\title{
GENERA PLAN'TARUM
}

SECUNDUM

\section{ORDINES NATURALES}

DISPOSITA

\author{
A U C T $\mathbf{O}$ R $\mathrm{R}$ E \\ STEITANO ENIDICIIER
}

VINDOBONAE

APUD FR. BECK UNIVERSITATIS BIBLIOPOLAM

$1836-1840$ 


\title{
B.Lab 1858.36
}

\section{ECoN}

QK

97

.$E 5$

Botam. Soal.

\author{
1898 fune 23
}

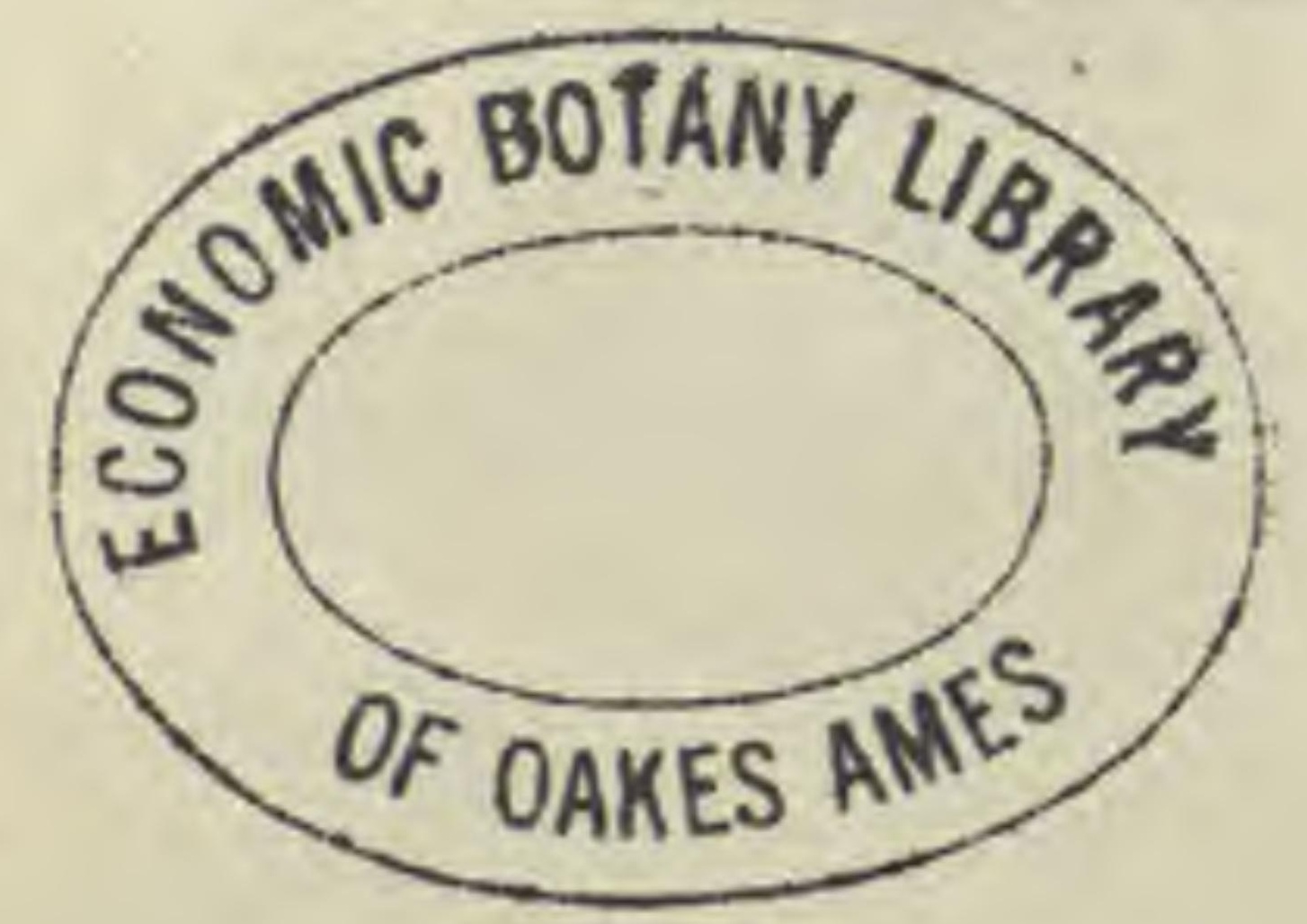

A. Tragusio

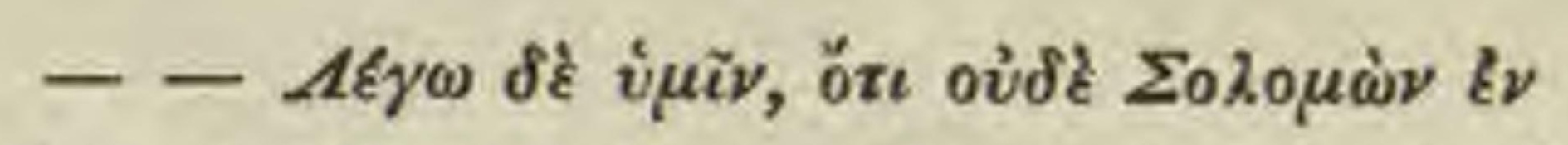

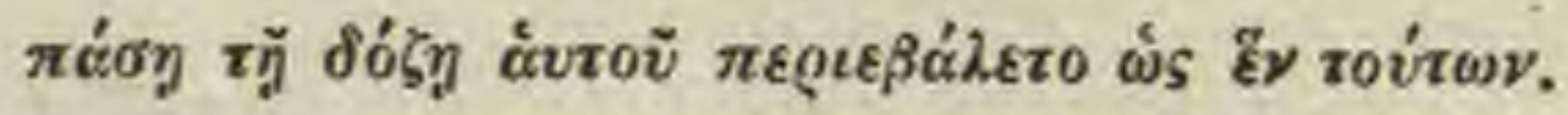

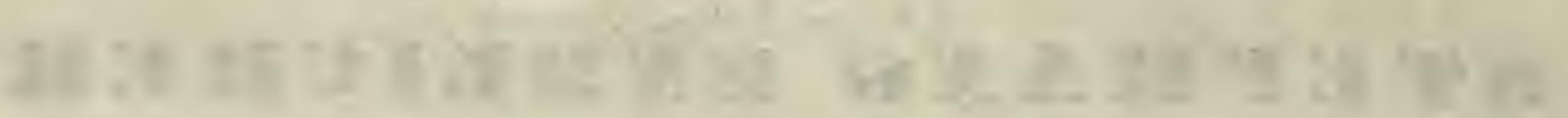

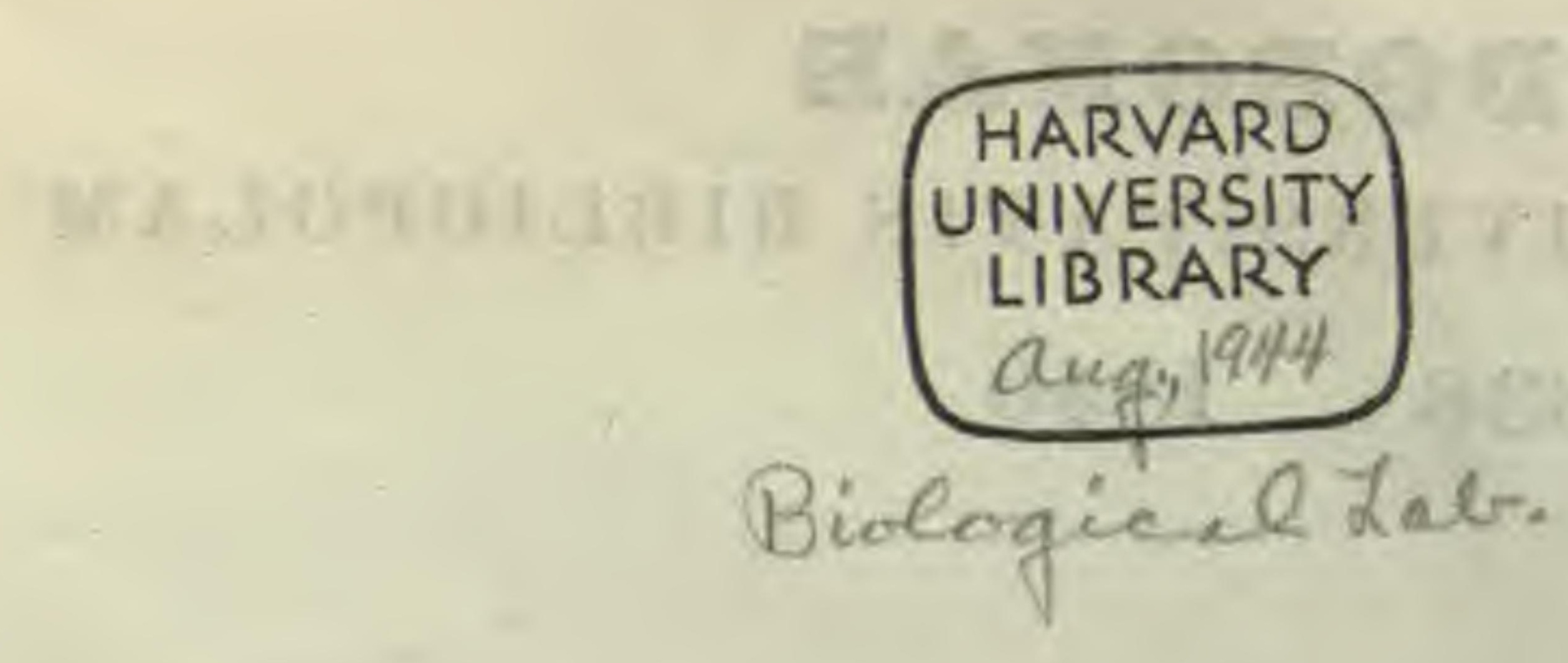




\title{
HOC VOLUMEN
}

\section{ANTONIO LAURENTIO DE IUSSIEU DUM IIV VIVIS VERSAIRETUR}

\author{
SA CRATUM \\ EREPTO METHODI NATURALIS PARENTE \\ TANTI NOMINIS DIGNISSIMO HAEREDI \\ ADRIANO DE IUSSIEU
}

DICA T

$\begin{array}{llllll}A & \boldsymbol{U} & \boldsymbol{C} & \boldsymbol{T} & \boldsymbol{O} & \boldsymbol{R}\end{array}$ 


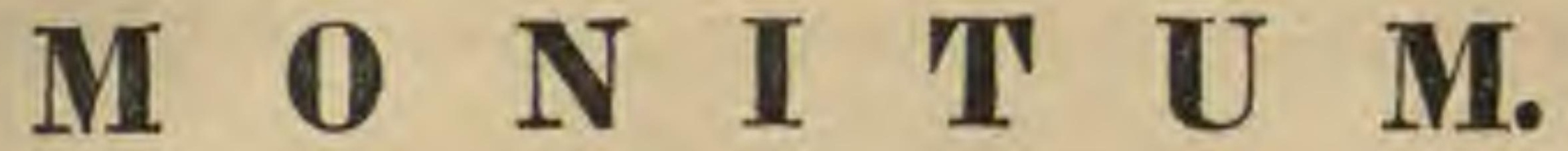

Rationes vasti operis, cujus hodie particulam primam botanicis tradimus, facilius absoluto volumine, quam in ipso libri limine exponuntur.

Sectiones primariae secundum vegetationis modum, juxta systema e characteribus anatomicis a cl. Ungero mecum olim elaboratum, et tum in prolegomenis hujus operis, tum in „Aphorismis botanicis" uberius exponendum, dispositae sunt.

Fasciculi, qui in tanta nostra parsimonia, denorum duodenorumve numerum vix excedent, singuli denis absoluti plagulis, quanta per typographos et diorthotas licuerit celeritate, emittentur, singulos generum in quovis contentorum indiculus comitabitur.

Prolegomena, ordinum characteres synoptici, index universalis et supplementa cum ultimo fasciculo evulgabuntur.

Vindobonae 20. Augusti 1836. 


\section{Wecturis salutem!}

$\mathbf{P}$ auca sunt quae in limine vasti voluminis, eui laetus hodie finem impono, praemonenda habeo, eaque potissimum imperfectiones operis spectant, quod unius hominis humeris fere gravius, audendum tamen putavi; persuasus, non citra scientiae nostrae detrimentum, unam hodierni systematis botanici imaginem diutius posse desiderari. Circumspiciens enim per ornatissimorum virorum coetum, quorum doctrina res herbaria floret, et nostra superbit aetas, vidi plurimos, et laude mea majores, qui acutissimis studiis augendae et amplificandae plantarum cognitioni toti incumbentes, nobilissimis inventis scientiae terminos quotidie proferunt; neminem ita sui oblitum, ut non a labore ingrato, auctori suo inglorio, servilis 
potius diligentiae et obscurae pertinaciae, quam ingenii aliqualis documento, abhorreret.

Perpensis itaque operis rationibus, quod generum plantarum characteres juxta unam formulam exponeret, cum me suppelectili non facile a quovis paranda instructum viderem, et utut doctrina imparem, improbi tamen laboris constantia nemini secundum sentirem, me devovendum putavi; opus aggressus plenum aleae et mole sua taediosum, in quo nunc ad finem perducto quanta fortuna versatus sim, aequo peritorum judicio relinquo.

Ordinum naturalium dispositio hodiedum fere arbitraria est; meam, mihi ipsi non in omnibus aeque probatam botanicis obtrudere, vel universi regni vegetabilis divisionem et familiarum seriem, hoc loco propositam, prae aliorum auctorum dispunctione commendare, nullus contendo. Res in hoc opere minoris dignitatis est, quod in describendis generibus naturalibus versatur; in quo ipso tamen non reformandum fuit, sed referendum, et ita alienis inventis utendum, ut cunctas hodiernae scientiae botanicae imperfectiones in me unum susciperem. Nullibi enim singulis inhaerendum fuit, sed ita citato et aequali pede per longam metam decurrendum, ut una sisteretur ingentis aedificii imago, et quid in hac mole sanum, quid 
aegrum, quid erroribus squalidum v. dubiis obscurum, quid denique periti artificis manum prae reliquis exposcat, appareret.

Imperfectiones universi operis et singularum partium naevos nemo, nisi similem librum ad calcem perduxerit annuo labore, me ipso melius perspectos habere potest. His futurae aetatis diligentia medebitur. Mihi in poliendo et perficiendo hoc opere porro quoque desudare propositum est; nam vitae quod superest, emendando et augendo uni, quem cernitis libro impendere, constitui. In hoc autem ita versabor, ut edenda quotannis, vel pro re nata etiam saepius, generum plantarum supplementa, praeter novorum synopsim et veterum mantissam, simul unius vel alterius ordinis retractationem proponant. Hoc itaque consilium viris botanicis iterum commendo, et commendatum fore ab illorum amicitia confido. Ea enim hodierna scientiae dignitas, illa doctorum virorum contentio est, ut singuli posthabitis privatae aemulationis rationibus, in unum scopum et publica quodammodo emolumenta conspirent, aequo animo aliena coepta amplexantes. In quo quidem rei herbariae cultores reliquarum etiam scientiarum alumnis praelucere, vetus fama est, et ego saepe saepius in hoc opere expertus sum; ita ut nullus sit inter omnes, qui per terrarum orbem dispersi habitant, viros scientiae nostrae laude illustres, cujus amicus animus et nobilis benevolentia mihi non 
esset praedicanda; singulos autem, quorum auxilio res nostra potenter crevit, recensere, botanicorum aetatis nostrae catalogum esset texere. Vobis itaque omnibus viris illustribus et amicis charissimis hoc loco porrigo dexteram, et grates dico, quas scientiae rependere pro virili conabor.

Qui autem, dum in hoc opere desudo, nobis occidistis piae animae! vobis terram levem opto; vestra fama manebit.

Scripsi VINDOBONAE Kal. Januar. MDCCCXXXXI. 


\section{CONSPECTUS DIAGNOS'TICUS.}

\section{REGIO I. THALLOPHYTA.}

Oppositio caulis et radicis nulla. Vasa nulla, organa sexualia nulla. Sporae germinantes undique elongatae.

\section{SECTIO I. PROTOPHYTA.}

Sine humo enata, elementum nutriens undique haurientia, fructificationes indefinite explicantia.

\section{Classis I. Algae.}

Protophyta aquatica.

I. DIATOMICEAE. Individua crystalliformia, lineis rectis $\mathbf{v}$, rarius curvis circumseripta, plana, fragilia, libera v. varie consociata. Gen. 1 - 24.

1. Diatomeae. Individua lineis rectis circumscripta, fuscescentia. Gen, 1_18.

a) FRUSTULIEAE. Individua nuda. Gen. 1-12.

b) HXDROLINEAE. Indis dua tubulis inclusa. Gen.13-18.

2. Dermatileae. Individua cylindriea, viridia. Gen. 19_24.

c) MiCrasterieak. Individua nuda. Gen. 19-21.

d) ECHINELLEAE. Individua muco communi determinata, v. tubulis inclusa. Gen. 22-24.

II. NOSTDCIInNAE. Gelatina figurata, globulis v. filis fareta. Gen. $25 \_36$.

111. CONFEIR WACEAE. Fila articnlata, libera v. reticulatim cohaerentia, simplicja v. ramosa. Gen. 37 -75.

1. Leptomiteae. Fila arachnoidea, hyalina, obsolete articulata. Gen. 37_38.

2. Oseillatorieae. Fila mucosa, demum indurata, e matrice gelatinosa, granulis v, annulis seriatis fareta. Gen. 39_47.

3. Batrachospermese. Fila mucosa, ramos transversos heterogeneos exserentia. Gien. 48 _52.

4. Conferveae. Fila rigidiuscula, plerumque viridia, libera v. reticulata, sporidiis farcta. Gen. $53-56$.

5. Ceramieae. Fila rigida, plerumque celorata. Conceptacula v, tubercula ramulis apice intumescentibus innata. Gen. 57-74.

1v. Cma re ceAa. Tubuli septati, in caules convolnti. Organa propagationis dimorpha, globuli et sporangia apice dentibus quinque coronata. Gen. 76-77.

V. ULVACEAE. Frons plana v. tubulosa, ecostata. Sporidia frondi inspersa v. vesiculis inflatis excepta. Gen. 78_86.
1. Siphomene. Sporidia vesiculis excepta. Gen. 78 -82.

2. Ulveare. Sporidia frondi inspersa. Gen, 83_ 86.

VI. FIORIDAE. Frons plana v. filiformis, corticata, nervosa, purpurea v. rosea. Sporidia purpurea, in apotheciis tuberculiformibus adnatis, v. punctiformibus innatis. Gen. $87-103$.

VII. FUCACEAE. Frons plana v. filiformis, corticata, nervosa, olivacea. Sporidia nigra, in capsulis receptaculo proprio exceptis v. frondi immersis. Gen. 104-122.

\section{Classis III. Liehenes.}

Protophyta aërea.

VIII. CONIOTEALAnI. Apothecia primitus aperta, nucleo in sporidia nuda soluto. Thallus pulvereus, nucleo coêtanens. Gen. 123 - 130.

1. Pulverarieae. Thalli stratum medullare in fructificationem abiens; apothecia nulla. Gen. 123 - 126.

2. Caly eieae. Apothecia primitus aperta. Gen. 127 - 130.

Ix. IDIOTHAnam. Apothecia demum aperta, nucleum gelatinosum, sensim indurescentem enitentia. Gen. $131-146$.

1. Crmphidese. Nuclens oblongus v, linearis, e thalli strato corticali ernmpens, excipulo proprio, raro obliterato. Gen. 131_-136.

2. Clyplnideae. Nneleus oblongus v, linearis, thalli strato medallari immersas, eodem ernmpente exceptus, Gen. 137_-139.

3. Limboriene. Excipulum proprium orhiculare, e thallo prorumpens v, eidem immersum, excipulo thallode cinctum. Gen, 140_14t.

4. Fyximeae. Excipulum preprinm thallo superficialiter impositum, Gen. 145_-146.

x. Aasteredruanami. Apothecia semper clausa v. excipulo irregulariter discedente aperta. Nucleus ascigerus, deliquescens v. fatiscens. Gen. 147-159.

1. Verpucarleae. Excipulum proprinm simplex, corneum, ostiolatum, nucleum includens. Gen. 147-150.

2. Trypethellaceae. Excipulum verrncaeforme, e thalli strato medullari formatum, ostiolato-pertusum, nucleam deliquescentem includens. Gen, 151_-154.

3. Endocarpeae. Excipulum thallodes ostiolatnm, nucleum difluentem includens, Gen.155 $-157$.

4. Sphaeroplsereae. Excipolum thallodes pertusnm, nueleus fatiscens. Gen. 158_159. 


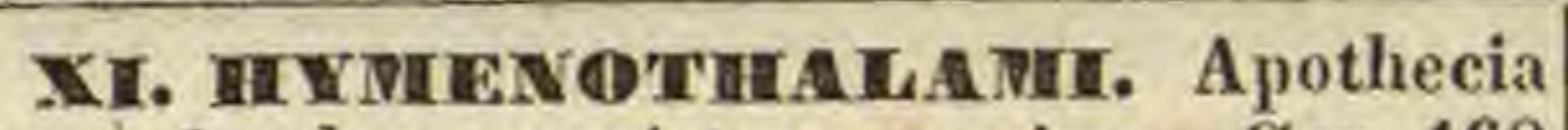
aperta. Nucleus persistens, asciger. Gen.160 179.

1. Collemaceae. Excipulum gelatinosum, saepe confusum. Gen. 160-164.

\&. Eleeidineae. Excipulum nullum v. proprium. Gen, 165_ 169.

3. Prameliaceac. Excipulum thallodes, primum connivens, demum hians. Gen, 170_174.

4. Ustreacene. Excipulnm thallodes, primitus apertum. Gen. $175 \_179$.

\section{SECTIO Il. HYSTEROPHYTA.}

In organismis languescentibus $\mathbf{v}$, emortuis enata, intussusceptione e matrice nutrita, organa omnia simul explicantia, definite pereuntia.

\section{Classis III. Fungi.}

Incunabula velata. Sporidia nuda v. ascis inclusa.

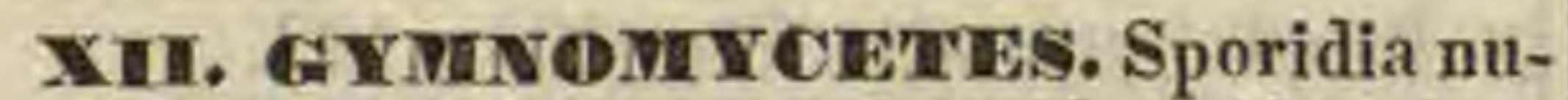
da, simplicia v. septata, sub epidermide plantarum v. intra matricem enata, receptaculo e matrice formato $\mathrm{v}$. proprio solido, innato aut superficiali imposita. Gen. 180_207.

1. Eutoplayti. Sporidia varia, e parenchymate morboso plantarum sub epidermide orta, hac rupta emergentia, et varie saepius mutata stipata. Gen. 180_187.

z. Sporodermei. Sporidia in floceos demum dilabentes concatenata, sub epidermide emergentia. Gen. 188_192.

3. Stilbosporef. Sporidia sub epidermide in nueleum compacta, demum erumpentia. Gen. 198_-200.

4. Tubereularoni. Sporidia stromati proprio imposita, in discum denudatum conglutinata. Gen. 201_207.

XIII. ITY PIIOMI YOETES. Flocci nudi, tubulosi v. solidi, a matrice discreti. Sporidia e floccorum divisione $v$, intra floccos enata, saepe intra eorum apices vesiculoso - inflatos (peridiola) contenta, v. stromati floccifero imposita. Gen. 208_270.

1. Sepedonfei. Sporidia cumulata, matrici incumbentia, floceis discreta. Gen, 208__216.

2. Mueedines. Sporidia intra floccos tubulosos, pellucidos, saepe septatos enata, iisilem tandem inspersa v, catenatim adhaerentia. Gen, 218 _229.

3. Dematiei. Sporidia e floceis solisis, opacis, corticatis extus enata, v. e floceorum dissolutione orta. Gen, 230_241.

4. Inveorima. Sporidia intra tubum floccosum genita, demum in capitula terminalia, nune gelatina obvoluta, nune vesieula (peridiolo) varie dehiscente excepta, collecta. Gen, 242_261.

5. Cephalotrielheil. Flocei in stroma (receptaculum) verticale v. horizontale coaliti. Sporidia e stromate enata, simplieia, libera. Gen. $262 \_270$.

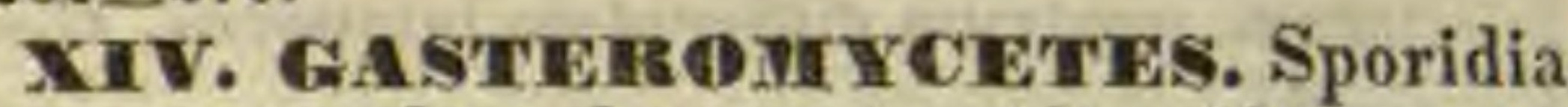
intra receptaculum clausum (peridium) libera, in centro collecta $v$. immersa et concreta, floceis inspersa v. receptaculis propriis (sporangiis) excepta. Gen. $271-359$.

1. Perisporiaceí. Peridium subglobosum, apice dehiscens, pulpa gelatinosa farctum. Sporidia in centro collecta, pulpae immersa, libera v. peridiolis inclusa. Gen. 221_280.

a) APIOSPOREI. Peridium thallo vestitum, hie ergo obsoletus. Gen, 271-275.

b) PERISPOREI. Thallus effusus, dissolutus, raro obsoletus, Gen, 276-280.

2. Selerotiaceil. Peridium carnoso-vesicnlosum, enm massa interna sporidia fovente connatum, undique v. solo apice fruetificans. Sporidia connata, alia demum libera, subemergen tia. Gen. 281_-290.

c) SCLERotiet. Peridinm confusum, semper clausum, intus obscure vesicnlosum, sporidifferam. Sporidia demum emergentia. Gen. 281-286.

d) RHIZOGONEL. Peridium libere evolutum, intus obseure loculosum. Fructificatio saepe obsoleta. Gen. 287 $-29 \mathrm{~S}$.

3. Treielnodermacei. Peridium e floceis cuntextum v. membranaceum, fugax Sporidia sub peridio in stratum peripherienm v. discoideum collecta, plerumque compacta, nullo capillitio genuino intertexta. Gen, $291 \_304$.

e) AEgERitel. Peridium fere obsoletum. Sporidia compaeta, haud diseoidea. Gen, 291-294.

f) TRICHODERMEI. Peridium effusam. Sporidia discoidea. Gen. 295-299.

b) ONYGENEI. Peridium eapitatum, floccis velatum. $\mathrm{S}_{\mathrm{p} o-}$ ridia subperipherica. Gen. 300-30't.

4. Trielhas permeí. Peridium genuinum, continuum, plerumque duplex, demum dehiscens, sporidia effundens. Sporidia nuda, in centro coacervata, floceis plus minus effiguratis intertexta v. distincta. Gen. 305_336.

A. MYXOGASTERES. Primum mucilaginosi fluxiles, demum varia metamorphosi effigurati. Gen. 305_322.

h) TRICHIACEI. Muellago primaria plura peridia dis. creta eonjungens. Flocei sporidiiferi liberi, intorti, elastici. Gen. 305-309.

i) STEMIONITEI. Mucilago primaria plura peridia disereta fovens. Flocci sporidiferi reticulatim connexi, adnati v. innati. Gen. $310-314$.

k) PHYSAREI. Mueilago primaria late serpens, in plura peridla abiens. Flocei sporidifferi aduati, recti, vagiGen. $315-318$.

t) AETHALINEI. Macilago primaria in unicum peridium abiens. Gen. 319-322.

B. TRICHOGASTERES. Primum carnosi, indarati. Gen. $323 \_336$.

m) CENococcel. Capilitium nullum. Sporidia primum conglutinata. Gen. 323-324.

n) PODAXIDEI. Capillitium laxum, colnmellae eentrali adnatum. Gen, 326-327.

o) SCLERodermeI. Capillitium celluIosum. Sporidia conglomerata. Peridium induratam. Gent. 328-331.

p) LYCOPERDEI. Capillitium effusum. Peridiun adnatum. Sporidia discreta. Gen. 332-336.

5. Angiogasteres. Uterus rotundatus, apiee rumpens, receptacula (sporangia) solitaria v. plura, clausa v. aperta fovens. Gen. 337_-359.

q) CARPOBOLEI. Uterus sporangium vesieulaeforme solitarium ejieiens. Gen. 337-339.

r) NIDULARIACEI. Uterus demum apertus, sporangiis pluribus clausis liberis foetus. Gen. $340-344$.

ə) TUBERACEI. Uterus demun apertas, carnosus, sporangiis v. peridiolis inspersis. Qen. $345-354$.

a) Tu ber ef. Uterus intus carnosus, venosus. Sporangia auda v. peridiolis inclusa, uteri parietibus immersa. Gen. 345-352.

8) 11 y m e nogas ter ei. Uteri peridinm exterias saepe fugax, interius hymenino-cellulosum Peridiola celIulis peridli interioris imposita. Gen. $353-354$. 
b) PHALLOIDEI. Uteras gelatina distentas, apice rumpens. Receptacolum elastice protrusum, apertum. Sporidia in receptaculi strato mucoso nidutantia. Gen, 355 -359 .

XV. PVE ENODIYCITES. Perithecium induratum, primo clausum, deinde poro pertusum v. rimose ruptum, nucleo molliore farctum. Sporidia muco involuta v. ascis basifixis inclusa. Gen. 360-397.

1. Xylomacei. Perithecium rumpens. Nucleus sporidiis nudis faretus. Gen. $360 \_364$.

2. Cytispored. Perithecinm ostiolatum. Nuclens sporidiis nudis $\mathbf{v}$, ascorum rudimentis inclusis faretus, diffluens Gen. $365 \_368$.

3. Planciallacel. Perithecium ostiolatum, Asci discoidei, erecti, fixi. Gen. 369_382.

a) PHACIDIEI. Perithecium subdimidiatum, demum apertum. Nucleus nudus. Gen. 369-373.

b) GLONIEI. Perithecium integrum, rimis arcte conni ventibus dehiscens. Gen. $37 \%-376$.

c) DERMEI. Perithecium denum apertum, cum receptaeulo floccoso connatum. Nucleus receptaculo impositus. Gen. 377-379.

d) TYMPANIDEI. Peritheeium marginatum, joperculo v. velo clausum. Gen. 380-382.

4. Splaneriacel. Perithecium clausum, demum ostiolato pertusum. Nucleus ascigerus, diffluens. Gen. 383-397.

e) DOTHIDINI. Peritheeia in stroma celluliferum confluentia. Ostiolum nullum v. subtile, porosum. Gen. $383-385$.

f) STRIGULINI. Stroma duplex, discretum, in crustam corneam matrici innatam abiens. Ostiolum inaequale, saepe ampliatum. Gen. 386-389.

g) DICHAENEI. Peritheeium rimose dehiscens. Stroma diseretum, matrici adnatum. Gen. 390-393.

h) SPHAERINI. Perithecium ostiolo plus minus rotundato, rarius compresso apertum. Stroma aduatum. Gen. 394 -397 .

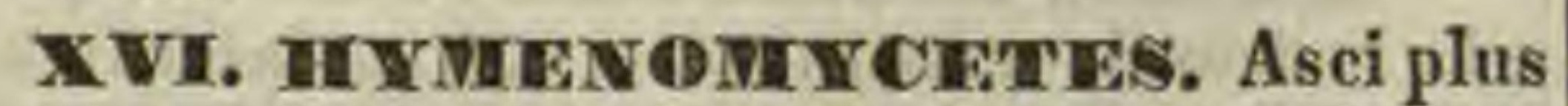
minus perfecti, membranae fructificanti, receptaculum diversae formae obtegenti immersi. Gen. 398 - 453.

1. Tremenina. Hymeninm cam receptaculo aperto vago confluens. Asci obsoleti. Gen. 398_ 411.

a) HXMENULI. Receptaculum coriaceo v. eeraceo gelatinosuns. Sporidia obsoleta. Gen. 398-399.

b) TREMELLEI. Receptaculum gelatinosum. Hymenium amphigenum. Gen, 400-403.

c) CUPULARES, Receptaeulum gelatinosum ₹. coriaceum. plerumque eupulaeforme, submarginatum. Hymenium superum, papillosum. Gen. 40\%-406.

d) PILEOLARES. Receptaculum membranaceum, siccnm, pileatum, excentrice substipitatum. Hymenium inferum, laeve. Gen, $407-411$.

\%. Clavariei. Receptaculum clavaeforme, simplex v, ramosum. Hymenium amphigenum. Asei sublineares, vix paraphysophori. Gen. 412 - 421.

e) Clavulati. Hymenium eonfluens. Asci abbreviati v, obliterati. Gen. $412-415$.

f) MItrulini. Hymenium diseretum, receptaculam ambiens. Asci elongati. Gen. 416-419.

g) PILEOLATI. Hymenimm $\mathrm{cum}$ receptaculo effigurato contluens. Asel breves. Gen. $420-121$.

3. TElvellaceî. Receptaculum orbiculatum. Hymenium superum. Asci elongati, clavati, pa raphysophori. Gen. 422_429.

h) CUPULATI. Receptaculum eupulatum, aequabile. Hy meniam discoidenm, Junius subelausum, marginans. Gen. 422-423.

i) CLAVICUlarES. Reeptaculum lenticulare, apertum. Hymenium marginatum. Cen. 42\%-427.

k) CuPULAT1. Receptaculum cupulatum, prima elausum. Hymenium marginatam. Gen. 428-131. l) MITRATI. Receptaculam pileatum, bullatum, primitus apertum, haud marginans. Hymeniuu coucretua, persistens, nudun. Gen. $432-435$.

4. IPilleauf. Receptaculum pileatum. Hymeni um inferum, suheffiguratum, raro laeve. Asci lineares, fixi, vix paraphysophori. Gen. 436-453.

m) AURICULARINI. Hymenium laeve v. papillosum. Gen. $436-437$.

n) HYDNEI. Hymenium subulatum v. tuberculatum. Gen. $438-443$.

o) POLYPORFI. Hymenium porosum v. mucosum. Gen. $44 x-448$.

p) AGARICINI. Hymenium lamellatum v. plicatum. Gen. $449-453$.

\section{REGIO 11. CORMOPHYTA.}

Caulis et radicis oppositio polaris. Vasa et organa propagationis sexu distincta in perfectioribus.

\section{SECTIO III. ACROBRYA.}

Caulis incrementum e solo apice, parte inferiore immutata, succos tantum adducente.

COHORS I. ANOPHYTA. Vasa nulla. Genitalia utriusque sexus. Sporae intra sporangia liberae.

\section{CIassis IV. Mrepaticae.}

Calyptra basi circumcirca soluta, pedicellus evaginatus. Sporangia $2-4 \mathrm{val}$ via v. dentibus dehiscentia. Sporae saepius elateribus mixtae.

XVIr. MCCHAcesz. Frondosae. Involucrum nullum. Sporangia irregulariter rumpentia. Elateres nulli. Aquaticae. Gen, 454 458.

XVIII. ANTHIDCERTTEA E. Frondosae v. foliatae. Involucrum nullum. Sporangia 1 2valvia, columella centrali. Elateres. Gen. $459-460$.

XIX. TA REGIONIACEAE. Frondosae. Involucrum heterogeneum. Sporangia dentibus dehiscentia. Wlateres. Gen, 461. 462.

XX. MIARCHAN'THAEAE. Frondosae. Involucrum et involucella. Sporangia dentibus irregulariter dehiscentia, varia. Elateres. Inflorescentia eapitata. Gen. 463_470.

XXI. JUVGEIRTANNIACEA E. Frondosae v. foliatae. Involucrum varium, involucella interdum nulla. Sporangia 1 4valvia. Elateres. Inflorescentia sparsa. Gen, 471_474.

\section{Classis v. Musel.}

Calyptra basi circumscissa, plerumque latere fissa, rarius persistens, medio rumpens. Pedicellus vaginatus. Sporangium operculatum, columna percursum. Sporae absque elateribus. 
XXiI. ANidreanaceas. Calyptra textura frondis. - Frondes tenerrimae, stobasi circumscissa. Sporangium quadrivalve. matiis destitutae. Gen. 657_658.

Operculum columnae adnatum, valvas post dehiscentiam connectens. Gen. 475.

XXIII. SEULACACEAE. Calyptra medio rupta, persistens. Operculum dissiliens, stoma nudum, colımna sub maturitate obsoleta. Gen. 476.

XXIV. BRYACEAE. Calyptra basi circumscissa. Operculum dissiliens, v. rarissime indehiscens. Stoma rarissime nudum, plerumque effiguratum, saepe annulum elasticum dejiciens. Columna manifesta. Gen. 477 - 600 .

COHORS II. PROTOPHYTA. Fasciculi vasorum plus minus perfecti. Genitalia mascula nulla. Sporae intra sporangia uni-plurilocularia, liberae.

\section{Classis vI. Equiseta.}

Caules aphylli, articulati, articuli vaginati. Fructificatio terminalis.

XXV. EQUISETACEA. Sporangia in receptaculis polygonis, in strobilum terminalem collectis, hypogena, unilocularia, polyspora. Sporae basi elateribus geminis involutae. Gen, 601_602.

\section{Classis VII. Filices.}

Frondes foliaceae in rhizomate sparsae, v. juxta ejus apicem rosaceo-congestae, vernatione circinnatim involutae. Sporangia unilocularia, plerumque dorsalia v. marginalia, venis imposita, in acervolos nudos $v$. squamula aut margine frondis tectos collecta.

XXVI. POI YPODIACEAE. Sporangia hypophylla, annulo verticali v. excentrico cincta, irregulariter transversim dehiscentia. Indusia varia, saepius nulla, - Frondes simplices v. cumpositae, stomatiis praeditae. Gen. 600 - 656 .

1. Polypodieae. Sporangia pedicellata, annule verticali. Sporae subglobosae v. oblongae. Gen. 603-644.

2. Cyatheaceac. Sporangia sessilia, annulo lato excentrico. Sporae triquetrae v. trilobae. Gen, 650_654.

3. Parkerieae. Sporangia sessilia, annulo incompleto, lato, basi approximato, interdum obsoleto. Gen, 655_656.

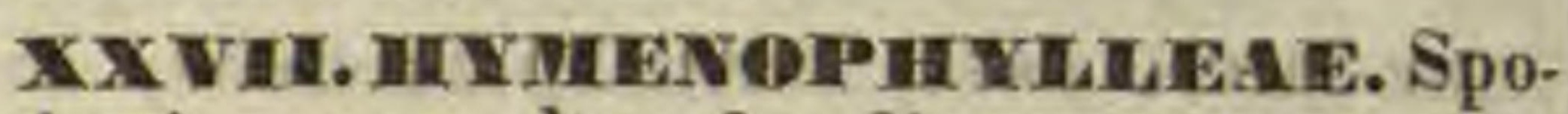
rangia in vena ultra frondis marginem producta sessilia, annulo completo excentrico, transversim dehiscentia. Sporae hine convexae, inde tetraèdro-pyramidatae. Indusinm

XXVIII. GLEICHENIACEAE. Sporangia hypophylla, sessilia, annulo completo lato, transverso v. subobliquo, introrsum transversim dehiscentia. Sporae oblongae $v$. reniformes. Indusium nullum v. spurium. Frondes pinnatae, saepissime dichotomae furcatae, stomatiis praeditae. Gen. 659-660.

XXIX. SCHIZAEACEAE. Sporangia hypophylla, sessilia, annulo completo verticali, contracto, longitrorsum dehiscentia. Sporae pyramidales v, conicae, sporodermi cristata v. echinata. Indusia varia. - Frondes simplices, dichotomae v. pinnatae, stomatiis praeditae, fertiles contractae. Gen. 661_664.

XXX.OSIIUNDACEAE. Sporangia hypophylla, v. frondibus contractis paniculata, pedicellata, annulo dorsali, lato, incompleto, vertice dehiscentia. Sporae oblongae v. subglobosae. Indusium nullum. - Frondes bipinnatae, stomatiis praeditae, fertiles saepissime contractae. Gen. 665_666.

XXXI. MARATTLCEAE. Sporangia hypophylla, exannulata, distincta v. inter se connata, vertice $v$. latere aperta. Sporae ellipsoideae. Indusium nullum, superficiale v. cum sporangiis concretum. - Frondes simplices v. pinnatae, stomatiis praeditae. Gen. $667-670$.

XXXII. DPHII OGXOSSEA E. Sporangia in fronde contracta sessilia, interdum incomplete bilocularia, exannulata, distincta $v$. inter se connata, semibivalvia. Sporae farinosae. - Frondes geminae, biformes, vernatione strictae, altera expansa sterilis, stomatiis praedita, altera in rhachim contracta. Gen. 671_674.

APPENDIX, Fillees fossiles. . . Gen, 675-687.

\section{Classis VuI. IIy dropteriales.}

Folia a caule discreta, sessilia v. petiolata, limbo saepius composito, interdum abortivo. Sporocarpia ad basim foliorum, organis dimorphis foeta. Herbae aquaticae, cylindro vasorum centrali percursae.

XXXIII. SAMVINIACEAE. Sporangia in eadem stirpe dimorpha, corpuscula angulata v. globosa includentia, uni-bilocnlaria, v. sporangiis juxta columellam basilarem pedicellatis, sporas liberas includentibus foeta. Caulis natans, pinnatim ramosus, foliis alternis, sessilibus. Gen. 688_659.

XXXI\%. MARSTLACACEAE. Sporocarpia uniformia, bi-quadrilocularia, loculis continuis v. transversim plurilocellatis. Sporangia in loculis locellisve dimorpha, placentis parietalibus affixa, monospora v. granulis 
in mucilagine natantibus foetae. Caulis repens, petioiis alternis, vernatione circinnatis. aphyllis v. foliolis quatuor verticillatis termi natis. Gen. 690_692.

\section{CInssiss IX, Selagines.}

Truncus foliatus, foliis simplicissimis, sessilibus. Sporocarpia in axillis foliorum v. bractearum saepissime valvata, sporis dimorphis foeta. - Herbae interdum suffrutescentes, fasciculis vasorum centralibus percursae.

XXXv. IS由ETEA. IIerbae submersae, trunco abbreviato. Folia subulata, fragilia, trunco excentrice imposita. Gen. 693_694.

XXXvi. HXCOPODIACEAE. II rbae terrestres, interdum suffrutescentes. Folia spiraliter trunco inserta, sessilia v. decurrentia, nunquam articulata. Gen, 695_698.

XXXVII. HEPIDOIDENDIREAF. Trunci fossiles, areolis rhomboideis, convexiusculis, spiraliter dispositis obsiti. Areolae prope apicem folii cicatrice transversa notatae. Gen. $699-703$.

\section{Classis $\mathbf{X}$. Zamiae.}

Organa utriusque sexus distincta. Antherae apertae. Ovula nuda. Embryo perfertus.

KXXVIT. CYCADEACEAE. Flores dioici. Folia juxta rhachin communem perpendieularia, subtus pollinifera. Folia ovulifera imbricata, crenata, crenaturis uniovulatis, $v$. in rhachi perpendicularia, disco subtus uni-biovulato. Seminum testi ossea. Embryones antitropi, in axi albuminis carnosi plures; radicula elongata, cotylédones apice connatie, basi subdistinctae. - Truncus arboreus, frondes pinnatisectae, vernatione circinnatae. Gen. 704 $-713$.

\section{COHORS II. HYSTEROPHYTA.}

Genitalia utriusque sexus perfecta. Semina aëmbrya, polyspora. Vita parasitica.

\section{Classis XI. Rhizantheae.}

Plantae parasiticae, acaules v. caudice simplici aut ramoso praeditae. Folia squamaeformia, nunquam viridia, stomatibus destituta. Flores monoici v. dioici, nunc hermaphroditi. Semina in ovarii uni-plurilocularis loculis solitaria, pendula; v. plurima, parietalia.
XXXIX. IBALANQIPUIREA E. Stipites e rhizomate solitarii v. plures. Flores sexu distincti, in eodem $v$, in diversis receptaculis. Masculi 1_3_4andri. Perigonii foliola totidem, libera v. gamophylla. Femineis perigonium nullum. Ovaria 1-2locularia, 1-2styla. Orula in loculis solitaria, pendula. Fructus coriacei, uniloculares, monospermi. Gen, 714_-722.

1. Sareophyteac. Receptacula in eodem stipite plura, distineta. Flures triandri; stamina libera, Ovarium uniloculare. Stigma sessile. Gen, 714 .

2. Topluoplayteac. Receptacula in eodem stipite plurima. Flores monandri. Ovarium biluculare, distylum. Gen. 715_716.

3. Cymomarieace. Receptaenlum solitarium stipitem terminans. Flures 1_tandri. Stamina libera. Ovarium uniloculare, monostylum. Gen, 717-718.

4. Helosieae. Receptacula solitaria, stipites terminantia, Flores Bandri. Stamina symphysandra. Ovarium biloculare, distylum. Gen. $719-722$.

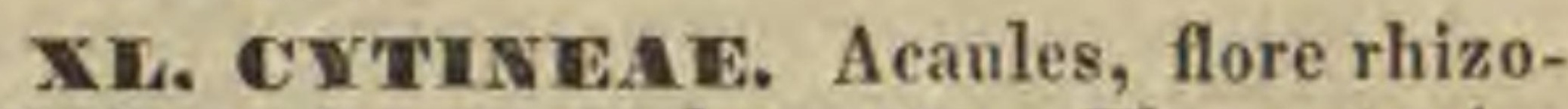
mati imposito v. caulescentes. Flores typice hermaphroditi, abortu unisexuales. Perigonium tubuloso - campanulatum, 3_4_6lobum. Stamina simplici v, duplici loborum perigonii numero, filamentis inter se et cum stylo connatis; antherae bi-multiloculares, loculis appositis, longitudinaliter dehiscentibus. Ovarium inferum, uniloculare, placentis parietalibus plurimis, multiovulatis. Gen. 723 - 724.

XHI. HAFICESHACEAE. Flores solitarii, aliarum stirpium radicibus epigaeis v. ramis innati, hermaphroditi $v$, abortu dielines. Perigonium globosum v. campanulatum, limbo quinquepartito: Staminum synnema columnare, perigonii tubo adnatum v. liberum. Antherae plurimae, distinetae, uni-bi- v. concentrice multiloculares, poro verticis dehiscentes. Ovarium inferum, uniloculare, placentis parietalibus plurimis, multiovulatis. Gen. 725 - 727.

\section{SECTIO IV. AMPHIBRYA.}

Caulis ambitu crescens. Vegetatio peripherica.

\section{Classis XII. Glumaceae.}

Flores in spiculas dispositi, bracteis imbricatis, glumaceis vestiti. Perigonium nunc nullum, nunc squamiforme v. setiforme. Ovarium liberum, uniloculare. Ovulum unicum, parietale amphitropum, v. basilare anstropum. Caryopsis. Embryo ad basim seminis, albumini farinaceo applicitus, v. ab codem inclusus. 


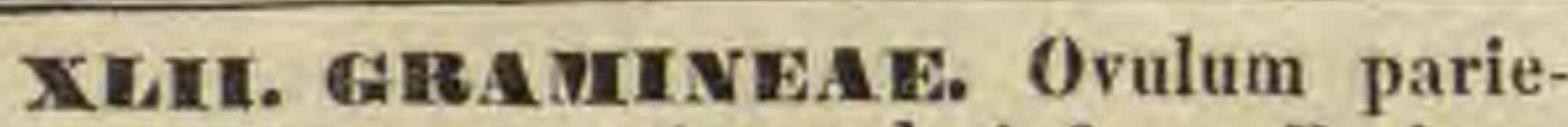
tale amphitropum, micropyle infera. Pericarpium cum testa connatum. Embryo ad basim seminis albumini farinaceo applicitus. Caules saepissime nodosi, teretes, foliorum vagina fissa, plerumque ligulata. Gen. $72 \mathrm{~S}$-956.

1. Dryzeae. Spieulae nune 1forae, glumis saepe abortientibus, nunc 2_3florae, floribus inferioribus unipaleaceis, neutris. Paleae chartaceo-rigidae. Flores plerumque diclines, saepissime hexandri. Gen. 728_740.

2. Phallatrideae. Spiculae hermaphroditae, polygamae, v. rarius monoicae, nune fflorae, accedente interdum floris superioris rudimento stipitiformi, nunc 2florae, flore utroque hermaphrodito $v$, maseulo, nune 2 3florae, flore terminali fertili, reliquis incompletis, Glumae plerumque aequales. Paleac saepins nitidae, in fructu induratae. Gen. $741-759$.

3. Panicene. Spiculae 2florae, flore inferiore incompleto. Glumae paleis teneriores, inferior saepe, rarissime ambo abortientes. $\mathrm{Pa}$ leae coriaceae v. chartaceae, plerumque muticae, inferior concava. Caryopsis a dorso compressa. Gen, 760 - 792 .

4. Stipacene. Spieulae 1florae. Palea inferior involuta, apice aristata et in fructu plerumque indurata, arista simplici $v$. trifila, basi saepissime torta et articulata. Gen, 793 -802 .

5. Arostaleae. Spiculac 1 flerae, accedente interdum floris superioris rudimento subula to. Glnmae paleaeque 2, membranaceo-her baceae, palea superiore saepius aristata. Gen. $803-816$.

6. Arumalinaceae. Spiculae 1 llorae, accedente interdum floris superioris rudimento, nune multiflorae. Flores plerumque pilis longissimis, mollibus obsiti v. basi cineti, Glumae et paleae 2, membranaceo-herbaceae, glumae flores saepe aequantes $\mathbf{v}$. superantes, palea inferior aristata v. mutica, Gen.817_826.

7. Pappophoreae. Spiculae 2-multiflorae, superiores tabescentes. Glumae paleaeque 2, membranaceo - herbaceae. Palea inferior trimultifida, laciniis subulato-aristatis. Inflorescentia capitato - spicata v. paniculata. Gen. $827-833$.

8. ChIoridleae. Spiculae in spicis unilaterales, uni-multillorae, floribus superioribus tabescentibus. Glumae et paleae 2, membranaceo-herbaceae, paleae muticae v. aristatae; glumac in rhachi persistentes, antica altius inserta. Spicae digitatae v, paniculatae, rarissime solitariae. Rhachis continua, haud articulata. Gen. 894 - 855 .

9. Avenacene. Spiculae 2-multiflorac, flore terminali plernmque tabescente. Glumae paleacque 2, membranaceo-herbaceae, palea inferior plerumque aristata, arista saepe dorsali, tortili. Gen. $856 \_874$.

10. Festucaceac. Spiculae multiflorae, rarius pauciflorae. Glumae et paleae 2 , membranaceo-herbaceae, rarius coriaceae, hae plerumque aristatac, aristis haud tortis. Infloreseentia vix non semper panieulata. Gen. 875 -911.

a) BROMEAE. Gramina herbacea. Stamina 3, Gen. 875 -903.

b) BAMBUSEAR. Gramina fruticosa v. aborescentia. Stamina 3_6. Gen. 904_-911.
11. Firorelle aceae. Spiculae 3-multiflorae, flore terminali plernmque tabescente. Glumae (rarissimae deficientes) paleaeque 2 , herbaceae. Spiea simplex, solitaria, rhachi interdum alata. Gen. 912_919.

12. IR ottboelliacene. Spiculae 1-2-rarissime Sflorae, in rhacheos saepissime exarticulatae excavationibus solitariae v. geminatae, altera tunc pedicellata, saepe tabescente. Flos inferior v. superior plernmque tabescens. Glumae 1 v. 2, interdum plane deficientes, plerumque coriaceae. Paleae membranaceac, muticae v. raries aristatae. Gen. $920 \_932$.

13. Andropogomeae. Spiculae 1_-2florae, flore inferiore semper incompleto. Paleae glumis teneriores, semper hyalinae. Gen. 933 -956 .

XXIII. CYPEEACEAE. Ovulum basilare anatropum. Pericarpium semini haud adnatum. Embryo in basi albuminis farinacei inclusus. - Caules saepissime enodes, trigoni, foliorum vagina integra, ligula nulla. Gen. 957 1002.

1. Cariecae. Spiculae diclines, masculae multiflorae, floribus undique imbricatis, unipaleaceis, femineae uniflorae, accedente saepius spiculae masculae pedicello, biglumes, gluma antica plana, postica biearinata, marginibus in utriculum coalita. Paleae nullae. Gen. $957-959$.

2. Elymeae. Spiculae Iflorae, unisexuales, v. bi-pluriflorae androgynae, maseulae interdum ad pedicellum redaetae. Gluma 1 , antica. Paleae 2, rhachi parallelae, antica minor in spiculis androgynis deficiens. Gen. 960_962.

3. Selerieae. Spiculae diclines, masculae multiflorae, paleis distiche $\mathbf{v}$. multifariam imbricatis, infimis saepe vacuis; femineae uniflorae, glumis plurimis, multifariam imbricatis v. nullis, paleis 2, oppositis v. suboppositis. Gen. 963 _ 965 .

4. ER Iny neluosporeae. Spiculae hermaphroditae v. polygamae. pauciflorae v. 1florae, paleis distiche $v$. plurifariam imbricatis, infimis summisque saepe vacuis. Gen. $966 \ldots 978$.

a) RHYNCHOSPOREAR VRRAE. Perigoniam setosum distinctum, rarissime fugax v. nullum, stylo tune apice Indiviso ₹. obsolete bi - trideatato. Gen, 966 -974 .

b) SCHoznoIdEAE. Perigonium nullum. Gen. 975 -979 .

5. Cladieae. Spiculae 1_3florae, paleis multifariam imbricatis, infimis semper vacuis, extremis solum floriferis. Gen, 980_484.

6. Chrysitrielneac. Spiculae androgynae, monocarpicae, paleis plurimis, rhachillae discoideo-depressae mnltifariam insertis, flore terminali hermaphrodito, masculis plurimis monandris cincto. Gen. $985 \_986$.

\%. Ifipoear pheae. Spiculae hermaphroditae, 1florae, paleis 2_4 v. interdam solitariis. Gen. $987-989$.

8. Funtemeae. Spiculac hermaphroditae $\mathbf{v}$. rarins polygamae, multiflorae, interdum 1 8florac, paleis di-tristiche $\mathbf{v}$. multifariam imbricatis. Gen. 990-991.

a) MELANCRANIDEAE. Spieulae paneiflorae, liermaphroditae $v$, polygamae, apice masculae, compres. kae. Paleae distíche $v$. plurifariam imbricatae, in spicam undique scarioso-bracteatam, v. in capituIum foliacea-bracteatum dispositae, spieulis istra quamvis bracteam solitariis v.geminis. Gon.990_992. 
b) HEMICHLAENEAE. Spiculae pauci - v. pluriflorae, hermaphroditae, compressae, paleis distiche imbricatis, terminales v. laterales, solitariae, geminatae v. ternatae, praeter involucrum commune bracteis nullis interstínetae, Gen, 993_994.

c) FICINIEAE. Spiculae moltiflorae, rarissime uniflorae, liermaphroditae, paleis undique imbricatis Gen. $995+998$.

D. Seirpene. Spiculac hermaphroditae, multiflorae, paleis undique v, rarissime subdistiche imbricatis, omnibus conformibus, infimis sterilibus. Gen. 999-1001.

10. Cypereae. Spieulae hermaphroditae, multiflorae, rarins 1 _ $3 f$ lorae, paleis distiche imbricatis, omnibus conformibus, marginibus plerumque per rhachillae angulos decurrentibns, infimis plerumque vacuis. Gen, 1002 $-1003$.

\section{CIassis XIII. Enantiololastae.}

Flores paleati v. perigoniati, perigonio regulari, biseriato, exteriore paleaceo v. calycino, interiore saepius corollino. Ovaria saepius plura distincta, $\mathbf{v}$, in unum connata, libera. Ovula solitaria v. plura, orthotropa. Fruetus capsularis v. nucamentaceus, uni-trilocularis. Embryo antitropus, albumini applicitus.

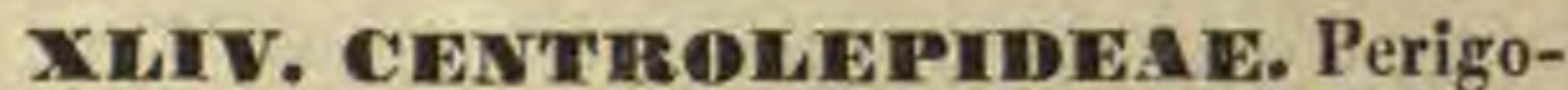
nium glumaceum, gluma antica v. 2 suboppositae, paleae nullae v. glumis parallelae. Stamen 1. Ovaria plura, unilocularia, supra axim deorsum imbricata. Ovulum 1, pendulum. Utriculus monospermus. Gen. 1004_1007.

XWv. RESTIACAE. Perigonium glumaceum, calyciforme, glumis $2-6$ biscriatis. Stamina 2_3. Ovarium 2-3loculare, rarissime 1loculare. Ovula in loculis solitaria, pendula. Capsula 3locularis, loculicida, v. nux monosperma. Gen. 1008-1021.

XIVI. ERTOCAULONEAE. Perigonium duplex, exterius rude 2 - 3 phyllum, interius tenerius subtubulosum, 3fidum. Stamina perigonio interiori inserta, duplici loborum numero, alterna saepe castrata. Ovarium 2-3loculare. Ovula in loculis solitaria, pendula. Capsula bi - trilocularis, loculicida. Gen. 1022 1024.

XWVIT. X TeIDEAF. Perigonium duplex, exterius glumaceum, 3 phyllum, interius corollinum, tubulosum v. hypocrateriforme, trifidum. Stamina 6, perigonii interioris tubo inserta, alterna sterilia. Ovarium 1_3loculare. Ovula plurima, horizontalia. Capsula polysperma, 1locularis, ad suturas dehiscens, v. trilocularis loculicida. Gen. 1025_1027.

XIVIII. COVIIERTNACEAE. Perigonium duplex, utrumque triphyllum, exterius calycinum, interius corollinum. Stamina 6, hypogyna, nonnulla sterilia. Ovarium 3locula- re, ovula in loculis pauca, situ varia. Capsula oligosperma, 2-3locularis, loculicida, v. bacca. Gen. 1028 -1036.

\section{CIassis Xiv. Helohiae.}

Perigonium duplex, rarissime nullum, interius saepius corollinum. Ovaria plura libera, distincta $\mathrm{v}$. subdistincta, unilocularia, uni-multiovulata. Ovula anatropa v. campylotropa. Carpidia follicularia, distincta, mono-polysperma, Embryo exalbuminosus, homotropus.

XFIX. AESTIACA. Ovula solitaria v. bina, carpidiorum suturae inserta. Gen. 1037 $-1043$.

1. Juneagianeae. Perigonium utrumque conforme, interdum nullum. Embryo rectus, Gen. 1037 - 1040.

2. Alismeae. Perigonii foliola interiora petaloidea. Embryo uneinatus. Gen. 1041_1043.

T. BUTTOMA CEA E. Ovula plurima, placentae parietali reticulatim ramosae afixa, Gen. 1044 - 1046.

\section{Classis XV. Coromariae.}

Perigonium plerumque corollinum, rarissime glumaceo - scariosum, regulare, biseriatum, serie utraque conformi. Ovarium liberum v. vix adhaerens, 3loculare. Ovula plurima, rarissime definita $\mathbf{v}$. solitaria, directione varia. Capsula v. bacca. Embryo intra albumen inclusus.

LI. JUVCACEAE. Perigonium 6phylIum, glumaceum v, subpetaloideum. Stamina 6 , perigonii foliolis ima basi inserta. Ovarium 3loculare, $\boldsymbol{v}$. septis incompletis 1loculare. Ovila in loculis solitaria v. plurima, erecta, anatropa. Capsula 1_3locularis, loculicide v. septifrago dehiscens. Embryo in basi albuminis carnosi orthotropus, radicula infera. Gen.1047 -1050 .

* ASTEliEaE. Perigonium semiglumaceum. Ovarium unitriloculare, tri - multiovulatuth. Bacea 1-polysperma. Gen, 1051-1052.

* RAPATEAE, Perigonium exterius glumaceum, triphyl. Ium, interius corollinam, trifidum. Ovarium 3loculare. Ovula ia Joculis soltiaria, basilaria, anatropa. Capsuia trilocularis. Gen. 1053.

** FLAGRLLarieaE. Perigonium coloratum, 6partitum. Ovarium 3loculare, ovulis intra loculos solitarils, basilaribus, anatropis. Drupa monosperma. Embryo leaticularis. Gen, 1054 .

*ae XEROTIDEAE. Perigonfum subeoloratum, 6partitam. Ovarium 3loeulare, ovulis intra localos solitarifs, azphitropis. Capsula y, bacea 3locuiaris, 3sperna, seminibus peltatis, Gen, 1055_-1056.

жa** KINGIACEAE. Perigoniam 6partitum. Ovariam mi. loculate, ovulls tribus, $v$, trilocalare, ovulis intra loculos solitarijs, basilaribus, aatropia. Utriculus monospermus. Gen. 1057-1058. 
******* CALECTASIEAE. Perigonium hypoerateriforme, lín. bo 6 partito. Antherae poris dehisceutes. Ovarium uniloculare, ovulis 3 basilaribus, auntropis. Utriculus monosperuius. Gen. 1059.

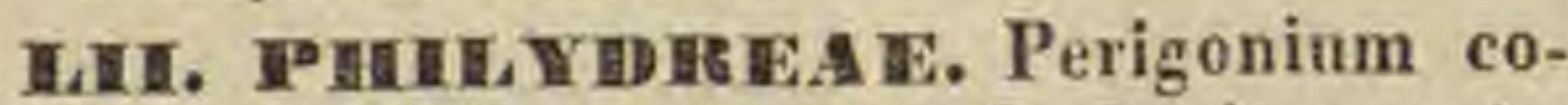
rollinum, diphyllum. Stamina 3 , basi connata, lateralia castrata, petaloidea, intermedium monantherum. Ovarium 3loculare. Ovula plurima, anatropa? Capsula 3locularis, loculicida. Embryo in axi albuminis carnosi orthotropus? Gen. $1060-1061$.

CIII. VIELANTIIA CEAE. Perigonium corollinum, hexaphyllum, foliolis aestivatione valvatis v. induplicatis. Stamina 6 v. 9. Ovarium 3loculare. Ovula plurima, anatropa v. amphitropa. Capsula tripartibilis. Embryo in tra albumen carnosum $v$. cartilagineum rectus. Gen, 1062_1086.

1. Weratreac. Perigonii foliola lihera, sessilia v. breviter unguiculata, interdum in tubum brevissimum cohaerentia. Gen, 10621083.

\%. Colelaieene. Perigonii foliola longissime unguiculata, unguibus plerumqne in tubum connatis. Gen. 1084_-1086.

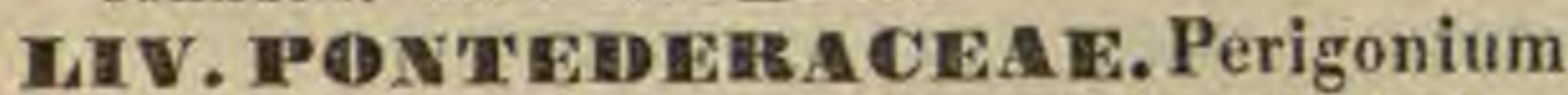
corollinum, hypocrateriforme $\mathbf{v}$. infundibuliforme, limbo 6partito. Stamina perigonii tubo inserta, 6 v. 3 et tunc laciniis interioribus opposita. Ovarium 3loculare, multiovulatum, v. loculis duobus cassis lloculare, ovulo unico, pendulo, anatropo. Capsula perigonii tubo tunicata, 3locularis, polysperma, loculicida, v. unilocularis, monosperma, indehiscens. Embryo in axi albuminis farinacei orthotropus. Gen. 1087_1089.

E.V. HILIACEAE. Perigonium corollinum, hexamerum. Stamina hypogyna v. perigyna 6 , rarius 3. Ovarium 3loculare. Ovula pauca v. plurima, anatropa v. amphitropa. Capsula pleiosperma, 3locularis, loculicida, rarissime septicida, v. bacca. Embryo intra albumen carnosnm homotropus. Gen. 1090-1175.

1. Tulípaceae, Perigonii foliola omnino distincta $\mathbf{v}$, ima basi cohaerentia, saepe nectarifera. Stamina hypogyna v. obscure perigyna. Fruetus capsularis. Semina anatropa, plerumque compressa, testa pallida, fusea, spongiosa v. dura. Eimbryo minimus, rectus $v$. parum incursus, in basi albuminis inclusus. - Herbae bulbusac. Gen. 1090_1099.

2. Agapantheae. Perigonium tubulosum, limbo sexfido. Stamina perigyna. Fructus capsularis. Semina anatropa, compressiuscula, testa membranacea, saepins pallida. Embryo orthotropns. - Herbae perennes, radice tuberosa v, fibrosa. Gen, 1100-1112.

3. Aloineae. Perigonium tubulosum v. sexpartitum, interdum subirregulare. Stamina hypogyna v, perigonii tubo inserta. Fruetus capsularis v. baceatus. Semina compressa, angulata $v$, alata, testa membranacea, pallida v, atra. Embryo orthotropus. - Herbae carno- sae, interdum frutescentes v. arborescentes. radice fibroso-fascieulata. Gen. 1113 _1117.

4. Aspla delleae. Perigonium tubulosum v. sexpartitum, regulare. Stamina hypogyna $v$. perigonii tubo inserta. Fructus capsularis v. baceatus. Semina globosa v, angulata, testa crustacea, atra. Embryo homotropes, rectus: v. incurvus. - Herbae radice bulbosa, fasciculato-fibrosa v, tuberosa. Gen. $1118-1175$.

a) HYACINTHEAE. Perigonium fubulosum ₹. 6partitam. Stamina perigonio inserta v. rarius hypogyna. Fruetus capsularis. Radix bulbosa. Gen. 1118-1137.

b) ANTHERICEAE. Perigoniam 6partitum, patens. Stamina at plurimum hypogyna. Fructus capsularis. Ra. dix fibrosa v. tuberosa. Gen. 1138-1153.

- conanthereae. Gen, 1154-1158.

* TUlbagiliNeAE. Gen, 1159.

c) ASPARAGEAE. Perigonium 6partitum, patens v. rarissiare tutulosum. Pructus baccatus. Seminum nmbilicus saepius stroplioiatus. - Herbae, frutices $\nabla$. arbores, radice tuberosa ₹. fibrosa. Gen, $1160-1167$.

* APHYLla NTHEAE. Gen. 1168 - 1173.

$\Rightarrow$ GiLliEsiacear. Gen, 117t_1175.

HVI. SNILACEAE. Perigonium corollinum, hexamerum, rarius tetra-octomerum. Stamina hypogyna v. rarius perigyna. Ovarium tri- rarius bi - quadriloculare. Ovula panca v. solitaria. Fructus baccatus, oligospermus. Semina globosa, testa membranacea, umbilico nudo. Embryo intra albumen dense carnosum v. cartilagineum rectus. Gen, 1176_-1188.

1. Fto

2. Convallarieae. Styli connati, Gen,1179 1188.

1) AsPidistreaE. Gen. 1189_1191.

2) OPHIOPOGONEAE. Gen, 1192_1194.

3) HERrerieaE, Gen. 1195.

4) ERIospermeak. Gen. 1196.

5) ROXBURGHIACEAE. Gen, 1197.

6) PHilesieaE, Gen, 1198_1199.

\section{Classis XVI. Artorlhizae.}

Perigonium herbaceum v. corollinum, regulare, sexpartitum, superum. Stamina 6 . Ovarium inferum, uni-triloculare. Ovula pauca, anatropa v. amphitropa. Capsula v. bacca. Embryo intra albumen in regione umbiliei.

LVII. DIOSCOREA Evarium triloculare. Ovula in loculis solitaria v. bina anatropa. Capsula v. bacca oligosperma. Gen. 1200 - 1203.

LVIII. TACCACEAE. Ovarium uniloculare, placentis parietalibus 3 . Ovula plurima, anatropa v. amphitropa. Bacca polysperma. Gen. 1204_1205.

\section{Classis Xvu, Ensatae.}

Perigonium superum v. semisuperum, regulare v. irregulare, hexamerum. Stamina 3 v. 6, rarius plura, cum stylo haud connata. Ovarium inferum, pluriloculare, triloculare. Ovula plurima, anatropa v. amphitropa. Capsula v. bacca. Embryo exalbuminosus, v. intra albumen inclusus. 


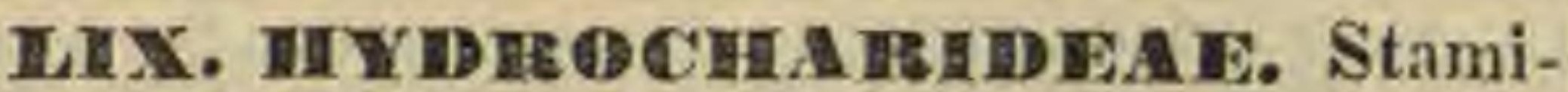
na 6 v. indefinita. Ovarium 1_6_9loculare. Semina exalbuminosa. Gen. 1206_-2016.

1. An anelnaridleae. Ovarium floculare. Stigmata 3. - Caulescentes, foliis oppositis v. verticillatis. Gen. 1206_1208.

2. Wallísneriene. Ovarium 1loculare. Stigmata 3. - Acaules scapigerae, foliis radicalibus linearibus. Gen. $1209-1210$.

3. Strotiotidleac. Ovarinm pluriloculare, Stigmata 6. - Acaules seapigerae. Gen.1211 1216.

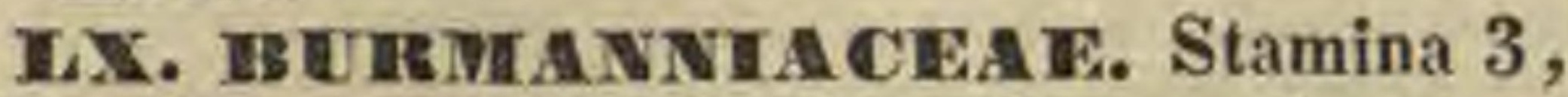
perigonii laciniis exterioribus alterna, Ovarium 1_3loculare. Semina albuminosa. Gen. 1217 $-1219$.

耳XI. IE ILEA E. Stamina 3, perigonii laciniis exterioribus opposita, antheris extrorsis. Ovarium 3loculare. Semina albuminosa. Gen. 1220_1248.

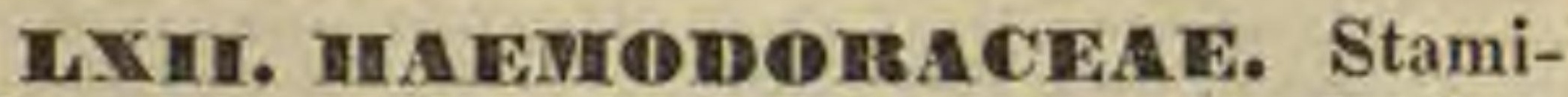
na 6 , quorum 3 perigonii laciniis exterioribus opposita saepius ananthera. Ovarium plus minus liberum, 3loculare. Semina albuminosa. Gen. $1249-1260$.

* Vellozieae. Gen. 1261_1262.

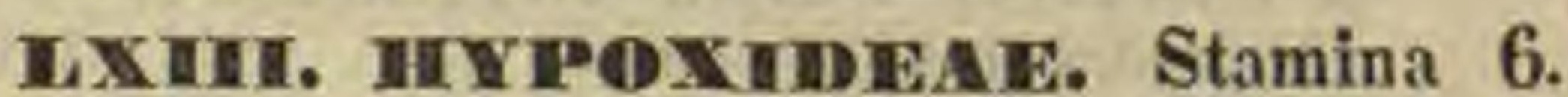
Ovarium 3loculare. Semina albuminosa, strophiolata. Gen. 1263 -1264.

IXIV. AUIAYHLIDEAE. Stamina 6 v. plura, sterilia saepius in coronam coalita. Ovarium triloculare. Semina albuminosa. Gen. $1265-1296$.

1. Amnryllexe. Stamina sterilia nulla. Scapigerae radice bulbosa. Gen $1265 \sim 1281$.

2. Nareisseae. Stamina sterilia libera $v$, in coronam faucis coalita. - Scapigerae, radice bulbosa. Gen. 1282_ 1290.

3. Anomalae. Caulescentes radice fibrosa, v. bulbosa ; rarius seapigerae, rhizomate tuberoso - fasciculato, Gen. 1291_ 1296.

* Agaveae. Gen. 1297_1298.

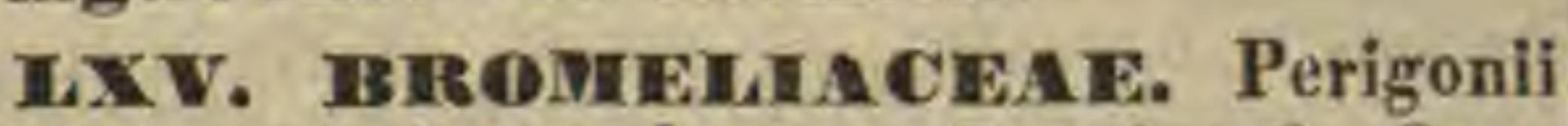
segmenta exteriora calycina. Stamina 6. Ovarium 3loculare, plus minus liberum. Semina albuminosa, saepius comosa. Gen. 1299_1315.

\section{Classis XVIII. Aymandeae.}

Perigonium corollinum, superum, irregulare. Stamina 3 , cum stylo connata, lateralia plerumque sterilia. Ovarium uniloculare, placentis parietalibus 3 , v. triloculare. Semina plurima, saepissime scobiformia, exalbuminosa.

CXVY. DECWIIDEAE. Ovarium uniloculare, placentis parietalibus tribus. Gen.1316 -1618 .

1. IIalaxideae. Stamina Iateralia sterilia, intermedium fertile. Anthera terminalis v. opereularis. Pollen in massas ceraceas indefinitas cohaerens, stigmati immediate applicitum, tela cellulosa accessoria nulla. Gen. 1316_1369.

a) PLeUrothalleaE. Columna geuitalium erecta, cum ovario contiuua v. basi parum producta. Gen. 1316_ 1348.

b) DENDROBIEAE. Columna genitalinm ovario inenmbens, basi longius produeta. Gen, 1349_-1369.

2. Wpidenalaeae. Stamina lateralia sterilia, intermedium fertile. Anthera terminalis, opercularis. Pollen in massas ceraceas, definitas cohaerens, tela cellulosa in caudiculas elasticas pulvereas, saepe replicatas cohaerente; glandula propria nulla. Gen. $1370 \ldots 1397$.

3. Wamelleae. Stamina lateralia sterilia, intermedium fertile. Anthera terminalis, raro dorsalis, opercularis. Pollen in massas ceraceas definitas cohaerens, sub anthesi lamellae elasticae et stigmatis glandulae adhaerens. Gen. 1398_ 1506 .

4. Dplaryalene. Stamina lateralia sterilia, intermedium fertile. Anthera terminalis, erecta $v$, resupinata, persistens, loculis completis. Pollinis massulae ceraceae, indefinitae, ope axeos arachnoideae, elasticae, glandulae stigmatis adglutinatae in massas binas colligatae. Gen, 1507 -1543.

5. Ciastroditeae. Stamina lateralia sterilia, intermedium fertile. Anthera terminalis, opercularis. Pollen e massulis majusculis, elastice in massas cohaerentibus, axi distineta nulla. Gen, $1544 \_1546$.

8. Neottieae. Stamina lateralia sterilia, intermedium fertile. Anthera stigmati parallela, persistens, loculis approximatis. Pollen pulverenm, e granulis laxe cohaerentibus, stigmatis glandulae affixum, Gen, 1547_-1586.

ซ. A retianseae, Stamina lateralia sterilia, intermedium fertile. Anthera terminalis, opercularis. Pollinis massae pnlvereae v, e corpusculis angulatis, basi aut infra apicem affixae, Gen, 1587 - 1617.

8. Cy gripedieae. Stamina lateralia fertilia, intermedium sterile. Gen, 1618.

HXVII. A POSTASIEAE. Ovarium trilocnlare, placentis centralibus. Gen. 1619 1620.

\section{Classis XIX. Seltamineae.}

Perigonium corollinum, superum, irregulare, nunc simplex hexamerum cum staminibus senis, nunc duplex, exterius trimerum rudius, interius hexamerum cum stamine unico. Ovarium triloculare. Semina in loculis solitaria v. indefinita, albuminosa.

UXVIII. ZINGIBEIRACEAE. Perigonium duplex, calyx trimerus et corolla hexamera. Stamen 1, corollae laciniae exteriori posticae insertum. Vitellus carnosus embryonis apicem vaginans. Gen. 1621_1640.

1. Clobbae. Herbae rhizocarpicae; inflorescentia terminali, laxe paniculata, racemosa $\mathbf{v}$. spicata. Gen, 1621. 
8. Zingriberea. Herbae rhizocarpicae, radicibus carnosis, tuberosis, inflorescentia dense spicata. Gen. 1622_1625.

3. Amoma. Herbac perennes, radicibus tuberosis, fasciculatis, v. saepius repentibus, lignosis, inflorescentia plerumque radicali, spicata, nunc terminali, bracteis dense munita. Gen. 1626_1630.

4. Alpimiae. Herbae perennes, inflorescentia caulem v. scapum terminante, ut plurimum laxe paniculata v. racemosa. Gen, 1631_1637.

5. Costi. Herbae perennes, foliorum vaginis tubulosis, inflorescentia terminali, dense spicata. Gen. 1688.

LxIX. CANNA Ceate. Perigonium duplex, calyx trimerus et corolla hexamera. Stamen 1, corollae laciniae interiori laterali insertum. Vitellus nullus. Gen. 1641_1646.

HXX. MUSACEAE. Perigonium simplex hexamerum. Stamina 6, quorum unum plerumque abortivum, nonnulla interdum castrata. Gen. 1647_1658.

1. Melleonieae. Semina in loculis solitaria. Dehiscentia septicida. Gen, 1647.

8. Ura mieae. Semina in loculis plurima, Dehiscentia loculicida. Gen. 1648_1650.

APPENDIX. SCITAMINEAE FOSSILES. Gen, 16511654.

\section{Classis $\mathbf{X X}$. Fluviales.}

Perigonium nullum v. rudimentarium, rarissime perfectum. Ovarium 1 v. plura distincta, libera. Ovulum 1, erectum v. saepius pendulum, orthotropum v. campylotropum, rarissime anatropum. Semina exalbuminosa. Embryonis radicula infera.

IXXX. NAJADEAE. Fiores ut plurimum monoici, rarius dioici, in axillis foliorum solitarii v. conferti, v. in stipite spadiciformi alternantes, feminei superiores, rarius masculi cum femineis in florem hermaphroditum combinati. Gen. 1655_1664.

* NAJAdraE Fossiles. Gen. 1665_1667.

* LEMNACEAE. Gen. 1668.

\section{Classis XXI. Spadieinorae.}

Flores supra spadicem sessiles, feminei inferiores. Ovarium uni-multiloculare. Semina albuminosa v. germinatione incepta exalbuminosa.

LXXII. AROIDEAE. Fructus baccatus, seminum umbilico nudo. Cotyledon rimula pro plumulae emissione instrueta. Gen. 1669 -1708.

1. Araceae. Flores androgyni, perigonio destituti. Gen, 1669-1696.

2. PISTIACBAF. Flores masenll a femineo solitario remoti. Orarian uniloculare. Ger. 1669-1670.
2. CRYPTOCORYNEAE. Flores mascull a femineis plu. ribus, eirea basim spadieis verticillatis, et in ovarium pluriloculare connatis remoti. Gen. 1671_-1672.

3. DRACUNCULINAE. Flores maseuli et feminel plures, genitalibus rudimentariis interstiucti, spadix appendice nuda desinens. Antherarum loculi connectivo ma. jores. Gen, 1673_1681.

a) A ris a rea e. Filamenta manifesta. Stylus distinetus. Gen. 1673_1674.

b) Euaroldeae. Antherae congestae, sessiles. Stigma sessile, Gen, 1675_-1679.

c) Pyth on ie a e. Antherae congestae, substipitatae. Stylus distinetus. Gen. 1680_1681.

4. CALADIEAE. Flores masculi et feminei plures, contigui v. genitalibus rudimentariis distineti, spadix sae. plus appendice nuda termiastus. Antheraram locull connectivo crassissimo, peltato immersi, Gen.1682-1690.

a) Colocasieae. Spathae tubus persistens. Antherae plures connatae. Ovarium uni-quadriloculare. Gen, 1682 - 1689.

b) Philodendrea e. Spatha tota persistens. Antlierao liberae. Ovarium multilocalare. Gen. 1690.

5. ANAPOREAE. Flores masculi et feminei plures contigui, genitalibus sterilibus saepius eum femineis mixtis, spadix rarissime appendice uuda terminatus. Antherarum loculi connectivo crassissimo, peltato im. mersi, Gen. 1691_1696.

a) Spathicarpeae. Spadix spathae adnatus. Ovaria unilocularia, uniovulata. Gen, 1691-1693.

b) Richardiea e. Spadix liber. Ovaria uni-trilocularia, ovulis solitariis v. plurimis. Gon, 1694-1696.

7. Callacene. Stamina perfecta cum ovariis in flosculos hermaphroditos, nudos v, perigonio instructos consociata. Gen. 1697_1708.

6. CAlleaE. Perigonium nullum. Gen, 1697-1699.

7. ORONTLACBAE. Perigoninm regulare. Folia plana, integra v. palmati- aut pinnatisecta. Gen.1700 1706.

a) Pothoina e. Spatha foliaeca. Filamenta complanata. Stigma sessile. Gen. $1700 \_1703$.

8) Dracontieae. Spatha eolorata. Filamenta subulata. Stylus distinctus. Gen, $170 t_{-} 1705$.

c) Orontiaceae. Spatha nulla. Filamenta complanata. Stigma sessile. Gen, 1706.

8. ACOROIDEAE. Perigoninm regulare. Folia ensiformia, veruatione amplectentia. Gen. 1707_1708.

HXXIII. TYPHACEAE. Fructus drupaceus, seminum umbilico nudo. Embryonis albumine parum brevioris cotyledon integra, extremitas radicularis supera. Gen. 1709_1710.

CXXIV. PANDANEAE. Fructus drupaceus $\mathbf{v}$. baccatus, ex ovariis plurimis in phalanges connatis specie multilocularis, seminum umbilico nudo v. strophiolato. Embryonis minimi cotyledon integra, extremitas radicularis infera. Gen. 1711_1718.

1. Pandaneae verae. Folia simplieia. Perigonium nullum. - Gerontogeae. Gen, 1711 $-1712$.

2. Cyelantheae. Frondes flabellatim partitae r. pinnatae. Flores saepius perigoniati. - Americanae. Gen. 1713_1715.

Genera Paudaneis affinia. Gen. 1716_1717.

Pandanea fossilis, Gen, 1718.

\section{Classis XXII. Prineipes.}

Flores supra spadicem simplicem v. ramosum sessiles ve pedicellati, perigonio duplici perfecto. Ovarium 1_3locu- 
lare. Albumen cartilagineum. Embryo in foveola albuminis, in peripheria locatus.

EXXv. PamMa E. Perigonium duplex, calyx et corolla, utrumque trimerum. Ovarium liberum, e carpidiis 1 - 3 distinctis v. connatis. Ovula in loculis solitaria, rarissime bina, erecta. Fructus baccatus v, drupaceus. - Habitus peculiaris, plerisque arboreus. Gen.1719_1783.

1. Arecinase. Ovarium carpidis 3 v. 2 primitus connatis 3_2loculare, rarissime carpidio unico 1 loculare. Fructus lobis distinctis, baccatus v. tenniter drupaceus, endocarpio loculorum distincto, abortivorum a fertilium formatione excluso, Gen, 1719_-1735.

3. Tepidoenryimae. Ovarium carpidiis 3 v. 2 primitus distinetis 3 _2loculare, Fruetus plerumque abortu monospermus, baccatus, tessellato - corticatus, Gen, 1736_1744.

3. Borassinae. Ovarium carpidiis $3 \mathrm{v}, 2$, rarissime 4 primitus distinctis 3 _tloculare. Fructus drupaceus v. baceatus, indivisus v. lobatus. Gen, 1745_1752.

4. Coryplhinae. Ovarium carpidiis 3 primitus distinctis triloculare, rarissime carpidio unico uniloculare. Fruetus baceatus, Iobis distinctis, carpidiis abortivis a fertilium formatione exclusis. Gen, 1753_1763.

a) SABALINAE. Flabellifrondes, Gen.1753_1762.

b) PHOENICINAE. Pinnatifrondes. Gen, 1763.

5. Coeoinae. Ovarinm carpidiis 3 , rarins 2 , 4 v. 6 primitus connatis 2_6loeulare. Drupa monopyrena, tri-unilocularis, loculis abortivis in fertilium endocarpio osseo v. lapideo inclusis. Gen. 176t__1777.

PALMAR FOSSILES. Gon, 1778_1783.

APPENDIX. Acrobryae fossiles, dubii ordinis. Gen. 178' $-1788$.

\section{SECTIO IV. ACRAMPHIBRYA.}

Caulis apice simul et ambitu crescens. - Vegetatio peripherico-terminalis.

\section{COHORS I. GYMNOSPERMAE.}

Ovula nuda, micropyle materiam foecundantem immediatim recipiens.

\section{Classifs XXIII. Comiferae.}

Flores diclines, perigonio nullo v. rudimentario, in amenta collecti. Ovula squamae v. cupulae apertae inserta. Embryo albuminosus, axilis, di-polycotyledoneus.

LXXvi. CUPRESSINA E. Squamae ovuliferae axi insertae. Ovula erecta, orthotropa. Gen. 1789_1794.

HXXVII. ARIETUNAE. Squamae ovuliferae axi insertae. Ovula inversa, orthotropa. Gen. 1795_1798.
HXXVII. TAXINEAE. Cupula aperta, uniovulata. Ovulum erectum, orthotropum v. anatropum. Embryo albuminis fere longitudine. Gen. $1799 \_1803$.

LXXIX. GNETACEAE. Stamina e perigonio transversim rupto exserta. Cupula aperta, uniovulata. Ovulum erectum, orthotropum. Embryo albumine multo brevior. Gen. 18041805.

APPENDIX, Coniferae fossiles. Gen, 1806-1816.

\section{COHORS II. APETALAE.}

Perigonium nullum, rudimentarium $\mathbf{v}$. simplex, calycinum v. coloratum, liberum v. cum ovario connatum.

\section{Classis XXIV. Piperitae.}

Flores hermaphroditi v. diclines, spicati, bracteolati. Perigonium nullum. Semina albuminosa. Ovula orthotropa. Embryo antitropus, intra saculum amnioticum extrarius, v. apici albuminis inclusus.

LXXX. CULG DRA NTHA CEAE. Ovarium uniloculare. Ovulum unicum, pendulum. Radicula infera. Gen. 1817_1819.

WXXXI. PIPEIRACEAT. Ovarium uniloculare. Ovulum unicum, erectum. Radicula supera. Gen. 1820 - 1823.

IXXXII. SAURUREAE, Ovarium pluriloculare. Ovula plura, adscendentia. Radicula supera. Gen. 1824_1828.

\section{Clansis XXV. Aquatieac.}

Flores hermaphroditi v. diclines. Perigonium nullum v. rudimentarium. Ovula orthotropa v. amphitropa. Embryo exalbuminosus $\mathbf{v}$. in axi albuminis rectus.

HXXXIII. CERATOPIITIEAE. Ovarium nniloculare. Ovulum unícum, pendulum. Albumen nullum. Radicula infera. Plumula polyphylla. Gen. 1829.

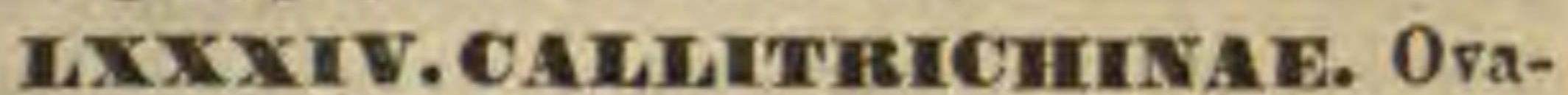
rium quadriloculare. Ovula in loculis solitaria, pendula, amphitropa. Albumen carnosum. Radicula supera. Gen. 1830.

HXXXV. FPIDSTEMIIEAE. Ovarium bi-triloculare. Ovula plurima, adscendentia, amphitropa. Albumen nullum. Radicula infera. Gen. 1831 - 1835.

Gea. dubia 1836-1837.

\section{Classis Xxvi. Juliforae.}

Flores diclines, rarissime hermaphroditi, saepius amentacei. Perigonium nul- 
Ium v. rudimentarium, rarius perfectum, calycinum. Ovula in ovarii uni-plurilocularis loculis plerumque solitaria, situ admodum vario. Fructus ut plurimum monospermus. Embryo exalbuminosus, v. albuminosus intrarius.

LXXXV. CASUAIEINEAE. Flores diclines. $\sigma^{*}$ Perigonium 2phyllum bibracteolatum. \& Bracteolae 2. Perigonium $\bigcirc$. Ovarium 1loculare, distylum. Ovulum 1, pendulum, anatropum. Caryopsis monosperma. Semen inversum. Embryo exalbuminosus, radicula supera. - Rami articulati, vaginati, aphylli. Gen. 1838.

EXXXVII. MIYRICEAE. Flores diclines. $\sigma^{x}$ Bracteolae 2. Perigonium 0 . क Squamae hypogynae 2_6. Ovarium uniloculare, distylum. Ovulum 1, erectum, orthotropum. Drupa monosperma. Semen erectum. Embryo exalbuminosus, radicula supera. - Rami continui, folia alterna, stipulae fugaces, succus aqueus. Gen. 1839.

HXXXVIII. HETEHACEAE. Flores diclines. $\delta$ Perigonium. squamaeforme v. calyciforme. \& Perigonii loco squamae cum fructu increscentes. Ovarium 2loculare, distylum. Ovula in loculis solitaria, pendula, anatropa. Nucula monosperma. Semen inversum. Embryonis exalbuminosi radicula supera. - Rami continui, folia alterna, stipulae fugaces, succus aqueus. Gen. 1840 1841 .

LXXXIX. CUPULITERA F. Flores diclines. ${ }^{*}$ Perigonium squamaeforme v. calyciforme, $q$ involucrati. Perigonium adnatum, limbo supero. Ovarium inferum $2-3$-6loculare, 2-3-6stylum. Ovula in loculis solitaria v. 2 collateralia, pendula, anatropa. Nux monodisperma. Semen inversum. Embryonis exalbuminosi radicula supera. - Rami continui, folia alterna, stipulae caducae, succus aqueus. Gen. 1842-1848.

xc. uhma ceare. Flores ఫৃ. Perigonium campanulatum. Ovarium liberum, 1 -2 loculare, distylum. Ovula in loculis solitaria, pendula, anatropa. Samara monosperma. Semen inversum. Embryonis exalbuminosi, recti radicula supera._Rami continui, folia alterna, stipulae fugaces, succus aqueus. Gen. 1849 1850.

XCI. CelTudeAe. Flores polygami. Perigonium calyciforme. Ovarium uniloculare, distylum. Ovulum 1, basilare, amphitropum. Drupa monosperma. Embryonis in axi albuminis falcati radicula supera. - Rami continui, folia alterna, stipulae fugaces, succus aqueus. Gen. 1851_-1854.

XC世. MOREAE. Flores diclines. $d$ Perigonium calycinum, $f$ nudi v. involucrati.
Perigonium calyciforme. Ovarium uni-biloculare, mono-distylum. Ovulum unicum, parietale, amphitropum. Caryopsis monosperma. Embryo in axi albuminis curvatus, radicula supera. Rami continui, folia alterna, stipulae fugaces, succus lacteus. Gen. 1855 - 1860 .

XCRII. ARTOCA ISPEAE. Flores diclines. $\delta$ Perigonium calyciforme, $f$ involucrati. Perigonium calyciforme liberum, v. nullum. Ovarium 1loculare, mono-distylum. Ovu$\operatorname{lum} 1$, erectum, orthotropum, v. parietale amphitropum, rarissime pendulum, anatropum. Fructus baccati monospermi, saepe concrescentes. Embryonis exalbuminosi radicula recta v. subinflexa, supera v. centrifuga. - Rami continui, folia alterna, stipulae fugaces, succus lacteus. Gen. 1861 - 1878.

XCIV. URTICACEATE. Flores polygami. \& Perigonium calyciforme. ㅇ Perigonium calyciforme liberum, saepius rudimentarium $\mathbf{v}$. nullum. Ovarium uniloculare, mono - distylum. Ovulum 1, erectum, orthotropum. Embryonis in axi albuminis recti radicula supera. - Rami continui, folia alterna v. opposita, stipulae persistentes v. fugaces, succus aqueus. Gen. 1879 $-1887$.

* Cynocrambeat Gen. 1888.

** GUNNERACEAK Gen, 1869.

XCV. CANNARHNeAE. Flores diclines. $\sigma^{x}$ Perigonium calyciforme. $\&$ Perigonium squamaeforme. Ovarium uniloculare, distylum. Ovulum pendulum, campylotropum. Nucula bivalvis, monosperma. Semen pendulum. Embryonis exalbuminosi, uncinati v, spiralis radicula supera. - Rami continui, folia alterna v. opposita, stipulae persistentes v. deciduae, succus aqueus. Gen. 1890_1891.

XCVI. ANTID ESMIEAT. Flores diclines. $\sigma^{x}$ Perigonium calyciforme. $f$ Perigonium calyciforme liberum. Ovarium uniloculare, stigmatibus pluribus. Ovula 2, collateralia, pendula, anatropa. Drupa monosperma. Embryonis in axi albuminis recti radicula supera. Rami continui, folia alterna, stipulae fugaces, succus aqueus. Gen. 1892_1893.

* pUTranJiveaE Gen. 1894_1895.

* ForEstierEaE Gen 1896.

** SCEPACEAR Gen. 1897_1699.

$* * * *$ GARRYACEAE Gen. 1900 .

XCVII. PLATANean. Flores diclines. Perigonium nullum. Ovarium uniloculare, monostylum. Ovula 2, collateralia, pendula, orthotropa. Caryopsis monosperma. Embryonis exalbuminosi radicula infera. Gen. 1901.

XCVIII. BALSAMIIFLUAE. Flores diclines. ${ }^{x}$ Perigonium nullum. Stamina plurima, squamis immixta. o Perigonium nullum. Squamae plurimae, demum cum ovario concrescentes. Ovarium 2loculare, distylum. Ovula 
plurima, septo adnata. Capsulae in strobilum connatae, biloculares, bivalves. Semina peltata. Embryo in axi albuminis cornei, radicula supera. Rami continui, folia alterna, stipulae caducae, succus resinosus. Gen. 1902.

XCIX. SALICINEAF. Flores diclines. Perigonium nullum. Torus glandulaeformis v. urceolaris. Stamina 2 v. plurima. Ovarium uniloculare, distylum, placentis parietalibus duabus. Ovula plurima. Capsula unilocularis, bivalvis, valvis medio placentiferis. Semina plurima, erecta, basi comosa. Embryonis exalbuminosi radicula infera. Gen. 1903. 1904.

* HENSLOWIACEAE. Flores diclines. Perigonium urceolatum, quinquefidum. $S \mathrm{t}$ a $\mathrm{m}$ in a 5 , disco perigyno inserta. Ovarium biloculare. Ovula in placentis septo adnatis plurima, horizontalia, anatropa. Stylus brevis; stigma obsolete bilobum. Fructus ..... Arbuscula, ramis tetragonis, foliis oppositis, integerrimis, exstipulatis, floribus racemosis, Gen, 1405.

C. IACISTEmean• Perigonium profunde quadripartitum. Stamen unicum, apice bifidum, diantheriferum. Capsula unilocularis, bi-trivalvis, valvis medio seminiferis. Semina pauca, inversa, rhaphe arillaeformi. Embryo in axi albuminis carnosi, radicula supera, Gen. 1906. 1907.

\section{Classis XXVII. Dleracene.}

Flores diclines v. hermaphroditi. Perigonium calycinum $\mathbf{v}$. coloratum, regulare. Ovarium uniloculare. Ovulum unicum v. plura. Fructus utricularis v. nucamentaceus, Embryo rectus antitropus, v. curvatus homotropus.

CI. CHEN DPDDEA Ferigonium herbaceum, tri-pentaphyllum, saepissime ebracteatum. Ovulum 1, amphitropum. Utriculus monospermus. Embryo annularis v, bicruris, nunc spiralis. Gen. 1908_1953.

1. Cyelolobene. Embryo hippoerepiens v. annularis. Albumen centrale. Gen, 1908-1938.

1. SALICORNIEAE. Flores hermapliroditi ve polygami conformes. Seminis verticalis testa membrauacea. Caulis artieulatus. Gen, 1908_1909.

2. ATRIPLICEAE. Flores polygami, perigonio imascala a femineo diverso. Seminis verticalis v. horizontalis testa crustacea v. membranacea. Caulin continuus. Gen. 1910_1915.

8. CHENOPODIEAE. Flores hermaphroditi v. polygami conformes. Seminis verticalis $\mathrm{v}$, horizontalis testa crustacea v. membranacea. Caulis continuus. Gen. 1916_ 1938.

a. Camphorosmeae. Flores ebracteolati. Seminis verticalis testa membranacea. Gen. 1916_1920.

b. Bifte a e. Flores ebracteolati. Semials verticalis testa crustacea. Gen. 1921 1923.

c. Koch i a e. Flores ebracteolati. Seminis horizontalis testa crusacea v. membranacea. Gen, 192' -1936. d. Anredereac. Flores bibracteolati. Seminis verticalis testa membranacea. Gen, 1937_1938.

8. Spirollobeae. Embryo spiralis, Albumen nullum v. parcum, bipartitum, excentrieum. Gen. $1939-1949$.

1. BASELlEAE. Seminis verticalis testa membranacea. Embryo plano-spiralis. Gen, 1939.

2. SVEDINEAE. Seminis horizontalis v. verticalis testa erustacen. Gen, 1940_-19'2.

8. SALSOLEAE. Seminis horizontalis v, vertiealis testa membranacea. Embryo conico-spiralis. Gen. 1943_1949.

a. H a limo en emiden e. Squamulae hypogynae nullae. Gen. 1943_1946.

b. An a b a s e e. Squamulae hypogynae staminibus alternae. Gen. 1947-1949.

* Genera Chenopodeis affinia. Gen, 1950-1953.

CII. ANA ARANA CEAE. Perigonium subscariosum tetra-pentaphyllum, bibracteolatum. Utriculus mono-polyspermus. Embryo annularis v. bicruris. Gen. 1953_1978.

1. Gomplareneae. Ovarinm uniovulatum. Antherae uniloculares, Gen, 1954_1959.

2. Achyrantheae. Ovarium uniovulatum. Antherae biloculares. Gen, 1960_1973.

0. Polyenemeae. Flores axillares, solitarif, sessiles, bibracteolati, follo bracteae anticae locam tenente. Utriculus evalvis. Gen, 1960_1961.

b. Aë r v в a e. Flores tribracteati, laterales abortivi nulli. Utriculus evalvis. Ger, 1962_1868.

c. Des mo cha et e a e. Flores tribracteatt, bracteae praeter florem fertilem abortivos plures, fa eristas v. gla. ehides mutatos in axillis foventes. Utriculus evalvis. Gen. 1969-1971.

d. A m a ranteac. Flores tribracteatl, laterales abortivi nulli. Utriculus efrcumseissus. Gen. 1972_1973.

3. Celosiene. Ovarinm multiovnlatum. Antherae biloculares. Gen, 1974 -1978.

CIII. PDIYGANEAE. Perigonium herbaceum v. subcorollinum. Caryopsis monosperma, semine erecto. Embryonis antitropi recti v. arcuati radicula supera. Gen. 1979 1999.

1. Froîogeneae. Involuerum tubulosnm, uni-multiflorum. Ovulum erectum. Gen, 1979 -1982 .

2. Polysonese verae. Involucrum nulInm. Ovulam erectum, Gen. 1983_1997.

3. IPolyogneas spuriae. Involucrum nullum. Ovulum e funiculo brevi basilari pendulum. Semen erectum. Gen. 1998_1999.

CIV. MTCYACINAAE. Perigonium subcoloratum v. plane corollinura. Achenium perigonii basi persistente inclusum, monospermum, semine erecto. Embryonis conduplicati v. recti radicula infera. Gen. $2000 \_2013$.

\section{Classis xxvili. Thymeleae.}

Flores hermaphroditi v, diclines. Perigonium saepius corollinum, v, extus rudius, intus coloratum. Ovarium unum v. plura, libera v. inter se connata. Ovula e carpidiorum suturis solitaria v. plura, ana- 
tropa. Fructus follicularis, nucamentaceus v. drupaceus. Embryo orthotropus.

CV. MONIMIEAEAE. Perigonium calyciforme. Stamina indefinita. Ovaria plura, libera, uniovulata. Gen. 2014_2022.

1. Monimieae. Flores diclines, Antherae longitudinaliter dehiscentes. Ovulum pendulum. Drupae monospermae. Embryo in axi albuminis cai so-oleosi rectus, radicula supera. Gen. 2014_2019.

क. Antherospermeac. Flores diclines v. hermaphroditi. Antherae valvulis adscendentibus dehiseentes. Ovulum erectum. Nuculae monospermae, stylis plumosis caudatae. Embryo in basi albuminis mollis rectus, radienla infera. Gen. 2020_2022.

CvI. Laurineae. Perigonium calycinum. Stamina simplici v. multiplici loborum perigonii numero, fertilia cum sterilibus alternantia. Antherae valvulis dehiscentes. Ovarium unicum, uniloeulare, liberum, uni-triovulatum, ovulis pendulis. Fructus drupaceus v. baceatus, monospermus, semine inverso. Eimbryonis exalbuminosi radicula supera. Gen, 2023 2067.

1. CINNAMOMEAE. Hermaphroditae, staminodils perfectis, antheris quadrilocellatis, interioribus extrorsis, perigonil limbo articulato, gemmis incompletis, foliis perenantibus, per paria approximatis, tri- $\nabla$. triplluervils - Arbores fudiae. Gen. 2023.

2. CAMPHOREAE. Hermaphroditae, staminodits perfectis, antheris quadrilocellatis, interioribus extrorsis, perigonii limbo deciduo, gemmis perulatis, foliis perennantibus, longe petiolatis, triplinerviis, in axillis costarum glandulosis subtusque porosis. - Arbores asiaticae. Gen. 202\%.

3. PHOEBEAE. Hermaphroditae, staminodils perfectis, antheris bi - v. quadrilocellatis, interioribus extrorsis, perigonii limbo persisteate, in capulam baecae adpres. sam indurato, gemmis incompletis, foliis perennantibus, penninerviis, venosis. Arbores indicae, canarienses et antillanae, Gen, 2025 -2026.

4. PERSRAE. Hermaphroditae v. rarius diclines, staminodiis perfectis, antheris bi-quadrilocellatis, interioribus extrorsis, perigonli limbo $v$. persistente, fructifero immutato, patulo, v. declduo, discum orbieularem relinquente, pedicellis fructiferis saepissime incrassatis, gemmis incompletis, folis perennantibus, penniaervils. - Arbores americanae, canarlenses et paucae indieare. Gon. 2027_2032.

5. CRXPtocaryeak. Hermaphroditae, staminodiis perfectis, antheris bi- $v$. rarius quadrilocellatis, Iocellis faciei insertis, interioribns extrorsis, perigonii limbo deciduo $\mathrm{v}$. persistente, fructu siceo $\mathrm{v}$. baceato, perigonif tubo baccato $y$, durescente plus minus incluso, rarius duro perigonil basi imposito, gemmis incompletis, folits pereanantibus, venosis, in paucis nervosis. - Arbores indieae, et australasicae, pacae americanae tropicae. Gon. 2033_2039.

6. ACRODICLIDIA. Hermaphroditae, staminodils nullis v. dentiformibus, compressis, staminibus tribus v. novem, antheris subsessilibus, juxta apicem locellis binis poriformibus dehiscentibus, interioribus extrorsis v. introrsis, fructu primum perigonio laciuiis conniventibus clauso v. umbonato recondito, demum emergente, baceante, gemmis incompletis, folis perennantibus, venosis, cuspidatis. - Arbores Amerleae tropicae. Gen. 20'10_20'33.

7. NECTANDREAK. Hermaphroditae, staminodils dentiformibus, rarius subcapitatis, staminibus novem, antheris subsessilibus, latis, loeulis basia versus in arcum dispositis dehiscentibus interloribus extrorsis, perigonii lacintis latiusculis, patentibus, deciduis, exterioribus latioribus, fructu baccante, cupalae pro. fundae truncatae inserto, gemmis ineompletis, foliis perennantibus, penninerviis, venosis, in axillis venarum costalium quandoque porosis. - Arbores Ameri. cae tropicac. Gen. 204 t.

8. DICXPELLLA. Dioicae s. polygamae, staminodiis nullis, staminibus ordinum duorum exteriorum in femi. neis floribus linbi laciuits consimiltbus, et cum iisdem persistentibus, calyculum crassnm, radiatum sub fructu formantibus, $v$. cadentibas, antheris interiori. bus 3-6 sessilibus, quadriporosis, fruetu baceato, gemmis incompletis, folils perennantibus, venosis. Arbores brasilieases. Gen. 2045_2047.

9. OREODAPHNEAE. Dioicae v. polygamae, staminodiis nullis v. subulatis, antheris filaneatis distinctis prae. ditis, bi-quadrilocellatis, fruetu baceante v. cupulae profundae immerso, aut perigonio immntato suffulto, uunc pedicello incrassato, subcarnoso imposito, gemmis iucompletis, folitis perenantibus, venosis. - Arbores Americae tropicae, mauritianae et canarienseg. Gen. 2048-2055.

10. FLAVIFLORAB. Dioieae v. polygamae, staminodiis nullis, staninibus norem, antheris bi-quadrilocellatis, introrsis, perigonio rotato, tenui, flavo, bacea pedicelto subnudo, interdum facrassato imposita, gemmis perulatis, foliis membranaceis, deciduis. - Arbores boreali - americanae et nepalenses. Gen. $\overline{2056}$ 2057.

11. TETRANTHEREAE. Dioleae, staminodils nullis, sta. minibus noven $v$. octodecim, antheris bi-quadrilocellatis, introrsis $\vee$. rarissime extimis extrorsis, bacen perigonii tubo patelliformi v. explanato imposita, gem. mis incompletis, follis veuosis, saepissime perenuantibus, - Arbores indicae, europeae et americanae, Gon. 2058-2062.

12. DAPHNIDINAE. Dioicae v. hermaphroditae, staminodis pullis, stamiaibus novem-novemdecim, antheris bi-quadrilocellatis, omnibus introrsis, baees perigonii tubo discoideo $v$. cyathiformi, rarius pedicello audo imposita, gemmis perulatis, foliis perennantibus, venosls v. nervosis, Gen, 2063_2066.

13. CASSYTEAE. Hermaphroditae, staminodiis perfect's, stamiuibus novem, antheris quadrilocellatis, tribus interioribus extrorsis, caryopsi perigonio baceante inclusa. - Herbae parasiticae, aphyllae, cuscutiformes. Gen. 2067.

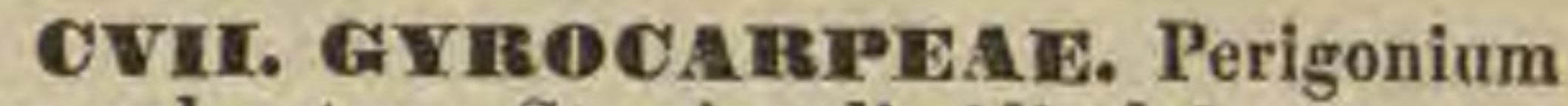
intus coloratum. Stamina dimidio loborum perigonii numero. Antherae valvulis dehiscentes. Orarium cum perigonii tubo connatum, uniloculare, uniovulatum, ovulo pendulo. Drupa monosperma, semine inverso. Embryonis exalbuminosi radicula supera, cotyledones eirca plumulam diphyllam spiraliter convolutae. Gen. 2068 2069.

CviII. Santataceare. Perigonium intus coloratum, basi interdum calyculatum. Stamina simplici loborum perigonii numero. Antherae longitudinaliter dehiscentes. Ovarium cum perigonii tubo connatum, uniloculare. Ovala 2-4, ex apice placentae centralis liberae pendula. Drupa v. nucula monosperma, semine inverso. Embryo in apice albuminis carnosi, radicula supera. Gen. 2070_2084.

* GRUBBIACEAE. Flores in strobilum connati. Perigonit limbus superus, quadri-quinquepartitus. Stamina 8 -10. Ovarium inferam, uniloculare, bi-triovulatum. Nuculae monospermae, connatae. Gen. 2085.

* NYSSACEAE. Flores masculi perigonio quinquepartito, staminibus 10, hermaphro- 
diti perigonii limbo supero quinquepartito, staminibus 5. Ovarium inferum, uniloculare, uniovulatum. Drupa monosperma, putamine fibroso. Embryo foliaceus, Gen,2086.

* ANTHOBOLEAE. Flores diclines, Stamina libera. Ovarium liberum, uniovulatum (?) Drupa monosperma, semine inverso, Gen. 2087_2088.

* PSEUDANTHEAE, Flores diclines. Stamina monadelpha. Ovarium liberum, pluriovulatum. Capsula monosperma, sexfariam dehiscens. Gen. 2089.

* HeL WingIACEAE. Flores dioiei, epiphylli. Ovarium inferum, tri-quadriloculare, loculis uniovulatis. Gen, 2090.

CIX. DAPHENABDAE. Perigonium tubulosum, coloratum. Stamina simplici v. duplici loborum perigonii numero, nunc pauciora, sterilia interdum petaloidea, Ovarium liberum, uniloculare. Ovulum unicum v. panca superposita, pendula. Drupa mono-trisperma, seminibus inversis. Embryonis exalbuminosi cotyledones plano-convexae, carnosae, radicula supera. Gen. 2091_2106.

* herNANDIACEAE. Cotyledones maximae, tuberculatae v. lobato-torulosae. Gen. 2107 2108.

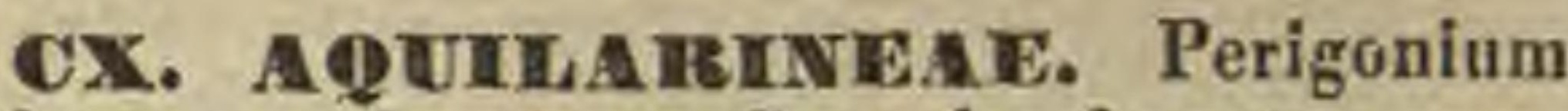
tubulosum, coloratum. Capsula obovata, compressa, incomplete bilocularis, bivalvis, monodisperma. Semina inversa. Embryonis exalbuminosi radicula supera. Gen. $2110 \_2111$.

CXI. BLA EATENAE. Perigonium calycinum $v$. intus coloratum. Stamina duplici loborum perigonii numero, v. simplici et tunc iisdem alterna. Ovarium liberum, uniloculare. Ovulum unicum e basi erectum. Fructus perigonii basi indurata inclusus, monospermus, semine erecto. Embryo in axi albuminis parce carnosi, radicula infera. Gen. $2112-2115$.

CXIE. PENAEA CEA E. Perigonium coloratum. Stamina simpliei loborum numero iisdem alterna. Ovarium liberum, quadriloculare. Ovula in loculis gemina, collateralia, e basi erecta. Capsula quadrilocularis, loculicide quadrivalvis, locnlis dispermis. Seminum umbilicus carnosus, cum rhaphe solubilis. Gen. 2116 -2118.

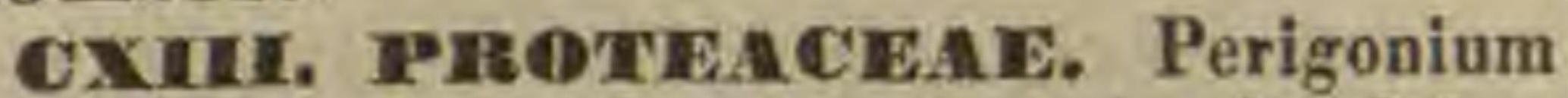
coloratum, extus rude. Stamina simplici loborum perigonii numero, iisdem opposita. Ovarium liberum, uniloculare, uni-multiovulatum. Fructus nucamentaceus v. follicularis, monopolyspermus. Embryonis exalbuminosi radicula infera. Gen. $2119-2159$.

I. Nueamentaceae. Fructus indehiscens. Gen. 2119-2141.

1. PROTEINEAE. Antherae inter se liberae, medio v. apteibus coneavis laminarum perigonil insertae. Orarium uniovulatum. Nux v. Sumara. Flores eapitath. Gen. 2119_2130.
2. CONOSPERMEAE. Antherae primum inter se cohaerentes, viciaarum loeulis contiguis loculum unicum eorstitueutibus. Ovarium nniovalatum. Nux. Flores spicati v. capitati, Gen, 2131-2133,

3. FRANKLANDIEAE. Antherae perigonif hypoerateri morphis tubo aduatae. Ovarium uniovulatum. Nux. Flores spicati. Gen. 2134.

4. PERSOONIEAE. Stamina saepins medio v, basi folio. lorum perigonii inserta, rarissime hypogyna. Ovarium uni biovulatum. Nux, samara v. drupa monosperma, rarissime disperma. Flores spicati, Gen, 2135_2141.

耳. Follienlares. Folliculus coriacens v, ligneus, mono-polyspermus. Gen. 2142_2159.

1. GREVILLEAE. Ovarium uniloculare. Follieulus unilocularis, mono-polyspermus, Gen, 2142-2156.

a. Hakea ea e. Ovarium bi-quadriovulatum. Fructus mono-tetrasperwus. Gen, 2142_2151.

b. Embothriene. Ovarium multiovalatum, Bructus polyspermus. Gen, 2152-2156.

2. BANKSIEAE. Ovarium uniloculare, biovulatum. Fol. lleulus biloeularis, seminam collateralinm testis in dissepinentam liberum, lignenm, bifidum eoneretis. Gen, 2157_2153.

\section{Classis XXIX. Serpentarlac.}

Perigonium calycinum, coloratum. Stamina in masculis in columnam superne antheriferam concreta, in hermaphroditis styli basi adnata. Ovarium pluriloculare, multiovulatum. Fructus indehiscens v. loculicidus, polyspermus. Semina albuminosa.

CXIV. ARISTdLACHIEAIE. Perigonium superum, saepius coloratum. Stamina styli basi inserta. Embryo in basi albuminis minimus. Gen. $2160 \_2166$.

CXV. NERPATUREATE. Perigonium liberum, calycinum. Stamina in columnam superne antheriferam connata. Embryo axilis, albuminis longitudine. Gen. 2167.

\section{COHORS III, GAMOPETALAE.}

Perigonium duplex, exterius calycinum, interius corollinum, gamopetalum, rarius abortu deficiens.

\section{Classis XXX. Flambaginef.}

Calyx liber. Corolla hypogyna, scariosa, gamopetala v. eleutheropetala. Stamina numero loborum corollae v. pauciora, in gamopetalis hypogyna, in eleutheropetalis petalorum unguibus inserta. Ovarium uni-biloculare, loculis uni-multiovulatis. Embryo intra albumen rectus.

Oxvi. PLANTAGIVAE. Ovula amphitropa. Fructus mono-polyspermus. Radicula infera. Gen, 2168_2170. 
CXVII. RHUVEBATINEAE. Ovulum pendulum, anatropum. Fructus monospermus. Radicula supera. Gen. 2171_2177.

1. Statieene. Corolla pentapetala, nnguibus staminiferis. Styli distincti. Pericarpium demum basi solutum, calyptraeforme. Gen, 2171 $-2173$.

8. Hinmbagineae verae. Corolla gamopetala. Stamina hypogyna. Styli connati, stigmatibus distinctis. Pericarpium subcapsulare. Gen. 217t_2176.

* SALVAdoRACEAE. Bacca monosperma, semine erecto. Embryonis exalbuminosi cotyledones peltatae, radiculam inferam includentes. Gen. $217 \%$.

\section{Classis XXXI. Aggregatae.}

\section{Corolla supera. Ovarium inferum,} uniloculare, uniovulatum, v. triloculare, loculis duobus efoetis. Fructus monospermus.

CXVIT. VATERIAvEAE. Stamina corollae lobis plerumque pauciora, libera. Ovarium triloculare, loculis duobus efoetis, tertio uniovulato. Ovula pendula. Embryonis exalbuminosi radicula supera. Gen, 2178_2189.

CXIX. IIIPSACEAE. Stamina corollae lobis saepe aequalia, libera. Ovarium uniloculare, ovulo unico pendulo. Embryonis albuminosi radicula supera. Gen. 2190 2195.

1. Norimeae. Corolla ringens, Flores vertieillati, Gen, 2190.

\%. Seabiosere. Corolla saepins inaequalis, hand ringens. Flores supra receptaculum capitati, capitulo involucrato. Gen. 2191_2195.

CXx. COIIPDIRAE. Stamina corollae lobis numero aequalia, synanthera. Ovarium uniloculare, ovulo unico erecto. Embryonis exalbuminosi radicula infera. Gen.2196_3032.

\section{TUBULIFLORAE. Flores qui herma-} phroditi tubulosi, regulariter quinque- $v$. quadridentati. Gen. 2196_2898.

1. Vernomiaceae. Stylus hermaphroditorum eylindraceus, ramis saepins subulatis, elongatis, rarius obtusis, brevibus, semper aequaliter et longe hispidis. Glandularum stigmaticarum series ante medios ramos desinentes, Gen, 2196_2251.

1. VERNONIEAE. Capitula homogama, discoidea, Gen, 2196_2241.

a. EUVERNONIEAE. Antherae ecaudatae. Involucrum haud compressum, polyphyllum. Gen, 2196 - 2230.

๔. Eth allea a Pappus nullus v. simplex, coronlformis, Gen, 2196_2201.

$\beta$. Heter oc om e a e. Pappus uni-bi-pluriserialis, serie intima nuuguam coroniformi. Capitula haud fascieulata. Gent. 2202-222t.

$\gamma$. Albertin iea e. Pappus unl-bi-pluriserialis, serie intima uunquam coroniformi. Capitula saepius oligoce. phala, in glomerulum faseiculata. Gen. 2222_2230.

b. ELEPHANTOPEAE. Antherae ecaudatao. Involucram coapressum, squamis alternis conduplicatis. Gen, 2231 c. ROL $A N D R E A E$, Antherae ecaudatae, Iuvoluernm capitali uuiflori oligophyllum, squamis saepe coneru. tis. Gen. $2232-2237$.

d. BOJERTE AE. Antherae bicaudatae, Gen.2238_2241.

2. PECTIDEAE. Capitula heterogama, radiata. Gen. 2242_2251.

a. $\angle I A B E A E$. Corollae discl regulariter quinquefidae. Stigmata elongata. Folia eglandulusa, eciliata. $G e n$. 2242-2247.

b. EUPECTIDEAE. Corollae disel saepe irregulares. Stigmata abbreviata. Folia glandulosa, basi saepe ci. liata. Gen. 2248_2251.

2. Eupatoriaceac. Stylus hermaphroditorum eylindraceus, ramis longis, subclavellatis, extus superne puberulo-papillosis. Glandularum stigmaticaram series parum prominulae, saepius ante medios ramos desinentes. Gen. 2252_2291.

1. EupatorieaE, Capitula homogama, Gen. $2252 \_2283$.

a. ALOMTE 2 E. Pappus nullus, Gen. 2252_2257.

b. $\angle G E R A T E A E$. Pappus paleaceus v. partim squamellatus. Gen, 2258_2267.

c. ADENOSTYLEAE. Pappus setosus, scaber v. plamosus. Gen. 2268_2283.

2. TUSSIlagiNEAE. Capitula heterogama v. dioiea. Gen. 2284_2291.

a. PETASITEAE. Flores feminei tubulosi, Gen, 228' 2287.

b. EUTUSSILAGINEAE. Flores feminei ligulati. Gon. 2288 _2291.

3. Asteroideae. Stylus hermaphroditorum cylindraceus, ramis linearibus, extus subplanis et superne aequaliter $v$, minute pubernlis. Glandularum stigmaticarum series prominulae, fere usque ad originem pubis exterioris protensae. Gen. 2292_2453.

1. ASTERINEAE. Capitula homogama v. heterogama, saepius radiata. Antherae ecaudatae. Folia plerisque alterna. Gen. 2292_2392.

a. $1 M E L L E A E$, Receptaculam paleatum. Gen. 2292_ 2295.

c. E u a mell e e. Capitula heterogama, radiata, re ceptaevlo paleato. Gen, 2292_2294.

$\beta$. Heteroth a I a mea e. Capitula dioica, masculorum receptaculo uudo, femineorum paleato. Gen. 2295.

b. $\triangle S T E R E A E$, Receptaculum epaleatum. Capituls radiata, ligulis heteroehromis. Gon. 2296_2356.

a. Euastereac. Ligulae uniseriales. Pappus pilosus, disci et radii conformis, uai-plariserialis, setis aequalibus. Gen, 2296_2317.

B. D ip Iopap peae. Ligulae uniseriales. Pappus disci et radil conformis, biserialis, serie exteriore brevi, subpaleacea, Interiore setosa, elongata. Gen. 2318 2324.

$\gamma$. Erigereae. Ligulae plariseriales. Pappus pilosus, conformis v, inaequalis. Gen, 2325_2334.

f. Het e ropappe a e. Ligulae uniseriales. Pappus in disco et radio diversus. Gon, 2335_2344.

E. Belliea e. Ligulae uniseriales. Pappus paleaceus, plurisquamellatus, Gen, 2345_23\%7.

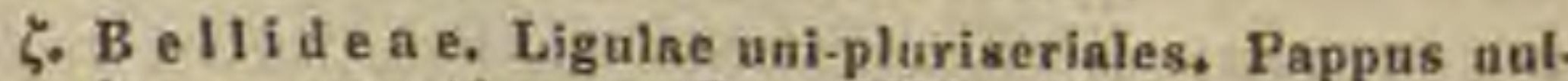
lus v. coroniformis. Gen, 2348_2356.

e. OHRYSOCOMEAE. Receptaculum epaleatum. Capitula lutea, nune homogama, nunc radiats, ligulis diseo homochromis. Gen, 2357_2386.

a. Gymuospermeae. Ligulae uniseriales. Pappus nullus. Gen. 2357-2360.

B. A chyridea e. Ligulae uniseriales. Pappus palea. ceus. $2361-2364$ 
$\gamma$. Heterot he ceae. Ligulae uniseriales. Pappus ra. dii et disci diversus. Gen. 2365.

f. P s i a die a e. Ligulae pluriseriales. Pappus in disco et radio conformis, spepissime nniserialis, v. setis in pappo biseriali similibus. Gen. 2366_2372.

ع. Chrysopsideae. Ligulae uni-hi-triseriales. Pap. pus duplex, exterior brevis, subpaleaceus, interior sefosus. Gen, 2373-2374.

3. Solid agine a e. Ligolae uniseriales v. nullae. Pappus in disco et radio couforais, uniserialis, pilo sus. Gen. 2375 - 2386.

d. SOLENOGYNEAE. Recptaculum varium. Capitulum discoideum, heterogamum. Gen. 2387_2392.

2. BAGCHARIDEAE. Capitula heterogama v. dioisa, nunquam radiata, floribus femineis filiformibus. Antherae ecaudatae. Folia alterna. Gen. $2393 \_2410$.

a. CONYZEAE. Capitula heterogama, monoica. Gen. 2393 -2408.

c. Sphaerant he a e. Capitula in glomerulos sphae. ricos conesta, ad bractearum axillas sessilia. Gen. 2393 -2395.

$\beta$. Grangeinea e. Capitula in glomernlum haud congesta. Pappus unllus v. subuullas. Gen. 2396_2't00.

$\gamma$. E u conyze a e. Capitula in glomerulum haud congesta. Pappus pilosus, uui-hiserialis. Gen. 24012408.

b. EUBACCHARIDEAE. Capitula dioica. Gen. 2409. -2410 .

3. TARCHONANTHEAE. Capitnla heterogama v. dioiea, nunquam radiata, floribns femineis filiformibus. Antherae candatae. Folia alter na. Gen. $2411 \_2424$.

a. EUTAROHON $A N T H E A E$. Capitala dioica. Gen. 1411 $-2412$.

b. PLUCHEINEAE. Capitula monoica v. heterogama. Gen. 2413_2424.

4. INULEAE. Capitula plerumque heterogama, floribus radii femineis ligulatis, disco concoloribus, rarius homogama, discoidea, nunquam disica. Antherae eandatae. Receptaculum nudum v, rarissime paleatum. Folia al terna. Gen. 2425_2438.

a, EUINULE AE. Capitula pluri-multiflora, in glomeruIum liaud conereta. Gen. 2425_2437.

b. CAESULIEAE, Capitula uniflora, in glomerulam aggregata. Gen. 2438.

5. HUPHTHALMEAE. Capitula rarissime homogama, saepissime heterogama, floribus radii ligulatis v. rarius tubulnsis. Receptaculnm paleatum. Antherae caudatae v. rarissime ecandatae. Pappus coroniformis, lacerns v. piloso - dentatus. Folia alterna. Gen. 2439 2444 .

6. ECLIPTEAE. Capitula heterogama, floribus radii ligulatis. Receptaculum paleatum. Antherae ecaudatae. Pappus nullus v. aristatus. Fulia alterna. Gen. 2445_2453.

4. Senecionideae. Styli apice cylindracei, hermaphroditorum supernebifidi, ramis apice penicillatis $v$. truncatis, nunc ultra penicilInm in appendiculum $v$. conum productis. Glandularum stigmatiearum geries ad penicillum $v$, coni ant appendicis originem productae, latiasculae, prominulae. Gen. 2454 2821 .

1. MELAMPODINEAE. Flores omnes unisexuales, in isdem v. distinctis capitulis. Receptaculum vix non semper paleatum. Antherae ecaudatae. Pappus nullus, subeoroniformis v. aristatus, nunquam setosus. Gen. 2454 2491.

a. EUXENTEAE, Capitula dioica, discoidea, multiflora. Achenia ecorticata. Gen. 2454-2456.

b. MILLERIEAE. Capitula heterogama, floribus fenibeis paucis, ligulatis v. trifidis. Gen. 2457-2471.

c. SILPHIEAE, Capitula heterogama , multiflora, floribus radiiligulatis. Receptachli paleae liberae. Achenia ecorticata, calva v, biaristata. Gen, $2472-2477$.

d. MEL AMPODTE AE. Capitola heterogama, multiflora, floribus radii ligulatis. Receptaculi paleae liberae v. cum acheniis coneretae. Achenia calva. Gen. 2478 2479 .

e. $2 M B R O S I E A E$. Capitula mascula multiflora, feminea uni-paueiflora, involueris saepius gamophyllis. Anthe. rae Iiberae, approximatae, Gen. 2480_2482.

f. IVEAE. Capitula heterogama, discoidea. Antherae Iiberae, upproximatae. Gen, 2483_2486.

g. HEL1 ANTHEAE. Capitula heterogama, floribus radit ligularis, uniseriatis. Áchenia heteromorpha. Gen. 2487 -2491.

2. HELIANTHEAE. Capitula heterogama, radiata, floribus disci hermaphroditis, radii femineis $v$, neutris, rarius discoidea, homogama. Antherae ecaudatae. Stigmata truneata, penicillata, nunc cono v. appendicula lineari superata, Achenia tetragona, teretia v. obcompressa. Pappus nullus $\mathbf{v}$. coroniformis, aristatus ant partim paleaceus, nunquam omnino setosus, nec omnino paleaceus. Folia saepius opposita. Gen. 2492_2570.

a. HELIOPSIDEAE. Capitula heterogama, ligulis femineis, rarius homogama, discoidea. Achenia angulata v. compressa, crasse corticata. Pappus nullus v. coroniformis aut setis paueis, rigidulis constans. Gon. 2492_2512.

b. RUDBECKIE $A E$. Capitula heterogama, ligulis neutris. Aclienia erostria. Pappus nullas v. coroniformis. Gen. 2518_2527.

c. COREOPSIDEAE, Capitula heterogama, ligulis neutris. Acheaia erostria. Pappas ex aristis $2-4$, wune ex aristis et squamellis constans. Gen. 2528_-2539.

d. BIDENTIDEAE. Capitula heterogama, ligulis neutris, rarissiase homogama, discoldea. Achenia rostrata, plerumgne in aristas $1-4$ producta, rarius calva. Gen. 2540_25!3.

c. PERBESINEAE. Capitala heterogama, ligulis femineis, rarius homogama, discoidea. Achenia erostria, compressa v. obcompressa, rarius trigona. Pappus nullus v, aristaeformis. rarius vaglnaeformis $v$. rigidule setosus. Gen, 25't' 2570 .

3. FLAVERIEAE. Capitula nunc uni-panciflora, heterogama, flore femineo unico, reliquis hermaphroditis homogamis mixta, nunc multiflora, floribus femineis pluriseriatis, reliquis masculis. Receptaculnm in pancifloris nudum, in multifloris paleatum. St gmata saepissime exappendiculata. Aehenia calva, aptera, basi longe attenuata. Folia opposita. Gen. 2571_2574.

4. TAGETINEAE. Capitula multiflora, heterngama, floribus radii femineis, plerumque ligulatis, nune homogama, diseoidea. Receptaculum planum, epaleatum. Achenium erostre, elongatum, basi attenuatum. Pappus ex aristis, squamellis v. setis constans. Folia alterna v. opposita. Gen. $2575-2582$.

a. TAGETEAE. Capitula saepius heterogama, radiata. lavolaeri squamae, saltim interiores, omníno connatae. Gen. $2575-2581$.

b. POHOPHYLLEAE. Capitula homogama, discoidea. Involucri squanae liberae, v. basi tantum conbatae. Gen. 2582. 
5. HELENIEAE. Capitula multiflora, heterogama, floribus radii nniseriatis, femineis $\mathbf{v}$. neutris, ligulatis v. ampliato-tubulosis, rarius homograma. Receptaculum nudum v. paleatum. Stigmata truncata $v$. cono aut appendice apice pilosa superata. Achenia erostria. Pappus multipaleaceus. Folia alterna, rarius opposita. Gen. 2583_2634.

a. GAILLARDIEAE. Pappi paleae membranaceae, saepissime integerrimae. Receptaculum epaleatum, nudum sive alveolatum v. fimbrillifernm. Gen, 2583_2611.

c. Eugaillardieae. Flores radii ligulati, neutri. Gen, 2583-2585.

$\beta$. E u hele $n$ ie a e. Flores radii nulli, v. ligulati, feminei. Gen, 2586_2611.

b. GALINSOGEAE. Pappi paleae uniseriales, integrae v. plumosae, rarius nullae. lnvolucri squamae pla. niuseulae. Gen. 2612_2627.

$a$. Eugalinsogeae. Flores radii dam adsunt ligulati, feminei. Pappi squamellae planiusculae. Gen. 2612 -2625.

$\beta$. Sphouogyneae. Flores radii ligalati, neutri. Pappí paleae obtusissimae, contorta-convolutae. Gen, 2626_2627.

c. MADIE $A E$. Involucri squamae convolutae v, complicatae, achenia radii includentes. Gen. 2628_2634.

6. ANTHEMIDEAE. Capitula saepissime heterogama, ligulis femineis v, neutris. Antherae ecaudatae. Stigmata truncata, ba rbata, rarissime cono superata. Achenia angulata, teretia, radii obcompressa. Pappus nullus v. coroniformis, rarius squamellis v. pilis capillaribus constans. Folia saepissime alterna. Gen. 2635_2710.

a. EUANTHEMIDEAE. Receptaculum paleatam. Capitula radiata. Gen. 2635_2653.

b. CHRYSANTHEMEAE. Receptaculam epaleatum. Ca. pitula radiata. Gen. $2654-2680$.

c. COTULEAE, Receptaeulam epaleatum. Capitala discoidea, homogama v. heterogama. Gen. 2681_2686.

d. $A T H A N A S I E A E$, Receptaculum paleatum. Capitula diseoidea. homogrua, corollis oninibus teretibus. Gen. 2687 -2692.

e. ARTEMISIEAE. Receptaculum epaleatum. Capitula discoidea, homogama v. heterogama. Corollae disei teretes, stylo bifido. Gen. 2693-2704.

f. HIPPIEAE. Receptaculum epaleatum. Capitula monoica, discoidea. Corollae teretes. Stylus disei simplex, clavatus. Gen. 2705_2709.

g. ERIOCEPHALEAE. Receptaculum paleatum. Capitula monoica, floribus femineis paucis; ligulatis v. tubulosis. Stylus disei simplex, clavato-truncatus. Gen. 2710 .

7. GNAPHALIEAE. Capitula homogama v, heterogama, discoidea v, rarissime radiata, interdum uniflora. Antherae candatae. Achenia pappo piloso v, setaceo coronata, rarissime calva. Folia saepius alterna. Gen, 2711_2785.

a. ANGIANTHEAE. Capitula pauciflora, in glomerum involucro generali einetum dense aggregata. Gen, 2711 $-2722$.

b. CASSINIEAAE. Capitula hand glomerata. Receptaen. Iom totum v. margine paleatum. Gen, 2723_2726.

c. HELICHRYSEAE. Capitula haud glomerata. Recep. taculua epaleatum, nudum v. fimbrilliferum. Gen. 2727 $-2759$.

d. SERIPHIEAE. Capitula uniflora, libera v. in glomerulum involuero generali nuaquam cinctum aggregata. Gen, 2760 -2762.

e. ANXENNARIE, $A E$, Capitula in glomerulum hand aggregata, multillora, dloica v. subdioica, aut mouolea heterogama, florom masculorum stylo simplicissimo, apice elavato-truacato. Receptaculum epaleatum $v$. margine tantum paleatum. Gen. 2763_2769.

f. LEXSSEREAE. Capitula radiata, multiflora, ligulis femineis. Receptaculum epaleatum. Pappus nunquam corouiformis, squamellis aliis paleiformibus, aliis setiformibus. Gen. 2770_2774.

g. RELHANIEAE. Capitula multi-pauciflora, homogama v. radiata, ligulis femineis v. neutris. R teeptaculum nudum, fimbrilliferum v. paleatum. Pappus uullus v. e squamellis distinctis v. plus minus connatis, coroniformis aut multipaleaceus. Gen. 2775_2785.

8. SENECIONEAE. Capitula homogama v. saepius heterogama, nunquam dioica, discoidea v. radiata, ligulis ut plarimum uniseriatis. Receptacninm plerumque epaleatum. Antherae ecaudatae. Achenia pappo piloso v. setaceo coronata, exteriora interdum calva, Gen. 2786_2821.

a. NEUROL $A E N E A E$. Receptaculum paleatum. Gen. 2786.

b. ERECHTITEAE. Receptaculum nudum v. alveolatofimbrilliferum. Capitula discoidea, heterogama, flori bus radii tubulosis. Gen. 2787_2791.

c. EUSENECIONEAE, Receptaculum nudum v, alveolato-finibritliferum. Capitula discoidea homogama, v. radiata, heterogama, ligulis femineis v. rarissime neutris. Cotyledones planae. Gen. 2792_2819.

d. BALBISIEAE. Reeeptaculua nudum. Capitula discoider homogama, v. radiata, subdiolca. Cotyledones involutae. Gen, 2820_2821.

5. Cymareace. Styli superne nodoso-incrassati, ad nodum saepe penicillati, ramis coneretis v. distinctis, extus puberulis. Glandularnm stigmaticarom series in ramorum apice confluentes. Gen. 2822_2898.

1. CALENDULACEAE. Capitula multiflora, heterogatno-monoica, floribus radii ligulatis, femineis, fertilibus, disci tubulosis quinquedentatis, hermaphrodito-sterilibus v. masculis. Involuerum uni-pauciseriale. Receptaculum nudum, alveolatum. Antherae basi brevissime barbatae. Stylus radii longe bifidus, disci indivisus, nodulosus, brevissime subbifidus. Gen. 2822_2829.

a. CALENDULEAE. Capitula radiata, ligulls femineis, uni-triseriatis, floribus disci hermaphroditis, stylorum abortu saepe unisexualibus. Involucri uni biserialis squamae liberae. Achenia radii fertilia, rostrata, epap. posa, diversiformia, disci saepissime sterilia. Gen. $2822-2824$.

b. OSTEOSPERMEAE. Capitula radiata, ligalis femineis, uniseriatis, floribus disci hermaphroditis, style. rum abortu unisexualibus. Involucri pauciseriati squamae liberae. A ehenia radii fertilia, erostria, epapposa, forma varia, disci sterilia, Gen, 2825.

c. OTHONNEAE. Capitula heterogama, floribus marginalibus ligulatis v. tubulosis, femineis, centralibus abortu masculis. Involueri uni-paueiseriati squamae liberae v. plus minus inter se connatae. Achenia pap. posa, pappo setoso. radil saepius multiseriali, disci uniseriali v. nullo. Gen, 2826 _2829.

2. ARCTOTIDEAE. Capitula multiflora, homogama, discoidea, v. heterogama, radiata, ligulis uniseriatis, femineis v, neutris, floribus disci hermaphroditis, centralibus saepe sterilibus, Involucrum inerme $\mathbf{v}$, spinosum. Receptaculum epaleatum. Antherae breviter caudatae. Styli rami concreti. Achenia erostria, nune pappo paleaceo v. setoso, nunc nullo. Gen. 2830_2846.

a. ARCTOTEAE, Involucri squamae inermes, liberae. Capitula radiata, ligulis fenineis v, mentris. Acheaia plerumque alata. Gen, $2830 \_2838$. 
b. GORTERIAE. Involucri squamae, saltim exteriores et mediae in spinam productae, plus minus connatae. Capitula discoiden v. radiata, ligulis neutris. Achenia exalata, Gen, 2839_2846.

3. ECHINOPSIDEAE. Capitula uniflora, in glomerulum globosum, foliolis plurimis involucratum aggregata, supra receptaculum commune articulato-sessilia. Gen. 2847_2848.

4. CARDOPATEAE. Capitula pauciflora, homogama. Involucrum eylindraceum, multisquamosum. Corollae palmato-quinquefidae. Antherarum caudae retrorsum hirtae. Achenia rostrata. Pappus paleaceus, uniserialis. Gen. 2849.

5. XerANTHEMEAE, Capitula multiflora, dis coidea, floribus in ambitu uniseriatis, femineis, Involucri scariosi squamae multiseriatae, imbricatae, liberae. Corollae hermaphroditorum quinquefidae, feminarum bi-trifidae. Achenia turbinata, hermaphroditorum villosa, feminarum glabra. Pappus paleaceus, longus, Gen, 2850_2852.

6. CARLINEAE. Capitula multiflora, nunquam dioica. Involucri squamae multiseriales, distinctae, saepe spinosae. Corollae hermaphroditorum quinquefidae, feminarnm v. sterilium varie difformes. Staminum filamenta libera, nuda. Antherarum cadae saepius longe barbatae. Achenia saepins villosa. Pappus unibiserialis, pilosus v. plumosus, rarius ramosus, Gen, 2853_2864.

7. CENTAUrieaE, Capitula multiflora, discoidea, floribus marginantibus saepe sterilibus, ampliatis v. irregularibns. Involueri squamae multiseriales, inermes v. spinosae. Staminum filamenta libera. Achenia areola laterali, plus minus antica. Pappus pilosus v. paleaceus, nunqnam plumosus, interdum saltim in ambitu nullus. Gen 2865 - 2873 .

8. CarthameaE. Capitula multiflora, floribus omnibus hermaphroditis v. exterioribus paucis sterilibus. Involucri multiseriati squamae exteriores bracteiformes. Staminum filamenta medio pilosa v. barbata. Achenia glaberrima, tetragona, areola laterali. Pappus nullus v. multipaleacens, rarins pilosus, Gen. 2874 2877.

9. SILYBEAF. Capitnla multiflora, floribus om. nibus hermaphroditis v, exterioribus sterilibus. Involucri multiserialis squamae exterio res apice spinosae. Staminum filamenta mon adelpha. Antherae ecaudatae. Achenia gla bra. Pappus plumosus v. pilosus, Gen. 2878 -2880.

10. CARDUINEaE. Capitula multi- et aequaliflora, floribus omnibus hermaphroditis v, dioicis. Involueri multiseriati squanae liberae, saepe spinosae. Corollae quinquefidae, lobis exterioribus paullo magis distinctis. Staminum filamenta libera, papillosa v, glabra. Antherae brevi caudatae v. ecaudatae. Achenia glaberrima, areola terminali. Pappas pilosus v. plumosns, setis saepius basi in annulum concretis. Gen. 2881_2892.

11. SerratuleaE. Capitula multiflora, floribus omnibus hermaphroditis $\mathbf{v}$. dinieis, rarius marginalibus paueis femineis. Corollae quinquefidae. Staminum filamenta Jibera, papil- losa v. plumosa. Antherae ecaudatae. Achenia glabra. Pappus pilosus v. plumesus, margine circulari cinetus. Gen. 2893_2898.

II. LABIATIFLOREAE. Flores hermaphroditi saepissime bilabiati. Gen. 2899_2964.

6. IIntisiaceae. Stylus hermaphroditorum superne cylindraceus v, subnodosus, ramis saepins obtusis v. truncatis, extus valde convexis, in parte superiore pube minuta aequali, rarius nulla. Gen. 2899_2942.

1. MUTISIEAE. Capitula homogama v, heterogama, floribus femineis uniseriatis, reliquis hermaphroditis. Stylus crassus, stigmata obtusa v. acuta, dorso convexa, hermaphroditorum brevia, extus cum styli parte superiore puberula, v. longiora et tunc glaberrima. Gen. 2899_2933.

8. GERBEREAE. Antherae ecaudatae. Gen.2899_2907.

b. EUMUTISIEAE. Antherae caudatae. Gen, 2908_2933.

2. LERIEAE. Capitula heterogama, homocarpa, floribus femineis pluriseriatis, reliquis ovario efoeto masculis. Stylus basi bulbosus, stigmata extus superne pubescentia. Gen. 2934 2839.

3. FACELIDEAE. Capitula heterogama, floribus femineis uni-pluriseriatis, masculis v. hermaphroditis paucis, quinquedentatis. Stylus tenerrimus, hermaphroditorum stigmata truncata, inclusa, superne extus puberula, Gen. 2940_2942.

ซ. Nassaviaceae. Capitula homogama, radiatiformia. Stylus basi bulbosus, stigmata semicylindracea, truncata, subpenicillata, glandularnm stigmaticarum seriebus intus prominentibus, haud confluentibus. Gen, 2943. 2964.

1. POLYACHYRIDEAE. Capitula biflora, homogama. Gen. 2943.

2. NASSAVIEAE, Capitula subquinqueflora. Involncri foliola subbiseriata, interiora amplexiflora. Receptaculum epaleatum. Gen. 2944. -2949.

8. TRIXIDEAE, Capitula quinque-multiflora, Involueri foliola bi-pluriseriata. Receptaculum paleatum v. epaleatum. Gen. 2950_2964.

III. IIGULIFLORAE. Flores omnes hermaphroditi, ligulati. Gen. 2965_3032.

8. Cielaoraceae. Stylus superne cylindraceus, superne stigmataque plus minus longa, obtusinseula aequaliter pubescentia, glandularum stigmaticarmm seriebus ante medios ramos desinentibus, nuspiam confluentibus. Gen. 2965 -3032 .

1. SCOLYMEAE. Receptaculam paleatum. Pappus coruniformis v. paleaceus. Gen, 2965 2966.

2. LAMPSANEAE. Receptaculnm epaleatum. Pappus nullus. Gen. 2967_2971.

3. HYOSERIDEAE. Receptaculum epaleatum. Pappus coroniformis $v$, paleacens, paleis integris, latiusculis, saepissime brevibus. Gen, 2972_2983.

4. HYPOCHAERIDEAE. Receptaculum paleatum. Pappus paleaceus, paleis angustissime semilanceolatis, interioribus $v$. achenioram in- 
teriorum plumoso-pinnatisectis. Gen. 2984_ 2988.

5. SCORZONEREAE. Receptaculum epaleatum. Pappus paleacens, paleis angustissime semilanceolatis, interioribus v. acheniorum centralium plumosis, rarissime omnibus seabris. Gen. 2989_3001.

6. LACTUCEAE. Receptaculum epaleatum v. rarissime paleatum. Pappus piliformis, plerumque inaequalis, molitissimus, fugax, pilis linearibus, nunquam basi dilatatis, nec plumosis. Gen. 3002_3022.

7. HIERACIEAE. Receptaculum paleatum v. epaleatum. Pappus piliformis, rigidus, demum saepe sordidus v. flavescens, pilis linearibus, nunquam basi dilatatis nec plumosis. Gen. 3023_3032.

CXXI. CAUTCEREAT. Stamina corollae lobis numero aequalia, synanthera. Ovarium uniloculare, ovulo unico pendulo. Embryonis exalbuminosi radicula supera. Gen. 3033 - 3036 .

\section{Classis XXXII. Campanulinae.}

Corolla supera v. rarissime hypogyna. Stamina hypogyna v. perigyna. Ovarium rarissime liberum, plerumque inferum, rarius uniloculare, plerumque pluriloculare. Ovula rarissime definita, plerumque plurima. Fructus capsularis, baccatus v. nucamentaceus, mono polyspermus.

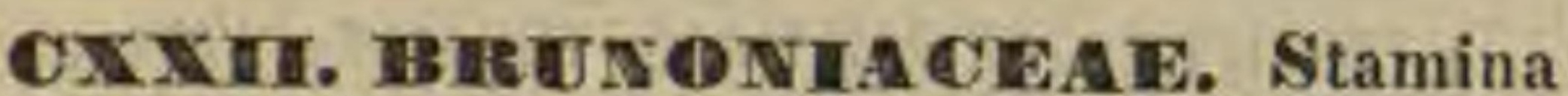
hypogyna, libera. Ovarium liberum, uniovulatum. Stigma indusiatum. Utriculus monospermus. Embryonis exalbuminosi radicula infera. Gen. 3037.

CXXIII. GODIDENIACEAE. Stamina epigyna, libera. Ovarium inferum, unipluriloculare, uni-multiovulatum. Stigma indusiatum. Fructus nucamentaceus iे. drupacens, seminibus definitis, v. capsularis, polyspermus. Embryonis exalbuminosi radicula infera. Gen. $3038-3050$.

1. Seaevoleae. Fructus drupaceus v, nueamentaceus, seminibus definitis. Gen. 3038 $30 \div 0$.

2. Goodenieae. Fructus capsularis, seminibus indefinitis, Gen. $30 \% 1$-3050

CXXIV. LGIBELIACEAE. Corolla irregularis. Stamina epigyna, in tubum connata. Ovarium inferum, uni-triloculare, multiovulatum. Stigma nudum. Fructus capsnlaris v. baccatus, polyspermus. Embryo albuminosus. Gen. $3051-3070$.

1. Climtonieae. Ovarium unilocnlare, placentis 1_2 parietalibus. Capsula opereulata v. valvata. Gen. 3051 _3054.
8. Hobelleae. Ovarinm bi triloculare, placentis septo adnatis. Capsula locnlicide valvata. Gen. $3055-3062$.

3. Delisseacene. Ovarinm biloenlare, placentis septo arlnatis. Fructus evalvis, siccus v. baccatus. Gen. $3063-3070$.

CXX甘. CANIPANUTACEAE. Corolla regularis. Stamina epigyna, libera v. subcohaerentia. Ovarium inferum, pluriloculare, multiovulatum. Stigma nudum. Fruetus capsularis. Embryo albuminosus. Gen, 307 J_-3091.

1. Waln lenbergieac. Capsula apice dehiscens. Gen. 3071 -30st.

a. Jasioneae. Antherae connatae. Capsula apice valvatim dehiscens. Gen. 3071 .

b. Light footie a e. Antherae distinctae. Capsula apice valvatim dehisceus. Gen. 3072_3079.

c. Pris matocarpeac. Antherae distinctae. Capsula elnngata, apice rupta v. poro dehiscens. Gen. 3080 3081 .

2. Camp pamuleae. Capsula latere v. basi poris dehiseens. Gen. 3082_3091.

* PONGaTIEAE. Capsula circumscissa. Gen. 3092.

CXXष耳. S'TWIIDEAF. Stamina epigyna, cum stylo conferruminata. Gen. 3093 3095 .

\section{Classis XXXul. Caprifolia.}

Corolla supera. Stamina corollae inserta. Ovarium inferum, bi-pluriloculare, loculis uni-multiovulatis. Embryo albuminosus.

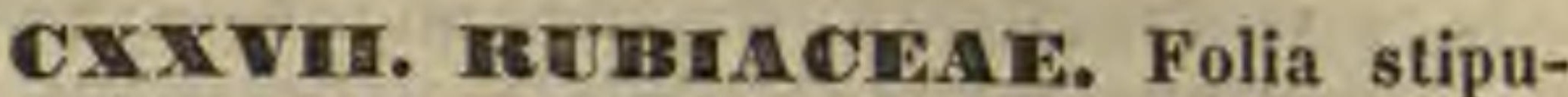
lata. Gen. 3096 -3331.

I. COFFEACEAE. Semina in loculis solitaria v. rarissime gemina. Gen. 3096_3221.

1. Dperealarieae. Flores in capitulum concreti. Ovaria unilocularia, uniovulata. Fruetus connati, dehiscentes. Radicula infera. Gen. 3096_3097.

2. Stellatac. Floreg distineti, Ovarium biloculare, loculis nniovulatis. Carpidia sicca v. baccata, secedentia, indehiseentia. Stipulae foliiformes, verticillum mentientes. Gen. 3098 -3104 .

3. Anthospenmeae. Flores distincti. Ovarium biloculare, loculis uniovnlatis. Carpidia sicca, secedentia, monosperma. Stipulae parvae, petiolo adnexae. Gen. 3105-3109.

4. Spermacoene. Flores distineti, interdum aggregato-capitati, nee tamen connati. Ovarium bi-quadriloculare, loculis uni-biovulatis. Carpidia sicca v. earnosa, secedentia, indehiscentia v. varie dehiscentia. Vagina stipularis setoso-lacera. Gen. $3110-3138$.

a. Putorie a e. Fruetus subcarnosus, haud bipartibilis. Gen, 3110_3117.

b. E uspermaco ceae. Pructos siccus, bi-quadripartibilis. Gen, 3118_3137. 
c. C e $p$ h a la ntheae. Flores supra receptaculum glo. bosum aggregati, sessiles. Fructus bi-quadripartibilis. Gen. 3138.

5. Paychotrieae. Flores distincti, interdum aggregato-capitati, nunquam tamen eonnati. Ovarium biloculare, loculis nniovulatis. Bacca dipyrena. Albumen cornenm. Stipulae utrinque geminae, liberae $v$, connatae. Gen. 3139 -3179.

a. Cep haelideae. Flores capitato-fasciculati, involucrato-bracteati. Gen, 3139 - 314k.

b. Cof fe a e. Flores hand aggregati, exinvoluerati. Gen. 3145 -3179.

B. Paederiene. Flores distincti. Ovarium biloculare, loculis uniovulatis. Fruetus dicoceus, coccis a calyce solutis, compressis, ex axi filiformi pendulis. Gen. $3180 \_3182$.

\%. Curettarealeac. Flores distincti v. connati. Ovarium bi-multiloculare, loculis uniovalatis. Drupa di polypyrena, Albumen carnosum. Stipulae utrinque solitariae. Gen. 8183 - 3219.

a. Morindeae. Flores fruetusque sinpra receptaculum dense aggregati, counati. Gen, 3183 .

b. Euguettardeac. Flores fruetusque distineti. Gen. 3184 -3219.

8. Cordierene. Flores axillares glomerati,v. terminales involucrati. Ovarium bi-quinqueloculare, loculis uni-biovulatis. Bacea biplurilocularis. Albumen carnosum. Stipulae latae. Gen $3220 \_3221$.

1I. CINCHONACEAE. Semina in loculis plurima. Gen. 3222-3315.

D. Hamelieae. Frnctus baccatus, multilocularis. Gen. 3222_3233.

10. Isertieac. Fructus drupaceus, pleiopyrenus. Gen. 3243_3237.

1. Fildyotid ease. Fructus capsularis, loculicide valvatus v. rarissime evalvis, Semin a aptera. Gen. $3238 \_8262$.

12. Cinelhomeae. Fructus capsularis. S e min a alata. Gen. $3263 \_3280$.

a. Eucinchoneae. Flores distincti, pedicellati. Gen, 3263 - 3279 .

b. Na uclea e. Flores supra receptaculum globosum aggregati. Gen, 3280.

13. Garalenieae. Frnctus baceatus, bi. v, abortu unilocularis Gen. 3281-3315.

a. Sa reocephaléae. Flores in receptaculo communi sessiles, fruetibus distinctis v. connatis. Gen, 3281 $-3285$.

b. Eugardenieace. Flores in eapitulum haud colleeti. Gen, 3286_3315.

Genera dublae affinitatis. Gen. 3316-3331.

CXXVIII. LONICEIBAAE. Folia, exstipnlata. Gen. $3332-332$.

a. Tonicereae verae. Corolla tubulosa, limbo regulari v. irregulari. Stylus,filiformis. Seminum rhaphe extrorsa. Gen. 3832_3339.

b. Sambuceae. Corolla rotata v. breviter tubulosa, regularis. Seminum rhaphe introrga. Gen. 3840 - 3342 .

\section{Classis XXXIV. Contortae.}

Corolla hypogyna, regularis. Stamina corollae inserta, ejusdem lobis numero aequalia v. interdum panciora. Ovarium dimerum. Ovula solitaria v. plurima. Fructus capsularis, follicularis, baccatus v. rarius drupaceus. Embryo albuminosus v. exalbuminosus, rectus. - Folia opposita v. verticillata.

CXXIX. JAS HINEAE. Corolla hypocraterimorpha, quinque - octofida. Stamina 2. Ovarium biloculare. Ovula 1 v. 2 collateralia, adscendentia. Bacca, v. capsula septicide bipartibilis. Embryo exalbuminosus. Gen. 33423345 .

CXXX. DHAACEAE. Corolla tetrapetala, v. gamopetala, infundibuliformis v. subcampanulata. Stamina 2. Ovarium biloculare. Ovula in loculis 2 v. plurima, pendula. Bacca, v. capsula indehiscens v. loculicide bivalvis. $\mathbf{E m}$ bryo exalbuminosus. Gen, $3346-3358$.

1. Dleineae. Fructus drupaceus v. baceatus. Gen. $3946-3852$.

2. Fraximene. Fructus capsularis, indehis. cens v. septicide bivalvis. Gen. $3353-3358$.

CXXXI. HDGANIACEAE. Corolla quadri-decemfida. Stamina corollae lobis numero aequalia, rarissime unicum. Ovarium bi-quadriloculare, loculis uni-multiovulatis. Folia stipulata, v. exstipulata corollae aestivatione tunc valvata, succo aqueo. Embryo exalbuminosus. Gen. $3359-3371$.

耳. Stryelnmeae. Corollae aestivatio valvata. Gen. 3359 _ 3363.

1. Eustryehneae. Baeca bilocularis, polysperma. Semina peitata, aptera. Gen. 3359 _.3360.

2. Gardneríea e. Bacca bilocularis, disperma. Semina peltata, aptera. 3361 .

3. A nton ie a e. Capsula bilocularis, bipartibilis, dis. perma. Semina peltata, alata. Gen. 3362 .

4. Labordieac. Capsula triloecularis, polysperma. Semina ....... Gen. 3363

II. Togramiene. Corollae aestivatio convolntiva, Gen. 3364 _3371.

5. Euloganieac. Capsula bilocularis, polysperma. Semina peltata, aptera. Gen. 3364_3365.

6. Usteriea e. Capsula bilocularis, bipartibilis, poly. sperma. Semina peltata, alata. Gen, 3366.

7. Potalie a e. Bacea bilocularis, polysperma. Semina peltata, aptera. Gen. 3367_3369.

8. Gärtnerene. Bacea dicocea, coceis monospermis. Semina e basi erecta. Gen, 3370_3371.

CXXXII. APQCXNACEAR. Corolla quinque- rarius quadrifida. Stamina corollae lobis numero aequalia. Pollen granulosum. Folia exstipulata. Corollae aestivatio contorta v, rarissime valvata. Succus lacteus. Embryo exalbuminosns. Gen. $3372-3430$.

I. Carisseae. Ovarium simplex, biloculare, placentis dissepimento insertis, v. uniloeulare, placentis parietalibns. Fruetua baceatus v, rarissime capsularis. Gen, $3372-3883$. 
11. Dphioxyleae. Ovarium duplex. Fruetus drupaceus. Gen. 3384 -3393.

III. Euapoeyneae. Ovarium duplex. Fructus bifollienlaris, folliculis interdum earnosis, pulposis, Gen, 3394-3930.

1. PI a ni e ri e a e. Semina ecomosa, saepissime peltata. Gen. 339'-3'i07.

2. A Is to nie a e. Semina peltata, ciliata, ciliis elonga. tis utraque extremitate comosa. Gen, $3^{\prime} 08$.

3. Echitea e. Seuina ad unbilicum basilarem comosa. Gon. 3409_3428.

4. Wrightieae. Semina ad extremitatem umbilico oppositam comosa. Gen. 3489_3430.

CXXXIII. ASCEREIADEAT. Corolla quinquefida. Stamina corollae lobis numero aequalia, plerumque in tubum connata. Pollen in massas determinatas, bursiculatas coalescens. Folia exstipulata. Corollae aestivatio contortoimbricata v. rarissime valvata. Embryo exalbuminosus. Succus lacteus. Gen. $3431-3527$.

T. Peroiploceae. Filamenta subdistincta $v$. libera, Antherae 1_4loculares. Pullinis mas. sae 5-20, granulosae, solitarie v, quaternatim apiribus dilatatis corpusculornm stigmatis applicitae. Gen. 3431 -3440.

II. Secamoneae. Filamenta connata. An therae biluculares. Pollinis massae 20 , quater natim apicilus corpusculorum stigmatis ap plicitae. Gen. $3441-3443$.

10. Aselepiadeae verae. Filamenta con nata. Antherae biloculares. Pollinis massae 10 , per paria stigmatis procesaubus suleo Iongitudinali bipartitis affixae. Gen. 344 ' 3527.

1. Cy nancheae. Pollinis massae pendulae, apice $v$. supra medium lateris atfixae. Gen. 3444_3493.

a. Astephaneae, Corona stamiuea nulla. Corolla tubo faucrque esquamata. Gen, 3444_3 346 .

b. Metastelmeae. Corona stawinea nulla. Corolla tubo fauceve squamis instrueta. Gen. 34'7 3454 .

e. Ditasseae. Corona staminea consosita, seriebus 2_3 insertione distinctis. Gen, 3455_3459.

d. Cynoctoneae. Corona staminea simplex, gamophylla. Gen. 3460_3470.

e. Calotropideae, Corona staminea simplex, pentaphylla. Corolla subesmpanulata. Gen. 3'71-3478.

r. Euasclopieae. Corona staminea simplex, pentaphylla. Corolla subrotata, Gen, 3'79__3453.

2. Gonolobeae. Pollinis massae transversae, extre. mitate exteriori aftixse, sub stigmate occultatae. Gen. $3494-3496$.

3. Pergutarieae. Pollinis massae ereetae v. eonni. ventes, stigmati iscumbentes, basi v. Infra medium latere affixae. Gen, $3497 \_3527$.

1. HOYEAE. Antherae appendice membranacea termina. tae. Gen. 3:97-3512.

a. Sarcolobeae. Corona stawinea nulla, Gen. 3497 -3498.

b. Tyluphoreae. Coroua staminea pentaphylla. Ger: $3499-3512$.

2. STAPELIEAE, Antherae apice simplices. Gen, 3513 -3527 .

1. a. Leptadenieae. Corona staniuea aulla. Gen, 3513 -3514 .

t. Ceropegieae. Tuhus stamineus extus oppendiculatus, Gen. 3515-3527.

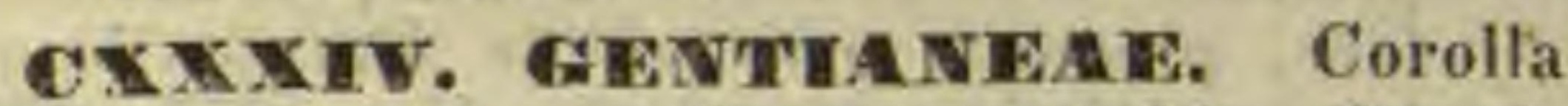
quadri-quinquefida, rarius sex-octofida. Stami-) na corollae lobis numero aequalia, libera. Pollen granulosum. Ovarium uniloculare, rarius biv. pseudo-quadriloenlare. Folia exstipulata, Corollae aestivatio contorta v. induplicata. Embryo exalbuminosus. Succus aqueus. Gen. 35283567.

I. Gentianeae verae. Corollae laciniae aestivatione dextrorsum contortae. Albumen cavum seminis explens, Gen. 3528_3561.

1. Chironieae. Capsula uniloeularis v. plus minus complete bilocularis, placentis suturalibus, Gen, 3528 $-3556$.

2. S e b a e a e. Capsula valvarum marginibus introflexis, placeutam centralem unlcam, demum liberam prehendentibus bilocularis, Gen, 3557_3561.

Genera dubia, Gen, 3562_3563.

II. Nienyantheae. Corollae aestivatio indnplicativa. Albumen cavo seminis minus. Gen. 3564_8565.

Genera Gentianeis affinia. Gen. 35663567 .

CXXXV. SPICEIIACEA. Corolla quinquefida. Stamina corollae Jobis numero aequalia. Ovarium biloculare, placentis basilaribus. Folia stipulata. Corollae aestivatio valvata. Succus aqueus. Embryo albuminosus. Gen. 3568.

\section{Classis CXXXV. Nuenliferne.}

Calyx liber. Corolla hypogyna, gamopetala, regularis v. irregularis. Stamina corollae tubo inserta, ejusdem lobis alterna, numero aequalia v, pauciora. Ovarium saepius tetramerum, rarius monomerum, loculis saepissime monospermis. Fructus nucamentaceus, lobis saepe distinctis, rarissime utriculiformis $\mathbf{v}$. baccatus. Embryo intra albumen homotropus v. exalbuminosus.

CXXXvi. IA ABATAE Corolla irregularis. Stamina 2 v. 4. Achenia quatuor. S emina erecta. Embryonis exalbuminosi radicula infera. Folia opposita v. verticillata. Gєn. 3569 -3682 .

I. Deimolateae. Stamina declinata. Corolla subbilahiata, lobis quataor snperioribus planis, subaequalibns, binisve supremis coalitis, infimo declinato, saepe difformi. Antherae demuin saepissime patelliformes, Gen. $\mathbf{3 5 6 9}$ -3585 .

1. Moschosmeae. Corollae laciniae subaequilongae, infima angustior, declífata, subplana. Gen.3569-357'f.

2. Plectrantheae. Corollae laeinia infima elougata. eoncava. Gen. $3575-3579$.

3. Hyptideae. Corollae Iaciuia infima snbstipicata. transverse subcallosa, deaum saccata. per authesim abrupte dejecta. Gen. $3580 \_3584$.

4. Ia a u d uleae. Corollae labium superius bilobum, inferius trilobum. Stabilna tubo inclasa. Gen, 3585. 
II. Mientholdeae. Stamina distantia, recta v. divergentia, nec per paria approximata. Corolla subeampanuleta $v$. infundibuliformis, tubo calycem vix superante, limbi quadriquinquefidi lobis subaequalibus. Gen. 3586 $-3596$.

1. Pogostemeae. Antherae terminales, confluentim nniloculares. Stamina subdeclinata. Gen. 3586_3587.

2. Elsholtzieae. Antherae versatiles, loculis divari. catis, demum coufluentibus. Stamina isterdum subadsceudeatia. Gen. $3588-3589$.

3. Mentheac. Antherae biloculares, loculis parallelis. Gen. 3590_3595.

4. Meriaudrea e. Antherae loculis disjunctis, eonnectivo filiformi. Gen, 3596.

III. DI omaredene. Curolla bilabiata. Stamina 2 inferiora fertilia adsepndentia. Antherae bilo. culares, loculis contiguis: v. connectivo 1 ineari sejunctis, luculo altero saepius casso. Gen. 3597_-3603.

1. Salviea e. Stamina 2. Connectivum filiforme, cum filamento articulatum. Gen, $3597-3598$.

2. Rosmarineae. Stamiua 2. Connectivan parvum. Gen, 3599-3602.

3. Ho rm i nea e. Stamia 4. Connectivam parvum. Gen. 3603.

IV. Satmeinae. Corollae tubus calyeem vix aequans, limbus sublilabiatus, labio superiore integro v. bifido, inferiore trifido. Stamina distantia, recta, divergentia, a equalia v. postica breviora aut abortiva. Gen. 3604 $-3614$

1. Origanea e. Calyx 10-13nervis. Stamina 4 fertilia. Gen, 3604_3611.

2. Hyssopeae. Calyx 15uervis. Stamina 4 fertilia. Gen. 3612.

3. Cunileae. Stamina 2 inferiora fertilia. Gen. 3613 $-3614$.

W. Melissinae. Calyx quinquedentatus, plerumque bilabiatus, rarins aequalis, decem- v. tredecimnervis. Corollae tubus plerumque exsertus, limbi hilabiati labio superiore integro v. bifido, inferiore trilobo. Stamina adscendentia, superiora breviora, interdum abortiva. Gen. 3615_3623.

VI. Seutellarineae. Calyx bilabiatus, labio superiore trancato integro $v$. subtridentato. Curulla tubo exserto, adscendente, intus annulato, nudo. Stamina 4 , sub labio superiore adscendentia, inferiora longiora. Gen. 3624 $-3627$.

VII. Prostanthereae. Calyx eampanulatus, bilabiatus v, aequalis quinquedentatus. Corolla tobo brevi amplo, fauce lata, limbo bilabiato. Stamina 4, corolla breviora, inferiora nonnunquam abortiva, dum adsunt superiori bus longiora. Achenia coriacea, rogusa, stylo subpersistente. Gen. 3628_3634.

vill. Nepeteae. Calyx aequalis v. obliquus, subbilabiatus, dentibus snperiuribns majoribns. Cornlla inclusa v, exserta, fauce plerumque inflata, labio superiore subfornieati, in feriore patente. Stamina , inferiora lon Ginra, adscendentia v, divergentia, Gen. 3635 -3639.

1X. Staelayaleae. Calyx irregulariter venosur $v$, quinque-decemnervis, aequalis, nhliquns $v$, rarius subbilabiatns, tri-decemdentalus. Corullate tubus inclusns $v$. exsertus, intus saepe annulatus, limbi bilabiati labio superiore galeato v, plano, integro v, emarginato, inferiore varie trifido. Stamina 4 , adscendentia, superiora breviora, omnia fertilia, v. inferiorum antherae nonnunquam dimidiatae sive efoetae. Gen. 3640_3672.

1. Melitteae. Calyx post anthesim inflatus v. bi-qua. drilobus. Corolla longe exserta. Cien, 3640_3643.

2. Lami eac. Calyx quinquedentatus, limbo laud dila tato. Corolla subplana ₹. fornicata. Stamiaa e tubo exserta. Gen, 364t_3653.

3. Marrableae. Stamiaa corollae tabo Jaclusa. Gen. $3654-3657$.

4. B alloteae. Calycis limbus dilatafus v. sex-decem. deatatus, wuse ore truacato inter dentes subaembra. naceo, v. Latissime membranaeeo eampanulatus, Corollae lablum superiun saepe compresso.galeatum. Sta. wiaa e corollae tubo exserta. Gen. $3658-3672$.

X. Prasieae. Calyx subaequalis. Corulla bilabiata, Stamina 4, adscendentia, inferiora longiora. Achenia subbaccata. Gen. 8673 3676 .

XI. Ajug ideae. Corollae labim superins nunc brevissimum, nune fissum, lacinits abbreviatis, rarissime erectum, fornicatum, inferius elongatum. Stamina 2_4, adscendentia, saepissime exserta, labio opposita. Achenia plus minus reticulato-rugosa. Gen. 3677 - 8681 Genus dubium. Gen, 3682.

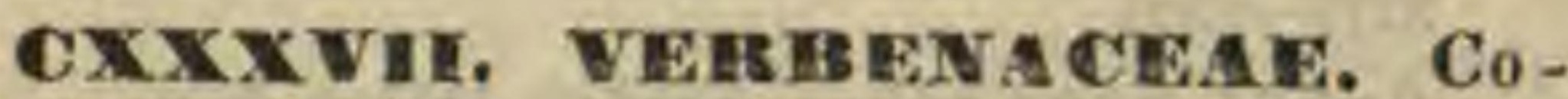
rolla irregularis v. regularis. Stamina 2 v. 4 , rarius 5, rarissime plura. Fructus drupaceus, di-tetrapyrenus, pyrenis uni-bilocularibus, rarius baceatus, - bi-quadrilocularis, Semina adscendentia. Embryonis exalbuminosi v. subalbuminosi radicula infera. Gen. $3683-3716$.

1. Iippleae. Fructus drupacens, maturitate in elementa carpica secedens. Gen. 3683_3693.

2. Iantameae. Fructus drupacens, havd dilabens. Gen, 3694_3710.

3. Aegiphilleae. Fructus baceatus. Gen. $3711-3716$.

Genera duhia. Gen. 3718_3720.

* Avicennibae. Gen. 3722.

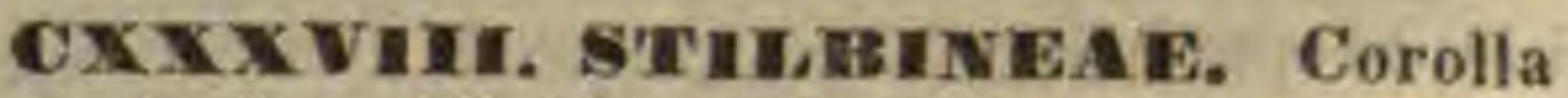
subregularis v: bilabiata. Stamina 4 v. 5. Capsula bilocularis, apice quadrifariam dehiscens v. utriculus monospermus. Semina erecta. Enbryo in axi albuminis carnosi orthotropus, radicula infera. Gen. $3723-3724$.

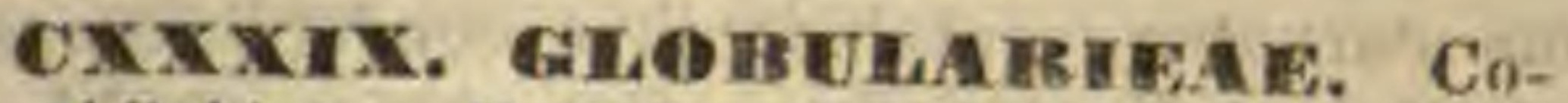
rolla bilabiata. Stamina 4. Caryopsis semine inverso. Embryo in axi albuminis carnosi orthotropus, radicula supera. Gen. 3725.

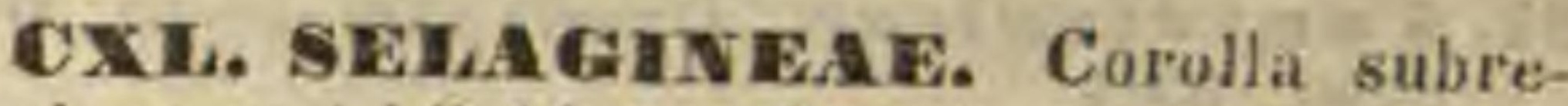
gularis v, uni-bilabiata. Stamina 2 v. 4 . Achenia 2, saepe heteromorpha. Semiua inversia. Embryo in axi albuminis carnosi ortrotropus, radicula supera. Gen. 3726--3732.

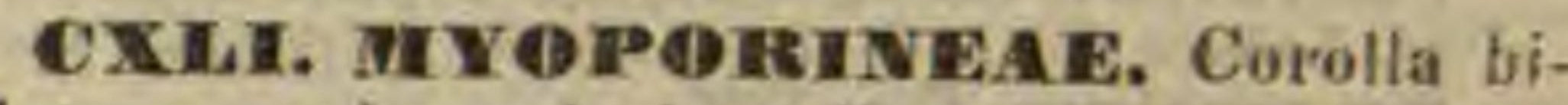
labiata v, subregularis. Stamina 4. Fructus drupaceus, Joculis mono-tetraspermis. Seurina 
inversa. Embryo in axi albuminis carnosi orthotropus, radicula supera. Gen. $3733 \_3737$.

CXHII. CORDIACEAE. Corolla regularis. Stamina corollae lobis numero aequalia. Fructus drupaceus, loculis monospermis. Semina inversa. Embryonis exalbuminosi cotyledones carnosae, longitudinaliter plicatae, radicula supera. Gen. 3738 .

Genera dubia. 3739 _3742.

CXHII. A SPREIFULAE. Corolla regularis v. subbilabiata. Stamina 5. Achenia 4, rarissime per paria coalita. Semina inversa. Embryo exalbuminosus v. albumine tenui inclusus, radicula supera. Gen. $3743-3787$.

I. Eluretiaceae. Stylus terminalis. Gen. $3743+3752$

a. Tournefortie ae. Semina albuminosa. Gen, 3743 $-37 \div 9$.

b. Heliotropeae. Semina exalbuminosa. Gen. 3750 -3752 .

II. EBorraginene. Stylus inter lobos ovari transiens. Gen, 3753_3786.

a. A n c huxe a e. Nuces receptaculo affixae. Gen. 3753 -3778 .

b. Cynoglosseae. Nuces styli basi adnatae. Gen. $3779-3786$.

Genus anomal $1 \mathrm{~m}$, nucibus duabus. 3787 .

\section{Clessis XXXVI. Tubiflorae.}

Calyx liber. Corolla hypogyna, gamopetala, regularis. Stamina corollae tubo inserta, ejusdem lobis numero aequalia et alterna. Ovarium tri-quadri-quinqueloculare, ovulis saepissime indefinitis, anatropis v. amphitropis. Fructus capsularis v. baccatus. Embryo intra albumen rectus $\mathbf{v}$. curvatus.

CXIIV. CONVDLVUHACEAE, Ovarium bi-quadriloculare, columna centrali septifera, rarius apocarpum, carpidiis unilocularibus, duobus distinctis v. quatuor per paria connatis. Ovula in loculis solitaria v. gemina collateralia, e basi erecta. Fructus capsularis v. baccatus, Embryo intra albumen mueilaginosum plus minus curvatus, cotyledonibus conduplicato-corrugatis, radicula infera. Gen, 3788 -3814.

1. Diehomdreae. Ovaria apocarpa. Gen. $3788 \_3789$.

11. Convolvuleae. Ovaria gamocarpa, Gen. $3790 \_3814$.

- Er jeibeae. Ovarium uniloeulare, quadriovulatum. Bacea monosperma. Embryonis carnosi, mueilaginoso albuminosi cotyledones contortuplicatae, radieula infera. Gen. 3815 .

* Cuscute a e. Herbae aphvlleae. Capsula circumscis. sa. Kabryo filiformis, indivisus, cirea albumen spira. liter convolutus. Gen. 3816.

* Nola aeae. Ovaria plara libera. uni-sexlncularia, diseo carnoso inserta. Drupae distinctae, monospermae.
Embryo filiformis, annularis, albumen carnosum cingens. Gen, 3817 .

CXIU. BOHEMIONIACEAE, Ovarium tri-quinqueloculare, columna centrali septifera. Ovula in loculis solitaria v. plurima, biseriata. Fructus capsularis. Embryo intra albumen carnosum rectus. Gen. $3818-3826$.

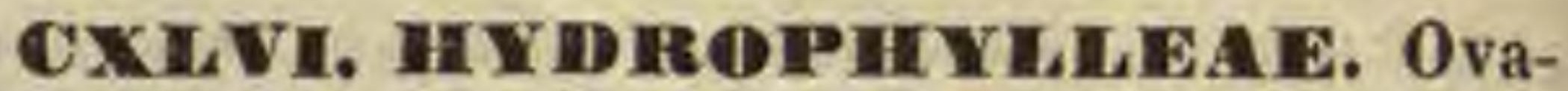
rium uniloculare $\mathbf{v}$. incomplete biloculare, semiseptis placentiferis. Ovula juxta quodvis placentae latus solitaria v.plurima. Fructus capsularis v. subbaceatus. Semina pauca. Embryo intra albumen cartilagineum rectus, axilis v. subexcentricus. Gen. $3827-3832$.

CXIVIII. HYTIEDTEACEAE. Ovarium bi-rarissime triloculare, Ioculis multiovulatis. Styli 2, distincti. Capsula septifrage v. loculicide dehiscens. Semina plurima, testa laxe membranacea. Embryo in axi albuminis carnosi rectus. Gen. $3833-3837$.

CXIVIII. SOLANACEAE. Ovarium bi-quinqueloculare, placentis septo adnatis $v$. ex angulo centrali porrectis, multiovulatis. Ovula plurima, amphitropa. Stylus simplex. Fructus capsularis v. baccatus. Semina plurima, a latere v. a dorso compressa. Embryo in his intra albumen carnosum axilis, rectus, in illis intra albumen subperiphericus, arcuatus v. spiralis. Gen. $3838-3869$.

I. Nieotianeae. Embryonis plus minus arcuati cotyledones semicylindricae. Capsula bilucularis, loculicide bivalvis. Gen. 3838 _ 3844 .

11. Datureae. Embryonis plns minus arcuat cotyledones semicylindricae. Capsula v. bacea incomplete quadrilocularis, dissepimento primario medio v. secus angulum parietalem utrinque placentifero. Gen, 3845 - 3846 .

III. Fl yoseyameae. Embryonis plus minus arenati cotyledones semicylindricae. Capsnla bilnenlaris, opereulo circumseissa. Gen. 3847 -8849 .

IV. Solaneae. Embryonis plus minus arenati cotyledones semicylindrieae Bacea bi-plurilocularis placentis centralibus, rarissime capsula evalvis, Gen, $3850-3864$

V. Cestrineace. Limbryonis recti cotyledones foliaceae. Bacca bilocularis. Gen, 3865_3867.

VI. Vestiene. Embryonis recti cotyledones foliaceae. Capsula bilocularis. Gen. 3868 _ 3869 . GENERA DUBIA, $3870 \_3874$.

INCERTAE SEDIS.

* DESFONTAINEAE. 3875.

** RETZIACEAE. 3876_3877.

\section{Classis XXXvir. Pergonatae.}

Calyx liber v, cum ovario connatus. Corolla hypogyna v, perigyna, gamopetala, saepissime irregularis, bilabiata. Stamina corollae tubo inserta, ejusdem lobis 
saepissime pauciora. Ovarium dimerum, uni-biloculare, ovulis saepiscime indefinitis, anatropis v. amphitropis. Fructus capsularis v, rarius baccatus. Embryo intra albumen homotropus $\mathbf{v}$, exalbuminosus.

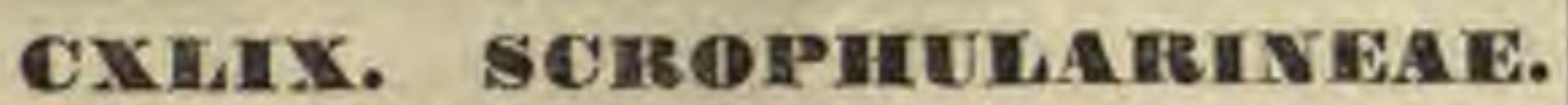
Fructus capsularis vi rarissime baccatus, superus, bilocularis, dehiscentia varia. Semina exalbuminosa. Gen. 3878_-4026.

1. Werbasceac. Corolla tubo abbreviato v. subglehoso, limbo zexplanato, quadri-quinquefido v. bilabiato, haud ringente. Stamina fertilia 2 v. 5, hand declinata. Antherae approximatae v. cohaerentes, uniloculares v. subbiloculares, loculis divaricatis, conflnentibus. Capsula septicide bivalvis, valvis saepe bifidis, placentas eoadunatas nudantibus. Seminum testa solida. Gen. 3878_3883.

\%. Fennimerideae. Calyx quinquefidus v. pentaphyllus. Corolla tubo brevissimo, limbo explanato, subrotato, bilabiato $v$. personato, late quadri-quinquelobo, basi saceato, bifossulato $v$, uni-bicalcarato. Stylus simplex. Stigma parvum, subcapitatum. Capsula bivalvis, valvulis integris, bifidis v. bipartitis. Gen. 3884 - 3889 .

3. Antimelnineace. Córolla tobulosa, limbo personato v. ringente, bilabiato v, rarios aequali. Stamina 4 , didyma. Antherae biloculares, per paria approximatae. Capsula biJoenlaris, dentibus v. operculis dehiscens, rarius plurivalvis, nune irregulariter rupta. Seminum testa solida, v, laxa, arilliformis. Gen. 3890 - 3897 .

4. SaIpinglossideae. Corolla tubo saepius elongato, limbo nnne bilabiato, nune subaequaliter quinquelobo, plano. Stamina fertilia 2, v. saepius 4, didynama, declinata, quintam sterile $v$, nullum, rarissime aeque fertile, antherae subbileculares, loculis apice confluentibus. Capsula bilocalaris, septifrage bivalvis, valvis integris $\mathbf{v}$. bifidis, dissepimentu plaeentifero paralielis. Embryo reetus v, plus minus arcuatus. Gen. $3898-8907$.

5. Digitaleae. Corolla tobulosa, saepins ventricosa, limbo bilabiato. Stamina basi de clinata, apice saepissime adscendentia, quatuor fertilia, didynama, quintum sterile v. nullum. Antherae biloculares, loculis demum divaricatis, confluentibus, Capsula dura, septicide bivalvis, valvis bifidis $\mathbf{v}$, bipartitis, dissepimento e valvularnm marginibus introflexis duplicato, demum bipartibili, placentis adnatis v. tandem solutis. Gen. $3968-3917$.

B. Gratioleae. Corulla limbu bilabiato $\mathbf{y}$. subaequali, laciniis subplanis. Stamina fertilia 2 v. 4 , adscendentia, antherae biloculares, muticae. Capsula bilocularis, loculicide ant septicide, $\mathbf{v}$. septifrage bivalvis, valvis integris v. bifidis, dissepimento placentifero demum libero, rarius baceata. Semina aptera. Gen, 3918_3958.

*. Bachnereae. Calyx quinquefidus v, quinquedentatus. Cornlla limbo quinquefido $v_{\text {. in- }}$ aequaliter quadrifido, nune bilabiato, laciniis omnibus planis. Stamina 4 , adscendentia, didynama, rarius duo approximata, antherae uniloculares. Stig ma parvum, subcapitatum. Capsula bivalvis, valvis integris v. bifidis, rarissime carnosa, indehiscens. Gen. 3959_3970.

a. RUbuchnereae. Capsula loculicide bivalvis, valvis integris. Cien, $3959 \_3963$.

b. MANULEAE. Capsula septicide bivalvis, valvis bifidis . Gen. 396t-3970.

8. IBualdileieae. Corolla tubo recto, limbo plano, patente, aequaliter quadrifido. Stamina 4 , omnia fertilia, aequalia, antheris distantibus, bilocularibus, Capsula bilocularis, septicide bivalvis. Gen. 3971 _3972.

3. Veromiceace. Corolla rotata, infundibuliformis v. rarins irregulariter bilabiata. Stamina 4 , aequalia, fertilia, v. saepius 2 postica, sterilium rudimentis nullis. Capsula bilocularis, loculicide bivalvis, valvis saepissime juxta dissepimentum bifidis, nunc septifrage bivalvis. Gen. 3973_3989.

10. Gerardieac. Corolla campanulata, infundibuliformis v. tabulosa, limbo quinquefido, laciniis rotundatis, planis. Stamina 4, omnia fertilia, adscendentia. Antherae biloculares, loculis discretis, saepe acuminatis. Capsula bilocularis, loculieide bivalvis, valvis indivisis v, bifidis, Semina nucleo saepissime intra testam laxam, reticulatam, arillaeformem minimo. Gen. 3990_4002.

11. Fillainantheae. Corollae limbng bilabiatus, labio superiore concavo, galeato v. lineari, integro $v$. emarginato, inferiore trifido. Stamina 4 v, rarius 2, adscendentia, Antherae biloculares, loculis discretis, parallelis, saepe acuminatis. Capsula loenlicide bivalvis, valvis medio septiferis, saepissime integris. Seminum testa solida, v. lava arillaefurmis, nune in alam expansa. Gen, 4003 -4019 .

Genera d u bi a. 4020-4023.

Genera Serophularineis affinia. 4024_4026.

XIL. ACANTurackAE. Fructus superus, capsularis, bilocularis, loculicide dehiscens, placentatione in axi dissepimenti bipartibilis et ad interiorem ejusdem marginem. Semina retinaculis saepissime subtensa. Embryo exalbuminosus, rectus v. curvatus. Radicula descendens, centripeta. Gen. 4027-4103.

1. Thlatumbergiene. Seminum retinacula in cupolam corneam dilatata, adnata. Gen. 4027 -4030 .

II. Nelsonifeae. Seminum retinacula in papillam contracta. Gen. 4031 -4036.

IIII. Eelannatacanthe. Seminum retinacula uncinata, subtendentia. Gen. 4037-4101.

1. HYGrophileae. Corolla ringens. Stamiaa 4 v. 2 . Antherae biloeulares, loeslis parallelis, moticis. Capsula polysperma. Retiaseula brevia. Gen. 4037-4010.

2. RUELLiEAE. Corolla limbo aequali v. subbilabiato. Stauina 4 v. rarissime 2. Antherae biloeulares, localis saepissime parallelis. Capsula dj-telra-polysperma. Gen. $4041-4059$.

3. BARLERIEAE. Calyx quadripartitus, Iaciulis antica et postica majoribus, lateralibus interioribus, nuas bilabiatus v. quinquepartitas. Corolla infuadbulifor. 
mis v. bilabiata. Stamina 4 , pare altero brevissimo, antherae blloculares. Capsula, di-tetrasperma. Gen. $4060 \_4067$.

4. ACANTHEAR. Calyx quadripartitus, lacinits antica et postica majoribus. Corolla unilabiata, basi cartilaginea. Stamina 4 . subdidyaama. Capsula di-tetrasperma. Gen. 4068_4072.

5. JUSTICIBAE. Calyx quinquefidus, rarins quadrifidus, lacinia postica saepe minore. Corolla bilabiata v. ringens, rarius regularis. Stamina 2 , antheris bilocula ribus, v. 4 , antheris omnium v. staminum brevioram unilocularibus. Capsula tetrasperma, rarius pleiosperma. Gen. 4073 - 4090.

a. Aphelandreae. Stamina 2 v. rarius 4 , antherarum luculis parallelis, Capsula sessilis, tetra-polysperma. Gen. $4073-4078$.

b. Gendarusseae. Stamina 2 v. rarissime 4 , antherarum loculis parallelis v. divergentibus. Capsula unguiculata, tetrasperma. Gen. $4079 \_4086$.

c. Eranthemeae. Stamina 2, antherarum loeulis paralletis v. superpositis. Capsula longe unguiculata, ditetrasperma. Gen, 4087_4090.

6. DICLIPTEREAB. Calyx quinquepartitus, aequalis. Corolla bilabiata, saepe resupiuata. Stamina 2 v. 4 , antheris uai-bilocularibus. Capsula tetra-monosperma. Gen. 4091 -4098.

7. ANDROgraPhideaF. Calyx quinquefidus. Corolla bilabiata v. riogens, saepius resupinata. Stamina 2 v. 4 , antheris unilocularibus v. bilocularibus, loculo inferiore barbato. Capsula sessilis, pleiosperma. Gen. $4099-4101$.

Genera dubia. $4102 \_4103$.

CXIM. IBIGNOWIA CEAE. Fructus superus, capsularis, uni-bi-quadrilocularis, valvis columnam septantem margine seminiferam nudantibus v. rarius nudis placentiferis. Semina saepissime transversa, plerumque alata. Embryonis exalbuminosi, recti radicula plerumque centrifuga. Gen. 4104-4133.

1. Sesameae. Capsula valvarum marginibus in dissepimenta introflexis, et nervo medio columnam centralem quadrifariam semin feram attingentibus quadrilocularis, septicide bivalvis. Semina adscendentia v. lowizontalia, aptera v. membranaceo marginata. Gen. 4104 $-4105$.

1. Eceremocarpere. Capsula uni-bilocularis, bivalvis, valvis medio semisepta, margine interiore seminifera gerentibus, Semina horizuntalia, alata. Radicula centrifuga,Gen. 4106_4108.

III. Inearvilleae. Capsula hinc sntura dehiscens, dissepimento contrario, intra margines seminifero. Semina pendula, alata. Radicula supera. Gen. 4109_4110.

I. Towrotiene. Capsula dissepimento tetraptero quadrilocularis, bivalvis, dissepimenti alis oppositis angustioribus, valvis contrariis intra marginem seminiferis. Semina alata, pendula. Gen. 4111.

ซ. It: vis, valvis dissepimento marginihus utrinque seminifero contrariis v. parallelis. Semiaa transversa, alata $v$, rarissime aptera, Radicula eentrifuga. Gen. 4112 _-4125.

1. ARgylieaE. Dissepimentua valvis contrarium, Semi sa aptera. Gen. 4112.

2. TECOMEAE. Dissepimentum valvis eontrarium, Semina glata. Gen, 4113_4118.
3. RUBIGNONIEAE, Dissepimentum valvis parallelum. Gen. $4119-4125$.

Genera an omala. $4126 \_4127$.

Genera du bia. $4128-4133$.

CHII. CHSNEICACAE. Fructus unilocularis, placentatione parietali, superus v. inferus. Semina exalbuminosav. parce albuminosa. Gen. $4134-4170$.

I. Cy retandilneae. Semina exalbuminosa, Gen. $4134-4154$.

1. DIDYMOCARPEAE. Fruetus capsularis, Gen. 4134 -4145 .

2. EvCYRTANDreaz. Fruetus baecatus. Gen, 4146_ 4150 .

Genera dubia. Gen. 4151_4154.

III. Gesmereae. Semina exalbuminosa, Gen. 4155

1. BESI.EREAE. Ovarium superum. Fruetus baceatus. Gen. 4155_4159.

2. EPISCIEAE. Ovarium superum. Fruetus capsularis. Gen. $4160-4164$.

3. KUGESNEREAE. Ovarium inferum v. semiinferum. Frucius eapsularis, Gen. $4165 \_4169$.

Genera dubia. 4170.

* CrescentieaE. Gen. 4171_4173.

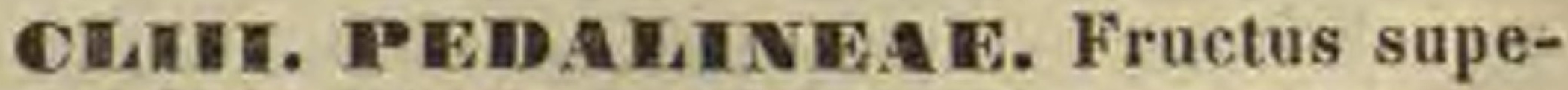
rus, subcapsularis v, drupaceus, saepe cornutus, uni-bi-quadri-octolocularis. Semina in loculis pauca. Embryo exalbuminosus, orthotropus. Gen, $4174-4181$.

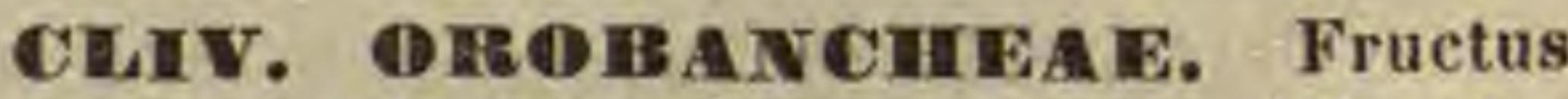
superus, capsularis, uni- v, rarissime bilocularis, placentatione parietali Semina plurima. Enbryo in axi albuminis carnosi minimus. Herbae parasiticae aphyllae. Gen. 182-4192.

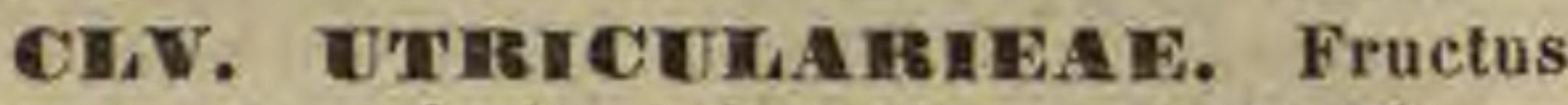
superus, capsularis, placenta centrali libera. Semina plurima. Eimbryo exalbuminosus, orthotropus. Herbae aequaticae v. hygrobiae. Gen. $4193-4195$.

\section{Classis XXXVIII. Petalanthae.}

Calyx liber v. rarissime cum ovarii basi connatus. Corolla hypogyna v, rarissime perigyna, gamopetala, regularis. Stamina corollae inserta, ejusdem lobis numero dupla v, multipla, rarius aequalia et tunc saepissime opposita. Antherae biloculares, exappendiculatae. Ovarium uniloculare, loculis multiovulatis, v. pluriloculare, loculis uni-pauciovulatis. Ovula amphitropa v. anatropa. Fructus capsularis v. drupaceus. Einbryo intra albumen homotropus v. exalbuminosus.

CTVI. PIRMULACEAE. Calyx liber v. rarissime adnatus. Stamina corollae lobis numero aequalia et iisdem opposita. Ovarium 
uniloculare, placenta centrali libera. Ovula plurima, amphitropa v. rarius anatropa. Fruetus capsularis, polyspermus. Semina albuminosa. Herbae, rarissime suffrutices. Gen. 4196 4226.

1. Proinamieae. Capsula libera, valvatim dehiscens. Semina amphitropa, nmbilico ventrali. Gen. 4196_4211.

a. A u dros a ce a e. Acaules. Gen, 4196_4203.

b. Ly simachie a e. Caulescentes. Gen. 4204_4211.

II. Anagallialene. Capsula libera, operculo dehiscens. Semina amphitropa, umbilico ventrali. Gen. 4212 - 4213 .

III. Hottonieae. Capsula libera, valvatim dehiscens. Semina anatropa, umbilico basilari. Gen. 4214.

19. Samoleae. Capusla basi adnata, vertice libero valvatim dehiscens. Semina anatropa, umbilico basilari, Gen. 4215 .

Genus Primulaceis affine. Gen. 4216.

CHWII. NIVISSINEA C. Calyx liber v. rarissime adnatus. Stamina nunc corollae lobis numero aequalia et opposita, antheris introrsis, nunc dupla, alterna lobis opposita fertilia, antheris extrorsis, alterna sterilia squamuliformia. Ovarium uniloculare, placenta centrali libera. Ovula plurima, amphitropa. Fructus drupaceus $v$. baccatus, abortu saepe monospermus Semina albuminosa. Arbores v. frutices. Gen. $4217-4230$.

耳. Ardisiene. Stamina sterilia nulla, Antherae introrsae. Ovarium liberum. Fructus mo nuspermus. Gen. 4217 _ 4226.

11. III aeseace. Stamina sterilia nulla. Anthe rae intrursae. Ovarium adnatum. Fructns potyspermus, Gen. $422 \%$.

III. Theoplnmasteae. Stamina sterilia cnm fertilibus et corullae lobis alternantia. Antherae extrorsae. Ovarium liherum. Fructus polyspermus Gen. 4228_4230.

- Genera dubia. Gen, 4231-4232.

* aeglcerear. Gon, 4233.

CLVIII. SAPQTACEAE. Calyx liber. Stamina fertilia nunc corollae lobis numero aequalia et opposita, nunc plura, bi-pluriseriata, sterilia fertilibus alterna, rarissime nulla. Ovarium liberum, pluriloculare. Ovula in loculis solitaria, e basi anguli centralis adscendentia, anatropa, Bacca plurilocularis v. abortu unilocularis, loculis monosperıis. Semina nncamentacea. Embryo exalbuminesus, cotyledonibus carnosis, v. exalbuminosus, cotyledonibus foliaceis. Arbores v. frutices, succo lacteo. Gen. 4234_4246.

CLIX. EABNA CEA E. Calyx liber. Stamina nune corollae lobis numero aequalia et iisdem alterna, nunc dupla v. quadrupla, sterilia nulia. Ovarium liberum, pluriloculare. Ovula in loculis solitaria, ex apice anguli centralis pendula. Fructus baccatus, mono-oligo- spermus. Albumen cartilagineum. Arbores v. frutices, succo aqueo, ligno denso, Gen. 4247 -4251 .

* STYRACEAE. Gen. 4252_4257.

* halestaceae. Gen, 4258.

* SYMPLOCEAE. Gen. 4259-4261.

GENERA DUBIAE AFFINITATIS.

- NAPOLEONEAE. Gen. 4262 -4263.

* columelliaceae. Gen. 4264 -4265.

\section{Classis XXXX. Iieornes.}

Calyx liber v. cum ovario connatus. Corolla annulo hypogyno v. epigyno inserta, gamopetala, regularis. Stamina cum corolla inserta, rarius corollae adnata, ejusdem lobis numero aequalia (rarissime pauciora) et alterna, v. dupla. Antherae simplices v. apice bifidae. Ovarinm monopentamerum, placentis centralibus. Semina indefinita $\mathbf{v}$. rarius definita. Embryo intra albumen rectus.

CRX. FPACIEIDEAE. Corolla hypogyna. Antherae sinplices, receptaculo pollinifero unico, interdum septum completum constituente. Gen. $4266 \_4293$.

T. Styphelieae. Ovula in loculis solitaria, pendula. Fruetus saepissime drupaceus. Gen. 4266 _4280.

II. Epaereae. Ovula in loculis plarima. Fruetus capsularis, polyspermus. Gen. 4281_4293.

CHXI. ERICA CEA E. Corolla bypogynâ v. epigyna. Antherae biloculares, loculis basi v. apice discretis, Gen. 4294-4354.

I. Erieimeae. Corolla hypogyna, Antherae mutirae v, dorso aristatae, Fruetus capsularis, Ioculicide $v$. rarissime septicide dehiscens, rarius bateatns v, drupaceus. _ Folia saepissime acernsa. Gemmae nudae, Gen. $4294-4328$.

1. ERICEAE. Corolla persistens, Gen, $429 \%-4316$.

R. $S A L A X I D E A E$, Ovarium Inculis uniovalatis. Antherae muticae. Gen. 429\%-1308.

r. Coilostigmeae. Stigma cyathiforme, - Brae. teae wullae v. minutissimae. Gen, $4294-4298$.

B. S y mpieze a e. Stigma obtusum. - Braeteae sae. pissine tres. Gen. $4299-4308$.

b. EUEHICE AE. Ovarium loculis pluriovulatis. Gen. $4309-4316$.

2. ANDROMEDEAR. Corolla decidua. Gen, 4317_4328.

11. Vaceinieae. Corolla epigyna, Antherae aristatae $\vee$. rarins muticae. Fructus drupaceus. - Folia plana. Gemmae squamis imbricatae v. rarius nudae. Gen. 4329 _ 4337.

TII. Fhodollendreae. Curolla hypogyna. Antherae muticae. Fructus capsularis, septieide dehiscens. - Fulia plana. Gemmae squamosae, strobiliformes. Gen. 4338_434t.

- DIAPENSIACEAE Gen. 4345-4346.

- PyrolaceaE. Gen. 4347-4349.

- MoNotropeaE. Gen. 4350-4354. 


\section{COHORS IV. DIALYPETALAE.}

Perigonium duplex, exterius foliolis distinctis v. coalitis, liberum, v. cum ovario connatum, calycinum v. interdum coloratum, interius corollinum, elementis distinctis $\mathbf{v}$. rarissime staminum ope basi cohaerentibus, insertione hypogynum, perigynum v. epigynum, interdum abortu nullum.

\section{Classis XK, Diseanthae.}

Calyx gamophyllus, tubo cum ovario v. ejus basi connato, rarius libero. $\mathrm{Co}$ rollae petala disco perigyno, rarius hypogyno inserta, calycis laciniis numero aequalia. Stamina nunc cum petalis inserta, iisdem numero aequalia et alterna $v$. opposita aut dupla. Ovarium bi-quinqueloculare, loculis uni-pluriovulatis. Fructus loculi monospermi. Embryo albuminosus, orthotropus.

CHXII. UNIB EUTHERAR. Calyx cum ovario connatus. Corollae petala 5 , diseo epigyno inserta, unguiculata, aestivatione involuta. Stamina 5 , petalis alterna. Ovarium inferum, biloculare, loculis uniovulatis, ovulis pendulis. Styli 2. Fructus carpidia (mericarpia) 2, maturitate cum calycis tubo a basi stôcedentia, ex apice columellae pendula. Folia simplicia, saepissime dissecta, petioli basi vaginante. Gen. $4355-4549$.

I. Drtlagspenmae. Albumen latere interiore planum, nee convolutum nec involutum. Gen. $4355-4497$.

1. HXDROCOTYLEAE. Fructus a latere contractus. Mericarpia dorso convexa v. rarius acuta, jugis primariis 5, fnterdnm obsoletis, lateralibus margioalibus $v$. commissuralibus, intermediis plerumque validioribns, secundariis fillformibus, subnallis v. penitus obsoletis. Gen. 4355_4367.

2. MULINEAE. Fructus merioarpiis ad suturam valde contractis, quinquejugis, a dorso plano-compressis quadratus v. parallele biseutatus. Gen, 4368-4377.

3. SANICULEAE. Fruetus subteres. Meriearpia jugis primariis 5, aequalibus, secundariis nullis v, obsole. tis. Gen. 4378 -4389.

4. AMMINEAE. Fruetus a latere compressus v. lateribus contractis subdidymus. Mericarpia jugis prima. riis 5 , filiformfbus $v$. alatis, omnibus aequalibas, lateralibus marginantibus. Semen dorso convexum, facie planiusculum v. undique teres. Gen. 4390_4415.

5. SESELINEAE. Fructus teres v. teretiusculas. Mericarpia jugis 5, fillformibus v. alatis, lateralibus mar. ginantibus aequalibus. $v$. nonnunquam latioribus. Semen dorso subtereti-convexum., facie planum. Gen. 4416 -4449.

6. Pachypleureas. Fruetus a dorso lentieulari-compressus, rhaphe marginali v, submarginali. Mericarpia. jugis primariis quiaque, crassis, subaequalibus, la. teralibus marginantibus. Somen dorso convexum, facie planum. Gen, $4 \mathbf{4} 50$-4452.

7. ANGeliceaE. Fructus a dorso compressus, margine dilatato-alato, ob rhaphen centraleu $v$. subcentralem duplieato cinctus. Meriearpia jugis 5 , tribus dorsalibus, v, alatis, duobus lateralibus marginalibus, semper in alam dorsalibus latiorem expansis. Semen dorso convexiasculum, facie planiusculum. Gen. 4453_4457.

8. PEUCEDANEAE. Fructus a dorso plano v. ienticulari compressus, margine integro, dilatato, laevigato, alato, complanato v. convexiuseulo einctus, rhaphe marginali. Mericarpia jugis 5, filiformibus v. rarius alatis, lateralibus marginantibus v, dilatato contiguis, nunc in marginem abeuntibus. Semen complanatum, a dorso convexiusculum. Gen, 4458-4483.

9. SILERINAE. Fructus a dorso lenticulari-compressus. Meriearpia jugis primarlis 5, secundariis 4, minus prominulis. Semen antice planum. Gen. $4484-4487$.

10. CUMinEAE. Fructus a latere contractus. Meriearpia jugis primariis 5 , lateralibus marginantibus, secundariis 4 , magis prominulis, omnibus apteris. Semen rectum, antice planiuscalum. Gen, 4488 - 489.

11. THAPSIEAE. Fruetus a dorso compressus v, seetione transversali subteres. Mericarpia jugis primariis $\mathbf{5}$ filiformibus, interdum setulosis, plano commissurali impositis, secundariis 4 , filiformibus, exteriorlbus marginautibus v, omnibus alatis. Semen subcomplanatum v, subtereti-convexum, facie planum. Gon. 4490 -4494 .

12. DAUCINEAE. Fructus a dorso lenticulari compressus v. sectione transversalt subteres. Meriearpia jugis primariis 5, filiformibus, setulosis, lateralibus plano commissurali impositis, secundaris 4, magis prominulis, aculeatis, aculeis liberis $v$. in alam conatis. Semen complanatum v. subsemitereti.convexum, antice planiusculum. Gen. 4495-4i97.

11. Campylospermae. Albumen marginibus involutis facie interiori sulco v. canali longitudinali notatum. Gen. 4498_4544.

13. ELAEOSELINEAE. Fruetus eylindraceus, a dorso subcompressus. Mericarpia jugis primariis 5 , filiformibus, secundariis 4 , dorsalibus, nerviformibus, la. teralibus in alam expansis, margiuibus nervi. v. jugiformibus. Semen iuvolutum semilunare. Gen. 4498 -4499 .

14. CAUCALINEAE. Fruetus a latere contractus v. sub. teres. Mericarpia jugis primariis 5 , setosis v. aculea. tis, lateralibus plano comnissurali impositis, secun. dariis 5, magis prominulis, aculeatis, v. aculeorum copia totam valleculam obtegente obliteratis. Semen involutum v. margine inflexum. Gen, 4500-4503.

15. SCANDICINEAE. Fructus a latere compressus v. contractus, saepius rostratus. Meriearpia jugis primarils 5, filiformibus, interdum alatis, lateralibus marginantibus, omnibus aequalibus, nonvnaquam basi obliteratis ot solo apice manifestis. Semen tereti-convexum, facie interiori sulco profundo percursum, v. margive subiavolutum. Gen, $450 \%-4517$.

16. SMYRNIEAE. Fruetus targidus, saepius a Iatere compressus v. contractus. Mericarpia jugis primarils 5 , lateralibus marginantibns $\mathbf{v}$. ante marginem sitis, $\mathbf{i n}$. terdum subobliteratis. Semen involutum $v_{-}$intus sul. eatua, semiluoare v. complicatum. Gen. 4518_45t4.

IIII. Coelos permae. Semen a basi ad apicem involuto-curvatum. Gen. 4545 _ 4549 .

17. CORIANDREAE. Fructus globosus, v. mericarpiis subglobosis didymus. Meriearpia jngis primarils 5, depressis, flexuosis et suleum obsoletum formantibus, lateralilus aute marginem accessorium sitis, secundariis nullis v, saepius quatuor, magis prominulis, omnibus apteris. Gen, 4545 - 4549 .

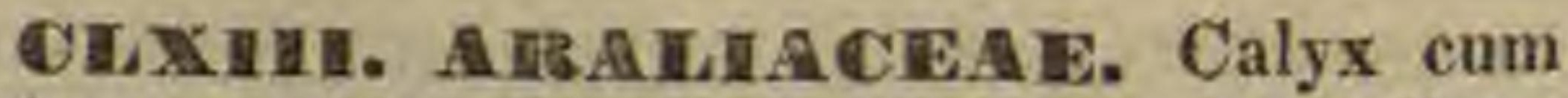
ovario connatus. Corollae petala 5 v. 10 , disco epigyno inserta, lata basi sessilia, aestivatione valvata. Stamina cum petalis inserta, iisdem 
numero aequalia et alterna, rarius dupla. Ovarium inferum, bi-multiloculare, loculis uniovulatis, ovulis pendulis. Styli loculorum numero, distincti v. coaliti. Fructus baccatus v. exsuccus. Folia simplicia, integra v. palmatim aut pinnatim composita. Gen. $4550-4565$.

CHXIV. AMPERIDEAE. Calyx liber. Corollae petala 4 v. 5 , disci perigyni margini inserta, aestivatione valvata. Stamina 5, cum petalis inserta, iisdem opposita. Ovarium liberum, bi-tri-sexloculare. Ovula in loculis solitaria, v. gemina collateralia, adscendentia v. erecta. Baeca bi-sexlocularis, loculis mono-dispermis. Folia simplicia, palmata, imparipinnata v. rarius bipinnata. Gen. $4566-4569$.

I. Viteae. Petala et stamina libera. Ovarium biloculare, loculis biovulatis. - Cirrhi oppositifolii. Gen. 4566-4568.

II. Leeaceae. Petala basi cohaerentia. Stamina monadelpha. Ovarin in tri-sexloculare, loculis uniovulatis. Gen. 4569.

Genera d u bia, $4570-4572$.

CHXv. COR IEAE. Calyx cum ovario connatus. Corollae petala 4 , disco epigyno inserta, aestivatione valvata. Stamina 4 , petalis alterna. Ovarium inferum, bi-triloculare, loculis uniovulatis, ovulis pendulis. Stylus simplex. Fructus drupaceus, bi-trilocularis. Folia simplicia, integra. Stipulae nullae. Gen. 4573 -4574 .

GENERA CORNEIS AFFINIA. 3575-4576.

GENERA DUBIA. $4577-4580$.

CHXVT. TORANTHACEAE. Calyx cum ovario connatus. Corolla nulla v. petala $4,6,8 \cdot v$. rarissime 3 , disco epigyno inserta, libera v. varie coalita, aestivatione valvata. Stamina calycis v. corollae partibus numero aequalia, iisdem opposita et inserta. Ovarium inferum, uniloculare, ovulo unico v. interdum pluribus, ex apice loculis pendulis. Stylus simplex. Bacca monosperma. - Frutices saepissime parasitici, foliis simplicibus, integris. Stipulae nullae. Gen. $4581-4587$.

CHXVIT. HAMAMELIDEAE. Calyx tubo củm ovario connato, limbo supero vo semisupero, quadri-quinquefido. Corolla nulla v. petala calyci inserta, ejusdem laciniis alterna, basi valvata, apice saepe singillatim spiralia. Stamina in apetalis indefinita, in corollatis petalis opposita sterilia, cum totidem fertilibus alternantia. Ovarium semiinferum, biloculare, loculis uni-multiovulatis, ovulis pendulis. Styli 2. Capsula semisupera, bilocularis, septicide bivalvis, loculis monospermis. Folia afterna, bistipulata. Gen. $4588-4595$.

1. Ir amameleae. Ovarii loculi nniovulati. Gen. 4588-4593.

a. EUHAMAMELEAE. Flores corolla donati. Gen. 4588 $-4591$. b. FOTHERGILLEAE, Flores apetali, Gen, 4592 -4593.

2. IBveklandieae. Ovarii loculi pluriovulati, ovulis superioribns difformibus. Gen. 4594 - 4595 .

CLXVIII. IB HEUNACEA C. Calyx gamophyllus, liber v. eum ovario connatus. Corollae petala 5 v. 4 , calycis fauci inserta, aestivatione imbricata. Stamina eum petalis inserta, isdem alterna, Ovarium uni-bi-triloculare. Ovula in Joculis solitaria, v. gemina collateralia, pendula. Fructus capsularis, septicide dehiscens v. nucamentaceus. - Folia acerosa, estipulata. Gen, $4596-4604$.

GENERA DUBIA, $4605-4606$.

\section{Classis XII. Cornicullatae.}

Calyx gamophyllus, liber v. cum ovario plus minus connatus. Corollae petala perigyna, interdum basi coalita, quandoque nulla. Stamina cum petalis inserta, iisdem numero dupla $v$. aequalia et alterna. Ovaria plura, libera v. coalita, pluriovulata v. rarius uniovulata. Embryo albuminosus, orthotropus.

CHXex. Crassula cean. Calyx liber. Corollae petala imo calyci inserta, ejusdem laciniis numero aequalia, libera $\mathbf{v}$. interdum inferne in tubum coalita. Stamina simplici v. duplici petalorum numero. Ovaria tot quot petala, libera v. in axi coalita, basi extus squamula aucta, ovulis plurimis v. rarius subdefinitis. Capsulae folliculares. - Plus minus carnosae, foliis simplicibus, rarius ternatis v. imparipinnatis. Stipulae nullae. Gen, 4607 4625.

1. Crassuleae. Capsulae liberae, argulo interiore dehiscentes, Gen, 4607_4623.

1. CRASSULEAB ISOSTEMONBS, Stawina petalis nuaero aequaliát. Gen, 4607-4615.

a. Eucrassulea e. Petala plane libera, Gen, 4607 -4611 .

b. R a c h e a e. Petala plus minus inter se coalita. Gen. $4612-4615$.

2. CRassuleae Diplostemones. Stamina duplo petalorum numero. Gen. 4616_4623.

a. Um b ili c a e. Corolla gamopetala. Gen. 4616_4621.

b. S edea e. Petala omaia libera. Gén. 4622_ 4623 .

2. Diamorplaeae. Carpidia bayi v. juxta totam longitudinem in capsulam plurilocularem coalita. Gen, 4624_4625.

- fRANCoACEAE. Gen. 4626-4627.

* cephaloteas. Gen. 4628.

CIXX. SAXTERA ACAEE. CalyX liber v. cum ovario connatus. Corollae petala calycis fanci inserta, ejusdem laciniis numero aequalia. Stamina petalis numero aequalia et alterna, rarius dupla, rarissime indefinita. Ovaria 2 , rarius 3 v. 5 , distincta $v$, coalita, ovu- 
lis plurimis, rarius solitariis. Fructus capsularis v. rarissime nucamentaceus. - Folia simplicia, ternata v. imparipinnata. Stipulae nullae, v. interpetiolares, deciduae. Gen. 4629 -4678 .

I. Saxifrageae. Herbae foliis alternis v. oppositis, exstipulatis v. petioloram basi dilatata stipuliformi. Flores racemosi, panicnlati v, rarius solitarii. Gen. $4629-4646$.

II. Cumonieae. Frutices vilarbores, foliis oppositis, simplicibas v. compositis, stipulis interpetiolaribus. Calyx liber v. plus minns adhaerens. Corollae petala 4,5 , nunc nulla. Ovarium bi-quadriloculare. Gen. 4647 -4667.

III. Hydrangeae. Frntices foliis oppositis, simplieibus, exstipulatis. Ovarium inferum, rarius liberum. Fruetus capsularis aut rarissime baccatus. Gen. 4668 -4673.

IV. Eseallonieae. Frutices v. arbores, foliis alternis, exstipulatis, simplicibus. Ovarium inferum v. liberum. Styli $2-5$, in unum connati. Gen. $4674-4678$.

- argophylleae. Gen. 4679.

* ROUSSeacear, Gen. 4680.

* BREXIACEAE. Gen. 4681.

CLXXI. IRIBESIACEAE. Calyx coloratus, tubo cum ovario connato, plus minus supra ovarium producto. Corollae petala calycis fauci inserta, ejusdem laciniis numero aequalia. Stamina petalis numero aequalia et alterna. Ovarium inferum, uniloculare, placentis parietalibus nerviformibus, semiseptis adnatis, multiovulatis. Bacca puiposa. Semina in rhaphe libera reclinata. Gen. $4682 \rightarrow 4683$.

\section{Classis XIII. Polyearpieae.}

Calyx liber, deciduus. Corollae petala hypogyna, libera. Stamina indefinita, rarissime monadelpha. Ovaria plura, verticillata v. spicata, libera v. interdum coalita, rarissime solitaria. Fructus capsularis v. baccatus, rarissime drupaceus. Embryo in basi albuminis copiosi minimus, rarius albumen parcum aequans, rarissime exalbuminosus.

CHXXIY. MENISPERTICEA W. Flores saepissime unisexuales. Stamina definita, Iibera v. coalita. Ovaria plura, libera, unilocularia, uni-pluriovulata. Fructus baccati v. drupacei, lunulati, monospermi, Gen. $4684-4705$.

I. Menispermeae. O varia uniovulata. Embryo intra albumen parenm majnseulus, rarius exalbuminosus. - Folia simplicia. Gen. $4684-4696$.

- PhytocrentaAk. Gen, 4697 -4698.

11. Eardizabaleae. Ovaria pluriovulata. Embryo intra albumen copiost m minimus. Folia composita, Gen, 4699-4705.12

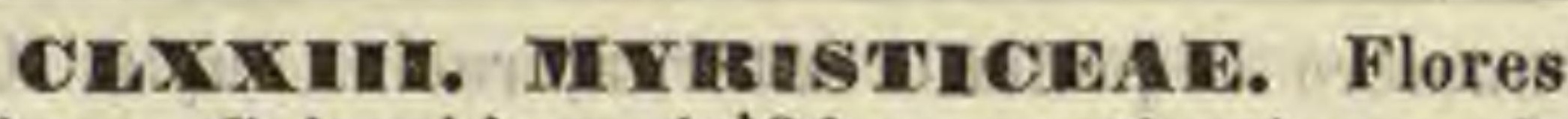
dielines. Calyx bi-quadrifidus, aestivatione valvatus. Corolla nulla. Stamina monadelpha. Ovarium unicum, liberum, uniloculare, ovulo unico v. rarius duobus, e basi erectis. Bacca capsularis, bivalvis. Semen nucamentaceum, erectum, arillo carnoso, multifide lacero. Embryo in basi albuminis ruminati minimus. Gen. 4706 -4708 .

CEXXIY. ANONACWAE. Flores hermaphroditi. Calyx triphyllus. Corollae petala 6, libera. Stamina saepissime indefinita. Ovaria plurima, ovulo unico erecto, v. pluribus adscendentibus. Fructus capsularis v. baccatus. Semina erecta v. horizontalia, arillo nullo. Embryo in basi albuminis ruminati minimus. Gen. $4709-4729$.

a. Eocagea e. Stamina definita. Ovula pauca, suturae ventrali inserta. $G e n, 4709-4712$.

b. Xylopieae. Stamina indefinita. Ovula panca v. plurima, suturae ventrali inserta. Gen. 4713_4718.

c. Anoneae. Stamina indefinita. Ovula in loculis solitaria v. gemina collateralia, e basi erecta. Gen. 4719 -4724.

* eupomatieaz. Gen, 4730.

GENERA DUBIA. $4725 \rightarrow 4729$.

CHXXV. SCUIVANDIRACEAE. Flores diclines. Calyx tri-hexaphyllus. Corollae petala $6 \rightarrow 9$, libera. Stamina indefinita, libera v. antheris inter se cohaerentia. Ovaria plurima, uniloeularia, ovulis geminis, superpositis, pendulis. Fructus baccatus. Embryo in basi albuminis carnosi, aequabilis minimus. - Frutices sarmentosi, foliis integerrimis v, denticulatis, exstipulatis. Gen. $4731-4734$.

CHXXVI. THA GNOHACEAE. Flores hermaphroditi. Calyx tri- rarius di-tetra-hexaphyllus. Corollae petala 6 v. plurima, libera. Ovaria plurima, unilocularia, ovulis geminis collateralibus v. superpositis, v. plurimis, pendulis. Capsulae dehiscentes v. indehiscentes, coalitae, mono-pleiospermae. Semina arillo carnoso, saepissime colorato, funieulo extensili. Embryo in basi albuminis aequabilis minimus. - Folia integerrima, stipulata, Gen, $4735-4745$.

I. Magmollene. Ovaria secus torum spicata. - Folia epunctata v. obsolete pellucide punctata. Stipulae decî́duae. Gen. 4785 - 4740 .

II. Hulcieae. Ovaria simplici serice verticillata. - Folia pellucide punctata. Stipulae caducae v. nullae. Gen: $4741-4745$.

CLXXVII. DILELNIA CEA IE. Flores saepissime hermaphroditi, symmetrici v. staminibus unilateralibus asymmetrici. Calyx liber, pentaphyllus. Corollae petala 5, libera. Stamina indefinita. Ovaria plura, libera, unilocularia, ovulo unico erecto, v. pluribus adscendentibus. Capsulae folliculares v, baccalae, monodi-polyspermae. Semina saepissime arillata. 
Embryo in basi albuminis minimus. Gen. 4746 $-4767$.

1. Dilleneae. Antherarum connectivam aequale $x$. apice angustatum, loculi lineares. Gen. $4746-4758$.

2. Delimeae. Antherarum connectivum apice dilatatum, loculi subrotundi. Gen. 4759 $-4767$.

CHXXVIII. RANUNCULACEAE. Calyx liber, tri-penta-hexaphyllus, interdum coloratus. Petala nune nulla, nunc ealycis foliolis numero aequalia, dupla v. multipla, forma varia, plana v. varie effigurata. Stamina indefinita. Ovaria pauea v. plurima, libera, unilocularia, uni-pluriovulata. Achenia monosperma, v. capsulae folliculares, pleiospermae. Semina erecta, horizontalia v. inversa. Embryo in basi albuminis cornei minimus. Gen. 4768 -4804 .

1. Clematideae. Calyx coloratus, aestivatione valvatus v. induplicatus. Corolla nulla v, petala calyce breviora, plana. Achenia stylis barbato-plumosis caudata. Semen inversum. Gen. 4768-4770.

7. Anemoneae. Calyx saepissime coloratus, aestivationé imbricatus. Corolla nulla v petala plana, rarissime ungue tnbnloso. Achenia saepe stylis barbatis caudata. Semen inversum. Gen, 4771 4781.

3. Famumeuleae. Calyx aestivatione imbricatus. Córollae petala ungue tubuloso, bilabiata, labio interiore squamaeformi v. nullo. Achenia sicca. Semen erectum. Gen. 47824785.

4. Welleboreae. Calyx corollinus, aestivatione imbricatus. Corolla nulla v. petala irregularia, saepins bilabiata Capsulae folliculares, polyspermae, liberae v. basi coalitae, sutura ventrali dehiscentes, Gen, 4786-4797.

5. Paeonieae. Calyx corollinus v. foliaceus, aestivatione imbricatus. Corolla nulla v. planipetala, rarissime petalis basi nectariferis, Ovaria multiovulata, rarius nniovulata. Capsulae dehiscentes v. baceatae, abortu saepe monospermae, Gen, 3798-4804.

CLXXIX. IBEIER EIBIDEAT. Calyx tri-tetra-enneaphyllus, foliolis uni-triseriatis. Corollae petala basi biglandulosa v. ungue poro instructa. Stamina petalis numero aequalia et opposita, rarius dupla. Antherae extrorsae, biloculares, valvulis a basi revolutis v. rimis longitudinalibus dehiscentes. Ovarium unicum, uniloculare, ovulis juxta placentam parietalem indefinitis, v. ebasi erectis definitis. Bacea $\mathbf{v}$. capsula evalvis, v. operculo dimidiato aperta, v. siliquaeformis bivalvis, valvula altera medio seminifera. Embryo in axi albuminis carnosi. Gen. $4805-4815$.

\section{Classis XuIn. Rhoendeae.}

Calyx liber, deciduus. Corollae petala libera, hypogyna, aequalia v. interdum asymmetrica, rarissime nulla. Stamina hypogyna, indefinita $\mathbf{v}$. definita, libera $\mathbf{v}$. rarissime diadelpha. Ovarium unicum, e carpidîs duobus v. pluribus conflatum, uni-biloculare. Ovula solitaria v. plurima. Fructus capsularis, siliquosus, nucamentaceus v. baccatus. Embryo in basi albuminis minimus, v. exalbuminosus, curvatus.

CHXXX. PAPAvereaceAv. Calyx di- rarissime triphyllus. Petala calycis foliolis dupla v. quadrupla. Stamina indefinita, libera, v. sex diadelpha. Ovarium sessile, uniloculare, placentis intervalvularibus. Capsula v. bacca. Semina albuminosa. Gen. $4816-4844$.

I. Papavereace. Stamina libera. Petala regularia, rarius nulla. Succus lacteus, rarins aqueus, Gen. 4816 - 4832 .

a. ARGEMONEAR. Súceus saepissime eroceus. Gen. 4816 $-4826$.

c. Boecioniea e, Petala nulla v, aestivatione baud corrugata. Gen. 4816_4818.

B. Papavereac vera e. Petala aestivatione corrugato-plicata, Gen, $4819=4826$.

b. HUNNEMANIEAE. Suceus aqueus. Capsula bivalvis, valvis margine seminiferis. Gen. 4827-4829.

c. Platystrmonear. Succus aquens. Capsula trizal. vis, valvis margine seminiferis, v. capsulae plures, liberae, in articulos mónosperzios secedentes. Gen. $4830-4832$.

II. Fumariaceae. Stamina libera $\mathbf{v}$, in phalanges connata. Petala disparia. - Succus aqueus. Gen. 4833 _4844.

d. HYPECOEAE. Stamina libera, Gen. 4833_4834.

e. PUMARIBAR. Stamina in phalanges duas connata. Gen. 4835 -4844.

$\alpha$. Dicentreae. Carollae petalum antieum et posti. cum conformia, basi saccata v. calcarata. Gen. 4835 -4837 .

B. Corydaljdeac. Corollae petalum posticum basi saecatum v. calearatum, anticum planum. Gon, 4838 -4844 .

CHXXXI. CEUCIFERAE. Calyx tetraphyllus. Corollae petala 4. Stamina 6, tetradynama. Ovarium sessile, biloculare v. rarissime uniloculare, placentis intervalvularibus duabus. Fruetus siliquosus, siliculosus, nucamentaceus v. lomentaceus. Semina exalbuminosa. Embryo curvatus, Gen. $4845-4982$.

1. Plenrorlhizeac. Cotyledones planae, radiculae rimali acenmbentes. $(\mathrm{O}=$ Gen, 4845 -4901 .

1. ARABIDEAE. Siliqua elongata v. rarins abbreviata, teres v. compressa, bivalvis v, interdum evalvis, val. vis planis, subcauvexis aut carinatis. Semina plurima, uni.biseriata. Cotyledones septo parallelae, warginibus placentas spectantes, radicula nuscéndente placentam oppositain spectante. Gen. 4845 _ 4862.

2. ALXSSINEAE. Silieula bivalvis v. rarius iadebiscens, septo fatd, valvis septo parallelis, planis $v$, coneavis. Catyledones septo parallelap of rarissime contractae. Gen. 4863 - 4883 .

- SelenieaE. Gen. 4884.

3. THLASPIDEAE. S ilicala bivalvis, septo contrarie compressa, valyis aavicularibus. Cotyledones septo 
contrariae, radicula ascendente $\checkmark$. iaterduin desceudente - septum v. valvarum carinam spectante. Gen, 4885 I4891.

* cRemolobeaE. Gen. 4892 _ 4893.

4. ANASTATICEAE. Silicula oblonga v. ovalis, valvis longitudinaliter dehiscentibus, intus in septula loenlos monospermos constituentia productis. Semina pauca, compressa. Cotyledones planae, accuabeates. Gen, 4894 -4895 .

5. EUCLIDIEAE. Silicula indehiscens, valvis concavis, Indistinctis $v$, pertinaciter connatis, septo elliptico, interdum evanido. Catyledones septo dum adest paral lelae. Gen. 4896_4898.

6. CAKILINEAE. Siliqua v. silicula trausverse in articulos uui-biloculares, nono-dispermos secedens. Cutyledones septo dum adest parallelae. Gen. 4899-4901.

II. Notor lineace. Cotyledones planae, radidiculae exacte dorsali incumbentes. (OII) Gen. $4902-4947$.

7. SISXMBRIEAE. Silíqua elorgata v. rarissime abbre. viata, bilocularis $\mathbf{v}$. rarissime nuilocularis, bivalvis, rarissime indehiscens, valvis planiusculis, concavis v. cariaatis. Semiaa plurima, oni-biseriata. Cotyledo. nes septo parallelae. Radicula adscendens, placentam op positam spectains. Gen. 4902-4917.

8. CAMELINEAE. Silicula ovata v. oblonga, dissepimento parallele compressa $\vee$. turgida, bilocularis, bivalvis, valvis planis v. convexis. Semina plurima, bise. riata. Cotyledones septo contrariae. Radicula adscendens, placentae oppositae parallela. Gen. 4918-4926.

9. LEPIDINEAE. Silieula septo angustissimo, valvis carinatis v. valde concavis. Semina in loculis solítaria v. pauca. Cotyledones septo parallelae. Gen, 4927 - 4935.

10. ISATIDEAE. Silicula indehiscens, abortu monosperma v. rarissime disperma. Semina pendula $\%$. rarissime horizontalia. Gen. 4936_4943.

11. ANCHONIEAE. Silieula indehiscens, transversim in articulos clausos, saepissime monospermos secedens. Gen, $4944-4947$.

III. Drthoploceae. Cotyledones ineumbentes, longitudinaliter plicátae, radienlaim dorsalem in plicatura foventes. $(\mathrm{P} \gg)$ Gen. 4948 _ 4972 .

12. BRASSICEAE. Slliqua elongata, téretiuscula, bivalvis, septo lineari, valvis plerumqiue concavis. Semina plurima, unl-biseriata. Gen. 4948-4956.

13. VELLEAR. S S i e u ta bivalvis, septo lato, elliptico, valvis concavts. Semina in loculís 2 v. 1 , rarissime plurima, subglobosa. Gen. 4957-4961.

14. PSXCHINEAE. Silicula bivalvis, a Tatere compressa, septo angustissimo, valvis carinatis $v$. navicularibus, aut in alam dorsalem expansis. Semina plurima, com. pressa. Gen. $4962 \_4963$.

15. ZILLEAE. Silicula indehiscens, subglobosa, uni-biloeularis, valvis indistiaetis. Semina in loculis solitaria, globosa. Gen, 4964 -4966.

16. RAPHANEAE. Silicula v, siliqua articulata sive lomentacea, rarius subeontinua, plernique in artieulos mono-polyspermos, clausos secedens. Semina saepissime globosa. Gen. 4967 _ 4972 .

IV. Spirolobeae. Cotyledones lineares, incumbentes, circinnatim convolutae. Gen.4979 4974.

17. BUNIADEAE. Silicula nucamentacea, indebiscens, bilocularis, loculis septo transverso bipartitis, locellis monospermis. Cotyledones circinuatae. Gen. 4973.

18. ERUCARIBAE. Siliqua Iomentaceo-articulata, artículo inferiore bi-superiore uniloeulari, ensiformi. Cotyledones replicatae, subeircinnatae. Gen. 4974.

V. Diplecolobeae. Cotyledones lineares, incumbentes, bis transversim plicatae. Gen. $4975-4982$.

19. SENEBIEREAE. Silicula didyma, Valvis ventricosis clausis, loculis monospermis. Gen. 4975_4976.
20. SUBULARIEAB. Silieula ovalis, bivalvis, septo elliptico, valvis convexis, Ioculis polyspermis. Gen, 4977.

21. HELIOPHILEAE. Siliqua elongata, oblonga v. ovalis, bivalvis, septo líneari v. ovali, valvis planis v, compressiusculis, loculis polyspermis. Gen, $4978-4979$.

* SchizopetaleaE. Gen. 4980.

Ge nè r all u bi a, Gen, $4981-4982$.

CUXXXII. CAPPARIDEAE. Calycis foliola 4 libera, v. plus minus inter se coalita. Corollae petala 4 , rarius 8 , saepius nulla. Stamina 6,8 v. plurima. Ovarium saepissime stipitatum, uniloculare, placentis intervalvularibus duabus v. pluribus. Fructus capsularis siliquaeformis, v, baccatus. Semina exalbuminosa. Embryo arcuatus v. conduplicatus. Gen. $4983-5006$.

I. Cleomeae. Fructus capsularis. Gen. 4983 -4990 .

II. Cappareae. Fructus baccatus, Gen. 4991 -5006 .

Genera dubia. $5007-5008$.

Genera Capparideis affiaia. 5009.

CLXXXIII. IRESE DACEAE. Calyx quadri-septempartitus, Corollae petala $4-7$, rarissime 2, v. nulla, tri-multifida. Stamina $3-40$, disco carnoso, postice producto intus inserta, Ovarium sessile v. stipitatum, uniloculare, apice apertum, placentis intervalvularibus 3-6. Capsula polysperma. Semina exalbuminosa. Embryo hippocrepicus, Gen. 5010 $-5014$

CIXXXIV. DATESCEAE. Flores saepissime unisexuales, apetali. Calyx cum ovario connatus, Ovarium uniloculare, vertice saepius hians, placentis in nervo medio foliorum carpicorum sitis. Capsula polysperma. Embryo in axi albuminis carnosi orthotropus. Gen. 5015 $-5016$

\section{classis xurv. Nelumbia.}

Calyx liber v. mediante toro cum ovario cohaerens. Corollae petala plura, hypogyna, v. toro ovaria includenti diversa altitudine inserta, Stamina plurima, rarissime definita, cum petalis inserta. Ovaria plura, distincta v. coalita. Fructus baccatus v. nucamentaceus. Semina albuminosa v. exalbuminosa. - Herbae aquaticae.

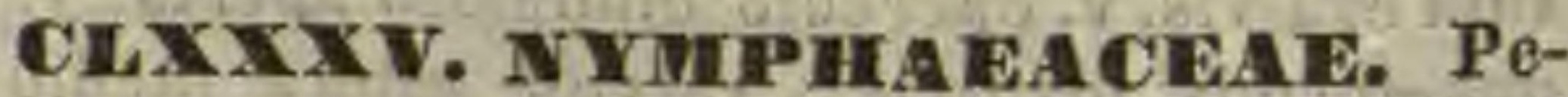
tala toro ovaria includenti, ovariis v, simul etiam calyci adnato inserta. Ovaria plura, verticillatim inter se et cum toro in ovarium multiloculare, multiovulatum, coalita. Semina plurima. Embryo intra sacculum nuclei inclusus, albuminis cavitati superficiali immersus. Gen. 5017 -5022 . 
1. Wuryalene. Calyx tubo cum ovario connato. Corvilae petala libera. Gen.5018_5019.

2. Nuplazarînae. Calyx liber. Corollae petala lisera, Gen. 5020-5021.

3. IBarelayeae. Calyx liber. Corolla gamopetala. Gen 5022.

* Sarraceniaceae. Gen. 5023.

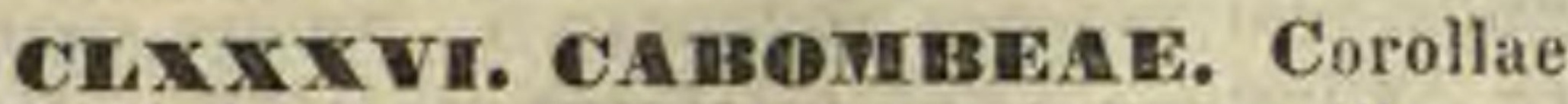
petala hypogyna. Ovaria 2 v. plurima, libera, unilocularia, ovulis $2-3$ juxta suturam ventralem superpositis. Embryo intra sacculum nuclei inclusus, albuminis cavitati superficiali immersus, Gen, 5024-5025.

CLXXXUIL. NEEUMBONEAE. Corollae petala ad basim tori truncati inserta. Ovaria plurima, tori foveolis singillatim immersa, unilocularia, ovulo unico v. duobus in funiculo e basi loculi adscendente pendulis. Embryo exalbuminosus. Gen. 5026 .

\section{Classis XIV. I arietales.}

Calyx liber v. cum ovario connatus. Corollae petala hypogyna v. perigyna, interdum nulla. Stamina definita v, indefinita. Ovarium saepissime uniloculare, placentis parietalibus, saepissime multiovulatis. Fructus nunc superus, capsularis v. baccatus, valvis medio seminiferis, nunc inferus, placentis cum valvis alternantibus. Embryo in axi albuminis rectus, rarius subexcentricus, arcuatus v. spiralis.

CHXXX vill. Cistimeae. Corolla regularis hypogyna. Stamina indefinita. Ovarium liberum, placentis parietalibus 3 _5. Stylus simplex. Capsula valvis medio seminiferis. Embryo antitropus. Gen. 5027-5032.

CHXXXIX. DIROSEIEACEAE. Corolla regularis hypogyna. Stamina petalis numero aequalia v. dupla, rarius tripla v. quadrupla. Ovarium liberum, placentis parietalibus $3-10$. Stylus divisus. Capsula valvis medio seminiferis. Embryo orthotropus. Gen. 5033 -5038 .

\section{- parnassieae. Gen. 5039.}

CXC. vionarenate. Corolla irregularis v. rarius regularis, hypogyna. Stamina petalis numero aequalia. Ovarium liberum, placentis parietalibus tribus. Stylus simplex. Capsula trivalvis, valvis medio seminiferis. Embryo orthotropus. Gen. 5040_5049.

1. Violeae. Flores irregulares, petalo postico dissimili, rarins petalis longe unguienlatis subregularis. Gen. 5040-5046.

2. Alsodineae. Flores regulares, petalis brevissime unguiculatis, basi oblique imbricatis, apice patentibus. Gen. 5047_5049.
CXCI. SAUVACESIRA E. Calyx quinquepartitus v. pentaphyllus. Corolla regularis, hypogyna. Stamina petalis plura, extima sterilia. Ovarium liberum, placentis parietalibus, v. juxta dissepimenti incompleti marginem stperiorem. Stylus simplex. Capsula trivalvis, valvis margine seminiferis. Embryo orthotropus. Gen. 5050_5052.

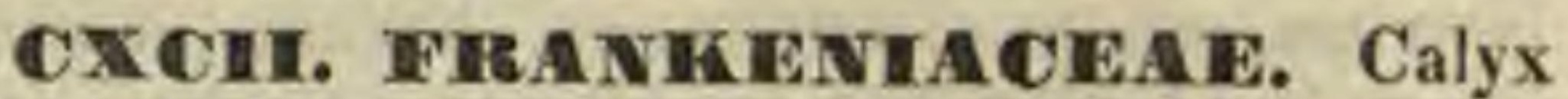
longe tubulosus, quadri-quinquefidus. Corollae regularis petala bypogyna, longe ungniculata. Stamiua saepissime 6. Ovarium liberum, placentis parietalibus $3 \mathbf{v}$. 4. Stylus stigmatibus 3 v. 4 distinctis. Capsula tri-quadrivalvis, valvis medio inferne seminiferis. Embryo orthothropus. Gen. 5053.

\section{* Folquieracear 5054 5055 .}

CXCAII. TURNERA CER E. Calyx breviter tubulosus. Corollae petala 5, perigyna, Stamina 5, subhypogyna. Ovarium liberum, placentis parietalibus 3 . Styli 3. Capsula trivalvis, valvis medio seminiferis. Semina strophiolata. Embryo orthotropus. Gen. 50565058.

CXCIV. SAMTIDEAT. Calyx tubulosus, quadri-quinquefidus. Corolla nulla. Stamina perigyna, calycis laciniis numero dupla, Iripla v. quadrupla, basi monadelpha, omnia fertilia v. alterna sterilia. Ovarium liberum, placentis parietalibus 3 v. 5 . Stylus simplex v. trifidus. Capsula tri-quinquevalvis, valvis medio seminiferis. Embryo in apice albuminis minimus, orthotropus. Gen. 5059-5060.

CXCV. IBIXACEAE. Calyx partitus v. foliolis distinctis. Corolla hypogyna v. nulla. Stamina indefinita, hypogyna v. subperigyna. Ovarium liberum, placentis parietalibus dnabus v. pluribus. Stylus simplex v. ad basim partitus. Bacea, v. capsula valvis medio seminiferis. Embryo orthotropus. Gen. $5061-5084$.

1. Biximeae. Stylus simplex. Fructus dehiscens. Gen. 5061-5065.

2. TProelkieae. Stylus simplex. Fructus indehiscens. Gen. 5066-5078.

3. Flacourtianeae. Stylus multiplex. Fructus indehiscens. Gen. 5079-5081.

4. Tigellarieae. Stylus multiplex. Fructus dehiscens. Gen. 5082-5084.

* PANGIACEAE 5085.

CXCVI. HIOMALInear. Perigonium liberum v. basi cum ovario connatum, laciniis interioribus petaloideis. Stamina calycis fauci inserta, ante limbi laciuias interiores plura, ante exteriores pauciora v. nulla. Ovarium plus minus adnatum, placentis parietalibus, versus basim deliquescentibus. Bacca v. capsula valvis medio seminiferis. Embryo orthotropus. Gen. $5086-5092$. 
CXCUI II. HASETLOHEAE. Perigonium liberum, corollinum. Stamina perigonii fauci v. basi inserta, nunc hypogyna, cum ovarii stipite coalita. Ovarium stipitatum, placentis parietalibus tribus v. quinque. Styli 3 v. 5 apicales. Bacea, v, capsula valvis medio seminiferis. Embryo orthotropus. Gen. 5093-5107.

1. Paropsieae. Flores hermaphroditi. Ovarinm sessile v. stipitatum. Fructus capsulariș. - Caules non scandentes, ecirrhosi. Gen. $5098-5095$.

2. Passiflorene verae. Flores hermaphroditi. Ovarinm stipitatum. Fructus baccatus v. rarios capsularis. - Caulis scandens, pedicellis axillaribus cirrhosis. Gen. 5036 5102.

3. Modlecene. Flores unisexuales. Ovarinm stipitatum. Fructus eapsularis. - Caulis scandens, pedicellis cirrhosis. Gen. 5103_5107.

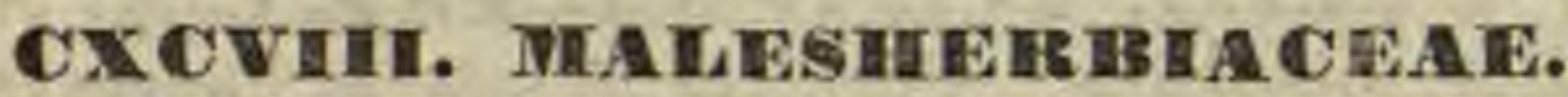
Calyx tubulosus v. campanulatus, corona faucis membranacea. Corollae petala 5, calycis fauci inserta. Stamina 5, hypogyna, cum ovarii stipite coalita. Ovarium stipitatum, placentis parietalibus 3. Styli 3, dorsales. Capsula trivalvis, valvis medio seminiferis. Embryo orthotropus. Gen. $5108 \ldots 5109$.

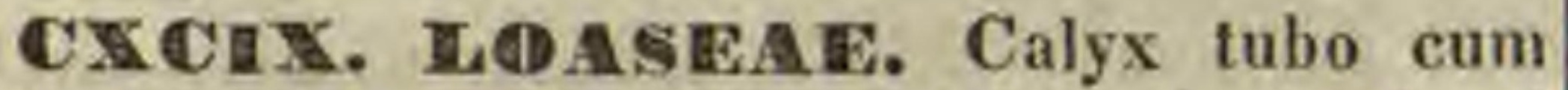
ovario connato. Corollae petala calycis fauci inserta, ejusdem laciniis saepe dupla, saepissime fornicato-concava. Stamina definite plura, exteriora plerumque in phalanges coalita, interiora sterilia. Capsula infera, (rarissine baccata) placentis intervalvularibus. Gen. 5110 $-5118$.

CC. IAPATACEAE. Flores diclines. Masc. Calyx quinquedentatus. Corolla gamopetala, quinquepartita. Stamina 10, corollae fauci inserta. Fem. Calyx liber. Corolla hypogyna, pentapetala. Ovarium liberum, placentis parietalibus 5. Stylus simplex. Stigma radiato-quinquelobum. Bacca pulposa. Gen. 5119_5120.

\section{Classis Xavi. Peponiferae.}

Flores saepissime unisexuales. Calyx et corolla pentamera, saepissime gamopetala. Stamina 5 v. pauciora, libera $v$. coalita, rarissime plura. Ovarium inferum, uni-pluriloculare, uni-multiovulatum. Bacca v. capsula. Semina exalbuminosa v. albuminosa.

CCI. MHA NDIREISERAE. Stamina 5 v. 10 , alterna tunc sterilia. Ovarium inferun v. semiinferum. Styli 3 distincti. Bacca trilocularis, loculis ob columnam crassam parieti admotis, oligospermis, seminibus e basi erectis.
Enbryonis exalbuminosi cotyledones crassae, carnosae. Cirrhi axillares. Gen. 5121_5122.

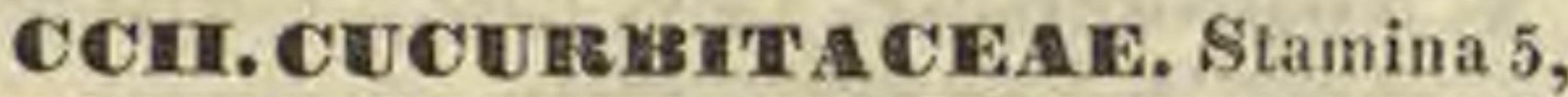
nunc $3 \mathrm{v} .4$, libera, monadelpha v. per paria coalita. Ovarium inferum, uni-multiloculare, uni-multiovulatum. Bacea. Embryonis exalbuminosi cotyledones foliaceae v. rarius carnosae. Cirrhi e stipula laterali abortiva. Gen, $5123+5151$.

1. Telfairieae. Carpidiorum margines seminiferi intra locnlnm porrecti, parietem hand attingentes. Semina plurima, nucamentacea, cotyledonibus carnosis. Gen. 5123.

2. Cucun Ibiteace. Carpidiorum margines revoluti, parietem attingentes. Semina plurima. Cotyledones foliaceae. Gen. 5124-5145.

a. Con ia udreae. Stamina 5, exserta. Antherae unilocnlares, loculo lineari, recto, antice adnato. Qen. $5124-5125$.

b. Me lothrieae. Stamlna 2-5. Antherae biloculares, localis connectivun integrum marginantibus, rectis v. isflexis. Gen. 5126_5129.

e. Bryonieae. Stamina 5, saepissime triadelpha. An. therae uniloculares, loculo lineari, connectivum lobatum gyrose margiaante. Gen, 5130_5136.

d. Cu cumeri aeae. Stamina 5, saepissime triadelpha. Autherae plus uiaus connatae, loculis linearibus, extus adnatis, sursum et deorsum flexis. Gen, 5137-5142.

f. Cyclanthereae. Stamina monadelpha, columsae apice in discum orbiculatum, margine antheriferum dilatato. Gen. 5143.

Generd mius nota. Gen. 5144_5145.

3. Sicyoideac. Ovarium uniloculare. Ovnlum unicum, ex apice loculi pendulum. Gen. 5146 -5147 .

Gevera penitus dubia, 51/4 -5151.

* gronoviEaE. Gen, 5152.

CCIII. IEACIIACEAE. Stamina plurima. Ovarium inferum, triloculare, multiovulatum. Capsula trialata, loculicide trivalvis, polysperma. Embryo in axi albuminis carnosi. Gen. 5153 .

\section{Classis XHVII. Opuntiae.}

Calyx cum ovario connatus, limbo multiplici, sensim in petala pluri-multiseriata transeunte. Stamina indefinita, libera. Ovarium inferum, uniloculare, placentis ad suturas parietalibus tribus v. plurimis, multiovulatis. Bacca polysperma. Embryo exalbuminosus v. albumine parco inclusus, rectus v. arcuatus.

CCI士. CACTEA Arbores v. frutices habitu peculiari, succo aqueo v. lacteo, foliis nullis v. alternis simplicibus. Gen. $5154-$ 5162.

1. Tulbulosae. Corolla tubo supra ovarium producto. Gen. 5154-5159.

2. Fotatae. Corolla rotata, tubo supra ovarium hand pruducto. Gen. $5160_{-5162}$. 


\section{Classis XIVICI. Caryoplnyllimae.}

Calyx liber v, rarissime cum ovario connatus. Corollae petala et stamina definita v. rarissime indefinita, hypogyna v. perigyna. Ovaria rarissime plura, plerumque unicum, placentis basilaribus e loculorum angulo centrali, rarissime e nervo medio carpidiorum. Ovula saepissime amphitropa. Embryo periphericus, curvatus v. annularis, albumen farinaceum cingens.

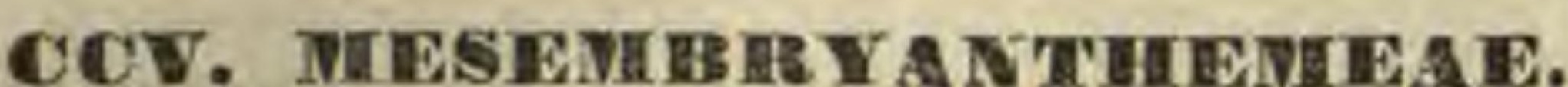
Calyx tubo cum ovario connato. Corollae petala et stamina indefinita, summo calycis tubo inserta. Ovarium pluriloculare, placentis carpidiorum nervo medio adnatis, fundum loculi occupantibus. Capsula depresso-radiata, multivalvis. Gen, 5163.

CCVI. TERTERACACEAE. Calyx liber v. cum ovario connatus, diphyllus v. triquinquefidus. Corolla nulla v, petala difinita, basi interdum coalita, tenerrima, fluxa. Stamina hypogyna v. perigyna, calycis laciniis numero aequalia et alterna, v. dupla, tripla aut indefinita. Fructus uni-octolocularis, mono-polyspermus, indehiscens v. operculo aut loculicide dehiscens, interdum calyce adnato drupaceus. Gen. 5164_5195.

1. Tetroasonieae. Calycis tri-quinquefidi tulus cum ovario connatus. Corolla nnlla. Ovarium tri-novemloculare, loculis uniovnlatis. Fructus drupaceus v. nucamentaceus, ad angulus costatus $v$. alatus, uni-novemlocularis. Semina in loeulis solitaria, pendula Gen, 5164.

2. Aizoldene. Calyx liber, quadri-quinquefidus v. partitus. Corolla nulla. Styli $2-5$. Capsula lignosa, bi-quinqueloenlaris, abortu interdum unilocularis, ad angulos loculicide dehiscens. Semina in luenlis $1-10$, ex apice columnae centralis pendula. Gen, $5165-5167$.

3. Sesuvieae. Calyx quinquefidos, rarius bifidus v. bipartitns, liber v. tubo ovario semiadnato. Corolla nulla, v, rarius petala $4-6$. Orariom uni-quinqueloculare, loculis mnltiovulatis. Capsula circumscisse dehiscens. Gen. $5168-5174$.

4. Portulacarieae. Calys diphyllns, liber, persistens. Corulla persistens, Ovarinm unileculare, ovulo unico basifixo. Stigmata 3. Capsula triptera, indehiscens, monosperma. Gen. 5175 .

5. Callandrinieae. Calyx liber, diphyllus, bipartitus $\vee$. bifidns, rarissime trifidns. Corollae petala libera v. basi in tubum coalita, rarissime nulla. Ovarium uniloculare. Capsula valvata, Gen. $5176-5183$.

6. Mollugimeae. Calyx liber, quinquepartitus, rarius quinquefidus, rarissime quadri- partitus, persistens. Ovarium nune: unitoculare, multiovulatum, nunc tri quinqueloeulare, Joculis uni-multiovulatis. Ovula basilaria v. anguli centralis medio aut ouni ejusdem longitudini funiculis distinctis inserta. Capsula loculicide valvata. Gen. 5184_5198.

\% Polpodeae. Calyx liber, quadripartitus, lacinis petaloideis, fimbriato-laceris. Corolla nulla. Stamina 4, hypogrna. Capsula obcordata, bilocularis, bivalvis, disperma, seminibus medio culumnae centralis insertis. Gen. 5194.

8. Ademogrammeae. Calyx quinquepartitus. Corolla nulla. Stamina 5. Ovarium uniloculare, ovnlo nnico. Stylus filformis, stigmate capitato. Capsula indehiscens, monosperma. Gen. 5195.

Genus Portulaceis affire. 5196.

CCVII. CAR VOPHTHLEAE. Calyx liber v. rarissime adnatus, gamophyllus, quadri-quinquedentatus. Corollae petala 4 v. 5 , rarius pauciora, interdum nulla. Stamina calycis laciniis numero aequalia et opposita, rarius pauciora, nunc dupla, interiora interdum castrata. Ovarium sessile v. stipitatum, uni-plnriloculare, uni-multiovulatum. Stigmata distincta. utriculus indehiscens v. basi dehiscens, rarisrime fructus nucamentaceus, saepissime capsula valvis v. dentibus dehiscens, quandoque baccata. Gen. $5197-5253$.

1. Paromyehieae. Herbae v. suffrntices, foliis oppositis v. rarius alternis, scarioso stipulatis. Gen. 5197-5220.

1. ILleckbreat. Flores exappendiculati. Calycis laciniae plerungue rigide mueronatae v. spinescentes. Ovarium uniovulatum. Fruetus utricularis v. rarissime nueamentaceus. Semiois chalaza cum umbilico con. fluens. Enbryo annularis, curvatus v, rarissime rec. tiusculus. Gen, 5197_5203.

a. Corrigioleac. Fructus nucamentaceus, calyce membrauaceo inefusus. - Folia alterna. Gen, 5197.

b. Euparonychiea e. Utriculus membranaceus, indebiscens v. a bast in lacinias plures apice cohaerentes apertas, ealyce membranaceo v. indurato. cartilagiaeo iaclusus. - Folia iaferiora opposita, summa alteraa, rarissime pseudo-verticillata. Gen. $5198 \_5203$.

Genera non satis nota. Gen, 5204_5205.

2. PTERANTHEAE. Flores axillares ternati, appendicuIis lateralibus pinnatipartitis, simplicibus v. ramosis, Ovarium uaiovulatum. Utriculus membranaceus, inde. hiscens, calyce inclusus. Seminis chalaza lateralis at umbilica reaota. Gen, 5206-5207.

3. POLliChiFaE. Calyx quinquedentatus, tubo urceola. to, fruetilero baccato. Ovarium biovulatum, ovalis basilaribus, filo eonductorio eentrati. Utricnlus indehiscens, mouospermus, ovalo altero efoeto, Gen. 5208.

4. TELEPHIEAE. Calyx quinquepartitus. Ovarinm incomplete tri-quadriloculare, plariovulatum. Folia aiteraa. Gen, 5209.

5. POLXCARPEAE. Ovarinm unilocalare, pluri-multiovulatum, columelfa ceatrali distiucta v. obsoleta. Cspsula apice in valvas stylorom numero delíscens, olizo. polysperma. Folia opposita v, pseudo-verticillata. Gek. $5210-5220$.

a. Löfling í a e. Calyeis laciniae margine supra basim setaceo appendiculatae. Gen. 5210.

b. Sperguleap. Calycis laciniae wargine labd appendiculatae. Gen, 5211 -5220. 
2. Seleramtheae. Herbae foliis oppositis, exstipulatis. Stamina tabi calycini fauci in serta. Ovarium uni-biovulatum. Utriculus monospermus, calycis tubo indurato, fauce constricto inclusus, Gen. 5221_-5223.

3. Alsineac. Herbae v. suffrutices, foliis oppositis, exstipulatis. Stamina perigyna v. subhypogyna. Ovarium pluri-rarissime uniovulatum. Styli a basi distineti. Capsula simplici v. daplici stylorum numero in dentes $v$. valvas dehiscens. Gen, 5224-5212.

1. SABUlineaE. Ovarium uniloculare. Capsula simpliei Joborum calycis numero in valvas dehiscens, valvis integerrimis. Gen. 5224_5230.

a. S a ginea e. Styli tot quot calycis laciniae, lisdem alterni. Capsulae valvulae calyeis laciniis oppositae. Gen. 522'.

b. Eualsinea e. Calyx quadri-quinquepartitus. Styli $2 \_3$, interdum 4 5 , calycis laciniis in aestivatione exterioribus v, omnibas oppositi, Capsulae valvulae calycis laciniis alternae $\mathbf{v}$, dom fisdem pauciores iuterioribus oppositae. Gen, 5225-5230.

2. MERKIEAE. Ovarium iucomplete $v$. complete tri-quinqueloculare. Capsula in valvas tot quot styli dehis. cens, valvis integerriais, Gen, 5231-5232.

3. Stellarinear. Ovarium uniloculare. Styli 2_5, calyeis Iaciniis alterni et oppositi. Capsula duplo stylorum numero in valvas integerriuas deliscens, v. valvis tot quot styll, apice bidentatis bifidisve. Gen. $5233-5242$.

a. A renarieac. Styli $2 \_3$, rarissime 4 v. 5 , ealyeis laciniis opposíti. Capsula globosa, ovoidea v. oblon. ga, rarissime coniea. Gen, 5233-5240.

b. Cerastieae. Styli 5 , rarissime 4 v. 3 , calycis laciniis oppositi. Capsula cylindrica v. eylindrico-conica, recta $\vee$. incurva, duplo stylorum numero dentibus dehiscens. Gen. 5241 .

c. Malachieae. Petala bipartita. Styli 5, ealycis laciniis alterui. Capsula ovoideo-pentagona, sinaplici stylorum numero in valvas apice bideotatas, calycis laciulis oppositas dehiscens. Gen. 5212 .

4. Silemene. Herbae v, suffrutices, follis op positis, exstipulatis. Calyx gamophyllus. $\mathrm{Pe}$ tala cum staminibus gynophori plus minus distineti apici hypogyne inserta, Gen, 52k3 $-5253$.

a. Diant he a e. Capsula apice dentibus v. valvulis dehiscens, polysperma. Semina placentae columellari peltatim affixa. Embryo excentricus, rectus. Gen. 52t3 -5244.

b. Ly chnideace. Capsula apice dentibus v. valvulis dehiscens, rarissime baceata, polysperma. Semina umbilieo marginali funiculis distlactis affixa. Embryo periphericus, annularis v. hemieyclicus. Gen. 5245_5251.

c. Drypideac. Capsula inferne membranacea, superne chartacea v: crustaeea, medio transversim ieregulariter rampens, mono-oligosperma. Semiaa umbilico apicali. Enbryo periphericus, anaularis v. subspiralis. Gen. 5252-5253.

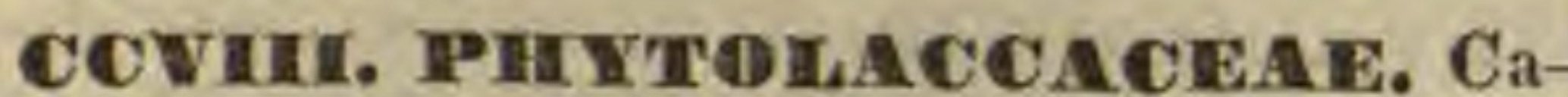

lyx liber, quadri-quinquepartitus. Corolla nulla v. petala perigyna $4-5$, aut interdum pauciora. Stamina calycis laciniis numero aequalia et alterna, v. plura, interdum indefinita. Ovaria plura verticillata, v. interdum unicum, excentricum, ovulo unico, stylis introrsum lateralibus. Fructus utricularis, baccatus, cocciformis, nucamentaceus v. samaroideus. Gen. 5254 -5263 .

I. Petiverieae, Cotyledones convolutae, Folia stipulata. Gen, 5254-5257.
1. Petiverieae verae. Embryo rectus v. curvatus, cotyledonibus eonvolutis, albumine parco v. nullo. Gon. 5254_6255.

2. Rivinieae. Eubryonis annularis albumen farinaceum chugentis cotyledon exterior major, interiorem minorem involutam amplectens. Gen, 5256_5257.

II. Playtolaceeae. Cotyledones planae v. plano-convexae. Folia exstipulata. Gen. 5258 -5263 .

3. L i me ae. Seminum testa membranacea. Gen, 5258 -5259 .

4. Gies ek iea e. Seminum testa erustacea. Gen. 5260 $-5263$.

* GXrostemoneaE. Gon. 5264_5265.

\section{Classis XITX. Colummiferae.}

Calyx liber, aestivatione valvatus. Corollae petala hypogyna, calycis laciniis numero aequalia et alterna, aestivatione convolutiva, saepe nulla. Stamina indefinita, saepissime monadelpha, v. definita. Carpidia uni-multiovulata, libera v. cum axi centrali et inter se coalita. Fructus capsularis, rarius baccatus $v$. nucamentaceus. Embryo albumine parco, mucilaginoso v. carnoso solido inclusus, rarius exalbuminosus. Cotyledones foliaceae, corrugatae v. plicatae aut carnosae.

CCIX. MALVACEAE. Calyx persistens v, rarissime deciduus. Corollae petala 5, saepissime basi unguibus inter se et cum tubo stamineo connata. Stamina indefinita. Antherae simplices, receptaculo pollinifero unico. Gen. 5266 - 5296.

1. MIalopeae. Calyx involncello cinctus v. rarius nudus. Carpidia plurima, unilocularia, monosperma, in capitulum congesta. Gen. $5266-5268$.

2. NaIveae. Calyx involucello cinctus. Carpidia 5 v. plurima, verticillata, libera $\mathbf{v}$. in capsulam polycoceam coalita. Gen. 52695275.

3. Hibisceae. Calyx involucello einctus. Carpidia 3 v. 5 , rarissime 10 , in capsulam loculicide dehiscentem $\mathbf{v}$ rarins indehiscentem coalita. Gen. 5276-6286.

4. Sideae. Calyx involucello nullo nudus. Carpidia 5 v. plura, verticillata, in capsulam loculicide dehiscentem eonnata $v$, in fructum polyeoccum obiter coalita. Gen. 5287-5295. Genus dubium. 5296.

CCX. STERCUHACEAE. Calyx deciduus. Corolla saepius nulla, nune pentapetala. Stamina saepissime indefinita, monadelpha. Antherae biloculares v. subbiloculares. Folia simplicia v. palmatim composita. Gen. 5297 $-5321$.

1. Bombacene. Fiores hermaphroditi. Calyx quinquefidus, saepe irregulariter divisus, aes- 
tivatione tunc obscura. Corolla regularis, rarissime nulla. Filamenta in tubum ovaria superantem coalita, Antherae solitariae v. plures coadunatae, loculis distinctis $v$, confluentibus, saepe anfractuosis, Ovarium sessile. Fructus e carpidiis coalitis saepissime capsularis. Semina saepissime lana carpica v. pulpa involnta. Folia simplicia v. palmatim composita. Gen. 5297_5807.

Ge u us a ffine, Gen. 5308.

Ge ze r a du bia. Gen, 5309. 5310.

II. II elietereace. Flores hermaphroditi, Calyx et corolla saepissime irregularis. Stamina in tubum ovaria superantem v, carpophorum ambientem coalita, apicibus distincta. Ovarium sessile v. stipitatum. Fructus e carpidiis distinetis $v$, coalitis, mono-polyspermis. Folia simplieia. Gen, 5311-5318.

1. MYRODIEAE. Tubus stamineus ultra ovarium sessile longe protluetus. Antherae sessiles v. subsessiles. Gen, 5311-5314.

2. EUHELICTEREAE. Tubus stamineus elongatus, ovarium stipitatum ambiens. Antherae in singulorum filamenturum apieibus liberis singulae. Gen. 5315_5316.

3. REEVESIEAE. Tubus stamineas elongatus, ovarium stipitatum ambiens. Antherae plures, supra tubi apicem sessiles, Gen. 5317_5318.

DII. Stereulieae. Ftores abortu unisexuales. Calyx regularis. Corolla nulla. Filamenta in tubum earpophoro connatum coalita. Antherae plus ninus perfecte biloculares, enrvatowblongae, ad ovarii perfecti v. efoeti basin. Fructus e carpidiis follicularibus verticillatis, sutura ventrali dehiscentibus $v$, indehiscentibus. Folia simplicia v. palmatim eomposita, petioli apice tumido. Gen. 5319-5321.

CCXI. EÜTTNERIACEAE. Calyx deciduus v. persistens. Corolla pentapetala v. rarius nulla. Stamina petalis numero aequalia et alterna, nune dupla v. multipla, sterilia calycis lobis opposita, v, omnia fertilia, varie coalita. Antherae biloculares. Folia simplicia. Gen. $5322-5357$.

I. Ihasiogetaleae. Calyx corollinus. Petala 5 , minute squamaeformia v. nalla. Stamina libera v. basi coalita, fertilia 5 petalis opposita, sterilia nulla v. fertilibus sulitarie alterna. Antherae extrorsae, incumbentes. Ovarium tri-quinqueloeulare. Carpidia libera v. in capsulam localicide dehiscentem coalita. Semina strophiolata, Embryo in axi albaminis carnosi orthotropus, reetus, cotyledonibus foliaceis, planis. Gen. 5322_5327.

II. Füttmeriear. Potala 5, sessilia v. ungnieulata, coneava v. fornicata, superne saepissime in ligulam producta. Tubns stamineus apice in lacinias plures fissus, laciniis sterilibus cum petalis alternantibus, fertilibus isdem oppositis, mono-triantheriferis. Ovarium quinqueloculare. Fruetus capsularis, Iocalicide v. septicide dehiscens. Semina nada v. strophiolata. Embryo exalbnminosus, cotyledonibus plicatis v, convolutis, $\mathbf{v}$. in axi albuminis earnosi rectus, cotyledonibus foliaceis, planis. Gen, 5328_5334.

* KLEINHOVIAE. 5335.

III. II Termanmieae. Petala 5, plana. Stami na 5 , petalis opposita, basi monadelpha, ste- rilia nulla. Ovarium uni-pluriloculare. Capsula loculicide dehiscens. Embryo in axi albnminis carnosi rectus v. homotropearcuatus, cotyledonibus foliaceis, planis. Gen. 53865341

IV. Honabeyaceac. Petala 5, plana. Stamina 15 _ 40 , rarissime omnia fertilia, plerumque 5 sterilia, ligulaeformia, petalis subopposita. Ovarium quinque-pluriloculare. Fructus capsularis, loculicide v. septicide dehiscens. Embryo intra albnmen carnosum, parcum, cotyledonibus foliaccis, saepe bifidis, contortnplicatis, rarius planis. Gen. 53425353.

W. Erioltaeneac. Petala 5, plana. Stamina plurima, moltiseriata, in columnam connata, omnia fertilia. Antherae biloculares, erectae. Gen. 5354-5355.

Genera d u b i a. $5356 \ldots 5357$.

- PHILlPPOdENDREAE. Gen. 5358. 5359.

CCXIII. THLIACEAE. Calyx deciduus. Corollae petala 4 v. 5 , rarissime nulla. Stamina duplo v. multiplo petalorum numero, omnia fertilia v. extima sterilia, libera v. in phalanges connata, Antherae biloculares. Folia simplicia. Gen. $5360-5391$.

I. Tiliaceac verae. Corolla nulla v. petala integra. Antherae longitudinaliter dehiscentes. Gen. 5360_5381.

1. SI na neae. Corolla uulla. Americanae. [Gen, 5360 $-5363$.

2. Gresie a e. Corollae petala integra. Amphigeae. Gen. $536{ }^{\prime} t$ - 5381 .

Genera dubia $5382 \_5383$,

耳. Elaeocarpeae. Corollae petala incisa v. fimbriato-lacera. Antherae apice valvola transversa apertae. Gen. 5384 _5391.

1. Elaeocarpeae verac. Fruetus drupaceus. Gen. 5384 - 5386.

Genera dub 1 a. 5387 -5338.

2. Tricuspidarleae. Fruetus eapsularis v. baceatus. Gen. 5389-5391.

\section{Classis Lif. Guttiferae.}

Calyx liber v. rarissime ovario adnatus, imbricatus. Corollae petala calycis foliolis numero aequalia et alterna v. plura, rarissime nulla. Stamina indefinita v. rarius definita, saepissime polyadelpha. Carpidia plura, in ovarium uni-pluriloculare coalita. Embryo rectus, saepissime exalbuminosus, rarissime albumine carnoso inclusus.

CCXIIT. IDPTERTCATPEAE. Calyx pentamerus, foliolis liberis v. in tabum coalitis, limbi laciniis saepissime inaequalibns, demum inaequaliter auctis. Corollae petala 5, hypogyna, aestivatione convolntiva. Stamina plurima. Ovarium triloculare, loculis biovulatis, ovulis ex anguli centralis apice collateraliter pendulis. Fructus abortu unilocularis, mo- 
nospermus. Embryonis orthotropi, exalbaminosi cotyledones maximae, saepe inaequales v. subfoliaceae, chrysaloideo-contortuplicatae. Folia alterna $v$, ad basim ramulorum opposila. Gen. 5392-5396.

* lophiraceae. cien. 5397.

CCXIV. CHLAENACEAE. Flores involucrati, v. involucello persistente, indurato v. baccato cincti. Calyx triphyllus, liber. Corollae petala 5 v. rarius sex. Stamina saepissime indefinita, rarius duplo petalorum numero. Ovarinm triloculare, loculis nunc biovulatis, ovulis ex apice anguli centralis collateraliter pendulis, nunc multiovulatis, ovulis in angulo centrali biseriatis. Capsula trilocularis, loculis dispermis v. abortu unilocularis. Embryo in axi albuminis carnosi v. cornei orthotropus. - Folia alcerna. Gen. 5398_5402.

* eucryphieae. Gen, 5403.

* HUgONIACEAE. Gen, 540't.

CCXV. TERENTIR D̆VTACEAE. Calyx liber v. rarissime inferne cum ovarii basi connatus. Corollae petala hypogyna, calycis foliolis numero aequalia et alterna. Stamina indefinita. Ovarium bi-tri-quinque-pluriloculare. Ovula pauca v. indefinita, pendula v. adscendentia, amphitropa, campylotropa v. anatropa. Fructus indehiscens v. capsularis. Embryo exalbuminosus v. albumine carnoso inclusus. Folia alterna v. rarissime opposita. Gen. $5405-5426$.

1. Coehlospermeae. Calyx pentaphyllus. Corolla pentapetala. Antherae basifixae, apice poro unico dehiscentes. Ovarium septis placentiferis incompletis uniloculare. Ovula plurima, amphitropa. Fructns capaularis. Semina reniformia, dense lanata, Embryo in axi albuminis homotrope arcuatus, cutyledonibus planis. - Folia alterna, palmatiloba, petiolo bistipulato, Gen, 5405 ,

刃. Termströmieae. Calyx pentamerus, liber v. cum ovarii basi connatus. Curollae petala 5, rarissime 6, libera v. coalita. Anthe. rae basi insertae, longitndinaliter dehiscentes. Ovarium bi-quinqueloculare. Ovula plu. rima, campylotropa. Bacea sicca v, capsula irregulariter dehiscens. Embryo cylindrieus, homotrope bicruris, exalbuminosus $\mathrm{v}$, albumine carnoso inclnsus, - Folia alterna, in. tegra, exstipulata, Gen. 5106-5413.

3. Savmanjeae. Calyx pentamerus, liber Corollae petala 5, distincta. Antherae ineum bantes, loculi basibus discretis sursum spectantibus poro aperti. Ovarium quinquelo. culare. Ovula plurima, anatropa. Capsula apice loeulicide dehiscens. Semina aptera. Embryo in axi albuminis carnosi orthotropus, subcylindricns. - Folia alterna, integra, exstipulata. Gen. 5414-5415.

4. Laplaceae. Calyx tetra-pentaphyllus. Co. rollae petala $4-9$. Antherae incumbentes v. erectae, longitudinaliter dehiscentes. Ovariam tri-quinque rarius pluriloculare, Ovula plarima, rarios solitaria, anatropa. Capsula Joculicide v. septieide dehiscens, axi seminifero persistente. Semina alata. Embryonis exalbuminosi cotyledones planae. - Folia integra, alterna v. rarissime opposita, rarissime stipulata. Gen. 5ł16-5+22.

5. Gorelloaieae. Calyx pentaphyllus. Corolla gamopetala, Antherae erectae v, versatiles, longitudinaliter dehiscentes. Ovarium quin. queloculare. Ovula pauca. Capsula loculicide dehiscens. Semina pendula, alata. Embryonis exalbuminosi cotyledones longitudinaliter plieatae. - Folia alterna, integra, exstipulata. Gen. 5423-5424.

6. Camelliae. Calyx penta enneaphyllus. Corollae petala 5-9. Antherae incumbentes, longitudinaliter dehiscentes. Ovarimm triquinqueloculare. Ovula pauca. Capsula loculicide dehiscens. Semina nucamentacea. Embryonis exalbuminosi cotyledones crassae, carnoso-oleosae, cum radicula brevissima articulatae, - Folia alterna, integra, exstipulata. Gen. 5425-5426.

Genera Tern 8 trömiaceis affinia. 5427-5431.

* aristoteliaceaE. Gen. 5 \$32.

COXVI. CLUSIACEAE. Calyx tetrahexaphyllus v. interdum poiyphyllus. Corollate petala calycis foliolis numero aequalia, iisdem alterna v. opposita, rarius plura. Stamina indefinita v. rarius subdefinita, libera v. in annulum, phalanges v. tubum coalita. Ovarium unibi-quinque v. pluriloculare. Ovula in loculis solitaria v. gemina, in ovario uniloculari subquaterna v. plurima, orthotropa v. anatropa. Fructus eapsularis, drupaceus v. baccatus. Embryo exalbuminosus, rectus. - Folia opposila, saepissime nervis transversis lineolata, pellucide punctala, Gen. 5433-5449.

I. Clusieae. Ovarinm plurilnenlare, locnlis unipluriovulatis. Capsula valvata, columnae centralis demum liberae angulis septantibus. Gen. 5433-5459.

II. Woronobeae. Ovarium pluriloenlare, toenlis pluriovulatis. Fruetus laceatus, indehiscens, plurilocularis, loculis pleiospermis. Gen, $5440 \_5141$.

1II. Gareinieae. Ovarinm pluriloculare, loculis uniovulatis. Fructus drupacens v, baceatus, loculis monospermis. Gen. 5442-5446.

IV. Caloplnyllene. Ovarium biloculare, localis biovulatis, v. uniluculare, nni-triovnlatum. Fructus capsularis v. drupacens, nnilocularis, mono-tetraspermus, Gen. 5447-5449.

Ge nera dubia, 5450_5455.

* CaNellaceae. Gen. $5456-5458$.

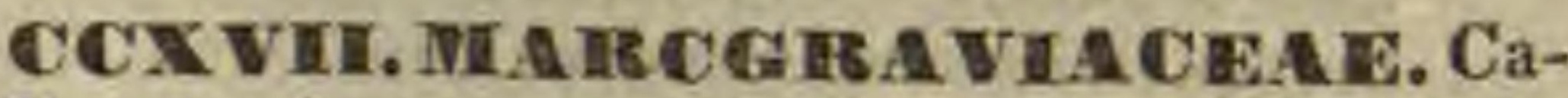
lyx di-tetra-hexa-pentaphyllus. Corollae petala ealycis foliolis nune numero aequalia, libera $v$. basi coalita, nunc plura, in calyptram basi circumscissam coalita. Stamina plerumque indefinita, rarissime calycis foliolis numero aequalia et opposita. Ovarium tri-quinque-pluriloculare. Ovula plurima, anatropa. Fructus capsularis v. 
baccatus. Embryo exalbuminosus, homotrope incurvus. - Folia allerna. Gen. 5459-5461.

Genus dubiua. Gen, 5462 .

CCX VIII. III YPRECINEA E. Calyx liber, pentamerus v. rarius tetramerus. Corollae petala calycis laciniis numero aequalia et alterna, ungue nudo $\mathrm{v}$. basi intus foveola sive squamula aucto. Stamina plorima, libera, monadelpha v. saepissime in phalanges coalita. Ovarium tri-quinqueloculare v. septis abbreviatis uniloculare. Ovula plurima, anatropa v. rarissime amphitropa. Fructus eapsularis. Embryo exalbuminosus, orthotropus. - Folia opposita v, verticillata. Gen. $5463-5472$.

1. IIypericeae. Glandalae inter stamina nullae. Gen, 5463-5464.

2. Elodeae. Glandulae v, squamulae hypogynae, cum staminum phalangibus alternae. Gen, $5465-5 \pm 72$.

Genus dubiae affinitatis. 5473 .

* OCHRANTHACEAE, Gen. 5474.

CCXIX. ELATINEAE. Calyx tri-quadri-quinquepartitus, liber. Corollae petala $3-5$, calycis laciniis alteria. Stamina simplici v. saepius duplici petalorum numero. Ovarium triquinqueloculare v. septis abbreviatis uniloculare. Ovula plurima, anatropa. Fructus capsularis. Embryo exalbuminosus, orthotropus v. homotrope incurvus. - Folia opposita, juniora in axillis fasciculata. Gen. 5475-5477.

Genus dubium. 5478 .

CCXX. FEAUVHERACRAE. Calyx quinquefidus v. polyphyllus, liber. Corollae petala 5 , nuda v, basi squamulis duabus aucta. Stamina nunc indefinita, polyadelpha, nunc 8 v.10, basi in annulum coalita. Ovarium placenta basilari septifera inferne bi-quinque- superne uniloculare, panciovulatum, ovulis adscendentibus. Capsula membranacea, oligosperma. Embryo intra albumen parcum, farinosum orthotropus. - Folia alterna, plus minus carnosa, resinoso-glandulosa. Gen. 5479-5481.

COXXE. TAUIRISCIVEAE. Calyx pentaphyllus v. rarius tetraphyllus. Corollae petala 5. Stamina 5 v. 10. Ovarium uniloculare, placentis parietalibus 3 , rarius 2 v. 4 , multiovulatis. Semina ad chalazam apicalem comosa. Embryo exalbuminosus, orthotropus.

- Folia alcerna, carnosula. Gen. 5482-5484.

\section{Classis HII. Hesperides.}

Calyx liber, imbricatus. Corollae hy pogynae petala calycis laciniis numero aequalia et alterna, valvata $v$. convolutiva. Stamina duplo v. quadruplo, rarius simplici v. multiplo petalorum numero, libera, monadelpha v, polyadelpha. Ovarium uni-pluriloculare, loculis uni- multiovulatis. Embryo saepissime exalbuminosus, rarius albumine carnoso inclusus.

CCXXII. TUVIrLACEAL. Stamina duplo v. quadruplo petalorum numero, rarius indefinita. Antherarum connectivum in ligulam crassam, obtusam productum. Ovarium quadrisexloculare, loculis uni-biovulatis, ovulis superposite pendulis, interdum septo secundario segregatis. Drupa monopyrena, putamine uniquinqueloculari. Semina inversa. Embryo in axi albuminis carnosi orthotropus. - Folia allerna, simplicia, exstipulata. Gen. 5485-5487.

CCXXIII. OLACINEAE. Stamina petalis numero aequalia et alterna $v$. saepius dupla, filamentorum ope petala connectentia, saepissime alterna inter petala sita sterilia. Ovarium uniloculare, columella centrali libera, nunc tri-quadriloculare. Ovula solitaria v, gemina aut rarius terna, collateraliter pendula. Drupa monosperma. Semen inversum. Embryo in axi albuminis carnosi orthotropus. - Folia alterna, simplicia, exstipulata. Gen, 5488-5492.

Genera penitus d ubia. Gen. 5493-5497.

Genus Olacinels affine. Gen, 5498 .

COXXIV. AURANTIACEAE. Stamina duplo v. multiplo petalorum numero, monadelpha v. polyadelpha. Ovarium quinque-pluriloculare. Ovula in loculis nune solitaria, nune gemina, collateralia v. superposita, nunc plurima, biseriata, pendula v. rarius horizontalia. Bacca mono-polysperma. Embryo exalbuminosus, orthotropus, cotyledonibus amygdalinocarnosis, v, crassis, viridibus, lobatis. - Folia imparipinnata, saepe trifoliolata v. foliolis lateralibus abortivis unifoliolata.Gen. 5499-5514.

1. Limonea e. Stamina duplo petaloram numero. Ovula in foculis solitaria v. gemina collateralia. Gen. 5499_5505.

2. Clauseneae. Stamina duplo petalorum numero. Ovula in localis gemina, superposita. Gen. 5506_5511.

3. Citreae. Stamina petalis numero dupla $\mathbf{v}$. multipla. Ovula in loeulis plurima, biseriata, Gen. 6512-5514.

Genus dubium. 5515 .

CCXXv. MEEHACEAE. Stamina duplo petalorum numero, filamentis latis, complanatis, in tubum coalitis, apice bidentatis v. bifidis. Ovarium bi-pluriloculare. Ovula in loculis solitaria, v. gemina collateralia ant superposita, rarissime quatuor, anatropa, semianatropa, amphitropa v. orthotropa. Fruetus capsularis, rarius baccatus v. drupaeformis. Semina in loculis solitaria, saepe arillata. Embryo nunc albumine inclusus, cotyledonibus foliaceis, nunc exalbuminosus, cotyledonibus crassissimis. - 
Folia simplicia v, pinnatim composita. Gen. $5516 \_5545$.

1. IIelieace. Embryo in axi albuminis tenuis, carnosi, cotyledonibus foliaceis, radicula exserta. - Folia simplicia v. bipinnata, rarius simpliciter pinnata, foliolis plerumque dentat is. Gen. $5516-5523$.

2. Trielhilieae. Embryonis exalbuminosi cotyledones crassae, radicula brevis, plerumque retracta, - Folia alterna, simpliciler pinnatai, foliolis integerrimis. Gen. 5524_5545.

Genera dabia. 5546_5547.

Genas Meliaceis affine. 5548 .

CCXXVI. CEID IEREACEAE. Stamina duplo pelalorum numero, alterna petalis opposita breviora, nonnunquam ananthera v. penitus deficientia, filamentis coalitis, apice bifidis, v. distinetis, simplicibus. Ovarium triquinqueloculare. Ovula in loculis $4,6,8,12 \mathrm{v}$. plurima, biseriata, anatropa. Capsula valvis ab axi septifera, persistente solutis. Semina biseriata. Embryo albumine parco inclusus v. exalbuminosus, cotyledonibus planiusculis v. carnosis. Gen. $5549-5556$.

I. Swietenieae. Corollae aestivatio contorta. Stamina in tubum coalita. Umbilicus in apice alae, rhaphe percursae situs. Gen. 55k9-5552.

I. Cedreleae. Corollae aestivatio convolutiva v. contorto-convolutiva. Stamina libera. Umbilicus si semen superne in alam productum ad ejus basim sitns. Gen. 5553-5556.

Genus dubium. Gen. 5557.

\section{Classis LIII. Acera.}

Calyx liber, imbricatus v. subvalvatus. Corollae petala calycis foliolis numero aequalia v. uno deficiente pauciora, interdum nulla. Stamina petalis numero aequalia v. dupla, rarius multipla. Carpidia saepissime 3 , rarius 2 , rarissime 4 v. 5 , coalita v. subdistincta, nunquam tamen libera, uni-bi-rarissime multiovulata. Embryo curvatus, convolutus v. rarius rectus, exalbuminosus $\mathbf{v}$. interdum albumine carnoso inclusus.

CCXX XII. ACERTMEA pentamerus, deciduus, eglandulosus. Corolla nulla v. petala $4-5$, breviter unguiculata. Stamina calycis laciniis numero aequalia v. plura. Ovarium biloculare, bilobum, loculis biovulatis, stylo centrali. Ovula superposita, amphitrope pendula. Cocei 2, samaroidei. Embryo exalbuminosus, conduplicatus v. convolutus, radicula descendente. - Folia opposita, simplicia palmatilob̉a, v. imparipinnata. Gen. 5558 -5560 .

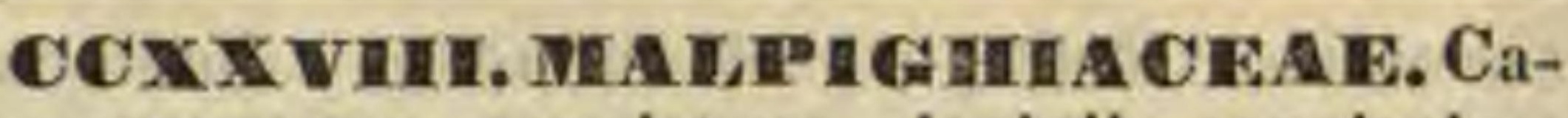
lyx pentamerus, persistens, laciniis saepissime biglandulosis. Corollae petala 5 , longe unguiculata. Stamina petalis numero aequalia v. dupla, monadelpha v. rarius libera, alterna v. plura castrata. Ovarium tri-v, rarius bilobum, loculis uniovulatis, stylis centralibus liberis v. coalitis. Ovulum lycotropum. Cocei 3 v. 2, saepissime samaroidei. Embryo exalbuminosus, rectus v. conduplicatus. - Folia opposita, rarissime ternata $v$, alcerna, simplicia, integerrima, rarius dentata v. lobala. Gen. 5561-5592.

1. Melostemenes. Stamina petalis numero aequalia et alterna, nonnulla saepissime sterilia, nunc plura, nunquam tamen dupla. Stylus simplex, tribus coalitis v, fuobns abortivis, rarius triplex, duobus tune minoribus, Carpidia varie alata v. aptera, umquam carnosa, saepe filo rhaphaeformi subtensa, et ex eodem sulubili pendula, Gen, 5561-5565.

2. Diplestemones. Stamina duplo petalorom numero. Styli $2-3$, plerumqne distincti, rarissime partim v, omnino connati, v, unins ant duorum alurtn solitarii. Carpidia nune alata, ala marginante v. dorsali, nune: aptera, lignosa, coriacea v. earnosa. Gen, 5566-5592.

a. Pleuropterygine. Carpidia alata, ala marginante. Gen. 5566 5574 .

b. Notopterygiac. Carpidia alata, ala dorsali. Gen, 5575_5584.

c. Apteryg i a e. Carpidia aptera. Gen, 5585_5592.

Genera dubia. Gen, 5593_5595.

* CoriarieaE. Gen. 5596.

CCXXIX. ERTTHEOXYGAE. Calyx pentamerus, persistens, eglandulosus. Corollae petala 5 , basi squamulis duabus sibi invicem impositis et ungui adnatis aucta. Stamina 10 , basi in urceolum connata, omnia fertilia. Ovariun bi-triloculare, loculis uniovulatis, v. unico fertili, reliquis efoetis. Ovulum pendulum. Styli 3 , distineti v. coaliti. Drupa monosperma. Embryo in axi albuminis eartilaginei, parci orthotropus. - Folia alterna v, rarissime opposita, simplicia, integerrima. Stipulae intraaxillares. Gen. 5597.

CCXXX.SAPINDACEAE. Calyx pentamerus, foliolis saepe inaequalibus, duobus posticis non raro in unum coalitis. Corolla nulla, v. petala quinque aut postico deficiente quatuor. Discus in glandulas v. annulum tumens. Stamina duplo loborum calycis numero v. abortu pauciora, rarius plura. Ovarium centrale v. excentricum, tri- rarius bi- v. quadriloculare. Ovula in loculis solitaria, v. gemina, rarius plura. Fructus bi-quadrilocularis, eapsularis v. samaroideus. Embryo exalbuminosus, rarissitwe rectus, saepe curvatus v. spiraliter convolutus. - Folia alterna v, rarissime opposita, plerumque composila, rarius foliolorum lateralium abortu v, vere simplicia. Pedunculi apice interdum cirrhosi. Gen.5598-5630. 
1. Sapinadeae. Ovula in loculis plerumque solitaria. Emhryo curvatas v. rarias rectus. Gen. 5598_562i.

2. Dodomacaceac. Ovula in loculis $2-3$. Embryo spiraliter convolutus, Gen. 5622-5627.

Genera a иomala. Gen, 5628-5630.

Genera penitus dubia. Gen. 5631_5638.

* MELiOSMEAE. Gen. 5639.

* HIPPOCASTANEAE, Gen. 5640. 5641.

CCXXXI. HFIIIBDERAE. Calyx quinque-sexpartitus. Corollae petala 5 -8. Stamina indefinita. Ovarium quadri- sexloculare, loculis uniovulatis. Nuces $4-6$, v. abortu pauciores, axi cohaerentes. Embryo exalbuminosus, curvatus, radicula maxima. _ Folia opposita, palmatim tri-quinquefoliolata. Gen. $5642-5643$.

\section{Classis LIV. Polygalineae.}

Flores regulares, calycis aestivatione valvata, petalorum induplicativa, staminibus hypogynis liberis, v. irregulares, aestivatione imbricata, staminibus cum petalis connatis. Ovarium liberum, biloculare, loculis uni-biovulatis, Fructus capsularis v. drupaceus. Semina carunculata. Embryo intra albumen carnosum orthotropus v. rarius exalbuminosus.

CCXXXII. TREVINANIDEAE. Flores regulares. Antherae extrorsae, biloculares v. quadriloculares, loculis apice in tubulum poro pertusum productis. Gen. $5644-5645$.

CCXXIIT. PQLXGALEAE. Flores irregulares. Antherae uniloculares v. rarius biloculares, apice poro unico v. geminis dehiscentes. Gen. 5646-5653.

Genera vix nota, Gen, 5654_5655.

Genera a nomala. Gen. 5656_5658.

* TrigoniaceaE. Gen. 5659.

\section{Classis IV. Frangulaceae.}

Calyx liber v. cum ovario connatus. Corollae petala calycis laciniis numero aequalia, libera v. basi subcoalita, rarius nulla. Stamina petalorum numero, iisdem alterna v. opposita, rarius plura, Ovarium bi-tri-quadri-pluriloculare, v. septis incompletis uniloculare, loculis uni-bi- rarissime multiovulatis. Fructus capsularis, baccatus v. drupaceus. Embryo intra albumen orthotropus.

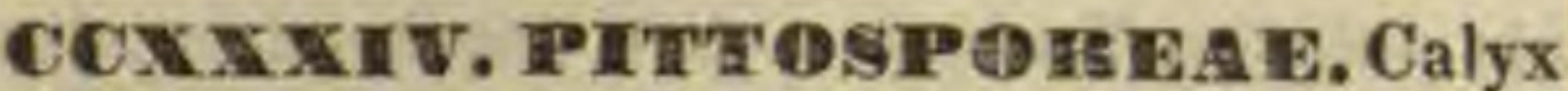
liber, pentamerus. Corolla hypogyna penta- petala. Stamina 5 , petalis alterna. Ovarium incomplete bi-quinqueloculare, multiovulatum. Fructus capsularis v, baccatus. Embryo in basi albuminis copiosi minimus. - Folia alterna, simplicia, exstipulata. Gen. 5660-5668.

Genera Pittosporeis affinia. Gen. 5669_5670.

CCXXXV.STAPHTLEACEAE. Calyx liber, pentamerus. Corolla perigyna, pentapetala. Stamina 5, petalis alterna. Ovarium bi-trilobum, pluriovulatum, ovulis horizontalibus v. adscendentibus. Fructus capsularis v. baccatus. Embryo intra albumen copiosum magnus. - Folia opposita v. rarissime alterna, trifoliolata $v$. imparipinnata, bistipulata. Gen. $5671-5673$.

CCXXXVI. CELASTIRINEAE. Calyx liber, tetra-pentamerus. Corolla perigyna, tetra-pentapetala. Stamina 4 v. 5, petalis alterna. Ovarium bi-quinqueloculare, loculis uni-bi- v. rarissime pluriovulatis, ovulis adscendentibus. Fructus capsularis v. drupaceus. Semina saepissime arillata, erecta v. adscendentia. Embryo in axi albuminis, ejusdem dimidio longior, cotyledonibus foliaceis. - Folia alcerna v, rarius opposita, simplicia, stipulis caducis. Gen. $5674-5690$.

1. Evonymeae. Fructus capsularis, loculicide dehiscens. Gen, 5674-5682.

2. Ellaeodiendreae. Fructus drnpaceus, Gen. $5683-5690$.

Genera d u bia. 5691 _5698.

Genus affine. 5699 .

CCXXXVIIT. HIIP PCEATEACEAE. Calyx liber, pentamerus. Corolla perigyna, pentapetala. Stamina 3. Ovarium triloculare, pluriovulatum, ovulis adscendentibus. Fructus capsularis v. baccatus. Embryo exalbuminosus. - Folia opposita, simplicia. Stipulae caducae. Gen. 5700 - 5702.

Genus affine, 5703 .

COxxxviri. ITHCInEAE. Calyx liber, tetra-hexamerus. Corolla hypogyna, subgamopetala. Stamina 4-6, petalis alterna. Ovarium bi-sex-pluriloculare, loculis uniovulatis, ovulo pendulo. Fructus drupaceus. Embryo in apice albuminis parvus. - Folia opposita, simplicia, exstipulata. Gen. 5704-5709.

Geaera dubia $5710 \_5711$.

Genera a ffinia $5412 \_5713$.

* NitrariaceaE. Gen. 5714.

CCXXXIX. HEAMNDAE. Calyx liber v. cum ovario connatus, tetra-pentamerus. Corolla perigyna, tetra- pentapetala. Stamina 4 v. 5, petalis opposita. Ovarium bi-quadriloculare, loculis uni- v. collateraliter biovulatis, erectis v. adscendentibus. Fructus drupaceus v. capsularis, septicide in cocca delabens. Embryo intra albumen parcum magnus. - Eolia 
allerna v. rarius opposita, simplicia, bistipulata. Gen. 5715-5748.

I. IPaliureae. Fructus semiinferns, siccus, alatus, nuce lignosa foetns. - Folia alterna, basi obliqua. Gen. 5715 _5716.

II. Framgaleae. Fructus superus v. semiinferus, calycis cupula fultus, drupaceus v. capsularis, coecis indehiscentibus $v$. intus rima apertis. - Folia alterna, rarius opposita. Gen. 5717-5729.

III. Colletieae. Fructus superus, calycis cupula fultus, siecns, apterus. Folia opposita. Gen. 5780_5735.

IV. Plnylicene. Fructus inferus, capsularis, apterus, calycis limbo persistente coronatus v. deciduo areolatus. Folia alterna, ericoidea. Gen. 5736-5742.

W. Ponaderreac. Fructus capsularis, coccis intus basi foramine membrana tenui velato apertis. Folia alterna. Gen. 5743_5744.

VI. Gounanieae. Fructus inferus, capsularis, calyce deciduo areolatus, pyriformis v. trigonus, apterus v, alatus, eoccis intus rima apertis. - Frutices cirrhosi v. herbae. Gen. $5745-5748$.

Genera d u bia $5749-5750$.

Genera affinia $5751-5756$.

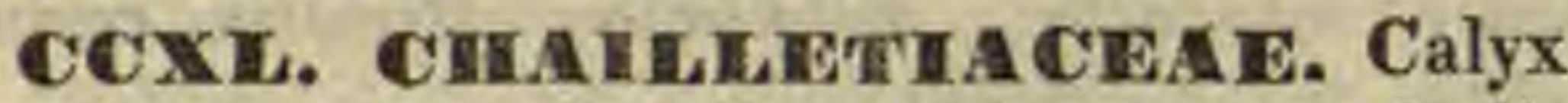
liber, pentamerus. Corollae perigynae petala libera v. interne subcoalita. Stamina 5 , petalis alterna. Ovarium bi-triloculare, loculis collateraliter biovulatis, ovulis pendulis. Fruetus capsularis v. drupaceus. Semina in loculis solitaria, arillata. Embryo exalbuminosus. - Folia alterna, simplicia, bistipulata. Gen. 5757-5759.

\section{Classis LVI. Trieoceae.}

Flores plerumque unisexuales, saepissime incompleti. Calyx liber. Petala definita v. nulla. Ovarium saepissime trirarius bi- multiloculare. Fructus capsularis, septicide in cocca delabens, axi centrali persistente, rarius drupaceus $\mathbf{v}$. baccatus. Semina in loculis solitaria v. gemina collateralia. Embryo in axi albuminis carnosi orthotropus.

COXII. EMIPETIEAR. Drupa baceata di-enneapyrena, pyrenis monospermis. Semina erecta. Gen. 5760_5762.

COXIII. STACIKITUSIACEAE. Fruetus tri-pentacoccus, coccis siccis, apteris v. alatis, ab axi persistente solutis, indehiscentibus, monospermis. Semina erecta. Gen. 5763 $-5764$.

CCX tus di-tri-polycoceus, capsularis v. rarius baceatus. Semina in loculis solitaria v, gemina collateralia, pendula. Gen. 5765-5878.
1. Euphorbieae. Ovarii loculi uniovulati. Flores monoici, apetali, intra involucrum commune masculi cum femineis. Gen. 5765 -5768 .

2. Hippomaneae. Ovarii loculi uniovulati. Flores apetali, spicati, bracteis uni- multifloris. Gen. 5769_5781.

3. Acalyplecae. Ovarii loculi uniovulati, Flores apetali, glomerato-spicati v, racemosi. Gen. 5782_5796.

4. Crotonear. Ovarii Ioculi uniovalati. Flores saepissime corollati, funiculati, spicati, racemosi v. paniculati. Gen. 5797-5836.

5. Playllamtheae. Ovarii loculi biovulati. Stamina centrofluris inserta. Gen. 5837-5859.

6. IBuxeae. Ovarii loculi biovulat:. Stamina sub ovarii rudimento sessili inserta. Gen. $5860-5878$.

Genera dubia $5879-5888$.

\section{Classis HVII. Terebinthineae.}

Flores hermaphroditi v. abortu unisexuales, rarissime incompleti v. unisexuales. Calyx liber v. rarissime adnatus. Corollae petala calycis laciniis numero aequalia, hypogyna v. perigyna. Stamina duplo petalorum numero, rarius plura. Ovarium unicum v. plura, libera v. plus minus coalita, uni-bi- rarius multiovulata. Embryo rectus v. curvatus, exalbuminosus v. albumine plus minus copioso inclusus.

CCXUIV. JUGIARDEAE. Flores unisexuales. Masc. Amentacei. Calyx bi-trisexpartitus, bracteae squamaeformi complanato-adnatus. Corolla nulla. Stamina 3 v. plurima. Fem. terminales aggregati, bracteolati, v. racemosi, involucello demum adnato cincti. Calyx cum ovario connatus. Corolla nulla v. minuta. Ovarium uniloculare, ovulo unico in apice columellae basi septiferae erectum, orthotropum. Drupa monosperma, epicarpio irregulariter v. subvalvatim secedente, putamine bivalvi. Embryo exalbuminosus, antitropus, cotyledonibus erassis, carnosis bilobis, sinuoso torulosis. - Folia allerna, impari-v. abrupte pinnata, exstipulata. Gen. 5889-5892.

CCXNV. ANACARIDIACAE. Flores saepissime abortu unisexuales. Calyx liber v. rarissime cum ovario connatus. Petala calycis laciniis numero aequalia, interdum nulla. Stamina nune petalis numero aequalia et alterna, nunc dupla, rarius plura. Ovarium nune unicum uniloculare, nunc plura, distincta, praeter unum efoeta, saepe ad stylum reducta. OvuIum unicum, funiculo e basi loculi adscendenti, libero v. ejusdem parieti adnato insertum. Fruc- 
tus drupaceus v. rarius exsuccus, monospermus. Embryo exalbuminosus. - Folia alterna, simplicia composita. Gen. 5893-5919.

* SPONDIACEAE. Ovaria quinque, in unicum quinqueloculare coalita, Gen, 5920_5921.

Genera dubia $5922-5926$.

Qenus anomalnm 5927 .

CCXU⿴囗十. IRURSERACEA IE. Flores saepe abortu unisexuales. Calyx liber. Petala calycis laciniis numero aequalia. Stamina duplo petalorum numero. Ovarium bi-quinqueluculare, loculis collateraliter biovulatis, ovulis pendulis. Drupa mono-pentapyrena, pyrenis osseis, monospermis. Embryo exalbuminosus. - Folia alterna, composita, bistipulata. Gen. 59285939.

Genera vix nota 59\%0-5946.

* AMYrideaE, Putamen chartaceum. Gen. 5947.

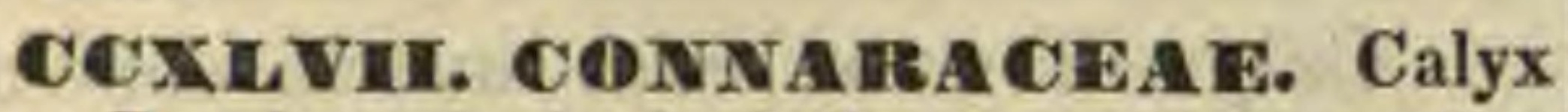
liber. Petala calycis laciniis numero aequalia. Stamina duplo petalorum numero. Ovaria quinque, biovulata, ovulis collateraliter erectis v. adscendentibus. Capsulae quinque, sutura ventrali dehiscentes. Embryo exalbuminosus. Folia alterna, composita, exstipulata. Gen. 5948 - 5950.

Genera d u bia 5951 _ 5952.

* SURIANEAE. Gen, 5953 _5955.

CCXIVIII. DCHNACEAE. Calyx liber. Petala calycis foliolis numero aequalia v. rarius dupla. Stamina duplo, rarius triplo, quadruplo v. subquintuplo petalorum numero. Antherae apice rimula brevi v. poro dehiscentes. Ovaria 4,5 v. plura, mediante stylo plus minus coalita, uniovulata. Carpidia drupacea v. baccata, distincta, monosperma. Embryo exalluminosus, v. albumine parco inclusus. - Folia alterna, simplicia, bistipulata. Gen. 5956 $-5961$.

1. Casteleae. Antherae introrsae. Semen inversum, exalhuminosum. Gen. 5956_5957.

2. Delnueae. Antherae introrsae. Semen erectum, albuminosum. Gen, 5958_5959.

Geuer,a dabia $5960 \_5961$.

CCXIIX. SIMAREURACEAE. Calyx liber. Petala calycis laciniis numero aequalia. Stamina duplo petalorum numero, filamentis squamulae dorso insertis, antheris longitudinaliter dehiscentibus. Ovaria 4 v. 5, libera, uniovulata. Drupae distinctae, monospermae. Embryo exalbuminosus. - Folia alterna, composila v. rarius simplicia, exstipulata, Gen. 5962 -5965.

Genera affinia 5966_5967.

CCL. ZANTHOXYLEAE. Flores saepissime unisexuales. Calyx liber. Petala caly-
cis laciniis numero, aequalia. Stamina simplici v. rarius duplici petalorum numero, filamentis basi aequalibus v. rarius squamulae dorso insertis. Ovaria plura, libera v. coalita, singula bi- v. rarius quadriovulata. Fructus varius, indehiscens v, carpidiis sutura ventrali dehiscentibus. Embryo in axi albuminis carnosi rectus v. leviter arcuatus. - Folia alterna v. opposita, simplicia v. composita, exstipulata. Gen. $5968-5977$.

Genler a affinia 5978_5980.

Genera dubia 5981_5987.

CCLI. DIOSMIEAE. Calyx liber. Petala calycis laciniis numero aequalia, libera v. interdum coalita. Stamina petalis numero aequalia v. dupla, alterna iisdem opposita tune breviora v. ananthera. Ovaria plura, libera v. plus minus coalita, biovulata, ovulis collateralibus v. oblique superpositis, rarissime quadriovulata. Capsula pleiococca, coccis abortu saepissime monospermis, endocarpio cartilagineo, soluto, elastice bilobo. Embryo albumine inclusus v. exalbuminosus, rectus v. subincurvus. - Folia alterna v. opposita, simplicia v. composita, saepe glanduloso-punctata, exstipulata. Gen. 5988-6024.

1. Cusparieae. Stamina petalis numero aequalia v. subdupla, plura ananthera. Ovala 2 , superposita. Seminum testa coriacea. Embryonis exalbuminosi, curvati cotyledones corrugatae, exterior interiorem involvens, radicula inflexa, inclusa. - Folia alterna $v$. rarissime subopposita, uni-v, saepius trifoliolata. Gen. 5988-5994.

2. Pillocarpeae. Stamina petalis numero aequalia v. rarius dupla, omnia fertilia. Ovula 2 , superposita v, collateralia. Testa coriacea, crustacea v. membranacea. Embryo exalbuminosus, rectus. - Folia alterna v. opposita, uni-bi-trifoliolata. Gen, 5995_6001.

Genus non satis notum. 6002.

3. Horeniene. Stamina dupla, rarissime simplici petalorum numero, omnia fertilia. Ovnla 2, superposita. Seminum testa crustacea. Embryo in axi albuminis carnosi reetus. - Folia opposita v. alterna, simplicia, rarius ternata $v$, imparipinnata. Gen. 6003-6013.

4. Eudiosmeae. Stamina fertilia simplici petalorum numero, saepissime cum totidem sterilibus alterna. Ovula 2, superposita v. collateralia, Seminum testa coriacea, rarius suberustacea. Embryo exalbuminosus v. rarissime subalbuminosus, rectus. - Folia alterna v. opposita, simplicia. Gen. 6014-6023.

5. Hietammeae. Stamina duplo petalorum numero, omnia fertilia, Ovala 4. Seminum testa atra, nitida. Embryo intra albumen carnosum rectus.-Folia alterna, imparipinnata. Gen. 6024.

CCHAI. RU'TACEA. Calyx liber. Corollae petala calycis laciniis numero aequalia, libera. Stamina duplo v. rarissime triplo petalorum numero. Ovarium tri-quinquelobum, lo- 
culis bi-quadri-multiovulatis. Capsula loculicide dehiscens, v. septicide in cocea, introrsum dehiscentia soluta. Embryo in axi albuminis plus minus arcuatus v, rectus. - Folia alterna, simplicia, saepissime lobala v. decomposita, glandulosa, exstipulata v.substipulata. Gen. 6025 -6029 .

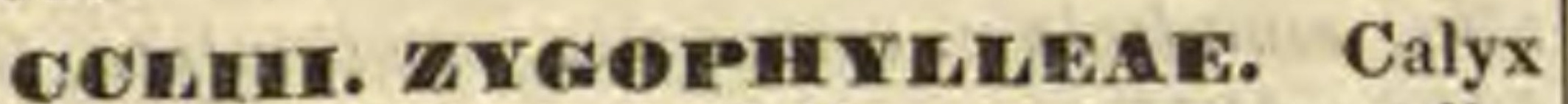
liber. Petala calycis laciniis numero aequalia. Stamina duplo petalorum numero, omnia fertilia, filamenta basi aequalia v. squamulae dorso inserta. Ovarium pluriloculare, loculis bi-multiovulatis, rarissime uniovulatis. Capsula loculicide dehiscens, septicide in cocca bivalvia v. indehiscentia delabens. Embryo exalbuminosus v. albumine corneo-cartilagineo inelusus. Folia opposita, impari v. abrupte pinnata, bistipulata. Gen. 6030-6041.

1. Tribuleae. Semina exalbuminosa. Gen. $6030-6031$.

2. Zyaoplaylleae verae. Semina albuminosa. Gen. 6032-6041.

Genus affine 6042.

* MeLIANTHEAE. Gen. 6043.

* BIEBERSTEINIEAE. Gen, 6044.

\section{Classis LVII. Aruinales.}

Flores hermaphroditi. Calyx liber. Corollae petala calycis laciniis numero aequalia v. pauciora, hypogyna. Stamina hypogyna, petalis numero aequalia v. alterna, $v$. dupla, rarius tripla, saepe monadelpha, alterna interdum ananthera. Ovarium e carpidiis immediatim coalitis $\mathbf{v}$, axi cen. trali adnatis compositum. Ovula in loculis solitaria, gemina v. rarius plura. Fructus capsularis v, rarius baccatus. Embryo exalbuminosus $\mathbf{v}$, albumine carnoso inclusus.

CCHIV. GERANIACEAE. Flores regulares v. subirregulares. Carpidia 5, colummae centrali adnata, biovulata. Semina exarillata, exalbuminosa. Embryo curvatus, cotyledonibus plicatis v. convolutis. Gen. 60456048 .

* RHYNCHOTheCEAE, Gen. 6049.

* LEDOCARPEAE. Gen, 6050-6051.

* VIVIANIEAE. Gen. 6052-6055.

CCEV. THNEA Flores regulares. Carpidia $4-5$, connata, biovulata. Semina exarillata, exalbuminosa. Embryo rectus v. subarcuatus, cotyledonibus planis, Gen, 6056-6057.

COEDI. DXAHIIDAR. Flores regulares. Carpidia 5, connata, uniovulata v. multiovulata. Semina arillata, albuminosa. Gen. $6058-6059$.

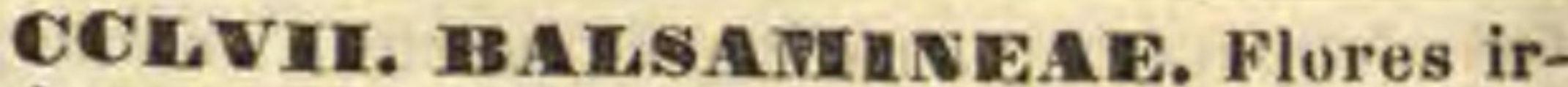
regulares. Carpidia 5, connata, paucí-multiovulata. Semina exarillata exalbuminosa. Embryo rectus, cotyledonibus plano-convexis. Gen. $6060-6061$.

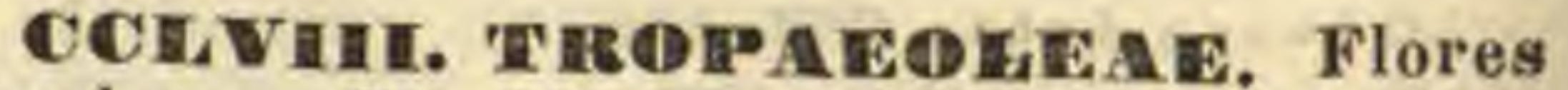
irregulares. Carpidia 2 v. 3, coalita, uniovulata. Semina exarillata, exalbuminosa. Embryonis recti cotyledones crassae, inter se conferruminatae, basi biaurieulata. Gen. 6062 6064 .

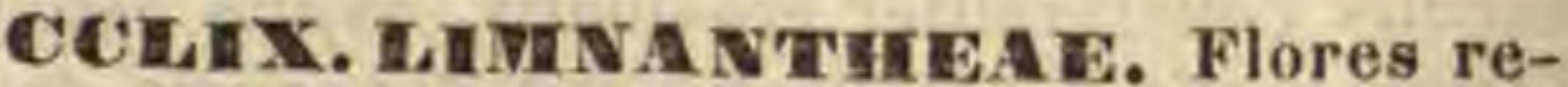
gulares, Carpidia 3 v. 5 , coalita, uniovulata. Semina exarillata, exalbuminosa. Embryonis recti cotyledones carnosae, plano-convexae. Gen. $6065 \_6066$.

\section{Classis Hix. Calyeiflorae.}

Calyx liber v. cum ovario connatus, valvatus, Corollae petala calycis fauci inserta, ejusdem lobis numero aequalia v. interdum pauciora. Stamina cum petalis v. infra petala inserta, plerumque duplo eorundem numero, rarius multiplo v. simplici pauciora. Ovarium uni- pluriloculare, loculis uni- multiovulatis. Embryo exalbuminosus $\mathbf{v}$. in axi albuminis carnosi orthotropus.

COHX. VACHYSICEAE. Calyx liber v. rarissime adnatus. Corolla saepissime monopetala. Stamen plerumque unicum. Ovarium liberum, triloculare, multiovulatum, v. adnatum, uniloculare, biovulatum, ovulis ereetis. Embryonis exalbuminosi cotyledones foliaceae, corrugatae, v. semicylindricae, rectae. Folia opposita v. verticillata, bistipulata v. exstipulata. Gen. 6067-6074.

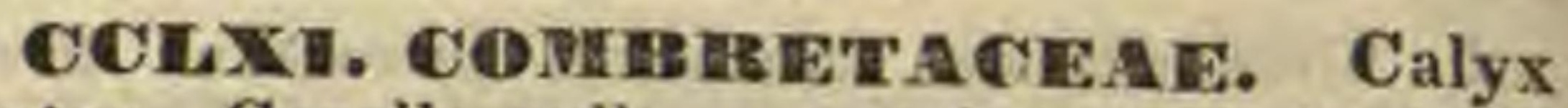
adnatus. Corolla nulla, v. petala calycis laciniis numero aequalia. Stamina simplici, duplici v. rarius triplici petalorum numero, Ovarium inferum, uniloculare, ovulis pluribus, ex apice loculi pendulis. Embryonis exalbuminosi cotyledones foliaceae, spiraliter convolutae v. crassiusculae, secundum longitudinem v. irregulariter replicatae. - Folia alterna v. opposita, exstipulata. Gen. 6075-6090.

1. 'Temminalieae. Calyx quinquefidns. Corolla saepissime nulla. Stamina 10. Cotyledones foliaceae, spiraliter convolutae. Gen. 6075-6086.

2. Combretere. Calyx quadri-quinquefidus. Corollae petala 4 v. 5 , Stamina 8 v. 10 . Cotyledones crassae, irregulariter v. Iongitudinaliter plicatae. Gen. 6087-6090.

Genera dubia 6091-6095. 
CCHXII. A HANGIEAE. Calyx ad-1 natus. Corollae petala calycis laciniis numero aequalia. Stamina simplici, duplici v. quadruplici petalorum numero. Ovarium uni-biloculare, ovulo unico ex apice loculi pendulo. Embryo intra albumen rectus, - Folia alterna, exstipulata. Gen. 6096-6097.

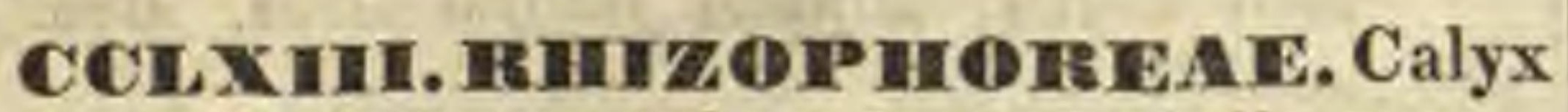
adnatus. Corollae petala calycis laciniis numero aequalia. Stamina duplo v. triplo, rarius multiplo petalorum numero, saepissime geminatim iisdem opposita. Ovarium bi-tri-quadriloculare, loculis collateraliter biovulatis, v. uniloculare, sexovulatum, ovulis pendulis. Embryonis exalbuminosi, intra pericarpium germinantis radicula longissime exserta, - Folia opposita, stipulis interpetiolaribus. Gen. 6098-6104.

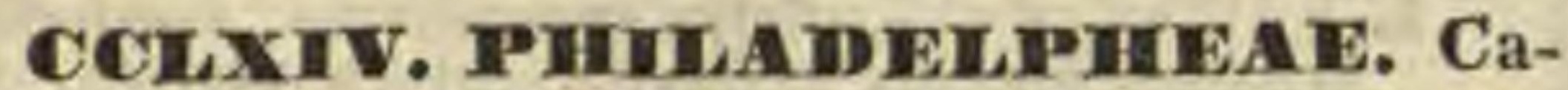
lyx adnatus. Corollae petala calycis laciniis numero aequalia. Stamina duplici v. multiplici petalorum numero. Ovarium tri-mulıiloculare, placentis centralibus multiovulatis. Embryo in axi albuminis carnosi rectus. - Folia opposita, exstipulata. Gen, 6105-6107.

CCLXv. OENOTHEIREA Calyx adnatus. Corollae petala calycis laciniis numero aequalia. Stamina simplici v. duplici petalorum numero, rarissime iisdem pauciora. Ovarium inferum, pluriloculare, loculis multi- rarissime pauciovulatis. Embryo exalbuminosus, cotyledonibus foliaceis v. subcarnosis, basi saepissime biauriculatis. - Folia opposita v. alcerna, exstipulata. Gen. 6108_6132.

I. Jussieuese. Calycis tubus ultra ovarium haud prodactus. Stamina petalis numero aequalia v. dupla, Fructus capsularis, septicide dehiscens. Semina inappendiculata. Gen. 6108_6111.

IX. Epilobieae. Calycis tubns saepissime supra ovarium plus minus productus. Stamina duplo petalorum numero. Fructus capsularis, loculicide dehiscens, polyspermus. Semina nuda, fimbriata v. papposa. Gen. 6112_6122.

III. Montimieae. Calyx tubo supra ovarium producto v. eidem aequali. Fructus capsularis, loenlicide dehiscens, polyspermus. Semina alata. Gen. 6123_6124.

IV. Fuchsiene. Calyx tubo supra ovarium producto. Stamina duplo petalorum numero. Fructus baccatus, polyspermus. Gen, 6125.

V. Hopezieae. Calyx tabo supra ovariom produeto. Petala 4 , v, interdum nulla. Stamina 2 v. 1. Fruetus capsularis, polyspermus. Gen. 6126-6128.

v1. Circaeaceae. Calyx tubo ultra ovarium haud producto, limbo bilobo. Petala 2. Stamina 2. Fructns bilocularis, indehiscens. Semina in loculis solitaria. Gen. 6130 .
VII. Gaureae. Calyx tubo supra ovarium producto. Stamina duplo petalorum numero. Fructus nucamentaceus, mono-tetraspermus. Gen. 6131_6132.

Genus dubium 6133 .

CCHXvi. Hatoragene. Calyx adnatus. Corolla nulla v. petala calycis laciniis numero aequalia. Stamina caly cis laciniis numero aequalia v. dupla, interdum duplo numero triente pauciora, nonnunquam unicum. Ovarium uni-pluriloculare, loculis uniovulatis, ovulis pendulis. Embryo in axi albuminis carnosi rectus. - Folia opposita verticillata, rarissime alterna, exstipulata. Gen. 6134 $-6139$.

* TRAPEAE. Embryonis exalbuminosi cotyledones valde inaequales, Gen, 6140 .

CCLXVII. LYTHEARIEAR. Calyx liber. Corollae petala calycis fauci inserta. Stamina petalis numero aequalia v. saepius dupla aut tripla. Ovarium bi-pluriloculare, multiovulatum. Embryo exalbuminosus. Gen. 6141-6168.

I. Eulythrarieae. Semina aptera. Gen. $6141-6160$.

II. Tagerstrobmieae. Semina alata, Gen. $6161-6166$.

Genera dubla 6167_6168.

\section{Classis Hx. Myrtiflorae.}

Calyx liber v. cum ovario connatus, valvatus. Corollae petala calycis fauci inserta, ejusdem laciniis numero aequalia. Stamina cum petalis inserta, duplici v. multiplici eorundem numero. Ovarium pluriloculare, rarissime uniloculare. Embryo exalbuminosus.

CCIXXIII. IIEIASTORHACEAE. Calyx liber v. adnatus. Stamina $8-12$, aestivatione induplicata. Antherae longae. - Folia epunctata. Gen. 6169-6268.

I. MELASTOMEAE. Antherae apice uni-biporosae. Gen. 6169-6262.

1. Lavoislereac. Antherae unl-biporosne. Ovarinm liberum, apice saepissime glabrum, Capsula sicca. Semina recta, ovata v. angula ta. Gen. 6169-6191.

2. Rhexie a e. Antherae uniporosae, Ovarium Hberum, vertice plerumque glabrum. Capsula sicca. Semina cochleata. Gen. 6192_6206.

3. Os becklea e. Antherae uniporosac. Ovarium Hiberum v. adnatum, vertice saepissime setis v. squamis coronatum. Semina cochleata, Gen, 6207_6225.

4. Miconieac. Antherae nul-biporosae. Ovarium ad. natum. Fructus baccatus. Semina haud eochleata. Gen, $6226-6262$. 
II. ChariantheaE. Antherae rimis longitudinalibus dehiscentes, Gen. 6263-6268.

* MEMECYLEAE. Gen, 6269-6271.

* OLINIEAE. Gen. 6272-6274.

CCLXIX. MYRTACEAE. Calyx adnatus. Stamina saepissime indefinita, aestivatione haud induplicata. - Eolia pellucido-punctata. Gen. 6275-6339.

I. Chamael laceieae. Ovarium uniloculare, ovulis basilaribus, sotitariis $\mathbf{v}$. pluribus. Capsula monosperma, indehiscens $v$, apice incomplete bivalvis. Gen. 6275-6288.

II. Heptosperaneae. Ovarium bi-multiloculare, loculis multiovnlatis v. rarius uniovalatis. Capsula loculicide v. septicide dehiscens, rarius indehiscens. Gen 6289_6311.

III. Mlyrteac. Stamina libera. Ovarium bipluriloculare, loculis multiovulatis. Bacca biplurilocularis, loenlis abortu saepissime monospermis. Gen. 6312-6324.

1У. IBarringtoraifene. Stamina monadelpha. Ovarium bi-pluriloculare, loculis panci-multiovulatis, Gen. 6325-6327.

Genera du bia. $6328 \_6330$.

ॠ. Heeythideae. Stamina in urceolum hine abbreviatum, illinc in ligulam petaloideam, sterilem v, antheriferam productam coalita. Ovarium pluriloculare, loculis multiovulatis. Fructus siceus v, carnosus, indehiscens v, disco epigyno opereulatim secedente apertus. Gen. $6331-6394$.

Genera penitus dubia. $6335-6339$.

* granateaE, Gen, 6340.

\section{Classis IXI. Fesifforne.}

Calyx liber v. cum ovario connatus, imbricatus v. rarius valvatus. Corollae petala calycis fauci inserta, ejusdem laciniis numero aequalia et alterna. Stamina cum petalis inserta, saepissime indefinita. Ovaria plura, libera $\mathrm{v}$. inter se et cum calyce connata, uni-multiovulata. Fructus nucamentaceus, drupaceus, baccatus v. follicularis, mono - polyspermus, Embryo exalbuminosus.

CCHXX. POMACEA E. Ovarium inferum, bi-quinqueloculare, rarissime uniloculare. Fructus baccatus. Gen. $6341-6354$.

CCHXXI. CALYCANTHEA E. Ovaria plurima libera, calycis tubo intus undique inserta, uniovulata. - Folia opposita, simplicia, e.cstipulata. Gen. 6355-6356.

CCLXXII. ROSACEAE. Ovaria plurima libera, calycis fundo inserta, uniovulata, rarius bi-multiovulata. - Folia alterna, composita, stipulata. Gen. 6357-6403.

I. Itoseae. Calyx tubo ventricoso, fauce constricto. Stamina indefinita. Ovaria plurima, inclusa, ovulo unico, pendulo. Achenia calyce baccato inclusa. Semen pendulum. - Suffrutices $v$, arbusculae, foliis imparipinnatis, rarissime nullis, stipulis foliiformibus. Gen. 6357 -6358 .

II. Iryadeae. Calyx nudus $v$. bractenlis adnatis, cum laciniis alternantibus auctus. Stamina indefinita v. rarius definita. Ovaria plarima, rarius panca v. solitaria, receptaculo convexo v, stipitiformi insidentia, uni-biovalata. Achenia plurima, calyci explanato imposita, rarius pauca v. solitaria, ejusdem tubo inclusa. - Herbae v. frutices, foliis digitatim v. pinnatim compositis, rarius simplicibus, Gen. $6359-6389$.

1. Dalibardea e. Calyx ebracteolatus, saepissime imbricatus. Stamina indefiuita. Ovaria plurima. Stylus terminalis v. subterminalis. Radicula supera. Gen. $5359-6360$.

2. Fragarieae. Calyx valvatus, bracteolis imbrieantibus. Stamiua indefinita. Ovaria plurima. Stylus latera. lis v. terminalis. Radicula supera. Gen. 6361-6363.

3. C h a ma e r hodeae. Calyx valvatus, nudus v. bracteolatus. Stamina 5_10. Ovaria 5 - 10, v. interdua plura. Styli laterales v. terminales. Radieula supera. Gen. $636 t$ t 6367 .

4. S a ng u is or be a e. Calyx valvatus, rarius imbricatus, nudus v. bracteolatus, fruetifer clausus, indura. tus. Carolla saepius nulla. Stamina pauca $(1-15)$, ra* rius plura. Ovaria 1 -2, rarius plura. Styli termisales v. laterales. Radicula supera. Gen, 6368-6379.

5. C e r e c a r pe a e. Calyx imbricatus. Stamiaa plurima. Ovarium unieum. Stylus terminalis. Radicula infera. Gen. 6380_6381.

6. Eudryadeae. Calyx valsatus, nudus v, bracteolatus. Stamina plurima. Ovaria plurima. Stylos terminalis. Radicula infera. Gen, 6382_6389.

IIII. Spiraeaceae. Calyx aestivatione imbricatus v. rarius valvatns. Stamina indefinita. Ovaria saepissime 5 , verticillata, rarius $2 \mathrm{v}$. solitaria, bi-multiovulata, ovalis pendulis $\mathbf{v}$. adscendentibus. Follicnli capsulares, dehiscentes, mono-polyspermi. - Frutices v, arbusculae, rarius herbae, Gen. 6390_6400.

1. Spireae verae. Semina aptera. Gen. 6390_6395.

2. Quillaje a e. Semina alata, Gen, 6396-6400.

IV. Neuradeae. Calyx tubo cum ovario conerescente. Stamina 10, Ovaria 10 , coalita. Fructus eapsularis, loculis monospermis. Semina pendala. - Herbae, foliis sinuato-pinnatifidis $v$. bipinnatifidis, bistipulatis. Gen. 6401 - 6403 .

CCHXXEI. AMYGDALEAE. Ovarium unicum, rarissime plura, libera, biovulata, ovulis collateraliter pendulis. Fructus drupaceus. - Folia allerna, simplicia, exstipulata. Gen. 6404-6406.

CCLXXIV. CHIRYSOBALANEAE. Ovarium unicum, liberum, biovulatum, ovulis e basi erectis, collateralibus. Fructus drupaceus. Gen. $6407-6417$. 


\section{Classis HXII. Hegumainosae.}

Calyx liber, imbricatus v. rarius valvatus. Corollae perigynae v. rarissime hypogynae petala calycis laciniis numero aequalia v. abortu pauciora, inter se inaequalia imbricata, v. aequalia valvata. Stamina duplo petalorum numero $v$. indefinita. Ovarium simplex, uniloculare. Legumen v. Iomentum. Embryo exalbuminosus aut parce albuminosus, rectus $\mathbf{v}$. curvatus.

COLXXV. RAPILIONACEAE. Corolla perigyna, irregularis, papilionacea v. subpapilionacea, imbricata. Stamina 10, libera, monadelpha v. diadelpha. Embryo curvatus v. rarius rectus. Gen. $6418-6810$.

1. Podalyriene. Corolla papilionacea. Stamina 10, libera. Legumen bivalve, rarissime indehiseens et tune calyce brevius. Embryonis cotyledones germinatione foliaceae, radieula incurva. - Folia unifoliolata v. palmatim trifoliolata, rarissime imparipinnata. Gen. $6418-6450$.

1. Eupadaly ríea e. Ovarium pluriovulatum. Leguminis suturae haud introflexae. Gen. 6418-6432.

2. P u Ite na a e. Ovarium hiovulatum. Leguminis saturae haud introflexae, Gen, 6433-6447.

3. Mirbeli e a e. Ovariom bi-plariovalatum. Leguminis suturae istroflexae. Gen. 6448-6450.

2. Hoteae. Corolla papilionacea. Stamina 10 , monadelpha. Legumen bivalve, continuum. Embryonis cotyledones germinatione foliaceae, radicula incurva. - Folia unifoliolata v. palmatim bi-plurifoliolata, saepissime imparipinnata. Gen, 6451_6577.

1. Genistea e. Legumen uniloculare. Stamina saeplssime monadelpha. - Falia simplicia v. palmata, ra. rius pinnata, Caulis saopissime fruticosus. Gen, 6451 - 6506.

2. Trifolieae. Legumen uniloculare. Stamina diadelpha. - Folia saepissimo palmatim tríquinquefoliolata, rarissime imparipinnata, primordialia alter. na. Caules herbacei, rarius frutescentes. Gen. 6507 $-6521$.

3. Galege a e. Legumen uniloculare, Stamina saepissime diadelpha, - Folia pinnatim trifoliolata $v$. mul. tijuga cum impari, primordialia opposila. Caules fruticosi v. arborei, rarius herbacei. Gen. 6522 -6568 .

4. Astragaleac. Legumen sufura altera introflexa longitudialiter blloculare v. semibiloculare. - Folia pinnata, primordialia alterna. Caules herbacei $v$. suffruticosi. Gen. 6569_6577.

3. Wîcieae. Corolla papilionacea, Stamina 10 , diadelpha. Legamen bivalve, continumm. Kubryonis cotyledones crassae, germinatione hypogeae, radicola incurva. - Fo. lia saepissime abrupte pinnata, petiolo communi in setam v, cirrhum producto, Gen, 6578 -6583 .

4. Inedysareac. Corolla papilionacea. Stamina 10, monadelpha v. diadeipha. Legu- men transversim in articulos monospermos secedens. Embryonis cotyledones germinatione foliaceae, radicula incurva, - Folia uni-trifoliolata $v$, imparipinnata, saepissime stipellata. Gen. 6584-6629.

1. Coronille a e. Flores umbellati. Legumen teres s. compressum. Gen, 6584-6589.

2. Buhedysareae. Flores racemosi v. spicati. Legumen compressum. Gen, 6590_6624.

3. A 1 h a ge a e. Flores racemosi v. spieati. Legumen teretiusculum, Gen, 6625-6629.

5. Plnaseoleae. Corolla papilionacea. Stamina 10, monadelpha v. diadelpha. Legumen bivalve, continuum $v$, isthmis inter semina interceptum, nec tamen in articulos secedens. Embryonis cotyledones crassae, germinatione hypogeae v, epigeae, radicula incurva. - Folia pinnatim trifoliolata v. rarius plurijuga, saepissime stipellata. Gen $6680-6699$.

1. Clitorie a e. Inflorescentla simplieiter v. fasciculato racemosa. Vexillum exappendiculatum, saepius amplum. Stamen vexillare liberum v. medio conuatum, nunquam genicnlatum. Ovarium pluriovalatum. Semina estrophiolata. Gen. $6630-6640$.

2. Ke n ned y e a e. Inflorescentia simpliciter v. fasciculato-racemosa. Vexillum blappendiculatum v. exappendiculatum. Stamen vexillare basi connatum v. omaino liberum, haud geniculatum. Ovarium pluriovulatum. Semina saepissine stropliulata. Gen. 6641_6645.

3. GIy eineae. Inflorescentia saepissime nodoso-racemosa. Vexillua plerumque blappendiculatum. Stamen vexillare basi conatum $v$, omuino liberum. Ovarium piuriovalatum. Stylas non induratus, Semina estrophiolata. Gen. 6646-6656.

4. Di ocleac. Inflorescentia saepissime nodoso-racemosa. Vexillum plerumque biappendiculatum. Stamen ve. xillare ima basi liberum, supra basim eum reliquis conuatum. Ovarium pluriovalatum. Stylus non induratus. Semina estrophiolata v. rarius strophiolata. Gen. $6657-6664$.

5. Erythrinea e. Inflorescentia nodoso racemosa, Vexillum exappendiculatum. Stamen vexillare liberum. Ovarium pluriovulatum. Legumen ladehiscens. Gen. 6665 -6670.

6. Wisteriea e. Ovarium pluriovulatum. Inflorescentia racemosa. Vexillum saeplssime biappendiculatum. Stamen vexillare liberum. - Folia bi-multijuga, Gen, $6671-6673$.

7. Euphas eoleae. Ovarium pluriovulatam. Inflorescentia nodoso racemosa. Vexillum biappendiculatum. Stamen vexillare supra basim saepissime geniculatum, liberum, v. rarius medio cum reliquis connexum. Ovarinm pluriovulatum. Stylus supra medium induratus. Gen, 6674-6684.

8. Cajanea e. Ovarium pluriovulatum. Legumen extus libeis transversis v, obliquis coustrictum. Gen, 6685 -6689 .

9. R h y $\mathrm{n}$ cho s I e a e. Ovarium biovulatum. Gen, 6690 -6697 .

10. A hrinea e. Stamina 9, monadelpha. - Folia $a b$ rupte pinnata. Gen. 6698.

6. Dalbergieae. Corolla papilionacea. Stamina 10, monadelpha v, diadelpha. Legumen indehiscens, intus saepe isthmis interceptum. Embryonis cotyledones crassae, carnosae, radicula incurva v, rarius reeta. - Folia pinna$t a$, foliolis saepe alternis, rarius unifoliolata. Gen. $6700-6735$.

\%. Sophoreae. Corolla papilionacea. Stamina 10 , rarins 8 v, 9, libera. Legumen indehiscens v, bivalve. Embryonis cotyledones 
foliaceae $\mathbf{v}$. crassiusculae, radicula incurva $\mathbf{v}$. recta. - Folia imparipinnata v. simplicia. Gen. 6736-6750.

9. Caesalpinieae. Corolla irregularis subpapilionacea, v. fere regularis, interdum nulla. Stamina 10 v. pauciora, libera v. rarius coalita, Embryo rectus. - Folia impari $v$. abrupte pinnata, interdum bi-tripinnata, nonnunquam simplicia. Gen. 6751-6810.

* MORINGEAE. Gen. 6811.

CCLXXVI. SUEARTZIEAE. Calyx valvatus. Corolla hypogyna, imbricata v. nulla. Stamina hypogyna, definita v, indefinita, libera. Embryo curvatus. Gen. 6812-6815.
* DetarieaE. Corolla nulla. Stamina perigyna, Gen, 6816_6817.

CCLXXVII. MITMOSEAT. Calyx valvatus v. rarissime imbricatus. Corolla hypogyna v. subperigyna, valvata $v$. rarissime imbricata, saepius gamopetala. Stamina hypogyna, rarissime perigyna, saepissime indefinita, libera v. monadelpha. Embryo rectus. Gen. $6818-6838$.

1. Parkieae. Calycis et corollae aestivatio imbricata staminibus hypogynis, v. subimbricata staminibus perigynis. Gen. 6818-6819.

2. Acacieae. Calycis et corollae aestivatio valvata. Gen. 6820 _ 6838. 
GENERA PLANTARUM. 


\section{CONSPECTUS DISPOSITIONIS.}

\section{I.}

\section{THALLOPHYTA.}

1. Protophyta.

2. Hysterophyta.

\section{CORM O PHYTA.}

3. Acrobrya.

1. Anophyta.

2. Protophyta.

3. Hysterophyta.

4. Amphibrya.

5. Acramphibrya.

1. Gymnosperma.

2. Apetala.

3. Gamopetala.

4. Dialypetala. 


\title{
II.
}

\section{REGIO I. THALLOPHYTA.}

\section{Sectio 1. Protopling.}

\author{
1. Algae. 2. Lichenes. \\ Sectio z. Il ysterophyta. \\ 3. Fungi. \\ REGIO II. CORMOPHYTA. \\ Sectio s. Acrobrya. \\ Cohors 1. Anophyta.
}

4. Hepaticae. Id 5. Musci.

Cohors 2. Protophyta.

6. Equiseta. 7. Filices. 8. Hydropterides. 9. Selagines. 10. Zamiae.

Cohors 3. Hysterophyta.

11. Rhizantheae.

\section{Sectio 4. Amphibrya.}

12. Glumaceae.

13. Enantioblastae.

14. Helobiae.

15. Coronariae.
16. Artorhizae.

17. Ensatae.

18. Gynandrae.

19. Scitamineae.
20. Fluviales.

21. Spadiciflorae.

22. Principes.

\section{Sectio5. Aeramphibrya.}

\section{Cohors 1. Gymnosperma.}

23. Coniferae.

Cohors 2. Apetala.

24. Piperitae.

26. Juliflorae.

28. Thymeleae.

25. Aquaticae.

27. Oleraceae.

29. Serpentariae.

Cohors 3. Gamopetala.

30. Plumbagines.

31. Aggregatae.

40. Discanthae.

41. Corniculatae.

42. Polycarpicae.

43. Rhoeades.

44. Nelumbia.

45. Parietales.
32. Campanulinae.

33. Caprifolia.
34. Contortae.

36. Tubiflorae.

35. Nuculiferae. 37. Personatae. 39. Bicornes.

Cohors 4. Dialypetala.

46. Peponiferae.

47. Opuntiae.

48. Caryophyllinae.

49. Columniferae.

50. Guttiferae.

51. Hesperides.
52. Acera.

53. Polygalinae.

54. Frangulaceae.

55. Tricoccae.

56. Terebinthinae.

57. Gruinales.
58. Calyciflorae.

59. Myrtiflorae.

60. Rosiflorae.

61. Leguminosae. 


\section{Regio I. Thallophyta.}

\section{Sectio I. Protophyta.}

\section{CLASSIS I. ALGAE.}

1. Diratomacene $1-24$.

1. Diatomeae $1-18$. a. Fristulieae $1-12$. b. Hydrolineae 13-18.

2. Desmidlieae 19-24. c. Mierasterieae $19-21$. d. Echivelleae 22-24.

2. Nostoelninae $25-36$.

3. Confervaceac $37-75$.

1. Leptomiteae $37-38$.

2. Oscillatorieae $39-47$.

3. Batrachospermeae $48-52$.

4. Conferveae $53-56$.

5. Ceramieae 57-75.

4. Characeae $76-77$.

5. Ulvacene $78-86$.

1. Siphoneae 78-82.

2. Ulveae $89-86$.

6. Floridate $87-103$.

7. Fucaceat $104-122$.

\section{CLASSIS II. LICHENES.}

8. Comịt)thalamê $123-130$.

1. Pulverarieae 123-126.

2. Calycieae 127-130.

9. Idît ha Inani $191-146$.

1. Graphideae 181-136.

2. Glyphideae 137-139.

3. Limboriear $140-144$.

4. Pyxineae 145-146.

10. Casterothallama $147-159$.

1. Verrncarieae $147-150$.

2. Trypetheliaceae $151-154$.

3. Endocarpeae 155-157.

4. Sphaerophoreae 158-159.

11. IIIymemothal amai 160179.

1. Collemaceae $160-164$.

2. Lecidineae $165-169$.

8. Parmeliaceae 170-174.

4. Usneaceae 175-179.

\section{Sectio II. Hysteropleyta.}

CLASSIS III. FUNGI.

12. Cymmomycetes 180-207. 1. Entophyti $180-187$.
2. Sporodermei 188-192.

3. Stilbosporei $193-200$.

4. Tubercularini $201-207$.

13. IIIy pliom yeetes 208-270.

1. Sepedoniei 208-216.

2. Mucedines 217-229.

3. Dematiei 230-241.

4. Mucorini 242261.

5. Cephalotrichei 262-270.

14. Gasteromyeetes 271-359.

1. Perisporiacei 271-280. a. Apiosporei $271-275$. b. Perisporel 276-280.

2. Selerotiacei $281-290$. c. Sclerotiei $281-286$. d. Rhizogouei $257-290$.

3. Trichodermarei $291-304$. e. Aegeritei 291-294. f. Trichoderniei 295-299. g. Onygenei $300-304$.

4. Trichospermei $305-336$.

A. Myxogasteres $305-\mathbf{3 2 2}$.

b. Trichiacei $305-309$.

i. Stenmonitei $310-314$.

k. Physarei $315-318$.

1. Aethalinei $319-322$.

B. Trichogasteres 323-336.

m. Cenoenceei 323-324.

u. Podaxidei $325-397$.

o. Sclerodermei $328-331$. p. Lycoperdei $332-336$.

5. Angiogasteres $337-359$.

q. Carpobolei $337-339$.

x. Nidulariacel $340-344$.

s. Tuberacei $345-354$. ic. Tuberei 345-352. B. Hymenogasterel 353-354. t. Phalloidel $355-359$.

15. Pycenomy eetes $360-397$.

1. Xylomacei $360-864$.

2. Cytisporei $365-368$.

3. Phacidiacei $869-382$.

a. Phacidiel $369-373$.

b. Gloniei $374-376$.

c. Dermei $377-379$.

d. Tympanidei 380-382.

4. Sphaeriacei $383-\mathbf{3 9 7}$.

e. Dothidini $383-385$.

f. Strigulini $386-389$.

g. Dichaenei $390-393$.

b. Sphaerini $394-397$.

16. Hym enowa yetes $398-453$.

1. Tremellini 898-411.

a. Hymenulf $398-399$.

b. Tiemellei $400-403$.

e. Cupulares 404-406.

d. Pileolares 407-411,

2. Clavariei $412-421$.

e. Clavulati 412-415.

f. Mitrulini 416-419.

g. Pileolati $420-421$.

3. Helvellacei $422-435$.

h. Cupulati 428-423.

i. Clavieulares $424-427$. k. Cupulati $428-431$.

l. Mitrati $432-435$.

4. Pileati $436-453$.

m. Auricularini $436-437$.

n. Hydnei $438-443$.

o. Polyporei $446-448$.

p. Agaricini $449-453$.

\section{RegioII. Cormophyta.}

\section{Sectio III. Acrobrya.}

Cohors I. Anophyta.

CLASSIS IV. HEPATICAE,

17. Hichiacene $454-458$.

18. Antirecenotere $459-460$.

19. Trargioniaceac $461-462$.

20. II arelaantiaceas $463-470$.

21. Jumgermammiaceae 471 -474 .

Classis V. MUSCI.

22. An direa eacene 475 .

23. Splasganceae 476 .

24. Trayaceae $477-600$.

Cohors 11. Protophyta.

CLASSIS VI. EQUISETA.

25. Equisetaceae 601-602.

CLASSIS VII, FIUICES.

26. Polypodiaceae $603-656$.

1. Polypodieae 603-619.

2. Cyatheaceae 650-654.

3. Parkeriaceae 655-656.

27. IIIymenoplinglleae 657-58, 28. Tleicheniacene $659-660$. 29. Selainacacene $661-664$.

30. Dsmand aceace $665-666$.

31. Tliaratiaceae $667-670$.

32. D phiozlossene $671-674$.

* Filices fossiles 675-687.

CLASS, VIII. HYDROPTERIDES.

33. Salviniacene $688-689$.

34. NIarsileacene $690-692$.

CLASSIS IX. SELAGINES.

35. Isoetene $693-694$.

36. Lyeo podíneeae $695-698$.

37. Lepidrodemalleae 699-703. 
CLASSIS X. ZAMIAE.

38. Cyeadeaceae $70 t-713$.

Cohors III. Hysterophyta.

Classis XI. RHIZANTHEAE.

39. IBallanoplaoreae $714-722$.

1. Sarcophyteae 714 .

2. Lophophyteae 715-716.

3. Cynomorieae $7 \mathbf{7 1 7}-718$.

4. Helosieae 719-722.

40. Cytineare 723-724.

41. Fenflesiaceae $725-727$.

Sectio IV. Amphibrya.

CLASSIS XII. GLUMACEAE.

42. Cramineae $728-956$.

1. Oryzeae $728-740$.

2. Phalarideae $741-759$.

8. Paniceae $760-792$.

4. Stipaceae 793-802.

5. Agrostideae $803-816$.

6. Arundinaceae $817-826$.

7. Pappophoreae 827-833.

8. Chlorideae $834-855$.

9. Avenaceae $856-874$.

10. Festucaceae $875-911$.

a. Bromeae $875-903$.

b. Bambuseae 904-911.

11. Hordeaceae $912-919$.

12. Rottboelliaceae $920-932$.

18. Andropogoneae $933-956$.

43. Cyperacene $957-1003$.

1. Cariceae $957-959$.

2. Elyneae $960-962$.

3. Sclerieae $963-965$.

4. Rhynchosporeae $966-979$. a. Rhynehosporeae verae $966-974$ b. Schoenoideac 975-979.

5. Cladieae $980-984$.

6. Chrysitricheae $985-986$.

7. Lipocarpheae $987-989$.

8. Fuireneae $990-998$.

a. Melaneranideae $990-992$. b. Hemichlaeneae 993-994. c. Ficineae 995-998.

9. Scirpeae 999-1001.

10. Cypereae $1002-1003$.

CL. XII. ENANTIOBLASTAE.

44. Centrolepialene 1004-1007.

45. Festiacene $1008-1021$.

46. Eriocanioneae 1022-1024.

47. Xyridene 1025-1027.

48. Comnmelymaceae 1028 1036.

CLASSIS XIV. HELOBIAE.

49. Alismaceae $1037-1043$. 1. Juncagineae $1037-1040$.

2. Alismeae 1041-1043.

50. Tatomaceae $1044-1046$.

Classis XV. Coronariae.

51. Jumeaceae $1047-1050$.
* Astelieae 1051-1052.

* Rapateae 1053.

* Flagellarieae 1054.

* Xerotideae 1055-1056.

* Kingiaceae 1057-1058.

* Calectasieae 1059.

52. Ihily dineae' $1060-1061$.

53. Di ellamthaceae $1062-1086$.

1. Veratreae 1062-1083.

2. Colchiceae 1084-1086.

54. Fonted eraceace 1087-1089.

55. Hilineeae $1090-1175$.

1. Tulipaceae 1090-1099.

2. Agapantheae 1100-1112.

3. Aloineae 1113-1117.

4. Asphodeleae 1118-1175.

a. Hyacintheae $1118-1137$.

1. Anthericeae $1138-1183$.

* Conanthereae 115/-1158.

* Tulbaghineae 1159.

c. Asparageae $1160-1167$.

- Aphyllantheae 1168-1173.

* Gilliesiaceae 1174-1175.

56. Smilaceae $1176-1188$.

1. Parideae $1176-1178$.

2. Convallarieae 1179-1188. * Aspidistreae 1189-1191.

* Ophiopogoneae 1192-1194.

* Herrerieae 1195.

* Eriospermeae 1196.

* Roxburghiaceae 1197.

* Philesieae 1198-1199.

CLASSIS XVI. ARTORHIZAE.

57. Fioseoreae $1200-1203$.

58. Theeaceace $1204-1205$.

CLASSIS XVII. ENSATAE.

59. Hy droelharideae $1206-$ 1216.

1. Anacharideae 1206-1208.

2. Vallisnerieae 1209-1210.

3. Stratiotideae 1211-1216.

60. Bunganmiaceae 1217 1219.

61. Trivilene $1220-1248$.

62. Hilnemodoraceae $1249-$ 1260.

*Vellozieae 1261-1262.

63. Fifyoxideae 1263-1264.

64. Amaryllideae $1265-1296$.

1. Amarylleae 1255-1281.

2. Narcisseae 1282-1290.

3. Anomalae 1291-1296.

* Agaveat 1297-1298.

65. Bromeliaeeac $1299-1315$.

CLASSIS XVIII. GYNANDRAE.

66. Drehidaleae $1316-1618$.

1. Malaxideae 1316-1369. a. Pleurothallese $1316-1348$.

b. Dendrobieae 13:49-1369.

2. Epidendreae $1870-1397$.
3. Vandeae 1398-1506.

4. Ophrydeae $1507-1543$.

5. Gastrodieae 1544-1546.

6. Neottieae 1547-1586.

7. Arethuseae 1587-1617.

8. Cypripedieae 1618.

67. Apostasieae 1619-1620.

CLASSIS XIX. SCITAMINEAE.

68. Zingiberncene 1621-1640.

1. Globbae 1621.

2. Zingibera 1622-1625.

3. Amoma 1626-1680.

4. Alpiniae 1631-1637.

5. Costi 1688-1640.

69. Camancene $16+1-1646$.

70. Mrusacene $1647-1650$.

1. Heliconieae 1647.

2. Uranieae 1648-1650.

* Scitamineae fossiles 1651-1654.

CLASSIS XX. FLUVIALES.

71. Najadene 1655-1664.

* Najadeae fossiles 1665-1667.

* Lemnaceae 1668.

CLASSIS XXI. SPADICIFLORAE.

72. Aroideae $1669-1708$.

I. Araceae 1669-16:96.

1. Pistiaceac $1669-1670$.

2. Cryptocoryneae $1671-1672$.

3. Dracunealineae $1673-1681$. a. Arisareae $1673-1674$ b. Euaroideae 1675-1679. c. Typhonieae 1680-1681.

4. Caladieae $1682-1690$. a. Colocasiear 1689-1689. b. Philodendreae 1690 .

5. Anaporeae 1691-1696. a. Spathicarpeae 1691-1693. b. Richardieae $1694-1696$.

II. Callaceae $1697-1708$.

6. Calleae 1697-1699.

7. Orontiaceae $1700-1706$. a. Pothoinae $1700-1703$. b. Dracontieae 1704-170s. c. Oronticae 1706.

8. Acoroideae $1707-1708$.

73. 'Ty plaseeae $1709-1710$.

74. Pamallaneae $1711-1715$.

1. Pandaneae verae 1711-1712.

2. Cyelantheae 1713-1715.

* Genera Pandaneis affinia 1716 -1717 .

* Pandaneae fossiles 1718.

CLASSIS XXI. PRINCIPES.

75. Palduae $1719-1783$.

1. Arecinae 1719-1735.

2. Lepidocaryinae $1736-1744$.

3. Borassinae 1745-1752.

4. Coryphinae $1753-1763$. a. Sabalinae $1753-1762$.

b. Phoenicinae 1763 .

5. Cocoinae 1764-1777.

* Palmae fossiles 1778-1783.

* Acrobryae fossiles dubii ordinis $1784-1788$. 
Sectio V. Acramphibrya.

Cohors I. Gymnospermae.

CLASSIS XXIII. CONIFERAE.

76. Cunpressinae $1789-1794$.

77. Abietinane $1795-1798$.

78. Traximeae 1799-1803.

79. Guetaceae $1804-1805$.

* Coniferae fossiles 1806-1816.

Cohors II. Apetalae.

CLASSIS XXIV. PIPERITAE.

80. Chaloranthaceae 1817 1819.

81. Piperaceae $1820-1823$.

82. Saurureae 1824-1828.

CLASSIS XXV. AQUATICAE.

83. Ceratoplaylleae 1829.

84. Calliticilainae 1830.

85. Podlostemmeae 18311837.

CLASSIS XXVI. JULIFLORAE.

86. Casuarimeae 1838.

87. Myricene 1839.

88. Betullaceae $1840-1841$.

89. Cupuliferae $1842-1848$.

90. Ulmaceae $1849-1850$.

91. Celtideae 1851-185\%.

92. Noreae $1855-1860$.

93. Arterarpene $1861-1878$.

94. Urtienceae 1879-1887.

- Cynocrambeae 1888.

- Gunneraceae 1889.

95. Cannabineae $1890-1891$.

96. Antillesmene $1892-1893$.

* Putranjiveae 1894-1895.

- Forrestiereae 1896.

* Scepaceae 1897-1899.

* Garryaceae 1900.

97. Plataneae 1901.

98. Balsamifluae 1902.

99. Salieinae 1903-1904.

* Hensloviaceae 1905

100. Laeistemmeae 1906-1907.

CLASSIS XXVII. OLERACEAE,

101. Chenepodeae 1908-1938.

I. Cyclolobeae 1908-1038.

1. Salicornieat 1908-1909.

2. Atripliceae $1910-1915$.

3. Chenopodieat $1916-1936$.

a. Camphinosmeae 1916-1920.

b. Btiteae $1921-1993$.

e. Hochieae 1994-1936.

4. Anredereae $1937-1938$

II. Spirolobeae 1939-1949.

1. Baselleae 1939.
2. Suedineae $1940-1942$

3. Salsoleae 1943-1949.

a. Halimocnemideas 1943-46.

b. Anabaseae 1947-1949.

* Genera Chenopodeis affinia 1950-1953.

102. Amarantacene 1954-1978.

1. Gomphreneae $1954-1959$.

2. Achyrantheae $1960-1968$.

a. Polycnemere $1960-1961$.

b. Aervene $1968-1968$.

3. Desmochacteae 1969-1971.

4. Amaranteae 1972-1978.

103. Polysomeae 1979-1999.

1. Eriogoneae 1979-1982.

2. Polygoneae verae 1983-1997.

3. Polygoneae spuriae 19981999.

104. Nyetagineae 2000-2013.

CLASSIS XXVIII. THYMELEAE.

105. MIominniaceae 2014-2022.

1. Munimieae 2014-2019.

2. Atherospermeae 2020-2022.

106. Lavurineae $2023-2067$.

1. Cinnamomeae 2023.

2. Camphoreae 2024 .

3. Phoebeae 2025-2026.

4. Perseae 2027-2032.

5. Cryptocaryeae $2033-2039$.

6. Acrodiclidia $2040-2043$.

7. Nectandreae 2044 .

8. Dieypellia $2045-2047$.

9. Oreodaphueae $2048-2055$.

10. Flaviflorae $2056-2057$.

11. Tetranthereae 2058-2062.

12. Daphnidinae $2063-2666$.

13. Cassyteae 2067.

107. Gypoenppeae 2068-2069. 108. Santalaceae $2070-2084$.

* Grubiaceae 2085.

* Nyssaceae 2086.

* Anthoboleae 2087-2088.

* Helwingiaceae 2090.

109. In aphoidene 2091-2109. 110. Aquilarinene 2110-2111. 111. Elacagneae $2112-2115$. 112. Penaerecae $2116-2118$. 113. Protenceas 2119-2159.

I. Nucamentaceae $2119-2141$. 1. Proteinae 2119-2130,

2. Conosperweas $2131-2133$.

3. Franklandieae 2134 .

4. Persoonieae 2135-2141.

II. Folliculares $2142-2159$.

1. Grevilleae $2142-2136$.

a. Hakaeeae $2142-2151$.

b. Embothrieae $2152-2156$.

2. Banksieae $2157-2159$.

CLASS. XXIX. SERPEN'TARIAE,

114. Aristoloehieae 2160 2166.

115. Nepentheae 2167.
Cohors III. Gamopetalae.

CLASSIS XXX. PLUMBAGINES.

116. Plantagineae 2168-2170. 117. Plumbaginea e 2171-2176.

* Salvadoraceae 2177.

CLASSIS XXXI. AGGREGATAE.

118. Valerianeae $2178-2189$.

119. Dipsaceae 2190-2195.

1. Morineae 2190.

2. Scabioseae $2191-2195$.

120. Compositae 2196-3032.

1. Teubuliflorae 2196-2898.

1. Vernoniaceae 2196-2251.

1. Vernonieae $2196-2241$.

a. Euvernonieae 2196-2230.

c. Ethulieae 2196 -2210.

B. Heterocomeae 2202-2921.

$\gamma$. Albertinieae 2928.2230.

b. Elephantopeae 2231 .

c. Rolandreae $2232-2237$.

d. Bojerieae $2238-2241$.

2. Pectideae $2248-2251$.

a. Llabeae $2242-2247$.

b. Eupectideae 2248-2251.

2. Fupatoriaceae $2252-2291$.

1. Eupatoriene $2252-2883$.

a. Alomieae $2858-2257$.

b. Agerateae $2258-2267$.

c. Adenostyleae $2268-2283$.

2. Tussilagineae $2984-2291$.

A. Petasitene 2284-2987.

b. Entussilagineas 2288-2291.

3. Asteroideae 2292-2453.

1. Asterineae $2992-2392$.

a. Amelleac 2992-2995.

c. Euamelleae 2292-2294.

B. Heterothalameae $\mathbf{2 9 9 5 .}$

b. Astereae 2996-2356.

c. Euastereac $8996-2317$.

ค. Diplopappeae 2318-2324.

$\gamma$. Erigereae 2325-2334.

j. Heteropappeae 2335 2344.

ع. Bellieae 2345-2347.

C. Bellideae $2348-2356$.

c. Chrysocomeac $2357-2392$.

c. Gymnoxpermeae 2357 2360.

P. Achyrideae 2361-2364.

$\gamma$. Heterotheceae 2365.

8. Psiadieae 2366-2372.

ह. Chrysopsideae 23732374 .

ל. Solidagineae 2375.2392.

2. Baccharideae $2393-2410$.

a. Conyzeae 2393-2408

c. Sphaerantheae 2393.2395.

B. Grangeineae $2396-2400$.

$\gamma$. Euconyzeac $2401-2408$.

b. Eubaccharideae $2409-2410$.

3. Tarehonatheae $2411-2424$.

a. Eutarchonantheae 2411-2412.

b. Plucheinere $2413-2424$.

4. Inuleac $2485-2438$.

a. Euinaleae $2425-2437$.

b. Caesulieae 2438 .

5. Buphthalaeae $2439-8444$.

6. Eclipteate $\mathbf{2 4 4 5}-\mathbf{2 4 5 3}$.

4. Senecionideae $2454-2821$.

1. Melamopodiacae $2,454-2491$.

a. Euxenieae $2454-2456$.

b. Millerieae $2457-2471$.

c. Silphieas $8472-2477$.

d. Melaupodieae $2478-2679$.

e. Ambrosicac $8480-2681$ 
f. Iveae 2482-2486. g. Parthenieat 2487-2491.

2. Heliantheae $2492-2570$.

a, Heliopsideae 2492-2512.

b. Kudbeckieae 2513-2527.

c. Coeropsideae 2528-2539.

d. Bidentideae $2500-2543$

e. Verbesineae $2544-2570$.

3. Flaverieae $2571-2574$.

4. Tagetisieae $2573-2582$. a. Tageteae $2575-2581$, b. Poropliylleae 2582 .

5. Helenieire 2583 _ 2634 a. Galllardieae $2583-2611$.

c. Eugaillardieae 2583 2585.

B. Eukelenicae $2586-2611$

b. Galiusogeae 2612-2627.

a. Eugalinsogeae 2612-2625. $\beta$. Sphenogyneae 2626.2627

c. Madieae $2628-2634$.

6. Anthemideae $2635-2710$.

a. Enanthenidear $2635-2653$.

b. Clarysaathemege 2654-2680.

c. Cotuleae $2681-2686$

d. Athariasiear $2687-2692$.

e. Artenlsieae 2693-2704.

f. Hippieae $8705-2709$.

g. Brioceplialeae 270 .

7. Guaphalieae $2711-2785$.

a. Augiantheae $2711-2729$.

b. Casslaieae $2783-2786$

c. Helichryseae 2727-2759.

d. Seriphieae $2760-2768$.

c. Antenaarieae 2763-2269.

f. Leyssereae $2770-2874$.

g. Rellianieae $2775-2785$.

8. Senecioneare $2886-2821$.

a. Neurolaeneae 2786

b. Erechtiteae $2787-2791$.

c. Eusenecionear $2792-2819$.

d. Balbisiear $2820-2821$.

5. Cynareae 2822-2898.

1. Calendulaceae $2829-2829$.

a. Calenduleae 2829-2824.

b. Osteospermeae 2825

c. Othenueae $2826-2829$.

2. Aretotideae $8830-2846$.

a. Aretoteae $2830-2838$.

b. Gorterieae 2839-2846.

3. Eehinopsideae 28:47-2848.

4. Cardopateae 2849

5. Xeranthemeae 2850-2859.

6. Carlineae 2853-2864.

7. Centaurieace $2865-2873$.

8. Carthameae 2874-2877.

9. Silybeae $2878-2880$.

10. Carduinae $8881-2892$.

11. Serratuleae $2893-2898$.

\section{Inabiatifforae 2899-2964.}

6. Mntisiaceae $2899-2942$.

1. Mutisieae 2899 - 2933.

a. Gerbereae $2899 \quad 2907$.

b. Eumutisleae $2908-2933$.

2. Lerieae $2934-2939$.

3. Facellateac $2940-2942$.

7. Nassaviaceae 2943-2964.

1. Polyachyrideae 2943.

2. Nassavieae 2944-2949.

3. Trixideac $2950-2964$.

III. ILigreatollovere 2965-3082.

8. Cichoraceae $2965-3032$.

1. Scolymeae $2965-2966$.

2. Lampsaneae $2967-2971$

3. Hyoserideae $2972-2983$.

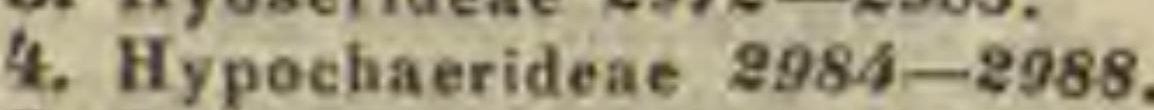

5. Seorzonereae $2989-3001$.

6. Lactuceae $3002-3028$.

7. Hieracieae 3023-3032. Genera dubia 1-14.

121. Calyeereae $3033-3036$.

\section{XXXII. CAMPanUlinaE.}

122. Brumeniaceae 3037 .

123. Goodeniacene 30383050 .

a. Scaevoleae 3038-3040.

b. Goodenieae $3041-3050$.

124. Tobelliaceae $3051-3070$.

1. Clintonieae $3051-3054$.

2. Lobelieae 3055-3062.

3. Delisseaceae $3063-3070$.

125. Campanulaceae 3071-91.

1. Wahlenbergicae $3071-3081$.

a. Jasionease 3021 .

b. Lightfootieae 3072 -3079.

c. Prismatocarpeae $3080-308 t$.

2. Campanuleae $8082-3091$.

* Pongatieae 3092.

126. Stylidene $3093-\mathbf{3 0 9 5}$.

\section{CLASSIS XXXIII. CAPRIFOLIA.}

127. Rubiaceae $3096-3331$.

I. Coffeaceae $3096-3221$.

1. Opercularieae $3096-3097$.

2. Steflatae $3098-3104$.

3. Authospermeae $3105-3109$.

4. Spermacoceae $3110-3138$.

a. Putorieae $3110-3117$,

b. Euspermacoceae 3118.3137 .

c. Cephalantheae 3138 .

5. Psyehotriene 3139-3179. a. Cophaélideae $3139-3144$.

b. Coffeaceae $3145-3179$.

6. Prederieae $3180-3189$.

7. Guettardeae $3183-3219$.

a. Morindeae 3183 .

b. Euguetlardeae 3184-3219.

8. Cordiereae $3220-3281$.

II. Cinchonaceare 3222-3315.

9. Haweliere $3229 \_3233$.

10. Isertieae $3234-3237$.

11. Hedyotideat $3238-3262$.

a. Hedyoteat $3238-3241$.

b. Rondeletieae 3242-3262.

12. Cinchonene $3263-3280$.

a. Eucinchoneae 3263-3273.

b. Naunlecae 3280 .

13. Gardenieae $3281-3315$.

a. Sarcoeephaleae 3281.3285 .

b. Eugardenieae $3286-3315$.

Genera dubiae affinitatis $3316-3331$.

128. Homicereace $3332-3341$.

I. Lonicereae verae 3332-3339.

II. Sambuceae $3340-3341$.

CLASSIS XXXIV, CONTORTAE.

129. Jasmineae $3342-3345$.

130. Dleaceae $3346-8358$.

I. Oleineae $3346-3352$.

II. Fraxineae $3353-3358$.

131. Loganiaceae $3959-3371$.

I. Strychneae $3359-3363$.

a. Kustrychneae $3359-3360$.

b. Gardnerieae 3361 .

c. Antonieae 3362 .

d. Labordieat 3363 .

II. Loganieae $336 t-3371$.

e. Euloganieae $3364-3365$.

f. Usterieare 3366 .

g. Pofalieae $3368-3369$.

h. Gărtnereae $3370-3371$.

132. Apoeymaeeae $3372-3430$.
1. Carisseae $3372-3382$.

2. Ophioxyleae 3384-3393.

3. Euapocyneae $3394-3430$.

a. Plumerieae 3394-3407.

b. Alstonieae 3408 .

c. Echiteae 3409-3488.

d. Wrightieae $3429-3430$.

Genera dubia 3431.

133. A sellepiadeace $3431-3527$.

1. Periploceae $\mathbf{3 4 3 1 - 3 4 4 0}$

2. Secamoneae $3441-3443$.

3. Euasclepiadeae $3444-3527$.

a. Cynancheae $3444-3493$,

1. Astephaneae 3443-3446.

2. Metastelmeae $3447-3454$.

3. Ditasseae $3455-3459$.

4. Cynoctoneae $3460-3470$.

5. Calotropideae $347 t-3478$.

6. Euasclepieae 3479-3493.

b. Giublobeae 3494-3496.

c. Pergularieae 3497-352\%.

$\alpha$. Hoyeae $3497-3512$.

1. Sarcolobeae 3497-3498.

2. Tylophoreae $3499-3512$.

$\beta$. Stapelieae $3513-3527$.

1. Leptadenieae 3513-3514.

2. Ceropegieae 3515-3527.

184. Gentianeae $3528-3567$.

1. Gentianeae verae 3528-3563.

c. Chirouieae $3528-3556$.

$\beta$. Sebeaceae 3557-356t.

$\gamma$. Genera dubia $3562-3563$.

2. Menyantheae $\mathbf{3 5 6 4}-\mathbf{3 5 6 5}$.

Genera affinia 3566-3567.

135. Spigeliaceae 3568 .

CLASSIS XXXV. NUCULIFERAE.

136. Cabiatae $3569-3682$.

1. Ocimoideae $8569-3585$.

c. Moschosmeae 3569-3574.

$\beta$. Plectrantheae $3575-3580$.

$\gamma$. Hyptideae $3581-3584$.

d. Lavanduleae 3585.

2. Menthoideae $3586-8596$.

a, Pogostomeae 3586-3587.

b, Elseholziear 3588-3589.

c. Mentheae $3590-3595$.

d. Meriandreae 3596 .

3. Monardeae $3597-3603$.

a. Salvieae $3597-3598$.

b. Rosmarineae 3599_3608.

c. Hormineae 3603 .

4. Satureinae $3604-\mathbf{8 6 1 4}$.

a. Origaneae 3604 -3611.

b. Hyssopere 3612 .

c. Cunileare $3613-3614$.

5. Melissinae $3615-3623$.

6. Scutellarinae $3624-3627$.

7. Prostanthereae 3628-3634.

8. Nepeteae $3635-8639$.

9. Stachydeae $3640-\mathbf{3 6 7 2}$.

a. Melitteae $3660 \div 3643$.

b. Lamieae 3644 - 3653 .

c. Marrobieae $3654-3657$.

d. Balloteae 3658 - 3682 .

10. Prasieae $3673-3676$.

11. Ajugoideae $3677-8681$. Genus dubium 3682.

137. Verbenaceae 3683-3722.

1. Lippieae $3688-3693$.

2. Lantaneae $3694-3710$.

3. Aegiphileae $3711-3716$.

Genera dubia $3717-3721$.

- Avicennieae 3722. 
138. Stillbineae $3723-3724$.

139. Globularieae 3725 .

140. Selagineae $3726-3732$.

141. NIyoporinene $3733-3737$.

142. Comolliaceace 3788.

Genera dubia $3739-3742$.

143. Asperifoliace $3743-3787$.

1. Ehretiaceae $3743-3752$.

a. Touruefortieae 3743 - 3749 .

b. Heliotropicea e $3750-3758$.

2. Borragineae $3753-3787$.

a. Anchuseae 3753 -3778.

b. Cynoglosseat $3779-3786$.

Genus dubium 3787 .

CLASSIS XXXVI. TUBIFLORAE.

144. Convolvulaceae 3788 3814.

1. Dichondreae $3788-3789$.

2 . Convolvuleae $3790-3814$.

* Erycibeae 3815 .

* Cuscuteae 3816.

* Nolanaceae 3817.

145. Folemonáceae 3818 3826.

146. Hy difroplinylleae 3827 3832 .

147. II y dirolleaceae $3833-3837$.

148. Sollanaceae $3838-3874$.

1. Nicotianeae $3838-3844$.

2. Datureae $38 \pm 5-3846$.

3. Hyoseyameae $3847-3849$.

4. Solaneae $3850-3864$.

5. Cestrineae $3865-3867$.

6. Vestieae 3868-3869. Genera dubia 3870_3874.

* Desfontaineae 3875 .

* Retziaceae 3876-3877.

\section{Class. XXXVII. PERSONATAE.}

149. Seroplaularimae 3878 4026.

1. Verbasceae $\mathbf{3 8 7 8 - 3 8 8 3 .}$

2. Hemimerideae $\mathbf{3 8 8}$ - $\mathbf{8} 889$.

3. Antirrhineae $3890-3897$.

4. Salpiglossideae 3898-3907.

5. Digitaleae $3908-3917$.

6. Gratioleae 3918-3958.

7. Buchnereae 3959-3970.

a. Eubuchnereae 3959 _ 3963 .

b. Manuleae $3964 \_3970$.

8. Buddleeae $3971-8972$.

9. Veroniceae $3973-3989$.

10. Gerardieae $3990-4002$.

11. Rhinantheae $4003-4019$. Genera dubia $4020-4023$. Genera affinia 4024-4026.

150. Aeanthaceae $4027-4103$.

1. Thunbergieae $4027-4030$.

2. Nelsonieae 4031-4036.

3. Echmatacanthi $4037-4101$.

a. Hggrophileae $4037-4000$.

b. Ruellieas $4041-4059$.

e. Barlerieae $4060-4067$.

d. Acantheae $4068-4072$.

e. Justicieae $4073-4090$.

$\alpha$. Aphelandreae 4073-4078.

$\beta$. Gendaruseae $4079-4086$. $\gamma$. Eranthemeae $4087-4090$.

f. Dicliptereae $4091-4098$.

g. Andrographidea e $4099-4101$. Genera dubia 4102-4103.

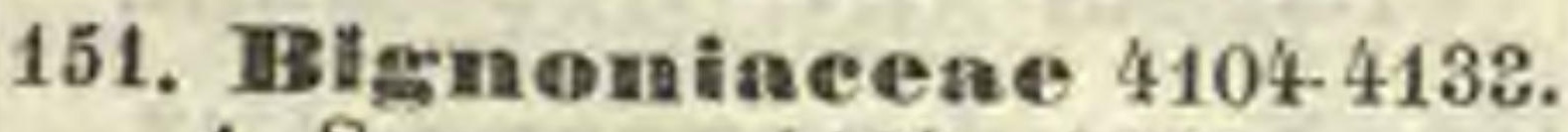

1. Sesameae $4104-4105$.

2. Eccremocarpeae 4106-4108.

3. Incarvilleae $4109-4110$.

4. Tonrretieae 4111 .

5. Bignonieae $4112-4125$.

a. Argylieae 4112.

b. Tecomeae $4113-4118$.

c. Bubiguonieae $4119-4125$.

Genera anomala 4126-4197.

Genera dubia 4128-4133.

152. Cessmeraceace 413ł-4169.

1. Cyrtandreae $4134-4154$.

a. Didymoearpeae $4134-4145$.

b. Eacyrtandreae 4146-4150. Genera dubia 4151-4154.

2. Gesnereae 4155-4169.

a. Beslereae 4155-4159.

b. Episcieae 4160-4164.

c. Eugesnereae $4165-4169$.

* Crescentieae 4170-4173.

153. Fedlallineae $4174-4181$.

154. Drobanelhene 4182-4192.

155. Utroicularoleace 4193-4195.

CL. XXXVIII. PETaLanthaE.

156. Primallaceae $4196-4216$.

1. Primuleae 4196-4211.

a. Androsaceae $4196-4203$,

b. Lysimachieae 4204-4211.

2. Anagallideae $4212-4213$.

3. Hottonieae 4214 .

4. Samoleae 4215 . Genus affine 4216.

157. Niyrsineae 4217 .

1. Ardisieae 4217-4226.

2. Maeseae 4227 .

3. Theophrasteae $4228-4230$. Genera dubia 4231-4232.

* Aegicereae 4233 .

158. Sapotaceae $4234-4245$.

159. Ebenaceae $4247-4251$.

* Styraceae 4252-4257.

- Halesieae 4258.

* Symploceae 4259-4261.

Dubiae affinditatis.

* Napoleoneae 4262-4268.

* Columelliaceae 4264-4265.

CLASSIS XXXIX, BICORNES.

160. Epaerideae 4266-4293.

1. Styphelieae $4266-4280$.

2. Epaereae 4281-4293.

161. Erienceae $4294-4344$.

1. Ericinae $4294-4328$.

a. Ericeae 4294-4316.

c. Salaxideae 4294-4308.

1. Coillostigmeae 42944298.

2. Sympiezeae $4299-4308$.

$\beta$. Euericeae $4309-4316$.

b. Andromedeae 4317-4328.

2. Vaccinieae $4329-4337$.

3. Rhododendreae $4388-4844$.

* Diapensiaceae 4345-4346.

* Pyrolaceae 4347-4350.

* Monotropeae 4351-4354.
Cohors IV. Dialypetalae.

\section{CLASSIS XL. DISCANTHAE.}

162. Unabelliferae $4355-4549$.

I. Orthospermae $4355-4497$.

1. Hydrocotyleae $4355-4367$.

2. Mulineae $4368-4377$.

3. Sauiculeae $4378-4389$.

4. Ammineae $4390-4415$.

5. Seselinear $4416-4449$.

6. Pachypleureae $4450-4458$.

7. Angeliceae $4453-4457$.

8. Peucedaneas $4958-4483$.

9. Silerinae $4484-4487$.

10. Cumineae $4488-4489$.

11. Thapsieae $4490-4494$.

12. Daucinere $4498-4497$.

II. Campylospermae 4498-4544.

13. Elaeoselineae 4498-4499.

14. Caucalineae $4500-4503$.

15. Scandicineae 4504-4517.

16. Smyrueae $4518-4544$.

III. Coelospermae 4545-4549.

17. Coriandreae $4545-4549$.

163. Araliaceae $4550-4565$.

164. Ampelideae $4566-4569$.

1. Viniferae $4566-4568$.

2. Leeaceae 4569. Genera dubia $4570-4572$.

165. Cornea 4573-4574. Corneis affines 4575-4576. Genera dubia $4587-4580$.

166. Horant hacene 4581-4587.

167. Hamamelid eae 4588-95.

1. Hamameleae 4588 _ 4593 .

a. Euhamameleae $4588-4591$.

b. Fothergilieae $4598-4593$.

2. Bucklandieae 4594-4595.

168. Brumiaceae 4596-4606.

Classis Xli, CORNiculatae.

169. Crassulacene $4607-4625$.

I. Crassuleae $4607-4623$.

1. Isostemones $4607-4615$. a. Eucrassuleae $4608-4611$. b. Rocheae $4611-4615$.

2. Diplostemones $4616-4623$. c. Umbiliceae $4616-4621$. d. Sedeae $4622-4623$.

II. Diamorpheae $4624-4625$.

- Francoaceae 4626-4627.

- Cephaloteae 4628.

170. Saxifragaceae $4629 \cdot 4681$.

1. Saxifrageae $4629-4646$.

2. Cunonieae $4647--4667$.

8. Hydrangeae $4668-4673$.

4. Escallonieae 4674-4678. Escallonieis affines.

* Argophylleae 4679 .

* Rousseaceae 4680.

* Brexiaceae 4681.

171. Ribesiaceae $4682-4683$.

Classis XLII. POLYCARPICAE.

172. Menispermaceas 4684 -4705 .

1. Menispermeae $4684-4696$. * Phytocreneae 4697-4698.

2. Lardizabaleae $4699-4705$. 
173. Il yruisticeae $4706-4708$.

174. Anomaceae $4709-4729$.

1. Bocageae $4709-4712$.

2. Xylopieae $4713-4718$.

3. Anoneae 4719-4724. Genera dubia 4725-4729.

* Eupomatieae 4730.

175. Selhizandiraceae 4731 4734.

176. Ningmolliaceace $4735-4745$. 1. Magnolieae 4785 - 4740 .

2. Illicieae $4741-4745$.

177. Hillemataceac $4746-4767$.

1. Dilleneae $4746-4758$.

2. Delimeae 4759-4765.

Genera dubia 4766- 4767.

178. IRamumeulaceae 4768 4804.

1. Clematideae $4768-4770$.

2. Anemoneae $4771-4781$.

3. Ranunculeae $4782-4785$.

4. Helleboreae 4786-4797.

5. Paeonieae 4798-4804.

179. Berly eridieat $4805-4815$.

CLASSIS XLIII, RHOEADES.

180. Papaveraceace 4816-4844.

I. Papavereae 4816-4832.

1. A rgemoneae 4816 _ 4826 .

a. Bocconieae $4816-4818$.

b. Papavereae verae 4819 4896.

2. Uunnemannicae 4827 - 4829 .

II. Fumariaceae $4833-4844$.

3. Hypecoeae 4833 - 4834.

4. Fumarieae 4835 - 4844 .

B. Dicentreae $4835-4837$.

b. Corydalideae $4838-4844$.

181. Cruclerae $4845-4980$.

I. Pleurorhizeae 4845-4901.

1. Arabideae $4845-4868$.

2. Alyssilleae $4863-4884$.

3. Thlaspideae $4885-4891$.

* Cremolobeae 4892_4893.

4. Anastaticeae 4894-4895.

5. Fuclidieae $4896-4898$.

6. Cakilinae $4899-4901$.

II. Notorhizeae $4902-4947$.

7. Sisynbrieae $4902-4917$.

8. Camaelineae 4918-4926.

9. Lepidineae $4928-4935$.

10. Isatideae $4936-4943$.

11. Auchonieae 4944-4947.

III. Orthoploceae 4948-4972.

12. Brassiceae $4948-4956$.

13. Velleae $4957-4961$.

14. Psychineae 4962-4963.

15. Zilleae $4964-4966$.

16. Raphaneac $4967-4972$.

IV. Spirolobeae $4973-4974$.

17. Buniadeae 4973.

18. Rrucarieae 4974.

V. Diplecolobeae $4975-4980$.

19. Senebiereae $4975-4976$.

20. Subularieae 4977 .

21. Heliophileae 4978-4979.

- Schisopelaleae 4980.

182. Capparidea e $4983-5010$.

1. Cle nmeae 4983-4990.

2. Cappareae 4991 $\sim 5009$. Capparideis affines 5010.

183. Tieseriaceae 5011-5014.
184. Datisceae $5015-5017$.

CLASSIS XLV. NELUMBIA.

185. Nymplareaceae 5018 5022.

1. Euryaleae 5018-5019.

2. Nymphaeaceae 5020-5021.

8. Barclayeae 5022 .

- Sarracenieae 5023 .

186. Cabounbeae 502t-5025.

187. Nelumboneae 5026 .

Classis XLVI, PARIETALES.

188. Cigtíneae 5027-5032.

189. Droseraceac $5033-5038$.

- IP armassieae 5039 .

190. Violnoieae $5040-5049$.

1. Jonidieae 5040-5046.

2. Alsodineae 5047-5049.

191. Sauvagesieae 5050-5052. 192. Framkeniaceare 5058 .

* Fongraieraceac $5054-5055$.

193. Turneraceare 5056 - 5058 .

194. Samy dileae 5059-5060.

195. Hixaceae $5061-5084$.

1. Bixineae 5061-5065.

2. Prockieae 5066-5078.

3. Flacourtianeae $5079-5082$.

4. Erythrospermeae 5083-5084.

* Harngiaceac 5085 .

196. Fivmalineae $5086-5092$.

197. Passiflozeae 5093-5107.

1. Paropsieae 5093-5095.

2. Passifloreae verae 5096-5101.

3. Modecceae 5103-5107.

198. Inalesherbiacene 5108 -5109 .

199. Woaseae $5110-5118$.

200. Papayaceae $5119-5120$.

CLASSIS XLVII. PEPONIFERAE.

201. Nam diln irobeae 5121-5122.

202. Cucurbitaceae 5123-5151.

1. Telfairieae 5123 .

2. Cucurbiteae 5124-5145.

1. Coniandreae $5124-5125$.

2. Melothrieae $5126-5129$.

3. Bryonieae $5130-5136$.

4. Cucumerinae $3137-5142$.

5. Cyclanthereae $\mathbf{5 1 4 3 .}$.

Genera minus nota $5144-5145$.

3. Syeioideae 5146-5147.

Genera dubia $5148-5151$.

* Gronovieae 5152.

203. Fegoniacene 5153 .

\section{CLASSIS XLVIII. OPUNTIA.}

204. Caetene 5154-5162.

1. Cacteae tubulosae 5154 5159.

2. Cacteae rotatae $5160-5162$.
CL. XLIX. CARYOPHYLLINAE.

205. Illesembryanthemeae 5163.

206. Portulaceas 516 h -5196 .

1. Tetragonieae 5164 .

2. Aizoideae $5165-5167$.

3. Sesuvieae 5168-5174.

4. Portulacarieae 5175 .

5. Calandrinieae $5176-5183$.

6. Mollngineae 5184- 5193 .

7. Polpodeae 5194.

8. Adenogrammeae $5 i 95$. Genus Portulaceis affine stg6.

207. Caryophylleae 5197-5253.

I. Paronychieae $5197-5220$.

1. Illecebreae $5197-5805$.

1. Corrigioleae 5197.

2. Euparonychieae $5198-5205$.

2. Pterantheae 5206-520\%.

3. Pollichieae 5208 .

4. Telephieat 5909 .

5. Polycarpeae 5210-5220.

a. Lófflingieae 5910 .

b. Sperguleae $5211-5220$.

II. Selerantheae $5221-5223$.

III. Alsineae 5224-5242.

1. Sabulineae 5224-5230.

1. Sagineae 5224 .

2. Eualsineae $5225-5930$.

2. Merchieae 5231-5232.

3 . Stellarineae 5233-5243.

1. Arenarieae $5233-5240$.

2. Cerastieae 8241 .

3. Malachieae 5242 .

IV. Sileneae 5243-5253.

1. Diantheae $5243-5244$.

2. Lyehnideate $5245-5251$.

3. Drypideae $5252-5253$.

208. Plnytolaceaceae $5254-$ 5268.

1. Petiverieae 5254-5257.

1. Petiverieae verae $5854-5855$.

2. Rivineae $5856-5257$.

2. Phytolacceae 5258-5263.

3. Limeae $5258-5859$.

4. Giesekieae $5260-5263$.

* Gyrostemoneae 5264-5265.

CLASSIS L. COLUMNIFERAE.

209. Malvaceae 5266-5296.

1. Malopeae 5266-5268.

2. Malveae $5269-5275$.

3. Hibisceae $5276-5286$.

4. Sideae 5287-5296.

210. Sterculiacene 5297-5321,

1. Rombaceae $5297-5307$.

* Bombaceis affines 5308 5310.

2. Helietereae $5311-5318$.

1. Myrodleae $5311-5314$.

2. Euhelictereap $5315-5316$.

3. Reevesieae $5317-5318$.

3. Sterculieae $5319-5321$.

211. Fifit theniaceae 5322-5359.

1. Lasiopetalae $5322-5327$.

2. Büttneritae $5328-5934$.

- Kleinhovieae 5335.

3. Hermannieae $5336-5341$.

4. Dombeyeae $53+2-5853$.

5. Eriolaeneae 5854-5355. Genera dubia 5356-5357.

* Philippodendreae 5358-5859. 
212. Thiliaceae $5360-5391$.

1. Tiliaceae verae $5360-5383$. 1. Sloaneae $5360-5363$. 2. Grewleae $5364-5383$.

II. Elaeocarpeae $5384-5391$. 3. Elaeocarpeae verae $5384-5388$ 4. Trienspidarieae $5389-8391$.

\section{CLASSIS hI. GUTTIFERAE.}

213. Dipterocanpeae $5392-$ 5396.

* Lophiraceae 5397.

214. Clalemaceac 5398-5402.

* Eucryphieae 5403.

* Hugoniaceae 5404 .

215. Termstrobmiaceae 5405 -5431 .

1. Cochlospermeae 5405.

2. Ternströmieae $5406-5413$.

3. Sauraujeae $5+14-5415$.

4. Laplaceae $5416-5422$.

5. Gordonieae 5423-5424.

6. Camellieae 5425-5+26. Genera dubia 5497-5431.

* Aristoteliaceae 5432.

216. Clasiacene $5433-5458$.

1. Clusieae $5433-5439$.

2. Moronobeae $5440-5441$.

3. Garcinieae $5 \$ 42-5446$.

4. Calophylleae 5447-5449. Genera dubia $3450-5455$.

* Canellaceae 5456-5458.

217. VIracaraviaceac 54595 562.

218. Hy perieineae 5463-5472.

1. Hypericeae 5463-546'.

2. Elodeae 5465-5472. Genus dubium 5473 .

* Oehranthaceae 5474

219. Elatineae $5475-5478$.

220. Ir eammaniacear 5479 5481 .

221. Tramariseinear $5482-$ 5484 .

\section{CLASSIS LII, HESPERIDES.}

222. Huaniriaceae $5485-5487$.

223. Dlacineare $5488-5492$. Genera dubia 5/93-5497. Genus Olacineir affine 5498.

124. Aurantiaceace 5499-5515.

1. Limoneae 5499-5505.

2. Clanseneae 5506-5511.

3. Citreae 5512-5514. Genus dubium 5515.

225. Mreliaceae $5516-5547$.

1. Melieae 5516-5523.

2. Trichilieae $5524-5545$. Genera dubia $6546-5547$. Genus Meliaceis affine $\mathbf{5 5 0 8}$.

226. Cedrelaceae 5549 .

1. Swietenieae 5549-5552.

2. Cedreleae $5553-5556$. Genus dubium 5557.
CLASSIS LIII. ACERA.

227. A cerinae 5558-5560.

228. Iralpightaceae $5561-95$.

1. Meiostemones 5561-5565.

2. Diplostemones 5566 .

1. Pleuropterygiae $5566-5574$.

2 . Notopterygiae $5575-5584$.

3. Apterygiae $5585-5592$. Genera dubia 5593-5595.

* Coriarieae 55:6.

229. Erythroxyleae 5597.

230. Sapindaceae $5598-5638$.

1. Sapindeae 5598-5621.

2. Dodonaeaceae $5622-5627$. Genera anomala 5698-5630. Genera dubia 5631-5638.

* Meliosmeae 5689.

* Hippocastaneae 5640-5641.

231. Mhizoboleae $5642-5643$.

Classis liv. POLYgalinae,

232. 'Tremandil reae $5644-5645$.

233. Polygaleae $5646-5653$.

Genera vix nota ${ }^{5} 654-5655$.

Genera anomala 5656-5658.

* Trigoniaceae 5659.

Classis LV. Frangulaceae.

234. Pittosporeae $5660-5668$. Genera affinia $5669-5670$.

235. Staplnylaeacease 5671 5673.

236. Celastrineace $5674-5698$.

1. Evonymeae $5674-5682$.

2. Elaeodendreae $5683-5690$. Genera dubia $5691-5698$. Genus affine 5699.

237. Ii ippoerateaceac 5700 -5702 .

Genus affine 5703.

238. HIieinea e $5704-5711$. Genera dubia $5710-5711$. Genera affinia $5712-5713$.

* Nitrariaceae 5714.

239. Thammeae $5715-5750$.

1. Palinreae $5715-5716$.

2. Franguleae $5717-5729$.

3. Colletieae 5730-5735.

4. Phyliceae 5736-5742.

5. Pomaderreae 5743-5744.

6. Gonanieae 5745-5748. Genera dubia 5749-5750. Genera affinia 5751-5756.

240. Cla illetiaceac $5757-$ 5759 .

\section{Classis LVI. TRICOCCAE.}

241. Empetreae 5760-5762.

242. Stackhousiaceae 5763 $-576 t$.

243. Euphorbiaceae $5765-$ 5888.

1. Euphorbieae 5765-5768.
2. Hippomaneae $5769-5781$.

3. Acalypheae 5782-5796.

4. Crotoneae 5797-5836.

5. Phyllantheae 5837-5859,

6. Buxeae 5860-5878.

Genera dubia $5879-5888$.

CL. LVII. TEREBINTHINEAE.

244. Juglandeae 5889-5892.

245. Anaeardiaceae $5893-$ 5919.

* Spondiaceae 5920-5921. Genera dubia 5922-5926. Genera anomala 5927.

246. Bursernceas 5928-5938. Genera vix nola 5934-5946.

* Amyrideae 5947.

247. Connaraceae 5948-5950. Genera dubia 5951-5952.

* Surianeae 5953-5955.

248. Delhnaceae $5956-5959$.

1. Casteleae 5956-5957.

2. Oehneae 5958-5959. Genera dubia $5960-5961$.

249. Si marubaceace 5962-5965.

* Simarubaceis affines 59665967.

250. Whanthexyleae 5968-5977.

* Zanthoxyleis affines 59785980.

Genera dubia $5981-5987$.

251. Diosmeace 5988-6024.

1. Cusparieae 5988-5994.

2. Pilocarpeae 5995-6002.

3. Boronieae 6003-6013.

4. Eudiesmeae 6014-6023.

5. Dictamneae 6024.

252. Futaceae $6025-6029$.

253. Zyyophylleae 6030-6044.

1. Tribuleae $6030-6031$.

2. Zygophylleae verae 6032-41.

- Zygophylleis affines 6042.

* Meliantheae 6048.

- Biebersteinieae 6044.

\section{CLASSIS LVIII, GRUINALES.}

254. Geraniaceae $6045-6048$.

* Rhynchotheceae 60!9.

- Ledocarpeae 6050-605I.

* Vivianieae 6052-6055.

255. Lineae 6056-6057.

256. Dxallideae $6058-6059$.

257. Balsamineae $6060-6061$.

258. Tropapoleae $6062-6064$.

259. Limmanthea e $6065-6066$.

CLASSIS LIX. CALYCIFLORAE.

260. Voelnysiaceae $6067-6074$.

261. Combreta ceaé 6075-6095.

1. Terminalieae $6075-6086$.

2. Com'reteae $6087-6090$. Genera dubia 6091-6095.

262. Alangleae 6096-6097. 
263. IBIhizopluoreae 6098-6101. * Legnotideae 6102-6104.

264. Plailladelplueas $6105-$ 6107.

565. Demothereae $6108-6133$.

1. Jussieveae $6108-6111$.

2. Epilobieae $6112-6122$.

3. Montinieae $6123-6124$.

4. Fuchsieae 6125.

5. Lopezieae 6126-6129.

6. Circaeaceae 6130 .

7. Ganreae 6131-6132. Genus dubium 6133.

266. Tilaloragene $6134-6139$. * Trapeae 6140.

267. Tythroureae 6141-6167.

1. Enlythrarieae $6141-6159$.

2. Lagerströmieae $6160-6165$. Genera dubia 6166-6167.

\section{CLASSIS LX. MYRTIFLORAE.}

268. Melastomaceae 6168 6274.

1. Melastomeae $6168-6262$.

1. Lavoisiereae $6168-6191$.

2. Rhexieae $6192-6206$.

3. Osbeckieae $6207-6924$.

4. Miconieae 6225-6262.

2. Chariantheae $6263-6268$.

* Memecyleae 6269-62z1.

- Olinieae 6272-6274.

269. Myyrtacea e 6275-6340.

1. Chamaelaucieae $6275-6288$.
2. Leptospermeae 6289-6311.

3. Myrteae 6312-6324.

4. Barringtonieae $6325-6327$. Genera dubia 6328-6330.

5. Lecythideae $6931-6334$. Genera penitus dubia 6335 6339.

- Granateae 68to.

CLASSIS LXI. ROSIFLORAE.

270. Pomaceae $6341-6854$.

271. Calyeantheae 6355-6356.

272. Eosaceae $6357-6403$.

1. Roseae $6357-6358$.

2. Dryadeae $6359-5390$.

1. Dalibardeae 6359-6360.

2. Fragarieae $6361-6363$.

3. Chamaerhodeae 6364.

4. Cercocarpeae 6380-6381.

5. Eudryadeae $6382-6390$.

8. Spiraeaceae $6990-6 \div 00$.

1. Spiraeaceae verae $6390-6394$. Genus affine 6395.

2. Quillateae 6396-6400.

4. Neuradeae 6401-6403.

273. Anyoglaleae $640 \%-6106$.

274.Chroysobalaneae 6407.14.

Genera dubia 6415-6417.

CLASSIS XLII. LEGUMINOSAE.

275. Papilionaceae 6418-6811.

1. Podalyrieae 6\$18-6450.

1. Eupodalyrieae $6418-6432$.

2. Puiteneae $6433-6447$.

3. Mirbelieae 6448-6450.
2. Loteae $6451-6577$.

1. Genistere 6451-6506.

2. Trifolieae $6507-6521$.

3. Galegeae 6582-6568.

4. Astragaleae $6569-6577$.

8. Vicieae 6578-6583.

4. Hedysareae 6584-6629.

1. Coronilleae $6584-6589$.

2. Euhedysareae $6590-6694$.

3. Allageae $6625-6629$.

5. Phaseoleae 6630.

1. Clitorieae $6630-6640$.

2. Kenuedyene $6641-6645$.

3. Glycineas $6696-6656$.

4. Diocleae $6657-6664$.

5. Erythrineae $5665-6670$.

6. Wisterieas $6671-6673$.

7. Ruphaseoleae 6674-6684.

8. Cajaneae 6685-6689.

9. Rhynchosieae $6690-6697$.

10. Abrineare 6698 . Genera dubia 6699.

6. Dalbergieae 6700-5735.

7. Sophoreae 5736-6750

8. Caesalpinieae $6751-6810$.

* Moringeae 6811.

276. Swartzieae $6812-6815$.

- Detarieae 6816_6817.

277 . Nimoseas $6818-6838$.

1. Parkieae $6818-6819$.

2. Acacieae $6820-6838$.

\section{Gemera dubiae seallis.}

a. Apetala 6839-6856.

b. Gamopetala $6857-6875$.

c. Dialypetala $6876-6895$.

* Genera nondum descripta. 


\section{REGIO I. THALLOPHY'TA.}

ANA NDRAE Link, in Berl. Magas. TII. 1. ss. VII. 1. ss. Abhandl. Berl. Academ. 1824. p. 15t. ss. ACOTYLEDONEAE Agarth Aphorism. 72. HoMoNEMEA Fries syst. orb. veg. Lundao 1825. 8vo. APHYLLAE Lindt. introduct. 330. CRYPTOPHYTA Link. Handb. 163.

Thallophyta; pantachobrya arrhiza. Oppositio caulis et radicis nulla. sporae germinantes undique elongatae. Vasa nulla. Organa sexualia nulla.

PI anta e contextu cellnloso imperfecto, irregulari, ad formam regularem anmulatam tendente, varie effigurato, compositae. Vas a spiralia, lymphatiea et propria nulla. Epidermis stomatibus destituta. Substantia tota homogenea, in perfectioribus subheterogenea, organis indistinetis, in thallum (frondem) coadunatis. Sexus distinetio nulla. S porae (testa et embryone destitutae) nunc per totam plantae superficiem sparsae, ex ipsius textura emergentes, nune intra thecas proprias enatae, germinatione undique in filum homogeneum elongatae. Opositio caulis et radicis nulla.

Vegetabilia imperfectiora, per totum orbem sparsa, terram mareque copiosa prole incolunt; plurima aquis innatant, v. submersa oceani vestiunt abyssus, alia primaevis innascuntur saxis, alia in solo v. in organismis languescentibus ant emortuis genita, in summis montium verticibus et in imis cryptarum latebris, locis perfectioris florae soboli inaccessis luxuriant, nee thermarum aestum, nec extremi septemtrionis aeternam fugiunt glaciem, sed a variis momentis cosmicis varie determinata, ubique nobilioribus plantis solum sternunt et viam parant.

Regio seriem animalibus evertebratis analogam constituit, formarum in ipsa sua simplicitate dives. Infimae generatione originaria quottidie enatie v, e partibus organicis in functionibus suis turbatis, et ad propriam vegetationem liberatis evolutae, multimode crescunt et multiplicantur; perfectiores sporis intrinsecus natis absque sexuum concursu propagantur.

\section{SEC'YO I. PROTOPHYTA.}

sine humo enata, elementum nutriens undique haurientia, fructificationes indefinite explicantia.

\section{Classis $\mathbf{H}$. Igae.}

ALGAE A gard h, dispositio Algarum Sueciae Lund. 1811. 4to. Algarum decades 1-4. Lund. 1812. 4to. Mretamorphosis Algarum Lund. 1820. 8vo, Species Algarum Gryphsw. 1821-1828. 8vo. 2 $\mathrm{Vol}$. Systema Algarum Linnit. 1824. 12 mo. Icones Algarum ineditae Lund 1820 . 4to. $f$ 1.2. yeones Algarum europ. Lips 1828. f. 1. 2. B o ry, in Diet. class. hist. nat. t. 1-17. Histoire des Hydrophytes, recoltees par dUrville et liesson. Paris 1829. fol. - B rogniart. in Mem. soe A n. Paris. I. 301. - Dillwyn, British Confervae. Jondon 1809. 460. Deutsch von Weber et Mohr. Gôtting, 1803-1805. 8vo. - Esper, Icones Fu corum. Nurenb. 1797. \$s. Ato. - Galllon, Essai sur Fetude des Thalassiophytes. Rouen 1820. Svo. Dict. sc. nat. LIII. 350. - Girod. C hat it a n s, Recherches chimiques etc. Paris 1802. Ato. - G reville, Algae Britan. nicae. Edinb. 1830. 8vo. - L a m a u ro a x, Dissert. sur glusienrs especes de Fucus. Agen 1805. Ato. Essai sur les genres des Thalassiophyles. Paris 1813. 8vo.-L y u g bye, Tentamen Hydrophytologiae danicae. Hafn. 1819. Ita, Nees v оп Eseabeek, die AIgen des süssen Wasser. Bamb. 1814. 8vo. - Roth, Catalecta botanica, Lips. 1797 -1806. Svo. Bemerkungen ïber das Studium der Süsawas. seralgen. Mannov, 1797. 8vo. Botanische Bemerkungen. Lripz 1800. 8vo - $\mathrm{R} u \mathrm{iz}$, Ae Fuci natantis fructificatione. Madr. 1798 svo. - Stakhou\&p. Nereis britannica. Ba. thon. 1801. fol. Eilit. 2da. Oxonil 1816. 4to. - Tu ruer, Synopsis of the British Fuci. Lond. 1802. 12mo. 2 Fol. feones Fucorum. Lond. 1807 . sa. fol. $4 V_{o} l$. - V a u e her, Histoire des Conferves d'eau douce. Geneve 1803. hto.
Protophyta aquatica, contextufilamentoso.

Vegetabilia submersa v. rarius hygrobia, nuda vel in gelatina nidulantia, substantia mucosa, gelatinosa, membranacea v. coriacea, continuo vigentia, contextu toto organico e cellulis variae formae, saepissime elongatis et in fila simplicia v. ramosa, continua v, articulata, libera v. in formam variam consociata, dispositis composito; tota superficie elementum nutriens haurientia; vivipartu, partitione v. prolificatione continua, perfectiora s p or i d i is intrinsecus natis, nudis (superficiei inspersis) v. intra sporangia inclusis propagata. Infinae formae inter vitam animalem et vegetahilem fuctuant, quaedam sub diversis evo. lutionis stadiis utriusque regni cives.

\section{Drdo T. Diatomeceqe.}

DIATOMEAE Agralh syst. XII. Conspectus Diatomea. rum. Lund. 1830-33. 8vo. Kütziag in Linnaea VJH 599. s. DIATOMEARUM pars Fries pl. kom, 395 . FRAGILLARIEAE et CHAODINEARUM par $\mathrm{s}$ Bory in Dict. class. $I .593$.

Corpuscula crystalliformia, plerumque lineis rectis circumseripta, aciformia, cuneiformia v. quadrangula, rarius lineis eurvis inclusa, semper plana, rigida, fragilia, plerumque in muco nidulantia; in varias formas; infima in paral- 
lelogramma v. stellatim, summa in filum consociata, demum iterum varie sejuncta. Caespitum color e fusco-luteus, exsiccatione viridi olivaceus, vernicosus, individua hyalina v. lutea aut rarius viridia.

Mare aquasque dulces incolunt Algarum formae infimae, transitum ad regnum inorganicum simulantes, quoad naturam intimam et vilae rationem nondum satis cognitae. Plurimae in sequentibus recensitae rectius fortassis animalculorum microscopicorum primordia $v$. excuviae erunt habendae.

SUEGER I. DIATOMEAE Kïtz. in Linnaea VIII.531. Individua plerumque lineis rectis circumscripta, plana, fuscescentia, rigida, solitaria v, varie consociata. inclusa.

TFETEES I. FRUSTULIEAE. Individua non

1. Froustulifa $A G$. Individua libera, rigida, medio plerumque Inngitudinaliter uni-bicarinata, solitaria v. binatim cohaerentia.

Frustulia Agardh syst. XIIT. Kätz, in Linnaea VIII. 353. C y mella et Frustulia Agardh consp. 1. et 43.

a) CYCLOTELLA $K t z$. I ndivid u a sphaerica, medio unibicarinata, solitaria.

Cyelotella Küz, l. c. (f. r.) Fr. opereulata Ag.

b) HAPLOTELLA. Individu a linearia v. Lauceolata, ecarisata, solitaria.

Aplotella Kütz. l. c. $(f, 2,3$.$) C ymbellae sp. Ag.$ Echiuella acuta Lymb. t. 69.

c) CXMBELLA Itz. I $\mathrm{a} d \mathrm{iv}$ id u a linearia v, cymbiformia, uni- bicariatate, binatim conjuacta.

C. y m hella Kütz. $l$. $c$. $(f, 4-11,13-15,17,18$. A gardh ic. f. 1. 2.) Cymbellae sp. Ag. Bacillariae sp. Nitzseh Bacilt. t. 3. f. 15, 16. - Navicula Bory in Dict. class. XI. 472. Turp, Mem. Mus. XVI. t. 13. f. 1. 2. Atl. t. $1 . f$ 1. 2 .

OBS. Pandurellas, Paltonellas et SigmelI a s Kätz, l, c, animalibus adaumeramus.

2. Styllaroisg $\mathcal{A}$ G. Individua lihera, cnneiformia plana, longitudinaliter striata, apice eroso-denticulata, solitaris.

Styllaria Agardh consp. 37. Rhabdium Wallr. f. germ. $\pi$. 116. Eehinella cuneata Lyngb. $t$. 70 . Frustnliae sect. Sphenella Kütz. in Linnaea VIII. 556. $f$. 32. Styllariae sp. Bory.

3. NTerothiom $A G$. Individna in muco nidulantia, cuneata, radiatim in circulum plus minus completum, plannm, coadunata.

Meridion Agardh syst. XIV. Consp. 3s, Leibl, in Flora 1830. $t .1$. Kütz. in I.innaea Vul. 558. $f$. 37. E e hi n e 11 a olivacea Lyngb. t. 70 . E. circularis Grev. in Mrem. Fern. soc, TV. i.s. f. 2. Scot. $t 35$.

8. Thennopluora $A G$. Individna libera plana, flabelliformia, basi attenuata cohaerentia, apice discreta.

L i em o p hror a Agardh in Flora 1827. p.628. Consp. 40. ercl. sp. Ex 11 a ri a Grev. scot. $\ell$, 298, excl. reliq. Kütz. in linnaea VTH. 559 f.38-41. P s y g matella Kätz. mse. Eefinella taselenlata Lyagh, t.70. Grev. seot, $t, 16$.

- Obs. A ristel Ia m Kütx. in Linnaea PHI. 563, f. 42. (Frustulia crintta Martens) animalibus esse adinume raudam, nullus dubitat.

5. Gomphomemas $A G$. Individna libera, fila hyalina flexilia, simplicia v. ramosa terminantia.

Go m p ho n e m a Agardh syst. XV. Leibl. in Flora 1830 . p. 32\%. Kritz, in Linnaea VIII. 563 .

a) CY MBөРноRA Ftz. Individun cymbifornia v. elliptica.

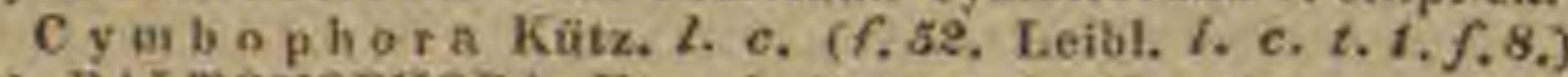

b) PALTONOPHORA $K t z$. Individna fusiformia.

Paltonopliora Kütz. t. c. (Leibl, l. c. $f, 7$. )

c) SPHENOPHORA $K t z$. Individua cuneiformia.
Sp hen op hora Kï̈tz, l,c. (f, 43-5t, Leibl. L, c, f. $1-6$. Grev. scot. t. 2ii.) - Eehiuella paradoxa Lyngb. t. 70. Grev. scot, t, 25. Exilaria s p. Gres. scot, $t .289$. 991. L i cuophorac sp. Ag.

B. Aeluranathes BY. Individua lihera, linearia $v$. quadrata, in $f r n n d e m$ quadratam $v$ filiformem, stipite laterali sustentam, coadunata.

A cha a nthes Bory in dict. class. $r$, 79. et 593. c. ic. Grev, scot. $t .287$. 295. Kiitz, in Linnaed 1711. 5n3. f. 5356. - Achua thes et Striakella Agarth consp 55. 60. - Diatomatis et Confervae sp. E. B. C. tges, 2iss.

ซ. Egdgozaza $f G$. Indi $\mathrm{r}$ idu a libera, rigi dinseula, obliqqua, symmetrice intus cellulosa, extremitatibus varje cuhacrentia.

Isthmia Agards consp. 55. Kuith, in Iinnaen FII. 579. f. 59. Conterva obliquata R. B, t. 1889. Dia

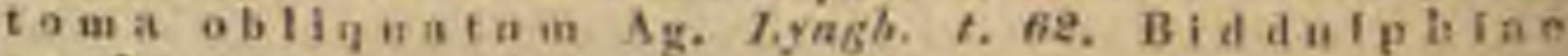
sp. Gray.

9. EDaadocana DC: Individna libern, teträedra, plana, primum in 1 a mina $u$ v. Iil $4 \mathrm{~m}$ paralleliter coadunata, demum soluta, anzrols akternation cohacrentia.

Diatoma DC. Al. fr. II. 4s. Agurith in Swersk Bof. t. 491. Consp. 46. Kutz, in tinnaea TIII 380 . f. $60-68$. 6e.

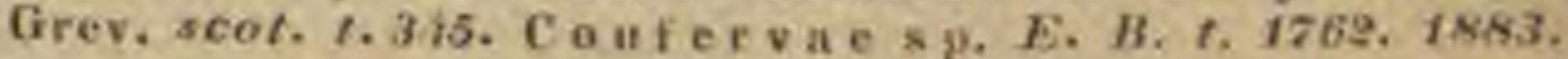

D. Deloancella $f G$. Individua libera, quadrata, alternatim angulo in stipitem productor in filn m cohacentia.

Odoutellis Agardh. consp. 56. Diatoma a uritur Lyngh. $6,62, k 7$. dan. $t$, $195 \%$.

16. Wraseaberola $L B Y$. Ind i vid a a lihera. linearia, transversim in $\mathrm{fil}$ n m coad anata, demusn penitus secedentia.

Pragilaria Lyngb. 182, 6. 63. Agardh syst. XIV. Kütz. in finnnea Tril 586. Nemuto p Iata Bry in dict. class. $4.593 . X I$. 499. $c$. ie. T e m a $\mathrm{ch}$ in m Wallr. fl. germ. 11. 116. Fragilaria et Gramuonema Agardi consp. 69. 63. Confervae sp. Dillw. $t, 24$. E. B. $t$. J611. B a. cill a riate sp. Nitzsch Bacill, $t, f, f, \pi$.

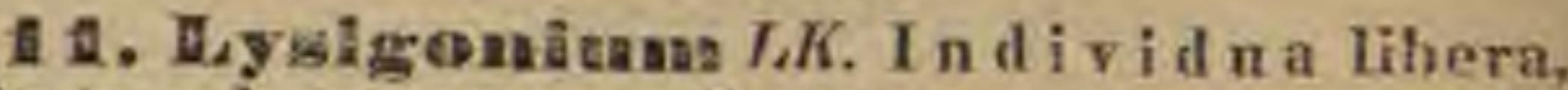
quadrata v. hexagona, medio transversim unistriata, in fil $\mathrm{n}$ in teres coadunata.

Lvsigouinm Linh in hor phys, 4. Molasira Agardy syst. XIV. Consp. 64. Küt. in Linnaca JIII. 587. f. 68-72, Gaillonella Bory in Dict, class. IV. 3.23. YIN, 101. Fragilaria numuloides Lyngh. t. 63 Coufervae s. Mall. in Act. Holm. 1783, t.3. f. $1-5, F L$. dan. t. 1548 . f. 1. E. H. t. 2287

12. Bencoloynosa $A G$. Individua glabosa, pnetiformia, in $8 \mathrm{t} r$ a $\mathrm{t} \mathrm{m} \mathrm{m}$ curiacen-gelatinosum coadunata. - Genus vix notum, affinitat is dubiae.

0 u co b y r s a Agarih in Flora 1827. p. 629.

TUE tubulis inciusa.

A 3. Eareyoreana $K T Z$. Individ na cymbiformia intra $\mathrm{fil} \mathrm{um}$ gelatinosum hyalinnm, liberum, simplex, uniseriala. _ Genus cum sequente jurtgendum?

E n с у o и em a Kütz, in Jinnaen VTIT, 589, f. 23.

14. RIy almolinaras $L N K$. Individua iinearia v. elliptica intra fila gelatimusa, simplicia v. ramosa, libera v. in muco nidulantia, uni-pluriseriata.

H y dralinum tink in hor. phys. 5. Sehizone ut a Agardh syst. XY. Consp, 11. Ic. $t, 3$. - Mout uta Grev. scot. $t$ 286. 297. 309. 358 Burkele y a Grev. seot. $t$. 204. Gir o dell a Gaill, in Turp. itl. I. t, 27, 28, Spermago. I i a Bonuemais, in Jmurn. Phys. XOIF. 199. B a Lyugb, $t, 2 a-26$. U1sae sp. E. H, t. 2101. Cintervat sp. Dillw, $t, 28,10 k$. E. B., $t, 1700$. Gloiou e mat is sp. Grey. $s \cot$ t. 30 ,

15. उEgane lanerolata, intra frond em tubulosam, ramosam. binatim in series plures distantes disposisa. 
Homoeneladia Agardh in Flora 1827. p. 629. 1e. t. 5. Consp. 24.

16. Gloiodietyon $A G$. I ndivid u glo bosa, binatim concatenata, $\mathrm{filis}$ reticulatis mucosis inclusa.

GI o iodicty o n Agardh consp, 25.

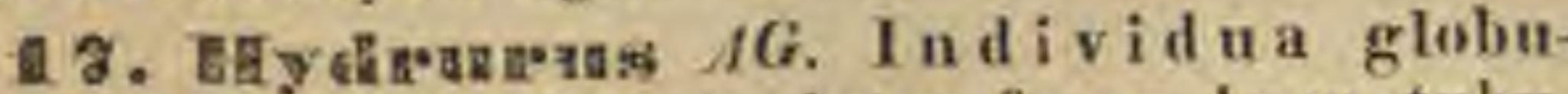
losa, in fil um coadunata, intra fron d e m tubnLosam ramulosam contenta.

Hydruras Agardh syst. XVIII. Schübler in Flora 1828. p. 65. c. ic. Cluzella Bary in Dict. class. III. 14. Turp. atl. I. $t, 30$. Corradorus Gray brit. pl. I. 350. $\mathrm{Pal}$ mellae sp. Lyugb. $t$. $\sigma s$. $f$. $c$. U I vae s p. Vauch. corf. $t, 17, f, 3$.

18. Thiseranacess $A G$. Individua lancoslata, intra $t u b u I$ s seriata, tubuli in fron d e in gelatinosam v. cartilagineam ramosam coadunata.

Mierom ega Agardh in Flora 1897. p. 688. Ic. t. 4 . Consp. 22. Cateothrix Dess. mse, Gloi anematis sp. Grev, in Mem. Wern. soc. IV. 215. t. 18. Scot. $t .30$.

SUMB Limnaea VIII. 591. Individna pleramque cylindrica, viridia, solitaria v. varie consociata.

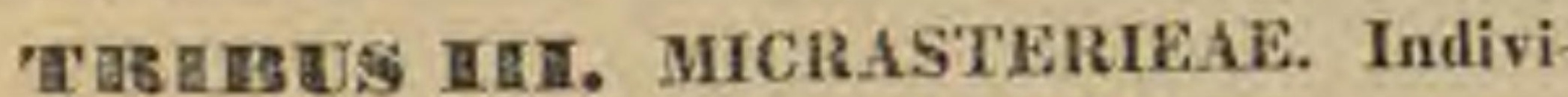
dua libera.

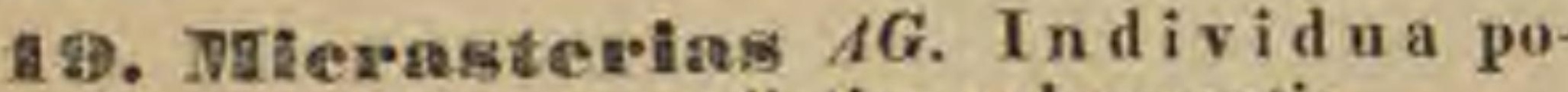
Jymorpha, stellatim v. radiatim cohaerentia.

Mierasterias Agardli in Flora 1827, p,642. Kätz. in Linnaea VII. 399. f. 83-86. 88-92. S t a u rast r a m Meyeu in N. A. N. C. XVI. $t, 43, f .37,3 s$, P ed iast rum Meven $2, c . t$. 43. $f .1-5$. S phaerastram Meyen $l$. $c$. f. 23. 24. - ? Helierella Bnry in Dict. class. VIII. 98. Turp. in Mem. Mus. XVI, t, 13 f, 20-22, P ot a r c us Raf. in Journ. Phys. LXXXIX. 107. Crueigenia Morren in Annal. sc. nat. X. $t .15$. S el e a a ea Nitzsch msc. Heliacti \& Kütz. msc.

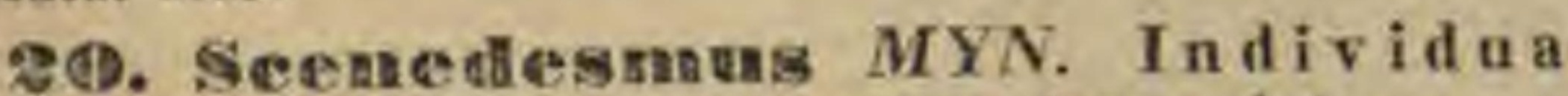
subglohosa v. fusiformia, transversim seriata.

S ce bedesu us Meyen in N. A.N.C. XV. 272. $t .43$. f. 26-35. Kütz, in Linnaea VIIL. 606, f. 93-100. A c li n at nthis s p. Bory, Turp. in Mem. Mus. XVT. t. 13. f. 1-12. Tessarthroula Turp, $l, c, f, 18$.

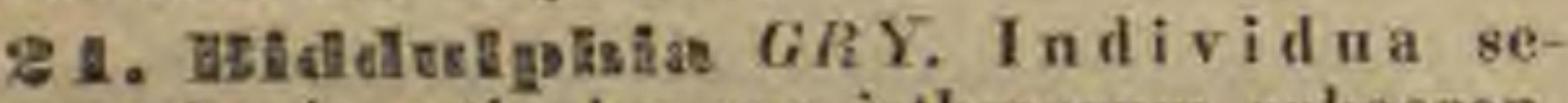
riata, series in articulos ope isthmorum cohaeren tes sulntae.

Bid d $1 \mathrm{ph}$ ia Gray brit. $p l$. I. 294. Kütz, in Linnaea VIIT. 610. Agarilh consp. 5i, Confervat B Idd u I phia a a E. B. ใ. 1762

OBS. Closterinm Nitzseh, Heterocarpellam Turp. et Trochisciam Kütz. partion animalia, partion aliarum Algarum sporas habeo.

TES muco communi determinata $\mathbf{v}$. tubulis inclusa.

2\%. Eetainglise $A C H$. Individua sphaerica, $t u b u l i s$ cylindrieis memhranateis inclusa, tubuli in fronde $\mathrm{e}$ radiosam, muco communi hyalino obvolutam, f:onsociati.

Eehinella Achar. in Web. et Mohr Beitr. II. 340. Kítz. in Linnaea VIII. $611, f, 101$.

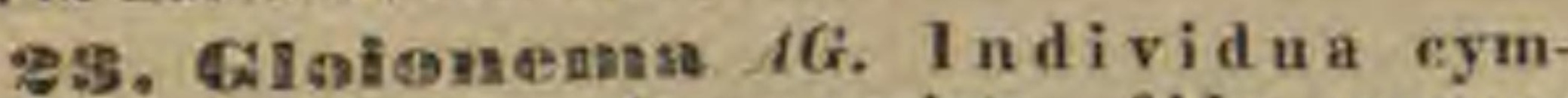
biformia v. elliptica, dense seriata, filo mucoso elastico inclusa.

GIoionema Agarth synops. $\mathrm{XXXV}$. Syst. XVIII. Consp. 30. Lelbl, in Flora 1830. t.1. f.11. Kutz. ibid. 1833. p. s13. ss. Linnaea VIIX. 612. f, 102.

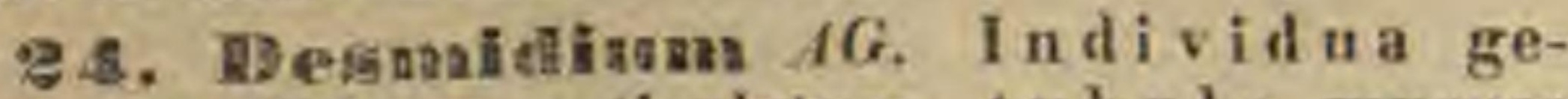
minata, in fil $\mathbf{u m}$ articulatum, $t$ uls alo mucoso inelnsum, seriata.

De 8 m id i u nt Agardh syst. XV. Grev, scot. $t, 292.293$. Kütz, in Linnaea VII. 613. D ia to $\mathrm{m}$ a S wartzii Lyngb. t. 61. Agardi in Swensk Bot. t. 491. $f, 1-3$.

\section{Drallo TI. Wostochinece.}

NOSTOCHINAE Agardh syst. $X Y$. CHAODINEARLM pars Bory.

Gelatina figurata, globulis v. filis simplicibus aut ramosis, continuis $v$. articulatis farcta. - Nostochina pleraeque aquis dulcibus innatant; aliae marinae, nonnullae meteoricae, quaedam in inundatis palustribus, aliquae in solo v. saxis roridis, imo in ipsa nive et glacie gignuntur.

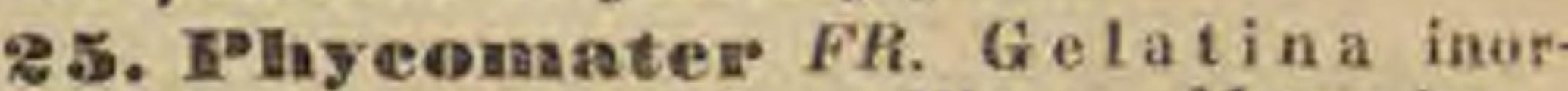
ganiea, effusa, granulis nullis. - Meteoricae.

Phy comater Fries pl. hom. 337 .

26. Clalorpeqeernan GREV. Granula sphaerica v. ellipsoidea, aggregata, strati expertia.

Chlorococeum Grev,scot.t.262.325. Olivia Gray br. pl.T. 349. Protos phateria Turp. Atl. I. t. 4. Mieralo a Biasolett. Alg. microscop. 47. t. 19. 20. P r ot a e o c cus Monas Agardh ic. t. 11.

28. Flacanat tococenas $A G$. G i o b u $1 \mathrm{i}$ rubri agmrerati, v. vesi c ula e pellucidae, gran ulis rabentibus sphaericis farctae. _ In nive aeterna, polari et alpina.

Huematococeus Agardhie, t. 22-2h. Proto o ce a aivalis Grev, seot. $t .23 t$. Uredo nivalis Ferd. Bauer in Journ. of sc, and arts VIT. C. 6 .

29. Frobtedectrs $A G$. Globuli sphaerici, plerumque rubri, saepe in s trato sabmacoso.

Protococeus Agardi ic. t. 21. Isepraria kerme. sia a Wrang. in Act. Holm. 1823, $t, 3$. Sphaerella Somuerf. in Magaz. for Naturwdensh. 1824. $I V$. 249. C n e co p h y $8 \mathrm{i}$ u m Link in Berlin. Academ. Abhandl. 182, p. 181 . Palmella rabra Fl. dan. 2 . 1952. $f$. 2. Treuella ruenta E.B. 1800.- ? Zoogalactina Sette Memoire Venez, 1827, 8vo. Pauls, in Schweig. Jahrb. 1897. H. 396. A ėrophyton Meyen Reise 1.54 .

25. Ealamella LYB. Massa gelatinosa globosa v. expansa, granulis diseretis, globnlosis v. ellipticis fareta. - Inundatae, puludosae.

Palmella Lyngb. t, 69. Agardh Ic. t. 12-14. Grev. scot. t. 243. 2/7. Co ceochloris Spreng. syst. IV. 314. Pristleya Meyeo in Iinnaea $\mathrm{H}$. $40 t$. excl. synon. Glo. 6 111 wa s p. Turp. atl. X. t. 7. 9. C haos Bory in Diet. class. III. 13. excl. sp, Merettia Gray brit. pl. 1.349.

30. Wuadtara FR. Frons gelatinosa, subglobosa, filis moniliformilsus enrvatis fareta. Paludosae $v$. marinac.

Uadina Fries pl. hom. 348. Hydroeoceus Link Handh, 1UI. 268. Nost o e Vauch. conf. 203. t. 16. Agardh syst. XVIIL. Tarp. AtL. I, t, 11. Grev, scat. t. 131. T r emetl a s s. Lin. Fl, dan, $t, 1885$.

3 1. Feathegin GRY. Fruns gelatinusa inflata filis snbramosis, septatis, apice clavalis, e communi centro rarliantibus fareta. - Marinae.

Leathesia Gray br. pl, $T$. 301, Cory ue phora Agardh syst. XXX. Grev, scot. $t, 53$, C I a gatell a Bory in Diet. class.excl.sp. Turp. Atl. I. l. 15.f. . C hate to $\mathrm{p}$ is or a ma rin a Lyugb. $t, 66$.

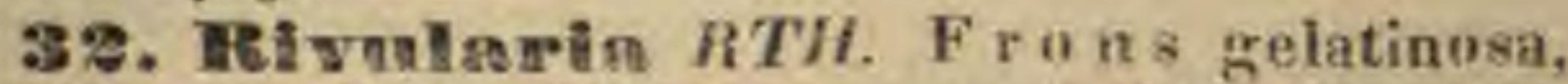
suloglobosa solida, filis granulo insidentibus annulatis, e communi centro radiantibus, fareta.

Palustres v, marinae, suturate virides.

Rivularia Roth catalect. $I$. 212. Agardh syst, XXIV.

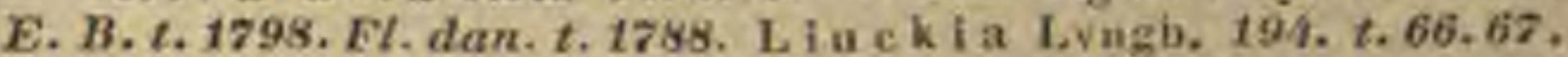
Gaillardotell a Bory in Diet, class.VIt. 100. Tarp, Atl. I.t. 26. S ty lob a s is Seliwab msc. St y p i io "Raf. Tre. mella a atans Hedw. theor. generat. t.36. f: $7-15$.

33. FIyrotomerana GPEV. Frons gelalinusa effusa, filis globulo insidentilous, simplicibus, subarticulatis, elavatis, paralielis farcta.

M y rionema Grev, scot. t. 300 .

34. Chasetosolnosa $A G$. Frons gelatinosa, glubusa v. lobata, $\mathrm{f} i \mathrm{lis}$ artienlatis ramosis, 
apice attenuatis, e communi basi radiantibus farcta. Palustres v. marinue.

Ch h e to phor a Schrank, Lyngb, s. 65. 66. Fl. dan. t. 1728. Agardh syst. XIX. Grev. scot. $t$. 150 . Rivula ria Bonuemais in Journ. phys. $X C I V$. 176. M y riodacty $10 \mathrm{n}$ Desv, in Journ, bot, 1809. p. 307. A n halti a Schwabe in rinnaed IX. 12\%. $t$. 2. f. 1. 2. B atrachospermi sp. Vanch. conf. t. 12. f. 1. 2. t, 13. f. 1.2.

35. Ky dreceryan $S C H W B$. Frons gelatinoso-spongiosa, elavata, filis araehnoideis intricatis farcta. - Palustres.

Hydrocoryne Selwwabe ex Spreng. syst, IV. 373. Wallir. Fl. germ. IV. 13.

36. Seythymena $A G$. F ro ns coriacea, effusa, e filis granulisque immixtis conflata.

Scythymenia Agardh syst. XX. UIva rupestris E. B. $t .2194$.

\section{Ordo IIT. Confervaceae.}

CONFERVOWEAE Agardh syst. $x \boldsymbol{X}$. ULVACEARUM pars Fries pt. hom. 335 .

Fil a capillaria, membranacea $v$. filamentosa, intus v. extus articulata, simplicia v. ramosa, libera (i. e. hand in frondem coalita), interdum tamen reticulatim contexta, viridia $v$ rarius fusea aut purpurea, in formis infimis hyalina. Sporidia viridia, fila farcientia v. inter articulos vesiculoso - inflatos contenta. Aquae marinae et dulcis vulgares hospites, in hemisphaerae borealis undis friyidiusculis maxima copia vigent. Nonnullae viviparae, aliae motu quasi spontaneo vitam animalem mentiuntur.

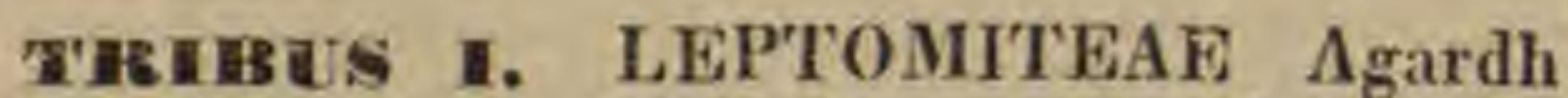
syst. XXII. excl. gen. Fila arachnoidea, subliyalina, obsolete articulata, corporibus organicis in aqua solvi incipientibus affixa. - Tribus multis rexala dubiis, inter Algas et Hyphaceas, Fungorum ordinem valde ambigua.

37. My amorpham v. memliranam tenuem contexta, fluitantia.

Hy grocrocis Agardls syst, XXIII. Biasolett. Alg, microscop. $6,1-12$. T y plio de $\mathrm{rma}$ Gray br. pl. I. 558.

38. Teptomitus $A G$. Fil a libera, erecta, fluitantia.

Lepto aitns Agardh syst. XxIII. Biasolett. Alg, microscop. $t \cdot 13-18$. Co nfervae s p. Dillw, $t \cdot 30.79 .-\mathrm{S}$ aproleg mia Nees in N. A. N. C. X. 613. Couferva ferax Gruithuis. op. cit. X. $43 \%$. 2.18. - A e hil y a Nees op. cit. $\mathrm{X} I$. 514. H ydran e m a Carus op. cit. XI. 493-50\%. 7. 58. - Pythium Nees op. cil. Xl.515. Mue or spinos as et imperceptibilis Sehrawk in Münchn. Denkschr. 1813. p. 14. t. 1. $f .1-4$. S p hat e r o til us Kütz. in Linnaea YIIT. $385, t, 9$.

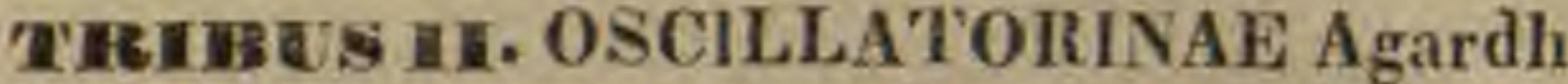
syst. XXIV. Substantia gelatinosa, elongata in fila subsimplicia, subcontinua, mucosa, demum saepe indurato - cornea, intus granulis v. annulis seriatis fareta, interdum motu oscillante $v$. ob rapidum incrementum quasi repente donata. _ Tribus inter hunc et praecedentem ordinem media.

39. Dseillaria BOSC. Fila muco obvoIuta, oscillantia, simplicia, articulata, articulis quadratis, annulo hine illine jnnetis v. terminatis.
O s cillaria Bose es Bory in Dict. elass. I. 594. XII. 457. c. ic, Oscillatoria Vauch. conf. t. 15. excl. sp. Triehophora Bonuemais. in Journ. Phys. XCIV. 176. Sphaerozy ga Agacdh in Flora 1827. p.634. O scilla. toria flexuos a Agardh ic. $t .10$.

40. Mieroeoleus DESM IZ. Fila libera, vaginis membranaceis fascicnlation prorepentia, simplicia, transversim lineolata, demum contexta.

Mierocoleus Desmaz, eatalog. pl. om. 7. Bory in Dict. class. X.584. Vag in a ria Bory op. cit. I. 594. c. ic. Oscillatoria vagiuata Vauch. conf. $t .15 . f .13$.

41. Ankbainat $B R Y$. F il a libera, repentia, simplicia, monilifoxmia, articulis ovalibus, diametro aequalibus.

A u abaina Bory in Dict. class. I. 593. c. ic, excl. sp. $(7, f \cdot 7 \cdot a \cdot c$.

4\%. Fyum toy a $A G$. F i l a libera, tranquilla, elongata, flexilia, intus lineolata.

L y $\mathrm{ng}$ b y a Agardh syst. XXV. Grev. scot. t. 303. C yclos perma Bonuenais, in Journ. Phys. XCIV. 179. H $\mathrm{u}$. ui a Giry br, pl. I. 281. U I oth ri $x$ Kutz. in Flora 1833. 519. Oscillatoriae sp. Agh. Confersa muralis Dillw, t. 7. E. B. $t .1554$.

43. Calothrix $A G$. Fila libera, tranquilla, brevissima, rigida, stricta, intus obsolete lineolata.

Catothrix Agardh syst. $\times X I V$. Grev, scot. $t$. 299. El is a Gray br,pl.I.282. Coufervae s p. Fl. dan. $t .820$. Dillw, t.22. E. B. t. 2587.

44. Bangia $A G$. Fil a libera, tranquilla, plana, flexilia, intus fasciis punctatis notata.

B a $n g$ i a Lyngb. z. 24. 25. excl. sp. Agardh syst. $X X V$. Ic. t. 25. - ? M e rizo m $\mathrm{g}$ ri a Pollin. in Hiblioth. ital. n. 21. p. 420, t. 7. f. 2. $a, b$.

45. Seytomema $A G$. F il a libera, coriacea, intus annulata.

$\mathrm{Scy}$ ton e m a Agardh syst. XXIt. excl. sp. Bory in Dict. class. IV. 393. - ? Pereursaria Bonmemais. in Journ. Phys. XOIV. 178.

46. Stígonema $A G$. F i l a libera, coriacea, intus punctis in annulos dispositis notata.

Stigonema Agardh syst. XXIT. Girardia Gray br. pl.I.285. Couf ervae s p. Dillw, t.25. B. Bangia a t ro. virens et ma millosa Lyugb, $t$. 25.

4\%. Splaneroplea $A G$. Fila libera, intus glob n I i laete coloratis farcta.

Sphaeroplea Agardh syst. $X X Y$. Cadmus Bory in Dict. class. f. 14. S pha rog o n a Link in Bert. Acad. Abhandl. 1824. p. 190 . S phater oplethia Duby Hot. gall. II. 985. Couferva anu

TEIEUS III. BATRACHOSPERMEAE Agardh syst. XXIII. Fil a mucosa, articulata, r amos transversos heterogeneos exserentia: Sporidia decoloria.

48. Myxonema $F R$. Fila gelatinosa, farcta, septata, ramosa, massa sporacea intra articulos transversali.

M y xanema Fries $p l$.hom. 343. Nematrix Fries msc. Myxotrix Fries stirp. fems. p. 44. - ? Conferve oru a t a Agardh syst. 104 .

49. Draparnaldia $B Y$. Fi 1 a gelatinosa cylindrica, artienlis zonatis, ramis fascienlato-penicillatis, appendice capillari tenuissimo terminatis.

Draparnaldia Bory in Annal. Mras. XII, 399. $t .35$. Lyagb. t. 65. Charos permu Link in hor phys.5. Conferva s p. Dillw. t. 2. E. B.t. 2087. Bat ra hos perm i s p. Vauch, t. 11. f.2. $t .12, f .1$.

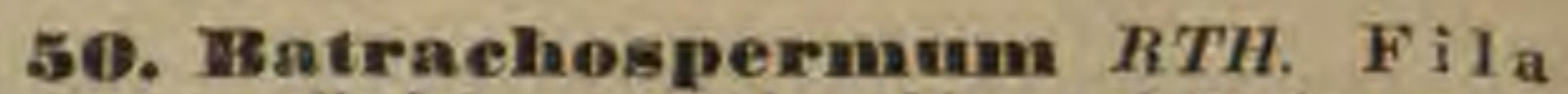
gelatinosa ezlindrica, articulis nodulosis, ram is subverieillatis moniliformibus, gemmiparis. 
Batrachospermum Roth germ. III. 480. Bory in Annat. Mus. XII.310. t, 29-31. Draparnaldina, Moni. $1 \mathrm{i}$ a a, Thorinia, Lemania Bory in Dict. class. IT. 226. - Gelat inaria Rouss. Fl. calvad. ex Desv. Journ. Bot. 1. 143. To rutaria Bonuemais, in Mem. Mus. XVI. 98. A e gir a Fries pl. hom.342.

51. NHegegloia $A G$. Fila gelatinosa $e y-$ lindrica, artie ulis aequalibus, ra mis brevissi mis moniliformibus, undique radiantibus dense vestita.

Mesoglof a Agardh ayst. XYIII. Lyngb, $t, 65$. Mesogloia et HeIminthoria Fries $p l$. hom. 341, 342. Du d resue y a Bonnemais. in Journ. Phys. XCI

Iariae sp. E. B. t.1627, 1818, 1819. 2466.

52. Hemanest $B Y$. Fila membranacea, rigida, eylindrica, artic nlis notulusis, intus floceos moniliformes penieillatos foventibus.

Le ma ne a Bory in Annal. Mins. TIT. 181. 1. 21, excl. sp. Diet. class. 1X. 274. Agardh in 1et. Holm. 1814. t. 1. Spec.MI.1. No d ularia Liuk in Schrad. Journ. 1809.p.9. Lyagb. $t$. 29. Fougyeladan Liak in hor. phys. 6. 'T' $\mathrm{r}$. chog o u s Palis, in Journ. bot. 1808. p. 123. exel. sp. Vertebrarja Rouss, ex Desv.Journ. bot. I. 143. - A po. n a Adans. 1. 2. - Pol y spermae sp. Vuuefi. $t .1, f .3$ t. 10 f.1. 2. Confervae s p. Dillw. t.29. E. B. t.1763.

TRTBUS IV. CONFERVEAE Agardh syst. $\boldsymbol{X X V}$. Fila articulata, viridescentia, omnino libera $v$. reticulatim connexa, plerumque entospora.

53. Nodularia MERT. Fila mucosa, membranacea, arachnoidea, genienlis tumido-globusis.

Nodularia Mert, ex Asardh syst. XXV.

54. Zygnema $A G$. Fila membranacea cylindrica, granuli s varie dispositis farcta, primum libera, demum ope tubulorum transversalium gramula transfundentiuin v, reticulatim conjuneta.

Z y g nem a Agardi synops. 98. Lyngb. 170. C o njuIf at a Vanch. conf. 37 .

a) SERPENTINARIA Gry. Fila geniculata, in geuiculis sese copulantia. G 1 ob uli in massam grumosau, tubum replentes, coadunati.

Serpentinaria Gray br, pl. I. 209. Mongeotia Agardle syst. XXVI. Couj u g a t a Link in hor. phys.5. G eu uflex a Link Handb. III. 261. Z y g $1 \mathrm{ema}$ Bory in Déct. elass. 1 . 395. c. ic. Ca a jag a tae sect. III. Vauch. $t .8$. f. $1-10$. Le da e s p. Bory.

b) STELLULINA Lnk, Fila recta. G $10 \mathrm{ba} 1 \mathrm{l}$ taudem in massus dias stellatas, fu quevis articulo compacta.

Stellatina Linh Handb.MI. 201. Agradlifa Gray t. c. Globulina Liak in Hor.phys. 5. Lucernaria Rauss, ex Desvx. Journ. bot. I. 143. T e ind uride a et Leit a e s p. Bory l.c. C o ajugatae sect.ll. Vaach. t. 6. 7 .

c) SPIROGXRA Lnk. Fil a recta. Gla buli intra articn. los in spiras 1-3 dispositi, demum in globum compacti. Spirogyra Link $7 l$. ce. Meyeu in Linnaea $M .410$. Cho a spis Gray l. $c$. Salmacis Bory op. cit. $X V .75$. c. ic. Coujug at a e sect. 1. Vauch. $t .4 .5$.

55." Ifydrodyedion $R T H$. Fila mem branacea, in rete coadunata, areolis polygonis. Artic uli grannlis nitentibns, demum in reticulum tandem efrusnm coèuntilus fareti.

H y d rodyetion Roth. germ. III. 52r. Vaneh. 82. t.9. El. dan. t. 1597. - ? D ict y lema haf. somiolog. n.55.

56. Conferva $A G$. Fila membranacea, libera, simplicia v. ramosa, mat eria viridi v. rarius colorata fareta.

Cenferva Agardh systoXYVI-Prolifera Vauch. 14. - Chloroniton Gaill. in Diet. sc. nat. LHI. 53. 0 edogouitom Link in Hor. phys. 5 . - Tiresias, Cad. mus, Zo ocarpa ete, Bory. - Hempelia Meyea in Flora 1827, p,715, t.2. - A gari sp. Link olim.

TRLBUS v. CERAMLEAE Duby in Mem. soc. h. n. genev, V. 321, ss. VI, 1. ss, c. icc.
Fila plerumque colorata, articulata, simplicia v. ramosa. Fruetific atio varia, nempe c onceptacula sessilia vedicellata, et t thbe reula globosa, apicibus ramulornm intumescentibus innata. - Plurimae marinae, paucae aquarum dulcium incolae, inter hanc et praecedentem tribum mediae.

5ซ. Leiblimia Fil a simplicia, brevissima, stricta, caespitosa, fusco-virescentia, a r ti culis abbreviatis, conceptaculis lateralibus subsessilibus, globesis. - Marinae.

Des maretella Bory in Dict, elass. v. 438. Duhy in rem. soc. $h, n$. genev. $V$. 34t. Conferva confervieola Dillw. $t .8$. Fl. dan. $t, 1484 . f, 1$. E. B. $t .2586$.

58. Bolboelnaete $A G$. Fila dichotomeramosissima, brevia, stricta, virescentia, a rticulis apice inflatis, alternation setas elongatas et concepta c u la subsessilia ovata exserentibus. fquae dulcis.

$\mathrm{B}$ u 1 bo chate te Agardh synops. XXIX. Lyngb. t. 45. Duby Mem.soc.h.n. genev. V. 3ht. C onferva vivipara Dillw, t.59. C. setigera Roth catalect. III. t.8. f. 1 .

59. CInantransåa $F R$. $\mathrm{F}$ il a ramosa, brevia, stricta, purpurascentia; coneeptacula in ramulis abbreviatis glomerata, lateralia v. terminalia, ovalia. - Aquae dulcis.

Chantransía Fries $p l$. hom, 979. (o.rel. sp.) A ud uinella Bory in Dict. class. IIX. 340, excl. sp. Bonnemais, in Mem. Mrus. XVI, 146, t.8. $f$ 10. Duby in Mem.soc, h. n. genev. $V .341$. G e n i cu I a ria Rouss, ex Desv. Journ. bot. I. 143. Confervae s p. Roth catalect. HI. t.8. f.2. Dillw. $t .91$, E, B. $t, 1996 . f .1$. E e to c a r p i 8 p. Lyugb. $t .44$. El. dan. $t, 1661, f, t$.

GD. Ellachisten $D U B$. Fila simplicia $v$. basi subramosa, brevissima, viridia, e one p tac ulis lateralibus oppositis, breviter pedicellatis, clavatis. Marinae.

E la ehistea Duby in Mem. soc, h, n. genev. $V .339$. Coufervas sutulata E. H. $t, 2311$.

61. Callithamuion $L B Y$. Fila ramosissima, purpuraseentia, geniculis pellucidis fasciatis; e onceptaculis sphaericis v. ellipticis, sessilibns v brevissime pedicellatis; perid io hyalino, n ncleo homogoneo e centro radiatim 3 - 4 partito. - Marinae.

C a 11 it h a m n i on Lyngb. 129. t. 28-41. Agarilh spec. II. 156. Lamnurouxi a Bonnenais. msc. Confervat $s p$. Dillw, $6,17.50 .$, .1. 73.100 .106$. E. B. t. 1637. 1741. 1816. 1838. 1913. 2205. 2339. 2352, 2665. C e r amif s p. Duby in

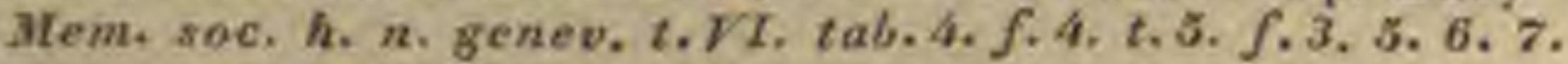

6\%. Ceramionm $A G$. F i l a ramosa, pur purassentia, geniculis elevatis granuliferis; concepta v: ula globosa, sessilia, saepe involuerata, peridio membranaceo tenaci, nucleo e granulis copiusis angulatis eonglohato. - Marinae.

C e r am in m Agardh synops. XXVI.Spec. II.138. Grev. scot. 1.318. 355. Daby in Mem. soc. h. n. genev. VT. t. 3. f. G. a. b. B o r y a a Gaill, in Dict. sc. nat. LIII. 39i. D i. cliderma Bonnemais. in Journ. Phys. XCIV. 185. A masperma et $\mathrm{E}$ pisperma Raf. somiolog. n. 46. 53. Caten aria Rouss. ex Desp. Journ. bot.I. 143. - ? Gail. If o u ia Rudolph, in Linnaea VI. 178. - Conferqae sp. Limu. Roth. E. B. t. 1116. 1742, 2312. 2428.

63. Areifrithsia $I G$. Fila diehotome $v$. verticillatim ramosa, rosea, geniculis ramnliferis ; concepta e a gelatinosa, involucro fibrarum articulatarum cincta. - Marinae.

Griffiths i a Agardl synops.XXYIII. Syst.XXIX. Spec. IT. 126. PI $\mathrm{uma} r \mathrm{i}$ i Link in hor, phys. 4. Polyehrom a Bonnemals, in Journ. Phys, XCIV. 19t. C eramiisp. De. Duby in Mem. soc. h, n. genev. VT. t, $4 ., f, 1-3$, t. 5. f. 2. 4.

84. Wrangelia $A G$. Fil a ramusa, rosea, solida, irregulariter cellulosa, apice articulata, e geniculis ramuram emittentia rauellos pedicellatos 
conceptaculiferos; conceptacula sphacrica, limbo hyalino cincta, tripartita. - Marinae.

Wraugeli a Agardh spec. II. 13\%.

65. 'Thosese $A G$. Fil a ramosa, olivacea, kolida, continua, undique emittentia ramellos abbreviatos, articulatos; conceptarula.... Iquae duleis.

Thorea Bory in Ann. Mus. XIL. 126. t. 18. (exel. f.34.) Hydroph. Voy. Duperr, t. 24. $f$. 3. Agardh spec. II. 123. Poly co m a Palis, in Journ, bot. 108, p, 123.

685. Dasya $A G$. Fila ramusa, purpurea, cuntinua, ramellos penicillatos, articulatos, dichotomos emittentia ; con e e pta cula rostrata, pedicellata, et alia oblonga, globulos discretos margine hyalinus eontinentia. - Marinae.

D a sy a Agardh syst. XXXIV. Spec. II. 116. Ie. t, 8. Stic ltoc arpus Agardh in Flora 1897. p, 636. - R ho do nema Merteas Reise t. 8. - Asperocanlon Grev. Fl. edin. 309. - Gratelo upia Bonnemals, in Journ. Phys. XCIV. 189. Ellis i ts Gray 1.333 . G a ill on a Bonnemais. in Mlem. Mus.XVI. 113. B a ill o uvian a Griselini Observ. Venet. 1758. Svo, c.ic.

G\%. CThaneppoำ LAMX. F i l a ramosa, purpureo-rosea, obsolete articulata, geniculis perviis, ramellis axillarilons aggregatis, granula elliptiea v. angulata, ternatim quaternatimve eonsociata interiori latere immersa ferentibus. - Marinae.

C h a mpia Laux. ess. 51. Agardh Spec. II. 113. Mer. tensia Roth in Schrad. Journ. II. 1. t.1. Catalect, IHL. 318. $t$.10. viva rugos a Thunb.

69. Naceraria. Fil a ramosissima, rubra, obsolete articulata, ramuli tumidi ramellis cooperti; s lobuli minimi sphaerisi in axillis ramellerum aggregati $v$. in $g l 0 \mathrm{~b} \mathrm{~m} \mathrm{~m}$ intra ramulum inclusnm compaeti. - Marinae.

Cliaetospora Agardh syst. XXIX. Spec. II. 112. non F. Br. - F a cus Wig ghii Turn. in Linn. Transact. VI. 135. Hist, Fuc, t, 102, E.B. $t, 1165$.

GP. Felysiplaomia $G R E V$. Fila ramosa, fusco-purpurea, articulata, articulis fasciatis; ramuli apine tumidi subsiliquaeformes, glo b a lis umiseriatis fareti, aut e on e e t a e u l a lateralia, sphaerica v. subclavata, granula pyriformia, basi affixa foventia. - Marinae.

Polvs ipltonin Grev. Fl. edinb. 308. Scot. t.90. 210. Duby in Mems soc. h. n. genev. .334 , H $\mathrm{n} t \mathrm{t}$. hi ns i a Agardh synops. XXVT. Spec. II. 55. Lyngb. t, 33-36. non R. Br. Gram it a Bonnemais, in Journ. Phys. ICIV, 186. C or radoria Mart. El. Bras. I. 16. B raussonetia Gratel. msc. Vertebrata Gray br, pl. I. 338. Hutchinsia Oicarpella, Brongniartella et Grateloupella Bory in Dict. class, III. 360. C oufervate s. Anct. Dillw. 2.33. 40. 44. 58. 70. 107. E. B. . 1429. 1686.1717. 176\%. 2340. 2365. 2489. 2589.

70. Thydiglolacen $A G$. F rons membranasea transversim striata, pinnatifida, purpurea ; e oncepta e a la tuberculiformia in pinnularum apieibus, globulos subangulatos includentia. - Marinae.

Ry tip h la e a Agardh syst. XXx. Spec. II. 50. Ic. 2. 19. 20. $\mathrm{S}_{\mathrm{p}}$ ha e rocueci sp. Mart, crypt. bras. t. 3. Fuei $\mathrm{sp}$. Turn. $t .224$.

a. Aetoeanpen AG. Fila ramosissima eaespitosa, olivacea, articulis diaphanis v, materia grumnsa repletis; conceptacula terminalia v. lateralia, sessilia v. pedicellata, sphaerica v. elongata, siliqnaeformia.

Eeto e a rpus Lymgh, 63. t. 43. 44. Agardh syst. XXX. Spee. II. 3E. Duby Mem. soe. h. n. genev. V.339. L y ug b y a Gaill. in Dict. se. nat. LIIII. Macroe arpus Bounemais. in Journ. Phys. XCIV. 193. - ? 0 pospe rurum et Calosperm a mi Raf. somiolog. n. 56. 57. Eetocarpus, Py. la iella et $A_{n}$ duinellae sp. Bory in Dict, class. $I V$. 093. Confervate sp. Dillw. t.56. E. B. t.999. 2290. 2319. 2351.2511 .

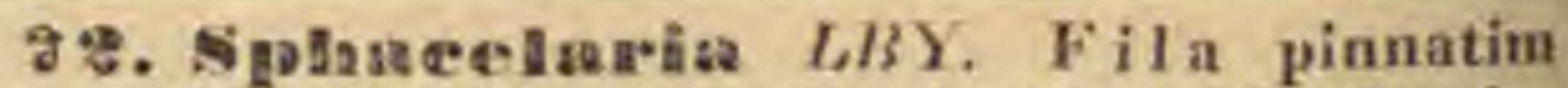
ramosa, olivacen-fuscescentia, artic n lis fasciatis, ramuli apice incrassati, truncati, pulverem subtilissimum inciudentes; con e e pta cula discoidea sessilia, margine hyalino cincta. - Marinae.

S ph a celaria Lyngb, 103. t.30-32. Agardh syst. XXX. Spec, IT. 17. Grev, scot. t.96. Daby in Mem. soc. h. n. Benev. 1.333. Sphacelaria, Delisella et Lyagbyella Bory in Dict. class. III. 340. C o n ferva e sp. Dillw. t. 52.86 . 95. E. B. t.1552. 2138. 2172. 2299. 2330.

2. D. Dasyeladus $A G$. Fil a articulata, lutescenti-ferruginea, ram ellis densissime vertieillatis, horizontalibus, ramosissimis; ramuli apice in $t \mathbf{u}$ b ercul $\mathbf{n} \mathrm{m}$ pulvere nigricante repletum intumentes. - Marinae.

Dasyeladus Agardle. spec. II. 15. Botrydium Targ. ex Bertolon ameen. 309. M y r sidinm Raf. caratt. t. 20. f. 12. Canferva claviformis Roth. Spreng. in Berl. Magaz, 1809, $t, 6, f, 8$. S pongin vermicularis Seop, carn. $t, 64$.

4. CIa el ostegolang $L B Y$. F i l a articulata rigida, simplieia v. ramosa, $\mathbf{r a m}$ is sulidis coriaceis, ramuli verticillati, setiformes, brevissime articulati; concepta e 1 a lateralia, elliptica, pedicellata. - Marinae.

C I a d os te phus Lyugb. 102. t. 30. Agardh spec. II. 9 . Duby in Mem. soc. h. a. genev. V. 332, Das y tric ha Lamx. ex Bonnemais. in Journ. Phys, XCIV, 185 . C on fer va s p. Dillw. $t$. 42, 55, E. B. . 1718, 2427, f. 2. F u c i s p. Turu. t.199. Stackli, $t, 17$.

\section{CONFERVACEAE FOSSILES.}

\section{ร5. Confervites BRONGN. Fila simpli-} cia v. ramosa, septata. - In creta.

Coufervites Brongn. hist, veg. foss. 1. 86.0 .9$.

\section{Ordo IV. Chardecene.}

Characea e L. C. Rich. in Humb. et Bonpl, nov. gen. et sp. I. 45. Agardh syst. Alg. XXVII. BartI. ord. nat. 21. Lindl. introduct. 325. C h a r oa e Bischoff crypt, Gewachs, 1. Agardh in Nov. Act. N. C. XIIT, 1, 87. Vaucher in Mem. soc. $h$, n. genev, I. 1. 168. Kaulfuss, über das Keimen der Charen. Leipaig, 1825. 8vo.

ALGAE submersae, vado affixae, annuae vel perennes, e tub ul is simplicibus clausis compositae, saepius crusta calcarea munitae. RHIzona simplex articulatum, articulis tumidis, glandulis vesiculosis obsitis, $r$ a d iculas tubulosas filiformes simplicissimas protrudentibus. Catues teretes, articulati, nunc e tubulis membranaceis simplicibus, diaphragmate clausis compositi, laeves, ram u Ii s exarticulatis simplicibus vel bifureis, verticillatim articulationi insertis; nune ramique e tubo centrali et pluribus exterioribus, spiraliter circa eundem dextrorsum volutis constructi, ra mi s circa internodia verticillatis, verticillatimque ramulosis. Articuli ramor u m nunc cirea circum, nunc interiori latere setis quaternis vel octonis, aequalibus v. inaequalibus, interdum subobsoletis donati. Organa propagationis dimorpha, in extremis ramorum axillis vel inter setas, secundum interius ramulorum latus sessilia, subsolitaria: globuli minimi praecoces, cinnabarini, e cellulis cuneiformibus, radiatim convergentibus, membrana decolori, tandem in partes triangulares rumpente, einctis, compositi, et s p ora $\mathrm{u} \mathrm{gi} \mathrm{a,} \mathrm{plerumque} \mathrm{in} \mathrm{iisdem,} \mathrm{rarius} \mathrm{in} \mathrm{diver-}$ 
sis individuis, e lamina duplici, nempe exteriore diaphana, apice dentibus quinque coronata v. nuda, et interiore firma, sinistrorsum spiraliter striata, sporas minutissimas, granu!osas, conglutinatas includente. SPonas spiraliter striatae, basi spinulis quinque instructae.

Characeac aquarum dulcium et littorum marinorum per totum fere terrarum orbem vulgares hospites, odore hepatico gravi praeditae esse solent.

E sedimento aquarum dulcium specierum exstinctarum sporangia, interdum etiam canles effodiuntur. Charas fossiles diu pro conchyliis habuerunt palaeontographi, et G y rogonitum nomine designaverunt.

86. Niteliar $A G$. Caules e tnbulis sim plicibus. Organa propagationis dimorpha, diclinia. Globuli et sporangia setis nullis stipata, vertice nuda. Auet.

ริ. Chara AG. Ca u les e tubulis pluribus spiraliter circa tulunlum centralem volutis. Organa propagationis dimorpha, approximata. GIobuli et s porangia setis stipata, coronata.

C ha ra Agardh syst, XXVII, Cha ra es p. Limm. et Auet.

\section{Drebs E. Elvecene.}

ULVACEAE Agardh syst, XXX. ULVACEARUM PaRS Fries $p t$. hom, 335 .

Frovs membranacea, continua, plana v. tubulosa, herbaceo - viridis v. rarius purpurea, ecostata. Sporidia frondi inspersa, v. ves icula inflata excepta. - Maris et aquarum dulcium incolae, rarius epigeae.

SUEATE I. SIPHONEAE Grev. Alg. brit. 183. Sporidia vesiculis (coniocystis $A g$. propagulis Mart. condyliis Wallr.) excepta.

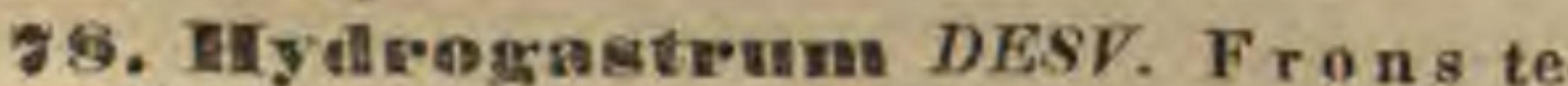
nuis, radiciformis, hypogaea ; p r o p a $g \mathrm{nl} u \mathrm{~m}$ terminale, epigaeum globosum, lat ic e limpido repletum, vetustate collapsum. _ In solo argillaceo post inundationes.

H y drog a s trum Desv. Fl. Ang, 19. Bory in Dict. class. VIIT. 423. Botr y dium Willr. Ann. botan, 153. Grev. Alg. brit. t.19. Mart. Fl, bras. 1. - Vau heria radicata Agardh. Tremell a graulat a Huds. E. B. t.324.

ซฐ. Watuefueria $D C$. Frons tubulosa, membranacea, continua, subramosa, irregulariter aggregata, materia grumosa fareta; p ro pag u la snbglobosa solitaria v. aggregata, sessilia v. peduneulata, opaea, s p o ridi is granuliformibus repleta. - Paludosae.

Va ueheria DC, in Vauch, conf, 25. Lyugb. 73. $t, 19-23$. E. B. t. 1766 . FI. Dan, t, 1784-1727, Grev, Alg. brit. t, 19 , Ec tosperma Vauch. t.2. 3. Uuger in N. A. N. C. XIII. 789. t. 40. Confervae s p. Dillw. $t, 15,16,41,74$. E. B. 4.939.

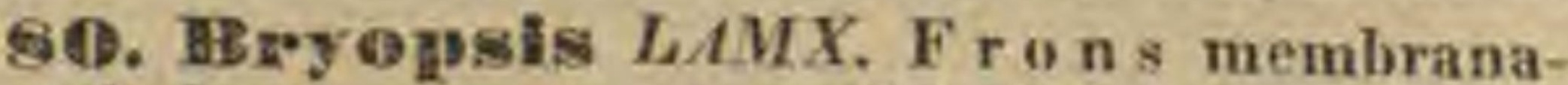
cea, tubulosa, ramosit, ramuli imbricati, nnne distichi pinnatique, humore viridi repleti; propagn」a.... Marinae.

B ry op s is Lamx, in Annal, Mus, XX, 281, t,7. Journ, bot. II, $t .1$, Elor, dain. $t, 1063$, Lyngh. $t, 19$, Bory Hydroph, voy. Duperr. $t, 24, f .1$. Grev. Alg, brit, $t, 19$. U I va sp. Huds. E, B. 7,2375 .
81. Codiusana $S T A C K H$. F ron s spongiosat viridis, crustacea, globularis, cylindracea v, plana, e filis tubulosis laxe intertextis composita; p ropag n la clavata, ad superficiem frondis subfastigiata. - Marinae.

C od ium Stackh. Nereis praef. 24. Agardh syst. XXXI. Spec. I. 45t. L a markia Olivi Zoolog. adr. 258, $i .7$. A g a r d hi a Cabrer, in Act, Soc physiogr. Lund. 1823. p. 99 . S p ongod ium et Flabellaria Lamx, in Annal. Mus. XX. 2ay t.12. Fuc i s p. Stackh. $t, 7-12$. Turn, $t, 135.136$.

63. Nemanalien $T A R G$. F r o n s gelatinoso membranacea, simpliciuscula, compressa, elongata, filis tenuissimis pellucidis obtecta; propa g n la filis immixta copiosissima, brevia, subela vata, intus materia viridi farcta. - Marinae.

Nemalion Targion. ex Bertolon. Amoen. 300. Duby Bot.gall,II.959. Fucus Nemali on Bertolon. l, c.t.5. f.g.

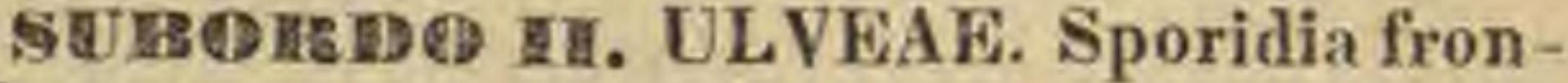
di inspersa.

33. Crullen ipa $L A M X$. F r on s stipitata, e surculo cylindrico reptante radicante adsmrgens, membranaceo-foliacea, viridis, nitens, pinnata, plana v. e ramentis dense imbricatis composita. Sporidia.... Marinae.

C a ulerpa Lanx. Journ, bot. Ir, 1/3, t. 2, 3. Agardh Spec. 1. 433. Bory Hydroph, voy, Duperr. t. 22. Chauvinia Bory op, cit. 204, t. 23. $f, 1,2$, Fuci s p. Turn. t. $53-58$. $171-175,195,200.229,230$.

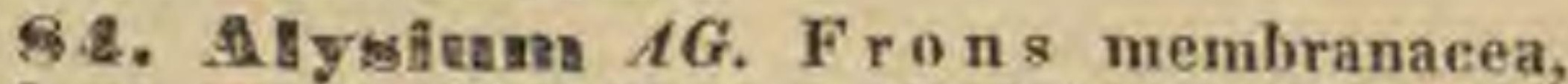
tubnlosa, eava, dichotoma, articulato-strangulata, viridis. Sporidia... - Marinue.

A I y siu m Agardh syst, $X \times \bar{X} r$. Spec. $I .433$.

OBSERV. Quid C oc co derm a Kunz. guian, inedit. a c1. Reicheabach consp, p. 27. prope A I y s i u m collocatum.

85. Wallonata $A G$. Frons membranacea, hyalina, saceata v. cylindrica, pagina interiori p u lvere copioso viridi conspersa .... - Ma rinate.

Val on i a Ginnan. op, post, I. 38, t. 45. Agardh Spec, I. 428. Martens in Flora 1830.p. 6\$1, t. 2. Ga s t ridi u m Lyngb. 72. $t$. 18 . $\mathrm{P}$ h y s y d $\mathrm{rum}$ Raf.

Q6. EI va $L A M X$. F ron 8 cellulosa fistulosa, v. plana membranacea, viridis v. purpurea, sub stantiâ tenerrimà ; $\$ \mathrm{poridia} \mathrm{granuliformia,} \mathrm{mi}$ nutissima, innata, sparsa. - Marinae et aquarum dulcium.

U1va Lamx, in Annal. Mus. NX, 297. Phylloma, Trepposa et Zonaria Link in har. phys, 6 .

a) ILEA Fr. Frons tubulosa, viridis, basi attenuata, contextu celluloso fibris areolato; sporidia deasis. sime aggregata.

11 e Fries pl.hom. 336. Euterom or ph a Liak in hor. phys, S. Grev, Alg. brit, t. ts. Hy dr os ole u Mart. FI. bras. I. . Sole il ia Agardh syst. 185. T u bularia Rouss. 2, $E$. Fistularia Grev, edin. 300. Seytosiphonis sp. Lyugb, $t, 15,16$. (E, B, $c, 2839$, Fl, duu, $t, 763, f, 1$. Turp. in Mem, Mus. XYIII. 1,11 .

b) ULVASTRUM $D C$. F rons membranacea, viridis, plana contexta celluloso; sporidia subquateraata per to. tam frondem aggregata.

Uivastrum DC.Bot.gall. I1.958. UIva et Porphyra Agardh spec. I. 401. Ic, t, 16.17,26-28. R a m u I ar in Rouss, ex Desv. Journ, bot. I. 143. Hallit h rid ax Targ, ex Berto. Lon, amoen, 93. (Fl, dan, $t, 899.859$.

c) TETRASPORA $A_{g}$. Prons gelatinosa, viridis v. purpurea, tubulosa v. Inflata; $\&$ poridia quaternata, per totam frondem laxe aggregati.

Tetraspora Agardh syst. XXXIT, Ie, t, 15. - ? Pexisperm a Rafill. somiolog, $n$. 42. (Walilenb. lapp. t, 30. f, 1.3

\section{Drelo VI. Floridae.}

Florid a e Lamx, ess, 125. Diet, class, IV, 2hn. Agardh syat. XXXIIT. Fries $p l$, hom, 330.

Froxdes continuae, corticatae, nervosae, membranaceae vel coriaceae, purpureae v. roseat, planat v. filiformes, e cellulis mini- 
mis aequalibus conflatae, radice scutata v. filiformi affixae. SPoridia purpurea, in apotheciis frondi adnatis tuberculiformibus, v. innatis punetiformibus.

Omnes marinae, pusillae, annuae, in zona temperata frequentissimae, inter $35^{\circ} 48^{\circ}$ lat. bor. maxima copia, inde versus polum et aequatorem, et universim in hemisphaera anstrali parcius repertae, ditissimum Algarum ordinem constituunt.

97. Polyides $A G$. F rons cartilagineogelatinosa, fisco-purpurascens, filiformis, eylinIrica, dichotoma; verrueae laterales spongiosae, fibrosae, sporidia rosea, peridiolo hyalino cincta, fulcientes.

Polyides Agardh syst. XXXIIT. Spec, I, 390. Fuci s.p. Gmel, Turu, $t, \tilde{S}$. Stackh, $t, 6, G$ ig artin a e sp, Lamx. Fureellariaesp. Lyugb.

88. Disenea $A G$. Frons cartilaginea prourea, filifurmis continna, setis confervoideis artieulatis obtecta.

Dige ue a Agardh syst. XXXIIT. Spec, I. 388.

89. Fillota $A G$. Frons cartilagineo-membranacea, purpureo - rosea, pectinato - pinnata; sporidia in globulos, involucris polyphyllis exceptos, congesta.

P til ot a Agardh synops. 39. Spec,I. 384. P I o c a m i i s p. Lamx. Fuci s p. Turn. $t, 60,61$.

DQD. Finodomella $A G$. Frons coriaceocartilaginea, sordide purpurea, filiformis, cylindrarea $v$. compressa, ramosissima, ad apicem saepe involuta; ramuli extremi saepissime inflati articnlati, granula conglobata includentia; sporidia pyriformia caudata a pothe ciis ovatis immersa.

B ho d o m ela Aghard syst. XXXXV. Spec. I. 368. Ie, t. J. Bory Hydroph, voy. Duperr. t. 22. f.1. Duby in Mem. h. n. genev. $Y$. 333. Lo phir os Targion. ex Bertolon. Amoen. 307. S corpi ura Stackh. Volu bilaria Lamx, in Dict. class. $V .387$. D ietyopteris Lamx. ess, t, 5 . Euspiros Targion. op. cit. p. 291. O d o n thalia Lyngb. 9. t.3. D iet y o m exia Grev. Alg. synops. L. Ploc am i i s p. Lamx. Fuci sp. Turn. $t$. 2. 8, 11-13.180, 207. 209, 255. Stackh. t. 15. Labill, nov. Holl. 1.255.

D1. Chomdiria $A G$. Frons cartilagineogelatinosa, carnea, cylindrica, interdum articulata, vage ramosa, saepe ramentis aucta; granula ternatim conglobata, ramulis immersa; sporidia pyriformia pedicellata $v$. sphaerica, intra apothe- ia subglobosa fasciculata.

Chondria Agardh syst. XxxIF. Spec. I. 336.

a) LAURENCLA Lamx. F ro o s fillformis ramentis subelasatis v, papillosis. S poridia pyriformia.

L a urencia Lamx, in Annal. Mus, XX. 130. B atrydi ou. Palyodus, Lasios et Lemu is eus Targion. ex Bertolon. Amoen. 301-30\&. Gelidii s p. Lyngb, t,9. GigartIn a e sp. Lamx. F nel s p. Turn, t.19, 21, 22, 30, z7. 81. 100, 132, 178, 202, 203. Stach h, t.11, 12.

b) GASTROPHYCUS $\mathrm{Lnk}$. Frons filiformis saepe articu-

lato constricta. S porid ia cuneiformia v. subglobosa.
Gastrop by cus Link Handb. III. 240. Lomentaria tyngh, 101. 2.30. A ean th o p hor a Lamx. op. cit. 308. G igartinae sp. Latux. Gastridiis p. Lyngb. Faei sp. Tura, 1. 29, 32. 79. 108, 181. 183, 225. Delile Aegypt. t. 56. f. 1 . Agardh Te, t.18,

28. Tralvmemisa $A G$. Frons coriacea $v$. membranacea, purpureo-rosea, explansta v. inbulosa, integra $v$. pinnatifida, saepe ramentis aucta; s poridia minima conglobata, in apotheeiis tuberculiformibus frondi immersis contenta.

Hal ymenia Agardh syst. XXxIV. Spec. I. 199. Dumo n tia Lamx. in Annal. Mus, Xx, 133, Diet. class, Y. 643. Turp, Ath. I, t, 40. H al y me n ia, D umontia et Cateuella Grev. Alg, synops, $L X I I, t, 17 . \mathrm{S} \mathrm{c}$ in a i a Bivon. D a w. an ui a Lamx. in Dies, elass, V. 367. Bory Hydroph, voy.
Duperr. 82, t.19. f. 1. Deless eriae sp. Lamx, Gastrid ii s p. Lyugb. t.17. Fue i s p. Linn. Tarn. $t$. 44, 107, 113. 116. 149. 241.-? Als idium Agardh Ic. t.. .

93. Corallopsis GREV. Frons cartilaginea, pallide - rosea, articulata, articulis concavis e centro proliferis; s p o ridia elliptica in filorum glomerulis intra a pothecia sparsa frondi immersa nidulantia.

Corallopsis Grev. Alg. synops, IIIT. Sp baerococeus S alie oruia Agardli $X_{c}, 6.8$.

D4. Splanerococens $A G$. Frons coriacea v. membranacea, purpurascens, varia; s p or idi a subrotunda $v$, angulata, conglobata v. seriata intra a pothecia sphaerica discreta, demum saepias poro pertusa.

S pha erococeus Stackl. Noreis $x X I V$. Agardh spee. I. 282. Gymuogongrus Mart. Irideae sp. Bory $\boldsymbol{H}_{\text {- }}$ droph, voy. Duperr. 100.

a) PHYLLOPHORA Grev. Frons membranacea, subcostata, e disco prolifera. Sporidia minima rotundata, intra apothe cia sphaerica. Granula simplieia receptaculis planis foliaceis inspersa.

Phyllophora Grev. Alg. synops. LVT. Phyllogenes. Lomation et Cylichnos Targion. ex Bertolon. Amoen. p. 289-304. Cho a dri s p. Lyugb. t. 3. D eles se. ri a e s p. Lamx. Fa ei s p. Turn, 39, 48, 43, 64, 238. Fi. dan. 17zz. (Agardh Ie, 1, 17.)

b) CHONDRUS Lamx. Fro as cartilaginea plana, dichotoma, segmentis cuneatis v. linearibus, plerumque obtusis. Ap othecia hemisphaerica in disco sessilia v. e margine pedicellata.

Choud rus Lamx. in Annal. Mus. XX. 120. C y pel. 1 o n Targion, op. eit. p. 292. Delesseriae sp. Lamx. Fuci sp. Turn. 2. 42, 72, 74-76. 197. 152, 215-217. 220. 229. 223. (Lyngb, t.3.)

c) ERINACEA I Lamx. Frons gelatinosa, cartilaginea v. cornea, a p ot he cils imnatis mamillaeformibus obsessa.

Erin a ce a Lamx, in Dict. class. $\mathscr{V}$. 387. Bowies i a Grev. Alg. synops. LVII. Deles s er i a e s p. Lamx. F u ei sp. Turn. t.16. 18. 25. 70, 239. 253. (Lyng b. t, 5. Agardh Te. $t .18,19$.

d) GELIDIUM Lamx. Fro n s cartilagineo-cornea, conpressa, pinnata. A pothecia ad apicem ramulorum subimmersa. Granula aggregata, in ramulis sparsa.

Gelidi um Lamx, in Arnal. Mus. XX. 128. L on charion et A mplioriscus Targion. op. cit. p. 294-297. De s mine sp. Lyngb. t. 7. Fuci s p. Turn. $t$. 28, 121.124. 137, 182, 208, 238, 234, 257.

e) RHODOMENIA Grev. Frons membranacea plana. A pothecia hemisphaeriea sparsa. Granula ter. natim aggregati, per frondem sparsa.

R to od omenia Grev. $t . C$. Delesseriae sp. Lamx. Gigartinaes s. Lyngb.t.11. Halymeniaesp. Agardh. Mastocarpi sp. Targion. op. cit. 295. Fuci sp. Turn. t.23. 45. 69. 115. 154. 237. Bory Iydroph, voy. Duperr. t. 16. 20. Grev, scot, t. $84.352,356,357$.

f) GIGARTiNA Iams. Frons cornea v. cartilaginea, filiformis, eylindrica, vage ramosa. A p o the cia sphaerica sessilia.

Gigartin a Lamx, op, oit, 134. Lyngb. 42, $t, 11$, Gracilaria Grev. Alg. Synops. LIV. P h y sotris Raf. Somiolog. n.42. Plocaria Nees in Hor. phys. 42, t. 6. H ypneal Lamx. op. eit, 131. Helminthoehortos Link Handb. III. 245. L a si os et Mastoe arpi s p. Targion. op. cil. 299. 303. F u ci sp. Turn. t. 9. 37. 78. 84. 113. 118, 125, 127. 133. 179. 180, 221. 233, 236.

95. Botryoearpa GREV. Frons car tilaginea, ecllnlosa, purpmreo-rubra, plana; s poridia ternata, ap othe $\mathrm{ci}$ is foliaceis per totam frondem aggregatis exeepta.

Botryo ear pa Grev. Alg. synops $X I I X$. Fucus bo. tryocrppus Turn, $t$. 2 .i6.

D4. Thannnoplaora $A G$. F $\mathrm{r}$ ons membranacea v. cartilaginea, purpurea, plana, pinnatifida; sporidia alia sphaerica, alia discoidea in cylindrum sibi invicem imposita, intra apoth ec i a filiformia aggregata contenta.

Tham nophora Agardh syst. XXXIV. Spec. I. 225. Fuei \& p. Limn. Turn, t,33.96. 120.

9\%. Gratelowpia $A G$. Frons membranaceo-eartilaginea, fusco purpurea, plana, basi 
ramentifera, s poridia elliptica, intraverrucas ramentorum poro pertusas aggregata.

Gratelo u pia Agardh syst, XXXIV. Spec,I. 221. - ?

$\mathrm{Ph}$ o $\mathrm{r}$ a $\mathrm{c}$ is Raf, caratt, 99, $\mathrm{F}$ u $\mathrm{c}$ i s p. Lian, Turn, $t, 26,150$.

98. Tomacmaisomia $A G$. Frons mucoso-membranatea, rubra, filiformis v, plana, pectinato-eiliata; s poridia pyriformia, concatenata, intra a pothecia sphaeriea apice perforata basi fixa.

B on nemais o n i a Agardh syst. XXXY. Spec, I, 196. Del is ea Lamx. ex Turp. Atl. $I$. $t$. 42, f.4. Pl oc a mi s p. Lamx. Fuci sp. Woodw, in Linn. Transact, 1I, t, 6. E. B, t.s71. Gmel. Fuc, t,10, f, 2 .

DS. Viferoeladia GREV. Frons membranacea, coccinea, plana, vage ramosa, ramis distichis; sporidia intra a pothecia sphaeriea, in v o I u e r o ramuliformi abbreviato excepta; g ranula ternata intra ramulorum apices intumescentes.

MicracladIa Grev. Alg. Synops. L. Fucus glan. dul o s u 8 Turn. $t .38$.

1DQ. Telesseria $L A M X$. F rons membranaceo-cartilaginea, rosea $v$, purpurea, foliacea v. filiformis, subcostata, venosa; sporidia globosa $v$. angulata intra a pot he cia costae v. margini imposita, conglubata; granula ternatim connata frondi sparsim innata.

Dele s seri a Lamx. in Ann. Mus. XX, 122, excl. sp. Agardh Spec, 1. 17o. Delesseria, Nitophyllum et H y men e n Grev. Alg. Synops. XLVII. Worms kioldia Spreng. Syst. IV. 312. Ploc as Targion, ex Bertolon, Amoen. 305. Ploc amil sp. Lamx. Choudri s p. Lyngb. Fuc i sp. Linn. Turn, $t, 14,15,36,36,59,68,71,80,138$. 144, $160,18 \%$.

101. Amamasia $L A M X$. Frons membra naceo - cartilaginea, rusea v. purpurea, foliacea, costata, transversim dense striata, areolata; s poridia quaternatim connata, a p othe ciis foliaceis nervis transversalibns affixis excepta.

A m a 1 s i a Lamx. in Bullet,philomat, 1809,t.6. Agardh Spec. T, 191. F uei s p. L. Turn, t, 201.

102. Clatudea $L A M X$. Frons membranacea, rosea, e reticnlo nervorum articulatorum composita ; sporidia ternatim quaternatimque connata, in a potheciis foliaceis utrinque reticuli nervis affixis agrregata.

Cl a u de a Lamx. in Annal, Mus, XX, 121. Turp. Atl.I. t. 41. Lamourouxia Agardh Synops. XIV. O neillia Agardh Spec. $I, 169$. Fue u $\mathrm{C}$ I a u dei Turn. $t .2 / 3$,

103. Thavenasia $A G$. F rons membranacea, sordide rubra, costis corneis rigidis articulatis reticulatis percursa.

Tha um a 8 ia Agardh syst, XXXIII. Ic. $t, 10$,

OBSERV. L i agoram Lawx. Polyp, 240, t,7. Agardh Sp.I.393, quae Eu s e e p e Targion, in Bertolon, Amoenit. 295. F u e i sp. Turn. t, 119. Esp, t, 50. Zoophytis adnumerare, uullus dubito.

\section{Drdo DI. Fucacene.}

Fucoideae Agardh syst. XXXV. Fucaceae Lamx. in Annal, Mrs. XX, 35. Dict, class, VIr. 66. Annal, sciene. nat. VII. Fries pl. hom, 326. Bartl. Ord, 10.

Frondes continuae, corticatae, nervosae, coriaceae v. rarius membranaceae, olivaceae, planae $v$. filiformes, e cellulis inaequalibus, saepe lacunis interjectis formatae, radice scutata $v$, filiformi affixae.

Sporidia nigra, nunc capsulis ovatis, limbo hyalino cinctis, et receptaculo proprio exceptis inclusa, nume in capsulis pyriformibus, frondi immersis, contenta.

Fuc a cea e omnes marinae, e nullo mari omnino exules. Nonnullae certis latitudinis gradibus inclusae, aliae late per oceanum et littora vulgatae, quaedam eximie sociales insularum instar ponto innatant, aliae annuae parvulae, aliae giganteae perennes, multiplicis in naturae et humani generis oeconomia usus.

Fucacearum mundi primigenii religuiae paucae in terra transitionis, in calce alpina et jurassica supersunt, plures in creta et calce grossa repertae fuerunt.

114. Asperococeans $L A M X$. F rons membranacea, tubulosa, continua; a p othe e ia paginae exteriori frondis insidentia maenlaeformia, a pie n10 s clavatos articulatos, basi hyalinos, apice materia sporacea nigricante repletos, gerentia.

As perococeus Lamx, in Annal. Mus. XX. 227. Bory Hydroph, voy, Duperr. t.11, f. 2, 3. En c o ellum Agardh Syst. XXXVI. Spec,I.14i. Grev. Scot, t. 290. UI v a s p. Linn. DC.

105. Thornaria AG. F rons membranaceocoriacea, flabelliformis v. cuneata, zonata, interdum costata; a pothecia in lamina frondis soriformia, nuda, includentia peridiola coacervata hyalina, s poridiis atris conglobatis repleta.

Z o u ari a Agardh Syst, XXXVI, Spec. I, 124. D ict yota Fries $p l$, hom, $p, 328$

a) PADINA Adans, Frons flabelliformis, zonata, sub. integra; a pot be eits in lineas concentricas dispositis.

$\mathrm{P}$ ad in a Adans, IT. 13. Lamx, in Ann, Mus, XX, 272, Bory in Dict, class. XIT. 389. Hydroph, voy. Duperr. t. 21. Rhipidion, Spyris et Pterigospermum Targion. in Bertolon, Amoen, 310. Padina et Cutleria Grev. Alg. synops. XLIV, t. 10. Riecia Fl. Jumin. XI. t. 116. U Iva e s p. Linn. E. B. $t, 1276,1913$, Mart. erypt. brasit. 1. 2. f.3. F nei s p. Gmel. Turn, t.245.245. (Link in Hor. phys. $t, 1$. Mart, op, cit, $t, 2, f, 12$.

b) DiCTyota Lamr. Frons ezonata, ecostata, simplex v. dichotoma, segmentis linearibus; apothecils sparsis.

Diet y o ta Lamx, in Dict, class. V. 483. Grev. op, eit. t.10. My $x$ odes et Euy phes Targion. op, cit.314. P u n $\mathrm{c}$ taria Grev, op. eit. t,9. Ulvae sp. Lyugb, t, 6. E, B. t. 744.1913

c) HALYSERIS Targ. Frons linearis costata; a po. the $\mathrm{ci}$ is in lineas loogitudinales dispositis.

Haly seris Targion. ex Bertolon, Amoen, 314. Agardh syst, $X X X Y T H$, Spec, I, 141. Grev, l, c. t, 8, D iety op teris Lamx. in Ann. Mus. XX. 270. Neuroearpon Weber et Mohr. Fuef s p. Lanx. diss, t. 2a, f. 1. Stackh, t. 6. Turn. t. 87, 158 , E. B, $t .1758$.

108. Dietyosiphon $G R E V$. F $\mathrm{r}$ o $\mathrm{n} 8$ membranaceo-coriacea, filiformis , tubulosa, ramosissima, apothecia sparsa....

Dictyosiphon Grev. Als. brit. 58, t. 8, Fucus s ubtilis Turn. $t, 234$. S cytos iphonis sp. Agardh FI. Dan. $t, 1595, f .1$.

10\%. Strotaria GREV. Frons membranacea, filiformis, cylindrica, ramosa; a poth e eia soriformia, in lineas frondem transversim ambienteg disposita.

Striarla Grev, $A l$ s. brit. $55 . t, 9$. C armichae 11 a Grev, seot, t. 288. Stil o p li o ra Agardh in Flora 1827. p. $692-$ ? H y d roelath rus Bory in Dict, elass, VIU, 419.

108. Taminaria $L A M X$. Frons coriaceo - cartilaginea, in laminam integram v. digitatofissam, enervem v. rarius costatam expansa; a pothe $\mathrm{c}$ i a maculaeformia sparsa, e Iamina frondis $t u$ mente, strato duplici, exteriori e granulis pyriformibus formato, interiori s poridia conglobata continente.

Laminaria Lamx. in Ann. Mus, $X X$, to. Agardh Spec. I. 107. A g a r u $\mathrm{m}$ Bory in Dict, elass, $1 X, 133.0 \mathrm{rg}$ a Stackl. Nereis t, 20, Bory op, cit. XIT. 35e, A gara m, Alaria et Costaria Grev. Atg, Synops. XXXXX. Fuci s p. Lina. Turn, $t, 117,226$, E. B. $t$. 1759, Palmaria Liak in Hor, phys, 7. F a s ciat a Gray brit, pl, J, 383, P basgo. 
non Walk. apud Gray l. c. (Bory Hydroph. voy. Duperr. t. 10.) D u rvilla a Bory op. cit. 63̈, $t, 1,2, f$. 1. Dict. class. t. 49. Fue us antaretie us Chamiss. in Chorisvoy. pitt. t.7. L esson ia Bory op. cil. 73. t.2. f.2. t.8. f.4.5.

10\$. EekIomía HORN. F rons coriacea, in laminam pinnatam enervem expansa; \& $\mathrm{poth}$ ee i a tuberculiformia, in margine pinnarum alternatim biseriata, s poridiis farcta.

$\mathrm{E}$ ck 1 o n i a Hornem. in Act. Mafn, 1828. IIT. 379. c.ic. (Fucus bucefnalis Lim. Turn. t.139.) - Marg inaria A. Rich Fl. Nov. Zeel. p.9. $t, 3.4$.

10. DIneroeystis $A G$. F rons coriaceocartilaginea, plana, ramosa, ramis basi vesiculosoinflatis, ecostatis; a pothecia tuberculiformia frondi immersa, poro pertusa, sporidia numerosissima conglobata includentia.

Maerocystis Agardh syst. XxXVIII. Spec, I. 46. Bory Hydroph, voy. Duperr. $t, 6.9$. Fue i s p. Linn. Turn. t. 27. 110. 148.

11. Tesmarestia $L A M X$. F rons coriaceo-cornea, plana $\mathrm{v}$. filiformis, distiche ramosa ; a poth ecia e corpusculis clavaeformibus, concentricis, articulatis, plerumque filorum confervoideorum penicillo coronatis composita.

De 8 marestia Lamx. in Annal. Mus. XX, 43, S p orochnus Agardh syst, XXXVI.Spec, I, 147. Ic, t, 30, Spinularia Rouss. ex Desv. Journ. bot. I. 43. Dichloria Grev. Alg. synops, $X L$. (Turn, $t$. 97.) $\mathrm{P}$ h y mat $\mathrm{inm}$ Link Handb. IIT. 232. (FI. dan. t. 1592, f. 2.) Trinitaria Bory Hydroph, voy. Duperr. 216, t. 24. $f$. 2 . De s mia e sp. Lyngb, t. 7. Fue i s p. Linn. Turn. t.98, 99, 140, 186-189.

1 1 2 . Seytosiplion $A G$. F r o n s membranaceo-coriacea, filiformis, simplex, fistulosa, ohsolete septata, tota superficie in fruetificationem abeunte, sporidiis pyriformibus obtecta.

Sey tos iphon Agardh disp. 24. Speo.I.160. Chorda Lamx. in Ann. Mus. XX, 46, Lyngb, t, 18, C h ord a r l a Link in Hor. phys, 8. F u cus Fil um Linn. Turn. t. 86.

11 3. Chored aria $A G$. F rons eartilaginea Inbrica, filiformis, dichotome $\mathbf{v}$, vage ramosa, tota in fructificationem soluta, e filis concentricis clavatis, apice in globulum sporidiis farctum tumentibus, composita.

C ho rd a ria Agardh syst, XXXVT. Spec, I. 164. F \& c i $s$ p. FI. dall, $t .650$. Turn. $t .85$. S c y tos iphonis s p. Fl. dall. $t$. 1594. Gigartinae sp. Lamx. Ceramii sp. FI. dan. $t, 1346$.

114. Fareeliaria $L A M X$. Frons cartilaginea, filiformis, dichotoma; apicibus in a pethecia intumescentibus, peridiolis hyalinis, sp oridi is nigrieantibus faretis, in centro coacervatis.

Fureellaria Lamx. in Ann. Mus. XX. 45. Agardh Spec, I, 101. Fu ci s p. Linn. Turn. t, 6. Fl. dan. $t, 393.419$. $154 . b$. E. B. t. 824 .

15. Cielnima $A G$. Frons cartilaginea plana, dichotoma; a potheeia ex intumescentibus apicibus tubereuliformia, subsphaeriea, poro pertusa, tandem explanata, 8 p oridi is, intra massam mncilaginosam in lineas radiantes dispositis, fareta.

Li e hin a Agardh synops. 9. Spec, I, 104, Grev. scot. t. 219. Fucus p yg mate us Lightf. Turn. $t, 204, f, a_{0}-h$. E. B. 1.1339 .

16. Seaberia GREV. Frons coriacea, filiformis, eylindrica, ramosa, foliis parvis verrucosis amplexicanlibus dense imbricatis; vesicula e inter folia sparsae, sphaerieae, sessiles, densissime verrucosae.

Se aberia Grev. Alg. synops. XXXVI.

11\%. Polyplanemin $A G$. Frons coriacea, plana, uninervis, prolifera, spinulosa; a potheeia terminalia, pedicellata, siliquaeformia.

Polyphacum Agardh syst. XXXVIT, Spec. I. 106. 0 s und a ria Lamx. in Ann. Mus, XX. 42, t, 1. f, a-6.
18. Splachanidiuan GREV. Frons $40-$ riacea, cylindrica, tubulosa, subinflata, pinnata; a $\mathbf{p}$ oth e $\mathrm{c}$ i i s tuberculiformibus per totam fronden sparsis, poro pertusis, peridiola hyalina ineludentibus.

Splachnidium Grev. Alg. synops. XXXYT. Futat ruges us Turn. $t, 185$.

19. Fueus $t G$. Frons coriacea, filiformis v. plana, plerumque dichotoma, sacpe costata, vesie ulis immersis ravis interdum donata; a $p$ nthe cia nnilocularia, tnberenlata, tuberenlis apice pertusis, peridiola hyalina, spuridiis nigri cantibus farcta, includentibus.

F u cus Agardh Spec. $I .83$.

a) HIMANTHALIA lyngb. Frows urceolato orbientaris; e centro apothecia elongata linearia dichotoma emittens.

H imanthalia Lyngb, 36. $t, 8$, Fucus 1 oreus Lina. Tarn. $t, 126$, E. B. $t, 569$.

b) FUCAStrum $D C$. Frons plana v. eyliadrica; $x \mathrm{p} 0$. the e i a elliptica, Iateralia v, terminalia.

Fucastrum DC. Bot. gall, IT. 938. Virsoon Adans.

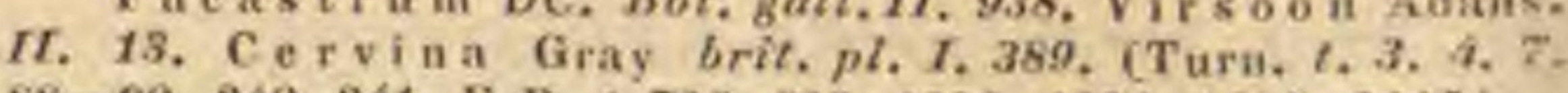
$88-90,240.241$. E. B. $t, 726,823,1036,1221.1685,2115$.

120. Cystoseira $A G$. Frons coriacea, plana, pinnata, ramis plermmgne filiformibus, ves iculis innatis coneatenatis instructis; a pothecia tuberculosa, loculusa, tuberculis pertusis peridio La hyalina filis articulatis intermixta continentibus.

Cystoseir a Agardh syst. XXXYIIT. Spec, L, 50.

a) HORMOSIRA. Frous tota fere abiens in a poth te i a moniliformia.

Moniliformia Lamx, in Dict, elass, VIT. 71. Bory Hydroph, voy. Duperr. 132. Mo n il i A. Rich. Fl. Nov. Zeel. p. 19. Fu ei s p. Labill. Nov. Holl, $t$. 2 . Turn. $t, t$.

b) COCCOPHORA Grev. Rami foliformes, ves ie u I a e nullae; a pot he cia sphaerica, racemoso-terminalia.

Coecophera Grev, Alg. synops, XXXIJ. Fueus Lang s d or fi i Turn. $t .165$.

c) SCYTOTHALIA Grev. Frons pinnata, ecostata, ve. si culae nullae; a pothecia e marginibus pinnarums breviter pedicellata, plana.

Sey tothalia Grev. $l$. c. Stackhousia Lamx. Fnus daryearpus Turn. $t, 143$.

d) SEIRococeus Grev. Fro n s plana, linearis, ecostate. vesiculae nullae; apotheci a marginalia coneateuata. t. 146 .

Seirocoecus Grev. 7. c. Fucus axfllaris Tarm-

c) CARPODESMLA Grov, Frous plana, ecostata, vesiculae nullae; a ot hecia basi frondis innata.

Carpodesmia Grev. l. c. Fucus zosteroides Turn. $t$. 231.

f) HALIDRYS Inngb. Frons compressa linearis, vesicula e tanceolatae, articulatae, peduncalatae; a 1. the cia lanceolata, compressa, pedinculati.

Ha $1 \mathrm{idry}$ s Lyngh.37, $t, 8$. Siliquaria Gray br. $p l$. $I$. 391. Lamx. Dict. class. YT. 71 . Bory ibid. XV. 430. Fucus sili quos us Linn. Tura. $t, 159$. Stakklt. $t, 5$. 11.

g) ACINARla Targ. Frons ramosa, ramis superue filiformibus, vesicula simplices v. subeoncatenatae, innatae $v$. pedicellatae.

A eiuaria Targion. ex Bertolon. Amoen. 284-288. Macka i a Gray l,c. I. 391. Cate naria Raf, in New-York: Medic. Reposit, IT. Hex. $V_{\text {. }} 361$. Fue i s p. Linn. Turn. $t .34$. 82. 112. 131. 155-157. 166. 176. 191. 192. 197. 209. 932. $9.99-252$.

121. Sargassama $A G$. Frons coriacea, ramosa, ramulis plerumqne foliformibns costatis, integerrimis, serratis v. pinnatifidis, vesi culis axillaribus instructis; a p othecia tubereulosa, Ioculosa, tuberculis pertusis, peridiola hyalina absque filis intermixtis includentia.

Sargas s m Agardh syst, XXXVIIT. Spec, I. 1 .

a) CARPOPHYLLUM Grev. Apothecia eylindriea, in racemis marginalibus.

Carpophylïm Grev. Alg. synops. XXXII. Sargassi $8 \mathrm{p}$. Agardh, Fuei s p. Tuen. $t .205 .206$.

b) TURBINARIA tamx. A p othecia cylindrica, ramnsn, axillaria. 
Turbina ria Lamx, in Diet. class, VTI. 71 . Bory $H y$ droph. voy. Duperr. 116. Fu c us t u r binat a s Linu. Turn. t. 24 .

c) BACCALARIA Gray. A p ot the cia linearia, racemosoaxillaria.

B a cealaria Gray. brit. $p l, I$. 393. Fuei sp. Linu. Turn. t. 17, 46-51. 65-62, 82, 83, 92-95, 103, 104, 111, 129. 130, 132, 167, 165, 177, 190, 194, 210-218, 214. 247, 248, (Rich, Fl. Nov. Zeel, t, s-7.)

\section{APPENDIX. FUCACEAE FOSSILES.}

122. Fucoldes BRONGN. Frondes con tinuae, nunquam artienlatae, simplices v. ramosae, integrae v. lobatac, enerves v. nervis obseuris vage ramosis, nunquam anastomosantibus percursae. Terra transitionis.

a) CAULERPITES Brongn. F r o n s ramosa, ramulis dense imbricatis.

C a ulerpites Bronga. t.c. (t.2. f. $6-19$. 22, 23. t.9. $f, 2,3, t, 9$, bis $f .1 .2,5$.)

b) AMANSITES Brongn. Frous dentato-pinnatifida, enervis.

A mansites Brongn. $2 . c .(t .6 . f .7-12$.

c) DiCTYOTITES Brongn. Frons flabellatim partita, enervis.

Dietyotites Brongn, $t$. c. (t, 9, f, t, t, 5, f.9. 10, t, 7 .

d) DELESSERITES Brongn, Frons pinnatifido-lobata, nervosa.

Delesserites Brongn. l.c. (t.7. f.2.4. t.8. f. ., 3.)

e) GIGARTINITES Brongn, Frous ramosa, ramis cylindricis earnosis.

Gigartinites Bronge. 2 . c. (2.4. f. 1-6. t, s. f. 1. 2. $4-8, t, 6, f .3,4 . t, 8, f, 4$.

f) ENCoslites Brongn. Frons simplex, ventricosa, punetulata.

Encoelites Brongn. l. c. (t.6. f.1. 2.)

g) LAMINARITES Brongn. Frons simplex integra, margine incrassata. nervo simplici crasso.

Lam in ar ites Brongu, $t, c,(t, 7, f .5$,

h) FUC1TES Brongn. F rons subplana, ramosa, nervo crasso percursa.

Fu e it es Brongn. $l$. c. $(t, 11, f, 1-5$.

i) SARGASSITES Brongn. Fron 8 ramosa, ranulis foliiformibus, saepius nervosis.

Sargassites Brongn. l. c. (t. 2. f. 20, t.3.f.t,)

\section{Classis II. Lichenes.}

ALGAE 6.3. LICHENES Juss, gen, 6 , Hoffmann, Plantae lichenosav Lips. 1798-1799. Fol. 3 Vol. Acharius, Prodromus Lichenum Lincöp, 1798. 8vo. Methodus Lichonum, Hamb. 1803.8vo, Tiehenographia universalis, Gütting. 1810. ito. Synopsis I.ichenum, Lundiae 1814.8vo. Eschweiler, Sy. stema Lichenum. Norimbergae 1824.4to. Fee, Methode lickenosraphique. Paris 1825.4to. Cryptogames des ecorces exo ligues, Paris 1825. Ato. Diot. class, IX. 360. G. F. W. Meyer, Entwiekelung, Metamorphose und Fortpflansung der Flechten, Gottingen 1825, 8vo. Wallroth. Naturgeschichte der Elechten. Frankf. a, M, 1825. Svo, 2Vol. Fries, Lichenographia ouropaea reformuta. Luntae $1831.8 \mathrm{vo}$.

Vegetaribia aërea, perennantia, indefinita, simplicia, asymetrica. Struetura imperfecte cellulosa, vasis destituta. Ce $11 \mathrm{ul}$ ae sphaeroideae v. eylindricae, tubulosae v. fibrosae, inanes vel materia grumosa plus minus repletae, inordinate et Iaxe aggregatae; in parenchymatis strata duo, corticale et medulare, rarissime inter se confusa, dispositae. Thablis (blastema, s. corpus quo pullulante licken crescit) nune irregulariter matrici instratus, vix circumseriptus, granulosus, strato corticali nullo, cellulis omnibus sphaeroideis, intermixtis paucis elongatis, interioribus viridibus (= Thallus pulveraceus); mune effusus v. expansus, matriei totus adnatus, continuus v. areolatus, tuber- culatus aut plicatus, margine simplici v. varie effigurato ; strato corticali et medulari praeditus, medullaris cellulis omnibus sphaeroideis, extimis, i. e. strato corticali proximis, materia saturate viridi repletis, reliquis plerumque albis, raro citrinis v. rubris (= Thallus $\mathrm{cru}$ staceus), v. tandem in formam foliaceam, fruticulosam v. filamentosam abiens, strato medullari superne e cellulis sphaeroideis, inferne e tubulosis v. fibrosis, nune laxe conflatis, nune constipatis v, penitus conglutinatis, composito (= Thallus frondosus). AротнесіA (fructus) componuntur e receptaculo, nunc e thalli substantia formato (excipulo thallode), nune heterogeneo (excipulo proprio), nunc duplici (thallode et proprio), primitus saepe clauso (perithecio), tandemque varie dehiscente, vel origetenus aperto; et e strato proligero, e sporis nudis, vel intra ascos inclusis, nunc in $\mathrm{nucleum}$ conglobatis vel in $1 \mathrm{am} \mathrm{i}$ n a m (discum) dispositis, conflato.

Lichenes nunc ipsa terra vel saxis, nunc diversis vegetabilium partibus, sive viventibus sive emortuis, nunquam tamen putrescentibus, truncis potissimum, et sub coelo tropico sempervirentibus foliis, in situ praeprimis septemtrionali et occidentali fulciuntur. Stirpes permultae sine discrimine in terra et vegetabilibus sedem figunt, aliae solo granitico imprimis vel calcareo privae, pauciores plantis propriae.

Vegetationis lichenosae conditiones primariae, humiditas aëris et Inx, extensionis terminos definiunt ab ipso circulo aequinoctiali usque ad polaris glaciem, et a littorum marinorum scopulis ad alpium terminum nivalem, ubi ingenti individnorum copia regionem propriam lichenosam constituunt. Stirpes omnes sociales, plurimae late diffisae, aliae endemicae; perfectiores versus aequatorem, crustaceae et frnticulosac versus polum et in montium eacuminibus frequentiores.

Principia in Lichenibus praevalentia gluten peculiare amylo simile, principium amarum et resina cum materia unguinosa pigmentifera, colores purpureos, citrinos et brunescentes praebens. Odor in foliace is urinosus, sapor plus minus amaricans, in nonnullis amarissimus, rarins subsalsus. Nulla stirps venenata. Usus multiplex.

\section{Drdo VHI. Comiothalami.}

Coniothalami Fries $p l$, hom, 275. H ypliopsorac Reichenb, consp. $I$. 19.

Apothecia aperta, nucleo in sporidia nnda soluto. Thall us pulveraceus, nucleo coetaneus.

SUACIEDQ 1. PULVERARIEAE. Strat u m medullare totnm vel ex parte in fructificationem abiens. Apothecia nulla. Stirpes maximopere dubiae, vix autonomae 
123. Arthromia $A C H$. Thallus nullus. TuberruIa solida (atra) sub epidermide latentia. - In corticibus arborum.
A rthrouia Achar. Tichen. 25. excl. pl.

124. Ineillaria $F R$. Thallns subnulIns. Tu bercala solida (alba) erumpentia, rimose dehiscentia. In corticibus arborum.

Incillaria Fries pl. hom. 281 .

125. Arthronaria FR. Thallus crustaceus tenuissimus (viridis), macnlis oblongis reticulatis (nigricantibus)._In cortice laevigato diversarum arborum.

Arthrouaria Fries $p l$, hom. 282.

2 26. Fulveraria $A C H$. Tha 11 u 8 in pul verem v. floccos solutus. - In fissuris rupium et cortice arborum.

Pulveraria Aehar, meth. 2. Lepra Haller helv. III. 102. L e p r a ri a Achar. synops, 329. P ulin a Adans. fam. $I T$. 3. P hyto e on is Bory partim, Le p tuberia Raf, in New York medic. Reposit. II. Hex, Y. 350 .

SUEOETO II. CALYCIEAE. A p o th eci a primitus aperta.

12\%. Comioearpon $D C$. Thallus crustaceus adnatus. A p othe $\mathrm{c}$ i a varia, flocculoso-seabra, e sporidiis (atris) in caespitulum coacervatis formata, excipulo nullo. _ In saxis, rarius in corticibus.

C on i o c a r p o in DC. Fl. fr. II. 323. Meyer Flecht. 324. Fries Lichen, 378. Coniolom a Flibrk. Lich, germ, II, 3. Eschweil. syst. 19, f, 28. (Fl. dan, t.1352, 1479, f,1.)

128. Tracleylia FR. Thallus crustaceus adnatus, subleprosus. Ap othe cia sessilia (rotundata $v$. irregularia) convexo-plana, e 8 p o ridi is prominulis scabra, excipulo nullo. - In rupibus.

Trachylia Fries. $p l$, hom. 276. Lichen. 402.

129. Calyeiuma PERS. Thallus crustaceus, subgranulosns, obliteratusve. A p ot h e cia crateriformia cornea, exeipulo proprio carbonaceo, diseum in s poridia coacervata solntum mar ginante. _In lignis aridis.

Caly cium Pers. in Usteri Annal. VIT. t. 3. f, 1-3. ercl. pl. Meyer Flecht,324. Fries Lichen. 384.

a) CYPHELIUM Ach. A poth e cia sessilia.

C y pheli u m Achar. in Vet. Acad, Handl. 1814. p, 215. t.6. 8. 1816. p. 110. Cal y cium Chev. A coli un Fée methoal. 13. t.3. f. 15, (FI, dan, t. 1848. f. ., E.B. t.810.)

b) CALYCIUM Ach. A pothe cia stipitata.

Ca 1 y $\mathrm{c}$ i um Achar. $l l, c c$, E.B. 1.1465 .1540 .1832 .1865$. 2463. Cyphelium Chev.

130. Conioeybe $A C H$. Thallus crustarens, subleprosus. Apotheeia stipitata sphaerica, immarginata (suberosa), e vertice fatiscentia, demum undique s poridiis conspersa, exciр и 1 o nullo. - In eryptis siecis.

$\mathrm{C}$ on ine y be Achar, in Vet. Acad. Handl, 1816. p. 283. Fries Lichen, 382 . S el e r o p ha ra Cliev. par, 315. t.9. f. 19. Fu I gia Chev. in Journ. de Phys. 1822. t.1. f.2. (E. B. t.1539. 2357.)

\section{Ordo IX. Idiothalami.}

Id f ot hal a mi Fries $p l$, hom, $26 s$.

Aротнесіа primum clausa, demum aperta, nucle um gelatinosum, sensim indurascentem emittentia.

TRIDUS I. GRAPHIDEAE Fries $p l$. hom. 272. Nucleus solitarius oblongus v. linearis, per thalli stratum corticale erumpens, indurascens, rimosus v, canaliculatus, excipulo proprio, riro obliterato. 'T'hallus crustaceus, adnatus, uniformis. - Copiosissime in arborum tropicar um corticibus, rarius in temperatis et frigidis vigent.

131. Coniangieme FR. Nucle us erumpens, perithecin destitutus, parenchymate in ${ }^{s} \mathrm{p}$ oras (coloratas) ewllabente, sistens t ub ereuI um rotundato - difforme, nudum. - In corticibus et lignis.

Cou iang i um Fries in Vet. Acad. Handl. 182t, p, 330. tichen. 37?.

132. Ustalia FR. Nuclens ernmpens, peritherio destitutus, solidus; sistens dis e $\mathbf{u m}$ depressum, primo (albido-) velatum, demum nudum (rubrum). - In arborum tropicarum corticibus.

Us talia Fries dianom, 1817, Plant, hom, 274. P y ro. chro a Esehweil.syst.15.f.9. Plat y gram ma Meyer Flecht. 332, partim.

133. Seleroplayton $E S C H W$. Nucleus immersus, perithecio mere infero fultus, tenuis, lineari-elongatus, ramosus, immarginatus. - In corticibus arborum regionnm culidarum.

Selerophyton Eschweil. syst. 14. f. 8. Fries $p l$. hom. 274 .

134. Leeamaetis ESCHW. Nucleus disciformis, perithecio infero lateralique (oblongo-difformi) immerso, eum tha11o submarginante concreto exceptus. - In corticibus, rarius in saxis.

Le e ana et is Eschweil. syst, 14. f.7. Mart, crypt. brasil. $t .7 . f .2-4$. Fries Lichen. 375. L e cau ot is Heichenb. consp. 21.

135. Dpegrapha PERS. Nucle us rotundatus, elongatusve, indurascens, a perith ecio integro dimidiatove, longitudinaliter rimose dehiscente marginatus. - In corticibus et saxis climatis temperuti et tropici.

Opeg rapha Pers. in Usteri Ann. VII. 29. Fries Lichen, 361 .

a) HYSTERINA Ach. Nucleus obverse conicus, vel trausversim sectns cordatus. Perithe cium integrum, marginibus inflexis.

H y steriua Fries pl. hom. Opegrapha Esehweil. syst. 14. f. 4 .

b) OXYSTOMA Eschw. Nueleus acute eonicus. Perithecium integrum, marginibus conniventibus.

$0 \times$ y s to m a Eschweil. syst. 14.f.5.

c) SCAPHIS Eschw. Nucleus diseiformis v. semicy. liudrieus. Peritheci um integrum, marginibus primum conniventibus, demum distantibus.

Seaphis Eschweil. syst. 14. f.6.

d) LEUCOGRAMMA Meg. Nuclens diselformis v. seml. cylindricas. Perithe $\mathrm{i} u \mathrm{~m}$ ob basim adnatam dimidiatum, margialbus primua conniventibus, demum patentibus.

Graph is Fschwell, syst, 13. f.3. Achar, Lichen, 46.t.3.

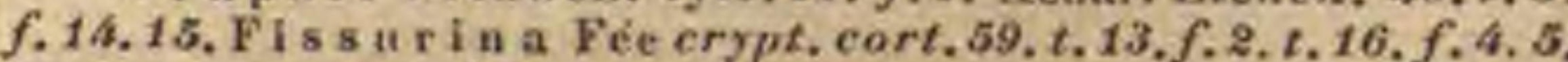
Method. 20. t,1. f.7. Le ueogramma Meyer Flecht.331.

136. Craphis FR. Nuclens tetraqueter, disciformi-canalieulatus, primum (albo-) velatus. Perith e cium dimidiatum, laterale, planum, apertum, cum excipulo thallode clanso, demum dehiscente connatum. - In corticibus arborum tropicarum.

Graph is Fries $p l$. hom. 272. L ei o r re um a Eschweil.

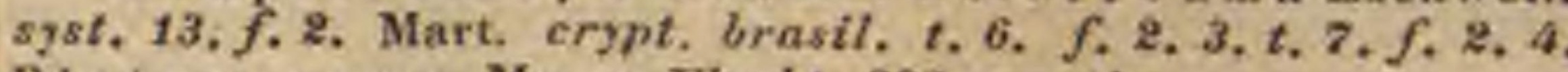
Plat y gr a m ma Meyer Flecht, 332, partim.

T'RIBES II. GLYPHIDEAE Fries $p l$. hom. 270. Nucleus strato medullari thallode immersus, eodem erumpente exceptus, apertus indurascens. 'Thallus horizontaliter expansus, adnatus, strato medullari fructificante verticaliter elevato.

13\%. Medusula ESCHW. Perithecia lineari-elongata, lateralia, immersa, cum $s t r$ a to uedullari maculas suhelevatas formante erum- 
pentia, aperta. Nucl eus asciger, primum velatus, s poridiis simplicibus. _ In arborum tropicarum corticibus.

Medasula Eschweil, syst. 19, f. 22. S areographa Fée crypt. cort. 58, t.16. f, 1-3. A s teri $\mathrm{c}$ a Meyer Flecht. 331. Pers. in Wetter. Ann, II. t.10. f. 1.

138. Chiodecton $A C H$. Perithecia infera, immersa, cum strato medullari verrucas depressas formante erumpentia, aperta. Nuol e us asciger, sporidii s simplicibns. - In arborum americanarum corticibus.

Ch io de t on Achar, in Linn. Transact. XIr. t, 3. f. z. Act, mosq. V. 170, t. 8. f. 6. Eschweil. syst, 19. $f$. 27. Fee crypt. cort. $t .18, f$. 20. Ann, sc, nat, XVII, t, 1-3.

139. Aly plhis $A C H$. Perithecia infra et lateralia immersa, cum strato medullari verrueas depressas formante erumpentia, aperta. Nucleas asciger, sporidiis annulatis. - In arborum tropicarum corticibus.

G I y $\mathrm{p}$ h is Achar. in Linn. Transact, XIT, t,3, f.1. Esch. weil, syst, 19, f.26, Mart, crypt, brasil, t,10. f.2.

TIRIBUS III. LIMBORIEAE Fries $p l$. hom. 267. Excipulum proprium (peri(hecium) e thallo prorumpens, v. saepius immersum, excipulo thallode corticato simul cinctum, orbiculare; ruptum nucleum disciformem subgelatinosum limbo saepius cingens. - Th allus horizontalis, adnatus, uniformis. A pothe cia dispersa. - Multae tropicae, paucae boreales.

140. Ureeollaria $A C H$. Thallas crustaceus subleprosus $\checkmark$. tartareus. A poth e $\mathbf{c i u m}$ nudum, primo immersum. Ex cipulu m thallodes verrucaeforme, rimose dehiscens, nucle $\mathbf{n m}$ disciformem subcarbonaceum marginans. - In corticibus et ad saxa, imprimis inter tropicos.

Urce olaria Achar. Meth. 141. excl, pl. Eschweil. syst. 17. f.17. Fée crypt. cort. t.25. f. 3. Fries pl. hom. 269. Lepropinaeiae sp. Vent. Polystrom a Clement. apud Achar. synops. 136.

14. Thelotrema $A C H$. Thallus cartilagineo-crustaceus. P e r it he ci u m dimidiatum, annulare, ex e i p u lo thallode verrucaeformi rupto inclusum, писl еш depresso-disciformem primo velatum eingens. - In corticibus, imprimis inter tropicos.

The lotrem a Achar. Lichen. 62. t. 6. f. 1. Eschweil. syst. 15. f. 12. Fée crypt, cort, t.23, $f, 1.2$. 4. Fries Lichen. 497. Volvariae sp. DC. $F l$. $f r, I I, 374$. H ymenoria Achar, msc. Anthrocarpum Meyer Flecht. 326. $\rightarrow$ ? P y. renula et As cidi um Fée op. cit. $t, 23 . f .3$ et 5 .

14\%. Timberia $A C H$. Thall us crustaceus. Perith e cim erumpens immersumve corneum, primo elausum, stellatim dehiscens, limbo laciniato, nucle um disciformem carbonaceum ambiens. - In corticibus, imprimis inter tropicos.

L i m b or ia Achar, excl. sp. Eschweil. syst. 16. f. 16. Mart. erypt. brasil. t, 10, f. 4 .

143. Cyrostomum FR. Thallus cartilaginens. Perithe $\mathrm{i}$ um erumpens, corneum, primo elausum, deinde ruptum, limbo orbiculato, inflexo, nuel e um subglobosum gelatinosum cingente. - In corticibus arborum tropicurum.

Gyrostom um Fries $p l$, hom. 268.

144. Clifostominm FR. Tha $11 \mathrm{us}$ crustaceus. Perithe cium superficiale carbonaceum clausum, collabescendo rugoso-plicatum, rugis demum rimose transversim dehiscens, nucle um ceraceo-gelatinosum includens. - Ad ligna fabrefarcta.

Cli i s $\mathrm{t}$ o m n m Fries pl, hom, 116, Lichen, 453. (Achar, in Vet. Acad. Handl. 1815, t, 6. f, 5.)

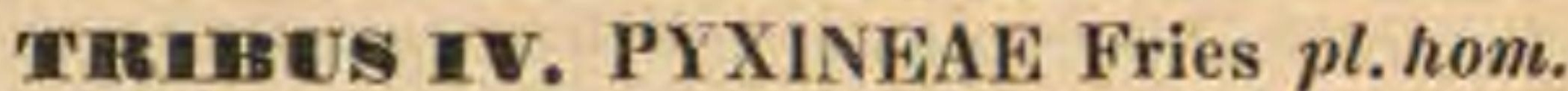
266. Excipulum proprium (perithecium) nudum, thallo superficialiter impositum, primo clausum. 'Thall u s horizontalis, foliaceus, subtus liber, discolor, contextu filamentoso.

145. Umbiliearia HOFFM. Thallus cartilaginens, foliacens, centro affixus. Peritheci um superficiale, lineari-elongatum, varie convolutum, gyrose dehiscens, nucleum occultans. Rupestres, versus polos et nivem alpinam frequentiores.

Umbilicaria Hoffm. pl. lichen. 1. 9. Schaerer in Seringe Mus. Helvet, I, 113. seq. Fries Lichen, 347 .

a) LASALLIA Merat. Perithe ei um subconcavam, d is co aequabili.

U mbilicaria Fée Method. 55. Dict. class.XIT. c. ic. $\mathrm{L}$ a s alli a Merat. Fl, paris. 202, (Hoffu, pl. lich, $t, 28, f, 1$. 2. t. 29. f. 4. Fl, dan. t. 597. f. 2. E. B. t. 1283.)

b) GYROPHORA Achar. Perfthecium convexiuseu.

lum, disco gyroso.

Gy rophora Achar. Lichen, 225. Fl, dan, t, 1744, E. B. t. 2066. 248i, 2486. Fće Method, 54. Dict. class, G y r o m i u m Wahlenb. Fl. suec. Ca pu i a Vent. p. 200. Umbilic a ria Merat l. c. (Hoffu. pl. lich. t. 44. f. $1-9 ., t .59 . f$. \&. $t$. 7o. t. $71, f .1-5$.

146. Pyxime FR. Thallns cartilagineus, foliaceus, fibrillis aflixus. Perithecium superficiale orbiculatum, ore circulari apertum, nucl e $\mathbf{n ~ m}$ ceraceum denudans. - In lignis et corticibus, imprimis inter tropicos.

P y $x$ in e Fries $p l$. hom, 267.

\section{Ordo X. Gasterothalami.}

Gasterothalami Fries $p l$,hom, 258. Myelocarpi Meyer Flecht.325, Gasterops or a e Reicheab. consp. 20. Pyrenothalami Bartl. Ord.pl. 8 .

A p othecia semper clausa v. excipulo irregulariter discedente aperta. Nucleus inclusus, ascigerus, deliquescens v. fatiscens.

TRIBUS I. VERUCARIEAE Fries $p l$. hom. 263. Excipulum proprium (perithecium) simplex corneum, ostiolatum, atrum, $\mathrm{nucle} \mathrm{um}$ includens. - Thallus horizontalis, expansus, uniformis, subinnatus.

14\%. Diorygma $E S C H W$. Th a 11 us erustaceus. Perithecin lineari-elongatum, subramosum, rima apertum. Nucleus gelatinosus, inclnsıs, deliquescens. - In arborum tropicurum corticibus.

Di or y g a Eschweil, syst. 13. f. 1. Mart. erypt. brasil. t. 6. f. 1 , (Pers, in Welter. Annal. $M . t .10 . f .5$.

14. Pyrenothea $F R$. Thall us subleprosus. Perithecium corneum, ostiolo apertum, demum sentellato - dilatatum. N u e l e u s gelatinosus, subsolutus, globuli instar erumpens, fatiscens. Ad terram, saxa, ligna, cortices.

Py renothe a Fries in Vet. Acad. Handl, 1821, p. 332. Lichen, 449. Leprantha Dufour. Thrombium Wallr. Flecht. $\boldsymbol{I}$. 170. partim, G elatinaria Flork. msc. (E. B. t. 1682.)

149. Pyremastram $E S C H W$. Thallus crustaceus. Perithe $\mathrm{c}$ i cornea, in collum elongata, ostiolo communi dehiscentia. Nucle u s ge latinusus, diffluens. - In corticibus arborum tropicarum.

Pyrenastrum Eschweil. syst. 15. f.15. Mart. crypt, Brasit.t. 8. f, 6, 7. t. 9. f. 1 . P a r m e a ta ri a Fée Method, 23 t. 1. f. 14. Crypt. cort. t. 20, f, 1 .

150. Verruearia PERS. Thalluscrustaccus. P erithecia cornea, discreta, ostiolis 
distinctis dehiscentia. Nueleus gelatinosus, diffluens. - Ad terram, saxa, cortices.

Verrucaria Pers. in Usteri Annal. VII. 22. Achar. synops. 87. excl. sp. Fries Lichen. 430. E. B. t.1681. 1711. 1891. Fl. dan, t, 1852. P y r e nula e s p. Achar, synops.117,

TRE IE IIS TR TRYTHELIACEAE Fries $p l$, hom. 261. Exe i p 1 u m verrucaeforme, e strato medullari thalli formatum, ostiolato-pertusum, nncleum deliquescentem includens. - Thallus horizontalis, crustaceo-adnatus, strato medullari in verrucae formam erumpente etiam verticaliter crescens.

151. Splnaeromplanie REICH. Nu c 1 e n s solitarius subglobosus, gelatinoso-fluxilis, intra excipulum simplex, e strato medullari thalli formatum, verrucaeforme (coloratum) papillato-ostiolatum. - In corticibus et saxis.

Sphaeromphale Reicheab. consp. 20. Segestria Fries pl. hom. 263. Lichen. 429. S e gestrella Fries Lichen. 460 .

15\%. DIycoporem MEY. N u cl e u s subglobosus, gelatinosus, perithecio destitutus, in verruca heterogenea multilocalari, prominente, ostiolis distinctis. - In corticibus arborum tropicarum.

M y copor um Meyer Flecht. 327. Porothelium Esehweil. syst, 18. f. 21. Mart. crypt, brasil, t, 9. f. 4. non Fries. P o rod ot hi u Fries pl. hom, 262.

153. Astrothelium $E S C H W$. Nuelens gelatinosus, perithe ciis confluentibus multiloeularis, intra verrucam heterogeneam prominentem, ostiolis in porum communem confluentibus. - In corticibus arborum tropicarum.

A s tro thel i u m Esehweil. syst. 18. $f$. 25. Mart, crypt. brasil. t. . . f. 5. t. 10. $f .1$.

154. Trypethelimun SPRENG. Nue le us gelatinosus, peritheciis distinctis, intra verrucam heterogeneam prominentem, ostiolo simpliei. - In arborum tropicarum corticibus.

Try pethellum Spreng. Anleit. ed. I. tom.III. 350. t. 10. f. 95. Achar. Lichen. 58, t. 4. f. 8, 9. Fée Meth, 24.t. 1 . f. 18. Crypt. cort. t. 18, f. 3, 4, t. 19. f. 2-6. Eschweil. syst. 18. f. 24. Mart, crypt, brasil. t.9. f.6. B a the $1 \mathrm{i}$ u m Aehar. neth. 111. t. 8. f. 3. Ophth a $1 \mathrm{midi}$ m Esehweil, syst. 18. 0 cell uI aria Meyer Fleckt.327.

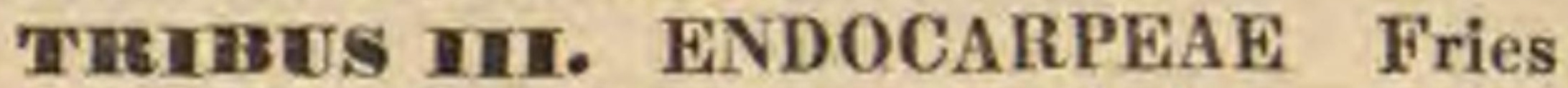
$p l$. hom. 258. Ex c i p ulum thallodes ostiolatum. Nucleus diffluens. Thallus horizontaliter expansus, subtus discolor v. adnatus.

155. Pertusaria $D C$. Th all u s erustaceus. Nucleus snbglobosns, gelatinosus, intra th a $11 \mathrm{i}$ verrucas bullatas, ostiolo apertas, inelnsus. - In corticibus et saxis.

Pertusaria DC. Fl. fr. $I I$. 318. Fries Lichen. 418. Pori a Achar, Lichen, 60. $t .7 . f .1$. 2. Fée crypt.cort. $t .20$. f. $2-4$. t. 21. f. 3. P o $x$ o phora Meyer Flecht. 326. (Linn. Transact. X. t.10. f.1. E. B. t. 1231. 2061. 2371.)

158. Sagredia $A C H$. Thallus subcrustacens. Nucleus subglobosus, ceracens, intra tha $11 \mathrm{i}$ verrucas elevatas, ostiolo elongato, apice scutellato - dilatato apertas, inclnsus. - In saxis humentibus.

Sagedia Achar, Lichen, 72. t, 6. $f .3-7$. excl, relig. Fries pl. hom. 259. Lichen. 412. Stig matidium Meyer Ftecht. 328. excl. sp. Enterog r a plia Fée meth, 17. $t$. $t$. f. 12. (E. B. T. 1752.)

15\%. Findoearpon $H E D W$. Thallus foliaceus. Nucle us subglobosus, gelatinosus, intra thalli verrucas superficiales, ostiolo prominente apertas, inclusus. _ Ad terram et suxa.

Endoe arpon Hedw. stirp. ergpt. II. 56. 6.20. Fries richen, 407. Dermato a r pon Eschweil. syst. 259. (E. B. t593-595. 1698. 2012, 25/1.)
TRTEUS IV. SPHAEROPHOREAE Fries $p l$. hom. 258. Excip ulum thallodes pertusum, nucleo fatiscente. Thallus verticaliter elongatus, fruticulosus, erectus v. pendulus, undique concolor, similaris.

158. Siphoula FR. A pothe $\mathrm{ci}$ a apicibus thalli intumescentibus, demum poro pertusis lacero-dehiscentibns inclnsa. Nucle us globosus, tandem explanatus, deliquescens. - Ad terram et rupes.

Siphnla Fries $p l$. hom, 238. Lich. 406. D ufourea Achar. Lichen, 103, t.11. f. 2. Nees in Hor. phys. t. ., f. 2.

159. Sphaerophoron PERS. A pothe $c$ i a apicibus thalli sphaerico dilatatis, demum lacero dehiscentibus inclusa. Nu c le u s globosus, floceoso-corticatus, in ambitu pulvereo fatiscens. Ad saxa et truncos, intra tropicos nobiliores.

Sphaerophoron Pers. in Usteri Annal. PII. 123. Achar. Lichen. 585, $t, 12, f .5,6, E, B . t, 8.974$. Fries Lichen. 404. Coralloides Hoffon. pl. lich. t. 31. f. . 3.

\section{Ordo XI. Hymenothalami.}

Hy menothalami Fries pl. hom. 233. H y m n o c ar. p i Meyer Elecht, 330 . H y m e u o 8 or a e Reichenb. consp, 21 .

Apothecium apertum. Nucleus disciformis persistens, asciger.

TIRIBUS I. COLLEMACEAE Fries $p l$. hom. 254. Apothecia varia, excipulo gelatinoso, saepe confuso. Thall u s similaris, gelatinosus v. in filamenta solutus.

160. Micarea $F R$. Thallus e granulis liberis gelatinosis, aggregatis. A p o th e c i a sphaerica, nuda, thallo inspersa. - Ad saxa et ligna madentia.

Micarea Fries ol. $h \mathrm{~cm} .256$,

161. Epluebe $F R$. Th a 11 u s filamentosus. A pothe cia scutelliformia, superficialia, excip u 10 thallode discum apertmm marginante. $-A d$ saxa irrigua.

E p he be Fries $p l$, hom. 256.

162. Collema HOFFM. Thallus foliaceus v. crustaceus, gelatinosus, contextu filamentoso. Apothecia seutelliformia, superficialia, excipulo thallode (primitus clauso) diseum immarginatum cingente. Ad terram udam.

Collema Hoffm. germ. II. 105. Fries pl. hom, 255. Geissoideae sp. Vent.

163. Theptogium FR. Thallus foliacens, membranacens, intus cellularis. A p ot hecia seutelliformia superficialia, ex cipulo thal lode discum erumpentem, primo clausum, marginatum cingente. - Ad terram udam, potissimum inter tropicos.

Leptogi u ur Fries pl. hom, $25 \%$.

164. Coenogonium EHRENB. Th a Il us laxe fibrosus. A pothe cia scutelliformia, substipatata, excip ulo proprio (colorato) discum convexiuscuIum marginante. - In corticibus inter tropicos.

Co e nog o n i um Elarenb. in Hor, phys, 120, t. 27. Fries pl. hom. 301 .

TISUEUS 1. LECIDINEAE Fries $p l$. hom. 247. A pothecia libera, nuda, ex e ipulo nullo v. proprio. - Thallus duplex, primarius horizontalis, secundarius verticalis.

165. Lecidea $A C H$. Thallus horizontalis macularis, verticalis saepe obliteratus. A pot h e cia adnata, scutelliformia, exci- 
p u 1 o proprio discum concolorem, semper apertum marginante. - In apricis super saxa et ligna.

Le e id e a Aehar. synops.32. Fries pl. hom. 258. Lichen. 281. Catillaria Achar. synops.11. - E c hinoplaca Fee meth. 35. t.1.f. 25. - M y riot rem a Fèe meth.34. Crypt. cort. $t, 25 . f$. 1. 2. - R hizocarpon Ramond in DC. Fl. franc. $I I, 366$.

186. IPatellaria PERS. Thallus horizontalis squamuloso-foliaceus $\mathrm{v}$. crustaceus, cum verticali saepe in podetia abennte confluens. Apothecia discreta solida, nucleo nudo, disco discolori demum convexo, immarginato. - Ad terram et ligna uda.

Patellaria Pers, in Usteri Annal. VII, 28, B i ato ra Fries dianom, 1817. Lichen. 247. L e p i d o m a Achar. synops. 50. $\mathrm{P}$ s o r a Hoffu. $p l$. lich. $t, 22, f .5 .6 . t$. 43. f. 1-3. C ireínnaria Fée meth, 18, $t, 2 ., f, 12,1 /$. Crypt. cort. t.30. f. 2,3, - Pulveraria Willd. Fl, berol. 10. Verruea

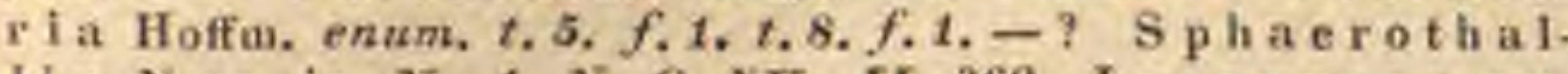
Iia Nees in N. A. N. C. $X \vec{V}$. Ir. 360 . Lecanorae sp. Eversm. Ibid, p, 350, t, 78, Li c he n es culent us Pall.

16\%. IBaeomyees PERS. Thallus horizontalis crustacens, verticalis in podetia solida abiens. A pothe e i terminalia convexa, nuda, s trat o hymenino indueta. - Ad terram glareosam.

B a e o m y ces Pers. in Usteri Annal. VII. 19. excl. sp. Fies pl. hom. 249. Lichen, 246. (Hoffm. enum, t.8. f. 3. E. B, t, 374. $\mathrm{Ft}$, dan. $t, 1003, f, 2$.

168. Cladionia HOFFM. Thallus horizontalis crustacens v. squamuloso-foliaceus, verticalis in podetia cartilaginea fistulosa abiens. A pothecia terminalia seyphiformia, mox discum, e s cipulum proprium tandem velantem, protrudentia. - In saxis, ad terram et cortices, versus polum frequentiores.

Cla d o n i a Hoffm. germ, 103. Flörke de Cladonitis comment. T, et II. Hostok, 1827, 1898, Bvo. Fries Lichen, 205, a) Cen om y ce Achar. Lichen, 105. Cap it u 1 a ria Flörke op. cit. Sey phoploor as et Helopodiam DC.Fl.fr. II. 338. et 341. Cladonia, S chasmaria et Ceraunia Aehar. Pyxidium Schreb. Pyxid aria Bory voy. 3. (FF. dan, $t, 1188, f .3, t, 1356, f .9$, E, B. t, 1835. 1836, 1867, 1284. 2439.) - ß) P y cnotheli a Achar. (F7, dan, t, 180. 539. E. B. t. 173. 970. Labill. Nov. Holl, t, 254. f. 2.)

169. Stereocaulom SCHREB. Th a $11 \mathrm{us}$ horizontalis subgranulosus, verticalis in podetia solida, intus filamentesa abiens. A p o th ecia terminalia, scutelliformia, ex eip u 10 proprio discum demum convexum marginante. - Ad saxa et terram, inter tropicos nobiliores.

St e r e o c a u l o n Schreb, gen, n, 1668. Achar. Lichen, 113. excl. sp. Pers, in Usteri Annal. II, t, 10. f. S. Fl, dan, t, 1721. Fries tichen, 200. A. Rich. Fl, Nov. Zeel. t.9. f.3,4. Th a mn i n m Vent.

TREIRES III. PARMELLACEAE Fries pl. hom. 240. Excipulum thallodes, primum connivens, demum hians. - Thallus horisontalis, e centro expansus, subtus dissimilis, saepe villosus v. matrici adnatus.

1\% D. Gyaleeta $A C H$. Tha11us crustacens, subtartareus. Apothecia urceolata, exe ip ulo thallode, discum gelatinosum demum induratum cingente. - Ad saxa irrigua.

G yale et a Achar. meth, 149. Fries Lieken, 194. V o 1. v a ria s s. DC. Fl, fr, II, 373. (Hedw, stirp, erypt, II. z. 10. f. B. E. B., t. 736, 1184. 1266.)

181. Dirina FR. Thallus erustacens, cartilagineus. Apothecia tubereuliformia demum seutellata, ex i i u 1 o thallode discum pruinoso-velatum, strato heterogeneo impositum, mar ginante. - In corticibus imprimis regionum cali diorum.

Dirina Pries pl, hom. 244, Lichen. 193. (Aehar.Lichen. t.7. $f .5$.
1\%. Parratia FR. Thallns cartilagineus varins, e centro horizontaliter expansus, bilateralis, hypothallo fultus. A p othecia seutelliformia horizentalia, exei pulo thallode discum subceraceum marginante. _ In apricis, versus polos copiosiores.

Parmelia Fries Lichen, 56. Parmelia, Lecano. ra, Urceolariae et Gyalectaesp. Achar.

a) SQUAMARIA DO. Thallus erustacens lobatus v. squamuloso-efiguratus. Hy pothall us glaber ma-

trici adnatns, saepe cum thallo confusus.

Parmeliae sect. III. Fries, Lichen, 99. Squamiti a DC. Fl. fr, II. 374. excl. sp.

a) URCEOLARIA Fries Lichen, 176. Phl yet is Wallr. Flecht, 597. (Hoffm. pl. lich, t, 11, f, ., 3. E, B. t. 820. 2156$.

B) PAtellaria Fries Lichen, 131. Patellariae s p. Hoffm. et Auct.

r) PSORA Fries Lichen, 122. Hoffin. pl. lich, t. 59. f. $t, t, 60 . f .3$. Ge is soideas sp. Vent. (E. B. e. 1275.1941 .)

d) PLACODIUM Fries Lichen. 99, Placo id ii s p. DC. (E. B. t. 1893, 2157, Fl, dan, t. 1946, 2008, f.1.)

B) ZEORA FR. Th allus subfoliaceus, demnm in eru. stau subgranulosam compactus. H y po thall us fibril. losus, supra matricem effusus, raro obsoletus.

$\mathrm{Z}$ e or a Fries $p l$. hom, 244. Lichen, 86. A m pli il o ma Pries $p l$, hom. 243. P a n naria Delis. in Dict. class, XIII. 20. (E., B, t, 983.)

C) LOBARIA HOEFM. $\mathrm{T}$ hall us foliaceus. Hy $\mathrm{p}$ ot ha $\mathrm{I}$. las fibrillosus, matriei adnatos.

L o b a ria Hoffm. germ. 159. Fries tichen. 57.

a) PHYSClA Fries $p l$, hom, 242, Lichen, 76, - B a r. rera Achar, exc, sp. Hagenia Eschw. syst. 20. (E, B, t, 1351, 1358, Fl, dan, t. 1719.)

B) IMBRICARIA Fries Lichen, 57. Im brieariae $\mathrm{s}$. Auet. - Pl a tis m a Hoffm. $p l$. Iich, t.31. $f .2$. t. 36. f. 4. t.38. f. t, t.39. f. 1. t, 4. f. 1 . Yée crypt. cont, $t$. 13. f. 1. (E. B. t. 1375. 1780. 1852, 2049. 2097.)

1ร3. Stieta SCHRER. Th a 11 us foliaceus, coriaceus, e centro expansus, subtus villosus. A pothecia seutelliformia, obliqua, exeipulo tha1l od e subtus libero subobliquo, discum ceracemm, primitus conniventem, marginante. - $A d$ terrem et truncos, inter tropicos frequentiores.

S ticta Sehreb, gen, n. 1668. De Iis e Monographie du genre Sticza. Paris, 1885. 8vo, c, tabb. Fée crypt. cort. c. 31. f. 16. t. 33. f. 1. Hook, miscell. t.13, 14. A. Rich, Fl. Nov. Zeel. t, 8.9. f.1. - $\mathrm{P} n \mathrm{Im}$ on aria Hoffm pl. lich, t. 1. f. 2, t. A. f. 2. - Retieularia Baumg. Fl. lips. $34 t$. Dermatode a s s. Vent. (Fl, dan, t, $100 \%$. E. B. $t, 1104$. 2359.) - C roco día Link Handb. III. 187. - ? P lectoс а г р а ғ Fée meth. 91. Orypt. cort. 49. t. 2. f.15.

18. 4. Peltigera $W U L D$ ). Tha 11 u \& folia. cens, coriacens, e centro expansus, subtus villosus, a pothecia peltaeformia, exeipulo thallode discum carnosulum innatum primum velante. - $A d$ terram inter muscos, in frigidis imprimis vegetae.

Peltigera Willd. El. berol. 347. Fries tichen. $\mathbf{~} 1$. Peltidea Achar, meth. 98 . A n tily s s il s Hall. helv. III. 85.

a) Erioderua Fée crypt. cort, 145, $t, 34 . f .2$.

b) Solorin a Achar. Lichen, 27, t. 1, f. 3.6 . S o m mer felt ia Flörk. (FI. dan, t. 539. f, 3. t, 263. E. B, t. 288. 494.)

c) Peltidea Achar, Lichen, 08, t. 10, f. 7-8, (E, B, t. 887. 888, 1119, 1834. 2299, 2300.)

d) Nephroma Achar. Jichen, 10t, t.11.f.1. A, Rich. Fl. Nov, Zeel, t. 9. f. 2. (Jacq, miscell, II, t, 10, f.1. Collect. IV, t, 12, f. 1, Fi, dan, t, 466, 764. 1430.)

THEDES 1\%. USNEACEAE Fries $p l$. hom. 232. Excip ul 1 m thallodes primitus apertum. Thallus verticalis, undique similaris.

4 5. Cetrapia $A C H A R$. Thallus cartilagineo-memliranaceus. A p ot he $\mathrm{c}$ i a scutelliformía margini thalli oblique affixa, excipulo tha! 1 o de disenm demum inaequabilem obliqne margi nante. - Ad terram inter muscos, in frigidis. 
Cetraria Achar, Lichen. 96, excl. sp. Fries pl. hom. 238. Lichen. 34.

a) Physcla DC. Fl. fr. II. 395. excl. sp. (El. dan. t. 598. E. B. t. 2111.)

b) Cornicularia Hoffm. pl. lich, t, 34. f. 1. (Fl, dan. t, 1126, E, R, t. 1994.1330.) - Co elo ca ulo n Link Handb. III. 165.

18. HBocedila $D C$. Thallus cartilagineus, rigidus. A p o $t$ h e $\mathrm{c}$ i a sentelliformia lateralia, excipulo proprio cupulari, thallode discom demum convexum inaequabilem marginante, tandem evanescente. - In rupestribus maritimis.

R o ceella DC. Fl. fr. $I$, 334. Achar. Lichen, 81. t.7. f. 8. 9. Fries Lichen. 33. (E, B, t, 211. 728.)

18. Femallima $A C H A R$. Thallus cartilagineus, rigidus. A poth e ci a orbiculata sparsa, excipulo thallode diseum tandem reflexum inaequabilem marginante. - In arboribus et rupibus.

$\mathrm{R}$ amallin a Achar. Lichen, 122, $t$. 13. $f .5-11$. Fries Lichen. 29. P I a t y phy $11 \mathrm{um}$ Vent. (E. B. t.688. 1181.)

18. Trerenia $A C H A R$. Thallus carti lagineus, mollis, intus stuppeus. A p ot he $\mathrm{cia} s \mathrm{eu}$ telliformia, marginalia, exeipulo thallode diseum aequabilem marginante. - Ad truncos.

Evernia Aehar. Lichen. 8i, t, $10, f, 1,2,-\mathrm{B}$ orrera Achar, op, cit. t.9. exel. pl. Al e etoria e, C oraicula. riae et Everniae sp. Achar. (E.B. t, 1853, 1850.) Bryopogon Link Handb. IIT. 164. - ? Neuropogon Nees et Flott, in Linnaea IX, 496.

19. Usmea HOFFM. Thalli stratmm corticale crustaceum, a medullari filamentoso solutnm. Apothecia peltata terminalia, excipulo thallode discum aequabilem marginante. - In arboribus, rarius in rupibus.

Dsne a Hotfm. pl. Lich, t.30. f.2. excl. sp. Fries $L t$ ehen. 17, Hook. misc, t,11. 12, Reichenbachia Spreng. ex Fée crypt.cort, 136. (Fl. dan, t, 1189, 1157. E. B. t. 257. 258. 872.)

\section{SECTIO II. HYSTEROPHYTA.}

HYSTEkOPHYTA Fries syst. mycolog. $I$. 20 .

In organismis 1 anguescentibus v. emortuis enata, intussusceptione e matrice nutrita, organa omnia simul explicantia, definite pereuntia.

\section{Classis IIT. Fungi.}

St erebec k, Theatrum Fungorum Amst. 1675. 4to.Al arsigli, de generatione Fungorum. Berol, 1753. 8vo. B at $t$ a ra, Fungorum agri ariminensis historia. Favent. 1755. - S c hat fer, Fungorum, qui in Bavaria et Pala. tinatu nascuntur, historia. Hatisb. 1769. 4to. 4 Part. Edit. nov. curante Persoon Erlang. 1800 . 4to. I Vol. - B a t s e h, Elenchus Fungorum Halae, 1783, Ato. - B olto n, History of Fungusses 1788. 4to. Geschichte der Pilzo, übers, von Willdenow, fortges, von Nees v. Esenbeck. Berl. 1799-1820. 4to. $4 \mathrm{Vol},-\mathrm{B}$ ull iard, Histoire de Champignons. Paris 1791. fol. 4 Vol. - P e r so on, observationes mycologicae. Lips. 1796. 8vo. a Fol. Tentamen dispositionis methodicae Fungarum Lips.1797. 8vo. Commentatio de Fungis clavav. formibus, Lips, 1797. 8vo. Icones et descriptiones Fungorum, Lips. 1799. 1800. fol. 2 fasc. Icones pictae specierum rariorum Eungorum. Paris 1804. 4to. A fasc. Synopsis methodica Fungorum, Göting. 1801, 8vo. 2 Vol. Traité sur les Champignons comestibles. Paris 1819,8vo, Mycologia europaea Erlang. 1892. 8vo. 3 Vol. - L in k in Berl. Magas. III. Nees von Ese nbeck System der Pilse und Schwämme. Wärzb. 1817. 4to. 8 Vol. K unze und S ehmidt, mycologische Hefte. Leipz. 1817 . Fh re b be rg, sylva mycologica berolinensis. Berol, 1817. 8vo. Fries observationes myco. logicae. Hafn. 1815. Systema mycologicum Griphswald. 1891-1829, 8vo. $3 \mathrm{Vol}$. Elenchus Fungorum Lundae, 1898. 8vo. 2 Vol. Brongniart. Essaí dune classification naturelle des Champignons. Strassb. 1825. 8vo.

Vegetabilia anandra, e corporibus organicis putrescentibus sive humo, quatenus ex or- ganismis in sua principia redeuntibus constat, enata; ex iisdem intussusceptione sese nutrientia, in ipso ortu velata, e cellulis plus minus difformibus composita, organa omnia simul explicantia, extremitatibns hinc deffinitis, ad formam sphaericam tendentia, semel fructificantia, definite pereunt. Sporidia nuda $v$. aseis inclusa.

Fungi inter reliquas plantas maximam gaz azotici quantitatem continentes, unde plures foetidi et venenati, non pauci vero nutritivi, subito faventibus momentis cosmicis oriuntur, et peracta definita vitae periodo brevi pereunt. Ubivis locorum nisu reproductivo ex organismis in functionibus suis turbatis, vel solvi incipientibus generantur, hinc species eximie sociales, plerumque late diffusae, nonnullae tamen, imprimis terestres et hypogeae, endemicae, tropicae nimis pancae hucdum cognitae.

\section{Ordo XIT. Gymmomycetes.}

CONIOMYCETES Fries syst, $I T T$. 455. GYMNOMYCETES Link spec. $I$. 1. UREDINEAE DC. et Duby Bot. gall. II. 877 .

S p ori di a nuda, sub epidermide plantarum v. intra matricem enata, simplicia v. septata, receptaculo (stromati) spurio ex epidermide matricis (peridium spurium), vel proprio solido, superficiali $\mathbf{v}$. innato imposita.

\section{PROLETARII.}

Hoc loce nominandi sunt varii status morbosi plantarnm, vegetatione antonoma careates, $\mathrm{E}$ at o phy tor um genera. tioni praeludentes.

a) MYCOMATER Fr, Mucus viseidulas e vulneribus arborum profluens, subcoagulescens, interdum granulis minimis $\mathrm{v}$. floceis tenerrimis inspersus.

M y e o m a ter Fries $p l$, hom. 200.

b) NOSOPHLAEA Fr. Pulvis rudis, e parenchymatis cellulis dissolutis ortus, saepe epidermide $v$. cortice tandem varie rupto effusus.

Nosophlaea et PhIoe o conis Fries pl. hom. 199. 200. Protom y e s Unger Exanthem. 341.

c) STRUMBLLA Fr. Tubercula atra e leguminibus protuberantia, in matricis substantiam sensim abeuntia, extus pulvere conspersa.

Strumella Fries $p l$. hom. 199.

d) SPERMOEDLA Fr. S e m i a graminum in corpus fungosum, extus furfure conspersum, tumentia.

Spermo ed ia Fries syst. IT. 268. Om Rost och-Brand Lund 1821. p. 12-48. S p ha ce I i a Leveill, in Annal. soc, Linn. paris, V. 378 . Nees offiz. Pflanz. Suppl. T. t. 24. Sclerotium Clavus DC. in Mem. Mus. IT. 416. t. 14. f.8. Clavi Siliginis et Secalis mater Veter. CAnalysin chemieam dedit Vauquelin in Mem. Mus. MT, 189.)

SEIBTED I. EN'TOPHYTI Nees syst. 9. Fries syst III. 461. S p o ridi a varia, e parenchymate morboso plantarum vivarum sub epidermide orta, hac rupta erumpentia, et varie saepe mutata stipata.

180. Papularia $F R$. S poridia simplicia globosa, epidermide tandem secedente nudata.

Papularia Fries $p l$. hom. 195. - ? Phy soderua Walle. Ft. germ, II, 192.

181. Uredo PERS. S poridia simplicia, epidermide vage rupta emergentia.

U $r$ do Pers. synops. fung. 225. Ca e o ma 8 ubs. I. Ure d o Link spec. H. 1 .

a) Ustilago Liwk in Berlin. Magaz. III. 6. Dittm. apud Sturm. IIT. $t .33 .37$. Re t i c u laria Bull. t. 472 . f. 1. Endo ph y $11 \mathrm{um}$ Levell, in Bullet. se. nat. Vr. 232, Annal. soc. Iinn. paris. IV. 202. t. 11. A e ci. 
dil s p. Sowerb, $t, 389, f .3,4$, (Sowerb, $t, 139,398 . f, 1$. Nees syst, f. 5. 10. Sellecht, in Hor. phys. t.20.f.13. Grev. scot, t.8. 12, 19. 31, 80, 95. 251.)

b) Urom y e s Link in Berl. Magaz, VII. 28, C a e om urus Link ibid. $\boldsymbol{I} \boldsymbol{I}$. $\boldsymbol{z}$.

182. A ecidium PERS. S p oridia sinplicia, epidermilem varie transformatam, p s e u d operidium praebentem, regulariter rumpentia.

A e cidi u ne Pers. synops. fung. 20\%.

a) CAEOMA $D C$. P s e ud o peridi a cyathiformia. S poridia effusa.

C a e o ma DC. Bot.gall. Ir. 903. C a e o m a s u bge n. II. A e ci d in m Link spec. IT. 42. L. y c operd i s p. Linn. Jaeq. collect. I. t. 4. f. 1. (Grex, t, 7, 69.)

b) RoEstelia Rebent. P s e ud operidia cylindrica elongata. Sporidia inclusa.

Roes teli a Rebent, neomarch, 350, t, 2. f.9. C a e o m a 8 abgen. Ill. Ceratites Link spec. II. 64. Cronarti $\mathbf{n}$ m Fries obs. $I$. 280 . L y e o p e rd l 8 p. Linn. Jaeq. Fl. austr. t, 17. FI. dan. $t$. 704. 838, 839. (Sowerb. t. 318. 319. Nees syst. f. 1. Grev. scot, $t, 4,97,180,209$.

c) PERIDERMIUM Link, Ps eudoperidia utrieulosa, apice rupta v. basi circumscissa.

Peridermium Link spec, $I T$. 66. (Wallr. El. germ. II. 263. Sphaerothe ea Desv. L yeoperdi sp. Willd. in Usteri Magaz. II. t. 4. f. 12. Nees f. 4. Grev. scot. t.7.)

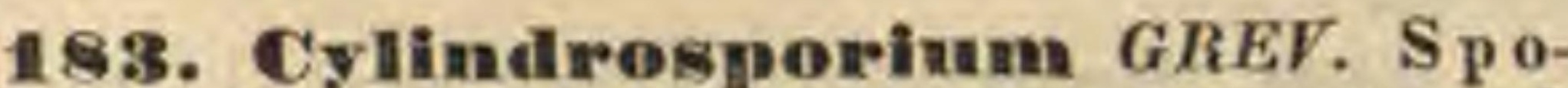
ridia simplicia, eylindriea, utrinque truncata, sub epidermide vage rupta emergentia, in acervum conglntinata.

C ylindros pori um Grev, scot, t.27. Fries syst. III. 481, in not,

184. TiBnIlnain $D C$. Sporidia oblonga, medio uniseptata, epidermide vage rupta tandem nudata.

Bullaria DC, Fl. fr. $T$, 296. Fries pl. hom, 195. Uredo bullata Pers, obs, $I$. $t .2 . f .5$. P u ceiniate $\mathrm{s}$. Link,

185. Fanceinin PERS. Sporidia unibi-tri-septata, saepe pedicellata, sub epidermide vage rupta emergentia.

Puceln i a Pers. disp. t. 3. $f$. 4. excl. sp. Link spec, $M$. 67. Grev. scot, t. 17. 29. 49. 75. Fries syst, III. 509. D i. c a e o ma Nees syst. 16. $f, 11-13$. T riph $\mathrm{rag}$ m i u Link sp. IT. 8\%. A e cidil s p, Sowerb. $t, 43$.

186. Smorein esmainan $L N K$. S p oridia multiseptata, saepe pedicellata, stromati effuso imposita. - In caulibus exsiccatis et ad ligna.

Sporidesm I n Link in Berlin. Magaz. ITI. f. 64. Nees syst. $f, 18, N_{0}, A_{,}, N, C, r X, 230, t, 5, f, 1,2, \mathrm{C}$ o $\mathrm{r}$ d a apud Sturm III, t.17-22. S porideriulu Grev. scot. t. 194 .

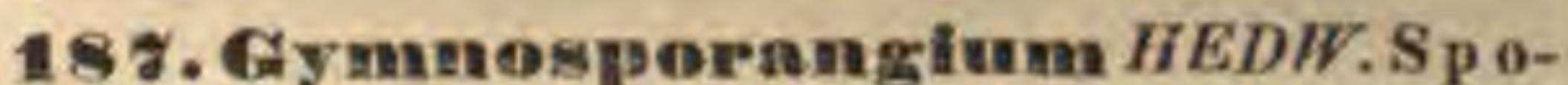
ridia miseptata pedieellata, stromati gelatinoso - vesiculoso adnata, - $E$ ramis vivis Juniperorum erumpens.

Gy munsporang I m R. Hedw,ex DC, Fl, fr, II, 217.

a) $\mathrm{P}$ od is o m a Link in Berl. Magaz. IIT, 9. Nees syot. 18. $f, 15$. $\mathrm{P}$ u ceiniae s p. Michel. gen. $t, 92, f .1$. Sehmidl Analys, HI. t. 66. Pers, disp. t. 2. f. 1. $a-c$. Gy m a sporaugiisp. DC.

B) Gymaosporang i um Liuk in Berl. Magaz. Mr. 10. Nees syst, 37. $f, 23, a$. Tremella juniperina Linn. Jacq. Hoffm. erypt,, , $t, 6, f, 4$.

SUBDIRDO IT. SPORODERMEI Fries syst. III. 460. Sporidia in floceos demum liberos dilabentes concatenata. _ In plantis vivis et mortuis.

188. Spiloenea FR. Sporidia globosa simplicia, sibi invicem et matrici seriatim adnata, sub epidermide plantarum vivarum erumpentia.

Spiloeaca Pries Novit. $V$. 79, Pt, hom, 198, Link epec. $\boldsymbol{H}$. 86 .

189. Torula PERS. Sporidia in floceos moniliformes concatenata, demum secedentia, ma- teria grumosa farcta. emortuis.

T or ul a Pers, obs. I. 25. Nees syst. f. 69. Fries syst. III. 495, C ord a apud Sturm IIT, 8, t.38. 39. 42. 43, 44. 48. A Iternaria Nees syst. $f$. 68. S y ne alles ia Agardh syst. XXIr. Hor mis cium Kunz. myc. Heft. t, 1. f. . . M onflia e sp. Link. Grev, scot. t. 225, - Xenod o chus Sehlecht, in Linnaea $I, 237, t, 3, f, 3,-$ ? T e $t$ ra e ol in m Kunze ex Link sp. I. 125. (N. A, N, C, IX, t, G, f, 16.)

190. Phreagnidiurm $L N K$. Sporidia in floces moniliformes longe pedicellatos coneatenata, singula globnlo solitario farcta, tandem secedentia. - Sub epidermide plantarum vivarum et emortuarum.

$\mathrm{P}$ h $\mathrm{r}$ ag in id $\mathrm{i} \mathrm{um}$ Link spec. IT, 84. Grev. scot, t, 15. 57 . A regma Fíries obs. r. 225. P u e ciniac sp. Auct. Nees syst. f. 14. Grev, scot, $t, 15,57$.

191. Plaragnotrielnum KUNZ. Sporidia rhombea, intus cellulosa, pedicellis cylindricis, in floceos moniliformes, $s t r o m$ a $t i$ gelatinoso innatos concatenata, demum secedentia.

In strobilis Abietis.

Phrag motrich um Kunze myc, Heft, II, \&t. t. 2. f.4. Link \$p. IS. 126.

192. Comoplea PERS. Sporidia subglobosa, simplieia, in flo e e os moniliformes, primum in tuberculum compactos, deinde liberos dilabentes cohaerentia. - Sub epidermide plantarum mortuarum erumpentia.

C o u o ple a Pers. Myc. europ. I. 12. Fries syat, III, 490. uon Auet.

SUBARIDA III. S'TILBOSPOREI Fries syst. HII. 459. Sporidia sub epidermide matricis in nucle um compacta, demum erumpentia. _ In plantis emortuis.

193. DeIaneonium $L N K$. Sporidia globosa, simplieia (atra), in acervum compacta, epidermide rupta effusa.

Melancon inm Link in Berl. Magaz. IIT. 9. Spec. IT. 89. Nees syst. $f .87$. Stil b o s pora e sp. Pers, obs. $I$. c.1.f.6. t.2. f.3. 6. - ? C o е с o s por a Wallr. Fl. germ, 1I. 176. - ? S p haerospor $\mathrm{im}$ Schwein, in Transact. Americ, philosoph, soc. IV. 303. t, 19. f.5.

1194. Entomayedirmen WALLR. S poridia fusiformia, simplieia (atra), medio sporidioI is farcta, in stratmm collecta, epidermide rupta emergentia.

En to m y celi u m Wallr. Fl, germ. $T, 189$,

195. Dialymasporienm NEES. Sporidia subglobosa v. oblonga, medio uniseptata (fuscu v. nigricantia), in acervam conglutinata, epidermide rupta effusa.

Didy mos porium Nees syst, 30, $f$. 29. Link spec, $r$. 93. Corda apud Sturm, IIT. $t, 23$. Stilbos pora e s p. Pers. Link. Grev. scot. t. 212. $f . t$.

196. Stiltosespora PERS. S p oridia oblonga, multiseptata (nigra), sporidiolis farcta, in acervum et varie inter se conglntinata, epidermide rmpta effusa.

Stilb o s por a Pers. disp, t, 3. f, 13. Nees syst. f, 17. Fries syst. ITI. 483. Stilbosp orae et MeIanconil sp. Link. S porodes mi s p. Corda apud Sturm. III. t, 29. Asterosporium Kunze in Flora 1819. p. 225. (Hoffm. Fl. germ, $t, 13 . f .3$, ) $\mathrm{C}$ beiros pora Moug. ex Fries $p l$. hom. 365. R h ab d a s p or i u m Chev. Fl. paris, 488, $t$. 11 . f.3. - Cerat os porím Seloweia. in Inansact. Americ. philosoph, Sac. IV. 300. t, 19, f.3.

19\%. Cryptesporium KUNZ. Sporidi a fusiformia simplicia (atra), sab epidermide in n ucle $\mathbf{n}$ m conglutinata, demum libera.

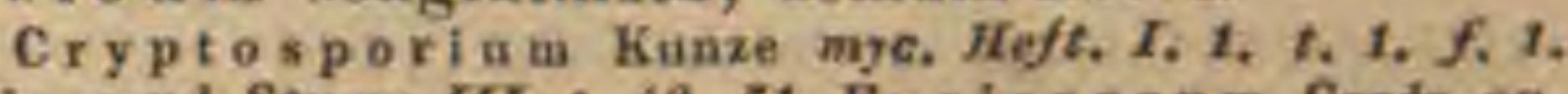
Corda apud Sturm IIT, 6. 49. 51, Fusic o e e u m Corda op. cit. t. s\%. 
198. Fusidiame FR. Sporidia fusiformia simplicia (colorata), in n u cleum compacta, epidernide demum secedente denudata.

F us id i u Fries syst. IIT. 480 .

199. Septoria $F R$. S p o ridia fusifermia septata (colorata), in nucle nm simplicem conglutinata, demum epidermide rupta cum gelatina cirrhose profluentia.

Septoria Fries Novit, I. 78, Elench, II, 117. Syst. IIT. 48t, Knnz Mre. Heft. M. 107. Grev, seot. t. 112. Link sp. IT. 87. Ph 1 oe os ora Wallr. Fl. germ. $I T$. 176, S tilb os po. r a e s. DC. Mem, Mus. IIT. \&, 4. f. 9.

200. Nezanspora PERS. S p oridi a subfusiformia, simplicia (colorata), in $\mathbf{n u c l e ~} \mathbf{u m}$ gelatinosum cellulosum juneta, epidermide rupta eum gelatina cirrhose profluentia.

N ema spora Pers. synops. fung. 109. Fries pl. hom, 194. Grev. scot, $t, 345$. M y x o s p o $\mathrm{r}$ i um Link spec. $I T .98$. Nemaspora et Libertella Desmaz, in Annal. sc. nat. $X I X, t, 5$.

SUIB DET IE. TUBERCULARINI Fries syst. III. 458. Sporidia stromati propri o imposita, in dis cum denudatum conglutinata.

201. Selnizoderma KUNZ. Sporidia subglobosa, simplicia (atra), in a e erv $\mathbf{n}$ erumpentem, supra stroma grumosum conglutinata.

$\mathrm{Schizod}$ e $\mathrm{rm}$ a Fries $p l$, hom, 194. H y p od e $\mathrm{rm}$ i um Link sp. II. 88. non in Berlin. Magaz. NII. H y poderma Nestl. msc. Uredinaria Chev. paris. 411. Sorospo$r$ i n m Rudolph, in Linnaea IV. 116, t. 2.

20R. Dieocenm $C O R D$. S p oridia ovata, uniseptata (atra), in dise $\mathbf{u m}$ erumpentem conglutinata, stromate obsoleto (?).

Dic o с с um Corda apud Sturm IIT. 9. t. 55. Fries oyst. ITI. 426 .

203. Corymemm FR. Sporidia fusiformia, multiseptata (atra), pedicellata, erecta, pedicellis basi in $8 \mathrm{tr}$ o m a coadunatis, parallele in discu m erumpentem constipata.

Cor y n e u $\mathrm{m}$ Fries syst. IIT. 473.

a) CORYNEUM Nees. Sporidia apice obtusa.

C o r y 1 e u m Nees syst.34. f.31. Kunz. et Schmidt myc. Heft. I. t. 2. f. 17, 18. Link spec, $11,126 .-$ ? Clasteri. epori um Schwein. in Transact. Americ. philosoph. Soc. IV. 300. 6.19. f. 4 .

b) SEIRIDIUM Nees. Sp oridia apiculo filiformi terminata.

$\mathrm{Se}$ iridi $\mathrm{um}$ Nees syst.23, f. 19. Link. spec. $I T .126 . \mathrm{S}$. cid i u $\mathrm{m}$ Spreng.

204. IBlemmoria MOLG. Sporidia cylindrica, utrinque truncata, simplicia (fusca), supra $8 \mathrm{trom}$ a gelatinosum in $\mathrm{d}$ is $\mathrm{cum}$ erumpentem conglutinata.

B leanoria Moug. ex Fries pl.hom, 366. Syst.III. 472,

205. Fussariuan NEES. Sporidia demum fusiformia simplieia (laete colorata), supra strom a gelatinosum amorplum erumpens in stratum dis posita.

Fusarium Nees syst. $f .31$. Grev. scot. $t$, 10. Corda apud Sturm 6. t. 7. 8. Fries syst, III. 469. Fusidiis p. Link.

206. Volentella TOD. Sporidia fusifermia septata (laete colorata), supra stroma suberosum cupulare erumpens in $\mathrm{d}$ is $\mathrm{c} \mathrm{nm}$ compacta.

Volutella Tode Meckl.I, 28.t, 5. f. 43. Friessyst.IIT. 466. Atractii sp. Link. Fu sari $8 \mathrm{p}$. Link, Nees in N. A. N. C. IX. t.5. f. . T. Tubereularia cillata Nib. et Seltwein. consp. t.5. $f .6$.

20\%. Tubereularia TOD. Sporidia subglobosa simplicia (colorata), supra stroma verrucaeforme carnosum erumpens in $s$ trat $u m$ dense compacta.
T uberen 1 aria Tode Meckl. $t$. 18. excl. sp. Nees syst. f. 32. 33. Link sp. II. 99. Fries syst. HI. 463. T r e mellat s p. Linı.

\section{Drdo A TII. Hoyphongycetes.}

HYPHОMYCETES Link sp. I. 4. Fries syse. IIT. 261 .

F locei nudi varii, tubulosi v, solidi, a matrice discreti, fertiles saepe a sterilibus distincti. Sporidia e floccorum divisione vel inter floccos enata, saepe intra eorum apices vesiculoso-inflatos (peridiola) contenta, vel stromati floceifero imposita.

SUADHED T. SEPEDONIEI Fries syst. III. 436. Sporidia cumulata, matrici incumbentia, et ab ea saepe enata, floc c is discreta. Mycelium floccosum.

208. Sporisoriam EHRENB. Sporid ia globosa, simplieia, sub epidermide viva coacervata, ermmpentia, floc cis paucis intertexta. In Sorghi germinibus.

$\mathrm{S}$ porix ori um Ehrenb, ex Link sp. $I$, 86 . Fries syst. IIT. 454.

205. Demulaima FR. S poridia globosa, simplicia, matrici innata, floccis tenuissimis effusis in maculam contextis discreta. _ In caulibus emortuis.

De ndrina Fries pl, hom, 186, Syst, III. 453, - ? Ch romos porium Corda apud Sturm III. $t$. 56 . (floceis eva nidis).

210. Aleurisma $L N K$. Sporidia subglobosa simplicia, e matrice enata, primum flocc is septatis convergentibus, mox evanidis, velata. In caulibus.

A l e u risma Link in Berl. Magaz. III. 18. Nees syst. f. 48. Fries syst, $11 \mathrm{t}$. 458.

Z1 1. IPsilomia FR. Sporidia varia, simplicia, e matrice enata, floceis contiguis, in caespitulum erumpentem iunctis, primum convergentibus, persistentibus, velata. - In corticibus.

P sil onia Fries pl. hom, 187, Syst. III. 450. Desmaz. in Annal. sc.linn, 1830. t. S. f.1. M e nis pora Pers. Myc, europ. I. 32. Link sp. 1. 32. C amptos porium Link in Ehrenb. sylv. Berol. 11. Cir e inot richum Nees stst. 19. f. 66.a, Link sp. 1. 35. Chev.paris.t.5. f.2. G y r ot $r$ ie hum Spreng. syst. $I V .554$.

212. Seolieotriellam $K U N Z$. Sporidi a oblonga, medio uniseptata, flo ceis continnis laxe intricatis velata. - In ramulis dejectis.

$\mathrm{S}$ coli cotrichum Kunze myc. Heft. 1. 10. t. 1. f.6. Link sp. $I$, 35. Fries syst. 111 . 449.

213. Epoelunium $L N K$. Sporidia oblonga, apiculata, septata, matrici adnata, floc $\mathrm{c}$ is effusis intricatis intertexta. - In plantis putrescentibus.

E p o e hn in m Lipk in Berl. Magaz. III. 18. Spec. I. 32. Nees syst. f. 40. Chev. paris, t. 4.f.1. Fries syst. III. 448.

214. Fusisporium FR. Sporidia cylindrica vel fusiformia, septata, in acervos matrici incumbentes conglutinata, floceis erectis v. decumbentibus, saepe evanescentibus. _ In plantis putrescentïbus.

Fus is porium Fries pl.hom, 186. Syst, IIT. 412. Fu. sis pori a mink in Berl. Magas, MII, 17. Desmaz. Ann, sc. nat. $X I X ., t, 18, f$. 2. Nees syst. $f, 40 . B$. F usidi um Link in Berl. Magas, III, 8. f. 5. Spec. II. 96. Dittm. apud Sturm $111, t .17 .18$, Grev. scot. $t_{.} 102$.

215. Collarium $L N K$. S poridia globosa v. simplicia, in acervum conglutinata, fl o c e is erectis decnmbentibusve, saepe evariescentibus cincta $\mathbf{v}$. intertexta. - In corporibus putrescentibus. C oll a $\mathrm{t}$ um Link in Berl. Magaz. MY, 17, f. 11. Nees syst. f. 42. Fries syst, $I I T$. 440. Co c cotri c b u in Liak sp, $I$. 25. Sporotrichisp. Liak. 
216. Tubureinâa FR. Sporidia subglobosa inaequalia, matrici innata, sporidiolis secedentibns farcta, fIo c e is intertextis mox evanescentibus primum adhaerentia. _ In plantis putridis.

Tubureinia Fries syst, 27,439 . Rhizoctonkace Sporotriehisp. Auct.

Z1 7 . Sepedomien $L N K$. Sp o ridi glo bosa, matrici innata, sporidiolis secedentibus fareta, floceis lanaeformibus vagis, mox evanescentibus, primum velata. - In Fungis putrescentibus.

Sepedon i um Fries syst. $I T r .438$. Se ped o nit sp. et M y c og a ne Link in Berl. Mag. MIT. 18. Spec. I. 28, 29. Nees, syst, $f$, 2S, Dittm. apuit Sturm $I V, t, 53$. Grev, scot, t.198. M y co banche Pers. Champ. comest. 13.

SUEBCRED IT. MUCEDINES Fries syst. III. 380. S poridia intra floceos tubulosos, pellucidos, saepe septatos enata, iisdem tandem inspersa, vel catenatim adbaerentia.

218. Sperendonema DESMAZ. S p orid ia globosa, intra fl o c c o s caespitosos primum seriata, tandem late effusa. _ In pinguedinibus corruptis.

S por end on e ma Desmaz. in Annol. sc, nat, Xr.t.at. Fries syst. MII. 43\%. Sepedoni i sp. Link. Torulae s p. Corda apul Sturm III. $t, 45$.

219. Enetrialianan $K U N Z$. Sporidia oblonga, ex articulis ultimis fl o $\mathrm{e}$ e or $\mathbf{u m}$ septatorum secedentia, medio materia or $\mathrm{r}$ m 0 s a farcta, apicibus hyalinis. - In lignis putridis.

Bactridium Kuaze myc, Heft. $I, 5, f$. 2, 20, 27. Nees in N, A, N. C, RX, t.1. f.3. t. 2. f. 21. Fries syst. III, 433.

220. Midiam LNK. Flocei biformes, septati, evanescentes et moniliformes, ereeti v. decumbentes, subramosi, articulis subglobosis pellucidis dilabentibus, materiam sporaceam effundentibus. In plantis putridis.

Oidium Link in Berl. Magaz. IIT. 18. Spec. I, 121 , Nees syst, $f$, 20. Fries syst, III, 497, 0 o s po r a Wath $F 2$. germ. IT. 18e. A e r os p orium Nees syst. $f .49$. B. Grev. scot, $t, 73$, Aly sidium Kanze myc. Heft, I. 18, f, G. Farin a ria Sowerb. $t .360, f$. $t$.

2: 1. Trieluotheeinme LNK. Sporidia uni-biseptata, floce cis eaespitosis septatis subpersistentibus immixta. - In plantis emortuis, siccis.

Trieboth e cin m Lík in Bert. Magaz, Iri, 18. Nee syse. f. 47. Grev, scot. $t$, 172. Fries syst, ITI, 426, D i p I os po ri um Liuk sp., , 64. Maerot $\mathrm{r}$ ie ham Grev, inc Edinb. philosoph, Journ, XXV. 64, t. 1. C ladotrie b a m Corda apud Sturna III. t. $2 \theta$.

22\%. Acremonium LNK. Sporidia simplicia, vesiculosa, ramulos tenuissimos laterales flo c corum septatorum terminantia. - In plantis putrescentibus.

A er e mo n i a m Link in Berl.Magaz, $T r r, 18, f$, 20 . Nees syst. f. 39. Dittm. apud Sturm III. $t$. 2. Grev, scot, $t, 124$. Kunze myc. Heft, IT. $f, 23$. Fries syst, III, 425.

283. Sporotrielamm LNK. Sporidia simplicia pellucida, floc cis erectis v. catespitosoconvergentibus, ramosis, septatis, primum obtecta v. intertexta, mox iisdem acervatim inspersa. In corporibus variis putredini praeludit.

$\mathrm{S}$ p o r o ti ch um Link in Berl. Magaz, IIT.12. Sp, I. 1 . excl. sp. Nees syst. $f .45$, Grev. seot, $t, 108$. Pries syst. IH. 415. B a try ti s s p. Link, Dittm. opud Sturm IIT. $t$. 35. 5 . Alytasporil sp. Auct, Grev, seat, t. 274. A cl a dii sp. Link. Nees syst. f. 50 . Ne matog o n a m Desmaz, in Nouv. Annal. sc. nat. II. 69, t.2. f.t. - Virgaria Nees syst. f. 52. - ? Geotri chum Link in Berl. Mragaz, MI, 17 .

294. Daetylium NEES. Sporidia ob longa v. clavata, septata, apicibus attenuatis flo e cor um septatorum simplicinm ramosorumve laxe adhaerentia. _ In plantarum partibus putrescentibus.
D a et y $\mathrm{linm}$ Fries syst. $I I T$, HA.

a) DACTYLIUM Nees. Floe ei simplices. Da ct ylin m Nees syst. 58. f. 58. Link sp, 1 . 27. - S p o r o ce p ba. I $\mathrm{m}$ Chev, paris. 59.

B) CLAdOBOTRYON Nees. Fl o e e i ramosi. C 1 a d o b otry on Nees syst. 55. f. 54. B ot ry tid is s p. Link, Dittm. apud Sturm III, $t, 41,50$.

225. DItomilla HILL. Sporidia globosa simplicia, in ramulos floce o or n m septatornm eatenatim cohaerentia, tandem dilabentia. - In corporibus variis putridis.

Monilia Hill, ess. 396. Fries syst. IIT. 409. B ria rea Corda apud Sturm III. t.6. Peni eilli i s p. Link. A s per. gilli s p. Michel, nov, gen, $t, 91, f .3,4$. Grev. scot. $t$. 32. Macor ea espitas ns Linn.

226. Penicilliem $L N K$. Sporidia globosa, simplicia, in soros coacervata, fl o c c o r u m septatorum ramulis terminalibus penieillatis adspersa. - In plantis putrescentibus.

Penieillium Fries syst. III. 406, - Penleilliam Link in Berl. Magaz. III. 16. Sp. I. 69. Nees syst. f. 59. Grev. scot. t. 58. - C o r e m i a m Link in Berl. Magaz. III. 19. Nees syst, $f .86$. F1 o e earia Grev, scot, $t, 301$.

23\%. IBotrytis MICH. Sporidia subglobosa, simplicia, ex apicibus ramulisve floc e or $\mathbf{m}$ septatorum emergentia, cirea eosdem conglomerata. - In corporibus variis putrescentibus.

B otry tis Michel, nov. gen, 212. Fries syst. IrI. 393.

a) SPOROCEPHALUM Chev. Sporidia eirea apiees froc cor am simplicium in capitulum laxe conglomezata, dilabentia.

Sporocephalum Ches. paris. 6o. t. 3, f.9. Aela. dii s p. Ehreab. Mucor glomerulosus Bull. champ. t.504. f. 3. - C e p hal o eI ad i um Reieheub, consp, 6. Haplotriehum Link sp. $x$. 59 . non Esehweil. A eladium

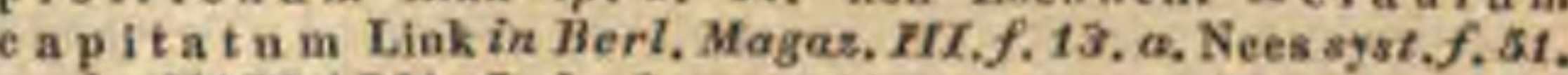

b) HAPLARIA Lnk. S poridia ad latera floceorum, simplicium v. subramosorum, in spicam interruptam congesta.

H a p la ria Link in Berl, Magaz. IIT, 11, Nees syst. $f .49$. Chev, paris. t. 1. f.11. Fum a $\mathrm{g}$ in is s p. Pers.

c) POLYACTIS Lnk. S poridia in apicihus multifidis floce o r um, simplieium v. parce ramosorum, spicata v. eapitato - cougesta.

Pol y a c tis Liak in Berl. Magaz. IIT. 16. f. 22, non spec.

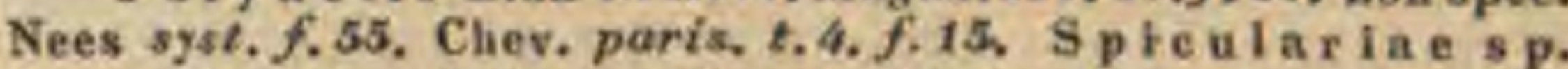
Pers. Verticilliti sp. Khrenb. Link. Macor racemo. s us Bull, champ t. 504. f. t. M. B otr y tis Fl, dan, $t, 777$. f. 1. (Michel, t. at. f. 4.)

d) SPICULARIA. Sporidía eirca apices floceoram umbellatim ramosos spicato - capitata.

Poly a ctis Link spec. I. 62. S pie u lariae sp. Pers.

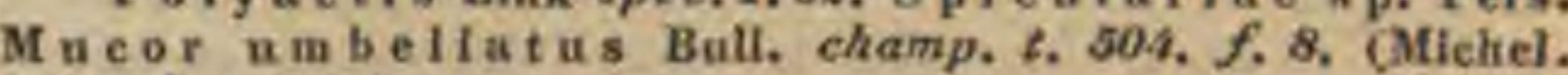
t. 21. $f, 1,2.3$.

e) VERTICILLIUM Nees. Sporidia subsolitaria, in flo c co $\mathrm{ram}$ ramosissimorum ramis suboppositis ver. ticillatisve terminalia.

Vertiellitum Nees syst. 57. f. 55. Link sp. I. 75. Corda apud Sturm III, $t, 8$, B o tr y ti s s p. Link, Nees syst. f.63. - Aa hue 0 n c o cl a d I u m Wallr. Fl, germ. M. 289.?

$f)$ VIRGaria Nees. Sporidia floceorim ramo. sissimorum ramos dicliotomos dense obsidentia.

Virgaria Nees syst. 54 . f. 52 .

238. Staelnylfdium $L N K$. Sporidia globosa, in ramulîs articulatis verticillatis fl o $e$ cor $\mathbf{m}$ septatorum sessilia, collabescendo sporidio I a effandentia. - In plantis putredine corruptis.

Stachylidium Link in Berl. Magaz, III, 16, f. 2t, Nees syst. f.56. Fries syst, 1IT. 389. Grev. reot. $t, 257$. Spond ylo eladi am Mart. erlang. 78. Link sp. $T$, 79. Seeptrom yces et Botry osporin m Corda apad Sturm $I I T, t, 4,5$,

229. Aspergillus MICH. Sporidia globosa, simplicia, in floce orum septatorum apicibus clavatis in eapitulum discoideum seriatim conglutinata, - In rebus variis putridis et siccis.

As pergillus Michel. $6 e n$, 3t2. $2.9 t$. $f .7$. 2. Nees syst. f. 60. Link sp. I. 65. Fries syot, IIT, 383. Corda opud Sturm III. t.7. S porodi a i a Link $s p, I$. 94. Monilliae 8 p. Pers. M u c or is sp. Lina. Ball. ehamp, t.50s. f.3. 10. 
Sowerb, $t, 378 .$, 10. -7 D end ry phion Wallr. Fl.germ. IT. 300 .

SUECEDD III. DEMATIEI Fries syst. III. 335. Sporidia e floce is solidis, corticatis (fibris), continuis annulatisve, subopacis, extus esiata, vel e floccorum dissolutione orta. - In plantarum parlibus siccis.

230. Cliotrielnum ESCHW. Sporidia globosa, simplicia, gelatinae fibris tenerrimis atetate rigescentibus assurgentibus intertextae, immersa. - In foliis arborum tropicarum.

Gliotrich um Fries syst. IIX, 378,- Gilotrichum

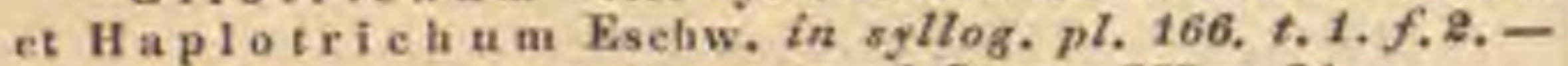
As eimotrie h um Corla apud Sturm III. t.21.

231. Antilerioniesm KUNZ. Sporidia varia, floce is caespitosis, suberectis, annulatis, septis crassiusculis opacis, immixta. I In foliis Glumacearum.

A rth rin in m Kamze myc. Heft. 1, 9. Fries syst. III. 375.

a) SPOROPHLEUM Nees. Sp o ridia oblonga, utrinque acuta, minima. - Spreng. Grunds. t.5. f.3. Link sp. I. 45.

b) CAMPTOUM Lnk. Sporidia ovata, enrvata, minima. - Link sp. $r$. 44.

c) GoniosponiuM Lnk, S poridia tri-polygona. Link sp. $T$. 45.

d) ARTHRINIUM $L n k$. S p or id i a fusiformia, septata, maxima. - Link sp. I. 43. CKunze I. 9. t. 1. f. 4. II. 102.

P3?. VIaerosporivm FR. Sporidia ereeta, stipitata, multiseptata (fibrae transformatae) e mycelio evanescente assurgentia. - In foliis languidis herbarum.

Maerospori a m Fries syst, $I T, 373$. He $1 \mathrm{~m}$ is porii s p. Kunz, Link, Nees in N.A.N.C.IX. t.5. f. 12. S e p t 0s poriu in Corda apud Sturm IIT. 11, t. 17.

233. Cladesporiunan LNK. Sporidia simplicia, seriatim connata, ramulorum instar fib$r$ is apice septatis adnata, demum dilabentia.

In plantarum partibus siccis.

Cla d o s por i m Link in Berl. Magaz. VIT. 37.Sp. I.39. Nees syst. f. 64, B. Fries syst. $I I I$. 368, A cla d ii s p. Link, olim. D e matil sp. Auct. - Azos m a Corda apud Sturm IIT. t. 18.

Z34. Holy Inzin eiman KUNZ, Sporidia didyma, e stromate spurio fibras clavatas annulatas jungente enata, demum fibris inspersa. - In folitis languescentibus Trifoliorum.

Polythriucium Kunze myc. Heft. $T$. 13. t.1. f. 8 . Grev. scot, t, 215. Corda apud Sturm IIT. 11,t. g. Link sp.I. 43. Fries syst. IIT. 367. Farinaria Trlfolli Sowerb. t.396, f. 7 .

235. Dematium FR. Sporidia globosa, simplicia, fibris rigidis, strictis, obsolete annulatis, catenatim glomeratimve adspersa. - In plantarum partibus siccis.

D e m a ti um Pers. disp. 41. Fries syst. MTI. 369. - Chlori d i u m Liak Berl. Magaz, TIT. 13. spec.I. 38. Nees syst.f.64. Chaetops is Grev, scot. $t$. 236. Couo plea et Coelos porium Link sp.I. 46. Cerat on ema Roth catalect.II. 252.p.part. E c h in o b o $\mathrm{r}$ y o n Corda opud Sturm, IIT. t.26.

236. Delmintinosporimm LNK. S p oridia septata, sporidiolis farcta, $f i b r i s$ rigidis obsolete annulatis, basi saepe stromate gelatinoso junctis, sparsim adnata, dein secedentia.

In lignis acrescentibus.

Hel minth os porinm Fries syst. TrI. 354 .

a) HELMINTHOSPORIUM Lnk. Ti bra e sporidififerne.

Helmfnthos porinm Link in Berl. Magaz. $I I T, 34$. Spec, I. 47. Nees syst.f. 65.N. A. N. . . RX. t. G.f.11-13. Grev. scot, t. 148. Corda apud Sturm III, t, 10-14. P o dos po$r \mathrm{i} u \mathrm{~m}$ Seliwein. in Transact. Americ. philosoph, soc. $X V$. t. 19. f. 1 . S a r c o p o d i u mi Corda apud Sturm Irr. 9. t.64. -? S te mi p y 11 um Wallr. Fl. germ, II. 300 .

b) EXosporium Lnk. Sporidia stromati imposita.
Exosporiam Link in BerI.Magas, HI. 9, Sp. IT, 121. exel. sp. Nees syst. f. 30. Grev, scot, $t$. 208. C o a op 1 e a e s p. Pers. - Quid C or y u od es w i u m Wallr. Fl.germ. III. 300 in not. C e phaloedium Kunze ex Reichenb, consp. A.

23\%. Cilelieosporianm NEES. Sp oridia spiraliter involuta, e fibris rigidiusculis apice septatis enata, mox diffnentia. _ In lignis vetustis.

Helicosporium Nees syst, 68. f. Co. Link sp. T. 51. Fries syst. III. 333. Corda apud Sturm III. 11, $t, 15,16$. Hetic o trie hum Nees in N. $, . N, C, T X, 246, t, 5 . f, 15$,

238. Actionoelaulanm EHRENB. Sp (1ridia subglobosa, simplicia, intra fibras apice hi-tri-multilidas vage sparsa. - In truncis vetustis. A e tiuocladia m Elirenb. in Link Jahrb, I. 32. Link sp. I. 51 . Fries syst, IIT, 358.

239. MIyxotriellamen KUNZ. Sporidia simplicia, conglomerata, primitus viscose conglutinata, fibris caespitosis subramosis inspersa. In lignis et corticibus.

Myxotrieh u m Kunze myc. Heft. IT. 108. Fries syst. IIT. 366. Gony triehum Nees in N. A.N. C. IX. 24h. t.5. $f .14$. Link sp. $I, 32$. O n cidlu m Fr. Nees apud Funse myc. Heft. II. 63. t. 2, f.1. Campso tric tr um Elirenb. in Link Jahrb. 1. 32, t. 1. f. 3. Hor, phys, 83, t, 17, f. .2. Link sp. I. 72.

240. Dealematurat $L N K$. Sporidia subglobosa, sporidiolis farcta, e fibris rigidis, simplieibus v, subramosis protuberantia. _ In truncis decorticatis.

Oedemium Link sp. r. 42. Corda apud Sturm IIT, 6. t. D. Fries syst. IIT. $34 \%$.

241. Sporecybe FR. Sporidia simplicia, in capitula fibras snbulatas rigidas terminantia congesta. - In truncis et caulibus dejectis.

Sporocybe Fries pl. hom, 170. Syst. III, 340. P e ricaniae sp. Nees in N.A.N, C.IX, t.5. f.9. R ha codif et Dematii s p. Auet.

\section{APPENDIX. BYSSI.}

Hoc loco aptissime recensenda erunt genera, ab auctoribus e stirpibus eryptophilis, hygrobiis, filamentosis constituta, et ab Algologis, Mycetologis et Lichenologis aeque arrepta, mox iternm repudiata, quarmu natura nobis saltim adeo in obscuro est, ut etsi de vera illarum autonomia ornnino ambigamus, et plerasque pro primordiis Fungorum, Lichenum degenerationibus, productis mere meteoricis et chemicis, vel morbosis aliarum plantarum statibus habeamus, sicco tamen pede in systemate praeterire nolimus naturae hos vegetativos nisus, solerti et physicorum et botanicorum studio commendandos.

SECTYI I. METEORICI Reichenb. consp. 5. Formationes aëreae, vegetatione destitutae.?

a) LANOSA Fr. Fila arachnoidea, fugacissima, haud deliquescentia. - Ad terram post nives, in vervactis post autumnales nebulas.

L a no s a Fries Stirp. Fems. 41, Pl, hom. 317. Chion y $\mathrm{ph}$ e Thienem. mse.

b) HXPHA Pers. Fila arachnoidea, ad tactom deliquescentia. - In cryptis et fodinis, aére hydrogenio ab. undante.

H y $\mathrm{ph}$ a Pers. myc. . 1.4t. Fries $p t$, hom. 318. Link $s p . T$. 141. Mesenterica Pers, synops. 706. Byssi s p. Humb. Frib. t. 2, f, 1, t, $4, f, 18$.

SECYIIC II. FERMENTATORII. Hyalinae, tandem amorphae, gelatinosac.

c) MYcoderma Pers. Fila hyalina, subartieulata, io gelatinam amorpham yel membranam contluentia. - In solutionibus chemicis.

M y coderm a Pers, myc, europ. I. 96. Desmaz, in Art. nat. soc. Linn. Paris. V. 372. t. 4, Bory in Dict, class. XI. 348.

SIECTIT ERT. DESTRUCTORII Reichenb. consp. 5. - E contextu dissoluto plantarum sellularium orti. 
d) MYCINEMA Fr. Flo eci simplices vel ramosi, continui v. septati. - E contextu Fungorum et Lichenum dissoluto, in cryptis.

M y cinem a Fries $p l$. hom. 312. Lepraria Fries $t$. c. a) CAPILlaria Pers. myc, europ. I. 50. Link sp.I. 21.

b) 070 NIUM Link in Bert. Magaz. ILI. 21. Spec, I. 138. R hizomorphae sp. Roth in Usteri Annal. I. 8. t. 1. f. 3. Cerone in at is s p. Pers. B y s s i et $\mathrm{H}$ ima $\mathrm{i}$ tiate sp. Auet.

c) Fibrillaria Pers. op. cit. 1. 52. Link spec, I. 40. Rhizomorphae sp. Auct.

d) ALYTOSPoRiUm Link sp. I. 23. Cart fei um Pers. op. cit. I. 38. Sporotrichi, Byssi, Ozonii et Himantiae sp. Anet.

e) ACRO THAMNIUM Nees syst. $f . r 1$. Link spec. $I$. 27 .

SECTET IV. CELLULARII Reichenb. consp. 5. - E pilis v, cellulis plantaram vaseularimm orti.

e) ERINEUM tink. Flocki slipplices v. subramosi, continui v, subseptati, fiater-ai granulis fareti, eaespitosi. - In folitis et caulibus.

E r i 1 e m Liak spec. I. 146. Grev. in Edinb. philosoph. Journ, 1S12. Jan. p.71. Sehlechtend, in Hegensb. Denkschr. II. 73, ss.

a) TAPHRINA Fr. Flo e ci clavati, inflati, subrotundi, in maenlam sericeani constipati.

Ta phrin a Fries pl.hom.317. Syst. 111 . 520. T a phria Fries obs. It. t. 8. f.3. Grev. scot. t. 33. 141. f. 1 .

B) GRUMARiA Kunz. Flocei elavati, abbreviati, apice collapso cupulaeformes, in maculam grumosam eonglobati.

Gr uma ri a Kunx, mye. Heft, $x$. 137. R ubigo Link in Berl, Magaz, MII. 29. Nees syst. f. 63. (Grev, in Edinb, Journ. t.3. f. 2. 7. 9. 12 14. Crypt. seot. t.141. f.2. t. 280.)

y) PHYLLERIUM Fr. F locei apice atteauati, elongati, in maculam tomentosam contexti.

P h y ll e ri u m Fries obs. II. 271. (Nees syst. f. 62. N. $A$. N. C. IX. t. 5. f. 10. Pers, disp. t.3, f. 2, Grev, Edinb. Journ. t. 2. f. $2-5$. 8, t. 3. f. 3. Crypt. scot, t, 29. 94. 263.

SECTIO W. RHIZOMORPHEI. E sporis germinantibus Muscorum, fibris v. radicibus et radicellis plantarum vasenlarium luxuriantibus orti, partitione $v$, prolificatione multiplicati.

$f)$ PROTONEMA $A_{g}$. Fila radieantia in stratum velutinum contexta. - Ad terram humidam.

Protonema Agardh syst. XXII. Herpotrichum Fries pl. hom. 313 .

g) TOPHORA Fr. Fil a libera septata, in caespitem con. texta. - In cryptis ot fodinis.

Tophora Fries pt. hom, 313. Confervae fodinaa m Agardh. - Plegmati a mies pl. hom. $31 \%$.

h) BYSSUS $t$. Fio e ci artienlati suberecti, eaespitosi, articulis opacis, massa sporace a faretis (2) siccitate fragilibus. - Saxicoli et lignitales colorati.

B y s s u s Liun. gen. n. 1208. Ft. dan, t, 899. $f$. 1 . Fries pl.hom. 309. A mphiconi u meessyst. 69. in not, C hraole p n s Agardh syst.34. S y n coeli in w Wallr. Fl. germ. $I$. 151.? Trentepohlia Mart. erlang. 35t. (E. B. t. 212. 1639. Lyngb, t. 14. $m . n$. F1, dall, t.718, $f .1+)-$ ? Helicomyees Link in Berl. Magaz. TII. 21. Sp. I. 131. Nees syst. f. 37 .

i) RHACODIUM Lnk. Floeci ramosi continui apicibus moniliformibus in globulos (ma 85 a m 5 pora $\mathrm{ec}^{\mathrm{a}} \mathrm{a}$ foventes i) implieatis. - In lignis fabrefactis cryptarum, in regionibus temperatis.

R h a e a d i m Pers. synops.701. encl.sp. Nees syst.73. Link sp. I. 26. Fries pl. hom. 304.

k) RHIZOMORPHA $n$ th. Fib ra e ramosae continuae, fatus stuposae, ramalis turidis mass a sporacea repletis? - In lignis defossis.

Rhizomorpha Roth catalect. I. 233. Eschweiler, Commentatio de fructificatione generis Rhizomorphae. Elberf. 1822. 4to.

SUEDTED सW. MUCORINI Fries syst. III. 2. 96. Sporidia intra tubum floceos u m genita, dein in capitula terminalia, nunc gelatina obvoluta, nune vesi cula (peridiolo) varie dehiscente excepta, collecta. Epiphyti.

242. Cilsosporimm FR. Peridiola membranacea, sessilia, irregulariter tandem hian- tia. Sporidia globosa, minima, gelatinosa, mox diffluentia. F I o c ci obsoleti.

CII sosporium Fries Novit, 1819, p. 80, Syst. III. 334. - Conferva mueoroides Agardh in Vet. Acal. Iandl. 1814, t. 4. f. B. S y n c alle s ia Agardl syst.32.

343. Wunrotiuma $L N K$. Peridiola mem branacea, sessilia, irregulariter tandem hiantia. Sporidia globosa, minima, gelatinosa, in aqua diffluentia. Flo c c i e basi perifloblorum radiantes.

Eurotium Link in Berl. Magaz. 31. f.41. Sp. I. 79. Nees syst. f. 91. Grev, scot, $t$. 164. Fries syst. IIT. 331. P y. robolus Weinm. msc.

244. Melédium ESCHW. Peridiola globosa, persistentia, in ramulis floceorum lateralibus terminalia. S p or i d i a quaterna, pellueida. Flocei solidi, ereeti, ramosissimi.

Melfdium Eschweiler Rhizomorph. 33. f. 10. Fries syst. III. 330 .

245. Azygites FR. Peridiola oblunga, in floccis Iateralia, pedicellos terminantia. Sporidi a in globum compacta. Fl o c c i tubulosi, ramosissimi, intricati, ramnlis assurgentibus.

A z y gites Fries $p l$, hom. 364. Syst. III, 330 .

240\%. Gyzyaites EIRENB. Peridiola in floceis lateralia, sessilia, bina opposita tanden copulata, medio globulam sporidiorum includentia. Flo e ei tubulosi, dichotomi, apicibus post copnlationem increscentes.

S y zy g it es Ehrenb, in Berl. Verhanall. N. Fr, I. 91. t. 2, 3. Link sp., , 94. Fries syst. $T I L .389$.

24\%. A Eroplayton ESCIIJ. Peridiola subglobosa, in floceornm apicibus elavatis sparsa. Sporidia minima. Flocei (epiphylli) solidi, artienlati, ramosi, albi.

Aérophyton Eschw, in Syllog. pt.t. 163, t, 1. f.t. Fries syst, $\{I I .323$.

285. Ceplandeares $K U N Z$. Peridiola ovata, in apicibns floccorum elavatis aggregatim terninalia. S p o ridi a minima. Flo e ei (epiphylli) tubulosi, continui, simplices, adpressi, radiantes.

Cephal e u ros Kunze ex Fries syst. IIX, 397. - ? Di cty o n em a Agardh syst. XXYT, status sterilis.

\$49. Didymoerater $M A R T$. P e ridiola ovato-cylindrica, ore orbiculari aperta, in apicibusfloccorum gemina, sessilia. S po ridia minima. F loc ci sparsi, septati, simplices.

Didy uo erater Mart. erIang. 303. Nov. A. N. C, X. 510. t. 46. f. 8. $8^{*}$ Link sp.I. 100. Fries syst, III. 326 .

250. Diamphora MART. Peridiola cylindrica, opereulo dehiscentia, in apicibus floccorum bifureis geminatim peltata. Sporidia elliptica, globosis mixta. Flo e e i erecti, basi ramosissimi; ramis intricatis, apice septati cernui.

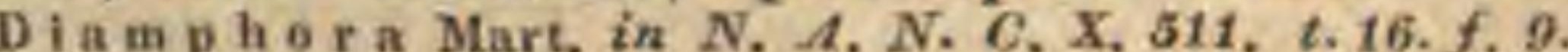
Fries syst. III. 325.

851. Dueor MICH. Peridiola snbglobosa, membranacea, rimose dehiscentia, in floceis terminalia. Sporidia subglobosa, disereta. Flocci tubulosi, subseptati, basi snepe ramosi, apiee indivisi.

M u cor Michel, nov. gen. 215. $t .95 ., f, 1$. excl. sp. Sehmidt Analys. III. t, z8. f.2. Bull. Champ. z. 480. f. 2, 3 . Nees syst. $f .76$. Grev, scot. t. 305. Mart, in N, A.N. C. X. t. 46. $f .1-3$. Fries syst. $I I T, 317$. - T ha m nidion o Lipk in Berl. Magaz, 31. f. 45. Sp. I. 99. Nees agst.f, 75, - T he Ia e tis Mart. in N. A. N. C. X. 509, t, 46. f. 4-7. - Rhi. zopus Ehrenb, Ibid, X, 198, $t, 11$.

252. Crateromyees CORD. Peridinla ovata, hyalina, ore orbienlari aperta, in floceis terminalia. Sporidia snbglobosa, disereta. Flocci septati, simplicissimi.

Cratero m yees Corda opud Sturm III. 2.30. 
253. Hydrophora TOD. Peridiolum globosum, primum aqueum, mox turbidum, tandem induratum persistens, in flocei apice aequali. S p orid ia eonglobata. F I o e c i saepe ramosi, tubulosi, septati, juniores roridi.

Hvdrophora Tode meckl. II. s., t. 8. $f$. 65. Fries syst. IIT. 313. Mucoris 8 p. Linn. Link, Nees syst. f. 77.78 .

254. Pilobolas TOD. Peridiol $\mathbf{u m}$ globosum, induratum, in flocei apice inflato, mox dissiliens. Sporidia discreta. Flo eci tubulosi simplices.

Pllobolus Tode meckl. r. 41. Berl. Schrift. Nat. Freunde III. 46,t.1. Link in Berl, Magaz, IIT. 32. f. 5o. Nees syst. f. 81. Fries syst. IIT. 308, - Gachet in Bullet. soc. Linn. Bordeaux II. 159. Montague, Monographie, Lyon, 1829. c. icc. $\mathrm{H}$ y drog er a Web. Holsat, 110.

255. Aseophorn TOD. Peridiolum suglobosam, vesiculosum, in apice flocei fistulosi, collabescendo dehiscens, tandemq̨ue reflexum pileolare. S poridia subglobosa, peridiolo adglutinata. Flo e ei basi ramosi, apice simplicissimi, septati.

Ascophora Tode mehl. $x$. 13, t. 3. f. 22, excl, sp. Link in Berl. Magaz, IIr, 30, Nees syst, f. 80. Grev, scot, t. 269. Fries syst, III. 309. Pil o pho ra Wallr. Fl. germ, II. 310. Mucoris sp. Auct.

Z56. Plnyeonyees $K U N Z$. P e ridiol $\mathrm{um}$ pyriforme, ab apice flocei aequali artieulo discretum, umbilicato apertum. Sporidia oblonga maxima. F lo e ci caespitosi, fistulosi, continui, nitentes.

Phycomyces Kunze myc. Hefte II. 113. t. . f. 9 . Link sp. . 48, Fries syst. IH, 308. U I v a it en s Agardh.

:5\%. Periecnia TOD. Peridiolnm globosum, vesiculosum, in flocei apice aequali ses-

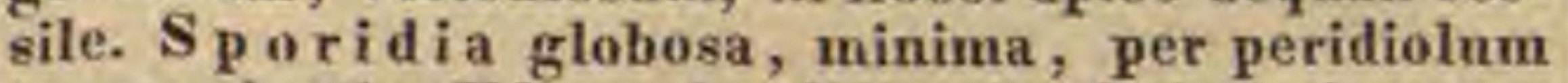
transsudantia. Flo e ei solidi, simplicissimi v. ramosi.

Periconia Tode meckl, I.2, t, 8.f.61. Alb, et Schwein, consp. 357, Fries syst. MI. 307.-? Ch or dos ty 1 a m Tod. op, cit. I, t. 7. f. 53 .

258. Themiegplne CORD. Peridiolum ovatum, vesiculosum, in flo c ci apice aequali sessile, circumseissum, basi persistente. Sporidia in globum mox protrusum, tandem deliqnescentem, compacta. Flo c ei simplicissimi, septati.

He m icy phe Corda apud Sturm III. t.28.

255. Caulogaster CORD. Peridiola ovata, membranacea, echinata, in floccis clavatis lateralia. Sporidia globosa, minima, discreta. (?) F lo e e i solitarii, tubulosi (?) clavati, simplicissimi, flexuosi v. subspirales.

C a u log a st or Corda apud Sturm. IIF, t.3t.

2B0. Sthbuma TOD. Peridiolum gelatinosum, flnxile, stipitem solidum terminans. S povidi a varia, demum nudata. F I o c c i continui, in stipitem contexti.

Stilb u m Tod, meckl. I. 10. t. 3. f. 16-21. Nees syst. f. 88, 89. Hoffu, $F \%$. germ. II. t, 10. f. 2. Dittm. apud Sturm. III. t, 45, 46. 28. 59, 60. Grev, scot, t. 281. Desuaz, in Annal. sc. nat. XIX. 1. 18, f. 1. Fries syst. IHT. Cili i i p o d i n m Corda apud Sturm IIT. 8.29 . Atracti um Liak in Berl. Magaz. IIT, 10, f, 11. Nees syst. f.34.

261. Calyssosporivan CORD. Perid i ol n m membranaceum, terminale, stipiti pervium, demum lacerum. Sporidia globosa, compacta. Stipites heterogenei, rigidi, simplicissimi, annulati, subsolitarii.

CaI y s sosporinm Corda apud Sturm IIT. t, 27.

SUEARDO $\mathrm{V}$. CEPIIALOTRICHEI Nees syst. I. 84. Flocci in stroma (receptaculum) verticale vel horizonlale coaliti. S p o r idia e stromate enata, simplicia, libera.
RBS. Ceratiman A. SCH. Receptacu$1 \mathrm{~nm}$ subeornutum, mncilaginoso-fluxile. Sporidia floceis receptacnlum obtegentibns inspersa.

Ceratium Alb. et Scliwein. neisk, 359. $t$. 2. f. 6. 7. Liak in Berl. Magaz. MI. 19. Sp. IT. 118. Nees syst. $f$. 82. Grev. scot. t. 168. Fries syst, $H$. 294.

283. Epielhysian TOD. Receptacu$1 \mathrm{n} \mathrm{m}$ hypocrateriforme, e floceis ramosis contextum. Sporidia floceis ramosis, receptaculo intus adnatis, affixa.

Epichysium Tode meekl. IT. 1. $t$. $8 ., f$. 60 . Alb. et Schwein. neisk. 356. Nees syst. $f_{4}, 90$. Fries syst, $I I I .293$.

264. Dnerina FR. Receptaculum eaespititium, e floceis conglutinatum, in ramulos articulatos, proliferos, rigidos abiens. Sporidia globosa, superficiem glabram vestientia, mox secedentia.

Dacrina Fries pl. hom, 172. Syst. IIT. 291. Mero. sp ori um Corda apud Sturm III, t, 23.

265. Seorias FR. Receptacnlnm (2pedale) e fibris rigidis botryoso-ramosis continuis, gelatina conglntinatis, ambitu compactioribus, formatum. Sporidia maxima e ramulis fibrillosis.

$\mathrm{S}$ corias Fries $p l$. hom. 17t. Syst. $I I T .290$.

266. II Y peelhnass FR. R e e e p t a $\mathrm{c} u \mathrm{Iu} \mathrm{m}$ planum expansum, e floceis contextum, subprninosum. Sporidia floceis, in globulos villosos adspersos intrieatis, eincta.

H y p o ch in us Fries obs. IT. 28I. Syst. IIT. 289. Elirenb. in Hor. phys. 86. t. t7. f. 3. Fée crypt, cort. t. 5. f. 1. -? Triclini um Fee erypt, cort. 147. t.34. $f .1$.

26\%. Peadbotryon FR. Receptaculu m rotundatum, sublobatum, e floceis tenerrimis laxis intricatissimis. Sp o ridia in floceis periphericis, ramosis, racemosu-congresta.

Peribotryon Fries syst, IrT. 287. B y s ins Pavoni Duf. (Cfr. Montagne in Nouv. Annal, sc. nat. II. 375. t. 16. f. 2.)

268. Anthina FR. Receptaculum verticale, elongatum, stipiti rigescenti attenuato continuum, apice dilatatum, e foccis septatis parallele constipatis laxe contextum, floceis apice liberis plumosum v, villosum. Sp o ridia inspersa, rara.

Anthina Fries $p l$. hom. 160, Syst. IIT. 281. C e rato. ne mat is 8 p. Roth catalect. II. 253. t. 3. f. 1. t. 8. f. 2. Pteral a Fries in Linnaca III. $331, t, 11.6 .4$.

269. CefolnaIotrielnume $L N K$. R e e pta cu I u m stipitiforme, subnlatum, rigidum, capitulo discreto e fluceis contortis. Sporidia globosa, floceis eapituli interspersa.

Cephal otrichum Link in Berl. Magaz, Iir. 19. $S_{p}$. 1I. 111. Nees syst. f. 87. Fries syst. III. 280. Pericon ia Alb. et Schw. neisk, t. $4, f, z . \mathrm{E} \mathrm{m}$ b o I u s Hall. Helv. z. 48. f. 1 .

270. Isaria PERS. Receptaculum elongatum, subclavatum, e fleceis dense intricatis coalitum. Sporidia floccis patentibus, receptaculum obtegentibus, inspersa.

Is a ri a Peps. synops, 6.37. Fc, et deseript. t. 3.f. 1. Nees sjst. f. 83-85. Dittu, apad Starm IIT. t. 19. 37. si -sz. Grev, scot, $t, 3$. Link sp. IT. 112, Fries syst. III. 270, $-\mathrm{A} \mathrm{m}$. phieorda Fries pl. hom. 170. (Chev, in Journ. Phys. 1822. t. $1 . f .5$.

\section{Ordo XIV. Giasteromycetes.}

GASTEROMYCETES Fries $p l$.hom. 19s. LYCOPERDACEAE ef CraturaceaE, Brongn. in Dict.class. IX, 54t. IV, 190.

Fungr e cellulis coneretis determinati, in formam rotundatam tendentes, primo clausi, deinde irregulariter rumpentes $\mathbf{v}$. ostiolo aperti, massa interna demum fatiscente v. deliquescente, fructificante. Integumentum (peri- 
dium) varium, contextu subvesiculoso; simplex v. duplex, rarius multiplex. Sporidia libera, distincta, in centro collecta, v. immersa et concreta, floceis inspersa vel receptaculis propriis (sporangiis) excepta.

Gasteromycetes plerique in corporibus putredine corruptis viventes, elegantissimis formis scrutatoris admirationem excitant, nune sub terra nati, gulosis aphrodisiacum effodiuntur ferculum. Phalloidei foetidissimi, nauseosi, venenati, Lycoperdei in officinis recepti. - Ordinis diagnosis posita est in peridio, i. e. receptaculo primitus clauso, sporidia nuda, nec ascis inclusa colligente.

SUBBDHDO I. PERISPORIACEI Fries syst. III. 220. Peridium subglobosum, e vesiculis obscuris compositum, persistens, apice dehiscens, pulpa subgelatinosa hand diffluente farctum. $\mathrm{S}$ p orid ia in centro collecta, pulpae immersa, simplicia, libera $\mathbf{v}$. peridiolis inclusa. - Fungilli gregarii, paucis subterraneis exceptis, epiplyyt, minimi, lente crescentes, diutius persistentes, vernales et aestivales, pauci autumnales.

TIIISUS I. APIOSPOREI Fries syst. III. 224. Peridium thallo vestitum, hic ergo obsoletus. - Minimi, epiphyti.

271. HLsporinam MART. Peridinm gelatinosum, fatiseens. Sporidia globosa, pellucida; peridiolo hyalino eincta. - Fungilli gregarii, rubentes, plerumque in Lichenibus parasitici.

III osporium Mart. Fl, erlang. 325 Fries syst. III. 258, Lichen roseus Schreb. $-F l$,dan, t, 1243. f.1, Pal. nt ell a ros e a Lyngb. Grev, scot. $t, \not s t$.

2\%. Selerococeum FR. Peridium subcorneum, nudum, superne exesum. Sporidia globosa, opaca, inter se et cum peridio in tuberevulum connata. - Fungilli gregarii atri, in crustis Lichenum parasitici, diu pro Lichenum apotheeiis habiti.

Selerococeu m Fries $p^{l}$, hom, 179. Syst. HT. 257. S piloma sphaerale Aehar. - 2 0 stracoecum Wallr. Fi. germ, Ir. 261 .

2 3 . Coníosporiana LINK. P e rid i u m firmum, rotundatum, extus pulvere grmmoso conspersum. Sporidia minima, opaca. - Fungilli opaci, atri v. alivacei, in lignis pineis fabrefactis, et gramimum culmis emortuis crescentes.

Con i o sporin m Linh in Berl. Mngaz, IIT. 8. Nees syst. f. 22. Fries syst, 1II, 2sa.

2 24. A piosporium KUNZ. Peridium firmum, pyriforme, extus pulverulentum. S p o r idia globosa, pellncida, pulpae gelatinosae immersa. - Fungilli opaci, olivacei, in acervulos collecti, in lignis emortuis nati. 255.

A piosporiu in Kunz. mye. Hefr, I. 8. Fries syst. III.

2ร5. Chaetomatam $K U N Z$. Peridium membranaceum, subglobosum, pilis opacis vestitum, demum medio aperium. Sporidia simplicia, pellucida, gelatinae immixta. - Fungilli gregarii, nigricantes, diversis plantarum partibus superficialiter adnati.

Ch a e to m i u munze myc. Heft. I, 15. Fries syst. IIt. 253. (Grev. scot. t, 230 ?) V a nhalli a Marchand Crypt. Luremb. 26t.

OBSERvatio. Guid Cojlacystis Knnz, et Podo strom bi u u Kunz, boe loca a cl. Reichenbach Consp. p. 8. nominatae.
TEEIRUS TI. PERISPORII Fries syst. III. 223. Th a 11 u s eflusus, dissolntus, floceosus, raro obsoletns. - Minimi, epiphyti.

296. Perisporium FR. Peridium subearnosum, nudum, apice dehiscens, collabesceado-umbilicatum, intus subgelatinosum. S p oridia globosa, pulpae immersa. - Fungilli epiphylli $v$. caulicoli, superficialiter adnati $v$. liberati, thallo nullo $v$, maculari.

Peris porium Fries $p l$. hom. 161. Syst. 111 , 248. Peziza e s p. Alb. et Seliwein. neisk. $t, 12, f . z$.

2ร ช. Teysibe REBENT. Peridinm carnosum, globosum, apice dehiscens, collabescendosnbumbilicatum, peridiolo solitario v, pluribus repletum. Sporidia saepius sporidiolis referta. - Fungilli minimi, in diversis omnium fere plantarum vascularium (Con if eris, Ericine is, succulentis et aquaticis exceptis) partibus vivis, superficiales, libere evoluti; thallo floccoso, nonnisi rarissime deficiente insidentes.

Ery siphe R. Hedw. ex DC. Fl. franc. II. 8z2. Fries syst. HI. 234. Exy s i b e Rebent. neomarch, 360. Link sp. $\boldsymbol{X}$. 100. Ehrenb. in N. A. N. C, X. 21.

a) AERISMA, Thallus nullus. Facies Perisporii,

Erysiphe detons a Fries syst. III. 247.

b) PODOSPHAERIA Kunz. Tha11 us nullus, ejus loco fulerum e peridio ortum, horizontale.

Podos plia ería Kunz. myc. Meft. II. $11 t$.

c) ALPHTTOMORPHA Wallr. Thallus floccosis; prae. terea saepius pili fulerantes e peridio egressi.

A I phitom orph $\pi$ Wallr. in Berl. Verhandl. $I, 31$. (N. A.N, C, X. t, 12, 13, Grev, scot. t, 134. 296.)

288. Cusiolootreys SPR. Peridium carnoso-corneum, globosnm, nudum, apice collabescens, p eridiolo solitario, massa granulosogelatinoso repleto, farctum. Sporidia globosa, s poridiolis repleta. - Fungilli aggregati, nigricantes, in Lonic erarum folits vivis superficiales $v$. epidermide secedente liberati, thallo e fibris simplicibus, radiantibus, interdum tamen obsoleto, fulti.

Las 1 o botrys Spreng. ex Kunz. myc. Heft. II, 88. Grev. scot. $t .191$. Fries syst. III. 233.

2 ช 3. IIYxotheciam $K U N Z$. Peridium tenne, rotundatum, apice dehiscens, subdepressum. Sporidia simplicia, globosa, pulpae gelatinosae immixta. - Fungilli tropici, nigricantes, ple rumque hypophylli, libere evoluti, superficiales, caespitosi, peridia fibris simplicibus, continuis, e stromate subgrumaso exsurgentibus suffulta.

M yx otheci um Kunz. ex Fries syst, III. 231.

280. Antemmalaria REICH. P e ridin subcornenm, rigidnm, indehiscens, ant demum lacerum v. friabile. Sporid ia submoniliformi-coneatenata, pulpae gelatinosae immersa. - Fungilli fusco-nigri, in ramis vivis et emortuis viventes, nonmulli cryptophili, thallo nigricante, e floccis ramosis haud continuis dense intricatis, septatis v. moniliformibus contexto, interdum amplissimo, laxo.

A n ten a ari a Libk in Schrad. N. Journ. ITI. 16. f.97. Nees syst. f. 228. Fries syst, III, 228. An te n 1 ula $r$ ia Rejelient. consp. 5. (? R a codi $\mathrm{mm}$ cellar e. Pers. Nees syst. f. 70. Grev. erypt, seot, t. 289.)

SUBOTHO II. SCLEROTIACEI Fries pl. hom. 153. Peridium carnoso-vesiculosum, cum massa interna sporidia fovente connatum, undique v. solo apice fructificans, intus solidum, similare. Sp oridia connata, contextum fere omnem intra corticem constituentia, alia demum libera, subemergentia.Fungi plerumque parvuli, brumales el hiberni, 
prioris tribus epiphyti, posterioris hypogaei, epirrlisi.

TIRIBETS III. SCLEROTIEI Fries $p l$. hom. 157. Peridium confusum, semper clansum, intus obscure vesiculosum, sporidiferum. S Poridia demum emergentia.

281. Selerotium TOD. Peridium subrotundum, cartilagineo - carnosum, intus similare, cortice tenuissimo, membranaceo, inseparabili, Sporidia pruinatim undique emergentia v, obsoleta. - Fungi parvuli, durissimi, glabri, gregarii, liberati $v$. adnati, thallo nullo, interdum tamen subiculo villoso sustenti, epiphyti, lignatiles, fimicoli v. rarius subterranei.

Selerotium Tode meckl. I. 2. DC. in Mem. Mus. IT. 401. excl. sp. Fries syst. II. 246.

a) POMPHoLXX, E pi p la 11 a. difformia, bullata, fus cescentia, contextu subpulveraceo, imata, saperue cum epidermide nunquam rupta, basi applanata snbconcreta.

X y lo m a Link in Berl, Magaz. KIT. 35. Nees synops. 73. Selerotium X y Ioma Fries syst. $I$. 261. Pezizat s p; Abb. et Schwein. neisk. t. 12. f. 5. (DC, op. cit. t. 14. f. 8 , Fries observ. II. t.7. f. $5, a, b$. Grev, seot, t. 77,)

b) PHLXCTENE. Eatophyta v. ea ulicola, nigra, intus albida, solida, glaberrima, saperficialia, basi adnata, nuda v. uatricis epidermide secedente tecta.

Selerotia $5 \pi$ a a d ata Fries $t$. $c$. Nees syst. $f .138$. DC. op. cit. t. 14. f. 3. 5. 7. Grev. scot. $t$. 1 .

c) CoccopleUM Ehrenb. Epiphyta, varia, primum inclusa, dein erumpentia, sublitera, globosa v. depressa, glabra.

C o ceople u m Ehrenb. sylv, mycolog. 27. S cle rot a er um pentia Fries l. c. DC. op, cit. $t$. 14. $f$. 2 .

d) SPERMomorPhiA $L_{k}$. E p i p h y a, uula, subregularia, glabra, primum mollia, pallida, demum nigricantia, undique libera, extus fruetificantia.

Spermomorphia Link in Berl. academ. Abhandl. 1834. p. 178. Sclerotia libera Fries $l$. $c$. Nees syst.

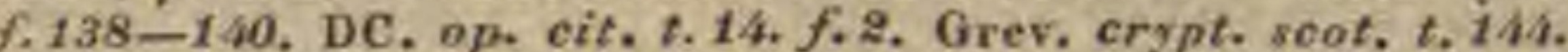

c) RHIzogoniA. Epirriza, v. in Muscis, Fangis alisve plantis putreseentibus orta, glaberrima, difformia, plerumqus lobata, immutata, vix fruetifieantia.

$\mathrm{S}$ cl eratia Iibera S. 11 . Fries $k$. $c$. Nees syst. $f i 136$. 137. Biv. stirp. rar. IV. t. 6. f. 1. 2. Grev. scot. t. 101.

282. Dryophilum SCHWEIN. Peridinm pezizaemorphum, disco depressiusculo $v$. umbonato, intus similare, cortice durinsculo glabro v. fibris erassinsculis densis tecto. S poridia...

Fungi parvuli, in foliis Quercu $\mathrm{m}$ bor ealia mericanarum sparsi, spredicei, sessiles $v$. papilla basilari stipitati. _ Genus vix notum; an revera hujus loci?

Dry o philnm Schwein. in Transact. Americ. philosinphic. Soe. IV. 268 .

283. A erosperranan TOD. Peridi n m elongatum, snbclavatum, sacpe stipitatum, cartilagineo - carnosum, intus similare, cortice tenuissimo, membranaceo, persistente. $S$ por id i a ex apice demum intumescente pruinatim emergeniia. - Fungi minuti, rigidi, tenaces, plantis emortuis, imprimis $A g a r i c i s, b a s i$ subadnali.

A crospermum Tode meekl. $r$. 8. $t$. 2. f.13. Fries syst, IT. 244. Grev. scot, t.182. X y Iog Iossu m et ScIerogloss um Pers. Clavariae sp. Pers. clavar. N. 3 . f. 4 .

284. Fisstullatia FR. Peridium elongatum, cylindricnm v. subclavatum, laxe carnosnm; intus similare, cortice tenuissino, membranaceo, persistente. Sporidia ex apiee prninatim emergentia. _ Fungi exiles, carnosi, tenues, epiphyti. ficnus a praecedente vix distinctum.

Pistillaria Fries syst. $T$. 496. Elech. $T$. 136. Pliacorrhixa ers, mye, estrop. T. 193. excl. sp. Clavariae sp. Hotfu. crypt. t.7. f. 2. Sowerb. $2.33 \%$. f. 1. Pers. clavar. t. 3. f. G. Nees syst. $f$. 15/. Grev. sent. $t .82$.
285. Periola FR. Peridium rotundatum, carnoso-gelatinosum, intus similare, cortice in villos persistenteg fatiscente. Sporidia obsoleta, ubique in ambitn dispersa. _ Fungilli gregarii, libere evoluti, in radicibus et Fungis putrescentibus viventes.

Periola Eries syst. TI. 266. Selerotium hirsut $\mathrm{m}$ Flor, dan, t. 1320. - Chat ostroma Corda apud Sturm III, t. 61.

284. Aeinula FR. P e rid i m globosum, farinaceo-granulosum, diffnens, nuclenm conformem discolorem, vesiculoso carnosum, persistentem includens. S paridia . . . Fungillus minutus, cortice candido, nucleo fusco, intus pallido, ad folia putrescentia inter nives deliquescentes repertus.

A einula Fries syst. II. 2or, M y $x$ omphalos Wallr. Fl. germ. II. 320 .

TEIIBIS IV. RHIZOGONEI Fries $p l$. hom. 153. Peridium libere evolutum, intus obseure loculosum. Frnetific a $t$ io saepe obsoleta. - Terrestres v. subterranei, epirrhizi.

28\%. Anixia FR. Peridium irregulare, subglobosum, carnosum, intus lemum cavum, apice dehiscens. Sporidia simplicia, pulpae carnosae hine inde immersa. - Funrus semunicalis, sessilis, $v$, basi in stipitem attenuatus, villosus, albus, thallo contexto - floccoso in humo radicans.

An $1 \times$ in Fries in Petense. Academ. Handl. 1819, P, 111. Syst, III, 296.

289. Nlylitta FR. Peridi um globosum, induratum, extus verrucoso-furfuraceum, massam siceam heterogeneam corticans. Sporidia in maenlis difformibus, indeterminatis, discoloribus, primum subgelatinosis, demum siccis, subcorneis, massam internam variegantibus, nidulantia. _Fungus subterraneus, fulvus, fibrillis $R$ o b in ia e Pse udaca cia e radicibus adhaerens.

M y litta Fries pl.hom. 15/. Syst, IIT.225.-? S p la a c b. n a m y ces Corda apud Sturn $I I T, \varepsilon, Z$.

28D. Floizoetonia $D C$. Peridium difforme, varium, cartilagineo-carnosum, intus similare, cortice tenuissimo membranaceo inseparabili, fibris radiciformihus byssoideis, ex angnlis emissis, plura indivitua conjungentibus. F r u et i f i $\mathrm{ca}$ tio....-Fungi subterranci, libere evoluti, radicibus diversarum stirpium incumbentes, easque enecantes.

Rhizoctonia DC. Mem. Mrus. Tr. 216. Fries syst. II. Elench. $I T .43$.

a) BRYOCHISIUM Lk. Intus obscure tetraëdro-cellalo. sam. - Ad radices Muscarum.

B r y o e h ts in Limk Handb. ITr. alt. - A llos p h e$r \mathrm{in}$ m Liak in Bert, academ. Abhand, 1834. p. 178. Rh i. octonia mus corum Fries.

b) THAXATOPHXTUM Nees, Adultum sporangiolis instructum? - dil radices plantarum perfectiorum, imprimis cultamu, in bubbis Crocorum et in taberibus ipomovae Batatas famosum.

Thanatophytum Neessyst. $f .135$. (DC. op. cit.t.8.)

850. IPaclayana FR. Pè ri i um difformi suliglobosum, lignoso-squamosum v. twbereulosurn, n u c l e u carnoso-suberosum, similarem, corticans. F r a t if i e t in.... Fungi maximi, subterranei, elimatum ealidiorum, vix noti, a $M a l$ a $y$ is, Sinis et Americae borealis autochtonibus ob vires medicas laudati.

Pachy u a Fries syst. IT. 242. T u ber $r$ eg in m Rnmph.

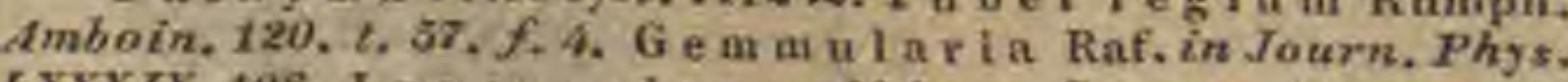
LXXXIX, tob. Lye a per do n solid a m Gronov. (Transace. Linn. sac. XII. 368,

SUBDFEO ITI. TRICHODERMACEI Fries syst, HI. 200. Pe ri di n $\mathrm{m}$ varium, e floccis plus minus laxe contextum, raro mem- 
branacenm, fugax. S poridia sub peridio in strate peripherico aut discoideo coacervata, simplicia, pulveracea, plerumque compacta, nullo capillitio genuino intertexta.

TRIBUS V. AEgERITEI. Fungi sessiles subsphaerici, peridio fere obsoleto; sporidis compactis, haud diseoideis. Genera vix nota.

291. Anphisporium $L N K$. P eridium subglobosum, demum complanatum, membranaceum, tenue. Sporidia globosa sub peridio peripherica, alia in centro collecta fusiformia. - Fungillus veriscolor, ad bulbos Tulipae, in aqua germinantes, semel observatus.

A mph is porium Link in Berl. Magaz. VIT. 40, Fries pl. hom, 150 .

292. Aegerita PERS, Peridium subglobosum sessile, tenuissimum, fatiscens. Sp oridia globosa, receptaculo grumoso laxe incumbentia. - Fungilli gregarii, lignatiles, farinacei, peridio squamuloso-fatiscente.

A ege rita Pers, disp. 10, Nees syst, 30. f. 24. Grev. scot, t, 268, f, 1, Fries syst. MII. 219.

293. Dielhosporium NEES. P e rid in m rotundatum, difforme, membranaceum, strato granuluso corticatum. Sporidia ovata, conglobat3. - Fungillus corticola, albidus, subconfluens. Genus maxime dubium, an Conopleae status?

Dichosporium Nees synops, 62, Syst.f, 99. Fries syst, LIT, 218.

294. Wralterophora. Peridium subglobosum, tomentoso - glanduloso subvillosum, appendicibus setiformibus auctum, intus pulveraceum. S poridia... - Fungillus corticola, fulvus, vix notus.

Tip ularia Chev, Fl, paris. 7. 344. Journ, Phys, 1829. t. $1 . f .3$. Fries syst. $I I I, 218$,

TREEUS VI. TRICHODERMEI Fries syst. III. 202, R e ceptaculam effinsum v, nullum. - Peridium evanescens. Sporidia discoidea.

295. Myrotheeium TOD. Peridium indeterminatmm, e fluceis delicatis laxis contextum, apice fatiscens. S p oridt a minima, globosa v. elliptica, primum pulposa, demum in disenon coacta. Epiphyli, fimicoli.

My r o the ei am Tode fung. meekt. I. 25, f. S. f.38, excl. sp. Dittm. apud sturm IIT, t. 3, 4 . Nees iyst. f. 98 . Grev. scot, t. 140. Yries syst. IIT. 216, Fl,dan, t, 2083, f.1.

296. Asterotlaecium $W A L L R$. Peridi um subglobosum, tenuissime membranaceum, pilis septatis adpressis strigosum, demum apice collabente scntellato-deplanatum. S p o ridia globosa, ambitu vesiculifera, angulato - stellata, libera super discum effusa. - Ad terram glareosam.

Asterotheefu m Walrothmse. 18f6. Stephano ma Wallroth $F l$. germ, IT. 669 .

29ซ. Triehoderma PERS. Peridinm indeterminatum, subrotundum, e floceis septatis, ramosis, laxe contextum, haud discretum, evanescens. Sporidia minima, sicea, in diseum conglobata, floccis immixtis. - Fungilli polymorphi, compacti, in plantarum partibus emortuis et ad res varias putrescentes nati.

Trich od erma Pers. disp, 12, excl. sp. Nees syst. f.74. Grev, scot, t, 27t. Fries syst. IIT. 215.

298. IIyphelia $F R$. P e rid inm effusum, indeterminatum, e villo in pelliculam fragillimam cohaerente contextum, primo discretum, demum evanescens. Sporidia laxa, coacervata, floceis haud intertexta. - Fungilli lignatiles v, raro terrestres, thallo radiante plerumque fultt.

H y phelia Fries pl, hom, 149. Syst. IIT, 211. Trieho. d ermatis s p. Fers. obsgmyc. I. t. . f. $f .8$.

299. Dstracedlerma FR. Peridium rotundatum, crustaceum, glabrum, tenue, fragile, medio fatiscens. Sporidia laxa, coacervata, floccis haud intertexta. - Fungus albidus, thallo nullo conspicuo, solo inter Muscos impositus.

Ostracoderma Fries pl. hom, 150. Syst. III. 213.

TREIBUS VII. ONYGENEI. R e e ptac ulu m capitatum, superne floceis velatum. Sporidia subperipherica.

309. Institale FR. Pexidin m eapituliforme, sessile, intus solidum. Sporidia in strato supero peripherico, villo fugaci tecto. Thallus fibroso-membranaceus, liber, radiatim expansus. Fungi elegantes, fusci, ad truncos arborum reperti, soli Sowerbeio cogniti.

Institale Fries syst. $T H$. 210. L y coperdon a ea$r$ if orme et radiatum Sowerb, $t, 145,146$.

301. Dnymena PERS. Peridium eapitatum, stipitatum, e floceis contextis corticatum, varie ruptum, demum evanescens. Sp o ridia rotundata, in stratum dense compactd. Thall us nullns. - In animalium exuviis, rarius in truncis reperti. Genus verisimiliter dividendum.

On y gen a Pers, obs, II, 71, t, 6, f.3. a-c. Desv. Journ. Bot, IT, 30, t.2. Nees syst, f. 121. Fl, dan, t, 1309,f.1. Ditm. apual Sturm IIT, $t, 18$, Grev, scot, $t, 343$. Chev, paris, $t, 8$, $f .8$. Fries syst, $I I T .206,-\mathrm{P} i 1 \mathrm{ig}$ e a a Scham. Fl. sael, $I$, 211. Fl, dan. $t$. 17ho, $f$, 2 . H y p o e h a e a Fries syst. $I I T$. 209. - P h le og e na Link Handb. IV. 396.

302. Asteropliera DITTM. Perid ium eapitatum, a stipite discretum, e floccis contextum, apice indeterminate rumpens, demum evanescens. Sporidia angulata, in stratum superum dense compacta. Thallus nullus. - Fungilli gregarii, meteorici, in Agaricis putrescentibus viventes, contextu fibroso; nondum satis explorati.

Asterophora Dittu, in Sckrad, n. Journ. III. 3. p.56, t.2. f. 2. Sturm IIT, t, 26. Fries ksst. IIT. 205. F в ago id a s tri sp. Miehel, nov. gen, $t, 82, f .1, \mathrm{Ag}$ ariei s p. Bull. $t, 519 . f .1$. Nees sjst. $f, 194$, Sowerb, $t, 279$,

303. Pillacere FR. Peridi um capitatum, stipitatum, ad insertionem stipitis umbilicatum, tenuissime membramacemm, apice fatiseens. S poridia ovata, in stratum superum dense compacta. Th allus nullus. - Fungillus gregarius, lignatilis, antumnalis, capitulo lenticulari, primo incarnato, demum fusco.

PiIacre Fries aysc. TII, 204.

304. Spadonia FR. Peridium fugax; receptacul um stipitatum mitraeforme, diseretum, superne rugesnm. S poridia in stratum supernm, pulveraceum, tenax, dense compacta. Th a 11 us radienlosus. - Fungus brasiliensis tropicus, phalliformis, stipite celluloso-reticulato.

Spadonfa Fries afst, $I I, 203$. 2 Foetidaria St. Hil. in Nouv. Ann, sc. nat, II, 191.

SUROIRD IV. TRICHOSPERMEI Fries syst. III. 1. Pe rid i m genuinum, continuum, plerumque duplex, demum dehiscens, sporidia effundens. S p oridi a nuda, majuscula, subglobosa, pulveracea, in centro coacervata, laxa, floccis plus minus effiguratis intertexta v. distincta. Contextus subvesiculosus.

SECTIO I. MYXOGASTERES Fries syst. III. 67. Primum mucilaginosi, fluxiles, 
demum varia metamorphosi effigurati. $-\boldsymbol{R} e$ gionum imprimis temperatarum cives, plu rimi meteorici.

TEEIBIS VIII. TRICHIACEI Fries syst. III. 76. M u cil a g o primaria plura peridia discreta conjungens. Floc e i liberi, intorti, elastiei.

3๑5. Cirrlaollas $M A R T$. Peridium simplex, globosum, membranacenm, demum irregula riter ruptum, enl um ella spirali, elastice prosi liente. Sporidia minima, globosa, floceis haud intertexta. - Fungillus pallide flavus, $c$ rimis lig norum Brasiliae tropicae seriatim propullulans.

Cirrholus Mart, in N.A.N. C. X, t. 46. f. 10. Fries syst. ITI. 199.

306. Tieea $S C H R A D$. Perid in varium, tenue, membranaceum, laeve, irregulariter dehiscens. Sp oridia esacervata, laxa, nullis floccis intertexta. - Fungilli polymorphi, lignatiles, thallo mucilaginoso saepe acervatim conjuncti.

I te a Schrad, nov, gen, I. 16. Fries syst. IIT. 193.

a) PHELoNitis Chev. Peridia sparsa, rotunda, miniua, punctiformia.

Phelon itis Chev, paris, III, 198, t, 9. f, 21. 2 M y ro po ri u m Corda apud Sturm IUI. t.32.

b) SERPULARIA Fr. Peridia distineta, basi applanata, varia, saepe serpendo elongata.

Se rpularia Fries 2.c. (Schrad. l.c. t,6.f.5. 6.)

c) TuBULiNA Pers. Peridia stipato-connata, vertiealiter elongata, macilagine juncta.

$\mathrm{Tubnlina}$ Pers. disp. 11. Tu bulifera Gmel, syst. Dermodium Nees syst. $f$. 103. S phaerocarpi sp. Bull. t. 38\%. 47o, f. 3. Re ticula ri a e s p. Sowerb. t. 199. (Nees syst. f. 102. Grev. scot. t.308.)

398. Perielnaena FR. Peridium varium, simplex, submembranaceum, persistens, nudum, demnm saepe circumscissum. Sporidia 1luceis raris liberis immixta. _ Fungilli lignatiles, aggregati, persistentes, plerumque subglobosi, imprimis autumnales.

Perie hate ua Fries syst. rIT. 190. Grev, scot. $t$. 252. 975. Fl, dan, t, 209i. f.3. S p hate roearpi s p. Bull. $t .417$. f.5. Sowerb. $t .258$. T ric thine s p. Pers. obs. I. t.6. f. 1.2. Lic e a e s p. Anct. Nees f. 101. Dittm. apud Sturm III, t, 20 .

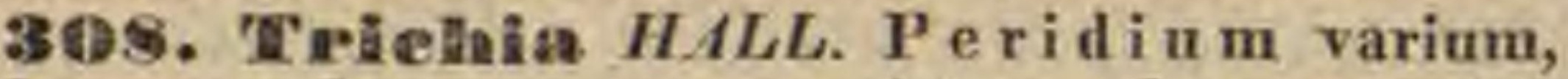
simplex, membranaceum, persistens, demum apice irregulariter ruptum. Spo ridi a capillitio dense implexo, floceis rersus basim adnatis intortis sese elastice expandentibus, inspersa. - Fungilli lignatiles, plerique autumnales, hubitu vario.

Trieli ia Hall. Helv, III, 114, excl. op. Fries syst. ITr. 182 .

a) GONIOSPORUM $L k$. Perid 1 a $\mathrm{m}$ irregulariter ruptum, e ap illiti m laxiusculum. S p oridia obsolete angulatii, saturate flava. Sessiles, primum albae, mox favae.

Go ni os por um Link in Schrad. n. Journ.1809. p. 18. M u eilago Michel, nov. gen, t.96.f. 4. S p ha e r o c a r p i sp. Bull. t. 417. f. 2. 4. (Pers, ic. et descript. t. 12. f.1. t. 14. f.3, Nees syst. f, 11, $-F l$. dan, $t, 1313 . f .1-3$. Grev. scot, $2,266$.

b) HEMIARCYRIA Fr. Peri dium irregulariter eircum. scissum, eapillitio prominente. Sporidia glo. bosa, fulva v. rubentia. Stipitatee, rubree.

H e miarc y $r$ i a Fries syst.TIX.183. (Sowerb. $t .400 . f . b$.

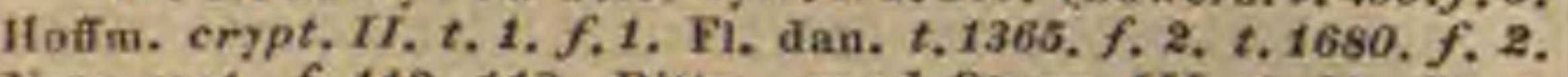
Nees syst. f. 112, 113. Dittm. apud Sturm $I I T, t, 25$. Chev. par. t, 9. f.24.

309. Areyria HILL. Peridium varium, simplex, tenue, membranacem, circumscissum, parte superiore fugaei, inferiore saepe persistente. Sporidia capillitio dense implexo, floceis e basi ascendentibus contortis, elastice expansis, inspersa.

Fungilli gregarii, lignatiles, hygrophiti.

A e y ria Hill. hist. 47. Fries syst. ITr. 1s7.

a) LACHNOBOLUS Fr. Peridium tenerrimum, totum in sqaamas fatiscens, fugax, Sessiles.

Laeh nob olus Fries syst. III, 177 . b) CLATHROIDES. Peridif pars inferior persistens, calyeularis. Stipitatae.

Clathroides Michel. gen, 214, $t, 94, f, 1,2$, Tri. chiae sp. Bull, $t$. 368. 477. f.3. Sawerb, $t, 49$. Clath ri s p. Limn. Jaeq. miscell,, , $t, 6$. (Nees syst. f. 114. FI. dan. 1364. f. 2. t. 1975. f. 1, 2, t, 2090. $f, 1-3$. Dittm. apud Sturm, III. $t \&$ 4i. Grev, scot, t. 130, 139.)

TIBI III. 75. Mucilago primaria plura peridia discreta fovens. Floce i reticulatim connexi, adnati v. innati.

310. Croilbraria SCHR $A D$. Peridium subglobosum, simplex, membranaceum, fatiscendo dimidiatum, fl o c e is innatis reticnlatum, reticulo demum libero. S poridia coacervata, per reticulum sparsa. - Fungilli lignatiles, stipitati, sporidiis laete colorat is.

Cribraria Schrad. Nov, gen, T. 2. t. 1. f. 1-5. $t$. f. 3. 4, t. 3. f. 1-5. Fries syst. IIT. 164. FI. dan, $t, 2085$. f. 2 .

31 Al. Dietydium SCHRAD. Peridinm subglobosum, simplex, tenuissime membranacen, indeterminate dehiscens, floc $\mathrm{cis}$ innatis venoso nervosum, nervis demmm nudatis clathratum. Sporidia intra capillitium coacervata. - Fungilli lignatiles, stipitati, sporidïis fusco-purpureis.

Di e ty di m Sehrad. Nov. gen. T. 11. t. 3. f. 6. t.4. f. 1. 6. Nees syst, 117. Grev, scot, $t, 153$. Fries syst. III, 164. Fl. dan, $t, 2085, f .2$.

3月. Stementis GLED. Peridium globosnm v. cylindricum, tennissime membranaceum, demum evaneseens, capillit i um determinatum stipiti setaceo adnatum, illumque reticulatim ambiens, denudans. - Fungilli lignatiles, stipitati, floceis sporidiisque purpurascenti fuscis.

S tem on itis Gleditsch meth, 140. Fries syst. IIT. 156.

a) coscinium. Peridi u m sulaglobosum, subtas ambilicatum, eircumscissum, basi persistente.

Triehita $s$ p. Sowerb. $t, 412, f .3$.

b) EMBoliUM. Peridi u m ventricosum, fugacissimun. $\mathrm{M}$ ucor $\mathrm{E}$ in bol as Lina. (Pers, disp. $t, 1, f$. A. Fl, dan. t. 149. 2091, f, 1, 2.)

c) CLATHROIDASTRUM Mich, Peridia cylindrica, primum mueflagine juncta.

C I a throidas trum Michel. nov.gen. 214. 2. 94.f. 1.2. $\mathrm{E} \mathrm{mb}$ o1 a s Batsch cont, $I$. 263. $t, 30$. f.176. (Sowerb. $t, 50$. Elirenb. sylv. f.s-7. Grev, scot, $t, 170$. )

313. IDacluea FR. Peridium ovato-oblongum, simplex, membranaceum, frustulatim deciduum; $c$ a pillitium e colu mella floceoso-grumosa pulverulenta radiato-reticulatum denudans. Sporidia floccis inspersa. - Fungillus epiphytus metcoricus, stipite floccoso suffultus, capillitio albo, sporidiis atro-rubris.

Diachea Fries syst. IIr. 155. Stemonitis ete. gans Trentep. Trichiae s p. Bufl, $t$. 502. $f$. 2 .

3 4. Fuerthememan $B O W N$. Peridin m globosum, simplex, membranaceum, demum evanescens, stipitem conicum apice pileolatum, pilen subtus floecos ascendentes intortos ferente, denudans. Sporidia floceis inspera. - Fungillus stipitatus, thallo membranaceo-gelatinoso, Que rс ии $m$ ramis decorticatis adnatus.

Enerthe ne ma Bowmann in Transaet, Linn, sac, XVI. 153. t. 26.

TRE IEUS X. PHYSAREI Fries syst. IIT. 75. Mueilago primaria late serpens, in plura peridia abiens. Flocei adnati, recti, vagi. S p orid i a fuliginea v. atra.

315. Crateriam TRENTEP. Peridium varium, simplex, papyraceum, rigidum, persistens, operculo demum deciduo clausum. Ca pillit in m e floceis congestis subloculosum, demum erectum. Sporidia atra, floceis inspersa. - Fungilli epiphylli, caulicoli, nunquam lignatiles, meteorici. 
C raterin m Trentep. in Roth catalect. $I$. 224. Fries syst. III, 148, F u ug o id e s Michel. nov. gen, 204.

a) APOMA. Opereulum tenuissinum. Stipes firmus sulcatus. Flocei ramosi, discreti.

Trich i a s p. Auct, $F l$. dan. $t .1314$. f. 2. Dittmar apud Sturm IIT. t. 11. Grev. scot, $t, 65$. (Fl. dan, $t$, 2087. f. 2.)

b) SPHAEROCARPA Schmm. Opercalmm e peridio circumscisso. Fl o e e i ennglomerati, interdum obsoleti.

S pli a eroe ar pa Sehum. sael, t. II. 220,-? C ylic h. n i m Wallr. Fl,germ. II. 267. S p h a e roc a r pi s p. Ball. t. 484. f. 1 . P h y s a ri s p. Chev, paris, t.9. f. 9. (Fl, dan. t. 2003. f. 3.)

c) CXClopoma. Operculum discretum, cretaceum. Stipes gracilis laevis. Flo e e 1 rudes.

Craterium Treatep. $l$. $c$. Dittu, apud Sturm $t, 9,10$. Nees syst. $f .120$.

316. Ploysandaran PERS, Peridinm varium, regulare, simplex, membranaceum, nudnm, irregulariter dehiscens. Sporidia nigro-fuliginosa, fl o c c is peridio adnatis intertexta. - Fungilli lignatiles, caulicoli, epiphylli, varie colorati.

Ph y s r r m Pers, disp. 8, excl,sp. Fries syst. IIT. 127.

a) ANGIORIDIUM Grev. P exidia subeffusa, varia, batsi applanata aduata, irregularia, saepe confluentia.

Angioridium Grev. scot. $t$, 310. Reticulariae sp. Bull. $t$. 466. $f$. 2. Sowerb. $t$. 6 . L y cog a I a e s p. Grev. op. cit. t. 40. 106. (Pers. obs. I. t.1.f.2, FI. dan.t.2087.f. 1.)

b) EUMorpHA. Peridfa sessilia, subglobosa, stipitata glomerataque, uunquam conflueatia.

Licea e sp. Sehrad. nov. gen, t, 6.f. 4. (Dittm. apud Sturm IIT. $t, 40.61$. Fl. dan. $t, 1980 . f, 2$.

c) ASTYLON. Peridia sessilia v. stipite flaccido deeum. bente fulta, tenerima.

S phaerocarpi s p. Bull. $t$. 417. f. 1. (Pers. disp, t. 2. f. 4.) Fl. dan, t.2093. f. 1, 2.

d) Eucormos. Peridia lentiformia, sphateriea v. tur. bisata, stipite disereto ereeto folta.

Sph a rocarpi $\mathrm{sp}$. Bull, $t$. 368. f.2. $t$. 407. $f .2 .3$. t. 481. f. 1. t. 48t, f. 2. (Pers, disp, t. 1. f.6. Dittm. apud Sturm III. t. 22-24. 41, 62. Grev, scut. $t$. IR/. Fl. dan. t.2095. 2096.)

31\%. Didymanum $S C H R A D$. Peridium varium, regulare, membranaceum, tenue, irregulariter dehiscens, cortieatum, cortice adnato mox in squamulas furfuraceas v. villum farinosum fatiscente. Sp oridia fuliginoso-atra, floceis vagis peridio adnatis immixta, - Fungilli albo-cineruscentes, habitu vario.

Did y mi m Sehrad. nov. gen, 29. excl. sp. Fries syst. fII. 113.

a) ACIONisciuM. Peridia adnata-sessilia, basi applauata. C o I u mella unlla.

Physarisp. Nees syst. $f .10 z$.

b) ACORMOS. P e ridia subsessilia. S tipes aullas v. miniuus. C o l u mella distincta.

Retle n lariae $\times$ p. Ball. 6.446. f.9. (Sehrad. op. cit.

t. 5. f. 5. Nees syst. f. 104. Fl, dan, t. 2094. f. .).

c) PSEDDOCORMOS. P e ridia congesta. stipitibus spuris submembranaceis cohaerentibus. Col a mella nulla.

Did y mia botryos a Fries syst. III. 121.

d) Cionity Dittm. Peridium stipite distincto firmo suffitum. Coln mella plus miaus evoluta, raro obsoleta.

Ci onf um Dittm, apud Sturm IIT, t. 7. 43. Nees syst. f. 106. Reticulariac s p. Bull, t.4i6. f.1. Sowerb. t. 19. Physa ri s p. Fl. dan. $t, 145 \%$. $f, 1, t, 1972 . f$. 2 . (Schrad. op. cit.t.5.f.6. t. 6. f. 2.3. FL dan. $t, 2092, f . t-3 . t .2094 . f .1$.

31 8. Didlerman PERS. Peridium varium, regulare, duplex; exterís crustaceum, discretum, fragile, dehiscens, interi us tenerrime membranaceum, evanescens. S poridia fuliginoso-atra, floce is ragis basi adnatis intercarsa.

- Fungilli epiphyti, colorati, meteorici.

Diderm a Pers. disp. 9. Fries syst. TIT. 90.

a) PSEUDOSTYLIS. Pe ridia sparsa v. conglomerata, sessilia, thallo evanido. Colume 11 a spuria v. nulla.

(Nees syst. f. 105. Dittm, apud Sturm III. t. 59. HI. dan. t. 1980. $f .1,2$.

b) EUSTYLIS. Peridit sparsa v. gregaria, sessilia, t li a 11 o evanido. Columell a genuina.
Reticulariae sp. Bull, $t$. 446, $f$. 2, Leangli sp. Grev, scot, t. 132. (Dittm. apud Sturm III. t. 6. Grev. op. cit. t. 122.)

c) LEOCARPUS Lk. Pe ridia congesta, thallo mucilaginoso fulta, stipitibus spariis laxis, coalescentibus. Col um ella subnulla.

Le o c a r pus Link in Berl, Magaz, $r T$, 2J, Nees syc. 110. Grev. scot. 6. 11t. Reti cula ria e s p. Bull. $t$. 380 . f. 3. $t$. 424. f. 2. Sowerb, t. 280. (FI. dan. t. 1312. f. 2. $t .1973$. f. 1. 2. t. $1978, f .2$.

a) LEANGIUM $L h$, Peridia sparsa, stipite discreto solldo suffulta. Col u mell a magaa.

Le a ngium Link in Berl. Magaz. IIT. 26. Nees syst. f. 109. Dittm. apud Sturm III. t, 2l. S p ha e ro ca r pi sp. Bull. $t .311$. 484. f.3. D i d y m i $\mathrm{s}$. Schrad. nov. gen. $t$. 5 . f. 3. A, Phy sari s p. Pers, synops, $t, 3, f .11,12$. (FL, dan. t. 1972. $f, 1$, .

THE IIBUS XI. AETHALINEI Fries syst. III. 74. Mueilago primaria in $\mathrm{u} n \mathrm{i}$ c um peridium abiens.

3 A 5 . Sgenanania PERS. Peridium indeterminatum, simplex, crustaceum, flocculosocellulare, fatiscens, flo c cis internis nullis. S p oridia fuscescentia, plicas membranaceas adscendentes, varie effiguratas, ambenntia. _ Fungus ixregulariter effusus, gramin ibus aestate adhaerens.

S p u m uria Pers. synops. 162. t, $1 . f .1$. Nees syst.f.9.4. Fl. dan. $t, 1978, f .1$. Grev. scot, $t, 267$. Fries syst. III, 94.

320. Aethaliouna $L N K$. Peridium indeterminatum, membranoso-cellulare, fragile, fatiscens, externe strato floccoso evanescente corticatom, intus cellulosum, e $\mathrm{flo}$ c $\mathrm{c}$ is instrata membranacea coalitis. S poridia fuliginosa, in cellulis demum evanescentibus coacervata. - Fungus effusus, indeterminatus, caloratus, ad ligna mucida jove ptuvio calido vegetans.

A ethalium Lluk in Berl. Magaz. IIT, 2f. Grev, seot. t. 272. Pries syst, III, 92, $Y$ uli g o Hall. helv, III, 110. Pers. synops. 159. Fl. dan, $t, 1363 . f . t$. Mucilag o Michel, nev. gen. 217. Pittoearpium Link op. cit. Pecila Lepell. in Bullet, soc. philomat. 1892 , p. 109.

32 1. Fetieularia BULL. Peridinm indeterminatum, simplex, nudnm, tenue, irregulariter dehiscens, fugarissimnm, floecos adnatos ramosos reticulatos denudans. S porid ia fuligineoatra, laxa. - Fungimeteorici, super plantarum varias partes emortuas, nec tamen putrescentes effusi, fugaces.

Retic u J ria Bull. champ. 85, t. 446. f.4.t. 476.f. $1-3$. exct, relín. Fries syst, $\Pi I, 83$. Strangy Ii u tu Ditm. apua Sturm III. t. 38. D ipthe ri u m Ehreab. sylv, 27, f.3, E 11 . te ridium Elirenb. in Link Jahrb. I. 2, p.55. e, ic. Lig ni. d f um Liak in Berl. Magaz, III, 24. Nees syst, f. 93.

322. Lyeograla MICHEL. Peridium determinatum, duplex, utrumque membranacenm, persistens, apice rumpens. Sporidia colorata, floce is peridio undique adnatis, tenerrimis, vagis immixta. _ Fungi terrestres, lignicoli, sessiles, rotundati, varie colorati.

Ly cog a 1 a Michel. gen, 216. excl. sp. Nees syst, f.96. 97. Grev, scot, $t .38$. Fl, dan, $t, 2086, f, 1-3$. G a I e perd on Web, holsat. 10s. L y e op erd i s p. Lian. Fl. dan, $t$, 780 . Bull, $t, 303$. Sowerb, $t .58$. Holusk. ot. $I$. $t, 31$.

SECTIO II. TRICHOGASTERES Fries syst. III. 3. Primitus earnosi, indurati, haud museilaginosi. My celi a m distinctum, flocc is in tubercula rotundata solida abeuntibus, radicellis (in generibus hypoyaeis dificientibus) et peridii cortice exteriore e mycelio formato. G leba interi or demum subpulposa, tandem exsiccando in s poridi a fatiscens. Flo cci e peridio enati. Cortex exterior (peridium ex(erius) raro deficiens. - Coeli cali- 
dioris potissimum proles, pleriqui terrestres, plurimi arenicoli, nonnulli subterranei.

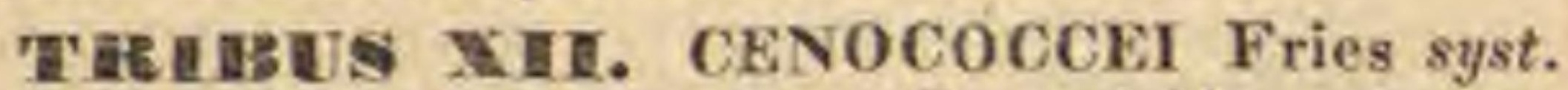
III. 6. Capillitium nullum. $\mathrm{S}_{\mathrm{p}}$ oridia primum eonglutinata.

323. Cenococeum FR, Peridium ecorticatum, crassum, subcroso-corneum, indehiscens; intus primum similare $d$ ein in s poridia pulvernlenta, nullis floceis intertexta fatiscens, centro cavum. - Fungilli subterranei v. lignatiles, globulares, arrltizi, thallo floccoso, raro obsoleto, insidentes.

Ceno coec u m Fries $p l$, ham, 36h. Syst. $I I T, 65$. Lye p perdo in graniforme Sowerb, $t, 2 z 0$.

324. Mitremyees NEES. Peridium papyraceo-cornenm, ore determinato, squamis coloratis clauso; extus ealyptra basi disrupta squamosum, a peridio inte riori, solis ostioli squamulis affixo, discretum. Sporidia conglomerata, filis destituta. - Fungus terrestris, b o real $i$ - a mericanus, hiemalis, sessilis, radice stipitiformi, peridio interiori pendulo, $a b$ exteriori ambitu vacuo discreto.

Mitrem y ces Nees syst, 136.f. 129. Seliwein. carol.34. Fries syst. IIT, 63. Calosto ma Desv. in Journ. bot, 1809. p. 94. G y r o po dium Hitcheok in Sillim. Americ, Journ. IX. 56. Lycoperdon heterogeneum Bose. in Berl. Magaz, V. 87, $t, 6$.

THEIISES XEIT. PODAXIDEI Fries syst. III. 5. Capillitium laxum, columellae centrali adnatum.

325. Podaxon FR. Peridium simplex a stipite in columellam elongato percursum, basi dehiscens, columellam nudans. Sporidia conglomerata, fl o e e is columellae undique adnatis intertexta. - Fungi terrestres regionum calidarum, radicantes, stipitati, peridio subelavato.

Pedaxon Fries syst. III. 62. Sehweinitzia Grev. in Edinb. philosoph, Journ. XVI. 258, t.6.

a) PODAXIS Desv. Stipes e fibris eontortus.

Poda $\mathrm{x}$ is Desw. in Journ. Bot. 1809. p.79. L y coperdon pistillare Lino. et $\mathrm{L}$. a $\mathrm{x}$ a $\mathrm{t} \mathrm{u}$ Bose in Annal. Mus. I. 4r. t. 11 .

b) CaTachyon Ehrenb, Stipes laevis.

Catachyon Ehrenb. ex Fries l. c. Lycoperdon c arcinomale Linn. $t$.

326. Cauloglossume FR. Peridium simplex, cum stipite continumm, demum ad latera lacerato dehiscens, col $\mathrm{nmella}$ floceosa percursum. Sporidia columellae inspersa. - Fung $i$ terrestres regionum calidarum, clavaeformes, radicantes.

C a ulog $108 \mathrm{sum}$ Fries syst.IIT. 60. He r cule a Fries syst. II. 278. L y coperdon transversarium Bose in Berl. Magas. F. 87, t.6. f.9. Nees syst. f. 129. $B$.

39\%. Cyeloderma KL. Peridium globosum, duplex, ext eri us coriacenm, molle, discretum, interius tenuissime papyracenm. Sporidia globosa, capillitio colnmellam seyphiformem cum peridio interiori radiatim coniungenti inspersa. - Fungillus terrestris, nucis Juglandis mole, stipite brevi spongioso, radiciformi, ex India orientali adlatus.

C y cloderma Klotsels in Linnaea VII, 203. t.0. f.6.

TERIEUS XEV. SCLERODERMEI Fries syst. III. 5. Capillitin m rellulosum. Sporidia conglomerata. Peridi u un induratum.

329. Elaphomyees NEES. Peridin suberosum, indehiscens, intus floce is in venas intersecantes contextis loculosum. S poridia congesta, conglomerata, demum soluta, pulverulenta.
Fungi subterranei, aestivales, globosi, arrhizi, extus verrucoso-scabri.

Elaphomyces Nees. Fries. syst. HIT. 5z. Vittad. Tuberac. 62, t, 3. 4, Н y $\mathrm{p}$ og a $\mathrm{e} \mathrm{um} \mathrm{Pers.} \mathrm{disp.} \mathrm{7.} \mathrm{P} \mathrm{hy-}$ mat fum Chev, paris, 361, C e ranuion Wallr. Ft. germ. II. 405. Ly co perdon cervinum et L. solidum Linn. T u be ris s p. Nees syst, f. 147 .

329. Hyperelhiza BOSC. Peridium suberosnm, irregulariter dehiscens, intus solidum, peridiolis oblongis, contortis, connatis faretum. Sporidia soluta pulverulenta, inter peridiola nidulantia. Fungi epigaei, subglobosi, extus fibrillosi, fibrillis saepe in cuudicem connatis, rhizoideis.

H y perr hiz a Bose. in Berl, Magaz, V. 88, t, 6. f. 62 . Nees syst. f. 146. Fries syst. $I I T, 56,-\mathrm{Melan}$ og a s te $\mathrm{r}$ Corda apud Sturm IIT. 2. C. 1. H y 8 terangi $\mathrm{i}$ m et 0 e taviania Vittad. Taberae, $p, 13,15,4,3,4$.

330. Polysacenm $D C$. Peridium simplex, rigidum, indeterminate dehiseens, intus stuposofibrosum, sublamellosum, cellulosum. Peridiola inaequalia, discreta, in cellulis nidulantia, sp or idia floccis intertexta includentia. - Fungi terrestres, autumnales, difformi-subglobosi, stipitati, radicati $v$, arrhizi sessiles.

Paly s a e c um Desp. et DC. Rapp. Vof. bot. I. 8. Fries syst. IIT. 51 . P is olithus Alb. et Sehwein, neisk, 89, t. 1. f. 3. P is o c ar p f 11 m Link in Berl. Magas. ITI. 33. E u d ac i n u 8 Ruf. somiolog. n.64. P o I y p e r a Ficin. Fl. dresd. 306. $t$. $1, f .51$. - Ciliciocarpus Corda apud sturm. III. $t .3$.

331. Seleroullerma PERS. Peridium firmum, innato-corticatum, irregulariter dehiscens. Flo e ei peridio adnati, in cellulas coeuntes. Sporidia glomerata, in cellulis nidulantia. Fungi subglobosi, terrestres, arenicoli, radicati, sessiles.

Sclero der ma Pers. synops. 159. exel. sp. Nees syst. f. 123. Fries syst, $I I, 44$. Grev, scot, t, 48, 66. Fi. dan, $t, 1969$. f.2, L y c o p e r d i s p. Linn. et Auct. Bull, c. 24, 270. Sowerb. t. 268. 311 .

TUREUS XV. LYCOPERDEI Fries syst. III. 5. Capillitinm effusum. Peridium adnatum. Sporidia discreta.

332. Tulostoma PERS. Peridinm basi discretum, papyraceum, cortice secedente denudatum, apice determinate dehiscens. S poridia coacervata, floce is peridio adnatis parce intertexta. -Fungi stipitati, radicantes, campestres, arenicoli.

Tulos to m a Pers. disp. 6. Nees syst. f. 130. FI. dan. t, 1740. f. 1. Grev. scot. t,340. Fries syst. III. 41. D ip 1 o. st o m a Liuk in Berl. Academ, Abhandi, 1824, $p$, 178. Sch $\mathrm{f}$ zos to ma Elirenb. mse.

333. Hyeoperdon TOURN. Peridium membranaceum, flacescens v. superne evanescens, cortice adnato subpersistente, in squamas v. verucas abeunte. Capillitinm molle, densum basi compactae sterili peridioque adnatum. Sporidi a laxa, coacervata. - Fungi terrestres $v$, rarius truncicoli, radiculati, stipite non discreto.

L y c op erd on Tournef. inst. s63. Sehaeff, $t, 184.186$. 189. 190. 193. 294. Bull, $t, 32$, 430, 435. 445, 475. Sowerb. t. 332. FI, dan. t. 1120, 1139, 1920. Nees syst. f., $124,125$. Grev, scot. $t .304$. Fries syst. IIT, 26.

334. Fovista FR. Peridium papyraceun v. subsuberosum, persistens, cortice discreto, contiguo, demum secedente. Capillitium compactum, peridio undique adnatum. Sporid ia subpedicellata, eapillitio inspersa. - Fungi aestivales, per hiemem persistentes, pratenses $v$. arvenses, radiculosi, stipite discreto nullo.

$\mathrm{B}$ o vis ta Fries syst. III. Grev, scot. $t$. 336, L y e aperdi s p. Sowerb, $t .331$. Bull. $t, 192,950, f .1$.

335. Diploderma $L K$. Peridium duplex, exterius lignescens, discretum, clausum, 
interius papyraceum. Capillitium fuscum. Sporidia inspersa. - Fungus subglobosus, arenicola, Europae australis; peridio externo e fusco luteo, interno albo, floccis et sporidiis badiis.

Diploder ma Link in Berl. Magas. VIT. 31. Handb. IT. 399. Nees syst. 132.

336. Geaster MICHEL. Peridium duplex, utrumque persistens, exterins corticatum, discretum, demum stellation fissum, patens; interius papyraceum, apice dehiscens. Capillitinm laxum, peridio undique adnatum. S poridia subpedicellata, capillitio inspersa. - Fungi radiculosi sessiles, perilio interiori tamen saepius pedicellato, ab America tropica usque ad Europa boreales alpes adscendentes, climatis campestris maritimi potissimum proles.

Ge a s ter Michel. gen. 220. Fries syst, $I I T, 8$.

a) MYriostoma Desv. Peridzi interioris os eribrosum, ostiolis eillatis.

M y riostam a Desv, in Journ. Bot, 1809. p, 103. Po. I y stoma Gray brit, $p l, r, 586$. L y e operdon colif or. me Dicks. erypt, brit. $t, t, 3$. f. 4. Sowerb. $t, 313$.

b) Plecostoma Desv. Peridii iuterioris os elougatum, conicum, plicato - sulcatum.

Plecostoma Desv l.c. Geastroides Battar. fung. to'39. $f .1-4$. L y en perdi \& $p$. Sowerb. t. 198. Sehmid analys. t. 37. f. 11-14. (Nees f.138.)

c) GEASTrum Desv. Peridii interioris os depressum, planum, aut late conieum, ciliato - fimbriatum.

Geas trum Desv, l.c. (Schmidl op, eit. t,46.)

d) ODONTOSTOMA. Peridii interioris os dentien. latum.

(Schmidl op. cit, t. 43. 53. f.1-3. FI. daн. $t$. 1433, So. werk. $t .80$.

e) Actinodermium Nees. Peridium interius ra. diato - multifidum.

Sterrebecks a Link in Berl. Magaz. VII. 34. Actiu 0 de $\mathrm{rmi} \mathrm{im}$ Nees syst. 136 .

Quorsua $\mathrm{R}$ im eli a Raf, in Journ, Phys, LXXXIX, 106. et A e in o p ho ra Raf. in N. York Medic. Heposit, IT. Hex. V.p. 350.?-Quid 1, a te rr a d e a Rasp, in Annal. Europ. 1824. octob, p. 233. t.6.?

SUBDISED V. ANGIOGAS'TERES Nees syst. 138. Fries $I$. 277. Uterus distinctus, rotundatus, apice rumpens. Reeeptac ula solitaria v. plura, ab ntero discreta, determinata, clausa v. aperta. S p oridia globosa, minima, in receptaculis collocata, immersa v. inclusa, nunquam pulverulenta. Fungi epipleyti, fimicoli, perfectissimi terrestres, multi ephemeri, meteorici; perfectiores sub coelo tropico, sui generis.

TIIISUS XVI. CARPOBOLEI Fries syst. II. 305. U terus rotundatus, urceolatus, s p or a n $\mathrm{g} \mathrm{i} \mathrm{m}$ vesicnlaeforme, solitarium, s p or idiis foetum saepe ejiciens. - Gregarii, minimi, meteorici.

33 ซ. Sphaerobolus TOD. Uterus immerso-sessilis, rotundatus, demum stellatim fissus. Peridium duplex, interius membranacemm, tandem elastice inversum, sporangiun globosum solidum projieiens. S porid $\mathrm{i}$ a in medio coacervata.

Fungilli gregarii, minimi, epiphyti, innato-sessiles, persistentes.

S phaerobolus Tode meckl, I. 43, Link in Berl. Magaz, VII.f. 49. Nees kgt.f. 122. Grev. scot. t. 158. Desmaz. in Trav, soc. scienc, de Lille, 1823, p, 225. c. ic. Fries syst. II. 309. C a r p o bol u s Michel, nov, gen. 29t, $t, 101, f, z$. Lyeoperdoa Carpobalus Lion. Fl, dan. $t .865$. So. werb. $t, 22$.

338. Thelebolus TOD. Utern s sessilis subrotundus, tandem cupularis. Sporangium vesiculoşum, globosum, demum protrusum, ore apertum. Sporidia mucosa, tandem effusa.
Fungilli gregarii, minimi, terrestres v. fmicoli, carnoso-gelatinosi.

Thel ebolns Tode meckl. 1. 4t. $t$. 5. $f .56$. Alb, et Sehwein. neisk, $t$. 2. $f$. 4. Nees syst. $f .363$, 36\%. Fries syst. 11. 306 .

339. Atractobolus TOD). Uterus sessilis, cupulaeformis, apertus, op ere ulo umbonato (velo) tectus. Sporangium vesiculosum, fusiforme, clausum, demum operculo dejecto prosiliens. $\mathrm{S}$ poridia mucosa. - Fungillus gregarius, minimus, autumnalis, pezizaeformis.

Atractobofus Tode meckl, I. 45. f.9. Fries syst. IT. 305. Elench, II. 50.

TTEIBSES XEIT. NIDULARIACEI Fries syst. II. 296. Uterus varius, demum apertus, s porangi is pluribus fuetus. Sporangia clausa, libera, spuridiis referta. _ Epiphyti, aulumnales.

340. Eolvangivan $L N K$. Uterus he misphaeriens, vesieuluso-flocessus, demum apertus. S porangia pauca, oblonga, floccis nullis. Sporidia grumosa, compacta. - Fungilli gregarii, minimi, in truncis projectis roseidis provenientes.

Pol y a nginm Link in Berl. Magaz. HI. 49. Dittm. apud Sturm III. $t, 27$. Nees syst, $f, 131$. Fries syst, II. 304.

341. Myriocoecum FR. U t e r us difformis, floccuso - furfuraceus, demum evanescens. Sporangi a plurima, globosa, floccis intertexta. S poridia conglobata. - Fungilli gregarii, sub confluentes, in quisquiliis sylvarum vere nascentes.

M y $r$ i o c a e $u$ m Fries syst, $\pi$. $30 \pi$.

38\%. Araehnion SCHWEIN. Uterus subglobosus, peridio exteriore tenui, evanescente, interiori suberoso, irregulariter rupto. Sporangia plurima, globosa, floceis nullis. Fungi sericei, nueis minoris mole, ad terram tritam udam Americae borealis reperti.

Ar achnion Schwein. synops. fung. Carolin. 14, t.1, f. 2. Fries syst. IT, 303. - ? Testicularia Klotzsch in Linnaea $V I I$. 202, t, 9. f. $a$.

343. Niclularia FR. U terus globosus v. difformis, coriaceus, irregulariter rumpens, intus e pulpa exsiceata membranaceo-fleceosus. S p orangia lenticularia, margine affixa. Sporidia coacervata. - Fungi minuti, gregarii, autumno in lignis putridis nascentes.

Nidula ria Fries symb. 2. Nees syst. f. 133. C. Nid n. la ria e s p. Bull. Roth. catalect. $I$. $t, 7 . f$. 2. Elireub. aylv. berol. f.8. $a-h$.

344. Cyathus HALL. Uterus eyathiformis, coriaccus, epiphragmate orbieulari, demum rumpente tectus, intus e gelatina exsiceata vernicosus. S porang ia lenticularia, medio subtas umbilicata, et ope funiculi peridio partiali affixa. Sporidia coacervata. - Fungi minuti, gregarii, in lignis putridis vel in solo per totum terrarum orbem reperti, mira imagine fructus perfectos ludunt.

C y a th u s Hall. Helv, III, 127. Fries $n y m b, 2$, Nees syat. f. 132. 133. Cy athoides Michel. nov.gen. 282. Cyathis P. Brown. Jam. 78. Ni du lariae sp. Bull. c. 40. 488. Sowerb. $t, 28-30$. Nid u $\mathrm{l}$ ari a e s e t. Fries syst. II, 297 .

TRIIUS XVIII. TUBERACEI Fries syst. II. 289. Vittad. Monograph. Mediol. 1831. 4to. Uterns rotundatus, sessilis, arrhizus, thaIlo radicante, clausus v.demum adultus apertus, junior intus pulposns, carnosus, venis marmoratus v. eancellatus. S porangia v. peridiola minuta, mollia, inspersa. S p o ridia nuinima. - Fungiterrestres, epirrhizi v. hypogaei. Ceterum genera non nimis acute limitata ultro fatemur.

SUBTTRIBUS T. TUBEREI Vittadini Tuberuc. p.12. Ute rus intus carnosus, venosus. 
Sporangia nuda ve peridiolis inclusa, nteri parictibus (peridio) immersa.

345. Eratogene LNK. Uterus subglobosus, extus floccosus, intus grumosns. Sporang ia globosa, minima, memhranacea, s p o ridiis repleta. - Fungillus Pisi mole, in sylvis abiegnis Muscorum radicibus adhaerens.

End o g on e Link in Berl. Magaz. III. 33. f. 59. Nees syst. f. 195. Fries syst. II. 295.

346. Polygraster FR. Uterus subglobosus, extus flocculoso-tuberculosus, intus cellalosi-carnosus. Sporangia subglobosa, majuscula, aggregata, s poridi is coacervatis. - Fungi indici, sesquipollicares, epirrhizi.

PoI ygaster Fries syst, II. 295. Tu ber sampada. ri u m Rumph Amb. XI, p. 123.

34\%. Pieor VITT. Uterus subglobosus, extus muricato-seaber, intus carnosus, obsolete venosus. S p or a ng i a splhaerica, vesiculosa, venis immersa, sporidia conglobata, muco involuta ineludentia. - Fungus hypogaeus, Avellanae mole in Juniperetis Italiae superioris observatus.

Pic o a Vittadini Tuberac. $p, 54, t, 2, f, 8$.

34. E. EHaizoposan $F R$. Uterus rotundato-difformis, extus floceulosus, demum irregu lariter ruptus, intus carnosus, reticulatim venosus. Sporangia globosa, sessilia, membranacea, venis inspersa, sporidiis primum pulposis, demum distinetis repleta. - Fungi nucis Juglandis mole, in Europa media et boreali hypogaei, basi fibrillis reticulatis radicantibus obducti, insipidi $v$. nauseosi.

Rhizopogon Frles symb. 5. Syst, $I I, 293$. T u ber a I b u m Bull, Champ. I. 80, t, 404 .

349. Clagiromyces VITTAD. Uterus rotundato-difformis, extus laevis, indehiscens, (?) int us carnosus, reticulatim venosus. Perid i o I a vesicnlosa, pyriformia, Iongissime pedicellata, lateribus venarum imposita, $8 \mathrm{p}$ o $\mathrm{r}$ a $\mathrm{n} \mathrm{g}$ i o $1 \mathrm{i} s$ sphaericis echinatis suboctonis farcta. - Fungi subterranei, maiusculi, candidi, in apricis effodiuntur, iuniores nauseosi, maturi a nonnullis vorantur.

Choir o m yces Vittadini Tuberac, p.30, t, 2. f. 1, 2. Huc, nisi me omnia fallunt, $T$ ube $r$ a 1 b a m Dest., quod $T$ exfez Leonis Africani Libr, $X I$.

350. Tulber MICHEL, U terus subglobosus, extus laevis v. papilloso-verrucosus, indehiscens, intus coriaceo - carnosus, reticulatim venosus. Perid i o la membranacea ovata, subpedicellata, venis undique inspersa, sporangiolis sphaericis echinatis binis-senis farcta. _ Fungi pugni satepe mole, in temperatis totius hemisphaerae borealis hypogati, a subus avide efossi vorantur, et aphrodisiaca gulosorum condiunt fercula.

$T$ u be r Micheli nov. gen. 221, Nees syst. f. 197. Turp.

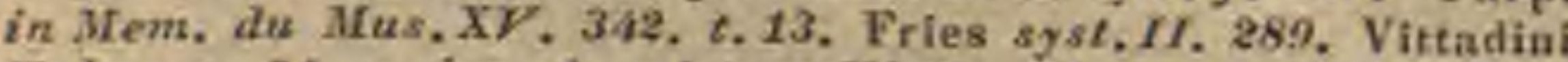
Tuberac. 3t. c. icc. A s chio n Wallr. Fl. germ, $11,864 . \mathrm{L}$ -
coperdi $\mathrm{s}$. Lim.

351. IBalsamin VITTAD. Uterns rotnndatus $v$. angulatus, extus verrucosus, indehiscens, intus celluloso-carnosus. Peridiola membranacea, oblonga, pedicellata, in cellularum parietilous seriata, immersa, sporangiolis eylindrieis, la evibus, suboctonis fareta. - Fungi subterranei, cum Tuberibus in It a lia efossi, et infumi lucro venditi, ubi cum sagina ingeruntur, tormina et ventris proftuviem producunt.

BaIs a m ia Vittadiai Tuberae, p.30. t.1.f.2.

35. Cremea VITTAD. Uterns rotundato-difformis, ext n s plicato-lacunosus, irregulariter dehiscens, int ns floccoso-muricatus, centro carnosus. Pe rid io la membranacea, cylindriea, in centro transversa $v$ - horizontalia, s porangio1 is snbglobosis, laevibus, suboctonis fareta. Fungilli graveolentes, in Italia superiori cum Tuberibus hypogaei $v$, subemersi.

Ge n e a Vittadini Tuberac, $27, t, 2, f, 7, t, 3, f, 13,18,-$ ? Hydnoear y on Wallr. Fl. germ. II. 860 .

SE ETTEIBEUS IT. HYVENOGASTEREI Vittadini Tuberac. 11. exel. gen. Ut eri peridi a m exterius saepe fugax, interius (receptaculum) hymenino-cellulosum. Peridiol a cellulis peridii interioris imposita.

353. Hymenogaster VITTAD. U terus subglobosus, peridio exteriore laevi, persistente, interius alveolis hymeninis exsculptum obtegente. Peridiola cylindrica, alveolis perilii interioris imposita, sporangiolis fusiformibus, demum emergentibus, fareta. _ Fungi minores lycoperdiformes, hypogaei, maturitate emergentes.

Hy menog as ter Vittadini Tuberac. 20. t.2.f.5. t.3. f. 2. 5.9. 15, 17, t. 4. f.9. B ulll a rd i a Jughun in Linnaea V. 008. A r g y 1 i u m Walle. Fl, germ, IT. 873. Tи be r mo. $8 \mathrm{ch}$ a t u m Bulliard champ, t. 479 .

35.4. Cantiera VITTAD. Uterus rotundato-difformis, p e ridio exteriore fugacissimu, interius alveolis hymeninis exsculptum denudante. Peridiol a fusiformia, alveolis peridii interioris imposita, sporangiolis (?) farcta. Fungi minores, morchellaeformes, basi fibrillis radicantibus instruet $i$, in Italio superiore efossi.

Ga u tier a Vittadini Tuberac, p. 25.t.3. f.6. t. 4. f. 13.

Quid P y rispora Rufin, in N.York medic. Aeposit. IT. Hex, Y. 350 .

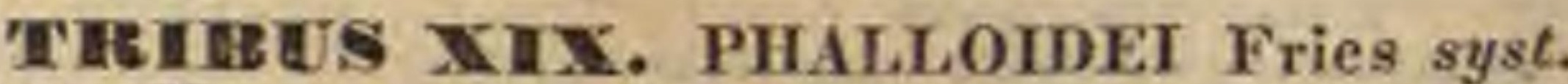
II. 281. Uterus sessilis, railivatus, gelatina distentus, apice rumpens. Re e pta culum elastice protrusnm, ab utero discretum, apertum, forma varium. Sporidia in receptaculi strato mucoso, nudo nidulantia, et cum eo colliquescendo diffluentia. - Mujores, meteorici, aestivi, foetidi, suspecti.

355. Clathreus MICHEL. U t e r u sessilis, globosus, laciniato-dehiscens. R e c e $t$ a $c \mathbf{u} \mathbf{l} \mathbf{~ m}$ sessile, globosum, cavum, e ramis clathrato-coniunctis eompositum. Sporidia in strato mucosogelatinoso interius ramorum latus obducente. Fungi receptaculi forma mirabiles, foetidissimi, in Europa australiore et America tropica et subtropica raro obvii.

Clat h rus Michell nov. gen, 21\%. Fries syst, $I T$, 287.

a) LATERNEA Turp. Receptaenli rami simplices, basi et apice tantum eonjuncti.

L a ternea Turp. atl. f.s. Colon naria Rafin, in N. York med. Reposit. If. Her. $V$. 250. (Bose in Berl, Magaz. V. t. . . f. 5 . Nees syst. $f .26 t$.)

b) COLEUS Cav. et Seck. Receptaculi rami simplices, basi in stipiten connati, apice clathratim conaati.

Cole us Cavalier et Sechier in Nouv. Annal. sc. nat. IIT. $233, t, 8$

c) CLETHRIA $P, B r$. Receptaculi rami ramosissimi, anastomasantes.

Clethria P. Brown Jam, 78. Dictycia Rafin, $l, c$. (Micheli op. cit, $t, 93$. Ball, $t .441$. Nees syst. $f$. 261, Turp. 4tl. f.3.)

356. Hysuras FR. Uterus sessilis, rotundatus, rumpens. Reeeptaculum stipiti cavo continum, quinquefidum, laciniis ereeto conniventibus. Sporidia in strato mucoso, receptaculi lacinias extus (!) obvestiente. - Fungus apud Sin as in radicibus Mori coelo torante nasoitur, rapidissimo incremento portentosus.

L y s urus Fries syst. IT. 285. Mak usin Cihot in Nov, Comment. Potropolit.x., 373. t.5.

35\%. Aserod LABILL. Uterus sessilis, rotundatus, rumpens. Receptaculum stipiti 
cavo continum, quadri-quinquefidum, laciniis apice bifidis, stellato-patentibus. Sporidia in strato mucoso, reeeptaculi lacinias supra (intus!) obvestiente. - Fungi elegantissimi, rubentes, in Austra lasia reperti.

A s c roé Labill, voy. 145. c. io. Fries syst. II. 285. Endl. Atakt. t.5o.

359. HPallens $M I C H E L$. Ut e r n s rotundatus, peridio exteriore ab interiore gelatina distento, Iobato rumpens. R e ce pta c u I um capituliforme, stipiti fistuloso continunm v. ab eo discretum. Sporidia in strato mueoso, capitulum undique obtegente. - Fungi majores terrestres $v$. lignatiles, meteorici, venenati, foetidissimi, aspectu foedi.

Ph a 11 us Micheli nov, gen, 201. Fries syst. II. 281.

a) CXNOPHALIUS F́r. Capit u I u m stipiti continuum, tuberculosum, impervium.

Cy no phallus Fries $t$. c. Huds. - Fl. dan. 2.1259. Nees syst. $f .260$.

b) SIMBLUM $K L$. Capitnlum stipiti continuam, alveo. lato - cellulosum, Impervium.

Sim b I $\mathrm{nm}$ Klotzseh in Hook, Bot, misc, II, 164, t. 66.

c) LELOPHALLUS $\mathrm{Fr}$. C a pitu 1 u m a stipite discretum, Iaeve, apice pervium.

L eiophallns Fries $l$. $c$. Satyrus Bose in Berl.

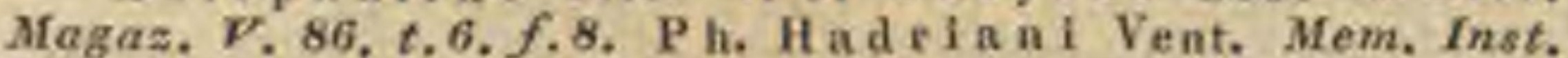
I. 517 . H y me a $\mathrm{ph}$ alli s p. Nees syst. $f$. 258. $B$.

d) ITYPHALLUS Fr. Capitulum a stipite discretum, reticulatum, apice pervium.

It y hallus Fries $l$. $e$. Ph. i m pudie us L.Flor, dan. t. 175. Sehaetrer Gichtschw. $t, 1-5$. Bull. $t, 182$. Nees $f, 159$.

e) HYMENOPHALLUS Nees. C apitulam indusio stipi-

tem velante subtus discretum, reticulatum, apice pervium.

Hymea ophallus Nees syst. 251. $f$. 258. Dictyoph or a Desv. in Journ. Bot, 1809. p. 02, D iety o peplos Hasselt in Fonst en Letter Bode 1824. p.227. S o p h ronia Pers. in Gaudich, vay. Freye, 178. $t$, 1. $f$. 2. Retige r u s Radd. (Bose l, $c, t, 6, f, 7$, Vent, $, ., ., t, 7, f .3$. Hook. App. to Becchey's Voy. $t, 20$, Fl. flum. XI, 1, 118.)

359. IBnttarea PERS. Uterus subglobosus, peridio exteriore ab interiore gelatina distento, lobato-rumpens. R e e epta $\mathbf{c} \mathbf{~} \mathbf{l} \mathbf{u}$ m pileiforme, a stipite fistuloso discretum. Sporidia in pilei superfieie villoso-pulverulenta, peridii interioris membrana calyptrata. - Fungi arenicoli, agariciformes, utero subterraneo, stipite squammoso.

B attare a Pers, synops, 129. Nees syst, $f$. 257. Fries syst. III. 6. Montagne in N, Annal, se, nat. IJ. t. 4. f.1. Dendrom y ces Libosehitz Monographie, Mien 1814. c. ic. Ly coperdo a phallo ides Dicks. Woodw, in Philosoph. Transact. LXXIV. 423, $t$, 26. Smith spic, $t$. 12. Sowerb. $t, 390$.

Quid Oedycia, VoIvy eium et Drupasia Rafin. in N. York, med, Reposit. II. Hex. V. 350 .

\section{Ordo XV. Pyrenomycetes.}

PYRENOMYCETES Fries $p l$, hom, 97 . HXP0XXLA DC. Fl. fr. $I$ II. 280.

Fongi plerumque nigrescentes, indurati, contextu obscure celluloso, solitarii v. aggregati ant connati v, strom ate (basi communi) juncti, coriacei v. lignoso-indurati, primo clausi, dein apice poro pertusi v rimose rupti, n u cleo distincto, molliori, subdeliquescente farcti. S p o ridia muco involuta v. a s c is elongatis, subcylindricis clavatisve, basi fixis inclusa.

Pyrenomycetes epiphyti, parvuli, ingenti individuorum copia ex omnibus plantarum emortuarum lignosis potissimum partibus, ubique terrarum nascentes, hine ad Coniomycetes, illinc ad Lichenes accedunt.
TREDES I. XYLOMACEI Fries $s y s t, I I$, 319. Perithecium rumpens. Nucleus sporidiis nudis (i. e. ascis haud inclusis) farctus.

\section{XYLOMACEI ASPORI.}

Fructificatio wulla. - Exanthemata et perfectiorum Pyrenomycetum primordia.

a) DEPAZHA Fr. Puncta minima diseoloria, foliis inuata.

De paze a Fries obs. II. 365. t.5. f. 6.7. Syst. II. 603. $\mathrm{P}$ h y 1108 tiet a Pers. mse.

) ASTEROMA DC. Maculae fibrillulosize, follis innatae.

A s t e rom a DC. in Memt, du MLus. III, 329. t, 4. f, 1-5. Fries syst. II. 609, Libert in Annal, soo. Linn, paris. $V$. 404. t. 5. f. 2. 3. A ctin on e ma Pers, myc. I. 32 .

c) ECT0STroma Fr. Macnlae effusae, follis inmatae.

Ectostrowa Fries syst. II. 601. X y 10 mat is sp. DC.

d) XXLOMLA Pers. Tuberenla vesiculoso - indurata, folis innata.

$\mathrm{X}$ y 1 o m a Pers. synops. 105. exel, sp. Fries syst. Tr. 601.

360. Nueptostromat FR. Pe rith $\mathrm{e}$ i $\mathrm{um}$ innatum, dimidiatnm, effusum, centro subumbonatum, nec ostiolatum, demum basi circumscissum v, totum a matrice secedens. - In epidermide variarum stirpium.

Leptostrom a Fries obs, I. 197. t, 1. f. 6. II.361, t.7. f. 4. Syst, $I T, 597$. S e hizod e r ma Elirenb, sylv. 27. Lep. tot h y $\mathrm{x}$ i m Kunz, myc. Heft. $\Pi$, 79 .

36 1. Actingtheyneinge $K U N Z$. Perithec i n in inatum, sentiforme, radiato-fibrosum, apice fatiscens. - In culmis et foliis graminum.

Actin ot h y $\mathrm{ri}$ a m Kmaz, mye. Heft. $H$, st. Fries syst. II. 597 .

382. Eabrella FR. Perithecinm innatum, rotundato-difforme, apice rima dehiscens. Sporidia massae gelatinosae immersa. - In caulibus et foliis variarum stirpium.

L a brell a Fries elench, II, 149. non Desmaz.

363. Prostloeminan KUNZ. Peritheci um immersum, dimidiatum, apice rumpens. Sporidia fusiformia, septata, stromati deplanato primmm innata, demum effusa. - In corticibus.

Prostheminm Kunz, myc, Heft, $T$. 17 .

364. Sphinetrima FR. Perithecium integrum, ore orbieulari dehiscens. Sporidia globosa, in diseum coacervata. - In corticibus.

Sphinctrina Fries pl. hom, 120. Calicium turbiantum Achar, synops. S6, Hypoxylon $8 \mathrm{phinetri}$. o u in Bnil. t, 1 iti. f. 1 .

Quid Bryocladiom Kanz. et Sphinctosparium Kunz, a cl. Heichenbaehio consp. n. 243, et 333, eammemorata.

THEIEUS TI. CYTISPOREI Fries syst. II.318. Peritheci um ostiolatum. Nucle us sporidiis nudis $v$, inter ascorum rudimenta inclusis farctus, dissolutus.

385. Phoma FR. Perithe cinm spu. rium, e matrice formatum, ostiolo pertusum. N ncle us grumosus, demnm s poridia simplicia rejiciens. - Entophylli, fuscescentes, pustulaeformes.

Phom a Fries syst, IT, S46. Elench. IX, 119. Na emas pora Elirenb. in Hor. phys. t. 18. f.7. S phacriae sp. Sowerb. $t .372, f .1, t .374 . f, 2,-$ ? S a ci d i a $\mathrm{m}$ Fr. Nees in Kunz, myc. Heft, II, 64, t, 2, f. . .

366. Ceuthospora FR. Perithe $e$ in m innatum, in tuberculo vesiculoso-carnoso reconditum, astomum, demum irregulariter dehiscens. Nucleus dissolutus. - In foliis coriaceis.

C e n tho spora Fries $p l$. hom, 119. Grev. tcot. t. 253. 254. - 2 Helf eobolus et Coceobolins Waltr. Fl. germ. II, 731. A s coxy ta Libert crypt. ard. $f, 1$.

367. Cytispora EHRENB. Perithec i u m innatum, cellnloso-multiloculare, loculis difformibus, ostiolo communi elongato apertic. 
Sporidia simplicia, cum gelatina demnm indurascente eirrhose profluentia. - Entophylli.

C y ti s pora Elırenl, sylv, 28, Fries syst. IT.540. Elench, II, 116. B o s r y chia Fries in Fet. Acad. Handl. 1818. p.119. Variolariaes p. Bull. $t$. $432 . f .2 . \mathrm{H}$ y pox yli sp. Bull, $t, 487, f .4$. S p hae riae s p. Sowerb. $t$. 138. Hoffm. veg. crypt. t.5. f. 5. Na e mas por a e s p. Pers. Grev. scot. t,20. Cryptosp hatriat sp. Grev, scot, $t, 13$.

368. Splhaeromema FR. Perithe eium innato-superficiale, estiolo simplici. Sporidia simplicia, mucosa, sacculo tenuissimo inclusa, ernmpentia, in globnlum tandem fatiscentem indurata. - In lignis, imprimis pineis.

Sp hatorom a Fries obs, I. 187. t. 2. f.7. 8. Syst.IT. 335. Grev, seot, $t, 189,-\mathrm{z}$ th ha Fries $p l$. hom, 118. $\mathrm{S}$ pha eriae s p. Tod meckl. t.114-119. Nees f.325. Alb. et Schw. neisk, t.8.f.8. t, 10. f. 5 .

TRIBU III. PHACIDIACEI Fries syst. II. 317. Perithecium ostiolo dehiscens. A s ci discoidei, erecti, fixi.

SURTIRISUS . PHACIDIEI Fries $p l$. hom, 117. Perithecium subdimidiatum, demum apertum. Nucleus nudus.

369. Exeipula FR. Perithe ciu m subinnatum, orbiculare, margine inflexo clansum, dein ore orbicnlari discoideo-apertum. N nel e u s mollis, subdeliquescens. - Fungilli lignicoli, atri, minimi.

Exeipula Fries syst, II, 189, Elench, II, 146, Grev,

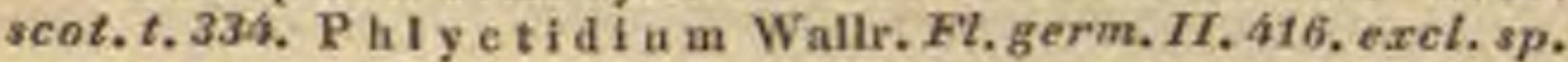

3ร0. Nysterium FR. Perithecium sessile, ovale vel elongatum, rima longitudinali primum clausa, hians. Nuclens linearis, subpersistens. A s ci erecti, fixi, paraphysibus stipati.

Fungilli epiphyti, gregarii, minuti, nigricantes, persistentes.

H y sterin m Fries syst. Tr. 579. Elench, II, 137.

a) LOPHODERMIUM Chev. Innatae, perithecio dimidiato.

Lophoderminm Chev. paris. 436. Hypodermil s p. DC. (Grev, scot, t. 26.60, 87. 88. 129.)

b) HYSTERIUM $D C$. Superficiales, perithecio integro.

Hy s t e ri u m DC. Ft. fr. IT. 304. (Grev. scot. i. 16\%. f.2. $t .233$.

381. Plnaeidium FR. Perithecium subrotundum, simplex, apice in lacinias plures dehiscens. Nucl e u s disciformis, subpersistens. A s c i erecti, fixi, paraphysibns stipati. - Fungilli corticoli, lignicoli, epiphylli, nigricantes.

Phacidium Fries syst. $I$. 5\%t. Elench. $I I, 129 . \mathrm{P}$. lidi u m Kunz, myc. Heft. IT. 92. S clerot if s. Fl. dan. t. 1380 . X ylomatis s p. Pers. ic. pict. $t, 10, f$. 1 . Dittm. apud Sturm II, t.63. T r ib Ii d i u m Fries syst. I, 183, Elencl. II. 130. Cliev, par, t.8. f.9. (Grev, scot, t. 103.)

3\% 2. Araplaiola POIT. Peritheein ovale, duplex, exterius crustacemm, apice in lacinias dehiscens; interius membranaceum laceromultifidum. Nucleus subgrumosus, tandem in pulverem paraphysibus inspersum fatiscens. Fungillus elegans, in folits $P$ hoen icis dactylife$r a e$, etiam in caldarits non infrequens.

G $\mathrm{r}$ a $\mathrm{p}$ hi ol a Poit, in Annal. se, nat. I. 278, t, 26.f. 2, Kunze in Flora, 1826, I. 278. Trichodes mi nm Chev. paris, 389, t, 11, f, 1. - $\mathrm{Ph}$ heidium $\mathrm{Phoenicls} \mathrm{Mong.}$ Fríes. - ? Elpid ophora Ehrenb. ex Link in Berl. Acad. Abhandl. 1824, p. 172.

383. Thingisma FR. Perithe eium innatum, difforme, rima flexuosa frustulatim apertum. Nucle n s placentaeformis, persistens. A s c i erecti, fixi, paraphysibus stipati. _ Fungilli epipliyti, pu stulaeformes.

$\mathrm{R}$ b y $l$ is m a Fries syst. IT. 565. Elench, $I$, 126. Corda apud Sturm $F I T$, \& $t, 14-16$. P 1 a c un $t$ in m Ehrenb, iu Hor. phys. 101. X e il a ri a Libert crypt. ardenn, exsicc. $f, 1$. -
? Cryptom yces Grev. scot, t, 206, X y $10 \mathrm{mat}$ is s p. DC. Mem. Mus. III, t.3. f. 5.9. Grev, scot. t. 118.

SUETRERE T. GLONIEI. Perit heci um integrum, rimis arcte conniventibus dehiscens.

3\%4. Aetidium FR. Perithecinm sessile, rotundatum, a eentro versus ambitum rimid canalienlatis dehiscens. As ci erecti, fixi, eylindrici, persistentes, s p o ridits simplicibus rotundatis. Tha 11 u \& nullus. _ Fungilli lignatiles, aterrimi, contextu granuloso.

Actidium Fries obs. 1, 190, t. 3. f, 1. Syst.IT, 596. Fr. Nees in Meliq. Haenk, I. 2. 1.1. f., 1.

3ร5. Loploivm FR. Perithesium subsessile, elongatum, compressum, rima Iongitudinali dehiscens. A s e i ererti, fixi, eylindrici, fatiscentes, sporidiis simplicibns, rotandatis. Th a 1lu s crustaceus v. nullus. E Fungilli epiphyti, atri, fragiles, conchaeformes.

L op h 1 u m Fries syst. $I T$. 533. Grev. scot. t. 177. H y. sterium mytilinum Pers. Nees f. 301 ,

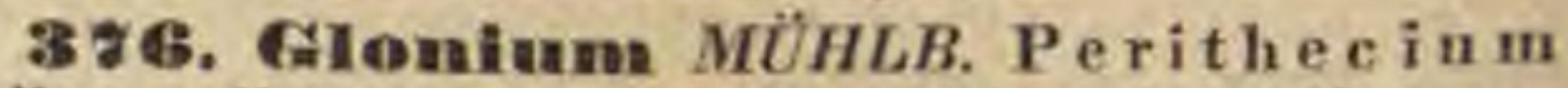
sessile, radiato - ramosum, ramis teretinsculis prostratis, rima longitudinali dehiscentibns. Ase i erecti, fixi, clavato-teretes, sporidiis fusiformibus uniseptatis. ThaIl u s byssinus, persistens. - Fungillus fusco-nigricans, in lignis cariosis 1 m e r $i$ e a e borealis repertus.

G10n Ium Mtihlenb, catalog. Americ, 101. Fries syst. IT. 593. Sole n a rium Spreng. pugill. I. 66. Kunz. myc. Heft I. 48. ז.2. f. .

SUETHETS MI. DERMEI Fries $p l$. hom. 114. Perithecium (excipulum) demum apertum, cum receptaculo floccoso connatum. Nucle us disciformis, ascigerus, receptaculo impesitus.

3ร\%. Heterosplaneria GREV. Perith e ci i m integrum, limbo libero connivente cum strato discigero connatum. As c i filiformes, persistentes, sporidia demum in globulum viscidum collecta secernentes. - Fungilli caulicoli, minuti.

Heterosplateria Grev. scot. t. 103. Fries $p l$. hom. 112. Sphaeria Patella Tod.

388. Cenangium FR. Perithecium integrum, coriaceo-corneum, ore connivente apertum, a strato discigero distinetum. A s e i filiformes, persistentes, sporidia discreta explodentes. Fungilli polymorphi, epiphyti, fusco - nigri v. atri.

C e na $\mathrm{g} \mathrm{i} \mathrm{m}$ Fries syst. $I T, 177$. Elench. IT, 20 .

a) CLITHRIS Fr. Frumpentes, hysteriiformes, rima Iongitudinali aperti.

C lithris Fries $I t, c c$, C a 1 po ma Wallr. Ft. germ. $M$. 492. Pezizae sp. Auet. Hy steriis p. Tod. meckl. $t$. 8 . $f .64$. Nees syst. $f .300, \mathrm{~S}$ pha e ria e s.p. Sowerb. $t, 373 . f_{0}, 3$. Variolariae s p. Bull, $t, 432$. $f .4$. (Grev, seat. t. 197.)

b) SCLRRODERRIS Pers. Erumpentes, sphaeriaeformes, ore orbiculari integro aperti.

Scleroderris Pers. Fries $2 l$. ce. sphaeriae sp. Auet. Tode meckl. t.14. $f, 113$. Pexiz a e s p. Auet. Alb. Schwein, neisk. t.8.f. 2, C e ratost om a Fries obs, IT, 338 .

c) MICROCRATER. Superficiales, pezizaeformes, ore orbiculari repando aperti.

Peziza Cratorium Schwein. car. p.9. t.1.f. $z-11$.

3\%9. Dermea FR. Perithecinm integrum, suberoso - coriaceum, ore lato apertum, cum strato discigero demum plano confluens. As ci distincti, fixi, persistentes. - Fungillus nigricans, pezizaemorphus, epiphytus.

Dermea Fries $p l$. Aom, 114. S phaerlae sp. Pers. ic. pict, t, 20. f.1. Peziza e s p. Roth eatal, II, $t, 9 . f .3$. 
SURTRERES IV. TYMPAVIDEI Pe$r$ it he $c$ in $\mathrm{m}$ apertum, marginatum. operculo v. velo clausum.

380. Tymenamis TOD. Perithecium cyathiforme, marginatum, apertum, velo tenui, fatiscente tectum. 1) is c is receptaculo (strato proprio) impositus, demum fatiseens. Is c i filiformes, fixi. - Fungilli gregarii, nigricantes, per epidermidem ramulorum erumpentes.

T y mpan is Tod. mechl. I. 23, t.4. f. 37. Fries syst. II. 173. Elench, II, 17. Grev, scot, t.338.

391. Teeanidion $E N D L$. P e rit he $\mathrm{c}$ in m pateHaeforme, marginatum, apertum, velo tenui, cam nucleo conflnente tectum. Discus demum a s $\mathrm{e}$ is annulatis erumpentibus pulverulentus. Fungilli epiphyti, erumpentes v. superficiales, gelatinosi v. coriacei.

Lecanidion Endl. El,pos. p.46. Cy cledinm Wallr. FL. germ, II, što. P at ella ria Fries syst. II. 158. Elench. IT. 15. uou Achor. Patella Chev. par. 302. nou Zoolog. Pezizae sp. Bull. t. 438. f.1. Nees f.265. Lichenis sp. Hedw, musc, frond, $11,61, t, 21, f, a$.

3Sz. Sterilla REICHENB. Perithecium patellaeforme, marginatum, operculo decidun apertum. Dise us ceracens ex a s e is erectis, fixis, emm paraphysibus mixtis, demum diffluentibus. - Fungilli epiphyti, superficiales v. erumpentes.

Stegllla Reieheab. consp. 11. Sphaerothyrinm Wallr. W7. germ, II. 431. S te gi ia Fries syst. II. 152, t. 8. f.9. non DC. E ustegi a Fries sjst. II. 539, Elench, II, 119, non R. Brown.

TIREBS IV. SPHAERIACEI Fries $p l$. hom. 103. Perithecinm elausum, ostiolo pertusum, n nc] eo ascigero subdiffluente faretum.

SUBTERBU I. DOTHIDINI Fries $p l$. hom. 111. Perithecia in stroma celluliferum confluentia. Os tio I um nullum v. subtile porosum.

383. Ascosphora FR. Perithecia innata, ostiolo simplici. Nurle us granuloso-gelatinosus, as cis subglobosis oblongisve faretus, demum diffluens, subeirrhose propulsus. epiphylli, innati, nigricantes.

Ascophora Fries $p l$, hom, 119 , S phaeria Aeg apodil Pers. obs. T. 17.

384. Dothidea FR. Perithecium dimidiatum, cum stromate celluloso confusum, ore simplici apertum. Nucle us cereus. A sci erecti, fixi, subpersistentes, paraphysibus stipati. - Fungilli epiphyti difformes, nigricantes. Genus moximıpere nobis dubium, intactum servamus.

Dothidea Fries obs. II. 3az. Syst. II, BA8. Elench. II. 120. - Pol y stigma DC. op. cit, p.330. t.3.4. Grev. scot. t. 120 . (S p hae riae s p. Nees syst. f. 31\%. N. A. N. C, IX, t, G. f.21. Xylo matis s p. Fries obs. T, t.4.f. 7.) Py re no chi a Link in Berl, Aeadem, Abhandl, 1824, p, 171. (D. pyrenophora Fries.) - Spltaeriomorphium Link $L, c$. (D. s phaeroides Fries.) - T y phodium Link op.eit.p.176. (D. typhina Fr.) - ? S porothe ca Corda apud Sturm. t.54. - Exospori i sp. Auct.

385. Vermienlaria TOD. Perithecium depressum, astomum, lacero-dehiscens. A s ci annulati, vermiculati. - Fungilli epiphyti, setosi. Genus nemini non dubium.

Vermicularia Tode meckl, H, 15. f.8, Fries pl.hom, III. Elench, IT. 107. Grev. scot. t. 345. - M y d a il atriehum, Colletotrichum, Triehostoma et Osprio. s. por in Corda apud Sturm III. t. 19. 21. 26. Exospo. rif s p. Link.

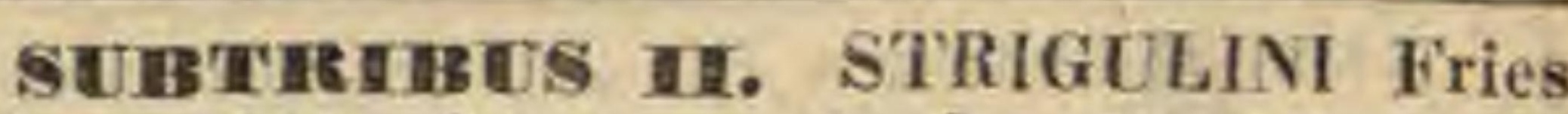
pl. hom, 1to. Strom a duplex discretum, in crustam corneam, matrici innatam abiens. Ostiolum inaequale, saepe ampliatum.

Cruslae lichenosae, folia viva arborum tropicarum conspurcantes. Transicus manifestus ad Lichenes. Genera mihi, etiam quo ad locum in systemate, maxime dubia, ex herbario a me saltim non extricanda.

386. Neliola FR. ${ }_{2}$ Perithecia cornea, globosa, fib ris septatis innatis imposita, os ti olo longissimo. Asei distincti, convergentes." $\mathrm{Fr}$.

Meliola Fries $p l$, hom.111. $2 \mathrm{~T}$ ri charia Fée crypt. cort, $t .3 . f .1 s$.

38\%. 5trigana FR. $P$ e r ithe $\mathrm{c}$ ia carbunacea, globusa, fareta, os tiolo rimuso, inaequabili. Nucleus sicens, fatiscens (?) Stroma corneum, subeffiguratum. ${ }^{D} \boldsymbol{F r}$.

Strigula Fries $p l$. hom, 111, Elench, H. 114. Stigmatidiam Mejer Flecht, 228.

Huc etiam geaera is quammariea epiphylla" a cl. Fé e eondita:

a) NEMATORA Fée, „Th thall as byssoideus, expansionibus divergentibus. Modosis, apice turgidis obtusisque. A pothecia (tubercula) in extremitate ramulorua snbimmersa, aterrima, intus lomogeuea. ${ }^{\circ}$

Neinatora Fee Meth. Liehen, 43. i.2. f.4.

b) RACOPLACA Fée. wT Thallus membramaceus, laevissimus, in lacinulas angustas anastomosantes partitus. Apothecia (tubercula) sparsa, aterriua, uitida, intus lomogeuea.

Racoplaca Fée Meth. Lichen, $43, t, 2, f, 5$.

c) PHYLLOCHARIS Fee. , Th a ll as erastaceas, uniformis, orbicularis, e ramulis divergentibins, eonilnentibus adpressisque formatus. A p ot li e efa ceaber. cula) sparsa, atra, perforata, intus homogenea, margine abtuso:

Phy $110 \mathrm{eharis}$ Yée Meth, tichen. 4h, t, 2. f.3.

d) CRASPEDON Fée. ${ }^{\mathrm{T}} \mathrm{h}$ a $11 \mathrm{lu}$ s crassus, sublobatorotundus, fimbriatusque, impressionibus punetiformibus, in tota superficie sparsis. Apothecia (tuberoula) sparsa, aferrima, nitida, intus homogenea."

Crasped on Fée Meth. Lichen. 4h. t.2. f.3.

c) MELANOPHTHALMUM Fée, , Thall a s orbicalaris, crustaceos, snblobatinsque, inaequalis. Apothecia (tubercula) atra, nitida, $4-6$ in centro thalli cangesta, sed non eonfluentia."

Melanophthalm a m Fee Meth. Lichen. 45. t. 2. f.9.

f) AULAXINA Fee. "Thallus orbiealaris, membrataceus, striis concentricis notatus. Apotheclum (pseudo-lirella) triangulare, impressum apertumque, angulis acutis.

A ulax in a Fée Meth, Lichen, 4s, t, 2, f.7.

388. Corynelia $A C H$. Perithe einm sulglobosum, stipiti subclavato cavo impositum, poro demum ampliato inaequali-apertum. Asci clavati, breves, demum in pulverem fatiscentes. Fungi caespitoso-gregurit, stromati subrotundo convexo nigro insidentes, in foliis Iridearum capensium.

C or y Syst. $I$. 534. M ucor clavat as Lian.

389. Thammomyees EHAENB. Perithe cia subglobosa in stipite cavo terminalia, porn pertusa. Ase i irregulares, sporidiis fareti. Fungi caespitoso-gregarii stromati subrotunda impositi, nigricantes rigidi, stipite simplici $v$. ramoso, in corticibus arborum tropicarum viventes.

Th a m o om y ces Ehrenb, in Hor. phys, 79, t. 17. f, 1 . Fries in Linnaea $V$. 534. Montague in Nows. Ann, se, nat. II. $35.7 .4 .$, . 4 .

SUB'TRIBUS III. DICHAENEI Fries pl. hom. 108, Perithecium rimose dehiscens. Str o ma discretum, matrici adnatum. 
350. Gibbera FR. Perithecium rotundatum, velo destitutum, apice rimis irregularibus dehiscens. Asci erecti, convergentes, diu persistentes. - Epiphyti, solitarii v. aggregati, innati, demum erumpentes.

G ib bera Fries $p l$.hom, 110.S phae rtae $s$ p. Sowerb. t.373. $f, 1$.

391. Dstropa FR. Perithecium ro tundatum, per velum innatum erumpens, rima transversali marginata fissum. As ei diflluentes. In ramis emortuis solitarii, erumpentes.

ostropa Fries $p l$. hom. 109. Spliateria ScIeroti $u$ m et $\mathrm{S}$ ph. barbara Fries syst, II, 468, et 490.

392. Hy pospilla $F R$. Perithecia glo bosa, relo communi discreto innato tecta, ostiolo oblongo aperta. As ci convergentes, mox diffluentes. - In ramis languescentibus arborum tropicarum. Achar.

Hy pospila Fries pl. hom. 109. Spiloma iu us tu

393. Dichaema FR. Perithecia rotundata, per velum commune discretum innatum erumpentia, irregulariter dehiscentia. As c i erectiuseuli, subpersistentes. _ In ramis viv s erumpentes.

Diehaena Fries $p l$, hom, 108. Elench, 11 . 141. Pa i $\mathrm{m}$ or $\mathrm{ph} \mathrm{hm}$ Chev, in Journ, Phys. 1822, t,3. f.2.3. S c hi zoder ma Chev. paris. 438. 2. 11. f.21, Phlae oscotis Wallr. Heterographu Fée Melh, Lich, 16. Dich, olass. VIII, 184.

SUBTIEIBET I\%. SPHAERINI Fries pl. hom.103. Peritheci u m ostiolo plus minus prominente, rotundato, rarius compresso, apertum. Strom a adnatum.

394. Splhaeria $H A L L$. Perithecia ceracea, gelatina diu farcta. As ci subclavati, s p orid i a simplicia, pellucida, villi v. fumi instar propellentia. - Epiphyti, innati, primum epidermide tecti, dein erumpentes, velo nullo.

S p ha eria Hall. helv. TII. 120. Fries pI. hom, 108. Aecidiun Hill, hist. veg. 62. Pustularia et PerispoAlaria Rouss. ex Desv. Journ. bot. I. 143. - Exor matostoma Gray br. pl. I. 521 . Cueurbitaria Gray br. pl. I. 509. Grev. scot. $t, 50,84,135,195$. S pl a ne hu a e u a Corda apud Sturm l. ak. Cryptos phaeriae sp. Grev. scot. $1,13,45$.

3פ5. Vallsa $A D A N S$. Perithe cia membranacea, nueleo fluxili. As c i subelavati, sporidia subsimplieia, pellueida, gelatinae instar propellentia. - Epiphyti, immersi, demum plus minus erumpentes, velo nullo.

$V$ a 1 s a Adans fam. $I I$. 5.. Fries $p l$. hom, 108. VarioI a tia Rouss. ex Desw.Journ. Bot, I, 143, - Engyxosto ula Gray br, $p l . T$. 519 . Cireinaria Pers. Sphaeriae b p. Nees syst. f. 321. 399, 331, 332, 333, 336.337. C r y p to- p ba eria s p. Grev. scot, $4,68,201$.

396. Fllyoxylom BULL. Perithecia subcornea. A s ci i slavati, s p oridia septata, opaca, pulveris instar explodentia. - Epiphyti, rigidi, nigri, adnato-superficiales, velo pulverulento fugaci.

H y p ox y 1 on Bull. champ. 316. Fries pl. hom. 116. Grev. scot, 324.397. - Por u i a Willd. Fl. berol. 400 . X y I a r la Pers. synops. 289. Grev, scol, t, 86.237. Peripherosto ar a et Nemania Gray br. pl. T. 513 . S phaeriae s p. Auct. Nees syst. f. 307.316,345, 348, 357. Grev. scot, t, 6 . 39. $47.82 .138,152.175 .186 .32$. C r y pto o phaeriae sp Grev, scot.t. 78. Stro matos p baterlat sp. Grev. scot. t. 32. 135. 204. 215 ,

387. Hypderea FR. Peritheia membranacea. A s $\mathrm{c} i$ filitormes, $s p$ is $\mathrm{r}$ i $\mathrm{i}$ a simplicia pallida, flocei $r$. globuli instar prorumpentia, Carnosi, laete colorati, epiphyti et epizoi, supra matricem effusi $v$. floceis adhaerentes.

H y poerea Fries pl, hom. 101. Sphatia s p. Auet. Tiees vost. f. 304.305. 360-362, - Quid Erios p o rs ug i u a Bertero ex Bullet, se, nat, $\mathrm{X}$,, $\mathrm{III}$.

\section{Dralo XVI. Hymenomeycetes.}

HYMENOMYCETES Fries $p l, h o m, 97$. FUNGI Brongn, it Dict, class, III. 461 .

Fungi carnosi, suberosi, spongiosi v. gelatinosi, forma globosa, cupulata, clavaeformi v. pileata, contextu vesiculoso homogeneo, v. solido subfloceoso, membrana fructilicante (hymenio) obtecti, cui sporidia intra ascos plus minus evolutos immersa.

Hysterophyta perfectissima, terrestria, lignicola $v$, fimicola, vix unquam in stirpibus vivis parasitica.

SEIRTED I. TREMELLINI Fries sysc. II. 207. Receptaculum vagum, gelatinosum, siccitate indurascens, apertum, undique v. superne tantum fructificans. Hymen i m glabrum, cum receptaculo confluens. A s c i nulli. Sporidia globosa, sub hymenio nidulantia. Contextus vesiculosus v, floccosus, uniformis. Epipleyti, perfectiores lignicoli, in Europa, Asia et America boreali observati, brumales potissimum et vernales, e patria vix diversi.

TRIBUS I. HYMENULI Fries $p l$. hom. 94. Receptaculum coriaceo - v. ceraceo-gelatinosum. Sporidia obsoleta.

398. Leidalerma PERS. R e ce p $t$ a $c u^{-}$ I $\mathrm{m}$ cum hymenio confusum, adnatum, applanatum, laeve, tenuissimum, hamidum molle subgelatinosum, siceum coriaceum. Sporidia (?) immersa. - Fungi epiphyti, Sclerotia referentes.

L eio der a a Pers. myce europ. 109. H y menella Fries syst. $I T$. 233. Н у в е и и l a Eries $p l$. hom. 94.

399. Agyrivm FR. Receptaculum compactum, homogeneum, ceraceum, humidum gelatinosum, innato-sessile, sphaerieum, laeve, undique fructificans, s u perficie demum in s p oridia fatiscente. - Fungilli lignatiles, punctiformes, gregarii, floceuloso-contexli.

A gyriu m Pries syst, 1X. 231. Grev scot, t, 238. S tictis $r$ a $f$ a Pers. obs. $I t, t, G, f .1$.

TEDIRUS II. TREMELLEI Fries $\mathrm{pl}$, hom. $9 \mathrm{~s}$. Receptaculum gelatinosum. II y menium amphigenum.

400. Pyrenium TOD. Receptacu I um subrotindum, sessile, pulpa gelatinosa faretum, cortice laevi, tandem sporidiis emergentibus pruinoso. - Fungillus gregarius, arrhizus, in terra squallida obiter observatus.

Pyrenium Tosle meckl, I.35, 1,6.f.50. Fries syst. II. 243. Elench. Ir, 39. Grev, scol, t. 276.

401. Dacrymyees NEES. R e $c$ e $\mathrm{p}$ t a $c u$ 1 u m carnoso - gelatinosum, homogenenm, und i qu e fruetificans, glahrum, demum subdeliqnescens. Contextus floccosus, floecis assurgentibus, quibus sparid ia interspersa. - Fungi minores, epiphyti, subrotundi $v$, disciformes, subsessiles.

Dacr y my ces Nees syst. 89. $f$. 90. Fries syst, IT. 228. Elench. Ir. 35. Grev, scot, t. 139. Tremella e s p. Bull. t. 455. f.3. Pers. ic. pict, t. 10. $f, 1$, - An hue $\mathrm{X}$ ylis s $n$ s.

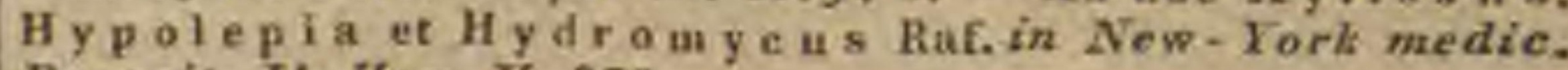
Reposit. 11 . Hex. D. 356 .

402. Naematelia FR. R e ce p $\mathrm{t}$ a $\mathrm{c} \mathrm{u}$ u $\mathrm{m}$ gelatinosum, undique fructificans, glabrum, nucleum carnosum compactum hetcrogeneum incIadens. Sporidia in ambitu dispersa, demum emersa. - Fungi minores, epiphyti, rotundati, sub. 
pulvinati, inumarginati, sacpius substipitali, superficie plicata $v$. gyrosa.

Naematelia Fries syst. IT. 227. Encephalium Link. T remella eneepla Ia Willd. in Usteri Magaz, $I$. 17. 4.4. f. 1\%.

403. Treanellin DILL. Rereptac n I m gelatinosum, molte, homogenenu, subpellucidum, multiforme; undique fruetilieans $v$. hy menii membrana tenui tectum. Sporidia in ambitu utringue dispersa, subemergentia. - Fungi epiphyti, libere evoluti, basi saepe radicantes.

Tremell a Dill, muse, 41 . Fries syst. II. 210. Elench, IT. 32. Nostoe Vaill, bot.paris. 144.

a) PHYLlopta Fr. Cartllagineo-foliaceae. - In Fungis parasiticae.

Phyllopta Fries syst. II. 219.- An lue A mphiphytu u Schweis.?

b) CORYNE Fr. Caruoso-gelatinosae, subclavatae. Ramicalae.

C ory ne Nees syst, $127, f, 163$, T re m ell a e s p. Schiaeff. t. 323. f. $1.3-6$. Bull, $t, 400 . f, 5$. Bolt. $t, 101, f$ 2, Pers. ic. pict, t. 10. f. 1. A eros permis s. Tod. in Usteri Magaz. 1V. t, 12. Clavaria galeata Holmsk. ot. I. 25. c. ic.

c) CEREBRiNa. Pulposae, targidae, primum compactae, e sporidiis pruinosae. - Ramicolac.

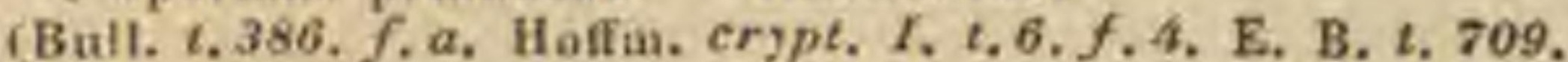
1870.2177. Nees f.142.)

d) MESENTERIUM. Caespitosae, foliaceo - expansae, flaccilae, nudae, - Ramicolae.

Gelatina et He pataria Raf. in New-Yorkmed. Re

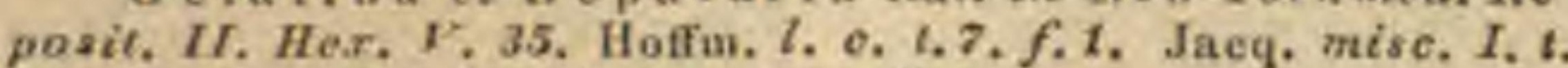
13. (Bull. t, 279. 406. f, a, b, d, t, 499.)

TIE UE US III. CUPULARES Fries pl. hom. 92. Recepta $c \mathbf{I} \mathbf{u m}$ gelatinosnm v. coriaceum, plerimque cupulacforme, submarginatum. H y m eni u m superum, papillosnm.

404. Exialia FR. Rece p ta u lum molle, gelatinosum, homogeneum, horizontale, submarginatum, supra tantum fructificans. Hy me $n$ i $x$ m persistens, papillis duris prominentibus tectum, demum costato-plicatum undulatumve. Sporidia primum ascis plus minus obsoletis inclusa, dein elastice exsudantia. - Fungi lignatiles, simplices v. caespitosi, libere evoluti, rotundati, concavi vel pluniusculi.

Ex id a Fries syst. IT, 220, Elench, II, 33.

a) SPICULARIA Chev. Planlusculae, undulatae, subtas rugosae. Asci obsolets.

Spicularia Chev, par. 94. Tremellae sp. Bnll. t. 480. f. 1 , FI. dan. t, 884, Hoffm. crypt, I. t, 8. f. 1 .

b) MAgomyCES, Pezizoideae, plieatae, subtus villosae v. punctato-scabrae. Aset distineti.

A arieulartae sp. Link. Ehrenb. in Hor. phys. berol. t. 19. f. 9. T re ue ila s p. Lien. Bull, t, 427. $f$. 2. $t$, 460. Bolt, $t, 107$. Dittni, apud Sturm t, 13. Nees syst. f.141. E. B. $t, 2452$, (Fr. Nees offic. Pflanz, ic.)

405. Lemalis $F R$. "Receptaculum ceracen-gelatinos me, submarginatum. H y men i u superum laeve, demum sporidiis secedentibus pruinosum." $\mathrm{Fr}$. - Genus inquirendum.

L e malis Fries $p l$. hom, 93,

40Q5. Hifrmeoln FR. „Receptaculum coriaceum, cupulaeformp. H ymenium superum, papillosum, pubeseens." Fr. _ Fungillus antilla$n u s$, vix notus.

Hiraeola Fries ph. hom, 93. Peziza flava Swartz Fl. Ind. occid. IKr. 1933 .

TREIB US IV. PILEOLARES Fries pl.hom.92. Recepta $c \mathbf{l} \mathbf{l}$ m membranaceum, siceum, pileatum, excentrice substipitatum. H y m e $\mathrm{n}$ i u in inferum, laeve.

40r. Laselnia FR. Recept a culum gelatinosum, expansum pileato - dimidiatum, h y men io nullo discreto, pagina inferiore faroso-retien- lata, fructificante. - Fungillus gu in eensis, lig. natilis, pileo semiorbiculari margine postico adnuto, fuscescente.

\section{Las chia Fries in Linnaea $V .5 .33$}

408. Craepinia $F R$. Receptacnlum cartilagineo-gelatinosmm, pileatum, varie tortum. H y men i $\mathrm{mm}$ discretum, gelatinosum, unilaterale, subinferum, intns obscure tubulesnm. - Fungi terrestres $v$. lignatiles, sessiles v. substipitati, laete colorati, inter tropicos ut videtur nobiliores.

Guepinia Fries $p l$, hom. 92. Elench, $I I, 30$. Gyro. cep halus Pers, in $A n n$, soc, linn, paris, IIT. 75. Tre. mella e sect. 1. Hygroin itra Fries syst, IT. 211. Tre. mella helvelloides DC.et T. rufa Jaeq. misc. I. 2, 16. Merulii sp. Seliwein. carol, $n, 834$, i, $2, f, 1-3$.

465. Cyphella FR. ReceptaenIum submembranaceum, concavm, obliquum, cernuum, hymenio nullo discreto, subtus fructificans. Sporidia globosa, majnscnla, pulveris instar secedentia. - Fungi lignatiles v. muscicoli, cupula subsessili v. excentrice stipitata, tandem lacera.

C y phella Fries syst. II. 201. Elench. II. 28. Pezi-

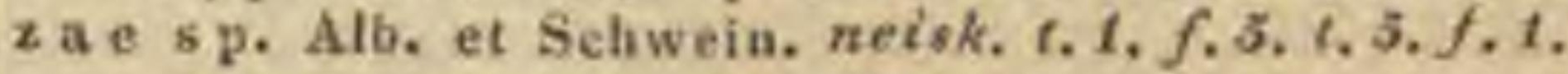

410. DRiflotis FR. Reeeptaculum cartilagincum, ovato-oblongum, stipitatum. Hy m eni u m inferum, discretum, separabile, laevissimnm, tandem rimosum. As ei immersi, longi, s poridiis uniserialibus fareti. - Fungus truncicola, rufo-badius, lateraliter stipitutus, Midue aures in mentem revocans.

Midotis Fries $p l$, hom. 363. Elench. IT. 29.

411. IIIfotium TOD. $R$ eceptacuI n m membranaceum, pileatum, stipite suffultum, integrum, subtus fruetificans, Fr. - Genus inquirendum.

Helotím Tode meckl. I. 29, Fries pl. hom, 92. Peron a Pers. myc. ourop, KI. .

SUEGIB DA II. CLAVARIEI Fries syst. I. 461. Receptacnlum clavaeforme, perjendiculare, subcylindricum, simplex v. ramosum, immarginatum, stipite vix distincto. H ymenium amphigenum, laeve. Asci sublineares, vix paraphysophori. Substantia carnosa. - Infimi epiphyli, perfectiores terrestres; simplices serotini, ramosi ut plurimum vernales, saepe meleorici. Duratio brevis. Mijores in cibariis recepli. Fixolici vix noli.

TURE Substantia gelatinoso-cornea v. carnosa. I y m en i um confluens. As ei abbreviati v, obliterati.

41Z. Frerala FR. R e e p ta e u 1 n m filiformi setaceum, subcoriaceum, cum stipite confluens, undique hymenio cinctum, apice sterili multifido. A s ei nulli, sporidia immersa. - Fungilli terrestres, caespitosi, climatis calidioris.

Pter u la Fries in Linnaea $\nu$. 531. t. 1t. $f .4$. P en i. eillaria Chev. par. $I$. 111. Clavariae 8 . Bull. 1 , 48. f. 3 .

43. Typhaila FR. Receptaeulum simplex v. ramosum, carnusum, subcylindricum. H y m e ni um clavaeforme, terminale, a stipite filiformi discretum. As c i obsoleti. - Fungilli tenaces, in foliis deject is nascentes.

T y phula Fries abt. IT. 296. Syat. 1. 494. Elench. I. 235. -? Cho rdos ty 1 u m Tode meckl, t, 6. f.55. C 4 axa. naria Corda IIT. $t, 25$ Phacorrhizae s p. Grev. icot.

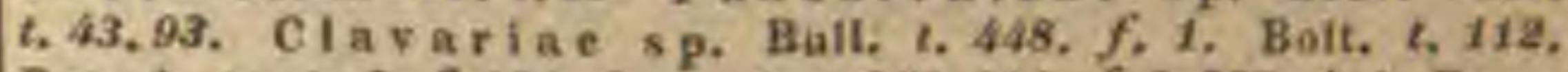
Batseh cont, 1. $f, 194$. Sowerb, $t, 253,386, f, s_{1} 387 . f, 4$. Pers. synopr. s.2. $f .14$. Clavaria capillaris Holars. t. 3. c. ie. 
41. Calocera FR. Receptaculum simplex r. ramosum, corneo-gelatinosum. H y meni um persistens totam superficiem vestiens. A s c i tenues. - Fungilli lignatiles, tenaces, viscosi, radieati, absque stipite discreto, fulvi v. Lutei, sparidiis albis.

Catocera Fries syst. I. 485. Elench. T. 233. C1ava. riat s.p. Schaelr. $t$, 154. 289. Sowerb. $2,40,199$. Hoffin. cropt. II, t. 7. f. 1, Fl. dat. t. 1305. f.1. 9. Clavaria medillaris et gelatinos a Holmsk. ot. 1,80 , 81. c. ic.

4 15. Clavaria $V A I L L$. R e cepta $\mathrm{e}$ u $\mathrm{In} \mathbf{m}$ erectum, eylindricum, homogeneum, cum stipite confusum. If y me n i m concretum, laeve, superficiem totam occupans, sed superme tantum ascigeram. Asci tenues, distincti. - Fungi terrestes $v$. truncicoli, ramosi, ramis plerumque attenuatis, v. simplices, sursum incrassati.

Clav a ria Vaill. paris. 39. Fries syst, 1. 466. Elench. I. 298. Coralloldes Tournef. inst. 564 .

a) CORYNOIDES, Simplices, solitariae v. caespitosae, baxi attennatae. - Terrestres, rarius epiphytae.

Clavariae s p. (Bull, $t, 244.364,463$. Sowerb. $t$. 294. 235. 253. 277.333 . Jaeq. mise. 11. t. 12, f. 2. Fl, dan, t.775, f. 1, t. 837.f., t. . . t. 873. f. 1, t. 1255-1257.) Nees syst. f. 155.

b) RAMARIA Holmsh. Ramosae, truneo terui erecto, basi subfibrilloso, rumis gracilibus, - Plerumque truncicoLae, rarius terrestres.

Ramaria Holnsk. ot. 99. Fries syst, 1. 468. (Bull. t. 358. 4j8, f. 2. t. 496, f. . . Sowerb, Fl. dan, $t$. 836, f.2. t.775. f. 2. t. 1309 . 1304. 1376. Nees syst. f. 151. 139. Pers. clav. t. 1. f. 2. t. 3. f., 1. 5. t. 4. f. 2. 3. Ehrenb. in N. A. N. c. X. 213, t. 14, Grev, scot. t.117.)

c) BotRYOLDS. Ramosae, truaco crassiusculo, ramis obtusis, fastigiatis v. brevibus difformibus, - Magnae, terrestres, meteoricae, plarimae edules.

Clasariae s p. (Jaeq. collect. IT. 6.13. Fl, dan, 1303. Bull, $t, 222$. Nees $f .150$. Grev. scot, $t \cdot 64$.)

TUEI H ymeninm discretum, receptaculum ambiens. Ase i elongati.

4 6. Crimula FR. R e cepta $\mathrm{culum}$ erectum, cylindricam, hymenium apicem cinrens penetrans. H ymeninm heterogeneum discretum, capituliforme, deliquescens, sporigerum. - Fungillus rarissimus, corticola, gregarius, stipite subsimplici, corneo, nigricante, capitulo gelatinoso, primum olivaceo, demum albido. r. 79

4\%. Ceoglossman PERS. R eceptacuIn m erectum, clavaeforme, subcompressum, in stipitem attenuatrm. H y m e $\mathrm{n}$ i u m coneretum, clavulam incrassatam ambiens, a stipite vero diseretum, undique aseigerum. As ci elongati. - Fungi terrestres carnosi, tenaces, nigricantes, rarius laete colorati.

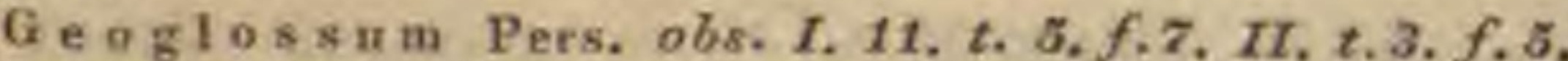
Fries syst, I, 487. Elench, II, 233. Nees syst. $f$. 157. Grev. $s c o t, t, 185,211$. C lavariae s p. Holmsk. Bull, $t$. 872. Fi. dall, $t, 1076, f .2, t, 1258$. $f .1,-\mathrm{H}$ e y deri a Fries syst, 1.492. CM it rula Hey deri Pers. disp. t. 3.f.12. Fl. dab, $t, 1670$. f. 2.j

48. Mitrula FR. R e c e $t$ a cul u m erectum, in stipitem discretum attenuatnm. H y menium ovatum, inflatum, basi stipitem arcte cingens. A s c i elongati. S porid ia elastice exsudantia. - Fungilli carnosi, simplices, in foliis dejectis in paludosis subcaespitoso-gregarii, dilute incarnati, vel flavi.

Mitrula Fries syst, I. 491. Elench, I, 23\%. Leotia sp. Persoon synops. t.3. $f .13$. F1, dan, $t, 1377$. Grev, scot. t. 81.312 .

419. Spatinulea $F R$. Receptaculum erectum, in stipitem discretum attenuatum. Hymenium verticale, compressum, utrinque in stipitem decurrens, superne ascigerum. Asci elon- gati. Sporidia elastice exudantia. _ Fungus epiphytus, carnoso-membranaceus, autumnalis, solitarius, primum albidus, dein subferrugineus.

Spathulea Fries $p l$. hom, 89 , Grev. seot. $t$, 16.5. Spathularia Pers, elavar. 5i. Nees syst, $f, 156, a . b$. Fries syst. I. 49o. Clavarias sathulata FL, dau. C.658. Sctrmiall ic, $t, s 0, f .1$.

TYREDES VIE. PILEOLATIFries $p l$. hom. 88 . Recepta eulum effiguratum, confluens. Asei breves.

4:0. Sprerassis FR. Recepta enlum carnosnm, ramosissimum, ramis dilatatis, planis, laeviuseulis, e membrana hymenina duplici connesa, utrinque ascigera. Asci elongati. Sporidia alba. - Fungus pedalis, albido-flavus, in pinetis terrestris, carnosus, fragilis, e basi tuberasa ramosus, ramis serobiculato-rugnosis, ramulis compressis crispatis in catspitem globosum intricatis.

Sparassis Fries syst. I, 46.s. Elench. I, 297. HeI. vella e s. p. Schaeff. $t, J 63$. C Ia va ria $\mathrm{e}$ p. Wulf, in Jacq. mise. II, $t, 11 . f .1$.

4a 1. Wrartella SCOP. Receptacu $1 \mathrm{~nm}$ carnosum, simplex, apice $t$ ub nlis hymeninis subnlatis, undique ascigeris nbsitum. As ei tenues, breves. Sporidia... - Fingi magni, epiphyti, carnosi, albi, flavi $v$. cinerascentes, truncum referunt apice aculeis congestis obsitum.

Martella Seop. pl. subterr. 151. Herieium Fries pt. hom. 88. Hy da a Gon $\mathrm{phi}$ Fries syst. I. 410.

SETARDD IIT. HELVELLACEI Fries syst. II. 1. Receptaculum determinatum, distincte marginatum, circumscriptione orbiculatum, in infimis subobliteratum, in perfectioribus cupulatum; cupula in perfectissimis reflexa pileum faciente. Velum nullum v. floccosum, perithecium distinctum, superum, ascigerum. As ci elongati, clavati, paraphysophori, suboctospori. Contextus fluecoso-fibrosus ; substantia carnosa v. membranacea, rarissime gelatinosa. Libere evoluti, e loco natali haud mutali.

'TE IE TES VIII. CUPULATI Fries syst. It.35Receptac n I n m cupulatum, aequabile, hy me. n i $\mathbf{m}$ discoideum, junius subelatism, marginans.

423. Solenia PERS. neceptac $\mathrm{n} l \mathrm{~nm}$ elongatum, tobuliforme, simplex, mesabranaeeum, erectnm, ore constricto, integro; absque hy menio distincto. Asei nnlli. Sporidia elastice secedentia ? Fr. Fungilli epiphyti, gregarii, conferti, magnopere dubii.

Solen ia Pers. disp. 36. Myc. europ. t. 12. f. 8. 9. Hoffut. crypt., , 8. f. 9. Pries syst. I. 200.

423. Stietis PERS. R e e e p ta $\mathrm{n} \mathbf{l} \mathrm{um} \mathrm{cu}$ pulaeforme, immersum, limbo saepe obliterato. H ym e $n$ i um laeve, receptaculo inmersum. As ci tennes, fixi. Sporidia globosa, seredentia. Fungilli epipliyti, minimi, cupula undique udnata, substantia ceraceo-mémbranacea $v$. rarius gelatinasa.

Sti etis Pers. abs. II. 73. Mye, europ. 335. Fries syst. II, 191. Eleneh. II, 24.

a) PROPOLIS Fr. H y me ni i m difforme, in pulverem fatiscens.

Propolis Fries syst. IT. 198. X y $\log \mathrm{r}$ am ma Wall. Fl. germ. II. 509. T r emellae s p. Alb. et Schweia. neisk.
e.9. f.7.

6) XYLOgRAPHA $F_{r}$. H y menin m. ellipticum, deliquescens.

Xylog rapha Friessyst. II. 198. H y stex it sp. Pers. L he hen parellus Achar.

c) EUSTICTIS. H y m e $\mathrm{i}$ um orbiculare, inmatum, cera. ceum, perststens. 
Pezizae s p. Pers, ie. pict. t.8. f. 1. 2. Obs, II. t.6. f.7. Nees syst. f. 293. Grev. seot. t.228. Sphaeroboli x p. Tode meckl, I. t.7. $f .58$ L y coperdonis s p. Lian.

d) CORTICA Fr. H y meni um subliberum, erumpens, gelatinosuat, persisteas.

C ortica Friex syst. 1I. 192. MeI a nostroun Corda apud Sturm. III, $t, 61$.

TEEHBES IX. CLAVICULARES Fries $p l$. hom. 86. Recepta e $\mathbf{l} \mathbf{~ u m}$ lenticnlare, apertum. H y $\mathrm{m}$ e n i u marginatum.

424. Ditiola FR. Receptaculum tuberculatum, suberosum, velo secedente patellatum. Hymeni $\mathrm{nm}$ adnatum, demum corrugato-plicatum, deliquescens. As e i tenerrimi, fixi, diffinentes. S poridia ovata. - Fungilli gregarii e lignis exsiccatis, inter quarum fibras radicibus mucedineis late serpint, erumpentes, distincte stipitati, diu persistentes.

Ditiola Fries syst. HT. 169. Tu bereularia Tode meckl. $I$. 18, t. 4. f. 32-34. Hel o tit s p. Nees syst. f. 161 . Leotiae sp. $F l$, dam, $t, 1378, f .2$.

4:5. Volentella TOD. ReceptacnIum hypocrateriforme, stipitatum, margine revolstum, apertum, velo partiali. If y me n i um unguinosum, in resinam coagulandum. - Fungillus coriaceus fulvescens in ramulis exsuccis sparsus, soli generis autori notus.

Volutella Tode meckl. I. 28, t.5. f. 43. Fries syst. II. 123.

426. Sarea FR. Receptaculum lenticulare, stipitatum, subtus demum exclavatum. H ymenium nudum, plano-convexum. Asci fixi, persistentes. _ Fungilli pezizoidei, lignicoli, stipite simplici $v$, ramoso, saepius villoso.

Sarea Fries pl. hom, 86. Helotinm Pers, synops. 677. Fries syst. II. 155. Pe ziza e s p. Pers. ic. et descript. t. 11. $f$. 2. Nees syst. f. 2s7. L e o $t 1$ ae s p. Pers,obs. 1I. $t, s$. f. 1.4.5. t.6. f.1. 2. Helvellae s p. Bull. t. 473.f.1. Bolt.

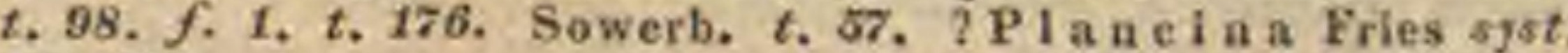
II. 158.

4\%ซ. Vilbrissea $F R$. Recepta cu1 $1 \mathrm{~m}$ capitato-pileatum margine primo undique stipiti adnato, mox libero. H y m e $\mathbf{n}$ um pileum vestions, nudum, persistens, primum lacve, demum as cis paraphysibnsque erumpentibus (oseillantibus) velutinum. - Fungi carnoso-ceracei, gregarii, lignatiles, vernales, olidi, stipite tenui, capitulo hemisphaerico, marginato, subtus cancavo.

Vibrissea Fries syst. I1. 31, Leotiae sp. Alb, et Schwein. neisk. 6.3. f.2. Pers. myc, europ. I. 6.11. f.9.

TIREIS X. CUPULATI Fries pl. hom. 85 . Receptac nlum cupulatum, primo clansum. H y m enium marginatum.

428. Tulgaria FR. Receptaculum orbiculatum, marginatum, ventricoso-turbinatum, mox apertum, planiusculam, intus glutinosum, extus spbrugosum. H y m e ni $\mathbf{i}$ m discoideum, nuilum, persistens. Asei ampli, immersi, demnm eum sporidiis elastice erumpentes, paraphysibus persistentibus immistis, - Fungi pezizoidei, mucidi, in corticibus sero autumno gregarie erumpentes.

B u $1 \mathrm{~g}$ a ria Fries syst. II. 166, Ches. paris, I, t.9.f.4. Poly moxp ti us Naumb. diss. Erf. 1732. p. 28. Burcardia Schuidi anal. pl. ItI. 261. $t, 69.70$. Klvelae sp. Sebaeff. $t$. 158. 323. 324. P eziza a s p. Bull. $t$. 410. $f .1$. $t .460 . f .1$. Sowerb. $t .428$, FI. dan. $t, 1017.0 \mathrm{ctosporate}$ s. Hedw. musc. frond. $I_{+} t, 6 . f .5 .6 .7 . f .6$. A sco b oli $8 \mathrm{p}$. Nees syst. $f .296$.

428. Ascobolus PERS. ReceptacnIn $\mathrm{m}$ orbiculatum, submarginatum, mox apertum disco patellaeformi. Hy m en i um disceide $\mathbf{n m}$, persistens. As ci ampli, clavati, maturescentes enmersi, discreti, demum elastice dissilientes, paraphysibus evanescentibus. Sporidia (nigra) la- tici innatantia, uniserialia, ovata. - Fungi minuti gregarii, molles, fimicoli, post autumnales pluvirs copiosi.

A s cobolus Pers. disp, 35. Obs. I. \&. 4. f.3-6. Alb. et Schweill, neisk, t. G. f. 6. Nees syst. f, 997. Fries syst, II. 161. Grev, scot. t. 30\%. P ezix ae s p. Ball, t.3a6. Sowerh. t. 18. 389. f. 3-6. 0 et os pora s p. Hedw. musc. frond. II. t. . . $f . a$.

430. Peziza DILL. Receptacul um eupulaeforme, marginatum, primo subclausam, mox expansum. If y mén i um laeve, persistens, distinetum. As ci ampli, distincti, fixi, sporidia elastice ejieientes, paraphysibus stipati. _ Fungi notissimi epiphyli vel terrestres, cupula centro affixa, saepissime stipita, cava, demum planiuscula, disco discolori.

Pe ziza Dill, gen. 74. Fries syst. II. 40. Elench, II. 4. Peziza et Trombetta Airas. Ir. 6. Eneoelia Hill. syst. $I$. 56 . Oetos pora Hedw, musc, frond. $I T, 4$. $\mathrm{P}$ atella Weber.

d) PHIALA Fr. Ep iphy tae, ceraceae vo membranaceae, rarius gelatinosae, glabrae. Hymenium concretum.

1. $\mathrm{Ph}$ hala Fries syst. $I$. 116.

a) $\mathrm{P}$ intella Fries syst, 11. 1.99. Sowerb. t. 389. f. 8 . Nees syst.f. 265. Fries obs. I. t. 4.f. 1 .

b) Mol1 is i a Fries syst. 1 . 137.

a) CeracelI a Fries syst.11. 146. (Sowerb. t.389. f. 7. Pers. ic. et descript. t, 1. f. a. z. Nees syst. $f .266$.

B) Catliurgia. Oetosporae sp. Hedw. $I T$. t.6.f.6. (Bull. t.376. f.2. t. 416.f.1. Sowerb. t. 64, 152, F1. dan, t. .79, f.3. t, 1490, f.2. Nees syst, 267,3

7) Rhopalnm. (Alb, et Schwein, neisk, t.2,f.3.)

c) Calyeulas. Pexixacealyeinae Nees syst. 263. Fries syst. II. 128.

a) Helotioides. Oetosporae s p. Hedw, $I$. t. 9. f. a. t. 22, f. c. (Ball, t. 300, 467. f. 2 . Sowerb. $t, 3(69, f, 6$.

B) Buccinoldes. Octosporae sp. Hedw. II. t.8. f, $a$, (Sowerb, $t, 116,160,337,369, f .7$. Holmsk. ot, $\Pi, t, 12$.

d) Ну mедо ссурһus Nees syst. 266. Fries syst. II. 117 .

a) Volutella rin. (Batseh cont, I. f. 148. Tod. meckl. $t ., t, 6 . f .44$.

B) Capula, Octasporae s p. Hedw, II. $t, 9$. f. $b, t, 10, f, a$, (Bull, $t$. 416. f. 4 . Fl. dan, $t, 1016$. f. $1, t, 1380, f, 1$. Nees $f .293-295$. Holmsk. of. II. $t$, 22.)

y) Ciborium. Oetosporae sp. Hedw. II. t, 9. f.3. (Ball, t. 500 . f. 1. 2. F1. dan. t. 1016. f. 2 . Holmsk. ot, $I I, t, 11,111$.

B) LACHNUM Rets. Subepiphytac, ceraceae, extus pilosae v. villasae. Hymenfum distinctuw, coneretuu.

rr. L a ehau m Retx, prodr, 399. Fries syst. $n$. 7 .

c) Eibrina Fries sqgt, IT, 111, (Alb, et Sehwein. neisk, t. 2, $f, 3, t, 3, f, 4, t, 10, f .7, t, 11, f, 8$. Nees syst. 26i, Holmsk, ot. IT. t. 17.)

A) Ta p ezla Pers. myc. europ. I, zzo. Fries syst, 1 . 103. Pers, ic, et descript, t.7, f.1. Nees syst. f. 271.272.$)$

g) Dasyscy ph us Fries syst. II. 89. (Bult. t. 410.

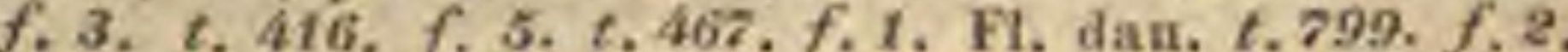
t.1016. f. 4. t. 1430. f. 2. t. 1600 . Nees syst. f. 270. 283. 284, Grev, $s c o t, t, 83$.

h) Sarcosoyphus Fries syst. IT. 78. Ostosparae 8 p. Hedw. $Z$, $t, 3, f, a, b$. (Jacq. $F l$. austr. t. 169. Coll. t, 10. 204. 467. Nees syst, f. 286. 288. Grev, scot. $t .171$.

9) AIEURIA Fr. Subterrestres, earnosae v. car noso-membranaceae, pruinosae $v$. floceoso-furfuracere. IIT. A le uria Fries sjst. II. A2.

i) Eneoelia Fries syst. II, z4. Pliballis Wallr. Fl. germ. Ir. 44S. Oetospor ae sp. Hedw, $I I$. t.22. (Alb. et Schwein. t.t2. f. . Pers ic. et deseript. t.8. $f, 4$,

6) $\mathrm{H} \mathrm{umaria} \mathrm{Fries} \mathrm{syst.} I$, b7, Octosporac sp. Hedw, IT. t. 4. f. a, t. 5, f. \&. (Bull. t. 480. 485. f. 1. Sowerb. $t, 369, f .10,11$. FI. dan, $t, 656, f, 2$, Holinsk, ot, $I T$, t, 21. Nees syst, f, 268, ?

t) Ge o p y xis Pers, myc. 22d. Fries syst. $I \pi, 55$.

a) Catinus Detosporae sp. Hedw. IT. $t .5$. f. c. t. 6. f. d. (Bull. t, 369. f. 3. t. $438, f .3$. 
Sowerb, t, 148. F1. dan, $t, 655$, f. 2. Pers, obs. $I$. t, G, f. 7. Holmsk. ot, II, t, 8.)

B) Cacabus. Octosporae sp. Hedw. IT, $t, 10$ f. b.c. t, 19. f. b. c. (Bul!. t, 196. 457, 485, f. 2, 3. FI. dan. $t, 10 z 8, f, 1, t, 1200 . f .2$. Nees syst. $f$. 289 . Holmsk, ot, II. t.910. Grev. scot, t, zo.)

m) Helvellopsis. Pexizae helvelloideae Fries. syst. II. 43.

x) Crucibulum. Oetosporae sp. Hedw. II. t, 6. f.a. (Sowerb. t, 3. 4. Pers. ic, et descript, t.s. $f .3$. Grev, seot. t. 59,107 .)

B) Cochlidiam. (Bull, 154, f, b.t.474. Sowerb. t, s, 78,79. Nees syst, f, 279 Dittm, t, 16. Holmsk. ot. $I T$, (, 6.7.)

r) A cetabularium. (Bull. $t, 485, f$. 4. Sowerb. t. 39. Pers. synops. t.5.f.1.)

43 1. Fingina FR. Receptaculn m effusum, erustaceum, bullatum, subtus concavum, fibrillis radiciformibus margineque deflexu suffultam. H y m e $\mathrm{i} u \mathrm{~m}$ totam superficiem snperiorem vestiens, laeve, persistens. As c i ampli,fixi. Sporidia ovato-oblonga, sporidiolis duobns. Fungi terrestres, subautumnales, rigidi, fragiles, pileo sub. rotundo-convexo, sessili.

R hizina Fries obs. myc, $I, 161$. Syst. II, 32, 0 ctos pora e sp. Hedw. musc. fr. II. t, S. f.a. Elvella e s p. Sehaeff. $t, 153$.

Trex mES X. MITRATI Fries syst. II. 3. Receptaculnm pileatum, bullatum, nunquam elausum, nee hymenium marginans. Hy $\mathrm{m}$ en i $\mathrm{m}$ coneretum, persistens, nudum.

432. Heotia HILL. Re e ptac a $1 \mathrm{um}$ pi leatum, centro stipitatum, orbieulare, patens, mar gine subtus revoluto. Hy $\mathrm{m}$ en i $\mathrm{m}$ superum, un dulatum v, laeve, persistens. Asci fixi, clavatoeylindrici, - Fung $i$ gregarii, terrestres, aestivales, carnoso-molles, subtremellosi, pileo subirregulari, tandem viscoso margine repando.

Le otia Hill. hist. 43. Fries syst, II, 25. Elench. II. 3. Hypolys sus Pers.

a) HYGROMITRA Fr. Pile us gelatinosus, margine sub. tus adnatus. - Noxiae, flava-virides.

H y e r om itra Fries syst, 11 . 48. C ucullaria Pers. myc. europ. 201. Hel vella e s p. Bull. t. 473. f.2. Sowerb. t.70. P halli s p. F1. dan. t. 654. f. 1, t.719, (Pers. myc. t.9. f. 1 -3. Grev. scot, t. 56.)

b) CUCUllaria Fr. Pile us carnosus, margine liber. Edules, albo-cinereae v. cinnamomeae.

C u e ullaria Fries syst. IT. 26. (Pers. ic. et descript. t.5. $f .-7$.

433. Verpa $S W$. Receptaculuin cla vato-pileatum, centro suffultum, deflexum, conicum, subtris concavum, supra undique hymenio tectum. H y m e n i m laeve l. rugulosum, persistens. As ei fixi. Fungi lerrestres, meteorici, curnoso - membranacei, stipite cavo, a piteo discreto.

$V$ e r p a Swartz in Act. Holm, 1815. p. 129. t. A. Fries \$yst. II. 23. Corda apud Sturm $I, t, 1-6 . \mathrm{P}$ halli s p. Fl. dau. t. 654 .

434. Helvella LINN. Receptac n I u m pileatum, centro suffultum, deflexum, subinflatrum, sinuosum, subtus coneavum, snpra margineque hymenio tectum. Hy m enium laeve, persistens. As $1 \mathrm{i}$ fixi. - Fungi terrestres v. lignicoli, autumnales, persistentes, ceraceo-membranacei, stipite cum centro receptaculi continuo, cavo v. medulla flaccosa fareto.

Helyella Linn. gen, n, 1214, excl, sp. Fries syst. IT. 13.

a) OMPHALоMitra. Stipes elongatus, tenuis. Pileus liber, umbilicatus, tandem deflexus.

a) HeIrellae pezizoldeace Fries syst, $I I, 19$. Boleto-tiche u Juss, act, paris, 1728 p. 268. (Bull. t. 242. Sowerb. t, 15\%. Fl. daa. t, 534. f. 1 . Holmsk, ot, $I T, 2,25,26$.

b) MITRA Fr. Stipes brevis, basi fucrassatus. Pileus primum stipitf adnatus, tandem deflexus.
B) Mitra Fries syst, II, 14, Phalli sp. Fl, dan. t.835, (Bull. . 466 . Fl. dan. ใ. 1500 . Holmsk. ot. II.t, 24. Nees syst.f, 163. Tratt, essb. Schwämm. t. cc, dal. Chev, par, t, 6. f, 5 . Grev, scot, L, 36.)

435. Noreluella DILL. Receptacu$1 \mathrm{um}$ clavatum v. pileatum, rotundatum, centra impervium, suffulium, supra hymenio tectum. H y menium costis elevatis cellulosum v. lacunosm, persistens. A s ci fixi. - Fungi majores, vernales, terrestres, edules, ceraceo-carnosi, stipite subcavo in pileum transeunte.

Morebella Dill. gen. 74. Fries syst, II. 5. Tratt. essb. Schwämm, $t$, ee, Nees $f, 167$. Grev, scot, t, 68, B ol e $t \mathrm{~ns}$ et Phallo-Boletus Mich, gen. 202. 203. G yrocephall s p. Pers. Helvellae s p. Sowerb. 4.51. Phalli sp. Lian.

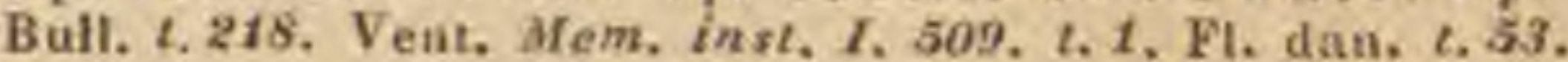

SUIBOFEA IV. PILEATI Fries syst. I. 3. Stip es erectus v, adscendens, snbcylindricus, pileo plus minus contiguus, interdum obliteratus. P'ile us horizontalis, dilatatus, in formam orbicularem tendens, sensim explanatus, marginatus. Velum saepius praesens. Hy menium inferum, subeffiguratum, raro laeve. A s ci lineares, fixi, vix paraplyysophori.

Fungi perfectissimi extraeuropaei pauci cogniti, plerique aestivales $v$, autumnales, pauci vernales $v$. brumales, multi edules, plures venenati.

TREIBUS XIT. AURICULARINI Fries $p l$. hom, 81. et 363 . H y m e ni u m papillosum v. laeve.

436. Thlebia FR. Hymenium cum pileo homogenenm et eonsretum, interrupte et irregulariter rugosnm, undique ascigerum. As c i lineares, fixi. - Fungi carnosiusculi, pileo sessili, supra truncos v. muscos efluso, resupinato.

$\mathrm{Phle}$ b ia Fries syst. I. 426. Elench. I. 133. Grev, scot.

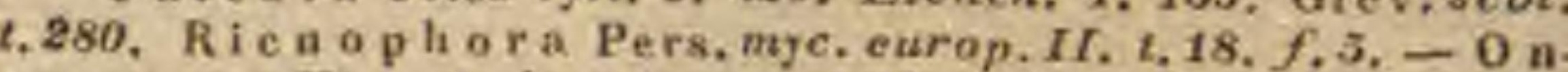
com yees Klotsch in Linnaea VII. 195. Phle bia mesen. terica Fries Elench. I. 134.

438. Thelephora EHRH. H y meninm cum pileo homogeneum et coneretum, laeve v. papillis subrotundis, obtusis, sparsis ubsitum, undique ascigerum. As e i tennes, sabimmersi. Fungi lignicoli v. fterrestres, pileo sessili, rurissime stipitato, coriaceo, persistente, irregulari, fibroso-floccoso.

Thelephora Ehrh, crypt, 178. Fries syst. $I$, 488. PL. hom, 81. Elench. I. 156. Z o в a ri a Rouss. ex Desv. Journ bot. r. 43. Thelephora et H y phoderma Wallr. El. germ. II, 576 .

a) LEIOSTroMA Fr. Ligaicolae, subeffusae, adnatae, grumosae, ascis obsoletis.

Lelostroma Fries syst, $T$. 459. Corticium Pers.

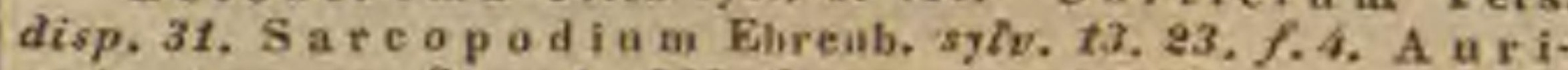
culariac 8 p. Sowerb. 288. Grev. scot, $t, 231$.

b) TERANA $\mathrm{Ad}$. Liguieolae, resupinatae, effusie, aduatae. contextu floceso, ambitu subuudae.

Tera na Adaus. II, 5. (Th. coriacea Fries Elench. I. 212. Nees syst. $f$. 255.)

c) HINANTIA Fr. Liguicolae, resupiuatae, effusac, subtus fibrlllosae, ambitu byssino.

Him antia Fries $s y s t$. I. 450. Elench. I. 200. A urie uI a ria e s p. Sowerb.t.383, Н y p o $\mathrm{ch}$ u i s p. Fries obs.TI.278.

d) CONIOPHORA $D C$, Lignicolae, resupinatar, effukae. macedineac, hymenio ex ascis erumpentibus pulverulento.

Coniophora DC. Fl. fr. $N$. 3k. Fries Elonch. I. 193. Tomeutella Pers. obs, II, 18. Athelia Pers,myc. ourop. 1. 18. A u ri c ularia e 8 p. Sowerb. $t$. 214 .

e) PHELLINA. Lignicolae, resupinatae, suberoso-lignosae, marginatae, concentrice sulcatae.

The I e phorate stratos a e Fries Elench. I. 190.

f) AURICULARIA Fr. Lignicolae, resupinatae v. Iatera. liter aduatae, submarginatae, coriaceo cartilagineae y, suberosae. 
A urienIaria Fries Elench. $I$. 174. (Nees syst. f. 2ra. N. A, N. C. XIII, 1.2. Grev. scot, t. 149. 295. Humb. et Boupl. nov. gen, et sp, t, 628. Klotseh in Hook, mise. II, 2. 81, 84.)

g) PHYLACTERIA Fr. Ligaicolae v, terrestres, lateraliter adnatae, submarginatae, earnoso-fibrosae.

Phylacteria Pers. myc. europ. 1 . 11i. Pries Elench. 1. 170. A urieulariae sp. Bull. $t$. 436. f. 2. t. 483. f. 6 . Sowerb. t, 213. Merulii s p. Holmsk, ot, II. t. 56. (Pers. obs. I. t, 6. f. 8, 10. Grev. scot, t. 264.)

h) STEREUM Pers. Liguatlles, lateraliter adaatie, ca. riaceo-rigidae, extus erustaceae, intus flamentosae.

Stere um Pers, synops. 566. Fries Elench, 1.172. A n$r i c u l a r i a c$ sp. Sowerb. $t, 25-97.349$. Bull, $t, 402,483 . f$. 5. (Fl. dan, t, 1619. f.1.2. Chev. par. I. t.7. f.1.) Grev.seot. t. 256 .

i) MERISMA pers. Terrestres, pileo stipiteque coufusis, in ramos compressos tuberenlososve abeunte.

Me ris m a Pers,clavar, 92. Chev, par, I. t, 6. f, 4. Grev. scot. t. 26. Crat erella Pers. disp. 23, Ic, et descript, $t, 1$. f.3. C lavariae sp. Bull, t.41J. f. $x$, t, 459. f. 1. . . Sowerb. 4. 156, 158. Tel ep hor a e s p. Fries, Grev. scot, $t, 178$.

k) CRATERkLLA Pers. Terrestres, pileo integro dimidiatove, stipite discreto.

Craterell a Pers, disp, 32, Ic, et descript, t.1. f.3. (Sowerb. $t, 155,213$. Fl, das. $t, 1198$. Nees syst. f. 250.)

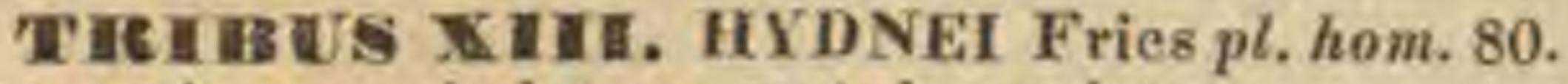
H y m e n i m subulatum v, tuberculatum.

438. Heatulum FR. Hymenium hine inde tubereulnsum, tub e reulis papillaeformibus v. aculeiformibus, undique ascigerum. _ Fungi epidendri, resupinati, effusi, erumpentes vel cortici interiori innati. t. 278 .

B a d u 1 u a Fries pl.hom, 81. Elench, 1. 148, Grev, scot.

435. Gyroloplaiom KUNZ. H y m en i u inferum, interrupte tuberculosum, $t a b$ erc ulis in fascias conecntricas basi coadunatis, undique aseigerum. - Fungus ma uritianus, epiphytus, pileo charlaceo-membranaceo, sessili, sonato.

Gy rol op hi a m Kunze in Siteb. erypt, exsic, n, 69 .

440. Irpex FR. H y meninm inferum, subulatum, subulis in series vel reticulum dispositis, basi plicis concatenatis, ascigeris. _. Fungi lignicoli, pileo tibere evoluto sessili v. postice substipitato, subcoriuceo.

Irpex Fries pl, ham, 81. Elench, 1. 142. Xylodon Elureub, sglv. 30. Sistotrematis sp. Alb. et Schwein. neisk. 6. 6., f.7.

44. Sistotrema Fr. Hymenium a pileo subaliscretum, dentato-Jamelnsum, I a $m$ e 1Iulis interruptis, varie gyrosis, utrinque ascigeris. - Fungus terrestris, stipite centrali lateralive, pileo carnoso, irregulari, continuo.

Sist otre un a Fries syst, $I$, 426. Grev. scot, t. 245. H y d n i s p. Bull. champ, $t, 453, f . t$. Sowerb, $t, 112$,

448. Eyalmom LINN. Hymenium pileo homogeneum et concretum, acnleatum; a e ule is clausis, liberis v. basi connatis, ext us ascigeris. - Fungi terrestres, pileo stipitato v. sessili, plerumque irregulari, substantia floccoso-exsucca.

H у d п и m Liun. gen. n. 1026. Yries syst. $T, 397$.

a) Ería aceus Mieh. gen, 132. O dontía Pers, disp. 30. L.A.f.6.7. Sistotremat is sp. Perk. myc. europ. t, 22, f.3. Nees $x y, f, 230.231,-2$ D icurp bus Kai. in New-York. med, Repnrit, Hs. Hex. V. 335. (Bull. t. 281. Sowerb. t.397, 328. Nees syat. f.246248.)

b) A p u s Pries l. c. (Pers. ic. et descriph, t. 14, f.1. Sowerb. $t, 14$. Nees $f, 215$, )

c) Hericlu u Pers. clavar. 28. C er a phora Raf. l.c. Medusin a Chev, par. (Bulf. t. 390. Nees f.33.)

d) B id a a a Adaus. II. 5, A co o t la Hill. syit. II. 41. M a u i u m Scop, $p I$, sublerr. $t_{t} x$. Prifapus Raf. l.c. (Jacq. Fl, austr, 1, 239. Fl. dan, 276. 717, 1020. 1439. 1500. Sowerb, 1. 73, 156, 267. Bull, 1, 34, 156, 409, 419 . 453.)

4s3. Fistulian BULL. Hymenium heterugeneum, receptaruli fibris acretum, primo ver- rucosum; verrucae floceis radiantibus velatae, mox $t \mathbf{u} b u \mathbf{l o s}$, tandem apertos, in $\mathbf{m s}$ ascigeros protrudentes. - Fungus quercicola, edulis, pileo lobato polymorpho, sessili vel oblique stipitalo, molli, succoso, viscido, sed fibris tenacibus percurso.

Fistulin a Bull. champ. 3t4. $t, 74,464,497$. Fries syst. I. 396, Elench. I. 128. Grev, scot. 1.270 . H y po d r y s Pers. Champ. comest,245. B ug 1 os 8 us Wahlenb. upsal, 459, B oleti s p. Schaeff. t, 116-120. Sowerb, t, 53. Fl. dath, 4, 1039.

TIEIBES XIV. POLYPOREI Fries $p l$. hom. 79. H y m en i m porosum v. sinosum.

44. Forotheleama FR. Hymenium interruptnm, porosum, poris in papillas distinetas, superficiales, collectis. A s e i obsoleti. - Fungi in corticibus resupinati, effusi, immarginati, ambitu byssino, subfimbriato.

P a r o the ele a m Fries syst, I. 506. Pl. hom, 80. Elench. I. 125. Boletus byssiuas et subtilis Selorad. spie. 172. ,.3. f. 1.2.

445. Vervaltugs $H A L L$. Hy me $\mathrm{n}$ i m heterogeneum, pileo eoncretum, gy roso-poros $\mathbf{u m}$, interrupte ascigerum. - Fungi trunciali, pileo sessili, resnpinato $v$, effuso, subfloccoso, tenui.

Meruli u \& Hall, helv, 150, excl, sp. Fries syat, T, 327. Elench. 1. 56. Fi. dau, t, 1553, Grev, scol, t. $147 . \mathrm{X}_{\text {y }} 1$ o p ha gus Link in Berl. Magaz. M a cil ag o Hoflm. crypt, t, 12.

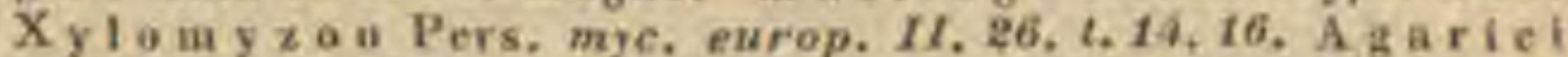

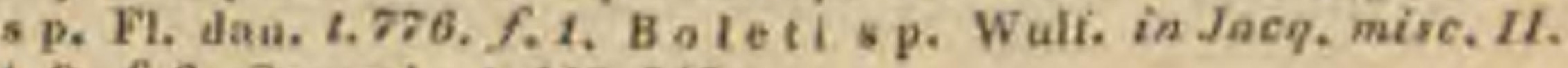
t. 8. f. . . Sowerb. 2.113 .346 .

446. Haedalea PERS. I ymenium pi leo homogeneum et coneretum, profunde sin u n$8 \mathbf{~ m}$, sinubus intus ascigeris. - Fungi truncicoli, pileo plerumque sessili, rarius stipitato v. effuso, coriaceo v. suberoso.

Daed a le a Pers. synops, 499. Fries kyat. T.331, Elench. I. 6i. Palis. Fl, owar, t, 25, Grev, scot, 235. S ex d a, $S$ u e. sia et Striglia Adans. II. 10. Vo n K hout Stereb, n, 128. B o l e ti s p. Lian. Bull, $t$, 310, 408, 409, 482. 49t, $f$. 1 . $50 t$. f.3. Sowerb. 6. 193. 195.325. A gariei s p. Ball. t. 358. 428. 537. 541 Sistotre a a $t$ is s p. Pers. Nees $f .228$.

44. Polyporas FR. I y m e n i m pileo homogeneum et concretum, porosum, poris subrotundis, dissepimentis simplicibus, intus ascigeris. - Fungi terrestres v. lignicoli, pileo carnoso-lento v. suberoso. I. 72 .

Poly por us. Fries obs. I. 191. Syst, I. 351, Etench.

a) POLYSTica Fr. Porf superfieiales. Pil e us resupiuatus, effusus.

Pol y st te a Fries synt, $T$, 38d. Eleneh, $I$. 12.3. M y a o u Adank. II, 10. (Miebel. $t, 68$ 63.)

b) PORIA Hill. Pa ri minati, subrotandi, Plle us resapiuatus, effusus. adnatus.

Poria Hill, syst, It, do, Pers. disp, 29, Leptopora Raf, in New-York Medic. Reposit, II. Hex, V, 356, P hy ko porns Chevall. par. $r$. 239. Boleti sp. Lian. Boil. t, 165. 166. Jacq. mise, $r, t, r 1$, FL dan, $t$, 716. 1299. Sowerb. t.326.387. Pers, obs. II, t, 4.f.1. Ic. pict, t,6. f. 1, Myc. curop. II, $1,6, f, 3.4$. Nees ryst. f. 223.

e) AGARICON Adans, Po rí miauti, subrotundi. Pile u* diasidiatus, sessilis, lateralis, hurizontalis v, efluse reflexus.

Ag aricon Adank. IT. 10. Retipor a s Batseh Eleneh. 107. B oletl s p. Limm. Jaeq. Fl, austr. t. 307 . Miscell. IL. 164. seq. Bull, $i, 86,210,312,452,458,469,478,493,601,953$. Sowe b. 1, 88, 132, 135, 190, 195, 211, 218, 226, 228,829,250,35k. 387. FI, dall. t, 1130, 1254.1298. Nees syst. $f$. 221, 229, C e rato phora Hamb. Fl. frib, 119, t. J. (monstr.) (Grev, seol. 4. 14. 289. Nees in N. A, N, C. xITI. C.3. Fr. Nees pl. offie. ic.)

d) CLADOporus Pers. Po r i niunti s subrotuadi, saepe laeeri. Stlpe s cam pile o rameso $\checkmark$, maltipliej conAlueas, interdusu obsoletus.

Cladoporus Pers. Champ. comest, 225, Ptabellaria Chev. par. I. 230. B a leti \&p. Lina. Fi, dan. I. 9se. Bnit.

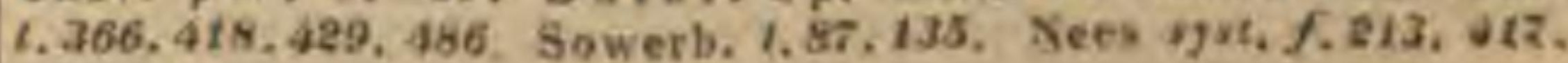
210, 226. 
e) MLROporus Palir. Pori minuti, subrotundi, Stipes distinctus, lateralis v. centralis, simplex.

Microp or u \& Palis. fl. owar., , 12, t. 43. f. 1. Mo n. ka Alanx. Il. 1. Poly paras Michel. gen, 199. Mill e pora $\times$ Batscb Elench. 103. B ol eti sp. Linn. Jaci. EV anstr. t. 51 . Miscell. $T$. t. 12, Collect, app, t, 8.8. FI. dan. t, 1075, 1253. 1618 , Bnll. $t, 28.96 .360 .445,469$. Sowerb. to $80,134$. 192, Nees stst. f. $210-213$ N. A. N.C, XIII, t,3-6. Girev. $\sec (, 296)$

f) PLATYPORt'S Pers. Povi ampli, augulati, intus taeves. Pilens, xexsilix v. stipitatus.

PIatyporas Pers. myc. carop. 11, 35. Hexagona Pollin, pl.now, 35, Pho $x$ im a Raf, t. C. Favol us Palis. Fl owar, 12, t, 42. f. 2. B ol vti s, p. Linn. Fl. dan, 2, 983. 1196, Balt, t, 16a, Buth, t, 10, 144. 491 . Boxce in Berl, alagaz. 1811. t.4. f. 1, Nees syst. f. 292 . (Grev, scot. 2. 207.)

8) SCENIDION Klotsch, Pori ampli, angulati, iatas setosi. Pileas xuxsilis.

Scenidiou Ktotsch in Sinnaea VIS. $200, t, 10$.

4.8. Boletans DILL. Hymenium hete rogencum, a piles diseretum, e $t$ abulis separabilibus, intus ascigeris conflatum. - Fungi terrestres v. lignicnli, pileo hemisphaerieo, carnoso, molli, stipite centrali, saepius reticalato.

Botetus Dillen. Fries sytr. I. 385. Suillus Miehel. gen, 126.

a) LEUCOSperus Fr. Sporidia alba. Tubuli albiv, cierini. Stipes cavus, uedinlla sponglosa farctus. Ve. Inm nullum.

Le ue osparu s Fries op. cit, 1.395. (Bull, $t, 369$,

b) AYPORHODIUS Pr. Sporidia rosea. Th a ulis albidi. Stipes solidus, xubeticulatus. Velom nulluor.

Hy porliodius Fries op. cit. . 394. Bull. 7,379 ,

c) DERMinus Fr. Sporidia nbscure ferruginea. Ta. b u Li altridi. Stipes solidas, squnmosus. Velum fugax. Dormin us Fries op. cit. T. 393. (FI. dar. t, $833,1252$. bolt. 2.86 . Bull. $t .132,236,489$, Sowerb. 2.110 .175$.

d CoRTINARIa fr. S poridia subochraced. Tubuli Iutel v, ferruginej. Stipes soliaus. Velum praexeus, saepe fugax.

Cortinaria Fries op. cit. I. 386. Ceriomyees Batt. Aise, 62. (Bull, f, 60, 328, 339, 431, 490, 494, El, dall, \&. 1018, 1074. 1135 . Sowerb. $1.36,141.150$. Neex sfst, f, 204, 205. - Gyxad on Opatawsk, in Wiegu. Journ. 1886. 1. 5.

THE Hy $\mathbf{m} \mathrm{cu}$ i $\mathrm{um}$ lamellatum $\mathrm{v}$, plicatum.

449. Cyelonayees KUNZ. Hymenium lamellatum, la mellis concentricis, inciso-dentatis, imuerse ascigeris, - Fungus mauritianus truncicola pileo sessili, coriaceo, sonato.

Cy ctam y cex Kunze in Sieb. crppt. exsice, $\pi, 63$. Fries in Iinnaer $V$, s12, t. $11, f, 3$. Lo o o ph y 11 u m Klotsch in Hook, misc. IT. 130. 2, 29.

450. Selnizoplnyituma FR. Hy menin m lamellatum, lamelli s radiantibus, flabellatis, longitudinaliter bifidis, 1 a me 11 u 1 is margine involutis extns ascigeris. - Fungus cosmopolitu, truncicola, pileo sessili, subernsa-coriaceo.

Sehizaphy 11 um Frles obx, 1, 103, Syst. 1.330. So hi.

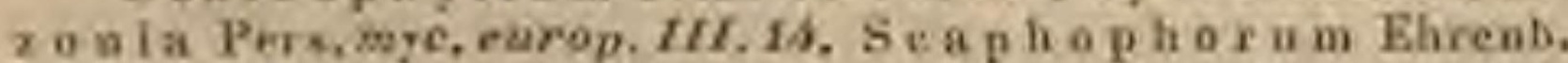

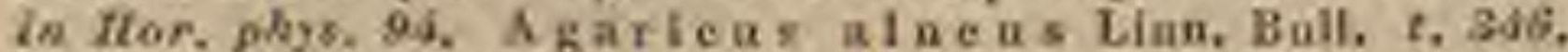
581. Nees xyt, f. 181 .

4ธ 1. Camtharellass ADANS. Hy nen i n m plicatum, plic is radiantibns ramosis, subparallelis, undique aseigerum. _ Fungi terrestres v. epiplayti, pileo carnoso v. membranaceo, sessiliv $v$. stipilato.

Cant ha rell a s slans fam, II. 11. Fies $228 \%$. I. 316 .

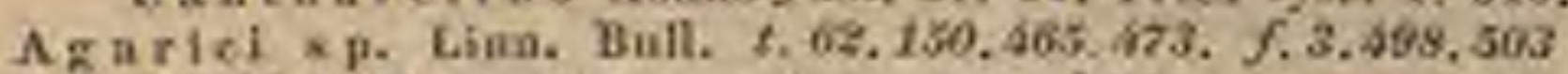

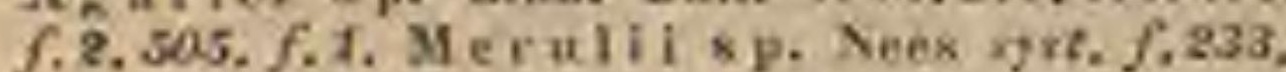

4.52. Fraveluas FR. H y menium lamellafum, lamejlis in alveolos liexagonos anastomusantibus. - Fungi trancicoli, ut plurimum tropici, pileo coriaceo lento plerasuque dimidiato.

Favolus Fries pl. hom, 76. Elenct. $\boldsymbol{I}$. 44 . Linnaea V. 511, 2, 11. f. 1.2, non Palis.

453. A mariens LINN. Hymenium lamellatum, lamellis a pileo discretis, radiantibus, longitudinaliter ascigeris. - Fungi notissimi, per fectissimi, ubique vigentes, stipite rarissime obsoleto, nunquam reticulato, pileo carnoso v. membranaceo, adulto horisontali, velo vario $v$, nullo.

Ag a rie u s timn. Jgen, n, 1674. excl. sp. Fries xyst. I, 8. Pi, hom, 65, Elench, $T, 2$.

$I$, GOMPHU S Fr. $V$ e I u m subuniversale glutinosum, pi. leam velleris instax tegens. Lam ella e decurrentes. persisteutes. Sporidia nigra. - Stipes ceatralis.

60 in phus Fries syzt. I, 314, (Pers. io, et descript. 6. 13. $f, 1-3$. FI. dan, 2. 12.47.)

IT. Copkivus Pers, Vel u m universade, concretam, floc cosum. fugax. La mella e liberae, tandem nigricautex. cuw pilea deliquescentes. Sporid 1 in nigra, -5 tipes centralis.

Coprinus Fers. disp, 62. Fries cyut, I. 306. H y drapho rus Batt. hist, 54. (PI, dian. f. 835. 1050, 1134, 1370. 16:1.)

IIT. PहATELLA Pers, Vel n m praesens, пumquam ara. nessam. La u e llace ilecolorantes, nebviosie, dissolubiles, Sporidfa furco-purparea. - Stipes centralis.

Pratella Pers, disp, 36. erel, sp, Pratella \& Fries yst, $x .11$.

a) Coprinaria * Fries syst. $I$. 300 . Ve Iu m marginale fogacissimm. Lamellne subtinluentes. S poriata nigrieantia. (Fries Flench, $I$. 49. Sawerb. $t .128,13 t$.)

b) Ps inthyca Frien syst. $r$. 295. Velu m marginale fu. gacisximum. L a me 11 a e adfixav. Pile us stipesciue fraciles. (Y7, dan, 6,1673,$)$

c) Psilocybe Friex syot. T. 289. Velu marginale fu. grocissimam. La ne llace adfixac. Pile us stipesque tenaces. (Sowerb. t,200, f,1. Pers. ic, et descript. $t, 11, f, 1,3$

d) Hyph of oma Fries sysz, I, 287. Ve 1um marginale, fugax. Lamella e emarginatre. Silpes bulborus. (F). dău. $t, 980$. Nees syst. f, 198.)

e) Psalli ota Fries syst, $T, 280$, Vol u $\mathrm{m}$ aunlliforme persistens. $\mathrm{L}$ a uelia e liberar i. affixae. $S t i p e x$ firmus, a pileo viscoso v. fibrilloso discretus. (FI. Alan. t. $204.1008 . f .2$.

f) Volvaria Kries syst. 1.278 . Vela m nuiversale dis. oretum, stipite tandem protruso lacialato-ruptum. Lamella e Hberae, latae, seatrícoszo. Stipex soIfdus, a pileo viseidulo discretus. (Sowerb. $\ell, 1$. FI. dai. $t, 1670 . f .1$.

IV. DERMINUS Fr. Velum praesens fiand araneosum. Lamellate deeoloratae subpersistentes. Sporidia ferroginea.

De $r$ m inus Vries sgst. I. 10.

a) Crepidatus Fries syst. 1. 272. Yel am tennissi. mum, fibrillosum. Pil eus excentrieus vel sexsilis. (F1. dan, $f, 1078,1023, f, 1,7,1556$. Nees syst, $f, 175$. $179,150$.

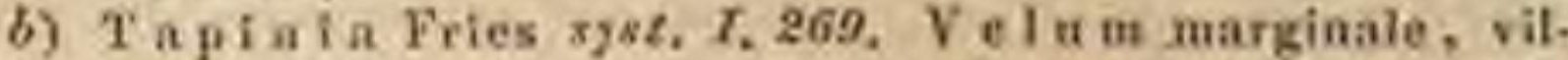
losum. PiJeus nubilicatus, earnosas, margine involatus. (Sowerh. 1.98.)

c) Galera Fries syst, $L$, 204. Vel am Haceosum, fuga cissimum. Pll e us mentbranacens, campanulatas. Sti. pes firtulosus (Bulliard 2. $560, f, 1$, B u I ta Batt. 58 . c. $28 . x$.

d) Na ucoria Fries syst. $T$. 200. Vel um fugacissimum, cam pilei integromento squamnloso confusam. L. a m e lI ine einnatomeac. (Pers, ic, et desoript. t, 12. f.13. Nees iyst. $f .186$.

c) $100 \mathrm{cy}$ bn Fries syse, I. 25\%, Velom cam fibrillis fongitudinalibus pilei continuam. fogacissimum. L a m e I live albilac. (Bull. t, 370, 539, f,2. Perr. ic, et de. script, t. 1. f. S.)

A $\mathrm{F} 1$ a $\mathrm{mm} \mathrm{n}$ la Fries syst. $I$. 230. V el a marginale, fibrilloxum, fagacissimam, Pileas viscidulus. (Boll. $t$. 5.56. $f .1$.

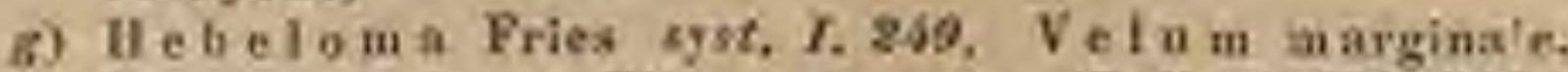
Aloceoxum, fagax. Plleas viscasus. (Bull, t. 30s, A76.)

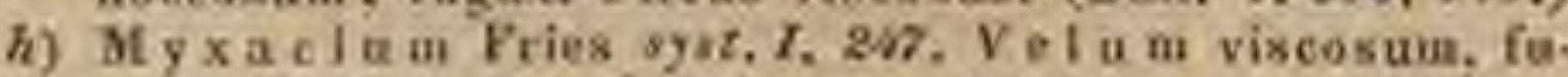
gax. (Bull. A. 106. f. l. Sowerb. . . 9.)

c) Plioliota Fries syst, $x$, 290, Velum sicoum, annu. lare, arembranaceum y. Hoccoso - radiatum. 6h. đan. t. 1496.1675.$)$

D. Contixaria Fr. Velum praeseas, araneosum. La. mellate decolorantes, areseentes. Sporidia ochrio cea. - Stlper centralis.

Cortinaria Fries syst, $I, 10$.

a) Dermooy be Fries syzt, 1. 217. Vel a m sicenm, fugatissinum, L a molla e confertae, latiusealae. (Bull. 
t. 5i4. f. 2. Sowerb. t. 43. Pers. ic. descript. t.4. f.4 $\rightarrow 7$.

b) Phlegmatium Fries syst. I. 226. Velum viscosum fugax. La mella e adnato-decurrentes.

c) 1 i o $10 \mathrm{~m}$ a Fries syst. I, 217. Vel $\mathrm{um}$ marginale, in fila libera araneasa solutum, fugax. La $m$ el l a e emarginatae. S tipe s bulbosus. (Bull. , 250.598, $f .2$ a.)

d) Tela mon ia Fries syst. r. 2to. $\mathrm{Vel}$ a m annuliforme, eontextum, subpersistens. Lamellae distantes. (BuIl. t.600.)

VT. HYPORHODIUS Fr. Velum nullum. L amellae de. colorantes. Sporidia rosea. - Stipes centralis.

a) Eecilia Fries syst, $\boldsymbol{T}$. 20r. Pileus umbilieatus. L amellae adnatae.

b) Nolane a Fries syst. $I$. 204. Pileus membranaceus, campanulatus. (Bull. t. 4t.3. f. 2. $t$.526.)

c) Leptouia Fries syst. 1 . 201. Pileas earnoso-membranaceus, convexo planus. (Pers, ic. et descript. $t$. 6. 7. 5.7

d) Clitopilus Fries syst. I. 194. Plle us earnosns, convexus. (Bull, t.534,5\%7. f.590. Nees syst. f. 201 . 202.)

e) M u ce ron Fries syst. $I$. 193. Pil e u s earnosus. demum depressus. La mella e longe decurrentes. (Bull. t. 1 i2. Sowerb. $t .143$.

NIT. LEUCOSPORUS Fr. Vel u m varium v. nullum. Lamella e immutabiles. Sporidia alba.

a) Le ucosporus Fries syst. I. 9. P I e urotus Fries syst. $I$. 178. V e l u m nullum. P il e u $s$ excentricus v. lateralis. (Sowerb, t. 242, Fi. dan. t. $891,1292, f .2$. Fers. ic, et descript, t, $6 . f .4$. Nees $f, 176,177$.

b) $0 \mathrm{mphalia}$ Fries syst. $I, 162$. Vel u m nullum. P ile us membranaceus, junior umbilieatus. - Stipes centralis. (Bull, $t, 364, f, a$, Sowerb, $t, 10,363$, Nees syst. $f .192$.

c) M y e en a Fries syst. T, 140. Velu m nullum. Pil e us membranaceus, campanulatus. Stipes centralis, fistulosus. (F. dan. $t, 830, f, 2, t, 1251,1614, f .1$. d) Coll y bia Fries syst, I, 129. Velum mullum. P ile us earnoso-membranaceus, planiuseulus. Stipes centralis. (Fl, dan. $t, 1613$.

e) Clitoey be Fries syst. I, 78, Velum uallum. Pi. le us carnosus, ianior convexus. Lamell ae inaequales, exsuccae. Stipes centralis. (Bull. $t$. 434. 520.534. $f .1 .548 . f$. a. 585. f. 1.587. f. 1.594. Fl. dan. t.1292. Sowerb. t.24i.384. f.3.)

f) Gallorhens Fries syst, 1 , 61. Velum nullum. Pi. le us earuosus, demum depressus. La mella e inae. quales, lactescentes. Stipes centralis. (FI. dan. $t$. 1068, 1069. $f, 1,1131,1132$.

g) Russ u la Pers,obs.I. 100. Velum nullum. Pil e as carnosus, demum depressus. L a mella e aequales. exsuccae. Stipes centralis. Sporidia in nonnullis lutescentia. (Fries syst. 1, 54. Bolt, t.1. Sowerb. t, 201. FI. daa. $t, 1009$.

h) Tricholom a Fries syst, r. 36. Velum fugacissimum, flocenlosum, marginale, L a m ell a e emargina.

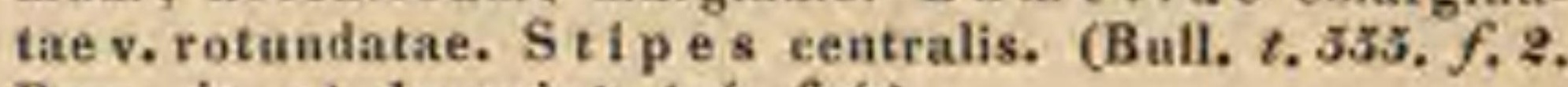
Pers, ic. et descript. t.4. f. 4.)

i) L imaci um Fries syst. $I$. 31. Vel u m fugacissimum, viscosum. Lamella e adnato-decurrentes, Stipes eentralis. (Sowerb, $t, 8,146$ )

k) Armillaria Fries syst. 1.26. Velum simplex, par. tiale, discretum, annuliforme, subpersistens. Stipes centralis. - P o I y m y e s, Cham a m y ces et Calantriea Batt. $t .30-33$. (FI. dan. $t, 773.1013$.

t) Lepiota Fries syst. $T$. 19. V el a m simplex, universale, concretum, aunuliforme, subpersisteas. Stipes centralis. (FI. das. $t, 772,1915$.

m) A manita Fries syst, I. 12, V elum duplex, uni. versale diseretum, partiale annuliforme, subpersistens. Stipes centralis. (Bull, $t, 190$. Fi. dan. $t$. 1129. Nees syst. f. 16.5. Vittadini, Amanitarum illu. stratio. Mediol. 1826. 4to.) 


\section{REGIO II. CORMOPHY'TA.}

Cormophyta, chorobrya, phyllophora. Cauliset radicisoppositio polaris. Vasa et organa propagationis sexu distincta in perfectioribus,

Plantae e radice centripeta et e ca ule centrifugo, nunc solo apice, nune ambitu, nunc ambitu simul et apice crescente constantes, e contextu cell ulos o regulari compositae, superiores etiam vas is donatae, omnes foli is plus minus discretis, rarissime deficientibus, semper certo ordine dispositis, in perfectioribus etiam stomatibus pertusis, instructae. Multiplicatio per g em mas extus nascentes, propagatio per sporas ve sema, intra matricem pullulantia, in perfectioribus non citra sexuum concursum ad vitam individuam excitata.

\section{SECTIO III. ACROBRYA.} consp. X.

Caulis incrementum e solo api(:), parte inferiore immutata, succos tantum ad ducente. Vasa in inferioribus nnlla, in superioribus plus minus perfecta; folia in infimis vix discreta. Organa propagationis foliis plus minus transformatis, in orbem collectis coadunativestipata; maseula, humorem foecundantem pluentia, in vasculosis nulla. Sporae, testa et embryone destitutae, intra porangia inclusa, e cellulis parietis interioris sporangii dissolutis, germinatione in fila confervoidea v. Iaminam (proembryum) elongata.

Sectio artificialis, cohortes vere naturales, sed parum inter se aflines, diversissimo nempe coelo genitas, colligens. Prior $H$ epaticas et Mus c os complectens, hodiernae quippe telluris soboles, vegetabilia evascularia, sed genitalibus masculis satis perfectis donata complectitur; in posteriore praeter Equisetaceas, Ilydropterides, Filices et SeI a gines colligente, quam e protogaea credimus superstitem, structura intima longe perfectior, cum absentia discriminati sexus combinata est; huic appendicis loco Cy cadeas, nullam harum sectionum vere intrantes, et sui omnino juris, anomalas subiungimus. Addimus tertiam (Rhizantheas), vegetatione terminali cum prioribus omnino convenientem, sed organorun utriusque sexus fabrica multo perfectiorem, et tamen quoad crescendi modum et alia vitae phaenomena $T h$ allo phytis $\mathrm{Hys}$ terophytis analogam, in limine norae periodus vitae vegetabilis constitutam.

\section{COHORS I. ACROBRYA ANOPHYTA.}

CELLULARES FOLIATAE DC. theor, elem, 299, PSEU. DOCOTYLEDONEAE EVASCULARES Agardh aphorism. 103. HETERONEMEA Fries pl. hom. 33. excl. pl. MUSCOIDEAE Lindl. introduct. 320. MUSCINAE Bischoff, in N.A. $N$. C. XVII. 2. 958. M a \& $\mathrm{c} i$ Link Handb. IV. 38 .

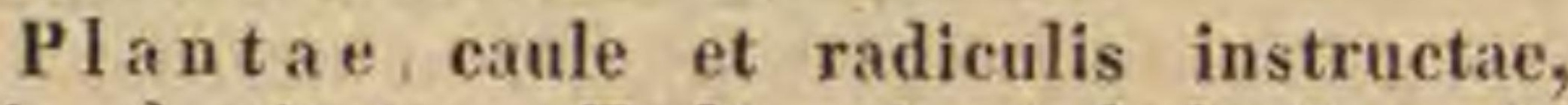
vasis destitutae. Folia in inferioribus in frondem coalita, in superioribus discreta, caulem ornantia, stomatibus plerumque destituta, aquam absorbentia. Genitalia maseula utriculiformia, rorem foecundantem secernentia. Sporangia capsulaeformia, a caule et foliis discreta, unilocularia, plerumque definite dehiscentia. Sporae numerosissimae, intra sporangium liberae, sporodermi cinctae.

\section{Classis IV. Hepaticae.}

HEPATICAE Juss. gen. 7. MUSCL HEPATICI Hedwig theoria generationis 1798. - Scliwagrichen, historiae Mus. corum hepaticorum prodromus. Lipsiac, 1814. Svo. - Weber, historiae Muscorum hepaticorum prodromus. Killae, 1815. 8vo. - Hooker, the briftish Jungermanniae, London. 1818, fol. 2, Vol. - Raddi, Jungermanniographia etrusca. Modena, 1818, 4to. et in Opuse. scientif. die. Bologn. IT. - Dumortier, Commentationes botanicae. Tour. nay, 1823, 8vo, - Lindenberg, synopsis Hepaticarum euro. paearum, Bonnae, 1899. 4to. - Corda, Monographia Rhi. zospermearum ot Hepaticarum. Pragae, 1899. Mlo. Die Gattungen der Lebermose. Prag, 1829. Svo. Deutschlands Jungermannien. Nurenberg, $1830,12 m o$. f.1.2. ex Sturm. Flora IIT. 2. - Echart, Synopsis Jungermanniarum Germaniae, Coburgi, 1832. 4to. - Nees Hepaticae javanicae. Wratislawiae, 1831. 8vo. et in Mart. Flor. bras. I, 29439o. Naturgeschichte der europäischen Lebermose. Erstes Bändchen. Berlin, 1833. Svo. - Hubener, Hepaticologia

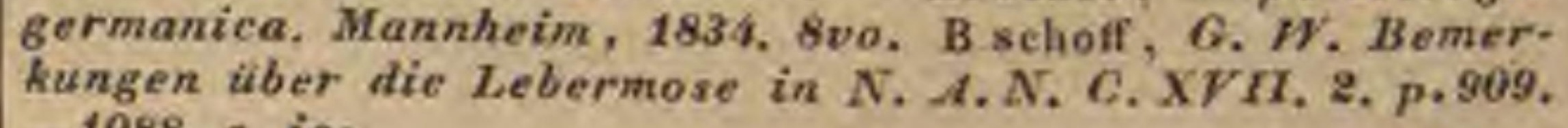
-1088. c. ice.

Vegetabila annua v. perennia, contextu celluloso laxiusculo; pleraque procumbentia, radicantia. Fous nune in frondem enervem, vel nervo valido percursam coalita, nunc discreta, disticha, saepe dentata, vel lobata, interdum stomatibus donata, saepe stipulis (amphigastriis) aucta. $M \| 1 \mathrm{ti}$ plicatio per 
gemmas et propagula varia, propagatio per flores sexu distinctos. Flores masceu (antheridia) utrieuli membranacei, humore mucilaginoso, saepe in granula coagulescente repleti, sessiles v. stipitati, in frondosis saepe frondi inmersi, vel in $d$ is $\mathrm{cum}$ collecti, et ma rgine foliaceo eincti; in toliosis axillares, braeteis stipati. Flores fкMINke solitarii vel plures, plerumque in receptaculum capituliforme pedunculatum collecti, involuero commui, partialibusque e foliis in orbem collectis, et varie saepius inter se comnatis cincti, interdum filis articulatis (paraphysious) mixti. Geruer primum intra bracteam membranaceam, calyptratim connatam (epigonium, calyp(ra) in processum styliformem, saepius apice stigmatoideg terminatum, liberum, rarissime nudum, tandem in pedicello plus minus longo, interdum brevissimo, elevatum, calyptram apice irregulariter rumpens, pedicello basi calyptrae parte inleriore persistente vaginato. Sporavela capsulaetormia, cava, v. rarissime col u un ell a pereursa, plus minus complete bi-quadrivalvia, interdum dentibus dehiscentia, vel vertice irregulariter fatiscentia. Sporas numerosissimat, liberae, e spermodermi simplici et nucleo homogeneo compositae, saepissime cellulis elongatis, intus spiraliter striat's, sporangii parieti interiori adnatis (elateribus) mixtae.

Hepaticae per totum terrarum orbem inmumeris formis dispersae, in humidis umbrosis potissimum vigent, infimae aquis innatant; frondosae prioris regionis memores, Lichenes in mentem revocare videntur.

Diagnosis inter Hepaticas et Muscos posita est in calyptra apice $v$. Latere rupta, nee basi circum circa suluta; in defectu vaginulae pedicellum sporangii cingentis; in sporangio exoperculato, et in sporis elateribus saepius mi.ttis.

\section{Drdo X XIE. Bicciacene.}

RicctEAE Nees Leberm. s6. pro part. Höbener Hepati colog. 25. Bischoff in N. A. N. C. XVII. 2, 964 .

Plivevan annuae, frondosae, hygrobiae v. natantes. Flores masculi (anlleridia) frondi immersi. Flores femenei sparsi, exinvolucrati, nudi vel calyptrati. SPoraxara membranacea, immersa, sessilia v, breviter pedicellata, irregulariter fatiscentia, vel rumpentia. Sporae absque elateribus. - In aquis staynantibus et ad terram argillosam humidam per totum orbem observatae, rarissime tamen fructificant.

454. Theeia MiCHEL. Antheridia frondi immersa, cuspidibus exertis, remotis, unipluriseriatis. Flures feminei frondi immersi, ealyptra nulla. Sporangium stylo persistente siperatum.
Rice ia Michel. nov, gen, 107, exel. sp. Lian. gen, n. 1666. Bischoff in N. A. N. C. XVIT. 2. $103 \%$.

a) LICHENOIDES Bisch. Fructus in frondis paginasuperiore protuberantes, denum prorumpentes. Frondis evolutio ceutrifuga. (Michel. nov, gen, t.57. f.5.6.8. Bischotf op, eit, $t .71, f .1-4$.

b) RICCLELLAE $A$. Braun. Fruetus in frondis pagina inferiore protuberantes, demum prorumpentes. Frondis evolutio centrifuga.

Riceiella A. Braun in Flora 1821. Ir, 757. (Michel. nov. gen. 6.4. f.6. Bischoff op. oit. t.70. f.5.)

c) Hemiseumata Bisch. Fr uet a s immersi, tandem froudis partitione deundati.

Ri e clo e a r pur Corda apual Sturm Jungerm, 103. exel. ic. Sal viniell a Hüben. Hepaticol. 30. - ? He m na Raf. in N. York Monthl. Magaz. 1817, 1. (Hook, Miscell. I. t. 22. f.3. Bischolf op, cil, t.71. f, 5.6.)

455. Splinemoenrpus MICHEL. A nthe ridia clobosa, per frondis substantiam sparsa, mutiea. Flores fem in ei superficiales, e aly ptra pyriformi, apice perforata. Sporangium brevissime pedicellatum, stylo deciduo.

S pha er ac ar p us Michel. nov. gen, 4, t, 3. Schwein. in Journ. Acad, philadelph. III. $361 . f .1$. Bischot in N. $A$. N. C.XIII.392, t. $44 . X V I I$, \&. 1036.

456. Dxymaitra BISCH. Antheridia immersa, cuspidibus exsertis lineam inmarginatam constituentibus. Flores femin ei superficiales, eal y ptra pyramilata, clausa. S p orangium sessile, st y lo persistente superatum.

$0 \times y \mathrm{~m}$ it r a Bischoff in Lindenb. synops. 124, 125, N. $A$. N. C.XVIL. 1037, t. 70. f. 2,3. R u p pi u i Cordia non Linn. Ric ciae sp. Miehel. $t$. 57 . f. 2. Raddi in Opusc, scientif?. di Bologn. II. 350, t, 15. $f .3$.

45\%. Corsinia RADD. Antheridia immersa, cuspitibus exsertis lineam ntrinque vri stato-marginatam constituentibus, Flores feminei superficiales, ealy ptra globosa, elausa. Sporangium brevissime pedicellatum, s ty Io deciduo.

Corsinia Raddi in Opuse. scientif. di Bologna II. 35i, t. 13. f. t. Bisehaif in N. L. N, C. XVIT, 1037, t, 70. f. t. Gü ntheria Treviran. in Jahrb. der Gewächsk. III. 15?. c. ic. Bris s o carpus. Bischoff in Lindenb. synops. 123. Ricciae sp. Acut.

458. Sedfswiekia $B O W D$. Antheritia superficialia, catervatim ntrieulis membranaceis, paleis densissime einctis inclusa, Flores feminei superficiales, sessiles, singuli involuer b e paleis plarimis conflatu cincti, c a l y ptra nulla. Sporanuinm sessile, st y lo persistente sinperatum. - Genus dubium.

Sedgwickia Bowdich Madeira 35. $\epsilon$, ic. Bischotf in N. A. N C.XVII, 10a9, C, 10, A, A. A it a it ia Forst. Gen, 147. Comment. Götting. IX, s6. R и p pinía Linn. Amoen. Aca. dem. X. $t, 15, f, 5, \mathrm{C}$ or $x \mathrm{i} n \mathrm{i}$ a $\mathrm{l}$ a me ell osa Nees et Bisebouf in Flora 1830. Ir. 401.

\section{Dralo XVIII. Anthocenoterte.}

ANTHOCEROTEAE Nees Leberm, 57 . Hubeses Hepatico. log. 20. Bischoff in N. A. N. C. XVII. . .962.

Plantae annuae, frondosae vel foliatie, fronde enervi v. nervesa, suborbiculata, lobata, radieante. Flozes masevi (antheridia) frendi immersi, demuin emergentes. FLовеь ғвмквI sparsi, exinvolucrati, calyptrati. Sporangium pedicellatum, uni-biralve, columella centrali. Sporae elateribus mixtae. A A tho e e ote a e columellae centralis praesentia ab omnibus Hepaticis distinctissimae, in limosis et super arborum truncos totius terrarum orbis reperiuntur.

459. Anthoceros MHCHEL. Antheridia agregata, primum immersa, deinde tam re cep- 
ta culo eupulaeformi emergentia. Flores feminei sparsi, calyptra tubulosa, apice oblique fissa, persistente. Sp orangin medicellatum, lineare, incomplete bivalve, col u m na centrali filiformi persistente. S pora e elaterilsus mixtae. Frondosac, enerves, cosmopolitue, terrestres.

A $n t$ ho ceros Miehel.gen, 11. t.7., f. 1.2. Hedw, theor. generat. ed. 2. t. 29.30. Selutidl Ic. t.19.47. Corda monograph, $t, 5$.

480. Nionoelea HOOK. Antheridia aggregata, receptacnlo patellari, marginato, immersa. Flures feminei sparsi, calyptra tubulosa, apice oblique fissa, persistente. Sp or a ngi $\mathrm{um}$ pedicellatum, lineare, hine longitulinaliter fissum, colnm a centrali filiformi persistente. S pora e elaterihus mixtac. - Frondosae, fronde nervosa, v. foliatue; tropicae, in arboribus parasiticae.

Mo noelea Hook. Mruse, exot, t.174. (male) Misc, Ir. ..t. . . (opt.) Nees Hep. Jav. 4. Anthoceros univalvis Forst. A. bras ilie ns is Raddi Rettili e piante t.4. f.4. Crypt. bras. 29. (? A. cris p us Swartz.) (Antheridia et columellam, ut in Anthocerote, in specie brasiliensi ipse vidi.)

\section{Drdo XIX. Targioniacene.}

TARGIONIEAE Nces $\mathrm{N} a t u \mathrm{rg}$ e $\mathrm{ch}$. 85. Hüberrer Hepaticolog. 16. Bischoff in N. A. N. C.XNII. 2.961.

plaxtulae perennes, frondosae, enerves simplicissimae $\mathbf{v}$. lobatae, prostratae, radicantes. Flores masculignoti. Florns femineI sub apice vel e sinn frondis solitarii, sessiles, inrolucro hetorogeneo cincti, calyptrati. Sporanterer subsessile, laciniis inaequalibus v. dentibus dehiscens. Sporas elateribus mixtae.

'Targioniaceae in terra hnmida aprica per totum fere terrarum orbem observatae, sitn floris feminei solitarii subhypophyllo-terminali facile dignoscuntur.

461. Tangionia MICHEL. Flores feminei sub apice frondis. Involuerum coriaceun, bivalve. Calyptra bivalvis, persistens. Sporangium subghobosum, brevissime pedicellatum, apice irregulariter rnptum. Sporae elate ribus mixtae. - Frons linearis simplicissima, epidermide porosa. Species europeae, americanae, capenses.

T a rg fo n i a Michel. nov. gen, 3, t.3, Limn. gen, n, 1314, Sehreber in Naturfiorsch. X F. t. 5. f.1-17. Weber et Mohr crypt, t, 12. $f .4$-6. Corda apud Sturm Jungerm, $t, 30$.

482. Cyathodiome LEHM. Flores feminei e sinn frondis. Involuerum coriaceum, eyathiforme, bilabiatnm. Caly ptra... S porangium globosum, subsessile, apiee dentibus subsenis dehiseens. S porac elateribus mixtae.

Frondes lobatae, tenerrimae, diaphanae. Species unica, antillana.

Cy athodium Lehw. pugill. VT. 17. - An huc Carpobobolus Scloweinitz in Journ. Academ, philadelph. II. 367. fig. 2,?

\section{Dralo XX. Dirarchantiaceare.}

MARCHANTIEAE Nees Naturgesch. 84. Hubener Heparicolog. 1 . Bischoff in $N . A, N, C, X V T I$. CEPHALOTHECAE Dutuort. comment, 115.

Plantan hygrobiae, perennes, frondosae, fronde lobata, saepe porosa. Kuores mascul nunc frondi immersi, nunc disciformes, sessiles; interdum peltiformes, pedicellati. Frones PBMINeI in capitulo pedunculato, subtus vel rarius ambitu florifero, involucro in- volucelli sque cincti, calyptrati. Sporavgrum pedicellatum, pedicello saepius immerso, varie dehiscens. Sporat elateribus mixtae.

Marchantiace ae ubivis terrarum repertae, receptaculo floris feminei pedicellato, subtus v. ambitu florifero facile a $J \mathbf{u} n$ germanniaceis et Targioniaceis dignoscuntur.

463. Grimanaldia $R A D D$. F 1 o r e s $m$ a se uli disciformes, frondi immersi $v$, in ea sessiles. Capituli fem ine i rhachis incrassata, hemisphaeriea, subtus flurifera. Invo I a erum nullum. I n v o I a c 11 a expuliformia, truncata, inter se distincta, cum rhachi confinsa. Cal yptra brevis, persistens, sporangii basim eingens. Sp or a ng i u circumscissum, ped i cello hrevissimo, immerso. - Species in Europa media et australi, Africa boreali et in insulis Antilla$n$ is hucdum observatae.

Grimmaldia Raddi in Opusculi scientif. di Bologn. IT. 356. Lindenberg in Flora, 1833. I. 175. Bischoff in N. $A$. N. C. XVIT.971, t, 68. $f .1-3$. D a v a lli a Nees in Berl, Magaz. VII, 272, t. 10. M are hantiae s p. Lina, et Auet. (Michel, nov. gen. t. 2. $f .3$. )

464. Fimbriaria NEES. F 1 ores $\mathrm{m}$ a 8 c uli discifurmes, frondi immersi. Capituli fem in e i rhachis inerassata, hemisphaeriea v. conica, subtus florifera, Invol u era monantha, tnbulosa, truncata, inter se distineta, cum rhachi confusa. Involncellum longe exsertum, multifidum. Calyptra fugax. Sporang i um circumscissum, pedicello brevissimo immerso, intra involucelIum latitans. - Species paucae, late per orbem vulgatae.

$\mathrm{Fim}$ briaria Nees in Hor. phys. 44. t. 5. f.3. Bischoff in N. A. N. C.XV1I, 971. t. 69. f.2.3. Fimbriaria. Hypenantron et Syndonis e Corda in Opiz Beitr, 6is. Marcliantia e sp. Linn. et Auet.

455. Condeeplanilus HILL. F $10 \mathrm{res}$ maseuli disciformes, sessiles, sntmmarginales. Capituli fem in ei rhachis vix inerassata, umbonulata, subtus florifera. Invol n e r um nullmm. Involucella tubulosa, apice oblique fissa, inter se connata et cum rhachi confusa. Calyptra persistens, apice bi-quinqueloba. Sporangium dentibus quinis-ortonis tandem revolntis dehiscens, cum pedicello brevi decilumm. - Species europeae.

Conoceph a I и s Hill. syst, 119. Dumort, comment. 115. Biseloff in N. A.N.C.XVII, 971, t. 68. $f .4 \mathrm{~F}$ eg a tell a Raddi in Opusc, seientif. di Bologn. 11, 356. Ma rela antiae s p. Lion. et Auct.

486. Iumularia MICHEL. F 1 o $\mathrm{r}$ e s masculi disciformes, sessiles, submarginales. Capituli feminei rhachis exigua, convexiuscula, ambitu florifera. Invo I u $\mathbf{r} \mathbf{r} \mathbf{m}$ nullum. Involucella tubulosa, truneata, inter se distincta, cum rhachi confusa. C a ly p tra subbifidorupta, persistens. Sporangium quadri-oetovalve, pedicello exserto. - Species paucae, per Europa $m$ diffusae.

$\mathrm{L}$ n u l aria Michel. nov. gen. 4. $t$. 4. Raddi in Opusc. vcientif. di Bologna II. 355. Nees in Flora 1830, $I$. 398. Bischoff in N.A.N.C.XVIT. 2, gro. t. 67. Sta ax o phora Willd. in Berl, Magaz. III, 2, 101. Marchantiae sp. Linn.

46\%. PIagioehasma LEHM. F lores maseuli disciformes, frondi semiimmersi. Capitulifeminei rhachis exigua, plana, ambitu florifera. Involuernm nullum. Involucella 
rhachim velantia, inter se distineta, vertiealiter bivalvia. Caly ptra inaequaliter rupta, persistens. Sporangium dentibus inaequalibus dshiscens, pedicello subnullo. - Genus nepalense, a sequente vix nisi rhacheos capituli feminei diversa evolutione distinctum.

Plagioc has ma Lehm. pugill. $I V .13$. Bischoff in $N$. A. N.C.XYII. 2. 970 .

468. UBelountilia $R A D D$. Flores mase $\mathrm{li}$ disciformes, frondi semiimmersi. Ca p it uli fem in ei rhachis pileiformis, subquinqueloba, subtus florifera. In vo I u crn m nullum. Invol uce l1a inter se distinuta, rhachi adnata, rima longitudinali hiantia. Cal y ptr a brevissima, lacera, persistens. S porang $i$ m apice lacero dehiscens, pedi cello brevissimo immerso. - Europa australis.

Re bouillia Raddi in Opusc, scientif. di Bologn. $T I$. 357. Bischotf in N.A.N. C. XVIT.970, t.69. f. 1, A e hiton Corda in Opiz Beitr. 648. Marehantia hemisphae. rica Liun. (Michel, nov. gen, t.2. f.2.)

465. Thunetiera NEES. F I ores mase uli disciformes, sessiles, marginati, snloumbonati. Capituli feminei rhachis dilatata, convexa, quatri-oetoloba, subtus florifera. In v o I ue rum nollum. Involue e 11 a inter se distincta, rhachi adnata, bivalvia. Calyptra fugax. S porangi $\mathbf{i} \mathrm{m}$ apice irregulariter dehiseens, pedicello brevissimo, immerso. - Genus inter tropicos late diffusum, a priore vix nisi floribus masculis perfectioribus, et calyptra fugacissima diversum.

Do mortier a Nees in N. A. N. C. XII, A1O. Bischoff ibial. XVIT. 2, 969. Mar cha utla hirsuta Swartz.

4รง. VIarelanutia MARCH. Flores ma se uli disciformes, submarginales, ve peltiformes, limbu crenato ant lobato. Capitn 1 i feminei rhachis radiata, radiis membrana frondiformi iunctis, subtus floriferis. In volu era mono-hexantha, radiis alterna. Involu e ella quadri-quinquefida. Caly ptra subbifido rupta, persistens. Sporangium in lacinias demum revolutas dehiscens, pedicello exserto. - Genus polymorphum, polychorum.

Marchantia March. fot. in Let. Paris 1713. p. 307. t. 5. Bischoff in N. A.N. C, XVIT. 269. $t, 68, f .5, t, 69, f .4 .5$. (A n atom. Mirbel in Nouv. Annal, de Mus, 1. 55. 6. icc.) Preissta et Chomioca rpou Corda in Opiz Beitr. 6 rz. -? Chlamidium, Rhakiocarponet Otiona Carda I. $c$.

\section{Drdo XXI. Jungernanniaceae.}

JUNGERMANNIEAE Nees Naturgesch, 84. Hübener Loberm. 32. Bischoff in N. A. N. C.XVII. 2, 960.

Plantak annuae v, perennes, frondosae, v. distincte foliatae, surculosae, saepius stipulatae. Flones mascou (antheridia) sparsi, liberi, stipitati v. immersi, sessiles. Flores FEMINEI solitarii v. rarius plures intra involucra immediate e caule v, fronde orta, calyptrati. Sporaxgium rarissime univalve, alias quadrivalve, pedicellatum. Sporaz elateribus mixtae.

Jungermanniace ae nobilissimus Hepaticarum ordo, ingenti formarum et individuorum copia, in umbrosis humidiusculis, imprimis super alias plantas sedent.

4r 1. Codonia DUMORT. Involu c $\mathrm{rum}$ floris feminei monophyllum. Involucellum nullum. Ca I y ptra rupta, basi persistente. S p o- ran g i um subglobosum, dentibus irregulariter dehiscens. - Foliu succuba.

Codonia Dumort. ex Nees Naturgesch. 99.

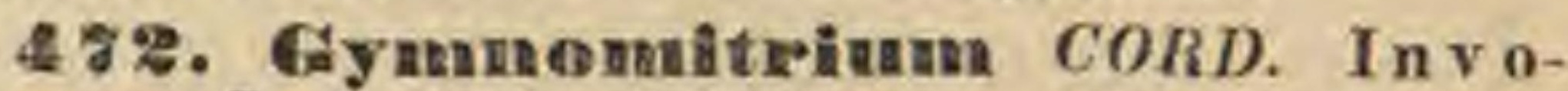
1 u c r u m floris feminei foliaceum, libernm, v. gamophyllum. Involuc: I l n m nullum. Calyptra conica, apice rupta, persistens. S porang ium subglobosum, qualrivalve. - Frondosae et foliatae.

a) MRTZGERIA, I n v ol u er u m brevissimum, gamophy 1lum, subeyathilorme. Cal yptra exserta, laevis v. echinata, apice perforata. Frondosae.

Metzgeria Raddi Jungerm. 34, Fas cioIa Dumort. Merckia Borkh. Eebinomitrím Corda apud Sturm Jungerm, t.2t, 22. 38. Nees teberns. 99. Jung e rman $\mathrm{n}$ ia. f u re a t a Linu. Hook. Jungerm, $t, 55.56,-\mathrm{Röm}$ e ri a Ruddi op. cit, 35. Me tz g e r ia Corda op. cit, 1. 19.24. Nees Leberm. 99. A n e $\mathrm{r}$ a Dumort. Ju agerma an ia pins a is et mul. tifi di a Linu. Hook. Jungerm. t, 45.46, - P elli ia Raddi op. cit, 38. Corda op, cit, t.39. Nees op. cit. 99. S e opulina Damort. J. e p ip h y 11 a Lìn. Hook, op. cit. $t .47$.

b) SCHISMA Nees. 1 и v 1 и e $\mathrm{r}$ m m longius ganoophyllum, ore multíido. Calyptra iuclusa, apice perforata. Foliatae, folits quadrifariis.

$\mathrm{S} \mathrm{ch}$ is ura Duzart. Nees Leberm. 28. J. juuiperina Swartz. Hook. Jangerm. 2. 4. Suppl. t.1.

c) HAPLOMTRIUN. Invo f и с ru m pleinphyllnm. CaI y ptra inclusa v. exserta. Foliatae, foliis distichis tristichisue.

G y mo om itrium Corda op. cit. t, 3.4. Gymnomitri um et Haplouitrinm Nees op. cit, 98. Muiopsis et Sehismatis sp. Dunort. J. eoncinnata Lightf. Hook. Jungerm. t.3. J. Hook eri E. B. t, 25s3. liook. op. cit. $t . s \%$.

4.3. Sarreoseyplavas CORD. Involuer um foliaceum, gamophyllum. In vo 1 u ce 11 um cum involucro connatnm, ore libero eius faucem coronan8. Calyptra conica, apice rupta. Sporangium suhglobosnm, quadrivalve. _ Foliatae, folits distichis succubis.

Sareosey phus Corda in Sturm Jungerm. $t, 5$. Nees Leberm. 129. J. e marg inat a Ehrh. Hook. Jungerm, $t, 27$. J. F u a k if Web. et Mohr. Mart, erlang. t. 5. $f, 35$.

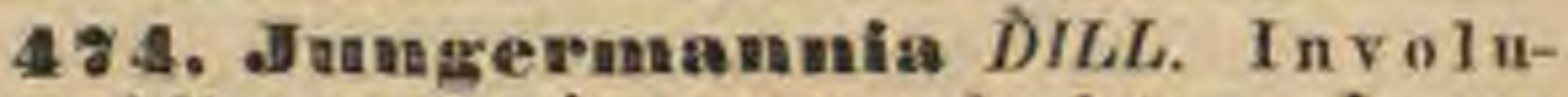
c $r$ u $\mathbf{m}$ foliaceum varium, raro olssoletum. Invo1 u e e $11 \mathrm{n} \mathrm{m}$ distinctum, tubulosum, gamophyllum, terminale v. laterale. C a ly ptra apice rupta. S po rangium subglobosum, quadrivalve. - Frondosae et foliatac.

Juдgегtиanuia Dillen. Linn. gen, $n$, 1662. excl, sp. B lasia Mieheli $n$. gen. 14, $t$ \%. Selimidel dissert, Erl, 1759. Forel la Linu.gen, $n, 1186$. (coll.Dicks. in Linn.Transact.IIT. 238.) Dink Jeria, Heimea, Nitophyltumet Riehardsonia Neck. elem, 1733-1256. Jungermannia, Me. *ophylla, Radula, Jubala, Madotheea, Lejea. uia, Phragmicoma. Dilaena, Saceogna, Cinefnnulus et Trieholet Damort, comm. bot. ea Nee. Leberm. 93-99. Lej е Annal, Bruxell,VI. L.97. Bellineiuia, Antolria, Frul. lania, Candollea. Jungermanuia. Fossombro. nia, Calypogeia Raddi Jungerm, etruse 7-33. Frul. Ianoides et Viviaula Radd. crypt. bras, 13. 18. Jungermannia, Allicularia, Cheiloseyphus, Dilomitrion, Siekorea Corda in Opiz Beitr. 652. 55. ungermannia, Pilidium, Mastigophora, Her. petium. Jubula, Radula, Lejeunia, Diploni trion, Cordaea, Blasia, Saceogyna, Geocalyx, Cal y pogeia et Triehole a Nees Leberm. 93-98.

OBSERVATIO. Genus ab auctoribus nune in plurima di. remfum, partium valore noudum satis perspecto, et forais pluribns in natura a nobis baud observatis, interim, exclusis speciebns javolacella omoino destitutis vel involucello cum involucro connato douatis, intactuon servanus; tutius rati in veteribus aquaiescere, quam in tanto seriptoram dissensu no. vos errores erroribus saperaddere. Ceterum etsi nulli dabitemus genns e fructu olim esse snbdividendum, manihus pedibusque in illustr. Neesii (Enum, pl, crypt. Jav, p. 5.)

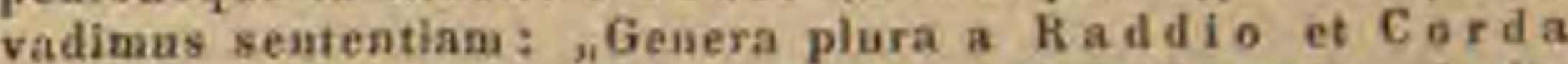
nuper e Jungerma a $\mathbf{a}$ ia apprime naturali genere, invita matara procreata. 


\section{Classis V. MIusel.}

MUSCI Dillenius, Historia Muscorum Oxonii 174t. Ato. Edit. II, 1763. 4to. Juss. gen, 10. Neeker, Methodus Muscorum. Mannh, 1771, 8vo. Hedwig, Fundamenta historiae naturalis Muscorum Lips, 1782. 4to. $2 \mathrm{Vol}$. - Theoria ge nerationis ot fructificationis plantarum eryptogamicarum. Lips, 1784, 4to. Edit, II. Lips, 1798. 4to. - Descriptiones et adumbrationes Muscorium. Lips. 1787 - 1792. fol. $4 \mathrm{Vol}$. - Species Muscorum, cur. Schwägrichen. Lips. 1804. Ato. - Supplementum specierum, cur. Sehwägrichen. Lips.1811. ss. Ato. 2 Vol. - Bridel, Aluscologia recentiorum. Gothae, 1797-1803. 4to. 4 Vol. - Muscologiae recentiorum supplementum Gothae, 1806-1817, 4to, $3 \mathrm{Vol}$. - Methodus nove Muscorum, Gothae, 1819. 4to.-Bryologia universa, Lips. 1826. 1828. 8vo. 2 Vol. - Palisot de Beauvois, Prodrome de la cinquieme ot sixieme famille de $P$ Aethëogamie. Paris, 1805, 8vo. - Muscologie. in Annales de la societe linneénne de Paris. Tom. 1. 388. ss. - Fr. Nees de Muscorum propagatione. Erlangae, 1818. 8vo. - Horuschuch in Nov, A. N. C. X. 413. ss. - Hooker et Taylor, Muscologia britannica. Lond. 1818. Svo. - Hooker, Musci exotici. Lond. 1818-1820. 8vo. $2 \mathrm{Vol}$. - Fr. Nees, Hornschuch et Sturm. Bryologia germanica. Norimb. 1823. ss. 8vo. 3. Vol. - Greville et Walker Arnott. a new arrangement of the genera of Mosses in Mem. Worner. Sociot. IV. 1. 109. ss. - Walker Arnott in Mem, soc, hist, nat. de Paris. II. 209. ss. - Häbener, Muscologia germanica. Leipz. 1833. 8vo.

Vegetabina plerumque perennia, conte $x t$ u celluloso, laxiusculo, radiculis fibrilIulosis, subarticulatis. Caules (surculi) teretes, e cellulis elongatis conflati, simplices v. ramosi, abbreviati v. elongati, dense foliosi, erecti v. procumbentes, ex axillis radicantes. Fo lia sparsa $\mathbf{v}$. disticha, sessilia, obsolete decurrentia, simplieia, integra v. integerrima, nune dentata aut serrulata, enervia v. uni-binervia; nervis e cellulis elongatis densioribusque compositis, stomatibus porisve destitnta. Multiplicatio per gemmas, propagatio per flores sexu distinctos, sexubus nunc dioecis, nune monoecis, rarissime hermaphroditis.

Frores mascubi nune in foliorum axillis (flores gemmiformes), nune in caulium apieibus (flores disciformes), nunc in apice caulis aut pedunculi globoso flores capitiformes), constant e foli is abbreviatis, dilatatis, in orbem collect is (foliis perigonialibus), ex a nthe'rid i is numero indefinitis, membranaceis, cylindricis, subincurvis, apice incrassatis, poro v. ore plus minus regulariter dentato v. laciniato dehiscentibus, humorem mucoso-granulosum (pollen) effundentibus, et ex immixtis filis pellucidis, subclavatis, transversim septatis (paraphysibus, antheridiis abortivis $v$. radicellis succedaneis.)

Fuores feminei laterales v. terminales, rarissime solitarii, plerumque tres ad viginti, involucro communi (perichaetio), immixtis interdum antheridiis, cineti; singuli primum intra bracteam calyptratim comnatam (calyptram, saeculum, utriculum membranaceum externum Auct.) reclusi, apice attenuato, infundibuliformi inpervio (stylo Hedw.) cum bractea connati, ceterum liberi, omnes, unico v, rarissime pluribus exceptis abortivi, persistentes (adductores Hedw,), fertilis rarissime sub- sessilis, plerumque in pedunculo gracili (seca, carpophoro Auct.), plusminus longo, basi semper membranula annulari (vaginula, recep(aculo proprio, sessili v. rarissime stipitalo), cincto, sensim adscendens, bracteam calyptratam basi circa circum rumpens et secum anferens, quae sporangii grossificatione demum saepe lateraliter fissa, ejus apici adhaeret. Sporangrem (theca, capsula Auct.) duplex; exterius (sporangium sensu strictiori) e foliolis quatuor, pedunculi apici plus minus incrassato (apophysi Auct.) continuis, inter se in tubum eylindricum, ventricosum v, angulatum ; arctissime connatis, rarissime tandem solutis, tubo columnae centralis extremitate dilatata operculato, nunc inaperto, nunc post opereuli lapsum a n n ul u m minutissime denticulatum dijiciente. Sporang i um interius (sporanyidium) e foliolis duplo v. multiplo partium exterioris numero, alternatim bi-pluriseriatis, sacpissime dissimilibus, inter se et plerumque cum exterioris tubo connatis, summo apice (peristomio) inter se distinetis v. per paria cohaerentibus, aut in membranam columnae centrali impositam (egiphragma), ab eadem in operculum transeunte et poro pertusam, confluentibus. Columna centralis (pedunculi continuatio) teretiuscula, quadrangula, costata, libera v. sporangio interiori costis subadnat, apice in collum, cum o p e rculo variae formae et diversinode rostrato primitus connatum tumens, intus solida. SpoRAE globosae, numerosissimae, sporangii cavitatem replentes, liberae, nec ejusdem parietibus nec columnae unquam affixat, $g$ e $\mathrm{rm}$ in attione in tubules confervoideos, septatos, ramoses, e ramorum axillis folia evolventes, undique elongatie.

M usci per terrarum qua late patet orbem diffusi, omnem humum avide occupant, et innumera grege incolunt; ita ut eorum beneficio paludes conerescant, arenae frecundentur, saxa vireant, et laborioso mortalium generi fertilis soli primitiae in futuram cuituram parentur.

Quamvis in zonae temperatae et frigid a locis editioribus, ob hunorum abun. dantiam cum aurae temperie cunjunctam, sint frequentissimi, nnotamen deest imprimis in syl varum, quae sub torrido sidere aeternum virent umbrosis recessibus, nobilioris formae Muscorum ingens caterva. Species plurimae endemicae, multae tamen per ommem hemisphaeram borealem, nonnullae late per orbem vulgatae; leges tamen juxta quas dispunctae, hodie Muscis exoticis vix primis delibatis labiis, et topographis bryologicis etiam europacis tantopere imperfectis, haud eruendae.

Dignoscuntur autem Musci ab Hepaticis facillime tum sporangii operculati, e pluribus (duplici saltem) foliorum cyclis couflati, con- 
formatione; tum calyptra vix non semper basi undequaque soluta, denique receptaculo fructus in membranam pedicellum vaginantem transeunce.

In sedimento aquarum dulcium Muscorum paucae reliquiae observatae fuerunt.

\section{Drdo XXII. Amdreaencene.}

MUSCI SCHISTOCARPI Brid. Bryolog. II. 725. ANDREAEAE Corila Jungerm, 1. 22.

Musci habitu Jungermannias aemulantes, caespitosi, erecti, ramusi, riøidiusculi, e rubro v. fusco nigricantes. Folia imbricata, sparsa, crassiuscula, enervia $v$. uninervia. Calyptra basi circumscissa. Sporaveia breviter pedicellata, in valvnlas quatuor secedentia. Operculum columnae et sporangio pertinaciter adnatum, valvulas post dehiscentiam connectens.

Andreacaceac inter Muscos et Hepaticas mediae, paucae nomnisi in hemis$\mathrm{ph}$ aerae borealis regione temperata et $\mathrm{fri}$ gida, locis potissimum editis, usque ad ipsum nivis aeternae terminum, saxa rupesque denso caespite vestiunt.

4\% 5. Andreaen $E H R H$. Flores masc nli subterminales. Flore s feminei terminales. Calyptra subglobosa, demun latere fissa. Vaginula substipitata apophysiformis, pedicellam brevissimum occnltans. Sp o rang i um medio quadrifidum, valvulis basi, et apice opereulo persistente junctis.

A $n$ d r e aea Ehrh. Beitr. 1, 15, 180. Hedw, sp. t.3. f, 2. Schwägr. suppl. II, 106. Web. et Mohr Taschenb. t, 1t, f. 3 -8. Palis. prodr, 12, t, 1. f. 1. Hook. in Linn. Transact. $X$. 381. t, 31, f, 1-4. Hook, et Tayl. Musc. t. 8. E. B. t. 127 . 2507. Brid, Bryolog. II. 725. Corda Jungerm, t.2. Brueh in Münehn. Denkschr. X. $t, 7 . f$, 13-16, Petroplila Brid. mac. J ung e rmanniae sp. Lian.

\section{Drdo XXIII. Spleagneaceae.}

MUSCI evaginnlati eladoe arpi Brid. Bryolog, $I_{\text {. }}$ t. SPHAGNOIDEAF, Corda Jungerm, $\%$.

Muscr molles, flaccidi, spongiosi, in sicco erecti, in aquis fluitantes, ramosi; $r$ a $\mathrm{m}$ is in latere caulis fasciculatis. Folia imbricata, concava, enervia, diaphana. Caly ptra basi persistens, medio rupta. Sporasgia in apice ramorum brevissime pedicellata, exannulata. Opereulum planum, dissiliens. Stoma nudum.

$S p h a g n a c e a e$ in turfosis uliginosis et ericetis udis totius orbis tractus ingentes occupant, foecundi solis primordia, liangiferis pabulum, Hyperboreis panis.

476. Splasanuma DILL. FIores terminales; mas culi clavati, $f$ em inei discifurmes. Calyptra medio rupta, persistens. Faginula apophysiformis, pedicellum brevissimum occultans. Sporangium operculum planum dejiciens, stomate nudo, col umella sub maturitate obsoleta.

$S p$ h a g $n$ a $m$ Dillen, musc, 250, Linw, gen, n, 1187, Hedw, fund, 11, 85, 4.3 . Schwaigr. suppl. I. t. 3. Hook, et Thyl. musc. t. 4. Bryolog. germ, I, $1 ., f, 1-4$. Brid. Brgolog. I. 1 . Corda Jungerm. $t .1$.
Ordo XXIP. Bryaceae.

MUSCI vaginulati Brid. Bryolog. I, XLIT.

Muscr centrales, habitu vario, fructificatione terminali (acrocarpi) v. laterali (pleuro. carpi). Calyptra basi circumscissa. SPoRANGIA operculati, annulata, indebiscentia, v. o perculo dejecto aperta, stomate vario.

M u s c or u m numerosa nimis genera, quae segnius a nobis in natura fuisse observata fatemur, Bridelii ductu potissimmm hic enumerantur.

4\% . Arelaidionas $B R I D$, Calyptra basi persistens, medio laciniatim rupta. Spora n g i n m indehiscens, columna ohsoleta. Pedicellus vaginulac apophysiformi immersus. - Genus europaeum, plane unomalum, Bryaceas cum Sphagna. ceis jungens, rectius fortassis his accensendum.

A reh i d i u m Brit, Bryolog. I. 7a7, t. 3. Brueh et Schinip. Fragm. bryolog. II c, ic. Phas cum globiferum Bruch in Flora 1825, p. 281, $t, 1$.

48 8. Flhaseun $L I N N$. Calyptra campannlato-dimilliata, basi integra. Sporang i u m terminale, basi aequale, in d e his cens. - Pusilli, in temperatis utriusque orbis gregarii, epigaei.

P h a s c u m Linn, gen. n, 1189. Schreb. dissert. de Phasoo Lips, 1780, 4to. Hedw. Fund, II, 85. Musc. Frond, t,9-11. 34. 35. La Pylaie in Journ. Bot. I. 177, Hook. et Tayl, muse. 5. t,5. Schwagr. Suppl, t, 2, 3,101. Hook. musc, exot.t.105. Bryolog. germ, 1. 1. Brid. Bryolog. I. 21. t. 1. Brueh et Schimp. Fragm, bryolog. IU. e. ic. P y xid i um Elirh. Beytr. IV. 44.

499. Pleuridianm $B R I D$. Calyptra eucnlliformis, basi lacera. S p o ra $\mathrm{ng}$ i n m laterale, basi aequale, ind e h i s e e ns. - Cosmopolitue, terrestres.

Pleuridium Brid, mant, 10. Bryolog. I1. 160. t. 8. Phas e i sp. Hedw. et Sebwagr. Suppl. t, 10. E. B. t, 2107.

480. Treachia SCHWAEGR. Calyptra campanulata, basi fissa. S pora n g i n m terminale; apophysatum, rostellatum, inde his cens. - Muscus púsillus, in nivosis Vogesor $u m$ repertus.

B r uchia Seliwïgr. Suppl. 11. 9t. $t$. 127. Brueh et Schinap. Fragm, bryolog. Ir. C. ic. Voitia Moug. et Nest. erypt. voges. $f, 8$, non Horusch. Sa p r o ma Brid. Bryolog. I. $59, t .1$.

481. Physedium $B H I D$. Caly ptra cuculliformis, basi integra. S porang i um terminale, apophysatum, rustellatum, indeh i scens. Muscus pusillus, e apen sis.

Physedium Brit. Brolog. I, 51. t. 1. Phas cum

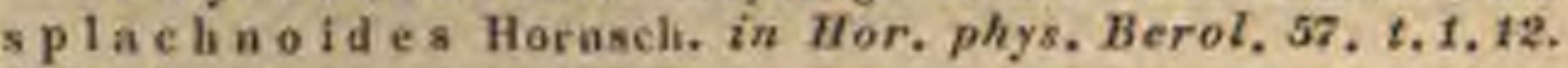
f. $1-4$.

483. Voitia HORNSCH. Calyptra caculliformis, sporangio adhaerescens. Spuranginm terminale, basi aequale, rostellatum, in deh is e ens. - Musci majusculi, caespitosi, ramosi, ad nives alpium Europae mediae, et in insulis $A m e-$ ricae hyperborea observati.

Voiti a Horusch. de Voitia et Systylio, Erlang. 1818, p. 5. t. 1. Hook, musc. exot, t.97. Schwagr. Suppt. t. 101. 126. Araot et Grev. in Transaet. Werner. Soc, IV, 109. 1.7. Brid, Bryolog, 1,34 . t. 1. Bruch et Schiaip. Fragm. Bryolog. II. c. ic,

483. Gymoestomuma $H E D W$. Ca ly ptra cuculliformis v ventricosa, subulata. S por a ng i um terminale, basi aequale; o perenlum conicum vel rostratum, sto in a nudum. - Musci gregarii, cosmopoliti, annui v. perennes, terrestres.

G y m uо $\mathrm{t} \alpha \mathrm{mum}$ Hedw, Fund, Ir. 8 . Brid, Bryolog. I. S7. $t, 1$, Br y o u Adats. 
a) GYMNostomum Brid, C a l y ptra cuculliformis, basi integra.

G y m nost om um Brid, $t$. $c$. Hedw, musc. frond, $I$. $t$. 6. 30. II. $t, 34$, spec. $t .1, f .1-9, t .2, f .1-3, t .3 . f .1-4$. t. 4. f. 1-4 Bryolog. germ. I. t.9. f. 1-9. t. 10. f. 13-22. t. 11, f, 23, 25-28,34, Hook. musc. exot, $t$, 42, 154. P o t t i E!rrl. Beytr, 11. 187. An o d o n ti um Brid. Spec. I. 41.

b) PHYscomitrium Brid. Caly ptra veatricoso-subulata, latere fissat, basi lucera.

Physcout itri utu Bri.l. Bryolng. I. 97. Hedw. Fund.

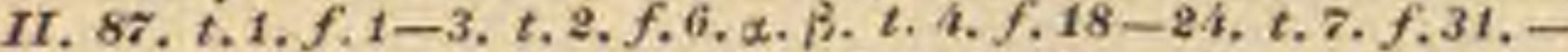
Spec.t. 4. f. S-8. Schwagr. Suppl.t.8.105.-Bryolog.germ. t.9. f.3. t. 10,f.10.11.)

484. Hy ruenostomenn $R$. $B R$. C a ly ptra cucnlliformis. S poran gi um terminale, bas aequale; op erculum conicum; st om a subobliquum edentulum, e $\mathrm{i}$ ph $\mathrm{rag}$ a t e centro demum evanescente clausum. - Musci perennes, e uropae $i$, epigaei.

H y m e n o s om un R. Brown in Transact. Tinn. Soc. XII. s72. - Bryolog. germ. I. 193. t. 12. Brid. Bryolog. II. 73. G y m n o s to mi s p. Hedw, musc. frond. 111 . t. 30. $S p$. t. 3. $f .8-11$.

485. III ymenostylinan $B R I D$. Caly ptra cuculliformis. S porang $\mathbf{r}$ um terminale, basi aequale; operculu m rostratum; stoma edentulum, col u ime 11 a e apice dilatato reclusum. _ Mus cus nepalensis, caespitosus, epigaeus.

Hy me nost y $1 \mathrm{i}$ am Brid. Bryolog. 1.81. G y m nos to. mi s p. Hook. musc. exot. t. 153 .

486. Fyramaintarm BRID. Calyptra pyramidata, primum latere fissa, demum basi soluta, sporangio adhaerescens. Sporanginm terminale, basiaequale; o perculum conicum ; stoma nudum. - Muscus annuus, in Europae m cdiae arvis caespitosus.

P y ramidium Brid. Bryolog. I. 107. P y ramidula Brid. Mtant. 20. - Bryolog. germ. I, 86. t. 8. f. 1. G y m nos to m i 8 p. Schwägr. Suppl. $t, 8$.

$48 \%$. Il yoplaila $B R I D$. Caly $\mathrm{p}$ r a cuculliformis, basi integra. Sporangi um terminale, apophysatum; operculum conicum; stoma nudum. - Musci perennes, in Indiae orientalis calidis epigaei.

H y ophila Brid. Bryolog.I. 260. Rottle ria Brid. op. cit. $I$. 105. t. 6. non Roxb. G y m no $\mathrm{s}$ o m i 8 p. Schwïgr. Suppl. t, 3. Nees et Blam in Nov. Act.N. O. XI. t. 14, f.2.

489. Wntosthymenium BRID. C alyptra cuculliformis. S Soranginm terminale, apophysatum; opereulum... stoma edentulum, $\mathbf{m} \mathrm{em}$ bran a annulari, tandem lacinulata, munitum. - Muscus luridus, perennis, in Gallia a ustrali epigaeus.

Entos thymen i um Brid, Bryolog. 1. 761.

48D. Selnistialium BRID. Calyptra mitracformis v. eampanulato - coniea, basi laciniata, v. hine longitudinaliter fissa. Sporangi um terminale, basi aequale; opercul um convexinsculum; s to ma nudum, - Musci perennes, in temperatis et calidis totius orbis epigaei.

$\mathrm{Sch}$ is tid in m Brid, mant, 20, Bryolog. 1. 113. - Bryo2og. germ. T. 88, t. 8. f,1-5. H a $\mathrm{r}$ is o nia Adans. fam. II. 14. A u o e ct a ng ii s p. Schwägr. Suppl.t. 12.105. Hook. et Tayl, musc. t.6. Hook. musc, exot. t, 41, 106. H ed wig fae

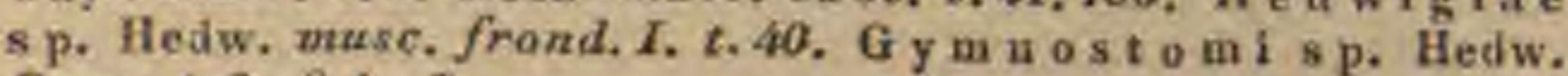
spec, t.3. f, 1-7.

420. Grimmia EHRH. Calypira mitraeformis, basi sublacera, laevis v. striata. S p 0$\mathbf{r}$ a $\mathrm{ng}$ i um terminale, basi aequale; op e r cu In m convexiusculo-conicum; persitomi simplicis dentes sedecim, pyramidati, pertusi $\mathbf{x}$, imperforati, reflexiles. - Musci perennes; in toto orbe epigaci $v$, rarius truncicoli.

Grimmia Ehrh. Beytr. I. 176. Hedw. Fand, II. 89. Musc, frond. I. t. 39. III. ᄂ.31. Spec, t. 15 f.1-13, Sehwïgr. Suppl. t, 23-26, 45, 97. 116. Hook, musc. exot, t.42,43,131.
Brid. Bryolog. I. 160, - Bryolog. germ. II, 1. 64. t. 16-24. B ry i sp. Lina.

491. Iryelloopogen BRID. Calyptra, mitraeformis, basi integra. S porang i m terminale, basi aequale; o pere u l um planum; peristomii simplicis dentes sedecim, breves, obtusi, solidi, apiee bifidi, conniventes. - Muscus perennis, in Americae tropica fluviis degens.

Hy dropogon Bria. Bryolog. T. 769 . Grim mia fon. ti n a lo ides Hook. muse. exot. IT, $t$. 11 .

492. Dreyptodon $B R I D$. Calyptra mitraeformis, basi lacera. S porang inm terminale, basi aequale; o pereulum convexum, rostellatum; peristomii simplicis dentes sedecim, apice inaequaliter bifidi v. lacero fissi. - Musci perennes, caespitosi, in temperatis utriusque orbis saxicoli.

Dryptodon Brid. Bryolog. I. 191. C ampylopodis s p. Brid. Mant, 71. Di or a i s p. Helw. musc. frond. 'III. t. 43. a. Sehwägr. Suppl, t. 47. F is s id e n t is sp. Hedw. Spec, t, 11.f.4-6. Triehost o m i s p. Sehwägr. Suppl. t. 37. G rim miae sp. Hook. musc. exot, t, 2, 129. B r y i s p. Linn. Lu id a e s p. Adans.

493. Treeomitritum $B R I D$. Caly ptra mitraeformis v, eampanulato-subulata, basi lacera. S porangium terminale, basi aequale; o pereu$1 \mathrm{um}$ conicum v, acuminatum; peristomii simplicis dentes sedecim, ad basim usque in lacinias plures filiformes fissi. - Musci perennes, in temperatis hemisphaerae imprimis borealis terricoli, rarius aquatici.

Ra e omitrium Brid. Bryolog. I. 20z. Trichosto$\mathrm{m} \mathrm{i} \mathrm{s}$. Hedw, musc. frond, II. t. 25. III, t. 2, 3. 33. Spec. t.23. f. $1-5$. Seliwagr. Suppl. t.38.39. Hook. et Tayl, musc. t. 19. H урдi sp. Hall. Bryi sp. Lim. Luidae sp. Adans.

494. Hollomitriom $B R I D$. Calyptra angustissima, elongato - conica, basi coarctata, integerrima. Sporangi um terminale, basi aequale; operculum aciforme; peristomii simplicis dentes sedecim, usque ad basim bifidi. Musci a us tralasici caespitosi, perennes, epigaei, perichaetiis elongatis, pedicellum vaginantibus insignes.

Holn mitrium Brid. Bryolog. T. 226. Triehost om i s p. Hook, musc, exot, $t, 64,73$.

495. Drethotheea BRID. Calyptra angusta, conico-mitraeformis, basi coarctata subintegerrima. Sporangium terminale, basi aequale; operculum aciforme; peristomii simplicis dentes sedecim, integri, per paria approximati. - Musci americani, tropici et extratropici insulares, epidendri.

Orthotheca Brid. Bryolog. I. z78. Dicrapi sp. Selıwägr. Suppl, t. 40 .

496. Cinelidetars PALIS. Calyptra mitraefurmis, basi lacera. Sporang i m terminale, basi aequale; operculum conicum; $p$ eristomii simplicis dentes sedecim, profunde bi-tri-quadrifidi, cruribus linearibus supra basim anastomosanti-cancellatis, siccitate spiraliter tortis. - Muscus perennis, in fluviis rivisque Europa lignis saxisque, imprimis calcare is, adhaerens.

Cinclid o tus Palis, prodr. 28. Hook. et Tayl. musc. 29. $t$. 11. Brid. Bryolog. I. 228. - $\mathrm{Sek}$ ra Adans. II. 14. Tricliostomi s p. Hedw, musc. frond. III. 36. $t, 14$. Fo $\mathrm{u}^{-}$ tinalls s p. Lina.

498. T'etaralais $H E D W$. C a I y ptra mitraeformis, suleata, basi la cimiata. S p o ran $\mathrm{g}$ i u m terminale, basi aequale; op erculum conieum; peristomii simplieis dentes quatuor, pyramidati. - Musci in hemisphaera boreali viventes, habitu vario. 
Tetrap his Hedw. Fund. II. 87. Brid. Bryolog, 1. 129. Bryolog. germ, II. 1. $t$. 13.

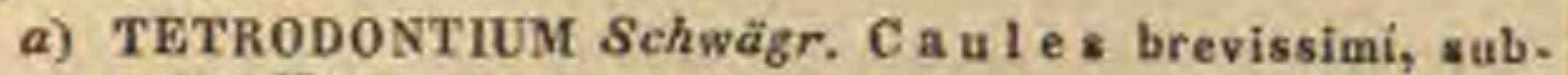
nulli. Vit a annua.

Tetrodontium Schwägr. Suppl. Ir, 102, $t, 128$.

b) TETRACMIS Brid. Ca ules elongati. Vit a perennis.

Tet r a $\mathrm{em}$ is Brid. l. c. Ge or g i a Ehrh. Beytr. I. 188 . Tetrapitis Hedw. Spec. C. 7. f. 1, a. $-f$. Theor. gen. t. 8. M n il s p. Limn.

4D8. Syrrothopolom $S C H W A E G R$. C aIyptra subeampanulata, basi fissa. Sporangi $\mathbf{u m}$ terminale, basi aequale; o perculnm planiusculum v.restratum; perist o mi i simplicis dentes sedecim, horizontales, 8 to ma recludentes. - Musci in corticibus arborum Indiae orientalis dense caespitosi, perennes.

S yrrhopod on Schwägr. Suppl. IT, 110, t. 131. 132. Cleisostona Brid. Bryolog. 1 . 153. Pterogonit sp. Hook, in Transact, Linn. Soc. XI. 310, t. 26. f. 4 .

499. Campylopurs BRID. Calyptra conica, latere fissa v. basi fimbriata. Spor angiu m terminale, basi aequale v. subapophysatum; o perculum cuspidatum; peristomii simplicis dentes sedecim, bifidi v. bifissiles, cruribus aequalibus. - Musci in temperatis et calidis utri usque orbis supra terram $v$, in truncis perennantes.

Campylopas Brid. Bryolog. I. 468. Dieranis p. Hedw, Spec, $t$, 2d, f, $1-7, t, 37,38, f, 1-6$, Hook. musc. exot. t, 138. Polla Adans. B ry i sp. Linu. - Thys a nomitrio n Schwägr. Suppl. $11,1, p \cdot 61, t, 118$.

500. Dedipodinum SCHWAEGR. CaIy ptra campanulata, latere fissa. S porangi um terminale, subapophysatum; operculnm eonvexiuseulum; stoma edentulnu, membrana fugaci reclusum. - Muscus pusillus, annur, caespitosus, in montibus frigidis $B$ rit an $n$ ia e repertus.

Oedipodi un Sehwagr. Suppl. Ir. 15. $t$. 105. Brid. Bryolog. II. 83. G y m a os to m 1 s p. Smith E. B. t. 1938.

501. Brtlnoullon BORY. Calyptra mitraeformis, basi laciniata, pilosa. Sporangium terminale, subapophysatum; operen l um hemisphaerico-convexum; p eristomii simplicis dentes octi, remotiusculi, ereeti. - Muscus in truncis arborum insulae Bourbon et in Nepalia caespitosus, perennans.

Orthod o n Bory apud Schwägr. Suppl, Mr. 23, t. 106. Brid. Bryolog. I. 23i. Oetablephari s p. Hook. musc. exot. t. 136. S p lateh i s p. Hook. in Transact. Linn. Soc. IX, 308. t. 26. f. 2 .

502. Eremodon $B R I D$, C a ly pt ra cam paniformis, basi subintegra. Sporangi um terminale, apophysatum; op erculum conico-convexum; peristomii simplicis dentes octov. sedecim, aequidistantes, ereeti v. recurvuli, linea longitudinali exarati. - Musci in uliginosis montium editorum Europae, et in regionibus arcticis antarcticisque perennantes.

Eremadou Brí. Bryolog. I. 233. - Bryolog. germ. II. 2, 161 .

a) Cy rtod o n R. Brown Suppl, to Par. voyag. p. 299 Dis so do n Grev. et Aruott in Annal.Soc, Linn. de Paris 1826. p, 229. Weis s ia sp lach hoides Sehwär. Suppl. I, t, 63, t, 17.

b) Aplodon R. Browa 2. c. Splachui sp. Schwägr. Suppl. t. 14. t, 108, Fl, dan, t. 1659.

508. Splaehwum LINN. Calyptra campanulata, subintegerrima. Sporangium terminale, apophysatum; o perc alum obtusum; peristomii simplieis dentes sedecim, per paria coadunati, linea longitudinali exarati, tandem reflexi. - Musci in paludosis et turfosis frigidiuscutis utriusque orbis perennes, $v$, rarius annui.

Spla e b n u Linu. gen, n, 1191. Brid. Bryolog. t. 239. a) Pycuapophysinm Reichenb. consp. 34. Apo. ph y s is conoidea v, ovoidea. (Hedw. musc. frond, $I I$. t. 1t-13. IIT.t.40. Spec. t, 8. Sehwïgr. Suppl. t. 14.)

b) Discapophysium Reichenb. 2. c. Apophysia sphaeroidea. (Hedw, musc, frond, II, z, 15. 16, Schwägr. Stupl, t. 15.)

c) Cystapophysium Reielrenb. 7. c. Apophysix ampullaeformis. CHedw. Fund. IT. 88, t. 7. f. 33. 34. Musc, frond. $I I, t, 14$.) A pod at a th a s La. Pylaie in Desv. Journ. bot. 1813. p. 20, t. 33. f.1. (efr. Brid. Bryolog. $I T, 772$.

d) Sciadophysium. Apophysis umbraculiformik. (Hedw, musc, IX, t,17, 18. Sehwaigr. Suppl, t. 109.)

504. Systylinan HORNSCH. Caly ptra campanulata, apiculata, basi lacera. Sporangi um terminale, apophysatum; opereulum obtuse conirum, columellae tandem exsertae adnatum; peristomii simplicis dentes triginta duo, breves, per paria approximati, basique connati. - Muscus elegans, in rupibus madidis alpium editissimarum Germaniae perennans.

Systy Ifum Hornsel. Comment. de Noitia et Systylio p. 15. t, 2. Schwigr. Suppl. II. 25. t, 107. Hook, musc, exot. t.98. Brid. Bryolog. 1. 263.

505. Seoulleria $H O O K$. Caly ptra campanulato - dimidiata. Sporangium terminale, basi aequale; operenlnm planum, columellae tandem exsertae adnatum; peristomii simplicis den te s triginta duo, apice fissi, tandem reflexi. Muscus in rivulis dmericae boreali-occidentalis perennans.

S couleria Hook. Miscell. $x, 33,4,18$.

508. Tayloria HOOK. Caly ptra campanulata, basi lacera. Sporang inm terminale, apophysatum; opereul u m convideum, incurvum, a cofumella tandem exserta dejectum; perist omii simplicis dentes triginta duo, per paria approximati, elongati. - Muscus in editioribus Europae mediae et borealis in rupibus perennans, motu peristomii oscillante notabilis.

Tayjoria Hook. musc, exot. $t$, 172, Hookeria Schleich. apud Brid, mant, 103, t. 1. f. 8. Bryolog, I. 265. Sehwagr, Suppl. t. 100. non Suith. Phrissotrichia Brid. mse.

50\%. Erachysteleum REICHENB. Calyptra mitraeformis, striata, glabra, basi lacera. Sporangi um terminale, basi aequale; operc u $I \mathbf{u m}$ acuminatum; perist omi implicis dentes sedecim, aequidistantes, pyramidati, conniventes. - Muscus in arboribus capensibus perennans.

Brachysteleum Reichenb. consp. 34. Brachy po. d ium Brid. Bryolog. $\boldsymbol{I}$, 14z. non Palis, GI y phomitrion Brid. mant, 30. non Schwägr. Eacaly pta erispata Hedw. Spec, t, 10. Schwigr. Suppl, t, 17, f, 1, Orth o tri. e hi s p. Hook. et Grev, in Edinb. Journ, of Scienc, 1826. t, $1, p, 115$.

508. GIyplhomitrinm SCHW $A E G R$. Calyptra campanulata, striata, glabra, hine fissa, basi lacera. S p o rangi um terminale, basi aequale; operculum rostratum; peristomii simplicis dente 8 sedecim, per paria approximati, pyramidati; transversim sulcati, conniventes. - Musci humiles, perennes, in rupibus maritimis et basalticis Britan nia e reperti.

Gly phomftrium Schwägr. Suppl. II, 41. t, 113. Hook. ot Grev, in Edinb. Journ, of Scienc, 1824. t.1. p. 115. t, 6. Brid. Bryolog. I, 267, Griffith i a R. Brown in Linn. Transaet, XIT, 2, 275. E n $e$ al y ptae 8 p. Smith $E, B, t, 12$. 81. G r Im miae s p. Hook. et Tayl. musc. T. 13.

509. Drthotrielawm HEDW. Calyptr a conica v, campanulata, sulcato-carinata, basi subintegerrima, pilosa. Sporangi um terminale, basi aequale, tandem sulcatum ; opereulum acuminatum; peristomii simplieis dentes se- 
decim, per paria primum nohaerentes, demnm soluti, reflexi, interium ciliis totidem introrsum horizontalibus distineti. - Musci perennes, in toto orbe terrarum, imprimis super arborum truncos, rarius in terra gregarii, speciebus pluribus latissime dillusis.

Orthetrichum Hedw. musc. frond. II. QS. Bril, Bryolog. I. 269. Navia Borlh, disp. plant. 151. Grimu ia Hedw. F'und. II. 89. We issia Sehreb. gen, n. 16as. Dorcadio a Adans. IT. 492.

a) BRACHYTRICHUM Rohl. Peristo $\mathrm{m}$ ii dentes eillis haud distincti.

Brachytrichum Röhl, in Wetteran. Annal. IM. 47. (Hedw, musc. frond, IT, t, 37. Schwagr. Suppl, t, 56, 53.)

b) orthotrichum Röhl. Peristomii dentes eillis octo-sedecim distincti.

Orthotrich u u. Röhl, l. c. Hedw, musc, frond, II. $t$. 36. Schwagr. Suppl. t.50-55.138. Grev, scot, t.105.137. Hook. et Tayl, muse, t, 21.

510. Uleta MOHR. Calyptra conica, laevis, pilosa, basi fimbriato-lacera. Sporang i u m terminale, basi aequale; o per c u I u m acuwinatum; peristomii simplicis dentes sedecim, per paria primum cohaerentes, demum soluti, reflexi, ciliis linearibus introrsum horizontalibas inter paria interjectis. - Musci caespitosi, perennes, in to to orbe super arbures, $v$. rarius in sacis reperti.

L'tota Mohr in Web, tab. synopt, musc. Brid, Bryolog. I. 298. - Blankara Adans. II. 498. Orthotricliisp. Hedw. musc. frond. 1 . $t$. 35. Seliwägr. Suppl. t. 51. 52. Grev. scot, t, 115. L e in the e a Brid. Bryolog. $I, 305,726$. $0 \mathrm{rth}$ otrich i sp. Hook. musc. exot, t, 120. Hooh, et Grev. in Eidinb. Journ, of Scienc. 1824. I, p, 111, t.4.

511. Nueromitrium $B R I D$. C a ly pt $\mathrm{r}$ a mitraeformis, campannlato-conica, laevis v, striata, glabra, basi multilida. S porangi um terminale, basi aquale; operenI $\mathbf{m}$ acieuliforme rectnm; peristomium duplex; exterioris dentes sedecim, per paria approximati, inte. $r i u s$ in coronam membranateam multifido-laceram confluens, rarissime obsuletum.

Musci tropici $v, s u b t r o p i c i$, in arboribus perenuantes.

M a cromitrium Brid. mant. 132. Hryolog. I. 306. 735. Selowagr. Suppl. t. 111. 112. 199. O rth ot rich i s p. Hook, musc. exot, t, 24, 25. 27, 44, 45, 124, 127, 136. Schlot he $\mathrm{i}$ mi ae s p. Hornsch, in Hor, phys. Berol. t. 12.

51\%. Selnilotheimia BRID. Calyptra conico-mitraeformis, laevis, glabra, basi apendicibus quaternis senisve aucta. Sporangium terminale, basi aequale; operculum acmminatum; peristomium duplex; exterioris dentes sedecim, per paria approximati, spiraliter revoluti, interius in coronam membranaceam, plicatoconicam, tandem apice irregulariter multifidam coalescens. - Musci ramosissimi, inter tropicos et in subtropicis hemisphacrii austra$l i$ s super arbores percnnantes. (Columna tandem retracta v. obliterata.)

Sehlotheinia Brid, mant, 111, t, . . f. 10, Bryolog. I. 320 Selhwigr. Suppl. t.56. 57.139 . H y p u i s p. Hedw. Spec. t.83, f. 4-7. O r thotrichi \& p. Hook. muse. exot. $t, 128$.

513. Drthodontiam SCHW AEGR. C a1 y ptra..... Sporangi um terminale, basi aequale; o perculum conicum; peristomium duplex; exterioris dentes octo, aequilistantes, erecti; interioris dentes totidem, exterioribus subconformes, iisque alterni, erectiusculi. Musci parvuli, caespitosi, in Brasilia et $C_{a-}$ pite bo na spe i observati, non satis noti.

Orthodontium Sehwagr. Suppl. II, 125. $t .188$,

514. Zygodon HOOK. Calyptra cuculliformis, laevis. S porangium terminale, sub- apophysatum; o per $\mathbf{n} \mathbf{n} \mathbf{1} \mathbf{m}$ suboblique rostratum; peristominm duplex; exterioris dentes sedecim ; per paria arcte cohaerentes, reflexi; in terioris cilia octo, paribus dentium alterna, introrsum subhorizontalia. - Musci perennes, in arboribus $v$. rarius in terra elimatis temperati utriusque orbis habitantes.

Z y f o don Hook. et Tayl, musc. brit, ro, t, 3. Selwwigr. Suppl. 136. Brid. Bryolog. I. 590 . Hook, musc, exol. t. 150. Amplidi ium Nees in Sturm's Flor. germ, II, 17. G agea Radd.

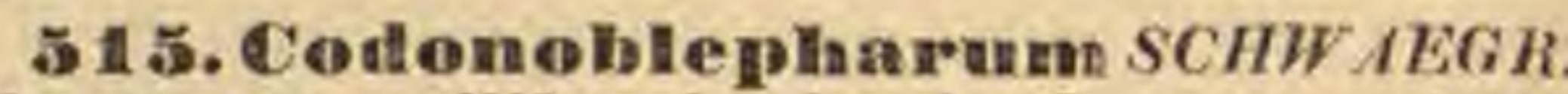
Calyptra cueulliformis, laevis. Sporangium terminale, basi aequale; operculum oblique rostratum; peristomium duplex; exterioris dentes sedecim; per paria approximati, reflexi; interioris cilia totidem, coronae membranaceae exsertae imposita, conniventia. - Muscus ramosus, dense caespitosus, in arboribus Novae Z eelan. diae perennans.

Cod o nobleph ar um Sebwägr. Suppl. II, 142, t, 137. Brid. Bryolog. I. 594. - Quid Grevilleanum L. C. Beck in Amerie. Journ. of se, and arts $\mathrm{X} I, 183$. ?

516. Weissia $H E D W$. Calyptra cuculliformis. Sporan $g$ in m terminale, basi aequale; opereulum rostellatum; peristom i simplicis dentes sedecim, erecti, aequidistantes.

Muscicaespitosi, u bivis terrarum in terrav. sa$x$ is, rarius in arboribus perennantes.

We is sia Hedw, Fund. II, 90. Musc, frond, I. 7, 8, 38 . II. t.39. III, t. 5. 34.35. Spec. 11, 12, 11, 13. Bryolog. germ, II. 2.7. t.25-35. Scliwingr. Suppl. f. 18-20.26.114, A f ze.

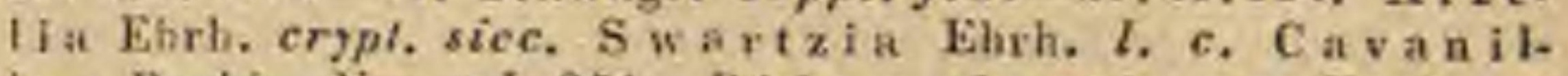
Ie a Barkh. disp. $p l$. 251. Did ymodontis sp. Hook. et Tayl. musc. L. 20. Hook. musc. exot, t, 126. B r y i sp. Lima. - Brachyodus Fürur. in Flora 1827. app. 112. 1829. 594. app. 11t. Isryolog. germ, II, 2 p. 1. t. 12. f. 29. t, 25. B r a ch yod o n tinm Forar. in Flora 1827, app. 37. G y m. nostom um trieltodes. Weher et Mohr Archiv $1, t, 4 . f .1$. An o ec laug i i sp. Sehwägr. Suppl, t, 12 .

51\%. Discelium $B R I D$. Caly $\mathrm{p}$ ra subdimidiata. Sporang in terminale, basi gibbosum; operculum ohtuse conicum; peristomi i simplicis dentes sedecim, aequidistantes, usque ad medium bifidi, subconniventes. - Museus caespitosus, in urgillosis juxta rivulos Britanniae et Luppon iae perennans.

Dise elium Brid. Bryolog. I. 365. Weissiac sp. Hook, et Tayl, musc. $t, 14$. Sehwigr. Suppt, t, 1s, Wahlenb. Fl. Lapp. t. 19 .

518. Catascopinm BhID. Calyptra elongato-conica, apice perforata, in pedunculum defluens. Spurangium terminale, subapophysatum, subhorizontale; "perculu m convesiusenlun, acuminatum; peristom i simplicis dentes sedecim, aequidistantes, acnti, solidi, subconniventes. - Muscus in turfosis subalpinis Europae mediae caespitose perennis.

C a t a s cop i u Bril. Bryolog. X.368. - Bryolog. germ. IT. 2.191.t.42. M ela ni a Brid, msc. We is s itae sp. Hedw. musc. frond. III. t. 39. Hook, et Tayl, musc, $t .14$.

519. Coseinodon SPRENG. Caly $\mathrm{p}$ t $\mathrm{r}$ a cuculliformis. Sporangium terminale, hasi aequale; opersulum rostellatum; peristomi simplicis dentes sedecim, aequidistantes, basi subeonnati, perfurati, ereeti. - Musci ranosi, caespitosi, perennes, in Europa media et A merica borcali epigaei.

Coscinodon Spreng. Einleit. 281. Brid. Bryolog. $I$. 370. Leersia Hedw. Frind. II. 56. t.23. A n a eal y p ta Róbl. Moosgatt. 108. Bryolog. germ. MI. 2. 125. T r i ma. tiu m Fröhlieh msc, Encalyptae sp. Hedw. Spec. 63. Weissiae s p. Heok. e: Tayl, musc, $t, 14$. Schwägr. Suppl. t. 20.117 . 
520. Mielieh ho Peria HORNSCH. C a1 y ptra cuculliformis. Sporanginm terminale, apophysatum; operculum conicum, submucronato-rostellatum; peristomii simplicis dentes sedecim, acquidistantes, e basi lata lanceolati, solidi, incurvi. - Musci graciles, fastigiato-ramosi, in rupibus udis montium editissimorum Europae media e perennantes.

Mieliehhoferia Hornsch. Bryolog.germ. 179, c. ic, Eur y bas is Brid.Bryolog. I. 384, in not. Oreas Brid.l.c. p.380. non Cham. nec Zoolog. A u che nang i u m Brill, mso. We is s iae s p. Sehwagr. Suppl. t. 114. 115. Hook. musc, exot, t. 42-102.

521. Calymperes $S W A R T Z$. Caly ptra persistens, tandem apice solnta, laciniata. Sporangium terminale, basi aequale; operc u l u m rostratum; s to ma edentulnm, membrana spongiosa whsolete radiato-striata teetum. - Musci ramosi, in lumidis inter trapicos et in regionibus subtropicis, super arbores potissimum perennantes.

Calymperes Swartz in Link Jahrb. t. 1. f. 11. 15. Schwägr. Suppl. t, 98, 197. Brid. Bryolog. 11.85 . C r y p h i u m Palis. msc.

529. Detoblepharam $H E D W$. C a Iy p tra longe coniea, integra. Sporanginm terminale, basiaequale; op e r c ulum acuminatum; peristonii simplicis dentes octo, subulati, imperforati, erecti. - Muscus pusillus, albidulus, in regionibus tropicis subiropicis que latissime diffusus, in terra arboribusque caespitose perennans.

0 etoblephar un Hedw. mise. frond. III. 15. $t$, $\sigma$. Brid. Brrolog. I.136, O et o h l epharis Sehreb.gen.n, 1640. B r y I s p. Linu, L uidae s p, Adaus.

523. Campylodontiom SCHWAEGR. Calyptra.... Sporanginm laterale, basi aequale; operenlum .... peristomii simplicis dentes sedecin, lanceolati, ineurvi, primum conniventes, tandem reflexi. Muscus pensylvanicus, perennis, vage ramosus.

C a m p y l od outi um Schwagr. Suppl.t.211.

524. Leveopluanes $R R I D$. Ca lyptra conico-mitraeformis. Sporanginm terminale, subapophysatom; opercul $1 \mathrm{~m}$ rostratum; peristomii simplicis dentes sedecim, lineares, in. curvi. - Musci albo-glaucescentes, in insulis Oceani indici cpigaci.

Le ucophanes Briá. Bryolog. I, 763 .

52.5. Dneoploprus $B R I D$. Calyptra cuculliformis. S pura n gr im terminale, strumosoapophysatum; opereulum rostratum; peristom ii simplicis dentes sedecim, apice ineurvo bifidi. - Musci in uliginosis extratropicis utriusque orbis perennantes.

0 ncophorus Brid. Bryolog. I. 389. Dierani sp. Hedw, musc. frond. Ir. t. 29. f.2. IIT. $\iota .32,37$. Spec, t. 32 . f.1-7. Sehwägr. Suppl, t, 45, 47.121. Hook. et Tayl. musc. t. 17. F is s id e nt is s p. Hedw, muse, frond. $11, t, 51,32$. Cecaly phisp. Palis prodr. 31 .

586. Trematodon $R I C H$. Calyptra cuculliformis. S porang in m terminale, substrumoso-apophysatum; operculnm subulato-rostratum; peris to m i simplicis dentessedecim, lineari-lanceolati, perforati. - Musci annui, in temperatis hemisphaerae borealis epigaei.

T rem atod on Rich. in Mich.x. Flor. amer, bor. II. 289. Schwügr Suppl. t.70. Palis. prodr. 4.4. f. 1. Britl. Bryolog. I. 385, - Bryolog. germ, II. 2, 198, t, 43. D i ex a a i \$ p. Hedw. musc. frond. 11, t, 36 .

52\%. Dieranam $H E D W$. C al y $\mathrm{p}$ tra cucullifurmis. Sporangin terminale, basi aequale $v$, subapophysatum; opere $1 \mathrm{~km}$ subulatorostratum; peristomii simplieis dentes sede- cim, areuato-conniventes, ad medium bi-trilidi, cruribus parallelis subaequalibus. - Musci erecti, ramosi, perennes, per tot um orbem epiguci, rupincoli v. rarius epidendri.

D jor a n u Hedw. Fund. IT. 91, t. 8. Kusc. frond. $I$,

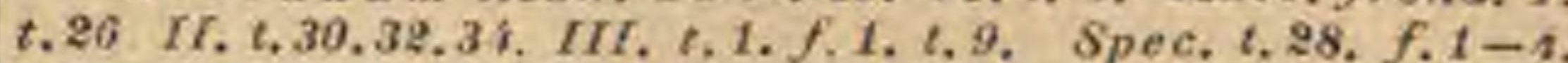

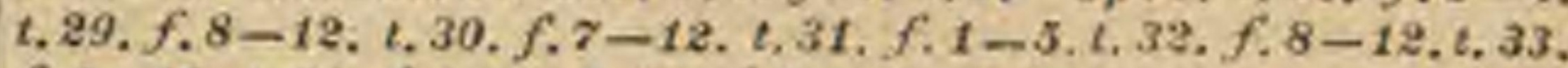
f. $6-10$. t. 34. f. $1-5$. t. 35 f. $8-13$. Sehwigr. Suppl. $4.40-$ 18. Hook, musc. exot, t, 134, 139, 140, 14t, 14t, 149. Brid, Bryolog. I. 406. Gla ue pis Brid. msc. Dicrati i et Cecaly. phi sp. Palis, Fascinae 8 p. Scheank. Bryi 8 p. Lian.

528. Ceratoalom BRID. Calyptra euculliformis. Sporanginm terminale, hasi substrumoso-apophysatum; op excul u m rostratum; peristomii simplieis dentes sedecim, basi distincti, apice in erura filiformia, inferne trabeenlis transversis juncta, fissi. - Musci cuespitosi, ramosi, ad terrom nudam hemisple a eri $i$ barealis perennantes.

Ceratodon Brid. Bryolog. $I$. 480. Aegiceras Green apud Brid. mant, 69, non Gaertn. D ie ra i s p. Hedw. Spec. 6.33. f. 1-4. t, 35. f. $1-7, t, 36 . \mathrm{D}$ i d y mo do a $\mathrm{t}$ is $8 \mathrm{p}$. Hook. et Tayl, musc. $t$. 20 . E a s e in a sp. Selirank. Mail sp. Lian. $L$ a id a e s p. Adaus.

525. 'Troielhostomenua $H E D W$. Caly ptra cuculliformis. Sporangium terminale, hise compressum, basi subaequale; o percula elongato-conicum; subobliquum; peristom ii simplicis dentes sedecim, distineti, juxta totam longitudinem in crura filiformia bi-tri-quadrifidi. - Musei cuespitosi, in terra nuda vel arborum truncis per $t$ "Itum terrarum orbem perennantes.

Trich os tom um Hedw, musc, frond. I. t. 87. Spee. 4.94. f. 1-13. Sehwïgr. Suppl. t. 35.30.118. 123. Hook, mune. exot, t, 150. Brid. Bryolog. ., 488. Dicra a i s p. Weber $x t$ Mohr Taschenb, $t, 7, f, 12,13$. D i d y modon tis sp. Hooh. et Tayl. musc. $\iota .20$. B $x$ y i s p. Liau.

530. Hiallymodon $H E D W$. Calyptra cneulliformis. S porang i am terminale, basi aequale; operculum breve, conicum; peris tom ii simplicis dentes triginta-duo, lineares, per paria approximati, basi interdum trabeculis nexi, imperfurati. - Musci in montibus et alpibus E $u$ ropa perennantes.

Did y mo d o n Hedw, musc, frond, MIT, 8. t, 4. Spec, $t, 23$. Schwigr. Suppl, t. 29, 124. Hornsch. Hor, phys, Berol, t.t3. Brid. Bryolog. I. 593. D it rieh ium Timm. Fl. megap. $n$. 777. S w artxia e s p. Heilw. musc, frond, 1, 2, 28, III. 37. B. C y u o d out ii s p. Soluwiigr, Suppl, t. 29.

581 . Pillipogon $B R I D$. Calyptra vilcnllifurmis, basi ciliata. S p o ra ng i u m terminale, basi aequale; op ereulnm acieulare; perist $n$ mi i simplicis dentes sedecim, filiformes, per paria approximati. - Muscus grandiusculus, in udis regionis temperatae $A n d i u m Q u i n d i u$ ens $i u m$ caespitose perennans.

Pilipogon Brid. Bryolog. T.519. Didy modon gra. cillis Hook. musc. exot, $t$. 6 .

532. Plambelia $B R I D$. Caly ptra cuculliformis. Sporang i um terminale, basi aequale; operculum rostratum; peristomiam simplex e membrana rudi faucem coronante, apice in lacinias irregulares, indefinitas fissa. - Museus antillanus, ramosiusculus, caespitosus, epigaeus. perennis.

P I a a beli a Brid. Bryolog. I, 559, $t, 8$.

533. Desmatodon BRID. Calyptra cuculliformis. Sporang i nm terminale, basi aequale; operculum subulatum; peristomii simplicis dentes sedecim, usque ad basim bilidi, membrana spongiosa juncti. - Musci ramosi, eaespitosi, in hemisphaerio boreabi epigat, perennes. 
Desmatod on Brid. mant. 86. Bryolog. 1. 593. Dierani sp. Hedw. musc. frond. 1 . $t, 33$. B a r bula e $s$ p. Hedw, op. cit, III. t.31. Schulz in N. A. N. C.XI, t.32, f.2,

534. Teucoloma $B R I D$. Caly ptra cuculiformis (?). Sporangium laterale, basi aequale; opereulum subulatum; peristomii simplicis de ntes sedecim, usque ad basim bifidi, distincti. - Muscus elongato-gracilis, in Africae australis insulis tropicis perennans, a Trichostomo sporangii situ et habitu diversus.

Le uc o I o m a Brid. Bryolog. Ir. 218 et 751 . Trieh ost om i sp. Sehwigr. Suppl. t, 122 . Z y gotrichia Brid. Bryolog. 1. 520. Barbula leucostoma R. Browa in Lppend, to Parrys I. Voy. p. 298.

535. Barbula $H E D W$. C a l y $\mathrm{p}$ ra cueulliformis. S porangin terminale, basi aequale; operculum subulatum; peristomii simplicis d e nte s sedecim v. triginta duo, distineti v, basi membrana juncti, spiraliter convoluti. - Musci in to $a$ terrarum orbe, frequentius tamen in temperatis, magna specierum copia crescentes, perennes, v. rarius annui.

B arbu la Hedw. Spec. 115. Sehulz monographia B a rb ula in N. A. N, C.XI.192-232, t.32.34. Brid. Bryolog. I. 527. Molli a Schrank Fl. Salisb, n, 832. Streblotric ha m Palis. prodr. 27. T ortula Hedw. Spec. 122. Hook. et Tayl. musc. 30. Hook. et Gres. in Edinb. Journ, of Scienc. $1824, I, 294$.

536. Symtrielnia WEB. et $M$. Caly $\mathrm{p} t \mathrm{ra}$ cuculliformis. Sp orang i m terminale, basi aequale; operculum subulatum; peristomii simplicis de ntes sedecim v. triginta duo, capillares, basi in coronam membranaceam, cylindricam, tesselatam conjuncti, apice in spiram contorti.

Musei perennes, in he mis phaeraboreali utriusque continentis, etiam in summis alpibus, et in regionibus hyperboreis in terra v. rarius in arboribus dense caespitosi, perennes.

Syntriehia Web. et Mohr Taschenb, 214, t, 8, f, 4, 5 . Brid. Bryolog. $X$. 578. Schulz monograph, in N. A.N. C.XI, Tortula e s p. Schwägr. Suppl. II. 66. t. 24.120. B arb ula s s. Hedw, Spec. 121. Molli a s p. Schrank. M nif s p. Linn.

537. Enealyota HEDW. Calyptra cylindrico-campanmlata, laxa, sporangio longior. Sporangium terminale, basi aequale; operculum aciforme; peristomii simplicis dent es sedecim, angusti, erecti, fngacissimi. - Musci epigaei, in temperatis et frigidis he mis $p h$ a eri $i$ borealis caespitose perennantes.

Kac aly p ta Hedw. Spec, 82, t.10, f.10-18. Schwägr. Suppl. t. 16. Brid, Bryolog. X. 138. - Bryolog. germ, II, t.2S. 2. 14.15. Le ersia Hedw. Fund. II. t. 4. f. 19. 24. Musc. frond, $I, t, 18,19$. Theor, gen, t, 9. B r y i s p. Linn.

538. Cymodentiam BRID. Caly $\mathrm{p}$ ra cuculliformis. Sporangium terminale, basi aequale; operculum conieum; peristomii simplicis dentes sedecim, lanceolati, per paria approximati, perforati. - Musci perennes, in montanis alpinisque Europae mediae et borealis epigaei, caespitosi.

Cy nod ontium Brid. Spec. I. 155. Schwăgr. Suppl. t. 25. Cynontodium Hedw. Spec. 58. C yoodon Brid. Bryolog. I. 500. S wartziae sp. Hedw. musc. frond. ri. t, 27. Didy modo $\mathrm{ntis} \mathrm{s}$. Hook. et Tayl, musc, $t, 20$. Afxeliae sp. Ehrli.

539. Ptyelhostomum HORNSCH. Caly tra cneulliformis. Sporangium terminale, basi aequale; opercul um conicum, obtusum; peristomium duplex; exterioris dentes sedecim, ereeti, apice hyalini; interius corona membranacea, hyalina, plicata, exterioris dentes in conum, tandem lacerum connectens. caespitosi, in alpibus Europa mediae et Indiae orientalis, et in Americae antarctic a e insulis perennantes.

Ptychostom um Hornsch. in Syllog. plant. IT. 62, Brid. Bryolog. I, 597. Schwigr, Suppl,t, 113. C y no do nti i sp. Hedw. Spec. $t, 9 .-$ B rach ymenium Hook. apud Schwägr. Suppl, II, 131, t, 135. Hook. misc, I, t, 38. Brid. Bryolog. I, 601.

540. Hilemisimapsium $B R I D$. Caly pt ra cuculliformis. S p o rangin m terminale, apo. physatum; operculnm obstuse conicum; perist om in m duplex; exterioris dentes sedecim, acuminati, erecti; interius corona membranacea, basi cum exteriore connata, apice in cilia sedecim, dentibus alterna fissa. _. Musci ramosi, majusculi, in uliginosis ins u la e Melville reperti.

Hemisinapsium Brid. Bryolog. I. 604. Pohlia bryoides et arctica R. Brown.

541. Cladedium BRID. Caly ptra cu culliformis. Spor a ng i um terminale, basi aequale; operculum convexiusculum; peristomium duplex, exterioris dentes sedecim, erecti, apice subconniventes; interi us corona membranasea, apice in eilia sedecim divisa. - Musci perennes, in alpibus Europae, et in montibus arcticis insulisque hyperboraeis caespitosi.

Cladodium Brid, Bryolog. I. 620. Pohlia incli. n a ta Swartz musc. Suec, 45,96, t.5. f.11. Sehwigr. Suppl. t. 63 .

542. Isprum $L I N N$. Calyptra euculliformis. S porangium terminale, basi aequale $v$ psendapophysatum; o p er $\mathbf{c} \mathbf{l}$ um convexum v, conicum, rarissime rostratum; $p$ eristo $\mathbf{m i} \mathbf{u m}$ duplex; exterioris dentes serlecim, latinsculi, acuti; interius corona membranacea, carinato suleata, in processus sedecim latiusculos, perforatos, ciliis interjectis producta. - Musci epigaei, annui vel perennes, per totum terrarum orb em ingenti specierum numero diffusi.

B ry u m Linn. gen, n. 1194, Bridel Bryolog. I, 623.

a) WEBERA Hedw. FI o res hermaphroditi.

Webera Hedw. Spec. $t$, 41. f, 1-5. Musc. frond. I. t.3.3. Brid, Bryolog. I. 624. B r y i s p. Hedw. Fund, II. t. 3. $f$. 12. et Auct. plur. $0 \mathrm{rth}$ op $\mathrm{y} x$ id is $8 \mathrm{p}$. Palis, M acra ucheni a a Brid. Bryolog. I. 45. 843. Weberae $8 \mathrm{p}$. Hedw. Spec, t, 41. f, 1-5.

b) BRYUM Hedw. Flores monoeci v. dloeci, masculi gemmiformes v. eapituliformes.

B r y u m Hedw. Fund. II. 2, 6. f. 29. Musc. frond. I, t. 20. III. t. 28, Spec, t. 42, f. 8-12, t. 43. t. 44, f. 1-4. Schwigr. Suppl. t. 68-75. Treitep ohl ia Hofím. Fl. germ, II. IV. $\mathrm{Mn}$ i i s p. Hedw, muse, frond. $I I I, t, 7.8$.

c) POLLA Adans. Fl ores dioeci, mascull disciformes; rarius hermaphroditi, discoidei.

Polla Adans. IT. 499. Beid. Bryolog. I. 688. M n i i s p. Hedw. musc. frond. $1.1,88$, Spec. t, 10. f. 1-4. 1, 45. $f$, 5-8. Scliwagr. Suppl, t, z7, 80, f, 158-160. B r y i s p. Hook. et Tayl. musc, t. 26, 28-31. Hook, musc, exot, $t, 133$.

543. Cinelidium $S W A R T Z$. C al y $\mathrm{p} \mathrm{t}$ ra cuculliformis, angusta. Sporan $\mathrm{g}$ i u m terminale, basi aequale; o per $\mathrm{c} 1 \mathrm{um}$ hemisphaericum, mncronulatum; peristomium duplex; exterioris dentes sedecim, inflexi; interius corona membranacea cupuliformis, apice elausa, sedecim radiata, foraminibus totidem oblongis e regione dentium pertusa. - Muscus in paludibus $A l p i u m$ et Europae borealis caespitose perennis.

C in elidiu m Swartx in Schrad, Journ, 1801, 1. 25. t.2. Sehwagr. Suppl. t, 67. Brid. Bryolog. I. 714. A m b I y od o Palis, prodr. 41.

544. Teptostomum $R . B R$. Caly ptra laevis, glabra. Sporangium terminale, subapophysatum; o per e ul $1 \mathrm{~m}$ hemisphaerico-conicum; peristomium simplex, e membrana an- 
nulari erectiuscula, integerrima v. obsolete denticulata. - Musci perennes, caespitosi, terrestres, in hemisphaerio a ustrali extra tropicos, et in archipelagi Sandwicensis insulis observati.

L ept os to m a m R. Browa in Transact, Linn. Soc, X.130. Brid, Bryolog. I. 124. Mant, p.24.t.1.f.1. Seliwígr. Suppl.t.104. G y m n os to mi s p. Hook. musc., exot, I. t. 168. 169. II. t.5. 29. B r y i s p. Hedw. musc. frond, IIT.t, 10 .

\section{Teptotheea $S C H W A E G R$. Caly p-} tra.... Sporanginm terminale, basi aequale; operculum .... peristomium duplex, exterioris dentes sedecim, lanceolato - lineares, erecti, sporangii parieti interiori adnati; int eri u s corona membranacea, brevis, tenera, apice in cilia sedecim, dentes acquantia, ciliolorum rudimentis interjectis fissa. - Muscus perennis, in Nova-Hollandia epigaeus.

L ep to theca Sehwägr, Suppl.Ir, 135, t, 1.37. Brid. Bryalog. I. 838 .

546. Negalangimm BRID. Cal y $\mathrm{t} \mathrm{ra}$ cucnlliformis. Sp orangium terminale, basi apophysi lineari auctum; operculum convexum, mamillatnm; peristomium duplex; exterioris dentes sedecim, marginati, obtusi, mucronulat, introflexi; in terius e membrana reticulata, carinata, in processus sedecim, profunde hipartitos, cilio interjecto, fissa. - Muscus perennis, in editissimis $A n$ di $u$ m $Q$ uit eñ s $i$ um caespilose epigaeus.

Megalangium Brid. Bryolog. $T$. 28. Maerothe. cí u Brid. op. cî. $I, X L I V$. A cidodonti um Schwāgr. Suppl, t.190. B гу и m megal a earp on Kunth.

548. Pollita $H E D W . C$ a lyptra cueulliformis. Sporangium terminale, apopliysatum; o perculum convexo-conicum; peristomium duplex, exterioris dentes sedecim, interi u s corona membranacea elongata, sedecies denticulata. - Musci teneri, caespitosi, in montibus et alpibus Eu rop a e mediae perennantes.

Polalia Hedw. musc. frond. I. 96. t, 36. Schwigr. Suppl. 1.64. Brid. Bryolog. I. 607. A mphirhinum Green msc. Lagenium Brid. msc. Bryi sp. Hook, et Tayl, musc, 1. 30 .

548. Paladella EHRH. Calyptra cuculliformis. S porangi um terminale, hasi aequale; operculam conicam; peristomium duplex; exterioris dentes sedecim, lanceslati, acuti; interius corona membranacea brevissima, in dentes sedecim imperforatos, puncto prominente intermedio, producta. - Muscus caespitosus, in paludosis apricis Europae borealis perennans.

Pal a de 11 a Ehrh. phytophyl. 69. Brid. Hryolog. II. 1. B rу um squarrosum Hedw, Spec, t. 44. f. 6-11.

549. IInimm DILL. Caly ptra cuculliformis. Sporangium terminale, basi gibbosum v. subaequale; o p e r culu m convexum; subacuminatum; iperistomium duplex; exterioris dentes sedecim, latiusculi, erecti; interius membrana carinata, in processus sedecim varie perforatos, saepins tandem bipartibiles fissa. - Musci perennes, in hemisphaeria boreali utriusque orbis in humidis paludosisque epigaei.

M n i um Linn. gen, n. 1193. Brid, Bryolog, MI.3. Ortho p y $x$ is Palis, prodr. 78 . part.

a) AULACOMNION Schwägr. Flos masculus terminalis, disciforanis.

A u l a comni on Schwägr. Suppl, t, 215, Gy mn o eephal us Schwägr. Suppl, I. 87, non Zoolog. Fusiconia Palis, in Annal. Soo.Linn, de Paris, t, 7. f.5. M n i um a ndrog y n u m Linn. Hedw. theor, 140, $t, 12 . f, 48-50$. B r y. u m Hedw. fund, musc. I, t. 5. f. 35. 36. - P erom ni o a Selwwigr. Suppl, t, 250. b) ARRHENOPTERUM Hedw. FI os masculus axillaris, gemmiformis.

Arrhenopter um Hedw. sp. 198. t.46. f.1-9. Mas. chalarrhen Spreng. Mni um heterostichum et me u bra nace u m Brid.

550. Bartramia $H E D W . \mathrm{C}$ aly $\mathrm{p} t \mathrm{ra}$ cuculliformis.S porang i um terminale, basi subaequale, stomate saepins coarctato, sublaterali ; o p e r cuI u m conicum; peristomi um duplex; exterio$r$ is dentes sedecim, enneiformes; interius membrana earinata, sedecimpartita, segmentis bifidis, apices dentium introflexos recipientibus. - Musci erecti, perennes, rupes et sylvarum umbrosos recessus hemisphaerii borealis, vel editissimos regionum calidarum montes caespite amoene virente vestiunt.

B a rtra mi a Hedw, musc. frond. III.111 t, 40. Schwägr. Suppl. t. 50, 58,60,63.68, Brid. Bryolog. $I T$. 32. We ber a e s p. Hedw. Fund, If. 95. t. 6. f. 30, C e p hal oxis Palis. prodr. 31. B ry i s p. Liun. L u i da e sp. Adans.

551. Phallonotis BRID. Caly ptra cuculliformis. Sporangium terminale, basi subinaequale, st o mate obliquo; operculum conicum v. convexiusculum; peris tomi um duplex; exterioris dentes sedecim, acuti, inflexi; interius membrana carinata, in lacinias sedecim integras v. bifidas, eiliis interjeetis partita. - Musci erecti, caespitosi, ramosi, in udis scaturiginosis montanis alpinisque totius orbis terrarum perennes.

Philonotis Brid. Bryolog, II. 15. Bartranike sp. Schwägr. Suppl. t. 61. Hook, et Tayl. muse. $t, 23$. Hook. musc, exot, I. t, 81, IT, t.19. M n Hi s p. Hedw, musc, frond. II., , 19, IIT, t, 38. B r e w er Adaus, II, 492, B r y i s p. Liun. Cyrtopodi um Brid. Bryolog. IX.30. Cryptosote Hook. msc. B r y $4 \mathrm{~m}$ bartramioides Hook, muse, exot. $I$, ,, 18 .

552. Clyphoearpus R.BR. C a ly $\mathrm{ptra}$ cuculliformis. Sporang ium terminale, angulatum, basi aequale; o percul um conicum ; stoma edentulum, memlirana laxa, tandem filis sedecim orificio adhaerentibus instructum. - Musci erecti, ramosi, caespitosi, in saxis et super arbores regionis capensis perennantes.

Gly phoearp us R. Browu in Transact, Linn, Soc, XII. 575. Sehwägr. Suppl, t, 128. Brid. Bryolog. II, 90, B ar tra. mi a e s. Hornsch. in Hor. phys. Berol, 2. 13. Hook, musc. exot, $I, t, 122$. G y mnost o mi s p. Hook, op, cit, I. $t, 165$.

553. Plagiopus BRID. Caly ptra... Sporangium terminale, gibbosum; opercu$1 \mathrm{um}$ obtnse conicum; peristominm duplex; exterioris dentes sedecim, lancenlati, acutiuscoli, aequidistantes; in terius e ciliis totidem filiformibus, ereetis, dentes subaequantibus, iisdemque alternis. - Muscus perennis, in uliginosis alpium $\mathrm{H}$ elv etia e densissime caespitosus.

Plag fopus Brid. Bryolog. I. 596. t.5.

554. Conostomenn SW ARTZ. Caly ptra brevissima, conico - subulata, hine v. utrinque fissa. Sporanginm terminale, basi subaequale, suleatum; op ereulum eonicum, subineurvum ; peristomii simplicis dentes sedecim, subulati, in conum persistentem conniventes. Musci caespitosi perennes, in summis montium Europae cacuminibus, in Asia Americaque aretica, nec non in America antarctica epigaei.

Conos to nu um Swartz in Schrad n.Journ. I. 3. p. 14. t. 5.6. Sehwägr. Suppl. t. 20 et 130 . Hook. et Tayl. musc. t. 20. Brid. Bryolog. 1.130 . Bryolog. germ, IT, 1. 20, 4.13. Gri m mi a e sp. Suith $E, B, t, 1135$.

555. Entosthoden SCHWAEGR. CaIy p tra dimidiato - cam panulata, subulata. S p oran gi um terminale, apophysi pyriformi instructum; o perc a l u m convexiusculum, mammillatum; periostomii simplieis dentes sedecim, rigidi, imperforati, stomati demissius inserti. - Muscus 
caespitosus, perennis, in rupibus humentibus riparum Hiberniae observatus.

Entosthodon Schwägr. Suppl. $I$. 44. $t$, 113. Brid. Bryolog. 1 . 378. 779 . Weissia Tempeltoul Hook. et Tayl, musc. $t, 14$.

5ธธ6. Fumaria $H E D H$. Calyptra cuculliformis, ventricosa, hasi subtetragona. Spor a $n$ or i m terminale, subinaequale, pyriforme; opercnIum planiasculum, laeve v. sulcatum; peristomium duplex; exterioris dentes sedecim, obliqui, apice cohaerentes; interioris cilia totidem, basi in coronam membranaceam cohaerentia, dentibus opposita. _ Musci annui, caespitosi, super terram nudam per totum orbem vigentes.

Fun aria Hedw. Spec, 179. Scbwägr. Suppl, t, 65, 66. Hook, et Tayl, musc. t.20. Brid, Bryolog. II. 49. Ko el r e uter a Hejw. Fund. II, 95, t, 10, f, 68-69. S trep hedi u m Palis. prodr. 89. M a ii s p. Lino.

$55 \%$. Nleesia $H E D W$. Caly ptra cuculliformis, angusta. Sporanginm terminale, inaequale, pyriforme; operculam convexiusculum; peristomium duplex; exterioris dentes sedecim, brevissimi; interioris cilia tutiflem, lacunosa, membrana tenera fugaci retienla11- connexa. - Musci in paludosis turfosis montium hemisphacrii barealis perennes.

Me es ia Hedw. Fund. $T$ T. 97, $2.9, f .56,57$, Musc. frond. I. t. 1.2. Spec, t. 41. Brid, Bryolog. II. $59 . \Delta \mathrm{mbliod}$ a m Palis, prodir. 41. B ry i sp. Liau. Hook. et Tayl. musc, t.28. Hook. musc. exot. I, t.99.

๘59. Diplesonainan $W E B$. Calyptra caculliformis. Sporang iu m terminale, inaequale, pyriforme; opere a lnm obtusum; peristominm duplex; exterioris dentes sedecim, ohtusi, brevissimi; interiuris. eilia sedecim, lifera, per paria approximata. _. Mirsci erecti, caespitosi, radiculoso-tomentosi, in paludosis turfosis, frigidis temperatisque he misphaeri $i$ borealis perennantes.

Diplocomium Web. et Mohr Taschenb. 374. t.9. f.5. Brid. Bryolog. II. 65. Tristi chis Ehrh. phytophyl. 59 . Mestia $10 \mathrm{ug}$ is et a Hedw, musc. frond. I, t.21,22.

559. TEmona $H E D W$. C aly ptra cucnlliformis. Sporangium terminale, inaequale, subapophysatum; o perculum convexum, vertice depressum; peristomin duplex; exterioris dentes sedecim, latiusculi, acuminati; interius e membrana sedecies laciniata, laciniis dentibus oppositis irregulariter porosis - Musci paludosi, rupicoli, in hemisphaera boreali eaespitose perennantes.

Tim mia Hedw. musc. frond, $I, 84, t, 31$, Spec, t. 42, Hessler Comment, de Timmia, p. 11. Brid. Bryolog. $1 T, 68.0 \mathrm{~m}$ phatoph ora Brid. msc.

560. Polytrielnuma $L I N N$. C a lyptra cueulliformis, minuta, saepe viscosa. Sporang i um terminale, angulatum, apophysatum v. subapophysatum; opereulum rostellatum; peristomii simplicis dentes triginta duo v, sexaginta quatuor, breves, inflexi, apieibus in membranam aridam confluentes. - Musci erecti, stricti, in terra arida totius orbis gregarie perennes.

Palytrich um Linn. gen, $n, 1192$.

a) POLYTRlChuM Patis. Caly $\mathrm{ptr}$ a apice villosa. CoI u u e Il a alata.

Poly trich um Hedw. Fund, 1. t.9. f. 62-64. 11. t.7. f.37. Spec. 2. 18. f, 6-10, t, 19, f, 1, a Brid. Bryolog. $I$. 134.

b) POgONATUM Palis, C al y ptra undiquevillosa. C aI u mell a eyllindrica.

Pogonatum Pults. prodr. 38, t, $11, f .3$. Brid. Bryo. log. Ir. 107. $\mathrm{P}$ ol y $t \mathrm{rich}$ i sp. Hedw, musc. frond. 1. 6. 13.

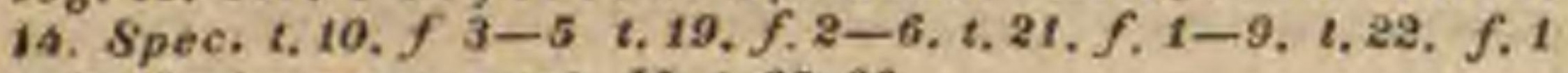
-5. Hook, musc. exot, II. 1, 65.66. c) CATHARiNea Ehrh, Caly ptra pilosa. Col u me 11 a cylindrica.

Catharinea Elirh. Beitr. I. 178. Web. et Mohr Ta. schenb. 216, t, 8, f,6. OHig ot $\mathrm{ric}$ b a $\mathrm{mC}$. Fl,frane. Atrichum Palis. prodr. 42. Cally briam Web. werth. 290. Polytrichis s. Hedw. musc, frond, I. t. 15-19. Spec, $t$. 20. f. 1-2. Hook, musc, exot, t. 75. B r y i s p. Limu. Pollav s p. Adans.

561. Feilomilum BRID. Calyptra eucnlliformis, glabra Sporang i um terminale, ventricoso-inaeguale, exapophysatum; op e r cul u m obtuse conicnm; peristomii simplicis dentes sedecim v,triginta duo, brevissimi, inflexi. Muscus erectus, epigaeus, in arenosis humidis $\boldsymbol{E} u \mathrm{ro-}$ pae et Americae arctica gregarie epigaeus.

Psilopil um Brid. Bryolog. II. 95. Poly triehum Iaevigatum Wahlenb. Fl. Lapp. $t$, 20, Sehwägr. Suppl. t, 157 .

562. Tyellia R. BR. Calyptra cueulliformis, apice setuloso-scabra. Spo rangium terminale, hine planum, inde convexum, apice $c y$ lindrieum; o p e r e $\mathbf{l}$ u m conicum, rostratum; s to ma edentulum, epiphragmate centro columellae crassae, plicato-rugosae adhaerente clausm, mox ejusdem retractione apertum, apertura tandem iterum columellae elongatione ohturata.

Muscus caespitosus, perennis, epigaeus, in Nepalia lectus.

Lyellia R. Beown in Transact, Linn, Soc, XII. 561 . Hook, musc, exot, t, 161. Schwägr. Suppl, II, 170, t, 149. Brid. Bryolog. II. II. 93. Go mp ho phor us Brill. msc.

563. IBuxbaumia H.LL. Calyptra mitraeformis, conica, acuta. Sporangium terminale, ovato-gibbosum, subobliquum, apophysi spuria auctum; oper cul um conicum, acutiusculum; peristomium Inplex; exterioris dentes sedecim, squamuliformes, truncati, inaequales, fugaces; interius, corma membranacea apice lacera interposita, conicum, seriesies plicatum, apice tandem pervium. - Musri unnui, habitu abnormi, caule brevissimo bulbiformi, subterraneo, apice foliis minimis, confervoideis vestito, pedunculo scabro, sporangio maximo; in le $m$ is phaerio boreal $i$ utriusque orbis in terra vel truncis putrescentibus rari.

В и х b a $и$ i i Hall, Stirp. helv, n. 1728. Hedw. Fund. musc. IT. 96. t. 3. f. 10. t.9. f.51. Brid. Bryolog. I. 328. t.2. Suppl. Grevill. in MLem. Wern. Soc. IIT. Mie. Bruch et Sehimp. Fragm, bryolog. c. ic. S a c e op th or um Palis. prodr. 29. H i p p o p o di u m Röbl. Fl, gern. III. 120.

5\$4. IDiplnyseium $W$ ER.ET $M$. Caly $\mathrm{p}$ tra mitraeformis, conica, acuta. Sporangium terminale, ventricoso-ovatum, obliquum, depressiusculum; o percul um conicum, acutum; peristominm duplex; e $x$ te $x i n s$ e solo stomatis margine obsolete crenulato, interins membrana coniea, truncata, sedecies plicata, plicis cum crenulis stomatis alternantibus. - Muscus annuus, pusillus, Phascum referens, in glareosis et rupestribus hemisphaerii borealis utriusque orbis gregarius. D ip hy s e iu m Web. et Molir Taschenb. 37\%, t.11. f. 1 . Brid. Bryolog. I. 325. Brueit et Sehimp. Fragm. bryolog. If y me nopog o o Palis.prodr. 60. B u x b a um i a folios a He.iw. Fund, $I T, 95, t, 9$. f. 51 .

565. Hawsonia $R$. BR. Calyptra conica, hinc fissa, apice scabra, indumento villoso vestita. S porangium terminale, hine planum, inde convexum; opercnlnm rostratum; peris to mi um simplex, penicillatum, e cilis numerosissimis ex annulo stomati panllo demissius inserto, et e colunellae apice erectis, aequalibns, exarticulatis, basi planis, apiee tubulosis. - Musci simplicissimi, erecti, in Nova Hollandia epigaei, cuespitosi, perennes. 
Daws o nia R. Brown in Transact. Linn. Soe. X. 316. 1. 23. $f, 1$. Schwïgr. Suppl, $t, 150$. Hook. musc. exot, $11, t .162$. Brid. Brjolog, II. 156. Triplocona La. Pylaie in Desv. Journ. bot, $V$. 7. Styloc $0 \mathrm{~m} 1 \mathrm{~m} \mathrm{~m} \mathrm{Brid.} \mathrm{msc.}$

566. Hypmume LINN. C a ly ptra euenlliformis, glabra. Sp o ran g i um laterale, gibbum, slomate obliquo; "p ereulum conicum, rostratum; peristomium duplex; exterioris dentes sedecin, lanceolati, reflexiles; interius e membrana carinato-suleata, in cilia totídem perforata v. solida, eiliolis interjectis partita. - Mus ci perennes, per totum terrarum orbem epigaei, rarius truncicoli v. aquatici.

H у р п и m Lins. gen, n. 1195. Brid. Bryolog, II, 388, t. 10.

a) HXPNUM Brid. Peristomii interioris eilia imperforata.

It y p n u m Beid. Bryolog. II. 390. (Hedw. musc. frond. ID. t. 29. Spec, t. 60-62. Hook, et Tayl, musc, t, 34.)

b) STEREODON Brid. Peris to mili interioris eilia per. forata.

Stere od on Brid. Bryolog. II. 550. H y pni sp. Hedw. musc, frond, $I V, t, 18,23,24,25,30,31,32,34,36,37$, Spec. t. 64. f. 5-10,t.70. f.7. 10.t.75. f. 4-9.t.77. f. 1-5. Sehwigr. Suppl, 2. 87. 88, 94, 142, 144, 145. Hornsch, in Hor. phys. Be. rol. $t, 13 . f, 1-5$.

56\%. Fabromán $R A D D$. Calyptra euculliformis. Sporangi um latcrale, basi aequale; opereulnm convexum; peristomii simplicis dentes sedecim, coriacei, per paria approximati, introrsum flexi, integri v. bifidi. - Musci tenelli, in lerra $v$. arborum truncis zonae temperatae et sublrojicae ulriusque hemisphaerii perennes.

Pa b r on ia Raddi $A H i$ dell acad. di Siena IX.230. Brid. Bryolog. II. 168. Sehwigr, Suppl. 1.99.247. Hook. musc. exot. $1,3,169$. S tero ph y 11 u m Brid. msc.

568. Daselhalantlats SCHULZ. CaIyptra cueulliformis. Sporangium laterale, basi aequale; op er culum conicum, saepe rostratum; peristomii simplicis dentes sedecim, aequidistantes, solidi, erectiusculi. - Musci perennes, in temperatis calidisque totius orbis terrarum epiguei v. epidendri.

M aseha 1 a $n$ thas Sehulx Starg. 356. Pterigynand $\mathrm{r} \mathrm{um}$ Hedw. musc. frond. IV. t. 6. f. 8. 9. 1, 7. t. 20. Spec, t. 18. f. 1-5. t, 65. f. 1-4. Brid. Bryolog. $I$. 173, 1.8. Pterngo a i um Swartz musc. suec, 26. Schwägr. Suppl. 27. 28. 210, 211, Hook. et Tayl. muse, 1, 14. Hook, musc, crat. t. 172, 148. Maschalocarpus Spreng.

569. Teptolnymentume SCHWAEGR. Calyptra......... Sporangium laterale, basi aequale; operculum rostratum; peristomium duplex; exterioris dentes sedecim, breves; interius membrana subtilis, dentes conjungens, tandem apice fatiseens. -- Muscus nepalens is caespitosus, truncicola.

Lep to h y me itum Schwigr. Suppl,t.246. Haplo hy menium Schwägr. t. 27t. P terogonfum te nue Schwägr. Suppl, t, 108. Ne cker a te u u is Hook, in Transacl, Linn. Soc, IX, t. 27. f. 3.

580. A macamptoulon $B R I D$. C aly $\mathrm{p}$ tra cuculliformis. Sporanginm laterale, basi aequale; operculum obtuse rostratum; peristominm duplex; exterioris dentes sedecim, pyramidati, primum reflexi, tandem sporangii dorno appressi; interieris cilia totidem, capillaria, dentibus hreviora et alterna, introflexa. - Muscus caespitosus, perennis, in Germania media et a us $t$ rali Abietum cortici tenaciter adhaerens.

A na camptad a a Brhe mant, 136, t, 2, f.11. Bryolog. IT. 224. $t, 9$. Neckerae s p. Sehwägr. t. 182.

591. Hylaisaen $D E S V$. C a ly ptra cuculliformis. Sporanginm laterale, basi aequale; operculum conicum; peristominm duplex; exterioris dentes sedecim, lanceolati, ereeti, trabeculato-serrulati; interius membrana denti- bus adhaerens, tandem soluta, apice lacero-fissa. Muscus perennis, repens, in Gallia arborum cortici lenuciter adhaerens.

P y la is a a Desv. Jeurn, bot, V. 24, t, 33, f.2. Brid. Bryotog. II. 281. t.8.

5ระ. Thesำia HEDW. Caly ptra cuculliformis. Sporangium Jaterale, basi acquale; o perculum convexum, saepe rostellatum; peristomium duplex; exterioris dentes se decim, subulati, inflexi; interius corona nembranacea, in cilia $v$. processus sedecim pyramidatos v. lineares fissa. - Musci perennes, ramosi, repentes, in toto orbe terrarum epigaei v. truncioli.

Leskia Hedw. Fund, II. 93. Brid. Bryolog, II, 283. t. 10 .

a) Les kia Brid. 1, c. Hedw. musc, frond, IV. t, 1, 2.9.

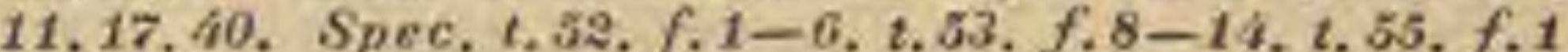
-6. 13-18, t.56. f. $1-7.18-18$, t. 57. f. 1-16. 1. 59 . f. 1-5.8-15. Schwitgr, Suppl, t, 86,140. Hook, musc. exot, t. 55,166

b) 0 malia Brid. l. c. (Hedw. musc. frond. IV. t, 10. f. $62-65, t .11$, )

c) Hemi rag is Brid. $t$. $c$. (Seltwïgr. Suppl, $t, 86$, ) H e. lic a d on tín Sehwägr. Suppl, t,293.294.

583. Isotheeimus $B R I D$. C a ly ptra caculliformis. Spor ang in m laterale, basi aequale; opercultm conicum, saepe rostratum; peristomium duplex; exterioris dentes setesim, acuti, reflexiles; interins corona membranacea, carinato-suleata, in eilia sedecim, ciliolis interjectis divisa. - Musci hypnoidei, perennes, plerique epidendri, tropici v. sublropici, paucissimi europaei.

Is a the citum Brid. Bryolog. II, 355, t, 10. Hy pui s p.

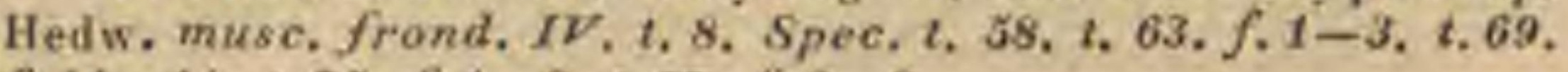
f. $11-14$, t. 75. $f, 1-3, t, 77, f, 6-9$.

5\% 4. A noedamginme HEDW.Cal y $\mathrm{ptra}$ cueulliformis. Sporangium laterale, basi aequale; operculum conicum, rostratum; stoma nudum. - Musci epigaei, in summis $A$ merica a equin octialis montibus gregarie perennantes.

Anoectangi um Hedw, Spec, 40. Brid, Bryolog. $I I$. 164, 2, 8. Hedwi gia Hook, musc, exol, $t, 46,139$. Sehwagr. Suppl, ¿.104. - Erpodi a m Brid. Bryolog. 11. 167.

5\%5. Neelkera $H E D I V$. Caly ptra cuculliformig. Sporangium laterale, basi aequale; operculum conieum, saepe acuminatum; peristomium duplex; exterioris dentes sedecim lanceolato-lineares, erecti; interioris e $\mathrm{i}$ lia totidem, filiformia, erecta, dentibus alterna. Musci perennes, cacspitosi, in temperatis calidisque totius orbis viventes.

Neckera Heiw. Bril. Bryolog. IT. 226. t, 9.

1. NECKBRA Rohl, Polia inilieata. Pedunculus rectus, elongatus.

$\mathrm{Ne}$ e k e r a Röhl. Fl. germ, III. 8.3. Hedw. Fund, I, $t, 3$ f.11. II. t.8. f.49.50, Spec, $t$ 47. 48. Hwok, in Transact, Linn. Soc, IX, t, 27, f, 2. Muse, exat, t, 43. El e ut he ria Pa. lis. prodr, 56 .

2. CYRTOPUS Brid, Folia inbricata. Pedüeulax areantus, brevis.

C y rtopus Brid. Bryolog. II. 235. (Hedw. Spec, $t, 5$. f.4-6. Hook. in Transaet, Linn. Soc. IX. 4.28. f.4. Muse. exot. 6, 6, 151, 152.)

3. DISTIChla Brid. Foli a disticha. Cal y p r a saepe pllosa.

Dis tichia Brid. Bryolog. II. 238. 757. C ryptopor dia Rohl. Deutschl. Flora III. 82. Neeheriats p. distichate Hedw. musc, frond, III, \&.19-2J.

526. A etinodontium SCHW AEGR. $\mathrm{C}$ aly ptra mitraeformis, basi lacinulata. S porang i um laterale, basi aequale; operculum aciculare; peristomium duplex; exterioris dentes sedecim, patentissimi; interioris eilia totidem, dentiam longitudine, membrana annulari angusta juncta. _. Muscus $j$ a va $n$ ic us, caespitosus, perennis. 
A ctin o d ontiu in Schwägr. Suppl. IT, 75. t, 174. f.12 -16. Brid. Bryolog. II, 755. A e ti no d on Brid. msc.

5\%ซ. Daltomia HOOK. Caly ptra mitraeformis, cuspidata, basi ciliato-fimbriata. S p o ra $\mathrm{g}$ i um laterale, subapophysatum; operculn m conico-rostratum; peristomium duplex, exterioris dentes sedecim, latinseuli, trabeculati, hinc.inde flexi; in terioris cilia totidem, tenerrima, dentibus alterna. - Muscus humilis, ramosus, perennis, in Britannia et Germania epigaeus.

Dal ton ia Hook. et Tayl. musc, 80, t. 22. $f$. 1. excl. reliq. Brid. Bryolog. H. 255. Ma crod o n Arnott in Annal. Soc. Linn, de Paris.

58. Regmatoulon BRID. Calyptra cuculliformis. Sporangium laterale, basi subinaequale; o percu I um conicum, incurvum; peristomi simplieis dentes sedecim, suberecti, lineari-subulati, rima longitudinali a basi ad medinm hiantes. - Muscus n ep alens is, caespitosus, perennis, arborum cortici adhaerens.

Reg ntatodon Brid. Bryolog. IX. 204. t.9. Pterog onil s p. Hook, in Transact, Linn, Soc, IX, t. 26. f.3.

5\%9. Seleredontiann $S C H W A E G R$. CaIy ptra cylindrico-subulata, basi fissa. Sporang i u m laterale, inaequale; peristo mii simplicis dentes sedecim, coriacei, distincti, rimis longitudinalibus pertusi. - Muscus perennis, arborum cortici laxe adhaerens, in Brasilia et NovaHo llandia observatus.

Selerodo n ti u mehwägr. Suppl. II. 1. p. 124,1,145. Brid. Bryolog. 11. 205. 1.9. $\mathrm{L}$ e u e o do at is s. p. Hook, musc. exot. t. 172. f.7.8.

590. Hemeodion $S C H W A E G R$. C a ly $\mathrm{p}$ tra cuculliformis. Sporangium laterale, basi aequale; opercul um coniem, subincurvum; peristomii simplicis dentes sedecim, brevissimi, membranacei, stomati demissius inserti, perforati, tandem bifidi. - Muscicaespitosi, in regionibus te mperatis utriusque hemisphaerii super arbores, rariusve in terra perennantes.

1. e ue od on Schwägr. Suppl. I. 2. p. 1. II. t,125.133. Hook. et Tayl. musc. 63. 1.2.20. Brid. Bryolog. II, 207. F u se in a Sehrank.Fl.Bav, II. 45e. C e c al y ph u m Palis.prodr. 51. Fis sidentis sp. Hedw. Fund. II, t.8. f. 45.46 .

581. Leptodion $W E B$. Caly $\mathrm{p}$ r a cuculliformis, pilosa. Sporangi um laterale, basi aequale ; o p e r c a I u m conicum, oblique rostratum ; peristom ii simplicis dentes sedecim, brevissimi, lineari-lanceolati, integri. _ Musci epidendri, in te mperat $i$ s hemisphaerii borealis perennantes.

Leptodon Web. in Mohr obs. 27.

a) LKPTODON Brid. Cafy ptra basi pilis longissimis hirta.

Le ptodon Brid. Bryolog. II. 197. t. 3. suppl. H y p n i s p. Hedw. Pterogonii sp. Hook. et Tayl, musc. $t$. 14. Schwägr. Suppl. t. 109.

b) LASLA Brid. CaI y ptra sursum pilosa.

$\mathrm{L}$ a s i Brid. Mant, 133. Bryolog. 200. $t, 8$. T rie li o m itrinm Reichenb. conspect. n. 565. Pterigy na ud ri s. Hedw. Spec, t.16, f. 1-6.9-2.

582. Diememone SCHWAEGR. Caly tra mitraeformis, apiee scabra, basi multifida. Spor ang ium laterale, inaequale; opereu $\mathbf{l u m}$ conicum, rostratnm; peristomii simplieis dentes sedecim, basi connati, ultra medium bifidi. cruribus nodosis, incurvis. - Musci austrula$s$ ic $i$, epidendri, caespitosi, perennes.

D i c e m on Sebwägr. Suppl. II. 1, p. 126, t, 132. Brid. Bryolog. II. 215, 2, 9, E a en em is Brid.msc. Hollia Sieb. in Flora 18:6, p. 223. Brid. Bryolog. II. 772. Le uc a d ontis 8 p. Schwagr. Suppl, t, 124. Hook, musc, exot, t, 17.20.

583. Astrodontium SCHW AEGR. Caly ptra ventricoso-subulata, sporangium includens, latere fissa. S poranginm laterale, basi aequale; opercnlum rostratum, curvatum; peristomium duplex; exterioris dentes sedecim, lato-lanceolati, parenchymatosi, patentes; interius membrana annularis subhorizontalis, sedecies crenata. - Muscus perennis, incurvato-ramosus, in insulis Canaris et Madagascaria arbores sylvarum umbrosarum denso crespite vestiens.

A s trod o $\mathrm{ti}$ u m Schwagr. Suppl. II. 1. p. 128, t. 134. Beid. Bryolog. 1I. 219. t.9. Pla n beli a Brid. msc. Hedwigiae s p. Hook, musc, exot, t, 170 .

584. Antitrielna $B R I D$. C a l y ptra euculliformis. S p or an $\mathrm{g}$ i $\mathrm{m}$ laterale, basi acquale; o perculn m oblique rostratum; peristo min m duplex; exterioris dentes sedecim, linearilanceulati, inflexi; interioris cilia totidem, dentibus opposita, isque hasi adnata, fugacissima. Muscus perennis, dense caespitosus, epigaeus, in Europa, Capitebonae spei et Patagonia repertus.

Antitrichia Brid, mant. II.222. Bryolog. II, 222. t. 9. A nom od on Hook. et Tayl. musc,79.t,22. Ne eke rae sp. Hedw, H y pui s p. Linn.

585. Climaeium $W E B$. Calyptra cu culliformis. Sporangin m laterale, basi aequale; o percul um conien-rostratum; peristo mi u m duplex; exterioris dentes sedecim, linearilanceolati, inflexi; interioris cilia totidem e corona membranacea sealato-perforata. - Musci habitu dendroideo insignes, epigaei, perennes, in zona temperata et frigida, et in editissimis montium a equino ctialium jugis gregarii.

Climacium Web. et Mohr Taschenb,225. Brid. Bryo. log. $I I .271 . L$ u id a e $s$ p. Adans.

a) Porotriehum Bricl. l.c. Rami complanati. (Neche$\mathrm{r}$ a e s p. Hook, musc, exot, t, 1.69.)

b) Z y gotrichia Brid. l. c, Rani teretes. (Schwägr. Suppl. t.81. Leske ae s p. Hook, musc. exot, t. 164 .

586. Turachyloma BRID. Caly ptra cuculliformis. S porangi um laterale, basi aequale; opercuIn in conico-subulatum; peristomium duplex; exterioris dentes sedecim, filiformes, erecti; interioris eilia totidem, setacea, denticulata, e corona membranacea reticulata. - Muscus dendroideus, in Oce a nia gregarie epigaeus, perennis.

Trach y 10 ua Brid. Bryolog II. 277. Neckerae sp. Hedw, sp. $t$. 48. f. $1-3$. Hook. musc. exot, $t, 23 . f .3-8$.

58\%. Hookeria SMITH. Caly ptra mitraeformis, basi fissa, rarius integra. S porangi um laterale, basi aequale; operculum rostratum; peristominm duplex; exterioris dentes sedecim, lanceolato-lineares; in terioris cili a totidem, e corond membranacea solida, rarius ciliolis interjectis distincta. - Musci perennes, ramosissimi, epigaei $v$. rarius truncicoli, inter $t r o-$ $p$ icos frequentiores, in temperatis rari, caespitosi, perennes.

Hook eria Smith in Transact, Linn, Soc, IX.1275:t, 23. non Schleieh. et alior.

a) PTERYGOPHYLLUM Brid. Cal y p tra glabra.

Pter ygoph y 11 u m Brid, mant, 149. Bryolog. II. 431. t. 10. Hook e r i a Hook. et Tayl, musc, t, 3, 27. Hook. musc, exot. II. t. 38 (5t, 54, 109. Hy pni et Leskeae sp. Hedw. Fund. t. 1. f. 4-6, spec, t. 58. f. 7-12, t. 53. f.1-7. t. 54. f. 13-11.t.61.f.1-6. t. 68. $f .1-7).-\mathrm{H}$ y pop ter y g i $\mathrm{m}$ Brid. Bryolog. II. 709. Pterigy a ndri s p. Hedw. Spee. t. 22. $f .7-13$ ใ. $51, f .8-13$. Ho okerla e s p. Hook. musc, exot. II. t. 34.35. - Heli e o ph y 11 u m Brid. Bryolog. II. 771. A noeetangii sp. Hook. musc. exot, 41. Sehwigr. Suppl. $t, 103,-\mathrm{C}$ y a t h o ph or a m Palis. prodr. 52, $t, 8, f .6$ : Brid. Bryolog. II. 721, t,3, suppt. Hook erlae sp. Hook. musc. exot. t. 163. Leski a e s p. Labill. Nnv. Holl. t. 253, f.1. Anoectangii s p. Hedw. Spec. t. 6. f.1-S.

b) CHAETEPHORA Brid. Caly p tra pilosa-hirta.

Cha e tephnra Brid. mant. 148. Hornsch. in Hor.phy,. berol. 65. t, 13. $f, 1-7$. Brid. Bryolog. II, 335. $t, 10$. Erio- 
pus Brid. I. c, II. 339. Leskeac s p. Hedw. Spec. t. 49. (Hook. musc. exot. t.53,121.)

588. Thacopillum PALIS, Caly ptra mitraeformis eampanulata, hine fissa, basi laciniata. $\mathrm{S}$ p o r a $\mathrm{ng}$ i u m laterale, inaequale, sulcatum; opereulum rostratum; peristomium duplex; exterioris dentes sedecim, lanceolati, aristati; in teri u s corona membranacea, carinato-sulcata, apice in cilia sedecim, perforata, ciliolis interjeetis fissa. - Musci caespitosi, in uliginosis regionum tropicar $u$ et temperatarum perennantes.

Raco pilum Palis, prodr. 36. t,9. f.6. Brid. Bryolog. II.718, 1, 10. A u berti a Palis, ms. Hy p n is p. Hedw, muse. frond. IV. T. 19 .

589. Cryplazen $B R I D$. Caly ptra mitraeformis, basi subintegra. Sp or ang i um laterale, basi aequale; operculum conicum, acutum; peristo mi um duplex; exterioris dentes sedeeim, lineares, erecti; interioris eilia totidem, filiformia, libera, dentibus alterna. Musci perennes, in temperatis tropicisque gregarie epidendri.

Cr y p h a e a Brid, mant, 139. Bryolog. H. 249. t,9, D a ltonia s p. Hook, et Tayl. muse. 1.3. f. 1-4. Neckerac s p. Hedw. musc. frond. III, t, 16. 16. - Pilotric bum Palis, prodr. 3\%, excl. sp. Brid. Bryolog. $I I$. 256. t.9. Neckerae sp. Hedw, muse, frond. III, $t, 17.18$. Schwägr. Suppl, t, 83, 140. Hook, musc, exal, t, 122. - Mete or lun Brid. $l$. c. Ne ek erae 8 p. Hook, musc, exot, $, 157,158$.

590. Carovaglia Calyptra mitraefor mis, subintegra. S p or an g i m laterale, basi aequale; operculum planiusculum, rostellatum, stomatis limbo marginatum; peris tomi um duplex; exterioris dentes sedecim stomati in crassato paullo demissius inserti, bicrures, cruribus massa pulposa pertinaciter connexis; in t eri oris cilia totidem, libera, minima, fugacissima, dentibus alterna. - Muscus ramosus, caespitosus, ex insula Jav a adlatus.

\section{Es en be ekin Brid. Bryolog, II. 753, non Mart.}

5. 1. Tepielopillam $B R I D$. Calyptra mitraeformis, integra, squammuloso-seabra. S p orangi im laterale, basi aequale; opereulum subulatum; peristomium duplex; exterioris dentes sedecim, lineares, erecti; interioris cili a totidem, libera, dentes aequantia, isqne alterna, basi medio fissa. - Musci americani tropici, epidendri, gregarii, perennes.

L epi d o piln w Brid. mant, 141. Bryolog, IT. 267,, 9. Trachypodium Brid. Neekera e sp. Hedw. Spec.t.61. f.7-8. Sehwigr. Suppl,t, 82, Ho oke ri a s s. Hook, muse. exot, t. 52 .

592. Fomtimalis LINN. Caly ptra mitraeformis, integra. S porangium laterale, basi hequale; o perculum conieum v. subulatum; peristomium duplex; exterioris dentes sedecim, latinsculi, acuti, erecti; interius corona membranacea, conica, reticulata. - Musci aquatici, in temperatis frigidisque hemisphaerii bor e al is caespitosi, perennes.

Fontinalis Linn. gen, n.1109. Hedw. Fund. IT. 97.2.9. f.53-55. Musc. frond, III, $t, 12,20$. Hook, et Tayl, musc. t.22. Brid. Bryolog. II, 657.

5D3. Spineidens NEES. Cal y ptra cuculliformis. Sporangium laterale, subinaequale; op erculum conieum, elongato-rostratum; peristomium duplex; exterioris dentes sedecim, lanceolato-lineares, apice spiraliter torti; intorioris cilia totidem, e membrana re ticulata, subsolida, apice libera, conjunctaque. Muscus grandis, in excelsis insulae Jav \&e sporadice epigaeus.
Spirideas Nees in N. A.N.C.XI.143. t, 17. Sehwigr. Suppl. t. 149. Brid. Bryolog. IT. 279. Hook. miscell. $t .1$.

594. Iflizominum $B R I D$. Caly ptra caculliformis, subulata. Spor ang i um terminale, basi aequale; operenlum rostratum ; peristomium duplex; exterioris dentes sedecim, lanceolati, acuminati; in t e $\mathrm{r}$ i us corona membranacea; reticnlata, apice in cilia sedecim, ciliolis interdum interjectis fissa. - Musci a ustralasie $i$ perennes, pusilli, caulibus dimorphis; sterilibus frondiformibus, folits distichis, fertilibus brevissimis, subnullis, foliis imbricatis.

R hizonium Brid. Bryolog. II. 663. 1.2. Suppl. Leski a e sp. Schwägr, Suppl,, 83 . Sk it o phy 11 i $\mathrm{sp}$. La-Pylaie in Desv. Journ. IIT, l.36. f, 17. H y pil $\mathrm{i}$ p. Swartz in Schrad. Journ. IV. t.3. f. 1 .

5.D. Selhistostega WER. Calyptra mitraeformis, integra. Sp o rang i m terminale, apophysatum; opereulum convexum, obtusum. tandem radiato - ruptum; st o m a nudum. - Mus cus annuus, in Europa media epigueus, rarus, caulibus dimorphis; sterilium folis in frondem pinnatifidam confluentibus, fertilium pinnatis.

$\mathrm{Sch}$ istostega Web, et Mohr Taschenb.99. t.6. Hook. et Tayl. musc, $t, 8$. Bryolog. germ, I. 108. t.9. f.1. Brid. Bryolog. $1.109 . t, 1$. D i e ks o n ia Ehrh. pl. crypt. 65, nou Herit. G y m n o s to m i s p. Hedw, musc. frond. $I, t, 29$.

\section{Drepanophyllum RICH. C aly p-} tra... S poranginm laterale, basi aequale; o perenlnm conicum, vertice depressum; stoma nudum; orificio interno e membranula brevissima, lacinulata. - Muscus epidendrus, m as carenus, cauliculo simplicissimo frondiformi, foliis falciformibus, equitantibus, distichis.

Drepano ph y linm Rich, ex Hook, musc, exot, $I$. $t$. 145. Brid, Bryolog, $T$, 668, t, 10. D i c ran i s p. Hook, musc. exol. 1.1 .82 .

$59 \%$. IPlayllogonimm BRID. Caly p tra cuculliformis, pilosiuscula. Sporang ium laterale, basi aequale; o per en $\mathbf{u}$ m rostratum; pe. ristom i simplicis dentes sedecim, aequidistantes, subulati, integri. - Musci tropici, epidendri, aureo-viscidi, foliis dense distichis, equitantibus, complicatis.

Phyllog on in m Brid. Bryolog. IT. 671, t.3. suppl.

a) PhYllogonium Brid. Bryolog. . $c$. Pedunen I os brevis. Folia enervia. Pteriginandri sp. Hedw. musc, frond, $I Y, t, 39$.

b) EUSTíhia Brid, $l$, $c$, Pedanculus longas. Folia nervosa.

598. Detodicezes BRID. Caly ptra cuculliformis. Sporang i m laterale, basi aequale; opereulum conieum, acuminatum; peristomii simplicis dentes octo, bifidi, cruribus aequalibns. Musci perennes, in aquis fontanis $c l i m a t$ is te mperati ulriusque orbis rari, foliis laxe distichis, nervosis, duplicato-fissis.

0etodiceras Brid. mant, 186, t, 1, f. z. Bryolog. $u$. 675. 1.10. Skitophyli sp. La-Pylaie in Desv, Journ. IIT. t.36. $f .14, t, 39, f, 13, \mathrm{Fi} s \mathrm{~s}$ i de $\mathrm{n} \mathrm{t}$ is s p. Anct.

599. Fissidens $H E D W$. Caly ptra cnculliformis. Sporangium laterale, subaequale; operculnm conicum, rostratum; peris tom ii simplicis dentes sedecim, latiusculi, bifidi, eruribus subinaequalibus, divergentibus. - Musci elegantissimi, foliis dense distichis, equitantibus, duplicatura antica caulem amplectentibus, per totum orbem terrarum epigaei, nullibi copiosi.

Fis siden s Hedw. Fund. II. 91. Musc. frond, III. 26 -30. Spec, t.3. f. 7-9. Palis. prodr, 37. 2. 2. $f .3$. Brid. Bryolog, II. 679., 10 . P u s c in a Schrank FI. Bav, $I T, 45 I$. $\mathrm{Se}$ histophyllum Palis. ms. Skirophyllis s. La-Py-

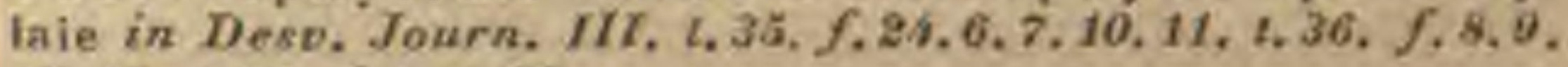
15, 18, t. 38. $f, 1, t, 39$. 


\section{APPENDIX. MUSCI FOSSILES.}

600. IIIuseites BRONGN. Ca ules simplices v, ramosi filiformes, fol $\mathrm{i}$ is membranaceis sessilibus v. amplexicaulibus, imbrieatis v. subpatentibus tectus. - Sedimentum aquarum dulcium.

Museites Brongn, Hist, veg. foss. 93.

a) SPHAGNITES. Rami siaplices, follis rhomboideis, obtusis, cauli arete adpressis, imbricatis, vix nervosis tecti.

Muscites squamatns Brongn. op. cit, t, 10. f. $3-7$. Lycopodites squamatns Brongn, in Cuv. et Brongn, Descript. Geolog. des env. de Paris. 359. t.11. f.3.

b) HYPNITES. R a m i elongati, flexuosi, flagelliformes, foli is patentibus v. laxe imbricatis, subtrifariis, concasiusculis enerviis. f. $1-2$.

Muscites To urnalii Brongn, Mist, veg. foss. t. 10.

\section{COHORS II. ACROBRYA PROTOPHYTA.}

ENDOGENAE CRYPTOGAMAE DO, theor, elem, 249. PSEUDOCOTYLEDONEAE VASCULARES Agardh Aphorism. 103. HETRRONEMEA Fries $p l$, hom, 33, part. FLLlCOLDEAE Lindl, introduct, 310 .

Praxtae caule et radiculis instructae, e contextu celluloso, fasciculis v a s or um plus minnsve perfectis, centralibus v. periphericis percurso, compositae. Folia in inferioribus nulla, in superioribus discreta, stomatibus donata. Genitalia mas cula nulla v. problematica. Sporangia varia, axillaria v. epiphylla, uni-plurilocularia. S p or a e plurimae, intra sporangia liberae, sporodermi cinctae.

\section{Classis VI. Equiseta.}

Caubes aphylli, articulati, striati, articulis vaginatis clausis, centro cavis, ambitu lacunosis, lacunis fasciculis vasorum, vaginarum dentes intrantibus percursis. Fructific a ti o terminalis.

\section{Ordo XXV. Equesetacene.}

EQUISETACEAE DC, Fl. $f r, I I$. 580 . Vauch, in $M t \mathrm{~cm}$. soc, h. n. genev, I. 2. 330. Brongn. hist veg. foss, 99. Bartl. ord. nat. 21. Lindl. introduct, 312.

Plantae terrestres, limnobiae, rhizomate subterraneo, repente. Caubes teretes, sulcati, rigidi, articulati, simplices $v$. verticillato-ramosi, articuli clausi, apice folio r u m minimorum verticillo, in vaginam membranaceam, scariosam, truncatam denticulatamve connato, stipati, singuli centro cavi, ambitu lacunosi, lacunis extus lineas elevatas, sulcis interstinctas formantibus, lacunis lineisque articulorum contiguorum alternantibns, fascicnlo vasorum annulatorum percursis; fasciculo hine vaginam intrante, illine in sequentis articuli lacunam deflectente. $R$ a m i verticillati, ad basim vaginarum extus nati, structura caulis, centro solidi. Frectricatio terminalis, in caule v. ramis $\mathbf{v}$. scapo decolori, a fertilibus herbaceis distincto. Receptacula plurima, squamaeformia, peltatim stipitata, subpolygona, verticillata, in strobili formam collecta. Sporavora sena v. septena, membranacea, paginae inferiori recepta- culorum adnata, unilocularia, sporis plurimis foeta, introrsum longitudinaliter dehiscentia. Sporas liberae, basi elateribus filiformibus binis, utrinque in apices spathulato granulosos desinentibus involutae.

Equ is et ace a e quo ad veram affinitatem et partium fructificationis naturam summopere dubiae, etab omnibus hodierni orbis plantis distinctissimae, exstinctae florae gens gigantea, cujus nepotes pygmaei pauci fata tulerunt hodiedum superstites, in $t$ emperat $i$ s potissimum vigent, in frigid is nonnihil minores, inter tropicos rarae, sed majores, e plerisque hemisphaerii a ustralis regionibus plane exules.

(1) R. Equisetum $L I N N$. Ca nlis cylindricus, laevis, striatus, fistulosus, articulatus, simplex v. verticillato-ramosus. Vag ina erectae, articulos terminantes, caulem arcte cingentes, multidentatae. Fructific a tio terminalis.

a) EQUISETUM. Minores, hodiedum vigentes $v$, in sedimento superiori sepultae.

Equisetum Lim. gen. $n$. 1169. E. brachyodon Brangn, hist. veg. foss. t, 12, f.11.12.

b) ONCYLOGONATUM. Giganteae, in terra lithanthracum fossiles.

Oneylogouatum König in Geolog. Transact, II. sor, $I$. 300, t.32. f. 1-6. (Brongn. hist, veg. foss. t, 12.13.)

8D2. Callamites SUCK. Caulis subcylindricus, sulcatus, articulatus, sulcis articulorum alternantibus, saepius convergentibus. V a g in a e patentes, profunde multidentatae v. earum loco in apicibus artieulorum tubercula, inter sulcos symmetrice disposita. Fruet if ic a t io ignota. - Giganteae, in lithanthracum fodinis fossiles.

C a la mites Suckow in Act. Acalem. Theod, Palatin. V. 357. t. 15-19. Schloth. Petrefo, t, 20. Sternberg Fl. der Voriv. t, 13, f. 3.t.17, f. 2. $t .22, f .1, t, 49 . f .5$. Artis Antediluv, Phytolog, t, 4, 6,11.13,24. Brongu. hist. veg. foss, 121 . t.14-27, Lindl. foss. Fl. t. 15. 16.20-22. $77-70$.

\section{Classis VIr. Fillices.}

FILICES Linn. praelect. 594. Jus8. gen, 14. Swartz, Synopsis Filicum. Kuliae, 1806.8vo. Kaulfuss, onumeratio Ftlicum, Lipsiae, 1824.8vo. Kaulfuss, des Wesen der Farrem. krdiuter. Leipz, 1897. 4lo. Raddi, Filices Brasilienses Florent. 1820 . Hooker et Greville, Icones Filicum. Londini, 1897 -1830. fol. \& Vol. Blume, Flora Javae, Filices, Bruxellis 1829. fol. Gaudichaud, Botanique de la Doyage de Ereycinet. Paris, 1826. Brongniart, Hist.veg. foss. p. 141. Schott, Genera Filicum. Vindab. 1835, 46o. H. Mohl, de structura caudicis Filicum erborearum, in Martius, Plant. crypt. Brasil. p. 44.55 .

Phantae herbaceae, rhizomate perennantes, rarius $t r u n c o$ arborescente erecto praeditae; truncus corticatus, e contextu prosenchymatoso, cylindro fasciculorum lignosorum integro in duas partes concentricas diviso, altera angusta inter corticem et lignum posita, altera majori centrali, medullari, ope rimarum cylindri lignosi, versus petiolos vasorum fasciculos emittente, cum exteriore communicante. Foli a in rhizomate sparsa, vel in apice caudicis rosaceofasciculata, vernatione circinnatim involuta, annua v. perennia, petiolorum parte infima persistente, eaudici acrescente; simplicia aut pinnata, integra vel pinnatifida, venosa, venis e cellulis elongatis compositis, saepius stom a- 
tibus cutaneis donata. Sporangia in foliorum dorso v. margine venis imposita, in acervulos nudos (soros), vel squama membranacea aut folii margine transmutato (indusio) tectos collecta, pedicellata v. sessilia, unilocularia, indefinite dehiscentia. Sporas plurimae, liberae, globosae v. angulatae, germinatione primum undique elongatae, deorsum radiculas, sursum cauliculum exserentes.

Filices dum caudicis structura, dum fructuum situ et conformatione, habitu denique peculiaria reliquis plantis distinctissimae, e protogaea proculdubio superstites, in insulis tropico circulo inclusis vel vicinis ingenti specierum et individuorum numero crescunt, in terra continenti parciores; in temperatis imprimis rarescentes, in regionibus veteris continentis frigidioribus, a mari circumdatis, iterum copiosiores. Arborescentes in regionibus extratropicis hemisphaerii borealis haud repertae. Exstinctae plurimae, fossiles.

\section{Ordo XXVI. Potypodiaceae.}

GXRATAE Swartz synops. 1. FILICES VERAE Willd. sp. pl. V.99. POLYPODIACEAE R. Brown prodr. 145. Agardh. Aphorism, 116. Kaulf. enum, 55. Bory in Dict. class. VI. 386.

Sponaxgia hypophylla, annulo verticali v. excentrico cincta, irregulariter transversim dehiscentia, pedicellata v. sessilia. Frondes simplices v. compositae.

Suborello I. POL Y PODIEAE Endl. prodr. Fl. Norf. p. 7 . Sp or angia subglobosa, annulo verticali. Sporae subglobosae v. oblongae.

603. A erostielnum L. S porang ia glomerata, frondis faciem inferiorem v, utramque obtegentia. Indusium nullum. - Filices inter tropicos utriusque hemisphacrae, rarius in regione subtropica, obviae, caudice repente, simplici v. ramoso, frondibus ternatis, pinnatis, tripinnatisve, fertilibus conformibus $v$, contractis.

A crostich am Linn. gen, n. 1173. Swartz synops, 9 ,

a) POLYBOTRYA Humb. Sp or ang fa faciem frondis dis. paris contractac, primo inferioris, deinde utramque dense obtegentia. Fr ond es pinnatae, steriles interdum simplices.

Poly b otry a Humb. et Bonpl. in Willd. sp. $V$. 99. Kunth, nov, gen, ot sp. t, 2. Kanlf. enum, 55. Hook, et Grev. ic, 81, Blum. Fl. Jav, 13. t.1-3. Mart, pl. erypt. Bras. 87. z. 25. Sehott, gen. Filic. fasc, II. $t$. 2. - 01 f e r si a Radd, synops. Fil, t. 1. - Plant, Bras, t. 14. 15. Sehott, gen, Filic, fasc. II. $t$. 1 . $\mathrm{E}$ e nolphia Schott op. cit. fasc. $I V$. ¿. 1. Poly botr y at e s. Blum.

b) ACROSTICHUM Kanlf. Sporang $\mathrm{i}$ a frondis immutatae $v$. vix contractae snperficiem inferiorem totam, $v$. ejus partem dense obtegentia. Frondes simpliees v. pinaatae.

Acrostic hum Kaulf. enum. 58. Blum. FL, Jav, 20. $t$. 4-16. Bory in Belang. voy, t, 2, 3. Hook, et Grev, ic, t, t2, 21-23. 61, 86, 95, 99, 110,118, 119, 145, 146, 164. 205. 221. 235. 237. Mart. pl. crypt. Bras. 83. t. 21-28. - G y m n o pteris Beruh. in Schrad, n. Journ, 1806. I. 20, - Poik i. lopteris Esebw, in Linnaed IT. 11\%. (A crostielin in scaudens Radd.) - Bolbitis Selwtt gen. Ftl. fasc. MI. t. 3. (A. serratifolium Mert. A. diversifolium Blum. A. re. pandum Blum. ete.) - El a phog l os s u m Sehott l. c. in not. A. simplex, Sw. A. conforme, Sw. A. apodum, Kaulf, A. viscosum, Sw.) - R hipid op teris Sehott $l, c$, in not. (A. flabellatum, Hab. A. peltatam, Sw.) c) NEUROPLATYCERos Pluckn. Sporang ia frondis immutatae paginam inferiorem totam, $v$. ejus partem dense obtegentia, squamis peltatis (bulbillis plantae viviparae) mixta. Fr o n d es simplices, labato-dichotomae.

Neuroplatyceros Pluekn. Amalth. 151. P1 atyceri um Desv, in Annal, soc. Linn. Paris. VI, 171. Blum. Fl. Jav. 43. $t$. 18. - A l eicornl um Gaudich. voy. Freyc. 48. - A. aleicorne et flabellatum Sw.

604. Hlemionitis LINN. Sporangia venulis reticulatis frondis insidentia. In dusium nullum. - Filices caudice herbaceo, exiguo, hirsutiusculo, fronde cordata, integra, palmato-quinqueloba, villosa (ambitu sinubus bulbillifera), in ins $u$ lis Caribaeis et in India orientali hucdum observatae.

H e m i on it is Linm. gen, n. 1176, excl.sp. Kaulf, enum. 68. Hook. exot.Fl, t.33. Hook, et Grev,ic, t.54, Schottgen. Filic, fasc, $I I T, t, 4$.

6DS. Antropleyum $K A U L F$. S p or a ngia venis primariis, reticulatis impressis immersa. Indusium spurium, e parenchymate circa venas impressas contracto. - Filices herbaceae, caudice repente, fronde simplici v. sublobata, in trop ic is imprimis archipelagi indici, parcius in insulis Oceani et in India occidentali reperiuntur.

A ntroph y u Kaulf. enum. 197. Blum. Fl. Jav. 89.

a) Antrophy um 37 . Sori subcontinui, reticulati. Ge. rontogeae et antillanae.

A n trop b y m Blum. op. cit, t. 30-35. Hemionitis reticulata Forst. Schkuhr. crypt. $t$. 6 . H. immersa Willd. H. plant aginea Cav. H. Ianceolata L.

b) LoXogramma Bl. Sori interrupti, lineares, eostae obliqui. Gerontogeae.

L o x o g r a m m a Blum. op. cit. (t.36.37. Hook, et Grev. cc, $t$.46.) Solenopteris Wall. msc.

c) POLXTAENIUM Desv. S o ri subcontinui, lineares. costae paralleli. Antillanae.

Poly ta e ium Desv. in Annal. soc. Linn, paris, VI. 218. Vit taria 1 a nce ol a t a Swartz. Sehkuhrerypt, $t, 101, b$.

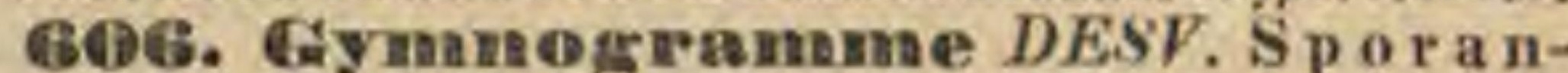
g i a venis primariis furcatis pinnatisve imposita, in s o r o s lineares oblongosve collecta. In d u s i u m nullum. - Filices in utriusque hemisphaerii $r$ eg ion $i$ bus tropicis et $s u b$ tropicis rarissime in $t$ e mperat is epigeae, caudice herbaceo plerumque abbreviato, frondibus compositis, decompositisque, rarius simplicibus, saepe pube discolori furfuracea conspersis.

Gy m nog ramme Desv. in Berl. Mag. $V$. 304. Journ. Bot, I. 25. Kaulf. enum, Schlechtend, adumbr, t.6. Blum. Fl. Jav. 88. t.38-44. Hook, et Grev, ie. t. 2/. 15. 89.90. 91. 95. 153. 156. Mart. pl. crypt. Bras. 88, $t, 26 .-$ e ter a ele Adans. fam. $I$, . 20, DC. Fl, fr. $I I$. 866 . (A s p I e n i u m C ete ra ch Linn. Bolt. fil. t. 12. E. B. t.1244.)

80\%. Cramemitis $S W$. Sporangia venulis simplicibus $v$. bifurcarum eruri superiori imposita, in soros lineares $v$. subrotundos colleeta. Ind usinm nullum. - Filices in tropicis utriusque hemisphaerii, rarissime in temperatis frigidiusculis hemisphaerii australis obviae, caudicibus repentibus rariusve caespitosis, fronde simplicî (rarissime bifida $v$. pinnata) integcrrima repanda $v$. pinnatifida.

G ra mmitis Swartz synops. 21. Blume Fl. Jav. 104.

a) GRAMMITIS Kaulf, S o r i lineares, ovales v. subrotundi, costae parallell.

Grammit1s Kaulf. enum, 84. Hook. exot, Fl, $t .78$. Hook, et Grev, ic. t, 6, 43,53,62. Blum, Fl, Jav, t, 46, 47, f, 2. t. 48. 49. f. 1. t. 50 .

b) XIPHOPTERIS Kaulf. S o r i lunulati, margini approximati, eodemque reflexo saepius tecti.

Xiphopteris Kaulf. enum, 85. excl. sp. Micropte $\mathrm{r}$ is Desv. in Annal, soe. Linn. Paris. VI, 217. Paly. podil sp. Nees in $N, A, N, c, X I, t, 12, f, 3,-\mathrm{G}$ r a m miti s s p. Blum. Fl.Jav, t. 49. f. 2. t.50. f.3.4. (G. tayosaroldes Sw. Sehkahr t.7.j

BD8. Alosurans $B E R N H$. Sporangia venis eostae obliquis simplicibus furcatisve imposita, in soros lineares subrotundosve collecta. 
Indusi um spurium, e marrinibus frondis involntis. - Filiculae glabriusculae, frondibus caespitosis bi-tripinnatifidis, centralibus fertilibus contractis, in Europa media, America aretica et in summis Indiae orientalis et Andium a mericanarum jugis hucdun repertae.

Allosurus Berah. in Schrad. n. Journ, T. \&. p. 36. Cryptogram a R. Browu. Append, to Eranll, narrat. 767. Hook. et Grev, ic. $t, 29.158$. P ho r olo bus Desv, in Annal. soc. Linn. Paris, VI. 291.

609. Selliguea $B O R Y$. S porangia reticulo venularum venis parallelo imposita, in sor o s lineares, continnos vel interruptos, inter venas solitarios collecta. Indusi um nullum. - Filices in Indiae orienta lis terra continente insulisque rarae, caudice repente, fronde simplici stipitata, coriacea $v$. membranacer.

Selligue a Bory in Dict, class, 587, c. ic. Blum. Fl. Jav, 122, t. $51-33$. D i a g r a m m e Blum. enum, pl. Jav, II. 118. C eterach 8 p. Hook. et Grev. ic. $t, s$.

G10. NEeniseimm SCHRER. Sporangia venulis transversis imposita, in s o r o s sublunulatos collecta. Ind us i um nullum. - Filices pari fere specierum numero in tropicis utrius$q$ ue orb $i s$ obviae, caudice subterranco repente, in unica specie americana arboreo, erecto, frondibus pinnatis trifoliatisve.

M e $n$ is c i $u$ m Schreb. gen.n. 1630. Sehkuhr. crypt. $t .5$. Hook. et Grev, ic. t.120. Blum. Fl. Jav, 100, t. M5. Sehott gen. Filic. fasc. III. $t, 2$.

611. Taenitis $S W$. Sporangia in so$x$ u m linearem, continumm $v$, interruptum, utrinque inter costam et marginem solitarium, huic parallelnm, venis contrarium collecta. Indus i um nullum. - Filices tropicae, in utroque orbe obviae, caudice herbaceo brevi, fronde in speciebus americanis simplici, in gerontogeis saepius pinnata.

Taenitis Swartz synops. 24. Schkuhr crypt. t. 66. Hook. exot, Fl, t.77. Hook. et Grev. ic. t.7.63. Blum. Et. Jav. 68. t.28. f.2. $t .29$. T a enitis et $\mathrm{P}$ te ropsis Desv, in Annal. soc. Linn. Paris. VT. 218.

61:. NIonogramme COMM. S porang i a costae imposita, in s or $\mathrm{m} m$ linearem apicem costac obtegentem collecta. Indus i um spurium, ex apice frondis complicato. - Filices admodum exiles, caudice hirsuto, repente, fronde lineari simplici $v$. bifurca, in India occidentali et in insulis Mascarenis hucdum observatae.

Monogramme Commers. Sehkuhr erypt. 89. $t$. 87 . Desv, in Berl, Magaz. $\nu$, t, 7. f.5. Journ. Bot. 1. t. 2. f.3. Sehott ger. Filic. fase, $I V$. . $t .3,-\mathrm{C}$ och $1 \mathrm{i}$ di um Kaulf. enum. 85. Schott Gon. Filic, fase, IV.t. 2, Grammitis grau inoides Swartz.

613. Adenopleorus $G A U D$. Sporang i a extremitati costae incrassatae imposita, in 50 r n m subrotundum, sub apice frondis collecta, glandulis stipitatis mixta. In d u si n m spurium, ex apice frondis reflexo. - Filices exiles, frondibus bipinnatifidis, utrinque imprimis subtus rubro glandulosis, in insulis Moluccis et in Polynesia tropica repertae.

Adenophorus Gaudich, in Freyc, voy, 365. $t .8$. Hook. et Grev. ic. t. 174-176. A m phoradonium-Desv. in Annal, soc. Linn. Paris. VI. 335. - On ych iu m Refinw. in Syllog. II, 2, - the canopteris Reinw, in Flora 182s. Beilag. 48. Blum. onum. pl, Jav, II. 120.

614. Nodhoeliliaena $R$. BR. Sporan$\mathrm{g}$ ia in sorum linearem, marginalem, continuum v. interruptum, setis pilisve frondis velatum colleeta. In dus i um nullum. - Filices caudice herbaceo brevi, frondibus simplicibus, pinnatis, tripinnatisve, hirsutis, inter tropicos utriusque orbis obviae in Europa a straliore et regione mediterranea rarae.
Nothoehlaena R. Brown prodr, 146, Labill, Nov. Caled.t.7. Presl, in Reliq. Haenk. t.1.f.2. - Cineinua. li s Desv. in Berl. Magaz. V. p. 310. - P te rid is s p. Linn. Swartz synops. t.2. f.3. Schkuhr crypt. t.87.99. - An hue Marg inaria Bory in Dict. class, VI. 587, X,176, Duperr. Voy. t.31. f. 2. (absque analys.) cui auctor sorum ipsi margini impositum, eqnitantem tribuit?

B 15. Polyportivm LINN. Sp orangia venis imposita, in so ros subrotundos sparsos seriatosve collecta. Indusium nullum. - Filices caudice repente $v$. erecto, plerumque herbaceo, rarissime arborescente, fronde simplici, integra $v$. pirnato-composita et decomposita, per to t um orbem sparsae, inter tropicos veteris orbis imprimis copioste.

Poly podf um Linn, gen, n. 79. Blum. Fl. Jav. 129.

1. LASTRAEA Bory. V e nae pinnatae. Sori apleiv. medio venarum inserti.

L as trae a Bory in Dict. class, NT, 588, IX, 232, excl. pl. Poly podif s p. Linn. Schkuhr, erypt, t.25. - Poly. podia spuria $n$. 4. Blum. l. c, p, 133.

2. DICRANOPTERIS. $\boldsymbol{B} l$. V ena furcatae, altero apice sorophorae.

Polypodia spuria n. 3. Blam. l. c.

3. CTENOPTERIS Bl. Venae simplicissimae, apice inerassato nonosorate.

Cten opteris Blum. $l$. c. (N,, , N, $C, X I, t, 12, f .2$.

4. AGLAOMtorPHA schott. V e a e fureatae, eruribus apiee eombinatis monosoris.

A g la o m orplia Sehott gen. Fil. fase. IV. t. 4 .

5. GoNiOPHLEBIUM $B l$. Ve a a e pinnatae rami reticulati, infimo libero apice inerassato monosoro.

Gon iophlebium Blum. l. c.

6. DRYNARIA Bory. Ve u a reticulatim anastomosantes, ramulis nonnulis liberis uncinatis. Sori ramulis libe. ris paulo infra apicem $\nabla$. reticuli ramis dectssatutibus impositi.

Dry naria Bory in Annal. sc. nat. $V$. 464. t. 12-14. (Schkuhr t. 13.) - Dipteris Reinw, in Syllog. pl. II. 3 .

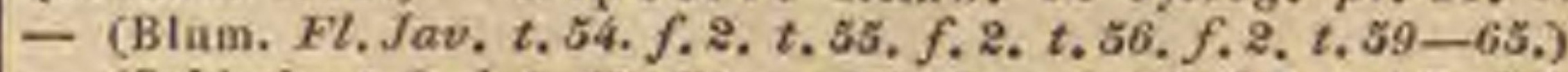
- (Sehkuhr t, 8. d.9.17. Blam. F7. Jav. t.54. f. 1. t.55. f. 1 .

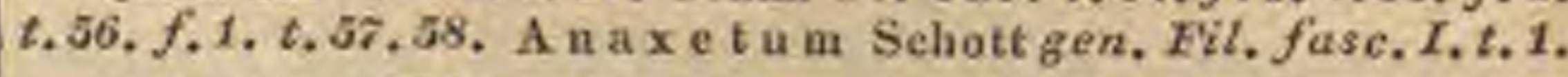

616. Fleopeltis $H U M B$. Sporangia venis reticulatis imposita, in s or o s rotundos sparsos seriatosve, squamis paleaceis peltatis copiosissimis subimbricatis velatos, collecta. - Filices caudice repente, frondibus stipitatis, linearibus, integris $v$. pinnatifidis, utrinque $v$. subtus paleaceo squamulosis, in America tropica, Capite bonae spe $i$ et in insulis Mas car e $n$ is observatac. - Genus a Polypodio vix diversum.

PleopeItis Humb. et Bonpl. pl. aequinoct, MI. 189. t. 140. Nov. gen, et sp. t. 1 . Hook. exot. Fl, t, 61-63. Hook. et Grev. ic, t.67, 137. - ? $\mathrm{P}$ a r ag r a m m e Blum. enum, pl. Jav. II, 119 .

61\%. Nipliobelus $K A U L F$. Sporangia papillas frondis ambientia, so ros subrotundos confertos sparsosve, pilis stellatis velatos, formantia. Ind usium nullum. - Filices inter tropicos et in regionibus calidioribus veteris orbis provenientes, in America nondum repertae, caudice repente squamoso, frondibus coriaceis, simplicibus, integerrimis, stipitatis costatis, enerviis, subtus incano-lepidotis, apice vel superiore parte fructificantibus.

Niphobolus Kaulf. enum, 12\%. Blum. Fl. Jav, 48, t. 19-24. Hook, et Grev. is. t. 44,93,94. Hook, ad Beechey t. 18. - C a ndallea Mlirb. in Buffon edit, Detesv. $V .87$. - Cyelophorus Desv, in Berl, Magaz. $\nu, 360$, t. $7 . f .4$. Journ, Bot. I. 19. Annal. soc. Linn, VI. 224. non Zoolog. - Pyrrhosia Mirb. in Bullet. soc. philomat. an $I X$. 70 . Desv. $l$. C.

618. Cheilanthes $S W A R T Z$. Sporan$g$ ia apieibus venularum discretis imposita, in s.oros subrotundos, margini frondis approximatos collecta. Indusi um spurium, e margine frondis reflexo. - Filices caudiceherbaceo v, rarissime arborescente, frondibus pinnatis, pinnatifidis, bipinnatis supradecompositisve, in tropicis subtropicis- 
$v e$ totius orbis, rarius in temperata zona utriusque hemisphaerae vigentes.

C heflan the s Swartz synops.129.t.3.f. $5-7$. Sehkuhr crypt. t. 123-125. Hook, et Grev. ic. $t, 134,151$.

619. Tonehitis $L I N N$. Sp orangia apicibus venularum anastomosantibus imposita, in soro s lunulatos in sinubus frondis collecta. In dusia margini frondis continua, reflexa. - Filices in utroque orbe tropica e, caudice herbaceo hirsuto $v$. aculcato, frondibus bipinnatifidis, laciniis crenatis v. sinuatis.

Lonchitis Linn. gen, $n, 1177$. Selukuhr crypt $t, 86$. Schott gen. Filic. fase. III. t. 1 .

620. Adianteme $L I N N$. Sporangia apicibus venarum discretis, in receptaculum lineare v. punctiforme intumescentibus imposita, in sor o s marginales disposita. Indusia margini frondis continua, receptaculo adnata, introrsum libera. Filices caudice herbuceo, plerumque repente, frondibus compositis supradecompositisve, rarissime simplicibus, tenerrimis $v$. coriaceis, nitidis; in tropicis utriusque orbis, imprimis tamen in novo continente copiosae, in te mperatis rarae.

Adiantum Linn. gen. n. 1180. Sehkuhr crypt. t. 115 -120. Hook. exot. Fl, t. 104. Raddi pl, Bras, t. 77. Hook. et Grev. io. $t .30 .98,103.104 .132,173.188,190$. Mart. ic. pl. orypt. Brasil. 92. 1.56.68.63.

62 1. Cassebeera $K A U L F$. Sporangia apicibus venularum anastomosantibus imposita, in soros lineares subcontinuos, margini approximatos disposita. In d usia intramarginalia (interdum confluentia) fornicata, introrsum libera. - Filix brasiliensis, caudice herbaceo repente, frondibus erectis, ternatis pinnatisque, pinnis crenatis.

Cas s e be era Kaulf. enum. 216. t. 1. $f$. 11. Mart, pl. crypt. Brasil. 21. $t$. 61. Adiantum triphyllum Smith ic, inedit, $t, 74$.

692. Pteris $L I N N$. Spor ang ia apicibus venularnm, in receptaculum nerviforme frondis marginem ambiens combinatis imposita, $80 \mathrm{r} \mathbf{m m}$ marginalem continuum formantia. I u du siu m margini frondis continumm, seariosum, introrsum liberum. - Filices habitu admodum vario, caudice repente $v$. sacpius erecto, interdum subarborescente, frondibus compositis $v$. rarissime simplicibus, $c l i$ matis tropic i et temperati cives, in veteri orbe nonnihil frequentiores.

P teris Linn. gen, n, 1174. Scbhulir orypt. t. $88-98$, Labill, Nov, Holl. t.244. 245. Nov. Caled, t.8. Gaudich, voy. Frejc. $t, 19$. Raddi pl. bras, t, $63-70$. Hook. et Grev, ic. $t$. 8. 28, 107, 116, 126,130,142. A. Ricl. Fl. Nov. Zeel. $t, 18$. Neuropteris Desv, in Annal. soc. Linn, de Paris VT. 292. $t .8, f .2$.

523. Inunesomia HOOK. Sporangia prope basim costae in sorum subglobosum, pilis velatum collecta. In d u s i u marginifrondis continuum illumque ambiens, introrsum liberum, a soro remotum. _ Filicula peruan a, pedalis, fronde pinnata, pinnis reniformibus. - Genus imperfecte descriptum.

Jamesonia Hook. et Grev, ic, t. 178. - Pteris imbricata Swartz.

624. Blechnum $L I N N$. S porang i a in sor os lineares geminos, costae utrinque parallelos continuos collecta. In d u s i a scariosa, fornicata, continua versus costam libera. - Filices caudice herbaceo, interdum elato arborescente, frondibus pinnatifidis pirnatisve, rarissime simplicibus, in tropicis subtropicisve obviac, in temperatis rarae, in hemisphaera australi nonnihil frequentiores.

B I e h $\mathrm{n} \mathrm{um} \mathrm{Linn.} \mathrm{gen,} \mathrm{n.} \mathrm{1175.} \mathrm{Juss,} \mathrm{gen.} 15$.

a) BLEChNUM Filld. In d u s ia intramarginalia. F г о s fertilis vix mutata.
B l e ch nu m Sehkuhr crypt, $t, 108,109,110, b$, Labill, Nov, Caled, t. 3. Raddi $p 1$, Bras, t, 60, f, 2, 3, t, 62. Hook. et Grev. ic, t, 192, 225. Bory voy. Duperr. t.36. - S a dlex ia Kaulf. enum. 161. (B le c h num Fontanesianum Gau. dich, voy, Freye. $(.15$.

b) LOMARLA Willd. Indusia submarginalia. Frons fertilis contracta, pagina tota soris obricta.

L o ma $x$ i a Willd, $s p$. V. 289. Labill, Nov. Caled. t.46. Hook. et Grev, ic, $t$, 207. Ste g a n i a R. Brown prodr. 159, A. Riclr. Fl, Nov, Zeel. $t, 13$, B I e e h n i s p. Labill, nov. Holl. 2.246.21\%. 0 u o cle a e 8 p. Schkuhr crypt, t, 105.b.106. 110 . - Quid L cptostegia Don nep. 14.

695. Leptoelhilus $K A U L F$. Sporangia in sor 0 s lineares, continuos, utrinque juxta costam deeurrentes eollecta. Ind usiu m textura frondis bivalve, valvula altera margini, altera costae continua. - Filicula in insulis Philippi$n$ is in arboribus parasitica, fronde sterili oblongo lanceolata, fertili axillari stipitata lineari. - Genus dubium.

Le p to ehil as Kaulf, enzem, 147, $t, 1, f, 10$. A e ro stie h u m axillare Car.

6:6. Vittaria SMITH. Sporangia in soros lineares, continuos, costae parallelos collecta. Indusium textura frondis bivalve. - Filiculae in tropicis subtropicisque utriusque orbis parce provenientes, frondibus linearibus, integerrimis, soris nune costae nunc margini approximatis.

Vittaria Smith in Mem. Acad, Turin, $\nu, 413, t, 9 . f, \sigma$. Sehkuhr crypt. t, 101, b. Hook. et Grev, ic. t, 186.187.

628. IIymenolepis KAULF. Sp orangia venulis reticulatis costae approximatis imposita, in sor $\mathbf{u m}$ linearem per apicem frondis contractum continuum collecta. In $\mathrm{d}_{\mathrm{u}} \mathrm{s}$ i $\mathbf{u m}$ duplex, verum hyalinum, squammatim sedecens; s pu ri um e marginibus frondis involutis. - Filicula in insulis Mascarenis et Mariannis reperta, fronde simplicissima lanceolata, apice fertili lineari, spicaeformi.

Hymenolepis Kaulf. enum, 146. Belvisac sp. Mírb. A crostiehum 8 picat um Línn. Smith ic, inedit. t. 49 .

628. Struthiopteris WILLD. S porangia venis primariis costae obliquis imposita, in s o r o s lineares collecta. In du sium duplex, s p u$r$ i $\mathrm{m}$ commune e margine frondis involuto; $p$ a $r$ tialia membranacea, inter soros septiformia. Filix bipedalis, frondibus steritibus bipinnatifidis, fertilibus bipinnatis, in Europa media, in America et Asia borcali habitans.

$\mathrm{S}$ truthlopteris Willd. sp. $V$. 288. 0 sm und a $S t r u$. thiopteris Linn.

629. Bnoelea LINN. Sporangia apicibus venarum imposita, in $50 \mathrm{ros}$ subglobosos collecta. Indusium duplex, commune spurium e margine frondis involuto, in formam baccae coalescente; partialia membranacea, fornicata, soros involventia. - Filices bore al $i$ - $a m e$ ricanae, frondibus sterilibus pinnatis, fertilibus bipinnatis, pinnulis recurvato globosis.

0 noclea Linn. gen, n.1170. excl, sp. Angiopteris Mitehell, in Act. Nat. Curios, VIIT. 29. C a ly pteriu mi Bernhard. in Schrad. Journ, 1801. p. 22. t. 1. f.9.10.

630. Asplemium LINN. Sporangia venis transversalibus imposita, in soros lineares collecta. Indusia membranacea, e vena lateraliter orta, versus costam Iibera. - Filices habitu admodum vario, in toto orbe, praeter extremum septemtrionem obviae, frondibus simplicibus, interdum amplissimis, pinnatifidis, pinnatis, decompositisque.

Aspleainm R. Brown prodr. 149 .

a) ASPLENIUM Juss. So ri per frondis paginam sparsi, indurils rersus eostan tiberis. 
A s p I е п i n m Juss. gen, 15. Sehkuhr crypt, t, 64-81. Rad. pl. Bras. $t .31-57$. Gaudich, voy. Freyc, t.13. Labill. Nov. Caled. t. 2. Hook. et Grev. ic. t. 27.71-73.88.92.100.114, 136, 137, 147, 150,152, 165. 172, 186.189. 195.217, 220,228.239. Bot. Mag. t, 3001. On o p teris Neck. elem, n. 1721. B elvisiae sp. Mirb.

b) DAREA Juss, Sori in lobis pinnularum profunde incisis solitarii, marginales, in d us i is respectu lobi extrorsum, respeetu costulae introrsum liberis.

D a re a Juss. gen, 15, Labill. Nov, Holl, t, 243. C a ca o p teris Berg. in Nov. Act. Petrop. IX, t. $d-f$. Sehkuhr crypt. t. 82. Hook. et Grev, ic. $t .193 .-$ Acrop ter 1 s Link hort. berol. II. 55 .

631. Allantodila R. BR. Sporangia venis imposita, in soros lineares costae obliquos collecta. In d u sia membranacea, fornicata, utroque margine costae adnata, introrsum dehiscentia. - Filices in Nova Hollandia extratropica, insulis Moluccis, India orientali, Japonia et Madera repertae, caudice herbaceo erecto, frondibus bipinnatis, flaccidiusculis.

Allantod ia R. Brown prodr. 149. Wallich, pl. As, rar. t.58. A s pidil s p. Swartz. Schkuhr crypt, $t .61$.

B3\%. Doodia R. BR. S p o rangia venulis prope costam reticulatis imposita, in 8 or os lineares lunulatosve, costae utrinque parallelos collecta. In d u s i membranacea, plana, e venula anastomosante orta, introrsum libera. - Filices in Nova Hollandia et Oceania intra et extra tropicos viventes, caudice herbaceo erecto, frondibus lanceolatis pinnatifidis pinnatisve, serrulatis.

Doodia R. Brown prodr. 15t. Hook. exot. Fl, t.8.25. Spreng. N. E. t.3. f.1. Gaudich. voy, Freye. t.14.

633. Woodwaredia SMITH. S p o r a ngia venulis prope costam reticulatis imposita, in so ros oblongos, costae utrinque parallelos collecta. In d u s i coriacea, fornicata, venulae anastomosanti utrinque inserta, introrsum dehiscentia. Filices caudice lerbaceo erecto, frondibus pinnatis, sterilibus interdum pinnatifidis, in hem is pha era boreali, imprimis novi continentis, inter $25^{\circ}$ et $42^{\circ}$ lat. bor. obviae, in Americatropic a rarissimae.

Wood wardia Smith in Act. Acad. Turin. V. 411,t.9. f. 3. Sehkuhr erypt, t.111-113.

63 4. Seolopenallium $S M I T H$. S p or a n$g$ i a venarum bifurcarum cruribus imposita, in soro s oblongos, e diversarum venarum cruribus contiguis geminatos collecta. Ind u si a membranacea, e vena lateraliter orta, super soros comniventia, hinc spurie bivalvia. - Filices in Europa media et australi, in Japenia, Nepalia et America tropica hucdum observatae, frondibus lanceolatis, cordatis hastatisve, integris.

Scolopendrium Smith in Mem. Acad. Turin. $\not$. M10. t. 9. f.2. Schkuhr erypt, t.83.84. Bory in Duperr, voy, $t .37$. f. 1 .

635. Dnyelnium $K A U L F$. S porangia reticnlo venarum imposita, in soros oblongos, ad costulam utrinque geminos collecta. In dusia e vena anastomosante orta, fornicata, super costulam conniventia, hine spurie bivalvia. - Filices flaccidiusculae, caudicibus caespitosis, frondibus triplieato-pinnatis decompositisve, in Capite bonae spei et Manilla a Chamissone repertae.

On y h hum Kanlf. enum. 144. $t .1 . f .8$.

636. IDiplazinam $S W$. S por a ngia venis furcatis imposita, in s oros lineares, juxta venae crura utrinque geminatos collecta. In d u s ia e vena orta, hine inter se confluentia, illine líbera. - Filices inter tropicos utriusque hemisphae- $r$ a e obviae, caudice repente $v$. erecto, in nonnullis arborescente, fronde simplici, pinnata bipinnatave.

D iplaz i u m Swartz synops.91, t.2.f.4. Sehkuhr crypt. $t, 75, a, b, 85$. Spreng. in N. A, N, $C, X, t, 17, f, 1.2$. Raddi $p l$. Bras, t. 5\%, a. c. t. $5 \%, f .2$. Bory in Belang. voy, t. 4. C al. lipteris Bory voy. 1. 282 .

63\%. Didymechlaema DESV. S p o r a ngi a venis subsimplicibus imposita, in so ros oblongos, juxta venae extremitatem utrinque geminatos collecta. Indusium soris geminis commune, venae subexcentrice impositum. Filix arborescens inter tropicos America et in Moluccis observata, frondibus bipinnatis, pinnulis rhombeooblongis, apice dentatis.

Didy mochlena Desv, in Berl. Magaz. V.t.7. f.6. Journ. Bot. 23. t.2. f.4. Gaudich, voy. Freyc, $t$. 12, $f, 3, d$. e.f. Monoclila e a Gaudich. op. cit. p. 340. H 1 ppodium Gandich, mse. Tegularia Reinw. in Syllog. $I I .3$. C eram ium Reinw. Hy steroearpas Langsdorf. msc.

635. Neplarolepis SCHOTT. Sporangia receptaculo ex apice ramuli superioris venae intumescenti imposita, sorum subglobosum formantia. Ind u sium reniforme, hinc sinu affixum. Filices in tropicis utriusque orbis obviae, caudice repente, frondibus pinnatis bipinnatisque.

Nephrolepis Schott gen.Fil.fasc.I.t.3. As pidi um exaItatum Sehkuhr $t .39$. Nephrodi i sp. Auct.

639. Neplnrodium $R I C H$. Sporangia receptaculo e medio venae intumescenti imposita, s o r o s subrotundos, seriatos formantia. Indus i$\mathbf{u} \mathrm{m}$ reniforme, hinc sinu affixum. Filices in te $\mathrm{m}$ peratis et tropicis totius orbis obviac, caudice herbaceo, frondibus pinnatis bipinnatisque.

Nephrodium Rich, in Michx. Fl. bor. Amer, 11, 266. Bory in Belang. voy, t. 6. Hook, et Grev, ic. $t$. 4 . $, 70,93,94$. 102, 162, 234. As pidil s p. Swartz, - Neuronia Don nepal.6. (Hook, exot. Fl. t. S.)

640. Aspidium $S W$. Sporangia receptaculo columnari, ex apice, medio $v$. anastomosi venularum tumescenti imposita, in soros subrotundos sparsos seriatosve collecta. Indusia receptaculo continua, subrotunda, peltata, margine undique libera. - Filices habitu admodum vario, in tropicis temperatisque totius orbis viventes.

A spidium Swartz synops.51. Psid opodium Neck. elem. n. 1718. - Te ctari a Cav. praelect. n. $621 .-\mathrm{Hy}$. popeltis Rich. - 0leandra Cav, praelect. n, 623. Ophiopteris Reinw, in Syllog. $I T$. 3. - Rumohria Raddi synops. 12, t, 2. Pl. Bras, t. 43. Gaudiel., voy. Freye. 344.

a) ASPIDIUM. Sori e venulis anastomosantibus.

(Sehott gen. Fil. fasc, I, t. 2. Hook. et Grev, ic. t. 26.69. 140. 184.202.)

b) POLYSTICHUM Roth. Sori venularum furcatarum cruri superiori medio impositi.

Poly stieh a m Roth. Fl. Germ. 111. 84. Gaudich. voy. Freyc. $t$. 1t. Sehott gen. Fil. fasc. II. $t, 4$. Polypodii $s \mathrm{p}$. Linn. (Hook, et Grev, ic. $t, 59$. )

641. Cystopteris BERNH. Sporang i a receptaculo e medio venae intumescenti imposita, in soros subrotundos, in disco laciniae solitarios collecta. I n d u si a ovata (hyalina), basi afrixa, versus marginem frondis libera. - Filiculae caudice herbaceo, frondibus bi-tripinnatisque, in $t$ e mperatis utriusque orbis et in $s u m m$ is $A n-$ di $u$ jugis observatae.

C is to pte r is Beruh. in Schrad. n. Journ. 1806.p.49. t.2.f.7. Desv, in Annal. sac. Linn. Paris. VT. 263. Schott gen, Fil. fasc. IT.t.3. Pol y po di i s p. Linn, Jacq. ic. rar, $t, 6.48$. Schkuhr erypt. $t, 21$. As pidii s p. Swartz, Sehkuhr $t .57$. 62. - A thy rii sp. Roth? H y m e o e ystis A. O. Meyer Verz. caucas. 229.

842. Hindsrea SMITH. Sporangia apicibns venaram imposita, in $80 \mathrm{r} u \mathrm{~m}$ continuum, marginem frondis ambeuntem collecta. Ind u s i u m 
membranaceum, continuum, frondem ambiens, extrorsnm liberum. - Filices inter tropicos utrius que orbis provenientes, caudice herbaceo, frondibus simplicibus, pinnatis, decompositisve.

L in d s a e a Dryand. in Linn. Transact. 111, 39. t. 710. Smith in Mem, Acad, Turin, V, 413. t, 9. f. 4. Labill. Nov. Boll, t, 248. Nov. Caled. t, 9. Raddi pl. Bras, t. 74. Hook. et Grev. ic, t. 75. 87. 111, 144.194.296. Bory in Duperr. voy. t.37. f.2. - S chiz o 1 o m a Gaudieh. Voy. Fregc, 378, t.16 -18. - H y me not o m i a Gaudich. $l$. $c$.

G43. Davallia $S M I T H$. S p o r a g i a apicibus venarum imposita, soros subrotundos, margini approximatos formantia. Indusinm vena e continuum, lata basi v. etiam marginilous adnatum, vertice extrorsum liberum. - Filices caudice herbaceo, repente $v$, erecto, frondibus simplicibus, pinnatis decompositisque, intertropicos utriusque orbis obviae, in hemisphaera australi frequentiores, in regionibus subtropicis et in America antarctica rarissimae.

Davallia Smith in Mem. Acad, Turin, F. 414.t.9. f.6. Schkuhr crypt, t. 126-129. Hook, et Grev, ic. t. 105, 138. 139, 141. 143.183.230. 231.238. Bory ad Belang, t.7. - H umata Cav, praelect, 130. - Wibeli a Beruh, in Schrad. Journ, 1801. p. 122, t. 1. f. 2. S e y p h of Illix Thouar. gen. madagase. $n, 2$.

644. IDielusomia HERIT. Sporangia apici venarum imposita, s or os subrotundos marginales formantia. Indusium duplex, verum membranaceum venae continuum, spurium e lobulo frondis reflexo alterum equitans. - Filices caudice erecto, arborescente, frondibus pinnatis, bipinnatis triplicatopinnatisque, inter $t r o p i c o s$ utriusque orbis et in regionibus extratropicis hemispha erii a ustralis obviae, in Am erica boreali rarissimae.

Dieks ou i a Herit, sert. 31. Schkuhr erypt.t.199-131. Labill. Nov. Caled, t, 10, - B alanti um Kaulf. enum, 228, $t, 1, f, 13$, Dieksouiae sp. Herit. - Sitolobium Desv. in Annal, soc. Linn. Paris, VI, 208. Dicks o ala pubes e ens Sclikuhir crypt, $t, 13 t$.

C45. Cilbotimma $K A U L E . \mathrm{S}_{\mathrm{i}}$ or a $\mathrm{n}$ i a apicibus venularum imposita, so r o s subglobosos, margini approximatos formantia. I $n$ d $\mathbf{z} 8 \mathrm{i}$ a coriacea, bivalvia, valvis fornicatis, oris callosis conniventibus, exteriore majore. - Filix $S a n d w i c e n s i s$, caudice arborescente, frondibus bipinnatis.

Cibotinm Kaulf. enum. 299. t. 1. f. 19. Pinoula Gaudich, voy. Frege. 369, t.21. - 2 D ickson ia a $t$ tarcti e a Labill. Nov, Holl, t. 2i9.

646. Woodsian R.BR. Sporangia medio venarum imposita, s oro s subrotundos sparsos formantia. Ind u s ia soris substrata, membranacea, subglobosa, patellaeformia, ore multifido lacero. - Filiculae caespitosae, frondibus pinnatis, in hemisphaerae borealis temperatis et frigidiusculis, in $s u m m i s ~ A u d i u m j u g i s$ et in America antarctica observatae.

Woods ia R. Brown in Linn. Transact. XI. 1. 173. Hook, et Grev, ic. $t, 68,191$, Poly podium 11vense Swartz. - Pliys ematium Kaule, in Flora 1829. p.341.

observatio. H y poderis, geuns a el. R. Browu in Wall. $l$. As. rar. I, 16. commemoratum, habitu As pidi i trifoliati, differt a Weodsia veanlarum furcatarum craribus radiatim confluentibus, sporangisque anastomosi impositis.

G4\%. Saceoloma KAULF. Sporangia apicibus venarum imposita, 8 or o 8 marginales, indus iis pateraeformibus exceptos, formantia. - $\mathrm{Fi}$ lices caudice erecto, frondibus simpliciter pinnatis, in insulis Sandwicensibus et in Brasilia observatae.

Saccolotia Kaulf, entum, 224, $t, 1, f, 12$. Depacia thaol. et Grev, ic. 2,157 .
648. Diaealpe BLUM. Sporangia receptaculo punctiformi, e medio venae tumenti imposita, soros subglobosos sparsos formantia. Indusia soris substrata, glohosa, medio laceratim dehiscentia. - Filix javanica, caudice herbaceo, fronde triplicato-pinnata, membranacea, glabra.

D i a c a l p e Blum. enum, pl. Jav, II, 241.

649. Splnaeroptering R. BR. Sporan gia receptaculo glohoso, e medio venae pedicellato imposita, soros glohosos formantia. Ind $\mathrm{n}$ s i a receptaculis substrata, globosa, elausa, ver tice longitudinaliter bivalvia. - Filix nepalen sis, stipite pedali, fronde membranacea, triplicatopinnata.

Spha exopteris Wallickpl. As, rar. I. 41.t. 42. Sehot: gen. Filic. fasc. $r$. $t$. 4. P e ran e ma Don nepal. 12 Podeilema R. Brown msc. Prionopteris Wall. cata. log. n. 184.

SUIBCRED II. CYATHEACEAE Endl. prodr. Fl. Norf. 15. S porangi a in receptaculo saepe plus minus elevato sessilia, annulo lato excentrico. Sp or a e triquetrae $v$. trilobae.

B50. Tlayrsopteris $K U N Z$. S porangia in receptaculo breviter pedicellato sessilia, soros globosos formantia. Indusia spuria, e frondis partitionibus contractis formata, primum subglobosa, sensim vertice aperto poculiformia, insertione laterali obliqua. _ Filix in insula $\mathbf{s}$. Juan Fernandezab. Bertero reperta, frondibus triplicato-pinnatis, pinnulis pinnatifidis, lobulis infimis fertilibus.

Th y r o p te $r$ is Kunze in Linnaea IX. 507 .

651. II Temaitelia R.BR. S p o rang i a re ceptacnlo e latere venae simpliciasculae orto im posita, sor os subrotundos sparsos formantia. Ind $\mathrm{s}$ i a receptaculo subtus inserta, extrorsum libera, tandem reclinata. - Filices in America tropica et in Capite bonae spei obviae, caudice saepissime arborescente, frondibus pinnatis, bipinnatis, tripinnatisve.

Hemitelia R. Brown prodr, 158. Cyatheae sp. Smith., Hamb. et Boupl.

65ะ. Alsoplhila $R$. BR. S porangia in receptaculo globoso v, oblongo, e venae bifureatione v. medio orto sessilia, s oros sparsos seriatosve, interdum subconfluentes formantia. Indusia e pilis squamisve laceris receptaculi. - Filices plerumque arborescentes, inter tropicos utriusque orbis, et in Australasia extratropica obviae, frondibus bipinnatifidis bipinnatisve.

A Is o phil a R. Brown prodr. 158. Hook. et Grev, ie, $t$. 213-215. Mart, pl, crypt. Bras, 62, t, 37-51. C y a the a e 8 p. Swartz et Auet. - C h n o op h or a Kanlf. enum. 250. Cyathea villosa Humb. et Bonpl. - Trichipteris Presl, delic, prag. 172, Sehott gen. Filic. fasc. T. 2.5. A m. phidesmi um Schott $l$. $c$, in not. (Hook. et Grev, ic. $t, 232$. - Arachniodes Blum. enum.pl.Jav, ${ }_{\text {. }}$ 241. - G y m no. sphatera Blum. enum. pl. Jav. II. 242.

653. Cyathea SMITH. Sporangia in receptacnlo subgloboso, e venae bifureatione $\mathbf{v}$, medio orto sessilia; soros hemisphaericos v. subglobosos formantia. Ind us ia receptaculo substrata, globosa, clausa, demum lacero dehiscentia, v. irregulariter circumscissa. - Filices habitu et patria ab Alsophilis non diversae.

C y at he a Smith in Mtem, Acad. Turin, V. 417. Sclihahir crypt, t. 132, 133. Hook. et Grev. te. $t, 106$. Mart. pl. crypt. Bras. 75. t. 59-54. S phaeropteris Beruh, in Schrad. Journ. 1800, II, 122, $t, 1, f, 1$.

654. Mattonĩa $R$. BR. Sporangia circa receptaculum ex anastomosi plurium venarum 
orto uniseriata, soros subglobosos formantia. I ndus ia depresso-sphaerica, clausa, basi tenuiter membranacea mox evanescente. _ Filix sesquipedalis, fronde pinnata, pinnis linearibus pinnatifidis, in monte $O$ ph ir prope urbem Mala cc a reperta.

M a t to a i a R. Brown in Wall. pl. As. rar, I, 16. t, 16 .

SUEOTED TII. PARKERIEAE Hook. et Grev. ic. 97, Spor angi a hypophylla, tenuissime membranacea, annulo incompleto lato, basi approximato, interdum obsoleto cincta. - Aquaticae.

855. Ceratopteris BRONGN. Sp orangi a annulo lato articulato completo cincta, venis Jongitudinalibus imposita. Sp or a e globosae, trifariam striatae. In d $\mathbf{n}$ si um e margine frondis revoluto ortum, hyalinum, sutura longitudinali dehiscens. - Filices annuae, in aquis stugnantibus Asiae et Africae tropicae crescentes, frondibus crassis sueculentis, sterilibus infimis sinuatopinnatifidis, inferioribus bipinnatifidis, fertilibus tripinnatifudis.

C eratopterls Brongn. in Bullet. soc. philomat. 1821. p.184. c. ic, Gaudich, voy. Freye. t, 20, - E11 o b o c a rp us haulf. onum. 14. Entrickl, der Farrenkr, f.7-9. - T eI eоz о ma R. Browa Append. to Frankl. narrat. 767. Cryptogenis Rich. msc. - Furearia Desv. in Annal. soc. Linn. Paris, VI. 299, - Cryptogramma Grev. ex Desv, l. c. p. 336 .

658. Farlkeria HOOK. Sp orangia annulo basilari subobsoleto cincta, venis longitudinalibus imposita. Sporae trigonae, concentrice striatae. In dusium e margine frondis revoluto. - Filices in aquis stagnantibus Americae tropicae observatae, frondibus sterilibus sinuato-pinnatifidis, sinubus bulbilliferis, fertilibus bipinnatifidis. - Genus vix satis a praecedente diversum.

Parkeria Hook. exot. Fl. t. 1/47, et 231. Hook. et Grev. ic. $t .97$.

\section{Drdo XX II. IIymenophyllece.}

HYMENOPHYLLEAE Endl, prodr. $F l$, norf. 16. Mart ic. pl. crypt. Bras. 102.

Sporavgra receptaculo e vena ultra frondis marginem producta imposita, sessilia, a n n u10 completo, excentrico, quo ad insertionis punctum transverso. Sporae hine convexae, inde tetraëdro-pyramidatae. Indusi u m textura frondis. - Cavdex repens, frondes tenerae, subpellucidae, hygrometricae, stomatiis destitutae, vernatione circinnatae.

65\%. IIrmenogliglium SMITH. S p o$r$ angia circa venam ultra frondis marginem in colum ella m subclavatam productam sessilia, indusio frondi continuo bivalvi cincta. Filiculae tenellae, frondibus lobatis, pinnatis aut decompositopinnatifidis, inter tropicos et in $h e m i s p h a e-$ rae australis regionibus extratropicis temperatis et frigidiusculis obviae, species una cosmopolita.

Hymenop hy 11 um Smith Fl, brit, 111, 1141. Schkuhr crypt. t. 135. Labill, Nov. Holl, t. 250, Raddi $p l$. Bras, t.79. Gaudich, voy. Freye, $t, 5$. Bory in Duperr. voy. t.38, f.3. ad Belang. t. 8. A. Rich. Fl. Nov. Zeel, t, 14. Hook. et Grev. ic. t. 34. 35, 60.76. 77, 83, 84. 123, 124. 127-129, 133, 135, 148 . 167.196-198, 208, 219. Mirt. pl. crypt. Brus. 107, t.67.

\$58. Thoîtela omanes $L I N N$. S p orang i a circa venam ultra frondis marginem in e olu melI a m filiformem productam sessilia, ind u s i o frondi continuo cyathiformi cincta. - Filiculae caudice repente, frondibus sparsis v. caespitosis, lobatis pinnatis aut decompositis, in tropicis imprimis novicontinentis, et in haemisphaerio australi extra tropicos provenientes, species una in Hibernia vivit.

Trieh omanes Lino. gen, n. 1181. excl. sp. Sebkuhr erypt. t. 13i. Hook. exot. Fl. t.52, 76. Gaudich. voy. Freyc. t. 12. Raddi $p l$. Bras. $t, 79$. Bory in Duperr, voy, $t, 38$, ad Belang. t. 8 , Hook. et Grev, ic. $t, 9.13,31-33,78,85,115$. 117. 199 155. 166. 179. 199. 201. 201. 206. 211.218.236. 240. Mart. pl. crypt. Bras, 164. t. 68. - D i d y mog los s $\mathrm{um}$ Desv, in Annal, soc. Linn. Paris. VI, 330. - H y meno. staehys Bory in Dict. class, VITT. 468, c, ic, Trieho. manes elegans Rudg. guian, $t, 35$. (pro parte.) - Feea Bory in Diet. class, DJ, 446. $c$. ic. Tric homanes ele. g a ns Rudg.guian. $t, 35$. pro part. (frondis parenchymate dis. soluto, venis fertilibus sxperstitibus spicau mentientibus.)

\section{Dralo XIXIIT. Gleicheniacene.}

GLEICHENEAE R. Browa pror. 160. Kanif. enum, 36. GLEICHENIACEAE Mart. ic, pl. erypt. Bras, 10 s.

Sporangia hypophylla, sessilia, annulo completo, lato, striato, transverso v. subobliquo, introrsum transversim dehiscentia. Sporaz oblongae v. reniformes. Indusiu m nullum v. spurium e margine frondis revoluto. Caunex repens, frondes stipitatae, pinnatae, dichotomae, furcatae, pinnis saepissime pinnatifidis.

6.5D. Aleielnemia SMITH. Sp orang ia in soros subrotundos collecta. Indusium nullum. - Frondes furcalae $v$, dichotomat.

Gleichen ia Smith in Mem. Acad, Turin. $\mathcal{V}$. 118. R. Brown prodr, 160.

a) GLEICHENIA. Sporang $\mathrm{i}$ a in soris definita, subimmersa. Capenses et australasicae.

Gleichenia Smith $l, c, t .19 . f .10$. Scbkulir crypt. $t$. 149. Mart. $p l$. erypt. Bras. t.59. fig. $I T$.

b) MERTENSIA Willd. Sporang ia in soyis subindefinita, pauca, superficialia, globosa v. lenticularia. Ame. ricanae tropicas.

Mertensia Willd, $s p, \mathcal{V}, \pi 3$. Mart, $p l$, crypt, Bras. 106. $t, 59 ., f, 1, I$. $t .60$. Gl e ic he niae sp. Hook, et Grev. ic. $t .15$.

c) DICRANOPTERIS Bernh. S p o rang i a in soris indefinita, molta, superficialia, ovata v. pyriformia. Americanae, indicae, capenses, australasicae.

Dicranopteris Bernh. in Schrad. n. Journ. 1816. $t$. 3. $f, 13$, Merten s ia e s p. Auet, Mart. op. cit. $t, 60$. $f .2$. Gleichenia sp. R. Brown. Hook. et Grev. ic. 1.14.

680. IPlatyzoma $R$. BR. Sporangia in sorum punctiformem collecta. Indusi um spnrium, e margine frondis revoluto. - Filicula glabra, in Nova Hollandia tropica reperta, caudice repente, frondibus indivisis pinnatis, pinnis orbiculatis, subtus sulphureo, pulverulentis.

Platy z om a R. Browa prodr, 160. Guillem. ic. lithogr. t.13. - Genus a praecedente nullo pacto diversum ceuseo, 6. a 1 pina R. Br. (Hook. et Grev, ic, t. 58.) characterem artiticialem etiam infringente.

\section{Drdo XXIX. Schizaencene.}

SCHIZAEACEAE Mart. $p l$, crjpt. Bras, 112.

Sporangia hypophylla, sessilia, vertice annulo completo, contracto, longitrorsum dehiscentia. SporaE pyramidales v. conicae, sporodermi cristata v. echinata. In d us ia varia. - Frondes variae, interdum volubiles, vernatione circinnatae, fertiles contractae.

661. Aneimia $S W A R T Z$. S porangia in frondis laciniis lateralibus geminatis, in rhachin multiplieato - paniculatam immarginatam contractis, biseriatim sessilia, nuda, extrorsum longitudinaliter fissa. Indusium nullum. - Filiculae in 
Americatropica et extratropica australi obviae, nuperrime etiam in Capite bonae $s p e i$ observatae, rhizomate ascendente $v$. repente, frondibus stipitatis, sterilibus ternatis, pinnatis, bipinnatifidis decompositisve; fertilibus ternato - pinnatis supradecompositisque.

A n eimia Swartz synops. 155. Schkuhr ergpt. t. 141. 142. Hook, exot. Fl, t, 28. Hook, et Grev, ic, $t, 16$. Raddi $p l$. Bras, t.8-13. Mart. pl, crypt. Bras, 112, t.55, 58. 0 г n ithop teris Bernh. in Schrad. Journ, 1806, I. 50. t.3.

862. Selnizmea $S M I T H$. S porang i in laciniis linearibus membranaceo-marginatis, in apice frondis pectinatim oppositis digitatisve bi-quadriseriatim sessilia, pilis stipata, extrorsum longitudinaliter fissa. In d $\mathbf{n}$ si u m nullum. - Filices in regionibus tropicis subtropicisque parce provenientes, rhizomate setoso, frondibus simplicibus stipitiformibus $v$. dichotome partitis aut flabelliformibus.

Sehizaea Smith in Mem. Read. Turin. V.419, t.9.f.9. Schkuhr erypt, t.136.137. Kaulf. onum, t,1.f. 7 . Guillem. ic. lithogr. t. 20. Hook, et Grev, ic. t, 17. 47, 48, 54. Bory in Duperr. voy. t. 27. Mart. pl. crypt. Bras, 115. t. 55. 56. L o. phidium Rich. Rhipidium Bernh. in Schrad. Journ. 1802. $I 1,127, t .2, f, 3,-$ A ctinosta ehy 8 Wall, catal. n. 1. Schizaea digitata Swartz (efr. Mart. $l$. c.)

683. Tyzoditum $S W A R T Z$. Sporang ia in laciniis marginalibus frondis alternatim biseriata, sessilia, longitudinaliter dehiscentia, singula indusio squamaeformi, cucullato, venis transversim adnato velata. - Filices in $t$ rop $i \mathrm{cis}$ totius orbis obviae, in regionibus subtropieis admodum rarae, caudice volubili, scandente, frondibus conjugatis, palmatis, lobatis, pinnatisve.

Lygo di m Swartz in Schrad. Journ, 1801. II, t. 2, $f$. 2. Schkuhr crypt, $t, 189,140$. Kaulf, enum, $t, 1, f, 6$. Hook, et Grev, ic. t. 55. A. Rich, Fl. Nov. Zeel. t. 15. H y d roglos $\mathrm{nm}$ Willd. in Let. Acad. Erfurt, 1802. p. 24. Raddi pl. Bras, t, 81. Ugena Cav. ic. t, 893 . C $\mathrm{t}$ e is $\mathrm{fum}$ Rich. in Michx. Fl, bor. Amer. II. 275. R a mo nd ia Mirb. BulZet. soc. philomat. XI. 179. O do nto pt eris Bernl. G iso p ter is Bernh. in Schrad, n, Journ, I, 129. Valli. Fi. Iix Thouar, gen, madagasc, $n, 1$.

6๕4. VIIolneia $S W A R T Z$. S p or ang ia juxta marginem frondis uniseriata, sessilia, extrorsum Iongitudinaliter dehiseentia. Indus i um spurium e margine frondis revoluto. - Filicula spithamea, in Capite bonaespei et in insulis Mas c a renis habitans, fronde bipinnata, paleacea.

Mo h ri a Swartz synops. 159, t, s. Schkuhr crypt, t.143, Polypodiom Caffrorum Linn.

\section{Ordo XX. Osmandacene.}

OSMUNDACEAE Mart. consp. 3.

Sporangia hypophylla, v. frondibus contractis paniculata, pedicellata, tenuissime membranacea, annulo dorsali lato incompleto, vertice dehiscentia. Sporaf oblongae v. subglobosae. In d u si a varia. - Frondes bipinnatae, stomatiis praeditae, vernatione circinnatae, fertiles saepissime contractae.

BB5. Dsmanda LINN. Sporangia in panieulam v. juxta frondis marginem disposita.

Filices in temperatis et frigidiusculis utriusque hemis phat rii, borealis potissimum, provenientes, frondibus bipinnatis, fertilibus saepe contractis paniculaeformibus.

$0 \mathrm{sm}$ u $\mathrm{n}$ da Linn. gen, n. 1172, excl. sp. Swartz in Schrad. Journ, 1801. Ir. t.1. f. 4.5. Sehkuhr orypt. t.144156. Bernh. in Sehrad. n. Journ. 1. 2, p.40.41. Kumze in

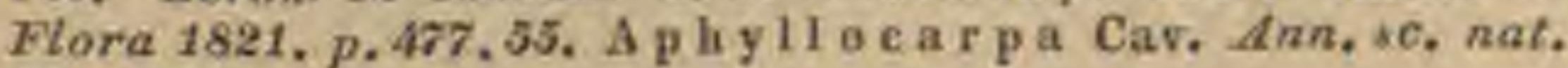
V. $\pi, 14$.
866. Todlea $W I L L D$. Sporangia venulis frondis imposita. - Filices in Capite benae spei, Nova Hollandia extratropica et Nova $Z$ e elandia repertae, frondibus bipinnatis.

To de a Willd. in Act. Acad. Erf. 1802, p. 14. Schkuhr crypt. $t$. 147. Kaulf, enum, $t .1, f, \delta$. Hook, et Grev, $i c, t, 101$ A. Rich. Fl. Nov. Zeel. t. 16 .

\section{Drdo XXX页. Mlarationcene.}

MARATtiaCEAE Kaulf, enum, 31. Brongn. hist, veg̈. foss. 14\%. Gaudich. voy. Freyc. 291. MESODMEAE Blum. onum. pl. Jav. II. 260.

Sporangia hypophylla, exannulata, sessilia, distincta $v$. inter se connata, vertice $v$. latere aperta. Sporas ellipsoideae. Indus iu m nullum, superficiale v. cum sporangiis concretum. - Frondes simplices, pinnatae $v$. triplicicato-pinnatae, foliolis semper elongato-lanceolatis integris, stomatiis praeditae, vernatione circinnatae.

6e\%. IKaulfussia $B L L M$. Sporangia venarum anastomosi imposita, radiatim connata, so r o s subrotundos formantia, vertice rima aperta. Indusinm nullum. - Filix $j o$ anica, fronde stipitata, ternata.

$\mathrm{K}$ au ifussia Blum, enum, pl, Jav, II, 260, Hook, et Grev, ic. $t$. 229 .

658. Angioptexis HOFFM. S p or a ng i a juxta venarum transversarum apicem biseriatia, distincta, sor os lineares formantia, latere exteriore rima aperta. Ind us i $\mathbf{u m}$ nullum. - Filix arborescens, frondibus bipinnatis, in Oceania tropic a erescens.

Angiopteris Hoffm. in Comment, Götting. XIT, 29. t. J. Swartz in Schrad.Journ. 1801, p. 306. Bernh, in Sehrad, n. Journ, I. 2, p. 42, t.2. Kaulf, enum, t.1. f.4, Hook, et Grev. ic. t.36. CI e m e 1 t e a Cav. praelect, $n, 1164$.

689. Dantea $\$ M I T H$. S porangia juxta venas transversas biseriata, in 80 ros lineares connata, poro aperta. In $\mathbf{u} s$ i a superficialia, soros cingentia. - Filices in Americae tropic a e littoribus provenientes, caudice erecto, fronde simpliciter pinnata, pinnis integris.

D a na e a Smith in Mem. Acad. Turin, V. 420,t.9.f.11. Kaulf, enum, 33. t.1.f.3. Hook- et Grev, ic, t, 18,51.52.

6r0. Marattia SWARTZ. Sporangia juxta venarum transversarum apicem biseriata, inter se connata, soros oblongos formantia, rimula verticali transversim hiantia. In dusia coriacea, cum soris connata, longitudinaliter bivalvia. _ $\mathrm{Fi}$ lices elegantissimae, frondibus stipitatis, bipinnatis triplicato-pinnatisque, in America tropica, Africa extratropica, nec non in Oceania intra et extratropicos crescentes.

Marattia Swartz synops. 168. Smith ic. inedit. 1 . 17 . Schkube crypt. t.152. Labill, Nov, Caled, $t .13 .14$. Raddi $p l$. Bras. t. 81. Mart, ic. pl. orypt. Bras. 119. t.69-72. Sehott gen, Filie. fasc, III. $t .5$. My riotheca Commers. in Juss. gen. 15. Cel a n th e r a Thouin Mem, Aead, Paris, 1786. OBSERV. Ta eniopterides fossiles (infr. n. 683.) Marattiaceis esse adscribendas, nullus dubito.

\section{Ordo XXXII. Opleioglosseae.}

OPHIOGLOSSEAE R. Browa prodr. 163. Kaulf. enum, 29.

Sporangra sessilia, unilocularia v. septo transverso incompleto subbilocularia, exannulata, coriacea, evasculosa, distincta v. inter se connata, semibivalvia. Spozak farinaceae. Frondes caule rhizomatoide exclusae geminae, bilormes, vernatione strictae, altera 
expansa sterilis, stomatiis praedita; altera in rhachin contracta.

68 1. Dplaionlossum LINN. Spora ngia in spicam disticham articulatam connata, unilocularia, transversim dehiscentia. - Filiculae in to to orbe terrar $u m$ obviae, fronde sterili late ovata, fertilem vaginante.

Ophioglos s um Linn. gen, n, 1171, excl.sp, Kaulf, in Flora 1822, I. 97.ss, Fl, dan, t, 147, Hook, et Grev, ic, t, 20.40. 80. Mart, pl. crypt. Bras, 39. ₹. 49.

6ร2. Oplhioulereana $B L$. S p orang i a in spicam disticham articulatam connata, incomplete bilocularia, transversim dehiscentia. - Filix spicis solitariis geminisve pedunculatis, e basi frondis linearis elongatae indivisae $v$. apice furcatue, ex arboribus Moluccarum et Oceaniaetropicae pendula.

Ophioderma Blum. enum. pl. Jav. II. 259, O phioglos 1 um pendutam Linu. Hook. et Grev, ic, $t .19$.

G58. Helminathestaclays $K A U L F$. S p orangia in spicam densam subcylindricam glomeratim connata, unilocularia, semibivalvia. - Filicula Asiam tropicam incolens, fronde ternatim composita, laciniata.

H elm int ho s ta chys Kaulf. enum. 28. $t, 1 . f .1$. B otryopteris Presi in Reliq. Haenk. t.12. f. 1 . Ophiala Desv, in Annal. soc. Linn, Paris, VI. 195. Ophiogloss um 1 acinintum Rumph Amb. VT. t, 68.f,3.

6r4. Botryeloium $S W$. Sporangia distincta, in spicam compositam disposita, unilocuTaria, semibivalvia. - Filiculae frondibus pinnatis bipinnatisve, in temperatis hemisphaeriiboreaIis obviae, in regionibus antareticis rarissimae.

B otry ch in m Swartz synops. 171. Schkuhr crppl, 154. 155. Hook, et Grev, ic. $t, 19.82,161$. B o try pus Rich. in Mich. Fl, bor. Amer. II. 274.

\section{APPENDIX. FILICES FOSSILES.}

Gร5. Frelaypteris BRONGN. Frons pinnata $v$. bipinnata; pinnula e coriaceae, integerrimae, enerves, v, nervo simplici percursae, basi constrictae, nee rhachi arnatae. S o ri. . Oolithes inferior.

$\mathrm{P}$ a c h y pter is Brongn. prodr. 50. Hist.veg. foss. 166 . t.45.f. 1.2. S p he nopteris 1 a ni e o I a t a Phillips Yorksh, t. 10. f.6. Neuropteris laevigata Phillips op. cit, $t$. 10. $f .9$.

626. Splnemopteris BRONGN. Frons bi-tripinnatifida; $p$ innnla e basi constrietae nee rhachí adnatae, Iobatae, lobis inferioribns majoribus, subdivergentibus; $\mathbf{n}$ ervis bipinnatis, subflabellatis. Sori... In terra oolithica inferiore, poecili et lilhanthracum.

S phen opteris Sternb. Tent.15. (FI. der Vorw. t,23. f. 2, t. 31. f.3. $t, 36, f .5 ., t .42, f .4 . t .5 t$. f. 1 .) Brongn. prodr. 5o. Hist. veg. foss. 169. t. 16-58, Phillips Yorksh, t. 8. f.6. 7. t. 10. f. 8. Lindl. foss. fl. t. 45-48, 53.100, 101. 109. 115. 193. 131. 138, 146, 147, 148, 181, 156, 164, 168, 176, $a$, H y m enopteris Mantell Sussex. t.3. f.7. t, 3. f. 2, t.20.,f.1.2.

6\% . Cyelopteris BRONGN. Frons simplex, suborbicularis v. reniformis, integerrima, enervis; venis plurimis subflabellatis, dichotomis, aequalibns. So ri. . - In terra oolithica inferiore, in terra lithanthracum, et in anthracite transitionis.

$\mathrm{C}$ yelopteris Brongn. prodr. 31 . Hist, veg. foss, 215 . t.61. $t, 61 .{ }^{*}$ Lindl. foss. h. ,64.90.91. (Parkins, organic. rem, $1, t, 5, f, 5$.

OBSERV. Cycl opterides plurimae, monente amic. Göp pert, aliarum Filicum germinantium protophylla.

689. Dtopteris $L I N D L$. Frons pinnata; pinnae basi subobliquae, auriculatae, sessiles, integerrimae, enerves; ven is flabellatis con- fertissimis. Sori. Terra oolothica et calx Gryphitum.

0 to $\mathrm{p}$ te $\mathrm{r}$ is Lindl. foss. fl, $t, 128,132,150,155 . \mathrm{C}$. clopteris Beanil Lindl, op. cit. $t$. 44. Neuropteris $\mathrm{D}$ u f r es n oy i Bronga. Hist. veg. foss, t.74. f.4, 5 ,

6ร. Glossomteris BRONGN. Frons simplex, integerrima, sublanceolata, basi sensim angustata; nervo primario valido, apice evanescente, secundari is obliquis, areuatis, repetito-dichotomis, basi interdum reticulatim anastomosantibus. S ori. . - Terra oolithica media, arena calcis Gryphitum, terra lithanthracum.

Glossopteris Brongn. prodr. 51. Hist. veg. foss, 929, t. 61.* f.5. 1.69. 63. f. 2,3. Lindl. foss. $f$. t. 63, Filici-

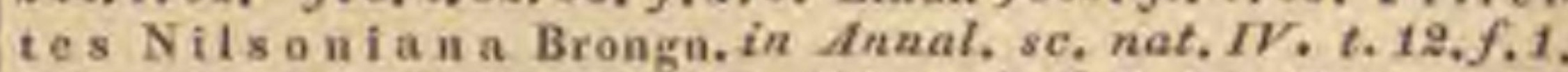
(Nils, in Act, Holm, 1820. T, 115. t. 5. f. 2. 3.) Pecopte. ridis sp. Phillips Yorksh, t.8. f.8.

680. Newropteris BRONGN. Frons uni-bipinnata; p innulae basi subcordatae, a rhachi distinctae; nervo medio validiusculo apice cvanescente, secundariis obliquis arcnatis, repetito-diehotomis. S o ri oblongi, paulo supra nervorum bifurcationem siti, ind $u s$ io ramulo exteriori inserto, introrsum aperto. - In terra lithanthracum frequens, parcior in terra poecili.

Ne u r opteris Brongn. prodr.52. Hist.veg. foss, 226.

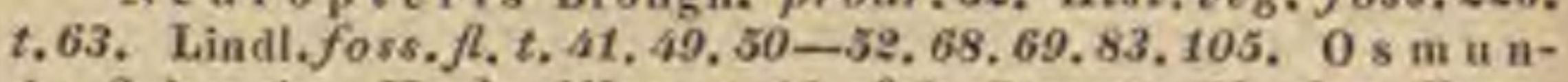
da Seheucliz, Herb. diluv, t.10.f.3. Sternb. Fl. dor Vorw. t.32. f.2.

681. Dilontopteris BRONGN. Frons bipinnata; pinnulae tenuissime membranaceae integerrimae, basi lata rhachi adnatae; n ervo medi o nullo, secundari is tenuissimis, simplicibus v. furcatis, e rhachi nascentibus. Sori. . In terra lithanthracum.

Od o ntopteris Brongn. prodr. 60. Hist, veg. foss. 250, t.75-78. Lindl. foss. fl, t. 40 .

682. Amomopteris BRONGN. Frons pinnata; pinna lineares integerrimae, basi inter se et eum rhachi connatae v. distinctae; nervo medie valido, secundariis suboppositis ad angulum rectum divergentibus, arcuatis; (folii substantia inter nervos infiata, subbullata.) Sori subrotundi, in nervulis solitarii. (Nervuli in apice pinnarum sterili confertiores soros lineares arcuatos mentiuntur.) - In terra poecili.

A n o m op teris Bronga- prodr. 69. Hist. veg. foss. 257. t. $69-71$.

683. Taeniopteris BRONGN. Frons simplex, integerrima, sublanceolata, basi angustata; nervo primario valido, apicem attingente, se cundari is suboppositis, fere ad angulum rectum divergentibus, simplicibus v. basi bifurcis. S ori punctiformes, remoti, in lineam nervo medio utrinque parallelam dispositi. - Terra calcarea Gryphitum et thalassico-calcarea vicentina. - Genus Marattiaceis affine.

T a en i op teris Brongu, prodr, 61. Hist, veg, foss. 269 . t. 82. Lindl. foss. fl, t, 62.92.176, b.

654. Peeppteris STERNB. Frons pinnatifida $v$. bi-tripinnatifida; pinnula e basi aequali v. dilatata rhachi adnatae, interdum confluentes, rarissime basi contractae; nervo primario valido apicem attingente, secundariis rectiuseulis, simplicibus v. fureatis, rarissime pinnatis. Sori subrotundi in nervis secundariis terminales, juxta marginem seriati, interdum subconfluentes. - In terra lithanthracum et in Oolithe._Genus dividendum.

Pecopteris Sternb. Tent. t. 23. f. 1. t, 26. f.3. t. 50 . f.5. t. $59 .$, . 2. Bronga. classif. t.. . f.3, Annal. sc. nat. IV. t. 19. f. 1.2. Prodr. 56. Hist. veg. foss. 207. t. $83-199$. Lindl. foss. A. t, 37, 38. 60, 84, 94, 106, 107, 119, 120.122. 126. 
134. 145. 153, 154, 157, 158, 169,174. A l e th o p t e r i s Sternb. Tent. t.53. f. 2. Filicites Sebloth, t. 4. f.7.8. t. 6. f.9. t. 8. f.13.14. t. 9. f. 16, t. 10, f. 19. 2.11. f. 22. 6.14. f. 27. Artis Antediluv, phytolog. $t, 4,17,21$.

685. Tomelnopteris BRONGN. Frons bi-tripinnatifida; pinnnlae rhachi adnatae; nervo medio apicem attingente, secundari is reticulatis, aequalibus, areolos uniformes formantibus. Sori. . - In terra carbonifera, et in sabulo ferruginoso infra cretam.

L on ehopter is Brongn. prodr. 59. Hist. veg. fass. 367. $t$. 131. Lindl. foss. $f$, t. 171. P e cop terid is s p. Mantell in geolog. Transact. IT. ser. $t .16 . f, 1, t, 17 . f .3$.

8S6. Illiebopteris BRONGN. Frons pinnatifida; $p$ innae basi coadnnatae; nervo primario valido infra apicem evanescente, sec und a riis juxta costam reticulatis, in nervulos simplices furcatosve excurrentibus. S ori subglobosi, juxta costam utrinque uniseriati. - Terra ootithica inferior.

Phle bopteris Brongn. hist. veg. foss. $t, 83$. f. a. $t$. 132. 133. Lindl. foss. $f$. $t$. 144 . D i e t y o p h y $11 \mathrm{um}$ Lindl. foss. l. $t .104$.

68\%. Clathropteris BRONGN. Frons pinnatifida; pinnae integerrimae; nervo medi o valido apicem attingente, nervis secundariis simplicibus confertis parallelis, costae perpendicularibus, nervulis transversis copiosis in areolos quadratos conjunctis. Sori. . . - In terra calcarea Gryphitum Scaniae.

Cl at hropter is Brong.prodr. 62, Hist, veg. foss. $t, 134$.

OBSERV. Filicum exstinetarnm plurimarum fructificatio. nes a el. Góppert nuper repertac fuerunt. Inventa viri amicissimi propediem eum orbe erudito eommunicanda, in praesentis operis usum' converti nondum potaisse, impense dolenus.

\section{Classis VIIr. Hydropterides.}

RHIZOCARPAE Batsch Tab, Afïn, Agardle Aphorism, 111. Bartl. ord. nat. 15. RHIZOSPERMAE Roth. DC. Fl. fr. 111, $3 z 7$, HYDROPTERIDES Wille. sp, $V$, 534. MARSILEA. CRAE R. Brown prodr, 166. SALVINIEAE Juss, in Mirb. elem. 833 .

Herbae aquaticae, cylindro vasorum centrali percursae. Fulia a caule discreta, sessilia v. petiolata, limbo saepius composito, interdum abortivo. Sporocarpia ad basim foliorum, uni-plurilocularia, organis dimorphis foeta.

\section{Ordo XXXIII. Salviniaceae.}

SALVINIACEAE Bartl, ord, nat. 15. Mart. pl. erypt. Bras. 123.

Herbae natantes, pinnatim v, radiatim ramosae, radiculosae, foliis alternis cellulosis, astomis, saepe papillosis. Sporocarpia in eadem stirpe dimorpha, prope foliorum basim sita; alia corpuscula angulata v. globosa (flores maseulos) inelndentia, uni-bilocularia; alia s p orangiis juxta colnmellam basilarem pedicellatis, sporas liberas paucas v. solitarias includentibus, foeta.

Salviniaceae Hepaticas aquaticas habitu mirabiliter revocantes, et quo ad partium fructificationis naturam maximopere dubiae, iterum iterumque in examen summendae, in aquis puris climatis temperati et tropici totius orbis terrarum repertae, universim in ex- tratropicis hemisphaerii anstralis paullo frequentiores esse videntur.

B89. Azolla LAM. Organa propagationis dimorpha, caulis et ramorum basi adnata, deorsum speetantia. Fem. S porangia plurima, globosa, longe pedicellata, indusio membranaceo, irregulariter fisso inclusa, granis globosis, pilosis foeta. M a s c. (?) discreta v. organi feminei lateri applicita, solitaria ant gemina, intra $c$ a ly ptram demum circumscissam, e vesicnla basilari materia grumosa farcta, et e columella huic imposita, vertice rum calyptra concrescente, tricruri, craribus apice in corpuseula antheriformia tumentihus, axi applicitis ejusque foveolac semiimmersis. - Plantae pusillae, Jungermanniae facie, in Nova Hollandia et in $A \mathrm{me}-$ rica a Canada ad Fretum magellanicum aquis purioribus innatantes, pinnatim $v$. radiatim ramosae, caulibus filiformibus, foliis alternis, imbricatis.

A z olla Lam. in Dict. encyclop. I. 343. R. Brown gen. Rem, 612. t. 10. Prodr, 166. Mart. pl, crypt.Bras, 123, t, 74. 75. Azolla et Rhizos perma Meyen Heise I. 337. -? Car $a_{\mathrm{n}} \mathrm{th}$ us Raf. in New-York medic. Reposit. H. Hex. V. 350 .

OBSERV. Differentia inter A zollas Lamarkii a mericanas (Azolla Mey.) et inter Azollas Brunonis anstralasieas (Rhizosperma Meg.) teste amicissimo Meye a posita est in crurium columnulae numero, et in gra. norum sporangil conformatione, in his angulatis, euspides 2-6 fasciculatos, radiculiformes exserentibus ; in illis sphaerieis, pilis hyalinis obsessis. - Mihi olim Az ollam pian at am dissecanti flos masculus ita conformatus videbatur. ut illum typice hermaphroditum habuerim, ovario infero efoeto, et synemate triandro donatum; organa pedicellata pro fioribus typice femineis deseripsl. Corpuscula in eruribus terminalia globulis $\mathrm{SaIviniae}$ anologa habui.

689. Salvinia MICH. O rgan a propagationis dimorpha, in ramis submersis aphyllis glomerata, radiculis fluitantibus stipata. F em. Sporangia plura subglobosa, ex apice colnmnae subclavatac pedicellata, indusio commun subgloboso, e membrana duplici lacunis interjectis connata inclusa, singula s p o r a solida foeta. I a sc. (?) Globuli sphaeriei, e columella penicillato-ramosissima pedicellata, intra indusinm subglobosum, e membrana pariter dupliei connata, contenti, materiam mucilaginosam recludentes. - Herbae aquaticae pusillae, caule natante, fitiformi, ftexuoso, foliis alternis imbricatis, in hemisphaerio boreali utriusque orbis, et in America $t r o p i c a$ pariter ac a u \& $t r a l i$ observatae.

$\mathrm{S}$ a I v i i a Michelf $n$. gen. 107, $t, 58$. Guettard in Hist. academ, roy, des sc. 1762 . p.546. ss. Duvernoy Dissert. de Salvinin. Tubing, 1825. 4to. c. ie. Bischoff in N. A. N. C. XIV. 45. ss. 4, 4. 5. Crypt. Gewächs, II, 95, t.9. f. 2-3, Mart. pl. erzpt. Bras, 129. $t, 75.76$. M a r $8 \mathrm{il}$ a e a Neck. elem, $n$. 1680. Marsilate s p. Lim.

OBSERV. De organorum, quae sporangia díximus, natara dubitare amplius non licet, postquam sub acutissimorum abservatormm oculis spora io his contenta, in novam plantam increvit. Globuli a plerisque pro maseulis organis habiti, rec. tius fortassis sporangia abortiva dicentar. Quid si in hao ge. pere organum columellae Azolla e revera comparaudam ad hac literet?

\section{Drdo XXXIV. MTarsilaeaceae.}

MARSILAEACEAE VERAE Brongn. in Dict, class, $x, 169$. Bartl. ord, nat, 15.

Ненвае in innndatis paludosis repentes. CAulis filiformis, prostratus, sarmentosus, radicans, intus longitudinaliter lacunosus; compositus e cylindro vasorum centrali, canale medullari percurso, et e strato cellularmm 
hunc ambiente, ope dissepimentorum radiantium cum stratis cellulosis, sub epidermide stomatibus pertusa sitis, conjuncto. Foura alterna; petioli caulis structura, vernatione circinnatim involuti, nunc lam in a destituti, nunc terminati foliolis quatuor, subverticillatis, haud articulatis, obovatis obeordatisve, stomatibus instructis, flabellatim dichotome venosis.

Sporocarpia capsulaeformia, uniformia, in axillis foliorum subsessilia $v$. juxta petiolnm varie disposita, solitaria v. aggregata, globosa v. obovata, coriacea, pilosa, nunc e carpidiis duobus (in foliatis) nune (in aphyllis) e carpidiis quatuor conflata, marginibus introftexis dissepimenta constituentibus bi- v. quadrilocularia; plus minus complete septicido bi-quadrivalvia; $10 \mathrm{culi}$ in quadrilocularibus continui, basi aequales, in bilocularibus septis secundariis membranaceis transversim plurilocellati, extus prope basim uno latere gibbi (rudimento carpidii alterius). Placentae parietales, subgelatinosae, plus minus prominulae, in Ioculis perpendiculares, in locellis horizontales.

Sporangia in loculis singulis locellisve dimorpha, perfecta (sporophora) et imperfecta (mascula?). Sporangia perfecta singula intra tunicam cellulosam, longitudinaliter placentae adnatam contenta, strato gelatinoso corticata, spora unica, basi truncata, apiculo mutico, in germinatione vaginam cotyledonarem exserente, instructa, foeta. S p or a ngia im perfecta (organa mascula?) in placentis perpendicularibus earundem partem superiorem obsidentia, in horizontalibus ad basim singulorum sporangiorum perfectorum bi natim v. subquaternatim sessilia aut pedicellata, vesicnlosa, globosa v. clavata, tandem irregulariter rupta, gran ula elliptica v. subglobosa, in mucilagine natantia, aut singula gelatina obvoluta pluentia.

Marsilaeaceac a Salviniaceis et Is o eteis, quibuscum olim confusae, petiolorum vernatione circinnata, et sporocarpiis liberis, uniformibus, valvatis, distinctissimae, in inundatis paludosis et aquis dulcibus omnium climatum hemis phaerae orientaIis vivunt, in novo continente nuper primum repertae.

890. Pillularia LINN. Spor angia axillaria, subglobosa, sessilia, quadrilocularia. $\mathrm{P} 1 \mathrm{a}-$ centae in loculis perpendienlares. Sporangi a perfecta inferiorem, imperfecta superiorem placentae partem obsidentia. - Herba e $и$ ro pa ea perennis, caudice repente, radicante, petiolis alternis aphyllis, lineari-subulatis.

Pill u lari a Vaill. bot, paris, t.15. f.6. Linn. gen, n.1183. Hedw, thear, t,8. Spreng. Anleit, t.2. f. 40. Bisehoft crpptogam. 94. t.8. f.1-6. 1. G. Agardh, dissertatio de Pillu. laria. Lundae, 1833. 8vo.
BD1. MHarsilaea $L I N N$. Sporocarpia juxta basim petiolorum pedicellata $\mathbf{v}$. subsessilia, globosa, hine gibba, bilocularia, locnlis transversim plurilocellatis. Placenta e in locellis horizontales. Sporangia perfecta singula basi imperfeetis binis quaternisve stipata. - Herbae perennes, in aquis stagnantibus om $n i u m$ climat $u m$, arctico et antarctice excepto, parcius tamen in novo continente obviae, caudice repente radicante, petiolis alternis, erectis, foliolis quatuar subverticillatis, haud articulat is terminatis, vernatione circinnatis.

Mars fl a e a Limn. gen, $n$, 1184. Spreng. Anleit, IT, 2,2 . f.42. Delille Fl, aegypt, t. 50. Hook. et Grev, ic. Filic, t, 159 . 160. Biselsoff creptogam, 95, 1, 8, $f, 30-37$, A. Brongn. Dict. class. X. 198. c. ice. Le m ma Juss. gen, 16 , Z g 1 uzia a 8 kia Neek, elem. $n, 1708$.

\section{GENUS FOSSILE, MARSILAEACEIS AFFINE.}

69). Splhemophyllam BRONGN. C a nle s simplices v. ramosi, articulati, vestiti fol i olis verticillatis senis, octonis, denis duodenisve, cuneiformibus; nunc integris, apice truncatis, denticulatis; nunc bilobis, lo b is bipartitis v. laciniatis; nune bifidis, lobis linearibus angustis. - Terra lithanthracum.

Spheд op h y II um Brongn. classif. $t, 2, f, 8$. Prodr. 68. - Rotularia Sternb. Flor, protog. t, 26. f. 4. t. 50. f.4. t.55. f.4. Bischoff oryptogam. $t .13 . f .1-3$. Kaulf. et Germ. in N. A. N. C. XV.2. t. 65. f.3, t.66. f.1. $\mathrm{P}$ a $1 \mathrm{mac}$ tes verticillatus Sehloth. Petref. 396. Sternb. t.2. f.8.

OBSERV.Sphen op h y 11 a habitu Marsilaeam satis bene quidem referunt, folioram numero et dispositione distícta, ast vera affinitas, partium fructificationis vestigiis nondum observatis, admodum dubia est.

\section{Classis $\mathbf{T}$. Selagines.}

LYCOPODINEAE Bartl. ord, nat, 19. LYCOPODALES Lindl. introduct. ed. 2. p, 408.

Truncus foliatus, fasciculis vasorum centralibus percursus. Sponocarpia in axillis foliorum v. bractearum, saepissime valvata, sporis dimorphis foeta.

\section{Ordo $\mathrm{X} \times \mathbf{X}$. Isoetecte.}

ISOETEAE Rieh. Bartl. ord, nat, 16.

Herbae submersae, trunco ábbreviato, subnullo, discoideo, centro depressiusculo, carnoso, e cellulis hexagonis, materia amylacea repletis, et e vasorum intricatorum glomerulo centrali, fasciculos vasorum versus folia et radices arcuatim radiante compositus. Radices e basi lateribusque trunci fascienlatim enatae, filiformes, radiculosae, cavae, vasorum scalariformium fasciculo excentrico percursae.

Folia numerosa, trunco concentrice imposita, subulata, stricta, fragilia, dorso convexiuscula, facie subcanaliculata, e basi dilatata, utrinque membranaceo-auriculata amplectente, sensim angustata, cellulosa; ductibus aëreis quatuor, transversim septatis, versus apicem deliquescentibus, et nervo subexcentrico, e vasis annulatis composito, facie interiori prominula, percursa ; stomatibus destituta.

Sporocarpia basi foliorum dilatatae, excavato-impressae, sub squamula cordi- 
formi, et processu membranaceo semilnnari immersa, plano-convexa, ab apice usque ad medium longitudinis folii nervo medio dorso suo adnata, tenuissime membranacea, intus filis numerosis transversis, e pariete dorsali radiatim exeuntibus multilocellata, repleta nunc sporangus primitus quaternatim connatis, ovatis, glabris, granulis ovalibus v. ellipticis, linea longitudinali percursis, farctis; nune corpusculis tetraedris, crusta muricato-granulosa, irregulariter secedente obductis, annulo concentrico inaequaliter bipartitis, medietate superiore majore radiis tribus versus apicem confluentibus percursis, germinatione undique in truncum incrassatis.

Is o et a a genere unico, paucisque speciebus per Europam, Asiam mediam et australem, nec non $\Lambda$ mericam b or eal em hucdum repertis, comprehensae, quo ad fructificationis naturam maximis opressae dubiis, ob sporas dimorphas, in diversis receptaculis contentas, et analogam trunci structuram intimam $\mathrm{S}$ elaginibus accensentur.

695. Isoetes LINN. S poroc arpia basi foliorum immersa, iisque dorso adnata, evalvia, transversim pluriseptata, corpusculis dimorphis foeta. - Herba acaulis, foliis radicalibus lineari-subulatis, basi dilatatis.

Is o e tes Limn, gen, n, 1184. Spreng. Anleit, t.2. f. 41 . Wahlenb. A. lapp, t.26. Tausch in Flora 1819, p. 501. DC. organogr. II, 140, t.56.57. Bischoff eryptogam, 95. t. 9. f. 35-ai, Delille in Mem. Mus. XIV, 100, 6,6.7. Cala maria Dillen. musc, šit.

\section{GENUS FOSSILE, ISOETEIS AFFINE.}

694. Stiomaria BRONGN. Truncus axi distincto, plerumque excentrico, fasciculos vasoruin spiraliter versus folia emittente percursus. Folia simplicia vel bifureata, linearia (verisimiliter carnosula), basi attenuata, cicatrices rotundatas relinquentia. - Lithanthraeum fodinae.

Stiguaria Brongn. prodr. 87. Lepidodendron anglicam et WeItheimia a u m Sternb. A.protog.t.29. f.3. t. $58, f .3, V$ ariolarial ficaides Sterub.

\section{Drdo XXXVI. Lyeopodiaceae.}

LYCOPODINEAE Swartz synops, 87. R. Brown prodr. 164. Agardh aphorism. 112. Hook. et Grev. in bot. Mise. $I I$. 360. ss. Bartl. ord, nat. 19. LYCOPODIACEAE DC. Fl. fr. IT. 257. Brongn, in Dict, class, IX, 561. Lindl, introduct. edit, 2. 403 .

Plantae herbaceae perennes, ant suffrutescentes, rarissime annuae; caule erecto v. postrato, tereti, angulato v. compresso, alternatim v. dichtome ramoso, folioso. Folia spiratim cauli inserta, saepissime conferta, imbricata, simplicia, semper sessilia v. decurrentia, numquam articulata, plernmque subulata, plana v. lanceolata, uninervia, ex axillis radiculas filiformes emittentia. Sponocarpia in axillis foliorum, nune juxta totam caulis longitudinem v. juxta ejusdem apicem sessilia, aut brevissime pedicellata, nunc in apicibus ramulorum, foliis in bracteas squami- formes mutatis stipata, amenta formantia, tritetracocca, cordiformia v. reniformia, v. subglubosa, uni- v. rarius bi-trilocularia, bitrivalvia, plerumque uniformia, interdum in iisdem individuis biformia; alia bivalvia pulvere farinaceo, e granulis tetraedris glabris vel papilloso-spinulosis quaternatim cohaerentibus, foeta; alia tri-tetracocca, tri-quadrivalvia, corpusculis paucis subglobosis, vertice rhaphe tricruri notatis, foeta.

Lycopodiaceae super terram v. in arborum truncis, rarissime in saxis viventes, inter tropicos copiosissime crescunt, in hem is phaera boreali montium juga celsiora, et regiones frigidiusculas eligunt.

695. Fistotam R. BR. S porocarpia sessilia, uniformia, bi-trilocularia, rima verticali incomplete bi-trivalvia, pulvere farinaceo foeta. Herbae perennes; inter trapicos utriusque orbis et in hemisphaerae australis regionibus temperatis saepissime epidendrae, caulibus simplicibus v. furcatis, foliis sparsis, interdum minimis, sterilibas indivisis, fructiferis bipartitis, sporocarpiis sub divisione folii insertis.

Psilotum R. Browa. prodr. 164.

a) TMESIPTERIS Bernh. Caulis simplex, angulatus. Folia majuscula. Sporocarpia bilocularia, loeulis bivalvibus.

Tmesipteris Bernh. in Schrad. Journ. 1800. 131 2. f. 5. Schkuhr t. 165, b. Labill. Nov. Holl. t. 252.

b) PSILOTUM Swartz. Caulis dichotomus, compressus, subtriqueter. Foli a minutissima, setiformia. S p orocarpia subglobosa, triloeularia, loculis incomplete bivalvibus.

Psllotum Swartz in Schrad. Journ. 1800. II. 132. Synops, t. 4. f.5. Bischoff cryt. t. 11. f.13. Be ruhardia Will. Mid. $p$, 109. Ho f $\mathrm{m}$ a n $\mathrm{n}$ i a Willd, in Usteri Magaz. VI, 17. Tristeca Palis. L y e opodium nodum Linn.

896. Lyeopodium LINN. Sporocarpia unilocularia, uniformia v. biformia; farinifera subreniformia, bivalvia; globulifera subglobosa tri-quadriloba, tri-quadrivalvia. - Herbae annuae v. plerumque perennes, interdum suffrutescentes, foliis nunc polystichis, omnibus similibus, nunc tristichis $v$. tetrastichis, lateralibus tunc majoribus; sporocarpiis globuliferis in paucissimis observatis, amentorum partem inferiorem oceupantibus.

L y e o p o d i u m Lisn. gen, n. 118a. Bisehoff erypt. H. t. 10 -12. Hook. et Grev. Miscell. H. 363. s8. Mart. pl. crypt. Bras. 37.

a) SELAGO Hook, et Grev. Sp or oc arpla indistincte axillaria. Fol i a polysticha, omnia eonformia.

S el a go Hook. et Grev, Misc, l. c. - Ly copodi um Brongn, in Dict. elass, $I X$. 557. H u per $z$ ia Beruh. P laIn anthus Palls. in Annal. soc. Linn. Paris. VT. 180. (E. B. t. 233. Hook. et Grev. ic. Fil. t.37.38.49.50.131.244.)

b) LEPIDOTIS Palis. S poroe arpia intra bracteas spicatas libera, v. bracteis aut axi adnata. F olla poly. sticha, ommia conformia.

Lepidotís Palis. $l, c, C$ hamaeclinis Mart. catalog, hort, monac, 1829. p. 3. (E., B. t, 224, 239. 1148, 1727. Labill. Nov, Holl, t, 251, Nov, Caled, t, 15. Sehleeht. adumbr. c.3.4. Bory ad Duperr, $t, 26$. Gaudich. ad Freyc. $t, 22,23$. Hook. et Grev, ic. Filic, t. 109.112, 113.181 185,212.)

c) STACHYGYNANDRUM Brongn. Sp orangia intra bracteas spicatas libera. Folia oligosticha, minora stipuliformia.

Stachygynandram Brouga, 1 . c. Hook. et Grev. 1 . c. Staehygynandrum, Diplostachlum, Selagi

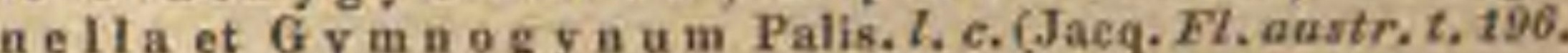
Bory ad Duperr. t.25. Hook, et Grev, ie. 1,39. 127, 200.)

\section{LYCOPODIACEAE FOSSILES.}

69\%. Tyeopodites BRONGN, R a mu i pinnati, continui, foli is pelystichis v. distichis se- 
riebus oppositis, eicatrices vis distinctas relinquentibus. - In terra lithanthracum.

Lyeopodites Brongn. prodr. 83. Lycopodiolithes Schloth. Petref.t. 29, f.3. Wal chi a Sterab. Tent. 22.

958. Sellaginates BRONGN. Caules dichotomi, foli is polystichis, imbricatis, basi dilatatis, eisatrices vix distinctas relinquentibus. - In terra lithanthracum.

Selaginites Brongn. prodr. $8 \%$.

\section{Ordo XXYIE. Lepidoden- dreae.}

Truncr fossiles, in lithanthracum fodinis obvii, saepe gigantei, repetito dichotomi, a reolis convexiusculis, rhomboideis, spiraliter dispositis, sulcis reticulatim interstinctis obsiti. Ar e olae prope extremitatem superiorem folii cicatrice transversa notati, medio Iinea longitudinali, plus minus elevata e cicatrice decurrente; nonnuli (vetustiores ut videtur) ramulorum adventitiorum distichorum eicatrices orbiculares monstrantes. $\mathrm{R}$ a muli adventitii strobiliformes abbreviati, foliis dense imbricatis tecti, extremitatibus dichotomiarum saepius incrassatis, confertius foliosis, conformes.

ConI cylindracei, plerumque elongati, e squamis rhomboideis, stipitatis, axi lignoso perpendiculariter insertis et deorsum imbricatis compositi; squamarum stipitibus inverse pyramidatis, utroque margine in alam membranaceam productis, dis co planiusculo excavato, corpore molliori, cavitati conformi, ejusdem basi affixo farcto.

Sporangia obcordata, acuminata, dorso convexa, facie plana, binatim faciebus sibi invicem applicata, tandem separata.

Lepidodendrearum nomine colligimus hoc loco diversas plantarum partes fossiles, separatim semper adhucdum repertas, unde nexus earum dubius est. Trunci L ycopodiaceis, strobi Coniferarum strobilis omnino comparandi. Strobos Lepidostrobi nomine descriptos, unico excepto, fortassis et ipso Cycade ace is accensendo, ramos adventitios, Ly copodi o rum gemmis prolificis comparandos, et truncornm crassiorum cicatricibus orbicularibus respendere, credimus.

699. Tepialodendron BRONGN. Trunei diehotomi, apice incrassato foli is linearibus lanceolatisve obsiti, cicatricibus folioram rhomboideis orbiculatisve tecti.

Le pidodendron Brongn. pradr. 58 .

a) LEFIDODENDRON. Trunci dichotomi, eieatricib as rhomboideis.

Le pidode adron Sternb. Tent, $t, 1-3.6 .8 .53$. Lindl. foss. $\{, t, 4.7 .8,9.12 .19-98,99,112,113.118,161$. S ag ena ria Brongn, classif: $1,4 . f .1$.

b) LEPIDOPLOYOS Sternb. Trunei dichotomi, cicatrieibus orbienlatis.

Le pid ofl o y os Sterub. Tent, t, 13. t. 2. f. $2-4$.

g00. He pidoplayllum BRONGN. F ol i a sessilia, simplieia, integerrima, lanceolata v. linearia, uni-trinervia.
Lepid o p hy 11 u m Brongn. prodr. 87 . Lindl. foss. $\Omega$. t.7.152, Po acites Brongn. classif.t.3.f.2. Glos opte. ridis s p. Brongin. $l$. c. $t .8, f .4$.

G1. Ulodendroin RHOD. Trunci simplices (?) foliornm cicatricibus rhomboideis teeti, ramos distichos, strobiliformes, foliis dense imbricatis tectos, deciduos proferentes.

U to de $n d$ ro a Rhode Beitr, t.3. f. 1 . Lindl. foss. fl, $t$, 5, 6. Lepido stro bus Liadl. op. cit. t. 10, 11,26.162, 163. non Brongn.

รDQ. Tepidostrobus $B R O N G N$. Stro b i cylindriei, e squamis rhomboideis stipitatis, axi lignoso perpendiculariter insertis, stipite inverse pyramidato, membranaceo - alato, disco planiusculo, excavato.

Lepidastrobus Brongn. prodr. 87. (Parkins. org. rem. $I, i, 9 . f, 1$.

\% (D3. Cardiocarpon BRONGN. Cap \& u1a e lenticulares, compressae, obcordatae v. reniformes, acuminatae. R. $t, 76$.

a rdloc arp o n Brongn, prodr, 87, -? Lindl. foss.

\section{Classis IX. Zammiae.}

Truncus arboreus, medulla cylindro lignoso cincta faretus. Foli a vernatione circinnata. Organa utriusque sexus distincta. Antherae apertae. Ovula nuda. Embryo perfectus, albuminosus.

\section{Ordo XXXVIIE. Cycaleaceae.}

CYCADEAE L. C. Richard in Pers. synops. IT. 630, De Coniforis et Cycadeis. Paris 1826. p. 172. R. Browa prodr. 346. Append, to Capt. King's Voyage 5 19 . Brongulart in Annal, sc. nat, XVT, 589. H. Molil, in Denkschr. der Mïnchner Academ. 1832. X. p. 399-442. Bartl, ord,nat.93. CYCADACEAE Lindl, introduct, edit. 2, p. 312.

Arbores v. arbusculat, habitu Palmas aemulantes. Truncus cylindricus, erectus, simplicissimus, interdum elatus, nonnunquam abbreviatus, subglobosus, extus frondium delapsarum cicatricibus brevibus, latis, squamosus; e corpore medullari amplo, et e cylindro lignoso annulari illud vaginante compositus. Cylinder lignosus e stratis duobus concentricis, $1 \mathrm{igne}$ o interiori, et libro exteriori constans, strato ligneo radiis medullaribus percurso, e meris vasis spiralibus et scalariformibus conflato; fasciculis sensim extrorsum deflectentibns, cum fasciculis libri (e cellulis brevibus dissepimentis horizontalibus sibim et impositis conflati), intra corticem sursum sese insinuantibus, tandemque in ramulos plurimos fissis, petiolos intrantibus. Frondes apicem trunci coronantes, pinnatisectae, segmentis integerrimis vel dentatis, coriaceis, nervosis, aveniis, basi interdum calloso-constrictis, alternis oppositisve, vernatione circinnatim involutis, saepe hirsutis.

Flores dioeci, nudi, organis utriusque sexus apertis, in strobilos vel conos terminales colleetis.

Flores mascula. Foli a pollinifera (antherae) juxta rhachim communem perpendiculariter inserta, patentia, plana, nervo 
medio (connectivo) rarissime subobsoleto, saepe in stipitem attenuato percursa, apice incrassato inflexo, v. dilatato et reflexo, interdum peltiformia, facie inferiore nune juxta totam longitudinem, nunc solo apice pollen secernentia, polline saepius a nervo medio quasi in strata duo segregato. Pollinis granula subglobosa, binatim quaternatimve cohaerentia, sulco longitudinali hiantia.

Frores feminei. Folia o vulifera (carpidia) aperta; nune plana, in formam coni sessilis laxiuscule imbricata, crenata, crenaturis ovula solitaria foventia; nunc juxta rhachim communem collecta, strobilum, saepissime pednnculatum, formantia; singula peltatim stipitata, disco subtus utrinque ovulo unico foeto; ovulis a stipite (dissepimento) sejunctis. Ovula orthotropa, lata basi sessilia, erecta v. inversa, nuda vel carpidio circa circum protuberante quasi cupulae immersa, apice attenuato pervia.

Fructus carpidiis laxe patentibus coniformis, v. strobiliformis, carpidiis discretis v. interdum subcohaerentibus s y n c a $\mathrm{r} p$ i u m mentiens.

Seminum testa ossea, epidermide tenuiter carnosa vestita v. carpidii protuberantia fungosa (arillo) excipulaeformi excepta, erecta, v. inversa. Chalaza basilaris lata, fungosa, $\mathbf{h} \mathbf{i}-$ Ius orbicularis huic e diametro oppositus, saepius impressus, foraminibus pluribus, in cavitates steriles, materia resinosa repletas ducentibus, v. pluribus interdum fecundis exsculptus. Albumen carnosum, duriusculum.

Emвryo orthotropus, axilis, albuminis longitudine; radicula in funiculum longissimum, subspiralem, complicatum desinens; cotyledones dnae, inaequales, apice inter se connatae, basi subdistinctae, germinatione hypogeae, p lu m u la m conicam includentes.

Cycadeacae in tropicis utriusque orbis, in Africae australis regione subtropica, et in Nova Hollandia extratropica provenientes, vegetatione terminali cum organis utriusque sexus distinctis nudis, et embryone albuminoso dicotyledoneo, saepins multiplici, cum vernatione foliorum circinnata conjuncto, a reliquis plantarum ordinibus distinctissimae, hine Filicibus conterminae, illine Acramphibryis g y mnospermis (Coniferis) affines, nobis sectiones systematis primarias e vegetationis modo ordinantibus, aptissime hoc loco collocantur, ita ut $\mathbf{Z}$ amia e quasi in ipso A crobry a r um fastigio positae, Coniferis, tum trunci tum fructus structura analogis, sed vegetationis modo diversissimis, in ipso A $\mathrm{c} \mathrm{r} \mathrm{a} \mathrm{m-}$ phibr y ar u m limine constitutis, respondeant.
Plantarum exuviae in terrae stratis secundariis sepultae, ad Cycadeaceas ab anctoribus relatae, magnopere nobis dubiae sunt.

ro4. Cyeas LINN. Flores masenii: Antherae apertae, in strobilum terminalem sessilem collectae, undique rhachi commnni insertae, singulae oblongo-cuneatae, apice sursum flexo, facie inferiore polliniferae, connectivo plus minus obliterato. Flores feminei: Carpidia plurima, monophylla, aperta, in conum terminalem laxiuscule imbricata, singula elongato-spathulata, plana, crenata, ov ulis in crenaturis solitariis, sessilibus, erectis. Fructus e carpidiis patentiusculis v. reflexis. Semina subglobosa, testa ossea, epidermide carnosula cincta. Fmbryo saepins multiplex, in axi a lbuminis carnosi inversns, radicula supera. - Arbores v. arbusculae, in tropicis Asiae, Nova $\mathrm{Hollandiac}$ et Oceaniae viventes, frondibus pinnatis, pinnis subdecurrentibus uninerviis.

Cy e a s Liun. gen. $n$, 1228. Praelect, 55. Juss. gen. 16. Smith in Transact. Linn, soc, VI. 312, t. 29. Thouar's Pl. il. austr. d.Afr. 1, t, 1. R. Brown prodr. 34r. Ferd. Bauer Illustr, pl. Nov. Holl. $\ell, 382-386$, inedit. Richaril Conif. et Cycad. p. 197, $t, 24-26$. Gaudich. in voy, Freyc. p. 432-441. Hook, in bot. Mag. t. 2963. 2961. - 01 us c aI a p poides Rumph $2 m b$. 1.86. $t, 20-24$. To d d a pa n Rheed. Malab, III, $9, t, 13-21$.

ซอร. Enceplanaratos LEHM. F lores mas culi: Antherae apertae, in strobilum terminalem pedunculatum collectae, undique rhachi communi insertae, singulae oblongo-cuneatae, apice incrassato obtusae v. acuminatae, acumine sursum flexo, connectivo plus minus distineto. Flores feminei: Carpidia plurima monophylla, aperta, in strobilos terminales pedunculatos collecta, rhachi communi undique inserta, singula basi in stipitem attenuata, apice in peltam rhomboideam dilatata, pelta subtus ntrinque ovulo unico, inverso, foeta. F r n c tus syncarpium, e carpidiis laxiuscule coalitis. S emina ovoidea, tes ta ossea, saepius carpidii processu fungoso cupulatim excepta. Embryo inversus, in axi albumi nis carnosi, radi cula respectu rhaeheos communis centripeta. - Arbores, interdum giganteae, in Africa australi subtropica (regione Caffrorum) et in Nova Hollandia extratropica obviae, frondibus pinnatis, pinnis lata basi sessilibus, multinerviis, apice saepius spinoso-denticulatis. Genus, praeter levioris momenti characteres, floribus masculis Cycadis cum floribus femineis $\mathrm{Za}$ miae combinatis, optime distinctum.

Ene e phalart os Lebmanu pugill. VI. 3. t. 1-3, Z ami a e s p. Llun. Jaeq. fragm. t. 25-31. R. Brown prodr. 348. Ferd, Bauer illustr, pl, Nov, Holl, t, 387-391, inedit. Bot. Mag. t.2006.

g(1). Zamia LINN. Flores masculi: Anthera e apertae, in strobilos terminales, pedunculatos collectae, undique rhachi communi insertae, singulae ovoideae, basi in stipitem attenuatae, apice incrassato peltiformi subbilobae, lobis subtus polliniferis. Flores feminei: Carpidia plurima, monophylla, aperta, in strobilos terminales pedunculatos collecta, rhachi communi undique inserta, singula basi in stipitem attenuata, apice in peltam hexagonam dilatata, pelta subtus utrinque ovulo unico, inverso, foeta. Fructus e carpidiis subdiscretis. S emina ovoideo-subglobosa, testa ossea, epidermide tenuiter carnosa cincta. E m b r y o inversus, in axi albuminis carnosi, radicula respectu rhacheos communis centripeta. Arbusculae in $A m$ erica $t r o p i \in a$, imprimis in In- 
diae occidentalis insulis obviae, frondibus pinnatis, pinnis basi calloso-constrictis, multinerviis, nervis simplicibus, indivisis.

Z a mia Linn, gen, n, 1297. ercl. sp. Richard Conif. et cycad, 198. t, 27. 28. Jaeq. ic. rar, t, 633.636. Hort, Schönbr. t.397.398. Bot, Mag, t, 174t, 1838, 1851, Lehm. pugill, VI.3. A r throzamia Reíchenb. consp, $\pi, 751$.

\section{CYCADEACEAE FOSSILES.}

รD\%. Thamaiostrobns. Strobus subcylindricus, utrinque obtusiusculus, e carpidiis rhachi communi spiraliter insertis, apertis, singnlis oblongo spathulatis, apice incrassato inflexis, imbricatis, facie superiore infra medium semine unico, inverso, foetis. - Strobilus in An glia effossus, generi exstincto inter Encephalartum et $Z$ a miam intermedio adscribendus videtur, carpidiis monospermis, ferme ad modum foliorum in Cycade et Encephalarto polliniferorum conformatis, admodum insignis.

$\mathrm{Z}$ a mia macrocephala Henslow in Lindl. foss. $f$. t. 125 .

ร (1). Thalaeozamåa. Frondes pinnatae, pinnis approximatis sessilibus, basi subconstrietis callosis, apice acutis denticulatis, nervis parallelis v. subdivergentibus. - Terra jurassica, jurassica schistoidea, et oolithica inferior.

$\mathrm{Z}$ am i a e fossiles, Bronga, prodr. 94. Lindl. foss. $f$. t. 17s. Polypodiolithes pectiniformis Sternb. Fl. protog. 44. $t .33 . f . t$.

- OD. Zhamites BRONGN.Frond es pinnatae, pinnis approximatis, subimbricatis, basi auriculatis cordatisve, apice acntis, n ervis divergentibns arcuatis, interdum bifureatis. - Terra oolithica et roü Lias.

$\mathrm{Z}$ amites Brongn, prodr. 94, Eilieites Brongn. in Annal. sc. nat. IF. 222. $t .19 . f .3-6 . \mathrm{Z}$ a m f a Lindl. foss. A. $t .165$.

10. IPteropliyylluma BRONGN. F ronif es pinnatae, $p$ in $n$ is basi tota latitudine insertis, apice truncatis, nervis parallelis. - Terra colithica inferior.

Pterophyllam Brongn. prodr. 94. Annal.. sc. nat.

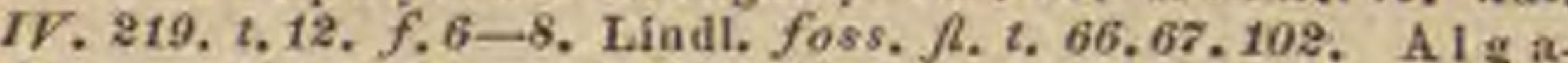
eftes filic oides Schloth. Nachtr. p. 46. $t, 4 . f, 2$. 0 ismundites. pectinatus Jiger Pfanzenverst. $v$. Stuttg. p.29. $t .7$.

81 1. Nilsonia BRONGN. Frondes pinnatae, pinnis approximatis, basi tota latitudine insertis, apice rotundatis, nervis parallelis, nonnullis validioribus. - Terra toú Lias.

Nil s o ui a Brongn. prodr. 95. Annal. sc. nat. IV.218. 2.12. $f .3 .4$

y2. Cyeadiltes BRONGN. Frondes pinnatae, $\mathrm{p}$ inn is distantibus linearibns, basi tota latitndine sessilibus, apice acutis, nninerviis.

Creta inferior.

C yea dites Brongn, prodr. 93. Nilson in Act. Academ. Holm. 1824, I. 147, t, 2, f.4-6.)

913. Ilamtellia BRONGN. Trunci cylindrici $v$. subsphaeroidei, a $\times \mathrm{i}$ indistineto, ci c atricibus frondium rhomboideis, latis, brevibus, exseulpti. - Terra calcarea portlandica et conchyliifera. 143.)

M a ntellia Bronga. prodr. 96. (?Lindi. foss. $R$. $t$.

\section{COHORS III. ACROBRYA. HYSTEROPHYTA.}

Plantae in aliis stirpibus parasiticae, iis dem saepius implantatae, vasis imperfectis sparsis donatae. Folia nunquam viridia, stomati- bus destituta. Grnitalia utriusque sexus perfecta. Seuina aëmbrya, polyspora.

\section{Classis $\mathrm{X}$. Ihizantheae.}

RHZANTHEAE Blum. Fl. Jav, Rhizanth, p, 1, Schott et Endl. Melel, p. 10. Lindl. introduct, edit. IT.389. Unger, Beiträge zur Kenntniss, der parasitischen Pfanzen, in An. nal. des Wiener Museums. Vol. II. inedit.

Plantae e contextu celluloso, fasciculis vasorum scalarariformium imperfectis, paucis, sparsis, saepius reticulatim connexis, vel deliquescentibus percurso, conflatae; aliarum stirpium partibus hypogaeis $\mathbf{v}$. epigaeis adhaerentes $v$. iisdem implantatae, nunc acaules, nunc rhizomate repente, interdum etiam caudice erecto, simplici v, rarissime ramoso donatae. F oli a squamaeformia, nunquam viridia, stomatibus vasisque orbata, saepius imbricata. FuoREs utriusque sexus perfecti, saepissime floribus imperfectis mixti, sexubus nunc a se invicem remotis, monoecis v. dioecis, nunc in eodem flore combinatis, et varie inter se connatis ; altero tunc plerumque imperfecto. P erig on i a plus minus perfeeta, $v$. nulla aut rudimentaria. Semra nune in ovarii interdum plurilocularis, loculis solitaria, ex apice pendula, nunc in placentis parietalibus plurima; test a dura, nucle $v$ e tela cellulosa, corpusculis sporidiformibus scatente.

\section{Ordo XXXX. Balanophoreae.}

BALANOPHOREAE L. C. Riehard in Mem, du Mus, VIII. 428. Barti, ord, nat, 79. Schott et EndI. Melet. p. 10. Mturt. nov, gen, et sp, III, 150. Lindl. introduct, edit, 2. p. 393.

Herbaz carnosae, rhizomate hypogaeo subgloboso vel repente, ramoso, aliarum plantarum radicibus adnatae, vel radiculis rhizomatis aliarum stirpium radicibus affixae. $\mathrm{S}$ tipites ex eodem rhizomate singuli, vel saepius plures, spatha abbreviato tubulosa, apice plurifida primum inclusi, tandem ima basi cincti, subcylindrici, erecti, simplicissimi ant rarissime apice ramosi, nune toti floribus obsiti, nunc basi steriles, nudi v. s qu a m is (foliis) dense imbricatis, aut plus minus dissitis vestiti.

Frores unise $\mathrm{xuales,}$ monoeci v, dioeci, conferti, masculi rarissime in apice stipitis ramosi subpaniculati, nunc in capitulo solitario stipitem terminante unisexuales, $v$. masculi femineis mixti, floribus abortivis et squamis peltatis interjectis primum velati; nunc in capitula plura sexubus discretis dispositi, capitılis dioecis v. monoecis, femineis tunc inferioribus, saepius bractea squamaeformi sustentis. Frores masculi sessiles v. subpedicellati, mono-tri-tetrandri. Perigonium in monandris squamaeforme, truncatum, antice rimula superficiali filamentum recipiente exsculptum, vel illud vaginatim ambiens, interdum squamu- 
lis pedicello diversa altitudine insertis, subverticillatis, quandoque elongatis stipatum; in tritetrandris tri-tetraphyllum, phyllis liberis, vel basi in tubum plus minus longum connatis, apice distinctis, aestivatione rarissime imbricatis, plerumque valvatis $v$. induplicatis. St amina numero phyllorum perigonii, iisque opposita, in eleutherophyllis eorundem basi inserta, in gamophyllis tubo imposita. Fil a m e nta plus minus longa, in monophyllis et eleutherophyllis discreta, saepius flaccida, in gamophyllis in tubum connata. Antherae basi fixae, in triphyllis elentherandris uniloculares, vertice extrorsum rimula fissae, in monophyllis biloculares, loculis oppositis, subinaequalibus, juxta totam longitudinem apertis; in monadelphis extrorsae, dorso inter se connatae, biloculares, loculis appositis saepius inaequalibus, interdum septo secundario longitudinali bilocellatis, vertice vel juxta totam longitudinem dehiscentibus. P o ll e n subglobosum. 0 va rii rudimentum in nonnullis intra tubum stamineum latitans.

Flores feminer sessiles v. brevissime stipitati. Oraria plurima, saepissime paleis interstincta $v$. interdum contigua et inter se concrescentia, nune omnino nuda, nune cellulis parietis exterioris in annulum verticalem tumentibus quasi coronata, rarissime squamis aliquot unilateralibus superata; e carpidio unico v. saepius binis inter se connatis conflata, uni-bilocularia, loculo altero minore, tandem obliterato. Ovula in loculis solitaria, apici appensa.

Strues in ovariis unilocularibus ex eiusdem vertice lateralis, filiformis; $\mathbf{s t i g m a t e}$ subcapitato terminatus caducus v. terminalis brevissimus, in stigma disciforme dilatatus persistens, in ovariis bilocularibus styli dno filiformes, e centro verticis ereeti, stigmatibus capitatis, decidui.

Froctus coriacei, sicci, rarissime subbaccati, interdum plures inter se connati v. cohaerentes, uniloculares, monospermi. SЕмко pericarpii cavitati conforme, test a coriacea dura v. subossea, nucleo e tela cellulosa, massa sporacea farcta conglobato.

Balanophoreac inter Rhizantheas tum florum dispositione, tum habitu et ovarii conformatione distinetissimae, hinc Cytineis proximae, illinc Aroideis aliquatenus analogae, in regionibus tropicis ntriusque orbis, in Africa australi extratropica, et in regione mediterranea parce hucdum observatae fuerunt.

Tribus I. SARCOPHYTEAE. R e eptacula in eodem stipite plura, distineta. Stamin a libera. Ovarium uniloculare.

914. Sareoplayte SPARRM. Flores dioeci: Irasculi paniculati. Periguninm tri- phyllum, phyllis duobns inter se remotioribus aestivatione tertium amplectentibns. Stam in a 3 , phyllis opposita; filamenta libera; antherae uniloculares, circumscisse dehiscentes. Fl or es feminei: capitula plurima globosa, snbpaniculata. Perigoninm nullum. Ovaria receptaculo subgloboso imposita, inter se concrescentia, unilocalaria. Stylu s terminalis, brevissimus, stig mate discoideo-peltato, persistente. Syncarpium glohosum, subbaccatum. - Herba fungoso-carnosa, olida, in Capite bonae spei basi car nosa Mimosarum radicibus adhaerens, stipitibus dodrantalibus, basi squamis imbricatis cinctis, bracteis squamaeformibus ramos ramulosque paniculae subtendentibus.

S a re o phy te Sparrm. in Lct. Holm, XXXVIT, 300. t. 7 . Endl. dissert, inedit. I chth yosma Schlechtend. in Linnaea $I T$. $68 t, t, 8$.

OBSERVATIO. Sarcophyte, cujus specimina pluri ma floribus utriusque sexus, et fructibus onusta, beaevolen-

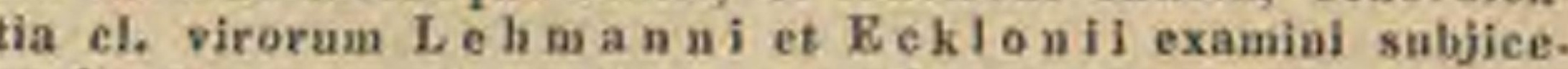
re licuit, genus in ordine nonaihil anomalum, tum perigonif masculi structura, tom styli et stigmatis conformatione, Imprimis vero antherarum natura, quae e tubulis plurimis eylindricis polliniferis, filamenti apief eontinuis, partim inter se conjunetis et membrama communi, primum rimula lateral fissa, mox basi circumscissa, velatis, componuntur; qua quidem fabrica aliqua cum antheris $R$ a f $f($ es $i$ acear $u m$ ana. logia indicatur. Stamiaa $S$ a $x$ e o p h y tes singula typice pro totidem capitulis masculis, perigonii phylla pro bracteis ha. beri possent. Nuclei natura eaden quae in reliquis generibus.

Tribus II. LOPHOPHYTEAE. Schott et Endl. Melet $p .11$. Receptacula in eodem stipite plurima. S $t$ a m in a libera. O vari a bilocularia.

915. Hoglnophytum SCHOTTet ENDL. Flores monoecit Maseuli in capitnlis in superiore stipitis parte sessilibus glomerati. Perigonium squamula carnosa, antice canaliculata. Stamen e canalieulo squamulae perigonialis emergens; filamentum flaccidum; antherae oblongae, bilocularis, loculi oppositi, inaequaliter affixi, rima longitudinali dehiscentes. Flores femine $\mathrm{i}$ in capitulis hemisphaericis, ad basim stipitis sessilibus. Perigoninm nullm. Ovaria plurima; reveptaculo discoideo (?) imposita, bilocularia, vertice nuda. Styli duo, fliformes, stigmatibu 8 capitatis. - Herba carnosa, sesquipedalis, in Brasilia tropica matrice fungosa arborum radicibus adnata, stipite simplicissimo, e basi bipollicari sensim attenuato, basi squa$m$ is opposite imbricatis vestito, capitulis femineis bracteatis. - Genus imperfecte cognitum, ex icone descriptum; an sequenti jungrendum?

Lophophytum Sehott et Endl. melet, 1 , $t$. 1 .

76. Dmberoplaytum POEPP. Flores monoeci: Mascnli in receptaculis superiorem stipitis partem tegentibus, obconicis, vertice truncato-dilatato nudis, sessiles. Perig on iu m squamulae carnosae, canaliculatae, inter se connatae. Stamina e rimulis squamularum perigonialium emergentia; fil amenta flaccida; antherae oblongae bilocularis locnli oppositi, rimula verticali lirevi dehiscentes. Flores feminei in receptaculis masculifloris conformibus, inferiorem stipitis partem tegentibus. Perigonium nullum. Ovaria plarima, in receptaenlo sessilia, bilocnlaria, vertice nuda. Styli duo filiformes, stigmatibus capitatis. - Herba carnosa, assata in modum Fungorum edulis, in sylvis Andin is Peruviae sub primis anni imbribus repente emergens, rhizomate scutato uliarum stirpium radicibus affixa, stipite pedali 
srassiusculo, basi involucro carioceo-lignoso amplo cyathiformi, apice bi-trifido; volvae instar cincto, receptaculis floriferis, immixtis receptaculis aliis abortivis tandem subsuberosis, tecto, apice sterili truncato dilatato viscosis. - Genus a praecedente praeter staminum dehiscentiam, etiam receptaculorum forma, et involucri stipitem ambientis conformatione diferre videtur.

$0 \mathrm{mbr}$ op hy tum Pöppig in Leips. Literaturzeit.1833. p. 1874.Nov.gen, et sp. Vol. II. inedit.

Tribus III. CYNOMORIEAE Schott et Endl. melet. $p$. 11. Receptaculum solitarium stipitem terminans. Stamina libera v. symphysandra. Ov a ri um uniloculare.

7\%. Cynomerium MICHEL. Flores masculi in eodem capitulo femineis mixti, paleis numerosis cincti, squamis peltatis mixti. Mas culi subsessiles. Perigonium monophyllum, obconico-truncatum, filamenti basim amplectens. St amen unicum ; fil ament um filiforme basi a perigonio vaginatum, eique partim adnatum; anthera e extrorsae bilocularis loculi oppositi, rima lon gitudinali dehiscentes. Feminei: Perigonii loco paleae aliquot, $0 \mathrm{v}$ a $\mathrm{ri}$ brevissime pedicellati unilocularis, verticem diversa altitudine nno latere coronantes. Stylus e vertice ovarii lateralis, filiformis, stigmate subeapitato. - Herba carnosa, coccinea, pedalis, in regione mediterran e a tuberibus globosis fruticum littorearum radicibus irradicata, stipite subclavato basi squamis contiguis tecto, floribus palcisque densissime confertis obsesso, floribus inferiaribus plerumque abortivis.

C y n o mo ri u m Micheli gen, 17, t, 12, Richard in Mem. Mus. VIII. 420, t, 21. Fungus ty phoides melitens is Boccone ic. pl. rar. 80, t.43, Mem. Fisic. 69. t. 1 .

18. IBalanoplaora FORST. Flores monoeci, in eodem capitulo, $\mathrm{m}$ a $s \mathrm{eu}$ i inferiores (?) pauci, feminei superiores plurimi. Masculi pedicellati (?) P erigon i um (?) tri-quadrifidum, cadneum (?) St am in a plura, symphysandra, a nthe rae extrorsae connatae, rimis longitudinalibus dehiscentes. F e m in e i circa receptacnla glandulaeformia glomerati. Perigoni u m nullum. Oraria ovoidea, nnilecnlaria. St y I u s terminalis (?) setaceus. - Plantae carnosae fungoideae, tuberibus carnosis Ficuum radicibus in insulis As ia e tro $p$ ic a e irradicatae, stipite brevi cylindrico basi squamis parcis tecto, parte inferiore sterili, superiore florifero.

B a l a n o p th or a Forst. char. gen, so, et in Rich. Mrem. afus. VIII. 42/. Blum, enum, pl. Jav. I. 87. pro part.

OBSERVATIO. Generis imperfectissime cogniti, et a nobis non visi characterem ad species monoicas, prototypam tannensem a Forstero descriptam, et alteram javanicam a el. B 1 n meo indicatam, restrictum, e eitatorum anctoram Iibris exstruximus. Species dioicae ad Cy nopso1 e n nostraur pertinere videntur.

Tribus IV. HELOSIEAE. Re e pt acul a solitaria stipites terminantia. Sta m in a symphysandra. O v ari u m biloculare.

719. Cymopsole. F10 res dioeci. Masculi sessiles, singuli bractea canalicnlata exeepti. Perigon i m tnbulosum, limbo quadrifido, laciniis subinaequalibus aestivatione imbricatis. St amina 4, symphysandra; $8 \mathbf{y} \mathbf{n ~ e ~} \mathbf{m}$ a tubo adnatum et a $\mathrm{th}$ e $\mathrm{r}$ a connatae, extrorsae, biloculares, loculis subinaequalibus, longitudinaliter dehiscentibus, Orarii rudimentum nnllum. Flores feminei. . . Planta digitalis, carnosa, ex insulis Moluccis adlata, rhizomate tuberoso subglobo- so alienis radicibus innata, stipitibus ex eodem rhizomate pluribus, basi squamis imbricatis cinctis. 1. 88 . -? Balanophora elongat a Blum. enum, pl. Jav.

20. Seybalium SCHOTTet ENDL. F 10 res in distinetis stipitibus monoeci. M a s cu Ii sessiles, paleis copiosis immixtisque filis elongatis (floribus femineis abortivis) stipati, Perigoni um tubulosum, limbo trifido, laciniis aestivatione subinduplicato-valvatis. St a m in a $3,8 y$ mphsandra; synema fauci perigonii adnatum; antherae connatae, extrorsae, biloculares, loculi aequales, apice rimula laterali dehiscentes, rimulis loculorum contignorum diversarum antherarum confluentibus. O varii rudimentum receptaculi substantiae intra perigonii tubum semiimmersum. F1o res feminei paleis numerosis stipati, filis nullis, Ovaria sessilia, truncata, $1 \mathrm{im}$ b o brevissimo homogeneo coronata, bilocularia. Styli duo terminales, stigmatibus capitatis. Herbae palmares $v$. digitales, stipite obconico et disco florifero deplanato Fungum pileatum referentes, rhizomate tuberoso in $A$ mericae tropicae sylois alienis radicibus implantatae, stipitibas ex eodem tubere saepius pluribus, feminifloris interdum masculum ambientibus, squamis imbricatis obsessis, disco florifero plano lato, squamis dimidiato rhomboideis excentrice subpeltatis, mox dejectis, primum velato.

$\mathrm{Scy}$ balium Sehott et Endl. melet. 3.t.2. Cynomo. ri i s.p. Swartz.

g1. Helosis RICH. Flores monoe $\mathrm{c}$, in eodem receptaculo masculi femineis (praecocioribus) mixti, paleis plurimis stipati, squamis subrotundis peltatis (claviformibus) primum velati. Masculi: sessiles. Perigonium tubulosum, limbo trifido, laciniis per aestivationem valvatis. Stamina 3, symphysandra; synema fauci perigonii adnatum; antherae connatae extrorsae, biloculares, loculi aequales, apice rimula laterali dehiscentes, rimulis loculorum contiguorum diversarum antherarum confluentibus. O varii rudimentam receptaculi substantiae intra perigonii tubum semïmmersum. Flores femine i brevissime pedicellati. Ovaria truncata, limbo brevissimo homogeneo coronata, bi-trilocularia. St y li duo $v$ tres, terminales, stigmatibus capitatis. Herbae carnosae, per omnem $A$ mericam tropica $m$ observatae, e rhizemate repente ramoso, alienis radicibus adhaerente, stipites plures basi involucro brevissimo subtrifido cinctos, cylindricos, nudos, capitulo ovato-subgloboso terminatos exserentes; flores primum squamis subrotundo peltatis receptaculum dense obsidentibus velati, mox iisdem dejectis primum feminei stylos exserentes, tandem masculi sub ovariorum grossificatione emergentes.

Helos is Riehard in Miem, Mus. VII. 416, t. 20. Schott et Eadi. Melet, p.21. Martius Nov, gen, et sp. III, 184, t. 300 . Caldas la Mutis Semin. Nov. Granad, 1810. Cynomorif s p. Flor. mex, ic, inedit.

g23. Tangsulorfia MLRT. F lores in distinetis stipitibus mono-dioeei (?) Masculi inter paleas clavatas, basi complanata in modum favi nexas sessiles. Perigoni um tubulosum, tubo filiformi, limbo trifido, laciniis aestivatione induplicato-valvatis. S ta min a 3, symphysandra; synema fauci perigonii adnatum (brevissimum); anth era e connatae, extrorsae, biloculares, 10culi aequales, juxta totam longitudinem dehiscentes. Ovarii rudimentum (?) Flores feminei (in diversis stipitibus) imperfecti, densissime constipati, setiformes, basi subeonnati, medio et apice bulloso-granulosi; perfecti 
Herbae brasilienses, carnosae, e rhizomate hypogaeo crassiusculo, repente, subramoso, radiculis fliformibus alienis radicibus affixo, stipites digitales squamis imbricatis obsessos exserentes, receptaculis floriferis subcylindricis $v$. depressiuseutis, esquamatis; floribus femineis perfectis nondum repertis.

$\mathrm{L}$ ang $\mathrm{s}$ d or $\mathrm{fi}$ a Martius in Eschweges Journ, von Brasil. II, 179. Nov, gen. et sp. IIt. 181, t. 299. Richard in Mem. Mus. VIII. 412, t. 19. Sehott et Endl. melet, p.12. Püppig et Endl. Nov. gen, et sp. Fol. IT. inedit.

\section{Ordo XI. Cytineat.}

CYTINEAE Brongn. in Annal. sc, nat. $x$. 29. Bartl.ord. nat, 80. Schott et Endl. meler. 13, CYTINACEAE Lindl. inttroduct. ed, IT. 399. PISTIACEARUM p ars Agardh Aphorism, 240, ARISTOLOCHIARUM pars Juss., Link, E. Meyer.

Herbae carnosae, in aliarum stirpium radicibus parasiticae; nunc acaules monanthae, $\mathrm{e}$ solo floro compositae, nunc stipite brac$t e$ is squamaeformibus dense imbricatis obsesso donatae, in axillis bractearum filoriferae.

Flores typice hermaphroditi, in genere acauli organa utriusque sexus in eodem flore perfecta, in stipitatis inferiores antherarum abortu feminei, superiores ovario efoeto masculi, singuli basi bi-tribracteolati.

Prergoniom tubuloso-campanulatum, limbo tri-quadri-sexlobo, lo b is aestivatione imbricatis v. induplicato-valvatis, intus nonnunquam lobulo aucíis.

Sтаніка symphysandra, simplici v. duplo loborum perigonii numero, iisque dum numero aequalia opposita; synema perigonii tubo vel fauci impositum, nunc tubi parieti adnatum, nunc liberum cum ovario efoeto connatum, stylorum rudimentis superatum; a n the ra e extrorsae, biloculares vel multiloculares, loculi oppositi, aequales recti, vel inaequales subflexuosi, longitudinaliter dehiscentes.

Ovarius imo perigonii tubo innatum, uniloculare, placentis parietalibus plurimis membranaceis, interdum subseptiformibus, utraque facie multiovulatis, ovulis sessilibus.

Sryuus terminalis, numc simplex brevissimus, liber, $\mathrm{s} \mathrm{t} \mathrm{g} \mathbf{m}$ a te lato discoideo terminatus; nunc styli plures inter se connati, a p icibus stigmat oideis subdistinctis.

FRUCTUs baccatus v. subcoriaceus, unilocularis, intus pulposus.

Semixa plurima, in pulpa nidulantia, tes $\mathrm{t}$ a coriacea dura, nucle o tela mere cellulosa conflato arcte adnata.

Cytineae in regione mediterranea et Africa australi extratropica hucdum observatae, a Raffles i ce is, quibuscum olim conjungendae, vix nisi antherarum panllo diversa fabrica differunt.

z 23. Cytiaus LINN. F lore s monoeci, in apice eanlis squamis imbricatis tecti, inferiores abortu feminei, superiores masculi, singuli in axilla bracteae, bracteolis stipati. Masculi: Perigonium tubulose eampannlatum, limbo patente tri-quadri-sexlobo, lobis aestivatione imbricatis.
St a mina symphysandra, duplo loborum perigonii numero; sy nema cylindricum ultra tubum exsertum, cum stylorum rudimentis connatum, extus membranis septiformibus perigonii lobis alternis cum ejusdem tubo cohaerens; antherae in capitulum stigmatum rudimentis superatum connatae, extrorsae, biloculares, loculi appositi, aequales, longitudinaliter dehiscentes. Flores feminei: Perigonium maris, epigynum. Ovarium inferum, uniloculare, placentis parietalibus octo, multiovulatis. Styli in cylindrum, membranis septiformibus perianthii tubo adhaerentem, sti $\mathrm{g} \mathrm{ma}$ te subgloboso terminatum, connati. B a c c a mollis, pulposa. Herbae palmares vel digitales, in regione mediterranea Cistorum, in regione capensi et insula Bourbon aliarum stirpium radicibus adhaerentes, stipite simplici subclavato, squamis imbricatis tecto, floribus axillaribus sessilibus bi-tribracteolatis.

Cytinus Linn. gen. n. 1232. Tratt, thesaur, $t, 29$. Hook. rot. Fl. t. 163 . Brongn. in Annal. se. nat, J. 29. 4. 4. Н y poeystis Tournef, coroll. 46 . As a ri sp. Linn. sp. 633. -? P hely p a e Thunb. nov. pl. gen. $V$. 91, H y pole p is Pers, ench. II. 598. (coll, Juss, in Annal. Mus. XII. 439.)

g 24. Illyduorea THUNB. Flos hermaphroditus radicalis, solitarius. Perigonium tubulosum, tubo basi cum ovario connato, limbo trifido, laciniis intus ramentiferis, per aestivationem valvatim induplicatis, apice interdum inter se connatis, basi lobulo auctis. Stamina 3 , perigonii lobis opposita ; fil a menta in annulum tubo adnatum concreta; antherae basi cohaerentes, apice discretae, multiloenlares, loculi oppositi, paralleli, elongati, snbinaequales, flexuosi, longitudinaliter dehiscentes. O va ri um perigonii tubo innatum, uniloculare, p I a se $\mathrm{t}$ is parietalibus plurimis, primum septiformibus margine ovuliferis, mox parietibus dissolutis filornm instar e vertice cavitatis pendulis, multiovulatis. Sty 1 n s terminalis, brevissimus, st igma te late pulvinato. B a se a globosa, corticata, cortice ad basim circumseisso, semina plurima in pulpa nidulanta. - Plantae fungiformes rhizomate repente, in radicibus Euphorbiarum capen si um parasiticae.

Hy dn ora Thunb. in Act. Holm. 1725, p.69. t.2.17\%7. p. 141. t. 4. f. 1. E. Meyer in N. A. N. C.XPI. 273. 8s. 2. 58. 59. A ph y tei a Linn. Amoen. Academ, VIIT. 310 .

OBSERVATIO. Singularis est placentarum in ovario grossificante fahrica, quas post el. Meyerna filiformes et e vertice eavitatis sub stigmate suspensas vidi. Easdem in ovario virgineo parietales, versas eeutram porreetas, eavitatom in loculos plarimos, subeompletos dispartientes observare licuit, septis tenuissime membranaceis, prope marginem utraque tamen facie ovulorua aliquot seriebns, versus apicem confertioribus, basi subdeliquescentibus onustas. Septorum portio sterilis parietibus ovarif contigua, mox de. struitur, remanente substantia lacera spongiosa eorum originem indicante, pars vero ovulifera, basi ubi ovula sensim deliquesennt solvitur, quo fit ut placentae filorum instar $e$ vertice peadeant.

\section{Drdo XII. Rafflesiaceat.}

RAFFLESIACEAE Schoti et Endl. melet, p, 14. Lindl. introduch edil. II. 392.

Plantae e solo flore, minuto vel giganteo, aliarum stirpium radicibus epigaeis v. ramis innato, primum bracteis sqnamaeformibus veLato, constantes.

Flones hermaphroditi, $v$, abortu unisexua les, interdum diclines. Perigonium globosum v. campanulatum, limbo quinquepartito, laciniis per aestivationem imbricatis v. indupli- 
catis, fauce callis, interdum in annulum confluentibus obsessa; rarins tetraphyllum, phyllis ima basi coalitis, aestivatioue imbricatis.

Staniva symphysandra, s y nema subglobosum, hypocrateriforme vel columnare pileolatum, basi perigonii tubo adnatum v. ab eo distinctum.

Antherae plurimae, distinctae, v, subconnatae, infra synematis verticem sessiles, horizontales, v. deorsum spectantes, uni-pluri seriatae, uni-biloculares, loculis appositis, poro apicis dehiscentibus, v. concentrice multiloculares, loculis ostiolo communi apertis.

Ovanum inferum, cum perigonii tubo et synemate connatum, uniloculare.

Placentae parietales plurimae, multiovulatae, ovula pendula. St y li plurimi, conici, inter se intra synema connati, apicibus exsertis, distinctis, synematis verticem obsidentibus. Stigma...

Fructus bacca globosa, corticata, durissima, intus pulposa.

Semrna plurima, in pulpa nidulantia. Testa ossea, areolata. Nucleus solidus, e cellulis immixtisque filis subgrumosis conflatus.

$R$ afflesiace ae florum mole et structura merito portenta naturae dictae, radicibus epigaeis Cissorum in archipelagi indici insulis innatae, nuper accessione generis paullo heterocliti, in America a strali et tropica in Leguminosarum ramis parasitici locupletatae et illustratae fuerunt.

g.5. Frostia BERT. Flores dioeci. Masculi: Perigonium tetraphyllum, phyllis ima basi connatis, aestivatione imbricatis, intus glabris. S y nema columnare, vertice pileolari papilIosnm. An th erae infra verticem sessiles, horizontales, triseriatae, contiguae, uniloculares, apice apertae. Ovarii rudimentum nullum. Flores fem in ei... - Flores minimi bi-trilineares, e cortice ramulorum Adesmiae arboreae in Chili et Bauhiniarum $B$ rasilia e prorumpentes, bracteis biseriatis, serie exteriori paulo demissius inserta, calycem simulante, perigonio glabro flavorubro vestiti.

Frostia Bertero Mrc. Novemb. 1829, in Herb. Steud. n. 1005. Pilostyles Guillem. in Nouv. Annal. sc, nat. II, 21, $t, 1$,

OBSERVATIO. FROSTIAM (cujus species duas, alteram prototypam a cl. Steudelio benevole concessam, alteram a b. Pohlio e Brasilia eum ramulis $B$ a u hinia e enjusdam relatani, (P a rado a ha $u$ hiniae folla Pohl msc. in Herb. Mus. Vindob.) examinavimus) plantam esse autonan, nee floris papilionacei degenerationem, quisquis plantam vi. derit concedet. Flores feminei, in utraque speele hucdum desiderati, dubia olim solvent. Ceterum APODANTHEM Poit. (Annal. sc. nat, III. A21. ᄂ. 26. $f .1$.$) cui "Flores dioeci,$ "c ignoti, \& perigonium semiadhaerens, 4lobum, "Tobissubrotundis coarclatatis; $8 q u$ a ma $\mathrm{a}$ 4, epigynae, pentaliformes, ovato-cordatae, basi appendiculatae, peri. ngonit lobis altornae; Ovarium subglobosum, tlocu. ,lare, placentis parietalibus quatuor, multiovulatis "stylus brevis crassus subconicus; stigma incrassa"fum, truncatum, subulobum" tribuuntur, nisi $\mathrm{V}_{\mathrm{r}}$ ostiae florem feminean snspicarivells, Caseariac macrophyl. I a e florem esse monstrosum, generis auctore ipso id nue concedente, el. Kun $\mathrm{tbio}$ et Meyenio (Cfr. Raspail in Bullet. sc. nat, IV. 358. Meyen in MVigm, Archiv, I, 197, et Guillem, in Nouy. Annal, sc. nal, $I$. 223.) faclle largior.
ร 26. IB ronganansia BLUM. F 1 o r e s hermaphroditi: Perigoni u m tubuloso-campanulatum, li m b o quinquefido, lobis bi-trifidis, aestivatione valvatim induplicatis, e or on a faucis interrupta. Sy ne ma subglobosmm, perigonii tubo adnatum, vertice stigmatoideo piloso, centro excavato impresso. An $t$ herae infra verticem sessiles, sublurizontales, uniseriales, connatae, deplanatae, biloculares, loculi oppositi, singuli poro dehiscentes. Ovari $\mathbf{m}$ synematis et perigonii fundo innatum, uniloculare, pla e entis parietalibus plurimis, multiovulatis. Styli cum synemate et ejus vertice stigmatoide o confusi. - Radicibus Cissorum in insula Java innascuntur flores pugni mole, primum bracteis sordide violaceis velati, mox pandentes perigonium exalbidum, intus ramentis hirtum.

Brug ma us i Blum. Bijdr. II. 489, Flor.Jav. fasc.I. 17. $t, 3-6$.

ร2\%. IEnflesia $R$. BR. Flores hermaphroditi v. abortu diclines. Perigonium tubnlosum, $1 \mathrm{imb}$ o patente quinquefido, lobis integris, aestivatione imbricatis, $\mathbf{c}$ o r o n a faucis annulari, integerrima. Synema hypocrateriforme, perigonii tubo adnatum, vertice lato deplanato, marginibus subrevoluto. Antherae sub verticis margine revoluto sessiles, multiloculares, loculis concentricis, poro communi verticali apertis. Ovarium synematis et perigonii fundo innatum, uniloculare, placentis parietalibus plurimis, multiovulatis. Styli cum synemate connati, apicibus interdum exsertis, conicis, discum obsidentibus. - Species plures, florum diametro tripollicari tripedalive, pariter in radicibus Cissorum in insulis Java et $S u m m a t r a$ parasiticae, perigoniis primum bracteis sordide caerulescentibus velatis, Brassicae caput referunt, tandem perigonium pandunt intus ramentosum vel glabrum; colore carneo et odore cadaverino muscas, nuptiarum ministras alliciens.

$\mathrm{R}$ afflesia R. Brown in Transact. Linn. soc. XIII. $20 \%$. t.15-29. Blam. Fl. Jav. I. 9. 1,1-3.

OBSERVAT10. Genus e Rhizanthearum caterva monente illustr. R. B r ow a sistere videtur planta a f $\mathrm{rica}$ in $\pi$ tropica, parasitica, ab Is e r tio (Reise nach Guinea p. 283) conmemorata, a nobis olim, HAEMATOSTROBL nomine donatum.

\section{SECTIO IV. AMPHIBRYA.}

MONOCOTYLEDONES Juss, gen. 21. Desy. in Mem,1nst. I. 478. ENDORHIZEAE Richard Analyse du fruit. 1808. ENDOGENAE DC. Theor. elem. 207. CRYPTOCOTYLEDONEAE Agardh Aphorism. 73.

Caulis e contextu celluloso fasciculisque vasorum longitudinalibus, sparsis, compositus, cortice et canale medullari indistinctis, ambitu crescens. Folia stomatibus donata, saepissime cauli acreta, nec articulatim inserta, plerumque alterna, in paucis opposita v. verticillata, saepissime simplia integrav, integerrima, venis simplicibus parallelis v, rarissime reticulatim ramosis. Organa utriusque sexus perfecta, integumentis floralibus simplicibus, numero saepissime ternario dispositis, quandoque deficientibus. Embryo plerumque albumine inclusus v. suffultus, 
indivisus, hinc in rostellum (radiculam) radiculas exserentem, illinc in cotyledonem solitarium, gemmulam amplectentem desinens.

\section{Classis XI. Glumaceae.}

GLUMACEAE Bartl. ord, nat, 25.

Herbas annuae et perennes, rarius suffrutices. Culmi simplices v. ramosi. Folia alterna, integerrima, basi vaginantia. Flores in spicalas dispositi, bracteis imbricatis vestiti. PERIGovium nullum, nunc squamiforme v. setiforme. Ovarium liberum, uniloculare, uniovulatum; ovulo erecto. Carxopsis. embryo ad basim seminis, a lb um in $\mathrm{i}$ farinaceo applicitus.

\section{Ordo XIII. Gramineat.}

GRAMINEAE Juss, gen, 28. R. Browu prodr, 168. Gen. Rem, app. Flind. IT, 580. Palisot de Beauvois, Essai d'une nouvelle Agrostographie. Paris, 1812. 4to. Trinius, Fundamenta Agrostographiae, Vientae, 1820, 8vo, Dissertatio de graminibus unifloris ot sesquifloris Petrop, 1894. 8. Icones Graminum Petrop, 1820. 15, ato. 2. Vol. Raspail in Annal, sc, nat, IV, 271, 422, V. 287, 433, VI. 224,38d, VIT. 335. Link Hort, berol, edit. H. 1827 . Nees ab Eseubech, Agro. stographia brasiliensis in Mart. Fl. bras. Stuttg. 1829, 8vo. Kunth Mem, du Mus. II. 62, ss, Revision des Graminees, Paris 1830. fol. 2 Dol. - Agrostographia synoptica, Stutlg. 1833-35. 8vo. $2 \mathrm{Nol}$. - Petermann, de flore gramineo dis. sertalio. Lips, $1835.8 v o$.

Herbas plernmque humiles, annuae vel perennes, saepissime caespitosae, rarius snblignosae frutescentes $v$, arborescentes. $R \mathrm{~h}$ iz o$m$ a nunc abbreviatum et in fibras solutum ( $\mathrm{ra}$ dix fibrosa) vel repens, ex articulis radicantibus stolones emittens (radix repens). C a ulis (culmus) cylindraceus, rarius compressus, fistulosus v. interdum faretus, articulatus, nodis annularibus tumidis, plerumque coloratis, rarissime (in Molinia) contractis, distinctus; simplex vel interdum ramosus, gemmae axillaris nudae folivlo primario tune dorso suo caulem spectante. F o lia e nodis oriunda, distiche alterna; petiolus complanatus, caulem vaginatim ambiens, interdum in tubum connatus; stip ula axillaris cum petiolo connata, nonnisi apice libera (ligula); lamin a plerumque angusta, linearis, rarius oblongolanceolata v. ovata, parallelinervis; nervis rectis v. curvis, medio plerumque fortiori, margine integro, saepissime scabro.

Flores hermaphroditi, interdum monoeci v. rarissime diveci ant polygami, spicati; $s p i-$ culae in apice caulis et ramorum paniculatae, racemosae v. spicatae, interdum rhachi incrassatae immersae, rarissime plures fasciculatim congestae $v$, inter se connatae, spatha propria exceptae.

Calyx et corola nulla. Floscum bracteis binis ( $p$ aleis, corolla Linn, calyce Juss. stralgulo Palis. gumellae valvulis Link) suboppositis, anticum et posticum ab axi latus spectantibus tecti; tres $v$. plures pedicello com- muni alternatim impositi, distichi, spicu1 a m (locustam Palis.) uni-multifloram constituentes; flosculus superior $\mathbf{v}$. inferior, rarius ambo cujusvis spiculae incompleti, infimus v. bini infimi vix non semper ad bracteam anticam redacti, (quo casu bracteae anticae tamquam communes spiculae spathae: gluma Juss. calys Linn. lepicena Rich. Iegmen Palis. glumae valvae Link audiunt), rarius plane obliterati.

Palearom (vaginarum transformalarum) antic a uni-trinervis, saepissime carinata, dorso vel apice arista (lamina folii superstite) instructa vel mutica; postic a paullo altius inserta, plerumque binervis et mutica, intus interdum ad basim utrinque squamula, (ligulae bifidae vestigio) auriculata, nonnunquam penitus evanescens.

Squamulat hypogynae (nectaria Schreb. corolla Michel. lodicula Palis. parapetala Link) succulentae, irregulares, duae v. tres interdum inter se connatae, saepissime minimae v. penitus obliteratae.

Staniva hypogyna, definita, v. rarius in floribus masculis indefinita, sex vel saepissime abortu pauciora, rarissime quatuor in Tetrarrhena et Microlaena) plerumque tria, vel rarius duo aut unicum, in floribus hexandris circa ovarium verticillata, in triandris anticam ovarii faciem et ejus Iatera stipantia, anticum longius et praecocius, in floribus diandris obliteratum, lateralia in monandris suppressa. Fil amenta filiformia libera, v. interdum basi connata. Antherae lineares, incumbentes, biloculares, loculi oppositi, utraque extremitate discreti, per totam longitudinem vel solo apice dehiscentes. Pollin is granula libera, subglobosa, laevia.

Ovaвivм unjenm, (dnorum abortu constanti), uniloculare, liberum, uniovulatum; o vuI u m ovarii parieti posticae pertotam longitudinem v. basi affixum, rarissime infra apicem suspensum. Styli duo, interdum basi connati, rarius tres, alterius nempe stigmate bifido v. umbone ovarium terminante in stigma converso. Stig mat anum ad tria, indivisa, plumosa v. hispidala, pilis simplicibus vel ramosis, saepe dentatis.

Fructus caryopsis libera, vel paleis adnata. Pericarpium skmini adnatum, tenue, chartaceo-membranacenm, rarissime crustaceum. Hil us instarmaculae basilaris vel lineae longitudinalis hinc pericarpium cum testa connectens. A l b u m e n farinaceum copiosum.

Emвryo albuminis lateri antico versus basin applicitus. Cotyledon (vilellus Gärtn. hypoblastus Rich.) scutelliformis, carnosus, extus sulco longitudinali exaratus, sulci marginibus interdum in tubulum connatis. Corc 1 l u m (plumula et radicnla, blastus Rich.) 
fusiformi cylindraceum, cotyledonis sulco plus minusve receptum, interdum inclusum et adnatum, utraque extremitate vel solo apice liberum, nonnunquam antice versus medium appendice unguiformi (epiblasto Rich.) auctum; extremitas terminalis (plumula; cotyledon Rich.) conica, primum undique clausa, foliorum convolutorum primordia occultans, sub germinatione in vaginulam tubulosam, foliis erumpentibus apice fissam producta; extremitas basilaris (radicula; radiculoda Rich.) obtusata, in germinatione tubulis aliquot intus latentibus, in totidem radicellas excrescentibus perforata.

Gramina ubique terrarum sociatim vigent, laeta praebent pecudibus paseua et humano generi annonam. Regiones temperatae specierum nonnihil feraciores; Paniceae, Chlorideae, Saccharineae, Oryzeae, Olyreae et Bambuseae in z on a tor rid a, Bromeae, Hordeaceae, Agrostideae et Stipaceae majori copia in temperat a vigent.

Tribus I. ORYZEAE. Kunth gram. 5. "Spiculae nunc uniflorae, gl $\mathrm{mm}$ is saepe „abortientibus; nunc bi-triflorae, floribus in„ferioribus unipaleaceis, neutris, terminali so„lo fertili. Pale a e chartaceo-rigidae. _Flo"res saepe diclines, plerumque hexandri. „Phalarideis affines." Kunth.

2.8. Leersin SOL. Spicula e hermaphroditae uniflorae. GI u ma e 0 . Pale a e 2, compresso - carinatae, subaequilongae, inferior latior, muticae. St a mina 3 _6 v. 1. Ova rium sessile. Styli 2 ; stigmat a plumosa, pilis ramosis. Cary opsis compressa, paleis obtecta. - Gramina in America tropica copiosa, in Europa rarissima, panicula simplici v. ramosa, spiculis racemosis, breviter pedicellatis subunilateralibus, cum pedicello articulatis, caryopsi cotyledoni contrarie compressa.

L e e r i a Soland. msc. Swartz Fl, Ind. occid. $T$. 119. Host. gram, I. t. 35. Trin. agrost, 113. Nees in Mart. FL. Bras. II. 510. Kunth gram. 5. 1.1.2. Agrost. 5. Aspre11 a Sehreb. gen. 105, Palis. agrost. 2. t. 4. f. 2. H o n a I ocenchrus Mieg ex Pollich. palat. 56. Phalaridis sp. Linn.

299. Oryza LINN. S p icula e hermaphroditae uniflorae. Gluma e 2, parvae, concavinsculae. Palea e 2, compresso-carinatae subaequilongae, inferior latior, apice plerumque arista reeta basi subarticulata. Squ a ma e 2, glabrae. St a mina 6. Ovarium sessile. Styli 2 ; stigmata plumosa, pilis ramosis. Car y op s is compressa, paleis inclusa. - Gramina tro pica, foliis plunis, paniculis ramosis, spiculis racemosis pedicellatis, compressis, hispidis, caryopsi cotyledoni contrarie compressa, paleis arcte inclusa, nee tamen adnata.

0 r gz a Limn. gen. $n$. 448. Mill. illustr. t. 19. Lam, $t$. 264. Palis, agrost, $t, 7, f, 7$. Trin, agrost, 19\%. Nees in Mart, Fl, Bras. II. 517. Kunth gram, 6. 6.4. 101. Agrost, 7 . - Maltebrunia Kunth gram. 6. t. 3. Csolo aristae defectu differt.)

530. Potamoplaila $R$. $B R$. Spienlae polygamae, superiores nunc hermaphroditae uniflorae, v. biflorae, flore inferiore neutro unipaleaceo, nune masculae; inferiores femineae, uni-biflorae, flo- ribus sessilibus perfectis, staminibus efoetis. Glama e 2, parvae, concavae. Pale a e 2, concavae, subaequales, inferior quinquenervis, superior trinervis saepe longior, muticae. Squa mula e 2 glabrae. Stamina 6 . Ovarium sessile. Styli 2 ; stig m a t a plumosa, pilis bifidis v. subdichotomis. C a ry o p sis compressiusenla libera. Gramen in Novae Hollandiae orientalis fuviis caespites densos efformans, culmis subramosis, foliis angustis subinvolutis, ligula longa lacera, panicula effusa erecta, spiculis pedicellatis, basi $\mathrm{cum}$ pedicello articulatis.

Potam aphila R. Brown prodr. 211. Kunth gram. 6 . t. 3. Agrost. 8 .

93 1. Ifryalnochloa $P . B . S_{p}$ ienla monoicae, femineae in eadem cum masculis panicula superiores; uniflorae. Ma $8 \mathrm{c}$. G I $\mathrm{nm}$ a e 0 . P a l e a e 2 coneavae, subaequilongae, inferior mueronata quinquenervis, superiorem trinervem involvens. S q u amulae 2 , glabrae. Stamina 6 . Ovarii rudimentnm. F em. Glum a e rudimentum cupuliforme, orbiculatum. P a l e a e 2 , lineares, inferior in aristam longam desinens, trinervis, superiorem angustiorem nninervem involvens. Squammlae 2 , glabrae. Sta min u m rudimenta. Cary ops is cylindrica, rostrata, paleis inclusa. - Gramina aquatica boreali-americana, folïs planis, paniculae ramosae ramis inferioribus femineis, spiculis pedicellatis, racemosis.

$\mathrm{H} \mathrm{y} \mathrm{dr} \mathrm{o} \mathrm{chl}$ o a Palis. agrost. 169, H y d r o p y $\mathrm{r}$ u m Link hort, berol. I. 258. Kunth gram, 7. Agrost. 9. M e.l in u m Link Handb. $I$. 96. Zi $\mathrm{x}$ a ni a a q u a tic a Lamb. in Trans. act. Linn, soc, VIT, t. 13.

g32. Zizania LINN. Spieulae monoicae, femineae in eadem cum masculis panicula superiores; uniflorae. M a 8 e. $\mathbf{G} \mathbf{l} \mathbf{u m}$ a e 2 , minutissimae rotundatae, in cupulam orbicularem connatae. $\mathrm{P}$ ale a e 2 , concavae, subaequilongae, inferior mucronata quinquenervis, snperiorem trinervem involvens. St a m in a 6 . Ovari i rullimentum nullum $\mathbf{F}$ em. Gluma e 0 . Pal ea e 2 , oblongae, inferior in aristam desinens septemnervis, superiorem trinervem involvens. Squa mula e bilobae subfaleatae. Stamina 0 . Ovarium breviter stipitatum. St y In s 1 ; st ig m a t a plumosa, pilis simplicibus. C a ry op8 is stipitata, lenticulari compressa, libera. - Gramen aquaticum, bor eali-a mer $i$ c an $u m$, foliis involuto-canaliculatis, paniculae ramosissimae patentis ramis inferioribus masculis, superioribus femineis, spiculis pedicellatis, pedicellis apice clavato-incrassatis.

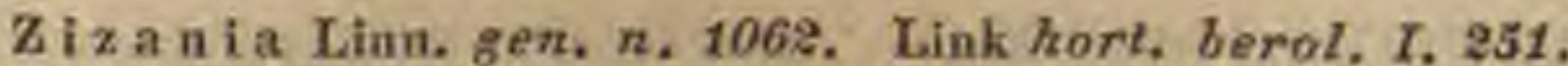
Kunth gram. 7 . Agrost. 9, $\mathrm{Z}$ iza in $f$ a miliace a Rich.

\%38. Hy maphroditae, uniflorae. Glu ma e 2, subaequales, inferior caudato-setigera, superior acuta. Pale a 1 , tenerrima, apice denticulata. Squamulac 0 . $\mathrm{S}$ a $\mathrm{m}$ in a 3 , O variu m breviter stipitatum. Stylus 1; stigmat a plumosa, pilis ramosis. Ca ryo psis stipitata, compressiuscula, mucronata.

Gramen pedale, ind ic um, folïs oblongo-lanceolatis, basi rotundatis, racemis approximatis, subfustigiatis, spiculis pedicellatis.

H y g $x$ o $\mathrm{r}$ y $\mathrm{z}$ a Nees in Edinb. n. philos, Journ. Juli. 1833. p. 380. Pharus eiliatus et a ristatus Retz obs. V.23.

\%34. Caryolaloa TRIN. Spie ula monoicae, in eadem panicula uniflorae. Masc- G1 uma e 2 , muticae. Pale a 0 . Stam ina 6 . F em. Gluma e 2 , muticae. Pale a e. Ovarium sessile. Styli 2; stigmata plumosa Caryopsis globosa, libera. - Gramen brasiliense tropicum, culmis caespitosis, panicula terminali. 
Caryochloa Trin. ex Nees in Mart. Al. Bras, Mr. 299. A rrozia Schrad, msc. Kunth agrost. 11. (Arroz de Mato Brasil.)

835. Cuziola JUSS. Spiculae monoicae, femineae in distinctis paniculis, multo quam masculae minores nniflorae. Mas c. G I u mae 0 . Palea e 2 , subaequales, concavae, nervosae, muticae. Squamulae 3 . Stamina 6_-11. Ovarii rudimentum nullum Fem. Glumae 0 . PaIeae 2 , ut in masc. Squamae 2. Stamina 0. Ovari um sessile. Styli 2 ; stigmat a villosoplumosa, pilis simplicibus. Caryopsis elliptiea, libera, paleis obtecta. _ Gramen american um tropicum, aquaticum, caespitosum, ramosum, foliis planis, panicula mascula terminali, femineis 1_3 brevioribus, $e$ vaginis foliorum inferiorum erumpentibus.

Luzi o La Juss, gen, 33. Palis, agrost, 136, t, 24. f. 1 . Kunth in Humb. of Bonpl, nov. gen, et sp.I. 199. Gram.8. Agrost. 10. Nees in Mart. A. Bras. II. 300.

*36. Wharlareta THUNB. Sp icula e triflorae, floribus approximatis, inferioribus neutris, terminali hermaphrodito, Glu m a e 2, muticae. Neutr. Palea 1, carinata, mutica, mucronata v. subulato-aristata. H e rma p hr. P a I e a c 2 , carinatae, muticae, inferior latior. Squa $\mathbf{m u l a}$ e 2, bifidae, glabrae v. ciliatae (c. paIeis alternantes). Stamina 3 v. 6 . Ovarium sessile. Sty $1 i 2$; stigmata plumosa, pilis simplieibus. Caryops is compressa, libera, paleis obtecta. _ Gramina capens ia, culmo basi saepius bulboso, simplici $v$. ramoso, foliis planis, paniculis ramosis, spiculis pedicellatis, caryopsi embryoni contrarie compressa.

Ehrharta Thunb. in Act. Holm, 1779. p. 216. t, 8. Swartz in Transact, Linn, soc, VT, 47, t, 34. Smith ic, inedit. $t, 35$. Palis. agrost, 60, $t, 12, f .2$. Sehrad, in Göting. Anseig. 1821.Nr. 208. Kunth gram. 9, t,6. Agrost, 11. Brongn. in Duperr, voy, 1, 24. Troohera Rich. in Hoz.Journ, XIII. 295. $t, 3$. Palis, agrost. 61, $t, 12, f .3$, A i r a e s p. Linn, f. Melicae sp. Thunb.

รืร. Tetrarr.hena $R \cdot B R$. Spiculae triflorae, floribus distiche imbricatis, inferjoribus nentris, terminali hermaphrodito. Glu mae 2, parvae, concavae, inaequales. Neutr. Palea 1 , floris inferioris ovato-elliptica truncata, carinato-coneava, septemnervis, fluris superioris paJeae floris hermaphroditi eonformis. He rma $p h r$. $P$ a le a e 2 , naviculares, inferior ovato-oblonga rotundato emarginata, superior brevior angustior, uninervis. Squa mula e 2, glabrae (c. paleis alternantes) Stamina 4 . Ovarium sessile. Styli 2 ; $\mathrm{stig}$ mata plumosa, pilis simplicibus. Caryops is compressa, libera, paleis obtecta. - Gramina australasica, culmis simplicibas v. ramosis, folits planis, spica racemosa simplici.

Tetrarrhe na R. Brown prodr. 209. Knnth gram, 9. Agrost, 15, Ehr ha r ta e s p. Labill. Nov. Holl, . 117.

238. Mierolaema $R . B R$. $\mathrm{Sp}$ i cula e triflorae, floribus approximatis; inferioribus neutris, terminali hermaphrodito. G1 u mae 2 , parvae, concavae, inaequales, a floribus remotae. Ne u tr. Pa1 a e a 1 , linearis subulato, aristata-quinquesulea, floris superioris major. He rma $p$ hr. neatris brevior Palea e 2, inferior carinata, acuminata, superior triplo brevior, linearis, hyalina. Squamula e 2, glabrae, (c. paleis alternantes.) St a mina 4 . $0 \mathrm{va-}$ ri um sessile. Styli 2 ; stigmat a pulmosa, pilis simplicibus. Caryo psis linearis, compressa, libera, paleis obtecta. _ Gramen pusillum, e Nova Holtandia extratropica et insula Diemen adlatum, culmo filiformi, foliis brevibus, li- gula incisa, racemo nutante, floribus intra glumam pedicello barbato sustentis.

Mierolaena R. Brown prodr. 210. Kunth gram, 10. Agrost, 16. Eltrharta stipoides Labill. Nov. Holl. t. 118 .

59. PInarus P. BR. S pi cula e uniflorae monoicae, geminae, fem in ea major ad basim pedicelli maseuli sessilis. Masc, Glumae 2, parvae, concavae, inaequales. Pal e a e 2 , inferior acnta, trinervis, superior binervis. Squ a mula e $\mathbf{2}$, glabrae. Stamina 6. Ovarii rudimentum. F em. G 1 u m a 2, parvae, concavae, subaequales. Pal e a 2 , elongatae, inferior indurata tereti-involuta, superiorem angustam binervem includens. S $t$ amina et squamula e nullae. Ovarinm sessile. StyIus 1; stigmata 3 , pilosa. Caryop8 is linearis, acuta, hine suleata, palea inferiore laxe inclusa. - Gramina americana tropica elata, foliis planis, latis, nervosis, petiolatis, paniculae terminalis ramis simplicibus subfastigiatis, spiculis spicatis.

P harus P. Brown Jam, 34t. Lam, t, 769. Palis, agrost. 125. t. 22. f.8. Kunth gram. 10. Agrost, 16. Nees in Mart, fl. Bras. II. 201,

\% 4D. Heptaspis $R$. BR. S p i u l a e uniflorae monoicae. Masc. Gluma e 2, parvae. . . . Paleae 2, inferior ovata, concava, superior linearis plana. Squamulae nullae. Stamina 6 . O varii rudimentum? ..... Fe m. Gl uma e 2, parvae. $\mathbf{P}$ alea e 2 , inferior ventricosa, subglobosa, apertura apicis angustata; superior minuta, linearis. Stamina et squamula nullae. Ovarium sessile. Stylus $1 ; s t i g m a t a ~ 3$, villosa. Caryopsis palea inferiore demum ancta inflata obtesta. - Gramina australasica tropica, foliis lanceolato-ensiformibus, paniculae rarae ramis strictis, paucifloris. 17.

Leptaspis R. Browu prodr. 211. Kunth 11. Agrost.

Tribus II. PIIALARIDEAE Kunth gram. 12. Spiculae hermaphroditae, polygamae v. rarius monoicae; nune uniflorae, cum $v$. absque rudimento stiptiformi floris alterius superioris; nunc biflorae, flore utroque hermaphrodito v. masculo, nunc bi-triflorae, flore terminali fertili, reliquis incompletis. G I u ma e plerumque aequales. Pale a e saepius nitidae, in fruetu induratae. Styli v. stigmata in plerisque elongata. - Ory $\approx e i s$ simillimae, hine Agrostideis per Crypsim, illinc Avenaceis mediante Hierochloa affines.

7.41. Hygeum LINN. Sp icul a e biflorae, hermaphroditae, floribus oppositis connatis; folio spathaeformi involutae. GI um ae 2 , basi carnosae, in tubum extus villosum connatae, apice liberae. Palea 1, postica, duorum florum dorso inter se connatae et glumis adnatae. Squamulae nullae. Sta mina 3 . O varium brexissime stipitatum. Styla \& 1. Stigma simplex, glabrum, hine convexum, latere plano basi poro infundibuliformi. Cary o p sis oblonga, hine convexa, in loculo gIumarum cum paleis connatarum inclusa. - Gramen mediterrane $u$ m junceum, culmis simplicibus caespitosis, basi vaginis aphyllis obtectis, folits tereti-subulatis, lingrula elongata instruetis, spatha terminali solitaria, spiculam unicam includente, genitalibus elongatis exsertis.

L y g e u m Lian. Loffl it, 285. t. a. Rich. in Mom. soc. h, $n$, paris. p. 28. t. 3. Palis, agrost, t, 25. f. 6. König Arth. of bot. II. 548, t. 15. Kunth gram, 12. Agrost. 18. t. 2, 
\% 4. Zer LINN. F lores monoici, maseuli terminales racemosi, feminei axillares dense spicati, vaginis aphyllis involuti. Masc. Spi culae biflorae, floribus perfectis sessilibus. Glumae 2, concavae, inferior trinervis, superior binervis. S q a amula e 2, collaterales, glabrae. St a min a 3 . F e m. Spieulae biflorae, flore inferiore neutro. Glumae 2, latissimae, inferior emarginato-subbiloba. Nentr. Paleae 2. Fem. perf. Paleae 2 -3 , concavae. Squamula e et $s t a m i n$ a nulla. Ovarium sessile, obliquum. Stylus 1; stigmata 2, subulata, puheseentia. Caryopsis reniformis, glumis paleisque eincta. - Gramen annum, in America tropica indigenum, cultura cosmopolitum, culmo crasso fareto, foliis latis planis, ligula brevi ciliata, racemo masculo simplici vel basi subramoso, spiculis geminis pedicellatis, spicis femineis sessilibus, spiculis multiseriatis, per paria approximatis.

$\mathrm{Z}$ e a Lian. gen, $n, 1042$. Palis. agrost, 136, t. 24. f. 3. Kuath gram, 12. Agrost, 19. Nees in Mart, Fl, Bras. II. 311.

743. Coix LINN. Flores monoeci spicati ; s pieula e 3 , basilares, media sessilis feminea, Iaterales pedicellatae neutrae, involucro ovato apice perforato, demun lapidescente inclusae, masculae in spica v. panicula ex involucro exserta. Masc. Spicula e biflorae, flore ntroque sessili. G 1 uma e 2, muticae, inferior planiuscula, marginibns earinato-alatis, superior trigono-concava. Paleae 2, muticae, superior bicarinata, Squamulae 2, glabrae. Stam ína 3 . Neutri. Spic $\mathbf{u} \mathrm{l}$ a e minimae, saepe ad pedicellum redactae. $\mathrm{F} \mathrm{e} \mathrm{m}$. Spieulae biflorae, flore inferiore neutro. Glam ae 2, carnosae, concavae, muticae. Ne ntr. Palea 1. Fem. perf. Pa le a e 2, carnosae, superior binervis. Squamulae nullae. Stamina efoeta, minuta. Ovarium sessile. Stylus 1; stigmat a $2-3$, elongata, pilosa. C a ry opsis subglobosa, demum intra involuerum libera.

Gramen ind icu m, annuum, ramosum, culmo farcto, foliis latiusculis planis, spicis fasciculatis, pedunculatis.

Co ix Lìu. gen, n, 1043. Palis. agrost. 137. t. 24. f, s. Kunth gram. 13. Agrost, 20, t. 3 et 4. Nees in Mart. Fl. Bras. II. 310. Lit hagros $t$ is Gaertn. I. 7. $t, 1$.

-44. Cormueopiae LINN. Spiculae hermaphroditae uniflorae, fasciculatae, involucro membranaceo, infundibuliformi-campanulato exceptae. Gl u m a e 2, subaequales, carinatae, basi connatae. $\mathrm{P}$ a l e a 1 , basi quinquenervis, apice biloba, marginibus usque ad medium connatis, infra medimm dorsum aristata. $\mathrm{S} q \mathbf{q}$ a $\mathrm{mul}$ a e nullae. $\mathrm{Stamina} 3$. Ovarinm sessile. Styli 2 ; stigmata 2 , elongata, pubescentia. Cary o psis lenticularis, libera. - Gramen annuum, orientali-mediterrane$u m$, culmis caespitosis, foliis planis, vaginis ventricosis, pedunculis in apice ramulorum solitariis vel geminis, sulcatis, superne incrassatis, incurvatis.

C ar nuc opiae Lina. gen, $n, 72$. Selureb. Ir. $t, 41$ Smith spic, t, 14, Linn, Transact, VIT, t, 12. f. 1, Sibth, Fl. graec. t. 51. Palis, agrost, 3. t.4. f.3.4. Kunth gram, 14. Agrost. 21 .

\%4. Orypsis AIT. Spieulae hermaphroditae, uniflorae. GI $\mathbf{n}$ ma e 2 , earinatae, muticae, inferior paullo minor. P a le a e 2, muticae, inferior compresso - carinata. Sq a a mu Iae nullae. Stamina 2-3. Ovarium sessile. Styli 2; stigmata 2, elongata, plumosa. Caryopsis libera. - Gramina annua, caespitosa, in Europa imprimis orientali et Asia media provenientia, foliis planis, paniculis coarctatis spicaeformibus, folio spathaeformi sustentis.
Cryps is Ait. Hort. kew. 1. 48. Kunth gram. 14. Agrost. 21.

a) ANTITRAgUS Gaert. FIos intra glumam brevissime pedicellatus. P a le a superior uainervis. S $t$ a m $\mathrm{i}$ n a 2 . Antitragus Gaerta. II. 7. t. 80. Pallasia Seop.

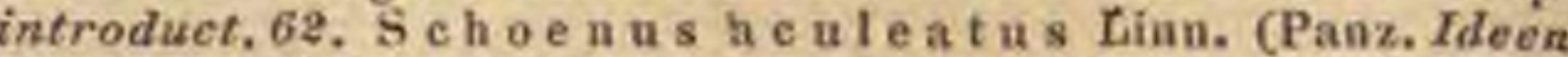
I. 24. t. 8. f. A. a, d. Host gram, $I$. t, 31. Palis. t, 6. f. 12.)

b) HELEOCHLOA Host. Flos sessilis. Pale a superior binervis. St amina 3 .

He I e o e hlo a Host gram, $I, 23, t$, 29. Palis. $t, 7, f, 3$. Pauz. Iteen t.8. f.3. a, d. (Delile aegypt. t.9.)

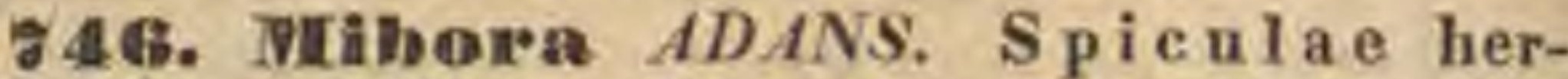
maphroditae uniflorae. $\mathbf{G} 1 \mathbf{u} \mathbf{m}$ a e $\mathbf{2}$, carinatae, rotundato-truncatae, inferior paullo brevior. $P$ ale a e 2 , truncatae, inferior latissima quinquenervis, superiorem obsolete binervem includens. $S q \mathbf{n}$ a $\mathbf{m} \mathbf{~} \mathbf{l}$ a $\mathrm{e}$ 2 , glabrae. Stam in a 3 . Ova ri u m sessile. Styli 2 , stig m a ta elongata, pilosiuscula. Ca ry ops is elliptica, compressa, paleis olitecta. _ Gramen pusillum, annuum, in Europ a media et occidentali observatum, culmis capillaribus, caespitosis, foliis complicatis, obtusis, spica simplici, spiculis brevissime pedicellatis, unilateralibus.

M ib or a Adans. IT. 495. Palis. agrost. 29. t, 8. f. 4. Knappia Smith E. B. $t, 112 \pi$. Sturta ia Hopp, in Sturm's El. germ, VII. c, ic. Cha mag ro st is Borkh, apud Schrad. Fl.germ, 1 , 158, Kunth gram, 15.

\% 4. Alopecuning LINN. Spienlae hermaphroditae uniflorae. G I u m a e 2, navieulares, subaequales, basi connatae. Palea e 2 , inferior carinata, marginibus inter se connatis $v$. distinctis, dorso plerumque aristata, superior brevior uninervis vel nulla. Squamula e nullae. Stamina 3 . Ovarium sessile. Styli 2 (basi saepius connati); stigmat a 2, pubescenti-plumosa. C a ry o psis elliptica, compressa, inter glumas induratas paleasque libera. - Gramina plerumque perennia, in Europa imprimis meridionali, Asia mediterranea et media, Americaboreali, nec non et in regione Magellanica observata, foliis planis, paniculis sinuplicibus confertis, spicaeformibus, cylindricis. 23.

Alopecurus Linn.gen, n.78. Kunth gram.16. Agrost.

a) ALOPECURUS. Glu ma e basi connatae, aequales. $\mathrm{Pal}$ a $\mathrm{e}$ inferioris margines connati, superior nulla.

A 10 pe curus Palis. agrost. $5 ., t .4 . f$. 5.6 . Fl. dan. $t$. 679.861, 1565. Host, gram, II. t. 31, 39, IIT. t, 12. Jaeq. f. Eclog. II, $t, 15$, Trin, ic. IV. $t, 37-44$. Kunth gram, $t, 7$. Brougn. ad Duperr. 16 .

b) COLOBACHNE. G I u ma e basi subconnatae. Paleate inferioris margines distineti, superior uninervis.

Colo ba ch ne Palis. 28, $t$. 6. $f, 9$. Sibth. Fl. graec. $t$. 64. Trin, io. 45. 46 .

c) TOZZETTIA, GI uma e basi connatae, ventricoso-gibbosae. Pale ae inferioris margines conuati, superior nalla.

Toxzettia Savi in Usteri Annal, XXIV, 50. Memor. matemat, della soc. ital. VIIT. 2. 477. P h I e i s p. Jacq. ic. t. 301. Sibth. El. graeo, t. 63. Host. III. t, 7. Triu. ic. I. $t$. 1. 2 .

2 48. Iimanas TRIN. Spicula e hermaphroditae, uniflorae. Glum a e 2, naviculares, angulato - trieostatae, inferior paullo minor. $P$ al e a e 2 , inferior compressa, acuta, infra medium aristata; superior minor, arista tortili. Squa mula e 2 , laterales, elongatae. Sta $\mathrm{mina} 3$. Ovari $\mathbf{u m}$ sessile. Stylus bifidus; stigmata plumosa. Caryopsis...-Gramen camts chatkicum, Cenchri facie; culmis eaespitosis, foliis setaceis, radicalibus elongatis, panicula simplici pauciftora, pedicellis apice incrassatis, eum spicula articulatis. 521.

Lim na s Trin. fund, 116. t. 6. Ic, t. 18. Kunth agrost.

45. TBeckmantain HOST. Spicnlac biflorae, floribus hermaplurolitis sessilibus. G I a- 
mae 2 , obovatae, navicnlares, aequales. Pal e a e $\mathbf{2}$, inferior ovata, acuta, trinervis, superiorem binervem, apice bifidam marginibus amplectens. S qu amulae 2, bifidae, glabrae. Stamina 3 . Ovarium sessile. Styli $2 ; 8 \mathrm{t}$ i g m a t a plumosa. Caryo psis teres, libera. - Gramen perenne, in Europa orientali, Asia media et Americ a bore a $l i$ observatum; foliis planis, ligula elongata, spicis sessilibus alternis, in apice culmi spicatis, spiculis sessilibus, unilateralibus, biseriatis.

B e e k m a nui a Host gram. III. $t$. 6 . Kunth gram. 17. Agrost. 27. Joachimia Tenor. neap. 16. t. 5 . B ruch. mannia Nutt. gen. $I$. 48, Phalaris erueaeformis Linn.

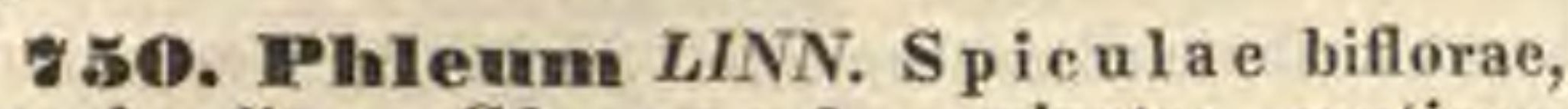
hermaphroditae. G1 u m a e 2, carinatae, muticae, acuminatae vel in aristam productae. Pale ae 2, inferior truncata, mutica, mueronata $v$. dorso aristata; superior biearinata, basi saepe rudimento stipitiformi alterius floris aucta. $\mathrm{S} q u$ a $\mathbf{m} \mathbf{u}$ la e 2 , inaequaliter bilobae, glabrae. $\mathrm{S} t \mathrm{am}$ in a 3 . O varin m sessile. Styli 2 ; stigmata plumosa. Caryopsis oblique elliptica, teretiuscula, libera. - Gramina ut plurimum annua, in Europa mediterranea et orientali potissimum provenientia, in Asia media et boreali parce reperta, in America septemtrionali rarissima ; foliis planis, paniculis confertis spicaeformibus, cylindricis.

Ph J e um Linn. gen, n. 77. Tria. agrost. 101. Kunth gram. 17. Agrost. 27. Stelep h u rus Adans. $I$. 31 .

a) CHLOCHLOA Palis. G $1 \mathrm{um}$ a e acuminatae. Rudimentum floris neutri.

Chiloehloa Palis, agrost, 37. t, 7. f. 2. Phal aridis s p. Linn. Host gram, IT, t. 37. 37. IV. t. 20. (FI. dan. t.915. Host $I$. $t, 35$.

b) PHLEUM Palis. G 1 a ma e truncatae, aristatae. R u dime n t $\mathrm{mm}$ floris neutrí nullum.

Pble и m Palis. 24, t.7, f.4. Schrad, Fl. germ. t, 1. f. 2 . Host IIT. $t, 10,11, I V . t, 21$.

c) ACHNodonton Palis. Glumae obtusae. Rudimentum floris neutrí nullín.

Achnodanton Palis. 25. $t .7$. f.5. A ehnodon Link Hort. berol, I. 65. P halaridis s p. Linn. Host $I I, t, 36$.

-51. Elagerinuthia NEES. S p icula e bi-triflorae, fleribus pedicellatis, inferioribus hermaphroditis, superiore neutro. Glum a e 2 , earinatae, aristatae. He $r m$ a $\mathrm{ph} . \mathrm{P}$ a 1 e a e 2 , inferior carinata, ex apice obtuso brevi setigera, quinqueseptemnervis; superior brevior, earinata, obtuse bidentata, binervis, Squamulae 0 . Stamina 3 . Ovarium sessile. Styli 2 , elongati; $8 \mathrm{tigma-}$ ta villosa. Caryopsis.... Nentr. Palea 1 , obcordata, complicata, e sinu obtuso breviseta.

Gramen ca pense; spica oblonga, spiculis cum pedicello articulatis deciduis, floris neutri pedicello in canalem paleae superioris floris hermaphroditi recepto. 448.

Finger huthia Nees ex Lindl. introduct. edit. $I I . p$.

ชร2. Irillaria H.B.K. Sp iculae monoe eae, basi ternatim connatae, anteriores duae masculae, uni-triflorac; postica feminea, uniflora. M a s c. Glu ma e 2, carinatae, inaequilaterae, inaequales; inferior brevior, apice bifido aristata; superior mucronata. $\mathrm{P}$ a 1 e a e 2 , apice rotundato-emarginatae; inferior brevior carinata, superior bicarinata. Squamulae 0. Stamina 3. Fem. G lumae 2, oppositae, aequales, navicnlares, inaequilaterae, bilobae, inter lobos aristatae. $\mathrm{P}$ a $\mathrm{I}$ e a 2 , compressae, apice angustatae, rotundato-emarginatae; inferior trinervis, smperior longior, angustior, binervis, bicarinata. Squamula e 0 . Staminum rudimenta. Ovarium sessile, Styli 2 ; stigmat a pubescentia. Caryopsis compressa, in- tra paleas libera._Gramen perenne, mexican $u$ m, ramosum, repens; foliis planis, ligula abbreviata, laciniata, spicis terminalibus solitariis, simplicibus, spiculis ternatim rhacheos dentibus alternis insidentibus, cum rhachi articulatis, hispidulis.

Hilaria Humb. et Kunth nov. gen. ot sp. $T$. $t$. 37 . Gram. 18. Agrost. 30. H e xa r r he n a Presl in Reliq. Haenk. I. $326 . t .45$.

953. Flhallaris $L I N N$. S p i c u 1 a e triflorae, floribus duohus inferioribus squamaeformibus minimis, nentris, summo hermaphrodito. Gluma e 2 , naviculares, earina plerumque alatae, subaequales. Palea e 2 , navieulares, muticae, inferior major, snperiorem involvens. S q a a m u la e 2, glabrae. Stamina 3 . Ovarium sessile. Styli 2 ; stigmata plumosa. Caryopsis oblonga, lenticulari-compressa, intra paleas demum arcte reclusas libera. - Gramina perennantia; foliis planis, paniculis spicaeformibus, coarctatis $v$, diffusis, spiculis pedicellatis. Species in regione mediterranea imprimis o c cidentali frequentiores, nonnullae late diffusae, una nep al ens $i s$, altera americana tropica, tertia chilensis, paucae boreali-americanae.

Ph alaris Linn. gen.n.74. Kunth gram, 10, Agrost,31,

a) PHALARis $P$. Gluma $\mathrm{rum}$ earina alata. Panjen. I a coarctata.

P h a laris Palis, agrost, 36. t. 7. f. 1. Trin, ic, t, 74 . 82. Sibth. Fl, graec, $t$, 55-58. Host. gram. II. $t, 38-40$.

b) DIGRAPHIS Tr. GI umarum earina aptera. Panicu la diffusa.

Dig raphis Trin, agrost, 127. Baldingera Gaertit. Fl. wetter. 99. Ty phoides Mönch meth, 201. A $\mathrm{r}$ u $\mathrm{a}$ d i. n is et Calamagrostidis sp. Auet. E. B. $t .402$, (Host $\{1 . t .33$. FI. dan, $t .259\}$

ร4. 4. IIIteus LINN. Spieula e biflorae, floribus pedicellatis, inferiore hermaphrodito, superiore masculo. Glum a e 2 , naviculares, subaequales. Hermaphrodit. Palea e 2 , inferior navienlaris, mutica; superior bicarinata. Squamulae $\mathbf{2}$, bilobae, glabrae. Stam in a 3 . Ovarium sessile, pyriforme. Styli 2; stigmata plumosa. Caryopsis libera. Masc. Palea inferior sub apiee aristata; reliqua ut in hermaphrodito. Ovari $\mathrm{rm}$ efoetum (rarissime fertile.) _ Gramina potissimum perennia, per Europam et Americam borealem vagantia; foliis planis, paniculis ramosis, spiculis pedicellatis, interdum trifloris. - Species ind ic a e ab auctoribus commemoratae verisimiliter e genere eliminandae.

Holcus Linn, gen, $n, 1156$. Palis, agrost, 87, 1 , 17. $\mathrm{f}$. 10. Host gram, $I, t, 2,3$, F1, dan, $t, 1181$. Kunth gram, 20. Agrost. 39.

-55. Thereelhoa GMEL. S p icula e triflorae, floribus sessilibus, dnobus inferioribus maseulis, summo hermaphrodito. G 1 um a e 2, earinatae, subaequales. Ma s c. Pale a e 2 , inferior carinata; superior biearinata, saepe aristata. Squa mu la e 2 , bilobae. Stamina 3 . Hermaphr. Palea e 2, earinatae, muticae. $\mathbf{S q u}$ a $\mathbf{m} \mathbf{u} \mathbf{l}$ a e 2 , bilobae. Stamina 2. Ovari um sessile. Styli $2 ; s t i g m a t a$ plumosa. C a r y o p sis elliptica, subeompressa, libera, paleis obtecta. - Gramina perennantia, odorem aromaticum spargentia, inter $40^{\circ}-75^{\circ} \mathbf{L}$. B. et inter $35^{\circ}-54^{\circ}$. L. A. observata; foliis planis, paniculis diffusis $v$. coarctatis, spiculis pediccllatis.

H ieroch1 o a Gmej. sibir. L. 100. Palis, agrost, 68. $t$. 12. f.5. Kunth gram, 20, t, 8. Agrost. 35. Brongn, in Du. perr. voy, t. 23. D is a $r$ rhe num Labill. Nov. Holl, $\Pi$. 83. t.332. D i u e ria Raf. in Journ. Phys. LXXXrx, t. 12, f. 7. H o I e i s p. Linu. Host gram, I, ᄂ,4,IIT, L, 3, Vl. dan. t, 963 1508.

758. A athoxantlarem LINN. Spienla e triflorae, floribus duobus inferioribus neutris, 
summo hermaphrodito. Gluma e 2 , earinatae, inferior brevior uninervis, superior trinervis. Ne utr. Palea 1, canaliculata, apice emarginata, dorso aristata. Her m a p hr. Paleae 2, naviculares, muticae; inferior superiorem nninervem involvens. S q $\mathbf{u}$ amulae nullae. Stamina 2. Ovarium sessile. Styli 2; stigmata distiche plumosa. Caryo ps is teretiuscula, intra paleas arete reclusas libera. - Gramina aromatica, perennia, in Europa media, australi et orientali indigena, in Americam borealem transfuga; foliis planis, ligula elongata, panicula simplici conferta, spicaeformi.

A $\mathrm{u}$ th ox a $\mathrm{t}$ h $\mathrm{um}$ Linn. gen. n. 49. Palis. agrost. 64, t. 12. f. 8. Host gram, Y. t. 5. Fl, dan. t.666. Trin. ic. II. $t$. 13_16. Kunth gram, 21, Agrost. 37.

ร5\%. Atuxia R. BR. Spicula e triflorae, flore inferiore masculo, intermedio neutro, terminali hermaphrodito. G $1 \mathbf{u} \mathbf{m}$ a e 2 , inaequales. M a s c. Paleae $2 \ldots$ Ne utr.Palea $1 \ldots$ Her maphr. Pale a e.... - Gramen habitu Anthoxanthi, ex insula Java in Angliam allatum, a R. Broumone obiter indicatum, necdum descriptum.

Ataxia R. Brown Chlor. Melv. 35. Kunth gram. 22, Agrost. 39.

ร 5. Theynaudia KUNTH. S p ic ul a e uniflorae, flore sessili. G 1 u ma e 2 , carinatae, apice bifidae, aristatae, inferior paullo brevior. Pal e a e 2, carinatae, inferior apice bifida, breviter aristata, subquinquenervis; superior mucronata, binervis. S q u amula e 4, duae exteriores in filum productae. S tamin a 2 , unilateralia. Ovarium sessile. St y Ii 2 ; stigmata penicilliformia. Caryopsis... Gramen do mingen se, perenne, caespitosum; foliis setaceis, panicula simplici spicaeformi.

Reynaudia Kunth gram, 28. 4. 9. Agrost, 39.

ร5. Despretzin KUNTH. Spicula tri-quadriflorae, flore inferiore femineo, superioribns masculis, remotis, summo tabescente. Gluma e 2 , subaequales, clausae, muticae, apice trilobae, retieulato-nervosae, inferior septemnervis superior trinervis. Fem. Pale a e 2 , inferior concava, apice quadriloba, novemnervis; superior paulo longior, bicarinata. S qu a m u lae et stamina 0 . Ovarium sessile. Stylus 1 ; stigmata 2 , plumosa. C a r y op s i eompressinsenla, libera. M a s c. $P$ ale ae 2 , inferior concava, emarginata, quinquenervis; snperior bicarinata. Squamulae 2, collaterales. Stamina 3 . Ovarii rudimentum.

Gramen mexicanum, cacspitosum; foliis ovatis, basi rotundatis, petiolatis, nervosis, vaginis fissis, ligula abliterata, paniculae ramosae, depauperatue, patentissimae spiculis pedicellatis, cernuis.

Despretzia Kuath gram, 2. 157. Agrost. 39.

TER IB US III. PANICEAE Kunth $\mathrm{gram}$. 23. Spicula e biflorae, flore inferiori incompleto. Glumae paleis teneriores; inferior saepe, rarissime ambae abortientes. P a le a e plus minus coriaceae $\mathbf{v}$. chartaceae, plerumque muticae, inferior concava. Ca ry opsis a dorso compressa. Kunth.

\%6. Feimaria FLUEGG. Spicula e biflorae, flore inferiore neutro, superiore hermaphrodito. Gluma e 0 . Neutr. Pale a subulata trinervis. Hermaphr. Pale a e 2, lanceolatae, inferior trinervis, superiorem obsolete binervem involvens. Squ a $\mathbf{m} \mathbf{u} \mathbf{l}$ a e 2 . Sta $\mathrm{m}$ in a 2 . Ovarium sessile. Styli 2 , terminales; stigmat a aspergilliformia, pilis simplieibus. Caryop s is oblonga, compressiuscula, intra paleas li- bera. - Gramen amazonicum, repens; spicis quaternis quinisve, rhachi continua, spiculis unilateralibus sessilibus.

$\mathrm{R}$ e i m a r i a Fligg. Monograph. Pasp. 213. Kunth in Humb. et Bonpl, nov. gen. et sp. t. 21. Gram. 23. Agrost, 40.

761. Prespalarm LINN. Spieulae biflorac, cum pedicello articulatae, flore inferiore nentro, superiore hermaphrodito. G lu ma 1 , v. rarissime 2 , inferior minuta, superior (antica) florem neutrum aequans. Neutr. Palea membranacea, mutica. Herma p hr. Palea e 2 , coriaceae, muticae, inferior coneava, superiorem binervem amplectens. Squam ula e 2, carnosae, breves. Orarin m sessile. Styli 2 , terminales; stigm at a aspergilliformia, pilis subsimplicibus, dentienlatis. Car y ops is oblonga, compressiuscula, intra paleas induratas libera. - Gramina, ut plurimum tropica; rhachi spicata, continua, spiculis unilateralibus.

Pas palum Linn. gen. n, 73. Jaeq. ic, t, 11, 302. Flügg. monogr. Lecoute in Journ. Phys, XCr. 284. Palis, Fl. owar, t. 84.92. Rudg.guian, $t$, 26. Kunth, in Humb, et Bonpl. nov. gen. et sp. t.23-27. Gram, t, 164. Agrost. 40. Trin. ic.t, $97-163$. A x in op u s Róm. et Sehult, syst, 11,14 , C e re 8 i a Pers. tynops. $I, 85$. Jacq. fragm, 86. S a b s a b Adans. It. 31, - Garnotia Brongn, ad Duperr. 132, $t, 21$,

762. Difliam LINN. Sp i e u la e biflorae, pedicello continuae, flore inferiore neutro, superiore hermaphrodito. Gluma 1, antica, membranacea, concava. Neutr. Pale a membranacea, concava. Hermaphr. $\mathbf{P}$ a 1 e a e 2 , subcoriaceae, unticae, inferior concava, superiorem binervem amplectens. Squ a mula e 2 , earnosae, longae. Stamina 3. Ovarium sessile. Styli 2 , terminales, brevissimi; stigmata plumosa, pilis distichis denticulatis, apice bifidis. Ca r y o p$\mathrm{s}$ is oblonga, compressiuscula, intra paleas induratas libera. - Gramina per Europam, Asiam mediam et Americam tropicam diffusa, erecta; foliis planis convolutisve, paniculis ramosis, diffusis, spiculis pedicellatis.

Milf u m Linn. gen, $n$, 79. Host. gram, t, 22. Palis. agrost. t. 5. f.5.6. Kunth, in Humb. et Bonpl. nov, gen. et sp. t. 29. Gram, t. 163. Agrost. 65. Miliarium Möneh. meth. 204. Le p t o c or y p h $\mathrm{i}$ m Nees in Mart. Fl. bras. $I I$. 83. Pas pali s p. Kunth in Humb. ot Bonpl. nov. gen. et sp. $t, 29$.

9633. Amplniearpum RAFIN. SpicnI a monoecae, biflorae; flore inferiore nentro; Pemineae radicales, masculae terminales paniculatae. Mas c. G I u ma 1, antica, membranacea, concava. $P^{2}$ a le a e 2 , concavae, muticae, inferior superiorem binervem amplectens. S qu a mu Iae 2 , carnosac, truncato - trilobae, collaterales. St a mina 3 . Ov arium efoetum. F em. Gluma 1, antica, membranacea, concava. Palea e 2 , ut in mare. S qu a mula e 2 , carnosae, truncato-bilobae, collaterales. Sta mina efoeta. Ovarium sessile. Styli 2, terminales, brevissimi; stig$m$ a t a plumosa, pilis denticulatis, simplicibns bifidisve. Caryopsis oblonga, teretiuscula, intra paleas libera. _ Gramen bore a $l i$-a merican $u m$, caespitosum; foliis planis vaginaque pilosis, paniculae masculae, simpliciter ramosae spiculis pedicellatis, pedicello continuis, pedunculis femineis fasciculatis, unifloris, vaginatis, fructiferis subterraneis.

A mp hi carpum Raf, in Americ. Monthl. Magas. Jan. 1818. Kunth gram. 28. Agrost. 67. Mill um am $\mathrm{ph}$ ic arp um Pursh fl. bor. amer. I. 62, t, 2.

764. DIyra LINN. Spical a e monoecae in eadem panicula, masculae inferiores. M a $8 \mathrm{c}$. 
Spicula uniflorae. Glumae 0 . Paleae 2, membranaceae, concavae, antica acuminato-aristata; postica mutica, binervis. Squa mu Ia e 3, subcarnosae. Sta mina 3 . Ovarii rudimentum nullum. Fem. Sp icula e biflorae, flore inferiore mipaleaceo, neutro. G $1 \mathbf{u m a ~} 1$, antica, membranacea, concava, acuminato-aristata, Palea e 2, coriaceae; inferior concava, superiorem conformem involvens. Sta mina 0 . Squamula e 3 , carnosiusculae, glabrae. $\mathrm{O}$ a rium sessile. St y Iu s 1; terminalis; $8 \mathrm{ti} \mathrm{gmat}$ a 2 , pilosa, pilis ramosis, pubescentibns. Caryopsis glabra, intra paleas Iibera. - Gramina americana tropica; foliis membranaceis, latis, paniculis terminalibus vel axillaribus, spiculis cum pedicello articulatis.

0 I y r a Linn. gen, n. 1045. Palis. agrost, 124, t. 22. f.7. Sehlechtend, in Berlin. Magaz, VIIT. 147. ss. Kunth gram. 29. t. 12. Agrost, 68. Brongn, in Duperr. voy. $t$. 22. Nees in Mart. A.bras, II. 303. Lit ha e h ne Palis. Agrost. 135. t. 24. $f$. 2. R addia Bertol. in opusc. scientif. di Bologn. III. 40.

855. Streplnivam SCHRAD. Spiculat in distinctis racemis monoecae, biflorae. M a s c. Glumae 0. Palea e 2, lineari-lanceolatae, inferior acuminata. Squ am ula e.... Stamina 3. F e m. G I uma e 2 , ovato-lanceolatae, acuminatae. $P$ al eae 2, cartilagineae. Squam u la e. Ovarium. ... Sty 1 us 1 ; 8 tigmata 2 . Caryopsis ovata, paleis cortieata. - Gramen brasiliense, caespitosum; foliis subdistichis, racemis axillaribus paucifloris.

Strephium Sehrad. ex Nees in Mart. fl,bras, II. 298.

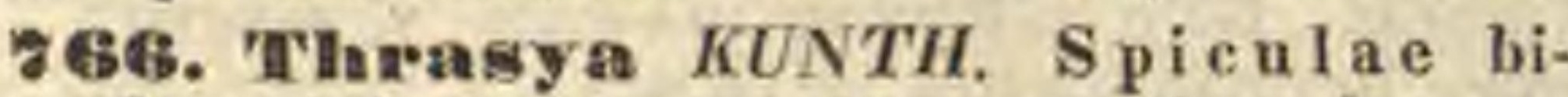
florae, flore inferiore masculo, superiore hermaphrodito. G $1 \mathbf{n}$ m a e 2, membranaceae, muticae, antica minor, interdum abortiens. Ma $8 \mathrm{c}$. Pa I e a e 2 , inferior bifida; superior integra, bincrvis. $\mathrm{S} q \mathrm{q}$ amula e 2 , carnosae, lobato-truncatae. $S t$ a $m$ in a 8. Herma phr. Palea e 2, membranaceo-chartaceae, muticae, inferior superiorem involvens. Squa mu la e 2, collaterales, carnosae, integrae. St a m in a 3, v. abortu 2. Ovarium sessile. StyIi 2, terminales, elongati; stig mat a aspergilliformia, pilis simplicibus. Caryops is oblonga, intra paleas libera. - Gramina americana tro$p i c a$; culmis simplicibus $v$. ramosis, foliis latiusculis, planis, spicis solitariis, rhachi membranacea, complicata, ciliata, spiculis unilateralibus, imbricato - uniseriatis.

Thras y it Kunth in Humb. et Bonpl. nov. gen. et sp, I. 121. t.39. Gram. 29, t.102, Agrost,70. Nees in Mart.fl. bras, II, 93. Trin. ic, t.151.

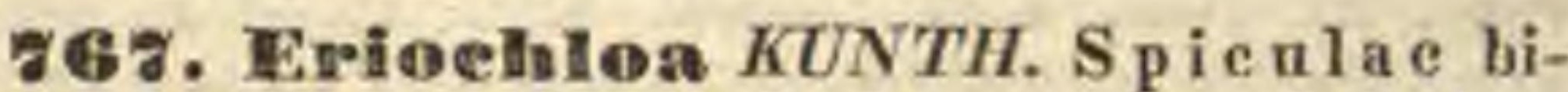
florae, cum pedicello articulatae, flore inferiore masculo v. neutro, superiore hermaphrodito. Gluma e 2 , antica minutissima $v$. abortiens. Ma $8 \mathrm{c}$. Paleae 2. Stamina 3 ; interilum palea superiore et staminibus obliteratis nenter. H ermaphr. Paleae 2, coriaceae, concavae, inferior mucronata. Squam ula e 2, truncato-emarginatae. Stamina 3. Ovarinm sessile. Styli 2, terminales; stigm a t a penicilliformia, pilis denticulatis bifidisque. Caryo psis elliptica, compressa, cum paleis decidua. - Gramina planifolia, inter tropicos totius mundi, frequentissime tamen in America reperta, in Asia extratropica rara; spicis paniculatis, interdum geminis, rhachi continua.

Erloch Ioa Kunth in Humb. et Bonpl. nov. gen. et sp. I. 95. t.30.31. Gram, 30,t.13. Agrost. 21.0 ed ip a e hne Link Hort. berol. I. 51, H e lo $\mathrm{p} \mathrm{u}$ s Trin. fund. 103. t. 4. Milif sp. Linn. P ipt atheri sp. Palis, t,5.f.11, Mon a ed- a es s p. Palis, t. 10, f. 9. Paspali s p. Thunb. jap. t, 8 . Trin. ic. t.133.155.156. Panici sp. Raddi Trin, ic. t.178.

\%6. Uroelndere PALIS. Spicae biflorae, flore inferiore nentro, superiore hermaphrodito. G $1 \mathrm{u} \mathrm{m}$ a e 2 , concavae, muticae, inaequales. Neutr. Palea 1, mutica. Hermaphr. Paleae 2 , concavae, inferior apice mucronato-aristata. Squ a $m$ ulae 2 , subtrilobae. Stam ina 3. Ova. ri um sessile. Styli 2 , terminales; $s \mathbf{t i g} \mathbf{m}$ at a penicilliformia, pilis simplicibus. Caryopsis elliptica, compressa, intra paleas libera. - Gramina planifolia, tropica; spicis geminatis, digitatis $v$. acemosis, rhachi saepe setis diaphanis vestita.

U roc h lo a Palis, agrost. 52, t, 11,f.1. Kunth gram, 31, $t$. 14. 103. Agrost, 73. Axonopus Palis, agrost, 12. C arid o chlo a Nees in Edinb, $n$, philosoph, Journ. Juli 1832. Panici s p. Lam., Brown, Trin. ic, $t, 183$.

859. Fingueluellytrum NEES. Spienla e biflorae, flore inferiore masculo, superiore hermaphrodito. G I u mae 2 , inferior minima ; superior ventricosa, apice bidentata, inter dentes aristata. M a s c. Paleae 2, inferior glumae superiori conformis; superior binervis, canaliculata. Stamina 3. Hermaphr. Paleae 2, demum induratae. Squamula e 2 , bifidae. Stamina 3 . Ovarium sessile, in stylum rostriformem attenuatum; stigmata elongata, plumosa. Caryo p si s compressa, paleis inclusa. Gramen c apense, nondum satis cognitum, a generis statore inter Urochloam et Thrasyam collocatum, ex ejus tamen sententia nulli Panicearum generi propinquum, sed $\mathrm{Holco}$ aut $\mathrm{H}$ ierochloa quodammodo affine.

Rhynehelytrum Nees ex Lindl. introduct. ed. $\boldsymbol{I}$. p. 446

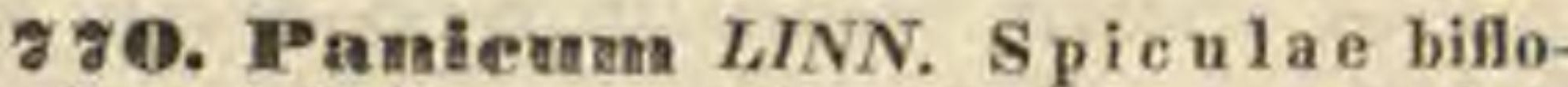
rae, flore inferiore masculo v. neutro, superiore hermaphrodito. GI u m a $\mathbf{2}$, inaequales, concavae, muticae. M a s c. Pa I e a e 2 ; stamina 3 , interdum palea superiore et staminibus abortivis nenter. II erma phr. Pale a e 2 , subaequales, concavae, inferior superiorem parinervem amplectens. S quamu la e 2 , collaterales, dolabriformes, v. trunea to-bi-trilobae. Stamina 3. Ovarium sessile. Styli 2 , terminales, elongati; $s$ tigmata penicillata, pilis simplieibus denticulatis. _ Gramina planifolia, floribus spicatis paniculatisve, rhachi continua, in tropicis utriusque orbis copiosa, extra tropicos rara, species nonnullae late diffusae.

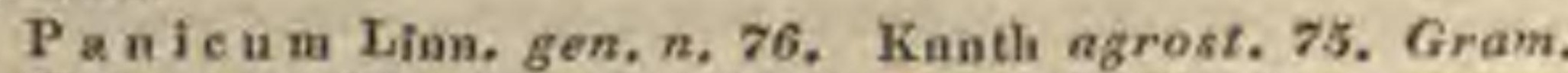
icc. Trin. ice. D Igitaria Scop. carn, 1. 62. D a ctylon Vill. Delph. II. 69. S y ut th eri $8 \mathrm{~m}$ a Sehrad. fl. germ. 160 . t.3.f.7. H y m e n a $\mathrm{eh}$ ne Palis. agrost. 49.t.10.f. 8. S t re pto stach y s Palis. agrost. 49, t, 10.f,11. Monat ehe Palis. agrost, 168. t, 10, f. 10. A u I a $\mathrm{xan}$ th us Elliot carol. 1. 103. A u laxia Nutt. gen. 1.47. Th hla 5 i u m Spreog. eur. post. 30. Trich a chne Nees in Mart. Fl, Bras. MI. 85. 0 ta eh y rium Nees in Mart, $f$, bras, II, 173. P a n i с и ш pterygodium Trin. Kunth.

g.7. Ielaranthes PALIS. Spiculae biflorae, flore inferiore mascnlo v.neutro, superiore hermaphrodito. G1 $1 \mathrm{~m}$ a e 2 , inaequales, concavae, muticae. M a s c. Pa lea e 2 , inaequales. Stam ina 3 , v. abortu nulla. Hermaphr. Paleac $z$, inaequales, involuto - coneavae, inferior major, basi utrinque squamula, in pedicellum deenrrente aucta; superior binervis. Squ a mula e 2 , truneatae. Stamina 3 . Ovarium sessile. Styli 2 , terminales; st ig m a ta aspergilliformia, pilis simplicibus. Ca ryo psis. .. - Gramina americana $t$ ropica, ramose paniculata, a Panico solis paleae inferioris squamulis in flore hermaphrodio diversa. 
I $\mathrm{c}$ h na $\mathrm{n}$ th u s Palis, agrost. 56.t.12.f. 1. Kunth gram. 41. t. 34. 168. Agrost. 134. Brongn. in Duperr. voy. 118. t. 18. Navie ulariae s p. Raddi agrost. bras, 40, P a u i ci $\mathrm{s}$. Nees, Trinius ic, $t .217$.

ร ร. IBIaffia NEES. S p i u la e biflorae, flore inferiore masculo, superiore hermaphrodito. Glum a e 2, inaequales, subulato-acuminatae. Masc. Palea e 2 , inferior subulata; superior tenerior bifida, laciniis acuminatis, antrorsum auriculatis, genitalia amplectentibus. Squ am ula e 2 , membranaceae, repandae. Stamina 3 . Hermaphr. Pal e a e, chartaceo-coriaceae, subaequales, inferior convexa, aeuminato-aristata, superior mucronata, basi utrinque auriculata, genitalia amplectens. Squamulae 2. Stamina 3 . Orari$1 \mathrm{~m}$ sessile. Styli 2 ; $\mathrm{st}$ i g $\mathrm{m}$ at a plumosa. C aryopsis....-Gramen capense; racemis digitatis, spiculis geminatis, cum rudimento mucroniformi spiculae tertiae abortientis.

B I u f fi a Nees ex Lindl, introduct. ed. IT. p. 447.

F 8. Isachne $R$. BR. Spiculae biflorae, flore inferiore masculo v. hersiaphrodito, superiore femineo, interdum hermaphrodito. Glum a e 2 , subaequales, concavae, obtusissimae. M a s c. P a l a e 2, subaequales, concavae, inferior superiorem binervem amplectens. S qua mulae 2 , collaterales, truncatae. F em. Palea $\mathrm{Ft}$ in flore masculo. S $t a \mathrm{~m}$ in u $\mathrm{m}$ rudimenta. Ovarium sessile. Styli 2 , terminales; $8 \mathrm{tigm}$ at a plumosa. Caryo psis intra paleas induratas libera. - Gramina in As ia tropic a indigena, hygrobia, glabra; folïs latis, planis, vaginae collo barbato, spiculis pedicellatis, paniculatis, pedicello continuis.

Is ac bne R. Brown prodr. 196. Trin. ic. $t .85,86$. Kunth gram. 42. t. 33. 117. Agrost. 133. Meneritaria Herm. Zeyl. 24 .

\% 8. Stenotaplarum TRIN. Sp i u 1 a e biflorae, flore inferiore masculo, superiore hermaphrodito conformi. G 1 u m a e 2 , concavae, muticae, inferior minima. P a I e e 2 , subaequales, inferior concava, superiorem bicarinatam amplectens. S qua mulae 2 , collaterales, truncatae. Sta mina 3. Ovarium sessile, inter stylos acutatnm. Styli 2, terminales, elongati; stigmat a penicilliformia, pilis simplicibus elongatis. Ca r y $0 \mathrm{p}$ $s$ is libera. - Gramina in tropicis subtropicisque totius orbis parce reperta, repentia, ramosa; foliis planis, spica compressa, sinubus secundis alternis exsculpta, spiculis in sinubus gemi$n i s$, una sessili, altera pedicellata, tabescente, $v$. quaternis senisve, spicatis, omnibus fertilibus.

St en ot a p lr $\mathrm{r} u \mathrm{~m}$ Trin. fund. 125. Nees in Mart. Fl. bras, II. 91. Kunth gram, 42. Agrost. 137. Rott boella Swartz in Berl. Magaz, IV. 88, t. s. Palis, agrost.180, t,21. f. 8. Panici et Rott boella e s p. Linu. Lam. $t .48, f .1$.

ร ชั. A Arratherim $L I N K$. Spicnlae biflorae, flore inferiore neutro, superiore hermaphrodito. Gluma e 2 , inaequales, muticae, inferior minor. N e utr. Paleae 2 , laeves, exterior trinervis, interiorem minorem recludens. H er $\mathbf{m}$ aphr. Pal e a e 2, pilosac, exterior aristata, arista torta, geniculata, interiorem obtusam semibifidam includens. Squ amula e 2, truncatae, subdenticulatae. Stamina 3 . Ovarium sessile. Styli 2 ; stigmata plumosa. Caryopsis.

Gramen e seminibus nepalensibus in horto berolinensi enatum; culmo bi-tripedali, foliis scabris, basi pilosis, paniculae ramis racemosis, strictis, confertis, ramulis brevibus.

A er at he r u m Link hort. berol. I. 230.

76. Melinis PALIS Spicula biflorae, cum pedicello articulatae, flore inferiore neutro, superiore hermaphrodito. G1 u m a e 2 , inaequales, muticae, inferior minima. Neutr. Palea apice bifida, aristata. He rm a pr. Pale a e 2 , subaequales, muticae, concavae, inferior apice biloba. S qua mu la flabellato-truncata. S t a m i n a 3. Ovari um sessile. Styli 2 , terminales; stigm at a penicilliformia, pilis simplicibus, dentienlatis. Caryopsis...._-Gramen ramosum, in campis Brasiliae tropica e repens; foliis planis vaginisque viscidulo-villosis, paniculis ramosis, contractis.

$\mathrm{Me} \mathrm{i} \mathrm{in}$ is Palis. agrost. 54. t, 11. f. 4. Nees in Mart. Fl. Bras. 1I. 407. Kunth gram. 43, Agrost, 138. S u a rdia Selirank hort, monac. II. $t$. 58. Tristegis Nees in Hor, phys. 47. 2.8.

98. Clanetiuma NEES. Spiculae biflorae, flore inferiore neutro, superiore hermaphrodito. GI umae 2, inferior setiformis, superior lanceolata, apice rostrato-setigera. Neutr. Pale a rostrato-setigera. H erm a phr. Pa le a e 2 , subaequales, inferior setigera, superiorem binervem amplectens. Squ a mu la e 2, collaterales, bifidae. $\mathrm{St}$ a min a 3 . Ovarium sessile, inter stylos acuminatum. Styli 2, terminales, elongati; stigmata plumosa, pilis simplicibus. Caryopsis tridentata, intra paleas libera. _ Gramen brasilicnse caespitosum; foliis planis, racemo composito spicaeformi, pedicellis fasciculatis, subsecundis, medio articulatis.

$\mathrm{C}$ h a tium Nees in Mart. Fl, Bras. 1I. 269. $0 \mathrm{pli}$ is. men i sp. Kunth.

ร8. Dplismenus PALIS. Spiculae biflorae, flore inferiore masculo v. neutro, superiore hermaphrodito. G $1 \mathbf{n} \mathrm{m}$ a e 2 , inaequales, concavae v. subcarinatae, saepissime aristatae. Ma s c. $\mathbf{P}$ a leae 2 , inferior aristata. $\mathrm{S} t$ am in a 3 , interdum palea superiore et staminibus abortivis neuter. Herma phr. Pa lea e 2, subaequales, inferior acuminata, mucronata, superiorem parinervem amplectens. Squa mula e 2 , collaterales, truncatae. Stamina 3 . Ovarium sessile. Sty li 2 , terminales, elongati; stigmata plumosa, pilis simplicibus. Caryop 8 is intra paleas libera. Gramina planifolia, per totum orbem diffusa, inter tropicos et universim in novo continente frequentiora; spiculis spicatis, spicis racemosis paniculatisve, rhachi continua.

Oplis me nus Palis. Fl. owar. II. 14. Kunth grom. 43. Agrost, 138

a) ORTHOPOGON $R, B r$. GI u ma e subaequales, cari. natac, aristatae. Spicat racemosae, alternae, secundae, interdum panciflorae.

Orthopogon R. Brown prodr. 194. 0plismenus Palis. Pl. ower, t, 67. Agrost, 33, t. 11. $f$. 3 . H i p agrostis Rumph amboin. $I I, t, \delta, f .2$. Paniei s p. Linn. Host. IIL, t. 52. Trin, ic. t, 187, 191-193.

b) ECHINOCHLOA Palis. GI uma e inaequales, concavae, muticae, floris neutri arista valida, Spica e paniculatae v. rarius racemosae.

Echinoehlo a Palis. agrost, 53, t, 11. f. . Panici s p. Linn. Host gram, II, t. 19, IT, t, 31, Jaeq, f. Eclog. $t$. 20. Trin. ic. $t, 160-162.164 .166$.

ร ช9. Herelintollatia PRESL. Sp icula biflorae, flore inferiore neutro, superiore hermaphrodito. G I n ma e 2 , lanceolatae, arista elongata recta terminatae; inferior basi in formam stipitis barbati convoluta. Neutr. Pale a glumis conformis, aristato-mucronata. H e rma phr. Pa1 e a e 2 , inferior ovalis, aristato-mucronata, superiorem obtusam, versus apicem denticulatam marginilus involvens. Squamula e..... St amina 3 . Ovarium sessile. Styli 2 , terminales, elongati; stigmata aspergilliformia, C aryo psis cylindrica, apice bicornis. - Gramen mexi- 
canum, erectum; foliis planis, hirsutis, panicula simplici, subsecunda, contracta, spiculis infimis geminatis, superioribus solitariis, pedicellatis, rhachi continua.

Ber ehtoldia Presl in Reliq. Haenk, $x$. 323. t. 43.

780. Chama eraphis $R$. BR. SpieuIa e biflorae, arista basilari elongata, persistente fultae, flore inferiore masculo, superiore femineo. GI 1 m a e 2 , inaequales, mutieae, inferior minima. Mas c. Pa 1 e a e 2 , membranaceae, aequilongae, mnticae. Squ a mu Ia e 2 , collaterales, obtusae. Stamina 3 . Fem. Pale a e 2, chartaceae, concavae, muticae, inferior superiorem binervem amplectens. Squa mu I a e 2, collaterales, obtusae. Stamina 2 , antheris efoetis, difformibus. Ovarin m sessile. Styli $2 \_3$, terminales; $8 \mathrm{tig}-$ mata plumusa, pilis simplieibus. Caryo psis intra paleas eartilagineas libera. - Gramina $a u$ stralasica, perennia; foliis planis, spicis simplicibus, spiculis subsessilibus pedicellatisve, pedicellis juxta apicem intus arista longissima instructis.

Chamaeraphis R. Browa prodr. 194. Kunth gram. 45. t. 26. Agrost. 148. Panicum paradoxum Brown. Kunth gram. $t, 39$. Gaudich. ad Frejc, $t, 24$.

ร81. Penuisetana RICH. S p i cula e bi florae, aristis pedicellorum basim v. apicem stipantibus involucratae, flore inferiore maseulo v. neutro, superiore hermaphrodito. Glum a inaequales, concavae, muticae. M a s c. Pale a e 2, membranaceae, et $\mathrm{s}$ ta $\mathbf{m}$ in a 3 ; nunc paleae $8 \mathrm{u}-$ perioris et staminum abortu flos nenter. Hermaphr. Pa le a e 2 , coriaceae, coneavae, muticae, inferior superiorem parinervem amplectens. Stamina 3. Squa mula e 2, collaterales, truncatae, interitum minimae v. obliteratae v. emarginato-bilobae. $O$ vari um sessile. Sty li 2 , terminales, elongati, basi interdum connati; $8 \mathrm{tigm}$ at a plumosa, pilis simplicibus. Ca r yo p s i s compressa, intra paleas libera. - Gramina per tot um orbem diffusa, inter tropicos copiosa; culmis simplicibus $v$, saepius ramosis, folïs planis, paniculis spiceformibus confertis $v$, rarius diffusis, rhachi continua.

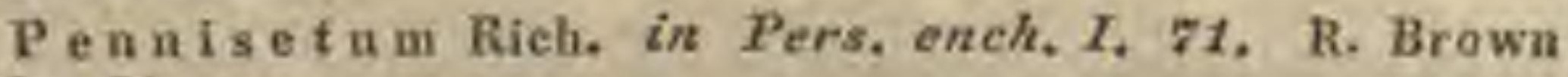
prodr. 51 .

a) SETARIA Palis. Involuerum unilaterale persistens. Sq a amala e carnosae, trincatae, obtusae. - Panieulae diffusas v. confertae.

Set a ri a Palis, agrost, $31, t, 13 . f .3$. Ft. owar. II. 81. t.110, Kunth gram. 46. t. 37. 118. Agrost, 149. Jacq. f. Ec. log. $t, 29,25,27$. P aniel s p. Linu. Host gram, $I I, t, 13-$ 17. IV. t, 14. Trin. ic. t, 95, 96, 195. 196, 198.201.202.

b) GYMNOTHRIX Palis. Invo I u e rum completum, deciduum. Squamula e integrae v. irregulariter bilobae. - Spicae cylindricae.

Gy mnothrix Palis, agrost, 59. $t$. 13. $f$. 6 . Kunth in Humb, et Bonpl, nov.gen, et sp.t.678. Gram. A8.t, 38. Agrost, 158. Bronga. in Duperr, voy, t. 10, 11. Nees in Mart, Fl. Bras. II.277. C a t a te r o p ho r a Steudel in Flora 1829. IT. 265. A lo pecurisp. Hinn. Panieisp. Willd. Penaiset i s p. Tria, ic, $t, 19$.

c) PENNISETUM Palis. Involueri completi decidni setae interiores basi plamosae. S quamula e minimae v. obliteratae. - Spicae cylindricae.

$\mathrm{P}$ е $\mathrm{n}$ is $\mathrm{e}$ t $\mathrm{n}$ m Rich, apud Pers, ench, I. 21. Palis, agrost. 59. $t, 13, f .5$. Kunth in Humb. et Bonpl. nov. Gen. et sp. $I$. 114. $t, 34$. Gram. 48, $t, 39-11$, 119. Agrost, 160. Trin, ic. 2. 20 .

ร8. Penieillaria $S W A R T Z$. S pieula e biflorae, aristis pedicelli apicem stipantibus involucratae, flure inferiori breviore, abortu saepius masculo, superiore hermaphrodito. G l u ma e 2 , brevissimae, hyalino-membranaceae. Pa le a e 2 , muticae; inferior herbacea, superiorem tene- riorem breviorem quadrinervem amplectens. Sta$\mathrm{m}$ in a 3 , antherarnm loculis apice barbatis. $\mathrm{S} q \mathbf{q}$ a$\mathbf{m} u$ lae 0 . O v a $\mathbf{r}$ i $\mathbf{n} \mathbf{m}$ sessile, apice ad basim styli latere interiore cuspidatum. St y lus 1, terminalis, elongatus; stigma bifidum, plumosum, pilis simplicibus papilloso-denticulatis. C a r y o psis....-Gramen annuum, inter tropicos veteris continentis diffusum; foliis planis, crassinerviis, paniculae subspicatae cylindricae ramis verticillatis, apice spiculas $1-2$ gerentibus, involucellis dimidiatis, setaceis, scabris,

Penicillaria Swartz in Schrad, n. Journ. II. 2. p. 40. Palis. agrost. 58, t.13. f.4. Jacq. f. Ectog. t. 17. Kunth gram. 50. Agrost. 165. Hol cus spleatus $\mathrm{L}$. Pennise. t um typhoide um Delile aegype, $t .8$.

ร83. Cenelnrus LINN. S picula e biflorae, flore inferiore masculo $v$. neutro, snperiore hermaphrodito; nune solitariae, nune geminae v. plures, intra involucru m multifidum, extus setis stipatrum, cum fructu induratum et decidunm congestae. GI n m a e 2 , inaequales, membranaceae. I a $8 \mathrm{c}$. hermaphrodito subeonformis, i terdum paleae superioris et staminum abortu nenter. H e $r$ ma $\mathbf{p} \mathbf{r}$. Pa l e a e 2 , sulieoriaceae, concavae, inferior superiorem amplectens. S $\mathbf{t}$ a $\mathbf{m}$ i n a 3 . Squam ulae 0. Ovarium sessile. Styli 2, elongati, interdum basi subconnati; $8 \mathrm{tigmata}$ plumosa, pilis simplicibus, denticulatis. Caryops is compressinscula, intra paleas libera. - Gramina ut plurimum annua, in tropicis utriusque or bis, imprimis Am ericae obvia, in regionibus subtropicis rara; culmis suepissime ramosis, foliis planis, spicis terminalibus simplicibus, spiculis sessilibus, rhachi continua.

C enchras Linn. gen, n, 1149. Gärntn. I1. t. 8. f. s. Cav. ic. t, 461, 462. Palis, agrost. 57, t, 13. f, 7. Labill. Nov, Caled, t, 19. Kunth in Humb. et Bonpl. nov. gen, et sp. I. $_{\text {. }}$ 115. t, 35. 36. Gram, 50, Agrost, 165. Nees in Mrart. Fl. Bras. IT. 287. Panie as trella Miebel, gen, 37, Rar a m Adans.

84. Traellayoums REICHENB, S p icu1a e biflorae, flore inferiore neutro, superiore hermaphrodito; juxta rhachin congestae, fertiles minoribus efoetis mixtae. G $1 \mathbf{n}$ m a e 2 , planinsculae, lanceolato - subulatae, rigidae, inferior brevior, indurata. Ne n tr. Pal ea e 2 , inferior maxima, ovata, acuminata, rigida, multinervis, margine undulata, superiorem minutam membranaceam incladens, et flosculnm hermaphroditum amplectens. Squamula e 2, hyalinae, truncatae. Ge nitali a nulla. Herm a p r. Pa le a e 2, subaequales, concavae, acutae, chartaceae, inferior superiorem binervem amplectens. Squamula e 2 , hyalinae, truncatae. Stam in a 3 , filamentis elongatis. $0 \mathrm{v}$ ari um sessile. St y 1i 2, terminales, elongati, basi subconnati; stigmat a plumosa, pilis simplieibus. Caryops is oblonga, compressiuscula, intra paleas induratas libera. - Gramen ramosum, annuum, in India oriental $i$ indigenum; foliis planis, mollibus, spicis terminalibus conjugatis, spiculis fasciculatim rhacheos membranaceo-dilatatae, articulatae, excavatae, dentibus subdichotome multifidis, unilateralibus insidentibus.

Trachyoz us Reichenb. consp. 48. Trachys Pers. ench, $T$. 85. Palis, agrost, 107, $t, 21 . f$. 7. Kunth gram, Ge. Agrost, 168. Traeh y sta e hy s Dietr. $s p, p l$. IT. 16. Cenchrus muricatus L. Sehreb. gram. IT, t. 34, Panie um squarasum Retz obs. IV. $V . t, 1$. Roxb. corom. t. 206 .

ร85. Anthephora $S C H R E B$. Sp i $i$ u la biflorae, flore inferiore nentro, superiore hermaphrodito; quaternatim basi connatae, duae plerumque efoetae, ad glumas redactae. G1uma $e$, inaequales, inferior (exterior) flores superans, co- 
riacea, acuta, planiuseula, multinervis, superiorem (interiorem) brevem, lanceolato-subulatam, membranaceam, carinatam basi amplectens. Neutr. Pal ea 1, membranacea, florem hermaphroditum amplectens. Herma phr. Pal e a 2 , subaequales, chartaceae, concavae. Squa mula e 0 . Stamina 3 . Ovarinm sessile. Sty 1 i 2 , terminales, elongati, basi connati; stigmata plumosa, pilis simplicibus. Ca ryop sis elliptica, compressiuscula, intra paleas libera. _ Gramen annuum, in America tropica indigenum; culmo ramoso, foliis planis, spica terminali simplici, rhachi conti. nua, spiculis quaternis, fasciculatis, basi connatis, faseiculis breviter pedicellatis, pedicello basi articulalo.

A in the $\mathrm{p}$ h or a Schreb. gram, $t .34$. Palis, agrost.58, $t$. 13. f.8. Kunth gram. 51. Agrost, 169. Nees in Mart. Fl. Bras. II. 289. Collad o a Pers. synops. I. 107. non Cav. T rip. a a um hermaphroditam Linn, dec, 17, $t$, 9. Lam. $t$. 730. $f .2$.

ร 86. Wappage $S C H R E B$. S p i cula e uniflorae, geminae v. quinae pedicello brevi insidentes. G luma e 2, inferior (interior) minuta, plana, tenuiter membranacea, superior (exterior) concava, subcartilaginea, echinata. Palea e 2, oblongae, acutae, chartaceo-membranaceae, concavae, inferior superiorem breviorem binervem ampleetens. Squam u lae 2 , hyalinae, securiformes. Stam ina 3. Ovarium sessile. Styli 2 , terminales, divaricati; stigmata plnmosa, pilis simplieibus denticulatis. Caryopsis oblonga, compressiuscula, intra paleas libera. _ Gramen annuum, diffusum, repens, inter tropic os latissime diffusum, nec in Europa australi et Asia media rarum; foliis planis, racemis terminalibus solitarïs, haud articulatis, ramulis brevibus terminatis, spiculis binis quinisve, superioribus saepissime efoetis, minoribas.

L a p a go Schreb. gen, 131. Host gram, I, t, 36. Sibth, F2. graec. t. 10t. Kunth gram. 52. Agrost. 169. Trag us Hall. helv n. 1413. Palis, agrost.23. t, 6. f. 13. Nees in Mart. F7. Bras, II. 286, $\mathrm{N}$ a zi a Adans. $I I .31$.

98\%. Folbellia $W A L L$. F1o res monoeci v. polygami, racemosi. Spi enla e uniflorae. G I $\mathrm{uma}$ a. Palea e 2, lateraliter compressae, acute carinatae, carina cristatae, inferior (exterior?) bicristata, basi inflato-globosa, galeaeformis; superior (interior?) multo minor, unicristata, infra apicem dente valido instructa. $S$ qua $\mathrm{mul}$ a e ... Stamina... Ovarinm... Styli 2; stig mata plumosa. Caryopsis paleis induratis teeta, oblonga, subacuminata, basi superne gibba, inferne depressa. - Gramen ex Indiae montibus relatum, radice fibrosa annua, culmis caespitosis, e basi decumbente erectis, foliosis, vaginatis, foliis planis rigidiuseulis, undulatis, cartilagineo-marginatis, supremo subtendente racemum terminalem, simplicem, lineari-cylindraceum, multiflorum, rhachi strieta, scabriuscula, pedicellis sursum incrassatis, utrinque ciliatis, basi geniculatis articulatisque, florem unicum caput aviculae simulantem ferentibus. - Genus vix notum, an Lee $r$ sia e affine?

Hotboelli a Wallich in Mook, misc. IT. 144. $t, 76$,

ซS8. Hatipes KUNTH. Spiculae uniflorae, quaternae ramo brovi complanato, apice bifido per paria insidentes, altera cujnsvis paris tabescens, ad glumam relacta, spiculae contiguae glumam inferiorem constituens. GI uma superior (exterior in una, interior in altera cujusvis rami spicula fertili), coriacea, acuminata, canaliculata, tuberculato-echinata; inferioris loco spi- culae contiguae tabescentis gluma superior. Pale a e 2 , gluma breviores, inferior ovata, naviculari-carinata, ciliata, membranacea, interdum infra apicem mucronata, superior dimidio brevior, lanceolata, hyalina. S q u a m ula e 2 , hyalinae, truncato-bilobae. Stamina 3. Ovarinm sessile. Styli 2, terminales, distineti; stigmata pilosa, pilis simplicibus. C a ryopsis oblonga, com pressa, intra paleas libera. _ Gramen se ne g a mb iс и m, planifolium; racemo terminali, rhachi continua, ramis sparsis brevibus, complanatis, tandem reflexis.

\section{Latipes Kunth gram.53. 6.42.}

\% 89. Eela inollaena DESV. Spiculae biflorae, flore inferiore masculo, superiore hermaphrodito. Gl u ma e 2, coriaceo-induratae, navienlari-concavae, inaequales, papilloso - pilosae, inferior saepins glabra. Masc. major. Pale a e 2, subcoriaceae, muticae. Stamina 3 . He rma $p$ hr. Palea e 2, coriaceae, muticae, concavae, inferior superiorem binervem amplectens. Squ am n1 a e 2, collaterales, carnosulae, rotundatae $v$. truncato bi-trilobae. Stamina 3 , Ovarium sessile. Styli 2, terminales, distincti; stig mata plumosa, pilis simplicibus. Car yo psis hine plana, illinc convexa, paleis arcte inclusa. - Gramina a mericana tropica, ramosa, diffusa; foliis planis, spicis terminalibus solitariis, basi geniculato-inflexis, spiculis sessilibus unilateralibus, vel spicis pluribus distantibus, spiculis pedicellatis.

E c hin ol a e a Desv. Journ. Bot. IIT. 75. Kunth gram. 5\%.

a) ECHINOLAENA Kunth. Spica solitaria. Spicnla e unilaterales, sessiles. GI uma e ambae papillosae, papillis piliferis.

$\mathrm{E} \mathrm{e}$ h i nol a e a Kuth in Humb, ot Bonpl. nov. gen.et spec. t. 38. C e n c bri s p. Rudg. guiar. $t, 25$.

b) NAVICUI ARIA Bertol. S $\mathrm{S}$ icae plures, distantes. Spieulae pedicellatae. Gl um a superior echinatoglochidata, inferíor glabra.

Navicularia Bertol, in opuso, sciontif. di Bologn. IIT. 408. Raddi agrost. bras. 38. P a n i c i s p. Nees, Trin. ic, $t, 157,210,216,224$.

990. Thouraten PERS Spicula biflorae, flore inferiore (interiore) in infimis cujusvis spicae spiculis masculo, superiore (exteriore) hermaphrodito, ambobus in spiculis superioribus masculis. Gluma superior (exterior) ovato-oblonga, concava, membranacea, floribus brevior, inferior deficiens. Mas c. Pale a e 2, membranaceae, inferior ovata, acuta, superiorem bicarinatam amplectens. Squamulae 2. Stamina 3 . Herma phr. Pal ea e 2 , subaequales, chartaceae, muticae, inferior coneava, superiorem binervem amplectens. S qu a m ula e 2, carnosae, truncato-subemarginatae. St a m ina 3 . Ovariu m sessile, inter stylus in acumen productum. St yli 2, terminales, distincti; st igmat a plumusa, pilis simplicibus, longis, densis, Ca ryops is elliptica, compressinscula, intra paleas libera.

Gramina in Madagascaria, Nova Hollandia et Oceania tropica provenientia; culmis repentibus elongatis, ramis erectis simplicibus, foliatis, folïs planis, spica terminuli solitaria, vagina aphylla spathaeformi velata, spiculis unilateralibus, uniseriatis, sessilibus, infimis fertilibus fruetiferis, a rhachi canaliculata, coriacea, continua demum involutis.

Thou a r a Pers, ench, I, 110. Palis, agrost, 127.t.22. f. 9. R. Brown prodr. 197. Kunth gram, 54. $t$. 35. Agrost. 173. Microthouarea Thouar, gen, madagasc, $n, 9$.

91. Sginaifex LINN. F lo res polygamodiveci, spiculis masenlis solitariis, ad basim rha- 
cheos elongato-subulatae; androgynis spicatis in distineta planta. Mase. Sp i cula e biflorae flores subaequales. G 1 u m a e 2, membranaceae, canaliculatae, superior panllo longior. P a le a e 2, membranaceae, inferior oblonga, canaliculata, superior bicarinata, carinis eiliata. Squamulae 2, carnosae, integrae. Stamina 3 . Androgyn. Spicula e biflorae, flore inferiore masculo $v$. nentro, snperiore hermaphrodito. Glu ma e 2, subaequales membranaceae, ovatae, concavae. Ma sc. Pal e a e 2, membranaceae; stam ina 3 , nunc paleae inferioris et staminum abortu flos nenter. Hermaphr. Pa le a e 2, coriaceae, oblongae, concavae, inferior superiorem binervem ampleetens. Sqnamula e 2, carnosae. Stamina 3 , filamentis elongatis. Ovarinm sessile. Styli 2, terminales, elongati, basi subcohaerentes; stigma ta plumosa, pilis elongatis, simplicibus. C ary op sis oblonga, compressa, intra paleas libera. Gramina suffrutescentia, ramosissima, in Novae Hollandiae et rarius in Indiae orientalis littoribus arenosis repentia; spicis masculis ad basim rhacheos apice nudae, in acumen pungens productae, haud arliculatae, umbellato congestis; femineis fasciculatis, fasciculis in capitulum congestis.

Spin if ex Linn. mant. 300. Palis. agrost, 137, t. 25. $f$. 1. Labill. Nov, Holl, t, 230, 231, R. Brown prodr, 198, Kunth gram, 55. Agrost.174.

รST. Neuraelane $R, B R$. Spic ula e biflorae, flore exteriore neutro, interiore hermaphrodito. G I um a e 2, coriaceae, nervosae, acutae, hispidae, exterior paullo minor, fructiferae induratae. Neutr. Pa le ae 2 , exterior glumis subsimilis. Hermaphr. Palea e 2, hyalino-membranaceae. Squamulac 2. Stamina 3. Orarium sessile. Styli 2 ; stigmata plumosa. Caryopsis libera, e paleis delabens. - Gramen perenne, in Novae Hollandiae littore australi observatum, culmo multiplici erecto, ad genicula sericeo-barbato, foliis planis, brevibus, spica terminali, ovata.

Neuracline R. Brown prodr. 196. Kunth gram, s6. Agrost. 175.

TEIBEUS IV. STIPACEAE Kunth gram. 57. Spiculae uniflorae. Pale a inferior involuta, apice aristata et in fructu plerumque indurata; arista simplici v. trifida, saepissime torta et basi articulata. O vari u m stipitatum. Squa mula e plerumque tres. - Mediante Oryzopsi et Piptathero Paniceis, imprimis Urochloae et Milio proximae; per Lasiagrostidem Deyeuxiae, Calamagrostidi et Arenae affines. Kunth.

ร93. Dryzopsis RICH, Spicula e uniflorae, flore breviter stipitato. G l u m a e 2, membranaceae, subaequales, flore paullo breviores. Pal eae 2, coriaceae, subaequales ; inferior convexa, marginibus involnta, apice aristata, arista simpliei basi artieulata, decidua; superior binervis. Squa mula e 2, lanceolato-cultiformes, apice ciliatae. S ta min a 3 , antheris apice integris, piloso-barbatis. Ovarinm brevissime stipitatum, apice puberulum. Styli 2 , terminales; 8 tig mata plumosa, pilis simplicibus. Caryopsis.

- Gramen perenne, in Americ a boreali indigenum; folits planis, panicula depauperata, spiculis pedicellatis, haud articulatis.
O ryzopsis Ricl. in Michx Fl. bor. Amer, I. 51,t.9. Palis. agrost. t. 6. f.5. Nutt. in Journ. Acad. nat, sc. Philadelph, IIT. 125. excl. sp. Kunth gramt, 57. Agrost. 176. Dilep y um Raf. in New-York Aledic, Reposit, II. Hex. V. 350 .

\%94. Fiptadinervan PALIS. Spicula e uniflorae, flore sessili, G 1 u ma e 2 , membranaceae, subaequales, muticae, flore paullo majores. Pal e a e 2 , subcoriaceae, inferior convexa, superiorem binervem involvens, apice aristata; arista simplici, basi articulata, decidua. S quamula e 3, interior minor, difformis. S $t$ a $\mathrm{m}$ i n a 3 , antherarum loculis apice distinctis, saepius barbatis Ovari nm stipitatum, glabrum. Styli 2, terminales, breves; $\mathrm{st} \mathrm{igmata}$ intus plumosa, pilis simplicibus. Ca ryops is elliptica, hine convexa, illine plana, sulcata, eum paleis decidua. Gramina perennia, in regione mediterranea et Asia media provenientia; culmis erectis, foliis planis, paniculis ramosis, diffusis, spiculis pedicellatis, sparsis

Pip tatherum Palis, agrost. 18, t. 5. f. 10. Kubth gram, 57. Agrost,176. Urachne Trin. fund, 110, Ledeb. $F l$. alt, $t, 221$. M ili i s p. Scop. Desf. Lapeyr. Ft, pyren. $t$. 54. Hast gram, I, t. 28. A grostidis s p. Lina. Hast III. 45.

ร5. Lasiagrogtis $L I N K$. Spienla e uniflorae, flore breviter stipitato. G 1 u m a e 2, membranaceae, muticae, florem superantes, inferior paulo major. Pal ea e 2 , membranaceae, inferior subearinata, extus hirsuta, apice bifida, inter lobos aristata ; arista simplici, basi haud articulata, vix torta, medio subgeniculata; superior brevior, involuta, binervis. S q u a $\mathrm{m}$ u la e 3 , subcultriformes, membranaceae, ovarii stipiti adnatae, interior lanceolata. $\mathbf{S t a m}$ in a $\mathbf{3}$, filamentis ovarii stipiti adnatis, antherarum loculis ntrinque distinetis, apice barbatis, basi mucronatis. Ovarium stipitatum, apice glabro bilobum. Sty li 2 , terminales, breves; stigmata intus plumosa, pilis simplicibus. Ca ryops is fusiformis, intus obsolete suleata, intra paleas libera. - Gramina in regione mediterranea et $A s i a$ media ob. servata, clata; foliis planis, paniculis ramosis, diffusis.

La s i a g rost is Link Hort, berol, $X$. 99. Kunth gram. 58. Agrost, 172. Arn nd o s pe cios a Sehrad. FI. gernt. $t$. 5. f. 8. Calamagrostis s pecios a Host gram.IV.1.45.

ร26. Dicluelaelane ENDL. Spicula uniflorae, flore breviter stipitato, stipitulo barbato. G $1 \mathrm{um}$ a e 2, membrana ceae, acuminatae, florem aequantes, inferior paullo minor. $P$ a le a e 2 , inferior membranacea, scabra, apice bifida, inter lobos aristata; arista simplici haud arliculata, subtorta, medio eurva; snperior brevior, tenerrima, linearis, apice bidentata, dentibus inciso-denticalatis. S q u a m u la e 3, subfaleatae, interior conformis, tenerior. Stam in a 3 , antherarum loculis utrinque distinetis, obtnsis, imberbibus. Ovarium sessile. Styli 2 , terminales, distincti; sti g. m a t a plumesa, pilis simplicibus. Ca r yop sis fusiformis, intra paleas libera. - Gramen sesquipedale, ex insula Norfolk adlatum; folïs convolutis, panicula coarctata.

Dichelachne Kudl. prodr. Fl. norf. p. 24.

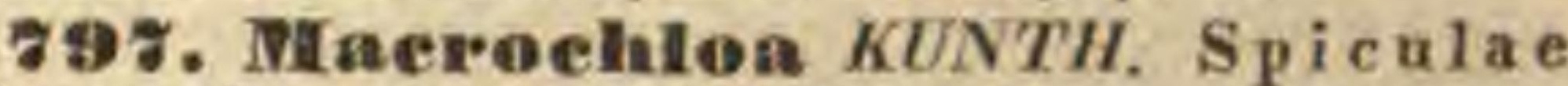
uniflorae, flore stipitato. G $\mathbf{l} u \mathbf{m}$ a $e 2$, membranaceae, lanceolatae, acutato-subulatae, concavae, trinerves, subaequales, flore majores. Pale a e 2, membranaceae, extus sericeo-hirsutae, inferior quinquenervis, involuta, apice bifida, inter lobos aristata; arista simplici elongata, torta, basi articulata; superior binervis, apice bienspidata. S q u a- 
mulae 3 , integrae, basi ovarii stipiti adnatae, exteriores subcarnosae, interior membranacea. Stam in a 3 , filamentis basi ovarii stipiti adnatis, antherarum lobis apice distinetis, barbatis. $O$ varin m stipitatum, apice glabro bilobum. Sty li 2, brevissimi; stig a ta intus plumosa, pilis simplicibus. Caryopsis....-Gramina in Europa mediterranea et occidentali indigena, elata; foliis convolutis, panicula ramosa, conferta $v$. divaricata.

Macroch1o Kunth gram. 58. Agrost, 178, Stipa tenacis 81 m a Linn. Desf. Fl, atl. $t, 30$. Stipa arenaria Brot, lusit, $t, 7,8$.

g.8. Stipa LINN. Spiculae uniflorae, flore stipitato, stipitulo vario. Glu ma e 2, membranaceae, canaliculatae, florem superantes, subaequales. Pale ae 2 , coriaceae, cylindraceo - involutae; inferior apice aristata, arista simpliei torta, basi articulata; superior brevior, binervis. S y u mula e 3, carnosae, ovarii stipiti basi adnatae, interior saepe difformis. Stamin a 3 , antherarum loculis apice plerumque barbatis. Ovari um stipitatum, glabrum. Styli 2, terminales, breves; stigmata plumosa, pilis simplieibus. Caryopsis teretiuscula, paleis arete involuta. - Gramina perennantia, in temperutis utriusque orbis obvia, inter tropicos rara; foliis planis $v$. convolutis, spiculis pedicellatis, paniculatis.

Stip a Linn. gen. n. 90. Trin. in nov. Act. Petropolit, VI. 1. p. 72, excl. sp. Kunth gram. 59. Agrost. 179.

a) NASELLA Trin. Floris stipitulus planiusculus, brevissiuns. Pale ac oblongae.

Nisella Trin. $l$, c. part. Piptoehaetium Presl in Reliq. Haenk, $r$. 222. $t$. 37. $f$. 1. Stipa trichotoma Nees. St. panic oides Lam. Kunth t, 121.122.

b) ARISTELLA Trin. Floris stipitulus planiusenIns. P ale ae eylindraceac.

A risteHa Trin. l. c. part. Sibth, Fl.graec.t, 87. Host gram. $I V$. t. 34. Cav, ic. t. 467. f.2.

c) STIPATrin. Floris stipitulus conleus. Paleae cylindraceae.

Stip a Trin. 2. c. part. Host gram. IIT, t. $5 ., I V, t, 33$, Jarava Ruiz et Pav.

ร95. Eripeoma NUTT. Spiculae uniflorae, flore subsessili. Glumae 2, membranaceae, inflato - gibbae, apice coarctatae, cuspidatae, florem superantes, subaequales. P ale a e 2, coriaceae, villosae; inferior apice aristata, arista (brevi) simplici haud torta, basi artienlata; superior brevior binervis. Squamula e 3 . . St am in a 3 , antherarum loenlis apice barbatis. Orarium . Styli 2, basi connati; stigmata plnmosa. . . Ca r y o p si s subglobosa. _ Gramen b oreali-americanum; foliis involutis, spiculis longe pedicellatis, paniculatis. Pursh.

Eriocoura Nutt. gen. $T$. 40 . Stipa membranacea

S00. Streptachne R. BR. Spiculae uniflorae, flore stipitato. Glum a e 2, laxae, mutieae. $\mathrm{Pa}$ le a e 2, inferior cylindraceo-involuta; arista terminali, basi torta, hand artículata. S q u amulae. ... Stamina $3 .$. Orarium... Styli 2... stigmata plumosa. Caryopsis.

- Gramen in Nova Hollandia tropica indigenum, facie Aristidae $v$ Stipae, a qua, monente generis auctore, arista haud articulata differt.

Streptachne R. Brown prodr, 174. Kunth gram, 60 . Agrost.186.

801. Aristida LINN. Spienlace uniflorae, flore stipitato. G1 im a e 2, membranaceae, inaequales, inferior ut plurimum brevior. Pa le a e 2 , inferior coriacea, tereti -involuta, apice aristata ; arista tripartita $v$ trifida, basi plerumque arti- culata ; superior membranacea, minima, mutica, Squa mu lae 2, integrae. Stam in a 3 , filamentis basi ovarii stipiti adnatis. Ovarium stipitatum, glabrum. Styli 2, terminales, distineti; $8 \mathrm{tigm}$ a $\mathrm{t}$ a plumosa, pilis simplicibus. Cary op8 i s teres, intra paleas libera. - Gramina in temperatis tropicisque totius orbis obvia, in America frequentiora; foliis involutis, spiculis pedicellatis, racemosis $v$. paniculatis.

Aristid a Linn. gen, n, 94. Kunth gram, 61. Agrost. 187.

a) Chantaria Palis. Arista tripartita, paleae contiuua.

Chaetaria Palis, agrost. t. 8. f. 5. 6. Nees in Mart, Fl. Bras. II, 380. - Curtopog o n Palis. agrost. 2. 8. f. 7. A ristida dich oto ma Rich. Spreng, in Mem, Acarl. Petersb, 1810, II. t.6.

b) PSEUDACHNE. Arista trifidae, paleae continuae, lobi laterales minini.

S treptachne Kunth in Humb. et Bonpl. nov. gen. et sp. I. 124. t. 40.

c) Arthratherum Palis. Arista trifida, eum pa. lea articulata.

Arthr ththerum Palis, agrost. t. 8. f, 8. 9. Aristi. da Palis. $t, 8, f .10$. Kunth gram. t. 171-174. Vahl symb. I. $t$.3. Desf. Fl. all. $t .35, \mathrm{~K}$ ie $\mathrm{lbul}$ Adans, $I t .31$.

802. Stiparrostis NEES. Spiculae uniflorae, flore stipitato. G1 n m a e 2 , membranaceae, subaequales (flore longiores). Pale ae 2 , inferior chartaceo-membranacea, tereti-involuta, apice emarginato - biloba, inter lobos aristata, arista trifida basi articulata; smperior brevior, obtasa. S qua mulae 2, membranaceae, spathulatocochleariformes. Stamina. . Ovarium. . Caryopsis subcylindriea, hine sulcata, intra paleam induratam libera. - Gramen capense; foliis teretiusculis, spiculis pedicellatis, paniculatis.

Stipagrostis Nees in Linnaea PII. 291. - ? A r istida obtus a Del. Fl, aegypt, $t, 13, f .2$.

\section{TRIDES V. AGROSTIDEAE Kunth} gram. 63. Spiculae uniflorae, rarissime cum rudimento subulato floris secundi superioris. Gl umae paleaeque duae, membranaceo-herbaceae; palea superior saepius aristata. Stig mat a plerumque sessilia. Mediante $M$ ï h I n b e r gia Stipaceis affines. Kunth.

808. Trithlembergia SCHREB. Spicula e uniflorae, flore sessili, basi barbato. Glu$\mathbf{m}$ a e 2, inaequales, flore plerumque breviores, muticae v. breviter aristatae. Pale a e 2 , herbaceae, demum induratae, inferior apice in aristam simplicem producta; superior bicarinata. Squamula e 2, membranacere, integrae. St am in a 3 , filamentis basi enm ovarii stipite connatis. Ovarium stipitatum, glabrum. Sty li 2 , terminales; stigma ta plumosa, pilis simplicibus. Caryopsis teretiuscula, intra paleas libera. - Gramina in America cis a equatorem in regionibus temperatis tropicisque obvia, trans a equatorem admodum rara; culmis caespitosis, saepe ramosis, spiculis pedicellatis, haud articulat is, paniculatis.

ML ühle a bergl a Schreb, gram. H. t. 50. 51. Trin. uniff. t. 5. Kunth agrost. 198. Podos a e mum Kunth in Humb. ot Banpl, nov. Gen. etsp.t,681-683. Trichochloa Trin. fund, 117. Roem. êt Sehult. syst. II. 18. D i le p y $\mathrm{r}$ u $\mathrm{m}$ Michx. Fl. bor. Amer. I. 6o. Cle om e n a Palis. agrost. 28. 1.7. f. 10. B r a h y el y $\mathrm{tr}$ u m Palis. agrost. 39.

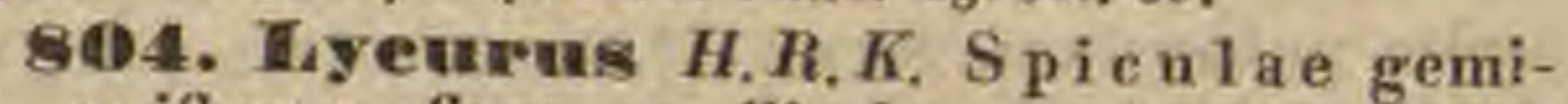
nae, uniflorae, flore sessili; hermaphrodita pedicellata, et mascula sessilis, minor, eacterum conformis. G 1 um a e 2, subaequales, flore breviores, inferior apice in aristas $2-3$ producta; superior 
apice bidentata, inter dentes in aristam producta. Pa le a e 2 , inferior apice in aristam producta, snperior mutica, binervis. S q $\mathbf{n}$ a mula e 2 , truncatae. Stamina 3, Ovarinm sessile, Styli 2, terminales; stigmata plnuosa, pilis simplieibus, denticnlatis. Caryopsis intra paleas libera. - Gramina mexicana; culmis ramosis, foliis linearibus planis, spicis terminalibus simplicibus, rhachi continua.

Lycurus Kunth in Fumb. et Bonpl, nov. gen, et sp. I. 148, t. 45. Gram, 64. Agrost, 203.

8๑5. Coleanthas SEID. Spiculac uniflorae. Glum a e 0 . Pal e a e 2 , membranaceae, inferior ovata, uninervis, carinata, apice in acumen aristacforme producta; superior dimidio brevior, binervis, bicarinata, apice acute biloba. $\mathbf{S} q \mathbf{u}$ a m $\mathbf{u}-$ 1 a e 0 . Stamina 2. Ovarium sessile; stigm a $t$ a 2, sessilia, elongata, denticulis subulatis obsita. Caryopsis oblonga, teretiuscula, basi paleis stipata. - Gramen pusillum, annuum, in paludosis $B$ oh o e miae vivens; culmis filiformibus, foliis linearibus, canaliculatis, subfalcatis, vagina inflata, paniculis terminalibus, subsimplicibus, spiculis pedicellatis, subfasciculatis.

Col ea nth us Seidel apud Röm. et Schult, syst. II, 11. Kunth gram. 65. Agrost. 204. S e h mid tia Tratt. Fl, austr. I. 12, t, 451 . Sternb, in Flora 1819. t, 1. Willib al da Sternb, $l, c$.

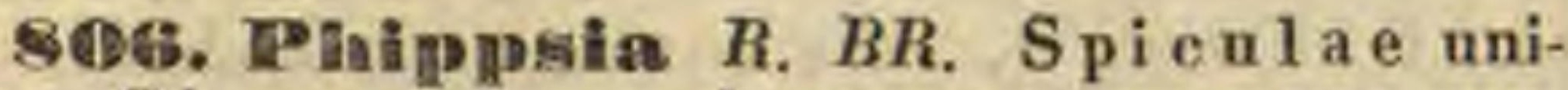
florae. G I u ma e 2, membranaceae, concavae, muticae, nanae, inaequales ; inferior minima, enervis, interdum evanescens, superior obsolete uninervis. $\mathbf{P}$ a le a e, membranaceae, mutieae, inferior concava, obsolete trinervis, acutiuscula; superior nonnihil brevior, hinervis, bicarinata, apice tri-quadridentata. Squa m u la e 2 , minimae, membranaceae, integrae. Stamina $1-3$. Orarin m sessile; stigmata 2 , sessilia, pilosa. Caryopsis oblonga, teres. - Gramen arctic um, hygrobium, pusillum, caespitosum, glabrum; culmis erectis basi subramosis, foliis linearibus planis, panicula simplici, ramis pedicellisque semiverticillato - fasciculat is, spiculis pedicellatis, pedicello continuis.

Phippsia Triu, in Spreng. N. E. II. 37. R. Brown suppt. to Parrys voy. 285. Kunth gram. 65. Agrost. 204. Agrostis alg id a Wahl, FV, Lapp, $t, 1$. Fl. dan. t. 1515 . Vilfae s p. Trin. io. $t .83 .84$.

807. CoIfopeltum TRIN. Spie u la e nniflorae, flore suhsessili, accedente interdum floris alterius superioris rudimento setuliformi. G I $\mathbf{u m}$ a 2, membranaceae, acutae, subcarinato-coneavae, superior paullo major, flore brevior. Pale a e 2, membranaceae, apice hyalinac; inferior carinatoconeava, trinervis, apice rotundato-emarginata, dorso interdum mucronato-subaristata; superior nomnihil brevior, eoncava, apice rotundata, binervis. S qua mula e 2 , laterales, semibifidae, membranaceae, ovarium aequantes. St a mina 3 . O vari um sessile. St y 1 i 2 , terminales, brevissimi; stigmata dense plumosa, pilis imbricato-papillosis, integris bi trifidisque. C a ryopsis.

- Gramina glabra, pusilla, in Asia et America arctica, nec nom in summis Asiae mediae alpibus huedum reperta, foliis planis, paniculae coarctatae ramis semiverticillatis, spiculis pedicello continuis.

C o I p o d f um Trin. fund, 119. f.7. R. Brown suppl. to Parrys voy. 286. Knnth gram.66. Agrost. 205. Ledeb. Fl, alt. t. 226. Agrostis versicolor Stev.

808. Cimma LINN. Spiculae uniflerae, flore pedicellato $\mathbf{v}$. sessili, accedente interdum floris alterius superioris rndimento stipitiformi. Glu- ma e 3 , carinatae $\mathbf{v}$. convexae, flore breviores. $P$ aleae 2 , inferior acuta, apice $\mathbf{v}$. infra apicem mucronato-aristata, snperior binervis. Squa mulae 2. Stamina 1_- Ovarinm sessile. Sty$1 \mathrm{i} 2$, terminales, brevissimi; $s \mathrm{t}$ igmata elongata, plumosa, pilis simplicibus. Cary opsis libera. - Gramina planifolia, ramosa, in $A$ merica cis a equatorem, nonnulla $e$ genere fortassis melius eliminenda in Nova Hollandia viventia; paniculis confertis, interdum spicaeformibus, spiculis pedicello continuis.

C i n a a Linn. gen, n. 15. A b o I a Adans. fam. IT, 31 .

a) CINNA. Glu m a c carinatae. Flos pedicellatus. Pale a e basi nudae, inferior infra apicem mucronata. Pa n i u la conferta. Boreali-Americanae.

Cinua arundinacea Linn. Schreb. gram, $t$. 49. Palis, agrost, 3t, t, 7, $f, 12$,

b) EPICAMPES Prest. G I u ma e convexae. Flos sessilis. Pale a e basi pilosae, inferior paullo infra apicen aristata. Panie ula spleaeformis. Mexicanae.

E pic a m pes Presl. in Reliq. Haenk, I, 238.t.39. A g r astis pubescens et lanata Hamb.

c) BCHINOPOGON Palis. Gl um a e carinatae. Flos subsessilis. Pale a e basi pilosae, inferior infra apicem aristata, superior basi rudimento setuliformi floris alterius aucta. Panieula ovata, spicaeformis, Australasicae.

E chinopogon Palis. agrost. 49. t.9.f. ov a ta Forst. Labill. Nov. Holl, t.2i.

8D9. Sporebolus $R$. BR. Spienlae uniflorae. G1 u mae 2, carinatae, inferior minor. Palea e 2, muticae, inferior acutinseula; superior minor, biearinata. Squamulae 2 . S tam ina 2_3. Ovarinm sessile. Styli 2 , terminales; stigmata plumosa, pilis simplieibus. C ary ops is lihera (epiearpio laxo, solubili.) - Gramina in regionibus tropicis subtropicisque totius orbis obvia, in tem peratis rarissima; paniculis diffusis $v$. spicato-confertis, spiculis pedicellatis, minutis.

Sporobolus R. Brown prodr, 170. Palis, agrost. 26. t. 6. f.11, Fl,owar, t, 80. Kunth gram, 67, t, 45, 46, 123-127. Agrost.209. Brongn. in Duperr, voy. t. 4. He le o chloa Palis, agrost. 24. A g rost fie ul a Raddi agrost. bras. 33.1. 1. f. 2. - $\mathrm{C}$ al o the e a Stendel in Flora 1829. p. 488. A gra$s$ tidis s p. Sehreb. gram. t. 27. $f$. 3. Jacq. ic. rar. $t, 20$. Cav, ic. t, 114. Delil. aegypt, t, 10. Labill. Nov. Holl, t. 23. V ilf a e sp. Auet, Kunth. in Humb. et Bonpl, $n$. g. et sp. t. 684, 685. Trinc. ic. $1.10-12,13.24 .47 .48 .56-60$.

810. Agrostis $L I N N$. S p iculae uniflorae, interdum floris superioris pedicello accedente. GI I m a e 2, subaequales, carinatae, muticae, flore majores. Pale a e 2 , inferior mntica $v$. dorso aristata, superior biearinata, interdum minima $v$. plane obliterata. Squa mula e 2, subintegrae. Stamina 3. Ovarinm glabrum. Stigmata 2, subsessilia, plumosa. Caryopsis Jibera.

Gramina caespitosa, in regionibus temperatis et frigidiusculis totius orbis obvia, in calidioribus admodum rara; culmis simplicibus v. ramosis, foliis planis aut interdum involutis, paniculis diffusis $v$. rarius contractis, ramis fasciculato-verticillatis.

Agrostis Kunth gram,68. Agrost.217. Agrostis, Apera, Triehodinm, Vilfa Auet.

a) AGROSTIS. Floris superioris rudimentum unllam.

A grost is Host gram. IV. t.49-58. Tria, ic. $4,25-36$. Kunth gram, $t .128-130.169$.

b) ANEMAGROSTIS. Floris superioris pedicellus ad basim paleae superioris.

Anemagrostis Trin.fund, 118. A pera Palis, agrost. 31. (Host. gram. III, 2, 47.)

811. Castridiam PALIS. Spiculae uniflorae. Gl $\mathbf{n}$ ma 2 , subaequales, basi ventricosae, flore multo majores, clansae. Pa leac 2 , inferior apice truncato-dentata, mutica $y$, infra 12 
apicem aristata, superiorem binervem, bicarinatam amplectens. Squa mula e 2, integrae, ovario majores. Stamina 3 . Ovarium sessile; $s \mathrm{tigma-}$ ta 2, subsessilia, plumosa. Caryopsis elliptica, compressiuscula, intra paleas libera. - Gramina mediterranea, annua; foliis planis, paniculis contractis, spicueformibus, spieulis pedicellatis, pedicellis clavatis, compressiusculis.

Gastridium Palis, agrost.21, t,6, f.6. Kunth gram. 71. Agrost. 230. Mil i um lendige r um Sehreb. gram. $I$. 1. 23.f.3. Host gram. III. t.24. Sibth, Fl.graec.t.63. Agrostis a ustralis Linn.

812. Mowodivoriliga PRESL. Spicula e uniflorae. G $10 \mathrm{ma}$ e 2 , subaequales acutatomucronatae, carinatae, carina pectinato-spinulosae, flore multo majores, basi elausae, apice patulae. Pale a e 2, inferior ovata, apice truneata, mucronato-dentata, infra apice, aristata, arista caduea; superior multo minor, enervis, coucava, apice trumcata, denticulata. S qua mula e 2 , subenltriformes, ovarium superantes. Stamina 3 . Ovarium sessile; stigmata 2 , subsessilia, plumosa. Caryopsis hine convexa, inde plana, intra glumas paleasque libera. - Gramen $c h$ il ense; foliis planis, panicula interrupte glomerata, spiculis fasciculatis, pedicello hispidulo clavato continuis.

Nowod wor 8 y a Presl in Heliq. Haenk. I. 351, $t, 10$. Raspailia Presl op, cit, p. 239. - C haetotropis Kunth gram. 72, t, 47, Agrost, 231.

813. Poly pogon DESF. S p i c a l a e uniflorae. Gl u m a e 2 , subaequales, carinatae, aristatae, flore multo majores. Palea e 2 , inferior apice truncato-emarginata, sub apice aristata $v$. mutica; snperior bicarinata. Squa mula e 2, subfalcatae, ovarium superantes. St a $\mathrm{m}$ in a 3.0 vari $\mathrm{m}$ sessile. Stig mata 2 , subsessilia, plumosa. Cary o p s is obovato-elliptica, intra paleas libera. - Gramina annua, in littoribus tempe$r$ at is utriusque hemisphaerii provenientia; foliis planis, paniculis ramosissimis, saepe contractis spicaeformibus, spiculis pedicello continuis.

P ol y pog o n Desf. Fl, atl. 1 , 66. Palis, agrost, 17, $t$. 6. f.8. Pauz. Ideen 29. t. 9. f. 2. $a$. d. Kunth in Humb. et Banpl. nov. gen, et sp. t. 4\%. Gram. 72. Agrost. 232. S anti a Savi in Memor. matemat, d. soc. ital. VIII. 2. 479. Alo pecuris p. Linn. Phlei s p. Schred, Sibth. Fl.graec. ช. 62 .

Q14. Clnaeturms LINK. S picula e uniflorae. G1 umae 2, subaequales, inferior aristata, superior acuta, flore paullo majores. Pale a e 2, muticae, inferior smperiorem multo minorem involvens. Sq u a $\mathrm{m} u 1$ a e 2 , integrae, ovarium superantes. Stamina 3 , Ovarium sessile; stigmat a 2 , subsessilia, plumosa. Caryopsis.

Gramen b ericum, caespitosum, planifolium; panicula simplici, spiculis in apiee ramorum gemi$n$ is $v$. ternis, sessilibrs.

Chat tur a s Liah in Schrad. Journ, 1796, II. 313. Palis, agrost, 15.t.5. f.7. Panz. Ideren 29, t.9. $f, 1, a-d$. Kunth gram, 73. Agrost. 23\%. Poly pog on s ubs picat us Willd.

815. Alegopogor WILLD. Spieulae nniflorae, flore stipitato; geminae v. ternae, laterales saepe tabescentes v abortu masculae. Gl uma e 2 , subaequales, apice bifidae, aristatae, flore breviores. $\mathbf{P}$ a I e a e 2 , inferior trinervis, apice triaristata, superior binervis, apice biaristata. Squa mula e 2 , subbilobae. Sta in in a 3 . Orarinm sessile. Styli 2 , terminales; stigmata plumosa. Caryopsis libera. - Gramen a mer $i$ canum tropicum; culmis caespitosis, ramosis, foliis planis, spicis secundis, rhachi continua.
A egapogon Willd, sp. IV. 899 . Kunth in Humb, et Bonpl. nov. gen. ot sp. I. 132. 6.48.43. Gram, 73. Agrot. 235.

816. Pereilema PRESL. S p i u la e uniflorae, flore sessili, basi piloso; binae v. quaternae involuero e setis pedicelii apicem obsidentibus involucratae. Gl u ma e 2, subaequales, carinatae, apice bifidae, inter lacinias aristatae, flore breviores. Pal e a e 2 , superior trinervis, apice aristata; inferior binervis, acnta. Squa mulae. . Stamina 3. . O Orarium. . Caryopsis. . Gramen panamense, annuum; folits planis, panicula spicaformi interrupta, spiculis glomeratocongestis.

Pereilema Presi in Reliq. Haenk. 1 , 233. $t, 37$.

TIRIBUS VI. ARUNDINACEAE Kunth gram. 73. S piculae nunc uniflorae, cum v. absque rudimento floseuli superioris, nune multiflorae. Flores plerumque pilis longis mollibus obsiti v. basi cincti. Glum a e et paleae duae, membranaceo-herbaceae, illae saepe flores aequantes v. superantes, ex his inferior aristata v. mutica. Gramina plerumque elata. Kunth.

S1\%. Calamagrostis ADANS. $\mathrm{Sp}$ i, $\mathrm{u}$ la e uniflorae, flore sessili, basi pilis longis stipate. Gl a mae 2 , subaequales, canalienlatae, acutatae vel subulatae, florem longe superantes. Pale a e 2 , inferior apice $v$. infra apicem aristata, rarissime mutica; superior binervis. Squamulae 2 , integrae. Stamina 3 . Ova $\mathrm{r}$ i u m sessile; stig ma ta 2, subsessilia, pilosa. - Gramina in Europa et Asia media indigena, elata, planifolia; panicula ramosa.

Ca I a magrost is Adans. fam, $I X$. 31. Roth FI. germ. P. 34. Pal.s. ogrost. 15. Sehrad. Fl. germ. 2, 4. f. 1-4. Trin. unifl. 4 , 4. f.2. Host gram, IV. $t, 42$, 44, 47. A r undin is s p. Liun.

818. Deyeuxia CLAR. Spicula e uniflorae, flore inferiore hermaphrodito sessili, basi barbato, superiore ad pedicellum plumosum redacto. Glum a e 2, subaequales, canalienlatae, muticae, florem subsuperantes. Pal e a e 2 , inferior dorso aristata, arista torta; superior bicarinata. Squa$\mathbf{m u} \mathbf{l}$ a e 2 , inaequaliter bilobae. $\mathrm{S} \mathbf{t}$ a $\mathbf{m}$ i $\mathbf{n}$ a 3 . Ovarium sessile. Styli 2 , breves; stigmata plumosa Caryopsis libera. - Gramina planifolia, ramose paniculata, in lemperalis et frigidiusculis totius orbis reperla, in America tropica alpicola.

Deye uxia Clarion apud Palix. agrost. $t, 10, f .9,10$. Kunth in Humb, et Bonpl. nuv. gen, et sp. . 46.686. Agrost. 239. Cal a magrostidis s p. Host $1 V, 4,46$. 48,40. Trint. unifl. t.4. f. 10-12, Lach a g r o's tis Trin. fund, 128 .

81. Dentrpogon $R, B R$. Spien I a uniflorae, flore stipitato, basi barbato. G 1 u mae 2 , snbaequales, carinatae, muticae, flore minores. Pa le a e 2 , inferior apice quadridentata, quinquearistata, arista intermedia majore tortili; snperior minor, mutica. S qua mulae. . St a mina 3. Ovari n nessile. Stigmata 2 , sessilia, plumosa. Caryo psis...... Gramen in insula Diemen indigenum; folitis planis, spiculis paniculatis.

Pentapagon R. Brown prodr, $X$. 173. Kunth gram. 76. Agrost, 239. A grostis quadrifid a Labill. Nov. Holl, t. 22. Palis, agrost, t, 8. f. 11 .

8\% D. Ammoplaila HOST. Spieulae biflorae, flore inferiore hermaphrodito, stipitato, basi barbato, smperiore ad pedicellum plumosum redacto $G 1$ um a e 2 , aeguilongae, inferior uni-su- 
perior trinervis, carinatae, muticae, flore majores. Pa l a e 2, inferior carinata, quinquenervis, infra apicem bifidum mucronata $\mathbf{v}$. breviter aristata; superior bicarinata. Squamula e 2, lanceolatae, acuminatae, ovario multo longior. 8 . Stamin a 3 Ovari $\mathbf{~ m}$ sessile; stigma a 2 , sessilia, plumosa. Cary o p is libera. - Gramina in littoribus arenosis Europacet $A$ mericae borealis repentia; folïs convolutis, panicula coarctata spicaeformi.

A m mophila Host gram. IV. t. 41. Kunth gram, 77 . Agrost. 245. P s a m a Palis, agrost, t. o. f. 1. A r un do a reuaria Linn. F1. dan. 4.917 , E. B. $t$. 520 . Amagris Raf. in Journ. Phys, LXXXIX, 262.

821. Arundes LINN. Spieula e bi-quinqueflorae, floribus distiehis, remotiusculis, hermaphroditis, summo tabescente. G 1 um a e 2, subaequales, canaliculato - carinatae, acutatae, int $r$ se remotae. Pale a e 2 , inferior apice bifida, inter lobos subulatos breviter aristata, extus, imprimis basi sericeo-pilosa; superior brevior, bicarinata, Squamulae 2 , carnosae. Stamina 8 . Ovarium sessile, glabrum. Sty li 2 , terminales, elongati; stigmata plumosa. Caryopsis libera. - Gramina hygrobia, elata, interdum frutescentia, in temperatis et calidis totius orbis modico specierum numero obvia; foliis planis, paniculis ramosissimis, diffusis.

A r u n do Liun. gen, n, 93. excl.sp. Kunth gram, 78, t. 48. 49. Agrost, 246. Host. gram.IV,t.38, - D o a a x Palis,agrost. 79. t, 16. f. 5. exel. sp. S coloch Io a Koch Fl. germ. Trichoon Roth calalect. $I I .2$.

822. Anpelodermos LINK. S piculae bi-quadriflorae, florihus distichis, remotiusculis, hermaphroditis, summo tabescente. Gluma e 2 , subaequales, canaliculato-carinatae, subulatae. Pale a e 2 , inferior acutata, extus sparsim pilosa; superior brevior, bicarinata, apice breviter bifida. S qua mu I a e 2, lanceolatae, ciliatae. $S t$ amina 3 . Ovarium sessile, apice pilosum. Styli 2 , terminales, breves; stigmata plumosa. Cary opsis libera. - Gramen elatum, Africam et Europam mediterraneam incolens; foliis involutis subulatis, paniculis ramosissimis, laxis.

A mpel o d e 5 mo os Link Hort, berol. I, 136. Kanth gram. 79. Agrost, 2a9. $\Lambda$ rund o tenax Vabl. Cyrill, neap. $I$, $t$. 12. - ? Brongn. ad Duperr. $t, 6$.

823. Craplaephorrm DESV. Spieu1 a e bi-quinqueflorae, floribus distichis, remmtinsculis, hermaphroditis, summo tabescente. Gluma e 2 , carinatae, acutae, superior major. PaI e e 2 , pilis rhacheos involntae, inferior concava, acuta; superior brevior, bicarinata, carinis cilia1is. S q a a m u la e 2, inaequaliter bilobae. S $t$ a m ina 3 . Ovarium sessile. Styli 2 , terminales, brevissimi; stigmat a plumosa. Caryopsis libera. - Gramen boreali americanum; foliis planis, scabriusculis, panicula subsimplici, coarctata. Graphe phor u m Desv.Journ,Bot, I.71. Palis agrost, 77. t. 15. f.8. Kunth gram, 79. Agrost, 250, Agrasits meIicoides Miehx. citivis.

824. Ilarasmaites TRIN. Spiculae tri-sexflorae, floribus distichis, remotiuscnlis, infimo masculo, reliquis hermaphroditis. Gi $\mathbf{u}$ m a 2, carinatae, acutae, smperior major (interdum monandra). Pa 1 e a e 2, inferior elongata, angustato-subulata; superior bicarinata. Squamulae 2 , integrae. Stamina 3 . Orarium sessile. Styli 2 , terminales, elongati; stig mat a plumosa. Caryopsis libera - Gramina etata, potamobia, latissime per ommes regiones temperatas diffusa; folits latis, planis, paniculis ramosissimis, diffusis.
Phrag mites Tris. fund. 134. Kanth gram, 80, $t, 50$. Agrost.250. C z e rny a Presl gram, sicul. 22. A r undo P h a g m ites Lim. Host gram, IV, $t .39$.

825. Amphialonax NEES. Spiculac bi-triflorae, geminatae, aborta polygano-monoicae, floribus subsessilibus. Glu m a e 2 , carinatae, acutae, superior major. Pal e a 2, basi hirsutae, inferior acnminato - subulata, superior obtusa. Squa mulae 2, bilobae. Stamina 3 . Ovarium sessile. Styli 2 , terminales, elongati; stig mata aspergilliformia. Caryupsis libera. Gramen bengalense; foliis angustis demum complicatis subuliformibus; panicula ramosa, diffusa.

A mp bidonax Nees ex Lindl, introduct, ed. II. p. 449.

826. Gymeriarah $\boldsymbol{U}$. B.K. Sp ic ul a e biflorae, dioecae, flore altero scssili, altero pedicellato. M a s c. G I n m a e 2 , earinatae, acutae, superior triente longior. Palea e 2, glabrae, inferior acutata, uninervis; superior brevior, bicarinata, mutica. Squam u la e 2, collaterales, minutae. Stamina 2_3. Fem. G 1 um a e 2, canalicnlatae, apice angustato -subulatae, superior triplo Iongior. Pale a 2, inferior angustato-subulata, basi pilosa; superior multo minor, bicarinata, carinis pectinato-ciliatis. Squamulae 2 , integrae, ciliatae. Stamina 2 , efocta. Ova ri $\mathbf{m}$ sessile. Styli 2 , terminales; $8 \mathrm{tigm}$ a ta plumosa. Caryopsis.... - Gramina americana tropica; culmis elatis, caespitosis, foliis elongatis, spinuloso-serrulatis, paniculis ramosissimis, diffusis.

G yne r I u m Humb. et Bonpl. pl. aequinoct. t, 115. Pa. lis, agrost. 138. t, 24. f.6. Nees in Mart. Fl. Braf, I1. 461. Kunth gram, 80. Agrost. $2 \delta 1$.

Tr RIBS VUI. PAPPOPHOREAE Kunth gram. 82. Sp i cula e bi-multiflorae, superiores tabescentes. Gl u mae paleaeque duae, membranaceo - herbaceae. Palea inferior trimultifida, laciniis subulato-aristatis. Inflorescentia capitato-spicata v. paniculata. Kunth.

82\%. Amplaipogon $R$. BR. Spiculae uniflorae, flore sessili y, stipitato, glmmas superante. G I umae 2 , concavac, muticac, inferior brevior. Paleae 2, inferior tri-superior bifida, laciniis lanceolatis, subulato-aristatis, aristis rectis, subaequalibus. Squa mula e 2, integrae. Stamina 3 . Ovari um sessile. Styli 2 , terminales, basi subconnati; stigmata pilosa. Caryopsis ....-Gramina Novam-Hollandiam ex tratropicam incolentia, caespitosa; foliis setaceis, floribus spicatis, saepius capituliformibus, spiculis extimis sterilibus verticillatis, involucrantibus.

A m phipogon R. Brown prode. 175. Kuntl gram, 82. Agrost. 252. A egopogou is s p. Palis.

828. Diglopogon $R$. $B R$. Spienlae uniflorae, flore stipitato, glumis recInso. Gluma e 2, subaequales, laxae, aristatae (hirsutae). Pa leae 2, inferior apice triaristata; arista intermedia dissimili, tortili, interiorem biaristatam involvens. Squa mulae 2 , integrae. Stamina 3. Ovarium sessile. Styli 2 , terminales, basi connati; stigmata plumosa. Caryopsis.

- Gramen e Novae IIollandiae ora meridionali relatum; culmis caespilosis, foliis setaceis, spica ovata subcapitata, spiculis extimis sterilibus verticillatis, involucrum praebentibus.

Diplopogon R, Brown prodr. 176. Kuuth graen, A3. Agrost.253. Dipogonia Palis. agrost. t25.

829. Trirhaphis R. BR. Spiculae trimultiflorae, floribus distichis, infimis hermaphes- 
ditis, reliquis abortu masculis $\mathbf{v}$, neutris. GI nm a e 2, aequales, muticae. P a l e a e 2 , inferior apice trifida, laciniis subulato - aristatis, elongatis, rectis, intermedia longiore; superior bicarinata, mutica. Squ a m u la e 2 , obovato-euneatae. S $t$ amina 3 . Ova ri $\mathbf{u m}$ sessile. Styli 2 , terminales; stigmata plumosa. Caryopsis.

Gramina in Nova Hollandia tropica et $A f$ rica media indigena; spiculis paniculatis.

Trirbaphis R. Browa prodr. 185. Palis. agrost. 83. Kunth gram, 83. Agrost, 253.

S34. Pappoplaotrana SCHREB. $\mathrm{S}_{\mathrm{p}} \mathrm{i}$ c u 1 a e bi-quadriflorae, flore infimo hermaphrodito, reliquis tabescentibus. G I $\mathbf{u}$ ma e 2, mutieae, flores superantes, inferior brevior. $P$ ale a e 2 , inferior apice in aristas $9 \_13$, subulatas, rectas producta; superior longior, hicarinata. Squa mula e 2 , truneatae. Stam ina 2 - 3 . Ovarium sessile. Sty li 2, terminales; $8 \mathrm{tigmata}$ alumosa. C ary opsis intra paleas libera. _ Gramina in regionibus tropicis subtropicisque provenientia; foliis planis, paniculis coarctatis, spicaeformibus.

Pap pophor am Schreb. gen, n, 1715. Kunth gram. 83. t.51. Agrost, 254. Nees in Mart. h. bras. $I$. 410.

a) ENNEAPOGON Desv. S p i e u I a e biflorae. Gluma e tri-septemerves. Pal ea inferioris arisiae novem, plumosac. - Species potissimum a us $t$ ralalasicae, paucae capenses, una ex Arabia felici dubia.

Eu ne a pogon Desv. in Journ. Bot. 1XR. 70. Palls. agrost. t. 16, f. 11 .

b) POLYRHAPHIS Trin. SpicuIae tri-quadriflorae. Glumae uninerves. Pale a e inferioris aristae subfredecim, denticulatae. - $A m \in r i c a n a c$ tropicae.

Poly $\mathrm{r}$ ha $\mathrm{ph}$ is Trin. in Act. Petrop. VI. 1. p. 5. (Palis. agrost. $t, 17, f .1$. Vahl sjmb. III. $t$. 51 . Kunth gram. $t$. 131. 139.)

c) EURHAPHIS Trin. Spicula e sexflorae. Glumae. - Pale a e inferioris aristae in flore infimo quinque, in secundo sxptem, in reliquis novem. - Species unica $o$ Persia, an revera hujus generis?

Eurhaphis Trin. $l$, c. P. P umilio Trin.

831. Cottaea KUNTH. Spiculae sexnovemflorae, floribus distichis, distantibus, hermaphroditis, summo tabescente. Gl u ma e 2, concavae, apice trilobae, lobis acutato-mucronatis, superior paullo minor, apice interdum integra. $\mathbf{P}$ ale a.e 2 , inferior apice quinquefida, in aristas subundenas, rectas, inaequales producta; superior bicarinata, apice bifida, lobis acute mueronatis. Sq a mula e 2 , subdolabriformes. Stamina 3. Ovarium sessile. Styli 2, terminales; stigmata plumosa. Caryopsis intra paleas libera, (epicarpio membranaceo, solnbili)._Gramen p er $u$ vian $u$, planifolium, ramosum; paniculae ramosae ramis diffusis, spiculis breviter pedicellatis, sparsis, subracemosis.

Cot t a e a Kunth gram, 84. t.59. Agrost. 256.

832. Eehinaria DESF. Spiculae biflorae, flore superiore pedicellato, saepe tabescente, v. ad pedicellum redacto. G $\operatorname{luma}$ e 2 , carinatae, inferior biaristata, superior longior, uniaristata; aristis rectis, subulatis, interdum evanescentibus. Pa lea e 2 , inferior coneava, apice quinquefida, laciniis subulatis, rigidis, divaricatis, intermedia majore, maryinibus tenuiter membranaceis, crenatis, superiorem apice bifido-subulatam amplentens. Squamula 2, subdolabriformes. Stamina 3. Ovarinm sessile, apice pilosum. Styli 2 , terminales, elongati; $8 t i g m a t a$ glabra. Ca ryo psis intra paleas libera. - Gramen mediterraneum, annuum; culmis caespitosis simplicibus, foliis planis, spicis capitato-subglobosis.

E c hinaria Desf. Fl. atl. II. 385. Palis, agrost. 83, $t$. 17. $f$. 2. Kuntl gram. 84. Agrost. 256. C e neh r u e a pitatus Linn. Sibth. Fl. graec. 1,100 . S es leriae s p. Host gram. IIT. t. 8. Panicas trella Mönch meth, 206.

833. Cathesteeum PRESL. SpicuI ae ternae, laterales inferiores sessiles, biflorae, intermedia pedicellata quadriflora; floribus omnibus hermaphroditis. Spiculae laterales: Glumac 2, lineari-lancealatae, subcarinatae, setosohispidae, inferior major (colorata). Pale a e 2, inferior ovata, apice bifida, inter lacinias et utroque margine aristata, aristis rectis, plumosis ; superior multo minor, obtusa, binervis, nervis marginalibus, sub apice in mucronem excurrentibus. \$ quamulae..Stamina 3 . Ovarium sessile. Sty1i 2 , terminales, elongati. Cary ops i s...... Spicula intermedia. Glumae 2, oppositae, inferior apice bifida, inter laeinias aristata, superior brevior, apice emarginata, $\operatorname{sinn}$ aristata; aristis plumosis. Pale a e 2 , inferior quadrifida, inter lacinias aristata, aristis ternis plumosis; superior et genitalia ut in spiculis lateralibus. - Gramen mexican u m, prostratum, ramosum, radicans; foliis planis, spicis pedunculatis, subsecundis, paucifloris. C a the ste cum Presl in Reliq. Haenk, I, 295. t.42.

TrIBES VIIT. CHLORIDEAE Kunth gram. 86. S piculae in spicis unilaterales, uni-multiflorae; floribus superioribus tabescentibus. G lum a e et paleae duae, membranaceo-herbaceae, hae muticae v. aristatae, illae in rhachi persistentes, antica altius inserta. S picae digitatae vo paniculatae, rarissime solitariae. Rhachis continua, haud articulata. Kunth.

D34. Irierochlon $R$. BR. S p i i 1 a uniflorae, flore sessili. G I u ma e 2, ublongae, acutinsenlae, muticae, subaequales, inferior subcarinata. Pa le a e 2, hyalinae, extus pilosae, inferior late ovata, truncata, submueronata, mucrone membranaceo, concava, trinervis; superior bicarinata. Squamula e 2 , paleae superiori semiadnatae. Stamina 2 - 3 . O varium sessile. Styli 2 , terminales; stigm a ta plumosa. Caryop sis...... Gramen pusillum, caespitosum, inter tropicos totius orbis repertum; foliis angustis, complicato-falcatis, spica terminali solitaria, falcata, spiculis unilateralibus subbiseriatoimbricatis.

Mice ochloa R. Brown prodr. 208. Palis, agrost, 115. t. 20. f.8. Kunth in Humb, et Bonpl. nov. gen, et sp, t, 2 . Gram. 86. Agrast, 258. Nees in Mart. Fl. Bras. II. 4 H. Nardus indiea Linn. Rottboella setacea Roxb. carom. $t, 132$.

835. Selneenefeldia KUNTH. $\mathrm{s}_{\text {picu- }}$ lare uniflorae, flore sessili, basi barbato. GIum a e 2, subaequales, acutato - subulatae, carinatae. P a le a e 2 , inferior sub apice elongato-aristata, concava; superior canaliculata, dorso ciliata. $\mathrm{Squ}$ a mula e 2 , minimae. St a m in a ... Ovarium .... Caryopsis fusiformis, libera, (epiearpio diaphano, solubili). - Gramen se ne g a mbicu $m$; foliis angustis, involuto-filiformibus, spicis terminalibus solitariis ternisve, sessilibus, spiculis biseriatis, glumis persistentibus.

$\mathrm{S}$ choenefeld ia Kunth gram, 86, t. 53, Agrost, 258.

836. Cynodlon RICH. Spirn lae uniflorae, flore inferiore hermaphrodito sessili, superiore ad pedicellum subuliformem redacto, inter- 
dum deficiente. Glum a e 2, carinatae, muticae, subinaequales, superior inferiorem amplectens. P aI e a 2 , inferior carinata, acuta, mutica v. $8 u b$ apice mucronata, superior bicarinata. Squa $\mathbf{m} \mathbf{u}-$ I a e 2 , carnosae, plerumque connatae. Stam in a 3 . Ovarium sessile. Styli 2 , terminales; stigmata plumosa. Cary opsis libera. - Gramina ut plurimum tropica, nonnulla per totum fe$r e$ or $b$ em diffusa, repentia, ramosa; foliis planis, spicis digitatis, geminat is racemosisve, spiculis unilateralibus.

Cynodon Rieh, in Pers, ench, I, 85. Palis, agrost.37. t. 9. $f$. 1. Kunth gram. $87, t, 133$. Agrost. 259. D ig i t ari a Juss.gen. 29. F i bigi a Kóel. gram, 308. C a prio I a Adaus. II. 31. C a brera Lagase. diagn, 5. P a n i c i 8 p. Lina. Host gram, II, $t, 18$. Sibth. Fl, graec, $t .60$,

S3\%. Dactyloctenionm $W I L L D$. S pic nIa e bi-multiflorae, floribus distichis, hermaphroditis, summo tabescente. Glumae 2, carinato-compressae, flore breviores, superior aristata, inferiorem muticam amplectens. Palea e 2, inferior carinato-navicularis, acutato-mucronata, superior bicarinata. $S q u$ a $\mathrm{u} 1$ a e 2 , truncato-bitrilobae. Stamina 3 . Ova rium sessile. Styli 2 , terminales; stigmata plumosa. Caryop sis libera, (epicarpio membranaceo, laxo, solubili). _ Gramina repentia, planifolia, per regiones tropicas subtropicasque dispersa; spicis digitato-fasciculatis $v$, rarissime solitariis, spiculis unilateralibus.

Da ct y l a c te $n$ i u m Villd. enum. IT. 1029. Palis, agrost. 72. $t$ 15. f.2. Kunth gram. 87. Agrost, 261. Nees in Mart. Fl. Bras, II, 436. Tria, ic, $t$. 69, С y n o s u r us a eg y pti us Linn.

838. Funstacliys DESV. SpicuIae biflorae, flore inferiore hermaphrodito, sessili, superiore stipitato, tabescente. GI u ma e 2, superior apice emarginato - biloba, mucronato-aristata, inferiorem minorem mutieam amplectens. Pale ae $\mathbf{2}$, inferior carinata, sub apice mucronata, superior bicarinata. Squamulae 2 , emarginatae. Stamina 3. Ovari n m sessile. Styli 2 , terminales; st igma ta penicilliformia. Car y opsis. - Gramina planifolia, in America trop ica et tempe rata utriusque hemisphaerii, nec non in $\mathbf{C a}$ pite bonae spei observata; culmis compressis, ramosis, repentibus, spicis digitato-fasciculatis, spiculis unilaterulibus.

Eustachys Desv, in Journ. Bot. MTr. 69. Nees in Mart. Fl. Bras. II. 418. Kunth gram, 88, t.54, Agrost, 269. Schultesia Spreng. pug, II, 17. Chloris petraea Thunb. Jaeq, f. Eclog. $t, 1 i$.

S39. Chloriss SWARTZ. Spicula e bimultiflorae, floribus distichis, inferioribus hermaphroditis, aristatis v. mucronatis, superioribus neutris, aristatis $v$, muticis. G $1 \mathbf{u} \mathrm{m}$ a e 2 , carinatae, acutatae, muticae v. superior brevissime aristata, rarissime utraque mueronata. Pale a e 2 , inferior trinervis, trigono-earinata, sub apice aristata v. mucronata; superior bicarinata, apice in aristam rectam, rarissime abortientem producta. Squamula e 2, integrae. Stamina 3 . Ovarium sessile. Styli 2 , terminales; stigmata plumosa. C a r y opsi s libera, (epicarpio tenui solubili), - Gramina tropica, pleraque americana, paucissima asiatica et africana; culmis simplicibus $v$. ramosis, foliis planis, spicis digitato-faseiculatis, rarissime solitariis v.geminatis, spiculis unilateralibus, sessilibus.

Chloris Swartz prodr. 25. excl, sp. Palis, agrost, 7s. Durand disquisit. de Chloridis speciebus. Montp. 1808. Ato. Nees in Marl, Fl, Bras, II, 420. Kanth gram, 89. Agrost. 263, a) APOGON. S p iculae biflorae; palea inferiore floris hermaphroditi sub apice submuerouata, flore superiore neutro unipaleaceo.

Chloris s abmutica Humb. et Bonpl, nov. gon, et $s p, t .50$.

b) EUCHLORIS. Spiculae tri-quadriflorae, flore infimo hermaphrodito, aristato, reliqquis sterilibus aristatis, summo plerumque mitico.

Kunth apud Humb, et Bonpl. t. 49. Jacq. f. Eclog. t.8, . Panz. Ideen t, 10. f. 2, a. $f$.

c) ACTINOCHLORIS. S picula e bi.octoflorae, flore in. fimo hermaphrodito, reliquis sterilibus, ommibus ari statis.

Panz, t. c, $t$. 10, f, 3, a, e. Kunth gram, $t, 55,86,134$. $178-180$.

d) GEOPOGON. Spicula e tri-quadriflorae, doribus inferioribns hermaphroditis aristatis, summo tabescente mutieo, difformi.

C. d is tac hy a Kunth gram. $t .57$.

e) TETRAPOGON Desf. Spicula e quadriflorae, flores duo inferiores hermaphroditi, superiores neutri uni. paleacei, omnes aristati, accedente interdum quinto, ad aristam redacto.

Tetrapogon Desf, Fl, atl, Ir.389, t, 255. (Kunth gram. $t .58$.

840. Heptochloa PALIS. Spiculae bi-multiflorae, floribus distichis, omnibus hermaphroditis v. summis tabescentibus. Gl n ma e 2, carinatae, muticae, superior inferiorom amplectens. Pa 1 e a 2 , inferior trinervis, carinata, mutica, mucronata $v$, aristata; superior bicarinata, apice in aristam rectam producta. Squamula e 2, integrae. Stamina 3. Orari $\mathrm{mm}$ stipitatum. Styli 2, terminales; stigmata penicilliformia. Ca ry op sis libera. - Gramina ut plurimum tropica, potissimum americana, pauca geronto gea, late diffusa; foliis planis, spicis plurimis racemosis, spiculis unilateralibus, sessilibus.

Leptochlo a Palis, agrost. 71, t. 15. f. 1. Trin. agrost, 133. Nees in Mart. Fl, Bras. IT, 431. Kunth gram, 90, t. 135. Agrost. 268. Leptostachys Meyer Essequeb, 73, 0xyd e n I a Nutt.gen, I, 76. R ha bdo chloa e sp. Palis, agrost. 84. Ch lo ridis $8 \mathrm{p}$. Humb. et Bonpl. D in e brae $\mathrm{sp}$. Jaeq. fragm, t, 121. $f .1$. Delile aegypt, $t, 11, f .3$. Ele usines s p. Jacq. f. Eclog. t, 4. C y no s u ri s p. Linn. - D ipla chne Palis, agrost. 80, t. 16. f. 9. Link Hort. Berol. I. 154. Eestucae s p. Linn., Michx. Delile argypt. t. 11. f.1.

841. Elewsine GAERTN. S pirnla e biflorae, floribus distiehis, omnibus hermaphroditis. G 1 и m a c 2 , carinatae, muticae, superior inferiarem amplectens. Pa 1 e a e 2 , muticae, inferior carinata, superiox biearinata. \$ qua $\mathbf{m} \mathbf{u} \mathbf{l}$ a e 2 , emarginato-bilobae. St a mina 3. O vari $\mathbf{x m}$ sessile. Styli 2, terminales; stigmata plnmosa. Car y o p sis libera, (epiearpio membranaceo, solubili). - Gramina anmua, latissime per regiones tropicas dispersa; foliis planis, spicis digitatofasciculatis, spiculis unilateralibus.

Ele usin e Gaerta. $r$. 8. $t, 1$. Lam. t. 48. Palis, agrost. 72. $t, 15, f .3$. Kunth gram, 91. Agrost. 27\%. Nees in Mart. Ft. Bras, IT. 439. Trin. ic, $t, 70-72$. C у п о s u ri s p. Linn. Schreb. gram, $I, t, 35$.

848. IrIarpoellalon KUNTH. Spic u 1 ae quadriflorae, flore inferiore hermaphrodito, superioribus tabescentibus G1 umae 2 , carinatae, mntieae, snperior inferiorem triplo breviorem amplectens. Palea e 2, muticae, inferior obovata, carinata, superior bicarinata. Squamulae 2 . Stamina. O Orarium sessile. Styli 2 , terminales; stigmata elongata, plumosa. - Gramen capense; foliis complicato-falcatis, rigidis, spica terminali subfalcata, spiculis imbricato-biseriatis.

H a r pochloa Kunth gram. 92. Agrost, 274. C yno 5 u$r$ s f a l cat as Thunb. Chloris faleata Swartz in Berl. Verhandl. III. 159. 2,1. f.1. C am pul a a e sp. Desr. Campulasi sp. Palis. 
843. Ctenium PANZ. Spiculae quadri-quinqueflorae, floribus duobus inferioribus neutris, uni-bipaleaceis, tertioque hermaphrodito, aristatis, reliquis tabescentibus, muticis. Gl um a e 2 , superior medio tuberculata, tuberculo nudo $v$. aristato, arista horizontaliter divaricata, inferiorem multo breviorem, muticam amplectens. $\mathbf{P}$ ale a e 2 , inferior trigono-carinata, sub apice mucronata $\mathbf{v}$. aristata; superior longior, bicarinata. Squamulae 2. Stamina 3 . Orarium sessile. Styli 2 , terminales; stigma ta elongata, plumosa. Ca ry opsis.... Gramina in Amer $i$ ca boreali et tropica, nec non in Senegambi a reperta, gracilia, planifolia; spica unica sub. falcata, spiculis unilateralibus, imbricato - biseriatis.

Cte n i u m Panz.Ideen 36. t. 13. f. 3. $a-f$. Kunth gram. 92. 1.59. 136.137. Agrost. 274, C a m p ulo a Desv, in Journ. Bot, III, 69. C a m p ulos u s Palis, agrost, 73. t. 13. $f .1$. Monocera Elliot. carol. $I$. 176. Monothera Raf. in Journ. Phys.LXXXIX.262. Chloris monosta chy a Miehx. Naxdus Gaugitis Lin.

844. Chondrosium DESV. S p i u 1 a $\mathrm{e}$ biflorae, flore inferiore sessili, hermaphrodito, superiore pedicellato, tabescente, triaristato. GI uma e 2, carinatae, acutato-subulatae, superior inferiorem breviorem amplectens. $P$ ale ae 2 , inferior trinervis, carinato concava, apice trifida, laciniis lateralibus subulato-aristatis, intermedia sub apice bifido aristata, aristis rectis, haud articulatis, quandoque abortientibus; snperior bicarinata. Squamulae 2. Stamina 3. Ovarium sessile. Styli 2 , terminales, elongati; stig ma$t$ a penicilliformia v. plumesa. - Gramina a mericana tropica, caespitosa; foliis linearibus planis, spicis plerumque solitariis, subfalcatis, geniculatis, spiculis unilateralibus sessilibus, imbricato-biseriat is.

Chondrosium Desv, in Journ. Bot, Irr. 69. Palis. agrost. 41. t. 9. f. 7. Kuath in Humb. et Bonpl, nov, gen. et sp. t. 56-58. Gram. 93. Agrost. 275. A c tino chlon Willd, apud Röm, et Sehult, syst.1I, 22. B o ute lo u o a Lagasc. diagn, 5. A the ropog on is $8 \mathrm{p}$. Jacq. f. Eclog. t.12. D inebrat s p. Humb. $t .53$.

845. Opizia PRESL, Spieula e triflorae, flore inferiore hermaphrodito sessili, superioribus pedieellatis, difformibus, inter se connatis, triaristatis. GIun a e 2, inferior ovata, quinquedentata; dentibus tribus intermediis in aristas productis, lateralibus obtusis, superiorem multo minorem, muticam amplectens. Pale a e 2, ovatae, inferior apice bifida, lobis muticis, obtusis; superior minor, integra, bicarinata, abruptim acuminata. Squamulae.... Stamina... Ovarium sessile. Styli2, basi connati; stigmata villosa. Gramen me xic a num, annuиm, repens; folïs linearibus, planis, spicis terminalibus, solituriis, spiculis subsecundis.

Op izia Presl in Neliq. Haenk, 1. 293. t.41. f, 1.

846. Spartina SCHREB. Spicula e unifforae, flore sessili, imberbi. G 1 uma e 2, carinatae, muticae, superior inferiorem multo minorem amplectens. P a le a e 2, muticae, inferior compresso-carinata ; superior longior, navieularis, linervis. Sq $\mathrm{namulae} 2$, interdum defieientes. Stamina 3 . Ovarium sessile. Styli 2 , terminales, elongati, inter se connati v. apice distineti; st i gm a ta elongata, plumosa. Caryo p$\mathrm{s}$ is intra paleas libera. - Gramina maritima, paucissima tropica, caespitosa, repentia, rigidiuscula; folits plerumque involutis, spicis racemosis, spiculis unilateralibus, sessilibus, arcte imbricato-biseriatis, rhacheos apice nudo rigido.
S partina Selureb. gen, n, 98. Palis, agrost, 25, $t, 7$. f.6. Panz. Ifleen 27. $t, 10 . f .4 . a-f$. Trin. agrost, 115. Kunth gram. 94. Agrost. 277. Brougn, ad Duperr. voy. t. 2. Nees in Mart. Fl. Bras. II. 408. L im ne $\mathrm{t}$ is Rieh. in Pers. ench. I. 73. Host gram, IV. t. 66. Trachynotia Michx. FI. Bor. Amer. I. 74. P o n e leti a Thouar. Fl. aguan. 36.

84\%. Eutriama TRIN, Sp iculae bimultiflorae, floribus inferioribus hermaphroditis, summo tabescente, triaristato v. ad pedicellum subulatum redacto. G1 um a e 2, earinatae, mutieae, superior inferiorem breviorem amplectens. $\quad P_{a}$ le a e 2, inferior apice trifida, laciniis in flore inferiore subulatis, in superiore subulato-aristatis; superior bicarinata. Squamul a e 2. Staminas. Ovarium sessile Styli2, terminales; stigmata plumosa Caryopsis..... Gramina americana, pleraque tropica, ramosa, diffusa; foliis planis, spicis racemosis abbreviatis, spiculis unilateralibus, sessilibus, alternis, rhacheos apice subulato, mudo.

Eutriana Tria. agrost, 161. Gram, unif. 137. Hunth gram, 95. Agrost, 28. Nees in Mramt. Fl. Bras, II. 413.

a) ATHEROPOGON Mizhlenb. S pi cula e billorae, flore superiore ad pedicellum redacto; laciniae palea inferioris floris liermaphroditi subulatae.

Atheropogon Mühlenb. apud. Willd. sp. $T$. 937, Jacq. f. Eclog, t, 7, Panx. Ideen 39, 1,9, f. $4, a-h$, D i ne b a curtipe и и 1 а DC. Palis,agrost, $t, 16, f, 1, a-d$. B outeo u o a e s p. Lagase.

b) ARISTIDIUM. Spicalae biflorae, flore superiore tabescente, triaristato; laciniae palea e inferioris floris hermapliroditi subulatae.

Dinebra aristoides Funth in Humb. et Bonpl. nov. gen, et sp. t. 695 .

c) HETERostegA Desv. Spicula triflorae, flore terminali tabescente triaristato $v$. ad pedicellum re. dacto; laciniae $\mathrm{p}$ ale a e inferioris floris infimi subulatae, floris superioris aristatae.

Heterosteg a Desv, Journ. Bot, IIT. 68. Dinebrae s p. Kunth apud Humb. et Bonpl. t, 51.52. B o n te lo u o a e s p. Lagasc, - ? E n te r op og on Nees ex Liadl. introduct. ed. $I I, p, 448$.

d) TRIPLATHERA. S pie ulae quadri-multillarae, flore infino hermapbrodito, triaristato, superioribus sterilibus, in fasciculum longissime muttiaristatam congestis.

E. maltis eta Nees. Kunth gram, $t .138$.

848. Trinthera DESV Spieulae biflorae, flore inferiore hermaphrodito sessili, superiore breviter pedicellato tabescente, ad aristas tres elongatas redacto. Gluma e 2, carinatae, acuminato-subulatae, superior inferiorem breviorem amplectens. $\mathrm{Pa}$ le a $\mathrm{e} 2$, inferior oblongo-lanceolata, apice trifida, Jaciniis subulatis; superior lanceolata, biearinata, apice bifida. S q u a mula e 2 , subdolabriformes. Stamina 3. Ovarium sessile. Styli 2 , terminales; stigma ta plumosa. Ca ryopsis....-Gramen domingense, ramosissimum ; folits involuto-setaceis, rigidis, spiea solitaria, simplici, spieulis sessilibus, alternis, distichis, rhachi continua.

Triat her a Desv. in Journ. Bot, MI1, 67. Palis, agrost. 39. t.9. f. 4. Kunth gram, 96. Agrast, 283.

849. Gymopogon PALIS, $\mathrm{S}_{\mathrm{p}}$ iculae biflorae, flore inferiore hermaphrodito sessili, basi barbato, superiore pedicellato, tabescente, aristato. Gl u ma e 2, carinatae, lanceolato-subulatae, subaequales. Pa leae 2, inferior cylindraceo-involuta, sub apice biloho aristata, superior bicarinata. Squamulae 2, truncato-bilobae. Stamina 3. Ovarinm sessile. Styli 2 , terminales; $s$ tigmata penicilliformia. Caryopsis libera. - Gramina boreali-americana et brasiliensia; paniculae simplicis ramis alternis, subfastigiatis, simplicibus, spiculis subsessilibus, remotis, alternis. 
Gymnopogon Palis. agrost. 41. t. 9. f. 3. Kunth 2 , acuminatae, inferior paullo brevior. Pa 1 e a e gram, 96. t. 139. Agrost. 28s. A nt ho pog on Nutt. gen. 1. 82. A 1 a e a $t$ he ros Elliot. carol. $I$. 145.

850. PoIyoulon H. B. K. S p i en la e biflorae, flore inferiore hermaphrodito, sessili, su periore breviter pedicellato, sterili. Gluma e 2, muticae, subaequales. Hermaphr. Pale a e 2 , inferior quinquedentata, dentibns lateralibus et intermedio in aristas productis, superior biearinata, apice acute bifida. $S q u$ a $m u$ la e. . Stamina... Ovarium. .. Caryopsis libera. Neutr. Palea e 2, inferior septemdentata, dentibus alternis in aristam productis; superior minima, subaristata, - Gramen pusillum Quitense; culmo ramoso, foliis planis, rhachi spicata, apice bifida, nuda, spicis brevibus, racemosis, distichis, spiculis unilateralibus, sessilibus.

Poly o d on Kunth in Humb. et Bonpl. nov. gen, et sp. 1. 175. t. 55. Gram. 170. A6rost. 282.

S.5 1. Hentarrlanglhis $H, B, K$. S p i cula e triflorae, flore infimo hermaphrodito, sessili, medio masculo sessili, summo sterili ad pedicel$\mathbf{l u m}$ aristaeformem redacto. $\mathbf{G} 1 \mathbf{~} \mathbf{~ m}$ a e 2 , inferior ex aristis quinque, basi subconnatis composita; superior bidentata, inter dentes in aristam brevem producta. H e rma phr. Pa lea e 2 , inferior septemdentata, dente medio lateralibusque in aristas productis; superior bicarinata, truncato-denticulata. Squamulae.... Stamina 3. Ovarium. . Caryopsis intra paleam superiorem reclusa. Mas e. Palea e 2 , inferior quinquedentata, dentibus lateralibns et intermedio in aristam productis; superior apice integra, acuta. Stam ina 3. - Gramen mexicanum perenne, erectum, ramosum; folïs planis, spica terminali solitaria, rara, spiculis alternis, sessilibus.

Pe ntarrhaphis Kunth in Humb.et Bonpl, nov.gen, et sp. I. 175, t. 60. Gram. 170. Agrost. $28 \%$.

852. Polyseloistis PRESL, Spiculae biflorae, flore inferiore hermaphrodito sessili, snperiore neutro, pedicellato. G $1 \mathrm{u} \mathrm{mae} 2$, inferior quadripartita, laciniis lineari-subulatis; superior linearis, acuta. He $r \mathrm{~m}$ a $\mathrm{hr}$. Pal eac 2 , inferior quinquedentata, dente medio lateralibusque in aristas productis; superior linearis, plana, apice bidentata. Squa mula e. ... Si amina 3 . Ovarium sessile. Styli 2 , terminales; $s$ ti $g$ mat pilosa. Neutr. $P^{3}$ a le a e 2 , inferior quinquefida, Iaciniis subulato-aristatis; superior bicarinata, apice bidentata. - Gramen manillense, annum, caespitosum, erectum; foliis planis, spicis terminalibus, solitariis $v$. quinis, spiculis alternis sessilibus, secundis. - An genus a praecedente revera diversum?

Poly s chis tis Presl in Meliq. Haenk. I. 294. $t .41$.

853. Treiacena $H . B . K$. S picula e biflorae, flore inferiore hermaphrodito sessili, superiore neutro, triaristato. G I u m a e 2 , subaequales, inferior basi aristata, arista nsque ad medium adhaerente. Pale a e 2 , acuminatae, muticae, superior paullo brevior. Squa mu 1 a e. .. Stam ina 3 . Ovarium sessile. Styli 2 , terminales; stigmata plumosa. Caryopsis intra paleam superiorem libera. - Gramen mexicanum, annuum, ramosum; folits planis, spicis terminalibus solitariis, spiculis alternis, remotiusculis, pedicellatis, distichis.

T r la en a Kunth in Humb. ot Bonpl. nov. gen, et sp. 1. 179, t.6t. Gram. 170. Agrost, 284.

S54. Triplasis PALIS. Spiculae quadriflorae, floribus distichis remotis, inferioribus hermaphroditis, summo sterili setiformi. Glumae 2 , inferior bifida, inter lacinias subulatas longissime aristata; superior multo minor, apice integro reflexo pilosa. $S q u$ a $\mathbf{m}$ u $l$ a e. . . . S $t$ a m ina.... Ovari um sessile. St y i 2 , terminales, basi connati; stigmata plumosa Caryopsis satis notum, spiculis racemosis.

Triplas is Palis. agrost, 81, $\iota, 16, f .10$.

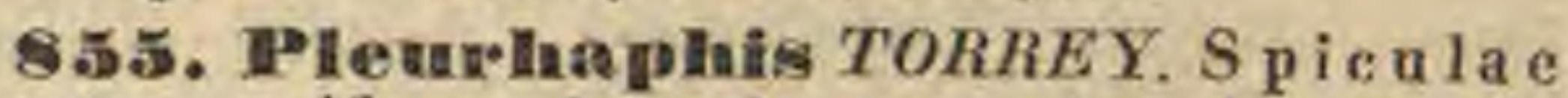
ternatae, uniflorae, laterales masculae, intermedia hermaphrodita, basi villis involucratae Masc. G $\mathrm{l} \mathbf{u} \mathrm{m}$ a e 2 , apice integrae, inferior matica, saperior paullo major, medio dorso aristata. Pale ae 2, mutieae. S quamula e. .. Stamina 3. Hermaphr. Gluma e 2, subaequales, cuneatae, emarginato - bilobae, quinquearistatae. Pa l e a e 2 , iuferior apice truncata, in aristam producta; superior binervis, apice bifida, mutica. Squamula e Stamina 3 . Ovarium sessile Styli 2 , terminales; $8 \mathrm{tigmata}$ plumosa. Caryopsis ¿... Gramen boreali-americanum; foliis angustissimis, spica terminali simplicissima

Pleurhaphis Torrey in Ann. L.yc. New-York. I. 138. t.10.? - H y me a thecium quinques etum Lagase.

TreI I U US IX. A VENACEAE Kunth gram. 97. Spicula e bi-multillorae, flore terminali plerumque tabescente. Glumae pale a qu duae, membranaceo-herbaceae; palea inferior plerumque aristata; arista saepe dorsalis, tortilis. Kunth.

856. Corymeplinoras PALIS, Spicula biflorae, floribus hermaphroditis. G1 uma e 2, carinatae, muticae, subaequales, flores superantes. Pa lea e 2, inferior integra, supra hasim aristata, arista recta medio geniculata, ad geniculum barbata, apice clavata; smperior basi bicarinata, apice triloba, mutica. Squamula e 2 , bifidae $S t a$ min a 3. Ovarin sessile. Stigmata 2 , subsessilia, plumosa Caryopsis paleis cohaerens. Gramina in Europa media et australi indigena, cacspitosa, ramose paniculata; spiculis pedicellatis.

Cor y uep ho r u s Palis. agrost. 90, $t, 18 ., f .2$. Kunth gram, 97. Agrost. 286. Weing a r tu e ri a Bernh.erford 51 . A irae sp. Lian. R. B. t. 1100 . Fl, daa. $t$. 1023. Desf. atl. c.13.

Q57. Deselaampsin PALIS. Sp ie ulae bi-triflore, floribus distichis, hermaphroditis, summo sacpius tabeseente GIu ma e 2, carinatae, mutieae, subaequales, floribus breviores. Pa l e a e 2 , inferior supra basim aristata, arista brevi recta, apice truncato-quadridentata; superior biearinata, apice bifida, mutica. Squamula e 2 , integrae. Stam ina 3 . Ovarium sessile; stigmata 2, subsessilia, plumosa. Caryopsis libera. - Gramina in Europa et Asia media, in America boreali et arctica indigena, ramose paniculata, spiculis pedicellatis.

Des $\mathrm{c}$ h a m p s i a Palis, agrost, 9,t, 18,f.3. Kunth gram. 97. Agrost. 286. C a mpell a Link hort. berol. $r$. 128, Aven a e s p. Host gram. $I$. $t$. 42. Fl, dan, $t$. 220. Alrace sp. Auct.

858. Dupontia $R, B R$. Spiculae bitriflorae, floribus distantibus hermaphroditis, snmmo saepe tabescente, clavato $v$. setiformi. Gluma e 2, concavae, mutieae, subaequales, flores aequantes. Paleae 2 , subaequales, basi barbatae, muticae; inferior coneava, trinervis; superior angustior, binervis. Squ a m u 1 a e 2 , apice erosodenticalatae. Stamina 8 . Ovarium sessile; 
stig un a a 2 , subsessilia, plumosa. C a ry ops is Gramen hyperbore um, glabrum, erectum; foliis linearibus planis, panicula simplici coarctata, fusco-purpurascente, spiculis pedicello continuis, floribus cum rhachilla articulatis.

Dupoutia R. Brown in Parry's voy, 101, Kunth gram. 98. Agrost. 288. Melic a Fis che ri Spreng.

8.5. ira $L I N N$. S p ic ulae biflorae, floribus hermaphroditis, sessilibus. G1 nm a e 2, carinatae, muticae, subaequales, fleribus majores. Pale a e 2 , inferior apice bifida, dorso aristata $y$, rarissime mutica, arista basi torta; superior bicarinata, Sq $\mathbf{n}$ amulae 2, acutatae v. inaequaliter bilobae. Stamina 3 . Ovarium stssile. Stigmata 2, sessilia, subterminalia, plumosa. Caryopsis libera. - Gramina in hemisphaerae bor ealis temperatis frigidisque obvia, versus polum frequentiora, in Ameriea australi extratropica rarissima, caespitosa; foliis planis $v$. involuto - setaceis, paniculis ramosis, diffusis $v$, rarius coarctatis, spiculis pedicello continuis.

A ir a Kunth gram. 98. Agrost. 288. Host gram. II. t. 43. 44. IV.35. Fl, dan, t. 157. 961. - ? Peri b alli a Trin. fund, 133. (Cav, ic. t.44. f. 1.) -? Po i d $\mathrm{i} \mathrm{m}$ Nees in Lindl, in troduct. edit. $I T, p, 450$.

860. Airopsis DESV. Spieulae biflorae, floribus hermaphroditis, sessilibus, Gl u ma e 2 , naviculares, floribus majores. Pa le a e 2 , muticae, subaequilongae, inferior lata, obsolete triloba, concava, extus pilosa; superior planiuseula, bicarinata. Squamula e 2, falcato-lanceolatae. Stamina 3. Ovarium sessile, compressum. Stigmata 2, subsessilia, terminalia, plumosa. Caryopsis suborbiculata, plano-convexa, paleis adhaerens. - Gramen in Hispania et Gallia observatum; foliis involutis, panicula ramosa, stricta, spiculis cum pedicell is apice clavatis continuis.

Airopsis Desv. Journ. Bot. 1. 200. excl. sp. A ira gl obos a Tliore op. cit. p. 197. t. 7. f. 3. 4. II. 208. Mili a u tenellum Cav, ic, t.2fz. f. 1 .

861. Trisetaria FORSK. Spicul a e biflorae, flore inferiore hermaphrodito, breviter stipitato, basi barbato, superiore longius pedicellato, tabescente, ad aristam redacto. Glumae 2 , carinatae, subulatae, inaequilaterae, floribus majores. Paleae 2, inferior lanceolata, tereti involuta, apice biseta, infra apicem aristata, arista subgenieulata; superior bicarinata. Squamulae 2 , emarginato-bilobae. Stamin a 3 . Ovarium sessile. Stigmat a 2 , terminalia, plumosa. Caryopsis....-Gramer annuum, in Syria et A e g y pto indigenum; culmis strictis, foliis planis, panicula contracta, spicaeformi. - Genus vix a sequente diversum.

Trisetaria Forsk, aegypt. 27. Delile aegypt, $t, 12$. Kunth gram, 100. Agrast, 294. Trisetum arenarium Labill, $p l, s y r, \bar{r}, t .7$.

862. Lagurug LINN. Spicnlae biflorae, floribus pedicellatis, flore inferiore hermaphrodito, basi barbato, superiore abortivo subuliformi. G I u m a e 2 , canaliculatae, subulatoaristatae, subaequales, floribus majores. $\mathrm{PaI}$ e a $\mathbf{2}$, inferior concava, apice biaristata, arista tertia infraapicali, longiore subgeniculata; superior brevior, biearinata. Squamula e 2, integrae $v$. apice lobatae. St a min a 3 . Ovarium sessile; stigmata 2, terminalia, pilosa. Caryopsis oblonga, libera. - Gramen in Europa a ustra. liore et Asia mediterranea obvium, annuum, molle; foliis planis, panicula coarctata spicaeformi, ovato-oblonga, subcylindrica, glumi plumosis.
L a g u r u Linn. gen, $n, 92$. Host gram, $I T, t, 46$, Sibth, Fl. graec. $t, 90$, E. B. $t, 1334$, Kuntb gram, 101, Agrost, 294,

863. Trisetum $K U N T H$, S p i u lae biquadriflorae, floribus hermaphroditis v. summo tabescente. G In ma e 2 , carinatae, muticae, sul. aequales, floribus breviores. P a l e a e 2 , inferior apice bidentata $\mathbf{v}$. bisubulata, dorso aristata v. rarins mutica, arista tortili; superior bicarinata. Squamnlae 2, integrae v. lobatae. Stamina 3. Ora rium sessile. Stigmat a 2 , terminalia, villoso-plumosa. Car y o p sis compressa, libera.

Gramina plerumque monticola $v$. alpicola, in Europa et America tropica observata; folius planis, paniculis spicato-confertis $v$. rarius diffusis.

Tris et m munth gram. 102. Agrost, 299. Trin. in Act. Petrop. VI, $1, p .44$.

a) COLOBANTHUS Trin. Pale a inferior mutica v, brevissime aristata.

Colobanthus Trin. l,c. Koeleria pensy Ivani. e a DC. Aira pens ylvanica Spreng. in Mem, Acad, Pe. tersh, 1810, $p, 299, t, 7$.

b) Rostraria Trin. Palea inferior bidentata, denti. bus et arista abbreviatis.

Rostraria Trin. $l$, $c$, Koeleria Link Hort, berol. Koeleriaes p. DC, Festucae sp. Auet. Host gram, III. t.21. (Kunth op. cit. t.60.)

c) TRICHAETA Palis. Pale a e inferioris dentes subulati, arista reflexo-patens.

Trich a e ta Palis. agrost, 86 . B r om us ovatus Cav. ic. t. $591 . f .2$.

d) ACrospelion Bess. Pale a e inferioris dentes subulati, arista recta.

Acrospelion Ress. apud Trin. 1. c. Ventenata Koel. gram. 273. A v e n a e sp. Linn. et Auct. Host gram, IT. t. 55. III. t. 28-40, 45. Desf. Fl, att. t. 31. f. 2. t, 32. Berl. Magas, II, t.8. f, 3.4. Kunth gram, $t, 149$.

864. Avena $L I N N$. S pieulae triflorae, floribus remotis hermaphroditis, summo tabescente. Glumae 2, muticae, subaequales. Paleac 2 , inferior apice plerumque bicuspilata, dorso supra basim aristata, arista torta; superior bicarinata, mutica. Squa m u la e 2 , bifidae, majusenlae. Stamina 3 . Ovari um sessile, apice hirsutum. Stigmat a 2 , distantia, villoso-plumosa. Cary op s is teretiuseula, hine snlcata, apiee pilosa, paleae superiori adhaerens. - Gramina caespitosa, in hemisphaerae borealis temperatis copiosa, inter tropicos et universim in novo conti. nente admodum rara; foliis planis, rariusve involuto-setaceis, spiculis paniculatis, racemosis v. spicatis.

A ven a Linn, gen, $n, 91$, Host gram, II. t. 50-58. $56-59, I I I, t, 39,41-41, I V, t, 30-32$. Sibth. Fl, graec, $t$. 88. Kunth gram. t. 175. Agrost. 299. - ? Lep to p y r a m Raf, in New - York sted. Theposit. V. 350. - G a ud inia Palis, agrost. 95. $t, 19, f .5$. A rth rosta e hy a Link Hort. berol. II, 151. (Host II, $t, 5 \%$. Sibth, $t, 88$. Kunth op. cit. t.61.)

865. Arrolnemathervan PALIS. S picula e triflorae, flore inlimo masculo, secundo hermaphrodito, tertio sterili, filiformi, G I n mae 2, concavae, muticae, superior longior, flores aequans. Masc. Paleae 2, inferior concava, dorso prope basim aristata, arista elongata, basi torta ; si. perior bicarinata, mutica. Squamulae. . . Stamina 3. Ovari $\mathbf{m}$ efoetum. Hermaphr. Palea e 2 , inferior concava, apice brevissime bifida, dorso infra apicem aristata, arista brevi, recta; superior bicarinata. Squamula e 2, elongatolineares, integrae. Stamina 3 . Ovarin messile, apice pilosum. Stigmata 2 , terminalia, villoso-plumosa. Caryopsis teretiuscula, hinc: suleata, paleae superiori adnata. - Gramina elata, per omnem Europam diffusa, foliis planis, 
paniculae ramosae, diffusae ramis verticillatis, basi bulboso - incrassatis; spiculis pedicellatis.

A $r \mathrm{r}$ he $n$ at therum Palis, agrost, 55, t.11. f. s. Kunth gram, 104. Agrost. 307. A v e na e la ti o r Lins. Host gram. IT. $t .49$.

868. Troistaclaya NEES. Spienlae biflorae, flore inferiore sessili, masculo v. neutro, superiore pedicellato, hermaphrodito, basi barhato. G 1 um a e 2, canalienlatae, superior Iongior, floribus najores. Mas c. Pale a e 2 , muticae, inferior trinervis; superior brevior, binervis. S quamula e 2 , carnosae, integrae. Stamina $2, v$. nulla. Ovarii rudimentum lineare v. nullum. He rma h r. Pal e e 2, subaequales, inferior cylindraceo-convoluta, superiorem involvens, apice bifida, inter lobos elongato - aristata ; arista basi articulata, torta ; superior suleato-binervis. S qu a mula e 2, carnosae, integrae. Stamina 2_3, Ovari u m sessile, glabrum. Styli 2 , terminales, elongati; $s$ tigmata plumosa. Caryo psis. . . Gramina americana tropica et capensia (?); foliis planis $v$, convolutis, paniculae simplicis ramis elongatis.

T r is t a ch y a Nees in Mart. Fl. Bras. II. 459. Kunth gram, t. 140.141. Agrost. 308. Mon op og o n Prest in Relig. Haenk, I. 325, t. 44.

86\%. Azisopogon $\boldsymbol{R}, \boldsymbol{B R}$. S p icula e bi florae, flure inferiore hermaphrodito pedicellato, snperiore neutro setiformi. Gluma e 2 , subaequales, muticae, flore majores. Palea e 2, inferior eylindraceo-involuta, apice bifida, lobis aristatis, arista tertia inter lobos media, elongata, basi torta; superior longior, dorso suleata, apice bifida. $S q u$ a mula e 3 ; laterales cultriformes, basi incrassatae, tertia oblonga, coneava. Sta mina 3. Ovarium stipitatum, compressum, apice pilosum. Stigmata 2 , terminalia, plumosa. Ca-

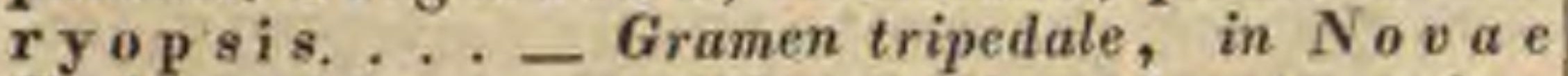
Hollandiae ora orientali extratropica indigenum, Avenae facie; foliis involutis, panicula effusa.

A nis opogon R. Brown prodr. 176. Kunth gram, 105. t. 62. Agrost, 308. Dat uonia Anisopogon Trin, ic. $t, 61$.

888. Treichopterya NEES. Spiculae triflorae, flore infimo masculo, secundo hermaphrodito, tertio rudimentario. G1 u ma e 2 , muticae, floribus majores, inferior minor. Mas c. Pa1 ea e 2, muticae Stamina 3 , Herma $\mathbf{p h r}$. $\mathbf{P}$ a 1 e ae 2, apice bifidae, laciniis setigeris, interjecta arista, basi complanata torta. $\mathrm{S} q \mathbf{u}$ a $\mathbf{m} \mathbf{~ u} \mathrm{la}$ e 2 , obconicae, emarginatae. Stamina 3. Ovarium sessile, glabrum. Styli 2, terminales; s tigmata..... Caryops is.... Gramen capense, angustifolium, vix notum; panicula angrusta, pedicellis infra spiculas barbatis, haud articulatis.

Trich opterya Nees in Lindl. introduct. edit. $I T$. p. 449.

S65. Friaenne $R$. BR. S pienla e biflorae, floribus sessilibus, hermaphroditis, Gluma e 2 , aequales, muticae. Pal eae 2, barbatae, inferior apice in aristam producta, v. mutica; superior bicarinata. $\mathrm{S} q \mathbf{u}$ a $\mathrm{mu} \mathbf{l}$ a e 2 , integrae $\mathbf{v}$, obsolete emarginato-bilobae, $\mathrm{S}$ tamina 3 . Ovarin m sessile, glabrum. St y 1 i 2 , terminales; stigmata plumosa. Ca ry o ps is libera. - Gramina in Nova Hollandia tropica indigena, plerumque pubescentia; foliis angustis planis, spiculis paniculatis.

Eriachne R. Brown prodr. 183. Kunth gram, 105. Agrost. 309.

a) ACHNERIA Palis. Pale a inferior mutica.
Achneria Palis, agrost. 93. (Kunth $l, c, t, 63$ )

b) ERIACHNE Palis. Palea inferior apice in aristam producta.

Eriach ne Palis, agrost. 72. (Kunth l. c, t. 64.)

8\%0. Branaltia KUNTH. Spieula biflorae, floribus sessilibus, inferiore hermaphrodito, superiore femineo. Gl um a e concavac, muticae, inferior major. Hermaphr. $P$ a 1 e a e 2 , inferior concava, apice rotundata, mntica; superior minor. $S \mathrm{qu}$ a m u l a e 2 , cuneato-dolabriformes. Stamina 3 . O v a $\mathbf{r}$ i m sessile, glabrum. Styli 2, terminales; stig mata plumosa. Caryopsis elliptica, compressa, libera. F em. Palea e 2, inferior coneava, superiorem involvens, apice aristata, arista torta, geniculata. Squamulac, ovarium et caryopsis vt in hermaphrodito. - Gramen indicu $m$; foliis planis, paniculae ramosae, erectae spiculis pedicel. latis $v$. subsessilibus, basi articulatis.

B r a nd ti a Kunth gram. II. 511. t. 170. Agrost, 310 .

8\% 1. Danthomia DC. S piculac bi-multiflorae, floribus distichis, summo tabescente. Gluma e 2 , subcarinatae, muticae, subaequales, flores aequantes $v$, superantes. Paleae 2 , inferior concava, maltinervis, apice bifida, inter lacinias mutieas $\mathbf{v}$. aristato - subulatas aristata; arista basi complanata, spiraliter torta, $v$, brevissima, recta; inferior bicarinata. Squ a $\mathrm{m} u \mathrm{Ia}$ e 2 , integrae, glabrae v. apice pilosae. St am ina 3 . O va ri u m stipitatum, glabrum. Styli 2 , terminales; sti g. mata plumosa. Ca ryopsis compressa, libera, Gramina caespitosa, in Europa media et australi, Nova Hollandia et Africa austra. li extratropica obvia, in America borea$l i$ rarissima; foliis planis, spiculis pedicellatis, ra. cemosis $v$. paniculatis, palea inferiore barbata.

Dant ho ni a DC. Fl. f. 2. III. 32. Kunth gram. 106. Agrost. 311.

a) SIEGLINGiA Bernh. Pale a e inferioris arista brevis v. bresissima, dentiformis, recta.

Sieglingla Bernh. erford. 4i. T ri o d i a Palis. agrost, 76. Festucace s p. Linu. P o a e s p. Schrad, Host II, $t, 72$, A ven a e sp. Vahl, Delile aegypt, t, 12. (Triu, ic. 49.)

b) DANThonia Palis. Palea e inferioris arista elongata, basi torta.

Dauthonia Palis. agrost. 92. Av enae sp. Linn. et Auet. A rund InIs s p. Labill. Nov. Holl, t, 33.34. (Kunth gram, $t, 65,176,177$.$) T'rin, ic, t, 51-54,62,65,67,68,-\mathrm{T}$ r $\mathrm{f}$. pogo n Röm. et Sehult. syst, IX. 600. Roth nov. sp. 79 . Triathera Roth mse. - Pentameris (Palis. agrost. 93, t. 18. f. 8. Kunth gram, 107. t.66. Agrost. 315. Nees in Linnaea VII. 310. Da athon la e sp. Sehrad. Trí. ic. $t$. 50.63, 63.66.) "fructu elliptico, teretiusculo, apice truncalo, sintus ad basim suleo notato, pericarpio crustaceo, semíne ylibero" diferre dieitur. - Quid Chaetobrom a 8 Nees in Lindl, introduct. edit, $I$. p. A49. ?

8g. Uralepis NUTT. Spicula e multiflorae, floribus hermaphroditis, distichis, summo tabescente. G 1 u m a e 2 , subcarinatae, muticae, inaequales, floribus breviores. P al e a e $\mathbf{2}$, inferior trinervis, concava, apice bifida, laciniis interdum extus denticulo subulato, auctis, inter lacinias aristata, arista brevi subulata complanata, recta ; superior bicarinata. $\mathrm{S} q \mathrm{u}$ a $\mathrm{m}$ la e 2 , truncato - rotundatae. Stam in a 3 . Ovarium stipitatum, glabrum. Styli 2, terminales; stifm ata plumosa. Caryopsis teres v. plano-convexa. - Gramina repentia, $A m$ er ic am cis a equ ato rem incolentia; foliis angustis, carinatis v. convolutis, spiculis in apice culmi racemosis paniculatisve.

Ura l e pis Nutt. gen, I. 62, Kanth gram, 108. Agrest. 317.

a) DIPLOCBA Raf. Palea inferioris laciniac edeatulae. Cary op bia teres. 
Diplocea Raf, in Sillim. Josrn, I. 252. A i ra purpurea Walt. Triodia Kunth in Humb. et Bonpl. nov. Gen, et sp. $2,47,48$. (Kunth Gram, t, 67.)

b) WINDSORIA Natt. P a leae inferioris laciniae dente subulato auetae. C a r y o p s is plano-convexa.

Wi ud s o ri a Nutt. gen, I. zo. Tricus p is Palis. agrost. 77. T'ride n \& Röm. et Schult. syst. IK. 399 . T riod i a Jaeq. f. eclog. 2.16. (Kunth gram. t.68.)

8\%3. Troicalia $R, B R, \mathrm{~S}_{\mathrm{p}}$ i cula $\mathrm{l}$ bi-multiflorae, floribus distiehis, hermaphroditis, GInma c 2 , conravae, mnticae, subaequales. P a l e a 2 , inferior tridentata, dentibus subaequalibus, muticis; superior integra. Squamulae 2 ... S tamina 3 . Ovari um sessile. Styli 2 , terminales; stigmata plumosa. Caryo psis... - Gramina in Nova Hollandia tropica indigena, perennia, rigida; foliis planis $v$. involutis, spiculis panieulatis. 319.

Triodia R. Brown prodr. 182. Kunth gram, 108, Agrost.

8.4. Fomeremila LINN. FIL. S picula e subsexflorae, floribus arcte imbricatis, duobus inferioribns neutris, unipaleaceis, superioribus hermaphroditis similibus, snmmo tabescente. GI nm a e 2 , a floribus remotae, inaequales, inferior lanceolata, concava, trinervis, mutica; superior minima, subulata. Pale ae 2 , inferior concava, trinervis, apice quadrifida, dorso divaricato-aristata; lacinits interioribus lanceolato-subulatis, mueronato-aristatis, exterioribus majoribus alaeformibus; superior bicarinata, binervis, acuta. Squa mulae 2 , subfaleatae. Stamina 3 . Orari um sessile. Styli 2 , terminales. Stig mat a plumosa. Caryopsis elliptica, plano-convexa, libera. - Gramina in dica, repentia; ramis erectis foliosis, folïs distichis, spicis terminalibus solitariis, folio spathaeformi involutis.

Pomere ulla Lins.f.nov. gen, gram, 3t. Roxb. corom. t. 131. Hunth gram, 109. Agrost, 320. Anaal, sc. nat. XXIII.t.7.

THIBUS $\times$. FESTUCACEAE. Kunth gram. 110. Spiculae multiflorae, rarius pauciflorae. G l u $\mathrm{m}$ a e et $\mathrm{p}$ a $\mathrm{l}$ e a e duae, membranaceo-herbaceae, rarius coriaceae, hae plerumque aristatae, aristis haud tortis. - Inflorescentia vix non semper paniculata. Ku:ith.

SUB'ITRIHES I. BROMEAE. Gramina hurbacea. Stamina tria.

8\%ธ. Seslenia $A R D$. Spiculae bi-sexflorac, floribus distichis, hermaphroditis. G Ium a e 2, minticae $v$, mueronatae, inacquales, Pale a e 2, inferior carinata, aristato-mucronata, saepe triquinquedentata, dentibus mueronatis; superior bicarinata, apice bifida. S qu a m и 1 a e 2 , integrac, $v$, bi-quinquefidae. $S t$ am in a 3 . Ovarium sessile, glabrum ₹. apice pilosnm. Styli 2, terminales; stigm at a elongata, plumosa, Cary op$s$ is thera. - Gramina curopaea, monticola et alpestria, caespilosa; foliis planis, interdum setifornuibus, spicis simplicibus, confertis, globosis, oblongis v. linearibus, busi interdum bracteatis.

Sesleria Arduin. specim. II. 18. Kunth gram. 110. Afrost, 321 .

a) OREOCHLOA Link. Glumae muticae. Palea inferior mucrouata, superior mutica.

Dreochloa Liak Hort, berol. $I$. 40. Poa disticha Wulf. Jueq, ic, rar. $t, 19$. Host gram. $I I, t, 76$.

b) SESLERIA Link. Gl u ma e mucronatie. P a Iea inferior aristata, superior mutiea.

Sesle r la Link Hort, berol, 1. 200. Host gram, II. $t$. 97-992 IV. 16. 29. Sibth, Fl, erace. t, 72. C ynosuri =p. 1.iva. c) PSilathera Link. Glumae mueronatae. Palea inferior quitquedeutata, superior bifida, dentibus mu. crouatis.

Psilathera Link Hort.berol. I. 121. (S es le ria te. ne Il a Host gram, II. $\iota, 100$.

876. Poa LINN. Spiculae bi-multiflorae, floribus distichis, hermaphroditis. Gl umae 2 , mnticae, subaequales. Pal e a e 2 , muticae, in. ferior carinata $v$, concava; superior bicarinata. Squamulae 2, integrae v, bifidae. Stamina 1_3. Ovarium sessile, glabrum, Styli 2 , terminales; stigmata plumosa. Caryopsis libera v. paleae superiori adhaerens. - Gramina per tot u m or bem diffusa, in extratropicis frequentiora; foliis planis, spiculis pedicellatis, paniculatis $v$ rarius racemosis, interdum sessilibus, spicatis, paniculatis contractis $v$. effusis, floribus abortu suepius dioicis.

Po a Liun. gen, $n$. 83. excl. sp. Iunth gram, 110, Agrost. 324.

a) AELUROPUS Trin. Spicula e multiflorae, compres. sae, spicato-racemosae. Palea inferior coriaces, multinervis, ecarinata, nervis haud prominentibus, margine membranacea.

A eluropus Trin. fund, 143. Brizopyrum Linh Hort, berol. I. 160, p. parte. Dis t i h I is Raf. Dacty Iis s p. Liun. Host gram. IV. t, 28, Un i o l a e s p. Linn. Labill. Sov, Holl. t. 24. Fest a e a e s p. Sibth. Fl. graec. $t .80$. (Kunth gram, t, 180,181.)

b) ERAGrostis Palis. S p i c n I a e quinque-multiflorae, compressae, paniculatae. Pal a inferior membranacea, trinervis, superior bicarinata, earinis elliata, d.utios persistens. Car y o p is libera, cum palea inferiore decidua.

Eragrostis Palis. agrost. 71. Megastachya Pa. lis. op. cit, 74. (Jacq. Hort. Vind. IIL, 56. Ic, rar. i, 17, 18. 304. Cav, ic, $t, 93$. Desf, Fl, atl, $t, 17$. Delile aegypt, $t, 10$. f. 2. 3. Host gram, II, t, 69. Sibth. Fl. graec, t.73. Jaeq. fil. Eclog. t. 3, Gaudich. ad Fregc, 1, 25. Kanth in Humb. et Bonpl. nov. gen. et sp. t.699. Gram. t. 146-149.183-190.)

c) POA Palis. Splicula e paucitlorae, compressac, piniculatae, floribus remotiusculis, basi plerumque vil. losis. Palea inferior herbacea, diaphana, uni-quinque - septemnervis.

CHost gram, II, t. 61-67, 70, 71,91, III, 13-15. IV.26. 27. E. B. $t .365 .1003 .1004$. 1072, 1123. 114t, 1720. Ledebour Fl. alt, $t, 294,225$. Huath gram. $t, 83,150-153$.

8\%ซ. Centotheea DESV. Spiculae triflurae, compressae, flovibus remotis hermaphroditis, summo tabescente. Gl um a e 2 , carinatae, muticae, snbaequales. Pale a e 2 , inferior carinata, mutica, in flore superiore margine versus apicem tuberculata, tuberculis retrorsum setosis; sajperior brevior, biearinata. S q u a $\mathrm{m}$ u a e 2 , sinuato-emarginatae. Stamin a 2 , ovarii stipitulo inserta. Ovarium stipitatum, glabram. Sty li 2 , terminales; 8 tigmata plumosa. Caryopsis oblique ovata, compressiuseala, glabra. - Gramen inter tropicos Asiae el Oceaniae diffusum, erectum, simplex; paniculae simplicis ramis fasciculato-semiverticillatis, spiculis racemosis, pedicellatis.

Centoth e a Desv. Journ. Bot. III, ro. Palis. agrost. 69. t. 14. f.7. Kuath gram, 117, t. 80. Agrost. 366. Ceachras 1 a p paceus Lisu.

88 8. Clyceria $R$. BR. S piculae multiflorae, floribus imbricate-distichis, hermaphroditis. G Inmae 2, concavac, obtusae, inferior brevior. $P$ ale a e 2 , subaequilongae, inferior ovato-elliptica, rotundato - obtaza v. obsolete triloba, septemnervis; superior bicarinata. $S_{q} \mathbf{n}$ a m u la e 2 , truncatae, plus minus inter se connatae. Stamina 2_3. Ovarium sessile. Styli 2 , terminales, elongati; stigmata plumosa. Caryopsis oblonga, libera. - Gramina aquatica, repentia, in regionibus temperatis utriusque hemisplac- 
rae obvia; foliis planis, paniculae simplicis v. ramosae ramis fasciculato-semiverticillatis,

Glyceria R. Brown prodr. 179. Kunth agrost. 367. II y d r o c h $\mathrm{I}$ o a Hartm. gram, suec. 8.

a) GLYCERIA Link. Spiculac cylindricae, floseulis basi callosis, cum rhachilla articulatis. S quamula e conuatite.

GI yeeria R. Brown $l$. c. Link Hort. berol. 1. 179. Deva uxia Palis, msc. Festuea flaitans Linn. Host sram. II. t. 7 .

b) HYDROCHLOA Link. Spicula e compressae, flosculis ecullosis, rhachillae continuis. Squ a mula e distinctae.

Hydrochlo a Link l. e. Exydra Endl. Ft. poo. 119. Poa a quatica Lim. Host gram. IT, $t, 16$.

8ร9. Plezropagon $R$. $B R$. Spiculae multiflorae, floribus remotis, hermaphroditis. Gluma e 2 , mntieae, inferior ovata, superior obovata, longior. $\mathrm{P}$ a I e a e 2 , subaequilongae, inferior obtusissima, coneava, quinque-septemnervis, infra apicem scariosum mncronnlata; superior profunde emarginata, binervis, bicarinata, nervis aristis geminis snperpositis, superioribus brevioribus instructis. $S$ quamulae 2 , collaterales, truncatae. Stamina 3. Ovarinm sessile. Sty li 2, terminales; stigmata laxe plumosa. Caryopsis compressa, libera. - Gramen elegans, $A m$ ericam hyperborea m incolens; foliis angustis, planis, racemis simplicibus, spiculis cernuis, purpureis, nitentibus.

Pleurapozon R. Brown in Parrye vog. 189. $t$. d. Kunth gram, 118, Agrost, 368.

880. Eatomin $R A F$. Spicula e biflorae, flore inferiore sessili hermaphrodito, superiore ad pedicellum clavatum redacto. G1 um a e 2 , carinatae, subaequilongae, inferior lineari-lanceolata, acuta, uninervis, superior obovata, obtusa, trinervis. Pal e a e 2, inferior obovato-oblonga, compresso-carinata, uninervis; smperior brevior, licarinata, emarginato-biloba. Squa m ula e 2, truncatae. Stamina.... Ovarium .... Caryopsis linearis, mueronata, palea inferiore inclusa. - Gramen in America boreali indigenum, gracile; culmo erecto, foliis angustis planis, paniculae ramosae contractae ramis semiverticillatis, spiculis subracemosis, cum pedicello artieulatis.

Eato nia Raf. in Journ. phys. LXXXIX, 104. Re b a u$1 \mathrm{e}$ a Kunth gram. . 341. t.84. Agrost. 368. A ira o b tus a Michx. - ? Cho ndrach y $\mathrm{r}$ um Nees ex Lindl. introduct. odit. II. p. 4.49.

88 1. Cataloresa PALIS. Spicula e biflorae, floribus hermaphroditis, inferiore sessili, superiore pedicellato. Glumae 2, concavae, parvae; inferior oblonga, uninervis; superior obovata, trinervis, apice crenata $v$. eroso-dentata. Pa 1 ea 2 , oblongae, subaequilongre, inferior trinervis, apice truncato - rotundata, trigono-carinata ; snperior binervis, concavo-bicarinata, apice subtrilobo-rotundata. S q u a m u la e 2 , subtruncatae. Stamina 3 . O va rinm sessile, glahrum. Car y o p is breviter stipitata, intra pateas libera. Gramen in aquosis regionum temperatarum hemisphaerae borealis repens; ramis erectis, simplicibus, foliis planis, paniculae ramosae diffusae ramis verticillatis, spiculis pedicellatis, floribus articulat is, deciduis.

C a t a b $\mathrm{r}$ o s a Palis, agrost, 97. $t, 19, f .8$. Kunth gram. 118. Agrost, 369. A ir a a qu a ti c a Linn. Host gram, $I I . t$. 41. Hydrochloae sp. Hartm.

882. Coelaelne $R . B R$. S p i u ula e biflorae, flore inferiore sessili hermaphrodito, superiore pedicellato, femineo. G1 1 m a e 2, subrotundae, ventricoso-concavae, subaequales, Pale a e 2, subaequilongae, muticae; inferior ovato-subro- tunda, obtusa, ventricoso-concava; superior enervis, subbiearinata. Squ a mula e 2, truncato-sub. bilobae. Stamina 3 . Orarinm sessile, glabrum. Styli 2, terminales; stigmat a plumosa. Cary opsis fusiformis, libera. Fem Paleace subaequales, ovatae, obtusiusculae, muticae, inferior coneava, superior bicarinata, carmis ciliatis. Ovarin m et caryopsis ut in hermaphrodito. Gramen in Nova-Hollandia tropica indigenum, tenellum, glaberrimum; foliis planis, ligula obsoleta, panicula angusta, spiculis parvis.

Coela ch ne R. Browa prodr. 187. Palis. agrost. 39. Kunth gram. 119. t. 143. Agrost, 370.

883. Ioniza $L I N N$. S p i c u l a e multiflorae, floribus hermaphroditis, imbrieato-distichis. Gluma e 2 , subrotundae, compresso-concavae, ventricosae. Pale a e 2, inferior subrotunda, com. presso-concava, basi cordata, apice rotundata, snperior multo minor, biearinata. Stamina 3 . $O$ varium sessile. Squamula e 2 , integrae $v$, subbilobae. Styli 2, terminales; stigmata plnmosa Caryopsis compressa, libera y. paleae superiori adnata. - Gramina elegantia, in Europa media et a ustrali obvia, quaedam latissime per terrarum orbem diffusa; foliis planis, paniculis simplicibus v. ramosis, spiculis pedicellat is, rhachilla tandem articulata.

B riza Linn. gen. n. 84. Palis, agrast. 67. Host gram. II. $1.28-30$. Sibth. Fl, graee. $2.75-77$. Kunth gram. 120. Agrost. 37t. - ? Neurolom a Raf.

884. Chaseolytruma DESV. Spicu1 a multiflorae, foribus hermaphroditis, imbricato-distichis. G1um a e 2 , navirulares, inaequales. Palea 2, inferier subrotunda, basi cordata, dorso convexa, apice mueronato-aristata; superior multo brevior, planiuseula, utroque margine carinata. Squamula e 2 , emarginato-bilobae. Stamina 1_3. Ovarinm sessile, glabrum. Styli 2, terminales; stigmat a elongata, plumosa. Caryopsis subrotunda, plano-convexa, libera. - Gramina in Ameriea tropica et australi extratropica indigrena, foliis planis, paniculae simplicis $v$. ramosac ramis solitariis, geminis $v$, semiverticillatis, spiculis pedicellatis, subrotundo-ellipticis, rhachilla articulata.

Chascolvtrum Desv. Journ. Bot. III. 7t. Kunth gram, 120. 4. 86-65. Agrost, 373. Cal o t b e cae sp. Palis. agrost, $t, 17, f, 6, \mathrm{~B}$ r iz a e s p. Lam.

885. Calotheca KUNTII. Spiculae multiflorae, floribus imbricato-distichis, hermaphroditis, summo tabescente. G1 uma e 2, obovato-oblongae, concavae, inferior trinervis, superior paullo major, quinquenervis. Pale a e 2 , inferior concava, utroque latere supra basim in alam falciformem producta, apice bifida et breviter aristata; superior multo brevior, plana, bicarinata, earinis ciliata, apice producto diaplano subspathulato. Squamula e 2 , lobulo laterali auctae. St am in a 3. Ovarium sessile, glabrum. Styli 2, terminales; stigmata elongata, pilosa. Cary ops is trigona, libera. - Gramina caespitosa, in $A$ merica a ustrali tropica et extratrop ica indigena; folits convolutis, panicula simplici depauperata, spiculis pedicellatis, rhachilla articulata.

C a lotheca Knnth gram. 121. Agrost. 374. C a Io thecae sp. Palis. agrost, $t, 17, f, 7$. Bromus brizoides Lan.

836. Antheehloa NEES. S p i c n la e triquadriflorae, floribus inferioribus hermaphroditis, summis abortivis. Gl $\mathbf{n} \mathrm{m}$ a e 2, muticae, inferinr paullo minor. Palea e 2 , inferior maxima, yul- 
rotunda; superior minor bifida, laciniis bifilis. Squamulae 2, acutae. Stamina... Ovarium ..... Styli 2 , terminales; stigmata maxima, plumosa, Caryops is ....-Gramen peruanum andinum; paniculae racemulosae ramis faseiculatis, paucifloris.

A a th o $\mathrm{ch}$ lo a Nees in Lindl, introduct, edit, II, p. 450 .

89\%. TIeliea $L I N N$. Spicula e tri-quinqueflorae, floribus duobus infimis hermaphroditis, reliquis tabescentibus. Gl u mae 2 , concavae, muticae, inaequales. Palea e 2 , muticae, inferior concava; superior biearinata. Squa mula e 2 , liberae $v$, inter se connatae, Stamina 3. Ovari um sessile, glabrum. St y li 2 , terminales; stigmat a plumosa. Cary ops is teres, libera. Gramina in Europa et Asia media obvia, in America tropica et extratropica, nec non in Capite bonae spei rarius provenientia; foliis planis, paniculis simplicibus $v$, ramosis, spicalis pedicellatis.

Meli ca Linn, gen, n. 89. Palis. agrost, t, 14. f. 5. Host gram, II, t.9-12. MY. 23. Sibth. Fl, graec. t.71. Cav, ic. $t, 472,473$. Kunth in Humb. et Bonpl, nov, gen, et sp. $t$. 693. Gram, t. 89. Agrost, 375. - B ulb 11 is Raf. in Americ. Magaz. 1819. Ses leria dactyloides Nutt.

838. TIOlinia MOENCH. S piculae biquinqueflorae, floribus hermaphroditis, summo tabescente. GI uma e 2, concavae, muticae, inaequales. $\mathbf{P a}$ e a e 2 , inferior convexo-semiteres, obtusa, mutica v. subaristato - mucronata, superiorem bicarinatam, subaequilongam involvens. Squ a mula e 2 , dolabriformes. Stamina 3 . Ov a rium sessile, glabrum. Styli 2 , terminales; stigmata plumosa, C aryo psis subfusiformis, libera. - Gramina in Europa et in Asia media indigena, rigida; culmorum nodis vaginis velatis insignia, paniculis ramosis contractis $v$. diffusis, spiculis pedicellatis, rhachilla articulata.

Mo I i n a Mönch, meth, 183. Palis. agrost. 68, t.14. $f$. 6. Kunth gram. 193, Agrost, 379. Ledeb. Fl. alt. t. 227. En adin m Lisk enum. 1. 79. Meli ca coerulea Linu. Host gram. $I T, t, 8$. H y d ro hio a s p. Hartm.

885. Koeleria PERS. Spiculae biseptemflurae, floribus distichis, hermaphroditis. G 1 u m a e 2 , carinatae, muticae, inaequales. $\mathrm{Pa}$ 1 e a 2 , inferinr aucta, mutica $v$. apice ant infra apicem breviter aristata; superior bicarinata, apice bifida. Squa mulae 2 , inaequales, bi-trifidae. Stamina 8 . Ovarium sessile, glabrum. Styli 2 , terminales; stigmata plumosa. Cary o psis teretiuscula, libera. - Gramina in Europ a media et australi obvia, in Asia et Americ a septemtrion ali rara; culmis eaespitosis, foliis planis, paniculis confertis, spicaeformibus, spiculis pedicellatis. $38 t$.

K o e le ri a Pers, ench. I. 97. Kunth gram, 123, Lgrost.

a) AirochloA Link. Palea inferior mutica.

A i r ochio a Link Hort, berol, $I_{0}$, 127, excl. sp. Air ae × p. Linn, E. B, t, Gis, El, dan, t.1566.

b) KoELERIA Link. Pale a inferior apice ve sub apice aristata.

Hoeleria Link l.c. Collinaria Ehrh. phyl.31. Ae. gialit is Trin. fund. 197, t,9. A eg i a li na Schult. mant.

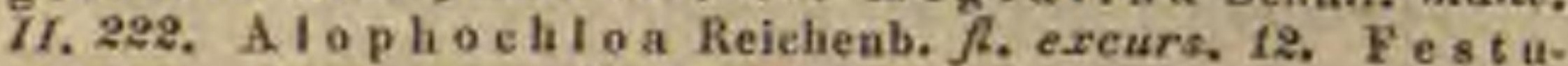
c a e s p. Host gram. IIT, t.24.

590. Seloismas PALIS. S pic u 1 a e quinque-septemflorae, floribus distichis, remotinsculis, hermaphroditis. Glu in a e 2, wvato-oblongae, acutiusculae, concavae, subaequales, inferior quadri-septemnervis; superior tri-quinınenervis. Pal e a e 2, subaequilongae, inferior obovata, apiee bifida, mutica $v$, mueronata, novemnervis; superior oblongo - spathulata, acuta, binervis, Squ a- mula e 2, truneatu-dolabriformes. St a min a 3 . Ova ri u m stipitatum, glabrum. Styli 2 , terminales; stigmata pilosa. Cary opsis obovata, compressiuseula, inira paleas libera. - Gramina mediter rane a, caespitosa; foliis pilosiusculis, rudicalibus involutis, caulinis planis, panicula simplici, coarctata.

$\mathrm{Se}$ b is m a s Palis, agrost, 74, t, 15. f. 4. Kunth gram. 124. Agrost. 38i. Festue a e sp. Linn. Cav, ic, 1.44.f.2, Hem is a eris steud. in Flora 1899. 11. 490.

891. Wangenheimia MOENCH. Spi. c u la e quadriflorae, floribus hermaphroditis, Glu. ma e 2 , subunilaterales, carinatae, muticae, flo. res superantes, inferior minor. Palea e 2 , inferior acuta, carinato - concava, uninervis; superior brevior, bicarinata, Squa mula e 2, bilobae. Stamina 3. Ovarium stipitatum, glabrum. Styli 2, terminales; stigmata plumosa. Caryopsis.....-Gramen ibericum, pusillum; culmis caespitosis, foliis angustissimis involu. tis, spicis solitariis, spiculis unilateralibus, sessilibus, imbricatis, rhachi continua.

W a gen hei mi a Mornch meth. 200. Kunth gram, 125. Agrost, 385, C yno \& a rax Lima Lofil. Cay, ic. t.91.

892. Dactylis LINN, Spicula e bi-septemflorae, floribns hermaphroditis. G l u mae 2, subinacquilaterae, carinatae, mucronato-aristatae, apice unilaterales, inaequales; superior saepe minor, enervis et concava. P a le a e 2 , inferior quinquenervis, carinata, mucronato - aristata, carina ciliata; superior bicarinata. $S q u$ a $m$ u l a e 2 , bifidae. Stamina 3 . Ovarinm sessile, glabrum. Styli 2, terminales; stigmata plumosa. Cary opsis libera. - Gramina in Europa media et australi, nec non in America et Asia septemtrionali indigena; foliis carinatis, paniculis glomeratis, secundis.

Da et y lis Linn. gen. n. 86. Palis. agrost, 85. Host gram. 1I. i. 94. E. B. t.335. Panz. Ideen t. 8. f. 2, $a, d, e$. Kunth gram, 125. Agrost. 385.

893. Lusioehloa KUNTH. Spiculae tri-quadriflorae, floribus hermaphroditis, distichis, basi callosis. GI uma e 2, mulicae, extus papilloso - hispillae, subaequales, Pa le a e 2 , inferior concava, acuta v, mueronata, novemnervis; superior brevior, bicarinata. Sq a a mula e 2, dolabriformes. Stam ina 3 , summo ovarii stipiti inserta. Ovarium stipitatum, glabrum. Styli 2, terminales; stigmata plumosa, Cary opsis...-Gramina capensia, caespitosa; foliis planis v. convoluto-filiformibus, paniculis glomeratis, rhachilla articulata.

L a si oc hio a Kunth 6ram. IT, 555, t. 192-193. Agrost. 387. Dactylidis s p. Thumb. Sehrad.

894. Cynosmens LINN. Spieulae biquinqueflorae, floribus hermaphroditis, immixtis spiculis sterilibus, pectiniformibus, e solis glnmis compositis. Gl u ma e 2, lanceolatae, carinatae, breviter aristatae. $P$ ale a e 2 , inferior apice mucronata $\mathbf{v}$. aristata; superior bicarinata, apice bifida. Squam ulae 2, subintegrae. Stamina 3. Ovarinm sessile, glabrum. Sty Ii 2 , terminales; stigmat a plumosa. Caryop sis libera. _Gramina mediterranea, habitu el spiculis sterilibus a Festuca diversa; foliis planis, paniculis confertis, spicaeformibus, secundis.

C ynosurus Linn. gen, n. 87. Kunth gram. 126. Agrast. 388.

a) CXNOSURUS Palis. S picula e mueronatae. t. 96 ,

c ynosurus Palis, agrost, $t, 14 . f$. 1 . Host gram, $1 I$.

b) CHRYSURUS Palis, Spiculae aristatae, 
Chrysurn s Palis, agrost. 123. excl. sp. (Host II, $t$, 95. Sibth. Fl, graec, $t, 78$. Desf, Fl, atl, $t, 17$.

855. Hanamekin MOENCH. Spiculae fertiles sterilibus crebris mixtae: fertiles biflurae; floribus remotis, altero hermaphrodito, altero rudimentario, basi arista fulto. Glum a e 2 , lanceolato-subulatae, a flore remotae. Pa le a e 2, inferior cylindraceo-convoluta, infra apicem bifidim aristata; arista recta; superior bicarinata. $\mathrm{Squa} \mathrm{mu}$ la e 2 , minutissimae. Ovari um sessile, glabrum. Styli 2 , terminales; 8 tigmat a pubescentia. Caryopsis oblonga, compressa, paleae superiori adhaerens. Spiculae sterile 8 quinque-octoflorae, floribus remotis. Gl u m a e 2 , lunulato-subulatae, a flore remotae. P a le a 1, ovato-subrotunda, coneava, mutica, apice erosodenticulata. - Gramen mediterraneum, an. nuum; folïs planis, paniculae simplicis, confertae spiculis pedicellatis.

L a marekia Mónchmelh. 201. Kunth gram. 127. Agrost. 389. C y os urus a ure us Liun. "Sibth. Fl. graec. $t .79$. Chrysuri sp. Palis, $t$. 22, $f$. $5 .-$ Pterium Desv, in Journ. Bot, $I I T$. $7 \overline{\text {. }}$.

898. Eetrosia $R, B R$. S picula e multiflorae, floribus distichis, remotis, infimo hermaphrodito, reliquis tabescentibus masculis v, neutris, longins aristatis. G $1 \mathrm{um}$ a e 2 , carinatae, muticae, subaequales, floribus breviores. P al e a e 2, inferior trinervis, carinata, apice biloba, inter lacinias aristata, arista recta; superior bicarinata, mutiea. S qua m u la e 2, cuneatae, emarginatae. Stamina 3 , ovarii stipiti inserta. Ovari um stipitatum, glabrum. St yli 2 , terminales; s tig mat a plumosa. Caryopsis fusiformis, libera. - Gramina in Nova-Hollandia tropica indigena; foliis convolutis, paniculae ramosae, coarctatae, spieulis pedicellatis.

Ectrosia R. Browa prodr. 185. Kunth gram, 127. $t$. 69. Agrost, 390 .

93\%. Lopleatherum BRO VGN. SpicuLa e multiflorae, flore inferiore sessili, hermaphrodito, superioribus pedicellatis, neutris, unilateralibus, Gl um a e 2, obtusae, muticae, inferior brevior. Hermaphr. Pateae 2 , inferior ovatoublonga, convoluta, septemnervis, apice in aristam brevem, rectam producta ; superior angusteublonga, obtasa, binervis. S q u a mn la e 2 , trun catae. Stamina 3 . Ovarium sessile, glabrum Styli 2, terminales; stigmata. . Cary. opsis... Neutr. Paleae 2, inferior ovato. oblonga, septemnervis, apice in aristam rectam, rigidam producta; superior binervis, brevior, in floribus superioribus abortiva. - Gramen a $m b$ o $i$ nense; foliis lanceolatis, petiolatis, pani ulae ramis alternis, simplicibus, distantibus, spiculis sessilibus, subunilateralibus, apice incurvatis.

Lop hat her um Brongn, in Duperr, voy, 49, $t, 8$.

898. Elytrophoras PALIS. Spicula tri-multiflorae, floribus distichis, hermaphroditis. GI u mae 2, carinatae, subulato-aristatae, subaequales. Pal ea e 2 , inferior earinata, trinervis, apice subulato -aristata; superior dimidio brevior, bicarinata, carinis membranaceo-alatis, apice triloba. $\mathrm{S}$ q u a u $\mathrm{I}$ a 2 , integrae. Stamen 1. Ovarium stipitatum, glabrum. Styli 2, terminales; stig mata elongata, puberula. Car yop 8 is teretiuscula, libera. - Gramen in $A$ s i a et Africa tro pic a observatum; foliis planis, panicula conferta, glomerato - spicata, cylindrica.

Elytrophorus Palis. agrost. 67. $t$, 14. $f$. 2. Huuth gram, 128. t. 154. Agrost. 391 . E chinalys fund. 198.
899. Testuea LINN. S picula e bi-multiflorae, floribus hermaphroditis, distichis. G 1 uma e 2 , carinatae, muticae, inaequales. Pa 1 e a $e$ 2 , inferior ecarinata, apice acuta, mueronata $\mathbf{v}$. in aristam producta; superior bicarinata. S qua$\mathrm{mul}$ a e 2 , acute bifidae. Stam in a 1 - 3 . Ovarium sessile, plerumque glabrum. Styli 2 , terminales; stigmat a plumosa. Caryopsis plano-convexa, glabra, libera $v$. paleae superiori adhaerens. - Grumina in hemisphaerae borealis temperatis copiosa, in hemisphaera australi admodum rara, inter tropicos rarissima; foliis planis v. setaceis, spiculis ut plurimum pedicellatis, paniculatis $v$. racemosis, rarius sessilibus, spicatis, rhachilla erticulata.

a) SClERochloA Palis. Spicula e pedicellatae, f10$r$ ib us obtusis $v$. mucronatis.

$\mathrm{Sclerochloa}$ Palis, agrost. 98. Sphenopus Trin. Po a e s p. Linn. Host gram, II, 63, 74, III, t, 17 .

b) CATAPODIUM Link. Spiculae sessiles, spicatae, floris us maticis.

Cat a podím Liak Hort. Berol. T. 45. Brachypo. d i $\mathrm{m}$ Palis, agrost, 100, excl.sp. Po a e s p. Linn. Jacq. ic, rar, t, 303. Tritici s p. Linn. Host gram, IT, t, 27.

c) VULPIA Gmel. Spiculae pedicellatae, floribus longe aristatis.

V ulpi a Gmel. Bad. I, 215. Link Hort, berol, I. 146. M y g I u r us Liak enum. $I$, 98. B romi sp. Linn.

d) FESTUCA. Spiculae pedicellatae, floribus mucronatis v, breviter aristatis.

Festuca et $\mathrm{S}$ choenodorus Palis. agrost. 99. Host gram, IX, t.79-91, IIT, 18-20, XY, 60-62.

900. Bromang LINN. Sp i c nl a e tri-multiflorae, floribus hermaphroditis, distichis. G1 um a e 2, plerumque earinatae, muticae, inaequales. Pale a e 2 , inferior dorso convexa, mutiea v. sub apice, interdum fisso, aristata; superior biearinata, carinis pectinato-ciliatis. S qua mu la e 2 , integrae. $\mathrm{Stam}$ in a 3 . O v a $\mathrm{r}$ i $\mathrm{m}$ sessile, apice hirsutum. Stig mat a 2, laterali-terminalia, plumosa. C ar yopsis plano-convexa, apice villosa, - Gramina planifolia, in toto terrarum orbe abvia, in temperatis hemisphaeraeborealis imprimis copiosa, inter tropicos rara; paniculis effusis $v$. confertis, spiculis pedicellatis, rhachilla tandem articulata.

B romus Linn. gen, n. 89. Host gram. I. t. 7. 9. 10. 18-17. Sehrad. Fl. germ, t. 6. f. 3. Desf. Fl, atl, t, 25, 26. Sibth. Fl. graec. $t, 82,83$. Jaeq. f. Eelog. $t, 15-\mathrm{C}$ erato e li lo a Palis. agrost. 55. c.15.f.7. L i b e $\mathrm{t}$ t ia Lejeune in N. A. N. C. XII, 757, t, 65. Mich elaria Dumort. agrost. 77. t. 16 .

SOD A. (1)theelada PALIS. Spiculae triflorae, floribus remotis, inferioribus hermaphroditis, summo tabescente. Gl uma e 2, carinatae, muticae, subaequales. Pal a e 2 , inferior carinata, acutato-mueronata ; superior navieularicompressa, bicarinata, basi carinis rhachillae adnata. S quamula e 2, subdolabriformes. St a mina 2. Ovari um sessile, glabrum. Styli 2 , terminales; stigmata plumosa. Caryopsis oblonga, compressa, paleis reclusa. - Gramina brasiliensia; folits planis, petiolatis, paniculae terminalis ramis semiverticillatis, fastigiatis, spiculis longe pedicellatis, cum pedicello articulatis, compressis.

Ortho el ad a Palis. agrost.69. t. 14. f. 9. Kunth gram. 136. L. 71. Agrost. 493, Nees in Mart, Fl. Bras. II. 520 . A i $r$ a 1 a $\times$ a Rich.

DO2. Uniola LINN. Spieal a s multiflorae, floribus distichis, infimis abortivis unipaleaceis, reliquis hermaphroditis. GI u ma e 2, earinatae, muticae, subaequales. Pa lea e 2 , inferior carinato-compressa; superior bicarinata, carinis alatis, alis saepins apice solntis, divergentibus. 
Squamulae 2, acute bifidae. Stamina 1-3. Ova ri um sessile, glabrum. Styli 2 , terminales; stigmata plumosa. Ca ry opsis libera. Gramina bore ali-americana; foliis latiusculis, planis, paniculae ramosae spiculis pedicellatis, cum pedicello articulatis, compressis.

UnioI a Limn. gen, $n$, 90, Kunth gram, 136, t, 72. Agrost. 424. Ch asmanthin m Link Hort, berol, $I, 159$. Trisiola Raf.

DOB. Diarrlhena PALIS. S pic u la e multiflorae, floribus distichis, hermaphroditis, summis sterilibus. Gl u má 2, concavae, muticae, inferior brevior. Paleae 2, inferior ovata, dorso convexa, trinervis, acuminato-mucronata ; superior brevior, bicarinata. Squamulae 2, subrhomboideae, ciliatae. St amina 2. Ovarium stipitatum, subobliquum, apice emarginatum. Stigmata 2, terminalia, plumosa. Caryopsis lihera. - Gramen boreali-americanum, elatum; foliis late linearibus, planis, panicula simplici.

D i a r hen a Palis. agrost. 142. $t, 25 . f$. 2. Kunth gram. 137. Agrost. 485. Diarina Raf. Roemeria Zea apud Röm, et Schult. syst, II. 287. Cory c arp us Zea in Act. natr. 1806. Lagase. Elench. 4. F es tuca dia ndra Michx. Fl. Bor. Amer, $1,10$.

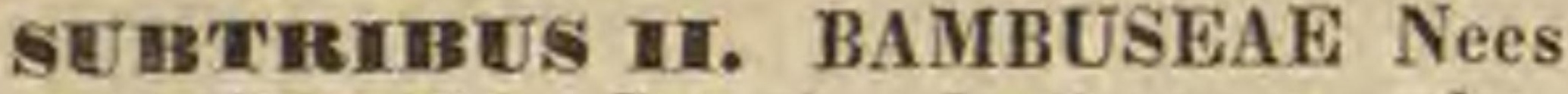
Linnaea IX. 461. Gramina fruticosa v. arborescentia. Stamina $3-6$.

DQ4. Aruadinaria RICH. S piculae multiflorae, floribus imbricato-distichis, remotinsculis, hermaphroditis v. masculis. G I um a e 2, concavae, muticae, parvae, inferior multo minor. Pale ae 2, inferior ovata, concava, acutato-mucronata, multinervis; superior bicarinata. Squ a$\mathrm{mul}$ a e 3 , acutae, snbeiliatae, ovario longiores. Stamina 3. Ovarium sessile, glabrum. Styli 3 , terminales; stigma ta plumosa. Ca ry o psis oblonga, subarcuata, teres, libera. - Gramina arborescentia, in $A$ sia et $A$ merica tropica et boreali calidiore indigena, ramosa; ramis fasciculato - semiverticillatis, spiculis paniculatis $v$. racemosis, multifloris.

Aru ndinaria Rich. apud Michr. Fl. Bor. Amer. I. 74. Palis. agrost. 144, t.25. f.7. Nees in Mart. Fl, Bras, II. 523. Kunth gram. 137, t, 155. 136. Agrost. 426. M i e gi a Pers. ench. $I, 102 . \mathrm{L}$ ud o Ifia Willd, in Berl. Verh. 1808. p.320. Triglossu m Fisch. Catalog. Gorenk, 1812. Röm, et Sehult. syst. II. 846. Macronax Raf. in New-York Med. Heposil. $\nu .350$.

905. Streptogyna PALIS. S piculae tri-quinqueflorae, floribus distichis, hermaphroditis, summis tabescentibus. G1umae 2 , involutae, acntatae, inferior dimidio brevior. Pa l e a e 2 , inferior involuta, tereti-compressiuscula, septemnervis, apiee in aristam produeta; superior acquilonga, involuta, compressiuscula, dorso bicarinata, apice bifida. S qua $\mathbf{m} \mathbf{a l}$ a e 3 , lanceolatae, arutae. Stamina 3. Ovarium sessile, glabrum. St y li 3, terminales, basi connati; s tigma ta elongata, spiraliter torta, piloso-hispida. Caryopsis....-Gramen in $A m$ erica calidiore indigenum, arborescens; foliis planis, spiculis breviter pedicellatis, racemosis.

Streptogy a a Palis, agrost. 80. t. 16. f. 8. Poir, itZustr. t, 912 .

D06. Chusquea KUNTH, $\mathrm{S} p$ i $\mathrm{a}_{\mathrm{i}} \mathrm{l}$ a $\mathrm{e}$ triflorae, floribus imbrieato-distiehis, inferioribus neutris, summo hermaphrodito. GI um a e 2, earinato - concavae, muticae, floribus multo breviores Neutr. Pale a concava, mueronata. H e rmaphr. Pal ea e 2, sut aequilongae, inferior sub- carinato-coneava, mueronata ; superior parinervis, dorso superne sulcato - biearinata, apice emarginato-bifida. Squamulae 3 , integrae, glabrae v, ciliatae, tertia minor. Stam in a 8,0 varium sessile, glabrum. Styli 2 , terminales; stigmata intus plumosa. Cary opsis linearioblonga, compressa, libera. - Gramina gigantea, in Americae tropicae regione montana per arborum truncos adscendentia; ramis pendentibus fasciculatis, foliis planis, paniculis terminalibus, ramosis, diffusis, spiculis pedicellatis.

C his u que a Kunth synops. I. 25i. Gram, 138, t.77,78. 191. Agrost. 427. Rett be r g ia Raddi agrost. brasil. 17. $t$. 1. f.1. - Plat onia Kunth gram, 139, $\ell$, 76. Agrost. 428 .

90\%. Merostaehys SPRENG. S picula $\mathrm{e}$ biflorae, flore inferiore breviter stipitato, hermaphrodito, superiore longius pedicellato, tabes. cente, minutissimo, sulco dorsali floris inferioris recepto. G l umae 2, inaequales, inferior parva, subulata; superior oblonge-lanceolata, acutatosubulata. Pa le a è 2, subaequilongae, inferior ovato-elliptica, acutata, cylindraceo-involuta ; superior dorso bicarinata. S q u a mu la e 3 , integrae, ciliatae. Stamina 3, Ovarinm sessile, glabrum. Styli 2, terminales; stigmata intus piloso-plumosa. C a r y op sis. ....-Gramina arborescentia, in $\mathrm{Br}$ asilia indigena; ramis e culmi nodis fasciculatis, foliis distichis, planis, spicis terminalibus, solitariis, basi vagina aphylla spa-. thaeformi involutis, spiculis unilateralibus, imbricato-subbiseriatis, lanceolato-oblongis.

Me rostachy s Spreng. syst. I. 132. Nees in Mart, EI, Bras. II. 527. Kunth gram. 139. t,79. Agrost. 499.

D05. Nastus JUSS. S p i c n la e multiflorae, floribus imbricato-distichis; inferioribus neutris, unipaleaceis, glnmaeformibus, sensim minoribus, summo hermaphrodito, basi flore pedicellato tabescente aucto. Glumae 2, concavae, muticae. Pale a e 2 , subaequilongae, carinatonaviculares, muticae, superior dorso sulcato-bicarinata. Squamula e 3 , integrae, ciliatae. Stamin a 6 , Ovarium sessile, glabriusculum. Stigmata 3 , snbsessilia, terminalia, intus plumosa. Caryopsis libera, stigmatum basibus induratis cuspidata. - Gramen borbonicum, arboreum; ramis e nodis fasciculato - verticillatis, apice floriferis, spiculis paniculatis, oblongis, eompressis.

Nast u s Juss. gen, 34. Kunth gram. 140. Agrost. 499. S tem at os permum Palis, agrost. 14t, $t, 25 . f .5$. B a mbusa alpina Bory voy, $t$. 12. - N. capitatus Kunth gram. t. 75. et N. T jankorreh Sehult. syst. NIT. $135 \%$. verisimiliter sui generis. - ? S ehizostach y u m Nees in Mart. Fl. Bras. HI. 135. Schult, syst, VII, 1355.

DQ9. Kambusa SCHRER. Spienlae multiflorae, floribus imbricato-distichis, infimis neutris, unipaleaceis, glumaeformibus, reliquis hermaphroditis v, nonnullis abortu masculis $\mathbf{G l u}$ mae 2 , concavae, muticac. Pal e ae 2 , subaequilongae, inferior concava, acuto-mucronata $\mathrm{v}$. subulata; superior angustior, bicarinata. S quamu $\mathrm{l}$ a e 3 , integrae, ciliatae. Stam in a 6. Ovarinm sessile, apice pubescens. Stylus terminalis, elongatus, apice bi-trifidus; stigmata plumosa, Ca r y opsis intra paleas libera. - Gramina arborescentia, in Asia, America et $A f r i-$ ca australi tropica indigena; culmis caespitosis, nodosis, e nodis ramos ramosissimos, interdum spinescentes emittentibus, spiculis verticillato-spicatis, spicis paniculatis.

B a nubus a Sehreb. Roxb, corom, 2.79.80, Kunth gram. 140. t. 73.74. Agrast. 330 . B a m bos Retzobs, V. 24. A r und in is s p. Linn. - G uadua Kunthsynops.1. 253. Agrost. 433. Gram. 141. B a mbusa s p. Humb. et Bonpl. pl. ae- 
quin. t. 20.21. - Dendroe ala mus Nees in Linnaea IX. 466. est Bambusa floribus omnibus perfectis, (staminibus tribus ?)

D10. Heeslar RHEED. S picula e trimultiflorae, floribus distichis, inferioribus masculis v. neutris unipaleaceis, Gl u ma e...... Pal eae 2 , acutatae, muticae. $S q u$ a m u la e. ... Stamina 6. Ovarium glabrum (?) Stylus terminalis; stigmata 3 , villosa. Pericarpi$\mathrm{n} \mathbf{m}$ maximum, baccatum, ovatum, acuminatum. Gramen indic u m, non satis notum; culmo arboreo, inermi, foliis lutis, ciliato-setosis, spicis e nodis fasciculatis, spathis spiculas involucrantibus.

B e es ha Rheede Malab, V. 119, $t, 60$. Kunth gram, 141 , Agrost. 434. Melo c a un a Röp, et Trin, in Spreng. N. E. II. 43. B a m b u s a baceif era Roxb, corom. t. 243.

Dil. Streptoelnaets NEES. S p icula uniflorae, bracteatae. G $\mathbf{1}$ um a e 3, lanceolatae, inaequales, exterior in aristam longissimam, apice spiralem desinens, interiores minores, acuminatae, muticae. Pale a e 3 , aequales, lanecolatae, muticac, altera alteram imbricatim a tergo involvens, intima genitalia amplectens. Squamulae

Stamina 5_6, filamentis connatis, basi germen ambientibus, apice liberis. Ova ri $\mathbf{u m}$. Stylus terminalis simplex; stigmata 3 . C aryopsis... - Gramen brasiliense, admodum paradoxum, vix rite descriptum; foliis planis, spica terminali, solitaria.

Streptochaeta Nees in Mart. Fl. Bras, IT. 836 . Lepldeil em a Trin. Act. Petropolit. 1830. 1.93.

TIREISE XI. HORDEACEAE Kunth gram. 142. Sp i culae tri-multiflorae, nonnunquam uniflorae. Flos terminalis tabescens. G $1 \mathrm{um}$ a e (rarissime deficientes) pa le a $q$ u $\mathrm{e}$ duae, herbaceae. St i $\mathrm{g}$ m a sessile. O varium plerumque pilosum. Inflorescentia spi cata, spica simplex solitaria; rhachis interdum alata, Kunth.

919. Tholieran $L I N N$. S p i e 1 a e multiflorae, flovihus distichis, imbricatis. G $1 \mathrm{um}$ a e 2 , subaequales, muticae, postiea saepins deficiens. Palea e $\mathcal{E}$, inferior concava, mutica $\mathbf{v}$. sub apice aristata, superior bicarinata. S q $\mathbf{4}$ a $\mathbf{m} \mathbf{~ u ~} \mathbf{l}$ a e 2 , acutae; integrae $v$, bilobae. Stamina 3 . Ovarium sessile, glabrum. Styli 2 , terminales; stigmata plumosa. Caryopsis paleae superiori alhaerens. - Gramina annua v. perennia, in he misphaerae borealis temperalis indigena, nune per totum orbem sparsa, nonnulla, unico in toto ordine exemplo, venenata; foliis planis, spicis simplicibus, spiculis sessilibus, rhachi continuae contrariis.

Lo li um Linn, gen, n. 95. Palis. agrost. 102, t. 20. $f$. 3. Host gram. I. t. 25, ILT. t. 25. Fl, dan, $t, 160$, Kunth gram. 6. 200. Agrost, 435, C ra ep ali a Schrunk Fl, Bav. I. 882.

913. Tritienm LINN. Spieulae trimultiflorae, lloribus distichis. Gl n m a e 2, suboppositae, subaequales, muticae v, aristatae. P'a$1 \mathrm{e}$ a e 2, inferior mutiea, mucronata $v$. aristata, superior biearinata, carinis aculeato-ciliata. $\mathrm{S} q u$ umu la e 2, integrae, saepius ciliatae. Stamina 3. Ovarium sessile, apice pilosum. Stigmata 2, terminalia, plumosa Ca ryop 8 is libera $v$. paleis adnata. - Gramina in hemisphaerae borealis regionibus temperatis obvia, in regione mediterranea orientem versus copiosiora, in Ameriea australi extratropica et Nova Hollandia admodum rara, inter tropicos in America eis acquatorem vix reperta; foliis planis, spiculis sessilibus spicatis, v, rarissime subracemosis, rhachi continuae parallelis, rhachilla tandem plerumque articulata.

Tritic um Linn. gen, n, 913. Kunth agrost. 438.

a) SPELTA. G I u mae ventricoso-concavae, ovato-ob. longae, obtusae $\vee$. truacatae.

Triticum Palis. agrost, 103. Host gram, $I T, t, 47, I I T$. ใ. 26-32. IV. . .5-8. Sibth, Fl, graec, t.97.

b) AGRopyrum Palis. Gl u w a e lanceolatae v, linearl. oblongae, acutatie v. obtusae. Spiculat sessiles, spicatae.

Agropyrum Palis. agrost. 101. (Host II. t. 21, 22, $I V, t, 33$. Sibth. $t, 29$. Kunth $t .90$.

c) BRACHYPODIUM Palis. GI u m a e laneeolatae, acttatae. S pie ala e pedicellatae, solitariae, geminae $v$. racemosie.

Braeh y podi um Palis. agrost, 100, excl. sp. B rom i $8 \mathrm{p}$. Linn. Host I, t, 21, 22, IV.t, 17, 18. Sibth. $t, 84,-\mathrm{T} r \mathrm{r}$. hy nia Link Hort. berol, I. 42, Bromus distachyos Linu. Host I, t. 20.

b14. Secale $L I N N$. S pieula e biflorae, floribus distichis, hermaphroditis, cum rudimento lineari floris tertii terminalis. G I $\mathbf{u}$ m a e 2 , suboppositae, subaequales, carinatae, muticae v. aristatae. Pal e a 2 , inferior aristata, carinata, inaequilatera, latere exteriore latiore, erassiore; superior brevior, biearinata. SquamuJae 2 , ciliatae. Stamina 3 . Ovarium sessile. S $t$ igmata 2 , subterminalia, plumosa. Car yop s i s apice piLosa, libera. - Gramina planifolia, in Europae a ustro-orientalis et Asiae conterminae planitiebus indigena; spicis simplieibus, spiculis rhachi saepius articulatae parallelis.

S e eale Linn. gen, n. 97. Palis, agrost, 105. Host ram. II. t. 48. IV. t, 11. Kunth gram. 145, Agrost. 49.

D15. Elymas LINN. Spieula e bi-mulLiflorae, floribus distichis, summo tabescente. G1 uma e 2, subsecundae, inaequilaterae, inaequales, muticae $\mathbf{v}$. apice in aristam produetae. Pa lea e 2, inferior concava, mutica $\mathbf{v}$, in aristam producta; superior bicarinata. Squam $\mathbf{u} \mathbf{l}$ a e 2 , integrae $\mathbf{v}$. inaequaliter bilobae, ciliatae $\mathbf{v}$. apice pilosae, rarius glabrae. Stamina 3 . Ovarium stipitatum, apice pilosum. Stigmata 2, subterminalia, plumosa. Ca ryopsis apise pilosa, paleis adhaerens. - Gramina planifolia, in hacmisple a erae borealis temperatis obvia, in $A$ merica $t r a n s$ capricornum admodum rara; spicis simplicibus v. rarissime ramosis.

Ely ut us Lian. gen, n. 96. Kunth gram, 146. Agrost. 449.

a) PSAMMOCHLOA. GI a ma e paleaeque muticae. 5 q a amala e integrae, pilosae.

(Host gram, IN. L, 12. E. B. $t, 1396$. Dellie Fl, aegspt. 1.13. $f, 1$.)

b) ELYMUS, G1 и m a e paleaque Inferior aristatae. $\mathrm{Squ}$ a mulae glabrite v. rarius ciliatae, uunc integrae, naue lobulo laterali anctie.

(Sehreb. Gram, I. t. 21, f. 1, t. 24. f.1,2, Host I. t, 27, 28.) Cuvie r a Koel, gram. 328. - ? S it a n i o n Raf. in Journ. phys. LXXXIX, 103.

916. Gymmostielauma SCHREB. Spiculae triflorae, floribus remotis, summo tabescente. G1 u ma e 2, rudimentariae, denticuliformes, altera interdam in setulam producta. Pa le a e 2, inferior canalieulata, apice in aristam producta, superiorem bicarinatam involvens. S ч u am ulae 2 , inaequaliter bilobae, ciliatae. Sta m in a 3. Ovarium sessile, apice pilosum. Stigmata 2 , terminalia, plamosa. Caryo psis apice pilosa, paleis adhaerens. - Gramen perenne, planifolium, in Oriente et Americaboreali reperfum; spicis simplicibus, distichis, rhachi continua, spiculis geminatis.

Gy mostichum Sehreb. gram. $t$. 33. Asprtila Huatb. ex Willd enum, 133. Kunth gram, 177 . Agrost, 450. 
H y t rix Mönch meth. 295. E1ymus Hystrix Lim. (Jacq. ic. rar, t, 305.)

9) 1. Hordeum $L I N N$. Spieula e biflo rae, flore superiore ad rudimentum subulatum redacto, ternatae, laterales plerumque tabescentes. G 1 u ma e 2, lineari-laneeolatae, subnlato-aristatae, paleis contrariae, subunilaterales, anticae. Pale a e 2, inferior concava, apice in aristam producta ; superior bicarinata. S quamulae 2 , integrae v. inaequaliter bilobae, ciliatae v. pilosae, rarins glabrae. Stamina 3 . O variu m sessile, apice pilosum. Styli $2 ; s t i g m$ a ta plumosa. Caryo $\mathrm{p}$ is apice pilosa, paleis adhaerens v. rarius $\mathrm{ii}$ bera. - Gramina in Europa et Asia mediter. ranea, nec non in $A$ frica et $A$ merica trans c an cr $u m$ indigena, unum late por littora vulgatum; foliis planis, spicis simplicibus, rhachi tandem saepiue articulata.

H o r d e u m Linn. gen, $n, 96$. Kunth gram, 148. Agrost. 454 .

a) ZEOCRITON Palis, Spiculac ternatae, laterales aborta masculae v. neutrae.

Z e o erit on Palis, agrost. 114. t. 21. f.1. (Host gram, I, t. 33.34, III. t, 36.37. Desf. Fl. att. t.37.)

b) HORDEUM Palis. Sple ula e ternatae, laterales aeque fertiles.

H o r d e u m Palis, agrost, 114, t. 21, f. 2, (Host III, t. 34.35. Sibth. Fl. graec, t.98.) - C rite si um Raf. (H. jub a t u m Linn.)

918. Aegillops LINN. Spiculae triquinqueflorae, flore terminali tabescente. G1uin a e 2 , collaterales, anticae, subaequales, concavae, apice truncato bi-quadridentatac, dentihus mnticis v. subulato-aristatis. Pa l ea e 2 , inferior concava, apice truncato bi-tridentata, dentibus omvibus v. intermedio subulato-aristatis. Squam ulae 2, integrae, apice pilosae. Stamina 3. Ova rium sessile, apice pilosum. Stigmata 2 , snbterminalia, plumosa. Cary opsis apice villosa, libera. - Gramina planifolia, annua, in Europa et Asia mediterranea indigena; spicis simplicibus, spiculis solitariis, distiche alternis, rhachi tandem saepius articulatae parallelis.

A e gil a p s Linn, gen, n. 1150. Host gram, 1I. t, 5-7. Sibth. Fl. graec. $t .93-95$. Kunth gram, 148, Agrost. 457.

D19. Pariana $A U B L$. S p i cula e uniflorae, verticillatae, geminae v. senae, exteriores pedicellatae, masenlae, centralis sessilis feminea. M a s c. G 1 uma e 2, collaterales, lanceolatae, muticae. $P$ al ea e 2, muticae, inferior concava, trinervis, superior quadri-sexnervis. Squamulae 4, duae anteriores ciliatae. Stamina plurima. F e m. Gl um a e 2, carinato-naviculares, subaequales, muticae. Pale a e 2 , aequales, muticae. S qu a mula e 3 , apice acuto ciliatae. Ovari n m sessile, glabrum. Stigma ta 2 , terminalia, plumosa. Caryopsis glumis paleisque obtecta. Gramina americana tropica, suffrutescentia, folïis latis, breviter petiolatis, spicis terminatibus simplicibus, rhachi articulata.

Parfau a Aubl. guian, II. 877, t, 337. Palls, agrost. 121. t. 22. f.2. Kunth gram. 148. Agrost. 459. Nees in Mart. Fl. Bras. $X I .291$.

TRI IBUS XIT. ROTTBOELLIACEAE Kunth gram. 150. Infloresecntia spicata, rhachis in plurimis articulata. S p i c u 1 a e uni-bi-rarissime triflorae, in rhacheos excavatione locatae; nunc solitariae, nunc geminae, altera pedicellata, saepe tabescens. Flos alter cujuslibet spiculae, inferior v. superior saepe incompletus. Glu ma una v. duae, interdum plane deficientes, plerumque coriaceae.
$P$ a le a e membranaceae, muticae $\mathbf{v}$, rarius aristatae. Stylus unicus v. duo, interdum brevissimi v. nulli. Kunth.

D24. Naredus $L I N N$. S pienlae uniflorae. GInmae 0 . Pal e a e 2 , inferior lanceolata, trigono-carinata, apice subulato - aristata, marginibus membranaceis superiorem breviorem, linearilanceolatam, bicarinatam amplertens. S qu a m nla e 0 . Stamina 3 . Ova ri nm sessile, glabrum. Stylus simplex; stigmate lineari, pubescente. C aryopsis linearis, teretinscula, paleae superiori adhaerens. - Gramen pusillum caespitosum, rigidum, in Europae mediae et australis nee non in Asiae caucasicae montibus habitans; foliis eonvolutis, subulatis, spicis simplicibus, spiculis secundis alternis, rhacheos illinc convexae, hinc excavatae dentibus membranaccis insidentibus.

$\mathrm{N}$ a rdus Linn. gen, $n$ 69. Leers $F l$, herb, $t, 1 . f, 7$. Host gram. II. t.4. Fi. dan. 1028. Kunth gram. 150, Agrost. 460 .

921. Psilnuress TRIN. Sp ic $\mathrm{n} l$ a e biflorae, flore inferiore sessili hormaphrodito, superiore pedicellato tabescente, saepe ad pedicellum redacto. G 1 u m a 1 , antica, minuta, ovata, mutica. Palea e 2 , inferior (postica) nninervis, apice in aristam producta, superiorem paullo longiorem, bicarinatam involvens. Squamula e 2, bifidae, glabrae. Stamen 1. Ovarium stipitatum, glabrum. Stigmat a 2 , terminalia, pubescentia. Caryopsis linearis, trigona, paleae superiori adhaerens. - Gramen caespitos um annuum, in Europae littoribus mediterraneis indigenum; foliis fliformibus involutis, spica filiformi, teretiuscula, articulata, articulis alternatim excavatis, spiculis sessilibus, in quovis articulo solitariis $v$. inferioribus geminis, altera tunc pedicellata, tabescente.

Psilurus Trin. fund. 93. Kunth gram, 150. Agrost. 461. A s prell a Host gram, $I V, t$. 29. Monerma Palis. agrost. 117. Nardus a ris t a ta Linn. Rot t boella mona n d ra Cav, ic. t.39. f. 1 .

D29. Hepturing $\boldsymbol{R} . \boldsymbol{B R}$. Spiculae bitriflorae, flore inferiore (postico) sessili, hermaphrs)dito, superiore pedicellato tabescente v. ad pedicellum redacto, rarius aeque perfecto, floris tertii rudimento tunc interjecto. G1 $\mathbf{x} \mathrm{m}$ a e 2, aentatosubulatae, subaequales, in flore terminali semper oppositae, in lateralibus rarius oppositae, plerumque collaterales, anticae, $v$, inferior deficiens. P a 1 e a e 2, muticae, glumis breviores, inferior (postica) superiorem binervem involvens. S q u a $\mathbf{m} \mathbf{~} \mathbf{l}$ a e 2 , integrae, glabrae. S t a $\mathbf{m}$ in a 3 , O v a ri um sessile, glabrum. Styli 2, terminales, brevissimi; stigmata plumosa. Caryopsis lihera. - Gramina in regione mediterranea et in Europa austro-orientali finitimaque Asia, nec non in Nova Hollandia et America tropica indigena; eulmis ramosis, erectis $v$. procumbentibus, suepe repentibus, foliis angustissimis, planis, spicis gracilibus rectis $v$. arcuatis, articulatis, spiculis rhacheos excavationibus immersis, solitariis.

Lepturus R. Brown prodr. 207. Kunth gram. 151. Agrost. 461.

a) MYURUS. Glumae $\mathbf{2}$, in spienlis lateralibus colla. terales, anticae. FIor is superioris rudimentum Iineare. Squamula e acutac. St y Ii subnulli.

Rottbo ella e $s$ p. Linn. Cav, ic. $t$, 21.3. Sibth. Fl. graee. $t, 91$, Host gram, $1, t, 23$. Savi giorn, Pisan, IV. 230. f.5,6. O phiuri sp. Palis.

b) MCRURUS. GIuma in spieulis Iateralibus solitaria, antica. Floris superioris rudimentum subaullum. S qua mulace aeutae. Styli longiusculf. 
Monerma Palis. agrost.117, part. Rot tboella s ubulata Savi $l$. c. f.4.8.

c) SYURUS. G I u ma in spiculis lateralibus solitaria, antica. F 1 o ris superioris rudimentum clavatum. $\mathrm{S} q \mathrm{q}$ am ula e truncato-emarginatae. S t y 1 i longiusculi.

R. repens Forst. Brongn. in Duperr, voy. t.16.

d) PHOLIURUS Trin. GI $\mathrm{m}$ ma e in spiculis lateralibus 2, oppositae, rhachi contrariae. Fios superior aeque perfectus, interjecto tertil floris rudimento. $\mathrm{S} q \mathrm{u}$ a m uIa e acutae. Styli breves.

Pholiurus Trin. fund, 131. Rottboella pannon ie a Host $I$. $t$. 2\%. - Le p to cereu 8 Raf. in Journ, phys. LXXXrX. 262. Le pturus panicalatus Nutt.

923. Oropetium TRIN. Spicula e biflorae, flore inferiore hermaphrodito sessili, superiore ad callum pilosum redacto. G $1 \mathrm{u} \mathrm{m}$ a e 2 , muticae, inferior (postica) minuta, ovata, superior lanceolata, convexinscula, flore longior. P a l e a e 2 , muticae, subaequilongae, inferior (postica) carinato-navienlaris; superior bicarinata. S qua m u1 a e 2 , subeuneatae, glabrae. St am ina 3 . Ovarium sessile, glabrum. Styli 2, terminales; stigmata subpenicilliformia. Caryopsis. .

Gramen pusillum, in India orientali indigenum ; folits setaceis, culmis apice fasciculato-ramosis, spica compressa, continua, bifaria, spiculis rhacheos compressae, flexuosae excavationibus marginalibus immersis, solitariis, sessilibus.

0 ropeti um Trin. fund. 98. Kunth gram, 15e. Agrost. 463. Nardus Thomatea Linn. Rot tboellae s p. Roxb. corom. t. 133.

924. Dphiurus GAERTN. Spienlae biflorae, floribus sessilibus, exteriore masenlo $\mathbf{v}$. neutro, interiore hermaphrodito. G 1 u m a e 2 , muticae, exterior cartilaginea, interior concava, membranacea. Paleae 2, membranaceae, mnticae, glumis minores. Squamulae.... Stamina 3. Ovarium. . . C Caryopsis. ... Gramen ramosum, planifolium, pubescens, in Malabaria et Nova Hollandia tropica observatum; spieis gracilibus, brevibus, subfaseiculatis, spathis foliaceis semïnclusis, terelibus, articulatis, spiculis articulorum excavationibus immersis, solitariis, sessilibus.

Ophiurus Gärtn.f. carp. HI. 4. R. Brown prodr. 206. K nuth gram, 159 . A $A_{8}$ rost. 464 . R o t t b o ell a cory mb os a Linn. Roxb. corom, t.181,

925. Hemarthria $R$. BR. Spiculae biflorae, flore inferiore unipaleaceo neutro, superiore hermaphrodito. G1 u ma e 2, rhachi parallelae, oblongae, acutatae, inaequales. Pa le a e 2, muticae, glumis breviores. Squamula e 2 , truncatae, glabrae. Stam ina 3 . Ovarium sessile, glabrum. Styli 2, terminales; stigmata plumosa. Cary o psis. ...-Gramina ramosa, in Europa mediterranea occidentali, America boreali, Nova Hollandia, India orientali et in Capite bonae spei indigena; foliis planis, ramulis apice monostachyis subfasciculatis, spicis subulutis, eompressiusculis, semiarticulatis, spiculis in quovis articulo geminatis, fertilibus, altera sessili mediante gluma postica rhachi adnata, altera pedicellata pedicello cum rhachi conferruminato, glumis liberis.

He marthria R. Brown prodr. 207. Kunth gram, 153. Agrost. 46a. Brongn, in Duperr.vog, t, 15, Lod i cularia Pal. agrost, 108, t, 11.f,6. Rottb o ell a e s p. Linn, Roxb, t. 156,

925. Mnesithea KUNTH. Spicula triflorae, floribus dnobus inferioribus nentris unipaleaceis, terminali hermaphrodito. G1nma 1, antica, oblique oblonga. N e utr. P a l ea 1, elliptico-oblonga, Hermaphr. Paleae 2 , inferior elliptico-olilonga, concava, superiorem involvens. Squa mu I a 2, truncatae, glabrae. Stamina 3.
Ovarium sessile, glabrum. Styli,2, terminales; stigmata plumosa. Caryopsis.

Gramen tranquebaricum, vix notum, planifolium; spicis teretibus, articulatis, spiculis in quovis articulo geminis oppositis, septo perforato.

Mnesithea Kunth gram. 153. Agrost, 465. Rott. boella laevisRetz, - ? Rott boella perforata Rexb. corom, t.182. - Thyrid o stachy u $\mathrm{m}$ Nees in Lindl.in. troduct, edit, II, p. 379.

92\%. Fottboella $R$. BR. Spiculae biflorae, flore inferiore masculo v. neutro et unipaleaceo, superiore hermaphrodito. G1 um a e 2, subaequilongae, inferior (antica) coneava, superior earinato-navicularis, quandoque deficiens. $\mathrm{P}$ a l e a e 2 , inferior coneava; superior bicarinata. S quam $\mathbf{n}$ la e 2, oblique truncatae, glabrae. $\mathbf{S} \mathbf{t a} \mathbf{m}$ in a $\mathbf{3}$. Ovarin m sessile, glabrum. Styli 2, terminales; Atigmat a plumosa. Cary ops is.... Gramina in Asia, Nova Hollandia et Oceania tropica, nec non et in Aegypto indigena, erecta, saepius exaltata, planifolia; spicis teretibus, articulatis, spiculis in quovis articulo geminis, rhachi adpressis $v$, immersis, altera sessili, altera pedicellata, tabescente, pedicello saepius cum rhachi connato.

R ottboellia R. Brown prodr. 1. 206. Kunth gram. 15\%. Agrost. 466 ,

a) HEMIPUS. Spfeula e rhachi immersae. GI uma postiea deficiens.

R. formos a R. Brows. Kunth gram, $t .91$.

b) STEgosia Lour. S p ic ula e rhachi immersae. GI umat 2 ,

Stegostine sp. Lour, Fl. eochinch. I. 206. RottboelI a e s p. R. Brown. Roxb. corom. 1.157. Brongn, in Duperr. voy. t. 14. - ? C y mbaehne Retz obs. VI. 36.

c) COEgorhachis Brongn. Spic ulae rhachi adpres. sae. GIumae 2.

Coelor ha chis Brongn, in Duperr. voy, 63,t,14. R ott. boella Coel or ha e his Forst. Labill. Nov. Caled. $t .20$. R. hirsuta Vahl. Delile aegypt. $t, 14, f, 1$. R. muricata Retz. Spreng, in Mem. Academ, Petersb, 1810, II, t, 7.

928. Ttatzeburgia KUNTH. Spiculae biflorae, flore inferiore neutro, unipaleaceo, superiore hermaphrodito. G1 $1 \mathbf{n m}$ a e 2 , inferior (antica) convexinsenla, reticnlato-serobienlata, apice membranaceo - producta, biloha, margine dentata ; superior subaequilonga, planiuscula. Pal e a e 2 , muticae, superiox minuta, triloba. Squam u la e 2, dolabriformes, repando - bilobae. St a min a, .... Ovarium sessile, glabrum. Styli 2 , terminales; stigmata plumosa. Caryopsis.

Grumen in India orientali indigenum, caespitosum, procumbens, stoloniferum; culmis simplicibus, monostachyis, spicis linearibus spiculis parallele compressis, rhachi vero directione contraria geniculato-flexusa, spiculis in quovis articulo ternis, lateralibus sessilibus, fertilibus, contiguis, intermedia pedicellata, tabescente.

Ratzebargla Kunth gram. 1.158. Agrost. 468. Wallich pl. as. rar. IIT. 46. Aikinia Wall. op. cit, t, 273.

929. Xeroelhion $\boldsymbol{R}, \boldsymbol{B R}$. Spiculae biflorae, flore inferiore masculo, superiore femineo conformi. Gl um a e 2, muticae, inferior (antica) minor. Paleae 2, glumis longiores, subulatae, muticae. Squamulae 0 . Stamina 3 . Ova ria m sessile, glabrum. Styli 2, terminales, basi connati; st igmata. . Caryo p 8 is oblonga, teretiuscula, styli basi mueronata, intra palean superiorem libera. - Gramina in Nova Hollandía tropica indigena, juncea, arida; foliis subulatis, strictis, vaginis culmum terminantibus alternis, spathaceis, singulis includentibus spicas aliquot abbreviatas, paucifloras, spicul is rhachi parallelis, ejusque excavationibus semi-immersis.

Xerochloa R. Brown prodr. 197. 
930. Tripsneum LINN. Spicula e diclines, monoicae. Masc. biflorae, flore utroque perfecto, femineae aeque biflorae, flore inferiore neutro, bipaleaceo. Gl u ma e 2 , mnticae, inferior (antica) concava; superior navicularis. Pal e a e 2, muticae, inferior concava, superior bicarinata. Squamulae 2, truncato - bilobae, glabrae. Stamina 3. Ovarinm sessile, glabrum. Stylus terminalis, simplex; stigmat a 2 , elongata, dense villosa. Caryopsi s. ... Gramina bo re ali-americana, planifolia; spicis solitariis ternisve, articulatis, basi femineis, apice masculis, spiculis femineis solitariis, articuli longitudine, masculis geminis in quovis articulo illoque longioribus.

Trips a c u minn, gen, n, 1044. Willd. Hort, berol,t, 1 . Palis, agrost, 118. t. 22, f.1. Kunth gram, 155. Agrost. 468 ,

931. Prionachne NEES. Spiculae biflorae, flore utroque hermaphrodito. G I u ma e 2 , complicato - cultriformes, inaequilaterae, $\mathrm{mu}$ rieatae. $\mathrm{P}$ a 1 e a 2 , glumis minores, inferior major, acuta; superior linearis, apice bidentata. S quamula e 2 , truncatae, repandae. $\mathrm{S}$ ta $\mathrm{m}$ in a 3 . Ovarium sessile, glabrum. St y Ii 2 , terminales; stig $m$ a $t$ a penicilliformia. Ca ry ops is.

Gramen c apense, annuum; foliis convolutis, spicis racemosis, spiculis laxe imbricatis.

$\mathrm{P}_{47} \mathrm{r}$ i o $\mathrm{n}$ a $\mathrm{c}$ h $\mathrm{n}$ e Nees in Lindl, introduct. edit. $I I$. p. 447 .

932. IInmisuris LINN. Spiculae geminae uniflorae, inferior hermaphrodita, snperior neutra v. mascula. Spienla hermaphrodita. Glumae 2, inferior suborbiculata, saccatoconeava, su perior minor, planinscula. Pal ea e 2, minimae, tennissimae. Squ a mulae. . Stamina 3 . Ovarium sessile, glabrum. Styli 2 , terminales; stigmata plumosa. Caryopsis paleis plerumque obtecta. Spicula sterilis. Glumae 2, subaequales. Pale a et genitalia nulla. - Gramina inter tropicos totius fere mundi diffusa, ramosa, planifolia; spicis in ramulis solitariis, basi folio spathaeformi involutis, spiculis unilateralibus.

Ma n is uris Linn, gen, n, 1334. Palls, Ft, owar, $t, 14$, Roxb. corom, t.117. 118. Kunth gram. 155, Agrost. 469. P eltop hor us Desv. in Journ. Bot. III. 73. Palis. agrost. $t$. 21. f. 11 .

THERE XIIT. ANDROPOGONEAE Kunth gram, 156. Spiculae biflorae, flore inferiore semper incompleto. Pale a e glumis teneriores, plerumque hyalinae. Kunth.

933. Ferotis $A I T$. Spiculae uniflorae, flore sessili. Glumae 2, subaequales, longe aristatae. Pal ea e 2, minutae, muticae. S qu a mulae 2 , integrae, glabrae. Stamina 3 . Ova rium sessile, glabrum. Styli 2, terminales, basi connati; stigmata plumosa. Caryopsis cylindrica, intra glumas libera, - Gramina in tropicis subtropieisque veteris orbis indigena, planifolia; spiculis spicatis, breviter pedicellatis.

Perotis Alt. Hort. kew. 2, I, 136. R. Brown prodr. 179. Kunth gram. $t .92$. Agrost. 470. Xystidium Trin. fund. $10 \mathrm{~s}$.

934. Ceptothrium KUNTH. S $\mathrm{p}$ i cuIa e uniflorae, flore sessili. G I um a e 2, acutatosubulatae, inferior brevior, subcarinata, inaequilatera; superior involuta, lateribns compressiuscula. Palea e 2, inferior ovata, subcarinata, uninervis; superior triplo brevior. Squamulae 2, truncatae, glabrae. Stamina 3. Ovarium sessile, glabrum. Styli 2 , terminales, distincti; stigmat a penicilliformia. Caryopsis.... -
Gramen a merican um tropicum, caespitosum, rigidum, glabrum; foliis involutis, ciliolatis, spicae simplicis rhachi triangulari, flexuosa, spiculis breviter pedicellatis, alternis, pedicello cum rhachi articulato.

Le p to thrium Kunth gram, 156. Agrost, 470. $\mathrm{Z}_{0} \mathrm{y}$. sia rigida Willd, herb.

935. Zoysia WILLD. Spiculae nniflorae, flore sessili. Gl n ma 1, antica, carinato-complicata, mutica v. macronato - aristulata, marginibns basi connata. Pale a e 2, muticae, inferior (postica) ovato-oblonga, uninervis, carinato - complicata ; superior brevior, enervis, carinata, interdum deficiens. St amina 3 , duo ante paleam superiorem, unum ante inferiorem situm. S q $\mathbf{u}$ a m nla e. Ovarium sessile, glabrum. Styli 2 , terminales, elongati; stigmata plumosa. Cary opsis glabra, libera. - Gramen pusillum, rigidum, in littoribus Indiae orientalis et Novae Hollandiae obvium; foliis distichis, canaliculatis, spica simplici, racemosa, continua, spiculis imbricatis.

$\mathrm{Z}$ o y s i a Willd, in Berl. Verhandl. IIT, 442. R. Brown prodr. 208. Palis, agrost, t.4. f.1. Kunth gram, 156. Agrost. 401. Matrella Pers. enes. X. 73, Oster d a my a Neck. elem, $n, 1593$. A grostis M a trella Linn.

פ36. Dimeria $R, B R$. Spic ula e uni-biflorae, flore inferiore neutro, unipaleaceo, quandoque nullo, superiore hermaphrodito. Gl umae 2 , subaeqnales, carinato - naviculares, muticae, basi barbatae, exterior crassior, latior. Paleae 2, exterior carinata, apice bifida, inter lobos aristata; superior minor, mutica. Squamulae 2. St a mina 2-3. Ovarium sessile, glabrum. Styli 2, terminales; stigmata plumosa, Caryopsis cylindrica, intra glumam exteriorem libera. Gramina in Australasia et India orientali indigena, tenella; foliis planis, spiculis alternis bifariis, sessilibus, omnibus fertilibus.

D i m e $\mathrm{r}$ i a R. Brown prodr, 204. Kunth gram, 157. Agrost. 471.

a) HAPLACHNE Prest. Spiculae uniflorae, flore hermaphrodito, diandro.

Haplachne Presl in Reliq. Haenk, I, 235, t. 38. D. ornithop od a Trin. fund, $t, 14$.

b) Dimeria. Spiculae billorae, flore inferiore neutro, nuipaleaceo; superiore hermaphrodito, triandro.

D. a cinaciformis $\mathrm{R}$. Brown prodr. 204 ,

D3\%. Pleuroplitis TRIN. Spiculae biflorae, flore inferiore nentro, unipaleaceo, superiore hermaphrodito. G I u mae 2, inaequales, concavae, muticac. Paleae 2, glumis breviores, inferior basi aristata. S qu a mula e 2 , subdolabriformes, glabrae. Stamina 2. Ovarinm sessile, glabrum. Styli 2, terminales; stig mata plumosa. Cary opsis fusiformis, intra glnmas libera. - Gramen ja ponicum, planifolium; spicis subfasciculato - confertis, spiculis sessilibus.

Pleuroplitis Trin. fund. 175. f. 16. - Lueaea Kunth gram. II. 489. t, 159. Agrost. 472.

939. Evioehrysis PALIS. Spiculae uniflorae, flore sessili. G1 umae 2, subaequales, ellipticae, muticae, pilosae. Pa le a e 2 , ciliatae, inferior elliptica, obtusa, concava; superior brevior, oblonga, acuta. Squa mulae 2, truncatae, glabrae. Stamina 3 . Orarium sessile, glabrum. Styli 2 , terminales; stigmata penieilliformia. Caryopsis subgloboso-acuta, libera. _ Gramen in America tropica indigenum, caespitosum, planifolium; paniculae ramosissimae, coarctatae ramis articulatis, spiculis geminis, altera sessili, altera pedicellata, terminalibus ternis, omnibus hermaphroditis. 
Eriochrys is Palis. agrost, 8, t. 4. f. 11. Turp. atl. II. Kunth gram. 157. Agrost. 473. Nees in Mart. Fl. Bras, II. 312. P laz e ri um Willd. mse.

939. Saeelaarum $L I N N$. S p i ulae biflorae, basi sericeo-pilosae, flore inferiore neutro unipaleaceo, superiore hermaphrodito. G I u ma e 2 , subaequales, muticae. Pa le a e 3 , minutae, muticae, inaequales. Squamn la e bi-trilobae, interdum in tubum connatae. Stamina 1_3. Ovarium sessile, glabrum. $S t \mathbf{y} 1$ i 2 , terminales, elongati; stigmata plumosa. Caryopsis.

Gramina elata, in $A$ sia parciusque in $A$ merica tropica indigena, ramosissime paniculata; spiculis geminatis, altera sessili, altera pedicellata, omnibus fertilibus, basi articulatis.

$\mathrm{S}$ a c c h a $\mathrm{r}$ u m Lins, gen, $n .73$. Kunth gram. 158. Agrost. 474. Nees\}in Marl, Fl. Bras, 1 . 317. P h rag m it es Adans.

a) SACCHAROPHORUM Neck. Squamula e distinctae. St a min a 3. - Asiaticae.

Saceharophorum Neck, elem, n.1576. (Tussac Fl. antill, $t$. 23-25. Hook. miscell. $I$. 95. t. 26.) - Trieh oIa $\mathrm{n}$ a Scbrad. in Schult, mant, $I X, 163$. Sacehari sp. Roxb.

b) ERIOPOGON. Squa mulae in tubum connatae. Stamen 1. - Americanae.

Saccharum contractum et S. dubium $H$. $B$. $R$.

940. Imperata CYRILL. Spiculae biflorae, flore inferiore neutro, unipaleaceo, superiore hermaphrodito. G 1 u ma e 2, subaequales, muticae, extus elongato sericeo-pilosae. P a I ea e 2 , subaequales, muticae. Sqnamulae 0 . Stamina 2. Ovarium sessile, glabrum. Styli 2, terminales, elongati; stigmata plumosa. Caryopsis oblonga, libera. - Gramen in regione mediterranea, Senegambia, India orientali et $A$ meriea australioceidentali indigenum ; panicula contracta, spicaeformi, cylindrica, spiculis geminis, sessili et pedicellata, utraque fertili, basi articulata.

1 m perat a Cyrill, ic, rar. II. t, 11. Host gram, $M, t$. 40. Palis, agrost, 165. Kunth gram, 159. Agrost. 47\%. L ag u ri s p. Linn.

54 1. Pogomatherom PALIS. S p i cu1 a e biflorae, flore inferiore mutico, masculo $v$. nentro et tune unipaleaceo, quandoque plane obliterato, superiore aristato, hermaphrodito v. femineo. Gl nmae 2, inaequales, inferior concava, mutica; snperior carinato - concava, sub apice longissime aristata. Pa I e a e 2 , glumis breviores, inferior (in floribus hermaphroditis) sub apice longissime aristata, Squamula e 0 . Stam ina 1 -2, Ovarium sessile, glabrum. Styli 2 , terminales, elongati; stigmata plumosa. Caryopsis oblonga, compressinseula, intra paleas libera.

Gramen in India orientali indigenum, caespitosum, ramosum; spicis in ramulis solitariis, simplicibus, articulatis, spiculis geminis, alterius sessilis flore inferiore masculo $v$. neutro, superiore hermaphrodito; alterius pedicellatae flore inferiore neutro, quandoque plane obliterato, superiore staminibus efoetis femineo.

Pogon at her a m Palis. agrost. 176. t.11.f.7. Kanth gram, 159. t. 161.162. Agrost, 477. Brongo. in Duperr. voy. t.17. Homeoplitis Trin. fund. 166. Saceharum pauice u m Lam. $t, 40, f, 3$.

742. Eulanthars RICH. S $\mathrm{p}$ i $\mathrm{c}$ l a e pilis sericeis involucratae, uniflorae, flore inferiore neutro unipaleaceo, superiore hermaphrodito. Glumae 2 , subaequales, muticae. P a I e a e 2 , glumis breviores, inferior floris hermaphroditi apice in aristam producta, superior mutica. Squamulae 2, integrae, glabrae. $\mathrm{S} t$ a min a 2_s. Ovarium sessile, glabrum. Styli 2, terminales, elongati; st $i$ g m a t a plumosa. C a r y o $\mathrm{p}$ s is libera. _ Gra- mina in regione mediterranea, America boreali et tropica, nec non in Nova Hollandia et Oceania tropica provenientia, ramose paniculata; spiculis geminis, sessili et pedicellata, utraque aeque fertili, basi articulata.

$\mathrm{E} r \mathrm{i}$ a $\mathrm{t}$ h us Rich, in Michx, Fl. Bor. Amer, I, 55. Palis, agrost. 14, t. 5. f.2. Kunth gram.160. Agrost. 478. Nees in Mart. Fl. Bras. II. 313. R ip id i u m Trin. agrost. 169. S a c e hari sp. Linn. et Auct. Host gram, IIT, $t, 1,-$ ? Microstegium Nees in Lindl. introduct, edit. II. p. $4 \mathrm{ir}$.

943. Eulalia $K U N T H$. S p ic u 1 a e biflorae, flore inferiore rudimentario, superiore hermaphrodito. Gluma e 2, muticae, inferior concava, snperiorem naviculari-carinatam involvens. $\mathbf{P a -}$ lea e 2 , inferior longissime aristata, superior mutica. SquamuIae 0 . Stamina 3 . Ovarium sessile, glabrum. Styli 2, terminales, elongati; stigmata plumosa, Caryopsis elliptica, intra glumas induratas libera. - Gramen borbonicum, repens, planifolium; spicis fasciculatodigitatis, articulatis, spiculis geminis, altera sessili, altera pedicellata, conformibus.

Rula lia Kunth gram. 160. t,93. Agrost, 479. Brongn. in Duperr. voy, t, 19. Erianthus aureus Palis.

94 4. Eliomenrus KUNTH. S p i cula e biflorae, flore inferiore neutro, superiore hermaphrodito, utroque unipaleaceo. GIn mae 2 , inferior apice bifida, lobis muticis $v$. in aristas produetis; snperior integra, mutica. Pal e a e 2 , muticae. Squamn 1 ae 2 , truncatae. Stamina 3 . Ovarium sessile, glabrum. Styli 2, terminales; stigmata plumesa Caryopsis oblonga, libera. - Gramina aromatica, therebinthinam redolentia, ramosa, planifolia, in America tropica et Senegambia reperta; spicis terminalibus solitariis, spiculis geminis, altera sessili, fertili, altera pedicellata, tabescente.

EI i o nurus Kunth in Humb. et Bonpl, nov. gen, et sp. 1. 154, t, 62,63. Gram, 161, t, 94. Agrost, 480. Nees in atart. Fl. Bras. IT, 355.

945. Anthistiria LINN. S p i $e$ n 1 a septenae, quatuor inferiores verticillatae, plerumque sessiles, neutrae, reliquas involucrantes, tres centrales, e quibus duae laterales pedicellatae, masculae v. neutrae, intermedia ut plurimum sessilis, biflora; flore inferiore neutro, unipaleaceo, superiore hermaphrodito, Glum a e 2 , tandem induratae, muticae, inferior superiorem involvens. Paleace, glumis breviores, inferior floris hermaphroditi in aristam Iongissimam, tortam producta. Squamulae 2, eroso-truncatae, glabrae. Stamina 3 . Ovarinm sessile, glabrum. Styli 2, terminales; stigmat a plumosa. C aryopsis libera - Gramina in tropicis subtrop icis que totius orbis, imprimis tamen Asiae, nec non in omnibus Novae Hollandiae oris obvia, ramosíssime paniculata; foliis planis, superioribus spathaeformibus.

A n th is tir ia Linn. gen, n, 1359, Gärtn, II. 465, t. 175. Desf, in Journ. Phys, XL, 292. $1,1,2$, Fl, atl, $t, 254$, Cav. ic. t. 459. Lam. t.841. Kunth gram. 161. Agrost, 481. Nees in Mart, Fl. Bras. T. 368, T h e me da Forsk. aegypt, 178. Calaminae sp. Palis.

946. Perolbaelane PRESL. SpienIae subduodenae, quatuor inferiores geminatae, subverticillatae, sessiles, involucrantes, superiores geminatae $\mathbf{v}$. ternatae, centralis sessilis, hermaphrodita, reliquae masculae. GIuma e 2 , inaequales, acutatae, setoso-pilosae. Pa lea e 2 , glnmis breviores, lanceolatae, muticae, inferior superiorem breviorem ampleetens. Squ am u la e 2, truncatae, emarginatae. Stamina 3, Ova rinm sessile, glabrum. Styli 2 , terminales; stigma- 
ta elongata, plumosa. Ca ry op is.

men in Moluccis et Philippinis repertum, ramosissime paniculatum; vaginis supremis spicularum fasciculos ambientibus, subcoloratis.

Perobach ne Presl in Reliq. Haenk. I. 348, t. 48. Androse pia Brongu, in Duperr. voy. 77. Anthistiri a $\mathrm{g}$ ig ante a Cav. ic. $t, 458$.

94\%. Diectomis KUNTH. $\mathrm{S}_{\mathrm{p}}$ i cula e bi florae, flore inferiore neutro, unipaleaceo, superiore hermaphrodito, geminae v. ternae, fertilis sessilis, reliquae pedicellatae, steriles difformes. Spiculae perfectae. Glumae 2, inferior lineari-lanceolata, mutica, superior compressonavicularis, sub apice longissime aristata. $P$ a 1 e a e 2 , inferior (floris hermaphroditi) $\mathrm{sub}$ apice bifido longe aristata. Squamula e 2 , oblique truncatae, glabrae. Stamina 3. Ovarium breviter stipitatum, glabrum. Styli 2 , terminales; st igmat a plumosa. Caryops is hebetate tetragona, intra glumas paleasque libera. Spiculae steriles: Glumae aristatae, inferior subfalcato-oblonga, multinervis. Pal e a e muticae. - Gramina americana tropica, planifolia, ramosa; spicis terminalibus solitariis, vagina aphylla suffultis, articulatis.

Diectom is Funth in Humb. et Bonpl. nov, gen, et sp. I. 155. t.64. Gram, 166. Agrost, 310. Nees in Mart. Fl. Bras. II. 339. non Palis, Andropogonis sp. Swartz. Polliniaesp. Spr.

948. Aplanda $L I N N$. S p i c u la e biflorae, flore inferiore masculo, superiore hermaphrodito, ternatae, bracteatae, intermedia sessilis, fertilis, laterales pedicellatae, tabescentes. Gluma e 2, muticae, inferior lanceolata, subcanaliculata, apice bifida, superior carinato-navicularis. Palea e 2, glumis breviores, inferior (floris hermaphroditi) infra apicem bifidum aristata. Squamulae 2, truncato - sublobatae, glabrae. Stam in a 3. Ovari u m sessile, glabrum. St y $1 \mathrm{i} 2$, terminales; stigmata plumosa. Caryo psis teretiuscula, intra glumas paleasque libera, _ Gramina in $A s i a$ tropica et in Capite bonae spei observata, planifolia, ramosissime paniculata; spiculis in ramulis terminalibus ternis, bractea spathaeformi suffultis.

A pluda Linn. gen. n. 1147. Sehreb. gram. 11. $t .42$. Kunth gram.166. Agrost. 516, Diect o $\mathrm{m}$ is Palis, agrost. 133. $t .23 . f, 6$, non Kunth. Cal a m in a e s p. Palis.

949. Tepeocereis TRIN. Spieulae biflorac, geminae, flore inferiore neutro, unipaleaceo, superiore in spicula sessili hermaphrodito, in pedicellata masculo. GI nma 1, ovata, truncata. Pa lea e 2, inferior floris hermaphroditi in aristam tortilem desinens, in flore masculo mutiea. Squamulae 3. Stamina. . Orarium. Gramen non satis notum, in India oriental $i$ indigenum; spica simplici, rhachi articulata, articulis barbatis, spiculis in quovis articulo geminis.

Lepeocercis Tria. fund. 203. $f .18$. Andropogon serratus Retz.

950. Anellropogon LINN. Spiculae biflorae, flore inferiore neutro unipaleaceo, superiore hermaphrodito v, unisexuali, geminae v. ternae, intermedia sessilis fertilis, reliquae pedicellatae, steriles. GI u m a e $\mathbf{2}$, tandem induratae, muticae. Palea e 2, glumis breviores, inferior floris perfecti mutica $v$, in aristam producta, superior minor, mutica, quandoque deficiens. S q u a mula e 2 , truncatae, plerumque, glabrae. Stamina 1_3. Ovarium sessile, glabrum. Styli 2 , terminales; stigmata plumosa. Caryopsis intra glumas libera. Grumina in tropicis tempe ratisque totius orbis obvia; rhachi spicata $v$. paniculata, spicis solitariis, conjugatis, fasciculatis v. paniculatis.

A ndropog on Linn. gen. n. 1145. ezcl. sp. pl.

a) ANATHERUM Palis, Flos superior hermaphroditus, unisexualis, muticus. Pale a superior saepe mulla.

An at herum Palis. agrost. 128. t. 22. $f .10$. 11. Nees in Mart. Fl, Bras, II. 320, - $\mathrm{C}$ y m b o pog o n Spreng. pugill. II. 15. Link enum. I. 10z. - H y pog y n i um Nees op. cit. p.364. - A ge a i m Nees ex Liadl. introduct. edit. II. p. 4 is.

b) TRACHYPOGON. Flos superior hermaphroditus. Palea inferior plus minus profunde bifida, inter lobos aristata, superior saepe nulla.

Trachypog on Nees in Mart. Fl. Bras. IT. p. 341. S chizachyrium Nees op, cit. p. 331. Pithecurns Willd msc. Sorg h u mers, ench, I, 101. Link Hort. Berol. I. 80. B l u m e n b e hi a Foel. gram, 29, (Kunth gram, t. 195. 196. 199.)

c) ANDROPOGON Nees. F1 os superior hermaphroditus, Palea inferior integra, apice in aristant producta,

A ndropogon Nees op. cit. p. 326. - Pol I i n i a Spreng. excl, sp. Link Hort. Berol. 1 . 243, Chry so. pogon Trin. fund. 161. - ? R h a $\mathrm{p}$ b is Loureir. cochineh. 676. Trin. ic. t.8.9. C e $\mathrm{n}$ tr o $\mathrm{p}$ h or $\mathrm{nm}$ Trin. fund. 106.f.s.

d) HETEROPOGON Pers. Flos superior masculas v. fe. mineus. Pale a inferior floris masculi untica, floris feminei apice in aristam produeta.

Heteropog o n Pers. ench. II. 533. Palis. agrost. 134. t, 23. f.8. Nees op. cit. $p, 361$.

951. Iselnaemum $L I N N$. S p i culae biflorae, flore utroque bipaleaceo, inferiore mascnlo $v$. neutro, superiore hermaphrodito. G $\mathbf{l} \mathbf{u} \mathbf{m}$ a e 2 , muticae $\mathbf{v}$. interdum subaristatae, tandem induratae. P a le a e 2 , glnmis breviores, inferior floris hermaphroditi aristata. Squamula e 2, oblique truncatae, sublobatae, glabrae. S t a m in a 3 . Ovarium sessile, glabrum. Styli 2 , terminales; stigmata plnmosa. Car y op s is intra glumas libera. - Gramina habitu et patria praecedentis generis, in hemisphaerio tamen orientali nonnihil frequentiora, $a b$ Andropogone nonnisi flore inferiore etiam bipaleaceo differunt.

I s ch a e m u m Linn. gen, $n$, 1148. R. Brown prodr. 294 . Kunth gram, t,98-100. Brongn. ad Duperr, t, 12.13. S e hi ma Forsk. descript. 118. I s $\mathrm{ch}$ a e m um et $\mathrm{Me}$ o s $\mathrm{ch}$ in m $\mathrm{Pa}$. lis. agrost. 107 et 111,t.21.f.4.5. A $\mathrm{rth} \mathrm{r}$ a $\mathrm{x}$ on Palis.op. cit. t. 21. f.6. Colla do a Cav.ic. t. 460. Spod i opogon Tria. fund, 192. $f .17$. Nees in Mart. Fl. Bras. IT. 339. A r u a dinell a Radd. agrost. Bras, 37. Nees op. cit. II. 465. G o I d. ba chia Trin. in Spr. N. E. II. 81. R i edelia Trin. msc. $T$ hy s a $n$ ache Presi $s y m b, I, t, \theta$.

958. Pogromopis PRESL. Spieulae uniflorae, geminae, pilis involucratae, altera sessilis feminea, altera pedicellata mascula. Ma s c. G1 u ma e 2, inferior ovato-lanceolata, acnta; superior ovata, apice in aristam produeta. . F e m, GInma e 2, inferior obovata, acuminata, superior ovata, apice in aristam producta. Pale a 1, glumae superiori opposita, ovato-lanceolata, apice bifida, inter lobos aristata. . Ov a ri um sessile glabrum. Styli 2 , terminales; stigmata aspergilliformia. Cary opsis...-Gramen mexicanum, tenerum, caespitosum, imperfecte descriptum et vix notum, e generis statore Andropogonibus Heteropogonibus propinquum; spicis terminalibus solitariis, longe pedicellatis, lateralibus intra vaginas subinclusis.

Pog on ops is Presl in Neliq. Haenk. I, 333. t. 46.

253. Thelepogon ROTH. Spieulae triflorae, floribus sessilibus, intermedio herma phrodito, lateralibus masculis. Glum a e 2, subaequales, muticae. H erm a phr. Pal e a e 2 , subaequales. Squamulae.... Stamina 3 . Ovarium Styli...; stigmata 2 , subinerassata. Caryopsis.... Masc. Pale a e 2, exterior floris interioris arista longa tortili, genicu- 
lata instructa. Stamina saepius efoeta. Ovarium 0. - Gramen indicum, pessime descriptum; involucro monophyllo cartilagineo apresso, spiculas includente, gluma exteriore apice bidentata, papilloso aculeata, extus undique gibbosa, elegantissime undulato papillosa, papillis compressis.

Thelepogon Roth nov. sp. 62. Rottboellaesp. Heyne msc.

954. Anthropogon NEES, Spiculae biflorae, basi villosae, flore inferiore masculo, superiore hermaphrodito. G 1 u m a e 2 , inferior subulata; superior naviculari-carinata, apice bifida, breviter aristata. M a sc. Pale a e 2 , inferior navicularis, obtnsa, quinquenervis; superior enervis, apice bifida. Squamulae. ..... Stamina 3. Ovarinm efoetum. Hermaphr. Paleae 2, inferior carinata, acuminata, uninervis; superior enervis, apice bidentata. $\mathrm{S} q \mathbf{q}$ a $\mathrm{m} \mathbf{u} \mathrm{l}$ a e 2 , dolabriformes, glabrae. Stam ina 3 . Ova ri um sessile, glabrum. Sty li 2, terminales; stigmata plumosa. Ca ry opsis. ... Gramen brasiliense caespitosum, plonifolium; paniculae simplicis, erectae ramis erecto - patulis, spiculis cum pedicello articulatis, omnibus conformibus.

Arthropogon Nees in Mart. Fl. Bras. II, 320. Funth gram. t.200. Agrost. 519.

955. Zheragites $P$. BR. S p i $\mathrm{cu}$ l a e triflorae, flore inferiore fémineo, sessili, masculis pedicellatis. Gluma e 2, exterior latior, concava, truncata, interior angustior, carinata. M a $8 \mathrm{c}$. Pa l e a e 2 , aequales, ovato-oblongae, compressae, muticae. S quamulae. . Stamina 3 . Fem. Palea 1, oblonga, coneava, apice margine dilatato scarioso cincta, arista terminali recta. Squamulae. ... Ovarium sessile. Styli 2 ; $8 \mathrm{tigmata}$ villosa. Ca ryopsis oblonga. - Gramen antillanum, elalum; foliis latis, planis, panicula ramosa.

Z e ugites P. Brown Jam, 341. t, 4. f.3. Willd, sp. WV. 204. Kunth agrost. 520. A p I u.d a Z e u git es Linn. amoen. VI. 412. Swartz observ. 384.

956. Alloteropsis PRESL. Spicula e quaternae, duae hermaphroditae sessiles dimorphae, duae pedicellatae neutrae; bracteis quatuor glumaeformis involutae. Sp i $\mathrm{c}$ a 1 a h e r m aphrodita inferior. Glumae 2, ovato-lanceolatas, apice bifido-dentatae. $P$ a 1 ea e 2 , inferior ad aristam longam, fractam, tortilem redacta, superior obtusissima, glumis brevior. Squamulae. . Stamina. . Ovarium. . Styli 2 , terminales; stigmata plamosa. Cary o psis oblonga, stylorum basi rostrata, intra glamas paleasque libera. Spicnla hermaphrodita superior. Glumae 2, subaequales, ovatae, inferior apice mucronato-aristata, arista recta. $\mathbf{P a}$ leae 2 , glumis breviores, muticae. Stamina. . Ovarium. . Caryopsis ut in spienla inferiore. - Gramen californicum, non rite descriptum, planifolium; spicis geminis spicatis, pedicellatis, alternis, spiculis neutris e sola gluma absque paleis compositis.

Alloter op si s Presl in Reliq. Haenk, I. 344. t. 47 .

\section{GENERA PENITUS DUBLA.}

a) PTERIUM Desv. Spiculac uniflorae. Glumate 2, hyalinae, subaequales, aristato - setosae. $\mathrm{P}$ a l e a e 2 , coriaceae, inferior longissiue aristato - setosa, supe rior acuta...... Gramen annum, in Oriente indigenum; foltis planis, spieis subglobosis, spicuIis subunilateralibus, involucro pectinato-setoso.

Pterium Desv. in Journ, Bot, 1813. p. 85.

b) RYTACIINE Desy. Spieula e biflorae, rhacheos ex. cavationibus immersac, flore inferiore hermaphrodito, superiore nasculo. Gi uma 1 , coriacea, transverse rugosa, aristata, $\mathrm{Pale}$ a 2 , ovatae, aristatae. Sta- mina 3. - Gramen antill anum, subcaespitosum, erectum, foliis involuto-setaceis, glabris, spica solitaria terminali.

R y $t$ a $c$ h ne Desy. ex Hamilt. prodr. $f l$. Ind. occid. 12.

c) XENOCHLOA Lichtenst. S p i c u $\mathrm{I}$ a e subbiflorae. G1 um a e 2. Pa le a e 2, basi lanatae.... Gramen caponse, arundinaceum, quinquepedale; culmis articulatis, glabris, leviter striatis, foliis linearibus involutis, panicula fusiformi conferta.

$\mathrm{X}$ e n o e h I o a Lichtenst, ex Röm. et Sehult, syst. II. 501 .

d) CARYochloA $s p r$. S piculae.... Glamae 2, aristatae. Pa le a e 2, cum fruetu concresentes. Arista lateralis, torta, elongata. Stamina 3 . Cary op s is grandis, dura, tuberculosa. - Gramen montevidense, cubitale, glabrum; folits filiformibus, spiculis paniculatis.

C a ry ochlo a Spreng. cur. post. 30.

\section{Drdo XLIII. Cyperaceare.}

CYPEROIDEAE Juss. gen, 26. Link Hort, berol. edit. II. p. 275. CYPERACEAE DC. Fl. fr. IIU. 99. R. Brown prodr. 212. Kunth in Mem, Mus, II, 147. Lestiboudois Essai ex Röm. et Sehult, mant. $I$. 1. 55. Bartling ord, nat. 32. Nees von Esenbeck, Uebersicht der Cyperaceen-Gattungen, in Linnaea IX. p. 273. ss. Lind, introduct, edit. II, p, 384. Fenzl, dissert. msc, 1836.

Нвrbae annuae v. perennes, plernmque caespitosae, nunquam frutescentes. $R$ h iz o$m$ a nunc abbreviatum et in fibras solntum (radix fibrosa), nunc repens, ex articulis radicantibus stolones vaginatos, extremitatibus in tubera nodosa tunicata (caulium nondum evolutorum bases hypogaeas) incrassatos, emittens. Caules (culmi) ancipites, triangulares v. triquetri, saepe cylindrici, rarius multangulati, nodosi ; no dis paucis plerumque constrictis, ad infimam caulis partem hypogaeam saepissimerestrictis, internodio ultimo elongato, solo epigaeo; hinc ut plurimum simplices, rarissime ramosi, primum farcti, parenchymate tandem fatiscente lacunas septaque transversa formante. Fo 1 i a e nodis oriunda, distiche alterna; petiolus in vaginam clausam, rarius fissam, saepe lamina destitutam, longiusque mucronatam connatus; la mina linearis plana, canaliculato-triquetra, rarius a latere compressa, ensiformis, equitans, rarissime lanceolata, parallelinervis, transversim venulosa, crassiuscula v. subcarnosa, margine integerrimo, saepissime scabro v. aculeato. Ligula nulla, sed margo vaginae laminae oppositus nonnunquam incrassatus, coloratus.

Fuores hermaphroditi v. unisexuales, monoici v. polygami, rarissime dioici, spicati; spiculae vel solitariae, terminales, vel in apice culmi fasciculatae, glomerato-capitatae, aut spicatae v. paniculatae, involucris bracteisque polymorphis fultae.

Flosculi bracteis solitariis v. rarius binis (paleis Juss, squa mis Linn., R. Br. Nees, glu m is Kunth, valvis Link), tecti, solitarii vel plures pedicello communi (rhachillae) alternatim di-tri-tetrastiche v. plurilariam impositi; spiculam uni-multifloram efformantes, bracteis infimis saepissime 
sterilibus, rarius heteromorphis, spiculae spath am (ylumam) constituentibus.

$P$ ale ae naviculares, rhachillae parallelae v. contrariae, saepissime uni-rarius bicarinatae, muticae v. mucronatae, apice integrae, interdum emarginatae, v. rarissime trifidae, marginibus nonnunquam in rhachillam decurrentibus, v. interdum a basi ad apicem inter se in utriculum connatis.

Praigonium nullum v. ejus loco se ta e tenues, rarius membranaceae v. cartilagineae, nunc inter se distinctae, nunc basi in annuIum coalitae, scabrae v. fimbriatae aut rarissime nudae, numero variae, fugaces aut persistentes.

Stamiva hypogyna, setis dum iisdem numero aequalia, opposita, plerumque tria, rarius pauciora, rarissime plura, quatuor, novem v. dnodecim; in floribus triandris unum anticum et duo postica, haec in monandris suppressa. Filamenta filiformia v. complanata, libera, marcescentia. Antherae basifixae, introrsae, biloculares, lineares, erectae; loculi oppositi, longitudinaliter dehiscentes; connectivum obliteratum, $v$. in apiculum loculos superans excurrens. Pollin is granula elliptica, rimula simplici.

Discus hypogynus (urceolus staminodiorum, perigynium Schrad, Nees) stipitem ovarii cingens, plus minusve in nonnullis distinctus, saepius nullus, in fructu manifestior, membranaceus, integer v. lobatus, vel tumidus pubescens, ant cartilagineus minimus.

Ovarium unicum (duorum abortu constanti) brevissime stipitatum v. sessile, liberum, uniloculare, uniovulatum. Ovulu m basi affixum. Styli duo v. tres, basi inter se connati, saepe incrassati et dilatati, et cum ovario articulati, rarissime sublaterales, quandoque in unum conferruminati, plerumque apice distincti; cruribus intus stigmatosis, simplicibus $\mathbf{v}$. interdum bifidis.

Fructus cary ops is libera, basi saepissime disco stipata. Pericarpium semini hand adnatum, chartaceum, crustaceum v. osseum, rarissime drupaceum, putamine fragili a nucula facile secedente, rugulosum, tesselatum, tuberculatum v. regulariter scrobiculatum, apice nudum v. styli basi persistente tuberculatum aut rostratum.

Semen pericarpio conforme, erectum; t e s t a tenera, rhaphe subtilissima ad chalazam apicalem procurrente. Alb u m en farinaceum v. carnosiusculum.

Емвв yo hilo basilari admotus, albumine inclusus, minimus. C o t y le d o n lenticularis, carnosus, indivisus, $\mathrm{P} I \mathrm{u} \mathrm{m}$ u l a haud manifesta, extremitas radicularis(rostellum)obtusa.
Cyperaceae ubique terrarum sociatim vigent, littora maris, paludes, ripas et prata humidiuscula, arida desertaque planitierum et montium cacumina praediligentes, amyli et sacchari fere expertes, vile pecudibus pabulum; sed radices nonnullarum ob vires tonico-solventes et roborantes inter pharmaca receptae. In regionibus arcticis antarcticisque pari fere cum Gramineis numero proveniunt, inde versus aequatorem numero minuuntur, inter tropicos iterum abunde, multo tamen minori quam Gramina copia vegetant. Carice ae et Scirpin e a zonam frigidam et temperatam, reliquae torridam praediligunt.

TRIBUS I. CARICEAE Nees in Linnaea IX, 305. S picae diclines $v$. androgynae, rarissime dioicae, involucro foliaceo v. spathaeformi exceptae. S pi c a m a s c l a e simplices, multiflorae, floribus undique imbricatis, unipaleaceis. Perigonium nullum. Stamina 3 , v. rarius 2 . S picae $\mathrm{fe}$ minea simplices v. compositae, spiculis undique imbricatis, androgynis, abortu plerumque unifloris, femineis. Glum a e 2 , antica plana, postica bicarinata, marginibus a basi ad apicem in utriculum apice bidentatum, cum fructu persistentem (nectarium Linn., corollam Willd., tunicam Juss., urceolum DC., perianthium $\boldsymbol{R}$. Br., perigynium Nees) coalescens, ovarium et pedicellum sterilem, setiformem, rarissime fertilem, masculiflorum includens. Pale a e perigoni um nullum. Stylus bi-trifidus. Caryo $\mathrm{p}$ s is a latere compressa v. trigona, angulo rhachim spectante. Herbae perennes $v$, rarissime annuae, glabrae v. rarius pubescentes aut piloso-lirlae, ut plurimum caespitosae; culmis simplicissimis foliatis, apice lateribusque spicigeris. Spicae mono-v. diclines, in apice culmi fasciculatae, glomeratae v. solitariae, interdum spicalae; femineae saepissime solitariae, axillares, pedicello intra folii vaginam recondito. Cariceae potissimum in hemis phaerae borealis temperatis frigidisque vigent, paucissimae tropicae,plures in hemisphaerae australis regionibus extratropicis et antarcticis indigenae.

95\%. Carex MuCH. Sp i c a e diclines, androgynae v. dioicae. Mas c. Spicula e uniflorae. Palea 1. Stamina $2-3$. Fem. Spieula e uniflorae, absque pedicello accessorio. G1 uma e 2, exterior paleae floris masculi simillima, interior in utrieulum ov a rium includentem connata. Sty lus bi-trifidus. Cary opsis trigona, biconvexa v. plano-convexa, chartacea. - Genus vastum, nemini non cognitum, trecentenas fere species amplectens, e quibus denae circiter inter tropicos, vicenae in hemisphaera australi extra tropicos vivunt, reliquae Europam, Asiam Americamque borealem incolunt. 
C a rex Micheli nov, gen, 33, Linn. gen, n, 1046. R. Brown prodr. 241. Link Hort, berol, I. 333. Sehkuhr Riedgraeser Leipzig, 802. Sturu, Carices. A. Rich. Fl. Nov. Zeel. t.21. Brongn. ad Duperr, t.25.28. Kunth in Wiegm, Archiv. II. 359. t.6. f.3. - $\mathrm{C}$ a $\mathrm{r}$ e $\times$ Palis, msc. Nees jun. gen, pl. fasc. IX, t, 21. (stigmatibus 3.) - V ig n e a Palis, $Z$. $c$. Nees op. cit. t. 22. (stigmatibus 2.) - S ehellt a mmeria Mönch... (C a r e $x$ e y p e r o i de s Linu. Sehkuhr car. $t, a, f .5$. Host gram, $I$. $t .43$. Vignea cy peroides Nees op. cit. $t, 22$. Stigmatibus 3 , utriculo apice bifido.) C a rex Rafin, in Journ. Phys. LXXXIX. 106. (utriculo bidentato; stylo bifido.) - Seuria Rafin. 1. $c$. (utriculo in tegro; stylo bifido.) - Triplim a Rafin. $l$. c. (utriculo integro; stylo trifido.) - Triodea Rafin. l. o. (utriculo bi-tridentato; stylo trifido.) - Trasus Gray brit. pl. $I I$. p.3. (stylo trifido.)

558. Uncinia PERS. $\mathrm{S}_{\mathrm{p}} \mathrm{i} \mathrm{c}$ a $\mathrm{e}$ diclines $\mathrm{v}$. androgynae. Masc. S pic ula uniflorae. Palea 1. Stamina 3 . Fem. Spie ulae abortu uniflorae, flore femineo sessili, masculorum abortivorum pedicello setiformi, apice plerumque uncinato. Glumae 2, exterior paleae floris masculi simillima; interior in utriculum ovarinm et pedicellum accessorium includentem connata. S t y 1 u s trifidus. C a r y o p s is trigona, chartacea. - Genus habitu Caricum; spicis elongatis, in Oceani insulis antarcticis potissimum proveniens, species paucissimae americanae tropicae, unica europaea.

Uncinla Pers. ench. IX. 534. R. Brown prodr. 241 Thouars Flor. Aguanat. t.J. 6. Kunth in Wlegm, Archiv. II. 358, t. 6. Carie is s p. Linn. Schkuhr car. t. G. f. 30 . Cavan, ic, t. 464 .

D59. Selnoenoxyphinm NEES, S p icula e androgynae, multiflorae, flore inferiore (postico) femineo, masculis anticis pedicellatis, saepe abortientibus ad pedicellum setiformem redactis. Glumae 2, exterior plana, interior in utriculum ovarinm et florum masculorum pedicelIum v. ejus rudimentum recipientem connata. $O$ v ari u m sessile, stylo trifido. Caryopsis trigona, chartacea, stylo persistente rostrata. Flo res masculi juxta apicem pedicelli undique imbricati. Palea 1. Stamina 3. - Herbae capenses, habitu Caricis; spicis in apice caulis fasciculatis, $v$. axillaribus solitariis.

$\mathrm{S} \mathrm{e}$ b o e nox y p h $\mathrm{i}$ m Nees in Linnaea VIT, 531, IX, 305. Runth in Wiegm. Archiv. II. 358. $t, 6$. C arex indic Selikuhr car. l, B. B. f.86. (excl, $f, 1, k, l$.

TIRIBUS II. ELYNEAE Nees in Lin naea IX. 304. Kobresieat Lestibour. Cyper. IV. n. 10. Spica e mono-diclines, spiculis unifloris, unisexualibus, v. bi - plnrifloris androgynis, masculis interdum ad pedicellum redactis. Gluma 1 , antica. Pale a 2 , rhachi parallelae, in floribus unisexualibus binae, postica inferior major amplectens, antica superior minor, in spiculis androgynis deficiens. Perig onium nullum, v. multisetum, setis laevissimis, mollibus, paleis brevioribus. Stamina 3 . Discus hypogynus nullus. Cary ops is trigona, plerumque styli basi rostrata. - Herbae habitu caricino, spicis androgynis $v$, dioicis, spicatis v. fasciculatis, rarius alaribus, longe pedicellatis. Genera primo dempto Europae alpestris incolae.

980. Trilepis NEES, $\mathrm{S}$ picula e uniflorae, unisexuales. Mase, Gluma 1 , antica. $\mathrm{Pa}$ le a e 2 , rhachi parallelae, inferior (postica) superiorem minorem, quandoque deficientem, amplec- tens. Perigoninm nullum. Stamina 2-3. Fem. Glumae et paleae maris. Perigoniu m multisetum, setae paleis breviores, laeves, inaequilongae. Dis cus nullus. Ovarinm stylo bi -trifido. C a ry op si s rostrata. - Herbae pusillae, habitu Caricis, in Himalaya et Brasiliae montibus repertae; spicis diclinibus $v$, androgynis, simplicibus compositisque aut laxe paniculatis, bractea spathacea scariosa exceptis.

Trilep is Nees in Edinb. new philosoph. Journ, July 1834.'p. 267. Linnaea $I X, 305$.

a) DILEPIS. Fioris mas e uli palea inferior (antica) saepius nulla. Stamina 3 . S piea e androgynae.

Tr. R o y lean a Nees $l$. $c$.

b) TRILEPIS. Flores mas e uli bipaleacei. Stam ina 2. Spieae diclines.

Tr. Lhotzkiana Nees l. c. Endl. Atakt, $t$. 49.

961. Elyna SCHRAD. S p i c $\mathrm{l}$ a e androgynae biflorae, flore inferiore (postico) femineo sessili, masculo (antico) brevissime stipitato, G I uma 1 , antica. Ma s c. Palea 1 , glumae contigua. Perigonium 0. Stamina 3 . Fem. PaIe a 1, rhachi contigua, florem masculum includens. Perigonium et diseus 0 . Ovarium stylo bi-trifido. Car y op sis chartacea, hebetate triangularis, styli basi mucronulata. - Herba perennis, Europae mediae et areticae alpes graniticas incolens; spica lineari, terminali.

Bl y a a Schrad. Fl, germ, I, 155. Nees jun. gen, pl. fase, $x$. $t$, 19. Frohlichia Wulf. msc. Carex Bellardi Allioni, Host gram. $W . t, 77$. C. herma p h rod it a Gmelin, Schkuhr carie. $D, n, 16$.

962. Kobresia WILLD. Spicula e polygamae distichae, inferiores androgynae v. abortu femineae, suprema mascula multiflora. S picula e androgyna e flore inferiore (postico) femineo, masculis anticis pedicellatis, saepe abortientibus ad pedicellum subuliformem redactis, G1 uma 1 , antica. Paleac 1 , postica, bicarinata, marginibus pedicellum masculiflorum v. ejus rudimentum amplectens. Perigonium et discus nullus. O v a ri u m stylo trifido. Caryopsis chartacea, trigona, styli basi mucronata. S pi cula e mascula e multiflorae, floribus undique imbricatis, nnipaleaceis. P e r i g o $\mathrm{n} \mathbf{n} \mathrm{m} 0$. S t a$\mathrm{m}$ in a 3 . - Herbae spicis in apice culmi congestis, in Europae mediae monticolat.

Ko bresia Willd. sp. $p l$. $I$. 20., Nees jun. gen. $p l$. fase. IX, t. 80, Carjeis s p. Altioni ped. t, 89. f. 8. Schknhr Caric. t.Rrr. f.161, - Schoenus monoieus Smith $E$. B., t. 1.410.

TIR IBUS IIT. SCLERIEAE Nees in Linnaea IX. 302. S pi cula e diclines, $\mathrm{mas}$ c ul a e multiflorae, paleis distiche v. plurifariam imbricatis, infimis nonnunquam vacuis. Stamina 1 , v. 3 , rarissime 5 . Spiculae femineae uniflorae, glumae plurimae, multifariam imbricatae, interdum nullae. Pale a e 2, oppositae v. suboppositae. Peri gon i um nullum. Di s c u s plus minus manifestus. Ca $\mathrm{ry}$ ops is saepius ossea, scrobiculata v. cancellata. - Caules foliati, angulati, plerumque foliayue scabri aut adpresse villosi, simplices $v$. apice in ramos floriferos paniculatos cymososve soluti. Folia plana v. canaliculatotriguetra, interdum ternata, vaginis saepius alatis. Inflorescentia paniculata, cymosa, fasciculata $v$. spicaeformis, spiculis diversi sexus plerumque remotis, solitariis, geminatis, ternatis quinatisque. Americae et 
Asiae tropicae potissimum indigenae, paucissimae Australasiam extratropicam et Americam borealem incolunt.

963. Diplaerum R.BR. Spicula e diclines, masculae laterales panciflorae, feminea in eodem faseiculo centralis, uniflora. Spiculae masculae pauciflorae. Pal a e membranaceae undique imbrieatae. Perig onium 0. Stamen 1. Spiculae femineae uniflorae. Paleae 2, oppositae, apice trifidae, lobo intermedio longiori acuminato, conniventes, clausae. Perig on i um 0. Dis cus planus, obsoletus. Ovarium stylo continuo, apice trifido. Caryopsis sphaerica, costata, styli basi mucronata, paleis inclusa. Herbae pusillae, in humidis Moluccaru $m, C$ ey. lonae et Novae Hollandiae tropicae repertae; caulibus prostratis, foliosis, vaginis integris, fasciculis spicularum subglobosis, axillaribus, pedunculo e vaginis vix exserto.

D ipla e r $\mathrm{um}$ R. Brown prodr. 2a1. Brongn. ad Duperr. 159. t. 26. Nees in Linnaea $I X, 304$.

9B4. Seleria BERG. Spicula e diclines, maseulae multiflorae, femineae uniflorae. M a scula e. Paleae distiche $v$. plurifariam imbricatae. Perigonium 0 . St a m e $\mathbf{n}, \quad v$. rarissime 5. F e m i n. G l u m a e plurimae, multifariam imbricatae, sensim majores. Pale a e 2, integrae, suboppositae. Perigonium 0 . D is e u s varius, subcylindricus, lobatus v. annularis, persistens. Ovarium stylo continuo, bi-trifido. C ary ops is ossea, subglobosa, lageniformis v. Ienticularis, laevis v. tesselata, paleis patentibus cineta. Herbae perennes, ut plurimum tropicae, habitu vario.

Seleria R. Brown prodr. 240.

a) SCLERIA Glu mae distiche v. tristiche imbricatae, inferiores minores, rarissime majores, alato-carinatae. Discus distinctus, cyathiformis, subeylindricus v. pateriformis, lobatus, repandus aut truncatus, eoriaceus, suberosus v. membranaceo-chartaceus, interdum setoso-pubescens, caryopsi ut plarimum firmiter adhaerens. Caryopsis globosa v. ovoidea, nuda, scrobiculata, rugosa v. cancellata, ut plurimum nitida, alba v. atro-purpurea. - Caules superne cymosi aut paniculati, rarissime simplices, foliis interdum ternatis vaginisque alatis.

Scleria Bergius in Act, Holm. 1765. p. 149. t. 4. 5 . Gaertn. $I, 13, t$. 2. f. 7. Cavan. ic. $t, 457$, Elliot carol. 2. $t$. 12. Brongn. ad Duperr. p. 164. - C y 1 indropus Nees in Edinb. new philosoph, Journ. July 1834.p. 266. Linnaea. IX. 303 (species disco subcylindrico-truneato.).

b) BEQUKREIA. Gl a ma e plurifariam imbricatae, supremae inferioribus semper majores, quandoque floriformes. Dis c us annularis $v$. disciformis, margine angustissimo, subeartilagineo, fere obsoletus, nonnisi delapsa caryopsi conspicuus. Caryops is ovoidea, lageniformis v. depresso-trigona aut lenticularis. Spiculae masculae plures ad basim femineae.

B equerela Brongn. in Duperr. voy, p. 161. $t, 27$. (disco aunulari, caryopsi trigono-depressa) - Lag eno e a rpus Nees in Linnaea IX. 304. diseo obsoleto, caryopsi lageniformi) - ? Caly p tro e a r y a Nees in Linnaec. IX, 304. (iloribus maseulis pentandris, disco obsoleto, glumis infimis bracteolae contrarils ?)

c) HXPOPORUM Nees. G1 u m a e plurifariam imbrieatae, subaequales. Discus caryopsi delapsa conspicus, sobstipitatus, pa'eriformis v. discoideus, margine obsolete triangulari, angustissime, cartilagineo. C a r yopsis sulcata, porosa y. cartilaginea.

H y p o or m Nees in Edinb. new philosoph. Journ. July 1834. p. 266. Linnaea IX. 303, S eleriae s p. Auct.

985. AmIacorlhymelnus NEES. S $\mathrm{p}$ c n la e diclines, masenlae multiflorae, femineae uniflorae. Mase. Pale a multifariam imbricatae, infimae steriles. Perigonium 0 . Stamina 8 .
F e m. G 1 u m a e plurimae, multifariam imbricatae, sensim majores. P a l a e 2 , integrae, suboppositae. Perigonium nullum. D is c n s annularis, obsoletus. Ovari um stylo elongato, basi bulboso, apice trifido. C a r y o p s is chartacea, lageniformis, venuloso - nervosa, rostro trisuleo, solido. - Herba capensis, a Scleriis vix nisi pericarpii indole diversa; culmis compressis foliatis, foliis filiformi-triquetris, scaberrimis, spiculis masculis in apice culmi fasciculato-capitatis, femineis in eadem stirpe solitariis $v$. geminis, in axillis foliorum vagina velatis.

\section{A ulacorhy $\mathrm{ch}$ us Nees in Linnaea $\mathrm{IX} .305$.}

\section{TIEIEUS IV. RHYNCHOSPOREAE} Nees in Linnaea IX. 294. S p i cul a e hermaphroditae $v$, polygamae, pauciflorae $v$. uniflorae, paleis distichev. plurifariam imbricatis, infimis summisque nonnunquam vacuis. $\mathbf{P e}$ rigonium e setis scabris, ciliatis v. plumosis, liberis v. basi inter se, interdum etiam cum disco connatis, rarius obsoletis. St a min a 3 . D is cus saepe obsoletus, plerumque cum caryopsi connatus. Car y o p s is cartilaginea v. crustacea, styli basi varie dilatata superata.Stirpes per tolum orbem diffusae, plurimae tamen tropicae, habitu et inflorescentia varia; spiculis in plerisque teretiusculis $v$. compressis, anguste lanceolatis $v$. linearibus, $r i$ gidulis aut subpungentibus, nonnunquam paleis apice patentibus turbinatis, rarissime ovalibus, obtusissimis, involucris variis anthodia arctissime imbricata referentibus cinctis.

SUPTYREDS I. RHYNCHOSPOREAE VERAF. Perigoni n setosum, distinctum, rarissime fugax v. nullum, s t y lo tunc apice indiviso vel obsolete bi - tridentato.

986. Traplostylis NEES. Spieulae panciflorae, polygamae, flore inferiore plerumque femineo, reliquis masculis. Pale a polystiche imbricatae. Perigonii setae seabrae, ciliatae v. plumosae, interdum fugaces v. obsoletae. Stamina 3. Ovarium stylo simplici, apice bidentato, elongato. Ca ry o p s is compressiuscula, styli basi inerassata, bulbosa aut mitraeformi rostrata. Herbae in America tropica, rariusque in India or ientali observatae; inflorescentia plerumque terminali, capituliformi, spiculis involucro polyphyllo squamoso, imbricato inclusis.

a) MORISLA Nees. Perig onii set a e solitariae v, obsoletae. Caryopsis styli basi tuberculiformi superata. - Herbae nepalenses.

Moris i a Nees in Edinb, new philosoph. Journ. Juty 1834. p. 265. Linnaea $I X$. 295. Rhynclios pora sp. Wallicle catalog, $n, 3422, a$,

b) Mitrospora Nees. Perigonif setate fugaces. C a r y o p s is styli basi erassa, mitraeforni, discreta coronata. - Species americanae.

Mitr os pora Nees in Linnaea IX. 295. R h y $\mathrm{n}$ e ho s paa poly phy 11 a Vahl.

c) HAPLOSTXLIS Nees. Perigonii setae capillares v. anguste lineares, distinctae. Car yops is basi styli rostrata. - Species asiaticae et americanae.

๔) Styli bas is in angulos caryopsis decurrens. Haplostylis Nees in Edinb, new philosoph. Journ. July 1834. $f$. 265. P te rothe $c$ a Presl symb. 1.35. t. 35. Chactosporae, Rhynchosporae et Seirpi sp. Auct.

B) Sty $1 \mathrm{i}$ bas is erassa, calyptraeformis. Cal y ptrost $y$ lis Nees in Linnaea IX. 295. 
$\gamma$ ) Styli bas is lata, lunata. Cephaloschoenus Nees $l$. $c$.

d) Styli bas is aristaeformis. Diplochaete Nees l. $c$.

d) Ceratoschoenus Nees. Perigonii setae cartilagineae, basi counatae. C a r y op s e o s rostrum longum, incurvum. - Patria? Ceratos ehoenus Nees in Linn, $I X$, 296.

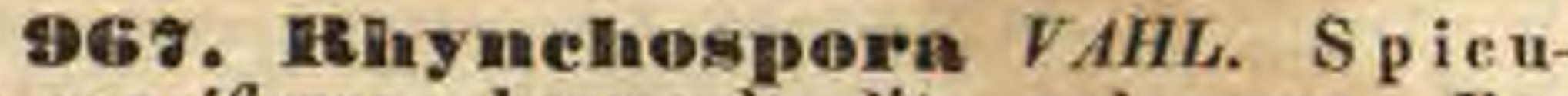
I a e panciflorae, hermaphrodito-polygamae. Paleae polystiche imbricatae. Perigonii setae rigidae, denticulatae. Sta $\mathrm{m}$ ina 3 . Ovari $\mathbf{m}$ s ty lo bifido. C a ry o p s is basi styli disereta longirostris. - Plantae inforescentia varia, paniculata, corymbosa v. spicato-capitata, in America tropica et boreali calidiore potissimum provenientes, in India orientali et Nova Hollandia rarae, unica species europaea.

R hy a chospora Vahl enum, II, 229. R. Brown prodr. 299. Nees in Linnaea $X X$. 297. Nees jun. Gen. $p l$. IX. t. 15. $\mathrm{Schoeni} \mathrm{sp}$. Liun et Auct. Rottboell gram. $t, 21, f .1$. Rudge guian. t, 18, Host gram, IV. t. 72. Schkuhr Handb. t. 7 .

DBS. Clnnetospona $R, B R$. Spiculat uni-triflorae, hermaphrodito-polygamae. Pale a e distiche v. polystiche imbricatae. Perigonii setae ciliatae $v$. plumosae. Stamina 3 . Ovarium sty lo trifido. Caryopsis triquetra, styli basi continua mucronata. - Stirpes rigidiusculue, in Capite bonae spei, Nova Hollandia extratropica et America antarctica, una etiam in Europa indigena; foliorum vaginis saepe ustulatis, spiculis fasciculatis v. capitatis, rariusve paniculatis.

a) CARPHA Banks et Sol. Spiculae uni-biflorae, subdistichae. Setae, stamina stylusque in angulos cary op 8 e os decurrens elougatus.

C ar ph a Banks et Sol. ex R. Brown prodr. 230. Nees in Linnaea IX, 300. Brongn, in Duperr, voy, 169, t. 30 .

b) CHAETOSPORA $\boldsymbol{k}$. $\boldsymbol{B r}$. S p ic u la e pauciflorae, distichae v. polystichae. Set a e staminaque paleis breviores.

Chaetospora R. Brown prodr. 232. Nees in Linnaea IX. 299. Sehrad. Analect. 31. $t$. 3. f. 2. 4. S ch o en s p. Auct. (Setae rigidae, saepius plumosac, caryopsis sub. globosa.) - S tre blidi a Link Hort. berol. I. 2r6. Nees in i.innaea IX, 299. Nees jun. Gen, pt. IX. $t, 17$. Sehoe nus ferrugine us Sclurad, Fl, germ, $I, t, 1, f$. 4. (Setae seabrae, earyopsis obsolete trigona.) - A s tero elta ete Nees in Linnaea IX. 300. (Setae brevissimae, apice scabrae, eary opsis granulata, mueronata.) - ? C y a th o e $0 \mathrm{~m}$ a Nees $l$. $o$. (Setae basi in urceolum connatae, stamina 5 v. 6.)

D69. Truanoptiles FENZL. S p i eulae biflorae, hermaphroditae. Pal e a subdistichae. Perigonii setae tres, lineares, plumoso-ciliatae, apice trifidae, lacinulis aristaeformibus, nudis, intermedia longiora. Stamina 3 . Dis cus callosus, minimus. Ovarium stylo bifido. Caryops is, disco cineta, styli basi dilatata, macronata. - Herba capens is, habitu Caricis pulicaris $v$. obtusatae; culmis simplicibus, foliatis, spiculis terminalibus lateralibusque congestis, spathaceo-involucratis.

Trianoptiles Fenzl gen, Oyperac, Ecklonia Stendel in Flora 1829, $p, 138$. Schrad. Analect. $p$. 34. Nees in Linnaea $I X$, 299, non Hornem. Un cinia spartea Spreng. C a r ex Ecklon n. 853. 854.

9) (1. Nomoehlon PALIS. Spiculae bi-multiflorae, hermaphroditae. $\mathrm{P}$ a l e a e subdistiche imbricatae. Perigonii setae tres v. sex, plumosae. Sta mina 3 . Dis eus obsoletus. O varinm sty lo usque ad basim bipartito. Caryop8 is lenticularis, styli rudimento superata. - Stir pes in America tropica et septemtrionali calidiore indigenae; culmis erectis, foliosis, spiculis in racemos $v$. paniculas parvas contractas, axillares, foliis multo breviores dispositis.

Nom oc b I o a Palis. ex Lestibond. Cyperac, in Rōm. et Schult, mant, IT. p. 5 .

a) NOMOCHLOA Nees. Car y op 8 is mueronulata.

No mochlo a Nees in Linnaea MX. 299.

b) PLEUROSTACHXS Brongn, C a r y ops is obtusa.

Ple urostachys Brongu. in Duperr, voy, 172, t.31. Nees in Linnaea $I X, 299$.

98 1. N⿴囗十 uni-biflorae, hermaphroditae. I'al ea e polystiche imbrieatae. Perigonii set a e 3 , minimae. D is c us obsoletus. Stamina 3 . Ovarium stylo trifido, continuo. Caryo psis styli basi in angulos decurrente triptera, brevirostris. - Herba antillana; foliis elongatis, ensiformibus, equitantibus, spiculis aggregatis, bracteis dense vaginatis, in paniculas alares terminalesque dispositis.

Machaerina Vahl enum, II, 238. Link Hort. Berol. I. 300. Nees in Iinnaea IX, 298. S $\mathrm{c}$ ho eni sp. Auct.

oBSERV. Machaerinae genus Chaetosporis nimis aftine, habitu El y a n thi speciebus foliis equitanti. bus (B a umeis Brongn.) ita accedit, nt vix nisi perigonii praesentia ab isdem differat.

982. Hatike florae, flore infimo hermaphrodito sterili, secundo fertili, tertio masculo, $\mathbf{P}$ al e a e distichae. P erigon i seta e 6 , annuli eartilaginei trilobi lobis bidentatis adnatae, eapillares, sursum seabriusenlae, deciduae. Discus... Stamina 3 . Orari um sty lo bi-trifido, lobis interdum bifidis. Caryopsis hebetate trigona, basi styli rugosa coronata. - Herba capensis, rigidula; culmis teretibus, basi vaginatis, vaginis foliiferis, foliis teretibus, faretis, basi canaliculatis, spiculis in rhachi compressa, undatim flexa alternatim fasciculatis, pedicellis brevibus, rigidis, spathaceo-involueratis, caryopsi decidua.

Bueckia Nees in Linnaea $I X, 300, X, 196$. Sehoe. nus punetorius Vahl.

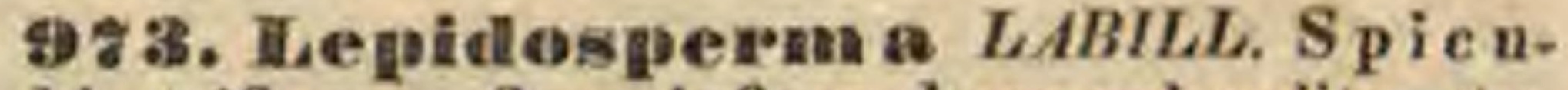
la e bi-triflorae, flore infimo hermaphrodito ste rili, secundo fertili, tertio masculo. Pale a e undique imbricatae. Perigonii seta e 6, subulatae, planiusculae, basi in annulum membranaceum, demum cartilagineum, connatae, apice nudae, ciliatae v, scabrae. Stamina 3 . Discus... Ovarium sty lo bi-trifido, deciduo. Caryo ps i s cartilaginea, ventricosa, mutica. - Stirpes in Australasia extratropica et in Capite bona e spei indigenae; culmis simplicibus aphyllis $v$. foliatis, foliis basi equitantibus, vaginis interdum fissis, fibroso-cancellutis cinctis, paniculis vel spicis, saepius compositis, terminalibus.

Lepid os p erm a Labill. Nov. Holl. I, 14. R. Brown prodr. 230. Lepid otosperma Rom, et Schult, syst. $I$. 1 .

a) LEPIDOSPERMA Nees. S e ta e chartaceo-membrana. ceae, apice laeves. - Australasicae.

Lepidospe rma Labill. op. cit. $t$. 11-17. Nees in Linnaea $\mathrm{TX} .302$.

b) SCLER0CHAETIUM Nees. Setae demum cartilagineae, apice scabrae v, cillatae. - Capenses.

Scle r o c b a ti u m Nees in Linnaea VII, 5t1, IX, 302. L e pidosper ma Schrad. Analect, 35. $t, 4, f .4 .6$. $\mathrm{s}$ c ho e. in i s p. Rottb. Gram, t, 18, f, . . t.19.f. 1 .

9\% 4. Dreebelins R. BR. S p i culae uniflorae, terminales. Glum a e 2, ancipites, 8 pathaceae. Pale a 1 , interdum deficiens. Perigonii setae 6 , lanceolatae, cartilagineae, persistentes. Stamina 3 . Dise us nullus. Ovarin m sty lo trifido, deciduo. Caryopsis crastacea, globosa, mutica, - Herbae pusillae, in insula Diemen et in Maclovianis monticolae, caespites densos, convexos efformantes; culmis vaginatis, 
basi divisis, foliis strictis, imbricatis, scapis brevibus, axillaribus, compressis v. angulatis, unifloris. 0 re obolus R. Brown prodr. 235. Gaudich. in Annal, sc. nat, V. 99. t, 2. f. 1.

SUIB'RIBIBUS GI. SCHOENOIDEAE. S $\mathrm{p}$ c u lae uni-panciflorae, rarius multiflorac. $\mathrm{Pa}$ Jea e subdistiche $\mathbf{v}$. plnrifariam imloricatae, infimae vacuae. Perigon i nm nullum. Caryopsis mutica, v. styli basi persistente superata.

Dร5. Spermodon PALIS. Spiculae uni-pauciflorae, floribns hermaphroditis v, poly gamis. Pale a e subdistichae. P erig oni u m nulIum. Stamina 1_3. D is c a s stipitiformis, cnm basi caryopseos coalitus. Ovarium stylo bi-trifido. Caryopsis cartilaginea, transversim rugosa, retusa, angulis prominentibus obsolete bitridentata, styli basi bulbosa, inter dentes rostrata. - Stirpes Americam tropicam et borealem calidiorem incolentes, habitu Rhynchos porarum, a quibus vix nisi perigonii defectu recedunt; culmis foliosis, spiculis terminali bus, fasciculatis.

Sperm od on Palis ex Lestibond. cyperac, n. $V$. Ròm. et Schult. mant. $I I$. 3. Nees in Linnaea $I X, 296$. S $\mathrm{ch}$ o e n s p. Bergius Act. Helv, VII, $t, 9$. Rotthoell Gram. $t, 21$. f. 2. - Triod o n Rich. ex Pers, ench, $I .60, n .48$. Scleria hirtella Mich. non Sw.

9ร6. Dielnumena RICH, S picula uni-plariflorae, floribus hermaphroditis v. polygamis. P al ea e bi-trifariam imbricatae. P erig o ni um nullum. Stamina 3 . Dis ce s annularis, v. obsoletus. Ovari um stylo bi-trifido. $\mathrm{C}$ ary o ps is crustacea, v. cartilaginea, transversim rugosa, styli basi discreta lata rostrata. - Herbae Americam tropicam, imprimis transa equatorem, paucissimae borealis plagam calidiorem incolentes; culmis foliosis, inflorescentia varia, habitu Rhynchosporas v. Cyperi species capituligeras plane referentes.

Dich rom e na Richard in Michx. Fl. bor, amer. $I .37$. Vaht enum. $I$. 240.

a) ZOSTRROSPERMUM Palis, S pi c u la e pauciflorae, acutae. - Habitus Rhynchosporarum.

$\mathrm{Z}$ os ter os perm a m Palis. in Hamilt, prod. Fl. Ind. oecid. p. 14. Róm. et Sehult, mant, III. 4. Nees in Linnaea IX. 297. Styli basis persistens utrinque sulcata. - E chin o$\mathrm{s}$ choen us Nees in Meyen Reise I. 116. Linnaea IX. 297. $\mathrm{S}$ ehoen isp. Auet. Styli basis persistens, compressa. Haloschoenus Nees in Linnaea $I X$. 296. R hynchosporae et $\mathrm{Schoeni} \mathbf{s}$. Auct. Styll basis persistens, lunata.

b) DiCHRomena Nees. S pieula e pluriflorae, ovatae, obtusiusenlae, eapitatae, involucro foliacen, basi colorato cinctae. - Habitus Schoeni mucronati v. Cyperi specierum capituligerarum.

Dichromena Richard $l$. c. Nees in Linnaea $I X, 291$. PresI Reliq. Haenk, 1, 197. t. 32. f. 2. S e h o e n i s p. Kunth. Meyer.

D\% \% Flymantliners PALIS. Spiculae subuniflorae, hermaphroditae $v$. polygamae. Palea subdistiche imbricatae, naviculares. Perigon i um nullum. Stamina 1_8. Discus obsoletus. Ovari am stylo trifido. Caryopsis trigona, styli basi persistente incrassata, simplici $\mathbf{v}$. in angulos decurrente apice corticata $v$. rostrata. - Herbae apleyllae v. foliosae, Afri c a m australem extratropicam tropicamque potissimum incolentes; foliis rigidis, angustis, vaginis saepius fissis, cancellato-fibrosis, v. latis, ensiformibus, equitantibus; spiculis ut plurimum lateralibus, rarius terminalibus, fasciculatis, interdum paniculatis v. umbellatis.

Elynanthus Palis, in Lestiboud, Cyperac. ex Rôm. et Schult, mant, $I$, 4 . a) ELYNANTHUS Nees $\mathrm{S}$ tyli bas is in angulos caryop. seos decurrens. Foli a angusta, rariusve equitantia.

E1yna nth us Nees in Linnaca rX. 298. S e hoeni s p. Auet. Rottboell. Gram. 4. 18, f. 2.4. (Styli basis bulbosa.) Tras i Palis. $l, c$. Nees $7, c$. Vincentia Gaudich. ad Frege, p. 417. (Styli basis trigona, non bulbosa, folia sae. pius equitantia.)

6) CHAPELLIERA Nees. Styli bas is in angulos caryopseos haud decurrens. Folia ensata, equitantia.

Chapelliera Nees in Linnaea $T$, 298. (Styli ba. sis haud rostriformis, glabra.) - B a $u \mathrm{~m}$ e a Gaudich. $a d$ Freyc. 416, $t$. 29. Brongn. in Duperrey vog. Ir. 167. Scir. pus anceps et lavarum Poir. Sce iridifolius Bory voy, ins. Afr, austr. II, 34, t, 23. (Styli basis rostriformis mucronata, saepius pubescens.)

9\%8. Selnoemus LINN. Spiculae unipanciflorae, floribus hermaphroditis. $P$ a le a distiche v. plurifariam aretissime imbricatae. Perigon i $\mathbf{~ m}$ nullum. Stamina 3 . Dis ens nullus. Ova $r i-$ n m sty lo trifido, basi simpliei, pyramidata $v$. bulboso-incrassata, decidua. Ca r y o $\mathrm{p}$ s is trigona, mutica $v$. mueronalata, styli rudimento nullo. Stirpes rigidae, europaea et australasicae, paucae a mericanae tropicae et extratropicae; culmis aphyllis $v$.foliatis, spiculis capitato-congestis vel fasciculatis, nunc spicatim confertis, paniculatisque.

$\mathrm{S}$ choen us Linn. gen, n. 65. Juss. gen, p. 27.

a) SCHOENUS Lestib. Stylus cum basi haud incras. sata deeidnus.

S e h o e n u s Lestib. Cyperac, ex Rōm. et Schult. mant, 5. Host. gram. III, t. 54, E. B. t. 1121. Labill. Nov. Holl, t, 18. 19. Schrad. Analect, t, 14. f. 1. Nees in Linnaea $I X$. 298. Nees jun. Gen, $p l$, fasc. IX, $t, 16,-T_{0}$ rulin i um Desv. in Hamilt. prodr. Fl. Ind. Occid. p. 15. Cyperus ferox Rieh. - ? S choenopsis Lestib. $2 . c$. Ciadiisp. R. Br.

b) GUSSONEA Presl. Styli basis incrassata, decidua. Gous sonea Presl in Reliq. Haenk, 1. 183. $t .33$. Brongn. in Duperr, voy. II, p. 171, t. 34. $\mathrm{S}$ choenops is Nees in Linnaea IX, 298. - Arthrosty lis R. Brown prodr. 229. (Paleae plurifariam imbrieatae.)

จรจ. Femirea $A U B L . S$ p icula e nniflorae, flore hermaphrodito terminali, $G$ I $\mathbf{m}$ m a e distichae, nervosae. Palea e 2 , inferior (antica) demum suberosa, colorata, a superiore (postiea) longiore inclusa. Perigo $\mathrm{nium}$ nullum. Stamina 3 . Dis cus 0. Ca r yopsis trigona, mutiea, intra paleas inclusa. - Gramen ramosum, in littoribus intertropicis totius mundi repens; ramis adscendentibus, foliis densis, rigidis, apice patulis, spiculis in spicas capitatas, terminales conglobatis, spicis involucro polyphyllo cinct is, confertissimis.

Remirea Aubl. Guian. 45. t. 16. $n$. Brown prodr. 236. Palis, Fl. dOwar. 1I, 29, $t, 73$. Nees in Linnaea IX. 286. Miegia Sclireb. gen, n. 1713, non Pers.

TrEFE US W. CLADIEAE Nees in Linnaea IX. 297. S p i cu lae uni-triflorae. Pa1 e a multifariam imbricatae, inferiores semper vacuae, extremae solum floriferae. P erigo n i m nullum. St a min a 2_12, plerumque 3_6, post anthesim plerumque elongata, transversim plicata et caryopsi adhaerentia. Dis cus nullus. Ovarium stylo bi-trifido, ramis saepius bifidis, rarissime basi bulboso, ut plurimum penitus deciduo. C a r y o p s is ossea, crassa, durissima, apice saepe incrassata, nuda v. styli basi tenni coronata, annc drupacea putamine fragili, ab endocarpio crustaceo solubili, rarissime crustacea, ventricosa, styli bulbo coronata. - Herbae ut plurimum rigidae, incerdum aphyllae, plerum. 
que foliatae, foliis saepissime elongatis planis, vel involutis culmisque scabris, culmis superne paniculatis, rarius spicis aggregalis sessilibus terminatis. - Tribus a praecendente caryopseos indole, et staminum numero vario potissimum dignoscenda.

950. Cladium $P . B R$. Spiculae snbuniflorae, floribus hermaphroditis. $\mathbf{P}$ a l e a e multifariam imbricatae, inferiores minores. Perigoni um nullum. Stamina $2 \_3$; filamentis persistentibus, haud elongatis. Ovariu $\mathrm{m} s \mathrm{tyl}$ o bi-trifido, deciduo; stig mat ibus indivisis. Caryopsis globosa v. obsolete trigona, drupacea, styli basi aequali mucronulata, endocarpio rugoso trisuleo, putamini demum suberoso plus minus adhaerente. - Herbae potissimum australasicae, unica europaea, quae tamen etiam in America trop ica reperta fuit; caulibus foliosis $v$. vaginatis, inflorescentia varia, paniculata $v$. subspicata, spiculis ut plurimum aggregatis.

C1 a di in m P. Brown Jam. 114. R. Brown prodr. 236. excl. sp. Sehrad. Fl. germ. t. 5. Link Hort. Berol, I. 295. Nees in Linnaea IX. 301. Nees jun. Gen, pl. fasc. IX. $t$. 18. S cho e n i sp. Linn. et Host Gram. III. $t$, s3. Fl. dan. t. 1202. Swensk Bot. $t$. 275. $E, B, t, 950$.

951. Lamaprecarya $R, B R, S_{p}$ i u $l$ a e uniflorae, flore hermaphrodito, terminali. $\mathrm{Pa}$ le a multifariam imbricatae. Perigonium nullum. S $\mathrm{tam}$ in a plerumque 4 , nunc 3 -6; filamentis demum elongatis, convolutis, fructum delabentem suspendentibus. Ovarinm stylo trifido, stigmatibus indivisis. Cary opsis ossea, styli basi suspidata, putamine apice incrassato, nucleo lacvi vel medio obsolete constricto. - Herbae australasicae; culmis foliatis, spiculis congestis paniculatis, paniculis foliosis.

L a m pr a c a r y a R. Krown prodir. 238. Nees in Linnaed IX. 301. - Morelotia Gandich, ad Freyc. 416. t.28, Melachne Sehrad. in Schult. syst. VIT, p. LXXXV. D i. d y monem a Presl $S y m b, I, 6, t, 3$. E piandria Presl in Okens Ysis 1828. p. 270, G a h ni a e s p. Labill, Nov. Holl. I. $t, 116$.

982. Gallomia FORST. Spicula e uniflorae, flore hermaphrodito, terminali. Pal e a e multifariam imbricatae. Perig on ium nullum. Stamina 3_6; filamentis demum elongatis. Ovarinm stylo trifido; $8 \mathrm{tigmatibus}$ indivisis v. bifidis. Ca ryopsis ossea, putamine aequabili, nucleo transversim pluries constricto. - Herbac australasica e; culmis foliosis, foliis elongatis, asperis, involutis, paniculis compositis, foliatis.

G a h n i a Forst. gen, n, 26, excl. sp. Gärtn, IIr, 181. t. 8. Labill. Nov. Holl. 1. 89. excl. sp. R. Brown prodr. 238. Nees in Linnaea IX, 301.

a) MELANOGAHNIA. Stamina 3. Stig ata indivisa. G. melanocarpa R. Brown prodr, 239.

b) EUGAHNiA. Sta min a 6 . Stigma ta bifida.

Gahniac verae R. Brown $l$. c. G. psittacorum Labill. Nov. Holl, $t, 115$.

983. Caustiss $R, B R$. Spicula e subuniflorae, flore hermaphrodito, terminali. $\mathbf{P a}$ le a e multifariam imbricatae, subfasciculatae. $\mathbf{P e}_{\mathrm{e}-}$ rigonium nullum. Stamina 3_5. Ovarium st y lo basi dilatato, bi-trifido; stigmatibus indivisis. Caryopsis crustacea, ventricosa, styli basi bulbosa rostrata, nucleo laevi. - Herbae australasicae extratropicae, Restiacearum quarundam habitu; culmis aphyllis, vaginis integris, sphacelatis, hinc in mucronem subulatum concolorem productis, inferne indivisis, teretibus, superne bi-trichotome paniculatis, semiteretibus, ramulis ultimis subulatis, compressis, foliiformibus, spiculis in ramis paniculatis axillaribus terminalibusve solitariis $v$. pluribus, pedunculatis, pedunculis vagina inclusis, paleis inferioribus vacuis superiores aequantibus $v$. subsuperantibus, hinc quasi fasciculatis.

Ca ustis R. Brown prodr. 239. Nees in Linnaea $r X$. 301. Guillem ic. Lithogr. t. 14.

DS4. Evandira $R$. BR. S picula e subuniflorae, floribus hermaphroditis, terminalibus. Palea multifariam imbricatac. Perigonium nullum. St a mina 12 , v. plura. Ovarium... Caryopsis crustacea, cylindrica, nucleo laevi. Herbae elatiores, in paludosis Novae Hollandiae meridionalis observatae; culmis foliosis v. aphyllis, inflorescentia composita, spiculis solitariis geminisve sessilibus, nunc in spicam, nunc in paniculam terminalem vel axillarem dispositis, turbinatis, squarrosis, paleis extus nigricantibus, superioribus intus subsericeis, dissimilibus.

Evandra R. Brown prodr. 230. Nees in Linnaea IX. 301 .

\section{TREIRUS VI. CHRYSITRICHEAE} Nees in Linnaea IX. 288. Spi cula e androgynae, monocarpicae. P al e a e numerosae, rhachillae discoideo-depressae multifariam insertae, arctissime imbricatae, interiores ab exterioribus majoribus inclusae, monandrae, infimarum una alterave vacua. Flos he rmaphroditus terminalis, paleis intimis 3 -12 monandris, tanquam perigonio paleaceo polyandro cinctus. Perig on ium propritum et discus nullus. Ovarium stylo bi-quinquefido. Cary op s is crustacea, globosa, rugosa, vertice nudo. - Herbae in Africa australi tropica et extratropica, nec non in Nova Hollandia inter tropicos indigenae, habitu Juncos el Sisyrinchia aemulantes, cum Evandra et Causti ad Restiaceas monospermas tendentes, habitu et spicularum conformatione ab omnibus Cyperaceis recedentes; culmis simplicissimis, basi foliatis, foliis teretibus farctis, v. ancipitibus, equilantibus, inflorescentia infra apicali composita, spicam strobiliformem solitariam, squamato - bracteatam, v. capitulum subglobosum, spiculis conglobatis ebracteatis exhibens.

985. Chryssithrix LINN. FIL. S p ic nla e multiflorae, polygamo-dioicae. Pal eae plarimae, in rhachi discoideo-depressa confertae, ecarinatae, lineares, monandrae, staminibus cassis. Fioris hermaphroditi stamina 12 , v. plura, antherarum connectivo in setam longe producto. Ovarium sty lo quadri-quinquefido, crasso, cum basi deciduo. C a r y op 8 i s stipitata, membranacea, basi conico-contracta, vertice obtuso radiatim costato. - Herba habitu Sisyrinchii, in arenosis planitierum Capitis bonae spei indigena; rhizomate repente, culmis foliisque basi confertissimis, equitantibus, ancipitibus; spicula solitaria infra apicem culmi erumpente, tubo urceiformi, bracteisque cartilagineis, cymbiformibus, apice circinnatis, confertissime imbricatis, demum delabentibus inclusa. 
Chry s it h rix Linb. fil. gen. gram, 27. $f$. 1. 2, Thunb. $F l$. cap. p. 431. Lam. illustr. $t, 842$. Nees in Linnaea $I X$. 288. $X, 144$.

\$86. Hepiaconata RICH. S p ic u l a e multiflorae, polygamae. P a l a e plurimae, in rhachilla brevissima imbricato - fasciculatae, monandrae. Floris hermaphroditi stamina $3-6$. Ovarium stylo bifido, deciduo. Caryopsis crustacea, globosa v. compressa, poroso-rugnlosa. - Herbae paludosae, Juncor $u$ m habitu, in Africa australi tropica, et in Nova Hollandia intra et extra tropicos indigenae; culmis simplicissimis foliisque teretibus, farctis, septis transversis nodosis, spiculis infra culmi apicem in capitulum bracteolatum v. nudum aggregatis, nunc in spicam lateralem, squamis cartilogineis, arctissime imbricatis bracteatam, strobiliformem dispositis.

Leptronia L. C. Richard in Pers. ench. I, zo.

a) CHONDRACHNE $R, B r$. Spiculae in spicam eartilagineo-bracteatam, strobiliformem dispositae. Australasicae el africanae.

Chond raehae R. Brown prodr. 220. Nees in Linnaea IX, 28s, Lepironia Rich. $l$. c. Restlo articulatus Retz. Scirpus coniferus Poir.

b) CHORIZANDRA $R$. $B r$. Spiculae bracteis nullis v. paleaceis obsoletis distinctae, capitato-glomeratae. Australasicae.

Chorizandra R. Brown prodr. 221. Nees in Linnaea $I X$. 288 .

Tribus EH. HYPOLYTREAE Nees in Linnaea IX. 287. excl. gen. S p i c ula e hermaphroditae, uniflorae, pale is 2_4, interdum solitariis. Perigonium et discus nullus. St a m i na $2 \_3$, v. $6 \_8$. 0 vari u m sty lo bifido. Caryopsis compressa, apice nuda v. suberoso-incrassata, nunc styli basi persistente compressa rostrata. Spiculae singulae in spicas capitato-congestas v. cymosopaniculatas, arctissime imbricato-bracteatas dispositae, singulae sub bractea glumacea absconditae. - Species spicis capitalo-congestis Kyllingias, reliquae Fuirenas aut Clad ia habitu aemulantes.

\$8\%. Hipeearollea $R$. BR. S piculae hermaphroditae. P a l e a e 2 , aequilongae, ecarinatae, inferior (postica) plana, superior (antica) convexiuscula, interdum deficiens. Perigonium nullum. Stamina 2_3. Ovarium stylo bifido, deciduo. Caryopsis crustacea, teretiusenla, vertice nuda. - Herbae habitu Kyllingiae, inter tropicos totius orbis obviae; culmis triquetris, basi foliatis, spicis globulosis $v$. ovoideis, in capitulum involucro foliaceo tri-pentaphyllo cinctum aggregatis.

Lipocarpha R. Brown Congo p. 459.

a) HEMICARPHA Nees. Palea 1, postiea.

Hemlcarph a Nees in Linnaea $1 X$. 287 .

b) LIPOCARPHA Nees. Paleae 2.

Lipocar pha Nees in Linnaca $I X, 287$. H y poel y pt um R. Brown prodr. 219. H y pely $\mathrm{t} \mathrm{z} \mathrm{m}$ Link Horl. Berol. I. 327. Hy polypti s p. Vahl et Auct. Hypolytri sp. Rieh. Kunth, Presi. T ang a e sp. Roxb.

988. Hypolytrum RICH. Spicula e hermaphroditae. P a l e a e 2_4, bracteae contrariae, marginibns interdum autice $v$. postice, nonnunquam ntrinque inter se coalitae Stamina 2_3. Ovarinm stylo bifido, decidne. Caryo psis crustacea, ovoidea, compressa, apice suheroso-inerassata, mutica. - Herbae Fu iren ae v. Cladii habitu, in America, Africa et In- dia tropica obviae; culmis foliosis, spicis cuneatis $v$. turbinatis, undique imbricatim bracteatis, per panioulas cymosas v. corymbiformes squarrosas dispositis.

H y poly trum L. C. Richard in Pers. eneh, $\boldsymbol{I}$, ro, exel. sp. Nees in Linnaea $I X, 207$. B e es a Palis, in Lestib. Cyperac. ex Röm. et Schult, mant, IT, 3. A I b ikia Presl in Relï. Haenk. I. 284. t. 34. 35. H y o el y trum nemorum et Sehoeni sp. Palis, Fl. Owar.t, 76 . H y pely pti s p. Vahl. Seirpi s p. Auct.

DSD. Hiplasia RICH. Spiculae hermaphroditae. Pale a e 4, duae inferiores bracteae contrariae, earinatae, duae superiores bracteae parallelae, planae, Perigonium nullum. Stamina 6_8. Ovari $\mathrm{m}$ stylo bifido, basi dila. tata, compressa, persistente. Caryopsis oblonga, compressa, styli basi hirsuta longe rostrata. - Herba guianensis; foliis Stratiotis aloidis, spicis primum cuneatis, fructiferis turbinatis, in paniculam rigide squarrosam dispositis.

Diplasia L. C. Richard in Pers. ench, I. 70. Nees in Linnaea $I X$. 288. Scirpus bromeliaefolius Rudge Guian, $t, 2 d$.

THBIBSE VIIC. FUIRENEAE Fenzl $m s c$. Spiculae hermaphroditae v. rarissime polygamae, multiflorae, rarius uni-triflorae. Pal eae di-tristiche v. multifariam imbricatae. Perig on i um nullum v. interdum setosum aut membranaceum. Stamina fertilia $2 \_3$. Discus plus minus distinctus, membranaceus, cyathiformis, truncatus v. lobatus, aut in staminodia distincta explicatus, stipitem caryopseos cingens $\mathbf{v}$. eidem adnatus, margine libero, basi fructus adpresso. Ovari u m s tylo bi-trifido, rarissime simplici, apice tridentato. Caryops is crustacea v. cartilaginea, trigona, disco excepta v. cincta. - Herbae habitu vario, ut plurimum capenses, paucis. simis inter tropicos totius orbis et in Americae borealis plaga calidiore indigenis; culmis foliatis $v$, aphyllis, simplicissimis v. ra. rissime ramosis, vaginis foliorum saepius ultra laminae originem in ligulam convolutam, hyalino - membranaceam, flaccidam, interdum elongatam productis, spiculis in spicam $v$. capilulum terminale, squamoso-aut herbaceo-bracteatum condensatis, v. ebracteatis solitariis, aut varie conferlis, rarissime fasciculato-paniculatis.

SUERTREOUS I. MELANCRANIDEAE Fenzl msc. S pi cula e paneiflorae, hermaphroditae v. polygamae, apice masculae, compressae. $\mathbf{P a l e a}$ e distiche $\mathbf{v}$. plurifariam imbricatae, in spicam undique scarioso - bracteatam, vel in eapitulum foliaceo - bracteatum dispositae, spiculis intra quamvis bracteam solitariis v, geminis.

DSD. TIelameranis $V A H L$. Spiculae hermaphroditae, bi-triflorae. Pal e a e plurifariam imbricatae, infimae dnae vacuae. Perigonin m nullum. St am in a 3 . Dis ens cyathiformis, trilobus. Ov a ri um st y lo bi-trifido, deciduo. C aryopsis crustacea, disco basi stipata. - Herbae capenses; culmis simplicibus, basi foliatis, spica terminali involucrata, scarioso-bracteata, spiculis intra bracteas solitariis.

Melaneranis Vahl enum. II. 239. Schrad. Analect. p. 49. $t, 2, f .4$. Nees in Linnaea $I X, 257 .-1$ y pole $\mathrm{p}$ is 
Palis, ex Lestiboud. apud Röm, et Schult, mant, IT.p.4. Nees in Linnaea VII. 521. excl. sp.

4) 1. Sielkmanuma NEES. Spiculae polygamae, superne masculae. $\mathrm{P}$ a $\mathrm{l}$ a e plurifariam imbricatae, omnes fertiles. Perig o n i um nullum. Stamina 3. Dise us cyathiformis, truncatus, margine denticulatus. Ovari um sty lo simpliei, apice bi-tridentato, deciduo. Cary o p s is cartilaginea, disco demum subsuberoso basi cincta. Herba capensis; culmo humili, foliisque longis, canaliculatis, rigidis, spiculis in capitulum foliaceobracteatum collectis, solituriis v. geminis, intra bracteas radiantes occultatis.

Siekman nia Nees in Linnaca IX. 292. X. 183. M efaneranis radiata Vahl Sehoenus radiatus binn.

932. Anospormun NEES. Spicnlae multiflorae, hermaphroditae. Pale a distiche imbricatae, omnes fertiles. Perigonium nullum. Stamina 3. Dis cus ntricularis, earyopseos stipitem constituens, apice evanescens. Ovarium sty lo simplici, apice integerrimo, deciduo. $\mathrm{Ca}$ ryopsis cartilaginea, disco spongioso basi stipata. - Herba in di ca, culmo triquetro, basi foliato, spiculis ovatis, incurvis, intra bracteam ovato-cordatam solitariis, in spicas imbricato-bracteatas in capitulum foliaceo-involucratum confertas dispositis.

A nospornm Nees in Edinb. now philosoph, Journ. July 1834. p. 262. in Linnaea $I X$. 287. C y per us monocephalus Roxb.

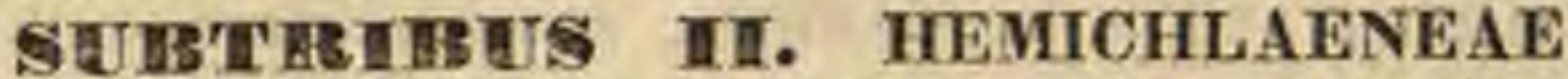
Fenzl msc. Spic nla e hermaphroditae, pauci-v. pluriflorae, compressae, pale is distiche imbricatis, terminales v. laterales, solitariae aut geminatae $\mathbf{v}$. ternatae, praeter involucrum commune bracteis nullis interstinctae.

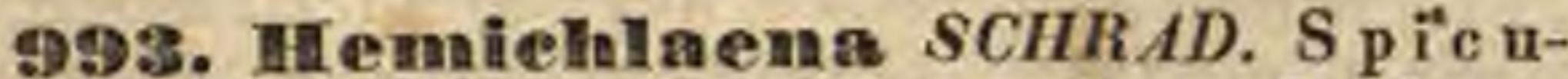
lae panci-multiflorae, hermaphroditae. Pal e a $e$ distiche imbricatae, carinatae, infimae vacuae. $P$ erigonium nullum. Stam ina 3 . Discus cyathiformis, limbo truncato, crenulato vel trilobo. Ovarium stylo trifido, deciduo. Caryopsis erustacea, disco stipata. - Herbae capenses; culmis ramosis, foliatis, foliis linearibus setaceis v. capillaceis, vaginis brevibus, fissis, spiculis terminalibus lateralibusque solitariis, pedunculatis, involucro nullo $v$. bracteaeformi suffultis.

a) HEMICHLAENA Schrad. S p i c u la e multiflorae. D is. e us trilobus. In yolu er u mullum.

$\mathrm{H}$ em iehla en a Sehrad, analect, 40, t, 3. f. 1 . $\mathrm{S}$ cho $\mathrm{e}-$ us e ricoides Steudel in Flora 1829, I. 137.

b) ACROLEPIS Schrad. Spieulae bi-triflorae. Discus truncatus, crenulatus. I avolue rum monophyllum.

A crolepis Schrad. analect. 42. $t .2 . f .5$. - H y p o. phialium Nees Advers, in Sieb, herb, cap, n, 95. in Linnaea $V I T, .530$.

994. Pleurachne SCHRAD. Spicula e pauciflorae, hermaphroditae. $P$ al e a e distiche imbricatae, carinatae, inferiores vaeuae. Perig on i m mullum. Stamina 3 . Dis cus cyathiformis, trilobus. Ovarinm st y lo trifido, deciduo v. basi persistente. Caryo psis crustacea, disco stipata, mutica v, mucronata. - Herbae capenses; culmis simplicibus, basi foliatis, vaginis la$x i s$, fissis, margine hyalinis, inferioribus superiores longiores arcte involventibus, spiculis spicatis, unilateralibus, sessilibus, remotiusculis, bracteatis.

Ple u r a ch ne Sehrad. analect. 47.t. 4. f.3. $\mathrm{S}$ choe $\mathrm{n}$ i sp. Vahl et Lam.

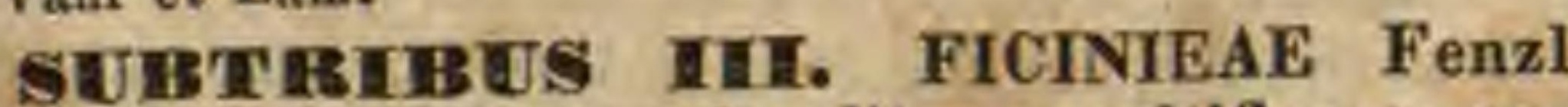
msc. Spiculae hermaphroditae, multiflorae, ra- rissime uniflorac, paleis undique imbrieatis. $\mathrm{Pe}$ rigonium trisetum, v. membranaceum triphyllum, rarissime nullum. $\mathrm{D}$ is $\mathrm{cus}$ inembranacens in staminodia distincta explicatus, v. cyathiformis lobatus aut dentatus, cum caryopsi deciduus.

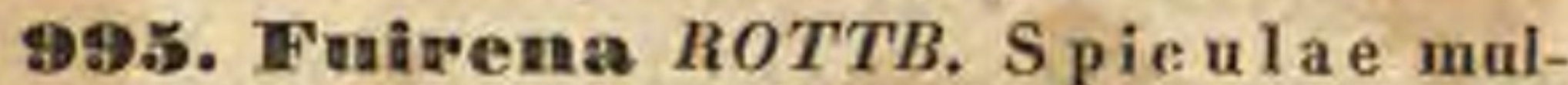
tiflorae, hermaphroditae. Pal e a e undique imbricatae, omnes fertiles, plerumque aristatae. Perigonii setae 3 , fugacissimae, parvae, restrorsum scabrae, interdum obsoletae. Stamina 3 . Discus stam inodiis 3 , spathulatis. Ovarinm stylo trifido. Caryopsis triquetra, staminodiis inclusa. - Herbae inter tropicos et in $A m e-$ rica boreali calidiore provenientes, habitu Scirpi sylvatici; culmis simplicibus foliatis $v$. rarius vaginatis, foliis nervoso-striatis, vaginis integris, ligula membranacea brevi instructis, spiculis subumbellatis, axillaribus terminalibusque, in radios inaequilongos squarroso-confertis.

Fuirena Rottboell gram. 70, t. 19. f. 3. R. Brown prodr. 220. Nees in Linnaea IX. 288. - Vaginaria L. C. Richard ex Pers. ench, $I$. $\% 0$. (perigonii setis manifestis.)

DS6. Vauthî̉ena A. RICH. Spicula e uniflorae, hermaphroditae. Pale a e undique imbricatae, vacuae, extrema solum fertilis. Perigoni um triphyllum, foliolis lanceolatis, hyalinis. Sta mina 3 . Dis cus cupulaeformis, sexlobns. Ovarium stylo trifido. Caryops is obsolete triquetra, disco stipata, styli basi sphacelato-acuminata. - Herba rigida, in Nova Zeelandia indigena ; culmis caespitosis foliisque semiteretibus, vaginis fissis, spiculis in spicas geminas, approximatas, spathaceo-involucratas dispositis.

Vant hi era A, Riehard Flor. Nov, Zeel. $t, 20$.

DS\% Fieinia SCHRAD. Spicula e multiflorae, hermaphroditae. Pale a e undique imbricatae, infima vacna. Perigoni um nullum. Stamina 3 . Dis e us cyathiformis lobatus, v. stipitiformis margine obsoleto, undnlato. Ovarium st y lo bi-trifido, cum basi deciduo. Cary o p s i s crustacea, trigona, diseo stipata. - Herbae capenses; culmis simplicibus, basi foliatis v. ra rius aphyllis, vaginis nunc truncatis, nunc laxis, in ligulam interdum praelongam, fissam, tenerrimum, convolutam productis, majorem culmi partem includentibus, spiculis terminalibus vel lateralibus, capitato-congestis, rarius solitariis, terminalibus, involucro diphyllo, rigido, erecto cinctis.

Fic in ia Schrad, analect. 43, $t, 2, f$. 3. Nees in Linnaca $I X$. 292. - S e boe a idfum Nees Linnaea $I X .201$ $X, 166$. (F. a ph y 11 a Nees in Endl. atakt. t. 12.) disci lo bis bidentatis. S choeni et S cirpi sp. Auet.

998. Fimbristylis VAHL. Spiculae multiflorae, hermaphroditae $\mathbf{P}$ a le a e undique imbrieatae, infima vacua. Perigoni nm nullum. St a mina 3. Discus membranaceus, integer, vix manifestus. Ovari um st y lo bi-trifido, basi bulboso - incrassata persistente. C a r y op 8 is crnstacea, nuda v. granulato - cehinulata, compressa v. trigona, diseo sphacelato, exiguo, stipata. Stirpes in tropicis totius orbis obviae, paucae usque ad $40^{\circ} \boldsymbol{L} . \boldsymbol{B}$. repertae; culmis enodibus, basi foliatis $v$. vaginatis, foliis angustis, saepius canaliculatis, marginibusque asperis, spiculis solitariis, capitatis $v$. in umbellam inaequaliter radiatam dispositis, involucro abbreviato, bracteaeformi v. foliaceo suffultis.

Fimbris $t$ y 1 is Vahl enum, II, 285. R. Brown prodr. 225. Nees in Linnaea $I X$. 290. Nees jun. Gen. pl. fasc. $I X$. t. 8. S cirpi s. p. Limn. et Auct. Host gram. MI, t. 6j3. Is o repi it is s. Kunth in Humb. et Banpl. nov. gen, t. 
68. - Trichelastylis Lestibond, et Nees part. - D i chelostylis. Palis, in Lestiboud. Cyperac. ex Röm. et Schult, mant. II. 2. - E chinoly $\mathrm{t}$ um Desv. in Journ. Bot. 1808. p. 20, et 176. t. 1. Nees in Linnaea IX, 289. (caryopsi echinulata.)

THRIBUS IX. SCIRPEAE Nees in Linnaea IX. 289. Spiculae hermaphroditae, pale is undique $v$. rarissime subdistiche imbricatis, omnibus conformibus, infimis sterilibus. Perig o n i u mullum v. setosum, s e t is capillaribus, retrorsum scabris, nunc laevissimis, post anthesim elongatis, rarius compressis, linearibus. D is c u s nullus. S ty lus bi - trifidus, basi saepius bulboso-incrassata, persistente. Caryopsis crustacea, bulbo styli plerumque coronata. - Stirpes culmis simplicibus, aphyllis v. foliatis, spiculis varie dispositis, saepius terminalibus solitariis, v. lateralibus conglobatis.

999. Isolepis $R$. BR. Sp icula e multiflorae, hermaphroditae. Pa le a e undique imbricatae, infimae vacuae. Perigonium nullum. Stamina 3, Ovarium stylo tri-v. rarissime bifido, cum basi simpliei $\mathbf{v}$. bulboso -incrassata decidno. Caryo psis crustacea, trigona, mutica v. compressa, mueronnlata. - Herbae potissimum in Capite bonae spei, Nova-Hollandia et India orientali, paucae in America et Eur ор а indigenae; culmis simplicibus v. caespitosis, basi foliatis, rhizomate unius speciei fluitante ramoso, spiculis terminalibus v. lateralibus, solitariis, aggregatis, capitatis, umbellatis $v$. cymosis, involucratis.

Is o lepis R. Brown prodr. 221.

a) ISOLEPIS Stylus bi-trifidus, basi haud artienlatus. Car y op s is compressa v. trigona.

Is ol epis R. Brown l. c. Link Hort.Berol. I. 285. Nees in Linnaea $r X$, 290. Schrad. analect. 14. t. 1. f. 1-7, Nees jun. Gen, pl. faso. IX, t.s. A. Richard Flor. Nov. Zeel. t, 18. 19. Hol os e h oenus Link Hort. Berol. $I$. 293. Nees jun. Gen, $p l$. fasc. IX, $t, 6$. El e o g it o n Link. $l$. c. Nees jun. op. cit. IX. $t$. 14. S c i r p i s p. Linn et Auct. Jaeq. Fl, austr. $t$. 148. Host. gram. IIT. $t, 62,64,65$. Rottboell gram. 17. $f .2 .4$.

b) TRICHELOSTYLIS. Stylus bi-trifidus, cum basi bulbosa deciduus.

Triehel osty Iis Lestiboud. Nees in Linnaea IX. 290. excl. sp. Dichostylis Palis. Nees op. cit. IX. 289. Nees jun. Gen. $p l$. fasc. IX. . 7. S $\mathrm{c}$ ir p i s p. Auct. Host gram. III. t. 69. C y p e ri s p. Linn. Rottboell gram, $t$. 14. f. 4. 5 .

10DO. Seirpus $L I N N$. S p ic u la e multiflorae, hermaphroditae. $\mathrm{P}$ a le a e undique $\mathrm{v}$. rarius subdistiche imbricatae, infimae vacuae. Perig o$\mathrm{n}$ ii s e tae capillares v. lineares, hispidae $v$. puberulae. Ovarium stylo bi-trifido, cum basi simplici v. bulbosa articulato. C a ry op s is crustacea, compressiuscula $\mathbf{v}$, trigona, basi styli coronata. - Herbae per totum orbem diffusae, ut plurimum aquaticae $v$. hygrobiae, culmis aphyllis $v$. foliatis, foliis planis, canaliculato-linearibus $v$. setaceis, spiculis solitariis terminalibus, spicatis $v$. glomeratis, sessilibus paniculatisque.

S c irpus Liun. gen. $n .67$. R. Brown prodr. 223.

a) PTEROLEPIS Schrad. P ale a e multifariam imbricatae. Perig onii s e ta e 2-6, membranaceae, lineares v. filiformes, compressae, pubeseentes v. fimbriato - ciliatae.

Pterolepis Schrad. in Göttinger Anseig. 1821. p. 2071. Analect, 30. M a la co e ha ete Nees in Linnaea $L X$. 292, Nees jun. Gen, $p l . f a s c .1 X, t .4$. H y menochaete Palis. in Lestiboud. Cyperac. Seluit. Mant. 1T. 2. Nees in Linnaea IX, 293. Elytrospermum C. A. Meyer in Mem. Academ. Petersb, PI, 1, p. 200, t. 2. S c Ir pi s p. Auct. Schrad. Flor, germ, t, $5, f, z$. b) SCIRPUS. Paleae multifariam imbrieatae. Perigo nii setae capillares, retrorsum hispidae.

a) Scirpus Palis. Caryopsis papillata aut mucronata. Spieula glomeratie, paniculatae. Scirpus Palis. ex trostiboud. Cyperac. l. c. Nees in Linnaea $I X$, 293. Nees jun. Gen. $p l$. fasc, $I X, t, 3$. Host gram, IIT, $t .61,66-69$. E. B. $t, 666.2321$.

B) B I y s m us Panz. Caryops is cuspidata. Spicnla e per spicam disticham dispositae. - B I y $\mathrm{s}$ us Pauzer ex $\mathrm{nöm}$. et Schult, mant. II. 41. Nees in Linnaea IX. 293. Nees jun. Gon, pl. fasc. $I X, t$. 9. S e hoeni sp. Linn. S eirpi s p. Auet. Host gram. III. t. 87. Fl. Dan. t. 1504, 1622. Sehrad. Flor. germ, t. 1. f. 3 .

$\gamma$ ) Baeothryon Nees. Caryopsis mueronata. Spiculae solitariae, terminales. Baeothryon Nees jun. Gen. $p l$. fasc, $I X$,, , 12, L i m n o e hlo Reichenb. Flor, excurs p. 78. Eleocharis s p. Link Nees.

c) ELEOCHARIS $\boldsymbol{n}$. Br. Palea e multifariam v. rarissime subdistiche imbricatae. Perigonif setae 8-9, iaterdum pauciores, fugaces, retrorsum hispl. dae. Caryopsis styli basi discreta, suberosa v. cartilaginea coronata.

Eleocharis R. Brown prodr. 224. Nees in tinnaea IX. 294. Link Hort, Berol, 1, 289, Nees jun. Gen. pl. fasc. IX. $t .11$. Eleogenus Nees in Linnaea $1 X$. 294. L i mnoehloae $\mathbf{s}$. Palis. Nees. Chaetoeyperus Nees in Linnaea IX. 289. S cirpidium Nees op. cit. p. 293. Nees jun. Gen. pl. fasc. IX. t. 13. S eirpi s p. Linn. Host gram. III. $t$. 55.56 .60 . Rottboell gram. $t$, 15. $f$. 2. 3 .

1001. Erioplaorum, LINN. S p i cu I a e multiflorae, hermaphroditae. Pa l e a e undique imbricatae, infimae vacuae. Perig on i u multisetum, setis laevissimis, demum increscentibns. Stamina 1_3. Ovarinm stylo filiformi, trifido. Cary opsis trigona, mueronulata, perigonii setis papposis condensatis inclusa. - Herbae in uliginosis Europae et Americae borealis obviae, in America australi extratropica rarissimae; culmis angulatis teretibusve, foliatis $v$. aphyllis, spiculis solitariis v. glomeratis terminalibus, $v$. umbellato paniculatis.

Eri o ph or u m Linn, gen, $n$, 68. FHost gram, $T$. $t$, 3840. IV, $t, 73,74$. Nees jun. Gen. pl. fasc. IX. t, 10. L i na. grost is Lam. Fl. fr.IIT.p.1164, - Tric ho h hor u m Pers. ench. I. 69. Nees in Linnaea $I X$, 298. S cirpi 8 p. Vall, Michx. (perigonii setis subsenis, brevibus.)

TREBUS $\mathbf{x}$. CYPEREAE Nees in Linnaea IX. 282. Spiculae hermaphroditae, multiflorae, rarius uni-triflorae, $p$ a le is distiche imbricatis, omnibus conformibus, marginibus plerumque per rhachillae angulos decurrentibus. Perigonium rarissime praesens, setosum, setis retrorsum hispidis. Di s cus nullus. St ylus bi-trifidus, rarissime basi bulbosus, deciduus. Caryo ps is crustacea, compressa, apice nuda v. mucronulata, rarissime cuspidata. - Herbae per tocum orbem dispersae, plurimae tropicae; caulibus simplicibus basi plerumque foliatis, rarius aphyllis, inflorescentia terminali, polymorpha, involucro polyphyllo plerumque cincta, rarissime spiculis cerminalibus solitariis.

1002. Duliehium RICH. Sp i u l a e multiflorae, hermaphroditae, infimae vacuae, conformes. Palea e distiche imbricatae, carinatae. Perigonii setae 6_8, retrorsum hispidae, persistentes. Stamina $2-3$. Ovarinm stylo bi-rarissime trifido, basi latiore. Cary ops is anceps, stylo cuspidata, - Herba boreali ame- 
ricana, culmo foliorum vaginis exserto, spiculis anguste linearibus, remote racemoso-spicatis.

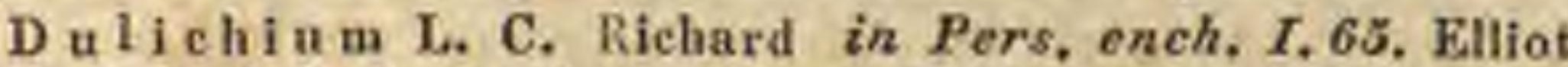
carol. t. 2. f. 3. Link Hort. Berol. I. 322. Nees in Linnaea IX. 283. P I eurant hus Rich, msc. Sehoeni et Cyperi sp. Linn. S e irpi s p. Miehx.

1003. Cygeras LINN. Spic u Ia e multiflorae, rarius uni-triflorae, hermaphroditae. $\mathbf{P}$ ale ae distiche imbricatae, infimae vacuae, interdum minores. Perigonium nullum. Stamina 2_3. Ovari um s tylo bi-trifido, deciduo, rarissime basi bulboso. C a y ops is crustacea, trigona v. compressa, obtusa v. mucronulata. Herbae cos mopolitae; culmis simplicibus aphyllis $v$. basi foliatis, vaginatis, inflorescentia varia, involucrata.

a) CXPERUS tinn, S picula e multiflorae. R ha c bilIa nuda v. ad angulos membranaceo-marginata. S tylas basi aequalis.

C y peri sp. Linn. Rottboell gram. $t .5-15$. Host gram. III. $t .70-75$. Jacy. ie rar. $t .295-299$. Cav, ic. $t, 204$. f. 1 . t.568. f. 2. Desf. Fl, atl. t.7-9. Sibthorp Fl. graec. t.4A48. Palis, Fl, owar, t, 20, Rudge guian. 1,19 . Sehrad. anaLect. t. 2. f. 2. Presl Reliq. Haenk. t, 32. A. Richard Ft. Nov. Zeel. t. 17. Nees jua. Gen. pl. fasc. IX. t. 1. - P ye r e u s Palis $F l$. owur. II. 48. $t, 86, f$. 2 . Nees in Linnaea IX. 283. Nees jun. gen, pl. fasc. IX. t. 2, Crperi sp. Rottboell gram, t.14. f.4, s. t.6.f.3. Sibthorp Fl. graec. $t$. 49. (stylo bificlo.) - To r re y a Raf, in Journ, Phys.LXXXIX. 105. (species diandrae stylo bifido.) - D is t i m us Raf. $l$. $c$. (species triandrae stylo bifido.) - Com os te $\mathrm{mum}$ Nees in Linnaea $I X$. 283. (species staminibus paleas superantibus.) - Papy rus Willd. in Abhandl, der Berl. Academ. 1812-1813. p.72. Enumerat. ed. II. 1.82. Thouars ex Humb. et Bonpl. nov, gen. et sp: I, 217. Nees in Linnaea $I X, 286$. (Cyrillo, Monographia Papyri. Neap, 1796. fol.)

b) KYLLINGIA Linn. Spiculae uni-triflorae. Pale a e 2 , infimae steriles, reliquis multo minores.

a) Mariscus Vahl. Spienlae bi-triflorae. Stylus trifidus. Maris c a s Vahl enum, II. 372. Kunth in Humb, et Bonpl. nov. Ben, et sp. t, 65-67. Turpin in Mem. Mus. V. t. 30. f. 19. Nees in Linnaea IX. 286. - A d u I p a Bose msc. K yllingla e sp. Jacq. ic, rar, $t, 300$. Rottboell gram, $t .4, f .2, \mathrm{~S} \mathrm{c} \mathrm{h}$ o en i 8 p. Jace. ic, rar. $t$. 10. S e ir p i sp. Linn. Gartn. $t$. 2. $f, 5$. - Courtoisia Nees in Edinb. new philosoph, Journ. Juli 1834. p. 261, videtur M a risc u s spiculis singulis bracteola distinctis, pressione mutua eidem contrariis, - O peti ol a Gärtn, I. 14. 2.2. f. 8, est umbella Marisei eujusdam, spiculis omnibus delapsis, rhachilla nodulis paleisque singulis adhaerentibus exasperata.

B) Kylliug ia Linn. Spicula e uni-subbiflorne. Stylus bifidus. K y Iling ia Linn. fil. suppl, p. 11, Rottboell gram. 1. 4. f. 4, 6. R. Brown prodr. 218. Palis. Fl. owar. t.8. f. 1, t.31. Nees in Linnaea $I X$. 286. Tryoe ephal on Forst gen. 65. S cirpi s p. Jacq. Hort. Vindob, t. 97.

c) ABILGAARDIA Vahl. S p i cula e multiflorae, paleis torsione rhachillae apice trifariam imbricatis. S t y $1 \mathrm{u} \mathrm{s}$ trifidus, basi pyramidato-bulbosa caryopsim coronans.

A b 11 g a a rdia Vahl enum, IT. 296. R. Brown prodr. 229. Palis Fl. owar, t. 86, $f, 1$. Nees in Linnaea IX, 289. exel, sp. Iria Richard ex Pers. ench, I. 65. C y peri s p. Linn. Rottboell gram. t.13. $f .3$. (Sloane gram, t. z9. f. 2.)

\section{GENERA PENITUS DUBIA v. DELENDA.}

a) MAPANIA Aubl. Spicula e uniflorae. Pale a e 6, ovatae acutae, dentatae, concavae. Perigoni um nullum. Stamina 3 , ovaril receptaculo inserta; antherae oblongae, tetragonae. Ovarium stylo longo, stigmatibus tribns. Fructus. . . . Herba in sylvis inundatis $G u i$ anae proveniens, culmis triangularibus aphyllis, basi dense vaginatis, spiculis capitalis, involucratis, involucro monophyllo trifoliolato, foliolis amplissimis, ovatis, acu. tis, glabris, nervoso-striatis.

M a pani a Aubl. guian. I. 47, t, 17 .

b) DLAPHORA Lour. Spi cae androgynae, spiculis nnifloris, infimis femineis, reliquis masculis. M a s c.
GI um a 3 , acutae, breves, intima aristata. Palea 2 , oblongae, muticae, glumis longiores. Stamina 10, filamentis subnullis, receptaculo paleolis, pa. leas aequantibus obsito insistentia, a $n$ the $r$ a e apice caudato acuto, diseolore. F em. G I uma e et paleae maris. Ovaritum trigonum, $s t i g m a t i b u s$ tribus, sessilibus, filiformibus. Ca ryopsis. ... - Herba cochinchinonsis agrestis; culmis triquetris, foliosis, folitis subulatis, asperis, basi pilosis, spicis paniculatis.

D la phor a Loureir. Fl, cochinch. ed. Willd, p. zos.

c) HAPLOSTEMUM Rafin. in Journ. Phys, LXXIX, 105. Scirpi sp. monandrae, stylo trifido.

d) DIPLARRHINUS Rafin. $l$. $c$. Scirpi sp. diandrae, stylo trifido.

e) DISTICHMUS Rafin. $l$. $c$. Scirpi sp. triandrae, stylo bifido.

f) NEMUM Palis, ex Desv, prodr. Fl, Ind, occid, 13. Squamae horizontales apice latiores, quadrifariam imbricatae. Styli duo. Senina minutissima, atro nitentia.

g) TETraria Palis. et CATAgyna Palis, ex Lestibond. Cyperac, apud. Röm, et Schult, mant. IT. 2. unice nobis nomine tenus cognita genera, alterum octandrum, alterum inter Elyaeas locandum.

\section{Classis XIII. Enantioblastae.}

\section{ENANTIOBLASTAE Mart, conspect. 8.}

Herbae annuae v.perennes. Caules simplices v. ramosi. Fo li a alterna, integerrima, basi vaginantia. Flones paleacei $\mathbf{v}$, perigoniati ; PRRIGonio regulari, biseriato, exteriore paleaceo, in t e ri o r e saepius corollino. Ovaria libera, plura, rarissime solitaria, interdum distincta, plerumque tria in unicum coalita; ov ul is solitariis v. indefinitis. Fru ctus capsularis v. nucamentaceus, uni-pluriloculares ; dehiscens. Skmixa orthotropa. Emвкxo parvus antitropus, in extrimitate seminis umbilico opposita, albumini applicatis.

\section{Ordo XIIV. Centrolepideae.}

CENTROLEPIDEAE Desv, in Annal, sc, nat. XIII. 36. Des vauxieae Bartl. ord. nat. 36. Lindl. Nixus p. 23. Introduct. edit. II. p. 386. Mart. conspect, n, 38, Re sti ac e a rum gene ra R. Brown.

Herbar a ustralasicae, pusillae, $\mathbf{C y -}$ peri v. Scirpi parvuli facie; radicibus fibrosis v. fasciculato-fibrosis. C n $1 \mathrm{~m} \mathrm{i}$ filiformes, indivisi, nudi. Fo lia radicalia, filiformi - setacea, basi vaginantia.

Spiculat hermaphroditae, distichae, uniflorae, v, terminales solitariae, uni-multiflorae. Gluma unica antica, v. duae suboppositae, rudes. P a le a nullae v. tenerae, unica v. binae, glumis parallelae.

Stamen unicum, anticum. Filam ent u m filiforme, simplex. Anther a introrsa, unilocularis, dorso supra basim affixa.

Ovarium nune unicum sessile, nunc plura axi communi diversa altitudine adnata, deorsum imbricata, unilocularia. Ovulum unicum, apici ovarii appensum, orthotropum, micropyle basim ovarii spectante. Styli filiformes simplices, basi inter se connati. Stigm a t a simplicia v. barbato - plumosa. 
Utriculi membranacei, latere longitudinaliter dehiscentes.

Semen orthotropum, pendulum. Testa coriacea, duriuscula. Albumen carnosum, copiosum.

Eмrвхо antitropus, lenticularis, in extremitate seminis umbilico opposita albumini applicitus, extremitate radiculari papillaeformi basim carpicam spectante.

Ordo perparvus, a $\mathbf{R}$ es tia c eis quibuscum seminis et embryonis fabrica convenit, floris structura simpliciore, perigonii defectu, stamine solitario, indefinito ovariorum numero, et insolita dispositione distinctus; hinc mediante A pheli a genere monogyno $\mathbf{C y p e -}$ race as, illinc per Gaimardi a m, quam ad ordinis calcem extra generum seriem collocamus, $R$ e s t i a $\mathbf{c}$ e a s attingens; mediante $P$ a e palan tho etiam Eriocaul on eis conterminus.

1004. A plinelia $R$. BR. S p i $c u l$ a e distichae, uniflorae. Gl uma antica, mucronata, $\mathrm{p}$ al e a m muticam, posticam includens. St a m en unicum, anticom. Ovarium unieum, sessile. St ylns filiformis; stigma simplex. UtricuI $\mathrm{ns}$ hine longitudinaliter dehiscens. S e m e n compressum. - Herba in Novae Hollandiae ora meridionali indigena, caespitosa; foliis radicalibus filiformibus, basi vaginantibus, scapis nudis indivisis, spicae terminalis glumis hispidis, acuminatis, inferioribus saepe sterilibus, longioribus.

Aphelia R. Brown prodr* 251. Desv, in Annal, sc. nat, XIII. 42. $t, 2, f, 1$.

1005. Alepyrum R, BR. S p icula terminalis, uni-panciflora. Gluma e 2, suboppositae, inferior elongata, superiorem breviorem amplectens. $\mathrm{Pal}$ a e nullae. $\mathrm{S} t \mathrm{am}$ en unicum, anticum. Ovaria 6_18, axi communi adnata, subsecunda. Styli simplices, basi connati; stigmat a barbato-plumosa. Utriculi hine longitudinaliter dehiscentes. S e m in a teretia. - Herbae easpitosae, minimae, in Novae Hollandiae ora meridionali indigenae; radicibus fasciculato-fibrosis, foliis radicalibus setaceis, basi semivaginantibus, scapis filiformibus indivisis, spicula solitaria terminatis. - Genus a sequente solo palearum defectu, et spiculis saepius unifloris diversum.

A le p y r um R. Brown prodr. 253.\&Desv, in Annal. sc nat, XIIT, 42, t. 2, f. 2 .

1006. Centrolepis LABILL. S p i c u la terminalis, multiflora. G1 u ma e 2, subaequales, approximato-alternae. $\mathrm{P}$ a l e a 2 , membranaceae, aequales. Stamen unicum, anticum. Ovaria 2_12, axi communi undique adnata v. subsecunda. Styli simplices, distincti v. baei inter se connati; stigmata barbata. Utriculi extrorsum longitudinaliter dehiscentes. S e m in a teretia.

Herbae caespitosae, in Nova Hollandia tropi$e a$, orientali et meridionali, nec non in insula Diemen indigenae; radicibus fasciculato-fibrosis, foliis radicalibus setaceis, basi semivaginantibus, scapis filiformibus, simplicissimis, spicula solitaria terminatis, glumis hispidis, muticis $v$. aristatis, flosculis interdum squamula minore interstinctis.
Centrolepis Labill. Nov. Holl. I. 7, t.1. Rudge in Linn. Transact, $X, t, 12$. Desv, in Annal, sc, nat. XIII. 42. t.2.f.3.4. Des va uxi a R. Brown prodr. 252, Guillemin ic. lithograph. t. 17. Mart. in N. A. N. C. XVII. t. I f.2.

\section{GENUS CENTROLEPIDEIS AFFINE.}

100\%. Gaimardia GAUDICH. SpienI a terminales, uni-biflorae. $\mathbf{G} \mathbf{l} \mathbf{u} \mathrm{m}$ a e 2 , inferior superiorem minorem amplectens. Palea nullae. Stam in a 2, glumis opposita, fil amenta filiformia, antherae uniloculares, medio dorso affixae. $O$ va ria 2 , stipitata, in unieum biloculare connata. Ovu Ia in loculis solitaria, apici appensa, orthotropa. Stig mat a 2 , sessilia, subulata, intus papillosa. Utriculi 2 , membranacei, faeiebus primum cohaerentes, mox soluti, dorso lon. gitudinaliter fissi. S e m en teres, pendulum, embryone antitropo, in extremitate umbilico opposita albumini carnoso applicito. - Herba pusilla, in insulis maclovianis indigena, glabra, caespitosa ; caulibus erectis, subfastigiatis, apice ramosis, dense foliosis, foliis imbricatis, subulato-triquetris, basi vaginantibus, ramis sparsis foliosis, spicula solitaria terminatis, spiculis unifloris, accedente interdum floris secundi ovario efoeto.

$\mathrm{G}$ a $\mathrm{m}$ ardia Gaudich, in Freyc. voy. 418, 4,30 .

\section{Drdo XIV. Restiacene.}

RESTIACEAE R. Brown. prodr, 243. excl. gen. Palis. ex Annal. se, nat. XIII. 41. Nees in Linnaea $V .627$. Martius in N. A. N. C. XIIT.

Herbae v. suffrutices, rhiz o mate squamato, repente. Caules ramosi, nodosi, v. scapiformes simplices. F oli a nunc omnia radicalia conferta, nunc caulina alterna, simplicia, integra, basi vaginantia, vagina hinc fissa, lamina saepius abortiva $\mathbf{v}$. anguste lineari.

Flores spicati, racemosi v. paniculati, b racte is scariosis interstincti, regulares, unisexuales $\mathbf{v}$. rarius hermaphroditi.

Perigonium glumaceum, quadri- v. plerumque sexglume, glumae biseriatae, exteriarum duae respectu bracteae laterales et una postica, interiores saepius minores v. majores, persistentes, interdum cum fructu increscentes.

Stamina 2_3, tot quot perigonii glumae interiores, iisque opposita. Fil a men ta filiformia libera, vel rarissime inter se connata. Antherae terminales, uniloculares, peltatae, rarius biloculares, didymae, utrinque bifidae.

Ovariom rarissime uniloculare, uniovulatum; plerumque bi-triloculare, e carpidiis loculorum numero conflatum, marginibus introflexis dissepimenta constituentibus. Ovula in loculis solitaria; anguli interioris apici appensa, orthotropa, micropyle basim carpicam spectante. Styli loculorum numero, carpidiis continui, liberi v. basi connati, intus stigmatosi, persistentes.

Fructus capsularis, trilocularis, loculicido dehiscens, v. nuc amentace us, abortu unilocularis, indehiscens. 
SEmiva in loculis solitaria, apici cavitatis appensa. 'T'esta coriacea dura, umbilico crassiusculo nudo, v. strophiolato. Alb u men copiosum, carnosum.

Емвгуо antitropus, lenticularis, in extremitate seminis umbilico opposita albumini applicitus, extremitate radiculari in fructu infera.

Restuaceae in Capite Bona e spei et Mad a g scaria, necnon in Nova Holland i a intra et extra tropicos obviae, habitu peculiari Cy peraceas aemulantes, perigonii conformatione a Centrolepideis et Xyrid e is nullo negotio distinguuntur, ab E ri oc a ulon e is tum habitu, tum inflorescentia et perigonio rudiori diversae. A $\mathbf{J}$ un ceis staminum numero et eorundem ante interiora perigonii foliola situ, antherarum in plerisque fabrica, embryone denique antitropo, albumini applicito, nec ab eodem incluso differunt.

1008. Heptocarpus $R, B R$. Flores dioici. Perigonium sexglume, aequale. M a s c. Stamina 3 ; antherae unilocnlares, peltatae. Fem. Ovarium uniloculare. Stylus simplex; stigmata 2_3. Utriculus monospermus, basi styli coronatus. - Herbae aphyllae, in Nova Hollandia tam tropica quam meridionali provenientes; culmis ut plurimum simplicissimis, vaginatis, vaginis hinc fissis, floribus fasciculatis, fasciculis subspicatis.

Leptocarpus R. Brown prodr. 230. Restionis sp. Forst. S ehoenod um ten ax femina Labill. Nov. Holl. $t .229$.

1009. Loxoearya $R, B R$, Flores dioiei. Masc.... Fem. Perigonium quadriglume, bibracteolatum. Ovarium uniloculare. Stylus subulatus, simplex; st igma indivisum. Folliculus monospermus, margine convexo dehiscens. - Herba in Novae Hollandiae ora meridionali vegelans; culmis aphyllis, vaginatis, pubescentibus, basi tereti simplicibus, superne paniculatis, ramis flexuosis, filiformibus, vaginis hinc fissis, altero margine equitantibus, floribus femineis ramulos terminanlibus, bracteolis mucronatis, pubescentibus, perigoniis muticis.

L o x o c a ry a R. Brown prodr. 249 .

1010. Chaetanthus $R, B R$. F $10 \mathrm{r}$ es dioici. Masc. ....F Fem. Perigonium sexglume, glu mis tribus interioribns minimis, setaceis. Ovarinm uniloculare. Stylus simplex; $8 \mathrm{ti} \mathrm{gm}$ a indivisum. $\mathrm{Nu} \times$ monosperma, perigonio parum aucto cineta. - Herba in Novae Hollandiae ora meridionali indigena, habitu Lepto. earpi,

Cha etanthus R. Brown prodr. 251.

1011. Hypolaena $R$. BR. Flores dioici. Perigonium sexglume, aequale. Mase. St amina 3 ; a ntherae uniloculares, peltatae. Fem. Ovarium.... Stylus bi-tripartitus, deciduus. Nux ossea, calva, monosperma, basi perigonio cincta. - Herbae in Novae Hollandiae ora meridionali indigenae, Restionis habitu; culmis ramosis, floribus masculis amentaceis, femineis in spica imbricata terminalibus, solitariis.

H ур о I e na R. Browu prodr. 251. - C ue allifera Nees in Lindl, introduct. edit. $I I$, p. 451, p la n ta c a pen- Is, fortassis ob bractean. spicae femineae peuultimam flo. riferam, terminalem longe unguiculatam, cucullatim convolutam, olim distinguenda.

1012. Willemowia THUNB, F lores dioici. Masc. Perigoninm sexglume, glu$\mathrm{mis}$ tribus interioribus minoribus. S tamina $\mathbf{3}$; anth er a e uniloculares, peltatae. Fem. Perigonium disco lobato, demum increscente osseo impositum. Ovarium...... Stylus bi-trifidus, deciduus. Nux ossea, monosperma, perigonio et disco cincta. - Herbae capense 8, habitu et inflorescentia varia, non satis notae.

Willden o wia Thunb. in $1 \mathrm{ct}$. Holm. 1790. p, 28.

a) WILLDENOWIA Nees. S picae utriusque sexus uniflorae, bracteis inferioribus vacuis, terminall sola fertili.

Willd enow ia Thunb, l, c. t.2. f. 2.3. Nees in Linnaea $V$. 664 . - Nematanthus Nees in Linnaea $V$. 661.

b) HYPODISCUS Nees. Spicae masculae multiflorae, bracteis plerisque fertilibus, femineae uniflorae, bracteis infimis vacuis, terminali solum fertili. Dise us crenatus v, repandus. laevis.

H y podiseus Nees ex Lindl, introduct, edit. II. p. 450.

c) LEUCOPLOEUS Nees. Spica e mas cat a multiflorae, bracteis omnibus fertilibns, fem in a e uniflo. rae, bracteis inferioribus vacuis v. Alores abortivos includentibus, terminali solum fertili. D is eus spongioso - echinulatus.

Leucoploeus Nees ex Lindl, introduct. edit. II. p. 450 .

d) MESANTHUS Nees. S picae masculae multiflo. rae, bracteis omoibus fertilibus, femineat pauciflorae, bracteis infimis vacuis, mediis fertilibus, summis flores abortivos includentibus. D is cus acetabuliformis, laevis.

Mesanthus Nees ex Lindl. introduct. edit. II. p. 451. (Genus fortassis ob stylos duos distinctos, epigynio umbraculiformi, ut in Cyperaceis quibusdam impositos, olim distia. guendum.)

1013. Amtlagelaortus NEES. F lores dioici. Masc. Perigonium infundibuliforme, sexpartitum, lariniis aequilongis, exterioribus angustioribus (!) Stam ina 3 ; antherac uniloculares, peltatae. F e m. .. Herbae c apenses, vix notae; culmis aphyllis, filiformibus, fasciculatim ramosis, floribus masoulis subracemosis. p. 451 .

Anthochortus Nees ex Lindl, introduct, edit. $\Pi$.

1014. Cenntocanyuma NEES. F I ores dioiei, Perigonium sexglume, glumis tribus interioribus minoribns. Stamina 3 ; antherae uniloeulares, peltatae. Fem. Ovarium Sty li 2, rigidi, intus spongioso-stigmatosi, demum divaricati. Nux coriacea, stylis cornuta, bilocnlaris, mono-disperma, perigonio eineta.

Herba c a pensis, non satis nota; culmis simplicibus aphyllis, spicis masculis thyrsoideis, femineis in apice culmi spicatim approximatis, bracteis inferioribus sterilibus, terminali solum fertili. p. 481 .

Ceratocaryum Nees ex Lindl. introduct. edit. II,

10 15. Thepidamthas NEES. Flores dioici. Masc. Perigonium triglume, bi-tribracteolatum. St a mina 3 , glumis opposita ; anthera e biloculares, versatiles. Fem. . Genus capense, vix notum, summopere dubium; culmis simplicissimis, aphyllis, floribus masculis terminalibus, spicatis.

\section{Lepidanthus Nees in Linnaea $V .665$.}

1016. Amarthria $R$. BR F Iotes dioici. Perigonium sexglume, subaequale. Masc. S tam in a 3 ; filamenta libera, antherae bilnculares, utrinque bifidae. Ov a rium trilocnlare. Styli 3 ; stigmata simplicia. Capsula trilocularis, triloba, trisperma. - Herbae perennes, in Novae Hollandiae ora meridionali indigenae; 
culmis compressis, simplicibus $v$. rarius polifero-ramosis, simplicibus enodibus, vaginis nullis, foliis distichis verticalibus, equitantibus, spicis terminalibus compositis, ramis bractea spathacea, cadaca subtensis, vel simplicibus floribusve solitariis, capsula in quibusdam nucamentacea vix dehiscente.

A narthria R. Brown prodr, 248.

101\%. Iysimia $R$. BR. Flores dioici. Perigoninm sexglume, aequale. Stam in a 3 ; filamenta in tubum connata; antherae biloculares, utrinque bifidae. Fem. Ovari um trilo. culare. Sty Ius tripartitus. Capsula trilocularis, ftriloba, trisperma, angulis salientibus dehiscens._Herbae in Novae Hollandiae ora meridionali indigenae; rhizomate squamato, repente, culmis simplicibus, teretibus, aphyllis, vaginatis, ad nodos solubilibus, spica terminali e fasciculis approximatis, singulis spatha vaginaeformi subtensis, femineis nonnunquam solitariis, unifloris.

II Lyginia R. Brown prodr. 248. - Schoenodum teu a $x$ m a s Labill. Nov. Holl. t.229.

1018. Lepyroulia $R$. BR. F lores dioiei v. hermaphroditi. Perigoninm sexglume, subaequale, uni-bibracteolatum. Ma sc. Stamina 3 ; antherae uniloculares, peltatae. Ovarii rudimentum. $\quad \mathrm{F}$ e $\mathrm{m}$. $O$ v a $\mathbf{r}$ i m triloculare. St y li 3. C a p s n l a trilocularis, triloba, trisperma, angulis salientibus dehiseens. - Herbae perennes, in Nova Hollandiae ora orientali et meridionali provenientes; culmis simplicibus, aphyllis, vaginatis, spicis compositis, rariusve simplicibus, floribus tunc hermaphroditis.

Le p y r odia R. Brown prodr. 247. Palis. in Annal.sc. nat. Xrit. t.3. f. 3 .

1019. Thamnoelhontars BERG. F1ores diviei. Perigonium sexglume, glumis duabus exterioribus compresso-carinatis, carina alatis. Stamina 3 ; antherae nniloculares, peltatae. Fem. Ovari um triloculare. Stylus indivisus; stig ma simplex. Nux monosperma, perigonio bialato inclusa. - Herbae capenses; culmis vaginatis, aphyltis, floribus spicatis, spicis racemosis fasciculatisve.

Thamnochortu s Berg. Fl. cap. 353, $t, 5$. R. Brown prodr. 244. Restionis sp. Auct.

1020. Elegia THUNB. Flores dioici. Masc. Perigonium sexglume, glumis tribus interioribus majoribus, St amina 3 ; antherae uniloenlares, peltatae. Fem. Perigonium sexglume, aequale. Ovariu m trilocnlare. StyI $\mathrm{s}$ tripartitus, lobis intus stigmatosis. Caps ula trilocularis, triloba, trisperma, angulis salientibus dehiscens. - Herbae capenses; culmis simplicibus $v$, ramosis, aphyllis, vaginatis, vaginis basi solubilibus, floribus paniculatis $v$. racemosis spicatisque, spathis laxis rumulos subtendentibus, floribus ebracteolatis.

Eleg i a Thunb. Fl. cap. p. 81. Liun. mant, 292. $\mathrm{C}$ h o ndrop ot a 1 u $m$ Rottb. Progr. 1772, p. 12. Descript. ot ic, $t, 3$. f. 2,3. Restionis s p. Anct.

10e t. Restio LINN. Flores dioici $v$. hermaphroditi. Perigoni n m quadri-sexglume, aequale. Stamina $2-3$; antherae uniloculares, peltatae. Ovarium bi-triloculare. Stylus bitripartitus, lobis intus stigmatosis. Caps a la bitrilocularis, bi-triloba, di-trisperma, angulis salientíbus dehiscens. - Herbae in Capite bonae spei, Madagascaria et Nova Hollandia obviae; culmis junceis, aphyllis, vaginatis, vaginis hinc fissis, simplicibus $v$, ramosis, floribus in amenta spicata $v$. paniculata collectis.

Restio Linn. gen, n, 1331. expl. ep. R. Brown prodr. 244. Labill. Nov, Holl. t, 226. 297. C a I o rop h u s Labill. op. cit. t.228. C a u $\mathrm{n}$ omo is Palis, in Annal, sc. nat. XIII, 43. t.3. f. 1. Calops is Palis. l. c. t.3. f.2.

\section{Drdo XIVI. Eriocauloneae.}

ERIOCAULONEAE L. C. Richard in Annal. du Mus. XVI. 59. Kunth in Humb. et Bonpl. nov. Gen. et sp. I. 261. Desv. in Annal. se, nat, XIII, 35. Mart, in N. A. N. C, XVII. 1. ss. Lindl, introduct, edit. $I I, p, 387$.

Herbae perennes, paludosae, acaules, scapigerae $v$, rarius caulescentes, interdum suffrutescentes. Folia linearia, acuta, basi semivaginantia, carnosula, interdum lacunosa; radicalia conferta, caulina dum adsunt alterna.

Flores minimi, densissime capitati, unisexuales, plerumque in eodem capitulo monoici, masculi in centro v. ambitu, rarius femineis per paria oppositi, interdum dioici; singuli brevissime stipitati, unibracteati, ebracteolati, pilis paleisve stipati, perigonio biseriato, exteriore rudiore, interiore subcorollino membranaceo, saepe discolore.

Flores masculi. Perigonium exterius diphyllum, foliolis respectu bracteae lateralibus, v. triphyllum, foliolis duobus lateralibus, tertio postico. Perigon i u in t er i u s tubulosum, subcampanulatum, limbo hifido, v. tridentato aut trifido, dentibus $v$. laciniis cum perigonii exteriori foliolis alternantibus, aestivatione imbricatis, faequalibus v. lacinia antica majore.

Stauiva tubo perigonii interioris inserta, duplici laciniarum ejusdem numero, majora iisdem opposita, alterna minora, saepe castrata v. rudimentaria. Fil a m enta subulata, aestivatione introrsum flexa. Antherae introrsae, biloculares, ovatae v. subglobosae, loculis oppositis, longitudinaliter dehiscentibus. Polli in is granula simplicia, rima simplici aperta.

Ovariorum rudimenta minima, glandulaeformia.

Flores feminei. Perigoniun utrumque triphyllum, i n t e r i o r is foliola plerumque teneriora, latiora, interdum in fasciculos pilorum soluta, nonnunquam basi angustata distincta, apice cohaerentia v. connata.

Ovarium liberum, bi-triloculare, e carpidiis 2_3 conflatum, accedente interdum carpidiorum serie secunda efoeta, fertili superposita. Ovula in loculis solitaria, angulo interiori prope apicem affixa, orthotropa. Stylus terminalis, brevissimus, simplex. Stig$m$ at a loculorum numero, indivisa $v$, bifida.

Capsona bi-trilocularis, stylo snperata, perigonio persistente cincta, loculicido dehiscens.

Sвmina in loculis solitaria, angulo interiori affixa, teretiuscula. T esta coriacea, nitida, pilorum tenuissimorum seriebus lon- 
gitudinalibus dense cristata. Albumen copiosum, farinaceum.

Emвryo antitropus, in extremitate seminis umbilico e diametro opposita albumini applicitus, subglobosus v. trochlearis, extremitate radiculari basim carpicam spectante.

Eriocauloneae hinc Res ti a c is, a quibus inflorescentia, perigonii conformatione et antheris bilocularibus facile distinguuntur, illinc $X_{y}$ rideis, quae ovulorum seminumque numero, et perigonio interiori magis adhuc elaborato differunt, proximae, per $P$ a e p a l a nthum ad Centrolepideas, alias satis diversas accedunt.

Specierum duae tertiae Amerieae tropic a e continentem incolunt, reliquarum pars dimidia in Nova Hollandia tropica indigena est, in India orientali tropica, Madagascaria et Sechellis admodum rarae. Am eric a bore al is usque ad $44^{\circ}$ Lat. Bor. specierum paullo feracior est, quarum una etiam in insula $\mathrm{Skye}$, Hiberniae adsita, reperta fuit.

102\%. Eripeaulon GRONOV. F I o res dioici, masculi in centro, feminei in ambitu capituli. Mase. Perigoninm exterins di-triphyllum, interins tubulosum, limbo bilobo v. tridentato. S $\mathrm{t}$ a $\mathrm{m}$ in a perigonii interioris tubo inserta, simplici v. duplici loborum ejusdem namero $2-6$, onnia fertilia, longiora iisdem opposita. Fem. Perigonium utrumqne di-triphyllum. Ovari nm bi-triloculare. Stig mata 2_6. C a p s u l a bi-trilocularis, locnlieida, - Herbae annuae $v$, perennes, acaules $v$, interdum caulescentes aut suffrutescentes, inter tropicos Asiae, Americae et imprimis Novae Hollandiae copiosae, in America boreali rarae, in $\boldsymbol{E} u$ rop a solum unica species in Hibernia reperta, paludosae; foliis radicalibus rosulatis, linearibus, acutis, carnosulis, caulinis nullis $v$, alternis, basi vaginantibus, capitulis scapos pedunculosve terminantibus solitariis v. rarissime aggregato-capitatis, globosis, floribus bracteatis, bracteis extimis saepe sterilibus, involucrantibus.

E r i o c a ul on Linn. gén, n. 100. Juss. gen. 44. Gärtn. II, 14. R. Brown prodr. 253. Bongard in Mem. Academ. Petersb. VI. 1, 601. ss. Mart. in N. A.N. C. XVII, 8.

a) NASMYTHIA Huds. Masc. Perigoninm exterius diphyllum, interius tubulosun, bilobum. S $t$ amina 2-4. F e m. P e ri g o n $\mathrm{i} u \mathrm{~m}$ utrumque diphyllum. Ovarium biloeulare. Stigmata 2 , simplicia. Species in Americaboreali et tropica, in Nova Hollandia et Europa repertae.

$\mathrm{N}$ a $8 \mathrm{~m}$ y th i a Huds. Fl. scot. Mart, in N. A.N. . XVIT. 13. Randalia Petiv. Qazophyl. t, 53. Palis. in Annal, sc. nat. XIIT, $t, 5, f, 2$. S $\mathrm{p}$ h a e r o $\mathrm{ch} \mathrm{l}$ o a Palis, op. cit, $t, \delta, f$. 1. (Bongard. Eriocaul, t. 4.)

b) ERIocaulon Mart, Masc. Perigoniam exteri us triphyllum, interius tubulosum, tridentatum v. trifidum. $\mathrm{S}$ t a mi a a 6 , vel rarissime 3 . Fem. Perig o n $\mathrm{fum}$ utrumque triphyllum. Ovari um triloeulare. Stigmata 3 , simplicia v. bifida. - Species atustralasicae ot indicae, paucae americanae.

Eriocaulon Mart, in N. A. N. $C . X V I 5.13$, t.1. f. 2. ot in Wall. pl, as, rar, t, 248, 249. Kanth in Humb.et Bonpl. nov. gen, et sp. t,69,70. Bongard Eriocaul. t. 14-17,19.20. 24, 22. 25. 27, - Le u co cephal a Roxb. Flor.Ind, ed.II, 3. p. 612. c) Paepalanthus Mart. Mas c. Perigonium exterius triphyllum, interius tubulosum, tridentatum. S $t$ amina 3 , et interdum ovariorum rudimen. ta. Fem. Perigonium utrunque triphyllum. 0 vari u m triloeulare. Stig mat a 3 , simplicia v. bifida, cum carpidiis tribus abortivis superpositis alternantia. - Americanaetropicae.

Paepalanthus Mart, in N. A. N. C.XVII. 13, t, 1.2. (Bongard Eriocaul, t, 1-3,5-13, 18, 21, 23. 26.)

1023. Tomina $A U B L$. Flores monoici masculi et feminei in eodem capitulo per paria oppositi. Ma sc. Perigoni um exterius triphyllum, interius tubulosnm, tridentatum. Stam in a 6 , perigonii interioris tubo inserta, 3 fertilia ejusdem dentibus opposita, totidem sterilibus alterna. F e m. Perigoninm exterius triphyllnm, interio$r$ is loco fascieuli tres pilorum. Ovarium triloculare. Stylus elongatus; $s \mathrm{tigmat}$ a 3 . Ca psula trilocularis, loculicida. - Herba aquatica, in America tropica indigena; caulibus fluitantibus, dense foliatis, foliis lanceolatis, patentibus, capitulis axillaribus breviter pedicellatis, folio brevioribus.

To n in a Aubl, guian, $I X$. 856. t.330. Palis, in Annal. sc. nat. XIII. t.5. f. 4. (mal.) Mart, in N. . N. $C$. XVI. 15. $t .4$. H y p h y d $\mathrm{r}$ a Schreb. gen, $p l, n, 1484$. E rio ca uII s p. Rottboell pl, surin. $7, t, 1, f .1$.

1024. Fhilodiee MART. Flor es monoici, masculi in ambitu, feminei in centro capituli. Masc. Perigonium exterins triphyllnm, i n t e $r$ i a $s$ tubulosum, limbi trifidi lacinia antica longiore. Stamina 3 , perigonii interioris tubo inserta, duo ejusdem laciniis minoribus opposita fertilia; tertium anticum sterile. Fem. Perigonium utrumque triphyllum, interio$\mathrm{ri}$ s foliola spathulata, unguibus liberis, Iaminis connatis. Ovari um triloculare. Stigmata 3 , bipartita. Capsula trilecnlaris, loculieida. Herba brasiliensis, caulescens; foliis linearibus flaccidis, pedunculis in apice caulis fasciculatis.

Philodice Mart. in N. A. N. C. XVII. 15. t, 3, -? S y m ph a chne Palis, in Annal. sc, nat, XIII. t. J.f.3.

\section{Ordo XLVII. Xyridene.}

XXRIDEAE Kunth in Humb. et Bonpl, nov, gen, et sp.T. 255. Agardh Aphorism, 158, Desv, in Annal. sc. nat. XIII. 49. Bartl. ord, nat, 38. Mart. consp. p. 8. XYRIDACEAE Lindl, introduct, edit, $I I, p, 288$.

Herbae perennes, paludosae, scapigerae, radicibus fibrosis. Fo $1 \mathrm{i}$ a radicalia ensiformia v. filiformia, basibus dilatatis, seariosis, equitantia. S c a p i radicales simplicissimi, basi vaginati, nudi vel medio bibracteolati. C a p i t u I a terminalia, solitaria, scariosobracteata, bracteis densissime imbricatis, unifloris, inferioribus nonnunquam vacuis, dissimilibus.

Flores hermaphroditi, regulares. Prrigosiom duplex, utrumque triphyllum, exteri us glumaceum, foliolis duobus respectu bracteae lateralibus, naviculari - concavis, persistentibus, tertium majus et tenerius anticum, perigonium interius calyptratim obtegens v. involvens, mox caducum, includentibus. Perigonii interioris foliola tria, petaloidea, unguiculata, lamina lata, ovata, unguibus ima basi vel juxta totam longitndinem in corollam tubulosam v. hypocrateriformem connata. 
Stamiva 3_6, perigonii interioris (corollae) tubo inserta, tria ejusdem lobis opposita fertilia, totidem sterilia isdem alterna, penicillata, quandoque deficientia. Fil a ment a filiformia, libera, Anther ae extrorsae, terminales, biloculares, loculi appositi, longitudinaliter dehiscentes.

Ovaniva sessile, liberum, e carpidiis tribus conflatum, carpidiorum marginibus placentiferis nunc simpliciter applicitis uniloculare, nunc iisdem basi v. juxta totam longitudinem in dissepimenta introflexis incomplete $\mathbf{v}$. complete triloculare. OvuI a plurima, sessilia, v. e funiculis longiusculis erecta, orthotropa, micropyle ovarii verticem v. funiculis demum nonnihil introrsum flexis ejusdem centrum spectantibus. Stylus terminalis, plusminus profunde trifidus. St ig mata bi-trimultiloba.

Capsura unilocularis, ad suturas dehiscens, v. trilocularis, loculicida; interdum basi trilocularis, valvulis a dissepimentis solutis fenestrata, apice uniloculari operculata.

Semrxa plurima, angulata, sessilia; v. subglobosa, e funiculis erecta; test a coriacea dura, costato-striata. A lb um en copiosum, earnosum.

Eмвв уо lenticularis, minimus, antitropus, in extremitate seminis umbilico e diametro opposita albumini applicitus.

Xxaneae Irideas habitu nonnihil aemulantes, in Asia tropica, Nova Hollandia intra et extra tropicos, potissimum autem in America tropica et boreali calidiore indigenae, hinc Eriocanlone is proximae, illine perigonii interioris natura plane corvllina, et ovnlorum numero ad $\mathrm{Com}$ melynaceas accedunt, ab utroque ordine antheris posticis, a priore seminum pluralitate, a posteriore habitu, inforescentia et perigonio exteriori glumaceo, nee calycino foliaceo, facillime distinguendae.

1025. Xyris LINN. Perigonii exteri o ris glumacei foliola 3 , anticum calyptraeforme cadueum, lateralia navienlaria, minora, persistentia. Perigonium interins corollinam, trifidum, lohis in ungnem attenuatis, lamina lata. Stamina 6 , tria fertilia, perigonii interioris unguibus inserta, tria alterna sterilia, penicillata, tubo continua. Ovarium uniloculare, v. basi incomplete triloculare; ovula in placentis parietalibus e funieulis ereeta. Stylus trifidus; 8 tig m a ta indivisa v, multifida, obtusa. Ca p 8 ula teretiuscula, unilocularis, ad suturas dehiscens, v. incomplete trilocularis, basi fenestrata. S e min a globosa, plurima. - Herbae paludosae; foliis radicalibus ensiformilius v. filiformibus, basi dilatata equilantilus, scapis nudis capitulo solitario terminatis, fioribus flavis. Specierum duae tertiae amenicanae, reliquae paucis asiatiois exceptis australasicae.

$\mathrm{X}$ y $\mathrm{r}$ is s Linn. gen, n. 6i, Juss. gen. p. 4i. R. Browa prodr, 111. Mart. in Wallich pl, as, rar. III. 27 . a) EUXYRIS. Ca p s ula unilocularis, placeatis parietalibus, ad suturas dehiseens.

$\mathrm{X}_{\mathrm{y}} \mathrm{ri}$ i s $\mathrm{s}$. Girtn. I. 52, $t$ 15. Willd, phytogr. 1, t, 1 . Rudge in Linn. Transact. X. $t .15$.

b) POMATOXXRIS. Capsula placentis basi unitis incomplete triloeularis, basi feuestrata, apice operculata.

X. operculat a Labill. Nov. Holl. t.10. Bot. Mag. t. 1158.

1025. Abolbodla HUMB. Perigoni exterioris glumacei foliolum anticum convolutum, cadtueum, lateralia navieularia, minora, persistentia. Perigonium interiug corollinum, hypocrateriforme, tubo filiformi, limbi patentis trilobi lobis nudis vel cristato-barbatis. Sta min a 3 , perigonii interioris tubo inserta, ejusdem lobis opposita. Ovarium triloculare; ovula in loenlorum angulo interiori sessilia, ereeta. Stylus trifidus; st ig mata simplieia v. bi-triloba. C a p8 ula triquetra, trilocularis, loculicida, columella seminifera tandem libera. Semina angulata, pauca. - Herbae in montanis Americae tropicae paludicolae; foliis radicalibus gramineis, distichis, scapis nudis $v$. medio bibracteolatis, capitulo solitario terminatis, floribus caeruleis.

$\mathrm{A}$ b $01 \mathrm{~b}$ o d a Humb. et Bonpl. plant, aequinoct. II. 110. t.114. Kunth nov. gen, et sp. 1. 256. C h I oe rum Willd. ex Liak Jahrb. III. 7i.

\section{GENUS XYRIDEIS AFFINE.}

102\%. Mayaea $A U B L$. P e r ig o n i $\mathrm{n} \mathrm{m}$ hexaphyllum, exterius calycinum, interius corollinum, persistens. St a min a 3 , perigonii exterioris foliolis opposita, persistentia; fil a m enta filiformia; an thera e introrsae, uniloculares, vertice rima dehiscentes. Ovarium uniloculare, placentis parietalibus tribus, pauciovulatis. St ylus terminalis, simplex, stigma obtusum. Ca p s uI a nilocularis, trivalvis, valvis medio seminiferis. Sem in a globosa, reticulato-scrobiculata. E mbr yo antitropus, subfungiformis, infra papillam umbilico oppositam albumini carnoso applicitus. Herbae pusillae, musciformes, in paludibus Americae tropicae et borealis calidioris indigenae; caulibus prostratis, vage ramosis, dense foliosis, foliis ternatim verticillatis, lineari-lanceolatis, sessilibus, pedunculis axillaribus, solitariis, unifloris, basi vaginatis, floribus violaceis.

M a y a c a Aubl. guian, 1. 42, $t, 15$. Juss. gen. 15. Eliot. carol. 1 . 50. Sehott et Eudl, Melet. p. 23, $\iota, 3$. B i a s Ii a Vaadelli ex Römer seript. 72. t.6. f.2. S y e n a Sehreb. gen. n. 88. Miehx. El, bor. amer. 1, 73. Nattal gen, 1, 28.

\section{Ordo XIVIHI. Commelynaceat.}

EPHEMERAR Batsch. Tab. affin, 125. pro part, COMB. LINEAE R. Browa prodr. 268. Rich. in Humb. ot Bonpl. nov. gen. et sp. 1, 2ss, COMELINACEAE Bart. ord. nat. 39. Lindl, introduct, ed, II, p.334.

Hgrbae annuae v. perennes, radice fibrosa v. tuberosa. Caule s teretes, nodosi, simplices v. ramosi, erecti v. procumbentes. Folia alterna, simplicía, integra, nervosa, plana v. canaliculata, basi vaginantia, vaginis integris.

Flores hermaphroditi v. ovariorum abortu polygami, regulares $v$. subirregulares, flavi $v$. caerulei, solitarii, fasciculati, umbellati v. subracemosi, bracteati, interdum involucris spathaeformibus, cucullatis v. complicattis, mono-diphyllis inclusi. 
Perigonirm liberum, duplex, utrumque triphyllum, ext e ri us calycinum, foliolis distinctis v. basi cohaerentibus, persistentibus; interius corollinum, caducum v. marcescens, interdum demum carnoso-incrassatum; foliolis sessilibus $v$. unguiculatis, distinctis aut basi in tubum brevem connatis, uno saepius difformi, nano v. abortiente.

Stamina 6, hypogyna, perigonii foliolis opposita, v. ternatim approximata, rarissime abortu pauciora $3 \_5$, nonnulla saepius castrata, decidua $\mathbf{v}$. rarissime persistentia. Fil amenta filiformia, libera, plerumque barbata, apice in connectivum dilatata. Antherae introrsae, biloculares, loculis plerumque connectivum marginantibus, discretis, rarius eidem antice adnatis, parallelis, subcontiguis, semper longitudinaliter dehiscentibus, nunc omnes fertiles, nunc plures castratae, difformes.

Ovarium sessile, liberum, e carpidiis tribus conflatum, carpidiorum marginibus in dissepimenta introflexis triloculare. $\mathrm{O} \mathrm{vula}$ in loculorum angulo centrali in placentis nerviformibus biseriata, pauca v. rarissime plurima, orthotropa, peltata, v. bina basifixa collateralia, v. alterum erectum, alterum pendulum. St ylus terminalis simplex; $\mathrm{sti} g \mathrm{~m}$ a indivisum, v. dilatatum, obsolete trilobum, interdum excavatum.

Capsura saepius perigonio stipata, v. eodem baccante indusiata, tri - vel abortu bilocularis, loculicido bi-trivalvis, valvis medio septiferis, rarissime indehiscens bacciformis, pericarpio fragili.

Sexina in loculis pauca, interdum abort bina v. solitaria, ovata, compressa, v, angulata aut quadrata, peltata v. basifixa. T e sta membranacea, duriuscula, reticnlato-scrobiculata v. rugosa, albumini arcte adhaerens, umbili co ventrali impresso v. basilari lato, interdum arillo carnoso, placentae continuo velato, pa pill a e mbry otega hine opposita, plus minus elevata.

Embryo antitropus, in foveola al bu $\mathrm{mi}$ n is umbilico e diametro opposita, infra papillam supra testam prominulam, eidem applicitus, trochlearis, extremitate $r$ ad iculari plerumque centrifuga, rarius verticem v. basim earpicam spectante.

Commelyacear in he $\mathrm{m}$ is $\mathrm{ph}$ ae $\mathrm{ra}$ o $\mathrm{r} \mathrm{i}$ entali inter Cancrum et $35^{\circ} \mathrm{L}$. A. inclusae, in hemisphaera oceidentali et Asiae orientalis insulis usque $40^{\circ} \mathrm{L}$. B. ascendunt, inter ipsos circulos tropicos copiosissimae.

Vis peculiaris inesse videtur fure nulla; diureticam in Trades cantiae specie lau dant Brasiliae medici populares. Plurimae ornamenti causa in hortis coluntur.
$X$ y $r$ i d e i s proxime affines et mediante Ma y a ca omnino conterminae sunt. Genera omnia denuo in examen revocanda, staminum situs acuratius in plerisque definiendus, involucrorum pondus perpendendum.

1025. Conmelyma DILLEN. Perigonii exterioris foliola 3 , extus calycina, persistentia; interiora $3 \mathrm{v}, 2$, petaloillea, unguiculata, decidua, tertio saepius dissimili v. abortivo. St a mina 6, fil amenta glabra, in connes:tivum reniforme dilatata, a ntherae loculis divaricatis, connectivum marginantibus, 3 (vel 2_4) dissimiles, cassae. Ovari um triloculare, locnlis pauciovulatis. S tylus filiformis, simplex; stigma indivisum. C a p s n la trilocularis, loculicido-trivalvis, valvis medio septiferis, $\mathrm{S}$ e $\mathrm{m}$ in a in loeulis 80litaria v. bina, raro plura, subquadrata. - Herbae in America tropica et boreali, in India orientali et Nova Hollandia indigenae, diffusae; foliis ovatis $v$. lanceolatis, floribus fasciculatis involucratis, $v$, nudis vage paniculatis.

C o m m e 1 y n a Dillen. Hort, ellh, 93. Linn. gen, n, 68.

a) Commely A $n$, Brown. I a vol u eram monophylIum, conduplicatum v. eucullatam, baseos marginibus connatum. Pedanculus apice fasciculatim multiflorus, floribus hermaphroditis, altero exteriore unifloro maseulo saepius stipatus.

Co m mel y n a R. Brown prodr, 269. Gärtn. $T, 49, t, 13$. f.1, 2, 3, excl. sp. Sclımid, ic. t. 30, 41. 49. Jacq. ic. $t, 293.294$. Ruiz et Prv. Fl, per, t, 279, 273 . Retlont. Liliac, t, 108, 206. 207. 359, 367, 390. Andr. Reposit. 4, 399. Bot. Mag. t. 1431. 2744. Hedwig i a Medik. in Act. Acad. palat. Le e hea Loureir. cochinch. $I, 76$, An an th op ns Raf. Fl. Ludo, 21.

b) ANEILEMA $\mathrm{R}, \mathrm{Br}$. I n v I u $\mathrm{c}$ u m nullum. Inflores. eentia vage paniculata.

A neflema k. Brown prodr. 27o. Palis. owar, $t, 38$. 87. Hook. exot, A. t. 204. Bot. Reg. t. 659, A p hil a x Salisb. $\mathrm{C}$ o m mel y a a e 8 . Palis. $\mathrm{Fl}$. owar. $4.93,104$.

OBSERVATio. Commelya $a$ a $\mathrm{m}$ b $i \mathrm{~g}$ u a Palis. Fl. owar, t.15. el. Reichenbach consp. 59. Pallsotl observationibus freto, genus a Commelyua distiactum, quod $\mathrm{P}$ al is o ta e no. mine salutat, eui perigonium Commelynae, stamina 3 , perigonii laciniis basi inserta, unum majus, ovario adhaerens, flamento crasso, anthera lala crassa, cantherifor $m i$, subdidyma, medio affixa, alia duo tenuia, gracilio$\mathrm{ra}$, filamentis filiformibius, antheris lanceolatis, acutis, angustis, selas plurimae, breviores, basi perigonit inter stamina insertae, ovarium Commelynae ot habilas Anei. lematis.

1029). Pollia THUNB. Perigonii exte $r i o r$ is foliola 3 , calycina, persistentia; interio ra 3 , petaloidea, sessilia, marcescentia. Stamin a 6 , filament a glabra, in connectivum dilatata, antherae loenlis parallelis connectivo antice adnatis, 3 ylanduliformes, cassae, $O$ v a r i $u$ m triloenlare, loculis multiovulatis. Sty lus subulatns, simplex; $\mathrm{sti} g \mathrm{ma}$ indivisum. B a ce a trilocularis, exsucea, polysperma. Sem in a angulata, Herbae in $A$ sia tropica indigenae, Commelynarum exinvolucratorum habitu, non satis notae.

Polli a Thunb, nov. gen, $I$. 12. Ic. $t$. 25. A cli is i a E. Meyer in Relig. Haenk. II. 138, t.25. Lamprocarpus Blum. in Schult, syst. VIT. 1615. 1726,

1039. Callisia LOEFL. Perig on i exterio ris foliola 3 , calyeina, persistentiá; inte$r$ io ra 3 , petaloidea, sessilia, persistentia. Stamina 3 , perigonii exterioris foliolis opposita, filam en ta barbata, apice in laminam subrotundam dilatata, ant herae globosae, loenlis parallelis, filamenti laminae antice adnatis, nonnullae sacpias eassae. Ovarium triloenlare, Ovula... Styl us capillaris, simplex; stigmat a 3 , penicellata. Caps u 1 a bi-trilocularis, loculicida. S e mina in loculis solitaria, excentrice peltata, subyuadrata. 


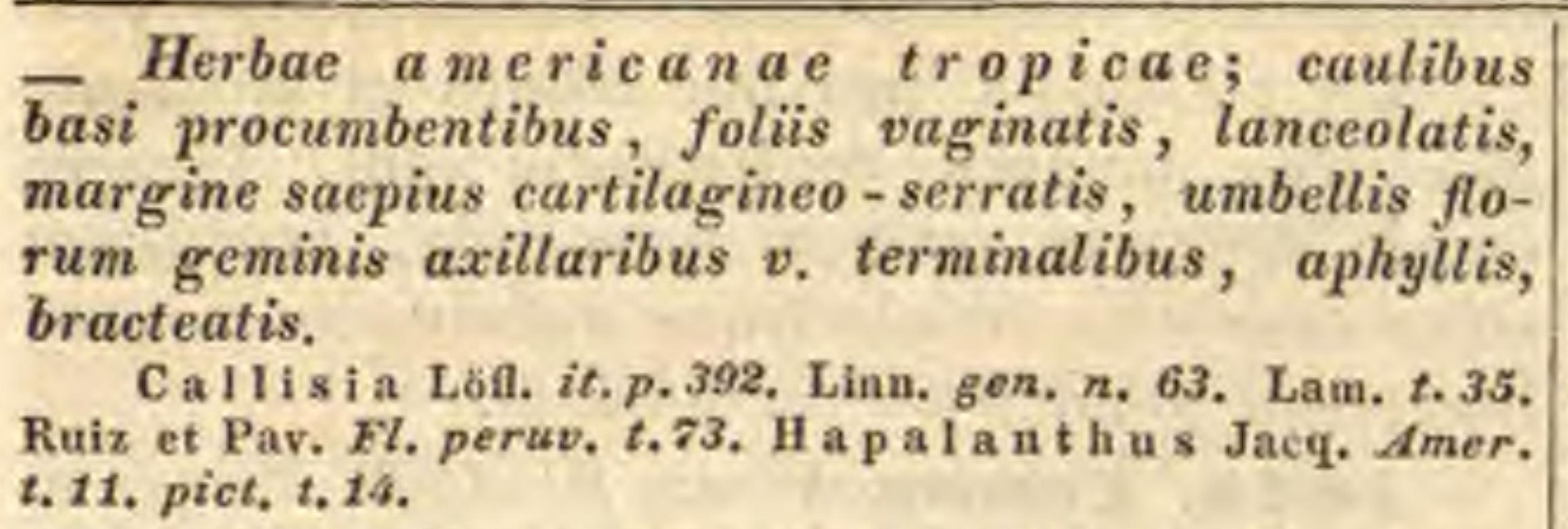

1031. Tradeseantia LINN. P e rigonii exterioris foliola 3 , calyeina, persistentia, demum conniventia; interiora 3 , petaloidea, sessilia, persistentia. Stamina 6 ; filamenta barbata v. rarius glabra, apice in connectivum dilatata, antherae loculis parallelis, connectivum marginantibus, omnes fertiles. Ovarium triloculare, loculis multiovulatis. Stylus filiformis, glaber; stig ma obtusum, trigonum v. suborbiculato - dilatatum, obsolete trilobum. Capsula bi-trilocularis, loculicido-trivalvis, valvis medio septiferis. S emina pauca, subquadrata, peltata. Herbae in America tropica et boreali calidiore obviae, in Asia tropica et Africa australi extratropica rariores, habitu Commelynae; floribus terminalibus $v$, axillaribus, umbellatis $v$. racemosis, nudis $v$, involucratis.

T r a d e s c a n ti a Linn. gen. $n .398$, Gärtn. $I, 51, t, 15$. Jaeq. amer. $t$. 64, pict. $t, 95,1 c$, rar, $t, 354,355$. Cav, ic, $t$ 74,75. Smith ic, pict. t.10. Vent. cels. t, 24. Redont, Liliac. t. 93. 95. 168. Humb, et Bonpl. nov. gen, et sp. t, 672. 673 . Roxb. Corom, t,109, Link et 0tto ic. select, t.7. Martius Amoen. monac. t.7. Bot. Mag. t. 105. 1192. 1340, 1597.1598 . 2330. 2935. Bot. Reg. t.482, 1055. E p h e m e r u m Tournef. instit. t. 193.

1032. Cyamotis DON. Perigonii exterio ris foliola 3 , calyeina, basi connata, persistentia, demum conniventia; in teriora 3 , petaloidea, unguiculata, unguibus in tubum connata, caduca. St a m in a 6 , perigonii interioris tubo inserta; fil amenta barbata, apice in connectivum reniforme dilatata, anthe rae loculis divaricatis, connectivum marginantibus, omnes fertiles. O vari um triloculare, o vula in locnlis bina, insertione collateralia, alterum erectum, alterum pendulum. Stylus apice incrassatus, pilosus; stigm a excavatum. C a p s u la trilocularis, loculicido-trivalvis, valvis medio septiferis. Semin a in Ioculis bina, v. abortu solitaria, angnlata, subpeltata. - Herbae annuae $v$. perennes, pubescentes, $v$. lanatae, rarius glabrae, in Asia tropica indigenae; caulibus e basi procumbente erectis, foliis ovato-lanceolatis, vaginis laxis, inflorescentia spathaceo-bracteata.

Cyanotis Don nep. 45. Zygomenes Salisb. in Hortic. Transact. I. 271 . Trades cantiae 8 p. Linn. Jacq. Hort. vind, t, 137. Roxb. corom, t. f07, 108, Bot. Mag. t. 1435,

1033. Campelia RICH. Perigonii exterioris foliola 3 , calyeina, basi connata, persistentia, demnm conniventia; in terior a $S$, petaloidea, sessilia, persistentia, demum baceantia. Stamina 6 ; fil amenta barbata, apice in connectivum subhorizontale dilatata, a $\mathrm{n} \mathbf{t h} \mathrm{e}$ a e loculis divaricatis, connectivi crura marginantibus, omnes fertiles. O vari u m triloculare, loculis panciovulatis. Stylus glaber, declinatus; s ti gma subcapitatum, obsolete trilobum. Ca ps u la perigonio baccante indusiata, trilocularis, trivalvis, valvis medio septiferis. Se min a pauea, ovata, compressa, peltata. - Herbae in Americ a et Asia tropica indigenae; caule erecto, foliis lato-lanceolatis, subtus pubescentibus, vaginis laxis, pedunculis oppositifolits, medio geniculatis, umbellis congestis, bracteis geminis, ovatis, involucrantibus.

C a mpeli a Rieh, analys. $d u$ fr. 46 . Nees et Mart. in $N$. A. N, C.XI, t, 2. Z a n a i a Plum, gen. 38. Sterub, in Flora
1822. p. 161. non Linn. C o melin a $\mathrm{Z}$ a no n ia Linn. Gârtn. t. 15. $f .1$. 4, Redout. Liliac. $t, 198$,

1034. Dielnorisanestra $M I K$. Perigonii exterioris foliola 3 , calycina, persistentia, supremum interdum crassius; interi or a 3 , petaloidea, sessilia, persistentia, demum subbaccantia, anticum paullo minus. St a m in a 6 (v.interdum 5) ternatim approximata; fil amenta glabra, apice aequalia, antherae loculis parallelis, connectivo antice adnatis, omnes fertiles. Ovarium triloculare, loculis multiovulatis. Stylus filiformis, glaber; stigma simplex. Ca psula perigonio subbaccante indusiata, trilocularis, trivalvis, valvis medio septiferis. Semina in loculis pauca, angulata, peltata, umbilico lato, carnoso. - Herbae brasilienses; foliis lanceolatis, acuminatis, saepius vaginisque villosis, racemis terminalibus $v$, subradicalibus, bracteatis, floribus nonnullis ovarii abortu masculis.

D i chori s a d r a Mikan delect, t, 3, Nees et Mart. in N. A. N. C.XI.13, t. 2. Bot. Mag. t. 1721. Bot. Reg, t. 682 .

1035. Cartonema $R$. BR. Perigonii exterioris foliola 3 , calycina, persistentia; interiora 3 , petaloidea, persistentia. $S$ ta m in a 6 , persistentia; fil am enta imberbia, seabriuseula, anthera basi fixae, locnlis parallelis, omnes fertiles. Ovari u m triloculare, loculis pauciovalatis. Stylus filiformis, persistens; s $t$ igm a barbatum. Ca p s la trilocularis, trivalvis valvis medio septiferis. Semina in loculis subbina, angulata, peltata. - Herba perennis, in Nova Hollandia tropica indigena, pubescens; pilis laxis, facie fere Philydri, radice infra fibras tuberosa, caule simplici v. parum ramoso, foliato, folïs linearibus, elongatis, amplexicaulibus, spica multiflora, terminali, floribus sessilibus, bibracteatis, bractea altera subtendente, altera interiore laterali, utraque foliacea persistente.

Carton ema R. Brown prodr. 271. Ferd. Bauer illustr. pl. Nov. Holl, $t, 7$.

1036. Forrestia $A . R I C H$. Perigonii e $x$ t e r i o r is foliola 3 , subcolorata, persistentia, interiora 3 , petaloidea, spathulata, caducissima. Stamina 6 , hypogyna; fil a menta filiformia, glabra, a $\mathbf{n} \mathbf{h} \mathrm{e} \mathbf{r} \mathrm{e}$, loculis lateralibus, suboppositis. 0 v a ri $\mathbf{~ m ~ t r i l o c u l a r e . ~}$ Ovu la in loculis bina, superposita. Stylus terminalis simplex; stig ma obsolete trilobum. Capsu la trilocularis, trivalvis, valvis medio septiferis. Semina in loculis 2 , excentrice peltata, testa rugosa. A 1 b u m e $n$ subeartilagineum. Emb r $0 . . .-$ Herba bipedalis, simplex, in sylvis Novae Guinea nuper reperta; foliis elliptico lanceolatis, glabris, basi attenuatis vaginantibus, vaginis integris hispido-lanuginosis caulem velantibus, floribus rubris, supra vaginam exsertis dense capitatis, hermaphroditis $v$. abortu unisexualibus, bracteis interstinctis.

Forrestia A. Richard Sert. Astrolab. p.1. $t, 1$.

\section{Classis XIV. Helobiae.}

Herbae perennes v, rarissime annuae, aquaticae, scapigerae. Folia radicalia, petiolis basi vaginantibus, lamina integerrima, cordato-ovata v. saepius abortiva. Flores regulares. Perigonium hexamerum, biseriatum, interius saepe corollinum, rarius perigonium nulIum. Ovaria plura libera, distincta v. subdi- 
stincta, unilocularia, uni-multiovulata. OvvLA anatropa v. campylotropa. Carpidia follicularia, distincta, mono-polysperma. Еивкхо exalbuminosus, homotropus.

\section{Drdo XLIX. Alismaceate.}

ALISMACEAE R. Brown prodr. 342. Bartl. ord, nat.73. ALISMACEAE et JUNCAGINEAE L. C. Richard in Mem, Mus. I. 365. Lindley introduct, edit. II. p.355 et 367 .

Herbae perennes v. rarissime annuae, paludosae, scapigerae, $\mathrm{rhiz}$ o m te repente carnoso. Folia radicalia congesta, petiol is basi vaginantibus, la $\mathrm{m}$ in a lata, plana, integerrima, nervosa, nervis curvis apice convergentibus, venis ramosis conjunctis, interdum abortiva, petiolis phyllodia linearia constituentibus.

Fuores hermaphroditi v, monoici, regulares, pedicellati, racemosi, interdum verticillati, v. rarius paniculati; interdum sessiles, spicati, perigonio tune nullo.

Perigoniua (rarissime nullum, genitalibus tunc sola bractea stipatis) plerumque hexaphyllum, regulare, foli olis tribus interioribus altius insertis, vel petaloideis, aestivatione imbricatis $\mathbf{v}$. involutis, caducis, exterioribus saepius foliaceis et persistentibus.

Stamina hypogyna v. perigonii foliolis basi inserta, iisdem numero aequalia, dupla, tripla v. multipla. Filament a filiformia, libera. Antherae introrsae v, extrorsae, biloculares, basi v. medio dorso affixae, loculis parallelis, contiguis $v$. connectivum marginantibus, longitudinaliter dehiscentibus.

Ovaria 3, 6, v. plurima, rarissime solitaria, verticillata v. capitatim congesta, nunc omnino distincta, nunc ventre aut basi inter se v. etiam cum axi centrali cohaerentia, unilocularia, interdum in ovarium pluriloculare connata, loculis alternis tunc saepius cassis. $0 \mathrm{vula}$ in loculis solitaria, basilaria, nune bina collateralia, v. suturae ventrali affixa superposita, alterum erectum, alterum horizontale, anatropa v. campylotropa. S t yli ovariorum numero, iisdem continui, interdum brevissimi, subnulli. Stigmata simplicia v. interdum barbato-plumosa.

Carpidia ovariorum numero, plus minus distincta, coriacea, demum inter se et ab axi soluta, sutura ventrali aperta, interdum basi firmius inter se cohaerentia, supra eandem circumscisse soluta, unilocularia.

Semrina in loculis solitaria, erecta, v. bina, alterum erectum, alterum horizontale, recta v. uncinatim incurva. T e s t a coriacea, in anatropis rhaphe ab umbilico ad chala$\mathbf{z}$ a $\mathbf{m}$ apicalem protensa percursa, in campylotropis transversim rugosa.
Emвryo exalbuminosus, homotropus, rectus v. curvatus, extremitate radiculari umbilico proxima, in fructu infera v. centripeta.

Alismaceae in tropicis temperatisque totius orbis obviae, nullibi copiosae, aquas fluentes stagnantesque, nonnulla prata subsalsa incolunt.

Herba plurium acrida, vires problematicae. Rhizoma nonnullarum edule. Alis ma Plantago olim in Hydrophobia commendatum.

SUBORTD I. JUNCAGINEAE L.C.Richard in Mem. Mus. I. 365. Perig on i um utrumque conforme, interdum nullum. Antherae extrorsae. $0 \mathrm{v} u l a$ solitaria v. bina collateralia, anatropa. Embryo rectus. Foliorum lamina abortiva.

1 103\%. Tillaea $H U M B$, et BONPL. F 10 res monoici. Masc. spicati, singuli unibracteati, Perigonium 0. Stamen 1, filamentum brevissimum; anthera extrorsa, basi fixa. Feminei alii spicati, singuli unibracteati, alii solitarii in foliorum axillis ebracteati. Perigonin mullum. Ovaria unilocularia, spicata vertice nuda, stylo brevi; axillaria apice bi-quadridentata, sty lo elongato; stig ma capitatum. Ov u$1 \mathrm{um}$ solitarium, basilare, anatropum. Ca ry o ps is membranacea. Semen erectum. Embryo exalbuminosns, orthotropus, rądicula infera. Herba acaulis, in paludosis $r$ egni Novogranatens $i$ s reperla; foliis radicalibus confertis, teretibus, apice subulatis, vaginantibus, glabris, spicis subglobosis scapos simplicissimos terminantibus, solitariis, floribus femineis solitariis, in axillis foliorum exteriorum sessilibus.

I. i I a e a Humb, et Bonpl. pl. aequinoct. $T$, 222. 2,63 . Nov. gen, et sp. I. 24t.

1038. Tetroncium WILLD. Flores dioici. Perigonium hexaphyllum, foliolis subcoloratis, ovato-concavis, tribus interioribus altius insertis. Stam in a 6 , foliolornm perigonii basi inserta, filamenta brevissima, antherae extrorsae, medio dorso affixae. Fem. Perigonium maris. Stamina 0 . Orarium. ... Styli 4 , subulati; stigm at a simplicia. Capsula quadrilocularis, stylis persistentibus mneronata. Se$\mathrm{m}$ in a in loeulis solitaria. ... Herba mag ellanica, tripollicaris; foliis lineari-ensiformibus, margine membranaceo-vaginantibus, scapo tereti, spica densa, floribus minutis, capsulis reflexo-adpressis. - Genus imperfecte descriptum, mihi incognitum, floribus dioicis et fructu tetramero, vix aliis nobis a sequente diversum.

Tetrone i u Willd, in Berl. Magaz, IT. 17. C a tha nthes Riehard in Mem, du Mus, 1 . 365. Trigloehin magellanicum Vahl.

1039. Trigloclain LINN. Flores hermaplıroditi. Perigoni um hexaphyllum, deciduum, foliolis subcoloratis, ovato-concavis, tribus interioribus altius insertis, rarissime deficientibus. Stam in a 6 , foliolorum perigonii basi inserta, filamenta brevissima; antherae extrorsae, medio dorso alfixae. Ovari um sexloculare, loculis alternis interdum sterilibus. Ovula in $10-$ culis solitaria, basilaria, anatropa. Styli 3_6, brevissimi, v. subnulli; stigmat a adnata, plumosa. Capsula subelavata tri-sexlocularis, car- 
p idia axi filiformi adnata (alterna interdum sterilia, septiformia), a basi soluta, sulco ventrali demum aperta. $\mathrm{S}$ e $\mathrm{m}$ in a in locnlis solitaria, eresta, test a coriacea. Emb ry o exalbuminosus, orthotropus, radicula infera. - Herbae scapigerae, in paludosis, nonnullae in subsalsis zona $\mathrm{e}$ temperatae et frigidae utriusque hemisphaerae obviae; foliis gramineis, planis $v$. teretiusculis, floribus spicatis, parvis.

Trig l o e h in Linn. gen, n. 453. Juss. gen, 47. Gärtn. I1.26. t. 84. Schkubr t. 102. Lam. t. 114. F. dan, t. 307, E. B. t. 225. Jaeq. ic. rar. t. 45t, Bot. Mag. t, 1445. Hook. Flor. Lond, icc. Nees jun. gen, pl, fasc. $I T . t$. 8 . J u n e a go Tournef. inst, $t, 142$, - Tris tem on Rafin, in Monthl. Ma. gaz. 1819. (species trigynae).-De germinatioue fr, Mirbel in Annal, du Mus. XVI. t, 16, et L. C. Richard Ibid. XVII. 231. t.5. $f .24$.

1040. Selneurelozeria LINN, Flores hermaphroditi. Perigonium sexpartitum, persistens, subcoloratum, laciniis tribus interioribus angustioribns. St am in a 6 , hypogyna; fil amenta brevia, anth e ra extrorsae, basi fixae, connectivo excurrente apiculatae. $O$ v aria 3 , ventre leviter cohaerentia, unilocularia, Ovula 2, collateralia, erecta, anatropa. Stig mat a papillosa, vertici extrorsum adnata. C a rpidia 3 , distincta patentia, unilocularia, sutura ventrali dehiscentia, mono-disperma. S emina erecta, te st a coriacea crassa. Embry o exalbuminosus, orthotropus, radicula infra, - Herba in paludosis turfosis Europae et Americae borealioris parce proveniens; caule erecto, flexuoso, foliis gramineis basi late vaginantibus, apice poro instructis, floribus parvis, racemosis.

$\mathrm{S}$ e h e $u$ e h z e r i a Linn, gen, $n$. 452. Juss, gen. 47. Schkuhr t, 100. Lam. t. 268. Fl. dan, t, 76. E. B. t, 1801, Nees jua. gen, pl, fasc, $I I, t, 9$.

SUBORED IT. ALISMEAE L. C. Richard $l$. c. $\quad \mathrm{P}$ e $\mathrm{r} \mathrm{i}$ g o $\mathrm{n}$ i i foliola interiora petaloidea. Antherae in hermaphroditis introrsae. Ov ula solitaria, v. bina superposita, campylotropa, E m b r y o uncinatus. Foliorum lamina nervosa.

1041. Alisma JUSS. F 1 o r e s hermaphroditi. Perigonii exterioris foliola 3 , ealyeina, persistentia ; interiora 3 , petaloidea, aestivatione involuta, decidua. $\mathrm{S}$ t a min a $6 \_9-12$, rarins plura, hypogyna; fi l a menta filiformia, a $n$ therae introrsae, dorso affixae. $0 \mathrm{va} r \mathrm{i}$ a plurima, disco depressiusculo imposita, verticillata $v$, subcapitata, distineta, unilocularia, uniovulata. Ovulum basilare, eampylotropum. Stylus ventralis brevissimus; 8 ti $\mathrm{g}$ m a terminale obtusum. Carpidia plurima, verticillata v. subeapitata, distincta, coriacea, evalvia, monosperma. S e m e n basilare uncinato-complieatum, testa membranacea, tenui. E mbry o exalbuminosus, homotropus, radieula infera._Herbae aquaticae $v$. paludosae, scapigerae, in zona te mperata hemisphaerii borealis vulgares, inter tropicos novi continentis (carpidius subcapitato-congestis insignes) paullo frequentiores; radicibus fibrosis, foliis ovalibus subcordatisve, nunc lamina abortiva linearibus, nervosis; floribus albis v. rubescentibus, saepe vertieillato-paniculatis.

A 1 i s w a Limn. gen, $n$. 460, excl. sp. Juss. gen. 46. Gärtn. $I T, 22, t, 84$, Fl, dan, $t, 129,561.1573$. Cav, ic, $t, 55$. Redont, Liliao, t, 268, 285. Hook. Fl, Lond, t.28. Reichenb. ic. $t .63$. Nees Jun. gen. pl. fasc. $V I, t, 18 .-\mathrm{E} \mathrm{c}$ hi inodo. $r$ u s L. C. Richard in Mem, du Mus. I, 36s, (sp, polyandrae.) - De germinatione cfr. Tittmaun in Regensb. Denkschrift. II. 111, et Mirbel in Annal, du Mus. XYI, t. 18.
1042. Sagittaria $L I N N$. Flores monoici. Masc. Perigonii exterioris foliola 3 , calycina, persistentia; interiora 3 , petaloidea, aestivatione imbricata, decidua. St am in a plurima; fil amenta filiformia, an $t h e r a e$ extrorsae, basi fixae. Fem. Perig on ium maris. Ovari a plurima, supra receptaculum hemisphaericum eapitato - congesta, distincta, unilocularia, uniovulata. Ov n I n m basilare, campylotropum. Sty1 u s ventralis brevissimus; $s t \mathrm{igma}$ terminale, obtusum. Carpidia plurima, capitato-eongesta, distincta, membranacea, evalvia, monosperma. S em en basilare, uncinato - complieatum, testa membranacea, tenuissima. E m b ry o exalbuminosus, homotropus, radicula infera. - Herbae aquaticae, saepius scapigerae, in temperatis hemisphaeraeborealis, imprimis Americae obviae, inter tropicos rarae, trans cancrum nondum visae; foliis hastatis, cordatis, oblongis linearibusve, floribus albis $v$, rubentibus, superioribus masculis, inferioribus femineis. - Genus vix servandum, Alismati olim jungendum, characteribus, si corollae aestivationem imbricatam dempseris, nullius sane ponderis nixum, nam antherarum loculi sublaterales, connectivum antice marginantes, in floribus mere masculis haud magni faciendi sunt.

Sagittaria Linn, gen, pl, n. 1067. Juss. gen, p. 46. Gärtn. IT. 21, t.84. FI, dan. t.172. Martius amoen, monac. t.3. Bot. Reg. t. 1141. Nees jun. gen. pl.fasc. VI. t. 19. (Geminatio apud Mirbel in Annal.Mus.XVI, t. 18, umbilico perperam locato).

1043. Damasomium JUSS, F lor es hermaphroditi. Perigonii exterioris foliola 3 , calyeina, persistentia; interiora 3 , petaloidea, aestivatione imbricata (?) decidua. Stamina 6, hypogyna; fil amenta filiformia, ant herae introrsae, dorso affixae. Ovaria $6 \_8$, disco plano imposita, verticillata, ventre connata, apice distineta, patentia, unilocularia, biovulata. 0 v nla 2, campylotropa, alterum basilare, alterum e suturae ventralis apice horizontale. Stylus ventralis brevissimus; stigma simplex. Carpidia 6 -8, ventre connata, acuminata, stellata, coriacea, evalvia, unilocularia, mono-disperma, tandem ab axi persistente soluta. S c mina 2 , v. aborta 1, uncinato-complicata, inferius erectum, snperius horizontale, testa membranacea, rugosa. Emb ry o exalbuminosus, homotropns, radicula centripeta. - Herbae aquaticae, scapigerae; foliis natantibus, cordato-oblongis, nervosis, floribus parvis, lilacinis, verticillatis. Species duae, quarum una ab Anglia ad Siciliam et Africamberealem diffusa, ex Europa media et orientali exul, altera in Nova Hollandia orientali reperta fuit.

Damasonium Juss. gen, 52. A ctinocarpus R. Brown prodr, 343. A lis un D a mas o u i um Linn. E. B. $t$. 1615. Redouté Liliac. t. 289. (De germinatione cfr. L. C., Richard in Annal. Mus. XVIT. 239, $t .5 . f .31$.

\section{Ordo I. Restomaceate.}

BUTOMEAE L. C. Richard in Mem. Mas, I. 36\%, Bartl. ord. nat, 74. BUTOMACEAE Lindl introduct, edit, II, p. 355.

Herвaе perennes, paludosae, scapigerae, glabrae, nonnullae latescentes. Foli a radicalia, conferta, petiolata, petioli s basi semivaginantibus, la mina ovata, lata, nerrosa, integerrima, interdum abortiva. Seapi simplices, uni-multiflori. 
FLores hermaphroditi, regulares, in apice scapi solitarii, v. umbellati, pedicellis membranaceo-bracteatis, albi, flavi v, rosei.

Perigonium hexaphyllum, foliola biseriata, exteriora 3 calycina, interdum subcolorata, in aestivatione tria in teriora, petaloidea, decidua, v. rarissime persistentia, imbricata, includentia.

Stamina plurima, subhypogyna, rarius subdefinita, perigonii foliolis exterioribus per paria, interioribus singillatim opposita, exteriora in polyandris saepius ananthera. Filam ent a filiformia, libera. Anthera e introrsae, biloculares, terminales, lineares; 10 culi sublaterales, paralleli, contigui v. connectivo interposito discreti, longitudinaliter dehiscentes.

Ovaria 6, v. plurima, verticillata, unilocularia, inter se distincta $v$. sutura ventrali aut basi leviter cohaerentia, multiovulata. Ovu la plurima, placentae parietali reticulatim ramosae undique affixa, erecta, funiculis brevissimis sustenta, anatropa, v. rarissime sessilia, campylotropa. Styli brevissimi rostellares, ovariis continui, distincti, introrsum stigmatosi, interdum nulli; stigmatibus ovariis tunc extrorsum adnatis.

Carpidia ovariorum numero, distincta, coriacea, stylis saepissime rostrata, sutura ventrali dehiscentia, interdum, ut videtur, dorso aperta vel fortassis indehiscentia, semper unilocularia, polysperma.

SEmina numerosa, reticulo placentari parietes intus vestienti aflixa, erecta, nunc recta, t esta membranacea, funiculo brevi et rhaphe umbilicum basilarem chalazae terminali jungente percursa; nunc uncinatim incurva, immediate placentae affixa, testa crustacea, transversim elevato-rugosa. Alb u m e n nullum.

Evвryo homotropus, rectus v. uncinatus, extremitate radiculari umbilico admota, basim carpicam spectante.

Butomaceae in temperatis tropicisque regionibus indigenae, nullibi copiosae, ab Alis m aceis arcte affinibus placentis parietalibus reticulatim ramosis facillime distinguuntur. Hydrocleis succo lacteo inter Amphibryas anomala.

1044. IButomang TOURNEF. P erigonii exterioris foliola 3 , subcolorata, persistentia; interiora 3 , petaloidea, aestivatione imbricata, persistentia. Stamina $9 ;$ fil ament a filiformia, an therae lineares, basifixae, loculis contiguis. Ovaria 6 , verticillata, ventre cohae rentia, unilocularia. Ovula plurima, placentae parietali reticulatim ramosae affixa, erecta, anairopa. Sty li rostellares, distincti; stigma sulciforme, ventrale. Carpidia 6 , coriacea, rostrata, basi colaerentia, sutura ventrali aperta, uni- locularia, polysperma. S e min a parietalia, erecta, testa membranacea, longitudinaliter suleata. E m b r yo exalbuminosus, orthotropns, radicula infera. - Herbae paludosae, scapigerae, in temperatis utriusque hemisphaerii obviae; foliis radicalibus linearibus elongatis, basi vaginantibus, floribus umbellatis, roseis, staminibus sex perigonii exterioris foliolis per paria oppositis, tribus interioribus ante foliola interiora sitis.

B u to m s Tournef, inst, t. 143. Linn.gen, n, 507. Juss. gen. 17. Gärtn. $I$. 47. $t$. 19. Sclikuhr $t, 111$, E. B, $t, 651$. Fl. dan. t.604. L. C. Richard in Mem. Mus. I. 366. Nees jun. gen, pl. fasc, VI, t. 20 .

1045. Fydrocleis RICH. Perigonii exterioris foliola 3 , calycina, persistentia; int eriora 3 , petaloidea, aestivatione imbricata, decidua. St amin a plurima, exteriora saepius castrata; fil amenta filiformia, antherae lineares, basifixae, loenlis lateralibus, connectivo sejunctis. Ov a ria 6_9, verticillata, ventre cohacrentia, unilocularia. Ovula plurima, placentae parietali reticulatim ramosae affixa, erecta, anatropa. St y li rostellares distincti; $s \mathrm{tig} \mathrm{m}$ a te lin. guaeformi ventrali. Carpidia.... - Herbae aquaticae americanae tropicae, stoloniferae, lactescentes; foliis radicalibus ovato-cordatis, nervosis, nervo medio cavo, aerifero, scapis unifloris, floribus flavis, - Genus imprimis perigonio interiore nobiliore deciduo, et stigmatibus magis elaboratis, vix aliis notis a praccedente diversum, semina, si ex ovulo judicamus, Butomi.

$\mathrm{H} \mathrm{y} \mathrm{drocle} \mathrm{is} \mathrm{L.} \mathrm{C.} \mathrm{Richard} \mathrm{in} \mathrm{Mem.} \mathrm{Mus.} \mathrm{T.} \mathrm{368,} \mathrm{t.} 18$. Lim nocharis $\mathrm{H} n \mathrm{mb}$ old ti i Richard op. cit.p. 368, t. 19. f.1. Bot. Mag. t, 3248. Bot. Reg. t, 1640.

1046. Itimnacinanis $H U M B$, et $B$. P erigonii exterioris foliola 3 , calycina, persistentia; interiora 3 , petaloidea, aestivatione imbricata, decidua. Sta m ina plurima, exteriora castrata ; filamenta filiformia, a n therae lineares, basifixae, loculis lateralibns, contiguis. Ov a ria $15 \_20$, verticillata, distineta, unilocularia. Ovula plurima, placentae parietali reticulatim ramosae affixa, erecta, campylotropa. Stylus nullus; stigmata papillosa, vertici ovarii extrorsum adnata, Carpidia $15-20$, coriacea, distineta, (indehiscentia? dorso aperta?) unilocularia, polysperma. Se min a parietalia, erecta, uncinato complicata, testa crustacea, transversim rugosa. Embryo exalbuminosus, homotropus, radicula infera. - Herba a mericuna tropica, scapigera; foliis ovato-cordatis, nervosis, floribus umbellatis flavis. _ Genus, quod ad unicam speciem restrinxi, altera ad Hydroclein relata, seminum fabrica inter Butomaceas anomalum, ad Alis. maceas tendens.

L i m no h a ris Humb. et Bonpl. $p l$, aequinoet. $T$, 116. t. 34. Richard in Mem. Mus. I. 370. t. 19. f.2. (excl. fig. 1.) 1.20. Kunth synops. $I$. 260, excl. sp.

\section{Classis $\mathbf{x}$ v. Coronariae.}

Невнае annuae v. perennes, interdum suffrutescentes. Caules simplices v. ramosi, basi ut plurimum bulbosi v. tuberosi. Folia alterna, integerrima, basi vaginantia, vel plus minus distincte petiolata. Flores perigonio ut plurimum corollino, rarius glumaceo scarioso, regulari, biseriato, exteriore interiori conformi. Ovaria libera, vel vix ima basi adhaerentia, tria in unum coalita. Ovura 
plerumque indefinita, rarius definita v. solitaria. Fructus capsularis dehiscens, v. baccatus indehiscens. Semina varia. Emвryo ut plurimum parvus, cylindricus, ab albumine inclusus, directione varia.

\section{Drdo LI. Juncaceae.}

JUNCl Juss. gen. p. 43, excl,pl. JUNCEAE DC. $F l$. fr. III. 155. R. Browa prodr, 257. Gen, rem. II, sz7. Laharpe in Mem, soc. $h$. $n$. de Paris. IIT. 89. Lindl. introduct, edit. II. p. 356. JUNCACEAE Agardh Aphorism. 156. excl. pl. Bartling ord, nat. 37 .

Herbae perennes, v. rarius annuae, $\mathbf{r h i -}$ z o mate saepins squamoso repentes. Caule s nodosi, simplices $v$. interdum ramosi, foliati v. abbreviati, vaginati, scapos floriferos exserentes. F o li a alterna, integra, nunc plana, aversa, nune canaliculata v. cylindracea, nunc lateraliter compressa, verticalia, nervoso - striata, saepius integerrima, glabra, interdum pilosa v. serrata, basi vaginantia, la min a saepius abortiva.

Frores hermaphroditi $\mathbf{v}$. abortu diclines, regulares, cymosi, spicati v. capitato-congesti, rarissime solitarii, singuli bracteolati.

Perigonium hexaphyllum, foliol a biseriata, aequalia, scarioso-glumacea v. subpetaloidea, persistentia.

Stamina 6, perigonii foliolis opposita, eorumque basibus inserta, rarius subhypogyna, interdum 3 , ante foliola exteriora sita. Fil a menta filiformia, libera, v. ima basi subcohaerentia. Antherae basifixae, introrsae, biloculares, loculi oppositi, paralleli, contigui, longitudinaliter dehiscentes.

Ovarium sessile, liberum, e carpidiis tribus conflatum, nunc carpidior um marginibus introflexis axim attingentibus, triloculare, nune iisdem plus minus incompletis, nempe basi integris versus apicem deliquescentibus, uniloculare. Placent a e nerviformes, carpidia marginantes, centrales v. parietales. Ovula tria basilaria, v. plurima placentis affixa, e funiculis erecta, anatropa. Stylu s terminalis, simplex; sti g $\mathrm{m}$ a $\mathrm{t}$ a tria, filiformia, distincta v. rarissime cohaerentia.

Capsula uni-trilocularis, trivalvis, valvis medio septiferis, interdum basi reunitis, rarius septifrage dehiscens, valvis nempe septorum altius tenaciusque unitorum portionem tantum auferentibus, parte superstite columnam trialatam mentiente.

Semina tria v. plurima, erecta. T e $\mathbf{s} t$ a membranacea, utrinque saepius relaxata, vel ad ch a laz a m apicalem, ope $r h$ a pheos longitudinalis umbilico basilari junctam, in filum producta.

Еивнхо in basi a lbum in is dense carnosi inclusus, extremitate radiculari incrassata, umbilico proxima, basim carpicam spectante.
Juncace ae habitu et perigonio glumaceo Restiaceis aflines, nec tamen a Coron ari is segregandae, per totum orbem sparsae, maxima in regionibus temperatis copia viģent.

Genera ad ordinis calcem recensita, denuo quo ad affinitatem scrutanda.

104\%. Huzula DC. Perigonium glamaceum, hexaphyllum, foliolis omnibus planis. St a m in a 6, perigonii foliolis opposita, interiorum basi inserta. O varium liberum, uniloculare. Ovula 3 , hasilaria, e funiculis crassinsculis erecta, anatropa. Stylus brevissimus; stigmata 3 , filiformia, undique villosa. Capsu Ia unilocularis, trivalvis. Semina 3 , erecta, testa utrinque incrassata, relaxata. $\mathbf{E} \mathbf{m b r y o}$ in basi a 1 b um in is dense carnosi inclusus, extremitate radiculari umbilico proxima. - Herbae perennes, in montosis sylvalicis hemisphuerae borealis, imprimis Europae obviae, in Americaboreali et australi extratropica rariores, in excelsis Americae tropica e jugis rarissimae, nonnullae late per regiones temperatas utriusque hemisphaerae vulgatae; foliis planis margine, pilosis, saepissime serratis, apice callosis, vaginis clausis, ore pilosis, paniculae ramis filiformibus saepius semiverticillatis, floribus bibracteatis.

Luzula DC. Fl. fr. $I I T$, 158. "Desvaux Journ, Bot, I. 136. c. ic. Meyer Synopsis Luzularum. Götling. 1823. Laharpe in Mem, soc. h. $n$. Paris. III. 159. Nees Ju日. gen. pl. fasc. II. t. 6. L u e i ol a Smith Fl. Brit. II. 177. J u nei s p. Touruef. Linn. Host gram. III, $t, 94$. E. B. $t, 1293$. Wahlenb. Lapp. $t .4$.

1048. Prionium E. MEY. P e rig on i um glumaceum, hexaphyllum, exterioris foliois duobus oppositis carinatis, tertio incluso, plano. Stami ua 6 , hypogyna, perigonii foliolis opposita. Ovari um liberum, triloculare. Ovula in loculorum angulo centrali plurima, e funiculis brevibus adscendentia, anatropa. Stylus brevissimus; stig mata 3 , plumosa, Ca p 8 ula trilocularis, trivalvis, valvis medio septiferis, septa basi bilamellata, medio seminifera. S e m in a plurima, adscendentia, test a pubescente fragili, ambitu relaxata. Fmbryo albuminis farinacei basi relaxatae semiimmersus. - Herba capen$s i s$, non satis nota; culmo folioso, foliis ensiformibus, planis, serratis, subtus canescentibus, caule paniculato, bracteis sub ramis ochreaeformibus, laxis.

Prionium E. Meyer in Linnaea VTI. 130. Juncus serratus Thunb. Acorus Palmita Liehtenst. Reise.

1042. Jumeus DC. Perigo n i m glamaceum, hexaphyllum, foliolis 3 exterioribus carinatis. Stamina 6 , perigonii foliolis basi inserta, interdnm 3, foliolis exterioribus opposita. Ova ri um liberum, triloculare. Ovu Ia in angulo loculorum interiori plurima, e funiculis brevibus erecta, anatropa. Stylus brevissimus; stigmat a 3 , filiformia, villosa. C a psula trilocularis $\mathbf{v}$. dissepimentis saepissime retractis, subunilocularis, trivalvis, valvis medio septiferis, septis basi reunitis, S emina plurima, testa nucleo conformi, utrinque laxata interdum elongata. Emb ryo minimus, in basi albuminis carnosi inclusus, extremitate radiculari umbilico proxima. - Herbae annuae $v$. perennes, paludosae $v$. hygrophilae, in temperatis frigidisque totius or bis obviae, in regionibus subtropicis rarae, 
inter tropicos praeter species quasdam cosmopolitas rarissimae, foliis glabris, cylindraceis $v$. carinatis, nune planis adversis, nunc plano-compressis verticalibus, paniculis lateralibus terminalibusve, saepissime contractis, floribus bibracteatis.

$\mathrm{J}$ u ne us DC. Fl. fr. IIT. p. 162. Meyer Junci generis monographiae specimen. Götting. 1819. Synopsis Juncorum, Gölting, 1823. Laharpe in MLm. soc, h, n. Paris, IIT, 104.

a) JUNCUS Desv. Capsulae trivalvis valvae medio septiferae. S e m in um testa nucleo conformis.

J u c us Desv, in Journ. Bot. I. 321. Host gram. $t$. 84. 86. 88.89. Fl. dan. $t, 817.1094$. Swensk. Bot. t. 470. E. B. t.665. 836. 2143, 2144, 2174. Desf. Fl, atl, t.91, 92. Neesgen. pl. fasc. II, t. $5,-\mathrm{R}$ os tho via Desv. op. cit. $t, 12, f, 1$.

b) MARSIPPOSPERMUM Desv. C a p s u I a e trivalvis valvae medio septiferae. S e m in um testa utrinque in saeculum relaxata.

Marsippos peraum Desv. op. cit, t. 12. $f, 1$. (Host gram, t, so. 93. FI, dan, t. 10\%. Jacq. Fl. vind, t.4. $f, 1,2$. Suith ic. inedit, t, 55 . E. B. $t .898-900.1614$.

c) CEPHALOXYS Desv. Ca p s a I a trilocularis septifraga, septis placentiferis paullo altius junctis, columellam trialatam mentientibus. Michx.

Cephaloxys Desv, op. cti, t.11. Juncus repens

1050. Narthecimm MOEHR. Perigoni nm subcoloratum, sexpartitum, $I$ a $c$ i $n$ i is subaequalibus, persistentibus. Sta in in a 6 , tria hypogyna, perigonii laciniis exterioribus opposita, tria lacinarum internarum basi inserta; fila ment a subulata, barbata; antherae oblongae, dorso supra basim affixae, biloculares. O variu m liberum, triloculare. Ov 1 a in loculis plurima, dissepimentorum basibus incrassatis affixa, e funiculis longis erecta, anatropa. Stylu s terminalis, conieus; st igma obtusum. Capsula acuminata, trilocularis, apice loculicido-trivalvis. Sem in a plurima, longe filiformia, funiculo erassius culo elongato, rhaphe lata in chalazam apicalem in acumen filiforme productam excurrente, nucleo minuto. En bryo minimus, intra albnmen carnosum prope umbilicum inclusus, extremitate radiculari basim fructus spectante. - Herbae perennes, in Europa et America borealiore indigenae; foliis gramineis, vaginuntibus, florum racemo terminali.

Narth e cium Möbring Ephemerid. N. C. 1742. p. 389. t. 5. f. 1. E. B. $t .535$. Hook, Fl, Lond. t, 139. Bot, Mag. $t$. 1505. Nees jun. gen, $p l$. fasc, $I$. $t, 1$. A b a m a Adans. fam. IT. p. 4r. DC. FL. fr. III. 170. Laharpe in Mem, soc.h. n, Paris. III, 179, A nt he rie am os sifrag a m Linn. FL. dan. $t .48$.

\section{GENERA JUNCACEIS AFFINIA.}

\section{* ASTELIEAE.}

1051. Astelia BANKS et SOL. Flores abortu polygamo-dioici. Perigonium sexpartitum, semiglumaceum, persistens. Stamina 6, imo perigonio inserta. Orari $\mathbf{u}$ triloculare, v. dissepimentis incompletis nniloculare, pIacent is parietalibus tribus. OvuIa plurima. Stylus nullus; stigmata 3 , obtusa. B a cea uni-trilocularis, polysperma. - Herbae in Insula Diemen, in Nova Zeelandia, in America antarctica et in insulis Sandwich observatae, habitu fere Tillandsiae, et saepius pariter in arbo rum truncis vivis vel emortuis parasiticae; radice fibrosa, foliis radicalibus imbricatis, lanceolato-linearibus $v$. ensiformibus, carinatis, utrinque $v$. subtus adpresse villosis, basi sericeo-lanatis, caule $n u l l o$ v. brevi planifolio, floribus racemosis $v$. paniculatis, rariusve subsolitariis, pedicell is haud artieulatis, unibracteatis, floribus extus sericeis.

Astelia Banks et Sol, ex R. Brown prodr. 291. Hook. Miscell. I. 5. t.3. Gaudich ad Freyc, $t$. 31 . H a meli A. Rlehard Flor, Nov, Zeel. p. 158, $, 2.24,-F$ u a i a Willd. in Berl. Magaz. II, 19. M ela $\mathrm{nth \textrm {hu }} \mathrm{pum}$ il um Forst. in Comment. Gölling. IX. 30. t.6. (Fructu capsulari ?)

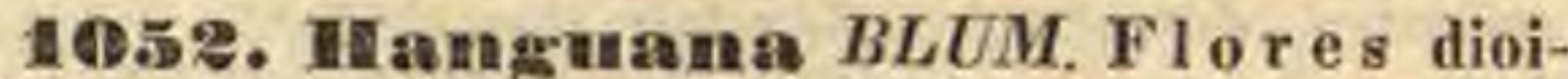
ci. Masc.... Fem. Perigonium sexpartitum, persistens. O vari u m triloculare, loculis uniovulatis. Stylus nullus; stigmata 3 , plana. B a c c a globosa, monosperma. - Suffrutex in insula Java monticola, e generis statura Asteliae affinis; radicibus fibrosis, caule simplici procumbente, foliis lanceolatis, trifariam approximatis, junioribus infra tomentosis, petiolis elongatis, carinatis, vaginantibus, spicis paniculatis terminalibus subtomentosis.

Hanguan a Blame enum, plant, Jav, I. 15.

\section{* RAPATEAE.}

1053. Ifapatea $A U B L$. Perigonii exterioris multibracteati foliola 3 , glumacea; int e ri oris corollini limbus trifidus. St a mina 6, perigonii interioris tubo inserta, inclusa; $\mathrm{fila-}$ menta brevia, dilatata, antherae basifixae, tetragonae, biloculares, loculi oppositi laterales, paralleli, bilocellati, locello postico apice productiore, longitudinaliter dehiscentes. Ova ri um brevissime stipitatum, subglobosum, triloculare. Ovnla in loculis solitaria, basilaria, anatropa. Sty I us terminalis, trigonus; stigmata $\mathbf{3}$, in spiram convoluta. Capsula trilocularis, trivalvis, valvis medio septiferis. S e mina.....-Herbae americanae tropicae, paludosae; foliis radicalibus lato-linearibus, basi vaginantibus, scapo ancipiti, floribus capitato-congestis, involucro diphyllo, ovato longe-acuminato; $v$. fasciculatis unilateralibus, involucri foliacei spathacei nervo medio insertis, perigonio exteriore squamis glumaceis multifariam imbricatis bracteato.

R a pate a Aubl, Guian, I. 308. t. 118. Schult. f. syst, VIr. 1149. Pöppig et Kadl. nov. gen. et sp, Vol. Ir. inedit. $\mathrm{M}$ a a s in $\mathrm{m}$ Sehreb. gen. S4h. - ? Rudge Guian. $t, 12, \mathrm{R}$ a $\mathrm{p}$ atea et $\mathrm{Spathanthus} \mathrm{Desvaux} \mathrm{in} \mathrm{Annal,} \mathrm{sc,} \mathrm{nat.} \mathrm{XIII.}$ p. 45. $t$.4. (M nasium unilaterale Rudge Guian. $t .11$. )

OBSERVATIO. Genus seminum fabrica nondum cognita quo ad veram affinitatem dubium, a $\mathrm{C}$ o m me 1 y $\mathrm{n}$ a $\mathrm{ce}$ i s ad quas nuper a cl. Lindley (introduct. edit. II. p. 355.) relatum fuit, ovulis anatropis basilaribus et liabitu omnino aljenom. Antherarum fabriea in speciebus duabus a me examinatís paullo diversa, nempe in $\mathrm{R}$ a $\mathrm{p}$ a $\mathrm{t} e \mathrm{a} \mathrm{gracili}$ Pöpp. et Endl. locelli postiei, dorso inter se confluentes, si a pra locellos anticos producuntur in acumen aeque pollisiferum, in $\mathrm{R}$ a pat le a $\mathrm{p}$ a $I$ ud o $s$ a $\mathbf{A} u b l$. locelli postice supra anticos producti, dorso faeieque inter se couflaunt in acumen obtusum, antice convexum, postice concavum, sterile, pigricans, antheram ovatam filamento tetragono impositam mentiens.

\section{*** FLAGELLARIEAE.}

1054. Flagellaria LINN, Perigonin m coloratum, sexpartitum, persistens, laciniis interioribus majoribus. St am in a 6 , hypogyna; filamenta filiformia, libera, antherae oblongae, medio dorso affixae, biloculares, longitudinaliter dehiscentes. Ovari nm sessile, liberum, triloculare. Ovula in locnlis solitavia, basilaria, sessilia, anatropa, St i g m a t a $\mathbf{3}$, sessilia, filiformia, patula. Drupa pisiformis, stigmatibus coronata, monosperma, epiearpio carnoso ab endocarpio osseo solubili. S em en subglobosum, testa membranacea tenui, nmbilico basilari, chalaza terminali late orbiculari. Embryo lenticularis minimus, albumin is farinacei foveolae basilari semiimmersus, extremitate radiculari punctiformi umbilicum attingente, infera. - Herbae perennes, in Asia et Nova Hollandia tropica indigenae; caule sarmentoso, foliis basi vaginantibus, 
vaginis connatis, caulem velantibus, lamina lanceolata nervosa, basi contracta, apice in cirrhum spiralem desinente, floribus paniculatis, bracteolatis, abortu saepe unisexualibus. - Genus embryone lenticulari nec penitus incluso in classe anomalum, Coronarias cum Enantioblastis jungens.

Flag ellaria Linn. gen, n, 450. Juss, gen,p. 41. Gärta. I. 61, t, 16. f. 9. Redonté Liliac, t. 257. R. Browa prodr. 264. Sehult. fil, syst. VIT. 1492.

\section{**** XEROTIDEAE.}

1055. Susuma BLUM. Perig o $\mathrm{n}$ in m coloratum, sexpartitum, persistens, la $\mathrm{cin}$ i is interioribus majoribus, tenerioribus. Stamina 6 , disco hypogyno trigono, perigonii laciniis interioribus adhaerenti extrorsum inserta; filamen$\mathbf{t}$ a filiformia, an the rae ovatae, medio dorso affixae, biloculares, longitudinaliter dehiscentes. Ov a r i m sessile, liberum, triloeulare, ov u la in loculorum angulo centrali solitaria, amphitropa (?). Stigmata 3 , sessilia, obtusa, patentia. Bacea stigmatibus coronata, trilocularis, trisperma. S e mina peltata (?). .... Herba $j a$ $v$ an ica, paludosa, anthelminthica; foliis radicalibus late lanceolatis, acuminatis, erecto-patentibus, scapo ramosissime paniculato, bracteis foliaceis ramos subtendentibus, floribus spicatis, minutis, bibracteolatis. - Genus non satis notum, Xeroti ut videtur proximum.

S u s n m Blume ex Sehult. f. syst. VIr. n. 1526. p. 1493.

1056. Xerotes R. BR. Flo res dioici. Masc. Perigonium sexpartitum, subcoloratum, foliolis omnibus, v. interioribus basi cohaerentibus. Stamina 6 , perigonio inserta; antherae peltatae. Ovari i rudimentum. Fem. Perigonium sexpartitum, subcoloratum, foliolis distinctis, persistentibus. Stamina efoeta. Ovari n m triloculare. Ovula in loculis solitaria, angulo centrali prope basim affixa, amphitropa. S tyii 3 , basi connati. ... C a p 8 u l a cartilaginea $v$. subbaccata, trilocularis, trivalvis, valvis medio septiferis. S emina peltata, testa laxiusenla, interdum arilliformi. E $\mathbf{m}$ bryo longitudinalis, rectus, in basi albuminis cartilaginei. - Herbae pe. rennes, in omnibus Novae Hollandiae oris obviae, aridae, rigidae, habitu peculiari Juncum v. Cyperum aliquatenus simulantes; fiorum structura et albuminis consistentia Palmis nonnihil affines; radice fibrosa, caule nullo $v$, brevissimo, interdum ramoso, folioso; foliis gramineis linearibus, planis, canaliculatis $v$. interdum filiformibus, basi dilatata scariosa semivaginantibus, apice nonnunquam dentatis, Roribus in apice scapi $v$. caulis paniculatis, racemosis, spicatis $v$. capitatis, sessilibus, bracteis scariosis imbricatis munitis, pedicellatis, ebracteatis, masculorum perigonio interiore magnitudine et consistentia saepe dissimili, capsulae cortice demum ab endocarpio solubili, interdum subbaccato.

Xerotes R. Brown prodr. 259. Brongn. ad Duperr. t.35. Lo m a nd r a Labill. Nov. Holl. t.119, 120, Dracenae s p. Thunb.

\section{***** KINGIACEAE.}

105\%. Elingla $R, B R$. Perigonium sexpartitum, glumaceum, persistens. St a mina 6 , imo perigonio inserta; filamenta filiformia, antherae hiloculares, basifixae, longitudinaliter dehiscentes. Ovarium triloculare. Ovn 1 a in loculis solitaria, angulo interinri prope basim affixa, erecta, anatropa. Sty lns trigonus; stig mata 3, denticuliformia. Peric a $\mathbf{r}$ i um monosper- mum, exsuccam, indehiseens, perigonio cinetum. Semen obovatum, testa membranacea. Alb nme $n$ dense carnosum. E m b r y o subglobosus, rostello acutiusculo, in basi albuminis semiimmersus. - Planta in Novae Ho l landiae ora meridionali reperta, habitu Xanthorrhoeae, cui pluribus etiam notis affinis, caudice arborescente, erecto, simplicissimo, cicatricibus basibusque foliorum exasperato, foliis caudicem terminantibus confertissimis, elongatis, linearibus, subtriquetris, undique patulis, pedunculis plurimis foliis brevioribus, bracteis vaginantibus tectis, primum terminalibus erectis, mox caudicis elongatione et foliis novellis product is lateralibus et divaricatis $v$. deflexis, capitulo dense globoso terminatis, floribus tribracteatis. Kingla R, Brown in King's Voyages of Discovery. $I$. p.530.t.c.

1058. Dasypogen $R$. BR. Perigoniu m duplex, exterius tubulosum, trifidum, interius triphyllum, foliolis semipetaloideis, oblongo - spathulatis. St a $\mathrm{m}$ i $\mathrm{n}$ a 6 , imo perigonio inserta; filamenta apice inerassata, a $n$ thera biloenlares, incumbentes, longitudinaliter dehiscentes. Ovari um uniloculare. Ovula 3 , basilaria, anatropa. S t y l u s subulatus; $s$ t i $g$ m a simplex. Utrieulas monospermus, perigonii exterioris tubo indurato inclusus. Semen subglobosum, te st a simplicissima, connata, e h a 1 a z a apicali vix manifesta. A 1 b u m e n carnosum. Embryo...: - Planta suffruticosa, in $N$ o $v a$ e Hollandiae ora meridionali indigena; caule simplicissimo, tereti, foliato, setis denticulatis reversis tecto, foliis gramineis, radicalibus confertis, caulinis sparsis, brevioribus, sessilibus, omnibus mucronatis, glabris, marginibus denticulato-asperis, capitulo terminali solitario, globoso, bracteis subulatis patulis involucrato, foribus sessilibus, bracteolis paleaceis lanceolatis immixtis.

Das ypogon R. Brown prodr. 263. Gen. Remt, 608. $t$. 8. Laharpe tn Mem, soc, $h$, n, de Paris. III. p.93.

OBSERVATIO. Genus pluribus notis ad B r o m e $1 \mathrm{i}$ a. ce as accedens, nullo tamen pacto $\mathrm{ab}$ affini $\mathrm{King}$ i a sepa. randum.

\section{****** CALECTASIEAE.}

1059. Caleetasian $R, B R$. Perigon i m tubulosum, hypocrateriforme, limbo petaloideo, sexpartito. Stamina 6 , fauci perigonii inserta ; filamenta filiformia, antherae bilocnlares, basifixae, conniventes, apice poro gemino dehiscentes. Ovari n uniloculare. Ovula 3 , basilaria, anatropa. Stylus filiformis; stig ma simplex. Utriculus monospermus, perigonii tubo indurato inclusus. Semen pyriforme, test a simplicissima, connata, e hal a za apieali incrassata. A I b u m n carnosum Embryo. ... Fruticulus Novae Hollandiae oram meridion alem cum praecedentibus generibus incolens, ramo. sissimus; foliis acerosis, basi vaginantibus, dense confertis vestitus, floribus in ramulis brevibus terminalibus, solitariis, perigonii tubo foliorum vaginis incluso, limbi stellati azurei laciniis tribus exterioribus disco pubescentibus.

Calectasia R. Browa prodr, 263. Gen, Rem, 609. $t$. 9. Poiret illustr. t. 939 .

\section{Drdo ILII. Philydreae.}

PHILYDREAE R. Brown Not.1835. Mart, consp.p. 8. Lindl. intraduct, edit, $I T, p, 357$.

Hвrbak perennes, in paludosis humidisque Novat Hollandiae et Chinae au- 
stralis vegetantes, glabrae $\mathbf{v}$. lanuginosae, radicibus fasciculato-fibrosis. Caules erecti, simplicissimi, foliati. F o I i a subcellulosa, basibus semivaginantibus, radicalia ensiformia, equitantia, caulina alterna, minora.

Flores in spica terminali simplici v, parum divisa, solitarii in axilla b racteae spathaceae sessiles, hermaphroditi, flavi, inodori.

Perigonium corollinum, diphyllum, marcescens, foliola bracteae parallela, aequalia, anticum in aestivatione a postico marginibus amplexum.

Staminum filamenta 3 , basi inter se connata, perigonii foliolo antico inserta, lateralia plana, petaloidea, integra v. inciso - dentata, intermedium e basi plana sensim teres, monantherum. Anthera introrsa, bilucularis, loc uli oppositi, discreti, reniformes v. lineares, basi divaricati, apice contiguo extrorsum spiraliter involuti, longitrorsum dehiscentes.

Ovarium sessile, liberum, e carpidi s tribus compositum, carpidiorum marginibus introflexis dissepimenta constituentibus, triloculare. $0 \mathrm{v}$ u la plurima, placentis filiformibus loculorum angulo interiori adnatis, vel margini dissepimentorum in cavitatem porrecto placentifero, hinc in quovis loculo duplici, affixa, horizontalia, anatropa (?) Stylus terminalis, simplex, marcescens; stigma capitatum.

Capsula trilocularis, loculicido-trivalvis, valvis medio septiferis et placentiferis, nunc valvis septa auferentibus, columellam placentiferam centralem nudantibus.

Semra plurima, horizontalia, minima, subcylindrica, utrinque obtusa; test a coriacea crassiuscula, nunc laevis haud effigurata, nunc spiraliter striata, ad umbilicum excavata, et in altera extremitate umbilico oppusita, (chalaza?) incrassata, pileoliformis.

Emв уо cylindricus, rectus, in axi albuminis carnosi, extremitate radiculari umbilico proxima?

Philydreas monente illustr. R. B rown floris structura ab omnibus distinetissimae, aliquam cum Xyride et Burmannia analogiam ostendunt, in quibusdam, quae ad structuram seminis et staminis spectant, cum Orchideis, alioquin diversissimis, convenientes. Nobis ob embryonem inclusum pone Juncaceas collocandae videntur.

1060. Hetaeria. P e r i g o n i n m diphyllum. Staminum filamenta 3 , basi con nata, perigonii foliolo exteriori inserta, lateralia sterilia, petaloidea, intermedium monantherum, an the rae loculis reniformibus. Ovarium liberum, triloculare. Stylus simplex; s tigma capi- tatum. C a p sula trilocularis, placenta centrali filiformi, demum libera. S em in a laevia, apice simplici. - Herba pusilla, glabra, in humidis or a e meridionalis Novae Hollandiae reperta.

Phily drum p y g ma u m R. Brown prodr. 264.

1061. Phily dirum $B A N K S$. Perigon $\mathrm{i}-$ um diphyllum. Staminum filamenta 3, basi connata, perigonii foliolo exteriori inserta, lateralia sterilia, petaloidea, intermedium monantherum, a ntherac loculis spiralibus. Ovari um liberum, triloculare. Stylus simplex; stig ma capitatum. C apsu la trilocularis, placentis dissepimentorum angulo interiori adnatis, bilobis, recurvis, facie exteriore seminiferis. S emin a spiraliter striata, apice pileolata. - Herba bi-tripedalis, in China e australis et Novae Hollandiae tropicae et orientalis paludibus vegetans, spicis cum perigoniis capsulisque lanatis.

$\mathrm{P}$ hll y d r u Banks apud Gärtn. $I .62, t, 16$. R. Brown prodr, 263. excl. $s p$. Guillem. ic. lithogr. $t, 5$. G a r ei a na Loureiro Fl, cochinch, edit. Willd. I. 19.

\section{Drdo IIII. Melanthaceae.}

MELANTHEAE Batsch $t a b$, affinit. 1802. COLCHICACE AE DC, Fl, fr. III, 192. Bartling ord, nat, 51. MELANTHACEAE R. Brown prodr, 272. Lindley introduct, edit. IT. p. 347. excl. gen, VERATREAE Salisbury in Transact, Hortic. Soc. I. 328. Agardh Aphorism. 166.

Herbae perennes, radicibus bulbosis, tuberoso-carnosis v. fasciculato-fibrosis. C a uli s nune abbreviatus, subnullus, nune simplex, vel rarius ramosus. F olia omnia radicalia, congesta, v. caulina alterna, simplicia, integerrima, saepius nervosa, basi amplexicauli vaginantia.

Flores hermaphroditi v. abortu polygami, regulares, radicales vel in scapo aut caule nunc axillares, nunc saepius terminales, paniculati v. racemoso - spicati, nudi v. bracteati, bracteolis interdum calyciformibus stipati.

Perigonium liberum v. rarissime ovarii basi subadhaerens, corollinum, hexaphyllum; foliola nunc omnino distincta, sessilia v. saepissime unguiculata, decidua, nunc basi cohaerentia, vel in tubum interdum praelongum coalita, saepissime persistentia, tria interiora exterioribus conformia, raro minora v. submajora, aestivatione plerumque induplicata, exteriora saepius valvata, nunc omnia induplicata, stamina ante anthesim segregantia, plerumque basi aequalia, rarius saccato-excavata, mellifera, saepissime ad ungues poris $\mathbf{v}$ foveolis nectariferis instructa.

Stamiva numero foliolorum perigonii, sex, rarissime novem, nempe ante foliola exteriora gemina, $y$. staminodi is singulis staminibus interjectis; nunc imis fuliolis inserta, nunc iisdem supra unguem imposita, rarissime obscure hypogyna. Fil a m e n t a filiformia, libera. Antherae biloculares, loculis linearibus ovatis, parallelis, contiguis, longitudinaliter dehiscentibus, nunc dorso adnatae et extrorsae, nunc dorso peltatim affixae, versatiles, 
in alabastro plerumque extrorsae, sub anthesi ut plurimum introrsum directae.

Ovarion liberum, vel ima basi cum perigonio cohaerens, sessile v. interdum fortassis brevissime stipitatum, e carpidiis tribus follicularibus, perigonii foliolis exterioribus oppositis, rarissime abortu paucioribus, ad axim nunc immediate, nunc ope columellae centralis, demum obsolete cohaerentibus conflatum, triloculare. $\mathrm{O} \mathbf{v} \mathrm{ula}$ placentis folliculos marginantibus, simplici $\mathbf{v}$. multiplici serie affixa, hinc in loculis plurima, rarissime definita, ut plurimum placentatione immediata orthotropa, v. semicampylotropa, interdum anatropa. Styli tres, nunc carpidiis continui persistentes, saepissime patuli; nunc centrales, e columellae productione, plerumque basi in unum coaliti, apice in $s \mathrm{tigm}$ at is ramos tres, intus papillosos soluti.

Fructes ut plurimum capsularis, trilocularis, in elementa carpica solutus, hinc tripartibilis, carpidiis demum sutura ventrali plus minus profunde apertis, rarissime loculicido - trivalvis, valvis medio septiferis, interdum baccatus, trilocularis, indehiscens, v. abortu nonnunquam unilocularis.

Semina plurima, v. rarissime definita ant abortu solitaria, globosa, angulata v. compressa. Testa membranacea, tenuis; umbilicus basilaris interdum carnosus. Al b ume n carnosum v. cartilagineum, copiosum.

Embryosis intra albumen inclusi subcylindrici directio varia, extremitate radiculari umbilico proxima v. ab eodem plus minus remota, interdum e diametro opposita.

Melanthaceae e perigonii conformatione satis commode in tribus duas dividuntur. Colchicace a e perigonii tubo elongato donatae, maxima copia in E n ropa mediterranea gignnntur, parcius in Euro p a media, in Caucaso, in Oriente et Africa septemtrionali proveniunt. Veratrearum, quae foliolis perigonii omnino liberis, saepissime unguiculatis et nectariferis $v$. in tubum brevissimum cohaerentibus facile dignoscuntur, una tertia pars Americam borea1 em, altera Africam a ustralem extratropicam incolit, reliquae per Indiam orientalem, Africae borealis littus atlantieum, Novam Hollandiam, Europam subalpinam et alpinam, Asiam mediam et per extremum septemtrion e m sunt dispersae. Paucissimae in excelsis Americae tropicae montibus repertae fuerunt.

Radices plurimarum specierum qualitate pollent vehemente nareotica et emetica. In nonnullis principium peculiare alkalicum (Veratriin) chemia recentior detexit.
Ordo perigonii aestivatione, antherarum directione et seminum testa ab Asphodele is satis distinctus, prioribus notis et ovarii simul structura a Smilaceis, quibus alias affinis, diversus; genera tamen fortassis adhuc nimis heterogenea colligens, et repurgandus. Stirpes plurimae quoad principales characteres, perigonii videlicet aestivationem, antherarum directionem, ovarii internam fabricam, fructus dehiscentiam et embryonis directionem prorsus incognita, autoptis monographis, imprimis botanicis boreali-americanis summopere commendendae. Anne genera baccifera, non obstante antherarum directione in quibusdam certe extrorsa ad Smilaceas repellenda, anne australasica loculicide - trivalvia in propriam tribum Tulipaceis propinguam colligenda? An fortassis genera stylis columnaribus donata, a reliquis stylis carpellaribus insignitis seggreganda?

TER II8 I. VERATREAE Nees et Ebermayer Handb. I. 150. Perigo n i foliola libera, sessilia v. breviter unguiculata, v. in tubum brevissimum cohaerentia.

10Ge. Tofieldia HUDS. Involucrum ealiciforme remotiusculum, trifidum persistens. Perig onium coloratum, hexaphyllum, folioIis sessilibus, subaequalibus, persistentibus. Sta$\mathrm{m}$ in a 6 , perigonii foliolis basi inserta; ant he $\mathrm{rae}$ versatiles. Ovarium triloculare. Ovula in loculorum angulo centrali plurima, anatropa. Sty $1 \mathrm{i}$ 3 , brevissimi, loculos terminantes; $8 \mathrm{tigmat}$ a capitata. C a p s u la trilocularis, tripartibilis, introrsum dehiscens. S emina in placentis septa marginantibus plurima, cymbiformia. Embryo orthotropus, in basi albuminis carnosi inclnsus, extremitate radiculari mmbilico proxima. - Herbae perennes, in Europa imprimis frigidiore obviae, sed in America boreali copiosiores, etiam in summis Andium Peruviae jugis observatae; radice tuberoso - fibrosa, foliis gramineis, plerisque radicalibus, floribus inconspicuis racemoso-spicatis, alternis $v$. oppositis, terminatisve subvertieillatis.

T of i e Id ia Hudson Fl. angl, 15\%. Smith in Transact. Linn, soc. XlI, 205, t.8. Redouté Liliac. $t .256 .324$. Hook, Fl: Lond, l, 100. Sternb, in Regensb. Denkschrift. I. 153, c. icc. Nees jun. gen, pl. fasc. II. $t, 11$. Hook, ad Beechey $t, 29$. Na r the ci um Gerard Gallopr. 142. Juss. gen, 67. Lam. illustr. $t, 268$. Wahlenb. Act. Holm. XXVT. 24. non Möhring. Helonias Willd. sp. $M$. 274. Heritiera Schrank Flor. bavar, 580. H e beli a Gmel. Fl. Bad. II. 117. c. icc, I s i. d $\mathrm{r}$ o g a 1 v $\mathrm{i}$ a Ruiz et Pav. Fl. peruv, III, 69. t. 302, f.6. Triantha Nuttall gen, americ, 1, 236.

1063. Plece $R I C H$. Perigoninm corollinum, hexaphyllum, foliola sessilia, subaequalia. . Stamina 9, hypogyna (?), ant herae versatiles. Ovarium triloculare. $O$ v u 1 a. ... Sty 1i 3, brevissimi, loculos terminantes; st igmat a. .. C a p 8 u la trilocularis, tripartibilis, introrsum dehiscens. Semina in placentis septa marginantibus plurima, teretiuscula, funiculo crassiusculo, elongato, $\mathrm{rhaphe}$ lata, in $\mathrm{ehalazam}$ apicalem in acumen filiforme productam exenrrente. - Herba in America boreali calidiore indigena; foliis linearibus gramineis, basi vaginantibus, caule simplici, foribus spicatis, spathaceobracteatis. - Genus Narthecio uffine. 
Ple a L. C. Richard in Michaux Flor. Bor. Amer. $I$. 246. t.25. Bot. Mag. t. 1956.

1064. Nolima RICH. Perigonium coloratum, hexaphyllum, foli o la sessilia, subaequalia, persistentia (?). Stamina 6 , perigonii foliolis basi inserta, antherae versatiles. Orarium triloculare. Ovula. ... Sty Ius terminalis, brevissimus; stigmat a 3 , brevia, recurva. C a p s u I a trilocularis, tripartibilis, loculis monospermis, duobus saepe sterilibus. Semen prope loculi basim peltatim affixum, angulatum (?) Herba in America e borealis siccis sylvaticis ad flumen Savannah observata, vix nota; bulbo tunicato; foliis linearibus gramineis, margine scabris, caule ramoso, foribus parvis racemoso-aggregatis.

Nolina L. C. Richard in Michaux Fl. Bor. Amer. 1 . 207. Nuttall gen. I. 231. Nolin e a Pers. ench, I. 399.

1065. Xeroploglluman RICH. Perigoni u m corollinum, hexaphyllum, foli o la sessilia, interiora minora, persistentia. Stamina 6, perigonii foliolis basi inserta, fil a mentis inferne dilatatis contigua; anthera e versatiles(?). Ovari um triloculare. Ov u 1 a. ... Stigmata 3 , centralia, filiformia, recurva. Caps u la trilocularis, apice loculicido-trivalvis. S e min a in loculis 2, basilaria, collateralia erecta. - Herbae boreali-a merican a e; foliis lineari-subulatis, canaliculatis, radicalibus congestis, racemo florum terminali.

$\mathrm{Xerophyllum} \mathrm{L.} \mathrm{C.} \mathrm{Richard} \mathrm{in} \mathrm{Michaux} \mathrm{Fl,} \mathrm{Bor.}$ Amer. . 210. Nuttall gen. I. 234. Bot. Reg. $t, 1513$. Hel on i a e s p. Limn. Pursh Fl, Bor. Amer. t.9. Bot. Mag. t.748. 1550 .

10G6. Juelomias LINN. P'erigon in corollinum, hexaphyllum, foliol a sessilia, subaequalia, persistentia. Stamin a 6 , perigonii foliolis basi inserta; fil am ent a inferne haud dilatata, antherae posticae. Ovarium trigonum, triloculare. Ovula. ... Styli tres corniformes, loculis continui, patentes. Ca p 8 u la trilocularis, tripartibilis, apice tricornis, introrsum dehiscens. Semina in loculis solitaria, pauca v. plurima, globosa v. compressa. - Herbae boreali-americanae; foliis radicalibus lato lanceolatis, caulinis linearibus, floribus spicato-racemosis, abortu saepius polygamo-dioicis. - Genus ex elementis ut videtur heterogeneis compositum, omnino revidendum.

H el on las Lînn, gen., n. A58. excl. sp. Redouté Lilliac. t. 13. Bot. Mag, t.747. 803.1560 . A a the rici s p. Jacq. $i c$. rar. . 419. C y a notris Raf. in Americ, Monthl. Magaz. 1819. A balon Adans. fam $I$. p. 47 . - C h a ma elirium Willd. in Berl. Magaz. II. 19. O phiostachys Delile in Redouté Liliac. $t$. 464. (Jacq. ic. rar, $t, 453$. Bot. Mag. $t$. 1062.)

1108\%. Veratumn TOURNEF. P erig on i m corollinum, hexaphyllum, foliola sessilia, persistentia. Stamina 6 , perigonii foliolis basi inserta; a $\mathbf{t} \mathbf{h}$ e $r$ a e reniformes, posticae. Ov a rium triloculare, OvuIa in loculorum angulo centrali plurima, adscendentia, anatropa. S tyli tres, loculis eontinui, divergentes, corniformes $8 \mathrm{tigmat}$ a obsoleta. Ca p sula trilocularis, tripartibilis, apice tricornis, introrsum dehiscens. $\mathrm{S}$ emin a plurima, compressa, te 8 ta laxa, supra rhaphen umbilicum basilarem chalazae apicali jungentem in alam producta. Emb ryo linearis, basi albuminis carnosi inclusus, extremitate radiculari incrassata, umbilico proxima. - Herbae perennes, in montibus edilis Europae, Americae borealis et $t$ ropicat cis aequatorem indigenae; radicibus repentibus, foliis ovatis $v$. ovato-lanceolatis, acuminatis, floribus paniculatis, aborlu saepe poly gamis.
Veratrum Touruef. inst. $t$, 145 . Linn. gen, n. 1146. Gärtn, Y, 71, t. 18. Jacq. Fl, austr, t, 335. 336. FI. dan. $t .420$, Bot. Mag. t. 963. 1096. Nees Jun. Gen, pl. fasc. II. t. 10. Plant, offic, suppl. t.2. H elon i a e s p. Don in Edinb. new philosoph. Journ. 1832. Octob. p. 234.

10BS. Zhy gadenus RICH. P e r i g o. n i m corollinum, hexaphyllum, foli ol a nnguiculata, supra unguem biglandulosa, persistentia. $S$ t a $\mathrm{m}$ in a 6 , unguibus foliolorum perigonii inserta; a $\mathrm{nthera}$ e reniformes, extrorsae. Ovari um triloculare. Ovula. ... Sty li 6 , loculis continni, divergentes, corniformes; stigmat a obsoleta. Capsula trilocularis, tripartibilis, apice tricornis, introrsum dehiscens. Sem in a in loeulis $3 \_6$, placentis dissepimenta marginantibus affixa, compressa, membranaceo-alata. - Herbae boreali americanae; foliis oblongo-lanceolatis, acutis, floribus paniculatis, abortu suepius polygamis.

Z y gaden us L. C. Richard in Michaux Flor. Bor. Amer. 1 . 214, $t, 22$. Redouté Liliac, $t$.416, Don in Edinb. new philosoph. Journ, Octob, 1832, p, 233. - L e imant hium Willd. in Berl. Mag, II, 24, Melanthli s p. Linn. Helonia s p. Bot. Mag. t, $985,1680,1703$.

1065. EBurelaradia $R$. BR. Perigon i u m corollinum, hexaphyllum, folio la subunguiculata, supra unguem foveola nectarifera decidua, Stam in a 6 , imis foliolis perigonii inserta; anthe rae peltatae, extrorsae. $O$ varinm trigonum, triloculare, ovula in loculis plurima, biseriata. Styli tres, loculis continui; stigmata acuta. C a p s l a trilocularis, tripartibilis, introrsum dehiscens. Semina plurima....- Herba in Novae Hollandiae ora orientali extratropica indigena; radice e fibris crassis fasciculata, caule simplici, foliis linearibus, vagina integra, supremis semivaginantibus, floribus umbellatis albis, pedicellis basi unibracteatis.

B a r chardia R. Brown prodr. 272.

197 D. Erythorostietus SCHLECHT. P erigonium corollinum, hexaphyllum, foliola subunguiculata, erecto-patentia, supra ungnem punctis duobus neetariferis, decidua. Stamin a 6, perigonii foliolis infra puneta neetarifera inserta; antherae extrorsae. Ovarium triloculare. . Sty 1 i 3 , subulati. ... C a p s u la trilocularis, tripartibilis. ... Herbae boreali-africa$n$ ae; radice bulbosa, foliis radicalibus laneeolatis $v$. linear - -subulatis, congestis, scapis subterraneis, floribus inter folia latentibus.

Erythrostietus Schlechtend. in Linnaea 1,90 . MeIanthium grauineun et punetatua Cav. in Annal. scienc, nat, III, 49.50, t, 26. f. 1, t, 27. f. 1, Ic, rar, t, 587. 588 .

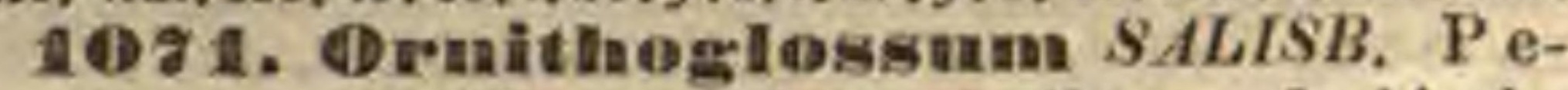
rigonium corollinum, hexaphyllum, foliola subunguiculata, patentia $v$. reflexa, supra nnguem foveola neetarifera instructa, decidua. Stamin a 6, perigonii foliolis infra foveolam nectariferam inserta; antherae extrorsae. Ovarinm triloculare, loculis multiovulatis. Styli tres subulati, centrales; 8 tig mat a obtusa. Caps u 1 a trilocularis, trivalvis, valvis medio septiferis. Semina plurima, in placentis dissepimenta marginantibus, angulato-subglobosa. E mb ry o antitropus, respeetn umbiliei transversus, ab albumine inclusus, extremitate radieulari seminis angulo umbilico opposito proxima. - Herbae capen ses; radice bulbosa, caule Rexuoso, foliis ovato-lanceolatis, acuminatis, undulatis, floribus racemoso-corymbosis, bracteatis.

Ornithoglos 8 um Salisb. parad. .5\%. Schlechtend. in Linnaea 1,81 . L iehtensteiaia Willd. in Berl. Aa. gaz. II. 20. Eymation Spreng. syst, II, 142. Melanthi um viride Linn. Bot. Mag. t. 994. Andr. Reposit. t.233. 
10r\%. Anguillaria $R$. BR. Perigon ium corollinum, hexaphyllum, foliola unguiculata, stellato - patentia, ungue vittato v. biglanduloso, decidua. Stamina 6 , basi foliolorum perigonii inserta; antherae extrorsae. Ovarinm triloculare, multiovulatum. Styli 3 , centrales. Ca p sula trilocularis, trivalvis, valvis medio septiferis. Semina in placentis dissepimenta marginantibus plurima, subglobosa. ....- Herbae habitu Melanthiorum capensium, in In $d i a$ tropica et Nova Hollandia indigenae, charactere vix ab Ornithoglosso diversae.

Anguillaria R. Brown prodr. 273. Wallich $p l$, as, $t$. 259. Melanthium indieum Linn.

10ร3. Melanthium LINN. Perig on iu m corollinum, hexaphyllum, foli ola unguienlata, basi subcucullata v. supra unguem bisaccata, nectarifera, decidua. S ta m in a 6 , foliolorum perigonii basi inserta; a $\mathbf{n} \mathbf{h}$ e $r$ a e extrorsae. Ovarium triloculare, multiovulatum. Styli 3, filiformes, centrales. C a p s u la trilocularis, tripartibilis, loculis apice distinctis, tricornis, introrsum dehiscens. $\mathrm{S}$ e $\mathrm{m}$ in $\mathrm{a}$ in loculorum angulo centrali biseriata, plurima, triangularia. ... Herbae ca penses; radice bulbosa, foliis linearibus $v$. lanceolatis, vaginantibus, saepe ciliatis, planis $v$. rarissime canaliculato-triquetris, floribus spicatis.

Me I a $\mathrm{t}$ h i u m Linn. gen, n. 454. excl. sp. Sehlechtend. in Linnaea $I .80$.

a) CRIOCEPHALUS Schlecht. Perigonii foliola basi subeucullata, sieca.

$\mathrm{C}$ ri ocephalus Schlechtend, in Linnaea $I$, 80. (Lam. illustr, t.269. f.2. Thunb. in Act. soc. Hafn, II. t, 8.)

b) MELiglossus Sehlecht. Pexigo a it foliola basi bisaceata, foveolis nectariferis.

Meliglossus Schlechtend. $l$. c. Dipidax Laws. catalog. 8. (Jacq. ic, rar. $t, 451$. Bot. Mag. $t$.558.)

110 4. ndroeymbitum WILLD. $\mathrm{Pe}$ rigoni um corollinum, hexaphyllnm, folio la unguiculata, supra unguem convoluto-cuenllata, cucullo nectarifero, decidua. $\mathrm{S} \operatorname{ta} \mathrm{m}$ in a 6 , cucullo nectarifero foliolorum perigonii inserta; a $t$ hera extrorsae. Ovarium triloculare, multiovulatum. Styli tres, conici, loculis continui. Ca p8 ula trilocularis, tripartibilis, apice introrsum dehiscens. Semina in loculorum angulo centrali plurima, biseriata. ...-Herbae capenses; radice bulbosa, foliis ovato-lanceolatis $v$. linearibus, basi cucullatis, florum spica abbreviata, intra bracteas foliaceas reconditu.

A $\mathrm{n} d \mathrm{r}$ o c y m b $i \mathrm{um}$ Willd, in Berl. Magaz. Ir. 21, Sehlechtent, in Linnaea I, 81. Sweet Fl. gard, t. 131. C y m$\mathrm{b}$ a n thes Salisb. in Horticult. Transact. I. 329, Melanthi $\mathrm{i}$ s p. Linn. Thunb. Jacq, ic, rar, t.452. Bot. Mag, t.64t.

10 5. Wurmbea THUNB. Perigonium corollinum, campanulatum, limbo sexfido, persistens. Stamina 6 , basi laciniarum perigonii inserta; antherae extrorsae. Ovarinm triloeulare, multiovulatum. Styli tres conici, loculis continui. C a p s u la triloeularis, tripartibilis, perigonio persistente tunicata, $\mathrm{S}$ e mina.... Herbae capenses; radice bulbosa, foliis lineari-lanceolatis, basi vaginantibus, floribus spicatis.

W u r m be a Thunb, nov, gen, 18. Lam. illustr, t, 27o. Schlechtend. in Linnaed 1 . 82. Melanthii s p, Bot. Mag. $t, 694,1991$.

OBSERVATIO. In Wurmbea campanulat a milld. ovula ovato-eylindrica, e funiculis recte protensa, micropyle umbilico e diametro opposita, unde embryonem antitro. puu divipare licet.

10\%6. Tedebouria ROTH. Perigonium corollinum, hexaphyllam, fo $I \mathrm{i}$ o $\mathrm{L}$ a sessilia, basi sicea, campanulato-conniventia, apice patentia, decidua. S tam in a 6 , basi laciniarum inserta; an- therae extrorsae. Ovarium substipitatum, triloculare. Ovula,... Stylus centralis, simplex; s t i g m a obsolete trilobum. C a p s ul a trilocularis, tripartibilis, loculis duobus saepins abortientibus. $\mathrm{S}$ e m in a in loculis solitaria, subglobosa. - Herba in India orientali indigena, imperfecte cognita, sed a $\mathrm{cl}$. R o yle propediem illustranda; radice bulbosa, foliis rudicalibus lato-lanceolatis, basi vaginantibus, scapis simplicissimis, florum racemo terminali.

Ledebouria Roth nov. sp. 195. Bot. Mag. $t, 3226$. Melanthium hyacinthinum Heyne mse.

10\%ซ. Baeometra SALISB. Perigoni um corollinum, hexaphyllum, foliola subsessilia, patentia, basi sicea, decidua. Stamina 6 , perigonii foliolis basi inserta; antherae extrorsae. Ov a rium eylindricum, triloculare, mnltiovulatum. Sti g a ta 3 , patenti-recurva, ovarii angulos terminantia. C a p 8 ul a elongata, eylindrica, trilocularis, tripartibilis, apice introrsum dehiscens. S e m i n a in loculorum angulo centrali biseriata, plurima, compressinscula, tetragona, angulo inferiore affixa. Emb r y o minimus, intra albumen carnosum seminis angulo interiori supero admotus. - Herba capensis, spithamea v. pedalis; radice bulbosa, foliis lanceolato-linearibus, basi vaginantibus, floribus spicatis.

B a e o metra Salisbury in Transact. Horticult. Soc. $\boldsymbol{T}$. 330. Ko I be a Schlechtend. in Linnaea $I, 80$. J a n i Schult. f. syst. FIT. XCVIT. M el a $\mathrm{n}$ h i i s p. Jacq. ic. rar, $t, 450$. Bot, Mag. $t, 267$. Tuli pa Breyniana Linn.

10r8. Sehelhammera $R$. BR. Perigonium corollinum, hexaphyllum, foli ola unguiculata, basi foveolata, campanulato-conniventia, decidua. St a m in a 6, perigonii foliolis basi inserta; antherae extrorsae. Ovarium clavatum, trilocnlare. Ovula plurima, biseriata, anatropa. Stylus centralis, simplex; stigmat a 3 , recurvo-patentia. C apsula trilocularis, trivalvis, valvis medio septiferis. S emin a pauca, subglobosa, ad umbilicum carnosa. Embryo minimus, intra albumen carnosum umbilico proximus. Herba perennis, in Nova Hollandia orientali extra tropicos indigena; radice fibrosa, caule basi subfrutescente, foliis latiusculis, nervosis amplexicaulibus, floribus terminalibus solitariis, longe peduncunculatis, ebracteatis. 2712.

Sehelhammera R. Brown prodr. 273. Bot. Mag. $t$.

1079. Kreysigia REICHENB. Perigon i m corollinum, hexaphyllum, foliol a unguiculata, basi campanulato-conniventia, decidua. St a m in a 6, perigonii foliolis basi inserta, staminodiis brevissimis apice trifidis stipata; anthe ra e extrorsae. Ova rium subglobosum, triloculare. Ovu la, .... St ylus trifidus.

Fructus....-Herba Novae Hollandiae, habitu Schelhammerae; pedunculis axillaribus solitariis.

K r e ysigi a Reichenbach $I c$, exot, t, 229, exct, syn. Genus ut videtur distinetissimum, et aceessaria stamiuodiorum grege in ordine toto anomalum; sed mihi magnopere du. bium; planta a cl. Reichenbachio depieta et obiter deseripta certe a Sehel ham mera multiflora R. Browa e Nova Hollandia tropica, quae monente illustri auetore a Scheltammera undulata fortassis separanda, toto coelo differt.

1080. Uvularia LINN. Perigoninm corollinum, hexaphyllum, foli ol a subunguicalata, basi rima nectarifera, eampanulato-conniventia, decidua. S t a min a 6 , hypogyna; an therae extrorsae. Ovarium subglobosum, triloenlare. Ovula in loculis plurima, biseriata, anatro- 
pa. St y lus centralis, simplex; stigmata 3 , revoluta. Capsula trilocularis, trivalvis, valvis medio septiferis. S e min a pauca, subglobosa, umbilico carnoso. E mb ryo eylindricus, minimus, intra albumen carnosum umbilico proximus. - Herbae in America boreali et in Indiae orien$t$ al $i$ s montibus vigentes, suffrulescentes, simplices $v$. ramosae; foliis latiuseulis nervosis, amplexicaulibus, pedunculis axillaribus solitariis, uniforis, medio unibracteatis.

Uvula ria Linn. gen, n. 412, exel. sp. Smith Exot, Bot. t.49-52. Barton 5l, Bor. Amer, t,5k. f. 1. Wallieh pl, as. t. 269 .

1081. Trieyrtis $W A L L$. Perigonium corollinum, hexaphyllum, foli ol a subunguieulata, campanulato-conniventia, tria exteriora basi gibboso-saceata. Stamina 6, perigonii foliolis basi inserta; a ntherae versatiles. Ovari$\mathrm{um}$ oblongum, triloculare. Ov u $\mathrm{l}$ a in loculis plurima, uniseriata. Stylus centralis, divarieatotrilobus ; stigmata 6, uncinata. Capsula prismatica, trilocularis, apice loculieido-trivalvis. S emina in loculoram angulo centrali densissime imbricata, ovata, testa laxiuscula (atra) rugosa. Embryo minutus, antitropus, in albuminis cavitate submucosa umbilico opposita. - Herba nepalensis, erecta, villis mollibus conspersa; foliis alternis ovato - cordatis, amplexicaulibus, florum panicula terminali, pauciflora, foliolosa, pilosa.

Triey rtis Wailieh Flor. nep, II, 61, t, 46. C o m p s o a Don nep. 51. C o m ps an thus Spreng, cur. post. 137.

1082. Disporum SALISB. Perigonin m corollinum, hexaphyllum, folio la basi carinata, subsaceata, in tubum angulatum cohaerentia, apice eampanulato-conniventia, decidua. $\mathrm{Stamina} 6$, perigonii foliolis basi inserta; a nthe ra e extrorsae. Ovari um subglobosum, loculis biovulatis. Stylus centralis, simplex; stigmat a 3 , revolnta. Cap 8 u la triloeularis, trivalvis, valvis medio septiferis. S e m in a in loculis 2 .

Herbae habitu Uvulariae, in India orient a$\overline{l i}$ indigenae; foliis brevissime petiolatis, pedunculis axillaribus pauciforis.

Dis porum Salisbury ex Don nep, 50 . Uvularia e hinens is Ker in Bot. Mag. 6.916.

1083. Hrapiezia $B L U M$. Perigon ium corollinum, hexaphyllum, foliola basi saceatocalcarata, campanulato - conniventia, decidua. St amina 6 , perigonii foliolis basi inserta; antherae extrorsae Ovarium triloculare, locnlis biovulatis. Stylus centralis, simplex; s tig mata 3 , revoluta. B a c ca uni-trilocularis. Semina in loculis solitaria, reniformia. $\mathbf{E} \mathbf{m}$ b ry 0 in albumine carnoso umbilico oppositus. - Herba ja va $n i$. c a, perennis; radice fibrosa, caule ramoso, ramis dichotomis, foliis brevissime petiolatis, nervosis, pedunculis oppositifoliis, medio foliaceo-bracteatis, pedicellis subumbellatis, unifloris, floribus purpurascentibus.

D rap iezia Blume enum. pl. Jav. 1. 8. Schult, f. syst. VIT. 1672. Let the ae s p. Noronha mse.

The UBUS 1I. COLCHICEAE Nees et Ebermeyer Handb. I. 50. Perigonii foliola longissime unguiculata, unguibus plerumque in tubum connatis.

1084. Monecaryam $R, B R$, Perigon i um corollinum, hypoerateriforme, $t u b o$ elon gato, $1 \mathrm{imb}$ o patente, sexpartito, laciniis subaequalibus. Stam in a 6 , basi laciniarum limbi inserta ; fil amenta subulata, alterna breviora, antherac versatiles. Ovarium simplex, uniloculare. Ovnla ad suturam parietalia. Stylus filiformis, indivisns; stigma simplex. _ Herba orientalis, bulbosa; foliis radicalibus vaginantibus, lineari-lanceolatis, acutis, spatha radicali, floribus aggregatis basibus hypogaeis.

M o n o e a r y u m R. Brown Append. to Denham et Clappert. p. 241. Hy poxis fas eicularis Linn. (Russel Aleppo p.34. t.2.)

1085. Titubecodium LINN. Perigonium corollinum, hexaphyllum; folio $l$ a longissime unguiculata, in tubum conniventia, ad faucem denticulis lateralibus inter se connexa, laminis aequalibus, erecto-patentibns. Stam in a 6 , perigonii foliolis supra ungues inserta; fila$m$ enta filiformia, a $t h$ e $r$ a e incumbentes. Ovarium triloculare. Ovula plurima, multiseriata, anatropa (?) Styli tres, terminales, distincti $\mathbf{v}$ inter se connati. Ca ps u l a trilocularis, tripartibilis, apice introrsum dehiscens. S e mina. ...- Herbae in $E$ u ro pa a ustrali et orientali indigenae, habitu Colchici,

B u 1 b o c odi um Lian. gen. n. $40 \%$.

a) MERENDERA Ram. S $t$ y I i tres distincti.

Merendera Ramond in Bullet, soe. philomat, 1798. n. $43, t, 12$. Redouté Liliac. $t .25$. Bieberst. pl. ross, $t, 50$. Ge o phila Beregeret Pyren. IT. 184. Colehici s p. Brot. phytogr. lusit. t. 50 .

b) BULBOCODIUM Linn. Sty 11 tres in unicum connati. Bu I b oc o dis im Redouté Liliac,t. 187. Bot. Mag. t. 153. Colehicisp. Bot. Reg. $t, 571$.

1086. Collehieum TOURNEF, Perig o n i m corollinum, infundibuliforme; $t$ u b o longissimo, anguloso, gracili, lim bo subcampanulato, sexpartito. Sta mina 6 , tubi fauei imposita; filamenta snbulata, antherae versatiles. Ovarium triloculare. Ovula in loculis plurima, bi-quadriseriata, orthotropa. St yli tres, filiformes, elongati; stig $m$ at a subelavata. Capsula trilocularis, tripartibilis, introrsum dehiscens. S e min a plurima, subglobosa, testa rugosa, ad umbilicum ventralem carnoso - incrassata. E m b r y o minntus, subcylindricus, in extremitate seminis ab umbilico remota, in albumine carnoso inclusus. - Herbae in Europa media et in regionibus mediterraneis indigenae; flaribus radicalibus, foliis ut plurimum serotinis, suepius cum fructu emergentibus.

Col c bie a m Tournef, inst, t, 181, 18\%, Linn, gen, n, 457.

a) Colchicum. Perigon if lobi intus uadi. Semina in Ioculis saepias quadriseriata.

(Gartu. I. 20, t, 18. Steven in Act, Mtosq. VIT. 65, t. 13. 14. Relonté Liliac. t. 228. Waldst, et Kit. pl. Hung, $t, 179$. Sibth. Fl. graec, 2 , 350. Bot. Reg. t, 45t, Bot. Mag. $t .1082$. 1128. 2673. - ? G ea $\mathrm{n}$ hi a Raf. in N. York Med. Reposit, V. 350 .

b) Hermodactylus $R$. Br. Perlgonil lobi intus basi bieristati, $0 \mathrm{v} u \mathrm{I}$ a in loeulis biseriata.

Colehicum (Hermodactylus) Ritchiei R. Brown Append, to Denh, et Clappert. p.24t.

\section{Drdo EIV. Pontederaceae.}

PONTEDEREAE Kunth in Humb. et Bonpl, nov. gen. et sp. 1 . 21t. Agardh Aphorism. 169. Mart. nov, gen. et sp., . $z$. Raspail in Mém. du Mus. XIV. 169. PONTEDERACEAE A. Richard Nouv. elem. edit. IV. 487. Lindl. introduct. edit. 2.

Herbae aquaticae v. paludosae, rhizomate repente perennantes. Foli a omnia radiealia, petiolis basi dilatata vaginantibus, lamin a plerumque lata, ovata, cordata v. sagittata, nervosa, integerrima, interdum abortiva, petiolis tune complanatis dilatatisque, ph yllodia linearia constituentibus. 
Flores e vaginis tubulosis oblique truncatis, v. e fisso foliormm petiolo exserti, nunc solitarii, nune in spicam, racemum v. umbellam dispositi; singuli primum spathaceo-bracteati, hermaphroditi, subregulares, caerulei v. rarius flavi.

Perigonium corollinum, marcescendo persistens, hypocrateriforme v. infundibuliforme, $t \mathbf{u}$ bo elongato $\mathrm{v}$. brevi angulato, $l i \mathrm{mbo}$ sexfido; laciniis biseriatis subinaequalibus, interioribus saepe minoribus, quinque superioribus plerumque approximatis, lacinia antica interdum intensius colorata, omnibus aestivatione spiraliter involutis.

Stauina sex, v. tria, et tunc perigonii laciniis interioribus opposita, nune omnia conformia, nunc tertium v. sextum anticum dissimile; fil amento plerumque longiore, et anthera majore heteromorpha $v$. saltim heterochroa instructum. Filamenta in floribus hexandris filiformia teretia, alternatim summo et medio tubo, rarius omnia imo tubo inserta, in triandris summo tubo imposita, et duo saepius medio incrassata et inflexa, tertium teres, patens. Anther a e introrsae, biloculares, basifixae, lineares v. ovatae, aut subsagittatae, loculis parallelis, contiguis.

Ovarium sessile, liberum, vel demum cum perigonii tubo partim concrescens, triloculare, v. septis axim vix attingentibus incomplete triloculare, nune loculis duobus cassis minimis, subuniloculare.

Ovvua in placentis dissepimenta marginantibus plurima, biseriata, erecta $v$. inversa, anatropa; nunc in ovarii subunilocularis cavitate fertili unicum, apici appensum. Sty lus simplex, terminalis. Stigma crassiusculum, obsolete trilobum.

Capsula perigonii tubo emarcido tunicata, vel interdum cum eodem concrescens, trilocularis, polysperma, loculicido-trivalvis, valvis medio septiferis et seminiferis; v. unilocularis, monosperma, indehiscens.

Senisa adscendentia v, inversa, ovata. Test a chartacea, costato-striata, umbilico basilari et chalaza terminali crassiuscula notata. Alb u men dense farinaceum.

Еивкуо orthotropus, axilis, albuminis fere longitudine, extremitate radiculari incrassata, umbilicum attingente, verticem v. basim carpicam spectante.

Pontederace ae in America inter $40^{\circ}$ L. B. et $30^{\circ}$ L. A. non infrequentes, in A sia et Africa tropica multo rariores, aquas stagnantes et prata paludosa incolunt; perigonii aestivatione circinnata, et habitu peculiari ab ordinibus conterminis facillime distinguendae.
108\%. Heteranthera RUIZ et PAV. Perigonium corollinum, persistens, hypocrateriforme; $t \mathbf{n b}$ o filiformi, elongato, $1 \mathrm{imbi}$ sexpartiti laciniis interioribus paullo minoribus, basi maculatis, quinque superioribus magis approximatis. Stam ina 3 , perigonii fauci inserta, limbi lobis interioribus opposita, aequalia $\mathbf{v}$. tertium dissimile. Ovari n m cylindraceo-fusiforme, triloculare. Ovula plurima, in loculorum angulo interiori pluriseriata, anatropa. St y lus terminalis, filiformis, elongatus; stig ma capitato-trigonum. Capsula perigonio emareido inclusa, dissepimentis vix axim attingentibus incomplete trilocularis, trivalvis, valvis medio septiferis. Semina plurima, in placentis septa marginantibus biseriata, ovata, erecta, testa chartacea, costato - striata. Embryo cuneatus, in axi albuminis dense farinacei, extremitate radiculari infera.

Herbae aquaticae, molles, in America inter $40^{\circ}$ L. B. et $30^{\circ}$ L. A. obviae; foliis reniformibus $v$. ovalis, petiolatis, petiolis vaginantibus, nunc laminis abortivis complanatis, phyllodineis.

Heteranthera Vahl enum. $I$. p. 42. Leptanthus Pers. ench. p. 56. Nuttall gen. $x .29$.

a) LEPTANTHUS $L$. C. Rich. St am ina aequalia; filamentis teretibus, an theris linearibus.

Leptant hus L.C. Richard in Michaux Fl.Bor.Amor. I. 24. t.5. f. 2. exel. sp. Hook. exot. Flor. t, 94. S c holl e. $\mathrm{r}$ a Willd. in Berl. Verhandl. 1IT. 438. (Presl. Symb. t. 10.)

b) HETERANTHERA Ruiz elPav. S tam i a inaequalia; fil a me ntis duorum superiorum medio incrassatis an therisque ovatis, inflexis, tertio tereti longiore, anthera sagittata v. saltim heterochroa.

Heteranthera Ruiz et Pav, prodr. p.9. t.2. Flor. peruv. I. 43. L.71. Humb, et Bonpl, nov. gen, et sp. I. 211. Martius nov. gen. et sp. $I$. 7. $t$. 3. Heterandra Palis. in Americ, philosoph. Transact. IV. 173.

1083. Fontederia LINN. Perigoniu m corollinum, persistens, infundibuliforme; t $\mathbf{u b}$ o angulato, saepius incurvo; $1 \mathrm{imb}$ o sexfido subaequali $v$. subbilabiato. St a min a 6 , inaequalia, summo et medio, vel omnia summo tubo inserta. Ov a ri u m subtrigonum, triloculare, Ioculis omnibus fertilibus, multiovulatis, v. duobus cassis, tertio uniovulato. $O$ v $\mathbf{~} 1$ a pendula, anatropa. Stylus terminalis, subulatus; stigma incrassatum, obsolete trilobum. Capsula perigonii persistentis basi tunicata, v. interdum cum eadem concrescens, trilovularis, loculicido-trivalvis, polysperma; vel unilocularis, monosperma, indehiscens. Semina ovata, inversa, testa chartacea, costato-striata. E mbr y o orthotropus, in axi albuminis dense farinacei, extremitate radicnlari incrassata, verticem fructus spectante. - Herbac perennes, aquaticae, in America tropica et boreali temperata non infrequentes, in $A s i a$ et $A f r i c a$ tropica rariores; radicibus fibrosis, foliis omnibus radicalibus, petiolis basi dilatata vaginantibus, lamina ovata, cordata v. sagittata, integerrima, nervosa, floribus spicatis, racemosis $v$. subumbellatis, e fisso foliorum petiolo exsertis, singulis spathaceo-bracteatis.

P onte d e r ia Linn. gen. n. 399. Juss. gen, p. 55. Kunth in Humb, et Bonpl. nov. gen, et sp. I. 266. Martíis nov. gen. et sp. I 9. t.4. Raspail in Mem. du Mus. XIV. 169. Blume enum, pl. Jav, I. 32. Sehult, fil. syst, $\nu I$. n., 1462 .

a) UNISEMA Raf. 0vari u m triloculare, loculis duobus cassis. $0 \mathrm{v}$ u $1 \mathrm{um}$ ia loculo fertili unicum, apici apensum. Utriculus monospermus, basi perigonii tabo adhaerens. - Species americanae.

$\mathrm{U}$ a is e ma Rafinesque in Journ. Phys. LXXXIX. 261. P. eardat a Lisn. Redouté Liliac, t.72. Bot. Mag. t.1156. Mirbel in Annal, du Mus. XVI, t, 16. Raspail in Mem. Mrus. XIV. t.9. $f, 1-6$. 11. iP. angustifolia Pursh. P. cordifolia Mart. 
b) PONTEDERIA. Ovari u triloculare, multiovula. tum. Capsula perigonii tubo tunicata, nec ei ad. haerens, irilocularis, polysperma. - Americanae et astaticae.

a) Pontederia Presl Reliq. Haenk, I, 116. Stam ina summo et medio tubo inserta, subaequalia. P. crassipes Mart. nov. gen, et sp.t.4. P. a $\mathrm{xu}$ rea Swartz. Hook. Bot. Mag. t.2932.

B) Monochoria Presl. op.cil.p.172. Stamina imo tubo inserta, anticum majus. - Asiaticas. P. vaginalis et hastata Roxb. corom, t,110. 111 . Raspail in Annal. du Mus. XIV. t.9. f.7-9.12.

1085. Henssia ENDL. Perigonium corollinnm, persistens, infundibuliforme; $\mathbf{t} \mathbf{u} \mathbf{b} \mathbf{o}$ brevi, $1 \mathrm{i}$ mb o sexfido, subbilabiato, lobis quatuor superioribus subaequalibus, duobus inferioribus brevioribus, postice superioribus cohaerentibus, antice distinetis. $\mathrm{S}$ ta $\mathrm{mina} 6$, medio tubo biseriatim inserta, inclusa. O v a $\mathrm{ri}$ u $\mathrm{m}$ subglobosum, triloenlare, loculis duobus cassis, nerviformibus, tertio uniovulato. $O \mathbf{v} \mathbf{l} \mathbf{n} \mathrm{m}$ apici loculi fertilis appensum, anatropum. Stylus terminalis, ineurvus; stigma bilabiato-trilobum. Utriculus monospermus, cum perigonii tubo concretus. Semen subglobosum; testa membranacea, costatostriata. E mb ryo orthotropus, in axi albuminis dense farinacei, extremitate radiculari cuneata, verticem fruetus spectante. Herba bra. siliensis, aquatica; caule fluitante, radicante, folits petiolatis, ellipticis, natantibus; petiolis basi in vaginas membranaceas latas, caulem velantibus, dilatatis, spathis foliiformibus, longe petiolatis, e foliorum vaginis exsertis, basi antice in tubum brevissimum connatis, trifloris, floribus flavis, duobus lateralibus pedicellatis, intermedio sessili.

Reussia Endlicher Atakta t,26.

\section{Ordo $\mathbb{L}$. Hilincene.}

IILIACEAE et NARCISSORUM pars Juss. gen. 48. 54. UEMEROCALLIDEAE, ASPHODELEAE R. Brown prodr. 274 . LIILACEAE, TULIPACEAE et ASPHODELEAE DC. ASPHODELEAE Bartl. ord, nat. 49. LIEIACEAE Lindl. introduct. edit. II. 351, excl. pl.

Неrвa e bulbosae $v$, tuberibus perennantes, interdum annuae, nonnunquam arborescentes v. suffrutescentes, trunco e foliorum vaginis conflato, cicatrisato. Caul is simplex v. apice ramosus, nunc foliatus, nunc aphyllus, scapiformis. Fo li a simplicia, integra, plerumque linearia, basi vaginantia v. amplexicaulia, radicalia congesta, caulina saepius sessilia, canaliculata v. teretia, interdum lamina dilatata nervosa praedita.

Flores hermaphroditi, regulares v. rarissime subirregulares, vix non semper terminales, nunc solitarii, nunc in racemos, spicas, umbellas v. capitula collecti, interdum paniculati, bracteis scariosis saepissime fulti, interdum bracteis spathaceis involucrati.

Perigonium corollinum, decidumm v. marcescendo-persistens, hexaphyllum; foliol a biseriata, libera, $v$. in corollam tubulosam campanulatamve, limbo sexdiviso donatam connata, sicea v. basi saepius mellifera.

Stamiva 6 , perigonii foliolis opposita, nunc distincte hypogyna, nunc perigonii basi inserta, rarius abortu tria, v. plura, serie una v. altera tune sterili. Fil a menta filiformia v. plaua, libera v. cum perigonii tubo plus minus connata, simplicia v, apice trifida aut tridentata, dentibus lateralibus sterilibus. A nth e r a introrsae, terminales, erectae, v. medio dorso affixae, versatiles, biloculares; 10culi oppositi, paralleli, connectivo obsoleto contigui, longitudinaliter dehiscentes. Polli n is granula pulveracea, laevia, rima simplici hiantia.

Ovarium e carpidiis tribus conflatum, carpidiorum marginibus introflexis axim plus minus distinctam attingentibus triloculare. Ov ula in loculis pauca v. saepius plurima, biseriati, anatropa v. amphitropa. Styli terminales, centrales, plerumque in unicum connati, stig matibus interdum distinctis.

Pericarpiem capsulare, triloculare, loculicido - trivalve, valvis medio septiferis, rarius septicidum, v. carnosum, indehiscens.

Seursa plurima, v. rarius abortu pauca aut subsolitaria, directione varia, funiculis ut plurimum brevissimis sustenta, v. placentatione immediata sessilia. Testa membranacea, pallida et interdum marginata, v. saepissime crustacea, fragilis et atra, $\mathrm{n} \mathrm{mb} \mathrm{i-}$ li co basilari cum chalaza terminali ope $\mathrm{rha}$ pheos plus minus manifestae juncto, v, ventrali lato, cum chalaza confiuente. Album en carnosum, copiosum.

Eмввуо in axi albuminis, rarissime excentricus, longitudine varia, homotropus, rectus v. curvatus, extremitate radiculari umbilico proxima, directione carpica varia.

Liliaceae ab affinibus Smilaceis aegre separandae, per totum terrarum orbem sparsae, universim in vetere continente, et in $\mathbf{r e -}$ gionibus temperatis subtropicisque paulo frequentibus habitant.

SUBORDA I. TULIPACEAE. Perigon i i foliola omnino distincta $v$. ima basi cohaerentia, saepe nectarifera. Stamina hypogyna v. obscure perigyna. Fructus capsularis. Semina anatropa, plerumque compressa, testa pallida, fusca, spongiosa v. dura. E m b ry o minimus, rectus v. parum incurvus, in basi albuminis inclusus. - Herbae bulbosae.

1090. Erythronium LINN. Perigon i n m corollinum, persistens, hexaphyllum ; foli o la basi campanulato-conniventia, medio patula, tria interiora basi bicallosa. St a m in a 6 , exteriora hypogyna, interiora basi foliolorum perigonii adhaerentia, Ovarium brevissime pedicellatum, triloculare. Ovula in loculis plura, biseriata, anatropa. Stylus terminalis, simplex; $8 \mathrm{t}$ ig ma breviter trilobnm. Capsula triquetra, trilocularis, loculicido-trivalvis, polysperma, $\mathrm{S}$ emin a ovoidea, inversa, testa fusca, rhaphe Iongitudinali percursa, ad chalazam terminalem in 
eandiculam elongatam, basi tumidam relaxata. E mb r y o minimus, rectus, umbilico proximus. Herbae bulbosae, in Europa australiore et in America boreali temperata indigenae; foliis radicalibus paucis, ovato-oblongis lanceolatisve, scapo unifloro, flore nutante.

Erythronium Linn. gen. n. 414. Jaeq. Fl, austr. app. t. 9. Redouté Liliac, t.194. Bot. Mag. t. 1113. Nees jus. gen. pl. fasc. IV. t.5. Bernhardi in Flora 1835. p.597. Den s canis Touraef.

1091. Tulipa TOURNEF. Perigon ium corollinum, deciduum, hexaphyllum; foli o l a campanulato-conniventia, subaequalia. Stam in a 6, hypogyna. Ovarinm triloculare. Ovula in loculis plurima, biseriata, anatropa. S $\mathrm{t}$ i g $\mathrm{m} \mathrm{a}$ terminale, sessile, trilobum, lobis patentibus, complicatis. Capsula trigona, trilocularis, loculicido-trivalvis. Semin a plurima, horizontalia, compresso - plana, testa rufescente, rhaphe et chalaza vix manifestis. Embry o rectus, dimidio albumine brevior, extremitate radieulari in crassata, umbilico proxima. - Herbae bulbosae, in Europa australiore et in Asia media indigenae; foliis radicalibus ovato-oblongis lanceolatisve, scapis unifloris, floribus erectis.

T u 1 i p a Tournef. inst. t. 199. 200, Linn. gen, n. 415. Gärtn. I. 64. t. 17. Sibth, Fl, graec. t.329.330, Redouté Liliac, $t$. 38. 111. 219. Ledebour Fl. alt. $t$, 85. Bot. Mag. $t, 2862$. Bot. Reg. '. 1106. 1143. Nees jun. gen. pl. fasc. IV. $t$. 3 . Beruhardi in Flora 1835. p. 597 .

1982. Drithyia $D O N$. Perigoninm corollinum, deciduum, hexaphyllum; foliola campanulato - conniventia, interiora in unguem angustata. Stamina 6, hypogyna. Ovarium triloculare. Stylus terminalis, simplex; stigma obsolete trilobum. C a p 8 u la trigona, trilocularis, loculicido - trivalvis. Se m in a plurima, horizontaIia, plano-compressa. - Herba bulbosa, in As i a media indigena, habitu Tulipae. Genus ob stylum manifestum, vix ob perigonii foliola interiora basi in unguem angustata, a Tulipa separandum, nullo modo Gageae, ob habitum alienum et perigonium deciduum jungendum.

Orith y i D. Don in Sweet Brit. Fl. gard, t, 336, O $\mathrm{ru}$ i thoga I u m niflor um Linn. Laxmann in Nov. Act. Petropolit. XVIIT, 599 . t. 6. f. 3. 0. o х y p eta $1 \mathrm{um}$ Ledeb. Ft. alt. t.380. Tulip a altalca Gebler msc.

1053. Cagea SALISB. Perigonium corollinum, persistens, hexaphyllum; fo 1 i o 1 a patentiuscnia, subaequalia. St a mina 6 , perigonii foliolis basi adhaerentia. Ovari um triloculare. Ovnla in loculis plura, biseriata, pendula, anatropa. Sty I us terminalis, trigonus; stigma trilobum, depressiuseulum. Ca psuia trilweularis, loculicido - trivalvis. Semin a in loculis pauea, inversa, subglobosa, testa flavida, rhaphe carnosiuscula percursa. Embryo rectus, dimidio albumine fongior, extremitate radiculari attenuata, umbilicum attingente. Herbae bulbosae, scapigerae, in Europa et $\overline{s i a}$ media ob. viae, in Africa mediterranea rarae; floribus umbellutis, umbellis foliaceo-bracteatis.

Gag a Salisbury in Annals of Botany $I T$. 555 . Reichenbach pl. erit. $t$, 117. 228. 329. Nees jun. gen, pl. fasc. $I V$. t. 15. Bernhardi in Flora 1835. p. $596.0 \mathrm{rnith}$. $\mathrm{xa}$ a thum Link Handh. I.161, O rait ho gali s p. Linn. Fl. dan. $t, 378$. 612,1313 , Desf. Fl, atl, $t, 84$. Sibth. Fl, graec, t.331. Re-
douté Liliac, $t, 308$.

1094. Taloyulia SALISB. Perigonium corollinum, persistens, hexaphyllum; foliola patentia, subaequalia, basi plica nectarifera transversa. St a $m$ in a 6 , perigonii foliolis basi adhaerentia. Ovarium triloculare. Ovula in loculis plurima, biseriata, horizontalia, anatropa. St ylus terminalis, subclavatus; st igma subtrigonum, vertice depressum. C a p s u la triquetra, trilocularis, apice loculicido - trivalvis. S e m in a in loeulis plurima, subhorizontalia, compresso-plana, testa fusca, membranaceo - marginata, rhaphe hinc per marginem decurrente. E m b r y o minimus, umbilico proximus, - Herbae bulbosae, in Europa media et australi, in Asiaboreali et in America arctica observatae; foliis linearibus basi dilatatis, caule unifloro $v$. subcorymboso.

Lloydia Salisbury msc. Reichenbaeh Et. excurs, 102. Nees jun. gen. pl. fasc. IV. t. 19. Bernhardi in Flora 1835. p. 596. Rhab do c ri n u meichenbaeh consp. 65. Nectaribothrium Ledebour Fl, alt, $I I, 36$. A it thericum serotioum et A. gra e cum Linn. Jacq. Fl. austr, app. $t$. 38. Redouté Liliac, $t, 270$, Sibth. Fl, graec, t. 436.

1095. Caloelnontus PURSH. Perigoni nm corollinum, deciduum, hexaphyllum; foliola sessilia v. subunguiculata, supra basim fovea nectarifera, exteriora minora, omnia v, interiora tantum intus barbata. Stamina 6 , perigonii foliolis basi adhaerentia. Ovarium triloculare. Orula in loculis plurima, biseriata, horizontalia, anatropa. Stigmat a 3 , subsessilia, libera v. basi coalita, reflexa, canalieulata, Ca p8 u la subgloboso - trigona, trilocularis, septicidotrivalvis, valvis demum bifidis. Sem in a in loculis plurima, subuniseriata, horizontalia, compressiuscula, te st a fusca, membranacea, laxiuscula, hine rhaphe percursa. $\mathbf{E}$ bryo rectus, teres, excentrieus (?). - Herbae in America boreali oceidentali, et in terris mexicaris indigenae, bulbosae, simplices; foliis ensiformibus vaginantibus, floribus speciosis umbellatis $v$. racemosis, purpureis $v$. albidis.

C a lochortus Pursh Flor. Bor. Amer. I. 240. Sehultes f. in van Hall Bijdr. IV. 127. Bernhardi in Flora 1835. p. 595 .

a) Calochortus Pursh. Perigonit foliola exteriora subcalycina, linearia, imberbia, interior a petaloidea, subunguiculata, exterioribus multo latiora, intus barbata.

Caloehortus Pursh $t$. c. Lindl. in Bot. Reg. t. 1152. 1567. 1669, 1670. Douglas in Hort. Transact. VII. 276. $t .8$. 9. Bentham op. cit, II. I, t. 15 .

b) CycloвотнRA Don. Perigonii foliola sessilia, subaequalia, exteriora breviora, omuia intus barbata.

Cyclobothra Don in Sweet Fl. Gard. t, 20. Bot. Reg. t. 1661-1663. Fritilla ria ba r bat a Kutb in Humb. et Bonpl, nov. gen, etsp, $t, 6 r 7$. C a lo ch orti s p. Sehaltes.

1095. Fritillaria LINN. Perigonia m corollinmm, decilunm, hexaphyllnm; folio la subaequalia, eampanulato-conniventia, intus suprat basim linea nectarifera. Sta m in a 6 , perigonii foliolis basi adhaerentia. Ovarium triloculare. Ovula in loculis plurima, biseriata, horizontalia, anatropa. Stylus terminalis, subclavatus; stigma tripartitum. C a p s la trigona, vel hexagona, angulis acutis, trilocularis, loculieido-trivalvis, $\mathrm{Se}$ min a in loculis plurima, biseriata, horizontalia, compresso - plana, testa fusca, membranaceo - alata, rhaphe hine per marginem decurrente. Embryo minimus, umbilico proximus. - Herbae in Eu ropa australiore et Asia media indigenae, bulbosae, caulescentes; foliis alternis v. subverticillatis, foribus axillaribus plerumque maculatis, nutantibus.

F ritillaria Linn. gen, $n$. 411 . Beruhardi in Flora 1835. $p, 593$.

a) FRITILlARIA Tournef. Capsula trigona, laevis, angulis obtusis.

Fritillaria Tournef. inst, t, 197, 198. 201. Juss. gen. p. 48. Jacq. Fl, austr, app, t, 32. Sibth. Ft. graec, $t, 328$. 
Bieberst. pl. ross, t.21. Ledeb. Fl. alt. t.2. Bot. Mag. $t .194$. 664. $853,857,952.962,1207,1215,1216,1537,1538,3083.3280$. Nees jun.gen, $p l$. fasc, $I V . t, 4$.

b) PETILIUM Linn. Caps u la hexagona, angulis acntis.

Petilium Linn. Hort. cléff. 119. Imperialis Juss. gen. p. 49. Corona imperialis Tournef. inst. 498-499. (Gïrtı. I, 63, t, 17. Redouté Liliac. t, 131.)

109\%. Fibihopedaluan FISCH. Perigo n i m corollinum, decidmum, hexaphyllum; foli ol a patentia, subaequalia, basi fovea nectarifera excavata, supremi fovea profundiore, in cornu adscendens producta. Stam ina 6 , perigonii foliolis basi adhaerentia. Ovari $\mathbf{u} \mathbf{m}$ triloculare. Ov u1 a in loculis plurima, biseriata, obovato ventricosa. Stylus terminalis, filiformis; stigma indivisum, truncatum. Capsula....-Herba uralensis, bulbosa; caule simplici, foliis lanceolatis, subconvolutis, flore terminali solitario, pallide lilacino.

$\mathrm{R}$ hinopetalum Fiselier ex Edinb. new philos.Journ. Jan, 1830. p, 19. Don in Sweet F\%. Gard, $t, 283$.

1498. Hilluma $L I N N$. Perigonium corollinum, deciduum, hexaphyllum; folio la basi subcohaerentia, infundibuliformi-campanulata, apice patentia $v$. revoluta, intus sulco nectarifero instructa. Stamina 6 , perigonii foliolis basi subadhaerentia. Ovari n m triloculare. Ovula plurima, biseriata, horizontalia, anatropa. Stylus terminalis, subelavatus, rectus v. subeurvatus; st igma subtrilobum. Capsula trigona, sexsulca, trilocularis, loculicido - trivalvis. Sem in a plurima, biseriata, horizontalia, plano-compressa, $t$ e $t$ a lutescente, subspongiosa, membranaceomarginata, rhaphe hine per marginem decurente. Embryo in axi albuminis carnosi rectus $v$. sigmoideus, extremitate radieulari umbilieo proxima. - Herbae in Europa et $A s$ ia media et septentrionali, in Japonia et in Indiae montibus, nec non in Americaboreali indigenae, bulbosae; foliis alternis $v$. subverticillatis, floribus magnis, speciosis, erectis $v$. nutantibus.

L ill a m Linn. gen. n. 410.

a) AMBLiRion haf. Rerig on it foliola sessilia, conniventia, 8 ulc o neetarifero obsoleto.

A mblirion Rafin, in Journ, de Phys, LXXXIX, 102. Lilla fritillaroide a Schult. syst. VII, 399.

b) MARTAGON. Perigonit foliola sessilia, revoluta, 8 u 1 e o nectarifero distineto.

(Gärtn. t. 83. f. 3. f.i. Jacq. Fl. austr, t.351. App.t.20. Redouté Liliac. t, 145,378. Bot. Mag, t, 3140.)

c) PSEUdoliriun. Perigouif foliola unguiculata, campanulato-eonniventia, $8 \mathrm{ulc}$ o nectarifero distiucto (Bot. Mag, t, 259.519. Bot, Reg, t.504.)

d) Eulirion, Perig o n i f foliola sessilia, campanulatoconaiventia, sul co nectarifero distincto.

(Gärtn. t.93. f.3. a-e. Jacq. Fl, austr, t.226. Redoute Liliac. t. 199$)$

e) CARDIOCRINUM. P e rig o n if foliola sessilia, campanulato-eonuiventia, suleo neetarifero distiucto, basi subsaceato.

(Wallich Flor, nep. t. 12, 13. Banks ic. Kaempf. t. 46,) Hemerocallis cordata Gärtn. $t .179$.

10S5. Nethomien HERM. Perigoni n m corollinum, hexaphyllum, marcescens; fol iola subaequalia, undulata, caudata, reflexa. St amina 6 , perigonii foliolis basi inserta, subhorizontalia. Ova ri um triloenlare. Ovula plurima, biseriata, horizontalia, anatropa. Stylus terminalis, oblique declinatus; stigma trifidum Capsu la subgloboso-turbinata, trilocularis, tripartibilis. Sem in a plurima, biseriata, subglobosa, te st a carnoso-spongiosa, coccinea, rh a p he filiformi umbilicum basilarem chalazae terminali (nigrae) jungente. $\mathbf{E m b r}$ yo in basi albuminis carnosi uncinato-complicatus, extremitate utraque umbilico proxima. - Herbac scandentes, ramo- sae, in Asia et Africa tropica indigenae; radice tuberosa, foliis sparsis, sub ramis oppositis vel ternatim verticillatis, sessilibus, lanceolatis, acuminatis $v$ in cirrhum productis, pedunculis unifloris, axillaribus terminalibusque.

M e th o n i a Herm. Lugdbat. 689. Juss. gen, 48. Lam. t.247. Redouté Liliac, t.26. G I o ri os a Lina. gen, $n .410$. Girtu, $1,69, t, 18$. Bot. Reg, $t, 77$. Bot. Mag, $t, 2539$. Bern. hardi in Flora 1835. $p$ 5.9.

SUEOTID II. AGAPANTHEAE. Pe rigonium tubulosum, limbo sexfido. Stamina perigyna. Ovarium triloculare. Ovula anatropa. Fructus capsularis. Semina compressiuscula, testa membranacea, saepius pallida. Embryo orthotropus. - Herbae perennes, radice tuberosa $v$. fibrosa.

1 1 6 D. Funkia $S P R$. Perigon i m corollinum, tubulosum; t $n$ bo brevi, 1 im bo sexpartito, subbilabiato, connivente $\mathbf{v}$. patentiusculo. Stamina 6 , basi limbi inserta, subfasciculatim declinata. Ovarium triloculare. Ovula plurima, biseriata, adscendentia, anatropa. Stylus filiformis, declinatus; stig ma subtrigonum, laeve. Ca p s u la oblongo-prismatica, trilocularis, loculicido-trivalvis. Se mi na plurima, adscendentia, plano-compressa ; test a membranacea, nigra, laxa, in alam apice longiorem producta, $r$ ha $p$ he intra testam libera, adscendente. E m b r y ones plures, dimidio albumine longiores, intra communem cavitatem axilem paralleli, extremitatibn s radi e ularibus incrassatis, umbilico proximis. - Herbae in China et Japonia obviae; radice fibroso-fasciculata, folis radicalibus petiolatis, ovatis cordatisve, acuminatis, plicato-nervosis, caulinis nullis v. subsessilibus, foribus racemosis, candidis $v$, caeruleis.

Funkia Spreng, syst. $I T$. 4t. Hosta Trattinik Tabular, $t, 89$. Thesaur t, 51, 52. B r y oeles Salisbury in Hort. Transact. I, 335. Nio be Salisb. Saussurea Salisb, in Linn. Transact. VIII. 11. Libertia Dumort. Hemeraeallis japonica et e a rulea Auet. Vent. Malmais. $t$. 18. Redoute Liliac, $t, 3,106$. Bot. Mag, $t, 894,1433$.

1 101. Hohomiame FORST. Perigon i u m corollinum, tubulosum; $t$ uh o brevissimo, l i $\mathrm{mb}$ i sexpartiti laciniis interioribus longioribus, apice patentibus. Stamina 6 , imo tubo inserta, alterna breviora, fi 1 a m e $\mathrm{t}$ a adscendentia. $\mathrm{O}$ ari u m triloculare. Ovul a plurima, biseriata, adscendentia, anatropa. Stylus trigonus, adseendens; stigma simplex. Capsnla oblonga, trigona, torta, trilocularis, loculicido-trivalvis, $\mathrm{Se}$ mina plurima, adseendentia, plano-compressa, t e st a chartacea, atra, laxa, in alam apice longiorem producta, $r$ ha phe intra alam libera, adscendente. Em br y o axilis, dimidio albnmine longior, extremitate radiculari umbilico proxima. Herba in NovaZeelandiaboreali, et in insula Norfolk indigena; radice tuberoso-carnosa, foliis radicalibus distichis, coriaceis, tenacissimis, lineari-lanceolatis, basi equitantibus, scapo ramoso, paniculato, ramis bracteatis, floribus flavis.

P h o r m f u m Forst. char. gen. t. 24. Thouin in Annal. Mus. II. 228. Faujas de St, Fond Ibid, XIX. 401, t,20, Redouté Liliac, t. 448.499. Thiebaud in Annal, soc, Linn, Paris. IV. 57, t.7. Cunningh, in Bot. Mag. t. 3199. Ch 1 am idi a Banks et Sol. apud Gärtn. I, 71, t.18.

1102. Agapanthus HERIT. Perigon i u m corollinum, tubulosum; $t$ ubo brevi, 1 i m bo sexpartito, aequali, patente. S t a m in a 6 , basi limbi inserta; filamenta inaequalia, subdeclinata. Ovari um triloculare. Ovula plurima, biseria- 
ta, adscendentia, anatropa. Stylus filiformis, declinatus; stig ma subtrigonum, laeve. Ca psula oblongo - trigona, trilocularis, septicidotrivalvis. Semin a plurima, adscendentia, planocompressa; test a membranacea, spadicea, superne in alam producta. E m b r y o minutus, in basi albuminis umbilico proximus. - Herbae c apenses, scapigerae; radice tuberosa, foliis radicalibus linearibus, florum umbella terminali, spathaceo - bibracteata.

Agapanthus Herit. Sert. 18. Redoute Liliac, $t, 6$. Bot. Mag. $t .500$. A b u m on Adans. fam, $I I, p, 54$. M a uhlia e sp. Thunb. Crinum africanum Liun.

103. Polianthes LINN. Perigoniu $\mathrm{m}$ corollinum, infundihuliforme; $\mathrm{t} \mathbf{u}$ bo longo incurvo, limbi sexfidi laciniis aequalibus, patentibus. Stamina 6, fauci inserta; filamenta brevissima, crassa, erecta. O v a ri um triloculare. Ovula plurima, biseriata, adscendentia, anatropa. Stylus filiformis; stigma incrassatum, trilobum. C a p su la trilocularis, loculieido-trivalvis. Se min a plurima, plana......Herba int er tropicos totius orbis reperta; radice tuberoso - bulbosa, foliis radicalibus linearibus elongatis, caulinis squamaeformibus, floribus spicatis, spatleaceobracteatis.

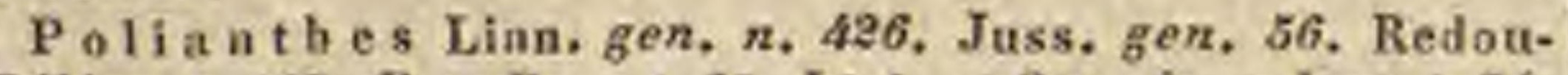
té Liliac, t, 147. Bot. Reg. t. 63. Link et Otto ic, select. l. 24. Mart. Amnen. monac. $t$. 16. A mi ca nocturnat Rumph amboin. V. 285. $t, 98$.

1 Ad4. BBIandifordia SMITH. Perigoni um corollinum, tubuloso-campanulatum, $1 \mathrm{im}$ bo breviter sexlobo, aequali. S $t$ a m in a 6 , basi tubi inserta; fil a m e $\mathrm{ta}$ filiformia, inclusa. Ovari um pedicellatum, triloculare. Ovula plurima, biseriata, horizontalia, anatropa. Stylus subu-latus; stigma simplex. Capsula prismatica, trilocularis, tripartibilis, introrsum dehiscens. $\mathrm{S} \mathrm{e}$ min a in placentis suturas marginantibus plurima, horizontalia, te s t a laxa, pubescente. E in b r y o rectus, dimidio albumine longior, e $\mathrm{xt} \mathrm{r} \mathrm{m}$ it a $\mathrm{e}$ $\mathrm{r}$ a d i $\mathbf{c}$ u $\mathrm{I}$ a $\mathbf{r} \mathrm{i}$ umbilico proxima. - Herbae in Nova Hollandia orientali extratropica indigenae; radice fibrosa, foliis radicalibus linearibus elongatis, caulinis distantibus abbreviatis, racemo terminali abbreviato, pedicellis bibracteatis, bractea altera interiore laterali minore, floribus puniceis, cernuis.

B Iandfordia Smith exot, Bot. I. 5. t. 4. R. Brown prodr. 295. Bot. Reg. t. 286. 911. A I e tris pun i e a Labill. Nov, Holl, t.111.

105. Lencoeoryme $L I N D L$. Perigoni nm corollinum, hypocrateriforme, $1 \mathrm{imb}$ o sexfido. St a m in a 3 fertilia, medio tubo inserta, antheris subsessilibus, 3 sterilia, carnosa, teretiuscula, fauci imposita, limbi lobis interioribus opposita. Ovari um sessile, triloculare. Ovula plurima.... Stylu s terminalis, cum ovario articulatus; stig m a simplex. Fructus. ...-Herbae chilenses, scapigerae; radicibus tuberosis, foliis linearibus, floribus umbellatis candidis $v$. cyaneis, pedicellatis, umbellis basi membranaceo-bibracteatis, perigonio cum pedicello contimuo.

Leucocoryne Lindl. in Bot. Heg. 2, 1293, - Bro. diae a $\mathrm{I}_{\mathrm{x}} \mathrm{i}$ id es Hook. Bot. Mag. $t$. 2389.

1106. Brodiaea SMITH. Perigoniu m corollinum, campanulatum, angulatum, limbe sexfido. St am in a 6 , perigonii fauci imposita, 3 fertilia, fil a mentis brevissimis planis; 3 sterilia, squamaeformia, limbi lobis exterioribus opposita. Discus hypogynus earnosns, trilobus. Ovari a m breviter pedicellatum, triloculare.
Ovu la plurima. ... Stylus terminalis, ovario continuus; stigma trilobum. Capsula pediceilata, perigonio cincta, trilocularis, loculicidotrivalvis. S e m in a in loeulis 4_5, obovata, compressa, te sta membranacea, atra. Embryo orthotropus, in axi albuminis carnosi. - Herbae scapigerae, in Americae borealis ora occident al $i$ repertae; foliis linearibus, floribus umbellatis, pedicellatis, caeruleis, umbellis basi membranaceo-bracteatis, perigonio cum pedicello continuo.

B rodia e Smith in Linn. Transact. $X$. 2. t. 1 . Hook. in Bot, Mag. t.2577. Lindl, in Bot, Reg. t. 1183, Ho o k eri a Salisb. parad. $t, 98,117$.

$119 \%$. Treiteleia HOOK. Perigoninm corollinum, hypocrateriforme, $1 \mathrm{imb}$ o sexpartito. Stamina 6, omnia fertilia, filament is brevibus, 3 medio tubo inserta, 3 fauci imposita, limbi laciniis interioribus opposita. $\mathrm{D}$ is e us liypogynus obsoletus. Ovarium longe pedicellatum; triloculare. Ovula plurima.... Stylus terminalis, ovario continuus; st ig m a trifidum. C a psula.... Herbae seapigerae, in America occidentali, australi et boreali indigenae; foliis linearibus, floribus pedicellatis, umbellatis, involucris di-triphyllis, foliuceis v. membranaceis, perigonio cum pedicello continuo.

Triteleia Hook. ex Lindl. Bot, Reg, n, 1203. t, 1685. Beatham in Hort. Transact. 1. 413. $t, 15$.

1108. Tristagma POEPP. Perigoniu m corollinum, tubulersum, $\mathrm{l}$ i m bo sexfidu. S $\mathrm{ta}$ mina 6 , omnia fertilia, fila m e $\mathrm{t}$ a brevissima, tubo medio biseriatim inserta. Discus lyypogynus obsoletus. Ovarium subsessile, triloculare, vertice poris 3 lateralibus, melliferis. Ovu la plurima, anatropa. Stylus terminalis, ovario continuus; 8 ti $\mathrm{gma}$ indivisum. Capsula trilocularis, polysperma. - Herba scapigera, in Chile a ustralis summis jugis observata; foliis linearibus, floribus paucis terminalibus umbellatis, involucro diphyllo, spathaceo, perigonio cum pedicello continuo.

Tristag ma Pôppig Frağm. synops, p. 8 .

109. Filla CAV. Perigoninm corollinum, hypocrateriforme, $t$ ubo elongato-campanulato, limbi plani sexfidi laciniis ohtusis, exterioribus angustioribus, sinu obtuso sejunctis. $\mathrm{S}$ tam in a 6 , fauci perigonii inserta; fil a mentis subnullis, antheris in conum conniventibus. Ovarium snbpedicellatum, triloculare. Ovula plurima. ... St y l u s cum ovario continums, teres; stig ma trilobum, fimbriato - papillosum. Ca ps u la trilocularis, trivalvis.... S emina plurima, atra, erustacea, angulata. ...-Herba mexicana, radice fasciculato-carnosa; foliis radicalibus cglindraceis, fistulosis, floribus scapum terminantibus, umbellatis, longe pedunculatis, albis.

Milla Cav. ic. IT. 76, t, 196. Liadl, in Bot.Reg.t. 155. - Geuus dubiae atlinitatis, milsi iguotum. - Milla biflara Hook. in Bot, Mag. t.3397. certe non hujus generis.

1 10 . Hesperosecralum $L I N D L$. P erig on ium corollinum, campanulatum, sexfidum, lacin i is exterioribus acuminatis, carinatis, interioribus obtusis. S ta m in a 6 , fauci imposita, omnia fertilia, fi 1 a m e n t a membranacea, dilatata, aequalia. Ovarium sessile, triloculare. Ovula plurima. ... Stylus cum ovario articulatus, teres; stigma simplex. Capsula trilocnlaris, loculicido-trivalvis. S e min a plurima, angnlata, suberustacea, nigra. - Herba bor e a $i i-a$ meric a $n a$; cormo induviato, floribus umbellatis, perigonio cum pedicello articulato. 
Hesperos e ordu m Lindl, in Bot.Reg. n, 1293. Brodiae a grandiflor a Nuttall gen. 215.

11 1. Calliprora $L I N D L$. Perigonium corollinum, campanulatum, sexpartitum; laciniis patentibus, aequalibus. S $\mathrm{t}$ a $\mathrm{m}$ i $\mathrm{n}$ a 6 , fauci imposita, omnia fertilia, filamenta petaIoidea, biloba, alterna breviora, an the $\mathrm{r}$ is inter flamentorum lobos sessilibus. Ovarium pedicellatum, triloculare. Ov u la plurima. ... St ylus ovario continuns, teres; stigma trilobum. Ca p s ula membranacea, triptera.... Herba californica; foliis radicalibus lineari-ensiformibus, floribus in scapo terminalibus, umbellatis, luteis, perigonio cum pedicello continuo.

C allip $\mathrm{r}$ or a Lindi. in Bot. Reg. t, 1590.

112 . IBessern SCHULT. Perigoniu $\mathrm{m}$ corollinum, campanulatum, $1 \mathrm{im}$ bo sexpartito. Stantina 6 , in coronam faueis cylindricam sexdentatam connata, fil am entis cum coronae dentibus alternis, exsertis. Ovarium sessile, triloculare. Ovula plurima, biseriata, adscendentia, anatropa. Stylus terminalis, ovario continuus; stigma capitato-depressum, fimbriatum. C a p s u l a perigonio stipata, trilocularis, septicido - trivalvis. Semin a plurima, biseriata, adseendentia, compressa, t e sta membranacea, atra. - llerba mexicana, scapigera; radice bulbosotuberosa, foliis radicalibus anguste linearibus, semicylindricis, florum umbella terminali, spathaceo-involucrata, perigonio cum pedicello continuo.

B e s s e r a Schult. fil, in Linnaea 1829, p. 121. Syst. VII. 996. P h a ri um W. Herbert in Bot, Reg. $t .1546$.

SUEB IRID III. ALOINEAE. Perig oni um tubulosum v. sexpartitum, interdum subirregulare. St a min a hypogyna, vel tubo inserta. Ovarium triloculare; ovula anatropa. Fru ctus capsularis v. baccatus. Sem in a compressa, angulata $v$. alata, testa membranacea, pallida v. atra. Em b r y o orthotropus. - Herbae carnosae, interdum frutescentes $v$. arborescentes, radice fibroso-fasciculata.

11 13. Samseviera THUNB. Perigoni um corollinum, infundibuliforme; t u bo longo, rectiusculo, $1 \mathrm{imb}$ o sexfido, laciniis patentibus $v$. revolutis. St am in a 6 , fauci inserta; $\mathrm{fi}$ l a m e $\mathrm{n}$ ta filiformia. Ovarinm triloculare. Ovula in loculis solitaria.... Stylus filiformis; stigma obtusum, obsolete trilobum. B a cea trilocularis, trisperma, v. abortu unilocularis monosperma. S e $\mathrm{m}$ i $\mathrm{n}$ a. .... Herbae in $A \mathrm{f} r$ i $\mathrm{c}$ a tropica et extratropica, nec non in 1 siae insulis tropicis observatae; rhizomate crasso, repente, foliis radicalibus equitantibus, carnosis, saepe maculatis, caulinis squamaeformibus, floribus racemosis $v$. thyrsoideis.

Sanseviera Thunb, nov, gen. 121. Redouté Liliac. t.290, 323. Ker in Bot, Reg. t. 160. Roxburgh corom. t, 184 . Bot. Mag. t. 1180, 2634. Andr. Bol. Reposit, t,361. A с y uth a Commel. Hort, II. t.21. Medieus Theodor, 96. S a l wi a Car. ic, III. 24, $t$. 246. A l et ris s p. Ling. Jacq. Hort. Vindob. t.84. - ? Girtn. I, 54, t. 15. f.6.

114 . Kuiphafia MOENCH. Perigon i u m corollinum, eampanulato-cylindrienm; $1 \mathrm{im-}$ b o brevi, sexdentato. St a m in a 6 , hypogyna, fil am enta exserta, alterna elongata. Ovarium triloculare. Orula plurima, biseriata, horizontalia, anatropa. Stylus terminalis, filiformis; 8 tigma obsolete trilobum. Capsula eartilaginea, ovata, obsolete trigona, trilocularis, septicidotrivalvis. Semina plurima, biseriata, horizonta- lia, angulata....- Herbae capenses, scapigerae; foliis radicalibus linearibus, canaliculatis, distichis, floribus spicato-racemosis, nutantibus.

$\mathrm{K} \mathrm{n}$ iph of $\mathrm{i}$ a Mönch meth, 631. Tritoma Ker in Bot. Mag. t.744. 258.764. Bot. Reg. 2,1745. Trit am a $\mathrm{t}$ the Link enum, I. 333. T rit om ium Link Handb. 1. 170. Aletris s p. Linn. Andr. Bot. Reposit, $t$. 54 . Veltheimiae 5 p. Willd. Redouté Liliac. $t$, 184, Al o es s p. Limn.

115. Alö TOURNEF. Perigonium corollinum, tubulosum, fundo nectariferum, sexfidum; li mb o regulari patulo v, recurve bilabiato, la cin ii s ligulatis, exterioribus interiores subaequales v. longiores imbricatim obtegentibus. S tam ina 6 , hypogyna; fil a m ent a adscendentia, subaequalia, inclusa v. exserta. Ovarium triloculare. Ov u la plurima, biseriata, subhorizontalia, anatropa. Stylus terminalis, trigonus; st igma obsolete trilobum. C a p s u 1 a scarioso-membranacea, teretinscula $v$. trigona, trilocularis, loculicido-trivalvis, S e min a plurima, biseriata, plano compressa $v$. angulata, te 8 t a membranacea, laxa, alata. E m b r y o axilis, albumine parum brevior, extremitate radiculari umbilico proxima. Plantae ut plurimum c a p e n s e $s$, paucissimae africanae tropicae, asiaticae v. americ an a ; caudice plerumque frutescente, foliis succulentis, imbricatis, margine et superficie saepe spinosis, spicis racemisve axillaribus aut terminalibus, simplicibus aut ramosis.

A 1 o ë Tournef, inst, t, 190 . Linn, gen, $n$, 430. Jass. gen, 52.

a) APICRA Haw. Perig o nf um regulare, cylindricnm, limbi laciniis brevibus, conformibus, apice rotundatis, patulis. - Suffrutices capenses, rigillissimi; foliis induratis, confertissimis, acutissimis, saepe spiraliter tortis, floribus erectis.

A piera Haworth Suppl. 61. Philosoph. Magaz. 1824. Octob, p.300. Cate vala Medik. Theodor. 68. (DC. pl.gr. t. 45. Jaeq. Fragm, t. 108, 109, 151.)

b) HAWORTHia Duv. Perigonii tubus reetus, limbus bilabiatus. $\mathrm{S} t \mathrm{a} m \mathrm{i} \mathrm{n}$ a perigonii basi adglutinata. Capsula costata. - Frueticuli capenses, vix caulescentes, floribus erectis.

$\mathrm{H}$ a w o r th i a Duval Pl. succ. hort. Alang. p. 7. Haworth Synops. 90. suppl,70. Philosoph. Magaz, 1824. Octob. p.301. A pier a Willd. In Berl. Magaz. W. 271. exel, sp. (Jaeq. Hort. schönbr. t. A22. Fragm. t.112. f.1. DC. Pl. gr, t.16. Bot. Reg. t. 1353, 1354. Bot, Mag. $t$, 455.756, 809, 814,815. 1314. 1337. 1345. 1353, 1454, 1360, 136t, 1417, 1452.)

c) GASTERiA Duv. Perig a nif tubus eurvas, basiventricosus. St a m in a perigonii basi adglutinata. C a ps a la subeostata. - Fructiculi capenses, vix canlescentes, scapis remote spathaceo-bracteatis, flo. ribus pendulis.

G a ste ria Duval Pl. succ, hort. Alanc. p. 6. Haworth Synops. 85, Revis. 46. Philosoph. Mag. 1824. Oet, p. 282. 1827. Nov, p. 3i8. (Jacy. f, Eclog. t, 31. DC. Pl. gr. t.63. 68. 91. Bot. Mag. t, 765. 837, 838, 979, 1322. 1331, 2304, 2369.)

d) RHIPIDODENDRON Willd. Pe rig a a il tubus rectus, basi aequalis, limbi lacialis oblongis, subconformibus, erectis. S $\mathrm{tam}$ in a perigonio hand adglutinata. C a psuIa. ... - Capenses, caudice arboreo, dicho. tome - ramoso.

Rhipidodendron Willd, in Berl. Magaz, V. 164. Haworth Revis, 45. $\mathrm{K} \mathrm{n} \mathrm{m}$ a $\mathrm{r}$ a Medik. Theodor, 74, $t$. 4. (DC. Pl. gr. t.75. Bot. Mag. t. 457.)

e) BOWIEA Haw. Perig on i um sexpartitum, laciniis subringenti - bilabiatis. S $\mathrm{ta}$ i i a cum stylo declinato flexuoso-adscendentia. C a p s u 1 a. . . . - Herbae c apenses, succulentae.

B ow ie a Haworth in Philosoph, Magaz, 1824. Octob. . 299. 1826. p. 132 .

f) ALOE Duv. Perig on il tubus cylindraceus, rectus, limbus regularis. S t a m $\mathrm{i}$ u a recta, perigonii basi adglutiaata. C ap s u I a subeastata. - Herbae succulentae $v$. frutices, plerique capenses, pauci a meri. can $i$, nonnulli arabici, unus sinensis, caulibus Roriferis spathaceo-bracteatis, floribus cernuts.

A lo é Duval PL. succ, hort. Alanc. p. 6. Haworth Sy. nops. 76. Revis. 203. Philosoph, Magaz. 1824, Octob. p. 298. (DC. Pl. gr. t, 15, 21, 27,39.4h, 80,85.91, Jaeq. f. Eclog. L 
61, Bot. Mag. t. 457, 472, 513,757, 828, 1270, 1278, 1306, 1323. 1332, 1346, 1355, 1369, 1415. 1460, 1474. Bot. Reg, t, 996.

6) PACHIDENDron Haw, Perig o nii tubulosi subincurvi limbus faleatim adsurgens. S ta min a basi perigonii adglutinati. - Arbusculae capenses, folitis terminalibus congestis, floribus in spica terminali nutantibus.

Pa eh ide nd ron Haworth Revis. 35. Bot. Mag. t.2517. A griodendron Haworth Z.c. (DC.Pl. gr,t.32. Bot. Mag. $t, 1975$.

1 i 6. Hometoplayllum $W I L L D$. $\mathrm{Pe}$ rigoninm corollinum, tubulosum, fundo siecum, sexpartitum; lim bo regulari, la cin i is exterioribus interiores subaequales imbricatim obtegentibus. Stamina hypogyna; fil am enta aequalia, inclusa. Ovarium triloculare. Ov u l a plurima. ... Stylns filiformi-setacens; st ig ma simplex. B a e ca coriaceo - carnosa, trisulea, trilocularis. Semina plurima, oblonga, angulosa, horizontalia, te s t a eartilaginea, nigro-splendente.

Plantae in in sula $B$ or bonia indigenae, pal moideo-arborescentes ; foliis lanceolato-elongatis, in apice caudicis congestis, margine cartilagineis, spinuloso-serratis, pedunculis axillaribus paniculato-racemosis.

Lom a top hyllum Willd, in Berl. Magaz. $V$, 166. $\mathrm{P}$ h y 110 ma Ker in Bot. Mag. t. 1585.

1 ใ xaphyllum; foliola aequilonga, interiora latiora, campanulato - conniventia, ima basi connata, marcescendo-persistentia. Sta $\mathrm{m}$ in a 6 , perigonii foliolis basi inserta, fil amenta brevia, plana, apice latiora. Ovari $\mathrm{um}_{\mathrm{m}}$ triloculare. Ovula in leculis plurima, horizontalia, biseriata, anatropa; stigmata 3 , sessilia, basi subconnata, apice patentia. C a p s u la oblonga, obtuse hexagona, subbaccata, vertice primum forata, demum loculicidosubtrivalvis, trilocularis, v. septis secundariis incomplete sexlocularis. S e m in a plurima, biseriata, v. septis secundariis interpositis discreta, uniseriata, horizontalia, obovata, compressiuscula. T e s t a coriacea, nigra. E m b r yo axilis, dimidio albumine brevior, extremitate radieulari umbilico proxima. - Plantae in America tropica cis a equatorem, et in borealicalidiore indigenae; caudice saepius arborescente, interdum hypogaeo, foliis in apice caudicis confertis, lineari-lanceolatis, crassis, rigidis, margine saepius spinulososerrulatis, scapo e foliorum centro bracteato, paniculato.

Y u c с a Linh. gen. n. 499. Juss. gen, 49. Gärtn. IT.5/4. 4.85. DC. Pl. gr, t.20. Redonté Liliac. t. 287. 326,327. 401. 402. Bot. Mag. t. 900, 1260,1700, 2222. 2236, 2262. Bot, Reg. t. 1690.1895.

SUEDIRDA 1\%. ASPHODELEAF. Perigonium tubulosum v. sexpartitum, regulare. Stam in a 6, hypogyna v, perigonio inserta. Ovarium triloculare. Ovula plurima v. subdefinita, anatropa v. amphitropa. Fructus capsularis v. baccatus. Semin a globosa v. angulata, testa crustacea atra. Emb r yo homotropus, rectus v. incurvus, radicula umbilicum spectante. - Herbae radice bulbosa, fasciculato-fibrosa v, tuberosa.

THEIBUS T. HYACINTHEAE. Perigoninm tubulosum v. sexpartitum. Stamina perigonio inserta v. rarius hypogyna. Fruct u s capsularis. - Radix bulbosa.

119. Museari TOURNEF. Perig on iu m corollinum, globoso-tubulosum, fa uce con- stricta, li m b o brevissimo, sexdentato. S $t$ a $m$ in a 6 , perigonii tubo inserta, filamenta filiformia brevissima, inclusa. Ovari um triloculare. Ovula panca, subhorizontalia, anatropa. St ylus brevis rectus; s $\mathrm{t} \mathrm{i} \mathrm{g} \mathrm{m}$ a subtrigonum, papillosum. Ca p s u la membranacea, acute triquetra, trilocularis, locnlicido-trivalvis. S e min a in loculis subbina, subglobosa, te $8 \mathrm{t}$ a crustacea atra, $\mathrm{nmbili-}$ co nudo. Embryo axilis, dimidio albumine longior, extremitate radiculari umbilicum attingente. - Herbae in Europa media et australi, in Asia media et mediterranea, nec non in Africa boreali indigenae, bulbosae, scapigerae; foliis radicalibus tinearibus, racemo terminali simplici, floribus superioribus saepe sterilibus.

Mnseari Tournef. inst. t. 180. Desf. atl. I. 309. Bot. Reg, t. 1085 . Nees jun. gen, pl. fasc. IV.t.9. H y a ci in th $\mathrm{i}$ s p. Linn. Jaeq, Fl. austr, t, 126. 187. Bot. Mag. i, 157. Redouté Liliac, $t, 132$.

119. Bellevalia $L A P$. Perigoninm corollinum, angulato-campanulatum, semisexfidum, la ciniis ereetis, extus apice plicatis. Stamina 6 , perigonii tubo inserta; fil a menta basi dilatata, inclusa. Ovari $\mathrm{mm}$ triloculare. Ovula pauca, horizontalia, anatropa. St ylus brevis, rectus; stigma acutum. Capsula membranacea, acnte triquetra, trilocularis, loculicido - trivalvis. S e m in a in loculis pauca, subglobosa, te sta crustacea atra, umbilico nudo. Embryo axilis, dimidio albumine longior, extremitate radie u l a ri umbilico contigue parallela._Herba bulbosa in Europa australiore indigena; florum racemo simplici scapum terminante.

Bellevalia Lapeyrouse in Journ, de Phys. LXVIT. 425. t.1. Nees jun. gen. $p l$. fasc. $I V$. $t, 8$. H y a $\mathrm{e} i \mathrm{n}$ th $\mathrm{us}$ r o un a u s Lian. Sibth. Fl.gr, t.340. Redouté Liliac, t. 334.

1 Iad. Hyacinthas $L I N N$. Perigonin m corollinum, infundibuliformi - eampanulatuin ; I imbo sexfido, la $\mathrm{c}$ in i is patentibus. S $t$ a mina 5, perigonii tubo inserta; fil a m enta brevissima, tubo adnata. Ovarium triloculare. Ovula in loculis pauea, horizontalia, anatropa. Stylus brevis, trisuleus; stigma obtusum. Capsula membranacea, triquetra, trilocularis, loculicido trivalvis. S e m in a in loculis bina, subglobosa, $t$ es ta erustacea atra, umbilico carnoso-incrassato. Emb ryo axilis, dimidio albumine longior, extremitate radiculari umbilico proxima.

Herbae in Europa a ustrali, in Asia media et mediterranea indigenae, bulbosae, scapigerae; florum racemo terminali simplici

H y a c in th us Lina. gen, n. 1427, exe!. sp. pl. Rednuté $L i$ liac, t. 14, 465, Bot, Reg.t. 995. Nees jun. gen, pl,fasc, IV, t, 7 .

121. Veltheimia GLED, Perigonia m corollinum, cylindraceo-tubulosnm, $1 \mathrm{imb}$ o brevissimo, sexdentato. S tamin a 6 , medio tabo inserta; fil amenta filiformia, inclusa. Ovarium triloculare. Ovula panea, horizontalia, anatropa. Stylus subulato-filiformis, declinatus; s $\mathrm{tig}$ a cuspidatum. C a $\mathrm{p}$ s 1 a diaphano-membranacea, alato - triquetra, toculicido-trivalvis. S emina in loculis subsulitaria, testa crustacea, atra... - Herbae capenses, bulbosae; foliis. radicalibus lanceolatis, undulatis, racemo simplici scapum terminante, floribus nutantibus.

Velt heimia Gleditseh in Act. Berolin, 1769. p. 66. Jacq. Hort. schönbr, $t, 77$. 78. Redouté Liliac, $t, 193.440$. Bot. Mag. t, 1091. Aletris s p. Liun. Bot. Mag. $2,305$.

11 2. Uropetalum KER, Pe rig on i $\mathrm{m}$ corollinum, infundibuliforme, profunde sexfidum, la ciniis apice patentibus, interiorilus brevioribus. Stamina 6, fauci imposita; filamenta 
basi dilatata, inclusa. O v a $\mathrm{r}$ i u m triloculare. Ovula plurima, uniseriata, horizontalia, anatropa. Stylu s rectus, trigonus; s $\mathrm{t}$ g ma obtusiusculum. Ca p 8 u la membranacea, acute triquetra, trilocularis, apice loenlicido-dehiscens. S e $\mathrm{m}$ in a plurima, horizontalia, plano-compressa, te s ta crustacea, atra, endopleura crassa, spongiosa. E mb r yo axilis, dimidio albumine longior, ex $t$ remitate radiculari umbilico proxima. Herbae bulbosae, in Europa australi et in Capite bonae spei indigenae; racemo simplici scapum terminante, bracteis pedicellos superantibus.

Uropetalum Ker in Bot, Reg. t, 156.974. Nees jun. Gen. pl. fasc. $I V$. t. 16. Pole m a n $\mathrm{n}$ ia Berg. in Linnaca I. 250. Z u e cag n ia Thunb. Fl.cap.328. D i p c a di Möaeh Suppl. 267. H y a ci int h i s p. Limn. Gärtn. $I$. 38. t. 12. Cav. ic. t.30. Jacq. ic. rar. t, 66. Redouté Liliac, t. 202.203.

1123. Agraphis LINK. Perigonium corollinum, sexpartitum, lacin i is campanulatoconniventibus, apice reflexo-patentilus $\mathrm{S}$ ta $\mathrm{m}$ in a 6 , mediis perigonii laciniis inserta; fil am entis adnato-decurrentibus, alternis saepe longioribus subexsertis. Ovari um triloculare. $O \mathrm{v} u I$ a plnrima, biscriata, horizontalia, anatropa. Stylus trigonus, rectus; stigma obtuse trigonum, $\mathrm{pa}$ pillosum. C a psu 1 a membranacea, obtuse trigona, trilocularis, apice loculicido-dehiscens. S emina pauca, subglobosa, testa crustacea, atra, umbilico nudo. Embryo axilis, extremitate radiculari umbilicum attingente. - Herbae in Europa australi et in Capite bo nae spei indigenae, bulbosae, floribus in racemo simplici scapum terminante nutantibus, pedicellis bibracteatis.

Agr a p his Link Handb. III. 166. Reichenbach Fl, germ. 105. Nees jun. Gen. $p l$. fasc. IV. $t$. 12. H y a e i n thi s p. Linn. S cillae 8 p. Smith. Redouté Liliac. $t$. 224.355. Bot. Mag, t,128,1102, 1461.

1124. Laehenalia $J A C Q$. Perigon u m corollinum, sexpartitum, Ia cini is campanulato - conniventibus, exterioribus brevioribus erectis, interioribus tenerioribus subinaequalibus, apice patentilus. Stamin a 6 , basi laciniarum perigonii inserta; filamenta filiformia, conniventiadscendentia. Ov a ri u m triloculare. Ovula plarima, biseriata, subhorizontalia, anatropa. StyI us subulatus, rectus; stigma obsolete trigonum. Capsula membranacea, alato - triquetra, trilocularis, apice loculicido-dehiscens. S e mi na pauca, subglobosa, atra ...-Herbae capen$s$ es, bulbosae; foliis radicalibus geminis $v$. pluribus, racemo simplici scapum terminante, floribus ut plurimum cernuis, pedicellis unibraeteatis.

L a c h e n a $1 \mathrm{i}$ a Jaeq. $i c$.rar. $t, 381-404$. Schönbr. $t, 82$. 83. Bot. Mag. t.82.314.588.590.735.745.766.817.993.1020. 1097, 1269. 1372, 1373, 1401, 1497, 1517. 1611.1704.

125. Drinnia JACQ. Perigoninm corollinum, sexpartitum, laciniis aequalibns reflexis, apice cueullatis. St a $\mathrm{m}$ in a 6 , basi lacinia$\mathrm{rum}$ perigonii inserta, fil a m enta basi dilatata, conniventia, tria superiora paullo breviora. Ovari u m triloculare. Ovula plurima, biseriata, horizontalia, anatropa. Stylus reetus, trigonus; stigma obtusum, muricatum. Cap 8 ula membranacea, acute triquetra, apice loculicido-dehiscens. S e min a pauea, subglobosa. Herbae capenses, bulbosae; foliis radicalibus oblongolinearibus, racemo scapum (saepius praccocem) terminante simplici, pedicellis unibracteatis.

D $1 \mathrm{~m}$ i a Jacq. ic, rar, $, .373,-377$. Jacq. f. Eclog. t. 30 . Bot. Reg. t. 1346, Schrad. Comment. Göting. IV. p. 114. Bet Mag. $t, 643.892 .1074 .1444$. L a ehe naliate s p. Jacq. ic. rar. t. 402. Andr. Bot. Reposit. t, 291. Bot. Mag, t, 1380.
1186. VIIassonia LINN. Perigonium corollinum, subhypocrateriforme, t $u$ bo subcylindrico, recto, $1 \mathrm{i} \mathrm{m} \mathrm{b} \mathrm{o} \mathrm{sexpartito,} \mathrm{patente} \mathrm{v.} \mathrm{re-}$ flexo. Stamina 6, coronae cylindricae tubo continuae, integrae $v$. incompletae imposita; fil amenta filiformia, alterna saepius longiora, exserta v. inclusa. Ova rinm triloculare. Ovula plurima, biseriata, horizontalia, anatropa. StyIn s subulatus, declinatus; stigm a punetiforme, hirsutiusculum, v. obsolete trilobum. Capsula membranacea, diaphana, alato-triquetra, trilocularis, loculieido-trivalvis. Sem in a plurima, subglobosa, biseriata, te s t a crustacea, atra. - Herbae capenses, bulbosae; foliis radicalibus pareis, saepe humo adpressis, rarius pluribus erectis, spica forum abbreviala, subumbellata, inter folia subsessili, involucro scarioso, multivalvi cincta.

M a s 8 on i a Lim. gen. n. 1381. Schult. fil. syst. VIT. 987.

a) ASTEMMA Corona staminea subuulla. Folia erecta.

Massoula e sp. Redouté Lilíac. t. 386. 392. Bot. Mag. $t$. 556. Manhliae sp. Thunb. Agapanthisp. Willd, $\mathrm{p}$ olianthis $\mathrm{sp}$. Jacq. ic, rar. $t, 380$.

b) MASSONIA Corona staminea couspieua. Fotia bina, humi alpressa.

M a s 8 o n i e s p. Jaeq. Hort. Schönbr, t, 454-461. Re. douté Liliac, $t, 183$. Bot. Mag. t. 859 . 736,848 . Bot. Reg.t. 694. 958 ,

119\%. Daubenya $L I N D L$. Perigonin m eorollinum, tubulosum, limb o bilabiato, labio superiore tridentato, nano; inferiore majore tripartito. St amina 6 , fauei inserta; filam ent a inaequalia, declinata, basi subeonnata. O va. ri um triloculare. $O \mathrm{vala}$ plurima. ...Stylus filiformis; s tig ma capitatum._Herba c a pensis, bulbosa; foliis geminis oblongis, carnosiusculis, humi adpressis, umbellam sessilem sinu foventibus, floribus luteis radiato-umbellatis, labio inferiore in floribus radii maximo, in floribus disei depauperato.

$\mathrm{D}$ a u ben y a Lindl. in Bot, Reg. $t, 1813$.

129. Eucomis HERIT. P e $\mathrm{r}$ igo $\mathrm{ninm}$ corollinum, sexpartitum, rotato-patens. Stam ina 6 , perigonii foliolis inserta; fil amenta basi dilatata, $m e m b r$ an a brevi ejusdem diseo adnata, connexa. Ovari um triloculare. Ovula plurima, adscendentia, anatropa. Stylus setaceus, incurvus; s t ig m a obsoletum. C a p s a 1 a coriacea, alato - triquetra, trilocularis, loculieido-trivalvis. Semina in loculis panca, adscendentia, testa crustacea, atra....- Herbae capenses, butbosae; foliis radicalibus paucis, lato-lanceolatis, racemo simplici scapum terminante, apice sterili comoso-folioso.

E n e o m is Herit, Sert. angl, 17. Redouté Liliac, t. 175. 208. Bot. Mag. t. 840.913 .1083 .1495 .1539 , B a sil a a a Juss. gen. 52.

1129. Cyanotris $R / F$. P e $r i g$ o n in m corolinum, hexaphyllum, foliola aequalia, quinque superiora adscendentia, sexto deflexo. Stamina 6, hypogyna, aequalia; fil amenta filiformia, adscendentia. Ovarin m triloculare. Ovula in loculis plurima, anatropa. Stylus filiformis, declinatus; stigma obsolete tridentatum. Capsula membranacea, trilocnlaris, loculicido-trivalvis. Sem in a in loculis sena, subglobosa, te $s$ t a nigra, nitida, $r$ h a h e et $c h$ al az a corrugatis. ...-Herba bulbosa, in America borea li indigena; folizis linearibus acuminatis, canaliculatis, racemo simplici scapum terminante, pedicellis scarioso-bracteatis, floribus caeruleo-purpurascentibus.

Bulbi ab Americae borealis autochtonibus eduntur.

Cy a otris Rafill. in Americ. Monthl. Magax, 1819. C a mas s i a Lindl, in Bot, Reg.t, 1486. P hal ang i u in Qua. mas h Pursh. 
1130. Seilla LINN. Perigonium corollinum, sexpartitum, campanulatum, rotato-patens. Stamina 6, perigonii laciniis basi inserta; filamenta aequalia, snbulata. Ovarium triloculare. Ovu1a in loeulis plurima, biseriata, horizontalia, anatropa. Stylus filiformis, rectus; $8 \mathrm{tigm} \mathrm{a} \mathrm{ob-}$ tusum. C a p s l a obtuse trigona, trilocularis, loculicide-trivalvis. Sem in a in loculis pauea, horizontalia, subglobosa, test a crustacea, juxta rhap he $n$ incrassata, atra v. pallescente-fusca. Embryo axilis, dimidii albuminis longitudine, extremitate radieulari umbilico parallele contiqua. - Herbae bulbosae, in Europa media, in regione mediterranea et Capite bonae $s$ pei obviae; racemo laxo scapum terminante, pedicellis bracteatis, floribus albis $v$, caeruleis.

$\mathrm{S}$ cilla Linn. gen, $n$, 419 , exel, sp. Nees jun. gen, $p l$. fase. $I V . t, 11$. Jaeq. $F l$, austr, t.117.210, Waldst. et Kit. pl. Hung. $t$. 189. Redonté Liliac. t. 106, 167, 190. 205. 298. 304.317. 321. Bot. Mag. t.663.749. 1140. 1574. 1999. 2023, 2774.

131. Uremea STEINH. Perigonium corollinum, sexpartitum, patens. Stamina 6 , periganii laciniis basi inserta; filamenta aequalia, subulata. O v a r i u m triloculare. O v 1 a plurima, biseriata, adscendentia. StyIn s filiformis, reetus; sti i $m$ a- obtusum. Capsula obtuse trigona, trilocularis, loculicido-trivalvis. Semina plurima, adscendentia, compressa, te st a spongiosa, nigra, laxinscula, $\mathrm{rh}$ a $\mathrm{phe}$ intra eandem lihera, adscendente. $\mathbf{E} \mathbf{m}$ bryo axilis, dimidii albuminis longitudine, extremit a t e $r$ adiculari umbilico parallele contigua. - Herbae in Europa et Africa mediterranea indigenae, bulbosae; racemo scapum terminante, pedicellis bibracteatis.

U $\mathrm{rg}$ in e a Steinheil in Annal. sc, nat, 1834. I. p.321. Nees jun. gen. pl. fase. X. t, 4. - Stell ar is Mōnch meth. 303. Seilla maritima Linn.

1132. Druithogalum LINK. Perigonium corollinum, hevaphyllum, foliolis patentibus. Stamina 6 , hypogyna; fil am en ta sabnlata. Ovarium triloculare. Ovula in loculis plurima, biseriata, horizontalia, anatropa. Sty. lus triqueter, rectus. Stigma obtusum, trigonum. Capsula membranacea, obtuse trigona, trilocularis, apice loculieido-dehiscens. Semina in loculis pauca, subglobosa $v$. angulata, te sta atra, rugosa, hine $r$ haphe pereursa. Embryo axilis, dimidii albuminis longitudine, extre $m$ it ate radiculari umbilicum attingente. Herbae bulbosae, in Europa imprimis mediterranea et in Capite bo nae spe $i$ indigenae; racemo corymboso scapum terminante, pedicellis bracteis membranaceis suffultis, floribus albis.

Ornithogal a m Link Handb. I. 146. Nees jun. gen. $p l$ fasc. $I V, t, 13$. Reichenbach $p l$. crit. t.265. Ornit hogali s p. Linn. Jacq. Fl, austr, t, 103.343. Hort, Schbrbr. t.91. Ic, $\operatorname{rar}, t .493-438$.

1133 . Abuea LINN. Perigonium corollinum, hexaphyllum $\vee$. sexpartitum, la cinits exterioribus patentibus, interioribus erectis, apice incrassato subfornicatis. Stam in a 6 , hypogyna, alterna saepius sterilia, fil amenta basi alatodilatata. O v a r i m triloculare. Ovula. Stylus pyramidatus; stigma trigonum, papilloso-hirtum. Cap $8 \mathrm{ul}$ a trilocularis, Ioculieidotrivalvis.... Semin a plana, alata. ... Herbae bulbosae, Ornithogali facie, in Capit e bonae $s p e i$ indigenae, Genus reformandum.

Albuca Línn. gen, n. 416. Jicq. ic, rar, 1, 63, 64, 439 -406. Redouté Liliac. 1.21.69.70. 195. Bot, Mag, t, 720.804. 871.1046. 1329.1481.1656, Bot. Reg. t.227.311.

1134. Dlyogalum $L I N K$, Perigonium hexaphyllum, foliolis campanulato-con- niventibus, aequalibus. S tamina 6 , hypogyna, omnia fertilia; filamenta petaloideo - dilatata, marginibus alternatim imbricata, apice biloba, inter lobos antherifera. $O$ va $\mathbf{r} \mathbf{i} \mathbf{~ m}$ trilocnlare. Ovul a plurima, biseriata, horizontalia, anatropa. Stylus crassinseulus, rectus; stigma subincrassatum, obtuse trigonum, papillosum. C a p8 ula carnosiuscula, obsolete trigona, trilocularis, loculicido-trivalvis. Sem in a in loculis panea, horizontalia, subglobosa, te st a atra, foveolata, ad $\mathbf{r}$ ha $\mathrm{p}$ h $\mathrm{n}$ inerassata. E $\mathbf{m}$ b r y o axilis, dimidio albumine param brevior, extremit ate radiculari umbilico contigue parallela. - Herba butbosa, in Europa med ia et a ustrali obvia; floribus in racemo scapum terminante albidis, nutantibus.

M y og a I u a Link Handb, I, 164. A I b u ce a Reichenb. Consp. n. 1367. c. Flor.germ. p. 109. Nees jun, gen, pl.fase. IV.L. 14. H on ori ua Gray Br.pl. Ir. 127. Or a itho g a l u m n utan s Linn. Jacq. Fl, austr. t. 301. Hook. Fl. Lond. t. 94 .

135. Puschkinia ADAMS. Perigon i m corollinum, sexpartitum, basi subcampannlatum, limbi patentis laciniis aequalibus. Stamin a 6 , filamenta in tubum cylindricum perigonii faucem coronantem connata, tubo apice sexlobo, lobis intus antheriferis. $O$ v a $\mathrm{r}$ i $\mathrm{u}$ m triloculare. Ovula plurima, biseriata, horizontalia, anatropa. Stylus filiformis, reetus; s $\mathbf{t} \mathbf{i g ~ m}$ a obtusum. Ca ps ula....-Herba bulbosa, in jugis Ararat indigena, Scillae facie; foliis lanceolatis, racemo laxiusculo scapum terminante.

Pusehkinfa Adams in Nov. Aet. Petrop. XIV. 164. t.B. Bieberst, Pl. ross, II. t, 91 . Bat. Mag, t. 2244. Lindl. Collect. t, 24. A damsia Willd. in Berl. Magaz, IT. 16.

1136. BBaremaredia $L I N D L$. Perigonium corollinum, hexaphyllum, foliolis aequalibus, patentibus. Stamina 6 , imis perigonii foliolis inserta; filame $\mathrm{n}$ ta basi in alam ovatam dilatata. Ovarium triloculare. Ovula in loculis solitaria, e basi erecta. Stylus subulatus, rectus; stigma simplex. Cap s a la....-Herbae bulbosae, in Chin a et Japonia indigenae, Scillae facie; foliis linearibus, cuspidatis, floribus racemosis, roseis.

Baruardia Lindl. in Bot. Reg. t.1029. Ornith og aI um $\mathrm{j}$ a p on $\mathrm{icum}$ Thunb.

113\%. Allium LINN. Perigonium corollinum, hexaphyllum v. sexpartitum, foliolis aequalibus, patentibus v. campanulato-conniventibus. Stamin a 6 , imis perigonii foliolis inserta; fi l am e n t a filiformia, aut basi dilatata subcohaerentia, alterna interdnm complanata, apice tridentata, dente intermedio antherifero. $O$ va ri u m triloculare, v. septis obsoletis uniloenlare. Ovula pauca, placentae subbasilari affixa, amphitropa. Stylus filiformis; stigma simplex. Capsula membranacea, trigona, v. vertice depressinsenlo triloba, trilocularis, $v$, unilocularis, loculicido-trivalvis, stylo super placentam brevissimam columnarem persistente. Se $\mathrm{m}$ in a in loculis subbina $\mathbf{v}$. solitaria, ovato-reniformia, umbilico ventrali, t $e-$ s t a atra, rugosa. E m b ry o in axi albuminis, homotropus, subfalcatus, extremitate radicuI a ri umbilico approximata. - Herbae bulbosae, olidae, sed mortalibus plurimis gratae, et maximi in oeconomia gentium nonnullarum momenti, in $z$ on a te mperat a hemisphaerae borealis obviue, in $r e-$ gione mediterranea, Europa orientaliet finitima Asia imprimis copiosae, in hemisphaerio australi rarae, inter tropicos in summis montibus rarissimae; caulibus foliosis simplicibus, v. saepius nudis, solidis v. fistulosis, foliis 
semi-cylindricis $v$. teretibus, plerumque cavis, interdum planis, florum umbella terminali, spatha unibivalvi $v$. rarius multifida cincta, pedicellis bracteolatis, ovariis saepissime in bulbillos mutatis.

A ll i u m Linn. gen, n. 409. Juss. gen. p. 53. Haller Monograph. Gölting. 745. 4. Treviranus Monograph. All. Wratisl. 1829, 4. Don in Mem. Wern. soc. DI. 1-102.

a) MOLY Mönch. Stam in a omnia aequalia, filiformia v. subulata. Ovarium triloculare.

M o l y Mónch, meth. p. 286. M ä a $\mathrm{c}$ h i a Medik. in Act.Aca. dem. Palat. DI.343. S a t u rn i a Maratti Diss. 18. A I I i um Touraef. inst, t.206. Redouté Liliac. t, 72, 102, 213.256.300. Reichenb. Pl. crit, t.615.659,671. Nees jun. Gen, pl. fase. IV. t. 16.

b) OPHIOSCORODON Wallr. Stamina omnia aequalia, subulata. 0 v ari u $\mathrm{m}$ uniloculare.

Ophioscorod on Wallr. Seked. crit, I.129. A 11 i u m u r $\mathrm{s}$ i $n$ u m Linn. Redonté Liliac. $t, 305$, E. B, $t, 122$.

c) CODONOPRASUM Reichenb. S ta mina omnia aequalia, basi in annulum perigonil foliola connectentem connata. O variu m triloculare.

Codonopras um Reichenb. $F l$, germ, 114. Geth ioi d e s Columna Ecphr. II. t. 7. f. 2. (Redonté Liliac, t, 119 . 272. 316. 352, 368. Reíchenb, Pl, crit, t. 601. 602. 603. 604. 616. 617.)

d) SCHOENOPRASUM Funth, S ta m in a alterna tricus pidata, dente medio antherifero. Ovarium triloeulare.

$\mathrm{S} \mathrm{ch}$ oe no p r a $\mathrm{s}$ u Kunth in Humb. et Bonpl. nov. gen. et sp. III, 277. P o r r u m Tournef, inst.t. 204. C e p a Tournef. inst, t, 205. S corodop r a s u m Micheli Nov, gen, t, 24. f. 2. (Gïrti, t. 16. f. 2, Sibth. Fl, graec, t. 312,316. Redouté Liliac. t, 385.391. Gaudin. Fl. Helv. II, t, 10,11. Nees Jun. Gen. $p l$. fase. $I V, t, 17$.

TIEIIBUS II. ANTHERICEAE. Pe $\mathrm{r}$ gonium patens. Ovula plerumque amphitropa. Fructus capsularis. Radix fibrosa $v$. tuberosa.

1138. Sowerbaea SMITH. Perigoni um corollinum, sexpartitum, 1 a ciniis aequalibus, patentibus. Stamina 6 , imo perigonio inserta, tria laciniis exteriorilus opposita sterilia; fil am en $t$ a filiformia, glabra. Ovarium triloculare. Ovula in loculis 2 , peltata....S tyIu s filiformis, persistens; stig ma simplex. Ca ps u la membranacea, triloeularis, loculicido-trivalvis, Se min a in loculis subsolitaria, peltata. Herba perennis, in $N$ ov a Hollandia orientali extratropica indigena; radice fasciculato-fibro$s a$, foliis radicalibus filiformibus, basibus dilatatis, scariosis, distiche equitantibus, supra in stipulam intrafoliaceam solutam productis, scapo simplicissimo, nudo, umbella congesta capiluliformi, bracteis membranaceis, exterioribus integris subsericeis, interioribus lacero-multifidis, pedicellis sensim erumpentibus, apice cum perigonio roseo articulatis.

So w e rbae a Smith in Linn. Transact, $V, 160, t, 6$. Andr. Bot, Reposit. t, 81. Ker in Bot, Mag. t, 1104. R. Brown prodr. 385. Redouté Liliac, $t, 34 t$.

139. Anemarmena BUNG. Peri g on inm corollinum, hexaphyllum, foliola oblongo-linearia, canaliculata, interiora paullo breviora et latiora. S $t$ a min a 3 ; fil a ment a nnlla, antherae perigonii foliolis interioribus medio inserta. Ovariu in triloculare. ... Stylus filiformis; stigma simplex. Capsula hexagona, trilocularis, loculicido-trivalvis. S e min a in loculis 1_2, oblonga, subalato - tri-tetraquetra, nigra..... Herba Asphodeli facie, in summis Chinae borealis montibus reperla; rhizomate horizontali, repente, foliis radicalibus lanceolatolinearibus, acuminatissimis, caule inferne foliis latis subulatis, superne bracteis hyalinis vestito, racemo terminali simplici, elongato, floribus glomeratosparsis, subsessilibus, bractea suffultis, minutis, lilacinis.
A ne mar hena Bunge Enum, pl, Chin, boreal, 66 ,

140. Fremanrus BIEBERST. Peri gonium corollinum, hexaphyllum, fo 1 i o 1 a aequalia, patentia, mox involnta. St a m in a 6 , hypogyna; fil am en $t$ a filiformia, glabra, primum induplicata, demum exserta, elongata. Ovarinm trilveulare. Ovula in loculis 2, collateralia, amphitropa. Stylus filiformis, reflexus; stigma simplex. Ca ps u la membranacea, subglobosa, trilocularis, loculicido-trivalvis. S e mina in loculis 2, triquetra, testa crustacea atra, laevi, umbilice ventrali lineari. $\mathbf{E}$ m b r yo axilis, umbilico parallelus, albuminis longitudine, extrem itate radiculari infera. - Herba tauricoa ucasica; radice e fibris crassis fasciculata, foliis radicalibus linearibus, scapo nudo, florum racemo elongato.

Eremn rus Bieberst. Pl, ross. $I I . t, 61$. Asphode I $\mathrm{s}$ a 1 taicus Pallas Act. petrop. 1729. p. 258. $t$, 10 .

14 4. Asplinodelus LINN. Perigonin $\mathrm{m}$ corollinum, hexaphyllum, foliol a aequalia, patentia. Stamina 6 , hypogyna, alterna breviora; fil a m enta basi fornicato-dilatata, declinato-adscendentia. Ovari $\mathbf{~ m ~}$ triloenlare. Ovula in loculis 2, collateralia, amphitropa. S t yI $\mathrm{s}$ filiformis v. subelavatus; stig ma capitato. trilobnm. Capsula membranacea, subglobesa, trilocularis, loculicido-trivalvis. Semina in loculis $2, v$. abortu solitaria, triquetra, te $s t$ a crustacea atra, transversim rugosa, $\mathbf{u} \mathbf{m b}$ ili c o ventrali, lineari. Embry o axilis, umbilico parallelus, albuminis longitudine, extremitate radiculari infera. - Herbae perennes, Europam a ustralior e m incolentes; radice fibroso - fasciculata, fibris saepe tuberoso-incrassatis, folits radicalibus subulatis, triquetris, v. lineari-lanceolatis, floribus in scapo simplici $v$. ramoso nudo laxe racemosis, bracteatis, albis.

A sphodelus Linn. gen, $n$. 421. exel. sp. Sibthorp. Fl. graec. t.334.335. Redoute Liliac. t, 178. Reichenb. Fl, germ. 117. Nees jua. Gen, pl. fasc. IV. t.20. A s p th odeloldes Mönch meth, $p, 634$.

14. Asplhodeline REICHENB. Perigonium corollinum, sexpartitum, tubo brevissimo, subgloboso, $1 \mathrm{i} \mathbf{m b} \mathrm{i}$ laciniis reflexo patentibus $S$ tamina 6 , perigonii tubo inserta, alterna breviora; fil a menta basi fornicato - dilatata, supra basim geniculata, adscendentia. Ovari m triloculare. Ovula in loeulis 2 , collateralia, amphitropa. Stylus filiformis; stigma simplex. Capsu I a carnosa, trilocularis, loculicido-trivalvis. S e mina in loeulis 2 , triquetra, te s ta crustacea, fuscescente, $u$ mbilic o ventrali, lineari. $\mathbf{E}$ m b r y o axilis, umbilico parallelus, albuminis longitudine, extremitate radieulari infera. - Herbae in Europa australi indigenae, perennes; radice e tuberibus oblongis, fasciculatis, caule dense folioso, foliis subulatotriquetris, brevibus, basi lata vaginantibus, floribus flavis v. albis, in racemum simplicem, densum dispositis, bracteatis.

Asphodeline Reichenb. Fl.germ. 116. Nees jun. Gen. pt. fasc, IV. $t$. 1. A s p hodeli sp. Linn. Jacq. Hort. Vindob, t,77. Jaeq. f. Eclog. t, 77. Redouté Liliac, t.223. Bot. Mag. t.773.2626.

14.3 . Hemerocallis LINN. Perigon i u m corollinum, infundibuliforme, tubo brevi, lim b o sexpartito, patente. Stam in a 6, fauci inserta, filamenta filiformia, declinato-adscendentia. Ovarium triloculare. OvuIa in loculis plurima, biseriata, horizontalia, anatropa. St y lns filiformis, cum staminibus adscendens; stig ma 
subeapitatum. C a p sula carnoso-coriacea, obtuse trigona, trilocularis, loculicido-trivalvis. S e mi$\mathrm{na}$ in loculis pauca, angulato-subglobosa, testa erustacea, atra, hinc $r h$ a $p$ e percursa. E m bry o axilis, dimidio albumine longior, extremit a te radiculari umbilicam attingente. - Herbae in Europa occidentaliet in Asia media indigenae; foliis linearibus carinatis, scapo radicali ramoso, floribus magnis, flavis.

H e me r o calli s Lina. gen. n. 433, exel, sp. Gärtn. $I T$. 14. t. 83. Jacy. Hort, Vindob, t, 139. Bot. Mag. t. 19.64. 873. Andr, Bot. Reposit, t. 24t. Redouté Liliac, t, 15.16. LillioAs phodelus Tournef. inst. $t, 179$.

14.4. Cyamella LINN. Perigonium corollinum, sexpartitum, foliola aequalia, subbilabiato-inflexa. Stam in a 6 , imo perigonio inserta; filam enta glabra, quinque superiora filiformia adseendentia, sextum complanatum, propendens, anthera difformi, Ovari um triloeulare. Ovula plurima.... Stylus filiformis, geniculato-adscendens; $s \mathrm{tigma}$ simplex. Capsula membranacea, subgloboso-trigona, farcto-nodulosa, trilocularis, loculicido-trivalvis. S e m i na plurima, angulata.

Herbae capenses; radice tuberoso-bulbosa; foliis radicalibus lanceolato-ellipticis $v$. linearibus, basi vaginantibus, scapo ramoso, floribus racemosis, bracteatis, caeruleis $v$. flavis, - Genus dubiae affinitatis, recognoscendum.

C y a n e Il a Linn. gen, n, 240. Jaeq. Hort. Vindob, t.35. Ic. rar. $t .447$. Redouté Liliac, t.373, Bot, Mag. t.368, 1238.

145. Antlaerieum LINN. Perigon i u corollinum, hexaphyllum, folio la aequalia, patentia v. campanulato - conniventia. Stamina 6 , hypogyna; fil a ne n ta filiformia, glabra v. barbata, Ovarium triloculare. Ovula in loculis plurima, biseriata, amphitropa. St $\mathrm{y}^{-}$ I $\mathrm{s}$ filiformis, declinato-adscendens; stig ma subcapitatum, obtusum. C a p \& u l a membranacea, subglobosa, trilocularis, loculicido-trivalvis. Semina in loculis pauca, angulata, dorso conveva, testa crustacea, atra, punetato-rugosa. E mb ryo axilis, parum eurvatus, albuminis longitudine, extremitate radisulari incrassata, infera. - Herbae in Europa media et australi, in Nova Hollandia et in Capite bonae spei indigenae; radicibus fasciculatofibrosis, foliis rudicalibus filiformibus, $v$. linearilanceolatis, interdum carnosis, saepe pilosis, floribus in scapo radicali racemosis $v$. paniculatis, al bis, pedicellis articulatis.

An th exi cum Linn. gen, n. 422.

a) ANTHERicum Schult, Perig on ium patens. Stamin a glabra.

Antherieum Sehult. f. syst. VIT. n. 1394. Phalangin m Juss. gen. 52. Redouté Liltac. 6.269.287. Antherici s p. Linn. Jacq. Fl, austr, t. 161. Hort. Vindob, t.83, Gärtu. I. 55, t. 16, Nees jun. Gen. pl, fasc. IV. $t .18$.

b) CZACKIA Andr. Perigou i um campanulato - connivens. St a mi u a glabra.

C z a chia Audr. Dissert. Itrziem, 1818. 4to. c. ic. Nees jun. Gen, pl. fasc, VI. t. 2. A 11 o b ragia Tratt. Fl. austr. 184. Lili as tr um Link Handb. $T_{\text {, }}$ 183. A n the rie u m Li. Ii as $\operatorname{tr} \mathrm{nm}$ Linn. Redouté Liliac. $t .255$.

c) BULbiNe Linn. Perigonium patens. Stamina omsia v. altersa barbata.

B u Ib in e Linn. Hort. Cliff. 122. Willd. Enum. 372. A n theric a m Juss. gen, 59. R. Brown prodr. 275,. Anthe rici s p. Jaeq. Ie, rar. t, 403-409. Hort. Vindob.t. 181. Redouté Liliac. t.283.379.423. DC. Pl. gr. t.8, 14.36. Bot.

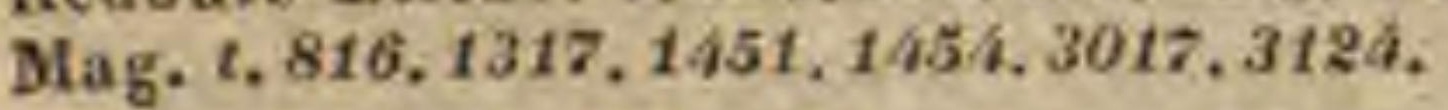

146. A cetheropodiam $R . B R$, Perigonium corollinum, sexpartitum, foliola patentia, tria interiora margine undulata $v$. fimbriata. Stamina 6, imo perigonio inserta; fila- menta barbata, Ovarinm triloculare. Ovula in loculis plurima. ... Sty lus filiformis; stigm a hispidalum. Ca psula membranacea, subglobosa, trilocularis, loculicido-trivalvis. S e m ina pauca, subangulata, umbilico mado.

Embryo curvatus. - Herbae australasicae extratropica e, glabrae; radice e fibris fasciculatis crassis, $v$. e bulbis pedicellatis composita, foliis linearibus faccilis, racemis laxis, pedicellis aggregatis $v$. solitariis, medio articulatis, floribus pendulis, purpurascentibus $v$. albidis, perigonio post anthesim connivente, mox supra basim persistentem cyathiformem circumscisso.

Arthropodium R. Brown prodr. 276. Bot. Mag. $t$. 1421. 2350. Bot. Reg. t. 709. 866. Antherici sp. Redouté Liliac, $t, 5 s$. $\mathrm{P}$ h a I a $\mathrm{a}$ if $\mathrm{s} \mathrm{p}$. Redouté $t .360$.

1147. Chllorepilnytume KER. P e rigoni $\mathbf{u m}$ corollinum, sexpartitam, patens. Stamin a 6 , hypogyna; fi I am en ta filiformia, glabra. O va ri um triloculare. Ovn I a plurima, biseriata, amphitropa. Stylus filiformis, rectus; stigm a capitellatum. Ca p s u la membranacea, lobato-triquetra, trilocularis, loculicido-trivalvis. S emin a in loculis 2_4, reniformia, compressa, tes t a crustacea, atra, umbilico ventrali. E mbry o axilis, parum incurvus, extremitate radiculari infera. - Herbae in Africa et Australasia tropica, nec non in Capite bonae spei indigenae; radicibus fasciculatis, fibris saepius carnosis, foliis radicalibus linearibus $v$. lanceolatis, nervosis, racemis simplicibus $v$. paniculatis, bracteatis, albis, pedicellis medio articulatis.

Chlorophytum Ker in Bot. Mag. t. 1021. 1223. R. Browu prodr. 297. Lindl. in Bot. Reg. t, 813. P ha langi p. Redoute Liliae, t.191. As p ho de 1 i s p. Iinn. Mill. Ic. t.56. H a r tweg i Nees in N. A. N. C.XNII.372,

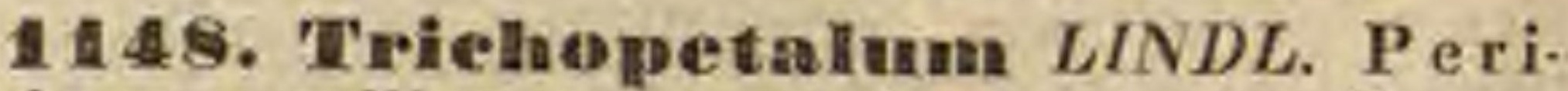
gonin corollinum, sexpartitum, la cini is recurvato - patentibus, tribus interioribus fimbriatobarbatis. S $\mathrm{t}$ a $\mathrm{m}$ i n a 6 , imo perigonio inserta; filamenta filiformia, glabra. Ovarium triloculare. O v u 1 a plurima, biseriata, amphitropa. Stylus filiformis, reetus; s $\mathrm{t}$ i $\mathrm{s} \mathrm{m}$ a obtusum, obsolete trigonum. Ca p s il a membranacea, oblonga, trigona trilocularis, loculicido-trivalvis, Semin a plurima, reniformia, compressa, testa crnstacea, atra, umbilico ventrali. Embryo axilis, parum incurvus, extremitate radic ula $\mathrm{ri}$ infera - Herbae chilenses; radicibus fasciculatis, carnosis, foliis lineari-ensiformibus gramineis, floribus albis, extus herbaceis, subsolitariis, racemosis $v$. spicatim paniculatis.

Triefio pet a l um Lisdl. in Bot. Reg, $t, 1535$. B at. tionate Colla Plant. Chil. 1 . $7, t, 1$. Anthericum p I u no os un Ruiz et Pavon Fl, peruv, t. 300. f.6. Bot. Mag. t. 3084 .

14\$. Stypandrea $R . B R$. Perigonio m corollinum, sexpartitum, foliola patentia, aequalia. St a $\mathrm{m}$ i $\mathrm{n}$ a 6 , imo perigonio inserta; f il a men ta basi attenuata, curvata, glabra, apice stupposo - barbata. Ov a r i $\mathrm{m}$ triloculare. OvuI a in loculis plurima.... S t y 1 a 8 filiformis; st igma simplex. Ca p s u la membranacea, subglobosa, trilocularis, loculicido-trivalvis. S e min a pauca, ovalia, laevia, $\mathbf{m}$ b ili co nudo. . . E E mbryo rectns.... - Herbae australasicae extratropicae, perennes ; rhizomate repente, foliis lineari-ensiformibus strictis, basi semivaginuntibus, floribus paniculato-corymbosis, cueruleis v. albicantibus, pedicellis cum perigonia articulatis, antheris demum revolutis.

Sty pandra R. Brown prodr. 278. -? Antheriei s p. Ruiz et Pavou Fl, peruv. $t, 299$, f. $a$, 
150. Thysanotus $R$. BR. Perigoni um corollinum, sexpartitum, 1 a cini is patentibus, tribus interioribus latioribus, fimbriato-ciliatis. S tam in a 6 , vel rarins 3 , hypogyna $v$. imo perigonio inserta; fil ament a filiformia, adscendentia, glabra, an therae lineares, interiores saepius elongatae, reelinatae. Ovarium triloculare. Ovu la in loenlis bina, superposita, anatropa, inferius erectum, superius pendulum $\mathrm{Sty}$ I us filiformis, declinatus; st $\mathrm{i} g \mathrm{~m}$ a simplex. C a p su I a oblonga, trilocularis, loculicido - trivalvis. S e m in a in loculis 2, ovata, compressiuscula, alterum erectum, alterum pendulum, $t$ es $t$ a crustacea, atra, fu n ic ul o brevi, basi in $\mathrm{rh}$ a p hen introrsum lateralem transeunte, strophiolo eyathiformi eincto. $\mathrm{Emb}$ ryo excentriens, subfalcatus, in seminis latere rhaphe opposita, extremitate radiculari umbilicum attingente. - Herbae perennes, in Nova-Hollandia, imprimis meridionali indigenae; radicibus fibrosis $v$. e bulbis carnosis, fasciculatis composita, foliis anguste-linearibus, saepius canaliculatis, nunc filiformibus v. abbreviatis, floribus terminalibus umbellatis, rarius sparsis, pedicellis medio articulatis, perigonio extus herbaceo, intus caerulescente.

Thysanotus R. Brown prodr. 282. Bot. Reg, t.655. 656. Ch 1 a m y s porum Salisb. Parad, t, 103. Ornithogali s p. Labill. Nov. Holl. t.109.110. (Structura ovuli e Th. junceo, seminis et embryonis in Th. dichotomo et $v$ ol u bili observata.)

151. Caesia R. BR. Perigoninm corollinum, sexpartitum, foliola patentia, aequalia. St a m in a 6, imo perigonio inserta; filamenta utrinque angustata, glabra. Ovarinm triloculare. Ovula in loculis bina, collateralia, e basi erecta, anatropa. Stylus filiformis; $8 \mathrm{tig}-$ ma simplex. C a p s u la trilocularis, evalvis, apice toroso- Iobata, interdum abortu unilocularis, clavata. S e min a in loculis bina v, abortu solitaria, e basi erecta, ovata, t e s ta crustacea, atra, $\mathrm{u} \mathrm{mbi}$ lic o basilari strophiolato. Embry o. ....- Herbae in Nova Hollandia tropica orientali, meridionali, et in insula Diemen indigenae; radice fasciculata, e fibris crassiusculis tuberibusve oblongis, saepius anrua, foliis gramineis, racemis divisis $v$. simplicibus, pedicellis aggregatis $v$. solitariis, cum perigonio articulatis, floribus albicantibus $v$. caeruleis, erectis $v$, rarissime nutantibus, perigoniis deftorat is spiraliter convolutis, mox deciduis.

C a e si a R. Brown prodr. 2rr,

152. Chloopsis BLUM. Perigo $\mathrm{i}$ u m corollinum, sexpartitum, foliol a patentia, aequalia. Stamina 6 , imo perigonio inserta; filamenta complanata, glabra. O v a ri u m triloculare. Ovula in loculis bina, collateralia, erecta. ... Stylus subulatus; stigma obsolete-tricuspidatum. C a p u la evalvis, alte sexloba, abortu bitriloba, lobis subglobosis, carnosis. S e mina in loculis solitaria, subglobosa. . . E m b r yo basilarís.....- Herbae javanicae, subacaules, glabrae; radice fibrosa, foliis fasciculatis, gramineis, nervosis, floribus racemosis, azureis, pedicellis medio articulatis, perigonio marcescente.

Genus imperfecte cognitum, an satis a praecedente distinctum?

C hloo psis Blume Enum. pl. Jav. I. 14. Sehult. fil. Syst. $\nu I T, 1691$,

1153. Tricoryme $R$. BR. Perigonium corollinum, sexpartitum, folio la aequalia, patentia. S $t$ a $\mathrm{m}$ in a 6 , imo perigonio inserta; fil a $\mathrm{m}$ ent a filiformia, penicillato-barbata. $O v a-$ ri u m trilobum, lobis basi st ylo junetis. $O \mathrm{vu}$
$1 \mathrm{a}$ in loculis bina, collateralia, e basi erecta, anatropa. Stylus filiformis; stigm a simplex. Carpidia 3 , v. abortu pauciora, clavata, evalvia, monosperma. Semina in loculis solitaria, erecta, ovata, te st a crustacea, atra, umbilico basilari nudo. E mbryo axilis, dimidii albuminis longitudine, extremitate radiculari umbilicum attingente. - Herbae in Novae Hollandi a e ora tropica, orientali et australi repertae; radice fibrosa, annua v, saepius perenni, foliis gramineis angustis, caule saepius ramoso, ramis stipula introrsum laterali auctis, floribus umbellatis, erectis, flavis, perigoniis cum pedicello articulatis, defloratis spiraliter comvolutis, mox deciduis.

Trico o y n e R. Brown prodr. 278. Ferd. Baner Illustr. pl. Nov. Holl, t.11.

\section{GENERA ANTHERICEIS AFFINIA.}

\section{* CONANTHEREAE.}

154. Zephyra DON. Perigoninm corollinum, hypocrateriforme, $t \mathrm{ubo}$ cylindraceo ovarii basi adhaerente, I imbi sexpartiti laciniis patentibus. Stamina 6 , perigonii fanci inserta, 2 sterilia, longiora; fil amenta compressa, glabra, a $\mathrm{t}$ h erae basifixae, distinetae, loculo altero basi productiore, apice poro gemino dehiscentes. Ovarium semiadhaerens, triloculare. Ovula in loculis plurima. Stylu s filiformis. Stigma simplex. Fructus....- Herba peruviana; caulibus erectis ramosis, glabris, basi foliorum rudimentis scariosis obvolutis, floribus paniculatis, asureis, pedicellis filiformibus, bracteatis, summo apice dilatato cum perigonio articulatis, perigonii tubo supra basim oum ovarii parte inferiore colhaerente, circumscisse deciduo.

$\mathrm{Z}$ epliy $\mathrm{r}$ a Dou in Edinb. new philosoph. Journ, July 1832. p. 236.

1 155. Cummingia DON. Perigoninm corollinum, campanulatum, $t \mathrm{u}$ b o ovari basi adhaerente, limbi sexpartiti laciniis patentibus. $\mathrm{S}$ ta $\mathrm{m}$ in a 6, perigonii tubo inserta; filamenta compressa, brevissima, glabra, an the rae basifixae; conniventes, loculo altero basi productiore, apice bisctac, poro simplici apertae. Ovarinm semiadhaerens, triloculare $O$ vala plurima, amphitropa. ... S tyla s subulatus; st ig ma simplex. Capsula membranacea, trilocularis, loculicidotrivalvis. Sem.ina in loeulis pauea, angulata, te s t a membranacea, cellulosa, fusca, $\mathrm{umbilico}$ ventrali lineari, E m b r y o axilis, umbilico parallelus, extremitate radiculari infera. - Herbae chilenses; tubere bulboso, fibrose tunicato, foliis lineari-lanceolatis, nervosis, scapo ramoso bracteato, floribus paniculatis caeruleis, nutantibus, perigonii tubo cum ovarii basi cohaerente, mox supra eandem circumscisse deciduo. - An genus satis a sequente distinctum?

Cummingia Don in Loudon's Magaz, of nat, hist. 1898. Nov. p. 362. f. 169. a. Sweet Brit. Fl. Gard, t. 88. Con a the rae s p. Hook. exot. E7,t.214. Bot. Mag. t, 2976. Bot, Reg. $t, 1193$.

1156. Comanthera $R U I Z$ et PAV. Perigonium corollinum, sexpartitum, basi ovarii adhaerens, la cin i is reflexo-patentibus. $S t$ a $m i-$ na 6 , imo perigonio inserta; filamenta compressa, brevissima, glabra, antherae basifixae, in connm conniventes, loculo altero basi productiore, apice nnisetae, poro simplici apertae. O v arinm semiadhaerens, triloculare, Ovala plurima. ... Stylus filiformis; stigma simplex. Cap su la oblongo-globosa, trilocularis, loculi- 
cido-trivalvis. Semina panca, subglobosa. - Herbae c hilenses; tubere bulboso, fibrose tunicato, foliis lineari-lanceolatis, nervosis, scapo ramoso, bracteato, floribus caeruleis, paniculatis, perigonio post anthesim spiraliter convoluto, mox supra basim cum ovario cohaerentem circumscisse deciduo. - An genus Arthropodio proximum?

C on a ther a Ruiz et Pav, Fl. peruv, III. 68, t. 301.

115\%. Pasithea $D O N$. Perigonium corollinum, sexpartitum, basi enm ovario cohaerens, la cini is reflexo-patentibus. Stamina 6, imo perigonio inserta; fil a m enta subulata, glabra, a $\mathbf{n t} \mathrm{h}$ e $\mathrm{r}$ a e incumbentes, longitudinaliter dehiscentes. Ovari n m eum perigonii basi cohae rens, triloculare. Ovula plurima. ... Stylus filiformis; st i g m a trifidum, lobis recurvis. F ructus,... Herbae chilenses; radice fasciculato-fibrosa, caule ramoso, glabro, foliis radicalibus lineari-lanceolatis, distichis, floribus cyaneis, diffuse paniculatis, perigoniis post anthesim spiraliter convolutis, mox supra basim cum ovario cohaerentem circumscissis.

Pas it he a Don in Edinb, new philosoph. Magaz. Jul, 1832. p. 236. A uthericum caerule um Ruiz et Pav. Fl. peruv. $I I I .67 .2 .299 . f .6$.

158. Eelneamatia $O R T E G$. P erigoniu m corollinum, hexaphyllum, foliola patentia, interiora majora. Stam in a 6 , imo perigonio inserta, fil am enta clavata, hispidula, a $\mathrm{n}$ h h er a basifixae, in conum connatae, intus longitudinaliter dehiscentes. Ovari u m liberum, triloculare. Ovula plurima, biseriata, anatropa. Stylus filiformis, medio articulatus, stig ma subglobosum. C a p s u l a subglobosa, membranacea, trilocularis, loculicido-trivalvis. S e min a plurima, orbiculata, compressa, testa membranacea, atra.... Herba mexicana; radice fibroso-fasciculata, foliis radicalibus lineari-ensiformibus, basi vaginantibus, scapo simplicissimo, racemo elongato, laxo, terminali, floribus flavis nutantibus, binis ternisve ex eadem bractea. - Genus Conantherae haud nimis propinquum, sed quo ad veram affinitatem omnino dubium.

E c heandia Ortega Dec.pl.90. DC. et Redouté Liliac. t.313. Conanthera e sp. Pers., Link et Otto Ic, rar. t.33. Anthericis p. Cav, Ic, $t, 241$.

\section{* * TULBAGHIEAE.}

159. Trulbaglaia LINN. Perigoniu $\mathrm{m}$ corollinum, urceolato-infundibuliforme, $\mathbf{t} \mathbf{u}$ b o cylindrico, limbi sexfidi lacinits aequalibus patentibus. Coron a faeis triphylla, foliolis bifidis, distinctis $v$. in annulum connatis, $S t$ a $m$ ina 6 , tria fanci, tria tubo inserta, filamentis brevissimis. Ovarin triloculare Ovula.

Stylusteres; stigma turbinatum, depressum. Caps ula perigonio fauce constricto vestita, membranacea, ovata, trigona, triloeularis, loculicidotrivalvis. Semina in luculis 2 , superposita, triquetra, testa crustacea, atra, umbilico ventrali. Embry o axilis, subsigmoidens, albuminis longitudine. - Herbae capenses, Allii odore; ra dice e fibris tuberoso - inerassalis, fasciculatis, foliis radicalibus linearibus $v$. filiformibus, florum umbella scapum simplicissimum terminante spathaceobibracteata.

$\mathrm{T}$ u 1 b a g h i a Linn. gen, n, 1300. Juss. gen, p. sh. Gärtn. I. 57. t. 16. Bot. Mag, t.806.

THERES III. ASPARAGEAE. Perigoni $u \mathrm{~m}$ patens $v$, rarissime tubulosum. F $\mathbf{r}$ uct u s baccatus. S e m i n a umbilico saepius strophiolato. - Herbae, frutices v. arbores; radice tuberosa v. fibrosa.

160. Diamella $L A M$. Perigonium corollinum, sexpartitum, aequale, patens. Stamina 6 , imo perigonio inserta; fil a m en t a curvata, apice incrassata, stupposa, antherae basifixae, lineares, strictae. O va ri u m triloculare. Ovula plurima, anatropa. Stylns filiformis; stigma simplex. B a c c a globosa, polysperma. S e mina ovalia, testa crustacea, atra, splendente, $\mathbf{n ~ m ~ b ~ i - ~}$ lico nudo. Embryo rectus, minimus, in basi albuminis, - Herbae perennes, in Asia tropica et in Nova Hollandia intra et extra tropicos indigenae; radice fibrosa, foliis gramineis elongatis, basi semivaginantibus, floribus paniculatis baccisque caeruleis, pedicellis cernuis, juxta apicem articulatis, basi bracteola unilaterali stipatis.

D i a nell a Lam. Illustr. t, 250. Jacq. Hort. Schänbr. t.94. Redouté Liliac, t, 179 Bot. Mag. t,505. 1408. Bot. Reg. t.743.751. D ian a Commers. msc. D ra ca en a e sp. Linin. Gärt, $t, 16, f .4$. - Excremis Willd, msc, ex Sehult. Syst. VII. 354. Dianella dubia Kuath in Humb. et Bonpl. nov. gen. et sp. t. G75. habitu et patria magis quam eharacteribus diferre videtur.

1161. Hovacophilla BLUM. Perigon i um corollinum, sexpartitum, patens, foli o la subaequalia, apice pubescentia. St a m in a 6 , hypogyna; filamenta utrinque angustata, antherae basifixae, lineares, strictae. Ovarium quadriloculare. Ovnla. ... Stylus quadrisulcus; stigma obtusum. Capsula subglobosa, tri-quadrisulea, tri-quadrilocularis. S e mi n a plurima, parva, testa.... n mbilieo strophiolato. $\mathbf{E} \mathbf{m}$ bry o umbilico approximatus, _ Suffrutices ramosi, circa Molucc arum crateres vulcanicos reperti; radicibus fibrosis, foliis gramineis, lineari-elongatis, subcarinatis, distichis, nervosostriatis, pedunculis axillaribus et terminalibus divisis, pedicellis subfasciculatis, versus basim unibracteatis, cum perigonio articulatis, floribus caeruleis.

R h u a cophil a Blume Enum, pl. Jav. $I$, 13. Sehult, f. Syst. $V I$. 1672 .

162. Eustreplaus $R$. BR. Perigoni u corollinum, sexpartitum, patens, foliolis interioribus fimbriatis. Stam ina 6 , hypogyna; fil ament a brevissima, distincta v. basi connata, antherae basifixae, lineares, strictae. Ovariu m triloculare. Ovula plurima, amphitropa. Stylus filiformis; stigma trigonum. Capsala baccata, trilocularis, loculicido-trivalvis. S e m in a plura, angulato-subglobosa, te s ta crustacea, atra, umbilico ventrali. Embryo excentrieus, subcurvatus, extremitate radiculari infera. - Suffrutices volubiles, in Nova Hollandia tropica et orientali indigeni; foliis ellipticis $v$. lineari-lanceolatis, nervosis, pedicellis axillaribus terminalibusque aggregatis, medio articulatis, floribus dilute purpurascentibus, capsula subglobosa, flava.

Eustrephus R. Brown prodr. 281. Bot. Mag. t, 1245.

1 183. Geitomoplesinam A.CUNNINGH. Perigonium corollinum, sexpartitum, patens, aequale, glabrum. Stamina 6 , basi laciniarum inserta ; fil am e n ta filiformia, apice curvatoconniventia, a $n t h$ e r a e basifixae, sagittatae. Ovari um trilueulare. Ovula panea, amphitropa. Stylu s filiformis, trisuleus; stigma simplex. Bacea globosa, monosperma. Sem ina subglobosa, t e s t a coriacea, atra, umbilico ventrali, nudo. Embryo subexeentrieus, enrvatus, extremitate radiculari incrassata, infera. - Suffrutices volubiles in Nova Hollan- 
dia tropica et orientuli, et in insula Norfolk indigeni, foliis elliptico-lanceolatis, nervoso-striatis, floribus cymosis v. umbellatis, terminales axillaresque, pedicellis cum perigonii basi attenuata articulatis, baceis nigris.

Geitonoplesium A. Cunningham in Bot. Mag. $t$. 3131. Endl. prodr. Fl. norf. 29. L u z u riag a R. Brown prodr. 281. non Ruiz et Pav.

1164 . Asparpagus $L I N N$. P erigoniu m corollinum, sexpartitum, aequale, campanulato-connivens, apice patens. S tam in a 6 , basi laciniarum affixa; filamenta subulata, anthera e peltatae. Ovarium triloculare. Ovula in Joculis 2, superposita, amphitropa. Stylu s brevis, trisulcus; stigma trilobum. B a e c a globosa, trilocularis. Sem in a in loculis 2 , angulato-subglobosa, te sta coriacea, atra, $\mathbf{u} \mathbf{m b i l i c o}$ ventrali, punctiformi, nudo. $\mathbf{E} \mathbf{m}$ b $\mathbf{r}$ y o excentricus subcurvatus, dimidis albumine longior, extre mitate radiculari vaga. - Herbae perennes, saepius suffrutescentes, ramosae, in temperatis subtropicisque, rarius inter tropicos veteris orbis indigenae, in novo continente nondum visae, ramis saepius spinescentibus, foliis angustis, in axillis ramorum fasciculatis, floribus saepius axillaribus solitariis, rarius racemosis, plerumque abortu dioicis, pedicellis medio articulatis.

A s parag us Linn. gen, n, 424. Juss, gen, 41. Gärtn. I. $581, t, 16$, Fl. dan. $t, 805$. Waldst. et Kit, pl, Hung. $t .201$. Redouté Liliac. . 107. Sibth. Fl. graec, $t$. 238, 239. Brester, generis Asparagi historia naturalis atque medica. Berolini 1826. 8vo. Nees jun. Gen. plant. fase. II, t, 1\%. (De germinatione cfr. Mirbel, in Annal, du Mus, XIIT, 156, t, 14. f. 28 -38. et Cruse, de Asparagi officinalis germinatione, Regiom. 1828. 8vo.)

1165. DIyresiplayllum $W I L L D$. P e r igo ni um corollinum, sexpartitum, aequale, campannlato-connivens, apice patens. Stamina 6, basi laciniarum affixa; fil a m ent a subulata, a $n-$ therae peltatae, erectae. Orarium pedicellatum, triloculare. Ovula in loculis 2, superposita, amphitropa. Styli 3, contigui, stricti, intus stigmatosi. B a c ca globosa, trilocularis. Semina in loculis 2 , angulato-8ubglobosa, t e $s t$ a coriacea atra, $\mathbf{n ~ m ~ b ~ i ~} 1$ i $\mathbf{c}$ o ventrali, punctiformi, nudo. Embryo. ... - Suffrutices capenses, volubiles; foliis breve petiolatis, ovato-lanccolatis, basi subcordatis, nervosis, floribus ad basim folii ex axilla squamulae scariosae geminis vel ternis, pedicellis nutantibus, medio articulatis

M y r s iphyllum Willd. in Berl. Magas. Ir. 25. M ede ol a e sp. capenses Linn. Redouté Liliac, $t$. 393. 442.

1166 . Cordyline COMMERS. Perigon i m corollinum, campanulatum, limbo sexfido, patente. St a mina 6, perigonii fanci inserta; filamenta subulata, antherae versatiles, basi bifidae. Ovari um triloculare. Ovn la plurima, anatropa. Stylus filiformis; stigma trilobum. B a c ca globosa, trilocularis. Se min a in loculis plura, v, abortu solitaria, testa... umbilico strophiolato. Embryo axilis, extremitate radiculari centripeta. - Plantae per regiones tropicas subtropicasque, imprimis hemisphaerii australis dispersae; caudice frutescente, interdum elato, foliis in apice caudicis congestis, elongato - lanceolatis, nervoso-striatis, petiolatis $v$. sessilibus, panicula terminali e spicis alternis multifloris, floribus bibracteolatis, bracteola altera interiore, sessilibus $v$. pedicellatis, perigonio cum pedicello articulato.

Cordyline Commers. R. Brown prodr.280. D racaen a e s. p. Liun. Forst, Bot. Mag. t. 2575. 2835. Bot. Reg.t. 956. 1749. C h a rlw oodia Sweet Fl. austral. t. 18 .
$116 \%$. Draeaema $V A N D E L L$. Perigon i m corollinum, sexpartitum, aequale, 1 a $\mathbf{c}$ in i is subrevolutis. St amina 6 , imo perigonio inserta; filam enta medio incrassata, antherae versatiles, basi bifidae. Ova ri $\mathbf{~ m}$ pedicellatum, triloculare. Ovula... St y lus angulatus; stigin a trifidum. B a c c a globusa, sexsulea, trilocularis. Semina in loculis solitaria. ... - Arbores giganteae, in India orientalitropica et in insulis $C$ a $n$ a $r i$ is vigentes; caudice elato, crasso, molli, dichotome-ramoso, foliis in apice ramorum confertis, ensiformibus, apice spinescentibus, florum racemo terminali, ramoso, foliaceo-bracteato, pedicellis infra apicem articulatis.

Dracaen a Vandelli monograph. Ulissip. 1768. Gleditseh Verm. Bemerk. 1. 180. Behreus, Dissert, Gütting. 1a79. Meyer in Nouv. Mem. Academ. Berol. 1796. p. 29. Berthelot in N.A.N.C.XV.,773, t, 3s-39. S tō r k ia et 0 ed era Crantz de duobus arboribus Draconis Vindob, 1768. T a tsi a Medikus Theodor. 82 .

\section{GENERA ASPHODELEIS AFFINIA.}

\section{* APHYLLANTHEAE.}

168. Alamia. Perigonium membranaceum, hexaphyllum, aequale, patens, persistens. St a m in a 6, hypogyna; fil am ent a filiformia, glabra, antherae... Ovarium triloculare. Ovula plurima, horizontalia, biseriata, anatropa. St ylus filiformis; stigma. .. Ca psu la coriacea, trilocularis, loculicido-trivalvis. S e $\mathrm{m}$ in a in loculis pauca, ovata, horizontalia, $t$ esta crustacea, atra, nitida, $\mathbf{m}$ bilico nudo. Albumen copiosum, carnoso-oleosum. Emb ry o. . .

Herba a cl. Alan Cunningham in campis aridis prope montes caeruleos Novae Hollandiae anno 1818 detecta; caulibus procumbentibus, dense foliosis, foliis grumineis, aridis, patentibus, busi dilatata scariosa ustulata semivaginantibus, scapis terminalibus, ancipiti-filiformibus, capitulo bracteolarum ovato, bracteis aliquot brevissimis involucrato, bracteolis seariosis glabris, exteriore interiorem latiorem pedicellum vaginatim amplexantem includente, floribus minutis, pedicellis filiformibus subfastigiatis, haud articulatis.

Ge u s novnm, inter Laxmanniam et Boryam A. Cunninghan msc, in Herb. Mus. Nindob.

169. Laxmanuia $R, B R$. Perigonium membranaceum, hevaphyllum, basi connivens, persistens. St a m in a 6 , tria exteriora imis, tria interiora mediis perigonii foliolis inserta; fila menta subulata, glabra, antherae peltatae, subglobosae. Ovarium triloculare. Ovala in loculis panca, amphitropa. Stylus filiformis, cum ovario articulatus; $8 \mathrm{tig}$ a obtusum. C a p sula perigonio persistente inclusa, trilocularis, loculicido-trivalvis $\mathrm{Sem}$ in a in loculis bina, superposita, peltata, testa atra, umbilico nudo. Emb ryo dorsalis, umbilico parallelus. - Herbae perennes, in omnibus Novae Hollandiae oris et in insula Timor observatae, facie Polycarpeae; radice fibrosa, caulibus procumbentibus filiformibus, foliatis ; foliis aceroso-filiformibus, radicalibus confertis, caulinis alternis, medio vaginae brevis scariosae, margine lanatae et apice fissae insertis, minorum fasciculis axillaribus, capitulis axillaribus sessilibus $v$. pedunculo brevi terminali, scapiformi sustentis, floribus subsessilibus, unibracteatis, parvis, purpurascentibus $v$, albis.

L a $x$ m a n ni a R. Brown prodr. 285. Decaisue in Nouv. Annal, du Mus, III, t, 16 .

11 \%. Forya LABLLL. Perigonium membranaccum, infundibuliformi-tubulosum, $1 \mathrm{i}$ m- 
bo sexpartito, aequali, marcescendo-deciduum. Stamina 6, perigonii fauei coaretatae inserta; fil amenta filiformia, glabra, an $t$ herae basifixae. Ovarium triloculare. Ovula. . . StyIus filiformis; stigma obtusum. Capsula trilocularis, loculicido-trivalvis. Semina pauca, te s t a crustacea atra, a l b u mine carnoso, suboleoso. Em bryo. ... Herbae perennes, aridae, in Nova Hollandia meridionali et occidentali indigenae; radicibus fibrosis longis, tenacibus, caulibus simplicibus $v$. divisis et repentibus, foliis acerosis, confertissimis, mucronatis, basibus dilatatis scariosis, semivaginantibus, scapo terminali, simplici, capitulo subgloboso, bracteis aliquot foliaceis involucrato, squamis floralibus scariosis, glabris, exteriore interiorem minorem, perigonium amplexantem includente.

B o r y a Labillardiere Nov. Holl, $1,81, t, 107$. R. Brown prodr. 286. non Willd. D avi es i a Lam. illustr. Suppl. 10. B a $\mathrm{mg}$ artenia Spreng. syst, $I I .91$.

11 I1. A phyllanthes TOURNEF. $\mathrm{Pe}$ rig on i m corollinum, sexpartitum, aequale, la $\mathrm{ci-}$ ni is basi in tubum conniventibus, apiee patulis, marcescendo-deciduum. St am in a 6 , perigonio supra basim inserta; fil a menta filiformia, glabra, antherae peltatae. Ovarium triloculare. Ovula in loculis solitaria, basilaria, anatropa. Stylus filiformis; stigma trilobum. Capsula membranacea, trilocularis, loculicido-trivalvis. $\mathrm{S}$ e $\mathrm{m}$ i $\mathrm{n}$ a in loculis solitaria, basilaria, testa erustacea, atra, $u \mathbf{m b i}$ lico nudo. E mbryo axilis, dimidio albumine longior, extremitate radic $\mathbf{n}$ la $\mathrm{ri}$ infera. _Herba perennis, in aridis $E u$ ropae australis obvia; scapis caespitosis aphyllis, basi vaginatis, capitulis terminalibus paucifloris $v$, unifloris, floribus squamis glumaceis imbricatis basi inclusis.

A playllanthes Tournef. inst. 657. Linn. gen, n. 608. Juss. gen, 145. DC, in Redouté Liliac, t. 483. Ker in Bot. Mag. t. 1132. Salisbury Parad, t.9.

11 2 2 . Johnsomia $R, B R$. Perigoni um corollinum, sexpartitum, aequale, connivens, marcescendo-deciduum. St a m in a 3 , imo perigonio inserta, laeiniis interioribus opposita; $\mathrm{fila}$ ment a basibus dilatatis inter se connata, anthera e basifixae. Ovarinm triloculare. Ovula in loculis 2, anatropa, alterum erectum, alterum pendulum. Stylus filiformis; stigm a obtusum. Ca psula membranacea, trilocularis, loculicido trivalvis. S em in a in loculis 2 , apici columellae centralis gracilis, capsula brevioris, demum liberae affixa, testa crustacea, atra, $\mathbf{n} \mathbf{m b i l i c o}$ strophiolato. Embryo...- Herba perennis, in Novae Hollandiae ora meridionali indigena; radice fibrosa, foliis distichis, aversis, linearibus, basi dilatata semivaginantibus, scapo simplici infra apicem monostachyo, spica oblonga, nutante, bracteis undique imbricatis, coloratis, infimis sterilibus, nanis, reliquis unifloris, ftores parvos, sessiles, bracteola laterali interiore stipatos velantibus. t. 1 .

Johns on ia R. Brown prodr. 287. Ferd. Bauer illustr.

$$
\text { ** }
$$

1183. Xamthorplhoea SMITH. Perigonium sexpartitum, subaequale, persistens; foiiola interiora concava, basi conniventia, Sta$\mathrm{m}$ in a 6 , imo perigonio inserta; fil amenta linearia, glnbra, exserta, antherae versatiles. Ovarium triloculare. Ovula plurima, amphitropa, micropyle prope umbilicum laterali. St y 1 us cylindracens, trisuleus; stigma simplex. Ca p s u I a triquetra, cartilagineo-lignea, trilocularis, loculicido-trivalvis. Se min a in loculis 1_2, ovata, compressa, t es t a crustacea, atra, marginata, ad $\mathbf{n m b i l i c u m}$ basilarem nudum emarginata. E m bry o linearis, transversus, sigmoideus v. uncinatus. - Plantae in Nova Hollandia indigenae, habitu proprio et $u b i$ abundant, regioni characterem proprium impertientes; caudice saepius resinifero, nunc elevato, et interdum diviso, crasso, nunc brevissimo v, subnullo; foliis longissimis gramineis, angustis, linearibus, subtriquetris $v$. ancipitibus, confertissimis, undique patulis apicibusve recurvis, basibus dilatatis, semivaginantibus; scapo terminali, cylindraceo, simplicissimo, tereti, saepius elongato, spica terminali, cylindracea, typhoidea, scupum quandoque aequante, floribus sessilibus, confertissimis, albis, parvulis, multibracteatis, bracteis indefinitis, imbricatis, unguiculatis, interioribus sensim minoribus, capsulis exsertis, nitidis.

$\mathrm{X}$ anthor $\mathrm{rboe}$ a Smith in Linn. Transact. IV. 219. R. Brown prodr. 287.

\section{*** GILLIESIACEAE LindI.}

1 4. Gilliesia $L I N D L$. Invol nernm exterius pentaphyllum, foliolis duobus posticis, uno antico majore, duobusque lateralibus multo minoribus interioribus; interius indefinite polyphyllum. Perigonium brevissimum, carnosum, triphyllum, fo $\mathrm{li}$ il $\mathrm{l}$ antico labelliformi, basi utrinque appendiculato, duobus posticis minntis linearibus. St am in a 6 , basi perigonii adnata et inter se in cyathum connata, tria postica ananthera. Ovarium liberum, triloculare, multiovulatum. Sty lus filiformis; stigma capitatum, simplex. Ca p s a l a trilocularis, polysperma, trivalvis, valvis medio septiferis. Semin a plurima, horizontalia, funiculo crassiusculo, $t$ e $s$ t a crustacea, atra. E m br yo eurvatus (?) in axi albuminis carnosi. - Herbae chilenses, bulbosae, glabrae; foliis radicalibus linearibus, flaccidis, scapo tereti subdecumbente, Roribus virescentibus, inconspicuis, umbellatis, umbella basi foliaceo-bibracteata, pedicellis cernuis, haud articulatis.

Gillies i a Lindl, in Bot, Heg. t.999. Introduct, edit. II. p. 331 . Hook, in Bot, Mag. t. 2216.

1 1 ร. II İergia $L I N D L$. Involuc rum exterius hexaphyllum, petaloidenm, interioris foliola totidem bifida, colorata, depauperata. Perigoni um regulare, urceolatum, subobliquum, earnosum, limbo constricto, sexdentato. Stamina 6, minima, fauci perigonii inserta. Ovarium triloculare. Ovula, . Stylus filiformis; stigma eapitatum. Ca psu la triquetra, truncata, trilocularis, vertice trivalvis. Semina plurima....-Herba chilens is, bulbosa, glabra; foliis radicalibus linearibus, erectis, obtusis, scapo nudo brevioribus, floribus virescentibus, inconspicuis, umbellatis, umbella parciflora, basi foliaceo-bibracteata, pedicellis brevibus, haud articulatis.

Miersia Lindt, in Miers Travel's in Chili II. 599. Bot. Reg. n. 992.

\section{Ordo I VI. Smilaceac.}

ASPARAGI Juss. gen, 40, exel, pl, SMILACEAE R. Browa prodr. 292.

Herbae v, suffrutices, $r$ h i z o m a $t$ e ut plurimum repente perennantes. F o l i a alterna v. verticillata, simplicia, integerrima, nervosa, nervis saepius venulis transversis inter se combinatis, sessilia v. basi inter- 
dum vaginantia, nunc petiolata, saepius abortiva, squamaeformia, ramis tunc foliaceo-dilatatis, folia vera simulantibus.

Flores regulares, hermaphroditi v. abortu diclines, axillares $v$. terminales, solitarii, racemosi, fasciculati v. subumbellati, pedicellis saepissime bracteolatis, articulatis.

Perigonium corollinum, liberum, biseriatum, aequale, saepissime sexpartitum, rarius quadri-octopartitum.

Stamisa hypogyna, $v$. perigonio inserta, eiusdem segmentis opposita et numero aequalia, iisque basi saepissime adglutinata. Filam ent a libera, v. rarius plus minusve monadelpha. Antherae introrsae, v. rarissime in monadelphis extrorsae, biloculares, basi vel dorso affixae, erectae, lo culi appositi, contigui, interdum filamento ultra eosdem producto utrinque adnati, longitudinaliter dehiscentes.

Orarium sessile, liberum, tri-v. interdum bi - quadriloculare. 0 v u 1 a placentis centralibus affixa, saepissime pauca, rarissime in loculis solitaria $v$. indefinita, unibiseriata, amphitropa v. orthotropa, interdum anatropa. Styli-loculorum numero, in unicum connati, v. interdum distincti. Stigma $\mathbf{t}$ a distincta, simplicia.

Pericarpium baccatum, indehiscens, triv. bi-quadriloculare, loculis mono-oligospermis; rarius abortu uniloculare, monospermum.

SEmiva subglobosa, loculorum angulo centrali affixa. 'T e s t a membranacea, tenuis, umbilico nudo. Albumen dense carnosum v. cartilagineo-corneum.

Eмвrуo parvus, in cavitate albuminis saepe ab umbilico remota locatus, extrem itate radiculari vaga.

Sullaceae maxima copia in novo continente gignuntur, specierum duabus tertiis a C an a d a ad fret u m magellanicum diffusis, frequentissime tamen, (nempe specierum omnium pars dimidia) A m e r i c a m b o r e l e m inhabitant. Reliquarum pars altera $\mathbf{E}$ u $\mathbf{r}$ o p a m et Asiam sub eadem latitudine incolit, altera per Indiam tropicam et Australasia m est dispersa. Rusci species Thunbergi an a e genere et ordine alienae, et $\mathrm{Sm}$ ilaceae ex Africa omnino exulare videntur. In terra lacustri palaeotherica, imo in psammitica poecili, quaedam hujus ordinis vestigia superesse videntur.

Ordo ab As phodele is bacciferis aegre, et nonnisi testa membranacea, nec atra et crustacea, et albumine densiore distinguendus, habitu fere dicotyledoneo magis quam characteribus recedens; unde Asparagineas veras Liliaceis Asphodeleis adscribere, et Smilaceas ad mentem Brownei arctioribus limitibus circumscribere, consultum duximus.

Convallaricarum nonnulla genera ob virtutem demulcentem diureticam magini in medicina facta. Parideae qualitatibus emeticis et narcoticis pollent.

\section{TRRIBUS I. PARIDEAE. S tyli distincti.}

1 76. Paris LINN. Flores hermaphroditi. Perigonium subherbaceum, octo-decaphyllum, foliola patentissima v. reflexa, persistentia, interiora mnlto angustiora, quandoque nulla. Stamina $8-10$, imo perigonio inserta; filamenta subulata, basibus dilatatis inter se cohaerentia, connectivo saepius ultra an therae loculos lineares marginales, in acumen elongatum producto. O v a r i u m quadri-quinquelocolare. Ovula plurima, biseriata, adscendentia, anatropa. Styli 4-5, distineti; $8 \mathrm{tig} \mathrm{m}$ a $\mathrm{t}$ a obsoleta. Ba ce a quadri - quinquelocularis. S e mina plurima, obovata, horizontalia $v$, adscendentia, te s $t$ a coriacea, fuscescente, $\mathrm{umb}$ il i co basilari, ope $\mathrm{rlh}$ apheos filiformis cum $c h a l a z a$ apieali conjuneto. F $\mathbf{m b}$ r yo minimus, in albumine carnoso prope umbilicum inclusus, extremitate radi $\mathrm{i}$ I a ri centripeta. Herbae perennes, in Europa et $A$ s ia media et boreal $i$ indigenae; radicibus repentibus, caule annuo simplicissimo, foliorum sessilium $v$. subsessilium, ovato-ellipticorum, nervosorum verticillo unico, flore terminali solitario, pedunculato, pedunculo nudo.

P a ris Linn. gen, n. 500. Juss. gen. 42, Ledebour Mo. nographia generis Paridum Dorpat 1827. fol.

a) DEMIDOVIA Hoffin. Perigonit foliola interiora nulla. A $\mathrm{n}$ the rae loeuli subterminales, eonnectivo hand superati.

Demid ovia Hoffm. Hort, mosq. f. 2. Paris in com. p 1 e ta Bieberst.

b) PARIS. Perig on i um completum. A n the rae loculi a connectivo plus minus longo superati.

Gärtn. $I T, 19, t, 83$. Schkuhr $t, 109$. Wallich $p l$, as, $t, 126$. Ledeb. $F l$. alt. $t, 16$. Nees jun. gen. $p l$. fasc, 1 . $t, 19$.

11 \%. Trinluama $M I L L$. F 1 o res herma phroditi. Perigoninm hexaphyllum, patens v reflexum, persistens; folio 1 a 3 calyeina, interinra majora petaloidea. St a min a 6 , perigonii foliolis basi inserta; fil amenta filiformia, libera, connectivo ultra a $\mathrm{n}$ h e r a e loculos lineares, marginales in acumen breve producto. O y a $\mathrm{ri} \mathbf{~ m}$ triloculare. Ovula plurima, biseriata, adscendentia, anatropa. St y li 8 , distincti, v. rarissime hasi connati, patentes, recurvi; stigm a ta obsoleta. B a c ea trilocularis. Se mina plurima, obovatosubglobosa, horizontalia, t e sta coriacea, fuscescente, $\mathbf{u m b i l i}$ co basilari, ope $r \mathrm{~m}$ a $\mathrm{p}$ he os filiformis cum e ha laza apicali conjuneto. Embryu minimns, in albumine dense earnoso prope umbilicum inclusus, extremitate radieulari centripeta. - Herbae perennes, in America boreali obviae, in Asia arctica et summis Indiae jugis rarissimae; caule simplicissimo, foliis verticillatis, sessilibus, ovatis, nervosis, flore terminali solitario, inter folia sessili $v$, pedicellato, pedicello nudo.

Trilli a m Linn. gen, n. 456, Lam, illustr, 1,267 . Re. donté Liliac, $t, 133$. Salisb, Parad, $t, 1$. Willdewow hort. be rol, $t, 35$. Reichenb, ic, exot, 4,29 . Bot. Mag, $t, 40,470,954$. 3002,3097. Phyllanther am, Irillium et Delostylis Rafiin. in Journ, Phys. XCr. 72 . 
1 78. Niledeola GRONOV. F lores hermaphroditi. Perigoninm subcorollinum, sexpartitum, aequale, deciduum, I a c in iis revolutis. Sta min a 6 , imo perigonio inserta; fil a m ent a filiformia, a $\mathbf{n} \mathbf{t}$ h e $\mathbf{r}$ a e lineares, incumbentes. Ovari um triloeulare. Ovula plurima, biseriata, adscendentia, anatropa. Styli tres, subulati, divaricati ; $s t i g m$ at a obsoleta. B a cea trilocularis. Semina in loculis 5-6, angulata.

Herba boreali-americana; rhizomate repente, nodoso-tuberoso, caule erecto, annuo, pubescente, foliis verticillatis sessilibus, elliptico-lanceolatis, nervosis, floribus terminalibus umbellatis, foliorum verticillo stipatis, pedicellis ebractealis, haud articulatis, cernuis.

Medeola Gronov, Virgin. p. 55. Lam. illustr. $t$. 266. f.2. Bot, Mag. t. 1316. G y r o m i a Nuttall gen, I, 238.

\section{ThIIBUS II. CONVALLARIEAE. St y-} li connati.

1) ร. Dr. Drymophilla $R$. BR. F lores hermaphroditi. Perigoni um corollinum, patens, aequale, deciduum. St a min a 6 , hypogyna; fila in enta filiformia, antherae ovatae, basifixae. Ovarium triloculare. Ov $\mathbf{l}$ a plurima, biseriata, subhorizontalia, anatropa. Stylus brevis, crassus; stigmata 3 , filiformia, revoluta. Bace a subglobosa, trilocularis. Semina plnrima, ovata, testa membranacea, flavida, cum nueleo connata, umbilico basilari punctiformi, rhap he obsoleta, $\mathbf{c h a l}$ a z a terminali. Em b r y o axilis, dimidio allommine Ingior, extremit at e ra d i c I a ri nmbilicum attingente, centripeta.

Herba perennis, in insula Diemen indigena; radice repente, nodosa, caule inferne simplici, erecto, aphyllo, stipulis semivaginantibus distantibus vestito, superne foliato, porrecto $v$, diviso, foliis distichis sessilibus, anguste lanceolatis, acutis, e baseos coarctatae torsione resupinatis, pedunculis axillaribus terminalibusque unifloris, ebracteatis, inarticulatis, floribus albis, baccis pendulis, caeruleis.

D r y mophil a R. Brown prodr. 292.

180. Streptopus L. C. RICH. Flores hermaphroditi. Perigonium corollinum, sexpartitum, campanulatum, apice patens, deciduum, laciniis interioribus carinato-complicatis. Stamina 6 , basi laciniarum inserta; filamenta brevissima, subulata, an th erae cordatae, basifixae. Ovarium triloculare. Ov n la plurima, biseriata, pendula, anatropa. Stylns filiformis; stigma obtuse capitatum. B a $\mathrm{c}$ c a trilocularis. S e m i n a plurima, obovata, t esta membranacea, albida, cum nucleo connata, $\mathbf{x}$ m b ilice basilari, punctiformi, $r \mathbf{h}$ a $\mathbf{p h}$ e lineari cum chalaz a apicali conjuncto. Embryo minutus, subclavatus, intra albumen carnosum prope umbilicum inclusus, extremitate radie $\mathrm{n}$ a ri supera. - Herbae perennes, in Europa et $A$ merica boreali monticolae; rhizomate horizontali repente, foliis ovato - oblongis, amplexicaulibus, nervosis, reticulato-venosis, subtus saepius lanuginosis, floribus axillaribus extraaxillaribusve subsolilariis, pedunculo ebracteato, medio geniculato.

Streptopus L. C. Richard in Michaux Flor. Bor. Amer. I. 201, t.8. Redonté Liliac. t. 259. Nees jun. gen. pl. fasc, II, $t, 8$, Hekorima Rafin. in N. York Medic, Reposit. V.350. U v ulariate sp. Lian. Waldst. et Kit. $p l$, hung. $t, 167$. Bot. Mag. t.1489. 1490.

18 1 1 . Polygonatum TOURNEE. F10res hermaphroditi. Perigoni um corollinum, infundibuliformi-tubulosum, lim b o breviter sex- fido, lobis erectis. Stamina 6 , medio tubo inserta; filamenta filiformia, inclusa, anthera e subsagittatae, basifixae. Ovarium triloculare. Ovula in loculis 2, superposita, horizontalia, orthotropa. S t y l u s trigono-filiformis; stigma obtusum, trigonum. B a c ca globosa, trilocularis. $\mathrm{S}$ e $\mathrm{m}$ i $\mathbf{n}$ a in loculis 2 , v, rarius abortu solitaria, subglobosa, t e st a membranacea, albida, cum nucleo conferruminata, u m b ili co basilari, lato. Em b r yo antitropus, minimus, in extremitate albuminis dense carnosi, umbilico opposita inclusus, extremitate radiculari centrifuga. - Herbae perennes, in temperatis et frigidis hemisphaerae borealis indigenae; foliis sessilibus $v$. amplexicaulibus, alternis verticillatisque, nervosis, Roribus axillaribus solitariis $v$. racemosis, nulantibus, inodoris.

Pol y go n a $t$ u mournef. inst. t. 14. Desf. in Annal. du Mus. IX. 48. Redouté Liliac. t. 229, 243. 244.258. Nees jun. gen. pl. fasc. II. t. 16. A xill a ri a Rafin. in Journ. Phys. LXXXIX, 102. C o nvallarla e sp. Linn. Jacq. Fl. austr. t. 232. Hook. Fl, Lond. t, 37, 38, Exot, Fl, t, 125. Ledeb. Fl. alt. $t .1$.

118\%. Convallaria DESF. Flores hermaphroditi. Perigon i um corollinum, campanulatum, $1 \mathrm{i} \mathrm{mbo}$ sexfido, revoluto - patente, deciduum. Stamina 6, subhypogyna; fil am ent a filiformia, libera, inclusa, anthera e subsagittatae, basifixae. Ovarium triloculare. Ovula in loculis 2, superposita, horizontalia, orthotropa. Stylus brevis, crassus; stigma obtusum, subtrigonum. B a c c a globosa, trilocularis. S e mina in loculis abortu subsolitaria, globosa v. angulata, test a membranaeea, alhida, cum nucleo conferruminata, $\mathbf{u} \mathbf{m}$ b i li co basilari, magno. E m b ryo antitropus, parvus, in extremitate albuminis dense carnosi umbilico opposita inclusus, extremitate radiculari centrifuga. - Herba in Europa, Asia et America boreali indigena; foliis radicalibus geminis, ellipticis, nervosis, glabris, scapo simplici, floribus racemosis, subsecundis, nutantibus, suaveodoris, pedicellis basi membranaceo-bracteatis.

Convallaria Desf. in Annal. du Mus. $I X$. BA. Redouté Liliac, t. 227. Curtis Fl.Londin, t. 303. Nees jun. gen. pl. fasc, II, t. 15. Convallaria majaIis Lion. Lili. u m C o uvalli u mournef. inst, t, 1\%. Mönch meth.636,

183. Smillacima DESF. Flores hermaphroditi. Perigonium corollinum, quadriv. sexpartitum, aequale, patens, decidunm. Stamin a 4 v. 6 , basi laciniarum inserta; fil a menta filifornia, antherae ovatae, incumbentes. O v a $\mathbf{r}$ i $\mathbf{m}$ bi-triloculare. Ovula in loculis 1_2, angulo interiori affixa, horizontalia, orthotropa. Stylus brevis, erassus. Stigma obtasum, obsolete bi-trilobum. B a ce a globosa, pulposa, abortu mono-disperma. Semina subglobosa, testa membranacea, albida, cum nucleo conferruminata, u m bilico basilari magno. E mbryo antitropus, minimus, in extremitate albuminis dense carnosi, umbilico opposita inclusus, extremitate radiculari centrifuga. - Herbae in hemisphaeraeborealis temperatis et frigidis, imprimis Americae indigenae; foliis alternis sessilibus vel petiolatis, ovatis cordatisve, nervosis, florum racemo terminali.

$\mathrm{S}$ mila c i na Desfont. in Annal. du Mus, IX. 54. Convallariae sp. Línn.

a) MAJANTHEMUM. Mönch. Perig o $\mathrm{n}$ i u m quadripartitum. Sta mina 4. Folia petiolata.

Majanthemum Mönch meth. 638. Redouté Iilliac. t. 216. Nees jun. gen. pl. fasc, Ir. t, 17. Un if oll um Hall. helv. $H .117, \mathrm{Evall}$ a ria Necker elem, $n, 1551$, B ifolium 
El. wetteraw. $I$. 209. $\mathrm{Scl}$ o phil a Heller wirceb. 185. S ty$r$ a $n$ d ra Rafin. in Journ. Phys. LXXXIX, 102.

b) SMILaciNa Desf: P e ri gonium sexpartitun. S tami ua 6. Folia sersilia v, amplexicaulia.

S mil a c in a Desf. op. cit. t.8.9. Reduuté Líliac.t. 230. Bot. Mag. t, 1155, 1403. Wallich pl, as, t, 144, 257. C I in tou i a Rafin. in Journ. Phys, LXXXIX, 102. S i gillaria Rafin. 2.c. Tovarla Neck. elem, $n, 1568$.

184. Smillax TOURNEF, Perigonium corollinum, hexaphyllum, patens, deciduum, foli olis exterioribus latioribus. Stamina 6 , perigonii foliolis basi inserta; fil amenta filiformia, libera, an thera e lineares, basifixae. Ovarium triloculare. Ovula in loculis solitaria, apici anguli affixa, orthotropa. Stylus brevissimus; stigmata 3 , crassiusenla, patentia. B a cc a uni-trilocularis, mono-trisperma. Semina globosa, te st a membranacea, albida, cum nucleo conferruminata, umbilic o basilari magno, colorato. E $m$ bryo antitropus, minimus, in extremitate albuminis cornei umbilico opposita inclusus, extremitate radiculari centrifuga. - Suffrutices sempervirentes, scandentes, in regionibus temperatis, calidioribus tropicisque utriusque hemisphaerii obvii; radicibus tuberosis vel fibrosis, caule saepissime aculeato, foliis alternis petiolatis, cordatis v. hastatis, nervosis, reticulatovenosis, stipulis intrapetiolaribus cirrhiferis, saepius acutis, floribus supra receptaculum globosum sessilibus, subcapitatis $v$. pedicellatis, umbellatis, pedicellis haud articulatis, umbellulis pedunculatis, axillaribus, racemosis corymbosisve, rarius solitariis $v$. geminatis.

$\mathrm{S}$ m Il a x Tournef. inst.t. 481. Linn. gen, $n, 1120$. Juss. gen. p. 42. Gărtn. I. 59. t. 16. Jacq. Amer. t, 179. Schkuhr.t. 328 R. Brown prodr. 293. Labill, Nov, Caled.t,22. 23. Bot, Mag. t. 1846, 1920. Blume enum, pl. Jav, I. 17. Nees jun. gen. pl. fasc, II, $t, 12$.

1185. Fipogonum FORST. Flores hermaphroditi, basi bibracteolati. Perigoninm corollinum, hexaphyllum, patens, deciduum, foli o la aequalia. St a m in a 6 , perigonii foliolis basi inserta; fil am enta subulata, libera, a $\mathrm{n}$ th erae sagittatae, basifixae. Ova ri um triloculare. Ovula in loculis solitaria, apiei anguli affixa, amphitropa. Stylus brevissimns; st ig mata 3 , crassiuscula, patentia. B a ec a nni-biloenlaris, monodisperma, $\mathrm{S}$ e min a globosa, $t$ e $\mathrm{t}$ a membranacea, albida, cum nucleo conferruminata, umbilice basilari magno, colorato. E mb ryo excentriens, subtransversus, extremitate radiculari vaga. Suffrutices in Nova Hollandia orientali et in Nova $Z$ e el andia indigeni, volubiles; caule saepius aculeato, ramis inermibus, folïs oppositis $v$, suboppositis, nunc verticillatis $v$. alternis, petiolatis, cordatis, triplinerviis, reticulato-venosis, petiolis ecirrhosis, tortis, racemis axillaribus terminalibusque, simplicibus vel ramosis, pedicellis ebracteatis, haud articulatis.

$\mathrm{R}$ i p o g o $\mathrm{u}$ m Forst. gen. 25. $t$. 25. R. Brown prodr. 239

186. Huzuriaga $R U I Z$ et $P A V$. F 10 res hermaphroditi. Perigoninm corollinum, hexaphyllum, aequale, patens, decidunm. Stamin a 6 , hypogyna; filame nt a brevissima, plana, basi submonadelpha, an th era e tetragonae, basifixae. Ovari um triloculare. Ovula in loculis 2 , superposita, amphitropa. S tylus triqueter; stig ma triangulare. B a c c a trilocularis Semina in loculis 2, v. abortu solitaria, snbre. niformia; te $8 \mathrm{ta}$ membranacea. .... Suffrutices chilenses et peruvian i, ramosissimi, per truncos arborum reptantes, radicantes; foliis allernis, acuminatis, nervosis, venosis, pedunculis axilla- ribus solitariis, articulatis, apice umbellato-divisis, floribus exalbido-lutescentibus, purpureo-punctatis. Luzuriaga Ruiz et Pav. Fl. peruv. III, 66, t, 893.

118\%. Callixeme COMMERS. Flores hermaphroditi. Perigonium corollinum, sexpartitum, patens, decidunm, la cin iis aequilongis, tribus interioribus basi biglandulosis. St a mina 6 , basi laciniarum inserta ; fil a $\mathrm{m}$ e $\mathrm{n} t$ a libera, basi dilatata, an therae ovatae, incumbentes $O$ varin m triloculare. Ovula in loculis pauea, amphitropa. Stylus crassus, trisulens; stigma obsolete trilohum. B a ec a trilocularis, pulposa. S e m i n a in loculis subterna, subglobosa, $t$ e s ta membranacea, tenui, cum nucleo connata, $n$ mbili co ventrali punctiformi. E m b r yo excentricus, in basi albuminis carnosi respectn umbiliei semitransversus, extremitate radiculari centripeta. - Suffrutex magellanicus, ramosus, basi nodosus, aphyllus, squamatus, superne foliatus; foliis alternis, semiamplexicaulibus, ellipticis nervosis, coriaceis, margine crassioribus, floribus terminalibus solitariis, folio stipalis, pedicellis brevibus, basi squamis 2_4 cinctis.

C a 11 ixene Commers. ex Juss. gen. 41. Lam. illustr. t. 298. Gaudich. in Annal. se, nat, V. t. 2. $f, 2$, E nargea Solander apud Gürtn. I. 283. t.59. f.3. (pess.)

11 88. Fenseus TOURNEF. F lo r e s dieici. Perig on in corollinum, hexaphyllum, patens, persistens, foliolis interioribus paullo minoribus. Stamina 3 v. 6 , in cylindrum ventricosum connata; antherae apici cylindri adnatae, reniformes, locolis divarieatis, in floribus femineis nullae. Ovari um (in floribns masculis efoetum) triloculare. Ovula in loculis gemina, colIateralia, amphitropa. Stylu s brevissimus, stigma obtuse capitatum. B a c ca globosa, abortu unilocularis, submonosperma. S em en subglobosum, te st a membranacea, albida, cum nucleo conferrnminata, u m bili e o majusculo, colorato. Embryo antitropus, minimus, in extremitate albuminis cornei umbilice opposita inclusus, extremitate radiculari infera. - Suffrutices sempervirentes, in Europa australiore indigeni; foliis squamaeformibus, ramulis foliaceo-dilatatis, margine $v$. medio floriferis, pedicellis aggregatis, squamoso-bracteatis, nunc ramulis sterilibus, floribus ex axilla folii squamaeformis racemosis.

$\mathrm{R}$ u s c us Tournef. inst. $t, 15$, Linn. gen, $n, 1139$, Juss. gen. 42.

a) RUSCUS Link. $\Lambda \mathrm{n}$ th erae 3 . F 1 ores ramulis folia. ceis insideates.

Ruscus Liak Handb, II, 276. Schkuhr t, 340. EndI. Fl. pos. $t, 1$. Bot. Mag. $t, 1898,2049$. Nees jun. gen. pl, fasc. Ir. $t, 13$.

b) DANAIDA Link. Anthera e 6. Flores racemosi, ex axilla folii squamaeformis, hine respectu ramuli faliiformis extraaxillares.

Danaida Link l. c. Danāe Medikus. - Rus cus racemos as Lian. Gärtn. $t .16$.

\section{GENERA SMILACEIS AFFINIA.}

\section{* ASPIDISTREAE.}

1 f89. Whodea ROTH. Flores hermaphroditi, dense spicati. Perigonium corollinum, truncato-subglobosum, or e brevissime sexfido, lobis incurvis. St a mina 6 , perigonii tubo inserta; filamenta brevissima, adnata, antherae subglobosae, loculis connectivum antice marginantibus. Ovari u m subglobosum, triloculare, v. septis incompletis uniloculare. Ovnla in loculis 2, superposita, amphitropa. Stigma sessile, radiato-trifidum. B a $\mathrm{c}$ e a monosperma. Se m en subglobosum, te st a membranacea, um20 * 
bilico laterali. Embryo cylindrieus, in axi albuminis cornei, umbilico parallelus, extremitate radiculari supera. - Herba japonica, acaulis, glabra; rhizomate repente, foliorum vaginantium basibus cicatrisato, foliis bifariis, oblongo-lanceolatis, nervoso-striatis, scapo e foliorum vaginis exserto, floribus dense spicatis, in rhacheos excavationibus sessilibus, bractea squamacea suffultis, primum sordide virescentibus, demum lutescentibus.

h lod e a Roth nov. sp. 179. Blume in Hoeven et Friese Tijdschrift. 1824. 1. 83, t, 3. f.a, b. O r on $\mathrm{ti}$ a m j a pou $\mathrm{i}-$ c 1 ㅁ Thunb. Lam. illustr, t.251. f.1. Bot. Mag. t.898.

1190 . Tumpistra KER. Flores hermaphroditi, dense spicati. P e rigon i um corollinum, campanulatum, sex-octofidum, la cin i is patentibus. St a min a $6 \_8$, perigonii tubo inserta f fil a m e nta adnata $v$. distincta, a $n$th erae dorso affixae. Ovari um subcylindrieum, minimum, tri-quadriloeulare. Ovula in loculis 2, subcollateralia, amphitropa. St y lus ovario continuus, erassus; stigma deplanatum, radiatotri-guadrilobum. Fructus. . . - Herbae ind $i$ c ae, acaules, glabrae; rhizomate crasso, tuberoso, foliorum basibus annulato, foliis bifariis, petiolatis, oblongo-lanceolatis, nervoso-striatis, scapo centrali, floribus sordide violaceis, unibracteatis obsesso.

Tupistra Ker in Bot. Mag. $t$. 1655. Bot, Reg. t.704. 1223. Blume in Hoeven et Friese Tijdschrift. 1837, I. 82. t. 3. f.c.

19. 1. spidistrea KER. F 1 o res hermaphroditi, solitarii. Perig on i um corollinum, campanulatum, sex-octofidum, la cin i is patentibus. Stamina $6 \_8$, perigonii tubo inserta; filamenta adnata, antherae dorso affixae. Ov ari u m minimum, subeylindricum, tri-quadriloculare. Ovula in loculis 2, superposita, aurphitropa. Stylus ovario continuus, brevis, crassus; stig m a discoideum, maximum, radiatotri-quadrilobum, perigonii fancem recludens. Fructus....- Herbae acaules, glabrae, in China a ust rali et Japonia observatae; rhizomate annulato, sobolifero, foliis subbifariis solitariisve, petiolatis, vaginatis, oblongo-lanceolatis, nervosostriatis, pedunculis radicalibus unifloris, squamoso-bracteatis, floribus sordide purpureis.

Aspidistrat Ker in Bot. Reg. t. 699. Blume in Hoeten et Friese T'ifdschrift. 1834. 1. 84, t. 3. f.d. t.4. M a c rog y ue Link et Otto. Ic, sclect. 69. $t, 31$.

\section{* OPHIOPOGONEAE.}

192. Dplaiopogon $A I T$. F $10 \mathrm{r}$ es her maphroditi. Perig on i um corollinum, basi ova rio adnatum, $1 \mathrm{imbo}$ sexpartito, rotato. Sta $\mathrm{m}$ in a 6. perigonii basi inserta ; $\mathrm{f} \mathrm{I}$ a m e $\mathrm{t}$ a brevissima, inferne dilatata, a nth e ra e sagittatae, basifixae, mneronatae. Ovarium cum perigonii basi cohaerens, trilosulare. $0 \mathrm{v}$ u 1 a in lueulis 2 , basilaria, anatropa. Sty 1 u \& trigono-pyramidatus, $s t \mathrm{igm}$ a brevissime trifidum. B a c c a uniloeularis, monosperma, v. $8 \mathrm{em}$ in a plura, ovario mox disrupto nuda, maturescentia. ...-Herbae in Asia austro-orientali indigenae; foliis $l i$ neari-ensiformibus, basi vaginantibus, florum racemo subsecundo scapum ancipitem terminante.

Oph iopogon Ait. hort. Kew. II. 281. Don. nep. 47. Bot. Mag. $t$. 1063 , Bot. Reg, $t, 593$, F। üg g e R Richard in Schrad, n. Journ, II, 1.p, 1-9. S 1 a te ri a Desvaux Journ. hot, I, 244. Polyg on a s: r um Mönch. meth. suppl. 268. Lir i o pe Loureir. Fl, cochinch, I. 200. Sanseviella Reichent. consp. n.783. C o u valla ría e sp. Linn. Redouté Liliae. +80 .
1193. Buabosperanam $B L U M$. P erigonium corollinum, sexpartitum. Stamina 6 ; fil amenta in urceolum denticulatum connata, antherae introrsum adnatae. Ovaria 3 , mo nostyla, suhcoalita, unilocularia, quadriovulata Stigmata simplicia. Ovula basi affixa. B a cca elures, monospermae, perigonio cinctae.

Herba jap anica, acaulis, habitu ad Eucomidem et Pelinsanthidem aliquatenus accedente; radice fibrosa, foliis radicalibus longe petiolatis, sapo simplici, superne bracteis subimbricatis unifloris obsesso, floribus virescentibus, pedicellatis. - Ge. nus non satis notum, nonne semina ut in Ophiopogone et Peliosanthide ovario disrupto nuda, pro baccis distinctis descripta?

B ulb os permum Blum. enum, pl. Jav. I. 15.

1 194. Peliosanthes. ANDR. P e rigo ni u corollinum, basi ovario adnatum, $1 \mathrm{imbn}$ rotato, sexfido, fauce corona annulari constricta. Stamina 6 ; fil am enta subnulla, antherae faucis coronae subtus adnatae. Ovarinm cum perigonii basi cohaerens, apice liberum, triloculare. Ovula in loculis 2 , collateralia, basifixa. Sty Ins trigonus, crassus, ovario continuus; $s$ tig $m$ a radiato-trifidum, Semin a $1-3$, ovario mox dirupto nuda, maturescentia. - Herbae in dica e, glabrae; rhizomate repente, foliis radicalibus longe petiolatis, vaginantibus, oblongo-lanceolatis, plicato-nervosis, scapis simplicibus erectis, floribus racemosis, viridibus, bracteatis, bracteis subtrifloris.

Pelios anthes Andrews Bot, Reposit. $t, 605,634$ Ker in Bot. Mag. t. 1302. 1532. Redouté Liliac, t. 415. R. Brown in Transact. Linn, soc, XII. 147. Reichenb. pl. cult. t. 14. T e t a Roxb. Fl. ind. $I$. 165.

\section{* * HERRERIEAE}

11D. Herreria $R U I Z$ et $P A V$. F lores hermaphroditi. Perig o $\mathrm{n}$ i $\mathbf{u m}$ herbaceum, sexpar titum, aequale; patens, persistens. Stamina 6 , imo perigonio inserta; fil am en ta subulata, a ntherae incumbentes, basi bifidae. Ovarium triquetrum, triloculare. Ovula in loculis plurima, horizontalia.... St y I z s trigonus, crassus, ovario continuus; $s$ tig $m$ a trilolum, papillosum. C a p 8 u la membranacea, triptera, trilocularis, loculicido-trivalvis. Se min a in loculis pauca, compressa, testa membranacea, nitida, atra....- Suffrutices in Brasilia et Chili indigeni, scandentes; rhizomate tuberoso, caule aculeato, foliis verticillato-fasciculatis, lanceolatis $v$, linearibus, nervoso-striatis, racemis axilla. ribus multifloris, floribus parvis, odoris, - Genus dubiae affinitatis, inter. Asphodeleas et Smilaceas ambiguum, huc ob habitum relatum.

Herreria Ruiz et Pav. Fl. peruv. III. 70, t. 303. f. a. Lindl. in Bot, Reg. t. $1042 \mathrm{~S}$ a I s a Feuill. $I T, 716$, t.7.

\section{**** ERIOSPERMEAE}

146. Crilosperentum $J A C Q$. Flores hermaphroditi. Perigenium corollinum, sexpartitum, subaequale, campanulato-connirens, persistens. Stam in a 6 , imo perigonio inserta; $\mathbf{f i}$ lamenta plana, basi dilatata, antherae sagittato-didymae, incumbentes. Ovarium triloculare. Ovula pauca, placentis in loculornm angulo imo brevibus affixa, adscendentia, anatropa. Stylus filiformi-triqueter; stig ma subcapitatum, ohsolete trifidum. Capsul a membranacea, ovato-trilobo-trigona, trilocularis, loculieido - trivalvis, valvis medio septiferis, demum stellato-patentibus. S e min a in loculis pauca, v. rarins solitaria, e basi erecta, lanceolata, fu- 
niculo brevi, apice in a rill $\mathbf{n m}$ papposum nucleo longiorem fisso. - Herbae c a penses; tubere magno perennantes, foliis praecocibus involuto-petiolatis, lato-ovatis, coriaceis, nervosis, reticulatovenosis, lamina subtus saepius bulbilbifero-gemmifera, scapo post foliorum interitum emergente, simplicissimo, tereti, stricto, floribus racemosis, pedicellis unifloris, basi scarioso-unibracteatis.

Genus dubiae affinitatis, an Roxburghiae comparandum?

E ri os perm u m Jacq. Collect. suppl. 81. f.1. Ic.rar. t. 420.422, Itort. schjinbr. t. 264, 265. Andr. Mot. Reposit. t.521. Ker in Bot. Mag. t. 1382. Bot. Reg. t.394.795.

\section{**** ROXBOURGHIACEAE WALL.}

$115 \%$. 1 Eoxhourglnia JON. F lores hermaphroditi. Perigon in m corollinum, octophyllum, foliola exteriora lata, patentia, inte $r$ io ra elliptica, acuminata, erecta. Antherac 4 , biloculares, lo e uli lineares appositi, discreti, perigonii foliolis interioribus facie adnati, con $n$ e ctivo, in apiculum uneinatum liberum producto, conjuncti, demum ex eodem penduli, lon gitudinaliter dehiscentes. Ovarium sessile, e carpidis duobus eonflatum, unilocnlare. Ovula in placentis geminis, prope basim parietalibus, cum suturis alternantibus, plurima, e funiculis longiusculis erecta, anatropa $\mathrm{S} t \mathrm{ig}$ m a. . . Capsula uniloenlaris, bivalvis. Sem ina in placentis parietalibus ad basim valvularum plurima, e funiculis elongatis, apice in arillnm stupposum solutis erecta, teretiuscula, cinnamomea, te st a suberosa, costato-striata, ad $\mathrm{ch}$ a I a $\mathrm{z}$ a apiealem, ope $r h a p h e o s$ filiformis cum $\mathbf{u m b i}$ lico basilari junctam, in acumen rectum obtusum prodncta. E $m$ br yo rectus, filiformis, in axi albuminis carnosi, extremitate radieuIa $\mathrm{r}$ i incrassata, umbilicum attingente, - Suffrutices scandentes, in India tropica et in Japo$n$ ia reperti; radice tuberosa, foliis oppositis v. verticillatis, rarissime alternis, petiolatis, ovato-cordatis, nervosis, pedunculis axillaribus, petiolaribus vel foliaribus, uni-paucifloris, floribus magnis, - Anne genus Methonicae aliquatenus affine?

Roxburghia Jones. msc. Smith exot, Bot. I. $t .37$. Roxh. corom. I. 29. 2. 32. Blume enum, pl. Jav. I. 8. Lindl. in Wallich pl, asiat. rar. III. 49. t. 282. S t e mo a a Lut reiro Fl, cochinch, II. 490. U b i m Rumph Amboin, $V_{*} 360$. Ł. 129.

$$
\text { ***** PHILESIEAE LINDL. }
$$

11 19. Plnilesia COMMERS. F 1 o res hermaphroditi. Perig oni um corollinum, sexpartituı ; laciniis exterioribus acuminatis, interioribus duplo longioribus, obtusis. Stamina 6, imis perigonii laciniis inserta; fil a m e n t a subuIata, basi inter se connata, anther a $\mathrm{e}$ lineares, versatiles. Ovari um uniloculare, placentis tribus parietalibus brevibns, ad hasim suturarnm. Ovula. ... Stylus simplex; stigmata 3 . B a ec a trigona, polysperma. ... Suffrutex magellanicus, Buxi facie; ramulis axillaribus flexuosis, basi bisquamatis, foliis alternis, ovatoellipticis, margine revolutis, petiolo brevi, amplexicauli, floribus solitariis, terminalibus, magnis, pedicello brevi, squamis distiche imbricatis tecto. Genus vix notum, an satis a sequente diversum?

Philesia Commers. ex Juss. gen. 41. Lam. illustr. t. 248. Lindl. introduct, edit. $I$. p.360.-C a pi a Domb. ex Jussieu apud Poiret suppl. $V_{2} 269$, a $\mathrm{P}$ hilles i a nonaisi pe. rigonii laciniis omuibus aequalibus differre dicitur, an $L$ a. pageriae congener, an Luzuriagae species?

11 ม\%. Iapageria $R U I Z$ et $P A V$. F 10 res hermaphroditi. Perigoninm corollinum, hexaphyllum, campanulato-connivens, foliola exteriora basi coneavo-carinata, interiora latiora, subunguieulata. Stam ina 6 , imis perigonii foliolis inserta, alterna paulo majora; fil ame nta subulata, Jibera, antherae basifixae. Ova. ri u m uniloculare, placentis parietalibus tribus, ad suturas longitudinalibus. Ovul a plurima, muco involnta, orthotropa. Stylus cylindriens; sti gm a clavatum. Bacea ovato-oblonga, unilocularis, polysperma Sem ina obovata, truncata, cornea, luteo - fulvescentia, in pulpa nidulantia. Suffrutex chilens is, volubilis ; radice fasciculatu, elongata, caule teretiusculo, foliis alternis, ovatolanceolatis, cuspidatis, nervosis, reticulato-venosis, pedunculis axillaribus solitariis, unifloris, squamoso - bracteatis.

La pageria Ruiz et Pav. Flor, peruv. III. 65, t. 297. Lindl. introduct. edit. II. p. 360.

\section{Classis XVI. Artorhizac.}

Нвввав v, suffrutices, saepe scandentes. C a u I e s v. scapi simplices aut ramosi, saepius volubiles, basi plerumque tuberosoincrassati; folia alterna v. opposita, petiolata, integerrima, nervosa, saepius reticulatovenosa, nunc omnia radicalia, palmata vel pinnatifida. Flores abortu saepius dioici, per i g o n io supero, regulari, sexpartito, biseriato, herbaceo v. subcorollino. Ovarion inferum, uni-triloculare. Ovura plura, anatropa. Fructus capsularis v. baccatus. SEmiva compressa v. teretia, embryo ne intra albumen incluso, umbilico approximato.

\section{Drelo IU III. Dioscoreat.}

DIOSCOREAE R. Brown. prodr. 294. Agardh'aphorism. 169. Bartl. ord. nat. 53. DISCOREACEAE Lindl, introduct. edit. $I I ., p .359$.

Herbae perennes v. suffrutices, sinistrorsum volubiles, radice in plerisque tuberosa, carnosa, nonnunquam lignosa, maxima. Foli a alterna, v. interdum opposita, petiolata, simplicia, palmatinervia, venosa, integra v. integerrima; rarius palmatisecta, $\mathrm{pe}^{-}$ tio lis basi saepius biglandulosis.

Frores ex axillis foliorum spicati v. racemosi, regulares, parvi, inconspicui, abortu dioici.

Prrigonium herbaceum v. subcorollinum, $\mathrm{t} \mathbf{u}$ bo in floribus masculis brevissimo, in femineis cylindrico $\mathrm{v}$. acute trigono, cum ovario connato, li m bo supero, sexfido, la c in i is subaequalibus, persistentibus, biseriatis.

Stamina 6, basi laciniarum perigonii inserta, in femineis nulla v. rudimentaria, glandulaeformia. Fil a m ent a filiformia v. subulata, libera. Antherae ovato-subglobosae, dorso paulo supra basim affixae, introrsae, biloculares; loculi oppositi, contigui, longitudinaliter dehiscentes.

Ovariur e carpidiis tribus conflatum, cum perigonii tubo connatum, triluculare. 
Ovula in Ioculis solitaria, v, plerumque bina, angulo interiori appensa, superposita, anatropa. Styli tres, approximati, v. basi inter se connati, apice distincti. Stigmat a obsoleta, v. rarius emarginato - biloba.

Frocrus nunc perigonii tubo ovario immediate adhaerente membranaceus, capsula$r$ is, acute trigono - trilobus, lobis compressis, trilocularis, loculicido ad angulos salientes dehiscens, v. loculis duobus abortivis nerviformibus, et tertio fertili, in alam dorsalem producto unilocularis, indehiscens; nunc parenchymate carnoso inter perigonii tubum et ovarium evoluto b a ccat us, indehiscens, trilocularis, v. septis demum obliteratis subunilocularis.

Semixa ovulorum numero, in loculis bina v. rarius abortu solitaria, in capsularibus foliaceo-compressa, aptera v. te st a membranacea undique producta, alata; in baccatis subglobosa; umbilic o semper nudo, cum chalaza apicali vasculosa ope $r h$ apheos filiformis conjuncto. A l b um en cartilagineum, v. dense carnosum, aequabile v. prope umbilicum cavitate hians.

Embrxo minutus, ovato-subglobosus, in cavitate albuminis prope umbilicum situs, nec tamen eandem replens, extremitate radiculari sursum centripeta.

Dioscoreae in regionibus tropicis subtropicisque totius orbis obviae, in temperatis admodum rarae, Smilaceis proxime affines, ab iisdem ovario infero, fructu capsulari, et seminis structura satis differunt; cum 'T a c c ac e is ovarii cum perigonio cohaesione, et seminis structura etiam convenientes, ab A ristolochieis structura caulis anatomica, magis quam characteribus floris et fructus diversae.

Tam u m, quamvis a Di os c or e a fructu baccato recedat, arctissime generi capsulari affinem habeo, facillime enim in ovario grossificante horizontaliter secto capsulam membranaceam, Dioscoreae more trigonam, ope parenchymatis carnosi cum perigonii tubo illam ambiente conjunctam, conspicimus; ita nt differentia potius in tubi perigonalis conformatione, in hoc teretis, in illis angulati posita sit, a quo simul charactere reliqua seminis globosi et compressi, albuminis aequaliis et basi cavitate majoris hiantis diversitas pendet.

Dioscoreae nonnullae, ob radices tuberosas edules, magni in vita gentium sub torrido sidere degentium momenti.

1200. Rajamia LINN. Flores dioici. Perigon i m herbaceum, tu bo inaequaliter triptero, cum ovario connato, limb o supero, sexpartito, subcampanulato, persistente. Stamina.6, basi perigonii inserta; filamenta subulata, anth er a e suloglobosae. Orarium cum perigonii tubo connatum, triloculare, loculis duobus minoribus. Ovula in loculis solitaria, anatropa. Sty li $\mathrm{s}$, approximati; stigmata obtusa. Capsula membranacea, abortn unilocularis, loculis duobns sterilibus, nerviformibus, fertili compresso, in alam producto, indehiscente. Sem en unieum, compressiusculum, apterum. Em b r y o minimus, in cavitate albuminis cartilaginei majore prope umbilicnm situs. - Suffrutices antill an $i$, habitu Dioscorae; caule sinistrorsum volubili, floribus axillaribus spicatis.

R a j a n i a Linn. gen, n. 1121. Juss, gen. 43, J a n raja Plum. ic. 255. f. 1.

1801. Dioseorea PLUM. F 1 ores dioici. Perigoni u merbaceum, t $\mathbf{n}$ bo triptero cum ovario connato, $1 \mathrm{imb}$ o supero sexpartito, persistente. S t a m in a 6 , basi perigonii inserta; fil am en ta subulata, an $\mathbf{t}$ hera e subglobosae. Ovari um eum perigonii tubo connatum, triloculare. Ovula in loculis 2 , superposita, anatropa. Styli 3 , distincti; stig mata obsoleta. Ca psula membranacea, trilocularis, triangularis, compressa, angulis salientibns loculicido-dehiscens, S e-

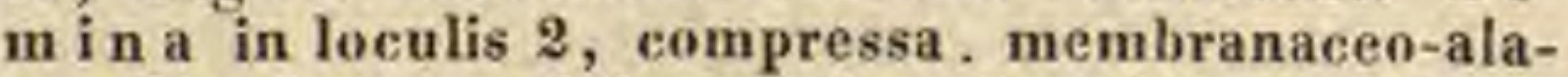
ta. Embryo minimus, in albnminis cartilagi. nei eavitate majore prope umbilieum situs. - Herbae perennes v. suffrutices, sinistrorsum volubiles, in regionibus tropicis subtropicisque totius orbis obvii; rhizomate tuberoso, interdum maximo, quandoque lignoso, foliis petiolatis, alternis $v$. nonnunquam oppositis, plerumque cordatis $v$. hastatis, nervosis, venosis, saepius integerrimis, interdum palmatifidis, floribus axillaribus spicatis v. racemosis.

Di o s c o r e a Plum. gen, t. 26. Linn, gen, n, 1129. Gärtn. I. 66. t. 17. Bot. Mag.t. 2825. - T e stud in a ri a Salisbury. Burchell trav. II. 147. (T a ms elephantipes Ait, Bot. Mag. $t, 1347$.$) nonuisi rhizomate epigaeo, maximo, subglo-$ boso, suberoso - lignoso differt.

1202. Tamans LINN. F lor es dioici. Perigonium subcorollinum, tubo tereti cum ovario connato, limb o supero, sexpartito, campanulato, patente. Stamina 6, basi limbi inserta; filamenta filiformia, an the rae subglobosae. Ovarium trigonum, cum perigonii tubo connatum, triloculare. Ovula in loculis 2 , superposita, pendula, anatropa. Stylus trifidus; stigmata dilatata, emarginato-biloba. B a c ca trilocularis, v. demum dissepimentis obsoletis nnilocularis. S e mina in loculis 2, v. abortn solitaria, subglobosa, pendula. Embryo minimus, intra albumen dense carnosnm, prope $\mathbf{u m b i l i ~} \mathbf{c}$ m collocatus. Herbae sinistrorsum volubiles, in Europa et $A$ sia temperata indigenae; radice tuberosa, foliis cordatis, venosis, longe petiolatis, petiolis basi saepe biglandulosis, floribus axillaribus, racemosis.

$\mathrm{T}$ a m us Linn. gen. $n, 1119$. Schkuhr t.327. Nees jun. gen. pl. fasc. Ir. t, 20. Tamaus Tournef. inst. $t$, 28. Juss. gen. 43.

1203. Dneus LOUREIR. Flores hermaphroditi; basi bibracteolati. Perigonium pilosum, tubo basi cum ovario cohaerente, I im bo parvo, sexfido, laciniis subulatis. Stam in a 6 , basi laciniarum perigonii inserta. .. O vari $\mathbf{~} \mathbf{~ m}$ basi cum perigonii tubo connatum, sexsuleum. Ovula. . Sty lus brevis, tripartitus; st igmata oblonga. B a ec a oblonga, trilocularis. Semina plurima, subglobosa. - Suffrutex cochinchinensis, volubilis; radice tuberosa, maxima, farinosa, eduli, foliis alternis, petiolatis, 
cordatis, acuminatis, spicis terminalibus laxis. Genus vix notum, an lipogono magis affine?

O n c us Loureiro Fl, cochinch, I, 290.

\section{Drdo LIIIL. Taceacene.}

TACCEAE J. S. Presl in Reliq. Haenk, I. 149. Bartl. ord, nat. 82. TACCACEAE Lindl, introduct. edit. II. p.33t.

Herbae scapigerae, radice tuberosa perennantes. Foli a omnia radicalia, petiolata, petiolis basi semivaginantibus, nunc integerrima, nunc palmatisecta v. bipinnatifida, nervosa, venosa.

Flores hermaphroditi, regulares, in apice s c a p i radicalis, simplicissimi, teretis v. angulati umbellati, umbellae basi involucro foliaceo tetraphyllo stipatae; involucri foliis integris, subdecussantibus; pedicellis longis, nudis, sterilibus filiformibus, elongatis, intermixtis.

Perigonium corollinum; $t \mathbf{t} b$ o cylindrico nervoso, cum ovario connato, li mb o supero, sexpartito, la cin i is biseriatis, interioribus paullo majoribus, omnibus patentibus v, reflexis, persistentibus.

Sтамiмa 6, imis limbi corollini laciniis inserta. Filamenta petaloidea, apice concava v. fornicato-cucullata. Antherae introrsae, biloculares; loculi discreti, paralleli, concavitati filamentorum intus adnati, apice liberi, erecti $v$. inflexi, longitudinaliter dehiscentes.

Ovariva inferum, placentis parietalibus tribus, simplicibus uniloculare, v. iisdem bilobis, axim fere attingentibus incomplete triloculare. Ovula in placentis plurima, multiseriata, subadscendentia anatropa, v. horizontalia amphitropa. St y I us brevis, crassus, trisulcus. Stigma orbiculatum, vel depressiuscule capitatum, radiato-trifidum, lobis emarginato-bilobis.

Bacca perigonio persistente umbilicata, unilocularis, vel incomplete trilocularis.

Semra plurima, ovata, angulata vel lunata; test a coriacea, striata, ab endopleura tenuissime membranacea solubili, u m bilico parvo basilari v. ventrali, nudo. E m b r y o ovoideus, in basi al b u m i n i carnosi inclusus, umbilico basilari proximus v. a ventrali remotus.

T a c c a c a e in humidis maritimis Asiae et Oceaniae tropicae indigenae, nonnullae ob tuber radicale fecula nutriente scatens etiam cultae, hinc Dioscoreis, illine ob foliationis habitum A roide is alias diversissimis affines, ab Aristolochie is vix nisi structura anatomica, in utroque ordine diversissima differunt.

1204. Tacea FORST. Flores hermaphroditi. Perig onii corollini tubus cum ova- rio connatus, li mb u s superus, sexpartitus, subaequalis, patens, persistens. Stamina 6, basi laciniarum limbi inserta; fil am enta lata, superne cucullata, a $\mathbf{t}$ b era e introrsae, biloculares, locu Iis discretis parallelis, cucullo intus adnatis, apicibus solutis deorsum spectantes. Ovari u m cum perigonii tubo connatum, uniloculare; placentis parietalibus tribus. Ov u l a plurima, horizontalia, anatropa. Stylus brevis, crassus, trisuleus; stig ma orbiculatum, stellato-sexradiatum, lobis emarginatis. B a c c a unilocnlaris, polysperma. S e m in a ovata, angulata, test a coriacea, striata. Embryo minimus, in basi albuminis carnosi, umbilico proximus. - Herbae in maritimis Asiae et Oceaniae tropicae spontaneae, glabrae; radice tuberosa, subglobosa, foliis omnibus radicalibus longe petiolatis, palmatis $v$. bipinnatifidis, venosis, scapo radicali indiviso, umbella terminali simplici, involucro foliaceo subtetraphyllo, floribus longe pedicellatis, pedicellis sterilibus filiformibus intermixtis.

T a e c a Rumph, amb, V.328, t. 114.115. Forst. gen. n. 35. Plant, esc, 28. Linn. suppl. 251. Gärtu. 1. 43. t. 14. Lam. illustr. t. 232, R. Brown prodr.340. Blume enum, pl. Jav. I. 82, excl. sp. J. S. Presl in Reliq. Haenk. I. 149.

1 IOS. Ataceia $J$, S. PRESL. Flores hermaphroditi. Perigon ii corollini tubus cum ovario connatus, li m bu s superus, sexpartitus, la ciniis interioribns majoribus, reflexis, persistentibus. Stam in a 6 , basi laciniarum limbi inserta; fil amenta lata, superne concava, anthe rae introrsae, biloculares, 1 o enlis discretis, parallelis, concavitati intus adnatis, erectis. Ovarium cum perigonii tubo connatum; placentis parietalibus tribns, bilobis, axim fere attingentibus, subtriloculare. O v u 1 a plurima, amphitropa. Stylus brevis, crassus, trisuleus; $s$ i g m a capitato-trilobum, lobis emarginatis. Bace a semitrilocularis, polysperma. Semina lunata. Embryo minimus, in basi albuminis carnosi ab umbilico remotus. - Herba in In di a e orientalis humidis vigens; radice tuberosa, subconica, foliis omnibus radicalibus, petiolatis, ovatooblongis, acuminatis, venosis, integerrimis, petiolis canaliculatis, basi subvaginantibus, scabris, scapo basi foliorum vaginis velato, indiviso, umbella terminali simplici, involucro subtetraphyllo foliaceo, floribus pedicellatis, pedicellis filiformibus sterilibus intermixtis. - An genus satis a praecedente diversum?

A t a cei a J. S. Presl in Reliq. Haenk. T. 149. T a ec a integrifolia Ker in Bot. Mag. $t$, 1488, Roxb. corom. t. 257 .

\section{Classis XVII. Ensatae.}

Herrae perennes, interdum suffrutescentes. Caules simplices v. ramosi, basi saepius tuberosi, rarius bulbosi. Folia integra, saepissime ensiformia, basi vaginantia, equitantia. Perigoni um cum ovario plus minus connatum, limbo saepius omnino supero, regulari v. irregulari, tri-v. sexpartito, lacini is exterioribus saepius calyc in is, interioribus corollinis, nune omnibus petaloideis. Stamisa dimidio v. simplici laciniarum perigonii numero, rarius plura, nunquam tribus pauciora v. quina, semper a stylis distincta. Ovarum cum perigonii tubo 
connatum v. omnino inferum, placentis plerumque centralibus. Ovora plerisque anatropa, indefinita. Fructus capsularis v. baccatus. Semina nonnisi in primo ordine exalbuminosa, in reliquis albuminosa, e m b r y o$\mathrm{n} \mathrm{e}$ intra albumen incluso.

\section{Ordo LIX. Hydrocharideae.}

HYDROCHARIDES Juss, gen, 67. exel, gen. HYDROCHARIDEAE DC. $F l$. fr. III, 265. R. Brown prodr, 344. L. C. Riehard in Mem, de $l$ Institut 1811, p. 1. 55. Agardh Aphorism. 137. Bartl. ord. nat. 74. Lindl. introduct. 354 .

Нвrвав aquaticae, ut plurimum perennes. Caules nunc abbreviati, repentes, scapos exserentes, nunc elongati, nodoso-articulati, teretes. Folia plerumque radicalia, conferta, rarius remota, opposita v. verticillata, fluitantia v. natantia, interdum etiam emersa, petiolata, l a m in a integerrima, nervose - venosa, vernatione convolutiva, petiolo interdum basi vaginante, saepius laminae abortu in phyllodium longitudinaliter nervosum, plerumque margine denticulatum, dentibus setula terminatis mutato.

Flores dioici v. rarius hermaphroditi, regulares, ante anthesim s $p$ a $t h$ a inclusi; $s p$ ath a membranacea v. herbacea, sessilis aut pedunculata, mono-diphylla, interdum tubulosa v, hine longitudinaliter fissa.

Flores masculi intra spatham monodiphyllam plerumque plures, rarius solitarii, singuli pedicellati, interdum s pathill a propria muniti, raro sessiles.

Perigonium hexaphyllum; foliolis tribus exterioribus caly $\mathrm{c}$ in is, basi subconnatis, per aestivationem margine leviter imbricatis; tribus interioribus petaloideis, rarissime deficientibus, exterioribus plerumque longioribus, interdum etiam latioribus, aestivatione irregulariter contortuplicatis.

Stausa fundo perigonii inserta, nunc simplici laciniarum perigonii exterioris numero, iisque opposita, nunc duplo, triplo v. quadruplo, pluriseriata, nonnulla interdnm sterilia. Fil am ent a libera, v. ima basi breviter coalita, brevia, teretia v. compressa, quandoque clavata, nonnumquam apice bifurca, lobo tuo antico, altero postico, saepius ananthero. Antherae introrsae, vel in filamenti bifurci lobo postico etiam extrorsae, biloculares, ovato - globosae v. lineares; loculi appositi, filamento saepius ultra eosdem in acumen brevissimum producto adnati, longitudinaliter dehiscentes. pans.

Ovari rudimentum, centrum floris occu-

Flores feninei et heruaphroditi intra spatham plerumque tubulosam, interdum hine longitudinaliter fissam solitarii, ut plurimum sessiles.
Perigonil tubus cum ovario connatus, limbus superus, sexpartitus, ut in floribus masculis biseriatus, serie exteriore calycina, interiore petaloidea.

Stauina imo limbo inserta, rarissime fertilia, plerumque sterilia, filamentosa.

Ovariem cum perigonii tubo connatum, inferum, e carpidiis pluribus conflatum, uni- v. sexloculare. $0 \mathrm{v} u 1$ a placentis parietalibus affixa, adscendentia, anatropa. Stylus brevissimus, vix manifestus, vel elongatus, cum perigonii tubo connatus. Stigm ata 3 v. 6 , omnia plerumque plus minus profunde bifida, intus glanduloso-papillosa. Processus filiformis, e vertice ovarii inter stigmata (ut in Nelumboneis) saepius exsertus.

Fructus submersus, subulatus, linearis, oblongus v. ovoideus, saepius costatus, apice nudus v. rarius perigonii limbo persistente coronatus. Epicarpium coriaceo - carnosum, indehiscens, maceratione tandem dissolutum, cavit a te modo simplici, modo processubus membranaceis simplicibus stigmatum numero iisque oppositis, a pariete ad idealem axim porrectis tri-sex- v. pluriloculare. Placentae parietibus partimque septis adnatae, gelatinoso-pulposae.

Semina indefinita, adscendentia. Testa membranacea, duriuscula, filis brevissimis, cylindricis, apice saepius inflatis echinata, u $\mathrm{m}$ bili co basilari nudo, cum ch a laz a terminali in acumen clavatum, cylindricum $v$. difforme producta, ope $\mathbf{r h a p h e o s}$ filiformis juncto. Endopleura membranacea, tenuissima, e basi testae brevissime stipitata, et eidem nonnisi ad chalazam adhaerens. Alb um en nullum. Емввуо orthotropus, ovoidens v. cylindricus, extremitate radieulari umbilicum attingente, gemmula in plerisque manifesta, versus mediam illius longitudinem plus minus laterali.

Hydrocharidearnm species paucae hucdum cognitae, per totius orbis aquas quietas dulces vulgatae, nonnullae etiam in aestuariis subsalsis repertae, quaedam late diffusae; Ottelia Nilum, Gangem et Australasiae rivulos custodit; Valli sn eria, oestri venerei miraculum, exiguo Europae anstralis angulo inclusa, in India et Australia reperta fuit. Hydrocharis et Stratiotes in Europa boreali copiosae, in australi parceissime reperiuntur, rarissime fructum maturant. B o oti a m, genus insigne, nuper ex India superiore tulit Wallichius. $\mathbf{E} \mathbf{n}$ a $1 \mathbf{i}$, plantae marinae, fructus edulis. Bootiae folia juniora inter olera ab Avanis laudantur.

Ordo primum a Caridolleo suis circumscriptus limitibus, reliquae Ensat a rum 
seriei minus arcte affinis, a cunctis $\mathbf{A ~} \mathrm{m}$ ph ibryis, duplici ovarii inferi et seminum exalbuminosorum charactere, facillime distinguendus.

Embryonis situm orthotropum contra cl. Richard, qui illum antitropum, extremitate radiculari umbilico e diametro opposita describit, in plerisque generibus confirmare licuit.

THEIISUS I. ANACHARIDEAE. Ovarium uniloculare. Stigmata tria. - Caulescentes, foliis uppositis verticillatisve.

1206. Udorsa NUTT. Flores hermaphroditi. Spatha sessilis tubulosa, ore obliquo, uniflora. Perigonii, tubus filiformis elongatus, basi cum ovario connatus, $1 \mathrm{im}$ b u s superus, sexpartitus, lobis ovalibus, exterioribus calycinis; interioribus petaloideis, omnibus conformibus. Stamina 3 , limbi laciniis exterioribus opposita; filamenta subulata, an therae cordatae, basifixae, loculis contiguis. Ova rium inferum, cum basi tubi perigonialis connatum, uniloculare; placentis parietalibus tribus. Ovula plurima, adstendentia, anatropa. Stylus setiformis, elongatus, cum perigonii tubo connatus; st $\mathrm{igm}$ a $t$ a 3 , staminibus alterna, oblongo-cuneiformia, apice breviter bifida. B a c c a subtrigona, unilocularis, polysperma. S e mina parietalia, cylindrica, erecta. Embryo exalbuminosus, orthotropus, extremitate radic alar $i$ infera. Herbae annuae, caulescentes, graciles, a rivulis Canadae ad Orinocci fluenta diffusae; foliis verticillatis, sessilibus, lineari-lanceolatis, serratis, spathis axillaribus, perigonii laciniis exterioribus purpurascentibus, interioribus candidis.

U d o r a Nuttal gen. II, 242. E lo de a L. C. Riehard in Michaus Fl, bor. amer. I, 20, Mem. de I'Instit. 1811.II.61. t. 1. Humb, et Bonpl, $p l$. aequinoct, $I T$. 130. 6.128 . P hilotria Rafin, in Americ. Monlhl. Magaz. 1819.

120\%. Amaelnaris RICH. Flores dioici. Masc. $\mathrm{S} p$ a th a sessilis, tubulosa, ore inflato bifido, uniflora; fl or pedicellato. Perig on iu $\mathrm{m}$ sexpartitum, l a $\mathrm{c}$ in $\mathrm{i}$ is exterioribns $\mathrm{c}$ alycinis ovato-oblongis; interioribus petalo ideis oblongo-linearibus. Stamina 9 ; filam e nt a basi in columnam brevem connata, a ntherae oblongae, basifixae, loculis connectivo angusto sejunctis. F e m. ...- Herba montevideensis, annua, caulescens; foliis oppositis, sessilibus, linearibus, serrulatis, spathis axillaribus, perigonio reflexo, natante.

A u a charis L. C. Richard in Mem, de l'Inatit. 1811, II, 61. $t, 2$.

1209. IIydrilla RICH. Flores dioici. M a sc. S p ath a sessilis, subglobosa, irregularitér rupta, uniflora; flore pedicellato. Perigonium sexpartitum, la eini is exterioribus calycinis ovalibus; interioribus petaloideis cuneato-oblongis. Stamina 3 , perigonii laciniis exterioribus opposita; fil amenta brevia, filiformia, anthera e subovatae, loculis contiguis. F em. Spath a sessilis, tubulosa, ore obliquo, uniflora; flore sessili, Perigonii tubus filiformis, elongatus, basi cum ovario connatus, limbo sexpartito, laciniis exterioribus calycinis spathulato-oblongis; interioribns petaloideis conformibus, panllo minoribus. Ovaria m cum basi tubi perigonialis connatum, uniloculare; placentis parietalibus tribus. Ovula plurima, adscendentia, anatropa. Stylus setiformis, elongatus, cum perigonii tubo connatus; st ig m a $\mathbf{t a} 3$, lineari-lanceolata, indivisa. B a cc a subtrigona, unilocularis. Se $m$ in a pauea, eylindrica, adscendentia, $\mathbf{E} \mathrm{m}$ b $\mathrm{r}$ y o exalbuminosus, orthotropas, extremitate radiculari infera. - Herba caulescens, gracilis, annua, in Indiae orientalis fuviis reperta ; foliis verticillatis, sessilibus, ovalibus v. oblongis, serrulatis, spathis axillaribus, perigoniis natantibus, narium reflexo, feminarum patulo.

H y d rilla L. C. Riehard in Mem, de l'Instit. 1811. II. 61. t.2. Serpicula verticillata Roxb. corom. t. 16i.

TRIBUS II. VALLISNERIEAE. $0 \mathrm{v}$ ari um uniloculare. Stigmata tria. - Acaules scapigerae; foliis radicalibus (phyllodiis) linearibus.

1209. Wallismeria MICHEL. Flores dioici. Masc. Spatha scapnm brevissimum terminans, ovata, inaequaliter trivalvis, multiflora; f 1 o r i b u s brevissime pedicellatis, supra receptaculum conicum congestis. P e rig o ni um calycinum, tripartitum, 1 o b i s obovatis, concavis, aestivatione valvatis. Staminodia 4 , petaliformia, tria perigonii lobis opposita, inaequalia, quartum iisdem alternum. S $\mathbf{t}$ a $\mathrm{m}$ in a 3 , perigonii laciniis alterna, abortu interdum 2 v, 1 ; fil amenta semiteretia, antherae subglobosae, basifixae, Joculis contiguis. Fem. S p a tha seapum longissimum filiformem terminans, tubulosa, ore bifido ; flore solitario sessili. Perigonii tnbus cum ovario connatus, limbus tripartitus, lo bis ovalibus. Stam inodia 3 , perigonii laciniis alterna, unum saepius bifidum. Ovarium cum perigonii tubo connatum uniloculare; placentis parietalibus tribus. Ovula plurima, adscendentia, anatropa. Stylus subnullus; stigmat a 3 , maxima, ovalia, saepe bifida. B a $\mathbf{c}$ a cylindriea, perigonii limbo coronata, unilocularis. Se mina plurima, cylinilrica, adscendentia. E mb r y o exalbuminosus, orthotropus, extremitate radi c n la ri infera. - Herbae perennes, acaules, stoloniferae, in Europae australioris, Americae borealis, Indiae orientalis et Novae Hollandiae aquis stagnantibus et lente fluentibus observatae, nullibi copiosae; foliis linearibus elongatis, basi vaginantibus, apice serrulatis. Flores miris famosi sponsalibus, masculi minimi, innumeri, primum spatha scapo brevi sub vado retenta inclusi, mox ruptis valvarum claustris et a pedicellorum vinculis soluti, aquae superficiem petunt, perigonium pandunt, ratemque faventibus credentes ventis, feminae laxata longissimi scapi spira emergenti catervatim adnatant, copioso polline prona irroraturi stigmata. Postquam satis litatum est, admissariorum grex perit, mater scapo revoluto gravidum sub unda recondit alvum, in profundo copiosam enixura sobolem.

Vallis a eria Miebell gen. $n, 10$. Juss. gen. 67. L. C. Richard in Mem, de l'Instit. 1811. II. 62, t, 3. Jacq. fil. Eclog. t. 1. Wight in Hook, Miscell. suppl. t. 23. 24. L. C. Trevirauus symb. phytolog. 74 . Nees jun. gen, pl. fasc. VI. t, 17. $\mathrm{P}$ b y s $\mathrm{k}$ i u m Loureir. $F t$. cochinch, $I$ 814. - ? Valli s. neria alternifolla Roxb. corom, t.165. Wight in Hook. Misc, III. 344. t.11. H y d rill a e $8 \mathrm{p}$. Hamilt, in Brewster's Journ. 1.34.

19 10. IBIyxa THOUAR. Flores dioici, Masc. Spatha seapum brevem terminans, tubulosa, ore bifido, multiflora; flo r ib us pedicellatis, pericellis inaequalibus. Perigonin m sexpartitum, Iaciniis exterioribns calycinis oblongis spathulatisve, interioribus petaloideis 
lineari - oblongis. Stam in a $3-8$; fil a menta filiformia, antherae oblongae, apiculatae, 10eulis connectivo angusto junetis. Ova $\mathrm{ri}$ superi rudimentum subglobosum, s ty lo setaceo trifido. Fem. S p a $t h$ a $u t$ in mare, uniflora; flore sessili. Perigonii tubus elongatus, basi cum ovario connatus, $1 \mathrm{imb} u \mathrm{~s}$ ut in mare. Ovari n m cum perigonii tubo connatum, uniloculare; placentis parietalibus tribus. Ovula plurima, adscendentia, anatropa. Stylus filiformis elongatus, cum perigonii tubo connatus, apice breviter exserto, libero; $\mathrm{st} \mathrm{g} \mathbf{m}$ a $\mathbf{t a}$ tria, linearia, integra. Bace a eylindrica, unilocularis. S e mina plurima, adscendentia. $\mathbf{E} \mathbf{m}$ b $\mathbf{r}$ y o orthotropus, extremitate radiculari infera. - Herbae perennes, stoloniferae, Indiae orientalis et Madagascariae rivulos incolentes; foliis radicalibus basi vaginantibus, linearibus, integerrimis, scapis ancipitibus, floribus emersis.

B 1 yxa Thovars gen, madagase. $n, 14$. L. C. Richard in Mem. de l'Instit. 1811. II. 63.t. 4. S. S a ivata Wallich catalog. $n, 5047$. Vallis neria oet a nd ra Roxb. corom. $t .165$.

TREI BUS IIR. S'TR ATIO'TIDEAE, 0 varium pluriloculare. St ig $\mathrm{m}$ a $\mathrm{t}$ a sex. Acaules, scapigerae.

1211. Stratiotes LINN. Flores dioici. Mas c. S patha scapum terminans, diphylla, multiflora, f I o $\mathrm{r} \mathrm{um}$ pedicellis basi spathilla monophylla munitis. Perigonium sexpartitum, Iaciniis exterioribus calycinis ovatis; interioribus petaloideis obovato - orbieulatis. Stamina plurima, exteriora (23_25) sterilia lineari - ligulata, interiora $\left(12 \_13\right)$ f e r t i li a; filamenta brevia, subulata, antherae lineares, locnlis discretis, connectivum marginantibus. Fem. Spatha maris, uniflora. Perigonii tubus cmm ovario connatus, I imbus sexpartitus ut in mare. Stamina sterilia plurima. Ovari um cum perigonii tubo connatum, placentis parietalibus sex axim attingentibus sexloculare. Ovula plurima, dissepimentorum parietibus affi$\mathrm{xa}$, adscendentia, anatropa. Stylu s brevis cylindricus, cum perigonii tubo connatus; stigmata 6, linearia, bifida. B a c ca ovata, hexagona, sexloeularis. Semina in loculis pauca, dissepimentis parietalibus affixa, oblonga, ereeta. E mbry o exalbuminosus, orthotropus, extremitate radi cu lari infera. - Herba perennis, stolonifera; folis radiealibus confertis, basi vaginantibus, latolinearibus, elongalis, spimuloso-serratis, in Europae imprimis borealis aquis stagnantibus puvioribus obvia. Feminae a maribus longissimo saepe terrarum intervallo remotae, unde multiplicatio per semina rarior, per stolones frequens et copiosa. Embryonis plumula ut in $\mathrm{H}_{y}$ drocharide lateralis.

Siratiotes Linn. gen. $n, 691$. Gärta. 1 , 48. $t, 14$. (mal.) Fl. dan, t. 337. Engl. Bot, t.37\%. Schikubr t,335, $\alpha_{,} b$. L, C. Ricliard in Mem, de l'Instit. 1811, II. 64. t. 6. Nolte Bemerkangen über Stratiotes und Sagittaria. Kopenh, 1825. 4to, c. icc. L. C. Treviranus ogmb, phytolog. 76. Nees jun. gen. pl. fasc. VI, 1, 16. A 1 o i d e s Boerh. Lugit. Batav. II. 172 .

1212. Enlugius L. C. RICH. Flores dioici. M asc. . . F em. Sp ath a seapum terminans, diphylla, carina fibrillosa, uniflora. Perig onii tubus cum ovario connatus, limbus sexpartitus, laciniis exterioribus (eoloratis) oblongis, interioribus linearibus. Stamina sterilia 12 , lineari-ligulata. Ova ri um inferum, Stigmata 4-6. Fructus ovatus, compressus, drupaceus, pluriloeularis, Sem in a quatuordecim.
Herba in aestuariis Ind i a e insularis a patribus observata; fotiis radicalibus confertis, linearibus, obtusis, apice serratis, basi vaginiferis, edulibus, drupa ovata, compressa, fibrillosa.

$\mathrm{E}$ ahalus L. C. Richard in Mem, de IInstit. 1811. II. 64. Stratiotes acoroides Liun. f. suppl. 268. A co. rus ma rinus Rumph amboin. $P I, 91, t$. $75, f .2$.

1213. Dttelia PERS. Flores hermaphroditi. S p a $t$ h a scapum terminans, tubulosoalata, ore bifido, uniflora; flore sessili, perigonii limbum exserente. Perigonii tub u cum ovario connatus, li mbus sexpartitus, lacin i is exterioribus ealy $\mathrm{c}$ in is oblongis; interioribus petaloideis obovatis, singulis glandulae depressae basi extrorsum insertis. S $\mathrm{t}$ a $\mathrm{m} \mathrm{i} \mathrm{n}$ a 6_12, filamenta cuneato-oblonga, antherae basifixae lineares, loculis connectivo angusto sejunctis. Ovarium cum perigonii tubo connatum, placentis parietalibus sex $v$, octo ad axim tendentibus incomplete sex- v. octoloculare. $O \mathbf{v} \mathbf{u}$ 1 a plurima, dissepimentorum parietibus affixa, adscendentia, anatropa. St $\mathrm{g} \mathbf{m}$ a t a 6 , sessilia, linearia, bifida $v$. hipartita. B a c e a perigonii limbo coronata, oblonga, teretiuseula, incomplete sex- v. octolocularis. S emin a plurima, dissepimentorum parietibus affixa, ovata, adscendentia. Embryo exalbuminosns, orthotropus, extremitate radiculari infera. - Herbae perennes, ad ostia Nili, Gangis et in Australasia observatae; foliis radicalibus longe petiolatis, cordatis, nervosis, petiolis basi dilatatis, vaginantibus, fructu intra spatham recondito.

Ot tellia Pers. ench. T. 400. L. C. Riehard in Mem, de 1'Instit. II, 1811. 64. t. 7. D a mason i m Selireb. gen. $n$. 694. Roxb. corom, t. 185. Bot. Mag. t, 1201. H y m e noth er e a Salisb. Stratiotes alismoides Linn. Smith exot. Bot. $t$. 15. Ottel - A m bel Rheede malab. $3 X .95$. $t, 46$.

1214. Fowtia WALL. F 1 o r e s dioici. M a sc. S p ath a scapum terminans, tubulosa, inflata, ore contracto multidentato, multiflora; floribus pedicellatis, pedicellis inaequalibus, nudis. Perigonium sexpartitum, laciniis exterioribus calyeinis oblongis; interioribus petaloid e is obovatis. Stamina 12, exteriora breviora; fil a m e nt a subulata, a nt hera e ovatae, loculis linearibus diseretis, connectivum marginantibus. Ovarii superi rudimentum subgloboso-trilobum, stigmatibus bifidis. Fem. S p a th a scapum terminans, tubulosa, eylindrica, ore multidentato, uniflora; flore sessili. Perigonii tubus cum ovario connatus, $1 \mathrm{im}$ bus sexpartitus ut in mare, la ciniis petaloideis, singulis basi glandulae depressae extrorsum insertis. S $\mathrm{Stamina}$ sterilia linearia. Ovarin m cum perigonii tubo connatum, placentis parietalibus novem axim attingentibus novemlocnlare. Ov ula plurima, dissepimentorum parietibus affixa. ... S $\mathrm{t}$ i $\mathrm{g} \mathrm{m}$ a $\mathrm{t}$ a 9 , bifida. Fructus. ... Herba perennis, in ripis fuvii Irravadi regni Avae observata; foliis radicalibus, aliis submersis elongato lineari-lanceolatis, aliis natantibus longe peliolatis cordatis multinerviis, scapis elongatis emersis.

\section{Booti a Wallich pl. as, rar. $x, 51, t, 65$.}

1215. Wimnohimen L. C. RICH. F10res dioici. M a sc. S p a th a scapum terminans, diphylla, pauciflora; floribus pedicellatis, pedicellis basi spathilla monophylla munitis. Perigonium sexpartitum, 1 a c in i is exterioribus e a ly ein is oblongo-ovalibus; interioribus peta$10 \mathrm{id}$ is columnae stamineae paullo altius insertis, oblongo-linearibus. S tamina 6_9; fil amenta in columnam centralem solidam connata, anthe- 
rae basifixae, lineares, loculis discretis connectivum marginantibus. O va ri i superi rudimentum bi-trisetum, columnam stamineam terminans. Fe m. $\mathrm{S}$ p a tha radicalis diphylla, uniflora; flore pedicellato, pedicello nudo. Perigonii tnbus cum ovario connatus, limbus sexpartitus, la cini is exterioribus calycinis oblongo-ovalibus; interioribus petaloideis disco epigyno paullo altius insertis, oblongo-linearibns. S t a $\mathrm{m}$ in a sterilia $3_{-} 6$, subulato-setacea, solitaria $\mathbf{v}$. gemina ad basim laciniarum interiorum perigonii. $\mathrm{O} v$ a $\mathrm{ri} \mathbf{\mathrm { m }} \mathrm{cum}$ perigonii tubo connatum, placentis parietalibus sex axim attingentibus sexloculare. Ovula plurima, dissepimentorum parietibus affixa, adscendentia, anatropa. Stig m a t a 6 , subulata, bifida v. bipartita. B a e e a ovata, teretiuscula, sexlocularis. Semin a plurima, dissepimentorum parietibus affixa, ovata, adscendentia, E $\mathbf{m}$ b r y o exalbuminosus, orthotropus, extremitate radiculari infera. Herba perennis, stolonifera, in Americae borealis aquis stagnantibus inter 10 et $40^{\circ} \mathrm{L} . \mathrm{B}$. observata; foliis radicalibus con fertis, petiolatis, orbiculato-reniformibus, nervosis, subtus spongioso-reticulatis, petiolis basi dilatatis, semivaginartibus, floribus masculis parvulis, femineis majoribus, pedunculo fructifero cernuo.

L i m n o i um L. C. Richard in Mem. de IInstit. 1811. Ir. 66. $t, 8$. $\mathrm{H}$ y drom istria G. T. W. Meyer Essequeb. 158. J a lambicea Llave et Lexarz. nov. gen, $I T, 12$. Hydrocharis Spongia Bosc.

1216. Hy ellrocluariss $L T N N$. F 1 o r e s dioici. Masc. Spatha seapum brevem terminans, diphylla, subtriflora; floribus pedicellatis, perdicellis nudis. Perigon i nm sexpartitum, laciniis exterioribus calycinis ovalibus; interioribus petaloideis suburbieulatis, columnae stamineae paullo altius insertis. Stamina 12 ; fila$m$ e $n t$ a basi in columnam brevem connata, apice bicruria, crure postico saepins ananthero (floribus tunc hex-enneandris), a $\mathrm{n}$ h e r a e basifixae, ovatae, loculis discretis, connectivum marginantibus. Ovarii smperi rudimentum trilobum, columnam stamineam terminans. Fem. S p a th a radicalis monophylla; flore longe pedicellato. Perigo n i t ubus cum ovario connatus, $1 \mathrm{i} m$ bu s sexfidus, laciniis exterioribus calycinis ovalibus; interioribus pet a l o ideis orbienlatis, singulis glandulac epigynae depressae basi extrorsum insertis. Stamina abortiva 6 , subulata, perigonii lobis exterioribus per paria opposita. Ovari u m cum perigonii tnbo connatum, p la e ent is parietalibns sex axim attingentibus sexloculare. O v uI a plurima, dissepimentorum parietibns affixa, adscendentia, anatropa. Sty $\mathrm{Iu} s$ brevissimus crassus; stig mata 6 , oblongo-cuneata, divaricatobicornia. B a c ca ovata, teretiuscula, sexlocularis. $\mathrm{S}$ e $\mathbf{m}$ i $\mathbf{n}$ a plurima, dissepimentorum parietibus affixa, adscendentia. E $\mathbf{m}$ b r y o exalbuminosus orthotropus, extremitate radiculari infera. - Herba europaea, perennis, stolonifera, florifera natans, fructifera demersa ; foliis petiolatis reniformibus, petiolis basi in vaginam biauritam dilatatis. Testa seminum laxa, carnosula, verrucis e cellulis spiralibus formatis obsita; embryonis plumula lateralis exserta.

H y drocharis Linn. gen. $n$, 1126. Fl. dan. $t$. 878 . Engl. Bot, t.808. Schkuhr $t, 333$. L. C. Richard in Mem. de IInstit. 1811, II, 67, t,9. Annal, du Mus, XVIT. 248. Nees jun. gen, pl. fasc, VI, t. 15. Stratiotes Dillen. gen. 9. Morsus $\mathrm{R}$ anae Tournef, inst. t. 4. Microleucony mphae a Boerh.

\section{Drdo LX. Bammaniaceat.}

BURMANNIAE Spreng. syst. 1. 123. Lindl. introduct, 357. BURMANNIACEAE Blum. enum, $p t$. Jav, $\pi$, 27. Bartl, ord. nat. 41.

Hrrbae annuae graciles, radice fasciculato-fibrosa, fibris interdum carnosis, in tubera oblonga incrassatis. C a ulis simplex, quandoque aphyllus v. squammatus. Folia radicalia graminea, conferta, interdum nulla, caulina nulla v. brevissima, simplicia, alterna, remota, sessilia, semiamplexicaulia.

Flores hermaphroditi regulares, terminales; solitarii, bini v. quaterni, rarius in spicis bifidis secundi v. congesti, subcapitati, albi, flavi v. cocrulei.

Perigonil corollini $t$ u b u $s$ cum ovario connatus, cylindraceus, teretiusculus v, triqueter, saepe in alas tres membranaceas, longitudinales, plus minus prominentes productus; limbus superus, minutus, sexfidus; la cin i a e inaequales, tres majores exteriores, alis tubi continuae, tres minores his alternae, introflexae, interdum deficientes.

Stamiva tria, perigonii laciniis majoribus alterna, hinc minoribus dum adsunt opposita, tubo infra faucem peltatim affixa. Filament a brevissima, elliptica v. subtriangularia, apice emarginato-biloba. Antherae introsae, biloculares, Io с иli oppositi, sejuncti, utrinque filamenti margini infra medium aflixi, transversim hiantes. Polle n oblongum, sulco longitudinali exaratum.

Ovarium perigonii tubo adnatum, e carpidiis tribus, perigonii laciniis exterioribus oppositis conflatum; earpellorum marginibus nunc in dissepimenta introflexis, axim attingentibus triloculare; nunc iisdem simpliciter applicitis uniloculare. Placentae in ovariis trilocularibus e loculorum angulo centrali tumentes; in unilocularibus parietales, perigonii alis oppositae, multiovulatae. Ovula .... Styl us simplex, filiformis, triqueter v. trisulcus. Stigmata tria, globosa v. dilatata, petaloidea, interdum biloba et staminibus adhaerentia.

Capsula perigonio marcescente coronata, polysperma, nunc unilocularis, apice irregulariter dehiscens; v. trilocularis, valvis irregulariter aut fenestratim solutis.

Semina minutissima, oblongo - linearia, utrinque attenuata, longitudinaliter striata, arillata? Albumen carnosum? Embryo minimus, axilis ?

Burmanniaceae inter tropicos utrius que orbis in udis pinguibus graminosis, saxis irriguis vel super arborum putrescentium radices repertae, in novo continente, ubi usque $35^{\circ}$ lat. bor. adscendunt, frequentius habitare videntur. 
Ordo seminum fabrica nondum satis explorata, quoad locum in serie lineari paulisper dubius. Haemodoraceis staminum situ convenit, ab Irideis, quae perigonii et stigmatum structura similes, staminum ante perigonii lacinias interiores situ, et antherarum directione introrsa diversus. Brownius affinitatem Burmanniae cum X yride et Philydro indigitat, longius distare censet ab $\mathrm{H}$ ypoxideis et a Bromeliaceis, quas inter B urmanni am Jussieus militare olim jusserat. Gonyanthis semina arillo setiformi inclusa dicuntur, qua nota revera ad T'ilI and si am accederet singulare hocce genus.

121\%. Aymuosiploon BLUM. Perigoni corollini tubus cum ovario connatus, teres, limbus superus trifidns. Stam ina 3 , perigonii laciniis alterna. Ovarium uniloculare, placentis tribus parietalibus. Sty I us trigonus; $8 \mathrm{tigm} \mathrm{a-}$ $t$ a 3 , dilatata. C a p 8 u 1 a unilocularis, apice irregulariter dehiscens, polysperma. Semina minima, striata. - Herbula ja vàn i ca, aphylla; facie Burmanniae, scapo ramoso, squamoso, floribus spicatis secundis.

Gymnosiphon Blum. onum. pl, Jav, p, 29.

1818. Gomyanthes BLUM. Perigon ii corollini tubus cnm ovario connatus, triqueter, limbus superus trifidus. St am in a $\mathbf{3}$, perigenii laciniis alterna. Ovari $\mathbf{~} \mathrm{m}$ triloculare, $\mathrm{pla}$ centis tribus centralibus, semibifidis, perigonii angulis oppositis. Stylus trisuleus; stigmata 3, dilatata, cum staminibus cohaerentia. Ca $\mathbf{p}$ в I a trilocularis, valvis tribus loculicidis fenestratim aperta, polysperma. Semina minima, arillo membranaceo setiformi inclnsa. - Herba pusilla subcarnosa, tota albida, in radicibus arborkm putridarum insulae Javae parasitica; radice fibrosa, fibris subcarnosis, tuberibus oblongis intermixtis, caule simpliciusculo, aphyllo, squamis paucis alternantibus vestito, superne corymboso bi-quinquefloro.

G ony a thes Blum. cnum. pl. Jav, p. 29.

1219. Eurmannia LINN. Perigoni i corollini tubus cum ovario connatus, teres vel tripterus, limbus sexfidus. S $\mathrm{t}$ a $\mathrm{m}$ in a 3 , perigonii laciniis interioribus opposita. Ovarium triloenlare, placentis tribus centralibus bilobis, perigonii alis oppositis. Stylns filiformis; stigmata 3 , globosa, dilatata v. biloba. Cap sn I a trilocularis, apice incomplete locnlicido-trivalvis, polysperma. S e min a minima, fusiformia, striatula. - Herbae in udis pinguibus $r e g i o n u m$ calidarum utriusque hemisphaerae provenientes; foliis radicalibus gramineis confertis, caulinis nullis vel brevissimis, scupis apice uni-bifloris, v. spicam bifidam multifloram gerentibus.

B u rman Mart. nov. Gen. et sp. I, 9, t.5. Blum. enum, pl. Jav.p. 27. - Tripterella Rieh. in Michx, Fl. Bor. Amer, I, 19.t. 3. - Vogelia Gmel, syst, 107. - Maburaia Thouars gen. Madagasc, $n, 13$.

OBSERVATI0. Quartum genus ineditmm javanieum conmenorat Blume famill. exposit, p. 4 .

\section{Ordo IXI. Iridene.}

IRIDFS Juss. gen, 57. ENS 4 TAE Ker in Annal. of Botany I. 219. IRIDEAE R. Brown prodr. 302. Ker Iridearum genera. Bruxellis 182\%, 8vo. Bartl. ord, nat. 44. IRIDACEAE Lindt. introduct. edit, $1 T$. 332.

IIERBae $v$, rarius suffrutices, $r h i z o m a-$ te tuberoso $v$. bulboso, interdum $r$ adice fibrosa perennantes, glabrae, v. pube simplici vestitae. Folia saepissime omnia radicalia, aversa, equitantia, disticha, ensiformia v. linearia, angulata, nervosa, integerrima, caulina alterna, vaginantia. C a uli s centralis articulatus v. enodis, interdum scapiformis $v$. subnullus, nunc simplex, nunc ramosus v. ramosissimus.

Flores hermaphroditi regulares v. irregulares, terminales, spicati, corymbosi v. laxe paniculati, rarius solitarii, saepius majusculi speciosi, polychroi, plerumque fugacissimi, singuli bracteis duabus spathaceis v. rarius pluribus, ut plurimum seariosis cincti, spatha communi diphylla subfoliacea.

Perigonium corollinum superum, tubulososexfidum v. hexaphyllo-partitum, lacin i is aequalibus $v$. interioribus saepius minoribus dissimilibus, interdum subnullis v. rarissime majoribus, regularibus v. bilabiatis, nt plurimum caducissimum, nonnunquam post anthesim spiraliter convolutum, marcescens.

Stamina 3, epigyna ve perigonii tubo laciniarumre basi inserta, semper laciniis exterioribus opposita, erecta v. subsecunda, exserta v. inclusa. Fil a m enta filiformia, subulata v. subclavata, libera v. basi aut juxta totam longitudinem in tubum connata, A nthe ra e extrorsae, oblongae, ovatae $v$. sagittatae, basifixae v. medio dorso insertae, versatiles ; loculi oppositi, contigui v. basi discreti, juxta longitudinem dehiscentes.

Ovarium inferum, vel rarins vertice exserto semisuperum, trigonum v. prismaticum, rarius teres v. subglobosum, triloculare. $\mathrm{O} v \mathrm{u}$ 1 a in loculis plurima, rariusve pauca, bi-pluriseriata $v$. interdum uniseriata, angulo interiori immediatim, vel columnae centrali in loculos prominentí inserta; nt plurimum horizontalia, interdum adscendentia v. pendula, anatropa. Stylus simplex. Stigmata 3 , staminibus alterna v. opposita, saepissime petaloideo-dilatata v. convoluta, integra, bitrifida $v$, bilabiata.

Capsula membranacea v. coriacea, interdum cartilaginea, trigona $v$. gibboso-triloba, trilocularis, loculicido-trivalvis, valvis medio septiferis; placentis nerviformibus dissepimentorum margini adnatis, $v$, in col $\mathrm{nm} \mathrm{ma}$ centralem, a dissepimentis solutam persistentem connatis.

Semisa plurima, rariusve pauca, subglobosa v. pressione mutua angulata, aut in situ horizontali saepius plano-compressa, marginata v. alata. Test a membranacea, saepius laxa $v$. chartacea, aut interdum coriacea $v$. carnosa, u mbilico basilari ope rhapheos saepius 
liberae v. solubilis cum $\mathrm{ch}$ a laza apicali, vix non semper manifesta, conjuncto. A I bu me n copiosum, carnosum v. cartilagineum, imo subcorneum.

Еиввуо axilis, v. in seminibus pressione mutua deformatis etiam sublateralis, albumine plerumque brevior, extremitate radiculari umbilicum attingente, in fructu ut plurimum centripeta, rariusve infera $v$. supera.

Irideae in temperatis subtropicisque totius orbis obviae, ingenti copia in Capite bonae spei crescunt, inter tropicos rarae.

O r do staminum ante perigonii lacinias exteriores situ, antherarumque directione extrorsa et stigmatum fabrica distinctissimus, hinc Burmanniaceis, quae antherarum situ et dehiscentia, illine Haemodoraceis, quae vel staminum numero v. eorundem ante perigonii lacinias interiores situ facillime distinguuntur, proxime conterminae.

Genera nimis fortassis multiplicata, et difficillime circumscribenda, denuo sub incudem revocanda sunt.

Rhizomata nonnullarum viribus stimulantibus, aliarum catharticis pollent. Crocorum stigmatibus principium peculiare colorans (Polychroit) inest.

1 \& 00 . Sisyeimelnimme LINN. Perigoni um corollinum superum, hexaphyllo-partitum, la ciniis subaequalibus patentibus v. basi in tubum conniventibus. Stamina 3 , imo perigonio inserta; fil amenta basi v. juxta totam longitudinem in tubum connata, anth er a e basi emarginata insertae. Ovarium inferum, obtuse trigonum, triloculare. Ovula plurima, in loculorum angulo centrali bi-pluriseriata, horizontalia, anatropa. Stylus brevis; stigmata 3 , involntofiliformia, acuta, staminibus alterna. Capsu la membranacea, obovato-clavata, trilocularis, locuIicido-trivalvis. S e min a plurima, subglobosa v. angulata, test a coriacea dura, $r h$ a $p h$ e obsoleta. Embryo axilis v. sublateralis, a lbumine cartilagineo parum brevior, extremitate radiculari umbilicum attingente, centripeta. Herbae in America tropica et temperata obviae, in Nova $H_{0}$ ll andia rarissimae; radice ut plurimum fibrosa, foliis bifariis vaginantibus, caule saepius ramoso, ancipiti, spathae communis bivalvis, partiales plures includentis valva exteriore saepe foliiformi, floribus inconspicuis, fugacissimis. S is y rin ehi um Linn.gen,n.1017. Cavanilles Dissert. VT. 190. 192. Jacq. hort, schönbr. t,1t.12 Wilt, hort, berol. t,91.92. Bot, Mag, t, 94. 464, 2116, 2117, 2312, 2787. 2965. Bot. Reg. t.616.1067.1090.1915. B e r m a d I a na Touraef, inst. t. 32. Gitrtn. I. 208. $t, 11$. S y o $\mathrm{r}$ h y u $\mathrm{eh} \mathrm{ium}$ Hoffmansegge Nachtr. II. 216. M aric a e sp. Bot. Mag. t.655.983. Souza Flor. Flumin. DII. t.1-3. - O rthros a nt bus Sweet Fl, austral, t, 11 .

1221. Hibertia SPRENG. Perigoniu m corollinum superum, hexaphyllo-partitum, la cini is exterioribus subherbaceis, interioribus majoribus basi saepius unguieulato-angustatis, patentibus. Stamina 3 , imo perigonio inserta; filamenta basi connata v. distincta, apice patentia, antherae ovatae, dorso supra basim affivae. Ovarium inferum, obtase trigonum, triloculare, 0 v 1 la plurima, in loculormm angu- to centrali biseriata, adscendentia, anatropa. StyIn s brevissimus; stigmata 3 , involuto-filiformia, acuta, staminibus alterna. Ca psula membranacea, obovato-clavata, trilocularis, loculicido - trivalvis, S e m in a plurima, angulata....- Uerbae in hemisphaerae australis regionibus extratropicis sylvicolae; rhizomate repente $v$. radice fibrosa, foliis gramineis laxis, nervosis, caule teretiusculo, simplici $v$. subrumoso, inflorescentia subpaniculata, fasciculis alternis, umbellatis, spathis persistentibus, floribus albis.

L ib ertia Sprengel syst. $I$. 168. Bot. Mag. t.3894. Bot. Reg. $t, 1630$. Ren a $1 \mathrm{~m}$ i a R. Brown prodr. 590 . Sweet $F l$. gard.I. t.64. Ne matostig m a Dietrich syst. Willd. $n .228$.

1222. Cipura $A U B L$. Perigonium corollinum superum, tubo brevissimo, limbi sexpartiti la $\mathrm{c}$ in i is interioribus minoribus. S $t$ amina 3 , perigonii tubo inserta; fil am enta distincta, antherae oblongae basifixae. Ovarium inferum, obtuse trigonum, triloculare. Ovula plurima, in loculorum angulo centrali biseriata, adscendentia, anatropa. Stylus brevissimus; stigmat a 3 , petaloideo-dilatata indivisa, staminibus alterna, erecta v. patentia. Ca p s u la membranacea, obovato-clavata, trilocularis, loculicido-trivalvis. S e min a plurima, angulata. ... - Herbae americanae tropicae et subtropicae; radice bulbosa, foliis ensiformibus nervosis, spathis terminulibus elongatis, imbricatis.

Ci p u ra Aubl, guian. $I, 38, t, 13$, Kunth in $H u m b$, et Bonpl. nov. gen. et sp. I. 257. Marica Schreb, gen. $n$. 81. Bot. Mag. $t$. 646. 654. - ? T rimeriza, Hy dis ty. 1 is et $\mathbf{G}$ a lat he Salisb. in Transact, Hortic, Soc. I.280.

12:3. Wheusseuxina ROCHE, $\mathrm{P}$ erigon i m corollinum superum, hexaphyllo-rotatum, laciniis exterioribus basi unguieulato - angustatis, saepe barbatis, interioribus multo minoribus subulatis vel tricuspidatis. St a mina 3 , diseo epigyno imposita; fil amenta in tubum connata, anthera eblongae, basifixae. Ovarium inferum, oblongo-prismaticum, triloenlare. 0 v $\mathbf{n}$ 1a plurima, in loculorum angulo centrali biseriata, horizontalia, anatropa. St y la s brevis, filiformis; 8 tigmata 3, petaloideo-dilatata, biloba, staminibus opposita. Caps ala coriacea, obtuse trigona, trilocularis, loculieido-trivalvis. Se min a plurima. ...- Herbae capenses; rhizo. mate tuberoso, foliis paucis ensatis, caule tereti. paniculatim ramoso, fioribus intra spathas diphyl. las herbaceas solitariis, pedicellatis.

Vie us seuxia de la Reche Dissert. Lugd. Batav. 1786. 40. DC. in Annal. du Mus, II. 137. Redouté Liliac. $t$, 42. I rld is sp. Linn. Jacq. hort, schönbr. $t$, 10. Mor a e a s p. Jaeq. hort. vindab. t, 20. Ic. rar, t. 224. Bot. Mag. $t$. 571.393.696.702.772. 10.77. 1247. -? Freuchenia Eckl. Verz, 14.

1224, Nirmea LINN. Perigoninm corollinum superum, tubo brevissimo, limbi sexpartiti patentis la ein iis interioribus minoribus, post anthesim convolatis. St a $\mathrm{m}$ in a 3 , perigonii tubo inserta; fi l a m enta distincta, antherae oblongae, basifixae. Ovari um inferam, oblongo-prismaticum. Ovnla plurima, in loculorum angulo centrali biseriata, horizontalia, anatropa. Sty lu s triqueter graeilis; stigmat a 3 , petaloideo-dilatata, bi-trifida, stamiaibus opposita. Ca psula membranacea, obtuse trigona, trilocularis. S e m i n a plurima, angulata.

Herbae capenses; rhizomate repente $v$, tuberosobulboso, folïs bifariis ensatis, spathis elongatis, subimbricatis. 
M o rat a Linn, gen, n. 60, excl, sp, Salixb. parad, $t$. 10. Andr. Bot. Reposit, t, 45.83. Bot. Mag. t, 577, 587,613. 712.750.771. 1012. 1045. 1061. 1238. 1276. 1284, 1407. Bot. Reg. t.312. - Ho me ria Veat. Dec, nov.gen, 2, Sweet Fl. gard. I. $t$. 158. 178. (Jacq. hort, schönbr, t. 12. Bot. Mag. t. 1033. 1133. 1283. 1612.) - ? Dietes Salisb. Morae a iridioi. des Jacq. hort, schönbr. t. 196. Bot. Mag. t. 693. Bot. Reg. t. 1074 .

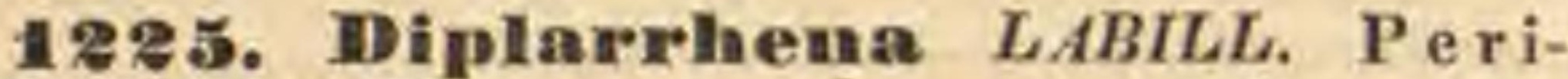
gonium corollinum superum, sexpartitum, Iacin i is interioribus minoribus, postica dissimili fornicata. Stamina 3 , imo perigonio inserta, duo sub lacinia interiore postica conniventia, tertium castratum. ... O vari $\mathbf{~} \mathbf{m}$. ... S t i g m a tripartitum, bilabiatum. Ca p s u 1 a oblonga, trigona. Semina plano-depressa, in loculis uniseriata. - Herba in insula Diemen reperta, perennis, glabra; radice fibrosa, caule foliato simplici, foliis ensiformibus, caulinis alternis brevioribus vaginantibus, spatha communi bivalvi foliacea, partialibus inclusis, confertis, scariosis, floribus pedunculatis, albis, laciniis interioribus pictis.

D iplarrhe n a Labill, voy. I. I57, t. 15. Nov, Holl, II. 117. R. Brown prodr. 304.

1226. Inis LINN. Perigonium corollinum superum, tubo brevi, limbi sexpartiti lacini is exterioribus saepissime reflexis et basi barbatis $v$. rarius nudis; interioribus erectis, saepe minoribus $v$. nonnunquam minimis. St am i na 3 , perigonii laciniis exterioribus basi inserta; filamenta filiformia $v$. subulata, antherae oblongae, basifixae. Ovari um inferum, obsolete trigonum, triloculare. Ovula plurima, in loculorum angulo centrali biseriata, horizontalia, anatropa. Stylus triqueter, basi saepins cum perigonii tubo connatus; stigm ata 3 , Fetaloideodilatata, supra carinata, subtus canalieulata, plica transversa bilabiata, staminibus opposita. Caps u la coriacea tri-hexaguna, trilocularis, apice loculicido-trivalvis. Semina plurima, horizontalia, compresso-plana, marginata, rhaphe tenui intra $t$ esta $m$ laxam libera. Em bryo axilis, a Ib nmine carnoso multo brevior, extremitate radiculari umbilicum attingente, infera. - Herbae perennes; in hemisphaerae borealis temperatis obviae, nonnullae aquaticae; rhizomate tuberoso v. rarius bulboso, foliis gramineis, interdum quadrangularibus, saepissime ensatis, equitantibus, caule saepius compresso, ramoso, floribus speciosis magnis, terminalibus, solitariis $v$, spicatis, spathis uni-mullifloris.

Ir is Limn. gen. n, 59. Juss. gen. 57. Gärtn. 1 . 38, t. 13. Nees jun. gen, $p l$, fasc. $Y, t, 18$. Redouté Liliac, $t, 18$ 236. 263. 995. 336, 360. Bot. Mag, t. 1,9.16,21, 50, 58,61, 9t, 187. $412.531 .669-671.679 .681 .685-687.703 .787 .870 .986$. 1113, 1123, 1131, 1261, 1393.1496, 1504, 1514, 1515, 2939, 2396. 2331.2435. $2588,2861.2886$. Bot, Reg. t. $549.801,1218$. I r i s, Xiph ion, Hermodactylus et Sisyrinchium Tournef. inst, $t, 186.187$. I s is Trattiniek Tabular, 668.

$18 \% \%$. nerbertin SHEET. P erigonium corollinum superum, hexaphyllo-partitum Iaciniis exterioribus triangularibus acutis reflexis; interioribus aequilongis, apice rotundatis erectis. Stamin a 3 , perigonii lacinis exterioribus basi inserta; filamenta basi conniventia apice dilatata, reflexa, antherae. .. O variu m inferum, teretiuseulum. . . Sty 1 is filiformis; stifmata 3 , trifida, laciniis recurvis, in termedia minore. C a psula. Herbae pusillae, in America australisubtropica indigrenae, milis penitus incognitae; folis radicalibus angulatis, scapum apice faseiculatim multiflorum aequantibus.
Herbertia Sweet Fl. gard. I, t. 228. Ferraria p u s 111 a Link et Otto ic. pl. select, t. 59 .

1285. Cypella HERB. Perigonium corollinum superum, hexaphyllo-partitum, lacin i is basi coneavis, exterioribus majoribus patentibus; interioribus minutis, convolutis, apice reflexis. Stam in a 3 , perigonii laciniis exterioribus basi inserta, fil am ent a brevissime coalita, subulata, a n thera e oblongae, basifixae, loculis connectivum marginantibus. Ovariu m inferum, oblongo-prismaticum, triloculare. Ovu la plurima, in loculorum angulo centrali biseriata. Stylus brevis, filiformis; stigma dilatatum, trilobum, lobis erectis, trifidis, basi transverse appendiculatis. Capsula membranacea, oblongoprismatica, trilocularis, loculicido-trivalvis. $\mathcal{S}_{\mathrm{e}}$ min a plurima, angulata. ... - Herbae perennes, in America tropica et australisubtropica indigenae; rhizomate bulboso-tuberoso, caule erecto, folioso, apice ramoso, foliis late lineari-lanceolatis, plicato nervosis, floribus laxe paniculatis, magnis, speciosis, spathis diphyllis, unifloris.

C y pell a Herbert in Bot. Mag. n. 2637. Sweet Fl. gard. II. $t$, 33. Tigridia Herberti Bot. Mag. $t, 2899$. M oraca Herberti Lindl, in Bot. Reg.t. 949. Maric a e s p. Ker.

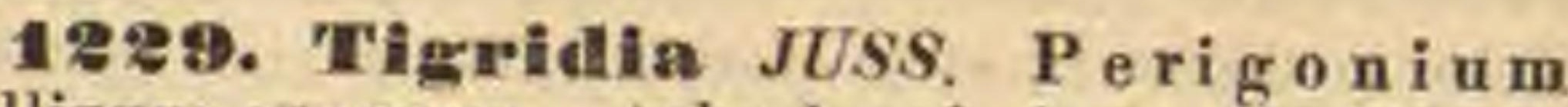
corollinum superum, tubo brevissimo, limbi sexpartiti patentissimi lacini is exterioribus majoribus; interioribus minoribns subpanduraeformibus. Stamin a 3 , perigonii tubo continua; fil amenta in tubum longissimm connata, antherae loculis connectivo antice adnatis. Ovari$\mathbf{u m}$ inferum, triloculare. $\mathrm{O}_{\mathrm{v}} \mathrm{u} \mathrm{I}$ a plurima, in loculorum angulo centrali biseriata, horizontalia, anatropa. Stylus flliformis, tubi staminei longitudine; $s \mathrm{tigmata} 3$, filiformia, bipartita. Caps 1 la membranacea, trilocularis, loculicido - trivalvis. S emina plurima. ... - Herba mexic an $a$; bulbo radicali tunicato, foliis bifariis ensiformibus, basi vaginantibus, plicato-nervosis, floribus in caule cylindrico terminalibus, magnis, speciosis, purpureis, disco maculatis, spatha bivalvi cinctis.

Tig ridia Juss. gen. 57. Ker in Annal. of Bot. I. 246. Gen. Irid. 25. Fer raria pavonia Lina. Cav, diss, VI. t.189. F. Tigridia Ker in Bot. Mag. t. 532. A coloxoh it i Hernand. Hist. 276.

1930. Fempara LINN. Perigoni nm corollinum superum, sexpartitum, Iaciniis oblongis, undulatis, patentibus v. reflexis; exterioribus latioribus. Stamina 3 , imo perigonio inserta; filamenta in tubum connata, anthera e basifixae, ovato-didymae. $0 v$ ari u $m$ inferum, triloculare. Ov $\mathbf{\text { u }}$ a plurima, in loculornm angulo centrali biseriata, horizontalia, anatropa. Sty 1 u 8 filiformis; $8 \mathrm{tig} \mathrm{m}$ a ta 3 , petaloideo-dilatata, conniventia, bifida, lobis penicillato-multifidis. Capsula coriacea, trigona, trilocularis, loculieido-trivalvis. Semin a plurima, baceata, orbiculato-ovata, ad ch a 1 a z a m terminalem umbilicato - impressa. _ Herbae capenses, gloucescentes; rhizomate tuberoso, foliis bifarïs ensiformibus, crassiusculis, nervosis, caule imbricatim folioso, simplici vel paniculatim ramoso, inflorescentia aggregata, spathis plurivalvibus, floribus caducissimis.

Fe r a ria Linn, gen. n, 1018, Cav, dissert. VT, $t, 190$. Mag. $t .144 .751$. Sweet $F l$. gard. I. $t .148 .161,192$.

1931. Pardamtihus $K E R$. P e rigoniu m corollinum superum, hexaphyllo-rotatum 
la ciniis aequalibus, basi unguiculato - angustatis. Stamina 3 , epigyna, subsecunda; fila menta subulata, anth e ra eblongae, basifixae, conniventes. $O$ v a $\mathbf{r}$ i $\mathbf{~ m}$ inferum, subelavatum, triloculare. Ovula plurima, in columna centrali biseriata, horizontalia, anatropa. St y 1 us clavatus, apice trifidus; $8 \mathrm{t} \mathrm{i} g \mathrm{~m}$ a $\mathrm{t}$ a 3 , petaloideosubdilatata. C a p sula coriacea, triloenlaris, apice loculicido-trivalvis, valvis tandem a columna centrali solutis. S e min a plurima, biseriata, globosa, testa carnosa....-Herba in arenosis Indiae, Chinae et Japonia e proveniens, ubique in hortis culta; rhizomate carnoso stolonifero, foliis bifariis ensiformibus, nervosis, cuule flexuoso, folioso, paniculato-dichotomo, floribus laxe aggregatis, pedicellatis, speciosis, perigonio flavo, atro-purpureo maculato, mox spiraliter contorto, persistente.

Pardanth us Ker in Annal. of Bot.I. 246. Gen. Irid. 15. B elem cand a Rheede malab. XI. 308. $t$. 7 . Redonté $L i$ liac, $t$.121. Ixia cbinensis Linn. Bot. Mag. 6.171.

1232. Aristea SOLAND. Perigoniu m corollinum superum, sexpartitum, lacini is patentissimis aequalibns, $v$. interioribus multo majoribus. Stam ina imo perigonio inserta, erecta v. subsecunda, inclusa; fil amenta subulata, antherae oblongae, basifixae. Ovarium inferum, obsolete trigonum, triloculare. Ovula pauca $v$. plurima, in loculorum angulo centrali uniseriata, subhorizontalia, anatropa. St y lus erectus, subelavatus; $s \mathrm{tig}$ a ta 3 , subcapitata v. cucullato - dilatata. Ca p s I a membranacea, oblongo - prismatica, trilocularis, loculieido-trivalvis. Semina in loculis bina v. plurima, horizontalia, compressa. . .-Herbae capenses; radice tuberosa saepius lignescente, foliis ensatis equitantibus, caule ancipiti, saepius ramoso, spathis fasciculatis diphyllis, scariosis $v$, rarius herbaceis, perigonio tandem in spiram contorto, persistente.

A riste a Solander in Ait, Hort, kew, I. 67. Redoute Iiliac, $t$, 464. Andrews Bot. Reposit. $t, 10$. 160. Bot. Mag. 2.458,520,605, 1231. Ker Irid, gen. 10, Cle an the Salisb, Moraea sp. Lina. Thunb. - ? Bobartia Linn. Fl. zegl. 41. Sehumacher in Act. soc, h, n. hafn. IHI. 9. $t$. 1. M o r a e a e 8 p. Thunb. Limu, t. 33. f. 2. Bot. Reg. t. 229. -? Wredowia Eek1. Verz. 16 .

1938. Witsemia THUNB. Perigoni$\mathbf{n m}$ corollinum superum $\mathbf{v}$, semisuperum, tubulosum, limbi sexfidi la $\mathrm{ein}$ i is aequalibus, patentibus v. conniventibus. Stamina 3 , perigonii fauci inserta, inclusa ; filamenta filiformia, hrevissima, a $\mathbf{n} \mathbf{t}$ e $\mathbf{r}$ a e sagitatae, basifixac. Ovarium inferum v. semiinferum, obsolete trigonum, triloculare. Ovula plurima, in loenJorum angulo eentrali biseriata, horizontalia, anatropa Stylus filiformis exsertus; stigma tridentatum v. brevissime trifidum. Capsula cartilaginea, ovato - trigona, trilocularis, loculicidotrivalvis. Se m i n a plurima, angulata.

Suffrutices capenses; radice tuberosa, cuudice erecto, lignescente, uncipiti, foliorum reliquiis cicatrisato, saepius supra basim stolonifero, foliorum ensatorum nervosorum coma disticha terminato, scapo herbaceo simplici $v$, paniculato, nunc corymboso, laxe folioso, interdum abbreviato subnullo, spathis diphyllis unifloris.

Witsen i a Thunb. nov, gen, $I T$, 34. Smith exot, Bot. t. 68. Redouté Liliac, t. 245. Bot. Mag. t.895. Bot, Reg. t.5. Ker Irid. gen. 1. - Nivenia Vent. Doc, nov, gen. n. 5. Gen Iisi a Reichenb. cansp, 60, non St. Hil. - Sophro. n la Lichtenst. in Röm, ef Schult. syst. $I$. 482, genitalibus exsertis, antheris incumbentibus (?) stigmatibus discretis, habitu et florum eolore a Witsenia diferre dicitur. - Ta- pe in ia Commers. ex Juss. gen, 59. quae Ixia pumila Forst, in Comment. gotting. IX. 20. $t$. 8. herba magellanica, bipollicaris, caule ancipiti, folis ut in Witsenia dispositis minibuis, floribus parvulis, solitaris, terminalibus, inter folia, quoram tria superiora spatharum aemula, sessilibus, perigonio tabuloso, limbo profunde sexpartito aequali, stigwate trifido, sui ut videtur generis, inquirenda.

1234. Pratergonia $R$. BR. Perigoniu m corollinum superum, hypocrateriforme, tubo longo gracili, limbi sexpartiti l a c i n iis interioribus minntis. Stamina 3 , perigonii fauei inserta; fil amenta in tubum brevem connata, a $n$ therae ovatae, loculis connectivum marginantibus. Ovarium inferum, prismaticum. Ovnla plurima, in Joculorum angulo centrali biseriata, adseendentia, anatropa. Stylus capillaris, apice saepins incrassatus; stig mata 3 , laminaeformia, subeucullato-convoluta, indivisa, C a p s ula memb anacea, prismatica, trilocularis, loculicidotrivalvis. Semina plurima, oblongo - angulata, testa coriacea, rugosa, rhaphe tenni $\mathrm{nmbi}$ li c um basilarem $c$ ha laz a e apicali incrassatae jungente. E mbryo axilis, a $1 \mathrm{~b}$ umine carnoso brevior, extremitate radiculari umbilicnm altingente, infera. - Herbae perennes, in oris apricis aridis Novae Hollandiae extratropicale provenientes; radice fibrosa, caule nunc nullo, nunc simplici abbreviato $v$, rarius ramoso, foliis anguste ensiformibus, compactis, scapo radicali $v$. caulem terminante simplici ebracteato, spatha communi bivalvi, partialibus pluribus inclusis, confertis, unifloris, floribus sensim erumpentibus speciosis, caeruleis, fugacissimis.

Paters on i a R. Brown prodr. 303. Bot. Mag. $t$. 1041. 2677. Bot. Reg. t.51. Ker Irid, gen. 14. Sweet Fl. austral. t. 15, 39. Ge nosiris Labill. Nov, Holl, t.9.

1235. Galaxia THUNB, Perigonium corollinum superum, infundibuliforme, tubo tereti gracili, limbi sexpartiti la cini is aequalibus, oblongo-cmeatis; exterioribus basi foveola nectarifera. Stamina 3 , perigonii fauci inserta; fil am enta in tubum brevem connata, anthe$r$ a e sagittatae, basifixae. Ova ri u m infernm, obtuse trigonum, triloculare. Ovula plurima, in loculorum angulo centrali biseriata, adscendentia, anatropa. Stylus filiformi-triqueter, clavatus ; stig mata 3 , lamellaria, convoluto - cucullata, fimbriata. Cap 8 ula membranacea, trisulco-trigona, trilocularis, locnlicido-trivalvis. Sem in a plurima, globosa. .. Herbae ca penses pusillae; rhisomate bulboso-tuberoso, in stipitem apice foliis floribusque onustum producto, folits terminalibus, bifariis, angustis, convolutis, plurimis, cxtimis brevioribus, spalhis univalvibus folio interstinctis, perigoniis mox involutis emarcescen. $t i$-persistentibus.

Galaxia Thumberg nov, gen. II, 50. c, ic. Cav, Dia sert. VI. t.189, f. ., 3. Jacq. collect. II, t. 18. f, s. It. rar, t.291. Audr. Bot. Reposit. 1.94. 164. Bot. Mag. t. 1292.

1236. Dolieda SPRENG. Perigonin m corollinum superum, infundibuliforme, tubo filiformi-triquetro, ad faucem constricto, limbi sexpartiti erecti $v$, patentis 1 a $\mathrm{c}$ i $\mathrm{n}$ i i s aequalibus. S ta m in a 3 , fauei perigonii inserta, ereeta $v$. subsecunda; fil amenta subulata, antherae oblongae, basifixae. Ora $\mathrm{ri}$ m inferum, triquetrum, triloculare. Orula plnrima, in loculorum angulo centrali hiseriata, adscendentia, anatropa. Stylus filiformis; stig in a ta 3 , anguste linearia, conduplicata, bipartita, lobis revolutis. $\mathrm{C}$ a s u la membranacea, trilobo - triquetra, trilocularis, loeulicido-trivalvis. S em in a plnrima, tripolyedra, - Herbae in Afriea auslrali indi- 
genae; rhizomate bulboso-tuberoso, caule ancipiti v. triquetro, simplici $v$. ramosissimo, foliis paucis $v$. plurimis collateralibus, gladiatis $v$. bifariis canaliculatis, nervosis, saepius rigidis et margine scabris, exterioribus plerumque falcatis, caulinis decurrentibus, sensim decrescentibus, florum spica. terminali solitaria, interdum in fasciculum contrac ta, spathis bivalvibus, herbaceis, saepius sphacelatis.

O vieda Spreng. syst. $I$. 147. Lapeyrousi a Pourret in Act. Academ. Tolos, III, 79. t.6. Ker in Annals of Bat. I. 238. Gen, Irid, 107. Bot, Mag, t, 595. 1246. Bot. Reg. t, 1903, Sweet Fl. gard. I, t. 143, IT. t. 39. non Thunb. P e y r ous i a Sweet Hort, Brit. 499. non DC. Me ris os tig ma Dietrich Willd. sp. $p l, n, 227$. I xiae, Gladioli et Gala$x$ i a e $\mathbf{s}$. Lian. Jacq. ic, rar, $t, 268,270,288,291$.

123\%. Anomatheca $K E R$. Perigoniu m corollinum superum, hypocrateriforme, tubo filiformi triquetro, ad faucem constricto, limbi sexpartiti 1 a e in i is oblongis, cuneatis, patentibus, tribus posticis approximatis. Stamina 3 , fauei perigonil inserta, subsecunda; fil amenta brevia, filiformia, a $\mathbf{n} \mathbf{h}$ e $\mathbf{r}$ a e oblongae basifixae. Ova ri um inferum, ovato-subglobosum, triloeulare. O v u 1 a plnrima, in loculorum angulo centrali biseriata, subhorizontalia, anatropa. Stylus filiformis; stigmata 3 , anguste linearia, complicata, bifida. Ca p sula ovato-subglobosa, papilloso - aspera, trilocularis, apice loculicidotrivalvis. Semina plurima, subglobosa.

Herbae c a penses; rhizomate bulboso-tuberoso, foliis bifariis ensatis, caule tereti subjunceo, paniculato-multifloro, floribus spicatis, subsecundis, spathis herbaceis brevibus diphyllis.

A nom atheca Ker. in Annal. of Bot, r. 2r\%. Gen. Irid, 111. Bot. Reg. t, 1369. A nom a a Laws, cat, 2. G 1 adi ol us junce us Linn. Jaeq, hort. schönbr. $t .491$,

1938. IBabiana KER. Perigonium corollinum superum, infundibuliforme, tubo brevi ad faucem dilatato, limbi sexpartiti regularis $v$. subbilabiati lacini is aequalibus. Stamina 3 , perigonii fauci inserta, erecta v. subsecunda; f i l a m e nt a subulata, antherae versatiles. Ova ri um inferum, ovatum, triloculare. OvuI a plurima, in loculorum angulo centrali biseriata, horizontalia, anatropa. Stylus filiformis; stigm a t a 3 , cuneato-ligularia, conduplicata, indivisa. Ca psula coriacea, subovata, triloeularis, loculieido - trivalvis. S em in a pauea, globosa, baccata. - Herbae capenses, humiles, ut plurimum villosae; rhizomate bulboso-tuberoso, foliis bifariis ensatis, plicato-nervosis, basi fistulosovaginantibus, caule simplici $v$. ramoso, spica laxa subsecunda, v. densa bifaria, spathae bivalvis valva interiore bipartita, floribus majusculis speciosis,

B abian Ker in Annal. of Bot. I, 231. Gen, Irid. 138. Bot. Mag, t, 410. 576. 583, 621, 626. 637,638.680, 1019. 1052, 1053. A cast e Salisb, msc, 1 xi a e 8 p. Linu. Jiteq
ie. rar, t. 233, 237. 253. 264. 284, 287.

1839. Gladiolus TOURNEF. Perigoni um corollinum superum, irregulare, tubo teretiuseulo, limbi sexpartiti bilabiati lacinits inaequalibus. Stamina 3 , perigonii tubo inserta, menta v. subsecunda, inelusa v. exserta; filamenta filiformia, anthera lineares, dorso supra basim affixae. Ovari um inferum, obtuse trigonum, triloculare. Oval a plurima, in loculorum angulo centrali pluriseriata, pendula, anatropa. Sty lus filiformis; st ig mata 3 , petaloideo - dilatata. C a p su I a membranacea, trilocularis, Loculicido-trivalvis. S e min a plurima, pendula, compresso-plana, alata, v. rarius globosa,
subbaceata, testa laxa v. carnosa, rh a p h e intra testam libera, valida. E m b r y o axilis, a 1 b u m i ne carnoso parum brevior, extremit ate radicul a ri umbilicum attingente, supera. - Herbae in $E$ u ropa media et in regione mediterranea rariores, in Capite Bonae ${ }^{s} p e i$ copiosae, multiformes; radice bulboso-tu. berosa, foliis distichis equitantibus, floribus in spica simplici secundis, saepius nutantibus, spatha bivalvi persislente.

Gladiolus Linu. gen. n. 57. Jaeq. ic. rar, $t, 233$. 242. 244. 248. 256. Sibthorp Fl, graec. $t$, 37. Bot. Mag. $t$. 86 , 135. 279. 450, 538, 556, 562.569.574.578.582,591.592,602.610. 625, 632, 677, 648 719, 727. 874. 992. 1042, 1483.1564.1585.1665. 2608. Nees jui. gen. pl. fasc. $V, t, 19$, H e b e a et Lemo. "I i a Pers. ench. $K$. 44. part. Ho mog los s um Salisb. mse. S ynotia Sweet Fl, gard. I, t.50, (Gladiolus galea. tus Jaeq. ic. rar. $t .258$.$) - Streptanthera Sweet$ Fl. gard. I. $t$. 209. Bot. Mag. $t$. 3519. Bertera Sweet hort. brit. 501. GI. seg et um Fl. graec. $t .38$. - $\mathrm{Au}_{\mathrm{u}}$ th ol y 2 a Liun. gen, n. s8. Ker Gen, Irid. 154, Redoute $L i$ liac. t. 110. 387. Bot. Mag. $t .361$. - C u a on i a Butta. de Cunon. Amst. 1750. An is a $t^{t h}$ us Sweet Hort. brit. 800 . A $n$th o l y a $\mathrm{C}$ a non ia Linn. Redouté Liliac, t.12. Bot.Mag. G 1 adiolus quadrangularis Ker. Bot. Mag. $t$. $56 \%$.

1240. Watsonia MILL. Perigon ii m corollinum superum, tubo brevi, ad faucem saepe plicato, limbi sexpartiti la cini is subaequalibus v, bilabiatis. St a m in a $\mathbf{3}$, infra faucem perigonii inserta, erecta $v$. subsecunda; filamenta subulata, antherae versatiles, Orari u $\mathbf{m}$ inferum, oblongo-teretiusculum, trilocnlare. Ovula plurima, in loculorum angulo centrali biseriata, pendula, anatropa. Stylus filiformis; stigmata 3 , linearia, conduplieata, bipartita, lobis filiformibus. C a psula cartilaginea, elongata, teretiuscula, trilocularis, apice loculieido-trivalvis. S e min a plurima, deorsum imbricata, polyedra, undique v. antice membranaceo-marginata. ..- Herbae c a pen ses; rhizomate bulboso - tuberoso saepius gummifero, foliis collateralibus angustissimis v. late ensatis, spicis laxis grandifloris, vel densissime minutifloris,
spathis bivalvibus rigidis.

Wat sonia Mill. ic. 276. t.294. f. 2. Ker in Annal. of Bot. I. 299. Gen. Irid. 122, Bot. Mag. t. 418.441.523.533. $537,553,600.601,608,631,1012,1193,1406,1530 .-$ M i cra ath us Pers. ench. $I$. 46. P hal ang i um Houttuyn syst, $I T$. et Ixia e Jaeq. hort, schönbr, $t, 6$, 13, Ir. t. 49. G I a di oli et $\mathrm{I} x$ la e Jacq. hort, schönbr, $t$. 6. 13. Ic. rar, t. 229_231. 44. 235. - ? Ne u beria Eekl. Verz. 37.

124. Sparaxis KER. Perigonin m corollinum superum, infundibuliforme, tubo brevi gracili, limbi ampli sexpartiti lacini is subaequalibus, stellato-patentibus. Sta m in a 3 , tubo perigonii inserta, adscendentia, inclusa; filamenta subulata, antherae lineares, dorso supra basim affixae. Ovarinm inferum, obtuse trigonum, triloculare. Oval a plurima, in loculorum angulo centrali biseriata. . S Sty-
l u s filiformis; st ig mata 3 , linearia, complicato-carinata, recurva. Ca p s u l a membranacea, obsolete trigona, subtorulosa, trilocularis, loculicido - trivalvis. Ś em in a plurima, subglobosa. . - Herbae c apenses; rhizomate bulboso-tuberoso, reticulato-tunicato, foliis ensatis nervosis, caule simplici v. paniculato, floribus spicatis, magnis, speciosis, intra spatham bivalvem membranaceam, aristato-laceram, plerumque spha-
celatam solitariis, sessilibus.

S parax is Ker in Annal. of Bot, $T$, 225. Gen. Irid. 19. Bot. Reg. t. 1361. Sweet Fl. gard. 131. - lxiae s p. 1942. VI Q intloretio $D C$. corollinum superum, subeam $D C$. Perigon i m 
losum, limbo sexfido regulari v. subbilabiato, 1 acin i is basi callosis. Stam in a 3 , infra faucem perigonii inserta, subsecunda; fil am ent a filiformia, antherae versatiles. Ovarium ovatum, teretiusculnm, triloculare. Ovu I a plurima, in loculorum angulo centrali biseriata... Sty lns filiformis; $8 \mathrm{tigmata} 3$, ligularia, angusta, complieata, integra v. breviter bifida. Ca psula coriacea, subclavata, trigibba, trilocnlaris, loculicido-trivalvis. Semina plurima, subglobosa.... - Herbae capenses; rhizomate bulboso - tuberoso, foliis collateralibus ensatis, caule junceo, tereti, gracili, simplici v. ramoso, floribus spicatis, saepius resupinatis.

Montbretia DC. in Bullet. soc, philomat. n. 89. Redouté Liliac, t. 53, Hexaglot ti s Vent. Dec. nov, gen, n. 3. Tritonia Ker in Annal, of Bot, $T$, 228. Waizir Reichenb. consp. 60. Ho ut t u y ni a Houtt. syst, Xrr. 408. t. 85. Freesa Eeklon Verz. 30. Bellen den i a Rafin. Gladioli sp. Jacq. Yc. rar. $t$, 24t. 261.267. 289. Ixi a e s p. Linn. Jaeq. Hort. schönbr, t, 24. -?

1243. Ixia $L I N N$. Perigonium corollinum superum, hypocrateriforme, tubo gracili, limbi sexpartiti patentis la ciniis aequalibus. Stamina 3 , fauei perigonii inserta; filamenta filiformia ablreviata, antherae versatiles. Ovariu $\mathrm{m}$ inferum, ovatum, trigonum, triloculare. Ovula plarima, in loculornm angulo centrali biseriata, horizontalia, anatropa. StyI us filiformis; stigmata 3 , anguste linearia, conduplicata, recurva. Ca p s u I a membranacea ovato-subglobosa, trigibba, trilocularis, loculicido - trivalvis. S e m i n a plurima, subglobosa. ... - Herbae capenses; rhizomate bulboso-tuberoso, foliis collateralibus ensatis, caule tereti gracili, simplici v. subramoso, floribus spicatis dissitis, majusculis, diutius persistentibus, spatha bivalvi cinctis.

Ixla Linn. gen, n. 56. excl. sp. Jacq. Hort. schönbr. 2. 18, 20.21. Ic. rar. t. 275, 278. Redonté Liliac, t, 86. 476. Andr. Bot. Reposit. t. 23, 155. 159. Bot. Mag, t, 128, 539. 542 . 589.599, 623.624.630.846, 1173. 1285, 1379. Ker Gen, Irid. 96. - ? M o r phixia Ker Gen. Irid. 105. H y alis Salisb. A x i a e s p. Jaeq. Ic, rar, t. 281, 282. Bot. Mag, t. 570.617. 1013.) Eurydiee Pers. ench. I. 48. Agretta Ecklon Verz. 23.

1244. Thisåa $D C$, Perigonium corollinum superum, sexpartitum, aequale, patens, la cin i is enspidatis. Stamin a 3 , imis laciniis inserta, subsecunda; fil am enta filiformia, antherae oblongae basifixae, conniventes. Ovari u m inferum, triloculare. Ovula.... Styl u s filiformis adscendens; $-s \mathrm{t} i \mathrm{gmat}$ a 3 , anguste linearia, conduplicata, recurva. Cap sula chartacea, turbinato-subglobosa, triloba. S emina pauca, subglobosa. ..- Herbae c apenses; rhizomate bulboso-tuberoso, foliis collateralibus ensatis, caule tereti paniculato, foliis infra ramos ternatis, floribus in rhacheos capillaris elasticae sinubus secundis, spathae bivalvis valvis divaricatis, extima disco herbacea, margine membranaweo cincta.

Di a sia DC. in Bullet, soc. philomat, n, 80. Redouté Liliac. $1.54,163$. A gla e a Pers. ench, T. 46. M elas $\mathrm{p}$ ha erula Ker in Annal, of Bot. t. 231. Gen. Irid, 157. P halang i um Burm. Cap. n, 3. Gladioll s p. Jaeq. ic. rar. t. 236 .

2245. II 4esperremtha KER. Perigonium corollinum superum, hypoerateriforme, limbi sexpartiti tubnm aequantis la $\mathrm{c}$ in i is aequalibus, patentibns. Sta mina 3 , tubo perigonii inserta; filamenta filiformia, antherae versatiles. Ovari um inferum, trilocnlare. Ovula in loculorum angulo centrali biseriata. ... Sty- lus filiformis; $s \mathrm{tigmata} 3$, elongata, anguste linearia, conduplicata, reclinata. Capsula trigona, torulosa. S e min a plurima, polyedra.

Herbae ca penses; rhizomate bulboso-tuberosa, foliis collateralibus ensatis, floribus laxe spicatis, vespere expansis odorem suavem exhalantibus, interdiu clausis inodoris, spathae bivalvis valva exteriore tubum perigonii aequante $v$. superante.

Hesperantlia Ker in Annal. of Bot. I. 225. Gen. Irid. 88. He s pera ut h us Salisb. msc. Ixiae sp. Jacq. ic. rar, t, 276, 279.280.

1246. Creigsonluiza KER. Perigonium corollinum superum, infundibuliforme, trbo brevi, limbi ampli sexpartiti la ciniis subaequalibus, basi poro nectarifero instructis, erectopatentibus. Stamina 3 , tubo perigonii inserta, suberecta, inelusa; fil amenta filiformia, a nthera e lineares, basifixae. Orari um inferum, obtuse trigonum, triloculare. Ovula plurima, in loculorum angulo centrali biseriata, subhorizontalia, anatropa, Stylus filiformis, declinatus; stigmata 3 , cuneato-linearia, conduplicata, margine subfimbriata. Capsula membranacea, prismatico-trigona, trilocularis, loculicidotrivalvis. S e min a plurima, minima. . . - Herbae in Capite bonae spei indigenae, etiam in Abyssinia reperlae; rhizomate bulboso-tuberoso, exuviis crustaceis $v$. scariosis deorsum imbricatis tunicato, foliis radicalibus paucis setaceis, lineari- v. lanceolato-ensatis, saepius nervosis, caule simplici v. ramoso, spica saepe flexuosa, secundiflora, floribus majusculis, singulis intra spatham bivalvem sessilibus.

Geis s orliziz Ker in Annal. of Bot, I. 224. Bot. Mag. t. 678. Gen. Irid. 83. I x i a e 8 p. Jacq. Ic. rar. $t .277$. -? Weihea Ecklon Verz. 22, Ixia exeis a Thunb. -? Spat al ant his Sweet Fl. Gard. $I . t, 300$.

18. 4. Troichomenan KER. Perigonia m corollinnm superum, infundibuliforme, tubo brevi, limbi sexpartiti I a $\mathrm{c}$ ni is aequalibus, patentibus. Stamina $\mathbf{3}$, tubo perigonii inserta; filamenta erecta, inclusa, anthera e oblongae, basifixae. Ovariu m inferum, obtuse trigonum, triloculare. Ovula plurima, in loculorum angulo centrali biseriata, adscendentia, anatropa. Stylus filiformis; stigmat a 3 , linearia, condaplicata, bipartita, laciniis brevibus, recurvis. C a psula menbranacea, giblıoso-subtriloba, trilocularis, loculicido-trivalvis. S e m in a plurima, adscendentia, angulato - subglobosa, testa coriacea, rhaphe valida solubili ad ehalaz am apicalem impressam procurrente. E mbryo axilis v. sublateralis, alb $\mathrm{nm}$ ine carnoso parum brevior, extremitate radiculari umbilieum attingente, infera. - Herbae pusillae, in region e mediterranea rarae, in Capite bonae spei copiosae; rhizomate bulboso-tuberoso, foliis angustis subtetraquetris, scapi teretis inter folia absconditi ramis exsertis, basi folio brevi stipatis, flore solitario, intra spatham bivalvem tubum perigonii velantem sessili terminatis.

Trich on e ma Ker in Annal, of Bot. I, 224. Gen, Irid, 79. Nees jun. gen. $p l$. fasc, $\nu$. $t$, 20 . R om u le a Maratti Dissert. Hom, 1772. $8 v 0$. I x i a s p. Sibth. Fl. graec, t, 36 . Jacq. Ic, rar. t, 270, 200.

1948. Croeus TOURNEF. Perigoniu $\mathrm{m}$ corollinum superum, infundibuliforme, tubo elongato, limbi sexpartiti la $\mathrm{cini}$ is interioribus paullo minoribus, erecto patentibus. Stamina 3 , fauci perigonii inserta, erecta, inclusa; $\mathrm{fil}$ amenta filiformia, antherae sagittatae basifixae. 0 va $\mathbf{r} \mathbf{i}$ in infernm, obtuse trigonum 
triloculare. Ovula plurima, in loculorum angulo centrali biseriata, adscendentia, anatropa. Stylus filiformis elongatus; $8 \mathrm{tigmata} 3$, dilatata, cuneata, carnosa, apicibus cucullata et dentienlata. C a p s u 1 a membranacea, trigona, trilocularis, loculicido - trivalvis. S em in a plu. rima, subglobosa, testa coriacea carnosula, ad umbilicum rugulosa, rhaphe tenui ad $e$ halaz a m apiealem excurrente. E m bryo axilis, a 1b $\mathbf{n m i n e}$ corneo multo brevior, extremitate radicnlari umbilicum spectante infera. - Herbae in Europa et Asia media et in regione mediterranea indigenae, acaules; foliis anguste linearibus, floribus radicalibus magnis speciosis, ovariis subhypogaeis, nonnullae ob peculiares stigmalum qualitates etiam cultae.

Crocin s Tournef, inst, $t, 183.184$. Linn. gen. n, s5. R. B. t. 343.344. 191, 2645. Bot. Mag. t, 45.652, 845, 860, 1110.1111. 1267. 1384, 2240. 2646.2655. Nees jun. gen, pl. fasc. V.t.21.

\section{Ordo HXII. Haensodoracene.}

HAEMODORACEAE R. Brown prodr, 299. Bartl. ord. nat. 43. Lindl. introduct, edit, II. 330 .

Herbae perennes, radicibus fasciculato fibrosis. Caules simplices v. subramosi, interdum abbreviati v. subnulli.

Foura alterna, plerumque disticha, integerrima, ensiformia, equitantia, basi vaginantia.

FLoREs hermaphroditi regulares, racemosi v. corymbosi, pedicellis continuis, bracteolatis.

Perigonium tubulosum, coloratum, extus saepissime rude, lanatum v. pilosum, intus glabrum, t ubo libero v. cum ovario plus minus connato, nunc supra ovarium producto, nunc statim expanso in limbum regulariter sexfidum, aequalem, erecto patentem, vel laciniis biseriatis interdum supra subsecundis antice fissum.

Stamisa 6, perigonii laciniis basi inserta, tria exterioribus opposita saepissime ananthera v. plane deficientia, interdum e fertilibus unum difforme. Fil a m ent a filiformia v. subulata, libera v. perigonii laciniis partim adnata, interdum easdem marginantia. Antherae introrsae biloculares, dorso v. basi affixae, loculi appositi, saepissime connectivo crassiusculo dorsali adnati, longitudinaliter dehiscentes.

Ovariux liberum v. cum perigonii tubo ejusve basi plus minus connatum, e carpidiis tribus, perigonii laciniis interioribus oppositis, marginibus introflexis dissepimenta axim attingentia constituentibus triloculare, rarissime dissepimentis incompletis uniloculare. Ovula in placentis e loculorum angulo centrali tumentibus solitaria, bina $v$. rarius indefinita, peltatim affixa, amphitropa, v. rarius anatropa. Stylus ovario continuus, simplex, basi interdum pyramidata cava stigma indivisum.
Capsula supera, perigonio stipata; v. infera saepius limbo persistente superata, trilocularis, apice v. juxta totam longitudinem loculicido-trivalvis, valvis septa auferentibus, v. columnam septiferam nudantibus, rarius nucamentacea indehiscens, unilocularis, monosperma.

Semra in loculis solitaria, bina $\mathbf{v}$, indefinita, peltatim v. basi affixa. Testa chartacea, durinscula, glabra v. pilosula. Al b um en cartilagineum durum.

Eмвкуо rectus, inclusus, albumine multo brevior, extremitate radiculari plerumque ab umbilico remota.

Haemodoraceae in America boreali, Africa australi extratropica, et in Nova Hollandia obviae, nullibi copiosae, I r i d e i s conterminae censentur. Vellosie a e Haemodoraceis arcte affines, ad calcem ordinis recensentur. Genera ovario libero donata, quamvis a reliquis nequaquam avellenda, denuo scrutanda sunt.

Radices nonnullarum rubro tingentes.

\section{* Stamina 3_6. Ovarium liberum.}

1245. THagenbaelnia NEES et MART. Perigonium membranaceum, glabrum, sexpartitum, laciniis exterioribus patulis, interioribus latioribus basi glanduloso-callosis, apice conniventibns. Antherae 3 , in marginibus laciniarum interiorum perigonii subsessiles, loculis appositis secedentibus. Ovari um liberum, trigonum, triloeulare. Ovula... Stylus filiformis; stigma simplex, incrassatum. Capsula subglobosa, trisulea, triloeularis. . . Semina in loculis 2, compressa. ... - Herba brasilien$s$ is; radice fasciculato-fibrosa, foliis radicalibus ensiformibus, elongatis, laxis, scapo triquetro, virgate ramoso, floribus fasciculatis, fasciculis basi unibracteatis, pedicellis brevibus, basi bracteolatis, medio articulatis. - Genus non satis notum, huc ex auctorum sententia collocatum, Asphodeleis fortassis magis affine. t. 2 .

Hagenbachia Nees et Martius N. A. N. C. XI. 18.

1250. Xiplatioum $A U B L$. Perigoniu m covollinum, hexaphyllum, foliolis patentibus, exterioribus dorso puberulis, interiorib u s paullo minoribus glabris. Stamina 3 , hypogyna, perigonii foliolis interioribus opposita; fiIamenta filiformia, antherae basifixae. Ovari $\mathbf{~ m ~ l i b e r u m , ~ t r i g o n n m , ~ t r i l o c u l a r e . ~} 0 \times \mathbf{u l a}$ in placentis e loculorum angulo centrali tumentibus plnrima, amphitropa. Stylus filiformis; stigma capitato - trilobum. Capsula snbglobosa, carno8o-mollis, trilocularis. . . Semina plurima, subglobosa...- Herba perennis, in $A m$ e r $i$ c a tropica cis aequatorem obvia; radice fibrosa, caule simplici hirsutiusculo, basi folioso, foliis ensiformibus equitantibus, acuminatis, integerrimis $v$. subserrulatis, floribus paniculatis, subsecundis, nutantibus.

X i p h id it in Loffl. it. 179. Aubl, guian, $t$, 11. Swartz Fl. Trd. accid. I, 19, t. \&, 
1251. Wnehendiorfia BURM. Perigo ni um corollinum, extus rude, sexpartitum, laciniis patentibus tribus, superioribus magis approximatis, exterioribus basi subsaceatis, postica extima in calear saepe pedicello adnatum producta. Stamina 6, imo perigonio inserta, tria perigonii laciniis exterioribus opposita sterilia v. interdum dificientia; filamenta filiformia, adscendentia, divaricata, antherae incumbentes. Ovarium liberum, acute trigonum, triloculare. Ovula in placentis e loculorum angulo centrali tumentibus solitaria, anatropa (?) S tylus filifor mis adscendens; stigma simplex. Capsu la chartacea, turbinata, acute triquetra, trilocularis, loculicido - trivalvis. S e m i $\mathrm{n}$ a in loculis solitaria, compressiuscula, peltata, basi attenuata, t e sta membranacea alata, paleaceo-hirta. $\mathbf{E}$ m b r y o minimus, in basi a l b $\mathbf{n} \mathrm{m}$ in is farinosi inclusus, extremitate radiculari infera. - Herbae ca. penses; radice tuberosa trinacata, foliis radicalibus basi vaginantibus, plicato-nervosis, caulinis squamaeformibus sphacelatis, caule tereti, pubescente, saepius cavo, apice paniculato-ramoso racemoso-multifloro, pedicellis bractea subspathacea suf. fultis, perigoniis post anthesim spiraliter contortis, sero deciduis.

Wachendorfia Burm. Wachendorfa, Amst. 1757. fol. Linn. gen, n. 61. Juss, gen. 59. Gârtu. I. 32, t. 15. Redouté Liliac. t, 92.93. Bot. Mag. t. 614.616, 1060 1166, 2610. Pedil on i a Presl Monograph. Pragae 1830. 4to.c.ic. (coll. Tausch in Flora 1830. p. 556.) - Wa che a dorfia orinocensis Kunth in $T u m b$. et Bonpl. nov. gen. et sp. $t$. 698. perigonio basi aequali, antheris basifixis, et ovarii loculis multiovulatis a speciebus capensibus diversa, distincti generis, fortassis inter Xiphidium et Waehendorfiam intermedii, typus.

1252. Hophiola KER. Perigonium corollinum, extus lanatum, sexfidum, $t$ u bo brevi tereti, limbi refracto patentis laciniis tribus interioribus disco barbatis. Stamina 6 , imo perigonio inserta; filamenta filiformia, antherae basifixae. Ovarium liberum, ovato-pyramidalum, triloculare. Ovula in placentis e loculorum angulo centrali tumentibus plurima, biseriata.... Stylus subulatus tripartibilis; stigma simplex, Capsula basi cum perigonii tubo connata, triquetra, trilocularis, apice loculicido-trivalvis. Semina plurima, oblongo-subeylindriea, basi inserta, striata....- Herba boreali americana; radice repente, foliis radicalibus distichis, lineari-ensatis, pube rara adspersis, caulinis paucis squamaeformibus, caule tereti stricto, lanato, apice paniculato, floribus cymosis subsecundis, pube simplici.

Lophiola Ker in Bot. Mag, t, 1596. C onostylis a ure a Pursh Fl. Bor. Amer. $t .7$.

\section{** Stamina 3. Ovarium inferum. Se- m in a definita, peltata.}

1953. IIIaemodorum SMITH. Perigonium corollinum glabrum, tubo cum ovarii basi connato, $\mathrm{limbi}$ superi sexpartiti laciniis angustis, persistentilus. Stam ina 3 , perigonii laciniis interioribus basi inserta; fil amenta subulata, antherae loculis connectivo antice adnatis. Ovari um basi cum perigonii tubo connatum, orbiculato-depressiusculum, obsolete trilobum, triloculare. Ovula in placentis e loculorum angulo centrali exsertis fungoso-subglobosis bina, peltata, amphitropa (?) Stylus filiformis; stigma simplex. Ca p sula semisupera, triloba, trilocularis, loculicido-trivalvis. Semina in loculis bina, compressa, marginata; test a membranacea, umbilico ventrali peltatim affixa. $\mathbf{E} \mathbf{m b r y}$ o minimus, in basi albuminis carnosi, extremitate radiculari infera. - Herbae a ustral as $i$ c a $e$ perennes, glabrae; radice e tuberibus fasciculatis, fusiformibus, coccincis, caulibus simplicibus foliatis, foliis aversis, planis $v$. teretiusculis, basi semivaginantibus, floribus corymbosis $v$, ramis spicatis. H a e modo rum Smith in Linn. Transact, IV. 213, R. Brown prodr. 300. Bot. Mag. $t .1610$.

1254. Dilatris BERG. Perig on ium corollinum extus hirsutum, $t \mathbf{u}$ b o cum ovario connato, limbi superi sexpartiti laciniis erectis, persistentibus. Stamina 6 , perigonii laciniis basi inserta, tribus sterilibus minimis, fertilium uno filamento breviori, anthera maxima difformi. Orarium cum perigonii tubo connatum, triloculare. Ovula in loculis solitaria, placentae coIumnaris triquetrae faciebus inserta, peltata, amphitropa. Stylus filiformis; stigma simplex. Capsula infera, subgloboso-trigona, trilocularis, loculicido-trivalvis, valvis placentam columnarem nudantibus. Semina in loculis solitaria, plano compressa, t e s ta membranacea, u mbilic o ventrali peltatim affixa. E mbryo minimus, in basi albuminis carnosi, extremitate radiculari infera. - Herbae capenses, interdum suffrutescentes; radicibus fibrosis, rubris, foliis radicalibus ensiformibus basi vaginantibus, floribus corymbosis. - Genus Wachendorfiae affine, olim dividendum.

Dilatris Bergius Flor. cap. 9. t.3.f.s. Linn. suppl. 10. Lam. $t, 34$. Gärta. f. IIY. 11, $t, 182$. Smith exot. Bot. t. 18.

1255. Hachmanthes ELLIOT. Perigonium corollinum extus lanatum, tubo basi cum ovario connato, $1 \mathrm{imbi}$ superi sexpartiti laciniis erectis, persistentibus. Stamina 3 , perigonii laciniis interioribus inserta, subaequalia; filamenta filiformia, exserta, antherae lineares, versatiles. Ov a ri n m cum perigonii tubo connatum, triloculare. Ovula in placentis subglobosis e loculorum angulo centrali tumentibus pauca (6-7), peltata, amphitropa. Stylns filiformis declinatus; stig ma brevissime trifidum. Capsula infera, subgloboso-trigona, trilocularis, loculicido - trivalvis, valvis placentas auferentibus. S e min a rotundato-compressa, peltata. ... Herbae boreali americanae; radice fibro$\overline{s a}$, rubra, caule erecto simplici lanato, foliis alternis ensiformibus basi vaginantibus, floribus paniculato-corymbosis.

Laehnanthes Elliott Carolin. . 47. Heritiera Gmel. syst. 113. Redouté Liliac. t. 247. Michaux Fl. Bor. Amer, , 4. G y rot he ca Salisb, msc. Dil at ris s p. Pers. Nutt. St amina 6. Ovarium inferum. $\mathrm{S} \mathrm{e}-$ min a indefinita.

1256. Lamaria THUNB. Perigoni$\mathrm{um}$ corollinum extus plumoso - lanatum, t $\mathrm{ubo}$ basi cum ovario connato, limbi superi sexpartiti laciniis patentibus, persistentibus. Stamina 6 , perigonii laciniis basi inserta; fil am enta filiformia, antherae basi emarginatae, versatiles. Ovarium cum perigonii tubo connatum, triloculare. Ovula. ... Stylus filiformis; stigma brevissime bi-trifidum. Capsula infera, trilocalaris. ... S e mina in toculis 2_3. . . . Herba capensis; radice fibrosa, fibris crassis fasciculatis, foliis radicalibus ensiformibus canaliculatis, 
nervosis, caulinis abbreviatis basi semivaginantibus, caule simplici $v$. corymbose ramoso, florum panicula terminali decomposita densa, plumoso-lanata.

L a naria Thubb. prodr. 63. Argolasia Juss. gen. 60. Lam. $t .34$. A u ge a Retz obs. $V .3$.

125\%. Anigosanthus LABILL. Perigonium corollinum extus lanatum, t $\mathbf{u}$ b o basi cum ovario connato, elongato, tandem deciduo, Iimbi sexfidi laciniis subaequalibus supra secundis. Stamina 6, fauci perigonii inserta, adscendentia; filamenta filiformia, antherae loculis connectivo antice adnatis. Ovarium cum perigonii tubo connatum, triloculare. Ovula in placentis e loculorum angulo centrali prominentibus plurima. ... Stylus fliformis; stigma simplex. C a p s n I a infera, subglobosa, trilocularis, apice loculicido-trivalvis. Semina plurima.

Herbae perennes, in Novae Hollandiac ora meridionali indigenae; radicibus e fibris crassis fasciculatis, caule simplici $v$, apice ramoso, piloso. lanato, foliis ensiformibus aversis, basi semivaginantibus, floribus magnis, speciosis, subcorymbosis, e spicis brevibus, bracteis suboppositifloris, perigoniis extus lanatis, pilis ramulosis coloratis.

Anigos anthus Labill. voy. 1. 411, t.22. Nov. Holl. IT. 119. Redonté Litiac. $t, 176$. Bot. Mag. $t, 1151$. Salisb. parad. 1.97. R. Brown prodr. 301. Sweet Fl. gard. II. $t$. 265. Anigozia Salisb, mse. Anoegosanth us Reichen. bach consp. 60 . S $\mathrm{chwäg}$ ri cluen i a Sprengel syst. II. 26 .

1258. Comostylis R. BR. Perigon iu m coloratum, extus piloso-lanatum, tubo cum ovario connato, limbi superi subcampanulati sexfidi laciniis erectis, persistentibus. Stamina 6 , imis perigonii laciniis inserta; filamenta brevissima, antherae loculis connectivo antice adnatis. Ovarium inferum, triloculare. Ovula in placentis subglohosis e loculorum angulo centrali prominentibus plurima. .... Stylus conico-dilatatus, cavus; 8 ti gma simplex. Capsula infera, stylo eavo tripartibili coronata, trilocularis, apice locnlicido-trivalvis, valvis a columna centrali placentifera solutis. Semina plurima... Herbae perennes, in Nova Hollandiae ora meridionali indigenae; radice fasciculato - fibrosa, foliis radicalibus distichis, aversis, ensiformibus, basi semivaginantibus, equituntibus, floribus scapum saepius simplicem terminantibus capitatis, corymbosis $v$. subspicatis.

Conostylis R. Brown prodr. 300. Bot. Mag. t. 2989. A. Richard Sert. Astrolab. t.28.

1259. Aletris LINN. Perigonium coloratum, extus bullato-lepidotum, tubo cum ovarii basi connato, limbi semisuperi infundibuliformis sexfidi laciniis erectis, persistentibus. Stamina 6, imis perigonii laciniis inserta; filamenta camplanato-subulata, antherae subsagittatae, adnatae. Ovarium basi cum perigonii tubo connatum, triloculare. Ovula in placentis subglobosis e loculorum angulo centrali prominentibus plurima.... St y $1 \mathrm{i}$ tres filiformes, basi distincti, apice stig m a t e simplici connexi. Capsula semiinfera, trilocularis, trieocca, coceis placentas auferentibus. Semina plurima, minutissima, areuata, striata. . - Herbae perennes, boreali-americanae; radice fibrosa, foliis radicalibus distichis aversis, subensiformibus, basi vaginantibus, caule simplici, racemo terminali spicato. - Genus non satis mihi notum, an revera hujus loci?

Aletris Lim. gen, $n$. 428, Ker in Bot, Mag. $t, 1610$. Bigelow Fl. Bor, Amer, 6. 30 .
**** Stamina 6 . O v a $\mathrm{ri} u \mathrm{~m}$ inferum. Nux monosperma.

1960. Hinlelboearya $R$, BR. Perigo nium imberbe, tubo cum ovario connato, limbo supero sexpartito persistente. Stamina 6 , basi laciniarum perigonii inserta; antherae tetragonae, subsessiles. Ovarium cum perigonii tubo connatum, uniloculare. Ovula 3. St y lus filiformis; stigma simplex. Nux corticata, peri gonio coronata, monosperma. ... - Herba in Novae Hollandiae ora meridionali reperta, perennis, subacaulis; foliis distichis, equitantibus, angusto-ensiformibus, ciliatis, panicula subsessili foliis breviore, floribus parvis, inbricatis.

Phleboearya R. Browa prodr. 301.

***** VELLOZIEAE D, Don in Edinb. $\boldsymbol{n}$. philosoph, Journ, 1830.1 . 164.

St a min a $6 \mathrm{v}$. indefinita, disco perigonii limbum basi vestientem inserta; fil amenta simplicia v. apice tridentata, dente medio antherifero. Ovari u m inferum, triloculare, dissepimentis e carpidiorum marginibus introflexis duplicatis, angulo centrali utrinque in placentam tumentibus. O $\mathrm{v}$ u l a plurima, horizontalia semianatropa. Cap sula apice incomplete loculicido-trivalvis, valvis septa et placentas auferentibus. S e min a plurima, cuneata, tes ta coriacea, $\mathbf{n} \mathrm{m}$ bilic o basilari incrassato, ope rhaphis filiformis chaI azae laterali impressae conjuncto. $\mathbf{E} \mathrm{m}$ b r y o axilis, rhaphi parallelus, albumine carnoso multo brevior, extremitate radiculari umbilicum attingente, in fructu centripeta. _ Caudices saepissime arborei, dichotome ramosi, foliorum rudimentis vestiti, apice foliosi. In Brasilia e montibus primaevis inter 10 $23^{\circ} \mathrm{L}$. A. magna copia, rarissime in Madayascaria et in insula Franciae repertae.

1261. IBarbacenia $V A N D$. Perigonium corollinum infundibuliforme, extus piloso - resinosum, tubo basi cum ovario connato, $1 \mathrm{imbi}$ sexfidi laciniis aequalibus, erecto-patentibus. Stamina 6 , imis limbi laciniis inserta, ereeta, inclusa; filamenta plano-compressa, apice tridentata, dente medio minore antherifero, anthera e lineares, medio dorso v. prope basim affixae. 0 varium inferum, triloculare. Ovula in placentis e loculorum angulo centrali exsertis plurima. ... Stylus triqueter, tripartibilis; stigma capitato-trigonum. Capsula infera, subtrigona, trilocularis, loculicido-trivalvis, ralvis medio septigeris, placentas auferentibus. Semina plurima, angulata. - Herbae perennes, in Brasilia inter $14^{\circ}$ et $23^{\circ} \mathrm{L}$. A. in siccis apricis montium primaevorum obviae; caudice simplici vel dichotome ramoso, brevissimo $v$, bi-tripedali, foliorum exuviis dense tunicato, foliis spiraliter dispositis terminalibus semiamplexicaulibus, erecto-patentibus, angustis, acutis, carinatis, duriusculis, basi succo viscoso - resinoso conglutinatis, pedunculis s. scapis inter folia solitariis $v$. pluribus, unifloris, teretiusculis $v$. trigonis, apicem versus pilis resiniferis $v$. glandulis clavatis obsessis, rarius simpliciter pubescentibus v. glabriusculis, floribus magnis, extus 
in scapi modum vestitis, pulcherrime viridibus, rubris $v$. Jlavis, intus glabris, saepe discoloribus.

$\mathrm{B}$ a r b a ce n i a Vandelli in Römer script, 98, t, 6. f.9. Martius nov. gen. et sp. I. 18. t. 10_14. Bot. Mag. t. 27z7. $V$ is nea Steud.

1262. Vellosia MART. Perigonium corollinum, tubo rudi cum ovario connato, limbi glabri hexaphyllo-partiti campannlati foliolis aequalibus. Stamina imis limbi foliolis inserta, nune 6 libera, nune indefinita, in phalanges plures nudas, $\mathbf{v}$. basi squamula anctas coalita; filamenta filiformia brevia, antherae lineares, basi emarginata insertae. Ovarium inferum, triloculare. Ovula in placentis e loculorum angulo centrali exsertis plurima, horizontalia, semianatropa. Stylus triqueter, tripartibilis; stigma capitato-trigonum. Capsula subglobosa, slavata v. trigona, trilocularis, loculicido - trivalvis, valvis medio septigeris, dissepimenta auferentibus. Semin a plurima, horizontalia, cuneata, testa coriacea, umbilico basilari incrassato, ope rhaphis filiformis $\mathbf{c h a l a}$ zae laterali impressae conjuncto. Embryo axilis, rhaphi parallelus, al bumine carnoso multo brevior, extremitate radiculari nmbilicum attingente, in fructu centripeta - Plantae in Madagascaria rarissimae, in Brasilia, ubi in apricis siccis montium adamantiferorum abundantius proveniunt, regioni characterem peculiarem impertientes, caudicibus foliorum exuvis exaridis tunicatis, plerumque erectis, dichotome ramosis, et ramis erecto-patentibus, subdichotomis apice foliiferis, foliis spiraliter $v$. trifariam dispositis, rarius alternatim distichis, linearibus $v$. lineari-lanceolatis, rarius acerosis, rigidis, serrulatis $v$. integerrimis, carinatis, erecto-patentibus, basi succo resinoso-viscoso conglutinatis, floribus solitariis nunc in ramorum innovatione sessilibus, nunc in scapis terminalibus versus apicem saepius hispidulis, floribus albis, caeruleis $v$. violaceis magnis, erectis aut rarius nutantibus, perigonii tubo saepius pilis densis hispido, tandem echinato, rarius scabriusculo v. glabro, nitido.

$\mathrm{V}$ e 11 o s i a Martins nov. gen. et sp. $T$. 13. Pohl pl. Brasil. $\boldsymbol{T}$. 20.

a) XEROPHYTA Commers. Stamina 6. - Brasilien. ses et Madagascaricae.

$\mathrm{X}$ e r o p hyta Commers. in Juss. gen, so. Schult. f. syst, DIt. 289. Vello siae sp. Mart. op cit, t. 6. g. Pohl op. cit. $t .94 .97$.

b) VELLOSIA Vand. Stam in a $12,15,18,24$, in phalanges tres v, sex, nudas v. basi squamula auctas coalita. - Brasilienses.

Vellosia Vandelli in Römer script. 112. Milan deleot, II. $t$. \&. Martíus op. cit, t, 7.8. Pobl op. cit, t.93.95. 96.98_100. C a mpde ri a A. Richard in Bullet, soc, philomat. 1822. p. 79. $\mathrm{R}$ a d $\mathrm{i}$ a A. Richard in Kunth synops. I. 360 .

\section{Ordo IXIII. Hypoxídeae.}

HXPOXIDEAR R. Brown in Flinders Voyage $I I, 587$, Bartl. ord. nat. 43. Lindl, introduct, edit. $I$, 257 .

Herbae perennes, scapigerae, radice tnberosa v. fibrosa. Folia omnia radicalia, linearia, integerrima, plicata. Sc api simplices v. apice ramosi, teretiusculi, quandoque abbreviati subnulli.

Flokes hermaphroditi v. rarissime abortu polygami, regulares, nunc radicales sessiles, nunc in scapo elevati, solitarii, fasciculati v. paniculati, uni-bibracteati.
Perigonidm corollinum, $t u$ bo cum ovario connato, limbi superi sexpartiti patentis v. decidui laciniis biseriatis, exterioribus saepe rudioribus.

Stamixa 6 , basi laciniarum limbi inserta. Fil amenta libera. Antherae introrsae, biloculares, erectae; l o culi suboppositi, paralleli, basi sagittatim divergentes, longitudinaliter dehiscentes.

Ovarium cum perigonii tubo connatum, triloculare, loculis perigonii laciniis exterioribus oppositis. O vula loculorum angulo centrali affixa, plurima, bi-pluriseriata, amphitropa. Stylus terminalis, simplex. Stigmat a 3 , distincta v. styli angulis adnata.

Fructus indehiscens, siccus v. baccatus, tri-v. abortu uni-bilocularis.

Semrsa plurima, subrotunda; testa crustacea, atra, u mbilico laterali rostelliformi, ab endopleura tenui membranacea solubilis. Albumen molle, carnosum.

Eмввуо rectus, axilis, albuminis fere Iongitudine; extremitate radiculari ab umbilico remota, supera.

Hy p oxid ea e nullibi copiosae, in Africa australi et Nova Hollandia extratropica, in India orientali, in America boreali et tropica repertae fuerunt.

o r d o seminum fabrica ab Amaryllide is, ab Haemodoraceis etiam carpidiorum situ diversus, ab As phodeleis, quibus testae indole et habitu accedit, umbilici processu laterali et ovario cum perigonii tubo connato facillime distinguitur.

1263. Curenligo GAERTN. Perigonium corollinum, tubo basi ventricoso cum ovario, apice filiformi eum stylo connato persistente, li mbo sexpartito, plano, deciduo. Stamina 6, limbi laciniis demissius inserta. Ovarium inferum, triloculare. Ovula plurima, bi-pluriseriata, amphitropa. Styl n 8 basi cum perigonii tubo connatus, apice liber. Stigmata 3 , angnlis styli adnata, rarius distincta. Bac ea perigonii tubo apiculata, abortu uni-bilocularis. Semina pauca, strophiolis carnosis pulposis distincta, umbilico laterali rostelliformi. - Herbae pererenes, in Africa australi extratropica, in Nova Hollandia tropica et in India orientali indigenae; radicibus tuberosis, carnosis, foliis omnibus radicalibus ensiformibus, floribus radicalibus aut in scapo simplici fasciculatis $v$, subspicatis, spatha membranacea monophylla convoluta exceptis.

Curculigo Gärtn. I. 63. t. 16. Roxb, corom, t. 13, R. Browu prodr. 289. Labill. Nov, Caled, $t, 24$. Bot. Mag. 2. 1076. Bot. Reg.t.345.754.770. For b e s i a Ecklon Verz. 4. Molin eria Colla hort, ripul, opp. IJ, 333, t. 18. Pabriclae Thunb, in Fabric, it. Norveg. 29, Hypoxidis $\mathrm{s}$. Linn. Ge th y llidis s p. Jaeq. hort. schönbr. t. 80 . Genus verisimiliter olim, fruetus et seminis fabrica in pluribus speciebus explorata, dividendum. Species nna oapen. sis (Forbesia Eckl.) a speeíebus quinque indicis et dua. bus australasiaticis huedum indieatis, corollae tabo Iongis. simo potissimua differre videtur. 
1264. Wypoxis LINN. Perigoninm corollinum, tubo cum ovario connato, $l i m b o$ sexpartito plano persistente. Stamina 6 , limbi laciniis mediante disco epigyno inserta. Ovarium inferum, triloculare. Ovula plurima, biseriata, amphitropa. Stylus liber; stigmata 3 , angulis styli adnata, rarius distincta. Capsula limbo emarcido coronata, trilocularis, evalvis. Semina plurima; umbilico laterali rostelliformi. - Herbae perennes, habitu Curculiginis, floribus spatha bivalvi, bracteaeformi $v$, subglumacea exceptis. E speciebus circiter quinquaginta, olim fructu in omnibus rite examinato in sectiones $v$. genera distribuendis, plurimae capenses sunt, paucae americanae et australasiaticae, indica vix genuina.

H y pox is Limn. gen. 417. exel. sp. Gärtn. I. 33, t. 11. R. Brawn prodr. 288. Jacq. ic, rar, t, 367-372. Smith spicileg. t.16. Labill. Nov. Holl. t, 108. Redonté Liliac, t. 170. Barton Fl, Am. bor. t. 35. Andr. Bot, Reposit. t, 171, 195. Bot, Mag. t. 662.709_711. 1223. Bot. Reg. t. 169. 663. F a. briciae s p. Thunb. in Fabric, it. Norveg. 29. Ni ob a a et Coela nt hus Willd, Reliq.ex Schult,syst. VII. XLVI, et 762 .

\section{Drdo LXIV. Amaryitideae.}

NARCISSORUM sectio II. Juss. gen. 54. NARC1SSEAE Agardh Aphorism. 173. AMARYLLIDEAE R. Brown prodr. 296. Bartl, ord, nat. 45. Lindl, introduct, edit, II. 328, excl. sect. 1 .

Herbaf perennes, bulbosae, scapigerae, rarissime radicibus fasciculatis caulescentes. Folia radicalia simplicia, integerrima, linearia, amplexicauli-vaginantia, striata. Scapus nudus, teres v. angulosus, solidus $\mathbf{v}$. fistulosus.

FLones hermaphroditi, regulares v. irregulares, solitarii v. umbellati, plerumque magni, speciosi, bracteis spathaceis inclusi.

Perigoniux corollinum epigynum, deciduum v. marcescenti-persistens, hexaphyllum, v. infundibuliformi - tubulosum, limbi sexpartiti regularis $v$. ringentis laciniis biseriatis, exterioribus imbricatis, interiores saepius dissimiles obtegentibus.

Stramra disco epigyno imposita, $v$. perigonii tubo faucive inserta, ejusdem laciniis numero aequalia et opposita, nunc plura rarissime fertilia, saepius sterilia in coronam perigonii fauci impositam connata. Fil a m e nta libera $v$. basi dilatata inter se connata, erecta aequalia, v. declinata inaequalia. A ntherae introrsae, biloculares, oblongae $v$. lineares, basi v. medio affixae, erectae v. plerumque incumbentes, loculi oppositi contigui, v. rarissime connectivo antice adnati, interdum septo secundario bilocellati, juxta totam longitudinem $\mathbf{v}$. apice dehiscentes.

Ovarium inferum triloculare, v. rarissime septis incompletis uniloculare; loculi perigonii laciniis exterioribus oppositi. O vula plurima, in loculorum angulo centrali biseriata, interdum definita, in ovario uniloculari parietalia, ut plurimum horizontalia, nunc pendula $v$. rarius adscendentia, semper anatropa. Stylus terminalis simplex, erectus $v$. declinatus. Stig $m$ a trilobum $v$, indivisum.

Fructus plerumque capsularis, trilocularis, loculicido-trivalvis, valvis medio septigeris, polyspermis, nunc abortu uni-bilocularis, oligo- v. monospermus, rariusve b a cc at us.

Semina horizontalia v. pendula, aut rarissime adscendentia, globosa v. compressa aut angulata, saepius abortiva, bulbiformia. T es $t$ a tenuis membranacea, saepius in marginem v. alam producta, nunc erassa, carnosa, nigra, lusca v. badio variegata, u mbili c o basilari ope rhaphis immersae v. saepius carnosae cum $\mathrm{chal}$ a a apicali conjunctus.

Eurroxo axilis, rectiusculus, alb umine plerumque multo brevior, extremitate radi cu l a ri umbilicum attingente.

A maryllideae in regionibus tropico circulo inclusis copiosissimae, universim in hemisphaera orientali frequentius (specierum omnium fere $2 / 3$ ) habitant. Am arylleae, quo nomine genera perigonio simplici nec coronato donata in unum colligimus, in $\mathrm{E}$ uropa a ustrali et media rarissimae, candidae veris nuntiae, per Africam a ustralem extratropicam et Americam tropi a m ac meridionalem pari fere copia, (utroque loco specierum fere $1 / 3$ ) superbiunt, Adonistarum deliciae; pareissime in Nova Hollandia, Africa tropica et Americ a b oreali gignuntur. Na reis s e e (perigonio coronato donatae) in E u ropa media et per regionem mediterraneam magno numero luxuriant (specierum omnium $3 / 4$ ), in A m e r ic a utraque minus copiosae, in India or $\mathrm{i}$ e ntali et Austral a sia rarissimae, ex Africa trans cancrum plane exules. Genera plurima endemica, e uropaea, capensia, a mericana, a ustralasica, nonnulla tamen late per littora vulgata. Species nimis a scriptoribus multiplicatae, ob foecundam hybridarum sobolem dificillime extricantur.

B u I b i plurimarum specierum qualitate pollent acri, amaricante et emetica, nonnulli insigniter venenati Africae meridionalis autochtonibus perniciosa largiuntur tela.

A maryllideae Haemodoraceis Irideisque proxime affines, ab his v. staminum numero et antherarum directione, ab illis perigonii aestivatione, albuminis indole et embryonis directione facillime distinguntur.

AMARYLLEAE. Stamin a sterilia nulla. Scapigerae. Radix bulbosa.

1265. Galanthus LINN, Perigonium corollinum superum, hexaphyllum, campanula- 
tum, foliolis exterioribus coneavis, semipatentibus, interioribus brevioribns, erectis, cuneifornibus, emarginatis. Stamina 6 , disco epigyno inserta; fil amenta brevissima, antherae erectae, convergentes, subtetragonae, apice in setam productae, ibidem dehiscentes. Ovarinm inferum, triloculare. Ovala plurima, in loculorum angulo centrali biseriata, horizontalia, anatropa. Stylus rectus, filiformis; $s \mathrm{tigma}$ simplex, acutum. Capsula carnosa, demum loculicido-trivalvis. Semin a plurima, subglobosa, test a membranacea, rhaphe carnosa umbilicum basilarem $c$ hal a z a e terminali jungente. Embryo minimus, in basi albuminis carnosi, extremit te radiculari umbilicum attingente. - Herbae in Europa media et australi, nec non in Asia ca ucas ic a nive deliquescente florentes; bulbo radicali ovali, acri, foliis radicalibus paucis, linearibus carinatis $v$. lanceolatis margine plicatis, basi vaginatis, scapo compressiusculo subuniftoro, spatha monophylla, latere plano fissa, flore pedunculato candido, capsula maturescente scapum prosternente, sub terra dehiscente.

Ga l a $n$th u s Limn. gen, n, 401, Jacq. Fl. austr. $t, 313$. Schkuhr t.89. Hook. Fl, Land, t. 14. Redouté Liliac. $t .200$. Bot. Reg. $t .545$. Bot. Mag, $t$. 2162. Nees jun. gen. pl. fasc. $V T, t, 3$. Er a ngelfa Renealm. spic, $t .96$.

1266. Heveojum $L I N N$. Perigonium corollinum superum, hexaphyllum, campanulatum, foliolis subaequalibns, ovatis, basi coalitis, apice incrassatis. Sta mina 6 , disco epigyno inserta; filamenta brevia, antherae erectae, tetragonae, ab apice juxta totam longitudinem dehiscentes. Ovari u m inferum, triloculare. Ovula plurima, in loculorum angulo centrali biseriata, horizontalia, anatropa. Stylns rectus, clavatus v. rarius filiformis; stigma simplex. C apsula carnosa, demum loculicido-trivalvis. Semin a pauea, globosa, testa crustacea atra, laxiuseula, rhaphe vix manifesta. Embryo axilis, dimidii albuminis longitudine, extremitate radiculari nmbilieum attingente. - Herbae in Europa media et in regione mediterranea indigenae; bulbo radicali globoso, tunicato, foliis lato-linearibus v. filiformibus, scapo angulato solido $v$. fistuloso, spatha monophylla, oblonga, compressa, latere plano fissa, multiflora, floribus albis.

L e u c oj u m Linn. Ben, n. 402, Jacq. Fl, austr. $t, 203$. 312. Schkuhr t. 89. Redoute Liliac, t. 150. 217. Salisb. Parad. $t$. 21. 74. Bot. Mag, t, 46, 960, 1993. 1210. Bot. Reg. $t$, 545. Reiehenb, ic, t, 703.704. Nees jun, gen, pl. fasc, VI. t. 4. Nivaria Mönelı Meth, 280. A c is Sweet Fl. gard. $I$. t. 297. (De germinatione cfr. Mirbel in Annal. Mus. XVI. t, 17.)

1268. Lapiedra LAGASC. Perigonin m corollinum superum, hexaphyllum, patens. Stamina 6. . . filamenta erecta, antherae sagittatae, incumbentes. Ovarium inferum, triloculare. ... - Herba iberica, obiter descripta, vix nota; bulbo radicali tuni ato, foliis lineari ligulatis obtusis, fascia longitudinali alba, scapo ancipiti brevioribus, spatha di-triphylla, umbella suboctoflora, floribus erectis, pedicellis triquetris spatha brevioribus, perigonio intus albo, marcescente.

L a p i e d r a Lagasc, nov. gen. et sp. 14.

1865. Carpolyza $S A L I S B$. Perigonium corollinum superum, infundibuliformi - campanulatum, tubo brevi, limbi regularis sexfidi laciniis exterioribus subulato-mucronatis, interioribus paullo angustioribus. S $t$ a $\mathbf{m}$ in a 6 , tubo perigonii biseriatim inserta; filamenta subulata, brevissima, antherae erectae, ovatae, basi sagittatae. Ovarium inferum, globoso-triquetrum, triloculare. Ovula. ... Stylus rectus, filiformi-triqueter; stigmata 3 , filiformia, recurvata. Cap s n la membranacea, trisulea, trilocularis, loculicido-trivalvis. Sem in a in toculis $2-6$, angulato-subglobosa. ...-Herba capensis, digitalis; bulbo radicali ovato, tunicato, foliis linearibus recurvatis, scapo basi spiraliter convoluto, spathae bivalvis valvulis linearibus, floribus albis nutantibus.

Carpolyza Salisb. parad, t. 63. Hessea Bergius in Linnaea 1 . 252. Strumaria spirallis Ait. Bot. Mag. t.1383. Crinum tenellum Jaeq. ic. rar. t. 363. Crim n m s piral e Andr. Bot. Heposit, t, 92 .

1289. Strumaria $J A C Q U$. Perigoninm corollinum superum, hexaphyllo - partitum, stellatim patens, laciniis omnino distinctis $v$. basi in tubulum brevissimum cohaerentibus. Sta$m$ in a 6 , perigonii disco inserta, filamenta subulata, libera $\mathbf{v}$. inter se ant $\mathrm{cum}$ styli basi dilatata inferne cohaerentia, anther a oblongae, versatiles. Ovarium infernm, globoso-triquetrum, triloculare. Ovula plurima, in loculorum angulo centrali biseriata, anatropa. Stylus rectus, infra medium incrassato-strumosns, suleato v. alato-triqueter; stigmata 3 , acuta, replicata. Ca ps u la membranacea, subgloboso-turbinata, trilocularis, loculicido-trivalvis. Semin a in loeulis pauea, subglobosa v. compressiuscula. . . Herbae capenses; bulbo radicali tunicato, fibro$s o$, foliis e vagina radicali linearibus planis $v$. filiformibus, umbella scapum teretiasculum terminante laxa $v$. congesta, multiflora, spatha foliacea umbella breviore.

S trum a ria Jacq. ic, rar, $t$. 356_361, Hort, schönbr. t,71, Ker in Bot. Mag. t, 1363. 1620. Bot. Reg. t,460. A m aryllidis s p. Jacq. Hort, schönbr. $t$. 72. Le ueoji sp. Thunb. Crini sp. Linn.

1280. Sternberogia WALDST. et KIT. Perigonium corollinum superum, infundibuliforme, $t u b$ o recto sensim ampliato, $1 \mathrm{imbi}$ sexpartiti regularis laciniis erectis subaequalibus v. exterioribus paullo majoribus. Stam ina 6, summo tubo inserta; filamenta filiformia, reeta, alterna breviora, antherae subcordatae, versatiles. Ovar i m inferum, triloculare. Ovula plurima, in loculorum angulo centrali biseriata, horizontalia, anatropa. Stylus filiformis, erectus; st i g m a trigonum v. obsolete trilobum. Ca psula baceata, oblongo-trigona, trilocularis, indehiscens. Semina plurima, subglobosa, testa crustacea, atra, rhaph e carnosa cristaeformi, umbilicum basilarem $c h$ alaza e in altero seminis latere infra apicali jungente. $\mathbf{E} \mathbf{m}$ bryo dimidia a $1 \mathbf{b}$ minis carnosi longitudine, subexcentricns, extremitate radiculari umbilicum attingente. Herbae pusillae, colchiciformes, acaules, in Europa australi indigenae; foliis linearibus v. filiformibus, floribus solitariis in scapo brevi, v. radicalibus, spatha tubulosa, apice hinc fissa.

Stern berg i a Waldst. et Kit. pl. Hung. II, 172, t. 159. Nees jun. gen. pl. fasc. VI. $t .5$. $0 \mathrm{p}$ o $\mathrm{ra} \mathrm{n} \mathrm{th}$ u 5 et Sterubergia Herb. app. 38. A maryllidis sp. Linn. Sibthorp Fl. graec, $t, 311$. Redonté Liliac. $t$, 148. Rafin. caratt. $t, 18$. $f, 2$. Bot. Mag, $t .290$.

1281. Tayloekia HERB. Perigonium corollinum superum, infundibuliforme, $t \mathbf{u b o}$ recto sensim ampliato, $1 \mathrm{imbi}$ sexpartiti regularis laciniis subaequalibus, semipatentibus. St amina 6 , limbi laciniis basi biseriatim inserta; fil a $\mathrm{m}$ e $\mathrm{n} \mathrm{ta}$, brevissima, a $\mathbf{n} \mathbf{t h}$ e $\mathrm{r}$ a e lineares incumbentes. Ovarium inferum, triloculare. Ovula plurima.... Stylus filiformis, rectus; $8 \mathrm{t} i \mathrm{~g} \mathrm{~m}$ a 
trifidum, laciniis apice recurvatis. Capsula trigona, trisulca, triloeularis, loculieido-trivalvis. Semina plurima, deorsum imbricata, hine complauata inde convexa, test a nigra..... Herbae in $A$ mericae meridionalis extratropicae littore orientali observatae, habitu omnino Sternbergiae, ovario cum tubi parle hypogaeo, capsula matura tandem protrusa.

Ha y lockia Herb. in Bot. Reg, $t$. 137t. S ternbergi a a merie an a Hofmansegg. Verz. 197. $f .5$.

12\%2. Coopenia HERB. Perigo n i m corollinum superum, $t \mathrm{u}$ b o elongato gracili ad faucem ampliato, $1 \mathrm{imb}$ i sexpartiti regularis laciniis aequalibus, patentibus. St a m in a 6 , fauci inserta; filamenta brevissima, antherae subulatae, dorso supra basim affixae, conniventes. Ov ari u m inferum, triloculare. Ovula plurima.

Sty lus filiformis rectus, inclusus; $s \mathrm{tigma}$ incrassatum, obsolete trilobum. C'a p 8 u 1 a,

Se mi na plurima, complanata, t e st a tenui nigra foliaceo-alata. ... Herbae ex Americ a e borealis regione $T$ exas nuper relatae; bulbo radicali tunicato, foliis linearibus, canaliculatis, scapo fistuloso unifloro, spalha tubulosa apice hinc fissa.

C o o peria Hook, in Bot. Mag. t. 3488.

12 \% 3. Amarezllis LINN. Perigoni um corollinum superum, tu bo brevi v, nullo, $1 \mathrm{im} \mathrm{bi}$ sexpartiti subringentis laciniis subaequalibus recurvatis, fauce saepius squamulosa. Stamina 6 , fauci perigonii inserta; filamenta libera, declinata $v$. erecta subaequalia, $v$. alterna situ et longitudine inaequalia, a $\mathbf{t} \mathbf{h}$ e $r$ a e versatiles. Ovarium inferum, triloculare. Ovula plurima, loculorum angulo centrali biseriatim inserta, subhorizontalia, anatropa. Sty I us filiformis, elongatus, staminum directione; stigma hians v. trifidum, lobis reeurvis. Ca p s u la membranacea, oblongo - trigona, $\mathbf{v}$, depresso-sphaerica teres, trilocularis, loculicido-trivalvis. S e $\mathrm{m}$ in a plurima, globosa v. paleaceo-compressa, marginata v. alata, interilum carnoso-baccata, abortu solitaria loculum totum v. omnem capsulam explentia. E mbryo axilis, dimidii a 1 bu $\mathrm{m}$ in is longitudine, extre $\mathrm{m}$ it a te $\mathrm{r}$ adiculari umbilicam attingente.

Herbae in regionibus tropicis, subtropicisque australibus Americae obviae, in Capite bonae spei minus frequentes, in India rarae, bulbo radicali tunicato, folïs scapo coëtaneis $v$, serotinis, spatha uni-bivalvi, uni-multiflora, pedicellis nudis $v$. basi bracteatis.

A maryllis Linn. gen, n. 406. Lilio-Nareis $\mathrm{s}$ us Tournef. inst. 207 .

a) ZEPHYRANTHES Herb. Perig onium infundibulare aequale. St a mi a a basi laciniarum limbi inserta, uno saeplus sejuncto. Stylus declinatus; $8 \mathrm{tigma}$ trifidum. Capsula trilobo-trisulea. Semina in loculis biseriata, compressinscula, deorsum imbricata, te st a crustacea, atra. - Americanae, tropicae; folits serotinis, scapo cavo uni-bifloro, spatha cylindriea $v$, in bifloris bifida.

$\mathrm{Z}$ e p h y r a $\mathrm{n}$ the s Herb. append. 36. Bot. Mag. $t .2583$. 2593. Bot, Reg. t. 902. 1361. (Sehkuhr 4.90. Bot. Mag. 4. 239. 1586. Bot. Reg. t. 724.)

b) PYRoulion Herb. Perig o n i m infundibulare, tubo apice ventricoso, limbi laciniis aequalibus. Stamina fauci inserta, erecta, aequalia. Stylus de. clinatus; stigma trifidam. Capsula. ... ruvianae; folitis angustis suberectis, scapo cavo uniforo, spatha bifida.

P yrolicion Herb. app. 37. Guiz et Pav. Fl. peruv. t. 286. f. a. b.)

c) HABRANTHUS Herb. P e rig on i um campanulatum, tubo brevi ad faucem juerassato, squamuloso, limbi lacinils subaequalibus. Sta $\mathrm{m}$ in a favel inserta, fas. ciculata, valde inaequalia. Stylus declinatus, sursum curvatus; stigma trifidum. Caps ula trisulca.
Se $\mathrm{mina}$ in loculis biseriata, compressa, horizontalia, testa crustacea, atra. - Americae tro. picae et australis extratropicae indigenae; foliis angustis, bifarits, flaccidis, scapo cavo multifloro, spatha apice bifida.

$\mathrm{H}$ a b ranthus Herb, in Bot. Mag. 1, 2464, 2485. 2597. 2639. Sweet Fl, garll, II. $t, 107$. (Bot. Reg. , 1125. 1148.)

d) SPREKELIA Heist. P erigo n ium ringens, tubo bre. vissimo, limbi laciniis inaequalibus, postica recta, reliquis deflexis, geuitalia amplectentibus. St a mina fauci inserta, basi membrana fimbriata juncta, declinata, apice sursum curvata. Stylus directione staminum; s tigm a trifidum. - Herba in America meridionali et insula St. Helenae ut videtur indigena, per saecula in hortis nostris culta, foliis serotinis, lorato-elongatis, canaliculatis, scapo cavo, uni-bifloro, spatha bivalvi, foliolo altero lineari incluso, altero folliculoso apice bifido, floribus magnis, puniceis, speciosissimis.

S p r e k e I i a Heist. Trew Ehret, pict, t. 24. Herb. app. 34. Sweet FZ. gard, II. t. 14h. A mar yllis formos is 8 i ma Linn. Bot. Mag, t. 47. 1450. Redouté Liliac, t. 4 .

e) Hippeastrum Herb. Perig on i u m subinfundibnlare, tubi fauce coarctata intus laevi, gibbosa v. fimbriata, limbi laciaiae inaequales. St a $m$ i a a fauei inserta, declinata, apice sursum eurvata, inaequalia. Sty $!$ us directione staminam; $8 \mathrm{t} 1 \mathrm{~g} \mathrm{ma}$ trilobum $v$. trifidam. Capsula trisulea. Semina in loculis aniseriata, imbricata, testa nigra saepe marginata. Herbae Americanae, ut plurimum tropicae; foliis bifariis, scapo cavo, bi-multifloro, spatha bifida.

H i p peastrum Herb. app, 33. Bot. Mag. 4. 2273.2278. 3548. 3549. $\mathrm{\Lambda m}$ a r y lli i Sweet Hort.brit.ed.II, p.506. - C ob u r g i a Herb. app.34. L e o pold ia Herb, in Hort.Transact. IV. 151. A u aryllidis $8 \mathrm{p}$. Redonté Liliac, t. 23.38. 164. 226. Lindl. collect, $t$. 11. 12. Bot. Mag, t. 365. 543.657 .876$. 2278. 2315. 2475. 2573. Bot. Reg. t. 23. 38. 164. 199. 296. 234. 332. 44.1038. (De germinatione efr. Mirbel in Annal. Mus. XIII, 76. t. 3. f. 37, et Poitean ibid, t. 28. f. 27.)

$f$ ) VALLOTA Herb. Perigo n $\mathrm{fum}$ infundibulare, tubo intus costato, fauce ampliata, limbi lacinis inaequalibus. St a min a fauci(alterna demissins)inserta, conniventia. Stylus declinatus; stigma trigonum, indivisum. Capsala triquetra. Semina in loeulis biseriata, compressa, nigra, foliaceo-alata. - $\mathrm{Ca}$. penses; foliis distichis, perennantibus, scapo cavo, umbella 4-5flora, spatha bifida.

$\mathrm{V}$ all ot a Herb. app. 29. (Jacq. Hort. schünbr, $t, 62$. Bot. Mag, t. $359,1430$.

g) BELLADONNA Sweet. Perigonium infundibulare, tubo costato, limbi laciniis undulatis patentibus, alternis brevioribus. St a mina fauci inserta, recta v. adscendentia. Stylus declinatus; $s t i g m a$ trilobum, fimbríatum. Capsula trisulea. Semina globosa, magna, carnosa, eapsulam rumpentia. - Capense 3 ; foliis praccocibus v. serotinis, scapo solido, umbella muliffora, spatha diphylla.

Bella d o n $\mathrm{n}$ a Sweet Hort. brit. edit, $I r .506$. A m ary 11 is Herb. app. 15. Callír o E Link Ilandb. $T, 193$. Amaryllis Belladonnae Limn. Redouté Liliac. $t .180$. Bot. Mag. t, 783, Bot. Reg. t, 714.

h) LYCoRIS Herb. P e rig a nium infundibuliforme, tabo trigono, fauce ampliata nuda v. coronata (?), $1 \mathrm{fm}$ bi lacinifis undulatis sursum eurvatis, alternis brevioribus. S t a min a fauci inserta, assurgentia, curvata, alterna longiora. S ty lus sursum eurvatus; st ig ma simplex, fimbristum. - Africanae ot Indicae; folits distichis, scapo solido, umbella multiflora.

L y coris Herb, app. 20. (Jacq. Hort, schünbr. t. 73 . Bot. Mag. t.409. Bot. Reg. t.596,611.)

i) NERINE Herb. P e rig on i a m regulare, hexaphyllum. St a $\mathrm{n}$ in a imis foliolis inserta, subaequalia, filamenta basi dilatata, gibbosa. Stylus suberectus; $s t i g m a$ bifidum, fimbriatum. Capsula bisulea. Semina angulata. - Caponses; folits bifariis, scapo so. lido, umbella multiflora.

Nerine Herb. app. 18, Bot. Mag. 1, 1089, 1090. 2124. 2407. G a l a th ea Herb, in Bot. MLag. $n, 2113$. (Jaeq. Hort. schönbr. $t, 66,67.69$. Redouté Liliac. . 33. 274, 499. Bot. Mag, t, 294. 369, 725.726. Bot. Reg. $t, 172$.

1274. Intunsigia KER. Perigoniu $m$ corollinum superum sexpartitum, urceolatocampanulatum v. infundibuliforme, limbo aequali 
v. irregulari. St a m in a 6 , imo perigonio inserta ; fil a ni enta deelinata v. suberecta, libera v. basi cum perigonii tubo connata, a nth e rae versatiles. Ovarium inferum, triloculare. Ovala. . StyIus filiformis directione staminum; stigma simplex, vel obsolete trilobum. Cap s u la membranacea, subdiaphana, turbinatim trilobo-trigona, lobis depressis $v$, alatis, triloeularis, loculieidotrivalvis. S e m in a in loculis pauca, oblonga, testa nigra, saepius tuberosa, fuscescente.

Herbae c a penses; bulbo radicali globoso, saepius scarioso-tunicato, foliis crassiusculis spathulatooblongis $v$. ligulatis, serotinis $v$, rarius scapo varie compresso coaetaneis, umbella multiflora, pedicellis bracteis scariosis plerumque interstinctis, spatha communi bivalvi.

Brunsyigia Ker in Ait. Hort. Hew. ed. 2, II, 230. Bot. Reg. $n .192$.

a) I m h of ia Herb. Perigonll tabus brevissimus reetus, limbi laeiniae subundulatae, reflexae. Filament a erecta, subfaseiculata. Stylus rectus; stigma obtusum, trigonum.

Imbofia Herb, app. 18. Amaryllis marginata Jacq. Hort. sehönbr. t. 65 .

b) BRUNSVIGIA Herb. Perigonii tubus subinfundibaliformis, Jimbi laciniae haud undulatae, eurvatae, alternae minores. Filan enta sursum curvata, alterua basi tubo adnata. Stylus apice sursum cur. vatus; st fgma obtusum, trigonum. Capsula trisulea.

Brunsvigia Herb. app. 18. Bot. Reg, t. 192, 193.954. 1335. Bot. Mag. t. 1619.2578. C ob urg i a Herb. in Hortic. Transact. IV.181. A m a r y llid is $8 \mathrm{p}$. Jacq. Hort. schönbr. t.68,70.74.

c) BUPHANE Herb. Perigonii tubas subinfundibuliformis, subtrigonus, limbi laciniae haud nndulatae, apicibus reflexae, alternae minores. Stamina patentia. Stylus rectus; stigma obsolete trilobum.

B uphane Herb. in Bot. Mag. n. 2578. B ooph ane Herb. app. 18. A maryllidis sp. Linn. Haemanthi 8 p. Jacq. fragm, $t$. 39. 40, f. 1. t. 41. f. 2. Bot. Mag, $t, 1217$.

d) AMMocharis Herb. Perigonit tubus subinfundibuifformis, subtrigonus, limbi lacinize haud usdalatae, subpatentes, apice reflexae, altermae minores. Filame nta declinata, apice sursum curvata. Stylus declinatus, apice sursum eurvatus; stigma brevissime trilobum.

Ammocharis Herb. app. 17. A maryllidis sp. Ait. Ker in Bot. Heg. t, 139.1219. Crini s p. Jacq. Hort. vindob. III. t. 60. (Bot, Mag, t, 1448.)

1\%ร.5. Griffinia KER. Perigonium corollinum supcrum, $t \mathbf{a b}$ o brevi, li mbo sexpartito inaequali subbilabiato. Stam in a 6 , summo tubo inserta; fi I amenta filiformia, unum adsurgens, reliqua declinata, a nth era e versatiles. Ovarium inferum, triloculare. Orala in loculis 2 collateralia, ex anguli interioris basi adscendentia, anatropa. Stylus trisulcus; stigma indivisum v. obsolete trilubum. C a ps u la membranacea, trisulea, trilocularis.... S e min a in Joculis subsolitaria, obovata, ereeta, testa ochroIncea, nitida, $r$ h a $p$ h e filiformi immersa, $\mathbf{n ~ m b ~ i - ~}$ li $\mathrm{c} \mathbf{n}$ basilarem $c h$ a $\mathrm{I}$ a a $\mathrm{e}$ acali fuscae jungente. Embryo axilis, dimidii albuminis longitudine, extremitate radiculari umbilicum attingente, infera. - Herbae basilienses; bulbo radicali tunicato, foliis paucis coriaceis, petiolatis, lamina oblonga, costato-nervosa, reticulato-venosa, scapo subcylindrico solido, umbella multiflora, spa. tha bivalvi, arida.

$\mathrm{Gr}$ if $\mathrm{f}$ ini a Ker in Bot. Reg, n.414, t,511.990. A maryllidis 8 p. Bot. Reg, $t, 163$.

12\% G. Crinum LINN. Perigonium corollinum superum, $\mathbf{t} \mathbf{u}$ bo elongato gracili fauce haud ampliato, limbi sexpartiti laciniis subaequalibus, erectis, patentibus v, reflexis. St a m i n a 6 , summo tubo inserta; filamenta filiformia patentia v. declimata, antherae lineares, versatiles. Oyarium inferum, triloculare. Ovula plurima, in loeulorum angulo centrali biseriata, horizontalia, anatropa. Stylus filiformis, inclinatus; st i g ma obtusum v. obsolete trilobum. Capsula membranacea, depresso-sphaerica, triv. abortu uni-bilocularis, irregulariter rumpens. Semina panea $v$, solitaria, angulato-subglobosa, saepe in bulbillos carnosos mutata. - Herbae inter tropicos veteris orbis obviae, in America aequinoctial $i$ minus frequentes, in $C a p i t e$ Bonae spei ef in Nova Hollandia extratropica parce repertae; bulbo radicali columnari $v$. sphaerico, foliis multifuriis, scapo solido, umbella multiflora, spatha bivalvi, pedicellis bracteis ramentaceis interstinctis.

C r i n u m Linn. gen, n. 405. excl. sp. R. Brown prodr. 297. Jacq. Hort, schönbr, t. 200. 202. 428. 494. 495. Ic, rar. t. 362. Bot. Mag. t. 1034, 1073, 2121. 2133, 2180, 2268. 2217. 2231. 2292, 2301. 2352, 2355. 2397. 2463.2466. 2522, 2531, 2592. 2635. 2636, 2684, 2688, 2908. Bot. Reg, t. 52.171.179. 597. 1049. 1297. Hook. exot. Flor, $t$. 200. - De semiaibus bulbiformibus cfr. R, Brown l. $c$, et A. Richard in Annal. sc. nat. 11. 12. t. 1 .

12\%\%. Collamia SCHULT. F. Perigonium corollinum superum, tubo basi gracili, cylindrico, superne late ventriceso, limbi urceolato-campanulati sexfidi regularis laciniis brevilous, patentinsculis. Stam in a 6 , imo tubo inserta; filamenta filiformia, exserta, erecta v. adscendentia, antherae ovatae, versatiles. Ovari um inferum, triloculare. Ovala plurima... Sty 1 u 8 filiformis; $8 \mathrm{tigma}$ trigonum. Capsula ovato-trigona, trisulea, trilocularis.... S emina plurima. ....-Herbae $a$ mer $i$ c $a n a \mathrm{e}$ tropica e, Haemanthi habitu; bulbo radicali tunicato, foliis subbinis, crassis, latis, scapo solido flexuoso, umbella terminali pauciflora, spathae polyphyllase foliolis lineari-lanceolatis, exterioribus majoribus marcescentibus.

Colla $n$ ia Sehult. fil. syst. VII. 6111. 893. Ureeolari a Herb, app. 28. non allor. Urceolin a Reichenb. consp. 61. non Zoolog. Crínum urceolat am Ruiz et Pav. Fl.

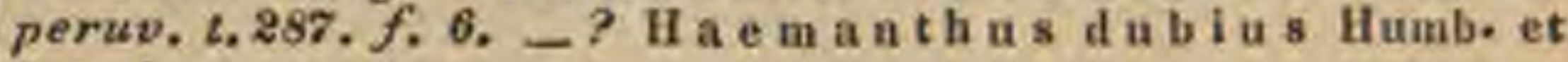
Bonpl.

1298. Thaemanthus LINN. Perigon i um corollinum superum, tabo brevi, limbi regularis sexfidi laciniis erectis v. patentibns. S $t$ a m in a 6, summo tubo inserta, erecta, exserta; fil a m enta filiformia, antherae ovato-oblongae, dorso supra basim affixae. Ovarium inferum, triloculare. $O$ v 1 I a in loculis pauea, e Iocnlorum angulo centrali adscendentia v. pendula, anatropa. Stylus filiformis, rectus; stigma simplex, v. obsolete trilobum. B a cea globosa v. oblonga, abortu nni-bilocularis. S e mi$\mathrm{na}$ in loculis solitaria, loculum reptentia; t esta membranacea adnata, $\mathbf{r h}$ a $\mathrm{phe}$ immersa, $\mathbf{u} \mathbf{m b}$ li c:um basilarem $\mathrm{ch}$ a $\mathbf{l}$ a $\mathrm{z}$ a e apicali discolori jungente. E m b r yo minimus, in basi albuminis dense carnosi, extremitate radieulari umbilicum attingente. - Herbae, paucis africanis tropicis exceptis, capenses, glabrae v. pubescentes; bulbo tunicato, saepius bifariam squamoso, foliis paucis, saepius binis, coriaceis, crassiusculis, plerumque planis, orbiculatis, erectis v. humistratis, rarius angustis elongatis, canaliculatis, rarissime petiolatis, petiolis vaginantibus, lamina oblonga, scapo brevi basi saepius bracteis 2 radicalibus, interdum coloratis stipato, umbella terminali, multiflora, spatha ut plurimum polyphylla, foliolis erectis coloratis, umbella longioribus, rarius diphylla v. reflexa. 
H a em ant hus Tonrnef. inst, 2. 433. Linn. gen, n, 400. Gärta. $I, 31, t, 11, f .4$. Jacq. Hort, schönbr, t. 58-61. 40z A12. Bot. Mag. t, 961, 1075, 1523. 1705. 1618. 1995. Bot. Reg. t, 187.382, 309.984. Tristeg i a et Poly steg ia Reichenbach consp. 61 .

12ร9. Cyntamthus $A I T$. Perigoniu in corollinum superum, infundibuliformi-tubulosum, t $\mathrm{n}$ bo Jongo curvo, sensim dilatato, interdum ventricoso, limbi brevis sexfidi laciniis subaequalibus, erectis v. patentiusculis. St a mina 6 , fauci inserta, inclnsa; fil am enta filiformia, conniventia, alterna breviora, antherae ovatae, incumbentes. $0 \mathrm{v}$ a $\mathrm{r}$ i $\mathbf{m}$ inferum, triloculare. Ovu 1 a plurima, in loculorum angulo centrali biseriata, horizontalia, anatropa. $S t y l u s$ filiformis, erectus $v$. declinatus; stigma breviter trifidum. Capsula trigono-ovata, trilocularis, loenlicido-trivalvis. S e mina plurima, paleaceoeompressa, testa nigra. . . Herbae capenses; foliis bifariis angustis elongatis, umbella terminali mulliflora, spatha bivalvi, pedicellis bracteis scariosis interstinctis.

C y $r$ anthus Ait. Hort. kew, $T$. 1448. Timm ia Gmel. syst. . 538. - C yrtanthus Herb. app. 79. Cyrtan. thus obliqu us Jaeq. Hort. sckönbr, $t$. 75. Redouté $L i-$ liac. 6. 381. Bot. Mag. 2. 1133, A maryllis a mbrella Herit. sert, t, 16. C ri h i s p. Linn. - Monell a Herb, app. 29. (Jacq. Hort, «chönbr. 1,z6. Redouté Liliac, L.182. Bot. Mag. t. 271. 2671. 2534. Bot. Reg. t. 162, 167. 503,) - G as t ro ne ma Herb. app. 30. Bot. Mag, t, 229t. A maryllid is s p. Herit. (Bot. Reg. $t$, 168.)

1280. Sphaerotele PRESL. Perigoninm corollinum superum, infundibuliformi-tubulosum, $t u$ b o recto sensim ampliato, I i $m$ bi sexfidi erecti laciniis aequalibns, obtusis. St a m in a 6 , fauci inserta; fi l a m e n $\mathrm{t}$ a filiformia, erecta, exserta, a $t_{\text {h }}$ erae. . Ovarinm inferum, trigonnm, triloculare. Ovula plurima. . Stylus filiformis; s tig m a capitato-hemisphaerium. Herba peruviana, radix et folia ignota, scapus teretiusculus, umbella terminalis quinqueflora, spatha diphylla. _ Genus maximopere dubium, anne idem ac Chrysiphiala?

$\mathrm{S}$ p ha e rot el e Presl in Reliq. Haenk. I. 119, t, 16. f. . .

1281. Chlidanthas LINDL. Perigoni um corollinum superum, infundibuliformi-tubulosum, tubo recto sensim ampliato, $l i m b i$ sexfidi laciniis aequalihus, subbilabiato-patentibus. $S t a m i n a 6$, fauci inserta; fil a m onta basibus lilatatis connata, alterna limbi laciniis exterioribus opposita breviora, bidentata, alterna subulata simplicia, antherae oblongae, Ioculis connectivo crassinseulo antice adnatis. Ovari u inferum, triloculare, $O \mathbf{v}$ la plurima, in loculorum angulo centrali biseriata. ... St y 1 u 8 filiformis, rectus; stigma trilobum. Capsula subeartilaginea, trilocularis, loculicido-trivalvis. S e m in a plurima, test a brnnea, membranaceo-marginata. Herbae chilenses; bulbo radicali tunicato, fotiis serotinis, linearibus, scapo tereti, umbella terminali, pauciflora, spatha scariosa, mono-diphylla, floribus magnis, luteis.

Chifd a $t$ th us Lindl. Gollect, t. 34. Bot. Reg. $t$. 640. - Clina ut hus Herb. app. 40.

* * NARCISSEAE. Stamina sterilia libera, v. in coronam faucis connata. gerae, radice bulbosa.

128\%. Eustephia $C A V$. Perigoninm corellinum superum, t $\mathrm{u}$ b o brevissimo, limbi sexpartiti convoluto clansi laciniis apice subringentibus. Stamina fauci inserta, 6 fertilia; fila- menta filiformia declinata, antherae oblongae, incumbentes, totidem sterilia subuliformia bre. vissima, libera v. cum fertilibns et inter se basi connata. Ovarium inferum, triloculare $O$ vula plurima, in loculorum angulo centrali biseriata.

Stylus filiformis, declinatus; $s$ tigma simplex, incrassatum. Ca p 8 u la trilocnlaris, loculicido-trivalvis. S e m in a plurima, complanata, tes $t$ a cinerea, membranaceo-marginata. - Herbae in America australi extratropica indigenae; bulbo radicali atro-tunicato, foliis linearibus, canaliculatis, scapo tereti, umbella terminali multiflora, spatha bi-quadrivalvi, floribus rubris $v$. purpureis.

Euste phia Cavan, ic. IIT. 20. $t$. 238. Phy cella Lindl. in Bot, Reg, $n, 928,4,1341$. Hortic. Transact, VI, 88. VII. 1. 74. Sweet Fl, Gard, II, t, 121. A ma r y llid is s p. Bot. Reg. t.809. Bot. Mag. $t, 2390$, Quid P lacea Miers Travels in Chili p. 520. quod geaus Phycellae proximum dicitur.

1283. Fuerosias KER. Perigonium corollinum superum, t $\mathbf{u}$ bo brevi obliquo, li mb i sexpartiti subringentis laciniis exterioribus angustioribus. St a m in a 6 , fauci inserta; fil am enta filiformia, longe exserta, declinata, inferne in tubum postice fissum, basi intus sexglandulosum inaequaliter connata; a n therae oblongae, incumbentes. Ovarium inferum, triloculare. Ovula plnrima, in loculorum angulo centrali biseriata. S t y 1 u \& filiformis, directione staminum; st igma obtusum. Cap 8 u la ovata, trisulea, trilocularis... - Herba in America australi extratropica indigena; bulbo radicali tunicato, foliis lanceolatis breve petiolatis, scapo compressiusculo, umbella terminali pauciflora, spatha plurivalvi membranacea.

Eucros fa Ker in Bot. Heg. 1. 207. Herb, in Bot. Mag. t. 2490. Hook, exot, Fl. t. 209.

1984. Chrysipluiala $K E R$. Perigonin $\mathrm{m}$ corollinum superum, infundibuliforme, $t \mathbf{n}$ bo medio constricto, $1 \mathrm{imbi}$ brevis sexfidi regularis laciniis erectis v. patentibus. Corona faucis turbinata, eylindrica, inclusa v. subexserta, sexdentata, dentibus subulatis antheriferis; antherae oblongae, incumbentes. $\mathrm{O}_{\mathrm{v}}$ ari $\mathbf{m}$ inferum, triloculare. Ovula plurima, in loculorum angulo centrali biseriata. . . Stylus supra basim fusiformi-inerassatus; stigma clavatum, obtusum. C a p 8 u la oblonga, acute trigona, trilocularis, loculicido-trivalvis. Semin a plnrima, compressiuscula, testa nigra. . . Herbae a mericanae tropicae; bulbo radicali tunicato, foliis linearibus canaliculatis, $v$ petiolatis, lanceolato-oblongis, scapo tereti, umbella terminali paciflora, spatha membranacea, di-polyphylla, floribus luteis. Anne potius Panoratii sectio?

C hr y siphiala Ker in Bot. Aeg. 't. 778 . Hook, exot. Flar. 6.132. - Stenomesson Herb: app. 40. Bot. Mag. t.2660. 26.41. Pa neratii s p. Ruiz et Pav, Fl.peruv, $t .284$. $f . a . t, 283 . f$. b. Redonté Liliac, $t, 187 .-\mathrm{C}$ a r po de tes Herb. app. 40. Pau eratium recurvatum Ruizet Pav. Fl. peruv. t.285. $f . a_{*}-\mathrm{L}$ e periz a Herb. app. 40. $\mathrm{P}$ as. cratiun latifoliom Ruiz et Pav, $l$. c. $t, 284 . f .6$.

185. Coburgia SWEET. Perigoniu in corollinum superum, infundibuliforme, $t u-$ bo elongato, angulato, incurvo, supra medium ventricoso-dilatato, I imbi sexfidi regularis laciniis imbricato-patentibus. Corena faucis subcampanulata, duodecimdentata, dentibns alternis brevissimis, bifidis, alternis subulato-filiformibus, antheriferis; antherae lineares, incumbentes. $O$ varium inferum, triquetrum, triloculare. OvuI a plurima, in loculorum angulo centrali biseria- 
ta.... Stylus filiformis; stigma inerassatum, obtuse trigonum. Ca p $\mathrm{s}$ la oblonga, trilocularis. Semin a plurima, alato-marginata?

Herbae peruvianac; bulbo radicali tunicato, foliis linearibus glaucescentibus, scapo ancipiti, umbella terminali pauciflora, spatha membranacea ditetraphylla, floribus aurantiaceis, magnis, speciosis.

Co b u rg ia Sweet Fl. Gard. II. t, 17. Pancrat in m ince rnat um Humb. et Bonpl.

1286. Earryeles $S A L I S B$. P e rigo n i m corollinum superum, infundibuliforme, $t \mathbf{n} \quad \mathbf{b} 0$ brevi, limb i sexpartiti regularis laciniis patentibus. Coron a faucis ad basim sexpartita, laciniis tridentatis, dente medio elongato, antherifero; antherae sagittatae, versatiles. Ovarium inferum, triloculare. Ovula in loculorum angulo centrali gemina, collateralia, anatropa, alterum erectum, alterum pendulum. Stylus filiformis, rectus; stigma simplex. Capsula tricostata, dissepimentis incompletis subunitocularis. S em i n a pauca, bulbiformia. . . - Herbae in Asiae insularis tropicae et Novae Hollandiae extratropicae orientalis littoribus obviae; bulbo radicali tunicato, foliis petiolatis cordato-subrotundis, costato-nervosis, venosoreticulatis, scapo teretiusculo, umbella terminali pauciftora, spatha bi-trivalvi, floribus candidis.

Euryeles Salisb, in Hortic. Transact. 1. 337. Bot. Reg. $t, 1506$. Proiphys Herb. app. 42. Paneratium a nu o in ense Lian. Redouté Lilliac. $t .384$. Salisb. parad. t.84. Bot. Mag. t.1419. Bot. Reg. 2.715.

128\%. Callostemma R.BR. Perigoni$\mathbf{u m}$ corollinum superum, infundibuliforme, $\mathbf{t} \mathbf{u}$ b o brevi, limbi sexpartiti regularis laciniis patentibus. Corona faucis tubulosa, exserta, ore duodecimdentato, dentibus alternis subnlatis antheriferis; a $n$ therae oblongae, versatiles. Ovari $\mathbf{m}$ inferum, nniloculare. Ovula $2 \_3$, parietalia, superposita, anatropa. Stylus filiformis rectus; st i $g \mathrm{ma}$ obtusum. B a c ca mono-disperma. Semina bulbiformia. - Herbae in Nova Hollandia orientali extratropica indigenae, habitu Pancratii; floribus parvis, luteis v. purpureis.

C a l o s te m ma R. Brown prodr.298. Bot. Mag. 1,2106، 2101. Bot, Reg. 4.421 .429$.

1288. Pameratimun $L I N N$. Perigonin $\mathbf{m}$ corollinum superum, infundibuliforme, t $\mathbf{u}$ b o longo gracili, limbi sexpartiti regularis v. rarissime irregularis laciniis patentibus $\mathbf{v}$. reflexis. Corona faucis tubulosa, exserta, libera v. perigonio adnata, varie dentata, dentibus v. intus staminifera ; filam enta aequalia v. alterna breviora, ereeta, conniventia v. declinata, a n th e r a e oblongae, incumbentes. Ovari $\mathbf{u m}$ inferum, triloculare. Ovula plurima, in loculorum angulo centrali biseriata, horizontalia, anatropa. Sty 1 us filiformis, staminum directione; $8 \mathrm{ti} g \mathrm{ma}$ simplex. Ca p s u a membranacea, trilocularis, locnlicidotrivalvis. Semina plurima, subglobosa v. abortu pauca, bulbiformia, perfectorum te $s t$ a crustacea atra, umbilico basilari ope rhapheos carnosae $\mathrm{eh}$ a $\mathrm{I}$ a za e apicali juncto. E $\mathrm{mbr}$ b axilis, dimidio alb umine parum longior, extremitate radiculari umbilicum attingente, - Herbae ut plurimum littorales, in America tropica copiosue, in India orientali et in regione mediterranea rariores; bulbo tunicato, foliis linearibus $v$. lanceolatis, nunc petiolatis, lamina late ovata, scapo tereti $v$. anguloso, umbella terminali uni pauciflora, spatha uni-bi-v. rarius plurivalvi.

Pancratium Liun, gen, $n$, s0\%. a) HYMBNocallis Herb. Perigonil tobus rectus, limbi laciniae flaceidae. C or o na e sexdentatae dentes in filamenta aequalia elongati. Semina pauca, bulbiformia. - Americae tropicae et subtropicae cives.

$\mathrm{H} \mathrm{y}$ me n o e alli is Herb. app. 43. Bot. Mag. L. 2621. Bot. Reg. t, 970. (Jacq. Hort, vindob. IIT. t. 10, 15. Salisb. in Linn. Transact. $I, t, 10,12,13$, Redouté Liliac. $t .135,156$. 358. 380. 412. 414. Bot. Mag. t. 825_827, 1453. 1467. 1879. 194t. Bot. Reg. $t$. 43. 221, 265.)

b) Schizostephanium Reichenb. Perigonii tubus rectus, limbi laciniae patentiusculae. C o ron a sexden. tata, filamenta aequalia, dentibus coronae integris bifidisve alterua. S e min a plurima. - Mediterraneae et inditae.

Schizostephanium Reichenbach Fl. germ. I. 89. $\mathrm{H}$ a $1 \mathrm{~m} \mathrm{y} \mathrm{r}$ a Salisb. in Hortic. Transact. $I$. 336. P a ne rati n m Herb. app. 39. Redouté tiliac. t. 8. 153, 471. Sibth. Fl. graec. t. 309. Salisb, l. e, t, 9, 14. Bot, Reg, t, 161, 171 . 413.997. Bot. Mag, t,718, 2338. Nees jun. Gen. pl. fase, X. t. 5 .

c) ISMENE Herb. Perigonii tubus incurvus, limbi Itciniae patentes. Corona duodecimdentata, dentibos alternis emarginatis, sinu staminiferis. Semia a pauca, lublbosa. - Americanae tropicae.

Is me ue Herb. in Bot. Mag. n. 2685. Narcissi s p. Raiz et Pav. Fl. peruv. t, 281. f.a. (Redouté Liliae. L, 352. Bot. Mag. $t, 1224,1561$.)

d) LIRIOPSIS Reichenb. Perig o n i i tubus rectus, limbi Iaeiniae ringentes. Coron a declinata, basi intus staminifera, filamenta declinata. - Americanae tropicae.

Liriopsis Reichenb. consp. 61. Liriope Herb. app. 41. Pane ratium ringeas Ruiz et Pav. Fl. peruv, t. 283. f.6.

1289. Nareissus LINN. Perigoninm corollinum superum, hypocrateriforme, t $\mathbf{u}$ bo subcylindrico recto, lim b i sexpartiti laciniis aequalibus, patentibus v. reflexis. Coron a faucis infundibuliformis, campanulata $\mathbf{v}$. rotata, integra $v$. lobata, tubo brevior v, longior. Stamina 6 , summo perigonii tnbo infra coronam biseriatim inserta, inclusa; filamenta brevissima, libera v. tubo adnata; antherae oblongae, incumbentes. Ovarinm inferum, triloculare. Ovula in loculormm angulo centrali plurima, pluriseriata, horizontalia, anatropa. Stylus filiformis; stigma obtnsum. Cap sn Ia membranacea, obtuse trigona, trilocularis, loculieido-trivalvis. Semina plurima v. panca, subglobosa, testa atra rugosa, rhaphe immersa. Emb ryo axilis, rectus v. subincurvus, albumine carnoso parum brevior, extremitate radienIari umbilienm attingente. - Herbae mediterraneae; bulbo radicali tunicato, scapo tereti $v$. anguloso, spatha monophylla hinc fissa, uniflora, floribus speciosis, albis v. flavis, sacpias nutantibus.

Na refs s us Linn, gen, n, 403. Salisb, in Hortic. Trans. aet, I, 337. Loiseleur in Mem. Sav, etrang, IT, 502. Haworth in Linn. Transact, $D$. 2/2. Sprengel N. E. II. 1.55.

a) Corbularia Haw. suppl. 121. (Bot. Mag. t. 88.)

b) A jax Haw. suppl. 111. (Redouté Liliac, t, 188. Bot. $\mathrm{Mag}$, t, 6.51.301,924.1187, 1300, 1301.)

c) Diomedes Haw, in philosoph. Magaz, 1823, Dec. 440. (Bot. Mag. t. 2588. Bot. Reg. t.762.)

d) Queltia Haw. suppl. 123. (Redouté Liliac, t, $11 \%$. 220. 410. Bot. Mag. t. 121.123.)

e) Schizanthes Haw. suppl. 123. N. orientalis Linn.

f) $\mathrm{G}$ a ny medes Haw. suppl, 123. (Bot. Mag. 2. 48, 925.)

b) $\mathrm{Philog}$ y ne Haw. suppl. 132. (Redouté Liliac.t. 428. Bot. Mag. t, 78, 934.)

h) He rmione Haw. suppl. 139.

(6) Jonquillia DC. (Bot. Mag. t. 15, 379. Bot. Reg. t.816.)

B) $\mathrm{T}$ a z e t $t$ a DC. (Bot. Mag. 1.940.946.947.1185, 1298. 1299.)

i) Chloraster Haw. in philosoph, Magaz. 1824, Febr. p. 103. N. $v$ iridiflor us Schonsb. Bot, Mag. $t, 1687$.

k) Nare is s us Haw. suppl. 148. Redouté Liliae, t. 16. E. B, t, 276. Bot, Mag. 4.193.

1290. Cethyllis LINN. Perigoninm corollinum superum, t $\mathbf{u} \mathbf{b}$ o filiformi elongato. 23 * 
$1 \mathrm{imbi}$ sexpartiti laciniis aequalibus, patentibus. Stamina fanci imposita 6_12_18; fil am enta subulata, libera v. basi per paria aut ternatim connata; antherae lineares basifixae, rectae $v$. apice producto inflexae, aut spiraliter tortae. $O \mathrm{v}$ ari um inferum, triloculare. Ovala in loculoram angulo centrali plurima, pluriseriata, subadscendentia, anatropa. S t y l u s cum perigonii tubo connatus, apice exserto libero; sti $\mathrm{gm}$ a capitatotrigonum. B a ce a trilocularis. S e m in a plurima subcompressa, sphaeroidea, in pulpa gelatinosa nidulantia, te st a laxa hyalina, Embry o axilis, a 1b u min e carnoso graveolente; parnm brevior, extremitate radiculari umbilieum attingente.

Herbae capenses; rhizomate bulboso, imbricatim tunicato, foliis radicalibus serotinis, linearibus, saepe spiraliter convolutis, basi scarioso vaginatis, floribus radicalibus, perigonii tubo pedunculum mentiente, bacca clavato-cylindrica, diaphana, eduli, primum hypogaea, demum emergente, embryonis plumula valde evoluta.

Getby 11 is Linn. Gen. n. 590 . Jaeq. Hort. schönbr. t.70. Bot. Mag. $t$. 1088. P a p y ri a Thuab. Act. soc. Lund. I, 2, p. 111, c. ic. A bap us Adans. fam. $I$. 57 .

* * amaryllideaE anomalaE. Caulescentes; radice fibrosa aut bulbosa, rarius scapigerae; rhizomate tuberoso-fasciculato.

1291. Clivia LINDL. Perigonium corollinum superum, hexaphyllum, foliolis in tubum conniventibus, imbricatis, basi subconnatis, exterioribus paullo brevioribus. St a m in a 6 , perigonii foliolis basi inserta, aequalia, subexserta; filamenta subulata, antherae lineares, versatiles. Ovari um inferum, triloculare. Ovula plurima....Stylus filiformis, rectus; stigma trilobum. B a c $\mathrm{e}$ a abortu monosperma. S e m en adscendens, subgloboso-compressum, testa carnosa areolata, umbilic o et $\mathrm{chal}$ a zateralibus $\mathrm{rha}$ phe brevi elevata conjunctis. E $m$ bryo axilis, a 1b u m i n e carnoso copiosu dimidio brevior, extremit ate radiculari umbilico parallele contigua, infera. - Herba c apensis, radicibus fibrosis fascieulatis, fibris carnosis tuberoso-incrassatis, foliis radicalibus distichis, scapo plano - convexo, apice umbellatim multiforo, floribus nutantibus

Clivia Lindl. in Bot. Reg. t.1182. $1 \mathrm{mat}$ o phyll a m Hooker in Bot, Mag. 4 , 2856. H i ma n t o p h y 11 u $\mathrm{m}$ Spreng. gen, $p l, n, 1433$.

1292. Bravor LLAV. et LEXARZ. P erig o n i m corollinum superum, infundibuliforme, fauce ampliata, limbo brevissime sexfido. Stamina 6 , imo perigonii tubo inserta, subexserta; filamenta filiformia libera, antherae lineares. Ovarium inferum, triloculare. Ovula plurima. .. Sty lns filiformis; stigma dilatatum, subinfundibuliformi-excavatum. Cap sula trilecularis, loculieido - trivalvis. Semina plurima, reniformia. ...- Herba mexican a; rhizomate bulboso, folitis radicalibus linearibus carinatis, caulinis alternis basi vaginantibus, caule tereti, pedicellis axillaribus geminis, racemosis, busi scarioso bibracteolatis, floribus nutantibus, extus puniceis, intus lutescentibus.

B r a vo a Llave et Lexarza Nov, veget. descript, I. 6. C a e to c ap n i a Link et Otto $I c, p l, r a r, 35,1,18$.

1293. Ixiolixion FISCH. Perigonium corollinum superum, hexaphyllo - partitum, subcampanulato - patens, la ciniis exterioribus angustionibus, mueronulatis. Stamina 6 , imis perigonii foliolis inserta, inclusa; filamenta subulata, alterna breviora, a n the rae oblongae, basifixae, demum revolutae. Ovari um infernu, triloculare. Ovula plurima. ... Sty In s filiformis; stigmata 3 , patentim recurva. Capsula oblonga, basi angustata, multistriata, triloeularis, loculieido-trivalvis. Sem in a plurima, ovali-oblonga. . . Herbae in Libano, in Tauria et Sibiria observatae; bulbo radicali ovato, foliis radicalibus anguste linearibus subulatis, caule flexuoso otigophyllo, spathis axillaribus subunifloris, terminali polyphylla multiflora.

Ixiolirion Fischer msc. Herb. app, 18. Amaryll1. di s s p. Pallas it. app, t.D. f.1. Labill. Syr, dec, II, $t, 1$. Redonté Liliac, $t, 2 \& 1$.

1294. Campynema $L A B I L L$. Perigonium corollinum superum, hexaphyllo - partitum, foliolis elliptico-lanceolatis, aequalibus, patentibus, persistentibus. St am in a 6 , imis perigonii foliolis inserta; fil amenta recurva, a n the ra e cordatae, versatiles. Ovarium inferum, triloculare. Ovula plurima. Styli tres, recurvi; st igmata simplicia. Capsula oblonga, trisulea, trilocularis, septicido-tripartibilis, intus dehiscens. Semina plurima, uniseriata, depressa, testa spongiosa....- Herba in insula. Diemen indigena, glabra; radice fasciculata, fusiformi, foliis gramineis, semiamplexicaulibus, floribus terminalibus paucis.

C a m p y n e m a Labill. Nov, Holl, T.93.t. 121. R. Brown prodr. 290. C a m p y lon em a Poir. illustr, t, 9h0. - Ge. nus dubiae affinitalis, soli $B i l i$ ardier o notum, Amaryllideis e cl. n. Brown sententia vix associandum, fortassis Melanthaceis, non obstante ovario infero, propius accedens, non solum propler habilum haud dissimilem, stylum partitum et capsulam tripartibilem, sed quantum ex icone Billardieri judicare licet, perigonit aestivationem.

1295. Alstroemeria LINN. Perigoni um corollinum superum, sexpartitum, subcampanulatum, regulare v. subbilabiatum, foliola interiora angustiora, duo basi subtubulosa. Stamina 6, imo perigonio inserta; filamenta erecta v. declinata, an therae ovales, erectae. Ovariom inferum, triloculare. Ovula in locilis plurima, horizontalia, anatropa. Stylus filiformis, directione staminum; stigma trifidum, lobis replicatis. Cap sul a oblonga v. globosa, trisexcostata, trilocularis, loculicido-trivalvis $v$. rarins baceata indehiscens. Semina in loculis plnra, subglobosa, horizontalia, te st a membranacea, rugosa, rhaphe immersa umbilicnm basilarem ch a laza e apieali tuberculiformi jungente. Embryo axilis, a I b um ine carnoso dimidio brevior, extremitate radiculari umbilicum attingente. - Herbae in America tropica et australi extratropica indigenae; radicibus tuberoso-fasciculatis, caule folioso, erecto, scandente v. volubili, floribus terminalibus umbellatis.

A I s t romeria Linn. gen, n. 432. Gartn. T, 41.

a) BOMAREA Nirb. Caule seandente v, volubili, staminibus, capsula depresso-globosa.

Bo $\mathrm{m}$ ar e Mirbel in Poiret suppl. I, 677. (Cav. Ic. $t$. 76. Bot. Mag, t. 1613.2848. Tussac. Fl, antill, $t, 14$.

b) ALSTRÓMERIA Mirb. Caule erecto, staminibus declinatis erectis, eapsula oblonga v. globosa.

A 1 s tr bo m ría Mirbel 1 . c. Gärtn. I. t. 13. Bot. Mag. t,195.139, 491,3033,3060,3103.3350. Hook, exot. Flor, t. 64. 65. 181. Bot. Miscell. $2,95$.

1296. Doryanthes CORREA. Perigonium corollinum snperum, sexpartitum, infundibuliforme, deciduum, laciniis tribus interioribus basi latioribus. Stam in a 6 , basi laciniarum perigonii inserta; fil am enta subulata, anthera e tetragonae, basi eava insertae, erectae. 0 va- 
ri $\mathbf{m}$ inferum, triloculare. Ovula plarima, in loculorum angulo eentrali biseriata, horizontalia. Stylus trisuleus; $8 \mathrm{tig}$ m a trigonum. C a p8 ula turbinato - trigona, corticata, intus lignosa, Ioculicido - trivalvis, septis demum bifidis, Semina in loculis biseriata, plano reniformia, testa rugosa, nucleo unilaterali subtriquetro. Em b r y o axilis, fungiformis, a $I$ b u $\mathrm{m}$ in e carnoso dimidio brevior, extremitate radiculari nmbilieum attingente. - Herba in Novae Hollandiae ora orientali extratropica indigena; radi. cibus fasciculatis, caule excelso, tereti, folioso, foliis radicalibus late ensiformibus, caulinis multoties minoribus, capitulo terminali e spicis suboppositis confertis paucifloris composito, floribus alternis, puniceis, breviter pedunculatis, bracteis semivaginantibus pedunculisque coloratis.

Doryanthes Correa in Linn. Transact. VI.211.1, 23. 24. R. Brown prodr. 298. Ferd. Bauer illustr. t. 13-15. Bot. Mag. $t, 1685$.

\section{**** A G A V E A E.}

129\%. Agrve LINN. Perigoninm corollinum superum, infundibuliforme, persistens, 1 imbi sexpartiti laciniis subaequalibus. St amina 6 , tubo perigonii inserta; filamenta filiformia, aestivatione inflexa, sub anthesi exserta, a nthe ra e lineares, versatiles. Ovarium inferum, triloculare. Ovula plurima, in loculorum angulo centrali biseriata, horizontalia, anatropa. Sty In s fliformis, exsertus, cavus, apice pervius, stigma capitato-trigonum. Capsula coriacea, trigono - triquetra, trilocularis, loculicido-trivalvis. Semina plurima, plano-compressa, te sta chartacea marginata, rhaphe laterali $u m b i l i c u m$ prope basim lateralem chalaz a e subapicali jungente. E mbry o cylindricus, axilis, a I b a m in is carnosi longitudine, extremitate radiculari umbilicum spectante. - Herbac acaules $v$. caulescentes, interdum giganteae, longaevae, sed semel florentes, in Americutropica et subtropica $c$ is a equatore $m$ indigenae, quaedam nunc a mortalibus late diffusae; foliis radicalibus carnosis, interdum maximis, marginibus spinosis, floribus in scapo radicali bracteato paniculatis, numerosissimis.

A g ave Linn. gen, n. 431.

a) AGAVE. Perig a n i laciniae erectae.

A gav e Jacq. Ie,rar, t, 378. Redouté Liliac, t.328.329. 485. Andr. Bot. Reposit. $t .438$. Bot. Mag. t.115\%. Zucearini in N. A. N. C. XVI. t. $49-51$.

b) LITTAEA Tagliab. P e rig o n i laciniae revolutae.

L it t a e a Tagliabue in Biblioteca italian. $I, 100$. Bonapartea Willd. enum. suppl. 18, non Ruiz et Pav. A gave geminiflora Brandes Journ, of sc. III, $t, 1$. Turpia Ailas. $I X . t .55$. Bot. Reg. $t, 1145$.

1298. Fameroya VENT. Perigoninm corollinum superum, deeiduum, hexaphyllo partitum, foliolis aequalibus, patentiusculis. Stamina 6 , epigyna; filamenta basi cuneatodilatata, aestivatione erecta, sub anthesi inclusa, antherae ovatae, medio dorso affixae, erectae. Ovari um inferum, triloculare. Ovula plurima, in loculorum angulo centrali biseriata, horizontalia.... Stylus triqueter, basi strumoso - incrassatus, subexsertus, eavus, apice pervius; stig ma obtusum, fimbriatum. Capsula coriacea, trilocularis, loculicido-trivalvis. Sem in a plurima, plano-compressa. ... Herbae in $A m e-$ rica calidiare cis a equatorem indigenae, longaevae, semel florentes, caudice interdum giganteo, apice folioso, scapo terminali paniculatim ramoso, multifloro.
Furcroy a Vent, in Usteri Annal. $X \subset x, 54$. DC. pl.gr. t. 126. Zucearini in $N$. A. N, C, XVI. $t$, 48. A g aves sp. Jacq. Amer. piet. t. 260.

\section{Drdo LXV. Bromeliaceae.}

BROMELIEAE Juss. gen. 49. BRoMELIACEAE Lindl, in. Bot, Reg, n, 1068, Introduct, edit, II, p. 334. Bartl. ord. nat, 46 .

Herbae nonnunquam suffrutescentes, saepius acaules, candice perennantes, radicib u s fibrosis, plurimae in truncis arborum pseudoparasiticae. F oli a rigida, canaliculata, basi vaginantia, margine plerumque spinosodentata, epidermide saepins squamosa, secedente, saepissime omnia ad basim caulis congesta.

Frones hermaphroditi, regulares subirregularesve, spicati, racemosi v. paniculati, singuli bracte a scariosa suffulti.

Perigoniva liberum, semisuperum v. omnino superum, sexpartitum, biseriatum, exterius calycinum, laciniis duabus posticis saepius inter se connatis, tertia antica interdum breviore, omnibus per aestivationem erectis, valvatis v, rarius spiratim imbricatis; interius corollinum, laciniis inferne plus minus cohaerentibus v. connatis, basi intus saepius squama aut crista nectarifera instructis, per aestivationem spiraliter contortis $v$. rarissime valvatis, marcescentibus.

Sтамгла sex, epigyna, perigyna v. etiam hypogyna. Fil amenta subulata, basi saepius dilatata, libera $v$. inter se et cum perigonii foliolis interioribus plus minus cohaerentia, nunc superne latiora, in annulum connata. Antherae introrsae, biloculares, basi v. medio dorso affixae, erectae v. incumbentes, loculi oppositi, paralleli, basi interdum discreti, rima longitudinali dehiscentes.

Ovarium omnino liberum, nunc semisuperum v. plane inferum, triloculare, e c a rpidi is tribus, marginibus introflexis dissepimenta constituentibus inter se connatis. Ovula nunc plurima, in placentis in loculorum angulo centrali sitis biseriata, adscendentia $\mathbf{v}$. horizontalia, nunc definita $\mathbf{v}$. subdefinita, e placentis e summo v. imo angulo tumentibus pendula v. erecta, semper anatropa. Stylus simplex, trigonus, interdum tripartibilis. Stigmata tria, distincta, simplicia v. rarissime bifida, interdum carnosa v. petaloideo - dilatata, erecta v. spiratim contorta.

Fructus trilocularis, baccatus, indehiscens, v. plerumque capsularis, septicido- $\mathbf{v}$. rarius loculicido-trivalvis, valvis saepius endocarpio membranaceo mox soluto duplicatis.

Semra in loculis plerumque plurima, raro pauca, oblongo-ovata, apice saepissime 
ad chal az a m abruptim acuminata, basi f u $\mathrm{n}$ i c u 1 o plus minus longo, interdum in c o m a m semini parallelam fatiscente sustenta. Test a coriacea, ut plurimum fuscescens. Albumen farinostum, copiosum.

Eмвгуо in basi albuminis parvus, rectus v. uncinatus, extremitate radiculari incrassata, umbilicum attingente.

Bromeliaceae in America calidio$r i$ indigenae, inter ipsos circulos tropicos frequentissime habitant.

Ordo Ensatarum seriem claudens, hinc Hydrocharideis conterminus, illine mediantibus generibus ovario libero donatis in Lilia cea s transit.

\section{* Ovarium inferum. Fructus baccatus.}

1299. Amanassa LINDL. Perigonii superi sexpartiti l a ci n i a e exteriores c a I ycin a e erectae, interiores petaloideae erectae, ligulatae, basi intus bisquamosae, squamis tubulosis. Stam in a 6, epigyna, perigonii laciniis interioribus opposita; fil am entis inter earundem squamas retentes, antheris linearibus erectis. Ovari $\mathrm{n} \mathrm{m}$ inferum, triloculare. Ovula in placenta palmatifida, ex apice anguli centralis loculorum protuberante pendula. Sty1 us filiformis; stigmata 3 , carnosula, erecta, fimbriata. B a c c a e inter se et cum bracteis in syncarpium conferruminatae, loculis plerumque abortivis aspermis, rarissime bi-triloculares. S e min a in loculis solitaria, ex apice loculorum pendula, ovoidea, compressinscula, testa membranacea, fusca, striata, $r$ h a phe fasciaeformi alba $u \mathrm{mbi}$ li cum basilarem $c h$ al a $\mathrm{z}$ a apicali tuberculiformis jungente. Embryo minimus, in basi albumin is farinacei rectus, extremitate radicuI a ri umbilicum attingente, supera. Herbae americanae (?), pertropicos totius orbis diffusae, foliis linearibus integerrimis $v$, spinuloso-serratis, florum spica densa, demum carnosa, connata, saepe coma foliorum terminata.

A n a n a s a Lindl, in Bot. Reg. n. 1068, t. 1081. DC. in Mem, soc. h, n. Genev. VII.161,t, 1,2. A nanas Tournef. t.426_428. B r o m e $1 \mathrm{i}$ a e 8 p. Linn. Redouté Liliac. t.454.456.

1300. Bromelfa $L I N N$. P e $r$ ig o $\mathrm{n} i \mathrm{i}$ superi sexpartiti laciniae exteriores $\mathrm{c}$ a 1 y $\mathrm{c}$ in a e erectae, carinatae, interiores p e ta 10 id e a e convolutae, erectae $\mathbf{v}$. apice patentes, basi intus nudae. Stamina 6 , imo perigonio inserta; fil amentis brevibus, crassiusculis, basibus dilatatis, plerumque inter se et cum laciniis connatis, antheris linearibus subsagittatis, erectiusenlis. Ovarium inferum, triloculare. Ovula in placentis e loculorum angulo centrali prominulis plurima, versus apicem confertiora, horizontalia, anatropa. Stylus brevis, trigonus; stigmata 3 , brevia, carnosa, erecta. B a c ca oblonga $\mathbf{v}$. ovata, trilocularis, pulposa. Semina plurima, ovata, te sta coriacea fusca, $r$ haphe lineari concolore, umbilicam basilarem chalazae apicali tnberculiformi jungente. Embryo parvus, in basi a I b um in is dense farinosi uncinatus, extremitate radiculari incrassata, centripeta. - Herbae americanae tropicae, acaules v. caulescentes; foliis radicalibus linearibus ca- naliculatis, dentato-v. ciliato - spinulosis, floribus laxe spicatis $v$. dense corymbosis, bracteatis.

B romelia Linn. gen, n, 395. excl, sp, Lindl, in Bot, Reg. n. 1068. Jice. Hort, vindob, I. t, 31, 32. 1II, t.73.74. Hort, schönbr, t, 35. Ic. rar. t.60. Salisb. parad. t. 40. Lindl. collect. t. 1. Bot. Mag. t. 2392. Bot. Reg. t, 766. Ka ratas Plum. gen. p. 10. A n a n a s Gärtn. $r, 30, t, 11$.

1301. A eehmea RUIZ, et PAV. B ractea e sub singulo fare cyathiformes. Perigonii superi sexpartiti laciniae exteriores calycinae, aequales, spiraliter convolutae, aristatae v. muticae, apice binc oblique dilatatae, interiores petaloideae, exterioribus multo longiores, inferne convolutae, basi intus squamosae $v$. rarius nudae. St a min a 6 , imo perigonio inserta; fil am e n ta filiformia, tria laciniarum interiorum basi adnata, antherae ovatae, dorso affixae, subincumbentes. Ovari um inferum, triloculare. Ovula plnrima, e loculorum angulo centrali pendula, anatropa Stylus filiformis; stigmat a 3 , linearia v.petaloidea, spiraliter convoluta. B a c c a ovato-subglobosa, trilocularis. Semina plura, ex apice loculorum pendula, testa coriacea fusea, umbilico filo brevi gracili appendiculato. Emb ryo minimus, rectus, in basi a lb $\mathrm{um}$ inis dense farinacei, extremitate radiculari umbilicum attingente, supera. - Herbae americanae tropicae, saepe in arborum truncis pseudoparasiticae; foliis radicalibus ligulatis $v$, ensiformibus, crassis, coriaceis, integerrimis $v$. spinuloso-serulatis, scapo ramoso paniculato, rhachi flexuosa, bracteis sub singulo flore cyathiformibus spinosoaristatis, integerrimis $v$. tricrenatis, floribus terminalibus abortivis.

A e ch me a Ruiz et Pav. prodr. 47. t, 8. Flor. peruv. III. 37. $t$. 264. Lindl. in Bot, Reg, $n, 1068$. Schult, fil. syst. VII. 1271. Bot. Mag. t. 3186. $0 \mathrm{e} \mathrm{ch} \mathrm{me}$ a Juss, in Jeaume St. Hil. exposit. fam. I. 103.

1302. Ballbergia THUNB. Perigonii superi sexpartiti laciniae exteriores calycinae, aequales, ecarinatae, erectae $\mathbf{v}$. spiraliter convolutae, aristatae v. muticae, apice hinc oblique dilatatae, interiores petalo id ea e, exterioribus multo-longiores, apice patentes v. erectae, intus basi squamosae $v$. bieristatae, rarius nudae. Stamina 6, epigyna; filamenta filiformia, tria plerumque perigonii laciniis interioribus adnata, antherae ovatae, dorso affixae, incumbentes v. suberectae. Ovari $\mathbf{u m}$ inferum, triloculare. Ovula plurima, e loculorum angulo centrali pendula, anatropa. Stylus filiformis; stigmata 3 , petaloidea, convoluta, v. linearia crispa. B a e c a sulglobosa, trilocularis. S e m in a plura, nuda v, u in bili cum filo gracili appendiculata. . . - Herbae a mericanae tropicae, saepius super arborum truncis pseudoparasilicae, exscapae v. scapigerae, foliis ligulatis, linearibus $v$. ensiformibus, ut plurimum spinuloso-serrulatis, floribus spicatis, paniculatis, v. racemoso-paniculatis, spathis floralibus nunc nullis, nunc parvis v. amplis, coloratis.

B illb e rgla Thunb. et Holm. Dec, pl, bras, III. 30. Lindl, in Bot, Reg. t. 1068. 1181. Bot. Mag. 2 . 2892. B r omelia s p. Ruiz et Pav, Flor, peruv, , 255. Bot. Mag. $t$. 1732. 2686. Bot. Reg, t.203.344.766.1732, Hook. exot. Flor. t. 41. 42, 143. Reichenb. BLagaz. t.94.

1303. II olhenbergia SCHULT, FIL. Pe$r i g o n$ i superi sexpartiti laciniae exteriores calycinae, pyramidato-trigonae, postieae complicatae, alato-carinatae, antica brevior dorso convexa ; interiores petaloideae, exterioribus longiores, basi nudae v. minute squamulosae, demum spiraliter contortae. Stamina 6, 
annulo epigyno calloso inserta; filamenta linearia, tria perigonii laciniis interioribus basi adnata, apice incrassata, a $\mathbf{n} \mathbf{t} \mathbf{h}$ e $\mathbf{r}$ a e lineares, medio dorso affixae, erectiusculae. Ovarium inferum, triloculare. Ovula plurima, c placenta ex apice anguli centralis loculorum tumente pendula. Stylus filiformis; stigmata 3 , linearia, spiraliter convoluta. B acea globosa, triquetra, trilecularis. Sem in a plura, oblonga, pendula, ad u mbilieum filo gracili appendiculata. - Herbae brasilienses; foliis radicalibus coriaceis, carinatis, spinoso - dentatis, scapis simplicibus $v$. ramosis, floribus dense spicatis, singulis spathaceo-bracteatis.

Hohe ubergia Schult, fil. syst. VII. LXXI. 1251. - ? Bill berg i a e p. Lindl, in Bot. Reg. t. 1130.

\section{* * orarium semisuperum. Fr u c t u s capsularis.}

1304. IBrocellainia SCHULT. FIL. P e r igonii semisuperi sexpartiti laciniae exteriores calyeinae, oblongae, coneavae, obtusae, dorso rotundatae, interiores petaloideae, exterioribus aequilongae, unguiculatae, fornicatoconcavae, basi intus nudae. Stamina 6 , imo perigonio inserta; filamentis inter se et cum ejusdem laciniis ad medium fere connatis, an therae erectae, ovato-sagittatae. Ovarium semiinferum, triloculare. Ovula in loculerum angulo centrali plurima, biseriata, horizontalia.

Stylus brevis trigonus; stigmata 3 , brevia, patentia. Capsula clavato-cylindrica, dura, trilocularis, apiee septicido-trivalvis. S em in a plurima, horizontalia, oblonga, utrinque appendice ensiformi subulata..... Herba brasiliensis, foliis late ligulatis abruptim acuminatis, in spinam callosam desinentibus margine integerrimis, panicula pyramidata furfuraceo-squamulosa, spathis infra ramos acuminatis pungentibus, floribus spicato-racemosis subdistichis.

B roc hinia Sehult. fil. syst, VII, LXX, 1250.

1305 . Fiteairmana HERIT. P e rigonii semisuperi sexpartiti laciniac exteriores calycinae, basi inter se connatae, lanceolatae, acuminatae, carinatae, erectae, interiores petaloideae, longiores, inferne in tubum approximatae, apice galeatim incumbentes $v$. aequaliter patentes, basi intus squamosae $v$. rarius nudae. Stamina 6 , annulo perigyna inserta; fil amenta libera, subulata, antherae lineares, basi sagittatae. $O$ va $\mathbf{r}$ i m seminiferum triloculare. Ovula in loculorum angulo centrali plurima, adseendentia, anatropa. Stylus filiformis; stigmata 3 linearia, spiraliter contorta. Capsula semisupera, ovato-pyramidata, trilocularis, apice septicido-trivalvis, valvis introrsum demum fissis. Semin a plurima, adscendentia, teretiuscula, te st a fusca scrobiculata, $\mathrm{e}$ h a laz a late discolore umbilicum setiformem chalazae apicali in acumen longe productae jungente. E mb $r$ yo minimus rectus in basi a $I b u m i n i s$ dense farinosi, extremitate radieulari umbilicum attingente, infera. - Herbae a mericanae tropicae, foliis linearibus $v$. ligulatis saepe spinoso-dentatis, caule erecto, simplici, floribus race mosis, bracteatis.

Pitcairuia Herit, sert, angl. VIT, t, 11. Ruiz et Pav. Fl. peruv, $t, 258$ 260. Redouté Liliac, $t, 73$-76. Jacq. fil. Eclog. $t$. 79. Andr. Bot. Reposit, t. 249. Bot. Mag. $t .824$. 856. $1416.1462,1347,2411,2642,2656.2813$. Bot. Reg. $t, 1011$. 1069, 1092. E. Meyer in Reliq Haenk, II, $t, 23$, Schrad. in
Comment, Göting. VI. 110. t.3. He pet is Swarte prodr. 56. Spirastigua Herit. mac.

****

Ovarium liberum. Fructus capsu-
laris.

1306. Tillandsia LINN. Perigoni i liberi sexpartiti la $\mathrm{e}$ i $\mathrm{n}$ i a e exteriores $\mathrm{c}$ a $\mathbf{l} \mathrm{y}$ cinae, aequales basi cohaerentes spiraliter convolutae, duo altius inter se connatae, tertia minor, interiores petaloideae, inferne in tubulum convolutae v. connatae, superne patentes, basi intus nudae $v$. rarius squamosae. Stamina 6 , hypogyna; fil amenta linearia, alterna sacpius perigonii laciniis interioribus adhaerentia; antherae incumbentes, basi sagittatoemarginatae. O v a r i m liberum, triloculare. Ov u la in loculorum angulo centrali prope basim plura, biseriata, adscendentia, anatropa. St y I us filiformis; $8 \mathrm{ti} \mathbf{g}$ a trifidum, lobis abbreviatis v. filiformibus aut apice dilatatis, rectis v. contortis. Ca p sula cartilaginea, linearis v. ovata, trilocularis, loculicido-trivalvis, valvis endocarpio mox soluto duplicatis, explanatis v. tortis. Semina plurima e basi dissepimentorum erecta, lineari-elavata, stipitata, stipite pilis papposis cincto, testa dura, chalaza terminali mamillari. Embryo in basi a lb $\mathbf{n m i n i s}$ farinosi rectus, extremitate $r a d i c u l a r i$ infera.

Herbae in America tropica el extratropica calidiore indigenae; ut plurimum pseudoparasiticae, lepidotae, caulibus foliosis simplicibus $v$. rarius ramosis, floribus spicatis $v$, paniculatis, rarius solitariis, bracteatis.

Till an ds i a Linn. gen. n. 369. Ruiz et Pay. Flor.peruv. t. 265_281. Lindl, in Bot, Reg, $n, 1068$. Bot. Mag. $t$. 1529, 2811. 3275. Bot. Reg. $t .105,749,1157.1338 .1357$. Hook. exot. Flor, t. 154. 173. 205. 218, Rudge guian. t. 50. Rossi Cafalog. hort, madoet, t. 1 _-3. Presl in Reliq. Haent, t. 24. Leconte in Annal, Lyc, n. h. New-York, 1826. TI. 129. Brongn. ad Duperr. $t$. 36 . Re ne al m ia Plom. gen. 37. Strepsia Nuttall gen. $I$. 208. A $\mathrm{m}$ at lia Hort. Hisp.

OBSERVATI0. In Tillandsia bicolore ex observatione cl. Brongniart $l$. c. nsemina erecta margini iuteriori ,dissepimenti affixa, lineari-clavata, e basi papposa ; pappns e strato exteriori testae lacerato-efformatus, filamentis simnplicibus denticulatis; testa elongato-cylindrica tubulosa. "iir apice paallulum inflato uucleum, membrana interiore „libera apiceque perforata inclusum, chalaza suspensum conntineus: mucleus ovato-oblongus, nembrana teuui, apice ${ }_{n}$ chalazae opposito manilla superatus; perispermium fari. wnaceum, partem superiorem nuclei oecupaus; embryo obnconicus, superne truncatas, dimidiam partem inferiorem "omuino replens."

130\%. Caragnata PLUM. Perigonii liberi sexpartiti laciniac exteriores calyci$\mathrm{n}$ a e, aequales, basi cohaerentes, suherectae, interiores petaloideae, in tubum apice breviter trilobum connatae, basi intus nudae. St a min a 6 , perigonii interioris tubo adnata, apice filamentorum brevi libero; antherae erectinsculae, basi sagittato-emarginatae. Ovari $\mathbf{~} \mathbf{m ~ l i -}$ berum, triloculare. Ovula in loeulorum angulo centrali prope basim plura, biseriata, adscendentia, anatropa. Stylus filiformis; stigmata 3 , brevia, obtusa, erecta. Capsula cartilaginea, oblonga, trilecularis, loculicido-trivalvis, valvis endocarpio mox soluto duplicatis, explanatis $v$. tortis. S emin a plurima, e basi dissepimentorum erecta, p i 1 i s papposis cincta..... Herbae antillanae, in arborum truncis pseudoparasiticae, foliis lingulatis acutis basi saepius ventricosodilatutis, florum spica simplici, apice interdum comosa. 
C a r a guat a Plum. gen. 10. Lindl, in Bot.Reg,t, 1068. Devillea Bertero msc. Tilland siae $\mathrm{s} \mathrm{p}$. Jacq. amer. $t$. 62. edit, pict. t.92.

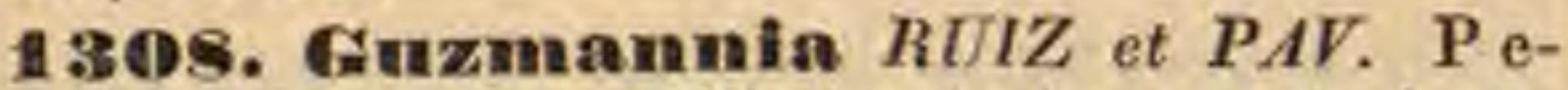
rigonii liberi sexpartiti laciniae exteriores calycinae aequales, basi cohaerentes, spiraliter convolutae, interiores petaloideae, inferne teneriores in tubum convolutae, apice firmiores, erectae, basi intus nudae. Stam in a 6 , hypogyna; filamenta basi perigonii laciniis interioribus agglntinata, superne latiora, apice connata, anth e ra e dorso affixae, utrinque acntae, in eylindrum coalitae. Ovarium liberum, triloculare. $O \mathrm{vula}$ in loculorum angulo centrali prope basim plurima biseriata, adscendentia, anatropa. Stylus fliformis; $s \mathrm{tigmata} 3$, linearia, brevia, erecta. Capsula cartilaginea, oblongo-cylindracea, trilocularis, loculieido - trivaivis, valvis endocarpio mox solutu duplicatis, explanatis $v$. tortis. Semina plurima, e basi dissepimentorum erecta, oblonga, acuminata, $\mathrm{p} \mathrm{i-}$ lis papposis stipata. ... Herba a mericana tropica, foliis radicalibus lineari-ensiformibus cartilagineis planis, basi involutis, scapo inferne squamoso, floribus spicatis inter bracteas latentibus.

Guzm a nni a Ruiz et Pav. Flor. peruv, III.38, t.261. Lindl. collect, t, 8, Hook, exot, Flor, $t, 163$.

130 . BBomapartea $R U I Z$ et $P A V$. P erigonii liberi sexpartiti la $\mathrm{c}$ in ia exteriores caly cin a e, aequales, basi cohaerentes, spiraliter convolutae $v$. duo altius inter se connatae, tertia minor, interiores petalo id e a e, inferne in tubum convolutae, apice lineari-lanceolatae, patentes, basi intus nudae. Stamina 6 , hypogyna; filamente subulata, antherae exsertae, versatiles, basi sagittato-emarginatae. Ovariu m liberum, triloculare. Ovul a plurima, in loculornm angulo centrali biseriata, adscendentia, anatropa. Stylus filiformis; stigmata 3 , lineari-oblonga, fimbriata, spiraliter convoluta. Ca p s n I membranacea, ovato-pyramidata, trilocularis, loculieido-trivalvis, valvis columnam trialatam sinubus placentiferam nudantibus. Semina plurima, linearia, basi attenuata, el a I a$\mathrm{z}$ a apieali in setam producta. Herbae a mericanae tropicae, pube furfuracea conspersae; foliis radicalibus subulatis $v$, ensiformibus, basi convolutis, scapo squamato, spicae simplicis strobiliformis $v$. thyrsoideae floribus bracteatis.

B on a partea Ruiz et Pav. Flor. peruv.III, 38.t, 268. 263. Schult. f. syst. VIT, 1197. A e a thos pora Sprengel Anleit. II. 255. SI is a n d a Dietrich.

1310 . Navia MART. Perignnii liberi sexpartiti lacinia e exteriores calycinae, naviculari-oblongae, basi cohaerentes, superne valvatae, superiores complicatae, acute earinatae, inferior brevior, obtuse carinata; interiores petaIoideae, inferne in tubum conniventes, apice patentes, basi intus nudae. Stam in a 6 , hypogyna; filamenta filiformia, erecta, demum flexnosa v. nutantia, a nt he rae lineari-tetragonae, incumbentes, basi emarginatae. Ovar iim libernm, ovato-trilobum, triloculare. Ovula in loculorum angulo centrali $5 \ldots 6$... St y lus subulatus, tripartibilis; stig mata 3 , filiformia, suberecta, demum flexuosa, patentia. Capsula membranacea, trilocularis, loculicido-trivalvis, septis demum bifidis. Se mina pauca, rotundatoovata, nuda, costata. - Herbae brasilienses tropicae; caudice simplici v. subracemoso, apice folioso, foliis lanceolatis acuminatis dense conge. stis $v$. rosulato-patentibus, scapo simplici lanato $v$. tomentoso, floribus in bractearum axillis dense fasciculato-congestis, bracteolatis.

Navia Martius in Schult. fil, syst, II. LXV. 1195.

1311 . Cottend orfia SCHULT. FIL. P erigonii liberi sexpartiti laciniae exteriores calycinae erectae, superiores paullo breviores, interiores pet a lo id e a e, exterioribus longiores, erecto - patentes, basi intus nudae. St amina 6, hypogyna; fi lam enta subulata, glabra, antherae subincumbentes, ovatae, sagittato-emarginatae. Ovari um liberum, pyramidato-trilobum, triloculare. Ovu 1 a in loculorum angulo centrali prope basim 3 -6. Styl u s subnnllus; stigmata 3 , filiformia, semipatentia, spiraliter torta. Ca psula. ... - Herba brasiliensis rupicola; foliis radicalibus linearibus subulato-acuminatis, acumine convoluto, scapo elato, squamuloso-tomentoso, panicula ampla, laxa, Cottendorfia Sehult. fil. syst, $V I T$. LXIV, 1193.

1312 . Dyekia SCHULT. FIL. P erigon i liberi sexpartiti lacin iae exteriores cal yc in a e, subaequales, erectae, ellipticae, concavae, interiores petaloideae, nrceolato-campanulatae, ovato - rhomboideae crassiusculae, basi intus nudae. Stamina 6 , hypogyna (?); filamenta lanceolata, acuminata, in cylindrum basi laciniarum interiorum perigonii adnatum coalita, a $\mathbf{n}$ h e ra e erectae, ovato-lanceolatae, basi sagittato-emarginata insertae. Ovariu m liberum, pyramidato - trilobum, triloculare. O v n 1 a plurina, in loculorum angulo centrali biseriata.... Stylus brevissimus, tripartibilis; st i g mat a 3 , patentia, apiee bifida. C a p sula. . . Herbae brasilienses monticolae; folïs radicalibus lanceolatis $v$.lineari-lanceolatis, acuminatis, scapo simplici spicato-multifloro, bracteis spinuloso-denticulatis.

D y ekia Schult. fil. syst, $V I I, L X V$. 1195. Bot. Mag. $\ell$. 3/is. Bot. Reg. t, 1782

1313 . Enelnolineinm $M A R T$. Pe rigoni i liberi sexpartiti laciniae exteriores $c$ alycinae, aequales, breves, erectae, interiores petaloideae, rectiusculae. Stamina 6 , hypogyna; filamenta basi dilatata, plana, demum excrescentia, arcuatim convoluta, anthera e lineares, suherectae. Ovarium liberum, pyramidato-trigonum, triloculare. Ovula plurima... Stylns trigonus; stigmata 3 crassiuseula, ovato-oblonga, contorta. Capsula... S em in a oblongo - compressa, membranaceo-marginata. . - Herba brasiliensis scapigera; foliis radicalibus rosulatis, lineari-lanceolatis, margine spinosis, floribus racemosis bracteatis. 1233.

E n chollirium Mart, in Schultes f. syst.VIr. LXVIIr.

1314 . Poarretia $R U I Z$ et $P A V$. Perigoni liberi sexpartiti lacinia exteriores $c$ aIy eina e, aequales, subconvolutae, interiores petaloideae, inferne convolutae, apice patentim reflexae, marcescendo spiraliter convolutae. St am ina 6, hypogyna; filamenta subulata, antherae incumbentes, lineares, basi emarginatae. Ovarium liberum, trigonum, triloculare. Ovula plurima, in loculoram angulo centrali biseriata, horizontalia, anatropa. Stylus filiformis; stigmat a 3 , linearia, spiraliter contorta. Ca psula cartilaginea, pyramidato-trigona, trilocularis, loculicido - trivalvis. Semina plurima, compressa, hinc anguste membranaceo-marginata. . - Herbae in $A m$ e rica tropica et australi extratropica monticolae; caule sim- 
plici interdum subarboreo folioso, foliis angustis spinosis, spicis bracteatis, solitariis $v$. paniculatis.

Pourretia Ruiz et Pav. Flor. peruv. III, 33, $t, 256$. 257. Pöppig et Endl, nov. gen, et sp. $t$, 141. P u y a Molina Chili p. 176. Juss, gen, 4i7. Schult. f. syst, VII, $n .1480$. A c hu pall a Humboldt Vues des Cordill. t.30.

\section{GENUS DUBIUM.}

1315. EVeldenia SCHULT, FIL, Perigonium corollinum liberum, hypocrateriforme, t $\mathbf{u b}$ o filiformi longissimo, I i mb i tripartiti laciniis subaequalibus obovatis obtusis, patentibus, demum reflexis. Stam in a 6 , perigonii fanci inserta, alterna limbi laciniis opposita paullo majora; fil amenta filiformia, antherae ovatae, basi bifida insertae. Ovari $\mathbf{m}$ liberum, oblongum, triloculare. Ovula in loculis $3 \_4$, angulo centrali affixa, subglobosa.... Stylus filiformis, erectus; stigma trigono-capitatum. Fructus. . . - Herba mexic an a; foliis radicalibus congestis, imbricatis, lineari-lanceolatis, integerrimis, glaberrimis, floribus plurimis albis in centro foliorum subsessilibus, spathis tubulosis apicem versus dilatatis, demum hinc longitudinaliter fissis, unifioris.

We id enia Schult, fil, in Flora 1899, p, $1, t, t$.

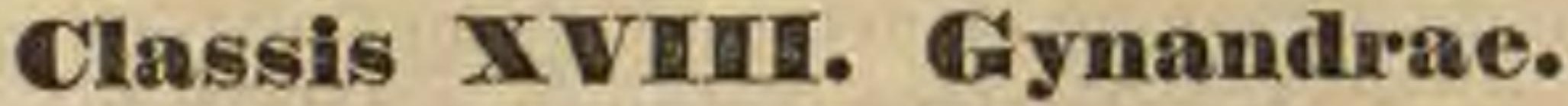

Herвae v. suffrutices, radicibus fibrosis, tuberileris, v. rhizomate repente perennantes. C a ul es simplices v. ramosi, saepe aphylli, foliis radicalibus basi varie saepius connatis inclusi. Folia integra, basi vaginantia, parallele venosa. Perigosium corollinum superum, hexaphyllum, irregulare, foliolo interiore postico plus minus dissimili. Stamisa 3 , cum stylo connata (gynandra); rarissime $2 \mathrm{v}$. 3 , plerumque unicum fertile, reliqua abortiva, rudimentaria. Ovariom inferum, uniloculare, placentis parietalibus tribus; rarissime triloculare, placentis centralibus. Ovula plurima, anatropa. Frverus capsularis v, rarius baccatus. Snura plerumque scobiformia, exalbuminosa, embryone homogeneo.

\section{Ordo $\boldsymbol{L} \mathbf{X I}$. Orchideae.}

ORCHIDES Juss. gen, 64, ORCHIDEAE R. Brown prodr. 309. Observations on the sexual organs of Orchideae and Asclepiadeae. London, 1831. 4to. L. C. Richard de Orchideis europaeis adnotationes. Parisits, 1818, 4to. et in Mem, du Mrus. IV. 23, 55 Bartling ord. nat. 5\%. Lindley, Orehidearum sceletos. Lond. 1826. 8vo. et in Linnaea II. 587. The genera and species of Orchideous plants. London, 1830 1833. 8vo. Part. 1_4. The genera and species of Orchideous plants illustrated by drawings on stone from the sketches of Francis Bauer. London, 1830 1834. Ato. Port. 1_9. ORCHIDACEAE Lindley introduet. edit. II. p.336.

Herbae radicibus fasciculato-fibrosis, nonnunquam tuberculiferis, $\mathbf{v}$, rhizomate repente perennantes, rarius suffrutescentes, nunc acaules foliorum basibus in truncum brevem (pseudobulbum) connatis, scapis radicalibus v. terminalibus, nunc caulescentes, pube rara, dum adest saepins glandulosa. Caules v. scapi saepissime simplices, teretes $\mathbf{v}$. angulati, nune aphylli, vaginati. Foli a plerumque ad basim caulis conferta, caulina alterna v. subopposita, basi vaginantia, carnosa v. membranacea, integerrima, parallele nervosa, rariusve reticulato - venosa.

Frones hermaphroditi, irregulares, plerumque speciosi, spicati, racemosi v. corymbosi, rarius paniculati, nunc solitarii terminales, pedicellati v. sessiles, bractea solitaria fulti.

Prrigoniux superum, corollinum, v. rarius herbaceum, nunc membranaceum $\mathbf{v}$, interdum carnosum, persistens v. deciduum, e foliolis sex compositum, ut plurimum irregulare, saepissime ringens, rarius subaequale v. aequale. Foli ola biseriata, libera v. plusminusve inter se coalita, tria exteriora, (sepala auct.) non raro rudiora, nempe duo l a $\mathrm{t}$ e $\mathrm{r}$ a $\mathrm{I} \mathrm{i}$ a, basi saepius inaequalia, interdum postice approximata et in unum connata, et unum a nticum (supremum) ovarii v. pedicelli torsione plerumque posticum, saepe lateralibus conforme et subaequale, directione ut plurimum dissimile; interiora 2 , inter exteriora lateralia et anticum sita, iisdem conformia, panllo dissimilia v. aequalia v. plerumque minora aut rarius majora, nunc libera, nunc cum foliolis exterioribus interdum etiam cum columna genitalium connata, quaadoque admodum nana, rarissime plane deficientia; tertium vosticum (labellum), pedicelli torsione saepissime anticum, inter exteriora lateralia situm, a reliquis substantia, forma, directione et magnitudine plus minus diversum, basi columnae genitalium adnatum v. liberum, ejusdem basi productae continuum v. cum eadem articulatum, unguiculatum v. sessile, basi saepe saccatum v. calcaratum, limbo plano, cucullato, integro v. saepius trilobo, disco nudo, calloso v. lamellato.

CoLumsa genitalium e stylo staminibusque in corpus solidum conferruminatis (gynostemio) conflata, ita ut stylin a materies ejusdem faciem anticam, labello obversam stigmate, st a minea dorsalem antheris terminatam constituat, recta v. basi plus minusve producta, in ovarii vertice obliqua v. prona.

Sтамиха tria: anticum, perigonii foliolo exteriori antico, et lateralia, duobus interioribus lateralibus opposita, haec vix non semper abortiva, v. rudimentaria, illud plerumque solum fertile, v. dum lateralia perfecta abortivum. Anthera bilocularis, nunc septo incompleto unilocularis, nune loculis septis secundariis plus minusve completis quadrilocularis, v. loculis etiam transverse plurilocellatis, erectiuscula $v$. in foreola, in quam saepius columnae apex excavatur (clinandrio) prona, nunc dorso columnae continua, nune ejusdem in 
filamentulum brevissimum contractione stipi- misphaerae australis regionibus subtata, v. sessilis, per angustam baseos partem tropicis temperatisque pariter ut plurimum postico clinandrii margini immediate affixa, epigaeae, triplo quam in isothermis hemisphaev. marginalis, ipso clinandrii margini inserta, rae borealis regionibus frequentiores.

v. intramarginalis, i. e. intra interiorem clinandrii marginem affixa. Pollin is granula in massits 2 - 4 v. 8 (pollinia), figurae determinatae conglobata, massae nunc e globulis (massulis) plurimis angulosis, materia glutinosa cohaerentibus formatae, nunc circa axim cellulosam conglobatae, subpulvereae, lamelliformes, e granulis facile solubilibus compositae, nunc ceraceae et laeves, stigmati v. immediatim applicitae et supra illud deliquescentes, nunc ope prolongationis axeos (caudiculae) glandulae stigmatis affixae.

Ovarivm inferum, uniloculare, saepissime tortum, longitudinaliter sexcostatum, costis alternis crassioribus perigonii foliolis exterioribus oppositis, tribus alternis intus placentas. parietales nerviformes multiovulatas gerentibus. Ov ula plurima, in funiculis brevibus anatropa? Stylus cum staminibus connatus, columnae faciem labello obversam occupans, apice infra antheras in processum carnosum, rarissime plus minusve horizontalem (rostellum) productus. Stigma (gynixus) in columnae facie obliquum, concavum, mucilaginosum, cum columnae cavitate communicans, apice lateribusve glandula simplici v. duplici, nuda v. stigmatis plicatura (bursicula), duplici glandulae communi v. pro singulis singula, pollinis massas affigente, instructum.

Capsula membranacea v, coriacea, rarissime intus pulposa, sublignosa, unilocularis, fenestratim trivalvis, valva e medio placentiferae, a costis tribus validioribus persistentibus, basi apiceque cohaerentibus, solutae.

Semina plurima, parietalia, minutissima, integumento laxo reticulato, utrinque attenuato scobiformia, rarissime solida. Albumen nullum. Emnryo carnosus, solidus.

Orchideae mira multiformis floris conformatione, et anomala genitalium structura a reliquis plantis distinctissimae, et inter A cramphibryas Asclepiadeis analogae, hine mediantibus Apostasieis cum Scitaminearum classe conterminae, illinc per genera nonnulla, perigonio subregulari donata, $\operatorname{lr}$ id e a s spectantia, juxta naturales generum tribus per universi orbis climata diffusae, maximo numero in $z$ on ae tropicae sylvis humidis gignuntur, ubi innumera specierum copia imprimis super arborum truncos vegetant, in hemisphaerae borealis temperatis etfrigidis epigaeae, $v$, in radicibus parasiticae, multo minori copia obviae, versus polos et in alpibus numero imminuuntur, in he-

Plantae ob mirum florum leporem singalari quidem pratis lucisque, imprimis montanis regionum temperatarum, et sylvarum tropicarum secessibus ornamento, et nune hortorum nostrorum deliciae, sed parci in oeconomia generis humani usns; nonnullae tamen (Eulophiat sp.) ob radices succulentas principio peculiari nutriente (Banorin) scatentes, magni faciendae, aliae (Vanillae) etiam ob capsulas pulpa aromatica suavissima repletas cultae, et verisimiliter plurimis vires adhuedum nos latentes insunt.

De floris orchidei morphonomia variae auctorum sententiae, nos vulgatissimam, quae labellum pro simplici perigonii interioris foliolo postico (pedicelli v. ovarii torsione ut plurimum antico) habet, in ordinis descriptionem recepimus quidem, sed monemus, labelli singularem structuram ejusque varium situm, variamque cum columna genitalium cohaesionem, vix e sola folioli perigonialis metamorphosi satis posse explicari, et huic organo tantopere vario, et quo ad singularum partiun intimam significationem per singula genera perpendendo, aliquid naturae stamineae et stylineae inesse. Certe in flore orchideo, in axi sua plus minusve excentrico, stamina tria cum stylo dimidiato conferruminata, nequaquam tribus perigonii foliolis exterioribus respondent, sed solum fertile perigonii foliolo exteriori postico, (sepalo supremo) est oppositum, sterilia (staminodia) ante foliola interiora lateralia, (i. e. ante petala, nec ante sepala exteriora, ut vulgaris est opinio) sita sunt, unde, etiam Apostasieis nihil in contrarium probantibus, conjecturae locus est, stamina postica, quorum situs necessario ante foliola exteriora lateralia et interius posticum esset, cum hoc foliolo, nisi in plurimis plane est suppressum, in labellum transfigurari, stylina materie $e$ columnae basi etiam plus minusve in illud transeunte, superiorem labelli faciem centro floris obversam occupante.

Generum, quorum plurima a me visa non sunt, characteres in prioribus subordinibus e cl. Lindl. monographia classica mutuatus sum.

SUROIDDO I. MALAXIDEAE Lindley Orchid. 1. Pollen in massas ceraceas definitas cohaerens, stigmati immediate applicitum, tela cellulosa accessoria nulla, A n ther a terminalis v. opercularis. - Herbae terrestres v. epiphytae, foliorum basibus v. caulibus saepius incrassatis. Malaxideae pleraeque Indiae orientalis terram 
continentem et insulas incolentes, in archipelago malayano imprimis copiosae. Pauciores Americam tropicam, Africae australis insulas et littus oc $c i$ dentale tropicum, nonnullae Novam Hollandiam et Oceaniam incolunt, paucissimae in hemisphaera boreali, $A m e$ rica videlicet septemtrionali, Sibiria et Europa, ubi $68^{\circ}$ L. B. petunt, vigent; $e$ regione mediterranea, Africa capensi et America australi extratropica omnino exules.

TER IBS I. PLEUROTHALLEAE Lind]. Orchid. 3. Columna erecta, ovario continua, v. basi parum producta.

13 16. Plewnothallis R, BR. Perigonii foliola exteriora conniventia, subaequalia, lateralia v. omnia connata; in teriora minora. $\mathrm{L}$ a be $11 \mathrm{um}$ liberum, columnae paralleIum, difforme, integerrimum. Col umna elongata, ovario continua, libera, aptera. Anthera bilocularis, apice membranacea. Pollinia 2, saepius candicula pulverea apice juncta. - Herbae americanae tropicae, epiphytae; rhizomate filiformi, repente, caulibus filiformibus monophyllis, floribus axilluribus solitariis, fasciculatis $v$. racemosis, herbaceis $v$. fuscis.

Plenrothallis R. Brown in Hort. Kew. ed. 2. $V$. 211. Hook, exot. El. t. 123.197. Bot, Reg, t 1298. 1797. 1825. Bot. Mag. 1. 3030. Linalley Orchid, 4. Pöppig et Eudlicher nov. gent. et sp. t. 82_s7. E p ide nd ri sp. Linu. Jacq. amer. t. 133, f. 3 .

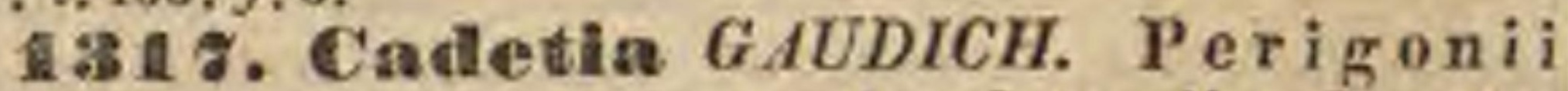
foliola extexiora patentia, lateralia obovata, labello supposita et adnata, superius oblongum, galeatum; interiora lineari-subulata, arcuata. L a b e 11 um concavum, calcaratum, trilobum, lobis lateralibus minimis, calcare retuso-didymo. Col umna ovario continua, semiteres, aptera, utrinque appendice subuliformi, clinandrio bidentato. Anthera uniloenlaris, apice membranacea. Po Ilinia 2. ...- Herba moluc cana, pusilla, epiphyla; caulibus fasciculatis, simplicibus vaginatis apice monophyllis, folio carnoso, enervi, plano, cum vagina articulato, floribus terminalibus pedicellatis, fasciculatis, albis, capsula obovata, echinato-tuberculosa.

$\mathrm{C}$ a d e ti a Gaudich. ad Freyc, 422, $t, 33$.

1318. Speelationia LINDL. Perigonii folio la exteriora conniventia, aequalia, omnia distincta, lateralia basi saceata, extus gibbosa; interiora multo minora. Labellum liberam, conforme, basi saccatum. Col um na nana, ovario continua, libera, membranaceo-alata. A nther a bilocularis, oblique terminalis. PoIlinia 2 , caudiculae communi insidentia. - Herbae in America tro pica epidendrae, pusillae; caulibus filiformibus monophyllis, foliis coriaceis, pedunculis axillaribus uni-paucifloris.

Specklinia Lindley Orchid. 8. Pöppig et Endl, nov. gen. et sp. t, 89. 20. E pidendri s p. Swartz. Hook, exot. Fl. $t, 109$. D e n d r o b i i s p. Swartz.

13 19. Plnysosiphon LINDL. P e rigoniifoliola exteriora in tubum ventricosum, apice trifidum connata; in teriora in fundo tubi nana, carnosa. Lab e 11 u m nanum, foliolis interioribus subconforme. Co I и $\mathrm{ma}$ ovario continua, nana, mutica. An thera. . . Pollini a 2, sphaerica. - Herbae americanae trop icae, epiphytae, habitu Pleurothallidis.
Phy sosiphon Lindley in Bot, Reg. n. 1797. Pletlrothaillis tubat a Loddig. Bol. Cab. t. 1601 .

$13 \% 0$. NYyoxantlans PÖPP. et ENDL. Perigonii foliola basi in cyathum connata, aequalia, elongato-filiformia, exteriora lateralia altins eohaerentia, basi saceata; interiora conformia. Labell am nanum cum columnae pede artieulatum. Co I um n brevis, ovario continua, basi producta, aptera, apice marginata. Anthera unilocnlaris, opercularis. Pollinia 2, caudicula nulla. - Herba in sylvis elatioribus Peruviae epidendra; rhizomatis fibris in caespitem intertextis, cuulibus caespitosis monophyllis, floribus axillaribus sessilibus, in capitulum subglobosum aggregatis, pubescentibus.

M yoxanthus Püppig et Endil. nov, gen. et sp, I, 50 . t. 88 .

1 321. Aspegremia PÖPP. et ENDL, $\mathrm{Pe}$ rigonii foliola libera, conniventia, exteriora lateralia labello supposita; in teriora aequalia. Labell $\mathrm{m}$ cum columnae basi continuum breviter unguiculatum, erectum, trifidum, laciniis lateralibus filiformibus, intermedia lata, triloba. Columna ovario continua, basi vix producta, nana, semiteres. Anther a quadrilocularis, terminalis, nuda. Pollini a 8, collateralia. - Herba peruana epiphyta; caulibus teretibus vaginatis scirpoideis, floribus laterulibus fasciculatis, paleaceobracteatis. t. $11 \overline{\text { A }}$.

A s pegreuia Propig et Endl, nov, gen, et sp. II. 12.

1323. Detomeria R. BR. Perigonii foliola exteriora patentia, aequalia, hasi breviter cohaerentia, Iateralia cum basi colummae producta connata; in teriora conformia. Labe II u cum pede columnae artieulatum, basi saccatum, subtrilobum, patens. Col um na elongata, ovario continua, basi leviter producta, semiteres. Anthera quadrilocularis, terminalis, crista callusa. Pollinia 8, collateralia, quaternatim cohaerentia. - Herbae americanae tropicae; caulibus teretibus articulatis, fibroso-vaginatis, monophyllis $v$, rarius foliosis, foliis coriaceis, floribus axillaribus fascieulatis $v$. solitariis, interdum terminalibus racemosis, pedicellis imbricato-bracteatis.

Oetomeria R. Brown in Hort. Kew. 2. V. 211. Hook. Bot. Mag. 1. 2764. 2823. Lindl. Orehid, 9. Frane, Bauer gen. t.4. Kuli et Hasselt Orchid, edid, Breda t, 5.11.12. Ep ide ud ri s p. Linn.

OBSERVATIO. BRYOBIUM, genus novam Oetomeria afline, floribus parvis leerbaceis, psendobulbis, foliis caruosis, colamar mana, pollini is octo in. cumbentibus, et a $n$ ther a biloculari diversum, a cl. Lindley introduct, edic. $I$. p. 466 , commemoratur.

13\%3. Evelyma PÖPP. et ENDL. P erigonit foliola exteriora erecta, libera; interiora subaequalia. La b e 11 um cum pede coIumnae continuum, eirca eandem convolutum, obcordatum, basi saccata bicallosum, disco nudum. C o l u m na ovario eontinua, basi parum producta, semiteres, clavata, medio antice processu brevi aucta. Anthera terminalis, bilocularis, loculis incomplete quadrilocellatis. Pollinia 8, collateralia, basi quaternatim subeohaerentia. - Herbae peruana e epiphytae; caulibus vaginatis foliosis, floribus spicatis $v$. subcapitatis, imbricatobracteatis.

Evelyna Poppig et Endlieher nov. gen, et sp. 1.32. t. 56 _ 58 .

1324. Fepanthes SWARTZ. Perigunii foliola exteriora patentia, aequalia, lateralia paullo altins connata; interiora nana, libera. La b e 11 um columnae adnatum, bilohnu. $24 *$ 
Colum a elongata, teres. . . Anthera.

Pollinia 2....- Herbae antillanae, epiphytae, caulibus filiformibus monophyllis vaginatis, spicis axillaribus, floribus minutissimis, luteis v. sanguineis, columna semper sanguinea. - Genus maximopere dubium.

Lepanthes Swartz in Act. acad. Upsal. VI. p. 85. Lindl. Orchid. 10. Bot. Reg. t,1762. Hook. Journ. of Bot, t. 94 .

1325. Stelis $S W A R T Z$. Perigoni foliola exterior a globoso-conniventia, valvata, basibus subconnata; interiora nana. Labe 11 um conforme, aequilongum. CoIumna nana, ovario continua, mutica. Anth era unilocularis. Pollinia 2 , ceracea, ovata, distincta, vel apice materia viseida cohaerentia. - Herbae a mericanae tropica epiphytae, habitu Pleurothallidis.

Stelis Swartz in Schrad, Journ, 1799, p. 239. t. 2. $f$. 3. Hook, exot, Fl, t, 158, Lindl, Bot, Reg. t,935, Orohid, 11 . Póppig et Endl. nov, gen. et sp. $t .79$. 81 . H u m bo I d tia Ruiz et Pav, prodr. 121, $t, 27$. E pide n dri s p. Linn. Jacq. Amer, t.133. f. 2.

1386. Dsyreern BLUM. Perigoni foliola exteriora subringentia, basi subconnata, lateralia omnino conereta; interiora minora. La b e $11 \mathrm{~nm}$ cum colnmnae ungue calloso articnlatum, ventricosum, indivisum, limbo convexo, glandnloso. Columna ovario continua, brevis, semiteres, apice bialata, alis trienspidatis. Anthera semibilocnlaris, antice in laminam glandulosam expansa. Po 11 in i a 2 , pulposo-ceracea, ovalia, basi cohaerentia. - Herba javanica, epiphyta; foliis lineari-lanceolatis, e pseudobulbis moniliformibus, spicis radicalibus, floribus purpurascentibus.

Os y ricera Blume Bijdr. 307.f.58. Lindl. Orchid.13.

132\%. Clarysonlossuma BLUM. P e ri gonii foliola exteriora ringentia, basi leviter coalita, lateralia labello snpposita; interiora subaequalia. Labelinm ungui columnae calloso elastice affixum, basi auriculatum, intus lineis prominentibus cristatum, limbo sublobato, patente. Coln n na ovario continua, semiteres, basi alata et callosa, apice utrinque in cornu producta. An thera bilocularis. Pollinia 2, snbgloboso - angulata, libera. - Herbae terrestres, javanicae; radicibus repentibus, annulatis, fibrilliferis, foliis in pseudobulbis subsolitariis, pedunculis radicalibus, floribus laxe spicatis, pedicellatis, bracteatis.

Chry 80 glossum Blame Bijdr. 337. fig. 7. Lindley Orchid, 13.

1328. Gastrogiottis BLUM. P erigonii foliola exteriora patentia, lateralia latiora labello supposita basique connata; in teriora conformia. Lab e $11 \mathrm{um}$ cum basi columnae connatum, limbo erecto, semitrifido. Col um a ovario continua, superne libera, apice attenuata. Anthera denticulo dorsali affixa, bilocularis. Polli nia 4 , obovata, per paria pilis glutinosis cohaerentia. - Herba javanica terrestris; radicibus fibrosis, caule simplici erecto, foliis oblongolanceolatis, plicatis, pedunculo terminali, elongato, apice multifloro, floribus parvis sessilibus, fiavovirentibus.

Ga 8 troglot $t$ is Bluare Bijdr. 397. Lindl. Orehid.14,

1324. I Festrepla KUNTH. Perigonii foliola exteriora patentia, lateralia labello supposita, omnino connata; interiora filiformia, basi triangulari breviter connata. $\mathrm{L}$ a b e $11 \mathrm{um}$ liberum conforme, basi biauriculatum v. bicorne patens. Columna ovario subincumbens, brevis, semiteres, apice in alam producta. An $t \mathbf{h}$ e ra antica, nnilocularis. Pollin ia 2 , ceracea, oblonga. - Herbae americanae tropicae parasicae; caulibus caespitosis monophyllis, floribus axitlaribus solitariis $v$, fasciculatis, majusculis.

Restrepla Kunth in Humb. et Bonpl, nov. gen. ot sp. I. 367, t. 94. Lindl, Orchil. 14. Puppig et Endl, nov,gen. et sp. I. 34. t.59.

1330. Dberomia LINDL. Perigoni i foliola exterio ra patentia v. reflexa, subaequalia, libera; interiora minora, conformia v. linearia, interdum erosa. L a b ellu m liberum, adscendens, cum columna haud articulatum, varium, saepins elongatum, plus minus distincte quadrilobum, lobis lateralibus dentiformibus, intermediis fere connatis. Colum a ovario continua, minima, stigmate elevato. Anthera bilocularis. Pollinia 2 , solida, pyriformia. - Herbae in India orientali, imprimis insulari saxicolae et epidendrae, saepius acaules; folits semper distichis, scapis ut plurimum ancipitibus, floribus nunc in racemo elongato verticillatis, nunc alternis, viridibus $v$. luteis.

Oberonia Lindl. Orohid. 15. Brongn, ad Duperr. $t$. 40. A. Rich, sert. Astrolab. t, 2,3, P le urot ballid is s p. A. Rich. Mem, soc, h, n. paris. IV. t, 8. f.1.

1331 . 'Ritumia ENDL. Perigonii foliola exteriora lateralia reflexa, supremum angustius, patens; interi ora minora, conformia. La b e Il u m posticum, adscendens, trilobum. Col u m na ovario continua, minima, teres, apice utrinque unidentata. Anthera bilocularis. Pollinia 4, incumbentia. - Herba pusilla in insula Norfolk indigena, habitu Oberoniae; foliis distichis, scapis angulatis, floribus racemosis, coccineis, minutissimis.

Tit a ni a Endl. prodr, Elor. Norfolk, 31.

1332. Carteretia $A$, RICH. Perigonii foliola exteriora lateralia basi obliqua, adscendentia, acuta, supremum paullo angustius subconcavum, obsusum; interiora paullo minora, obtusa. L a b e 11 um columnae parallelum, concavum, basi in calcar productum, tripartitum, laciniis ereetis, intermedia trifida. C o $1 \mathbf{u ~ m ~} \mathrm{n}$ a ovario continua, brevis, semiteres. Anthera bilocularis, antice apiculata. Pollin ia 2 , subglobosa. - Herba in Nova Hibernia parasitica; foliis pedalibus, scapo ramoso vaginatim bracteato, floribus racemosis parvulis, virescentibus.

Carteretia A. Richard Sert. Astrolab. 10, t, 4 .

1 333. Empusaria REICHENB. P erigonii foliola exteriora patentia, lateralia basi inaequalia, labello supposita eique inferne oblique connata; posticum et in te ri o ra linearia, patentia. L a be $11 \mathbf{n m}$ erectum, cueullatum, basi auriculatum et cum colnmna connatum, bituberculatum, limbo patente indiviso. Col umna ovario continua, elongata, semiteres, arcuata, apice utrinque alata. An thera bilocularis. Pollinia 4 , collateralia. Herba nep alens is, epidendra; caule pedali membranaceo-alato, foliis membranaceis, plicatis, racemo terminali multifloro, floribus ochroleucis.

Em p u saria Reichenb. consp, p. 69. Empus a Lindl. Bot. Reg. 825. Orchid, 17 .

1334 . Platystylis BLUM. Perigonii foliol a exteriora patentia, libera, lateralia labello supposita, angustiora; inter iora flliformia. L a b $11 \mathrm{um}$ liberum adscendens, integrum, medio sulcatum, etuberculatum. Co lu m n a ovario continua, erecta, compresso - dilatata, discifor- 
mis, stigmate marginato. An the ra bilocularis, parva. Pollin i a 4, collateralia. Herbae $j a$ vanicae in arborum truncis parasiticae, pseudobulbis ovatis compressis, pedunculis erectis vel nutantibus, floribus racemosis $v$. in apice pedunculi confertis, bracteatis.

Platystylis Lindl. Orchid. 18. Malaxis sect. 2. Platysty I s Blume Bijdr. 389. fig. 54 .

1335. NHerostyllis NUTT. Perigoni i foliola exteriora patentia, libera, lateralia basi aequalia, saepius breviora; interiora filiformia v. linearia, patentia. Lab ellum patentissimum, basi excavatum, sagittatum $\mathbf{v}$, auriculatum, integerrimum v. denticulatum, etuberculatum. Col u $\mathrm{m} n$ a ovario continua, minima v. paullo producta, apice bidentata v. biaurita. An the$r$ a bilocularis. Pollinia 4, collateralia, apice per paria cohaerentia. - Herbae terestres $v$. epiphytue, inter tropicos utriusque hemisphaerae, in Europa et America boreali et frigida parce obviae; foliis plicatis v. membranaceis, basi interdum incrassatis, floribus herbaceis, flavescentibus $v$. discoloribus.

Microstylis Nutt. gen. II. 196. Lindl. Orchid, 18. Bot. Reg. t. 1290, Pöppig et Endl, nov. gen, et sp. t. 110. Crepidi um Blume Bijdr. 387. $f_{i g}$.63. Monorehis Mentz. pug. $t . s, f .12$. A chroanthes Raf, in New-York medic. Reposit. $V$. 350. P terochilus Hooker ad Beechey $t, 17$, Oph ry dis s p. Limm. Jaeq. collect. IY. t. 13. f. 2. M ala $\mathrm{x}$ id is s p. Swartz. Loddig. Bot. Cab. $t, 116$.

1336. Diemia $L I N D L$. Perigonii foliola exteriora patentia, libera, lateralia basi aequalia, saepius breviora; interiora filiformia, patentia. Lab ell u m erectum, basi columnae adnatum, nunc concavum membranaceum, acute triIobum, nune excavatum, margine callosum, apice trilobnim v. indivisum. Co I u mna ovario continua, recta, semiteres, clavata, elongata, v. cum labello concavo minutissima. A $\mathrm{n}$ th e $\mathrm{r}$ a bilocularis. Po 11 in i a 4, collateralia, apice per paria cohaerentia. - Herbae terestres, in $A m$ er $i$ catropica et in Asia tropica et boreali repertae; foliis basi subinerassalis, membranaceis, plicatis, scapo tereti $v$. angulato, aptero, floribus terminalibus racemosis $v$. spicatis, parvis, herbaceis v. fuscis, fructus angulis saepius crispatis.

D ien i a Lindl, Bot. Reg. t. 825. Orehid. 22. Pedile a Lindl, Orchid, scelet, p. 27, eum ic.

$133 \%$. Nlalaxis $S W A R T Z$. Perigoni foliola exteriora patentia, libera, subaequalia; interiora duplo minora, conformia. Lab 11 um posticum conforme, adscendens, concavum, integerrimum, etuberculatum. Col um $\mathrm{na}$ ovario continua, minima, teres, apice utrinque dentata. A n thera bilocularis. Pollinia 4 , in cumbentia. - Herba in paludosis turfosis Euro pae mediae et borealis obvia; foliis paucis, venosis, basi carnosis, floribus racemosis luteovirescentibus.

M a 1 a x is Swartz Act, Holm, 1800, p. 233, t. 3. Lindley Orchid, 23, Hook. Lond. t. 197. Frane, Baner Orchid, t.1.

1335. Nephelaphyllum BLUM. $\mathrm{Pe}$ rigonii foliola exteriora linearia, paten tia $v$, reflexa, libera aequalia; interiora conformia. Lab ell um liberum, columna paralle Ium, calcaratum, linea media elevata, integerrimum. Col u m n a ovario continua, recta, semiteres. Anthe ra bilocularis, triangularis, carnosa. Pollinia 8, subquadrata, quaternatim incumbentia. - Herbae javanicae, terrestres, subcaulescentes, glabrae; foliis ovatis, petiolatis, plicatis, supra nebuloso-pruinosis, subtus purpuras- centibus, pedunculo terminali multifloro, floribus purpurascentibus.

Nephelaphy 11 um Blume Bijdr. 372. fig. 22.

1339. Corrallorlhiza HALL. Perigon ii folio la conniventia, libera, exterior a oblongo-linearia, interioribus conformilus sulaequalia. L a b ell u m basi columnae adnatum, patens, ecalcaratum, basi subsaccatum, trilobum, lobis lateralibus minimis, basi callis dnobus linearibus, disco nudum. Columna ovario continua, recta, semiteres. Anther a terminalis bilocularis, loculis subtransversis. Pollinia 4, subglobosa, incumbentia. - Herbae aphyllae, in E uropa media et America boreali indigenae; rhizomate corallino, e tuberibus subpalmatis, scapo vaginato, floribus spicatis.

Corallorhiza Hall, Helv, II, 159, t, 44, R. Browa in Ait. Hort. Kew. II. 5. 209. L. C. Richard Orchid. europ. 31. Nees jun. Gen. plant. fase. VI. t. 9. Ophry s Corallorhiza Linn. Elor. dan. 4. 451. Hooker Flor, Lond, ic. - A plectrum Nuttall gen, II. 197. (Corallarhiza hiemalis) labello unguiculato, anthera infrapicillari, polliniisque lenticularibus diferre dicitur.

1340. Liparis L.C. RICH. Perigonii foliola exteriora patentia, libera, lateralia basi aequalia, saepius breviora; interiora linearia v. filiformia, raro aequalia. Labe $\mathrm{Ilum}$ erectum v. adscendens, columnae pedi breviter adnatum, supra basim saepins bituberculatom, integrum v. mucronibns aliquot instructum. CoI u m a ovario continua, elongata, semiteres, incurva, apice marginata. Anthera bilocularis. $\mathrm{P}$ o $1 \mathrm{l}$ i n $\mathrm{i}$ a 4 , collateralia. Herbae in Ind ia orientali obviae, in he misphaerae borealis temperatis frigidiusculis rurae, terrestres $v$. epiphytae; foliis basi saepissime in pseudobulbum concretis, nunc membranaceis, plicatis, nunc subcoriaceis, venis minus distinctis, scapo tereti, angulato v. ancipiti, floribus parvis, racemosis, herbaceis, ramis luteis $v$. albis.

L i par is L. C. Richard Orchid, europ. 30. f.10. Lindl. Orchid. 26.

a) STURMIA neichenb. Folia membranacea plieata. Pleraequae terrestres.

Sturmia Reichenb. consp, $n$, 1564. Ophrydis $8 \mathrm{p}$. Lim. R. B. $t$. 47. FI, dan, $t$. 877 . Malaxis Thouars Orchid, afr. $t .25$ _27. Bot. Mag, t. 2004. C y m b i di i s p. Hook. exot. Fl, t, 116. (Richard op, cit, $f, 10$, Bot, Reg, $t, 1175$. )

b) CESTICHIS Thouars. Folia subcoriacea, haud plicata. - Plures epiphytae, scapis anoipitibus.

Cestichis Thouars op, cil. $t, 90$. Malaxidis sp. Thouars op. cil. t. 89, 90. (Bot. Reg, $t, 882,2709$. Wallich Pl. as, rar. t.35.)

1341. Dendroehilim $B L U M$. Perigonii foliola patentia, libera; exteriora et interiora conformia. Labellum liberum, sulsconforme, integerrimum, basi concavum, carinatum v. cristatum. Col a mn a evario continua, brevis, semiteres, antice bicornis, apice dentata $v$. rostrata. Anthera infrapicillaris, bilocularis, valvis anticis nullis. Pollin i a 4, libera, incumbentia. - Herbae javanicae, epiphytae; foliis coriaceis, in pseudobulbis ut plurimum solitarïi, spicis terminalibus v. lateralibus, filiformibus, multifloris, floribus junioribus inter bracteas bifariam imbricatas lutentibus.

De ud roch il u m Blume Bijdr. 398. Sig. 39 . Lindl, Or. chid. 34. B olb op hy $11 \mathrm{i}$ s p. Thouars Orchid, t. 93.94.

1342. Dtoelhilus LINDL. Perigonii foliola patentia, libera, exteriora et interi ora conformia. Labellum trilobum, lohis lateralibus brevibus colnmnam amplectentibus, intermedio elongato, patente, eeristato. Col umna ovario continua, elongata, semiteres, clavata. An- 
the ra terminalis, bilocnlaris, septo medio bipartibili bivalvis, valvis anticis et posticis medio septiferis. Pollin ia 4, incumbentia, basi materia granulosa cohaerentia. - Herbae in India bor caliore super arborum truncis repentes; rhizomate nullo, pseudobulbis ex apice lateraliter soboliferis, racemis multifloris e pseudobulbis lateralibus, basi vaginatis, stigmatis labio superiore ovato, producto.

Ot o chilus Lindl. Orchid, 35. Wallich Pl. asiat.t.68. Broughtonia Wallich msc.

1343. Coella LINDL. Perigonii foliola exteriora patentia, libera; interiora panllo minora. Labe $11 \mathrm{um}$ nnguiculatum, basi columnae continuum, integerrimum. Col um a ovario continua, basi leviter producta, nana. Anthera e bilocularis loculi connectivo tenui colsaerentes, ovati, inappendiculati. Pollinia 4, per paria cohaerentia, oblonga, extus convexa, intus cava. - Herba jamaicensis, epiphyta, acaulis; foliis plicatis et scapo radicali e squamis subcoriaceis erumpentibus, ovariis novemalatis.

C o elia Lindl. Orchid, 36. Frane, Bauer gen, $t, 3$, E p i. dendrum tripter um Smith Ic. piet. t.14.

1344. Plnolidata LINDL. Perigoni i foliola in globum conniventia, libera, exteriora interioribus paullo majora. Label$1 \mathrm{um}$ liberum, columnae parallelum, cucullatum v. ventricosum, trilobum v. indivisum. Co lu mn a ovario continua, semiteres v. alata, clinandrio cucullato. Anth era bilocularis, bi-quadrivalvis, valvis anticis, dehiscentia solutis. Pollinia 4 , globosa, distincta. - Herbae indicae, epiphytae; rhizomate carnoso arliculato, v. pseudobulbifero, foliis plicatis, spicis terminalibus, saepius imbricatis, nutantibus.

$\mathrm{P}$ holid o t a Lindl, in Hook. exot. Fl. t.138. Bot. Reg. t, 1213. 1727, Orchid, 36. Wallich Pl, asiat, t.239. Ptil o cnem a Don prodr. nep. 33. Crí a on ia Blame Bijdr. 338.

1345. Dilloelnin $L I N D L$. Perigonii foliola exteriora comniventia, libera; interiora subaequalia. Labellum columnae continuum, cncullatum, trilobum, basi subsaccatum, trilamellatum. Columna ovario continua, clavata, alata, apice cucullata, dentata, Anthera quadriIocularis, ovata, eristata. Poll in ia 4. - Herba indic a, caulescens; foliis coriaceis, acutis, distichis, subcostatis, racemo terminali e squamis coriaceis erumpente, bracteis coriaceis, distantibus, divaricatis, persistentibus, floribus speciosis, perigonii foliolis interioribus tenerioribus.

\section{Dil o e hi a Lindley Orchid, 38 .}

1346. Earina LINDL. Perigoni foliola ext e riora erecta, aequalia, acuta, membranacea, earinata; interio ra carnosa, obtusata. L abe $11 \mathrm{um}$ posticum, columnae continumm et subparallelum, carnosum, cucullatum, trilobum, disco nudo. Co l u m n a nana, teres, stigmatis obliqui labio inferiore prominulo, clinandrio declivi. Anthera bilocularis. Pollinia 4, per paria cohaerentia, collateralia. - Herba $\mathrm{No}$ vae Zeelandiae caulescens; rhizomate articulato, repente, foliis linearibus distichis, vaginantibus, floribus parvis, articulatis, bracteis cartilagineis, striatis, cucullatis.

Earina Lindley in Bot. Reg. $n, 1699$. Epldendrum a u $t$ un nal e Forst.

$134 \%$. Coelogyne LINDL. Perigoni foliola exteriora conniventia $v$. patentia, libera, aequalia; interiora conformia v. linearia. L a b ellu m encullatum, saepius trilobum, lineis disei elevatis v. cristatis, nunc integerrimum, ecristatum. Co In mna erecta, libera, alata, apiee dilatata v. euenllata; stigmate bilabiato. Anthera infrapieilaris, bilocularis, septo medio haud partibili. Pollinia 4, incumbentia, li bera $v$, basi materie granulosa cohaerentia. Herbae indicae, in arborum truncis et supra saxa vigentes; rhizomate nunc crasso squamoso, nunc fere obsoleto, foliorum basibus in pseudobulbos dilatatis, foliis coriaceis saepe vennsis, venis aequalibus, nunc quibusdam crassioribus costata $v$, plicata, racomis terminalibus $v$. radicalibus, $e$ squamis corneis erumpentibus, floribus speciosis, saepe odoratis.

C o e 1 o g y $\mathrm{n}$ e Lindley collect, $p, 33$. Orchid. 38.

a) CHELONANTHERA Blume, L a b ell u $\mathrm{m}$ cristatum, trilobum. Columna apice dilatata. Pollinia libera.

C he 1 on a ut hera Sect. 2 et 3. Blume Bijdr.382. (Bot. Reg. $t, 868$. Wallich $P t$, asiat, $t, 38,53,54,218$.

b) GoMPHosTyLis Wall. La bell u m fimbriatum, basi saccatum. Colum na apice petaloidea, cucullata. Pollinia materie granulosa cohaerentia.

Gomphostylis Wallieh msc. Plei one Don prodr. tep. p. 37. Epidendris p. Smith exot. Bot. t,97.98.

c) PANISEA Linall, $\mathrm{L}$ a be $11 \mathrm{um}$ integerrimam, eerista. tum, perigonii foliolis conforme. Col amna alato. marginata.

$P a n$ is e a Lindley op. cit, 40. Dendrobium demis. s um Don.

1348. Illexisea LINDL, P e r i on i clansi foliola exteriora angusta, lateralia ab invicem disereta, basi columnae adnata; interi or a libera, subaequalia. Labell u m posticum, eum columna connatum, refractum, inapendiculatum, integerrimum, perigonii foliolis exterioribns conforme. Columna ovario continua, erecta, apice biaurita. An thera dorso convexa, quadrilocularis, valvulis membranaceis longitudinaliter dehiscentibus. Pollinia 4 , collateralia, materie parea, granulosa stigmati annexa. - Herba peruana, epiphyta; caulibus teretibus, adscendentibus, articulatis, foliis linearibus coriaceis, apice emarginatis, racemis terminalibus paucifloris, bracteis magnis membranaceis, e squamis cartilagineis imbricatis erumpentibus.

Hexise a Lindley in Hooker Journ. of Bot. 7. - ? Elean thes Presl in Reliq. Haenk, 9r.

'TRIBUS II. DENDROBIEAE Lindley Orchid. 45. Columna ovario incumbens, basi longius producta.

1345. Coehlia $B L U M$. Perigonii foliola exteriora erecta, lateralia basi connata; interiora minora. Labell um cum pede coIumnae articulatum, adscendens, snperne in limbum semilunatum, margine revolutum et verrucosum dilatatum. C o l $\mathrm{u}$ m $\mathrm{n}$ a in ovario recumbens, apice bicornis. Anth era colnmnam postice terminans, semibilocularis. Pollinia \&, libera, ovata. - Herba javanica, epiphyta; caulibus vaginis scariosis imbricatis, foliis coriaceis, ovato-ellipticis, supra convexis, subtus concavis, pedunculis lateralibus, solitariis, foribus capitatis violaceis.

Co chli a Blume Bijdr, 320. frg. 59 .

1350. Hyraea $L I N D L$, Perigonii foli ola ext erior a conniventia, inaequalia, lateralia inter se et cum pede colnmnae connata; interiora nana, spathulata. Labe Il u m pedi columnae continuum, bilobum. Columna in ovario recumbens, nana. Anthera.... Pollinia 2 , in unum connata. - Herba mauritiana, epiphyta et saxicola; folïs geminis coriaceis e pseudobulbo subtetragano, scapo radicali gracili, basi squamato, floribus lutescentibus, in spicam raram 
dispositis, ex axilla bracteae semicordatae, amplexicaulis.

L y r a a Lindl. Orehid. 46 . B u 1 b ophy $11 \mathrm{um}$ pris. maticum Thowars Orchid, $t, 109$. A. Rich, in Mem, soc. h. n. paris. IV. t, s. f.3.

1351. Megaelinium LINDL. Perigonii foliola exteriora erecta, inaequalia, lateralia minora, eum columna connata; interiora nana. L a bell um cum basi columnae elastice articulatum, integerrimum, nanum. Colum na in ovario prona, nana, marginata, basi vix producta. An thera obsulete bilocularis. Pollinia 4, aequalia, per paria cohacrentia. - Herbae africanae tropicae, epiphytae; rhizomate repente pseudobulbifero, foliis coriaceis, aveniis, racemis radicalibus, rhachi dilatata, compressa, labello oscillante.

\section{Megaclinium Lindl, Bot. Reg. t,989. Orchid. 47.}

135\%. Bolbophyllum THOUAR. $\mathrm{Pe}$ rigonii foliola exteriora erecta, acuminata, subaequalia, lateralia basi obliqua, cum pede columnae connata; interiora nana v. rarissime exterioribus subaequalia. Labellum cum pede columnae articulatum, unguiculatum, saepins integrum et posticum. Columna nana, antice bidentata v. bicornis. Anthera uni-bilocularis. Pollinia 4, valde inaequalia, per paria cohatrentia v. connata, altero cujusvis paris minuto, lobnliformi. - Herbae gerontogeae, tropicae, epiphytae; rhisomate repente pseudobulbifero, foliis coriaceis, aveniis, racemis radicalibus.

B olboph y $11 \mathrm{um}$ Thouars Orehid, $t, 95 \_97.99-108$. A. Rich. Mem, soc. h. n. paris. IV. 33. t.8. f. 5. Wallich Pl. asiat, $t .69$. Lindl. Orchid, 47 . D i p hy e s Blume Bijdr. 310. $f_{g}$. $66.0 \mathrm{~d}$ onto st y lis Blume $F l$.Jav, praef.p. VHI. Kuhl et Hasselt Orchid. edid. Breda t.4. T ri b r a c hi a Lindley Collect. 61. f. a. Bot. Reg. t. 963. Ge $\mathrm{s}$ in fa Neraud ex Gaudich, ad Freyc. p.27. An is o pet a $1 \mathrm{um}$ Hook. exot. Ft. $t, 149$. De adrobii s p. Wallich Fl, nepal. T, t.28.

1353. Cirrellowetaluna $L I N D L$. P ericonii folio la exteriora ringentia, Iateralia multo longiora, acuminatissima, valde obliqua, columnae basi productae adnata; interiora nana. L ab ell um integrum, cum basi columnae articulatum, Col um a minima, basi longe producta, apice cornubus duobus petaloideis. A nthera bilocularis. Pollinia 4 , duo interiora multo minora lamelliformia. - Herbae ind ic a e, epiphylae; rhizomate repente, pseudobulbis monophyllis, foliis coriaceis, avenïs, floribus dense racemosis $v$. in apice scapi radicalis umbellatis.

CirrhopetaIum Lindl. in Bot. Reg, t.832. Orehid, 58. A rides Roxb. msc. Zygoglossum Reinwardt in Flora. 1825. II. 4. - ? Ephippi um \$. 1. Blume Bijdr. Fog. fig. 65. ? S est o chilus Kuht et Hasselt Orchid. edid. Breda $t, 3$. B ol b o $\mathrm{p}$ h y $11 \mathrm{i}$ s p. Thouars Orchid.t.98.

1354. Trias LINDL. Perigonii foliola exteriora patentia, aequalia, ovata, basibus connata, pedi columnae vix cohaerentia; interi ora minima, ereeta. Lab ell um minimum, indivisum, cum basi columnae articulatum et eidem incumbens, margine subdentatum. Columna basi leviter producta, nana, semiteres, marginata. Anthera bilocularis, apice in membranam petaloideam, cuneatam, emarginatam producta. Pollin ia 4 , duo interiora minora. Herbae ind $i$ c a e, pusillae; pseudobulbis subglobosis, glabris, in caespitem compactis, foliis parvis coriaceis, aveniis, pedunculis radicalibus erectis, foliis brevioribus, unifloris, floribus majusculis, viridi-fuscis, apertis triangulum formantibus.

Trias Lindl. Orchid, 60. Wallich $P l$, asiat. $t, 70$.
1355. Xracrostomaiom $B L U M$. Perigonii foliola exteriora reflexa, lateralia cum basi producta et inter se in calcar breve connata; interiora reflexa. L ab ellu m ecalcaratum, unguiculatum, pedi columnae continuum, medio dilatatum, concavum, limbo elongato, spathulato, emarginato, supra columnam fornicato. Columna nana, canaliculata. Anthera bilocularis, convexa, denti dorsali columnae inserta. Pollinia 2, bipartibilia, ovato-oblonga, stigmatis margini ligulato adhaerentia. - Herba javanica, epiphyta, nondum deseripta.

M a c r o s $t$ o minm Blume Bijdr. 335. fig. 37. Lindley Orchid, 60 .

1355. Mierocoelia LINDL. Perigonii foliola exteriora libera, aequalia; interi o ra conformia, paullo minora. La bell um cum columna articulatum, calcaratum, calcare ventricoso, limbo indiviso, nano. Co I n mna ovario continua, libera, minima. Anthe ra bilocularis, stipitata, apice membranacea. Pollinia 2, libera, medio foveata. - Herba madagascariens is, ut videtur aphylla, caulescens; radicibus numerosissimis intricatis, spicis plurimis filiformibus adscendentibus, floribus minutissimis.

M i e r o c oelia Lindl. Orehid, 60.

$135 \%$. Epierianthes $B L U M$. Perig onii foliola exteriora integra, patentia; in teriora multifida, laciniis clavatis, carnosis, appendiciformibus. Lab ell um breve, cum columnae pede incurvo articulatum, integrum, margine revolutum, glanduloso-tamidum. Co $1 \mathrm{~lm}$ na simplex. Anthera semibilocularis. Pollinia 2 , ovata. - Herba javanica, epiphyta; caulibus scandentibus vaginatis, pseudobulbiferis, pseudobulbis tetragonis, monophyllis, foliis ovali bus supra convexis, subtus concavis, pedunculis unifloris e caule ad basim foliorum ortis.

Epicrianthes Blame Fl. Jav, praef. p. VI. Ep i. cr an thes Blume Bijdr. 306. fg. 8. Lindl. Orchid. 61 .

1358. DI tonomeria LINDL. Perigoni i foliola exteriora ringentia, lateralia a supremo valde remota, interstitio denticulato, basi inter se et cum columnae pede connata, intus barbata; interiora nulla. Labellum eum pede columnae artieulatum, incumbens, ovatum, trilobum, disco lamellis quatuor parallelis, lobis lateralibus antrorsum falcatis, apice hidentatis. CoI umna basi longe producta, semiteres, apice minute bicornis. Anthera unilocularis, eristata. Pollinia 4 , in massam unicam cohaerentia. Herba nepalensis; rhizomate crasso, repente, pseudo-bulbigero, foliis solitariis, coriaceis, aveniis, racemis radicalibus multifloris.

Monomeria Lindley Orchid. 61.

1359. Stemoglossuman $H . B . K$. Perigonii foliola exteriora conniventia, lateralia cum basi columnae connata, aequilatera; interiora conformia, minora. Labe 11 um posticum, cum columna in urceolum connatum, limbo spathulato longe unguieulato. Colum na... Anthera biloenlaris. Pollinia 4, libera. Herba novogranatensis, epiphyta, caulescens; caule folioso simplici, floribus terminalibus racemosis, bracteatis.

Stenogloss um Kunth in Humb. et Bonpl. nov. gen. et sp. $I .356, t, 87$. Lindl, Orchid. 62.

1360. Diglyphis BLUM. Perigonii foliola exteriora subringentia; interiora latiora. Labell um columnae pedi elastice adhaerens, adscendens, concavum, intus membra- 
naceo-cristatum, limbo indiviso, patente. CoI m na semiteres, apice inenrva. Anthera bilocularis, convexa, antice bifida. Pollinia 2, angulata, compressa.- Herba javanica, epigaea, ebulbis; rhisomate repente fibroso, caule tereti, subcarnoso, apice monophyllo, folio membranaceo, nervoso, elliptico-lanceolato, glabro, pedunculo radicali basi vaginato, apice racemoso multifloro, pedicellis bracteatis.

Digly $\mathrm{p}$ his Blame Fl. Jav. praef. p. VI. D igly $\mathrm{p}$ hos a Blume Bijdr. 336. fig. 60. Lindl. Orchid, 62.

13651. NIy earidanthes BLUM. Perigonii foliola exteriora conniventia $v$. patentia, aequalia v. inaequalia, extus lanata, lateratia basi aequalia, pedi colnmnae adnata; interiora minora. Lab e $11 \mathrm{um} \mathrm{cum}$ pede columuae articulatum, trilobum, cueullatum, disco crista to $v$. appendiculato. Co I um n nana, basi longe producta, marginibns alatis, introflexis. Anthe$r$ a bilocularis, terminalis, loculis quadrilocellatis. Pollinia 8, ovata, parva. - Herbae in arboribus et rupibus insulae Javae crescentes, caulescentes; foliis carnosis v. coriaccis, haud plicatis, racemis terminalibus multifloris.

Mycaridanthes Blume Fl. Jav, praef. p. NII. Mye a ra $\mathrm{a}$ thes Blume Bijdr. 352. fig. 87 . Lindley Orchid. 62. Eiriae s p. Lindley Collect. $t, A 1, B$,

11362. IPloreatia LINDL. P erigonii foliola exteriora conniventia, subaequalia, lateralia cnm pede columnae connata; interio$\mathrm{ra}$ minora, conformia. L a b e $11 \mathbf{~} \mathbf{m}$ integrum, carnosum, cum pede colnmnae articulatum. C oI $\mathrm{m} \mathrm{m} \mathrm{na} \mathrm{nana,} \mathrm{margine} \mathrm{membranaceo} \mathrm{subintegro,}$ elinandrio immerso. Anther a bilocularis, intra cliandrium recondita, loculis obsolete quadrilocellatis. Poll in a 8 , sphacrica, materie viseida cohaerentia. - Herbae in dica e, epiphytac, caespitosae, pseudobulbosae; foliis membranaceis, coriaceis $v$, carnosis, scapis radicalibus. Blume.

Phreatia Lindley Orchid, 63. Dendrolirii sp.

1363. Eria LINDL. Perigonii folioI a exteriora semipatentia v. clausa, inaequalia, extus lanata v. glabra, Iateralia basi valde obliqua, cum pede colnmnae connata, calear simulantia; interiora exteriori postico aequalia v. minora. Lab e $11 \mathrm{~nm}$ cum pede columnae articulatum, trilobum, raro subintegrum, cucullatum, disco calloso v. cristato. Co 1 u m n a basi longe producta. Anthera bilocularis, terminalis $v$. dorsalis, loculis obsolete quadrilocellatis. Pollin i a 8 , omnino libera, y. materie elastica glandulam mentiente cohaerentia. - Herbae indicae, epiphytae; caulibus carnosis, vaginatis, foliorum rudimentis cicatrisatis, foliis saepius plicato-nervosis, racemis simplicibus, erectis, bracteis saepius dilatatis, floribus tunc inconspicuis.

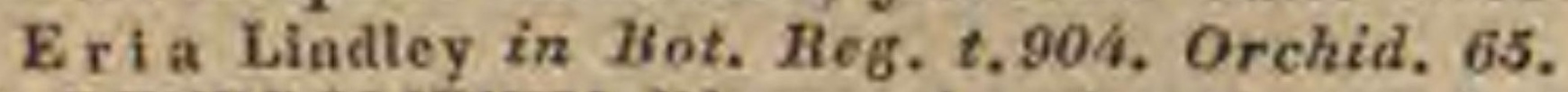

a) DENDROLIRIUM Blame. An the ra terminalis. Pa 1 Ii nia omnino libera.

Dendrolirium Blume Bydr. 343. fg. 69. exel. sp. Bot, Reg. t, 904. Wallich $P l$, asiat. $t, 36,134,169,197$. D e n. d $\mathrm{r}$ ob i i s p. Hook. exot. Fl. t. 124.

b) PINALia Hamilt. An thera dorsalis. Pollinia apice materia viscida cohaerentia. (Columua teres, cla vata. Stigma prominens.)

Pinalia Hamilt, ex Don prodr. nep. $p .31$. Lindley orchid. scelet. p. 23. cum ic.

1364. Aporum BLUM. Perigonit foliola exteriora carnosa, erecta, lateralia majora, obliqua, cum pede columnae connata; interiora minora. Lab ell $\mathbf{n m}$ cum pede coIumnae articulatum, posticum, indivisum v. tri- lobum, limbo cristato, calloso v. nurlo. Col u mna semiteres, basi longe producta. Anther a bilocularis, sessilis, apice interdum membranaeea. Poll in ia 4 , per paria collateralia. - Herbae epiphytae, indica $e$, caulescentes; foliis distichis, equitantibus, ancipitibus, floribus subsolitariis, e paleis membranaceis erumpentibus, saepius herbaceis.

A porum Blame Bijdr, 334. fg. 39. Lindl. Orchid. 70. Brongn. ad Duperr. $t, 42 . \mathrm{S} \mathrm{ch}$ is mo ceras Presl in Reliq. Haenk. I. 96. t. 13. f. 2 .

1365. Dxystoplaylluma $B L U M$. P e r igonii foliola exteriora erecta, lateralia majora, obliqua, cum pede colnmnae connata; interiora exteriori postico subaequalia. $\mathbf{L}$ abe $11 \mathrm{um}$ cum pede columnae articulatum, indivisum, limbo carnosio, subtus tuberculato. C $\boldsymbol{o}_{-}$ lum na semiteres, basi longe producta, clinandrio marginato. Anther a bilocularis, columnae denti dorsali insidens, convexa. Po Il ini a 2 , non partibilia, - Herbae javanicae, epiphytae, caulescentes; foliis equitantibus, ensiformibus, basi vaginatis, rigidis $v$. carnosis, floribus subcapitatis, axillaribus, sessilibus, paleis cinctis.

0 y s t o ph y 11 um Blume Bijdr. 335. fig. 38. Lindley Orchid. 71 .

13 GG. Eollystaelnya HOOK. P e r igonii foliola exteriora erecta, acuta, lateralia majora, cum pede colnmnae connata; int eriora minora. Labe 11 um sessile, cum pede columnae articulatum, trilobum. Col um a brevis semiteres. An thera bilocularis. Pollinia 4, collateralia, aequalia, per paria cohaerentia. - Herbae in Africa et America tropica observatae, epiphytae, caulescentes, v. pseudobulbosae; foliis leviter nervosis, floribus paniculatis, parvis, alabastris trigonis.

Poly stachy a Hook, exot, Fl. t. 103. Lindl. Orchid. 72. Bot. Reg. t. 851. Dendrobil sp. Thouars Orchid, $t$. $85,86,87$.

$136 \%$. Netaclhiluman $L I N D L$. Perigonii foliola exteriora conniventia, subaequilonga, lateralia cum columnae pede connata; interiora nana. Labell um ventricosum, integrum, cum margine pedis columnae connatum, intus appendiculatum. CoI um a pede elongato, stigmate prominente, apice membranaceo-bilobo. Anth era bilocularis, dorsalis. Pollinia ...- Herba indica, epiphyta; caulibus pendulis, teretibus, distiche foliosis, floribus parvis, lateralibus terminalibusque spicatis, capsulis reflexis.

Metachil a m Lindley Orehid. 7 ,

1385. VIracrolepis A. RICH. Perigonit membranacei foliola erecta, exteriora e basi lata acuminata, lateralia paullo majora cum columnae pede connata; interiora conformia, nana. La be $11 \mathbf{~} \mathbf{m}$ cum pede columnae articulatum, erectum, oblongo-lineare, carnosum, anceps, basi dilatata subconcavum, utrinque lobulis duobus subobsoletis auctum. Colnmna basi longe producta, elongata, semiteres, apiee antrorsum bicornis. Anthera bilocularis. Pollinia 2? ... - Herba in insula Vani-Koro, epiphyta; rhizomate repente pseudobulbifero, pseudobulbis monophyllis, foliis planis coriaceis ellipticis, acutis, scapo laterali tereti elongato, floribus spicatis, bracteis coriaceis lobis amplexicaulibus stipatis.

M a crole pis A. Richard Sert, Astrolab. 25, $t .19$.

1365 . Dendrobium $\$ W A R T Z$. P e rigonii membranacci foliola exteriora erec- 
ta v. patentia, lateralia majora, obliqua, eum pede columnae connata; in teriora conformia, exteriore postico majora $\mathbf{v}$. minora. $\mathbf{L}$ a b ell um cum pede columnae articulatum v. connatum, sessile, indivisum v. trilobum, saepius appendiculatum. C o I n m n a semiteres, basi longe producta. Anthe ra bilucularis. Pollinia 4 , per paria collateralia. - Herbae indicae, epiphytae, caulescentes, $v$. rhizomate repente pseudobulbifero; foliis planis saepius venosis, floribus solitariis, fasciculatis $v$, racemosis, majusculis, speciosis.

Den d r o b i um Swartz Nov. Act. Upsal. PI. p. 82. t.3. f.5. R. Brown prodr. 339. Lindley Orchid. 74. Smith exot. Bot, t.10,11. Hook. crot. Fl, t. 9. 7t. 18t. Bot. Reg. t.548. 1291, 1290, 1314, 1315, 1610, 1691, 1756, 1779, 1865. Bot. Mag, t 2906.3418. Wall. Pl. asiat. t. 29.39.40.195.196. A. Ricl. Fl. nov. Zeel. t, 26. Sert, astrolab, t.5_9. Brongn, ad Duperr, $t, 41$. Franc, Bater gen, t. $5.6 .-0 \mathrm{n}$ y ch i u m Blume Bijdr, 323. $f_{g} .10$. - $\mathrm{Pe}$ dil o n i n m Blame op. cit. 320. $f_{g}$. 36. - Desmotriehum Blume op. cit. 329. fig. 35 . Sarcostoma Blume op, cit. 339. fig. 45. - Gastrid i um Blume op. cit. 333. - Ce raia Lour. $\bar{F}$ l. ench. $I$. 518. - Keranthus Lour. in Herb. Banks. - Bontia Petiv, gazoph, $t$. 44. f. 10 .

SUT(DID II. EPIDENDREAE Lindl. Orchid. 95. Poll e n in massas ceraceas (pollinia) definitas cohaerens, tela cellulosa in ca udiculas elasticas pulvereas, saepe replicatas cohaerente, glandula propria nulla. An thera terminalis, opercularis. - Herbae epiplytae $v$. terrestres, saepe caulescentes, nunc foliorum basibus v, caulibus incrassalis, rarissime radicibus carnosis lobatis.

Species vix non omnes novi contine $\mathrm{t}$ is regiones intratropicas incolunt, paucae in Asia torrida vigent, paucissimae Indiam borealem vicinasque imperii sinensis plagas inhabitant, unica in Florida et Carolina meridionali reperta fuit.

13\%๑. Collabium BLUM. Perigoni foliola exteriora patentia v. reflexa, lateralia basi in calear obtusum connata; interiora conformia. Labe $11 \mathrm{~nm}$ ecalearatum, ungue brevi perigonii foliolis exterioribus lateralibus adnatum, limbo plano semilunato, basi intus bicalloso columnam amplectente. Co 1 um $\mathrm{n}$ a obtusa, tortuosa, aptera. Anthera bilocularis. Pollin ia 2 , oxato-globosa, caudiculis elasticis affixa. - Herba javanica, terrestris; rhizomate repen-

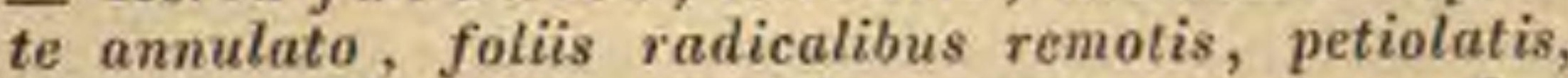
elliptico-oblongis, nervosis, membranaceis, nebulosis, pedunculis radicalibus indivisis, elongatis, fioribus racemosis, nutantibus.

Coll a bi m Blume Bijdr, 337. Lindl. Orehid. 97.

13\%1. Epidendran LINN. Perigonii foliola exteriora patentia, subaequalia; interiora aequalia $v$. angustiora, aut rarius latiora. L a b e 11 a m ungue enm marginibus columnae omnino v. partim coneretum, limbo integro v. partito, disco saepius calloso, costato v. tu berculato, interdum in calear ovario adnatum productum. Co I n m n a elongata, clinandrio marginato, saepius fimbriato. A n the ra carnosa, bi-quadrilocularis. Pollin i a 4 , candienlis totidem replicatis. - Herbae americanae tropicae, epiphytae; caule nune basi $v$. apice pseudobulboso, nunc elongato, upice folioso, folitis carnosis v. rarissime striato-venosis, ftoribus spicatis, racemosis, corymbosis $v$, paniculatis, terminalibus ateralibusve.

Epide nd r um Lian. gen, n. 1016, excl. sp. Swartz Nov. Aet. Upsal, VI, 66, t, 5. f. 2, Jaeq. Ic. rar. . 605. Redoute

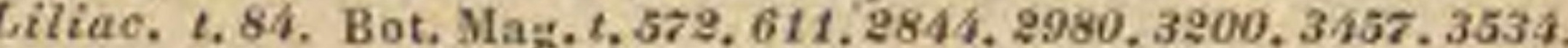
3543. 3557. Bot. Reg. t, 784, 1693, 1765, 1867, 1870, 1879.1881. 3233.3298, 1898. Hook. exot, Fl.t.50. 207, Joum, of Bot.t.98. Brongn, ad Duperr. t. 43. Póppiget Eudl, nov. gen. et sp. 601_103. Lindl. Orchid.96. A uliza et $\mathrm{Amphiglot}$ m Salisb. in Transact. Hortic. Soc, 1, 261. Encyelia e s p. Hook, in Bot. Mag, t.3013.

1:ร 2 . Dimema $L I N D L$. Perigonit foI io I a herbacea, patentia, subaequalia, exterio $\mathrm{ra}$ et interiora conformia. Labellum ma jus, membranacemn, indivisum, nnguiculatum, cum basi columpae connatum. Columna nana, bicornis. Anthera biloeularis. Pollinia 4 , per paria caudiculis duabus replieatis adnata. - Herba in Antillis et in Mexico observata, epiphyta; rhizomate repente, annulato, pseudobulbifero, foliis coriaceis, floribus terminalibus solitariis, pedunculo vaginato.

Dinema Lindley Orchid. 11t. Epidendrum polybulbon Swartz. Hook. exol, Fl, t, 112.

13 38. Wiothomea $L ! N D L$. Perigon i foliola exteriora conniventia, distineta, lateralia paullo longiora; interiora supremo. concavo conformia et subaequalia. Lab ellum cum cyatho e columnae lateribus dilatatis membranaceis formato articulatum, obsolete lobatum, basi bilamellatum, foliolis lateralibus multo Iongius, dependens. Columna erecta, elinandrio cueullato. Anther a obsolete quadrilocularis. Pollinia 4 , solida, pyriformia, apice materie pulverea cohaerentia. - Herba epiphyta, peruana, ramosa, ebulbis; folits lineari-lanceolatis, striatis, cartilagineo-marginatis, racemis multifloris, floribus majusculis.

Di o th o nea Lindl, in Hooker Journ, of Bot, 12.

13 3. Wancyella HOOK. P erigon i f 0 lio I a patentia, subaequalia, exteriora et interiora conformia. Labellum posticum, cucullatum, columnam involvens, apice trilobum, basi callosum. Col um a libera, semiteres, cla vata. Anther a quadrilocularis, septis marginatis. Pollini a 4, collateralia, eandieulis totidem revolutis. - Herba brasiliensis, epiphyta; pseudobulbis ovatis, scarioso-vaginatis, foliis ensiformibus bifariis, subrecurvis, panicula terminali, multiflora.

Ency cl ia Hook, in Bot, Mag. t, 2831. (exel. $t$, 3013.) Lindley Orchid. 111. Poppig et Endlicher nov. gen. et sp. $t, 113,114$.

1375. Isqelnilus $R$. BR. Perigonii foliola exteri ora conniventia, subaequalia, libera, v. lateralia basi paullo dilatata, breviter connata; interiora conformia. Labe $11 \mathrm{um}$ eum columna articulatum, indivisum, perigonii foliolis interioribus plerumque conforme. Col u mna clavata, semiteres, hi-tricornis. Anthera quadrilocularis. Pollin ia 4 , collateralia, candieulis ligulatis, replicatis. - Herbae america. nae tropicae, epiphytae; caule tereti, distich: folioso v. basi pseudobulboso, apice folioso, floribus parvulis, albis v. purpureis.

Is o e hil ns R. Brown in Fort. Hew, V. 209. Kunth in Humb. et Bonpt, nov, gen, et sp. T.340. t. 78, Bot, Reg, t. 745. 825. Lindl. Orchid. 112. E pide ndri sp. Linn. Jacq. C y m bidi i sp. Swartz.

13 \% 6. A roplayllum $L L A V$, et $L E X A R Z$. Perigonii foliola patentia, exteriora lateralia basi in gibber connata; interior a multo angustiora. La bellum cum columnae basi pro- 
ducta articulatum, indivisum, concavum, breviter calcaratum, Columna erecta. Anthera. Pollinia 8, pyriformia, manipulis glutinosis colligata. - Herba mexicana, ebulbis, vix nota et affinitatis dubiae; scupo e sinu folii coriacei orto, foribus parvis, dense spicatis.

A r pophy 11 a m Llave et Lexarz, nov, veg. IT. 19. Lindlev Orchid, 151 .

13รร. Ponera LINDL. P e rigon i membranacej foliola exteriora conniventia, Iateralia paullo majora, basi in saccum connata; interiora multo angastiora. Labellum posticum, ungue concavo, cum hasi producta folio loram perigonii exteriorum articulato, ascendente, lamina refracta lineari, subsagittata, truncata, subemarginata. Col um a ovario continua, semi teres. Anthera bilocnlaris. Pollinia 4 , collateralia, caudiculis totidem reflexis. - Herba in exic ana, epiphyta; caule erecto, simplici, filiformi-tereti, foliis linearibus canaliculatis, secundis, racemo ex axilla folii terminalis subbifloro, fioribus parvis, bracteis vevatis, acutis.

Ponera Lindley Orchid. 113.

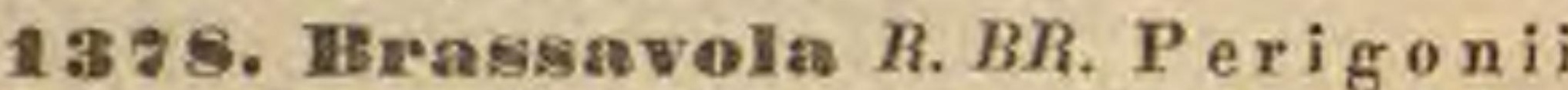
foliola subaequalia, libera, acuminata, ext e$x$ iora et interiora conformia. Labe $1 / \mathbf{n m}$ cucullatum, integrum, columnam involvens. CoI $\mathrm{m}$ na clavata, marginata, stigmate infundibulari, clinandrio postice tridentato. An ther a quadrilocularis, septis marginatis, loculis semipartitis. Pollinia 8 , subaequalia, aliis minoribus intermistis. - Herbae a mericanae tropicae, epiphtytae, caulescentes, apice mono- $v$. oligophyllac; foliis semicylindricis carnosis, supra sulcatis, apice subulatis, floribus terminalibus magnis, speciosis.

B rassavola R. Brown in Hort, Tew, V. 216. Hook. in Bot. Mag. 1. 2858. 3008. Bot. Reg. t, 1465, 1914. Lindley archid. 114. Foppig et Endl. nov. gen. et sp. t. 104. E p ide ndri s p. Lim. Jacq. C ymbidit sp. Swartz.

11 ส liola explanata, exteriora lanceolata, aequalia; interiora majora, subdifformia, carnosa. LabeII um posticum, tripartitum, lamellatum, cirea columnam convolutum. Co 1 a m n a carnosa, aptera, antice canaliculata. Anthera.... Pollinia 8, caudiculis 4, elastieis. - Herbae mexic a $n a$ e, epiphylae; rhizomate pseudobulbifero, foliis carnosis, scapis terminalibus pauci-multifloris, floribus speciosis, odoratis.

L a e lía Lindiey Orchia, 115. Bot. Reg, $t$, 175t, Blet la e s p. Liave.

1350. Cattleya $L I N D L$, P e r igon i i foliola exteriora membranacea $v$. carnosa, patentia, aequalia; interiora saepius majora. Labe $11 \mathrm{~nm}$ cum columna articulatum, cucullatum, integrum v. trilobum, columnam involvens. Col um na clavata, clengata, semiteres, marginata. Anthera quadrilocularis carnosa, septorum marginibus membranaceis. Pollin ia 4 , cau diculis totidem replicatis. - Herbae americanae tropicae, epiphytae, pseudobulbiferae; foliis solitariis geminisve coriaceis, floribus terminalibus magnis, speciosis, saepe e spatha magna erumpentibus.

Cattley a Lindley Colloct, $t, 33,37$. Bot. Reg. $t .953$. 1172, 1406. 1859. 1919. Lindley Orekid, 116. Hook. exot. El. t, 157, Bot. Mag. $t, 2831,3265$. Mart. Amoen, monac, $t, 10$. Melaevia Dumort. Dissert. Bruxell, 1834, Mto.

1381. Brouglutomia $R \cdot B R$. Perigoniifoliola exteriora patentia, angusta, lateralia basi obliqua, cum labelli basi connata et decurrentia; interiora latiora, Labe $1 \mathrm{lnm}$ in divisum, adscendens, cum columnae basi connatum, in calcar lineare ovario adnatum decurrens. Col u m a brevis, crassa, apice dilatata Anthera quadrilocularis, septorum marginilsus membranaceis. Pollinia 4 , caudiculis totidem replicatis. - Herba pseudobulbosa, in insulae $J a$ maicae arboribus littoreis parasilica; folits car nosis, scapo terminali racemoso, multifioro.

Broughtouia R. Brown in Hort. Kew, V. 217. Lod. dig. Bot. Cab. t,793. Bot. Mag t. 3536. Lindley Orchid, 11s, Epidendrum sang uin e um Swartz.

1382. Leptotes LINDL. Perigonii foliola patentia, linearia, exteriora et interiora subaequalia. Labell um posticnm, co. lumnae parallelum, trilobum, laciniis lateralibus minoribus, circa columnam convolutis, intermedia oblonga, marginibus reflexis. Col um a brevis, crassa, semiteres. Anthera... Pollin ia 6, incumbentia, duo superiora pyriformia, obliqua, compressa, quatuor inferiora inaequalia, tenuiora, anteriora duplo minora. - Herbe brasiliens is; caulibus brevibus, teretibus, squamis vaginatis, foliis teretiusculis, scapo terminuli racemoso-trifloro.

Lept o tes Lindley in Bot. Reg. $t .1625$.

1383. Tetramiera LINDL. Perigonii foliola lineari-oblonga, patentia, subaequalia; exteriora et interiora conformia. Labell um columnae parallelum, explanatum, tripartitum, lacinia intermedia subunguieulata, disco lineata, basi in calcar ovario adnatum decurrens. Columna alata, in labellum prona. Anthera octolocularis, loculis quatuor mineribus. Pollinia 8 , alterna minima, candiculis quatuor cohaerentia. - Herba domingensis; seapo elongato, tereti, squamoso, apice racemoso, foliis brevibus, linearibus, carnosis, recurvis.

Tetrantera Lindley Orchid, 119. Bot. Reg. $t, 1627$. C y mbidium $x$ ig id am Willd. (Plum. Ic, $181 . f .1$.)

1384. Spatlooglottis BLUM. Perigonii foliola exteriora patentia, libera, aequalia; interiora paullo latiora, patentia $v$. conniventia. Labellum cum basi columnae articulatum, saepins saccatum, tripartitum, lacinia intermedia unguiculata, basi tuberculata v. cristata, saepins utrinque unidentata. Coln $\mathbf{m}$ a alata, petaloidea. Anthera bilocularis. Pollini a 8. . . - Herbae indicae, epigaeae; cormis subterraneis, foliis ensiformibus, plicatis, scapis racemosis.

Spathoglottis BIame Bijdr, 600. fg.76. Lindl. Or. chid. 119. Wall, Pl, asial, rar, $t$. 203. B lettice sp. Gau. dieh. ad Freye, t.32.

1385. Iletia RUIZ et PAV. Perigonii foliola exteriora patentia, aequalia; interio $r$ a subaequalia, patentia v. conniventia. Lab e 11 и $\mathrm{m}$ cum columnae basi articulatum, cueullatum, saepius saceatum, trilobum, disco saepius lamellato v. tubereulato. Columna elongata, semiteres. Anthera octolocularis, carnosa. Pollinia 8 , aequalia, caudieulis quatuor pulvereis cohaerentia. - Herbae americanae tropicae, subterrestres; foliis ensiformibus plicatis, scapis racemosis, multifloris, floribus saepius magnis, speciosis.

B1 etia Ruix et Pay, prodr. $t$. 26. R. Brown in Hort.

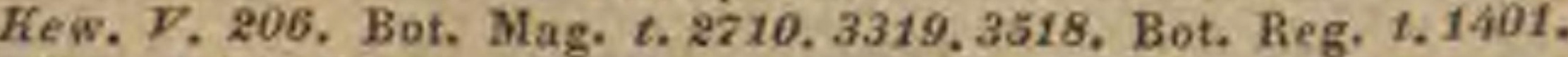
1681. 1760, Lindley Orchid. 120. Püppig et Endl, nov. gent. et sp, t.96. Gy as Salisb, in Transact, Hortic. Soc, I. 261. T a u k r villi ia Link Handb, I. 251, T t i e ba udja Colla L i mod ori $\mathrm{sp}$. Jacq. Ic, rar, $t$. 602 . Thunb. Pl. jap, $t, 9$. 
C y ub bidi i sp. Swartz. - ? Pa cliy st om a Blume Bijdr. 376. Pachyehilus Blume Fl. Jav. praef. $V I$.

1384. Ipsea LINDL. Perigonit foriola exteriora pubescentia, explanata, aequalia, lateralia basi ubliqua, enm pede columnae connata, saceum mentientia; interiora subaequalia. Labelln ungue brevi saccato cum pede columnae articulatum, eidem parallelum, concavum, trilobum, lamellatum. Colu in na elongata, semiteres, subelavata. Anthera biloenlaris, membranacea, basi intus tuberculis duobus carnosis. Pollinia oeto, candieulis quatuor pulvereis per paria cohaerentia, altero cujusvis paris minore. - Herba in montibus insulae Ceylon epigaea; radice carnosa, subbiloba, lateralibus fibrosis, foliis serotinis, ensiformibus, plicatis, scapo simplici vaginato, flore terminali solitario specioso, pubescente.

$1 \mathrm{p}$ se a Lindley Orehid, 124.

1358. Armmaltua BLUM. Perigonii foliola exteriora patula, lineari-lanceolata, subaequalia, basi breviter connata; interiora conformia. L a b e I I n m columnac continuum, eirca eandem convolutum, trilobum v. integrum, disco cristatum v. elevato-lineatum, lobis plicatis. Co I um na reeta, labello parallela, semite res, clavata. Anthera quadrilocularis. Pollinia 8 , aequalia. - Herbae indicae, epigaeae, caulescentes; foliis distichis, ensiformibus, plicatis, floribus purpureis, magnis.

A r u ndi a Blume Bijdr. 401. fig. 73. Lindl. Orch. 125.

1388. MPajous LOUREIR. Perigonii foliola subaequalia, patentia, exteriora interioribus conformia. Lab ell u m saepius cucullatum, basi columnae adnatum, calearatum, integrum v. trilobum, diseo saepins carinatum, lamellosum v. cristatum. Co 1 u m na erecta, clongata, semiteres, marginata. Anthera octolneniaris. Polinia 8, subaequalia. - Herbae indicae, epigaeae, acaules $v$. caulescentes; foliis latis, plicato-nervosis, scapis radicalibus, floribus magnis.

P h a j us Loureir. Fl. cochinch. IT. 529, Lindl. Orchid. 126. Wall. Pl, as, rar. t, 158, 198, P ac b y ue Salisbary in Transact. Hortic. Soc, I, 261. B t e ti a e s p. R. Brown. Bot, Mag. 1. 8719 . Fr. Bater Illustr. orchid, t. 6, L i ma d or i s p. Ait. Pers.

1383. Cytheris LINDL, Perigonii foliola exteriora patentia, suhaequalia, lateralia basi labelli caleari adnata; supremum interioribus latioribus membranaceis parallelum, recurvum. Labe 11 um posticum, planum, calcaratum, disco cristatum. Col umn a brevis, clavata, alata. Anthera bilocnlaris, membranacea. Poll in i a octo, aequalia. - Herba terrestris, indica, spithamea ; foliis petiolatis, cordatis, scapo terminali, floribus parvulis.

C y the ris Lindley Orchid, 128.

1390. Tylostylis BLUM. Perigoni foliola exteriora erecto-patentia, lateralia subtus connata; interiora paullo angustiora. Lab ellum eum columnae pede calloso, incarvo elastice articulatum, parvum, integrnm, disco callosnm. Columna incurva, clavata. Anthe$r$ a bilocularis, loculis quadrilocellatis. Pollínia 8 , compressiuscula, eaudiculis elasticis connata. - Herba javaniea, epiphyta, caulescens; caulibus radiciformibus pseudobulbiferis, foliis lanceolatis, oblique retusis, rigidis, scapis terminalibus, spicalo-multifloris.

Tylostylis Blume Fl. Jav. praef. $V T$. C allosty Iis Blame Bijdr. 330. Ag. 7i, Lindley Orchid. 199.
1391. Aata $L I N D L$. Perigonii foliola lineari-lanceolata, acqualia, conniventia; exteriora interioribus conformia. Labell nm cam basi columnae interdum producta in calcar v. saceum connatum, trilohum, planum, medio lamellatum. Colnmna erecta, elongata, alata. Anthera sex-octolocularis. Pollinia 8 , aequalia v. alterna minora. - Herbae in $d i$ c a $e$, epiphytae; rhizomate repente, foliis plicatis, membranaceis, solitariis, scapis multifloris.

$$
\text { A n i a Lindley Orchid. } 129 .
$$

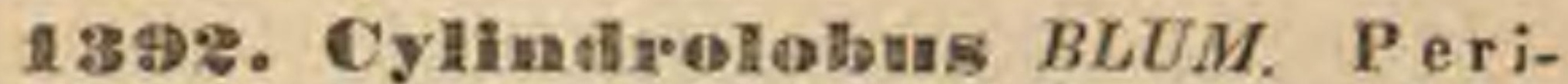
gonii foliola exteriora subringentia, lateralia pedi columnac oblique inserta, erecto-patentia; interiora breviora, erecto-conniventia. Lab e II um cum columnae pede articulatum, adscendens, concavam, intus eristatum, limbo semitrilobo, undulato, fornicato. Co I u m n a ereeta, semiteres. Anthera quadriloenlaris. PoIlinia octo, alterna minima, candiculis elasticis colligata. - Herba javanica, epiphyta, canlescens; caule simplici, foliis sessilibus, lanceolatis, coriaceis, spieis oppositifoliis solitariis, floribus bracteatis.

C y lindrolobus Blume FT. Jav, praef. FT. Cerati u m Blume Bijdr. 34t. fig. A6. Lindley Orchid, 130.

13593. Apatorisa LINDL. Perigonii foliola exteriura pulescentia, patula, lateralia interdum majora, basi obliqua; in teriora angustiora, patentia. Labellum unguieulatum, com pede colnmnae plus minus producto articulatum, basi ventricosum, carnosum, apice trilıbum, diseo cristatum. Colu m n a teres, clavata, areuata, clinandrio alato. An th e ra quadri-octolocnlaris. Pollinia 8. ... Herbae ind icae, epigaeae, aphyllae; scapis vaginis scariosis, filamentosis vestitis, bracteis membranaceis, floribus racemosis, nutantibus, pubescentibus.

A paturia Liudley Orchid, 130.

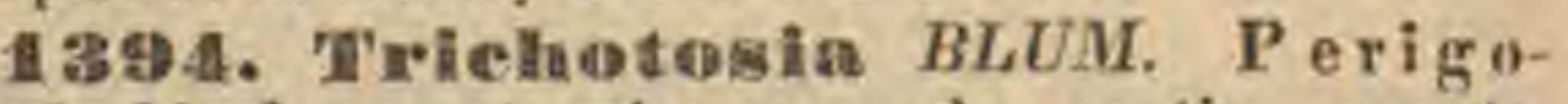
nii foliola exteriora pubescentia, erecta, Iateralia pedi columnae aduata, calear mentientia; in teriora conformia, glabra. Labellum nnguiculatum, pedi colnmnae basi adnatum, limbo integerrimo v. sublobato. Colum a erecta, semiteres, basi longe producta. Anthera biloenlaris, loculis quadrilocellatis. Pollinia 8 , aequalia, basi materie elastica cohaerentia. - Herbae javanicae, epiphytae, caulescentes, pilosiusculae; caulibus simplicibus, foliis sessilibus, corinceis $v$. subcarnosis, pedunculis oppositifoliis, solitariis, pauciftoris, floribus bractealis.

Trie hota sia Bfume Bijar. 34. fig. 11. Lindley Or. chid. 131.

1 395 . IDitopetnlum BLUM. Perigonit foliola exteriora ringentia, acuminatissima, lateralia labello supposita, pedi columnae adnata; interiora conformia. Labellum cum columnae perle articulatum, indivisum, acaminatam, intus lineatum, perigonii foliolis brevius. Coln $\mathbf{m} \mathbf{n}$ a recta, semiteres, basi producta. Anthera carnosa biloenlaris, loculis obsolete quadrilocellatis. Pollin ia octo, materie elastica, pulverea quaternatim cohaerentia. - Herba javanica, terrestris, glabra; caule radicante, foliis membranaceis plicatis, longe petiolatis, petiolis basi bulboso-tumidis, scapo laterali spicalomultifloro.

Mito petalam Blume Fl. Jav. praef, VIIT. Tafn fit Blume Bijdr. 354. fig. 48, Lindley Orchid. 132.

1395. Fleceglottis BLEM. Perigonii foliola exteriora ringentia, lateralia la$25 *$ 
bello supposita, basi connata; interiora minora, apice incurva. L a b ellum basi utrinque plieis membranaceis inflexis columnae connatum, limbo convexo, indiviso, patente, demum erecto. Co 1 m nna erecta, apice libera. Anthera bilocolaris. Pollinia 4 , subglobosa, caudienlis duabus longis, crassiuscnlis, replicatis cohaerentia. Herba javanica, epigaea; foliis in petiulo tumido solitariis, oblongo-lanceolatis, plicatis, scapo radicali erecto, multifloro, floribus pedicellatis, bracteolatis.

Ploc oglottis Blume Bijdr. 380. fig. 21. Lindley Orchid, 152.

$135 \%$. Soplaroutis LINDL. Perigonii foliola patentia, exteriora aequalia lilera; interiora conformia, paullo angustiora. l.abeIlum basi cum columna connatum, integrum, cucallatum, linguaeforme, medio erista iransversa simplici. Col um a apice utrinque alata, alis integris supra eristam labelli connirentibus. Anthera terminalis, octolocularis, cardine crasso. Pollinia 8 , antice et postice parallela, candicnla duplici pulverea. - Herba brasiliensis, epiphyta, pusilla, monophylla, ebulbis; racemis axillaribus effusis paucifloris, floribus majusculis.

Sophrouitis Lindley in Bot. Reg. t.1129.

TRE IBS IIE. VANDEAE Lindley $\boldsymbol{O} r$ chid. 135. Polle $\mathrm{n}$ in massas ceraceas definitas cohaerens, sub anthesi lamellae elasticae (candiculae) et stigmatis glandulae affixum. Anthera terminalis, raro dorsalis, opercularis. - Herbae epiphytae v. terrestres, nunc (imprimis americanae), pseudobulbis oligophyllis gaudentes, nunc (praesertim asiaticae) caulescentes. _ Tribus vix non tola tropicis circulis inclusa, formarum dives, speciebus per Asiam et A meric a $m$ pari fere numero distributis. Calypso utriusque orbis extremum incolit septemtrionem.

1358. Namoales $L I N D L$. Perigonii foliola exteriora ringentia, posticum fornicatum, lateralia labello sabopposita, eique basi connata; interiora lateralibus conformia et subparallela, libera. Lab ellu m cum columna connatum, carnosum, indivisum. C o I u m a clin andrio alato. A $\mathrm{nth}$ e $\mathrm{r}$ a bilocularis, rostrata. Pollinia 4, compressa, collateralia, in gland $\mathrm{l}$ l a ovata sessilia. - Herba brasilen$s i s$, epiphyta, caespitosa, caulescens, humilis ; foliis coriaceis, vaginantibus, distichis, approximatis, floribus in apice caulis inter folia solitarie sessilibus.

$N$ a nodes Lindley in Bot, Reg. $t, 1541$, Orchid, 139.

1599. Aspasia LINDL. Perigonii foliola patentia, aequalia, exteriora lateralia libera; posticum cum interioribus hasi connatum. Labell um oblongum, concavum, ecalcaratum, obsolete quadrilobum, columnae semiconnatum. Co I um a labello parallela, semiteres, marginata. Anthera. . . Pullinia 2, pyriformia, postice snleata, ca udi cula plana, cuneata, glandula parva, - Herba in America tropica occidentali indigena, epiphyta, caulescens, pseudobulbosa; folitis subcoriaceis, spicis radicalibus brevibus.

Aspas in Linclley Orehid. 139. Bot. Reg. t. 1507 .

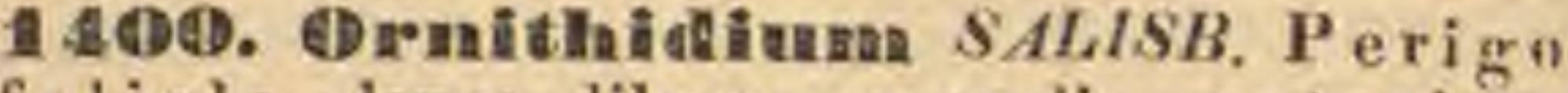
ni foliola clausa, libera, aequalia, extexiora et interiora conformia. L a bell a m cum basi columnae connatum, cucullatum, disco callosmm. Culumna labello parallela, teretiuscula, rostello brevissimo. Anthera bilocularis. Pollinia 2, bipartibilia, lobis incumbentibus, in glanduli parva, triangulari sessilia. - Herbae antilla. na e, epiphytae, caulescentes; caulibus ramosis, in axillis pseudobulbiferis, foliis subcoriaceis, racemis sessilibus, axillaribus, effusis, nutantibus.

Ornitlridium Salisb. in Hortic. Transact. 1 . 293. Hook, exot. Flor, t, 38. Bot. Mag, t. 3306. Lindley Orchitt. 139. Proppig et Eudl. nov, gen, et sp. t.96. E pid e $\mathrm{nd} \mathbf{r} \mathrm{m}$ c oc сi и e um Linn. Jaeq. Americ. $t$. 135 . C y mbidium сосе ін еи

1401. Aeriopsis BLUM. Perigonii foliola patula, subaequalia, exteriora lateralia labello supposita, in unicum connata ; int e rio ra conformia. Labellum cum basi columnae in tubum connatum, limbo patente cordato, cristato. Columna erecta, utrinque cornubus dnobns porrectis, apice glandulosis. Ant hera bilkenlaris, intra clinandrinm cueullatum absconditit. Pollinia 2, fusiformia, eaudicula filiformi ylandulae parvae subglobosae insidentia.

Herba javanica, epiphyta; foliis in pseudobulbis sessilibus, lineari-lanceolutis, oblusis, pedunculis radicalibus paniculatis, floribus pedicellatis.

A criopsis Blume Bijdr. 376. fig. 71. Reinwardt in Flora 1825, IT, 4. Lindl. Orchid, 140.

1402. Trizerxiss LINDL. Perigonii subglobosi foliola exteriora lateralia labello supposita, inter se, supremum interiorihus conformibus connata. Labellum posticnm, basi columnae brevissime adnatum, integrum, concavum, acntum. Colnmna labello parallela, teres, clavata; 8 tigmate longitudinali. Anthera unilocularis, carnosa. Pollinia 2, basi discreta, solida, e a ud i cula maxima, oblonga, glandula parva, ovali. - Herbula antillana, epiphyta, acaulis; foliis falcatis, distichis, scapis paniculatis, floribus aggregatis, minutis.

Trizeuxis Lindley Colleot. t.2. Orchid, 140.

1403. Druithoeeplanirs HOOK. P erigonii patentis foliola exteriora obtusa, lateralia reflexa, supremum fornicatum; in teriora conformia, ineurva. Labe $11 \mathrm{um}$ postieum, ecalearatum, unguiculatum, acuminatissimnm, perigonii foliolis exterioribus longius. Culn mna brevis, aptera, rostello elongato, subulato. Anthera quadrilocnlaris, rostello conformis. Pullinia 4, solida, caudiculae longissimae, subulatae eruciatim affixa; glandula parva, ovalis. - Herba antillana, epiphyta, acaulis; foliis equitantibus, carnosis, spicis axillaribus, bracteis amplexicaulibus, floribus inconspicuis.

Ornithocephal us Hook, exot. Flor, $t, 127$, Lindley Orchid, 141.

1404. Cimplarea LINDL. Perigonii patentis foliola libera, exteriora aequalia; interiora multo angustiora, linearia, flexuosa. Labellum columnae continuum, longe unguiculatum, tripartitum, laciniis angustis, intermedia minore. Columna erecta, teres, clavata; $8 \mathrm{t}$ i $\mathrm{g}$ a $\mathrm{t} \mathrm{e}$ subquadrato horizontali, rostello cirrhato. Anthera dorsalis, membranacea, incomplete bilocularis. Pollinia 2, parallela, oblonga, compressa, elastice prosilientia, caudic ula brevi cornea, glandula nulla. - Herbae brasilienses, epiphytae, pseudo-bübosae, 
fotiis plicatis, racemis radicalibus pendulis, multijloris, floribus magnis, variegutis.

Cirrtrae a Lindley in Bot, Reg. n. 930, t, 1539. 1889. Orchid, 141. Gougorae sp. Hook. Bot, Mag. t. 2978 .

1405. Sareociniliens $R$. BR. Perigonii patentis foliola exte $\mathrm{r}$ o $\mathrm{r}$ a lateralia eum ungue labelli subtus connata; interiora libera, conformia. Labellum postienm, ungui colnmnae continuum, ecalearatum, calceiforme, lobo intermedio carnoso, solido. Colnmna. ... A nthera... Pollinia 2, in glandala deltoidea sessilia. - Merba in Nova Hollandia orientali extratropica epiphyta, acaulis v. brevissime caulescens; foliis distichis, lineari-lanceolatis, falcatis, racemis axillaribus paucifloris, secundis, bracteis brevibus, late ovatis, floribus speciosis.

Sarcochilus R. Brown prodr. 332. Lindley Orchid. 142. Bot. Reg, $t, 1832$.

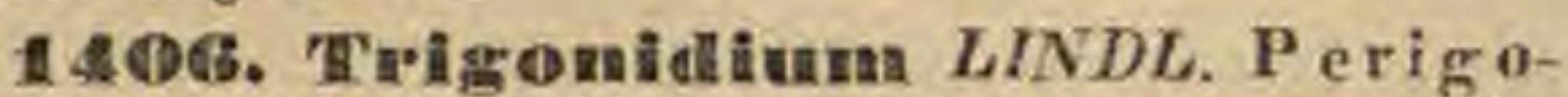
nii campanulati foliola exteriora aequalia, semiherbacea, in eyathum trigonum conniventia, apice patula; interiora petaloidea, duplo minora, venosa. Labe $11 \mathrm{um} \mathrm{cmm}$ columna articulatum, nanum, trilobum, medio carnosum. Colu $m$ na libera, nana, semiteres. Anthera unilocularis. Pollinia 4, cohaerentia, dorsalia minora, glandula e triangulari, $s t i g m a$ parvum triangulare tegenti, insidentia. - Herbae a mericanae tropicae, epiphytae; rhizomate repente florifero et pseudobulbifero, foliis coriaceis, pedunculis erectis unifloris, vaginatis.

Trigonfdi um Lindley in Bot. Reg, t, 1993.

140\%. IIaxillaria $R U I Z$. et $P A V$. Perigonii patentis v. conniventis foliola exteriora lateralia cum basi producta columnae in sacenm connata; interiora subconformia. Labellum cum basi producta colunmae articulatum, sessile, trilobum, cucullatum. Column a semiteres, aptera. Anthera incomplete bilocularis, opercularis. Pollinia 2 , bipartibilia $v$. integra, caudiculis brevibus gland nlae transversae affixa. - Herbae americanae tropicae, epiphytae, pseudobulbosae, caulescentes $v$ saepius acaules; foliis plicatis v. coriaceis, pedunculis radicalibus axillaribus $v$, terminalibus, uni-multifloris.

Maxil1aria Ruiz et Pav, prodr. 116. 2.25 . Lindley Orehid, 142. Püppig et kindl. nov. gen. et sp. I. 36.

a) COLAX Lindi. L a b ell um anticuns. Pedunculi radi. cales.

Colax Lindley in Bot. Reg. t.987. Dendrobit sp. Kunth in Humb. et Bonpl. nov. gen. et sp. t. 88. Hooker erot. Flor, $t, 119,120 . \mathrm{C}$ m bi dil s p. Link et 0 tto Ic. pl. rar. t. 52. (Bot. Mag. t, 2729. 2789. 2806. 3146, 3154, 3173. Bot, Reg. $t, 1428,1510,1802$. Hook. exat, Flor, $t, 217.219$. Loddig. Bot. Cab. t. 1318. 1612. 1824. Pöppig et Endl. op. cit. $t, 62-67$.

b) XYLOBIUM Lindl. L a bellum posticum. Pedunculi radieales.

c) eumaXilinaria Lindl. L a bell u m anticum. Pedunculi axillares.

E um axilla ria Lindl. Orekid, 142. Dendrobil s p. Hook. exot. Flor, t, 142.

d) NOTHIUM Lindl. Labellam anticum. Peduncali terminales e spatha vaginante erumpentes. Caules cylindracei haud bulbosi.

Noth i um Lindl. Orchid. 151,

1408. Epipluera LINDL. Perignnii explanati foliola exteriora libera, acuta, lateralia basi aequalia; interiora breviora, obovata. L a b e $11 \mathrm{um}$ posticum, cum columnae basi producta articulatum, sigmoideo - nnguiculatum, carinatum, trilobum. Col um a basi paullo producta, dorso prona, inversa; stigmate verticali, margine trituberenlato. Anthera unilocularis Pollinia 4 , $c$ a u dic $n$ l a e lineari affixa. Herba capensis, epiphyta, subbulbosa; folïs bi. nis, oblongo-lincaribus, planis, apice paullo obliquis, racemo terminali.

Ep ipbor a Lindley in Bot. Mag. Compan, II. 201.

1409. Siagomanthas PöPP. et ENDI, Perigonii ringentis foliola exteriora Jateralia patentia, basi cum columnae pede connata; interiora supremo conformia, erecta. Lab el I $\mathrm{nm}$ eum pede columnae articulatum, unguicrlatum, adscendens, medio infractum, integrum. Columna basi producta, clavata, arcuata. Anther a bilocularis, carnosa. Pollinia 2, postice biloba, caudicula brevi gla $\mathrm{n}$ it u la e deltoideae affixa, - Herba p eruana, epiphyta, pseudobulbifera; pedicellis axillaribus fasciculatis, uniftoris.

S iagonanthus Pöppig et Eadl. nov. gen. et sp. $I$, 40, $t, 96$,

14 A D. Treicthocentroum PÜPP. et ENDL. Perigonii patentiusculi foliola libera, exteriora et interiora aequalia. Labellum basi cum marginibus columnae eonnatum, elongatscalcaratum, erectum, integrum, disco callosum. Columna nana, semiteres, apice truneato ci liato-fimbriata. Anthera postica, bilocularis, pilosa. Pollinia 2, integra, candicula bifisla, glandula ovali convexa. - Herba peruanu, epiphyta, ebulbis; foliis radicalibus basi incrassatu cavis, uninervilis, pedunculis radicalibus brevissimis, unifloris, floribus magnis, speciosis.

Trichoceutrum Pöppig et Endl. nov. gen, ot sp. $I t$. 11. $t .115$.

141 1. IB ifrenneia $L I N D L$. P e rig (1nii patentis foliola libera, exteriora subaequalia, lateralia basi prodncta columnae adnata vix obliqna; interi or a duplo mina ra. L a b e $11 \mathrm{u} \mathrm{m}$ eum pede columnae mucronato articulatum, cucullatum, trilobum, medio eallosum. Col u m na brevis, semiteres, mntica. An the ra bilocularis, suberistata, mutica. Pollinia 4, per paria incumbentia, caudiculis dnabus distinctis, rostelli materiae viscidae adhaerentia. - Herbabrasiliens is, epiphyta; bulbis ovatis, tetragonis, foliis oblongo-lanceolatis, plicatis, racenis radicalibus trifloris, floribus atropurpureis, odoratissimis.

B ifren a ria Lindley Orchid, 158, Bot. Reg. $t, 1875$. Maxillaria atropurpurea Loddig. Bot, Cab, $t_{+} 1827$.

$140 \%$. IBatemana $I I N D L$. Perigo. nii ringentis foliola exteriora patentia, lateralia labello subopposita, unguienlata, basi aequalia; interiora latiora, basi obliqua, pedi producto columnae adnata. Labell um cum pede columnae articulatum, trilobum, eucullatum. CoIn mna elongata, semiteres, basi prodncta, elinandrio marginato. Anther a bilocularis, parva, membranacea. Pollin ia 2, postice biloba, glandula triangulari, caudicula nulla. - Herba americana tropica, epiphyta; pseudobulbis ovatis subtetragonis, foliis obovato-oblongis, plicatis, racemo radicali pendulo, bracteis rhombeis, cucullatis, inflat is, floribus longe pedicellatis, fuscopurpureis.

Batem a i i Lindley in Bot. Beg. t. 1714 .

14113. Seaplaysiottis PÖPP. et ENDL. Perigonii conniventis foliola esteriora lateralia basi paullo producta, cum pede columnae connata, labello subopposita, supremum lineare, convexum; interiora conformia, paullo breviora. Labe Il nm columnae pedi parum produe- 
to continuum, eique parallelum, oblongum, canaliculatum, margine subrepandum. Coln m na marginata. Anthera bilocularis. Pollinia 4, teretia, in glandula cuneata sessilia. - Merbue americanac tropicae, epiphylae, caulescentes $v$ ex axillis pseudobulbosae; foliis coriaceis angustis, floribus axillaribus parvis, pedunculis dense vaginatis.

Seapbyglottis Pöpig et Endl. nov. gen. et sp. $I$. s8. $t .97-100$. Lindley in Bot. Heg. t, 1901. C1 a do bi um Iindley introduct, edit. IT. p. 446 .

1414. Elerypta LINDL. Perigonii foliola erecta, libera, exteriora aequalia; interiora conformia, paullo minura. Labellum eum columna articulatum, oblongum, obsolete trilobum, carnosum, callo disci interrupto. CoI umna ovario continua, semiteres, ad basim antice clavata, clinandrio convexo. Anthera incomplete bilocularis. Pollin a 4, complanata, ineumbentia, postica minora, candicula brevi lineari g 1 a n d u 1 a e lunatae affixa. - Herbae americanae tropicae, epiphytae, acaules $v$. caulescentes; foliis coriaceis, ligulatis, distichis, pedunculis axillaribus, solituriis, brevissimis, unifioris, basi vaginatis.

Dicrypta Lindl. Orchid. 44 et 152. Póppig et Endl. nov. gen. et sp. I. 39. t.68. Hete $\mathrm{r}$ ot ax is Liudi. in Bot, Reg. $1,1028$.

14.5. Govemia LINDL. Perigoni i bilabiati foliola exteriora lateralia faleata, labello supposita, basi paulalum connata, supremo nonnihil majora; interiora breviora, obliqua, retrorsum conniventia. Labe $11 \mathrm{~nm}$ cum basi producta columnac artieulatum, sesşile, integerrimum, concavum, ecalearatum. Columna basi partm producta, subfusiformi-teres, apice utrinque marginata. Anthera unilocularis, calyptraeformis. Pollin i 4, solida, incumbentia, candicula communi brevi glandulae minutae triangulari affixa, - Herba mexicana, epigaea; foliis plicatis, spicis radicalibus multifloris, floribus aurantiacis, sanguineo-maculatis.

Govenia Lindl. in Loddig. Bot. Cab. t. 1709, Orchid. 153. Bot. Reg. t, 1795. Püppig et Endil.nov. gen, et sp.t.10\%. Maxillaria superba Llav. et Lexarz.

14 46. A Isanamia LLAV. et LEX. Perigonii patentis foliola aequalia, exteriora lateratia basi in calcar connata. L a b e $11 \mathrm{um}$ conforme, basi glandulosum v. tuberculatum. CoI I m n a carnosa, trieuspidata, basi in ealcar tubulosum producta. An the $\mathrm{r}$ a quadrilocularis. Pollinia 4, pedicellata. - Herbula mexica$n a$, epiphyta, vix eognita; pseudobulbis diphyllis, scapis simplicibus multijloris, floribus puniceis, speciosis.

Ala mania Llav, et Lexarz. Nov, veget. descript. It. 31. Lindl, Orchid, 153.

$14 \%$. IPsttacogiossum LLAV.et LEX. Perigon i patentis foliola exterio$r$ a elongata, lanceolata, lateralia infra labellum subcimnata; i n t e r i o r a conformia, angnstiora, incurra. L a b e 11 i m crassum, scabrum, obsolete articulatum, ad unguem tuberculo concavo instruetum. Column a clavata, subtriquetra, incurva. Anthera bilocularis, petaloideomitrata (?) Pollinia 4 , lentienlaria, exteriora majora. ...-Herba m exicana, epiphyta; pseudobulbis ancipitibus monophyllis, scapo unifloro, squamis membranaceis, distiche imbricatis tecto, flore magno, atropurpureo.

Psittacoglossum Llav, et Lexarz. Nov, veg, de script. 11 , 29. Lindley Orchid, 15i.
14 3. Cyemoelnes LINDL. Perigonii explanati folio I a exteriora lanceolata, lateralia infra labelium subconnata, supremum angustius; interior a latiora, falcata, decurva. Lab $1 / \mathbf{u m}$ columnae continunm, liberum, lanceolatum, ecalcaratum, integerrimum, ungue abrupto calloso. Columna elongata, arcuata, teres, apice clavata, clinandrio utrinque falcato - auriculato. Anthera bilocularis. Pollinia 2, postice sulcata, subpediecllata, caudicula lineari grandula grossae affixa. - Herba surin amen$s i s$, epiphyta, pseudobulbosa; scapis radicalibus, floribus racemosis.

C y c noehes Lindley Orchial. 154. Bot. Reg. , 1742.

1413. Zygastates LINDL. Perigonii membranacei foliola exteriora reflexa; interiora multo majora, dilatata, fimbriata, patula. L a b e 11 u m membranacenm, cum columna articulatum, cymbiforme, patens, basi intus cornutum ant dentatum. C o I $n \mathbf{m}$ a te. res, antice excavata, basi utrinque brachio lineari patentissimo, apice globose, perigonii foliola exteriora aequante, rostello longiseimo, subulato, arenato. Anthera rostrata, unilocularis. Pollinia 2 , caudicala subulata, gland u I a minima. - Herbae brasilienses, epiphylae, acaules; racemis pendulis, floribus parvis, viridi-luteis.

$\mathrm{Z}$ ygosta te s Lindley in Bot. Reg. n. 1927.

1l 429 . Catasetum L.C. RICH. Perigonii globoso-conniventis $v$. explanati foliola exteriora et interiora subaequalia. Labellum crassum, carnosum, nudum, ventricosum v. explanatum, fimbriatum, sub apice saceatum, obsolete trilobum. Columna erecta, libera, aptcra, apice vel basi utrinque cirrhosa aut mutica. A $\mathrm{nth}$ era incomplete bilucnlaris, antice truncata. Pollinia 2 , postice biloba $\mathrm{x}$. suleata, ca ud i c ul a maxima nuda, demum elastice contractili, glandula cartilaginea, subquadrata. - Herbae americanae tropicue, epiphytae $v$. epigaeae, caulibus brevibus fusiformibus, foliorum exuviis vestitis; foliis basi vaginantibus plicatis, scapis radicalibus, floribus speciosis, racemosis, viridibus, interdum purpureo-maculatis.

Cataset u m L. C. Richard in Kunth synops. pl. aequinoct. I. 330. Lindley collect. bot. t. 40. Orchid, 155. Bot. Reg. 1. 840,966. 1667, 1708. Hook. exot, Flor. t. 90. 91. 151, g13. Bot. Mag. t, 3269, 3329. 3388, Loddig. Bot. Cab. 1. 1344. Nees pl.hort.Bonn.rar. t. 1. Ang a 10 a e s p. Link in Verhandl. des prenss. Gart. Ker. I. t. 6 .

Cataseti generis merae varietates accidentales, el. Lindley in litteris monente, sunt:

Monachanthus Lindley in $B o t . n c g .7,1338$. Or. chid. 157. - M y a thus Lindley in Bot. Reg. t, 1538, 1721. 1778, 1896. Orchid. 154. Bot. Mag. t. 3514 . et M ormodes Lindley in Bot, Reg. t.1861.

1421. Stanhopea HOOK. Perigoni i membranacei patentissimi $v$. reflexi folio la exteriora libera, subundulata; interiora conformia, angustiora. Labellum liberum, anticum, ecalcaratum, carnosum, utrinque cornutum, dimidia parte superiore (epichilio) convexo, inferiore (hypochilio) excavato. Colnmna elongata, petaloideo-marginata. Anthera bilveularis. Pollinia 2, elongata, fissa, caudicula brevi glandnla e stipitatae bilobae affixa. Herbae americanae tropicae, epiphytae, pseudobulbosae; foliis pliatis, scapis radicalibus vaginatis, paucifloris, floribus maximis, maculatis.

$\mathrm{S}$ tan ho pea Hook. in Bot. Mag. $t$. 29a8. 29.49. 3359. Liudl, in Bot. Reg. t. 1529, 1800. 1837. Orchid. 157. C er a- 
to chil us Lisdl. in Loddlo. Bot. Cab. t, 1414. 1764. nou Btume.

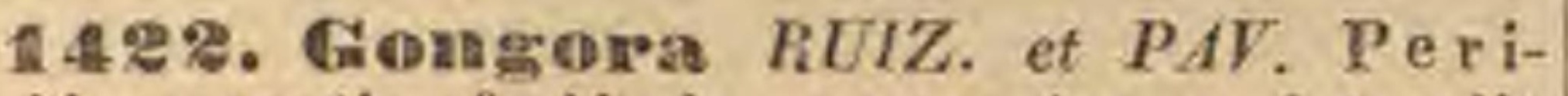
gonii patentis foliola exteriora lateralia libera, divaricata, supremum columnae dorso adnatum ; interiora minora, columnac medio connata, Labellum cum basi columnae continuum, liberum, unguiculatum, dimidio inferiore (hypochilio) explanato, utrinque cornuto, superime (epichilio) vertieali, ancipiti, (faciebus oppositis complicatis, connatis) acuminato. Columna elongata, arcuata, clavata, marginata. Anthera incomplete bilocularis. Pollinia 2, linearia, in caudicula cuneata sessitia. Herbae peruanae, epiphytae, pseudobulbosae; foliis plicatis, ravemis elongatis flexuosis, multifloris,

Go ngora Ruiz et Pav, prodr, 117, t, 25. Hook. cxot, Flor. t. 178, Lindl, Orchid, 158. Bot, Reg. t. 1616.

1483. Coryantloes HOOK. Perigonii patentissimi foliola exteriora dilatata, flexuosa, conduplieata, lateralia maxima, basi distincta; interiora multo minora, erecta. I. ab e $11 \mathrm{um}$ columnae basi continuum, unguiculatum, maximum, galeatum, tridentatum, in medio unguis appendiee poculiformi eircumdatum. Colum a elongata, teres, basi bicornis, apice recurva, bialata; stigmate transverso rimaeformi. Anthera bilocularis. Pollinia 2, compressa, postice suleata, caudicula lineari arcuata, gland ula e lunatac apicibus recurvatoapproximatis. - Herbae americanae tropicae, epiphytae, pseudobulbosae; foliis striatis, racemis pendulis, floribus maximis.

Coryanthes Hook. in Bot. Mag. $t$. 3109. Lindl. Orckid, 159. Bot. Reg. t. 1793, 18.41. G ong ora e s p. Hooker in Bot. Ming. l. 2755 . Bot. Misc. t. 80 .

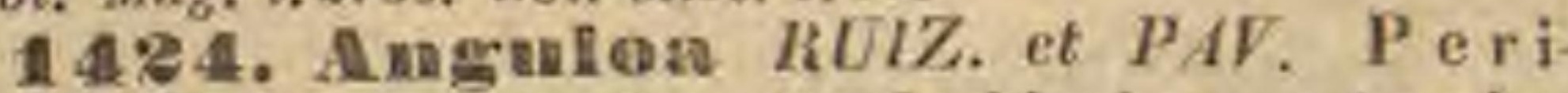
gonii globoso-conniventis foliola exteriora basi inter se connata, lateralia labello supposita, ejusdem ungui adnata; interiora minora. Lab e $11 \mathrm{~nm}$ cum coluunae basi continumm, longe unguiculatum, lamina adscendente columnae parallela, ealceiformi, apice inaequaliter triloba. Colnm a brevis clavata, marginata. Anthera hilocularis, terminalis, carnosa. Pollinia 2, solida, hine suleata, in glandula stigmatis peduneulata pendula, sessilia. - Herbae perua$n a e$, epiphytee $v$. terrestres, pseudobulbosae; foliis plicatis, scapis unifloris v. spicato-multifloris.

A n $\mathrm{g}$ u $\mathrm{J}$ o a Ruix et Pav. prodr. 118. t, 26. Kunth in Humb. ot Bonpl, nov, gen, et sp. I, 343, t, 73. Lindl. Orchid. 160. Pöppig et Eudl. nov. gen. et sp. I. 43. t.74.

1485. Peristera HOOK. Perigonii globosi foliola exteriora concava, subconnata, lateralia labello supposita; interiora libera. L a b e 11 n m columnae continumm, erectum, medio articulatum, epichilio pulvinato obovato, truncato, hypochilio licorni. Colamna erecta, semiteres, basi magna, dilatata. Anthera bilocularis, erecta. $P^{2} \circ 11$ i n i a 2 , postice fissa, g l a n du 1 a sessili nuda, rostellum involvente. Herba panamensis, epigaea, pseudobulbosa; foliis pluribus plicatis, scapis radicalibus vaginatis, multifloris, floribus speciosis.

Peris ter a Hook. Bot. Mag. $t$. 3116. 3479. Lindl. Or chid. 160 .

1426. Tuenemals $L I N D L$. Perigoni bilabiati foliolum e $x \mathrm{t}$ e $\mathrm{ri}$ us posticum cum interioribus parallelum, galeatum, lateralia labello indiviso simplici supposita, cum columnae pede brevi connata. Columna alato-marginata. A n thera.... Pollinia 4 , collate- ralia, per paria connata, caudicula lineari, glandula parva. - Herba mexicana; foliis: plicatis, membranaceis, ex ochrea infundibulari exsertis, scapo terminali remote vaginato, multifloro.
Eпc nem is Lindley Orchid. 161

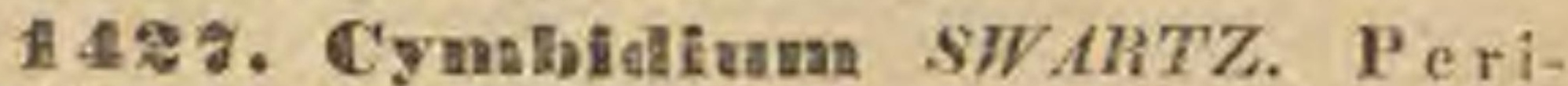
onii explanati foliola libera, exteriora et in teri or a snbaequalia. Labe 11 um sessile, $l i-$ berum, cum basi columnae articulatum v. leviter connatum, indivisum v. trilobum. CoI um a erecta, semiteres. Anthera bilocularis. Pollinia 2 , saepius postice biloba, in glandula subtriangulari subsessila. - Herbae epiphytae, inter tropicos obviae, in veteri continente paullo frequentiores, pseudobulbiferae $v$. crulescentes.

C ymbidlum Swartz in Nov. Act. Upsal. VT. 70. Lindl. Orchid. 161.

a) EUCXMBidium Linall. Acaules, ebulbes; foliis saepius ellsiformibus, floribus zaleatis. Labelli lamella dapiici

Encymbidium Lindl. $l$. $e$. Epidendri sp. Smith spicileg. t, 2t, Andr. Bol, Heposit, t. 216. Bot. Mag, t, 888. 1751. Roxburgh Corom, t. 44. Limodori sp. Thouars Orchid. t. 39. 40. (Bot. Reg. t. 529. Hook. exol. Flor. t. 31.)

b) LUISA Gaudich. Caulescentes, ebulbes; floribus patentibus.

Lu is a Gaudich. ad Freyc, 127, t,37, Mes oclastes Lindl. Orchich. 44. Psend o-V a ud a Lindl. op. cil. 167. Vauda triehor hiza liooh. exof, Ftor, $t, 72$.

c) CAMARIDiUm Lindl. Caulescentes; axillis pseudobut biferis, tloribus liaud galeatis.

C a maridium Liadl, in Bot, Neg, t, 844. Orchid, 168. C y mbidil s p. Kuntb.

d) BOLBIDIUs tindt. Rhizoma repens, pseudobulbos mono - diphyllos gerens.

Bolbidium Lindley $l$. $c$. Limodorum difuram Jacy. Ic, rar. 0.603. Maxillariae s p. Loddig. Bot. Cab. t, 1837. (Bot, Reg, $t, 1530$. )

c) ANGiDiUM Lindl. Acaules, tuberosae; follis plicatis, columna alata, labello nudo, polliniis 2 , integris.

A u ig idum Líndley $l, c$, Limodornm utrieula t u m Jacq. Fragm. bot. t.32.

14:8. Grobya $L I N D L$. Perigoni foliola exteriora lateralia Jabello supposita, basi connata, sigmoidea, supremo erecto hreviora; interiora dilatata hoe multo majora, ereeta, conniventia. La b e 11 u m liberum, nanum, cum basi eolumnae articulatum, lobatum, nudum, adscendens. Col umna erecta, semiteres, arcuata, hasi incrassata. An th e $r$ a in stigma fornicatum proclivis. Pollinia 2 , postice lobata, c audiculis dnabus brevibus g landulae ovali adnatis. - Herba brasiliensis, epiphyta, pseudobulbosa; foliis gramineis, racemis radicalibus pendulis.

G $\mathrm{r}$ ob y a Lindley in Bot. Reg, 1,1740 .

14:39. Acropera LINDL. Perigonii foliola exteriora patentia, supremum galeatum, lateralia divarieata; in teriora nana, obliqua, apice truneata, subpatentia. La b e $11 \mathrm{um}$ cum columnae hasi elastice articulatum, unguiculatum, trilobum, lobo intermedio minore, saccato. Col umna erecta, marginata, basi produeta saccato - concava. Anthera bilocularis, rostello subulato. Pollinia 2 , linearia, convoluta, ca udicula lineari-subulata, glanduI a minuta. - Herba mexican a, epiphyta, pseudobulbosa; racemis radicalibus cernuis, multifloris.

A eropera Lindl. Orehid, 172. Maxillaria galeata Lindl, in Loddig. Bot, Cab, t, 1645.

1. 36 . Cremastra LINDL. Perigonii foliola exteriora interioribus subaequalia, omnia libera, basi tubulose conniventia, apice patentia. Labe 11 u m colnmnae parallelum, longe unguieulatum, apice dilatatum, trifidum, 
appendice ad basim limbi carnoso, naviculari, adscendente. Columna elongata, semiteres, erecta, libera. Anthera. . Pollinia 4 , ovata, plana, caudicula... gland n la dilatata. - Herba nepalensis, rupincola v. epidendra; pseudobulbis annulatis, aggregatis, foliis membranaceis, subplicatis, scapo vaginato, floribus racemoso - congestis, pendulis

Cre an a tra Lindl. Orchid, 172. C ymbidium ap. pendiculatum Don.

1431. Grannanatoplhyllum BLUM. Perigonii explanati patentis foliola exteriora et interiora subaequalia. Labellum cam columna articulatum, nanum, trilobum, cncullatum. Columna arcuata, erecta, semiteres, hasi callosa. Anthera subbilocularis. Pollin ia 2 , globosa, basi sulcata, in apicibus gland $u$ i a e lunatae sessilia. - Herbae indicae, epi phytae, caulescentes; caulibus simplicibus inorassatis, foliis linearibus, distichis, striatis, pedunculis radicalibus elongatis multifloris, floribus mag nis, speciosis.

Gra m mato phy 11 u m Blume Bijdr. 377. fig. 20. Lindley Orehid. 173. Gabertia Gaudicli, ad Freyc. 425. E p idendram seriptum Liuu. Angraeeum seriptum Rumph. Amboin. VI. 93. t. 49.

1432. Trielnoceros $H . B, K$. Perigonii explanati foliola exteriora, interiora et I abeflum subaequalia. Columna nana, villosa, utrinque processu petaloideo piloso, rostello acuminato. An the ra unilocularis, in dorso rostelli. Pollinia 2 , solida, obovata, caudic ula simplici, elongata. - Herbae a mericanae tropicae, epiphytae, psendobulbosae, caulescentes; scapis vaginatis multifloris, floribus mediocribus.

Trichoceros Kuath in Humb. et Bonpl. nov, gen, et sp. $I$. 337, $t$, 76. Lindl. Orchid, 174. Epide $\mathrm{d}$ r $\mathrm{um}$ a $\mathrm{n}$ tе иn if erum Humb. et Bonpl. pl, aequinoct, $t, 28$.

1433. Geoderanan JACKS. Perigon i conniventis foliola libera, subsecunda, exteriora et interiora subaequalia. Labe $11 \mathbf{u m}$ columnae continuum, sessile, cucullato-ventricosum, versus basim saceatum. Columna brevis, erecta, semiteres. Anth era bilabiata. Pollinia 2 , postice biloba, caudicula communi lrevissima, glandula transversa.

in India orientali et in Nova Hotlandia tropica indigenae, radicibus tuberosis, foliis plicalis, racemis multifloris, apice recurvis.

$\mathrm{G}$ e d a ru m Jackson in Bot. Keposit. 1.626. R. Brown in Ait. hort, Ke'w, II, 5. 207. Lisdl. Orchid, 175. Bot. Reg. t. 1687. O $\mathrm{ta}$ ind $\mathrm{r}$ a Salisb. in Horticult. Transaet. I. 261. C istella Blume Bijifr. 293. fiğ. $5 \tilde{s}$. L i mod ori s p. Roxb. Corom. 1. 39, 40.

1434 . A cantheploippinm $B L U M . \mathrm{Pe}-$ rigonii ventriensi foliola exteriora conglutinata, lateralia ungui columnae adnata, supremum cum interioribus spathulatis fornicatum. Labellum cum pede columnae longe producto elastice articulatum, unguicnlatum, limbo trilobo, eomplicato, disco lamellato. CoI una. . A A th e ra carnosa, bilocularis. Pollinia 8, inaequalia, sessilia, - Herbae indicae, epigacae, subcaulescentes; caule inferne bulboso, vaginato, foliis oblongo-lanceolatis, plicatis, pedunculo vaginato, paucifloro, foribus speciosis.

A canthephippium Blume Bijdr. 353. Sg. 47, Lindley Orchid, 177. Bot. Reg. $t, 1730$.

1435. Doritis LINDL. Perigonii explanati foliola exteriora lateralia basi valde obliqna, cum columnae pede longe producto con- nata, superins interioribus obtusis conforme. Labellum cum colnmnae pede elastice articulatum, ungniculatum, deflexum, lamina hastato - triloba, linea media clavata. Colum na alato-marginata, rostello proboscideo porrecto. Anthera ovata, acuminata. Pollinia 2 , postice biloba, caudicula subulata, elongata, g la nd ula parva, ovata. - Herba indiea, epiphyta, caulescens, undique rhizophora; foliis distichis, spicis axillaribus strictis, multifloris.

\section{Doritis Lindley Orchid. 178.}

1436. Chellomanthera BLUM. Perigonii patentis foliola exteriora ovalia $v$. oblonga; interiora linearia. Labe $11 \mathrm{~nm} \mathrm{cum}$ basi columnae artieulatum, emarginatum, utrinque dente inflexo auctum. Col um na erecta, petaloidea, infra apicem antherifera. Anthera bilocularis, (quadrivalvis transversim dehiscens). Pollinia 4, hemisphaeriça, cava, caudiculis duabus filiformibus, glandula hamata. Her. bae javanicae, epiphytae, pseudobulbosae; pedunculis multifloris, floribus bracteatis, distichis.

Chelo nanthera Blume Bijdr. 382. fig. 51 . excl. sect. 2. Lindley Orchid, 178.

143\%, Acantinogiossmen BLUM. Perigonii patuli foliola subconformia, exteriora latiora. L a b e $1 \mathbf{1} \mathbf{~ u m}$ basi ventricosum, limbo reflexo-patente, bilobo, interne bicalloso. Columna superne libera, membranaceo-mar ginata. An th e r a bilocularis, infrapicillaris, rostello emarginato incumbens. Pollin ia 4 , obovata, glandula hamata. - Herba javanica, epiphyta, pseudobulbosa; pedunculis multifloris, floribus bracteatis, distichis.

A eanthoglossum Blume Bijdr. 381. Lindley $O r$. chid. 179.

1438. Sumipia $B U C H A N$, Perigonii ringentis foliola exteriora aequalia, basi discreta, lateralia labello supposita; interiora nana. L a b e $11 \mathrm{~nm}$ (cum columna articulatum?) posticum, integrum, erectum, perigonii foliolis interioribus majus. Columna nana. Anthera dorso affixa, bilocularis, loculis discretis, verticaliter dehiscentibus. P o. I I i n a 4, per paria e audiculis duabus gland ulae communi affixa. - Herbae nepalenses, epiphytae, pseudobulbis monophyllis; foliis carnosis, spicis radicalibus distichis, multifloris, floribus parvis, bracteis longis spathaceis stipatis.

S unipia Buchanan in Recs cyclop, art. Stelis. Lindley Orchid, 179 .

1435. Calypse SALISB. Perigonii patentis foliola exteriora et interiora aequalia, secunda. L a b e $1 \mathrm{l}$ a m coneavam, sub apice saccatum, trilobum, lobis lateralibus connatis, intermedio dilatato barbato suppositis. ( 0 1 un a erecta, petaloidea. Anthera bilocularis, infrapicillaris. P o 11 i $\mathbf{n}$ i a 2 , bipartita, in g l andula membranacea subquadrata, transversa, sessilia - Herba terrestris, in Europa, Asia et America boreali inter 60 et $68^{\circ} \mathrm{L} \mathrm{B}$. indigena ; rhizomate bulboso, foliis solitariis plicatis, flore terminali unico specioso.

C a 1 y ps o Salisb, Parad, t, 89. Hook, exot, Flor. t, 12. Bat. Mag, t, 9763. Lindl, Orchid, 180.0 $0 \mathrm{r} \mathrm{ch}$ id i um Swarts Swenks Bot, 1,518. Norn a Wahlenb. Flor, succ. 561 . C ypripedium buibosum Linn.

1440. Eulophia $R$. BR. Perigonii explanati foliola exteriora et interiora subaequalia, libera v. cum columnae pede plas minus producto connata. $\mathrm{L}$ a b e $\mathrm{I}$ l u m sessile, 
cornutum v. breviter calcaratum, trilobum vel indivisum, venis cristatis, harbatis v. omnino laevibns. C o l u m n semiteres, marginata. Ant hera ni-bilocnlaris, Pollinia 2, postice biloba v. cava, caudicula brevi lineari, glandula transversa. - Herbae in India orientali et in Africa tropica et a ustrali indigenae, epigaeae, pseudobulbosae; foliis longis, membranaceis, plicatis $v$. costatis, scapis radicalibus multifloris.

Eu lophia R. Brown in Rot. Reg. n. 578. 686, Lindl. in Bot. Reg. t. 1147. 1821. Orchid, 180, I i modor i sp. Thouars Orchid, 1,43.45_67. Roxb. Corom, t. 38.

1441. Dipóliman $R$. BR. Perigonii patentis foliola exteriora et interiora aequalia. Labe $11 \mathrm{um}$ subconforme, basi saccatum et cum columna connatum, utrinque infra medium auriculatum, disco barbatum. Colu m na erecta, semiteres, marginata. Anthera bilocularis, membranacea. Pollinia 2 , oblique biJoba, candiculis duabus glandulae communi affixa. - Herbae in Nova Hollandia orientali extratropica, in insula Diemen et in Nova-Caledonia observatae, epigaeae, aphyllae; radice crassa, ramosa, caule squamato, racemo multifloro, floribus speciosis.

D i podium R, Brown prodr. 330. Lindl. Orchid. 186. Dendrobium punctatum Smith exot. Bot. I, t. 12. -? Armodorum Kuhl et Hasselt Orchid. edid, Breda. t. 6 .

14.8. Falleanalma LINDL. Perigon i patentis $v$. conniventis foliola exteriora et interiora aequalia, adscendentia, libera. L ab ell $1 \mathrm{~m}$ sessile, infundibuliforme, ealcaratum, indivisum, intus laeve, margine saepius fimbriato. Anthera galeaeformis, crista recurva dorso clinandrii affixa. Pollinia 2, postice exeavata, caudicula brevi, cum glandula elongata, hasi divergenti-biloba articulata. - Herbae af $r$ e ana e tropicae, epigaeae; foliis plicatis, scapis radiculibus $v$. racemis terminalibus multifloris.

Ga le and $\mathbf{r}$ a Lindl, in Franc. Bauer illustr. Orchid. t. 8. Orchid. 186. Eul op hi a gra eilis Lindl. in Bot. Reg. t.742.

1443. Wysopetalum HOOK. Perigonii explanati foliola exteriora et interiora subaequalia, adscendentia, eum columnae pede producto connata. Labe $11 \mathrm{um}$ anticum, indivisum, patens, ungue adscendente, crista magna, transversa, carnosa. Co $1 \mathbf{m}$ ma brevis, arcuata, semiteres. Anthera incomplete biloeularis. Pollinia 2 , bipartibilia, in gland $\mathbf{l} \mathrm{I}$ a transversa subsessilia. - Herbae americanae tropicae, epigaeae, subacaules; foliis plicatis patentibus, floribus magnis, speciosis, labello discolore.

Z y go o eta I u m Hook, in Bot. Mag. $t$, 2748. Lindl, in Bot, Reg. t. 1433. 1857. Orchid, 187, Loddig. Bot. Cab, t. $1664,17 \% 6,1687$.

144.4. Cyrtopodiame R. $B R$. Perigon i explanati foliola exteriora et interio$\mathbf{r}$ a aequalia, libera. Lab ell um pedi producto columnae continuum, unguiculatum, tripartitum, explanatum, ecalearatum. Co 1 umna erecta, semiteres. An th e ra bilocularis. Pollinia 2, postice biloba, ca udicula lineari, brevi, glandula ovata. - Herba Indiae orientalis epigaea, suffruticosa; caulibus fusiformibus carnosis, foliis plicatis, scapis radicalibus vaginatis, floribus flavis, speciosis.

Cy rtopodium R. Brown in Ait, hort. kew. I1.5.216. Bot. Mag. $t, 1800,3507$. Lindl. Orehid, 188. excl. sp. amer. E y mbidium Andersonii Bot. Heposit. $t, 651$.
1445. Chysis LINDL. Perigonii foliola exteriora basi paullo cohaerentia, lateralia pedi columnae prodncto adnata, calear simulantia; in teriora libera, conformia. Lab e 11 um patulum, trilobum, venis basi callosis. Columna marginata, canalicnlata, mutica, rostello laminato, convexo. Anthera opercularis, subrotunda, glabra. Pollinia 8 , in laminam luteam confusa, quatuor exteriora tenuia, quatuor interiora crassiora abscondentia. - Herba a mericana tropica, ex arboribus pendula; caulibus Cyrtopodii depauperatis, foliis nervosis, basi vaginantibus, racemis lateralibus multifloris.

C h y s is Lindley in Bot, Beg. t. 1937.

1446. Cyrtopera LINDL. Perigonii explanati foliola exteriora et interiora subaequalia, adscendentia, cum columnae pede longe producto connata. $\mathbf{L}$ a b e $11 \mathrm{um}$ ecalcaratum, concavum, subventricosum, trilobum, venis longitudinalibus callosis, eristatis v. tuberculosis. Columna semiteres, marginata. Anthera uni - hilueularis. Pollinia 2 , postice biloba, caudicnla brevi, subtriangulari. - Herbae terrestres, in America tropica, India orientali, Madagascaria et in Capite bonae spei observatae; caulibus carnosis, nunc abbrevial is, nunc fusiformibus elongatis, foliis plicatis, floribus racemosis, speciosis, scapis radicalibus.

Cyrtopera Lindley Orchip. 189. C y rtopodii sp. Bot. Mag.t.1814. Bot. Reg.t. 1508, L im o d o ri s p. Thouars Orchid. $t, 41.42$.

144\%. ILssoelnilus $R$. BR. Perigonii explanati foliola exteriora herbacea, libera, parva, reflexa, v. uti interiora maxima, alaeformia, patentia. Lab ell um liberum v. eum eoIumnae basi connatum, saceatum, coneavum, subintegrum v. trilobum. Colu m na brevis, erecta, semiteres. Anthera bilocularis, cristata. Pollinia 2, postice biloba, e a udieula brevi, lineari, g I a n d u 1 a triangnlari. - Herbae in Africa tropica et extratropica, imprimis a ustral $i$ indigenae, terrestres, acaules, pseadobulbosae; foliis striatis $v$. plicatis, racemis radicalibus multifloris, floribus speciosis.

L is 80 ehil u s R. Browa in Bot, Reg, t. 573, Liadley Collect, t.31. Orchid.191. E ul ophía e s p. Bot. Reg.t.1002. Bot. Mag. $t, 2931$.

1448. Notylia LINDL. Perigonii explanati foliola exteriora et interiora aequalia, lateralia connata, labello supposita. Lab e $11 \mathrm{~nm}$ liberum, ecalearatum, patentissimum, integrum, medio callosum. Col $\mathbf{l}$ mna erecta, teres, acuminata, stigmatis rima verticali. Anth er a unilocularis, dorsalis, stigmati parallela, clinandrio plano, antice calloso, postice marginato. Pollinia 2, integra, eaudicula elongatocuneata, glandal a minnta. - Herbae americanae $t$ ro p i c a e, epiphytae; foliis solitariis, striatis, ut in Pleurothallide stipitatis, spicis radicalibus, floribus inconspicuis.

Notylla Lindley in Bot. Reg. n, 930, Pleuroth a b. $1 \mathrm{~d} \mathrm{i}$ s $\mathrm{s}$. Ker in Bot. Reg. L, 759. Kunth in Humb. et Bonpl. nov. gen. et sp. t. 91. Gom ez a e s p. Loddig. Bot. Cab. t. 806 .

14.49. Mrasulevallia $R U I Z$, et $P A V$. Perigonii foliola exteriora in tubum connata, apice libero Ionge lignlata; interiora libera, nana. Labell um cum columna articalatum, sessile, oblongum, concavum, nanum. Columna incurva, semiteres. Anthera bilocularis, terminalis, opercularis. Pollinia 2, integra, ca udiculis duabus filiformibus, elastice 
replieatis, glandulae conicae affixa. - Herbae peruanae, epiphytae; rhizomate parvo repente, foliis oblongo-lanceolatis, basi in petiolum angustatis, scapis radicalibus unifloris, floribus majusculis.

M a s de vallia Ruiz et Pav, prodr. 122, $t$, 27. Kunth in Humb. et Bonpl. nov. gen. et sp. I. 361, ᄂ. 89. Liudley Orchíd. 192. Pöppig et Eudl. nov. gen, et sp. II. 6. t. 108.

145. Cryptoelnillus $W A L L$. Perigoni i tubulosi, fauce contracti, basi antice gibbosi foliola exteriora connata, apice breviter distincta; interiora panllo minora, libera, Labellum columnae basi productae continuum, liberum, indivisum. Co I $\mathbf{m} \mathrm{m} \mathbf{n}$ a semiteres, clinandrio quadridentato. An th $\mathbf{h} \mathbf{r}$ a bilocularis. Pollinia 8, per paria glandula e communi adhaerentia. - Herba nepalensis, terrestris; pseudobulbis aggregatis, foliis semicoriaceis striatis, spica secunda multiflora, floribus sanguineis, pollicaribus, pubescentibus.

C ry p to chil us Wallich Tent. Flor, nepal, 36.t. 26. Lindley Orchid. 193.

1451. Trielhopilia LINDL. Perigonii patentis foliola exteriora et interio$r$ a aequalia, linearia, crispa. Labellnm magnum, convolutum, columnae parallelum, trilobum, lobo intermedio subbilobo, planiusculo, intus nudum. Columna teres, clavata, clinandrio cucullato, trilobo, villoso-fimbriato. Anther a unilocularis, compressa, antice convexa. Pollinia 2 , postice suleata, caudicula e tenui cuneatae adhaerentia, gland ula minima.

ba mexicana, terrestris (?); pseudobulbis carnosis, vaginis maculatis tect is, monophyllis, foliis coriaceis, planis $v$. leviter complicatis, floribus axiltaribus, solitariis.

Triehopilia Lindley in Bot, Reg. $t .1863$.

1452. Jomopsits $H$. B. K. Perigonii clausi foliola exteriora lateralia inferne approximata, cum basi labelli connata; interiora conformia. La bell $\mathbf{n m}$ multo majus, basi saccatum, ungue calloso colnmnae parallelo, lamina explanata patente, biloba. C o l u m n a ereeta, semiteres, aptera, rostellata. Anthera unilocularis, rostrata. Pollinia 2, postice sulcata, caudicula lineari inclusa, glandula obovata. - Herbae americanae tropicae, epiphytae, acaules; foliis coriaceis, scapis paniculatis, vaginatis, floribus parvis, pallidis.

J on ops is Kunth in Humb. et Bonpl. nov. gen, et sp. I, 348, t. 83. Lindl. Orohid, 103. Bot. Reg. t. 1904. Ja ntha Hook. exot. Flor. t. 113. Cybellon Sprengel syst. III. 721 .

1453. Díadenimm PÖPP. et ENDL. Perigonii patuli foliola exteriora angusta, basi cohaerentia, lateralia in unicum connata, cum supremo in calcar longum producta; interiora latiora, erecta, apice patentia, basi cum columna connata. $\mathrm{L}$ a b e $11 \mathrm{u} \mathrm{m}$ colnmnae continuum et parallelnm, basi eandem amplectens, panduriformi-oblongum, disco subtus incrassatum. Colum na clavata, semiteres, basi biaurita, clinandrio marginato. Anthera unilocularis, convexa. Pollinia 2 , caudiculae basi operculatae, apice dilatatae, big I a ndulo. s a e affixa. - Herba peruana, epiphyta, ebulbis; rhizomate repente, tortuoso, folits paucis, oblongo-lanceolatis, nervosis, scapo tereti, remote bracteato, paniculatim ramoso, floribus raccmosis, pedunculis brevibus, sigmoideis. t. 71

Di a denium Püppig et Endl, nov, gen, et sp. I. 41.
1454. Conaprettia PÖPP. et ENDL. Perigonii conniventis foliola exteriora angusta, basi cohaerentia, Iateralia in unicum connata, basi in calcar producta, supremum inferne columnae adnatum; interiora paullo latiora, libera. Labe $11 \mathrm{~nm}$ posticum, cum columna unguiculatum, ungue basi subtus in cornua duo intra calear abscondita producto, lamina reniformi, integra v. basi bidentata, convexa, emarginata, disco cristata. Colu in na semiteres, membranaceo-marginata, medio inflata. Anthera bilocularis, membranacea. Pollinia 2 , caudiculis duabus filiformibus elasticis, glanduI a e ovali convexiusculae adhaerentibus. - Herbae peruana e, epiphytae, pseudo-bulbiferae; pseudobulbis exiguis, monophyllis, folio oblongo, obtusiusculo, nervoso, racemis radicalibus simplicibus $v$, ramosis, subsecundis, bracteatis.

C o mparetti a Poppig et Endl. nov. gen, et sp, T. 42. 1.72,73.

1455. TRediriguezia RUIZ. et $P A V$. Perigonii patentis subaequalis foliola ex teriora lateralia connata, labello supposita. $\mathrm{L}$ a b e $11 \mathrm{um}$ unguiculatum, integrum, basi cornutum, medio callosum, ungue cum columna parallelo. Co Inmna teres, apice barbata. Anthera unilocularis, carnosa, clinandrio nudo, retrorsum declivi. Pollinia 2 , postice excavata, caudicula elastica. - Herbae americanae tropicae, epiphytae, pseudobulbosae; foliis coriaceis $v$. membranaceis, plicutis, spicis secundis, floribus speciosis.

Rodriguezia Ruiz et Pav. prodr. 115. t. 25. Kunti in Humb. et Bonpl, nov. gen, et sp. I. 367. t, 92. Lindley Orchid. 194. Hook. in Bot, Mag. t. 3497. 3304.3524. Trans. act, Hortic. soc. VXI. 67. Go meza R. Brown in Bot. Mag. t.1748, Bot. Cab. t, 660. Pleurothallidis s p. Hook, in Bot, Mag. 2, 2746.

1456. IBourlingtomia LINDL. Perigon i membranacei, convoluti, obliqui foliola unguiculata, ex terior a lateralia labello supposita, inter se connata, basi subsaccata; int erior a exterioribus aequilonga, sed paullo latiora. L a b e $11 \mathrm{um}$ unguiculatum, foliolis majus, apice dilatatum, bilobum, basi brevissime calcaratum v. aequale, ungue cum columna parallelo, canaliculato, lamellato. Co I um na teres, longe clavata, apice interdum appendieibus duabus coloratis (staminodiis) aucta, clinandrio retrorsum declivi, stigmate utrinque cornuto. Anthera unilocularis. Pollinia 2 , c a udicula refracta, apice dilatato - bifida, g l a n d u I a e naviculari affixa. - Herbae americanae tropicae, epiphytae, pseudobulbosae; pseudobulbis basi foliatis, apice mono-diphyllis, floribus racemosis, speciosissimis.

Burlingtonia Lindley in Bot. Reg, t, 1927. - Rodrig uezla Bate ur a 1 Lindley msc. Pöppig et Endl. nov.
gen, et sp. $t$, zo.

145\%. IIrerademin $R$. BR. Perigonii explanati foliola libera, exteriora et in teriora subaequalia. Labellum sessile, cucullatum, coneavum, integrum, acuminatum. Col umna ereeta, labello aequalis, semiteres, clavata, lobis lateralibus apicis in cucullum antheram amplexantem conniventibus, rostello longo, subulato. Anth era bilocularis, rostro produeto rostellum involvente. Poll in i a 2 , solida, c a u d i c n 1 a euneata, basi longe angustata, g I a n u l a ovali. - Herba antillana, epiphyta, pseudobulbosa; foliis coriaceis, scapis radicalibus multifloris, floribus luteo-viridibus, intus fusco-purpureo maculatis. 
Macradenia R. Brown in Bot. Reg, t. 612. Lindley Orchid, 195. Bot, Reg. $t, 1815$.

1458. Cryptarrinena R. BR. Perig onii explanati foliola libera, exteriora interioribus obovatis aequilonga, Labe $11 \mathbf{n m}$ unguiculatum, dependens, ecalearatum, limbo convexo, truncato, utrinque bicorni. Columna nana, tumida, aptera. A $n t h$ e $r$ a columnae apice cncullato inclusa. $\mathbf{P}$ o $11 \mathrm{i}$ n i a 4 .

Herba jamaicênsis, acaulis ; foliis caespitosis, coriaceis, scapo terminali multifloro, floribus parvis, luteis.

Cryptarrhena R. Brown in Bot,Reg. t, 153. Lindley Orchid, 195.

145\%. Cuitlazuinia $L L A V$. et $L E X$. Perigonii explanati foliola exteriora et interiora subrotunda, carnosa, ut plurimum irregularia. $\mathrm{L}$ a b e $11 \mathrm{u} \mathrm{m}$ unguieulatim, ungue canaliculato, limbo bilobo, undulato, rugoso. C o 1 u m n a brevis, tumida, apice auriculis tribus, petaloideis. A $\mathbf{n} \mathbf{h}$ e $\mathbf{r}$ a unilocularis, petaloidea, cucullata. P o 11 in i a 2 , pyriformia, eava, c a n d i c u 1 a commnni juncta. Herba mexicana, epiphyta; pseudobulbis depressis, rugatis, diphyllis, folitis coríaceis, scapo radicali pendulo, nudo, multifloro, floribus speciosis, odoratissimis.

Cuitlauzinia Llave et Lexarz. Nov, veg. M. 32. Lindley Orchid, 169.

1460. Dueldinum SWARTZ. Perigonii explanati foliola exteriora saepius undulata, lateralia libera v. sub labello connata; interiora conformia. Labell nm maximum, columnae continuum, ecalcaratum, lobatum, basi tuberculatum v. eristatum. C o I $\mathbf{~ m ~} \mathrm{n}$ a erecta, semiteres, apice utrinque alata. An $t h$ e $r$ a incomplete bilocularis, rostello abbreviato v, elongato, rostrato. Pollinia 2 , postice suleata, candie ula plana, glandula oblonga. - Herbae americanae tropicae, epiphytae, saepius pseudobulbosae; foliis coriaceis, planis, complicatis, triquetris v. teretibus, scapis paniculatis, vaginatis, rariusve simplicibus, floribus speciosis, ut plurimum luteis, saepe maculatis, rarius albis.

0 uc id ium Swartz in Act. Holm, 1800, p. 239. R. Brown in Ait. Hort. kew. II. 5. 215, Kanth in Humb. et Bonpl. nov. gen. ot sp. t.79-82. Lindley Collect. t, 22. Orchid, 196. Bot. Mag.t, 1491, 2203, 2773, 2795, 2990, 3109, 3393. 3486. 3499. Bot, Reg. t, 910,920, 1007, 1050, 1542, 1569, 1651. 1698, 1758. 1787, 1789. 1830. 1851. 1887. 1901. 1920. 1929. Fr. Bauer Gon, orchid. $t .7$. Pöppig et Endl, nov. gen. et sp.
$t .60$. E pidendri sp. Jacq. Amer. $t, 131, f .2, t, 133 . f .4$. t. 141.142. Bot. Mag. $t .777$.

1461. Fermandezia RUIZ. et $P A V$, Perigonii patentis foliola exteriora libera; interiora conformia, retro columnam conniventia. Labe $11 \mathbf{n m}$ anticum v. posticum, liberum, ecalcaratum, trilobum, disco tubereulatum. Col um na brevis, utrinque anrita. A nthera bilocularis Pollinia 2 , solida, obovata. . . - Herbae americanae tropicae, epiphylae, caulescentes; foliis distichis, equitantibus, imbricatis, racemis lateralibus terminalibusve paucifloris, floribus parvis, luteis.

Fernazdezia Ruiz et Pav. syst. 239. exel. sp. Pro drom. Lindley in Loddig. Bot, Cab. t, 1214. Orchid, 207. Bot. Reg. t.1806. Lo e k ha rtia Hook, in Bot, Mag.t, 2715.

146\%. Prelnyplnyllum $H, B, K$, Perigonii conniventis foliola libera, acuta, exteriora interioribus aequalia. Labellum liberum, indivisum, sessile, basi uni-apice bituberculatum. Colnmna petaloidea. Pollinia 8. ... - Herba peruana, epiphyta, caulescens; foliis distichis, spicis axillaribus recurvis, bifariam imbricatis, floribus inconspicuis, capsulis echinatis.

$\mathrm{P}$ a ch y phyllum Kunth in Humb. et Bonpl, nov. gen. et sp. I, 339. Lindl. Orchid, 208. F e r n a nd e zi a e 8 p. Ruiz et Pav, prodr, t.27, f. $2-4$. (excl. f. 1.)

483. Dielarea LINDL. Perigonii conniventis foliola libera, acuta, exteriora interioribus aequalia. Labell $\mathbf{n m}$ cum columna articulatum, unguieulatum, nudum, ecalcaratum, deltoideum. Columna erecta, teres, aptera. Anthera bilocularis. Pollinia 4 , geminata, collateralia, c a u dicula cuneata, glandula minuta. - Herbae americanae tropicae, epiphytae, caulescentes, repentes; foliis parvis, distichis, floribus axillaribus, solitariis, minutis.

D i c h a e a Lindley in Hook. Journ. of Bot.p. 5 . Orchid, 208. Pöppig et Endl, nov. gen. et sp. t. 105. 106. Epidendri et $C$ y mbidiisp. Swartz. Limodorisp. Aubl. guian, $t .328$. I $\mathrm{s} 0 \mathrm{ch}$ ili s p. Hook. exol, Flor, $t, 106$. Fern a n d ez ia e s p. Ruiz et Pav. prodr. t. 27. $f .1$.

1464. Playmatidium LINDL. Perigonii patentis foliola membranacea, libera, exteriora et interiora subaequalia. LabelI $\mathbf{~ m}$ subunguiculatum, indivisum, basi callosum. Col u m na libera, alato-marginata, basi tumida. Anthera.... - Herbae brasilienses, epiphytae, acaules, ebulbes; foliis gracilibus brevibus, floribus distiche racemosis.

P h y matid i m Lindley Orchid, 209.

1465. Cymtoelnillam $H . B . K$. Perigonii explanati foliola libera, exteriora lateralia unguiculata; i n t e r i o r a paullo minora. L ab ellum cum basi columnae continuum, ungue tuberculato, ecalcaratum, indivisum. Co 1 u mn a brevis, alata. Anthera bilocularis. Pollinia 2 , caudicula filiformi, glandula minuta. - Herbae americanae tropicae, epiphytae $\bar{v}$. terrestres, pseudobulbosae; foliis coriaceis, scapis radicalibus paniculatis, floribus speciosis.

C y $x$ to ehilum Kunth in Humb. et Bonpl, nov. gen. et sp. I. 349. t. 84. Lindley Orchid, 210, Bot. Reg. t. 1627. Pöppig et Endl, nov. gen, ot sp. t,61.

1466. Odontoglossum $H . B . K$. P erigonii explanati foliola angusta, acnminata, libera, exteriora et interiora aequalia. Lab ellum unguiculatum, cum columnae basi continuum, ecalearatum, indivisum, lamina patente, basi cristata. Columna erecta, membranaceomarginata, apice ntrinque alata. Anthera bilocularis. Pollinia 2, solida, caudicula lineari, glandula hamata. - Herbae a mericanae tropicae, epiphytae, pseudobulbiferae; folits plicatis, scapo terminali vaginato, floribus speciosis.

Odontoglos s um Kunth in Humb. et Bonpl. nov. gen. et sp. I. 351. t. 85. Lindley Orchid. 211.

146\%. Irbrassia R. BR. Perigonii explanati foliola libera, angusta, exteriora interi oribus aequalia v. majora. Labell um coImmae continuum, ecalcaratum, planum, indivisum, basi bicristatum Columna nana, libera, aptera. Anthera nnilocularis. Pollinia 2, postice suleata, caudie ula brevi, glandula crassa. - Herbae americanae tropicae, epiphytae, pseudobulbosae; foliis rigide membranaceis, scapis radicalibus vaginatis, floribus spicatis, speciosis.

B rassia R. Brown in Ait. Hort, kew. II. 5. 215. Bot. Mag. t. 1691.3451. Lindley in Bot. Reg, t, 832.1954 . Orchid. 212. Föppig et Endl. nov. gen. et $s p . t_{4} 117$. Link et Otto Ie. t. 12, Ep ide $n$ d $x$ u $\mathrm{m}$ a a d a $\mathrm{t}$ m Linn.

1468. Tetrapeltis $W A L L$. Perigonii subpatentis foliola exteriora libera, aequa- 
lia; interiora angustissima, aequilonga. $\mathbf{L a -}$ b e 11 um liberum, sessile, saccatum, geniculatum, trilobum, lobis lateralibus abbreviatis, intermedio indiviso. Co I $\mathbf{m} \mathrm{ma}$ erecta, semiteres, clavata, clinandrio cueullato, rostello recto rostriformi. Anthera. . . Pollinia 4, globosa, postice foveata, per paria $c$ a u i c u 1 is duabus angustis, gla $\mathbf{n} \mathbf{d} \mathbf{l}$ a e communi adhaerentia. - Herba nepalensis, epiphyta, caules cens; caulibus squamoso-vaginatis, curvis, foliis geminatis, lanceolatis, plicatis, spica erecta, multiflora, foliis breviore, floribus albis.

Tetrapeltis Wallieh mse. Lindley in Bot. Reg. $n$. 1522. Orchid. 212.

1463. Plnallaenopsis BLUM. Perigo nii explanati patentis foliola exteriora li bera, aequalia; interiora multo majora. L abellum columnae pedi parum producto continuum, liberum, basi callosum, trilobum, lobis lateralibus recurvato-adscendentibus, intermedio angustiore, bicirrhoso. ( $:$ ol $\mathrm{um} \mathrm{n}$ a in ovario recumbens, semiteres, rostello gladiato. Anthera bilocularis. Pollinia 2, subglobosa, e a dicula plana, spathulata, glandula maxima cordata. - Herba moluc cana, epiphyta; cauli bus simplicibus, radicantibus, foliis rigidis, latoLanceolatis, apice oblique retusis, floribus paniculatis, magnis, albis.

$\mathrm{Ph}$ alaenops is Blume Bijor. 294. fig. 44. Lindley Orotid. 213. Epide u d rum am abile Linn. (Rumph. Am. boin. VI. 99, t. 13.)

1480. 'Triehoglottis $B L U M$. Perigonii patentiusculi foliola exteriora aequalia, lateralia labello supposita; interiora paullo minora. Lab e $11 \mathrm{~nm}$ cum marginibus columnae connatum, saceatum, utroque margine cornutum, limbo carnoso, indiviso, basi callo saceum claudente. Columna erecta, basi unicornis. Anthera bilocularis. Pollinia 2 , globosa, biloba, caudicula unica lineari, glanduIa parva, hamata v. peltata. - Herbae javanicae, epiphytae, subramosae, radicantes; foliis coriaceis aut carnosis, pedunculis lateralibus v. oppositifo liis, brevissimis, uni-paucifloris.

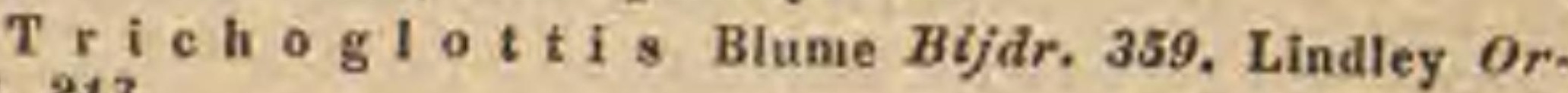
chial. 213.

a) TRICHOGLOTTIS. L a bell $\mathrm{nm}$ intus pubescens, lim. bo patente, basi utrinque dente inflexo aucto. $\mathrm{C}_{0}$ I uma apice utrinque dente instrueta. Pollinia inaequalia.

Trichoglottis Blume op. cit. fig. 8.

b) ATRichoglotTis. Lab e i 1 u $\mathrm{m}$ imberbe, limbo abbre. viato, subfornicato, basi atrisque dente obtuso. C $\mathrm{C}_{\text {- }}$ I um a obtusa. Pollini a aequalia, basi suleata.

Trichoglottis rigida Blume.

1478. Telipogon $H . B$. K. Perigonii explanati foliola exterinra angusta, "acuta; interiora late ovata. Labellum foliolis interioribus conforme, paullo majus. Columna teres, pilosa, clinandrio postice processu subulato uncinato instrueto. Anthera unilocularis, alte bivalvis, stipitulo elongato, fistnloso, uncinato, elinantrii processui affixa. $P$ o 11 in i a 4 , caudicula...., glandula. Herbae americanae tropicae, epiphytae; caulibus foliosis, floribus terminalibus paucis, subspicatis, pedicellatis, flavescentibus.

Telipogon Kunth in Humb. et Bonpl. nov. gen. et sp. I. 336, t.75. Lindley Orchid. 214.

14 2. Vanda $B . B R$. Perigonit explanati patentis foliola exteriora et interiora subaequalia. L abell um cum basi colnmnae continuum, saccatum v. obconico-calearatum, sub- trilobum, lobo medio carnoso. Col um a abbre. viata, crassa, libera, rostello obtuso. Anthera bilocularis. Pollin ia 2 , oblique biloba, can di cula lineari, glandula subrotunda. - Her bae indicac, epiphytae, caulescentes; folitis disti chis, coriaceis, spicis oppositifoliis, floribus spe-
ciosis.

V a nda R. Brown in Bot, Reg. t, 506. Lindley Collect. t. 38. Orchid, 215. Bot, Reg. t. 1809. Bot. Mag, t. 3a16. -? Kuhl et Hasselt Orchid. edid. Breda t. 13. - Fiel di a Gaudich. ad Freye. 424, t. 36. E p ide n d ri s p. Linn.

1483. Fenanthera LOUREIR. Perigonii explanati, patentis foliola exteriora linearia, lateralia saepius majora; interiora conformia, subaequalia. Lab ellum cum columna elastice articulatum, liberum, nannm, medio satcato-concavum, trilobum, lobo intermedio car noso. Col u m a erecta, abbreviata, aptera. Anthe ra bilocularis. Pollinia 2 , biloba, $c$ andieula nnica, glandula subtriangulari peltata. Herbae in Moluccis, China australi et Jap on ia indigenae, epiphytae; caulibus radicantibus, ramosis, scandentibus, foliis coriaceis, floribus paniculatis, speciosissimis.

R e na $\mathrm{t}$ he r a Loureiro Fl. cochinch. IT. 521. Lindley in Bot. Nleg. t. 1131, Orchid. 217. Bot, Mag. t. 2097. 2998. A érides Swartz in Schrad. Journ. 1799. I1, 233.t. 2.f. A. Blume Bijdr. 366. f. 24. non Loureiro, - A ra ch n is Blume Bijdr. 365. fig, 26. A $r$ a ehn anthe Blume Flor. Jav. praef. Vl. Epidendrum Flos aërís Linn.

1484. Diplocentruma LINDL. Perifonii subelausi foliola libera, exteriora lateralia paullo obliqua, supremo multo majora; interiora nonnilil minora. Labe I l um cum columna articulatum, indivisum, biealcaratum. Columna minuta, semiteres, rostello obtusin. Anthera.... P o 11 in i a 2 (?), caudicula subnlata, g landula maxima, concava. Herba indica, epiphyta, caulescens; folits complicatis, carnosis, racemisque paniculatis recurvis, floribus $\mathrm{mi}$ nulis, calcaribus brevibus, obconicis, incurvis.

Di plo e entrum Lindley in Bot, Heg. $n, 1358$. Or.
chid. 218 .

14\%5. IVIcrosacens BLUM. Perigoni i patentiuseuli foliola exteriora linearia, lateralia labello adnata; interiora conformia. L a be $11 \mathrm{~nm}$ columnae antice adnatum, basi saccatum, limbo abbreviato, fornicato. CoI $\mathbf{m}$ ma nana, aptera, obtusa. Anthera incomplete bilocularis. Pollinia 4 , obovata, basi foveata, c a u d c u la communi juncta. - Ierba javan ica, pusilla, epiphyta; caulibus simplicibus compressis, foliis scalpelliformibus, equitantibus, rigidis, pedunculis intrafoliaceis, paucifloris.

Mier os a c us Blume Bijdr. 367. Liadl. Orchid, 218.

14. B. Comamotis LINDL. Perigonii explanati foliol a exteriora lateralia inter se et cum dorso labelli connata, apice distincta; interiora paullo minora, libera. L abe $11 \mathrm{~nm}$ obovatum, canaliculatum, apice sub appendicula subulata inflexa calcaratum. Col umna erecta, teres, libera, longissime sigmoideo-rostrata. Anthera dorsalis, apiculata, incomplete bilocularis. PolIinia 2 , eandicula elongata, subulata, glandula forficata. - Herba indica, caulescens; foliis distichis, coriaceis, oblongo-linearibus, apice emarginatis, racemis axillaribus, multifloris.

C a marotis Lindley Orchid, 219 ,

147\%. Chilosehista LINDL. Perigonii subpatentis foliola exteriora lateralia, cum interioribus multo majoribus columnae basi longe productae adnata. Labell um cum 
columnae basi articulatum, bipartitum, medio eristatum. CoI n mna minima, erecta, semiteres. Pollinia 2, caudicula brevi, subulata, glandula minuta. - Herba nepalensis epiphyta, humilis, hirsuta, aphylla; radicibus complunatis viridibus, subfoliaceis, racemis erectis, floribus albis, odoratis, ovariis pubescentibus.

C hilos chista Lindley in Bot. Heg. n. 152. Orchid. 219. Epidendrum us neoides Don.

1485. Gumnia $L I N D L$. Perigoni $\mathrm{i}$ herbacei ringentis foliola Jateralia subfalcata, erecta, ungui labelli adnata; in terio ra snblanceolata, obtusa, libera, exteriori supremo pendulo parallela. Labell n m carnosum, ungue longe producto, lineari, erecto, cum basi columnae continuo, bilobum, antice cornutum, muerone infle xo, disco tuberculato. Colum na semiteres, nana, aptera, rostello bifido. An thera.... Pollinia 4 , in paria subglobosa coadunata, e a ndienIa lineari. - Herba in insula Diemen epiphyta; rhizomate longo, tortuoso, repente, foliis lanceolatis, falcatis, distichis, basi articulatis, racemo simplici stricto, foliorum longitudine.

Gunn i a Lindley in Bot. Reg. $n, 1699$.

14\%9. Nieropera LINDL. Perigon i patentis foliola aequalia, exteriora lateralia basi labelli adnata. Labell nm cum hasi columnae continuum, calceiforme, leviter trilobum, lobo intermedio minimo, lateralibus majoribus, erectis. Columna brevis, rostello maximo, inflexo. Anthe $r$ a.... Pollinia 2, caudicula subulata. - Herba indica, epiphyta, caulescens; foliis distichis, linearibus, arcuatis, apice emarginatis, aequalibus, racemis lateralibus horizontalibus, folitis brevioribus, floribus citrinis.

M i er opera Lindley in Bot, Reg. n. 1522. Orchid, 219. A ërídes pallidum Roxb.

1480. Saceolabium LINDL. Perig onii explanati patentis foliola aequalia, v. exteriora lateralia saepius majora. Labellum basi columnae adnatum, indivisum, calcaratum. Columna erecta, semiteres, rostello subulato. Anthera incomplete bilocularis. Pollinia 2, subglobosa, eaudicula elongata, gl andula minuta. - Herbae indicae, epiphytae, caulescentes; foliis distichis, coriaceis, apice saepius obliquis, floribus axillaribus racemosis $v$, solitariis.

S a ce olab ium Lindley Orchid,220. Bot, Reg. t, 1552. $\mathrm{Sacco} 1 \mathrm{ab}$ i um Blume Bijdr. 292. $f_{g} .50$. S a c c e h il us Blume Flor. Jav, praef. VIT. - Gastrochilus Don nepal.32. non Wall. - Robiqueti a Gaudieh. ad Ereyc. 426. t. 3\%. - Gus s on e a A. Rich, in Mem, soc. h, n. Paris, $\mathbb{F}, 67$. t. 11. $f, 1$. (Thouars Orchid, $t .79$. 73.) Rhyn chost ylis Blnme Bijdr. 285. fig. 49. E pidendri sp. Roxb. Sarcanthi s p. Bot. Reg. 2.1443.

1481. Taeniophyllum $B L U M$, P e rigonii conniventis foliola exteriora basi connata, lateralia labello adnata; interiora aequalia. Labell um calcaratum, basi columnae adnatum, limbo integro, calcare inappendiculato. Colu m na erecta, nana, rostello ovato. Anthera incomplete bilocularis. Pollinia 4, caudicula capillari, glandnla minutissima.

Herbae javanicae, epiphytae, pusillae, acauLes; foliis fasciculatis, linearibus, planis, fasciatis, floribus minutissimis, spicatis, bracteolatis.

T a e u i o p h y 11 u m Blume Bijdr. 225. Lindl. Orehid, 226,

148\%. Cleisostoma BLUM. Perigoni patentis foliola libera, exterior a linearia, labello supposita; interiora aequalia. Labell um calcaratum, basi columuae adnatum, limbo tridentato, calcaris ore dente clauso. Col umna ereeta, semiteres. Anthera incomplete bilocularis. Pollinia 2, biloba, subglobosa, caudicula filiformi, gland ula minuta, hamata. - Herbae indica e, epiphytae, caulescentes; caulibus radicantibus, foliis distichis, rigidis, subcarnosis, spicis oppositifoliis, subramosis.

CI eis os to mi a Blame Bifdr.362. Lindley Orchid.226. Poly chilos Kuhl et Hasselt Orchid, edid. Breda t. 1 .

483. Appendieula $B L U M$. Perigonii clausi foliola exteriora basi subconnata, lateralia columnae pedi longe producto oblique adnata, calcar obtusum aemulantia, supremum subfornicatum; interiora minora. L ab e 11 um pedi columnae longe producto affixum, liberum, concavum, indivisum, basi appendienlatum v. margine elevato cinctum. Columna nana. A n $t$ h e $r$ a dorsalis, bilocularis, loculis subquadrilocellatis. Pollinia 8, v. abortu pauciora, clavata, basi attenuata, ecaudiculata, glandula longa. - Herbae javanicae, epiphytae, simplicicaules v. ramosae; foliis distichis, ut plurimum membranaceis, pedunculis spicatomultiftoris rariusve solitariis.

A р реnd $\mathrm{ic}$ u l a Blume Bijdr. 297. $f_{g}$. 40. Lindley $O r$. chid, 227.

1484. Cryptoglottis BLUM. Perigonii clansi foliola exteriora basi connata, lateralia cum pede columnae in calcar longum, basi didymum producta, supra medium inter se cohaerentia; interiora paullo minora. Labellum inclusum, cum pede columnae elastice articulatum, unguiculatum, integerrimum. Columna nana, in ovario recumbens, rostello subulato, erecto. Anther a fere dorsalis, bilocularis. Pollinia 4 , clavata, inaequalia, sterilibus quibusdam intermixtis, ca udien Ia tenni, brevi, gl and ula hamata. - Herba javanica, epiphyta, pusilla, subramosa; folits linearibus, cuspidatis, pedunculis terminalibus subsolitariis, paucifloris, floribus parvis, bracteolatis, albidis.

Cryptoglottis Blume Bijdr. 230. fig. 42. Lindley Orchil. 230.

1485. Ceratostylis BLUM. Perigoni i clansi foliola exteriora inferne connata, lateralia basi producta, calcar breve obtusum aemulantia, supremum et interiora subaequalia. L ab ellum subinclusum, ungue longo incurvo, limbo indiviso, concavo, crasso. Columna brevis, lasi Ionge produrta, libera. Anthera bilocularis, loenlis quadrilocellatis. Pollinia 8 , in glandula sessilia. Herbae javanic a e, epiphytae, caulescentes, ebulbes; pedunculis unifloris ad basim foliorum, paleis cinctis.

C e.rat os tyli is Blume Bijdr. 304. $f_{g}$. 56 . Lindley $O r$. chid, 230.

1486. Eplnippiuan $B L U M$. Perigonii subringentis foliola exteriora latiora, cum columnae pede producto connata, supremum fornicatum, interiorib ns aequale. Labell um cum columnae pede elastice articulatum, parvum, integrum, scabelliforme. Columna in ovario recumbens, nana, antice bicornuta. Anthera bilocularis. Pollinia 2, bipartibilia, e audicul a clavata. - Herbae javanicae, epiphytae; caulibus radiciformibus, foliis solitariis, ut plurimum pseudobulbo insidentibus, coriaceis, pedunculis a basi pseudobulborum inferne vaginatis, apice pauci- $v$, multifloris, floribus subpedicellatis, bracteatis, purpurascentibus.

$\mathrm{E}$ phippium Blume Bijdr. 308. fig. 65. excl, seet. 1. Lindley Orehid, 231. 
145\%. Ceratoehilus BLUM. Perigonii patentis foliola exteriora aequalia, lateralia labello supposita; in teriora angustiora. $\mathbf{L}$ a b e 11 n m parvum, cum columna connatum, saceo v. caleare compresso, fance biglandulosum, limbo trifido v. integro. Columna nana. Anther a bilocularis. Pollinia 2, globosa, biloba, caudicula filiformi, glandula hamata. - Herbue javanicae, pusillae, epiphytae; caulibus simplicibus v. subramosis, foliis distichis, cressis, linearibus, subtriquetris, floribus pedunculatis, solitariis.

C e ra to chilus Lindley Orchid. 232.

c) CERATOCHILUS Blum. La belli ealear ventricosum; lamina subulata. - Caules simplices.

C eratochilus Blume Bijdr. 358. fig. 25.

b) OMOEA Blum. L a belli ealcar compressum, emarginatum; laninae trifidae lacinia media erecta, incrassata. - Caules subramosi, Rexuosi.

0 m o e a Blume Bijdr. 359.

1488. Eehioglossum $B L U M$. P erig onii explanati patentis foliola libera, exteriora et interiora subaequalia. Labellum cornutum, trilobum, lobis lateralibus erectis, intermedio difformi, utrinque calloso, in ligulam bifidam patentem producto, cornu dente clauso. C oInmna semiteres, aptera. Anthera bilocularis. Pollinia 2, bipartibilia, eaudicula filiformi medio aurienlata, glandnla arcuata, dilatata. - Herba javanica, epiphyta, caulescens; foliis distichis, lineari-lanceolatis, cuspidatis, rigidis, spica opposilifolia, pubescente.

Echioglossum Blume Bijdr. 364. fig. 28. Lindley Orchid. 233 .

1489. Sameantlaus LINDL. Perigonii explanati patentis foliola libera, exteriora et interiora subaequalia. Labellum hreve, calcaratum, cum columna articulatum, trilobnm, caleare intus semibiloculari. Columna erecta, semiteres. Anth era bilocularis. Pollinia 2 , postice lobata, caudicula glanduI a que variis. - Herbae sin $i$ ca e, epiplaytae, caulescentes; foliis distichis, planis v. teretibus, racemis oppositifoliis, floribus speciosis.

Sarcanthus Lindley Collect. $t .39 . B$. Bot. Reg. $t$. 1014. Orchid, 233. Franc. Bauer Orchid. gen.t.9. V a nd a e sp. R. Brown. Lindley Collect, t, 6 .

1450. Podeehilus BLUM. P e rigonii clausi foliola exteriora inferne cohaerentia, lateralia latiora, cum v. sub pede columnae producto connata; interi or a angustiora, libera. Labe $11 \mathrm{~nm}$ cum columnae pede elastice articulatum, integrum, unguiculatum. Col um$\mathrm{na}$ in ovario recumbens, clinandrio membranaceo, bicorni. Anth era bilocularis, subdorsalis. Poll inia 4, eaudiculis duabus membranaceis, convolutis. - Herbae indicae, epiphytae, caulescentes; foliis distichis, parvis, floribus exiguis, solitariis $v$. spicatis, saepe terminalibus.

Podochilus Blume Bijdr. 295, fig. 12. Lindley or

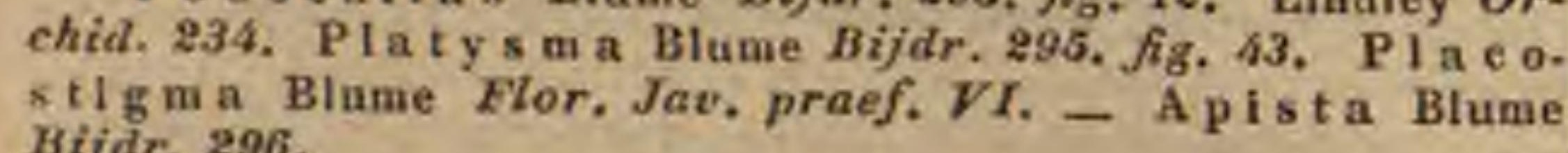
Bijir. 296,

141. Adenomeos BLUM. Perigonii foliola exteriora et interiora ereeta, subaequalia. Lab ell $\mathbf{n m}$ concavum, carnosum, intus glanduloso-tumidum, erectum, limbo indiviso. Columna brevis, obtusa. Anthera incomplete bilocnlaris. Pollinia $4,(2$, bipartibilia?) globosa, compressiuscula, caudicula brevi, glandnIa peltata. - Herba javanica, e minoribus, epiphyta; caulibus simplicibus, folitis distichis, linearibus, acutis, earnosis, superne ca- naliculatis, pedunculis oppositifoliis, solitariis, paucifloris, floribus sessilibus, virentibus.

A de a oncos Blume Bijdr. 381. Lindley Orchid, 23s,

1492. Deceoclades $L I N D L$. P erigonii patentis, ringentis v. conniventis foliola libera, exteriora et in teriora subaequalia. L a b ell um liberum, sessile, cum columna articulatum, nudum v. basi bilamellatum, calcaratum, caleare curvo, saepe obeonico, lamina lobata, cucullata, complicata v. concava. Columna plerumque elongata, semiteres. Anthera bilocularis. Pollinia 2, postice suleata, eandi cula angusta, glandula minuta. - Herbae epiphytae, ut plurimum indicae, paucae a mericanae et africanae tropicae, acaules $v$. caulescentes, nonnullae pseudobulbosae; foliis coriaceis $v$. rarius membranaceis, nunquam plicatis, floribus plerumque minutis.

Oe ce o el a des Lindley in Bot. Reg. n. 1522. Orchid. 235. Angra eci s p. Thouars Orchid, $t$. $60, \pi$. Lindley Collect, t, 15. Ge odor i sp. Link et Otto Abbild. $t$. 14 .

1493. Aërides LOUR. Perigonii patentis v. clausi foliola subaequalia, ext eriora lateralia basi saepius obliqua, cum pede prodneto columnae connata; in $t$ e $r$ i o $r$ a. . . L a b e I l n m cum pede columnae articulatum, saccatum v. calcaratum, trilobum, lobis lateralibus nanis, limbo cucullato v. subulato, nune abbreviato-tumido v. subfornicato. Co ium a in ovario recumbens, brevis, aptera. Anthera bilocularis. Pollinia 2, postice sulcata, $c$ a ndicula lata v. filiformi, gland u I a peltata, subrotunda. - Herbae indicae, epiphytae, caulescentes, subsimplices, radicantes; foliis distichis, coriaceis $v$. subcarnosis, floribus racemosis $v$. spicatis.

A ëri d es Loureiro Flor, cochinch, 595. Lindley Orchid, 238. De nd r o colla Blume Bijdr. 286. fig. 67.

a) CUCUlla Blum. Labelli limbus cucullatus v. rarins expansus. - Spicae bracteis carinatis, saepius carnosis.

Cu culla Blume 2. c. (Bot. Reg. $t, 1485$.

b) TUBERA Blum. L ab elli limbus callosus, abbrevia. tus. - Spicae bracteis coalitis v. scrobioulatis. t. 42.

T ubera Blume $l$. $c$. Epidendri sp. Roxb, corom.

c) FORNICARIA Blum. La be 11 li limbus foricicas, abbreviatus. - Spicae superne bracteis subulatis, congestis.

Forniearia Blume 2 . $c$.

d) PILEARIA $L i n d l$. L a b e $11 \mathrm{u} \mathrm{m}$ pileiforme, appendicula tabulari carnosa e dorso calearis. - Racemi flexuosi. Pil e a r i Lindley Orchid. 242.

e) ORNITHochiLUS Wall, Labe IIi lamina biloba, dilatata, unguiculata. - Racemi stricti.

Ornithochilus Wallich msc. ex Liudley $7 . c$.

114영. Selnoemoreling $B L U M$. Perigonit classi foliola exteriora et interiora aequalia, labello multo minora. $\mathrm{L}$ a b e $11 \mathrm{um}$ basi columnae adnatum, calcaratum v. saccatum, limbo obsolete trilobo. Columna semiteres, aptera, basi bicornis, rostello cornuto. Anthera incomplete bilocularis, cornuta. Pollinia 2 , bipartibilia, glubosa, e a u d i u 1 a filiformi, gl an dula parva, hamata. - Herbae javanicae, epiphylae, caulescentes; caulibus teretibus, subramosis, foliis linearibus v. subulatis, carnosis, spicis simplicibus $v$. ramosis.

$\mathrm{S}$ choen orc his Blume Bijdr. 36t. Reinwardt in $\mathrm{syl}$ loge plant. II. 4. Liadley Orchid. 243.

1495. Aëranthus $L I N D L$. Perigon i i conniventis foliola exteriora acuminata, lateralia majora, basi obliqua, pedi producto columnae adnata; interiora supremo panllo minora, 
Lab ell a m cum pede columnae articulatum, integrum, cucullatum, calcaratum, foliolis interioribus conforme. Columna brevis, in ovario recumbens, apice alata. A $n t h$ e $r$ a bilocularis. Pollinia 2, globosa, hinc perforata, caudicula nulla, glandulis duabus. - Herbae madagascarienses, epiphylae, caulescentes; foliis distichis, emarginatis, scupis radicalibus squamosis, unifloris.

A ëranthus Lindley in Bot, Aeg. 2,817 . Orchid. 243. Angraeci s p. Thouars Orchid, $t, 66,67$. Dendrobil s p. Thouars op. cit. $\ell .88$.

1498. Croyptopus LINDL. Perigon i explanati foliola exteriora libera, spathuIata, aequalia; interiora paullo majora, unguiculata, lobata. L a b ell u m cum basi columnae connatum, ealearatum, quadripartitum. CoI umna brevis, erecta, teres. An thera bilocnlaris. Pollinia 2, obovata, postice sulcata, caudiculis duabus apice exeavatis, glandulis 2, dimidiatis, villosis. - Herba madagascariensis, epiphyta, caulescens; foliis coriaceis, distichis, paniculis multifloris lateralibus, floribus speciosis.

Cryptop u e Lindley in Bot. Reg. n.817, Orchid, 244, Hook. Journ. of Bot. 45. t.95. B e e la r d i a A. Riehard in Mem, soc, h. n. Paris. IV. 69. t.11. f.3. excl, reliq. A ng raecum elatum Thouars Orchid, 1.79.80.

149. Deomia LINDL. Perigonii explanati foliola libera, exteriora et interi or a aequalia. Labellum sessile, horizontale, cuenllatum, trilobum, ealearatum. Col umna erecta, nana. Anthera bilocularis. Pollinia 2, postice biloba, caudicula nulla, g landulis duabus. - Herbae madagascarienses et borbonicae, epiplaytae, caulescentes; foliis distichis, coriaceis, spicis oppositifoliis multifloris, floribus speciosis.

0 e o n a Lindley in Bot, Reg. n. 817, Orchid,244, B eelardiae $8 \mathrm{p}$. A. Richard in Mem, soc. h, $n$. Paris, t. 11 f. 2. Ep idendri sp. Thouars Orchid, t, 81, 83,84.

1498. Angracenme THOUAR. Perigonii patentis foliola libera, exteriora et interiora subaequalia. Labellum basi columnae continuum, sessile, carnosum, indivisum, perigonii foliolis multo latius, calcare recto cornuto, saepius cylindrico, perigonio multo longiore, rarius obconico. Col um na nana, subteres, rarius elongata, semiteres. Anthera bilocularis, truncata Pollinia 2, bipartibilia, caudicula brevi, angusta, gland u 1 a triangulari. - Herbae madagascarienses et borbonicae, nonnullae fortassis capenses, epiphytae, caulescentes; foliis coriaceis, ligulatis, apice obliquis, floribus solitariis $v$. racemosis, albis, citrinis $v$. herbaceis.

Angra e cum Thonars Orchid, $t .48 \_58,62 \_65.68$ 71.75.76.78, excl. relig. A. Richard in Mem, soc. $h, n, \mathrm{~Pa}$. ris. IV. $t, 10$. Lindley in Bot, Reg. $t, 1522,1272,1781,1844$. Orchid. 245. Hook. Journ, of Bot. 4. 46. 47. Aërobion Sprengel syst, $I I I, 716$.

1499. NIystacidium $L I N D L$, Perigonii patentis foliola libera, exteriora et interiora aequalia. Labellum cum columna articulatum, calcaratum, indivisum. Col um na brevis, recta, semiteres, carnosa, apice utrinque processu longo lineari aucta, rostello ovato, elongato, convexo, nudo. A nt h e $\mathrm{r}$ a bilocularis, membranacea. $\mathrm{P}$ o 11 i n i a 2 , dorso exeavata, caudienla bicruri, cruribus glandulis membranaceis peltatim insertis. - Herba capensis, epiphyta, brevissime caulescens; folits distichis obtusis, oblique emarginatis, racemo multifloro, subsecundo.

My stacidi a m Lindley in Bot. Mag. compan. p. 205 .

1500. Agrostophyllum $B L U M$. $\mathrm{Pe}$ rigonii explanati foliola exteriora lata, aequalia, lateralia labello snpposita; in teriora linearia. Labellum cum basi columnae connatum, saccatum, medio constrictum, limbo indiviso, truncato. Colum na erecta, semiteres. Anthera bilocularis, loculis bilocellatis. Pollinia 8, cuneata, sessilia. Herba javanica, epiphyta, caulescens; foliis linearibus, acuminatis, floribus capitatis, terminalibus, bracteis paleaceis cinctis.

A grast op hyll um Blume Bijdr. 368. $f_{g}$. 53, Lindley orckid. 53 .

1501. Calamtlae $R$. BR, Perigoni i explanati foliola exteriora et interiora subaequalia, libera v. lateralia labello paululum adnata. L a b ell u m cum columna connatum, lobatum v. integrum, calcaratum v. muticum, disco lamellatum v. tubereulatum. Col u mn a brevis, rostello saepius rostrato. Pollinia 8 , basi valde attenuata, quaternatim glanduI a e bipartibili adhaerentia. - Herbae indicae, terrestres; scapis erectis, multifloris, foliis latis, plicatis, floribus albis, lilacinis v, rarius luteis.

$\mathrm{C}$ a lanthe R. Browa in Bot. Beg. $\iota_{+}$. 20 . Liudley Or. chid. 249. Bot. Reg. t. 1646. C ent rosia A. Rich. in Mem. soc. h. n. Paris. IV. 39. t. 7. f.3. Alls moreh is Thouars Orchid, $t .35,36$. A m bl y gl o tt is Blume Bijdr, 370 . $f_{b}$. 65. St y loglos s u Kubl et Hasselt Orchid. edid. Bre. da $t, 7$.

1502. Antherielis RAF. Perigonii patentis foliola exteriora obovata; interi oribus conformibus latiora. Labell um liberum, nanum, trilobum, longe calcaratum. $C_{\text {o- }}$ l $\mathbf{m m}$ a erecta, marginata, labello aequalis. Anthera bilocularis. Pollinia 2, bipartita, caud i c u l a lineari, gland nla parva, transversa. Herba boreali-americana, terrestris; pseudobulbis caespitosis, monophyllis, folio plicato, floribus racemosis, viridi-purpurascentibus.

An thericlis Rafinesque in Journ, Phys. LXXXXX.261. Tipula ria Nuttall gen. 11 . 195. Lindley Orchid.252, $0 x$ ehis discolor Pursh.

1503. Limatodes $B L U M$. Perigoni erecto-patentis foliola libera, exteriora et interiora subaequalia. Labellam liberum, indivisum, calcaratum, limbo intus tumido. C 0Iumna erecta, semiteres. Anthera bilocularis, loculis subquadrilocellatis. Pollinia 8 , obovata, $c$ a udicula brevi, filiformi, glandula minuta. - Herba javanica, terrestris; caulibus basi tumidis, foliis lato-lanceolatis, nervosis, membranaceis, pedunculis lateralibus solitariis, paucifloris, floribus albis.

Limatodes Blume Bijdr, 375. fig. 62. Lindley $O r$. chid, 252.

1504. Glomera BLUM. Perigonii clausi foliola exteriora lateralia latiora, carinata, labello supposita; interiora angusta. $\mathrm{L}$ a b e $11 \mathrm{um}$ liberum, indivisum, saceatum, columnam amplectens. Colum na brevis, carnosa, versus apicem dilatata. An th er a truncata, bilocularis, loculis incomplete bilocellatis. P o 1linia 8 , ovata, compressa, in glandula sessilia. - Herba javanica, epiphyta, caulescens; caulibus simplicibus, elongatis, compressiusculis, foliis lineari-lanceolatis, oblique emarginatis, coriaceis, floribus terminalibus dense capitatis, paleaceo-bracteatis.

G 1 o m e $\mathrm{r}$ a Blume Bijdr, 379. fig. 68. Lindl, Orchid, 253. 
1505. Dxyanthera BRONGN. Perigonii erecti foliola libera, snbaequalia, exte riora ovato-triangularia ; in teriora ovatolanceolata, angustiora. Labell um conforme erectum, integrum, concarum. Col um a bre vis, subquadrangularis, lateribus laminis membranaceis subquadratis appendiculata. A $\mathrm{nt}$ h e $\mathrm{r}$ a erecta, e latere postico columnae brevissime stipitata, superne in acumen triangulare producta, bilocularis, loculis discretis. Pollin ia 6 (?) apice materie granulosa cohaerentia. - Herba moluccana, epiphyta, dubiae affinitatis; radicibus fasciculatis, filiformibus, caule brevissimo subnullo, foliis distichis, lineari-oblongis, membranaceis, scapis axillaribus, floribus spicatis.

$0 \times y$ a ther a Brongniart ad Duperr. 197. $t .37, b$.

1506. Thelasis $B L U M$. P e r ig o $\mathrm{n} i$ clausi folio la exteriora basi connata; interi or a minora, libera. L a b e $11 \mathrm{~nm}$ liberum, ecalcaratum, indivisum, coneavum, columnae parallelum. Col u m a semiteres, rostello elongato, cornuto. Anthera dorsalis, bilocularis, rostrata. Pollinia 8, subglobosa, caudicula longa, filiformi, glandula hamata. - Herbae $j a$ vanicae, epiphytae, sociales; foliis subcarnosis, saepius in pseudobulbis sessilibus, floribus in scapo radicali spicutis.

Th el a s is Blume Bijdr.385. fig.75. Lindl. Orchill.253.

TREIBUS IV. OPHRYDEAE Lindley Orchid. 257. Pollen e massulis ceraceis innumeris cohaerentibus, ope axeos arachnoideae elasticae, glandulae stigmatis adglutinatae, in massas binas colligatis. An the r a terminalis, erecta v. resupinata, persistens, loculis completis. - Herbae epigaeae; radicibus tuberiferis, in regionibus temperatis subtropicisque totius orbis obviae, in Europa media et mediterranea, deinde in Africa australi extratropica imprimis copiosae, inter ipsos circulos tropicos nullibi quidem desunt, rarius tamen observalae fuerunt. - Genera hujus tribus minus bene circumscripta videntur.

150\%. Drehis LINN. Perigonii galeati foliola subaequalia, exteriora lateralia convergentia $v$. reflexa, supremum cum interioribus conformibus in fornicem connivens. Labellum anticum, cum basi columnae connatum, integrum v. tri-quadrilobum, basi calcaratum. Anthera erecta, loculis contiguis, parallelis. Pollinia glandulis 2 distinctis, stigmatis plicaturae enenllatae biloculari (bursiculae) inclusis. - Herbae terrestres, per veteris contincentis regiones temperatas frigidiusculasque late diffusae; radicibus tuberiferis, foliis plerisque radicalibus mollibus, subsucculentis, floribus spicatis.

Orch is Linn. gen. $n, 1009$. excl. sp. Swartz in Act, Holm, 1800, p. 205, R. Brown in Ait. hort. kew. edit, II. 5. 188. L. C. Richard Orchid, 25. f.2. Lindley Orchid. 258.

a) ANDRORCHIS. Perigonif foliola exteriora lateralia patentia v, reflexa.

Orehides masculae Lindley 2 . c. Jaeq. Fl. austr. t. 43. 108. Ic, rar, $t, 180,181$. Fl, dan, $t, 266,876.933$. E. B. t, 631.632, 2308. Desfont. Flor, atl. t. 248. Tenore Flor, neapolit, t. 86 _88. Reichenb, Ic, crit. $t$. $563 . \$ 64,566.770 .808-$ 810. 831.848. Bot. Reg. t. 1701 .

b) HERORCHIS Lindl. Perigonii foliala exterio. $r$ a in galeam conniventia.
Herorehis s. Orehides milltares Lialley 2 . $e$. Jaeq. Flor, austr, t, 122. 176, 255. Ic, rar. t, 182. 183. 59s. 599 . E. B. $t$. 168. 2059.2075. Desfont. Flor, atl. $t$, 246. 247. Reiehenb. 1c. crit. t. 569. ro1. Bot. Mag. $t$. 1932, 1944. Bot. Reg. t. 202,557.367.375. 1155 .

1508. Anaeamptis $L . C, R I C H$, Perigon ii galeati foliola subaequalia, exterio ra lateralia patentia, supremum cum interioribus conformibus erecto-connivens. L a b e Il u m anticnm, cum basi columuae connatum, trilobum, basi calcaratum et lamellis duabus parallelis prominentibus instructum. Anthera erecta, loculis contiguis, parallelis. Po $I I$ in a candiculis distinetis, glandulae communi bursiculae simplici inclusae affixa, - Herbae habitu Orchidum, in $\boldsymbol{E} u$ ropa media et australi indigenue.

A n a c a m p t is L. C. Richard Orchid, europ, 25.

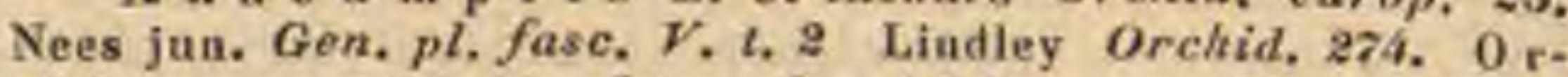
chis py ramidalis Linn. Orehidis sp. Tenore Flor. neapol. t.89. Bivona $p l$, sic, $I, t, 1, f, 2$.

1509. Aymmadenia $R$. BR. Perigoni galeati folio la subaequalia, exteriora lateralia patentia, supremum cum interiorib u s paullo brevioribus fornicato-connivens. Labe $11 \mathrm{um}$ anticum v. posticum, basi columnae adnatum, trilubum, calcaratum. Inthera erecta, loculis contiguis, parallelis, inferne cucullatis, a rostello marginatis. Pollinia glandulis duabus distinetis lateralibus, ebursicnlatis. - Herbae in hemisphaerae borealis temperatis utriusque continentis obviae, Orchidum habitu.

G ymna deuia R. Brown in Ait, hort, kew. edit. 2. $\mathcal{V}$. 191. L. C. Richard Orchid. europ. 26. fig. 5 . exel, sect. 2. Nees jun. Gen, plant, fasc. $V . t, 6$. exel. $f, 13-20$. Lindley Orchid. 275. - S i e beria Spreng. Anleit, 11.282 , $0 \mathrm{r}$ chid is s p. Linn. Jaeq. Flor. austr. $t, 138,264$. Fl. dan. t. 224. E. B. $t$, 10. Tenore Flor, neapol, t. 90. Hooker exot. Flor. $t .81$. Reicheub. $I c$, crit, $t, 814$.

1510. Perularia LINDL. Perigonii carnosi foliola exteriora lateralia reflexa, supremum rotundatum, crenulatum, cum interi oribus retusis erectum. Labe 11 um anticnm. calcaratum, carnosissimum, indivisum, medio tuberculatum. Anthera recumbens, nana. $P \circ I 1 \mathrm{i}-$ nia glandulis duabus, in bursiculis distantibus, bivalvibus. - Herba sibiric a; foliis radicalibus binis, obovatis, spica laxa, multiflora.

Perularia Lindley in Bot, Heg, t, 1701. Orchid. 281. 0 rchis fuscescens Linn. (Gmelin Sibir. $I$. t.4. f. 2.)

1511. Nignoitella L. C. RICI. P erigonii membranacei foliola exteriora et interi ora aequalia, patentia. Labell um posticum, ovato-acuminatum, concavum, basi scrotiformi-calcaratum. An ther a erecta, loculis parallelis, contiguis. Pollin ia glandulis duabus distinetis, bursiculae integrae loculos antrorsum singillatim ocelndentibus, hine seminndis. Herbae in Europa media alpicolae; ralicibus bituberiferis, foliis gramineis, floribus spicato-capitatis.

Nigritella L. C. Richard Orchíd, europ. 26. fig. 4. Nees jun. Gen. plant, fasc, $X, t$. 8. Reichenbach 1c, crit. $f$. 1009. 1010, Lindl. Orchid, 281. Sat y rium nig r a m Linn. Jacq. Flor, austr, t, 368 .

151\%. Aceras R. BR. Perigonii foliola exteriora cam interioribus multo angustioribns conniventia. La bell $\mathbf{n m}$ brevissime saccato-calcaratum $\mathbf{r}$ gibbosam, tripartitum, patens v. pendulum. Anthera erecta, bilocularis, loculis parallelis, basi approximatis. Pollinia caudieulis distinctis, glandulae communi, bursiculae simplici insertae, affixa. - Herbae in $E u$ ropa media et australi, nec non in regione ca ucasica parce obviae, in India orientuli 
rarissimae; radicibus carnosis, fasciculatis, lobo uno alterove incrassato, floribus laxe spicatis, luteo - herbaceis $v$. abscure violuccis, labello saepius discolore, maculato, nonnunquam longissimo.

Aceras R. Brown in tit. hort. kew. 2. V. 181. Lind. ley Orchid. 282. Bot. Reg, t, 1525. Nees jun. Gèn, plant. fase. V. t.4. Lorogloss u m L. C. Richard Orchid, eutrop. 32. Nees op. cit. 4. 3. Hi ua ntog los s u m Sprengel syst, III. 694. S at y rii sp, Linn. E. B. t. 34. Ophryatis $s$ p. Lina. E. B. $t, 29$.

1518. Holothrix L.C.RICH. Perigo nii foliola exteriora aequalia, conniventia; interiora multo majora, libera, patula, Lahe $I 1 \mathrm{um}$ cum columna connatum, calcaratum, lobatum, concavum. Anthera erecta, loculis parallelis. Pollinia 2, glandulis distinctis, in bursiculis duahus segregatis inclusis. - Herbae capenses, parvulae; foliis radicalibus minutis, scapo esquamato, floribus herbaceis, minutis.

H olot hrix L. C. Richard Orchid, europ. 33. Lindley Orchid. 283. Or chis his pidula Lim.

1514. CHossaspis LINDL. Perigonii galeati foliola exteriora et interiora conformia. L a be $11 \mathbf{n} \mathrm{m}$ tripartitum, laciniis lateralibus elongatis, caleare brevi inflato. Ro ste IIn maximum, plicatum. Polli nia glandulis distinetis, cucullis duobus discretis inclusis. - Herba chinensis; foliis Orchidis, floribus parvis, viridibus.

GI os s a sp is Sprengel syst. III. 694. Lindley Orehid. 284. GI os a la Lindey in Bot. Reg. t. 869 .

15 15. Fllatanthera $L, C, R I C H$. Perigonii galeati foliola subaequalia, exterio$r a$ et interiora conformia. Labe 11 u m elongatum, indivisum v. tripartitum, calcare filiformi. Anthera erecta, loculis basi divergentibus, rostello plano antherae adnato, canalibus ejus bases recipientibus, processubus carnosis nullis. Pollin ia glandulis duabus sublateralibus, nudis, Herbae in hemisphaerio boreali utriusque continentis obviae, inter tropicos veteris orbis rarae; caulibus monophyllis $v$. foliosis, floribus spi catis.

Platanthera L. C. Richard Orehid, europ. 35. Lindley Orckid. 284. Reichenb. pl, crit. t. 1173 -1135. Nees jun. Gen, plant. fasc, Y.t.7. H a b enaria e s p. R. Brown. Hooker exot. Flor. t, 93. 145. O r chid is s p. Lian. Fl. dan. t. 333. E. B. $t$, 22, Suith exot. Bot. $t, 100$.? Meeos Blume Bijdr. 403.

15 18 . II eanailpillia $L I N D L$. P erigoni galeati foliola subaequalia, exteriora patentiuscula; interiora paullo minora. L a b e $11 \mathrm{um}$ cum basi columnae connatum, elongato-calearatum, oblongum, trilobum. Anthera subhorizontalis, basibus divergentibus, adnatis, rostello fornicato libero, ultra antherae loculos producto, processubus carnosis nullis. Pollin i glandulis distinctis, apieibus canalinm cuculliis dimidiatis exceptis. - Herba boreali-indic $a$; folio unico, cordato, amplexicauli, florum racemo secundo.

Hem ipilia Lindley Orchid. 296.

151\%. Pentstylus BLUM. Perigoni campanulati folio la subaequalia, exteriora et interiora conformia. Labellum integrum $v$. tripartitum, calcare brevissimo sçrotiformi. Anthera erecta, loculis basi divergentibus, rostello plano antherae adnato, canale ejns bases reeipiente, processubus carnosis nullis. P o 11 inia glandulis duabus sublateralibus, nudis. - Herbae habitu Platantherae, per veteris or bis regiones tropicas et boreales temperatas frigidiusculasque dispersue, rectius fortassis cum Platanthera, a qua sola perigonii forma, et labelli calcare brevissi mo recedunt, conjungendae.

Peristylus Blume Bijdr. 404. fig. 30. Lindley Or. chid. 25r. B e n th amia A. Richard in Mom, soc. h, n. Pa. is. IV.37.t. 7, S atyrii s p. Lina. E. B, $t, 94.505$. Fl. dan. 113. Thouars Orchid. $t, 10$. O $\mathrm{rch}$ id is $8 \mathrm{p}$. Willd. Salisb. parad. t.110. H a benariae sp. R. Brown. Bot. Mag. $t$. 3164. Nees jun. Gen, plant, fasc, $\nu, t, 8$. Thouars Orchid. t. 16. A. Richard $t . c, t, 3$, Hooker exot, Flor, $t$, 175. Bot. Mise. $t .55$. H ex mini i s p. Lindley Bot. Reg, $t, 1499$.

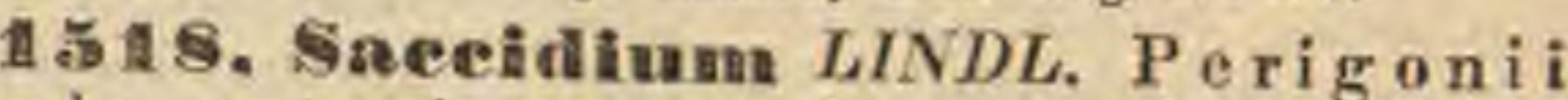
foliola exteriora conniventia, lateralia labello supposita et saccata; interiora carnosa, spathulata, duplo longiora. Labe 11 um posticum, magnum, convolutum, basi breviter calcaratum, apice carnosum et divisum. Anthera reclinata, loculis basi distantibus, adnatis. Pollin ia parva, glandula vix a caudicula crassa distinguenda. - Herba capens is, pilosissima; spica longa, cylindracea, densissima, floribus purvis.

S a c e id i u m Lindley Orchid. 301.

1519. Preeluites LINDL. P e r i g o i i foliola exteriora patentia, supremum paullo majus; in t e ri or a angustiora. $L$ a b e $11 \mathrm{u} \mathrm{m}$ posticum, ecalearatum, perigonii foliolis interioribus conforme, Anthera stipitata, resupinata, loculis basi fere adnatis, haud elongatis, divergentibus, rostello subyuadrato crassissimo, utrinque brachiis duobus canaliculatis. Pollinior u in glandulae nudae. - Herbae capenses, rigillae; foliis radicalibus gramineis, spica crassa, rigida, floribus parvis.

Pachites Liadley in Bot. Meg. t.1701. Orchid, 301.

1.5ะ๑. Coeloglosguna LINDL. P erigonii foliola exteriora conniventia, aequalia, libera; interiora conformia, ungui labelli adnata. L a b e 1 l n m carnosum, unguiculatum, calcaratum, tripartitum, disco saepins tuberenlatum, ungue carnosissimo, concavo, adscendente, margine eroso et glanduloso, saepius processubus duobus carnosis, clavatis, parallelis, ex ore calearis ortis, adnatis, aucto. An the $r$ a parva, lobis basi adscendentibus, rostello brevi tridentato adnatis. Pollin i a glandulis nudis.- Herbae indica e; radicibus testiculatis, caule folioso $v$. vaginato, floribus spicatis, minutis.

Coeloglos sum Limdley in Bot. Heg, n, 1701. Orchid. 302.

H521. Momotuis LINDL. Perigonii foliola exteriora membranacea, postice con. nata, lateralia antice distincta; interio $v i b u s$ carnosis, acuminatis duplo minora. Labe $11 \mathrm{n} \mathrm{m}$ foliolis interioribns aequilongum, liberum, basi cornutmm, apice carnosum, trifidum, cucullatum. Anth e ra libera, erecta, loculis basi divergentibus, valvulis exterioribus dilatatis, incurvis, polliniorum glandulas tegentilus. - Herba capensis; radicibus testiculatis, folio radicali minimo, caule retrorsum hispido, floribus parvis, secundis, bracteis et perigonii foliolis exterioribus margine hispidis.

Mo notris Lindley in Bot, Reg. n. 1701. Orchid. 303.

15:3. Scopulara $L I N D L$. Perigonii foliola membranacea, ex teriora conniventia, lateralia minora; interiora lacero-multifida, cirea labellum convoluta. $L$ a be $11 \mathrm{um}$ membranaceum, erectum, convolutum, basi calcaratum, apice lacero-multifidum. An ther a libera, erecta, loculis approximatis, parallelis, basi dilatatis, adscendentibus, cucullum magnum inaequilaterum, polliniorum glandulas tegentem formantibus. - Herba capensis; radicibus testiculatis, 
foliis radicalibus membranaceis, caule aphyllo, spica elongata, subsecunda.

S cop u laria Lindley in Bot.Reg. n. 1701. Orchid. 303.

1523. Aopla LINDL. Perigonii bilabiati foliola exteriora lateralia deflexa, supremum erectum, cum interioribus aglntinatis galeam formans. La b e $11 \mathrm{um}$ lineare, ecalcaratum. Anthera erecta, lobis brevibus adscendentilus, rostello decurvo, elongato. Polli$\mathrm{n}$ i o $\mathrm{r} \mathbf{n m}$ glandulae nudae. - Herba indica; radicibus testiculatis, folio radicali solitario, spica laxa, secunda, floribus herbaceis.

A opl a Lindley in Bot. Reg, n.1701. Orchid. 304.

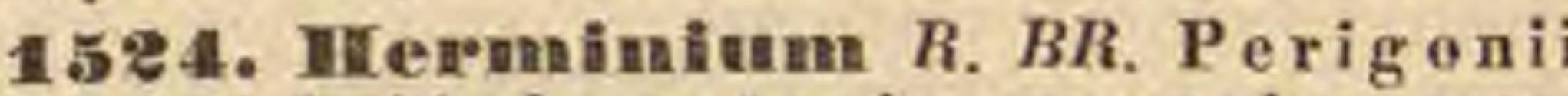
campanulati foliola exteri or a membranacea, subaequalia; interi or a angustiora, medio bi dentata, subcarnosa. L a b ell $\mathbf{n}$ m basi saecatum, hastato-trifidum. Anthera erecta, loculis bas divergentibus, processu rostellari nullo; staminodiis squamaeformibus. Poll in i o $\mathbf{r} \mathbf{m}$ caudicu lae brevissimae, glandulae maximae, cueullatoconcavae, nudae.

Herba in $E$ u r op a e et Asiae finitima e pratis subalpinis proveniens; radice bituberata, tubere altero juniore remoto, foliis radicalibus binis, ovato-oblongis, spica cylindrica, densa.

Herminium R. Brown in Ait, hort, kew. 2. V. 191 . L. C. Rtchard Orchid, europ. 27. Hooker Flor. Lond. ic. Nees jun. Gen. plant. fasc. $\mathscr{Y}, 4.9$. Ophrys Monorch is Linn. E. B. $\ell, 71$,

1525. JI Jabenaria WILLD. Perigon i i galeati foliola subaequilonga, exte rior a cum interioribus multo angustioribus, integris bi-trifidisve, conniventia. Labellum elongatum, pendulum, integrum bi-trifidumve, elongato-calearatum. Anthera erecta, locnlis soIutis, basi divergentibus, eanalibus stigmaticis adhacrentibus, rost ello plano, antherae adnato, processubus duobus stigmaticis, variis, saepius ori stigmatis adnatis. Pol I i n ior $\mathbf{~ m}$ glandulae nudae. - Herbae habitu Orchidis, majusculae, inter tropicos totius orbis obviae, in Am erica, ubi etiam in extratropicis utriusque hemisphaerii occurrunt, frequentiores, in $A$ sia $t$ e mperat a rarae.

H a be naria Willd. $s p . I V$. 4h. Thouars Orchid, $t, 17$. 18. A. Richard in Mem, soo, h, n. Paris. IV 18, t, 1, 2. Hook. Jot. Mag. t, 2726.2957. Exot. Flor, t. 136. Lindley Orchid, 306. Pöppig et Endl. nov. gen. et sp. t,75_78.

1526. Ate $L I N D L$. Perigonii galeati foliola exteriora lateralia reflexa, supremum cum interioribus angustioribus, bifidis, pubescentibus connivens. L ab e I l um pubescens, pendulum, trifidum, ealcare filiformi. An $t$ hera cresta, loeuli basibus divergentibus canalibus stigmaticis adnati, processubus earnosis, liberis, lamina cornea, spathulata, deflexa, interposita. Staminod i a e basi lata angustata, apice inerassata, antheram aequantia. Pollin iorum glandulae nudae. - Herba in peninsula Indiae orientalis monticola; radice tuberculifera, caule folioso, rucemo laxo, secundo, floribus bracteatis, herbaceis.

\section{A te Liadley Orchia, 326 .}

15:7. Homaten WILLD. Perigonii galeati foliola exteriora lateralia patentia, supremum cmm interioribus integris bifidisve, glabris v, pubescentibus connivens. L a b e $11 \mathbf{~} \mathbf{~ m}$ pendulum, tripartitum, calcare filiformi. A nth e ra erecta, loenlis solutis, basi divergentibus, canalibus stigmaticis adhaerentibus, ros tello li- bero, elongato, cucullato v. complicato, proces. subus stigmaticis carnosis, longissimis v, abbreviatis. Pollinior $\mathbf{~ u m}$ glandulae. ... - Herbae habitu Orchidis, sola rostelli evolutione ab Habenariis diversae, in Capite $B$ onae spei, $M a$ dagascaria et Brasilia observatae.

B on a te a Willd. sp. IP. 43. Lindl. Orehid. 398. Frane. Bauer Orehid. t. 12, 13. Bot. Mag. t, 2926. - B il a b rella Lindley in Bot. Reg. n. 1701.

1589. Miglomeriss DON. Perigonii campanulati foliola exteriora aequalia; interioribus breviora. Labellum perigonii foliolis interioribus aequale, indivisum, ealearatum. Anthera horizontalis, basibus loculornm elongatis, liberis, distantibus, rostello maximo, membranaceo, dilatato, plano, processubus duobus carnosis collateralibus, nune cohaerentibus, stigmatis labium inferius simulantibus. Polliniorum glandulae nudae. - Herbae in dicae, humiles, paucifoliae; radicibus tuberculiferis, caulibus nudis $v$, unisquamatis, bracteis cucullatis, subsolitariis.

D iplomeris Don nepal, 26. LindI. Orchid. 330. D iplochilus Lindley in Bot, Aeg, $n$, 1499. Paragnat his Sprengel syst. III, 694.

1529. Cymorehis THOUAR. Perigonii foliola exteriora subaequalia, conniventia, interior a sub supremo conglutinata. L a b e I I a m columnae connatum, calcaratum, saepius quadripartitum, perigonii foliolis majus et textura diversissimum. An thera horizontalis v. resupinata, loculis distantibus, elongatis, rost ello plano, dilatato, tripartito, stigmatis lobis duobus carnosis, rostelli lobis lateralibus suppositis. Polliniorum glandulae nudae. - Herbae madagascarienses et mauritianae; radicibus testiculatis, caule saepius medio squama vaginato, floribus coloratis.

C y u oreh is Thouars Orchid. t. 13_1z. Lindley $O r$. chid. 330. A m p horeltis cal carata Thoukrs op. eit. $t$. 4. G y mnade $\mathrm{n}$ ine $\mathrm{s} \mathrm{p}$. A. Richard in Mem, soc, $h, n, \mathrm{~Pa}$ ris. IV. $t, s, 6, f, 1.2$.

1530. Treyphia LINDL. Perigonii foliola ext eriora herbacea, conniventia, aequalia; interiora membranacea, linearia, exterioribus longiora, faciei baseos labelli adnata, eique similia. Lab ell um membranaceum, cum columna connatum, breviter calearatum, tripartitum. Anthera erecta, nana, lobis divergentibus, rostello ovato, ntrinque leviter plicato. Poilinior um glandulae inter rostelli plicas jacentes. - Herba capensis; radicibus testiculatis, foliis membranaceis, radicalibus, racemo secundo.

Tryphia Lindley in Bot. Reg. n. 1701. Orchid. 333. Bot. Mag. Comp. II, 209.

1531. Isuceulina $L I N D L$. Perigoni ringentis foliol a exteriora galeata, lateralia basi labelli oblique adnata, supremum minns; interi or a duplo majora, earnosa, ererta, dentata, conniventia (an cohaerentia?). Labellu m concavum, quinquepartitum, laciniis linearibus, calcaratum, diseo barbatum, columnae marginibus productis ejusdem faciei adnatis. Anther a.

Herba capensis, acaulis; radicibus testiculatis, foliis orbiculatis, horizontalibus, scapo evaginato, glabriusculo.

B ue culin a Lindley in Bot. Mag. Comp. IT. 209.

1538. Apmottia A. RICH. Perigonii foliola exteriora inaequalia, lateralia majora alaeformia, patula, supremum minus, erectum ; interiora angustiora, adseendentia. Label- 
I $\mathrm{m}$ posticum, eealearatum, foliolis interioribus basi coalitum et conforme. Anthera resupinata, loculis subparallelis, basi divergentibus, rostel1o ovato, plano. Pollini or $\mathbf{m}$ glandulae nudae. - Herba ma uritiana; radice tuberculifera, caule monophyllo, floribus spicatis.

Arnotti a A. Richard in Mem. soc.h.n. Paris. MV.29. t.7. f.1. Lindley Orchid. 333. A mphorehis in ermis Thoaars Orehid, $t, 5$.

1533. Stendsilottis LINDL. Perigonii foliola exteriora conniventia, libera, ae qualia; in terio ra teneriora, fimbriato-serrulata, libera, concava. La be $11 \mathrm{um}$ lineare, canaliculatum, ecalcaratum, basi tubereulo instruetum, apice trifidum. Anthera erecta, loculis basi divergentibus, rostello minimo, tridentato, utrinqne leviter saceato, stigmatis labio inferiore elongato, linguaeformi, Pollin i o $\mathrm{rum}$ glandulae retro rostelli sacculos alssconditae. - Herba cap ensis; radicibus fusciculatis, foliis rosulatis, scapo vaginato.

Stenoglottis Lindley in Bot. Mag. Comp. IT, 209.

1534. Bartholina $R$. BR. Perigonii ringentis foliola exteriora basi in tubum antice connata, laciniis aequalibus secundis; interiora exterioribus parallela, falcata, labello subeonnata. La b e Il u m calearatum, explanatum, patens, trilobum, lobo medio multifido, lateralibus trilobis, laciniis omnibus filiformibus. Anthe ra erecta, elongata, lobis parallelis, eneullatis, cncullis distinctis, inter valvularum bases inflexas absconditis. Pollinia parva, caudiculis clongatis, canaliculatis, glandulis intra cucullos inclnsis. - Merba capensis, hirsuta, pusilla; radicibus tuberculiferis, folio solitario reniformi, caule unifloro, ovario intra bracteam cucullatam abscondito.

B a rthalin a R. Brown in Ait, hort, kew, 2. $V$. 194. Ker in Brandes Journal IV, 204, t, J, $f, 2$. Bot, Reg, $t, 1653$. Orchis B ur manuiana Linn. Swartz in Weber ot Mohr Archiv., . 5z. t. 3 .

1535. Bicormella $L I N D L$. Perigon i foliola exteriora inaequalia, lateralia majora, labello extus oblique adnata; in teriora cum supremo in galeam convexam conglutinata. Lab ell um columnae nanae adnatum, calcaratum, indivisum, angustum, canalieulatum. Anthera subhorizontalis, lobis adscendentibus, basi elongatis, rostelli trifidi lobis lateralibus extus appendice lingruaeformi (staminodio) auctis, adnatis, lobo intermedio ovato, plano, abbreviato. PolI in a minima, candiculis longis, linearibus, inferne antherarum basibus elongatis tectis. - Herba madagas cariensis; caule folioso $v$. subfolioso, floribus spicatis, parvis.

B i cornell a Lindl, in Bot, Reg, $n, 3701$. Orchid. 334.

1536. Satyrimm $S W A R T Z$. Perigonii folio la basi connata, antrorsum dependentia, exteriora interioribus panllo minora. Labell nm posticum, sessile, erectum, fornicatoconcavum, basi bisaceatum v. bicalcaratum. CoI m ma teres, elongata, areuata. Anthera horizontalis, Jobis basi adscendentibus, clinandrio indiviso incumbentibus. Pollinia biloba, caudienlis brevibus canaliculatis, glandulis peltatis, nudis. - Herbae in Africa australi extratropica indigenae; radice tuberosa, caule folioso, floribus spicatis, bracteis laxis.

5 a $\mathrm{t}$ y i u $\mathrm{s}$ wartz in Act. Acad. Holm, 1800. 214. et in Schraders n. Journ. I, t, 1, C. Ker in Journal of so. and arts VIIT. $t$. 3. f. 1. Bot. Reg, $t$. 416, 703. Frane. Bauer $I t-$ lustr. Orchid. $2,11-13$. D i p l e e trum Thouars Orchid, $t$.
21. 22. Orchidis s p. Línn. Jacq. Hort, schönbr. t. 179. Audr. Bot. Reposit. $t .315$.

153\%. Disa BERG. Perigonii foliola exteriora libera, patentia, supremum galeatum, basi in calcar productum; in te ri or a nana, basi columnae adnata. L a b ell um basi columnae insertum, porrectum, sessile v. unguiculatum, lamina indivisa $v$. triloba. Col u m n a bialata, alis petaloideis, clinandrio dilatato, antice supra stigma prominente, trilobo, lobo medio inflexo. Anthera verticalis, loculis basi divaricatis, adscendentibus, clinandrio incumbentibus. P o Ili n i suleata, candienlis distinetis, glandulis nndis. - Herbae capenses; tubere radicali tunicato, caule folioso, foliis lato-lanceolatis $v$, anguste linearibus, florum spica densa v. saepius la$x a$, paucifiora, bracteis latiusculis, coloratis, saepius cucullatis.

D is a Bergius Flor, cap. 348, t. 4. f. 7 . Swartz in Act, Acad, Holm. 1800, p.208, t.3. f.b. et in Schrad. Journ. I. $, 1, B$. Ker in Journal of se. and arts IV. $t, 6, f, 1,3$. V. t. 1, f. 1, VI. t. 1. f. 1. Bot. Reg, t. 219. 324. 926. Franc. Bauer Illustr. Orchid. t. 14.

OBSERVAT10. Genera a D is a distineta tria commemo. rat el. Lindley, quorum autem deseriptiones nondum evulgatae sunt, et eharacteres e specimiaibus nostris siccis man. cisque eruere haud licet, sunt autem:

a) REPANDRA Lindiey in Bot, Reg. n, 926. $=\mathrm{D}$ is a cornuta Thunb. eolumna aptera a Disa differre dicitur.

b) MONADENIA Lindley Introduct, edit, $I T, p$, 146. = Dis a rufescens Willd.

c) PENTHEa Liadley $l, c,=D$ is a patens Willd. D. filicorais Thub. D. melaleuca Wifld. D, ten is if ofia Willd.

1538. Serapias LINN. Perigonii foliola exteriora in galeam cucullatam connata, interiora e basi dilatata longe cuspidata. $\mathrm{L}$ a be $11 \mathrm{um}$ basi columnae insertmm, sessile, basi bilamellatum, disco pilosum, subtrilobum, lobis lateralibus adscendentibus, terminali elongato, deflexo. C o I $\mathrm{g} \mathrm{mn}$ a elongata, aptera, clinandrio postice in aenmen petaloideum producto, antice supra stigma prominente, indiviso, in cueullum plicato. Anth era verticalis, loculis basi adscendentibus, clinandrio incumbentibus. Pollinia esulca, caudiculis distinctis, glandula communi intra bursiculam recondita. - Herbae ne diterran e a $e$; radice bituberata, caule folioso, floribus laxe spicatis, bracteis magnis, cucullatis, coloratis.

Serapias Linn. gen, n.1012. exel. sp. Swartz in Act. Academ. Holm. 1800, p. 223. t. 3. f. h, et in Schrailers n, Journ. I. t. 1. H. L. C. Richard Orchid. europ. 25. Andr. Bot. Reposit, t, 475. Hook. exot, Flor, t, 11. Lindley in Bot, Reg. t, 1189. Nees jun. Gen. plant. fase, X, $t, 7$, Hell e b o rin e Pers, synops. II, 512. Tenore Flor. neap. t.98.

1539. Pterygodium $S W A R T Z$. P e rigonii foliola exteriora lateralia patentia, concava, supremum galeatum, cum in terioribus connivens. L a be $11 \mathrm{~nm}$ columnae adnatum, bilabiatum. Columna brevis, aptera, clinandrio antice supra stigma prominente, in bursicalas duas distinetas excavato. Anthera horizontalis. Pollinia 2, caudiculis glandulisque distinctis, bursiculis divaricatis reconditis. - Herbae capenses; caule folioso, floribus dense spicatis, bracteatis.

Pterygodi um Swartz in Act. Academ. Holm. 1800. p. 217, $t, 3, f$. $c$, et in Schraders $n$. Journ,. . t, I, E. Ker in Journ. of sc. and arts VI. t, $1, f, 3, V I I I, t, 3, f, 2$. 0 p h r y dis s p. Linn.

1540. Coryeinm SWARTZ. Perigonii foliola exteriora lateralia in nnmm connata, supremum anguste galeatum, adscendens; 
interiora latiora, basi ventricosa, patentia. Labell $\mathrm{nm}$ apici columnae insertum, subunguiculatum, lamina replicata, patente. Columna brevis, apice bialata. Anthera colnmnae snb labello adnata. Pollinia 2 , caudiculis glandulisque distinctis, bursiculis remotis, ala utraque tectis. - Herbae capenses; folïs distichis carinatis, v. alternis cucullatis, apice undulato crispis, spica densa, bracteata.

C or y c ium Swartz in Act. Academ. Holm. 1800, $p$. 290. t, 3. f. g. et in Schraders n. Journ. I, t, 1, G. Ker in Journ, of se, and arts VI. t. 1. f, 1, VIIT. $t, 3, f .3$. Franc. Bauer Illustr. Orchid. t, 15. $0 \mathrm{phr}$ y is sp. Lim. A re. thus a $8 \mathrm{p}$. Thunb.

1541. Clanaraerepes SPRENG, Perigonii conniventis foliola exteriora aequalia; interiora paullo minora. L a be $11 \mathrm{um}$ colamnae basi insertum, sessile, planum, obsolete trilobum, deflexum, Colnmna brevis, aptera, antice incrassata, clinandrio bibursiculato. A nthera verticalis, mutica. Pollinia caudiculis rectis, glandulis distinetis inter bursiculas reconditis. - Herba parvula, in Europa media al. picola; radice bituberata, foliis grumineis, basi vagina inclusis, spiça foliosa.

$\mathrm{C}$ h a m a c repes Sprengel syst. IIT. 702. Nees jun. Gen. plant. fasc. $X, t, 9$. C ham or $\mathrm{ch}$ is Richard Orchid, ourop. 27. 0 phrys alpina Linn.

1ธ4ใ. Pringys $L I N N$. Perigonii fo1iola exteriora lateralia patentia, supremum galeatum; interiora distincta, minora. Inbe I I n columnae basi insertum, sessile, cartilagineo-rigidum, planinsculum, carinatum v. saepe lobatum. Co Iu m a brevis, aptera, clinandrio antice fisso, bibursiculato. Anthera verticalis, mutica. Pollinia caudiculis rectis, glandulisque distinctis intra bursiculas reconditis. - Herbae in Europa media rarae, in regione me. diterranea obviae, habitu Orchidis; floribus laxe spicatis, labello varie picto.

0 p li r y 8 Lian. gen, n. 1011. exel. sp. L. C. Richard Orchid, europ, 26. Jacq. Ic, rar, $t, 184,185$, E. B, $t, 64,65.383$. Andr. Bot, Meposit, t. 470. Hooker exat. Flor, t, 10. Bot, Reg. t. 205.370, 1021, 1087, 1093, 1197. Bot. Mag. I. 2516. Tenore Flor, neap.t.94_96. Nees jun, Gen, plant, fasc, V.t.s.

1548. Disperifs SW ARTZ. Perigoni foliola exteriora lateralia patentia, basi saccata v. calcarata, supremum cum interioribus galeatum. Labellu m basi celumnae insertum, erectum, unguiculatnm. Co 1 и $\mathrm{m}$ a brevis, aptera, clinandrio antice longe producto, reclinato. Antherae loeuli basi divarieati, adscendentes. Pollinia 2, caudiculis glandulisque distinetis, bursiculis remotis. - Herbae c apenses; caule mono-diphyllo, glabro v. puberulo, uni-biftoro, rarius spicatim multifloro.

Disperis Swartz in Act. Aeadem. Holm, 1800, p.218. t.3. $f$. 5. et in Sehraders n. Journ. $T, t, 1 . F$. Ker in Journ, of sc. and arts $V . t .1 . f .2 .3 . V T . t, 1, f, 4.5$. D ipera Sprengel syst, III. 696, -? D y o pei a Thouars Orchid. 1. 1 -3. A. Richard in Mem. soc. h. $n$. Paris IV. 30.

SUBOARDO IV. GASTRODIEAE LindI. scelet. . Polle n e massulis majusculis, elastice in massas cohaerentibus, axi distincta nulla. An thera terminalis, opercularis. Herbae in radicibus aliarum plantarum parasilicae, aphyllae, admodum rarae, in $\mathbf{E} u$ ropa el Asia media, in insula Java et in Nova Hollandia extratropica observatae.
1544. Gastroodia R. BR. Perigonium tubulosum, basi ventricosum, limbi breviter quin quelobi lobis antrorsum subsecundis. Lab ellu m posticum, inclusum, Jibernm, unguiculatum, marginibus undulatum, columnae incumbens. Co. I umna elongata, teres, apice cavo, basi antice incrassata, stigmatosa. Anthera terminalis, mobilis, decidua, loculis approximatis. Pollinia 4 , per paria cohaerentia. - Herbae in Nova Hol landia extratropica orientali et in ins u l a Java e observatae, supra radices parasilicae; rhizomate carnoso, ramoso, articulato, scapo aphyllo vaginato, floribus racemosis, porrectis, albicantibus $v$. ochroleucis.

Gastrodia R. Brown prodr. 330. Epip hanes Blu. me Bijdr. 421.

1545. Epipogivam GMEL. Perigonii ringentis foliola exterior a aequalia, linearia, patentia; interiora conformia, paullo latiora, L a b e 11 u m postieum, sessile, erectum, trilobum, Iobis lateralibus parvis, patentibus, intermedio maximo, integerrimo, concavo, intus glanduloso, basi in calcar inflatum, adscendens producto. Col u mn a longa, semiteres, apice cavo, basi antice incrassata, stigmatosa, Anthera terminalis, stipitata, antice mucronata, persistens. Pollinia 2 , caudiculis duabus basi cohaerentibus, rostelli subfornicati glandulae affixis. - Herba in Europa et Asia media, in umbrosis montanis inter folia putrida rarius obvia; rhizomate ramoso, carnoso, corallino, scapo aphyllo, vaginato, basi tumido incrassato, floribus racemosis, majusculis.

Ep ipogi um Gmelin Sibir. 1. 11. R. Brown prodr. 330. Richard Orchid, europ. 28. Nees jun, Gen, plant. fasc, X. 4.10. Limodorum Epipagiam Lisn.

1546. IIysteria REINW. Perigonii foliola exteriora canaliculata; interiora unguiculata. Lab e 11 um unguiculatum, indivisum, reflexum. Colnmna teres, stigma sagit. tatum, bifidum. Anther a postica, persistens, apice dehiscens. Pollinim bipartitum, granulare, botryoideum. Herba javanica, epigaea, caulescens, veratrifolia; spica terminali, obiter descripla, vix hujus loci, ubi interim ob pollinis massam granularem collocatur.

H y steria Reinward in Sylloge plant. II. 5 .

SUIBCDO V. NEOTTIEAE Lindley scelet. 7. Pollen pulvereum, e granulis laxe cohaerentibus, stigmatis glandulae aflixum. Anthera stigmati parallela, persistens, loculis approximatis. Herbae terrestres, radicibus fibrosis, fasciculatis, tuberosis v. bulbosis, acaules v. rarius caulescentes.

Neotlieae in temperatis cropicisque tolius orbis reperlae, in Africa rarissimae, in Asiae summis montibus el in Nova Hollandia excratropica frequenlissime habitant.

154\%. Spireanthes L. C. RICH. Perigonii foliola exte $r$ i o $r$ a lateralia labello supposita, basi aequalia $\mathbf{v}$. in saccum brevem deeurrentia, supremum cum interioribus connivens, v. plus minus connatum. L a bellum breviter unguiculatum, canaliculatum, colummam inferne amplectens, lamina integerrima v. fimbriata. Columna brevis. Anthera terminalis, stipitata, bilocularis, rostello laminato, recto, 
apice bifido incumbens. Pol I in ia 2 , lineari-clavata, glandulae communi affixa. - Herbae epigaeae, inter tropicos et in temperatis totius orbis observatae; radicibus fasciculato-tuberosis, foliis radicalibus lanceolatis v. ovatis, membranaceis, nervosis v. venosis, scapo vaginato, spica multiflora, saepissime spirali, floribus bracteatis, ut plurimum secundis.

a) SPIRANThes $L$. $C$. Rich. Perigonil follola exteriora lateralia basi aequalia, supremum et interiora approximata.

Spiranthes L. C. Richard Orchid. curop. 37. LindIey Colloct, t.30, Bot. Reg, t, 823, 1043. 1934. Nees jun. Gen. plant. fasc. $V, t, 13$. Pöppig et Endl. nov. gen. et sp. KI. 7. t. 110. Gyrostactys Pers. ench, II. 511. Ib idium Sa. lisb. in Transact. Hortic, Soc. I. 261. $0 \mathrm{ph} \mathrm{r}$ y dis $\mathrm{s} \mathrm{p}$. Lina. E. B. $t, 541$. Neottia e sp. R. Browu. Bot. Mag. $t, 1562$. 2026. - ? Ste n o p tera Presi in Reliq. Maenk, I, 65.t. 14.

b) Cyclopogon Presl. Perigonii foliola exteriora lateralia basi aequalia, supremum et interiora connata.

Cyelopogon Presl in Reliq. Haenk. I. 93. t.13.f.1.

c) STENORHXNCHus $L$. C. Rich. Perigonii foliola exteriora lateralia basi in saccum decurrentia, suprenum et hiteriora connata.

S ten orhynch is L. C. Richard Orchid, europ. 37. Päppig et Eudl. nov. gen. et sp. II, 7, t, 109. N e ot ti a e sp. Hooker exot. Flor, t.39. 296. Bot. Mag, t. 1374, 2797.3703.

d) SARCoglotTis Presl. Perigonil foliola exteriora basi in saccum decurrentia, supremun et interiora fornicato - conniventia.

Sateoglottis Presl in Relig. Haenk, I, 95, t. 15.

1548. Adenostylis BLUM. Perigonii conniventis foliola exteriora lateralia labello suppesita, supremum cum interio ribus connivens, fornicatum. Lab e $11 \mathbf{u m} \mathrm{cum}$ columna comnatum, basi ventricosum, intus pubescens, limbo spathulato, incrassato, incliviso, patente. Colnmna brevis, apice emarginata, ntroque latere glanduloso-tumida. An th era dorsalis, bilocularis, ovata. Pollinia 2 , ovata, subbiloba, caudicula communi, glandula. ...- Herba ja$v$ anica; caule basi radicantc, foliis linearibus acuminatis, spica spirali, floribus sessilibus, bracteatis, ulbidis.

A denostylis Blume Bijdr, 414. fig. 17. - Cioni. s accu $s$ Kuhl et Hasselt Orchid. edid. Breda $t . \bar{s}$.

15.49. Wamtha HOOK. Perigonii foliola exteriora erecta, lateralia obovata, crispata, papillosa, supremum ovatum, planum; interiora lateralibus subconformia. L ab ell um breviter unguiculatum, late oblongum, crispatum, papillosum, disco lamellatum. Col n m na erecta, semiteres. Anth era terminalis, apientata. PolIinia 4, basi recurvata, apice cohaerentia. Herba antillana; caule erecto, folioso, foliis oblongo-lanceolatis, striatis, floribus spicatis, magnis, speciosis.

U lantha Hooker in Bot. Mag. t. 2990. N e o t t i a grandiflora Hooker in Bot. Mag. $t, 2956$.

1550. Plexamere ENDL. Perigonii foliola exteriora lateralia labello supposita, basi obliqua, patentia, supremum fornicatum; interio ra breviora, subunguiculata, falcata, adscendentia. Labellum nngue cum pede columnae connatum, lamina porrecta, saceata, limbo reflexo. Columna brevis. Anthe ra terminalis, stipitata, bilocularis, rostello lamellari, apice bidentato incumbens. Pollinia 8 , caudiculae communi affixa. - Herba pusilla, in insula Norfolk indige na, dubiae affinitatis; radicibus fibroso-fasciculatis, foliis equitantibus, lineari-lanceolatis, carno sulis, scapo teretiusculo, squamato, floribus dense spicatis, minimis.

Ple x a ure Find. prodr, Flar. Norfolk. 30.
1551. Neottia LINN. Perigonii conniventis foliola conformia, exteriora et interiora subaequalia. L a b e $11 \mathrm{n} \mathrm{m}$ pendulnm, basi saceatum, trilobum, lobis lateralibus minimis, intermedio bifido. Col $\mathbf{n} \mathrm{m} n$ a brevis. A $\mathrm{n} t \mathrm{~h}$ e $\mathrm{r}$ a terminalis, bilocularis, clinandrio abbreviato, rostello lamellari, indiviso incumbens. $P$ o 11 in i a 2 , glandula communi juncta. - Herba in sylvis Europae mediae et borealis vegetans; radicibus fibrosis, carnosis, fasciculatis, scapo vaginato, testaceo, demum fuscescente, spica densa, floribus flavo-virescentibus.

Ne ot tia R. Brown in Hort, kew. 2, V. 201. Ne ot tid t $\mathrm{nm}$ Link Handb. I. 249. Nees jun. Gen, plant. fasc, $\mathcal{V}, t .15$. Diostomaea Spenn. Fl. Frib. O phrys Nidus avis Linn. E. B. $t, 48$. Fl. dan. $t .181$. Listera Nidus avis Hooker Flor. Lond. $t, 58$.

155\%. Hilstera $R$. BR. Perigonii subconniventis foliola conformia, exteriora interioribus paullo latiora. $L$ abellum pendulum, basi aequale, bifidum. Col am a brevissima. Anthera intramarginalis, bilocularis, clinandrio elongato abscondita, rostello lamellari indiviso incumbens. Pollinia 2 , glandula communi juncta. - Herbae in Europa, America et $A$ sia boreali indigenac; radicibus fibroso-fusciculatis, caule vaginato, basi bifolio, jloribus spicatis, viridibus.

$\mathrm{L}$ is te r a R. Brown in Hort, kew. 2. $\boldsymbol{V}$. 201. Nees jum. Gen, plant, fasc, $V$. t. 14. D iphyllnm Rafin, in Journ. Phys. LXXXIX, 26I. Ne ottia e sp. L. C. Richard. Op hrys ov a ta et eordata Linn, E. B. $t, 353,1548$.

1553. Eplpaetis $H A L L$. Perigoni patentis foliola conformia, exteriora et interior a subaequalia. Lab e Il $\mathbf{n}$ m patens, interruptum, hypoehilio coneavo nectarifero, epichilio latiore basi bicalloso. Col um na erecta, teres. Anthera terminalis, biloeularis, stigmatis subquadratirosteilo lamellari incumbens. Pollinia 2, glandulae communi affixa. - Herbae in Europa media et australi indigenae; rhizomale repente, caule folioso, floribus laxe spicatis, virescentibus $v$. coloratis, puberulis.

Epipactis Hall, enum, stirp, Helv, $I$, 277. Hook, Fl. Lond, t. 89. Nees jua. Gen.plant. fasc. V. t. 10. Waldst, et Kit. plant. Hung. t, 270. S e ra pias Pers. ench. II. 512 . S e r api a dis s p. Linn. E, B, $t, 267.269$. V1. dan. $t .811$. Schkuhe t.274.

4554. Pellexia POIT. Perigonii ringentis foliola exteriora lateralia dependentia, labello supposita et basi adnata, supremum cum interioribus connivens. Labell $\mathbf{m}$ sessile, porrectum, indivisum, columnae parallelum, et eandem marginibus ampleetens, basi in calcar ovario connatum productum. Colnmna brevis. Anthera terminalis, stipitata, bilocularis, rostello laminato recto incumbens. Po 1 I in i a 2 , lineari-clavata, glandelae communi affixa. - Herbae americanae tropicae; foliis radicalibus ovato-lanceolatis, nervosis, scapo basi vaginato, apice piloso, florum spica laxiuscula.

Pelexia Poiteau ex Richard Orehid, europ. 37. Lindley in Bot. Reg. $t$. 985. C o ll a e a Lindley in Bot. Heg. n. 760 , Ne ot tiat ad u a t a Swariz.

1555. Sanrogilossuma LINDL, Perigonii conniventis foliola exteriora lateralia lincaria, areuatim patentia, basi valde obliqua, in ovarium decurrentia, supremum cum in terioribus subconformibus conglutinatum. Labe 1 in anticnm, lineare, canaliculatum, ecallosum, basi dilatatum. Col um na elongata, semiteres, basi producta, apice subspathulata, clinandrio de- 
clivi, immarginato, rostello acuto. Ant hera. Pollinia 2, bisulca, caudicula brevi, glandula ovali. - Herbae americanae tropicae; radicibus carnosis, foliis omnibus radicalibus, oblongolanceolatis, scapo foliaceo-vaginato, floribus racemosis.

$\mathrm{S}$ a uroglossum Lindley in Bot, Reg, $t, 1618$.

1558. Eucosia BLUM. P e rigonii conniventis foliola exteriora interioribus latiora. Labellum foliolis exterioribus conforme, intus villosum, columnam amplectens. C olum a brevis, obtusa, indivisa. Anthera bilocularis, denti dorsali affixa, acuminata. Pollinia 2, biloba, caudiculis binis, apice connexis, nudis. Herba javanica, carnosa, caulescens; caule inferne radicante, foliis alternis, petiolatis, ovatis, nervosis, membranaceis, spica terminali, villosa, pauciflora, basi bracteis duabus alternis, floribus alternantibus, sessilibus, bracteatis, carneis, extus pubescentibus.

Eucosia Blume Bijdr. 415. $f g .18$.

$155 \%$. Feorelhis LINDL. Perigoni cylindrici, conniventis, basi ventricosi foliola subaequalia. L a be $11 \mathrm{um}$ anticum, sessile, basi intus pilosum, cucullatum, apice convolutum. Col u m a brevissima, clinandrio elongato, acuminatissimo, imuarginato. Anthera acuminatissima. Pollinia 4 , minnta, caudiculis totidem longissimis, setaceis, separabilibus. - Herbae indic ae, nondum descriptae.

Georchis Lindley in Wallich Catalog. n. 7379. Bot. Reg, $n, 1618$.

1558. Aetheria BLUM. Perigoni rin gentis foliola exteriora lateralia latiora, labello supposita, supremum cum interioribus conglutinato - fornicatum. L ab ell um basi ventricoso-produetum, intus biglandulosum, limbi indivisi, subfornicati, incrassati marginibus invoIntis, glandulosis. C o l u m a brevis, crassa, apice semitrifida, Iacinia intermedia profunde emarginata. Anthera dorsalis, bilocularis. Pollinia 2 , oblonga, subbiloba, candiculis brevibus, glandula communi columnae emarginaturae intermediae affixa. - Herbue javanicae; caulibus inferne radicantibus, foliis alternis, nervosis, membranaceis, floribus spicatis, extus saepius glanduloso-pubescentibus.

A et heria Blume Bijdr. 409. fig. 14.

1559. Toodyera R. BR. Perigoni subringentis foliola exteriora patentia, interiora angustiora, cum supremo conformi conniventia. $L$ ab ell $\mathrm{m}$ sessile, basi exeavatum, in ligulam brevem canaliculatam acuminatum. Col um na semibifida, rostello erecto, bicorni. Anthera cernua, mutica. Pollinia 2, indivisa, glandulae subquadratae inter rostelli cornua affixa. - Herbae in hemisphaerae borealis temperatis provenientes; radicibus fasciculato-tuberosis, folïs radicalibus membranaceis, floribus spicatis.

Goodyera R. Brown in Hort, kew, edit. 2, V. 198. L. C. Richard Orchid, europ. 27. Bot. Mag. 6. 2540. Loddig. Bot. Cab. 2. 952. Hooker exot, Flor, t. 39. Lindley Gollect, t. 23. Gonogona Link Handb. I. 268. Tuss a a Rafiu. in Journ. Phys, LXXXrX, 261. Ne ottia e s p. Willd. Bot, Reg. t. 659. E. B. t.289. - ${ }^{\circ}$ Platyle pis A. Richard in Mem, soc, h, n. Paris, IY. 34, t. 6.f.4. Go od y exa oc c u $1 \mathrm{t}$ a Thouars Orchid, $t, 28$.

1560. Hillesanara $L I N D L$. Perigonii explanati folio la exteri or a lateralia reflexa, supremum et interiora conniventia. Labell um anticum, liberum, basi bicallosum, testiculato-saccatum, apice obliquum, unguiculatum, subsagit- tatum, planum. Co I n m na teres, clavata, clinandrio carnoso, cneullato, oblique torto, rostello acuminato. A $\mathrm{n} t \mathrm{~h}$ e $\mathrm{r}$ a bilocularis, acuminata, clinandrii cucullo semiocenltata. P 011 i n i a 2 , sulcata. ...- Herba brasilien sis; rhizomate carnoso, repente, foliis crassiusculis ovalibus, subtus purpurcis, scapo hirto, bracteato, floribus laxe spicatis, majusculis.

H a maria Lindley Scelet, p. 9. Bot. Reg. n. 1618. Goodyera discolor Ker in Bot, Reg. t, 271.

1561. Hyloplaila LINDL. Perigonii conniventis foliola lateralia oblique recurva, subuncinata, supremnm arcuatum; interiora

L ab ellum anticum, nanum, liberum, saccatum, dependens, apiculatum. Col umna brevissima, clinandrio proclivi, rostello curvo, subnlato. Anthera subulata. Pollinia 2, caudicula subulata. - Herbae indicae, nondum descriptae.

$\mathrm{H}$ y $\mathrm{l}$ o phil a Lindley in Wallich Catalog, n, 7396, Bot. Reg. $n, 16 i s$,

15SE. Mieroelhilns PRESL. Perigoni subringentis foliola exteriora lateralia lineari-lanceolata, patentia, supremum eum interioribus in fornicem apice tridentatum connatum. L a bellum subpendulum, basi angustum, in calcar scrotiforme productum, apice dilatatum, bilobum. Columna... Anthera acuminata, bilocularis. Pollinia....-Herbae peruanae; rhizomate elongato, repente, foliis lato-lanceolatis $v$, ovali-ellipticis, scapo basi folioso, spica lineari, elongata, floribus parvis.

Microchilus Presl in Reliq. Haenk, Ir. 94. Symb.t. 15. - ? P hysurus L. C. Richard mse.

1563. Erythredes $B L U M$. Perigoni foliola erecto-conniventia, exteriora subaequalia, lateralia labellum amplectentia; in ter i o ra unguiculata, angustiora. $\mathbf{L}$ a b e $11 \mathbf{n ~ m}$ basi.in calcar subdidymum productum, limbo brevi, rotundato-emarginato, reflexo. Col am na brevis, setaceo-acuminata, emarginata. Anthera dorsalis, bilocularis. Pollinia 2 , oblonga, coalita, glandulae hamatae affixa. - Herba javani$c a$; caule inferne radicante, foliis alternis, petiolatis, nervosis, membranaceis, lato-ovatis, floribus spicatis, bracteatis, extus rufo-pubescentibus.

Erythrodes Blume Bijdr. hio. Psychechilos Kuhl et Hasselt Orchid. edid. Breda. t.9.

1564. Symassa $L I N D L$. Perigoni conniventis (?) folio la exteriora labello supposita, basi in calear cum ovario connatum producta, superius enm interioribus conglutinatum. L a b e $11 \mathrm{~nm}$ cum columna omnino connatum, apice crispnm, dilatatum, callis duobus infra apicem acuminatum. Columna. ... A nthera....Pollinia 2, bisulea.... Herba peruan $a$, corymbosa, nondum descripta.

S y n a s a Lindley Scelet. n. 21. Bot. Reg. n. 1618.

1585. Tropidia $L I N D L, P$ e $\mathrm{r} g \mathrm{on}^{\mathrm{i}} \mathrm{i}$ conniventis foliola exteriora lateralia majora, basi oblique producta, calcar mentientia, supremum et interiora. . L L b e 11 u m liberum, sessile, ventricosum, compressum, lateribus reflexis lamellatis, apice constrictum, cucullatum. Col um a teres, clinandrio longe infra stigma excavato (?). An $t h$ e $r$ a dorsalis, mutica. Pollinia 4 , in massas duas bilobas cohaerentia, caudicula brevi. - Herbae ind ic ae, nondum descriptue.

Tropidla Lindley in Wallich Catalog, n, 7386. Bot. Heg, $\pi, 1618$. 
1566. Cmemidia LINDL. Perigonii conniventis foliola exteriora lateralia semiconnata, basi in calcar spurinm produeta; in teri ora. ... L a b e I I um posticum, liberum, calcaratum, canaliculatum, acuminatum. Co 1 um na teres, apice acuminata, elinandrio declivi immarginato. Anthera subulata. Pollinia 2, caudicula subulata. - Herbae indicae, nondum desoriptac.

C ne mid ia Lindley in Bot Reg.n.1618. Deca is nea Lindley in Wallich Catalog. $n$, 7388, non Brougu.

15G\%. Gallera BLUM. Perigonii conn'ventis foliola exteriora interioribus angustiora. L a b e $11 \mathrm{u} \mathrm{m}$ basi obtuse calcaratum, concavum, limbo indiviso, undulato. Col u m na brevis, crassa, fornicata. Ánther a intramarginalis, turbinata, carnosa, bilocularis, loenlis bilocellatis. Pollinia 2, subbiloba, caudiculis arcuatis, ad antherae latus exterius affixis. - Herba javanica, caulescens; radice tuberosa, caule aphyllo vaginato, apice spicato-multifloro, floribus pedicellatis, bracteatis, nutantibus, ovariis infra florem in collum attenuatis.

G a l e ra Blume Bijdr. 415.

1568. Herpysma LINDL. P e rig on ii conniventis foliola exteriora lateralia a snpremo paullo sejuncta, eum in terioribus antrorsum arcnata, Labe $11 \mathrm{~nm}$ anticum, calcaratum, eum columna connatum, basi dilatatum, apice abrupte rotundatum, sub apice bicallosum. Col u m n a semiteres, clinandrio marginato. A nthera... Pollinia 2, caudiculis distinctis, polline sectili. - Herbae indicae, nondum descriptae.

Herpysma Lindley Bot. Reg. $n, 1618$.

1569. noeetsehilus $B L U M$. P e $\mathrm{r}$ igon ii ringentis foliola e xteri or a latiora, labello supposita, et basi leviter connata, supremum cum interioribus minoribus inaequilateris in galeam conglutinatum. Lab e $11 \mathrm{um} \mathrm{cum}$ columna connatum, basi ventricoso-productum, apice canaliculato - unguiculatum, limbo dilatato, semibilobo, patente. Columna brevis, superne incurva, attenuato-emarginata, utroque latere callosa, antice appendicula bilamellata. Anthera terminalis, bilocularis. Pollinia 2, subbiloba, caudiculis brevissimis, glandula communi oblonga. - Herbae javanicae, caulescentes, basi radicantes; foliis membranaceis, nervosis, floribus spicatis, bracteatis.

Anoectochilus Blume Flor.Jav. praef. $V T$. A noecoehilus Blume Bijdr. 411. fig. 15 . Chrysobaplius Wallich Fl. nepal, t, 17, (Ramph Amboin. VI. t. 41.f.3.) Orehiped u m Kuht et Hasselt Orchid. edid, Breda, t. 10.

15รอ. IIyoda $L I N D L$. Perigonii reflexi foliola exteriora lateralia lihera, supremum cum interioribus conglutinatum. Labell u m anticum, cum columna connatum, apice unguiculatum, hastato-tripartitum. Column a teres, clavata, clinandrio carnoso, cueullato, rostello acuminato, obliquo, stigmate parvo, punctiformi, bilabiato. A nthera ovata. Pollinia 2. ....- Herbae indica e, nondum descriptae.

M y od a Liudley in Wrallich Catalog. $n, 7390$. Bot. Reg. n. 1618 .

15\%1. Cheirostylis $B L U M$. Perigon i i bilabiati foliola exteriora basi in tubum ventricosum connata; interiora libera, aequalia. $\mathbf{L}$ a b e Il um multo majus, unguienlatum, intus bicallosum, limbo dilatato, profunde bilobo, pa- tente. Colu mna brevis, longe rostrata, rostro emarginato. Anthera intramarginalis, bilocularis, loculis bilocellatis. Pollini a 2, biloba, caudicula communi crassiuscula. - Herba javanica; caule remote trifoliato, superne pubescente, foliis lanceolatis, nervosis, membranaceis, spica basi bi-tribracleata, floribus sessilibus parvis, albidis.

Cheirost y1 is Blume Bijdr. 413. fig. 16 .

1582. Tripleura LINDL. Perigonit explanati cruciati, quasi tetraphylli, foli ola exteriora lateralia linearia, patentissima, supremum cum interioribus conglutinatum. Lab e $11 \mathrm{~nm}$ posticum, liberum, concavum. Column a brevissima, teres, antice processubus duobus membranaceis corniformibus (staminodiis) aucta. Anthera terminalis, subrotunda, apiculata. Herbae indicae, nondum descriptae.

Triple ura Lindley in Fallich Catalog. n. 7391. Bot. Reg. n. 1618.

15\%3. Ponthieva R. BR. Perigonif foliola exteriora patentia, supremum cum interioribus connatum. Labellum basi coIumnae insertum, concavum, indivisum. Colu mna brevissima, subulata. Anthera postica, linearis, quadrilocularis, rostello incumbens. Pollin i a 4, lineari-clavata, glandula communi juncta. - Herbae americanae tropicae; foliis petiolatis, ellipticis, scapo tereti, glabro v. piloso, bracteato, floribus laxe spicatis.

Pouthieva R. Browu in Ait. Hort, kew. 2. Y. 197. Lind. ley in Bot. Reg. t.760. Neottia glandulosa Sims in Bot. Mag, t. 8,22 .

15\%4. Cramielnis SWARTZ. Perigonii ringentis foliola conformia, exteriora interioribus subaequalia. Labellum erectum, fornicatum, concavum. Col umna medio dilatata, apice emarginata. Anthera postica, incomplete quadrilocularis. Poll inia 4 , glandula conmuni juncta. - Herbae a mericanae tro$p$ ica $e$; radiculis faseiculatis, foliis ovato-ellipticis $v$. lanceolatis, petiolatis, caulibus vaginatis, rariusve foliatis, floribus spicatis, bracteatis, virescentibus $v$, albidis.

Cranichis Swartz in Aet. Academ. Holm. 1800, p. 220. t.3. $f . k$, Kunth Synops. I. 324. O p hrydis s p. Humb. et Bonpl, nov. gen. et sp. t.7\%.

15\% ร. Presseottia LINDL. Perigonii foliola exteriora aequalia, reflexa; interior a minora, erecta v. reflexa. Labell nm posticum, erectum, cucullatum, integerrimum, carnosum. Col um na nana, teres, elavata. Anther a opercularis, rotundata, loculis connectivo erasso divaricatis. Pollinia 4, geminata. Herbae in Brasilia et Peruvia observatae; foliis radicalibus solitarïs v. paucis, ovato-oblongis, cauli nis nullis v. paucis, floribus herbaceis, parvis, ut plurimum densissime spicatis.

Prescottia Lindley in Hook, exot, Flor, t. 113. Bot. Reg. $t .1916$.

1576. Alensteinia $H, B K$, Perigonii foliola basi cohacrentia, exteriura aequalia; interiora paullo angustiora, omnia revoluta. La b ell um foliolis majus, sessile, erectum, indivisum. Co ln mna brevis, erecta, teres, apice emarginata, denticulata. Anth er a loculis discretis, apici columnae extus longitudinaliter ad. natis, stigmati oppositis. Pallinia 2, pedicellata. - Herbae quitenses; radice tuberosa, caule foliute, floribus dense spicatis.

Alte nsteinia Kunth in Humb. et Bonpl, nav, gen, et sp. L. 332, t, 72,73 . 
15\%7. Zeuxine LINDL, P exigon i conniventis foliola exteriora lateralia connata, supremum basi saccatum; in teriora.

$\mathbf{L}$ abellum anticam, basi membranaceum, bicallosum, cum columna connatum, apice nnguiculatum, carnosum, dilatatum, concavam. CoI umna brevissima, teres, clinandrio membranaceo antheram involvente. Anthera. . . PolI in ia 4 (an 8), in duas massas connata, caudiexla brevi ligulata, glandula uneinata. - Herba ind ica, nondum descripta.

$\mathrm{Z}$ e uxinc Lindley Scelot, n, 18. Bot. Reg. n. 1618 ,

15\% 8. Hophostemen $B L U M$. P erigo nii conniventis foliola exteriora carinata; interiora minora. L a b e $11 \mathrm{um}$ ecalcaratum, concavum, erectum, limbo sublobato. Col um a clavata, apice profunde exeavata. Anthera coIummae denti dorsali affixa, bilocularis, carnosa. Pollinia 2, subliloba, caudienlis brevissimis margini stigmatis insidentia. .- Herbae java $n$ icae, acaules; radice tuberosa, folio radicali petiolato, ovato-cordato, nervoso, pedunculo radi cali basi vaginante, nutante, floribus laxe racemosis, cernuis.

Rophostem on Blume Flor. Jav. praef. $\nu 1$. Cor dy 1 a Blume Bijir. 416 .

15\%9. Cryptostylis R. BR. Perigo nii foliola patula, ex te riora lineari-subulata; interiora conformia, paullo minora. Lab e $11 \mathrm{n} \mathrm{m} \mathrm{magnum,} \mathrm{posticum,} \mathrm{carinatum,} \mathrm{basi} \mathrm{ven-}$ tricosa columnam occultans. Columna brevissina, erassa, clinandrii margine calloso. Anthe$\mathrm{ra}$ dorsalis, bilocularis. $\mathrm{P} 011 \mathrm{i} \mathrm{n}$ a 2 , biloba, glandula communi affixa. - Herbae in $N o v a$ Hollandia extratropica, et etiam in insula Javae indigenae; bulbis radicalious fasciculatis, foliis radicalibus planis, petiolatis, paucis, nervosis, membranaceis, scapo vayinato, floribus terminalibus spicatis, sordide rufis, inodoris.

Cryptostylis R. Brown prodr. 317. - Z osterost y lis Blume Bijdr. A18. Malaxidis $\mathrm{s}$. Labill. Nov. Holl. t. 212 .

1580. Calloelailless $R$. BR. Perigoni ringentis foliola exteriora lateralia labello supposita; interiora sessilia, erecta, minora. L a b e 1 I u m sessile, perigonii foliolis lungius, acuminatum, disco intus marginibusque barbatum. Col um na teres, nana, basi nuda v. bituberculata. Anthera mutica, loculis approximatis. Pollinia 2, biloba. - Herbae glabrae, in Nova Hollandia extratropica indigenae; bulbis radicalibus indivisis, nudis, foliis caulinis paucis, linearibus, infimo canaliculato, elongato, reliquis abbreviatis, spica racemosa, rara, pauciflora, floribus porrectis, rufis, majusculis.

Calo e tillas R. Brown prodr. 320. Bot. Mag. t. 3187.

1581. Prasophyllmm $R$. BR. Perigonii ringentis foliola exteriora distineta, v. basi cohaerentia; interiora inaequilatera. Labe $11 \mathrm{~cm}$ postieum, unguiculatum, adscendens, indivisum, ecalearatum. Columna trifida, laciniis lateralibus (staminodiis) membranaceis, integris bifidisve. Anthera mutica, mucronata aut rostrata, loculis approximatis. Poll in i a 2 , biloba, apici stigmatico affixa. - Herbae in Nova Hollandia extratropica indigenae; bulbis indivisis, caule monophyllo, basi vaginis aliquot brevibus instructo, folio tereti, fistuloso, quandoque abbreviato, vagina longissima instructo, floribus spicatis.

P ras a ply $11 \mathrm{um} \mathrm{R.} \mathrm{Brown} \mathrm{prodr.} 317$.

158\%. Genoplesfum R. BR. P e rigo $\mathrm{ni}$ ingentis foliola exteriora lateralia lon giora, interiora basi cum columna connata. $\mathrm{L}$ a b e 1 I u m postieum, indivisum, eealcaratum, basi cucullatum. Col umna semibifida, laciniis lateralibus nullis. Anthera loculis approximatis. Pollinia....- Herba in Nova Hollandia orientali extratropica indigena, habitu Prasophylli.

\section{Genoplesium R. Brown prodr. 319.}

15983. Orthocerras $R, B R$. Perigon i ringentis foliola exteriora lateralia linearia, erecta; interiora sessilia, nana, sub supremo ovato galeato conniventia. Labellum sessile, trifidum, ecalcaratum. Col um a brevis, utrinque lobo petaloideo (staminodio) ancta. Anther a mutica, loculis approximatis. Pollinia 2, biloba. - Herba in Nova Hollandia orientali extratropica indigena, habitu Diurium, a quibus sola perigonii conformatione differt.

Orthoceras R. Brown prodr. 316.

1584. IDiumis SMITH. P e ri gonii subringentis foliola exteriora lateralia linearia, elongata, labello trifido supposita, supremum multo latius, subfornicatum; interiora unguiculata, patula. Labe 11 u m sessile, trifidum, cealcaratum. C o I u m na brevis, utrinque lobo petaloideo (staminodio) ancta. Ant he ra mutica, loculis approximatis, Follinia 2 , biloba. - Herbae in Nova Hollandia et in Nova Zeelandia indigenae, glabrae; bulbis radicalibus indivisis, foliis radicalibus linearibus paucis, seapo vaginato, floribus majusculis, spicato-racemosis.

D i 1 ri s Smith in Linn. Transact. IV. 222. Exot. Bot. 1. t.9.30. R. Brown prodr. 315. Bot. Mag. t. 3156. A. Rich. Flor. Nov, Zeel, t, 2s. $f .1$.

1585. Eppiblenas $R$. BR. P e r ig o n i i subregularis foliola exteriora et interiora aequalia, patula. Lab ellum unguiculatum, ecalearatum, ungue canaliculato, marginibus callosis e columnae basi productis, lamina integra, basi processubus filiformibus fasciculatis. C oI um na petaloideo-marginata. Anthera intramarginalis, mutica. Pollini a 2, biloba. - Herbae in Novae Hollandiae ora australi indigenae, habitu Thelymitrae, floribus caeruleis, speciosis.

Ep iblema R. Brown prodr. 315.

1586. Thelymitre FORST. Perigonii regularis foliola exteriora interioribus aequalia, semipatentia. La be 11 um sessile, ecalcaratum, perigonii foliolis conforme. Colum na bifida, clinandrio petaloideo encullato, apiec trifido, lobis lateralibus (staminodiis) penicillatis barbatisve aut rarius nudis. Anthera intramarginalis, clinandrii lobo intermedio demissius inserta, mutica v. mueronata, loculis bilocellatis. Pollinia 4, stigmatis glandulae affixa. - Herbae in Nova Hollandia extratropica et in No va $Z$ e el a ndia indigenae, glabrae; radicibus fasciculatis bulbiferis, caule foliato, vaginato, folits linearibus canaliculatis, floribus laxe spicatis, majusculis, speciosis, ut plurimum caeruleis, albis $v$. carneis, rarius flavis.

Thely mitra Forst, char. gen. 49. Smith exot. Bot.I. t. 29. Swartz Act. Holm, 1800, p. 228, t. 3. f. l. R. Browu prodr. 314. Blume Bijdr, 419. A. Richard Flor. Nov, Zeel. t. $25, f .2$.

SUBQIRDQ VT. ARETHUSEAE Lindl. Orchid. Scelet. 10. Pollin is massae pulvereae, v. e corpusculis angulatis, basi aut infra apicem affixae. $\mathbf{A} \mathrm{n}$ th e $\mathrm{r}$ a terminalis, opercularis. - Herbae terrestres, acaules 
$v$. caulescentes, radicibus fibrosis v. bulbosis. - Arethus eae maxima copia in hemisphaerae australis regionibus extratropicis temperatis obviae, in regionibus tropicis utriusque continentis, et sub coelo temperato hemisphaerae bore alis rarius obviae sunt.

158\%. Deeaisnea BRONGN. Perigonii foliola subaequalia, basi inter se connata, exteriora lateralia labello supposita, inferne gibbosa, labello adhaerentia; interiora supremo aequalia. Labe $I 1 \mathrm{um}$ conforme, basi foliolis lateralibus connatum, limbo libero incluso, indiviso, concavo. Col um a brevis, compressa, clinandrio postice membranaceo, biaurito. Anther a terminalis, opercularis, loculis discretis. Pollinia 2, stigmatis apiei soluto affixa. - Herba brasilien$s i s$; radice e fibris clavatis, foliis radicalibus rosulutis, ovatis, membranaceis, nervosis, basi vaginantibus, caulinis lanceolatis, squamaeformibus, spica cylindrica densa, floribus parvis, confertis, bracteatis.

De e a i s ne a Bronguiart ad Duperr, 192, t, 39.

1588. Mierotis $R$. BR. Perig on ii rin gentis foliola exteriora lateralia sessilia, labello supposita, supremum galeatum; interiora lateralibus subconformia, adscendentia. Lab ell um cum columnae basi producta subunguiculatum, oblongum, indivisum v. bilobum, basi eallosum. Columna infundibuliformis, apice biaurita. Anthera terminalis, persistens, mutica, loculis discretis. Pollinia 4, stigmatis apiei soInto affixa. - Herbae glabrae, in Novae Hol landiae extratropicae ora orientali et meridionali indigenae; bulbo radicali indiviso, nudo, folio caulino unico fistuloso, tereti, longe vaginato, spica multiflora, densa, floribus parvis, virescentibus $v$, albis.

Mi erot is R. Brown prodr. 320. Hooker in Bot. Mag. t. 3377.3378 .

1589. Aeianthus $R$. BR. Perigonii subringentis foliola exteriora aristata, lateralia angustiora, labello supposita; interi ora minora, erectiusenla v. reflexa. L a bellum dissimile, foliolis brevius, porrectum, indivisum, basi bicallosum, diseo inappendiculato. Col $\mathrm{mm}$ n a semiteres, arcuata, aptera. An thera terminalis, persistens, loculis approximatis. Pollinia 4, distincta v. per paria cohaerentia. Herbae tenerae, glabriusculae, in Nova Hollandia extratropica orientali indigenae; bulbis radicalibus nudis, indivisis, novellis pedicellatis, caule unifolio basi vagina brevi incluso, superne ebracteato, folio profunde cordato, acuto, trinervio, reticulato - venoso, subtus rufo, floribus racemosis $v$. solitariis, rufis. A cianthus R. Brown prodr. 321.

1590. Cyptostylis R. BR. Perigonii bilabiati foli a mutica, exteriora lateralia cum interioribus subaequalibus patula, supremum erectum. Lab e $11 \mathbf{n m}$ dissimile, foliolis paullo brevius, porrectum, indivisum, basi bicallosum, disco inappendienlato. Col um a semiteres, apice dilatato - auriculato. Anthe ra terminalis, persistens, loculis approximatis. Pollini a 4, compressa, distineta. - Herba in Nova Hollandia orientali extratropica indigena; habitu Acianthi, a quo vix nisi columnae apice dilatato differt; folio reniformi multinervi, reticulato-venoso.
Cyrtostylis R. Browu prodr. 329. Hooker Journal of Bot, t. 135 .

1591. Chileglottis $R$. BR. Perigon i bilabiati foliola exteriora lateralia labello supposita et basi adnata, canaliculata, apice teretia, supremum apicem versus dilatatum, in acumen desinens; in terior a lanceolata, reflexa. L abe $11 \mathrm{um}$ unguiculatum, basi bicallosum, diseo laminae glanduloso, basi appendicula lingulata. Column a areuata, apice aurieulato-bifida. Anthera terminalis, persistens, loculis approximatis. Pollin i 4, compressa. - Herbae glabrae, in Nova Hollandia extratropica orienta$l i$ indigenae; bulbo solitario nudo, caudicem descendentem radicantem terminante, foliis radicalibus binis, approximatis, ovalibus, multinerviis, basibus angustatis vagina scariosa inclusis, scapo unifloro, medio unibracteato, flore rufo, ebracteolato.

Chilo glottis R, Brown prodr. 322. Ferd. Bauer $\mathrm{Il}$ tustr. $t .8$.

1592. Eribelnilus $R$. $B R$. Perigoni bilabiati foliola exteriora lateralia unguiculata, labello supposita, deflexa, supremum cum interioribus minoribus sibi conformibus erectum. Labe $11 \mathrm{um}$ unguiculatum, ungue cum coInmna parallelo, inappendiculato, lamina patente, disco pubescente, eglandulosa. Co I um n a erecta, semiteres, apice simplici. Anthera terminalis, persistens, mutica, loculis approximatis. P o $11 \mathrm{i}$ n i a 8 , quaternatim cohaerentia, incumbentia, antiea minora. - Herba in Nova Hollandia extratropica orientali et meridionali observata; bulbo subgloboso nudo, caudicem descendentem terminante, folio radicali unico, subovato, nunc cucullato, basi vagina scariosa incluso, scapo uni-trifloro, bracteis praeter florales nullis, floribus albis purpurascentibusve, extus ovariisque pube subglandulosa brevissima conspersis.

Eriochilus R. Brown prodr. 323, Epipactis enc ullat a Labill. Nov. Holl. II, 61, t.211. f.2.

1593. Caladenta R. BR. Perigoni foliola subaequalia, exteriora lateralia cum interiorib $n$ s in labium inferius patentia, snpremum erectum. L a b e 11 u m ungniculatum, cucullatum, subtrilobum $\mathrm{v}$. apice angustatum, disco glandulis seriatis ornatum. Columna membranaceo-dilatata. Anthera terminalis, persistens, saepissime mucronata, loculis approximatis. Pollinia 2, a latere compressa, semibiloba, lobo antico minore. - Herbae pulcherrimae, in Nova Hollandia intra et extratropicos, nec non in insula Diemen indigenae, glanduloso-pubescentes, pilis simplicibus intermixtis; bulbo indiviso caudicem descendentem terminante, lamelloso-tunicato, folio unico subradicali, saepius lineari, basi vagina incluso, scapo bractea praeter florales unica instructo, uni-trifloro, floribus inodoris, colore vario, extus glanduloso-pubescentibus.

C a l a de n i a R. Brown prodr. 323.

a) EUCALADEN1A. Perig onii foliola subaequalia, quatuor labium inferius efformantia.

Caladenia verae R. Brown $l$. c.

b) LEPTOCERAS. Perigonif foliola exteriora lateralia labłum inferius efformantia, interiora elongata, adsceudentia, angustata.

Leptoceras R. Brown $l$. c.

1594. Clossodia R. BR. Perigonii foliola patentia, exteriora et interiora aequalia. Lab e II um dissimile, brevius, sessile, indivisum, eglandulosum. Appendix ligularis inter labellnu et columnam. Col nma membranaceo-dilatata. Anthera terminalis, persi- 
stens, mueronata, loculis approximatis. Pollinia 4, compressa. - Herbae pilosae, in Nova Hollandia orientali extratropica indigenae; bulbo radicali indiviso, lamelloso-tunicato, folio radicali unico, basi vagina membranacea incluso, scapo uni- $v$, rarius bifloro, medio unibracteato.

Glos sodia R. Brown prodr. 325.

1595. Pterostylis $R$. BR. Perigonii ringentis foliola exteriora lateralia labello supposita, et inferne adhaerentia, basi inter se connata, supremum inferne colnmnae adhaerens, galeatum; interiora paullo minora, libera. Lab e 11 um unguiculatum, subinclusum, lamina indivisa, basi appendiculata $v$. gibbosa. Colum a basi cum galea connata, superne libera, apice late anriculato-alata, medio stirmatosa. Anthera terminalis, persistens, loculis approximatis. Pollinia 4, compressa. - Herbae glabrae, in Nova Hollandia extratropica orientali, et in insula Diemen indigenae; bulbis nudis indivisis, caudicem descendentem radiciformem terminantibus, foliis nunc omnibus radicalibus stellatis, membranaceis, nervosis, scapo aphyllo, bracteato, nune caulinis alternis, radicalibus tunc nullis, floribus solitariis rariusve racemosis, ochroleucis $v$. viridirufis, saepius majusculis.

Pterost ylis R. Brown prodr. 326. Ferd. Bauer $\mathrm{Il}$ Iustr, t. 2. Guillem. Ic. lithogr, t, 2. 6. Bot. Mag. t. 3085. $3086,3172.3400,3401$, Honker Journal of Bot, t, 36.

1596. Iyperantlaus $R$. BR. Perigonii ringentis foliola exteriora lateralia cum interioribus subaequalibus patentia, supremum latius, fornieatum. Labe $11 \mathrm{n} \mathrm{m}$ foliolis brevius, marginibus columnae parallele adscendentibus semicueullatum, disco glanduloso v. papnloso, margine integro v. fimbriato. Columna linearis, areuata. Anthera terminalis, persistens, acutiuscula, loculis approximatis. Pollinia 4 . Herbae in Nova Hollandia extratropica orientali et meridionali indigenae; bulbo nudo, indiviso, caudicem descendentem, supra bulbum radicantem terminante, caule juxta basim monophyllo, supra bracteis praeter florales duabus, vaginantibus instructo, floribus racemosis, atro-rufis, saepius resupinatis, glabris.

Ly perauthus R. Brown prodr. 325.

1597. Corysantines $R$. BR. Perigonii ringentis foliola exteriora lateralia linearia, cum interioribus subaequalibus deflexa, a labello occultata, supremum maximum, galeatum. Labellum maximum, eucullatum v. tubulosum, basi muticum v. bicalcaratum. CoI n m na brevis, semiteres. Ant he ra terminalis, unilocularis, semibivalvis, persistens. Polli n ia 4. - Herbae pusillae, glabrae, in Nova Hollandia extratropica orientali indigenae, admodum rarae, bulbis rudicalibus nudis, indivisis, folio radicali unico subrotundo, quandoque sublobato, flore subsessili, pro statura plantulae maximo, saturate rufo.

Corysanthes R. Brown prodr. 326 .

a) CORYSANTHES. Labellan ecalearatum, inferne cucullatum, superne dilatatum, narginibus inflexis finbriatum. $G$ a le a sessilis.

Corysanthes fimbriata R. Brown $l$, $c$. et Gen. Hem. $t, 10$,

b) STELEOCORYS. I a b el 1 u m ccalcaratum, tubulosum, apice aperto obliquo. Gal e a unguiculata.

Corysanthes ung uiculata R. Brown.

c) CORYBAS Salisb. L a b ell u m tubulosum, apleis aperti dilatati marginibus refiexis, basi bicalcaratum. $G$ ale a sessilis.
Corybas Salisly. Parad, 1.83 . Corysanthes bi. calcarat it R. Brown.

1598. Caleya $R$. BR. Perigonii foliola linearia, subaequalia, exteri or a lateralia labello supposita, supremum cum interioribus adscendens v. reflexum. Lab ell um unguiculatum, lamina peltata, eava, extrorsum aperta. C o I r m n a petaloideo-dilatata. A nthe $r$ a terminalis, persistens, locnlis approximatis. I'ollinia 4. - Herbae glabrae, in Nova Hollandia orientali extratropica indigenae; bulbo rudicali indiviso, caudicem descendentem supra jibrosum terminante, novello pedicellato, folio radicali unico, lineari, basi vagina incluso, scapo braclea praeter florales unica $v$. nulla, pauciftoro, floribus fusco-viridibus, labello irritabili columnaque rufis.

Caley a R. Brown in Ait. Hort. kew. 2. $V$, 204. C a. le a n a R. Browu prodr. 329.

1599. Calcearia $B L U M$. Perigonii ringentis foliola basi connata, exteriora lateralia linearia, cum interioribus conformibus ereeto patula, supremum spathulatum, fornicatum. L a b e 11 u m sessile, maximun, basi scrotiformi colnmnam amplectens, lamina patente subbiloba, intus bitallosa. Columna brevis, aptera, obtusa, clinandrio antice in dentem producto. Anthera terminalis, persistens, unilocularis. Pollinia 2, biloba. - Herba pusilla, in insula Javae monticola; radicibus tuberosis, foliis radicalibus cordatis, membranaceis, reticulato-nervosis, floribus solitariis sessilibus, unibracteatis, purpureis.

\section{Calee a ria Blume Bijdr. 118.}

1600. Callopogon R. BR. Perigonii erecto-conniventis foli o la subaequalia, exte. riora lateralia basi obliqua; interiora nonnihil angustiora. L a b e $11 \mathrm{um}$ posticum, unguiculatum, patentiusenlum, lamina disco barbata. Columna semiteres, ineurva, apice alata. Anther a terminalis, loculis approximatis. Pollinia 2, angulata. - Herba boreali american a; foliis radicalibus lanceolatis, scapo elato, floribus laxe spicatis, purpureis.

C al o pogon R. Brown in Ait.Hort, kew. 2, V. 204. Sweet Ft. Gard. t. 115. Cat lie a Salisb. C y mb i d i um pulchel. $1 \mathrm{u} \mathrm{m}$ Willd. Li modari s p. Bot. Mag. t.116.

1601. Pogonia JUSS. Perigonii erecto-conniventis foliola exteriora et interiora aequalia. Lab e $11 \mathbf{u m}$ sessile $v$. unguienlatum, cucullatum, lamina disco papilloso cristata. Co l u m n a semiteres, apice clavata, marginata. Anthera terminalis, loculis divaricatis. Pollinia 2, sulcata. - Herbae in America borea li et antarctica indigenae; radicibus tuberosis $v$. fasciculatis, caule monophyllo v. oligophyllo, foliis saepius subradiealibus verlicillatis, uni-trifloro.

Pog on i a Juss, gen, 65, R. Brown in Hort. kew. 2, $V$. 203. Bot. Reg. $t$. 148. 908 . Hooker exot. Flor. $t$. 70, Pöppig et Endl, nov. gen, et sp. t. 123. Pogon i a et Triph or a Nuttall Gen, IT. 192. Nervilia Commers, ex Gaudicli. ad Freyc. 421, t. 35. 0 do nectis Ratin, in New-York medic. Heposit, II. Hex, V. 350. Is o tria Rafit. in Journ. Phys. LXXXIX, 261. (A rethusa verticillata et medeo. loides Linn.) A rethnsae sp. Linn. Calopogon Les. s o n ii Brongu. ad Duperr. t, $37 . a$.

1602. Apethusa GRONOV. Perigoni i foliola acqualia, basi cohaerentia, exterior a lateralia basi in gibber brevissimum producta, cum supremo et interioribus in galeam eonniventia. Labell n basi columnae adnatum, 
superne cucullatum, disco intus cristatum. Co I um a linearis, apice petaloideo-dilatata. Anthera terminalis, loculis approximatis. Polli nia 4, angulata. - Herba boreali americana, aphylla, radice tuberosa, scapo simplicissimo vaginato, flore terminali solitario, roseo.

A rethus a Gronoy. Virgin. 184. R. Brown Hort, kew. 2. V. 205. Hooker exot. Flor. t. 17o. Bot. Mag. t. 2204.

1603. ILaplostellis $A . R I C H$ P erigo nii foliola exteriora anguste linearia, pa tentia; in teriora subaequalia. Labell um sessile, erectum, apice dilatato truncatum. Co I u mn a recta, longinscula, aptera. Anthera termi nalis, mobilis, bilocularis. Pollin ia 4 , subglo bosa. - Herba mauritiana, vix nota, simplex, aphylla, tri-quadripollicaris; radice fibrosa, scapo medio unibracteato, flore terminali solitario, erecto.

H a plostellis A. Riehard in Mem. soc. h. n. Paris. $I V, 36$. A rethusa si mplex Thouars Orchid. $t$. 24.

1604. Chlloraea LINDL. Perigonii membranacei foliola exteriora subaequalia, lateralia labello supposita, apice incrassata, dellexa, supremum cum interioribus conformibus in galeam connivens. L a b e 11 u m sessile, cncullatum, integrum v. trifidum, disco cristatum, saepius incrassatum. Col u m a elongata, semiteres, marginata. Anthera terminalis, loculis incomplete bilocellatis, stigmati in apice columnae transverso incumbens. P $P$ llin ia 2 , bipartita, postice cohaerentia. - Herbae a $u s t r$ - am ericanae, extratropicae, in terris chilensibus a maris littore ad Andium nives perpetuas repertae; radicibus fasciculatis, carnosis, grumosofarinaceis, scapis simplicibus ima basi foliosis, superne bracteis reticulatis vaginatis, foliis oblongis, nervosis, venosis, praecocibus, floribus spicatis magnis, speciosis, albis, virescentibus, flavidis v. croceis, perigonii foliolis membranaceis reticulato-venosis, venis intensius coloratis, saepe nigricantibus.

Chlorae a Lindley in Brandes n. Journ. of sc, 1827. p. 43. Pōppig et Eadl. nov, gen. et sp. I. 28. $t .46-50,52$ 55. (excl. t. 51.) Brouga. ad Duperr. t. 44. E p ipactis Feuill, Peru,, ,, , 18. 19 .

1605. Asarea LINDL. Perigonii membranacei foliola exteriora lateralia labello supposita, patentia $v$. deflexa, supremum et in t erio ra panllo minora, erecta v. patula. L ab e I$1 \mathrm{um}$ unguiculatum, trilobum, basi bicallosum, lobo medio cristato. C ol um na areuata, membranaceo-marginata, apice dilatata, stigmate antico convexo. Anthera terminalis, opercularis, loculis incomplete bilocellatis. Pollinia 2, bipartita, postice cohaerentia. - Herbae a $u s t r$ oamericanae, extratropicae, habitu omnino Chloreae, a qua perigonio, labello et columna leviter differunt.

A s a r a Lindley in Brandes $n$. Journ. of sc. 1827. p. 52. Pöppig et Endl, nov. gen, el sp. II, t, $118-120$. G avilea et As area Pöppig Fragm, 18, 19. Epipact is Feuill. Peruv, $1,17$.

1 BDS. Bipinmula COMMERS. P e rigoni i membranacei folio la exteriora lateralia labello supposita, elongata, fimbriata, supremum multo minus galeatum, cum interioribus subaequalibus connivens. L a b e $11 \mathrm{um}$ sessile, cucollatum, integrum, cristatum, appendieibus filifor mibus fimbriatum. Col u m na elongata, semite res, marginata. Anthera terminalis, opercularis, bilocularis. Pollinia 2, bipartita, postice cohaerentia. - Herbae austro-americanae, extratropica e; radicibus fasciculatis, folïs planis radicalibus, scapis squamosis, floribus spi- catis, v. aphyllae, scapo unifloro. - Genus vix a Chloraea satis diversum.

B ip i n u la Juss. gen, 65. Linalley in Brandes Journ. of sc. 1827. p. 43. A retli a sa biplumata Lian. Smith Ic. inedit. t. 23. - ? ChIorae a $\mathrm{flmb}$ miata Póppig et Endl, nov, gen. et sp, t, 51 .

1 BOF. Himodormm TOURNEF. Perigonii foliola exteriora aequalia, conniventia, supremum subfornicatum; inte $\mathrm{r}$ i o r a multo angustiora. Labe $11 \mathrm{~nm}$ unguiculatum, erectum, ungue basi in calcar longum producto, lamina articulata, indivisa, columnam amplectens. CoI $\mathbf{m}$ na elongata, semiteres. An ther a terminalis mobilis, persistens, loculis approximatis. Pol I in i a 2, integra. - Herba pedalis, in Europ a media et a ustrali raro obvia; radice fibrosa, scapo aphyllo vaginato, florum spica elongata, laxiuscula.

L im a d o r u m Tournef, instit. 437. L. C. Richard Orchid, europ. 20. Nees jun. Gen, plant, fasc, $\mathcal{V}, t, 11.0 \mathrm{r}$. ch is a b o rtiva Lian. Jaeq. Fl, austr. $t, 193$.

oBSERVATIO. A nt ho go n i um Wallich. Cat, n, 7398. a cl. Lindley Introduct, edit. $I$. p. 341. pone Limodorum collócatum, mihi omniuo ineognitum est.

1605. Ceplnalauthera L.C.RICH. P erigonii foliola semipatentia, exteriora et interiora aequalia. Labe $11 \mathrm{um}$ sessile, interruptum, hypochilio saceato-concavo, cum epichilio apice recurvo articulato. Col umna elongata, semiteres. Anthera terminalis, stipitata, mobilis, persistens, loculis incomplete bilocellatis. Pollinia 2, biloba. - Herbae in Eur op a me dia et australi sylvicolae; radicibus fibrosis, caule folioso, foliis lanceolatis, nervosis, spica laxa, foliosa v. bracteata.

Cephalanthera L. C. Bich. Orchid, europ. 21. Nees jun. Gen.plant. fase. V. t.12. Se rapidis s p. Lín. E. B. t. 271.437 .494$.

1609. Crybe LINDL, Perigonii clausi foliola conniventia, exteriora et interio$r$ a aequalia, lateralia basi obliyua. Labe $1 / \mathbf{u m}$ majus, basi enm columna connatum, membranaceum, cueullatum, erectum. Col umna clavata, membranacea, medio bidentata. Anthera terminalis, opercularis. ... Herba mexicana; foliis ex apice pseudobulbi epigaei erumpentibus, pedalibus, lanceolatis, plicalis, scapo laterali, vaginato, racemo pauciftoro, floribus majusculis, nutantibus.

C r y be Lindley in Bot. Reg. t, 1872.

1810. Cyathoglotiss PÖPP. et ENDL. Perigonii clausi foliola conniventia, exte$r$ iora et interio ra inter se, lateralia etiam basi aequalia. L a b e $11 \mathrm{um}$ minus, facie inferne cum columnae basi connatum, marginibus candem amplexans, lamina indivisa, plana. Coln mna clavata, membranaceo-marginata. Anthe ra terminalis, opereularis....- Herbae peruvianae, and icola $e$, in truncis arborum parasiticae; radicibus repentibus caespitosis, caulibus suffruticosis, foliis oblongo-lanceolatis, rigidis, nervosis, floribus spicatis $v$. racemosis, fugacissimis, croceis $v$. candidis.

Cy athoglottis Póppig et Endl. nov. gen. et sp. $t$. 35. $t .94$.

1611. Sobralia $R U I Z$ et $P A V$. P e rigonit foliola exteriora patentia $v$. reflexa, lateralia labello supposita; interiora erecta, angustiora. Labell nm sessile, liberum, indivisum, eirca colnmnam in tubum convolntum, disco plicato barbatum. Colnm na semiteres, anguste alata, infra stigma bituberculata, apice trifida, lobo medio antherifero. Anthera termi- 
nalis, stipitata, persistens, loculis approximatis, incomplete bilocellatis. Pollinia 4 , compressa, basi retroplieata. - Herbae in rupestribus apricis calidissimis Peruviae saepius dumeta densa efficientes; radicibus simplicibus, fibrosis, caulibus suffruticosis, interdum triorgyalibus, simplicibus $v$. ramosis, foliosissimis, floribus in racemum terminalem $v$. axillarem dispositis, niveis, roseis, sanguineis v. violaceis, magnis.

Sobralla Ruiz et Pav, prodr. 120, t, 120. Pöppig et Eudl. nov, gen, et sp, T. 33. $t, 93$.

$161 \%$. Episteplaimm $H, B$. K. Perig 0ni i basi calyculo nrceolato denticulato excepti foliola exteriora patentia v. reflexa, lateralia labello supposita; interiora erecta, angustiora. Lab ell um sessile, liberum, indivisum, cirea columnam in tubum convolutum, disco barbatum cristatumve. Colu m a semiteres, anguste alata, infra stigma bituberculata, apice trifida, Iobo medio cucullato, antherifero. Anther a terminalis, persistens, loculis approximatis, incomplete bilocellatis. PoIlinia 4 , compressa, basi retroplicata. - Herbue in America aequinoctia li epigaeae, Sobraliae habitu, a qua nonnisi calyculo accessorio ovarii apici continuo, unico inter Orchideas exemplo, differunt.

$\mathrm{E}$ p istephium Kunth in Humb. ef Bonpl. nov. gen. et sp. VIT. 158, t. 632. Pöppig et Endl. nov. gen, et sp. I. 52. $t, 91,92$,

1613. Cymtosia BLUM. P e r i g n i i conniventis foliola conformia, exteriora et interiora subaequalia, Labellum carnosum, concavum, intus discoideum, cum columna inferne connexum, limbo rotundato $r$. emarginato, recto. Columna subincurva, superne dilatata aut subalata. An the ra carnosa, biloeularis, coIumnam postice terminans. Po 1 linia 2 , reniformia, farinoso-pulposa, libera. Capsula siliquaeformis, carnosa. $\mathrm{S}$ e $\mathrm{m}$ i $\mathrm{n}$ a scobiformia. Herbae javanicae, epigaeue, caulescentes; radicibus tuberosis, conglobatis, difformibus, caulibus aphyllis (stipulis instructis?) floribus spicatis $v$. paniculatis, bracteatis.

C y rt os i a Blume Bijdr.396. fig. 6, Lindley Orchid, 25.

1614. Vanilla SWARTZ. Perigoni cum ovario articulati foliola erecto-patentia, conformia, exteriora et interiora aequalia. L a be I l um columnae adnatum, planum, apice convolutum. Colum a reetiuscula, aptera. Anthera terminalis, opercularis. Pollin ia 2, granulosa. Capsula siliquaeformis, carnosa. Semin a globosa, testa solida. - Herbae in America et Asia tropica indigenae, in fissuris rupium crescentes, et super arbores altissime scandentes, nonnullae ob capsulas pulpa armatica, oleo essentiali et acido benzoico scatente repletas, in America cultae; foliis oblongis, nervosis, floribus spicatis.

V a n ill a Swartz Flor. Ind, occid, IIT, 1518. R. Brown Hort. kew, 2. $V$, 220. Andr. Hot, Reposit. $t$. 538. Nees Jun. Plant, offec. Frane. Bauer Illust. Orchid. .8. E p idend rum Vanilla Linu.

\section{GENERA DUBIAE AFFINITATIS.}

1615. VIaerostylis KUHL et HASS, Perigonii patentis foliola libera, exteriora et interiura aeqnalia. Labellum posticum, unguiculatum, erectum, columnam amplectens. Col um a clongata, teres, recta, apice incrassata. Anthera postica. Pollinia 2 , in lobulos sectilia, in ca dieulam communem, stigmatis denticulis duobus retentam desinentia. Capsula dehiseens, columna persistente terminata. - Herba terrestris, javanica; caule erecto, decempedali, foliis distichis, lanceolatis, plicatis, racemis axillaribus.

Ma erostylis Kuhl et Hasselt Orchid, edidit Breda 1. 2.

1616 . Thelyelitom ENDL. Perigon i erecto-patentis foliola libera, exteriora et in te ri ora aequalia. L ab e $11 \mathbf{u}$ m sessile, conforme, planum, ecarinatum. Col $\mathbf{m}$ n a brevissima, annularis, stigma centrale sessile ambiens, limbo subbilabiato, labio antico intus proscolla, postico anthera terminato. An $t$ hera terminalis, operenlaris, bilocularis, loculis bilocellatis. Pollinia t, pulverea, basi subcohaerentia. - Herbae in insula Norfolk ut videtur epiphytae, pseudo. bulbosae $v$. cuulescentes; pseudobulbis mono-triphyllis, scapis radicalibus pauciftoris, $v$. racemo terminali subcorymboso. - Genus distinctissimum, sed difficulter collocandum.

The ly e hit o n Endl. prodr. Elor. Norfolk. p. 32.

1817. A eromia PRESL. Perigonii patentis foliola exteriora lateralia inter se, suprenum cum interioribus connata, elongato-acuminata. Labe $11 \mathrm{um}$ usque ad basim bifidum, laciniis linearibus, divergentibus. Co I u mna brevis, erectiuscula, apiec orbiculato-dilatata. An $t$ h e r a sessilis, decidua. Pollinia 2, pulverea. - Herba p eruana, ut videtur epigaea; scapo solitario, erecto, monophyllo, folio late ovato, nervoso, amplexicauli, spica terminali laxa, flo ribus majusculis, purpurascentibus.

A cron i a Presl Reliq, Haenk, I. 10\%. Symb, II, 9, t, 37.

observatio. Callista Loureir. Flor, cochinch. $M$. 633. G a l eol a Loureir. op. cit. 635. et $\mathrm{T}$ h rixs p erm u m Loureir, op. cit. 634. collocari nequeunt.

\section{SUEDIRT VIT. CYPRIPEDIEAE} Lindl. Scelet. $p . \boldsymbol{z}$. Antherae laterales fertiles, intermedia sterilis, petaloidea.

1618. Cypripedium LINN. Perigonii patentis foliola exteriora lateralia uninervia, labello supposita, libera $v$. inter se connata, supremum conforme, quinquenerve; interio $r$ a angustiora. L a be $11 \mathbf{u} \mathrm{m}$ maximum, inflatum, calceiforme. Co I u m n a brevis, cernua, apice trifida, lobis lateralibus subtus antheriferis, intermedio sterili, petaloideo-dilatato. An th e rae loculis discretis, subbivalves. Poll en pulticeogranulosum. Stigma deltoideum, columnae faciem infra antheras occupans. C a p s u la nuilocularis, placentis parietalibus tribus. Semina plurima, scobiformia. - Herbae in hemisphaerae borealis temperatis et frigidiusculis obviae, in $A m$ e $r$ ic a nonnihil frequentiores; radicibus fibrosis, caulibus foliosis, floribus magnis, speciosis. C y pripedinm Linn. gen, n. 1015, Salisb, in Linn. Transact, I. t. 2, 3. E. B. t. 1. Andr. Bot, Reposit, t. 538. Bot. Mug. t. 192, 216. 324, 911, 2938.3024. 3412. Bot. Reg. t, 788. 1534. 1666. Redonté Liliac. 1,19 . Lindley Collect, $t, 32$. Hooker exot, Flor. t,34.35. Sweet Brit, Fl, Gard, t, 71, 80,213. 240. II. 1. - C r i o s a $n$th es Rafin. in Journal Phys. LXXIX, 102 .

\section{Drdo IXVII. Apostasieae.}

APOSTASIEAE R, Brown in Wallich p1. As, rar, 1,74 . Blume Nov. famil. exposit, 7 . Lindley introduct, edil. $I I$. p.324. 
Herbae terrestres, laeves, rigidusculae, Indiae orientalis terram continentem et insulas parce incolentes. $\mathbf{R}$ adices fibrosae. C a u les graciles, cylindrici, indivisi $\mathbf{v}$. simpliciter ramosi. Foli a numerosa, alterna, approximata, graminea, quinquenervia, multilineata, e basi amplexicauli vaginante angustata. R a cemi in summorum foliorum alis v. terminales, multiflori, nutantes.

Flores hermaphroditi, regulares (in Apostasia) v. irregulares (in Neuwiedia), parvuli, inconspicui, fragrantes, breviter pedicellati; pedicelli bracteis persistentibus, carinatis, saepius demum incrassatis fulti, interdum bracteolis imbricatis obsiti.

Prrigonium corollinum, superum, subobliquum, hexaphyllum, deciduum; foli a sublinearia, planiuscula, basi conniventia, apice patentia, biseriata, exteriora anticum et duo lateralia; interiora subangu stiora, duo lateralia et unum posticum, aliquando (in Neuwiedia) dissimile, labelliforme.

Stamisa 3, duo perigonii foliolis interioribus lateralibus opposita, stylo paullo supra ejus basim inserta, eidem parallele adscendentia, tertium e regione folioli antici, stylo paullo altius adnatum, rarissime aeque fertile (in Nenwiedia), plerumque castratum v. plane deficiens. Filamenta brevissima, subulata. Antherae introrsae, biloculares, dorso paullo supra basim affixae, erectae, oblongae, filamento duplo longiores; loc uli appositi, sulco longitudinali discreti, basi aequales v. oblique acutati, longitudinaliter dehiscentes. Pollen e granulis distinctis.

Ovarium inferum, oblongo-cylindricum, obsolete trigonum, triloculare, multiovulatum. Ovula loculorum angulo centrali inserta. Stylus teres, gracilis, stamina aequans vel paullo superans. S tigma terminale, obtusum, trigonum v. obsolete trilobum.

Capsula membranacea, trilocularis, 10culicido-trivalvis, valvis medio septiferis, basi et apice cohaerentibus.

Semrxa plurima, minntissima, ovata, testaque nucleo conformi; v. scobiformia, tes t a membranacea, utrinque relaxata.

Ordo Gynandrarum classim absolvit, Orchideas cum Burmanniaceis et Iride is connectens, a quibus tamen, non solum staminum cum stylo symphysi, sed etiam eorundem ante perigonii foliola interiora lateralia et anticum seriei exterioris situ, optime distinguitur.

1619. Apostasia BLUM. Perigoni corollini superi foliola 6 , aequalia. S $\mathrm{t}$ a min a
3 , dno ante perigonii foliola interiora lateralia antherifera, tertium extimo antico oppositum, sterile v. plane deficiens; filamenta stylo inserta, antherae biloculares. Ovarium inferum, triloculare. Ovala in loculorum angule centrali plurima. Stylus simplex; stigma obsolete trilobum. Ca p s a la trilocularis. S e mina plurima, ovata, testa nucleo conformi. - Herbae per Indiae continentem insulasque diffusae; caulibus gracilibus, foliosis, racemis terminalibus axillaribusque nutantibus.

A p osta si a Blume Bijdr. 493. Nov. famil. exposit. 9. R. Brown in Wallich pl. As. rar. I. 74.

a) ADACTYLUS. Staminis tertil vestigfum nullam. A n $t$ he rarum loculi basi aequales. - Pulo-Penang.

A postas ia nuda R. Brown in Wallich pl. As. rar. 65. Franc. Bauer Rllustr. orchid, t.10.

b) MLSODACTYLUS Wall. Staminis tertii filamen tum anantherum. A nthe ra $r$ u loculi basi inaequales. - Nepalia, Java, Nova Guinea.

Mesodactylus Wallieh msc. Apostas ia odora. ta Blume Bijdr, 423. fig. S. et A. Wallichii R. Brow: op. cit. $t .84$.

1620. Newwiedia $B L U M$. Perigon i corollini superi foliola 6 , intimum posticum (labellum) difforme. Sta $\mathrm{m}$ in a 3 , acque fertilia: fi l amenta stylo inserta, antherae biloculares. Ovarium inferum, triloculare. Ovula in loeulorum angulo centrali plurima. Stylus simplex; stigma trigonum. Ca psula triloeularis. Semin a plurima, scobiformia, testa membra nacea, utrinque relaxata. - Herba javanic $a$; caule simplici inferne radicante, foliis lato-lancelatis, nervoso-plicatis, racemo terminali puberulo, floribus breviter pedicellatis, unibracteatis, flavescentibus.

Ne uwiedia Blume Nov, famil. exposit. 12.

\section{Classis XTX. Scitamineae.}

Herbae interdum arboriformes. Caules simplices, foliati, interdum abbreviati, nulli. Folia basi vaginantia, lamina integerrima, uninervis, nervulis plurimis simplicibus, obliquis v. transversis, apice incurvis. Praigoniva epigynum, irregulare, simplex hexaphyllum cum stauininos senis; v. duplex, exterius (calyx) trimerum saepius rudius, interius (corolla) hexamerum cum stamine unico. Ovarieu inferum, uni-trilocnlare. Ovula in loculis solitaria, basilaria, v. plurima, horizontalia, campylotropa v. anatropa. Fructus capsularis v. rarius baccatus. SEMrva albuminosa. Emrryo axilis, homotropus, extremitate radiculari infera v. centripeta.

\section{Ordo LXVIIT. Zingiberaceae.}

ZINGIBERACEAE L. C. Riehard Anal. du Fruit, 36 , Lindley introduct, edit. Ir. p.322. SCITAMINEAE R. Hrown prodr. 505. AMOMEAE Juss, in Mirbel Elem. 854. Bartl. ord. nat. 60. ALPINIACEAE Liak Handb, I. 228.

Herbae rhizomate repente v. tuberoso, rarius fibroso perennantes, acaules $v$. caulescentes; caule dum adest simplici, foliato, e foliorum vaginis seapum ambientibus conflato. Foli a nunc omnia radicalia, nunc catlina, alterna, simplicia, petiolata, petiolo 
v a gin am longitudinaliter fissam, rarissime clausam, ore ligula instructam v. nudam formante, lamina plana, lata, integerrima, nervo medio valido, utrinque nervos secundarios simplicissimos, obliquos v. fere transversos, apice incurvos exserente. Inflorescentia radicalis $v$. terminalis, densius laxiusve spicata, racemosa $\mathbf{v}$, paniculata.

Frores hermaphroditi, irregulares, in axillis bractearum spathiformium, membranacearum, nudi v. saepius bracteati.

Perigoniex duplex, utrumque epigynum, exterius (calyx) brevius, plerumque co. loratum, tubulosum, tubo integro v. hinc fisso, limbo tridentato v. plus minus profunde trifido; in terius (corolla) corollinum, tubulosum, $\mathrm{t}$ ub o plus minus longo, limbi sexpartiti laciniis biseriatis, tribus exterioribus subaequalibus, v. duabus lateralibus inter se aequalibus, tertia antica (resupinatione postica) situ formaque nonnihil diversa, interiorib us lateralibus rarissime exterioribus conformibus, plerumque minimis, denticuliformibus v. plane abortivis, postica (labello) majore $v$. maxima, plana v. interdum saccata, integra v. bi-triloba.

Stamen unicum, cerollac laciniae exteriori posticae e regione labelli insertum. Fil a m e n $t$ u m lineare, planum v. carinatum, saepius ultra antherarum loculos longe lateque productum, indivisum v. lobatum, marginibus nudum v. appendicibus auctum, basi liberum v. cum corollae laciniis interioribus cohaerens, aut etiam antice cum labelli basi tubulatum. Anthera bilocularis, terminalis, erecta v. incumbens, ant plerumque filamento demissius inserta; loculis parallelis, plus minus a se remotis, marginalibus $v$. intramarginalibus, toto dorso adnatis, basi solutis muticis, v. in appendicem brevem calcariformem productis, longitudinaliter dehiscentibus. Pollin is granula globulesa, laevia.

Ovanum inferum, triloculare, rarissime bi- v, uniloculare. Ov ula plurima, in loculorum angulo centrali bi - pluriseriata, horizontalia, anatropa, in ovariis uni-bilocularibus solitaria, e basi erecta. Sty lus filifcrmis, inter antherae loculos transiens, et saepius ab iisdem retentus, basi glandulis earnosis epipynis, ut plurimum duobus plus minus distinctis, rarius in annulum vaginulaeformem confluentibus, stipatus. $S \mathrm{t}$ i $\mathrm{g} \mathrm{m}$ a terminale, capitato-incrassatum, saepissime infundibuliformi - excavatum.

Capsula infera, perigonii rudimentis snperata, membranacea $v$. rarius crustacea, interdum baccata, trilocularis, loculicido-trivalvis, dissepimentis saepissime centralibus demum ab axi valvularum solutis, substantia diversis, rarissime bi - v. unilocularis, indehiscens.

Semiva in fructu uni-biloculari in loculis solitaria, e basi erecta et eosdem replentia; in fructu triloculari plurima; subrotunda, pressione mutua angulata, nuda v. a rillo brevi carnoso, umbilicum basilarem excavatum recludente stipata. Testa cartilaginea, saepius rugulosa, rhaphe et chalaza vix manifestis. Albumen farinaceum, substantia radiata, versus umbilicum deficiens. Vitellus carnosus, subinfundibuliformis, umbilico contrarius, basi pro exsertione extremitatis radicularis embryonis perforatus.

Embrxo orthotropus, axilis, teretiusculus, apice a vitello vaginatus, nee ei cohaerens, extremitate radiculari umbilicum attingente, e vitello exserta, nec ab albumine inclusa.

A m o m e a e omnes tropicae, plurimae as iaticae, pauciores americanae, in Africa rarissimae, ob tubera et rhizomata succis propriis aromaticis $\mathbf{v}$. resinosis scatentia, et embryonis vitellum in plurimis aromaticum celebrantur.. Genera omnia denuo accurate examinanda.

SECTIO I. GLOBBAE Blume Enum. plant. Jav, I. 62. Herbae rhizocarpicae; inflorescentia terminali, laxe paniculata, racemosa v. spicata.

1621. Globha $L I N N$. C a I y $x$ laxe tubulosns, trifidus. Coroll a e tubus gracilis, limbi laciniae exteriores subaequales, interiores laterales angustae $\mathbf{v}$. minimae denticuliformes; la b ell um majus, integrum, cum filamento tubulatum. Fil a m e $\mathbf{t} \mathbf{m}$ lineare, carinatum, elongatum, ultra antheram nudam v. basi varie appendiculatam haud productum. Ovarium inferum, septis incompletis uniloculare. Ovula in placentis parietalibus tribus plurima, adseendentia, anatropa. Stylus filiformis, inter antherae loculos transiens; stig ma infundibuliforme. Capsula unilocularis, trivalvis, valvis medio seminiferis. S e mina plurima, arillata. Herbae asiaticae tropicae, annuae, humiles; foliis distichis, membranaceis, lanceolatis, vaginis fissis, inflorescentia terminali, laxe fasciculata, racemosa v. spicata.

G 1 o b b a Linn. gen, n. 1287. Rose, in Linn. Transact, VIII, 355. Scilam, t.40. Bot. Mag, t, 1428. Smith exot, Bot, t.117. f a.c. Roxb. Corom. t, 298, 229. Asiat. Research, XI. t, s. Blnme Enumerat. pl. Jav. I. 69. C a ti m b i u m Juss. gen. 69. - Hura Kouig in Retz. observ. III, 49, - $\mathrm{C}_{0}$. le b rookia Don Cat, hort. cantabr. 1. Ceratanthera Hornem. Hort, hafn. I.2, et 5 . G 1 ob b a marantina Linn. Smith exot. Bot. t. 103. Fiseher in Act. Mosq. I. 23. 2.2. f. e. Rose. Scilam, t, 64. - M a n tis I a Curtis in Bot. Mag. t. 1320. G lo b b a e s p. Roxb. Corom, t. 230. Rosc. Scitam. t.16. Bot, Reposit. $t, 117$.

SECTIO II. ZINGIBERA Blume Enum. plant. Jav. I. 41. Herbae rhizocarpicat; radicibus carnosis, tuberosis, inflorescentia dense spicata.

162\%. Zingiber GÄRT. Calyx tubnlosus, hinc fissus. Coroll a c tubus brevis, lim- 
bi laciniae exteriores aequales, interiores laterales nullae; labe 11 um trilobum. Filamentum supra antheram muticam in rostrum simplex ineurvatum elongatum. Ova $\mathrm{rium}$ inferum, triloculare. Ovula in loculorum angulo centrali plurima, horizontalia, anatropa. Sty Ius filiformis, filamento obvolutus; stigma infundibuliforme. Capsula subbaceata, trilocularis, loculicido-trivalvis. Se m in a plurima, arillata, in pulpa nidulantia. - Herbae in $I n d i a$ orientali tropica indigenae; radicibus tuberosis, articulatis, repentibus perennantes, caulibus annuis, foliorum membranaceorum distichoritm vaginis inclusis, spicis strobiliformibus, radicalibus $v$, rarius terminalibus, solitariis, $e$ bracteis imbricatis unifloris compositis.

Z ing ib er Gärtner $I .33, t, 12$. Blume Enumerat. $p l$. Jav. I. At. Smith exot. Bot. t, 112. Roxb. Corom. t. 253. Asiat, Research. X. t. J. Rose. in Linn. Transact. X. t. 20. f.7. Scitam, t.7. 22, 37, 46.71,79.87.94.95. Wallich $P l, A s$ rar. t. 55. - C a s s u m u n a $\mathrm{r}$ Colla Dissert. Taurin. 1830. c. icc. (Bot. Mag. t. 1426.) - La m p u a ng Rumph Amboin, $V$, L.64. f. 1 . A mo m i $8 \mathrm{p}$. Linn. Jaeq. Hort. Vindob. $t .54 .78$. Fiselier in Comment. Mosq, $r, t, 2, f . d . t, 4, f . f$.

1983. Carreuma $L I N N$. Ca l y x tubulosus, tridentatus. Corolla e tubus sursum dilatatus, limbi laciniae exteriores interioribus lateralibus conformes; la be II um majus, patens. Fil a me $n t \mathbf{~ m}$ petaloideo-dilatatum, carinatum, apice trilobum, lobo intermedio a $\mathrm{n} t \mathrm{~h} \mathrm{c}-$ $r$ a bicalcarata terminato. O v a $r$ i u $m$ inferum, triloeulare. Ovula in loculormm angulo centrali plurima, horizontalia, anatropa. Stylus filiformis; st igma capitatum. Ca p sula trilocularis, loculicido-trivalvis. Semin a plurima, arillata. Herbae in India orientali tropica indigenae, acaules; radicibus palmato-tuberosis perennantes, foliis herhaceis, petiolis vaginantibus, bi fariis, scapo simplici laterali v. centrali, spica simplici, erecta, comosa, inferne bracte is saccatis subimbricata, floribus flavescentibus, intra quamvis bracteam ternis quinisve approximatis, bracteolatis.

C и r с и a Liun. gen. n. 6. Blume Enumerat. plant. Jav, I, 45. Roxb. Corom. t, 151. 201. Asiat. Research, XI, t.3. Rose. Scitam, t. 15. 23, 24, 39.48. 56.72, 88,96. Wallieh Pl. As, rar, t. 9. 10, s7. Bot. Reg. t. 886. Bot. Mag.t. 1546. Z e r u m bet Rumph. Amboin, $V$. $t$. 68. A momi s p. Linn. Jaeq. Hort. Dindob, III, t. 4.

1624. I ämpferia $L I N N$. Cal y $x$ tululosus, hine fissus. Corollae $t \mathrm{ubus}$ elongatus, filiformis, limbi laciniae exteriores angustae, aequales, laterales patentes, postica fornicata, interiores multo majores; labelI u m planum. Filam entum breve, carinatum, supra a ntheram muticam in cristam bifidam expansum. Ovarium inferum, trilseulare. Ov n1 a in loculorum angulo centrali plurima, horizontalia, anatropa. St ylus filiformis, a filamento receptus; 8 tig $\mathrm{m}$ a urceolatum, ciliatum. Capsula trilocularis, Loculicido-trivalvis. Semina plarima, arillata. - Herbae Indiae orientalis tropicae, habilu Curcumae; bracteis saepius bifariam imbricatis, rarius saccalis.

K i mp feria Liun. gen, $n$. 7. Blume Enumerat. plant. Jav. I, 47. Jaeq. Hort, schönbr. t.317. Fischer in Comment. Mosq. $1 . t, 1, f .6 . t, 11, f$., . Hegetschw. Scitam, t. 13,17. Redonté Liliac. $t$. 49, 144. 389. Roxb. Carom, $t$, 278. Rosc. Seitam, t. 8, 14, 31, 38, 62. Wallich Pl, As. rar. t. 56. Bot. Mag. t. 850. Bot. Reg, t. 173. 1212. Soncorus Rumph. Amboin. F. t. 69. f. . .

16\%5. Resceea SMITH. Cal y $\mathrm{x}$ tubulosus. Corolla e tubus sursum dilatatus, limbi laciniae exteriores laterales angustac, patentes, postica fornicata, ereeta; interiores laterales breves, postice conniventes; labellum majus, b:lobum. Fil a m en tum brevissimnm, earinatum, antliera incurva, hasi bicalearata terminatum. Ovarium inferum, triloculare. Ovula in localorum angulo centrali plurima, horizontalia, anatropa. Stylus filiformis; stigma globulare, perforatum. C a p s u l a trilocularis, Coculicidotrivalvis. Sem in a plurima, arillata. - Herbae nepalenses; radice e tuberibus fasciculatis, caule erecto, folioso, spica subcapitata, bracteata.

Ros coe a Smith in tinn. Transact. XIT. 460. Exot. Bol. t. 108. Hooker exot. Flor, t, 144. Rose, Scitam, t, 86. Wallielt Pl, As, rar. t, 242. 255.

SECTIO III. АMOMA Blume Enum. plant. Jav. I. 41. Herbae perennes; radicibus tuberosis, fasciculatis, v. saepins repentibus, lignosis. Inflorescentia ut plurimum radicalis, spicata, v. terminalis, bracteis dense munita.

1626. Amomum LINN. Calyx tubulosus, apice trifilus. Co $\mathrm{r}$ o $l 1$ a e $t \mathrm{ub}$ u $s$ brevis, limbi laciniac exteriores laterales postica angustiores; interiores laterales nullae; labe Il u m maximum, explanatum. Filame $\mathrm{n} t \mathbf{u m}$ complanatum, lateribus apiceque ultra anther a m mutieam produetum, lobulis duobus auctum, lobo terminali bifido. Ova rium inferum, triloculare. $O \mathrm{v} u \mathrm{la}$ in loculorum angulo centrali plarima, horizontalia, anatropa. S ty Ius filiformis, inter antherae loculos receptus; st igma infundibuliforme. Capsula saepius baccata, trilocularis, loculieido-trivalvis. Semin a plurima, arillata. - Herbae inter tropicos veteris orbis indigenae, species americanae dubiae; radicibus arliculatis, repentibus, foliis bifariis, membranaceis, vaginis fissis, inflorescentia radicali, spicata, laxe imbricata.

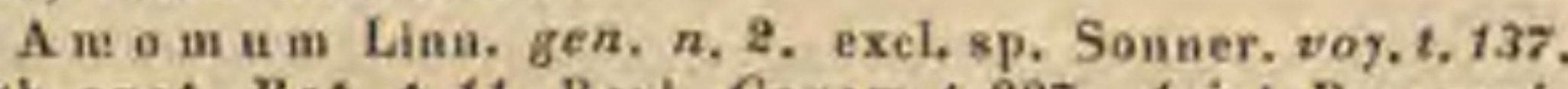
Smith exot, Bot, $t, 11$. Roxb. Corom, t, 227. Asiat, Research. $X T, t, 4$. Sims in Annal, of Bot, $t, 13$. Rose. Soitam, $t, 112$. Presl Reliq. Haenh. . 19. Bot. Reg. t. 999. Wallich Pl. As. rar. t. 929. Ruiz et Pav. Fl. peruv. $t, 1 . f .6 .1,2 .-\mathrm{Ca}$ d amo m u mumph. Amboin. $V_{0}, 2.5, f$. 1 . Mare a ga et A le$x$ is Salisb, Hornsted $t$ ia Retz Óserv. YT. 18.

16\%ซ. Elettaria RHEED. Calyx tubulosus, tridentatus, Coroll a e tub us elongatus, filiformis, limbi laciniae exteriores laterales postica angustiores; interiores laterales minimae, denticuliformes; 1 a b e 11 u m maximum, explanatum. Fil am entum complanatum, indivisum, truneato-emarginatum, supra antherac muticae loculos lateraliter adnatiss haud productum. Ovarium inferum, triloculare. Ovula in loculorum angulo centrali plurima, horizontalia, anatropa. Stylus filiformis, inter antherae loculos transiens; $s \mathrm{tigma}$ infundilouliforme. $\mathrm{C}$ a psula trilocularis, loculicido-trivalvis. Semina plurima, arillata. - Herbae in India orientali tropica indigenae; habitu Amomi, inflorescentia radicali, densius laxinsve spicata, bracteata.

Elettaria Rheede Malab. XI. 9. t,4.5. Dav. White et Mattou in Linn. Transaot, X. 229. Blume Enumerat, plant, Jav, $I$. So. M a t to nia Snith in Rees Cyclop.

a) CARDAMOMUM Salisb. Infforescentia laxe spicata.

White l. c. t. 4. S. Alpinia s s. Roxb, Corom, t, 27. 254, 326. A mo $\mathrm{m}$ i s p. Sonnerat Voy,, , 136.

b) GEANTHUS Reinw. Inflorescentia dease spieata v. capitata bracteisque imbricata.

Geanthus Reiawardt ex Blume Enumerat, plant. Jay. I. 51 .

1698. Donacodes $B L U M$. C a I y $x$ tubulosus, tridentatus. Cor oll a e tub us elongatus, 
filiformis; limbi la einiac exteriores laterales postica angustiores, interiores laterales minimae, denticuliformes; I abell um maximum, explanatum. Fila m e n $t$ um eomplanatum, ultra a $\mathbf{n t h e r a m}$ muticam in lobulum brevissimum, rotundatum, integerrimum productum. O varium inferum, triloculare. $\mathrm{O} \vee \mathrm{ula}$ in loculorum angulo centrali plurima, horizontalia, anatropa. St $\mathbf{y}$ Jus filiformis, inter antherae loculos transiens; stig ma infundibuliforme. Ca p s la trilocularis, loculicido-trivalvis. S e m i n a plurima, arillata. - Herbae moluccanae, Amomi et Elettarite habitu; inflorescentia radicali, dense spicata, bracteata, e rhizomatibus ut plurimum epigaeis, repentibus erumpente.

Donacodes Blume Enumerat, plant, Jav, I. 54 .

1629. In aracoles BLUM. C a lyx tubulosus, tridentatus. Co $r o 11$ a e tubus brevis, limbi laciniac exteriores laterales postica augustiores, interiores laterales nullae; la-

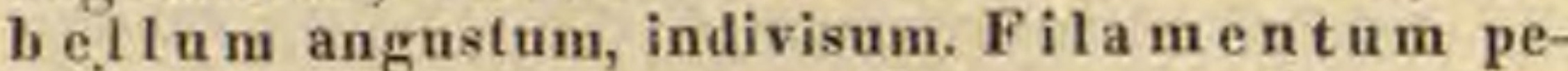
taloidenm, apice supra a $\mathrm{nthe}$ ram mnticam producto bilobum. Ovarium inferum, triloculare. Ovula in loculorum angulo centrali plurima, horizontalia, anatropa. Stylus filiformis, inter antherae locnlos transiens; $s \mathrm{tigma}$ infundibuliforme. Capsula trilocularis, loculieido-trivalvis. Semina plurima, arillata. - Herbae moluccanae, Amomi habitu; inflorescentia terminali, dense spicata, bracteis lineari-lanceolatis cincta.

Diracodes Blame Enumerat, plant. Jav. 1.55.

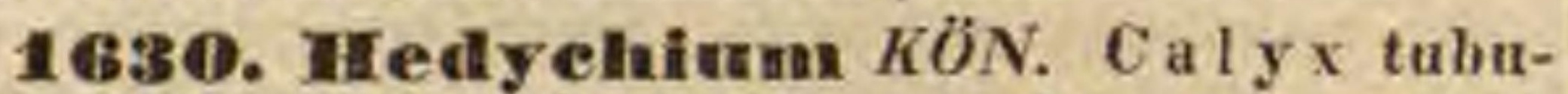
losus, tridentatus. Corollae $\mathrm{t}$ ub us elongatus, gracilis, limbi laciniac exteriores anga. stae, aequales, interiores conformes, paullo breviores; labell $\mathbf{n m}$ majus indivisum, v. saepius emarginatum aut bifidum. Fil a m e $t u m$ filiforme anthera terminalis, incumbens, utrinque emarginata. Stylns filiformis; stigma infundibuliforme. Ovari um inferum, triloculare. Ovula in loculorum angulo centrali plurima, horizontalia, anatropa. C a p s u la trilocularis, loculicidotrivalvis. Sem in a plurima, arillata. - Herbae in Asia tropica obviae, caulescentes; radicibus tuberosis, articulatis, horizontalibus, foliis in vaginis semiamplexicaulibus subsessilibus, inflorescentia terminali, spicata, spathis imbricala, floribus fasciculatis, bracteis involutis.

Hedychinm Kouig in Retz observ. III. 73. Blume Enumerat, plant. Jav. I. 55. Jaeq. Fragm, t. 130. 137. f. 1. Redouté Liliac, $t, 436$, Roxb. Corom, $t, 251$. Hooker exot, Flor, t. 46. Rose. Scitam, t. 3.4. 12. 13. 19.20, 28.29.35.36. 44, 45, 53, 60, 77, 85. Bot. Mag. $t$, 708, 2078, 2300, 2378, 3637. 2969.3039. Bot. Reg, $t, 157,526,767.774,1092,1209$. Wallich Pl. as, rar, t, 285. G a n d s uli um Ramph. Amboin, $V, t, 69$. f. 3 .

SECTIO IV. ALPINIAE Blume Enum. plant. Jav, I, 41. Herbae perennes; inflorescentia caulem v. scapum terminante, ut plurimum laxe paniculata v. racemosa.

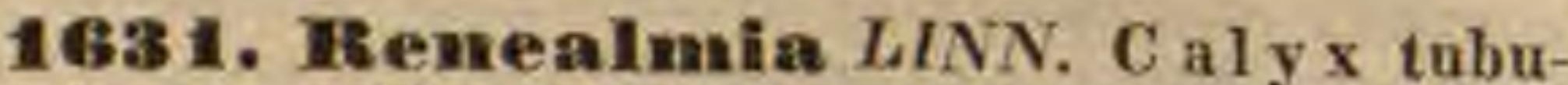
losus, laxus, tridentatus. Corolla e tubus brevis, limbi lacinae exteriores aequales, erectae, subconvolutae, interiores denticuliformes; lab ell um erectum, filamentum amplectens. $F \mathrm{i}$ lame ntum complanatum, brevissimum, uItra antherae muticae loculos laterales haud prodectum. Ovarium inferum, triloculare. Ovula in loculorum angulo centrali plurima, horizontalia, anatropa. Stylus filiformis, inter antherae loculos transiens; stigma capitato-trigonum, C a p sula trilocularis, loculicido-trivalvis. S emina pauca, arillata. - Herbae americanae tropicae; rhizomate repente, foliis distichis, in florescentia scapum radicalem $v$, caulem terminante, ut plurimum laxe racemosa, floribus singulis saepius intra involucrum calyciforme, inferum.

Ren e a I mi a Linn. Suppl. ?. Rase. Scitam, t, 108, A1 p in i a Plum. gen, 11. Gairto. $I .36, t$. 12. Pōppig et Endl. nov. gen. ot sp. II. t.134_136. G e th y r a Salisb. in Hor. tio. Transact, I, 282. P e p e rid i u m Lindl. introduct. edit. II, 446. (Bot, Reg, t, 777, Bot, Mag, t, 2494.)

1632. Alpinia LINN. Caly $x$ tubulosus, laxus, apice rumpens. C or oll a e tub u s brevis, limbi laciniae exteriores aequales, erectiuseulae, interiores laterales denticuliformes v. nullae; la b e 1 l $\mathbf{~ m ~ m a g n u m , ~ e x p l a n a t u m , ~ i n t e - ~}$ grum v, bi-trilohum. F i a $m$ e $\mathbf{t} \mathbf{n} m$ lineare, ultra antherae muticae, emarginatae loculos hand productum. O $\mathbf{v}$ a $\mathbf{r} \mathbf{i} \mathbf{m}$ inferum, trilocnlare. Ovula in loculorum angulo centrali plurima, horizontalia, anatropa. Stylus filiformis, inter antherae loculos transiens; st ig m a capitato-trigonum. Ca p s u l a baccata, trilocularis, indehiscens. Semina plurima, v. abortu pauea, arillata. - Herbae asiaticae tropicae; radicibus crassis, tuberosis, horizontalibus, caulibus pluribus, perennantibus, foliis bifariis, lanceolatis, vagina fissa, ligulata, inflorescentia caulem terminante, paniculata $v$. laxe racemosa aut spicata.

Alpinia Linn, gen. $n$. 4. exel. sp. Blume Enumerat, plant. Jav. I, 58, Roxb. Corom, t, 27. 254.326. Rose. Scilam. t, 5, 6, 21.56, 61, 87, 93, 102, 103, Bot, Reg. t. 141, 428, $\mathrm{Z}$ er u m be t Jaeq. Fragm. t. 68. Wendl. Hort, herrenh, $t, 19$. C ostus Pers. Synops. 1. 3, E than ium Salisb. in Hor-

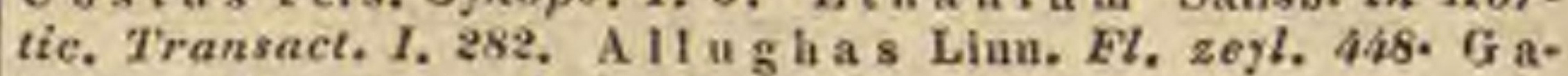
I a g a Rumph. Amboin, $V, t, 63$,

obServatio. Alpinam magnifie am Rose. Bot. Mag. t. 3192. el. Lindley introduct. edit. $I I, p .466$. P h a e ome ri a e nomine designat, sed charactere nullo distinguit; nobis plantae, ex icone solum cognitae, structura vix satis ab Alpiniis recedere videtur.

1633. Leptosolema PRESL. C a 1 y $\mathrm{x}$ tubulosus, apiee bifidus. Corolla e tubus elongatus, filiformis, limbi laciniae exteriores patentes, aequales, interiores laterales brevissimae, inter se in squamam filamentum postice stipantem connatae; 1 ab ell $1 \mathrm{~nm}$ majus, indivisum, dependens. F i l a $m$ e $\mathbf{n} \mathbf{t} \mathbf{m}$ brevissimum, truncatum, ultra a $\mathrm{n}$ he ra e locnlos apice divergentes hand produetum. Ovariu m inferum, triloculare. Ovula in loculorum angulo centrali plurima, horizontalia, anatropa. St y lus filiformis, inter antherae loculos transiens; s $t i g-$ ma infundibuliforme. C a psula trilocularis loculieido-trivalvis. Semina plurima, arillata. Herba luconensis; caule erecto, folioso, foliis oblongis, acuminatis, in vagina fissa ligulata sessilibus, panicula florum sessili, terminali, ramosa, basi bracteata.

Leptos ole na Presl Reliq. Haenk. I, 111. $t, 18$.

1634. Castroelhilus $W A L L$. Caly $\mathrm{x}$ tnbulosus, hine fissus. Coroll a e ta bus elongatus, filiformis, limbi la einiace exteriores aequales, patentes, interiores laterales latiores, basi cum filamento in tubum connatae; 1 a be I$1 \mathrm{um}$ maximum, saccatum. Fil a ment um lineare, ultra an herae muticae loculos connectivo longiores haud productum. Ovari $u \mathrm{~m}$ inferum, triinculare. Ovula in lotulorum angulo centrali plurima, horizontalia, anatropa. Stylus filiformis; stigma capitato-convexum. Capsula. Herbae indica e, acaules $v$, caulescentes; radice 
repente v, fibroso-ramosa, tuberibus subsessilibus fasciculatis, spica radicali $v$. terminali imbricata, floribus nutantibus.

Gastrochil us Wallieh Pl, As. rar. I. 29, $t, 24,25$.

1 G3.5. Hellemia WILLD. Caly $\mathrm{x}$ tubulosus, apice bi-tridentatus. Corollae tubns brevis, limhi laciniae exteriores laterales patentes, postica major, ereeta, interiores laterales minimae, denticuliformes; 1 a bell u m majus, patens. Filamentum lineare, ultra a $\mathrm{th}_{\mathrm{m}} \mathrm{e}-$ $\mathbf{r a m}$ marginalem muticam in lobulum brevissimum, rotundatum, integrum v. bilobum productum. Ovarium infernm, trilocnlare. Ovula in loculorum angulo centrali plurima, horizontalia, anatropa. Stylas filifurmis, inter antherae loculos transiens; $8 \mathrm{tig} \mathrm{ma}$ infundibuliforme. Ca $\mathrm{p}$ sula crustacea, trilocnlaris, loculicido-trivalvis. Semina plurima, arillata. - Herbae Alpiniae habitu, in Asia tropica indigenae, in Novam Hollandia extratropicam orientalem evagantes; inflorescentia paniculata $v$. laxe racemosa, caulem terminante.

Hellenia Willd, sp. I. 5, R. Brown prodr. I. 308. Blume Enumerat. plant. Jav. I. 60. Rose. Scitam. 1.30. Pres! in Heliq. Haenck, , 2t, Herit i e r a Retz Observ. VI, 17, $t$. 1. L a ng a a s König apud Retz op, cit. III. 67. (De germinatione efr. Mirbel in Annal. du Mus. XVT. $\iota, 19 ., f .2$. 1_8.)

1638. Nonoloplens $W A L L$, Ca ly $\mathrm{x}$ tubulosus, hine fissus. Corollae tubns elongatus, filiformis, limbi laciniae exteriores angustae, aequales, laterales erectae, postica deflexa, interiores laterales latiores, patentes; Iabell um bifidum. Filamentum lineare, complanatum, supra a ntheram muticam in ligulam obtusam, indivisam, reflexam productum. Ova ri$\mathbf{u m}$ inferum, triloculare. Ovu la.... Stylus filiformis; stigma infundibuliforme. Ca psn la. - Herba indica, caulescens; radice simplici, fibrosa, foliis oblongis, petiolatis, spica terminali, basi spatha nervosa involuta.

Monolophus Wallich $P l$. As, rar, $r$. 2f, Kămpferia elegans Wallich op, cit. t.27.

$163 \%$. Cenolophom $B L U M$, Ca lyx .

Corollae tubus.... limbi laciniae exteriores...., interiores laterales minimae, denticuliformes; labellum maximum, concavum. Fil a mentum compressum, ultra anthe r a in eristam subrotundam, cucullatam, obsolete quadridentatam productum. Ovarium inferum, triloculare. Ovula plurima. . Stylus. .... Capsula trilocularis.... Semina plurima....- Herba c elebica, habitu Alpiniae; caulibus maximis, foliis oblongo-lanceolalis, subtus villosis, inflorescentia terminali, racemosa.

C e nolophon Blume Enumerat, plant. Jav, 1. 60,

SECTIO $\mathrm{V}$. COSTI Blume Enumerat. plant. Jav. I. 41. Herbae perennes, foliorum vaginis tubulosis. Inflorescentia terminalis, dense spicata.

1638. Costas LINN. Cal y $\mathrm{x}$ tubulosus, trifidus. Corollac $\mathbf{t} \mathbf{u} \mathbf{b} \mathbf{s}$ infundibuliformis, limbi laciniae exteriores aequales, conniventes, interiores laterales nullae; label$1 \mathrm{um}$ maximum, campanulatum, dorso fissum. Filamentum petaloideum, supra antheram intramarginalem longe lateque productum. Ovarium inferum, triloculare. Ova la in loculorum angulo sentrali plurima, horizontalia, anatropa. S tyI s filiformis, inter antherae loculos transiens; stig m a bilamellatum, basi cornieulis binis instructum. Cap sula trilocularis, loculicido-trivalvis. Semina plurima, arillata. Herbae inter tropicos totius orbis, imprimis tamen As i a e repertae; radicibus tuberosis repentibus, foliis subcarnosis, vaginis petiolaribus supra folii insertionem in ochream oblique truncatam productis, inflorescentia spicata, terminali $v$. rarius radicali, bracteis imbricata.

Cost us Linn. gen, n. 3. Blume Enumerat, plant. Jav. I. 61. Jaeq. Ic, rar. t.1. Rose. Scilam. t.7.32, 55. 104. 110. 111. Bot. Reg. t. 683.899. Hegetsehw. Scilam, t, 3. f. 18_29. Tsjan a Gmel. Syst. 9. B a n k 8 e a Konig apud nets Obs. III. 75. Helle a ia Retz Obs. VI. 18. Gitis a ut he Salisb. Alpiniae sp. Jaeq. Amer, $t, 1, I c$, rar, $t, 202$. Hort, schünbr. $t$. 1 .

\section{GENERA DESCISCENTIA.}

1639. VIonoeystis $L I N D L$. Cal y $\mathrm{x}$ tubulosus, apice constrictus, limbo brevissimo, trilobo, reflexo. Corolla e tubus brevis, limbi laciniae exteriores aequales, lineares, apice cucullatae, erecto-patentes, interiores laterales minimae, dentieuliformes; 1 abe 11 a m majus suborbiculatum, complicatum, apice emarginatum, margine crispum. F i l a m e $\mathbf{t} \mathbf{~ a ~} \mathbf{m}$ lineare, ultra anther a e erectae loculos arcuatim convergentes hand productum. Ovarium inferum, spongiosum, uniloculare. Ovu I u m unicum, e basi erectum. Stylus filiformis, inter antherae loculos transiens; stigma trigonum, carnosum, cucullatum. Fruetus. . - Herba chinensis, caulescens ; foliis ovali-lanceolatis; acuminatis, ligula biloba, racemo terminali brevi, simplici.

M o no eys tis Lindley introduct. edit. II. p. 445. H el. I e $\mathrm{i}$ a a b a o $\mathrm{rm}$ is Lindley in Hortic. Transact. VII. 60.

1640. IKolewratia PRESL. Caly $\mathrm{x}$ tubulosus, hine fissus. Corollae tubus brevis, limbi laciniace exteriores aequales, laterales revolutae, postica erecta, fornicata, interi ores minimae, denticuliformes; labellum erectum, apice patens, trilobum. Filame nt $\mathbf{u m}$ lineare, ultra antherae mutieae loculos in lobulum brevissimum, obtusum productum. Ovarinm inferum.... Ovula. ... Stylus filiformis, inter antherae loculos transiens; $8 \mathrm{t} \mathrm{i} g \mathrm{~m}$ a infundibuliforme. Capsula lineari-laneculata, coupressa, bilocularis. Se min a in Ioculis solitaria, linearia, e basi erecta. - Herba $l u z$ on ens $i s$; caule erecto, foliorum distichorum vaginis obtecto, racemo terminali simplicissimo, pendulo, floribus distantibus, bractealis.

Kolowratia Presl in Neliq. Haenk, I, 113. t. 20.

OBSERVATIO. Quid Ny cto p by Iax? geuus novum ex Amomearum ordine, In Nova-Guinea a $\mathrm{Z}$ ip pelio defeetum, et in Flora 1829. p.286, nominatum. H itche a i Wallich, a cl. Lindley introduct, edit. II. p. 324. inter Amomum et Ziagiber collocata, milii penitus iguota est.

\section{Ordo LXIX. Camnaceae.}

CANNEAE R. Brown prodr, I.307. Lindley in Bot, Reg. 932. CANNACEAE Agardh Aphorism. 181. Bartl. ord, nat. 61. MARANTACEAE Lindley introduct, edit. II, p. 324.

Herbae rhizomate repente v. saepius radice fibrosa perennantes. Caules simplices v, apice ramosi, e vaginis scapum ambientibus conflati. Folia alterna, simplicia, petiolata, peti oli basi vaginantes, vaginae ore nudo, ad apicem saepius nodoso incrassati, geniculati, lamina plana, lata, integerri- 
ma, nervo medio valido, ntrinque nervos secundarios, simplicissimos, obliquos v. transversos, apice incurvos exserente. Inflorescentia terminalis, v. e foliorum vaginis lateralis, racemosa v. paniculata.

Fuores hermaphroditi, irregulares, b racteis suffulti, involucro communi spathaceo nullo.

Perigonium duplex, utrumque epigynum, exterius calyeinum triphyllum; interius corollinum sexpartitum, lacini is biseriatis, exterioribus subaequalibus, interioribus inter se plus minusve dissimilibus, varie cohaerentibus, nonnullis interdum minimis $v$, plane abortivis.

Stramsi unicum, corollae laciniae interiori laterali insertum. Filamentum filiforme v. lineare, petaloidenm. Anthera unilocularis (loculo altero abortivo), terminalis v. lateri filamenti adnata, longitudinaliter dehiscens. Polli n is granula globulosa, laevia v. echinata.

Ovarium inferum, triloculare, v, rarissime uniloculare. Ovula in loculis ut plurimum solitaria, angulo centrali prope basim inserta, campylotropa, rarius plurima, in loculorum angulo centrali biseriata, horizontalia, anatropa. Styl us crassiusculus, saepius uncinatus, v. linearis, petaloideus. Sti gin a terminale incrassatum, v. laterale adnatum.

Capsula unilocularis, v. ut plurimum trilocularis, loculicido-trivalvis ; loculis monospermis v. polyspermis.

Syuiva, dum in loculis solitaria uncinatosubglobosa, dum plurima angulato-subglobosa; testa coriacea, dura, umbilico basilari exeavato-impresso, arillo nullo. A l bum en farinaceum v, corneum, cavitate centrali homotropa, i. e. recta $\mathrm{v}$. uncinata, pro lectulo embryonis exsculptum, rarius cavitatibus pluribus parallelis, centrali solum embryonifera, lateralibus vacuis.

Eurryo in seminibus anatropis orthotropus, axilis, cylindricus, albuminis fere longitudine, extremitate radiculari albumen perforante et umbilicum attingente, colyledonari apice sub inflexa; in seminibus campylotropis nunc lromotropus, uncinat us, extremitate radiculari umbilicum attingente, cotyledone lectuli embryonalis crus alterum plus minus replente, nunc rectus, totus in lectuli crure radiculari locatus, cavitatis crure altero plane vacuo, unde in semine excentricus.

Cannaceae a $Z$ ingiberaceis staminis in corollae lacinia interiore laterali sitı, et vitelli defectu distinctae, ut plurimum Americam tropicam et subtropicam incolunt, in $\Lambda$ siae et $A$ fricae regionibus tropicis multo rariores, aromatico principio carent, sed rhizoma plurimarum fecula nutriente scatet.

1641. Thalia $L I N N$. Cal y x triphyllus. Corollae sexpartitae laeiniae exteriores subaequales, interio r $\mathbf{n m}$ lateralium altera unruiculata, altera basi processubus hinis filiformibus; I a be 11 u m semicirenlare, cueullatum. Filamentum filiforme, corollae laciniae laterali bisetosac insertum; an the ra laterali. Ovarin m inferum, uniloculare. Ovnlum nnicum, basilare, campylotropum. Styl us crassns, spiralis; 8 tigm a coneavum, inflexum, perforatum, subbilabiatum, labio inferiore elongato. Capsul a uniloea laris, monosperma. Semen uncinato-subglobosum, te sta crustacea, fusca, opaca. Albumen corneum. Embryo homotropus, uncinatus, extremitate radiculari umbilieum attingente; cavitates duae vacuac, embryonis lectulo parallelae. - Herbae in America boreali calidiore et tropica indigenae; foliis petiolatis, pruinosis, scapo pulverulento, spica florum composila, floribus intra spahtham bivalvem ut plurimum geminis, nudis $v$, bracteolatis.

Thalla Linn, gen, n, 8. Fraser et Sowerb. Monogr. Rose. Scitam, 1. 75. 76. R. Brown prodr. 307. Bot, Mag. t. 1690. Nees in Linnaea VI. 309, $t .4$. Peronia DC. Redouté Liliac, $t, 372$.

I648. Naranta PLUM. Ca $1 \mathrm{y} \times$ triphyllus. Corollae sexpartitae lacinia exteriores aequales, profundius distinctae, interiores laterales minores; I a bellum bifidum. FiI a me ntum petaloideum, bipartitum, hinc: a $\mathbf{n}$ theriferum, illine stylum involvens. Orariu $\mathrm{m}$ inferum, uniloculare. Ov $\mathbf{1} \mathbf{\mathrm { m }}$ unicum, basilare, campylotropum. Stylus carnosus, incurvus; stigma subtrigonum. B a cea monosperma. Semen uneinato-subglobosum, testa dara, rugosa. Albu ue corneum. Embryo homotropus, uncinatus, extremitate radiculari umbilicum attingente, cotyledone lectuli crure breviore. - Herbae in Americatropica in digenue, in $A$ sia rarissimae; caule herbaceo $v$. suffrutescente, puniculato, inflorescentia terminali, spicata $v$, racemosa.

Marauta Plum, gen, 36. Linn, gen, n, 5. HegetscliwScitam. t, 4. f. 23 28. Rose, in Linn, Transact, VHI. t. 20. f. 2. Nees in Linnaea VI, t. 3. Wallich Pl. As, rar. 1.286. Bot. Mag. t. 2398.

1643. Flneynioun $W I L L D$. C a l y x triphyllus. Corollae sexpartitae la ciniae exteriores subaequales, interiores laterales majores, inter se subinaequales; 1 abe $11 \mathrm{um}$ minus, bilobum. Fil a m e $\mathbf{n} \mathbf{u m}$ breve, in corollae lacinia interiori laterali insertum, anthera terminalis. Ovarium inferum, triloenlare. Ovula in Ioculis solitaria, hasilaria, campylotropa. Sty. Ins superne uncinatus; $8 t i g$ u te incurso, subinfundibuliformi. Ca p 8 n a triloeularis, loculieido-trivalvis. Semina in loculis solitaria, uncinata. Al bu nen corneam. Embryo rectus, excentricus, extremitate radiculari umbilicum attingente, lectuli embryonalis homotropi crure altero vacuo. - Herbae perennes, inter tropicos Asiac et Americae indigenae; radice repente, foliis longe petiolatis, caule nullo $v$, apice monoplyllo aut folioso, inflorescentia radicali $v$. terminali, spicato-capitata v. laxe capitata aut paniculata.

Phry nium Willd, sp. I, 17. Roxb, in Asiat, Research. $X I, t, 3$. Pöppig et Endi. nov, gen. et sp. t.125_128. Phy llades Laureiro Fl, cochinch, I, 16. 
1644. Calathea G. F. W. MEYER. Ca15 x triphyllus. Corollae sexpartitae lacinia e exteriores lanceolatae, interiores obtusae; la be $11 \mathrm{um}$ concavum, hine dente auctum. Filamentum petaloideum, a $\mathrm{th}$ era lineari, adnata. Orarium inferum, triloculare. Ovula in loculis solitaria, basilaria, campylotropa. St ylus petaloideus; stigma trigonum. Cap sula trilocularis, trisperma, v. abortu nnilocnlaris, monosperma. Semen uncinato-oblongum, umbilico lasilari foreato, testa coriacea. $A 1 \mathrm{bumen}$ arinosum. E $m$ b ry o rectus, excentricus, extremitate radiculari umbilicum attingente, lectuli embryonalis crure altero vacuo. - Herbae in America tropica indigenae, excelsae; foliis longe petiolatis, radicalibus maximis, spicis terminalibus, imbricato-bracteatis.

Cal a thea G. F. W. Meyer Esseq. 6. Bot. Reg. t, 932. 962, 1210, Pōppig et Endl. nov. gen. et sp. t. 129_131. G ö ppertia Nes in Linnaea VI. 337. M a rautac sp. Anet. Bot. Reg. t.485, 786. Bot. Mag. t.1926. Rose. Scilam. t.39.

1645. DIyrosma LINN. $F$, C a $l y \times$ triphyllus. Corollae limbus exterior tripartitus, interior bilabiatus, lahio superiore bifido breviore, inferioris trifidi laeinis longioribns, apice trilobis. Filame ntum subulatum, labii inferioris laciniae mediae margini adnatum, an $\mathbf{t h} \mathrm{e}$ ra ovata, compressa. Ovarium inferum, triloculare. Ovul a in loculorum angulo centrali plarima, horizontalia, anatropa. Stylus crassus, trigonus, deffexus, longitudinaliter fissus; stigin a bilabiatum. Capsula trilocularis, loculicido-trivalvis. S em ina plurima, angulata. ... Herbae americanae tropicae; caule apice monophyllo, racemis solitariis lateralibus, bracteis alternis diphyllis, bifloris, dense imbricatis.

M yrosma Lion. fil. Suppl, 8. Plirynii sp. Rose. Scitam, t.94,

1646. Canma LINN. Calyx triphyllus. Corollae limbus exterior trifidus, interior bilabiatus, labio superiore bi-tripartito, $r$. abortn nullo, inferiore indiviso. Fil am entum petaloideum, anthera marginali. Ovarium inferum, triloculare. Ovula in loculorum angulo centrali plurima, horizontalia, anatropa. S $\mathrm{t}$ lus petaloidens; stigma lineare, margini ad natum. Capsula membranacea, papilloso muricata, trilocularis, loculieido-trivalvis. S e min a plurima, sulghlobosa, te st a coriacea, dura. Alb ume n corneum. Em b ryo orthotropus, axilis, cylindricus, albuminis longitudine, extremitate radiculari albumen perforante, umbilienm attingente, cotyledonis apice subinflexo. - Herbae americanae, ut plurimum tropica paucae asiaticae, perennes, paludosae; caule simplici, foliis longe petiolatis, late-ovatis, spica terminali laxa, floribus bracteatis.

C a n n a Limn. gen. n. 1, Gärtı. $I$, 37, t. 12. Redouté Liliac. $t, 33,106,200,201.354$. Raiz et Pav. Ft. peruv. $t, 1$. Hooker exot, F.or. t. 47. 48, 53. Mirbel in Annal, du Mus. XVI. . 16 f. 1 -8. Hegetschw, Seitam, t, 1. Rose. Scitam, t.

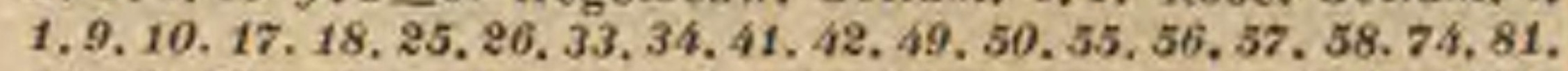
89, 89, 105. Bot. Mag, t, 444, 1968, 2085, 2309. 2316, 2317, 2323. 2498. Bot. Reg. t. 206, 470. 576. 609, 771,772 775.776.1231. 1276. 1311. 1358. C а п а е о и $\mathrm{s}$ Touruef. inst. 192.

\section{Ordo LXX. Mrusaceae.}

MUSAE Juss. gen. 61. MUSACEAE Agardh Aphorism. 180. Bartl. ord. nat.62. L. C. Richard de Musaceis Commentatio botanica, $a b A$. Richard terminata. ITralish. et Bon. nae 1831. Ato. Endl. prodr. Flor, norf. 34. Lindl. introduct, edit, $M$. p. 236.
Неrbae perennes, saepius giganteae. Canlis simplex, truncum arboreum referens, e foliorum delapsorum vaginis distinctis v. coalitis formatus, saepius abbreviatus v. subnullus. Fo li a alterna, petiolata, simplicia, integra; petiolis basi dilatatis, vaginantibus, l a $\mathrm{m}$ i n a vernatione convoluta, plerumque elongata, interdum abortiva, uninervi : nervo prominente, valido, utrinque nervos secundarios, obliquos v. transversos, apice subincurvos confertissime emittente. Peduneuli radicales $\mathrm{v}$. axillares, bra cteis alternis, distichis, spathaeformibus, acutis, amplis onusti.

Frores in axilla spathae sessiles v. pedicellati, nudi v. bracteolati, irregulares, hermaphroditi, speciosi.

Perigoniua epigynum, corollinam, simplex, hexaphyllum; foliolis inaequalibus, saepe dissimilibus, biseriatis, foli ola tria exteriora: anticum (plerumque maximum, saepe carinatum), et duo postica; tria alterna, interiora, duo nempe lateralia, saepe minora, et unum posticum, semper minimum, labelliforme; nunc omnia inter se distincta (in Ravenala et Heliconia), nunc varie inter se connata; interiora nempe lateralia (in S(relitsia) in tubum postice fissum, genitilia recipientem coeuntia, v. (in Musa) tria exteriora cum lateralibus interioribus in tubum postice apertum, apice quinquelobum concrescentia.

Stanisa sex, perigonii foliolis opposita, iisque basi v. ovarii vertici inserta, posticum (perigonii foliolo postico interiori oppositum) plerumque abortivum, nonnulla interdum castrata. Filamenta libera, planiuscula. Antherae introrsae, biloculares; loculi suboppositi, elongati, filanento ultra eosdem in acumen $v$. appendicem membranaceum prodicto utrinque adnati, paralleli, longitudinaliter dehiscentes. Polli in is granula globulosa.

Ovarium inferum, triloculare; loculi perigonii foliolis interioribus oppositi. O $\mathrm{vula}$ nune (in Uranieis) plurima, angulo centrali loeulorum bi-pluriseriatim inserta, nunc (in Heliconieis) in loculis solitaria, e basi erecta, anatropa. Stylus terminalis, simplex, teres, filiformis v. crassinsculus. Stigma tripartitum, laciniis linearibus, intus papillosis, v. obtuse sexlobum, excaratum.

Froctus apice perigonii delapsi cicatrice umbilicatus, trilocularis, loculis mono-polyspermis, nunc (in Musa) carnosus, indehiscens; seminibus in pulpa nidulantibus, aut subdrupaceus, epicarpio coriaceo-carnoso, endocarpio osseo, loculicido in valvas tres, medio seminiferas (in Ravenala), 
v. septicido in cocca tria monosperma (in $\boldsymbol{H e}$ liconia) dehiscens.

Semina ovoidea, altera extremitate v. cen tro affixa, funic u lo subnullo, v. in aril I u m membranaceum, lacerum aut pilosum (in Ravenala oleo essentiali scatentem) fatiscente. Testa coriacea, dura, laevis $\mathbf{v}$ rugulosa, chalaza umbilico e diametro opposita, rhaphe vix manifesta. Albumen album, farinaceo - carnosum.

Eмввхо orthotropus, axilis, oblongo-linearis v. fungiformis; extremitate radicuI a ri brevi, obtusa, albumen perforante, umbilicum attingente, in fructu infera $v$, centripeta.

Musacea e florae tropicáe eximia decora, ob nonnullarum fructus sapidissimos, et multiplicem foliorum usum, maximi in humani generis oeconomia momenti. Uranieae, pancissimis demtis, in veteri orbe sunt indigenae, $\mathrm{tr}$ o $\mathrm{p}$ i $\mathrm{cis}$ potissimum inclusae circulis. M us a e species nonnullae, olim in Americam introductae, nunc per utrumque continentem vulgatae. Heliconieae solam Americam tropicam incolunt.

Ordo Scitaminearum classim absolvit, staminibus omnibus perfectis, et principii aromatici defectu ab $\mathrm{Am} \mathrm{m} \mathrm{me}$ i s et Cannaceis distinctus, ab Amaryllidis perigonio irregulari potissimum diversus.

TREIBUS I. HELICONIEAE A. Richard Musac. 13. Stmina in loculis solitaria. Dehiscentia septicida.

164\%. IIItheomia LINN. Perigon ii epigyni foliola exteriora aequalia, basi in ter se concrescentia, interiora lateralia subconformia, approximata, genitalia amplectentia, posticum nanum. Stamina 5 , sexto postico abortiente, basi perigonii adnata. Ova rium inferum, triloculare. Ovnla in loculis solitaria, e basi axeos adscendentia, anatropa. Stylus filiformis; stigma depressiuseulum, obsolete sexlobum. Capsula subdrupacea, tricocea, coccis osseis, indehiscentibus. Semin a in coccis solitaria, obovato-subglobosa, basifixa, $\mathrm{te} \boldsymbol{s} \mathbf{t a} \mathrm{ab}$ endocarpio vix solubili. Embryo orthotropus, linearis, in axi a $\mathbf{l}$ b u $\mathrm{m}$ i $\mathrm{n}$ is farinaceo-carnosi, extremitate radiculari umbilieum attingente, infera. - Herbae americanae tropica e; foliis longe petiolatis, petiolis basi vaginantibus, scapum radicalem saepe velantibus, spathis pluribus distichis, in axilla floriferis.

Helic onia Linn. gen. n. 129\%. Jaeq. Hort. schönbr. t. 48. 49. Bot. Mag. t.309. Bot. Reg, t.374, 1648. Hook, exot. Flor. $t, 190$. Richard Musac. 13, t, 8_12, B i ha i Plum. gen. so, ic. 59 .

TIBIEUS II. URANIEAE A. Richard Musac. 11. Semina in loculis plurima. Dehiscentia loculicida.

1648. Musa TOURNEF. Perigonium epigynum, bilabiatum; labium inferius tubnlosum, postice usque ad basim fissum, apice quinquelobum, superins coneavum, nanum am- plectens: Stamina 5, sexto postico abortivo. Ovarium inferum, triloculare. Ovula in loeulorum angulo centrali plurima, biseriata, horizontalia, anatropa. Stylus erassus; $8 \mathrm{tigma}$ infundibuliformi-clavatum, breviter sexlobum. B a c e a oblonga, angulata, trilocularis; $8 \mathrm{em}$ inibus plurimis in pulpa nidulantibus, saepius efoetis farcta. Semina depressiuscule subglobosa, testa crustacea, atra, ad umbilicum impressa. Embryo orthotropus, fungiformis, in axi albuminis subfarinosi, extremitate radiculari umbilicum attingente, centripeta. - Herbae geroniogaeae tropicac et subtropi$c a e$, in $A$ meric a $m$ introductae, giganteae; trunco e petiolorum vaginis longissimis, scapum radicalem, solo apice liberum, floriferum velantibus conflato, lamina foliorum amplissima, valide nervosa, floribus in axilla spatharum confertis, ebracteatis.

M u s a Tournef, inst, 3. Linn. gen, n, 1477. Gïrtn, $I$. 28, t.2. Jaeq. Hort. schönbr, $t$. 445. 446. Redouté Liliac, $t$ 307. 308. Bot. Reg. t. 706. Andr. Bot. Reposit, t. 47, Desv. Journ. Bot. II. 1-45. R. Brown Congo 411. Tenore in Act. Academ, pontan. 1832. A. Riehard Musac, 11, t.11. (De germinatione efr. Mirbel in Annal, du Mus, XYI, t, 18.)

OBSERVATIO. Flores Mas a e abortu saepius unise. xuales, masculorum staminibus 5, perigonium subsuperantibus, femineorum staminibus totidem, perigonio dimidio brevioribus. Semina in speciebus cultis evanida, in M, S a. pie $\mathrm{n} \mathrm{tum}$ depressiuscule subglobosa, testa crustacea, atra, ad umbilicum tubulose inpressa, in altera extremitate, umbilico e diametro opposita inerassata, et processu obtuso homogeneo intra albumen sese insinuans. Embryo parvus, fungiforais, in centro albuminis subfarinosi, friabilis, a testae processibus utrinque umbilicati locatus, extremitate radiculari umbilicum attingente.

1649. Strelitzia $B A N K S$, P e rig o n i epigyni foliola exteriora subaequalia, anticum carinatum; in terio r a lateralia exterioribus subconformia, inter se connata, acuminata, la tere versns medium auriculata, genitalia amplectentia, posticum nannm, concavum. Stamina 5 , sexto postico abortiente. Ovari $u m$ inferum, trilocnlare. OVula in Joculorum angulo centrali plorima, biseriata, horizontalia, anatropa. StyI us filiformis; $8 \mathrm{tigma}$ tripartitum, laciniis linearibus. Capsula trilocularis, loculicido-trivalvis. Semina plurima, snbglobosa, funiculo brevi, in a rillu m stupposum fatiscente affiva, testa fuliginea, Iaevi. E mbryo orthotropus, linearis, in axi alb uminis farinaceo-cornei, extremitate radiculari umbilicum spectante, centripeta. - Herbae capenses; foliis radicalibus maximis, distichis, longe petiolatis, petiolis canalieulatis, basi dilatatis, vaginantibus, scapo radicali vaginis velato, floribus e spatha terminali obliqua erectis.

Strelitzia Banks in Ait. Hort. kew. I. 285. t, 2. Ker Strelitziae pictae. Redonté Liliac, $1.77,78$, Bot. Mag, $t, 119$. 120. Bot. Reg. t. 516. Richard Musae, 12, t, 2-3, -? H eI i со ді a Gärtn. II, 270. t.130.

1650. Ioavenala $A D A N S$. Perigoni epigyni foliola exteriora aequalia, antieum carinatum; interiora paullo minora, lateralia aequalia, approximata, genitalia amplectentia, posticum subconforme, nonnihil brevius. St amin a 6 , omnia perfecta. O va ri $u \mathrm{~m}$ inferum, triloculare. Ovala in loeulorum angulo centrali plurima, biseriata, horizontalia, anatropa. Stylus crassinscolus; $8 \mathrm{tig} \mathrm{ma}$ infundibnliformi-subclavatum, apice brevissime sexdentatum. Capsu I a lignosa, trilocularis, loculicido-trivalvis. Se mina plurima, depresso-sphaerica, mediante tuberculo umbilicali, in ar $\mathrm{i} / 1 \mathbf{u m}$ pulposum (azu- 
reum) semen obvolventem fatiscente affixả, te s t a fuliginea, laevi. Embryo orthotropus, fungiformis, altero latere truncatus, in axi albuminis subeornci, extremitate radiculari umbilicum spectante, centripeta. - Planta madagasc a riensis, ordinis sui longe nobilissima; trunco palmiformi, e foliorum vaginis confluto, foliis longe petiolatis, basi dilatata vaginantibus, alterne distichis, pedunculis terminalibus distichis, floribus in axillis spatharum distiche alternantium glomerat is, bracteolatis.

R ave nal a Adans. Fam, II, 67. Sounerat Voy. II. 223. t. 124. Jacq. Hort, sehönbr, $t, 93$, U ran i a Schreb. gen, $n$, 539. Richard Musac. 12. t, 4.5.

OBSERVATIO. Ravenalae characterem ad speciem gerontogaeam, caudice palmiformi, seminibus in loculis-biseriatis, depressis, fere disciformibus, tuberculo (funiculo) umbilicalt brevissimo, arillo pulposo azureo, exsicca tione membranaceo, lacero-fibrilliso, e coeruleo in colorem thalassinum vergente, embryone denique revera fungiformi, sed altero latere superiori minus expanso, quasi dimidiato insignem, restrinximus. Musaceac americanae eapsulares polyspermae, quarum flores videre nondum contigit, typum distincti generis ( $P$ h enak os perum Endl. prodr. Flor. Norf. 34. in not. U rania guianen$\mathrm{s}$ is Riehard Musac, t. 6.7.), sistere videntur, habitu Heliconiae donati, a Ravenala seminibus in loculis pluriseriatis, obovato-subglobosis, funiculo longiusculo rigido, in arillum comoso-stuposum, hiuc semen, illinc funiculum obvolventem fatiscente, embryone denique linearl, recta protenso distineti.

\section{APPENDIX. SCITAMINEAE FOSSILES.}

165 il. Cammopliayllites BRONGN. F oli a simplicia, integerrima, nervo centrali valido, secundariis obliquis, simplicibus, parallelis, inter se aequalibus. - Terra carbonifera.

Canuop hyllites Brongs, prodr. 130.

1659. Amomoenrpanm BRONGN. F r uctus trigonus, depressus, apice perigonii eicatrice umbilicatus, faciebus planis medio s ut u$r$ a e longitudinalis vestigio notatis. - Argilla insulae Sheppey.

A m o m o e a rp u m Brongn. prodr. 129 et 137.

1 G53. Treigonoearpum BBONGN, Fructus oroideus, $\mathrm{b}$ a $\mathrm{si}$ ad pedicelli insertionem impressus, sexcostatus, cost is basi incrassatis, tribus validioribus, apice a re ol a magna, hexagona, centro a styli insertione umbilicata exsculptus. Terra carbonifera.

Trigonocarpum Brongn. prodr, 137. Palmaeites Sternb, t. 56. f.6.7. t.58, f.3. (Parkins. Org. rem.t.1. t. $7 . f .6-8$.)

1654. IIusoearpum BRONGN. F r uctus eylindricus, b a $\mathrm{i}$ attenuatus, pedicello continuus, sexcostatus, apice arcola magna, hexagona, centro a styli insertione umbilicata exsculp tus. - Terra carbonifera.

Musocarpum Brongn. prodr. 137.

\section{Classis XX. Fluviales.}

Herbae aquaticae, foli is alternis v. rarissime oppositis, simplicibus. Flores monoici v. dioici, rarius hermaphroditi. PeriGosium nullum v. rudimentarium, rarissime perfectum. Stamisa simplici laciniarum perigonii numero. Ovaria solitaria $\mathbf{v}$. in eodem flore plura, libera, uniovulata. Ovusum erectum v. saepius pendulum, orthotropum v. campylotropum, rarissime anatropnm. Frucrus capsulares v. nucamentacei, monospermi. Skmixa exalbuminosa. Eмвryo macropodus, antitropus v. homotropus, extremitate radi cu l ar i infera.

\section{Drdo LXXI. Najadene.}

NAJADES Juss. gen. 18, excl. sp. FLUVIALES Vent. Tabl. II. 80. POTAMOPHILAE L. C. Richard. NAJADEAE $\Lambda$. Richard elem. 416. Barll. ord. nat, 21 ,

Неввав aquaticae, submersae, nonnullae sub florescentia emergentes, annuae v. saepius perennes, caule tereti v. compresso, nodoso articulato, saepissime repente, radicante, $\mathbf{r}$ a m i s adscendentibus, fluctuantibus. Folia alterna, saepissime approximata, rarissime opposita, petiolata, plana, integerrima, nervosa, venosa, p e t i o l o basi amplexicauli v. vaginante, saepissime 1 a mi$\mathrm{n}$ a e abortu in phyllodium lineare, latum $v$. angustissimum, integrum v. denticulatum mutato. Stipulae intrapetiolares membranaceae, amplexicaules.

Fuores ut plurimum monoici, rarius divici, in axillis foliorum solitaril v. conferti, v, in stipite spadiciformi alternantes, feminei superiores, rarissime masculi cum femineis in florem hermaphroditum combinati.

Perigoniun in masculis saepissime nullum, nunc ejus loco $t u n i c$ a membranacea cellulosa, simplex, antheras extus vestiens, irregulariter rumpens, v, apice subregulariter fatiscens, rarius cupuliforme, antheram basi recipiens, interdum squamiforme, squamis intus antheriferis, cum ovariis combinatis, floris hermaphroditi purigonium praebentibus.

Antherae filamento brevi v. plus minus longo sustentae, nune omnino sessiles, nunc uniloculares evalves, apice ruptae, v. bivalves, nunc bi-quadriloculares, $10 \mathrm{culi}$ it plurimum connectivo plus minusve crasso sejunctis, longitudinaliter dehiscentibus. Pollen globosum, v. e filis contervoideis, dense compactis.

Ovaria nune solitaria, nunc duo v. quatuor approximata, dorso convexa, facie plana, contigua sed libera, rarissime basi cupula annulari cincta, sessilia, v. interdum suspensa, v. singula tandem pedicellata, semper unilocularia. Ovul um unicum, rarissime erectum et tune anatropum, ut plurimum e sutura ventrali pendulum, orthotropum micropyle infera, v. campylotropum, micropyle supera. Styl us simplex, v. styli $2-3$ ovario continui, interdum brevissimi, nulli. Sti gm a lineare, v. discoideo - peltatum.

Fructus unilocularis, monospermus, nucamentacens v. capsularis, ant rarius baccatus 
indehiscens, $v$, irregulariter ruptus, rarissime bivalvis, epicarpio membranaceo saepius secedente.

Semex exalbuminosum, erectum $v$. pendulum, rectum v. uncinatum, testa membranacea tenuissima.

Emвrxo macropodus, homotropus, orthotropus $v$. uncinatus, extremitate radicula ri incrassata, umbilico proxima, v, e mbryo antitropus et extremitas radicularis umbilico e diametro opposita, infera $v$. supra, extremitas cotyledonaris nunc recta, nune super radicularem prona v. etiam spiraliter convoluta, saepins rimula laterali pro emissione plumulae valde evolutae instructa.

$\mathrm{Naj}$ adeae in aquis fluentibus stagnantibusque dulcibus, et in aestuariis marinis omnium clinatum repertae, nulli ordini arcte affines sunt, praeterquam Aroideis, quae cotyledonis rimula pro exsertione plumulae quodammodo conveniunt, alias diversissimae, et Il ydrocharideis, Bntome is Alismaceis que ( $\mathrm{J}$ uncaginear $\mathbf{r} \mathrm{m}$ imprimis subordini), quae utut embryone pariter exalbuminoso donatae, perigonii et genitalium multo elaboratiori fabrica recedunt. In universum ordines amphibryii aquatici, Najadea e videlicet, Alismaceae, Butomeat et Hy drocharideae, a cl. Bartling in He$10 \mathrm{biarnm}$ classim combinatae, nobis potius certam vegetationis periodum historicam designare, quam revera inter se aretiori affinitate connexi esse videntur.

1655. Caulinia $W I L L D$. F I ores monoici, in axillis foliorum glomerati. Anthera elliptica, evalvis, basi in filamentum crassinseulum attenuata, intra tunicam cellulosam, tnbulosam, medio ventricosam, apice apertam et denticulatam f́nclusa, polline globoso foeta. Ovarium sessile, oblongum, cum tunica cellulosa connatum, uniloculare. Ovulum unieum, e basi erectum, anatropum. Styli 2_3, ovario continui, subulati, introrsum stigmatosi. N ucula monosperma, tunica cellulosa tecta. S emen e basi ereetum, ellipticnm, test a tenui, longitulinaliter striata. E m b r y o exalhuminosus, macropodus, orthotropus, extremitate radiculari umbilicum spectante, infera. - Herbae aquaticae, submersae, in stagnis Europae et Americue borealis rarius obviae; caulibus simplicibus $v$. ramosis, foliis oppositis, junioribus in axillis fasciculatis, basi dilalatis, integerrimis $v$. saepius serrulatis.

Ca ulin ia Wilti, in Act. Academ, Berolin, 1798.p. 87. non DC. et R. Br. Nees jull. Gen, plant, fase, VI, t. 9. $1 \mathrm{tt}$ nera Gmel. Flor. bad, III. $t$, 4. Naj ad is sp. Allion. Schkubr t.296.

1656. Najas WILLD, F 10 res dioici, in axillis foliorum subsolitarii. Masc. Tnniea dnplex, exterior calyptraeformis, apice bieuspidata, hine fissa, interior demum perticellata, apice in lacinias quatuor rupta. A n th er a sessilis, tetragona, abruptim apienlata, quadrilocularis, polline globoso foeta. Fem. Tunica nulla.
O va ri um sessile, oblongum, uniloculare. OvuI $\mathrm{m}$ unicum, e basi erectum, anatropum. Styli 2-3, subulati, ovario centinui, introrsum stigmatosi. Nucula monosperma, epicarpio membranaceo, secedente. $\mathrm{S}$ e m e $\mathrm{n}$ e basi eretum, ellipticum, test a membranacea, tenuissima. E mb r y o exalbuminosus, macropoilus, orthotropus, extremitate radiculari nubilicum spectante, infera. - Herba aquatica, submersa, in lacubus Europae mediae obvia; foliis alternis approximatis, linearibus, basi dilatatis, serrulatis, mucronatis.

Najas Willd in Act. Aeadem, Berolin, 1798, p. 87. $\mathrm{N}$ a $\mathrm{j}$ a s m a j o $x$ Linn. Fl. dan. $t$. 2121, Nees jun. Gen. plant. fasc. VI. t, 10. f. 1_21, Fluvialis Michel, nov. gen, $t, 8$.

165\%. Cymodacen KöN. Flores divici, in pedicello primum folii vagina incluso, mox exserto elongato solitarii. Perigo n i m nullum. M a $s$ c. An therae 2, biloculares, oppositae, dorso inter se connatae, locnlis linearibus hasi apiceque distinetis, longitudinaliter dehiscentibus, p olline confervoideo foetis. F em. Ovari a 2, lihera, approximata, dorso convexa, facie plana, sessilia, unilocularia. Ovnl nm unicum, penduIum, campylotropum. Stylus filiformis, ovario continuus; stigmat a 2 , filiformi-subulata. Ca psulae 2, membranaceae, compressae, approximatae, bivalves, monospermae. S e m en pendulum, uncinatum, cruribus subaequalibus, test a tenuissime membranacea. E m bryo exalbuminosus, macropodus, homotropus, extremitate cotyledonari aeuminata, radienlari inerassatae parallela. - Herba in maris mediterra$n e i$ aestuariis vegetans; caule sarmentoso, radicante, urticulato, foliis ad articulos congestis, linearibus, obtusis, integerrimis, basi vaginantibus.

C y mod oce a Kónig Annal. of Bot, Tr. 96.t.7. P h u cagrostis major Cavolini Monograph, 13. t.1.

OBSERVATIO. A Cymodocea, si quid e solis floribus masculis a CI. Gaudichaud ad Freyc, t. 40 . depictis judieare licet, vix differre videtur $\mathrm{A}$ m $\mathrm{ph}$ ibolis Agardh syst. Als. 192. quae Gra $и$ ü II era Reichenb. consp. 43. sive $R$ u Ppia a ut a c tic a Labill. Nov. Holl. 1.40.

165s. Thalassia SOLAND. Flores dioici. MI a sc. S p a th a scapum terminans, monophylla, bifida, laciniis oblongis, obtusis. Perig on in m triphyllum, foliolis ovato-oblongis, obtusis. Antherae 9, sessiles, perigonio breviores, conniventes.... F e m. . . - Herbae vix notae, in mari mexicano et rubro observatae; foliis in apice caudicis congestis, linearibus, obtusissimis, basi vaginantibus, integerrimis $v$. serrulato-ciliatis, scapo e centro foliorum exserto.

Thalassia Solander ex Köuig Annal, of Bot. II. 96. Z o stera e sp. Forsk. Vaht.

16 6. Zestera LINN. Flor es monoici. $S p$ atha e folii parte ima longitudinaliter dehiscente, superne in laminam producta. Spadis compresso-planus, membranacens, dorso nudus, antice staminibus ovariisque alternatim biseriatis onustus, saepius appendiculis lateralibus inflexis auctus. Antherae filamento brevissimo peltatim affixae, oblongae, uniloculares, rimula longitudinali dehiscentes, po 11 in e confervoideo foetae. Ova ria antheris paueiora, isdem oblique apposita, dorso prope apicem affixa, unilocularia. Ovulum unicum, e puneto insertionis ovarii pendulum, orthotropum. Stylus ovario continuus, subulatus, persistens; stigmata 2 , capillaria. Utriculi membranaeei, monospermi, penduli, irregulariter rumpentes. Semen pen- 
dulum, subgiobosum, testa membranacea, longitudinaliter striata. $\mathrm{E}$ m b r y o exalbuminosus, macropotus, antitropus, extremitate radic $u$ la $r$ infera, rima laterali, pro receptione cotyledonis elongatae, inflexo-curvatae. - Herbae in aestuariis maris septentrionalis, at lantic $i$ et indici vegetantes; caule repente, radi canle, foliis anguste linearibus elongalis, obtusis, integerimis, basi vaginantibus.

z os te r a Linn, gen. 1032. exel. sp. Gärtn. I. 76, t, 19. Fl. dan. t, 2041. Nees jun. Gen. plant, fasc, VT. t, 14, P h ucagrostis minor Cavolini Monograph, cit.

1640. IPesidenia $K \ddot{O} \mathrm{~V}$. F I ores hermaphroditi, in spaticibus intra sp at ha m foliaceam bivalem eongestis, singnlis spathilla bivalvi einctis, 3-6 floris, floribus inferioribns alternis, extremo terminali. Perigonium nullum. Stamina 4 , hypogyna, antherae filamentis dilatatis aristatis basi extus afficae, biloculares, locnlis linearibus discretis, longitudinaliter dehiscentibus, polline confervoideo foetis. Ovari$\mathbf{u} \mathbf{m}$ uniloculare. $O \mathbf{v} \mathbf{~} \mathbf{l} \mathbf{~ u}$ unicum, parietale, amplitropum, micropyle infera. Stigma terminale, subsessile, villosum. C a p s u 1 a baccata, monosperma. S em en longitudinaliter adnatum. Embryo exalbuminosus, macropodus, extremitate radicalari infera, rima laterali pro receptisne cotyledonis elongatae, inflexo curvatae. - Herbae in aestuariis marits mediter ru$n e i$ et indic $i$ vegetantes; caule repente, radicante, ramoso, foliorum exuviis vestito, foliis in apice ramorum congestis, busi vagrinantibus, linearibus, elongatis, obtusissimis, integerrimis v. serrulutis, scapo lineari crassiusculo, e foliorum centro exserto, spatha diphylla foliacea, basi dilatata, spathillas pluras fovente terminato.

Posidonia Konig Arnal. of Bot, 93, t, 6. Canlini a DC. Flor, fr. III. IS6. R. Brown prodr, 339. nou WVilld. Ker a era Willd, sp $I V, 937$. Zostera oceanica Lim. Cavolini Monogr. cit.

1651. IBuppia LINN. Flores hermaphroditi, duo v. plures in $s p$ adise axillari filiformi, primum folii vagina incluso, mox exserto, alterni, sessiles. Perigonium nullum. Staun in a 2, opposita; f il a m e n t a brevissima, squamulaeformia, antherae magnae, extrorsae, biloculares, medio dorso affixae, loculis parallelis, discretis, facile secedentibus, rima longitudinali dehiseentibus, poIline curvato trihilato foetis. Ovaria 4, libera, dorso carinata, farie contigua, primum sessilia, demum stipitata, unilicularia. Ovulu m unemm, pendulum, eampylotropum. Stig m a terminale, sessile, peltatum, umbilicatum. Drupae 4, s. abortu pauciores, longiuscule stipitatae, compressiusculae, gibbosae. Semen pendulum, uncinatun, cruribus inaequalibus, test a tennissime membranacea. Embryo exalbnminosus, matropodns, homotropus, extremitate cotyledonari acuminata, supra radicularem incrassatam, superam prona. - Herba in aestuariis Europae et Americac borealis vegetans; caule filiformi ramoso, foliis lineari setaceis, basi dilatato-fornicata vaginantibus.

R uрріi Linn, gen, 175. Gärtn. II, 23. t. 84. Reichenb. Iconogr, t.30G. Nees jun. Gen. plant, fasc, VI, t. 12.

166\%. Zhandelnellia MICHEL. Flores polygrami, masculi et hermaphroditi in axillis foliorum solitarii, sessiles, stipula intrapetiolari membranacea fulti. Perigonium nullum. Mas c. Stam en unicum; filamentum filiforme, teres, anthera bilocularis, loculis oblongis, dis- cretis, oppositis, connectivo exeurrenti utrinque adnatis, basi sagitatim divergentibus, polline subgloboso foetis. Hermaphr. Stamen unicum, laterale. Oraria 4 , libera, dorso convexa, facie contigua, sessilia, basi empula commnni, brevi, membranacea exeepta, unilocularia, Ovu I n unieus, pendulum, orthotropum. StyI us brevis, ovario continuus; stigma peltatum, disciforme, introrsum sublaterale. Nuculac 4, coriaceae, sessiles, dorso suberenatae, uniloeulares. Semen oblongum, pendulum, t e s $t$ a membranacea, tenui. Embryo exalbuminosus, macropodas, antitropus, extremitate cotyledonari elongata, circinnatim inflexa, supra $r a-$ dicularem incrassatam inferam prona. - Her. bue in fossis et rivulis $E$ uropae et $A$ mericat borealis obviae; foliis approximatim alternis, junioribus subfasciculatis, filiformibus, stipulis in trafoliaceis, membranaceis, latis, anplexicaulibus.

$Z$ a un ic helli a Mieheli gen,, 3 i. f. 1.2. Lina. gen, $n$, 1034. Reichenb. Ioonogr. t,756_z60. Nees jus, Gen.pl.fase, VI. $t, 1 t$,

\section{BB3. Althenia PETIT. Flores mon-} oici, in axillis foliorum. M a s e. pauci, infra femineos solitarii, in pediecllo filiformi terminales. Cupula $e$ al y $c$ in a eyathiformis, tridentata. A nther a uniea, sessilis, elongato-linearis, ineurra, unilocularis, rima longitudinali dehiscens, valvis divaricato - patentibus, tandem a connertivo crasso persistente solutis. Fem. in apice pedicellorum terni, approximatim alterni, singuli basi bractea foliacea stipati. Perigonium nullum, Ovaria subfusiformia, compressiuseula, unilocularia. Ovulum unicum, pendulum, orthotropum, Stylus filiformis, longiusculus, orario continuns; stigna peltatum, disciforme, introrsum sublaterale, Ca p sula compressa, alato marginata, unilncularis, inaequaliter bivalvis, valvis epicarpio membranaceo, tandem fatiscente connexis. Semen oblongum, compressum, pendulum, test a mem. branacea, tenui. Em b ryo exalbuminosus, ma cropodus, antitropus, ex $t$ re m it a t e eotyle donari elongata, circinnatim involuta, radienI a ri crassa, infera. - Herba tenella, caespitosa, in lacubus maritimis Galliae australis nuper reperta; canlibus repentibus, nodoso-articulatis, foliis ad nodos allernatim congestis, brevibus, basi lata nervosis, vaginantibus, nervo medio elongato excurrente aristatis, floralibus muticis.

A Ithenia Felix Petit in Annales sc, obserp. $r$, 451. c, ic. Reichenb. Iconograph. 4.755. B ellev a I i a Delile.

16B4. Fotamogretom LINN. Flores hermaphroditi, spieati. P e r i g o $\mathbf{~ i ~ u ~ m ~ c a l y c i - ~}$ num, tetraphyllum, folio lis brevissime unguiculatis, aestiratione valvatis, snb anthesi patentibus. Stan ina 4 , ungraibns foliolornm perigonii inserta; filamenta brevissima, antherae biloculares, loculis oppositis, connectivo incrassato plus minus sejunetis, longitudinaliter dehiscentibus, polline globoso foetis. Ovaria 4 , libera, sessilia, dorso convexa, facie contigua, unilocularia, Ovu I um unicum, suturae ventrali infra apicem affixum, adscendens campylotropum. St ylu s terminalis, brevissimus $\mathrm{v}$. nullus; s $t \mathrm{i} g \mathrm{ma}$ peltatum, introrsum obliquum. Nucula e 4 , compressac, putamine coriaceo v. lignoso, monospermae. Semen nncinatum, testa membranacea, tenui. Embryo exalbuminosus, macropodus, homotropus, extremitate radicnlari incrassata, infera. - Herbae in aquis stagnantibus et fluentibus regionum temperatarum et frigidiuscularum totius orbis obviae, in sona 
tropica rarae; caulibus repentibus radicantibus, nodosis, ramis demersis, compressis teretibusve, foliis distichis alternis $v$, rarissime oppositis, membranaceis, pellucidis, integris, polymorphis, stipulis intrafoliaceis, liberis $v$. folio basi vaginanti adnatis, ligulaeformibus, spicis florum axillaribus pedunculatis, emersis, basi stipula intrafoliacea ceu spatha stipatis.

Pot a moget o n Tournef. inst, 103. Limn. gen, n. 174. Gärtm. II. 23. t. 8 . Treviranus Entwickl, des Embr, 11, 12. t. 1. f. 12-15. Tittm, Koim, 43. t. 6. f. 2. Mirbel in Annal. du Mus. XVI. 446. XVII, 233. L. C. Richard Endorhiz. 11. t. 1 . f. 34 , 37. E. B. $t$. 163. 215.323.377, $397,418,1012,1285$. 1286. 1829, 1985. 2253. Chamissn in Linnaea II, 137. $t .4-6$. Nees jun. Gen, plant, fasc, VI, $t, 13, \mathrm{P}$ e 1 t o p s is Rafin.

OBSERVATIO. Epigynantbus genus novum e Najadearum ordine in epistola cl. Blume ad Neesium in Flora 1825. p. 679, solum nominatur. - Halophila Thousrs (Barkania Ehrenb.), quatu hue referre solent auctores, lon ge allena, inter $\mathrm{P}$ od os $\mathrm{t}$ e $\mathrm{m}$ m e as recensetur.

\section{APPENDIX. NAJADEAE FOSSILES.}

1695. Caulinites BRONGN. Caules ramosi, cicatricibus semiannularibus, in seriebus duabus oppositis alternantibus, punetis minimis aequalibus notatis. - Calx grossa.

Caulinites Brongn. prodr. 115. Amphytoites parisiensis Desm.

16G6. Zusterites BRONGN. Folia oblonga $\mathbf{v}$. linearia, nervis paucis aequalibus erassiusculis, secundariis nullis. - Terra glauconia sabulosa, et sedimentum superius.

Z osterites Brongn. prodr. 114, Mem. soo.h. n. Paris. I. 317.t.21. $f, 3$ _. 8. A m p h ib olis s p. fossiles Agardh in Act. Holm. 1823. p. 111, t. 2. f.8.

$168 \%$. Potamoplaylites BRONGN. Fo1ia elliptiea, nervis plurimis, convergentibus, nervulis transversis conjunctis, nervo centrali fortiori nullo. - Terra aquae dulcis, infra calcem grossam.

Potamophyllites Brongn. prodr. 114. Phyllites multinervis Descript, des envir, de Paris, 360, $, 10, f .2$.

\section{* LEMNACEAE.}

1 Bes. Temma $L I N N$. F 1 o r es hermaphroditi $v$. abortu dioici, in fissura marginali frondis lenticularis, cellulosae. Sp a tha inclusa, tenuissime membranacea, subbivalvim rupta, valvula inferiore majore. Stam in a 2, hypogyna, exserta; fil am enta filiformia, inaequalia, antherae biloculares, didymae, loculis discretis, globosis, transversim late hiantibus, polline globoso papiltoso foetis. Ov a rium sessile, ovatum, membranteeum, uniloculare. Ovula basilaria, nnne unicum semianatropum, horizontale, nunc 2_4 anatropa, ereeta. Sty 1 us cylindricus, brevis; stigma subtruncatum, depressum, papillosum. Utriculas membranaceus, indehiscens, mono-tetraspermus. Semen horizontale v. erectum, testa membranaceo-coriacea, costata. Embryo exalbuminosus, orthotropus v. semiantitropus. Cotyled on crassa, farinacea, versus basim viridescens, inferne excavata, $\mathbf{r a d} i-$ c $\mathbf{l}$ a m compressam $v$. Iunulatam includens, infra centrum pl um ula m ovato-subglobusam, minimam involvens, secundum axim a chalaza usque ad plumulam perforata, tuboque membranaceo, sinuoso, globulis densis repleto (sacculi amniotici $v$. quintinae rudimento ?) percursa. - Herbae parvulae, nemini non cognitae, in aquis stagnantibus et lente fluentibus climatis te mpera$s i$ et frigidiusculi totius orbis innumera grege natantes; frondibus parvis, lenticularibus, solitariis v. margine proliferis, supra laevigatis, subtus spongiosis, radiculis simplicibus, spongilla majuscula terminatis.

L e mu a Linu. gen. $n, 1038$. Wolf Comment. de Temna Norimb. 1804. 4to. L. C. Riehard in Guillem. Archiv. Bot, I. 200. Brongn, Ibid, II, 97. Nees jun. Gen, plant, fase, VI, $t$. 9. Lenticula Michell Gen, 11 .

a) WOLFIA Hork. Orarium uniovulatum. Ovulum basilare, semianatropum. Utriculus monospermus. S e me n horizontale, transversum, juxta mediam longitudinem insertum, rhaphe inde ad $\mathrm{chalazam}$ alterau seminis extremitatem occupantem percuvsa. Embryoais extremitas radicularis chalazae e dia. metro opposita, a puncto insertionia seminis remota, eentrifuga.

Wolfia Horkel msc. Horkelia Reiehenb. ex Bartl. ord, nat, 176. non Cliam. - Le m n a minor Linn. Hook. Fl. Lond, t. 120 . Brongn. l, c. t, 12, f. 1 .

b) LENTICULA. 0 variu m bi-quadriovulatum. 0 v u la basilaria, anatropa. Utriculus mono-tetraspermus. Semina erecta, basifixa, rhaphe juxta totam seminis longitudinem ad $\mathrm{chal}$ a $\mathrm{zam}$ apicalem procurrente. En bryouis extremitas radieularis chalazae e diametro opposita, umbilico proxima, infera.

L e m n a $\mathrm{g} \mathrm{i} \mathrm{b} \mathrm{b} \mathrm{a} \mathrm{Linn.} \mathrm{Schkuhr} t$. 281. L. C. Richard op. cit. $t$. 6. Brongn, op, cit, $t$, 12. f. 2. L. trisulea Linn. Hook. op. cit, t, 119 .

\section{Classis XXI. Spadiciflorae.}

Herbae acaules v. caulescentes, rarius suffrutices, saepius scandentes. Foli a nunc omnia radicalia, nunc canlina, alterna, congesta v. spiraliter disposita, interdum laminae abortu phyllodinea, saepius petiolata, pe$\mathrm{t}$ i o $1 \mathrm{i}$ s basi vaginantibus, 1 a $\mathrm{m}$ i $\mathrm{n}$ a lata, palmati- v. pedatinervi, rarissime penninervi, integra v. dissecta aut decomposita. Flones in spadice, spatha foliacea plus minusve transformata munito sessiles, unisexuales, monodioici v. hermaphroditi. Perigonium nullum v. rudimentarium, squamaeforme, saepius asymetricum. Stamina in perigoniatis simplici partium ejusdem numero, iisque opposita. Ovaria uni-multilocularia. Ovula in loculis solitaria, basilaria v. parietalia, orthotropa v. anatropa. Frecres baccatus v. drupaceus. Semixa albuminosa, rariusve germinatione incepta exalbuminosa. Eмвryo axilis, orthotropus v. antitropus, saepissime rimula laterali pro plumulae plus minus evolutae exsertione instructus.

\section{Ordo EXXII. Aroideae.}

AROIDEAE Juss, gen, 23. R. Brown prodr, 333, Blome Rumph. 73. ss. ARACEAE Sehott. Melet. 16. Lindl. introduct, edit. IT. p. 363. CALLACEAE Bartl. ord, nat. 44.

Plantae ut plurimum herbaceae, succo decolori v. lacteo toetae, caustico volatili scatentes, tuberibus v. rhizomate repente perennantes, nunc acaules, nunc caulescentes $v$. suffrutescentes, caudice a petiolorum basibus dilatatis cicatrisato. F o 1 i a rarius e rhizomate solitaria, saepius supra rhizoma $v$. in apice caudicis conferta, alterna; $p e-$ ti oli basi dilatata vaginantes, la $\mathrm{m}$ in a saepius maxima, valide nervosa, nervis palmatis, 
pedatis peltatisve, basi saepius excisa, cordata $v$. hastata, integerrima v. parenchymate inter nervos fatiscente pertusa varie dissecta, ant etiam decomposita, vernatione convoluta. S ca p u s radicalis v. axillaris, simplicissimus, basi foliorum vaginis inclusus, partimque iisdem adnatus, in spad icem indirisum desinens. Spad $\mathrm{i} x$ simplicissimus, in axilla spathae monophyllae (e folii lamina ope petioli cum scapo concreti ortae), varie convolutae, saepissime coloratae, persistentis v. deciduae, sessilis $v$, stipitatus, liber $v$. etiam spathae nervo medio plus minus adnatus, nune totus floribus obsitus, nune in appendicem sterilem desinens.

Flores saepissime unisexuales, rarius hermaphroditi, plernmque androgyni, feminei in inferiori, maseuli in superiore spadicis parte sessiles, continui vel interstitio sterili sejuncti, genitalibus rudimentariis flores fertiles utriusque sexus discriminantibus, interdum etiam supra masculos praesentibus v. rarius cum femineis mixtis.

Perigonium nune omnino nullum, nunc in floribus hermaphroditis rudimentarium, squamaeforme, saepius asymetricum.

Stamina plurima, libera varie inter se connata, in perigoniatis perigonii squamis opposita, antheris extrorsis, in reliquis saepius bilocularibus, loculis connectivo crasso truncato ut plurimum immersis, longitudinaliter $v$. rimula ant poro verticis dehiscentibus, saepius polle n catenatim conglutinatum continuo secernentibus.

Ovaria saepissime aggregata, libera v. inter se connata, uni-bi-tri-mnltilocularia. O v u 1 a nunc solitaria, nune plura v. plurima, basilaria v. parietalia, erecta, sessilia, v. e funiculis adscendentia, ant in iisdem inversa, orthotropa v, campylutropa, rarius anatropa.

Stylus nullus v. simplex. Stigm a capitatum v. discoideum, indivisum v. lobatum.

Fructus baccatus, indehiscens, uni-plurilocularis, mono-polyspermus.

Sgura subglobosa v. angulata, tes ta coriacea, saepius crassa, $\mathrm{u} \mathrm{mbili}$ c o basilari micropyles cicatrici opposito, $\mathbf{v}$, ope $\mathrm{rh}$ a ph o $\mathrm{s}$ cum chalaza apicali conjuncto. A l b um e n carnosum, farinosum, copiosum, rarissime parcissimum v. germinatione incepta nullum.

Emrayo homotropus, v. antitropus, axilis, rectus, teres, extremitate radiculari obtusa umbilicum spectante, v. eidem e diametro opposita, supera, infera $v$. centrifuga, cotyled on e hinc rimula brevi longitudinali, extremitati radiculari aproximata. Plumula di-triphylla, foliolis margine involutis, exteriore cotyledoni opposito ab ejus- dem rimae marginibus amplexo, plus minus denudato, interiora opposita amplexante.

Aroideae inter tropicos totius orbis frequentissime obviae, in temperatis rarissimae, usque ad $64^{\circ}$ L. B. gradum proveniunt, in Americae aequinoctialibus sylvis primaevis calentibus, et in regione andina temperata frequentibus imbribus irrigata copiosissimae, in A sia e nemoribus humidis nonnihil ut videtur rariores, sed pluribus et nobilioribus formis ludentes.

Principium inest acre, corrosivum, cujis multiplex in medicina populorum asiaticorum usus. Caudices et tubera nonnullarum specierum, repetita maceratione et exsiccatione excocti, Asiae australioris et Oceaniae incolis praetiosam largiuntur annonam. Diagnosim ordinis facillimam a Najadeis et Lemnac e is praebet habitus, et albuminis in plerisque praesentia; a Ty phaceis foliorum forma et antherarum figura; a Pandane is facies, fructus et embryonis conformatio.

SUEORDO I. ARACEAE. F 1 o $r$ e $s$ nudi, androgyni.

TaEdidS I. PISTIACEAE Blume Rumph. 76. Spadix cum spatha connatus, indistinctus. Flores masculi a femineo solitario remoti. Antherae in apice v. in latere spadicis sessiles. Ovarinm uniloculare. Ovula plurima, in placenta basilari v. sublaterali erecta, orthotropa. Stylus distinctus. Genitalia rudimentaria nulla. $\mathrm{Sem}$ in a albuminosa. E $\mathrm{mbryo}$ antitropus.

Herbae rhizomate flagellifero $v$. tuberoso, foliorum lamina integra, plurinervi, spadicibus inodoris.

1659. Pistia LINN. S path a basi tubulosa, spadici connata, limbo patente, processu spadicem superne involncrante aucto. Spadix interrupte androgynus, basi femineus, apice libero masculns. An $t$ h e ra e 3 _ 8 , spadicis apici incrassato adnatae, subglobosae, suleo transverso dehiscentes. Ovarium unicum, spadicis basi adnatae oblique insitlens, uniloculare. Ov u 1 a plurima, e placenta prope basim parfetali subhorizontalia, orthotropa. Stylus terminalis, erassus; stigma subeyathiforme. Bacea unilocularis, Semina plurima, v, abortu pauca, subeylindrica, test a coriacea, crassa, $\mathbf{x m b i l i c o ~ b a - ~}$ silari funiculo brevissimo patelliformi insidentia Embryo minimus, in apice albuminis inclusus, extreinitate radieulari umbilico e diametro opposita. - Herbae aquaticae, inter tropicos totius orbis obviae, natantes, flagelliferae; radicibus fibrosis, foliis sessilibus, rosaceoexpansis, obovatis, integerrimis, retusis, nervosis, subtus radiato-cristatis, spadicibus axillaribus solitariis, breviter peduneulatis.

Pistia Linn. Flor, zerl. 152. Gen, n,919. A. Rieh, in Diet. class, XIII, 633. Turp. Atl. H. t. 7. Blame Rumph. 77. Z a la Loureiro Flor. cochineh. $I$. 491 .

1680. Ambrosinia $B$ ASS. S $p$ atha basi convoluta, superne cueullata, a spadice adna- 
to Iongitudinaliter biloculata. Sp a dix complanatus, in appendiculnm liberum desinens, antice basi femineus, postice superne maseulns. Antherae 10 , transversim biseriatae, longritudinaliter bivalves. O v a r i u m unicum, uniloenlare. Ov $u$ la plurima, in placenta basilari deplanata, e funieulis longiusculis erecta, orthotropa. Stylus terminalis, longiusculus; st i $\mathrm{g} \mathrm{m}$ a discoideum. Ba c e a unilocularis. Sem in a plurima, testa striata. . . Herbae in Europa mediterrane a indigenae; rhizomate tuberoso, ramoso, stolonifero perennantes, foliis congestis, petiolis basi tubuloso-vaginantibus, lamina integerrima, convergenti nervosa, scapo e folii intimi vagina erumpente, spatha terminali.

A m b r o sin i a Bussi Dissert. Banon. 1763. 4to. Lam. t.737. Schott Melet, 16, Blume Mumph, 81,t.36,f.B. U e ria Targioni ex Röm. Arch, zo, A ri sp. Linn.

TIRIIUS II. CRYP'TOCORYNEAE Blume Rumph. 83. Spadix s path a e inclusus et apice cum ea connatus, v. exsertus liber. Flores masculi a femineis pluribus remoti. Antherae in apice spadicis sessiles, v. fil am entis brevibus stipitatae. Carpidia plura, circa basim spadicis verticillata, in o v a r i u m pluriloculare connata. Ovula in loculorum angulo centrali plura, horizontalia $v$. adscendentia, orthotropa. St y1i carpidiorum numero distincti. Genitalia rudimentaria nulla, v, vix distincta. Semina albuminosa. Em br yo antitropus.

Herbae rhizomate stolonifero, foliorum lamina sub-uni - v. palmatinervia, integra, lanceolata, $v$, rarius basi excisa.

1681. Cryptocoryme FISCH. S p a th a basi breviter tubnlosa, limbo elongato, plica tubum claudente cum spadicis verlice connata transversin biloeularis. $\mathbf{S} p$ a $\mathrm{d} i \mathrm{x}$ inclusus, interrupte androgynus, medio nadus. Antherae plurimae, in spadicis apice confertim sessiles, deplanatae, vertice biporosae. Carpidia sex v. plura, circa basim spadieis verticillata, in ovariu m sex-plnriloculare connata. $O \vee u l a$ in loculorum angulo centrali plura, subhorizontalia, orthotropa. Styli loculorum numero, distincti, radiatim divergentes; stigmatibus discoideis, extrorsum sublateralibus. B a e a plnriluenlaris, umbilicata. Semina in loculis plura, testa fungosa, umbilico basilari funiculo brevi affixa. $\mathbf{E} \mathbf{m b} \mathbf{r y o}$ in axi albuminis antitropus, extremitate radicuI a ri nmbilico e diametro opposita. - Plantae indicae, paludosae, glabrae; rhizomate tuberoso, stolonifero perennantes, foliis subbifariam dispo sitis, petiolatis, oblongis, integerrimis, obsolete convergentim pennineroiis, inflorescentia solitaria, inter peliolorum basim vaginantem subsessili, au in scapo magis minusve manifesto elevata, spatha interne transversim rugrosa, limbo marcescente, parte tubulosa cum fructu maturo decidua.

Cryptocoryne Fiseher ex Wydler in Linnaea $V$. 428. Schott Melet. 16. Blume Rumph, 83, t. 36. f. C. A mbrosinia cillata Roxb, Corom, t. 262. A rum spiraIe Retz, Bot. Mag. t, 2220.

16\%?. Stylochaetom LEPR. Spatha basi longe tubulosa, limbo brevi subfornicato. Spadix apice exsertns, interrupte androgynus, medio nudus. Stamina plnrima, in apice spadicis conferta; filamenta breria, distincta, an- the ra e tetragonae, biloculares, longitudinaliter dehiscentes. Carpidia sex, v. plura, circa basim spadicis verticillata, in ovarium sex-pluriloculare connata, superne disco demum perforato velata. Ovala in loculorum angulo centrali plura, adscendentia, orthotropa. Styli losulorum numero distincti, e basi geniculata erecti; $8 \mathrm{tig} \mathrm{ma-}$ tibus capitatis. Ba cea plurilocularis. ... S emina.... - Planta humilis, in $S$ e $n$ e $g$ a mbia e collibus arenosis observata; rhizomate carnoso, stolonifero, foliis longe petiolatis, hastatis, nervosis, spatha inter petiolorum basim vaginantem sessili, squamis emareidis cincta, sordide violacea, persistente, fructu hypogaeo.

Stylochat ou Leprieur in Nouv, Annal. sc, nat. 1834. IT. 184. 1.5. Blume Rumph. 98.

TIRIB US TII. D R A C U N C UL IN A E Schott Melet. 16. Sp a d ix liber, v. rarissime imae spathae adnatus, interrupte androgynus v. rarius dioicus, medio plerumque genitalibus rudimentariis auctus, appendice nuda terminatus. Antherae liberae v. rarissine coadunatae, lo culis turgidis, connectivo majoribus. Ovaria plurima, libera, unilocularia. Ovula solitaria v. plura, orthotropa. Stylus brevis v. stigma sessile. Semin a albuminosa $v$, rarissime exalbuminosa. E mbryo antitropus. - Herbae rhi $\approx 0$ mate saepius tuberoso $v$, incrassato, foliorum lamina valide palmati- v. pedatinervia, integra, cordata, hastata v. sagittata, aut palmali v. pedatipartita, spadicibus saepissime foetidis.

SUE'TRIBUS I. ARISAREAE Schott Melet.16. $\mathrm{S}$ p a d $\mathrm{ix}$ liber, monoicus v. dioicus. Stamina laxiuscula, fil amentis manifestis, antheris peltatis, transversim sive poris dehiscentibus. Oraria ovulis plurimis paucisve, e placenta basilari v. prope basim parietali erectis. Stylus plerumque distinctus. Organa rudimentaria subnulla.

16r3. Arisarum TOURNEF. Spatha basi tubulosa, limbo fornicato. S padix inferne continuo androgynus, genitalibus rudimentariis nullis, superne nudus. St am in um filamenta discreta, conoidea, antherae hemisphaericae, transversim inaequaliter semibivalves. Ovaria pauca, unilateralia, unilocularia, 0 v u I a plurima in fnnieulis brevibus e placenta basilari ereeta, orthotropa. Stylus distinctus; stigma subcapitato-peltatum. Bac cae di-octospermae. S em in a subglobusa, erecta, te st a coriacea, crassinscula, elevato-striata, hilo basilari lato. E m bry o in axi albuminis antitropus, extremitate radicu I a ri nmbilico e diametro opposita. Herbae mediterranea ; rhizomate tuberoso subgloboso $v$. ramoso, repente, foliis longe petiolatis, basi vaginantibus, cordatis hastatisve, nervosis, spa tha scapum solitarium terminante, livido-purpurea. A ris a r um Tournef. inst. 131. Kanth in Mem. Mus. IV. 438. Martius in Flora 1831, 458. Schott Melet.16. L. C. Richard in Guillem. Arch. Bot, IT, 20, t, 2. Blume Humph. 89. A rum A r is a r u Linn. Jikeq. Horl, schónbr, t, 192. A. Proboscideum Lian. Boceone Alus, $I I, t, 50$.

1674. Arisuemn MART. S p a th a basi convoluta, limbo fornicato $v$. planiusculo. Spadix inferne unisexualis, superne genitalibus ru. 
dimentariis, interdum plane deficientibus auctas, apice exserto $v$. incluso nudus. Antherae in filamentis distinctis verticillatae, lo eulis discretis v. appositis, poro v. rima subtransversali dehiscentibus. Ova $\mathrm{r}$ a plurima, libera. Ovula 2 -6, rariusve plura, in funiculis brevibus e placenta basilari erecta, orthotropa. Stylus brevis v. subnullus; stig ma capitato-peltatum, v. depresso-hemisphaericum. B a c cae mono-oligospermae. Semina subglobosa, testa coriacea v.membranacea, $u \mathrm{~m}$ b il i co basilari lato. Embryo in axi albuminis antitropus, extremitate radiculari umbilico e diametro opposita. - Plantue perennes, in Asiac tropicae montibus, deinde in Asia extratropica orientali et in America boreali indigenae; rhizomale luberoso, acaules v. foliorum petiolis basi vaginantibus cum scapo centrali concretis caulescentes, lamina rarissime indivisa, nunc peltatisecta, nunc pedati- $v$. palmatipartita, segmentis sessilibus $v$. stipitatis, integerrimis v. rarius eroso-serratis, subreticulato - venosis.

A r i s a m a Martius in Flora 1831. p. 459. Sehott Melet, 16. Blume Rumph, 92, t. 27, 28, 37. $f$. E. A ri s p. Linn. et Auct. Wallich. Flor, nepal. t. 18_20. Pl. As, rar, t.114. 135. 136. Bot. Mag. 2.950. Bot. Reg. t.668,

SUITrEIBE IT. EUAROIDEAE Schott Melet. 16. Spadix liber, monoicus. An thera e congestae, subsessiles, rima $\mathbf{v}$. poris dehiscentes. Ovaria ovulis solitariis v. pluribus, placentae basilari v. parietali insertis. Stylus nullus. Genitalia rudimentaria infra et supra stamina, rarissime nulla.

16\%5. Eizerum SCHOTT. Sp a tha basi tubulosa, limbo plano patente. $S_{p a d} \mathrm{ix}$ inferne interrupte androgynus, genitalibus rudimentariis subuliformibus, supra v. etiam infra stamina raris, apice longe exserto nudus. Antherae sessiles, confertae, loculis oppositis, rima v. poro dehiscentibus. Ovaria plurima, lihera. OvuInm unicum, basilare, sessile, orthotropum. Stylus distinctus; 8 tigma subeapitatum. B a ce a e monospermae. Sem en subglobosum, testa coriacea, $\mathrm{umbil}$ i co basilari lato. Embryo in axi albuminis antitropus, extremitate radiculari umbilico e diametro opposita. - Herbae in regione mediterranea et in Syria indigenae, humiles, acaules; rhizomate tuberoso, foliis longe petiolatis, lineari-lanceolatis s, ovatis, indivisis, convergenti-penninerviis, petiolis basi membranaceodilatatis, vaginantibus, scapo solitario $v$. rarius pluribus, spalha extus sordide viridi, intus plerumque cum spadicis apice nudo atro-purpurea.

B i a rum Sehott Melet, 17. Blume Rumph. 111. H omin id Adans. fam. II, 170.

a) BLARUM $S c h . S$ a th a tulio manifesto. Genitalia rudimentaria infra et supra stamina. Antherae rimis dehiscentes. Styli brevissiai. - Europeae.

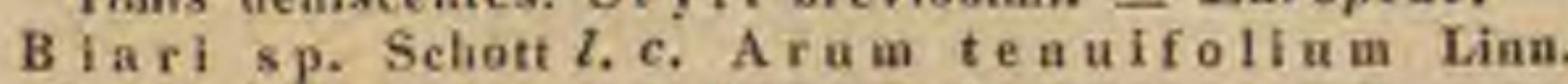
Bot. Reg. $t .512$. et A. gramine a m Lam.

b) ISCHARUM Bl. Spatha tubo brevissimo. Ge nitalia rudionentaria supra stamina nulla. Anthe$r$ a e poris dehiscentes. Sty $\mathrm{Ii}$ distincti. - Orientalis. t. 29.

Ischarum Blume $l$. c. Biarisp. Blume op. cit.

1676. Arum LINN. Spath a basi convoluta. $\mathrm{S}_{\mathrm{p}}$ ad $\mathrm{ix}$ inferne interrupte androggnus, genitalibus rudimentariis supra $v$. etiam infra stamina confertis v. raris, apice clavato nudus. Antherae distinctae $v$, connatae, loeulis bilateralibus, rima brevi dehiscentihus. Ovaria plurima, libera. Ovula 2_6, parietalia, superposi- ta, horizontalia, orthotropa. Stigma sessile, depresso-hemisphaericum, subexcentricum. B a cca mono-oligospermae. Sem in a subglobesa, horizontalia $v$. erectiuscula, te sta subcoriacea, crassa, u m bi lic o basilari lato, funieulis brevissimis affixa. Embryo in axi albuminis subobliquus, antitropus, extremitate radiculari umbilien opposita. - Herbae in Europa med ia et a ustrali, nee non in Asia contermina indigenae, acaules; rhizomate tuberoso perennartes, foliis longe petiolatis, nervosis, cordatis v. hastatis, integris, scapo inter bases petiolorum vaginanles enato, spatha concolori aut discolori, saepius maculata terminato.

A ru m Linu. gen, $n, 1028$, exel, sp. plar. Seltott Melet. 17. Blume Rumph 116.

a) GiGARUM Caesalp. Genftalia rudimentaria supra et infra stamina. O vari a multiovulata. - Europeae et orientales.

Ar. maculatam, italienm, pietum etc. L. C. Richard in Quillem. Archiv. Bot. I. 11. t. 1. Nees jun. Gen. plant, fasc, II. t. 5. Bot, Mag, t, 2432.

b) EMINiUM $B$ lum: Genitalia radimentaria infra stamina. Ovaria paueiovulata. - Orientales.

$168 \%$. 'Typlooniuan SCHOTT. Sp ath a hasi convoluta. $S p$ ad $i x$ inferne interrupte androgynus, genitalibns rudimentariis infra stamina confertis, apice subulato nudus. Antherae distinctae, lo culis oppositis, longitudinaliter dehiscentibus. Ovaria plurima, libera. Ovulum unicum, basilare, e funienlo longiusculo erectum, orthotropum. Sti $\mathrm{gm}$ a terminale sessile, depresso-hemisphaericum. B ace a e monospermae. S e men subglobosum, erectum, test a coriacea, crassa, rugoso-papillosa, n m bili co basilari lato sessilia. Embryo in axi albuminis, rectus, dimidia ejus longitudine, antitropus, extremit a te radiculari umbilico e diametro opposita, supera. - Herbae indica e, acaules; rhizomate tuberoso perennantes, foliis longe petiolatis, nervasis, cordalis hastatisve integris, scapo e foliorum basibus vaginantibus longe exserto, spatha concolore.

Typhonium Sehott in Wiener Zeitschrift 1829. III. 72. Melet, 17. Martius in Flora 1831. p. 45\%. Blume Rumph. t. 36. f. a. A ri sp. Lim. Roxl. Wight in Hook, Mtisc. Append. $t .3$. Bot, Mag. t, 359.2324. Bot. Reg. $t .450$.

168. Sauromateum SCHOTT. S p a th a basi tulumlosa, limbo plano, patente. Spa dix inferne interrupte androgynus, genitalibus rudimentariis infra stamina sparsis, apice subclavato nudus. Antherac distinetae, loculis oppositis, rimula brevi, subobliqua dehiscentibus. O vari a plurima, libera, unilocularia. Ov и la 2 , basilaria, e funiculis brevibus erecta, orthotropa. S tigm a terminale, sessile, depresso - hemisphaericum. Baceae monospermae. Semen... Herbae in dicae; tubere radicali globoso, carnoso, maximo, scapo radicali brevissimo, subsolitario, basi squamoso, spatha maculata, folio serotino, pedatipartito, multilobo.

Sanromatum Schott Melet. 17. Arum pedat a m Link, IIort. berol, t.8. A. g ut at u m Wallieh Pl, As. rar. t. 115 .

168S. Hracumeulus TOURN. S p a tha basi eonvoluta, limbo plano, patente. $\mathbf{S} p$ a dix inferne continuo androgynus, genitalibus rudimentariis infra et supra stamina, apice subclavato nodus. Anthera $\mathrm{e}$ in phalanges connatae, locaIis bilateralibus, apice rimula brevi, subobliqua dehiscentibus. Ovaria plurima, libera, unilocularia. O v u I a parietalia $3-7$, infimum basifixum, reliqua snbhorizontalia, orthotropa. Stig ma terminale, sessile, depresso-bemisphaerieum. 90 * 
B ace ae mono-oligospermae. Semina subglobosa $v$. angulata, erectiuscula, $t$ e $8 \mathrm{t}$ a coriacea erassa, umbilico basilari lato, fungoso. $\mathbf{E} \mathbf{m}$ b $\mathbf{r} \mathbf{o}$ in axi albuminis rectus, antitropus, extre $m$ it ate radiculari umbilico opposita. - Plan tae in Europa australi indigenae, acaules; tubere radicali subgloboso perennantes, foliis anno tinis pedatipartitis, segmentis confuenti-latinerviis.

D racu u c a lus Tournef, inst, 160. t. 70 . Schott Melet. p.27. Blume Rumph. 123, t, 27. f.g. A. D r arcunculus et A. criuitum L. Bot. Reg, t. 831 ,

SUB'TREUS IIT. P Y'THO N E A E. Spadix liber, monoicus. Antherae congestae, substipitatae, poris dehiscentes. $0 \mathrm{va-}$ ri a ovulis solitariis v. paucis, placentae basilari insertis. Stylus manifestus. Genitalia rudimentâria nulla.

1680. Py thominnm SCHOTT. S p a $\mathrm{h}$ a basi convoluta, limbo fornieato. S padix inferne continuo androgynus, genitalibus rudimentariis nullis, apice obtuso, nudo, corrugato-tuberculata. Antherae distinctae, filamento brevissimo, lo enlis quatuor, bilateralibus, poris quatuor dehiscentes. Ovaria plurima, libera, uniIocularia. Ovulum unieum, basilare, e funiculo brevi erectum, orthotropum. Stylus subulatus; stigma valvato-trilobum. B ace a e monospermae, Semen. ... - Herbae nepalenses; tubere radicali subgloboso, folits simultaneis, bipinnatifido - compositis, scapo erecto, longiusculo, basi vaginato, spatha reticulata, spadicem includente.

Pythonium Schott Melet, 17. Thomsonia Wallich Pl. As. rar. I, 83. t. 99. A r um bulbiferum Roxb. Bot. Mag. $t, 2508$.

1681. Anierphephallias $B L U M . \mathrm{S}_{\mathrm{p}}$ ath a basi convolnta, limbo plano, patente. Spadix inferne continuo androgynus, genitalibus rudimentariis nullis, appendice sterili elongata, laevigata v. depresso-dilatato, granuloso-verrucosa. Anthera e distinetae, fil am ento brevissimo, Ioculis duobus appositis, apice poro duplici dehiscentes. Ora ria plurima, libera, bi-tri-quadrilocularia. Ovula in loeulis solitaria, basilariu, anatropa. Sty lus distinctus v, nullus; stig$\mathbf{m}$ a rapitato-indivisum, $\mathbf{v}$. emarginato-ant depresso-lobatum. Bace a e mono-oligospermae. Semin a exalbuminosa (?). E m b r yo... - Herbae indica $e$; tubere radicali carnoso, scapo radicali brevi, foliis serotinis, subsolitariis, bipinnatifidodecompositis.

Amorphophallus Blume in Diar. Batav. 1825. Rumph, t.32_35.37, $f . H$. Dee, in Nouv. Annat. Mus, ITI. 366. Candarum Reichenb. Consp. 44. Sehott Melet. 17. P y. th ion Martius in Flora 1831, p, 455, A rum e ampan lat us Roxb. Corom, t. 272. Hooker in Bot. Mag. L, 28t2. A rum Ramphil Gaudich. ad Freje. . 39. - Gemus rectius fortassis inter Anaporeas collocandum.

Trineus IV. CALADIEAE Schott $M e-$ let. 18. Spa dix liber, continuo v. interrupte androgynus, medio plerumque genitalibus rudimentariis auctus, saepius appendice nuda terminatus. Anth e rie liberae v. saepius connatae, Ioculis connectivo crassissimo peltato immersis. Ovaria plurima, libera, unimultilocularia. 0 v u 1 a plura, orthotropa. Styli breves, v. stigma sessile. Semina albuminosa. Embry o antitropus. Herbae rhizomate tuberoso $v$. cảulescente, interdum scandente subarborescente, foliorum lamina pellali- v palmati nervia.

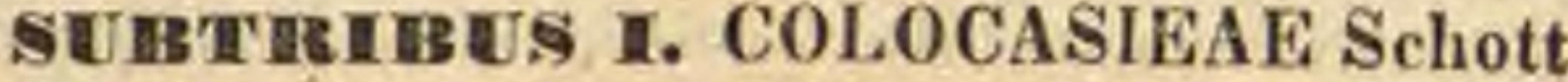
Melet. 18. S p a th a tubus persistens. Spadix medio saepius denudatus, appendice sterili interdum obsoleta $v$, nulla. Antherae plures connatae. Ov a ri um uni-quadriloculare. - Herbae ut plurimum lactescentes, rhizomate tuberoso v. caulescente, foliis confertis, pedunculis post foecundationem recurvis, vaginis petiolaribus elongatis, stipularibus nullis, sputhis suaveolentibus.

1682. Hemausatia SCHOTT. Sp a tha basi convoluta, limbo refracto, expanso. Spadix abbreviatus, interrupte androgynus, genitalih us rudimentariis infra ovaria et stamina, ap pendice sterili nulla. Antherae uniloculares, plnrimae, connectivis clavatis truncatis verticillatim adnatae, discretae, poro verticali dehiscentes. Ovaria plurima, conferta, dibera, septis tribns incompletis, apice coadunatis incomplete trilacularia. Ovula plurima, septis affixa, e inniculis brevibus horizontalia, orthotropa. StyI us brevissimus, attenuatus; $s t i g m$ a capitatum, siccum. Baccae..... Herba indica; succo decolori, rhizomate tuberoso, ramos elongatos, aphyllos, bulbilliferos exserente, foliis serotinis, peltatis, pedunculo bracteato brevi, spatha lutea.

Remusatia Schott Melet. 18. Caladium vivipa$\mathrm{r} u \mathrm{~m}$ Nees.

1683. Colocasia $R A Y$. Spath a recta v. cucullata. Spadix interrupte androgynus, genitalibus rudimentariis infra v. etiam supra stamina, ap pendice sterili clavata v. acuminata. Ant herae biloculares, plurimae, connectivis conoideis, truncatis, sessilibus v. substipitatis verticillatim adnatae, discretae, loculis contiguis, apice poro commnni apertis. Ovaria phrima, conferta, libera, unilocularia. Ovula in loculis subsena, placentis parietalibus tribus prope basim affixa, erecta, orthotropa. Sty I u s brevissimus; stigma snbcapitatum. Bacea.... Herbae indicae; rhizomate tuberoso $v$, caulescente, foliis simultaneis, peltatis, pedunculis subsolitariis $v$. ex eadem axilla pluribus, abbreviatis, vaginatis.

Coloca si a Ray Meth. 137. Seliott Melet, 18.

a) EUCOLOCAS1A Schott. S p at ha reeta, undulata. Ge. nitalia rudimentaria infra stamina. Spadi. $\mathrm{c}$ is appendix acuminata, laevis. C o nn étiva stipitellata. 0varia....- Herbae indicae, in Aegypto cultac; folits simultaneis, peltatis, supra lacvigatis, venulis infra adscendentibus, mar. gine anastomosantibus, pedunculis abbreviatis, vaginatis, ex una axilla pluribus, spatha flavescente.

Eaculocasia Schott $l$. c. A rum Golocasia et A rum esculentum Lina. (Ramph. Lmb, $V_{\text {. }}$. 100,f. 1 . 109.)

b) ALOCASIA Sohott. S patha eueullata, ineurva. Ge. nitalia rudimentaria infra et supra stamina. Spadicis appendix inerassata, currugato-venosa, obtusa. Con a etiva sessilia. Ovaria unilocu. laria, ovulis subsenis. - Herbae indicae; rhizo. mate caulescente, folits sirultaneis, peltatis, co. sta venisque utrinque prominentibus, pedunculis subsolitarits, brevibus, vaginatis, spatha glaucescente.

A I o cas i a Sehote L. $c$, Brougn, in Nouv, Annal, Mus.

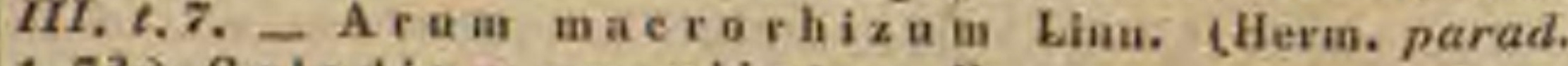
t. 73.) Caladium cucullatum. Pers.

1684. Caladium VENT. $S_{p}$ atha convoluta, recta. Spadix interrupte androgynus, 
genitalibus rudimentariis infra stamina, appendice sterili nulla. Antherae uniloca lares, plurimae, connectivis elavatis truncatis ver tieillatim adnatae discretae, poro apieis dehiscentes. Ovaria plurima, conferta, libera, bilocularia. Ovula in loculis 2_4, dissepimento affixa, e funiculis brevibus adseendentia, orthotropa. Sti rm a terminale, sessile, discoideum. B a $c$ c a uni-biloculares, oligospermae. Sem in angulata, testa coriacea, crassiuscnla, umbilico basilari lato. Embryo in axi albuminis antitropus, extremitate radiculari nmbilico e diametro opposita, supera. - Herbae americanae tropicae; rhizomate tuberoso, foliis simultaneis peltatis, hastatis, supra laevigalis, $i$ e. costa venisque ad superficiem haud productis, venulis subtus reticulatim anastomosantibus, scapis ebracteatis, solitariis, elongatis, spatha albida.

C al a d i m Veat. Cels. t.50, exel, retiq. Scliott Melet. 18. Bot. Mag. t. 2543, Hooker exot. Flor. t.26.

1695 . Leltandira $R A F I N$. S $\mathrm{p}$ a $t \mathrm{~h}$ a elongata, undulata, apice recurva. Spadix interrupte androgynus, gen it a libus rudimentariis infra stamina, appendice sterili brevissima, nuda. Antherae uniloculares, plurimae, abbreviatac, connectivis elavatis truncatis verticillatim adnatae, discretae, poro apicis dehiseentes. Ovaria plurima, sparsa, unilocularia. Ovula 5 -6. . . Stylus brevissimus; stig im a subeapitatum. . . Herbaboreali-americana; rhizomate tuberoso, foliis simultaneis sagittatis, nervosis, scapo e petiolorum vagina ex serto, soliturio, elongato, spatha viridi.

PeIt andra Rafinesque in Journ. Phys. LXXXIX, 3t, excl. sp. Schott Melet, 18. Caladium virgiafeum Hoo. Fer exol. Flor, t, 182. A ri s p. Lina.

efs96. Xantlinesoma SCHOTT. S p atha basi convoluta, recta. Spadix interrupte androgynus, genitalibus rudimentariis infra stamina, appenalice sterili nulla. Antherae biloculares, plurimae, connectivis conoideis truncatis vertieillatim aunatae, discretae, loculis contiguis, apice rimulis transversis apertae. $O$ v aria plurima, conferta, sty lis erassissimis placentaeformibus cohaerentia, subquadrilocularia. Ovula in loculis plurima, medio axi inserta, horizontalia.... Stigm a latum, depressum, lobatum, flavo-glutinosum. B a cea.... Her bae antillanae; rhisomate caulescente, erecto, foliis simultaneis, sagittatis, pedunculis subsolitariis vaginatis, spatha flavescente.

Xaithosoma Schott Melet. 19. Arnm xantho. rhiz. $11 \mathrm{~m}$ et s a git tif oli u m Jaeq. Hort, schönbr. t. 188 . Hort. Vindob, t.157, C a la di i s p. Vent.

$168 \%$. Acomtias SCHOTT. S p at ha basi convolnta, recta. $S_{p}$ a dix interrupte androgynus, genitalibus rudimentariis infra stamina, ap pendice sterili nulla. Antherae biloculares, plurimae, connectivis eonoideis truncatis verticillatim adnatae, discretae, lueulis contiguis, apice rimulis transversis apertac. O) varia plurima, conferta, stylis crassissimis placentaeformibus inter se cohaerentia, subtrilocularia. Orula in loculis plurima, medio axi inserta, adscendentia.... Stigma minutum, orbiculare, flavo-glutinosum. B a c ca. . - Herbae brasilienses; rhizomate tuberoso, fotiis simultaneis, lobato-pedatis, pedunculis nudis, elongatis, spatha viridi.

A coutfas Sclott Melet. 19. Arum helleborifo$1 \mathrm{in}$ m Jaeq. Ic. rar. $t, 631$. Ca 1 a d $\mathrm{i} i \mathrm{~s} p$. Vent.

1688 . Symgonium SCHOTT. Sp a tha basi convoluta, recta, genitalibus rudimen- tariis infra stamina rarissimis, appendice sterili nulla. Anthera e quatuor v. quinae biloculares, connectivo truncato angulato adnatae, loculis in angulis salientibus oppositis, apice poris dehiscentibus. Ovaria plurima, omnino inter se connata, nniloeularia. O vula solitaria, basilaria, sessilia, orthotropa. St ig $\mathbf{m}$ a $t$ a distincta, sessilia, albo-glutinosa. B a ec a e p I rimae, coneretae, monospermae....- Herbae Americanae tropicae; rhizomate in caulem elongatum scandentem mutato, foliis pedatopartitis, pedunculis brevibus, nudis, spatha sordide flavo-virente.

Syngonium Schott in Wiener Zeitschr. 1829. III. 780. Mielet. 19. Martius in Flora 1831. p. 457. A r u a au. ritu m Jacq. Hort, schönbr. $t, 191$.

1683. Culeasia PALIS. S p a th a recta, hians, abbreviata. Spa dix interrupte androgy nus, genitalibus rudimentariis et apendiee sterili nulla. Antherae sessiles, dun ex codem puncto. ... Oraria plurima, conferta, libera, unilocularia, uniovulata. Ovul $\mathbf{m m}$ basilare, sessile. . S tig ma capitatum. Bace a e. ... Herba africana tropica; foliis ovato lanceolatis, acuminatis, vaginis petiolaribus longis, scapum aequantibus, spatha sordide ex albo fuscescente. - Genus vix notum, an hujus loci?

Culcasia Palis. Fl. Ovar, t.3. Denhamia Sehott Melet. 19.

SUETIRERES IR. PHILODENDREAE Schott Melet. 19. S patha tota persistens, peracta florescentia reclusa. Spad ix continuo androgynus, appendice sterili nulla. A nthera e liberat. Ova ri um multiloculare.

Herbae succo decolori, rhisomate caulescente, vaginis petiolaribus abbreviatis, slipularibus elongatis, oppositifoliis, deciduis.

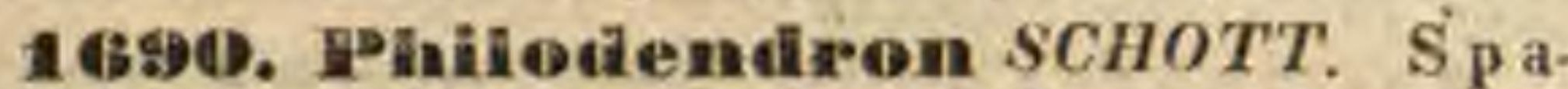
th a basi convoluta, recta, post florescentiam re clusa. Sp adix continuo androgynus, genit alibus radimentariis infra stamina, appendice sterili nulla. Anthera e biloculares, distinctae, 2-7 dorso per areolas dispositae, loculis intra connectivum delitescentibus, apice apertis. Ovaria plurima, conferta, libera, 5_ 15 locnlaria. Ovula plurima, e loculoram angulo centrali adscendentia, orthotropa. $S_{\text {t }}$ y $\mathrm{lu}$ s brevissimus, nullus; stigma capitatum, truncatum v. radiato-sublobatum. Bac cae discretae, polyspermae. Herbae americanae tropicae; rhizomate in caulem elongatum scandentem v. subarborescentem mutato, foliis remotis maximis, saepius lobato-laceris, vaginis petiolaribus brevissimis, stipularibus oppositifoliis, elongatis, deciduis.

Philodendron Schott in Wiener Zeitschr. 1830. III, 780. Melet. 19. Martius in Flora 1834. 456.

a) EUPHILODENDRON Schott. An the rarum loeuli latiusculi. $O$ v u $I_{\text {a }}$ iu loculis subterna, ad basim axeos inserta. S tig m a sessile, expitatum. - Spatha alba.

Euphilodendron Sehott Melet. 19. Cal adit sp. Jaeq. Hort, schönbr, t, 187, 190. Bot. Mag, t. 2693.

b) CALostigma Schoti. A ntherarum toculi latios. culi. Ovula in loculis subterna, diversa altitudiae affixa; stigma sessile, truncatum. - Spatha fava.

Calostigma Schott l. c. Ph. Im be Sehott.

c) Meconostigma Schoti. Antherarum locali an. gusti, elongati. 0 v u $L a$ in loculis subterna, diversa altitudine affixa. Stylus brevis. Stigina conve. xam, radiato-lobatum. - Spatha mubra.

M e e a os t $\mathrm{fg}$ m a Schott $l$. c. Pli. speciosu Schott.

d) SPHINCTERóstigma schou. Antherarum local angusti, elongati. $0 \times 41$ a in loculis subterua, diver. sn altitudine affixi. Stigma sessile, sphincterifor. 
me, disco convexum, spongiolosum, annulo laevi, suleato - creato cisctum. - Spatha extus fusco-pur purca, intus alba.

Sphincterostigma Sehott l. c. Ph. bipinnati. fi $\mathrm{d} u \mathrm{u}$ Schott.

TrEIE let. 20. Sp a dix liber v. spathae adnatus, androgynus v. genitalibus rudimentariis saepius cum femineis mixtis, rarissime appendice sterili terminatus. $\Lambda$ n therae liberae v. saepius connatae, connectivo crasso immersae, poris dehiscentes. Ovaria plurima, libera, uni - paucilocularia. Ovula plura v. solitaria, orthotropa. Stylus brevis v. stigma sessile. Semina albuminosa. Embryo antitropus. - Herbae rhisomate nodoso, acaules $v$. caulescentes, vaginis petiolaribus elon. galis, stipularibus nullis.

SUB'TRUEUS I. SPATHICARPEAE Schott Melet. 20. Spadix spathae adnatus. Ovaria unilocularia, uniovulata.

1691. Spathiearpa $H O O K$. S p a $t h$ a involuta. Spadix totus spathae adnatus, floribus triseriatis, serie intermedia mascula, lateralibus femineis. S $\mathbf{t}$ a $\mathbf{m}$ in a plurima, antherae 6.-8 uniloculares, ovatae, connectivo peltato, longe stipitato subtus adnatae, medio poro dehiscentes. Ovaria plurima, 8 taminodiis lentiformibus mixta, libera, unilocularia. Ovalum unicum, basilare, sessile, orthotropum. Stylus elongatus; stigma capitatum. B a ceace uniloculares, monospermae. _ Herba austro-america$n a$, ad fluvium Uragua $i$ reperta; folio radicali solitario, hastato-trilobo, scapo gracili erecto, folium superante, spatha lato-lineari.

S pathicarpa Hooker Miscell, II, 146. t. 77 . Schott Melet, 20 .

1692. Diefrembachia SCHOTT. Spatha convoluta. Spadix inferne pseudohermaphroditus, spathae adnatus, superne masculus, liber, appendice sterili nulla. Stamina plnrima, antherae $3 .-4$, biloculares, oblongae, connectivo truncato verticillatim adnatae, loculis parallelis, apice poro communi dehiscentibus. O varia plurima, libera, singula $s t$ aminodiis tribus clavatis, basi subconnatis cincta, unilocularia. Ovulum unicum, prope basim parietale, e funicnlo brevi adscendens, orthotropum. S $\mathrm{tig}$ ma discoideum, sessile. B a c c a e uniloculares, monospermae. S em en subglobosum, test a coriacea, crassinscula, umbilico basilari lato. Embrye in axi albuminis antitropus, extremitate radienlari umbilico e diametro opposita, supera. - Planta antillana; trunco crassiusculo e foliorum vaginis conflato, erecto $v$. basi procumbente, foliis obiongo-ovatis, cuspidalis, nervosis, ad costam saepius pictis, primum confertis, tandem remotis, pedunculo brevi, fructifero recurvo, spatha viridi.

Dieffenbachia Schott in Wiener Zeitschr. 1829. TII. 830. Melet. 20. Martius in Flora 1831. p. 457. C al adi и m Seguinum Vent. Bot. Mag. t, 2606. Hooker exot, Flor, $t, t$, (quoad ovaril internam fabricam male.)

1693. Atherurus BLUM. Sp at ha basi hians, soperne convoluta, $\mathrm{S}$ p a dix interrupte androgynus, parte feminea spathae adnata, a maseula, basi membrana septilormi spatham antice clandente libera sejuncta, genitalibus rudimentariis nullis, apendice sterili filiformi longe exserta. Antherae plurimae, confertae, sessiles, biloculares, loculis appositis, longitudinaliter bivalvibus. Ovaria plurima, conferta, libera, unilocularia. Ov u I u m nnicum, basilare, e funiculo longiusculo erectum, orthotropum. StyIus filiformis; stigma depresso-hemisphaericum. Bace ac uniloculares, monospermae. S eme n oblengum. Em bryo eylindrieus, in avi albuminis antitropus, extremitate radieulari umbilico e diametro opposita, supera. - Herba nondum descripta.

Atherurus Blume Kumph, t, 3\%, f, F. - Generis nondum deseripti, et nobis plane ineogniti, elraracterem ex icone aualytica a el. Blume edita, etiam cum erroris periculo mutuare, quam plantam memoratu dignissimam silentio in hoc opere praeterire, maluimus.

SUIBTERES II. R I C HA R D EA E Schott Melet. 20. Spa dix liber. Ovaria uni-trilocularia, ovulis solitariis $v$. plurimis.

1694. Aglaomema SCHOTT. Spatha hians, tandem elausa. S p ad ix continuo androgynus, staminibus rudimentariis cum ovariis mixtis, a p pendi ee sterili nnlla. Anthera plurimae, liberae, sessiles, quadriloculares, loculis connectivo cuncato, superne in discum repandum dilatato immersis, per paria oppositis, poro infra verticem dehiscentibus. Ovaria plarima, libera, unilocularia. Ovulum unicum, basilare, anatropum. Stig m a late discoideum, sessile. Bace a e nnilocnlares, monospermae. Semen ... - Herba indica, non satis nota, erecla; petiolis fere usque ad apicem vaginantibus, laminis oblongis, nervosis, pedunculis brevissimis, spatha a'bida, suaveolente.

Aglaon ema Schott in Wiener Zeitschr. 1829. IIT. 892. Melet. 20. Blume Rumph. t.36. f.D. A r u m in t e g r ifoli u m Link.

1695. Homalomema SCHOTT. S $\mathrm{p}$ atha hians, tandem reclusa. Spadix androgynus, staminibus rudimentariis cum ovariis mixtis, a p endice sterili nulla. Anther a e plurimae, sessiles. . . Ovaria plurima, libera, trilocularia. Ovula plurima, e loculorum angulo centrali adscendentia, orthotropa. Stigma sessile, trifidum, concavum. B a c c a e. . Herbae indicae, subcaulescentes; foliis cordatis v. sagittatis, pedunculis brevibus, spatha aromatica.

Homalonema Sehott Melet. 20. Calla aromatica Auct. C, oceulta Lour. Draeontium cordatum Houtt.

1696. Rielanalia $K U N T H$. S p a th a basi convoluta, limbo expanso marescente. S pa. dix continuo androgynus, staminibus $r u-$ dimentariis ovaria stipantibus, appendiee sterili nulla. Anthera e plurimae, liberae, sessiles, bilosulares, loculis connectivo late cuneato, superne in discum eonvexum glandulosum dilatato, prope marginem biporoso utrinque adnatis, vertice poro dchiscentibus. O va $\mathrm{r}$ a plurima, conferta, libera, placentis parietalibus tribus axim attingentibus incomplete trilocularia, staminodiis truncato-clavatis stipata. Ovula in placentis parietalibus, gelatinosis pauea, superposita, e funieulis longiusculis anatrope pendula. Siylus brevis; stigma convexiusculum, glandulosum. B a c ca e uniloculares, oligospermae. Semin a obovata; e funiculo longinsenlo, testa e crassae carnosae adpresso inversa, umbilico tuberculiformi. E mb r y o in axi albuminis antitropus, eoque dimidio brevior, extremitate radicula- 
ri incrassata, umbilien e diametro opposita, infera. - Herba capens is ; foliis radicalibus erectis, longe petiolatis, subhastato-cordatis, nervosis, petiolis basi vaginantibus, scapum centralem, subtrigonum inferne amplexantibus, spatha maxima, candida.

Richardia Kunth in Mem. du Mrus, IX. 437, $t .90$. Martius in Flora 1831. p. 457. Schott Melet. 20. Zantedes chia Spreng. syst. $I I T$. n. 3056. exel. sp. C alla a eth to pic a Linn. Bot. Mag. 1.832 .

SUBBIBDO II. CALLACEAE. S tamin a perfecta, cum ovariis in flosculos hermaphroditos consociata.

TRIIBUS VI. CALLEAE Schott Melet. 21. Spatha persistens v. decidua. Spadix ovariis circumpositisque staminibus tectus, perigonio nullo. Staminum filamenta planiuscula, antherae biloculares, loculis longitndinaliter dehiscentibus. O v a ri a uni-paucilocularia. O v u l a e basi erecta, anatropa v. campylotropa. Semin a albuminosa v. exalbuminosa. Embryo orthotropus, axilis, v. homotropus, uncinatus, extremitate radiculari inlera. - Herbae caule elongato, saepe flagelliformi, foliis subbifariis, demum remotis, vaginis stipularibus petiolo adnatis $v$. solutis et oppositifoliis, spathis spadice longioribus.

169\%. Calla LINN. Sp a th a explanata, persistens. Spadix stipitatus, inferne hermaphroditus, apice masculus. Stamina plurima, in spadicis parte inferiore orariis indefinite circumposita; filamenta filiformia, apice compresso dilatata, antherae biloculares, didymae, loculis oppositis, filamenti apisi adnatis, longitudinaliter dehiscentibus. Ova ri a unilocularia. $O$ v u 1 a plurima, e placenta basilari erecta, extrorsum anatropa. Stigma sessile, disciforme. B a ce a e distinetae, uniloeulares, oligospermae. Semina basilaria, sessilia, erecta, t e s t a coriacea crassa, eostata, nigro punctata, hine $r h$ a $p$ he valida umbiliemm basilarem $\mathrm{eh}$ a la z a e apicali conjungente percursa. A l b umen earnoso-corneum. Embryo orthotropus, axilis, albumine parum brevior, extremitate radicnlari umbilitum attingente, infera. - Herba in Europae et Americae borealis temperatis aquatica; caule prorepente, natante, foliis cordatis, petiolis vagina apice soluta munitis, spatha intus alba.

Calla Linn. gen. n. 1030. exel. sp. C. palustris

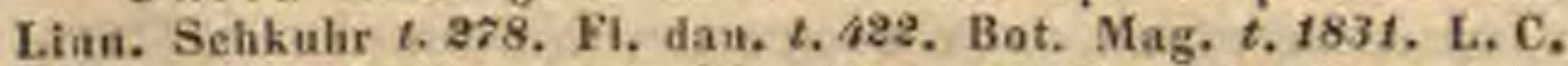
Richard in Guillem. Archiv. Bot. I. 15. $\ell$. 2. Nees jua. Gen, plant, fasc, $1 I, t, 4$.

1698. Dromstera $A D A V S$. $\mathrm{s}$ a $\mathrm{t} \mathrm{h}$ a hians, tandem decidua. Spadix sessilis, basi feminens, superne hermaphroditus. Stamina in spadicis parte supcriore ovariis subindefinite circumposita; fil amenta linearia, complanata, anthera terminales, ovatae, biloenlares, loculis oppositis, longitudinaliter dehiscentibus. O va ri a bilocularia. Ovnla in loculis bina, in dissepimenti basi subcollateralia, adscendentia, anatropa. Stylus brevissimus; stigma capitatum. Bac ca e inter se connatae, epiearpium tandem abjicientes. ... Herbae americanae tropicae; caule scandente, foliis ovato-oblongis, integris $v$. perforatis, petiolorum vagina laxiuscu- la, dilatata, spatha exalbido-flava, ovariis rhaphidophoris.

Mo nstera Adans. fam. Ir. 470. Sehott Melet. 21. Dracontium pertusum Jaeq. Hort. sehönbr. t. 184. 185. A rum Ii u latum Lian. (Plum. Ic. 26. t.37.) $\mathrm{P}_{8}$. thos cau n a efoli us Rudge. Bot. Mag, $t, 603$.

1699. Seinallapsus SCHOTT. Sp a tha hians, demum expansa, decidua. Spadix sessilis, basi femineus, superne hermaphroditus. Stain ina in spadicis parte superiore ovariis subindefinite circumposita; fil ament a cnneata, compressa, antherae terminales, biloculares, loeulis divarieatis, adnatis, lengitudinaliter dehiscentibus. Ovaria unilocularia. Ovula solitaria v. bina, basilaria, erecta, eampylotropa. Stigma sessile, oblongmm. B a c ca monospermae. Semen uneinatum. Embryo exalbuminosus, homotropus, hippoerepiformis. - Herbae indicae; caule scandente, foliis perforatis $v$, laciniatis, pinnatifidis, petiolis canaliculatis, vaginis stipularibus folio oppositis, deciduis v. stuppose decompositis, spathis flavescentibus v. sordide purpureis, florescentia tota rhaphidophora.

Seindapsus Schott Melet. 21. Pothos offieina. Iis Roxb. Flor. ind. I. 431. et P. g I a n $\mathrm{e}$ us Wallich $P l$. As. rar, t.156. - ? P. de cursivus Roxb. P. Pepla Roxb. P. pertasus Roxb. P. pinuatas Roxb. P. pinnatifid us Roxb. P. giganteus Roxb.

TRIBUS VIR. ORO NTIACEAE R. Brown prodr: 337. Spatha persistens v. rarius nulla. Spadix floribus hermaphroditis, perigonio instructis obsitus. Stamin a simplici loborum perigonii numero. 0 v aria paucilocularia. Semina albuminosa $v$. exalbuminosa. E m bry o $\mathrm{n}$ is directio in plerisque ignota. - Herbae acaules v, caulescentes, saepe scandentes, foliis spiratim alternis, confertis v. remolis subsolitariisque, integris $v$. palmati-aut pinnalisectis, aut etiam pedato-decompositis, vaginis stipularibus petiolo adnatis $v$. oppositifoliis, nunc cum petiolo alternis, spatha spadice breviore $v$. longiore.

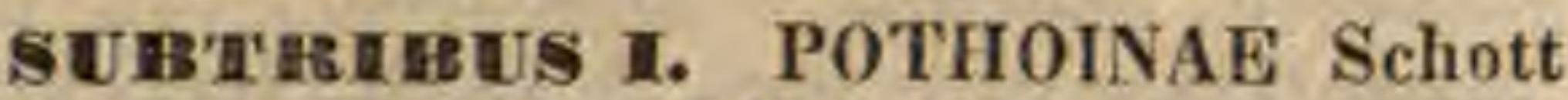
Melet. 21. Spath a foliacea persistens. Fila m e nta complanata, inclusa. Stigm a sessile. Embryo in indicis exalbuminosus, in americanis albuminosus.

1 gDD. Pothos LINN. Spat h a reflexa, persistens Spadix stipitatus, subglobosus, floribus hermaphroditis obsitus. Perigonium tetraphyllum. Stamina 4, perigonii foliolis op posita; filam enta linearia, complanata, antherae biloculares. Ovarium unilocnlare. Ovu la 1_3, basilaria, campylotropa. Stig ma sessile, nmbilicatum. Bacea mono-disperma. Semina exalbuminosa. - Plantae indicae, flagellis longis tenacissimis ex arboribus dependentes; foliis integris, vaginatis, petiolis apice dilatatis, pedunculis axillaribus solitariis, spadicibus reflexis.

P oth os Linn. gen. n, 1031. exel, sp. Sehott Melet, 21, Pothos scaudeas Lian. Bot. Reg. $t$. 1337 .

1 ซd 1. Hasia LOUR, S p a tha elongata, hians, tandem reclusa. $S_{p}$ adix sessilis, abbreviatus, cylindricns, floribus hermaphroditis obsitus. Perigonium tetraphyllum. Stamina 4, perigonii foliolis opposita; filamenta li- 
nearia, complanata, a n th e r a biloculares. Ovulum unicum, ex apice loculi pendulum, campylotropum. Stig ma sessile, subtruncatum. Bace a muricatae, uniloculares, monospermae. S emen exalbuminosum. - Herbae indicac, subacaules, erectae $v$. decumbenti-prorepentes, undique aculeis curvis horridae; foliis pinnatifidis, petiolis basi vaginatis.

L a s ia Loureiro Fl, conchinch, 1, 103. Schott Melet. 21. Pothos Lasia et P. heterophylla Roxb. Fl. ind. 1. $437,438$.

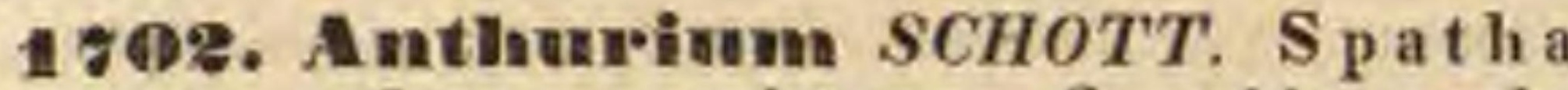
abbreviata, reflexa, persistens. Spadix subsessilis, cylindriens, floribus hermaphroditis obsitus. Perigonium tetraphyllum. Stamina 4, perigonii foliolis opposita; filamenta linearia, complanata, a n th e r a e biloculares. O v $\mathbf{I}$ a in loculis bina, collateralia, ex apice axeos pendula, anatropa. Stigma sessile, oblongum. B a e c a bilocularis, di-tetrasperma. $\mathrm{Semina}$ albuminosa, inversa. Embryo in axi albuminis parce carnosi orthotropus, extremitate radieulari supera. - Herbae americanae tropicae, subacaules, erectae v. scandentes; foliis palmatis, digitatis, v. saepius lobis lateralibus abortivis specie integris, petiolis apice tumidis, vaginis stipularibus (in speciminibus floriferis) cum petiolo alternantibus, persistentibus.

Anthurinm Schott in Wiener Zeitschr. 1829, III. 828. Melet, 22. Lindl. in Bot. Reg. $t .1635$. Pot hi s p. americanae Auct. Jacq. Ic, rar. 609. 611. Kunth in Humb. et Bonpl. nov. gen. et sp, t, 18 _20, Hook, exot. Fl. t. 35, 210. 211. Bot. Mag, t, 1375, 2801.2953, 2987.

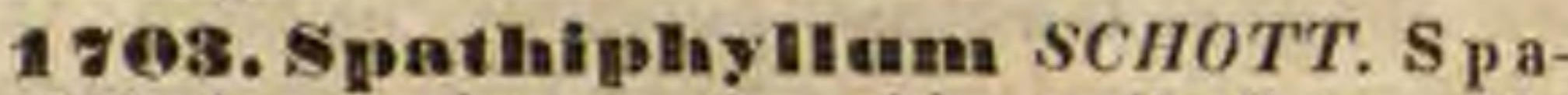
tha foliaris, persistens. \$ $p$ a d $\mathrm{i} x$ pedicellatus, abbreviatus, fluribus hermaphroditis obsitus. Perigonium penta-oetophyllum. Stamina 5_8, perigonii foliolis opposita; filamenta linearilanceolata, complanata, an therae biloculares. Ovarium triloculare. Ovu 1 a in loculis gemina, collateralia, axi appensa. Stigma sessile, trilubum. B a ce a trilocularis, loculis mono-dispermis, Semina albuminosa. - Herbae americana e tropica e, acaules; foliis oblongis sagiltatisve integris, petiolis longis, longe vaginatis, apice geniculatis, spadicibus suaveolentibus.

Spathiphy 11 um Schott Melet. 22. Dracoutium I anc a ofolinm Jacq. IC, rar, t, 619.

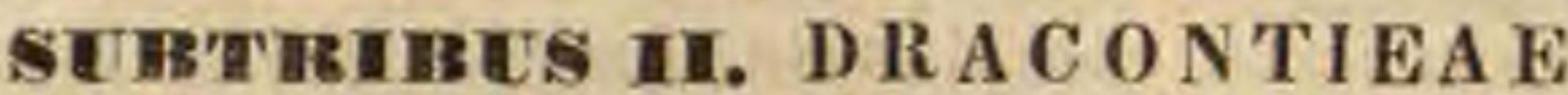
Schott Melet. 22. S p ath a colorata, persistens. Fil am ent a subulata, exserta v. inclusa. Stigma stylo impositum. Semina exalbuminosa. - Folia serotina.

1\%04. Dracontivm LINN. Sp atha cucullata. Spadix subsessilis, cylindricus, floribus hermaphroditis obsitus. Perigonium quinque - octofidum. Stamina $5-8$, basi laciniarium perigonii inserta; fi l a m enta lineari-subulata, exserta, antherae biloculares, loculis transversis. Ovarium triloculare. Ovula in loeulis solitaria, apici axeos appensa. Stylus subulatus, elongatus; stigma terminale, trigonum. B a $c$ a e distinctae, mono-trispermae. $S_{e-}$ mina exalbuminosa. - Herbae americanae tropicae, acaules; rhizomate tuberoso, placentiformi, sobolifero, foliis radicalibus subsolitariis, pedato-decompositis, petiolo elongato, spatha radicali subsessili, floribus foetidissimis.

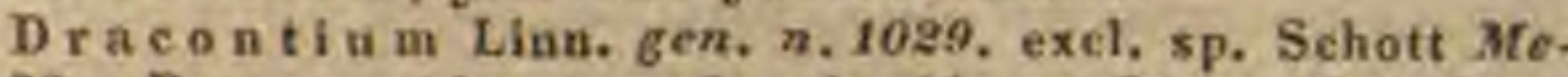
let. 22. Dracontifum polyphy 11 um Lim. Bot. Reg. t, 700 .
1 \%5. Symplocarpuss $S A L I S B$. S p atha cueullato-conehilormis, acuminata. $S \mathrm{p}$ adix pedunculatus, subglobosus, floribus hermaphroditis obsitus. Perigoninm tetraphyllum, demum baceatum. St a m in a 4, perigonii foliolis opposita; filamenta linearia, complanata, inclusa, antherae biluculares, loculis parallelis. Ovarium unilocnlare. Ovu $\mathrm{lum}$ unicum. Stylus tetragono-pyramidalis; $s \mathrm{tigma}$ teruninale, minutum. B a c c a coadunatae, uniloculares, monospermae. S e m e $n$ exalbuminosum. - Herbae in America et Asia borea$l i$ subaquaticae, acaules; foliis integris, petiolis vaginatis, spatha subsessili, floribus Allium redolentibus.

S y mploe arpus Salisb. ex Nuttall Gen, I. 105. Schott Melet. 22. Hooker in Bot. Mag. t.3224. I c to de s Bipelov Med. Bot. II. 41, t, 24. S path y e m a Ratin. in New-York. Med. Reposit. II. Hex, V., 173. D racout i um foe tid um et D. e a ut c hateense Linn.

SUIBTIIBUS IIT. ORONTIEAE Schott Melet. 22. Spatha nulla. F i l a m e $n$ t a complanata, inclusa. Stigma sessile. Emb r y exalbuminosus.

196. Drontium $L I N N$. S p ath a nulla. Spadix conieus, scapo continuus, floribus hermaphroditis obsitus. Perigonium hexaphyllum, foliolis fornicato-concavis. St am in a 6 , hypogyna, perigonii foliolis opposita; filamenta lata, plana, antherae biloculares, terminales, loenlis divaricatis, transversim dehiscentibus. Ovarium uniloculare. Ovulum unicum, basilare, transversum, excentrice amphitropum. Stigma minutum, obtuse conicum. U triculus monospermus. Semen exalbuminosum. - Herba aquatica, boreali-americana; foliis ovatis, parallele nervosis, venosis, natantibus, scapo cylindrico, apice incrassato. 0 ronti u m Linn. gen. $n$. 435. excl, sp. Lam. $t$. 258. f. 2. Nuttall Gen. I. 226. Schott Melet. 22. Or on tium a qu a tie u m Lias. Hook, exat. Flor, $t, 19$.

TreIISUS VIII. ACOROIDEAE Schott Melet. 22. Spatha phyllodinea, e phyllodio cum pedunculo connato, continua, haud convoluta. Flores hermaphroditi, perigoniati, spadicem tegentes. Stamina simplici loborum perigonii numero, iisque opposita. Ovaria uni-trilocularia. Ovulum solitarium v. plurima, ex apice loculorum pendula, orthotropa. B a c c a mono-trisperma. S emin a albuminosa. Embryo axilis, antitropus, extremitate radiculari infera. - Herbae oleo aromatico scalentes; rhisomate articulalo, foliis ensiformibus, vernatione amplectentibus.

190\%. Aymmostaclays R. BR. Spatha minuta, carinata. Spadix pedunculatus. Perigonium tetraphyllom. Stamina 4, perigonii foliolis basi inserta; filamenta lata, complanata, anth erae terminales, biloculares, oblongo-didymae. Ovarinm uniloculare. O vu$1 \mathrm{n} \mathrm{m}$ unicnm, ex apice cavitatis pendulum, orthotropum. Stig ma sessile, subcapitatum. Bacea nnda, monosperma. Semen inversum, albuminosnm. Embryo axilis, antitropns, extremitate radiculari incrassata infera. - Herba perennis, in Nova Hollandia orientali extratropiea indigena; ra- 
dice e tuberibus fusiformilns, fasciculatis, foliis radicalibus gramineis, elongutis, nervosis, scapo ancipiti, nudo, spadicibus versus apicem scapi ulternatim fasciculatis, gracilibus, pedunculatis, singulis spatha carinata, acuta, pedunculum vix superante subtensis, baccis caeruleis.

Gymostachys R. Brown prodr. 337.

1508. Acorus LINN. S p a th a elongata, compressa. Spadix lateralis sessilis. Perigo$\mathrm{n}$ i u $\mathrm{m}$ hexaphyllum. Stam in a 6 , perigonii foliolis basi inserta; filamenta linearia complanata; an thera e terminales, biloculares, globoso-didymae. Orari $\mathbf{m}$ bi-triloculare. Orula plurima, ex apice axeos pendula, orthotropa. Stigma punctiforme. B a c a perigonio persistente stipata, unilocularis, mono-trisperma. S e$\mathbf{m}$ in a inversa, albuminosa. E m b r y o antitropus, axilis, extremitate radienlari infera. Herbae indicae, una nunc per Europae paludes diffusa; rhizomate repente aromatico, foliis ensiformibus basi triquetris, scapo semicylindrico in acumen foliaceum ceu spatham producto, spadice solitario, baccis rubris.

A c o $\mathrm{r} 8$ Linn. gen, n. 434. Gärtn. H. 27. t. 84. Schknhr $t$. 97. Fl. dan, $t$. 1158, E. B. $t .356$, L. C. Richard in Quillem. Arch. Bot, I. 22. t. 3. Nees jun. Gen. pl. fasc. II. t. 5. De Acori Calami patria efr. Dierbach in Flora 1828. p. 545_558.

\section{Ordo IXXIII. Typhaceae.}

TYPHAE Juss. gen, 25. Aroidearum sec. III. R. Brown prodr 338. TYPHINAE Agardh Aphorism. 139. TYPHACEAE DC. Bot, Gall, 482. Lindl. introduct, edit. II. p, 335. Bartl. ord. nat. 69. A. Richard in Guillem. Archiv. de Bot. I, 198. TYPHOIDEAE et SPARGANIOIDEAE Link Handb. I. 132. 133. (Cyperacearum tribus.)

Herbae perennes, aquaticae v. paludosae, rhizomate crasso, repente. Ca ules cylindrici, enodes, farcti, simplices v, ramosi. F oli a alterna, linearia, integra, nervoso-striata, ad basim caulis conferta, vaginantia, sum ma ramos subtendentia, v. spadices ante anthesim involucrantia.

Flores unisexuales, monoici, in spicam nunc continuam, per intervalla spathis foliaceis caducissimis interstinctam, nunc interruptam dispositi, superiores masculi, inferiores feminei, omnes rhachi immediatim, v. parvulis ejusdem protuberantiis insidentes.

Flores masculi. Perigonium nullum, ejus loco fila simplicia v. squamulae membranaceae (in Sparganio) inordinate staminibus intermixtae.

Stamina plurima, e spadice immediate propullulantia. Fil a ment a filiformia, flaccida, simplicia v. apice brevissime bi-trifurca. Antherae oblongae, erectae, basifixae, biloculares; loculi appositi v. oppositi et bilocellati, longitudinaliter ab apice versus basim dehiscentes, connectivo ultra eosdem in acumen conicum producto. Pollen globosum.

Flores feminei. Perigoniom nullum, ejus loco setae subclavatae, plurimae (ovaria abortiva?), v. squamae ternae hypogy- nae (in Sparganio), singula ovaria stipantes, aestivatione imbricatae, persistentes.

Ovaria nune immediatim e rhachi oriunda, nunc juxta parvas ejusdem protuberantias spicata, nunc sessilia, libera $v$. interdum bina inter se connata, nunc tandem in stipite longissimo elevata, unilocularia, uniovulata. Ovulum ex apice loculi pendulum, anatropum. Stylus simplex, ovario cuntinuus, longiusculus. Stigma linguaeforme, unilaterale, elongatum.

Fructus subdrupacei, stylo persistente superati, pressione mutua angulati. E p i carp i u m membranaceum v. subspongiosum, maturitate hinc fissum; endocarpium coriaceum v, sublignosum, cum testa conferruminatum.

Semex inversum; t es t a membranacea, tenuissima, endocarpio adhaerens, ad chalaz a m incrassatam, u mbilic o e diametro oppositam cum eodem connatum, rhaphe obsoleta, unde semen in fructu maturo e basi erectum videtur. Albumen copiosum, subcarnosum. Емввхо orthotropus, axilis, albumine parum brevior, extremitate radiculari incrassata, verticem fructus spectante.

Ty phaceae per totum terrarum orbem sparsae; summa necessitudine hinc A r o i d e i s, illine Cyperaceis contiguae, proxime ad Pandaneas accedunt, a quibus vix nisi simpliciori fructus structura, et seminum situ differunt, ita ut Pandaneas Typhas tropicas terrestres facile dixeris.

1\%9. Typlaa TOURNEF. Flores monoici. S pic a mase ula culmum terminans, continua $v$. spathis cadueissimis interstincta. Stam ina plurima, e spadice pullulantia, setis stipata; fil ament a filiformia, flaccida, simplicia v. apice brevissime bi-trifurca; antherae hasifixae, oblongae, biloculares, quadrilocellatae. S piea feminea infra masculam continne cnl. mum obvestiens. Ovaria plnrima, immediatim e rhachi oriunda et juxta parvas ejusdem protuberantias spicata, setis plurimis subelavatis (ovariis abortivis) stipata, primum sessilia, tandem in stipite setis consito elevata, unilocularia. $O \mathbf{v u}$ $1 \mathrm{um}$ unieum, ex apice loenli pendulum, anatro. pum. Stylus simplex, ovario continus, stig$\mathrm{m}$ ate unilaterali, linguaeformi. Fruet us subdru paceus, minimus, epicarpio membranaceo, tan dem hine fisso, endocarpio lignoso, cum te sta cohaerente. Sem en inversum, basi cum endo. carpio connatum, situm erectum mentiens. Emb $r$ y o cylindricus, in axi albuminis carnosi, extr e mitate radieulari incrassata, supera. Herbae paludosae, per totum terrarum orbem sparsae, in zonae temperatae frigidiusculis nonnihil frequentiores; radicibus repentibus, culmo enodi, foltiis alternis, linearibus, strictis, basi dilatata vaginantibus, spica terminali clavata, compacta. T y p h a Tournef. inst, $t .301$. Linn gen, n. 1040. Gartn. 1. 8. t. 2. F1. dan. $t$. 645, Schkuhr $t$, 281, L. C. Richaral in Annal. du Mus. XVIT. . 5. f.8.9. Archives de Bot, T. 193. t. 5 . Nees jun, Gen, plant, fasc, II. $t, 1$. 
OBSERVATIO. In $\mathrm{T}$ y $\mathrm{p}$ h is endoearpium epicarpio sponte primum hine fisso, tandem undique soluto, suleis longitudinalibus exaratnm, tuberculisque minimis (mesocar pii residuo), exasperatum apparet. Seminibus in matre spontte germinantibus, radicula periearpii apicem perforat, et cotyledone intra albumen adhucium latente, solum petit. Filamentorum bi - trifurcorum singula crura pro flore integro habenda, et hane aatherarum dispositionem cum ovariorum in stipite situ esse comparandam, optime monuit divus Richardus.

1 \%10. Spparganium TOURNEF. FIores monoici, in capitula dense congesti, eapi$\mathrm{tu}$ lis bracteis foliaceis interstinctis, superioribus masculis. Stamina in reeptaculo hemisphaerico plurima, squamis membranaceis difformibus (staminibus abortivis) interjectis; filamenta brevissima; anthera e basifixae, oblongae, biloculares, loculis indivisis. Ovaria plnrima, in receptaculo hemisphaerico sessilia, libera v. bina inter se connata, singula perigonio e squamis 3 , imbricatis cincta, unilocularia. Ov u l u m unieum, ex apice loculi pendulum, anatropum. Stylus simplex, ovario continuus; stigmate unilaterali, linguaeformi. Fru ctus drupaceus, uni-bilocularis, epicarpio spongioso, endocarpio lignoso, apice pertuso, cum testa cohaerente. Semen inversum, basi cum epicarpio connatum, situm erectum mentiens. Embryo eylindricus, in axi albuminis carnosi, extremitate radiculari vix inerassata, supera. - Herbae aquaticae, per to $t u m$ orbem dispersae; foliis linearibus strictis, basi dilatata vaginantibus, capitulis in ramis simplicibus $v$. ramulosis.

$\mathrm{S}$ p a r a a $\mathrm{i}$ a m Tournef. inst, t.302. Linn. gen, n, 1041. Gärtu. I.73, t, 19. Selikuhr t. 289. Mtirbel in Annal. du Mus. XVI. t. 18. L. C. Richard Ibid, XVIT. t. 5. f. 7. Nees jun. Gen, pl. fasc. II, t, 2. P lat a a ria Gray brit, pl, II, 39.

\section{Drdo LXXIV. Pandaneate.}

PANDANEAE R. Brown prodr. 360. Agardh Aphorism. 133. Bartl, ord. nat.p. 69. Schott Melet, 15. Martius consp. p.5. PANDANACEAE Liadley introduct, edit. IT, p,36t. CYCLANTHEAE Poitean in Mem. Mus. IX. 34. Sehott $l$. $c$. Martius l. c. CYClanTHACEAE Lindley op, cit. p. 362. PHYTELEPHANTEAE Martius $l$, $e$.

Prastaf caudice saepius arborescente stricto, rarius debili decumbente, interdum stolonifero v. radicante, rariusve abbreviato, subnullo praeditae. Foli a plurima, confertim alterna, saepius imbricata, elongata, simplicia, nunc pinnata v. palmatifida, pet i o lo basi dilatato semivaginantia.

Flores monoici v. dioici, aut etiam polygami, supra spadices simplices v. etiam ramosos, s p a th a mono-pleiophylla, saepius colorata, persistente v. decidua stipato, dense conferti.

Floribus masculis: Perigonium nullum, v, regulare. Stanisa plurima. Fila m en ta filiformia. An therae terminales, bi-quadriloculares, longitudinaliter dehiscentes. $\mathrm{Pol}$ le n globosum.

Fioribus femineis: Ovaria ut plurimum nuda, rarius perig onio regulari, libero $v$. adnato cincta, unilocularia. $0 \mathrm{v} u l a$ solitaria, placentae suturali inserta, v. in placentis parietalibus plurima, adscendentia, anatropa. Stylus nullus, v. interdum ex ovarii basi lateralis. Stigma nt plurimum terminale, sessile, indivisum.

Froctus baccatus v. drupaceus, saepius ex ovariis plurimis in phalanges connatis compositus, hinc specie multilocularis, loculis monospermis v. polyspermis, interdum ovariorum parietibus destructis unilocularis.

Senixa ut plurimum parvula, saepius rhaphe carnosa, strophiolaeformi instructa. Albumen copiosum, carnosum v. corneum.

Euвrxo (in paucissimis cognitus) parvulus, in basi albuminis inclusus, extremitat $\mathrm{e}$ radiculari umbilico proxima, infera.

$P$ and a n e r $\mathrm{rm}$ genera, characteribus utut diversissimis a se invicem distincta, aretissima tamen affinitate connexa, in duas series abeunt; harum altera in veteri orbe, As i a videlicet tropica, et in 0ceania intra et extra tropicos, indigena, foliis simplicibus et perigoniorum defectu ab altera Americana, frondibus flabellatim partitis pinnatisve, et floribus perigonio instructis ad Palmas transitum praebente, distincta est. His accedunt $\mathbf{P h y -}$ telephas, genus americanum, nemini rite cognitum, cui asiaticam $\mathrm{Ni}$ a m, a cl. Martius nuper e Palmarum ordine ejectam, a nobis nunquam exploratam, ob aliquam habitus similitudinem, et albumen osseum subjunximus.

* PANDANEAE VERAE. Foli a simplicia. Perigoni um nullum.-Gerontogeae.

1 F 11 . Pandanus LINN. F.F lo r e 8 dioici. M a s. Spadix compositus, thyrsoideus. Stamina plurima, conferta; fi l a m enta filiformia; a $n$ therae hilocnlares $F$ em. Spadix simplex. Ovaria plurima, dense conferta, libera $v$, in phalanges connata, unilocularia. Ovulnm unicum, e placentae parietalis basi adscendens, anatropum. Stigmata sessilia, distincta. Drupae fibrosae, in phalanges connatae, putamine osseo. uniloculares. S emen solitarium, e basi placentae parietalis ereetum, testa membranacea, $r$ hap h e filiformi, obsoleta. Embryo in basi albuminis dense carnosi minimus, orthotropus, ex tremitate radiculari umbilicum attingente, infera. - Plantae in Asia et Oceania tropica obviae; caudice arboreo stricto, saepius stolonifero, foliis phyllodineis trifariam imbricalis, elongatolineari-lanceolatis, amplexicaulibus, margine saepius spinosis, spathis confertis, saepe coloratis, ex axilla spadices exserentibus.

P a n d a n us Lim. f. suppl.64. R. Brown prodr. 341. Jacq. Fragm, t. 14 f.2. Roxb. corom. t.94_96. Mirbel in Annal. Mus. XVI. t. 17. Sehott Melet. 15. A r th rod a et y 1 is Forst. charact. gen, n.57. Ke u r v a Forsh. aegypt. 172.

112. Freycinetia GAUDICH. Flores pseudopolygami. Mase. Spadix simplex, typhoidens. Stamina plurima; fi l amenta filiformia; antherae biloculares. Fem. Spadix simplex. Ovaria plurima, staminibus efoetis stipata, in phalanges connata, unilocularia. O v u la plurima, in placentis tribus parietalibus linearibus bi-triseriata, e funiculis brevibus adscendentia, anatropa. Stig mat a sessilia, distincta. B a cea e 
carnosulae, polyspermae, ex ovariis plurimis connatis multiloculares, nune ovariorum parietibus pereuntibus uniloculares. S e min a plurima, parietalia, e funiculis brevibus erecta; test a membranacea, rhap he laterali carnosa, strophiolaeformi. E $m$ bryo in basi albuminis dense carnosi minimus, orthotropus, extremitate radieu1 a ri umbilico proxima, infera. - Plantae in Asia et Oceania tropica, nec non extra tropicos in insula Norfolk et in Nova Zeelandia indigenae; caudice arborescente, saepissime radicante $v$. scandente, Pandanorum habitu.

Freyciaetia Gaudich, adFreyc. 431, t. 41-43. Schott. Melet. 16. Endl. Flor. norf. 24. Blume Rumph.p.156.t,39-43.

** CYCLANTHEAE. Frondes flabellatim partitae v. pinnatae. Flores saepius perigoniati. - Americanae.

1 13. Carludovien $R U I Z$ et $P A V$. Flores monoici in eodem spadice. Spat h a tritetraphylla, foliolis imbricatis. Spa dix eylindri cus, floribus dense obtectus. Mase uli quaterna tim agrregati, femineos solitarios stipantes. Pe rigonium obverse pyramidatum, hasi carnosum, limbi brevissimi multifidi lobis biseriatis, aestivatione imbricatis. St am in a plurima, perigonii parietibus inserta; fil amenta filiformia, brevissima; antherae lineares, biloculares, loculis oppositis, longitudinaliter dehiscentibus. F $10-$ res feminei. Perigonium eum ovario cubico connatum, limbo supero, quadrifido, persistente. Staminodia 4, limbi laciniis opposita et basi adnata, filiformia, elongata, decidua. Ovari $\mathbf{u m}$ inferum, uniloculare, placentis parietalibus quatuor. Ovu 1 a plurima, horizontalia, anatropa. St i g m a sessile, cruciforme. B a c c a tetragona, perigonii limbo superata, unilocularis. Semina plurima, oblongo-cylindrica.... Plantae a mericanae tropicae, caulescentes $v$. rarissime acaules; caulibus ut plurimum lignescentibus, saepissime scandentibus, radiculis aëreis arborum cortici adhacrentibus, interdum ex iisdem funium ad instar pendulis, semper tamen in solo radicantibus, foliis coriaceis in petiolum attenuatis, bi-v. rarius flabellatim tri-quinquepartitis, spadicibus axillaribus $v$. radicalibus pedunculatis, spathis membranaceis, albis $v$. roseis, floribus masculis caducissimis, femineorum staminodiis longissimis, primum lineis daedaleis circa spadicem flexis et eidem appressis, mox pendulis, cito deciduis.

C a r 1 u dovica Ruiz et Pav. prodr, 136. $t, 31$. Kunt in Humb. et Bonpl. nov. gen. et sp. I. 79. Poiteau in Mem. Mus, IX, 27, t. 1. Schott Melet. 15. Püppig Dissert. mse, $c$. ic. L u do via Pers. ench. II. 576 Bot, Mag. t. 2950.2951 $\mathrm{S}$ alm i a Willd, in Berl.Magas. $\mathrm{V} .399$.

1 \% 14 . Cyclanathes POIT. Flores mo noiei, spiraliter spadicem ambientes, seriebus masculis cum femineis alternanibus. Spatha tetraphylla, foliolis imbricatis. Mase. Stamina plurima, florum femineorum receptacula multiplici serie ambientia; filamenta filiformia, brevissima; antherae oblongae, lineares, quadrilocnlares, longitudinaliter deliscentes Flores fe mi n ei. Ovaria plurima, intra laminam duplicem spadicem ambienteu, basi ronniventem, apice pa tulam hiseriatim sessilia, uniloeularia. O v u la plurima, e placenta parietali adscendentia, anatropa Stylus brevis; stigma spathulatum. Fructus carnosns, spiralis, ovariorum confluentium parietibus obliteratis nnilocularis, polyspermus. Sem i n a plurima, compressa, placentis cristaeformibns, persistentibus, ope funiculi brevis affixa, $r h a p h e$ arillaeformi cincta. ..._-Plantae a meric a $n a e$ tropicae, acuules; foliis radicalibus longe petiolatis, bifidis, pedunculo radicali brevi, spathis integris v. apice bilobis, deciduis.

C y clanthus Poiteau in Mem. Mus, IX, 35, $t, 2.3$. Pöppig Dissert. mso. $c$, ic. Cy closanthes Poppig in Eroriep's Noliz, XXXI, 312.

1 ช ธ. Wettinia PöPP. Flores monoiei, in diversis spadicibus. S p a $\mathbf{t}$ ha coriacea, diphy Ila, hispida, rumpens. Sp a d i e es cylindrici, florihus dense obtecti, pannuso-villosi. M a s e. P erigon i $\mathbf{m}$ basi bracteolis $4-5$ squamaeformibus munitum, tri-tetraphylium, foliolis linearibus acuminatis, cartilagineis, acstivatione valvatis, $\mathbf{S t a -}$ m ina 12 v. 16, perigonii foliolis basi quaternatim inserta; filamenta brevissima, filiformia; antherac oblongo-lineares, connectivo in acumen setiforme exeurrente apiculatac, loculis oppositis, bilocellatis, longitudinaliter dehiscentibus, valvulis coriaceis, demum patentibus tetrapterae. Pollen globosum, laeve. F e m. Perigon i m basi bracteolatum, tri-tetraphyllum, ut in mare. 0 var i m sessile, inverse pyramidatum, obsolete pentago num, villosum, uniloenlare. Ovulum unicum. prope basim parietale, adscendens, anatropum, rhaphe crassa, carnosa. Stylus prope basim eodem cum ovulo latere insertus, rectus, ovarii longitudine; $8 \mathrm{tig} \mathrm{m}$ a $\mathrm{t}$ a 3 , anguste lanceolata, semipatentia, irregulariter convoluta. B a c c a coriacea, villosa, unilocularis, monosperma. Semen.... Planta palmiformis, a Pöp $p i g i o$ in sylvis montanis ad ripam borealem fluminis Tocache (Conversiones del Huallaga alto) Peruvia e frequentissime reperta, et ibidem ab indefesso peregrinatore pulcherrime depicta, et egregie descripta; rhisomale pyramidato 4-5 pedali, e radicibus arcte sibi invicem impositis conflato, caudice $25-35$ pedali, dia metro 5-- 6 pollicari, strictissimo, frondium cicatri bus annularibus obsoletis laevigato, juniore frondibus pinnatis alternis per totam longitudinem obsesso, frondibus in adultiore stirpe terminalibus, patulis, sex-octo pedalibus, pinnis 18 - 20 jugis, alternis, planis, cuneatis, praemorsis, spadicibus 8-15, versus apicem caudicis unico verticillo, a frondibus duorum v. trium pedum spatio remoto erumpentibus, masculis cum femineis mixtis, pedunculatis, primum deflexis, tandem erectis $v$. pedunculi torsione nutantibus, pedunculis vaginis coriaceis, remotis munitis, vagina suprema maxima, cyathiformi, integra $v$. dentata, spatha coriacea, rumpente, diphylla, pilis setosis hispidis adpressis dense vestita, rhachi spadicis cylindrica, pannosa, pro florum insertione irregulariter areolata.

Wettinia Pöppig Diar. msc. $V$. 2058. et Dissert, inedit. c. icc. - Generis a Pandaneis ad Palnas transitum praebeutis, et rectius fortassis olim his adusmerandi, charac. terem e manuscripto ab amicissino Püppigio, una cпm spadicum atriusque sexus particulis benevole communicato. mutuati sumus.

\section{GENERA PANDANEIS AFFINIA.}

116. Phyteleplaas RUIZ et $P A V$.

F lore s polygano-dioici, hermaphroditi $v$, abortu masculi. Spatha monophylla. Spadices simplices, clavati, floribus dense obsessi. Perigoni $\mathbf{~ m}$ urceolatum, obsolete multidentatum Stamina plurima. Ovaria... Stylus quinque. sevfidus. D rup a e agregatae, muricato-angulatae, quadriloculares, loculis monospermis. S emina alhumine osseo. - Plantae peruanae, palmifor mes, vix cognitae, acaules $v$. caulescentes; foliis longis, pinnatis, in apice caudicis confertis. 
Phytelephas Ruiz et Pav. Syst, Flor. peruv. 299. Kunth. in Humb, et Bonpl. nov. gen. et sp. I. 83. El e. p li an tus i a Willd. sp. IV. 1156.

1ระ. Nipa THUNB. Flores monuici, in spadice ramoso, ramis $8 \mathrm{p}$ ath a cinctis, lateralibus amentiformibus masculis, femineis superioribus, in eapitulum compactis. Ma 8 c. Perigoni m unibracteatum, hexaphyllum, foliolis linearibus, reflexis. Stam in a 3 ; fil am enta in coIumnam connata; antherae sex extrorsae, biloculares, synemate supra easdem producto. F e m. Perig oni um nullum. Ovaria plurima, in capitulum compacta, oblique truncata, glabra, unilocularia (?). Stig m t a tria, sessilia. Drupa e irregulares, fibrosae, uniloculares, monospermae(?). S emen osseum. Em hry o basilaris. - Planta in dica palmiformis, non satis cognita ; caudice humili torroso, frondibus terminalibus pinnatis, inermibus, pinnis aceroso -dentatis, floribus masculis minutissimis, fructibus in capitulum magnum aggregatis.

Nipa Thunb. in Act. Holm. 1782. p. 231. Nov. gen. 91. Juss. gen. 38. Sehreb. gen. n. 1698. Labill. in Mem. MIus. $V$. p. 297, $t, 21$. 22. Martius Progr. Palm, 12. N y p a Rumph Amboin. I. 72. ᄂ. 16.

\section{PANDANEA FOSSILIS.}

17 18. Pandanoearpum BRONGN. Drup a e conicae, tetra-hexagonae, basi lata lacerae, apice truncato nudae, uniloculares, monospermae. - Sedimentum superius.

Pandanocarpum Brongn. prodr. 138.

\section{Classis XXI. Principes.}

Phantae arborescentes, caudice e gemma terminali frondescente. Folia alterna, petiolis basi vaginantibus, pinnato $v$, palmatomultifida, aut simpliciter fissa, vernatione plicata. Spadices floriferi plerumque laterales, spatha unica pluribusve cincti. Flores regulares polygami, mono-dioici, rariusve hermaphroditi. Perigoniou duplex; caly x et coro 11 a, utrumque trimerum. STaniva 3 v. 6, aut ternato multipla. Ovanium liberum, e carpidiis $1-3$, connatis v. distinctis. Ovura in carpidiis solitaria, rarissime bina, angulo interiori paullo supra basim inserta, erecta, plus minusve complete anatropa. Fructus drupaceus v. baccatus, uni-trilocularis, saepius abortu unilocularis, monospermus. Atbumev cartilagineum, solidum v. centro cavum, aequabile v. ruminatum. Eмввуо in foveola albuminis in peripheria seminis locatus, rectus, situ varius, extremitate radiculari infera, supera $v$. centrifuga.

\section{Ordo LXXV. Prelmae.}

PALMAR Liun. Method. sexual, edit. 1737. p. 22. PraeLectiones, edid. Giseke p. 21 - 122. Jussieu gen, $37 . \mathrm{R}$ Brown. prodr. 266. Martius Palmarum familia ejusque geuera denno illustrata. Monachil 1824. Alo. Palmae brasilienses. Monachit 1834_1837. fasc.1. 6. Fol. Synopsis generum Palmar, Msc. Bartling ord. nat, 63. PALMACEAE Lindley introduet. edit. IT. p. 343 .

Plaxta lignescentes, acrobryae, habitu peculiari. R a d ix palaris, mox evanida; $r$ a diculat plurimae, cylindricae, simplices v. ra- mosae, fibrillosae, in molem conicam, saepe ex parte hypogaeam dense compactae. Trune us (sive caudex) saepissime arborens, plerimque simplicissimus, raro parte hypogaea caespitosoramosus, rarissime dichotomns, teres, subcylindricus, interdum ventricosus, cortice tenui, substantia versus peripheriam duriore, interdum fere cornea, enodis, foliorum basibus horizontaliter annulatus v, eorundem basibus persistentibus horridus, plerumque verticaliter erectus, non raro elatus, e gemma terminali, ut plurimum solitaria frondescens.

Folia (frondes) alterna, basi vaginali plerumque in reticulum v. fibrillitium solvenda, caudicem circa circum horizontaliter amplectentia, petiolo inferne convexo, superne postice concavo, antice semitereti v. ancipiti aut pentagono, faciebus duabus lateralibus parallelis, duabus superioribus angulo acuto conniventibus. L a mi n a pinnatim v. palmatim divisa, rarius simpliciter fissa; $p$ inn a e basi callosa in rhachi plerumque oblique sessiles, omnino discretae v. basi cohaerentes, longitudinaliter nervosae, rarissime venosae, vernatione plicatae, induplicatae v. reduplicatae, demum saepius secundum nervos secundarios longitudinaliter fissae, nervis interdum filorum specie persistentibus, indumento plerumque pannoso-tomentoso, aut lepidoto, rariusve simpliciter piloso aut nullo.

S pa $\mathbf{d} \mathrm{x}$ ex ala frondis basi amplexicaulis, plerumque spathis pedunculo adnatis, solitariis pluribusve distichis, nunc completis inclusus, nune incompletis tectus, v. ad ramificationes stipatus. In flores e entia varia.

Flores pro ratione stirpium parvuli, numerosissimi, plerumque alterius sexus abortu polygamo-dioici v. monoici, rarius hermaphroditi, breviter pedicellati v. sessiles, aut etiam spadicis foveolis plus minusve immersi ; b r a ctea bracteolisq u e duabus oppositis, liberis v. connatis, nunc ad calli speciem redactis r. plane deficientibus.

Perigonium duplex: $c$ al $y \mathrm{x}$ et corolla subcalycina, utrumque trimerum, persistens. Calyx triphyllus, foliolis liberis v. plus minus inter se connatis, saepe carinatis. CoroLLA tripetala, petalis cum calycis foliolis alternantibus, distinctis v. in corollam gamopetalam connatis, aestivatione in floribus masculis plerumque valvatis, in femineis saepius imbricato - convolutivis, longitudinaliter nervosis.

Stamina in toro carnosulo hypogyna, v. imo perigonio connata perigyna, plerumque sex, biseriatim calyci et corollae opposita, rarius ternatim multipla, rarissime tria, calyeis foliolis opposita, in floribus femineis non raro rudimentaria. Filament a libera v. basi plus 
minusve inter se in tubi v. urceoli speciem coalita, aestivatione erecta. Antherae introrsae, biloculares, lineares, dorso affixae, $10 \mathrm{culi}$ appositis v. suboppositis, longitudinaliter dehiscentibus. Pollen ellipticum v. ellipsoideo - sphaericum, longitudinaliter rimatum, interdum echinulatum.

Ovarium liberum, e carpidiis tribus, rariusve binis aut unico compositum, $\mathrm{c}$ a $\mathbf{r} \mathrm{p}$ i $\mathrm{d}$ i is ad axim inter se coalitis v. primitus subdistinctis, serius concrescentibus subglobosum v. trilobum, uni-triloculare, loculis duobus in ovario triloculari saepius efoetis, in floribus masculis plerumque rudimentarium. Ovula in loculis rarissime bina, collateralia, plerumque unicum, axi paullo supra basim affixum, erectum, orthotropum micropyle supera, v. plus minus complete anatropum $\mathrm{m}$ i cropyle ovarii parietem spectante, v. pone ovuli insertionem infera. Styli loculorum numero, brevissimi, in unicum coaliti v. rarius subdistincti. Stigmata simplicia, indivisa.

Frсстиs perigonio persistente, saepius coriaceo - indurato ima basi stipatus, baccatus v. drupaceus, aut solitarius trilocularis, interdum trilobus, rarius bi -v. unilocularis, trispermus v. rarissime dispermus, aut loculorum abortu unilocularis, monospermus, v, tres in flore distincti. Sarcocarpium carnosum v. fibrosum. Endocarpium chartaceum, fibrosum, lignoso-osseum v. lapideum, putamine in drupaceis mono-tripyreno.

SFMrN loculum replens, ovatum v. sphaericum, erectum v. lateraliter subappensum. Testa cum endocarpii superficie interna plerumque plus minusve coalita, ejusque vasis adhaerentibus venosa, $r h$ a $p h e$ ad medium $v$. apicem pertingente saepius notata.

Albumen densum, nucleum replens, aequabile v. fibroso radiatum, cartilagineum, corneum v. subligneum, lacteum, siccum v. oleosum, solidum v. cavitate ventrali aut centrali exsculptum, saepius plicis testae et vasis enducarpii ei adnexis ruminatum.

Euraxo indivisus, conicus v. cylindricus, in foveola propria albuminis juxta seminis peripheriam, varia a puncto insertionis distantia locatus, albuminisque strato tenui tamquam operculo tectus; extremitate radiculari seminis peripheriam spertante, juxta basim, peripheriam v, apicem fructus directa.

Palmae plantarum principes, sub totins orbis coelo fervido regali decore super aliarum stirpium catervam eminentes, in novi continentis solo, fecundi Phoebi irraptis exosculato radils frequentissime gignuntur, in hemisphaera orientali imprimis e virgineo insularum pullulantes gremio, in veteri Asiae et Africae tellure multo rariores.
Limes borealis stirpium, quas nobis novercum invidet sidus, in $A \mathrm{~m}$ erica $36^{\circ}$, in Europa $44^{\circ}$, in Asia $34^{\circ}$ L. B. In he misphaera a ustrali usque $35^{\circ} \mathrm{L}$. A. diffunduntur. Species plurimae adhucdum latent, plures, protogaeae decora, exstinctae.

Usus in generis humani oeconomia multiplex, utilitas ingens.

Genera hoc loco enumerantur ex illius, qui semper cum Palmis nominabitur Marti sententia, eorum characteres partim ex editis viri amicissimi voluminibus, partim e manuscriptis ejus schedis, pro eo, quo est in nos animo communicatis, exponuntur.

Trite IBE I. ARECINAE Mart. Palm,157. O vari i m e carpidiis tribus, rariusve duobus, primitus connatis, tri-v. biloculare, rarissime carpidio unico uniloculare. $\mathrm{Ovula}$ in loculis solitaria, rarissime bina, erecta v. lateraliter appensa, saepius in uno alterove loculo omnino deficientia. Fructus trilocularis, profunde tri lobus, vel saepius loculorum abortu uni - bilocularis, baccatus v. tenuiter drupaceus, endocarpio cujusvis carpidii distincto, ant abortivorum a fertilis formatione excluso. St a m in a hypogyna.- Frondes pinnatae v. pinnalo. fissae, rarius bipinnatae, pinnae reduplicatae. Flores in rhachi laevigata v. scrobiculata ses. siles. Spathae plures, rarius unica, rarissime nulla.

1\% 1 9. Clonmanedorea WILLD. Flores dioici, in spadice ramoso sessiles, ebracteati, spathis pluribns membranaceis compressis, persistentilıns. M a s c. Ca ly $\mathbf{x}$ cupularis, trilobus. C orolla tripetala; pet a Iis rotundatis, erecto-conniventibus, aestivatione valvatis. St a mina 6 , e fundo calyeis; filamenta teretia, brevia, anthera e lineari-oblongae. Ovarii rudimentum. F e m. C a I y x cupularis, tripartitus. C o r o I I a tripetala, ut in mare. Sta $\mathbf{m} \mathbf{n} \mathbf{n} \mathbf{m}$ rudimenta nulia. $O \mathrm{va}$ $r$ i u triloculare. Stigm a $t$ a 3 , sessilia. Bac $c$ a monosperma. A I b n m en aequabile, corneum. Embryo lateralis. - Palmae minores, in Americae continente inter octavum utriusque latitudinis gradum sylvas umbrosas suffocatas incolentes; caudice arundinaceo, annulato, frondibus terminalibus $v$. lateralibus, pinnato-fissis $v$, pinnatis, pinnis rhachi subverticaliter adnatis, planiusculis, spadicibus parce et vage ramosis, infra frondium vaginas longiusculas sessilibus, fructiferis corallino-rubentibus, spathis membranaceis, spadice increscente apice perfossis, in ejus pedunculo plus minus persislen. tibus, floribus flavescentibus v, virescentibus, baceis globosis $v$. subglobosis, minusculis.

$\mathrm{C}$ b a m a ed or e a Willd in.Act. Academ.Berolin, 1804. $p$ 40. Sp. pl. IV, 638. Martius Palm, 3. t, 3. 157, t, 126, 138, of t. $R$. N u n e z haria Ruiz et Pav, prodr. 1ár, $t, 31$. N u u. nezia Willd. sp. IV. 1154. Borassi sp. Iacq. Hort. Schönbr. t, 2א7, 248.

1\% 20. Hyospathe MART. Flores monoici, in eodem s padice, 8 path is duabus, interiore incompleta, ebracteati, masenli plernmque bini ad basim cujusvis feminei. Masc. Calyx eupularis, trifidus. Corolla tripetala; petalis 
lanceolatis, aestivatione valvatis. Stamin a 6 , basi petalornm inserta; fil am enta filiformia; antherae breves, lineari-oblongae. Ovarii rudimentum. Fem. Cal y $x$ tripartitus. Corolla tripetala, petalis ovatis, aestivatione coneavis. Staminum rudimenta nulla. Ovarium triloculare, losulis duobus minoribus. Stigma ta 3 , sessilia. B a c c a monosperma. A I b u m en aequabile, corneum. Em b ry o subbasilaris. - Palmae brasilienses, humiles, in sylvis udis sub aequatore degentes; caudice arundinaceo, annulato, frondibus terminalibus $v$, lateralibus pinnato-fissis, pinnis verticaliter adnatis, planiusculis, spadicibus simpliciter ramosis, infra frondium vaginas longiusculas enatis, spathis membranaceis, floribus pallidis, fructibus olivaeformibus.

H yos pat he Martius Palm. 1. et 161, $t, 1.2$.

18:1. Norenia $R U I Z$ et PAV. Flores dioici, in $8 \mathrm{p}$ adicibus ramosissimis, ${ }^{\mathrm{s}} \mathrm{p}$ ath is pluribus basilaribus, apice apertis cinetis, sessiles, ebracteati. M a s c. C a 1 y x cupularis, tridenticulatus. Cor olla tripetala, petalis carnosulis, late ovatis, aestivatione valvatis. Stam in a 6 , e fundo corollae; fil am enta filiformia; an thera oblongae, basifixae. Ovarii rudimentum. Fem. Calyx cupularis, tridentatus. Corolla gamopetala, rotato - campanulata, tubo brevi, limbi trilobi laciniis ovatis acutinsenlis, aestivatione valvatis. Sta $\mathrm{m}$ in $\mathbf{u}$ rudimenta 6 . Ova$r$ i $u$ m ovato-subglobosum, triloculare. Stigma$t$ a 3 , sessilia, deitoidea. B a c a monosperma, parce carnosa. Album en aequabile, corneum. Embryo supra basim dorsalis. - Palmae peruanae, rupicolae; caudice tenero arundinaceo, annulato, frondibus terminalibus pinnatis, pinnis planis aut leviter reduplicalis, inermibus, laevigatis, glabris, spadicibus infra comam verticillatis, simpliciter ramosis, spathis membranaceis, primum spadicis ramos omnino obtegentibus, tandem in pedunculo persistentibus, floribus albis $v$. flavidis, baccis olivaeformibus, viridibus.

Morenia Ruizet Pav. prodr. 150. t.32. Martius Palm. 161. t, 140, 141 .

1722. Fumtlaia $H$. et $B$. Flores monoici, in distinctis spadicibus, spath is pluribus basilaribus coriaceis, tubulosis, apice apertis cinctis sessiles, vix bracteati. M a s c. C a 1 y $x$ membranaceus, trifidus, laciniis acntiusculis. Coroll a tripetala, petalis carnosulis, ovali-oblongis. Stamina 6 , e fundo corollae; filamenta subulata, basi leviter cohaerentia; a nt herae lineares. O $\mathbf{y}$ a i rudimentum. F em. Calyx campanulatus, tridentatus. C or o 11 a tripetala, ut in mare. Staminum rudimenta nulla. Ovar i n m triloculare. S $t$ i g m a t a 3 , sessilia, acuta, revoluta. B acea monosperma, parce carnosa. A l b u men aequabile, cartilagineum, E $\mathbf{m b r y}$ basilaris. - Palma vigintipedalis, in temperatis Cordillerarum Nova-Granatens ium sub ipso aequatore observata ; caudice arundinaceo, annulato, frondibus terminalibus pinnatis, pinnis planis, acuminatis, spadicibus infra frondes verticillatis, simpliciter ramosis, spathis persistentibus, floribus albis.

Kunthia Hamb, et Bonpt. Plant, acquinoct, II. 128. 1, 128. Nov, Gen, et sp. I. 303. Martius Palm, 163, $t, 101$ f. 6.7, t. 142 .

1833. Iryophorbe GÄRTN, Flores divici, in $8 \mathrm{p}$ adieibus distinctis, sp atha basiIari unica (?) cinetis, v. masculi pauci femineis interspersi, subebracteati. Masc. Calys trigo. no-campannlatus, trilobus. Coro 11 a gamopetala, trifida, laciniis ovato-oblongis, aestivatione valvatis. St a m in a 6 , e fundo corollae; fil a m enta subulata,basi leviter cohaerentia; antherae ovatae, dorso affixae. Ovarii rudimentum. F em. Calyx et corolla, ut in mare. Staminum rudimentum cupulare, sexfidum Orarium ovatum, triloculare. Stigmat a 3, sessilia. B a c c a monosperma, sareocarpio fibroso-carnoso. Alb umen aequabile, cartilagineum. Embryo-verticalis. - Palma borbonica; caudice arundinaceo, elato, annulato, frondibus terminalibus pinnatis, pirnis longis, acutis, planis $v$. nonnihil reduplicatis, spadicibus simpliciter ramosis, infra frondes nascentibus, spathis membranaceis basilaribus solitariis, $v$. fortassis pluribus, floribus albidis, baccis olivaeformibus.

H y o p ho r b e Gärtn. II. 186, $t, 120$. Martius Palm, 164. t. 143. f. 1. t. $154 . \mathrm{S}$ a blinu ia Commers. Msc. Areca I utescens Bory.

1\%24. Teopolalinia MART. Flores monoici, in eodem $s$ adiee paniculato-ramosissimo, spathis nniversali et partialibus destituto, in foveis ramulorum sessiles, bracteati et bibracteolati. Mase. Caly x triphyllus, foliolis ovalibus, aestivatione imbricatis. Co roll a tripetala, petalis ovatis, aestivatione valvatis. St a mina 6 , e fundo corollae, inclusa; filamenta complanata, basi connata; antherae ovatae, bilobae, erectae. 0 v a $\mathrm{r}$ i rudimentum minimum. F e m. C a 1 y $x$ triphyllus, foliolis late ovatis. Corolla tripetala, peta 1 is ovatis. Stamin $\mathrm{m}$ rudimenta nulla. Ovari $\mathrm{m}$ turbinato-s $\mathrm{ub}$ trigonum, trilocnlare, loculis duobus minimis. Stigmata 3 , brevissima, patentia. B a e e a drupaeformis orbicularis, monosperma, sarcocarpio e fitris ramosis ligneseentibus. A I b a $\mathbf{m}$ e $\mathbf{n}$ aequabile corneum, medio cavum. Em br yo prope basim lateralis. - Palmae mediocres, in intimis continentis Americae a fluvium Amazonum prope aequatorem sylvarum loca humidiuscula ornantes; caudice extus fibrillitio reticulato circumtexto, intus molli, rubello, frondibus terminalibus pinnatis, inermibus, pinnis reduplicatis, spadice paniculato-ramosissimo, tomento ferrugineo, bracteas bracleolasque saepe penitus velante obtecto, floribus minimis, rubellis, facile defluentibus, baccis compresso-globosis, flavo-virentibus.

Le op oldinia Martius Palm. 58. et 165. 2,52,53.

1\%25. Esuterpe MART. Flores monoici, in eodem $s$ padi $\mathrm{ce}, \mathrm{s}_{\mathrm{p}}$ at ha duplici, interiore minore cincto sessiles, bracteati, masculi plures in parte ramorum superiure, v. bini juxta femineos singules. Mase. Calyx triphyllus, foliolis ovatis, carinato-concavis, aestivatione imbricatis. Corolla tripetala, petalis ovatis v. Ianceolatis, ereetis, aestivatione valvatis. Stamina 6 , e fundu floris; fil a m e nta subulata, libera v. basi confluentia, antherae lineares, subsagittatac, basifixae. Fem. Calyx triphyllus et corolla tripetala, aestivatione convoluto-imbricata. S tamin $\mathrm{um}$ rudimenta nulla. Ovarium triloculare, loculis duobus minimis. St $\mathrm{g} \mathbf{m}$ a ta 3 , sessilia. B a cea uniloeularis, monosperma, stigmatibus excentricis coronata, grumoso-fibrosa, endocarpio tenui membranaceo, eum nueleo connato. A s bumen ruminatum. Embry o lateralis v. subbasilaris. - Palmae brasilienses sylvicolae, grega. riae; caudice elato, gracili, apice saepius flexuoso, annulato, laevigato, intus fibroso, molli, frondibus omnibus terminalibus, petiolis basi longe vaginanti. 
bus, pectinato - pinnatis, pinnis acuminatis, spadicibus infra frondes simpliciter ramosis, ramis fructiferis divaricato - patentibus, tomento granuloso aut furfuraceo, fuscidulo $v$. albo inductis, spathis membranaceo -coriaceis, floribus imprimis inferioribus sive femineis distincte bracteat is bibracteolatis que, ochroleucis v. roseis, fructibus globosis, sordide violaceis. Gärta.

E u terpe Martius Palm. 28_3\%, et 165. $t$. 28_31, non

1\% G. Bemocanpus MART. Flores monoici, in eodem s padice, sp at ha duplici, interiore incompleta cincto, in serobieulis sessiles, bracteis haud distinctis emm rhachi coalitis, masculi gemini femineos stipantes $v$. antice solitarii. M a sc. Ca ly $x$ tripartitus, laciniis carinatis, aestivatione valvatis. Corolla tripetala; petalis ovatis v. oblongis, aestivatione valvatis. Stamina sex, e fondo floris; fil amenta subulata, libera v. basi confluentia; antherae lineares, sagittatae, dorso affixae. Ovarii rudimentum. Fem. Calyx triphyllus, foliolis orbicularihus, et corolla e tripetalae petal a conformia, aestivatione convoluto-imbricata. St a $\mathrm{m}$ i $\mathbf{n} \mathbf{m}$ rudimenta nulla. Ova rium triloculare, loculis duebus minimis. Stigmata 3 , sessilia. B a eca unilocularis, monosperma, stigmatibus exeentricis coronata, grumoso-fibrosa, endocarpio earnoso, eum nucles connato. A $1 \mathrm{~b} \mathrm{u} \mathrm{m}$ e $\mathrm{n}$ ruminatum $\mathrm{v}$. radiatum. E m br yo exacte basilaris. - Palmae elatae, in America inter octavum utriusque latitudinis gradum in pingui sylvarum humo, rariusque in sicco camporum solo crescentes; casdice annulato, intus molli, frondibus omnibus terminalibus pinnatis, pinnis subcrispis, spadicibus infra frondes simpliciter v. fastigiato-ramosissimis, ramis pendulis tomento Eranuloso fusco tenui obductis, spathis lignescentibus, floribus ochroleucis, baccis ovalibus, obscure violaceo-rubentibus, pruinosis.

0 e и о с а р us Martíus Palm, 21_27, et 165.t. 22_27.

1ระซ. Breodexa WILLD. F $10 \mathrm{res}$ monoici, in eodem spadice, spatha duplici, utraque completa cincto sessiles, bracteati et bibracteolati, masculi superiores $v$. inferne bini femineos singulos stipantes. Masc. Cal y x triphyllus, foliolis late ovatis, imbrieatis, tandem coalescentibus. Coroll a tripetala, petaIis oblongo-lanceolatis, aestivatione valvatis. St a min a $6 \_9-12$, e fundo corollae; fil a men$t$ a subulata; antherae lineares, dorso affixae. Ovarii rudimentum. Fem. Caly $\mathbf{y}$ et corolla, ut in mare. Sta min a rudimentaria, in cupulam sexdentatam coalita. Ovari $\mathbf{m}$ triloculare. S tigmat a 3 , sessilia, conniventia. Drupa baccata, sarcocarpio fibroso, putamine crustaceo tenui. A I bumen aequabile, corneum. Embryo basilaris. - Palmae in Americae tropicae insulis et continente vigrentes, nonnullae ob medullitium edule ctiam cultae; caudice gracili, procero, annulato, frondibus terminalibus pinnatis, petiolorum parte basilari cylindrica longe vaginante, pinnis pectinatim expansis, apice inaequaliler bifidis, lacinia postica minore, spalha interiore sublignosa, omnes spadicis ramos obvolvente, vertice demum aperta, floribus pallidis, bracteis minutis, drupis ovalibus.

0 reo doxa Willdenow in Mem, Academ. Bernlín. 1804. p. 34. Kunth. in Humb, et Bonpl. Nov, Gen. et p. T. 303. Martius Palm. 166.. 156.163. A r e c a ol e $x$ a ce a Jaeq. Amer. 278, t. 170. Edit, pict, 135, t, 235.

178. Areen LINN. Flores monoici, in eodem spadice, 8 patha duplici utraque completa cincto, in rhacheos serobicnlis sessiles, brac- teati, masculi superiores $\mathbf{v}$. inferne bini femineos singulos stipantes. Ma s c. Cal y x tripartitus, laciniis carinatis. Coroll a tripetala, petalis lanceolatis, aestivatione valvatis. Stamina $3_{-} 6$ -12, e fundo corollae; fil am enta subulata, ima basi cohaerentia; antherae ovatae, sagittatae. Ovarii rudimentum. Fem. Calyx triphyllus et corolla tripetala, aestivatione convoluto-imbricati. Sta $m$ in $n m$ rudimenta. 0 vari um ovaturu, triloculare. Stigmat a 3 , sessilia, patentia. D r n p a baceaeformis, monosperma, sareocarpio fibroso, putamine tenui, crustaceo $v$. membranaceo, cum testa connato. A Ib umen ruminatum v. rarius subaequabile, corneum. E mbry o basilaris v. prope basim lateralis. - Palmae inter tropicos Asia e, imprimis insularis, vulgares, una in insulis extratropicis usque ad $38^{\circ} \mathrm{L}$. A. re perta, ordinis limitem australem attingens; caudice ut plurimum valido, elato, rarius arundinaceo, gracili, stricto v. subflexuoso, annulato, lacvigato, inermi $v$. aculeato, frondibus omnibus terminalibus, pinnatis, pinnis pectinato-patentibus, lanceolatis, acuminatis, superioribus saepe confluentibus et apice praemorsis, rhachi inermi v. aculeata, petiolis basi cylindrica longe vaginantibus, spadicibus ut plurimum infra frondes inferiores enatis ramosis, $v$. duplicato ramosis, ramis fastigiatis, spathis membranaceis $v$. fibroso-coriaceis, bracteis bracteolatisque interdum inconspicuis, fructibus ovalibus $v$, rarius globosis, colore vario.

A r e c a Linn. gen, n. 1295. Gärtn. I. 19, t. 7. f. 2. Lam. t. 895. Roxb. Corom. t. 75. Martias Palm, 169. $t$. 102. 149. 155. 158. f. 4.5. E u te r pe Girtn. I. 24. t. 9. f. 3. II. 269. t. 139. f. 4. Lam. $t$. 895. non Mart. Pi wa n g a Rumph $\mathrm{Am}$ boin. $X$. 26. $\mathrm{S}$ u bl $\mathrm{im}$ iae sp. Commers.

1 \% 39 Dy losis NORONH. Flores monoici, in eodem spadiee, sp at ha incompleta simpliei v. duplici cincto sessiles, bracteolati, masculi superiores, $v$. inferne bini femineos singulos stipantes. Ma s c. C a I y x triphyllus, foliolis suborbienlaribus, imbricatis. Co rolla tripetala, petalis ovatis, acutis, aestivatione valvatis. Stamina 6 ; e fundo corollas; fi lam e nt a subulata, basi cohaerentia; antherae subglohosae. Ovarii rudimeninm. F em. Caly $x$ triphyllus et corolla tripetala, aestivatione convoluto-imbricati Stamin $\mathbf{u m}$ rudimenta nulla, Ovarium bi-triloculare. Stig u a ta $2-3$, subsessilia. Bacea monosperma, fibrosa. Al b u men ruminatum, corneum. Embryo dorsalis _ Palmulae madagas carienses, tenerae, arundinacae; frondibus pinnatis, saepe connexis, tandemque fissis, v. summis confluentibus, spadicibus tenuibus, ramosis, spathis membranaceis, apice apertis, floribus parvis, bracteis bracteolisque inconspicuis.

Dypsis Nornnha ex Thouar', Melang. 2. Martius Palm. 180. t. 1i3, f. 2. t. 138 f. 1 .

1 \%30 Seaforthín $R . B R$. Flores polygamo-monoici, in spadice ramoso, s p a th is pluribus incompletis stipato sessiles, bracteolati, maseuli superiores et inferne bini femineos singulos stipantes M a sc. CaIy $\times$ triphyllus, foliolis ovatis, imbricatis. Corolla trifida, laciniis oblongis, aestivatione valvatis. Sta $\mathrm{m}$ in a plurima, e fundo corullae; fil am enta filiformia, libera; anthera e lineares, subsagittatae. Ov a rii rudimentum. Fem. Calyx et eorolla maris, imbricato-convoluti. Stam inum rudimenta nulla. Ova rium uniloculare. St y lu s brevissimus, terminalis; s t ig$\mathrm{m}$ a $\mathrm{ta} 3$, patentia. B a cea monosperna, fibrosa. A lb n men ruminatum. Embryo hasilaris. Palmae elegantes, in Novae Hollandiae littore 
orientali tropico, et Asiae insulis finitimis provenientes; frondibus pinnatis, pinnis reduplicatis, erosis, baccis ovalibus, parvis.

Seaforthia R. Brown prodr. 267. Martius Palm. $t$. 105. 106. 109. 128. 129. - ? P y chosperm a Labillard. in Bem, de l'Instit, $1800, p$. 251 .

18 31. Drana 1 ra $B L$. F lores monoici, in diversis spadicibus, s path is pluribus basilaribns incompletis cinctis sessiles, bracteolati. Mase. Caly x triphyllus, foliolis margine imbrieatis. Co rolla tripetala, petalis aestivatione valvatis. Stamin a plurima; fil amenta filiformia, libera; antherae lineares. Floris feminei rudimentum inter duos masculos. F em. C a Iy x triphyllus. Corolla ureeolata, trifida. Sta min $\mathrm{um}$ rudimenta nulla, $O$ va $\mathrm{r}$ in m biloculare. Stigmat a 2, sessilia, acuta. B acea disperma. S emina hinc convexa, inde plana. Albumen aequabile, cartilagineum. Embryo dorsalis, extra medium positus. - Palmae elegantes, in insula Java et Nova Guinea indigenae; caudice gracili inermi, annulato, frondibus simpliciter pinnatis, pinnis cuneatis, sublobatis, eroso-denticulatis, nervis primariis solitariis $v$. pluribus, secundariis valde approximalis.

O r a n i a Blume apud Zippelium et Macklok in Bijdr. tol de nat. Wet. $V$. 142. in Forrusac Bullet, sc, nat, XVIII, 92. Elora 1829. p. 285. Martius Palm. t. 157. Synops, msc.

1832. Hineina HAMILT. Flores monoiei, in eodem spadice, $s$ p a $\mathrm{th}$ i s pluribus basilaribus incompletis cincto sessiles, bracteati; feminei inferne inter masculos plurimos bibracteolati. Masc. Caly $\mathrm{x}$ incrassatus, subcylindriens, tridenticnlatus. Coroll a tripetala, petalis aestivatione valvatis. St a mina 6 ; fil a menta brevia, libera; ant herae lineares. Ovarii rudimentum nullnm. F e m. Cal y x urceolatus, trifidus. CorolI a tripetala. Stam in u m rudimenta nulla. Ovarium bi-v. rarius triloculare. $S t i g m$ a $\mathbf{t}$ a $2-3$, connata. B a cea di-trisperma. Semina hine convexa, inde plana. Albumen aequabile, cartilagineum. Embryo dorsalis, extra medium positus. - Palmae indicae; caudice subterraneo, frondibus pinnatis, pinnis cuneatis praemorsis, spadicibus simpliciter ramosis, ramis pendulis, floribus ochroleucis, parvulis, baccis fuscis, siccis.

Harina Hamilton in Mem. Wern. Soc. $V$. p. 312. Martius Palm. t, 136. Synops mse. Wallichia Roxb. Corom. III. 91. $t$. 295. non DC, Wrig h te a Roxb. Flor. Ind. III. 621, non R. Br.

1533. Iriartea RUIZ. et $P A V$. F lores monoiei, in eodem spadice, $s$ a th is pluribus membranaceis v. coriaceis, imbricatis, interioribus tompletis, clausis, cylindricis, exterioribus in completis, apice apertis. Masc. Ca ly x triphyl lus, foliolis ovatis, coneavis. Cor olla tripetala, petalis ovatis, erectis. Stamina $12 \ldots 24$, corollac fundo inserta; fil a m e n a brevissima, teretia a ntherae tetragonae. Ovarii rudimentum. Fem. CaIy x triphyllus, foliolis orbicularibus, imbricato - convolutis. Coroll a tripetala, petali foliolis calycinis conformibus. Stam in u m rudiruenta nulla. Ovarium triloculare, loculis dus lus efuetis. Stigmata 3 , sessilia. B a ce a mo nosperma, endocarpio fibroso-gelatinoso. A I b ume $n$ aeqnabile, snbosseum. Em br yo basilaris. - Palmae pulcherrimae, parvo numero per vastissimum $A$ mericae a equin oc liulis interioris trac. tum, inter $6^{\circ} \mathbf{L}$. A. et $3^{\circ} \mathbf{L}$. B. effusac, in udis de pressis sylvarum solitarie degentes; caudice plerumque radicibus e terra emersis et in conum conniven tibus sustento, elato, annulato, inermi, medio saepius tumido, frondibus elegantibus pinnatis, petiolorum basibus cylindraceo-convolutis, tandem uno latere longitudinaliter apertis atque defluentibus, pinnis subdeltoideis, antice truncatis, dentatis $v$. erosis, spadicibus infra frondes sessilibus simpliciter ramosis, tomento detergibili adspersis, spathis plurimis, cito deciduis rariusve persistentibus, floribus dense confertis, ochroleucis, bracteis bracteolatisque obsoletis, baccarum epidermide virescenti-fusca, carne parca albida, subgelatinosa, nucleo violaceo - fuscescente.

Iriarte a Ruiz et Pav. prodr.139. t.32. Martius Palm. 35. t. 33-37. - Cerox y 10 n Humb, et Bonpl. Pl, aequi. noct. $I, 1, t, 1, \overline{2}$.

1 \%34. Arenga LABILL. F lores monoici, in distinctis spadicibus, $s \mathrm{p}$ ath is aliquot basilaribus completis cinctis sessiles, bracteati et bracteolati. Mas c. C a ly x triphyllns, foliolis oratis, imbricatis. Coroll a tripetala, petalis oblongis, aestivatione valvatis. Stamina plurima; filamenta filiformia, libera; antherae lineares, cuspidatae. Floris feminei rudimentum bibracteolatum inter duos masculos. Fem. C al y $\mathrm{x}$ triphyllus, foliolis aestivatione convolutivo-imbricatis. Coro 11 a tripetala, petalis aestivatione valvatis. Staminum rudimenta nulla. Ovari nm triloenlare. Stig mat a 3 , conica, basi connata. Drupa di-tripyrena. Pyrenae trigonae. A I b um e n aequabile. E m bryo dorsalis. - Palma indica; caudice crasso, procero, petiolis delapsis irregulariter unnulato $v$. eorundem basi persistente squamato, rete fibrarum crassarum passim incompte vestito, frondibus omnibus terminalibus, obscure viridibus, subtus pallidioribus, concinne pinnatis, pinnis reduplicatis, basi medio angustata sessilibus, auriculatis, spadicibus inter frondium bases emergentibus, simpliciter ramosis, ramis virgatis, basi spathis nonnullis deciduis vestitis, pendulis, masculis pluribus, tandem deorsum evolvendis, femineo unico terminali, floribus majusculis virescentibus, drupis globosis, flavescentibus.

A r eng a Labillard. Mem. de $l^{\prime}$ Inst. $I N$. 209. Martius Palm, t. 108. 1in. 148. Synops. msc. S agueras et $\mathrm{G}$ omu tus Rumph. Amboin. $I .57, t, 13 . \mathrm{S}$ a guerus Roxb. Flor. Ind. III. 623. G o m ut us Spreng. Gen, pl. n. 8228.

1735. Caryota LINN. Flores monoici, in distinetis spadicibus, $\mathbf{s}$ at $\mathrm{h}$ is aliquot basilaribus completis cinctis, sessiles, bracteolati. M a se. C a l y $x$ triphyllus, foliolis ovatis, imbricatis. $C_{0}$ roll a tripetala, petalis oblongis, aestivatione valvatis. Sta mina plurima; fil amenta brevissima, basi in urceolum connata; ant herae oblongae, acutae. F em. C a I y x triphyllus et c orolla tripetala, aestivatione imbricato-convolutivi. S t a$m$ in $\mathbf{u m}$ rudimenta nulla. Ovari u m triloculare. St igmata 3 , sessilia, depressa, connata. Bacca bilocularis, disperma. S e m in a hine convexa, inde plana. Alb um en cartilagineum, ruminatum. E mbryo dorsalis. - Palmae indicae; caudice mediocri, annulato, frondibus bipinnatis, pinnis praemorsis, petiolis basi vaginantibus, spadicibus magnis, simpliciter fastigiato - ramosis, floribus coriaceis, baecis purpureo-nigricantibus.

C a r y ot a Linn. gen, n, 1288. Girtn. I, 20, t, 7. Mirbel in Annal, alu Mus. XIII. t. 3. f. 29. Martius Progr. 18. Palm. $t$, 107. 108. Seguster in aj or Rumph Amboin. I. 64, t. 14 .

TRIBUES II. LEPIDOCARYINAE Mart. Synops, msc. O vari um e carpidiis tribus v. rarissime duobus, primitus connatis compositum, tri-v. biloculare. Ovulu $\mathrm{m}$ in quovis 
loculo unicum, erectum. Fructus plerumque abortu monospermus, rarissime $\mathbf{b i}-$ trispermus, baccatus, tessellato - corticatus, squamulis primum erectis, deinde resupinatis, imbricatis, corneis. Stamina hypogyna aut perigyna. - Flores plerumque diclines, sessiles, saepe bracteis circumcirca clausis, bracteolisque perfoliatis, spathaceo-unitis, yuasi amentacei. Spadices ramosi. Spathae plerumque plures, raro unica, completa. Frondes pinnatae aut palmato - flabelliformes, pinnis reduplicatis.

\section{** PINNATIFRONDES.}

1738. Calamans LINN. Flores dioici, v. polygamo-divici, in spadicis, spathis pluribus incompletis vaginati, amentis spathellulati Masc. C a I y $x$ tridentatus aut trifidus. Corolla tripartita $v$. fere tripetala. Stam ina 6 ; filam e $n$ a basi connata; a $\mathbf{t}$ he ra e sagittatae. $0 \mathrm{va-}$ rii rudimentum. Fem. Calyx et corolla maris. Stamina 6 rudimentaria, in urceolum connata. Ovarinm triloculare. Stigmata 3 , sessilia. B a c c monosperma, squamis retrorsis loricata. A Ib um en corneum, superficie pustulatum, aequabile, v. superficie laevigatum et ruminatum. E mbryo subbasilaris. - Palmae indica et africanae tropica e; caudicibus saepe caespilosis, gracilibus, debilibus, longissimis, super arbores fruticesque plerumque longe lateque vagantibus, alternatim et remote foliosis, frondibus laterulibus longe vaginantibus, rhachibus laxis, saepe omnino aphyllis, cirrhos rectos graciles (funem) exhibent, $v$. in acumen cirrhiforme attenuatis, spadicibus terminalibus, succrescente caudice lateralibus, spathis incompletis vaginatis, paniculato-ramosis, apice saepe pariter ac frondes in funem extenuatis, floribus in ramulis ultimis distichis, bracteis bracteolisque spathaeformibus, quasi amentaceis distinctis, parvulis, roseis aut virentibus, baccis globosis aut ellipticis, fuscis aut lutescentibus.

C a la m u s Linn. gen, $n$ 436. Gärtu, II. 267, t.139. Palis,Flor Owar. t. 9. 10. Martius Palm, t, 113, 114. 116, 198, 160. Synops. msc. Nees Pl.offic.I.39. $40 . \mathrm{P}$ a $1 \mathrm{~m} i \mathrm{j}$ a n $\mathrm{e}$ u s Rumph $A m b o i n . V$. t. 51. 53, 55. 56. 57. f. 1. 58. f. 1. Ts j e r u Ts j a rel et $\mathrm{Kad}$ u T s ju rel Rheed. Malab. XII, $t, 64,56$.

173\%. Zalacea $R E I N W$. F lo res dioici, in spadice ramoso, $s$ ath $i$ s pluribus partialibus, primum clausis, singula amenta teretia obvolventibus. M a sc. per paria dispositi, intra bracteas spathaceo - connatas bracteolati, bracteolis barbatis. Cal y x trifidus. Cor oll a tubulosa, trifida. Stamina 6 ; filamenta hasi connata; anthe$r$ a e lineares. F em. solitarii intra bracteam et bracteolas duas, naviealari connatas. C al y x tripartitns. Corolla tripetala. Sta mina 6 sterilia, in cupulam eonnata. Ovarium triloculare. St igmata 3 , subsessilia. Ba e c a corticata, intus carnosa, subunilocularis, mono-di-trisperma. A I bum en aequabile, cornenm, fossa centrali a vertice usque ad medium pertingente, testae sub. stantia repleta exsculptum. Em b r y o basilaris. Palma indica, acaulis; frondibus magnis, copiosis, congestis, petiolis rhachibusque subtus aculeis longis palmatis horridis, spadicibus ramosis $e$ sinu inferiorum frondium, spathis basilaribus apice aper tis, et partialibus primum completis clausisque, de mum siccis laceris persistentibus involucratis, flori bus rosaceo aut flavescenti-rubellis, fructibus fuscis.
Za lace a Reirwardin Sylloge $p$. II. Blune in Schul. tes syst. VII. 1333. Martins in Wallich PI. As. rar. t. 222. 224. Palm. t.118. 119.123. 159. fig.3. C a Ia mo $\mathrm{Z}$ alac e a Gürth. II, 267. t. 139. f. 1. PaImijuncus $\mathrm{Z}$ a lacca Rumph Amboin. $V$. 115. $t, 57$. $f .2$.

\section{Flectoeonia MART. Flores} dioici, in spadice clongato, in spieam simplicem v ramosam dispositi, sub spathis incompletis squamaeformibus, distiche imbricatis reeonditi. Masc. Caly $x$ trifidus. Corolla tripartita. St amina 6 ; fil amenta subulata, basi cohaerentia; anth era e lineares, fere basifixae. Ovarii rudimentum nullum. Fem. Calyx et coroll a maris. Stamina sterilia in cupulam hypogynam coalita. Ovariu m triloculare, loculo uno alterove saepe efoeto. Stigm a ta 3 , subsessilia, subulata. B a c ca squamis retrorsum imbricatis loricata, unilocularis, monosperma. A I b u m e n aequabile, corneum. Embryo basilaris. - Palma $j a$ vanica; habitu Calumi, frondium rhachi spinis palmatis horrente, spadicibus lateralibus elongais, ramosis, spathis coriaceis dimidiatis vestitis, floribus flavescentibus.

Ple etocomia Martius et Blume in Schultes $f$. sgst, VII. 1333. Martius Palm, $t$, 114. Synops, mse. C a l a m us m a x i m a R Reinwardt.

1\%39. Ceratolobus BLUM. Flores polygamo-monoici, in eodem spadice, spath a completa siliquaeformi, ancipite, longe pedunculata cincto, maseuli et hermaphroditi solitarii, spathel lato-bracteati. M a s c. breviter pedicellati. C a I y $x$ tridentatus. Cor o 11 a subtripetala. Stamin a 6 ; fil ament a subulata, cum corollae basi confluentia; antherae lineares, basifixae. Ova rii rudimentum. Hermaphr. sessiles. Caly y et curolla maris. Stamina 6 ; filamenta altius cum corolla coalita; antherae efortae (?). Ovarium triloculare. Stigmat a 3 , sessilia. subulata. Bacea squamis retrorsum imbriratis loricata, unilocularis, monosperma. A 1 b am en. .... E mb ryo...... Palma javanica; caudi. ce debili sarmentoso-scandente, frondium alternarum vaginis elongatis, dense et patentim aculeatis obtecto, frondibus pinnatis, pinnis cuneato-rhombeis, antice crenato - dentatis, subtus flavescentibus, spadicibus lateralibus, pedunculo tenui, longo, frondium interiori superficiei adnato, floribus intra spatham demum irregulariter rumpendam inclusis, pa niculatis, spathellis sub ramificationibus et infra flores vagis.

Ce rat olo b us Blume in Schulies $f$, syst. DIT. LXXX. et 1334. Martius Palm. t, 117, 125. Synops. msc.

17 40. Daemonorops $B L U M$. Flures monoici, in eodem spadice paniculato, sp at his pluribus completis vaginato, sub ramis spathellatho, solitarii, spathellulati. M a 8 c. C a I y $x$ eampanulatus, tridentatus. Coroll a tripartita. Stamina 6 ; fil ament a basi eoalita; antherat lineares, basifixae. Ovari rudimentum nullum. Fem. Calyx et eorolla maris. Stamina 6; fil a m e $\mathrm{n}$ a ananthera, in eupulam hypogynam coalita. Ova ri n m triloculare. St ylus brevissimus; stigmata 3 , subulata, recurva. B a c c a monosperma, sqnamis retrorsum imbricatis loricata. A I b a m e n ruminatum. Em b r y o subbasilaris. Palma javanica; habitu Calami, a quo spathis pluribus completis, et floribus in spadice paniculato sparsis, nec in ramulos ultimos amentiformes conglomerutis differt.

D a em o n o r a p s Blume in Schultes f. syst, N11, 1333. Martius Palm, t, 117 et 125. f. 1. Synops, msc. Calamu niger Willd. Palmifuncus wiger Rumph Amboin. $\nu, t, 32$ 
194. Sagus GAERTN. Fl o re s monoici, in eodem spadice ramoso, absque spatha communi pluribus incompletis vaginato, in amentis compressis distichis, bractea et bracteola cupularibus cincti. Masc. Caly $x$ tridenticulatus. Corolla tripetala. Stamina 6 v. 12 ; filamenta compressiuscula, basi dilatata; anther ae lineares, erectae. Ovari i rudimentum nullum. Fe m. C aIy $x$ tridenticulatus. Co rolla eampanulata, trifida. Staminum urceolus sexdentatus, antheris efoetis, sagittatis. O $\mathrm{varium}$ triloculare. Stig$m$ a $t$ a 3 , subulata, connata. B a cca squamis retrorsis loricata, monosperma. A I b a m e n ruminatum. Embryo supra fossam umbiliealem dorsalis. Pulmae in depressis maritimis inter tropicos Asiae, Africa e et Americae sparsae vel gre gariae, sylvas constituentes; caudice crasso, mediocris altitudinis, intus molli, rubello, frondibus terminalibus robustis, pinnatis, subcrispis, petiolorum basibus margine in jibras fissilibus, spadiciós ma gnis inter frondium buses pendulis, ramosis, perennantibus, floribus fuscescentibus, coriaceis, persistentibus, petalis subtortis, fructibus strobiliformibus, nitidis, fuscis $v$. castaneis, parce flavescenticarnosis, seminibus durissimis.

$\mathrm{S}$ a g us Rumph Amboin. I. 72. t. 17.18. G.irtn. I. FI, t. 10. Jacq. Fragm. t, 4. Martius Palm. t. 45. 48, Synops. msc. R aphia Palis. Fl, Owar, t. 44_4j. Desvaux Journ, Bot, 1809. p. 84 .

174. Netroxylon ROTTB. Flores monoici, in eodem spadice ramoso, absque spatha communi pluribus imeompletis vaginato, in amentis teretibus bractea squamaeformi distincti, et bracteola cupulari densissime villoso-barbata cincti. Mase. Caly $x$ trifidus. Corolla tripartita. Stamina 6 ; fil a ment a subulata basi connata; a therae dorso affixae. Ovarii rudimentum nulium. Fem. Caly $x$ et corolla maris. Staminum urceolus hypogynus, dentatus, anantherus. Ovari $\mathbf{m}$ triloculare. Stigmata 3 , tandem in pyramidem connata. B a c c a squamis retrorsis lorieata, monosperma. $A$ l b a m e n ruminatum. E mb r yo dorsalis. _- Palma a fricana tropica, habitu Sagi; caudice crassiusculo, frondibus omnibiss terminalibus robustis, pinnalis, petiolis saepe spinis longis armatis, pinnis margine spinulosis, spadicibus e sinu frondium pendentibus, distiche ramosis, spathis tublosis untice apertis distiche vaginatis, floribus rubello -fluvescentibus.

Metroxylon Rottboell in Act, soc. Hafn. 1783, Ir. p. 523. König Annals of Bot. I. 193. t, 4. Martius Palm. 1.102, 159. Synops. mse.

\section{** FLABELLIFRONDES.}

1743. IIauritia LINN. F. F lo res polygamo-dioici, in spadice distiche ramoso intra squamas amentorum teretium spathellati, coriaceo membranacei, 8 patha universali nulla, partialibus pluribus in ompletis. Ma s c. Cal yx cyathiformis, tridenticulatus. Corolla tripetala, petalis lanceolatis, erectis. Stamina 6 ; filain enta planiusicula; antherae lineares erectae. $O$ varii rudimentum nullum. Hermaphr. CaI y x campanulatus, tridentatus v, trifidus. Co rolla at medium tripartita, lacinis lanceolatis, ereetis. Stamina 6; fil a menta eomplanata, subpyramidalia; antherae ovatae, basi subbilubae. Ovarium tesselatum, triloculare. Stigma sessile, trilobum. B a c ca monosperma, tessellatocorticata. Sem en rhaphe unilaterali v. semicir culari, chalaza verticali, mamillaeformi v. rostrata. A thumen aequabile, osseum. E mbryo sapra hasim lateralis, extremitate radiculari raphen spec-
tans._Palmae elegantissimae, in A mericae tropicae humidis depressis, inter $1^{0}$ L.B. et $16^{\circ}$ L.A. gregariae; caudice elato $v$, mediocri, laevigato, in ermi v. spinis conicis horrido, intus spongioso - mol$l i$, rubello, frondibus flabelliformi-pinnatifidis, spadicibus saepius perennantibus, inter frondes e spathurum incompletarum sinu pendulis, distiche ramosis, ramis amentiferis, spalhaceo-articulatis, floribus coriaceis, rubello-fuscis, fruclu strobiliformi fusco-nitido, carne tenui flavescente.

Ma u ritia Linn. $f$. suppl, 1436. Humboldt Ansichten der Nat. 26. 131. Martius Palm. 42. t, 38_44. Le B a c he Aabl. Guian. Append. 103.

194. Lepialoearyum $M A R T$. F I o r es polygamo - dioiei, in spadice distiche ramoso, inter squam is amentorum compressorum spathellati, coriaceo-membranacei, spath a universali nulla, partialibus pluribus incompletis. Masc. Caly $\mathrm{x}$ campanulatus, subtrigonus, ore truncato, obiter tridentato. Cor olla tripetala, petalis lanceslatis, acutis, erectis. Stamina 6 , inclnsa; fil ament a crassiuscula; a nthera e oblongae, dorso adnatae. Ovari i rudimentum nullum. He rma $\mathbf{p} \mathbf{r}$. Cal y campanulatus, subtrigonus, ore truneato, obiter tridentato. Co ro Il a basi subcampanulata, tripartita, laciniis lanceolatis, acutis, erectis. St amin a 6; filam enta compresso-plana; anthera e parvae, oblongae, dorso adnatae. Orari um tessellatum, loculis duobus rudimentariis uniloculare. Stigmat a 3 , linearia, erecta, basi connata. B a c e a monosperma, tessellato-eorticata. S emen rhaphe semicirculari. Albumen aequabile, osseum. E m b r y o lateralis, extremitate radiculari a rhaphe aversa. - Palmae humiles, elegantes, in Americae uliginosis flumini Amazonum conterminis, sub ipso aequatore parce habitantes; caudice tenui, stricto v. flexuoso, intus duriusculo, rubello, petiolorum basibus persistentibus, vaginantibus vestito, obiter annulato, frondibus flabelliformibus, irregulariter fissis, margine spinulosis, spadicibus inter frondes patentibus, articulatovaginatis, floribus roseo-rubellis, fructibus rubrofuscis, parce carnosis.

Lepidocary um Martius Palm, 50, $t, 45_{-}$is.

'TRIBUS IRL. BORASSINAE Martius Synops. msc. Ovarium e carpidiis plerumque tribus, rarius duobus v. quatuor primitus connatis compositum, tri-v, rarius bi-quadriloculare. Ovala in lnculis solitaria, adscendentia v. resupinata. Fructus drupaceus v. rarius baccatus, indivisus v, lobatus. s $\mathbf{t}$ amin a hypogyna. - Flores plerumque dioici, masculi lextura yuasi ylumacea, spadicis foveolis e squamarum coalilione ortis immersi, sub anthesi emeryentes, quasi amentacei. Spathae aut incompletae spadices articulatovaginanles, aut rarius completae, eosque omnino cooperientes. Frondes palmato-flabelliformes aut pinnatae, pinnis in flatelliformibus induplicalis.

\section{* FLABELLIFRONDES.}

1745. Borassus LINN. Fi ores dioici, in spadice $8 \mathrm{p}$ ath is incompletis vaginato. Mas $\mathrm{s}$. A m ent a cylindrica, coalitione squamarum, floribns bractealis biseriatim in foveis aggregatis, sensim emergentibus. Calyx trifidus. Corolla tripartita. S tamina 6; fi l amenta libera; a n thera e sagittatac. $F$ e m. intra amenti squamas sub- 
solitarii. Cal y x triphyllus et corolla hexa-enneapetala sibi arete imbricato- convoluti. S $t$ a m in a abortiva $6-9$, filamentis basi coalitis, antheris efoetis, Ovarium tri-rarius bi-quadriluculare. Stig mat a $3, \mathbf{v}, 2-4$, sessilia. D rup a tripyrena, pyrenis obcordatis fibrosis, apice poro pertusis. Album en aequabile, demum cavum Embryo verticalis. - Palmae indicae; caudice elato, annulato-cicalrisato, intus duro, nigricante, frondibus omnibus terminalibus, palmato-flabelliformibus, petiolis spinoso-serralis, spadi cibus inter frondes emergentibus, masculis ramosis femineis minus divisis aut subsimplicibus, floribus masculis parvis, rubello-flavescentibus, drupa ma gna, fusca.

B o r a s 8 us Linn. gen, n, 1220. Roxb. Corom, t.71.72. Martius Palm, t, 121. Synops. msc. L on tar us Rumph Amboin. $I$. , 10. Gartn. I. 21, t.8. - 0 b s e r v a ti o. (I. Blume in Schult. $f$, syst. VIT. 1308. monente Lo nt a r as s y 1 . ve s t ris altera Rumpli 65. 6.12 , novum genus sistit, $\mathrm{P}$ h oli. docarpus dicendum, fructibus tessellatis, nuces 2_4 da. ras foventibus insigne, cui verosimiliter Borass us tu nicat us Loureir. erit adnumerandus.

1746. Touloicen $L A B I L L$. F lor es dioici, in spadice spathis incompletis vaginato. Mase. A menta cylindrica, e coalitione squamarum, floribus bracteatis, biseriatim in foveis amenti aggregatis, sensim emergentibus. Caly $\mathrm{x}$ et corolla profunde tripartita. Stamin a 24 36; fil amenta basi coalita; antherae lineares, obtusae. Fem. intra amenti squamas subsolitarii. Caly x triphyllus et corolla tripetala, convoluto-imbricati. Stamin um rudimenta nulla. O $\mathrm{va}$ ri a in triloculare, rarius bi-quadriloculare. Stig$\mathrm{m}$ a $\mathrm{ta} 3$, v. 2-4, sessilia, pyramidato-conniventia. Drupa ingens, fibrosa, plerumque monopyrena, rarius di-tripyrena, pyrena ossea, fibris adhaerentibus capillata, biloba, didyma v. pyrenarum coalitione et lohorum abortu triloba A ll, umen aequabile. Embryo in conjugatione loborum basilaris. - Palma Sech ellarum; eaudice crasso, procero, annulato, frondibus terminalibus palmato-flabelliformibus, spadicibus inter frondes emergentibus maximis, fuscis, floribus masculis flavescentibus, drupa olivaceo-viridi.

Lo doice a Labillardiere in Annal, du Mus, IX, 140. t. 13. Hooker Bot. Mag. t. 2734_2738. Martius Palm. t. 109. 122. et $\boldsymbol{X}$. Synops. mse.

174\%. Latania COMMERS, Flores dioici, in spadice s $\mathrm{p}$ ath is incompletis vaginato. M a s c. Ame n t a cylindrica, e coalitione squama rum, floribus solitariis ex amenti foveis sub anthesi emergentibus. Ca ly x triphyllus et corolla tripetala, marginibus imbrieatis. Stamina 15 (16) - 30 (32); fil amenta basi coalita; a ntherae lineares, sagittatae, fere basifixae. Fem. in amentis paucifloris(?). Cal y $x$ triphyllus et cor o la tripetala (?). O varium triloculare. Stigmata 3 , brevissima, sessilia. Drupa tripyrena, py renis extus ramoso - rugosis. A I b u m e n aequabi le. Embryo dorsalis, - Palmae in dicae; caudice mediocri frondium annulis cicatrisato, frondibus omnibus terminalibus palmato-flabelliformi bus, spadicibus inter frondes emergenlibus, masculis ramosis, ramis distichis vaginato-squamatis, $e$ sinu squamarum ramulos alternos apice amenta digitata $v$. pedata ferentes exserentibus, floribus masculis flavis, drupis lutescentibus.

L a t a $n$ i a Commers. ex Juss, gen. 39. Martius Palm. t.154. 162.1is, f.IV. Synops. msc. C le op h o r a Girtn. II,185, t, 120 ,

17.8. Hyphaene GÄRTN. Flores dioici, in spadice spathis incompletis vaginato, distiche ramoso, ramis masculis amenta subterna ferentibus, femineis plerumq' e pancioribns. Ma s c, Ca 1 y x tripartitus. Coroll a tripetala. Stamin a 6 ; fil amenta libera; antherae lineares, basi sagittata aflixae. Ovarii rudimentum nniIum. Fem. Calyx triphyllus et corolla tripetala, marginibus imbricata. Stamina 6 , rudimentaria. O v a $\mathrm{r}$ i u m tri-rarius biloculare. St ig mat a 3. v. 2, sessilia. Drupa aborta simplex v. bi-triloba, sarcoearpio fibroso, pntamine ligneo. A l b um en corneum, aequabile, cavam. Embryo vertiealis. Palma a gyptiaca; caudice mediocri, annulato, dichotome ramoso, frondibus in caudice adliuc simplici et in ramis terminalibus, palmato-flabelliformibus, filis inter lacinias plerumque pendulis, spadicibus inter frondes erumpentibus, floribus pallide flavis $v$, rubescenti-ochroleucis, fructibus pruinosis, lutescenti-fuscis.

H y $\mathrm{pha}$ n e Gïrtn. II. 13. t. 82. Martius Palm, 131. 132. 133. Synops. msc. Cu cifer a Delile Flor. Aeggpt. $I$. 57. $t, 1,2$. Do u m a Lam. Dict, $t, 900$. Cor y h h e sp. Lima.

\section{** PINNATIFRONDES.}

1749. Rentimekia BERRY. F lores monoici, in distinctis spadicibus, sp ath a simpliei cinctis. Mase. Caly x tridentatus. Corol. 1 a tripetala. S $t$ am in a 6 . Fem. Calyx bibracteolatus, tridentatus. Corolla tripetala, Stamina 6 , rudimentaria. Ovarium triloculare, loculis duobus efoetis. Stig mata... Bacea monosperma, sphaerica, succulenta, A1bumen. Emb ryo basilaris. - Palma elegans, in montibus Travancore Indiae orientalis observata, non satis nota, et forsan a sequente genere haud distincta; caudice arundinaceo, frondibus terminalibus pinnatis, spadicibus decompositis, infra frondes lateralibus.

Bentinek ia Berry ex Roxb. Flor. Ind. III. 621. Martius Palm. 163.

150. Keppleria $M A R T$. F 10 r e s dioici, in spadice s $\mathrm{p}$ at $\mathrm{th}$ is duabus (v. pluribus?) membranaceis basilaribus completis cincto, e foveis rhacheos bilabiatis emergentes, masculi nonnulli alternatim distichi, feminei subsolitarii. Mase. Calyx triphyllus. Coroll a tripetala. St a mina 6; fil amenta distincta; an $t$ herae lineares. Ovarii rudimentum. Fem Calyx et corolla maris. Stamina 6, ananthera. Ovari u m triloculare. Stigmata 3 , sessilia. Drup a monosperma, stigmatibus excentricis, subbasilaribus, sarcoearpio e fibris lignosis, ramosis, endecarpio papyraceo, nucles suleato. A1b u m en solidum, aequabile. E $m$ hr yo subbasilaris. - Palma indica; caudice tenui, arundina ceo(?), frondibus pinnatis, pinnis conduplicatis, spa this et spadicibus Geonomae, fructibus parvulis

Keppleria Martius Palm, t. 139. Synops, msc.

1851. Teomoma WILLD. F Iores mon. nici, spadicibus diversi sexus in eadem stirpe $\mathbf{v}$. androgynis, rarius dioisis, in foveolis rhacheos immersi, spatha duplici, exteriore concava. interiore compressa $v$. fosiformi. Mase. Caly $x$ tripbyllus, foliolis carinato-eoncavis. Corolla tripetala, petalis planis. Stamina 6 ; filamenta inferne in cylindrum connata, apice libera, a ntherarum locnlis divaricatis. Ovarii rudimentum. Fem. Calyx triphyllus, Corolla gamopetala, trifida. Urce ol u s sexdentatus, ovarimm ambiens. Ovarium triloculare. Stylus hasilaris, stigmatibus 3 , revolutis. Bacca mo- 
uosperma. Albumen aequabile. Embryo sublateralis v. basilaris. - Palmae Americae trop ic a e sylvas primaevas, inter $20^{\circ}$ L. A. et $10^{\circ}$ L. B. copiosius incolentes; caudice rarius nullo, dum adest arundinaceo, gracili, stricto, annulato, laevigato, frondibus primum simplicibus, mox in pinnas irregulares, integerrimas fissis, petiolis vaginantibus, partim caudici lateraliter insidentibus $v$, omnibus terminalibus, spaditibus inter frondes emergentibus, spicalis saepiusve paniculatis, spathis ut plurimum jam ante anthesim obliteratis, floribus primum in rhacheos excavationibus latentibus, slramineis v. purpurascentibus, baccis ovatis $v$. subglobosis, coloris obscuri, parce carnosis, insipidis.

Ge ou om a Willd. sp. IY. 593. Martius Palm. 6.t. 420. G y uest u m Polteau in Mem. Mus, IX, 385, t. 16_20.

185\%. Manieania GAERTN. F I o $\mathrm{r}$ e 8 monoici, in eodem spadice, 8 patha simplici fusiformi, reticulato - fibrosa, dilatabili, suh grossificatione irregulariter rupta cincto, alveolis densis immersi, bracteati, infimi ramorum feminei. Masc. Caly x triphyllus, foliolis seariosis, ovatosuborbiculatis, imbricatis. Cor olla tripetala; petalis coriaceis, oblongis. St a mina $24-30$; filamenta filiformia; antherae lineares, subsagittatae, erectae. F e m Calyx triphyllus, foliolis scariosis, ovatis, imbricatis. Corolla tripetala, petalis coriaceis, oblongo-lanceolatis. Stamina rudimentaria 12 ovarium turbinatum, trigonum, suleatuin v. angulatum, trilocu lare. Stigmata 3 , sessilia, ovato-triangularia, demum patentia. Drupa tricocca, rarius abortu mono-dicocea, cortice suberoso, angulato-echinato, putaminibus erustaceis, fibris reticulatis obvolutis, basi oblique foratis. Albumen cor neum, aequabile, centro cavum. Embryo basilaris. - Palma in America inter $3^{\circ} \mathbf{L}$. A. et $5^{\circ}$ L. B. in sylvis inundatis, limosis, submaritimis proveniens; caudice grosso, mediocris altitudinis, inermi, intus spongioso - molli, frondibus omnibus terminalibus, firmis, integris, oblongis, in tolo ut videtur ordine maximis et robustissimis, spadice in ramos plurimos, simplices, dense florigeros diviso, inter frondes persistentes erumpente, nutante $v$. pendulo, fusco-tomentoso, floribus roseo-ochroleucis majusculis, fructibus magnis, suberosis, testaceis.

Ma u ienria Gärtn. IT. 468. t. 176. Martius Palm. 139. 1. 108. 199. Pil o p h o r a Jaeq. Fragm. 32. t.35. 36. Willd. in Berliner Akadem. Abhandl, 1815. p. 1 .

TRIBUS Iv. CORYPHINAE Martius Synops, mse, Ovarium e carpidiis tribus primitus distinctis, demum aut distinetis $\mathbf{v}$. in unum connatis, omnibus v. uno alterove evolutis, rarissime carpidium unicum. Ovul a in loculis solitaria, erecta, lateralia v. resupinata. Fructus baccatus triplex, profunde trilobus, $\mathbf{v}$. abortu duplex aut simplex, carpidiis abortientibus a formatione evoluti exclusis, rarissime solitarius. St amin a hypogyna v. perigyna. - Spathae plures, vagae, incompletae, rariusve completae. Caudex in ermis. Frondes plerumque palmato-flabelli. formes, rarissime (in Ploenice) pinnacae, pinnis induplicatis. Flores sessiles, plerumgue hermaphroditi v polygamo-dioici.

SUETRIBUS I. SABALINAE Martius 1. c. Flabellifrondes.
1\%53. Coryplar LINN. F l ores herma. phroditi, in spadice 8 path is pluribus incompletis vagis cincto sessiles, v. subsessiles, bracteati. Caly cupularis, tridenticulatus. Corolla tripetala, aestivatione valvata. Sta $\mathrm{m}$ in a 6 ; fila menta basi dilatata, hypogyne cohaerentia; an therae ovatae. Ovarii earpidia tria, cohae rentia. Styli subulati, coalescentes, stigmate simplici. B a c a plerumque unica, monosperma. A Ibumen aequabile. Embryo verticalis. Palmae in Asia tropica indigenae, procerae, speotabiles; caudice annulato, frondibus omnibus terminalibus, amplis, palmato-fiabelliformibus, laciniis apice fissis, spadice in speciebus monocarpicis (an in omnibus?) terminali, amplissimo, spathis pluribus incompletis vaginato, floribus parvulis virescentibus, baccis lutescentibus.

C o r y p h a Linn. gen, n. 221. Roxb. Corom,, 255.256. Martius Palm, t. 102, et 127. excl. reliq. Synops. mse. T a. $1 \mathrm{i}$ e r a Martius Progr. 10. Ge m b a n g Blume in Flora 1825. p.580 et 678. Co d da-p a n a Rheede Malab. III. Lo t. 1 - 12

1854. Hivistoma $R$. BR. Flores hermaphroditi, in spadice $s \mathrm{p}$ a $\mathrm{th}$ is pluribus incompletis basilaribus cincto sessiles, bracteati. C a 1 y $x$ trifidus. Corolla tripartita. Stamina 6 ; filamenta in discum hypogynum coalita; antherae cordato - oblongae. O v a $\mathrm{r}$ i carpidia tria, intus cohaerentia. Sty li coalescentes; stigma $t$ i bus connatis v. distinetis. B a c c a plerumque unica, monosperma. A I b u m e $\mathbf{n}$ cavitate ventrali testae radio horizontali ruminatum. E mbryo dorsalis. - Palmae in Nova Hollandia et in $A$ sia tropica observatae; caudice mediocri, frondium basibus persistentibus squamato, frondibus flabelliformibus, laciniis apice bifidis, saepe filis interjectis distinetis.

L ivisto n a R. Brown pro dr.III. 123. Martius Palm, t,110, 111. 145. 146. Synops msc, Latania chinensis Jacq. Fragm, p. 16. t, 11, f.1.

185. Wiemala RUMPH. Flores hermaphroditi, in spadice alternatim ramoso, s p athis pluribus incompletis vaginato sessiles, aut brevissime pedicellati, bracteati. C a l y $x$ campanulatus, tridentatus. Corolla tripartita. Stamina 6 ; filamenta in eupulam subrepandam connata, apice brevissime libera; antherae sagittatae. Ovarii carpidia tria, basi et vertice leviter cohaerentia. Stylus trigonus; stigma tridentatum. Dru p a abortu unica, monosperma, putamine tenui. A 1 b um en corneum, parte ventrali spongioso - aut farinaceo - ruminatum. $\mathrm{Em}$ bryo dursalis. - Palmae asiaticae tropicae, plerumque hamiles; caudice subarundinaceo, frondibus omnibus terminalibus, digitato-aut palmatoflabelliformibus, spadice pleramque hirsuto, floribus saepius sericeo-pubescentibus.

Licuala Rumph Amboin. $I$. A4, t, 9. Thunb. in Aet. Holm. 1782. p. 284. Blume in Schultes syst. VII, LXXVII et 1301. Martius Synops. msc. Sartbus Rumph Nmboin. I. $t 2, t .8$. Cory $\mathrm{p}$ ha $\mathrm{s}$. Lour.

1\%5. Israhea MART. Flores hermaphroditi, in spadice $s \mathrm{p}$ at $\mathrm{h}$ is aliquot basilaribus (?) incompletis cincto sessiles, bractea bracteolisque duabus minimis, inter spadicis villum latentibus cincti. Caly $x$ triphyllus, foliolis margine imbricatis. Corolla tripartita. Stamina 6 ; fil amenta in cupulam hypogynam connata; antherae cordato - ovatae. Ovarii carpidia tria, arete connata. Styli prismatico-connati; stigma simplex. B a c c a plerumque nnica, rarius binae v. ternae. Albumen a basi ad verticem strato testae perfossum. Embryo dorsalis. 
Palmu in Andibus Peruviae cum quercubus et Coniferis mixta; caudice mediocri, frondibus fla belliformibus, pinnis induplicatis, filis saepe inter jectis, spadice magno ceranoideo - multiramoso, floribus parvulis virescentibus, baccis lutescentibus.

B ra he a Martius Palm. t, 137. Synops, msc. Cory pha dulcis Humb.

1\%5\%. Copenuicia MART. F $10 \mathrm{r}$ e 8 hermaphroditiv. polygami, in spadice ramoso, s p a$t h$ is incompletis vagis stipato sessiles. Caly $x$ cupularis, tridenticulatus. Co ro 11 a campanulata trifida. Stamina 6 ; filamenta in cupulam perigynam (corollae adnatam) coalita; an the ra e cordato-ovatae. Ovari i carpidia tria, minus cohaerentia. Stylus brevis; stigma capitatum. B a cea abortu unica, monospcrma. Albumen aequabile, medio cavum. Embryo subbasilaris. Palmae in America tropica obviae; caudice mediocri, superne frondium basibus persistentibus vestito, frondibus flabelliformibus, pinnis induplicatis, saepe filis interjectis, spadice $e \sin u$ frondium ramoso, villosulo, floribus parvulis virescentibus, puberulis, baccis lutescentibus, ellipticis.

Coperuicia Martius Palm. t. 50. A. Synops, msc. Corypha s p. Lumb. et Kuntit. Martius Palm. t.49.50. Caranaiba Marcgr. Piso.

1858. Sabal $A D A N S$. F Iores hermaphroditi, in spadice ramoso, $s p$ athis pluribus incompletis vaginato sessiles, bracteati. Ca I y x cupularis, trifidus. Corolla tripetala. Stamina 6 , hypogyna; fil am enta subdiscreta, subulata; antherae cordato-ovatae. Ovarii carpidia tria, primitus distincta, demum coalescentia. Stylus trigonus; stigma capitatum. Bac ca simplex v. profunde lobata, duplex ant triplex. A I b um en aequabile. Embryo dorsalis. $-\mathrm{Ial}$. mae boreal $i$-a mericana e, inter $29-41^{\circ} \mathrm{L}$ B.provenientes, et borealem ordinis limitem in novo continente attingentes, deorsum crescentes, gemma laterali, caudice cum frondium basibus persistentibus extra terram lateraliter porrecto aut partim immerso, in aliis tandem mediocri, frondibus fabelliformibus, pinnis induplicatis, spadicibus infra fromdes enatis, ramosis, floribus parvulis, albidis aut virescentibus.

$\mathrm{S}$ a b al Adaus. Fam. II. 495. Guerns. in Bullet, soc. philomat. n. 67. t. 25. Bot. Mag. t, 1434. Nuttall gen. I, 231. Martius Palm. t. 103, 130, 163. Synops, msc. Co s y phat sp. Jacq. Hort. Vindob. III. t.8.

1559. Chamaerops LINN. Flores polygamo-dioiei, alii hermaphroditi, alii masenli in eadem v. in diversa stirpe, in spadice $s$ pathis duabus v. quaternis, quarum interior completa cincto sessiles, bracteati. Masc. F a ly x tripartitus. C orolla tripetala. Stamina $6 \ldots 9$; fil a menta basi connata; antherae oblongae. Hermaphr. Calyx et corolla ut in mare. Stamina 6 ; filamenta in cupulam hypogynam connata; antherae ovatae v. oblongae. $O$ varii carpidia tria $v$. rarius plura, distincta. Stig ma t a subulata, subsessilia. B a c c a e tres v. raro plures, interdum abortu pauciores, monospermae. A I b u men ruminatum. Em bryo dorsalis. - Palmae in India boreali et in regione mediterranea indigenae, borealem ordinis limitem $\left(15^{\circ}\right.$ Cels. Isotherm.) in veteri continente attingentes, caudice in specie asiatica elato, in mediterranea humili, declinato $v$. erecto aut nullo, frondibus densis rigidiusculis, flabelliformibus, petiolis plerumque serrato-spinosis, floribus dense confertis, flavescentibus, baceis olivaeformibus.
C hamaerops Linn. gen. n. 1219. Lam. $t .900$. Meyer in $19 \mathrm{~cm}$. Lcadem. Berolin, 1796. p. J. Lambert in Jinn. Transact. $X$, 262, t, 8. Bot. Reposit. $t .599$. Martius Palm. 4 120. 124. 125. Synops, mso. Wallich Pl. As, rar. $t, 211$. Nees jun.gen. $p l$. fasc. $X, t, 2,3$. C h a ma e riphes Pouteder. Antholog. 10, Gartn, $I, 26, t, 9, \mathrm{P}$ hoenix Cav, ic. $I$. 12. $t, 115$.

l gBO. Tritheimax $M A R T$. F lores hermaphroditi v. abortu polygami, in spadice ramosissimo, spathis pluribus incompletis stipato subsessiles Caly x cupularis, trifidas. Corolla tripetala, petalis margine imbricatis. Stamina 6 ; fil a menta subulata, libera $v$. basi subconnata; antherae lineares. Ovarii carpidia tria, distineta. Styli subulati; stig matibus simplicibus. B a ce a abortu unica, menusperma. A I bu men aequabile(?). $\mathrm{Km}$ bry o prope verticem dorsalis. - Palma in Brasiliae meridionalis campis a Scllowio reperta; caudice mediocri, frondibus terminalibus palmato-flabelliformibus, pinnis induplicatis, spadice expanso, floribus numerosissimis, parvulis onusto.

Trithriuax Martius Palm. 149, $t$. 104. Synops msc.

1761. Filnapis LINN, F. Flores poly gamo-dioici, in spadice spathis aliquot incompletis vaginato sessiles, bracteati. M a s c. Cal yx cupularis, trifidus. Corolla eampanulato-trifida. St amina 6 ; filam enta filiformi-triquetra, corollae adnata, alterna crassiora, profundins distineta; an therae ovatae, extrorsae. Herma $p h$. C a l y $x$ cupularis, trifidus. Co ro II a tripetala (?). Stamina $6 \ldots$ Ovarium e carpidiis tribus distinctis .... B a c c a uniea? ... A I b um en $\ldots$ Embryo... - Palma in China et Japonia indigena, in hortis nostris solum flores masculos proferens; caudice brevi fibrillitio tecto, frondibus terminalibus et sublateralibus, palmato-divisis, pinnis in margine plicisque aculeato-denticulatis, flo ribus rubescenti-fuscis, crassiusculis.

R h a p is Linn, fil. msc. Ait. hort. Kew. III. MA. Herit. Stirp. IT. t. 100. Jaeq. Hort. Schönbr. t, 316. Bot. Mag. t. 1371. Martius Progr. 8, Sjuro, Sodio et $\mathrm{S}$ o o-T sik a Kämpf. Amioen, exot.898.

1862. Tharinax LINN. F. F loreg her maphroditi, in spadice alterne et duplieato-ramoso, spathis pluribus incompletis cincto breviter pedicellati, bracteati. C al y x profunde sexfidus. Co rolla nulla. Stamina $6-12$; filamenta subulata, basi connata; antherae oblongae, utrinque bifidae, erectae. Ovarinm e carpidio unico, uniovnlato. Stylus sursum in stig ma concavum tubuloso-ampliatns. B a c ca monosperma. A Ib n nen aequabile aut subruminatum Em bry o subvertiealis v, dorsalis, - Palmae antillanae; caudice mediocri, tenui, frondibus terminalibus, palmato-flabelliformibus, petiolorum basibus vaginantibus in reticulum solutis, floribus minimis.

Th ri n a x Linn. fil, in Schreber. gen. Swartz prodr, 57. Flor. Ind. occid, I. 614. Martius Progr. 8. Synops, mrc.

\section{SUIBTRERES TI. PHOENICINAE} Martius $l$. $c$. Pinnatifrondes.

1763. Flhoenix $L I N N$. F lores dioiei, in spadice ramoso, spath a simplici cincto sessiles. Ca I y x urecolatus, tridentatus. Corolla tripetala Stamina 6 v. 3 ; fil a menta brevissima, subnulla; antherae lineares. Fem. CaIyx nr ceolatus, tridentatus. C o r o I I a tripetala, petalis convolutis. O v a $r$ i carpidia tria, distincta, unicum maturescens. Stig mata unci. nata. Drupa monosperma. Semen hine sulco 
longitudinali exaratum Albumen reticulatum. E mbryo dorsalis. - Palmae in India oriental $i$ et Africaborealiore indigenae, per regionem medilerraneam cultae; caudice meliocri annulato, frondibus pinnatis, pinnis linearibus, spadice inter frondes erumpente, spatha sublignosa, ancipiti cincto, floribus ochroleucis, fructu eduli, molli, fulvo-fusco.

$\mathrm{P}$ h o e n ix Linn. gen, $n, 1224$. Juss, gen, 38. Gärtn. I. 23. t.9. Roxb. Corom, t. 74. et 273. Martius Palm. t. 120, 124. 136, 164. El ate Ait. Hort, Kew.III. 477.

TIRIIEU v. COCOINAE Martius $S_{y n}$ ops. msc. Ovarium e carpidiis tribus, rarius duobus, quaternis v. senis, primitus coalitis conflatum, triloculare, $\mathbf{v}$. rarius bi-quadri-sexloculare. Ovula in quovis loculo solitaria, erecta v. resupinata. Fructus drupaceus, monopyrenus, trilocularis aut saepissime unilocularis, loculis abortivis in fertilis putamine seu endocarpio osseo v. lapideo inclusis. Nucleus testae vasis reticulatis cum endocarpio plus minus cohaerens. Stamina hypngyna, filamentis basi confluentibus. - Flores intra spalham solita. riam v. plures, quarum intima completa primum reclusi, bracteali, sessiles, $v$. bracteis in opus foveolatum connatis foveis immersi, diclines, ochroleuci. Sarcocarpium fibrosum. Endocarpium crassum. Nucleus oleosus, albumine aequabili. Caudices in ermes $v$. aculeati, frondes pinnatae, pinnis reduplicatis.

\section{* ACUlfatae.}

164. Desmoncus MART. F L o r e s monoici, in eodem spadice, spath a duplici, exteriore brevi, coriacea, apice aperta, interiore cylindrica, ventre demum fissa, sublignosa cincta, in ramis flexuosis sessiles, feminei inferiores, solitarii. Masc. Caly $x$ membranacens, triangularis v. obiter trifidus, laeiniis acutinsculis carinatis. Corolla tripetala, petalis ovatis, acutiusculis, calyce crassioribus. S $t$ amina 6 , e fundo floris; filamenta filiformia; an therae lineares, eree tae. Fem. Caly x enpularis, ore truncato v. ubiter tridenticulato, basi pervius. Corulla gamopetala, arceolaris, ore truncato, obiter tridentato, basi pervia Ovari um ovatum, loculis duo. bus rudimentariis uniloculare. Stylus brevis; stig m at a 3 , acuta, revoluta, exserta. Drupa ovata v. subglobosa, monosperma, carne tenera. putamine tenui, vertice triporoso. A $1 \mathrm{lb}$ u men aequabile, corneum. Emhryo intra porum apiealis. - Palmae debiles, in Americae continente inter aequatorem et capricornum loca calida, umbro$s a$, virgultosa incolentes; caudice gracili subarundinaceo, flaceido, flexuoso, aliis plantis sustento $v$. interdum scandente, undique aculeis magnis, rectis v. hamatis horrido, frondibus per omnem caudicem sparsis, peliolis longe vaginanlibus, remote pinnatis pinnis parum reduplicatis, margine haud ciliatis, sed noduloso-inaequalibus, rhachi longe in eirrhum producta, ubique uncis recurvalis validi. munita, spadicibus inter frondes axillaribus solitariis, simpliciter vamosis, ramis subflexuosis, fasti- giatis, spatha interiore crassiore, plerumque aculeata, drupae rubrae carne parca, putamine nigro. Desmon e us Martius Palm, 85. $4.68,69.89,71$. f.5. Aititara Marcgrav. L'A voira savane Aubl.

1865. Wretris $J A C Q$. Flores monoici, in eodem spadice, $s p$ ath a dnpliei, exteriore breviore, apice aperta, membranacea, interiore fnsiformi, ventre tandem fissa, coriacea v. subligno. sa cincto sessiles, bracteolati, feminei imprimis in parte inferiore masculis pluribus interspersi. $M$ a s c. Calyx tener, tripartitus $v$ trifidus, laciniis sublanceolatis, carinatis. Corolla tripetala, petalis calyce crassioribus, ovatis, planiuseulis, longitudinaliter striatis. St a m in a $6{ }_{-9}-12$, e toro basilari crassiusculo, basi saepius petalis adnata; filamenta subulata; antherae lineares, subsagittatae, erectae. F em. masculis firmiores. $\mathrm{C}$ a I y $\mathrm{x}$ urceolaris $v$. rarius annuliformis, ore truncato, integerrimo v, obsolete tridenticulato. $\mathrm{Co}_{0-}$ rolla gamopetala, nrceolaris v. cylindrica, ore truneato, tridenticulato. $O$ v a $\mathbf{r} \mathbf{~ n ~ m}$ ovatum v. prismatico-trigonum, loculis duobus rudimentariis uniloculare. Stig mata 3 , sessilia, pyramidato-acnta, primum conniventia, mox revoluta. Drupa ovata v. subglobosa, monosperma, cortice coriaceo, carne pulposa, patamine osseo, versus apicem triporoso. A I b nm en aequabile corneum. Embryo intra porum apicalis. - Palmae americanae tropicae, imprimis sub aequatore sylvicolae, ad fluviorum ripas et in inundatis el paludosis frequentes; caudice mediocri $v$. humili, rariusve elato, arborescente $v$. arundinaceo, caespitibus et radicibus sobolifero, aculeis nigris aut fuscescentibus armato $v$. inermi, frondibus per totum caudicem sparsis vel sursum frequentioribus, patentibus, petiolorum basibus longe vaginatis, superstitibus caudicem involventibus, aculeatis $v$. etiam postice aculeatissimis, pinnatis, pinnis pectinatis v. sparsis, aut etiam connexis, spadicibus lateralibus el terminalibus simplicibus, $v$. simpliciter ramosis, spalhis armatis, floribus ochroleucis, femineis saepius virentibus ant roseis, drupis obscure ceruleonigricantibus $v$. rarius dilutis, pulpa gelatinoso-subfloccosa, albida, acidula scatentibus.

B a ctri s Jaeq. Amer. 279. Gärtn. II, 269, t. 139. excl. sp. Martius Palm, 92. 1.60.70, 74.

\section{Ge. Fuilielma MART. Flores mon-} oici, in eodem spadice, $\boldsymbol{s} \mathbf{p}$ atha duplici, exteriore brevi cylindrica, apice bifida, interiore li gnescente fusiformi, demum ventre aperta cincto sessiles, minute bractenlati. M a s. Cal y x planiusculus, triangularis, angulis acutiuseulis, tenere membranaceis. Corolla gamopetala, subg[i)bosa, profunde tripartita, laciniis suborbicalaribus v. obovatis. Stamina abortu 6 , corollae laciniis per paria opposita; fil ament a subulata; a $\mathrm{n}$ thera lineari-oblongae, incumbentes. Ovari i rudimentum, F e m. inter mares sparsi. Calyx membranacens, annuliformis, limbo obiter tridenticulato, basi pervius. Corolla coriacea, globoso-campanulata $\mathrm{y}$. turbinata, ore truncato. Ovari um subglohosum, loculis duobus rudimentariis uniloculare. Stigmata 3 , sessilia. Drnpa ovata, monosperma, fibrosn-carnosa, putamine osseo, vertice triporoso. A I b u m e n aequabile, cartilagineum. E mbry o intra porum apicalis. - Palma elata, in umbrosis udis inter Orinoc cu met $\mathrm{Ama}$. zon um fluvium degens, ab Indis Orinocci accolis etiam culta; candice annulato, aculeis horrido, intus duro, alro, frondibus omnibus terminalibus, pinnatis, peicolis aculeatis, pinnis linearibus appro- 
ximatis, aculeato-cilialis, spadicis simpliciter ramosi ramis crassiusculis, fusco-tomenlosis, floribus carnosiusculis, masculis ochroleucis, femineis virescentibus, drupae flavo-rubrae carne crassa, amylacea, eduli.

G u ili e I a Martius Palm, 81, t, 66, 67, Bactris G asipaes Humb.

1\% 6\%. NIsนtinezia RUIZ et $P A V$. F lo res monoici, in eodem spadice, $s$ path a duplici cincto sessiles. Mase. Cal y x triphyllus. Corolla tripetala. Stamina 6. Ovarii rudimentum. Fem. Caly $x$ triphyllus, Corolla tripetala. St a m in $\mathrm{m}$ abortivorum urceolus membranaceus, subsexdentatus, ovarium ambiens. Ovarium triloculare (?). S ti g mat a 3 , sessilia. Dru pa monosperma. Al b u me $\mathbf{n}$ aequabile. Em b r y o.....

Palma peruana, non satis nota; caudice aculeato, frondibus pinnatis, pinnis cuneatis, apice truncatis, erosis, spadice simpliciter ramoso.

Martinezia Ruiz et Pav. prodr. 138, t. 2. excl sp. plur. Kunth in Humb. et Bonpl. Nov. gen. et spo t. 245. Marlius Progr, 21.

1\% BS. A oici, in eodem spadice, sp a tha simplici. lanceolata, lignescente incluso. M a se. in smperiore ra morum parte densissimi, in foveolis sessiles. Caly $\mathrm{x}$ parvus, triphyilus, foliolis ovatis. Corolla tripetala, prismatico-cylindriea, petalis lanceolato-oblongis. St amina 6 , inclusa; fil a menta compressa; antherae lineari-oblongae, subsagittatae. Orarii rudimentum. Fem in inferiore ramorum parte remotiusculi, sessiles. Caly $\mathrm{x}$ triphyllus, foliolis ovato-suborbienlaribus. Coroll a tripetala, petalis ovatis, aestivatione imbrieatis. Cu p u 1 a annularis, sexdentata, ovarium aubiens. Ovarium ovatum, triloculare, hirsutum. Stylus brevis; stigmata 3 , lanceolata, revoluta. Drup a globosa, monosperma, epicarpio eartila ginco, mesocarpio mucilaginoso - fibroso, putamine crasso, lenticulari, lateribus triporoso, poris duobus coecis. A I b u m e n aequabile, durum. E mbryo intra porum lateralis. - Palma procera, in campis siccioribus, rarius in sylvis Americae tropicale obvia; caudice sacpius medio ventricoso, aculeato, intus fusco, nigro, fibroso, frondibus pinnatis, subcrispatis, petiolis spathisque aculeatis, spadicibus inter frondes inferiores persistentibus, simpliciter ramosis, primum erectis deinde pendulis, foribus masculis flavis, drupis olivaceo-fuscis, putamine duro, spadiceo-nigro.

Acrocom ia Martius Palm. 66, t. 56, 57, 100. f. 5 . Cncos a cule at a Jaeq. Amer, $t$, 169. (Edit, pict, $t$, 150.) Palmier Mocay a Aubl. Correa in Annal. Mus. X. 158. t. 10. $f$. 2. B a ctris minor Gartu. 1. 22. $t$. פ. f. 1 .

156. Astroerryume $C$. W. G. MEY. Flores monuici, in eodem 8 padice, 8 p atha sinplici, fusiformi, ventre aperta, ligneseente, diu persistente cincto. Masc. in superiore ramorum parte densi, in alveolis sessiles, $\mathrm{C}$ al $\mathrm{y} \times$ tripartitus v. trifidus, laciniis triangularibns, acutis. C o r olla gamopetala, tripartita, laciniis oblongolanceolatis, erectis, membranaceis v. versus basim carnosiusculis. Stamina abortu 6, petalis per paria opposita, raro plura, inclusa; filamenta filiformia, erecta; an th e r a lineari-subsagittatae, incumbentes. Or a rii rudimentum. F em. infra masculorum spicas solitarii, in rhachi v. in pedunculi parte dilatata sessiles. Cal y $\mathbf{x}$ urceolatus, obiter tridentatus, siccinsculus. Corolla gamo. petala, urceolata, carnosa, ore contracto subtri dentato, tandem irregnlariter trifido, intus basi in annulum membranaceum elevata, uti calyx fo- ramine orbiculari pervia. Orarium ovatum, loculis duobus rudimentariis uniloculare $S t y l^{\prime}$ s conicus; stigmata 3 , in corpus floccoso-gelatinosum, conicum v. lobatum confluentia. Drupa ovata v. subglobosa, monosperma, carne valide fibrosa, putamine osseo, vertice triporoso.. Alb u m en aequabile, corneum, centro cavum. Embr yo intra porum apicalis. - Palmae mediocris altitudinis $v$ rarius etiam acaules, in $A$ mericae tropicat locis sylvaticis, humentibus, calidis spar$s a e, v$. subcaespitose degentes; caudice exceptis annulis undique aculeis validis, atris horrido, frondibus terminalibus pinnatis, petiolis aculeatis, pinnis $l i$ nearibus aproximatis, aculeato-cilialis, subtus plerumque argenteo-albis, spadicibus simpliciter vamosis, aculeis $v$. setis horridis, saepius albo-tomento. sis, spathis lignescentibus, aculeatis inclusis, inter frondes persistentibus, floribus masculis flavescentibus, femineis virescenti-v. ochroleuco-pallidis, drupis flavis $v$. aurantiacis, fibroso-carnosis, perigonio persistente stipatis, inermibus $v$. spinulosis.

A strocary u m C. W. G. Meyer Essequeb, 265. Mar. tius Palm. 70, t.58_64. Tox o p ho e a i x Schott in Bravil. Nachricht, IT. App. 12.

\section{** INERMES.}

1\% 8. Attalea H. B. K. F lores monoici, in eodem spadice, spatha simplici cincto sessiles, bracteati, maseuli superiores, feminei versus basim ramorum panciores. M a sc. C a l yx triphyllus, foliolis liberis v, ima basi coalitis. Corolla tripetala, petalis membranaceis v. carnosulis, oblongo-laneeulatis, erectis. Stamina e toro basilari $10 \_24$, conferta; fil a m e n $t$ a subulata, subinaequilonga; antherae sublineares, erectae. F em. Caly x triphyllus, foliolis ovatis, imbricato-convolutis. Coroll a tripetala, petalis foliolis calycinis similibus, inclusis. O varin triloculare, raro quadri-v. quinqueloculare, rarissine biloculare. Dr u p a ovata v. elliptica, subrostrata, cortice fibroso-lignoso, putamine lapideo, biquinqueloculari, loculis basi porosis. Albumen subsotidum, amygdalino-oleosum Embryo intra fossam basilaris. - Palmae per omnem $A m e$ ricam tropicam diffusae, sylvas calidas praediligentes, rarius in montes adscendentes, procerae $v$. mediocres, aut inlerdum acaules; caudice crassiusculo, extus irregulariter cicalrisato, intus molli, fusco-rubello, frondibus terminalibus pinnatis, amplis, petiolis latiusculis, pinnis glabriusculis, reduplicatis, spadicibus inter bases frondium emergentibus, patentibus, simpliciter ramosis, fructiferis nonnunquam maximis, nutantibus, floribus ochroleucis, fructibus fuscis, seminibus edulibus.

A $t$ ta le a Kunth in Humb. et Bonpl. Nov. gen. et sp. I. 310, t. 95. 96. Martius Palm. 136. t. 41,75. 95. - 97.

17 \%. Elaels JACQ. F lore a mono ci, in diversis spadicibus corymhoso-ramosis, spatha duplici, utraque completa, tandem in fibras longitudinales sccedente, exteriore compressa, margine subaneipiti, apice ab interiore lanceolata perforata cinctis, e rhacheos foveolis emergentes. M a 8 c. C a l y x papyraceo-aridus, triphyllus, foliolis linearibus v. lanecolatis. C or olla membranacea, tripetala, petalis lanceolatis, erecto-conniventibus. St am in a 6 , inclusa; fila menta in urceolum apice sexfidum connata; anthera e oblongae v. ovatae, patentes. Ovarii rudimentum. F e in. C a lyx membranaceus, triphyllas, foliolik ovatis imbricatu - convolntis. C or olla membranacea, tri-hexapetala, petalis ovatis $\mathbf{v}$. ovato-oblongis, imbricato-convolutis. Stam in a m rudimenta 
nulla. Ovarium ovatum v. subeylindricum, triloculare, loculis duobus efoetis. Stig inata 3 , magna, uncinato-patentia. D ru pa ovato-angnlata, monosperma, sareocarpio fungoso-oleoso, fibroso, putamine vertice triporoso. A I b umen aequabile, corneum. Embryo. prope verticem lateralis. - Palmae inter tropicos Africae et Americae locis calidis, campestribus provenientes, solo argillaceo et calcareo gaudentes, africana species etiam in America culta; caudice mediocri, crasso, erecto $v$. decumbente, petiolorum basibus coronato $v$. cicatrisato, frondibus amplis, petiolis crassis, margine spinoso-serratis, pinnatis, pin$n$ is rigidiusculis, spadicibus dense corymboso-ramosis, tomento subpulverulento, fuscidulo adspersis, floribus e ramorum foveolis emergentibus, masculis densissime imbricatis, femineis laxius sparsis, strumineo-fuscis, drupis carnosis, amoene flavis, miniatis $v$. rubris.

E 1 a e Is Jaeq. Amer, t. 172. (Edit. pict, t. 257.) Gärtn. 1. 17, t. 6. Lam. t. 896. Martius Palm, 62. t. 54. - 36. A 1fou sia Kunth in Humb. et Bonpl Nov.gen. et sp. I. 246. Corozo Jacq. Amer. 171. f. 4.

1\%7. Cocos LINN. Flores monoici, in eodem spadice, spath a simplici lignosa, fusiformi v. clavata, ventre aperta et lanceolata cincto sessiles, bracteati, masculi in parte superiore plures, feminci in inferiore frequentiores. Mas e. Cal y x triphyllus, foliolis lanceolatis, carinatis, basi saepius connatis. Corolla tripetala, petalis membranaceis v. carnosiuseulis, erectis v. conniventibus. Sta m in a 6 , e toro basilari; fil a ment a subulata, subaequilonga; a $\mathbf{t}$ her a e lineares, subsagittatae, ereetae. Ov a rii rudimentum minimum v. nullum. F em. CaI y x triphyllus, foliolis suborbicularibus v. ovatis, imbricato-eonvolutis. Corolla tripetala, petalis membranaceis, suborbicularibus, imbricato-convolutis, ut plurimun calyce inclusis. O vari u m ovatum v. depresso-globosum, loculis duobus rudimentariis uniloculare. Stylus brevissinus v. nullus; stigmata 3 , pyramidato-triquetra, primum conniventia, demum revoluta. D r a p a ovata, elliptica v. ovato subtrigona, monosperma, mesocarpio crasso, fibroso, putamine osseo, basi triporoso. A I b u un e $\mathbf{n}$ aequabile v. obsolete radiatum, amygdalinum v. cartilagineum. E mbry o intra porum basilaris. Palmae inter tro picos Americae frequentes, syl vaticae $v$. plures campestres, in $A$ sia rarae, pelagi viciniam amantes, in Africam introductae; caudice excelso $v$, mediocri, inermi, annulato $v$ cicatrisato, interdum nonnihil flexuoso, saepius petiolorum basibus persistentibus squamato $v$, corona to, intus molli, spongioso, frondibus omibus ter minulibus, saepius vastis, pinnatis, petiolis basi fibroso-pannosa amplexicaulibus, nonnunquam spinoso-serratis, pinnis reduplicatis, saepius aggregalis, subrecto patentibus $v$. crispis, crassiuscule membranaceis, glabris, spadicum inter bases frondium exteriorum sessilium, patentium rhachi tere tiuscula, scorbiculata, in rumos plurimos simplices divisa, spatha mucronata, dorso longitudinaliter sulcata, floribus masculis ochroleucis v. flavescentibus, femineis virescentibus, fructibus quandoque naximis, sicciusculis, fuscis v, rubro-flavescentibus.

C o c os Linn, gen, n, 1223. Gärti. I, 15, t, 4, 5. Roxh. Coram, t. 75. Martius Palm, 114. t, 78-88. 101, 102, La ul gs do r fia Raddi in Mem. soc, ital. XVIII 349. c. ic.

173. $3 y a g r a s ~ M A R T$ F I or es monoici, in eodem spadice, spatha duplici, exteriore breviore, teneriore, apice aperta, interiore fusiformi, sublignosa, ventre aperta, tandem lanceolata eincto sessiles, bracteolati, masenli in parte 8 uperiore plures, in inferiore plerumque femineos geminos stipantes. Mas c. Caly $\mathbf{x}$ triphyllus, foliolis triangularibns, membranaceis. Corolla tripetala, petalis carnosiusculis, lanceolatis, carinatocristatis, erecto-conniventibus. Stam in a 6 , inclusa; fil amenta subulata, subaequilonga; anthe rac lineares, subsagittatae, erectae. $\mathbf{O}$ a ri i rudimentum minimum. F em. Caly x triphyllus, foliolis ovatis, carinatis, margine imbricatis. C oro Ila tripetala, petalis ohlongis, calycem superantibus, imbrieatis. Ova $\mathbf{r i n} \mathrm{m}$ ovato-globosum, loculis duobus abortivis uniloculare. $S t i g ~ m$ a $t$ a 3 , sessilia, pyramidato-trigona, conniventia. Drupa oblonga, monosperma, mesocarpio fibroso, putamine isseo, triporoso. A l b u m e $n$ aequabile, centro cavum, eartilaginem. Em bryo intra porum basilaris. - Palma humilis, in campis Amaz on $u m$ fluvio adsitis crescens; caudice inferne annulato, apice frondium rudimentis capitato, intus pallido, lento, frondibus omnibus terminalibus, luxiusculis, pinnatis, spadicibus inter frondes interiores provenientibus, parce et simpliciter ramosis, spathis dorso sulcatis, floribus masculis ochroleucis, fructibus sicciusculis, flavescenti-viridibus.

S y agrus Martius Palm. 129, t.89.90. Genus monente cl. Martius fortassis eum praecedente combinandum.

1ซ 4. Diplotiluemionan $M A R T$. F lores monoici, in eodem spadice, spatha dupliei, exteriore breviore, apice aperta, membranacea $v$. coriacea, interiore clavata v. eylindrica, mucrona. ta, ventre demum fissa, dorso sulcata, lignusa cincto quinconciatim dispositi, masculi in parte inferiore verucis callosis, hemisphaericis super femineos impositi, in superiore solitarii, sessiles, bracteis flores masculos geminos $\mathbf{v}$. intermedio femineo sociatos eingentibus, favoso-connatis. M a s c. subcarnoso-coriacei. C a l y x triphyllus, foliolis anguste lanceolatis, carinatis, ima basi connatis Corolla tripetala, petalis ovatis, subearinatis, erectis $v$. conniventibus. S $t$ a $m$ i n a $6-12$, v. indefinita, e toro basilari; filamenta subulata, inaequilonga; anthera e sagittatae v. sublineares, erectac. Ov a rii rudimentum minutissimum. F e m. coriacei, striati. Ca l y x triphyllus, foliolis ovatis, carinatis, imbricato-convolutis. Corolla tripetala, petalis ovatis, carinatis, integer rimis v. repando-dentatis. Ov a ri u in globoso-trigonum, loculis duobus rudimentariis uniloculare. Stigmat a 3 , sessilia, triquetra, pyramidato-conniventia, demum subpatentia. Drupa ovata v, obo vata, monosporma, cortice fibroso, pntamine la pideo, basi triporoso. A 1 b a m en aequabile, cartilaginenm. Fmbryo intra porum basilaris. Pulmae in Brasilia inter 23 et $100 \mathrm{~L} . \boldsymbol{A}$, in maritimis sabulosis, $v$, in campis siccis, herbidis, ventosis usque 1400 ped. elevationem sparse $v$. gregarie erescentes, plerumque acaules, rarius caudicem crassiusculam inermem, annulatum elevantes; frondibus pinnatis, breviter petiolatis, petiolorum basi vaginante fibroso-panniformi, tandem lacera, pinnis angustis, firmis, rigide patentibus v. crispis, interrupte aggregatis; subtus argenteis v. glauco roridis, spadicibus simplicibus, antice dense florigeris, spatha exteriore intra frondium bases latente, floribus majusculis, druparum flavescentium carne fibrosa, eduli.

Diplothe mium Martius Palm, 108, $6,70,75$ - 78 . 
198. Maximiliana MART. Flores monoici, sessiles, bracteolati, spadicibus in eadem stirpe aliis androgynis, aliis masenlis, s pathis simplicibus, crassis, lignosis, oblongis, longe rostratis, sulcatis cinctis. Mas c. C a ly x triphyllus, foliolis membranaceis, ovato-triangularibus. Corolla tripetala, petalis lanceolatis, subcoriaceis. St am in a 6 , imae corollae inserta; filamenta subulata; antherae lineares, dorso adnatae. Ovarii rudimentum minimum. Fem. Cal yx triphyllus, foliolis membranaceis, ovatis, imbricato - convolutis. Corolla tripetala, petalis ovatis, imbricato-convolutis, calyce parum longioribus. Cupula memliranacea, ovarium cingens. Ovarium ovato-conicum, loculis duobus rudimentariis uniloculare. S ty l u s brevis, teres; $8 \mathrm{tig} \mathrm{m}$ at a 3 , revoluto-patentia, intus glanduloso-viscosa. D ru p a ovata, monosperma, cortice fibroso, siceo, putamine osseo, basi triporoso. A $1 \mathrm{bum}$ e n aequabile, amygdalinum v. cartilagineum, rentro saepius cavum. Embryo intra porum basilaris. - Palmae speciosae, Brasiliae sylvas inter aequatorem et $5^{\circ} \boldsymbol{L}$. A. incolentes; caudice mediocri $v$. elato, recto, subreguluriter annulato, laevigato, intus' helvolo, lento, frondibus pinnatis, pinnis aggregatis, spathis inter frondes erumpentibus, persistentibus, crassis, spadicibus simpliciter ramosis, floribus dense compactis ochroleucis, drupis fuscescentibus.

Maximiliana Martius Palm, 131, t. $91-94$.

1\% 6. Jubaea H.B.K. F l ore 8 inenoici, in eodem epadice (?) 8 path a simpliei cincto. M a sc. panienlato-pedicellati. Caly $x$ tripartitus, laciniis lineari-lanceolatis. Corolla tripetala, petalis ovatis, acutis, concavis. St a $\mathrm{m}$ in a plurima, imae corollae inserta; fila menta filiformia, brevia, libera; antherae lineares. F em. Calyx et corolla maris. Ovarin m loculis duobus rndimentariis uniloculare. S $t \mathrm{igmata} 3$, patula. Drup a obovata, monosperma, cortice fibroso, putamine vertice triporo. All um en centro cavum. Embryo intra pornm verticalis. - Palma chilensis; caudice excelso, crasso, petiolorum rudimentis squamato, frondibus pinnatis, floribus in spadice ramoso ochroleucis.

p. J J baea Kunth in Humb. et Bonpl, Nov. gen, et sp. I. 308, t, 96. Moli na a Bertero ex Sillim. Americ. Journ. $X I X, 63$. C oquito de Clille Americ.

1\%ร. Drbignya MART. Flores monoici, spadicibus aliis masculis, aliis femineis in eadem stirpe, spath a simpliei completa cinctis, M a s c. Cal y x.... Corolla di-tripetala, petalis dentatis. Stam in a 12 , an $t$ heris spiraliter contertis. F em. Caly x triphyllus. Coroll a tripetala. O vari $\mathrm{am}$ conicum. Stigmata 3 , bifida, sessilia. Drup a putamine vertice triporo, trilocularis, loculis monospermis. A $\mathbf{l}$ b u m e $\mathbf{n} \ldots$ E mbryo. .... Palma austro-americana; caudice elato, frondibus pinnatis erectiusculis phalerato, spatha profunde sulcala, ventre longitudinaliter aperiunda, spadice masculo simpliciter ramoso, floribus masculis in ramis distiche sessilibus, aut etiam spadicifemineo admixtis?

Or b igny a Martius Synops, mse, Palmier C uci Orbigny Msc. c. ic.

OBSERVATIO. Ruid Drymophloeus Zippellus in Flora $1899 \mathrm{I}, 185$, et A lagopter a Nees in Nouried Reise, $I, 6 \mathrm{z}$ ?

\section{PALMAE FOSSILES.}

1\%ร9. Palmacites BRONGN. Trunci cylindrici sinplices, petiolorum semiamplexi- caulium basibus obtecti.

Terra calcis grossae inferior.

Palmacites Brongn. prodr. 120. Endogonites e chinatus Brongn. Descript, des envir, de Paris. 356. t. 10. f. 1 .

1\%ร9. Flabellaria STERNB. Frondes petiolatae, flabellifidae, lobis linearibus basi plicatis. - Terra carbonifera, calcis grossae et lacustris palaeotheriea.

Fia be II a ri a Sterub. Tent, II, 27,t, 18, et 21. Brongn. prodr, 120. P a l macites paris ie n s is Brongn. Descript. des envir. de Paris 364. t. 8.f. 2.

180. Plhoenieites BRonGN. Frondes petiolatae, pinnatae, pinnis linearibus geminatim approximatis, nervis tenuissimis, obsoletis. Sedimentum superius.

Phoenicites Brongn. prodr. 121.

1981. Nöggerathín STERNB. Fron. des petiolatae, pinnatae, pinnis obovali-cuneiformilus, lateribus petioli applicitis, versus apicem dentatis, nervis tenuibus, divergentibus. - Terra carbonifera.

$12 t$.

Nöggerathia Sternb. Tent. II. t.20, Brongn. prodr.

178\%. Zeugopliyllites BRONGN. F rondes petiolatae, pinnatae, pinnis oppositis oblongis v. ovalibus, integerrimis, nervis validis, paucis, aequalibus, basi et apice confluentibus. - Terra carbonifera.

Zeug o p byllites Brongn. prodr. 121.

1783. IBurtinia. Fructus ovoidei, obsolete trigoni, basi triporosi. - Sedimentum superius.

Cocós Brongn. prodr, 121. (Burtin Oryctogn. de Brurelles t. 30. f. a. Parkins. Org. Rem. I. t. 7. f. 1-3. Fan. jas Annal. du Mus. 1. 445. 2.89.$)$

\section{APPENDIX. ACROBRYAE FOSSILES, DUBII ORDINIS.}

1984. Buelklandia BRONGN. Caulis filuris reticulatis olsitus, folits imbricatis haud amplexicaulibus vestitus, petiolis usque ad basim distinctis. - Terra jurassica schistoidea.

Buck Iandia Brongn. prodr. 128, Conites B u ek1 a w d 1 Sternb. Tent, $t .30$.

1785. Clathrarta MANT, C a ulis ex axi fibris retienlatis obsita, et e cortice e petiolorum hasibus insertione rhomboidalibus, omnino connatis formato constans. - Terra glauconia sabulosa.

Clathraria Brongn. prodr. 128. Mantell in Transact. Geolog. Soc. Ser. I. p. 423, t. 45. f. 1. 2.3. t. 46. f. 5. $t .47$. f. 4. B п c klandia Sternb. Tent. 33.

1786. Smilacites BRONGN. Foli a cordiformia v. hastata, nervo medio valido, secundariis utrinque binis v. ternis margini parallelis, tertiariis reticulatis. - Terra lacustris palaeotherica. $\mathrm{S}$ milacites Brongn. prodr. 128,

178\%. Convallarites BRONGN. Folia linearia, parallelinervia, cauli recto vel eurvato verticillatim inserta. - Terra poecilis.

C onvallarites Brongn. prodr. 128.

1988. Poacites BRoNGN. Folia linearia, parallelinervia, venis aequalibus, transversis nullis. - Terra carbonifera.

Po a cites Brongn. prodr. 128. 


\section{SECTIO V. ACRAMPHIBRYA.}

Caulis apice simul et ambitu crescens.-Vegetatio peripherico terminalis.

\section{COHORS I. GYMNOSPERMAE.}

OvuJa nuda, in folio carpellari aperto v. in disco pervio, micropyle materiam foecundantem immediatim recipiente.

\section{Classis XXII. Coniferae.}

Coniferae Juss. gens. p. 411. L. C. Riehred Commentatio bolanica de Coniferis et Cycadeis, edid. A, Michard. Stutgandiae, 1826. 40.

Arbores v. Frotices ramosi, ligno saepius vasis spiralibus destituto, e cellulis elongatis porosis conflato, succis resinosis inter vasa propria corticalia receptis scatentes. Folia sparsa, opposita v. fasciculata, saepe rigida, acerosa. Fuores diclines, amentacei. Prerigoniem nullum. Ovola in squamis aper tis nuda, $\mathbf{v}$. intra discum perviun sessilia, erecta $v$. inversa, orthotropa, rarissime anatropa. Froc sus disco accrescente subdrupaceus, v. squamis indurescentibus strobilaceus. Skmisa nuda, albuminosa. Eиввro axilis, antitropus v. rarissime orthotropus, cotyled onibus $2, \mathbf{v}$. saepius pluribus, verticillatis.

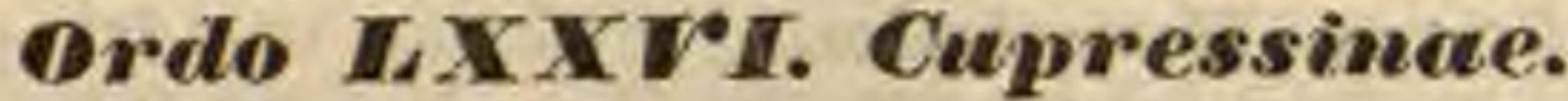
nat, 95 .

CUPRESSINAE L. C. Richard Conif. 137. Bartl. Ord.

Arborrs saepins excelsae v. Fructices ramosissimi, ramis plerumque sparsis. Folia opposita, verticillata v. sparsa, perennantia, rigida, anguste linearia, parva, saepius seriatim imbricata.

Flores monoici v. dioici, staminibus et $\mathbf{s q u a m} \mathbf{i}$ s ovuliferis (foliis carpicis apertis) axi communi insertis, imbricatis, ebracteatis, a m e $\mathrm{t}$ a terminalia v. lateralia, solitaria aut rarius conferta, interdum spicata constituentibus.

Amenta mascula. Stanisa plurima, nuda, axi undique inserta, subhorizontalia. Fil ament a brevissima, crassa, in connecti. vum squamaeforme, exeentrice peltatum, margine superiore angustius productum. Anthera e loculi quatuor ad duodecim, connectivi margini inferiori subtus adnati, ovati v. obIongi, paralleli, discreti, longitudinaliter dehiscentes. Pollen globosum.

A menta fem inea. Squamar ovuliferae paucae, circa axim abbreviatam verticillatae, imbricatae, v. juxta axim plus minus elongatam undique insertae, peltatae, ebracteatae. 0 v u I a ad basim squamarum v. juxta earundem stipitem solitaria, gemina v. indefinita, sessilia, erecta, orthotropa, apice pertusa et saepius in collum styliformem, peracta foecundatione obliteratum producta

Fructus squamis carnoso-incrassati v. li- gnoso-induratis, drupaceus v. strobilaceus, squamis plus minus inter se connatis v. arcte reclusis, maturitate saepius ad suturas dehiscentibus.

SEMiva ad basim squamarum solitaria, gemina v. plurima, erecta. 'Tes ta membranacea, lignosa v. ossea, interdum angulata, saepius utrinque in alam membranaceam producta. Alb u me n carnosum, pareum.

Eивауо antitropus, axilis, albuminis nt plurimum longitudine. C otyle don es duae, rarins tres ad novem, oblongae, obtusae. R a di cula cylindrica, apice cun albumine concrescens, verticem seminis spectans, puncto insertionis ejusdem e diametro opposita, ideoque respectu squamae supera.

Cupressineae ab affinibus Abietineis antherarum loculis cunnectivo peltato subtus adnatis, et ovulis erectis facillime distinguendae, climatis temperati coelum mitius praediligunt, Europam mediam et mediterraneam, Asiam imprimis maxime orientalem, Americam borealem, Caput bonae spei et Noram Hollandiam in. colentes.

1 7 85. Jumipervas LINN. F lo res dioici, rarius in diversis ramis monoici. $\mathbf{M}$ a s c, $\mathbf{A} \mathbf{m}$ e $\mathbf{n} \mathbf{t}$ axillaria v. subterminalia, globosa, minima. Stamina plurima, nuda, axi undique inserta; filamenta exeentrice peltata, imbricata; antherac loculis ternis v. senis longitudinaliter dehiscentibus, margini inferiori subtus adnatis. Fem. A m e n t a axillaria, ovata, basi imbrieato-bracteata. Involu c rum e squamis $3 \_6$, basi coalitis, uni - triovulatum. O v u I a e basi involueri erecta, orthotropa, lagenaeformia, apice pertasa. F r u c a s drupaceus, basi squamosus, involucro baceato, apice umbilieato et seminions osseis. S e m in a $1-3$, erecta, subtriquetra; testa ossea, versus basim foveolis resiniferis instrueta. E $\mathbf{m}$ b $\mathbf{y} 0$ in axi a $l$ b u min is carnosi antitropus, ejusdem longitudine, cot yled on i b u 2, oblongis, radic ul a cylindrica, supera. - Arbores $v$. arbusculae, in montanis regionu temperatarum veteris orbis obviae, in America bore ali rarissimae; ramis erectis sive pendulis, foliis lineari-lanceolatis, rigidis, saepius minutis, squamaeformibus, gemmis nudis.

Juniperus Lian. gen. n, 113i. Gärtu. II. 69, t. 91.

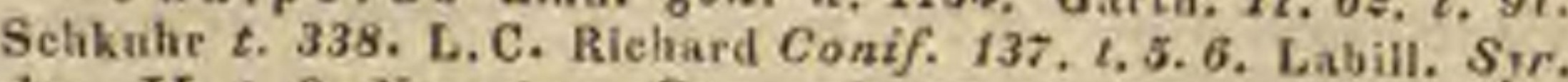
dec. II. t. 8. Nees jua Gen. pl. II. 12. J uniperus et Ce d r us Tournef. inst. 361 .

1 ร90. Thana TOURNEF. F lores in diver sis ramis monoiei. Masc. Amenta terminalia. ovoidea, minima Stamina plurima, nuda, axi inserta; fi la menta exeentrice peltata, laxe imbricata; anthera e loculis quatuor, longitudinaliter dehiscentibus, margini inferiori subtus insertis. Fem. A ment a terminalia, depressiuscula, minima. Squa ma e quadrifariam imbricatae, patentes. Ov u la ad basim squamarum gemina, sessilia, erecta, orthotropa, lagenaeformia, apice pertusa. Strobilus e squamis imbricatis, sub apice retorto mueronatis, lignescentibus, primum clansis, mox patulis. Se min a sub squamis 2 , e basi erecta; testa ossea $v$. membranacea, utrinque in 
alam angustam producta. $\mathbf{E} \mathrm{mbryo}$ in axi a I bumin is carnosi antitropus, ejusdem longitudine, cotyledonibus 2 , whlongis, radicula eylindriea, supera. - Arbores sempervirentes, in Asia et America boreali obviae; ramis compressis, foliis minimis, dense plurifariam imbricatis, gemmis nudis.

Th uj a Tournef, inst. 358. Linn. gen. $n$, 1078. Gärtn. II, 61, t, 91. Sihkuhr t, 309. Lambert Pin, $t, 67.68$. L. C. Richard Conif. 139, t, 7.8, Nees ju॥. Gen. pl. II. 11.

1591. Cupressus TOUNNEF. Flores in diversis ramis monoici. M a $8 \mathrm{c}$. A m en $\mathrm{t}$ a terminalia, elliptica. Stamina plurima, nuda, axi inserta; filamenta excenirice peltata; anthera e loculis 2-4, longitndinaliter hivalvibus, margini inferiori subtus inscrtis. F e n. A me $n t$ a sub. globosa, terminalia $\mathbf{S} q u$ a m a peltatae, axi quadrifariam insertae. Ovula in stipite squamarum plurima, biseriatim sessilia, erecta, orthutropa, lagenaeformia, apice pertusa. Strobilus e squamis lignescentilus, centro mucronatis, primun arcte conniventilins, demum hiscentibus. S emin a plurima, in stipite squamarum erfeta, angula ta; test a utrinque in alam membranaceam angustam producta. Em bryo in axi a 1 buminis par ci, carnosi antitropus, ejnsdem longitudine, eotyledonibus $2 \ldots 8$, obtusis, radicula in crassata, supera. - Arbor in regione mediterranea orientali, imprimis insulari spontanea, nunc per omnem Europam meridionalem dispersa, statura mediocri, ,natu morosa, fructu supervacua, baccis torva, folio amara, odore violenta, "ac ne umbra quidem gratiosa, Diti sacra, materie ra"ra sed durabili" ramis erectis pyramidatis, foliis minutis, squamaeformibus, appresso-imbricatis, gemmis nudis.

Cupress us Tournef. inst. 358. Linn. gen, n. 1079 Gartn. II. 64. t, 91. f. 5. Lambert Pin. t. 65. 66. L. C. Ri. chard Conif. 142. t. 9. Nees jun. Gen, pl. II. 10.

1ร82. Calliteis VENT. F lores in diversis ramis monoici. M a s c. A m e $\mathrm{n}$ t a terminalia, ovoidea. St a mina plurima, nuda, axi inserta; filamenta excentrice peltata, laxe imbricata; anthe$r$ a e loculis $2-5$, longitudinaliter bivalvibus, sti piti infra peltam insertis. Fem. Recepta $\mathrm{cuIum}$

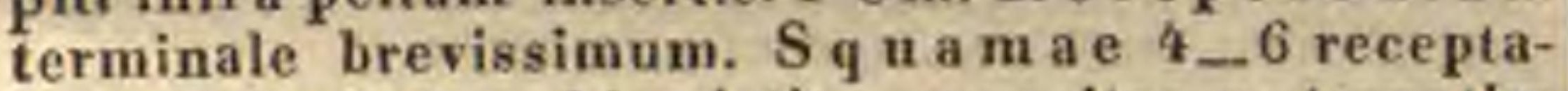
culum cingentes, biseriatim oppositac v. ternatim verticillatae, paribus sive verticillis forma et uvulorum numero inter se diversis. Ovula ad basim cujusvis squamae 3 v. 9 , sessilia, erecta, orthotropa, apice aperta. Strobilus e squamis lignescentibus, sub apice mucronatis, arcte conniventibus, demum in valvas 4.6 dehiseentilıns. Semin a e basi erecta; tes ta membranacea, utrinque in alam latam producta. Albumen... Embryo.... - Arbusculae cupressiformes, in Afrie a mediterranea orientali, et in Nova Hollandia extratropica repertae, ramosissimae; ramis articulalis, striatis, foliis minimis squamaeformibus, ad basim articulatis, striatis, oppositis $v$. ternatim verticillatis, gemmis nudis.

C a 11 i tris Vent. Dec. Nov, gen. 1808. R. Brown. in L. C. Hichard Conif. 114, t, 8, et 18. Brongu. in Annal. sc. nat. XXX. 189. Fresnelia Mirbel in Mem. Mlus. XIII. 30. $\mathrm{T}$ h u ja a $\mathrm{ticu}$ a ta Desf. Fl,atl, $t .252$,

1ร93. IPachylepis BRONGN. Flores monoici? Mase..... Fem. Recepta $\mathrm{culum}$ terminale, depressum. S quam a e 4, conformes, valvato-verticillatae. 0 vula ad basim cujusvis squamae $5-10$, uni-biseriata, sessilia, erecta, orthotropa, apice pertusa. Strobilus subglobo- sus, e squamis lignescentibus sub apice mucronatis, arcte conniventibus, apice subconnatis, basi tandem apertis. Semin a abortu pauca, e basi erecta, testa utringue in alam membranaceam latam expansa. A 1 b um en ..... Embryo. Arbores Ajricae australis extratropicae coniineniem et insulas incolentes; foliis alternis, lineari-lanceolatis, imbricutis.

Pachylepis Brougn. in Annal. sc, nat, XXX. 189. Thuja cupressoides Linu. et Cupressus juaipe. roid es Lim.

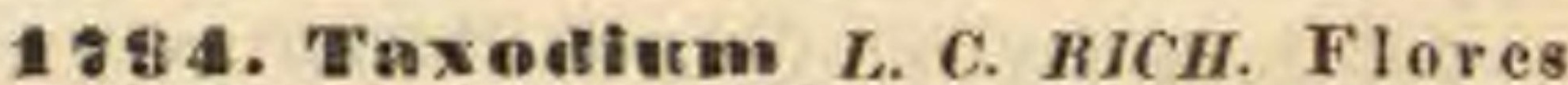
monoici, in iisdem ramis. M asc. Amenta pluri$m a$, in spieam terminalem pyramidatam disposita. St a m in a paca, versus apieem axeos basi nudae inserta; filamenta squmaeormia, exeentrice peltafa, remotiuscula; a $\mathrm{n}$ h erae loculis 2 - 5 longitudinaliter bivalvibus, margini inferiori subtus insertis. Fem. Amenta ovata, ad basim spicae masculae gemina. S qua ma e plnrimae, axi insertae, imbricafae, aculae, apice recurvato-patulae. Ovnla ad basim cujusvis squamae 2 , sessilia, erecta, orthotropa, apice pertusa. Strobilus snb lobosus, e squamis lignescentibns, subpeltatis, angulatis compositus. Semina e basi crecta; testa lignosa, irregulariter angulata. Embryo in axi alluminis parci, carnosi antitropns, ejusdem longitudine, cotyled onibus 6 - 9 linearibus, radieula cylindrica, snpera. - Arbores Americam borealem et Japoniam incolentes; ramis saepius pendulis, foliis linearibus, membranaceis, caducis, in ramulis alternantibus, distichis, folium pinnatum mentientibus, $e$ radice repente nonnunquam exostoses conicas, bi-sexpedales protrudentes.

T axod i u m L, C. Richard in Annal, Afus. XVI. 298. Conif. 143, $t, 10$. Lamlert Pin. $t$. 63, 64. S e hubertia Mirbel in Bullet. Soc. Philomat. 1813, p. 121. Cupressus distich a Lina. C. Japonic a Thunb.

\section{Ordo LXX II. Abietinae.} 94.

ABIETINAE L. C. Richard Conif. 145. Bartl. ord. nat.

Аввовеs ut plurimum excelsae, saepius giganteae, trunco conico, ramosissimo, rarius Frotices divaricato - ramosissimi. Folia saepissime perennia, rigida, linearia, angusta, sparsa v. fasciculata, fasciculis basi vagina scariosa cinctis, rarissime lato-elliptica, phyllodinea.

Flones monoici v. rarissime dioici, st aminibus et squamis ovuliferis (carpidiis apertis), saepissime bractea adnata, persistente v. mox evanescente stipatis, circa axim communem imbricatis, a menta terminalia $\mathrm{v}$. lateralia, solitaria, conferta v. spicata constituentibus.

Amenta mascula. Stamixa plurima, ebracteata, axi undique plus minus dense inserta. Fil a m ent a brevissima, crassiuscula, superne in connectiv u m squamaeforme lacernm, erectum v.inflexum producta. An therae nunc biloculares, loeulis ovato-oblongis, appositis, connectivo interposito angusto separatis, et eodem producto superatis, longitudinaliter dehiscentibus, v. rarius transversim 33 * 
ruptis; - nune tri - multiloculares, loculis cylindricis, e connectivo supra eosdem producto simplici v. duplici serie dependentibus, inter se liberis, sulco longitudinali apertis. Pollen globosum.

Amenta feminea. Squarae ovuliferae plurimae, axi plus minus elongatae undique insertae, imbricatae, apice incrassatae v. aequales, interdum acuminatae v. infra apicem mucronatae, rarissime (in sola Dammara) nudae, plerumque bractea libera v. saepius adnata, persistente v. mox obliterata stipatae. Ovula sub quavis squama gemina collateralia, v, rarissime terna ant solitaria, basi iisdem versus medium adnata, rarissime (in Araucaria) juxta totam longitudinem connata, inversa, orthotropa, apice deorsum spectante in collum mox obliteratum producta et pertusa, margine exteriore in alam membranaceam, e basi sursum directam dilatata.

Fructus strobilaceus, e squa mis lignescentibus $\mathbf{v}$. coriaceis, apice incrassatis, areolatis v. saepius attenuatis, persistentibus, aut rarius tandem basi solutis compositus, bracteis inter squamas obsoletis vel interdum persistentibus, easdem velantibus.

Semixa ovulorum numero, binav. terna, sub squamarum basi pro eorumdem receptione excavata, v. rarissime solitaria, et tunc cum squama connata, inversa. T e s t a coriacea v. lignosa, basi latere exteriore, rarius utrinque in alam membranaceam, persistentem et cum semine deciduam, interdum squamae pertinacius adhaerentem, et maturitate a semine solvendam producta. A l b u men carnoso-oleosum.

Eивryo (saepissime in eodem semine embryones plures), antitropus, axilis, albuminis fere longitudine. Cotyledones $3-15$, v. rarius 2 , oblongo-lineares, acutiusculae v. obtusae. R a di cula cylindrica, apice cum albumine concrescens, verticem seminis spectans, puncto insertionis e diametro opposita, ideoque respectu apicis squamae infera.

A bi etin a e obtruncos plurimarum specierum elatos, nonnullarum giganteos, et lignum resina terebinthina scatens, nec non et semina quarundam edulia, magni in gentium oeconomia momenti, nullum clima penitus fugiunt, e sola Africa ut videtur exules, in $\mathrm{hemi-}$ sphaerae borealis temperatis imprimis copiosae reperiuntur.

1 ซ95. Pinus LINV. F lo res monoici, M a s c. A m e n ta solitaria v. spicata. St a in in a plurima, axi inserta; filamenta brevissima; antherac bilocnlares, connectivo squamulaeformi superatae, loculis appositis, longitudinaliter dehiscentibns v. transversim irregulariter ruptis. F e m. A m e $n t$ a solitaria v. conferta. $\mathbf{S} q \mathbf{n}$ a $\mathbf{m}$ a e imbricatae, bractea saepins adnata stipatae. $0 \mathrm{v}$ u l a ad basim squamarum gemina, collateralia, inversa, orthotropa, apice deorsum spectante lacero-pertusa. Strobilus e squa- mis lignescentibus, basi pro receptione seminum excavatis. S e min a ad basim squamarum gemina, collateralia, inversa, nuculiformia; $t$ e st a lignosa v. coriacea, basi hinc in alam membranaceam prodneta. E in b r yo in axi albuminis carnoso-oleosi antitropus, ejusdem longitudine, cotyled on ib us 3-12 linearibus, radi $\varepsilon$ ula cylindrico-conica, infera. - Arbores excelsae v, rarits arbusculae hu. miles, in temperatis et frigidiusculis he mis $p h$ a erae borealis, a maris littore ad terminum vegetationis arboreae provenientes, in regione montana elatiore sylvas vastas constiluentes; foliis solitariis, sparsis aut distichis $v$. fasciculatis, fasciculis busi vaginula scariosa cinctis.

P i a u Lian. gen. edit. 2, n. 879. Lambert, Pinus Lond. 1803. fol. Edit. Ii. Ibid. 1837, 8. $2 \mathrm{Vol}$. P in $\mathrm{s}$ s et A bies Lian. gen. edit. 1. Juss. gen. 414, Riehard Conif. 145.142. P in us, A bi es et La rix Tournef. inst, t, 353,355.357.

a. PINUS. LINK. Amenta mascula ia spieam termiaalem disposita. A u thera loculi longitudinaliter dehiscentes. A menta femine a termiualia, $2-3 \mathrm{v}$, solitaria. Bracteac mox evanescentes. Squamae apice ineras satae, superne infra apicem muerone deciduo. Strob iI us confcus, e squamis lignescentibus, apice fucrassato angulatis, basi exeavatis, tandem divaricatis, persistentibus. Se mi n um testa lignosa, ala deciJua. - Folia fasci. culata, sempervirentia, fasciculis varina scarios cinctis, vermatione intra gemmas elongatas, perulis squamaeformibus cinctas curvativa.

Pinus Liak Handbuch IT. 476. Nees jan. Gen, pl. II. 6. $\mathrm{Pinus}$ s y Ivestris Lian. Richard, Conif. t. 11. etc. (Jäger Observationes de quibusdam Pini sylvestris monstris. Stultg, 1828, 8.)

b. PICEA LINK, A menta mas cula prope apicem ramorum sparsa, lateralia $\vee$. termialia. A $u$ th e ra $r$ u a loculi lougitudiaaliter dehisceates. A menta fe mi a ea terminalia, solitaria. B ractea mox evanescentes. Squamae apice atteanatae. Strobitus oblongus, e squamis lignescentibus, apice hand incrassatis, laevibus, basi excavatis, tanjem divergeutibus, persistentibus. S e mi n в testa liguasa, ala persisteus. - Folia binatim connata. haud fasciculata, vernatione curvativa.

P i c e a Link $l, c$. Nees jun. op. cil. $I T, 7$. P i n us A b les Linn. Riehard op. cit, t. 16. eto.

c. ABIES TOURN. A me ata mas cula axillaria, versus apieem ramulorum aggregata. A u herarum locull transversia laceri. A me nta feminea lateralia, sparsat. Bracteate persistentes. Squamae apice atteuuatae. Strobilus oblongus, e squamis sublignescentibus, apice attenuatis, laevibus, basi haud excavatis, cum semiaibus ab axi solutis. Sem in $a \mathrm{~m}$ als persisteas. - Folia scmpervirentia, solitaria, iparsa v. disticha.

A b i e s Tournef. inst. $t$. 353 . Nees jun. op. cit. IT, 8. $\mathrm{P}$ i a s excels a Lina. Richard op. cit. $t$. 14. 15. etc.

d. LARIX TOURN. A menta maseula gemmiformia, i. ramulis lateralia, squamis in urceolum persistentem coalitis cincta. A a herarum loculi longitudinaliter debiseentes. A ue nta feminea basl scariosa. B r a c tea e coloratae, persistentes. Squamae apice attenuatae. Strobilus e squamis lignescentibus, aplee atteuuatis, basi exeavatis, persisteatibus. S e $\mathrm{m}$ i $\mathbf{n} \mathrm{m}$ ala persistens. - Folia acerosa, annua, e gemmis subglobosis, apice tantum hiantibus prodeuntia, gemmis tandem in ramulos gemmis onustos excrescentibus.

Larix Tournef. inst. 357. Nees jun. op. cit. IT. 9. Piaus Larix Linn. Richard op. cit. $t$. 13. etc.

1 ร D. Cummingthamaia $R$. BR. F I ores in diversis ramis monoici. M a c. A menta terminalia, ovata. Sta mina plurima, axi inserta, imbricata; filamenta brevissima, in connectivum latissimum squamaeforme producta; an therae loculis 3, cylindrieis, e basi connectivi pendulis, liberis. Fem. A m e n ta terminalia, subovata. Squ a ma e acuminatae, imbricatae, bractea adnata stipatae. Ov u la sub squamis terna, collateralia, inversa, orthotropa, apice deorsum spectante pertuso. Strobilus ovatus, e bracteis coriaceo-lignosis, squamas induratas velantibus, dense imbricatis. Semina sub squamis terna, collatera. 
lia, inversa; te sta coriacea, utrinque in alam membranaceam angustam producta. Emb r yo in axi albuminis carnosi antitropus, ejusdem longitudine, cotyledonibus 2 , obtusis, radicula cylindrica, infera. - Arbor sinica; ramis cylindricis, foliis alternis, confertis, angusto-lanceolatis, acutis, rigidis, subspinescentibus.

Cunn ingla am ia R. Brown ex L. C. Richard Conif. 80. et 149. t, 18. Bot. Mag. t.2743. B elis Salisbury in Linn. Transact. VIII. 315. $\mathrm{Pi}$ us la aceolata Lamb. Pin. t. 34.

1ร9\%. Aratuearia JUSS. F lores dioici. Hasc. Amenta terminalia, ovato-cylindrica. St am ina plurima, axi inserta, imbricata; filamenta compressa, in connectivum squamaeforme, recurvato-lanceolatum producta; a $n t h$ e rae loculis $12-20$, cylindricis, e basi connectivi duplici serie pendulis, subeohaerentibus, longitudinaliter dehiscentibus. Fem. A m e n ta terminalia, ovoidea. Squam a bractea adnata stipatae, dense imbricatae, apice resurvato-lanceolatac. $O$ v u I u m sub squama unicnm, inversum, orthotropum, eidem longitudinaliter adnatum, apice deorsum spectante liberum, pertasum. Strobilus ovoideus v. subglobosus, e squamis coriaceis vel sublignosis, cum semine concretis, tandem ab axi solutis. S e m in a squamis solitarie connata, inversa; t e st a coriaceo-lignosa, aptera. E mbryo in axi albuminis carnosi antitropus, ejusdem longitudine, cotyledon i b u $2-4$, linearibus, obtusis, r a dic a la cylindrica, infera. - Arbores giganteae, pyramidatae, in reipublicae Chilensis terris australioribus et in insula Norfolk extratropicos, deinde in Nova Iollandia orientali, in Nova Caledonia et in Brasilia inter tropicos sylvas vastas constituentes; ramis verticillalis, patulis, foliis sessilibus, lanceolatis v. lineari-subulatis, rigidis, dense imbricatis, aliquando variis.

A r a uearia Juss. gen. 413. L. C. Riehard Conif. t, 20, 21. Lambert Pin. I, t. 39. 40, II, t, 4. 6.5, D o m b e y a Lamark. Dict. $t .828$. Colym bea et Eutas s a Salisbury in Linn. Transact, VIIT, 315 .

1ร 9. Damemara RUMPH. F $10 \mathrm{r}$ es dioici, Masc. Amenta extraaxillaria. Stamina plurima, axi inserta, imbricata; fil amenta brevissima, in connectivum crassum, euneatum producta; antherae loculis 8-15 cylindricis, e basi connectivi duplici serie pendulis, liberis. F e m. A m e n ta terminalia, subovata. S qua ma e ebracteatae, dense imbricatae. Ovula sub squamis solitaria, inversa, orthotropa, apice deorsum speetante pertusa. Strobilas ovato-globosus, e squamis coriaceo-lignosis, dense imbricatis, demum ab axi solutis. Se min a sub squamis solitaria, inversa; te$s t$ a coriacea, utrinque in alam membranaceam produeta, ala altera angusta, altera latissima. E m b r y o in axi albuminis carnosi antitropus, ejusdem Iongitudine, cotyledon ib ns 2, obtusis, radie ula eylindriea, infera.-Arbores excelsae, in Asia tropica et in Nova Z e elandia observatae; foliis sparsis, oblongo-lanceolutis, integerrimis, coriaceis striatis, utrinque angustatis.

Da mmara Rumph Amboin, II, 174.t.57. Lambert Pin, t. 54.55. A g a th is Salisbury in Linn. Transact, VIIT,311, t. 15. L. C. Richard Conif. 83, et 151, t, 19.

\section{Drdo IXXVIII. Taxineae.}

TAXINEAE L. C. Richard Conif, 124. Barti. Ord, nat. 95. Martius consp. 58. TAXACEAE Lindl. introduct. edit, II. p. 316 .
Armores excelsae v. Frotices, ramis sparsis, continuis, foliatis, ligno zonato. Foli a sparsa v, disticha, simplicia, integra, rigida, sempervirentia, rarius fasciculata, in phyllodia subflabelliformia, apice lobata, basi squamula stipata connata.

Frores dioici v. monoici, sexubus in diversis ramulis nascentibus, feminei solitarii, mas culi in amenta axillaria v. terminalia collecti.

Flores masculi. Anexta filiformia v. ovata, nuda v. basi bracteis squamaeformibus cincta. Stamixa plurima, juxta axim disposita, nuda. Fil a menta brevissima v. subnulla, in connectivum ovato - lanceolatum v. squamulaeforme lacerum producta, rarius in connectivum peltatum dilatata. An therae ut plurimum biloculares, l o culi is connectivo supra eosdem producto adnatis, parallelis v. transversis, nunc e connectivo pendulis; rarius tri - octoloculares, loculis connectivo peltato subtus adnatis, longitudinaliter dehiscentibus.

Flores feminei solitarii, basi bracteis imbricatis cincti, erecti v. ex apice bracteae inversi, $v$, in pedunculo nudo terminales.

Discus carnosus, cupulaeformis, plus minus apertus, ore integro, v. rarius solidus, limbo inaequaliter trilobo. $0 \mathrm{v}$ ulum solitarium, in centro disci sessile, et ab eodem plus minus velatum, orthotropum, micropyle terminali magis minusve manifesta ; rarius disci trilobi lobo postico insertum, anatropum, rhaphe valida, chalaza rostelliformi, micropyle infera.

Froctus drupaceus, e disco plus minusve incrassato carnoso, semen nuciforme cingente v. includente compositus.

SEMEN nuciforme, erectum; test a ossea, rarissime ubi $\mathrm{rh}$ a $\mathrm{p}$ h e adest, ab eadem carnose incrassata, velata. A I b u m en farinaceo - carnosum, copiosum.

Emrryo axilis, antitropus, cotyle donibus duabus, radicula puncto insertionis seminis (umbilico) e diametro opposita, supera; vel rarissime orthotropus, radicula umbilico contigue parallela, infera.

T axine ae florum femineorum situ a $\mathrm{Cu}$ pressineis et $\mathbf{\Delta b i e t i n e i s ~ d i v e r s i s s i m a e , ~ i n ~ t e ~} \mathrm{m}$ peratis totius orbis vigent, in $h \mathrm{e} \mathrm{mi-}$ sphaera a ustrali multo frequentiores, inter tropicos veteris orbis rarae.

1 รง9. Taxas TOURN. F lores dioici, axillares. Masc. A menta subglobosa, basi bracteis imbricatis, interioribus majoribus eincta. St a $\mathbf{m}$ i$\mathrm{n}$ a $6-14$, ad apieem axeos conferta; fil a m e nta brevissima; a nthera e loculis $3-8$, connectivo peltato deplanato sublobato subtus adnatis, longitudinaliter dehiseentibus. F e m. A me n t a gemmiformia, uniflora, bracteis imbricatis cincta. Dis cus cupuliformis, obsoletus, demum increscens. Ov I um solitarium, in centro disci sessile, orthotropum, apice pertusum. Fruetus subdrupa- 
ceus, disco acreto, carnoso, semen laxe involvente, apice ostivlo orbiculari aperto. S e men nueiforme, erectum; testa ossea. Embryo in axi albuminis farinaceo-carnosi antitropus, cotyledonibus duabus lorevissimis, radicula crassiuscula, apice attenuata, supera. - Arbores $v$. frulices, in temperalis et frigidiusculis $h$ e $m i$ sphaerae borealis utriusque continentis habitantes; foliis angusto-lanceolatis, rigidis, sempervirentibus, sparsis, gemmis axillaribus sessilibus, imbricato-bracteatis, foliis vernatione appressis.

Tax us Tournef, inst, t. 362. Linn. gen, n. 1135, Gïrtn. II. 65. $t$, 91. Schkulir $t$. 339. Kämpf. Amoen. exot, 814. L. C. Richard Conif, 131, t, 2. Nees jun. Gen, pl. II. 14.

1800. Pod dearpas HERIT. Flores dioiei. Masc. A menta terminalia aggregata, filiformia. An th er a e plurimae, juxta axim sessiles, reniformi-biloculares, valvula semicirculari a basi ad apicem apertae. F e m. axillares, sulitarii, ebracteati. Dis e us calyciformis, carnosus, solidus, apice inaequaliter trilobus. Ovu 1 n m unicum, disei lobo postico insertum, anatropum, $r$ h a $p$ he lata, chalaza apicali rostelliformi, mieropyle infera. F ructus subdrupaceus, disco rhapheque carnuso-incrassatis. S emen nueiforme; t esta ossea, a rhaphe carnosa abscondita. Embryo orthotropus, in apice albuminis farinacei inclusus, cotyledonibus duabus brevibus, radicula umbilico-basilari contigua, infera. - Arbores in Americae tropicae et extratropicae australis montibus celsioribus, nec non in C a pite bon a e spei, India orientali et Nova Zeelandia indigenae; foliis lanceolatis angustis, integerrimis, sempervirentibus, sparsis.

Pod oc a rpus Herit. msc. Kunth in Humb. et Bonpl. Nov, gen, et sp. Ir. 2. $t$. 97. L. C. Richard Conif. 124, t.1. et 29. A. Richard Fl. Nov. Zeel, t. 39. T a x i s p. Thaub. Willd.

180 1. D achy dînan SOL. F l o r es dioici, terminales. Mas c. A m enta ovoidea, basi bracteis imbricatis cincta. Sta mina plurima, juxta axim imbricata; fil a $m$ e $n$ ta brevissima, in connectivum ovato - lanceolatum dilatata; a $\mathrm{n} t \mathrm{~h}$ e $\mathrm{r}$ a $\mathrm{e}$ biloculares, loculis connectivi basi transversim adnatis, rima dehiscentibus. F e m. solitarii, in ramuli folio terminali subcymbiformi sessiles, ex ejus apice semi-inversi. Discus cupuliformis, carnosus, apice apertus, ovulum includens. OvuI $\mathbf{~ m ~ s o l i t a r i u m , ~ i n ~ f u n d o ~ d i s c i ~ s e s s i l e , ~ o r t h u t r o - ~}$ pum, apice pertusum Fructus drnpacens, disco carnoso, apice pervio, semen includente. S e m e n nuciforme, erectum; testa ossea. Embryu in axi albuminis farinosi antitropus, cotyledonib u s duabus brevibus, ra dicula supera. $-A r$ bores excelsae, in India orientali et Nova Zeel andia indigenae, sempervirentes, ramosissimae; ramis saepius pendulis, foliis minimis, acerosis, cruciatim oppositis, gemmis nudis.

Da ery d ium Snlander ex Forst. pl, esc. 80. Lambert Pin, 93. t. 69. L. C. Richard Conif, 127, $t, 2$.

180\%. Phylloeladias L. C. RICH. Flores monoici, in diversis ramulis terminales. Masc. Amenta spicaeformia, basi bracteis imbricatis cincta. S $t$ a $\mathrm{m}$ in a plurima, juxta axim disposita; filamenta brevissima, connectivo in squamulam laceram producto; a ntherae biloculares, loculis connectivo adnatis, Iongitudinaliter dehiscentihus. F em. A menta subglobosa, e bra cteis imbricatis, floribus terminalibus subternis, intermedio abortivo. Dis e us eupuliformis, earno sus, ovuli basim cingens. Ov n 1 um solitarinm, in centro disci sessile, orthotropum, apice attenuato oblique pertusum. Fructus subdrupaceus, disco carnoso, apice pervio, semen cingente. $\mathrm{Se}$ men nuciforme, erectum; trsta ossea. Embryo in apice albuminis farinaceo-carnosi inclusus, parvus, antitropus, cotyled o n ibus duabus brevissimis, radieula supera. - Arbores Novae Hollandiae, elatae; phyllodiis rhomboideis, flabellatim venosis, apice dentalo laceris.

Pli yllocladus L. C. Richard Conif. 129. t. 3. T la aI a mi a Spreng. Anleit. II, 218. B r ow ne te r a L. C. Rich. mssc. Podocarpus as ple uifolía Lab. Nov. Holl, t, 221.

1803. Salisburia SMITH. Flores dioici, axillares. Mas c. $\Delta \mathrm{m}$ e $\mathrm{n} t$ a filiformia, pedunculata, nuda. Sta mina plurima, juxta axim disposita ; filamenta brevia, connectivo in squamulam laceram producto; a ntherae biloculares, loculis e connectivo pendulis, demum divaricatopatentibus, longitudinaliter dehiscentibus. Fem. in pedunculis simplicibus $\mathbf{v}$. fasciculatim ramosis solitarii, terminales. D is c a s cupuliformis, e pedunceli apice inerassato, ovuli basim eingens. Ovul u m solitarium, in centro disci sessile, orthotropum, apice nmbilicato-pertusum. Fructus subdrupaeens, basi cupula carnosa cinctus. Semen nuciforme; testa ossea. Embryo in axi albuminis dense carnosi antitropus, ejusdem longitudine, coty l edonibus duabus linearibns elongatis, ra dicu I a brevissima, incrassata, supera. - Arbor magna, in Japonia indigena, apud $S$ in as passim culta; ramis divaricatis, phyllodiis alternis v. subfasciculatis, longe petiolatis, lato-rhomboideis, subflabelliformibus, coriaceis, inciso-bifidis v. lobatis, nervoso-striatis.

Salis buria Smith in Linn, Transact. III. 330. L. C. Richard Conif. 133. t. 3. a. et b. Ginko Kimpf, Amoen. exot. 811. Jacq. fil, in Oesterr. Medic. Jahrb. 1819. c. ic.

\section{Ordo IXXIX. Ginetacene.}

GNETEAE Blume Nov. famil, exposit, 23. GNETACEAE Lindley introduct, edit, $I T$. p.311.

Arbores v. Arbusculan ramosissimae, aut Frutices sarmentosi, ramis oppositis $r$. fasciculatis, nodoso-articulatis. Folia opposita, nunc minima, squamaeformia, nunc late ovata, integra et integerrima, penninerria.

Flores monoici $v$ dioici, in amentis cylindricis v. capituliformibus, bracte is decussatim oppositis, basi v. omnino connatis.

Floribus maseulis: Perigonen membranaceum, tubulosum, primum undique clausum, deinde vertice transversim bivalve. STaMEN e centro floris erectum, solitarinm, v. plura in colum am indivisam ant apice ramosam coalita. Antherae uni-quadriloculares, loculis contiguis $\mathbf{v}$. sejunctis, adnatis, ac apice versus basim rimula brevi oblonga apertis.

Flores feminei omnino nudi, v. gemini involueri diphylli foliolis oppesitis reliti. Ovarium sessile, apice pervium, unilocnlare. Ovulum unicum, e basi erectum, orthotropum, sub anthesi apicem in styli formam attenuatum et perforatum ex ovarii ore exserens. 
Frectus subdrupacei, nunc gemini involucri foliolis baccatis inclusi, nunc solitarii nudi, initio apice aperti, ex ovuli grossificantis apice exserto apiculati, mox ore reserrato mutici.

Senex unicum, e basi erectum, t $\mathrm{t}$ s $\mathrm{t}$ a membranaceav. coria ea, end ople ura tenui. A lbumen copiosum, carnosum.

Eивахо in axi albuminis antitropus, ejusdem fere longitadine, v. multo brevior, in superiore seminis parte collocatus. C o t y le d on e s duae, ovatae, distinctae, $\mathbf{v}$. in corpus solidum, apice bidenticulatum conuatae. $\mathrm{R}$ a dic u la brevis, cylindrica, supera.

Ordo perparvus, genera duo, habitu valde dissimilia, alterum cosmopolitum extratropic u $\mathrm{m}$, altecum $\mathrm{tr}$ o $\mathrm{p}$ ic u $\mathrm{m}$ amplectens, perigonii in floribus masculis analogo, ovulo intra cupulam (ovarium) exiguo ore apertam, mox reserratam recondito, et foliis in altero genere late ovatis, penninerviis, Coniferarum classim absolvit, hinc per generis aphylli habitum et flores femineos ad Cas uarineas, illinc mediante genere fuliato ad Cloranthaceas tendens.

1804. Eplinedrea LINN. F lores dioici v. rarius in diversis ramis monoici. M as c. A m e nta ovoidea, e bracteis quadrifariam imbricatis, floribus in bractearum axillis solitaris. Perigoni m membranaceum, compressum, transversim bifidum. Stamina solitaria v. suboctona; filamenta in columnam apice ramosam coalita; antherae terminales, bi-quadriloculares, Ioculis apice poro oblongo dehiscentibus. FIores fe$\mathrm{mine} i$ in pedicellis axillaribus terminales, intra invol u crum diphyllum, bracteis decussation oppositis einctum gemini. Ovaria 2 , contigua, libera, apiec aperta. Ovulum solitarium e basi ovarii erectum, orthotropum, apies in styli formam attenuato, exserto, perforato. Galb i I s basi squamosus, ex involueri squamis carnoso. incrassatis, et e carpidiis duohus coriaceis, dorso convexis, facie complanatis. Semin a intra carpidia solitaria, e basi erecta; $t$ e $s$ t a tenuiter membranacea. E $m$ bryo in axi albuminis carnosi an. titropus, ejusdem fere longitudine, cotyledon ibus 2 , oblongis, r a dicula cylindrica supera. - Arbusculae ramosissimae, in arena maritima climatis temperati utriusque hemisphaerae crescentes; ramis gracilibus, erectis v. pendulis, subfasciculatis, articulatis foliis squamaeformibus, mi. nimis, ad articulos oppositis, basi in vaginam connatis.

Ephedra Linn, gen, $n$, 1136. L. C. Riehard Conif. 135. $t, 4$, et 29. Nees jus. Gen, pl. II. 13.

1805. Cuhetan LINN. F I u res dioici v. monoici, in iisdem verticillis. A me nta cylindrica, interrupte verticillata, articulata, verticillis singulis involuc ro abbreviato, cupuliformi cinctis, floribus paleis fasciculatis, subarticulatis immersis. Masc. Perigonin m membraceum, clavatoprismaticum, apice transversim bivalve. Sta $\mathbf{m}$ e $\mathbf{n}$ unieum; filamentum simplex $v$, apice bifidum, anthera bilocularis, didyma, loculis contiguis v. in filamenti cruribus sejunctis, apice poro oblongo dehiscentibus. F e m. nudi, involucro pro- prio et perigonio destituti. $\boldsymbol{O}$ va $\mathbf{r}$ i u m sessile, apice pervium. Oval a m solitarium, e hasi ovarii erectum, orthotropum, apice in styli formam attenuato, longe exserto, pertuso. D ru pa baceata, monosperma. Semen e basi erectum; $t$ esta coriacea. E mb r yo in apiec albuminis earnosi antitropus, corporecotyledon ari ovato, apice bidentato, radicula eylindrica, supera. - Arbores erectac $v$. frutices sarmentosi, in Asiu tropica et in Guiana Americae provenientes; ramis geniculato-nodosis, foliis oppositis, exstiputatis, ovatis, penninerviis, integerrimis, glabris, amentis axillaribus et terminalibus pedunculatis.

Gnet $\mathrm{m}$ Linn. Mant. 125. Brongn. ad Dupperr. 5. $t$. 1. Bluure Nov. famil. exposit. 25. Tho a Aublet Guian. II. 874. t, 336. A b u ta Loureir. Fl. cochinch, II. 775. G n e. wo n Rumph Amboin, I, t, 71, 72, V, ᄂ, 7, 8. U I a Rheede Malab, VII, $t, 22$.

\section{APPENDIX. CONIFERAE FOSSILES.}

1840. Pinites $L I N D L$. Trunci e medulla centrali, ligni stratis concentricis, cortice et radiis medullarihus compositi, vasis destituti. Fib rae lignosae parietes reticulatae. - Terra carbonifera.

$\mathrm{P}$ i a ites Lindl. Foss, Flor. I, XXXIX.

190\%. Peace $L I N D L$. Trunci e medulla centrali, ligni stratis concentricis, cortice et radiis medullaribus compositi, vasis destituti. Fibrae lignosae parietes areolis oblongis deciduis, centro foramine orbiculari instructis notatae, - Terra carbonifera et oolithica.

Peuce Lindl, Foss. Flor. $I$. XXXIX.

1808. Arancarites. Trunci e medulla centrali, ligni stratis concentricis, cortice et radiis medullaribus compositi. F i b ra e lignosae parietes areolis suborbicularibus biseriatis notatae. - Terra carbonifera.

1809. Pytys. Folia $2-8-5-$ fasciculata, basi vagina cincta. Coni e squamis imbricatis, apice in discum rhomboideum dilatatis. - Terra sedimenti superioris.

Pi u us Bronga. prodr, 107.

1810. Flate. Folia solitaria, seriebus novem dupliei spira inserta, saepius inaequilonga et disticha. Con i e squamis imbricatis, apice haud dilatatis. - Terra oolithica et strata tertiaria.

A bies Bronga, prodr, 10z.

181 1. Woltzia BRONGN. Rami pinnati. Foli a undique inserta, sessilia et subdecurrentia v. basi dilatata, fere conica, sacpius disticha. Coni e squamis lase imbrieatis, apice plus minus profunde trilobis. - Terra psammitica poecilis.

Voltzi a Brougn. prodr. 108, Lindl. Foss. Flor, t, 195.

1812. Cupressites BRONGN. Rami inordinate sparsi. Folia seriebus $6 \_7$ spiraliter inserta, basi lata sessilia. Mas c. Amenta teruinalia, sessilia, ovato-oblonga. Antherae... Pollin is granula rotundiuscula, poris tribus mar ginalibus, aequidistantibus notata. Strobili s qua ma e peltatae, centro areola conica instruetae. - Terra carbonifera.

Cupress ites Bronn in Leonhard Zeitschr. $f$. Mine. ralog. 1828, p. 509. t. 4. Lethea II. 42, t. 8. f. s. Brongu. prodr. 109. Göppert Dissert. msc.

1813. Thuyites STERNB. $\mathrm{R}$ a mi alterni. Folia opposita, quaterna serie decussantia. Strobili squamae imbricatae, in discum superne in acumen interdum recurvam productum desinentes. - Terra lignitum et jurassica schisstoidea. 
Th u y ites Sternberg Tent, t. 33. f. 2. 3. t. 35. f. 4. t. 37. f. 1. 4. t. 38. f. 1. 2, t. 39. Lindl. Foss, Flor. t. 167. Th a y a et Th uy ites Brongn. prodr. 109.

1814. Iumiperites BRONGN. R a mi sparsi. Folia opposita, quaterna serie decussantia, basi lata inserta. - Terra lignitum.

Juniperites Bronga. prodr. 108. Thuy it es ali en $u=t$. $45 . f . \ell$.

1815. Taxites BRONGN. Folia brevipetiolata, articulata, spiraliter disposita, subdisticha. - Terra lignitum et lacustris palaeotherica.

T axites Brongn. prodr. 108.

1816 . BBraclnyplnyllum BRONGN. R ami pinnati, sparsi. F o li a brevissima, conica, spiraliter disposita. - Terra oolithica inferior.

Brachy phy 11 u m Brongn. prodr. 109. Lindl. Foss. Flor. $t .188$.

\section{COHORS II. APETALAE.}

Perigonium nullum, rudimentarium v. simplex, calycinum v. coloratum, liberum v. cum uvario connatum.

\section{Classis XXIII. Piperitae.}

Herbae v. Suffrutices. Caules nodosoarticulati, teretes v, angulati. Foli a opposita aut verticillata, rarius alterna, integra. Stipulae intrapetiolares v. nullae. Fuores hermaphroditi v. diclines, dense spicati, bracteolati. Perig on i m nullum. St am in a libera v. cum basi ovarii connata. Ovarium unicum, v. $2-4$ connata. Ovula solitaria, erecta v. pendula, ant in sutura plura, adscendentia, orthotropa. Fructus baccatus, drupacens v. capsularis. Semina albuminosa. Еивв хо antitropus, extrarius, intra sacculum proprium reconditus, $\mathbf{v}$. in apice albuminis inclusus.

\section{Ordo $\mathbf{L X X \times}$. Chloranthaceae.}

CHLORANTHEAE R. Brown in Bot. Mag. n. 2190. Lindley Collect. 17. E. Meyer de Houttuynia et Saurureis 51. Blume Flor. Jav. fasc, 8. Bartling Ord, nat. 85, CHLO RANTHACEAE Lindley introduct. edit. II. $_{\text {p. }} 183$.

Sufrretices aut Arbescolae, rarius Hвквав annuae, glabrae, odore et sapore aromatico praeditae, ramis oppositis, nodoso-articnlatis, foliatis. Folia opposita, petiolata, simplicia, penninervia, serrata v. rarius integerrima, petiolis basi in vagin a m brevem amplexicaulem, utrinque bistipulatam connatis.

Inflorescentia spicata, terminalis $v$ rarius axillaris, rhachi saepius ramosa, ramulis subarticulatis.

Frones parvi, hermaphroditi, dense spicati; v. diclines, mas culi spicati, feminei subpaniculati, sessiles, singuli bra ctea e naviculari subimmersi v. rarius nudi.

Perigoniur nullum. Stanina in mase ul is solitaria, axi inserta, rara et basi brac te a parva sustenta, v, conferta imbricata, nuda; filamento brevissimo; anthera biloculari, loculis linearibus connectivum margi- nantibus, longitudinaliter dehiscentibus; in hermaphroditis stamen unicum v. tria, cum dorso ovarii conferruminata; filament is carinatis, basi inter se connatis, lateralibus minoribus, anthera uniloculari, internedio lengiere anthera biloculari instructis; loculis introrsis, oppositis, longitudinaliter apertis.

Ovarium unicum, sessile, trigonum v, subglobosnm, uniloculare. O v u 1 u m unicum, apici cavitatis apensum, orthotropum. Stigm a terminale, sessile, obtusum v. depressum, sul. cato-emarginatum v. sublobatum, deciduum.

Drupa baccata, subglobosa v. triquetra, monosperma, putamine tenui, fragili.

SEMEx pendulum. Testa tenuissime membranacea. Albumen copiosum, carnosum.

Eмввуо antitropus, minutus, in apice albuminis inclusus. Co tyle do nes duae brevissimae, divaricatae. $R$ a di $\mathbf{c} u$ Ia puncto insertionis seminis e diametro opposita, infera.

Chloranthaceae Indiam, Oceaniam et Americam tropicam incolentes, foliis oppositis basi in vaginam commissis, ovulo pendulo, et embryone intra albumen incluso, sacculo proprio destituto, a $\mathbf{P i p e r a c e i s ~ e t ~}$ S a urureis nullo negotio distinguuntur.

Vires insunt aromaticae, stimulantes.

$181 \%$. Hedyosmum $S W A R T Z$. F lores monuici v. dioici. M a s c. monandri, dense spicati, ebracteati. Antherae subsessiles, patentes, oblongo-cuneatae, hiloculares, in connectivum obtnsum desinentes, loculi marginales, suboppositi, longitndinaliter dehiscentes. F e m. solitarii vel quaterni glomerati, sessiles, bracteati. Ova ri n m triangulare, uniloculare. $O$ v n $I$ a $\mathrm{m}$ pendulum, orthotropum. Stigma sessile marginatum, depressum, indivisum v. obsolete lohatum. Drupa monosperma, putamine cxustaceo, interdnm plures bracteis carnoso-incrassatis coadunatae. S emen pendulum; testa membranacea. E mbryo antitropus in apice albuminis carnosi inclusns, $r$ a d i $c u-$ 1 a infera. - Frutices $v$, arbusculae a mericanae tropicue, fragrantes, resiniferae; ramulis opposilis, nodoso-articulatis, foliis oppositis, petiolatis, penninerviis, serratis, petiolis basi cum stipulis intrapetiolaribus geminis in vaginam laxam amplexicaulem connatis, floribus axillaribus et terminalibus, masculis spicatis, spicis indivisis solitariis v. fasciculatis, femineis paniculato racemosis.

He d yos $\mathrm{m}$ u m Swartz prodr. 84. Flor. Ind.oceid. II. p. 957. 6. 18. K u n th in Humb. et Bonpl. Nov. gen, et sp. VIT. 164. $t, 634.635$. Ta falla Ruiz et Pav. prodr. $t .29$.

1318. Asenoina FORST. Flores dioici. Masc. monandri, laxe spicati, unibracteati. Filamentum brevissimum; anthera oblonga, quadrisulca. Fem. laxe spicati, unibracteati. Ovarium globosum, uniloculare. Ov ulu m unicum .... Stign a sessile, depressnm, obsolete trilobum. Drupa? .... - Arbor in Societatis insulis indigena, vix nota; foliis oppositis petiolatis, serratis, peliolis basi in vaginam amplexicaulem combinatis.

As ca rin a Forster Char, gen. n. 59 . 
1812. Cllorantites $S W A R T Z$. F 10 res hermaphroditi, laxe spieati, singuli intra lorae $t$ e a m navicularem sessiles. St a min a 3 , ovario supra basim antice inserta; fil am enta carinata, basi connata, lateralia minora, anthera uniloculari, saepe abortiva; intermedium anthera bilocnlari, loculis introrsis appositis longitudinaliter dehiscentibus. Ovarium oratum, uniloculare. Ovulum pendulum, orthofropum. Stigma sessile, subcapitatun v. depressum, sulcato-emarginatum. D rupa monosperma, staminis ciratrice gibbosa, putamine tenui, fragili, S emen penduInn; testa membranacea. Embryo antitropus, in apice albuminis carnosi inclnsus, $r$ ad i $c u 1$ a infcra. - Herbae annuae v. suffrutices, Asiam tropicam incolentes, ramosi; ramis nodoso articulatis, foliis oppositis petiolatis, reticulato-venosis, integerrimis v. serratis, petiolis basi dilatatis cum stipulis intra axillaribus in ochream laxiusculam connatis, spicis axillaribus $v$. terminalibus simplicibus ant ramosis.

C hlora $\mathrm{n}$ th us Swartz in Philosoph. Transact, LXXVIII. p. 359. R. Brown in Bot. Mag. t.2190. Blune Flor. Jav. fasc. 8. $t$. 1. 2. $\mathrm{Nig} \mathrm{r}$ in a Thuulerg. Nov. gen. 58. Act. Upsal. VII, 192. Creodus Loureir. Flor. Cachinch, I. 112. Cryp ha e a Hamilt. in Edinb. Journ. of se, 1825. 11 . p. 9. Pe peridia Reiclieub. consp. 212. Stropha Noronha msc.

\section{Oralo IXXXI. Piperaceac.}

PIPERACEAE L. C. Richard in Humboldt, Bonpl, et Kunth Nov. gen, et sp. I. 39. E. Meyer de Houttuynia et Saurur. 9. Bartling Ord, nat. 83. Lindley introduct, edit. II. p. 185.

Ifrвar annuaev. perennes, saepits sncculentae, vasorum fascirulis intra caulem sparsis, v. frutices vasnrum fasciculis intra medullam solitariis, in ligno radiatis, zcnis annotinis vix distirguendis. Caules simplices v. ramosi, teretes, nodoso-articulati, ramis axillaribus solitariis v. oppositifoliis, nunquam verticillatis. Folia opposita v, verticillata, aut interdum folio altero abortivo alterna, simplicia, integra et integerrima, nerrosa, reticulato - venosa, vernatione semel complicata v. convoluta. Petioli, interdnm brevissimi, basi vaginantes. Stipulae nullae.

Fuores hermaphrediti v. abortu staminum dioici, nudi (Ferigonio destituti), bractea peltata $v$. adnato-decurrente suffulti, in spadice carnoso subcylindrico sessiles, v, ejusdem foreolis semíimmersi, rarissime pedicello brerissimo crassiusculo insidenfes. Spadices solitarii v. fasciculati, terminales aut oppesitifolii, nudi v. spatha brevi foliacea (petioli ragina) stipati.

Stanisa duo, dextrum sinistrumque latus ovarii stipantia, v, rarius tria, duo lateralia et tertium posticum, saepius plura, sena $\mathbf{v}$. indefinita, nonnulla tunc abortiva, difformia. $F$ il a me nt a brevissima, linearia, basi cum ovario connata. Anth er a e ovatae, extrorsae, biloculares v, rarius uniloculares, lorulis adnatis, appositis v. oppositis, longitudinaliter dehis centibus. Pollin is granula laevia, subglobosa, pellucida.

Ovaвier unicum, sessile, orato-snhglebosum, uniloculare. $0 \mathrm{vul} \mathrm{um} \mathrm{unicum,} \mathrm{hasi-}$ lare, orthotropum, mieropyle rerticem ovarii spectante. Stylus nullus. Stigma terminale v. subobliquum, breve r. subulato-elorgatrm v. erbiculatum, indivisum v. tri - quadrilobum, glabrum v. hispidum.

Frvetus baccatus, monospermus, parce carresus.

Srmen e basi erectum, subglobosum, test a tenui, cartilagirea. Albumen dense carnosum v. fere cartilagineum, centro saepius cavum.

Emisro in apice seminis antitropus, in ravitate albuminis superfeciali contentus, et intra s a c culu m amnicticum persistentem inclusus, parvus, turbinatus v. lenticularis. Cot yle d on es duae brevissimae, crassiusenlae. R adicula seminis umbilico basilari e diametro opposita, supera.

Piperaceae intertropicos ntriusque hemisphaerae obviae, terrestres v.super arberum truncis pseudoparusiticae, in regionibus subtropicis hemis phaerae australis et etiam in Africa tropica rarae, insolita caulis inter plantas Acramphibryas structura notabiles, hine Urticareis, illine Polygon ace is affnes sunt, a quibus perigonii defectu et embryone respectu albuminis extrario superficiali, intra sacculum amnicticum incluso differunt. A Chloranthaceis ct $\mathrm{Sauru-}$ re is proxime affinibus ovario simplici, orulum unicum e basi orthotropum continente, embryonisque radicula supera facillime distinguuntur.

Qualitates insunt aromaticae stimulantes. Nonnullarum ingentes in organismum animalem vires.

1820. Piper LINN. S p d ix floribns tectus. Bracte a e peltatae v. adnato-decurrentes. Stamina 2 v. plura; an therae extrorsae, unibiloculares, loculis appositis. Ovari $\mathrm{nm}$ uniloculare. Ovul n m unirum, basilare, orthotropum. Stigma sessile, capitatum v. depressum, indivisum v, trilobum, pubescens. B a ce a monosperma. Som en erectum. Embryo in apice albuminis antitropus, radicula supera.-Herbae $v$. suffrutices, ut plurimum tropici, erectiv, scandentes, interdum repentes $v$. rarius acaules; foliis oprositis, allernis v. verticillatis, spadicibus oppositifoliis $v$. axillaribus, in acaulibus radicalibus, solitariis, geminis $v$. interdum fasciculatis ant subracemosis.

P i p e r Linn. gen, n. 43. Gärtn. Ir. 67, 1.92. Jacq. Te. rar. 212_216. Bot. Mag. $t$, 2943. Hook. Exot. Flor.t.21 - 23. 58. 66. 67, 92. 164,165 . Wallich $P l$. As, rar. $t .91$. Blume in Verhandl. Batav. Genotsc. IX, 169. P i per et $\mathrm{P}$ e pe rom ia $\mathrm{Ruic}$ et Pav Flor. Peruv. $t, 44$-64. Kunth in Humb. et Bonpl. Nov. gen. ot sp. $t .3$.

a. PEPEROMLA Gaudich. Bracteate peltatac crassae. S tig m a capit: to - flolosum, villosum.

Peperomia Gaudich. ad Ereje. 513.

b. DUGAGELIA Gaudich. Bractea e foliacene, sessiles. S tig m a capitato - subglobosxm, pilosum.

D i g a ge Ii a Gaudich, ad Frege. 513 .

. PIPER Gandich. B ractea foliaceae peltatap, sessiles v. decurrentes. $S t i g$ m tri-quadrifidum, prberblam.

$\mathrm{P}$ i per Gaudich, ad Freyc. 113.

1821. Zippelia BLUM. FIores her maphroditi dense spieati, in axilla hracteae mem 
branseeae, ew:ullato-coneavae brevissime pedicellati. Perigonium nullum. Stamina 6; filain enta brevia, basi cmm ovario connata; a ntherae introrsae, biloculares, ovato-oblongae, a medio ad basion rimula duplici dehiscentes. O varia m basi eam staminibus connatum, maricatum, nniloculare. $\Theta \mathrm{vu} / \mathrm{um}$ nicum, basilare, orthotropum. Stylus terminalis, brevis, crassiusculus pentagonus, stig ma quinquedentatum. B a c e a exsucea, setis gluehidatis hispida, monosperma. Sem en erectum, te 8 ta membranacea. Em bry o in apice albuminis carnoso - farinacei exeavato antitropus, parvus, turibinatus, radicula supera. Planta javanica, rhizomate repente, radicante perennans; caulibus herbaceis pluribus, simplicibus, geniculalo-flexuosis, foliis alternis, petiolatis, unistipulatis, ovato-oblongis, acuminatis, basi oblique cordatis, nervoso-reticulatis, membranaceis, glabris, spicis longe pedunculatis, solitariis, oppositifoliis, simplicissimis.

Z ippeli a Blame in Schult. f. syst. NIT. 1614. ot 1651. - Pateg líoboh et Serug-diuh Javan.

\section{GENERA DUBIA.}

1829. Hamrea GAUDICH. Spad ix subcylindricus, fluribus undique tectus. Fi o r e 8 hermaphroditi, b ra cte is 2 v. pluribus squamaeformibus villosis mixti. Stamina 2 ; antherae biloculares, subglobosae, loculis lateralibus oppositis, longitudinaliter dehiscentibus. Ova r i u m ovato-oblongum, uniloculare. $\mathrm{Ovulum}$. . S tigma elongato-subulatum, villosum. B a c c a? . . - Frutices $v$, arbores, in Guy ana indigenae; ramis nodosis, foliis oppositis integerrimis, acuminatis, basi subcordatis, supra glabris, subtus subtomentosis, stipulis petiolaribus geminis, spadicibus axillaribus,

La ure a Gaudich, ad Freyc.513. P ipe o tili a e fol 1 a m Desv. usc.

1323. Dttonia SPRENG. F lores amentacei, racemosi, squa mis distincti. Perigoni um nullum. Sta mina 4 ; f ilam enta brevissima decidua; antherae biloculares, ovatae, deciduae. Ovari um subglobosum, uniloculare? $O \mathrm{vn} \mathrm{I} \mathrm{mm}$ -..S Stigmata 4 , reflexa. A ehen i um qua. drangulare. . S Semen . . Embryo in axi albuminis cornei linearis, cotyledonibus patulis, radicula supera. - Frutex brasiliensis; ramis flexuosis, striutis, pubescenlibus, nodo. sis, foliis alternis, brevissime petiolatis, ublongolanceolatis, integerrimis, oblique cordatis, glabris, nervis venisque subtus pubescentibus, racemis oppositifoliis, erectis. - An Urticea?

Ottou i a Spreigel. Neue Entdeck, $\boldsymbol{I}$. 255. Grundzïge t. 3.f. 45 .

\section{Drdo LXXXII. Sammene.}

SAURUREAE T. C. Riehard Annal. du Fr, 1808. E. Meyer de Houttugnia el Saurureis. Regiomonti 1827, 8. Bartl. Ord. nat. 84. SAURURACEAE Liadley introduct. odit. II. p. 184.

Herвaz aquaticae v, paludosae, $r$ i $\mathrm{z}$ o ma. t e repente squamoso, $\mathbf{v}$. tuberibus perennantes. Canles nunc simplices varce ramosi, nodoso-articulati, teretes, foliati, nume abbreviati, subnulli, scapos exserentes. Folia in scapigeris omnia radicalia, congesta, in caulescentibus alterna, petiolata, simplicia, integra et integerrima, reticulato-venosa. P eti oli vaginae intrapetiolari hinc longitudinaliter fissae adnati, rarius intus nudi, inferne dilatati, vaginantes.

Flores hermaphroditi, dense in spadic e m congesti, v. racemosi aut spicati, spicis terminalibus, solitariis v. interdum conjugatis, nudis ant basi spathis pluribus coloratis stipatis, singuli bractea unica v. binis collateralibus, ut plurimum coloratis, perigonium corollinum mentientibus muniti.

Perigonieu nullum. Stamina $3-6$, v. plura, circa uvarium serie simplici verticillata, libera, hypogyna v. cum ovarii basi connata. Fil a me nt a subulata v. subclavata et tunc bracteis longiora. A $\mathbf{n} \mathbf{t h}$ e r a e introrsae, biloculares, ovatae v. oblongae, loculi s oppositis, contiguis $v$. connectivum crassiusculum filamento continuum marginantibus, longitudinaliter dehiscentibus.

Ova ri u centrale, e carpidiis $3-5 \mathrm{fol}-$ licularibus, basi vel juxta omnem fere longitudinem cohaerentibus tri - quinqueloculare, plus minus profunde tri-quinquelobum. Ovula ad carpidiorum suturas, i. e. respectu ovarii in loculorum angulo centrali biseriatim superposita, panca, adscendentia, sessilia, orthotropa. Stigmat a e carpidiorum apice libero attenuato, intus stigmatoso.

Frverus siccus v. subbaceatus, carpidiis fol. licularibus introrsum dehiscentibus.

Srmiva intra carpidia obortu pauca, v. interdum solitaria, quasi basilaria, erecta v. adscendentia, pericarpii cavitati fere confor$\mathrm{miz}$, ovato-subglobosa v. cylindrica. T es t a crasse coriacea, umbilico parvo, basilari. Alb u m e n farinosum v. corneum, apice cavitate superficiali exsculptum, centro interdum cavum.

Eиввуо in apice seminis antitropus, intra albuminis cavitatem locatus, et intra sacculum amnioticum persistentem inclusus, obcordatus. Cotyle dones duae, brevissimae, crassiusculae. R a di cula seminis umbilico basilari e diametro opposita, supera.

Saurureae a Piperaceis ovario multiplici distinctae, in paludibus et aquis fluentibus Asiae tropicae, Capitis bonae s pei et Americae, tam intertropieae quam borealis calidioris, parvo numero reperiuntur.

1824. Sampuras LINN. Flores denze racemosi, pedicello enm bracteac navicularis basi connato. Perigoni n mullum. Stamina 6 (interdum $4,7,8$ ) hypogyna; fil a menta libera, clongato-subelavata; a $\mathbf{t}$ herac loculis suboppositis, connectivum marginantibns. O vari um triquadriloculare, tri-quadrilobum, in $8 \mathrm{tig} \mathbf{m}$ a $\mathrm{t}$ a totidem desinens. O vula in Ioculorum angulo eentrali 2_4, adscendentia, orthotropa. Baeca triquadriloba, lobis mono-dispermis. Se min a e basi erecta, ovato-subglobosa, t e st a coriacea, rugosa. Embryo minimus, in apice exeavato albuminis farinosi intra sa e e lum carnosum antitropus, dicotylis, radien la supera. _ Herbae in paludo- 
sis Americae borealis temperatae rhizomate repente-perennantes; caulibus annuis, geniculato flexuosis, teretib us, foliis alternis, petiolatis, late-cordatis nervosis, puberulis, vagina stipulari petiolo adnata, summo apice libera, racem is ramo axillari in caulem sucerescente oppositifoliis, solitariis, exinvolucratis, erectis, apice cernuis.

S a uru rus Linn. gen, n. 464. Schkuhrt. 103, L. C. Richard in Michanx Flor. Bor. Amer. I. 218. Mirbel in Annat. du Mfus, XVI. t. 19. Jacq. f. Eclog. $t, 18$. E. Meyer de Houtt, el Saur. p. 13. A. Richard in Dict, class. XV. 195. c.ic. Mat tus chia Gmel. syst. 589 .

1825 . HI outtuynin THUNB, Flores in spadice eylindrico pedunculato, involucro tri-quadripartito colorato persistente cincto dense sessiles, singnli bracte a subuliformi, rarius in laminam coloratam expansa stipati. Perigoniu m nnllum. Stamina 3 , perigyna; filam enta $8 u-$ bulata, brevia, usque ad medium ovario alnata; a $n$ the rae loculis appositis, connectivum marginantibus. Ova $\mathrm{rium}$ triloculare, trirostre, in $81 \mathrm{ig}$ $m$ at a totidem recurvata, velutina desinens, OrnIa in loculorum angulo centrali 4_8, adsern. dentia, orthotropa. Capsula trifida, carpidiorım marginibus introflexis retractis unilocularis, placentis parietalibus tribus, duplieatis, polysperma. Sem in a adscendentia, obovata, testa coriacea, laevi. Embryo minimus, in apice excavato albuminis farinosi intra sa c cul u m carnosem antitropus, dicotylis, radi cula supera - Herba in Asiae tropicae et Japoniae paludibus rhisomate repente, articulato perennans; caulibus caespitosis, annuis, simplicibus, geniculato-flexuosis, teretibus, foliis alternis, petiolatis, lato-cordatis, acuminatis, nervosis, reticulato-venosis, subtus lepidotis, stipula intrafoliacea basi vaginante, cum petiolo connata, in ligulam obtusam producla, spadice terminali, solitario.

Ho uttu y $n$ i a Thunb.Flor. japon, 12. 234. Lam.t. 739. E. Meyer do Houltuyn. p. 1. Roxhargh Flor Indio, edit, Wallich $I$, 360. Hooker in Bot.Mag. 2. 2731. P ol y p a r a Loureiro Flor. Cochinch. I. 78 .

1826. Spathium LOUREIR. F lo res in spadice angulato pedunculato, in vo I u e r o monophyllo colorato caduco cincto dense sessiles, singuli bracteis geminis collateralibus coloratis stipati. Perigonium nullum. Stamina 6, hypogyna; filamenta libera, subulata, patentia; an the rae loeulisoppositis, contiguis. Ovari um tri-quadriloculare, tri-quadrirostre, rostris erectis, intus stig matosis. Ovula in loculorum anguli centralis basi 2 -4, adscendentia, orthotropa. $\mathrm{C}$ ap s u la tri-quadrilocularis, tri-quadrifida, introrsum dehiscens, locnlis mono-tetraspermis. Sem ina erecta, ovata, acuminata, testa coriacea, laevi. E mb r yo...- Herbae in paludibus As ia e tropicae rhizomate bulboso perennantes; foliis longe petiolatis, lineari-oblongis, basi cordatis, nervosis, natantibus, scapo obsolete trigono, involucro monophyllo petiolato, cordato, bracteis cuneatis, capsulis laevibus $v$. echinatis.

S path i u toureiro Flor. eochinch. T. 280. A p ous ogeton monostachys Linn. suppl. 214. Andr. Bot. Reposit.t. 406. Lam.t.276,f, 1, Roxb. Corom, t,81. S a u ru rus $n$ at a $\mathrm{s}$ Liun. mant, 227,

182\%. Aponogetom THUNB. F Iores in spicis terminalibus conjugato - binatis, involucro diphyllo cum spicis alternante colorato, persistente stipatis introrsum secundi, sessiles, remoti, singuli bractea solitaria v. geminis collateralibus, coloratis fulti, terminales tribracteali, infimus in spicarnm dichotomia sessilis. Perigonium nullum. Sta$\mathrm{m}$ in a 6_18, obsolete perigyna; fila menta snbulata, imae ovarii basi adnata, nonnulla interdnm abortiva; antherae loculis appositis, connectivum marginantibus. Ovariu $\mathrm{m}$ tri-quinqueloculare, tri-quinquerostre, in stipmata totidem subrecurvata desinens Ovula e loculorum anguli centralis basi 2_4, adscendentia, orthotropa. Cap sula tri-quinquelocularis, tri-quinquefida, introrsum dehiscens, loculis mono-tetraspermis. Semina ereeta, oblonga, testa coriacea, laevi, Embryo minimus, in spiec excarato alhuminis cartilaginei, intra sacculnm carnosum antitropns, dieotylis, radicnla supera. - Herbae in Capite bon ae spei et in Africa tropica indigenae, natantes, rhizomate tuberoso perennanles; foliis radicalibus longe petiolatis, oblongis, nervosis, natantibus, petiolorum marginibus vaginantibus, scapo flaccido, tereti, apice in spicam bifurcam desinente.

Ap onogeton Thusberg Nov gen. 72. exel. sp. Lam. t. 256. f 2. Andr. Bot, Reposit.t.290. Bot. Mag. t. 1268. 1292, B. Meyer de Houttuyn. p. 16.

\section{GENUS DUBIUM.}

1828. Duviramellea THOUAR. FIores spicati, bracteis tribus coloratis stipati. P crigonium nullum. Stamina 6 ; filamenta basi dilatata; an therae terminales. Ovaria 3 , stigmatibus sessilibus. Folliculi 8 , introrsum dehiscentes. Semina 2, basi affixa. Em bryo exalbuminosus (?) ; foli $\mathbf{n m}$ primarium plieatum in lobo. - Herba madagascariensis, aquatica; radice tuberosa, oblonga, foliis radicalibus petiolatis, demersis, pertusis, parallelogrammice fenestratis, scapo radicali medio inflato, spiculis aliquot terminato, floribus roseis, odoratis. - Anne Alismacea?

O a v r a n d r a Thonars Gen. madagase. n. 3. H y dr o.

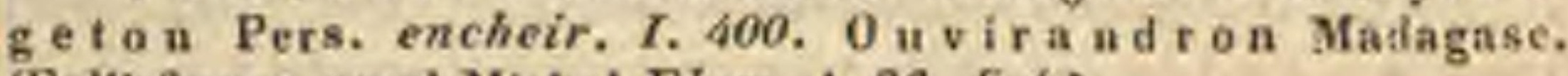
(Folil figura apud Mirbel Elem, $t, 26, f, 4$.)

\section{Classis XXIV. Aquaticac.}

Herbae aquaticae, habitı vario. Flobes hermaphroditi v. diclines. Prergoxium nullum v. rudimentarium. Ovariem uni-pluriloculare. Ovula solitaria v. plura, anatropav, amphitropa. Gis ro exalbuminosus, $v$. in axi albuminis situs, dicotylis, radicula supera.

Classis mere artificialis, ordines vix inter se aftines, sed nec aliis classibus commode subjungendos complectens.

\section{Dralo I $\mathbf{x} \times \mathbf{x}$ II. Ceratophylleae.}

CERATOPHYLLEAK Gay Arrangm. II. 554 . DC. prodr. II1. 73. Bartling Ord. nat.418, Lindley introduct, edit. Ir, p. 178.

Herbae submersae, ramosissimae, rigidae, caule ramisque teretibus, nodoso-articulatis. Fo lia rerticillata, sessilia, exstipulata, ditrichotome multisecta, laciniis filiformibus, acttis, subserratis.

Fuores monoici, in axillis sessiles. Mascul 1 is: Isroutcrum multifidum, laciniis 10 12, linearibus, aequalibus, integris v. ineisis. Periannium nullum. 
Avтuenat indefinitae, in centro involucri sessiles, dense congestae, ovato-oblongae, biloculares, lo cul is intra massam cellulosam immersis, collateralibus, demum irregulariter laceris, apice tricuspidatae. Polli n is granula parea, ovata.

Fenineis: Involucrom ut in masenlis. Orariur unicum, sessile, liberum, paullo supra basim uirinque in cuspidem brevissimum productum, uniloculare, uniovulatun. Ovouvn apici cavitatis appensum, orthotropum. STxLos cuspis terminalis, ovario continuus, apice abruptim patente hinc stigmatosus.

Nucela monosperma, coriacea, involucro persistente stipata, cuspidibus basilaribus excrescentibus, patentibus aculeata, stylo persistente apiculata.

Szмег apici cavitatis appensum. 'Testa tenuissime membranacea, ad umbilicum incrassata. A l bum e n nullum.

Euвrxo antitropus, viridis. Cotyledones quatuor, verlicillatae, duabus oppositis latioribus ovatis, duabus anguste linearibus. P'lumula brevissime stipitata, polyphylla, cotyledonum fere longitusline. Radicula brevissima, inlera.

Ceratophylle a e unico genere, paucisque specicbus $\mathrm{E} u \mathrm{ropae}$ et $\mathrm{Americae}$ borea$1 \mathrm{i}$ s aquas stagnantes et lente fluentes incolentibus comprehensae, nulli ordini aretius aflines, $\mathrm{N}$ a j a de as quodammodo repetere videntur. $\mathrm{Ab}$ O n a grari is et Urticace is longius recedere censeo.

1829. Ceratopluyllum LINN. Flores monuici Mase, Involu erum axillare, multifidum, sessile. Antherae plurimae, sessiles, biloculares, indehiscentes. Fem. Involucrum nt in mare, $O$ va $r$ in m unicum, sessile, unilwenlare. $O$ v ul a m unicum, pendulum, orthotropum. S ty l us ter minalis, apice hinc stigmatosus. N u c u I a coriacea basi aculeata, stylo apiculata. S e me n unicum, pendulum. Embryo exalbuminosus, cotyledonibus 4 verticillatis, per paria inaequilatis, plamula polyphylla, radicula brevissima, infera. - Herbae in Europa et America boreali sub aquis demersae; foliis verticillatis, rigidulis, di-trichotome multi,idis, involucris axillaribus solitariis.

Ceratophylla m Lian, gen. n. 1055. Gärta, I, 211. t. 44. Law. t, 775. Schkuhr t, 297, E. Bt, 679, 947. Chamisso

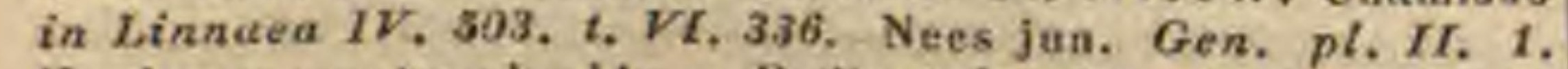

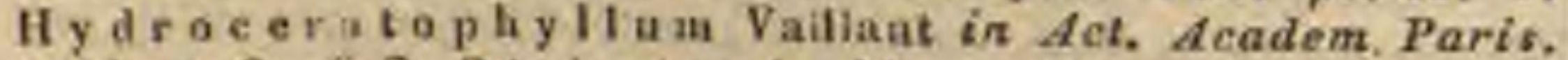
1719. $t$. 2. $\sqrt{ }$. 2. D i ch ot o $\mathrm{phy} \| \mathrm{u}$ a Dillea, Gon, 91, $t$. 3 .

\section{Ordo LXXXIV. Callit richince.}

CALLITRICHINAE Leveille in Annal, soc, Linn, Paris. 1824. p. 229. CALLITRICHACEAE Lindley introduct. edit. II. p. 191.

Неввав annuac, tenellae, simplices v.ramosae, natantes. C a ules teretes. Foli a opposita, sessilia, inferiora saepius linearia, superiora ovalia, integerrima, uni-trinervia, summa emersa, saepissime rosulato-congesta. Stipula e nullae.
Flores hermaphroditi, v. abortn dioici aut monoici, in axillis foliorum solitarii, sessiles.

Bractzolae 2, subcoloratae, carnosulae, subfalcatae, oppositae, respectu folii laterales, persistentes $\mathbf{v}$. deciduae. Pe rig o n i $\mathrm{m}$ nullum.

Staure unicum, hypogynum, posticum, in. terdum stamina duo, anticum et posticum ab axi floris latus tenentia. Fil am entum filiforme, elongatum. Anther a reniformis, basifixa, unilocularis, apice sutura hippocrepiformi dehiscens.

Ovarium primum sessile, demum saepius plus minus stipitatum, e carpidi is quatuor conflatum, quadriloculare, quadrilobum, interdum compressum, lobis per paria approximatis. Orula in loculis solitaria, angulo centrali prope apicem affixa, amphitropa, parte superiore breviore, et micropyle infra apicem introrsum laterali. St y li 2 , centrales, patentiusculi, stigmate acuto terminati.

Capsura carnoso-membranacea, indehiscens, quadrilocularis, quadriloba, v. loculis per paria compressis biloba, mutica v, carpidiorum dorso in alam angustam producta.

Sevixa in Jeculis solitaria, angulo centrali prope apicem appensa, $t$ e $s$ t a tenuissime membranacea. Al b um en carnosum, copiosum.

Eив х о rectus, axilis, albuminis fere longitudine. Cotyle do nes duae, brevissimae. Radi cul a longiuscula, umbilico parallele contigua, verticem fructus spectans.

Callitrichinae ob fructus indolem et perigonii defectum nullo modo cum Halorageis coadunandae, quo ad veram affinitatem magnopere dubiae sunt. Anne quaedam cum Euphorbiaceis affinitas?

1830. Callitrielne LINN. Flores hermaphroditi v. abortu polygami. Bracteolae 2, laterales. Perigonium nullum. Sta me n hypogynum posticum, rarissime 2, antieum et postieum; fil amentum filiforme; anthera reniformis, unilocularis. Ovari um quadriloculare, quadrilobum Ovula in loculis solitaria, pendula, amphitropa. Styli 2, centrales. Capsula indehiscens, quadriloenlaris. Sem in a in loculis solitaria, pendula. E mbryo in axi albmminis earnosi rectus, dicotylis, radi cula supera. - Herbae aquaticae, in Europa et America boreali obviae; folits oppositis, integerrimis, superioribus rosulato-congestis, floribus axillaribus solilariis, sessilibus.

Callitriche Liun. gen, n, 13. Gürti. I, 33o, t, 68 , Schkular. t. 1. A. Riehard in Dict. class. III. 59. DC. prodr. IIT. 70. Kützing in Neichenb. Ic. crit. n. 1179_1280. Nees jun Gen, plant, II. 4, Stellaria Dillen. Gen. 1t9. $t$. 6.

\section{Ordo 耳XXXE: Podostemmeat.}

PODOSTEMMEAE L. C. Ricbard in Humb. et Banpl. Nov. gen, etsp. I. 197. Martius Nov. gen. et sp. T. 7. Bartling ord. nat, 72. PODOSTEMMACEAE Liudley introduct, edit. II. $p$. 190. PHILOCRENACEAE Bongard in Mem. Academ. St. Petersb, VT. 3. P, 72 .

Неввав aquaticae, snbmersae, ca uli bus innorando proliferis, plerumque fluitantibus. 
Folia alterna, quandoque imbricata, laciniata $v$. integra, laciniis saepius capillaribus, tenerrima, in caule ramisque decurrentia et cum eo colliquescentia, nec articulata, stomatibus destituta.

Fuores hermapliroditi v, abortu unisexuales, axillares vel terminales, solitarii v. aggregati, distiche spicati v. subracemosi, parvuli.

Spatra sessilis, simplex, tubulosa, demum irregulariter rupta, aut bi-tri-polyphylla, florem solitarium primum sessilem includens, deinde saepissime flore in stipite plus minus longo elevato, pedicelli basim vaginans.

Perigoniva nullum, nune bi-tri-polyphyl. lum, foliolis liberis, membranaceis, coneaviusculis, angustis, acutis, interdum unilateralibus.

Stamen unicum, duo v, indefinita, hypogyna, ovarium cingentia v. unilateria, ovario adpressa. Fil amenta libera, v. basi inter se cohaerentia, aut etiam in tubum coalita, compressa, acuta, apice interdum bifurca, nonnulla saepe castrata. A n the rae introrsae, biloculares, dorso supra basim affixae v. etiam basi insertae, erectae, ovatae v. oblongae; loculi oppositi, nonnunquam connectivo interposito sejuncti, rimis longitudinalibus dehiscentes.

Ovarium globosum v, ellipticum, bi-triloculare, placentis e loculorum angulo centrali late tumentibus, v. septis incompletis uniloenlare, placentis parietalibus, valvularum marginibus adnatis. $0 \times \mathrm{vl}$ a plurima, adscendentia, amphitropa, micropyle prope umbilicum fere basilari. Styli loculorum numero, indivisi v. bifidi, persistentes, intus stigmatosi.

Capsura costata, stylis persistentibus superata, bi - trilocularis, septifrago bi-trivalvis, valvis placentas in columnulam persistentem coalitas nudantibus.

Senisa minutissima, in placentae foveolis erecta, imbricata. Testa tenuis, pellucida, laxa, cellulosa, mucilaginosa, membrana interior solida, fuscescenti-brunea. Alb u m en nullum. E m b r y o dicotylis orthotropus, cotyledonibus plano-convexiusculis. Radicula brevissima, umbilico proxima, infera.

Podostemuear, quarum nonnullae Muscos et Jungermannias habitu mirabiliter ludunt, aliae foliis capillaceo-multifidis et capsulis costatis distylis Umbelliferas referunt, v. fronde cum caule coalita lobata Fucos quosdam simulant,inter tropicos totius mu nd aruas quietas et aestuaria incolunt, radiculis minimis scopulis $v$. arborum truncis submersis aftixae.

Ordo diu cum $\mathrm{N}$ a y ad e is J un cag ine isqu e confusus, quo ad locum suum magnopere dubius, interim donec meliora nos doceat natura hoc loco collocatus.
1831. Munopsis MART. S pat ha tubuloso-campanulata, apice irregulariter fissa. F 10 s pedicellatus. Perigon in mullum. Sta mina 3 , collateralia, basi connata; filam e n ta lateralia ananthera, subulata, breviura, intermedium lineare, apice bifidum, cruribus singulis a $n t h e r$ a $s 2$, oppositas, biloculares gerentibus, dente filiformi inter crura interjecto. $O$ va ri $\mathrm{m}$ biloculare. Stig$\mathbf{m}$ a depressum, bi trifidum, Johis bifidis. C a p $8 \mathrm{n}$ 1 a ecostata bilocularis, bivalvis, valvula altera minore dissiliente, altera deorsum involuta persistente, lissepimentum placentiferum orbiculare, compresso-planum, valvis parallelum eructante. S emina plurima, imbrieata. - Plantula brasiliensis Jungermanniae facie, radiculis minimis in saxis submersis firmata, erecta, cacspitoso-ramosa, foliosa; ramis subdicholomis, erectis, innovando-fastigiatis, foliis amplexicaulibus distiche imbricatis, subsemiorbicularibus, serrulatis, adnato-decurrentibus.

M n i o s i s Martius Nov. gen. et sp. I. 1. t, 1. C re n f a s Sprengel $\mathrm{Cur}$. post. 246.

1832. Poulostemon L.C. RICH. S patha diphylla. F los pedicellatus. Perig on ium squamulac 2 , collaterales. Sta men 1 , inter perigonii squamulas insertum; fil a mentum filiforme apice bifurcum, eruribus singulis a $\mathrm{th}$ h $\mathrm{ram}$ unieam bilocularem gerentibus. Ovarin m biloculare. Stig mata 2 , subulata, divarieata, indivisa. C a p a I a costata, bilocularis, bivalvis, valvulae aequales, dissepimentum placentiferum orbiculare, medis tumidum, valvulis parallelum et persistens denudantes. S e m in a plurima, imbrieata. - Herbae tenellae, in confluentibus Orinocci et $O$ hio, nec non in rivulis Madagascariae saxis arborumve truncis demersis adnascentes, pendulae, dichotome ramosae; foliis capillaceo-multijıdis, floribus axillaribus et terminalibus solilariis $v$. fasciculatis.

Podostemon L. C. Richard in Michaux Flor. Bor. Amer. II. 164.t.44. Kunth in Humb. et Bonpl. Nov. Gen, et sp, I, 246. Di er a e i a Thorars Gen. Madagase, n, 4.

1833. Tomerea $A U B L$. S patha tuhuloso-campannlata, apice irregulariter fissa. F I os pedicellatus. Perig on i $\mathbf{m}$ squamulae 2, collate rales, v. plures indefinitae, verticillatae. S $t$ a $m$ in a 2 unilateria, v. 8-12 vertieillata, perigonii foliolis alterna; fil a menta filiformi-subulata, libera, indivisa; antherae terminales lineari-sagittatae, biloculares. Ovarium biloculare. Stig mata 2 , subulata, divaricata, indivisa. C a p s u la costata, hilocularis, bivalvis, valvolae aequales, dissepimentum placentifernm orhisulare, medio tumidum, valvulis parallelum et persistens denudantes. Semina plurima, imbricata. Herbae a nericanae tropicae, demersae; foliis multifidis, lobatis v. integris, imbricatis, floribus axillaribus v. terminalibus, solitariis $v$. congestis, rarissime spicatis.

Mourera Aublet Guian. I. 582. Chamisso in Lin. naea IX, 503, L a c is Sehreb. gen. n. 924. Martius Nov. gen. et sp. I.4. Bongard in Mem. Academ. St. Petersb. VI. 3. p. 73, excl. sp.

a. NEOLACIS Cham, Perlgouli squamae binae collaterales. S t a m In a 2, unilateralia. - Flores axillares subso. litarii.

Neolacis Chamisso l. c. t. 5 . L a eis Martís op. cit. t. 2. Bongard op. cit, t. 3. et 5 .

b. Marathrum $H$, et $B$. Perigonit squamae $4-8$ verticillatae. $\mathrm{S} t \mathrm{amin}$ a totidem, perigonil sqaanis alterna. Flores axillares solitarit, v. terminales congesti,

Marath r um Humb. et Bonpl. Pl, aequinoct. $I$. 40, t. 11 . Kunth in Humb. et Bonpl. Nov. gen, et sp. T. 240. Cham. t. c. t, 6. Bougars op, cit. $t$. 2. et 4 . 
c. MOURERA Aubl. Perigon i i squamulae plurimae, verticillatae. Stamina plarima, perigonii squamulis alterna. Flores spicati.

M o a re r a Aublet op. eit. $t .233$.

1834. Tuacis $L I N D L$. S p a th a tubuloso campanulata, apice irregulariter fissa. F lo s subsessilis. P erigon i m nullum. St a m in a 6_12, verticillata; fil am ent a in tubum membranaceum laxiusculum connata, apice libera; a $n$ therae terminales, oblongo-subsagittatae, biloculares. $0 \mathrm{va}$ rium biloculare. Stigmat a 2 , subulata, divaricata, indivisa. C a p 8 u a costata, bilocularis, bivalvis, valvulae aequales, dissepimentum placentiferum orbiculare, medio tumidum, valvulis paralleInm et persistens denudantes. Semina plurima, imbricata._Herbaebrasiliens es submersae, acaules; foliis oblongis, apice laciniato-lobatis, spica radicali, stipilata, disticha.

$\mathrm{L}$ a c is Liodley introduct, edit. II. p. 442. L a $\mathrm{c}$ is in a na deIpha Boagard in Mem. Academ, St. Petersb, VI. 3. p. 78. $t, 1$.

1835. Tristiellas THOUAR. S p a th a diphylla, foliolis oppositis. Flos pedicellatus. Peri g o n i foliola 3 , membranacea, concava, duo approximata. Stamen unicum, perigonii foliolis approximatis alternum; fil ame $\mathbf{n} \mathbf{t} \mathbf{u}$ filiforme, patentiuseulum, indivisum; a $\mathrm{n}$ h e $\mathrm{r}$ a terminalis, oblongo-linearis, bilocnlaris. Ov a $\mathbf{r}$ i $\mathrm{m}$ triloculare. Stigmata 3, subulata, patentiuscula, indivisa. C a p s u I a costata, triloeularis, septifrago-trivalvis, valvis basi et apice cohaerentibus, a placenta centrali trigona, membranac - - alata solutis. S em i na plurima, imbricata. - Herbulae musciformes, inter tropicos totius mundi in rivulis submersae; caule dichotome ramoso, foliis plurifariam imbricatis, subsemiorbicularibus, adnato-decurrentibus, integrerrimis $v$. minute denticulatis, floribus axillaribus, solitariis.

Tristic ha Thouars Gen. malagasc, $\pi, 8$. Presl in Reliq. Haenk, p. 86. D u foure a Bory in Willd. sp. D. 55. St. Hilaire Plant, Brasil, I. 82. A. Richard in Dict.class. $V$. 635. non Kunth nec Arhar. Philoc $\mathrm{rena}$ Bongard in Mem. Academ. St. Petersb, VI. 3. p. 80, t. 6.

\section{GENERA DUBIA.}

1936 . Hydrostaclays THOUAR. F 1ores dioiei, dense spicati. Masc. Perigonium squama axi perpendicularis, apice recurva. S $\mathrm{ta} \mathbf{m}$ e $n$ unicum; a ther,a sessilis, loculis dnobus distinctis. Fem. Perigonii squama ut in mare. Ova ri n m sub squama latens... Styli 2. Ca p s u l a ovata, hinc compressa, unilocularis, bivalvis. Se $m$ in a plurima, parietibus affixa. - Herbae $m a$ dagascarienses aquaticae; foliis variis, scapis centralibus, floribus in amenta spicaeformia dispositis.

Hy drostachys Thouars Gen, madagasc, n. $J$.

183\%. yilatoplata THOUAR. F I o r e 8 dioici, in axillis foliorum solitarii, sessiles. P e rigon i um spathaceum diphyllum, foliolis oppositis, subaequalibus, tenuiter membranaceis, concavis. Masc. Stamina 3 ; filamenta in tubum brevem, demum elongatum connata; antherae liberae, extrorsae, uniloculares, apertae foliaceae, oblongae, nervo medio pereursae, patentes. P o II en viscido-conglutinatum. Fem. Ovari n m peilicellatum, ovale, uniloeulare. Ovula placentis tribus (?) parietalibus inserta, adscendentia. St y $1 \mathrm{u}$ s elongato-filiformis, ovario continuus, stig $\mathrm{m}$ a $\mathrm{t}$ a $\mathbf{3}_{-5}$, filiformia, penieillata. C a p $\mathrm{u} \mathbf{l}$ a mem branacea, uniloenlaris, indehiscens (?). Se min parietalia, plurima, depresso-subglobosa, albida umbilico basilari, fusco; testa membranacea, reticulata, endopleura laevis, nitens. Alb u m en copiosum, farinosum. Em b ry o fnsiformis, spiraliter tortus, in regione umbiliei albumini inelusus, indivisus (?). - Herbulae in littoribus inundatis Madagascariae, maris rubri et Mariannarum observatae; caule filiformi, ramoso, repente, ad nodos radicante, foliis oppositis, longe petiolatis, ellipticis, trinerviis, integerrimis, pellucidis, stipula ad basim petiolorum extrorsum laterali, ova$l i$, concava, floribus axillaribus, solitariis, sessilibus.

H a l o $\mathrm{phil}$ a Thouars Gen, madagasc, n, 6. Gaudicb. ad Freyc, 429 . t. 40. f.1. B a rk a n i a Ehreub. msc. -? C a u. Ii u f a ovalis R. Brown, prodr. 339.

oBSERVATIO. Quid Lemnopsis Zippel in Flora $1829, I$, 284, solum nowinata ?

\section{Classis XXV. Juliflorae.}

Arboresvifrutices, rarius he rbae, succo aqueo $\mathbf{v}$. interdum lacteo foetae. Foli a altcrna aut in paucissimis opposita, sessilia v. petiolata, simplicia, integra ant rarius palmatiloba, rarissime nulla, ramis tune articulatis, vaginatis. Stipula liberae, persistentes v, deciduae. Fuores scepissime typice unisexuales v. aburtu polygami, rarissime hermaphroditi; amentacei v. in receptaculis glomerati. PERIGoviva nullum v. calyciforme, plus minusve perfectum, in floribus femineis saepius minus perfectum, interdum cum ovario connatum. Ovariom uni-pluriloculare. Ovola in loculis solitaria v. plura, directione admodum varia. Fructus nucamentaceus $v$. baccatus ant rarissime capsularis, plerumque abortu monospermus, rarius oligospermus v. polyspermus. SEmxa albuminesa v. saepius exalbuminosa. Erв хоо rectus v. curvatus, in seminibus albuminosis inclusus, $\mathbf{r}$ a $\mathbf{d i c} \mathbf{c} \mathbf{l}$ a rarissime basim $\mathbf{v}$. ambitum, plerumque verticem fructus spectante.

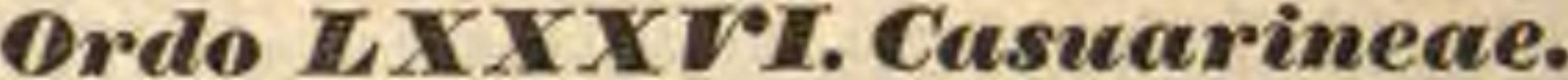

CASUARINEAE Mirbel in Annat, du Mus, XVI. 451, R. Brown in Flinders Voy, II, 571. Bartling Ord. nat, 97.

Arbores v, rarius frutices, Equiseti habitn, ramosissimae, ramis ramulisque verticillatis, nodoso-articulatis, sulcato-striatis. Foli a nulla. Vaginae breves, multidentatae, striatae.

Flores monoici v. dioici, masculi in spicas, feminei in capitula terminalia dispositi.

Flores masculi intra vaginas ramulorum supremas erumpentes, singuli basi bractea parva, persistente muniti.

Perigoniem diphyllum, bibracteolatum, rigide membranaceum. Bracteolae dextrum et sinistrum ab axi floris latus occupantes, foliola anticum et posticum, bracteolis minora, primum ab istem inclusa, apice calyptratim colıaerentia, demum a stamine increscente dejecta

Stamen unicum, centrum floris occupans. Fil amentum primum brevissimum, mox 
elongatum, filiforme, basi incrassatum. A nthera bilocularis. incumbens, loculi suboppositi, basi et apice discreti, longitudinaliter dehiscentes.

Flores feminei in apice ramulorum abbreviatorum capitati, singuli in axilla bra cteae persistentis sessiles, bracteolis duabus navicularibus, primum patentibus, demum basi inter se concrescentibus, clausis, fructum primum recondentibus, tandem iterum apertis stipati.

Perigonium nullum. Ovarium sessile, lenticulari-compressum, uniloculare, Ovul u m unicum, apici loculi appensum, anatropum. Stylus brevissimus, terminalis. Stig m a ta 2, filiformia, elongata.

Fructus e bracteis bracteolisque in formam strobili connatis. Ca r y op s i s compressa, api ce in alam membranaceam desinens, primum bracteolis inclusa, demum iisdem apertis nudata.

Srmex unicun, apici loculi appensum. Test a endocarpio cohaerens, ab endopleura tenuissime membranacea interpositis vasis spiralibus plurimis longitudinalibus sejuncta. Alb u m en nullum.

Eubryo orthotropus. Cotyle dones oblongae, planae. R a di e u la minima, umbilicum attingens, verticem fructus spectans.

Casu a rine a habitu insignes, maxima copia Nova m Hollandiam, imprimis tropico circulo vicinam incolunt, parcius in India e terra continente et insulis, nec non in 0 ce ani a tropiea reperiuntur.

1838. Casuarima RUMPH. F lores mono-dioici. Mas r. P erigonium diphyllom, bibracteolatum, foliolis ealyptratim cohaerentibus. Stamen 1; filamentum filiforme; an thera bilocularis. F em. Bracteolae 2, perigonium nullum. Ovarium uniloculare. Ovulum unicum, pendulum, anatropum. Stylus brevissimus; $8 \mathrm{tig} \mathbf{m a t a} 2$, filiformia. C a ry o psis lenticularis. Semen inversum. Embry o exalbuminosus, orthotropus, radic ula brevissima, supera. - Arbores $v$. frulices, ramis ramulisque verticillatis, nodosoarticulatis, aphyllis, articulis vaginatis, floribus masculis in spicas, femineis in capitula terminalia dispositis.

C a s u a rin a Rumph Amboin. III. 87. t, s8. Forst. char. gen. t. 52. Gartu, II. 63.t, 91, Lam. t, 746. Labill. Nov, Holl. t. 218. Andr. Bot, Reposit, t, 846. Vent, Cels, t, 64. Turpin Atl. t. 299. 300 .

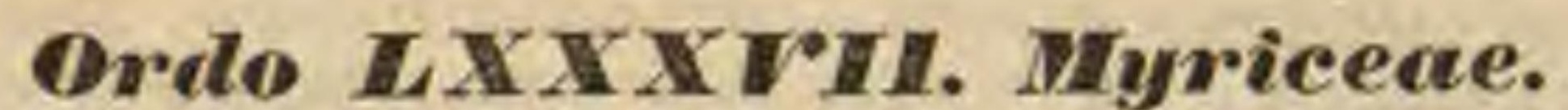

MYRICEAE L. C. Richard Annal, du Fr, 193.|Blune Flor. Jav. fasc. 17. Bartling Ord, nat,98. Lindley introduct, edit. II, p. 179 .

Frutices v. arbusculae, ramis teretibus, hand articulatis, sparsis. Folia alterna, simplicia, integra, plerumque serrata v. incisa, rarius integerrima, venulosa, punctis resinosis conspersa. Stipula e nullae v. fugaces.
Flores in amentis axillaribus v. terminalibus, simplicibus aut paniculato racemosis, monoicis v. dioicis, rarius androgynis, inferne nempe femineis, superne masculis, inter brarteas concavas, in amentis nondum explicatis imbricatas solitarii, sessiles.

Masculi in amentis fililormibus. Bract e o la e 2, utrumque squamae floriferae latus stipantes, quandoque delicientes.

Stamina duo, quatnor, sex v. rarissime octo, in axilla squamae floriferae, unum alterumve saepius abortivum. Filam en a filiformia, brevia, saepe inaequalia, libera vel basi in stipitem brevem cennata. Anthera extrorsae, biloculares, basifixae, subrotundo-didymae; Inculi suboppositi, latere juxta longitudinem dehiscentes. Pollen ovato-trigonum, angulis papillas diaphanas exserens.

Flores feminei in amentis ovatis v. cylindricis. Squamae hypogynae duae ad sex, interdum peltatae v. basi intus glandula carnosa auctae.

Ovarion unum, lenticulari-compressum v. subglobosum, basi cum squamis hypogynis connatum, uniloculare. Ovulum unicum, e basi ovarii erectum, orthotropum. S tylus brevissimus. Stigmata duo, elongata, subulata v. lanceolata, papillosa, patula.

Fructus siccus, indehiscens v. squamis hypogynis auctis tectus, drupaceus, monospermus.

Senen erectum, basilare. Te $\mathrm{s}$ t a tenuissime membranacea. A I b u m en nullum.

Eмвryo antitropus. Cotyled ones ovatae, plano-convexae, carnosae. R a di cula teretiuscula, umbilico e diametro opposita, verticem fructus spectans.

My riceae arcta affinitate $C$ as a rineis, quae habitu facillime dignoseuntur, et $\mathrm{B}$ e $\mathrm{t}$ ul ace is, quae vix nisi ovario biloculari et ovuli situ differunt, junctae, per totum orbem sparsae, in A $\mathrm{m}$ erica bo reali copiosae, in veteri continente imprimis in A frica a us trali extratropica, in montibus ' $\mathrm{T}$ 'i be $\mathrm{tan}$ is et in insula $\mathrm{J}$ avae observatae fuernnt. Unica species E u ropam, praeprimis occidentalem et borealem inhabitat.

Qualitate pollent aromatica et adstringente. Drupae nonnullarum ceram exsudant, aliarum sapide acidulae.

1839. Myriea LINN. F 1 ore s mono-dioici. Masc. Amenta filiformia. B ractea uniflorac, bibracteolatae. St a m in a $2 \ldots 8$; filam enta libera v. basi inter se connata; antherae biloculares. Fem. A m enta ovata v. cylindrica. B rae t e a e uniflorae, bibracteolatae. S quamula e hypogynae cum ovarii basi conereseentes. Ovari um uniloculare. Ovul um unicum, basilare, orthotropum. St y lus brevissimus, $8 \mathrm{t}$ igm a t a 2 , elongata. D r a a monosperma. S emen erectum. Em br yo exalbuminosns, antitropus, radi eula supera. Frutices vel arbusculae resinosae; foliis alternis, in- 
tegris, serratis $v$ laciniatis, aut interdum pinnatifidoincisis.

M y riea Lian, Gen, n, 1107. excl,sp. Blume Flor, Jur. fasc, 17. p. 5 .

a. ClARISIA Ruiz el Pav. Flores masculi diandri. $S_{\text {q }}$ u a ma hypogynae, peltatae.

Clarisia Ruiz et Pav. Prodr, 128, $t, 28$.

b. GALE Tourn. Flores masculi tetra-octandri. Squam a e hypogynae sessiles intus nudae.

Ga le Tournef. inst, $t$. 3. M y rica e sp. Linn. Gïrtn. I. 190 t. 39. Schkuhr $t$. 322. Flor, dan, $t .327$, E. B. $t .562$ Jacq. Ic, rar, t, 625. Fragm, bot. IT. $t, 1$. f. 4. Dubamel Arbr. edit. nov, III. t, 55. 56. Humb. et Bonpl. Nov.gen. et sp. t, 28. Mirbel in Mem. Mus, XIV. t, 27. 28. Blume Flor. Jav, 17. $t$. 1. Nees jun. Ben. plant. II. . .

e. COMPTONIA Banks. Flores masculi hexandri, Squa$m$ a e hypogyaae basi intus glandula auetae.

C omptonia Banks apud Gärtn.II. 58, t, 20. Watson Dendrolog.t.166. L i q u id a mb a $\mathrm{r}$ is sp. Linn.

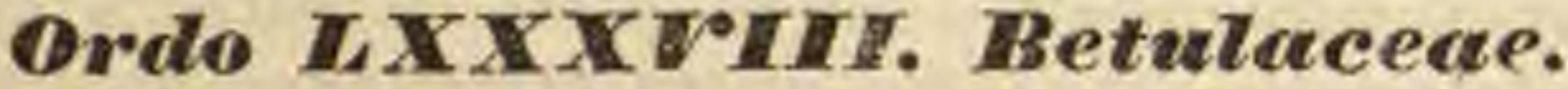

AMENTACEARUM fenera Juss, gen. 407. BETULINAE L. C. Richard ex $A$. Richard Elem, bot, edit, $I V, p, 562, \mathrm{BE}$. TULACEAE Bartling ord, nat, 99. Lindley introduct, edit. Ir. p. 171.

Arbones v, prutices, ramis teretibus, hand articulatis, sparsis. Foli a alterna, simplieia, dentata v. serrata. Stipula e liberae, caducae.

Flores monoici, in amentis terminalibus v. lateralibus, saepius in racemum dispositis, in axillis braetearum binati ternative, sessiles.

Floribus masculis: Bactea peltata, utrinque bracteolis squamaeformibus stipata, triflora.

Perigonium squamaeforme monophyllum, v. caly ciforme tetraphyllum.

Stamisa quatuor, perigonii basi inserta ejusque foliolis opposita. Fila me n ta brevissima, libera. Antherae basilixae, uniloculares v. biloculares, loculis oppositis, longitudinaliter dehiscentibus.

Floribus femineis: Bracteae sessiles, integrae v. trilebae, cum fructu increscentes, bi-triflorae.

Perigonium nullum, v. ejus loco squamae ovariorum basim stipantes, demum saepius lignescentes et cum fructu concrescentes.

Ovaria infra quamvis bracteam bina v. terna, libera, bilocularia. Ovula in loculis sclitaria, dissepimento paullo infra apicem aflixa, e funiculo longinseulo ererta, micropyle tunc ovarii verticem spectante, mox supra funiculum extrorsum reclinata, pendula. Stylus nullus, stigmata 2, terminalia, elongata, filiformia, patula.

Frectus: $\mathrm{N}$ uculae cum bracteis in strobili speciem coalitae, angulatae v. alatae, abortu uniloculares, monospermae.

Sexte inversum. Te s ta tenuissima, cum endocarpio concrescens. A $1 \mathrm{~b}$ u me n nullom.

Emaro orthotropus. Cotyledones planiusculae, germinatione epigaeae, foliaceae.
Radicula umbilicum attingens, verticem fructus spectans.

Betulacea in hemisphaeraeborealis regionibus temperatis potissimum vigent, nonnullae extremum septemtrionem et summa montium cacumina petunt, pancissimae in Asiae et Americaetropicae jugis excelsis reperiuntur. Corticis qualitas adstringens.

1840. Betula TOURNEF. Flores monoici. Masc. Amenti squamac peltatae, bibracteolatae, subtus triflorac. Perigoninm monophyllum, squamaeforme. St a $\mathrm{m}$ in a 4 ; filam ent a hrevissima; a n thera e oblongae, uniloculares, suleo Iongitudinali dehiscentes. Fem. A men$\mathrm{ti}$ squamae trilobac, imbricatae. Perigon in nullum. Ovaria sub quavis squama 3 , scssilia, bilocularia. Ovula in loculis solitaria, e dissepimenti apice pendula, anatropa. Stig mat a 2 , filiformia. Strobilus e squamis membranaceis, scariosis. Nuculae lenticulares, utrinque alatae (samaroideac) abortu uniloculares, monospermae. Se$\mathbf{m}$ en pendulum; testa tenuissime membranacea. Embryo exalbuminosus, orthotropns; cotyledones planiusculae, oblongae, radicula brevis, exserta, umbilicnm contingens, supera. Arbores et frutices sylvestres, in Europ a et $A$ sia boreali ac media obviae, in America boreali paullo frequentiores, in summis Asia e jugis rariores, in Am erica antarctica rarissimae; foliis alternis, integris, annuis, gemmis perulatis folia plicata equitantia foventibus, amentis cylindricis, gracilibus, masculis terminalibus et lateralibus, hyeme nudis, femineis lateralibus, contra brumae intemperiem perulatis.

Betula Tournef. inst, t. 360. Gärtn. IT, 5i. t. 90. f. 2. Schkuhr $t$, 288. Fl. Dan. $t, 91$. 1467. E. B, $t, 2198,2326$. Wats. Dendrolog. $t .94-97.151$ - 154. Pallas Elor, ross. I. t. 39. Willd. Arbr. t. 2. Wallich Pl, As, rar, t. 109. Nees jun. Gen, plant. 1.10.

184 1. Almans TOURNEF: Flores monoici. Masc Amenti squamae peltatae, quinquebracteolatac subtus, triflorac. Perigonium quadripartitum. Stamina 4 , perigonii lobis basi inserta, iisque opposita; filam enta brevissima; antherae ovatae, biloculares, loculis oppositis longitudinaliter dehiscentiluss. F e m. A m e n $t i$ squamae imbricatae, carnosae. Perigoni um tetraphyllnm, fuliolis squamaeformibns, cum amenti basi connatis. Ovaria sub quavis squamula 2 , sessilia, bilocularia. Ovula in loculis solitaria, e dissepimenti apice pendula, anatropa. Stigmata 2 , filiformia. Strobilus e squamulis lignescentihus, concrescentibns. Nuculae lignosae, compressae, ansulatae, apterae, aborta nniloculares, monospermae. Semen pendulum; tes ta tenuissime membranacea. E m b ry o exalbuminosns, orthotropus; eot y ledones planinscalae, cordato suborbiculatae, ra dic ula brevis, exserla, nmbilieum attingens, supera. - Arbores $v$ frutices, in $h e-$ $m i s p h a e r a$ e borealis temperalis obviae, in celsioribus Americae $t$ ropicae jugis rarae; foliis alternis, integris, annuis, gemmis pedicellatis, e squama unica, folia conduplicata, plicata fovente. amentis hyeme exsertis, masculis elongatis cylindricis, cum femineis brevibus, ovatis $v$. oblongis in racemum compositis.

A I u us Tonrnef. inst. t. 359. Hrok. Flor, Lond, 6.59. Wallich Pl,as, rar. t, 109. Kicliwald PI. caucas, $t, 2$, Tenore Flor, neap. t.92. Nees Jan. Gen.plant. I. 11. B etulae sp. LinB. Garta. IT. 54, $t, 90 . f$, E, B, $t, 1508$. 
oBSERVATI0. Betulacearum amenta fossilia, in Geanthrace (Lignite) ad pagum Salzhausen prope Niddam Weteraviae nuper a cl. G6ppert inventa, a nostris Betula et A Ino vix quidem genere differunt, sed liceat characteres generum Alnites et Betulites ab annieissimo viro mecum in litteris communicatos, hoc loco inserere.

BETUlites Göpp. Flores monoici. Mas c. Amenta cylindrica. S q u a mae peltatae, subtus utrinque squamula auctae. Perigonium.... Stam in a 4 , interiori squamarum parti inserta; fil a me $\mathrm{t}$ a brevissima, singula bian therifera; a ntherae (albidae) linerares, oblongae, sulco longitudiuali notatae. Polli n is granula flavescentia, pellucida, subtrigona, ellipsoidea, in angulis poris tribus aequidistantibus instructa. $\mathrm{F}$ em. A m en $\mathrm{ta}$.... squamae trilobae.... Strobili.....

ALNITES Gopp. Flores monoici, amentis utriusque sexus in racemum compositum junctis. Mas e. Amenta oblonga, eylindriea. Squa ma e peltatae. P e rigoni um quadripartitum. St am ina 4; filamenta brevissima; anthe rae (albidae) subovatae, biloculares, longitudinaliter sulcatae. Pollinis graunla planiuscula, flavescentia, pellueida, quinqueangularia, rotundiuscula, in angulis poris quinque aequidistantibus instructa. Fem. $\mathbf{A m e n t a . . .}$ Strobili e squanis lignescentibas compositi. Nuculae (fuscae) compressae, angulatae, apterae, monospermae.

\section{Ordo IXXXIX. Cupatiferae.}

CASTANEAE Adans, Fam. 366. CUPUliFeraE Richard Anal. du Fr. 32. et 92. Blume Flor. Jav. fasc, 11. ot 12. Bartling Ord. nat, 99. Lindley introduct. edit, II, p. 170, CORYLACEAE Mirbel Elem, $I$, 906, QUERCINAE Jus. sieu in Dict. sc, nat, suppl. II. 12.

Arbores saepissime vastae et procerae, rarius Frotices ramosissimi, $r$ a m is sparsis, teretiusculis, continuis. Fo li a plerumque alterna, simplicia, penninervit, saepius dentata, sinuata, lobata $v$. incisa, rarius integerrima. Stipulae petiolares, liberae, caducae.

Flores monoici v. rarius dioici.

$\mathrm{M}$ a s cu $\mathrm{li}$ in amentis cylindraceis $\mathrm{v}$, rarius subglobosis, bractea squamaeformi suffulti, sessiles v. breviter pedicellati.

Perigonium squamaeforme, simplex, monophyllum trifidum; v. calycitorme quadri-sexfidum, laciniis per aestivationem valvatis.

Stamina tot quot lobi perigonii v. duplo triplove eorundem numero, uniseriata, perigonio intus circa discum glandulosum inserta, in perigoniis monophyllis pluriseriatim imbricata. F il a $\mathbf{m}$ en $\mathbf{t a}$ brevia $v$. elongata, inaequalia, in alabastro erecta $v$. geniculatim infracta, basi interdum inter se coalita, bina, terna v, etiam plura usque ad medium inter se cunnata. Antherae introrsae, uni-biloculares, erectae, dorso $\mathrm{v}$. basi affixae, oblongo-lineares v. globoso-didymae; loculis suboppositis, parallelis, rima longitudinali lateraliter dehiscentibus; connectivo supra loculos producto, glandulaeformi v. complanato, interdum inflexo, saepe barbato.

Flores feminei amentacei ant fasciculati, interdum spicati, nunc solitarii, nunc bini v. terni rariusve plures sessiles intra inrolurrum commune foliaceum v. cyathiforme, extus saepe squamosum v. echinatum, demum increscens, membranaceum, coriaceum v. lignosum, fructum nunc includens, nune basi cupulatim cingens.

Perigonium ovario adnatum, limbo minuto, denticulato, saepius demum evanido.

$\mathrm{S} \mathbf{t}$ a $\mathbf{m}$ in $\mathrm{m}$ rudimenta perigonii denticulis in nonnullis oppesita et alterna.

Ovarium cum perigonio connatum, dissepimentis a pariete ad centrum porrectis demum plerumque evanescentibus, bi-tri-v, rarius sexloculare. $0 \mathrm{vula}$ in loculis solitaria v. gemina collateralia, loculorum angulo centrali apice v. parum infra apicem affixa, pendula, anatropa.

Stylus columnaris, teres v. trigonus, apice divisus in stig mat a loculorum ovarii numero, rigida, cartilaginea, teretiuscula v. compressa, longitudinaliter sulcata, erecta v, recurva, persistentia, rarissime punctiformia, in apice styli indivisi sessilia.

Fructus mucamentaceus, indehiscens, coriaceus v. osseus, loculorum abortu unilocularis, plerumque monospermus, basi lata in fundo involucri cupuliformis v. capsuliformis sessilis, eodem basi cinctus v. penitus inclusus.

SEMEN solitarium (v, rarissime per anomaliam bina v. plura) pendulum, apice saepius ovulorum abortivorum exuviis stipatum. 'Tes t a membranacea tenuis, rhaphe longitudinali et chal az a apicali notata. Albumen nullum.

Eмвкyo orthotropus. Cotyledones foliaceae, per germinationem epigaeae ; v. crassue, carnosae, facie interna interdum coalitae, hypogaeae. R a d i cula brevis, conica, plus minus retracta, verticem fructus spectans.

Cupuliferae, sylvarum decora, in $\mathrm{he}$ misphaeraeborealis temperatis abnndant, ita ut specierum hactenus cognitarum duae fere tertiae cis aequatorem habitent, novi imprimis continentis cives, ex Asia boreali omnino exules. Rarescunt versus aequatorem et alta montium petunt juga, in A m eri c a tro p ic a 6000_9000 ped. supra mare elevatione ab Humboldtio et Bonplandio repertae, et in In di a et Moluccis $4000 \_6000$ pedum elevatione a Wallichio et Blumeo non parva nuper copia detectae.A fri c a, si regionem mediterraneam occidentalem Quercuum species quasdam proferentem demseris, nullam Cupuliferarum stirpem gignit. Trans Capricornum inventae fuerunt Fagi species aliquot humiles, in And i um jugis et in regione Magellanica, parcissime in insula Diemen et in Nova $\mathrm{Z}$ eelandia vigentes, in Nova Hollandia nondum visae.

C a s $t$ a $n$ e a r $\mathbf{m}$ exuviae in terrae sedimento superiori obviae. Comptoniae fossiles Brongniartii (Aspleniopteris Sternb.) in argilla 
lignitum superstites, ad Fagum fortassis trahendae sunt.

Semina plurimarum edulia, nascentis hum ıni generis pabulum. Qualitate pollent omnes plus minusve adstringente, hinc in varios usus technicos et medicos conversae. In nonn:allarum specierum cortice suberoso principium peculiare (Suberin), residet. In Fagi pericarpiis substantiam venenatam latere dicunt.

Floris feminei involucrum diagnosim facillimam a Betulaceis praebet.

1842. Dstrya MICHEL. F lores monoici. M a s c. A m enta cylindrica, elongata, lateralia et terminalia. Perigon ii monophylli squamae simplices ebracteatae, imbricatae. S $\mathbf{t}$ a $\mathbf{m}$ in a 12 , plura, basi squamae perigonialis inserta ; fil a me nta ramosa; a $n$ therae ovatae, uniloculares, apice pilosae. Fem. A m enta terminalia laxa, bract e is parvis, deciduis, involucri squamis geminatis, basî pilosis, margine coalescentibus, uni-bifloris. Perigonii limbus superus, brevissime tu bulosus, indivisus, ciliatus. Ovari um inferum, bilocnlare. Ovula in loculis solitaria, apiei disse pimenti appensa, anatropa. Sty 1 us brevis; stig mata 2, elongata, filiformia. Strobilus ex involucri squamis membranaceis, nervosis, in utrieulos connatis. N u e u la e intra utrieulos solitariae, minutae, ovatae, laeves, apice pilosae, monospermae. Sem en pendulum; testa tenuissime membranacea. E mb r y o exalbuminosus, orthotropus; cotyledon ibus obovatis, plano-convexis; $r$ adicula brevi, exserta, supera. - Arbusculae $v$. frutices, in Europa australiore et in $A m e-$ rica boreali temperata provenientes; foliis alter$n$ is ovatis $v$. oblongis, serratis, annuis, vernatione inter gemmas perulatas plicatis, amentis coactaneis.

Os tr y a Mieheli Nov.gen, 223. t. 10\%. Watson Dendrolog. t, 143. Nees jun, Gen, plant, IT, 20, Ca r pin i sp. Linu.

1843. Carpians LINN. Flores monoici. M a s c. A ment a cylindrica, lateralia. Perigo n ii monophylli squamae simplices ebracteatae, imbricatae. Sta m in a 12 , v. plura, basi squamae perigonialis inserta; filam enta simplicia; anth era e ovatae, nnilocnlares, apice pilosae. F e m. Amenta terminalia, laxa, bracteis parvis deciduis, invol u eri biflori foliolis geminis petiolatis trilobis, lobis lateralibus minoribus. Perigonii limbus snperus, cupulaeformis, denticulatus. 0 va. ri $\mathbf{m}$ inferum, biloculare. Ovula in loculis solitaria, apici dissepimenti appensa, anatropa. StyI u s brevis; $s$ tig m t a 2 , elongata, filiformia. $R$ ac e mus fruetifer laxus, ex involucri foliolis membranaceis, nervosis, trilobis, nueulam a latere cingentihus. Naculae intra involucra solitariae, ivatae, coupressae, costatae, perigonii limbo apiculatae, monospermae. Semen pendulnm; testa tenuissime membranacea. E mbryo exalbuminosus, orthotropus; cotyledo nibus obovatis carnosis; radieula immersa, supera. - Arbores in temperatis frigidiusculisque Eu ropae et Ameri ca e borealis sylvicolae; foliis allernis, ovalis v. oblongis, integerrimis, annuis, vernatione intra gemmas perulatas plicatis, amentis coaetaneis.

Carpin as Lian. gen, n, 10z3. exel. sp. Gärtn. 11. 58 . t. 89. Selikulir $t$. 30 \%. B. B. $t$. 2032 . Watson Dendrolog. $t$. 98, 157. Nees jan. Gen, plant, II, 20.

1844. Corylus TOURNEF. FI ores mon viei. Masc. A m enta eylindriea, e squamis bra- ctealibus imbricatis. Perig onii squamae 2, collaterales, bracteis subtus et basi inter se connatae. $S t$ a m in a 8 , squamarum perigonii suturae versus basim diversa altitudine insertae; filamenta brevissima, filiformia, simplicia; a $n t h$ e r a e ovatae, uniloculares, apice setosae. F e m. Ge m ma e in ramulis terminales, bracteis integris, in volue ri nni-biflori foliolis $2 \ldots 3$, minutis, laceris, villosis, basi cohaerentibus. Perigoni limbus superus, minntissimus, denticulatus, villosus. O va ri u m inferum, biloculare. Ovula in loculis solitaria, dissepimenti apici appensa, anatropa, Stigm a ta 2 , elongata, filiformia. Nucu la e intra involuera magna foliacea, basi tubulosa, apice lacera solitariae, ovatac, osseae, monospermae. $S$ cme n pendulum; test a tenuissime membranacea, rhapheos et chalazae vasis ramosis hine pereursa. E mbryo exalbuminosus, orthotropus; cotyledonibus elliptieis, plano-convexis; radie ula immersa, supera. - Arbores $v$. frutices, in Europa et $A m e$ rica boreali temperata obvii, nuper etiam in In. dia su periore observati; foliis alternis, serolinis.

Corylus Tournef. inst. 347. Linn. gen. n. 1074. Gärtn. $I T$. 32, t. 89. Sehkuhr $t, 305$. FI. dan, $t$. 1468. Willd. Baumz. t. 1. f. 2. Wangenlt. Amer. t. 29. f. 36. Turp. Atl. D. t. 302. 303. Wallich Pl. As. rar. t. 87. Nees juu. Gen, pl. IT. 22.

1845. Dnerens LINN. F l o res monoici. Masc. Amenta gracilia, pendula, ebracteata. Perigonium calycinum, sex-oetopartitum, laciniis inaequalibus, ciliatis, nonnullis interdum bifidis. Sta m in a 6 _ 10 , perigonii basi circa discum glandulosum inserta; fil a m en ta filiformia, simplicia, inaequalia; a $\mathbf{t}$ hera e biloculares, didymae, loenlis subappositis. F e m. G e m ma e axillares v. in rhachi commnni scssiles, bracteis et involucri uniflori squamulis conformibus multiseriatim imbrieatis, in cupulam floris basim recipientem connatis. P e rigon i i limbus superus, sexfidus, v. obselete denticulatus. Ovarium inferum, triquadriloenlare. Ov $\mathbf{~ I}$ a in loculis gemina, collateralia, apici anguli interioris appensa, anatropa.S t yl us lirevissimus crassus; $s t i g m$ a $t$ a loculorum numero teretinscula v. compressa, abbreviata, obtnsa, erecta v. patula. Nu cula ovata v, oblonga, coriaceo-lignosa, involucro in cupulam lignescentem indurato cincta $v$. plus minus inclusa, monosper$m a$. Se m e n pendulum; testa memhranacea, tenui. E m bryo exalbuminosus, orthotropus ; cotyledonibus plano-convexis, crassis, carnosis; $r$ adicula immersa, supera. - Arbores $v$. rarius frutices, imprimis borealem Novi Continen$t$ is plagam, ab aequatore ad $45^{\circ}$ L. B. magna copia incolentes, versus septemtrionem frequentiores, in $\boldsymbol{E}$ u ropa usque ad 56' L. B. obviae, in regione mediter ranea paullo copiosiores, nec in montibus Indiae et Archipelagi moluccani rarae; foliis alternis, integerrimis v. saepius dentatis, sinuatis. lobatis $v$. incisis, deciduis $v$. sempervirentibus, vernalibus pubescentibus mallibus, autumnalibus coriaceis saepe glabris, stipulis petiolaribus geminis, minutis, fugacissimis, inflorescentia plerumque coaetanea in axillis superioribus $v$. terminali.

Quereus Linn. gen. n. 1070. Gärn. T. 182. t. 37. Sehkuhe t. 301. 302. Secondat, Mem, sur t'hist, nat. du Chene. Paris 1785. fol, c. ice. Michaux Arbr. IT, t.1-26. Histoire des Chenes de l Amerique. Paris 1801. fol. c. Zcc. Dutramel Arbr. t. 123, 124. Watson Dendrolog. $t .89$-93. Huab, et Bonpt. Pl. aequinoct. II. t. $75-96,199-131$. Roxb. Co. rom, $t, 129$, Blume Flor. Jav. fase, 13. 14, $t, t$ - 19 . Wallich Pl. As, rar. t. 46. 149, 150, 174. Eichwald Caue, $t, 1$. Nees jun. Gen. pl. Ir. 23. Q a er equs, Il ex et $\mathrm{S}$ u ber Tournef. inst. 3 ig. 350, p. $38 \%$. 
1846. Withoearpus BLUM. F lores monoici. Mas c. A ment a filiformia, floribus in terrupte glomerulatis, glomerulis bracteatis. Perigoninm calycinum, cupuliforme, sexfidum. Stamina 12_20, hasi perigonii inserta; filamenta filiformia, simplicia, inaequalia; anthe$r$ a b bloculares, didymae, loculis oppositis, e connectivi apice pendulis. Fem. Ge m m a evatac, in rhachi communi sessiles, bracteis et involucri uniflori squamis conformibus pluriseriatis, imbricatis, florem cingentibus. Perigon i limbus superus, minutissinus. Ovarium inferum, triloculare. Ovula in loculis solitaria (?) ex apice loculorum pendula, anatropa. St y lu s brevis, crassus; stigmata 3 , punctiformia. Nux rugesa, ossea, involncri squamis lignescentibus in gyrum connatis inclusa et conferruminata, monosperma. S emen pendulum. Em bry o exalbuminosus, orthotropus; cotyledonibus maximis, plano-convexis, basi sublobato-depressis; radicula brevi, supera._Arbor javanica excelsa; foliis alternis, integerrimis, perennantibus, amentis terminalibus $v$. in axillis superioribus, femineis supra masculos collocatis.

Li thoc ar pus Blume Flor. Jav,fasc. 13, 14, p.34.t. 20.

SYNAEDRYS Lindl, introduct, edit, II. p. 44t. N ux in foro Cantoniensi venalis, ossea, maxima pro parte cu puI a e immersa, apice depresso medio subtomentoso, basi intus semiquinquelocularis, monosperma, se min is inversi, exalbuminosi cotyled o n b us maximis, in lobos loculorum numero divisis, radieula supera.-Lithocarpi fortassis species.

184\%. Fagus TOURNEF. Flores monoici. M a s c. C a p it u l a longe pedunculata, pendula, squamis bractealibus minutis, deciduis. Perigon i m calycinum, campanulatum, quinquesexfidum. Stamina 8 - 12 , basi perigonii circa discum glandulosum inserta; fil amenta filiformia, simplicia; an thera e biloculares, locnlis oppositis, a connectivo interposito et excurrente sejunctis. F e m. G e $m$ m a in ramulis terminales, snbglobosae, bracteis plurimis linearibus, inaequalibus, com in volu cro hifloro ureeolato-subquadriloho connatis. $P$ e $r$ i g o n i i limlus superus, elongatus, laciniatus. Or a rium inferum, triquetrum, triluculare. $O v u I$ a in liculis solitaria, ex apice anguli centralis pendula, anatropa. Sty Ii tres filiformes; $8 \mathrm{tigmat} \mathrm{ibus}$ lateralibus rimulaeformibss. Fruetus eapsulaeformis, involucro lignoso, echinato, demum quadrivalvi, nueulis duabus foeto. Nucula e acnte triquetrae, perigonii limbo piloso superatae, monospermae, epicarpio coriaceo, endocarpio villoso. S emen pendulum; testa membranacea, tenui. Embry a exalbuminosus, orthotropus; cotyledonibus crassis, carnosis, intus irregulariter plicatis, arcte cohaerentibus; radicula subexserta, supera. Arbores $v$. frutices, in Europa majorem sylvarum montanurum parlem formantes, in $A$ merica boreali et antarctica, nec non in Nova-Zeelandia rarae; foliis alternis, grosse serratis $v$. repando-undulatis, floribus coaetaneis.

Fag u s Tournef, inst, 35t. Gärtn. I. 182. t,37. Sclihuhr t. 303. Michaux Arbr, II. t. 8, 9. Mirbel in Mem. Mus. XIV. t. 23 26. Nees jun. Gen. pl. IT, 24. - An huc Asple"i opteria Sternb. Flor. protog. $t, 21 . f$. 2. $t$. 24. $f .1$. Couptoniate sp. Bronga.

1848. Castanea TOURNEF. Flores monoiei v. rarissime hermaphroditi. M a s c, indefinite glomerati, rhaches axillares circumsedentes, rarius solitarii, bractenlati Perigoninm calycinum, profunde quinque-sexpartitum. St a m in a
8_15, basi perigonii circa discum glandulosum inserta; filamenta filiformia, elongata, simplicia; anth e rae biloculares, incumbentes, loculis oppositis. F em. et Herma p h. Gemmae axillares, subsolitariae, bracteis plurimis linearibus, inaequalibus, cum involnero canpanulato, uni - trifloro connatis. Perigonii limbus superus, quinqueoctofidus. Stam in a 5-12, saepissime abortiva, minima. Ova ri u $\mathrm{m}$ inferum, tri-sexlocnlare. Ov $1-$ 1 a in loculis solitaria, ex apice anguli centralis pendula, anatropa. Stylus brevissimus, crassus; stig m a t a loculorum numero, setiformia, patentia. Fruet us capsulaeformis, involucro coriaceo echinato, nuculis duabus, tribus $v$. unica foeto. Nuculae ovato-trigonae v. subangulatae, monospermae, epicarpio coriaceo, endocarpio fibroso. Semen pendulum; testa membranacea, plicis intra nuclei rimas sese insinuans. E $\mathbf{m b r y o}$ exal buminosus, orthotropus; cotyledonibus maximis, crassis, farinaceis, saepe inaequalibus, plicatis, arcte cohaerentibus; radicula immersa supera. - Arbores v. arbusculae elegantes, in Europa australi, Asia media, in Americaboreali et in excelsis Archipelagi moluccani montibus indigenae; foliis alternis, integerrimis $v$. serratis, floribus coataneis.

Ca st a ne a Tournef. inst. 352. Gïrtn. I. 181,t.37. Mi. chaux Arbr. IT. t. 6. 7. Turpin Atl, V. $t, 304.305$, Blume Flor.Jav, fasc, 13, $t, 21-24$. Wallich $P l, A s$, rar, $t, 107$. Nees juд. Gen, pl. II, 25. F a gi sp. Linn.

\section{Grdo XC. Ulmaceae.}

UL.MACEAE Mirbel Elem, 905. Lindley introduct, edit. II. p. 178, exclusis Celtideis.

Aввовеs v. frutices, foliis alternis, simplicibus, penninerriis, serratis, scabriusculis. St ipula fugaces.

Frores in ramnlis laterales, fasciculati, sessiles, hermaphroditi v. rarius abortu polygami.

Perigoniva calycinum, liberum, turbinatocampanulatum, limbo erecto, quadri-quinquefido v. rarius octofido, lobis aestivatione imbricatis.

Stamina perigonii basi inserta, ejusque lobis numero aequalia et opposita, rarius plura. Filamenta filiformia, libera. Antherae introrsae, biloculares, dorso connectivo dilatato panllo supra basim affixae; loculi oblique appositi, longitudinaliter dehiscentes.

Ovariva liberum, e carpidiis duobus conflatum, carpidiorum marginibus introflexis dissepimentum constituentibus biloculare, v. iisdem axim haud attingentibus uniloculare. Ovula in loculis solitaria, septo prope apicem affixa, v. in ovario uniloculari apici cavitatis appensa, anatropa. Styli duo, carpidiis continui, divaricato-patentes, intus juxta totam longitudinem stigmatosi.

Fructus basi perigenio persistente stipatus, membranaceus, samaroideus, v. coriaceus, laevis aut squamulosus, abortu unilocularis, monospermus.

SEmen pendulum. Test a membranacea, rh a phe elevata laterali ad chalazam apicalem procurrente notata. Al bum en nullum. $35 *$ 
Eubryo orthotropus. Cotyled ones planae. R a dicula brevis, umbilicum attingens et verticem fructus spectans.

$\mathrm{Ulm}$ ace ae per hemisphaerae borealis regiones temperatas diffusae, hinc ob ovarium biloculare et semina exalbuminosa praecedentibus ordinibus propinguae, illinc Celtideis, seminibus campylotropis et albuminis etsi parci praesentia satis distinctis, affines sunt.

1S4. IPIanera GMEL. Fl ores hermaphroditi v. abortu polygami. Perigonium membranaceum, turbinato-subcampanulatum, quadriquinquefidum. Stamina 4 -5. Ovarinm ovoidenm, uniloculare. O v l $\mathbf{n} \mathbf{m}$ unicum, apiei cavitatis appensum, anatropum Styli 2 , divaricatopatentes, intus stigmatosi. Capsula coriacea, indehiscens, laevis v. squamulosa, unilocularis, monosperma. S emen inversum. Embryo exalbuminosus, orthotropıs; radicula supera. Arbusculae $v$. frutices, in America boreali, et $a$ Graecia ad mare caspicum reperti; foliisal. ternis ovatis, crenato-serratis, scabriusculis, floribus fasciculatis, fasciculis inferioribus masculis, superioribus hermaphroditis $v$, rarius femineis

Planera Gmelin syst. 30s, L. C. Riehard in Michaux Flor, bor. Am. II, 247.

a) ABRLICEA Hon. Belli. Ca p s u la laevis. Folia subsessilia.-Graecia, Mare caspicum.

A b el i e e a Honorius Belli in Clus, Hist. plant, II. 302, Posa Mont. Bald. p. 112. Suith in Linn. Transact. $I X$. 126. Rh a mui sp. Pallas Flor, ross, I, t, 60, II, t. 10. U I m i sp. Sibth. Jaeq. hort. Sehönbr. t.262.

b. PLANERA. Caps ula seabra. Folia petiolata. - America borealis.

Planer a Guelin $l$, c. Watson Dendrolog. $t$. 106.

1850 . Ulmas LINN. F 1 or es hermaphroditi. Perigonium membranaceum, turbinatocampanulatam, quartri-quinque - v, octofidum. S ta mina 4, 5 v. 8. Ovarium ovoideum, compressum, biloculare. Orula in loculis solitaria, dissepimenti apiei appensa, anatropa. Styli 2 , divarieato-patentes, intus stigmatosi. S a mara membranacea, compressa, peripterygia, monosperma. S e me $n$ inversum. Em b r yo exalbuminosus, orthotropus; $\mathbf{r}$ a d ic ula supera.-Arbores $v$, frutices, per hemis phaerae borealis regiones temperatas diffusae; foliis alternis, serratis, scabriusculis, floribus praecocibus fasciculatis.

U 1 m u 8 Limn. gen, $n, 316$. Gärta. $I$, 224, $t$, 49. Sehkulır t. 57. E. B. t, 1886, 1882, 2161, 2248.2542, Pallas Elor, ross, I. t. 48. Michatux Arbr. III. t. 5. 6. Roxb. Corom. t. 78, Wallich Pl. As, rar. $t$, 200. Turpin Atlas t. 281, 289. Nees jun. Gon, plant, II.34.

\section{Dralo XCL. Celtideae.}

Arbores v. frutices, succo aqueo, $r$ am is alternis, saepius aculeis axillaribus horridis. Foli a alterna, saepissime trinervia, integerrima v, serrata, glabrav. pubescenti-scabra. St ipulae deciduae.

Flores hermaphroditi v. abortu ovarii masculi, in axillis foliorum solitarii, pedicellati, $\mathbf{v}$. cymoso-paniculati, ant racemosi.

Perigonivm calycinum, pentaphyllum v. quinquepartitum, persistens, foliolis ovatis concavis, aestivatione imbricatis, sub anthesi patentibus.
Stamina 5, imo perigonio inserta, ejusque foliolis opposita filamenta teretiuscula, ut plurimum brevia, apice primum incurva, demum elastice erecta. A ntherae introrsae biloculares, ovatae v. cordato-acuminatae, dorso affixae et cum filamento articnlatae, in alabastro saepius extrorsum versae; loculi subappositi, juxta totam longitudinem v. etiam incomplete dehiscentes.

Ovariuм ovatum, uniluculare, saepius inaequilaterum. Ov u l u m unicum, parieti prope apicem afixum, amphitropum, micropyle ovarii verticem spectante. Stigmat a 2 terminalia, elongato-subulata, indivisa $\mathbf{v}$. bifida, aut lobis abbreviatis, incurvatis in unicum confluentia.

Drupa monosperma, parce carnosa.

Semen pendulum, arcuatum. A 1 b u men carnosum, parcum v. subnullum.

Емвкуо in axi albuminis homotropus, uncinatus, v. sub-exalbuminosus. Cotyle d on es planiusculae $v$. conduplicatae, radiculae Iongiusculae, verticem fructus spectanti incumbentes.

Celtideae in A si a et A merica,tam inter tropicos quam sub caelo temperata calidore provenientes, M o r e is proxime aflines videntur, a quibus succo aqueo, inflorescentia, florum hermaphroditismo, stigmatis structura et fructu drupaceo differunt. Ab Ulmace is ovuli directione, et seminis fabrica longius recedunt.

185 1. Celtis TOURNEF. F lor e s polygami, hermaphroditi v. ovarii abortu masculi. P e rigon i $\mathbf{u m}$ pentaphyllum, persistens, foliolis aequalibus, concavis, aestivatione imbricatis. Stamina 5 , perigonii foliolis opposita; fi la me nta teretiuscula, apice incurva, demum rectinscula; an the rae introrsae, biloculares, cordato-acuminatae, dorso affixae. Ovar i u m ovatum, uniloculare. Ovu l u m unicum, parieti prope apieem appensum, amphitropum, micropyle supera. Stig mat a 2 , terminalia, elongato-acuminata, patentia v. recurva, glanduloso-pubescentia. Drupa carnosa, laevis. S e men pendulum, areuatum. Embr y o homotropus; cotyledonibus conduplicatis apice emarginatis, albumen centrale subgelatinosum includentibus; $r$ ad i cula crassiuscula, incumbens, supera. - $\mathrm{Ar}$ bores in hemisphaerae borealis temperatis calidioribus indigenae; foliis alternis, nervosis, serratis, floribus axillaribus solitariisg, pedicellatis.

Celtis Toarnet. inst, 383, Linn. gent. n, 1143. excl. sp. Sehkuhr 2,354 , Gärta. I. 374, $t, 77$. Nees jun. Gen, $p l$. II. 35.

1852. Sponia COMMERS. Flores polygami, hermaphroditi v. ovarii abortı mascnli. Perigonium pentaphyllum, persistens, foliolis aequalibus, concavis, aestivatione imbricatis. Stam i n a 5, perigonii foliolis opposita; f i l amenta teretiuscala; anth e ra e introrsae, biloculares, connectivo cum filamento articulato extrorsum refractae. Ovari $\mathbf{~ m ~} \mathrm{m}$ ovato-cylindricum, subexcentricum, uniloculare. 0 v u I u m nnicum, parieti prope apicem appensum, amphitropum, micropyle supera. Stig m a terminale bifidum, incurvatum. D r u a carnosula, inaequilatera, hine unicostata. Semen pendulam, arcuatum. Embryo in axi 
albuminis tenuis homotropus, faleatus; c o ty led onibus crassinseulis; ra d ic u I a elongata, smpera. - Arbores $v$. frutices, in Asia tropica et in australi extratropica insulari, nec non in America calida provenientes; folits alternis subtrinerviis, integerrimis $v$. serratis, glabris $v$. pubescenti scabris, floribus axillaribus cymoso-paniculatis.

$\mathrm{S}$ pon i a Commers. msc. ex Lam. Dict. $I \nu, 138$. No. 5. Decaisne in Nouv. Annal. Mus, ITI. 498. Sole uost igma Eudlicher Flor. Norf. 41. C elitid is sp. Linn. et Auct. Brongn. ad Duperr, 4. 48, - Nowen nostrum, etsi aequo jure contra Commersonianum, e Lamarkii nota postlimimio exhumatum, defendendum, retractavimus.

1853. Nentengis $H, B, K$. Flores polygami, hermaphroditi v, ovarii abortu masenli. Perigronium quinquepartitum, laciniis aequalibus, concavis, aestivatione imbricatis. Stamina 5, perigonii laciniis opposita; filamenta teretinscula, elastice prosilientia; antherae introrsae, biloculares. $O$ vari $\mathrm{n} \mathrm{m}$ ovatum, uniloenlare. $\mathrm{O}$ v uI $\mathbf{~ m}$ unicnm, parieti prope apicem appensum, amphitropum, micropyle supera. Sty li 2 terminales bifidi, lobis stigmatosis. Drup a baccata. S e m e n pendulum, arcuatum. E m b ry 0 .... - Arbores a mericanae tropicae; ramis aculeis axillaribus horridis, foliis alternis, basi aequalibus, trinerviis, integerrimis, racemis axillaribus, ramosis.

Mertensia Kunth in Humb, et Bonpl. Nov, gen, et sp. II. 31. t. 103. C eltid is sp. Auct.

\section{GENUS DUBIUM.}

1854. IBesea LINN. F I or es polygamodioici. Perigon i um membranaceum, bibractcolatum, quinquepartitum, laciniis aequalibus, conca$v i s$, imbricatis. S $t$ a $m$ in a 5 , imo perigonio inserta, ejusque laciniis opposita; filament a filiformia, brevia; a $\mathrm{n}$ th e ra evatae. $O$ varium ovatum, uniloculare, uniovulatum. Ovulum ..... S tigmat a 3 , linearia, indivisa, revoluta. D rupa subglobosa, parce carnosa, putamine crustaceo. S emen globosum hippocrepieum; testa membranacea. Em h ry o homotropus, curvatos, albumen farinaceum involvens; cotyledonibus foliaceis, ovato-oblongis; ra di c a l a crassiascula, infera. Frutex canariensis, dubiae affinitatis; ramis virgatis glabris, foliis alternis, exstipulatis, petiolatis, ovatis, acuminatis, nitidis, penninerviis, rasemis axillaribus et terminalibus, floribus minutis.

B o se a Linn. gen, $n$. 315, Gärtn. I. 376. t, 77. Jacq. f. Eclog. t. 25. Y e r v a o r a Ludewig.

\section{Drdo refl. Nitoreae.}

MOREAE Endlicher Prodr. Flor. Norf. 40. BROUS. SONETIEAE, MOREAE, CHLOROPHOREAE, FICEAE et DORSTENIEAE Gaudich. ad Freyc. 509.

Arbones v. Frutices lactescentes, saepius scandentes, rarius Herbaz acaules, foliis omnibus radicalibus, indivisis $\mathrm{v}$. lobatis. Foli a in caulescentibus alterna, integra v. juniora imprimis saepius lobata. Sti pulae saepius in cornu gemmam velans convolutae, persistentes v. deciduae, nonnunquam cicatricem semiannularem relinquentes.

Flores dioici v. monoici. Mas culi saepius spicati v, racemosi, fe min ęi densius spicati $v$, in receptaculis globosis conferti, nunc masculis mixti, in receptaculo plano, patente, v. pyrifurmi - clauso, apice pervio contenti.
Floribus masculis. Perigonium calycinum, tri-quadripartitum, foliolis ovatis, concavis, aestivatione imbricatis, sub anthesi plus minus patentibus.

Stamina 3_4, imo perigonio inserta, ejusque lobis opposita. Fil a me nt a filiformia v. subulata, laevia v. transversim rugosa, primum inflexa, demum patentia, perigonii foliolis paullo longiora. An th e ra e introrsae, bilocnlares, gvatae v. subglobosae, dorso affixae, erectae v. incumbentes, loculis subappositis, longitudinaliter dehiscentibus. Ovarii rudimentum plus minus manifestum v. nullum.

Floribus femineis. Perigonium calycinum, tetraphyllum v. quinquefidum, foliolis concavis, opposite biseriatis, exterioribus saepius majoribus.

Ova rivu sessile v. gynophoro plus minusve manifesto impositum, ovatum, uniloculare, v. rarissime biloculare, loculo altero minimo sterili. Ovu $1 \mathrm{um}$ unicum, mediae parieti insertum, amphitropum, incurvum, micropyle verticem ovarii spectante. St ylus terminalis bifidus, cruribus saepius inaequalibus, intus stigmatosis, v. excentricus, indivisus, hinc stigmatosus.

Achenia v. utriculi monospermi, perigoniis baccatis, liberis $\mathbf{v}$. in syncarpium coalitis inclusi, aut intra receptacula carnosa contenti, rarius in gynophoro baccato elevati, et ejusdem marginibus cincti.

- Semer unicum, pericarpium replens, uncinatum. Test a crustacea, fragilis v. tenuissime membranacea, umbilico ventrali. Alb umen carnosum, plus minus copiosnm.

Embryo intra albumen homotropus, uncinatus. Cotyle don e s oblongae, planiusculae, incumbentes. Radicula plus minus longa, verticem fructus spectans.

Moreac obfructus sapidos, dnlces, et varios ligni, libri et foliorum usus, inter quos Bombycis serici pabulum eminet, celebratae, in $\mathrm{r} \mathrm{e}$ gionibus tropicis calidioribusque totius orbis sponte proveniunt, in veteri continente nonnihil ut videtur frequentiores, arcta affinitate A rtocarpeis, quae tamen embryone exalbuminoso et varia ovuli directione distinguuntor, et Urticeis, quae embryone recto et succi lactei defectu differunt, conterminae.

Dorstenia habitu et perigonii obliteratione diversa, Fi c o nihilominus proxime affnis videtur.

185.5. Eplearpurans BLUM. FIores dioici. Mase. spicato-amentacei. Perigonium tetraphyllum, bibracteolatum. Stam in a 4 , perigonii foliolis opposita; filamenta elongata; antherae.... Fem. subsolitarii. Perigoninm tetraphyllum, persistens, demum increscens. $0 \mathrm{va-}$ rium stipitatum, nniloenlare. $O$ val a m parieti styligerae appensum, amphitropum. S t y I u s lateralis, profunde bifidns, laciniis filiformibus stigma- 
tosis. B a e ca perigonio stipata. S emen parietale, orbiculatum, compressum. Fm b r yo in axi albuminis carnosi curvatus; cotyledonibus crassiusculis, inaequalibus, contortuplicatis; r a dicu I a supera. - Arbores indic a e, lactescentes, ramosae; trunco saepius spinoso, foliis alternis, breviter petiolatis, oblongis, serrulatis, rigidiusculis, stipulis subulatis, deciduis.

Epicarpurus Blume Bijdr, a88, Decaisue in Nouv. dnnal. du Mus. IIr. 499. $t$, 21. A 1 b r a $n$ dia Gaudich. ad Freye,509. Trop his as per a Wallich Catalog. n, 4640. U rtica spinos a Blum. op. oit. 507 .

1856 . IIorus TOURNEF. F I o res monoici, dense spieati. Masc. Perigoni um quadripartitnm, laciniis ovatis, aestivatione imbricatis, demum patentibus. Stamina 4 , perigonii laciniis opposita; fil amenta filiformi-subulata, transversim rugosa, elastica; a $\mathbf{t h}$ ha e introrsae, biloculares, dorso affixae. Ovarii radimentum. F em. Peri gonium tetraphyllum, foliolis ovatis, concavis, oppositis, exterioribus majoribus, Ovari $\mathbf{m}$ sessile, ovatum, biloculare, loculo altero minore, $\mathrm{O}$ v $\mathrm{u}$ $1 \mathrm{a}$ in losulis solitaria, dissepimento prope apicem affixa, amphitropa, mieropyle supera. Sti $\mathrm{g} \mathrm{m}$ a$t$ a 2 , terminalia, elongato-filiformia, intus villosa. A ch e nium membranaceum v. subcarnosum, unileculare, monospermum, perigonio immutato stipatum v, eodem baccante inclusum. S e m e n pendulum, uncinatum; testa dura, fragili. E mbryo in centro albuminis carnosi homotropus, uncinatus; cotyledonibus oblongis, incumbentibus; $\mathrm{radi}$ c n la longiuscula, umbilico contigua, supera. Arbores v. frutices lactescentes, in regionibus tropicis et calidioribus totius orbis provenientes; foliis alternis, integris v lobutis, stipulatis, spicis axillaribus solitariis, masculis elongatis, femineis brevibus ovatis $v$. subglobosis, fructibus nonnullarum edulibus.

Moru s Tournef, inst, $t, 362$. Lian. gen, $n, 1055$. Schkulir t. 290. Gärtn. $I I$. 199. t. 126. Pallas Rost. $I I$. $t$. 52. Jacq. Ic, rar. t. 617. Guillem, Archiv, Bot. I, t, 7. Endlich, Atakt, t. 32. Nees jun, Gen. pl, II, 32 .

OBSERVATIO. Apud cl. Gaudichaud ad Fregc. 509. adhue a Moro distinguitur genus nobis prorsus incognitum:

FATOUA Gaudich. Flores masculi et feminei in eodem zeceptaculo orbiculari, margine ramoso-laeiniato. Calyx fructifer membranaceus. Ovarium obliquum, stigmatis bifidiloboaltero minuto. - Urtica japonic a Tbunb. et Parie taria a spera Leschen.

185\%. NIreIura NUTT. F I o res dioiei. Mas c. racemosi. P e rigoni u m quadripartitum, laciniis ovatis, aestivatione imbricatis, demum patentibus. St a m in a 4 , perigonii laciniis opposita; filamenta filiformia; an therae introrsae, biloculares, dorso affixae. O v a $\mathrm{r}$ i i rudimentum. F e m. super receptaculom globosum dense capitato-congesti. Perigonium tetraphyllum, foliolis oppositis, oblongis, cucullato-concavis, exterioribus majoribus, Ova ri u m sessile, lenticulari-compressum, uniloculare. Ovul a m unicum, mediae parieti affixum, amphitropum, incurvum, micropyle supera. Stylus terminalis bifidus, crure altero elongato longe exserto, intus stigmatoso, altero nano v, abortivo. A chenia monosperma, perigoniis baceatis inter se concrescentibus inclusa. Sem en ..... Arbor boreali-americana; liono croceo, succo lacteo, ramis alternis teretibus, spinis infra axillaribus, folits alternis, petiolatis, ovalibus, acuminatis, integerrimis, supra glabris, subtus pubescentibus, stipulis deciduis, capitulis femineis axil laribus, breve pedunculatis, syncarpiis globosis, aurantiaeis, tessellatis, sapidis.
Maclura Nuttall Gen, 11 . 234. Lambert Pin. IT. App. t, 12. Joxylon Rafin. - ? Morus tinetoria Sloane Jamaic. II. 3, C h I o r o p h o ra Gaudich. al Freyc. 509 .

1858. Hroussometia FENT. Floreg dioici. Masc. dense spicati, bracteati. Perig on i $\mathbf{~ m}$ quadripartitum, laciniis ovatis, acuminatis, aestivatione imbricatis, demum patentibus. Stamin a 4 , perigonii laciniis opposita; fil am enta filiformi-subulata, elastiea; a $t$ he $r$ a $e$ introrsae, biloculares, dorso affixae. F e m. super receptacuIum globosum dense eapitato-congesti, squamis pilosis (floribns abortivis) mixti. P e rigo n u m urceolatum, tri-quadridentatum. Ovarin m ovatum, uniloculare, gynophoro clavato demum elongato oblique impositum. Ovulam unicum, parietale, amphitropum, micropyle supera. Stylus filiformis, excentricus, hinc stigmatosus. A $\mathrm{ch}$ en i m subcarnoso - gelatinosum, gynophoro baceato, basi perigonio cincto, longe exserto elevatum, ejusque marginibus inaequaliter productis inclusum. S e$m$ en pendulum, uneinatum; $t$ e $s t$ a tennissime membranacea. Embryo intra albumen parcum carnosum homotropas, uneinatus; cotyledonib u s oblongis, ineumbentibus; $r$ adicula umbilico contigua. supera. - Arbor elata, lactescens, per Asiam insularem a Japonia ad Novam Zeelandia m diffusa; foliis alternis, supra scabris, subtus villosis, junioribus tri-quinquelobis, adultioribus subrotundo-ovatis, indivisis.

B rou s s on e tia Vent. Tabl. da reg. veget, 3, p. 347. Andrews Bot. Reposit, t. 488. P a p y $\mathrm{r}$ i u Lam, t. 762. Mor u s papy rifera Liun.

185\%. Fíeas TOURNEF. Receptacu1 u m carnosum, elausum, globosum v. pyriforme, basi squamoso-hracteatum, ore squamulis clauso. Flores plurinti minimi, in superficie interna receptaculi pedicellati, conferti, dioici, v. superiores masculi, reliqui feminei. Masc. Perigonin r tripartitum. S $t$ a min a 3 , perigonii lacinits opposita; filamenta capillaria; antherae introrsae, hilnculares, incumbentes. Fem. Perigon i $\mathbf{m}$ quinquefidum, tubo in pedicellum decurrente. Ovarium gynophoro brevi sublateraliter impositnm, uniloculare. Ov u $\mathbf{l}$ um unicam, parieti styligerae appensum, amphitropum, mieropyle snpera. Stylus lateralis gynophoro continuns, filiformis; 8 tig mate breviter hifido. Reee pta cu l n m fructifernm succulentum, utriculis membranaceis, exaridis, perigonii rudimentis stipatis foetum. Se$m$ en parietale, uneinatum; testa dura fragili. E m bryo in centro albuminis earnosi homotropus, nne natus; cotyledon ibus ellipticis, incumbentilons; radicnla elongata, umbilico contigua supera - Arbores interdum excelsae $v$. frutices scandentes, lactescentes, inter tropicos totius orbis copiosissime provenientes, in regionibus extratropicis calidioribus rarissime crescentes, una species obfructus sapidos culta, in Europa austra$l i$ subspontanea; foliis alternis, integerrimis $v$. lobat is, stipulatis, stipulis magnis convolutis, gemmas terminales velantibus, deciduis $v$. persistentibus, receptaculis axillaribus solitariis $v$. confertis, rarissime terminalibus racemosis

Fi e u s Tournef. inst.t. 420. Linn.gen, n, 1168. Sehkuhr. c. 358. Giirtn, II, 66, t. 91, Roxb, Oorom, t, $123-125$, Hookexot, Flor, t. 111. Bot. Mag. t. 2939. 3282. 3305. A. Richard Sert. Astrolab. t. 17. Nees jun. Gen. plant $I$. 33. Plant. offic. Suppl. V. t. 8. - E ros ma Both. Catalog. 113. Fieus radieans. - Character e Fic u c a ric a sumptus, vix atque ne vix quidea in numerosas geteris species, difficillime in maseis excutiendas quadrat.

1860. Dorstenia PLUM. Receptaculu m earnosum, concavo-planum. Fl o res pluri- 
$\mathrm{mi}$, in alveolis membranaceo marginatis laceris receptaculi, masculi femineis mixti. Mase. Al veoli superficiales. Perigon ium nullum. St a mi$n$ a 2 , v. plura; filame $n t a$ filiformia; a $n t h e-$ $r$ a e biloculares, globoso-didymae. F e m. in foveolis receptaculi solitarii. Perigo n i m nullum, Ovari u m breviter stipitatum, ovatum, uniloculare. Ovulum unicum, parieti styligerae appensum, amphitropum, micropyle supera. Stylus latera lis, filiformis; stigmate bifflo. Reeeptacu$1 \mathrm{um}$ fructiferum subsucculentum, utriculos demum circumscissos includens. $\mathbf{S}$ e $m$ e $\mathbf{n}$ parietale, uncinatum; te $s$ ta crostacea. $\mathbf{E} \mathbf{m b} \mathbf{r} \mathbf{0}$ in centro albuminis carnosi homotropus, uncinatus; cotyledonibus ovatis incumbentibus; $r$ adie $u l a$ longiuscula, umbilico contigua, supera. - Herbae acaules, a merica nae tropicae; foliis radicalibus palmati-v. pinnatifidis, receptaculo scapum terminante quadrangulo v. subrotundo, aut interdum lineari.

Dorstenia Plamier gen,t, 119. Linn. gen. n. 158. A. Richard in Dict, class. $V .600$.

a. SYCHINIUM. Desv. Re e p ta c a la m bifureum lineare, apice substerili ramoso piunatum.

S y chinium Desvaux in Annal soc. Linn. de Paris IV. 216. $t, 12$.

b. DORSTENIA. Recepta eulu m subrotundum v. quadrangulum.

Dor ste n i a Jacq. Ic, rar, t, 614, Sprengel in $n \bar{m}, A r$. chiv. I. t. 7. f. 1. Schrader Journ, 1800. I. t. 1. 2. Hooker Exot. Flor, 4, 6. Bot, Mag, t, 2017, 2476. 2804.

OBSERVATIO. Anquam huc referre solent vere congener Kos a ria Forsk. Aegypt. 164. ? Herba laetescens, caulescens, follis sparsis, involucris axillaribus pedunculatis 10_12 dentatis, intus carnosis, multif oris, floribus pressis, pulpae immersis, supra verrucaeformibus, verrucis conico-truncatis, aliis masculis bi-triandris, aliis femineis promiscuis, ovario monostylo monospermo, semine intra pulpam fatente.

\section{Dralo XCIIT. Artocarpeae.}

ARTOCARPEARtM pars DC. Bartling Ord, nat, 104.

Arbores v. Favtices lactescentes, $r$ a m is alternis, teretibus, nonnunquam nodosis, inter nodos fistulosis. Folia alterna, petiolata, simplicia, integra, v. integerrima ant serrata v. pinnati-ant palmatiloba. Stipulae liberae, caducae.

Flores monoici v. dioici, supra receptacula carnosa, nuda v. involucrata conferti, rariusve spicati.

Masculi rarissime perigonio destituti, staminibus squamisque peltalis supra receptaculum globosum dense confertis ; plerumque perigoniati, receptaculo globoso v. clavato, aut interdum ramoso impositi v. plus minus dense capitati v. spicati, nudi v. bracteolati, saepius in receptaculo plano v. convexo, involucro polyphyllo cincto sessiles.

Perigonium calycinum di-tri-tetraphyllum, foliolis rarissime distinctis, plerumque in tubum conniventibus v. connatis, limbo minuto.

Stamiva tot quot perigonii lobi, v. interdum pauciora, iisdem basi inserta et opposita. F i lamenta filiformia v. linearia, libera ant in terdum inter se connata, rarius brevissima $v$. subnulla. Antherae biloculares, erectae $v$. incumbentes, longitudinaliter dehiscentes, ra- rissime peltatae, bilamellatae, lamellis toto ambitu solutis apertae.

Flones fe m in ei nunc intra involucrum urceolato - tubulusum v. polyphyllum solitarii, v. rarius plures perigonio destituti aut interdum perigoniati, nune involucro orbati et perigonio instructi, circa receptaculum globosum dense conferti v. capitati, rariusve laxius spicati, ebracteati, imperfecti saepius perfectis mixti, interdumque basi v. etiam juxta Iongitudinem concrescentes.

Perigonie n tubulosum, limbo bi-tri-quadrifido $v$. etiam integro.

Ovarium unicum, sessile, liberum, uniloculare. $0 \mathrm{vul} \mathrm{u} \mathrm{m}$ unicum, nune basilare erectum, orthotropum, nunc parietale amphitropum, micropyle supera, v. ex apice loculi pendulum, anatropum. St ylus terminalis v. lateralis, saepius bifidus, lobis stigmatosis, ant indivisus, s $\mathrm{tig-}$ $m$ a te simplici laterali $v$. radiato-multifido terminatus.

Froctus varius, involucro baceato $\mathrm{v}$. sicco cinctus, v. perigoniis carnosis concrescentibus compositus, acheniis v. utriculis plurimis foetus.

Achenia sicca $\vee$. Utriceli membranacei, monospermi.

Sguen e basi erectum, v. e pariete aut ex apice loculi pendulum. T e st a coriacea, crassiuscula. Al b u me n nullum.

Еивкуо antitropus v. respectu umbilici lateralis transversus, aut rarius orthotropus. C otyled on es crassae, carnosae, saepius valde inaequales. R a dicu $l$ a brevis, recta $v$. incurva, verticem v. parietem fructus ab umbilico remotam spectans.

Artocarpeae inter tropicos Asiae et Americae indigenae, in novo contin en te nonnihil frequentiores, ob succos albos aut flavicantes, lacteos; in aliis insigniter venatos, in aliis innoxios, multiciplis usus technici et oeconomici, et fructus nonnullorum generum in annonam conversos valde memorabiles, embryone exalbuminoso cum succi lactei praesentia combinato, ab affinibus distingui possunt.

Genera plurima verisimiliter adhucdum nos latent, quibus olim cognitis ordinis diagnosis certior stabilietur a M oreis, quae utut arctissime affines, albuminis praesentia satis nobis distinctae videntur.

18B1. IBrosinamm SWARTZ. F lo res dioici. Mas c. super receptaculum globosum, squamis peltatis tectum eongesti. Per igonium nulIum. Stamin a solitaria, intra receptaculi squa. mas erumpentia; filamenta brevia; a nthera e terminales, orbieulatae, peltatae, bilamellatae, toto ambitu dehiscentes. Fem. Involuc rum biflorum, urceolatum, squamulis pellatis v. getis obsitum. Perigonium nullum. $O$ ra- 
ria cum involucro et inter se connata, unilocularia. Ovulum unicum, parietale, peltatoorthotropum. Stylus terminalis, bifidus, cruribus, filiformibus integris $v$. in lobos plumosos stigmatosos partitis. Bac ca sicciuscula, ex involuero increstente muricata $v$, echinata. S e m en subglobosum; testa membranacea tenuissima, umbilico ventrali lato. Embryo exalbuminosus, antitropus; cotyledonib us crasissimis carnosis, inaequalibus ; radi c a la umbilico e diametro opposita, brevissima, super cotyledonis dorsum incurva. Arbores americanae tropicae, lactescentes; foliis alternis, petiolatis, stipulatis, oblongo-lanceolatis, integerrimis $v$. serratis, glabriusculis pubescentibus, pedunculis axillaribus solitariis geminatis, indivisis.

B ros i m a m Swartz Flor, Ind. occid. I, 15. t, 1. Tussac in Jour. de Bot. 1808. p, 202. 4, 8. Pöppiz Nov. gen, et sp. II. t. 148, Pirat iner a Aublet Guian. II. 888, t, 340. -Ga I a c to de ndr um Humboldt Helat, hist. II, 106. 130. Kuuth Nov. gen, et sp. VIT. 163. P alo d e V a e c a Humboldt in Annal, du Mus. Ir, 180, Boussingault et Rivero in Annal, de Chemio XXIII. 219.

1862. Antiaris LESCHEN. F I o r e 8 mon oici. M a sc. In vo I u crum multiflorum, polyphyllum, foliolis plurifariam imbricatis, basi con natis, receptaculum orbiculare, planum v. conve xum, subtus coneavum eingentibus. Flos culi sessiles, dense congesti. Perigonium tri-tetraphyllum, foliolis subspathulatis, apice conniventibus. Stam in a $3 \ldots 4$, perigonit foliolis opposita; fil am enta brevissima, subnulla; a nthe rae extrorsae, biloculares, loculis appositis. F e m. Invol a e r um uniflorum, urceolatum, apice maltifidum. Perigonium nullum. Ovarium cum involuero connatum, unilocalare. Ova $1 \mathrm{u} \mathrm{m}$ unicum, ex apice loculi pendulum, anatropum. Stylus terminalis, bifidus, cruribus filiformibus s:igmatosis. D ru p a ex involucro baceato formata. Sem en pendulum. Emb r y o exalbuminosus, or thotropus; cotyledonibus maximis carnosis, ovatis, plano-convexis, laevibus; $r$ adi $\mathbf{c u l a}$ brevissima, supera. - Arbores v. frutices in Moluce $i s$ et in Nova Hollandia boreali tropica crescentes, lactescentes; foliis alternis, brevissime petiolatis, stipulatis, inaequilatere subcordato-oblongis, integerrimis, repandis $v$. denticulatis, costatovenosis, pedunculis axillaribus $v$. ob folia delapsa lateralibus, subsolitariis, simplicibus v. subramosis.

Antiaris Leschenault in Annal, du Mus. XVI, 476. $t$. 2. R. Brown in Elinders Voy. II. 608, $t .5$. Blume Rumph. 56. $t$. 22. 23. A r bor toxic aria I o mas Rumph $d m$ boin $I T$. 263. t, 87, I p o s. H i p o $\mathrm{C}$ amelli in Rai Hist, App. IIT. 87. I po Pers. ench. $I$. 566. A nts c har Horsfield in Verhandl. Batav. Genotsc. PII. 8. Antjar s. Antsjar Javan. Pohon U p a Malai. I p o Macass. et Tagal. - Ar. boris famosae bistoriam plaribus more suo elegantissime exposuit el. Blame op. cit. p. $46-59$.

1863. DImedia RUIZ et PAV. Flores dioici. M asc. Involucrum multiflorum, polyphyllum, foliolis plurifariam imbricatis, receptacu lum orbiculare planum v. convexum subtus concavam cingentibus. Flosen li sessiles, dense conferti. Perigon i n m tubulosum, bi-quadrifidum, laciniis erectis, conniventibus. Stamina $2-4$, perigonii laciniis opposita; filamenta fusifor mi-cylindrica; antherae introrsae, biloculares. ovatae, incumbentes. F e m. Invol ucrum uniflorum, polyphyllum, foliolis dense imbricatis. Pe rig on i um tubulosum, e basi ventricosa in collum angustum attenuatum, ore obsolete quadridentato. Ovarium ovatum, uniloculare. Ov u l um uni cum, ex apice loculi pendulum, anatropum. St y-
I u s terminalis, bifidus, cruribus filiformibus elongatis, apice stigmatoso terminatis. I rfup a perigonio baceato inclusa, involucro stipata. $\mathbf{S}$ e m e $\mathrm{n}$ pendulum. Emb r yo exalbuminosas, orthotropus; cot y led on ibus magnis carnosis, plano-convexis, laevibus v, rugosis; radicula brevissima, supera. - Arbores peruvianae, lactescentes; foliis alternis, breve petiolatis, oblongis, scabriusculis, nervosis, integerrimis $v$. dentatis, stipulis lanccolatis, deciduis, pedunculis axillaribus indivisis, subfasciculatis.

$01 \mathrm{med}$ ia Ruiz et Pav, Prodr, 129, t, 28. Kunth in Humb. et Bonpl. Nov. gen, et sp. VIT. 162. t. 623. Pappig Nov. gen, et sp, II. t. 143_-146. M a quira Aublet Guian. IT. $t .389$.

1864. Sorocea $S T$. HIL. Flo res dioici. I a s c. ..... F em. Involucrum uniflorum, ovato-tubulosum, obseare quinquedentatum, apice hine fissum. Perigoninm nullum. Ovarium liberum, uniloculare. St y I u s terminalis, bifidus; lobis intus stigmatosis. Ovulam parieti prope apieem appensum ..... В a c c a ex involucro demum accrescente, stylo coronata. Sem en pendalum. Emb r yo exalbuminosus, rectus; cotyledone altera minima; radicula brevissima, umbilieo proxima, supera. - Arbor brasiliensis; foliis alternis, simplicibus, serratis, floribus femineis axillaribus racemosis.

Sorocea St. Hilaire in Mém, du Mus, NIT, 473 .

1865. Cecropia LINN. F lores dioici, densissime spicati. Masc. ebracteolati. P erigoni $u$ m turbinato-angulatum, obtusum, apice biporosum. St amina 2 ; filamenta filiformia, brevia, e perigonii poris exserta; anth era biloculares, oblongo-tetragonae. F e m. ebracteolati. P erigon i nm campanulatum, bidentatum. St a min a 2 sterilia, perigonii dentibus alterna. 0 vari u m ovatum, uniloculare. Ov n l u m...Stigma terminale, subsessile, capitatum. A ch en i um perigonio persistente teetum, monospermum. S e men ......-Arbores americanae tropicae, lactescentes; ramis nodosis, inter nodos fistulosis, foliis ad nodos alternis, cordato-peltatis, palmatilobis, subtus saepius discoloribus, junioribus stipulis spathaeformibus involutis, spicis fasciculato-umbellatis, masculis plurimis, femineis paucioribus, basi bractea spathaeformi instructis.

Ce e o pia Loffling $I t$. 272. Jacq. Observ, $I T, t, 46, f, 4$. Juss. gen. 402, Lam. $\ell .800$.

OBSERVATio. Musanga Chr. Smith, genus africa. num tropicum, monente cl. R. Brown in Tuckey Congo 453 inter Cecropiam et Cassapoam medium, Cecropiae habitu proximum, steuctura et dispositione florum masculorum monandrorum, nec non ameuti feminei forma diversum, inflorescentia et floris masculi conformatione et habitu etiam ad M y ria n thum acceders.

18BB. Coussapor $A U B L$. F lores dioiei, capitato - congesti. M a s c. B ract e ola e 3 spatholatae, erectae, perigonimm cingentes, Perigon i m tubuloso-clavatum, cylindricum, bracteis aequilongam, ore minutissime bidentato. Sta mina 2 , e fundo perigonii; filamenta in unum connata, apice brevissime exserto libera; anthera extrorsae, bilocnlares, cordatae, pyramidatoconniventes. Fem. Bracteolae nullae. Perigonium e foliolis 4 , arete connatis ventricosotuhnlostum, ore angusto pervium. Ovariam ovatam, nniloculare. Ovulum unieum, basilare, orthotropum. Sty Ins terminalis, simplex; stigma setaceo-multifidum, radiatum. Drupa e perigoniis baccatis inclusae, ovatae, dense congestae. $\mathrm{S}$ e m e $n$ erectum. Embryo exalbuminosus, antitropus, 
cotyledonibus crassis, carnosis, subinacqua libus; radicula brevissima, supera. - Arbores ame ricanae tropicae, lacte scatentes, prime $m$ fruticosae, super alias arbores parasitice scandentes, ex earum cacumine ramos in solum demittentes, çui mox in truncum coaliti, nutrice stirpe quam circumdant suffocala, truncum arboreum formant, intus cavum, extus inaequaliter sulcatum, coalitionis suae vestigia prodentem, apice ramosum; ramis fungosis, iramulis cavis, foliis alternis, longe petiolatis, cordatis, ovatis v. oboratis, nervosis, tomentosis $v$.lrarius glabris, integerrimis $v$. crenatis, floribus axillaribus, capitulis masculis paniculatis, femineis solitariis, longe pedunculatis.

C o u s a p o a Aublet Guian. II. 955. t. 363. 363. Juss. gen, 406. Poppig Nov, gen, et sp. II, t, 147.

18B\%. Nyriantluess PALIS. F Iores monoici. M a 8 c. in receptaculo planiusculo ramoso conferti. Perigo n in tetraphyllum, foliolis ovatis, concavis. Stam ina 3 , e tundo floris; filamenta in columnam connata, apice brevissime libera; anth e rae terminales, biloculares. F em. Sy nearpium baceatum, apice strangulatum, radiatim 12_14 loculare. A $\boldsymbol{c}$ h e $\mathrm{n}$ ia (?) intra loculos plurima, villosa, membrana alacformi cincta. Embryo exalbuminosus; cotyledonibus ellipticis, planis; radicula brevissima, infera. (?) - Arbor mediocris, in Africa tropica obiter observata; foliis alternis, petiolatis, digitatis, foliolis sex inaequalibus lanceolatis, inaequaliter dentatis, supra pallide viridibus, subtus albidis, petiolis teretiusculis canaliculatis, basi inflatis, floribus masculis minimis in receptaculis panıculas nudas, laxas terminantitus dense confertis, syncarpiis pugni mole.

Myrianthus Palisot Flor. Owar, 16. t, 11. et 12. Genus vix uotam, hojus loci svadente cl. R. Brown App. to Tuckey Congo 449.

1868. Artocarpars $L I N N$. F lores monoici. M a sc. supra receptaculum clavatum amentiforme dense congesti, ebracteolati. Perigoni um di-triphyllum, foliolis erectis, subinacqualibus, basi plus minus cohaerentilus. Stam en unicum; $\mathbf{f}$ I amentum lineare, complanatum; anthera terminalis, bilocularis, lesulis oppositis. Fem. supra receptaculum globosum dense capitato-congesti, concrescentes. Perigon ium tubuloso-cylindricum, limbo-pyramidato, indiviso, ore pro styli exsertione pervio. Ora ri n m liberum, uniloculare. Ov u 1 n m unicum, parieti styligerae affixum, amphitropum, micropyle supera, introrsum sublateraii. St ylus lateralis, elongato-filiformis, exsertus; stig mate terminali, indivisov. bifido. Sy ncarp i $\mathbf{m}$ baceatum, ex utriculis inter perigonia carnoso-incrassata, sterilibus plurimis intermixtis, dense conferruminata, perigoniorum apieibus pyramidatis liberis muricatum. Utriculi membranacei, styli vestigio laterali notati, longitudinaliter rnpti. S e m en ovatum, parietale, umbilico ventrali affixum. Embry o exalbuminosus, respectu nmbilici transversus; cotyledonibus maximis crassis, valde inaequalibus; radicula brevissima supera, cotyledonum dorso incumbente. $-\mathrm{Ar}$ bores lactescentes, in $A$ sia et Oceania tropica indigenae, in $A m$ ericam introductae, et in annonam eliam in patria cultae; foliis alternis, breve petiolatis, obovatis, integerrimis, v. cuneatoobovatis, pinnatifido-lobatis, subtus scabriusculis, stipulis maximis, coriaceis, convolutis, gemmas velantibus, demum deciduis, pedunculis axillaribus, prima $m$ stipulis spalhaeformibus, max deciduis inclusis, foliorum lapsu lateralibns.

A r to c a r pu s Forst. Pl. esc. 53. Linn. f. suppl. 61. S fodfum Banks opudGărtn, 1.345. R a de no chia Thunb. Act. Holm. XXXNI. $252 . \mathrm{S}$ o c cu s Remph Amboin, I. 104110. a. JACA. Stiq n a lineate iudivisum. - Folia integra.

Artocarpus integrifolla Linn. Roxburgh Corom. t. 250. Hook. Rol. Mag.t.2833. 2834. R adem ach ia integra Thunl. 2. c. Sitodiem Basks opud Gärln. l.c. t. 71. et 72. $\mathrm{P}$ a J y phe ma Loureir. $F 7$, cochinch, $I I, 346$. Iridaps Conmers.msc.

b. PUSSAR. $\mathrm{Stj}$ g ma discojdeum peltatum. - Folia integra. Artocarpus rigida Blume. Bijdr. 482.

c. RiMA. Stig m a bifidum. - folia pinnatifido-lobata.

Arto carpus in cis a Linn. Hooker Bot. Mag.t.2869_ 2871. A. com munis. Forst. Monograph.1784. Ka dema. chia incis a Thunb. l. e. Rima Sonnerat Voy, 99, $t$. $57-60$.

1869. Conoceplanius BLUM. F I o res dioici, capitato-spicati, Ma s c. Perigoniu m thbulosum, tri-quadrifidum, laciniis erectis, carnosulis, subeucullatis. St a m in a $3-4$, perigonii laciniis opposita; 1 il a m e n a carnosa, pyramidata; anthera e introrsae, exsertae, biloculares, curdatae, loculis hasi divaricatis. Ovarii rudimentum. Fem. Perigon i um tubulosum, tri-quadrifidum, laciniis saepe inaequalibus. Ovarinm oblongem, uniloculare. O vu I n m unicum ... S tyIn s simplex; s tig mate oblongo, laterali. A chen ia perigoniis subbaccatis tecta, compressiusrula, dense congesta. Sem en pendulum; testa subchartacea. A l b umen parcum, demum evanidum. Embryo rectus; cotyledon ibus subfoliaceis, plano-convexis; radicn Ia brevi, supera. - Frutices indici, scandentes; foliis alternis, ellipticooblongis, repandis, capitulis subcorymbosis axillaribus, $v$. foliorum lapsu lateralibus.

Conocephalus Blume Bijdr. 48s. Lindley in Bot. Reg, t, 1203. A et B. Urtica naclefflora Roxb. OvuIf et seminis situs in hoc et in sequenti genere ab anctoribus non indicatur.

1850. Gyneeplatiuma BLUM. F 10 res dioici, capitato-congesti. Masc, Perignnivm quadripartitum. St a $m$ in a 4 , perigonii laciniis opposita; filamenta longa; antherac -. Ovarii radimentum. Fem. Perigonium tubulosum, subquadrifidum, Ovariu $\mathbf{m} \mathrm{cy-}$ lindricum, uniloculare, Ovulum.. Stylus brevis, scmibifidus. D rup a e perigoniis baceatis inclusae, angulatae, dense congestae. Sem e n...

- t e s t a fragili. A 1 bumen nullum. E mbry o rectus; cotyledonilus maximis, contertuplicatis; radicula supera. - Frutex javanivus, scandens; foliis allernis, cordatis, integerrimis, floribus femineis in receptaculis glotosis, masculis in capitulis spicato-paniculatis.

G y n o ce p b a $1 \mathbf{j}$ u m Blume Bijdr.483.-Genns praecedenti affine dicitur, perigonio floris masculo, stylo bifido et coty. ledonibns corrugatis diversum.

18 11. Trophis P. BROWN. Flores dioici, laxe spicati. M a 8 c. Perigonium tetraphyllum, foliolis ovatis, patentibus. St a m in a 4 , perigonii foliolis opposita et longiora; filamenta filiformia; a n th e ra e introrsae, biloculares, ovatae. Fem. Perigonin m tetraphyllum. Ovarium ovatum, uniloculare. Ovulum unicum, parieti prope verticem appensum, amphitropum. S tylus terminali-excentricus, brevis; $8 t i g m$ at e bifido. Drn a monosperma. S emen globosum, pendulem. Em bryo exalbuminosus; cotyledonibus crassis, carnosis, valde inaequalihus; $r$ adicula brevi inflexa, supera. - Arbores lactescentes, $A$ s $i a m$ et Americam tropicam incolentes: folits alternis, integris, spicis axillaribus. 
Tropla is P. Browae Jam, 357. t. 37. $f$. 1. Lian. gen. n. 1103. Swartz observ, 372. Lam.t, 806. Roxburgh Flor. Ind, IV, 760. S treblus Loureir. Fl, cochinch, 733. A $\mathrm{c}$ h y. $\mathrm{m} u$ s Soland. msc. - Species americanae ab asiatieis verisiasiliter genere diversae.

\section{GENERA VIX NOTA.}

18\%2. Foureuna $A U B L$. F lores dioici. Masc. ...... Fem. Perigoninm .... Ovari um hirsutum. Stigma sessile, peltatum, striatum. Cap su I a ovata, sabhirsuta, nnilocularis, bivalvis. Semen unicum, parietale. _ Arbores guianenses et peruanae; foliis alternis, trilo bis $v$. palmatis, junioribus stipula terminali spathaeformi tectis, pedunculis axillaribus corymboso-multifloris.

Pou r o u m a Aublet Guian,IT, 891,t,34t, Juss.gen. 406.

1573. Inraea GAUDICH. Fl o res dioici. Masc. $\ldots$. Fem. P e rigonium tubulosum, irregulariter quadridentatum, hine fissum, caducum. Ovari $\mathbf{m}$ obliquum. Stig ma laterale sessile, longissimum, hinc papilloso-fimbriatum. $\mathbf{C}$ a $\mathbf{p}-$ sula (?) hispida. Fratex bengalensis; foliis alternis, ovato-subcordatis, serratis (?) villoso-tomentosis, floribus terminalibus pedunculatis, bracteatis, bracteis foliaceis, glandulosis.

B r uea Gau lieh. ad Freyc. 511.

18\%4. Perebea $A U B L$. Flores dioici. M a sc. . . . F e m. in receptaculo multifloro, coriaceo, extus squamoso, margine dentato, primo concavo, demum reflexo-pileiformi sessiles. Per $\mathrm{i}$ go n i um tubulosum, quadridentatum. O vari um ovatum, liberum. Stylus terminalis, cylindricus; st i g ma bilobum. Fru ctus monospermus, perigonio baccato tectus. - Arbor gu ianens is; foliis alternis, coriaceis, serratis, junioribus stipulis mox caducis involutis.

Pere be a Aublet Guian. II.952, t. 361, Juss. gen. 402.

18\%5. IBasassa $A U B L . \cdots \ldots$ S y n carp i um subglobosum, extus granulatum, a $\mathrm{che}$ $\mathbf{n}$ i is ovatis, acuminatis, circa receptaculum centrale nidulantibus. - Arbor guianensis lactescens; ramis foliisque oppositis, ovatis, trilobis, stipulis caducis, syncarpiis aurantiiformibus, edulibus.

B a g a s a Aublet Guian, IT.suppl. 15.t, 376. Juss.gen. 406. An Maclurae species?

1876. Castilloa CERV. Flores monoici, in eodem ramo masculi femineis alterni. Masc. Perigoni um (involucrum?) hemisphae ricum, gamophyllum, squamis ovatis, acntis, im brieatis. Sta mina plurima, perigonii parieti in teriori inserta; fil a m e $\mathrm{ta}$ filiformia, exteriora sensim longiora; an therae snbrotundae. $\mathbf{F}$ em. Perigonium maris, squamis paullo latioribus et crassioribns, demm expansis. O varia plurima (15_20) ovata. Styli 2 , v. rarius 3 , divergentes, persistentes, apicibus revolutis stigmatosi. D $\mathbf{r} \mathbf{u}$ p a e 15_20, basi connatae, obsolete triangulares, apice excavatae; $n$ uce ovata, unilocnlari foetae, - Arbor mexicana lactescens; ramis alternis, ramulis pilosis, foliis alternis, oblongis, basi cordatis, utrinque villosis, obsolete serratis, stipulis membranaceis, floribus axillaribus, femineis solitariis sessilibus, masculis binis v. ternis pedicellatis.

C astillo a Cervantes in Gazeta de literat. de Mexico. 2. Jul. 1794. c, ic. Cavanilles Annales de Hist. Nat, 1800. 1I, 126. - Arbol de Ule, Holguah a it I Mexic.

18\%ซ. Aporosa BLUM. Flores dioici. Masc. densissime spicati. Perigonium profunde quadripartitum, laciniis biseriatis. Sta ni in a 2, brevia, a $\mathrm{nth}$ erarum loculis subrotundis. O varii rudimentum centrale Fem. .... Frutex javanicus; foliis allernis, oblongis, basi acutis, integerrimis, venosis, subtus scabriusculis, spicis masculis confertis, axillaribus, pedunculalis.

A poros a Blume Bijdr. 514 - Genus ex cl. auctore Cecropiae affiae, an Urticaceis propiaquias?

18\%8. Seiaphila $B L U M$. Flores monoici. Masc. Perigoni nm sexpartitum, laciniis reflexis, apice villosiusculis. An th e ra e 6 , perigonii laciniis adnatae. Fem. Perigoni um ut in maribus. Antherae steriles. Ovaria plura, receptaculo convexo imposita, unilocularia. OvuI $\mathbf{m}$ unicum ..... S $\mathrm{tig}$ ma sessile, punctiforme. B a cea e plares, glandulis pellueidis tectae. S e m en subtriquetrum; te $\mathrm{s}$ ta subcoriacea...-Herba javaniea, tenerrima, carnosa, aphylla; scapo simplicissimo, erecto, stipulis alternis, ovatis, floribus racemosis, nutantibus, superioribus masculis.

Seiapli ila Blume Bijdr, 514._Affinitas plane obscura.

\section{Ordo XCII: Unticaceae.}

URTICEAE DC. Elor, franc, HT. s17. Barting Ord, nat, 105. excl. Cannabineis.

Herbae v. Fretices interdum arborescentes, succo in plerisque aqueo, rarissime lacteo. Folia opposita v. alterna, simplicia, petiolata, penninervia, integra, dentata v. serrata, rarius palmatinervia, Jobata, plerumque ut et reliquae stirpium partes pilis nunc urentibus nunc fusilormibus adnatis, villo interspersis munitae. Stipulae petiolares liberae, integrae v. lobatae, ut plurimum persistentes, rarius deciduae $v$. omnino nullae.

Frores polygami, masculi ovarii abortu unisexuales, monoici v. dioici, spicati, capitati v. paniculati, nunc receptaculo carnoso impositi, saepius involucro communi libero $v$. gamophyllo cincti, bracteolati v. nudi.

M a s c. Perigonium calycinum, tetra-pentaphyllum, liberum, v. gamophyllum, quadriquinquepartitum, laciniis aeqnalibus, concavis, aestivatione imbricatis, sub anthesi patentibus, rarissime abortu (floribus masculis in ambitu receptaculi communis collocatis) monophyllum.

Staura imo perigonio inserta, ejusdem lobis numero aequalia tt opposita. Fil a m enta plerumque transversim rugosa, libera, filiformia v. subulata, rarissime basi petaloideo dilatata, aestivatione inflexa, sub anthesi elastice prosilientia, plus minus irritabilia. Anther a e introrsae, biloculares, medio dorso aftixae, loculis oppositis, contignis, basi et apice interdum discretis, longitudinaliter dehiscentibus.

Orarir rudimentum sessile v. stipitatum, basi v. apice pilosum, interdum ovulo imperfecto foetum.

Fem. Perigonium calycinum, di - tetrapentaphyllum, foliolis plerumque inaequalibus, nonnullis quandoque rudimentariis, rarius om- 
nibus abortivis, saepissime gamophyllum, tubuloso-ventricosum, limbo bi-quadridentato $\mathrm{v}$. partito. Stamina nulla v. rarius rudimenta squamaeformia, inflexa, perigonii laciniis opposita.

Ovarium sessile, liberum, ovatum, uniloculare. Ovulum unicum, basilare, sessile, orthotropum, saepissime hinc paullo infra micropslem superam cum ovarii pariete styligera, ope vasorum textus conductricis primum cohaerens, post foecundationem plerumque liberum. Stylus terminalis v, sublateralis, simplex; stigmate subcapitato venicillato terminatus, nunc uno latere stigmatosus, interdum brevissimus, v. nullus, stigmate tunc sessili, laciniato-multipartito.

Fructus nudus, v. perigonio persistente, membranaceo- sicco $\mathbf{v}$. interdum baccato inclusus, membranaceus $v$. crustaceus, evalvis, indehiscens, epicarpio laevi v. tuberculato, interdum compresso v. anguste membranaceo-alato.

Semen e basi erectum. Testa tenuissime membranacea, saepins cum endocarpio connata. Alb н men carnosum, plus minus copiosum.

Embryo in axi albuminis antitropus, ejusdem fere longitudine. Cotyledones ovatae, planae. $R$ a d i $c$ ula brevis cylindrica, umbilico basilari e diametro opposita, verticem fructus spectans.

Urticace a inter tropicos totins mundi, et in regionibus subtropicis copiosae, in temperatis rarae, nec ab hominum stationibus multum remotae, ab affinibus ordinihus succo vix non in omnibus aqueo, et principali ovuli basilaris, et embryonis in axi albuminis antitropi recti charactere facillime distinguuntur.

Genera, in quibus circumscribendis styli et stigmatis conformationi vix multum tribuendum esse videtur, difficillime definiuntur, accuratiori adhuc examini commendanda.

1899. Urtiea TOURN. F Iores monoici v. dioici, spicati v. glomerato - capitati. M a s c. Perigonium calyeinum regulare, qua dri-quinquepartitum, laciniis per aestivationem valvatis, sub anthesi patentibus. S ta min a 4 v. 5 , perigonii laciniis opposita; fil amenta filiformia, primum inflexa, deinde patentia; a n th er a e biloenlares, ellipticae, incumbentes. Ova rii rudimentum. F em. Perig on inm tetraphyllum, foliolis erectis, eruciatim oppositis, exterioribus minoribus, interdum abortivis, interioribus persistentibus, interdum baccatis. Ova ri um liberum, nniloculare. 0 v $1 \mathrm{~nm}$ unicum, e hasi erectum, orthotropum. Stig m a sessile, subeapitatum, villosum, pennieillatum v. elongato-filiforme. A $\mathrm{c}$ h en i u m oblongum, compressiusculum, laeve $\mathbf{v}$. tuberculatum, nudum v. perigonio baccato inclnsum. S em en erectum; test a cum epicarpio connata. Embryo in axi albuminis carnosiantitropus; c otyledonibus ovatis; radicula cylindrica, supera _ Herbae c os mo polit a e, annuae v. interdum suffrutescentes, pilis urentibus, interdum adnatis fusiformibus mixtis obsitae; foliis alternis v. oppositis, inciso-serratis, fioribus in paniculis $v$, racemis axillaribus, rarissine capitatis.

Urtic a Tournef. inst, 308, Liun. gen, n, 1054.

a. URTICA Gaudich. Mase. Perigon i u quadripartitnn. Stamina 4. Fem. Perigovii tetraphylli foliola iuteriota naxima, foliacea. $\mathrm{S} t \mathrm{ig}$ m a pevicillatuu. A $\mathrm{ch}$ e $\mathrm{u}$ i um rectum, lenticulari conipressum, lieve, perigonii foliolis interioribus immutatis inclusum. - Folia opposita.

Urtica Gaudich. ad Fregc. 496. Urtica e sp. oppo$\mathrm{s} i \mathrm{t}$ if oli a e. Linn et Nuct. - Nees jun. Gen. plant. II. 28. b. URERA Gaudich. Mas c. Perig on i u m quadri-quinquepartitum. Stamina 4 v. 5. Fem. Perigon i foliola iuteriora majora, exteriorum unum saepius abortivum. S tigma penicillatum. A $\mathrm{ch}$ e $\mathrm{n} \mathbf{j} \mathrm{u}$ oblique ovatum, compres. siusculum, laeve, perigonii foliolis interioribus baccatis fisclusum. - Folia alterna.

Urera Gaudich ad Frege, 496, Urticae s p. nltern if oli a e Linn. et Auct.

c. LAPORTEA Gaudich, Mas c. Perig on in muinquepar. titum. Stamina 5 . Fem. Perigonii foliola interiora majora, foliacea. Stig ma elongrto-subulatum. A chen f u m oblique ovatum, conpressiusculum, subtuberculatum, perigonii foliolis interioribus immutatis inclusum. Folia alterna.

L a portea Gaudich. ad Freyc, 498. Urtica canadens is Linn. ete.

d. FLEURXA. Gaudich, Mas c. Perig on i m quadripartitum. Stamina 4 . Fem. Perigonii bi-quadripartiti foliola inaequalia. St $\mathrm{g} \mathrm{gma}$ elongato-filiforme. A $\mathrm{ch}$ e $\mathrm{ni}$ um oblique ovatum, conpressiusculum, ala angusta marginatum, nudum. - Folia allerna.

Fle u r y Gaudich. ad Freyc. 497, excl, sp. Urtiea divaricata L. U. aestuans. L. U. $r a c e m o s a L$.

e, GIRARDINIA Gaudich. M a se. Pe rig on i u m quadripartitum. Stamina 4. Fe m. Perigouil quadripartiti laciniae fnaequales, tres basi connatae, quarta libera. A c ben i um oblique ovatum, Ienticulari-compressum, laeve.Folia alterna.

Girar dinia Gaudich, ad Freyc. 498. Urtica pal mata Leschen.

1890. Elatostemma FORST, Flores monoici v, rarius dioici, in capitulis sexu distinctis, bracteato-involucratis, in receptaculo plano subcarnoso sessiles $v$. pedicellati, uni-bi-tribracteolati. I a 8 c. Perigoni um quadri-quinquepartitum, foliolis aequalibus, concavis, sub anthesi patentibus. St a mina 4_5, perigonii foliolis opposita; fil a ment a filiformia, primum inflexa, deinde patentia; antherae introrsae, biloculares, dorso affixae, loculis appositis. Ovarii rudimentum, Fem. Perigoninm bi-tri-tetraphyllum, foliolis inaequalibus, saepe minimis, interdum nullis. Ovari $\mathbf{~ m}$ liberum, ovato-ellipticum, uniloculare. OvuI $\mathbf{m}$ unicum, basilare, sessile, orthotropum. S tigma terminale, sessile, laciniis multipartitis, A c h en i a elliptiea, receptaculo carnoso insidentia, bracteolis involuta. S e $\mathbf{m}$ e $\mathbf{n}$ erectum. $\mathbf{E} \mathbf{m} \mathbf{b} \mathbf{y} 0$ in axi albuminis carnosi antitropus; cotyI edonibus ovatis; radicula brevi, supera. Herbae v. suffrutices, in insulis Asiae austra$l$ is et in Oceania obviae; succo aqueo, foliis alternis obliquis, integerrimis, grosse dentatis, tuberculoso-asperis, stipulatis, capilulis axillaribus sessilibus v. breve pedunculatis.

206.

Elat ostemma Forst, Char, 53. Brongn. ad Duperr.

a. SClOPHILA Gaudich. Involuernm rudimentarium. Flores feminei bractea encullato-concasa stipati. Perigo n i u abortivum. - Folia integerrima.

$\mathrm{Se}$ iophila Gaudich, ad Freyc. 493, $t, 120$. Procris Commers, et Auct. excl. pl.

b. ELA TOSTEMMA Forst, Involuerum plus minus per. fectum. Flores feminei bi-tribracteolati. Perígoni um 
di-tri-tetraphyllum, foliolis inaequalibux. _ Folia grosse dentata.

Ei a tos tem ma Forst. op. cit. $t$. 53. Branga, ad Duperr. $t .43$ 45. E I a tos te m ma et $L$ a ngeveld i a Gau dich. ad Freyc. 493. 494. V a a ie r a Loureiro Flor, cochinch. IT. 690 .

1881. Selnyehowskya $E N D L$. F lores monoici, maseuli in apicious ramulornm receptaenlis carnoso-gramosis ramosis impositi, bracteis deciduis interstincti, feminei glomerati. M a s c. P e rigoniu m quadripartitum, foliolis aequalibus, concavis, sub anthesi patentibus. St a mina 4 , pe rigonii foliolis opposita; fil a m ent a basi petaloi deo-dilatata, apice filiformi primuı inflexo; a $\mathbf{n}$ the rae introrsae, biloculares, dorso adnatae, locu lis oppositis. Fem. Perigonium quadrifidum, lacinis inaequalibus. $\mathrm{O} v$ a $\mathbf{r} \mathbf{i} \mathbf{u m} \ldots \ldots$. A.th $\mathrm{e}$ niu un oblique ovatum, stylo sublaterali rostratum, compressum, mem sranaceo-alatum, tubereulosum. Semen erectum. Embryo in axi a lbuminis carnosi antitropus; cotyledonibus ovatis; radicula brevi, supera._Herba oceanica, basisuf fruticosa; foliis alternis, longe petiolatis, crenato serratis, tuberculoso-asperis, racemis axillaribus paniculatis.

$\mathrm{S}$ ch y chow sk y a Eadlicher in Annal. des Wien. Mus. 1, 187, $t$. 13. Urtica ruderalis Forst.

1889. Pilea LINDL. Flores monoici, masculi et feminei in eadem pinicula, bracteati. Masc. Perigonium quadripartitum, foliolis acqualibus, concavis, sub anthesi patentibus. Stamin a 4 , perigonii foliolis opposita; fila menta filiformia, transversion sulcata, primam inflexa, demum elastice prosilientia; antherae introrsae, biloculares, dorso affixae, loculis oppositis. F e m. Perig on i m trilobum, lobo uno miximo, cu callato, mutico, duobus collateralibus minoribus planis. Stamina rudinentaria 3 , squamaeformia, perigonii foliolis opposita, inflexa. Ovari u m liberum, ovatu - ellipticum, uniloculare. Ov u l um unicum, basilare, sessile, orthotropum. Stigma terminale, sessile, laciniato-multipartitum. A c he$n i a$ perigoniis carnosulis inclusa, laevia $v$. tuber culosa. S em en erectum. $\mathbf{E m b r y}$ o in axi a 1 b u m inis carnosi antitropus; cotyledonibus ora tis; radicula brevi, supera. - Herbae tropicae et subtropica e cosmopolitae; foliis oppositis, saepius longe petiolatis, stipulatis, integrerrimis $v$, den tatis, glabriusculis $v$. pilis fusiformibus saepius adnatis obsitis, floribus in paniculis axillaribus glomeratis.

Pile a Lindley Collect.t.4. D u b r uellia Gaudiel. ad Freyc. 495 . H a y a a Sehumaeh. in Act, soc. Havn, IV. 180. Urticacet Parietariae sp. Auet.

1883. Pellionia GAUDICH. Flores dioici? M a s c...... F emine i in receptaculo axillari carnoso glomerato-pedicellati, bractea minuta stipati. Perigonium quinquepartitum, laciniis fornicato-concavis, sub apice elongato mu cronatis, erecto-patentibus. St a m in a rudimentaria 5, lineari-squamaeformia, perigonii foliolis op posita, inflexa. O vari u m liberum, ovatum, uni loculare. Ovul u m unicam, basilare, sessile, or thotropum. Stigm a terminale, sessile, laciniato multipartitam, A che n i m nudum, tuberculosmm. Semen erectun. Eubryo in axi albuminis carnosiantitropus; cotyledonibus ovatis; radicula brevi, supera. Herbas moluceanae; foliis alternis basi obliquis, serratis, glabris.

Pelli o nia Gaudich, ad Freye. 494, 2, 119.

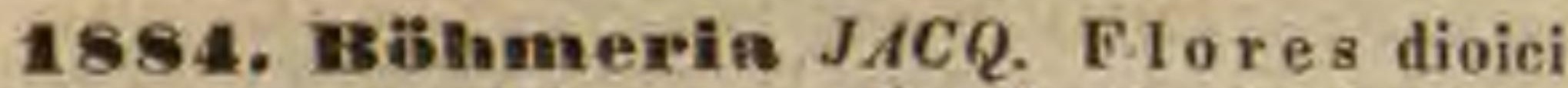
v. rarissime monoici, masculi spicati, fcminei in axillis conferti. M a s c. Perigoninm quadriquinquefidum, foliolis aequalibus, coneavis, sub anthesi patentibus. Sta mina $4-5$, perigonii foliolis opposita; filam enta subulata, primum infle$x a$, deinde patentia; anthera e introrsae, biloculares, dorso affixae, loculis appositis. Ovarii radimentum. Fem. Perigon i m tubuloso-ventricosum, ore suhquadridentato. Ova ri um liberum, sessile v. brevissime stipitatum, ovato-ellipticum, uniloculare. O $\mathbf{v} \mathbf{u} \mathbf{~ u ~ m ~ u n i c u m , ~ b a s i l a r e , ~}$ sessile, orthutropum. Stigmà terminale, elongatolineare, unilaterale, villosum $\boldsymbol{A}$ ch e n i um ellipticum v. depresso-conicum, stigmate apiculatum, laeve $v$. tabersulatum, perigonio membranaceo v. baceato tectum. Sem en erectum. Embryo in axi albu mini s carnosi antitropus; cotyledonibus ovatis; radie ula brevi, supera. - Suffrutices $v$, arbusculae, intert ropicos totius or bis communes; succo aqueo $v$. lactescente, folitis alternis $v$. oppositis, serratis, villosis, floribus masculis spicat is v. glomerato-spicatis, femineis axillaribus congestis, $v$. super receptaculum carnosum e folii axilla tumens conferti.

B 3 bmeria Jaeq. Amer, $t$, 157. B $8 \mathrm{hm}$ eria et Ne. r a ud i a Gaudich, ad Freye. 499.

a. BӧHMRRIA Gaudich. F I o r e s feminei axillares glomerati. Perigonium fructiferum siccum. A che ui um ellipticum. - Americanae opposilifoliae, succo aqueo.

B б̈ и m e ri a Jaiq. Amer, t. 157. Bonpl. Nav, t. 15. Bobueria et Daretia Gaudich. $l$. c. Urticat sp. Linn. Herit. stirp. $t, 20$.

b. PROCRIS Commers. FIores feminei in receptaculo axit. lari caraoso couferti. P e rigonium fruetiferam siceum. A ch e a i m ellipticum. -Gerontogaeae alternifoliae, suc. co aqueo.

Proer ris Commers. ex Juss, gen, 403. excl. sp. Gau dieh. ad Ereyc. $t, 118$.

c. NERAUDIA Gaudich. FIo res feminei axillares glowerati. Perigo ni um fructiferum haceatum. A e he ni um de. presso-conieain. - Oceanicae allernifoliae, succo lacteo.

\section{Ne raudia Gaudich. ad Frejc. $500, t, 117$.}

1895. IParietaria TOURNEF. Flores monoici, fasciculati v. eymosi, involuero communi ditriphyllo v. multipartito. Mas c. P erigoni um tetra-pentaphyllum, foliolis sabaequalibus, coneavis, sub anthesi patentibus. Sta mina 4 -5, perigonii foliolis opposita; filamenta filiformia, transversim rugosa, primum inflexa, sub anthesi elastice prosilientia; an the rae introrsae, biloculares, dorso affixae, loculis appositis. O va rii rudimentum stipitatum, ovulo inani foetum. F e m. Perigonium ventricoso - tubulosum, nervosum, limbo quadridentato, dentibus subaequalibus v. duobus oppositis minimis. Ovari u m liberum, sessile, ovatum, uniloculare. Ovulum unicum, basilare, sessile, orthotropam. St y i s terminalis, brevissimus v. nullus; stig ma capitato-penicillatum, v. lineare, unilaterale, villosum. C a r yo ps is perigonio inmutato arido v. carnosulo, interdum compresso et alato eincta. S emen e basi erectum; tes ta membranacea tenuissima. Em b r yo in axi a I b uminis carnosi antitropus; cotyledonib u s ovatis, planis; ra il is u I a cylindrica, supera. Plantae herbaceae $v$, suffrutescenles, glabrae v. villosae, in temperatis et calidis tot ius or bis obviae, in regione mediterranea, America boreali et in As ia tropica imprimis copiosae; foliis alternis et oppositis, floribus utriusque sexus axil laribus, involucro communi cinctis.

Parletaria Touruef. inst. 289. Lial. gen, n. 1152.

a. PARIETARIA. Gaudich. I a ra l u e r a m polyphyllum. Perigon $\mathrm{lu}_{\mathrm{m}}$ floris feminei teretiusculum, limbo quadridentato. S t y lus filiformis; $5 \mathrm{tig}$ ma capitato-villosum. - Eo. lia allerna. 
Parietaria Gaudich, ad Freyc. 50t. P. officinalis L. et P. jndaic a L. Schkuhr t. 346. Gärtn. 119. Nees jua. Gen, plant, II, 29.

b. FREIREA Gaudich, Involu c ru m tri-polyphyllum. Pe$\mathrm{rig} 0 \mathrm{ni \textrm {am }}$ floris feminei tubulosum, quadripartitum, fructiferum chartaceum. St y lus brevis; $s \mathrm{tig}$ m a capitato - villosum. - Folia alterna.

Freire a Gaudich, ad Freyc. 502. P. I us itanical. P. filiform is Tenor.

c. THAOMURIA Gaudich. I n 50 I u c $r$ um quinquefidum, sub. triflorum, laciniis duabus alternis majoribus, alaeformibns. Perigonium floris feminei tubulosum, angulatum, limbo quadridentato. Sty l a s brevis; 8 t ig ma eapitato-villosum. - Folia alterna.

Th a u u r i a Gaudich, ad Freyc. 502, P. c r et i c a Linn. d. GESNOUINIA Gaudich. I a v o I u c r u m campaualatum, sexfidum, bi-triflorum, lacinlis alternis minoribns. Perig o$\mathrm{n}$ i $\mathrm{um}$ floris feminei ovale, limbo quadrilobo. Stig ma lineare, eloigatum, hise villosum. - Folia alterna.

Ges no u inia Gandich, ad Freyc. 502 . Urtica a r borea Lluk. Bólimer!a rubesceus Jacq. B. a rborea Ait.

e. POUZ0LZIA Gaudich. Involucrum polyphyllum, floribus interdum dioicis. Pe rig o n i um femineum tubulosum. limbi quadrideatati dentibus duobus minimis, fruetiferum sulcato - angulatum v. complanato - bialatum, inferne cristatum, gibbum v. aequale. Stigma lineare, elongatum, hinc villosum. - Folia alterna $v$, rarius opposila.

Pouzolzia Gaudieh, ad Froyc. 503. P. in die a Linn. P. 1 a e vig a ta Foir.

f. ROUSSELLA Gaudich. In v o I u e r u m polyphyllum, flori. bus femineis binis inferne cohaerentibus, masculis racemo. sis. Perigoni um fruetiferum complanato-quadrialatum, alis duabus iuferioribus obsoletis. Stig ma subsessile, capitato - villosum. - Eolia alterna.

Rous selia Gaudicis. ad Freyc. 503. U r tie a la p puI a ce a Swartz.

1886. Soleirolia GAUDICH. Flores dioici, solitarii, Mas c. Involuerum trifidum. P erigon i m quadripartitum, laciniis subaequalibus, concavis, sub anthesi patentibus. St a m in a 4 , perigonii laciniis opposita; filamenta filiformia, transversim rugosa, primum inflexa, sub anthesi elastice prosilientia; an therae introrsae, biloculares, dorso affixae, locnlis appositis, Ovarii rudimentum basi lanatum. F em. Involu $\mathrm{c} \mathbf{r u m}$ tubuloso-ventricosum, trialatum, trifidum. Perigonium tubuloso-ventricosum, limbo quadrilobo Ovarium liberum, sessile, ovatum, uniloculare Ovulum unieum, basilare, sessile, orthotropum. Stylus terminalis, filiformis, brevis; $8 \mathrm{tigma}$ capitato-oblongum, hinc villosum. Caryopsis perigonio persistente, fauce recluso cincta. Se m en e basi erectum; t e $\mathbf{s}$ a membranacea, tenu issima. $\mathbf{E ~ m ~ b ~ r y ~ o ~ i n ~ a x i ~ a ~} 1$ b u $\mathrm{min}$ is carnosi anti tropus; cotyledonibus ovatis, planis; radicula cylindriea, supera. - Herbae mediter $r a$ neae, pusillae; foliis alternis, stipulatis, oblique rotundalis, integris, villosis, pilis fusiformibus adnalis conspersis.

Soleirolia Gandich, ad Freyc.504. He $1 x$ in e Requien. Annal. so.nat. $V$. 384. Pa rietaria lusitanica Viviani Flor. cors. App, t, 1.f. 1 .

188\%. Forelkolen LINN. Flores androgyni, in receptaculo lanato, involucro subcampanulato quinque-sexfido cincto, masculi peripherici, feminei centrales, sessiles. Masc. Perigo n i m monophyllum, canaliculato-coneavum, apice galeatum. Stamen nnicum; filam entum filiforme, transversim rugosnm, elastice prosiliens; a $n t h$ er a extrorsa bilocularis, dorso affixa, loculis appositis. Fem. Perigonium tubuloso-ventricosum, lanatum, limbo integerrimo. Ovarium ellipticum, uniloculare. 0 v u 1 u m unicum, basilare, sessile, orthotropum. Stylus terminalis, brevis; st ig m a lineare, unilatcrale, hinc villosum. Utricul 1 u s membranacens, perigonio persistente inclu$s u s . S$ e in e n e basi ercetum, $t$ e $s t$ a tenuissime membranacea. Embryo in axi a $1 \mathrm{buminis}$ carnosi antitropus; cotyledonibus ovatis, planis; radicula cylindrica, supera. - Herbae arabicae, asperae, tenaces v. subpungentes; foliis alternis, stipulatis, involucris axillaribus sessilibus, confertis.

Forsk ol ea Liun. gen, n, 1262. Juss.gen. 403. Schkuhr t. 125. Gärtn. I 332. t. 68. Jacq. Hort. vindob, I. t. 48. Murray Comment. Gotting, t, 2. Gaudich, ad Freyc. 504. C a i d b e ja Forsk. Aegypt. 82.

OBSERVATI0 : Forsholeae arcte affinia genera, a cl. Gaudichaud paveis verbis iudicata, nobis prorsus incognita:

DROGUETIA Gaudich, ad Freyc. 505. I g o luerum integrum, biflorum, flore altero masculo, altero liermaphro. dito.-Herbae maritianae; folis alteruis, punctulato-granulosis, floribus spicatis. Urtic a l eptostae hy s Pers.

AUSTRALINA Gaudich. ad Frege, 505. In volucrum subnullum, floribus masenlis $1-2$, et femiacis $2-3$ in eadem axilla. - Herba australasica pusilla; eanlibus filiformibus ramosis, repentibus, foliis alternis, floribus subsolita. riis peduaculatis, ebracteatis? - Urtica pusilla Herb. Desf.

\section{URTICACEIS $\triangle$ FFINES.}

\section{* CYNOCRA MBEAE.}

1888. Thelygonum LINN. Flores monvici in diversis axillis. Mas c. ebracteati, 2-3 sessiles. Perigoni um diphyllum, foliolis anticum et posticum ab axi floris hatus occupantibus, aestivatione sibi invicem applicitis, demum revoIntis. St a m in a indefinita $(2-20)$, imis perigonii foliolis inserta; fil amenta tenerrime capillaria, libera; a ntherac lineares, versatiles, biloculares, loculis longitudinaliter dehiscentibus. F em. plerumque terni v, rarins plures, sessiles, bractea postica, bracteolisque duabus anticis, totidemque lateralibus stipati, flore intermedio saepins majore, lateralibus quandoque efoetis. Perigonium cum ovario connatum, limbo subexcentrice supero, tubuloso, subclavato, apice a stylo perforato, sul grossificatione demum laterali. O v a r i m inferum, uniloculare. Ovalum nnicum, basilare, situ amphitropum, directione campylotropum. Sty l u lateralis; $s \mathrm{tigmate}$ elavato, indiviso. Drup a monosperma. Semen hippocrepicum; $t$ esta tennissime membranacea. Embryo in axi albuminis carnosi homotropus, uncinatus; coty ledon ibus linearibus incumbentibus; $r$ a di $\mathbf{c}$ l a cylindrica, infera. - Herba annua, subsuceulenta, glabra, in $r e$ gione mediterranea obvia; foliis petiolatis, inferioribus oppositis, superioribus alternis integerrimis, penninerviis, stipulis incisis, petiolorum bases connectentibus.

Thely go a m Linn. gen, $n$, 1068. Lam, $t, 757$. Delle in Annal, sc, nat, XIX,370,t,13, Nees jun. Gen,pl.JI, 69.

\section{* GUNNERACEAE.}

1882. Gana arege LINN. F l ores hermaphroditi v. dioiei. Perigonium ovario adnatum, li in bo supero quadripartito, laciniis duabus minutis dentiformibus, duabns alternis petaloideis, caducis, interdum abortientibus. St a min a 2 , epigyna, perigonii lobis duobus minoribus alterna. Ovarium inferum, uniloculare. Ovulum unicum (?) ex apice loculi pendulum, anatropum. St igmata 2 , sessilia, elongata, plumoso-villosa. Achen i hum drupaceum. S e men unicum, pendnlum. Embry o minutus, in axi a l bu minis cellu- 
loso-carnosi, ra dic u l a umbilico proxima, supera. - Herbae succo aqueo, in Africa et America australi extratropica, nec non in excelsis Americae tropicae et Archipelagi Sandwicensis montibus observatue, acaules; foliis radicalibus longe petiolatis, suborbiculato-reniformibus, crenatis, pilosis, floribus in scapo radicali composile spicato, ad ramulos bructeato, dense spicatis ebracteatis.

G un n er a Linn. gen, $n, 1272$.

a. MISANDRA Commers. Flo res dioici. Perigon ii lobi duo petaloidei abortientes.

M is a ndra Commers. ex Juss. gen, 40s. Gaudich. ad Freyc. 512. Dis om en e Banks et Sol. Gun n e ra magela n i a Lam, ill. $t, 801 . f$. 2 .

b. PERPENSUM Burm, Flores hermaphroditi. Perigon i l lobi duo petaloidei, caduci.

Perpensum Barmann prodr. 26. Gunnera Linn. Amoen. Academ, VII. 495. Jussieu gen. 405. Lam. $t .801$. f. 1. Ruiz. et Pav. Flor, peruv. t. 44. f. a. Kunth in Humb. et Bonpl. Nov. gen. et sp. II. 44. Bot. Mag. t. 2376. Gaudich. ad Freyc. 512. P a n ke Feuillé Observ. II. $1,30$.

\section{Ordo XCY. Cannabineat.}

Herbae annuae erectae, v. perennes volubiles, succo aqueo, fibris tenacibus, foli is oppositis v. superioribus alternis, incisis v. lobatis, serratis, hispidulis, stipulis persistentibus incisis $\mathbf{v}$. deciduis.

Flores dioici. Masculi racemosi v. paniculati.

Perigonium herbaceum, pentaphyllum, foliolis subaequalibus, aestivatione imbricatis, sub anthesi patentibus.

Stamiva 5, imo perigonio inserta, ejusque foliolis opposita. Fil a menta filiformia, brevia v. brevissima. Antherae terininales oblongae, biloculares, loculis oppositis quadrisulcae, muticae v. connectivo excurrente apiculatae, longitudinaliter dehiscentes.

Flores feminei spicato-glomerati, unibracteati, v. amentacei, bracteis foliaceis plurifariam imbricatis, bifleris.

Perigonium monophyllum, ovarium amplectens, v. conplicato-convolutum, basi ventricosa ovarium includens.

Ovarium subglobosum v, ovatum, compressiusculum, uniloculare. Ovul um unicum, e basi loculi erectum, orthotropum. Stylus terminalis brevissimus v. nullus. Stigmata 2 , elongato - filiformia v. subulata, pubescentia.

Caryopsis unilocularis, bivalvis, indehiscens, laevis, v. Achenia glanduloso - resinosa, perigoniis tandem increscentibus strobilum membranaceum formantibus inclusa.

SEMEx unicum, erectum. T es t a tenuissime membranacea, umbilico basilari, endopleura carnosula albumen mentiente.

Eмввхо exalbuminosus, uncinatus v. spiralis. Cotyledones rectae v. spiraliter convolutae; r a d i c u l a e superae incumbentes.

Cannabineac in Asia et Europa med $l a$, nec non in $A m e r i c a b o r e a l i$ indigenae, multiplicis usus.

Urticace is proximae, embryonis exalbuminosi directione heterotropa facillime distinguuntur.

1830. Cammabis TOURNEF. Flores dioici. M a s c. racemosi. P e rig on i um pentaphyl$\mathrm{lum}$, foliolis subaequalibus, aestivatione imbricatis, anthesi pateutibus. S t a min a 5 , perigonii foliolis opposita ; fil amenta filiformia, brevia; an thera e terminales, magnae, oblongae, pendulac, biloculares, loculis oppositis-quadrisuleae, longitndinaliter hiantes. O v a r i $\mathrm{i}$ rudimentum nullum. F e m. spicato-glomerati, unibracteati. Perigon i $\mathrm{m}$ monophyllum, complicato-convolutum, basi ventricosa ovarium inclndens. O va ri u m sulgglobosum, uniloculare. Ovulum nnicum, e basi loculi erectum, orthotropum. Stylus brevis, terminalis; stig mat a 2 , elongato-filiformia, pubescentia. Cary opsis unilocularis, bivalvis, indehiscens. S em en erectum, uncinatum; testa viridi tenuissime membranacea, umbilico colorato notata. E m bryo exalbuminosus, heterotropus, uncinatus; coty 1 edonibus incumbentibus, dorso convexis; radienla longa, umbilico opposita, supera. - Herba annua, in Asia media indigena, nunc ob multiplicem flbrarum tenacissimarum usum per omnem Europ am culta; caule erecto, foliis inferioribus oppositis, superioribus alternis, incisis, hispidulis.

C a n n a b is Tournef, inst, 1308. Linn. gen. n, 201. Gärtn. I. 357. . 75. Schkuhr t.325. Nees jun. Gen. plant. IX. 30.

1891. II Iumulus LINN. F lo res dioici. I a s c. racemosi v. paniculati, Perig on ium pentaphyllum, foliolis aequalibus, aestivatione imbricatis, anthesi patentibus. Stam in a 5 , perigonii foliolis opposita; filam en ta filiformia, brevissima; a n thera e terminales, magnae, oblongae, erectae, biloculares, loculis oppositis, connectivo excurrente apiculatac, longitudinaliter dehiscentes. $O$ v a ri $i$ rudimentum nullum. F e m. amentacei, bracteis foliaceis plurifariam imbricatis, bifloris. Perigoninm monophyllum, squamaeforme, ovarium amplectens, demum increscens. O varium ovatum, compressiusculum, uniloculare. Ovulum unicum, e basi loculi erectum, orthotropum. S $\mathbf{t} \mathrm{i} g \mathrm{~m}$ a $\mathrm{t}$ a 2 , terminalia, elongatosubulata, pubescentia. S trobil n s membranaceus, e squamis perigonialilons imbricatis increscentibus. A e h e $\mathrm{n}$ i a unilocularia, indehiscentia, resinoso-glandulosa. S e $m$ e $n$ erectum; t e s $t$ a tenuissime membranacea. E m bryo exalbuminosus, heterotropus; c ot y I e d o n i bus linearibus spiraliter involutis; $r$ a d i $c u$ la $e$ ineurvae superae incumbentibus. - Herba volubilis, in Eu ropa media et $A$ meric a bor e a li indigena, ob pericarpiorum glandulas principio resinoso amaricante foetas etiam culta, hispida; foliis oppesitis, cordatis, tri-quinquelobis, serratis, stipulis ovatis, integris $v$. bifidis.

H u m u u s Linn. gen. 902. Sehkuhr $t$. 326. Nees jun. Gen, plant. II. 31. Lu pul as Tournef, inst. 309. Girtn. t. 73. De glandulis Lupulinis efr. Raspail Nouv, systéme de Chimie organique. 


\section{Dralo XCE'I. Antidesmear.}

STILAGINkAE Agardh Aphorism, 199. Lindley introduct, edit, II. p, 179. ANTIDESMEAF Sweet Hort, Brit, edit, II, $p, 460$.

Arbores v. frotices, $r$ a $m$ is haud articulatis, teretiusculis. Foli a alterna, petiolata, coriacea, integerrima $\mathrm{v}$, angulato-dentata. S $\mathrm{t} \mathrm{i}$ pulae caducae.

Frores unisexuales, dioici, regulares, in spicas axillares, amentiformes dispositi, bracteati.

Floribus masculis: Perigonium calycinum, tri-quinquepartitum.

Stamiva numero loborum perigonii $v$. interdum panciora, iisdem opposita. Fil a m e nt a filiformia, exserta, libera v. basi toro glanduloso miaimo conjuncta. Antherae introrsae, biloculares, loculi connectivo incrassato sejuncti, eidem horizontaliter adnati, verticaliter aperti.

Ovari rudimentum.

Floribus femineis. Perigonium maris deciduum.

Ovariu m sessile, liberum, basi annulo glanduloso cinctum, uniloculare. $\mathrm{O}$ v u l a 2 , collateralia, ex apice locnli pendula, anatropa. St i gm a terminale sessile, depressum, radiato-triquinquelobum.

Drupa baccata, stigmate persistente coronata, unilocularis, monosperma. Putamen osseum, extus scrobiculis punctisque impressis, intus spinulas processusve in semen penetrantes efformantibus notatum.

Semen inversum. Test a membranacea et al b u m en copiosum carnosum a putaminis processubus scrobiculatum.

Емв хо orthotropus, axilis ; cotyledonibus magnis, foliaceis; radicula parvula, umbilico proxima, verticem fructus spectante.

Antidesmeae antherarum loculis solo apice affixis, disco annulari et putaminis indole facile ab ordinibus affinibus distinguendae, I n diam orientalem et Madagascariam inhabitant.

Pyrenacantha genus ovarii et fructus structura optime Antidesmati conveniens, staminibus cum perigonii lobis alternantibus, antherarum loculis oppositis, et succo lacteo valde anomalum, an revera affine?

Ad calcem ordinis genera plura, seminis albuminosi structura Antidesmeis affinia, enumeravimus.

Drupae nonnullarum sapide acidulae, edules.

1892. Antidesma $L I N N$. F 1 ores dioici. Masc. Perigonium tri-quinquepartitum. $\mathrm{S}$ ta $\mathrm{m}$ in a 2,3 v. 5 , disco annulari inserta; $\mathrm{fil}$ amenta filiformia; antherae biloculares, loculis divaricato-patentibus. Ova ri i rudimentum. Fem. Perigoninm maris. Disens annularis ovarii basim cingens. Ovari um ovatum, libernm, uniloculare, Ovula 2, ex apice loculi pendula, colla- teralia, anatropa. Stigma sessile, tri-quinqueradiatum. Dru p a monosperma, stigmate coronata, putamine intus spinuloso. S emen pendulum. A I b umen crassum, carnosum, putaminis processubus scrobiculatum. E mb ryo orthotropus, axilis; cotyledonibus magnis foliaceis; radienla brevi, supera. - Arbores $v$. frutices ind ic $i$ et $m a$ dagascarienses, hatd lactescentes; foliis alternis breve petiolutis, coriaceis, integerrimis $v$. angulato-dentatis, stipulis caducis, floribus axillaribus spicato-amentaceis.

a. Stilago Linn. Perigoni nm tripartitum. Stamina $2-3$. Stigna triradiatum.

Stilago Lian, gen, n, 1273. Roxb. Corom, t, 166. Flor, Ind. $I I T .315$.

b. ANTIDESMA Linn. Perigoniam quinquefidum. Stam i a 5 . St i gua quinqueradiatum.

Antidesma Linu. gen. n, 1110. Gärtu. I, 188, t. 39. Roxb. Corom, t. 167. Flor. Ind. III. 384 .

1893. Pyreuneantha $H O O K$. F lo res dioici. M a sc. spicati, braetea laterali. Perigon i u calycinum, quadripartitum, patens. S $\mathrm{ta-}$ mina 4, perigonii laciniis alterna et aequilonga; fil amenta basi dilatata, complanata; anthera e subrotundae, terminales, biloculares, loculis appositis, longitudinaliter dehiscentibus. O v a r i rudimentum. F e m. spicato-capitati, bracteolati. Perigonium calycinum, quadri-quinquepartitum. Ovarinm ovatum, liberum, uniloculare. Stigma sessile, multiradiatum. Ovula 2 , ex apice loculi pendula, collateralia, anatropa. D rup a monosperma, putamine fragili, intus spinis plurimis obtusis muricato. S e $\mathbf{m}$ e $\mathbf{n}$ pendulum. A l b um e n crassum, carnosum, putaminis spinulis perforatum. Embryo orthotropus, axilis; cotyledonibus magnis, foliaceis; radi cula brevi, supera. - Frutex indicus, lactescens; caule filiformi, tereti, scandente, foliis alternis, petiolatis, oblongoellipticis, retusis, integerrimis, scabriusculis, spicis supraaxillaribus. 9. 10 .

P y renacanth a Hooker Bot. Mrisc. II, 108, Suppl.t.

\section{ANTIDESMEIS AFFINES. * PUTRANJIVEAE.}

1894. Putramjiva $W A L L$. Flores dioici. Mas c. ex axillis foliorum glomerato-eapitati. Perig o n iu m calycinum, tetra-pentaphyllum, foliolis parvis, inaequalibus. St a mina 3 ; $\mathrm{fi}$ a$m$ en $t$ a filiformia, exserta, omnia v. bina inter se connata, tertio libero; a ntherae extrorsae, biloculares, magnae, subglobosae, loculis appositis, longitudinaliter dehiscentibus. F e m. ex axillis foliorum longe pedicellati, solitarii. Perigoninm pentaphyllum, foliolis subaequalibus, apice incisis. Ova ri u m ovato - oblongum, triloculare. Ovula in loculis gemina, collateralia, ex apice anguli interioris pendula, anatropa. Styli 3 , fitiformes; $s$ tig m a t a foliaceo-dilatata, subpeltata. Dr n pa baceata, monosperma. Sem en inversum. Emb r y o in axi a $1 \mathrm{~b} \mathbf{n m}$ i $\mathrm{n}$ is carnosi orthotropus; eoty led on ibus lato-ovatis, foliaceis; $r$ ad ic nla supera. - Arbor hindostanica; ligno duro, albido, fotiis alternis, petiolatis, oblongo-lanceolatis, minute serrulatis, glabris, stipulis minutis, villosis. Patranjiva Wallich catal. $n$. 6814. Royle Himalay, $t$. 100. Nageia Putranjiva Roxb. Flor. Ind. IIT.766. P o вg o 1 a m Rheed. Malab. VII. $t, 39$.

1895. Nageja GÄRTN. Flores divici, amentacei. Perigonium di tetraphyllum. Stamina 4 . ...... Ovarium ..... Styli duo. 
Drupa baceata, monosperma. Se men inversum. E $\mathbf{m b} \mathbf{r}$ y o in axi a l b u m in is carnosi orthotropus; cotyledonibus ellipticis, plano convexis; radicu l a elongata, crassa, supera. - Arbuscula $j a$ ponica, vix nota; foliis oppositis lanceolatis, integerrimis, aveniis.

$\mathrm{N}$ ag e j a Gärtn. 1. 191, t. 39. N a g i Kämpf. Amoen, exot. 874. Myric a Nagi Thubb.

\section{** FORESTIEREAE.}

1996. Forestiera POIR. Flores dioici. Amenta gemmiformia axillaria, e squamulis membranaceis decussatim multiseriatis, interioribus majoribus. Masc. inter intimas amenti squamas, terni senive fasciculati, pedicellati. Perigonium tetraphyllum, minimum, sub anthesi caducum. St amina 2_4, summo pedicello imposita; fil a menta subulato-filiformia, longiuscula; an therae biloculares, oblongae, basifixae, loculis oppositis, longitudinaliter dehiscentibus. O va rii rudimentum ovatum, stylo filiformi stamina subaequante, stigmate subcapitato. F e m. inter intimas amenti squamas solitarii, v. bini rariusve plures pedicellati. Yerigonium tetraphyllum, minimum, foliolis duobus oppositis majoribus, duobus quandoque defieientibus, omnibus sub anthesi deciduis. Ovari um ovatum, biloculare. Ovala in loculis bina, collateralia, apici septi appensa, anatropa. St y I us terminalis cylindricus; stigma depresso-capitatum, obsolete emarginato-bilobum. B a c c a cariacea, ovata, subinaequilatera, abortu unilocularis, monosperma.S e m e n e dissepimento pericarpii parieti applicito pendulum, oblongum; test a coriacea, longitudinaliter suleata, $r$ h a $p$ h e lineari et e ha laza apicali notata. E mbryo in axi a lbuminis dense carnosi orthotropus; e otyledonibus oblongis, planis; radie ula longiusenla, supera.-Frutices in Americaborealicalidio. re provenientes; ramulis saepius spinescentibus foliisque oppositis, integerrimis $v$. obiter serratis, coriaceis, glabris.

Forestier a Poiret Suppl, II.664. B igelow i a Smith in Hees Cyclop, non alior. B or y a Willdenow sp. IV. 711 . non Labillard. A de li a L. C. Richard in Michaux Flor, Bor. Amer, II. 223. 1. 48, non P. Browa e.

\section{*** SCEPACEAE.}

189\%. Seepr $L I N D L$. F $10 \mathrm{r}$ e $\mathrm{s}$ dioiei. Mase. amentacei. Perigoninm tetraphyllum, foliolis minimis, membranaceis, aestivatione imbricatis. Stamina 2, libera; filamenta brevissima; antherae biloculares, loculis appositis, longitudinaliter dehiscentibus. $\mathrm{F} \mathrm{em}$. in racemis axillaribus brevibus. Perigon in mexaphyllum, foliolis biseriatis, integris $v$. interioribus trilobis. Ovarium liberum, biloculare. Ovala in loculis 2, collateralia, e dissepimenti apice pendula, laminis e placenta pro singulo ovnlo late prominentibus mieropylen superam velantilus, hasi villis e loculi fundo surgentibus immersa. S $\mathrm{tig} \mathbf{m}$ a $\mathbf{t a} 4$, sessilia, fimbriata. Fructus ..... - Arbores indicae; foliis alternis, petiolatis, coriaceis, glabris $v$, villosis, stipulis membranaceis, junioribus gemmas velantibus.

Scepa Lindley introduct. ed. II, p, 441, L e pidos tachys villos a Walleh Catalog, $n$, 7298.

1895. Lepidostaehys $W A L L$. F lores dioici. M a s c. amentacei. Perigonium pentaphyllum, foliolis minimis, membranaceis, aestivatione imbricatis. Stam in a 5, libera; filamenta brevissima; a ntherae bilocnlares, loculis appositis, longitudinaliter dehiscentibus. F e m. in racemis axillaribus, brevibns. Perign nium te- tra-hexaphyllum, foliolis biseriatis. Ovarium liberum, biloculare. $O \mathrm{vaI}$ a in loculis 2, collateralia, e dissepimento prope apicem pendula, lamina conductrice pro singulo ovulorum pari late prominente, micropyles superas velante. $\mathrm{S}$ ti g mata 2, sessilia, emarginata, integerrima. C a p su la suhglobosa, bilocularis, quadrivalvis, endocarpio tenui, rigido, a sarcocarpio friabili secedente. Semina in loculis bina $\mathbf{v}$. saepius abortu solitaria, axillo succulento involnta. E mbryo viridis, in axi albuminis carnosi orthotropus; cotyledonibus planiusculis obovatis; radicula umbilico proxima, supera. - Arbor indica; foliis alternis, petiolalis, coriaceis, integerrimis, glabris, stipulis falcatis, ciliatis.

Le pidostach y s Wallich Catalog. n.6816. excl, reliq. Lindley introduct. edit, II. p. 441. A I a us d i o c a Roxb Flor Ind, III, 580 .

189D. Hymendeardia $W A L L$. F Iores monoici? dioici? M a s c. in amentis sessilibus. Perigon i um diphyllum. Stam in a 5, monadelpha; antheris oblongis, basi acntis. Fem. fasciculati, gemmacei. Perig oninm quinquepartitum. Ovari un liberum, biloculare. Ovula in loculis 2, collateralia, appensa, basi attennata et post foccundationem dilatata. Stigm a $\mathrm{t}$ a 2 , sessilia, setacea. Fructus compressus, membranacens, bialatus, bilocularis....... Arbor indica; foliis alternis, petiolatis, oblongis, integerrimis, junioribus villosis, adultis glabriusculis.

H y men ocaridia Wallich Calalog n. 3549, Lindley introduct, edit, II. p. 441.

\section{**** GARRYACEAE.}

1900. Garrya DOUGL. Flores dioici, in amentis axillaribus, elongatis, intra bracteas decussantes connatas, ternati. M a 8 e. P e rig o n i n m calycinum, tetraphyllum, folioiis linearibus, patentibus. Stamina 4 , perigonii foliolis alterna et breviora; fil am e $n$ t a libera, aequalia; antherae introrsae, biloculares, basifixae, loculis oppositis, longitudinaliter dehiscentibus. F e m. Perig on iu m cum ovario connatum, limbo supero, bilobo, lobis setiformibus, brevissimis. O v a $r \mathbf{i}$ u $m$ inferum, uniloculare. Ovula 2, collateralia, fnniculis brevibus cavitatis apici appensa, anatropa. Styli 2 , perigonii lobis alterni, subulati, basi connati, intus juxta totam longitudinem stigmatosi. Fructus baceatus, stylis persistentibus superatus, unilocularis, dispermns. S e m in a 2 , pendula, oblonga; testa tennis transversim rugosa, $r$ a $p$ h e elevata laterali ad chalazam apiealem exeurrente. A I bumen copiosum, earnosum. Em bry o minimus, orthotropus, axilis; cotyled on ibus 2 , germinatione hypogaeis; radicula supera. - Frutex californicus; ligno ezonato, ramulis telragonis, foliis oppositis, breve petiolatis, integerrimis, penninerviis, sempervirentibus, petiolis basi coadunatis, stipulis nullis.

Ga rry a Douglas ex Lindley in Bot. Rog. $t, 1686$.

OBSERVATIO. Garryne, obscurae omnino aftinitatis, ligaum, monente cl. Li ad ley, zonas nullas ostendit concen. tricas, sed maxima exparte constat e tubulis liguosir, graunlis olivaceo-fuscis punctatis, qui circa medullam copiosam, in lamellas processubus medullaribus crassis separatas radiatim dispositi sunt, vasis paucis annularibus retieulatisve inter liguum sparsis, pnactatis nullis interjectis. Affinitate proximam ceaset Garryam $\mathbf{C}$ up u liferis et $\mathbf{C}$ hlorantha. c e is, ab bis perigonil praeseutia et stipularnm defecta, ab IIlis trunci ezonati structura, foltis oppositis et perigonio femineo sapero distinctam. Nobis stamina perigonii lobis alteraa imprimis paradoxa sunt. 


\section{Ordo XCVII. Plataneate.}

PLATANEAF Lestiboud. ex Martius Hort, Monac, p. 46. Martius consp. 12. PLATANACEAE Liadley introduct, edit. II. p. $18 \%$.

Arbores saepius elatae, succo aqueo; f o$1 \mathrm{i}$ is alternis, petiolatis, palminerviis, palmatilobis. Stipulae nullae. Gemmae intra petioli basim latentes.

Flores monoici, masculi et feminei in diversis ramulis, super receptacula globosa, lateralia et terminalia dense conferti.

Mas culi. Perigonium nullum.

Stamina plurima, squamis subclavatis (staminibus abortivis) irregulariter mixta, dense conferta. Fil a m enta brevissima; antherae biloculares, loculis oblongis, connectivo-subclavato, apice peltatim truncato subapposite adnatis, contiguis, longitudinaliter dehiscentibus. Pollinis granula globulosa.

Flores feminei. Perigonicm nullum.

Ovaria plurima, inverse conica, dense conferta, sterilia squamaeformia fertilibus mixta, basi pilosa, unilocularia. Ovulum unicum v. gemina superposita, e pariete styligera pendula, filiformia, orthotropa, micropyle infera. Stylus subliteralis, elongato-subulatus, apice hine stigmatusus.

Nucula coriacea, basi pilis articulatis papposis prurientibus stipata, unilocularis, monosperma.

Semer oblongo-cylindricum, pendulum. Tes t a tenniter membranacea, u mbili c o obsolete piloso.

Embryo in axi albuminis parce carnosi antitropus; cotyledonibus planiusculis, ellipticis; radicula longa, cylindrica, infera.

Plataneae in As i mediterranea et in A meriea boreali indigenae, Balsamifluis proxime affines, ab Artocarpeis succo aqueo, et seminis structura longius distant.

1901. PIatamus LINN, Fl or e 8 monoici, super receptacula globosa conferti. Perigon i m nullum. M a $8 \mathrm{c}$. S t am in a plurima, squamis subclavatis mixta; filam enta brevissima; antherae biloculares. Fem, Ovaria plurima, inverse pyramidata, squamis mixta, unilocularia. Ovulum solitarium, v. 2 superposita, parieti appensa, orthotropa. Stylus sublateralis, elongatosubulatus, hinc stigmatosus. Nucula e coriaceae, basi papposae, monospermae. Semen pendulum. Embryo in axi albuminis parei carnosi antitropus; radicula infera. - Arbores $v$. frutices; foliis allernis, palminerviis, palmatilobis, estipulatis.

P I a ta n us Liau. gen. n. 1075. Gärtu, $T$. 57. t. 90. Nees jun. Gen, plant. II, 17. Moricaud Plant. Americ, $t, 13$.

\section{Drato XCEPIII. Balsannöfune.}

BALSAMIfLUAE Blume Fl. Jav, fasc, XVII, XVIII.

Аввоrкs procerae, e cortice succos balsameos stillantes, ramis alternis. Foli a alterna, petiolata, integra v. lobata, glanduloso-serrata.
Petioli basi stipulis geminis, fugacibus muniti. G e m m a e florales terminales, squamosae, foliis praccociores.

Frores in amentis unisexualibus monoici. Involucrum tetraphyllum, caducum; foliolis concavis, per aestivationem imbricatis.

AMENTa ma scula conica, elongatav. subglobosa, interdum subramosa, laxiuscula.

Stamisa plurima, squamulis minutis intermixta. Filam enta brevia, subulata, distincta, inter antherae loculos transeuntia. A nth e r a e majusculae, oblongo-didymae, biloculares, loculi oppesiti, filamento infra apicem adnati, longitudinaliter dehiscentes.

Amexta feminea globosa. Squam ulae parvae, numero indefinitae, ovariis circumpositae, plus minus inter se coalitae, demum increscentes.

Ovarie a biloculare, e carpidiis duobus conflatum, carpidiorum marginibus introflexis dissepimentum constituentibus. $O \mathrm{v}$ ul a plurima, dissepimento alfixa, amphitropa. Styli duo, carpidiis continui, elongati, subulati, primum approximati, demum divergentes, recurvati, intus Jongitudinaliter papilloso - stigmatosi.

Capsulae squamulis coalitis, apice induratis inclnsae, in strobili speciem connatae, obcordato-subbilobae, coriaceae, biloculares, stylorum basi persistente rostratae, inter stylos longitudinaliter introrsum dehiscentes.

Skmisa ovulis plerisque abortientibus pauea perfecta, compressa, margine membranaceo angusto, plus minusve completo cincta, dissepimento peltatim affixa. T'esta membranacea in marginem producta, cum endopleura arcte cohaerens. Albumen parcum, cartilagineum.

Exbryo rectus. Cotyle d ones foliaceae. R a di cula parva, verticem fructus spectans.

Ordo perparvus, unico adhucdum genere comprehensus, cujus tres species innotuerunt, quarum una A mericam borealeam, altera $m$ inorem Asiam incolit, tertia ex insula Java in Cochinchinam et maris rubri insulas evagatur.

Truncus et ramuli incisi v. igne cocti resinam largiuntur balsameam, Balsamo peruano suecedaneam, inter pharmaca stimulantia, aromatica receptam.

Balsamifluae hinc Plataneis, illine Salicineis proxime affines, embryonis radieula supera facillime distinguuntur.

190\%. Ihioguidambar LINN. Flores in amentis unisexualihns, involur.ro tetraphyllo, caduco cinctis, monoici. Amenta ma$8 \mathrm{eul}$ a conica v, suluglobosa. Antherae plurimae subsessiles, axi communi insertae. Amenta feminea subglobosa, e squamulis minutis ovaria cingentibus, inter se coalitis, demnm increscentibus. Ovariu miloenlare. $O \mathrm{vula}$ in dissepimento plurima, amphitropa. Styli 2 , subulati. Capsula e obcordato-bilobae, biloculares, 
in strobili speciem coalitae, inter stylos dehiscentes. Semina panca, peltata. E $\mathbf{m}$ b r y o in axi albuminis parci cartilaginei rectus; cotyledonibus foliaceis; radicula supera._Arbores foliis alternis, petiolatis, integris $v$. lobatis, glanduloso serratis, stipulis ad basim petiolorum geminis, amentis terminalibus racemosis, femineis in racemo paucioribus, inferioribus longius pedunculatis, pendulis.

Liquid a m b a r Linn. gen, n, 1076. Gïrtn. II. 57. t. go. Schkulir $t, 30 \%$. Michaux Arbr. III, $t, 4$. Nees Pl. offic. Suppl. II, t, 12, Blume Flor. Jav. fase. 17, p. 6, t, 1, 2, A1tingi a Noronh. in Batav. Verhandl. V.1 10.

\section{Drdo XCIX. Salicineae.}

AMENTACEARUM genera Juss. 407. SALICINAF L. C. Richard msc. A. Richard Elem, edit, $N$. p, 560, Bartling Ord, nat. 119, Lídley introduct, edit. Ir. p, 186.

Arbores excelsae $\mathbf{v}$. Frutices humiles, $r$ a$\mathrm{m}$ is alternis, teretibus. Foli a alterna, simplicia, integra, integerrima v. saepe serrata aut dentata, penninervia, in petiolum attenuata, decidua. Stip u l a e squamosae, deciduae, v. foliaceae, persistentes.

Flores dioici, in amenta in ramulis terminalia dispositi, singuli sessiles v. breviter pedicellati, bractea membranacea persistente, integra v. lobata suffulti.

Flores masculi. Perigoniom nullum. T orus in glandulam, annulum v. ureeolum oblique truncatum tumens.

Stamina e centro tori exserta, duo v, saepius plurima. Fil am en $t$ a filiformia, libera v. saepius basi, nonnunquam juxta totam longitudinem monadelpha. Antherae biloculares, basifixae; loculi appositi, paralleli, connectivo obliterato contigui, longitudinaliter dehiscentes. Ovarii rudimentum nullum.

F lo re s feminei. Perigonium nullum. Torus glandulaeformis v. urceolatus.

Ovarium liberum, sessile, e carpidiis duobus conflatum, carpidiorum marginibus valvatim connatis v. plus minus inflexis, nec tamen axim idealem attingentibus uniloculare. Placent a e lineares, breves, carpidiorum axi prope basim adnatae, Ov ul a plurima, adscendentia, anatropa. Styli duo, brevissimi, plus minusve inter se connati, singuli stig mat e bi-trilobo terminati.

Capsula unilocularis, bivalvis, polysperma, valrulis apice solutis, demum revolutis, basi medio seminiferis.

Semina plurima, erecta, minima. Tes ta membranacea. Umbilieus basilaris, truncatus. Funi culus brevissimus, crassus, in comam lanuginosam adscendentem, totum semen obvolventem fatiscens. Album en nullum.

Emaryo orthotropus. Cotyled ones plano convexae, ellipticae. R a d i cul a minima, basim fructus spectans.

S a li cin e a e diu cum reliquis Juliflorarum ordinibus amentaceis confusae, fructus et seminis fabrica distinctissimae, optime monente cl.
B a rtling, cujus deseriptionem ordinis mutatis paucis recepimus, Tam aris cine is fortassis propiores sunt quam A mentaceis. Nobis etiam Proteaceis aliquatenus affines esse videntur.

In temperatis et frigidiusculis $\mathrm{h}$ e $\mathrm{m}$ is $\mathrm{ph}$ a erae borealis utriusque continentis $\mathrm{Sali}$ cis imprimis species numerosis formis luxuriant, botanicorum crux et scandalum. Nonnullae species, adeo humiles ut herbaceas dixerint, extremum septemtrionem et summas alpes incolunt, pancae in A frica mediterranea et tropica, nec non in Indiae continente reperiuntur. Nonnullae in America a equinoctiali vivunt, quarum una late diffusa, etiam trans Capricornum observata fuit.

Populi Europam mediam et australem, nec non Afric am mediterraneam parce inhabitant, majori copia in A meric a s e p te mtrionali vigent, alibi non visae.

Principium peculiare adstringens febrifugum (Salicin) e Salicum cortice chemia recentior elicuit; Populi plures resinam plorant balsameam. Vis vitalis in omnibus ordinis stirpibus ingens.

1993. Sallix TOURNEF. FIores dioici, amentacei. M a s c. Amenti bracteac indivisae. Perigonium nullum. Tor us glandulaeformis. Stam ina $2,3-5$; fil amenta libera v. basi cohaerentia, rarissime in colnmnam connata, F em. Amenti bracteae indivisae. Ovari um uniloculare. Ovula in placentis prope basim parietalibus plurima, anatropa. St ylus brevissimus; stigmata 2, biloba, Ca p s ni a unilocularis, bivalvis, valvis prope basim medio seminiferis. Semin a plurima, erecta, comosa. Em b r yo exalbuminosus, orthotropus; r a di eula infera. - Arbores procerae $v$. frutices, in locis editis alpium depressi, repentes, in temperatis et frigid is $h$ emis phaerae borealis magno numero fluviorum et amnium ripas, et uda montium loca innumera grege accolentes, in Africa mediterranea, tropica et australi, in India orientali et America tropica et extratropica australi parce habitantes; foliis alternis, integris, serratis $v$. integerrimis, stipulis foliuceis persistentibus, $v$. squamaceis deciduis, gemmis squama simplici tectis, folia plano-imbricata foventibus, amentis sessilibus $v$. pedunculatis, coaetaneis aut praecocibus.

S a lix Touruef. inst. 365. Lian. gen, n. 1097. Gärtn, II. 56. $t, 90$. Schkuhr, Handb. $t, 317$. Humb. et Boupl, Pl, aequinoct. t. 29 - 102. Mirbel in Mem, du Mus, $X I V, t$. 20. Heffmann, $\mathrm{Hi}$ storia Salicum. Lipsiae, 1785 , fol. Seringe, Monographie des Saules. Berne, 1815. 8. Dnmortier, Verhandeling over het geschlacht der Wilgen, Amsterd 1825. 8. Host, Salix, Nindobonae, 1828. fol. Koelt, de Salicibus europaeis commenta. tio. Erlangae, 1828. 8. M. Sadler, Synopsises Salicum Hun. gariae, Pesthint, 1831, 8. Nees jun. Gen.pl. IT. 15.

1904, Poprilus TOURNEF. Fiores dioici, amentacei. M a s c. Amenti hracteae laciniatae, fimbriatae. Perigoni um torus urceolaris, antice oblique productus. Stamina $8-12$, v. plura; filam en ta libera. F em. Amenti bracteae laciniatae, fimbriatae. Perigoni n m torus urceolaris, antice Iongior. $\mathrm{O} v$ a $\mathbf{r}$ i m uniloeulare. 
Ovula in placentis prope basim parietalibus plurima, anatropa. Stylus brevissimus; st i$\mathrm{g} \mathbf{m}$ a $\mathrm{ta} 2$, elongata, bipartita. C a p $8 \mathrm{ula}$ unilocularis, bivalvis, valvis prope basim medio seminiferis. S em i na plurima, erecta, comosa. Embryo exalbuminosus, orthotropns; radicula infera. - Arbores saepius excelsae, interdum pyramidatae, in Europa et America borealiobviae; foliis alternis, angulato - dentatis, stipulis squamaceis, deciduis, gemmis imbricato-squamosis balsamiferis, folia involuta foventibus, amentis praecocibus $v$ coaetaneis.

P o p I I s Tournef. inst. 365, Linv. gen, n, 1123. Schkuhr t. 330. Gärtn, II, 56, t.90. Nees jun. Gen, plant. IT. 16.

\section{SALICINEIS AFFINES. \\ * HeNslowiaceae LindI.}

1905. Henslowia WALL. FIo res dioici. Masc. Perig on i um caly cinum, urceolatum, quinquefidum, lobis aestivatione valvatis. S $t$ a m in a 5, disco glanduloso perigyno imposita, perigonii lobis alterna; filamenta filiformia, longa, aestivatione inflexa; antherae introrsae, biloculares, loculi connectivum latum, crassiusculum, truneatum oblique marginantes, longitudinaliter dehiscentes. Ovarii rudimentum. Fem. Perigonium maris. Discus.... Ovarium liberum, biloculare. Ovula in placenta erassinscula septo adnata plurima, horizontalia, anatropa. $S t y l u s$ terminalis, brevis, cylindricus; stigma convexiusculum, obsolete bilohum. Fructus ...... Arbusculae in India tropica indigenae; ramis oppositis, tetragonis, foliis opposilis, petiolatis, simplicibus, integerrimis, coriaceis, estipulatis, floribus minutis, dense racemosis, bibracteolatis.

Henslowia Wallich PI. As, rar. III. 14. t. 221. Griffith in Lindley introduct. edit. $M$. $p, 173$.

\section{Ordo C. Lacistemeae.}

LACistemeAe Martíus Nov, gen, el sp. $I$, 154. LACISTEMACEAE Lindley introduct. edit. II. p. 183.

ARBorRs v. FRUTices, distiche ramosi. F oli a alterna, simplicia, coriacea, integerrima $v$. obiter serrata, sempervirentia. S t i p ul a e membranaceae, deciduae.

Flores in amentis cylindricis axillaribus hermaphroditi v. abortu monoici, bracteis concavis coriaceis unifloris, bracte ol is que duabus lateralibus membranaceis, rarius quatuor verticillatis stipati.

Perigoniom profunde quadripartitum, subregulare, minimum, lacin i is acutis, erectis, saepe ciliato-serratis.

Disces subcarnosus, genitalia cingens v, anticus, interdum obsoletus.

Stauen unicum, hypogynum, anticum. Fila m e n tu m complanatum, erectum, apice bifidum, diantheriferum. A ntherae uniloculares, in filamenti cruribus sessiles, transversim subverticaliter dehiscentes.

Ovaвıо и liberum, sessile, ovato-subglobosum, bi-triloculare, v. septis incompletis uniloculare. Ovula e placentis parietalibus in mediis carpellis plura, pendula, anatropa. Sty- 1i $2-3$, in unum coaliti v. rarius distincti, brevissimi v. subnulli. Stig m at a distincta, subulata, reflexo-patentia.

Capsula in quovis amento unica v. paucae, perigonio persistente basi stipata, substipitata, unilocularis, bi - trivalvis, valvulis coriaceis $\mathbf{v}$. subcarnosis, medio placentas lineares gerentibus.

SEMEN in quavis valvula unicum v, rarius plura, e placentae apice pendulum. Tes t a crustacea; umbilico basilari cum chalaza apicali ope rhapheos, in arillum carnosum semen obvolventem tumentis, juncta. A 1b u m e n copiosum.

Eмввуо orthotropus, axilis. Cotyle don es planae, incumbentes. Rad i cula cylindrica, umbilicum attingens, verticem fructus spectans.

$L$ a $c$ is t e meae quoad veram affinitatem valde dubiae, sed certe a Piperitis longe alienae, Americae tropicae sylvas humidas, locis depressis, imprimis versus aequatorem inhabitant.

1906. Symzyganthera $R U I Z$ et $P A V$. F lores amentacei, abortu polygamo-monoiei. Bract e a e uniflerae, bracteolae quatuor verticillatae. Perigonium quadripartitum. D iseus hypogynus nullus. Stamen 1, antieum; filam ento bicruri, diantherifero. Ovarium triloculare. Ovula.... St igma t a 3 , subulata, C a p8 u la baccata, trilocularis, mono-trisperma. S emen.... - Frutex peruvianus; foliis alternis, oblongo-lanceolatis, acuminatis.

Synzygathera Ruiz et Pav. Prodr. 137. $t$, 30 , Didy ma $n d r$ a Willd. $s p . r V .971$.

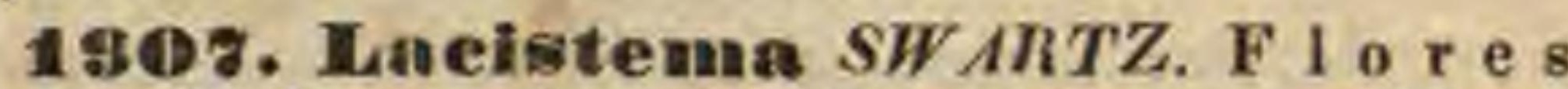
amentacei, hermaphroditi. B r a c t e a e uniflorae, bracteolae 2 , laterales. $\mathrm{D}$ is cus hypogynus carnosus. Stamen 1 , anticum; fil amento bicruri, diantherifero. Ovari $\mathbf{m}$ oniloculare. Ovu1 a plura, e placentis parietalibus pendula, anatropa. S ti g ma ta $2-8$, subulata. Ca p 8 ula unilocnlaris, ahortn tri-monosperma, trivalvis, valvulis medio - placentiferis. S e $\mathrm{m}$ i $\mathbf{n}$ a ex apice placentae pendula; $t$ e $8 \mathrm{t}$ a crustacea; $r \mathrm{~h}$ a $\mathrm{p}$ h $\mathrm{e}$ longitudinali in arillum semen obvolventem tumente. Embryo in axi albuminis carnosi orthotropus; cotyled onibus foliaceis; radienla supera. - Arbores $v$. frutices Americam tropicam incolentes; folits alternis, intcgerrimis $v$. obiter serratis, coriaceis, amentis axillaribus, aggregato-fasciculatis.

L a cis te ma Swartz Flor. Ind. occid, II. t. 21. Icon. t. 1. Kunth Synops. IV. 264. Martius Nov. gen, et sp. I. 156. $t, 94,95$, N e m a t o s p a r m u m L. C. Richard in 2 et. soc. h. n. Paris. I. 105. G n ille m in in Dict, rlass. XT. 499. Piperis sp. Berg. Aot. Helv. VIT. t. 10. Rudge Guian. i. 1.

\section{Classis XXVIr. Dleraceae.}

Herbar annuae v. perennes, rarius frutices v. arbores. Folia alterna v. rarius opposita, sessilia v. petiolata, simplicia, integra v. laciniata. Stipulae nullae $v$. in vaginam amplexicaulem coalitae. Flores saepissime typice 
hermaphroditi, haud raro abortu unisexuales, rarius sexubus typice diversis. P e r i g o n i $\mathbf{~ m ~}$ calyciforme v. coloratum, foliolis liberis v. plus minus inter se coalitis, regulare. $\mathrm{Ov}$ a ri u m unicum, uniloculare. $0 \mathrm{v} u \mathrm{lum}$ unicum, rarius plura, placentae basilari inserta, amphitropa v. orthotropa. Fructus utricularis v. nucamentaceus, nudus v. perigonio varie mutato stipatus, interdum etiam cum illo concrescens. S e$m$ in a albuminosa $v$. rarius sub maturitate exalbuminosa. Embryo rectus antitropus, v. homotropus curvatus, interdum spiralis, excentricus, albumen cingens aut involvens, v. intra illud lateralis, rarissime centralis; $\mathrm{radicula}$ infera, supera v. centrifuga.

Classis satis naturalis, directa serie in Caryophyllinas abiens, quas inter ordines apetali carpellorum circa axim centralem pluralitate typica, etiam in monocarpicis styli insertione sublaterali manifesta, distinguuntur.

\section{Ordo CI. Chenopodene.}

ATRIPLICES Juss, gen. 83. CHENOPODEAE Vent. Tabl. II. 253. DC. Fl. fr. IIT. 380. R. Brown prodr. 405. Bartling Beitr. II. 14t. Ord, nat. 296. C. A. Meyer in Ledebour Fl. Alt, I. 370. Moquin Tandon in Annal, sc, nat. XXIII. 207. 274, Nouv, Annal, I, 203. IV, 209. Liudley introduct, edit IT. 208.

Herbae annuae v. perennes, interdum frutescentes, radicibus fibrosis v. napiformibus. C a ule s continui; teretes v. angulati, foliati, erecti v, rarius volubiles, interdum articulati, aphylli. Folia alterna v. rarius opposita, interdum vermicularia, carnosa, nunc plana dilatata, simplicia, integerrima v. dentata, aut irregulariter incisa, sessilia v. petiolata. S tip ulae nullae.

Flones inconspicui, hermaphroditi v. aborta polygami, interdum etiam typice diclines, regnlares, nunc axillares solitaril v. glomerati, nune paniculati, cymosi v. spicati, nudi v. bracteati, rarissime etiam bibracteolati.

Perigoniou calycinum, saepissime tri-tetra-pentaphyllum, in floribus typice femineis diphyllum, foliolis rarius liberis, plerumque plus minus coalitis, quadri-quinquefidum, persistens, post anthesim saepius mutatum, increscens, siccum v. baceatum, foliolis demum haud raro carinatis v. dorso transversim appendiculatis aut spinescentibus.

Stausa numero partium perigonii, isque opposita, interdum per abortum pauciora, nunquam plura, receptaculo v. basi perigonii mediante disco ejusdem parieti adhaerente, plus minus manifesto inserta. Fil a $\mathrm{m}$ en $\mathrm{ta}$ filiformia v. subulata, libera, perigonio raro longiora. An the ra e introrsae, biloculares, ovatae voblongae, basi v. dorso aflixae, longitudinaliter dehiscentes. Squamula e hypogynae nullae, v. in paucis generibus staminibus alternae.
Ovariom ovatum v. oblongum, verticaliter compressum v. horizontaliter depressum, uniloculare, liberum v. rarissime primitus basi cum perigonii tubo cohaerens. O vulu m unicum, placentae basilari insertum, v. ex funiculo brevi pendulum, amphitropum ; micropyle basim, verticem v. ambitum ovaril spectante. $\mathrm{Sti} \mathrm{gm}$ a ta 3_4, libera, filiformia, omnino distincta $\mathbf{v}$. basi in stylum plus minus manifestum connata.

Fnoctos perigonio plerumque varie mutato, interdum baccato stipatus, inclusus v. etiam connatus, utricularis, compressus v. depressus, evalvis v. rarissime operculatim dehiscens, pericarpio ut plurimum membranaceo, rarius coriaceo $v$. interdum etiam baccato.

SEMEN unicum, verticale erectum v, inversum, aut horizontale decumbens, reniforme. 'T'esta crustacea, atra v. fusca, endopleura membranacea, v. t esta membranacea, endopleura haud manifesta. Alb ume n farinaceum, copiosum, parcum v. interdum sub maturitate evanescens. Embryo homotropus annularis v. bicruris periphericus, albumen plus minus complete cingens, radiculae apice albuminis ambitn absoluto interdum exserto; v. plano-spiralis, albuminis massas duas segregans, $v$. albumine omni consumto spirali-conicns (cochleatus), radicula extimum gyrum conficiente, dorsali v. marginali, basim aut rarius apicem, in semine decumbente ambitum fructus spectante, umbilico proxima.

Chenopodeae hinc Amarantaceis conterminae, illinc inter Caryophyllinas S cl eranthaceis, Paronychieisque analogae, pelagi et lacuum salsorum littora, et deserta olim undis marinis tecta praediligunt, in $\mathbf{r}$ e g $\mathbf{~ o -}$ ne mediterranea et Asia rossica imprimis capiosae. Aliae circa ruderata et hominum domicilia sedem figunt, montes salutusque exhorrentes, nullibi longius a mortalium consortio evagantes, in regionibus tropicis, quas affinium Amarantacearum gens magno incolit numero, in universum rarae.

Plurimae sudant salem, aliae oleo essentiali scatent, nonnullae per omnem vitam gaz ammoniacum exhalare dicuntur, aliarum rires anthelminticae et emeticae celebrantur. Non paucae ob herbam v. radices edules ubique coluntur.

SUBATID I. CYCLOLOBEAE C. $\mathbf{A}$. Meyer in Ledebour Flor. Alt. I. 369 . $\mathrm{E} \mathrm{m}$ b r y 0 annularis v. hippocrepicus. $\Delta 1$ b u m en plus minus copiosum, centrale.

TIRIEUS I. SALICORNIEAE C. A. Meyer in Ledebour Flor. Alt. 1. 371. Flores hermaphroditi v. polygami, conformes, ebracteolati, spicati. Squamula e hypogynae nullae. Seminis verticalis testa membranacea. Caulis articulatus. 
1909. Salieornia TOURAEF. Flores hermaphroditi v. abortu polygami, rhacheos excavationibus immersi, ad quensis articulum terni, decussatim oppositi, ebracteati. Perigonium monophyllum, utrienlato-peltatum, medio apertum, rima denticulata, demum fungosum. S $t$ a $m$ in a 1 2 , receptaculo inserta. S $q u$ a $m u l a e$ hypogynae nullae. Ovarium ovatum, uniloculare, uniovulatum. St igm a $t$ a 2 , basi coalita, indivisa v. lacinulata. Utriculus compressus, tenuissime membranaceus. Semen verticale, rostellatum; t est a membranacea, pubescente. Embryo hemicycli cus, periphericus, a I b u me n farinaceum, pareun cingens; radioula infera:-Plantae in litloribus maris et lacuum subsalsorum totius or bis provenientes, inter tropicos rariores, articulatae, herbaceae v. fruticosae, glabrae, aphyllae, succulentae; ramis oppositis, articulis basi vagina brevissima cinctis, florum spicis terminalibus

Sali e ornia Tournef. inst. 485. Linn. gen. n. 10. excl. sp. Sebkulir t. 1. Fl. dan. $t$. 303, 1621. Pallas Illustr. $t .1$ 9. f. 1. t. 3. 6. 7. C. A. Meyer in Ledebour Fl, Alt, I. \&. Nees juи. Gen. $p l$. $I$. 68 .

1809. II aloen enuma BIEBERST. F 10 res hermaphroditi, sub amenti bracteis decussatim oppositis bini v. terni. Perigon in m triphyllum, foliolis squamaeformibus adpressis, demum hand mutatis. Stamen 1, receptaculo insertum. S qu amulae hypogynae nullae. Ovarium ovatum, uniloculare, uniovulatum. Sty Ins simplex, apice bi-trifidus. Utricalus compressus, laxe membranaceus. S e m e n verticale, rustellatum ; $t$ es $t$ a micmbranacea. E $m$ bryo hemicyclicus, periphericns, a I b $\mathrm{n} \mathrm{m}$ e $n$ farinaceum, parcen cingens; ra di cula infera. - Fruticuli littorales articulati, glabri, aphylli; floribus in amenta terminalia collectis.

Halo enein un Bieberst. suppl. 3. C. A. Meyer in Ledebour Flor. Alt. I, J. S ali c ornfa e sp. Pallas Mllustr. t. 4. Gärtn, t. 127.

TIR I I IIS II. ATRIPLICEAE C.A.Meyer in Ledebour Flor. Alt. I.371. F 1 o res polygami, ebracteati; perigonio masculo a femineo diverso. Squamulae hypogynae nullae. Seminis verticalis, v. rarissime in floribus bermaphroditis horizontalis, testa crustacea v. membranacea. - Caulis continuus.

1910. Ceratoearpus $B U X B$. Flores monoici axillares, masculi aggregati, brevissime pedicellati, feminei solitarii, sessiles, ebracteati. Masc. Perigonium hyalinum, tubnlosum, apice bilobum, lobis earinatis, obtusis. Stamen 1 , receptaculo insertum, exsertum. Squamulae nullae. F em. Peri gon i um ealyeinum compressnm, a pice bilobum, lobis carinatis, setaceis, demum reclusis in cornua exerescentibus. O $\mathrm{r}$ ari $\mathrm{n} \mathrm{m}$ oratum, uniloculare, uniovulatum. Styli 2, setacei. Utriculus membranaceus, compressus, perigonio cuneiformi omnino clausn, lobis excreseentibus divaricatis setaceo-bicornuto reclusns. Semen verticale, compressum, ovato-oblongum; t e sta membranacea. E mbry o hippocrepiformis, peri pherieus, al bumen farinaccum cingens; radi e ula infera. - Herba annua, in arenosis Asiae me dia indigena, divaricato-ramosissima; foliis alternis, anguste lanceolatis, integerrimis, floribus maseulis in ramulorum divisionibus brevissime pedicellutis, quaternis $v$. quinis, femineis in foliorum axillis solitariis, sessilibus.

Ceratocarpus Buxbaum in Comment. Pelropolit. $I$. 246. t. 9. Linu. gen, n. 1035. Guldenstaedt in Nov. Com. ment. Petropolit, XYI. 553. t, 17. f. 7.,12. Gartn. II, 209. t. 126. C. A. Meyer in Ledebour Flor. All. IV. 198.

1911. Eurotia $A D A N S$. Flores monoi ci, masculi spicati, feminei axillares, sessiles, ebra. cteati. Mase. Perigonium quadripartitum, la ciniis aequalibus, inappendiculatis. Sta mina 4 , receptaculo inserta, perigonii laciniis opposita Squamulae nullae. Fem. Perigoninm tubulosum, sentibifidum, dense villosum, demum bicorne. Ovarium ovatum, uniloculare, uniovulatum. Stigmata 2 , filiformia, exserta. Utric n ln : compressns, herbacens, villosus, perigonio persistente inclnsus. Semen verticale, compressum, ovato-oblongum; testa membranacea. Embry hippocrepiformis, periphericus, a lb $\mathbf{~ m e n}$ farinaceum cingens; radicula infera. - Fruliculi erecti, pube stellata vestiti, in aridis $\bar{E} u r$ op a $e$ orientalis et Asiae mediae provenientes; foliis alternis, petiolatis, membranaceis, oblongis, integerrimis.

Burotla Adans. Fam. IT. 260. C. A. Meyer in Ledebour Flor. Alt, IV. 238. D i otis Selireber gen, n, 1423. Nees jun. Gen. pl. M. 65. C e ratos p e $r$ mu m Person Sy. nops. II. 552. G u I de rs taed ia Neck. elem, II. 204. Kras e heninniko via Gúldenstaedt in Nov. Comment. Petro. polit, $X V I, 545$, et $555, t, 17, f, 1 \_6$, et $f, 13$. A x y ri s ce ratoides Linn. Gartn. $t$. 128. Lam. $t$. 253. $f$. 1 .

1913. Atriplex LINN. F lores polygami, mono-dioici, masenli et hermaphroditi femineis mixti, ebracteati. Herma $p$ hr. et Mas c. Perigonium tri-quinquepartitum, laciniis aequalibus, inappendieulatis. Stam in a $3 \ldots 5$, receptaculo in serta, perigonii laciniis opposita. Squamula e nullae. Ovarium depressum, saepins abortivum. UtrienIus depressus. S e m e $n$ horizontale. F em. Perigoni am diphyllum, compressum, foliolis liberis v. plus minus inter se connatis. Ovari um ovatum, compressum, uniloculare, uniovu latum. Stigmata 2, filiformia. Utriculus mem branacens, compressus, perigonio aucto, saepissime muricato verrucoso inclusus $\mathbf{v}$, partim adnatus. Sem en verticale; test a coriacea $v$, snberustacea. E m b r 0 annularis, periphericus, a 1 b nme $\mathbf{n}$ farinaceum includens; $\mathrm{r}$ a d i e $\mathrm{a}$ la infera adscendente v. supera exserta. - Herbae annuae $v$, suffrutices, in regionibus temperatis totius orbis obvii, saepissime squamulis membranaceis lepidoti; foliis sparsis v. oppositis, petiolatis rariusve sessilibus, di lulatis, planis, integerrimis v. sinuatis, floribus sessilibus $v$, rarissime pedunculalis.

A triplex Linv. gen. n. 1153. R. Brown, prodr, 406 C. A. Meyer in Ledebour Flor. Alt. IV. 304.

a. EUAtripleX $C$. A. Mejer. Flo res polygami. Perig o uii feminei foliola libera, integerrima, fructifera laevia, utriculam includentia. Se $\mathrm{min} i$ s te $\mathrm{t}$ a suberustacea. $\mathrm{R}$ a dic u la infera, sublateralis, vix adscendens.

Euatriplex C. A. Meyer l. c. (Gürn, $t, 75, f$. 8. infer. Schhuhr $\iota, 349$. Nees jus. Gen. $p l, I T, 63, f$. 18_21.)

b. SCHZOTHECA $C, A$. Meyer. Flores monoici. Peri go ni i feminei foliola basi connata, deuticulata, fruetife ra saepius muricata, utriculum ineledentia. Semin is testa coriacea. R a d i cula lateralis, adscendens.

Sehizotheca C. A. Meyer 2. c. (Gírth. 2. c. fig. super. Schkuhr t. 347. 348. 350. Nees jon. l. e. f. 1 - 17. Ledebour $Y c, t, 41-43,46$.

e. OBIONE Gärtn. Flares atonoici v. dioici, Perigan í feminei follola basi connata, fruetifern snbbaceata, nuricata, utriculum includentia. S e $\mathrm{m} i$ ii is testa subcrustacea. $R$ a dic u la supera, exserto-porrecta.

0 b i o ne Gärtu. II. 198. t. 126. C. A, Meyer l. e. Atrk plex sibiricum Linn. Sehkuhr 4. $\mathbf{1 5 0}$.

d. HALIMUS. Wallr, Flores monoici. Perigonii feminei foliola juxta totam longitudinem connata, apice triloba, fructifera muricata, basi cum utrieulo concrescentia. 
Seminis testa membrauacea. Radicala sapera, exser. to- porrecta.

Halim us Wallroth Sched, crit, 117. Nees jun. Gen. pl. II. 64. C. A. Meyer $l$. o. A tríplex peduneula. t u m Lian. Sehkuhr $t$, 149.

1913. Axyris LINN. F lores monoici, masculi terminales, spicati, ebracteati, feminei axillares, bracteolati. Masc. Perigon ium tri-quadripartitum, laciniis aequalibus, inappendiculatis. Stamina 3 4, receptaculo inserta, perigonii la ciniis opposita. Squa mula e nullae. Fem. Pe rig on ium triphyllum, foliolis aequalibus, Ova ri um ovatum, uniloculare, uniovulatum. Stig mata 2, filiformia. Utri culus compressus, membranaceus, perigonio immutato inclnsus. S eme n verticale, compressum; test a crustacea $\mathbf{E}$ mbr yo hippocrepiformis, peripheriens, a $1 \mathrm{~b}$ u me n farina ceum cingens; r a d i $\mathrm{c}$ u a infera. _ Herbae annuae, ramosae, pube stellata canescentes, in $A s i a m e$ dia indigenae; foliis alternis, petiolatis, planis, dilatatis, integerrimis.

A x y r is Linn, gen, n, 1047, excl. sp. Schkuhr t, 285. 6. Lam. $t .753$. C. A. Meyer in Ledebour. Flor. Alt. IP. 237.

1514. Aenida MITCH. Flo res dioici ebracteati. Masc. Perigon i um pentaphyllum, laciniis aequalibus, inappendienlatis. Sta m in a 5 receptaculo inserta, perigonii laciniis opposita. Squamnlae nullae. Fem. Perigonium triphyllum, foliolis aequalibus. Ovari um ovato. oblongum, tri-pentagonum, uniloculare, uniovula tum. Stigmata 3 v. 5 , linearia, revoluta. A ch eni um tri-pentagonum, perigonio persistente basi stipatum. Sem en verticale, compressum; test a crustacea. Embry o hippocrepiformis, periphericus, a lb nmen farinaceum cingens; radicula infera. - Herbae boreali americanae, subpaludosae; foliis alternis, oblongo-lanceolatis, integerrimis, racemis axillaribus, fructiferis nutantibus.

A cuida Mitchell Gener, 28. Lian. gen, n, 1t14, Gärtu. II. 197, t. 126. Michaux Flor. Bor. Amer. IT. 233, t. so.

1515. Spinaneia TOURNEF. F In res dioici, ebracteati. M a s c. Perig on i m tetra-pentaphyllum, foliolis aequalibrs, inappendiculatis. Stamina 4 v. 5 , receptaculo inserta, perigoni foliolis opposita. Squam u I a e nullae. Fem. Pe rigon ium ventricoso-tubulosum, bi-tridentatum. Ovari u m ovatum, uniloculare, uniovulatum. St yI us brevissimus; stigmata 4 , elonirato-filifor mia. A chenium perigonio turgido, immutato $v$. dorso tri-bicornuto inclusum. Sem en verticale, rostellatum, compressum; testa membranacea. Embryo annularis, periphericus, a l b a men farinaceum cingens; radien la infera. - Herbae orientales, ab Arabibus primum in $H_{i}$ spaniam introductae, nunc ubique inter olera cultae; foliis alternis, hastatis, angulato-dentatis, floribus axillaribus, glomeratis

S pin a e i a Tournef. inst, 308, Linn. gen, n. 1112. Selikuhr t. 324. Gírtn. II. 198, t, 126, Gleichen. Pflanzenr. $t$, 25. Nees jü. Gen. pl. II. 66 .

TRERES ITI. CHENOPODIEAE C. A. Meyer in Ledebour Flor, Alt, I. 371. Flores hermaphroditi v. polygami, ebracteolati v. rarissime bibracteolati, conformes. $\mathrm{S} q \mathrm{q}$ a $\mathrm{m} \mathrm{u}-$ lae hypogynae nullae. Seminis verticalis v. horizontalis test a crustacea v. membranacea. - Caulis continuus.

SUR'TRIBUS T. CAMPHOROSMEAE. Flores ebracteolati. Seminis verticalis tes ta membranacea.
1916. Camploorosma LINN. Flores hermapluroditi. Perigonium quadrifidnm, laciniis duabus majoribus carinatis, demnm haud mutatis. St a min a 4, imo perigonio inserta, ejusque la ciniis opposita. Squamula e hypogynae nullae. O v a r i m compressum, unilocnlare, uniovnlatum. St y lus bi-trifidus, laciniis setaceis. Utri,cul n s membranacens, compressus, perigonio hand mutato inclusus. Semen verticale, compressum; t esta membranacea. Em b r yo annularis, peripherieus, a l bumen pareum, farinaceum inelutens; $r$ a d $i_{\text {- }}$ cula infera. - Herbae v. suffrutices in Europae australioris et Asiae mediae aridis subsalsis provenientes, ut plurimum pilosae; foliis linearibus aut subulatis, alternis v. fusciculatis, floribus axillaribus glomeratis, ebracteatis.

Cha in phoros ma Linn. gen, n. 164. Gärtn. f. IIT, 175. t. 213, (mal.) Lam. t. 86. Sebkuhr t. 26. Waldst, et Kit. Pl. Itung. I. 63. C. A. Meyer in Ledeb Fl. Alt. I. 150. Nees jua. Gen. pl. II. 60. C a m p h or a ta Mönch. Meth. 162.

191\%. Panalleria FISCH. et MEYER. F lores hermaphroditi v, ovarii abortu polygami. Perigonium urceolatum, quinquedentatum, demum dorso transversim appendicnlatum. S $\mathrm{tam}$ in a 5, imo perigonio inserta, ejusque lubis upposita. Squamula e hypogynae nullae. Ovari u m compressum, uniloculare, uniovulatum. Stylus bifidus, laciniis aentis. Ut ri e ulas memhranaceus, compressus, perigonio transversim appendieulato inclusus. Semen verticale, compressum; testa membranaeea. E mbry o annularis, periphericus, a Ib nmen farinaceum includens; radicula infera. - Herba annua, pilosa, in Asia media indigena; foliis sparsis, linearibus $v$. lineari-lanceolatis, membranaceis, floribus in axillis foliorum binatim $v$. quaternatim sessilibus, ebracleatis.

Pauderia Fischer et C. A. Meyer Index sem, hort. Petropolit. 1835. $I$. 46. P te r oc h $\mathrm{t}$ a m y s Fiseh. msc.

1918. Selerdiena $R, B R$. F lo res hermaphroditi. Perigoni am quinquefidum, laeiniis dorso immutatis, demum induratis, apice muticis v. spinescentibus. St a m in a 5 , imo perigonio inserta, ejusque laciniis opposita. Squa mula e hypogynae nullae. O va rium compressum, uniloculare, uniovalatum. Stylus bipartitus. Utricul us membranaceus, compressus, perigonio nucamentaceo, exsucco, laciniis muticis v. spinosis inclusus. Semen verticale, compressum; testa membranacea. E mb r yo annularis, periphericus, a l b u en copiosum, farinaceum includens; $r$ a dic u la supera. - Suffrutices incano-lanati, in $\mathrm{No}^{-}$ vae Hollandia e littore orientali provenientes; foliis alternis, anguste linearibus, floribus axillaribus solitariis v. glomeratis.

Sclerolaena R. Brown. prodr. 410.

1919. Anisacantha $R$. BR. Flores hermaphroditi. Perigoninm quadrifidum, laciniis dorso demum in spinas inaequales productis. Stam in a $3-4$ imo perigonio inserta, ejusque labis opposita. Squamulae hypogynae nullae. Ova ri um compressum, uniloculare, nniovalatum. Stylus bipartitus. Utriculus membranacens, compressus, perigonio nucamentaceo-exsucco, infra apicem inaequaliter quadrispinoso inclusus. S $\mathrm{e}$ m en verticale, compressum; t e st a membranacea. Em bry o annularis, periphericus, albumen copiosum, farinaceum includens; rad i $\boldsymbol{c}$ u I a snpera. Fruticulus glaber, Novae Hollandiae littus australe incolens; foliis alternis, teretiusculis, floribus axillaribus sessilibus, ebracteatis.

A a isacautha R. Browa prodr. 410. 
1920. Threlkeldia $R$. BR, Flores hermaphroditi. Perigoni um urceolatum, squa$m$ is tribus membranaceis intra marginem truneatum. Stamina 3 , hypogyna, perigonii squamis opposita. Ovarin m.... Utriculus perigonio drupaceo-baceato inclusus. S e men verticale, ovatum, albuminosum. E $\mathrm{m}$ b r yo periphericus; $\mathrm{r}$ adicula supera. - Suffrutex australasicus, lattoreus, diffusus, glaber; foliis alternis, scmiteretibus, floribus axillaribus, solitariis, sessilibus, ebracteatis.

Threlkeldia R. Browa prodr, 409.

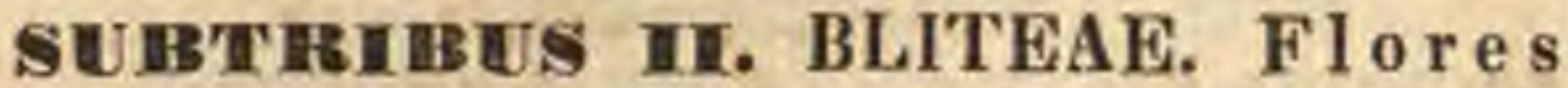
ebracteolati. Seminis verticalis testa crustacea.

1921. FIitum LINN. F 1 o res hermaphroditi v, staminum abortu polygami. P e rigon i u m tri-quinquefidum, demum baccatum. S $t$ ame n 1, v. rarius plura, receptaculo inserta, perigonii foliolis opposita, brevissima. Squa mula e hypogynae nullae. Ovari $\mathbf{m}$ ovatum, uniloculare, uniovnlatum. Sti g m a t a 2 , subulato-filiformia. Utriculus membranacens, compressus, perigonio baccato et colorato inclusus. S e m e n verticale, lenticulari-compressum; t e s t a crustacea. Embryo hemicyelicus, periphericns, a 1 b umen copiosum, farinaceum cingens; radic u la infera. Herbae annuae, carnosulae, glabrae, Europam et Asiam mediam incolentes; foliis alternis, trian gularibus, sinuatis, floribus dense glomerato-capitatis, ebracteatis, glomerulis axillaribus petiolo adnatis terminalibusve, fructiferis baccam compositam mentientibus.

B litu m Linn. gen. n. 14, Gărtn. IT, 200, t, 126. Sehkuhr t. 1. Lam.t. 5. Nees jun. Gen.pl.,II. 58. Moroca r u s Seo. poli Carn. I. 6. C he no p o di.i sp. Linn. Fl. dan. 2.1149. E. B. $t, 1721$. Curtis Fl. Lond. $I I, t .65$. Orth o s pori sp. Nees jun. Op. eil. II, 57. $f .1-10$.

1928. Agothophytum $M O Q$. F lores hermaphroditi v. staminum abortu polygami. P erigonium quinquepartitum, laciniis eearinatis, demum haud untatis. Stamina 5 , imo perigonio inserta, ejusque laciniis opposita. Squamulae hypogynae nullae. Ovarium ovatum, uniloculare, uniovulatum. Stylus brevis, crassus; s tigma.t a 2-4, elongato-subulata, patentia. Utricul us memhranacens, perigonio sicco immutato in- $f$ volutus. S e m e n verticale, lenticulari-compressum; te st a crustacea. Em bryo annularis, periphe riens, a l bu m en copiosum, farinacenm cingens; rad i cula infera. - Herba perennis, per omnem hem is phaera $m$ bore al em diffusa; caule angulato, foliis alternis, hastatis, floribus in spicam ter minalem disposilis, superioribus saepe abortu femineis.

Ag at ho phytum Moquin Taadou in Nouv. Annal.se. nat, I. 291.t.10. f. c. Orthospori sp. Nees Gen, pl. II. 57. f. 11_24. Orthosporum Bliti seetio C. A. Meyer in Ledebour Flor Alt. I, 11, pro parte.

OBSERVATIO. Ort h o s p or u m R. Brown prodr. 407. Chenopodii sectio, Ch. carinatum et Ch. Pamblio nem, species a nobis band visas complectens, a Chennpodio semine verticall et stamine unico, ab Agathophyto perigonil quin. quepartiti laciails alato-cariantis, hispidis differt.

1923. IRoubleva $M O Q$. Flores hermaphroditi v. staminum abortu feminei. Perigon i u m urceolatum, quinquefidum, laciniis concavis, demum transversim rugosis, coalescentibus. Stamina 5, imo perigmnio inserta, ejusque laciniis opposita. Squamula e hypogynae nullae. O vari um ovatum, compressum, uniloculare, uniovu- latum. Stylus brevissimus; stigmata 3 , elongato-subulata. Utriculus membranaceus, compressus, punctato resinnsus, perigonio capsulaeformi reclusus. S e me n verticale, lenticulari compressum; te sta crustacea. Embryo annularis, periphericus, albumen copiosum, farinaceum eingens; radieula infera. - Herba a ustroa mericana, prostrata, diffusa, pubescens; foliis alternis, pinnato-multifidis, laciniis dentatis, floribus axillaribus glomerulatis, glomerulis subverticillatis.

$\mathrm{R}$ o u bieva Moquin Tandon in Nouv. Annal. se. nat, r. 293. $t$. 10. $f$. 6. C be n op odium Pay co Moliua Chilt 283. Ch, mult ifidum Lim.

SUBTEI EUS III. KOCHIEAE. F 10 r es ebracteolati. Seminis horizontalis tes $t$ a crustacea v. membranacea.

1924. Beta TOURNEF. F 1 o res hermaphroditi.Perig on iu $\mathrm{m}$ urceolatum, quinquefidum, demum basi induratum, laciniis immutatis. Stamin a 5, annulo carnoso ad faucem tubi brevis inserta, limbi laciniis opposita. Squamulae hypogynae nullae. Ovarium depressum, uniloculare, uniovulatum. Stigmata 2 , brevia, basi connata. Utriculus subglobosus, perigonii tubo drupaceo inclusus, et limbo carnoso tectus, S eme n horizontale, depressum; te st a membranacea. E mbryo annularis, peripherieus, al bumen farinaceum cingens; radic ula centrifuga. - Herbae in Europa a ustraliore spontaneae, ob radices napiformes passim cultae; foliis allernis, ovato-oblongis, undulatis, floribus spicato-glomeratis, fructibus saepe concrescentibus.

Bet a Tournef. inst. 286. Linn, gen, n, 310. Gïrtn. I. 359. $t$. 75. E. B. $t$. 285 . Waldst. et Kit. Plant. Hung. $t$. 35. Nees Jun. Gen.pl. II. 67 .

1925. Enelhylaema $R, B R$. F lo r es hermaphroditi. Perig onium urceolatum, semiquinquefidum, demum baccatum. St a m in a 5, imo perigonio inserta, ejusque laciniis opposita. $S$ quam u la e hypogynaenullae. Ovari um depressum, uniloculare, uniovulatum. St ig m a t a $2-3$, filiformia. Utrieulus membranaceus, depressus, perigonio baceato, cennivente inclusus, S em en horizontale, depressum; test a membranacea. E m b ryo annularis, peripherieus, albumen farinaceum cingens; radi $\boldsymbol{c}$ ula centrifuga. - Suffrutices a ustralas $i c i$, procumbentes, ramosissimi; foliis alternis, carnosis, floribus axillaribus, ebracteatis, solitariis, sessilibus.

Ench y laena R. Brown prodr. 407.

1926. Londesia FISCH, et MEY. FIores monoiei M as c. Perigoni am urceolatum, quinquedentatum, demum induratum, haud appendicnlatum. S $t$ a m in a 5 , rarius $2,3 \mathbf{v} .4$, imo perigonio inserta, ejusdem dentibus opposita. Squamulae hypogynae nullae. Ovarii rudimentum. Fem. Perigonium maris, demum induratum, haud appendiculatum. S tam in $\mathrm{um}$ rudimenta nulla. O vari am depressum, uniluealare, uniovulatnm. Stylus bi-trifidus, laciniis elongatis. U triculus depressus, perigonio villosissimo inclusus et arete concretus. S e $m$ en horizontale, depressum; te 8 ta membranacea. $\mathbf{E}$ mbryo annularis, periphericus; a l b um en copiosum, farinacenm eingens; radicula centrifuga Herba annua, ramosa, in maris Caspii littore or ientali proveniens; foliis sparsis, sessilibus, oblongis, acutis, integerrimis, membranaceis, villis albidis adspersis, ramulis floriferis in foliorum axillis brevissimis, florum capitulo piloso villosissimo, foliis 
involucrato terminatis, floribus in foliorum floralium axillis sessilibus, parvis, ebracteatis.

L a ndesia Fiselier et C. A. Meyer Index Sem, hort. Petropolit. 1835. p. 40.

192\%. Eehimopstion $M O Q$. F 1 ores hermaphroditi v. staminum abortu polygami. Perigonium ureeolatum, quinquefidum, laciniis dorso demum in appendices spinulosas, patulas excrescentibus. St a $\mathrm{m}$ in a 5 , imo perigonio inserta, ejusque laciniis opposita. S q u a m u la e hypogynae nullae. Ovari um depressiusculum, uniloculare, uniovnlatum. Stylus bifidns, laciniis divaricatis. Utriculus membranacens, intra perigonium subchartaceum, depresso-orbieulare, radiato-quinquespinosum inclusus. S e men horizontale, orbiculatum; t es t a membranacea. E m b ry o hippocrepicus (viridis); a $1 \mathrm{~h} \mathrm{u} \mathrm{m}$ e $\mathrm{n}$ farinaceum, parcum v. saepius evanidum cingens; $r$ a di $\mathrm{c}$ u la centrifuga. - Herbae perennes v. suffrutices, per regionem mediterraneam et taurico-caucasic a m provenientes; caulibus elongatis, gracilibus, foliis villosis, anguste linearibus, planis v. semiteretibus et carnosis, floribus axillaribus, sessilibus, binis ternisve glomerulatis, subspicatis, terminalibus interdum abortivis.

Echinopsilon Moquin Tandon in Nouv. Annal. sc. nat. II. 127. Wille me ta Maerklin in Schraders Journ. I. 2. p. 321. III. p. 330. excl, sp. Moquin Taudon in Nouv. Annal. sc. nat, $I$, 206. $t, 9 . f$. 6. B a s s i a Allioni Misc, Taurin. III. 177. . 4. 4. f. 2. Ko e hi a R. Brown prodr. 409. in not. S a a ed a Reichenb Flor, excurs. 550. Kochia sp. spin os a e Auct. Schrader Halophyt, $t$. 3. Trattiniek Tabular. t. 24. Nees jun. Gen, pl. II. 39. $f, 18$ - 24. Chenopodil sp. Lian. S a Is o I a e s p. Pallas It. $t$. 1. ot $M$. f. 1. 2. Waldst, et Kit. $P l$, Hung. $t$. 106 . S u a d a e $8 \mathrm{p}$. Pallas rllustr. $t, 32 ., 37.45$.

1928. Thedola ROTH. Flores hermaphroditi. Perig o n i m ureeolatum, quinquefidum, laciniis dorso demum in alas membranaceas transversas excrescentibus. S $t$ a mina 5 , imo perigonio inserta, ejusque laciniis opposita. $\mathbf{S q u a m u -}$ la e hypogynae nullae. Ovari um depressiusculum, uniloculare, uniovulatum. St y l u s bifidus, laciniis divaricatis. Utriculas membranaceus, intra perigonium subchartaceum, depresso-orbiculare, radiato-pentapterum inclusus. S e me $\mathbf{n}$ horizontale, ellipticum; test a membranacea. $\mathrm{E}$ mbryo annularis, peripherieus, a $1 \mathbf{b} \mathbf{n m}$ en parcum, farinaceum includens; $r$ a d i c u la centrifuga.

Herbae v. suffrutices, Europam et Asiam mediam et Novam Hollandiamaustralem incolentes; caulibus prostratis, glabris $v$. pilosis, foliis sessilibus, anguste linearibus, planis v. teretibus, rarius nullis, floribus axillaribus, solitariis v. glomerulatis, ebracteatis.

Ko ehia Roth. part. R. Browa prodr. 409. Ko eh ia e sectio I. Selirader Halophyt. t. 3. f. B. Nees jan. Gen. p7. II. 59. $f .1$ - 17. Willemetia R. Brown 2. c. in not. $\mathrm{SaIs}$ I a e sp. Linn. Pallas Illustr. $t, 10.11$.

1929. Cyclolepis MOQ. Flores hermaphroditi v. ovarii abortu polygami. Perigonin in urceolatum, quinquefidum, laciniis dorso demum transversim appendiculatis, appendicibus scariosis in alam circularem coalitis. Stamina 5, imo perigonio inserta, ejusque lobis opposita. Sq $\mathbf{n}$ a u la e hypogynae nullae. Ovariu m sub. orbiculare, depressum, villoso-arachnoideum, nniloculare, uniovalatum. Stylus trifidus, laeinitis acntis. Utriculus membranaeeus, pubescens, perigonio pentagono clanso, ala transversa circulari appendiculato inelasns. S e men horizontale, orbiculatum, compressissimum; testa crustacea.
E m b r yo annularis, periphericus, a l b n men copiosum, farinaceum includens; radi $\boldsymbol{c}$ ul a cen $^{-}$ trifuga. - Herba boreali-americana, annua, pubescens; caule striato, foliis alternis, sinuatodentatis, post anthesim deciduis, fioribus terminalibus $v$, axillaribus solitariis, aut binis ternisve glomeratis, subcorymboso-paniculatis.

Cy clolepi Moquin Tandon in Nouv. Annal.sc. nat. I. 203. $t$. 9. $f$. a. Sals ola platy p hylla Mieliaux. S. radiata Desfont. in Annal. MIus. 1 . 28, $t, 34$. Ko c bia atriplicifolia Roth. K. dentata Will. Chenopod $\mathrm{i} u \mathrm{~m}$ radi at u m Schrad. Halophyt, t, 1, f. 2 .

1930. Chenopodium LINN. F1 ores hermaphroditi. Perigonium quinquefidum, laeiniis dorso demum longitudinaliter earinatis. Stam ina 5, imo perigonio inserta, ejusque laciniis opposita. S qua mu la e hypogynae nullae. Ovariu m depressum, uniloculare, uniovulatum. Stigmata 2 , filjormia, brevissima. Utrieulus membranaceus, depressus, perigonio connivente, pentagono inclusus. Sem e n horizontale, lentieulari-depressum; test a crustacea. E mbryo annularis, peripherieus, a l b a m e n copiosum, farinacenm cingens; ra di $\mathrm{cu}$ la centrifuga. - Herbae annuae $v$, rarissime suffrutescentes, in temperatis utriusque hemisphaerae obviae, plerumque glandulis farinaceis adspersae; foliis alternis, petiolatis, dilatatis, sinuatis v. dentatis, floribus glomeratis, ebracteatis.

C h e n op o d fum Linn, gen, n. 309. excl. sp. pl, Gïrtn. I. 370, $t, 75$. $f, 1$, B. B. $t$. $1480,1723,1724$. 199. FI. dan. t. 1153. Ledebour Ic. $t$. 10 . Nees jun. Gen. pl. II. 56.

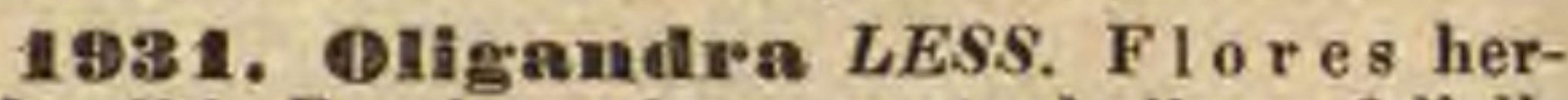
maphroditi. Perigonium pentaphyllum, foliolis ecarinatis. Sta $\mathrm{m}$ in a 2 , receptaculo ante perigonii foliola opposita inserta. Squamula e hypogynae nullae. $\mathrm{Ov}$ a ri $\mathrm{m}$ depressum, uniloculare, uniovulatum. St y lu s brevissimus; stig mata 2, filiformia. Utriculus depressus, tuberculato-reticulatus, perigonio immutato stipatus. S em en horizontale, lenticulari depressum; t e st a crustacea. E $\mathbf{m}$ b r y o annularis, periphericus, a l b $\mathbf{~} \mathbf{m}$ en copiosnm, farinaceum cingens; radi cula centrifuga. Herba caucasica, humilis, annua; foliis oppositis, petiolatis, dilatatis, floribus glomeratis, ebracteatis.

$01 i g$ a dra Lessing in Linnaea IX. 199.

193\%. Filangodia $R$. BR. Flo res hermaphroditi v. staminum abortu polygami. P e r igonium quinquepartitum, laciniis demum hand mutatis. Stamina $1-5$, imo perigonio inserta, ejusque laciniis opposita. Ovarinm depressum, uniloculare, uniovulatum. Stylus bifidus. Ac inus depressus, perigonio immutato stipatus. S eme n horizontale depressinsculam; tes ta crustacea. $\mathbf{E} \mathbf{m}$ b r y o annularis, peripheriens, a 1 bu $\mathbf{m}$ en copiosum, farinaceum cingens; $r$ a dic ula centrifuga. - Frutices v. rarius herbae, Novam Hollandiam incolentes; folitis alternis, floribus spicatis $v$. glomeratis, ebracteatis.

Rhagodia R. Brown prodr. 408. Cheuopodium baccatum Labill. Nov, Holl. $t .96$.

1\$33. Teloxys MOQ. Fl ores hermaphroditi. Perigon in m quinquepartitum, laciniis demum hand mutatis, vix carnatis. Stamina 5, imo perigonio inserta, ejusque laciniis opposita, filamenta basi dilatata. Dis c u 8 annularis, ovarii basim cingens, demum hand mutatus. Ovarium depressum, uniloculare, uniovulatum. Stylus crassiusculus, apice breviter et inaequaliter bifidns. Utriculus membranaceus, depressus, perigonio 
angulato, haud clauso einctus. S e m e n horizontale, depressiusculum; $t$ e $s \mathrm{t}$ a crustacea, marginata. $\mathrm{E}$ mb ry o annularis, periphericus, a l bumen copiosum, farinaceum cingens; radicula centrifuga.

Herba Sibiriam et Americamborealem incolens, rumosissima, glabra; foliis alternis, planis, linearibus $v$. lanceolato-linearibus, integerrimis, ramis floriferis cymosis, ramulis sterilibus aristato-setaceis, floribus minutissimis in ranulorum axillis solitaritis.

Teloxy s Moquin Tandon in Nouv. Annal. sc. nat, $I$. 289. $t, 10$. $f .1$. C h e no pod i um a r is tatum Linn.

1934. Tecanoenrpus NEES. Flores hermaphroditi. Perigoni um quinquepartitum, laciniis erectis, acutis, demum haud mutatis, vix carinatis. St a min a $1 \_2$, imo perigonio inserta, ejusque laciniis contiguis opposita; filamenta basi aequalia. Squamulae hypogynae nullae. Ov a r i u m depressum, uniloculare, uniovulatum. Stigmata 2 , subulato-filiformia. Utrie ulu s membranaceus, depresso-pateriformis, basi perigo nio stipatus, transversim marginatus, circumscisse dehiscens. Se m en horizontale, depressum; t e s ta crustacea. Embryo annularis, periphericus, alb um e n copiosum, farinaceum cingens; radic u la centrifuga. - Herba n ep alensis, erecta, annua; foliis alternis, deltoideis, inaequaliter dentatis, $c y$ mis axillaribus, ramulis sterilibus aristato-setaceis, floribus minimis, solitariis.

Lecanocarpus Nees Amoenit, Bonn. IT. 4. t, 2. A erogloc h in Selirader Catalog. Hort. Gütting. 1824. Blitant us Reichenbach Catalog. Hort. Dresd. 1824. A marantus diander Spreng. N. E. $I I T .20$.

1935. II ablitzia BIEBERST. F lores hermaphroditi v. abortu polygami. Per ig o n i n m rotato-quinquepartitum, laciniis cuneato-oblongis, obtusis, demum haud mutatis, ecarinatis. Stamina 5, imo perigonio inserta, ejusque laciniis opposita ; filamenta filiformia. Squamulae hypogynae nullae. Ovarium depressum, unilocnlare, uniovulatum. Stylus simplex; stigmate trilobo. Utrieulus membranaceus, depres. so-pateriformis, perigonio patentissimo stipatus, transversim marginatus, circumscisse dehiscens. Sem en horizontale, depressum, hine rostellatum; test a crustacea. E $m$ b r yo annularis, periphericus, albumen farinaceum cingens; radicula centrifuga. - Herba perennis, caucas ica; radice napiformi, caule volubili, foliis alternis, cordatis, integerrimis, cymis axillaribus, ramulis fertilibus.

H a b Ii tzia Bieberst. Cent. pl. ross, $I T$. t. 54. Reichenb, Iconogr. t. 754. Eichwald Pl. caucus t, 23.

1936. Cryptocanpas $H, B, K$. F lores hermaphroditi, elracteolati. Perigonium campanulatum, quadri-quinquedentatum. Stam in a 4 5, receptaculo inserta, perigonii dentibus opposita; fil am en ta filiformia, exserta, basi subcon nata; antherae globoso-didymae. Squamulae hypogynae nullae. O va ri um obovatum, compressum, uniloculare, uniovulatum. Sty I us simplex, subexcentricus; stigma acutum. A chenium compresso-subglobosum, cartilagineum, perigonio acuto connivente inclusum. S e $m$ e $\mathbf{n}$ verticale; testa membranacea. Embryo annularis, periphericus, alb nmen copiosum, farinaceum cingens; radic nla infera._Herbae americanae tropicae, procumbentes; foliis alternis, rhombeoovatis, integerrimis, floribus axillaribus spicatis, sub sessilibus.

Cryptocarpus Kunth in Humb, et Bonpl. Nov, gen. et sp, II, 187, t, 123, 124.
Generis affinitas plane dubia, anne svadente styli in. sertione sublaterali, non obstantibus staminibus, quae in iconibus citatis e regione dentium perigonii pinguntur, ad Phytolaceaceas referendum?

SUTRTIIBUS IV. ANREDEREAE. Flores bibracteolati. S e $\mathrm{m}$ in is verticalis testa membranacea.

$193 \%$. Anredera JUSS. F lo res herma phroditi, bibracteolati, bra et e o I is minutis, concavis. Perigonium membranaceum, quinquepartitum, laciniis duabus exterioribus carinatis, dorso Inngitudinaliter alatis, interioribus paullo brevioribus, concavis. Stam in a 5 , imo perigonio inserta, ejusque laciniis opposita; fil am enta subulata; antherae oblongae, sagittatae. Squamulae hypogynae nullae. Ovarium ovatum, uniloculare, uniovulatum. Styli 3 , distincti; stig mata simplicia. Utriculas coriaceus, perigonio siceo, diptero inclusus. S em e $\mathbf{n}$ verticale; testa membranacea. E m bryo annularis, periphericus, a Ibu m e n copiosum, farinaceum cingens; radicula infera. - Herbae Antillanae scandentes; foliis alternis, floribus spicatis, axillaribus.

A n re der a Jussien Gen.84. Gartn. $f$. III. 176. $t .213$. Kuuth in Humb, et Bonpl. Nov, gen. et sp. II, 190. Polygonam seandens Linn. Fagopyrum seandens Sloane Jam, t, 90, f. 1. B a s ell a ve s i e a r fa Lam. t, 215. f, 1 .

1938. Boussingraltia $H, B . K$. F I ore s hermaphroditi, bibracteati et bibracteolati, b rae te ol is florem subaequantibus, carinato-coneavis, inferne dorso longitudinaliter membranaceo-subalatis. $\mathbf{P}$ e $\mathbf{r} \mathbf{g}$ o $\mathbf{n} \mathbf{i} \mathbf{m}$ quinquepartitum, laciniis aequalibus, concavis, cearinatis. St am in a 5 , imo perigonio inserta, ejnsque laciniis opposita; filam enta subulata; antherae oblongae, basi bifidae. Squamu la e hypogynae nullae. Ovarium elliptico-trigonum, uniloculare, uniovulatum. StyI s terminalis, persistens, basi conico-incrassatus ; $8 \mathrm{tigm}$ a trilobum. Utriculus membranaceus, perigonio sicco, immutato inclusus. S e m en verticale, lenticulari-compressum; te sta membranacea. E m br yo annularis, periphericus, a 1 b u $\mathbf{m}$ en copiosum, farinaceum cingens; ra di $c$ ul a infera.Frutices $q u$ it enses et mexicani, volubiles; foliis alternis, integerrimis, aveniis, carnosis, petiolis basi articulatis, racemis axillaribus geminis v. ternis, simplicibus aut racemosis, floribus pedicellatis, albis, pedicellis basi uni-apice bibracteatis.

Bo us sing a ultia Humb. Bonpl, et Kunth Nov. gen, et sp. VIX. 194. $t, 645$.

OBSERVATIO. In Boussingaultia fide speciei ine ditae mexicanae distinguimus : bracteam rami (pedicelli), bracteas inflorescentiae (bractenlas $\mathrm{Kunth}$ ) ad florem unieum terminalem (ramulis quippe lateralibus abortivis) redactae, et bracteolas floris, tanquam perigonif septempartiti limbum exteriorem a cl. Kunth descriptas.

SUEORDO II. SPIROLOBEAE C. A. Meyer in Ledebour Flor. All. I. 370 . Embry o spiralis. A 1 b u me n nullum v. parcum, bipartitum, excentricum.

TIRIIBUS I. BASELLEAE. F lores bracteolati. Perigonium baccatum, cum caryopsi cartilaginea concrescens. Sq u amul a $\mathrm{e}$ hypogynae nullae. Seminis verticalis testa membranacea. Albumen parcum, in massulis duabus excentricis. E m b r y o planospiralis. - Caulis continuus, volubilis. 
1939. TBasella LINN, Flores hermapl.roditi, bibracteolati. Perig on in m urceolatum, quinquefidum, demum baccatum. St a m in a 5 , medio perigonio inserta, ejusque laciniis opposita; fiI amenta basi dilatata. Squamula e hypogynae nullae. Ovarium ovatum, basi cum perigonii tubo connatum, uniloculare, uniovnlatum. Sty lus filiformis, apice in $8 \mathrm{t} \mathbf{i g} \mathbf{m}$ a $\mathrm{ta} 3$, linearia, patentia divisus. Cary opsis cartilaginea, perigonio baccato inclusa et basi adnata. S e men verticale subrostellatum; testa membranacea. Em br yo plano-spiralis, albuminis farinacei massulas duas excentricas segregans; ra di cula marginali, infera. - Herbae in America et Asia tropica indigenae; radicibus fibrosis $v$. tuberosis, caule dextror sum volubili; foliis alternis, integrerimis, carnosis, spicis axillaribus, floribus pedicellatis.

B a sella Rheede Malab. VII, 45. $t$, 24. Linn, gen, $n$. 382. Gärta. II. 200. t. 126. Kunth in Hamb. et Bonpl. Nov. 6en. et sp.'II, 188. G a ud ol a Rumph Amboin. V. L. 15i.

TRIBUS 1. SUEDINEAE Moquin Tandon in Nouv. Annal. sc. nat. IV. 215. F lores bracteolati. Perigonium siccum, utriculum membranaceum includens, v. basi cum eo connatum. Squamula e hypogynae nullae. Seminis horizontalis verticalis t e st a crustacea. A l b u m en nullum v. parcum, in massulis duabus excentricis. $\mathrm{E} \mathrm{m} \mathrm{b} \mathrm{r} \mathrm{y} 0$ plano-spiralis._Caulis continuus, folia saepius vermicularia.

1940. Selhanginia C. A.MEY. F lores hermaphroditi v. staminum abortu polygami, bractcolati. Perigun i m tubuloso-urceolatum, subquinquefidum, laciniis demum haud mutatis. St amina 5 , medio perigonio inserta, ejusque laciniis opposita, in floribus femineis ananthera. S q uamulae hypogynae nullae. Ovarium ovatum, basi cum perigonii tubo connatum, apice liberum, uniloculare, uniovulatum. Sty lus conicus, apice in $s t i g$ a $t$ a $2-3$ subulata, patentia divisus. Utriculus basi perigonii tubo adnatus, apice liber, limbi laciniis stellato - patentibus cinctus. S e m en verticale, lenticulari-pyriforme, subrostellatum; te s ta crustacea. E m b r y o plano-spiralis, exalbuminosus; radicula marginali, infera. Herba a l t a ica, glaucescens, glabra; foliis alter nis, linearibus, carnosiusculis, floribus sessilibus, solitariis $v$. in glomerulos binos senosve dispositis, bracteolis minutissimis, squamaeformibus.

$5 \mathrm{eb}$ a ginia C. A. Meyer in Ledebour Flor. Alt. I. 394. Moquin Tandon in Annal. sc. nat. XXIII. 319. $t .21$. Nouv, Annal. sc, nat, $I V \cdot 218$. S u a d a Ii n if o li a Pallas Illustr. $t .40$.

1941. Suaedla FORSK. F lores hermaphroditi, bracteolati. Yerig oni um urceolatum, quinquepartitum, laciniis erassiusculis, carnosis, demum inflatis, interdum subearinatis, haud appendiculatis. Sta $\mathrm{m}$ in a receptaculo $\mathrm{v}$. imo perigonio inserta, ejusque laciniis opposita. Squamula hypogynae nullac. Disc u s annularis parvus, quandoque obsoletus. O vari im compressum v. depressum, uniloculare, uniovulatum. Sty I us apice in stig mata 2_5, divaricata divisus. Utric uI n membranaceus, depressus v. compressus, perigonio plus minus inflato inclusus. $\mathrm{S}$ e $\mathrm{men}$ lenticulare, horizontale v. verticale; test a erustacea. Embryo plano-spiralis, exalbuminosus; $r$ adicula externa. - Herbae glabrae v. suffrutices, in littoribus mediterraneis et in Asiae media e desertis salsis provenientes; foliis alternis, subteretibus, carnosis, floribus axillaribus, interdum basi foliorum adnatis, saepius glomerulatis, bracteolis minutissimis, squamulaeformibus, hyalinis.

$\mathrm{S}$ u a e d a Forsk. Aegypt, 69. Pallas Illustr. t. 39.41_47. Moquin Tandon in Annal, sc. nat. XXII. 303. t. 19-22, Nouv. Annal. sc, nat. IV. 216. Le re hi a Haller Hort. Götting. 21. Coehllospermum Lagasca. - Che no podil et $\mathrm{S} a \mathrm{l}$ sola e sp. Linn. Sibthorp Fl. graec. $t, 255$. Schrader Halophyt, t. 1. f. 3. S e ho b e ria e sp. Ledebour Ic. $t$. 44. 45. Nees jun, Gen, pl. II, 62.

1942. Selhoberia $C$. A. MEY. F lores hermaphroditi, bracteolati. Perig on i m profunde quinquefidum, laciniis subinaequalibus, demum cuenllatis, dorso bicorniculatis. S $\mathrm{t}$ a $\mathrm{m}$ in a 5 , receptaculo inserta, perigonii laciniis opposita. $\mathrm{S}$ q u amulac hypogynae et discus nullus. Ovarium depressum, uniloculare, uniovulatum. Stylus bifidus. Utriculus membranacens, depressus, perigonio clauso, irregulariter stellato inclusus. S cmen horizontale, lentieulari-depressum; testa erustacea. Embryo plano - spiralis, albuminis parei, farinacei massulas duas distinctas segregans; rad i cul a externa. - Herba altaica, glabra; folüs alternis, semicylindricis, depressis, carnosis, floribus axillaribus glomeratis, bracteolis minutis, squamaeformibus.

S choberia C. A. Meyer in Ledebour Flor. Alt, T. 399. 1o.t, 195. exel. reliq. Moquin Taudon in Annal.sc. nat. XXIII. 32t, t. 22. Nouv, Annal. sc, nat. IV, 216.

TRIBUS II. SALSOLEAE Moquin Tandon in Nouv. Annal, sc. nat. IV. 209. Flores bracteolati. Perigonium siccum, utriculum membranaceum includens. Squamula e hypogynae nullae. Seminis horizontalis v. verticalis testa membranacea. A I bum en nullum. Embry o conico-spiralis (cochleatus). - Caulis continuus $v$, articulalus, folia saepius semiteretia.

SUBTRIBES I. HALIMUCNEMIDEAE Squamulae hypogynae nullae.

1943. Traganum DEL. F 1 ores hermaphroditi, bibracteolati. Perig on in m pentaphyllum, foliolis demum inerassatis, haud appendiculatis. Stamina 5, receptaculo inserta, perigonii foliolis opposita; fil a m e nt a crassiuscula, compressa, superne dilatata, apice truncata; antherae sagittatae, acutae. Squamulae hypogynae nullae. O va riu m depressum, unilocnlare, uniovulatum. S t y li 2 , filiformes, basi coaliti. U triculus depressus, perigonio sublignoso nucaeformi inclusus. S e men horizontale, orbienlatum; tes ta membranacea. E m b r y o exalbuminosus, depresso-cochleatus; ra di cul a extraria. - Frutex in Aegypto et in insulis Canariis observatus; foliis alternis, parvis, subamplexicaulibus, subtriquetris, floribus axillaribus sessilibus, binis ternisve glomerulatis, villis involutis.

Trag a n un Delile Flor. Aegypt, 312, t, 22. f. 1. Mo. quin Tandon Nouv. Annal. sc, nat. IV. 215.

194. Salsola LINN. F lores hermaphroditi, bibracteolati. Perig on i u mentaphyllum, foliolis dorso demum transversim alatis. $\mathrm{S}$ tamin a 5 , v. rarius 3 , annulo depresso v, cyathulo hypogyno inserta, perigonii foliolis opposita; a nthe ra e ovatae, muticae. Squamula e hypogynae nullae. Ovarium depressum, uniloculare, uniovulatum. Styli 2, basi plerumque connati, rarissime nulli; stigmat a subeapitata, subses- 
silia. U triculus depressus, perigonio capsulaeformi exsuceo v. subbaceato, stellato-quinquealato reclusus. S e m en horizontale, subglobosum; t est a tenuissime membranacea. $\mathrm{E} \mathrm{m}$ br y o exalbuminosus, cochleatus; ra di cula extraria. - Herbae v. suffrutices, glabrae aut pubescentes, in lit toribus regionum $t$ emperatarum totius orbis obviae, inter tropicos rarae, nonnullae etiam per continentes vagantes; foliis alternis v. oppositis, subcylindricis, raro planiusculis, rarissime nullis, floribus axillaribus sessilibus, perigonii fructiferi alis maximis $v$. parvulis, saepius inaequalibus, striatis, scariosis, interdum coloratis, raro crassiusculis, unguiformibus.

S a ls ol a Linn. gen. n, 311. excl. sp. Gärtn. 1. 359. t. 75. Pallas Iltustr. $t, 12-30$, Schkuhr $t$. 257. Hook. Flor. Lond. Eiehwald Pl, caucas. $T$. 24-31. Moquin Tandon in Nouv. Annal. sc, nat. IV. 214. Kall Tournef. inst. 286. Caroxylon Thunb. Nov. gen, II, 38, Juss. gen. 85 .

1945. ITalimoenemis C.A.MEY. F lores hermaphroditi, bibracteolati. Perig on ium di-pentaphyllum, foliolis demum induratis, haud appendiculatis. Stamina $1-5$, receptaculo inserta, ejusque foliolis opposita; a n th e ra e muticae v, connectivo in rostrum ligulare v, cueullatum producto superatae. Sq a a m $\mathbf{n}$ la e hypogynae nullae. Ovarium compressiusculum, uniloculare uniovulatum. Styli 2, setacei, basi plerumque coaliti. Utric ulus compressus, subchartaceus, perigonio membranaceo-indurato, exappendiculato inclusus. S emen verticale, suborbiculare; test a membranacea. Em b r yo exalbuminosus, cochleatus; $\mathrm{r}$ a di $\mathrm{en} \mathbf{l}$ a dorsali. - Herbae $v$. rarissime suffrutices, pubescentes $v$. interdum glabri, in regione tauro-caucasica, in Sibiria et Arabia provenientes; foliis allernis $v$. oppositis, plus minus cylindricis, succulentis, floribus axillaribus, solitariis, bracteolis foliis conformibus, cum perigonio fructifero persistentibus et illud includentibus.

$\mathrm{Halima} \mathrm{c}$ emis C. A. Meyer in Ledebour Flor. Alt. I. 381. Moquin Tandon in Nouv, Anñal. sc. nat, IV. 212. Anabaseos sectio 11. Schrad. Polyenemi sp. Pallas Hlestr. $t, 48+35$.

1946. Hallogeton $C, A . M E Y$. F I o res hermaphroditi, bibracteolati. Perigonium tripentaphyllum, foliolis demum induratis, dorso transversim alatis. S $t$ a $\mathrm{m}$ in a 5 , receptaculo inserta, pe rigonii foliolis opposita, nune pauciora, $3-1$; antherae connectivo exeurrente mueronatae. Squa mulae hypogynae nullae. Ovarium compressiusculum, uniloculare, uniovulatum. Styli 2, setacei, basi cohaerentes. Utriculus compressus, subchartaceus, perigonio tri-quinquealato, membranaceo, interdum supra crassiusculo inclusus. S e m e n verticale, suborbiculare; testa membranacea. E mb ry o exalbuminosns, cochleatus; radicula dorsali. - Herbae $v$. suffrutices, glabri aut pubescentes, in regione mediter ranea, taurico-caucasica, in Persia et Sibiria provenientes; foliis alternis v. opposilis, semiteretibus, carnosis, floribus axillaribus, glomerulatis, perigonii fructiferi alis subinaequalibus, patentibus.

Halogeton C. A. Meyer in Ledebour Flor. Alt. I. 378. Ic. t. 40. Moquin Tandon in Nouv. Annal. sc. nat, IV. 211. S a $1 \mathrm{~s}$ ol a e sp. Pallas Illustr, 1.24 . 27. Labillard. Syr. Dec, IT. t. S. A n a baseos s p. Cav. Io, t, 283. Bieberst. Schrad.

SUBTIRIBU II. ANABASEAE. Squa mula e hypogynae staminibus alternae.

194\%. Nanopliytum LESS. F1ores hermaphroditi, bibracteolati. Perigonin mentaphyllum, foliolis demum induratis, haud appen- diculatis. S tamina 5 , receptaculo inserta, perigonii foliolis opposita; an th erae connectivo excurrente apiculatae. Squamulae hypogynae 5 , staminibus alternae. 0 v a r i $\mathrm{m}$ compressiusculum, uniloculare, uniovulatum. Styli 2 , setacei, basi coaliti. Utriculas compressus, subchartaceus, perigonio membranaceo - indurato, inappendiculato inclusus. S e m en verticale, suborbiculare; t e st a membranacea. E m br y o exaltuminosus, cochleatus; radicula dorsali. - Suffrutex caspicus, glaber; foliis alternis, imbricatis, subulato-pungenlibus, squamularum hypogenarum praesentia ab Halimocnemidibus diversus.

Na u op hytum Lessing in Linnaea $I X, 197$.

1948. Cornulaca DEL. Flores hermaphroditi, bibracteolati. Perigoni n m pentaphyllum, foliolis denum indurato-siceis, uno dorso spinifero. $\mathrm{S} t$ a $\mathrm{m}$ in a 5 , receptaculo inserta, perigonii foliolis opposita; a n th era e muticae. S quamula e hypogynae 5, staminibus alternae. Ovari u m compressinsculum, uniloculare, uniovulatum. Styli 2, filiformes, basi coaliti. Utriculus compressus, membranaceus, perigonio capsulaeformi, unispinoso inclusus. S e m en rerticale, suborbienlare; te st a membranacea. $\mathrm{E}$ m br y o exalbuminosus, cochleatus; radicula dorsali. - Suffrutex aegyptiacus, haud articulatus; foliis alternis, subtriquetris, carnosis, floribus villis involutis, squamulis hypogynis membranaceis, sublinearibus, erectis, inferne cum jilamentis coalitis, perigonii fructiferi spina longa, rigida, subverticali.

Corn ulaca Delile Flor, Aegypt, 318, $t$, 22, $f$. 3. Ma. quin Tandon in Nouv. Annal, sc, nat, IV. 211.

1949. Amabasis LINN. Flores hermaphroditi, hibracteolati. Perig oni um pentaphyllum, foliolis demum v. omnibus dorso transversim appendiculatis, v. duobns bractenlis oppositis apteris. Stamina 5, receptaculo inserta, perigonii foliolis opposita; anth erae muticae. Squamula e hypogynae 5, staminibus alternae. Ovarium compressum, uniloculare, uniovulatum. Styli 2 , brevissimi, divaricati. Utriculus compressus, succulentus v, subchartaceus, perigonio tri-quinquealato, subpulposo inclusus. S e in en verticale, suborbiculare; te st a membranacea. E m bryo exalbuminosus, enchleatus, radicula dorsali. - Frutices $v$. suffrutices articulati, aphylli $v$, foliolis parvulis, basi connatis instructi, in regione med $i$ ter $r$ an e a occidentali rarissimi, in orientali et regione taurico-caucasica, nec non in Asia media frequentiores; foliis sessilibus, oppositis $v$. abortu interdum alternis, squamulis hypogynis ciliatis $v$. villosis, a staminibus distinctis, perigonii alis suberectis.

A n a b a s is Linu, gen. n, 319. Gürtu, $I, 374, t, 77$. Pallas Illustr. t. 8. 9. Ledebour Ic. t, 39, 47. Moquin Tandon in Nouv. Annal, sc, nat. IV. 210. - B r a e h y lepis C. A. Meyer in Ledebour Flor. Alt, I, 370, Ic. t, 48, teste Tandonio nou differt, perigonio fructifero revera alato, sed alis minutis, colore perigonii, et ad ejus apicem applicatis, lifne vix conspicuis.

OBSERVAT10. M o no le pis Schrader Ind, sem, hort. Göting. 1830. Chenopodea boreali-americana, cui ex ancto. re: ,Flores polygami monaudri, perigonium squamacforue, ,utriculus compressus. semen verticile includens," ob de. seriptionem mancam eollocari haud potest.

\section{GENERA CHENOPODEIS AFFINIA.}

1950. A griephyllum BIEBERST. Flores hermaphroditi. Perigonium nullum. S tamen 1; filamentum filiforme; anthera bilocularis. O varium compressum, uniloculare, uniovulatum. Stigmata 2 , filiformia. Utrien- 
I us membranaceus, dorso prope basim foraminulo orbiculari fenestratim dehiscens. S e m e n vertica le, lenticulari-compressum; test a crustacea. E mb ryo hemicyelieus, periphericus, a 1 b um e $\mathbf{n}$ farinaceum cingens; radieula infera. - Herba annua, ta uro-ca ucasica; foliis alternis, linearilanceolatis, nervosis, bracteisque subulatis pungentibus, spicis axillaribus brevissimis, squarrosis.

A griophyll a m Bieberst. Flor. taur. cauc, IIT. 5. Corispermu u s quarros um Linn. Pallas Flor, Ross. II. t. 99. C. pungens Vahl. Rhagrostis Buxb. Cent. III. 30. t. 55 .

1951. Coris permuman $A N T$. JUSS. F 10 res hermaphroditi, ebracteati. Perigonii loco squamulae 3 , scariosae, rarius unica $v$. nulla. St am i n a $1 \ldots 5$, receptaculo inserta. O va $\mathbf{r}$ i $\mathbf{m}$ ova tum, compressum, marginatum, uniloculare, unio vulatum. Stigm a t a 2 , filiformia, ereeta. C a r y o ps is compressa, hinc plana inde convexa, marginata, pericarpio tenuissime membranaceo. S e m e n verticale, compressum; $t$ e $s$ a crustacea. E m b r y o annularis, periphericus, a 1 b u $\mathbf{m}$ e $\mathbf{n}$ copiosum, farinacenm cingens; rad ic u a infera. - Herbae in Europa imprimis orientali et in Asia media provenientes, annuae, ramosae, lanuginosae; foliis alternis, sessilibus, linearibus, integerrimis, floribus in axillis foliorum solitariis, sessilibus.

Corispermum Ant. Jussieu in Let. Paris. 1719. Linn. gen. n, 12. Gärtn. I. 36t, t, 75. Law t, J. Pallas Illustr. t. 59. C. A. Meyer in Lodebour Fl. Alt. I. 9. Nees jun, Gen, pl, II, 75 .

1952. Anthoelhiamys FENZL. F10res hermaphroditi. P erigon in m quinquefidum, campanulatum, coloratum, hyalino-membranaceum, laciniis apice bilobis, subserrulatis. $\mathrm{S}$ t a $\mathrm{m}$ i $\mathrm{n}$ a $4-6$, hypogyna, perigonii laciniis opposita (!); filamenta subulata, basi subconnata; an $\mathbf{t h e r a e}$ biloculares, oblongo-lineares, basi et apice bifidomucronulatae. O vari um lenticulari-compressum, uniloculare, uniovulatum. Stylus bipartitus; st $\mathrm{i}$ gmatibus filiformibus. Caryopsis compressa, monosperma, anguste alato-marginata. Se m e n .. Herba persica, annua, diffuse ramosa, glabra; foliis ellipticis, uninerviis, mucronulatis, floralibus abbreviatis, spica densa, demum elongata, floribus roseis, ebracteolatis.

A uthochlamy senzl msc, Corispermumpoly galoides Fischer et C. A Meyer Index sem. hort. Petropolit. I. 24.

1953. Dysphania $R$. BR. Flores polygamo - monoici. Hermaphr. Perigonium tripartitum, coloratum, foliolis cochleariformibus. St a $\mathrm{m}$ in a 2, distineta, imo perigonio inserta. $\mathrm{Sty}$ lus indivisns; stigm a te simplici. Fe m.Perigonium et pistillnm ut in hermaphrodito. Pericarpium turbinatum, semini adnatum, perigonio aueto cinctum. S emen albuminosum. E m b r yo periphericus; rad i cula supera._Herba pusilla, prostrata, glabra, in Nova Hollandia tropic a indigena; foliis alternis, exstipulatis, integerrimis, glomerulis axillaribus, floribus minutissimis, vicen is vix caput aciculae aequantibus, brevissime pedicellatis, ebracteatis, albis, extimo hermaphrodito, reliquis femineis.

Dysphania R. Brown prodr. 4 4t.
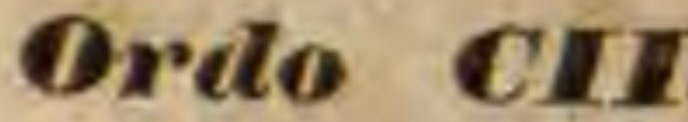

Amandantaceare.

AMARANTI Jnss. gen. 87. AMARANTACEAE R. Brown Prodr. 413, Martius Nov, Gen. et sp, II. 1, ss. N. A, N, $C$. $\mathrm{X} I T, 210$, s. Bartling Ord, nat, 297 . Lisdley introduct, edit. IT. p. 807 .
Herbae v. suffrutices, interdum arborescentes, caule ramisque saepe diffusis, teretiusculis aut rarius angulatis, nudis $\mathbf{v}$. plerumque pube plus minus copiosa consitis, Foli a opposita v. alterna, simplicia, integra, saepius subintegerrima, sessilia v. breviter petiolata, uninervia, venosa. Sti pulae nullae.

Flores hermaphroditi v. abortu polygamo-monoici, aut rarissime dioici, glomerati, capitati v. spicati, tribracteati, b ract e a a nti a majore, rarissime (ubi flos in folii axilla solitarius sessilis) deficiente, lateralibu s (bracteolis, calyce Mart.) minoribus, saepissime carinatis v. concavis, persistentibus, saepius plus minus scariosis, nunquam foliaceis, interdum flores laterales ahortivos, in cristam v. glochides mutatos in axilla foventibus.

Perigonium (corolla Mart.) siccum, subscariosum, herbaceum v. coloratum, tetrapentaphyllum, foliolis liberis $\mathbf{v}$ : interdum basi plus minusve inter se coalitis, glabris $v$, pube demum aucta instructis, nunc omnibus aequalibus, nune tribus interioribus $\mathbf{v}$. postico paullo dissimili.

Staura hypogyna, quinque fertilia, perigonii foliolis opposita, raro pauciora, sterilia nulla v. fertilibus alterna, lobuli- v. dentiformia, libera $v$. basi in cupulam aut tubum plus minus longum coalita. Filamenta fertilia filiformia v. subulata aut dilatata, interdum trifida, sterilia (staminodia) integerrima v. fimbriata, plana v. rarissime fornicata. Antherae introrsae, medio dorso affixae, nunc uniloculares, nunc biloculares, didymae, loculis longitudinaliter dehiscentibus. Po $11 \mathrm{i}$ n is granula plurima, minutissima, globulosa.

Ovarium unicum, ovatum, compressum v. rarius depressiusculum, uniloculare. $O$ v ul u m nune unicum, nunc plura, funiculis liberis, et si plura inter se distinctis, e fundo ovarii erectis singillatim appensa, amphitropa, micropyle basim ovarii respiciente. $\mathrm{Sty}$ I us terminalis simplex, nunc longiusculus, nunc brevis v. brevissimus aut subnullus. Stig $\mathrm{m}$ a capitatum $\mathrm{v}$. emarginato-bilobum, aut bitrifidum, cruribus filiformibus v. cylindricis, rarius multifidum.

Fructus utriculus membranaceus, mono-polyspermus, evalvis et irregulariter rumpens, v. rarius operculo transversim dehiscens, interdum caryopsis, rarissime bacca.

Sem in a lenticulari - reniformia, compressa, verticaliter appensa. T esta crustacea, nigra v. fusca, umbilico nudo v, rarissime arillato. End o ple ura tenuissime membranacea. Albumen centrale, farinaceum. 
E $\mathrm{m}$ bry 0 arcuatus $v$, cyclicus, albumen cingens. Cotyledones plano-convexae, incumbentes. R a di $\mathbf{c} u \mathbf{l}$ a umbilico proxima, infera adscendens, apicem carpicum respiciens.

A mara $n$ t a ce a Chenopodeis proximae, et vix charactere diagnostico ab iisdem distinguendae, quamvis notarum pluralite simul et habitu ábunde diversae, in t e r tropi cos utriusque orbis maxima copia gignuntur, in regionibus subtropicis non admodum rarae, in tem perat is parcissime provenientes, e climate frigido omnino exules.

Virtutes insunt nutrientes, emollientes, radicis in una vis tonica, stimulans laudatur.

TREIBUS I. GOMPHRENEAE. O $\mathrm{va}$ rium uniovulatum. Antherae uniloculares.

1954. Iresine WILLD. F I ores hermaphroditi v. abortu polygami, tribracteati. P erig on i um pentaphyllum. Stamina 5, libera v. basi in cupulam connata; fil a me nta filiformia; a $\mathrm{th}$ e r a e uniloculares; de nt i e u $\mathrm{l}$ is interjectis nullis. Ovari $\mathbf{m}$ uniloculare, uniovulatum. Stylus brevis; stigmata 2 v. 3, teretiuscula. Utric ul us evalvis, monospermus. S emen lenticulari-reniforme; testa crustacea. $\mathbf{E} \mathbf{m b} \mathbf{r}$ o arcuatus, periphericus, a $1 \mathrm{~b} \mathbf{n} \mathrm{m}$ e $\mathrm{n}$ farinaceum cingens; $r$ a die a la supera. - Herbae erectae $v$. procumbentes, ramosae, in America tropica et subtropica obviae, in Nova-Hollandia inter tropicos rarae; foliis oppositis, floribus laxe paniculatis $v$. dense spicato-capitatis.

a. IRESINE Funth. FIor'es polygamo-dioici, panieulati

Iresine Kunth in Humb. et Bonpl. Nov. gen. et sp. II. 198. Martius Nov. gen, et sp. II. 57. t. 153, 184. N. A. N. C, XIII. 306. R o s e a Martius Nov. gen. et sp. II. 59. t. 155. N. A. N. C. XIII, 305. $\rightarrow$ Cru e ita Loffling $1 t .203$. vix nisi floribus tetrameris diferre videtur, sed adeo imperfecte descriptum geaus, et a nemine post auctorem visum, in systenate nec recepi, nec collocari potest.

b. PHILOXERUS $\boldsymbol{R}$. Br. Flores hermaphroditi, spicatocapitati.

Philoxerus R. Browa prodr. 416. Kunth op. cit. IT, 203. Martius N. A. N C. XIII, 305.

1555. Trommsdorfia $M A R T$. F 1 ores hermaphroditi, tribracteati. Perigoni nm pentaphyllum. St a min a 5 , basi in cupulam connata ; fil a menta filiformia, lobulis minimis rotundatis interjectis; antherae uniloculares. Ovari n m uniloculare, uniovulatum. Stigma subsessile, capitato-bilobum. U tri c u l us evalvis, monospermus. Semen lenticulari-reniforme; t esta crustacea. E m b r y o arcuatus, periphericus, a I b umen farinaceum cingens; radicula supera.

Herbae v. suffrutices, Americam tropicam incolentes; folits oppositis, floribus terminalibus v. lateralibus in capitula congestis.

Trom m s d orfia Martius Nov, gen. et sp. II. 40. $t$. 139. N. A. N. C. XIII.308. Alternan therae $\mathrm{sp}$. Kunth.

1956. Al ernanthera FORSK. F lores hermaphroditi, tribracteati. P e rig onium pentaphyllum. St a mina 5 , basi in eyathum connata; filamenta filiformia, nonnulla saepius ca strata; antherae unilocnlares; staminodia interjecta dentiformia, integra $\mathbf{v}$. trifida, interdum obsoleta. Ovarium uniloculare, uniovulatum. Stylus brevis; stigmate capitato. Utriculus evalvis, monospermus. S emen lenticulari-reni- forme; t c st a crustacea. E $\mathbf{m b} \mathbf{r} \mathbf{o}$ areuatus $v$. annularis, a l b u $\mathrm{en}$ farinaceum cingens; radicula supera. - Herbae tropicae et subtropica e, ampligaeae, decumbentes; caulibus subgeniculatis, radicantibus, villosiusculis, foliis oppositis, brevissime petiolatis, floribus in capitula axillaria congestis.

Alternanthera Eorskael Aegypt. 28. R. Brown prodr. 417. Martius Nov, gen. et sp. II, 33, $t, 159$. N. $A$. N. C. XIII. 316. A llag a $\mathrm{t}$ her a Martius Hort. Erlang. 69. Gomphrenae et Illecebri sp. Linn.

155\%. Teleinuthera $\boldsymbol{R}$. $\boldsymbol{B R}$. Flores hermaphroditi, tribracteati. Perigonium pentaphylium. Stamina 5 fertilia, basi in tubum connata; fil amenta filiformia; a therae nniloculares; sta min odia interjecta ligulaeformia, inciso-dentata. Ovarin uniloeulare, uniovulatum. Stylus brevis; stigmate eapitato. Utriculus evalvis, monospermus. Sem en lenticulari-reniforme; testa erustacea. E mb ry o areuatus, periphericus, a 1 b u m e $n$ farinaceum cingens; $\boldsymbol{r}$ a $\mathrm{d}$ i eula supera. - Herbae rarius suffrutescentes tropicae, pleraeque americanae, paucae amphigaeae, erectae $v$. decumbentes, ramosissimae, villosiusculae, foliis oppositis, breve petiolatis, floribus in capitula terminalia $v$, rarius axillaria dispositis.

Teleianthera R. Brown in Tuckey Congo p. 477. in not.

a. BUCHOLzia Mart. Perig o n ii foliola 3 exteriora paullo majora. Tubus stamineus antheris quinque, stamino. di is dilatatis, ineiso-dentatis. - Capitula axillaria et terminalia.

B u c ho 1 z i a Martius Nov. gen. ot sp. II. 49.t, 147 151. N. A. N. C. XIII. 314. IIlle c e b ri s p. Herit. stirp. $t, 37$.

BRANDESIA Mart. Perig onii cum pedicello brevissimo vix articulati foliola subaequalia. T u b a s stamiaeus antheris quinque, st $\mathrm{s}$ minodiis dilatatis, ineiso-dentatis. - Capilula depresso-globosa v. spiciformia, lon. ge pedunculata.

B r a u des ia Martius Nov, gen, et sp. II. 25. t. 125. 128. N. A. N. C. XIII. 313. A c h y r a $\mathrm{t} t \mathrm{~h}$ is $8 \mathrm{p}$. Jacq. Hort. Schönbr. t. 350. Bot. Mag. t.830.

c. MOGIPHANeS Mart. Perigonii cum pedicello brevi columnari quinqueglanduloso articulati foliola aequalia. Tubus stamiueus autheris quinque, staminodi is dilatatis, Inciso-dentatis. - Capilula v. spicae longe pedunculatae.

Mogiploanes Martius Nov, gen, et sp, IT. 29. $t$. 129 134. N. A. N. O. XIIT, 312. Gomphrenae sp. Jacq. Ic. rar, $\ell, 366$.

1958. Gomplarema LINN. Flores hermaphroditi v. abortn polygami, tribracteati. Perigo n ium pentaphyllum. Stam ina 5 , in cupulam v. tubum connata; filamenta dilatata, apice trifida, lobo intermedio antherifero, lateralibns indivisis v. fimbriatis; a n thera e uniloculares. 0 varium nniloculare, uniovulatum. Stigma sessile, capitatum, indivisum $\mathbf{v}$. bilobum, lobis abbreviatis obtusis, v. elongato-linearibus. Utriculus evalvis, monospermus. S e m en lenticulari-reniforme; testa crustacea. Embryo annularis, periphericus, a lbumen farinaceum cingens; radicula supera. - Suffrutices $v$. herbae, in America tropica copiosae, in Asia et Nova Hollandia rarae, glabrae v, villosae; foliis oppositis, petiolutis, floribus in capilula aut spicas axillares v. terminales, densas $v$. laxas et panieulatas dispositis.

Gomphreua Lian. gen, n, 314, R. Brown prodr. 415. a. SERTURNERA Mart. Flo re s pulygamo-monoici. Sta. mina in cupulam connata, filamenta ciliata, lobis sterilihos minntis. St ig m a capitatum, emarginato-bilobum. - Flores in capitulis subglobosis, terminalibux, aphyllis. Serturnera Martius Nov. gen, et sp. IT. 36.t, 136 . 138. N. A. N. $C$. XIII, 310, Alte rnantlierac.sp. Kunth. 
b. PFAFFIA Mart. Flores hermaphoditi. Stamina in tubum connata, filamentorum lobi laterales fimbriati, antheris longiores. Stigma capitatum. indivisum. - Flores in capitulis $v$, spicis terminalibus, aphyllis.

P fa ffia Martius Nov, gen, et sp. IT. 20. l. 128. 124. N. A. N. C. XIIT. 311, Gonphrenae sp. Vahl, Spreng.

c. HEBANTHE Mart. FI o res hermaphroditi. S $t a$ m in a in cupulam connata, filamentorum lobi laterales nudi, in. termedio antherifero breviores. St ig m a capitatum, emarginato-bilobum. - Flores in spicas laxas, paniculatas dispositi.

He b a $n$ the Martius Nov, gen. et sp. II. 42, t, 140, 145. N. A. N. C. XIIT, 30\%.

d. GOMPHRENA Mart, Fl or es hermapliroditi. Sta mi in a in tubum elongatum eonnata, filamentorum lobi laterales integerrimi v. fimbriati, antheris longiores. Stig m a bifidum, Iobis cylindricis. - Flores in spicas v. capitula aphylla aut foliosa, axillaria v. terminalia conferti.

Gomphre a a Martius Nov. gen. et sp. II. 1. t, 101121. N. A. N. C, XIIT, 297. St. Hilaire Pl. us. t, 31, 32. Bot. Mag. $t, 2815, \mathrm{~S} \mathrm{ch}$ u 1 tes i a Selhrader in Götting. Anz. - Bragantia Vaudelli in Römer Script. 50. non Loureir.

1959. Frölielaia MÖNCH. F I ores hermaphroditi, tribracteati. Perigoni um tubulosum, apice quinquefidum. Sta $\mathbf{m i n a} 5$, in tubum elongatum, apice quinquefidum connata, laciniis medio antheriferis; a $\mathrm{n}$ th era e uniloculares. Ovari $\mathbf{u m}$ uniloculare, uniovulatum. Stig m a sessile, pennicillato-multifidum. Utric u 1 us evalvis, monospermus, perigonio indurato, basi bieristato inclusus. Semen ovato-reniforme; testa crustacea. E m bry o annularis, periphericus, a I b um en farinaceum eingens; radicula supera. Herbae in America tropica et boreali calidiore observatae, adscendentes $v$. erectae, diffusae, plerumque ramosae; foliis oppositis, brevissime petiolatis, floribus in pedunculis terminalibus axillaribusque elongatis, spicatis, spicis oppositis verticillatisque, primum capituliformibus.

Frolichia Monch. Meth. 50. Hoplotheca Nuttall gen, II, 78. Martius Nov. gen. et sp. II, 47, t, 166, N, A. N. C, XIII, 295. Bot. Mag. t, 2603, Gom phrenae sp. Herit. Stirp, I, t.3. Kuath, DC. Ce los I a e sp. Jaeq. Ic. rar. $t, s t$.

TEI BUES II. ACHYRANTHEAE, $0 \mathrm{v}$ arium uniovulatum. Antherae biloculares.

SUETRIBUS T. POLYCNEMEAE. FI ore $s$ axillares solitarii sessiles, bibracteati, folio bracteae anticae locum tenente. Utriculus evalvis.

1360. Polyenemum LINN. Flores hermaphroditi, axillares, solitarii, sessiles, bibracteolati. Perigoninm pentaphyllum, foliol's utrinque concoloribus. Stam in a $1 \_5$, saepius 3 , ima basi coalita; filamenta filiformia, antherae biloculares. O varium uniloculare, uniovulatum. Stylus brevissimus; stigmata 2 , brevia. Utric ulus evalvis, monospermus. S e men lentieularireniforme; te st a erustacea. Em b r y o annularis, periphericus, alb um en farinacenm eingens; $r$ adic u la infera adscendente, - Herba annua, in Europa imprimis orientali et in $A s i a$ media obvia, ramosa, puberula, minute verruculosa; foliis alternis, sessilibus, subulatis, integerrimis, mucronatis, inferioribus gemmarum abortivarum bracteis pseudo-stipulatis, bracteis scariosis.

Poly $\mathrm{c}$ em um Linn, gen, n. 83. Gärtn. II. 2tf. t. 198. Sehkubr t. 5. Jacq. Fl. austr. $t$. 365. Nees jun. Gen. pl. II. 76. Moquin Tandon in Nouv, Annal, sc, nat, VII, 41.

1961. Ilemiehroa $R . B R$. F I ores hermaphroditi, axillares, solitarii, sessiles, bibracteolati.
Perigonium pentaphyllam, foliolis intus coloratis. St a $m$ in a 2 v. 5 , ima basi connata; filamenta filiformia; antherae biloculares. Ova rium uniloculare, uniovalatum. Sty las brevissimus; stigu a ta 2, brevia. Utriculus evalvis, monospermus. Sem en lenticulari-reniforme; $t \mathrm{e}$ st a crustacea. E m b ry o hemicyelicus, periphericus, albumen farinaceum cingens; radicula infera, adscendente. - Suffrutices in Nova Hollandia australi littorei; foliis alternis, semitere tibus, exstipulatis.

He un ehroa R. Brown. prodr. 409. Moquin Tandon in Nouv. Annal, sc. nat, VTr. 41.

SUBTIREU I. AERVEAE. Flores tribracteati, laterales abortivi nulli. U triculus evalvis.

1969. Psilotrieluam BLUM. Flores hermaphroditi, tribracteati. Perigonium pen. taphyllum, foliolis lanceolatis. S $\mathbf{t a} \mathrm{m}$ in a 5 , basi in eyathum connata; fil a m e n t a filiformia; a nth e $r$ a e biloculares; $8 \mathrm{taminodia} \mathrm{interjecta}$ nulla. Ovari um nniloculare, uniovulatum. Styl us simplex; stigma capitatum. Utriculus evalvis, monospermus, perigonii foliolis conniventibus, nudis inelusus. Se men .... Herba javan ic a, ramosa, decumbens; ramis geniculatis, trichotomis, foliis oppositis, radicalibus spathulatis, reliquis lanceolatis, floribus spicato-capitatis, axillaribus et terminalibus.

Psilotrich um Blume Bijdr, 544. - Genus monente el. auctore vix a sequente diversum. Anue huc Lei osperm $\mathrm{u}$ m Wallich Catalog. $n$. 6923, sive A hy ra a thes ferr g i ne a Roxb. Flor. Indic. edit. Wallich II. 502.

1963. Trieluinium $R$. BR. F lores hermaphroditi, tribracteati. Perigonin m pentaphyllum, foliolis linearibus. Sta min a 5 , basi connata; fil amenta filiformia; antherae biloculares; $s t$ a $m$ in od ia interjeeta nulla, Ovarium uniloculare, uniovulatum. Stylus simplex; stig m a capitatum, U tri c n I n s evalvis, monospermus, perigonii foliolis basi conniventibus, apice patulis, plumosis inclusus. S e m e n lenticulari-reniforme; $t$ e $s t$ a crustacea. E mb r yo annularis, periphericus, al b ume n farinaceum cingens; radicula centrifuga. - Herbae annuae v. perennes, in Nova Hollandia intra et extra tropicos provenientes; foliis alternis, floribus terminalibus, capitatis $v$. spicatis, bracteis scariosis, nitentibus.

T richin iu m R. Brown prodr. 415. Gaudich. ad Freyc. 2. 49. Martius in $N$. A. N, C, XIII, 317,

1964. Ptilotus $R, B R$. F lo res hermaphroditi, tribracteati. Perigonium pentaphyllum, foliolis lanceolatis. St a mina 5, ima basi connata; fil amenta filiformia; antherae biloculares; staminodia interjecta nulla. Ovari u m uniloculare, uniovulatum. Sty I us simplex; 8 t i g a capitatum. Utrieulus evalvis, monospermus, perigonii foliolis tribus interioribus medio lana cohaerentibus, apice patentibus, nudis inclusus. S em e $n$ lenticulari-reniforme; $t$ est a crustacea. $\mathrm{Embry}$ o annularis, periphericus, a I bumen farinaceum cingens; r a d ic u la centrifuga._ Herbae annuae, glabrae, in Moluccis et in Nova Hollandia tropica observatae; folits alternis, angustis, floribus terminalibus, subcapitatis, bracteis scariosis, nitentibus.

Ptil ot us R. Brown prodr. 4t5. Martius in N. A. N. c. $x / 1 T, 318$,

1965. Nyssanthes $R, B R$, F lore s hermaphroditi, tribracteati, bracteis spinescentibns. 
Perigonium tetraphyllum, foliolis duobus ex teriuribus inaequalibus, spinescentibus. St $\mathbf{t} \mathrm{m}$ i $\mathrm{n}$ a 2 4, basi connata; fil am enta filiformia; antherae biloculares; st a minodia interjecta ligulata. Ovari u m uniloculare, uniovulatum. StyIus simplex; stigma capitatum. Utriculus evalvis, monospermus. S em en lentieulari-reniforme; testa crustacea. E mbryo annularis, periphericus, a I bumen farinaceum cingens; radicula supera. - Herbae v. suffrutices, in Nova Hollandia tropica et orientali provenientes; foliis oppositis, spicis glomeruliformibus, axillaribus et terminalibus.

Ny s s a n thes R. Brown prodr. 418. Martius in $N . \mathcal{A}$. N. C. XIII, 318 .

15Bs. Aehyramthes LINN, F lores hermaphroditi, tribracteati, bracteis spinescentibus. Perigonium tetra-pentaphyllum, foliolis aequalibus. St a min a $4-5$, basi in eupulam connata ; fi lamenta filiformia; antherae biloculares; $s \mathrm{tam}$ inodia interjecta dentata v. fimbriata, plana. Ovari um uniloculare, uniovulatum. Stylus simplex; stigma capitatum. Utriculus evalvis, monospermus, S e m en lenticulari-reniforme; te s t a crustacea. $\mathbf{E} \mathbf{m}$ br y o annularis, periphericus, albumen farinaceum cingens; radicula supera. - Herbae $v$. suffrutices, interdum arborescentes, in regionibus tropicis et subtropicis $v e t e-$ $r$ is orbis provenientes; foliis oppositis, floribus la xe spicatis, plerumque reflexis.

A chyrauthes Linn. gen, n. 288, excl. sp. R. Brown prodr. 417. Sibthorp. Fl. graec, $t, 244$. Miller Ic. $t, 11, f .2$. Martius in N. A. N. C, XIII. 319 .

196r. Centrostaelnys $W A L L$. Flores hermaphroditi, tribracteati, bracteis mutieis. P e rigonium pentaphyllum, foliis spinescentibus, postico augustiore, longiore. Stam ina 5 , basi in cupulam connata; fil am en ta subulata; a n therae biloculares; staminodia interjecta apice fimbriata, medio lacinula bifida fornicato - appendiculata. Ovarium uniloculare, uniovulatum. Stylus simplex; stigma capitatum. Utriculus evalvis, monospermus. S em en lenticulari-reniforme. Em b r y o annularis, peripheriens, a I bu men farinaceum cingens; radic n la supera. Herba indica, aquatica; foliis oppositis, lanceolatis, floribus dense spicatis, post anthesim patentissimis $v$. reflexis.

Ceutrostachys Wallich in Hoxb. Flor. Ind. II. 497. A e hyrat a thes aquatic a Roxb.

1968. Aerva FORSK. Flores hermaphroditi, tribracteati. Perigonium pentaphyllum, foliolis aequalibus, lanatis. S $t$ a $m$ i n a 5 , basi in cupulam connata; f i l a m e n t a subulata; antherae biloculares; staminodia interjecta plana, dentata. O va ri um uniloculare, uniovulatum. Stylus brevis; $8 \mathrm{tigma}$ bifidum. Utriculus evalvis, monospermus. Semen lenticulari compressum; t es t a erustacea. E m bry o areuatus, periphericus, a l bum en farinaceum cingens; radicula supera. - Herbae $v$. suffrutices erecti, albo-tomentosi, in Asia tropica et in $A f r i-$ ca boreali obvii; foliis alternis, floribus minutis in spicas axillares $v$. terminales densas congestis.

A e rva Forskel Aegypt. 170. Martius in N. A. N. C. XIIT. 290. Blume Bijdr. SM7. 111 e ce b ri s p. Liua. Mill. Ic, $t$. $11 . f$. 2. A e hy $x$ a athis s p. Willd.

SURTRIBUS III. DESMOCHAETEAE. Flores tribracteati. Bracteae laterales praeter florem fertilem abortivos plures, in cristas $\mathbf{v}$, slochides mutatos in axillis foventes. Utriculus evalvis.

1969. Digera FORSK, Flo r es hermaphroditi ternati, tribracteati, laterales steriles, in cristam horizontalem mutati, intermedius fertilis. Perigonium pentaphyllum. Sta mina 5, libera; fil amenta subulata; a $\mathbf{n}$ herae biloculares; s ta minodia interjecta nulla, Ovarium nniloculare, uniovulatum. Stylus brevis; stigmat a 2 , teretiuscula. Car 50 p s is tuberculata. Sem en ... - Herbae in A gypto, Arabia et in India orientali observatae, erectae, glabriusculae; foliis alternis, petiolatis, floribus racemoso-spicatis.

Diger a Forskael Aegypt, 65. Martius in N. A. N. C. XIII. 285. A ch y ranthis s p. Retz. Lam. Desmoehaetae sp. DC.

15\%0. Desmoelnata $D C$. Flores hermaphroditi ternati, tribracteati, laterales steriles in glochides mutati, intermedius fertilis. Perigoninm pentaphyllum. Stamina 5 , basi in cupulam connata; filamenta subulata; a ntherae biloculares; $8 \mathrm{taminodia} \mathrm{interjecta} \mathrm{nulla.}$ Ovarium uniloculare, uniovulatum. S t y I us simplex; stigma capitatum. Utriculus evalvis, monospermus, S e m e n Ientieulari-reniforme; te s ta crustacea. Emb ryo annularis, periphericus, albumen farinaceum eingens; radicula supera. - Suffrutices in Asia tropica provenientes, erecti, patuli; foliis oppositis, floribus glomerula. tis, glomerulis in spicas confertis.

Des mo chaeta DC. Catalog. Hort. Monsp, 1813, p. 102. exel. sp. A chyranthis sp. Linn. Lam. Pup alliat s p. Juss. Wellia Codiveli Rheede Malab. X. 117. $t .59$.

1981. Pupalia MART. Flores hermaphroditi binati v. ternati, tribracteati, laterales steriles in glochides mutati, intermedius fertilis. Perigonium pentaphyllum. St a m in a 5 , basi in cupulam connata; fi I am enta subulata; antherae biloculares; $8 \mathrm{tam}$ inodia interjecta lobuliformia, dentata. Ovari u m uniloculare, unio. vulatum. Stylus simplex; stigma capitatum. Utriculns evalvis, monospermus. Semen oblongum; testa crustacea. Embryo annularis, peripherieus, albume $\mathbf{n}$ farinacenm cingens; $r$ ad icula supera. - Herbae in America et Asia tropica indigenae, erectae $v$. prostratae, folits oppositis, petiolatis, floribus spicatis.

Pupalia Martius Nov, gen. et sp. Ir. 60, t, 156. 158. Des uo chae ta Kunth in Humb. et Bonpl. Nov. gen, et sp. II. 1971 . C y a th u I a Loureiro $F l$, cochinch, $I, 125$, Blume Bijdr. 5.8. P u pali a e sp. Juss.

OBSERVATIO. Desmochaetearum subtribui adnameranda videntur genera sequentia, b auetoribus indicata, nobis proh dolor! penitus incognita.

a. SALTIA R. Brown in Wallich PI, As, rar, I, 17, (non in App. to Salt Abyss.) - Acliy rantes papposa Forsk, mse, Genus Pupuliae proxinum dicitur.

b. POLYSCALIS Wallieh Catalog. n. 6939. 6940. Des mo. e hateta sequax Wallich in Roxburgh Flor. Ind. $I$. 506. cuí cl. auctor bracteas et perigonii foliola exteriora glochidata, et utriculum basi regulariter (transversim?) dehiscentem, tribuit.

SURTRIBUS IV. AM ARANTEAE. FIor es tribracteati, laterales abortivi nulli. U t ri. cul us circumscissus.

19\% 2. Amarantus LINN. Flores po lygamo-monoici, tribracteati. Perigon ium tripentaphyllum. S $\mathrm{tam}$ in a 3 v. 5 , rarius 2 v. 4 , libera; filamenta subulata; a ntherae bilocu-lares; staminodia nulla. Ovarium unilo 
culare, uniovulatum. St y l u s brevis; s t ig mat a $2-3$, fliformia. U i r i e u I u s circumscissus. S e m e $\mathbf{n}$ lenticnlari - reniforme, erectiusculum; t e $8 \mathrm{t}$ a crustacea, umbilico nudo. Embryo hemicyclicus, periphericus, a 1 b um en farinaceum eingens; radic ula infera. - Herbae inter tropicos totius orbis obviae, in temperatis rarae, annuae, erectae $v$. diffusae; foliis alternis in petiolos decurrentibus, floribus minutis in spicis v. glomerulis glomerulatis.

A marantus Linn. gen. n. 1060. Willdenow, Historia Amarantorum. Turici, 1790. fol, Martius in N. A.N. C. XIII. 288. Nees jun. Gen, $p l, I I, 71$. Reíchenb. $p l$. crit, $t, 421-$ 475. Poly chroa Loureir. Flor. cochinch. 684.

1 9 3. Chamissora $\boldsymbol{H}, \boldsymbol{B} . \boldsymbol{K}, \mathrm{F}$ lo res herma phroditi, tribracteati. P e rigon i u mentaphyllum. St a m in a 5, basi in cupulam connata; fil a m e $n$ ta subulata; antherae biloculares; staminodia interjecta nulla. Ovari um uniloculare, uniovnlatum. Stylus simplex; stigmata 2, filiformia. Utriculus circumscissus. Semen lenticularireniforme; test a crustacea, arillo brevi albo umbilicum lateraliter cingente. $\mathbf{E} \mathbf{m}$ b r y o annularis, periphericus, a 1 b u m en farinaceum cingens; radicula supera. - Herbae tropicae, glabrae $v$, pubescentes; foliis alternis, floribus in spicis axillaribus terminalibus aut bloboso-capitatis, foliis floralibus nullis.

$\mathrm{Ch}$ a mis so a Kunth in Humb. ot Bonpl. Nov. gen, et sp. II, 138. t. 125. Martius in N. A N, C, XIII. 286. C h a rpentie r a Gaudich. ad Frege. 444. $t$. 47. 48.

OBSERVATI0. Chamissoae indicae Mart. nobis prorsus ignotae, Allem an iae R. Br. nomine in Wallichii Catalog. n. 6890 _6892 Iaudantur.

TRIIEUS III. CELOSIEAE. Ovari u m multiovulatum. A n therae biloculares.

$19 \%$ 4. Cladestachys $D O N$. F 1 o r e s hermaphroditi, tribracteati. Perig on i um pentaphyllum, demum squarroso-patulum. St a m in a 5, libera; fil amenta filiformia; antherae biloculares; s ta minodia nulla. O varium unilocu lare, multiovulatum. Stig m a t a 3 , linearia, revoluta. Utriculus(?) evalvis. Semina plurima. Frutex indicus, ramosissimus, diffusus, glaber; foliis alternis, petiolatis, ovatis, acutis, spicis elongatis, paniculatis, floribus parvis, albis.

Cladostacliys Don Nep. 76. Martius in N.A.N.C. XIII. 294. Achyranthes muricata Linn. Blitum frutes e ens Rumph Amboin. $V .235 . t, 83 . f, 2$.

19\%5. Celosis LINN. Flores herma phroditi, tribracteati. Perigonium pentaphyl lum. Sta min a 5 , basi in cupulam connata; $\mathrm{fi}_{\mathrm{i}} \mathrm{a}$ menta filiformia; antherae biloculares; $8 \mathrm{ta}$ minodia interjecta nulla. Ovarium uniloculare, multiovulatum. Stylus brevis; $8 \mathrm{tigmate}$ capitato v. bi-trilobo. Utriculns circumscissns. Semina plurima, lentienlari-reniformia; $t$ e s $t$ a crustacea. $\mathrm{Km}$ b r y o annularis, peripheriens, a I bume n farinaceum cingens; radicula unbilico proxima. - Herbae in Asia et Africatropica obviae, in $A$ merica rarae, erectae, glabrae, interdum suffrutescentes; foliis alternis, in petiolos decurrentibus, floribus spicatis, nitide scariosis.

C e 1 a sia Linu, gen, n. 289. Martiu Cent. t. 7. Jacq. Hort. Schönbr. t. 15. Ic. rar. t. 339. Martius Nov. gen. et sp. II. 62, t, 157, 158, N. A. N. C. XIII. 299.

19 ร. Lestibudesia THOUAR. F Iores hermaphroditi, tribracteati. Pcrigon u m pentaphyllum. S $t$ a $\mathbf{m}$ in a 5 , hasi in expulam connata; filamenta filiformia; antherae bisoculares; $8 \mathrm{ta} \mathrm{mi} \mathbf{n}$ o i a dentiformia interjecta, O va ri $\mathrm{m}$ uniloculare, multiovulatum. Stig m at a 3_4, sessilia, filiformia, revoluta. U t ri- cu l u s circumseissus. S emina plurima, lenticnlari-reniformia; testa crustacea. Embryo annularis, periphericus, a $1 \mathbf{b} \mathbf{u} \mathbf{m}$ en farinaceum eingens; radicula umbilico proxima.-Frutex madag ascariensis; foliis alternis, floribus in glomerulis spicatis.

Lestibndesi a Thouars Gen. Madagasc, n, 17. Veg. Ins. Afr. 33, t, 16. Martius in N, A.N, C, XIII, 294.

19ร \%. Lamgia. F 1 o r e s hermaphroditi, tribracteati. $\mathrm{P}$ e $\mathbf{r}$ i g o $\mathrm{n}$ i $\mathrm{m}$ pentaphyllum. $S t$ a $\mathrm{m} i \mathrm{n}$ a 5 , basi in tubum connata; fi lamenta complanata, trifida, lobo medio antherifero; antherae biloculares. Ovarium uniloculare, multiovulatum. St y 1 us brevis; stig $\mathrm{m}$ a $\mathrm{t}$ a 3 , subcylindrica. U $\mathrm{t} \mathbf{r} \mathrm{i}$ c u $\mathrm{l}$ u s circumseissus. Semina plurima, lentienlari-reniformia; t $\mathrm{e}$ s t a crnstacea, E $\mathbf{m b r}$ y o annularis, periphericus, a l b nmen farinaceum cingens; radieula nmbilico proxima. - Herba capensis, erecta, ramosa, cano-glauca; foliis alternis, floribus in capitula terminalia, globoso-ovata, aphylla confertis, glabris.

Berzelia Martius in N. A. N. C. XIII. 292. non Brongn. Celos ia g la ue Wendland Hort. Herrenh, t. 2.

1988. Deeringia R. BR. Flores hermaphroditi, tribracteati. I'erigonium penta phyllum. Stam in a 5 , basi in cyathum connata; filamenta filiformia; antherae biloculares; sta $\mathrm{m}$ in odia interjecta nulla. Ovarium uniloculare, multiovulatum. Sty lus brevis; $\mathrm{s}$ tig mata 3 , semicylindrica. B a $\mathbf{c}$ a inflata. Sem in a plurima, lenticulari-reniformia; t e 8 ta coriacea. E mbr yo annularis, peripheriens, a l b um en farinaceum cingens; radicula nmbilieo proxima. Frutices glabri, debiles, super arbores et alios frutices decumbentes, in India orientali et Nova Hollandia indigeni; foliis alternis, spicis terminalibus et $e$ summis alis.

Deering ia B. Brown prodr. 413. Bot, Mag, t, 2717. Martius in N.A.N.C.XIII. 286. C el os i a ba c cat a Retz. obs. V. 23.

\section{Ordo CIII. Polygoneate.}

POLYGONEAE Jussien gen. 82. R. Brown prodr. 418, Bartling Ord. nat. 107. POLYGONACEAE Lindley introduct. edil. $I I . p, 211$.

Herbas annuae aut perennes, v. Frotices interdum arborescentes, erecti $v$. volubiles, inter herbas plures paludosae v. aquaticae. Ca ales et rami teretes v. sulcato angulati, nodosoarticulati, foliosi, rarius aphylli, v. scapiformes. F o li a alterna $v$, ad basim caulis congesta, rarissime opposita, simplicia, integra, integerrima v. interdum undulata aut incisa, saepissime penninervia, juniora marginibus revoluta, rarius sessilia, plerumque plus minus longe petiolata, petiolo basi vaginante, v. saepius stipulae intrapetiolari vaginanti clausae (ochreae), herbaceae $\mathbf{v}$. coriaceac aut membranaceae, plus minus laxae v. cauli adpressae, partimque adnatac, quandoque fere obsoletae inserto.

Flozes hermaphroditi v. abortu unisexuales, e foliorum ant b rac te a r u m foliacearum v. uchreaeformium axillis solitarii, fasciculati v. verticillati, racemosi v. spicati, nunc paniculati v. cymosi, interdum in capitula contracti, nudi aut rarius singuli ant plures involucro tubuloso vel cyathiformi inclusi. 
Penigoniom calycinum herbaceum, v. corollinum subcoloratum, album v. roseum, tri-tetrapenta-hexaphyllum, foliolis liberis $\mathbf{v}$. basi cohaerentibus, interdum in tubum connatis, uni-biseriatis, per aestivationem imbricatis, aequalibus $\mathbf{v}$. plus minus connatis, interioribus non raro majoribus, saepe demum increscentibus, fructum involventibus, nune omnibus marcescenti-persistentibus $v$, rarius deciduis.

Stamina tori margini angusto, imo perigonio adnato, rarius in annulum glandulosum incrassato inserta, ejusdem foliolis opposita, rarissime alterna, plerumque ante perigonii foliola exteriora geninata v. terna, ante interiora solitaria, hinc numero varia, nunquam tamen indefinita. Filamenta filiformia v. subulata, libera v. interdum basi cohaerentia, exserta v. inclusa. Antherae introrsae biloculares, ovatae, globosae v. oblongae, ut plurimum incumbentes et versatiles, rarius ereetae, basifixae, loculi oppositi, longitudinaliter dehiscentes.

Ovariom unicum, e carpidiis duobus, saepius tribus rariusve quaternis compositum, carpidiorum marginibus simpliciter applicitis uniloculare, lenticulari-compressum v. saepius trigonum rariusve tetragonum, liberum v, ima basi interdum perigonii tubo cohaerens, demumve concrescens, $0 \mathrm{v}$ u $\mathrm{l}$ u $\mathrm{m}$ unicum, basilare, sessile, orthotropum, hinc interdum prope micropylem verticem orarii spectantem ejusdem parieti ope textus conductricis cohaerens, rarissime ex apice funiculi basilaris longiusculi liberi inversum, mieropyle deorsum spectante, demum erectum. Styli angulorum ovarii numero $2,3 \mathbf{v} .4$, liberi v. basi connati, interdum brevissimi v. subnulli. S ti gm at a simplicia, capitata v. discoidea, interdum penicillato-plumosa.

Carxopsis v. acneniom monospermum, lenticulari-compressum v.triquetrum, aut rarissime tetraquetrum, angulis costaeformibus v. membranaceo-marginatis, interdum in alam, rarissime duplicem preductis, nunc omnino nudum, nunc perigonio emarcido $\mathrm{v}$. increscente tectum v. saepius ejusdem foliolis interioribus conniventibus inclusum, quandoque cum tubo baccante concrescens.

SEMEx unicum, cavitati subconforme, erectum, liberum v. cum pericarpio concrescens. Testa membranacea, umbilico basilari lato.

A lbumen farinacenm, rarissime subearnosum, plus minus copiosum.

Eмвнуо antitropus, albuminis lateri applicitus, rectus v. plus minus arcuatus, nune intra albumen inclusus, centralis v, excentricus, albuminis fere longitudine. Cotyle dones lineaI es v. ovatae, incumbentes $v$, accumbentes, inter dum late foliaceae, flexuosae, albumen bipartientes. R a di c u la elongata, umbilico basilari e diametro opposita, verticem fructus spectans.

Polygoneae per totum terrarum orbem diffusae, in regionibus temperatis veteris orbis paullo frequentiores, inter tropicos novi continentis arborescentes, hinc Chenopodeis, Amarantaceis et Nyctagineis proximae, illinc ad Piperitas accedentes, ab illis embryonis radicula ab umbilico remota, partium floris numero saepe ternario, perigonio in plurimis colorato, ochrearum praesentia et habitu facillime distinguuntur, ab his genitalium et perigonii nobiliori fabrica, et embryonis nudi, nec sacculo amniotico inclusi forma diversae.

Herbae nonnullarum edules, aliae ob albuminis farinacei copiam cultae, quarundam radices amaricantes, magni in medicina usus.

TREIBUS I. ERIOGONEAE. Involucru m tubulosum, uni-multiflorum. Ov ul u m basilare, sessile, orthotropum. Semen erectum. Embryouis antitropi radicula supera.

1Dร9. Pterostegia FISCH. et MEY. Invo I u c rum uniflorum, diphyllum, frnctiferum ampliatum, dorso eristatum. Fl ores hermaphroditi, interdum polygami (?) intra involucra solitarii, subsessiles. P e rig o $\mathrm{n}$ i $\mathrm{m}$ herbaceum, quinquesexpartitum, persistens. Sta m in a 5 v. 6 , perigonii basi inserta cjusque laciniis opposita; fil a m enta... O varinm trigonum, uniloculare. OvuI u m unirum, basilare, orthotropum. Styli 3 brevissimi; $8 \mathrm{tigmatibus} \mathrm{capitatis.} \mathrm{Caryopsis}$ triquetra, involucro inclusa. S e m e $\mathbf{n}$ erectum. E mb $r y 0$ in axi albuminis farinacei antitropus; $\mathbf{c o -}$ tyledonibus .... radicula supera. - Herba californica, annua, facie Drymariae, ramosissima, prostrata, pilis minulis simplicibus adspersa, subglabra; ramis elongatis, filiformibus, subdichotomis, foliis omnibus oppositis, obovato-spathulatis, subreniformibus $v$. suborbiculatis, in petiolum attenuatis, integerrimis, apice emarginatis, ochreis nullis, floribus axillaribus subsessilibus, minutis, involucri diphylli foliolis primum parvis, demum ampliatis, membranaceis, reticulato-venosis, inaequilateris, dorso cristato-alatis.

Pterostegia Fischer et Meyer Index sem.hort. Po. iropolit. 1835. II, 48.

198d. Tlueromes BENTH. I n v $1 \mathrm{n}-$ c r u m uniflorum, tubulosum, compressum, bidentatum, dentibus subulato-aristatis, inaequilongis. F lores hermaphroditi, intra involuera solitarii, subexserti. Perigonium herbaceum, sexpartitum, laciniis tribus exterioribus majoribns. S $t$ amina 9 , imo perigonio inserta, ejusdem lobis exterioribus geminatim, interioribus singillatim oppusita ; fi I a m enta filiformi-subulata, basi coalita; antherae .... Ovari um trigonum, uniluculare. Ovulnm .... Styli 3 brevissimi; stigm a tibus capitatis. A cheninm triquetrum. - Herba annua, californica, spithamea, pilosiuscula; ramis dichotomis, divaricatis, foliis inferioribus petiolatis, oblongo-linearibus, basi breviter va- 
ginantibus, bracteis ad dichotomias et sub floribus amplexicaulibus, stellato-trilobis, lobis lato-ovatis apice aristulatis, invalucris sessilibus, subverticillatis.

M ucroue a Bentham in Linn. Transact, XVII, 419. t. 20.

198 1. Chorizanthe R. BR. Involuc rum uniflorum, tubulosum, trigonum, sexdentatum, dentibns aequalibus $v$. inaequalibus, muticis $v$. mucronato-aristatis. Flor es hermaphroditi, intra in volucra solitarii, inclusi v. suberserti. Perigo. ninm herbaceum, tubulosum, limbi sexlobi lobis subaequalibns, biseriatis. $\mathbf{S}$ a $\mathbf{m}$ in a 9 , imo perigonio inserta, limbi lobis exterioribus geminatim, interioribus singillatim opposita; fil a m enta filiformisulublata, inclusa, basi coalita; a nth era e ovatae, versatiles. $O$ va $r$ i u trigonum, uniloculare. 0 v uIn m unicum, basilare, orthotropum. Styli 3, filiformes; stigmatibus capitatis. Achenium triquetrum, intra involucrum latens. S e m en trigonum, ereetum. E $m$ b ryo intra albumen subcarnosum excentricus, rectus, antitropus; cot y l e d on ibus ovatis, planis; radic ul a elongata, supera. - Herbue californicae et suffrutices chilenses; foliis alternis, ad basim caulis confertis et secus ramos subfasciculatis, saepe villosis, petiolis basi vix vaginantibus, inflorescentia cymosa, laxiuscula $v$. in capitula contracta.

Chor iz an the R. Brown msc. Bentham in Linn, Transact, XVII, 416, t, 17, f, 11, $t, 19$.

1982. Eriogonum L. C. RICH. Invo 1 u c r am multiforum, tabulisum, eampanulatum v. cyathifurme, vix angulatum, subaequaliter sex dentatum. F lo r e s hermaphroditi, intra involuera plurimi, e roceptaculo bracteolis instructo pedicellati, exserti, Perigonium subherbacenu, profunde sexfidum, laciniis biseriatis, interioribus minoribus. St am in a imo perigonio inserta, ejusdem Iariniis exterioribus geminatim, interioribus singillatim opposita; filamenta filiformia, exserta, basi subcealita; a $\mathrm{n}$ h $\mathrm{e}$ ra e ovatae, versatiles. $0 \mathrm{va}$. ri um trigonum, uniloculare. O v u ln m unicum, basilare, orthatropum. St yli 3 , filiformes; stigmali,bus capitatis. A chenium triquetrum, perigonio emarcido stipatum. Sem en trigonam erectum. Em b ryo intra albumen subearnosum excentricus, rectus, antitropus; cotyledonibus ovatis, planis; radicula elongata, supera. Herbae v. suffrutices boreali-americani, saepissime lanuginosi; foliis radicalibus congestis, caulinis alternis v. subfasciculatis, petiolis basi vix vaginanlibes, $v$. rarissime in ochream dilatatis, pedunculis di-trichotome v, umbellatim ramosis, involucris solitariis $v$ glomeratis.

Eriog on um L. C. Richard in Michaux Flor. Bor. Amer. I. 286, ใ. 24. Nuttill in Journ. Acad. Nat. Sc. PhiZadelp. VII. 50, t. 8. Benthaw in Linn. Transact. XVIT. 405. t. 17. f. 10, t, 18. E 8 p 1 n o sa Lagase.

TREIBUS IL. POLYGONEAE VERAE, In vol u c r u m nullum. O v u l u in basilare, sessile, orthotropum. Semen erectum. E mbry onis antitropi radicula supera.

1983. Oxy ria HILL. F lo res hermaphroditi. Perigonium herbaceum, tetraphyllnm, foliolis duobus interioribus latioribus. $\mathrm{S}$ ta $\mathrm{m}$ in a 6 , perigonii foliolis exterieribus geminatim, interioribus singillatim opposita; fil a m enta lrevia; a ntherae oblungae, versatiles. Ova rium unilo. eulare, compressum, marginatum. O v n l um unicum, basilare, orthotropum. Stig mat a 2 , subses- silia, pennicillata. A cheni um lenticulare membranacenm, ntrinque late alatum, perigonii foliolis interioribus persistentibus basi stipatum. S e m en achenio contrarie compressum, erectum. Embryo in axi albuminis farinosi antitropus, rectns; $\cot y$. le do n ib u s planis, ellipticis; ra dic ula elongata, supera. - Herbae perennes, humiles, in a lpibus Eurapae et Asiae et in regionibus arcticis obviae; foliis omnibus radicalibus petiolatis, cordato-reniformibus, scapis subramosis, ochreis sub ramis brevibus, oblique truncat is, florum verticillis dimidiatis, laxiusculis, basi unibracteatis, pedicellis articulatis.

Oxyria Hill, veg. syst. 10. p. 24. Campdera Rum. p. 153. t. 3. f. 3. R. Browa in App. Parry Vay. p. 281. Meisner in Wallich Pl, As, rar, III, 6i. Nees jun, Gen, pl. IT. 55. D о и а R. Browu in Ross Voy. Edit. I. p. 42. $\mathrm{R}$ aa ex digy n a s Linh. Garta. II, 180. t. 119. E. B. $t .910$. FI. Dan. $t$. 14. R h e um dig y $\mathrm{n}$ u Wahleub. Fl. lapp, $t, 9$.

1984. Theum LINN. Flores hermaphroditi. Perigoninm herbaceum, sexpartitum, laciniis aequalibus, marcescens. St a $\mathrm{m}$ in a 9 , $\mathrm{pe-}$ rigonii foliolis exterioribus geminatim, interioribus singillatim opposita; fil a menta subulata; a ntherae ovatae, versatiles. Ovari um trigonum, uniloculare. O v u I u m unicum, basilare, orthotropum. Stigmata 3 , subsessilia, integra, subdiscoidea, patula. C a ry op s is late alato-triquetra, basi perigonio emarcido stipata. S e m e n erectum, triquetrum. E $m$ bryo in axi albuminis farinacei rectus, antitropus; cotyled onibus planis marginibus caryopsidis facies spectantibus; radicula brevi, supera. - Herbae perennes, in Asiae mediae montibus indigenae, ob radicum amaricantium vires celebratae; foliis omnibus radicalibus $v$. caulinis alternis, amplis, basi vaginantibus, floribus paniculatis $v$. spicato-racemosis.

R h e um Lina. gen, $n$, 401, Gärtn. $I T, 177, t, 191, f, 1$. Sehkulir t. 110. Lam. t. 324. Desfout. Annal. Mus, II, $t .49$. Meisner Polygon. t. 2, $f$. d. Wallieh Pl. As, rar. $I I T, 65$.

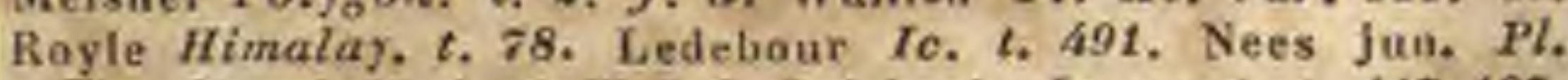
offic. Suppl. II. 4_6. V.5.6. Reicheab. Ic. exot. t. $117,127$. Sweet Fl. Gard, II. t.270. Bot. Mag. t.350s. - R ha barb a $\mathrm{r}$ m Tournef. inst. 18.

1985. KG Bnigia LINN. Floreg hermaphroditi. Perigonium herbaceum, triphyllum, foliolis aequalibus. St a m in a 3 , perigonii foliolis alterna; fil amenta filifurmia; a $\mathbf{t h e r a e ~ o v a - ~}$ tae, incumbentes. Ovari $\mathrm{mm}$ uniloculare, compressum. Ovulum unieum, basilare, orthotropum. Stigmat a 2-3, subeapitata. Ca ryops is leaticularis, perigonio persistente cincta. $\mathrm{S}$ e m e n compressum, erectum. E m b r yo intra albumen farinaceum lateralis, antitropus, arcuatus; cotyledonibus orbienlaribus; radie ula elnngata, supera. - Herba pusilla, in uliginosis maritimis et alpinis Islandiae et Lapponia e vegetans; folits alternis, obovatis, subsucculentis, busi in ochream brevem commissis, ftoralibus confertis, floribus terminalibus subfasciculatis, bracteis membranaceis interstinctis.

K z u ig i a Linn. gen, n, 1241, Flor. dan, t. 418. Lam. t. 51. Gärtn. $I I, 212, t, 128$. Wahlenb, Flor, Lapp. p. 45.

1986. Polygomum $L I N N$. F I o r es hermaphroditi v. abortn polygami. Perigoninm saepissime coloratum, quinquefidum, rarins triquadrifidum, la cin $i$ is interdum inaequalibus, demum pleramque auctum. Stam in a 5 v, 8 , perigonii laciniis singillatim v, interioribus etiam gominatim opposita, rarissime 4 v. 9 ; fil a menta subulata; a ntherae ovatae, ditymae, versatiles. Gland u lae perigynae $\mathbf{v}$. rarius hypogynae, staminilias alternae, interdum nullae. Ovarium uniloculare, compressum $v$. triquetrum. Ov u 1 um 
unieum, basilare, orthotropum. St y 1 i bi-trifidi, interdum subnulli; $s \mathrm{t}$ i $\mathrm{g}$ a $\mathrm{t}$ a capitata. A ehe ni u m lenticulare v. triquetrum, perigonio inclusum. Sem en achenio conforme, erectum. $\mathbf{E m b r y o}$ albuminis farinacei v. cornei angulum ambiens, antitropus, leviter areuatus; coty led o$n i b u s$ incumbentibus anguste linearibus, v. accumbentibus foliaceis latis, albuminis sulco receptis; ra di e u la longiuseula, supera._Herbae cosmopolita e, inter tropicos rariores, annuae v. perennes, interdum suffrutescentes, nonnullae aquaticae, quaedam volubiles; foliis alternis, petiolatis $v$. sessilibus, integerrimis $v$. sinuatis, interdum crispatoundulatis, nonnunquam pellucido-punctatis, ochreis membranaceis laxiusculis, floribus spicatis, racemosis v. paniculatis, interdum subcapitatis, bracteis nunc ochreis conformibus, nunc infundibuliformi-turbinatis.

P ol y g on a m Linn. gen, $n, 391$, exel. sp. Meisner, Mo. nographiae generis Polygoni prodromus. Genevae, 1826. 4. et in Wallich Pl. As. rar. IIL. 53.

a. BISTORTA Tournef. P e rig o n i u m coloratum, profunde quinqueficlum. S ta $\mathrm{m}$ in a 8 , rarissime 9 . Styli 3 , longi; stigmatibus exiguis. Achenium triquetrum. Coty le do nes accumbertes. - Rhisoma lignosum, repens, castes annotini herbacei, subsimplicirsimi, folia nunquam pellucido-punctata, racemi spiciformes, simpli. ces, bracteae paleaccae ochreaeque tenerae, obligue truncatae, nunquam ciliatae.

B is to rta Tournef, inst. 551. Meisner Polygon, 50. Wallich $P l$. As. rar. III. 53, t, 287. (E. B, t. 509. 669. Royle Himalaya t. 80. f. 2. 3.)

b. AMBLYGONON Meisn. Perigonium coloratum, profunde quinquefidum. Stami a 7 , rarios 5 v. 6 . StyIus medin divarieato bifidus. staninibus brevior; stig. matibus capitatis. A ebeninm lenticulare, compres. sum, obtusaugulum, acuminatum, pesigonio reeondifuw. cotyl edones incumbentes, IIneares. - Hadices fibrosae, herbaeque annuae, folia integerrima, spicae $l i$ neari-cylindricae, confertiflorae, bracteae turbinatae ochreaeque foliaceae, "glindricae.

A m b I y gonon. Meisn. Polygon, 53. t, 3. $f, k$, Wal lish Pl. As. rar III, 54. (Gartn. IT. 182, 1, 119. f. 5. Bot. Mag. t. 213.) La gu ine a Loureiro Fl, cochinch. I. 222.

c. PERSICARIA Tournef. Perigoninm coloratum, profunde quinquefidum. S $\mathrm{t}$ a $\mathrm{i}$ a 6 y, 8 , rarins 5 , rarissi. me 4. St y I us simi-bi-trifidus; s tig matibus exiguis. A e be $\mathrm{n} l \mathrm{u}$ m lenticulare v. triquetrum, obtusangulum, intra perigouium reconditum. C a ty led a a es accumbentes. - Radices fibrosae herbaeque annuae, rarius perennes, folia integerrima, ochreae cylindricae, circumscissotruncatae, flores racemoso-spicati, bracteae membranaceae, subinfundibuliformes.

Persiearia Tonruef, inst. 509. Gärtn, $I I, 180, t$. 119. $f$. 3. Meisner Polygon. 66. Wallich Pl. As, rar. II. 55. Tow ar a Adaus. Fam, II, 276. A n tenorna Rafinesque Flor, Ludov. 28. (FI, dan. t. 182, 702, E, B, $t$. 436. 756. 989, 1063. 1382. Nefs jun. Gen, pl. IT. 52, f. 1_5. et 7_13.) - ? Polygo ne II a Michaux Flor. Bor. Amer. II, 240. L y o 11 ia Rafiuesque in New-York Me. dic. Reposit, II, Hex. $\boldsymbol{V}$.

d. ECHINOCAULON Meisn, Perig on i u colorafua, quinquefidum, immutotuas. Stamina 5,6 v, 8. Stylus a medio bi-trifidus; $s t i g$ matibns exiguis. A chentum lenticnlare y. triquetrum. Cotyle dones accunhentes. Caules debiles, saepe tetragoni. retrorsum aculeati, folia basi cordato -incisa, ochreae cylindricae, circumscisso - truncatae, basi strigis v. aculeis retrorsis munitae. Spicae laxae, filiformes, v. compaclae, subcapiluliformes, saepissime geminatae.

Eeh jucanlon Meisn, in Wallich Pl. As.rar. III. 38. (Lam, t, 315. f. 3.)

e. Cepralophilon Meisn. Perigonín eoloratum, infundibuliforme, rarius compresso-nrecolatum, apice breviter quinquefidem v. rarius quadrifidum, saephus achenio demum agglutinatum. Stamina 8 , rarius 5 v. 6 . Sty1 us semi-bi trifidus; stig matibus parsis. Achenium triquetruar v, rarius leuticulare. Cotyledones accum. bentes. - Flores subsessiles, capitati, bracteae palea ceae v. scariofae, rarissime ciliatae.

Cephalophilo n Meisn. in Wallich Pl. As, rar. III. 59. Sectionis Persicariae et Aconogoni \$\$. 2. Meisn. Polygon. 59, ot 82 .

c. Didy a ocephalon Meisn. in Wallich l, $c$. Capitula geminata, rarins solitaria. Oehrea círeumseisso - truncatac. - Meisn. Polygon. $t$. 7 , f. 1. 2.

B. Corymbocepbaloo Meisn. in Wallich l.c. Capitula conferta, peduneulis subdichotonis, carymbosis, corymbis sulpaniculatis. $\theta$ chreate oblique truneatae.-Meisu. Polygon. $t$, 6 .

f. ACONOGONON Meisn. Perig oni um coloratum, profunde quínquefidum, lacintis patentibus, plavis. $S t$ a mina 8. Stylus trifidus. A chenium triquetrum, acntangulum, basi perigonio stipatua. Cotyledones accunbentes latae, albuminis rimae inmersae. - Herbne $v$. suffrutices monticoli. Oehreae cylindricae, nudae, flo. res racemosi, racemis pariculatis.

A couogonon Meisn. Polygon. 45. $t, B . f$. R. excl. \$. 2. Wallich Pl. As, rar. III, 61. (Gmelin Sibir. IIT. t. 8_10. Allion. Pedemont, t. 68, f, 1. Ledeb, Ic. 2,361,) g. AVICUlaria Meisn. Perigonium eolnratum, quin. qquepartitum. Sta mina 8 , rarius 5, v. 6 . Stigmata 3 , subsessilia, globosa, disereta. A chen $i \mathrm{~nm}$ trique. trum, perigonio parum aucto inclusum. Cotyledones ineumbentes. - Radices annuae $v$. interdum perennes. Ochreae tenerae, basi solum vaginantes, plerumque bipartilae, laciniis fimbriato-laceris, flores axillares, subsolitarii $v$. fasciculati, in ramorum apice saepius aphyllo, interdum spicas interruptas mentientes.

Avícularia Meisu. Polygon. 85, Wallich Pl. As. rar. III. 61. Poly g on w m Tournef, inst. t. 290. Jacq. Observ. III, t, 58. Allion, Pedemont, $t, 90 . f$. 2. Waldst. et Kit, Pl, Hung. t. 67. Sibthorp. Fl. graec, t, 36\%. Te. nore F7. neap, $t$. 3. Ledebour Ic, $t$. 4A4. Barton Med. Bot, $t, 95$. Nees jun. Gen, $p l .11, t, 52, f, 14,15$.

h. TINIARIA Meisn. Perigonii subeolorati quinquepartiti foliola inaequalia, tria exteriora dorso carinata, sae. pe in alam menbrauaceam demum auctam prodncta. Stam jna 8. Stignata 3 , sessilia, inerassata, medio con. fluestia. A chenium triguetrum, perigonio ancto totum reconditum. Cotyled on es accumbentes. - Nadices $f$. brosae, caules tereles, inermes, volubiles, folia cor dato-sagitlata, petiolata, bracteae ochreaeque conformes, pellucida-membranaceae, oblique truncatae, in. conspicuae, flores pedicellati, nunc in axillts fasciculati, nune racemosi $v$, paniculati.

Tin iaria Meisn. Polygon. 62, t. 5. f. 18, 20. exel. §. 2. Wallich Pl. As. rar, III. 63. He $1 \mathrm{x}$ і не Linn. gen. plant. edit. I. p 116. Fag o p y ri sp. Tournef. Möneh. (FI. dau, t, 244. E. B. t. G41. Barton Med, Bot, t, 100. 101. Nees jun. Op, cit. $f, 16-21$,

$1 \$ 8 \%$. Fagopgrum TOURNEF. Flores hermaphrodifi v. aloorin diclines. Perigonium coloratum, profunde quinquefidum, I a $\mathrm{e}$ i $\mathrm{n}$ i is aequalibus, demum haud anctis, marcescentibus. St a mina 8 , perigonii laciniis exterioribus geminatim, interioribus singillatim opposita ; fil a m en$t$ a filiformi-subulata; anthera e ovatae, versatiles. Glandulae 8 , hypogynae, staminibus alternae, Ovarinm trigonum, uniloeulare. Ovulum unicum, basilare, orthotropum. Styli 3 , longiusculi; 8 tigmat a capitata. A cheni $\mathrm{mm}$ triquetrum, perigonio emareido stipatum. Se un en achenio conforme, erectum. Emb ryo in axi albuminis farinosi bipartiti antitropus; cotyledonibus latis, foliaceis, palmatinerviis, conturtuplieatis, albnmen partim involventibus; $\mathrm{radicula}$ inclusa, supera. - Herbae annuae, in As ia media indigenae, per Europam cultae; foliis sessilibus cordatohastatis, ochreis semicylindricis, floribus cymoso-paniculatis.

F a g o p y $\mathrm{rum}$ Tournef, inst, t. 290. excl. sp. Gärtn. 1. 182. t. 119. Camplera Rum. 18, Meisn, in Wallich PI. As. tar. IIT, 63. Nees jus. Gen. pI. II. 33. Polygoni sectio Fagopyrau Meisn. Polygon. 61. Bat. Reg. $t$. 1065. 
1998. Dxyomuan BURCH. Flores monoici. Ma s e. Perigon i un coloratum, quadrifidum..... St a mina 8 ; fil a me $\mathrm{t}$ a, filiformia leongata; antherae ovatae. Fem. ..... C ar yo $\mathrm{p}$ s is oblongo-trigona, angulis membranaceo-alatis. Semen … - Herba capensis, annua, vix nota; foliis lanceolatis, incisis $v$. integris, floribus spicatis, pedunculatis, pluribus in spicae articulis.

$0 \times$ yg on um Burchell Travels $I$. 5is. Liadley Intro. duct. edit. $T I$. p. 443.

1989. Calligomama $L I N N$. F lore s her maphroditi, Perigoni nm coloratum, quinquepartitum, laciniis inaequalibus, duabus exterioribus panllo majoribus, marcescens. St a $m$ in a $12 \mathrm{v}: 15$, perigonii laciniis ternatim $\mathbf{v}$. interioribus geminatim opposita; fil am enta subulata, basi cohaerentia; antherae ovatae, versatiles, Ovarin m ovato tri-tetraquetrum, uniloculare. Ov ul u m unicnm, basilare, orthotropum. Styli 3. v. 4 , distineti; stigmatibus capitatis. Nux ossea, late tri-tetraquetra, angulis apteris costacformibus $\mathbf{v}$. in alam membranaceam duplicem expansis, inter angulos nuda v. setosa. S em en oblongo-tetraquetrum, erectum. E m b ryo ad latus albuminis farinacei rectus, antitropns; cot y led o n ib a s linearibus; radic ula supera. - Frutices in regione mediterranea orientali et in Asia media indigeni, aphylli; ramis dichotomis, articulalis, articulis vagina brevi membranacea, oblique truncata cinctis, floribus e vagina pedicellatis, pedicello medio arliculato.

Callig o n $\mathrm{m}$ Lian. gen. n. 600. Heritier in Linn. Transact. 1.179.

a. CALligonUM Linn. $\mathrm{N}$ ux angulis ia alam duplicem spinuloso-laceram expansis, spiuulis apice trifidis, cancellato-intertextis recta.

Callig o и и и Linn, 2, c, Juss. gen, 83. Lam. t, 410, Gärta. f. III. 28. $t$, 184. coll. p, 200, t, 215. f, 9. G. Polygouoides Tournef. It. II, 147. c, ic.

b. CALliPHXSA Fisch. et Mog. $\mathrm{N}$ u $\mathrm{x}$ augulis apteris, rotuadatis, costaeformibus, dense obtecta setis apice in membranam uucen vesicae instar includentem expansis. Calliphysa Fiseher et Meyer Index Sem. hort. Petropolit. 1835, I. 24.

e. PTERococcus Pall. Nux angulis in alam duplicem membranaceam, argute serratam expassis, inter angulos unda.

Pterocoecus Pallas $I t, I T$. App, 738, t, 5. P a 1 la si a Linu. f. suppl. 258, Gärto. f, IIT. 200, t. 215.

1990. Coceolloba $J A C Q$. Flores hermaphroditi. Perigonium subeoloratum, quinquepartitum, subaequale, demum increscens. Stamin a 8 , perigonii lacinis exterioribns geminatim, interioribus singillatim opposita, uno inter interiora contigua sito; fil a menta subnlata, basi cohaerentia; an the-rae globoso-didymae, versatiles. Ova ri am trigonum, basi eum perigonio connatum, unilocnlare. O v $\mathrm{I}$ u m unienm, basilare, or thotropum. Styli tres distineti; stigmat ibus capitatis. Cary op sis triquetra, spongiosa, perigonio baecato tecta partimque connata. Sem en triquetrum, ereetum. $\mathbf{E} \mathbf{m b}$ yo in axi albuminis farinacei antitropus; cotyled on ibus latiusculis undulatis; radicula supera. - Arbores americana e tropicae; ramis vaginatis, foliis alternis sessilibus $v$, pedicellatis, ochreis herbaceis oblique truncatis, racemis v. spicis oppositifolits elongatis, bracteis ochreis conformibus.

Coce ol o b a Jacq. Amer.t. 72, 78, Observ, 18, t, 8. 9. Gärtn. I.214. t.45. Hook. exot. Flor, t, 109. Bot, Mag.t, 3130. Nees Jun. Pl. offic. Suppl. I. 9. Meisner Polygon. t. 2. $f$. B. $C$.

1931. Ceratogonom MEISN. Flores polygami, masculi et feminei ex eadem axilla.
Masc. Perigonium coloratum, profunde quinquepartitum, foliolis aequalihus, obtusis, planis. Stamina 8 ; filam enta subulata; ant hera versatiles. Herma $p$ hr. Perigonium hexaphylI um, foliola tria exteriora coriacea, post anthesim aucta, dorso aente carinata, connata in tubum trigonum, medio dilatatum, utrinque acute attenuatum, apice brevissime tridentatum, angulis e medio in spinam patentem acutam excrescentibus; foliola tria interiora petaloidea, exterioribus alterna et inter corum dentes e tubo exserta, patula, marces. centia. Sta mina 8 , perfecta. Ovarium ..... Styli ..... A ehen i um perigunii tubo inelu$811 \mathrm{~m}$, eique acretum. S e in en erectum, trigonum, perigonii tabo conforme, angnlis medio in dentem obtusum productis. E in b $\mathrm{r}$ y rectns, in axi albuminis farinosi antitropus; cot yledoni bus planis, sibi invicem adpressis, late ovalibus, obtusis, trinerviis, inter angulum seminis et mediam ejus faciem huic angulo oppositam expansis, hine albumen in duas partes secantibus; radi c a la snpera. - Herba ul videlur annua, incertae originis, in horto calcuttensi culta; caule adscendente tereti, foliis petiolatis, voato-triangularibus v. hastatis, ochreis cylindricis, ore circumscisso setaceociliatis; spicis extraaxillaribus solitariis, laxissimis, filiformibus, bracteis cylindricis ciliatis, trifloris, pedicellis bractea subtriplo longioribus, sub fiore articulatis, demum deflexis.

Ceratogonon Meisner in Wallich. Pl. As. rar. III. 63. Polygo u u matriplicifolium Wallich.

1998. Famex NECK, Flores polygamomonoiei. Ma s c. Perig on i $\mathbf{m}$ herbaceum, quinque-sexfidum, laeiniis aequalibns, patentibus. Stamin a 4 6, perigonii foliolis exterioribus geminatim opposita; filamenta brevia; antherae oblongae, utrinque emarginatae, basifixae. F e m. Perigon i m nreeolato-infundibuliforme, demum incrassatum, limbi sexdentati dentibns exterioribus subspinescentibus, tandem reflexo-patentibus, interioribns minoribus, pyramidato-conniventibus. Ov a rin m uniloculare, obsolete triqnetrum. OvuI $\mathbf{~ m}$ unicum, basilare, orthotropum. St y 1 i 3 , breves, erectiusculi; stig mat a pennicillata. Caryo psis obsolete triquetra, perigonio incrassato trigono-costato inclusa, ejusdem dentibus exterioribus recurvatis mucronata, interioribus conniventibus pyramidata. Semen turbinato-triquetram, erectum. Embryo cyclicus, albumini farinaceo circumpositas; cotyled onibus elliptico-oblongis; radicula exserta, supera. - Herba mediterranea, annua, etiam in Capite bonae spei observata; caule spithameo, flexuoso, dichotomo, foliis alternis ovato-delloideis, undulatis, nodis floriferis, ochrea pellucida, caduca, floribus verticillatis, pedicellis haud arliculatis.

$\mathrm{E}$ m e x Necker Elem. IT. 214. Campdera Rum, 5\%, t. 1. f.1. Vibo Mōueh Mothod, 318. Ce atrapodium Bucchell

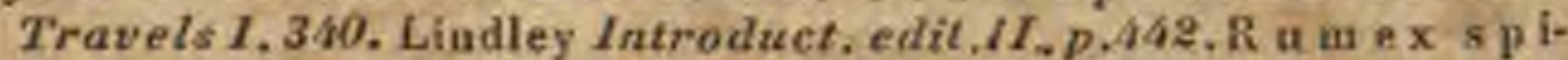
10 s us Linn. Giritn. II. 180, $t, 119$. Dirbel in Annal. du Mlas, XIII. 4. f. 44. Sibthorp Fl, graec. t. 347.

1933. LEmex LINN. Flores hermaphroditi v, aborta diclines. Perigonium hexaphyllam, foliolis tribus exterioribus herbaceis basi cohaerentibus, interioribus subeoloratis, majoribus, demum auctis, nudis v. granulatis, conniventibus, Stamina 6 , perigonii foliolis exterioribus geminatim opposita; filamenta brevissima, filiformia; a ntherae oblengae, basifixae. Ovari um triquetrum, nniloculare. O v n I u unicum, basilare, orthotropum. St $y$ li 3 ; filiformes, liberi $v$. 
ovarii angulis adnati; stigmatibus pennieillato-multifidis. C a r y op $\mathrm{s}$ is triquetra, intra perigonii foliola interiora valvatim conniventia libera. S emen conforme, erectum. Embryo albuminis farinacei angulum ambiens, antitropus, leviter arcualus; cotyledonibus angrstis, ineumbentibus; ra di cula elongata, supera. - Herbae annuae *. perennes, interdum suffrutescentes, acidae $v$, insipidae, in temperatis el frigidis utriusque haemisphaerae provenientes, inter tropicos rarissimae; foliis alternis, basi vaginantibus, floribus parvis, verticillato - racemosis, pedicellis articulatis.

Rumex Linn. gen, n. 357. exel. sp. Campdera, Mono graphie du genre Rumex. Paris 1819,4. Meisner in Wallich Pl. As, rar, III, 63 .

a. LAPATHA Campd. F1 ores hermaphroditi v. polygami, rarissime diolci. Perigonif foliola interiora erectodivergentia, extus plus minus granulata. Styli liberi; $s \mathrm{tigmatibus}$ multifidts. Se mi nis testa albieans $v$. sublutescens. - Herbae foliis penninerviis, vix acidis, verticillis multifloris, floribus 2_3_sserialibus, pedicellis basi articulatis.

L a pat h a Campd. op. cit. $t$. 1. f. 2. 3. t. 2. f. 1. (B. B. t, 725. 1533. 1576, 1932, 1998, 210\%. Curtis Fl. Lond. III. t, 21_23. F1. dan. t. 1208. 1334. Reichenb. lc. cril. t. 345. $368-370$. 486. 516 . 576. Nees jun. PI, offic. Suppl. III. 7-8. Meisner Polygon. t. 2. f. E. Nees jun. Gen. $p l$. IT. $54 . f .1$ 16.)

b. RUMASTRA Campd. Flores hermapliroditi v. rarius monoici. Perigonii foliola interiora vix $v$. ninime graudata. Sty í superne ovarii angulis adnati; stigmatibus pancifidis. Sem in is testa purpurascens. Suffrutices, folits palmatinervits, vix acidis $v$. plane insipidis, verticillis paucifloris, floribus uni-biseria. libus, pedicellis medio articulatis.

$\mathrm{R}$ a mastra Campd. op. cit. 6, 3. f. 7. (Jaeq. Hort. Pindob. III. t, 93. Mirbel in Annal. Mus, XIIL. t, 4. f. 46.)

c. ACETOSAE Campd. FIores hermaphroditi, monoici v. dloici. Perigoui foliola interiora extus Inevia v. pa. rum gravulata, noвnunquam abortiva. Styli superne ovarif angulis adnati; $s t i g m a t i b u s$ multifidis. Semi nis testa purpurascens v. albicans. - Herbae. suffrutices $\geqslant$. frutices; folis penni- $v$, palmatinerviis, ver ticillis pauciflnris, foribus uni-biserialibus, pedicellis saepe ad basim articulatis.

A cetos a e Campil. op. cit. t. 2. f. 3. 6. 7. (E. B. t. 127. 1674. Sibth, Et. graec. t. 345-349. Cav, ic. $t$, 41. f. 1. Jacq. Ie. rar. t. 6\%. Mirbel in Annal. Mus, XIIT, t. 4. $f, 43$. St. Hilaire in Mrem. Mus. IT, $t, 4 . f$. 23. Nees jun. Op. cil. IT. 54. f, 17. 18.)

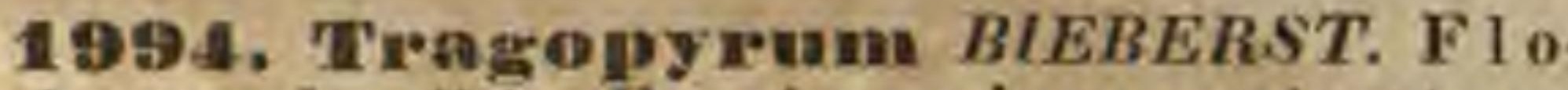
res hermaphroditi. Perigoniom coloratum, pentapliyllum, foliolis tribus interioribus majoribus. St a m ina 8 , perigonii foliolis exterioribus geminatim, interioribus singillatim opposita, uno inter interiora contigua sito; fil amenta subulata; antherae subrotundae, versatiles. Ovari um triquetrum, uniloculare. 0 v $\mathbf{I} \mathrm{l} \mathbf{m}$ unicum, basilare, orthotropum. St y li 3 , brevissimi, distincti v.basi eonnati; s $t$ ig m a $t$ i b u s capitatis. Caryopsis triquetra, perigonii foliolis interioribus conniyentibus inclnsa, exterioribus reflexis stipata. S e men triquetrum, erectum. E m br y o albuminis farinacei angulum ambiens, antitropus, leviter areuatus; cotyledonibus incumbentibus; radicula elongata, supera.-Frutices in Asia media indigeni, ramosi, divaricati; ramis mutiois $v$. apice spinescentibus, foliis alternis, oblongis v. ellipticis, integerrimis, coriaceis, breve petiolatis, ochreis tenuissime membranaceis, apice bifido-laceris, flaribus racemosis, pedicellis nutantibus, medio articulatis.

Tragop y r a Bieberst. Fl. Taur. Caucas. III. 284.

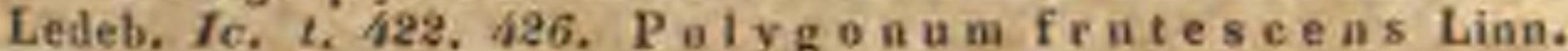
Gmelia Sibir. t. 12, f. 1, 2, Gärtw, t, 119,

1995. Atraplinaxis LINN. Flores hermaphroditi. Perigonium coloratum, tetraphyl. lum, foliolis duolins interioribus majoribus. Sta$m$ in a 6 , perigonii foliolis exterioribus geminatim, interiorihus singillatim opposita; fil am en ta subulata, basi incrassata; an $t$ berae subrotundae, dorso affixae. $O$ rari u miloculare, compressum, haud marginatum. Ov $\mathbf{l} \mathbf{u m}$ unicum, basilare, orthotropum. St y li 2 , brevissimi; $8 \mathrm{t}$ igmat $\mathrm{ibus}$ capitatis. Caryopsis lenticularis, compressa, perigonii foliolis duobus interioribus arcte conniventibus inclusa, exterioribus reflexis stipata. Sem e n compressum, erectum. Fmbryo intra albumen farinosum lateralis, antitropus, subcurvatus; cotyledonibus planis, elliptieis; radicula elongata, supera. - Frutices in $A$ sia media et in Capite bonae spei indigeni, ramosissimi, divaricati, rigidi; ramis saepe spinescentibus, foliis al. ternis, ovatis, integerrimis, coriaceis, axillaribus fasciculatis, ochreis petiolorum margini adnatis, utrinque in appendicem subulatam liberam productis, floribus in apicibus ramulorum axillaribus fasciculatis, albis $v$, pallide rubellis, pedicellis filiformibus medio articulatis, supra articulum paullo incrassatis, perigonii foliolis reticulato-nervosis.

A traphaxis Limi, gen, $n, 356$. Gärtn, II, 181, t, 119. Herit. Stirp. $T$. 27. $t, 14$. Lam. $t, 265$. Meisner Polygon, $t$. 2. $f$. $F$. Ledeb. Ic, $t, 411$.

1998. Hodopterus $H$. et $B$. Flores hermaphroditi. Perig o n i um coloratum, sexpartitum, laciniis tribus exterioribus coneavis, dorso late alatis, alis in pedunculum decurrentibus, trihus interioribus lineari-oblongis, planiusculis. Sta $\mathrm{m}$ in a 6 , perigonii lobis singillatim opposita; fil am enta subulata, basi cohaerentia; anthe$r$ a e oblongae, incumbentes. 0 va $\mathrm{r}$ i um uniloculare, triquetrum. Ovul um nnienm, basilare, orthotropum. Styli 3 , brevissimi; st ig mata eapitata. Caryop sis triquetra, perigonii foliolis exterioribus conniventibus, triptero-clavatis inclusa. S em en triquetrum, erectum. Em b r y o.... Frutex m exicanus spinosus; foliis faseiculatis, integerrimis, penninerviis, basi in ochream brovem dilatatis, floribus fasciculato-racemosis.

Podopterus Humb. et Bonpl. Pl, aequinoct. $\mathbf{I l} .89$. t. 107. Nov. gen, et sp. II. 181. Poiret Suppl. t. 940.

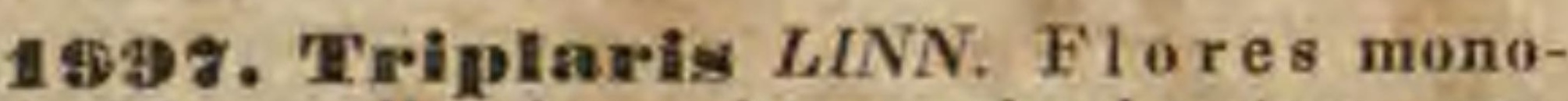
dioici. Masc. Perigoni um subcoloratum, sexoctopartitum, laciniis interioribus paullo angustioribus. Stam ina 9 , perigonii laciniis interioribus geminatim, exterioribus singillatim opposita, $v$, in perigonio oetopartito geminatim ante ejusdem lacinias interiures sita; fila menta filiformia; antherae oblongae, dorso affixae. Fem. Perigon i $\mathbf{m}$ membranaceum, coloratum, tubo ventrieoso, limbi sexpartiti laciniis tribus exterioribus maximis alaeformibus, interioribus minimis, quandoque nullis. Sta min a 3, sterilia, squamaeformia v. filiformia, perigonii laciniis exterioribus alterna, hypogyna v. medio tubo adnata. O va ri um unilocula re, triquetrum. Ovulum unicum, basilare, or thotropum. Styli 3 , breves; $s \mathrm{tigm}$ at ib us oh. longis. Ca ry upsis alato-triquetra, perigonii tubo inclusa, ejusque limbo lunge superata. S emen triquetrum, erectum. Em is r y o ...... Arbores $v$. frutices, interdum scandentes, in America tro pica indigeni; foliis alternis, breve petiolatis, integerrimis, penninerviis, ochreis brevissimis oblique iruncatis, floribus ravemoso-spicatis, bracteutis, pubescentibus.

Triplaris Lian. gen, n. 103. Jacq. Americ, 4, 173. f. 5. Aubi. Guian, t.347. Rotthoell Surinam 7. t, J. Chamiaso

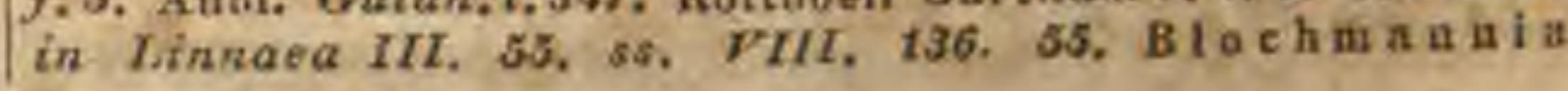


Weigelt Herbar. Surinam. - Genus fortassis dividendum, sed species plurimae tantum fructiferae cognitae.

TRIBES IT. POLYGONEAE SPU. RIAE. Involucrum nullum. Ovulum e funiculo umbilicali libero inversum, demum erectum. Sem e n erectum. Embry on is antitropi radicula supera.

1998. Brumnlelhia BANKS. Perigoni um herbacenm, campanulatum, quinquepartitum, Ia cin i is oblongis, coneaviusculis, aequalibus, apice conniventibus. Stamina 8 v. 10 , imo perigonio inserta; filamenta filiformia, libera; antherae ovatae, versatiles. Ovarium perigonii fundo immersum, liberum, uniloculare, triquetrum. Styli 3 , distincti, recurvati; 8 tigmat a capitata, emarginata. $\mathrm{Ov}$ u $1 \mathrm{um}$ e funieulo hasilari libero pendulum, micropyle infera, demum erectum. A ehenium triquetrum, intra perigonii tubum coriaceum subearnosum, fauce constrictum, limbo revoluto coronatum, pedicello compresso hine bisulco continuum, liberum. S em en pyramidatum, sexsuleum, erectum, sessile. E m b r y o excentricns, intra a 1 b u me $n$ farinaceam antitropus, leviter curvatus; cotyledonibus foliaceis, lineari-lanceolatis, subflexuosis, accumbentibus; $r$ a di $\mathrm{e} u \mathrm{l}$ a longiuscula, supera. - Frutex bor eali-america. nus, volubilis; foliis alternis, cordato-ovatis, ramisque glabris, petiolis semiamplexicaulibus, margine annulari puberulo caulem ambeunlibus, racemis paniculatis, apice cirrhosis, floribus primum confertis, demum remote racemosis, in axillis bractearum solitariis $v$. subternis, pedicellis medio articulatis.

B runnichia Banks apud Gärtn. I. 213, t. 45. Nuttall Gen. I, 256.

1959. Antigomon. Perigonium coloratum, pentaphyllum, foliol is inaequalibus, duobus exterioribus late cordatis, tertio semi-interiore obliquo, intimis oblongis, omnibus demmm increscentibus. Stamina 8 ; fil amenta subulata, aequilonga, basi in cupulam carnosulam connata; anthera oblongae, versatiles. Ovarium uni loculare, triquetrum. O v u lum e funicnlo basilari libero pendnlum, micropyle infera, demum erectum. Styli 3 , distincti, recurvati; stig m a capitatureniformia. A ch en i $\mathbf{u m}$ perigonio aucto emarcido stipatum, ovoideo-triquetrum. S e m en basilare, $e$ funiculo umbilieali erectum, pyramidatum. E m bryo in axi (?) a 1 buminis farinacei antitropus rectus, (?), radi $:$ ul a supera. - Suffrutices mexicani scandentes; ramis angulatis foliisque subtus subtomentosis, foliis allernis, cordato-ovatis, penninerviis, petiolis basi semiamplexicaulibus, ochreae rudimento squamaeformi oppositifolio, ramo tota facie adnato auctis, racemis apice cirrhosis, pedunculis ternis quinisve in axillis bractearum squamaeformium fasciculatis, apice articulatis.

A n redera sp. Andrieux Plant, mexic, exsice.

\section{Ordo CIV: Nyctagineate}

NYCTAGINEAE Jussieu gen. 90, Annal. du Muscium IT. 269. R, Brown prodr. 421. Bartling Ord.nat, 109. NYC. TAGINACEAE Lindley introduct. odit. $I T . p .213$.

Herbat annuae v, saepius perennes, radi cibus interdum tuberosis, nunc prutiegs $\mathbf{v}$. ARBoses, ramis teretiusculis, nodoso-articulatis, ramulis saepe spinescentibus. Folia opposita, altero ramum subtendente saepius minore, nune alterna, simplicia, penninervia, integra, plerumque integerrima, petiolata. Sti pula e v. vaginae nullae.

Flores hermaphroditi v. rarissime abortu dioici, axillares v. terminales, solitarii v. aggregati, saepissime involucro calyciformi, interdum colorato, polyphyllo v. gamophyllo, deciduo v. persistente, demum interdum aucto, uni-plurifloro cineti, rarius eymosi v. paniculati, pedicellis apice sub flore bi-tribracteolatis, rarius basi bracteolatis, b r a cte olis minutis, persistentibus $v$. deciduis.

Prriconium subcoloratum, extus saepe rudius et hirtum v. plane corollinum, cito marcescens, tubulosum, infundibuliforme $v$. hypocrateriforme, $\mathbf{t} \mathbf{u}$ bo basi saepe inflato et herbaceo, supra basim deciduo v. persistente, limbo quadri-quinque v. decem-partito, nunc truncats, obsolete dentato, per aestivationem plicato, plerumque cum tubi parte superiore deciduo, rarius persistente.

Stamiva hypogyna, perigonii laciniis plicisve pauciora v. plura, rarius isdem numero aequalia, interdum unilateralia. Fil a menta filitormia, libera v. mediante disco hypogyno plus minusve manifesto basi connata, interdum etiam perigonii tubo inferne adglutinata, saepissime inaequilonga, inclusa v. rarius exserta, in alabastro incurva. A n therae introrsae, biloculares, basifixae, oblongae, ovatae v. subgloboso-didymae, loculis appositis, parallelis, basi et saepius etiam apice distinetis, longitudinaliter dehiscentibus. Pollin is granula globosa, scabriuscula.

Ovariom sessile v. interdum brevissime substipitatum, liberum, uniloculare. 0 v u l u m unicum, erectum, sessile, micropyle infera. Stylus simplex, terminalis v. sublateralis, in alabastro involutus, $\mathrm{sti}$ g mate simplici, acuto $\mathrm{v}$. clavato aut subeapitato; rarissime nullus, st ig $m$ a te tunc sessili, penicillato-multifido.

Achenum intra perigonii basin v. tubum muticum v. limbo persistente coronatum, apice ore angusto pervium, induratum, costatum v. angulatum, nudum aut involucro cinctum, liberum, membranaceum.

SEMen erectum, testa cum achenii endocarpio connata.

Embryo nunc conduplicatus, cotyledoni bus foliaceis latiusculis, a l b u me n amylaceum plus minus copiosum, rarissime parcissimum involventibus, ra dicula extraria descendente; nunc rectus, cot yle do n i b us albumen pariter obvolventibus, ra dicula brevi, infera.

Nyctagineae plurimis characteribus et etiam interna caulis structura distinctissimae, nec ulli ordini arctius affines, ob aliquam cum Polygoneis et $\mathbf{C h e n o p o d e}$ is similitadi- 
nem hoc loco collocatae, inter tropicos totius orbis, imprimis tamen Americae proveniunt, in regionibus extratropicis Africae et Australasiae rarae, in $\Delta \mathrm{merica}$ extratropica cis aequatorem paullo frequentiores.

200D. IBderlhavia $L I N N$. In volu $\mathrm{crum}$ polyphyllum, multiflorum, foliolis squamaeformibus deciduis. Perig onium coloratum, tubulosum, tubo medio coarctato, li mbo subintegro, plicato, deciduo. S t a min a hypogyna 1_4, libera, subexserta. Ovari u m uniloculare. O v 1 i m nnicum, erectum, micropyle infera. S ty I u s simplex; 8 t ig ma obtusum. A ch he ium intra perigonii tabum induratum angulato-clausum liberum. $S$ e m e $n$ ereetum; $t$ es $t$ a endocarpio connata. $E \mathrm{mb}$ r y o $\mathrm{n}$ is conduplicati coty ledones albumen amylacenn involventes; ra di eula extraria, infera. - Herbae v. suffrutices, intertropicos totius orbis obviae; foliis oppositis, umbellis paniculatis.

Boerhatia Linn. gen, n. 38. Jussieu gen, 91. Annal. du Mus, II. 274. Jacq. Hort. Vindob, I, t. 4. 7, Gärtn. II. 208, t. 127. R. Brown prodr. 422.

200 \&. Colignonia. Involncrum poIyphyllum, multiflorum, foliolis deciduis. P e ri g oni $u$ in coloratum, infundibuliforme, $t u$ bo basi aequali, limbi profunde quinquefidi persistentis laciniis oblongis, apice inflexis. Sta $\mathrm{m}$ in a 5 , hypogyna, libera, subexserta; an thera e subglobosae. Ovarium unilocolare. Ovulum ....Styl $\mathrm{as}$ simplex; st i $\mathrm{gma}$ aennicillato-multifidum. A $\mathrm{ch}$ en ium perigonii tubo incrassato-pentagono tectum, limbo coronatum. S emen erectum; lesta cum endocarpio connata. Embry on is conduplicati cotyled ones albumen amylaceum involventes; ra d icul a extraria, infera. - Herba peruviana, andicola; folits oppositis, subrotundoovatis, obtusis, umbellis axillaribus solitariis, terminalibus congestis.

A bronla parviflora Kunth in Humb. et Bonpl. Nov, gen. ot sp, II. 216, t, 126.

2003. Abromia JUSS. Involucrnm pentaphyllum, moltiflorum, persistens. Perigonium coloratum, hypocrateriforme, tubo basi inflato, $l i m b i$ patentis quinquelobi lobis obovatis deciduis. Sta min a 5, hyporyna, inclusa, basi in vaginam brevem, perigonii tubo adglutinatam connata; antherae oblongae. Ovarium uniloculare. Ovulum unicum, erectum, micropyle in fera. Stylus simplex; stign a clavatum. A chenium intra perigonii basim induratam, angulatopentapteram, tubo apiculatam liberum. S em en erectum; $t$ e s t a cum endecarpio connata. E m b r y onis conduplicati cotyledones albumen amylaceum involventes; radicula extraria, infera. Herbae californicae; foliis oppositis, petiolatis, integerrimis, capilulis axillaribus solitariis, longe pedunculatis.

A broura Jussien gen. 448. Annal, du Mus, II, 274. Lam. t. 105. Gilirtn. f. III. t. 214. Hooker Exot. Fl. t. 193. 194. Bot. Mag, t, 2879. T r i cr a t us Heritier Monogr, inedit.

2003. Mrirabllis LINN. Involu erum calyeiforme, campanulatum, quinquefidum, uniflorum, persistens. Perigon inm corollinum, infundibuliforme, $t$ ub $\mathrm{i}$ elongati basi ventricosa herbarea persistente, limbo plicato-quinquedentato, decidao. St a min a 5, urceolo hypogyno inserta, subexserta. $O$ vari m uniloselare. $O$ v u l u m unicum, erectum, mieropyle infera. Stylus simplex; stigma capitatum. Achenium intra perigonii basim induratam pentagono - subglobosam, involucro immutato inclusam liberum. S e m e n ereetum; testa cum endocarpio connata. Embryon is conduplicati cotyledones albumen amylacenm involventes; radicula extraria, infera. - Herbae americanae tropicae; radice tuberosa, caule tereti, di-trichotomo, foliis oppositis, floribus terminalibus et axillaribus subcorymbosis, speciosis, citn marcescentibus.

M irabllis Linn. gen, $n$. 175. Girtn. $I T, t$. 127. Suith Exot. Bot, I. $t$. 23. Nyetago Juss. gen, 90. Annal, du Mus. II. 274. J a la p a Tournef. inst. 50 .

2004. Dxybaplaus HERIT. Involucrum calyciforme, campanulatum, quinquefidum, uni-tri-quinquefloram, persistens. Perigonium corollinum, infundibuliforme, $t \mathrm{u}$ b $\mathrm{i}$ brevissimi basi ventricosa, persistente, fauce constricta, $1 \mathrm{imb} 0$ plicato - quinquelobo, decidno. St a m in a 3 , hypogyna, basi in annulum brevissimum connata, exserta. Ovarium uniloculare. Ovulum unicum, erectum, micropyle infera. Sty lus simplex; st i g ma capitatum. A ch $\mathrm{c} n \mathrm{i}$ u m intra perigunii basim induratam, pentagonam, involucro scarioso demum aucto et explanato einetam liberum. S e m en erectum; t e $8 \mathrm{t}$ a cum endocarpio connata. E m bry onis conduplicati cotyledones albumen amylaceum involventes; rad icula extraria, infera. Herbae americanae tropicae et subtropic a e, superne dichotomae; foliis oppositis, floribus in apice ramulorum corymbosis.

0 x y b a p us Heritier Monogr. inedit. Jussieu in Annal. du Mus, II, 274. C a l y $\mathrm{x}$ h y m e $\mathrm{n}$ i a Ortega Decad. $V$. $t$. $t$. 8. 11. Ruiz et Pav. Flor. peruv. t, 75. Caly m $\mathrm{c}$ ia Nuttall Gen. $I$. 25. V ittma n i a Turra.

2005. Alliomia LINN. Involucrnm calyeiforme, campanulatum, quinquedentatum $\mathrm{v}$, triphyllum, triflorum, persistens. Perig oni nm corollinum, infundibuliforme, $t \mathbf{u b i}$ lrevis basi ventricosa persistente, $1 \mathrm{im}$ b o hine fisso, quadrilobo, St a min a 4, hypogyna, libera, inelusa. Ovarinm noiloculare. O vulum nnieum, erectum, micropyle infera. Stylus simplex; stigma capitatnm. A chenia intra perigoniorum bases incrassatas angulatas, dorso spinulosas, facie planiusculas silji invicem applicitas involucro immutato inclusas, libera. S e me n erectum; test a cum endocarpio connata. Embryonis conduplicati cotyled ones albumen amylacenm involventes; ra dicula extraria, infera. - Herbae a mericanae tropicae; foliis opposilis, pedunculis axillaribus, solitariis.

A 11 i o n i L Linn. gen, n, 117. Jussieu gen, 195. Annal. du Mus. II, 274. Kunth in Humb. et Bonpl. Nov. gen, et sp. $T I, 214$.

a ALLIONIA tioffl. I n $>$ o I u e $\mathbf{r}$ u campanulatum, quinque. deatatum.

A I lio n i a Lefting It, 181. A. viol a ce a Linn.

b. WVEDFLla Löffl. I и vo I n e r u m triphyllum.

W. ed elia Loffling $T t, 180$, A. In e ra at a Linn. Heritier stirp. $t, 31$. Lam, $t, 38$, Gärto. $f, I I T, 182 . t, 214$.

2006. Dkenia SCHIEDE. In vol uerum triphyllum, minimum, nniflorum. Perig on i n m corollinum, hypocrateriforme, $t \mathrm{u}$ h $\mathrm{i}$ basi ventricesa persistente, fance dilatata, et $l \mathrm{imb}$ o quinquelobo patente, deciduo. St amina $15-18$, hypogyna, basi in vaginam brevem perigonii tabo adglutinatam connata, inclusa. O va ri u m unilocolare. 0 vuI u m unieum, erectum, micrupyle infera. S t y I us simplex; stigma peltatum. A cheniam intra perigonii basim oblongam, suberoso-incrassatam elausam, longitudinaliter decem-costatam, inter co- 
stas transversim plicatam liberum. S e m en erectum; t e st a cum endocarpio connata. Em hr y onis conduplicati cotyledones albumen amylaceum involventes; radicula extraria, infera.

Herba mexican a, prostrata, caule folitisque oppositis glutinosis, pedunculis axillaribus unifloris, fructiferis hypogaeis

$0 \mathrm{k}$ a i a Sehiede in Linnaea $V .92$.

200\%. Trieyela $C A V A N$. Involu crum triphyllum, coloratum, nniflorum. Perigon inm corollinum, tubulosum, medio constrictum, $1 \mathrm{imb}$ i quinquelobi persistentis lobis erenatis. $\mathrm{St}$ a $\mathrm{m}$ in a 5, hypogyna, libera, subexserta. O va ri um uniloculare. Ovulum unicum, erectum. Stylus simplex, brevis; stigma subulatum. A chenium intra perigonii tubum induratum, angulatnm, $1 \mathrm{im-}$ bo coronatum, involncro persistente reconditum liberum. S emen erectum; test a cum endocarpio connata. E m b ryon is conduplicati cotyled on es albumen amylaceum involventes; $r$ a dicula extraria, infera. - Arbor in America australi extratropica orientali observata; ramulis alternis spinescentibus, foliis alternis, fasciculatis, oblongo-spathulatis, floribus e foliorum fasciculis solitariis, breve pedunculatis.

Tric y cla Cavanilles Io. VT. 79. t. 598. Annales de ciencias naturales. $V .63 .4$, 40. Jussieu in Annal. du Mus. II. 275.

OBSERVATI0. Trieyclae congener v. certe affine, si tamen ex hoc ordine, soli auctori notum genus: TORREXA, Spreng. Involucrum (calyx) quinquelobum coloratum, uniflorum, patens. Perig o i um (eorolla) tubulosum, limbo quinquefido reflexo. Sta min a 5, tubo adnata, exserta, spiralia, antherae didymae. ${ }_{3} \mathrm{P}$ is t ill a m simplex, stignate fili. formi. O vari um uncem referens, valvis introrsum flexis." - Frutex (2) brasiliensis; folizs oblongis, in petiolum decurrentibus triplinerviis, venosis, superioribus lanceo. latis sensim angustioribus, tandem in bracteas slipulasve paniculae ramis subjectas abeuntibus, paniculae ramis di. trichotomis, pubescentibus, patentibus."

Torrey a Sprengel Neue Entdeck. II. 121.

2408. IBngemvillea COMMLRS. I n vo l $\mathrm{u}$ c rum triphyllum, coloratum, foliorum nervo medio prope basim unifloro triflorum. Pe rigon in m corollinum, tubulosum, fauce angustatum, li $\mathrm{mb} \theta$ plicato, obsolete quinque v. decemdentato, persistente. Stamina 7-8, hypogyna, libera, inclusa. Ovari um uniloculare. Ovulum unicum, crectum. Stylus simplex; stigma clavatmm. A eheninm intra perigonii tubum induratum angulatum, intra involucrum persistens reconditum liberum. Sem en erectum; tes ta cum endocarpio connata. Embryonis conduplicati cotyledones albumen amylaceum involventes; $r$ ad i $: u l$ a extravia, infera. - Frutices a mericani $t$ ropici; foliis atternis, ovatis, spinis axillaribus, pedunculis axillaribus el lerminalibus, simplicibus v. apice divisis.

Bugenvillea Commerson ex Jussien gen, 91, Annal. du Mus. TI. 275, Lam. $t$, 294. Humboldt et Bonpl. Pl. aequinoct. $I$. 173.t. 49. Gärth, f. III, 206, $t, 216$. J o s e $\mathrm{ph}$ h Flor. Flum. IV, $t, 13$.

2BOS. EReicla endorelnin SPRENG, Involucrnm nullum. Perigonium coloratum, hypoerateriforme, tubo brevi, limbo plicato, quinquedentato, persistente. St a m i na 2 , hypogyna, opposita, libera, inelusa. Ovarium uniloculare. O vulu m unicum, erectum. Stigma sessile, penicillatum. A eh e n i m intra perigenii tubum induratum, costatum, $1 \mathrm{im} \mathrm{bo}$ involuto angulato coronatum liberum. Sem en ereetum. Embryonis conduplieati eotyledones albumen parcissimum includentes; $r$ a d i c u la extraria, in- fera. - Frutices brasilienses, pube stellata obsiti, demum glabrati; foliis alternis, floribus axillalaribus corymbosis, pedicellis basi bibracteolatis.

Reiche abachia Sprengel in Bullet, Soc. Philomat. 1823. p. 54. $t, 1$.

2010. Salpianthus $\boldsymbol{H}$. et $\boldsymbol{B}$. Involuerum nullum. Perig on i m coloratum, tubulosnm, l i m b o plicato, quadridentato, persistente. Sta $m$ in a 3 v. 4, hypogyna, unilateralia, basi subconnata, exserta. Ovarium nniloculare. Ovul u m unicum, erectum. Stylus simplex; stigin a acutm. A che ninm intra perigonii tubum induratum, costatum, I i m bo coronatum liberum. Semen erectum; testa can endocarpio connata. Embryonis conduplicati cotyledones albumen subcorneum includentes; radicala extraria, infera. - Suffrutices v. herbae mexicana $e$, cano-pubescentes; foliis alternis, floribus axillaribus et terminalibus, glomeratis v. corymbosis, ebracteatis.

Salpianthus Humboldt et Bonpl. Pl. aequinact. $I$. 155. t. Ki. Kanth in Humb. et Bonpl. Nov, gen, et sp, II. 218. Bo Id a Cavanilles Hort. Maslrit. t. 7. Lagas a Diagn. 10.

201 1. Neen $R U I Z$ et PAV. Involucrum nullum. Perigonium coloratum, tubulosum, fance constrictum, li mbo quadri-quinquefido patente, persistente. St a min a perigonii laciniis plura, 5-8 hypogyna, libera, inaequilonga, inelusa. Ovari u miloculare, $O_{\text {v }}$ a $1 \mathbf{n} \mathrm{m}$ unicum, erectum. Stylus simplex; stigma acutum. Acheninm intra perigonii tubum coriaceo-induratum, obsulete costatum, limbo coronatum, liberum. E m b r y o n is conduplieati cotyledones albumen amylaceum includentes; radicula extraria, infera. Arbores v. frutices americanae tropicae; foliis opposit is, floribus paniculatis vel corymbosis, basi uni-bitribracteolatis.

Ne e a Ruiz et Pav. Prodr. 52. t. 9. Jussleu in Annal. du Mus. M. 285. - M it s e he rl i $\mathrm{e} \mathrm{h} 1$ a Kunth in Berl. Acad. Abhandl. 1831, p. 209. et 1832, t. 3.

211 2. Fisonia PLUM. F lores ahorta dioici. Involuerum nullum. Perigoninm subcoloratum, infundibuliforme, $1 \mathrm{i} m$ b o quinqueplieato, truncato v. semiquinquelobo, persistente. Stamina 6 _ 10 hypogyna, libera, inaequilonga, exserta. O va ri $\mathbf{m}$ unileculare. Oru $1 \mathrm{~nm}$ nnieum, erectum. Stylus simplex; stigma sapitatum. A chenium intra perigonii tubum induratum, angulatum, subclavatum, angulis saepe murieatoglandulosum, $1 \mathrm{imbo}$ persistente coronatum liberum. Semen erectum; testa cum endocarpio connata. Embryonis recti cotyledones albumen amylaceum includentes; $r$ a d i $n$ la infera. Arbores $v$. frutices in regionibus tropicis totius orbis provenientes; foliis alternis et oppositis, deciduis, floribus subcymosis, basi minulissime uni-bibracteolatis.

P is on i a Plumier Ic, edit, Burm, $t, 297, f$. 1. Linn, gen. n. 897. Jussieu gen. 91. Annal. du Mrus. TI. 275. Gärti. I. t. 76. R. Brown prodr. deg. Calpid ia Thouars Hist. plant. Afr, aust, 23. t. 8, Pallavia Flor. Flum, 1V. t. 12.

\section{GENUS DUBIUM.}

2013. Epinthes BLUM. Flores monoiei. Mas c. Ca I y $\mathrm{x}$ brevis, quadridentatus. Petal a 4 , alterna. Sta $\mathrm{m}$ in a 8 , calyei inserta; $\mathrm{f}$ I a menta brevissima; an therae lineares, biloculares. G landula $\mathrm{e}$ in fundo ealycis. F em. Cay $x$ maris, superns, persistens. Petala nulla. Ovari um uniovulatum. Sty Ii nulli. Stigmata 4 , lateralia, pennicilliformia, persistentia. D : u- 
p a baccata, eostata, monosperma. - Herba javanica, tenella, facie Euphorbiae thymifoliae, rupes obtegens; foliis sparsis, lanceolatis, serratis, floribus femineis sessilibus, axillaribus, masculis pedunculatis intermixtis.

Epilithes Blume Bijdr. 734 .

OBSERVATI0. Axia Lour. a cl. Jussieu huc relata, nobis est genus inter Valerianeas dubium, Triplostegia e Wallech aliquatenus fortassis affine.

\section{Classis xxVII. Thymelaeae.}

Arbores v. frutices, rarius herbae, succo aqueo foetae. Folis alterna v. opposita, interdum verticillata, simplicia, integra aut rarins pinnatifida v. varie dissecta, plerumque coriaeea, perennantia. Stipulae nullae. Flores hermaphroditi v. per abortum unisexuales, rarius typice diclines. Perigonidu simplex, extus saepe rudius, intus coloratum v, totum corollinum, basi plus minus tubulosum, limbo regulari v. interdum irregulari, liberum v. cum ovario connatum. Stamiva perigyna $v$, rarius hypogyna, sterilia saepe petaloidea. Ovariom unicum v. plura, distincta aut inter se connata, libera v. perigonio connata. $\mathrm{O} \mathrm{v} u \mathrm{l}$ a e carpelli sutura solitaria, raro plura, situ varia, directione anatropa. Fructus follicularis, nucamentaceus v. drupaceus, mono-pleiospermus. S e min a albuminosa v, exalbuminosa. Eмвв yo orthotropus, intra albumen si adest inclusus, $r$ adicula parva umbilico proxima, basim v, apicem aut ambitum fructus spectante.

\section{Ordo CT: MIomimiacene.}

MONIMIRAE Jussieu in Annal. du Museum XIV. 130. Bartling Ord. nat, 103. MONIMIEAE et ATHEROSPERMEAE R. Brown in Flinders Voyage $I T$, $5 \pi 3$. MONIMIACEAE et ATHEROSPERMACEAE Lindley Introduct, edit, $I$, p. 188 , 189.

Arbores v. FRUTICEs, saepius aromatici. Folia opposita v. rarius alterna, petiolata, penninervia, integra, integerrima v. serrata, serraturis saepe glandulosis, interdum pellucido punctata, sempervirentia, glabra v. subtus tomentosa. Stipulae nullae.

Flores unisexuales, mono - dioici, v. rarius hermaphroditi, racemosi v. cymosi.

Prrigonion calyciforme subglobosum, qua. dri-quinquefariam fissum, v. plano-rotatum ant tubuloso-campanulatum, limbo quadri-decemfido, laciniis uni-biseriatis, interioribus saepe tenerioribus.

SтAм1кA in floribus masculis indefinita, perigonii parieti interiori undique inserta $v$. fundo imposita, in hermaphroditis fauci affixa. Filamenta nulla v. brevissima, nunc plus minus longa, basi nuda v. squamulis glandulisque juxta basim utrinque aucta, saepissime nonnulla ananthera, petaloideo-dilatata. Anther a e biloculares; loculi oppositi connectivo interdum ultra eosdem in acumen producto ad- nati, ovati v. oblongi, rima longitudinali v. valvula adscendente dehiscentes. Sta min a sterilia in floribus femineis nulla v. squamiformia. Ovaria in floribus femineis plurima, perigonii parieti internae undique inserta, v. fundo imposita, distincta, unilocularia. 0 v u l u m unicum, e basi ovarii erectum v. ex ejusdem apice pendulum, anatropum. Stylus simplex, terminalis si ovulum pendulum, v. lateralis aut basilaris si ovulum erectum. Stig ma simplex.

Drupae monospermae, sem in e inverso; $v$. Nuculae seminiformes, stylis plumosis caudatae, s e min e erecto, perigonii tubo saepe aucto reconditae, $v$. eidem regulariter fisso et expanso, aut interdum irregulariter rupto impositae.

Semen inversum, e mbry on e orthotropo, in axi albuminis carnoso-oleosi majusculo, cotyledonibus ellipticis planis, radicula supera ; v. SEMEN erectum, em bryon e orthotropo, intra basim a l b u m in is carnoso mollis minimo, cotyledonibus brevissimis, divaricato-patentihus, $r$ a di c ul a crassiuscula, infera.

M o n imi a ce arum nomine plantas seminis et antherarum fabrica utut distinctissimas, M o n i m i a s videlicet et Atherosperm e a s, praeeunte Jussieo adhucdum conjungendas putavimus, imprimis propter $R$ uiziam, calycinam perigonii naturam etiam in Monimieis nobis demonstrantem. Caeterum ordinis affinitas etsi paullo obscurior, commodissime tamen hoc loco pone Laurineas collocandus videtur.

Monimieae inter tropicos Asiae, Africae insularis et Americae proveniunt. Genus unum Chilense transitum ad $A$ therospermeas, in America australi extratropica et in Australasia indigenas, parat.

SUEOIDO I. MONIMIEAE R. Brown l. c. Flores diclines. Antherae longitudinaliter dehiscentes. Ovulu m pendulum. D rupae monospermae. $\mathbf{E m b} \mathbf{r y} 0$ in axi albuminis carnoso-oleosi rectus, $r$ a di c u la supera.

20 14. Ambora JUSS. F lores monoici. M a $8 \mathrm{c}$. Perigoninm ovato-subglobosum, demum quadrifariam fissum, patens. Stamina plurima, perigonium intus dense vestientia; filamenta brevissima, nuda; antherae biloeulares, basifixae, loeulis suboppositis, longitudinaliter dehiscentibus. Fem. Perigoninm tubuloso-subglobosum, apice umbilicato-pervium, ore nudo. Ov a ria plurima, perigonii parieti undique immersa, unilocularia. Ovu l um unieum, pendulum, anatro. pum. Stylus terminalis, brevis, filiformis; $s$ t $\mathrm{i}$ g m a te simplici. D r u p a plurimae, perigonio baccato inclusae, monospermae. Semen inversum. Embryo in axi alhuminis earnoso-oleosi rectus; eotyledonibus planis, ellipticis; $r$ adicula supera. - Arbores in Madagasearia et in insula Mauritii indigenae; folits suboppositis, integerrimis, sempervirentibus, sublus stellato- 
pubescentibus, floribus racemosis, rariusve solitariis, trunco et imis ramis innascentibus, femineis rarioribus, masculis mixtis.

A nu bo ra Juss. gen, 41. Annal. du Mus. XIV. 130. Tambouriss a Somuerat Vog, II, $t$. 134. Mithridate a Commers, mse, Schreb gen, n. 1706 ,

2415. II 1oninata THOUAR. Flores dioici. M a s c. P e rigonium ovato-subglobosum, demum quadri-quinquefariam fissum, patens. Stamin a plorima, perigonium intus dense vestientia; filamenta filiformia, nuda; anthera e biloculares, basifixae, loculis suboppositis, longitudinaliter dehiscentibus. F em. Perigoni nm tubuloso-subglobosnm, apice pervium, intus ramentaceopilosum. O v a ri a $5-6$ follicularia, e fundo perigonii breviter stipitata, unilocularia. Ov n I u m unieum, pendulum, anatropum. S ty $1 \mathrm{i}$ ovariis continui, hine stigmatosi, ex ore perigonii breviter exserti, stellato-patentes. Drupa abortu paucae, perigonio baceato, demnm lacero inclusae, monospermae. $\mathrm{Sem}$ e $\mathrm{n}$ inversum. E m b r yo in axi albuminis earnoso-oleosi rectus; cot y le do n ib a s planis, ellipticis; radicula supera._Frutices b orbonic $i$; foliis suboppositis, integerrimis, scabris, subtus stellatopubescenlibus, floribus axillaribus, racemosis.

Monimia Thouars Plant. Afric. 21. t. 7.

2D16. Kibara. Flores monoici. Perigonium turbinatum, basi bibracteolatum, ore squamis quatuor subconniventibus clauso. Stam in a $5 \_7$, perigonii parieti inserta, fi 1 a m en $t$ a brevia, nuda; antherae biloculares, basifixae, longitudinaliter dehiscentes, F em. Perigonium ut in mare. $O_{v}$ a $r i a$ plurima, perigonio intus inserta, pyramidata, unilocularia. Ov u I u m nicum, pendulum. Stigma sessile, obtusum. Bacca perigonio demum fisso convexiusculo umbellatim insidentes, monospermae. Se men inversum. Fmbryo in axi albuminis carnosi rectus; $r$ a dicula supera.- Arbor javanica, procera; foliis suboppositis, elliptico-oblongis, versus apicem repandoserratis, racemis axillaribus lateralibusve compositis.

Bronguiartia Blume Bijdr. 435, non Kunth.

201\%. Citrosma $R U I Z$ et PAV. Flores dioici. Masc. Perigoni um urceolato-campanulatum, fauce coarctatum, limbo quadri-octolobo. Sta mina indefinita, perigonii tubo inserta; $f$ I a m ent a brevissima, nuda, connectivo dilatato ; anther a e biloculares, loculis oppositis, longitudinaliter dehiscentibus. Fem. Perigonium maris. Ovaria 3 - 10, tubo perigonii inserta, unilocularia. Ovulum unicum, pendulum. Styli subulati,exserti; stig ma te simplici.D r u p a e abortu paucae, intra perigoninm baccatum demum elastice inaequaliter dehiscens nidulantes, monospermae. Semen....-Arbores v. frutices, $A m$ ericam tropicam incolentes; ramis patulis, ad articulationes compressiusculis, foliis oppositis, integerrimis v. serratis, racemis axillaribus paucifloris.

Citrosma Ruiz et Pav. prodr. 134. t. 29.

2018. Tledyearya FORST. F lo res dioici. M a s e. Perigoni nm plano-rotatum, octo-decemfidum. Stamina plurima; filamenta nulla; antherae in fundo perigonii sessiles, cordatae, biloculares, apice pilosac, loculis appositis, longitudinaliter dehiscentibus. F e m. Perigonium maris. Ovaria plurima, breviter stipitata, perigonii basi lanatae inserta, unilonaria. O vu lu m unicum, pendulum. Stigm a sessile, obtusum. D r u p a e abortu paucae, stipitatae, subvertieillatae, perigonio immutato stipatae, monospermae.
Sem e $\mathrm{n}$ inversum. E $\mathbf{m}$ br $\mathbf{y}$ o in axi albuminis dense carnosi rectus; c ot $\mathbf{y} \mathbf{l}$ ed on ib us planis, ellipticis; radicula brevi, supera. - Arbores in Nova Hollandia orientali extratropica, et in Nova Ze elandia indigenae; foliis oppositis, sempervirentibus, glaberrimis, denticulato-serratis, racemis axillaribus, corymbosis.

H e d y c a r y a Forst. Char, gen, t, 64. A. Richard Flor.

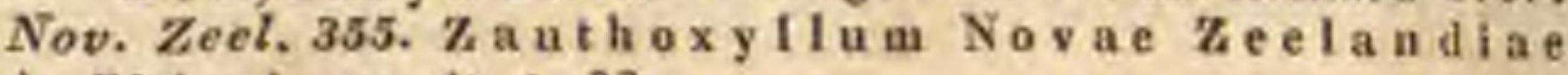
A. Richard op. cit. $t$. 33 .

2015. Fenizia $P A V$. F 1 ores dioici. Mas $\mathrm{c}$. Perigonium campanulatum, limbj quinquefidi laciniis patentibus, intus coloratis. $\mathrm{Sq}$ u a $\mathrm{m}$ a faueis petaloideae 5 , limbi laciniis alternae et aequales. St a mina plurima, perigonii tubo et fauci inserta; fil a me nta complanata, supra basim utrinque auriculata; anth erae biloculares, locnlis connectivo dilatato opposite adnatis, longitudinaliter dehiscentibus. F em. P erig on i m maris, faucis squamis angustioribus. St a $\mathrm{m}$ in a abortiva glandulaeformia, juxta faucem et per perigonii tubum sparsa. Ovaria $2 \_9$, coniea, e perigonii fundo brevissime stipitata, conniventia, apice subcohaerentia, unilocularia. O v u l u m unisum, pendulum. Styli filiformes, distincti; stigma ta simplicia. Drupa e 2_9, perigonio demum deciduo nudae, monospermae. Semen inversum. $\mathbf{m}$ m r yo in axi albuminis carnosi rectus; cotyledonibus planis, ellipticis; radi cula supera, _ Arbor chilensis aromatica; foliis oppositis, breve petiolatis, ovato-oblongis, coriaceis, sempervirentibus, integerrimis, papilloso-scabris, racemis axillaribus.

R uizia Pavon prodr, 135. $t$, 29. non Cav. B oldo a Jussieu in Annal, XrV. 134. non Cav. P e a mus Pers. Ench. II. 629. Р е um us Boldus Molina Chil. p. 200. Feuill. Observ. III. 11, t. 6 .

OBSERVATIO. M ollinedia Ruiz et Pav. ab auctorlbus hue relata, nobis est genus inter Anonaceas dubium.

SUIB IEDA 耳. ATHEROSPERMEAE R. Brown $l$. $c$. Flores diclines v. hermaphroditi. Antherae valvulis adscendentibus dehiscentes. Ovulum erectum. Nuculae monospermae, stylis plumosis candatae. E m b r y o in basi albuminis mollis rectus, radicula infera.

2020. Atherosperma LABILLARD. Flores monoici. Masc. Perigoninm campanulatum, t $u$ b o brevissimo, $1 \mathrm{imb}$ i octofidi laciniis brevibns, obtusis, biseriatis, interioribus tenerioribus, minoribus. Squam n la e facis nullae. Sta$m$ in a $10 \_20$, perigonit fundo inserta, fertilia sterilibus squamaeformibus mixta; filam en ta brevia, complanata, basi obsolete bisquamosa; a n thera e biloculares, loculi oblongi, connectivo mutico utrinque adnati, valvulis adscendentibus dehiscentes. Fem. Perigonium maris, limbo decidno; s q u a mulis fancis imbricato-pluriseriatis persistentibus. Ovaria plurima, oblonga, sessilia, distincta, unilocularia. Ovul u m unicum, ereetum, anatropum. Sty lus terminali-Iateralis, filiformis, villosus; stigma acutum. Nucula plurimae, monospermae, stylis plumosis caudatae, perigonii tubo incrassato-cupulaeformi, explanato, et fancis squamulis persistentibus radiato impositae. Sem e $n$ erectum. $\mathbf{E} \mathbf{m}$ b r yo in basi albuminis carnoso mollis minimus; cotyledonihus divaricatis; radieala infera. - Arbor Novae Hollandia e extratropicae orientalis, aromatica; ramulis tetragonis, folitis oppositis, ovato-oblongis 
glanduloso-serratis, reticulato-venosis, junioribus subtus pilosiusculis, pedicellis axillaribus unifloris, floribus bibracteolatis, bracteolis deciduis et perigonio villosulis. t. 224.

A the rosperm a Labillardiere Nov. Holland, 1 , 74 .

202 1. Pnvonia RUIZ. Flores monoici. Ia sc. Perigonium campanulatum, tubo brevissimo, 1 i m bi sexfidi laciniis patentibus, interioribus tenerioribus. Squam ulae faucis petaloideae 6 , limbi laciniis alternae et aequales, v, minimae et rudimentariae. St a m in a $6 \mathrm{v}$. 12 , perigonii tubo inserta, pluriseriata; fil am e nt a brevia, complanata, basi bisquamosa; anth era e biloculares, loculi oblongi, connectivo mutico utrinque adnati, valvnlis totidem adscendentibus dehiscentes. $\mathbf{O v a r i a}$ rudimentaria. F em. Perig onium maris, tubo longiore, limbo deciduo. Squamula e plurimae, faucem et tubum perigonii vestientes. Ovaria plurima, oblonga, sessilia, distincta, unilocularia. $O \vee \mathrm{n} I \mathrm{um}$ nnicum, erectum, anatropum. Stylus terminali-lateralis, subulatus, villosus; stigma obtusum. Nuculae plurimae, monospermae, stylis plumosis caudatae, intra perigoni tubum incrassatum, ovato-cylindricum, mox quadrifariam dehiscentem liberae. S e m e $\mathbf{n}$ ereetum. E mb r yo in axi albuminis carnosi mollis minimus; cotyledonibus divaricatis; radicula infera. Arbor chilensis; foliis oppositis, obovatis, in petiolum attenuatis, glanduloso-serratis, glaberrimis, cymis axillaribus paucifloris hirtellis, cymulis basi bibracteatis, trifloris, floribus pedicellatis, subfastigiatis, ebracteolatis.

Pav o n a Ruiz prodr. 127. $t, 28$, non Cav, La urelia Jussieu in Annal. Mus. XIV. 134. Th ig a Molina.

202\%. Doryplhora. F lo res hermaphroditi. Perigon i m campanulatum, t u bo brevi, $1 \mathrm{imbi}$ sexfidi decidui laciniis longe lanceolatis, acutis, biseriatis, aequalibus. Sta $\mathrm{m}$ in a 6 , perigonii fauci inserta, limbi laciniis opposita; filam enta brevia, hasi late hisquamosa; an the rae biloculares, loculi ovati, conncetivo in acumen subulato-filiforme elongatum producto utrinque adnati, valvulis adscendentibus dehiscentes. S $t$ a $\mathrm{m} \mathrm{i-}$ nodia subduodena staminibus fertilibus alterna, subulata, basi bisquamata. Ovaria plurima (5 20) ovata, brevissime stipitata, distincta, unilocularia. O v u I um unicum, erectum, anatropum, Sty$1 \mathrm{u}$ s prope basim lateralis, medio incrassatus, villosus, stigmat e filiformi nudo. Nucula plurimae, monospermae, stylis plumosis basilaribus caudatae, intra perigonii tubum incrassatum, costatum, basi ventricosum, apice constrictum, demum inferne hinc fissum, liberae. S emen erectum. Embryo in basi albuminis carnosi mollis minimus; cotyled onibus divarieatis; $r$ adic $\mathbf{n}$ la infera. - Arbor Novae Hollandiac orienta $l$ is interioris, quinquaginta interdum pedes alta; ramulis oppositis, tetragonis, folit oppositis,oblongo-lancenlatis, glunduloso-serratis, reticulato-venosis, pedunculis axillaribus solitariis trifloris, apice bibracteatis, floribus lateralibus in axillis bractearum subsessilibus, raro fructum maturantibus, intermedio pedicellato, pediccllo basi bibracteolato, bracteis bracteolisque deciduis et perigonio villosis.

A therospera a Sassafras A. Cuuningham moc. 1818.

\section{Drdo CEI. Hawrineae.}

LAURI Juss. gen, 80, Annal, Mus, VT, 197, LAURINAE Veat. tabl, II. 2is, R. Browa prodr, 401, Bartl. Ord, nat.
111. Nees in Wall. Pl. As. IT. 69. ss. Linnaea VIII. 1. fs. - Programma, Plantarum Laurinarum secundum affinita. tes naturales expositio. Vratislaviae, 1833. 4. Systema Lau. rinarum, Berolini, 1836. 8, LAUREACEAE Lindley Introduct. edit. $I T, p .200$.

Arbores saepe excelsae, frondosae, rarius sufFretices, nonnullae herbá aphyllae, parasiticae, volubiles.

Foura alterna, saepius approximata, in verticillos imperfectos coëuntia vel pseudo-opposita, simplicia, integra, nervosa $v$. penninervia, venuloso-reticulata, integerrima, plerumque coriacea, perennantia, interdum subtus glandulifera vel punctata. Sti pula e nullae.

Flores hermaphroditi v. abortu unisexuales, regulares, racemosi $\mathbf{v}$. paniculati, nune in umbellis axillaribus involucrati, v. rarissime spicati, tribracteati, pedicellis demum saepe increscentibus.

Perigoniom simplex, calycinum, gamophylInm, quadri-sexfidum, $l$ a c i n i s alternatim biseriatis, trinerviis, intus saepe pubescentibus, crassiusculis, quandoque fere obsoletis, a e stiva tio ne imbricatis. D is cus carnosus, perigonii fundo adnatus, cum ejusdem basi persistens, et saepius cum fructu increscens.

Sтамиха perigyna, disci margini inserta, quadruplici laciniarum perigonii numero v. abortu triplici, duplici v. interdum simplici, tuncque iisdem opposita, nonnunquam quintuplici v. etiam sextuplici. Fil am enta libera, glabra vel hirta, apice saepissime dilatata, interiora plerumque, rarissime exteriora, latere glandulis sessilibus stipitatisve stipata. A nthe rae nunc omnes extrorsae, nunc stamiuum exteriorum introrsae, interiorum extrorsae, intimorum saepe abortivae, filamento toto dorso adnatae, nune biloculares, lo culis appositis parallelis continuis, nunc iisdem dissepimento transverso divisis quadrilocellares, Joculis locellisve singulis valvula longitudinali a basi ad apicem soluta, persistente dehiscentibus.

Orarivm e carpidiis tribus valvatim connatis, uniloculare, liberum, pla cen tis nerviformibus ad carpidiorum margines omnibus prater unicam saepissime abortientibus, uniovulatum, rarissime placentis geminis contiguis superstitibus biovulatum. Ovulum ex apice locnli pendulum, anatropum. St y lus simplex, crassiusculus. Stigm a obtuse bi-trilobum.

Fructes baccatus v. drupaceus, pedicello incrassato exceptus $v$, perigonii basi increscente ampliata cupulatim cinctus, v. eodem persistente marcido tectus, semper monospermus.

Srmun inversum. 'Te st a chartacea, umbilico transversali in parte seminis angustiore sito, raphe obliqua ad chalazam in altera ejusdem extremitate sitam prorepente. End o pleura tenuis. Alb um e n nullum.

Embryo orthotropus. R adienla ad nmbilicum directa, verticem fructus spectans. Co t y- 
led on es magnae, plano-convexae, juxta basim peltatae. Plumula diphylla.

Ordo singularí antherarum structura A theros perme is propinquus, et etiam B e rberideis nonnihil affinis, qualitate Myristiceis, androecei et seminis fabrica abunde distinctis comparandus.

LAUrineas inter tropicos utrinsque hemisphaerae potissimum proveniunt, in montibus subfrigidis sylvas struentes. Paucae in Americaboreali, insulis Canariis et Europa mediterranea vigent, ex Asia boreali et Afric a e terra continente, praeter Cassyth am, omnino exules.

Cas s y tha habitu et vivendi ratione a reliquis distinctissima, et Cuscut a m simulans, ob floris fructusque fabricam mirum in modum conformem, ab ordine numquam removeri poterit, et invita plane natura ab Agardhio inter Loranthaceas collocata fuit.

G y roc arp us Jacq. diu Laurineis adscriptus, nunc sub proximo ordine militat.

Cortice foliisque aromaticis v. camphuratis Laurineae pleraeque pollent. Sassafras lignum odore et sapore foeniculaceo est insigne.

TRIBUS I. CINNAMOMEAE Nees Laurin, 29. Fl ores hermaphroditi v. polygami. Perigonii limbus articulatus. Staminodia perfecta. Antherae quadrilocellatae, interiores extrorsae. - Gemmae incompletae.

2D23. Cinmanasanam BURM. Flores hermaphroditi v, polygami. Perigon i um coriaceum, sexfidum, limbi parte superiore v. toto limbo a tubo enpuliformi deciduo. S $t$ a $m$ in a 12 , quadriseriata, 9 exteriora fertilia, 3 in tim a sterilia; fertili um tria intima staminodiis binis sessilibns glandulaeformibus ad basim stipata; a $\mathbf{n}$ hera ovatae, in seric 1 et $\mathbf{2}$ introrsae, in serie 3 extrorsae, omnes quadrilocellatae, valvulis totidem adscendentibus dehiscentes, locellis inferioribus magis lateralibus; sterilium capitula ovata. Ovari $\mathbf{m}$ uniloculare, uniovulatum. Stigma discoideum. B a ce a monosperma, perigonii basi cupuliformi, subsexfida stipata. - Arbores India e orientalis, ob corticem aromaticum celebres; folits nervosis, per paria upproximatis o. suboppositis, floribus paniculatis rariasve fasciculatis, exinvolucratis, gemmis nudis.

Ci an a momum Burmann Flor. Zegl. 68. R. Brown prodr. 401, in nor. Wallieh PI. As, rar. II, 73. Progr, 9. Laur, 31. Blume Bijdr. 570 . Tijdserft, $I$. 63. Rumphia 25. t. 10 21. Hayue Arzn, Gew, $t, 20$ 24. Nees jua. Pl, offic. suppl. IV, t. 8_to. Hooker Exot, Flor. 1, 126, M a l a b athru m Burinana EL, Ind. 2ta, I, a u ri s p. Lian. Gârtn. $I I$. t. 92. Nees Amoen. Bot, t. 2, f. a, t, 3, t. 4. f. 1.2.

TREBUS II. CAMPHOREAE Nees Laurin. 85. Flore s hermaphroditi. Perig on i limbus articulatus. Staminodia perfecta. Antherae quadrilocellatae, interiores extrorsae. - Gemmae perulatae.

2024. Camphora NEES. F lores hermaphruditi. Perigonium chartaceum, sexfidum, limbo deciduo. St a min a 15, quadriseriata, 9 exteriora fertilia, 6 interiora sterilia; fertili um triayintima staminodiis binis stipitatis, com pressis ad basim stipata; anthera e in serie 1 et 2 introrsae, in serie 3 extrorsae, interdum efoetae, omnes ovatae, quadrilocellatae, valvulis totidem adscendentibus dehiscentes; $s t \mathrm{erilium}$ capitulo ovato-glanduloso v. distinetius antheriformi. $0 \mathrm{va-}$ ri u m uniloeulare, uniovulatum. Stig m a discoideum. B a ce a monosperma, perigonii basi obeonicae, integrae insidens. - Arbores indica $e, o b$ resinam ingentium in organismum animalem virium celebratae; foliis alternis, triplinerviis, ramorum axillis in plerisque glandula immersa, poro subtus dehiscente instructis, gemmis foliorum axillaribus et terminalibus, perulatis, imbricato-multisquamosis, florum pariculis parvis subtrichotomis, exinvolucratis.

C a mpltora Nees in Wallich PI. As. rar. II. B1. et 72. Progr. 9. Laur. 87, C i n a m o m i sp. Nees jun. Pl. offic. t. 127, L a u ri s p. Jaeq. Collect. IV. t. 3. f. 2.

TRLEUS III. PHOEBEAE Nees Laurin. 93. F lores hermaphroditi. Perig on i limbus persistens, in cupulam baccae adpressam indurascens. St a $\mathrm{m}$ i $\mathbf{n}$ o d i a perfecta. An ther a e bi - v. quadrilocellatae, interiores extrorsae. - Ge mmae incompletae.

2025. A pollonias NEES. Flores hermaphroditi. Perigo n i um sexfidum, subacquale, laciniis membranaceis, demum in cupulam fructus induratis. St a mina 12, quadriseriata, 9 ext eriora fertilia, 3 interiora sterilia; fertilium tria intima staminodiis binis stipitatis ad latera stipata; a $\mathbf{n}$ therae in serie 1 et 2 introrsae, in serie 3 extrorsae, omnes oblongae, bilocellatae, valvulis totidem adscendentibus dehiscentes; s t erili a stipitata, capitulo globoso, quandoque in antheram mutato, glandnlis geminis stipitatis ad basim v. infra capitulum sessilibus aucta. Ovari nm nniloculare, uniovulatum. Stig ma depresso-capitatum. B a c c a monosperma, basi perigonio in capulam regularem sexfidam indurato conniventique immersa. - Arbor in insulis Canariis erescens, habitu Lauri nobilis; foliis alternis, sempervirentibus, obsolete venosis, penninerviis, gemmis parvis bivalvibus, floribus anguste paniculatis, nudis.

Apollonlas Nees Progr. 10. Laurin. 95. La u rus can a riensis Willd.

2026. Phoebe NEES. F I o r s hermaphroditi. Perig on i m sexfidum, subaequale, subcoriacenm, laciniis tuboque demum in cupulam frnetus induratis. St a mina 12, quadriseriata, 9 exteriora fertilia, 3 interiora sterilia; fertilium tria intima ntrinque staminodio glandalaeformi, substipitato, collaterali, libero praeditae; a $n$ therae in serie 1 et 2 introrsae, in serie 3 extrorsae, omnes oblongae, quadrilocellatae, valvnlis totidem adscendentibus dehiscentes; steriI i a stipitata, capitulo cordato-triengulari, dorso e -landulosa. Ovari um uniloculare, uniovulatum. Stig ma depressum, discoideum. B a c c a monosperma, basi perigonio in cupulam regularem sexfidam indurato conniventique immersa. - Arbores in India orientali et occidentali indigence; foliis penninerviis, gemmis parvis, squamis paucis, carinatis, foliaceis hiantibus, inflorescentia paniculata v. subcorymbosa, axillari.

Phoebe Nees Laurin. 9s. O coteae sp. Blum. Nees olim. Laurj sp. Swartz. 
TRERES IV. PERSEAE Nees Laurin. 120. Flores hermaphroditi v, rarius diclines. Perig o n i l limbus v. persistens et fructifer haud mutatus, v. deciduus discum orbicularem relinquens. St a m in o d i a perfecta. Antherae bi-quadrilocellatae, interiores extrorsae. Pedicelli fructiferi saepissime incrassati, succulenti v. subcarnosi._Gemmae incompletae.

302\%. Pergen GARTN. Flores hermaphroditi v. rarins diclines. Perigon i m profunde sexpartitum, subaequale v. inaequale (pubescens) persistens, demum ad basim usque evanescens. St a mina 12, quadriscriata, 9 ext e ri ora fertilia, 3 in teriora sterilia; fertili um filamenta filiformia villosa, tria intima staminodiis binis glandulaeformibns, globosis ad basim stipata; a n the $\mathrm{r}$ a $\mathrm{e}$ in serie 1 et $\mathbf{2}$ introrsae, in serie 3 extrorsae, omnes oblongae, quadrilocellatae, locellis oblongis, inaequalibus, valvulis totidem adscendentibus dehiscentes; sterilia stipitata, capitulo distincto cordato-triangulari. O va ri u m uniloculare, uniovulatum. Stig ma discoideo-dilatatum. B a c c a monosperma, pedicello plus minus incrassato carnoso, perigonio immutato primum coronato, demum denudato insidens. - Arbores in Asia et America tropica indigenae; foliis alternis, costatopenninerviis, gemmis bivalvibus, compressis, inflorescentia paniculata aut thyrsoidea, in nonnullis depauperata et pauciflora, e squamarum gemmae axillaris v. terminalis fugacium axillis, ramulis subumbellifloris, minute bracteolatis.

Pe r sea Gartn. III. 222. Nees in Wallich Pl. As, rar. IIT. 32. Linnaea VIIT. 49. Progr. 10. Laurin. 123.

a. GNESIOPERSEA Nees. Perig o a i laciniae aequales, v. duae miuores. S $t$ a n i a tertiae seriei ad basiu glandulis gemiuatis, collateralibus, substipitatis ; quartae serie sterilia apice auda. - Americanae et asiaticac.

G nesi o persea Nees Laurin. 12\%. (Weadl, Observ. bot. t. 3. $f .22$.

b. FRIODAPHNE Nees. Perigonil lacinine exteriores minores. Sta mi na 3 seriei glandulis geminatis sessilibus stipata; quartae seriel sterilia apice barbata, Imericanae.

E r i o d a p h ne Nees Laurin, 143. (Catesb, Carolin, t, 63.)

2028. Maeluilas NEES. Flores hermaphroditi. Perigoni um sexpartitum, chartaceum, aequale, persistens. S $t$ a m in a 12 , quadri seriata, 9 exteriora fertilia, $\mathbf{3}$ interiora sterilia; fertilium tria intima glandulis binis stipitatis liberis utroque laterae stipata; antherab in serie 1 et 2 introrsae, in serie $\mathbf{3}$ extrorsae, omnes oblongae, quadrilocellatae, locellis inferioribns duplo majoribus, valvulis totidem adscendentibus dehiscentes; sterilia stipitata, capitulo acuto antheriformi, dorso eglandulosa. Ovari am unilo culare, uniovulatum. Stig ma discoideum. B a cc a monosperma, perigonio haud mutato, patenti $\mathbf{v}$. reflexo insidens, pedicellu fructifero non incrassato. - Arbores indicae, monticolae; foliis alternis, penninerviis, subtiliter venosis, gemmis perulatis, imbricato-squamosis, inflorescentia paniculata, paniculis ad basim gemmae terminalis v, axillaris alternatim aggregatis, corymbosis, nudis, squamis bractealibus deciduis.

M a $\mathrm{chil}$ us Nees in Wallich Pl, As, rar, II, 61, excl. sp. Progr, 11. Laurin, 171 .

2039. Foldu FEUILL. F lores hermaphroditi. Perigonium sexfidum, subaequale, rotatum, laciniis chartaceis, haud mutatis, persis- tentibus. Stamina 12 , quadriseriata, 9 exteriora fertilia, 3 interiora sterilia; fertilium 3 intima glandulis geminis sessilibus stipata; anth $\mathrm{era} e$ in serie 1 et 2 introrsae, in serie 3 extrorsae, omnes subovatae, bilocellatae, valvolis totidem adscendentibus dehiscentes, locellis apicem antherae haud attingentilus; st erili a subsessilia, triangulari-subulata. O va $\mathrm{ri} \mathbf{u}$ uniloculare, uniovulatnm. Stig ma discoideum. B a c a monosperma, perigonio hand mutato snbrigeseente basi cincta, pedicello inrrassato imposita. - Arbor chilensis; foliis suboppositis, reticulatis, venosopenninerviis, gemmis bivalvibus, florum paniculis parvis, rigidulis, in axillis foliorum superiorum suboppositis.

B old u Feuillée Chit. II. 13, t.6. f. 2, Nees Progrr, 11 . Laurin. 177. P e nus us Boldus Molina Hist. nat. 160. et 311 . Boldus cbileusis Molina Sagg 158.

2030. Alseodaphne NEES. F lo res hermaphroditi. Pe rig on i n m sexfidum, charta ceum, limbo deciluo. St a m i n a 12 , quadriseriata, 9 exteriora fertilia, 3 interiora sterilia; fertilium 3 intima glandulis binis stipitatis compressis ad basim stipata, filamenta plerumque dilatata; a $\mathbf{n}$ he $\mathbf{r}$ a $\mathrm{e}$ in serie 1 et 2 introrsae, in serie $\mathbf{3}$ extrorsae, omnes oblongae, quadrilocellatae, valvulis totidem adscendentibns dehiscentes; s terilia stipitata, capitulo introrso, sagittatolanceolato, dorso eglandulosa. Ovarin uniloculare, uniovulatum. Stig ma discoideum. B a c c a monosperma, perigonii basi integrae, orbiculari, explanatae insidens. - Arbores indicae; foliis alternis, penninerviis, nervis primariis venosis $v$, costaeformibus, gemmis compactis, squamis pauois hiantibus tectis, paniculis e squamarum gemmae ter minalis axillis subcorymbosis, ramis nonnunquam subumbellifloris,

Als eoda pline Nees in Wallich Pl. As, rar. II. 61 . Progr. 11. Laurin. 181.

2038 1. II fufelamalia NEES. F1 ores hermaphroditi. Per ig o $n$ in m sexfidum, laciniis aequalibus, deciduis. St a m in a 12 , quadriseriata, 9 exteriora fertilia, 3 interiora sterilia; fertili u m 3 intima glandulis binis sessilibus, compressis ad basim aucta, filamenta brevissima, lata; antherae ovatae, biloenlares, valvulis adseendentibus dehiscentes, in serie 1 et 2 introrsae, planae, locellis mediis, in serie 3 extrorsae, tetragonae, loeellis magis inferis; s terili a triangularia, stipite brevi latoque. Ova $\mathbf{r}$ in miloculare, uniovulatum. St ylus brevis; stigma obtusum. B a ec a monosperma, perigonii basi truncatae insidens. - Arbores antillanae; foliis alternis, penninerviis, florum paniculis axillaribus.

H u fela nd i a Nees Progr. 11. t. 1. 2. Laurin. t. 187. Laurus pendula Swartz.

2032. Delnarasia BLUM. Floreg hermaphroditi v. abortu monoiei. Perigonium sexfidum. Iaciniis inaequalibus, tribus exterioribus nanis. St am in a 9 v. 12 , tri-quadriseriata, 9 ex teri o r a fertilia, 3 in teriora sterilia, quandoque nulla; fertili n m $\mathbf{3}$ intima basi extrorsum glandulis geminis sessilibus instructa; a $\mathbf{n}$ h e r a e subrotundae, bilocellatae, valvulis totidem adscendentibus sublateraliter dehiscentes, in serie $\mathbf{1}$ et $\mathbf{2}$, introrsae, in serie 3 extrorsae; st erilia triangalaria, sessilia, saepissime nulla, Ora ri um uniloculare, uniovulatum. St $\mathbf{g} \mathbf{m}$ a discoideo - triangulatum. B a c ca monosperma, pedicello carnosoincrassato-imposita. - Arbores in India, imprimis insulari provenientes; foliis alternis, penninerviis 
reticulatis, paniculis florum viridulorum ad ramulorum continuationem terminalem dispositis.

Deh a a sia Blume Rumph. 161. $t$. 44-47. H a a sia Blume apud Nees Laurin. 372, 675 .

TIRIBUS V. CRYP'TOCARYEAE Nees Laurin. 191. F lores hermaphroditi. Perig on i limbus deciduus v. persistens, demum carnoso-incrassatus $v$. induratus. $\mathrm{S} t$ a $\mathrm{m}$ in $\mathbf{0 -}$ dia perfecta, interdum nulla. Antherae bi-quadrilocellatae, locellis facie insertis, interiores extrorsae. Fruct us siccus v. baceatus, perigonii tubo baceato $\mathrm{v}$. indurato inclusus, rarius perigonii basi persistenti impositus. - Gemmae incompletae.

2033. Endiandira $R$. BR. F lores hermaphrodito-polygami. Perig on i m sexfidum, aequale, limbo deciduo. St a m in a 12 , quadriseriata, 6 exterior a rudimentaria, glandulaeformia, distincta $v$. in annulum faucis confluentia, 3 interio r a fertilia, intima sterilia v. nulla, fertilium filamenta brevia; a n the rae extrorsae, subquadratae, biloculares, valvulis totidem adscendentibus dehiscentes; sterilia stipitata, capitulo subgloboso, saepissime nulla. O varium nniloculare, uniovulatum. Stylus brevissimus, stigma subglobosum. B a ce a monosperma, perigenii iubo truncato immersa. - Arbores Novae Hollandi a e; foliis alternis, penninerviis, reticulatis, gemmis parvis laxis, e squamis foliaceis, carinatis, paniculis axillaribus, nutantibus.

Endiandra R. Brown prodr. 422. Nees Progr, 12. Laurin, 193.

2034. Bellselnatedia NEES. F lores hermaphroditi v. dioici. P e rig o n i um sexpartitum, aequale, limbo deciduo. St a $\mathrm{m}$ in a 12 , quadriseriata, 9 exteriora fertilia, 3 interiora sterilia; fertilium series 2 , v. interdum etiam 1, staminodiis glandulaeformibus stipitatis liberis antice stipata; a nth erae oblongae, bilocellatae, valvulis totidem adscendentibus, in serie 3 lateralibus subextrorsis; st erilia ovata, sulsstipitata. Ovarium semibiloculare, nniovulatum. S $t$ ig $\mathbf{m}$ a depressum, subdiscoidenm. B a c c a coriacea, monosperma, cum dissepimenti vestigio, perigonii basi persistenti imposita. - Arbores indica e; foliis alternis, venosis, inflorescentia axillari, pedunculo communi brevi articulato, primum squamis imbricatis uni-paucifloris tecto, floribus post squamarum lapsum racemosis.

Beilschmiedia Nees in Wallich Pl. As, rar. IJ. 61. Progr, 12, Laurin, 197.

2035. Ceeidodaphne NEES. F I o r e s hermaphroditi (?). Perig on ium subinfunáibuliforme, sexfidum, aequale, limbo deciduo. S $t$ am in a 12, quadriseriata, 9 ex te $r$ i o r a fertilia, 3 interiora sterilia ; fertilium 3 intima glandulis binis capitatis ad basim aneta; a $\mathrm{ntherae}$ in serie 1 et 2 introrsae, in serie 3 extrorsae, omnes ovatae, quadrilocellatae, valvulis totidem adscen dentibus dehiseentes; sterilia capitulo antheriformi, subulato. Ovari nm ..... Stigma disciforme. Fruetus .... - Arbor indica; foliis alternis, venosis, paniculis multifloris brevibus, e gemmae in ramo v. ramulo terminalis, crassae, dense squamosae, squamis singulis, paniculam densam, thyrsoideam, subglobosam constituentibus.

Cecidodapbue Nees in Wallich Pl. As, rar, II. 61. Progr, 12, Laurin, 202.
2036. Cryptoearya $R, B R$. Flores hermaphroditi. Perigonium subinfundibuliforme, sexfidum, aequale, limbo deciduo. Stam in a 12, quadriseriata, 9 exteriora fertilia, 3 interiora sterilia; fertilinm 3 intima glandula stipitata, libera ad utrumque latus instructa; antherae in serie 1 et 2 introrsae, in serie 3 extrursae, omnes oblongae, bilocellatae, valvulis totidem adscendentibus dehiscentes; sterilia substipitata, capitulo angusto, acuto. Ovarium tubo perigonii immersum, uniloculare, uniovnlatum. Stig ma capitatum. Ca ry opsis monosperma, intra perigonii tubum drapaceum subclausum libera. Arbores amphigaeae, tropicae, in Nova $\mathrm{Hol}_{0}$ landia etiam extratropicos observatae; foliis alternis, penninerviis, gemmarum squamis paucis, foliaceis, carinatis, inflorescentia paniculata, axillari $v$. subterminali, laxiuseula, in plerisque flexuosa.

C ryptocary a R. Brown prodr. 402. Nees in Wallich Pl. As, rar, 11. 61. Progr. 12, Laurin, 205.

a. EUCRYPTOCARYA. Gla ndula e ad basim staminum tertiae serief, et $s$ tamina sterilia quartae seriei stipltata. D rupa intra perigonii tubum, limbo orbatum et reclusum latens. - Gemmae herbaceae, squamis paucis.

Cryptocaryae genuina Nees Laurin, 206.

b. GXMNóCARYA Nees. G 1 and ula e ad basim staminum tertiae seriei et $s \mathrm{tamina} s t e r i l i a$ quartae seriei sessilia. Drupa futra perigonif tubum ore apertum, et limbi laciniis reflexis, diu persistentibus coronatum latens. - Gemmae subulatae, bivalves.

G y $\bar{m} \mathrm{n} 0$ e a r y a Nees Laurin. 220.

c. Pe umus Nees. GIandula e ad basim staminum tertiae seriei et $\mathrm{stamina} s t e$ rilla quartae seriei sessilia. Fructus ....-Gemmae perulatae, squamis plaribus.

Pe u m u sees Laurin. 222. La u r us Pen mo Dombey, Lam. Dict. III. 455. - G o m orte g a Ruiz et Pav. Syst. 108. A d enos te mo n Pers. ench, I. 467. Nees Laurin, 651. Ke ull a Molina.

203\%. Caryodaplane BLUM. F lo res hermaphroditi. Perig on ium infundibuliforme, tubo obconico, Jimbo sexfido, aequali, deciduo. St a min a 12, quadriseriata, 9 ext exiora fertilia, 3 interiora sterilia; fertilium 3 intima glandula stipitata libera ad utrumque latus instructa; an $\mathbf{t h}$ er a e in serie 1 et 2 introrsae, in serie 3 extrorsae, omnes oblongae (apice glandulosae) bilocellatae, locellis oblongis ab apice antherae distantibus, valvulis totidem adscendentibus dehiscentes; sterilia stipitata, capitulo longo, acuto. Ovari um tubo perigonii immersum, uniloculare, uniovulatum. Stigma discoidenm. Drupa monosperma, tubo perigonii truncato, clauso, drupaceo tecta et eidem connata. - Arbores javanicae; foliis trinerviis v, triplinerviis, gemmis axillaribus pedicellatis, squamis paucis subcoriaceis, carinatis, paniculis axillaribus rigidulis brevibus, trichotomis et subcorymbosis $v$. subsimpliciter racemosis.

Caryod a phue Blume in Noes Laurin, 225.

2038. Agathopleylluma JUSS. F lores hermaphroditi. Perigonium infundibuliforme, fance constrictum, limbo sexfido, aequali, persistente $v$. deciduo. S $t$ a $m$ i na 12 , quadriseriata, 9 exteriora fertilia, 3 interiora sterilia; fertiliu m 3 intima glandulis geminis sessilibus subglobosis ad utrumque latus instructa; a ntherae in serie 1 et 2 intrursae, ovatae, apice membranaceae, in serie 3 extrorsae, apiee subulatac, omnes bilocellatae, valvulis totidem adscendentibus dehiscentes; sterilia subsessilia, triangulari-acuminata. Ovarium uniloculare, uniovulatum. Stylus crassinsculus; stigma capitatum. C a ryo psis monosperma, tubo perigonii nudo v. laciniis 
persistentibns coronato, coriaceo, incrassato, intus quinque-sexplicato inclusa, basi angulato-lobata. Cotyledon es conformes, basi lobatae. - Arbor madagascariensis; foliis alternis, confertis, gemmis stipitatis bivalvibus, paniculis terminalibus, contractis.

A gath ophyllum Juss. gen. 431. Nees Prngr. 12. Laurin. 231. E v od I a Gärtu. II. 101, t. 103. Lam. $t .404$. Rave nsara Sonuerat Voy. II. 226, t. 127.

2039. MTespillodaphne NEES. F I o r e s dioici (?). Perigoni n $\mathrm{m}$ infundibuliforme, tubo obconico, limbo sexfido, aequali, persistente. S t amina 9 v, 12 , tri-quadriseriata, 9 exteriora fertilia, 3 interiora sterilia, quandoque nulla; fe rtilium $\mathbf{3}$ intima basi utrinque glandulis subglobosis sessilibns stipata; antherae in serie 1 et 2 ovatae, introrsae, in serie $\mathbf{3}$ angustiores, extrorsae, omnes quadrilocellatae, valvulis totidem adscendentibus; sterilia breviter stipitata, capitulo cordato-lanceolato, quandoque nulla. O varium uniloculare, uniovulatum. Stig ma ...... B a c e a monosperma, perigonii tubo carnoso-suberoso crasso recondita, laciniis primum umbonatim conniventibus, mox deciduis verticeque deraso subemersa. - Arbores brasilienses; foliis alternis, venosis, floribus in thyrsos v. paniculas axillares dispositis.

Mespilod a pline Nees in Linnaea VIII. 45. Progr. 12. Laurin 235. La u us Canelllla Willd.

TIRIIBUS VI. ACRODICLIDIA Nees Laurin. 243. Fl o r e s hermaphroditi. Per igoni limbus persistens v. deciduus. Staminodia nulla v. dentiformia, compressa. St a m i na fertilia 3 v. 9. A nt he rae locellis binis poriformibus juxta apicem dehiscentes, subsessiles, interiores interdum extrorsae. Fructus baccatus, primum perigonio laciniis conniventibus clauso aut umbonato reconditus, demum emersus, cupulae crassae, truncatae $\mathbf{v}$. appendiculatae profunde immersus.

2040. Aydendron NEES et MART. F lores hermaphroditi. Perigon inm infundibuliforme, sexfidum, limbi lacinits aequalibus, inaequaliter deciduis. Sta min a 12 , quadriseriata, 9 exteriora fertilia, $\mathbf{3}$ interiora sterilia, quandoque obsoleta; fertilium 8 intima glandalis compressis, sessilibus utrinque stipata; a $t$ thera bilocellatae, valvulis totidem adscendentibus dehiscentes, in serie 1 et 2 introrsae, latiores, brevissimae, ostiolis poriformibus infraapicalibus, in serie 3 extrorsae, minores, ostiolis magis lateralibus; sterilia compresso-subulata, obtusa, sessilia, squamiformia, quandoque obsoleta. Ovarium uniloculare, uniovulatum. Stylus brevis; stigma truncatum. B a cea monosperma, perigonii tubo incrassato, laciniis conniventibus recluso primum immersa, demum perigonio irregulariter truncato ealyculata, glandiformis. - Aibores a m er $i$ e an a e tropica $e$; foliis alternis, penninerviis, paniculis ad basim innovationum ramorum axillaribus, primum squamoso-bracteolatis, mox denudatis.

A ydendron Nees et Martius in Linnaea VIII. 36. Nees Progr. 13. Laurin. 245. - ? O ot ea Pichurim Humb.

2041. Evonymodaphne NEES. F 10res hermaphroditi. P erigonium subrotatum, patens, tubo brevi, limbo sexfido, aequali, persistente (?). S $t$ a min a 9 , tubi apici inserta, eglandulo- sa, 6 exteriora sterilia, a $\mathrm{n}$ th e ris petaloideis, in serie 1 sessilibus, in serie 2 unguiculatis, 3 in. teriora fertilia; antherae scssiles, depresso-tetragonae, in columnam repando-triangularem contiguae, (hirtae) vertice truncato in poros binos orbiculares, valvulis erectis introrsum dehiscentes. Ovari um tubo perigonii immersum, uniloculare, uniovulatum. Sty In s conicus; stig ma parvum, discoideum. Fructus......-Arbor peruviana subandina; foliis alternis, penninerviis, floribus parvis in racemos v. cymas simplices, graciles, in ramulo proprio apice gemmiparo axillares dispositis.

Evon y mod a ph ne Nees Laurin, 263.

2042. Aerodifelidium NEES. FIores hermaphroditi, Perig onium urceolatum, limbo quinquefido, inflexo, persistente. St a m in a 9 , tabi apici inserta, brevissima, 6 exteriora sterilia, petaloidea, eglandulosa, 3 in te $r$ i o r a fertilia, dorso basi glandulis geminis subquadratis stipata; an th er a e sessiles, truncato-tetragonae, conniventes, verice in poros binos orbiculares, valvulis erectis extrorsum dehiscentes. Ovarium tubo perigonii immersum, unilocnlare, uniovulatum. S tig m a simplex, acutum. Ca ry ops is monosperma, perigonio increscenti, ventricoso-urceolato immersa. - Arbores americanae tropicae; foliis alternis, penninerviis, floribus in thyrsulos axillares dispositis.

Acrodielidium Nees Progr. 13. Laurin. 266. Laurus triandra Swartz.

2043. Misanteea SCHLECHTEND. F lores hermaphroditi. P e rig on i m obconicoturbinatum, angulatum, limbo brevi sexlobo, inaequali, deciduo. S t a m in a 9, triseriata, tubi apici inserta, 6 exteriora sterilia, brevia, truneata $v$. retusa, eglandulosa, 3 in terior a fertilia majora; a n therae sessiles, in columnam quadrangularem basi obsolete glandulosam connatae, vertice in poros binos orbiculares, valvulis erectis extrorsum dehiscentes. Ovari um intra perigonii et antherarum tubum delitescens, uniloculare, nniovulatum. Sty lus cylindricus; stig ma depresso-capitatum. B a cea (?) perigonii tubo eyathiformi, crasso, angulato, truncato, obtuse multidentato profunde immersa, mucronulata. - Arbor mexicana; folits alternis, penninerviis, pedunculis ad basim gemmae innovationis aggregatis, cymam in capitulum densum multiflorum contractam formantibus.

M is anteca Schlechteadal in Linnaea VT. 367. Nees Progr, 13. Laurin. 272.

TBIIUS VII. NECTANDREAE Nees Laurin, 275. Fl o res hermaphroditi. Perig o ni i laciniae latiusculae, patentes, deciduae, exteriores latiores. Staminodia dentiformia, rarius subeapitata. St a min a fertilia 9 . Antherae locellis basim versus in arcum dispositis dehiscentes, interiores extrorsae. Fructus baccatus, cupulae profundae, trancatae insertus. - Gemmae incompletae.

2044. Neetandira ROTTB. F io res hermaphroditi. Perigoninm sexpartitum, rotatum, laciniis deciduis, tribus exterioribns paullo latioribus. St a min a 12, quadriseriata, 9 exterio ra fertilia, 3 interiora sterilia; fertilin m 3 intima glandulis geminis globosis dorso ad basim ancta; a $\mathbf{n t h e r} \mathrm{e}$ in serie $\mathbf{1}$ et $\mathbf{2}$ introrsae, in serie 3 extrorsae, omnes ovatae, subsessiles, locellis quaternis in arcum dispositis, ab apice antherae di- 
stantibus, valvulis totidem adscendentibus dehiscentes, sterilia dentiformia, basi biglandulosa, v. eglandulosa, capitulo parvo, ovali. Ovarium uniloculare, uniovulatum. Stylus brevissimus; stigma parvum, truncatum. B a c c a monosperma, perigonii tabo in cupulam truncatam integram expanso plus minns immersa. - Arbores Americanae tropicae; foliis alternis, penninerviis, inflorescentia paniculata $v$. corymbosa, axillari, laxiuscula, ampla.

Nectandra Rottboell in Act. Hafn. I. 279. Nees in Linnaea PIIT. 46. Progr. 14. Laurin. 277.

a. Pomatia Nees, Stamina quartae seriei sterilia, dentiformia, conniventia, basi biglandulosa. - Folia costata, reticulata, hirta $v$. tomentosa, inflorescentia strictior, fores ampliores, tomentosi v. sericei.

Pomatia Nees Laurin 277. O cotea e s p. Humb.

b. POROSTEMA Schreb. Stamina quartae seriei sterilia, subeapitata, eglandulosa. - Folia costata, hirta D. glabriuscula, inflorescentia laxa, flores minores, soricei, puberuli v. glabri,

Por os te ma Sehreber Gen.pl,n, 1226. Nees Laurin. 298. Nectandrae sp. Rottb. 0 coteae s p. Humb. Mart. B o r b o u i a e sp. Plumier, Gärta. 2, 282. L a uri sp. Aubl. Jacq. Collect. II, $t, 6, f, 2$.

TRI UEUS VIII. DICYPELLIA Nees. Laurin. 341. Flore s dioici v. polygami. S $t$ a $\mathrm{m}$ i$\mathrm{no} \mathrm{d} \mathrm{i}$ in masculis nulla, in femineis laciniis perigonii subconformia et cum iisdem persistentia, calyculum crassum, radiatum sub fructu formantia. Antherae interiores 3-6 sessiles, quadriporosae. Fru et us baccatus. - Gemmae incumpletae. Tribus monente auctore non satis cognita, olim dissolvenda.

2045. Dieypellium NEES, F l ores dioici. Masc. ...... Fem. Perigonium profun de sexpartitum, explanatum, laciniis dequalibus persistentibus. Stamina sterilia 12 , quadrise riata, 3 exteriora perfecte petaloidea, seriei 2 petaloideo-unguiformia, infra apieen inflexum quadriscrobiculata, seriei 3 sessilia, truncata, utrinque infra verticem biscrobiculata, a tergo glandulosobigibbosa, intima minima squamaeformia. Ovarium uniloculare, uniovulatum. Stylus brevis s $t$ ig $m$ a acutum. B a c $c$ a sicea, perigonio subcarnoso-rugoso, incrassato, patulo, staminibusque sterilibus auctis induratisque calyculata, disco dilatato sexangulari imposita. - Arbor brasiliensis; foliis alternis, penninerviis, reticulato-venosis, racemis simplicibus, paucifloris.

Di у y elli u m Nees Progr, 14. Laurin.343. -? L i ca$r$ i a Aublet Guian, I, 313, t. 121.

2046. Petalanthera NEES. Flores hermaphroditi (?). Perigon inm sexfidum, laciniis aequalibus, persistentibus. $S t$ a $\mathrm{m}$ in a 9 v. 12 , tri-quadriseriata, 3 v. 6 e x t e rio ra sterilia, petaloidea, sessilia v, unguiculata, 6 v. 9 interiora breviora, fertilia, filamenta angusta, basi biglandulosa; anthera e wvato-triangulares, quadrilo cellatae, locellis inaequalibus, valvulis totidem adsecendentibus introrsum sublateraliter dehiscentes. Ovarium uniloculare, nniovulatum. Stylus brevis; $\mathrm{stig} \mathrm{m}$ a subeapitatum. Fruetus ..... - Arbor brasiliensis; foliis alternis, penniner viis, costatis, venoso reticulatis, floribus primum in capitula squamis bractealibus tectu collectis, bracteis mox defluentibus nudis, glomeratis.

Petal a nthera Nees Progr. 15. Laurin, 346.

204\%. Plearothyrium NEES. F I res hermaphroditi. Perig onium sexfidum, tu- bo obconice, trigono, limbi laciniis patentibns oblongis, subaequalibus, crassiusculis, deciduis, Gl a nd u la e 6, triangulares, introrsum carinatae, perigonii laciniis alternae. $S t$ a $m$ in a 12 , quadriseriata, 9 ext eriora fertilia, subconformia, filamenta brevia, in serie $\mathbf{3}$ basi wbsolete biglandulusa; antherae subcubieae, quadrilocellatae, locellis lateralibus ovatis, parallelis, pare altero extrorsum, altero introrsum spectante, valvalis totidem adscendentibus dehiscentes, $\mathbf{3}$ in $\mathrm{tim}$ a sterilia, brevia, dentiformia, basi a tergo biglandulosa. $0 \mathrm{va-}$ ri u m uniloculare, uniovulatum. St y 1 u s brevis, crassus; stig ma discoideum, indivisum. B a c ea monosperma, perigonii tubo suburceolato, margine repando-crenato immersa. - Arbores brasilien$s$ es; foliis alternis, costatis, thyrsis $v$. paniculis axillaribus strictis, ramulis florum fasciculo terminatis v. cymoso-bijidis.

Ple a r oth y ri a m Nees Laurin. 349.

TRIBUS IX. OREODAPHNEAE Nees Laurin. 353. F lo res dioici v. polygami. Perigonii campanulati v. rotati laciniae subaequales, angustae. St a $\mathrm{m}$ i n a 6 v. 9, rarius duodecim, omnia fertilia v. intima sterilia. Anther a e filamento distincto praeditae, biquadrilocellatae, loculis in quadrilocellatis per paria superpositis, in serie 3 et 4 extrorsis. Fructus baccatus, cupulae immersus, v. perigonio immutato suffultus. - Gemmae incompletae.

2048. Teleiandra NEES. Flores divici. Masc. Perigonium rotatum, profunde sexfilum, laciniis inaequalibus, Stamina 12 , omnia fertilia, filamenta brevissima, lata, 6 ex teri or a eglandulosa, 6 int eri or a basi glandulis geminis globosis, sessilibus ad basim stipata; antherae in illis introrsae, in his extrorsae, omnes quadrilocellatae, locellis per paria sibi superpositis, valvulis totidem adscendentibus dehiscentes. $0 \mathrm{v}$ ari i rudimentum nullum. F e m. ..... Arbor brasiliensis; foliis alternis, penninerviis, paniculis ad basim ramulorum et innovationum nudis, parvis, cymulosis.

Teleiandra Nees in Linnaea VIIT. 46. Progr, 15. Laurin. 355.

2049. Teptodaplne NEES. Flores hermaphroditi v. abortu dioici. Perigonium infundibuliforme, limbi sexfidi laciniis aequalibns, deciduis. Stamina 9, triseriata, 6 exteriora fertilia, $\mathbf{3}$ interiora sterilia, quandoque olssoleta; fertilium alterna basi utrinque v. uno latere denticulo erecto aucta; antherae ovales, introrsae, quadrilocellatae, locellis per paria sibi superpositis, valvulis totidem adscendentibus dehiscentes; s terilia stipitata, infra apicem biglandulosa, quandoque rudimentaria $\mathbf{v}$. obsoleta. $O \mathrm{va}$ ri um uniloculare, uniovulatum. Stylus brevis; s tigma compresso-capitatum, subquadrilobum. B a ce a monosperma, perigonii tubo truneato-cyathiformi, integerrimo, subearnose basi immersa. Arbores brasilienses; foliis allernis, venoso-reticulatis, paniculis laxis, nudis, axillaribus v. circa bases innovationum positis.

Le p todaphne Nees Progr. 16, Laurin. 358.

2050. Aoven $A L^{\prime} B L$. Flores hermaphroditi, Perigonium infundilutiforme, sexfidum, limbi laeiniis aequalibus, persistentibus 
Stam in a 6, biseriata, perigonii laciniis opposita ; fi l a m e n ta filiformia, elongata, 3 interiora glandulis geminis subglobosis sessilibus hirtis ad basim stipata; antherae introrsae, ovales, bilocellatae, valvulis totidem adscendentibus dehiscentes. $O \mathrm{v}$ arium ..... Stylus longinsculus; stigma sexfidum. B a e c a monosperma, perigonii immutati laciniis erectis basi cincta. - Arbor gu ia nens is, soli Aubletio nota; foliis alternis, venosis, paniculis laxis axillaribus v. subterminalibus, bracteis cito defluentibus denudatis.

Ajovea Aublet Guian, I, 310. t, 20. Nees Progr. 16. Laurin, 262. Douglas 8 ia Schreher gen, n, 1761. Colowa duct, n. 277. L a u $r$ us hexandra Swartz.

2051. Coeppertia NEES. F lores polygamo-dioiei. Perigonium rotatum, sexfidum, laciniis aequalibus membranaceis, latiusculis, tandem deciduis. Sta min a 9 , triseriata, omnia fertilia; fil a m enta brevia, lincaria, plana, in serie 1 et 2 eglandulosa, in scrie 3 glandulis geminis dorsalibus compressis, substipitatis instructa; a ntherae bilocellatae v. quadrilocellatae, locellorum pari superiore inıperfecto, poriformi, valvulis adscendentibus dehiscentes; 6 exteriores suborbiculatae, trigonae v. quadratae, ostiolis magnis, subrotundis $v$. ovatis, introrsis; 8 interiores majores, ovatae v. trigonae, ostiolis ovatis oblongisve, extrorsis. Ova ri a m uniloculare, uniovulatum. Stylus brevis; stigma truncatum. B a ec a monosperma, glandiformis, perigonii tubo indurato, hemisphaerico imposita, - Arbores brasilienses et antillanae; foliis alternis, pube patula $v$. sericea vestitis, penninerviis, paniculis angustis, ramulis apice bi-trifloris.

Go e p pertia Nees Laurin, 365. Endll e her I a Nees in Linnaea VIII. 37. Progr. 16. S chauera Nees in Lindley, Introduot, edit, II, p, 202, in not.

205\%. Dreodlaplane NEES. Flores hermaphroditi, dioiei v. polygaui. P erigon i m sexfidum, limbo demum evanido. St a m in a 9 v. 12, tri-quadriseriata; 9 exteri or a fertilia, 3 interiora sterilia, quandoque nulla, fertilinm tria intima basi biglandulosa; filam en ta brevia angusta; antherae oblongae, quadrilocellatae, locellis per paria sibi superpositis, valvulis totidem adscendentibus dehiscentes, in serie 1 et 2 introrsae, in serie 3 extrorsae. Ova ri um uniloculare. uniovulatum. Stylus brevis; stigma discoideum. B a c c a monosperma, perigonii tubo in capulam profundam, crassam converso truncatogne plus minus inmersa. - Arbores americanae tropicae; foliis alternis, penninervits, inflorescentia paniculata v. racemosa, saepe densa v. brevi el thyrsoidea, interdum umbellulata.

Oreodaphne Nees in Linnaea DIIT. 39. Progr. 16. Laurin, 380.

a. APERIPHRACTA Nees. Flores hermaphroditi. Perigo. ni um rotatum, sexfidum, lacinilis paullo supra basin deciduis. St a mi ua 9 , fertilia, tria intima glaudulis bi. nis, subglobosis ad basim stipata; an therarum locelli paralleli, sulaequales. sterilia nulla. $\mathrm{S}$ tig a a diseoideum. - Flores majusculi, plerisque tomentosi v. seri cei, paniculae ampliores.

Aperiphracta Nees Laurin. 381. Ototear s p. Kunth. Martius.

b. AGRIODAPHNE Nees. Fi ores dioiei v. polygami. Perig o a i um rotatum v, campanulatum, raro subinfundibuliforme, limbo sexfido, aequali, deciduo. S t a m in a 9 , fertilia, tria iutima glandulis binis subglobosis ad basim stipata; a n therarum lacelli paralleli, subaequales, ste. rilia unlla. Stig m a discoideum. - Flores parvi, glabri $v$. strigilosi, paniculae minores $v$, racemuli axillares rariuve infraterminales.
A griodaphne Nees Laurin, 394. O cote a Gárta. f. HII. 227. t. 229, Ocoteae, Lauri, Perseae et Cryptocaryat sp. Auct.

- CrRamophora Nees. Flores diolel v. polygami, Per ig o n i u m masculum rotatum, femineum subinfundibuliforme, tubo in pedieellum continuato, liubo sexfido, ae. quali, deciduo, Sta mina 12, exteriora fertilia, interiora 3 sterilia, fertilium tria iutima basi glaudnlis binis sessillbus capitatisve stipata, $\mathbf{v}$. iisdem in collare connatis circumcincta; antherarum locelli paralleli, subaequales, sterilia filiformia pilosa vel capitulo cordato, unum alterumve interduns anliera uni-biloculari praeditum. $\mathrm{S} t \mathrm{~g}$. m a peltatum. - Paniculae ad basim v. apicem ramuli breves, pedunculatae, squamis bractealibus defluentibus.

Ceramophora Nees Laurin, 433. L a u ri et $0 \mathrm{co}$. te a e sp. Auet.

ct, Cer a mo phora e g e n in ae Nees Laurin, 434.

G l a $\mathrm{n} d \mathbf{a}$ I a e filamentorum seriei 3 liberae, mediocres. . A d e a trachellum Nees Laurin. 456. G I a n. d u lae filamentorum seriei 3 maximae, conlluentes, filamentum ad antheram usque involventes.

d. UMBELlULARIA Nees. Flores hermapliroditi. Ferig o n i u m brevi-campanulatum, ultra niedium sexfidum, lacinils rigidulis, acqualihus, deciduis. St am ina 12, exteriora 9 fertilia, interiora sterilla, fertilium 3 intima glandulis geuninis maguis, filamentum a tergo tegentibus, a utherarum in ser e 3 locelli 2 superiores introrsi, inferiores extrorsum laterales ; sterilia filiformia, Stig ma peltatun, subrepandum.- Umbellulae arillares, involucro olauso, globoso primum tectae et interstinctae, involucri foliolis alternatim approximatis, sub anthesi cadncis, tatiusculis.

U mbellularia Nees Laurin, 462, La urus ealiforniea Arnott.

\%O53. Campla oromera NEES. F10re 8 dioiei. Perig on i m sexfidum, laciniis aequalibus, persistentibns. St a $\mathrm{m}$ in a 9 , triseriata, omnia fertilia; filamenta linearia, in serie 1 et 2 eglandulesa, in serie 3 glandulis geminis dorsalibus, subglobosis, sessilibus instructa; antherae subquadratae, quadrilocellatae, locellis subrotundis, subaequalibus, per paria superpositis, valvulis totidem adscendentibus in 6 exterioribus introrsum, in $\mathbf{3}$ interioribus lateraliter dehiseentes. Ova ri um uniloculare, uniovulatum. St y l n s brevis; 8 tig ma depresso-capitatum. Bacca monosperma, perigonio una cum pedicello intumescen$t i$, in cupulam brevem, rigidam, aequaliter sexfidam mutato basi immersa. - Arbores brasilienses; foliis alternis, paucicostulatis, subtripli-quintuplinerviis, in aliis venuloso-reliculatis, membranaceis, racemulis simplicibus $v$, panicularibus, axillaribus subterminalibusque.

C a m p h or a mo e a. Nees Progr. 16. Laurin. 465.

2054. Deotea $A U B L$. Flores dioici v. polygami. P e rigon in m sexfidum, laciniis aequalibus, persistentibus. St a m in a 9 , triseriata, omnia fertilia; fila menta brevia, in serie 1 et 2 eglandulosa, in serie 3 glandulis geminis dorsalibus, subglobosis, sessilibus instructa; an therae 6 exteriorum ovatae, introrsae, 3 interiorum oblongae, extrorsae, omnes quadrilocellatae, locellis sabaequalibus, per paria superpositis, valvulis totidem adscendentibus dehiscentes. Ovarium uniloculare, uniovulatum. Stylus brevis, persistens; st igma depresso - capitatum. B a c c a monosperma, perigonio persistente explanato, nonnihil incresecnte, pednnculoque incrassato snffulta. - Arbores americanae tropicae; ramis angulatis, foliis alternis, penninerviis, paniculis in ramuli brevissimi gemnipari axillaris $v$, in innovationis basi parvis. parum compositis.

O e ot ea Aublet Guian, II. 580. t, 310, excl, descript. Fract. Nees Laurin. 471. Stry elu 10 d a plu e Nees in tin. naea VIIT, 39, Progr, 18. 
2๑5ร. Aymenolanus NEES. F 10 r e dioici. Perigonium sexpartitum, laeiniis subaequalibus, totmin deciduum. M a s e. ..... S t a m i n a 9 , triseriata, omnia fertilia; fil a m en ta brevia, in serie 1 et 2 eglandulosa, in serie 3 glandalis geminis dorsalibus, subglobosis, sessilibus instracta; antherae 6 exteriores introrsae, 8 interiores extrorsae, omnes quadrilocellatae, locellis per paria superpositis, valvulis totidem adscendentibus dehiscentes. Ovarium efoetum. Stylus elongatus. Fem. Stamina 9 , efoeta. Ovarium uniloculare, uniovulatum. St ylus brevis; stigma discoideo-unbilieatum. B a ce a monosperma, pedicello incrassato imposita, nuda v. imo perigonio brevi et angusto stipata. - Aibores americanae tropicae; foliis alternis, venosis, thyrsulis axillaribus, in stirpibus femineis subspicatis.

G y m nobal a n us Nees in Linnaea VIIT.38. Progr. 17. Laurin, 479 .

TIREUS X. FLAVIFLORAE Nees Laurin. 484. Flo res dioici v. polygami. Perig o n i m rotatum, tenue, flavum. S $t$ am in a 9 fertilia, sterilia nulla. An therae bi-quadrilocellatae, omnes introrsae. B a c c a pedicello subnudo, quandoque incrassato imposita. - Gemmae perulatae.

2055. Sassapeas NEES. F 1 or es divici, nudi. Perigoniam sexpartitum, membran iceum, laciniis aequalibus, hasi persistentibus. M a s $\mathrm{c}$. St a m in a 9, triseriata, omnia fertilia; fi l a men$t$ a filiformia, $\mathbf{S}$ intima glandulis gemin's, stipitatis, liberis stipata; a nth era e introrsae, lineares, quadrilocellatae, lecellis inferioribus lateralibus, snperioribus a valvulis inferiorum adscendentibus tectis. Ovarii radimentum nullun. Fem. Stamina sterilia 9 v. panciora, interiora saepe cum glandulis in unum corpus coalita. O varium uniloculare, uniovulatum. Stylus subulatus; stigma discoideum. B a c c a monosperma, pedicello apice inerassato carnosoque imposita, et perigonii laciniis immutatis distractis stipata. Arbores Am erica m borealem et Indiam orientalem incolentes; foliis alternis, decidtis, inflorescentia praecoci, racemosa, subcorymbosa, pedunculata $v$. fasciculata, floribus flavis.

Sa 8 a fras Nees Progr. 17. Laurin. 487. La u r us $\mathrm{S}$ a $8 \mathrm{~s}$ a f r as Linn. Nees Jun. Plant, offic, $t$, 131. Evos m i sp. Nattall.

205\%. Benzolin NEES. Flo res dioici, involucro tetraphyllo deciduo cincti. P e $\mathrm{r}$ i g oni 3 m sexpartitum, membranaceum, laciniis aequalibus, persistentibus. Masc. Stamina 9 fertilia, triseriata; filamenta filiformia; a ntherae introrsae, ovatae, bilocellatae, valvulis totidem adscendentibus dehiscentes; sterilia 6 v. 9 bi-triseriata, capitulo reniformi-emarginato, compresso, fertilibns serierum 2 et 8 v. omninm alterna. O varii rudimentum. Fe m. S $t$ a m in a sterilia 15 - 18, filiformia, acuta, cum spathulatis minoribus alternantia. Ovariu m aniloculare, uniovalatum. St $y$ I us brevis; stigma bilobum. B a cca monosper ma, perigonio persistenti, sexfido insidens. bores Americam borealem el Nepaliam incalentes; foliis alternis, deciduis, floribus umbellatis. umbellulis pedunculatis et fasciculatis, $v$. in pedunculo communi brevi umbellatis.

Be nz oin Nees Progr. 17. Laurix. 493. Evasmi s p. Nattall. La uri s p. Lina. et Auet. Bat. Mag, $t$, 1670.
TREMU XI. TE'TRANTIIEREAE Nees Laurin. 501. Flores dioici. Perig oni i laciniae numero diminntae v. nullae, in stamina conversae. St a min a 9 v. 18 fertilia, sterilia nulla. $\Lambda$ uth era e bi-quadrilocellatae, omnes introrsae, v. rarissime interiores extrorsae. B a c c a perigonii tubo patelliformi $v$. explanato imposita. _ Gemmae incompletae.

2059. Cylied ataphe NEES. F lores dioici, involuerati. Perigonin m sex- v, octofdum, laciniis subaequalibus, deciduis, Ma s c. Stam in a 12 v. 18, quadriseriata, seriei 1 et 2 perfectiora, basi nuda; a $\mathbf{n}$ h eris introrsis, quadrilocellatis, seriei 3 et 4 breviora, glantulis sulgeminis, capitatis, compressis basi stipata; a ntheris extrorsis, subbilocellatis, omnium ovatis, mucronatis, valvalis loculorum numero adscendentidehiscentibus. Ovarii vestigium nullum. F e m. S ta m in a sterilia, interiora basi glandulis stipata. Ovarium perigonii tubo immersum, uniloculare, uniovulatum. Stylus brevis, crassus; stigma depresso-peltatum. B a e c a monosperina, perigonii tubo cyathiformi, truncato immersa. - Arbores indicae; foliis penninerviis, crassis, inflorescentia umbellulata, umbellulis involucratis, racemosis.

Cylicodaphne Nees in Wallich Pl. As, rar. II. 61. Progr. 18. Laurin. 503.

205D. Tetranthera $J A C Q$. F lores dioici, rarius hermaphroditi, involucrati. Pe rigon i m sexpartitum, laciniis subaequalibus, deciduis, nune paucioribus, parvis, petaloideis, nunc omnino nullis Stamina in flore sexfido 9 , triseriata, fertilia, in petaloideo nudo $12-15-21$, in tima basi glandalis geminis sessilibus v. stipitatis munita; antherae omnium introrsae, ovatae, quadrilocellatae, valvulis totidem adscendentibus dehiscentes. Ovarium perigonii tubo immersum, uniloculare, uniovulatum. Stylu s brevis; stig ma peltatum. B a cca monosperma, perigonii tubo explanato, interdum laciniarum residuis praedito imposita. - Arbores As ia m tropic a $m$ incolentes, in Americ a rarissimae; foliis alternis v. nonnunquam suboppositis, pennitherviis, sempervirentibus $v$. deciduis, inforescentia umbellulata, axillari, aggregata, nuda v. esquamis gemmae prodiente, involucris deciduis.

Tet $r$ a n thera Jacq. Hort, Schönbr. T.59. t.113. Gärtn. f. $I I T, 295 . t$. 292. $f$. 2. Roxburgh Corom. $t, 147,1.48$. Nees in Wallich Pl. As. rar. IT. 68. Progr. 18. Laurin, 308, L its e a Lam. Dict. IIT. 374, et Auct. T o m e x Thanberg Jap. 190. Berrija Klein. moc. Sebifera et Hexanthis Loureiro Fl, cochineh, $I T, 241.783$. G I a b ra ri a Lim. Mant. 156. Fiw a Guelia syst. 745. La u ri s p. Mtehx. Bat, Mag. t. 1471 .

20BO. Polyadenia NEE5, F Lores dioici, involucrati Perigon i um sexpartitum, laciniis aequalibns, deciduis. M a $8 \mathrm{e}$. S $\mathrm{t}$ a $\mathrm{m}$ in a $6 \mathrm{v}$. 9, bi-triseriata, omnia fertilia, circa basim biglandulosa; antherae introrsae, breves, bilecellatae, valvulis totidem adscendentibus dehiscentes. Ovari i rudimentum. Fem. St a m in a sterilia 6 , omnia basi biglandulosa, v. 9, quorun tria exteriora eglantulosa. O vari um uniloculare, uniovulatum. Stylus brevis; $\mathbf{s t i g m a}$ peltato-bi-trilobum. B a eca mnnosperma, perigonii basi disciformi, integra suffulta. - Aibores indicae; foliis alternis, reticulatis, subtus subtomentosis, umbellulis pedunculatis, fasciculato-agglomeratis $v$. solitariis, involucris letraphyllis. 
Polyadenia Nees in Wallich Pl. As. rar, II. 61. Progr, 18. Laurin, 571.

8061. Hampung TOURNEF. F lores dioici v. hermaphroditi, involucrati. Perigonium quadripartitem, Jaciniis aequalibus, deciduis. M a s c. St a in a 12 , triseriata, omnia fertilia, medio vel supra medium biglandulosa; antherae introrsae, oblongae, bilocellatae, valvulis totidem adscendentibus dehiscentes. Ovarii rudimentum nullum. F em. Sta mina sterilia 2 v. 4, basi dilatata, ovarium cingentia. O vari u m uniloculare, uniovulatum. Stylns brevis, crassus; stigma subcapitatum. B a c c a monosperma, perigonii fundo irregulari insidens. - Arbor statura mediocris, facie nobilis, in Asia minori indigena, jam per omnem region e m m editerran eam diffusa; foliis alternis, venoso-reticulatis, umbellulis axillaribus pedunculatis, involucratis.

La urus Tournef. inst. 367. Nees in Wallich Pl. As. rar. II, 61. Progr. 18, Laurin. 579. La u $\mathrm{r}$ us no billis Liun.

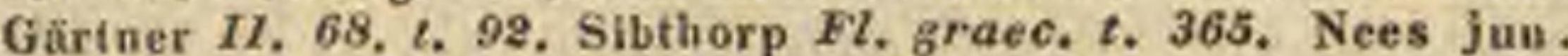
Plant. offic. t. 132. Gen. pl. II. 45.

2083. Lepidadenia NEES. Flores hermaphroditi, involucrati, Perigonium sexpartitum, laciniis subaequalibus. S $\mathbf{t} \mathbf{m}$ in a 12 , quadriseriata, interiora sensim minora, seriei 3 et 4 a tergo laminis geminis sessilibus obvallata; antherae introrsae, quadrilocellatae, valvulis totidem adscendentibus dehiscentes. Ovari $\mathrm{m}$. Fructus ....-Arbor indica; foliis alternis, costatis, umbellulis involucratis, pedicellatis.

Lepidadenia Nees in Edinb. n, philosoph. Journ. 1833. p. 379. Progr, 19, Laurin, 582.

TIREDUS XII. DAPHNIDINAE Nees Laurin. 583. Perig onii laciniae subaequales, deciduae. Stamina 9-19 fertilia, sterilia nulla. Antherae bi-quadrilocellatae, omnes introrsae. B a cca pedicello nudo $v$. perigonii tubo discoideo aut cyathiformi imposita. _ Gemmae perulatae.

2063. Doutecadtemia NEES. F I ores hermaphroditi, e gemma squamata solitarii. Perigon in m sex-novempartitum, laciniis subaequa libus, deciduis. St a min a 12 v. 15 , quadriseriata, $6 \mathrm{v} .9$ exteriora basi nuda, 6 interiora glandulis binis capitatis ad basim stipata; antherae oblongae, intrursae, quadrilocellatae, valvulis totidem adscendentibus dehiscentes. O v a ri u m uniloculare, nniovulatum. Stylus brevis; stigma infundibuliforme, dentatum $B$ a c c a monosperma, perigonio orbiculari - explanato imposita. - Arbor nepalensis; foliis alternis, penninerviis, venosis, inflorescentia gemmiformi, squamis imbricata.

D o decadenia Nees in Wallich Pl. As. rar. II. 61. Progr. 19. T,aurin, 587.

2064. Actinodaplume NEES. F I 0 res dioici, e gemma imbricata plures. Perigonium sexfidum, laciniis aequalibus, membranaceis v. chartaceis, lacero persistentibus v. juxta basim deciduis. Masc. Stamina 9, triseriata, omnia fertilia; 6 exteriora basi nuda, 3 interiora glandulis binis sessilibus v, stipitatis ad basim stipata; a nthera e oblongae, introrsae, quadrilocellatae, valvulis totidem adscendentibus dehiscentes. Ova $r i$ rudimentum. Fem. Stamina sterilia spathulata, semisagittata v. petaloidea. Ovari um unilocenlare, uniovnlatum. Stylus crassiusculus; stigma discoideum, repandum. B a ce a monosperwa, perigonii tulo ryathiformi, limbi laciniis laceris appendiculato imposita. - Arbores indicae; foliis rarius alternis, plerumque per intervalla aggregatis v. verticillatis, penninerviis aut subtriplimultiplinerviis, foribus paniculatis aut racemosis vel fasciculatis, fasciculonm vmbellulis ante anthesim gen.mae axillaris squamulis involutis.

Actinoda phue Nees in Wallich Pl. As. rar. II.68. ot III. 31. Progr, 19. Laurin, 590. J o z o s te Nees in Wallich Pl. As, rar. 11. 63. Progr. 19. Tetrautherae sp. Wallich, Lit s a e a $s$ p. Blume.

2165. Tnalumidimma $N E E S$. Flores dioici, involverati. P erig on ium sexpartitum, laciniis aequalibus, deciduis. Masc. St am in a 9, triseriata, omnia fertilia, 6 ext e riora basi nuda, 3 interi ora glandulis binis sessililus v. stipitatis ad basin stipata; antherae oblongae, introrsae, bilocellatae, valvulis totidem adscendentibus dehiscentes. Ovarii rudimentum. Fem. Stamina 9 , sterilia. Ovari u m niloculare, uniovulatum. Stylus crassiusculus; stigma inerassatum. Ba cea monosperma, perigonii fundo irregulariter persistenti insidens. - Arbores indic a e; foliis allernis, nervosis $v$, penninerviis, floribus fasciculatis axillaribus, ante anthesim squamis gemmae tectis $v$. umbellulatis et involucratis.

Da ph $\mathrm{nidi}$ um Nees in Wallich Pl. As, rar, II, 61, et 63. Progr. 19. Laurin. 606.

BD66. Hutsaen JUSS. Flores dioici, squamis gemmae tecti. Perigonium quadriquinque-sexpartitum, decidutu. N a \& c. Stamina 6, quornm quatuor v. duo in te ri o ra basi biglandulosa; an therae introrsae, quadrilocellatae, valvulis totidem adscendentilus dehiscentes. F e m. Sta min a sterilia 4 v. 6 , apice subinerassata, perigonii laciniis opposila. Glandala e 4 , sessiles, submecronatae, ovarium eingentes v. per paria approximatae, aut filamento sterili quinto et sexto adjectae. Ovarium uniloculare, uniovulatum. Sty I n s brevis; stig ma discoideo-lacerum. B a cc a monusperma, nuda, pedicello apice incrassatu imposila. - Arbores indicae; folits alternis, nervosis, floribus axillaribus fasciculatis, gemmis fioralibus sessilibus, geminis $v$ aggregatis, squamis dense imbricatis, deciduis tectis.

L It s a e a Jassien Dict. sc. nat. XXVIT, 79, pro parte. Nees Amoenit. Bonn, I, t, 5, 6. f, 6.7, Laurin, 62t, T e tradi e. in a Nees in Wallich PI. As.rar. II, 61. Progr. 19, non Beath.

TEREU XIII. CASSI TEAE Nees Laurin. 639. Flores hermapliroditi. Stam in odi a perfecta. St a m in a 9 , antheris intimorum extrorsis. Caryopsis perigoñi tubo bacrato, linbi laciniis conniventibus corenato inclusa. - Herbae parasiticae, aphyllae, cusculiformes.

206\%. Cassyta LINN. Flores hermaphroditi, basibibracteati. P erigon i u sexfidnm, tubo demum baceato, limbi laciniis persistentibus, tribus exterioribus nanis. Stam ina 12 , triseriata, 9 exteriora fertilia, 3 in teriora sterilia; fertilium 3 intima hasi biglandulosa; antherae in serie 1 et 2 introrsae, in serie 3 extrorsae, omnes bilocellatae, valvulis totidem adseendentibus dehiscentes; sterilia glanduliformia, stipitata. 0 var i m uniloculare, uniovulatum. Stylas brevissinus; st ig m a parvum, discoideum, umbilicatum. C a r y psis monosperma, subearnosa, perigunii tubo bacrato, apice pervio, limbi laciniis persistentibus coronato inelusa. - Herbae v. suffrutices volubiles, aphylli, radirulis papillaeformibus in aliis 
stirpibus parasitici, in Asia et Nova Hollandia tropica obvii, in Africa australiextratropica, Nova Hollandia orientali et Americ a a equinoctiali rariores, florum spica simplici v. composita aut glomeruliformi, basi bracteolis minatis membranaceis praedita.

C a 88 y ta Linn. gen, $n$. 505. Jacq. Amer. $t$, 116. Gärtner II. 133. t, 122, R. Brown prodr. 403. Hooker Exol. Flor. t. 167. Nees in Wallich Pl. As. rar. IT. 69. Progr. 20. Laurin. 641. V ol u te 11 a Forsk. Aegypt. 84. C a 1 o d 1 u m Loureiro $F l$. cochinch, $I, 302$,

OBSERVATIO. De generis inter Laurineas loco dubium esse nequit, affinitas cum Lorauthaceis certe nulla, nisi vitam parasiticam, diversissimo certe modo in Cassyta et in Loranthaceis sustentatam, vel antherarum in Visco structuram quasi aliquam analogiae umbram, argutius quam acute urgere quis velit.

\section{Ardo CrII. Gymocarpene.}

GYRocarpeaE Dumortier Analyse 14. Nees Progr. so. ILligerEaE Blume Nov, famil. exposit, 12. Nees Laurin, 695. ILLIGERACEAE Litdley Introduct. edit, Ir, p. 202. Laurinearum genus R. Brown.

Arbores excelsae v. Frotices erecti, aut saepius scandentes, ramis angulatis, in A s i a et Australasia intertropicos indigeni, in America tropica rarissimi. Folia álterna, longe petiolata, plerumque lobata v. ternatim secta, rarius indivisa. Sti pula e nullae,

Flores hermaphroditi v. abortu polygami, regulares, in paniculas cymosas, axillares dispositi, pedicellis bracteolatis sustenti.

Perigonivm ealycinum, intus saepe coloratum, tubo cum ovario connato, limbo supero, quadri-sex - octo-decemlobo, lobis biseriatis, aestivatione induplicatis, deciduis v. nonnullis persistentibus, cum fructu increscentibus.

Stamiva summo perigonii tubo imposita, ejusdem lobis exterioribus numero aequalia et opposita. Fil am en ta distincta, basi utrinque glandula stipitata, nunc filamento adnata, nunc ab codem distincta stipata. A n th e rae introrsae, biloculares, loculi appositi, paralleli, contigui, valvula longitudinali, a basi ad apicem soluta, persistente dehiscentes.

Ovarium cum perigonii tubo connatum, uniloculare, uniovulatum. Ovu I u m lateri prope apicem appensum, anatropum. Stylus simplex; st i g mate peltato $v$, obtuso subobliquo terminatus.

Froctus drupaceus, interdum perigonii lobis aliquot persistentibus, increscentibus apice alatus, monospermus.

Semen inversum. T e st a cartilaginea, dura. A l bum en nullum.

Enвrxo orthotropus; cotyled ones petiolatae, spiraliter circa plumulam diphyllam convolutae, ra dicula brevis, verticem fructus spectans.

Ordo perparvus, nuper primum ab illustri Blumeo distinctus, perigonii, antherarum stru. ctura et ovuli situ Laurineis proximus, a quibus tamen perigonii cum ovario cohaesione, et embryonis conformatione facillime distingui- tur. Remotior est Gyrocarpi cum Com b re$t$ a c e is affinitas, et aliqua saltim cum Dipterocarpeis analogia.

Species paucae, omnes tropicae, unica a $\mathrm{m}$ e ri c a $\mathrm{n}$ a, reliquae $\mathbf{A} \mathrm{s}$ i a $\mathrm{m}$, imprimis insularem incolunt.

Illigerae, quae habitn Cucurbitaceam v. Passifloram referre dicitur, semen nondum satis exploratum, anne genus Asarineis affine?

G y roc a r pi embryonem perperam erectum pinxit Gärtnerus.

2DBS. Gymoenplus $J A C Q$. Flores po lygami. Herma phr. Perigonii tubus cum ovario connatus, limbus superus, quadri-sex-octolobns, lobis duobus oppositis persistentibus, demum increscentibns. S $t$ am in a 4 , fil a m e n t a glandulis stipitatis, distinctis v, utrinque adnatis interposita ; antherae valvulis dehiscentes. Ovarium adhaerens, uniloculare, uniovulatum. Ov $\mathbf{l} \mathbf{n} \mathrm{m}$ ex apice loculi pendulam, anatropum. Sty lus brevis; stigma capitatum, subobliquum. Drupa apice bialata, monosperma. S e $m$ e $n$ inversam, $t$ est a cartilaginea, Em bry o orthotropus, exalbuminosus. Cotyled ones petiolatae, plumulae spiraliter circumvolutac. Masc. Perigonium liberum, et androecium nt in hermaphrodito. - Arbores; foliis alternis, integris lobatisve, paniculis florum cymosis, praecocibus, floribus hermaphroditis alaribus solitariis, reliquis masculis. Species quatuor, quarum una americana certe congener, si tamen specie $a b$ indica distincta.

Gy rocarpas Jaeq. Amer, 282, $t, 178, f$. 80 , Gärtu. II. 92. $t$. 97. (pessim.) R. Brown prodr. 404. Roxb. Corom. t. 1. Nees in Wallich Pl. As, rar, II, 68, Progr. 20. Laurin. 699. Blume Nov, famil. exposit, 15.

2069. Inligena BLUM. F Iores hermaphroditi. Perigonii tubus cum ovario connatus, limbus superus, decemlobus, lobis biseriatis, coloratis, deciduis. Stamina 5 , perigonii lobis exterioribus opposita; fil am en ta basi utringne glandula v. auricula aueta; a $\mathrm{n}$ h erae valvulis dehiscentes. Ovari um adhaerens, uniloculare, uniovulatum. Sty lus longus; st igma peltatum, lobulato-repandum. D r u a tetragona, aptera, monosperma .... - Frutices $j a v a n i c i$, scandentes; ramis enodibus, subangulato-striatis, foliis alternis, coriaceis, longe petiolatis, ternati-sectis, laciniis ansat is, integerrimis, penninerviis, paniculis axillaribus cymosis, pedicell is bracteolatis.

IIIiger a Blume Bijdr, 1153. Nov. famil. exposit, 14. Nees Laurin, 703.

OBSERVATIO. IIIIgerae pulchrae fructus immaturi semen monstrarunt cl. Blumeo unicum, nucleumque testae darae inclusum, e massa foliacea, contortuplicata constantem.

\section{Ordo CVIII. Santalaceat.}

SANTALACEAE R. Brown, prodr. 350, Gen, Rem. 568. Jussleu in Dict. sc. nat, XLVII, 287, Bartling Ord, nat, 112. Lindley Introduct, edit. $T$ T. p. 193.

Herbae annuae v. perennantes, frutices v, ARBones, ramis alternis v. oppositis, teretibus v. saepius angulatis, haud articulatis. F oli a alterna $v$. interdum in inferiore ramulorum parte subopposita, simplicia, indivisa, integerrima, penninervia, coriacea $\mathbf{v}$. interdum carnosula, quandoque squamaeformia, minima v. nulla. Stipulae nullae. 
Flores hermaphroditi v. abortu polygamomono-dioici, parvi, racemosi v. spicati, interdum paniculati, $\mathbf{v}$. axillares solitarii, bracteati bracteolatique.

Prrigonium simplex v. rarissime calyculo accessorio munitum, intus coloratum, tubulosum, tubo cum ovario connato, interdum plus minus super illud producto, limbo quadriquinquefido, persistente v. saepius deciduo, lobis per aestivationem valvatis, saepe intus basi incrassatis, glabris $v$. barbatis.

Discus carnosus varius, nunc ultra ovarii et tubi perigonialis symphysim haud productus, nunc in laminam epigynam plus minus crassam, lobatam, lobis cum limbi laciniis alternantibus tumens, $\mathbf{v}$. juxta tubi parietem productus in glandulas plus minus manifestas, interdum petaloideas, limbi laciniis alternas, quandoque etiam retro stamina in lobulos glabros v. ut plurimum fasciculato-pilosos solutus.

StanrNa perigonii lobis numero aequalia, iisque opposita et basi inserta. Fil amenta brevia, subulata, vix limbo longiora, glabra v. fasciculato-pilosa. A n the ra e introrsae, biloculares, v. rarissime quadriloculares, longitudinaliter dehiscentes.

Ovarium inferum, uniloculare. $0 \mathrm{vula} 2$ 4, saepissime 3 , (vix solitaria?) ex apice placentae centralis liberae, filiformis $\mathbf{v}$. columnaris crassiusculae pendula, anatropa. Stylus terminalis simplex, brevis. S ti g m a capitatum, breviter bi-trilobum, rarissime radiatum.

Frucrus nucamentaceus v. drupaceus, baccatus aut siccus, ut plurimum perigonii limbo persistente, nonnunquam etiam disco increscente styloque coronatus, rarius calvus, umbilieatus v. marginatus, $p$ u $t$ a $m$ in e crustaceo v. interdum subosseo, semper monospermo.

Semen inversum, placenta extenuata et repressa, nonnunquam etiam testa tenuissime membranacea cum endocarpio connata situm erectum mentiens. Al b u m en dense carnosum, copiosum.

Eмввхо intra apicem albuminis orthotropus, rectus v. nonnihil obliquus, brevis, rarissime dimidio albumine paullo longior; c ot yledonibus cylindricis; radicula brevi supera, verticem fructus spectante v. sursum centrifuga.

Saxtalaceae olim fortassis Loranthaceis Olacincisque approximandae, nullibi copiosae, per regiones temperatas utriusque hemisphaerae, et per A si am et $\Lambda$ ustralasiam tropicam dispersac, in Capite bonae spei et in Nova Hollandia paullo frequentius habitare videntur, ex A m erica et Africa tropica plane exules, in Europa et Asia media et in America trans Capricorn u herbaceae, in regione mediter- ranea suffrutescentes, in Novi contine $\mathrm{ntis}$ regionibus temperatis, et in $h \mathrm{em}$ is $\mathrm{ph}$ a e $\mathrm{ra}$ a ustrali ut plurimum arboreae.

Ordinis diagnosis facillimam praebet ovarium inferum cum ovulorum in placenta centrali libera situ, fructus monospermus, et embryonis intra albumen carnosum cylindrici radicula supera.

Genera quaedam ad ordinis calcem rejecta, novorum ordinum pignora. $\mathbf{G r}$ u b b i a staminum numero, Anthobolus et Exocarpus ovario libero, $\mathrm{N}$ ys a ovulo unico vertici ovarii appenso, et embryonis cotyledonibus foliaceis differunt. Pseudanthus et $\mathrm{Helwingia}$ pluribus notis longius recedunt.

Lignum nonnullarum aromaticum, in Oriente celebre.

20\%ด. Quinelhamalium JUSS. F10res hermaphroditi. Perigoninm ealyeulo brevi urceolato, alnato, quadridentato, dente uno majore, basi cinctum, superum, tubulosum, I i m b o quinquefido, deciduum. D is eus epigynus carnosus, annularis, integerrimus. St a m in a 5 , perigonii fauci inserta, limbi laciniis opposita; filamenta brevissima; antherae oblongae, biloculares. Ovari n m inferum, uniloculare. Ovala 3 , ex apice placentae centralis crassiusculae liberac pendula, anatropa. Stylus eylindricas, gracilis; 8 t igma depresso-capitatum. Nucula monosperma, calyculi limbo et disco increscente coronata. $\mathbf{S}$ e me $\mathbf{n}$ inversum. E $\mathbf{m b} \mathbf{r} \mathbf{0}$ in apice albuminis carnosi rectus v. subobliquus; $r$ adi $c u l a ~ b r e v i$ supera v. sursum centrifuga. - Herbae chilenses, annuae $v$, perennes, glabrac; radice palari simplici, caule e basi ramoso, ramis prostratis, adscendentibus $v$. erectis, folis allernis, linearibus v. lineari-lanceolatis, subcarnosis, floribus ad apicem ramorum dense spicatis, sessilibus, subcapitatis.

Quinchamalinm. Jussieu gen. 75. Ruiz et Pav. Flor, peruv. II, 1, t, 107. Brongn, ad Duperr, 228, t.51,52.

20r直. Arjooma CAV. Flores hermaphroditi. Perigonium basi bibracteolatam, superum, tubulosum, 1 i m b o quinquefido, deciduum. Discus epigynus carnosus, annularis, integerrimus. Stamina 5, perigonii fauci inserta, et squam ula e totidem pilosae minimae, limbi laciniis oppositae; fil a m enta brevissima; antherae oblongae, biloculares. Ovari um inferum, uniloculare. Ovula 3 , ex apiee placentae centralis liberae pendula, anatropa. Stylus filiformis; stigma obsolete trilobum. B a e c a monnsperma, ..... - Fruticulus chilensis; radice palari fusiformi, fibris tuberculiferis, folits alternis, linearilanceolatis, semiamplexicauli-sessilibus, nervosis, glabris, confertis, floralibus lanuginosis, floribus ad apicem ramorum dense spicatis, subcapilatis.

A r joon a Cavanilles Ic. IV.57, t. 383. Lam. t.921.

208 3. 'Tlhesium $L I N N$. F I o res hermaphroditi. Perigon i um basi cum ovario connatum, 1 i m b o supero infundibuliformi, quinquepartito v. quinquefido, eglandaloso, intus glabro $v$. dense villoso, persistente. $\mathrm{D}$ is e $\mathbf{n}$ s epigynus nullus. Stamina 5 , perigonii lobis opposita; fila$m$ e $\mathbf{t}$ a brevia, subulata, nuda vel dorso faseiculato-barbata; antherae biloculares. Ovarium inferum, uniloculare. O v u I a 2 , ox apice placentae 
centralis filiformis liberae pendula, anatropa. StyI s filiformis, simplex; stig ma capitatum. Nux monosperma, corticata, perigonii limbo coronata. Semen inversum. Embryo in apice albuminis carnosi rectus; $r$ ad i $c$ u la brevi, supera. Herbae v, suffrutices in Europa el Capite bonae spei provenientes; foliis alternis, planis $v$, triquetris, floribus spicatis, racemosis $v$. paniculatis.

The si um Linn. gen. n. 292. Juss. gen, 75. A $1 \mathrm{ch}$ im illa Tournef. inst. 289.

a, THESIUM $R$. Br. Perig onii limbus infundibuliformis v. hypocrateriformis, intus glaber. Stamina extus fa seiculo tenui villorum munita. - Europacae.

Thes in m R. Brown prodr. 353. Thesit s p. Schkuhr t. 51 . Jacq. $F l$. austr. . 416. Gärtn. $t, 86$. Reieheub. Pl. crit, t. 458-458, 705. Nees jun. Gen, pl. II. 48.

b. THESIOSYRIS Reichenb. Perigonii limbus quinque-

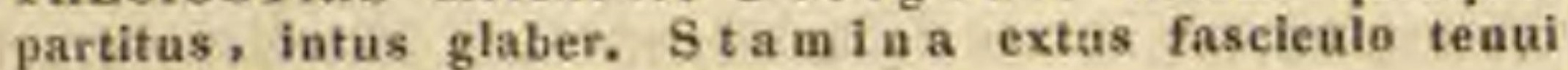
villorum munita.- Capenses.

Thesiosyris Reichenb. consp. 80 . Thesii sp. capenses Auct. Th. squarrosum, fragile, strictum, spinosum, sparteum, ericoides, euphorbioides. Coll. $\boldsymbol{n}$. Brown prodr. 253.

c. FRISCA Reichenb. Perigonil limbus profunde quiu quefidus, intus barba deusa, deflexa. Staminum filanenta imberbia. - Capenses.

Fris ca Reichenb, consp. 80. Thesi i s p. capenses Auet. Th. Frisca, erassifolium, funale, spieatum, teretifolium, debile, capitatum, clliatum, scabrum et divaricatum. Coll, $n$. Brown l. c.

2083. Namodea BANKS. F I o res hermaphroditi. Perigonium tubo hemisphaerieo, cum ovario connato, $1 \mathrm{i}$ m b o supero, quadripartito, eglanduloso, laciniis subdeltoideis, basi constrictis, persistentibus. D is eus epigynus nullus. Stamina 4, perigonii lobis opposita, imberbia; filamenta brevissima, suhulata; antherae biloculares. Ova ri u m inferum, uniloculare. Ovulu m unicum (?) placentae centrali filiformi, liberae affixum ...... St y Iu s brevis, bisuleus; stigma bilobum. Drnpa baceata, monosperma, perigonii limbo coronata, putamine osseo. Semen inversum. Em b r yo in apice albuminis carnosi rectns; radicula conica, supera. - Herbula magellan ica, sediformis; caule simplici, tereti, foliis sparsis, linearibus, crassiusculis, floribus terminalibus paucis, congestis, violaceis.

N a no de a Banks apud Gärtn. f. IIT, 251, $t, 225$, Gaudich in Annal, sc. nat. $V$. 101, t, 2, f. 3. Voy. Ereyc. 442. B alexer di a Commers. msc.

20) 4. Clatrethum R. BR. Flores hermaphroditi. Perigon in ealyeulo minutissimo, quinquedentato munitum, limbo supero, quinquepartite, persistente, laciniis fornicatis, carina interiore descendente. S tamina 5 , cavitate laciniarum inclusa; fil a menta brevissima; anthera e quadriloculares, quadrivalves. Ovarium inferum, uniloculare. Ovula $\ldots .$. Stylus brevissimus; stigma stellatum. Nucula monosperma, perigonii limbo aucto coronata. S em en inversum. Embryo $\ldots . .$. - Frutices Novae Holl andiae, sparlei, ramosissimi, habitu Leptomeriae; foliis sparsis, minutis, remotis, flores et ramulos solum subtendentibus, floribus parvis, albis, axillaribus $v$. terminalibus, solitariis v. aggregalis, quadribracteatis.

C horetrum R. Brown prodr. 33i,

2085. Heptomerla R. BR. F lores polygamo-monoici. Perig on in m tubo cum ovario connato, li mb o supero, quadri-quinquepartito, rotato, persistente, nudiusculo. D is eus epigynus quadri-quinquelobus; lobis cnm limbi laciniis alter- nantibus, adnatis $v$. solutis. St a $\mathrm{m}$ in a 4 -5, perigonii laciniis opposita; filam enta brevia, subulata, nuda; antherae biloculares. Ovarium inferum, uniloculare. Ovula ..... Stylus bre vissimus; $s$ tig $\mathrm{m}$ a bi-quinquefidum. Ornpa baecata v. exsucea, monosperma, perigonii Jimbo coronata. Semen ...... Frutices Novae Hollandiae; foliis sparsis, minutis, quandoque nullis, floribus minimis, albis, rufis v. virescentibus, spicatis, unibracteatis, bracteis deciduis, quandoque axillaribus ebracleatis.

\section{L e p tom eria R. Brown prodr. 353.}

a. XEROMERIA.F I o res quinquefidi. $S t i g \mathrm{~m}$ a emarginatum, obtusnm. D r u pa exsucca.-Folialae, floribus spicatis bracteatis, $v$, axillaribus ebracteatis.

Leptomeriae sectio III. R. Browu $l$, $c$.

b. OMPHACOMER1A. Flore s quadrifidi. S tig ma bilobum, obtusum. D r u pa baceata. - Aphylla, floribus glomera. tis v. solitariis.

Leptomeriac sectio Il. R. Browa l. c.

OXYMERIA. Flores quinquefidi. Stigma stellatin quiuquefidum, acutum. Drupa baceata. - Subaphyllae v, aphyllae, floribus spicatit.

Leptomerlace sectio l. R. Brown 2, c, Thesinu d rupa ceum Labillard. Nov. Holl. $t .93$.

20 86. Comandra NUTT. F lores hermaphroditi. P e rigonium tubo cum ovario connato, li m bo campanulato, supero, quinquefido, persistente. Dis c as epigynns quinquelobus, lobis cum limbi laciniis alternantibus. St a min a 5 , perigonii lobis opposita; fil a m enta brevia, subnlata; antherae biloculares, pilornm fascieulo dorsali limbi lobis adhaerentes. 0 v a ri u $\mathrm{m}$ inferum, uniloculare. Ovula ...... Stylus teres, simplex; stig ma capitatum. Nux monosperma, corticata, perigonii limbo coronata. Se men inversum. $\mathrm{Em}$ bryo in apice albuminis carnosi rectus; $r$ adicula brevi, supera. - Herbaboreali-americana, perennis; foliis alternis, oblongo-ovatis, integerrimis, reticulato-venosis, floribus interdum quadri-sexfidis, terminalibus, corymbuloso-paniculatis.

Co m a ndra Nuttall gen. $x$. 157. Th e s i um umbelt a t u m Linn. Pursh Flor. Bor. Amer, I, $t, 13$.

20\% \%. Fusanus LINN. Flores polygamo-monoiei. Perigoni $\mathbf{n}$ tubo cum ovario connato, $1 \mathrm{imb}$ o supero, profunde quadrifido, rotato, laciniis intus glabris, basi incrassatis, deciduis. D i s c n s epigynus quadrilobus, adnatus, lobis cum limbi laciniis alternantibus. S $t$ a $\mathrm{m}$ in a 4 , perigonii laciniis opposita; filam enta brevia, subulata, nuda; a nth era e biloculares, Ovarium inferum, uniloculare. 0 vula $2-3$, ex apice placentae centralis liberae pendula, anatropa. Sty l us brevissimns, simplex; stigma quadrilobum. Drupa baccata, globosa, monosperma, calva. S em en .. Frutices v. arbusculae glabrae, in Capite bonae spei et in Nova Hollandia australi provenientes; ramis ramulisque oppositis, foliis oppositis $v$. superioribus alternis, planis, crassiusculis, floribus axilaribus $v$. terminalibus subspicatis.

F us a n u s Linn. syst, 13. 765. Juss, gen, 75. R. Brown prodr. 355. Lam. t. 73, et 842. C o 1 p o o u Berg. Flor. cap. $38, t, 1$. Thesidu Colpo on Thunl.

2083. Dsyeis LINN. F 1 o r e s dioici. Masc. Perigonium tri-quadripartitum. D isens carnosus, depressus, perigonii fundum replens, tri-quadrilobus. St a m in a $3-4$, disco extus inserta, perigonii lobis opposita, imberbia; filamenta brevia, subulata; an thera e biloculares. Fem. Perigoninm turbinatum, tubo cum ovario connato, $1 \mathrm{i}$ m b o supero, tri-quadripartito. 
Discus epigynus tri-quadrilobus, lobis cum limbi laciniis alternantibus. St a $\mathrm{m}$ in a $3 \_4$, efoeta, perigonii lobis opposita, Ovari um inferum, uniloculare. 0 v a l a 3 - 4 , ex apice placentae centralis filiformis, liberae pendula, anatropa. Sty I us eylindricus, cum disco confluens; st ig mata $3 \_4$, patula, obtusa. Drupa monosperma, perigonii limbo coronata, putamine rrustaceo. Semen inversum. Em bryo in apice albuminis carnosi subobliquus; radicula brevissima, sursum centrifuga. - Frutices mediterranei, ramosissimi, glabri ; foliis alternis, exstipulatis, integerrimis, lanceolatis, coriaceis, floribus masculis racemosis, ramulis subtrifloris, bibracteatis, femineis axillaribus, subsolitariis.

Os y ris Limn. gen, n. 1101. Schkuhr t. 319. Gärtn. f. ITI. 204. $t$. 216. Nees jun. Gen,pl. II. 49. (Chalaza perperam pro umbilico descripta.) Decaisue in Nouv, Annal, se, nat. VI. 65. $t, 6$. C a s i a Tournef. inst. $48 s$.

20\%3. Sploaeroearya $W A L L$. F lores hermaphroditi. Perigoni nm tubo clavato, cum ovario connato, limbo supero, quinquepartito, persistente. G landula e fancis 10 , biseriatae, 5 exteriores petaloideae, limbi laciniis alternae, 5 interiores minutissimae, ciliatae, inter stamina et limbi lacinias sitae. St a min a 5 , limbi laciniis opposita; fil amenta brevia; anthera e biloculares. Ovari um inferum, uniloculare. Ovulum unicum (?) placentae centrali filiformi liberae affixum. St y l u s simplex; stigma obsolete bilobum. Drupa pyriformis, monosperma, perigonii limbo coronata. Semen inversum. Em bryo in apice albnminis carnosi brevis, subobliquus; radic ula conica, sursum centrifuga. - Arbores indicae; foliis alternis, ovato-oblongis, acuminatis, integerrimis, penninerviis, floribus racemosis, pedicellis brevibus, crassis, ebracteolatis.

$\mathrm{S}$ phaerocary a Wallich in Roxburgh Flor. Indic. II. 3ri. Don Syst. II. 27. Wight in Edinb. new philosoph, Journ. $X Y, 180$.

2080. Santallum LINN. Flores hermaphroditi. Perigonium basi cum ovario connatum, li mbo supero, tubuloso-ventricoso, quadrifido, decidno. G I a nd u I a e 4 , compressae, fanci insertae, limbi lobis alternantes. $\mathbf{S}$ ta m in a 4 , fauci inserta, limbi lobis opposita; filamenta subulata, postice fasciculo pilorum instructa; anthera e biloculares. Ovari um semiinferum, uniloculare. Ovula 2 , ex apice placentae centralis liberae pendula, anatropa. Stylus filiformis, simplex; stigma obsolete bi-trilobum. 1)ru pa baccata, monosperma, apice marginata. S e men inversum. Embry o in apice albuminis carnosi rectus; radicula supera. - Arbores $v$. frutices glabri, in Asia et Australasia tropica provenientes; foliis oppositis, planis, latiusculis, floribus in pedunculis opposite ramosis, ternis, bracteis caducis.

Santal u m Linu. gen, n. 215. nou Herbar, Linn. Willdenow sp. T. 691, R. Brown prodr. 355. Bot. Mag. $t$. 3235. Turpia All, ic. Gaudieh ad Freyc. $t$. 45. S iri u m Linn. gen. n. 203, Roxburgh Corom, t, 2. Lam. t. 74.

208 1. Prolda $A$. CUNNINGH. F 1 ores dioici? Masc. Perigonium tubo brevi hemisphaerico, limbo quadripartito. G I a ndulae faucis 8 , biseriatae, 4 exteriores minimae, limbi laciniis alternae, 4 interiores majores, ciliatae, inter stamina ef limbi lacinias sitae. Sta m in a 4, limbi laciniis opposita; fil am enta subnulla; anthera e biloculares. Ova ri i rudimentum. Fem. Perigonium tubo clavato, eum ovario connato, limbo supero, quadrifido, rotato, deciduo. D is eus epigynus quadrilobus. St a m in a efoeta 4 , limbi laciniis oppesita. Ova ri $\mathbf{~ m ~ i n f e r u m , ~ u n i l o c u l a r e . ~}$ O v u 1 a 3 , ex apice placentae centralis liberae pendula. Sty I u s brevis, eylindricus; st $\mathrm{igmata} 3$, patula, obtusa. Drup a baceata, nonosperma, umbilicata. Semen …. - Arbores Novae $Z$ e elandiae; foliis alternis, integerrimis, coriaceis, floribus axillaribus racemosis dob.

Mida A. Cunuiaghan msc, 1826. in Herbar. Mus. Vin-

\section{GENERA DUBIA.}

2082. Pyrularia L. C. RICH. Flores dioici. Ma se. Perigon um tubo subhemisphaerico, limbi quinquefidi laciniis revolntis. GIandu la e faucis 5, rotandato-obtusae, limbi laciniis alternae. St am in a 5 , limbi laciniis opposita; fiI a menta brevissima, subulata; antherae biloculares. Fem. Perigon i m tubo turbinato, cum ovario connato, limbi superi quirquefidi laciníis revolutis, persistentibus. D is e us epigynus, in glandulas 5 limbi laciniis alternas expansus. Ovarium semiinferum, uniloculare. Ovn!a .. Stylus brevis, crassus; stigma depresso-capitatum. D rupa pyriformis, putamine tenui, subgloboso, monospermo. S em en albuminosum. Frutex boreali-americanus; ramulis foliisque alternis, ovali-oblongis, acuminatis, integerrimis, pubescentibus, floribus perpusillis, spieatis.

Pyrularia L. C. Rieliard in Michaux Flor. Bor. Amer. II. 231. H a milt touia Mühleub. ex Willd. sp. IV. 1114. Calinux Ratiuesq.

2083. Detarilluma LOUREIR. Flore 8 hermaphroditi. Perigonium tubo brevi tetragono, cum ovario connato, limbo supero, quadripartito, laciniis acutis, carnosis. St a min a 4 , fauei inserta; filamenta brevissina; antherae oblongae, biloculares, incumbentes. 0 varium in ferum ..... Stylus turbinatus, staminibus longior; stigma crassinsculum. D rupa baccata, oblongo-ovata, monosperma, putamine oetogono, membranaceo, tenaci. S em en ..... - Frutex cochinchinensis, erectus; ramis scandentibus, inermibus, foliis alternis, lanceolatis, glabris, integerrimis, pedunculis axillaribus, solitariis, baccis rubris.

Octarillum Laureira Flor. cochinch. 113.

3084. Nigoselnillos RUIZ et PAV. F 10 res hermaphroditi (?) tribracteati. Pexigonium tubo cum ovario connato, $l \mathrm{im}$ bo supero, quinquepartito colorato, persistente. Stam ina 5 , limbi lobis opposita; fil am enta subulata; an therae subrotundae. Ovarium inferum .... Ovala ..... Stylus trigonus, brevis; s tigma trigonum. Dru p a oblonga, perigonii limbo persistente coronata, putamine subgloboso, monospermo. Semen ..... - Frutex chilensis; ramulis alternis, basi gemmae squamis persistentibus stipatis, foliis in ramulis alternis, approximatis, obovato-oblongis crispato-undulatis, spicis densis, cylindricis, amentiformibus, cum ramulis alternantibus.

Mf yos chilos Ruiz et Pason Prodr. 61, t. 34 ,

\section{GENERA SANTALACEIS AFEINIA.} * gRUBBIACEAE.

9085. Arubbia BERG. F 1 ores hermaphroditi, unibracteati, in strobilum subglobosum, 
hasi involucro diphyllo cinctum connati, involucri foliolis minimis, carinatis, Perigon i um tabo obconico, cum ovario connato, limbo supero quadri-quinquepartito extus lanato, patente. D is cus epigynus depressus, hirtus. S $t$ a $m$ in a 8 v. 10, disco extus inserta, perigonii laciniis per paria opposita; fi lam enta brevia, subulata; a nthera e biloculares. Ovari um inferum, uniloculare. Ovula 2 v. 3 , ex apice placentae centralis columnaris liberae pendula. S t y l u s brevissimus; 8 tigma truncatum, obsolete bi-trilobum. N u c ula e monospermae, connatae. - Frutices c a pen ses; ramis tetragonis, folïs oppositis, breve petiolatis, lineari-lanceolatis, coriaceis, integerrimis, margine revolutis, subtus discoloribus, florum strobilis axillaribus, gemmaeformibus

Grubbia Bergius in Act. Academ. Holm. 1767. $t$, \& Flor. cap. $t$. 2. $0 \mathrm{p}$ h ir a Linn. gen. n. 6 . 2. Lam. $t .293$.

\section{** NYSSACEAE.}

2056. Nysana LINN. F I ores polygauno dioici. Masc. Perigonium tubo brevi, limbo quinquepartito, deciduo. S t a m in a 10 , diseo planiusculo, perigonii fundum explenti extus inserta, limbi laeiniis opposita et alterna; fil am en ta subulata, limbo breviora; antherae biloculares, didymae. Hermaphr. Perigoninm tubo cum ovario eonnato, limbo supero, quinquepartito, deciduo. S $t$ a $m$ in a 5 , diseo epigyno planiusculo extus inserta, limbi laciniis opposita; fil am enta subulata; antherae simplices, efoetae (?). Ovarium inferum, uniloculare. Ovulum unicum, ex apice loculi pendulum, anatropum, Stylns subulatus, incurvus; stigma simplex. D rupa baccata, monosperma, putamine angulato, fibroso. Semen inversum. Embryo in axi albuminis parci, carnosi rectus; cotyled onibus foliaceis, undulatis; radicula brevi, teretiuscula, supera. Arbores boreali-americanae, ad rivulos aquasque stagnantes crescentes; foliis alternis, integerrimis v. angulato-dentatis; sublus glabris, reticulato-venosis v. tomentosis, floribus axillaribus, masculis racemosis $v$. subcapitatis, pedunculis femineis solitariis, uni-trifloris.

Nys sa Gronov, Virgin, 162. Linn. gen, n, 116. Jus. sieu Dict, sc. nat. gen, 75. Lan. $t, 851$. Michaux Arbr. fo. rest, t. 19 22. Gärtner f, $\mathrm{HI}, 201$, L 216. T u p el o Adans. Fam. 11,80 .

\section{*** ANTHOBOLEAE.}

208\%. Anthobolus $R, B R$. Flores divici. Masc. Perigonium triphyllum. Stamin a 8 , perigonii laciniis basi inserta; fil amenta brevissima; anthera e bileculares. Ovarii rudimentum nullum. F em. P erigonium triphyllum, decidunm. Ovarium liberum, uniloculare. Ovula ...... Stigma sessile, trilobum. Drapa monosperma. Semen inversum. Embryo in axi albuminis carnosi orthotropus, teres; $\mathrm{rad}$ icula supera. - Frutices in Nova Hollandia tropica indigeni, glabri, ramosissimi, spartei, habitu Osyridis; ramis ramulisque articulatim insertis, foliis sparsis, exstipulatis, sessilibus, cum ramulo articulatis, angustis, subfiliformibus, pedunculis axillaribus, masculis umbellatim tri-quadrifloris, femineis uni-trifloris, pedicellis simplicibus medio, ramosis ad divisuram articulatis, ibique bibracteolatis, bracteolis caducis, floribus parvis, flavicantibus.

A t thobolns R, Brown prodr. 357.

2089. Exocarpus LABILL, F 1 o r e s hermaphroditi v, abortu polygami. Perig onium quadri-quinquepartitum. St a m in a $4-5$, basi laciniarum perigonii inserta; fil a menta hrevia, complanata; antherae biloculares. Ovarium liberum, uniloculare. Ovula $\ldots .$. Stylus brevissimus; st igm a capitatum. N u x corticata, monosperma, pedunculo ampliato, baceato basi inserta. Sem en inversum. E $\mathbf{m}$ bryo in axi albuminis carnusi orthotrupus, teres; ra di c n la supera. Arbores mediocres $v$. frutices, in Nova Hollandia intra-et extratropica, parcius in insulis Moluccis provenientes; ramis ramulisque articulatim insertis, ultimis quandoque foliaceo-dilatatis; folïs sparsis, exstipulatis, saepius minutis, denticuliformibus, nunc majoribus, planis, integris, spicis axillaribus, flosculis minimis, subsessilibus, bracteis caducis, pedicello post fecundationem increscente, ampliato, baccato.

Exocarp us Labillardière Voy. T. 115. 2. 14. Nov. Holland. II. 123. R. Brown prodr. 456. Gen. Mem, 569. X y 10 phyllos ceramica Rumph Amboin. VII. 19. $\iota, 18$.

\section{**** PSEUDANTHEAE.}

2059. Psendanthus SIEB. Flores monoici. M a s culi in apicibus ramulorum glomerati, singuli unibracteati. Perigon i um coloratum, tubo brevissimo, limbi sexfidi laciniis lineari. bus, biseriatis, erectis. Stamina 6 , e centro floris; fil a ment a inaequilonga, libera v. juxta totam longitudinem connata; a nt herae extrorsae, biloculares, loculis appositis, adnatis, basi divergentibus, juxta totam longitudinem dehiscentibns. Flores feminei in foliornm inferiorum axillis solitarii, sessiles. Perigon ium calycinum, hexaphyllum, persistens, foliolis hiseriatis. Ovar in m liberum, sessile, e carpidiis tribus valvatim connatis uniloculare. Pla centa e tres filiformes, ad carpidiorum suturas duplicatae. Ovu la p'uri$\mathrm{ma}$, biseriata, pendula, anatropa (?). S $\mathrm{ti} g \mathrm{~m}$ a segsile, tricorne. Capsula unilocularis, monosperma, costata, sexfariam dehiscens, valvis coriaceis; tandem spiraliter revolntis. Semen unicum, parieti prope apicem funiculo brevissimo appensum. T e sta cartilaginea. Albumen copiosum, carnosum. Embry o axilis, orthotropus, altumine param brevior, cotyledonibus ellipticis; radicula brevi, sursum centrifuga. - Fruticuli a ustralasici, ericoidei, ramosi, ramis ramulisque oppositis verticillatisque, foliis alternis, dense imbricalis, coriaceis, sessilibus, utrinque stipula adnata, in caulem decurrente munitis, - Affinitas obscura.

P se udanthus Sieber ex Spreng. cur. post. 26. Guil. lem. in Dict, hist. nat. $X I V$. 318. Eadlicher Atakt. p. 11. c. 11 .

\section{**** HELWINGIACEAE,}

2030. Hilelving gia WILLV. F lo res dioici, epiphylli, in nervo medio solitarii v. fascicnlati, pedunenlati, pedunculis basi bracteolatis. Masc. Perigonium calycinum, tri-quadripartitum, laciniis ovatis, aestivatione valvatis, demum patentibns. S $t$ a min a 3 -4, circa discum obseure tri-quadriangulatum inserta, perigonii laciniis alterna; filamenta libera; a n therae introrsae, basifixae, biloculares, loculis discretis, longitudinaliter dehiscentibus. O va ri i rudimentum punetiforme. Fem. Perigoniu m cum ovario connatum, limbo supero, tri-quadrilobo, deciduo. 0 v ari nm basi turbinatum, disco epigyno coronatum, tri-quadriloculare. O vnla in loculis solitaria, apiei interno appensa, anatropa. Sty I us terminalis 
brevissimus, crassus; stigmat a loculorum numero, brevia, subulata, recurva, verrucoso-papillosa. Fructus exsuccus, styli discique reliquiis apiculatus, tri-tetracoccus, coccis lenticulari-compressis, chartaceis, rugosis, monospermis. S e min a counpressa, inversa, e funiculis brevibus pendula, rhaphe ad chalazam apiealem excurrente marginata. E m b ryo albuminosus (?) orthotropus. - Suffrutex japonicus, a Sieboldio in hortum Bruxellensem introductus, ramosus, glaber, trunco ramisque subangulatis, medulla suberosa repletis; foliis alternis, petiolatis, ovatis v, ovato-oblongis, acuminatis, setaceo-serratis, reticulato-penninervits, tenuibus, laete viridibus, stipulis petiolaribus angustissimis, setaceis aut setaceo-fissis, deciduis, floribus parvis medio nervo paginae superioris foliorum insertis, solitariis vel subfasciculatis, masculis minoribus, longius pedunculatis, pedunculis unifloris, ima basi bracteolatis.

Hel wingia Willd. sp. pl.IV, 716. Morren et Decaisne Observ, pl. Jap. Brux, 1836, p. 5, Nouv. Annal, sc, nat. VT. $68, t, 7,0 \mathrm{syr}$ is $\mathrm{j}$ a $\mathrm{p}$ on ica Thunb. Fl.jap. 31, Io. Dec. III. t. 1 .

OBSERVATIO. Genus dubiae affinitatis, e el. Decaisne Araliaceis et $\mathrm{Hamamelideis}$ affine, fortassis etiam cum Celastrineis et $\mathrm{R}$ h a mneis comparandum, et certe Dulongi a e analogum, interim ob aliquam etiam cum Santalaceis affinitatem, hoe loco inter genera dubiae affinitatis collocandum putavimus.

\section{Ordo CIX. Daphnoideae.}

THYMELEAEAE Jussieu gen, 76. R. Brown prodr. 358. Bartling Ord, nat, 114. Kunth in Linnaea V, 667. DAPHNOIDEAE Vent. Tabl. II. 235. DAPHNACEAE Lindl. introduct. edit. 2. p. 194.

Fruticbs v. arbescolae, rarissime hbrbae annuae, libro in frutescentibus tenaci, $\mathrm{r}$ a $\mathrm{mis}$ tertibus, articulatis. Folia sparsa v. opposita, simplicia, integra et integerrima, saepe nervosa, epunctata. Stip ula e nullae.

Flores hermajhroditi, interdum abortu dioici, regulares $v$. rarissime limbo subirregnlari, axillares v. terminales, nunc solitarii, nunc fasciculati, spicati v. capitati, quandoque involucrati, saepe bibracteolati, alhi, flavi, rubri v. rarissime caerulei.

Perigonium simplex, coloratum, tubulosum, li m bo quadri- v. rarius quinquefido, v. interdum fere obsoleto (in Dirca), laciniis plerumque aequalibus, v. duobus exterioribus oppositis paullo majoribus, per aestivationem alternatim imbricatis, persistens v. saepius deciduum, $t \mathbf{u b o}$ interdum supra basim articulato, articulo inferiore persistente. Discus perigy nus carnosus, perigonii basi adnatus, interdum obsoletus.

Stanisa definita, perigonil tubo faucive inserta, inclusa v. exserta, nune limbi laciniis numero aequalia, isque ut plurimum alterna, (in Drapele, Diarthrone et S(ruthiola) v. rarissime opposita (in Cansjera), nunc pauciora, ante lacinias exteriores inserta (in Pimelea), saepissime numero duplo orto $\mathrm{r}$. decem, biseriata, serie superiore laciniis opposita. Filame n t a libera, filiformia, interdum brevissima, aestivatione erecta. Antherae introrsae, bi- loculares, erectae, ovatae v. oblongae, loculis parallelis, contiguis, antice v. lateraliter juxta totam longitudinem dehiscentibus.

Squamulae petaloideae (stamina abortiva) summae perigonii fauci insertae, nune limbi laciniis numero aequales et alternae, nunc duplae iisdem per paria oppositae, saepissime nullae.

Squamulae hypogynae quatuor v. octo, liberae $v$. in tubulum coalitae, plerumque nullae.

Ovarivm liberum, unicum, uniloculare, simplex, nno latere plerumque subobliquum, altero rectum styligerum.

Ovusum unicum, parieti styligerae prope apicem appensum, anatropum, rarissime (in $\mathbf{L} a$ get(a) ovula duo v. tria, superposita. Stylus simplex, lateralis $\mathbf{v}$. subterminalis, plerumque brevis et inclusus, interdum nullus. Stig ma capitatum.

Fructus drupaceus aut nucamentaceus, nudus v. perigonii basi persistente tunicatus, uniIncularis, monospermus, v. rarissime bi-trisperinus.

Srmen pendulum, testa tenui, $r$ h a phe lineari ad $c h a l a z$ am apicalem producta percursa. A I b u m e n nullum, v. parcum carnosum.

Eмвrхо orthotropus, albumine dum adest inclusus. Cotyled on es plano-convexae, parallelae, carnosae. Radicula brevis v. brevissima, supera. Plumula inconspicua.

Daphnoideae Santalace is et Aquilarineis provime affines, ab his ovarii et fructus structura, ab illis ovulorum numero et origine, ovario libero, et albuminis defectu $v$. parca copia facile distinguendae, in temperatis calidioribus et tropicis utriusque hemisphaerae proveniunt, in hemisphaera australi, imprimis in Capite bonae spei et in Nova Hollandia frequentius habitantes, in America in universum rarae.

Daphnoideae principio acri canstico foetae, varii in medicina usus. Liber nonnullarum tenax in usus technicos convertitur.

Inocarpus et Hernandia ad ordinis calcem collocatae, praeter alias notas involucro et cotyledonum forma distinctae sunt; genera ovario biloculari et fructu dicocco donata dubia, ad Aquilarineas aliquantisper accedunt.

209 1. Direa LINN. F I o res hermaphroditi. Perigon in m coloratum, turbinato-campanulatum, limbo indiviso, subebliquo. Sta mina 8 , perigonii tubo biseriatim inserta, exserta, alterna breviora. S qu a mula e hypogynae nallae. Ovarin uniloculare. O v 1 и m unirum, pendalom, anatropum. Stylus terminalis, filitormis, exsertus; stig ma capitatum, emarginato-snbbilobum Drup a baccata, monosperma, nuda. Semen in versum. A J bumen nullum. Embryo orthotropus; cotyl cdon ibus plano-convexis, radicula brevi. supera. - Frutex boreali-americanus, 
paludosus; cortice tenaci, ramis virgatis, foliis alternis, integerrimis, gemmis axillaribus trifloris, floribus pallide flavis.

D ir a Linu. gon, $n$, 486. Amoon, Academ, III, 12. $t$. 1. f. 7. Sehkulir $4.107,6$, Lau, 1, 293, Duhamel Arbr. I, $t$. 212.

3492. 耳aplane LINN. Flores hermaphroditi. Perigonium infundibnliforme, limbo quadrifido, fauce esquamata. Sta $\mathrm{m}$ in a 8 , tubo prope faucen biseriatim inserta, inclusa. Squamula e hypogynae nuliae. Ovarium unilocnlare. Ovulum unieum, pentulam, anatropum. Stylus terminalis brevissimus; stigma capitatum. Drupa baceata, monosperma, nuda, putamine crustaceo. Semen inversum. Albumen nullum. Embryo orthotropns; cotyledonibus plano-convexis; radicula brevi, supera. Frutices v, arbusculae, in Europa et in Asia tam media quam tropica obviae, in Australas ia et in America tropica et australi temperata rarae; foliis sparsis $v$. oppositis, floribus axillaribus v. terminalibus, saepius glomeratis.

D a p h ne Linn gen, $n$. 485. Jussieu gen. 77 . Lam. $\ell$. 990. Schkuhr $t$. 107. Wikström Dissert. de Daphne. Stockholm. 1820, 4. Smith. Ic, incdit. II. t. 34. Spicileg. 1. 18. Jacd. Flor, austr. t, 126, 183, Hort. Schönbr, t, 351. Pallas Flor. Ross, t. 33. Bot. Mag. t. 313.428. 1282. 1587. 1875, 1917. Bot. Reg. t. 828 , 1178. Destout. Annal, du Mus, X. t. 20. Trat tinik Archiv. t, 133. Hooher ad Beochey t. 15 . Nees jun. Gen. pl. $I T$. 46. C a p u r a Linn. Mant. 224. S co po Il a Linn. f. suppl. 409. Th y mel a e Scop. carn. I. 276. Girtu. I. 188. t. 39.

OBSERVATIO. Genera duo brasiliana ut videtur affinia, a cl. Martius (nov, gen, et $s p . I$. 65.) indicata, e clatracteribus nimis brevibus collocari sequeunt.

a. DAPHNOPSIS Mart. Flores dioiei. Masc. Perigoni a quadrifidum. Stamia a 8 . 0 va ri i rudimentum. Squamula uullae. Fem. Perigouium quadrifi. dum, ad basim drupae persistens. Styl us brevissimus. Stigma capitato-bilobum. D r u pa sicea, nuee fibrosa,

b. SCHonnobiblos Mart. Flores dioici. Mase. Perigon i um infundibuliforme, limbi lacinis quatuor, reflexis. Stamina 4, exserta. Squamula nullae. Fe m. ignot.

2993. Dais LINN. Flores hermaphro diti. P e rigoni u m coloratum, infundibuliforme, tubo basi ventrieoso, limbo quadri-quinquefido, fauce esquamata. St a m in a 8 v. 10 , tubo prope faucem biseriatim inserta, inclusa. Squa m u I a hypogynae nallac. Ovarium nniloculare. OvuI um unieum, pendulum, anatropum. Stylas lateralis, filiformis; $\mathbf{s t i g m a ~ c a p i t a t u m . ~ D ~ r u p a ~}$ baceata, monosperma, perigonio persistente inclusa, putamine osseo. Semen inversum. Albumen parcnm, carnosum. Embry o orthetropus; cotyI edonibus ovatis, subfoliaceis; radicula longiuscula, supera. - Frutices v, arbusculae, in $\boldsymbol{C a}$ pite bonae spei, in Asia tropiea el media observatae; foliis alternis v, oppositis, floribus capilatis involucro quadri-quinquepartito cinctis, $v$. spicatis nudis.

D $n$ i s Lina, gen, $n$, 570, Jussieu gen, 77. Burm. Flor. ind, $t, 32, f$. 2. Lam, $t, 368$, Garto. $I, 187, t, 39$. Jaeq. Ic. rat, t, 77, Bot. Mag, t, 147. Eadlieher Sert, cabul, t. 3 .

2094. Haclomaea LINN. F lores hermaphroditi. Perigon ium coloratum, tubulosum, limbo quadrifido subirregulari, fauce esquamata. Stamina 8, fauci biseriatim inserta, exserta. Squamulae hypogynae nullae. Ovarium uniloculare. OvnIum unicum, pendulum, anatropum. St ylus lateralis, sursum incrassatus; stigma capitatum. N n $x$ monosperma, perigonio persistente inclusa. Semen inversum. A i bum en copiusum, carnosum. E nb r y o orthotropus axilis, teretinsculus, cotyledonibus linearibus; $r$ adicul a longiuseula, supera. - Frutices c a p en. se $s$; foliis alternis, conferlis, imbricat is, floribus capitatis, capitulo lanato.

L a e hn a e Linn. gen, n. 490. Jass. gen 77. Lam. t, 299. Gürtn. f. III. 195. 2.215.

2695. Fassering $L I N N$. Flores hermaphroditi v. abortu dioici. Perigonium eoloratum, infundibuliforme, tubo nrceulato $v$. cylindrieo, limbo quadripartito, fauce nuda. Stam in a 8 , tubo prope faucem biseriatim inserta, subinclusa. Squamulae hypogynae nullae. Ovarium uniloculare. OvuI um un cum, pendulam, anatropum. Stylus lateralis filiformis; stigma capitatum. Utriculas monospermus, perigonio persistente inelusus. S e m e $n$ inversum; t e $s$ t a lignosa. A 1 b um en nullum. Embryo orthotropus; c otyledonibus plano convexis; radicula brevi, supera. - Frutices $v$. rarissime herbae annuae, in Europa et Asia media parce provenientes, in Capite bonae spei frequentes; foliis alternis, foribus axillaribus solitariis $v$. confertis, bracteolatis.

P a s s erin a Lina. gen, $n$. 489. Jass, gen. 77. Lam, $t$. 991. Gärta. III. 197. $t$. 215. Ledebour Ic, .374. Nees jun. Gen. pl. II. 47. S tell e r a Linn. gen, $n$, 488. Juss, gen. 77. Lam, t. 203. Gätn, 1. 186. $t$, 39. Jacq, Ic, rar. $t .68$.

20A6. Diarthron TURCZ $A N$, FIores hermaphroditi. Perigonium tubo herbaceo, fauce nuda, limbo colorato, quadridentato, deciduo. St a min a 4 , fauci inserta, limbi dentibus alterna. S qua mula e hypogynae nullae. Ovarium uniloculare. Ovulu m unicum, pendulum, anatropum. Stylus sublateralis; stigma clavatum. Nux (?) monosperma, perigonii tubo persistente turbinato inclusa. Semen inversum. A 1 b u men tenue. Embryo orthotropus; cotyled onibus crassis; radicula supera._Herba annus, in Mongolia chinensi reperta; caule erecto, rumoso, folioso, glabro, foliis sparsis, lineari-lanceolatis, obtusis, breviler petiolatis, glabris, ciliolatis, racemis spicacformibus, ebracteatis, lateralibus et terminalibus, floribus breviter pedicellatis, pedicello clavato, cum flore articulato.

Diarthrou Turczaninow Decad, plant. Mongol. et Chin. p. 25.

201D. Drapetes $L A M$. Flores hermaphroditi. Perigonium coloratum, infundibuliforme, limbo quadrifido, fauce esquamata. Stamina 4 , fauci inserta, perigonii laciniis alterna, exserta. Squamula e hypogynae nullae. Ovari m uniloculare. Ovu lum $\ldots$.... Stylus terminalis (?) simplex; stigma capitatum. Nux monosperma, perigonii basi persistente inclusa. S emen inversum ...... Fruticulus magella. nicus, tri-quadripollicaris; caulibus filiformibus, caespitosis, erectis $v$. basi decumbentibus, ramosis, inferne nudis, cicatrisatis, superne foliosis, folits decussatim oppositis, sessilibus, ovatis, obtusis, integerrimis, sesquilineam longis, darso apiceque pilosobarbatis, fasciculis terminalibus pedunculatis, involucro diphyllo deciduo cinctis, floribus brevissime pedicellatis, pedicellis apice barbato-pilosis.

D rapetes Lamarek Journ, hist, nat, I. 189. $t, 10$. Bauks apud Gärtner f. III. 199. t. 215.

2098. Pimelea BANKS et SOL. Flores hermaphroditiv, dioici. P e r i g on i u m coloratum, infundibuliforme, limbo quadrifido, fauce esquamata. Stamina 2 , fauci inserta, perigonii laciniis exterioribus opposita, exserta. Squamulae 
hypogynae nullae. Ova $r$ i m uniloculare. Ovulin in unicum, pendulum, anatropum. Stylus lateralis; stigma capitatum. Nux monosperma, corticata, raro baceata. Sem en inversum. A I b um e n parcum, carnosum. Em bryo orthotropus; cotyledonibus plano-convexis, earnosulis; $r$ adicula brevi, snpera. - Frutices in Nova Holla $\mathrm{nd}$ ia insulisque conterminis provenientes; foliis oppositis v. rarissime alternis, floribus capitatis, terminalibus, foliis involucrantibus rameis similibus $v$. dissimilibus, interdum connatis, rarius spicatis $v$. axillaribus, perigonii tubo saepissime medio articulalo, articulo inferiore persistente.

Pimele a Banks et Soland. ex Gärtn. I, t.39. Dryander Annal. of Bot. II. 50S. Smith Nov. Holland. I. 31. R. Brown prodr. 359. В a u k 8 i a Forst. Char. gen, n. 4. Cookia Grelin. syst. I. 24,

s. THECANTHES Wickstr. Involuernm monophyllum infundibuliforme, quadrifidum, floribus pedicellis membra. naceo - dilatatis impositis,- Folia opposita.

Thee a nthes Wickstróm in Act. Holm. 1818, p. 271. Pimelea Cornucopiae Vahl et P. punicea R. Brown.

b. HETEROLAENA. Involucri tetraphylli folia rameis dissimilia. - Folia opposita.

Pimele a e sectio 1. R. Brown 2. c. exel. sp. 1. et 2. (Smith Nov. Holl. I, t. 11. Bonpl. Malmais. t.31. Labillard. Nov. Holland. $t$. 4. 5. Bot. Mag. t. 891 . 1458. 3459. Bot. Reg. t. 1578, 1827.)

c. PHYLlOLARNa. Involueri di-polyphylli folia rameis subsimilia, - Folia opposita.

Pimele a e sectio II. R. Brnwn $l$. c. (Labillard. op. cit, t, 6.7, Bot. Mag. t, 3276. 3281. Bot, Reg, t. 1268, 1439. 1582.)

d. CHORISTACHXs, I n voluerum nullum. F lores spica. ti. _ Folia opposita.

Pimele a e sectio 111. R. Brown. 2. .

e. MALISTACHYS. Flores axillares 2-4.-Folia opposita. Pimele a e sectio 1V. R. Browa $7 . c$.

f. EPALLAGE. Flores eapitati. - Folia alterna.

Pi me le a e sectio V. R. Brown 2. c. (Rudge in Linn. Transact. X, $t, 13 . f, 1$.

30S9). Strutlatola LINN. F Iores her maphroditi. Perigunium basi bilıracteolatum, coloratum, infundiluliforme, limbo quadrifido, fancis squamulis oeto, limbi laciniis per paria oppositis. St amina 4, tubo inserta, inclusa, limbi la ciniis alterna. Squamulae hypogynae nullae. Ovari um uniloculare, uniovulatum. Ovulum unicum, pendulum, anatropum. Sty lns lateralis; stigma capitatum. Nux monosperma, perigonii basi persistente inelusa. S em e n inversum. Albumen carnosum. E mbryo orthotropus; coty ledonibus plano-convexis; radicula supera.

Fruticuli capenses; foliis alternis v. opposilis, floribus axillaribus solitariis, perigonii tubo gracili.

Struthi ola Lian. gen, n, 124d, Jussieu gen. 77 . Lam. t, 78. Girtn. f. III. 194. t, 213 . Smith Exot. Hot. I. t, 46 Andr. Bot, Reposit. $t$, 43. 49. Bot. Mag, ᄂ. 222, 1212, 2138.

2HCB. Cinialia LINN. Flo res hermaphroditi v. abortu dioici. Perigoni u coloratnm infundibuliforme, limbo quadrifido, faveis squamulis quatuor integris v. bilobis, eum laciniis alter nantibus. Stamina 8 , tubo v. fauci biseriatim in serta, inclusa $v$. alterna subexserta. S qua mu lae hyporsnae nullae. Ovarinm uniloculare. Ov n In m unicum, pendulum, anatropnm. Sty I us lateralis; stigma eapitatum, hispidum. N ax monosperma, perigonii basi persistente inclusa. S e men inversum. A l bu m en paream, carnosum. Embryo orthotropus; cotyledonibus plano convexis; radicula brevi, supera. - Frutices c a penses; foliis ulternis $v$. rarius opposilis, conferti. floribus terminalibus capitatis, foliis involucrantibus interdum rameis dissimilibus, perigonii tubo supra ovarium articulato, articulo inferiore persistente.

Gu i dia Linv. gen. n. 487. Juss, gen, 77. Bot. Reg. t. 2, 19. 624. Bot. Mlag. $t$. 812, 1902, 2016, Ca nalia F, W. Schimidt Neue Pflanz. Prag. 1793,n.5. f, a, b.

2101. Thymelina HOFFMANS. Flores hermaphroditi. Periponium coloratnm, infundibuliforme, limbo quadrifido, faucis squamulis octo, limbi laciniis per paria oppositis. St a mina 8, biseriata, quatuor fauci inserta limbi laciniis opposita, exserta, quatuor alterna intra tubnm inclusa. Squamulac hypogynae nullae. Ovarinm uniloculare, uniovalatum. Ovulum unicum, pendulum, anatropum. Stylns lateralis; $8 t$ igma subclavatum, hispidulum. Nux monosperma, perigonii basi persistente inelusa. Sem en inversum. Frutices ca penses; foliis sparsis v. oppositis, floribus terminalibus capitatis, foliis involucrantibus rameis similibus.

Thy melina Hoffmansegg Verzeichn. I. 198. f. 2. Ne etandr a Bergius Flor, cap, 131, excl. sp. Juss, gen, 77. non Roland. G nfdia tomentos a Lims. non Willa. Bot. Mag, $t$. 2761. Bot. Reg. $t, 757$. Guid a imberbis Dryand. Bot. Mag. $t$ 1463.

2102. Hinostona $W A L L$. Flores hermaphroditi. Perigon i n m coloratum, tubulosum, limbo quinquepartito, squamulis faucis decem subclavatis, laciniis per paria oppositis. Stamina 10 , fauci biseriatim inserta, longe exserta. O varium uniloculare. Ovalum unicum, pendulum, anatropum. Stylus terminalis; 8 tig ma capitatum. Drupa sicca, monosperma, nuila. S em en inversum. A l b n men carnosum, parcum. Embry orthoiropns; cotyled onibus semiorbicularibus; radieula conica, supera. - Frutex indicus; fo. liis oppositis ; breve petiolatis, lanceolatis, integerrimis, glabris, florum umbella terminali, pedunculata.

Linostoma Wallich Catalog. $n$, 4203. Nectaudra Roxburglt Flor, ind, $Y$ I. 425. non alior.

2103. Cans.jerr JUSS. Flores hermaphroditi. Perigonium coloratum, urceolatum, limbo quadriclentato, fauce nuda. St am ina 4 , imo perigonio inserta, ejusdem dentibus opposita, inclnas. Squamula e hypogynae 4 , staminibus alternae, dentieulatae, ovarin adpressae, Ov arinm uniloculare. O v $\mathrm{I}$ um unirum, pendulum, anatropum. Stylus terminalis; stig ma capitatum. Drup a baceata, nuda, monusperma. Semen inversum. Emli ryo..... - Fritex indicus, scandens; foliis allernis, breve petiolatis, late lanceolatis, integerrimis, glabris, spicis axillaribus 80 litariis $v$. pluribus, densis, floribus flavescentibus, parvis, bracteis ovatis, adpressis, perigonio dimidio brevioribus.

Cansjera Jussieu gen, 448, Roxburgh Corom,It, t. 103. S e he ru- valli C a niram Rheede Malab. VIT. p. ?. t. 4. Ts jeru C a uiram Rheede $l, c, p .3, t, 2$.

2104. Eriosolema BLUM. F I o res hermaphroditi. Perigoninm coloratnm, extus villosum, infundibuliforme, limbo quadrifido, laciniie alternis brevioribus, fauce nnda. S t a $\mathrm{m}$ in a 8 , perigonii tubo superne biseriatim inserta, alterna suhexserta. Tubu 1 us ovarinm vaginans. Ovarinm unileculare, Ovulum unicnm ..... Sty I $\mathbf{n}_{8}$ brevis; stig ma capitatum. Drupa baceata, monosperma. Sem en …. - Frulex javanicus; folits alternis, oblongo-lanceolatis, subtus glau. cis, capitulis axillaribus solitariis, longe peduneulatis, bibractealis.

Eriosole日a Blume Mijdr. 65t. 
2105. Wieksteömia ENDL. Flores hermaphroditi. Perig o n i m coloratum, infundi. buliforme, limbo quadrifido, aequali, fauce nuda. Stamin a 8 , perigonii tubo superne biseriatim inserta, inclusa. Squ a m a la e hypogynae 4, lineares, basi snbcoalitac. O va ri $\mathrm{mm}$ uniloculare. O v a$1 \mathrm{~nm}$ unicum, pendulum, anatropum. S tylus terminalis brevissimus; stig in a eapitatum. Dr a pa baccata, monosperma, nuda. S em en inversum A l bumen nullum. Embryo orthotropus; cotyledonibus plano-convexis, carnosis; radicula brevi, supera. - Frutex in insula Norfolk indigenus; foliis oppositis, integerrimis, glabris, subtus venoso-reticulatis, racemo terminali, simplici.

Wickströmia Endlicher Prodr, Fl, Norfolk. 47.

2106. Hagetta JUSS. Flores hermaphroditi v. dioici. Perigoninm coloratum, tubulosum, limbo quadrifido, fance hispida. S t a m ina 8 , perigenii tubo superne biseriatim inserta, inclusa. Squa m a I a e hypogynae 8 , lineares, distinctae v. basi per paria connatae. O va ri u m uniloculare. Ovul am unicum, rarius 2 v. 3 , pendnla, anatropa. Stylus terminalis; stigma capitatum, emarginato subbilobum. Drupa perigonio baccato villoso tunicata, mono-tripyrena, putamine crustacee, fragili. S e m in a 1 _, inversa. A I b nmen nullum. Embryo orthotropus; cotyledonibus plano-convexis; radicula brevissima, supera. - Frutices $v$. arbores dense ramosae, in America tropica indisenae; librotenaci, deductili, foliis oppositis v. alternis, integerrimis, floribus terminalibus spicatis $v$, racemosis.

L. a getta Jussieu gen. 77. Lam. t, 289. Martius Nov. gen. et sp. I. 64. 4.39 . F u n i fer a Leandro de Sacram. mse. baphne Lagetto Swartz.

\section{GENERA DAPHNOIDEIS AFFINIA.}

\section{* HERNANDIACEAE.}

$210 \%$. Inoearpus FORST. Flo res hersuaphroditi, solitarii, calyculo tubuloso, hifido, deciduo cincti. Perigonium corollinum, tubulosum, limbo quinque-sexpartito, decidun. $\mathrm{St}$ amin a $10 \mathrm{v}$. 12, tubo corollae inserta, biseriata; fil amenta brevissima; antherae biloculares, didymae, latere longitudinaliter dehiscentes. $O \mathrm{va}$ rin m sessile, liberum, uniloculare. Ovu I $\mathrm{m}$ unieum, ex apice cavitatis pendulum, anatropum. Stigma subsessile, excavatum. Drupa monosperma, obovato-compressa, nuda, putamine reticulato-fibroso. Semen inversum. Em bryo exalbuminosus, orthotropus; cotyledonibus maximis, carnosis, tubereulatis; radi $\boldsymbol{c} u$ la brevissima, supera, plumula polyphylla. - Arbores resinosae, in Asia et Oceania tropica provenientes; foliis alternis, petiolatis,"subcordatis, integerrimis, floribus axillaribus, spicatis, seminibus edulibus.

Inocarpus Forster Char. gen, 66. Pl, esc, n, 18, Gärtn. f. III. 114, $t, 199$, 200. Roxburgh Corom, $t$. 263. Blume Bijdr. 551, A n io t a m Solander msc,

3108. Hernandia $P L U M$, Flores monoici, intra involuerum tetraphyllum terni, laterales maseuli, breviter pedicellati, nudi, intermedius femineus, sessilis, calyculatus. M a s c. Perig oni m corollinam, sexpartitum, laciniis biseriatis, interioribus majoribus. S ta $\mathrm{m}$ in a 3 , perigonii laeiniis exterimribus opposita; fil am en t a brevia, erecta, basi dilatata, utrinque glandula pedicellata stipata et subcohaerentia; a ntherae biloculares, loculis connectivum latiusculum marginantibus, longitudinaliter dehiscentibus. F e m. Perig on i u m tubulosum, c al y culo brevissimo, urceolato, eaduco cinctum, tubo ventricoso, fauce coarctata cum stylo cohaerente, limbi octopartiti, decidui laciniis biseriatis, exterioribus rudioribus. St amin a 4, rudimentaria, glandulaeformia, fanci inserta, inter se in annulum cum stylo coltaerentem coadunata. Ova ri u m sessile, liberum, uniloculare. Ovnlam unicum, ex apice eavitatis pendulum, anatropum. S ty I u s terminalis, simplex, elongitus, cum tubi fauce cohaerens, apice elavatus; $s t \mathrm{ig} \mathrm{m}$ a infundibuliforme, fimbriato-quadrilobum. D r u p a monosperma, octo-costata, perigenii tubo inflato-ventricoso inclusa, intus spongiosa. s' e men inversum, subglobosum; t est a crustacea, $r$ h a ph e annulari. E m b r yo exalbuminosus, orthotropus; cotyled onibus maximis, lobatis, torulosis; rad i cula brevi, supera. - Arbores in As ia et America tropica indigenae, excelsae, dense ramosae, foliosae; ramis teretiusculis, sparsis, foliis alternis, petiolalis, subpeltatis, integerrimis, stipulis nullis, floribus axillaribus, corymbosis.

He rin a n di a Plumier gen. 40. Lian. gen, n. 1049. Juss, gen. 81. Jacq. Amer. 245. Aublet Guian. $t$. 329. Lam. $t$. 755. Gärtn. I. 193, $t, 40$, Blume Bijdr. 850 , A r b or o vig er a Rumplt Amboin. IIT. 193. t. 123.

\section{** GENERA DUBIA.}

2109. Phaleria W. JACK. F lores hermaphroditi. Perigoninm coloratum, tubulosum, limiso quadripartito, fauce nuda. St a $\mathrm{m}$ i n a 8 , fauci inserta; fil amenta exserta; antherae bilobae. T u b n I a s nectarifer membranaceus, ovarii basim vaginans. Ovarium liberum, biloculare. $O \times \mathbf{l}$ a in loculis solitaria, ex eorundem apice pendula, anatropa. Stylu s brevis, simplex; stig $\mathbf{m}$ a eapitatum, papillosum. B a c c a corticata, bilocularis, disperma. S em in a inversa. Al bumen nullum. Em bryo orthotropus; cotyled onibus plano-convexis; ra dic ula brevi, supera. - Frulex summatrensis; foliis alternis v. suboppositis, breve petiolatis, ovato-lanceolatis, acuminatis, acutis, integerrimis, pedunculis axillaribus, solitariis, brevibus, floribus umbellatis, umbella involucrato-bracteolata.

Phaleria W. Jack. Mralay, Miscell. ex Hooker Comp. Bot, Mag. T. 156. - ? D rim y s p e r m u m Reinwardt in Sylloge plant, II. 15. (verisimiliter cotyledonibus pro albumine, radicula pro embryoue deseripta). Hue etiam probabiliter revocandae: D a is disperma Forst. prodr, n. 192, et Da is purpurea Gaudich ad Frejc, t, 44. - Genus vix a Daphnoideis removendum, ad Aquilariueas quodammodo transitum parat.

\section{Ordo CX. Aquillamineate.}

AQUHLARINEAE R. Brown in Tuckeg Cang. .... DC. prodr. 11 , 59. AQUILARIACEAE Liudley Introduct. edit. 11. p. 196.

Arbusculae indicae, $\mathbf{r}$ a $\mathrm{m}$ is teretiusculis, laevibus, Jibro tenaci. Folia alterna, breve petiolata, integerrima, juniora puberula, adulta glabra, lucida, reticulato-renosa. St ip u la e nullae.

Flores hermaphroditi, in foliorum axillis fasciculati, vel in umbellas alares aut terminales dispositi.

Perigonium simplex, coloratum, tubulosum, tubo longo basi attenuato v. urceolato, intus 
laevi v, retrorsum hispido, limbo quinquepartito, persistente, laciniis aestivatione imbricatis.

Squanulas fancis quinque v. decem (stamina sterilia), obsolete bilobae, in urceolum subexsertum coalitae.

Stamiva quinque, perigonii lobis opposita, v. decem biseriata, tubo prope faucem inserta. Filamenta compressiuscula, brevissima v. subnulla. Antherae introrsae, biloculares, oblongae, dorso supra basim affixae, loculis appositis, contiguis, juxta totam longitudinem dehiscentibus.

Ovarivu unicum, liberum, sessile v. stipitatum, e carpidiis duobus valvatim connatis, planiusculis conflatum, placentis duabus ventralibus, axim haud attingentibus incomplete biloculare, compressum. $0 \mathrm{vula}$ duo, ex apice cujusvis placentae pendula, extrorsum v. introrsum anatropa. Stylus terminalis filiformis, v. nullus. Stigma capitatum, simplex.

Capsula lignosa v, coriacea, obovata, compressa, incomplete bilocularis, bivalvis, valvis medio placentiferis, disperma $\mathbf{v}$, abortu monosperma.

Semina inversa, plano - convexa, $r \mathrm{~h}$ a $\mathrm{p}$ h $\mathrm{e}$ filiformi ventrali, v. membranacea dorsali (?), u $\mathbf{m b i}$ bi cum basilarem superum cum $\mathrm{chal}$ a$\mathrm{z}$ a apicali descendente fungoso-suberosa, arillaeformi conjungente. Alb u m en nullum.

Emaryo orthotropus. Cotyledones hemisphaericae, carnosae. Radicula brevis, umbilico proxima, supera.

Ordo perparvus, indicus, ob Aloës lignum celebris, a D a p h no id e is ovario e carpidiis duabus conflato, et chalazae evolutione facile distinguendus. Chaill etiaceae fructu drupaceo et foliis stipulatis dignoscuntur.

2110. Gyrinops GẌRTN. Flores hermaphroditi. Perigonin m coloratum, longe tubulosum, basi attenuatum, tubo intus laevi, limbo quinquepartito, patente. Squam ulae faucis 5 , obsolete bilobae, in urceolum subexsertum coalitae. Antherae 5, fauci insertae, perigonii lobis oppositae, dorso affixae, sessiles. 0 vari n m longe stipitatum, subfusiforme, compressum, uniloculare, placentis parietalibus duabus. Ov u Ia 2 , infra apicem placentarum solitarie pendula, anatropa. Stylus terminalis, fliformi-conicus; $8 \mathrm{tig} \mathrm{ma} \mathrm{com}-$ presso-subglobosum. Ca p s u a coriacea, stipitata, ohovata, eompressa, unilocularis, hivalvis, valvis medio placentiferis. S emina 2 , v, abortu solitaria, inversa, hinc convexa inde plana; $r$ ha $p$ he ventralifiliformi, in $\mathrm{c} / \mathrm{h}$ a la $\mathbf{z}$ a $\mathrm{m}$ apicalem suberosofungosam, triquetro-subulatam, elongatam excurrente. E mbryo exalbuminosus, orthotropus; cotyledonibus carnosis; radicula brevi, supera. - Arbuscula zeylanica, tota colore aurantiaco suffusa; libro tenaci, foliis alternis, breve petiolatis, clliptico-oblongis, acuminatis, floribus axillaribus fasciculatis.
G yrinops Gärtn. $I T$, 276. $t, 140$, DC. prodr, 1, 60. Arnott in Lindl. Introduct, edit, II. p. 442. Hooker Ic. $t, 5$.

21110. Aquilaria LAM. Flores hermaphroditi. Periguninm coloratum, nrceolatum, tubo intus retrorsum hirto, limbo quinquepartito, patente. Squa mula e faucis decem, obsolete bilobae, in urceolum exserium coalitae. Sta m in a 10 biscriata, fauci inserta, 5 perigonii lobis opposita paullo longiora; filamenta brevinscula, compressa. Ovarium sessile, obovatum, compressiusculum, uniloculare, placentis parietalibus duabus. Ovula 2, infra apicem placentarum solitarie pendula, anatropa.Stig m a sessile, convexiusculum. Ca ps u la lignosa, sessilis, obovata, compressa, nnilocularis, bivalvis, valvis medio placentiferis. Semina 2, v. abortu solitaria, plano convexa; raphe dorsali (?) membranacea; chalaza elongata, spongiosa, descendente. E m bry o .... Arbusculae indicae; foliis alternis, breve petiolatis, lanceolatis, acuminatis, umbellis axillaribus et terminalibus.

A q u 11 a ri a I, amarek Dict, I. 49. t, 356. Cavanill. Dis. sert, VIT. 377, t, 224. DC. prodr. I1. 59. Royle Himalay, 173. t. 36. Arnott in Lindley Introduct. edit. II. p, 409. Hoo. ker Io, t, 6. - ? O p h is p e $\mathrm{rm}$ a m Loureiro Flor. cochinch. I. 3 it.

\section{Ordo CXI. Elaeagneae.}

ELAFAGNEAE R. Brown prodr, 350. A. Richard in Mém, Soc. h, n. Paris. I. s7i. Bartl. Ord. nat, 113. Lladley Introduct. edit. II. p. 194.

Frutices, arbusculae v. arbores, ramulis interdum spinescentibus, haud articulatis. F oli a alterna $v$. opposita, breviter petiolata, simplicia, integra, integerrima v. dentata, uninervia, utrinque, imprimis subtus squamis scariosis, discoideis, peltatim affixis, margine stellato-dentatis $\mathbf{v}$. incisis bruneo- $v$. argenteo-lepidota. Stipulae nullae.

Fuones regulares, diclines, hermaphroditi v. abortu polygami, in axillis foliorum solitarii, spicati v. racemoso-paniculati.

Flores yascou (in Hippophaé) in amentum spicaeforme dispositi, singuli intra bracteam squamaeformem sessiles.

Perigoniun calycinum diphyllum (in Hippophaë), foliolis liberis, bracteae et axi oppositis, y. tetraphyllum (in Shepherdia) foli olis basi cohaerentibus in tubum brevissimum, toro in glandulas oeto, foliolis oppositas et alternas producto repletum.

Stauisa 4_ 8, nempe duplo foliolorum perigonii numero, iisdem alterna et opposita, tori margini inserta. Fil a m e n ta brevissima, subnulla. A n th erae introrsae, biloculares, erectae, basi v. dorso paullo supra basim affixae; loculi suboppositi, paralleli, lateraliter longitrorsum dehiscentes. Polli $\mathrm{n}$ is granula compressa, obsolete trigona.

Floribus nermaphrodits, staminum v. ovarii abortu saepe unisexualibus et FEMINEIs:

Perigonien tubulosum, liberum, extus rude, lepidotum, intus saepe coloratum, villosum, 
tubus interdum circa apicem constrictus, globoso-ventricosus, limbus regularis, campanulatus, bi-quadri-quinquefidus, laciniis per aestivationem imbricatis, vel conicus (in Conuleo) apice perforatus, circumscisse deciduus.

Torus in laminam perigonil tubum vestientem effusus, ad faucem in annulum glandulosum v. (in Conuleo) in conum carnosum, apice stylo pervium, perigonii limbum excedentem tumens; in floribus typice, nec abortu femineis (in Hippophaë) nullus.

Stanina summo toro ad perigonii faucem v. inter ejusdem lobos inserta, iisdem numero aequalia et alterna, v. dupla, per vices alterna et opposita. Filamenta et antherae uti in floribus masculis.

Ovarivm sessile, perigonii tubo obtectum, sed omnino liberum, uniloculare, uniovulatum. Ovul um ovarii lateri prope basim insertum, e funiculo crasso, brevi erectum, anatropum. Stylus terminalis, simplex, elongatus, linguaeformis, uno latere longitudinaliter stigmatosus.

Fructus perigonii basi persistente, demum incrassata, carnosa v. indurata, subossea, apice umbilicata vestitus, neque tamen cum ea cohaerens, ovoideus v. compressiusculus, monospermus, indehiscens. Ep ica r p i um crustaceo-membranaceum, tenue, longitudinaliter costatum.

Seuen adscendens, fructus cavitati conforme. 'Tes ta membranacea tenuis, v. cartilaginea dura, u $\mathrm{mbilico}$ basilari, per $\mathrm{rhaphen}$ lateralem prominulam cum $\mathrm{chal}$ aza apicali conjuncto. $\mathrm{A} I \mathrm{~b}$ u $\mathrm{m}$ e $\mathrm{n}$ carnosum, tenue, in basi seminis incrassatum.

Embryo orthotropns, axilis. Cotyledones crassae. Radicula brevis, conica, basim fructus spectans.

Elaeagneae ab E u ropa media per omnem Asiam temperatamet tropicam diffusae, in A merica boreali et tropica trans aequatorem rarissimae, in hemisphaerae australis regionibus extratropicis nondum repertae fuerunt.

Baccae nonnullarum acido malico scatentes, a Lothophagis, Persis et Indis inter cibaria receptae.

O $\mathrm{r}$ do apprime naturalis, diu in ancipiti positus, olim praeter $S$ antalace as, Combretaceas plerasque complexus, a Roberto B rown primum circumseriptus, et ab Achille Richardo egregie illustratus; differt a Daphnoide is arcte aflinibus ovuli solitarii situ, a Proteaceis perigonio regulari et fructu indehiscente monospermo, a $\mathbf{S}$ a ntalac e is ovario libero et ovuli insertione.
Combretaceae petalorum praesentia, orulorum numero et situ, embryonis denique conformatione longius distant.

2112. Fippoplane $L I N N$. F lor es dioiei. Masc. Perigonium diphyllum. Stamina 4. Fem. Perigoni un tubulosum, limbo erecto, bifido. Tor u $\mathrm{s}$ nullus. A che $\mathrm{n}$ i u merigonio baccato tectum. - Arbuscula Europam mediam et austro-orientalem sparsim inhabitans; foliis alternis, lanccolatis, sublus argenteo-lepidotis, spinis axillaribus, floribus masculis in amentum breve dispositis, singulis intra bracteum sessilibus, femineis axillaribus, solitariis.

H i p p a p ba fe Linn. gen. n, 1106. excl, sp. Gärtn, I. 199. t. 42. Schkuhr t, 332. Fi. dan, $t, 265, E, 16, t, 425$. A. Ricliard in Mém. Soe, $h, n$, Paris $I, 387$. t. 24, f. 2. Nees jun. Gen. pl. II. 44.

21 13 . Sineplaerdia NUTT. Flores dioici. Ma sc. Perigonium brevissime tubulosum, quadrifidum. St a mina 8 , toro perigonii tubum replenti inserta. F em. Perigoninm tubulosum, limbo quadripartito. T or u 8 in glandulas octo perigonii faucem obturantes tumens. A chenium perigonii tubo baccato tectum. - Arbusculae boreali-americanae; foliis oppositis, lanceolatis, subtus argenteo- $v$. ferrugineo-lepidotis, ramulis apice spinescentibus, floribus in apice ramulorum subracemosis.

She pherdia Nutt. gen. II. 241. A. Richard in Mém. Soc. $h, n$. Paris $I .386 . t, 24 . f$. 3. Le pa rg y $r$ e ia Ratin. in Americ. Monlal, Magaz, 1819. H i p p o p ha è s s p. Linn. Pursh.

2114. Comuleum L.C. RICH. Flores dioici. Mase. ..... Fem. Perigon i tubns cylindricus, limbus conicus, apice perforatus, circumseisse deciduus. Tor $\mathrm{s}$ ad perigonii faucem in connm stylo pervium, limbnm subexcedentem tumens. Fruetus ......-Arbuscula guianen$s i s$, inermis ; foliis oppositis, obovali-acuminatis, integerrimis, lepidoto-argenteis, floribus in axillis dichotome racemosis.

C on ule um L. C. Richard ex A. Richard in Mém, Soc. h. n. Paris I. 391. t. 25.

2115. IIneagnus LINN. F I ores hermaphroditi v. polygami. Perigonium basi tubulosum, limbo campanulato, regulari, quadri-6exfido. St a mina 4_6, limbi laciniis basi inserta, iisque alterna. $D i s$ i $s$ annularis $v$. conieus, tubi fauci impositus. A ch en i um perigonii tubo incrassato, carnoso, intus osseo, apice umbilicato tectum - Arbores v. arbusculae, ab Europa media per Asiam temperatam et tropicam usque ad Japoniam, ubi imprimis copiosae esse videntur, diffusae; foliis alternis, lepidotis, integerrimis, ramulis sacpius spinescentibus, floribus axillaribus, pedicellatis.

Elaeagnas Limn, gen, n, 159. Gïrtn. f. IIT. 203. t. 216. Pallas Fl. ross, I, t, 4, S. Thunb. Flor. jap. t. 14. A. Richard in $M \dot{m} m$. Soc. $h$. $n$. Paris. $I$. 381. L. 2.f. f. 1. Turp. Alt. Dict, sc, nat. III, t, 7. Bot. Reg. t, 1156. Nees jun. Gen. plant. II. 43.

\section{Drdo CXII. Penceaceat.}

PENAEACEAE R. Brawn ex Sweet Hort, brit. 347. Guillem, in Dict. hist, nat. XIIT. 171. Kunth in Linnaea $V .676$. Lindley Introduct. edit, II, p. 203.

Frutices capenses, sempervirentes. Foli a opposita, simplicia, integerrima, coriacea, imbricata. Stipulae nullae. 
Flones hermaphroditi, regulares, axillares v. terminales, bracteolis duabus lateralibus oppesitis, interdum bifidis, raro pluribus muniti.

Periconium simplex, coloratum, persistens, basi ventricosum, apice plus minusve profunde quadrifidum, lobis per aestivationem valvatis.

Stamiva perigonii limbo inserta, ejusque lobis numero aequalia et alterna. Fil a m e n ta brevia, erecta, libera v. mediante margine disciformi angustissimo, perigonii limbum vestiente basi conjuncta. Anth erae introrsae, biloculares, erectae, loculi oppositi, dorso connectivo crasso, carnoso adnati, nunc illud Jongitudine aequantes et eodem interposito sejuncti, nunc contigui, a connectivo dilatato superati, longitudinaliter dehiscentes.

Ovarium quadriloculare, liberum, constans e carpidiis quatuor, marginibus introflexis dissepimenta constituentibus, columna centrali nulla. $0 \mathrm{vul}$ a in quovis locnlu duo, collateralia, ex anguli interioris basi adscendentia, anatropa. Styli quatuor, in unicum conferruminati, teretes v. angulati, angulis cum carpidiorum dorso continuis. Stig $\mathrm{m}$ a terminale, simplex, capitatum v. obsolete quadrilobum.

Capsula intra perigonium persistens recondita, tetragona, quadrisulca, quadrilocularis, loculicido-quadrivalvis, valvulac coriaceae, medio septiferae.

Simisa in loculis dio, collateralia, erecta, oblonga, extus convexiuscula, intus subcomplanata, nonnulla plerumque abortiva. Tes ta dura, fragilis, v. coriacea, crassa, endopleura tenuis, membranacea. Umbilicus basilaris, fungosus, arillum mentiens, cum rhaphe lineari, crassa, carnosa, ad latus seminis exterius decurrente continuus et solubilis. Nucleus carnosus, indirisus. Embryo ....

Ordo perparvus, ca pe $\mathrm{n} \mathrm{s}$ is, ob seminis interiorem fabricam non rite cognitam, et frustra in speciminibus exsiceatis a nobis exploratam, quoad locum subdubius, interim ob aliquam cum Thymeleis et Proteaceis affinitatem hoc loco collocatus, cum Rhamneis olim fortassis comparandus.

Species pleraeque vix cognitae, et e Thunbergii phrasibus haud eliciendae. Penaeae Lonreirianae ab ordine longe recedunt.

Plurimae resinam fundunt viscidam, nauseosam, principio peculiari (Sarcocollim v. Collechair) cum acido nitrico in acidum oxalicum coeunte foetam, ab Arabibus inter vulneraria pharmaca receptam.

$\mathrm{Geissoloma}$ genus ob fructus et seminis fabricam incognitam, quoad locum sunm nobis magnopere dubium, a typo, qualem Penaea et Sarcocolla exhibent, perigonii aestivatione, sta- minum numero, antherarum fabrica et ovulorum situ recedit, interim e cl. Lindley sententia ad hujus ordinis calcem collocatum, Brun i a ce is fortassis olim approximandum.

2116. Pennea LINN. Perigoninm coriacenm, coloratum, campanulatum, limbi quadripartiti lobis triangulari-ovatis, aestivatione valvatis. Stamina 4, summo perigonii tubo inserta, ejusque lobis alterna; filamenta libera; antherae loculis connectivo crasso antice adnatis illoque brevisribus, Ovarium quadriloculare. Ovula in loculis bina collateralia, erecta, anatropa. St y l us tetrapterus, apice quadrifidus; s tig. m a t a truncato-rotundata. Ca $8 \mathrm{u}$ l a perigonio persistente tecta, tetragona, quadrisulea, quadriloeularis, loculicido-quadrivalvis, valvis coriaceis, medio septiferis. Semina in loculis 2 , e basi ereeta; testa dura, fragili; umbilico fungoso; rhaphe lineari, crassa. - Frutiees capenses, ramosissimi; folitis oppositis, coriuceis, integerrimis, floribus terminalibus solitariis v. paucis congestis, bracteis coloratis.

Pенаеа Linn. gen. n. 138. excl. sp. Gartn. f. $I I I .243$. t. 295. Kunth in Linnaea $V .670$. P. muerona in L. P. a yrtillaides et frueticulosa Thunb. CVent, Malm. t. 87. Bot. Mag. $t$. 2809.)

211\%. Sareocolla KUNTH. Perigon i um coriacenm, coloratum, fubulosum v. campannlatum, limbi quadripartiti lobis subrotundoovatis, basi latioribus, aestivatione imbricatis. St a mina 4 , summo perigonii tubo inserta, ejusque. lobis alterna; filamenta liberav. mediante disci margine angusto brevissime conjuncta; a $n$ therae loculis connectivo crasso, aequilongo antice adnatis. Ovari n m quadriloeulare. Orula in toeulis hina, collateralia, erecta, anatropa. S t y 1 u s filifurmis; st ig m a capitatum, integrum v. obsolete quadrilobum. Ca p 8 u la perigonio persistente tecta, totragona, quadrisulea, quadrilocularis, locnlicidoquadrivalvis, valvis coriaceis, medio septiferis. Semina in loculis 2, e basi erecta; testa coriacea, crassa; $\mathbf{u}$ bilic o fungoso; $r$ ha $p$ he lineari, in. crassata. - Frutices c a penses, viscoso-resinosi; foliis oppositis, imbricatis, coriaccis, inlegerrimis, floribus terminalibus, solitariis v, paucis congestis, sessilibus, bractealis.

$\mathrm{S}$ areocalla Kunth in Linnaed $V$. 678. Penaede sp. Linn. Thunb. in Berl. Magas. $1, t, 3, f ., 1$, Lam. t. 78, f. $1,2$. Meerb. $t$. 5i.f. 1, Bot. Reg. $t, 106$.

\section{GENUS ANOMALUM}

2118. Feissoloma LINDL. Perig 0n i m coriaceum, coloratum, quadripartitum, lacinits ovatis, aequalibus, aestivatione imbrieatis, sni anthesi patentibus, S ta m in a 8 , imo perigonio inserta, eoque breviora, quatuor ejusdem laciniis opposita reliquis paullo longiora; fila m en$t$ a subulata, basi disei margine angusto breviter conjuncta; antherae ellipticae, apienlatae, basi bifidae, dorso affixac, demum reflexac. Ovarium quadriloculare. Ovula in loculis 2, collateralia, pendula, anatropa. Sty lus subulatus; stig ma simplex, Ca ps ula .....-Frutices capenses; foliis oppositis, integerrimis, pedicellis axillaribus, solitariis, bracteolatis.

Ge is solom a Lindley ex Kunth in Linnaea $V$, 678. Penaca marginata Linn. - ? Penacae sp. Thunb. in Berl, Magas, I, t, 3, f. 2, 3. 


\section{Drdo CXIII. Protenceae.}

PROTEAE Jussieu gen, 78. PROTEACEAE R. Brown in Linn, Transaet, X, 45. ss. Prodrom, 363. Supplementum primum prodromi Lond. 1830. 8. Knight et Salisbury Proteaceae Lond, 1810, 8. Bartling Ord, nat, 113. Lindley Introduct, edit, II, p, 197.

Frutices v. Arbores vix excelsae, rarissime Herbae. Rami in plerisque annotino - umbellati. Folia alterna, rarius opposita v. verticillata, persistentia, coriacea, indivisa v. varie dentata seu incisa, aut profundius laciniata, rarissime composita, glandulis cutaneis in pluribus amphigenis. Stipulae nullae.

Fuones in plerisque hermaphroditi, in paucissimis abortu unisexuales, subspicati, modo laxius in racemum v. corymbum dispositi, saepe geminati, modo densius in capitulum congesti, v. supra receptaculum planiusculum aggregati, receptaculo involucro persistente, saepius imbricato subtenso, in nonnullis quasi abortione unifloro, involucro tunc calyculum simulante. Bracteae dum flores geminati singulis paribus communes, in capitatis persistentes, saepius demum auctac et induratae, rarius connatae, in aggregatis nanae, plerumque deciduae, quandoque nullae.

Perigoniom simplex, coloratum, subcoriaceum, arenium, extus saepe pubescens, intus glabrum, rariusve barba nt plurimum partiali instructum, tetraphyllum, foliolis valvatis, distinctis $\mathbf{v}$. saepius plus minus arcte cohaerentibus tubulosum, limbo quadrifido, aequali, laciniis subspathulatis, rarius irregulari, laciniis nempe pluribus cohaerentibus v. rarius inaequalibus; post anthesim deciduum v. marcescens, tubo saepius a basi tandem quadrifida secedente, quandoque basi integra diutius persistente.

Stamisa quatuor (uno interdum abortivo), perigonii foliolis opposita, iisdemque nt plurimum inserta, in plerisque juxta apicem rarius prope medium v. basim, rarissime hypogyna, nunquam perigonio longiora. Fil a menta brevissima v. mediocria, rarissime pro parte inter se coliaerentia. An the ra e introrsae, biloculares, adnatae, loculis linearibus, longitudinaliter dehiscentibus, contiguis v. loculis discretis bilobae, lobis contiguis vicinarum inter se connatis loculnmque primitus unicum, tandem bivalvem formantibus, altero lobo tune in nonnullis abortivo. Polle n triangulare, angulis pellncidis, v, ellipticum ant lunulatum, raro sphaericum.

Squamula v. Glaxdolaf hypogynae nune quatuor, perigonii foliolis alternae, liberae v. inter se connatae, nonnunquam etiam perigonii tubo basi intus adnatae, nunc panciores, unilaterales, interdum nullae, rarissime staminnliformes.
Ovarivm liberum, sessile v. stipitatum, rarissime cum stipitulo articulatum, e carpidio unico compositum, uniloculare. 0 v ul u m unicum v. bina collateralia, nune plura biseriata, suturae prope loculi basim medium v. apicem affixa, varie anatropa, micropyle infera, saepe elongata, primina nempe hinc longitudinaliter fissa, nucleum partim denudante. Sty lus terminalis, filiformis, simplex, perigonio in pluribus longior, persistens v. a basi aut supra basim deciduus. Stigm a plerumque indivisum, nunc emarginatum $\mathbf{v}$. rarissime bifidum, saepe obliquum, figura varium, in plerisque glabrum, nune papulosum, hispidulum v. tomentosum.

Froctos varius: Nux, samara v. drupa monosperma aut rarius disperma, nunc poLliculos coriaceus $\mathbf{v}$. ligneus, raro monospermus, plerumque dispermus v. polyspermus, unilocnlaris, v. ovulorum collateralium priminis in dissepimentum liberum bipartibile concrescentibus psendobilocularis.

Semina suturae immediatim affixa, in nucamentaceis saepins ventricosa, in folliculatis ut plurimum compressa, saepissime alata, test a in pleiospermis plerumque hinc soluta, membranam seminibus interpositam sistente, umbi li co basilari v. laterali, chal a z a venosa apicem v. Iatus umbilico oppositum occupante, rhapheos in nonnullis fere obsoletae, in aliis bicruris directione varia. A 1 b u m en nullum.

Euвryo rectus, dicotyledoneus v. rarius polycotyledoneus; radicula umbilico proxima v. parallela, semper infera. Plumula vix conspicua.

Proteaceac ob stirpium habitum mire formosum, et florum elegantem speciem regionum ubi abundant ornamenta, et viridariorum nostrorum svavissimae deliciae, imprimis in hemisphaerae australis regionibus extratropicis, in Capite bonae spei et Nora IIollandia imprimis anstrali copiosissimae proveniunt, in Nova Z e elandia et America australi extratropica rariores. In regionibus tropicis $N$ ovac Hollandiae et Americae transaequator em parce proveniunt, cis a equatorem inter tropicos Indiae et Americae orientalis rarissimae, unica ex Abyssini a relata, ex hemisphaerae borealis regionibus extratropicis omnino exules.

\section{SUBORED I. NUCAMENTACEAE.} Fru ct us indehiscens.

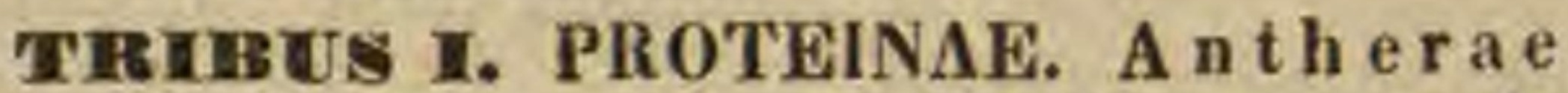
inter se liberae, medio v. apicibus concavis laminarum perigonii inserta. Ov ari u m uniovulatum. Nux v. S a mara. - Flores capilati

2119. Aulax BERG. Flores abortu diaici. Masc. racemosi. Perigonium tetraphyl. 
lum regulare. Sta $\mathrm{m}$ in a 4 , medio foliolorum perigonii inserta. Ova rium abortivum. F em. C apitulum multiflorum, bracteis subulatis. Perigonium maris. Squamulae 4 hypogynae. Ovarium unileculare, uniovulatum. Stylus filiformis; st i g m a obliquum, clavatum, hispidulum, emarginatum. Nux monosperma, exserta, ventricosa, barbata. - Frutices ca penses, gtaberrimi; foliis alternis, integerrimis, floribus terminalibus, unibracteatis, masculis in racemis aggregatis, nudis, femineis in capitulo solitario, cincto foliolis intus auctis appendiculo aceroso-multifido, capitulo quasi abortivo, racemis exterioribus maris analogo.

A u 1 a x Bergius Flor, cap, 33. R. Brown in Linn. Transact. X. 49. Prote a e s p. Linn. Thunb. Andr. Bot, Reposit. t. 76. 248 .

2120. Leueadendron HERM. F lores abortu dioici, eapitati, bracteis dilatatis. Perigon inm tetraphyllum, regulare. Stamin a 4 , apicibus concavis laciniarum perigenii inserta. $S_{q}$ u amulae 4 hypogynae, interdum obsoletae. Ovarium uniloculare, uniovulatum. Stylus filiformis; stig ma obliquum, clavatum, emarginatum, hispidulum. Nux v. samara menosperma, strobili squamis (interdnm eohaerentibus) inelusa.

Frutices $v$, interdum arbores ca penses, saepe sericeo-tomentosae; foliis alternis, integerrimis, capitulis terminalibus solitariis, bracteis imbricatis v. foliis verticillatis et subcoloratis plerumque cinctis.

L e u c ad e nd ron Hermann ex Plucken. Phyt. t, 200. f, 1 . R. Brown in Linn. Transact. $X$. 50. Co n o c a r p o d e a d ro n Boerh. Lugd, Bat. t, 198, 197,200.202_204. C oll o c a r p a s Adans. Fam, II, 284. E u r y s p e r m a m Salisbury Parad, $t$. 75. G is sonia et $\mathrm{C}$ b a $8 \mathrm{~m}$ e Salisb. Parad, 67. Prote ae s p. Linn. Gärtn. $t$. 51 . Wendl. Hort. Herrnh, $t, 14$. Andr. Bot, Reposit, t, 307, 429. 461. 541, 572 .

2121. Petrophilla $R$. BR. Capitulum indefinite multiflorum, braeteis persistentibus imbricatis. Perigonium quadrifidum, totum simul decidunm. St a min a 4, apicibus concavis laciniarum immersa. Squamula e hypogynae nullae. Ovarium uniloculare, uniovulatam. Stylus filiformis, basi persistente; stigma fusiforme, apice attenuato. $\mathrm{Nux}$ lenticularis monosperma, hinc comosa, v. sa ma ra basi barbata. - Frutices in Nova Hollandia, imprimis meridionali provenientes, rigidi; foliis glabris, variis, filiformibus v. planis, indivisis, lobatis $v$. pinnatifidis, quandoque in eadem stirpe diversiformibus, amentis ovatis $v$. oblongis, terminalibus et axillaribus, interdum aggregatis, strobili fructiferi squamis imbricatis, distinetis $v$. connatis.

Pet r o phil a R. Brown in Linn. Transact, X. 6\%. Prodr. 363. Suppl. 1. Petrophile Knight et Salisb. Prot. 92. A t y $1 \mathrm{i}$ sp. Salisb.

a. ARTHROSTIGMA. Stig ma artienlatum, articulo inferiore angulato, glabro, superiore tomentoso. N a $\times$ lentieulari-compressa, intas marginibusque comosa. Stro. bil us squamis distiuetis.- Folia filformia, indivisa.

Petrophilae sect. I. R. Brown prodr. 364. (Bot. Mag. $t$. 3669.)

b. PETROPHLE. $\$ t \mathbf{g} \mathbf{m a}$ inartieulatum, hispidiusculam. $\mathrm{Nu} \times$ lentieulari-compressa, intus marginibnsque comosa. Strobilus squamis distinctis. - Folia filiformia, bipinnatifida.

Petrophilae sect. 11. R. Brown l.c. Proteae s p. Schrader Sert. Hannover. 11. $t$. 7 . Cavanill. Ic. $t$. 850. 551. Bot, Mag. t, 796, (Guillem. Ic, lithogr, t, 18.)

c. SYMPHYOLEPIS. Stigm a iastieulatum, hispidiuscaInm. Samara foliacea. dilatata. Strobilus sqasmis connatis. - Folia plana, bipinnatifida.

Petrophilae sect. 111. R. Browa $l$. $c$. d. XEROSTOLE. StIg a a Inarticulatum, bispidiusculum, $\mathrm{S}$ a mara planfuscula. Strobilus squamis distinctis. - Folia plana, ternatim divisa.

Petrophila e sect. IV. R. Brown 7 . c.

212. Isopogon $R$. BR. Capitalnm indefinite multiflorum, bracteis persistentibus imbricatis, v. receptaculum planum, paleis deciduis subinvolucratum. P e rig on i um quadrifidum, tube gracili dintins persistente. $S t$ a $\mathrm{m}$ in a 4 , apicibns eoncavis laciniarum perigonii immersa. S quamulae hypogynae nnllae. Ovarium uniloculare, uniovulatum. Stylus filiformis, a basi deciduus; stigma fusiforme v, cylindracenm. Nux monosperma, sessilis, undique comosa. - Frutices rigidi, in Nova Holtandia, imprimis meridionali indigeni; foliis glabris, planis v. filiformibus, divisis $v$. integerrimis, floribus nunc densissime imbricatis, in strobilum collectis, nune fastigiatis, receptaculo communi planiuseulo, subinvolucrato impositis, paleis deciduis, congestis intermixtis.

Is o p ogon R. Brown in Linn. Transat, X, ro. Prodr. 365. Suppl. 7. Knight et Salisbury Prot.93, At ylli sp. Salisb.

a. EUSTRoBILUS. Flores imbrieati, strobilo globoso, squamis densis serius decidnis. - Folia omnia v, ra: rissime inferiora tanlum divisa.

Is opogonis sect. 1. R. Brown prodr. 365. P rote a e s. p: Cavauill, Ic. t. 558, 559, Bot, Mag. t, 697. Audr. Bot, Reposit. t. 332. (Bot. Reg. t. 900. 1288, Bot. Mag. t. 3491.)

b. HYPSANTHUS. Flo res supra receptaculum planam v. convexiuscnlum snbinvolueratum fastigiati, palein confertis, cadueis, - Folia indivisa v, rarissime fruticis adulti trifida.

Is o pog n n is sect. II. R. Brown l. e. (Guillem. Ic. lithogr, t. 19. Bot. Mag, t. 3450, 3539.)

2123. Protea LINN. Involucrum imbricatum polyphyllum, persistens, receptaculum multiflornm, paleis abbreviatis, persistentibus obsessum cingens. Perigonium bipartibile, inaequale, labii latioris laminis tribus cohaerentibus. St a m in a 4 , apieibus concavis laminarum perigonii inserta. Squamnlae 4 hypogynae. Ovarin m oniloculare, uniovulatum. St y Ins subulatus; stigma angustias, cylindraceum. Nux monosperma, undique barbata, stylo persistente candata. - Frutices capenses, etiam in Abyssinia reperti, modo proceriores, fere arborescentes, modo subacaules; foliis integerrimis, capitulis terminalibus $v$. rarius lateralibus, receptaculo planiusculo $v$. interdum convexo, saepissime glabro, nonnunquam paleis connatis alveolato, involucro magno, colorato, turbinato $v$, hemisphaerico, perigonii labio latiore saepe bi-triaristato.

Prote a Lian. gen, odit, 1, $n$, 59, R. Brown in Linn. Transact, X, 74 Smith Erot, Bot, I, t, 44, II, t, 81. Andr. Bot. Heposit, 2, 132. 133, 144. 270. 288, 289, 409. 437. 442. 453, 469, 500. 526. 532. Bot. Mag. $t, 346.933 .1713,2063$. 2467. 2720. Bot. Reg. t, 20, 47. Le ueade a ron Lina. gen. edit. 2. $n$. 74. Lepldoearpodendron Boerb. Lugit. Bat. 55. S e oly moeephalas Hermana Dendr. $t$. 9. Erodendrum Salisb. Parad, 67. 70. 108. Plearanthe Salisb. - Gag ue di Bruce Abyst, $Y$, s2, $c$, icc.

2124. Leweospermam $R$. BR. In v 0In ernm imbricainm polyphyllum, eapitulum in definite multiflorum, amentaceum v. depressum cingens. Perigonin irregulare, hilabiatum, unguibus tribus, rarius omnibns cohaerentibus, laminis distinctis. St a m in a 4 , apicibus concavis Jaminarum perigonii inserta. Squamulae 4 hypogynae. Ova ri um uniloculare, nniovnlatum. St yi s filiformis, deciduns; stigma inerassatum, glabrum, interdum inaequilaterum. Nux mono. sperma, ventricusa, sessilis, laevis.- Frutices e apenses, saepe humiles, quandoque arborescentes. 
plerumque tomentosi v. hirsuti; foliis integerrimis v. apice calloso-dentatis, capitulis terminalibus, floribus flavis, nunc imbricatis, bracteis persistentibus, induratis, nunc supra receptaculum planiusculum fastigiatis, paleis angustis, non mutatis, deciduis.

Le u cosperm $\mathrm{nm}$ R. Brown in Linn. Transact. X.95.

2. CONOCARPODENDRON Boerh. Capitulum amenta-

ceum, bracteis persistentibus subimbricatis.

Co n oc a rpo de $\mathrm{ndr}$ o n Boerh. Lugd. Bat. IT. 196. 198. Protea e $8 \mathrm{p}$. Thunb. Lian. Andr. Bot. Reposit. t. 17. Lam. $t$. 53. $f$. 3. L e uc a de a d r i s p. Linn.

b. DIASTElla Salisb. Receptaculum planiusculam, paleis angustis, deciduis.

D has tella Salisb. Proteae sp. Thunb.

2185. Viranetes $S A L I S B$. Involucrnm imbricatum polyphyllum, receptacnlum multiflorum planum, paleis angustis deciduis obsessum cingens. Perigonium quadripartitum, aequale, laciniis distinctis. Sta $\mathrm{m}$ in a 4 , apieibus concavis laciniarum perigonii inserta. Squamula e 4 hypogynae. Ovarium uniloculare, uniovulatum. Stylus filiformis, deciduus; stigma cylindraceum, gracile. Nux monosperma, ventricosa, sessilis, laevis. - Frutices capenses; foliis integerrimis $v$. calloso-dentatis, capitulis axillaribus, in quibusdam folio superiore cucullato amplexis, interdum terminalibus, involucris membranaceis, raro coriaceis, nunc dimidiatis, ovariis perigonia post anthesim flaccida superantibus, stigmatibus in plerisque acutis.

M i m e t e s Salisb. Parad. 67. R. Browa in Linn. Transact, X, 105. Reichenb. Hort, bot. $I, t, 92,93$. H y p ophyllo e a p o de nd ro a Boerh. Lugd, Bat. II. 206. Lepidocarpodendri 5 p. Boerl. op. cit. IT, 194. Protea e et Le ucadendris p. Linn.

2186. Serrumia SALISB. Capitulum indefinite multiflorum, paleis persistentibus imbricatis, involucratum v. nudum. P e rigon i u m quadrifidum, subaequale, unguibus distinetis. Stam in a 4, apicibus coneavis laciniarum perigonii immersa. Squamulae 4 hypogynae. Ovarium uniloculare, nniovulatum. Stylus filiformis, deciduns; stigma verticale, glabrum. N ux monosperma, brevissime pedicellata, glabriuscula v. barbata. - Frutices c a penses; foliis filiformibus, trifido-pinnatifidis rariusve integris, capitulis terminalibus $v$. e summis alis, simplicibus $v$ compositis, partialibus congestis, v. pedunculo communi diviso corymbosis, involucro imbricato, membranaceo, capitulo saepe breviore, in paucis longiore, quandoque nullo, floribus semper sessilibus, purpureis, ovariis perigonia aequantibus, stigmatibus clavatis rariusve cylindraceis, nucibus ovalibus, tenuiter pubescentibus, modo barbatis, aliquando glabriusculis.

Serruria Salisb. Parad. 67. R. Brown in Linn. Transact. X, 112. S e r raria Burmann Afr, 264. Prote a e et Le u cadeudri op. Lina. Andr. Bot. Reposit. 2.264. 349. 417.507 .

242\%. Nivenia $B$. BR. Involucrum simplici serie tetraphyllum, quadriflorum, fructiferum induratum, receptaculo plano, epaleato. Perigoninm quadrifidum, aequale, totnm deciduum. S $\mathrm{t}$ a $\mathrm{m}$ in a 4 , apicibus concavis laciniarum perigonii inserta. Squamulae 4 hypogynae. Ovarium iniloeulare, uniovulatum. Stylus filiformis, deciduus; stig ma clavatum, verticale. Nux monosperma, ventricosa, nitens, sessilis, basi integra. - Frutices capenses; folitis sparsis, inferioribus bipinnatifidis, filiformibus, superioribus in quibusdam indivisis, planis, involucris in spicam rariusve in capitulum terminale digestis, sessilibus, bractea unica subtensis, floribus purpurascentibus.

Niven ia R. Brown in Linn. Transact, $X$. 133. Pa ra nomus Salisb. Parad. 67. Proteat sp. Linn. Andr. Bot. Reposit, t. 243.
21:8. Soroceplanalos $R$. BR. Involncrum subsimplici serie tri-hexaphyllum, definite paueiflorum v. uniflorum, fructiferum haud mutatum, receptaculum epaleatum. Perigonium quadrifidum, aequale, totum (?) deciduum. Stamina 4, apicibus concavis laciniarum perigonii inserta. Squamulae 4 hypogynae. Ovarium nnileculare, nniovulatum. S ty lus filiformis, deciduus; stigma verticale, clavatum. Nux monosperma, ventricosa, brevissime pedicellata $v$. hasi emarginata. - Frutices capenses: ramis virgatis, foliis sparsis, jiliformibus v. planis, indivisis, infimis interdum bipinnatijidis, involucris subsessilibus, unibracteatis, in spicam capituliformem, nudam v. basi bracteis imbricatis subtensam congestis, floribus purpurascentibus.

S or ocephalus R. Browa in Linn. Transact, X, 139. Soranthe Salish. Spatallae sp. Salisb.

a. MISchocaryon, S p i e a nudiuscula. Involucra uni - tritlora. Nux brevissime pedicellata, basi integra. Folia filiformia, indivisa.

b. CARDIOCARYON. S pi e a subiuvoluerata. Involuera quadri-sexflora. $\mathrm{N}$ u x basi emarginata. - Folia filifor: mia $v$. plana, rarissime infima bipinnat ifida.

Protea lanata et P. imbricata Thuab. Prot. t. 3. et t. 5. Andr. Bot. Reposit, t, 527.

2 199. Spatalla SALISB. Involucrum simplici seriei di-tetraphyllum, uniflorum, v, definite pauciflorum, fructiferum haud mntatum, receptaculo epaleato. P erigonio m quadrifidum, lacinia interiore plerumque majore, totum deciduum. Stamina 4, apicibus concavis laciniarum perigonii immersa. Squamulae 4 hypogynae. O vari um uniloculare, uniovulatum. Stylus filiformis, deciduus; stigma obliquum, dilatatum. Nux monosperma, ventricosa, brevissime pedicellata. Frutices capenses; foliis sparsis, filiformibus, indivisis, involucris terminalibus, spicatis v. racemosis, unibracteatis, floribus purpurascentibus, anthera perigonii laciniae majori inserta proportionatim majore, in quibusdam sola fertili.

Spatalla Salisbury Parad, 67. excl. sp. R. Brown in Linn. Transact. $X$. 143.

a. collostigma. Invol ucram uniflorum. P erigon i u inaequale. Stig a a concavam, cochleariforme. Protea prolifera Thubberg Prot. $t .4$.

b. CXrtostigma. Invol u crum tri-quadriflorum. Perig onium subaequale. $S t i g m$ a convexiusculum.

Protea incurva et P. caudata Thunberg Prot. t. 2.3 .

2 13S. A diemanthos $L A B I L L A R D$. Involuer um tetra-octophyllum, uniflorum. Perigon i m quadrifidum, basi circumscissum. Stamina 4 , apicibus concavis laciniarum perigonii inserta. S q u a m a la e 4 hypogynae, perigonii basi persistenti adnatae. Ovarium uniloculare, uniovulatum. St y I us filiformis, perigonio longior; stig ma verticale. Nux monosperma, ventricosa, sessilis. - Frutices Novae Hollandiae austro-oceidentalis; foliis sparsis, indivisis v. trifidis, involucris axillaribus solitariis, floribus rubicundis, rarius terminalibus subuggregatis, floribus lutescentibus.

A de nan th os Labillard. Nov. Holland. 1. 28, $t, 36$ 38. R. Brown in Linn. Transact. X, 151, Prodr, 367. Suppl.9.

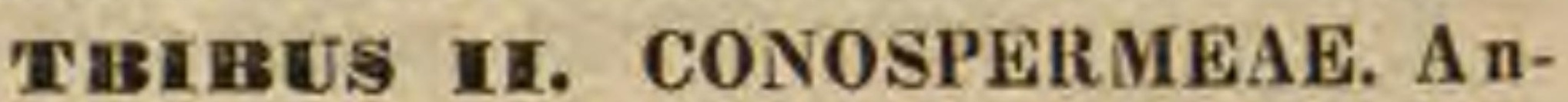
ther a primum inter se cohaerentes, vicinarum lobis contiguis loculum unicum constituentibus. Ovari um uniovulatum. Nux, - Flores spicati v, capilati.

2131. Symaplasea R. BR. Perigonium tubulosum, ringens, limbi quadrifidi lacinia postica 
latiore. S tam in a 4 , basi laciniarum inserta, inclusa; fila m enta brevia, posticum anantherum; fertilium anthera e bilobae, lobo altero lateralium abortivo, intermedii antici ambobus perfectis, omnibus primum cohaerentibus, vicinarnm lobis contiguis synantherii bilocularis loculum unum constituentibus, tandem discretis. S quamula e hy pogynae nullae. Ovar i m turbinatum, uniloculare, uniovulatum. Stylus curvatus, sursum incrassatus; st $\mathrm{igma}$ dilatatum, obliquum, hine stamini sterili connatum, inde bicorne v. acutum. Nux obovata, monosperma, papposa. - Frutices humiles, in Novae Hollandiae ora austrooccidentali provenientes; foliis sparsis, planis, pulcherrime reticulatis, circumscriptione cuneiformibus, lobatis $v$. inferioribus etiam indivisis, glandulis cutaneis amphigenis, petiolorum basi dilatata semivaginante, spicis axillaribus $v$. terminalibus, simplicibus $v$. ramosis, floribus alternis, solitariis, sessilibus, unibracteatis, perigonio fiavo, deciduo, quadripartibili, bractea cucullala, persistente.

Sy n a phae a R. Beown in Linn. Transact. X. 135. Prodr. 369. Gen. Rem. 606, t. 7. Suppl. 11.

213\%. Conosperinam SMITH. P erig onium tabulosum, ringens, limbi quadrifidi lacinia postica fornicata. S $t$ a $m$ in a 4 , basi Iaciniarum inserta, inclusa; fil am en ta brevia, anticum anantherum; fertilium antherae bilobae, lobo altero Jateralium abortivo, intermedii postici ambobus perfectis, omnibus primum cohaerentibus, vicinarum lobis contiguis synantherii bilocularis loculum unum constituentibus, tandem diseretis. Squamulae hypogynae nullae. Ovarium obconicum, uniloculare, uniovulatum. Styln s filiformis, sursum incrassatus; $8 \mathrm{ti} \mathrm{g} \mathrm{m}$ a obliquum, liberum. Nux obeoniea, monosperma, papposa._Frutices in Nova Hollandia orientali et meridionali provenientes; foliis sparsis, integerrimis, planis rariusve filiformibus, glandulis cutaneis amphigenis, spicis axillaribus v. terminalibus, compositis, sensim flerentibus, hinc corymbosis, floribus solitariis sessilibus, unibracteatis, albis v. caerulescentibus, perigonio deciduo, bractea cucullata, persistente.

Conospermum Smith in Linn. Transact. IV. 213. Exot. Bot, t, II. 45. R. Browa in Linn. Transact, X, 183. Prodr. 368. Suppl. 9.

a, Euconospermum. P e rig o $\mathrm{n}$ i i ringentis Iaciniae acutae, tubo vix longiores, postica multo latior.

Co nos perma vera R. Brown prodr. 368, (Smith Exot, Bot. II. t. 82. Bot. Mag, $t, 2724,2850$.

b. CHIlurus $R$. Br. Perigonil subregularis laciniae eaudatac, tubo longiores, postica basi paullo latior.

Ch il urus R. Brown prodr. 369.

c. ISOMERIUM $\boldsymbol{R}$. Br. Pe rig o nit laciniae lineares obtasae, aequales, intus convexae, tabum postice gibbum paullo superantes.

I s o m e $\mathrm{r}$ i u m R. Brown suppl. 11.

2133. Stirlingina. Perigonium regulare, tetraphyllum, unguibns cohaerentibus, laminis reflexis. Stamina 4 , perigonii foliolis supra medium inserta, exserta; fil a m en $t$ a eomplanata, geniculata, omnia fertilia; a nt herae bilebae, primum cohaerentes, vicinarum lobis contiguis synantherii quadrilocularis loculum unum constituentibus, tandem discretae. Squamulae hypogynae nullae. Ovari am obconieum, uniloculare, uniovulatum. Stylus filiformis; st igma dilatatum, coneavum. Nux obconica, monosperma, pilosa. - Frutices Novae Hollándiae meridionalis humiles, glabri; foliis alternis, filiformibus, repetito-dichotomis, laciniis aversis, glandulis cutaneis amphigenis, peliolorum basi dilatata, capilulis globosis, parvis, terminalibus, racemosis v. paniculatis, involucro brevi $v$. nullo, floribus flavis, glabris.

Sims ia R. Brown in Linn, Transact, X, 155. Prodr. 369. Suppl. 9.

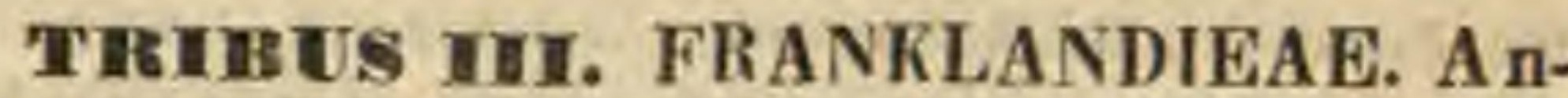
therae tubo perigenii hypocrateriformis adnatae. Ova ri um uniloculare. Nux. - Flo. res spicati.

2134. Frnaklamalia $R$. BR. Perigonin mypocrateriforme, limbi quadrifidi decidui laciniis destivatione induplicatis, tubi hasi persistente. St a mina 4 , medio tubo inserta, inclusa, limbi laciniis opposita; filamentis antheris$q \mathrm{q}$ e linearibus longitudinaliter perigonio arete adnatis. S q $\mathbf{u}$ a $\mathbf{m}$ a la e 4 perigynae, basi in vaginulam tubo inferne aceretam connatae. Ovarium fusiforme, nniloculare, uniovulatum. Stylus filiformis; stig ma turbinatum. Nux fusiformis, pedicellata, monosperma, tubi basi persistente stipata, apice dilatato papposa. - Frutex Novae Hollandiae austro-oceidentalis, humilis, glaber, glandulis aurantiacis pustilliformibus undique conspersus; foliis alternis, filiformibus, dichotomis, laciniis aversis, spicis axillaribus indivisis, floribus alternis, unibracteatis, serdide flavis.

Franklandia R. Brown in Linn. Transaet, X, 157. Prodr. 370. Gen, Rem, 604, t. 6. Suppl, 11.

ThinUs Iv. PERSOONIEAE. S tam in a saepius medio v. basi foliolorum perigonii inserta, rarissime hypogyna. Ovarium unibiovulatum. Nux, S a mara v. Drupa monosperma, rarissime disperma. - Flores spicati.

9135. Symplnyouema $R, B R$. Perigon i m tetraphyllnm, regulare, foliolis basi cohaerentibus. St am in a 4 , medio foliolorum perigonii inserta; $f$ i l a m e $n t$ a apice inter se cohaerentia; a nthera e distinctae. Gland $\mathbf{u}$ la e hypogynae nullae. 0 v a ri u m sessile, uniloculare, biovulatum.S t yI 8 filiformis. Stigma subtruncatum. Nux monosperma, eylindracea. - Suffrutices $v$. herbae, in Nova Hollandia orientali provenientes, glabrae v. parce glanduloso-pilosae; foliis inferioribus oppositis, superioribus alternis, omnibus tripartitis, lobis divisis, glandulis cutaneis hypogenis, spicis terminalibus et e summis foliorum alis simplicibus, floribus alternis, sessilibus, unibracteatis, perigonio flavo, deciduo, bracteis cucullatis, persistentibus.

S y m p h y on ema R. Brown in Linn. Transact. X. 157. Prodr, 370. Suppt. 11. Reicheab. Hort. Bot, t. $10 \%$.

2136. Agastaehys $R$, BR. Perigoni um teiraphyllum, regulare, foliolis basi cohaerentibus. S i a m ina 4 , medio foliolorum perigonii inserta; filamenta distincta. GI an d u I a e hypogynaenullae. Ovari um sessile, trigonum, niloculare, uniovulatum. Sty lus filiformis; stig ma bilobum. Fruetus ..... - Frutex insulae $D i$ e me n glaberrimus; foliis sparsis, integerrimis, planis, glandulis cutaneis hypogenis, spicis plurimis, terminalibus et e summis foliorum alis, floribus al. ternis, sessilibus, unibracteatis, perigonio flavescente, deciduo, stylo staminibus breviore, bracteis cucullatis, persistentibus.

A gastachys R. Browa in Linn. Transace. $x$. 158. Pradr. 371, Suppl, 11 .

213\%. Cenarnhenes $L A B L L A R D$. Perigonium tetraphyllum, regulare, foliolis apice 
angustatis. Stamina 4, basi perigonii inserta, distincta. Glandula e 4 hypogynae, staminulifurmes. O varin m sessile, uniloculare, uniovulatum. Sty las filiformis; stigma simplex. Drup a baceata, monosperma. - Arbor insulae Diemen glabra; foliis alternis, planis, dentate-serratis, nitidis, glandulis cutaneis hypogenis, spicis axillaribus, simplicibus, floribus alternis, sessilibus, unibracteatis, perigonio deciduo.

Ce a r r henes Labillard, Nov, Holl, $I, 36$. $t$. 50. Jus sieu in Annal du Mns. $V$. 224. R. Brown in Linn. Trans act. X. 158. Prodr. 371, Suppl, 12.

OBSERVAT10. Generibus praecedentibus affinis videtur stirps madagascarieasis, uon satis nota, a. cl. Thouars ad Laurineas relata

POTAMBLA Thouar. Perigonium ureeolatum, quadrilobnm. Sta m in a 4, lobis perigonit aftixa; filame n ta brevia, lata; antherae loeulis distinetis. G landulae hy. pogyaae 4 , subrotundae. 0 varium simplex. Stylus subnullus. D r u p ovata, versus basim attenuata, monosperma, putamine fragili. E mbryo exalbuminosus; cotyled o n i. bus crassis; radieula laterali, infera. - Frutex in $i n$. ula Madagascar secundum amnes crescens, expansus; ramis erectis, foliis alternis, lineari-lanceolatis, floribus axillaribus paniculatis, parvis, globulosic.

Pot a me ia Thouars Gen, madagase, n. 16.

2138. Persoomin SMITH. Perigonium tetraphyllum, regulare, foliolis supra recurvis. Stam in a 4, medio foliolorum perigonii inserta, exserta. Glandula e 4 hypogynae. Ovariu m stipitatum, uniloculare, uni-biovulatum. S tylus filiformis; stigma obtusum. D rupa baccata, putamine uni-biloculari, mono-disperma.

Frutices varbusculae Novae Hollandiae, cortice in quibusdam scarioso-lamelloso; foliis sparsis, integerrimis, planis, glandalis cutaneis amphigenis, pedunculis axillaribus, solitariis, ebracteatis, $v$. racemosis unibracteatis, floribus flavis, stipitulo ovarii in nonnullis articulato, cotyledonibus saepe pluribus.

Persoonia Smith in Linn. Transact, IV. 215. Exot. Bot. II, 2, 83. R. Brown in Linn, Transact, X, 160. Prodr. 571. Suppl. 12. Labillard. Nov. Holl, t. 45. Veat. Malm. t. 32. Audr. Bot, Reposit, t, 74. 77, 208. Bot. Mag, $t, 760$. Gartn. f. $I I I$. 218. $t$, 220. Pe n t a da c ty 1 on Gärtn. $l$. c. L i $\mathrm{k}$ ia Cavanilles IC. IV. 61, t. 389.

\& 139 . Brabeimm LINN. Perigonium tetraphyllum, regulare. St a $\mathrm{m}$ in a 4 , basi perigonii inserta. S qua mulae hypogynae in vaginulam connatae. Ovari um sessile, uniloculare, uniovulatum. Sty lus filiformis; stig ma verticale. Drup a exsucea, monosperma, putamine osseo. - Arbor capensis; foliis verticillatis, serrato-dentatis, spicis axillaribus, floribus fasciculatis ternis v. pluribus, bractea communi sublensis, plerisque ovario efoeto masculis.

B rabelam Linn, Mant. 168. Jussieu gen, 79. Lam. 2. 8*7. R. Brown in Linn, Transact, $x, 164$, B r a b y 1 a Lian. Mant. 137.

2140. Gaevinia MOLIN. Perigonium tetraphyllum, irregulare, foliolis tribus revolntis, quarto erecte. An th er a e 4 , apicibus concavis foliolorum perigonii immersae. Gland u la e 2 hypogynae, anticae. Ovarium uniloculare, biovulatum. Stylas filiformis; stigma obliquum. Drapa monosperma, putamine usseo. Arbor chilensis; folis alternis, pinnatis, racemis axillaribus, floribus geminis, pedicellatis, paribus unibracteatis, perigonio tomentoso, deciduo, drupa parum carnosa, nucleo amygdalino.

G uevin ia Molina Chil, 198. Jussien gen. 424. R. Brown in Linn. Transact. X. 165. Esehholtz in Mein. Academ, Petropolit. X. 281. Q u a d ri a Ruiz et Pavou Prodr. 10, $t, 33$. Flor. Peruv, I. 63, t, 99, f. 6. Gärtu, f. III, 290. t. 220. Nebu Feailléc Observ. III, 46. $t, 83$.
214 1. Belleademia $R, B R$. Perigon i $\mathbf{m}$ tetraphyllum, regulare, patens. S $t$ a m ina 4, hypogyna. GIand ulac hypogynae nullae. Ovarium stipitatum, uniloculare, uniovulatum. Stylus filiformis; stigma simplex. Sa mara aptera, mono-disperma. - Frutex in ins u la Diemen monticolus, glaberrimus; foliis planis, sparsis, apice trifidis, glandulis cutaneis amphigenis, spica racemosa, terminali, floribus sparsis, raro geminatis, perigonio albo, cito deciduo, ovario cum pedicello arliculato, samara colorata, margine altero sul cata

Bellende $n$ I a R. Brown in Linn. Transact, $X, 166$. 374. Supplem, 16, Guillemin Ic. lithogr. $t, 7$.

SUR OIRDA II. FOLLICULARES. Folliculus, coriaceus v. ligneus, mono-polyspermus.

TIRIEUS I. GREVILLEAE. O v a r i u m uniloculare. Folli cul us unilocularis, monopolyspermus.

\section{SUITTEIBUS . HAKEAEAE. $0 \mathrm{v}$ a-} ri um bi-quadriovulatum. Fructus monotetraspermus.

214\%. Anadenia R. BR. Perigonium tetraphyllum, foliolis subspathulatis, patentiuscalis. Antherae 4, foliolorum perigonii apicibns concavis immersae. Gland ulae hypogynae nullae. Ovari u m stipitatum, uniloculare, biovulatum. Sty l us declinatus; stigma conicum. Folli cuI s coriaceus, abortu monospermus. Sem en apterum. - Frutices Novae Hollandiae australis, glabri v. pube medio affixa vestiti; foliis pinnatijidis $v$. lobatis, circumscriptione cuneiformibus, glandulis cutaneis hypogenis, spicis terminalibus $v$. lateralibus, floribus parvulis, geminatis, paribus unibracteatis, summis quandoque praecocibus.

A nade a ia R. Browa in Linn. Transact, X, 165. Prodr. 374. Suppl. 16.

2143. Grevillea $R$. BR. Perigonium tetraphyllum v. quadripartitum, irregulare, laeiniis subspatholatis, secundis, revolutis. Anth e r a e 4, laciniarum apicibus concavis immersae. G I a nd ula hypogyna uniea, dimidiata, Ovarium sessile $v$. stipitatum, uniloculare, biovulatum. Stylus adscendens; stigin a obliquum depressum, v. subverticale conicum. Follic ulus coriaceus v. ligneus, unilocularis, dispermus. $\mathbf{S}$ e $\mathrm{m}$ in a marginata v. apice brevissime alata. - Frutices v. arbores per omnem Novam Holla ndiam observati, pube dum adest medio afjixu; foliis alternis, indivisis $v$. pinnatifidis bipinnatifidisque, glandulis cutaneis hypogenis $v$, rarius amphigenis, spicis nunc elongatis, racemosis, nunc abbreviatis, corymbosis $v$. fasciculiformibus, pedicellis geminatis, raro pluribus, paribus fasciculisve unibracteatis, perigoniis rubicundis $v$. flavis, in nonnullis oblique insertis.

Greville a R. Brown in Linn. Transact, X. 168, Prodr. 375. Suppl, 17.

a. LISSOSTYLIS $R, B r$, O va ri u m sessile v. stipitatut. Stylus glaber. Stig ma obliquum. Follie ulus co. riaceus, ecostatus, stylo stigmateque superatus. Semiu a ovalia, angustissime marginata, apice brevissime alata. - Folia integerrima, rarissime juniora pinnatifida, in plerisque marginibus refractis $v$. replicatis pseudo. trinervia. Flores fasciculati $v$, in racemo abbreviato.

Lissostylis R. Browu prodr. 376. Embothrii s. Smith Nov. Holland, t. 9. Cavanilles Ic, $t, 386$. Andr. Bot. Reposit, t. 272. L y s s a $n$ the Knight et Salisb. Prot. 118. part. (Bot. Reg, t. 1089, 1319. 1383, Guillem. 
Ic. lithogr. t. 8. Reicheab. Hort, Bot. t. 104. Sweet Flor. Austral. $t, 7$.

h. PTYCHOCARPA $\boldsymbol{R}$. Br. Ovarium sessile. Stylus hirsutus; stigma obliquam. Follicul u s coriacens costatus, stylo stigurateque superatus. S e m fua ovalia angustissime marghata, apice brevissime alata. - Folia omnia i tegerrima. Flores fasciculati v, in racemo ab. breviato, superiores praecociores.

Pty chocarpa R. Browa prodr. 378. L y s s a 1 the Kuiglit et Salisb. Prot, 117, part. (Hooker Exot. Flor. 1. 216. Sweet Flor. Austral, t. 30. Bot. Mag. t. 3185. 3285.)

c. ERIOSTYLIS R. Br. Ovarium stipitatum, lanatum. Stylus hirtus; stigma obliquam. Follieulus coriaceus, ecostatus, stylo stigmateque superatus. S e miIn a ovalia, augustissime marginata, apice bresissime ala. ta. - Folia omnia integerrima. Flores fasciculati, subumbellati.

Eriosty lis R. Brown prodr. 378. Stylurus Kuight et Sulisb. Prot, 115. 116. E m b o th rii sp. Suitl Nov. Holl, t.10. Cavanilles Ic. t.387. Andr. Bot. Rep. t. 218.

d. PLAGIOPODA $R$. Rr. O va $\mathrm{ri}$ u m stipitatum, stipitulo peduncul. apici obliquo, cui utringue dno perigonit foliola, unum supra alterua inserta aeretus. Stig m a obliquum. Folliculas coriacens, ecostatus, st y lo stigmateque superatus. S emina ovalia, angustissime marginata, apice brevissime alata, - Folia integerrima $v$. pinnatifida. Hacemus thyrsiformis.

Plag iopoda R. Brown prodr. 379. (Guillem. Ic. lithogr. t. 11. 16.)

e. CONogyne $R, B r$. O varfum stipitatum. Stigma verticale, conicum. Follicul us coriaceus..... Folia triternata.

Conogyne R. Browu Suppl. 21. Auadeniae sp. A. Cuuningh.

f. CALOTHYRSUS $R . B r$. O varium sessile v, stipitatun. Stig ma obliquum. Folliculus ecostatus, stylo stig. mateqne superatus. S e a in a ovalia, angustissime marginata, apice brevissime alata. - Folia pinnatifida, ra. rius passim indivisa. Racemus thrsiformis.

Ca lo thy rsu s R. Browa in Linn. Transact. X. 175. Greville a stricte sic dicta R. Browu prod. 379. (Ferd. Bauer Illustr. t. 9. Bot. Mag, t. 2807. 3133. Gaudich. ad Freyc. $\ell$. 46.

g. CYCLOPTERA $R$. Br. O varín m sessile v. stipitatum. Stig ma obliquum v, verticale, truncatum aut conicum. Folliculus ligneus, subrotundus. Semia undique latius alata. - Folia integerrima, pinnata bipinnatifidave. Racemi thyrsoidei.

Cy cl optera R. Browuprodr, 381. (Bot. Mag.t.3184.)

2144. Hilkea SCHR $A D$. Perigonium tetraphyllum, irregulare, foliolis subspathulatis, secundis. Anther a e 4 , foliolorum perigonii apicibus coneavis immersae. Glandula bypogyna unica, dimidiata, rarissime biloba. Ovarium stipitatum, uniloculare, biovulatum. S t y $\mathbf{l}$ s adscendens; stigma subobliquum, e basi dilatata mucronatum. Folli culu s ligneus, pseudobivalvis, excentrice unilocularis, dispermus. Semin a apice in alam nueleo longiorem producta. - Frutices rigidi, v, interdum arbores mediocres, in Nova Holiandia extratropica obvii, inter tropicos rarissimi, pube dum adest medio affixa; foliis sparsis, variis, in eadem stirpe diversis, glardulis cutaneis amphigenis, fasciculis v. racemulis saepissime axillaribus, gemmae floriferae squamis scariosis, caducis primum involucratis, pedicellis coloratis, in racemosis geminatis, paribus unibracteatis, floribus parvis, albis $v$. ochroleucis.

H a k a Schrader Sert. Hannover, 27, t. 17. Cavanilles Ic, 6. 24, t. 333-535. Labillard. Nov. Holland, t, 40. 41, R. Brown in Linn. Transact, X, 178, Prodr. 381. Suppl. 25. Bot. Mag. $t$, 2446, 2579, 3424. Bot. Reg. $t, 1489$. Sweet Flor Australas, $t, 27,43,45$. Con ch in in Smith in Linn, Transact, IV. 215. Ventenat Malmaís, t. 110. 111. Gärta. f. III 216. $t$, 219. E mbothrif 8 p. Andr. Bot. Reposit, t. 2L5. Banks iae sp. Smilh. Gärti, 1, 221. t, 47, f. 2, L a m b e rti a e s p. Gärtn. f, ITK, $t, 217$,

2145. Lambertia SMITH. Perigon i n tubulosum, quadrifidum, laciniis spiraliter revolutis. Stam ina 4 , perigonii laciniis iaserta, exserta. G land ula e hypogynae 4 , distinetae v. in vaginulam connatae. $O$ varium stipitatum, unileculare, biovulatum. Stylas filiformis; stigma subulatum. Follicu I us coriaceo-ligneus, apice hine cuspidatus, inde bicornis v. mutieus, unilocularis, dispermus. Se in in a marginata. - Frutices speciosissimi, in Nova Hollandia extratropica viventes; ramis verticillatis, foliis ternis, saepius integerrimis, glandulis cutaneis hypogenis, floribus terminalibus involucrutis, involucris solitariis, coloratis, imbricatis, unifloris v. plerumque septemfloris, deciduis, receptaculo plano, nudo.

L a mbertia Smith in Linn, Transact. IV. 214. t, 20. Cavauilles Ic, VI. 31. t. 547. R. Brown in Linn, Trans. act, X, 188. Prodr. 386. Suppl, 30. Prote a nectarina Weadl. Sert. IV. 5. t. 21.

2146. Xyloma elana SMITH. P e rigonin m tetraphyllum, regulare, foliolis subspatiulatis, apice revolutis. St a m in a 4 , perigonii foliolis infra apieem inserta, iisque recurvatis exserta. Glandulae hypogynae 4 , distinctae. Ovari um stipitatum, uniloculare, biovulatum. Stylus filiformis, deciduus; stigma verticale, clavatum, obtusum. Follic ulus incrassato-lignens, olpyriformis, excentrice unilocularis, dispermus. S $\mathrm{mi}$ n a apice in alam elongatam producta. - Arbores Novae Hollandiae extratropicae; foliis oppositis, junioribus dentatis, adultis integerrimis, glandulis cutaneis amphigenis $v$. hypogenis, spicis axillaribus, oppositis, amentaceis, florum paribus uni. bracteatis, infimis hermaphroditis, superiorum ovario efoeto, folliculo unico maturescente, tomentoso, crassissimo, intus sutura dehiscente, tandem partibili.

$\mathrm{X}$ ylomelum Smith in Linn. Transact, IV. 214. R. Brown I6id. X. 189. Prodr. 357. Suppl. 31. B a a ks i a pyrif or mis. Gärto. 1.220, $t, 47, f .1$, Hakea py riformis Cavan. IC. VI, 25. $t .836$.

214\%. Drites R. BR. Perigonium tetraphyllum, regulare, foliis subspathulatis, apice recurvis. St a mina 4 , perigonii foliolis infra apicem inserta, iisdem recurvatis exserta. G l a n d ula e hypogynae 4, distinctae, Ovari um sessile, uniloculare, biovulatum. Stylus strictus; stig ma verticale, obtnsum. Folliculas coriaceus, unilocularis, loculo subcentrali, dispermo. Se mi$\mathbf{n}$ a apice $\mathbf{v}$, utrinque in alam membranaceam produeta. - Frutices in Nova Hollandia orientali et in insula Diemen monticoli; foliis alternis, planis, integerrimis aut dentatis, v. teretibus supra sulcatis, spicis axillaribus v. terminalibus brevibus, florum paribus unibracteatis, omnibus hermaphroditis.

Orites R. Brown in Linn. Transach X, 189. Prodr. 387. Suppl. 31 .

a. ORITES $R \cdot B r$. A ntherae exsertae. Semina apice alata. - Folia plana, glandulis culaneis hypogenis.

Orites R. Browa prodr. 287. A. Rich. Sert. Aetrol. t. 2s. $f .2$.

b. AMPHIDERRIS $\boldsymbol{R}, \boldsymbol{B r}$. A a th era e laminis foliolorum perigonii inclusae. S е mi n a ntriaque alata. - Folia te. retia, superne suleata, undique glandulifera.

A mphideris R. Brown Suppl. 32. 0ritina R. Brown in Linn. Trans, X, 224. (A. Ruchard $l, c, t, 25 . f, 1$. )

2148. Thegala $A U B L$. Perigonium tetraphyllum, regulare, foliolis apice revolutis. St a m ina 4, perigonii foliolis supra medium inserta, iisque recurvatis exserta, $v$, apicibus concavis immersa. G I a n d $\mathbf{u}$ la e hypogynae $\mathbf{k}$, distinetac. Ovarium uniloeulare, biovulatum. Stylne fili formis, persistens; stigma verticale clavatum. Folliculus ligneu-coriacens, unilacularis, dispermus. Semina utrinque alata, marginata, nu- 
cleo centrali. - Arbores a mericanae tropicae; foliis alternis, rariusve verticillatis, simplicibus, integrerrimis $v$. dentatis, rarius pinnatis $v$, ternatis in eodem ramo, spicis axillaribus v, interdum terminalibus, racemosis, florum paribus unibracteatis.

$\mathrm{R}$ ho p al a Schreb. gen, n, 144. R. Brown in Linn, Trans. act. X. 190. excl. sp. Kunth in Humb. et Bonpl. Nov. Ben. et sp. t. 118_120. Pohl Plant. Brasil, t. 86_90. Ro u p a l a Aublet Guian, 1, 83. t, 32. Lam. t. 35. Gärtn. f. III, 212. t. 217. L e i nkeria $\mathrm{S}$ copoli Introduct, n, 1607. Dicknekar la Flor. Flum. I. t. 105. E mbothrii sp. Ruiz et Pav. Flor. Peruv, $t, 98,99$.

2149. Andripetalum SCHOTT. P erigon i $\mathbf{m}$ tetraphyllum, regulare, foliolis apice revolutis. St a $\mathrm{m}$ in a 4 , imo perigonio inserta, filamentis lineari-complanatis, perigonii foliola aequantibus. Gland u l a e 4 hypogynae, inter se connatae. Ovarium uniloculare, biovulatum. St y lus filiformis; 8 tig ma verticale, clavatum. Folliculus ...... - Arbores brasilienses; foliis alternis, integerrimis, spicis axillaribus racemosis, florum paribus unibracteatis.

Andripetal am Schott msc, Andriapetalum Pohl Plant. Brasil. $t .91 .92$ Rhopalae \&p. Kunth $t, 121$.

9150. IIelieia LOUREIR. P e rig on i m tetraphyllum, regulare, foliolis subspathulatis, apice revolutis. St a m in a 4 , perigonii foliolis infra apicem inserta, iisdem revolutis exserta. Glandula e hypogynae 4 , distinetae v. connatae. O vari u m stipitatum, uniloculare, biovulatum, ovulis adscendentibus. Stylus filiformis; stigma clavatum, aequilaterum. Foll i e u l u s coriaceo-lignosus, unilocularis, indehiscens (?) abortu monospermus. Sem en subglobosum, apterum. - Frutices v. arbores Asiae tropicae terram continentem et insulas decorantes; foliis alternis, simplicibus, integerrimis $v$. plerumque dentatis, racemis simplicibus, axillaribus lateralibusve, florum paribus unibracteatis, omnibus hermaphroditis.

Helicia Lourciro Flor, cochinch. I, 105. R. Brown Suppl. 32. Blume in Nouv. Annal. sc, nat. T. 214. non Pers. Helit op hy 11 um Blume Bijdr, 652. R hopalae sp. as iatica e Roxb. R. Brown olim.

2151. Knigintia $R$. BR. Perigonium tetraphyllum, regulare, foliolis subspathulatis, apice revolutis. St a mina 4 , perigonii foliolis infra apicem inserta, iisdem revolutis exserta. 0 v arium sessile, uniloculare, quadriovulatum. StyI $\mathbf{s}$ filiformis; stigma verticale, subclavatum. Folli culus coriaceus, stylo mucronatus, unilocularis, tetraspermus. Semina apice in alam arachnoideam producta. - Arbor Novae Zeel andia e excelsa; foliis sparsis, serratis, racemis axillaribus, floribus geminatis, paribus unibracteatis, folliculis oblongis, tomentosis.

$\mathrm{K}$ a ig hti a R. Brown in Linn. Transact, X, 103. $t, 2$, Congener ex R. Brown Suppl. 32, sed sectionem propriam (E uca $\mathrm{p} p \mathrm{~h}$ a) ob bracteas maximas, stylum deeidum et fortassis etiam seminum structuram efformans: $\mathrm{E} m$ b o $t \mathrm{~b} r i \mathrm{u} m \mathrm{~s} t \mathrm{ro}$. b 111 a u m Labillard. Nov. Holland, H1, 116, $t, 265$.

SUETIRIBUS II. EMBOTHRIEAE. 0 v ari u m multiovulatum. Fru ctus polyspermus.

215\%. Funbothrium FORST. Perigo$\mathrm{n}$ iu $\mathrm{m}$ irregulare, hinc longitudinaliter fissum, apice quadrifidum. Stam in a 4 , perigonii apicibus concavis immersa. Glandula hypogyna unica, semiannularis. Ovari um pedicellatum, uniloculare, multiovnlatum. S t ylu s filiformis, persistens; 8 tig in a verticale, elavatum. Follicul ns oblongus, unilocnlaris, polyspermus. S $\mathrm{em}$ in a apice in alam arachnoideam prodncta, pellicula interposita distincta. - Frutices v, arbusculae glabrae, in $\mathrm{A} \mathrm{m} \mathrm{e-}$ rica antarctica provenienles; ramulis quandoque gemmarum squamis persistentibus obsitis, foliis sparsis, integerrimis, racemis terminalibus, corymbosis, paribus pedicellorum unibracteatis, involucro communi nullo, floribus coccineis, glaberrimis.

$\mathrm{E} \mathrm{mb}$ o th ri um Forster Gen, 16, t, 8, lit, g, m. excl. reliq. Lam. t. 55. $f$. 2. Ruiz et Pav. Flor, peruv, $t, 96 . \mathrm{R}$. Brown in Linn. Transact. X. 195.

2153. Dreocallis R. BR. Perigonium irregulare, hine longitudinaliter fissum, apice quadridentatum. Stam in a 4 , perigonii apicibus concavis immersa. Glandula hypogyna nulla. Ovari nm pedicellatum, uniloculare, multiovulatum. Stylus filiformis; stigma obliquum, orbienlatodilatatum, concaviuseulum. Folliculus cylindraceus, unilocularis, polyspermus. Se min a apice in alam membranaceam producta. - Frutex speciosus, in Peruvia monticola; foliis sparsis, integris, subtus discoloribus, racemo thyrsoideo, terminali, exinvolucrato, paribus pedicellorum unibracteatis, floribus coccineis, glaberrimis.

Ore ocallis R. Brown in Linn, Transact. X. 196. Em. b oth rium emarginat am Ruiz et Pav. Flor. peruv, t. 95.

2154. Telopea $R$. BR. Perigonium irregulare, hinc longitudinaliter fissum, apice quadrifidum. St a m in a 4 , perigonii apicibus concavis immersa. Glandula hypogyna unica, semiannnlaris, $\mathbf{O}$ variu nu pedicellatum, polyspermum. StyI 8 filiformis, persistens; st $\mathrm{i}$ g m a obliquum, clavatum, convexum. F olli $\mathrm{c}$ I u s cylindracens, unilocularis, polyspermus. Semina apice in alam arachnoideam, hine immarginatam, inde vasculosam producta, membrana interposita sejuncta. - Frutices Novae Hollandiae orientalis et insusula e $D$ i emen; foliis sparsis, dentatis v, integris, glandulis cutaneis hypogenis, racemis terminalibus corymbosis, involucro imbricato, deciduo cinctis, paribus pedicellorum unibracteat is, floribus coccineis.

Telope a R. Brown in Linn. Transact. X. 197. Prodr. 388. Suppl. 32. Bot. Reg. t. 1128. H y log y ne Knight et Salisb. Proteac. 126. $\mathrm{E}$ m b o th $\mathrm{r}$ il $\mathrm{s}$. Smith Nov. Holland. t. 7. Bot. Mag. t. 1128. Gärtn. f, III. t. 218. fig. super. Cavan. Ic, t. 388. Labillard. Nov. Holland, $t$. 44.

2155. Homatia R. BR. Perigonium irregulare, tetraphyllum, foliolis ovatis, secundis. S $t$ a $m$ in a 4 , apicibus concavis foliolorum perigonii immersa. G I and ula e hypogynac 3 , secundae. Ova $\mathbf{r}$ i m pedicellatum, multiovulatum. Sty $\mathbf{l n}$ s filiformis, persistens; stigma obliquum, dilatatum, subrotundum, planiusculum. Foll i e nlus ovali-oblongus, unilocularis, polyspermus. S e mi$\mathrm{n}$ a apice in alam arachnoideam marginatam, disco evasculosam producta, v. utrinque alata, pellieula interposita sejuncta. - Frutices in Nova Hollandia et inAmericae australis extratropicae littore occidentali indigeni; foliis alternis, pinnatifidis bipinnatifidisve, rarius integris, dentatis, quandoque integerrimis, nonnunquam in eadem stirpe variis, glandulis cutaneis hypogenis, racemis terminalibus $v$. interdum axillaribus, elongatis, laxis, aut abbreviatis corymbosis, exinvolucratis, pedicellorum paribus unibracteatis, floribus ochroleucis.

L o m a tia R. Brown in Linn. Transact. X. 199. Prodr. 389. Suppl. 33.

a. EULOMATIA. S e m in a apice alata, nucleus farina sulphurea conspersus. - Novac Hollandiae.

Tric ond y l us Knight et Salisb. Prot. $121, \mathrm{E} \mathrm{mb}$ oth rif s p. Labillard. Nov, Holland. t, 42. 43. Gärtn. f. III. $t$. 218. fig. infer. (Bot. Reg. t. 1272.)

b. AMPHiloma. Semin a utrinque alata, nucleus nudus. - Chilenses.

E nibothrii sp. Cavanilles Ic. t. 385. Ruiz et Pav. Flor, peruv, $t, 94, a, 97$. 
2158. Stenoearpus $R$. BR. Perigon i m irregulare, tetraphyllum, foliolis secundis. S $t$ a $\mathbf{m}$ in a 4 , apicibus coneavis foliolorum perigonii immersa. Glandula hypogyna unica, semiannularis Ovarium pedicellatum, uniloculare, multiovulatum. St y l a s filiformis, deciduus; s t i gma obliquum, orbiculato-dilatatum, planinsculum. Folliculus lincaris, unilocularis, polyspermus. Semina basi in alam arachnoideam producta, pellicula interposita sejuncta. - Frutices glaberrimi, in Nova Hollandia orientali et in Nova Caledonia indigeni; foliis alternis, integerrimis, glandulis cutaneis hypogenis, umbellis axillaribus v. terminalibus pedunculatis, exinvolucratis, floribus ochroleucis.

Stenocarpus R. Brown in tinn. Transact. X, 201. Prodr. 390. Suppl. 34. Labillard Nov. Caled, t, 26. C y b e le Knight et Salisb. Prot. 123.

TIRIBES II. BANKSIEAE. Ovari u m uniloculare, biovulatum. Folli c u 1 u s bilocularis, seminum collateralium testis in dissepimentum liberum ligneum bifidum concretis.

215\%. IBambia LINN, FIL. Flores in amentum exinvolucratum collecti, paribus tribracteatis. Pcrigonium quadripartitum v. quadrifidum. St a min a 4 , apicibus coneavis laciniarum perigonii immersa Squamula e hypogynae 4 . Ovarinm uniloculare. Ovula 2 , collateralia, supra medium marginis affixa, priminae latere exteriore longitudinaliter fisso, nucleum nudante. Stylns filiformis; stig ma elavatum. Folliculus ligneus, bilocularis, ovulorum priminis in dissepimentum ligneum libernm bipartibile concretis. S em in a 2 , utrinque dissepimenti basi excavatae adplicita, superne in alam cuncatan producta. - Frutices v. arbores mediocres, in Nova Hollandia extratropica passim obviae, in littore intratropico rarissimae; ramis umbellatis, foliis sparsis, raro verticillatis, integris, serratis $v$, pinnatifidoincisis, in eadem stirpe saepe variis, glandulis cutaneis hypogenis, amentis solitariis, terminalibus $v$. raro lateralibus, cylindraceis $v$. interdum abbreviatis, bracteis aliquot brevibus, angustis subtensis, florum bracteis persistentibus majoribus solitariis, minoribus geminatis, collateralibus, interioribus, amenti fructiferi rhachi ut plurimum incrassata, et cum folliculorum basibus conferruminata.

B anks i a Linn. fil. Suppl. 127. Gärtn. I. 221. R. Brown in Linn, Transact, X. 202. Prodr. 391. Suppl, 34.

a. BANKSIAE VERAR $\boldsymbol{B}$. Br. Stylus perigonio longior, hine anguibus eitius solutis basi areuatus; stig mate laminis serius dehiscentibus incluso.-Amentum florife. rum cylindraceum, fructiferum folliculis transversis pluribus.

Banks i a e verae R. Brown l. c. (Gärtn. t. 221. Cavanilles I0. t, 537. 566. Smith New Holl. I. t, 4. Wendl. Hort. Herrenh. t. 8. Labillard. Voy, t. 23. Banpl. Na. varr. $t$, 48. Bot, Mag. t. 2270, 2803. 3052. 3060. 3120. 3535. Bot. Reg. .2. 1316. 1363. 1430, 1572, 1728. Hooker Exot. Flor, $t$,96. Sweet Flor. Austral, t. 14. 56.)

b. ISOSTYLIS $R . B r$. Stylus perigonio paullo brevior, laminis citius dehiscentibus, uegaibas Iongitudinaliter colnaereatibns exsertus. - Amentum foriferum abbre. viatum, floribus subfastigiatis, frucliferum folliculo verticali subsolitario v, inlerdum transversis pluribus, Is ostylis R. Brown $t$. c. Banksia ilieifolia R. Brown.

2158. Dryandier $R$. $B R$. F lores supra receptaeulum planum, involucro polyphyllo imbricato cinctum indeterminatim ennferti, paleis angustis rariusve nullis. P e rigo n i m quadripartitum v. quadrifidum Stamina 4, apicibus concavis laciniarum perigonii immersa. Squa mula e hypogynae 4. Ovari um uniloculare. Ovula 2 , col- lateralia, supra medium marginis affixa. Stylus filiformis; stigma clavatum. Folliculus ligneus, ovulorum priminis in dissepimentum liberum membranaceum bipartibile concrescentibus bilocalaris, vel iisdem leviter cohaerentibus unilocularis. Semin a 2, apice in alam produeta. - Frutices plerumque humiles, in Novae Hollandiae or a a us trali provenientes, ramis dum adsunt sparsis $v$. umbellatis; foliis sparsis, pinnatifidis $v$. incisis, glandulis cutaneis hypogenis, involucris solitariis terminalibus, raro lateralibus, sessilibus, foliis confertis, interioribus quandoque nanis obvallatis, hemisphaericis, bracteis adpressis, nonnunquam apice appendiculatis.

D ry a nd r a R. Brown in Linn. Transact, $x$. 211. Prodr. 396. Suppl, 37. Jo s e phia Knight et Salisb. Prot. 110,

a. DIPLOPHRAGMA $R$. $B r$. D is e pi ine u $\mathrm{t} u$ m e laminis membranaceis duabus planis, separabilibus, quibus extus s e mi n a conformia, apice in alam membranacenm persistentem prodaeta applicita sunt.

Diplophragma R. Brown Suppl, 37. (R. Brown in Linn. Transaet. t. 3. Bot. Mag. 4. 3236, 3500, 3509. 3513. Sweet Flor, Austral. t, 3, 33.) B a nksia e sp. Labillard. Voy. $t$. 24.

b. APHRAGMA $n, B r$. D is sepiment um nullum, se min a leviter cohaerentia, apice in alam arachnoideam per. sistentem producta, ala e stratis binis solubilibus, inte. riori membranaceo pellueido, exteriore crustaceo.

A phragma R. Brown Suppl. 3\%, Dryandra ner. vosa R. Brawa. Sweet Flor. Austral. t. 22. Bot. Mag. t. 3063 .

2159. Tremielidia $R, B R$, Flo res supra receptaculum planum, involucro polyphyllo imbricato cinctum indeterminatim conferti, paleis angustis. Perigon i um quadrifidnm. St a m ina 4, apicibns concavis laciniarum perigonii immersa. Squa mula e hypogynae 4 . Ovarium uniloeulare. 0 vula 2 , collateralia, snpra medium marginis affixa. Sty l a s filiformis; $8 \mathrm{tigma}$ clavatum. Fruetus suberustacens, undique barbatus, hine apice dehiscens, inde rumpens, ovulorum priminis in dissepimentum arachnoideo-membranaceum haud bipartibile coneretis bilocularis. S e m e $\mathbf{n}$ maturum unicum, ventricosnm, apterum, a dissepimento illine cum ovalo abortivo basi alato cohaerente solutum. - Frutex Novae Hollandiac meridionalis, habitu omnino Dryandrae, erectus, ramosissimus; foliis pinnatifidis, lobis mucronatis, pungenfibus, glandulis cutaneis hypogenis, involucris terminalibus solitariis, foliis confertis, interioribus nanis obvallatis.

Hemiclidia R. Brown Suppl. 40. Bot. Reg. t. 1475. Dryandra fa l e a $t$ a R. Browa prodr. 397.

OBSERVAT10. Geaus eochinchinense, summopere dubfum, ab auctoribus ad Proteaceas relatum, e senteatia Königii ( $\mathrm{An}$. nal. of Bot, I. 399) ab Dlea non diversum (efr. tamen R. Brown in Iinn. Transact. $X$, 224.) est:

CYLINDRIA Loureir, Fl. cochinch, $I .86:$, C alyx inferus, tulutoses, brevis, persistens, quadrifilus, laciniis pacutis, coloratis, patentibus. C o r o II a tubulosa, quadrifida, nlaciniis linearibus, acutis, caransis, in tabnm cylindraceum nconjunction protensis; fil a m enta subnulla, an therae 4 . bbiloeulares, subrotundae, compressae, cucullis laciniarum ninclusae. Germen ovatum. Stylus brevissimus; stig. „w a quadrifidum. B a c ca parva, subrotunda, exsucea, nanosperma. S e m e n unum, glohosum, lanuginosum. - Arbor mediocris ramis adscendentibus; folia lanceolata, nsubserrata, glabra, opposita, flor ruber, parvus, multas, „pedunculis subterminalibus, multifleris, bacea nigra."

\section{Classis XXIX. Serpentariae.}

H erb a e perennes, acaules v. caulescentes, saepius frutescentes, ligno ezonato. Folia alterna, simplieia. Flores hermaphroditi v. unisexuales. Perig on in munc liberum, calycinum, nunc tubo cum ovario connato, limbo 
supero obscure colorato. St a mina nunc in columnam superne antheriferam connata, nunc in hermaphroditis disco epigyno inserta, partimque etiam styli basi acreta, antheris extrorsis, bilocularibus. 0 v a $\mathrm{r}$ i u $\mathrm{m}$ pluriloculare. Ovula in loculis indefinita, horizontalia v. adscendentia, anatropa. Fruct us plurilocularis, coriaceus, indehiscens, v. capsularis loculicido dehiscens, polyspermus. S e mi n a albuminosa. E m b r y o in axi v. basi albuminis, ut plurimum minimus, radicula umbilico proxima, infera v. centripeta.

\section{Drdo CXIT:. Amistolochieae.}

ARISTOLOCHIAE Jussieu gen. 72. R. Brown prodr. 349. ASARINAE Bartling Ord, nat, 81. ARISTOLOCHIACEAE Liadley Introduct. II. p, 205.

Hвквав saepius acaules, rhizomate repente v. tuberibus perennantes, nunc svfrrotices $\mathbf{v}$. FRUTices non raro volubiles, ligno ezonato. C a ule s dum adsunt simplices v. ramosi, teretes $\mathbf{v}$. angulati, sulcati, nodoso-articulati, ad nodos saepe tumidi, foliati. Folia alterna, petiolata, simplicia; petiolo basi saepissime dilatato, semiamplexicauli, lamina admodum varia, lineari v. lanceolata aut ovata, plerumque cordata, integerrima, indivisa v. interdum pedatifida, penninervia v. saepius pedatinervia, ut plurimum reticulato-nervosa. St i p u la nulla v. oppositifolia, squamaeformis aut interdum subfoliacea.

Frores in axillis foliorum solitarii v, fasciculati, interdum racemosi, pedicellati, hermaphroditi $\mathbf{v}$. unisexuales.

Prrigonir tubus teres v. angulatus, cum ovario connatus, herbaceus, limbus superus, coloratus, ut plurimum luridus, coriaceus, interdum amplissimus, intus saepissime pilosus v, ramentaceus, nunc basi ventricosus v. incurvo-tubulosus, in ligulam obliquam productus, v. ringenti bilabiatus, deciduus, nunc regularis trifidus v. rarius quinque - sexfidus, persistens, laciniis per aestivationem valvatis aut induplicatis.

Stramina disco epigyno annuliformi v. cum styli basi confluente inserta, sex v. duodecim, rarius novem in phalanges tres disposita, rarissime indefinita. Filamenta brevissima, subnulla, styli basi adnata. Antherae extrorsae, biloculares, interdum connectivo in acnmen producto superatae, loculis appositis, longitudinaliter dehiscentibus.

Ovariom inferum, v. rarissime apice subexserto semisuperum, sexloculare v. rarius tri-ant quadriloculare, carpidiorum marginibus introflexis, dissepimenta constituentibus. 0 v u 1 a plurima, loculorum angulo centrali simplici v. duplici serie affixa, adscendentia v. horizonta- lia, anatropa. Stylus terminalis, brevissime columnaris. Stigmata sex, radiatim supra stamina expansa.

Fructus umbilicatus v. perigonii limbo superatus, capsularis v. interdum baccatus, subglobosus, trigonus v. interdum tetragono-siliquaeformis, tri - quadri-sexlocularis, loculicidodehiscens, v. interdum indehiscens.

Semina in loculis plurima, rarissime per abortum pauca v. subsolitaria, horizontalia $v$. adscendentia, angulata, bracteata, t es t a membranacea, dorso saepissime convexa, ventre excavata ibique $r h a p h e$ carnosa $v$. suberosofungosa, umbilicum basilarem $\mathrm{chal}$ a $\mathrm{z}$ a e apicali, interdum glandulosae jungente percursa. Albumen dense carnosum v. subcorneum.

Емввуо minimus, in basi axeos albuminis inclusus; cotyledonibus brevissimis, ante germinationem vix manifestis, $r$ adic ul a umbilico proxima, infera $\mathbf{v}$. centripeta.

Aristolochieae nulli ordini praeter Nepentheas, quae tamen ovario libero et embryone perfectiori differunt, aretius affines, Dioscoreis, 'Tacceis, $R$ afflesiaceis imo Cucurbitaceis multis characteribus bene conveniunt, a quibus tamen omnibus notarum summa adeo sunt diversae, ut hisce ordinibus analogae quidem haberi, nunquam conterminae dici possint.

Maxima copia in America tropica provenientes, in temperatis utriusque hemisphaerae et in India rarius gignuntur, in regione mediterranea paullo frequentius obviae, e regione Capensi et e Nova Hollandia extratropica omnino exules.

Vires plurimis tonicae et stimulantes.

2160. Asarum TOURNEF. F lo res hermaphroditi. Perig on i $\mathbf{~ m}$ coloratum, urceolatum v. campanulatum, tubo eum ovario connato, fauce nuda, limbo trifido, aestivatione valvato, persistente. St a m in a 12, disco epigyno inserta; filamenta brevia, libera; anthera e omnes extrorsae, biloculares, connectivo subulato superatae. 0 va ri $\mathrm{um}$ inferum, sexloculare. 0 v u l a plurima, loculorum angulo centrali biseriatim affixa, adscendentia, anatropa. S $t$ y $\mid$ u s brevis, columnaris; stigma sexpartitum. C a p su la coriacea, perigonii persistentis limbo superata, sexlocularis, irregulariter dehiscens. Semina in loculis pauca, adscendentia, hinc convexa, inde concava, rhaphe ventrali carnosa, in $\mathrm{chalazam}$ apicalem glandulosam desinente, $\mathbf{E} \mathbf{m b}$ ryo in basi albuminis cartilaginei minimus; radicula infera. Herbae in Europa et Americaboreali obviae, rhizomate repente perennantes; caulibus abbreviatis, basi squamosis, dichotomo-diphyllis, foliis cordatoreniformibus, pedunculo in dichotomia unifloro, perigonio coriaceo, pubescente.

A s a r u mournef, inst, 286. Linu. gen, n.589. Jussien gen, 73. Gärtn. $I, 47, t$, 1\%. Schkuhr $t, 127$. Flor, dan, $t$. 633. Nees jun. Gen. pl. II. 51 . 
2161. Meterotropa MORR. et $D E$ CAISN. Flores hermaphroditi. Perigonium coloratum, urceolatum, tubo late ventricoso, basi com ovario connato, fauce angustata, annulo introflexo plicato, limbi trifidi laciniis cordatis, aestivatione induplicatis. St a $\mathrm{m}$ in a 12 , disco perigy no, ovarii parti liberae adnato inserta ; 6 e x t e riora (stigmatibus opposita) filamentis triangu laribus, a ntherarum loculis subintrorsis, connectivo submutico interposito sejunctis, 6 interiora alterna, filamentis nullis, antheraru m sessilium localis extrorsis, connectivo dorsali in acumen lanceolatum producto contiguis. Ovari um semiinferum, sexloculare. $O \mathrm{vnla}$ in locuIorum angulo centrali plurima, adscendentia. Styli 6 , connati, stellatim expansi, singuli obcordati, inferne stigmatiferi; $8 \mathrm{tig} \mathrm{m}$ a t a ovato-attenuata, papillusa. Fruetus ....... Herba ja pon ica, habilu Asari, perennis; folïs binis profunde cordatis, obtusis, albo-maeulatis, floribus axillaribus so litariis $v$. geminis, breviter pedicellatis, folio abortivo bracteatis, intus sordide fuscis, faucis annulo albido.

Heterotropa Morren et Decaisne in Nouv. Annal, sc. nat. IT. 314. t. 10. A s a r u $\mathrm{m}$ irg in ic u ul Thuaberg. uon alior.

21 82. Aristoloelhia TOURNEF. F 10 res hermaphroditi. Perigonium coloratum, tu. bulosum, tubo inferne cum ovario connato, supra uvarium ventricoso, recto $v$. curvato, limbo obliquo, ligulato, nune bi-trifido. St a m in a 6 , diseo epigyno inserta; fi lam en ta brevissima,subnulla, an ther a e extrorsae, biloculares, dorso stylo adnatae. Ovarium inferum, sexloculare. Orula plurima, loculorum angulo centrali uniseriatim affixa, horizontalia, anatropa. Stylus brevis; stigm a radiato-sexpartitum. C a p s u I a coriacea, nuda, sexlocularis, septicido-sexvalvis. S e m in a plurima, bracteata; t e 8 t a coriacea, membranaceo-marginata, $r \mathrm{~h}$ a $\mathrm{p}$ h e lata, fungoso-suberosa, infera, in $\mathbf{c h}$ a $\mathrm{I}$ a$\mathbf{z}$ a $\mathbf{~ a p i c a l e m ~ i m p r e s s a m ~ d e s i n e n t e . ~} \mathbf{F} \mathbf{m b}$ b $\mathbf{0}$ in basi axeos albuminis dense carnosi v. cornei minimos; radi e u 1 a centripeta. - Herbae $v$, frutices, erecti, prostrati, scandentes $v$. volubiles, inter tropicos obvii, nec in regionibus extratropicis temperatis rari, e Capite bonae spei exules; foliis alternis, integris, integerrimis, v. lobatis, pedunculis axillaribus uni-bi-multifloris, floribus quandoque maximis, ut plurimum luridis.

A ristolochia Tournefort inst. t. 71, Linn. gen. $n$. 1029. Jussieu gen. 73. Gärtn. I. 45. $t .14$.

a. CLematitis. Perigonif limbus ligulatus.

Glos sula Rafiuesq. Med. Bot. n. 10. F Flor.l dan $t$ 1235. Nees jua. gen. pl. HI. 50. Kunth in Humab. et Bonpl. Nov. gen. et sp. $t, 110$-117. Martius Nov. gen, et sp. t. 51 5i. Bot. Mag. t. 1115. 1116. Bot. Reg. t. $1680,1824$.

b. PISTOLOCHIA. Perigonil limbus bilabiatus, ringens.

Pistolochia Rafinesq. l. $c$. (VahI symbal. $t$. Mr. Martius op. cit. $t$. 48 - 50. Bot. Mag. $t$. 2545. Bot. Reg. t. 689. 1399. 1453. 1543, Link Ic, select. 1. 13. Jacq. f. Eclog. $t$, 26.)

c. SIPHO Perigonii limbus aequaliter trilobus.

H ocqua rtia Dumort. Comment. p. 30. Siphis ia Rafinesq. l. c. (Herit. stirp. t.7. Bot. Mag. 2. 534. 1369.)

OBSERVAT10. Aristoloehiae sectiones h. I. propositae vix satis naturales, provisorie admittendae, donec specierum exoticarum genitalia acnratius indagata fuerint. Genera quaedau ats Aristolochia a Rafinexquio separata, mili penitus incognita sunt :

ENDODACA Raf. l. c. Stamina 12. A. dodeca adra et A. Serpentaria Bigelow non Alior.

EINOMENIA Raf. 1. Stamina 5. Capsula quinquelocularis. A. pestandra Jacq. Aurer. t. 147 .
2163. Bragantia LOUREIR. Flores hermaphroditi (?). Perigon i $\mathbf{m}$ tubo filiformitetragono, cum ovario connato, limbo supero campanulato-trifide, intus colorato, deciduo. St a m in a 6, disco epigyno inserta; fila menta brevissima, basi styli adnata, anthera extrorsae, biloculares. O v a ri u inferum, quadriloculare, Ovula in loculorum angulo centrali plurima, uniseriata, horizontalia, anatropa. Styli 4 , basi connati; $s t i g m a t a$ obtusa. Fruet us siliquaeformis, tetragonus, quadrilocularis, indehiscens. Semina plurima, triquetra, rugosa. Em b ry o ...... Fruticuli Asiam tropicam incolentes; folits alternis, coriaceis, ovali-oblongis, venosis, integerrimis, floribus racemosis, axillaribus v. lateralibus.

B ragantia Loureiro Flor, cochinch, II. 645. Blume Enum. pl. Jav. K. 81. C e ra m i u Blume Bijdr. 1134. V a nhallia Schult. f. syst. VII, p. XVIII. M u ehenb. Consp. 85 .

2164. Thettea ROTTB. Flores hermaphroditi. Perigonium tubotetragono, herbaceo, cum ovario connato, limbo supero campanulatotrifido, colorato, nervoso, extus hamato-piloso, intus tomentoso. St a m in a $30 \_40$, annulo epigyno carnoso bisulco, cum stylo connato, biseriatim extus adnata; antherae extrorsae, biloculares, didymae. Ovarium infernm ......... Stylus brevis, crassus, cum annulo staminifero connatus ; $8 \mathrm{tig}$ m a $\mathrm{ta}$ in discum depressum, multiradiatum eonnata. Fructus siliquaeformis, tetragonus, villosus, bilocularis (?). Sem in a ...-Erutex as iaticus; caule flexuoso, articulato, ad nodos tumido, foliis alternis, eoriaceis, ovatis, integerrimis, nervosis, subtus venosis, racemo alternifolio pauciftoro, floribus maximis.

Thotte a Rottboell in Dansk. Vidensk. Solsk. Skrif. nye Saml. 1T. 330. t. 2 .

\section{GENERA NON SATIS NOTA.}

21 65. Troichopodiuna LINDL. F I ares dioici (?). Mase. ...... Fem. Perigo$n$ in m losi tubulosum, limbo supero, sexfido. S $t$ amina, sterilia 6, foveis totidem inserta. Stylus simplex; stigmat a 3 , bipartita. Ovarium ... Ca p s u la triquetra, angulis membranaceis, mndulatis, trilocularis, indehiscens. Se min a in loculis solitaria v. gemina, superposita, adscendentia (?), angulata; testa membranacea, sulco ventrali. $\mathbf{K}$ mbryo in hasi albuminisacornei minimus; radienI a infera. - Herbae indic ae; foliis alternis, cordatis, ovato-lanceolatis, rariusve linearibus.

Trieho podium Liadley in Bot. Reg. n. 1543. Trichopus Garta. $T$. 24, ใ. 14.

2168. 'Tratareriza LINDL. Fl o res disiei? Ilase, Perigonium quinquepartitum. Stamina 9 , in phalanges tres dispusita. Stigmatis rudimentum urceulare, sexdentatum. Fem. Perigoniam ..... Orarium .... Capsula siliqnaeformis, quadrilucularis, quadrivalvis, poly sperma. Semina ..... - Herba zeylan ic a ; caule flexuoso, ad nodos tenuido, foliis alternis, ovato-lanceolatis, triplicostalis, subtus reticulatis, pubescentibus, racemis axillaribus, brevissimis, pan. cifioris.

T ri me riza Lindley in-Bot, Heg. n, 1543.

\section{Drdo CXV: Nepentheae.}

NEPENTHINAE Aristolochiaruar sect. Liuk Handb, I. 369. NEPENTHEAE Blune Enum. Pl. Jav. $\boldsymbol{T}$. 8\%. Bariling Ort. nat. 81. in not. R Brown in Edinb. philosoph. Magaz. 1832. Sept. NEPENTHACEAE Lindley Introduct. Edit. $I I$. p. 204. 
Plantae soffruticosae, caulibus decumbentibus v. sarmentosis, ligno ezonato, vasis spiralibus numerosissimis, per medullam et librum sparsis, lignum lato annulo circumdantibus. Folia alterna, petioli foliaceo-dilatati, lanceolati, nervosi, basi angustata brevissime vaginantes, cirrho nunc aphyllo, nunc in ascidium amplum dilatato terminati, $1 \mathrm{am} \mathrm{i-}$ n a cum ascidii ora articulata, illud recludens.

Flores plurimi, in racemum v. paniculam subterminalem, tandem succrescente caule lateralem dispositi, dioici.

Floribus maseulis: Perigonium simplex, calycinum, profunde quadripartitum, laciniis subovatis, extus hirsutis, intus foveolis minutis exsculptis, aestivatione alternatim imbricatis, duabus oppositis exterioribus paullo majoribus, internas obtegentibus.

Stauisa in columnam centralem solidam connata. An therae subsedecim, extrorsae, in capitulum sphaericum congestae, biloculares, loculis appositis, contiguis, longitudinaliter dehiscentibus.

Floribus femineis: Perigonium ut in masculis.

Ovarium liberum, tetragonum, e carpidiis quatuor, perigonii lobis oppositis, valvatim connatis, medio septiferis quadriloculare, columna centrali nulla. Ovala plurima, septis utrinque multiplici serie affixa, adscendentia. Sti gma sessile, discoideum, obsolete cruciatim quadrilobum; lobis septis respondentibus.

Capsula coriacea, tetragona, truncata, stigmate coronata, quadrilocularis, loculicido-quadrivalvis, valvis medio septa simplicia, faciebus seminifera gerentibus.

Semina plurima, septorum parietibus utrinque multiplici seriei immediatim affixa, elongato-fusiformia, adscendentia, imbricata. Testa membranacea, cellulosa, utrinque relaxata, longe tubulosa, u m bil i co prope basim laterali, rhaphe filiformi, intra testae basim adscendente, libera, supra medium adnata, ibique in chalazam, n u cl e u m subglobosum, Iiberum suspendentem desinens.

Enbryo in axi albuminis carnosi orthotropus, ejusdem fere longitudine, subcylindricus v. fusiformis. Cotyle d on es lineares, planoconvexae. Ra di cula brevis, umbilicum spectans, infera.

Nepentheae, prout et reliqui ordines petiolis aseidiophoris operculatis instrueti, unico genere paucisque speciebus, per Asiae tropicae continentem et insulas, nec non $\mathbf{M}$ adagascariam dispersis comprehenduntur, summa affinitatis necessitudine Aristolochie is conterminae, a quibus pluribus notis, ovario nempe libero, staminibus monadulphis, embryoneque elaboratiore commodissime distinguuntur.

216\%. Nepenthes $L I N N$. F I o res dioici. Masc. Perigonium calyeinum, profunde quadrifidum. Stam in a in columnam centralem connata; an thera e 16 , in capitulum subsphaericum congestae, biloculares, longitudinaliter dehiscentes, Fem. Perigonium maris. Ovari um liberum, subtetragonum, quadriloculare. Ovu la plurima, septorum parietibus adseendentim affixa, anatropa. Stigma sessile, discoideum, obsolete quadrilobum. C a ps u l a quadrilocularis, loculicido-quadrivalvis, valvis medio septiferis. S e mina plurima, setaceo-fusiformia, adscendentia, imbricata; test a membranacea, ntrinque relaxata; $\mathbf{n} \mathbf{u -}$ cleo centrali inverso, subgloboso. Embryo in axi albuminis carnosi cylindricus, orthotropus; radicula brevi, infera. - Suffrutices in $A$ s ia tropica et in Madagascaria indigeni; petiolis alternis, basi brevissime vaginantibus, foliaceo-dilatatis, apice cirrhosis, cirrho ascidiophoro, lamina articulata ascidium claudente, floribus racemosis $v$. paniculatis.

Nepenthes Linn. gen. $n$, 1019. Jussieu gen. 444. Gärtn, I. 18, t. 83. Brongn. in Aunal. so. nat. $T$. 49. $t .8$. (fig. 3. certe iuverteada). Nees Ibid. IV. 365. $t$. 19. 20. Bot. Mag. t. 2629. 2798, Graham in Edinb. ness philosoph. Journ. Jan. 1830. t, 6. Bluue Enum, pl. Jav. 1.84 . P h y II a mphor a Loureiro Flor. cochinch, $I I$. 744. C a $\mathrm{t}$ th a $\mathrm{r}$ i $\mathrm{fer}$ Rumph Amboin. V. 121. $t$. 59. B an d u r a Burm. Thes, zey. lan. $t$. 17. A m ram a ti co Flacourt Madagase. $f .43$.

OBSERVAT10. De radiculae situ infero, ehalazae e diametro opposito et umbilicum externam spectante, e male in. tellecta Richardi figura (Ann. so, nat. $x . t .8 . f$. 3.) in dubiam vocata, post repetitam diversarum specierum explorationem ambigi nequit.

\section{COHORS III. GAMOPETALAE.}

Perigonium duplex, exterius calycinum, liberum v, cum ovario connatum; interius corollinum, gamopetalum : hypogynum, perigynum v. epigynum, rarissime abortu nullum.

\section{Classis XXX. Flumbagines.}

Herbae acaules v. canlescentes, rarius suffrutescentes. Foli a in acaulibus radicalia, conferta, in caulinis alterna v. opposita, simplicia, integerrima v. incisa. Flores hermaphroditi v. rarius diclines. Ca ly $x$ gamophyllus v. divisus, liber. Co rolla hypogyna, seariosa, tubulosa v. elentheropetala, petalorum unguibus basi cohaerentibus. Sta $\mathrm{m}$ in a numero loborum corollae v. pauciora, in gamopetalis tubo inserta et limbi laciniis alterna, in eleutheropetalis unguibus petalorum inposita. Ovari um liberum, uniloculare, v. biloculare. O vul u m unicum v. plurima, anatropa v. amphitropa. Em b r y o intra albumen rectus, $r$ adicula infera, supera v. centrifuga.

\section{Drdo CXI. Plantagineat.}

PLANTAgINES Juss, zen, 89, PLANTAgineaE Vent. Tabl. 1I. 269. R. Brown prodr. 423. Rapin, Esquisse de l'histoire naturelle de Plantaginées, in Mrém, soc. Linn. Paris. 1827. VI. 437. ss. Bartliag Ord, nat. 125. PLANTAGINACEAE Linaley Introduct, cdit. II. p, 267. 
Herbaf perennes v. rarius suffrutices, caule in plurimis abbreviato, subterraneo, pedunculos scapiformes exserente, nunc elongato, ramoso, tereti. Foli a in plurimis omnia radicalia, rosulato-congesta, in aliis caulina, opposíta v. alterna, simplicia, nervosa, integerrima, dentata v. pinnatim incisa, in nonnullis carnosa, semiteretia, nunc sessilia, nunc in petiolum basi saepissime dilatatum attenuata.

Florks unisexuales, monoici, polygami v. hermaphroditi, masculi in pedunculo scapiformi medio unibracteato, basi femineis pluribus sessilibus stipato solitarii, hermaphroditi immixtis interdum floribus abortu femineis in spicam densam, simplicissimam, elongatam $v$. abbreviatam, capituliformem, p ed unculo scapiformi radicali v. terminali sustentam congesti, singuli bractea unica, plus minus lata, marginibus scarioso-membranacea stipati.

CALYX herbaceus, quadrifidus, laciniis subinaequalibus, margine scariosis, per aestivationem imbricatis, persistens, in floribus femineis triphyllus, foliolis subunilateralibus.

Corolla hypogyna, scariosa, tubulosa, limbo quadrifido, v. rarius trilobo, aequali v. interdum subinaequali, in floribus femineis urceolaris, ore contracto, et inaequaliter tri-quadrifido, persistens, tandem saepius a fructn grossificante per medias limbi lacinias fissa.

Stamina quatuor v, rarissime unicum, in floribus hermaphroditis medio corollae tubo inserta, in masculis hypogyna, limbi laciniis alterna. Fil a menta fililormia, in alabastro inflexa, sub anthesi longe exserta, flaccida, persistentia. Antherae introrsae, biloculares, basi v. supra basim affixae, versatiles, deciduae; loculi oppositi, contigui, longitudinaliter dehiscentes.

Ovarium liberum, in floribus femineis uniloculare; ov ulo unico e placenta basilari bre vissima crassiuscula erecto, amphitropum, v. eidem peltatim affixo, transversim amphitropo, in floribus hermaphroditis biloculare; ovulis placentae dissepimentum constituenti peltatim affixis, amphitropis, micropyle infera, in quovis loculo solitariis v. geminis collateralibus, aut indefinite plurimis. Styl us terminalis, exsertus, simplex; st igmate indiviso v. rarissime obsolete bifido.

Nucula ossea, monosperma, semine erecto v. peltatim transverso, vel capsula membranacea, bilocularis, loculis mono-di-polyspermis, quandoque loculis inter semina collateralia septulo secundario plus minusve completo bilocellatis spurie quadrilocularis, circumseisse dehiscens, dissepimento demum libero, faciebus seminifero.
Seminum tes ta membranacea v. mucilaginosa; u mbilic o ventrali, rarissime prope basim laterali. Al bu men dense carnosum.

Eмrвуо in axi albuminis rectus, cylindricus, ejusdem fere longitudine, rarissime subarcuatus, supra albumen transversim periphericus. Cotyledones plano-convexae. R a dicula cylindrica, ab umbilico remota v. interdum eidem parallele contigua, infera, rarissime centrifuga.

Plantagineae e nullo climate exules, imprimis hemisphaerae borealis regiones temperatas incolunt, in regione mediterranea et in Americaboreali imprimis copiosae, transaequatorem in Americ a paullo frequentius observatae.

Affinitas ordinis, e generibus utut fructus fabrica diversissimis, attamen arctissime cognatis conflati, panllo obscurio. Cum Plumbagineis imprimis corollae textura, cum Primula ce is orulorum directione, capsulae in nonnullis dehiscentia transversa convenit; prioribus quamvis ovulorum situ et radiculae directione satis distinctis, certe affinis, a posterioribus longius distare videtur.

2168. Littorella LINN. F I o res monoici, masculi in pedunculo axillari solitarii, feminei ad basim pedicelli masculi gemini v. terni, sessiles. Masc. C al y x quadripartitus, laciniis acqualibus. Corolla hypogyna, tubulosa, seariosa, limbo quadripartito. Stam ina 4, hypogyna, corollae laciniis alterna; fil amenta longe exserta, flaccida, an therae introrsae, biloculares, loculis oppositis, contiguis, longitudinaliter dehiscentibus. O varii rudimentum. Fem. Calyx triphyllus, foliolis linearihus, inaequalibns, unilateralibus. Corolla scariosa, urceolata, ore contracto, inaequaliter tri-quadrifido, persistens. Ova rin m liberum, uniloculare. O v $\mathbf{I}$ um unicum erectum. Styl a terminalis, filiformis, longe exsertus; stig ma indivisum. Nucula ossea, monosperma. Semen erectum; tes ta membranacea. E mbryo in axi albuminis dense carnosi rectus, cylindricus, ejusdem fere longitudine; cot y l e d o nibus ellipticis, planoconvexis; radie nla infera. - Herba aquatica, in Euro pa imprimis borealiore indigena; radice stolonifera, foliis omnibus radicalibus, lineari-subulalis, carnosulis, basi dilatata canaliculatis, peduncutis maseulis folia subaequantibus, supra medium unibracteatis.

Litt o roll a Linn. gen. n. 1328. Sebkulir $t$, 287. Hook. Fl. Lond, t. 168, Pla ntago uniflora Linn.

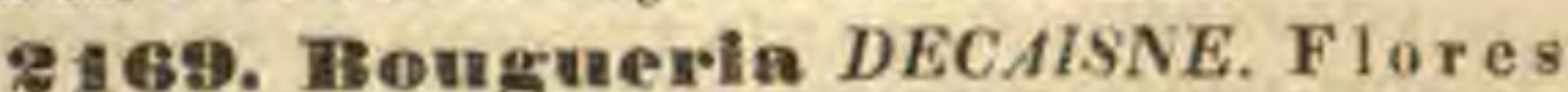
polygami, hermaphroditi cum fenineis spicato-capitati, singuli bractea medio carnosa, marginibus late membranacea teeti. C al y x quadripartitus, persistens, Iaciniis anticis paullo majoribus. Corolla hypogyna, tubulosa, seariosa, limbo brevi, irregulariter tri-quadrilobo. St a m en unicum, corollae tulo medio inter limbi lobos insertum; fil a m entum longe exsertum, flaccidum, anthera bilocularis, basi emarginata affixa, apiec brevissime mucronata, loeulis longitudinaliter dehiseentihus. Ova ri um liberum, rotundo-compressum, unilocnlare. Ovulum unicum, placentae brevi crassiusculae peltatim affixum, amphitropum. St y lus 
filiformis, longe exsertus, superne papilloso - stigmatosus. N n e ul a ossea, monosperma, compressa, medio utrinque costata, styli rudimento mueronata. Se $m$ en peltatum, reniforme; tes t a tenui, atrovirente. E m b r y o subareuatus, supra albumen earnosum transversim periphericus; cotyle do n ibus oblongis, carnosis, radic u la in teretem aequantilsus. - Herba andicola, bipollicaris, perennis; radice crassa, caespitosa, foliis linearibus, integrerrimis, carnosulis, glabratis, junioribus albo-pilosis, pedunculis axillaribus, foliis brevioribus, floribus spicato-capitatis, hermaphroditis paucis cum femineis pluribus absque ordine mixtis, bracteis latis, calycibus pilosis.

B o u g u er a Decalsue in Nouv. Annal. sc, nat. V, 132.

\& 1 \%. Flantago LINN. F l o res hermaphroditi, spicati, singuli unibracteati. Ca lyx quadripartitus, laciniis subaequalibus. Corolla hypogyna, tubulosa, scariosa, limbo quadripartito, persistens. St a mina 4 , tubo corollae inserta, limbi laciniis alterna; fil a menta longe exserta, flaccida, an therae introrsae, biloculares, locnlis oppositis, contiguis, longitudinaliter dehiscentibus. 0 va r i m liberum, biloculare. 0 va la dissepimento peltatim affixa, amphitropa, micropyle infera, in loculis solitaria, v. gemina collateralia, ant indefinita. Stylus terminalis, simplex; stigmate indiviso v. rarissime breviter bilobo. Caps u I a membranacea, bilocularis, v. loculis inter semina collateralia septulo secundario bilocellatis spurie quadrilocularis, circumscisse dehiscens, dissepimento demum libero, faciebus seminifero. Semina in loculis solitaria, bina $v$. indefinita; $t$ e $s$ a mucilaginosa, umbilico ventrali. $\mathbf{E} \mathbf{m b} \mathbf{r} 0$ in axi albuminis dense carnosi rectus, cylindricus, ejusdem fere longitudine; cot y l ed on ib n sellipticis, planoconvexis; $r$ a d i c u l a infera. Herbae cosmopolitae, in regionibus temperatis $\bar{h}$ emisphaerae borealis frequentius obviae, acaules $v$. caulescentes, rarissime suffrutescentes, glabrae $v$. pubescentes, aut lanatae; foliis in acaulibus confertis, in caulescentibus alternis $v$. oppositis, integris $v$. dentat is aut pinnatifido-incisis, nunc planis et nervosis, nunc semiteretibus, pedunculis scapiformibus, indivisis, axillaribus v. rarius terminalibus, floribus dense spicatis, spicis cylindricis, rariusve subglobosis.

Plantago Lian. gen, $n, 142$. DC. El, fr. III. 408. R. Brown prodr. 424.

a. PSYlliUm. Capsula bilocularis, loculis monospermis. - Caulescentes v. acaules.

Ps yllium Endlicher Flor, pos, 212. Ps yll1 n m et

Plantaginis sp. Tournef. Juss. (Jacq. Ic. rar. t. 28. Hort. Vindob. $t$. 126. 258. Fragm. $t$. 183. Allion. Pedemont, 2 85. f.3. Flor, dan. t. 243. 437. 581. Waldst. et Kit. Plant, Hung. t, 151. 203. Cav. Ic. $t, 135,249$. f. 1. Veat. Cels. t. 29. Ruiz et Pav. Flor. peruv. t. 79. Humb. et Boupl. nov. gen. et sp. t. 126. f. 2. Hook. El. Lond. t. 193. Endliel., Sert. Cabul. t, 1.)

b. CORONOPUS. C a psula hilocularis, loculis dispermis, inter semiua collaterulia septalo plus minosve completo bilocellatis spurie v, incomplete quadrilocularis. - Acau. les, folits dentatis $v$, pinnatifido-incisis.

C or on op us Tournef, inst. $t$. 49. (Fl. dan. $t$. 272. E. B. t. 892, Jaeq, Ic, rar. $t, 27$. Humb. et Bonpl, nov. gen. et sp. t. 127.) c. ARNOGLOSSON. Capsula bllocularis, loculis poly-
spermis. Acaules.

A $x$ nogl asson Endicher Flor. pos. 211. (Schkuhr c. 2h, Flor. dan. t. 461. Jacq. Ic. rar, t. 26. Ruiz et Pav. Fl, peruv, $t$. 78, Gaudich ad Freyc, $t .50$.

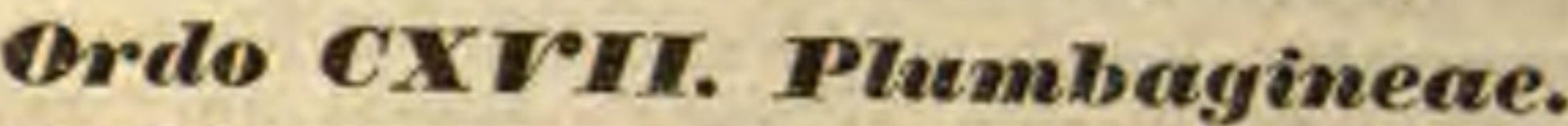

PLUMBAGINES Jussieu gen.92. PLUMBAG INEAE Ventt Tabl. II. 276. R. Brown prodr. p. 425. Bartling Ord. nat. 326. PLUMBAGINACEAE Liudley Introduct. edit. Ir. p. 269.
Herbae perennes v. frutices, acaules v. caulescentes. Folia nunc in apice rhizomatis multicipitis conferta, simplicia, integerrima, subamplexicaulia, $\mathbf{v}$. in caule nodoso-articulato, ramoso, tereti v. irregulariter angulato alterna, interdum in petiolum basi dilatatum, amplexicaulem attenuata, marcescentia. Stip нla nullae.

Fuorks hermaphroditi, in pedunculis saepissime scapiformibus, simplicibus v. ramosis, nunc spicati, spicis saepissime secundis, v. paniculati, aut in capitulum involucratum collecti, bracteis sub quovis flore ternis v. rarius binis, plerumque scariosis.

Calyx tubulosus, scariosus, coriaceus v. herbaceus, interdum coloratus, quinqueplicatus, quinquedentatus, rarissime pentaphyllus, persistens.

Corolla hypogyna, tenera, nune gamopetala, hypocrateriformis, tubo angusto, angulato, limbo quinquepartito, aequali ; v. pentapetala, petalis distincte unguiculatis, unguibus ima basi saepe cohaerentibus, laminis v. limbi lubis aestivatione contortis.

Stamina quinque, corollae lobis v. petalis opposita, eorundem unguibus supra basim inserta, v. in gamopetalis hypogyna. Fi la men ta filiformia, in alabastro erecta. Antherae introrsae, biloculares, incumbentes, loculis parallelis, contiguis, basi distinctis, juxta totam longitudinem dehiscentibus.

Ovarium liberum, sessile, uniloculare. Ovulum unicum, ex apice placentae filiformis liberae, e fundo ovarii adscendentis pendulum, anatropum. Styli 5, rarius 3 v. 4 , terminales, distincti $v$. in unicum connati; s t ig $\mathrm{m}$ a $\mathrm{t} \mathrm{ibus}$ totidem distinctis, simplicibus, capillaribus, interdum glandulis capitatis ramosis, rarissime capitatis.

Frectus membranaceus, monospermus, calyce inclusus, nunc capsularis, apice valvis quinque dehiscens, nunc utricularis, evalvis, a basi lacero secedens.

Semrn inversum, placenta filiformi saepius testae adnata situm erectum mentiens. Al bum en farinaceum, parcum, germinatione quandoque intra pericarpium incepta consumptum.

Емвкуо intra albumen orthotropus; cotyle donibus planis, radi cula brevi, supera.

Plumbagineae staminum ante petala situ et insertione in diversis generibus varia, ovulo unico e placenta libera pendulo, et stylorum pluralitate distinctissimae, in littoribus maritimis climatis temperati, et in desertis salsis olim submarinis copiosissime gignuntur.

TeIRUS I. STATICEAE. Cal y x scariosus v. coriaceus. C oroll a pentapetala, un- 
guibus staminiferis. Styli distincti. Peric a rpi um demum basi solutum, calyptraeforme.

21 1. Armeria WILLD. Capitulum involucratum, vagina reversa, receptaculo paleaceo. C a 1 y $x$ infundibuliformis, limbo quinquedentatus, quinqueplicatus, margine scariosus. Corolla hypogyna, pentapetala, petalorum unguibus basi villis cohaerentibus. St a m in a 5 , imis petalorum nnguibus inserta. Ovari um uniloculare. Ovulum nnicum, e placenta filiformi libera pendulum, anatropum. Styli terminales quinque distincti, apice intus stigmatosi. U trie ulu s membranacens, monospermus, calyce inclusus, demmm a basi multifido solutus, calyptraeformis. S e m e n inversum. Embryo intra albumen farinaceum parcum orthotropus; ra di cul a supera. Herbae perennes acaules, in Europa media et austra$l i$ provenientes; foliis radicalibus congestis, linearibus $v$. lanceolatis, nervosis, pedunculis scapiformibus monocephalis.

A rmeri a Willd. Hort, Berol. $333 . \mathrm{S}$ t a t 1 e e Tournef inst. t. 177. Statices spec. Liun. Selikubr $t .87$. E. B. $t .226$. F1. dan. $t$. 1092. Hooker Flor, Lond. $t$, 226.

21 2 . Statiee WILLD. Flores in spi cis secundis bi-tri-bracteati. C a $\mathbf{l} \mathbf{y} \mathbf{x}$ infundibuliformis, limbo quinquedentato, quinque-plicato mar gine scarioso. Co rolla hypogyna, pentapetala $v$ quinquepartita. Sta mina 5 , imis petalorum unguibus inserta. O v a $\mathrm{r}$ i $\mathrm{m}$ uniloculare. Ov $\mathbf{l}$ u m unicum e placenta filiformi libera pendulum, anatropum. Styli terminales quinque, distineti, apice intus stigmatosi. Utriculus membranacens monospermus, calyce inclusus, demum a basi multi fido-solutus, calyptraeformis. S e m e $n$ inversum. Fmbryo intra albumen farinaceum pareum or thotropus; radicula supera. - Herbae v. suffrutices, in Europa australi et orientali nec non in Asia media copiosae, in Nova Hollandia rarae; foliis omnibus radicalibus enngestis dilatatis spathulatis, integerrimis $v$. dentatis, aut linearibus, acicularibus, congestis, scapis ramosis spicis secundis.

St a ti ce Willd. Hort, berol, 333.Sibthorp Flor. Braec, 299 . Reichenb. Plant, erit, $t, 162,163,172,173,186$ - 188, 925.926. 237. 291.717_721.751,758. Ledebour Ic, t.258, 258, 316. L i. $\mathrm{m}$ on i $\mathrm{m}$ Tournef, inst, t, 177. T a a a th $\mathrm{e} \mathrm{m}$ a Necker elem. a. 202. R. Brown prodr, 426, Statices s p. Linn.

2173. Aegialltis $R$. BR. Flores spicato-panieulati, tribracteati. C a l y x coriaceus, tabulosus, plicato-angulatus, quinquedentatus. Corolla hypogyna, pentapetala, unguibus basi cunnatis. S ta min a 5 , unguibus petalorum inserta. Ovarium uniloculare, uniovulatum. OvuI u m unicnm, ex apice placentae crassiusculae liberae pen dulum, anatropum. Styli quinque, terminales, distincti; stigmatibus capitatis. Utriculas coriaceus, exsertus, subangulato-cylindraceus, a semine germinante apice ruptus. S e m en intra fructum germinans, exalbnminosum; embryonis rad $\mathrm{i}$ e 1 a supera, plumula diphylla, majusenla. - Frutex humilis, glaberrimus, in Novae Hollandiae littore tropico cum Rhizophoris crescens; ramis terelibus, fragilibus, cicatricibus petiolorum annulatis, foliis alternis, exstipulatis, planis, coriaceis, ovatis, integerrimis, petiolo late marginuto basique dilatato vaginante, spicis paniculatis, floribas alternis, subimbricatis, tribracteatis, albis. t. $5 t$.

Aegialitis R. Browa prodr. 426. Gaudich. nd Frege.
TREIBUS 耳. PLUMBAGINEAE VERAE. Caly $x$ herbaceus. C oroll a gamopetala. Stamina hypogyna. Pericarpium subcapsulare. Styli connati; stigmatibus distinctis.

2174. PIumbago TOURNEF. Cal yx tubulosus, qninquedentatus, plicatus, costis glandulosis. Coroll a gamopetala, hypocrateriformis, limbo quinquepartito. Stam in a 5 , hypogyna, corollae lobis opposita, inclusa; filamenta basi dilatata, fornieata, an therae ovatae. Ovarium uniloculare. Ovul um unicum, e placenta filiformi adscendente libera pendulum, anatropum. StyI us terminalis, filiformis; stigmata 5 , aenta. C a p u la calyce persistente inclusa, unilocularis, pentagona, apice quinquevalvis. S e men inversum. E m b r y o intra albumen farinaceum parcam orthotropus; radicula supera. - Herbae v. suffrutices caulescentes, in regionibus tropicis subtropicisque totius orbis, etiam in regione mediterranea provenientes, nullibi copiosae; foliis alternis, amplexicaulibus, spicis terminalibus, floribus tribracteatis, roseis $v$, albo-lilacinis.

PI u ub a g o Tournefort inst. t. 5. Lina. gen. n. 213. Juss. gen. 92. Gärtu. I. 234. t. 50. Sehkuhr t. 36. Bot. Mag. t. 12 29. Sibth. Fl. graeo, $t, 191$, - T The la Loureir. Flor. cochinch, I. 1 is?.

3175. Ceratostigma BUNGE. Calyx tubulosus, quinquedentatus, quinqueeostatus, costis transversim rugulosis, eglandulosis. Corolla gamopetala, hypocrateriformis, limbi quinquepartiti lobis obcordatis, dentieulatis. Stamina 5, hypogyna, corollae lobis opposita, inclusa; filam enta filiformia, anthe rae lineares, basi bifidae. Ovarium uniloeulare. Ovalum unieum ...... St y lus terminalis, filiformis; $8 \mathrm{tig} \mathrm{mata} 5$, elongato-filiformia, glandolis stipitatis ramosa, U tricul us (?) monospermus, Semen .....-Herba perennis, circa Peking lecta; folits obovatis, acutis, rigide ciliatis, floribus terminalibus, congestocapitalis, late caeruleis.

Ceratostigua Bunge Enum. pl. Chin. 55 .

216. Vogelia $L A M$. Cal y $x$ pentaphyllus, foliolis late ovatis, transversim suleato-rugosis. Corolla gamopetala, tubulosa, graeilis, plicata, limbo quinquelobo. S t a min a 5, hypogyna, corollae lobis opposita, inclusa; filamenta filiformia, an therae ovatac. Ovarium uniloculare. $O \times \mathbf{n I ~ a ~ m ~ u n i e u m , ~ e ~ p l a c e n t a ~ f i l i f o r m i ~ a d s c e n - ~}$ dente lihera pendulum. St ylus terminalis, filiformis; stigmata 5 , acuta. Fructus ..... Frutex capensis; ramis gracilibus, foliis alternis, subsessilibus, obcordatis, tuberculatis, integerrimis, floribus spicatis, arcte imbricatis.

Vogeli a Lamark Mllustr. t. 149.

\section{* SALVADORACEAE.}

247\%. Salvadora LINN. C aly x parvus, tetraphyllus. Co roll a gamopetala, quadripartita, membranacea. St am ina 4 , perigyna, corollae lobos connectentia; an $\mathbf{t h}$ era e introrsae, bilocalares, sulıglobosae, longitudinaliter dehiseentes. Ovari u m liberum, uniloculare. Ovulu m nnicum, e basi erectum, anatropum. S tig ma sessile, indivisum. B a c c a monosperma. S e m en erectum. E m b.r y o n is exalbuminosi cotyledones carnosae, plano-convexae, peltatae, radicula m inferan includentes. - Frutices glabri, glauco-pruinosi, per As iam mediam, ab India superiore ad 
mare mediterraneum, et per Africambo. realem a Nilo ad Senegambiam observati; eaule articulato, articulis subtumidis, foliis oppositis, petiolatis, integerrimis, coriaceis, obsolete venosis, floribus minutis, laxe paniculatis.

S a lva d or a Linn. gen, n, 163. Juss. gen, 84. Vahl Symb. . t. t. 4. Roxburgh Corom, t. 26. Lindley Introduct. edit. II. p. 269.

\section{Classis XXXI. Aggregatae.}

Herbae, arbores v. frutices. Folia alterna v. opposita. Stipula e nullae. Flores hermaphroditi v. abortu unisexuales, plerumque aggregato - capitati. Cal y $x$ tubo cum ovario connato, limbo supero, rarissime liber. Corolla epigyna, v, rarissime hypogyna, gamopetala, limbo saepe irregulari. St a m i n a corollae inserta, ejusdem lobis alterna. Ovari um inferum, uniloculare, $r$. triloculare, loculis duobus vacuis. Ov ul u m unicum, erectum v. inversum anatropum. Fruct us monospermus. Semen albuminosum v. exalbuminosum. Embryo in albuminosis intrarius, orthotropus, radi cula supera v. infera.

\section{Drdo CXVIII. Valerianeate.}

VALERANA Linn. gen, $n$,44. DIPSACEARUM sectio II. Jussieu gen, 195. VALERIANAE DC, Flor. fr, IV. 416. Collect. Memoir. YII. Paris. 1832, c. icc. Prodr, IV, 623 Jussien in Annal. du Mus. $\boldsymbol{X}$. 308. Du Fresne Hist, nat. et medic. des Valerianees. Montpell. 1811. 4. Kunth in Desvaux Journ. Bot, IT. 121. Bartling Ord, nat, 130. VALE. RIANACEAE Lindley Introduct, edit, II. p. 265.

Неквав annuae; radice gracili inodora, $v$. perennes interdum suffrutescentes, erectae $v$. volubiles, rhizomate sublignoso, crassiusculo, saepe aromatico. Folia radicalia congesta, caulina opposita, simplicia, integra v. pinnatifida aut pinnatisecta, subamplexicauli-sessilia v. petiolata, petiolo basi dilatato, semiamplexicauli. Stipula e nullae.

Flones hermaphroditi v. abortu unisexuales, mono-dioici, nunc in cymis dichotomis subfastigiati, $\mathbf{v}$. in ramorum dichotomiis solitarii v. fasciculato-corymbosi, bracteati, rarissime singuli involucro duplici gamophyllo cincti, albi, rosei ant caerulescentes, rarissime purpurei v. flavi.

Calycis tubus cum ovario connatus, limbus superus tri-quadrifidus, aequalis v. inaequalis, aestivatione rectus, post anthesim saepe anctus, persistens, v. sub aestivatione involutus, per anthesim in lacinias plurimas setiformes, papposas evolutus, deciduus.

Corolia gamopetala, disco epigyno inserta, decidua, infundibuliformi-tubnlosa, tnbo cylindraceo v. obconico, basi aequali v. antice in gibber aut calcar cavum producto, limbo plerumque quinquelobo, aequali v. interdum subbilabiato, rarius tri-quadrilobo, lobis obtusis, aestivatione imbricatis.
Stamiva tubo corollae prope basim v. infra medium inserta, ejusque lobis alterna, rarissime quinque, plerumque postico deficiente quatuor, nunc lateralium uno simul suppresso tria, v. postico solum praesente unicum. Fil a m ent a inter se distincta, e tubo corollae porrecta, in alabastro apice plerumque incurva. Anthe$r$ a e introrsae, biloculares, incumbentes, loculi parallele oppositi, longitudinaliter dehiscentes.

Ovariom calycis tubo connatum, triloculare, loculis duobus vacuis, plerumque minoribus, quandoque minimis, tertio fertili. Ovu I u m unicum, ex apice loculi pendulum, anatropum. St y lus simplex, filiformis; $\mathrm{s}$ tig $\mathrm{mat}$ a $\mathbf{2}-3$, libera $v$, in unum connata.

Fructus indehiscens, coriaceus v. membranaceus, apice nudus v. calycis limbo coronatus, nune loculorum sterilium ovarii suppressione unilocularis, nunc iisdem superstitibus, plerumque minoribus trilocularis, $\mathbf{x}$, interdumijisdem confluentibus bilocularis, semper monospermus.

Semen intersum. T e s $t$ a membranacea, tenuis, end op l e ura in nonnullis tumida. A lbu men nullum.

Emsryo orthotropus; cotyledonibus oblongis crassiusculis, ra di cula brevi; obtnsiuscula umbilico proxima, supera multoties longioribus.

Valerianea in veteri continente Europam mediam, regionem mediterraneam, et floraetaurico-caucasicae territorinm maximo numero incolunt, nnde in Orientem, Sibiri am, Nepaliam, ipsamque J a p on i m parva copia evagantur, in t er tropicos et trans Capricornum, si Valerianam capensem, magnopere dubiam demseris, nondum visae. In novo autem contine nte montium imprimis tractus juxta orientale littus porrectos, et tropico subjectos sideri magna copia inhabitant, inde copiosae per o r a chilensem diffusae, regi on em magellanicam et insulas maclovianas petentes, cis $\mathbf{C}$ an $\mathrm{crum}$ paucissimae vigent, unica species arctica utriusque orbis floram connectit.

Ordo Dipsaceis proximus, a quibus imprimis albuminis defectu, et ovario triloculari distinguitur.

Specierum perennium radices principio amaro, aromatico, varii in medicina usus scatent, annuarum folia juniora in acetariis gratae.

Triplostegia, genus involucro praeter calycem duplici, inter hune et sequeutem ordinem ambigit, ovarii et seminis fabrica nondum explorata, nobis quoad veram affinitatem subdubium, interim ob inflorescentiam et staminum numerum, et Wallichii et Candollei anctoritatem ad Valerianearum calcem collocatum. 
2189. Fatrinia JL'SS. C a l y $\mathrm{x}$ tube cum ovario connato, limbo supero, erecto, brevissimo, quinquedentato v. nullo. Co roll a epigyna, tubulosa, regularis, ecalcarata, limbo quinquelobo, obtuso. Stamina 4, v, rarissime 5 , corollae tubu prope basim inserta. Ora ri u m inferum, triloculare, loculis duobus minoribus, vacuis. $0 \mathrm{vulum}$ unicum, ex apice locnli majoris pendulum, anatropum. Stylus terminalis, simplex; stigma trigono-capitatum. Fructus membranaceus, calycis limbo coronatus, saepins braeteae paleaeformi adnatus, trilocularis, loculis duobus vacuis, cylindricis, tertio fertiti planiusculo, monospermo. S e m e n inversum. E mbryo exalbuminosus, orthotropus; radicula supera. - Herbae perennes, in Asia media indigenae; foliis radicalibus congestis, caulinis oppositis, pinnatilobis, flor ibus corymbosis, aureis.

Patrini a Jussien in Annal. du Mus. X. 311. Dufresue Valer. 33. Sweet Fl. Gard. t. 15\%. Reichenb. Ic, exot. t, 20. 83. 94. Mouffeta Necker elem, n. 210. G y to na u th u s Ra. finesq. in Annal. gen, sc, phys. VI. 88. Fe di a Adanson Fam. II. 152. Fedi a e s. Vahi. Gärtu t. 86. f.3. Va le rianate 8 p. Pallas. Bot. Mag, $t$. 714. Thuaberg Jap. $t, 6$.

21 ร. Nanedostaelnys $D C$. C a l y $\mathrm{x}$ tubo cum ovario connato, limbo supero, quinquepartito, lobis ovato-oblongis foliaceis, denticulatis, persistentibus. Corolla epigyna, tubulosa, regularis, ecalcarata, limbo quinquelobo, obtnso. S $\mathrm{t}$ a $\mathrm{m}$ in a 4 , corollae tubo prope basim inserta. Ova ri um inferum, triloculare, loculis duobus minoribus vacuis. $\mathrm{O}$ v $\mathrm{I}$ u $\mathrm{m}$ unicum, ex apice loculi majoris pendulum, anatropum. Stylus terminalis, simplex; stigma capitatum. Fructus membranacens, monospermus, calycis limbo coronatus. Sem e n ......-Herbae nepalenses, perennes, habitu Scorzoneram humilem referentes; radice odoratissima ad collum fibrillis erectis vestita, foliis oblongis, integerrimis $v$. dentatis, radicalibus elongat is, caulinis sessilibus oppositis, basi sublatioribus, caule simpli$c i$, floribus corymboso-fasciculatis, involucratis, corollis purpureis.

Nardostaehys DC. Mém. Valorian 4.t. 1.2. ProdrIV. 624. Royle Himalay. $t .34$. Nees jun. Pl. offic. Suppl. III. t. 18, Patriuia Don, nep. 159. Nardus indica Veterum.

21 180. Dufresmia $D C, C$ a $l y \times$ tubo cum ovario connato, limbo supero, tripartito, laciniis inaequalibus, ovatis, aentis, reticulatis, serratis, demum increscentibus. Co rolla epigyna, obeonico-tubulosa, regularis, ecalearata, limbo quinquelobo, obtuso. Stamina 3 ?.... Ovarium inferum ...... Stylus ..... F ruetus membranaceus, extns villosissimus, calyeis limbo aucto, scarioso coronatus, trilocularis, loculis duolous vacuis evlindraceis, inflatis, tertio fertili monospermo, complanato. Semen inversum. Kmbryo exalbuminosus, orthotropus; radicula supera. - Herba persica, humilis; caule basisuffruticuloso, simplici, foliis oppositis, oblongis, obtusis, integerrimis, cymis confertis subcapitatis, bracteis oblongis, patulis, serratis, floribus parvis, fortassis staminum obortu monoicis, ex sicco roseis.

Dufresnia DC. Mém. Valerian. 8. t. 3. f. 1. Prodr. IV. 624.

2151. Valexianella $M O ̈ N C H$. C a lyx tubo cum ovario connato, limbo supero, dentato. Corolla epigyna, tubulosa, regularis, ecalcarata, limbo quinquelobo, obtuso. St am in a 3 , corollae tubo prope basin inserta. Ovarium inferum, triloculare, loculis duobus vacuis, tertio fertili. Or u 1 u m unicum, ex apice loculi pendulum, ana- tropum. Sty $\ln s$ terminalis, simplex; stigma indivisum v. trifidum. Fruet $\mathrm{s}$ submembranaceus, indehiseens, calycis limbo varie dentato et aucto coronatus, trilocularis, loculis duglsus vacu is interdum septo evanido confluentibus bilocularis, tertio monospermo. S e me $\mathbf{n}$ inversum. $\mathrm{E} \mathbf{m}$ b r y o exalbuminosus, orthotropus; radi cula supera. Herbae annuae, parvae, in Europa media rarae, in regione mediterranea et in regione taurico-caucasica frequentes; caule apice dichotomo, foliis oppositis, oblongis aut linearibus, indivisis, $v$. basi dentatis, aut superioribus pinnatifidis, floribus in dichotomis solitariis aut fasciculatocorymbosis, bracteatis, parvis, albis $v$. roseis.

Vale ri anella Monch. Meth, 486. Beteke Animadvers. in Valerianellas. Rostochii, 1826. 4. DC. Mem. Valerian, 10. Prodr. IV. 62s. P ol y p rem un Adanson Fam. 11. 158. excl. sp. 0 d o a to c a r p a Necker elem, $n, 209$. Fediae sp. Vahl. Gïrtn. Reichenb. non Adiuns. et Mönch.

a. SELENGCOELAE DC. $l$.c. Fruet us triloenlaris, antice late suleatus, loculo fertili dorko baud incrassato, sterilibus duobus fertili latioribus, eurvis, sectione transversali lunulatis. - (DC, Mém. Valerian, t. 3. f. 9. 10. Dufresne Valerian. t. 3.f. $t$. Willemet in Archiv. Bot. II. t. 20. f. 12. Reichenbach 1o, crit. t. 61. 67.)

b. PLATYCOElaE DC. l. c. Fruetus trilocularis, antice sulcazus, localo fertili dorso haud incrassato, sterilibus duobus fertili diauefro latioribus ant subaerualibus coutiguis, sectione trausversall oruiculatis. - (DC. Mém. Valerian. t, 3. f.6_s. Dufresue $t . c, t .3, \bar{f} .3-5$. Wil-

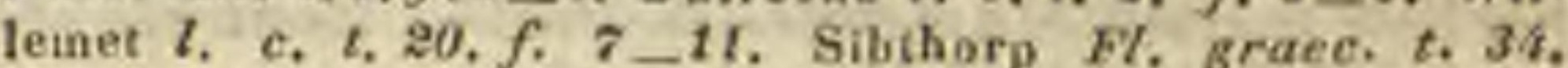
Gaudiu Elor. Helvet, t. 4. Reielienb. Le, erit, t. 63, 64. 66. 70. 113. 116,)

e. PSILOCOFLAE DC. l. c. Fruet us trifocularis, antice planiuseulus, loculo fertili dorso haud inerassato, sterilibus duobus filiformibus, fertili malto angustioribus, saepe dissitis, nerviformibus. - (DC. Mém. Valerian. $t, 3, f .45$, Dufresne $t, c . t, 3, f .4,6$. Willemet l. e. t. 20.f. 2_6. Desvaux Journ, Bot. II. t, 11.f.2. E. $B, t, 1370$. Reichenb, Io. crit, $t, 69,63.65 .68,69$. 115.)

d. Locustar DC. l.o. Fruetus bi-trilocularis, loculo uno fertili, dorso cellutoso-gibboso, duobas sterilibus fertill aeqnalibus aut latioribus, nne distinctis, nune septo-evituldo coadunatis. - (DC. Mem, Valerian, 1.3 . f. 2. 3. Dalresne t. c. t. 3. f. 8. Willemet $t, c, t, 20$. f.1. Reicheab. Te, crit, t, 60.)

2 182. A sirenglaia DC. C aly $x$ tubo cum ovario connato, limbo supero, brevissime quinquedentato v. subcampanulato. Coroll a epigyna, infundibuliformis, basi hine gibba, subealearata, limbo quinquelobo. Stamina 3 , corollae tubo prope basim inserta. O a ri $\mathbf{m}$ inferum, biloculare, loculo altero majore incomplete bilocellato vacuo. Ovulum unicum, ex apice loculi minoris pendulum, anatropum. Sty 1 us terminalis, apice trifidus; stig in a t ibus gracilibus. Fruetus membranacens, calycis limbo coronatus, bilocularis, loculo altero vacuo extus medio sulco impresso, altero monospermo. S e me $\mathrm{n}$ inversum. $\mathrm{Em}$ bryo exalhuminosus, orthotropas; radicala supera. - Herbae peruanae, annuae; foliis radicalibus subrhombeo-incisis, caulinis oppositis, imparipinnatisectis, segmentis ovali-oblongis, inciso-dentatis, floribus paniculatis aut corymbosis, albis.

Astrep hia DC. Mem, Valerian. 12. Prodr. IV. 699. He mesotria Rafinesq. in Annal. gen, sc. phys, VI. 88 , oligaeoce Willd. msc. Astrephiae sp. Dufresue $Y a$. lerian. 50 . Va Je rianae $8 \mathrm{p}$. Smith $I e$. inedit. III, $t, 53$. Ruiz et Pav. $F l$. peruv, $t, 69 f . a$. Fe diae s p. Kunth.

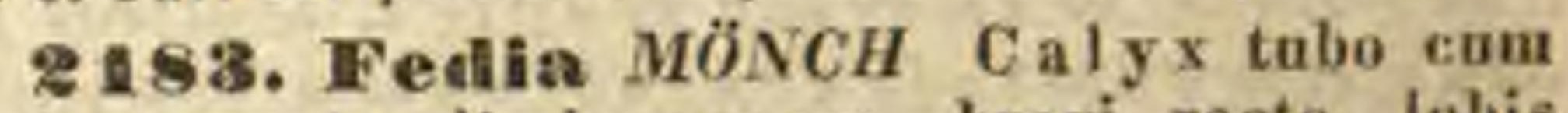
ovario connato, limbo supero, brevi, recto, lobis quatuor, subulatis, inaequalibus. Corolla epigyna, tubo filiformi, ecalcarato, limbo inaequaliter quinquefido, subringente. Stamina 2 , corollae 
tubo inserta. Ovari n m infernm, triloculare, loculis duobns minoribus, vaeuis. $O$ v $\mathrm{u} / \mathrm{nm}$ unicum, ex apice loeuli majoris pendulum, anatropum. S t yIu s terminalis simplex; stigma bifidum. Fruct us subfungosus, loculis duobus vacuis, angustis, tertio latiore monospermo. S e m e $\mathrm{n}$ inversum. E mbryo exalbuminosus, orthotropus; radieula supera. - Herbae mediterran ea e, annuae, glabrae; foliis oppositis, integerrimis aut de tatis, floribus capitato-corymbosis $v$. cymosis, roseis $v$. purpureis, bracteis adpressis.

Fe dia Mönch. Meth. 486. Jussien in Annal. Mus. $X$. 311. Dufresue Valerian. 54. t, 1. DC. Prodr. IV. 630. M itrophora Necher elem, n. 208. Valeriana Cornueop i a Linn. Sibthorp Fl. graec. $t$. 32 . Fediate $s$. Gärtn. IT. 36. $t .86$. $\mathrm{P}$ ol y p re m 1 s p. Adaus.

2154. Plectritis DC. Caly $\mathrm{x}$ tubo cum "vario connato, limbo supero, recto, integerrimo. Corolla epigyna, tubo basi breviter calcarato, antice gibboso, limbo quinquefido, hilabiato. S $\mathrm{ta}$ min a 3 , corollae tubo inserta. Ovarium inferum, triloculare, loculis duobns vacuis. Ov ulu m unicum, ex apice loculi fertilis pendulum, anatropum. St y l u s terminalis, simplex; st igma capitatum. C a p s u I a calycis limbo coronata, eartilaginea, trilocularis, loculis duobus sterilibus apertis alaeformibus, fertili monospermo. S e m e $n$ inversum...

Herba californica, annua, glabra; foliis.... floribus verticillato congestis, roseis, monoicis, bracteis multifidis, laciniis subulatis.

Pleetrltis DC. Mém. Valerian. 13. Prodr. IV. 631. Va lerianella congest a Lindl. in Bot. Reg.t. 1095.

2185. Centrantluus DC. Calyx tubo eum ovario connato, limbo supero, involnto, demum in pappum plumoso-multisetum, decidunm evoluto, Corolla epigyna, tubo obconico, basi calcarato, limbo regulari, quinquefido. St am en 1 , tubo corollae insertum. $O$ va $\mathrm{ri}$ u inferum, triloculare, loculis duobus minimis vacuis, tertio fertili. O vnl um unicum, ex apice loculi pendulum, anatrepum. Stylus terminalis, simplex; stig ma capitatum. Fructus membranaceus, nudus, unilocularis, monospermus. S e men inversum $\mathbf{E}_{\mathbf{m}} \mathrm{b}$ ry o exalbuminosus, orthotropus; radic ula supera. - Herbae mediterraneae, perennes v. rarius annuae, glaberrimae; foliis opposilis, indivisis v. pinnatisectis, floribus rubris v. albis, secus paniculae corymbosae ramos unilateralibus.

Centranthus DC. $F l, f r . I V$. 238, Mdm. Dalerian, 14. Prodr. IV. 631. K e ntranthus Necker elem, n. 207. Va. lerian a e 8 p. Lian. Sibthorp Fl. graec, t. 29. 30. Cavanill. Ic. $t .353$, E. B. $t, 1332$.

2186. Valeriama NECK. Caly $\mathrm{x}$ tuho cum ovario connato, limbo supero, involuto, de mum in pappum plumoso-multisetum, deeiduum evoluto. Co ro 11 a epigyna, tubo obconico v. cylindrico, basi aequali aut gibbo, ecalcarato, limbo obtuse quadri - quinquefido $v$, rarius trifido. S $t$ a$m$ in a 3 , tubo corollae inserta. 0 va $\mathbf{~} \mathbf{i} \mathbf{m}$ inferum, triloculare, loculis duobus minimis, vacuis. 0 v uI $\mathrm{m}$ unicum, ex apice loculi pendulum, anatropum. Stylus terminalis, simplex; st igma capitatum. Fructus membranaceus, nudus, unilocularis, monospermus. S e m e $n$ inversum. Em b r y o exalbuminosus, orthotropus; radicula supera. - Herbae v. suffrutices, in America tropica, imprimis andina, et in a ustrali extratropica tempera. ta copiosissime provenientes, in Europa media et India orient ali rariores, in $A m$ eriea bore a$l i$ rarissimae, acaules $v$.caulescentes; foliis radicalibus congestis, caulinis oppositis $v$, verticillatis, in- tegris v. pinnatifidis, saepe in eadem stirpe diversis, floribus corymbosis, capitatis aut paniculatis, in plurimis albis, rarius caerulescentibus, rubris, roseis aut flavis.

Valerian a Necker elem. n.208. DC. Mém. Valerian. 14. Prodr. IV. 632.

a. PHYLLACTis. Pers. C o ro Ila e limbus trifidus.-Caulis nullus. Folía omnia radicalia. Flores dense aggregati, involucellati et involucrati.

P h y lla e t is Persoon ench. I. 39. DC. prodr. IP. 623. (Ruiz et Pav. Flor. peruv, t. 65. f. c. d. t. 68. f. 6.)

b. $\triangle R E T I A S T R U M D C$. C o r o II a e tubus elongatus, limbo quadri-quinquefido. - Caules fructiculosi. Folia im. bricata, erasso-coriacea, integerrima, flores favi, pauci, inter folia suprema ocultati.

Aretiastrum DC. $l$. c. V. aretioldes Kusth. V. sedoides Urv.

c. PHU $D C$. C orolla e limbus quinquefidus. - Caules fruticosi v. herbacei, erecti aut scandentes. Folia om. nia indivisa, nunc radicalia inlegra, caulinis tripar. titis $v$, pinnatisectis, $v$, omnia pinnatisecta.

Phu DC. l. c. (Jacq. Flor, austr. t. 219, 267_269. Miscell. II. t. 17. Colleet. I. t. 24. Sibthorp Fl. graec. t. 33. Desfont. Corollar, t, 41. E. B. t. 1591. Hayue Pl. offic. $I I I, t, 31-33$. Nees $P l$, offic. suppl. III, $t, 9-11$. Smith Ic. inedit. III. t. 51, 58. Ruiz et Pav, Flor, peruv, t. 65. $f . a, b, t, 66, f, a, b, t, 67 . f, a, c, t, 68$. f. a. c. t. 69. f. b. t, 70. f. a, b. Cavanill. Ic. $t .456$ DC. Mém. Valerian, $t$. 4. Ledebour Ic,pl. $t$, 19, Hooker Flor. Bor. Amer. t, 101.)

218\%. Betebea DC. CaIyx tubo cum ovario connato, limbo supero, unidentato (?) deciduo. Coro 11 a epigyna, infundibuliformis, limbo quinquelobo. Sta $\mathrm{m}$ in a $3, \ldots \ldots 0 \mathrm{v}$ a $\mathrm{r}$ i $\mathrm{m}$ inferam ...... Fruetus nudus, unilocularis, triqueter, monospermus. S emen loculum replens. - Herba chilensis, annua, glabra, simplex, erecta; foliis indivisis, inferioribus obovato-oblongis, summis ovato-subrotundis, sessilibus, amplexicaulibus, cymis parvis, ad axillas foliorum breve pedunculatis, floribus parvis, albidis.

Betckea DC. Mém. Valerian, 18. Prodr, IV, 648. Valeriana s. Fedia samolifolia Bertero.- Planta a me non examinata.

\section{* gENUS ANOMALUM.}

2188. Triplostegia WALL. Flores singuli involucro duplici, exteriore quadripartito, quadriearinato, interiore tubuloso, octocostato, octodentato inelusi. C a l y x tubo cum ovario connato, limbo supero, minimo. quadridentato. Corolla epigyna, tnbulosa, regularis, eealearata, limbo quinquefido. St a mina 3 , tubo corollae infra medium inserta, a $\mathrm{n}$ h $\mathrm{e}$ ris subexsertis. Ovari um inferum ...... Ovulu m..... Stylus terminalis, simplex; stigm a eapitatum. Utrie úIn s monospermus, rostratns, calyeis limbo coronatus, involuero duplici tectus. Se men...... Herba nep al en sis; radice perennantc, longa, fibrillosa, inodora, caule gracili, obsolete quadrisulcato, simplici aut parce ramoso, superne pilis longiusculis, articulatis, apice glanduliferis obsesso, foliis ad basim caulis approximatis, petiolatis, ovato-lanceolatis, dentatis, basi pinnatijidis, supra pubescentibus, subtus villosulis, caulinis paucis, minoribus, pinnatifidis, corymbo glanduloso-pubescente, floribus purvis, ternatis, puberulis.

Triplostegia Wallich in DC. Mem. Valerian, 19. t. 4. Prodr. IV. 612.

\section{GENUS DUBIUM.}

2189. Axis LOUREIR. Cal y $\mathrm{x}$ triphyllus' foliolis acutis, brevibus, inaequalibus, deciduis. Co rolla campanulata, minima, limbo decemfido, 
aequali, plano, laciniis obtusis. $\mathrm{Sta}$ in a 3 ; $\mathrm{fi}$ la m e n ta filiformia, corollam aequantia, a $\mathbf{n} \mathbf{h}$ e$\boldsymbol{r}$ a e didymae, lobis globosis. Ov a r um inferum, ovatum, sulcatum. Stylus filiformis; stig ma crassiusculum. A cheni um ovatum, sulcatum, hirsutum. - Fruticulus cockinchinensis, bipedalis ; radice subfusiformi, radici Jin-seng succedanea, caule lignoso, multiplici, ramosissimo, nodoso, procumbente, rubente, foliis oppositis, ovato-lanceolatis, subcrenatis, tomenlosis, parvis, inaequalibus, racemis subterminalibus, floribus minusculis, albo-rubris.

A x i a Loureiro Flor, cochinch. I. 45.

\section{Drelo CXIX. Dipsacene.}

DIPSACEAE Jussieu gen, 194. excl. seot, II, DC, Fl. fr. IV. 291. Prodr. IV. 643, Coulter, Mémoire sur le Dipsacées. Geneve, 1823. 4. Bartling Ord. nat, 129. Lindley Intr oduct, edit. II. p. 264.

Herbae annuae v. perennes, interdum suffrutescentes. Caules ramique nodoso-articulati, teretes. Folia opposita v. rarissime verticillata, simplicia, in eadem stirpe saepius varia, radicalia a caulinis diversa, integra, lyrata, pinnatifida v. bipinnatifida, sessilia et amplexicaulia, interdum basibus inter se connata, aut in petiolum basi amplexicaulem dilatata. Stipula e nullae.

Flores hermaphroditi, irregulares v. subregulares, in capitulum densum, involucratum, supra receptaculum nudum v. bracteis singnlorum paleatum collecti, rarissime in axillis foliorum superiorum aggregato-verticillati. Bracteae sive paleae capituli exteriores interdum steriles; corollarum series extima saepe radians.

InvoLucellum singulis floribus calyciforme, turbinatum, tubo superne foveolato $v$. juxta totam longitudinem sulcato, limbo scarioso, integro v. dentato, persistens.

Calyx gamophyllus, tubulosus, tubo cum ovario connato, v. inferne libero superne adhaerente, $\mathbf{v}$. apice in collum cum styli basi connatum angustato, limbo supero, cyathiformi, subintegerrimo $\mathrm{v}$. dentato, saepits in lacinias setiformes, numero varias, nudas $\mathbf{v}$, barbato-plumosas, papposas desinente.

Corolia stimmo calycis tube inserta, gamopetala, tubulosa, limbo quinquefido, vel lobis duobns superioribus connatis quadrifido, rarissime ringente, saepe inaequali, lacinia infima majore laterales, supremas tegentes, per aestivationem includente.

Staurva 4, imo corollae tubo inserta, ejusque laciniis alterna, supremum infer corollae lacinias posticas saepissime deficiens. Filam en ta libera v. rarissime binatim juxta totam longitudinem connata, porrecta, saepe didynama, nempe staminum inferiorum breviora, interdum ananthera, omnia in alabastro incurvata. Anthera e introrsae, bilocnlares, lineares, in- cumbentes, deciduae; Joculi appositi, contigui, longitudinaliter dehiscentes. Pollinis granula laevia, tetraëdra.

Ovariom uniloculare, intra calycis tubum apice reclusum liberum, vel eidem totum aut saltim superne adnatum. $0 \mathrm{vul} \mathrm{um}$ unicum, apici cavitatis appensum, anatropum. Stylus terminalis fililormis, simplex, basi cum calycis collo connatus; stigma simplex, clavatum v. brevissime bifidum, lo bo altero interdum longiore.

Utricolus monospermus, intra calycis tubum involucello cinctum, limbo scarioso $\mathrm{v}$. setoso aut papposo coronatum liber, v. eidem plus minus adnatus.

Semen inversum, te $s$ ta tenuissime membranacea, ab endocarpio vix soIubili. Al bu men parcum, carnosum.

Embryo in axi albuminis orthotropus, ejusdem fere longitudine, c o t y l ed onibus ellipticis, subfoliaceis, radicula brevi, supera.

Dipsaceae a Valerianeis proxime affiaibus inflorescentia, involucello, ovario constanter uniloculari, saepius intra tubum calycis libero et semine albuminoso facillime distin. guendae, in regionibus temperatis et calidioribus extratropicis hemisphaerae bortaIi s veteris orbis, nec non in $C$ apite bonae s pe i gignuntur, in regione mediterranea orientali panllo frequentius obviae.

TERIEUS I. MORINEAE DC, Prodr. IV. 644. Coroll a ringens, limbo quinquefido. S $t$ a min a 4, libera, didynama v, binatim conereta. - Elores verlicillati.

2190. DIorima TOURNEF, FInres aggregato - verticillati, bracteati. Invol u cell a m tubuloso-eampanulatum, efoveolatum, limbo inaequaliter spinoso-dentato. C a ! y $x$ tubo ovario superne adnato, limbo foliareo-bifido, lobis oblongis, integris v. bifidis. Corolla epigyna, tubo elongato, limbi ringentis labio soperiore bi-inferiore trifido. St a m in a 4, libera, didynama, v, per paria juxta totam longitudinem connata. Ovarium inferum, uniloculare, uniovnlatum. Stylus filiformis; s tigma peltato-capitatum. Uiriculns monospermus, involucello inclusus, calycis limbo coronatus. Semen inversum. Embryo in axi albuminis earnosi orthotropus; radi $e$ u la supera. - Herbae orientales, a Parnasso per $S_{y}$ riam et Persiam in Indiam borea $l$ em diffusae,perennes, simplices, erectae; foliis oppositis v. verticillatis, oblongis, sinuatis, dentato-spinosis, rariusve integerrimis, floribus in foliorum superiorum axillis ag gregato-verticillalis, pedicellatis, pedicellis apice bibracteatis.

Moria a Tournefort Corollar. 48. Linn, gen, $n$, 4I. Juss. gen, 194. Coulter Dipsac. 21, DC. Prodr, $I D+64$. D i o to the c a Vaillant in Mém. Academ. Paris, 1722. p. 184. a. DIOTOCALYX DC. Calycis limbas bilobus, lobis oblongis, apice plus minus emarginatis, inermibus, Sta. mina binatim (an in omnibus) conuata. - Folia sinna. ta, spinoso-dentata.

D i o t o e \& I y x DC. Prodr. IV. 644, Lam, t. 21. Sibthorp Flor. graec, $t, 28$, Coulter Dipsac, $t, 1, f, t$. Roylo Himalay. $1,35 . f .1$. 
b. ACANTHOCALYX DC. Calyeis limbus obliques, irregulariter spinoso-dentatus. $\mathrm{S}$ t a $\mathrm{m}$ in a 4 , libera, didynama. - Folia caulina integerrima, floralia basi spinoso-dentata.

A c a th ocaly $x$ DC. Prodr. IV. 645.

TIERTE HIS. SCABIOSEAE DC.Prodr. IV. 645. C o rolla limbo quadri-quinquefido, saepissime inaequali, haud ringente. St a $\mathrm{m}$ n a 4-5, libera, subaequalia. - Flores supra receptaculum capitati, saepissime paleaceobracteali, capilutis involucratis.

2191. Jipssaeus TOURNEF. Flores capitati, involucro polyphyllo, paleas receptaculi subfoliaceas, acuminatas superante. Invo I uce II u im tetraëdrum, octosulcatum. C aly x tubo cum ovario connato, limbo supero subeyathiformi v. discoideo. Corolla epigyna, quadrifida. Sta m in a 4. Ovarium inferum, uniloculare, uniovulatum. Stylus filiformis; stigma longitudinale. Utri cul us monospermus, involucello inclusus, calyeis limbo subtetragono coronatus. S e m en inversum. E m b ryo in axi albuminis carnosi orthotrepus; radi $\mathrm{cula}$ supera. - Herbae biennes, in Europa et Asia media, nec non in India boreali obviae, erectae, pilosae v. aculeolatae; foliis oppositis, in pluribus basi connatis, dentatis laciniatisve, cupitulis terminalibus subglobosis v. pyramidatis, corollis lilacinis, flavescentibus $v$, albidis.

Dipsa cus Tournefort inst. 265. Linu. gen, n. 114 . Gärtn, II, 39, t, 86, Jacq. Flor, austr. t, 248, 402, 403, Fl. dan. t. 965. E. B. t. 877. 1039. 2080. Teatt, Tabular, t. 235. Coulter Dipsac. 21. f. 2_4. DC. Prodr. IV.645. Galedrago n Gray Brit, pl, IT. 475.

2182. Ceplualaria SCHRAU. Flores capitati, involucro polyphyllo, paleis receptaeuli muticis v, aristatis breviore. Involu cell um tetraëdrum, octosuleatum, corona quadri-octodentata. Ca ly x tubo cum ovario connato, limbo supero cyathiformi v. discoideo. Co rolla epigyna, quadrifida. Stamina 4. Ovarium inferum, nniloculare, uniovulatum. Sty lus filiformis; stig ma longitudinale. Utrien lus monospermus, involucello inclusus, calycis limbo tetragono coronatus. Semen inversum. Embryo in axi albuminis carnosi orthotropus; radicula supera. Herbae perennes, inermes, a Dipsacis vix nisi invotucro breviore diversae, in Europa $m$ edia et in Asia boreali et medilerranea, nec non in Capite bonac spei indigenae; foliis oppositis, dentatis $v$, pinnatifidis, capitulis terminalibus, subglobosis, paleis exterioribus sterilibus, corollts albidis, ochroleucis $v$. lilacinis.

C e p t a laria Schrader Index sem. Götting. 1814, Römer et Schult, syst, $I K$. n. 406. Coulter Dipsac. 24. f. 5_9. DC. Prodr. IV. 647. Le pie ph al us Lagasi. gen. et sp. 1816.p.7. Carlona ut h u Schott mse. Suceisa Vaillant Mém. Academ, Paris, 1729, p. 174. Wallroth Sched, crit. 46. Pyenocomon Wallr. msc. Seabiosne s p. Liau. Jacq. Hort, Vindob. t. 111. Waldst. et Kit. Plant. Hung. 1.13. 230. Sibthorp Flor. graec. t, 103, Reiclieab. Hort. Bot. t.17. Ic, orit, t. 121, 301, 314, 315. 356.

2193. Knautia COULT. Flores capitati, involucro polyphyllo, receptaculo hirsuto, epaleato. Involncellnm breviter stipitatum, compressum, quadrifoveolatum, denticulatum, dentibus duobus majoribus. C a 1 y $\mathrm{x}$ tubo cum ovario connato, limbo supero, cyathiformi. Coroll a epigyna, quadri-quinquefida. Stamina 4 . O va ri um inferum, uniloculare, uniovulatum. Stylus filiformis ; stigma emarginatum v. bifidum. Utriculus monospermus, involucello arete reclusus, ealycis limbo ciliato v. breviter setoso-aristato coronatus. S e m en inversum. Emb r yo in axi albuminis carnosi orthotropus; $r$ ad i e ula supera. Herbae annuae $v$. perennes, erectae, ramosae, saepius villosae, in Europ a imprimis orientali, nec non in Asia fin itima provenientes; foliis oppo. sitis, omnibus integerrimis v, saepius inferioribus pinnatifidis, capitulis terminalibus, saepe radiantibus, floribus rubris $v$, rubro-caeruleis.

K n a u ti a Coulter Dipsao. 28. DC. Prodr. IV, 650.

a. LYCHNOIDES $D C$. Involuerum erectum, cylindri. cum, hexa-decaphyllum. Fl ores supra receptaculum angustum pauci, 5-10. Involucell um brevissime maltidentatum, dentibus duobus paullo majoribus. $\mathrm{C}_{0}$. rollae valde irregulares. C aly $\mathrm{c}$ is fructiferi limbus obsolete ciliatus. - Herbae annuae, floribus dilute rubris.

Ly chuoides DC. Prodr. IV. 630. Lyehni. Scabi o s a Boerhave Lugd. Bat. 191. Kn autia Liun. gen, n, 116. Schkuhr t. 22. Lam. t. 58. Coulter Dipsae. t. 1. f, 11 .

b. TRICHEROIDES DC. Involuerum patens, dees. dodecaphyllum. Fl ores pauei v,plurimi. Invol a cel. la $\mathrm{m}$ bidentatum. Co rolla e parum irregulares. CaI y cis fructiferi limbus elliatus, subevanidus. - Her. bae annuae, floribus caerulescenti-rosets.

Trieheroides DC. Prodr. IV. 650. S cabiosac s p. Auet. Sibtliorp. Flor. graec. t, 104. (Coulter Dipsac. t. 1. $f, 10.12$.

c. TRICHERA Schrad. In volucrum patens, polyphyllum. Flores plurini, receptaeulo dilatato impositi. Invo I n e e II u m apice subtruncatum. C a I y e is fruetiferi limbus in setas $8-10$ aristaeformes divisus. C orolla subregulares.- Herbae perennes, floribus pur. pureo-caerulescentibus.

Triehera Sehrader Index sem. Götling. 1814. DC l. c. $\mathrm{S} \mathrm{c}$ a bios a e sp. Limn. E. B, t. 659. Jacq. f. Eolog. t.60. Waldst. et Kit. Pl. Hung, $t$, s. Reichenb, Ic. crit c. 273. 332. (Coulter Dipsac. ใ. 1. f. 13.)

2194. Pterocephalus $V A I L L$. F I o res capitati, involucro biseriatim tetra-hexaphyllo, multiflore, receptaculo villoso seu paleaceo. In vol a. c e 11 u m quadrifoveatum, dentatum v. aristatum. Calyx tubo eum ovario connato, limbo supero, aristato. Coroll a epigyna, quinquefida. S t a mina 4 , rarins 2 v. 3 . Ovarium inferum, uniloculare, uniovulatum. Stylus filiformis; stigma emarginatum. Utriculus monospermus, involucro inclusus, calyeis limbo in pappum multiradiaIum, plumoso-setosum desinente coronatus. S $\mathrm{S}$ men inversum. E m b r yo in axi albuminis carnosi orthotropus; radicula supera. - Herbae annuae $v$. suffrutescentes, in regione mediterra$n \in$ a provenientes; foliis oppositis, integris $v$, omnibus aut saltem superioribus pinnatijidis, capitulis terminalibus multifloris.

Pterocephal us Vaillant Act. Academ. Paris, 1789. p. 184, t. 13. f. 23. 24. Wallroth Sched, crit, 47. Coulter Dipsac. 31, $t, 1, f, 14 \ldots 17$. DC. Prodr, $I V .632$. S c a bio s a e et K a a u t i a e sp. Lian.Gärta. $t$. 86. Sibthorp Fl. graec, $t, 111.112$,

2195. Seatbiosa RÖM. et SCHULT. F10res capitati, involucro polyphyllo, multifloro, receptaculo paleaceo. I nvol u c ell um eylindricum, quadri-octofoveolatum, nuticum. Cal y ci s tubus cum ovario connatus, limbus longus, colliformis, in setas aristaeformes 5 , vel abortu pauciores desinens. Co roll a epigyna, quadri-quinquefida. O vari am inferum, unilocnlare, uniovnlatum. Stylus filiformis; stigma emarginatum. Utriculus monospermus, calycis limbo colliformi, elongato, subquinqueseto coronatus, $\mathrm{S}$ e m e $\mathrm{n}$ inversum. $\mathbf{E m}$ bryo in axi albuminis carnosi orthotropns; $r$ adi c ula supera. - Herbae perennes $v$. suffrutices, in regione mestiterranea obviae, in Europa 
et Asia media, in Capite bonae spei et in In dia bor eali rarae; foliis integris $v$. pinnatifidis, capitulis terminalibus, depressis.

S c abios a Römer et Schult. sgst. III.2. Coulter Dip. sac. 33. DC. Prodr. $I V$. 654. A ste r o e ephalus Vaillant in Act. Academ. Paris. 1729, p. 178. Wallroth Sched, crit. 46. S e lerostemma Schott msc. S eabios a sp. Linn.

a. ASTEROCEPHALUS Coult. Involucelli basis teres nec plicata, tubus octofoveolatus, corona ampla, mem. branacea, patula aut erecta. Caly cis iruetiferi setac 5 , exżertae.

A sterocephalus Coult. $l$ c.t. 2. $f .1_{-10}$. (Jacq. Ic. rar. $t$, 24, Hort. Vindob. $t, 15,96$. Desfont Fl. All. t. 39. Choix t. 40. Sibthorp Fl. graec. t. 107. 114. Kitaibel Pl. Hung. $t$. 188. Bot. Mag. $t .886$. Bot. Reg. $t .835$. Reichenb. Ic. crit. t. 326. Fenzl Sert, Cabul. t. 4.)

b. VIDUA Coult. Involucelli basis rotundata, plicata, tubi foveolis sacpe obliteratis, coronae limbo inflexo, spongioso. C aly e is fruetiferi setae 5, exsertae.

$\checkmark$ id ua Coult, l.c.p.37. t. 2. f. 11. Spougos tem. ma Reichenb. Flor. excurs, 194. (Desfont. Flor, All. t. 38. Bot. Mag.t.247, Gärtn. $t$, 86, f. 4.)

c. SUCCISA Coult. Involucellum foveolis a basi ad coronam brevem patulam, membranaceam exaratum. C a$1 \mathrm{y}$ e is fruetiferi setae 5, nune nonnullae nune omnes abortivae.

Suceis a Coult. op. cit. 37. t. 2. f. $12-18$. C a$1 \mathrm{u}$ u baria Thuill. Fl, fr. I, 72. (Jacq. Flor. Austr. t. 439. Hort. Vindob, t. 185. Cav. Ic. t, 183, E. B.t.878, 1311. Bot. Reg, $t, 211$. Kitaib. $P$, Hung, $t, 53,138$, Jacq. f. Eclog. t.59. Tenore Flor, neap. t.7. 8. Reichenb. Ic. crit, $2.353,354.381$.)

\section{Ordo CXX. Compositae.}

CompositaE Vaillant in Act, Academ. Paris, 1718_ 1721. Linn. Ord. nat. 21. Adanson Fam. IT. 103. R. Brown in Linn. Transact, XII. 76, Lessing Synopsis generum Com. positarum. Berolini, 1832. 8. DC. Prodr. V. 4. Lindley Introduct, edit. II, p, 251. SYNANTHERAE L. C. Richard in Marth. Catalog, hort, bot, 1801, p.85. Cassini Opusc, phytolog. I. 1. Dict. se, nat. LI. 443. Bartling Ord.nat.120.

Herbae ut plurimum perennes, interdum SUFFrutices, rarius a rboreseentes, succo aqueo, $\mathbf{v}$. in nonnullis lacteo. C a ules ramique ut plurimum teretes, nunc irregulariter angulati, scapiformes v, foliati, rami saepius corymbosi, centrales praecociores. Foli a alterna v. opposita aut interdum verticillata, admodum varia, simplicia, integra v. varie dissecta, nunquam vere composita. Stipulae nullae, earum loco petioli interdum auriculis stipulaeformibus praediti.

FLor Rs hermaphroditi $\mathbf{v}$, abortu unisexuales ant neutri, in cap it ulu $\mathrm{m}$ v. glemerulum, supra receptaculn m seu rami apicem planum, sive conicum aut elongatum, invol u c ro vario cinctum collecti, exteriores sive inferiores praecociores, interioribus sensim evolutis.

Capituri (floris compositi Vet. calathidis Mirb, anthodii Ehrh. cephalanthii Rich.) flores aut omnes hermaphroditi (capitulum homogamum); vel exteriores neutri s. feminei, interiores hermaphroditi v. masculi (capilulum he(erogamum), nunc omnes corollis tubulosis (capilulum discoideum v. flosculosum) v. liguhatis (capitulum ligulatum s, semiflosculosum) praediti, v. corollis in margine seu radio ligulatis, in centro sive disco tubulosis (capiculum radiatum), v. omnibus bilabiatis (capitulum falso-discoideum), $\mathbf{v}$, in margine ligulatis, in centro bilabiatis (capitulum falso-radiatum $s$. radiatiforme), marginalibus capituli discoidei et falso discoidei nonnunquam conformibus sed majoribus (capitulum coronatum) donati. Capitula ejusdem stirpis floribus masculis femineisque aequaliter praedita (capitula monoica), v. alia in eadem planta mascula alia feminea (capitula heterocephala), nunc juxta sexum per stirpes seggregata (capitula dioica).

INvoLderI (calycis communis Veter. perigynandrae communis Neck. periclinii Mirb. periphoranthii Rich.) s q u a m a e plures, uni-pluriseriatae, liberae v, dum simplici serie adsunt margine interdum inter se coalitae, siccae, scariosae, coriaceae, carnosae, spinosae, rariusve foliaceae, saepe appendice anctae, seriebus aequalibus v. saepe inaequalibus, imbricatis v. calyculatis, interdum varie et subinordinate elongatis.

Gromerour (capilulum Cass.) e capitulis pluribus, uni-paucifloris, involucris propriis instructis, dense et varie aggregatis et involucro generali cinctis, receptaculo communi insidentibus, capitulis centralibus saepe praecocioribus, exterioribus serius v. inordinate florentibus.

Receptacunom (phoranthium Rich. clinanthium Cass, rhachis Less.) nunc spica contracta, pale is (bracteolis Less.) involucri squamas referentibus et ad latus cujusvis floris externum sitis, supra basim articulatis, (quandoque in folia vera mutatis) obsessum (receptaculum paleaceum); $\mathbf{v}$. in ambitu tantum paleis donatum (receplaculum semipaleaceum); aut isdem plane destitutnm (receptaculum nudum v. epaleaceum); nunc u $\mathrm{mbella}$ contracta, singulis floribus tanquam involucello proprio alveoli basi squamosa, apice saepe in laminas $\mathbf{v}$, setas irregulares desinente (receptaculum fimbrilliferum), v, alveolis brevihus in setas non productis sed saepe denticulatis (receptaculum alveolatum), aut areola pentagona (receptaculum areolalum) cinctis.

Calyx tubo cum ovario connato, nune aeguaIi, nunc supra illud plus minus producto, limbo supero (pappo), nunc omnino nullo v. ad marginem minimum reducto, nunc rarissime foliaceo, plerumque scariosn, integro, dentato, lo bato v. plerumque expanso in squamulas paleaceas, v. setas piliformes, simplices v. ramosas, denticulatas ant plumosas, uni-bi-multiseriales, persistentes $v$, decidnas.

Corolua gamopetala, disco epigyno inserta, petalis singulis nervis duobus marginalibus do- 
natis, in tubo geminatim concretis (corolla nervamphipetala), adjectis interdum accessoriis, medium lobum occupantibus, in pancissimis solis obviis. Tubus longitudine varius, faux saepius ampliata, li mbu s saepius quinquelobus, rarius quadri-tri-aut bilobus, lobis per aestivationem valvatis, nunc omnibus aequalibus, nunc subaequalibus $\mathbf{v}$. irregularibus, inaequalibus sive palmatis, nunc bilabiatis, labii exterioris tribus, interioris duobus, v. exterio ris quatuor, interioris unico, nunc ad latus interius distinctis, illine in ligulam quinquedentatam planam concretis, Corollarum c ol o $r$ xanthicus v. cyanicus, capitula homochroma v. heterochroma, ligulis in heterochromis semper cyanicis, tubulis xanthicis.

Stamina quinque v. rarius quatuor, in floribus femineis neutrisve nulla aut rudimentaria, tubo corollae inserta, ejusque lobis alterna, nervis ideo congruentia. Filamenta tubo inferne adnata, superne liberata, aut omnino inter se distincta aut in tubum concreta, et monadelpha, versus apicem articulata, articulo superiore connectivi locum tenente. A nther a e erectae, uniseriales, rarissime distinctae, vix non semper in tubum stylo pervium concretae (syngenesae v. synantherae), lineares, introrsae, biloculares, rimis longitudinalibus dehiscentes, quadrivalves, apice saepissime in appendicem sive alam, forma, magnitudine et consistentia variam productae, basi saepissime in caudas plus minus longas desinentes. Pollen globosum v. ellipticum, laeve vel echinulatum.

Ovarium inferum, uniloculare, uniovulatum. O vu I um e basi erectum, anatropum. D is cus epigynus annularis, nectarium alveolare cingens. Stylus terminalis, teres $v$, rarius basi tumidus (bulbosus), in floribus masculis si adest simplicissimus, in femineis et hermaphroditis superne bifidus, ramis (vulgo stigmata dictis) superne planis, subtas convexis, nunc omnino liberis, nunc plus minusve inter se concretis. Glandulae stigmaticae (stigmata sensu strictiori) biseriales, in pagina superiore ramorum styli seriebus continuis marginalibus, scabriusculis, plus minnsve prominulis $\mathbf{v}$. confluentibus distinctis. Pili collectores rigidi, in floribus masculis et neutris obsoleti.

Aснекіо supra receptaculam articulatum, ut plurimum sessile, rarius stipitatum, areola basilari v. laterali instructum, tubo calycis supra ovarium interdum producto rostratum, v. eodem ovarium hand superante erostre, pappo persistente v. deciduo superatum.

Sеита unicum, e funiculo brevissimo erectum, t es t a cum endocarpio saepissime cohaerente, endopleura (albumen Less.) crassiuscula, tenera, diaphana, rhaphe bifida percursa.
Emвryo orthotropus, c otyledonibus plano-convexis v. rarissime curvatis; $r$ ad i $\mathbf{c}$ la brevi infera, plumula in plurimis vix conspicua.

Compositarum ordo plantarum vascularium vastissimus, per totum terrarum orbem obvius, decimam fere regni vegetabilis partem comprehendit, speciebus in regionibus temperatis hemisphaerae borealis copiosioribus, in America tropica copiosissimis, in A frica et Asia tropi ca paullo rarioribus, in regionibus frigidis parce provenientibus. Species herbaceae in climate frigido et temperato, frutescentes in calidioribus proveniunt, insulae nonnullae tropicae longius a continentibus remotae, $\mathbf{v}$. australes patenti adjacentes oceano Compositis arborescentibus superbiunt.

Vires insunt variae, nondum satis exploratae. Sapor saepius amarus, adstringens et aromaticus.

In generibus exponendis et ordinandis Candolleum presso pede aetas nostra sequetur.

SUBOIED I. TUBULIFLORAE. Flores hermaphroditi, corollis regularibus quinque- $v$. rarius quadridentatis.

TIEI IIS U. VERNONIACEAE Lessing Synopsis 145. Capitula uni - pauci-multiflora, plerumque homogama, discoidea, flo rib u s omnibus hermaphroditis v. rarissime dioicis; rarius heterogama, radia ta, floribus radii ligulatis, femineis. Rece ptaculum alveolatum, fimbrilliferum v. nudum, rarissime paleaceum. Flores cyanici, rarissime xanthici. Corolla quinquefida, plerumque regularis, interdum subbilabiata v. palmata. Stylus superne cylindricus, stig m at $\mathrm{ibus}$ aequaliter hispidis, longis, subulatis, rarius brevibus et obtusis, glandulis stigmaticis in series prominulas, angustas dispositis, supra medios ramos desinentibus.

SUIB'TREIBUS 1. VERNONIEAE Cassini Tabl. XX. C a p it u 1 a discoidea. S t y Ii rami elongati v. acuminati. - Folia alcerna $v$. rarius opposita. Flores albi, caerulei $v$. purpurei.

IDIVISIO I. EUVERNONIEAE DC. Prodr. V. 10. Ca pitula discoidea, plerumque multiflora, rarissime uni- v. panciflora. Involucru m teres, multiseriale, imbricatum. Receptacu lu mudum v. alveolatum, interdum fimbrilliferum. Coroll a tubulosa, regularis aut subpalmata. Antherae ecaudatae. Styli rami semisubulati. - Folia alterna v. in paucissimis opposila.

SUEDIVISIT T. ETHULIEAE DC. Prodr. V. 10. C a p itula uni-multiflora, di- 
stincta. Papp us nullus v. coroniformis, uniserialis.

2196. Adenoeyelus LESS. Ca pituI $\mathrm{um}$ uniflorum. Invol u er u m oblongo-cylindraceum, squamis coriaceis, interioribus multo longioribus. Receptaculum punctiforme. CorolIa regularis, limbi quinquefidi, a tnbo vix distineti lobis acuminatis. Achen ium obconicum, laeve, suleatum, nectario alveolari, diseo epigyno orbe glandularum notato. P a p p u s nullus. - Frutex a ntillanus; ramis junioribus petiolisque pubescentibus, foliis alternis, petiolatis, ovato-oblongis, acuminatis, subintegerrimis, glabris, corymbis terminalibus repetito-dichotomis, condensatis, corollis roseis.

Adeno y clus Lessiag in Linnaea V. 337. fig. 39-41. Synops. 16t. DC. Prodr. $V, 10$, Eupatori um eoudensat $\mathrm{u}$ m Reichenb.

215\%. Dolontoloma H. B.K. Ca pit $\mathrm{lum}$ uniflorum. Invo I u crum cylinairaceum, imbricatum, squamis coriaceis, interioribus longioribus. R e c ept a culum punetiforme. Cor olla regularis, limbi quinquefidi laeiniis acuminatis. A $\mathrm{c}$ h e n i a obeonica, glaberrima, nectario alveolari, disco epigyno magno. P a p p u s uniserialis, coroniformis, coriaceus, brevis, apice inaequaliter acute multifido-dentatus. - Arbuscula caraceasana; ramis fuscescenti-tomentosis, foliis sparsis, petiolatis, ovatis, integerrimis, acuminatis, supra glabris, subtus pulverulento-tomentosis, corymbis terminalibus, subsessilibus, ramosissimis, capitulis fasciculato-congestis.

Od on tol om a Kunth in Humb. ot Bonpl. Nov. gen. et sp. IV. 43. t. 319. Lessing in Linnaea IV. 337. f. 29. Synops. 147. DC. Prodr. V. 11.

2198. Diospermumn LESS. C a p it uI $\mathrm{n} \mathrm{m}$ multiflorum, discoideum. Invol ucr a m imbricatum, patens, squamis scariosis, acutis, hasi foliis inaequalibus, capitulo longioribus cinctum. Recepta eulum latum, nudum. Co roll a e regulares, limbi quinquefidi, a tubo vix distincti laciniis acuminatis. A chenia apice rotundata, sulcata, hispidula, nectario alveolari, disco epigyno parvo. P a P p и nullus. - Herba brasiliensis, ramosa, glabriuscula, repens; ramis adscendentibus, folitis alternis, petiolatis, ovato-lanceolatis, utrinque anguslatis, serratis, capitulis solitariis, longe pedunculatis, oppositifoliti, corollis pallide rubentibus.

0 i o s perm u $\mathrm{m}$ Lessing in Linnaed IV. 339. f. 69.7t. 72.78. Synops 148. DC. Prodr. V. 11. exel. sp. indicis. E th th Il a e sp. Nees et Mart. Calydermi sp. Spreng.

2199. Sparganophorus VAILL. C a p it u l u m multiflorum, discoideum. I n vol u cr um imbricatum, teres, squamis scariosis, squarrosis. Receptaculam nudum. Corolla regularis, limbi brevissimi, tri- v, rarissime quadrifidi, a tubo vix distincti lobis acuminatis. A $\mathrm{e}$ henia oblique obpyramidata, tri quinquecostata, glabra, glandulosa, collo apieali magno. P a p p n 8 brevis, coroniformis, uniserialis, cartilagineus. - Herbae annuae, in America et Africa tropica littorali indigenae; foliis alternis, ellipticis, breve petiolatis, serratis, capitulis axillaribus sessilibus.

S parganophor a 8 Vaillaut Act. Academ. Paris. 1719. p. 368. Gärtn. II. 396, t. 165. Cassini in Dict. sc, nat. L. 81. Lessing in Linnaea $I V$. 335. Synops. 147. DC. Prodr. V. 11. St ruchium P. Browae Jam. 312, $t$. 34. f. 2. Jussieu gen, 184. Palisot Flor. Owar, $t$. 48. Eth ulia sp. Linn. For. Fluuin. VIII, $\ell, 90$.
2200. Ethullia CASS. C a pitu l u m multiflornm, discoideum. Involucrum pluriseriale, teres, squamis subfoliaceis, acutis. Re ce ptacul u mudum. C or oll a e regulares, limbi campannlati, quinquefidi laciniis acuminatis, brevibus. A c h e n i a obpyramidata, tetraquetra, guadricostata, glabra, apice truncato tetra-pentagono. P a p p u 8 coroniformis, minimus, carnosus, integerrimus. - Herbae in Africa tropica et extratropica indigenae, ramosae, erectae; foliis alternis, oblongis, utrinque attenuatis, serratis v. integerrimis, pellucido-punctatis, capitulis parvis, corymbosis, corollis roseis v. purpureis.

Ethulla Cassiui in Dict, sc, nat. XV. 7. t, 487. Les. sing in Linnaea IV. 336. f. 26. 27. 35. 43. Synops. 148. DC. Prodr. $V$. 12, Kahiria Forsk. Aegypt. 153. P i erarda Adanson Fans. II. 499. L, e Ig h i a Seopoli Introduct, n. 412. Et hull a e sp. Linu. f. Dec, $I, t, 1$.

2201. IITerderia CASS, Capitulum multiflorum, discoideum. Rece p ta e u l um planum, nudum. I n v o I a erum campanulatum, biseriale, squamis foliaceis, oblongis, aequalibus. Rec e p ta c u l a m nudum. Co ro il a e regulares, limbi campanulati, quinquefidi laciniis acuminatis, brevibus, extus pubescentibus. A $\mathrm{c} h$ e $\mathrm{n}$ i a tritetraquetra, prismatica, glabra, angulis nerviformibus, annulo cupulari coronata. Pappus uniserialis, biformis, paleis 8 - 10 crassiusculis, oblongis, obtusis emarginatisque, eiliatis, demum stellato-patentibus, et setis $2-3$ elongatis, rigidis, scabris, cum achenii angulis continnis. - Herbae s e ne ga $m$ bic a e ripariue, ramosaev, ramosissimae; foliis alternis, obovatis, obtusis, apice subdenticulatis, capilulis terminalibus solitariis, floribus purpureo-violaceis, dense intra involucra eonfertis.

Herderi a Cassini in Dict. sc. nat. LX. 586.599. DC. Prodr, $\nu, 13$.

\section{SUIBTIVISIG II. HETEROCOMEAE} DC. Prodr. V, 14. C a p i t u l a uni-bi-multiflora, distincta. Pap pus uni-bi-pluriserialis, exterior setiformis, squamellatus aut rarissime coroniformis, interior semper setiformis.

220\%. Pacomrina $A U B L$, Capitnlum globnsum, multiflorum, discoideum. In vo I u e r a m floribus subaequale, imbricatnm, squamis latis, parallelinerviis, margine membranaceis, exterioribus foliaceis, spina terminatis, interioribus seariosis, obtusis. Receptaculam planum, carnosum, nudum. C o roll a e regulares, tubo brevi, limbi eylindriei, breviter quinquefidi lobis subaenminatis. Achenia longe cylindracea, glabra, cortice crasso, enervio. Pappns brevis, pluriserialis, pilis rigidis, crassiusculis, denticulatis, interioribus basi subeoncretis. - Herbae $A m e x i \bar{c} a m$ a equinoctiale $m$ incolentes, glabrae; caule tereti, foliis alternis, ovalibus aut oblongis, in petiolum marginatum, subamplexicaulem angustatis, capitulis oppositifoliis laleralibusve, sessilibus, solitariis, corollis purpureis.

Pa e ourina Aublet Guian, Ir. 800. 2. 316. Kunth in Humb. et Bonpl. Nov, gen, et sp. IV, 23. DC. Prodr. V.14. Pa courinops is Cassini Bullet, soc, philomat, Sept. 1817. p. 151. Dict, sc, nat, $\mathrm{XXXV1I}$, 212. Lessing in Linnaea IV. 3is. $\mathrm{P}$ a co u $\mathrm{r} \mathrm{i}$ n a Vernoniae sect. Lessing in Linnaea $V T$. 680. Synops. 146. Mefisteria Seopoll introduct, $n .383$. Ha yne a Willd. $s p$. III. 1787.

2203. Heteroeoma DC. Ca p it in I m multiflorum, discoideum. Involucrum campanulatum, teretinsculum, imbricatum, squamis coriaceis, subscariosis, plurinerviis, interioribus sub- 
longioribus, subpungentibus. R e c p ta $\mathbf{c u l} \mathbf{~ u m}$ paleis involucri squamas referentibus obsitum, alveolis in palearum axillis unifloris. Corolla e regulares, limbi quinquefidi laciniis linearibus, tubo tereti longioribus. A $\mathbf{c h}$ en i oblongo-cylindracea, glabra, disco epigyno magno, nectario alveolari. P a p u s biserialis, exterior brevis, coronaeformis, cartilagineus, crenatus, interior e setis filiformibus, apice serratis, Iongis, rigidis, caducis. - Suffrutex brasiliensis; foliis alternis, semiamplexicaulibus, oblongo-lanceolatis, utrinque albotomentosis, capitulis axillaribus, sessilibus.

Heterocoma DC. in Annal. Mas. XVI. 191. t. 7. Prodr. $Y$. 14. Lessing in Linnaca IV.339. f.50_52. Synops. 150.

2204. Vermonia $S C H R E B$. Ca $\mathrm{p}$ it $\mathrm{ul} \mathrm{um}$ uni-pluri-multiflorum, discoideum. In vo 1 u cr u m imbricatum, floribus brevius, $8 \mathrm{q} \mathbf{u}$ a $\mathrm{m}$ is interioribus longioribus. Recepta $\mathbf{e} \mathbf{l} \mathbf{u m}$ nudum v. rarius alveolato-subfimbrillosum, Corolla e regulares limbi quinquefidi lobis tubum subaequantibus. Achenia callo basilari cartilagineo, disco epigyno magno. Pappus ut plurimum biserialis, rarius aequalis, plerumque serie interiore setiformi exteriorem saepissime paleaceam superante. Herbae erectae $v$. frutices, interdum arborescentes, inter tropicos totius orbis obviae, habitu vario; foliis alternis $v$. rarissime oppositis, saepe glandulosis, inflorescentia varia, saepius scorpioidea, floribus in involucris rarissime solitariis, saepius paucis, plerumque plurimis, corollis purpureis, roseis $v$. albis.

Ver nonia Schreber gen. II. 5/1. Swartz Flor. Ind. occid. $11 I$. 317. Lessing in Linnaea $I V$. 294, Synops. 146. excl. sp. DC. Prodir. $V .15$.

a. ACILEPIS Don. Ca pitn I a multiflora, sessilia. 1 n v olueri squamae multiseriales, imbricatae, subpungentes. Receptaculum alveolatum. A ehenia angulato-villosa. Pap p us biserialis, serie exteriore brevissíma. Herbae indicae.

Acilepis Don nep. 169. DC. Prodr. $V .15$.

b. HOLOLEPIS DC. Capitula multiflora, ramulos axillares terminantia. I avolncri squamae coriaceae, adpresse imbricatae, exteriores breves, ovatae, interiores sensim elongatae. R e e p ta c u l um latum, planum, alveolatum, fimbrilliferum. A c h e n i a glaberrima. P a p p i paleae plurimae, uniformes, filiformes, rigidae, barbellulatae. - Herbae americanae tropicae.

Hol ol ep is DC. in Annal, du Mus, XVT. 190. Prodr. V. 16. Cassiai Dict, sc. nat. XXI. 308. Proteopsis Martius msc.

c. LEPTOSPERMOIDES $D C$. C a p it u 1 a multiflora, solitaria, terminalia. A chenia sericeo-villosa. Pappi serles inaequales, exterior brevis, paleacea. - Suffru. tices americani tropici et madagascarienses.

Leptospermoides DC. Prodr. V. 17.

d. VANillosma Less. Capitala pauciflora, aggregata, fasciculata, fasciculis axillaribus, folio brevioribus. A chenia glabra v. pilosa. - Erutices americani tropici, foliis petiolatis, penninervits, subtus saepis. sime incanis.

Va nillos m a Lessing in Linnaea PT, 630. DC. Prodr. V. 18. C a r p ho bol us Sehott in Spreng, Cur. post. 409.

e. STROBOCALYX Blum. Capitula tri-quinqueflora, involueri teretiuseuli squamis imbrieatis, ovatis, obtusis, floribus multo brevioribus. Papp us uniserialis v. subbiserialis, exterior setis pateis. - Arbores indicae et africanae, folitis peliolatis, planis, penni nervits.

Strobocalyx Blume ex DC. Prodr. $V$. 21.

f. TRIANTHEA $D C$. Ca pitala tri- v. rarius quadritlora, oblonga, in corymbum dicliotomum disposita. - Americae tropicae, trans aequatorem incolae.

Trianthea DC. Prodr. V. 23. Pollalesta Kunth in Humb, et Bonpl Nov, gen, et sp. IV. 36, L.32t, OI i. g a the s Cassini in Diet, sc, nat, XXXVI. 18. Gy mna $\mathrm{ntbemi}$ sp. Cass.

g. TEPHRODES $D C$. Capitula pauciflora, involucri squamis imbricatis, lanceolato-linearibus, interioribus sensim longioribus, demum reflexo-patentibus. Pappus exterior brevissimus, regularis, iuterior nniserialis tenuissimus. - Herbae gerontogaeae, ut plurimum annuae, cinerascentes.

Tephrodes DC. Prodr, V. 24. Is o m e ria Donmso.

h. LEPIDAPLOA Cass. Capitula plusquam quadriflora, in paniculas dichotomas $s$. fasciculos v. eymas scorpioideas disposita, rarius solitaria, involucri squamis apice simplicibus. - Herbae annuae v. perennes, suffrutescentes $v$,interdum arborescentes, inter tropicos totius orbis obviae.

Lepldaplo a DC. Prodr. V. 25. Le pidaploa et Vernonia sp. Cass. Vernouiae propriac Lessing. Bot. Mag, t. 2477. Bot, Reg. t. 522.

f. ASCARICIDA Less. C a pitula terminalia, solitaria v. pauca, corymbosa, involueri campanulati squamis fo. liaceis aut apice appendiculatis, plus mius pntentibus et inter se dissimilibus. - Herbae tropicae et boreali-amo. ricanae.

A s a ri cid a Lessing in Linnaea PT. 675. DC. Prodr. V. 60. Ascarieida et Centrapalus Cassiai in Dict. sc. nat. Suppl. III 38. VII. 383. B a c c a ro i des Liun. Flor, zegl, 196. Mönch. Meth, 578 .

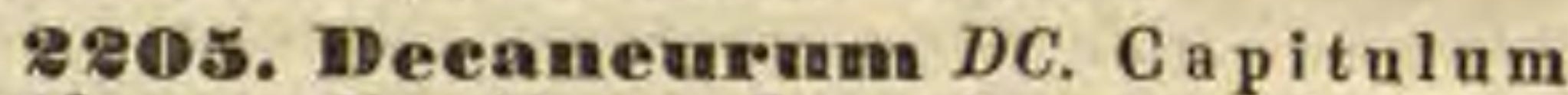
multiflorum, discoideum. Invol u er um imbricatum, pluriseriale, foliaceo-bracteatum v. nudum, squamis exterioribus brevioribus, aristato-cuspidatis, intimis apice scariosis v. muticis. R e c p tac $\mathbf{~} 1$ n m planum, nudum v, fimbrilliferum. CorolI a e regulares, limbi quinquefidi lobis tubum aequantibus. A chenimm nervis decem prominulis angulatum, glabrum. Pa p p u nniserialis, setis crassis, rigidis, dense barbellatis, junioribus basi in annulam connatis, demum seorsum decidnis.

Herbae $v$, suffrutices Indiam incolentes; foliis alternis, petiolatis, dentatis, capitulis saepius ad apicem ramulorum solitariis, rarius corymbosis, pedunculatis, floribus purpurascentibus.

D eсанеити DC. in Guillemin Archiv. Bot. II. 516. et in Wight Contribut. 3. Prodr. V. 66.

a. PHYllocephalum Blum. Ca pitula bracteis foliaceis amplis arete cincta. A chen i a basi aequalia.

Phyllocephalum Blume Bijdr. 888, DC. Prodr. V. 66. Wightia Spreng. msc. Rolfinkia Zenk. $P l$. Ind. $t, 14$.

b. GYMNANTHEMUM Cass, Capitula ommino ebracteata, v. bracteolis paueissinis, involucri squamas interiores refereutibus instructa. A che $n$ i a elongato-turbinata v. basi attenuata.

G y m n a $\mathrm{t}$ he m um Cassini in Bullet. soc. philomat. 1817. p. 10. Dict, sc. nat. XX. 108. excl. sp. DC. Prodr. V. 67 .

2206. Cyanopis BLUM. Cap ituln multiflorum, discoideum. I n v o 1 u c r u m plariseriale, hemisphaericum, squamis imbricatis, rigidulo-aristatis, apice laxiusculis. $\mathrm{R}$ e c e ptaculum planum, alveolato-subfimbrilliferum. Coroll a e regulares, limbi quinquefidi laciniis tubum aequantibus. A cheni a prismatico-pentagona, glabra, areola terminali lata, subcupulata. Pap p o s uniserialis, setis rigidis, scabriusculis, basi distinctissimis, deciduis. - Herbae indicae, annuae, erectae, ramosae; foliis alternis, petiolatis, ovatis aut lanceolatis, supra glabris, subtus plus minus villosis, capitulis ad apices ramorum paucis, pedicellatis, ebracteatis, corymbosis, floribus caerulescentibus.

C y an opis Blume msc. ex DC. Prodr. W. 69. C yanthillium Blume Bijar. 889. Is onema Cassini Bullet. philomat, 1817. p. 152. Dict. sc. nat. XXIV. 25, non R. Br. Centratheri sectio Lessing in Linnaea $I V$. 320 . Ver. It ou ia e et Conzac sp. Aut. 
220\%. Centratherrum CASS. Ca p itnl u m multiflorum, discoideum. I nvol u $\mathrm{crum} \mathrm{im-}$ bricatum, campanulatum, foliaceo-bracteatum squamis siccis, brevibus, adpressis, muticis v, spinoso-dentatis. Recept a cul um planum, nudum. Coroll a regularis, limbi quinquefidi laciniis acuminatis, tubo gracili brevioribus. A ehenia oblonga, subcylindracea, glandulosa, glabra, collo apicali parum prominulo. P a p p us uniserialis, setis inaequalibus, rigidis, serrulatis, caducissimis. - Suffrutices v. herbae, in America tropica indigenae; foliis alternis, ovatis aut oblongis, serratis, capitulis in ramulis terminalibus pedunculatis, floribus purpureo-caeruleis.

Cen trat he rum rassiui in Bullet, soc.philomat. 1817. p. 31. Dict, sc. nat, VII. 383. Journ, Phys, LXXXIX, 24. DC. Prodr, V.70. A m p he re phis Kunts in Humb. et Bonpl. Nov gen, et sp. IV. 24. $t .34,315$. Link et Otto Ic. select. t.29. S p I x i S Selirank Hort. monac, $t, 18$.

280S. Beelhium DC. C a p itu $\mathrm{l}$ a m multiflorum, homogamum, fioribus exterioribus subpalmatis. Involucri squamae bi-triseriales, subimbricatae, subaequilongae, exteriores hirtac, interiores angustiores, glabrae, apice subcoloratae. $\mathbf{R e}$ cepta culum alveolare. Corolla e disci regulares, tubulosae, quinquefidae. A chen ia teretiuscula, villosa. Pap p u uniserialis, pilosus, seabridus. - Herbae madagascarienses; foliis allernis v. omnibus radicalibus, ovali-oblongis, subsessilibus, subintegerrimis, supra scabris, capitulis terminalibus corymbosis, involucri squamis apice subscariosis floribusque purpureis.

Bechi um DC. Prodr. V. 70.

2209. Stoekesia HERIT. Ca p itu l u m multiflorum, homogamum, radiatiforme. In v o I uc r um subglobosum, basi bracteatum, pluriseriatum, imbricatum, squamis adpressis, exterioribus in appendicem foliaceam, patulam, eiliato-spinulosam productis, interioribus ciliatis. Re cept a c uI $\mathrm{um}$ carnosum, nudum. Co ro 1 l a e palmatae, glandulis conspersae, exteriores capituli majores, intus profundius fissae. A $\mathrm{n} t \mathrm{~h}$ e $r$ a $\mathrm{e}$ inclusae. Stig mata semisubulata. A $\mathrm{ch}$ enia brevia, tetragona v. rarius trigona, areola terminali lata, tetragona. Papp us uniserialis, paleis 4 -5 deciduis, longis, planis, scariosis, integerrimis. - Herba caroliniana, perennis, erecta, ramosa, glaucescens, glabriuscula; caule apice villoso-tomentoso, foliis alternis, inferioribus ovalibus, integerrimis, in petiolum longe attenuatis, superioribus semiamplexicaulibus, lanceolatis, ad basim serrato-spinosis, capitulis ramos terminantibus solitariis, floribus caeruleis.

Sto ck es i Heritier Sert, angl. 27. DC. in Annal. Mus. XVI. 154. Prodr, V, 71. Cassiai Diet, sc, nat. LI, 64. Lessing in Linnaea IV. 321, Synops. 148, C a r te s i a Cassiai Bullet. soc. philomat, 1816. p, 198. Ca rt ham us taevis Hill Kew, $57, t, 5$.

22 10 . Platy earpha LESS. C a p it $\mathrm{u} \mathrm{lu} \mathrm{m}$ multiflorum, discoideum. Involncri squamac pluriseriales, lanceolatae, elongatae, submembranaceae, integrae, acutae, interiores angustiores, receptaculi paleas simnlantes. Cor ollae tubo elongato, extus praesertim ad apicem hispidulo, laciniis quinque linearibus, aequalibus. Stam $\mathrm{j}-$ num filamenta glabra, laevia; antherae apice obtusae et suhaequaliter appendiculatae, basi ecaudatae. Stig mata elongata, apice divergentia, teretiuscula, fere undique papillosa. A c he ni a glabra, subcylindracea. $\mathrm{P}$ a p p us persistens, paleis septem v. novem scariosis, albis, linearibus, acuminatis, integerrimis, - Herba capensis, peren- nis, acaulis; foliis radicalibus longe petiolatis, pinnatipartitis, subtus albo-tomentosis, supra et in petiolo arachnoideis, lobis ovatis, dentatis, inferioribus dissitis, parvis, extremis majoribus, confluentibus, capitulis plurimis radicalibus, congestis, corollis violaceis,

PIatycarpha Lessing in Linnaca VI, 688. Synops. 148. DC. Prodr, V. 71. C y u a

2211. Dellontoearplas $D C$. C a pituI $\mathbf{m}$ pluriflorum, discoideum. Involucri oblongo-cylindrici squamae imbrieatae, adpressae. Receptaculam angustum, nudum. Corollae tubo brevi, fauce lata, limbi quinquelobi laciniis acutiusculis. Stamin um filamenta glabra, brevia; antherae ecaudatae. Stigmata breviter exserta, subulata, hispidula. A chen ia subcylindracea, striata, adpresse sericeo-villosa. P a p p u 8 uniserialis, persistens, paleis septem $v$. oeto lanceolatis, acntis, apice serratis. - Herba suffruticulosa, in Chile a Pöppigio detecta, gracilis, erecta, ramosa; ramis apice monocephalis, foliis alternis, anguste linearibus, aculiusculis, enerviis, basi ciliolatis, capitulis oblongis, foliis aliquot paueis stipatis, corollis purpureis,

0 doutocarpha DC. Prodr, V. 71 .

2:12. Weblola $D C$. Capitula pluriflora, discoidea, dioica. Invol a crum imbricatum, tri-quinqueseriale, disco brevius. Reeepta $\mathbf{c} \mathbf{u}-$ $1 \mathrm{u} \mathrm{m}$ alveolatum, alveolornm marginibns subexsertis, erosis. M a sc. Cor oll a e tubulosae, breviter quinquedentatae. Antherae lineares, inclusae. Sty lus indivisus $v$, apice brevissime bifidus. 0 va$r$ i $\mathbf{~ m}$ efoetum, villosum, p a p p o pauciscriali, setis vix dentatis. F e m. C o r o li a e tubulosae, limbi quinquelohi, lobis elongatis, angustis, crassiusculis. An the rac nullae v. efoetae. Stylus e tubo exsertus, lobis corollae brevior; stigmatibus elongatis, crassiusculis, extus stylique apice indiviso pilosiusculis. A e h en i teretia, seu turbinata, pluricostata, erostria, costis villosissimis, sulcis glandulosis. P a p n 8 pluriserialis, setis crassiusculis, dense barbellatis, exterioribus brevioribus, - Herbae suffruticosae, in Afric a trop ic a et in Capite bonae spei observatae; caule erecto, basi simplici, apice corymboso, foliis alternis, linearibus, margine subrevolutis, supra glabriusculis, subtus cum caule et involueris canescentibus, capitulis octo-decemftoris, corollis sligmatibusque purpureis.

Webbla DC. Prodr. $V$. 79, Canyzae sp. Thubb. Erigerontis sp. Houttuyn Pf. ogst, X. 629. $t$. 69. f. 2. Verin a fae sp. Lessing.

\&: 13. Hoploplnyllum $D C$. Capitul n m quinqueflorum, homogamum. Involueri ovato-oblongi squamae latae, imbricatae, obtusae, apice spinuloso-mucronatae. Re e pt a $\mathrm{cu} / \mathrm{um}$ angustum, fiubriliferum. Coroll a e tubulosae, glabrae, limbi profunde quinquefidi lobis linearibus, aequalibus. Sta m in nm filamenta brevia, glabra; a thera e ecaudatae. Styli a medio setis erectis hispidi; stigmatibus elongatis, per totam longitudinem hispidis. A chenia crassa, subtrigona, villosissima, apice glabra, sub pappo paulo constrieta. Papp us multiserialis persistens, squamellis rigidulis, exterioribus lineari-filiformibus, interioribus basi membranaceis, latioribus, sensim acuminatis. - Suffrutex capens is, glaber, rigidus; ramis teretibus, striatis, foliis alternis, rigidis, spinescentibus, integerrimis, vel hinc inde ad basim spinuloso-dentatis, crassiusculis, patulis; utrinque 
regulariter striatis, capitul is in supremorum foliorum axillis solitariis, sessilibus, inter folia approximata specie capitato-congestis, corollis pallidis.

Hoplophyllam DC. Prodr. $V$. 73. Pteronia $8 \mathrm{pi}$ nos a Lint. $f$.

2214. Itptoeoma CASS. Capitul n m pluriflorum, homegamum. Involueri ovatocylindrici, imbricati squamae coriaceae, siccae, ovato-aut obovato-oblongae. R e ceptacul u m angustum, nudum. Co ro Il a e tubulosae glabrae, tubo elongato, limbi quinquefidi lobos acuminatos, glandulosos superante. An th er a e inclusae. Stigm a ta semisubulata. A ch enia obcompressa, angulata, glabra, disco epigyno magno, nectario styliformi. P a p р и biserialis, serie exteriore brevissima, cartilaginea, crenata, interioris paleis plurimis, caducis, longis, planiusculis, subserratis, saepe tortis. - Suffrutices antillani et brasilienses; ramis plurimis, teretibus, tomentosis, foliis alternis, integerrimis, uninerviis, supra glabris, subtus tomentosis, capitulis plurimis ad apices ramorum subsessilibus, in glomerulum subumbellatum aggregatis, floribus purpureis $v$. roseis.

P ip to coma Cassinl in Bullet, soc, philomat. 1817. p. 10. 1818. p. 50, Diet, sc, nat. XLI, 111. Lessing in Linnaea IV. 315. f. 7.8. 10. 12. Synops, 147. DC. Prodr. V. 74.

221 5. Disteplamus CASS, C a p i $t$ uI m multiflorum, homogamum. Involueri imbricati squamae appendiculatae. Re cepta $\mathbf{c u l u m}$ areolatum, areolis in dentes seu fimbrillas breves productis. Corolla e regulares, limbi quinquefidi lobis tubum subaequantibus. Antherae eeaudatae. A chenia villosa. Pap pus biserialis, seriei utriusque paleis subdenis, lamellatis, coriaceis, exterioribus nune interiores subaequantibus, nunc dimidio brevioribus, latioribns, denticulatis, interioribus linearibns, barbellatis. - Frutices ma $u r i$ tiani et madagascarienses; ramulis folïsque alternis, integerrimis, tomentosis, capitulis dense corymbosis.

Dis te pha nus Cassini in Bullet, soc.philomat, 1817 p. 76. Dict. sc. nat. XIII. 361. DC. Prodr, V. 74. C o n y $\mathrm{z}$ a sp. Lam. Vernoniae sp. Lessing.

2816. Stroplugpappess DC. CapituI $\mathrm{nm}$ multiflorum …... Involueri imbricati squamae ovali-oblongae, obtusae, extus apice subtomentosac. R e ceptaculam vix alveolatum. Corolla e...... A $\mathbf{c}$ henia villosissima. Pap pus biseriatus, ntriusque seriei paleis planis, nitentibus, aequalibus, elongatis. - Frutex bras $i$ liensis, non salis notus; ramis teretiusculis, junioribus tomentosis, foliis alternis, sessilibus, oblongis, obtusis, coriaceis, subintegerrimis, supra glabris, subtus tomentosis, capitulis secus ramos ad axillas et apicem sessilibus, geminis, folio brevioribus.

Stroph opappus DC. Prodr. V.25.Stilp nopappus bi color Mart. msc.

221\%. IBlamelnetia DC. Capitulum pluriflorum, homogamum. Involucri ovati squamae imbrieatae, ovatae, mucrone acuminatae. Recepta cul u m angustum, epaleacenm. Co rolla e regulares, limbo profunde et aequaliter quinquefido. An th er a e exsertae, basi obtusae, apice acute appendiculatae. Stig mata exserta, acuminata, hispida. A e h en i g glaberrima, obovato-oblonga, subpentagona, striatula. Pa p p i paleae subbiseriales, subaequales, caducissimae, lineares, rigidulae, subciliatae. - Herba brasiliensis, suffruticulosa, erecta, alterne ramosissima; caule, ramis et petiolis tomento brevi, subrufescente, setis- que rigidis, nigris, patulis vestitis, foliis in caule alternis, ramorum sterilium saepius oppositis, petiolatis, ovali-oblongis, basi longe cuneatis, subintegerrimis, aut hine inde denticulatis, supra pube stellata parca, subtus tomento denso canescenti-rufis, capitulis in cymam umbellatam, foliosam dispositis, subsessilibus, confertis, ovatis, subaraneosis, corollis purpurascentibus, pappo albo.

B I a chetia DC. Prodr. $V$. 75 .

2218. Stilpnopappus MART. C a pitulum multiflorum, homogamum. Involneri campanulati squamae subbiseriales, aequales, acuminatae. Receptac $\mathbf{l} \mathbf{u m}$ alveolatum, fimbrilliferum. Corojila e regulares, limbo profunde et aequaliter quinquefido. A n thera e ..... A $\mathrm{che-}$ n i a villosa. Pap p a biserialis, paleaceus, planns, nitidus, seriei exterioris paleis brevibus, interioris vix pluribus, duplo longioribus. - Herbae brasilienses, annuae; caule ramoso, villoso $v$. tomentoso, foliis alternis, subintegerrimis, subtus cano-tomentosis.

Stilpnopappus Martius msc. ex DC. Prodr, $V$, $z$.

2219. IDiallesta $H, B . K . C$ a pitulum biflorum, homogamum. I $n$ v o I n e $r$ i imbricati cylindracei foliola sicea, uninervia, interiora longiora. $R$ e e e $\mathbf{t}$ a $\mathbf{c} \mathbf{~} \mathbf{l} \mathbf{~ m}$ minimum, nudum. C o ro I I a e regulares, limbi quinquefidi lobis acuminatis, tubo brevioribus. A $\mathbf{n}$ t h era e caudatae. Stigmat a semisnbulata. Achenia subeylindracea, multicostata, apice pilosiuscula, nectario styliformi. Pa p p u s biserialis, paleaceus, serratus, seriei exterioris paleis minimis, multis, inaequalibus, interioris elongatis, pancissimis, tortis. - Arbor (?) novo-granatensis; ramis canescenti- $v$. fuscescenti-tomentosis, foliis alternis, petiolatis, oblongis, inlegerrimis, supra glabris, subtus albido-ferrugineis, capitulis pedicellatis, solitariis, in corymbum terminalem approximatis, corollis albidis.

D f alest a Kanth in Humb. et Bonpl. Nov. gen, et sp. IV. 35, t. 320. Cassioj Tabl. XX, 40. Lessing in Linnaea IV. 315. f. 9. Synops. 146. DC. Prodr. V. 76.

2E20. DIIonosis $D C$. Capitul a uniflora, distincta. I n vol ncri oblongi squamae imbricatae, obtusae, flore multo breviores. R e e ptacul um punctiforme. Corolla e tubulosae, quinquefidae. Anthera e ecaudatac. Stig mat a longe exserta. A $\boldsymbol{c}$ henia glabra, teretiuscula. $P$ a P p s bi-triserialis, setis rigidulis, seabris, aequalibus, v, aequilatis sed inaequilongis. - Suffrutices indici et mexicani; foliis alternis, breviler petiolatis, obovato-cuneatis, acutiusculis, subintegerrimis, supra glabris, subtus cum peliolis ramisque tomentosis, paniculae nudae ramis apice capitula plurima, subumbellata, subsessilia, conferta gerentibus.

Monosis DC. in Guillem. Archiv. bot, IT. sts. et in Wight Contribut, 1. Prodr. $\nu$, 77 .

a. EUMONOSIS DC. $\mathrm{P}$ appi series exterior ab interiore hand discrepans, - Frutex indicus.

Eumonosis DC. Prodr. $\mathcal{V}$. 7\%. Conyza Wightian a Wallich.

b. EREMOSIS DC. P a p i serles exterior bevior, aequilata. - Frutices mexicani.

Kremos is DC, l,c. _ ? Turpinia Llave et Lexart. Nov. veget. 1. 24.

22:1. Glanwia FORST. Capitula uniflora, distincta. Involueri squamae quinque v. sex, regulariter imbricatae, adpressae, coriaceae, extus glandulosae, exteriores ovales, interiores oblongo-lanceolatae. R e e p tacul um punctiforme. 
Corolla infundibuliformis, limbo quinquefido. Stig mat a gracilia, exserta, divergentia. A che$n$ i a subeylindracea, villoso-subtomentosa. P a pp us achenio longior, paleolis filiformibus, inaequalibus, plurimis, basi subnudis, apice barbellulatis. - Frutex Novae Z elandiae; folvis alternis, ovali-oblongis, petiolatis, integerrimis, subtus ramis pedunculisque tomentosis, capitulis in paniculam dispositis.

S haw ia Forst. char. gen, 95. , 48. Cassini in Dict. sc. nat. XXXIV. 40, Lessing Synops, 156. A. Richard Flor. Nov. Zeel. 243, DC. Prodr. V. 78.

SUBDIVISID III. ALBERTINIEAE DC. Prodr. V. 78. C a pitula uni-panciflora, rarissime multiflora, in glomernlum aggregata. $\mathbf{P}$ appus uni-bi-pluriserialis, paleaceus ant setitormis.

222. IIaplostephium MART. C a p itn la uniflora, in glomerulum globosum aggregata, bracteis paueis foliaceis sub glomerulo. In v 0I ue ra partialia oblonga, squamis imbricatis, sublinearibus, acutis, coriaceo-seariosis, glabris. Receptaculum nudum. Corolla regularis, quinquefida. A $\mathrm{ch}$ e $\mathrm{n}$ i um obovatum, glaberrimum, nervis decem costulatum, umbone prominulo. $\mathrm{P}$ a ppus uniserialis, paleis caducissimis, linearibus, spiraliter tortis. - Frutex brasiliensis, Lychnophorae facie; ramis teretibus subverticillatis, adpresse sericeis, demum glabriusculis, foliis confertis, sessilibus, patulis, subrecurvis, basi subdilalata fere adnatis, lanceolato-linearibus, acuminatis, integerrimis, supra glabris, subtus sericeo-canis.

H aplostephium Martius msc. ex DC. Prodr. V.78.

22as. Hyehnophora $M A R T$. C a pitn 1a uni-quadriflora, homogama, in glomerulum subglobosum, nudum v. foliaceo-bracteatum dense aggregata. Invo luc ra partialia oblonga, squamis bi-triserialibus, lineari-oblongis, imbricatis, coriaceo-subscariosis. R e c e p ta c n la nuda v. alveolaria. C o r o 11 a e regulares, quinquefidae. A ch e $\mathrm{n}$ i a glaberrima, teretiuscula, multicostata. Pappus biserialis, utriusque seriei late paleaceus, exterioris paleis multo breviorilus, interioris tortis. - Arbusculae brasilienses, habitu peculiari; trunco inferne simplici, superne fastigiato-ramoso, ramisque teretibus densissime lanuginoso-tomentosis, foliis sessilibus, confertis, uninerviis, coriaceis, margine revolutis, subtus sacpe cano-tomentosis, glomerulis ramos terminantibus, corollis pallide roseis $v$. lilacinis.

L y e hnop hor a Martius in Regensb. Denkschrift. II. 149. DC. Prodr. $V .78$.

a. EULyChNofHora DC.Prodr. $V .79$. C a pitula uniflora.

Ly e hn oph or a Lessing in Linnaea IV.316. (Martius op. cit. t. 9.)

ab. LYCHNOPHOROIDES DC. Prodr, V. 79, C a pitula biquadriflora.

Vernoniae sectio Lychnophora Lessing in Linnaea

IV. 248. (Martius op, cit. t.4_8. et 10.)

2234. Albertinia SPRENG. Capitula uni - triflora, homogama, densissime in glomerulum subglobosum, rarins nudum, plernmqne involucro universali, brevi, polyphyllo cinctum collecti. Invofucra partialia squamis erectis, adpressis, saepe pressione ad alveolarum rudimenta reducta. R e ce p ta cula alveolaria. Cor oll a e regulares, quinquefidae. A $\mathrm{chen}$ ia glabra v. pilosiuscula. Papp ns bi-pluriserialis, setis omnibus filiformibus, subscabris, saepius coloratis. - Frutices brasilienses; foliis alternis, petiolatis, ellipticis, in- tegerrimis, glabriusculis v. subtus albido-subtomentosis, glomerulis ramos terminantibus.

Albertiuia Sprengel Neue Entdeck, Ir. 133. DC. Prodr. V. 80.

a. ANISOTRICHIA DC. Capitula nui-triflora. Pappi series exterior interiore doplo triplove brevior. A n isotrichia De. Prodr. P.so.

b. ISOTRiChia DC. Capitula uni-triliora. Pappi series exterior interiori aequitonga et aequilata.

Isotrichia DC. Yrodr. $\boldsymbol{V}$. 89 . Eremanthus Lessing in Linnaea IV. 317, VI. 682, Synops, 147, nou Cass.

2\%25. Hyenoeeploalum DC. Capitula bi-pluriflora, homugama, plurima in glomeruInm terminalem subglobosum, squamis paucis ovalibus, multistriatis involucratum collecta. In v 0lucra partialia squamis oblongo-lanceolatis, trinerviis, subciliatis. Receptacula nuda. Corolla e regulares, quinquelidae, glabrae. A ch en i a sericeo-villosa. Pa p p s pluriserialis, setaceus, scaber, setis exterioribus pancis, brevioribus, sensim interiores aequantibus. - Herbae brasilienses, scapigerae, perennes; folits radicalibus lineari-lanceolat is $v$. spathulato-oblongis, integerrimis, junioribus pubescentibus v, tomentosis, arluttis glabriusculis, scapo simplici, tomentoso.

Pycnocephalum DC. Prodr, $V$, 83, Veruoniae seetio Pyenoceplualum Lessing in Linnaea VT, 630.

22 26. Hychmoceghaiass MART. C a $\mathrm{p}$ it u I a octoflora, homogama, ovali-ublonga, plurima, densissime conferta in glomernlum terminalem subglobosum, involucro generali nullo, hraeteis sub singulis capitulis foliaceis, etiam in medis glomerulo hinc inde conspieuis. Involuera partialia oblongo - cylindracea, lanae immersa, squamis plurimis, glabriuseulis, obtusis. Co rolla e regulares, quinquefidae, glabrae. A $\mathrm{chenia}$ glabra, striato-suleata. P a p pu s hiseriatus, paleacens, paleis exterioribus brevibus, acutis, persistentibus, interioribus elongatis, spiraliter tortis, eaducissimis. - Frutex brasiliensis; ramis tcretibus, dense tomentosis, foliis petiolatis, ovalioblongis, obtusis, basi cuncatis, coriaceis, integerrimis, supra glabris, subtus petiolisque dense 10 mentosis.

Lychnocephal us Martius ex DO, Prodr. $V, 83$.

222\%. Clomomopappas $D C$. Cap it a Ia octo-decemflora, homogama, pauca, in glomerulum axillarem conferta, bracteis foliaceis cincta. Invo In era partialia ovalia, squamis imbricatis, acutis, lanceolato-linearibus, dorso tomentosis, interioribus angustissimis, subbreviorilus. R e c: ept a en I a nuda, Corolla e regulares, limbi quinquelobi lobis dorso hirsntis. A ehenia brevia, angulata, glaberrima. Pa p p u s duplex, uterque persistens, exterioris paleis brevibus, oblengis, acutis, interioris setis elongatis,serratis.-Frutex brasilien$s$ is; ramis teretibus apice subcompressis, valde lanuginosis, foliis petiolatis, ovatis, obtusis, integerrimis, adultis supra glabris, eminentiis duris prismaticis muricatis, subtus petiolisque cano-lanuginosis, glomerulis in axillis superioribus subsessilibus, spicam compositam, interruptam fere constituentibus.

Chrouopappus DC. Prodr. $V, 84$. Heterocoma bifrons DC. in Annal, du Mus, XVI, $t, 8$, Serratula bifrons Pers.

2288. Fithecoseris MART, Capituia tri-quadriflora, heterogama (?), in glomerulum ovatum dense congesta, sessilia, subspicata, ebracteata. I n vo I u era oblonga, squamis ereetis, glabriusculis, acnminatis, exteriorilius carinatis, interioribus planis, lanceolato - linearibus. Receptacn- 
la nuda. Coroll a e regulares, tubo extus hirsuto, limbi quinquelobi lobis glabris. A $\mathrm{e}$ heni a dimorpha, alia (sterilia ?) sericeo-villosa, p a p p o dupliei, exteriore brevissimo paleaceo, interiore pluriseriali setaceo; alia (fertilia?) glaberrima, oblonga, compressa, pap po setiformi pluriseriali, eaducissimo. - Herba brasiliensis, grandis, glabriuscula; caule tereti, ramis apice fistulosis, nudis, foliis sessilibus, aurito - semiamplexicaulibus, irregulariter pinnatilobatis, lobis ovatis, triangularibus, dentatis subsinuatisve, terminali majore, glomerulo ovato, glabro.

Pithecoseris Martius msc, ox DC. Prodr. V. 84 .

283D. Stachyanthus $D C$. C a pitula subdodecantha, secus rami apicem sessilia, spicata, subconferta, rhachi scrobiculata, bracteis nullis. Invo I u e ra squamis oblongis, adpressis, obtusis, interioribus snbmucronatis. Corolla e A chenia sericeo-villosa. Pappus pluriserialis, setaceus, serie exteriore brevi, basi flavida. - Herba brasiliensis, suffruticosa, pube brevi adpressa sericeo-canescens; caule tereti, ramoso, foliis petiolatis, ovato-rhombeis, basi integris, cuneatis, a medio ad apicem angulato-dentatis, pedunculis longissimis, nudis, glomerulo ova. to-globoso terminatis.

Stachy a thus DC. Prodr. V. 84.

2230. Chresta $A R R A B$. C a p itula triquadriflora, homogama, in glomerulos terminales sphaericos, ebracteatos collecta. I nv o l u cra squamis siccis, acuminatis, paucis. Receptacula nuda. Cor olla e regulares, quinquefidae, glabrae. Ach enia sericeo-villosissima. Pap p s multiserialis, setosus, serie exteriore breviore. - Herbae brasilienses, velutinae $v$. pubescenti-tomentosae; foliis alternis, sessilibus $v$. petiolatis, coriaceis, inte. gerrimis $v$. dentatis, ramis nudis, glomerulo subgloboso terminatis.

C hrest a Arrabo Flor. Flum, VIIT, $t, 150$. DC. Prodr. $\nu .85$. Vor u o niae sp. Mart.

DIVISIO II. ELEPHANTOPEAE Cassini $T a b l . X X, n, 111$. Ca p itul a discoidea, pauciflora. Invol u cr u m compressum, pluriseriale, Poliolis cujusvis seriei quaternis, alternis planis. Receptacul u m nudum v. alveolatum. Corollae palmatae. Antherae ecaudatae. Stig mata semisubulata. - Folia alterna.

?281. Eleplaamtopus LINN. CapituI a tri-quinqueflora, homogama, in glomerulos axillares nudos, v. terminales foliis dense cinctos aggregata. In volucra compressa, octophylla, foliolis biseriatis, siccis, oblongis, alterne planis et conduplicatis, interioribus saepius trinerviis. Recepta cula nuda v, obsulete alveolata. Coroll a e limbus quinquefidus, laciniis aenminatis, sinu uno reliquis profundiore palmatus. Staminum filamenta laevia. Antherae ecaudatae. Styli rami semisubulati. Achenia compressiuscula, multicostata, oblonga, pilosa. Pa p p u s paleis plurimis, uni-biseriatis, basi dilatatis, aequalibus v. nonnulis interdum longioribus. - Herbae perennes, erectae, pilosae, in America tropica obviae, in Carolina rarissimae, una per tropicos veteris orbis diffusa; foliis alternis, sessilibus, penninerviis, glomerulis ramos terminantibus, corymbosis $v$. axillaribus, spicam interruptam constituentibus.
Elephant op us Linn. gen, n, 297. Gärtn. IT. 414. a. EUELEPHANTOPUS $\mathrm{P}$ a p $\mathrm{p}$ s uniserialis, paleis on. nibus aequatibas, reetis, serratis. - Glomeruli in ramu. lis terminales, subcorymbosi, involucrati.

E u ele pha n to u s Cassini in Dict, sc. nat. XID.p. $34 t$. Lessing in Linnaea IV. 323. Synops. 149. DC. Prodr.

b V. 85. (Gärtu. t. 165. f. 1. .)

ELEPHANTOSIS Less. Pap us biserialis, paleis angustissimis, omnibus aequalibus, rectis v, interioribus tortis. - Glomeruli secus caulis apicem spicatim dis. positi.

Elephantosis Lessing in LinnaeaIV.322. f.14 17. Synops. 149. DC. Prodr. V. 87.

c. PSEUDELEPHANTOPUS Rohr. Pappus uniserialis, paleis duabus eaeteris longioribus plicato-conduplientis. - Glomerult in foliorum axillis subsessiles, spicam interruptam formantes.

Pseudelephatopus Rohr in Kiobenh. Selsk. Skrift. N. Samt. II. 2. p. 213. D istre pt us Cassini in Bullet. Soc, philomat, 1817. p, 66. Dict, se. nat. $X I I I$. 366. Lessing in Linnaea $I V$. 397. $f .19,33,34$. Synops. 149. DC. Prodr. V. 87. M a t a m oria Llav, et Lexarz. Nov. Veg. $I, 8$.

DIVISI0 III. ROLANDREAE Cassini Tabl. XX. sect. 5. Capitula uniflora, in glomerulum bracteatum collecta. Involuc rum uniseriale, ad summum tetra-pentaphyllum, saepissime gamophyllum, rarissime diphyllum, basi breviter bracteolatum. C oroll a e regulares, quinquefidae. Pap pus brevis, saepissime coroniformis. - Tribus monente $\mathrm{cl}$. Decandolle fortassis arlificialis.

223\%. Gundelia TOURNEF. C a itula uniflora, in bractearum axillis quinque v. septem, inter se ad apicem fere concreta, centrale solum fertile, reliqua sterilia. Involucra uniserialia, gamophylla, flore breviora, apice spinosa, demum inter se concrescentia. Co rolla e regulares, glabrae, limbo tubo longiore. Antherae inclusae. $\mathrm{Stigm}$ at a semisubulata, extus pilis erectis hispida, intus plana, glabra. A c he ni a glabra, compresso - subtetragona, nectario alveolari, basi pyramidato, disco epigyno magno. Pa p p us uniserialis, coroniformis, limbo brevi, spinuloso, Herba perennis, orientalis, Dipsaci facie, lactescens; foliis alternis, sessilibus, semi-amplexicaulibus, pinnatilobatis, lobis dentatis, spinosis, capitulis in capitulum generale ovatum, exinvolucratum collectis, corollis purpurascentibus.

G a ndelia Tournef. It. II. 251. Corollar. 51. Inst. 486. Linu. gen, n, 1000. Gartn. II. 586, t, 163. Miller Ic, $t$, 287. Cassiui in Dict. sc, nat. XX. 93. Lessing in Linnaea IV. 334. f.43. 47. 68, 74, 76. 79-83. Synops. 15t. DC. Prodr. V. 88. Ha e u b Vaillant Act. Academ. Paris. 1718, p, 150, G u a. d e I s be ime r a Cassini Tabl. $X X, n$, 58 .

2a33. Corymbium LINN. Capitul u m uniflorum. Invol ucrum eylindraceum, diphylIum, squamis canaliculatis, liberis, basi foliolis aliquot exiguis calyculatum. R e c e p t a c u l u m punctiforme. C o r o 11 a carnosula, regularis, limbo quinquepartito. Antherae inelusae (in sicco subliberae). Stig in a ta semicylindracea. A c henium teres, oblongum, basi longe attenuatum, extus undique pilis longis dense obsitum. P a pp 8 uniserialis, brevis, membranaceus, in laeinias piliformes fissus. - Herbae capenses; radice crassa, perenni, collo lanuginoso, foliis radicalibus phyllodineis, linearibus, parallele plurinerviis, caule subnudo, foliis parvis subamplexicaulibus, apice ramoso-corymboso.

C or y m b u nt Linn. gen. n. 1004. Lam, $t$, 723, Gürtn. II. 42. $t$. 85. Cassini in Dict. sc. nat. X. 880 . Lessing in Linnaea IV. 330. f. 13, 20_25. et VI. 691. Synops, 130, DC. Prodr. $V$. 88. Co nitare na Adans. Fam, IT, 120. 
2234. Folandra ROTTB. C a p itula uniflora, supra receptaculum generale piloso-fimbrilliferum, globosum aggregata. Invol u era bivalvia, compressa, valvis membranaceis, carinatis, aristatis, exteriore longiore. Receptaculum punetiforme. Corolla regularis, glabra, limbo subinflato, tri-quinquefido, ut plurimum quadrifido. Staminum filämenta laevia. Stig mata semisubulata. A $\mathrm{c}$ h e $\mathrm{n}$ i u $\mathrm{m}$ oblongo-ieretiusculum, quadricostatum, glabrum, glandulosum. P a p p u s uniserialis, coroniformis, brevis, dentatus, dentibus ciliatis. - Suffrutex in humidis Americae tropica e cis aequatorem crescens; foliis alternis, breve petiolatis, oblongis, utrinque attenuatis, supra glabris, submuricatis, subtus araneoso-villosis, albis, capitulis generalibus globosis, ramulos terminantibus, saepius ramulis abbreviatis pseudo-axillaribus, corollis albis.

Rol a n d r a Rottboell Collect, hafn. II, 256. Swartz Flor. Ind. occid, p. 1388, t, 17. Cassini in Dict. sc. nat. XLVI. 170. Lessing in Linnaea $I V$. 332. $f$. 44. 75. Synops. 130. DC. Prodr. $V$, 90, E chinops fruticosns Linn.

2235. Spiracuntha $H . B . K$, C a pitu1 a uniflora, in glomerulum ovatum, bracteatum aggregata, in bractearnm axillis solitaria, sessilia, bracteis subdistiche imbricatis, basi concavis, in spinam desinentilus. Involucra tetra-pentaphylla, foliolis lanceolatis, diaphano-membranaceis, subaequalibus. Corolla regularis, glabra, tubo gracili, fauce infundibuliformi, limbi quinquelobi laciniis lineari-lanceolatis. Staminum filamenta laevia. S tig m a $t$ a brevissima, acuta. A $\mathrm{ch}$ en i um obovato-euneatum, laeve. $P$ a $P$ p u 8 uniserialis, paleolis piliformibus brevibus, integris, scabridis._Suffrutex novo-granatens is humilis, ramosissimus ; ramulis subpubescentibus, filiformibus, foliis alternis, breve petiolatis, oblongis, utrinque attenuatis, integerrimis, supra glabris, sub. tus pube adpressa albis, glomerulis ramos ramulosque axillares terminantibus, corollis purpureis.

Spiracanth a Kunth in Humb. et Bonpl. Nov.gen, ot sp. IV. 28. 313. Lessing Synops, 150. DC. Prodr. V. 90. Acosta DC. msc.

2a36. Trielnospira $H, B . K$. GIomerulus moltiflorus, bracteis imbricatis, margine scariosis, apice fimbriatis, basi nni-apice trinerviis, in axilla unifloris. Involucra propria nulla. Corolla e regulares, glabrae, tubo tereti, fauce campanulata, limbi quadrilobi lobis obtusis. S $\mathrm{tam}$ in um filamenta laevia, antherae semiexsertae. Stigmata semisubulata, exserta. A ch e n i a compressa, oblongo - obovata, basi acuminata, puberula, medio utrinque tricostata. $P$ a p $\mathbf{p}$ s uniserialis, aristis duabus divaricatis, nunc quaternis v. quinis multo minoribus adjeetis. - Herbae annuae $v$. perennes, Filaginis facie, in America tro. pica indigenae; foliis alternis v. oppositis, subtus albo-lanato-tomentosis, sessilibus, integerrimis, penninerviis, glomerulis axillaribus et oppositifoliis, sessilibus.

Trieh ospira Kunth in Humb. et IBonpl, Nov, gen. et sp. IV. 13. t, 312. Lessing in Linnaea IV. 342, f, 57,58 . 63. 65, 66. 70. Synops. 150. DC. Prodr. V.90.

293\%. Lagaseea H. B. K, Capitula uniflera, plurima, in glomerulum bracteatum collecta. Involuera nniserialia, gamophylla, tubnlosa, quadri-quinquedentata. Corolla e regulares, extus puhescentes, tubo gracillimo, fauce dilatata, cylindracea, limbi quinquelobi lobis acuminatis. S $t$ a min $u m$ filamenta papillosa. Stigmat a semisulutata. A c he n i a obcompresso-tetragona, plu- ricostata. Pap p u s uniserialis, coroniformis, membranaceus, subinteger v. dentatus. - Herbae v. suffrutices, Americam tropicam incolentes; foliis oppositis, saepius triplinerviis, glomerulis terminalibus, bracteis plurimis, exterioribus oppositis obvallatis, corollis albis, flavidis $v$, rubris.

Lagascea Kunth in Humb. et Bonpl. Nov. gen. et sp. IV. 24. Lessing in Linnaca $I V .333$. f. 36-38. 45. 46. 48. 78 DC. Prodr. $V$. 91. Noc ca e Cassini in Dicl. sc. nat. $X X Y$. 108. non Monch.

a. LAGASCA Cav. P a p us coroniformis, minimus, sub. integer, ciliatus. - Herbae annuae; folits petiolatis, glomerulis ad apicem pedunculi elongati, nudi solita. rits, corollis albis.

La ga s e a Cavanill. Annal, sc, nat, $\mathcal{L}$. 333, t. 4h. Desvaux Journ, Bot II. 28. t. 2. DC. Prodr, V.91, Noec a e Jacq. Fragm. 58, t.85, $f$. 1 . Lessing Synops, 151. non alior.

b. NOCCA Cav. Pap p us paleis brevibus, subdentatis. Herbae perennes v. suffrutices mexicani; folits sessilibus v. vix petiolatis, glomerulis aggregatis, foliaceobracteatis, corollis albidis, ochroleucis v. purpurascentibus.

No c ca Cavanill. Ic. IrT. $12, t, 224$. No c c a e a Cassini l. c. Sweet Fl, Gard. t, 215. II. $t, 26$, DC. l, $c$. Lag as ce a Lessing Synops. 132. (Kunth op. cit. t. 311.)

DIVISIC IV. BOJERIEAE DC.Prodr. V. 92. C a itula pluriflora, homogama. A ntherae basi bicaudatae. Pappus setis uniserialibns. - Herbae, frutices v. arbores, omnes madagascarienses.

2a38. Symehodendron BOJ, Ca p ituI $\mathrm{m}$ pluriflorum, homogammm. Involucri obconici squamae multiseriales, imbricatac, coriaceae, siccae, glabrae, exteriores brevissimae, intimae longiores, lineares. R e c e $\mathrm{tac}$ c l um angustum, nudum. Corolla e tubulosae, aequales, quinquefidae. Antherae exsertae, basi longe caudatae. Stig mat a brevia, glabriuscula. A chenia teretiuscula, subvillosa. Pappus uniserialis, setis rigidulis, integris, sublaminatis, corollas aequantibus. - Arbor quinquagintapedalis, Compositarum maxima, in vallibus Mada gascaria e circa pagos culta, florescentia sua tempus Oryzae colendae indicans; ramis junioribus, petiolis foliisque pube brevi velutino-tomentosis, foliis allernis, petiolatis, integerrimis, orbiculatis art obovatis, superne demum glabratis, capitulis ante folia, secus ramos juniores et crassos sessilibus, fasciculatis, duas lineas longis.

S y nelt odendron Bojer msc, es DC. Prodr, $V$. 92 ,

2239. Centauropsis BOJ. CapituI $\mathbf{m}$ pluriflorum, homogamum. Involue ri oblongi squamae multiseriales, arcte imbricatae, coriaceae, obtusae, exteriores brevissimae, interiores elongatae, sublineares. Receptaculum angustum, areolatum, paleis linearibus, paucis, deriduis onustum. Corolla tubulosae, fauce vix dilatata, limbo quinquedentato, exteriores majores, incurvae. Anthera e loculis basi in appendices polliniferas productis. Stig m a tonga, exserta, divergentia, recurvato-reflexa, setis hispida, A chenia teretiuscula, gracilia, striata, glaberrima, erostria. Pa p p s uniserialis, e margine calyenli coroniformis, achenium coronantis ortus, rigidus, setis inaequalibus brevibus, acheniorum marginalium brevissimis v. subnullis. - Frutices madagas carienses, sylvicoli; folitis allernis, breviter petiolatis, subintegerrimis, obovatis v. ovalibus, basi cuneatis, penninerviis, capitulis corymbosis v, solitariis, obovato-oblongis, duodecim-vigintiftoris, corollis purpurascentibus.

Centaurops is Bojer msc, ex DC. Prodr. F. 23. 
2240. Teemarsis $D C$. Capitulum subsexflorum, homogamam. Invo I u cri oblongi, ante anthesim acuti squamae arete imbricatac, exteriores breves, obtusae, interiores lineares, subacutae. Recepta $\mathbf{c u l} \mathbf{u} \mathrm{m}$ angustum, nudum. Corolla e tubulosae, filiformes, inconspicuae. Antherae $\ldots .$. Stigmata ...... Achenia graeilia, subangulata, striata, glabra, erostria. $P$ a p u 8 uniserialis, setis basi in tubum concretis, subinaequalibus, erectis, subrigidulis, achenium subaequantibus, involucram subsuperantibus.

Frutex Madagascariensis, debilis; ramis teretibus, procumbentibus, apice setoso-ciliatis villosisque, foliis alternis, fasciculatis, glabris, obovatooblongis, acutis, basi cuneatis, paucidentatis, petio lis ciliato-villosis, brevibus, capitulis corymbosis, pedunculis ramosis, nudis, involucris glabris.

Te cmarsis BC. Prodr. $\nu .93$.

2241. Bojeria $D C$. Capitulum mul tiflorum, homogamum. Involucri eampanulati squamae plurimae, multiseriales, subaequilongac, acutae, exteriores lineari-lanceolatae, foliaceae, dorso villosae, interiores lineares, glabrinsculae. Receptaculum planum, subalveolatum. Co rolla e tubnlosae, limbo quinquefido. Antherae basi bicandatae. Stylus basi bulbosus; $8 \mathrm{tig} \mathrm{ma-}$ ta exserta, teretia, pube minima scabrida. A $\mathbf{c}$ h enia striato-subangulata, glabra, calyce cum pappo a pericarpio tereti solubili. $P$ a p p $\mathbf{~ s ~ u n i s e r i a - ~}$ lis, setis longis, subscabris, basi inter se varie breviter connatis. - Herba Madagascarien$s$ is elata; caule tereti, subdecempedali, ramoso, imprimis ad apices dense villoso, folis caulinis alternis, amplexicaulibus, ooato-lanceolatis, integris, supra sparse puberulis, subtus subtomentosis, capitulis ad apices ramorum solitariis, diametro pollicuri, floribus numerosissimis, corollis purpureis.

SUBTCERES III. PECTIDEAE Lessing in Linnaea $V$. 134. Ca pitula radiata, heterogama. Stig mat a floris hermaphroditi obtusa. - Herbae v. frutices americani; folia saepissime opposita, fores ut plurimum flavi.

DIVISI0 I. LIABEAE Cassiai Tabl.28. C or o 11 a e disci regulariter quinquefidae. Stigmat a longiuscula, - Herbae $v$. frutices; foliis saepius oppositis, eglandulosis, basi haud ciliacis, subcus tomentosis.

2242. Xanthisma $D C$. Cap itulum multiflorum, radiatum, floribus radii lignlatis, nentris, an femineis (?), disci hermaphroditis, tubn losis. Invol ueri hemisphaerici sqnamae imbricatae, coriaceae, fere ovales, obtusissimae, adpressae. R e cepta cula m fimbrilliferum, fimbrillis laceris, achenia superantibus. Corolla e disci tubulosae, limbi quinquefidi lobis erectis, radii ligulatae, integrae. Styli radii breves, indivisi, tubo inclusi, disci apice bifidi; stigmatibus linearibus, inclusis, abtusis, breviter hispidis. Ac henia obovata, obsolete angulata, pubescentia. P a ppus paleis elongatis, acuminatis, inaequalibus, exterioribus paullo brevioribus et angustioribus. Herba mexicana, annua, glabra, simplex, apice laxe ramosa, subcorymbosa; ramis erectis, foliosis, foliis caulinis alternis, sessilibus, oblongis $v$. linearibus, uninerviis, rigidulis, integerrimis v. apice acute serratis, Rortbis luteis.

Xanthis ma DC. Prodr. N. 94 .

2243. Heetorea $D C$, C a $i_{t} \mathrm{l} \mathrm{um} \mathrm{mnl}$ tiftorum, radiatum, floribus radii duadenis v. quin- denis ligulatis, femineis, disci hermaphroditis, tubulosis. Invol a eri pluriserialis squamae acuminatac, subimbricatae. Rec p t a c u l u m alveolatum. C orolla e glabrae, disei tubulosae, limbo quinquedentato, ra dii ligulatae, ligula apice tridentata. Sty lus basi aequalis; stigmatibns teretibus, hispidulis. A chen i a, teretia, villesa. Pappus biserialis, serie exteriore paleacea, brevi (alba), interiore elongata, setiformi, seabra (rufa). - Herba mexicana, basi suffruticosa, simplex, erecta, tota cano-villosa; caule tereti, ad apicem usque folioso, foliis alternis, confertis, erectis, oblongo-lanceolatis, integris, mucrone calloso superatis, capitulis ad apicem caulis breviter pedicellatis, subcorymbosis, floribus flavis.

Hectorea DC. Prodr, $V, 95$.

2244. Andromaelhia HUMB, et BONPL. C a pitul u m pauci-multiflorum, heterogamum, floribus radii uniseriatis, ligulatis, femineis, disei hermaphroditis, tubulosis. Invol u c ri squamae imbrieatae, siccae, acuminatae. R e c e p ta c u l u m breviter paleaceo-fimbrilliferum. C o roll a e glabrae, di s e i tubulosae, limbi quinquefidi lobis acuminatis, revolutis, tubo paullo brevioribus, $r$ ard i ligulatae, tubo longo, ligula oblonga. Styli basi bnlbosi; stigmatibus semieylindraceis. A $\mathbf{c h}$ en ia cylindracea, multicostata, valleculis hirsutis, nectario styliformi. Papp us biserialis, paleaceus, paleis seriei exterioris multo brevioribus et sublatioribus, - Herbae $v$. frutices Americat tropicae; foliis oppositis, petiolatis, subtus tomentosis, dentatis, capitulis corymbosis.

A nd rom a ch fa Humb. et Bonpl. Pl, aequinoct, II. 104. Kunth in Humb, et Bonpl. Nov. gen. et sp. IV. 99. excl. sect. 1. Lessing in Linnaea 12.318 . DC. Prodr. V. 95. $01 \mathrm{i}$ gaet is Cassini in Dict, sc, nat. XXXVI, 16. Diplos tephii sp. Spreng.

a. Pleionacís $D C$. Capitulum multiflorum, ligulis radii multis. - Herbae caulibus folitique subtus cano. tomentosis, radio favo.

Pleionactis DC. Prodr, V. 95. Andronic hiae verae Kuath op. cit. $t$. 337. Viviania Willd, msc. nou alior. (Hunb. et Bonpl. op. cit. $t$. 112. Lessing in Linnaea IV. f. 1 -3. 6.)

b. OLIGAC TIS Funth. Ca p it u I u m paueiflorum. ligulis radii $3-7$. - Frutices ramis glabris, radio pallido, Oliga etis Kunth op, cit, IV.101. DC. Prodr. V.96.

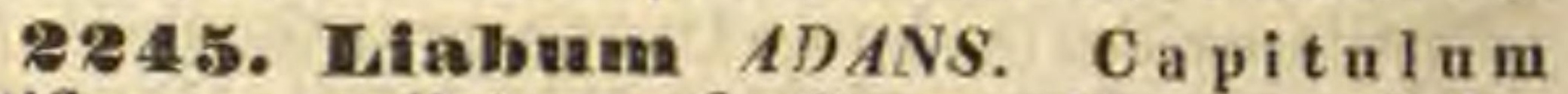
mnltiflorum, radiatum, floribus radii nniseriatis, ligulatis, femineis, disei hermaphroditis, tubulosis. Involucri squamae imbricatae, subulatae. R ecept a c n l n m fimbrillis membranaceis, subulatis hispidum. Corolla e glabrae, disei tubulosae, limbi quinquefidi lobis linearibus, tubo brevioribus, $r$ adii ligulatae, longe lineares, apice integrae. Styli disci basi aequales; stigmatibus semiterctibus, gracilibus, parce hispidis. A chen i cylindracea, striata, callo basilari. $\mathbf{P}$ a p p us uniserialis, setis filiformibus, barbellatis, subinaequalibus. - Herbae americanae tropicae, saepissime incano-lanatae, caulescentes $v$, acaules; foliis oppositis, triplinerviis, subdentatis, floribus flavis.

L i a bu m Adans. Fam, II, 131. cxel. sp. Cassint in Dict. sc. nat. XXVI. 203. excl, ap, Lessing in Linnaca $I V$. 319. DC, Prodr. 7.96.

a. CHRYSACTINIUM Funth, Ca pitula solitaria.

Clir ysactia i m Andromachiae sectio Kanth in Humb. ot Bozpl. Nov. gen. et sp. IV. 98. t. 336.

b. SIARKE A Willa. Capitula plurima, corymbosa. Starkea Will sp. III. 29t6. Starik a Jussieu in Dicl, sc, nat. I. 403. A nd ro ma $\mathrm{chia}$ Cassini in $B u l$ let. sac. philomat, 1817. p. 184. nou Humb. et Bonpl. A melli sp. Lina. S ol i dag o P. Browne, Lam. $t, 33, f, 2$. 
2746. Alibume LESS. C a p it u 1 um multiflorum, heterogamum, floribus radii uniseriatis, ligulatis, femineis, disei hermaphroditis, tubulosis. Involueri squainae biseriales, aequales, oblongo-ellipticae, mueronatae, plurinerves. R e e e pta culu m planum, nudum. Corolla e.... Styli....A. Achenia turbinata, hirsuta. Pappus dis ci biserialis, serie exteriore coroniformi dentata, interiore multiseta, radii nniserialis, coroniformis, dentatus. - Herba ad Pomalecte Americae tropicae ab Humboldtio lecta, trichotoma, erecta; ramis teretibus, hirsutis, folits op positis, obsolete auriculatis, basi connatis, ovato-ellipticis, integris v. basi pinnatifidis, supra hirsutiusculis, subtus tenuiter albo-tomentosis, capitulis solitariis, nutantibus.

A $11 \mathrm{~b}$ um Lessing Synops. 152, DC. Prodr. $\nu, 9 r$.

284\%. Cacosmia H. B. K. Capitulnm multiflorum, heterogamum, floribus radii uniseriatis, ligulatis, femineis, disci tubulosis, hermaphroditis. Involucri teretis squamae plurimae, imbricatae, siccae, plurinerves, interiores longiores. $\mathbf{R}$ ec e p$t$ a c u l um nudum. Corollae glabrae, dis ci tubulosae, limbi quinquefidi lobis acuminatis, revo lutis, tubo brevioribus, ra di i ligulatae, ligula late oblongo-elliptica, apice tricrenulata, tubum duplo superante. Stig mata semieylindracea. A chen i a obpyramidata, tetraquetra, truncata, glaberrima, nectario styliformi. P a p u s nullus. - Herba peruana andic ol a, suffruticosa, graveolens; ramis tenuiter lanatis, folïs oppositis, subpetiolatis, basi connatis, ovato-oblongis, trinerviis, remote dentatis, supra rugosis, subtus pubescenti-canis, corymbis ad apices ramorum axillarium, corollis flavis.

C a cos m ia Kunth in Humb. et Bonpl. Nov. gen. et sp. IV. 289. t. 404. Cassini Tabl. XX. n. 4. Lessing in Linnaea IV. 338. f. 31. 53-54. Synops, 158. DC. Prodr. V. 97. X a atholep is Willd. msc.

DIVISIO II. EUPECTIDEAE DC. Prodr. V, 98. C o r oll a e disci subbilabiatae v. rarissime regulariter quinquedentatae. St ig$\mathrm{m}$ a $\mathrm{t}$ a brevia, semicylindracea._Herbae ut plurimum annuae; foliis opposilis, basi subconnatis, pellucido-punctatis $v$, denticulis setigeris cilialis, rarius apice pellucido-punctatis.

2848. Peetidopsis DC. C a p it 1 um pluriflorum, heterogamum, floribus radii uniseriatis, ligulatis, femineis, disci hermaphroditis, tubulosis. Invo I a c r am cylindraceum, octophyllnm, uniseriatrm. Receptaculum nudum. Corollae disci regulares, limbo quinquedentato, ra dii ligulatae. Stigm a ta disci semicylindracea, brevia. A c h enia angulata, striata, callo basilari. Pappus paleaceus, uniseriatus, coroniformis, quinquedentatu8. - Herba annua, basi ramosa, diffusa, laevis, in Americae borealis montibus scopulo$s$ is proveniens; foliis anguste linearibus, basi dentato-ciliatis, capitulis brevissime pedicellatis, radio septem-octofloro.

Pectidopsis DC. Prodr. $V$. 98. Pectls ang usti. folin a Torrey in Annal. Lyc. New-York. II, 214.

2249. TPeetidfum LESS, C a p itu I u m pauciflorum, heterogamum, floribus radii uniseriatis, ligulatis, femineis, disci hermaphroditis, paueissimis, tubulosis.I n vo I a e ri cylindracei, pentaphylli foliola aequalia, amplexiflora, dorso glandolosa. Receptaculnm nudum. Corollae disci re- gulares, limbo quinquedentato, $r$ a d i i ligulatae, ligula tubo breviore. Stig mata disci $8 \mathrm{emicy}$ lin dracea, brevia. A che n i a angulata, striata, call" basilari. Pa p p i setae pancae, subulatae, rigidae, corneae, laeves, nudae, demnm divergentes. Herba antillana, annua, glabra, erecta, di-trichotoma; foliis linearibus, utrinque basi ciliis solitariis $v$. binis instructis, ad utrumque nervi medii latus grosse glandulosis, capitulis longe pedicellatis, solitariis.

Pect id i u m Lessing in Linnaea VT. 706, Synops. I58. DC. Prodr. V.98. Pe ctis Cassini in Dict. sc. nal. XXXVIII. 202. Pectis punctat a Jacq. Amer, $t, 128$. P. Iin ifo. li a Gärtn. II, t, 171, non Linn.

2250. Peetis $L I N N$. Capitulum plariflorum, heterogamum, floribus radii uniseriatis, ligulatis, femineis, disci hernaphroditis, bilabiatis. Involucri cylindracei, penta-octophylli foliola aequalia, amplexiflora, dorso glandulosa. Re ce p ta culum nudum. Cor oll a e disei bilabiatae labiis subfastigiatis, exteriore quadri- v, rarius tri dentato latiore, inferiore lineari, $\mathrm{r}$ a d i lignlatae, ligula tubo longiore. Stig mat a disci semieylindracea, brevia. A $\boldsymbol{c}$ h e nia angulata, striata, callo basilari. Pa p p s in disco et radio conformis, uniserialis, paleis basi scariosis, latis, apice setiformibus, serrulatis, saepius inaequalibus. - Herbac americana $t$ ropicae, annuae $v$, rarius peren. nantes; foliis glabris, margine angustissime cartilagineis, capitulis ramulos nudos aut medio unibracteatos terminantibus, aut subsessilibus, inter folia plus minus occultatis.

Pectis Liun. gen, n.965, exel. sp. Lessing in Linnaea VI. 708. Synops. 153. DC. Prodr. V. 98. Cavanill. Ic, $t, 324$. kunth in Humb. ot Bonpl. Nov. gen, et sp,t, 392. Lo r e n te a Lagasc, Nov. gen. 28. Cassiai in Dict, so, nat. XXYIt. 202. non alior. Chthouia Cassini in Bullet, soc. phílo. mat. 1817. p. 33 .

2851. Lorentea LESS. C a p itulum pluri-multiflorum, heterogamum, floribus radii uni seriatis, ligulatis, femineis, disei hermaphroditis, bilabiatis. Invo I u eri cylindracei, penta-octophyili foliola aequalia, amplexiflora, dorso glandulosa. Receptaculam nudum. Corollae disci bilabiatae, labiis subfastigiatis, exteriore yuadridentato latiore, inferiore lineari, radii lignlatae, ligula tubo longiore. Stigmat a disei semicylin. Iracea, brevia. A ch en ia angulata, striata, callo basilari. Papp u s d is ci biserialis, serratus, longus, inaequalis, serie exteriore breviore, capillacea. interiore setaceo-paleacea, $r$ adi $i$ cuminato-setiformis v. dimidiatus, auriculaeformis v. nullus. Herbae americanae tropicae, interdum basi suffruticulosae; capitulis pedicellatis v, rarissime ses. silibus.

Lorente a Lessing in Linnaea VI, 717, Synops, 153. DC. Prodr, V. 101. non alior. Pectidis sp. Linn.

a. CRYPTOPETALUM Cassini. Pappus radil e paleis pluriais, acuminato-setiformibus, pappo disei brevior. Cryptopetalum Cassinl in Dict. sc. nat. XII. 123, XXVII, 206.

b. STAMMARIUM Willd. $\mathrm{P}$ app us radil nulles, v. dimidiatus, auriculaeformis, brevis.

$\mathrm{Stammarium} \mathrm{Willd.} \mathrm{mse.} \mathrm{Lorente} \mathrm{a} \mathrm{Lessing} \mathrm{in}$ Linnaea $V$. 135, $f, \nabla_{-12}$. Pectidis sp. Kunth in Humb. et Bonpl. Nov. gen, et sp. t,393.

TRIIEUS 1I. EUPATORIACEAE Lessing Synops. 154. Capitula pauci- v. multiflora, nunquam uniflora, homogama, floribis tubulosis; $\mathbf{v}$. heterogama, floribus radii tubulosis v. ligulatis. Co r oll a staminigera regu- 
laris, quinquedentata, dentibus saepius erectis. Antherae ecaudatae. Pollen globosum, echinulatum. Stylus floris hermaphroditi superne cylindraceus; $\mathrm{st}$ i $\mathrm{m}$ at $\mathrm{ib}$ u s longis, teretibus s. clavatis, extus superne papillosis, rarius puberulis, floris masculi indivisis v. breviter bifidis, clavulatis; gl an dul a e stigmaticae in series angustas dispositae, parum prominulae, ante medios ramos desinentes, rarius apicem attingentes, rarissime confluentes. Herbae $v$. frutices; foliis saepissime oppositis, floribus (paucissimis exceptis) cyanicis.

SUETIEIIEUS I. EUPATORIEAE DC. Prodr. V. 104. Capitula homogama. Flores nunquam stricto sensu flavi.

DIVISI0. I. ALOMIEAE Lessing Synops. 154. P a p u s nullus. - Divisio monente $\mathrm{cl}$. Decandolle artificialis.

2852. Drsinia BERTOL. Capitulum sex-septemflorum, homogamum. In v ol u cri ovati squamae sex v. septem ovales, erectae, aequales. R e ce p t a c n l um nudum. C oroll a e tubulosae, hirtellae, limbi tri-quinquelobi lobis eiliatis. A ntherae inclusae, exappendiculatae. $S t i g m$ at a exserta, muriculata, obtusa. Achenia obcompressa, apice villosa. Pa p pus nullus. - Herba brasiliensis, suffruticans; caule tereti, pubescenti-velutino, apice ramoso-corymboso, foliis oppositis et alternis, breviter petiolatis, ovatis, rigidis, acutiusculis, acute serratis, penninerviis, reticulatis, supra scabridis, subtus secus nervos nervulosque dense hirtis, corymbis terminalibus, ramis lirsulis, capitulis subsessilibus, involucri squamis late ovalibus, subconcavis, pallidis, dorso puberulis, corollis albis.

Orsinia Bertoloni msc. ex DC. Prodr. $V$. 104. non Annal. se. nat. Eupatori u $\mathrm{m}$ Armani Balbis Plant, rar. hort. Taurin, 1810, p. 27, $t, 6$.

2253. Piqueria $C A V$. C a pitulum triquinqueflorum, homogamum. Invol u c r n m tripentaphyllum, nniseriale, oblongum. Receptac a I n mudum, planum, parvum. Coroll a e tubulosae, saepins hirtae, tubo brevi subdilatato, limbo quinquefido. Antherae appendice terminali sulnullo. Stigmat a obtusa. A $\mathrm{ch}$ en ia juniora compressa, adulta pentagona, glabra, cum stipite brevi articulata. Pap p u s nullus, _Herbae v. suffrutices, in Andibus peruanis, rarius in temperatis Mexici provenientes; foliis oppositis, plerumque trinerviis, capitulis corymbosis aut paniculatis, parvis, corollis albis.

P ique ria Cavanilles Ic. III. 19. Willd, sp, III. 1748. Cassini in Dict. sc, nat, XLI, 115. Lessiug Synops, 154. DC. Prodtr. V. 104.

a. EUPiQueria $D C$. Capitula quadriflora. Involu. c ri squamae obtusae. mucronatae. Corolla tubus hirsnto - barbatus. - Caules herbacei.

Eu pi queri a DC. Prodr. V. 104. (Cavanill, Ic, t. 235, Jacq. f. Eclog. 6. 48.)

b. PIQUBRIOIDES DC. Ca pit u la quinqueflora. Invo. I ueri squamae striatae, in appendicem subulatam desineutes. - Caules fruticosi, folia triloba.

Piquerioides DC. Prodr. V. 105.

b. ARTEMISIOIDES $D C$. C a p it u la tri-quadriflora. Involucri squamae acuminatae v. obtusae. Corollae glabrae, tubo longiusculo, basi supra ovarium subdilatato. - Caulos fruticosi, glabri v. summo apice pubescentes ant glutinosi. Folia petiolala, giabra.

Artemisioldes DC. Prodr. $D .105$, FIaveriae sp. Juss.
2254. Alomia $H, B$. K. Capitulum multiflorum, homogamum. In vol u eri campannlati squamae imbricatae, angustae, acutae. Rec e p t a cu l u m nudum, convexum. Coroll a e tubo gracili, glabro, limbo quinquedentato. An the$r$ a $\mathrm{e}$ in appendices ovato-oblongas, obtusas desinentes. Stigmat a elongata, obtusa. A $\mathbf{c h}$ enia quinquangularia, glabra. $\mathbf{P}$ a p p u s nullus. - Herba mexicana, glabriuscula; caule erecto, ramosissimo, foliis oppositis, petiolatis, ovatis, serratis, floribus corymbosis, albis.

A $10 \mathrm{~m}$ i a Kunth in Humb, et Bonpl. Nov. gen. et sp. IV. 151. et 312. $t, 354$. Lessing Synops, 154. DC, Prodr, V. 105.

2955. Plasilacraea $D C$. Capitulum multiflorum, homogamum. Invol u cri squamae suhbiseriales, aequales, trinerviae. Re c e p ta c n-. I u m nudum. Corolla e tubus basi piloso-hispidus, faux ampliata, limbus quinquefidus. Anthera e apice vix appendiculatae. St igmat a exserta, apice clavata. A ch en i compresso-angulata, glabra. Pa p p 8 nullus. - Herba peruana, pube brevi (viscida?) conspersa; foliis oppositis, petiolatis, late ovatis, basi truncatis, ad petiolum subcuneat is, grosse et interdum duplicato-dentatis, pedunculis nudiusculis, apice corymbosis, capitulis pedicellatis, corollis purpurascentibus.

Phalacrae a DC. Prodr. V. 105. - 2 Ageratum Iat if o li u m Cavanill. Ic. $t, 357$.

2356. Aymmocoronis DC. C apituI $\mathrm{um}$ multiflorum, homogamum. In v o I u e ri squamae uniseriales, acuminatae, subenerves. R e e pta culum nudum. Corolla tabo glabro, fauce hand dilatata, limbi quinquelobi lobis brevibus, conniventibus. Antherae $\ldots . .$. Stigmata exserta, clavata. Achenia compressa, dorso nervoso - subangulata, glabra. Pa P p us nullus. Herbae brasilienses, erectae, glabrae; caulibus inferne sulcatis, folits oppositis, petiolatis, oblongolanceolatis, acuminatis, dentatis, capitulis pedicellatis, subpuberulis, floribus albis.

Gy mocorouis DC. Prodr. V. 106.

2ะ5\%. Isoearplna $\boldsymbol{R}$. BR. Ca p itulum multiflorum, homogamum. Involueri squamae subbiseriatae, conduplicatae. Receptac u I u m conicum, palcis acuminatis, involueri squamas referentibus. Corolla tubulosae, limbo quinquedentato. Stig m a t a elongata, extus convesa, hispidula, acuta. A chenia prismatica, glabra. Pa p p us nullus. Herbae Americae tropicae, erectae; foliis opposilis, integerrimis $v$, rarius dentatis, capitulis terminalibus.

Is o c a r ph a R. Brown in Linn. Transact. XIT. 110. exel. synon. Lessing in Linnaea $\nu$. 141. $t$, 2. f. 14-16. $V I$. 405, Synops, 154. DC. Prodr, $V, 106$, B ide a $t$ is, $\mathrm{S} p \mathrm{il}$ a in th is et C a le a e sp. Linn.

DIVISE II. AGERATEAE Lessing Synops. 155. P a pi paleae membranaceat v. rigidae, distinctae v. plus minus in coronam concretae.

2258. Caelestinia CASS. Capitulum multiflorum, homogamum. Invol a crum cylindraceo-hemisphaericum, polyphyllnm, subimbricatum. Rec e p ta $\mathrm{cul} \mathbf{l} \mathrm{m}$ convexnm, paleaceum v. nudam. Corolla e tubulosae, quinquefidae. S tigm a t a cylindracea, obtusiusenla. A $\mathrm{c}$ h en ia pentagona. P a p p 8 coroniformis, membranaceus, inaequaliter dentatus. - Herbae mexicanae, ereclae, annuae, ramosae; caule tereti, foliis oppa- 
silis, breviter petiolalis, dentatis, capitulis corymbosis, approximatis, pedicellatis, corollis caeruleis $v$. purpurascentibus.

Coelestinfa Cassini in Dict. sc. nat. VT. suppl. 8. et XXVT. 227. Kunth in Humb. et Bonpl. Nov. gen. et sp. IV. 150. Lessing Synops, 155. DC, Prodr, V. 107.

a. ISOCARPHOIDES $D C$. Receptacul u m paleis liacaribus obsitum.

Is o carphoides DC. Prodr. $V, 10 r$.

b. AGERATOIDES $D C$. R e cepta culum nudum.

Ageratoides DC. Prodr. $V .108$. A geratum coelestinum Bot. Mag. $t, 1730$.

2855. Agerntum LINN. Capitulum multiflorum, homogamum, subglobosum. I n v olueri polyphylli, imbricati squamae lineares, acuminatae. $\mathrm{R}$ ecepta $\mathrm{c} \mathbf{l} \mathrm{l} \mathrm{m}$ nudum. Coroll a tubulosae, quinquefidae. Stigmat a elongata, eylindracea, obtusiuscula. A c he n i subpentagona, basi attenuata. P a p p us paleaceus, paleis quinque subserratis, acuminatis, aristatis, v. decem pectinato-ciliatis. - Herbae ut plurimum annuae, tropicae, polissimum americanae, una amphigaea; foliis oppositis, petiolatis, ovatis, dentatis, capitulis corymbosis, floribus caeruleis $v$. albis.

A ge r a tu m Linn. gen.n.936. Gärtn. IIT.398. DC. Prodr. V. 108. C a rell a Adans. Fam. $I$. 123. non Less.

a. EUAGERATUM $D C$. Pa p p f paleae 5 , ad basim u s q a distinetae, subserratae, apice acuminatae, aristatae.

E uag eratum DC. Prodr. V. 108, (Gärtn. $t, 165$. Schkuhr t. 238. Lam, t. 672. Hooker Exot. Flor, t. 15. Bot, Mag, $t, 2524$.)

b. PECTINELLUM DC. P a P I paleae eirciter 10, distinetae, per totam fere longitudinem pectiaato - ciliatae.

Pectiuellum DC. Prodr. V. 109.

2: BD. Anisoelnaeta DC. Capitula multiflora, dioica (?). In v o I n eri ovati, imbricati squamae lineari - lanceolatae, adpressae, disco breviores. Receptaculum nudum. Corollae tubulosae, profunde quinquefidae, glabrae. S ti g mata inclusa abortiva, in pancis floribus exserta, cy. lindracea, subelavata, vix papillosa. A chenia te. retiuscula, vix puberula, erostria (abortiva?). Pa ppus paleis saepius tribus, rarius quatuor $v$, quinque, erectis, squamellosis, angustis, acuminatissimis, inaequalibus. - Frutex capens is, non satis notus, subscandens; caule tereti, striato, subpubescente, ramis patulis, foliis alternis, petiolatis, late ovatis, basi sublruncatis, tri-quinquenerviis, grosse inciso-dentatis, glabris, petiolo nervisque pubescentibus, paniculis ramos lerminantibus subnudis, laxis, bracteolis secus pedicellos minimis, corollis albis.

A nis ocluaeta DC. Prodr. V. 110.

2861. Ademostemna FORST. C a pi tu I u m multiflorum, homogamum. Involucri campanulati, flores vix aequantis, demum reflexi squamae uniseriatae, foliaceae, oblongae. Receptacu i um planum, nudam, foveolatum. Corolla e tubulosae, fance vix ampliata, limbo quinquelobo, infra lobos villoso. Stigmat a longe ex serta, apice dilatata, colorata. A chenia obovato oblonga, subangulata. Pap pi aristae tres v. quinque, breves, rigidae, glandula globosa v. clavata terminatae. - Herbae tropicae, amphigueae, in As i a communes, in Americ a rarae, glandulosopilosat v. glabriusculae; foliis oppositis, petiolatis, ovatis s. rhomboideo-triplinerviis, dentatis, capitulis pedunculatis, corymboso-paniculatis, floribus albis.

A denost em ma Forst, char. 45. Cassini in Dict. sc. nat. XXV. 560. Lessing Synops, 156. DC. Prodr, $V, 110, \mathrm{~L}$ aveni a Swartz Prodr, 1ia, Flor. Ind, occid. 1329. Verbesinae et Cotulae sp. Lian.

2* SA. Selerolepis CASS. Ca pitulum multifloram, homogamum. Involucri squamae biseriales, lineares, acquales. Recepta c u lu m nudum. Corolla e tubulosae, glabrae, fauce vix a tubo distincta, limbo quinquedentato. S $t$ i g mata exserta, cylindraceo-clavata. A ch e $n$ ia quinquangularia. $\mathrm{P}$ a p p i paleae quinque, uniseriales, subeorneae, breves, obtusiusculae, aequales. Herba boreali-americana, simplex, glabra; foliis verticillatis, linearibus, capitulis saepius solitariis, rarius binis $v$. ternis, ramos superne aphyllos, breves terminantibus, corollis pallide purpureis.

Sclerolepis Cassini in Dict. sc. nat. XXV. 365. XXVT. 27\%. et 233. XLVIH. 155. Lessiug Synops. 136. DC. Prodr. V. 11\%. Sparganophorus verticillatus Michix. Nutt.

2263. Phania DC. Capitulum pluriflorum, homogamum. Involu eri octo-dodecaphylli squamae uni-biseriales, haud imbricatae. R ecepta culum nudum. Coroll a e tubulosae, glabrae, limbi quinquefidi lobis acuminatis. Stigmat a exserta, cylindraceo-clavata. A chen ia angulata, glabra. Pap pus paleis quinque v. octo, oblongo-linearibus, ciliatis. - Suffrutices a mericani tropici, glabriusculi; ramis tenuibus, folits oppositis, ovalibus, integerrimis v. subdentatis, basi subattenuatis, involucris puberulis, capitulis paucis, pedicellatis, corollis albis.

$\mathrm{P}$ ha a i a DC. Prodr. $V, 114$.

a. EUPHANIA $D C$. Corollae pappi longitudine, tubo subuullo, fauce obovata, limbl lobis brevibus, subacutis. - Suffrutex multicaulis, folits trifidis v, trisectis.

E uphania DC. $l$, $c$.

b. OXYLOBUS Moc. Corolla e pappum triplo fere superantes, limbi lobis acuminatis. - Frutices mexicani, foliis integerrimis v. subdentatis.

$0 \times$ y lobus Mocino Flor.mex, inedit, eDC. $t$. c. Ageratum arbutifolium Kunth.

2\&64. Stevia $C A V$. Capitulum quinqueflorum, homogamum. Involu cri cylindracei squamae quinque v. sex, acutae, acuminatae, subaequales, Re ceptac $\mathrm{Inm}$ nudum. Corolla e tubulosae, quinquefidae. Stigmat a exserta, cylindraceo-elavata. A che nia striato-nervosa v. angulata. Pa p p s paleis uniserialibus, nune omnibus scariosis, planis, parvis, nune in eadem saepius stirpe aliis (plerumque alternis) in aristas (1-5) rigidas, margine scabras abenntibus, v. omnibus in aristas (5_20) mutatis. - Herbae v. suffrutices in America tropica copiose, in australi extratropica parce provenientes; folits inferioribus oppositis, superioribus alternis v. oppositis, aut rarissime ternato-verticillatis, lineari-lanceolat is aut ovatis, saepius triplinerviis, integerrimis, serratis $v$, rarissime trifidis, capitulis in corymbum densum $v$, laxum dispositis, rarius subsparsis, longius pedicellatis, corollis albis, roseis $v$. purpureis, interdum ochroleucis.

Stevia Cavanill. Ic. $I V$, 33. Lagase. Nov. gen. ot sp. 26. Kunth in Humb. et Bonpl. Nov. gen, et sp. IV. 139. Cassini in Dicl. sc, nat. XXVI. 227, Lessing Synops, 135. DC. Prodr. $Y, 115$.

a. ACHAetosteviA. P a p p u exaristatas, paleaceo-scariosus, paleis 5_6, liberis v. in coronulam deatataus concretis.

Stevia e exaristatae DC. l.c. (Kunth op. eit.t.353.)

b. CHaEtostevia. Pappus e paleis paucis, scariosis, brevibus, et ex aristis $1-5$ rigidulis, scabrido - serrulatis constans.

Steviac paleaceo-aristatae DC. l. c. (Cavatill. Ic. t. 35t, 355. Kunth op. cit. t. 351, 352.) A gerati кp. Jacq. Hort. Schönbr, t, 300 .

c. POLXCHAETE. Pap pus paleis nullin ve subeullis, ex aristis $6-20$ constans.

S teviae multiaristatae DC. l. $c$.

Z265. Palafoxia LAGASC. Capitu $\mathrm{ln}$ pluriflorum, homogamam. Invol ucri oblongi v, 
campanulati, vix imbricati squamae octo ad quatuordecim, fructiferae stellato-patentes. R e cepta culum nudum. Coroll a e tubulosae, quinquefidac. Stigm a ta elongata, obtusa, semiteretia, dorso papillis elongatis subhispida. A chenia angulata, exteriora involueri squamis involuta. P a p i paleae octo ad duodecim, uninerves, pinnato-striatae, siccae, uniseriales, alternae breviores, v. biseriatae, exteriores breviores. - Frutices v. herbae, terras mexicanas et Americae borealis provincias calidiores incolentes, Steviae habitu; foliis inferioribus oppositis et superioribus alternis indivisis, capitulis laxe corymbosis, corollis albis, carneis $v$. purpureis.

$\mathrm{P}$ a 1 a foxia Lagasca Nov. gen. et sp. 26. Sims Bot. Mag, t. 2132. DC. Prodr, V. 124. Hook, Ic, t, 148, P a le ol aria Cassini in Bullet, soc, philomat. 1816, p.198. 1818, p. 17. Diet. sc, nat, Suppl.I. 59. XXXVII. 256, Lessing Synops. 155. Polypteris Nuttall Gen, 11,139 , non Less. S teviae et A gerati sp. Auet.

2966. Carella LESS, Ca pitulu multiflorum, homegamum. In v o lu eri campanulati squamae ovali-oblongae, bi-triseriales, margine membranaceae. Re e pt a c u l u m convexum, pilosinsculum. Corollae tubulosae, quinquedentatae. S $t$ ig m a $t$ a exserta, cylindracen-clavata. A $\mathbf{c h}$ h i a pentagona. Pap p u biserialis, aequalis, paleis brevibus, obtusis, enerviis, apice serrnlatis. - Fruticulus brasiliensis, villoso-canes cens; foliis oppositis, oblongo-ovatis, petiolatis, basi obtusis, capitulis dichotome corymbosis.

Carelia Lessing Synops, 156. DC. Prodr. $V$. 125. non alior.

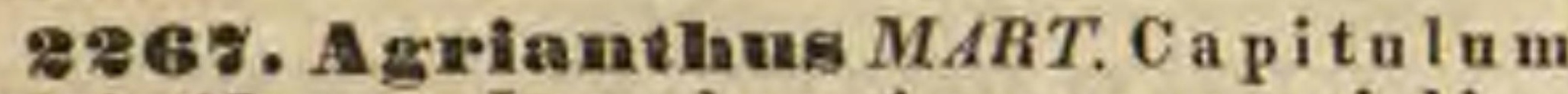
subvigintiflorum. Involu eri squamae uni-biseriales, lineares, acuminatae, subaequales. R e c e pta culum nudum. Corollae tubulosae, cylindraceae, limbo obtnse quinquedentato. Stigmat a longe exserta, cylindracea, obtusa. A chenia acute pentagona, secus angulos scabra, arcola basilari prominula. Pa p p s uniserialis (corolla brevior), squamellis lineari-lanceolatis, acuminatis, rigidulis, inaequalibus, dense barbellato - ciliatis. - Frutices brasilienses, humiles, ramosi, glabriusculi; ramis terelibus, foliis confertis, subimbricatis, alternis, rigidis, lineari-lanceolatis $v$, acerosis, capitulis in axillis supremis subsessilibus aut breviter pedicellatis, in corymbum densum, capitatum aggregatis, corollis pallide purpurascentibus.

Agrianthus Martius ex DC. Prodr. V. 125.

\section{TIUISTO III. $\triangle \mathrm{DENOSTYLEAE} \mathrm{DC.}$} Prodr. V.126. Pap pus pilosus, barbellatus v. plumosus.

\%288. Kulnmia $L I N N$. C a p itulum multiflorum, homogamum. In voln eri squamae panciseriales, adpressae. R e e ptac ul $\mathbf{u m}$ nudum. Corolla e tubulosae, fance hand ampliata, limbo quinquefido. Antherae interlum liberae v, saepius abortivae. Stig m a t exserta, cylindracea, ebtusa. A c hen ia elongata, sessilia v. stipitata. $P$ a p p s nniserialis, plumosus $v$, rarius barbellatas. - Herbaev. suffrutices, in America tropica et boreali provenientes; foliis alternis, uninerviis, rarius triplinerviis, linearibus $v$, lanceolatis, capitulis paniculato-corymbosis, pedicellatis, corollis purpurascentibus $v$, albis.

K u hnia Limu. sp. 1662. Vent. Cels. 91. Cassini in Dict. sc. nat, XXIV. 515. Lessing Synops, 157. DC. Prodr. V, 126.

a. STRIGIA DC. A chen ta teretinseula, multistriata. P a p p u s plumosus. - Involucri squamae imbricatae, extoriores breviores.
Strigia DC. Prodr, V. 126. Critonia Gärtn. $I I$. 411. $t$, 147, not R. Br, (Linn. f. Decad, II, $t$, 11. Vent. Cels, , 91.)

b. TRiChogONIA $D C$. A che $n$ i a pentagona, angulis piloso-scabris. P a p p s plumosus. - Involucri squamae aequales, haud imbricatae.

Trie hogoni a DC. Prodr. $V$, 126. (Kunth in Humb. et Bonpl. Nov. gen, et sp, t, 393,)

c. LEIOGONIA DC. A eh e i a pentagona, omnino laevia. - Papp us barbellatus. Involucri squamae paucae, subimbricatae.

Leiogonia DC. Prodr. V. 197.

2265. Clavigera $D C$. C a p i $\mathbf{u}$ l u m quinque-vigintiflorum, homogamum. Invol a cri pluriserialis, imbricati squamae longitudinaliter striatae, exteriores brevissimae, intimae elongatae, lineares. R e e p ta $\mathbf{c u l} \mathbf{~ u m}$ angustum, nudum. Corollae tubulosae, cylindraceae, brevissime quinquedentatae, dentibus extus glanduliferis. A ntherae apice appendiculatae. $\$$ tigm at a teretia, inclusa v. subexserta. A chenia subcylindracea, glabra. Pappus uniserialis, setis breviter barbellato-plumosis. - Suffrutices mexicani, erecti, ramosissimi; foliis alternis, integerrimis v. dentatis, linearibus aut oblongis, uninerviis, capitulis in paniculam spicaeformem v. corymbosam dispositis, floribus albis.

Clavigera DC. Prodr. $Y, 127$.

22\% D. Lîtris SCHREB Capitulnm quinque-multiflorum, homogamum. In vo l u c r u m panciseriale, imbricatum. Receptaculum nudum. Coroll a e tubulosae, fauce ampliata, limbi quinquelobi lobis elongatis. Stigmat a exserta, cylindracea. A chenia subdecemeostata, snbeylindracea. P a p u s uni-triserialis, setis plumosis v. barbellatis.- Herbae $v$. rarius frutices, in $A m e-$ rica $b$ oreal $i$ indigenae; radicibus tuberosis, resinosis, caulibus elongatis, simplicibus, foliis alternis, integerrimis $v$. in paucissimis dentatis, capitulis spicatis, racemosis, paniculatis $v$. corymbosis, corollis purpureis, roseis, rariusve variantibus albis.

Liatris Sehreher gen. n. 1263. Nuttall gen, II. 131. Lessing Synops. 157. DC. Prodr. V.128, non Don. A n o ny$\mathrm{mos}$ Walter carolin. 196.

a. EULIATRIS $D C$. P a p us miserialis, Ionge plumo. sus. - Herbae, radice globoso-tuberosa, deorsum vix subfibrillosa, caulibus simplicibus, capitulis spicatis v. simpliciter racemosis.

Euliatris DC. Prodr. V. 128. Liatris Cassini in Dict. sc, nat. XXVI. 235. S erratulae sp. Linn. E IIp a torll sp. Vent, Cols, t, 79. (Sweet Fl. Gard, t, 44. Hooker Flor. Bor. Amer. t. 105.)

b. SUPRAGO Gärtn. Pappus uni-triserialis, setis dense sed breviter barbellatis. - Herbae, radice globosotuberosa, deorsum vix subfibrillosa, caulibus simplicibus, capitulis spicatis $v$, racemosis.

S u p r ag o Gärtn. IT, 402, t. 167. exel. sp. Cassini in Dict, sc, nat, LIT. 385, DC. Prodr. $V, 129$. S e r ratul a e sp. Limn. (Andr. Bot. Reposit, t. 401. Bot. Mag. t. 1411, 1709. Bot. Reg. t. 395. Sweet Fl, Gard. t, 49, 87.)

c. TRILIS $\lambda$ Cass. Pap p us uni-triserialis, setis breviter et remote barbellatis. - Herbae v. suffrutices, radicibus e trunco subfibroso tuberosis, capilulis corymbosis $v$, paniculatis.

Trilis a Cassini in Dict. sc, nat, LV. 310. DC. Prodr. V. 131. (Andr, Bot, Reposit, t. 633.)

22\%1. Carplneploorus CASS. C a pitu Ium mnltiflorum, homogamum. Involucri squamae triseriales, imbricatae, adpressae. Recep ta culum paleaceum, paleis involucri squamas referentibus, flore brevioribus, deciduis. Corolla e tubulosae, quinquefidae. Stig mat a clavata, obtusa. A chen ia cylindracea v. decemenstata, basi attenuata. Pa p pus nni-pluriserialis, setis crassis, plumosis, v. grosse et irregulariter barbellatis. - Herbae perennes, in Asia boreali 
et media indigenae; caule simplici, foliis alternis, linearibus $v$. lanceolatis, integerrimis $v$. dentatis, capitulis corymbosis aut racemosis, corollis purpureis.

Carphephorus Cassini in Bullet, soc. philomat. 1816. p. 198. Dict. se. nat. VII, 149. Lessing Synops, 158. DC. Prodr. $V, 132$.

2ะซ2. Deenelhaetn $D C$. Capitulum vigintiflorum, homogamum. Invo I u eri ovati, imbricati squamae tri-quadriseriales, snbstriatae, caducae, exteriores ovatae, interiores oblongae, obtusiusculae. Receptaculum subconvexum, paleis linearibus, caducissimis inter flores onustum. Co rolla e tubulosae, glabrae, quinquefidae. Stigmat a clavata, obtusa, longe exserta. A $\mathbf{c h}$ en ia acute pentagona, glabra, areola terminali convexa. Pappas uniserialis, setis decem persistentibus, basi vix seabris, apice subclavellatis. - Suffruticulus mexicarus, erectus, glaber; ramis teretibus, foliis alternis, subpetiolatis, oblongo-lanceolatis, utrinque acuminatis, serratis, penninerviis, tenuiter reticulatis, thyrso terminali, ramis axillaribus apice eapitula racemoso-congesta, sessilia gerentibus.

De ca cluata DC. Prodr. V. 133.

2: 3. Chromolaena $D C$. C a pitulum multiflorun, homogamum. Involueri squamae innumerae, erectae, laxiusculae, imbricatae, oblongae, obtusae, subscariosae, apice coloratae, venis subelevatis, parallelis substriatae. Receptacu$1 \mathrm{um}$ paleis paucis, linearibus, apice coloratis inter flores conspersum. Corvila e tubulosae, eylindricae, limbo quinquefido. Antherae in appen dicem ovatam, subpetaloideam, coloratam desinen tes. S t i g m a t a crassa, elongata, glandulosa. A ehe nia pentagona, basi attenuata, glaberrima. Papp us uniserialis, setosus, seaber. - Herba brasiliensis, perennis, tota exceptis capitulis hirsuto-tomentosa; radicibus fibrosis, caule tereti, basi simplici, apice parce opposite ramoso, foliis oppositis, lanceolatis, breviter petiolatis, basi integerrimis, a medio ad apicem dentato-serratis, capitulis cymosis ad apicem caulium, medio subsessil praecociore, ramis ex hujus basi ortis mono- $v$. oligocephalis, involueris laete roseo-violaceis, forma capitula Humuli Lupuli, colore bracteas Salviae Hormini referentibus.

Chromolaena DC. Prodr. $V .133$.

23\%4. Doelinimun DC. Capitulum multiflorum, homogamum. Involueri squamae bi-pluriseriatae, imbricatae, deciduae. R e c e $\mathbf{t}$ acul um nudum, involuero delapso oviforme. Coro lla e tubulosae, fauce vix dilatata, limbo quinquefido. A $\mathbf{n} t h$ e ra e inclusae. Stigm a $t$ a cylindracea, obtusa, exserta. Ach enia angulata, glabra. Pa p p s uniserialis, setosus, seaber. _ Herbae americanae tropicae, suffruticosae, rarissime annuae; folitis oppositis, dentatis $v$. integerrimis, pedunculis saepius elongatis, monocephalis, corollis purpureis.

0 ocliulum DC. Prodr. V. 133, Eupatorium $r i-$ g i dum Swartz. - ? P r axelis Cassiai in Dict. sc. nat. $X$. 261.

2. ร. Comoelinisun $D C$. C a pitulum multiflorum, homagamum. Invol u cri campanulati squamae bi-triseriales, lineares, acutae, subaequales. Receptacu I am nudum, conieum. Corolla e tubulosae, fauce vix dilatata, limbo quinquefido. Antherae inclusae. Stigmat a cylindracea, obtusa, exserta. A chenia angulata, glabra Pa p p s uniserialis, pilosus, scaber. Herbac $v$, suffrutices, in America tropica et bo- reali provenientes; cau libus teretibus, striatis, fo liis oppositis, petiol atis, dentatis, corymbis termina libus confertis, corollis caeruleis $v$. purpureis.

Conoclinlum DC. Prodr. V. 135. Eupatorii sp.

22\%6. If multiflorum, homogramum. Involu c ri campanulati squamae pluriseriales, laxe subimbricatae, saepe in appendicem subcoloratam productae. $\mathrm{R}$ ec e ta c I l m elevatum, superne plano-convexum, pube brevi conferta hirtum, fere piloso-fimbrilliferum. Corolla tubulosae, fauce vix dilatata, limbo quinquefido. Antherae inclusae. Stigmata cylindracea, obtusa, exserta. A ehenia angulata. P a p p s uniserialis, piloso-scaber. Herbae americanae tropicae, pubescentes; caulibus teretibus, foliis oppositis, petiolatis, cordatis, acuminatis, dentatis, corymbis terminalibus compositis, confertis, corollis albis $v$, roseis.

Hebecllnium DC. Prodr, $V .138$.

a. AMBLYLEPIS. I a volucri squamae exappendiculatae. Eapatoriam macrophy II u m Lims.

b. UROLEPIS $D C$, I u vo 1 u er $i$ squamae omnes v. ple. raeque in appeudicem subcoloratam productae.

Urolepis DC. Prodr. $V, 136$.

225\%. Campyloelinionm DC. Capitalum multiflorum, homogamum. Involucri campanulati squamae bi-triseriales, inaequales, exteriores ovales, interiores angustiores, $R$ ec e p tac ulum convexum, hemisphaericum, nulum. Corolla e tubulosae, fauce vix dilatata, limbo quinquefido. Antherae inclusae. Stigmat a cylindracea, obtusa, exserta. A e h e n ia angulata, glabra. Pa p p 8 uniserialis, piloso-scaber. Herbae, rarius suffrutices, in $A$ m erica tropica provenientes, pilosi; foliis oppositis, petiolatis, integerrimis $v$. dentatis, capitulis pedicellatis, in co rymbum paniculatum dispositis aut solitariis, corollis purpurascentibus aut albidis.

CampylocJinium DC, Prodr. V. 136. Bapatoris sp. Anet. Smith Io. inedit. IIT. t, 68 .

28\%8. Boulbostylls DC. Capita $1 \mathrm{um}$ decem-vigintiquinqueflorum, homogamum. In v olucri squamae bi-triseriatae, laxe imbrieatae, lineari-lanceulatae, acuminatae, striatae. R e e e pt a c $\mathrm{c}$ l u m planum, angustum, nudum. Cor ollae tubulosae, basi dilatatae, limba brevissime quinquedentato. Antherae inclusae. Stylus basi bulbosus; stigmata cylindracea, obtusa, exserta. A chenia teretiuscula, striata, sessilia. Pap p $\mathbf{8}$ nniserialis, setosms, scaber. - Suffrutices mexic an $i$; ramis teretibus, foliis oppositis $v$, superioribus alternis, petiolatis, lanceolatis v. ovatis, serratis, glabris v. puberulis, subtus saepe glandulosis, nec pellucido-punctatis, paniculis subthyrsoideis, foliosis, capilulis oblongis.

Bulbostylis DC. Prodr. V. 138. Coleosanthus Cassini in Diet. sc, nat. X, 37. exel. sp. E upato rii sp. Aret. Cavanill. Ic. t. 98. Kunth in Humb, et Bonpl. Nov. gen, et sp, t. $44 t$.

2289. Critomia P. BROWN. Ca pitulu m tri-quinqueflorum, homogamum. Involueri oblongi, bi-triserialis squamae imbricatae, oblongae, striatae, obtusae. R e e pt a culam angustum, nudum. Corolla e tubulosae, fauce vix dilatata, limbo quinquefido. Antherae inclusae. St y In 8 basi aequalis; stigm a t a cylindracea, obtusa, exserta. A chenia acute pentagona, basi attenuatostipitata, inter angulos hispidula v. glandulifera. Pappus uniserialis, setosus, seaber. - Frutices antillani et mexieani, glabri, elegantes; rah 
mis teretibus, striatis, foliis oppositis, petiolatis, ovalibus, utrinque acuminatis, subserratis, membranaceis, punctatis, glanduloso-pellucidis, perforatis, contritis svaveolentibus, corymbis compositis, capitulis stramineis, ad apices ramorum corymbi congestis.

Crito nia P. Browne Jam. 490. t. 34. f. 1. DC. Prodr. J. 140, non Gärtu. uec Cass. D a le a P. Browne Jam. 314. non Linn. Wikst röm ia Spreng. syst, III. 434. non Alior. Eu p atoriu m Dale a Lina. Jaeq. Hort, Schönbr. t, 146.

2880. Eumatorifume TOURN. CapituI a m tri-multiflorum, homogamum. Involne ri oblongi, bi-triserialis squamae aequales v. inaequales, laxe $\mathbf{v}$. plus minus arete imbricatae. $\mathbf{R}$ eceptaculum planum, nudun. Corolla e tubulosae, fance vix dilatata, limbo quinquefido. A ntherae inclusae. Stigmat a exserta, eylindracea, obtusa. A chenia angulatav. striata. Pa ppus uniserialis, pilosus, scaber. - Herbae $v$, suffrutices, in regionibus extratropicis rarissimae, inter tropicos veteris orbis rarae, in America copiosissimae; foliis saepius oppositis, rarius alternis $v$. verticillatis, integerrimis $v$. denta. tis aut incisis, capitulis saepius corymbosis v. paniculatis, corollis cyanicis.

E u p a to ri u in Tournefort inst. 455. Liun. gen, n. 935. Gärtn. IT. 401. t. 166. Swith Ic, inedit, IIT. t. 67. 69. Vahl sjmb. III, t, 72, 73. Aublet Guian, t, 31\%. Jacq. Ic, rar. t. 170. Hort. Vindob, t, 164, Willd, Hort. Berol. t. 32. Vent. Malm. t. 3. FI. dan. $\ell$. 745. E. B. t. 478. Kunth in Humb. et Bonpl. Nov.gen, et sp.t. 340. 348_345, 327. 349. Sehraak Hort. Monac, t. 85. Cassiui in Dict. sc, nat. XVY, 2. XXV. 432, XXVT. 228. Lessing Synops. 157. DC, Prodr, V. 141. Trag anth a Wallr, mec.

2281. Nothites CASS. C a p i t $\mathrm{l}$ u m quinqueflorum, homogamum. Inv ol u cri oblongi, pentaphylli squamae uniseriatae, ereetae, oblongolanceolatae. Rec e p t a e $\mathbf{u} \mathbf{I} \mathbf{u}$ angustum, nudum. Corolla e tubo brevi, fauce elengata, angusta, limbo quinquefido. Antherae subinclusae, appendieibus obtusiusculis. Sti g m a $t$ a exserta, eylindracea, obtusa. A chen i subpentagona, hispidiuscula. P a p i setae denae-vicenae, uniseriales, filiformes, apice barbellatae, basi membrana angustissima marginatae. Herbae a mericanae tropicae; foliis oppositis v, rarius alternis, ut plurimum sessilibus, dentatis, corymbis terminalibus.

Nothites Cassini in Diot. sc. nat. XXXY. 163. DC. Prodr. V. 186. Mikaulae sp. Willd. Eupatorii sp. Lam. Less.

2\%82. NIIKania WILLD. Cap itulum quadriflorum, homogamum. Invol u erum tetraphyllum, basi v. infra basim nnibracteatum. Rece pta $\mathrm{cuI} \mathbf{\mathrm { m }}$ angustum, nadum. Coroll a e tubus brevis, faux dilatata, limbus quinquelobus. Antherae subexsertae. Stigmat a exserta, cylindracea, obtusa. A chen i a angulata. $\mathbf{P}$ a p p $\mathbf{x}$ uniserialis, pilosus, scabridus. - Frutices v. herbae, saepissime scandentes, in America tropica copiosissime provenientes, in Madagascaria et Capite bona spe $i$ rarae, in India rarissimae; foliis oppositis, sacpius petiolatis, basi coadunatis, interdum ad basim petioli auriculatis, limbo saepius cordato $v$. ovato, multiformi, capitulis spicatis, racemosis, corymbosis $v$. paniculatis, corollis albidis $v$ pallide flavescentibus.

Mikania Willd. sp. IIT. 1452, Hamb. et Bonpl. Pl. aequinact, t. 105. 106. Kunth in Humb, et Borpl. Nov. gen. et sp. IV. 134. Lessing Synops. 157. DC. Prodr. V. 187. Eupatorit s p. Linn. et Auet. Jaeq. Fe, rar, $t, 169$. $? \mathrm{C}$ ac alliae sp. Flor. Flnm. VIII. $t$. $33-63$.

2283. Adenostyles CASS, Cap itulum pauciflorum, homogamum. Invol ncri cylindra- cei squamae pancae, uniseriales. Receptacu$1 \mathrm{um}$ angnstum, nudam. Co roll a e tuhulosae, limbo campanulato, quinquedentato. An th e rae subexsertae; stigmata longe exserta, semicylindracea, undique papilloso-glandulosa. A chenia teretiuscula, striata. Pa p p a pluriserialis, setis piliformibus, scabris. - Herbae in Europae media e et a ustralis montibus et alpibus peren. nantes; foliis alternis, petiolatis, saepe basi auriculatis, reniformibus, capitulis pedicellatis, in corymbum compositum, nudum dispositis, floribus purpuraseentibus $v$, albidis.

Aden ostyles Cassini in Dict. sc. nat. $I$, suppl. 59. Lessing Synops, 157. DC. Prodr, V. 203, C ace a I i T Tourne. fort inst. 451. Gärtn, t. 266. f. 2. Jaeq. Flor, austr. t. 234.235.

SUETRIBUS II. TUSSILAGINEAE Lessing Synops. 158. C a p it ul a heterogama v. subdioica.

DIVISIO I. PETASITEAE DC. Prodr. V. 204. C a pitula heterogama v. subdioica, corollis femineis tubulosis. _ Flores albidiv. purpurascentes.

2254. 至omogyme CASS. Ca pitul u m multiflorum, subheterogamum, floribus radii uniseriatis femineis discique tubulosis. Involneri cylindracei squamae subuniseriales, oblongo-lineares, acutac, disco paullo breviores. R e e p $t$ a cuI um nudum. Corolla e radii filiformes, disci tubulosae, quinquefidae. St $\mathrm{i} g \mathbf{m}$ a $\mathbf{t}$ a floris feminei et hermaphroditi conformia. A $\mathbf{c}$ he $\mathrm{n}$ i a oblongocylindracea, sulcata, glabra. Pap p $\mathbf{s}$ pilosus, multiserialis. Herbae in Europa montibus perennantes; foliis plerisque radicalibus, petiolatis, cordato-orbiculatis, dentatis v. angulatis, scapo monocephalo, ima basi uni-bifoliato, apice parce squa. moso subcoaetaneis, floribus purpurascentibus $v$, albis.

$\mathrm{H}$ o $\mathrm{mog}$ y ne Cassini in Dict.sc, nat. XXI. 412. Lessing Synops, 15s. DC. Prodr. V.204. T us silago 8 y I vestris Lina. Jaeq. Fl. austr. $t$. 246. Sehkuhr $t$. 249. T. d i s c o 1 or Jacq. op. cit. $t$. 2i7. T. s y Ivest $\mathrm{r}$ is Scop. Jacq. op. cit. append, $t, 12$.

2885. Narulosmia CASS. Capitula multiflora, subdioica, $s \mathbf{u} \mathbf{b} \mathbf{m}$ a $s$ c $\mathbf{l}$ a floribus radii uniseriatis, femineis, ligulatis, disci abortu masculis tubulosis, pluribus; $8 \mathrm{ub}$ fe min ea floribus radii pluriseriatis, femineis, minutissime ligulatis, disci paucis (1_5) tubulosis. Involucri squamae nniseriales, floribns breviores $v$. subaequales. Receptac nlum nudum, plannm. Corollae mascula tubulosae, quinquedentatae, f $\mathrm{m} \mathrm{i-}$ neae ligula brevissima integerrima. Stigmat a ...... A chenia teretiuscula, glabra. $\mathbf{P}$ a p p pilosus, florum femineorum brevior, rarior. Herbae perennes, in Europa australi, in $A s i a$ et America boreal $i$ indigenae; foliis radicalibus petiolatis, basi cordatis, dentatis, scapo squamoso in thyrsum fastigiatum desinente subcoactaneis, floribus purpurascentibus $v$, albidis.

Nardosm ia Cassini in Dict. sc. nat. XXXIV. 180. Lessing Synops. 139. Hooker Flor, Bor. Amer. I. 307. DC. Prodr. V. 205. T us sil ag i a is s p. Linn, Flor. dau, $t, 61$. Ait. Hort, kew, $t, 11$.

2886. Petasites TOURNEF. Capitula multiflora, subdioiea, su b ma s cula floribus radii uniseriatis paucis (1-5) femineis, disciqne ovario exovulato masculis tubulosis; $8 \mathbf{u b} \mathrm{femin}$ ea floribus radii pluriseriatis femineis, discique paucis (1_5) masculis. Invol neri subuniscrialis, basi 
saepe bracteolati squamae floribus breviores. Rece pta cu I um nudum, planum. Corolla e mascula e tubo ad faucem dilatato, limbo quinquedentato, femine a filiformes, limbo truncato. Stigmata... A ehenia cylindracea, glabra. Pa p p 8 pilosus, marium multo rarior. - Herbae perennes, in humidis Europa e crescentes; scapo praecoci saepe tomentoso, squamis membranaceis, glabriusculis onusto, in thyrsum polycephalum desinente, foliis serotinis, reniformibus v. cordatis, dentatis, amplis, floribus purpurascentibus v. albidis.

Peta s it es Tonrnetort inst. 451. Gärtn. Ir. 406. t.166. Cassini in Dict. sc. nat. XXXIX. 199. Lessing Synops. 159. Tussilagi nis sp. Linn. Fl. dan. $t$, 524. 842 .

2\% 8\%. Aulemoeation $H O O K$. C a p it a$1 \mathrm{n} \mathrm{m}$ novem - decemflorum, heterogamum, floribus radii uniseriatis femineis, discique masculis tubulosis. Invo l u eri uniseriati foliola plura, demum reflexa. $R$ e c e pta c $\mathbf{I n ~ m}$ nudum, plannm. Coroll a e tubulosae, limbo quadri-quinquedentato. Stigmata ...... A chenia oblongo-obovata, superne glandulis stipitatis consita. Pa p p 8 nullus. - Herbae perennes, in America o c cidentali, boreali et australi observatae; caule albo-tomentoso, inferne folioso, superne aphyllo, laxe paniculato, glandulis stipitatis consperso, foliis alternis, petiolatis, penninerviis, subtrilobis, angulatodentatis, $v$. subrotundo-ellipticis, cordatis, subintegerrimis, supra glabris, subtus tomentosis.

Ad en o e a u lon Hooker in Bot, Misc. 1. 19. t. 15. Flor. Bor. Amer. I. 308. Lessing in Linnaca VT. 107. Synops. 139. DC. Prodr. V. 208.

HIVISI(1) II. EUTUSSILAGINEAE DC. Prodr. V. 208. Capitul a heterogama, radiata, floribus radii ligulatis, femineis; disci tubulosis, masculis. - Flores lutei, radii rarissime rosei.

2888. Thassilago TOURNEF. C a p i ul $\mathrm{n} \mathrm{m}$ multiflorum, heterogamum, floribus radii pluriseriatis, ligulatis, femineis, disci paucis, tubulosis, masculis. Involucri subuniserialis squamae oblongae, obtusae. Rec epta cu I u mudum. Coroll a e radil ligulatae, ligula angustissima, integerrima, disci tubulosae, limbo campanalato, quinquedentato. St y lus dis c i inclusus, aloortivus, radi i stigmata teretiuscula. A chenia radii oblongo-cylindracea, glabra, $d$ is ci abortiva. P a ppus radii pluriserialis, disci uniserialis, setis tenuissimis. - Herba perennis, in argillosis humidiusculis Europae totius, Tauriae, Sibiriae, Persiae et Indiae superioris obvia; rhisomate crassiusculo, hypogaeo, scapo praecoci, monocephalo, tomentoso, squamis alternis, oblongis, adpressis, involucri squamas referentibus onusto, foliis serotinis, petiolatis, cordatis, angulatis, subtus discoloribus, floribus flavis.

T u s s ilago Tournefort inst, 687. Gärtn. II, t. 170 Cassiut in Dict. se. nat, XXXIV, 190. exel. sp. Lessing $S y$. nops. 159. DC. Prodr. V.208. T u s sil a go F a f a ra Limu. Flor. dan. t. 595. E. B. t. 429.

228D. Celanisia CASS. C a pitu $1 \mathrm{um}$ multiflorum, heterogamum, florilsns radii uniseriatis, ligulatis, femineis, disci tubulosis, hermaphroditis. Involueri pluriserialis squamae inaequales, acntae, disco paullo longiores. R e ce pta e ul um latum, nudum $v$. alveolatum. Corollae $\mathrm{r}$ a d i i lignlatae, d i s e i tubulosae, quinquedentatae. Achenia oblongo-cylindracea, basi attenuata. Pap p us pluriserialis, paleis filiformi- bus, inaequalibus, barbellatis. - Herbae Novae Hollandiae; caule erecto, simplici, nudo, monocephalo, folitis radicalibus oblongis, floribus disci luteis, radii roseis.

C elmis i a Cassini in Dict. sc, nat, XXXVII. 259. (uon Vil.) Gaudich. ad Frege, 170, t, 91. DC. Prodr. V. 209.

2\%90. Aleiope $D C$. Capitu 1 u m mnltiflorum, heterogamum, floribus radii uniseriatis, ligulatis, antherarum abortu femineis, disei tubulosis, hermaphroditis. Involucri pluriserialis squamae subimbricatae, adpressae. Rece p ta c u lum nudum, latum. Corolla e ra di ligulatae, ligula oblonga, obsolete dentata, d is c i tubulosae, limbo quinquedentato. Stig mat a brevia, obtusa, parce papillosa, glabra, disci et radii subconformia. A chenia oblongo-cylindracea, subobcompressa. Pappus pluriserialis, setis scabridis, ima basi breviter coneretis. - Herbae capenses, suffrutescentes, erectae, ramosae; foliis alternis, petiolatis, integerrimis v. denticulatis, supra glabris, subtus petiolis et involucris cano-lanatis, capitulis ramos terminantibus, fiavifloris.

Alei o e DC. Prodr. V. 209. Celm is ia Cassini in Dict. sc. nat. VII. 357. (uon XXXIII.) A ruic a $\mathrm{tab}$ u I a ris, Ianata et grandis Thunb. Ligulariae sp. Less.

2291. Irraclnyglottis FORST, C a pitul n m subdecemflorum, heterogamum, fioribus radii uniseriatis, paueis, subligulatis, femineis, disci tubulosis, hermaphroditis (?). Invo I ueri oblongo-eylindriei, extus ealyculato-luracteolati squamae lineares, uniseriales. Receptaculum nudum. Corollae radii brevissime ligulatae $\mathbf{v}$. oblique tubulosae, disco fere brevióres, disci tubulosae, limbo quinquedentato. Stigmata radii exserta, revoluta, apice clavellata, obtusa, d i s $\mathrm{ci}$ ablireviata, subinclusa, aborliva (?). A e hen ia oblonga, basi non attenuata. Papp u nniserialis, setis densis, scabris, basi in annulum concretis. - Arbusculae Novae Zeelandiae; foliis alternis, petiolatis, ovalibus $v$, subrotundis, subtus tomentosis, corymbo paniculato.

Braehyglottis Porster Char, gen, 46. Cassini in Dict. sc. nat. XLVIIT. 464. DC. Prodr. $V .210$. S e ne ci o. $n$ is sp. Less. Cinerariae sp. Willd.

TrEIRES 1II. ASTEROIDEAE Lessing Synops. 161. Capitula heterogama, rarins homegama v. dioiea. Cor oll a e pellucidae, staminigerae tubulosae, regulariter dentatae. Pollen globosum, echinulatum. Stylus floris hermaphroditi superne cylindricus; stig$\mathrm{m}$ a $\mathrm{t}$ a duo, longiuscula, linearia, extus subplana, saepins subacuminata, rarius obtusa, glandulae stigmaticae angustae, prominulae, usque ad originem pubis externae extensae.

SUETRIIEUS I. ASTERINEAE Nees Ast. 3. C a p it ul a homogama v. heterogama, saepius radiata $R$ eceptaculum nudum v. rarius paleaceum. Antherae ecaudatae. Folia in plurimis alterna.

DIVISI T. AMELLEAE DC. Prodr. V. 213. C a pitula heterogama, radiata, rarissime dioica. R eceptacul $\mathrm{l} \mathrm{m}$ paleaceum.

SUBDI VESIO I. EUAMELLEAE DC. Prodr. V.213. Ca pitul a heterogama, radiata. 
2999. Amellus CASS. C a p i t $\mathrm{l} 1 \mathrm{um}$ multiflorum, saepius heterogamum, floribus radii subuniseriatis, ligulatis, femineis, disci tubulosis, hermaphroditis, rarius homogamum, discoideum. Involueri ovati squamae pluriseriales, imbricatae, rigidae, acuminatae, interiores sensim in paleas receptaculi abeuntes. $R$ eceptac u l u m subconicum, paleis inter flores confertis. Cor olla e ra d i ligulatae, ligula brevi, lanceolata, mox revoluta, disci tubulosae, limbo quinquedentato. Antherae ecaudatae. Stigmat a radii linearia, dis ci apice conico-incrassato hirtula. $A$ ch en i a cuneiformia, compressa, radii subtetragona, scabra, dis ci laevia, apice subdentata. $P$ a $\mathbf{p} \mathbf{p}$ s ra. dii paleis brevibus, uniseriatis, dis ci duplex, exterior paleaceus, pappo radii subconformis, interior quadrisetus, scaber. - Fruticuli v. herbae capenses; foliis inferioribus oppositis, superioribus alternis, oblongis, integerrimis $v$. parce dentatis, strigillosis aut canescentibus, pedunculis terminalibus, subsquamulosis, monocephalis, floribus radii caeruleis, disci extus pubescentibus, luteis.

A m ell u s Linn. gen, $n, 978$, excl. sp. Lam, $t$. 689. $f$. 1 . Jaeq. Collect. V. t. 10. f. 1. Cassini in Dict. sc. nat. VIII. 577. XVI, 210. XXXVII. 463, et 489. Nees Ast, 241. Lessing Synops. 161. DC. Prodr. V. 213. Bu phthatm I et Verbesinae sp. Linu. Asteris sp. Thunb.

2293. Corethrogyne $D C$. C a pitulu m multiflorum, heterogamum, floribus radii nniseriatis, ligulatis, neutris, disci tubulosis, hermaphroditis, Invol ucri squamae bi-triscriales, lanceolato-lineares, subaequales. Rece p ta culu m planum, paleis linearibus, apice scabridis inter flores. Corolla e radii ligulatae, lignla angusta, disci tubulosae, tubo brevi, fauce eylindrica, limbo brevissime quinquedentato. An th era e ecaudatae. Stigmata exserta, basi linearia, margine glandulosa, apice setas rigidas v. penicilliformes gerentia. A chenia turbinata, dense sericea, villis apicis pappum exteriorem simulantibus. Papp u s pluriserialis, setosus, scabridus. - Herba in California a Douglasio reperta, multicaulis, tota molliter incano-tomentosa; foliis alternis, acutis, inferioribus oblongo-lanceolatis, basi attenuatis, apice serratis, superioribus linearibus, integerrimis, capitulis ad apices ramorum solitariis, involucris parce villosis, radio purpureo, disco flavo, pappo rubente. Corethrogyne DC. Prodr. V. 215.

2294. ChiHetrielnuma CASS. Capitu$1 \mathrm{um}$ multiflorum, heterogamum, floribns radii uniseriatis, ligulatis, femineis, disei tubulosis, hermaphroditis. In v o I u cri squamae bi-triseriales, imbricatae, oblongae, acutae. Recepta cu I um convexum, paleis linearibus, apice barbatis inter flores. Corollae radii ligulatae, ligula oblongo-lanceolata, mucronulata, di s ci tubulosae, quin quedentatae. Antherae eeaudatae. Stig mat a disci subulato-linearia, elongata, puberula. A ch en ia gracilia, cylindracea, angulato-striata. F a ppus pluriserialis, setis filiformibus scabridis, inaequalibus, persistentibus. - Frutex parvus, ramosus, in Am erica antarctica indigenus; foliis alternis, sessilibus, coriaceis, integerrimis, margine revolutis, supra glabris, subtus plus minus tomentosis, pedunculis solitariis monocephalis, tomentosis, ligulis albis subtus purpurascentibus, disco flavo.

Chil iotrie h u m Cassini in Bullet, soc. philomat, 1817 p. 69. Dict. sc. nat. IV. suppl. 576. VIIT, 576. XXXVII. 463. et 489. Lessing Synops, 162. Nees Ast. 239. DC. Prodr, $V$. g16. Tropid ol epis Tauseh in Flora 1899. p. 68. A m e J. Ius diffusus Forst.
SUIBTETEUS II. HE'TEROTHALAMEAE DC. Prodr. V. 216. C a p i t u 1 a dioica, masculorum receptaculo nudo, ligulis uniseriatis, femineorum receptaculo paleaceo, ligulis pluriseriatis.

2995. Ireterothalamans LESS. C a p i tu la multiflora, radiata, dioica. Involu cri pluriserialis squamae siccae, lauceslatae, aequales, disco subbreviores. Masc. Recepta culum planum, nudum. Corolla e radii ligulatae, uniseriales, minimae, ovario effoeto nentrae, dis ci tubulosae, limbo quinquedentato. An thera e ecaudatae. Stigmat a imperfecta. A ehe n i a effoeta. P a p us uniseriatus, setis subclavatis, caducis. F e m. R e ce ta c u I u m conieum, paleis involncri squamas referentibus obsitum. Coroll a e fere omnes ligulatae, breves, femineae, centrales paucissimae quinquedentatae, masculae? Achen i angulata, glaberrima, basi attenuata. Pappus uniseriatus, setis apice acutis, caducus. - Frutices in Brasilia a ustraliore indigeni, erecti, glaberrimi; foliis alternis, lineari- v. oblongo-acutis, integerrimis $v$. serratis, capitulis subglobosis, masculis corymbosis, parvis, femineis in axillis ramorum sterilium breviter pedunculatis, duplo majoribus, corollis utripusque sexus flavis.

Heterothalamus Lessing in Linnaea $V$. 145. VI. 505, Synops. 295. DC. Prodr. V. 216.

DIVISIO I. ASTEREAE DC. Prodr. V. 217. C a p itul a heterogama, radiata. $\mathrm{R} \mathrm{e-}$ ce p tacul 1 m epaleatum, nunc nudum, nunc alveolatum v. fimbrilliferum.

SUEDIVISIO I. EUASTEREAE DC. Prodr. V. 217. Lig ul a e uniseriales. A chen i a compresso - plana. P a p u s radii et disci conformis, pilosus, uni-pluriserialis.

2298. NIaixia $D C$. C a p itulum multiflorum, heterogamum, floribus radii uniseriatis, ligulatis, femineis, disci tubulosis, hermaphroditis v. ovario efoeto masculis, Involucri bi-quadriserialis squamae imbricatae, margine membranaceae. R e c e p tac u l am nadum, subalveolatum. Corolla e radi i ligulatae, ligula elliptica, apice tridentata, di s c i tnbulosae, limbo quinquedentato. Anthera e ecaudatae. A $\boldsymbol{c}$ henia plano-compressa, erostria, glabra v. parce pilosa. Pappus in radio et disco conformis, uniserialis, setis plumosis. - Herbae rhizomate suffrutescente v, suffrutices, e Capite bonae spei; foliis alternis, oblongoobovatis aut linearibus, rigidulis, integerrimis v. dentatis, ramis caulibusve apice nudis, capitula solitaria gerentibus, floribus disci luteis, radii albis.

Ma irla DC. Prodr, V. 217.

a. PTEROPAPPUS Less, FI o res radil filamentis sterilibas interdum instrueti, disci hermaphroditi. - Herbae rhizomate sublignoso.

P teropappas Asteris sect. Lessing Synops. 166. Mairia Nees 1 st. 248. Arnica e sp. Thunb. Loddig. Bot. Cab. t. 901. Ge r be ra e sp. Bot. Reg. $t .855$.

b. ZYRPHELIS Cass, Flor es radil absque filamentis sterilibus, disci stylo rudimentario masculi. - Acaules $v$. fruticosi caulescentes.

Zy r p helis Cassini in Annal. sc, nat. XVII. 490. Dict. sc, nat. LX. 597. Nees Ast. $239 . \mathrm{Z}$ y $\mathrm{ph}$ h 1 is El p h e g e a e seet. Less.

2898. Felieia DC. Capitu I u multiflorum, heterogamum, floribus radii uniseriatis, li- 
gulatis, femineis, disci tubulosis, hermaphroditis v. interdum ovario efoeto masculis. Invol u cri bi-quadriserialis squamae imbricatae, angustae, adpressae. Re e p t a $\mathrm{cu}$ I $\mathrm{m}$ nudum, areolatum. $\mathrm{C}_{0-}$ rolla e radii ligulatae, lignla elliptica, apice tridentata, disci tubulosae, limbo quinquedentato. Anthera e ecaudatae. A $\mathrm{c}$ h en i compressa, glabra $v$. pubescentia. $\mathbf{P}$ a p $\mathbf{p} \mathbf{s}$ in radio et disco conformis, uniserialis, brevis, eaducus, setis filiformibus, flexuosis, serrulatis. - Herbae $v$. frutices capenses; caulibus ramosis, foliis alternis, angustis, crassiusculis, ramis monocephalis saepe fastigiatis, disco luteo, radio albo $v$. caeruleo.

Felicia DC.Prodr. $V$. 218.

a. HEBEC $A R P A E A$ DO. A chenia pilosiuscula v. subhirtella.

Hebe carpaea DC. Prodr. V. 219. Feli cia Cas. sini in Bullet, soc, philomat. 1818. p. 165. Dict. sc. nat. XXXVII. 464. et 490. LVI. 172. Nees Ast. 207. $\mathrm{P}$ oly lepis sect. As te ris Lessing Synops. 173. exel. sp. A s te ris sp. Linn. Bot. Mag.t.33.

b. ANHEBECARPARA $D C$. A che ui a glaberrima.

Anthebecarpaea DC. Prodr. $V$. 22t. Polyar. $\mathrm{r}$ h e a Cassini $1 l$. co. Nees Ast. 205. Poly a r $\mathrm{r}$ e $\mathrm{n}$ a E I p he ge a e sect. Lessing Synops. 184. Feliciae sp. Nees. Polylepidis sp. Less. A steris sp. Linn. Andr. Bot.Reposit, t. 93. Bot, Mag- t, 884 .

2298. Mungehia CASS. Capitulum multiflorum, heterogamum, floribus radii uniseriatis, ligulatis, femineis, disci tubulosis, hermaphroditis v. abortu masculis. Involu eri subtriseriati squamae imbricatae, adpressae. R e e ptac u l um nudum. Corolla e radii ligulatae, ligula brevi, disci tubulosae, limbo quinquedentato. An therae ecaudatae. Stig mat a filiformia, elongata, A chenia subcompressa, hirtella. Pappus in radio et disco conformis, setis pilosis, subserrulatis, uniserialibus, brevibus, caducis. _ Herbae ca$\boldsymbol{p}$ enses, diffuse ramosae, pilosiusculae; foliis oppositis, petiolatis, ovatis, papyraceis, parce et grosse dentatis, pedunculis terminalibus et axillaribus, aphyllis, elongatis, capitulis solitariis, disco flavo, radio albo, acheniis nigricantibus, pappo candidissimo.

M u n y c bia Cassini in Dict. sc, nat. XXXVIr. 462, et 683. DC. Prodr. V. 222, Felicia subgen. A s teris Lessing Synops. 181, non Alior. F eli ciae sp. Cassíui op, cit, XXYr. 97. Asteris sp. Lina. et Thub. Claeraria hirsuta Veut. Malm, $t, 95$.

2293. Agrothen CASS. Capitu $1 \mathrm{um}$ multiflorum, heterogamum, floribus radif uniseriatis, ligulatis, femineis, disci tubulosis, hermaphroditis v. abortu masculis. I n vo I u e ri campanulati, uni-biseriati squamae adpressae, complicato-carinatae, subherbaceo-rigidulae. $R$ e c e p ta c a l u m planum, nudum, vix alveolatum. Corolla e rad i ligulatae, ligula lineari-lanceolata, integerrima v. minutissiue tridentata, di sci tubulosae, limbo quinquedentato. Antherae ecaudatae. $A$ e he nia plano-compressa, nervo tumidulo marginata, pilis rigidis scabra, rarissime laevia, sterilia glabra. Pa p p u in disco et radio conformis, setis eaducis v. persistentibus, serrato-scabris. - Herbae v. suffrutices, e Capite bonae spei; foliis omnibus $v$. saltem infimis oppositis, integerrimis $v$. parce dentatis, hispidulis aut rarius glabris, pedunculis nudis, monocephalis, disco luteo, radio cueruleo.

A gat hae a Cassini in Bulletin soc. philomat. 1815. p. 175. Dict. I. suppl. 28. XIII. 116. XXXVII. 463. et 489. DC. Prodr. $V, 223$.

a. DETRIDIUM Nees. Flares disci steriles. Pappus e setis 5-6.

Detridium Nees Ast. 255. Detrioides Elphegeae sect. Lessing Synops. 182. b. DETRIS Adans. Flores disei plerique fertiles. P a ppus setis $10-15$.

Detris Adanson Fam, Ir. 131. A g a tha ea Nees Ast. 257. Detris Asteris seet. Lessing Synops. 168. Cinerariae et Asteris sp. Linn. et Auct. Miller

23DD. Bellidiastrum MICHEL. Capitulum multiflorum, heterogamum, floribus radii uni-biseriatis, ligulatis, femineis, disci tubulosis, hermaphroditis. In v o I u c r i subeampanulati, uni-biseriati squamae lineares, acutae, subfoliaceae. Receptaculum conieum, nudum, punetatum. Cor oll a e radi i ligulatae, ligula oblongo-elliptica, tridentata, disci tubulosae, limbo quinquedentato. Antherae ecaudatae. Achenia oblonga, subeompressa, hispidula. Papp u 8 in disco et radio conformis, uni-biserialis, setis numerosis, flexuosis, scabris. - Herbae in Europa monticolae; trunco abbreviato, radiciformi, foliis radicalibus petiolatis, obovato-oblongis, dentatis, scapo folia superante, monocephalo, radio albo $v$. rubescente, disco flavo.

Bellidiastrum Michelf Nov. gen, $t$, 29, Cassint in Dict. sc. nat. IV. suppl. 70. XXXVII. 494. DC. Prodr. $D$. 226. non Vaill, nee Less. M a r g a r it a Gaudia Flor. Helo, $V$. 335. Doron i eum Belli d i a s trum Lian. Jacq. Flor. Austr. t. 400. A ruicae sp. Hall. Asteris sp. Scopolf,

8301. Aster NELS. Cap it 1 um multiflorum, heterogamum, floribus radii uniseriatis, ligulatis, femineis, disci tubulosis, hermaphroditis. Involucri pluriserialis squamae laxe imbricatae, apice plus minus herbaceae, interdum foliaceae. Receptac u I um planum, alveolatum, alveolorum marginibus plus minus dentatis. Coro 11 a e ra di ligulatae, ligula oblongo-elliptica, tridentata $v$, integerrima, disci tubulosae, limbo quinquedentato. Antherae ecaudatae. A chenia compressa. Pa p $\mathbf{p}$ s in disco et radio conformis, pluriserialis, pilosus, persistens, setis scabridis, subinaequilongis. - Herbae perennes, caulescentes, rarius suffruticosae $v$. scapigerae, in $A m e$ riea boreali copiosissime, parcius in Asia boreali,

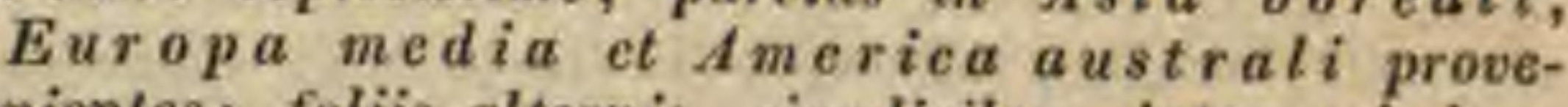
nientes; foliis alternis, simplicibus, integerrimis $v$. dentatis, capitulis solituriis $v$. plurimis, corymbosis aut paniculatis, disco flavo, demum interdum purpurascente, radio albo, caeruleo v. purpureo.

A s ter Nees Ast. 16 . Lindl. mac. DC. Prodr, $V .226$. A me ll us Adanson Fam, II. 125, nou Linn. Asteris spe-
eies Lino. et Auet.

a. ALPIGENI Nees Ast. 24. Involu eri squamae herbaceae, angustae, subaequilongre. Receptaculum na. dum, scrobienlatum. Stig m a ta brevia, triangularia. A chenia saepius hirta. Pa ppus paueiserialis. Caules mono-v. oligocephali, saepius hirsuti. Capitula majuscula. DC. Prodr. $V$. CO ritr o p hi u m sectio Asteris Kunth in Humb. et Bonpl.Nov. gen, et sp. IV. 91 . t. 332. et 332. bis. Asteris sp. Jaeq. Flor. Austr. t. 88 .)

b. AMELLI Nees Ast, 39. I n vol a c r I squamae ciliatae, squarrosae, exteriores herbaceae, interiores totae $\nabla$. apice membranaceae, coloratae. R e ceptac u I u m alveo. latum, alveolorum marginibus lacero-dentatis.S if $\mathrm{m}$ a $t \mathrm{a}$ apice lanceolata. A c h en $\mathrm{i}$ a hirta v. rarius glabra, C a u I es rigidi, corymbosi v. racemosi. $\mathrm{F}$ oli a scabrida, subintegerrina. C a pitula ampla. DC. Prodr. V. 229. (Gmelin Sibir.t. 80. f. 1. Jaeq. Flor, Austr. t. 435. Bot. Reg. t. 183. 273. 340. 1587. Bot. Mag. t. 2942.)

c. GENUINI Nees Ast. 52 . Involu c ri squamae imbricatae, laxae, margiae plus minus membranaceae, parte membranacea basim versus latiore, io arctius imbricatis totam basim occupante. Re cep t a c u I u m alvenlatum. alveolornm marginibus dentatis. A chenia glabra v. puberula. Pap p us opluríserialis. C a ulls altior, composite corymbosus, racemosus v. paniculatus. DC. Prodr. 
V. 233. - (Bot, Reg, t. 1500, 1509. 1527, 1571. 1597. 1619. 1656. Bot. Mag. t. 2995. Loddig. Bot. Cab. $t, 1636$. Colla Hort. Ripul,t, 12. S y m $\mathrm{p}$ h y o tri $\mathrm{c}$ h u m Nees Ast. 135.)

2302. Tripolium NEES. C a pitulum multiflorum, heterogamnm, floribus radii unirarissime biseriatis, ligulatis, femineis, disci tubulosis, hermaphroditis. Invol u cri squamae secus pedunculum bracteoliformes, sensim imbricatae v. subbiseriatae, interiores longiores, laeves. Receptaculum alveolatum, alveolorum margi nibus dentatis. Corolla e radii ligulatae, ligula lineari-lanceolata, tridentata, dis ci tubulosae, limbo quinquedentato. A chenia oblonga, compressa, glabra v. sparsim pilosa, basi setulis cincta. $\mathbf{P a p p u s}$ in disco et radio conformis, pluriserialis, simplex, setis tenuibus, remote denticulatis.

Herbae subcarnosae, perennes, in paludosis, salsuginosis Europa et Americae totius, imprimis borealis crescentes, glabrae $v$. ad margines foliorum scabrae; foliis alternis, angustis, integerrimis v. subserratis, capitulis corymbosis, disco flavo, radio albo v. caeruleo.

T ripolia m Nees Ast. 132. Lindl. msc. DC. Prodr. $P$. 253. Aster Adanson Fam, II, 124.

a. TRIPOLIA VERA DC. l. c. Involucri sabbiserialis squamae omnes obtusae, exteriores breviores. (Asteri s sp. Linn. Flor. dan. t, 615. E. B. t, 87 . Jacq. Hort. Vindob. $t, 8$.)

b. OXYTRIPOLIA DC. t. c. Involueri pluriserialis squamae imbricatae, interiores v. omnes acuminatae.

2303. Gallatella CASS. CapitnIn multiflorum, heterogamum, floribus radii uniseriatis, ligulatis, nentris, disci tubulosis, hermaphroditis. Involucrum disco brevius, squamis imbrieatis, inappendiculatis, exteriorilsns saepe trinerviis. R e e p ta $\mathrm{cu} \mathbf{l} \mathbf{u m}$ alveolatum, alveolorum marginibus dentatis. Corolla e radii ligulatae, ligula lanceolata, integerrima, dis c i tubulosae, limbo quinquedentato. A $\mathrm{ch}$ h $\mathrm{n}$ a dense hirsuta v. strigoso-sericea. Pappus pluriserialis, setis filiformibns, rigidis, scabridis. - Herbae perennes, in America et Asia boreali obviae, in Europa rarae; caule simplici, apice corymboso, foliis alter$n$ is, integerrimis, oblongis $v$. linearibus, omnibus basi saltim trinerviis, sessilibus, saepe punctatis, punctis imprimis epigenis, inıpressis, subglandulosis, disco flavo, radii ligulis distantibus, caeruleis, purpurascentibus $v$, albidis.

G a latella Cassini in Dict, sc, nat, XXXVIT, 463. et 488. Nees Ast. 158. Lindl. msc. DC. Prodr. $V$. 254. G a 1 a. te a Cassini in Dict, so, nat. XVITK, 56. Bullet. Soc, philomat. 1818. p. 165. Lessing Synops. 187. A s teris sp. Linn. et Auct. Cav. Ic, t. 232. Waldst. et Kit. Pl. Hang. t. 30. 109. Lediebour Ic. . 161.

3304. Turezaninowia $D C$. Capitu$1 \mathrm{u} \mathrm{m}$ pluriflorum, heterogamum, floribus radii 7 - 8 uniseriatis, ligulatis, femineis, disei totidem tubulosis, hermaphroditis v, nonnullis abortu maseulis. Involucri subbiserialis squamae lineares, obtusiuseulae, disco multo breviores. Re ce p tacu I n m alreolatum. Corulla e ra di i ligulatae, ligula integra, apice obliqua, disci tubulosae, limbo quinquedentato. A $n t h$ e $r$ a e ecaudatae. Stig mata $r$ a dii elongata, d is ci brevia, inclusa. A $e$ hen i compressa, glabra, colorata. Pappus in disco et radio conformis, uniserialis, setosus, setis sericeis, subscabris. - Herba perennis, in paludosis $D$ a huria e reperta, simplex, erecta, basi glabra, apice fastigiato-corymbosa, pubescenti-scabrida; folits alternis, lineari-lanceolatis, integerrimis, acutis, subuninerviis, corymbo composito, fastigiato, polycephalo, disco flavo, radio albo.

Turczaninow la DC. Prodr, $\mathcal{V}, 258$.
2305. Calimeris CASS. Ca pitulum multiflorum, heterogamum, floribus radii uniseriatis, ligulatis, femineis, disei tubulosis, hermaphroditis. In v o incri bi-quadriserialis squamae subaequales, herbaceae, margine membranaceae, laxe imbricatae. Receptaculum convexum v. conicum, alveolatum, alveolis subquadratis, ad angulos obtuse dentatis. Corolla e radii ligulatae, ligula lineari-lanceolata, integerrima, dis c i tubulosae, limbo quinquedentato. A $\mathrm{n}$ t $\mathrm{h}$ e $\mathrm{r}$ a e eeandatae. Stigmata apice conico-lanceolata, angustiora. A e henia compressa, marginata, hirta. P a P u s in disco et radio conformis, subuniserialis, setacens, inaequalis, scaber. - Herbae perennes, in Asia media et boreali indigenae; caule angulato, apice corymboso, foliis alternis, integerrimis $v$. inciso-dentatis, disco flavo, radio albo v. caeruleo. C all meris Cassini in Dict, sc, nat. XXIV.324. XXXVII. 464. et 491. (sub Kalimeri) Nees Ast,225. DC Prodr. V.258.

2306. Furybiopsis $D C$. Ca pitu in plariflorum, heterogamum, floribus radii uniseriatis, ligulatis, femineis, disci tubulosis, hermaphroditis. Involueri paneiserialis squamae imbricatae, lineares, acuminatae. R e ce ptacu I a m angustum, alveolatum. Cor o 11 a e radi i ligulatae, ligula ...... dis ei tubulosae, limbo quinquedentato. Antherae..... Stigmata.... A che n i a elongata, compressa, basi angustata, hispidula. Pap pus in disco et radio conformis, nniserialis, multisetus, setis scabridis, acuminatis. - Herbain Novae Hollandiae oraboreali-orientali ab A.Cunninghamio reperta, glabra, multicaulis; rhizomate crasso, lignoso, caulibus tenuibus, virgatis, parce foliosis, demum frulescentibus, foliis alternis, integerrimis, radicalibus lineari-oblongis, obtusis, caulinis linearibus, subacutis, capitulis ad apices caulium solitariis.

\section{Eu ry bi op s is DC. Prodr. $Y .260$.}

230\%. Fod oeoma CASS. Capituln m pluriflorum, heterogamum, floribus radii uni-biseriatis (?) ligulatis, femineis, disci tubulosis, hermaphroditis. Invol a crum irregulariter imbricatum, disco brevius. Receptac $\mathbf{c} 1 \mathrm{~nm}$ planum, nudum. Cor olla e radii ligulatae, ligula lineari, disci tubulosae, limbo quinquedentato. An therae ..... Stigmata..... A chenia oblonga, compressa, rostrata. $\mathrm{P}$ a $\mathrm{P}$ p $\mathrm{n} s$ in diseo et radio conformis, pilosus, pluriserialis. - Herbae bo narienses, non satis notae, perennes, multicaules; foliis infimis obovatis, dentatis, pubescentibus, caulinis sparsis, oblongo-lanceolatis, capitulis rumulos terminantibus subcorymbosis, disco flavo, radio albo, pappo rufo.

Po do com a Cassini in Rullet. soc. philomat. 1817. p. 137. Dict. sc, nat, XXXPIT. 462. et 484. XLVIIT, 60. Lessing Synops. 187. DC. Prodr. $V$. 261. Erigeroutis sp. Poiret.

2308. Asteropsis LESS. Capitu ium multiflorum, heterogamum, floribus radii uniseriatis, ligulatis, femineis, disci tubulesis, hermaphroditis. Invol ucrum pauciseriale $\ldots .$. Receptaculam epaleatum ...... Corollae radi $i$ ligulatae, $\ldots . .$. d is e $i$ tubulosae $\ldots . .$. Antherae ...... Stigmat a..... A chenia breviter rostrata ...... Pap $\mathbf{\text { P }}$ s in disco et radio conformis, uniserialis, pilosus. - Herba brasiliensis, vix nota; foliis alternis, integerrimis, capitulis solitariis.

Aster opsis Lessing Synops. 188. DC. Prodr. V.260.

2309. Aretogeron DC. Cap itu $1 \mathrm{um}$ multiflorum, heterogamun, floribus radif nniseria- 
tis, ligulatis, femineis, disci tubulosis, hermaphroditis. Involucri triserialis squamae imbricatae, adpressae, lanceolatae, acuminatae, earina virides et puberulae, margine albae, scariosae. $\mathbf{R}$ ec e p ta e u l um angustum, planum, subalveolatum. Corolla e radi i ligulatae, ligula ovali-oblonga, tridentata, involuero duplo longiore, dis ci tubulosae, limbo quinquedentato. Anthera e ecaudatae. S $t \mathrm{~g} g \mathrm{~m}$ a $\mathrm{ta}$ disci et radii crassa, brevia. A $\mathrm{ch}$ enia oblonga, subcompressa, sericeo-villosissima. $P$ appus in disco et radio conformis, simplex, pluriserialis, persistens, setis subinaequalibus, seabris. - Herba sibirica, Armeriae facie; rhizomate frutescente, caudiciformi, brevi, multicipite, foliis radicalibus confertis, lineari-subulatis, margine scabro-ciliolatis, caeterum glabris, rigidis, erectis, scapo vix folia superante, hirsuto, monocephalo, discoflavo, radio albo.

Aretogeron DC.Prodr. V.261. Erigeron gramiде u m Linn. Lam. t. 681. $f .4$

2310. Serieocarpus NEES. C a p itn$1 \mathrm{~nm}$ pauciflorum, heterngamum, floribus radii nniseriatis, ligulatis, femineis, disci tubulosis, hermaphroditis. Involueri multiserialis, ovati v. oblongi squamae imbricatae, latae, basi cartilagineae, enerves, apice herbaceae. R e e p $t$ a cul u m alveolatum, alveolorum marginibus saepe laceroeiliatis. Corolla e radii lignlatae, ligala oblonga, latiuscula, subintegerrima, d is ci tubulesae, limbo quinquedentato. An the r a e ecaudatae. S t i g$\mathrm{m}$ a t a filiformi-subulata, apice calloso-hirta. $A$ e h emi a obpyramidata, brevia, dense sericeo-strigosa. Pappus in disco et radio conformis, simplex, pauciserialis, rigidus, scaber. - Herbae b orealiamericanae, perennes; caule apice corymboso, foliis alternis, basi attenuatis, integerrimis, impunc tatis, capitulis ad apices ramorum aggregatis, disco flavo, radio albo.

Sericoearpus Nees Ast. 148. DC. Prodr, 261. Asteris sect. I. Blliot Carolin. IT. 340. Con yza e sp.
Linn.

2311. Machaeranthera NEES. Ca. pitulum multiflorum, heterogamum, floribus radii uniseriatis, ligulatis, femineis, disei tubulosis, hermaphroditis. Involu cri pluriserialis squatuae imbricatae, herbaceae, margine pallidae, apice patulae. Receptaculum nudam (?). Corollae radii ligulatae, ligula lineari, trinervi, apice bidentata, disci tubulosae, limbo quinquedentato. Antherae exsertae, ecandatae, appendice terminali, cultriformi. S ti $\mathrm{g}$ ma ta disci appendice lineari, elongato, sterili. A ch enia conica, compressa, strigoso-scabra, pilis pappum exteriorem simulantibus. Pappus pilosus, inaequalis, scaber.

Herba perennis, in hortis Mexici culta, pilis capitatis pubescens, facie Anthemidis; foliis alternis, pinnatifidis, lobis dentatis, cupitulis terminalibus, solitariis, ramo apice nudo pedunculiformi, disco flavo, radio albo $v$. in planta sicca purpurascente.

M a c ha a r a thera Nees Ast. 224. DC. Prodr. V. 262. Aster tanacetifolius Humb. et Bonpl.

231 1 2. Tetramolophum NEES. C a p itul u m multiflorum, heterogamnm, floribus radii uniseriatis, ligulatis, femineis, disci tubulesis, hermaphroditis v. nentris (?). Involncri paueiserialis squamae imbricatae, angustae. R e e ep taculum nudum, punctatum. Corollae radii ligulatae, ligula anguste lineari, dis c i tubulosae, limbo quinquedentato. In $t h$ e $r$ a e ecaudatae. Stigmata subulata, papilloso-hirta. Achenia quadrinervia, radii compressa, cuneiformia, disci lineari-tetragona. P a p p $\mathbf{8}$ in disco et radio conformis, uniserialis, setis capillaribus serrulato-scabris. Herba sandwicensis, Globulariae habitu; foliis confertis, spathulatis, integerrimis, pubescenti-scabris, margine setuloso-ciliatis, ramis apice nudis, monocephalis, radio albo, disco luteo.

Tetramol op i um Nees Ast. 202. excl. sp. DC. Prodr. $V, 262$, excl. sect, 2, Aster tenerrimus Lessing.

2313. IILnvieía CASS, Capitulum multiflorum, heterogamum, floribus radii pacis, uniseriatis, ligulatis, femineis, disci tubulosis, hermaphroditis. Invol ueri hemisphaerici, biserialis, discum aequantis squamae adpressae, aequilongae, exteriores foliaceae, ovali-acutae, interiores scariosae, obtusac. R e e p t a $\mathbf{c u l a m}$ convexum, nudum. Corolla e radii lignlatae, ligula,...... dis ci tubulosae, limbo quinquedentato, in therae..... Stigmata..... A chenia cylindracea, pilosiuscula. $\mathrm{Pap}$ p $\mathrm{s}$ in disco et radio conformis, setosus, seabridus. - Suffrutex madagascariensis, ramosus, non satis notus; folits alternis, breviter petiolatis, ovato-lanceolatis, serratis, rigilis, utrimque setuloso seabris, corymbo aphyllo, oligocephalo, pedicellis pilosis, involucris subhispidis, disco flavo, radio albo.

Hen ricia Cassini in Bullet. soe. philomat, 1817. p. 11. 1818. p. 123. Dict, sc. nat, XX. s67. XXXVIT, 491 . Nees
Ast. 219. DC. Prodr, V, 262.

231 4. Dollingeria NEES. Ca pitu $\mathrm{lum}$ multillorum, heterogramum, floribus radii paneis, ligulatis, femineis, disci tubulosis, hermaphroditis. I n vol u cri campanulati, disco brevioris squamae pluriseriatae, imbricatae. R e e p ta c u I um planum, sulvalveolatum. Corolla e radii ligulatae, ligula late elliptica, emarginata, disci tubulosae, limbo quinquedentato. A $\mathbf{n} \mathbf{h}$ e $\mathbf{r}$ a e eeaudatae, Stigm a ta disci brevia, obtusa, extus subhispida. A chenia angulata. $\mathbf{P}$ a p $\mathbf{p} 8$ in disco et radio conformis, pilosus, setis seabridis, aliis filiformibus, aliis apice inerassato - clavellatis. - Herbae in $J a$ ponia et China indigenae, rhizocarpicae, habitu Asterum; foliis allernis, serratis v, integerrimis, radio albo, disco luteo.

Döllingeria Nees Ast. 177. excl. sp. pl. DC, Prodr. V. 263. As ter scaber Thumb.

2315. II I Ieastram DC, Capitn $1 \mathrm{~nm}$ multiflorum, heterogamum, floribus radii ligulatis, femineis, disei tubulosis, hermaphroditis. InvoI n eri campanulati, disco brevioris squamae plariseriatae, laxe imbricatae, acuminatae, apice foliaceae, squarrosae. R e e p ta c n I n m alveolatum, alveolorum marginibns exsertis, acute dentatis. Corolla radii ligulatae, ligula oblongo-elliptiea, dis e i tubulosac, limbo quinquedentato. S tigmata elongata, acnminatissima, dorso hispida. A ehenia oblonga, angulata, utrinque attenuata, glabra. Pap p 8 in disco et radio conformis, biserialis, setis aequilongis, aliis filiformibns, aliis apice subelavellato - ensatis. - Herbae borealiamericanae, perennes; caulibus simplicissimis, foliis alternis, elongatis, acuminatis, integerrimis, radio albo v. caeruleo, disco flavo.

Heleastrum DC. Prodr. V. 263. Dollingeriae sp. Nees. As te ris sp. Auct.

2316. Fiotia DC. Capitulum multiforum, heterogamum, floribns radii ligulatis, femineis, disci tubulosis, hermaphroditis. In v o I u eri ovati, pluriserialis squamae arcte imbricatae, ad. pressae, non appendiculatae, interiores sensim longiores, angustiores. Re ceptaculum alveo- 
latum, alveolorum marginibus obtuse dentatis. Coro lla e ra di i ligulatae, ligula lanecolata, bidentata v. integerrima, disci tubulosae, limbo quinquedentato. Antherae ecaudatac. Stigmata disci hispida, acuminata, retorta. A ehenia elongrata, tricostata, glabra v. pubescenti-scabrida. Pap us in disco et radio conformis, setis rigidulis, filiformibus, scabridis, subinaequalibns. - Herbae boreali-americanae, rhizocarpicae, Asteris facie; caulibus erectis, apice corymbosis, foliis alternis, serratis, radicalibus amplis, petiolatis, caulinis alato-petiolatis, ovatis $v$. oblongis, radio pallido, disco flavo.

B i otia DC. Prodr. $\boldsymbol{V}$. 264. E u ry b i a e genuinae Nees Aot. 137. E u rybiac sp. Cass. in Dict. sc. nat. $X X X V I I$. Asteris sp. Auct. Bot. Reg. t. 1532.

231\%. Eurrybia CASS. Ca p it u l um pluriflorum, heterogamum, floribus radii ligulatis, femineis, disci tubulosis, hermaphroditis. Involncri oblongi, pluriserialis squamae imbricatae, chartaceo-membranaceae. Receptaculum parvum, planum v. subconvexum, alveolatum. C orolla e radii ligulatae, ligula lineari-laneeolata, snbintegerrima, dis ci tubulosae, limbo quinquedentato. Anth erae ecaudatae. Stigmata radii elongata, erecta, obtusa, vix hispidula. A ch en ia obovata v. oblongo-cylindracea, striato-angulata v, angulato-alata, glabra $\mathbf{v}$. apice puberula. $\mathbf{P}$ a p p $\mathbf{s}$ in disco et radio conformis, uniserialis, setis imprimis ad apieem seabris, aequalibus, interdum superne incrassatis. - Frutices Novae Hollandiae et Novae Zeelandiae; foliis alternis $v$. rarissime oppositis, coriaceis, petiolatis $v$. sessilibus, integerrimis, dentatis aut sinuatis, saepe subtus tomentosis, radio albo, violaceo v. carneo, disco flavo.

Eurybia Cassini in Bullet, soc. philomat, 1818, p. 160. Dict. sc, nat. XVI. 486. DC. Prodr, $V, 265$.

a. BRACHYGLOSSA $D C$. L ig u I a e stigmatibus breviores. B rach y ${ }_{\mathrm{g}}$ los a a DC. Prodr. $Y .265$.

b. ARGOPHXLlaEA DC. Ligulae stigmata longe superautes. A $\mathrm{ch}$ e $\mathrm{u}$ i a subeylindracea.

Argophyllaea DC. Prodr. V. 266. Euryblac heteroelltae Nees Ast. 144. Asteris s p. Labil. lard Nov. Holl. t. 201_203. Bot. Mag. t. 1509. 1563. c. SPONGOTRICHUM Nees. L ig u 1 a e stigmatibus longio. res. A cheni a conoideo-tetragoua, scabra.

Spongotrichum Nees Ast. 176. DC. Prodr.

269. A steris sp. Labillard. Nov. Holl. $t$. 197_200.

SUBDIVISI II. DIPLOPAPPEAE DC. Prodr. V. 271. Radius uniserialis. P a ppus in disco et radio conformis, duplex, exterior squamosus, interior pilosus.

2318. Dlearia MöNCH. Capitulam multiflorum, heterogamum, floribus radii uniseriatis, ligulatis, femineis, disci tubulosis, hermaphroditis. Involneri imbricati squamae primum ad pressae, demum patentes. Receptaculum alveolatum, planum, pednnculi apice eavo, obconico. Co rolla e ra dii ligulatae, dis s i tubulosae, quinquedentatae. $S \mathrm{t}$ a $\mathrm{m}$ in a $\mathrm{r}$ a di $i$ abortiva, dise i filamentis brevissimis. Sti $\mathrm{g} m$ a $\mathrm{ta}$ disci cochleariformia. A ch en i a cylindraceo-tetragona, villosa. $\mathbf{P}$ a P P us in disco et radio conformis, dupiex, exterior brevis, paleaceo - setosus, interior setosns, longus, scaber. - Frulices Novae Hollandiae, Eurybiae facie; foliis alternis, petiolatis, ovatis, repandis $v$. obtuse dentatis aut integerrimis, supra sparse villosis, subtus ramisque dense tomentosis, pedunculis ad apices ramorum solitariis $v$. paucis, rigidis, monocephalis, disco flavo, radio albo v. carneo.
Olearla Monnch Meth. suppl. 254. Nees Ast, 184. DC. Prodr. V. 271. Haxtonia Hort. D iplost ephia e urybioidea Nees Ast. 193. Diplopappi sp. Lessing. A ster is sp. Labillard. Nov. Holl. t. 195. 196. Schrader Sert. Hannov, t. 24. Andr. Bot, Reposit, t, 61,

2319. Diplostephium CASS, Cap i$\mathrm{t} \mathbf{\mathrm { l }} \mathrm{um}$ multiflorum, heterogamum, floribus radii uniseriatis, ligulatis, femineis, disci tubulosis, hermaphroditis. Involucri subeylindracei, disco brevioris squamae pauciseriatae, imbricatae, adpressae, coriaceae, margine membranaceae. Receptaculum planum, alveolatum, alveulorum marginibus dentatis. Co rolla e radii ligulatae, di s c i tubnle $\cdots e$, limbo quinquedentato. Antherae inclusae. $t^{\prime} \mathrm{g} m$ at a subulata, hispida. A $\mathrm{ch}$ enia elongata, angulata, hispidula. Pappus in disco et radio conformis, duplex, exterior setulosus, brevis, interior elongatus, filiformis aut apice clavellatus, scaber. - Herbue perennes v. frutices Americani, Asterum habitu; foliis alternis, disco flavo, radio albo $v$. caeruleo.

Diplostephiu massinf Dict. sc. nat. XXXVII. 486. DC. Prodr. V. 272.

a. EUDIPLOSTEPHIU $D C$. $\mathrm{P}$ a p pi interioris setae apice clavellatae. - Herbae boreali-americanae, rhizocarpicae.

Eudiplostephium DC. Prodr. $V$. 272. Döllingeriae sp. Nees. A steris sp. Auet. Bot. Reg. t. 1517. Bot. Mag. $t$. 2707 .

b. AMPHISTEPHIUM $D C$. P a p $\mathrm{i}$ interioris setae filiformes. - Erutices mexicani, foliis linearibus.

Amphistephium DC. Prodr. $V$. 273. Diplostephi u m Kuath in Humb. ct Bonpl. Nov. gen. et sp.IV. 97. $t .335$.

2320. Callistephus CASS. C a p it u $\mathrm{l}$ m multiflorum, heterogamum, floribus radii uniseriatis, lignlatis, femineis, disci tubulosis, hermaphroditis. Involucri bracteis foliaceis brevibus eincti squamae tri-quadiriseriales, patentes, ciliatae, obtusae. Receptaculum latam, subconvexum, breviter alveolatum. Corolla e radi i ligulatae, ligula late lanceolata, dis ci tubulosae, hermaphroditae. Anthera e ecaudatae. Stigmata disci apice ovata. Achenia obovato-eunciformia, compressa, $\mathrm{P}$ a p $\mathrm{u} s$ in disco et radio conformis, duplex, uterque uniserialis, exterior paleaceo-setaceus, setis in coronam subconcretis, interior setis longis, filiformiluse, scabris, deciduis. - Herba chinensis, annua, erecta, ramosa; foliis alternis sessilibus, grosse dentatis, subciliatis, ramis clongatis, monocephalis, capitulis amplis, in planta passim culta floribus aut omnibus ligulatis $v$, omnibus tubuloso-ampliatis plenis, disco flavo, ligulis tubulisve ampliatis omnes seriei cyanicae colores ludentibus.

Callis te phus Cassini in Dict. sc. nat. XXXYTr. 464. et 491. Nees Ast. 22t. DC. Prodr. $\mathcal{V}, 274$. C a 11 is te m m a Cassini in Bullet. soc. philomat. 18t7. p. 32. Dict. sc, nat. V1. suppl. 45. Opusc. phyt. t, 7. A ster e b inens is Linn. Diplopappi sp. Lessiog. - ? Poloa DC. in Guillem. Archiv. Bot. II. 514. et in Wight Contrib. 10.

2321. Diplopappus $D C$. C a p itul um multiflorum, heterogamum, floribus radii nniseriatis, ligulatis, femineis, disci tubulosis, hermaphroditis. In v o I u c r i pluriserialis squamae imbricatae. R e c e p ta cul um planum, subfoveolatum. Corollae radii ligulatae, disei tubulosae, limbo regulariter quinquedentato. An the ra e ecaudatae. Stigmata .... A chenia oblonga, compressa. P a p p 8 in disco et radio conformis, duplex, scabridus, exterior brevis, setulosus, interior longus, setosus. - Herbae $v$, frutices ca penses, indici, c a uca sici, boreali-americani, habitu vario, charactere artificiali in genus conjuncti. 
Dip I opappus DC. Prodr, V. 295. D iplop appi sp. Cassini in Dict. sc. nat, XIII, 308. Lessiag Synops. 163. Diplostephii sp. Nees.

a. PEDUNCULARES $D C, l$.c. In volu e $\mathrm{r}$ imbricati squamae adpressae, linea dorsali elevata, glandulis $1-2 \mathrm{se}$ ells lineam donatis, margine subscariosis. - Erutices capenses; folits integerrimis, uninervitis, glandulosopunctatis, glabris.

Diplostephia pedancularia Nees Ast. 193. Ast er is sp. Linn. Jaeq. Fragm. 1.5. f.4. Vent. Malm. t. 82. Bot. Maq. $t, 2286,2718$.

b. CALIMERIDEI $D C$. $l$. c. Involuc $\mathrm{ri}$ panciserialis squamae vix imbricatae, eglandulosae. - Herbae capenses, indicae, caucasicae; folits latis, saepius trinervits, integerrimis $v$, dentalis.

Asteris et $\mathbf{G}$ al atellae sp. Nees.

c. AMLELLOIDEI $D C, l$. c. Invo I u cri plariserialis squa. mae laxe imbricatae, eglandulosae v. glandulosae. Suffrutices bo reali-americani; folitis linearibus, rigidulis, ciliato-scabris, capitulis subcorymbosis.

Diplostephia amelloidea Nees Ast. 199. Asteris sp. Linn. et Auct. Bat, Reg. $t, 1693$. Bot. Mag. t. 3388. Loddig. Bol. Cab. t. 6 .

Huc, snspicante cl. Decandolle, referendam fortassis genus non satis notum:

ASTRROSPERMA Lessing Synops.389. Ca p itulum radiutum. Stig mat a diseí cono brevi, pube adseendente obsesso superati. A ehe nia exalata, erostria, pla. no-compressa, bicostata. P a p p us conformis, biserialis, serie exteriore brevi, interiore longa,- Fruticulus capensis, ramosissimus, Asteri hyssopifolio similis, hir. suto-canescens; folitis sparsis, lincaribus ramis su. perne aphyllis, monocephalis, disco luteo, radio caeruleo.

2382. IR lninaetina LESS. C a pitulum multiflorum, heterogamum, floribus radii uniseriatis, ligulatis, femineis, disci tubuloso-bilabiatis, hermaphroditis. In v o I $\mathbf{u}$ e $\mathbf{r}$ late campanulati squamae subtriseriales, imbricatae, membranaceae. Receptac ulum ...... Corollae radii ligulatae, ligula oblongo-elliptica, tridentata, disc i tubulosae, limbo a tubo vix distincto, bilabiato, labiis fastigiatis, exteriore quadridentato, interiore angusto, integerrimo. An thera e ecaudatae. Stigmat a acutiuscula. A chenia compressiuscula, villosa. $P$ a p p s in diseo et radio conformis, duplex, serrato-scabridus, serie exteriore brevi, interiore longiore, clavata. - Herbae sibirica e; rhizomate lignoso perennes; folits glaucescentibus, pilis brevissimis hirtellis, radicalibus obovatis, in petiolum attenuatis, obtusis v. submueronatis, caulinis alternis, paucis, caule simplici monocephalo, v. parce ramoso oligocephalo, disco flavo, radio caeruleo.

Rhinactina Lessing in Linnaea $V I$. 119. Synops. 162. DC. Prodr. $V$. 228. A ster obovatus Ledebour Ic. 4.498 .

23\%3. Notienstrum $D C$. Capitulum multiflorum, heterogamum, floribus radii uniseriatis, ligulatis, femineis, disci tubulosis, ovario efoeto nentris. In volu eri triserialis squamae lineares, acuminatae, extimae breves, intermediae coloratae et intimae subscariosae disco fere longiores. R eceptaculum planum, alveolatum. Corollae $r$ a di ligulatae, ligula lineari, integerrima, disci tnhulosae, limbo aequaliter quinquedentato. Antherac ecaudatae. Stigmata disci et radii elongata, subulata, dorso hispida. A c henia oblongo-Iinearia, pube sericea villosa, sessilia, subrostrata, ra dii fertilia, compressa, nervoso-striata, disci angusta, sterilia. Pap pus pluriserialis, persistens, setis rigidulis, scabris, extimis paullo brevioribus. - Herba chilens is, puberuloglandulosa, rhizomate frutescente perennis: caulibus subsimplicibus, teretibus, adscendentibus, folii radicalibus in petiolum attenuatis, caulinis sessilibus, subsemiamplexicaulibus, lanceolatis, mucrone calloso apiculatis, integerrimis, capitulis paucis ad apices ramorum solitariis, subcorymbosis, disco flavo, radii ligulis rubentibus, disco duplo longioribus, $j u$ nioribus convolutis.

Noticastrum DC. Prodr. $\nu, 279$.

2324. Distasis $D C$, Capitulum multiflorum, heterogamum, floribus radii uniseriatis, ligulatis, femineis, disci tubulosis, hermaphroditis. I nvolucri bi-triserialis squamae subaequales, lineares, acutae. R ecepta eulum angustum, breviter alveolatum. Co roll a e ra dii ligulatae, ligula ....... disci tubulosae, limbo quinquedentato. Antherae ...... Stigmat a .... A ehenia subcompressa, hirtella. Papp ns duplex, exterioris paleis quatuor $v$. quinque ovali-oblongis, brevibus, interioris setis totidem piliformilus, seabris. - Herba mexicana, ut videtur annua, ramosissima, puberula; foliis caulinis alternis, sessilibus, linearibus, obtusis, integerrimis, basi attenuatis, capitulis ramos terminantibus solitariis, laxe paniculato-corymbosis, disco flavo, radio albo. - Affinitas obscura.

Distas is DC. Prodr. $\mathcal{V} .279$.

SUEIIVISIO III. ERIGEREAE DC. Prodr. V. 279. R a dius pluriserialis. Papp us pilosus, uni-bi-pluriserialis, seric externa aequali $\mathbf{v}$. subbreviore.

2325. Mrelanodendron $D C$. C a pitu$1 \mathrm{n} \mathrm{m}$ muliflorum, heterogamum, florihus radii triquinqueseriatis, ligulatis, femineis, disci tuhulosis, hermaphroditis. I n v o I u e r i pluriserialis squamae imbricatae, lanceolatae, acuminatae, diseo subbreviores. Re e ptacul a m planum, tenuiter alveolatum. Corolla e ra di ligulatae, ligula angusta, disei tubulusae, limbo quinquedentato. Anthera e ecaudatae. S $t_{i} g$ at a exserta. A $c$ henia conformia, cumpres8o-tetragona, erostria, glabra. Pappos uniscrialis, setis seabridis. Arbor insulae St. Helenae maxima, glabra; foliis alternis, oblongis, basi attenuatis, integerrimis, obtusis, coriaceis, obscure viridibus, capitulis numerosis, pedicellatis, corymbum amplum formantibus, floribus albis.

Melanodendron DC, Prodr. $\nu$. 250, Solidago integrifolia Roxb.

23:6. Teptocousa LESS, C a pitulum multiflorum, beterogamum, floribus radii pluriseriatis, ligulatis, femineis, disci tubulosis, paucis, hermaphroditis. Invo I a eri campanulati, subbiserialis squamae ellipticae, acutae. Receptacul um planum, brevissime fimbrilliferum. Coroll a e ra di ligulatae, ligula minima, integerrima, d i s ci tubulosae, limbo quinquedentato (?). Antherae ...... S t y 1 i radii bifidi, ligulas aequantes, disci breves inclusi, A chen ia plano-compressa, glaberrima, costa marginata, disco epigyno parro, calloso, radii rostrata, disci erostria. Pa p p a 8 e setis 2_4, tennissimis, flexuosis, deciduis. - Herba nepalensis, erecta, rigidulı, vix puberula; foliis alternis, brevissime petiolatis, elliptico-lanceolat is, utrinque acuminatis, integerrimis $v$. obiter calloso-serrulatis, triplinerviis, supra sparse puberulis, subtus pallidioribus, glandulosopunctatis, ad nervos pubescentibus, pedunculis axillaribus distantibus, monocephalis, junioribus brevibus reflexis, adultis longioribus, patentibus, racenum foliaceum rigidum terminalem, sed ab apice versus basim florentem formantibus, floribus albis, parvis. 
L epto com a Lessing in Linnaea VY. 130. Synops, 188. Nees Ast. 220. DC. Prodr. $V$. 280. Lavenia rigida Wallich.

232\%. Wittrediana $A, R I C H$. CapituIn multiflorum, heterogamuı, floribus radii uni- (?) bi-triseriatis, ligulatis, femineis, disci tubulosis, hermaphroditis v. styli abortu maseulis. Involucri subbiseriati squamae snbaequales, lineares, margine seariosae. Corolla e radi ligulatae, dis e i tubulosae, eylindricae, limbo quinquedentato. Antherae ecaudatae. Stig mata ..... A che nia elongata, basi attenuato-substipitata, teretiuscula, striata. Pap p us uniserialis, setis confertissimis, scabridis. _ Herbae perennes, in Nova Zeelandia et Nova Hollandia indigenae, erectae $v$. diffusae; foliis alternis, dentatolobatis, rariusve integris, ramis apice monocephalis, disco flavo, radis ulbo v. purpureo, pappo rufo.

Vittadiuia A. Richard Flor. Nov, Zeel, 250, DC. Prodr. $V$. 280. B ra cli y eom es sp. Gaudich.

2328. Fullartonia $D C$. Capitulum multiflorum, heterogamum, floribus radii pluriseriatis, ligulatis, femineis, disci tnbulosis, mascnlis. Involucri polyphylli, bracteis foliaceis cincti, squamae uni-biseriatae, lineares, acuminatae. R ece ptaculum nudum, Corolla e radii ligulatae, ligula angnsta, dis ci tubulosae, limbo quiaquedentato. Antherae ecaudatae. Stylus radii stigmatibus duobus, glabris, di s $\mathrm{c}$ indivisus, apice eapitatus, truncatus, subbarbatus, A $\mathrm{ch}$ enia teretiuscula, erostria, radii glabra, calva, dis c i pilosula, papposa. Pappus in diseo uniserialis, scaber, rufus. - Herba in India boreal $i$-o e c $i$ dentali indigena, erecta, superne pilis sparsis, spice glandulosis hispidula; folis alternis, semiamplexicululibus, ovalibus, superioribus oblongis, grosse dentatis, capitulis al apices caulium et ramorum uxillarium solitariis, floribus pallide flavis.

Fullartonia DC. Prodr. $V .281$.

2329. FP olyactîlinum DC. Capituln m multiflorum, heterogamum, floribus radii plurimis, subbiseriatis, ligulatis, femineis, disci tubulosis, hermaphroditis. Invol a cri campanulati, bi-triseriati squamac lineares, subaequales. Re ce p tac ul um planum, nudum, minutissime punctulatum. Co ro Il a e rad i i lignlatae, ligula angustissima, disci tubulosae, limbo quinquedentato. Antherae ecandatae. Stigmat a.... A chen ia in disco et radio conformia, compressa, disco epigyno minuto. Pappus duplex, exterior brevissimus, coroniformis, dentatns, setulis subadpressis, interioris setis paucis, elongatis, scabris.-Herba mexicana, striata, hispidula; foliis alternis, pinnatifidis, laciniis linearibus, dentatis, supremis indivisis, integerrimis, eapitulis corymboso-paniculatis, disco flavo, radio pallide caeruleo v. albo.

Polyactidium DC. Prodr. D. 28t. Polyactls Lessing Synops. 188. Stenactis Cassini in Dict. sc, nat. I. 483. excl. sp. Erigerou delphialfoliam Willd. Hort. Berol. t.90.

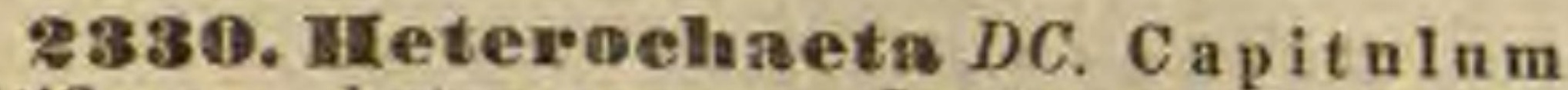
mnltiflorum, heterogamum, floribus radii plnriseriatis, ligulatis, femineis, disci tubulosis, hermaphroditis. Invol u eri bi-triserialis squamae aenminatae, subaequales. Rec e p t a c n l um nudum, punetulatum. Corolla e radil ligniatae, ligula lineari, dis e i tubulosae, limbo quinquedentato. Antherae ...... Stigmata...... A ehenia in diseo et radio conformia, puberula, compressa. Pappns conformis, duplex, exterior brevis, paleaceus, interior setiformis, scaber, longus.
Herbae indicae, fortassis etiam americanae, pilosae, villosae $v$. canescentes; foliis alternis, sessilibus $v$. petiolatis, capitulis terminalibus, solitariis disco flavo, ligulis albis $v$. purpurascentibus.

ti e terochaeta DC. Prodr. $V$. 289. $\rightarrow$ ? Erigeron g a a p allioides Kanth in Humb. et Bonpl. Nov. gen, es sp. $t .331$.

233 A. Therogeron $D C$. Capitulum multiflorum, heterogamum, floribus radii pluriseriatis, ligulatis, femineis, disci tubulosis, hermaphroditis. Involucri pluriseriati squamae lineares, acutae, subaequales. R e c e $\mathrm{tac}$ c $1 \mathrm{lum}$ nudum, foveolato-punctatum. Corolla e radii ligulatae, ligala lineari, dis ci tabulosae, limbo quinquedentato. Antherae ecaudatae. Achenia in diseo et radio conformia, eompressa, erostria. Pap pus radii uniserialis, pilosns, dis c i duplex, exterioris paleis subquinis, brevibus, lanceolatis, acutis, interioris setis quinis septenis elongatis. Saffrutices Nova e Hollandiae interioris, erecti, ramosi, glabri ; foliis alternis, lineari-lanceolatis, acutis $v$. obtusis, integrerrimis $v$, pacidentatis, capitulis ramos terminantibus solitariis, disco flavo, radio albo.

\section{The rogero n DC, Prodr. $V, 283$.}

233\%. Erigeron DC, C a p itu lum multiflorum, heterogamum, floribus radii pluriseriatis, ligulatis, femineis, disci tubulosis, nnne omnibus hermaphroditis, nunc exterioribus femineis, centralibus hermaphroditis v. masculis. Invol n $\mathrm{cri}$ pluriseriati squamac lineares, imbricatae. R e c e pt a c u l u m nudum, foveolato-punetatum. C o rolla e radii ligulatae, ligula lineari, disei tulunlosae, limbo truncato - integerrimo v, subquinquedentato. An therae ecaudatae. A chenia in disco et radio conformia, compressa, erostria. $\mathrm{P}$ a pp us conformis, uniserialis, pilosus, scaber. - Herbae $v$, rarius frutices, in Americ a frequentissime provenientes, in veteris orbis temperatis multo rariores; foliis alternis, integerrimis, dentatis v. lobatis, capitulis subhemisphaericis, disco flavo, radio albo, caéruleo aut purpurascente, rarissime ochroleuco.

E rigero n Linn. gen, n. 951, exel. sp. Lessing Synopt. 190. DC. Prodr. V. 283.

a. EUERIGERON $D C$. L igula e radii disco longiores v. subaequales. P a p 1 setae usque ad basim distinctae.

Euerigeron DC. Prodr. $V$. 283. Erigeron Cassint in Dict. sc, nat. XV. 181. XXXVIT. 462, et 489. (FI. dan. $t$. 298. Bot. Mag. 1. 232t. 2409. 2993. Bot. Reg. t. 10. 1577. Labillard. Nov. Holl. t. 193. Jacq. Hort. Schönbr. t. 303.) - Le p tostel ma Dou in Sweet. Fl. Gard. II. $t .38$. moneate el, Deeandolle receptaculo alveolato - fimbrillifero vix satis differt.

b. TRIMORPHAEA Cass. vi ores feminei plurimi, extimi uni-triseriales angustissime ligulati, interiores corol. la tubulost, angustissima, truncata, centrales hermaphroditi corollae tubulosae limbo quiuquedentato.

Trimorphaea Cassini in Dict. sc. nat, XXXVIL. 462, et 482. LV. 3/8. DC. Prodr. V. 290. (Sehkuhr. $t .241$. FI. dan. $t, 874$. E. B. $t, 464,1158$, Ledebour Ic, $t .31$ )

c. PTERIGERON $D C . P r o d r . P$. 293.L i g u l a pluriseriales, disco longiores, femineae. F 1 or es centrales pauci, tubulo. $\mathbf{s i}$, quinquedentati, hermapliroditi v, stylo indiviso ahortientes, masculi (?). Co r o Il a e tubulosae, fauce haud dilatata. Antherae convatae, ecaulatae, Pap p s scaber, rigidalus. Recepta e u I um alveolatum. H a bit us fere Conyzarum decurrentium. Sectio dubla. $D C, l, c$.

d. ELEUTHEROGERON DC. Prodr. $V$. 293, Ligula e pluriseriales, diseo longiores, feniaeae. Ftores centrales pauci, hermaphroditi, tubo tereti, favee dilatati campanulata, quinquedentata. A n the ra e liberae (eeaudatae). St yli rami subforcipati, acuti, hispiduli. Receptaculam punctatum. A chenia villosa, pappo barbellutato. Foli $n$ breviter decurrentia. DC, $t$. $c$. 
2333. Fhynehospermam REINW. C a p it u l u m multiflorum, heterogamum, floribus radii bi-triseriatis, lignlatis, femineis, disci tubulosis, hermaphroditis. Involucri hemisphaeriei squaniae numerosae, imbricatae, adpressae. Rec eptacul am subconvexum, scrobiculatum. Corolla e radi i ligulatae, ligula vix disco longiore, disci tubulusae, limbo quinquedentato. A n thera e ecaudatae.Stig mat ablono, brevia. A ch e$\mathrm{ni}$ a in disco et radio conformia, compressa, glabra, basi attenuata, apice breviter rostrata. Pa ppus uniserialis, setosus, setis apice tortilibus s. inflexis. - Herba javanica, perennis, glabriuscula; caule tereti, ramis alternis verticillatis, foliis alternis, lanceolatis, utrinque attenuatis, subpetiolatis, remote serrulatis, minutissime scabris, capitulis ex axillis foliorum longo-pedunculatis, summis nudis, subterminalibus.

R hy n chi o sperm um Reinwardt ex Blume Bijdr. 902. DC. Prodr. V. 296.

2334. Nierogyme LESS. C a p it $\mathrm{u} 1 \mathrm{um}$ multiflorum, heterogamum, floribus radii pluriseriatis, femineis, disci hermaphroditis, tubulosis. Involucrum ..... Receptaculam ...... Corolla e radii ...... disci regulares. Antherae ....... Stigmata...... Achenia erostria. P appus in disco et radio conformis, pluriserialis. - Herba brasiliensis, vix nota, annua, ramosa, canescens; foliis alternis, trifurcatis, laciniis linearibus, capitulis solitariis, ramos superne aphyllos terminantibus, pappo rufescente.

Mic rog y ue Lessing Synops, 190. DC. Prodr. V. 296. non Cass.

SURIIVISTO IW. HETER OPAPPEAE DC. Prodr. V. 297. R a di us uniserialis. Pap$\mathrm{p} u \mathrm{~s}$ in radio et disco diversiformis.

233.5. Simbloeline $D C$. Capitulum multiflorum, heterogamum, florilus radii uniseriatis, ligulatis, femineis, disci tubulosis, hermaphroditis v. abortu masculis, In v o l u eri pluriserialis squamae exteriores breviores tomentusae, imhricatae, interiores discum superantes glabrae, squarrosae. Rece ptaenl am alreolatum, alreolis elevatis, dentatis, subfimbrilliferis. Corollae radii ligulatae, ligula lineari, elongata, d is c i tubulosae, limbo quinquedentato. A $\mathrm{n}$ the r a ecandatae. A chenia radii oblonga, subeompressa, subglanduloso-pilosa, dis ci tenuia, sterilia, Pa ppu s $r$ adii uniserialis, setosus, seabridus, disci biserialis, nterque setiformis, exterior brevis, interioris setae pappo radii conformes. - Frutex peruvia$n$ us; folitis oblongo-lanceolatis, integerrimis, superne glabris, atro-viridibus, sublus ramulisque rufescenti-tomentosis, capitulis pedicellatis, laxe corymbosis, floribus ex sicco purpurascentibus, ligulis numerosis.

\section{Simblocline DC. Prodr. ${ }^{2} .297$.}

2336. Heteropappus LESS. C a pitu$1 \mathrm{u} \mathrm{m}$ multiflorum, heterogamum, floribus radii uniseriatis, ligulatis, femineis, disei tubulosis, hermaphroditis. Involucri biseriati squamae acuminatae patentes. Receptaculum …... Corolla e radii ligulatae, ligula oblongo-elliptica, dis c i tubulosae, limbo campanulato, quinquedentato. Antherae ecaudatae. Achenia planocompressa, hispidula, erostria. Pa p p us uniserialis, radii coroniformis, disci pilosus. - Herba ja ponica, erecta, ramosa, hispida; foliis alternis, inferioribus ablongo-obovatis, crenatis, superioribus laneeolatis, capitulis terminalibus solitariis, parvis, radio albo.

Heteropa p pus Lessing Synops, 189. DC. Prodr. V. 297. A ster bispidus Thuub. Banks Ic. Kämpf. $t .29$. Caltmeris hispida Nees.

233\%. Pla alacroloma CASS. Capitn$1 \mathrm{um}$ multiflorum, heterogamum, floribus radii uniseriatis, ligulatis, femineis, disei tubulosis, hermaphroditis. Invol ueri cylindraceo-campanulati, bi-triserialis squamae imbricatae. R ec e pta $\mathrm{c} \mathrm{u} l \mathrm{lnm}$ planiuseulum, nudum. Coroll a e radii ligulatae, dis c i tubulosae, limbo quinquedentato. A nth e r a e ecaudatae. A che nia compressa, erostria. Pappus radii nniserialis, coroniformis, disci biserialis, exterier radiali conformis, interioris setis plurimis, longis, scabris. - Herba perennis, boreali-americana, erecta, superne ramosa; foliis alternis, remotis, sessilibus, oblongis $v$. linearibus, inlegerrimis, hispidulis, capitulis laxe paniculatis, disco radioque flavo.

Phalacroloma Cassint in Diet. sc, nat, XXXIX, tos. excl. sp. Lessing Synops, 188. DC. Prodr. $\mathcal{V}$. 297. E r I ge-

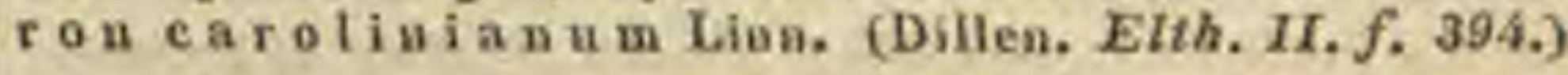

2338. Ninuras DC. C a pitulu multiflorum, heteroganum, floribus radii uniseriatis, ligulatis, femineis, disci tubulosis, styli abortu masculis. Involueri pauciserialis squamae imbricatae, lineares, acuminatae, margine scariosac. Receptaculum planum, nudum. Corollae radi i ligulatae, ligula lineari, di sci tubulosae, limbo quinquedentato. Anthera e ecaudatae. A ch enia dis ci subturbinata, sericeo-villosissima, $r$ adii gracilia, inania. Pa p u s $\mathbf{r}$ ad ii nniserialis, setiformis, setis plurimis, scabris, achenii pilis summis scriem exterioren, breviorem simulantibus, dis ci e paleis brevibus connatis, setis paucis, longis, scabris immixtis. - Suffrutices Novae Hollandiae interioris, erecti, glabri, ramosissimi; foliis alternis, acerosis v, linearibus, acutis, integerrimis, ramis apice plus minus denudato-monocephalis, radio albo.

Minuri a DC. Prodr, N. 298.

2339. Stenaetis NEES. Capitulum multiflorum, heterogamum, floribus radii uniseriatis, ligulatis, femineis, disei tubulosis, hermaphroditis. Invol a cri bi-triserialis squamae imbricatac, angustae. R e cept a $\mathrm{en} / \mathrm{nm}$ planum v. convexum, nuilum, panetulatum. Co rolla e radii ligulatae, ligula angusta, disci tubulosae, limbo quinquedentato. Anthera e ecaudatae. Achenia oblonga, compressa. Papp a radii uniscrialis, setacens, deciduns, disci duplex, exterior brevissimus, interior radiali conformis. - Herbae erectae, ramosae, in America boreali et tropica, nee non in India boreali spontaneae, una ex America boreali in Europam transfuga; foliis al(ernis, dentatis, capilulis ad apices ramorum solitariis, disco luteo, radio albo v. pallide violaceo.

S te nactis Nees. Ast. \&73. Lessigg Synops, 189. D i pla. pappi, Phalaerolomatis et Stenactidis sp. Cass. Aster anuus et vernus Linn. Flor. dan, $t .486$.

2340. Cymuesteplutum LESS, C a p i$\mathrm{t} u \mathrm{lum}$ multiflorum, heterogamum, floribus radii uniscriatis, ligulatis, femineis, disci tnbulosis, abertu masculis. Involucri subtriscrialis sqnamae imbricatae. Ree eptaculn mudum, areolatum. Coroll a e radi i ligulatae, ligula elliptica, disci tubulosae, limbo quinquedentato. Antherae ceaulatae. A chenia radii plano-com- 
pressa, erostria, subpilosa, dis c i linearia, incana. Pappus disei obsoletus, paucisetus, setis plumoso-serratis, radi i nullus.-Herbae capenses, ramosae; folits alternis, linearibus, integerrimis, capitulis pedunculatis, solitariis, parvis, disco luteo, radio caeruleo, involucri squamis saepius glandulis oblongis ut in Tagete notatis.

Gymnostephiu un Lessing Syzops. 185. Nees Ast. 253. DC. Prodr. V. 300.

23341. Cinarieis CASS. Ca p i $\mathrm{t} \mathbf{l} \mathrm{um}$ multiflorum, heterogamum, floribus radii uniseriatis, ligulatis, femineis, disei tubulosis, hermaphroditis. Involucri campanulati, biserialis squamae exteriores planae, interiores complicato - carinatae. Receptac u I um alveolatum, alveolarum marginibus subdentatis. Corollae radii ligulatae, ligula lineari v. oblonga, d is ci tubulosae, limbo quinquedentato. An the ra e eeaudatae. Stigm at a disei apice trapezoideo-depresso dorso puberula. A $\mathrm{c}$ he nia obovato-cuneiformia, compressa, nervo ealloso marginata, in paginis subenervia, hirtella, radii saepeinania. $P$ a $P$ a s $d$ is c i uniserialis, setis capillaribns, plumosis, ra di $\mathrm{i} n$ llns $v$. unisetus. Herba capensis, annua; foliis infimis oppositis, reliquis alternis, oblongis lanceolatisve, basi trinerviis, ramisque subluirtellis, pedunculis terminalibus aplyllis, capitulis primum subflavis, demım caeru lescentibus, disco radioque saepius discoloribus.

Charie is Cassini in Bullet, soc, philomat. 1817, p, 68. et 1821. p. 12. Dict. sc. nat. VIIT. 191. XXIV. 369. XXXVII. 463. et 489. Lessing Synops. 389. Nees Ast. 268. DC. Prodr. V. 300. Kaulfussia Nees Hor. phys. berol. 53, t. 11 .

2348. Chnetopappa $D C$. Cap it u lu m mnitiflorum, heterogamum, floribus radii uniseriatis, ligulatis, femineis, disci tubulosis, hermaphroditis. Invol neri squamae laxe imbricatae, apice scariosae, acuminatae. R e e p t a $\mathrm{c}$ a $\mathrm{u}$ in angustum, nudum. Corolla e radii ligulatae, disci tubnlusae, limbo yuinquedentato. A $\mathrm{n}$ th era e ....... Achen ia teretiuscula, Pappus duplex v. subduplex, exterioris paleae latae, hyalinae, in diseo brewes, in radio longae, interioris setae subquinae, rigidae, scabrae. _ Herba boreali-americana, annua, pusilla, ramosa $v$. simplex, pubescenti-scabra, foliis radicalibus obovato-spathulatis, in petiolum attenuatis, caulinis alternis, linearibus $v$. linea$\boldsymbol{r} \boldsymbol{i}$-spathulatis, integerrimis, ramis apice nudis, monocephalis, involucris glabris, nitentibus, disco flavo, radio albo, demum subpurpurascente.

Cha e topappa DC. Pradr. V. 301. Chaetophora Nuttall msc, non Alior.

2348. Woltomia HERIT. Capitulum multiflorum, heterogamum, floribus radii uniseriatis, ligulatis, femineis, disci tubulosis, hermaphroditis. In v o l u c ri biserialis squamae discum aequantes, adpressae, margine membranaceae. R e c e pta eulum hemisphaericum, alveolatum. Corolla $\mathrm{r}$ ad i lignlatae, ligula angusta, disci tubulosae, limbo quinquedentato. Anth er a e ceaudatae. A ehenia plano-compressa, calleso-marginata, glabra v. hispidula. Pa p p 8 brevissimus, setulosus, subaequalis $\mathbf{v}$. in disco setis duabus elongatis, sulbulatis, crassioribus. - Herbae boreali-americanae, annuae, erectae, ramosae, Asterum facie; foliis alternis, patentibus, lanceolatis, glancescentibus, laevibus, margine scabris, integerrimis $v$. inferioribus dentatis, capitulis laxe corymbosis, disco luteo, radio albo v. pallide purpurascente.

B o lt o ni a Heritier Sert, angl. 27. Cassini in Dict. sc. nat. XXXYII. 404, et 491. Bot. Mag, $t$. 2381, 2554. Lessing Synops. 185. Nees Ast. 23\%. DC, Prodr. K, 301. M a de a Solauder msc, Matricariae sp. Linn.
2344. Sommexpeltin LESS. C a p it a I $n$ m multiflorum, heterogamum, floribus radii uniseriatis, ligulatis, femineis, discitubulosis, maseulis Involucram imbricatum. Receptaculum epaleatum. Corollae radii ligulatae, disei regulares. Antherac ...... A chenia erostria. Pappus pilosus, radii pluri-dise i nniserialis. - Fruticulus brasilien $s$ is, vix notus ; foliis conferlis, pinnatisectis, rigidis, glabris, segmentis filiformi-subulatis, spinescentibus, capitulis solitariis, ramos superne aphyllos terminantibus. 302.

Som merfeltia Lessing Synops. 189. DC. Prodr, $\boldsymbol{V}$.

SUIBDTEIST W. BELLIEAE DC.Prodr. V. 302. Radi us uniserialis. P ap u s squamellatus.

2345. Calotis $R, B R$. C a p itulu m multiflornm, heterogamum, floribus radii uniseriatis, ligulatis, femineis, disei tubulosis, masculis. Invol ucri bi-triserialis squamae aequales, distinctae, discum aequantes. R e e p tac u l a m convexum, epaleatum, scrobiculatam. Corollae radii ligulatae, dis ci tnbulosae, limbo quinquedentato. Antherae esaudatae. Stigmat a gracilia, divergentia. A $c$ henia verticaliter compressa, cuneata. Pappus in disco et radio conformis, paleis duabus auricnlaeformibus aristisque $1-3 \mathrm{glo-}$ chidatis. - Herbae Novae-Hollandiae ramosae, pilosiusculae; foliis alternis, inciso-dentatis, capitulis ramos apice aphyllos terminantibus solitariis, disco flavo, radio caeruleo.

Calotis R. Brown in Bot. Reg. t. 504. Loddig Bot. Cab, t, 825. DC. Prodr. V. 302.

2346. Asteromana BLUME. C a pituI $\mathrm{m}$ multiflorum, heterogamum, floribus radii uniseriatis, ligulatis, femineis, disci tubulosis, herma. phroditis. Involn ori biseriati squamae subaequales, margine membranaceae, apice herbaceae. Coroll a e radi i ligulatae, disei tubulosae, limbo quinquedentato. Anthe $r$ a e ceandatae. S $\mathbf{t} \mathrm{gma-}$ ta disci apice lanceolata. A $\mathrm{c}$ h en i compressiuscula, quadricostata, basi attenuata, subpuberuloglandulosa. Pa p p 8 in disco et radio conformis, paleaceus, uniserialis, paleis basi subeoalitis, apiee setaceo-multifidis. - Herba annua, in hbrtis In. diae culta, Asteris habitu, erecta, glabriuscula; foliis alternis, caulinis ovali-oblongris, sessilibus, utrinque angustut is, integerrimis $v$, obiler serratis, rameis obovatis, capitulis ad apices ramorum solitariis, radio albo $v$. caeruleo, disco luteo.

As te r om a a Blume Bijdr, 901. Nees. Lst, 232. Lessing Synops, 191. DC. Prodr. V. 302. Aster indieus Lian.

234\%. Belligum $L I N N$. Ca pital a m multiflorum, heterogamum, floribus radii uniseriatis, ligulatis, femineis, disci tubulosis, hermaphroditis. In vo lu e ri uni-biscriati squamae oblongae. Rec e p t a culum ovoideo-conicum, nuinm. Co rolla e radi ligulatae, dis ei tubulosac, limbo quadri- $v$. rarius quinquedentato. Antherae ecandatae. Stigmat a subforcipata. Acheni a compressa, obovalia, subpuberula. Pap pus in disco et radio conformis, squamis subquinis, membranaceis, truncatis, setisque totidem cum squamis alternantibus. - Herbae mediterraneae, annuae $v$. perennes; foliis subradicalibus, obovatis, integerrimis $v$, interdum dentatis, pedunculis scapiformibus. monocephalis, capitulorum disco luteo, radio albo.

Bell i u Linn. Mant, 157. Lam. t. 684. DC. Flor. fr. IV. 923. Viviani Fragm, $t, 10 . f .1$. Cassini Dicl. se, nat. 
IV. Suppl. 41. et XXXVII. 454. Lessing Synops. 191. DC. Prodr. $V$. 303. Bellidis sp. Tournef. Doronici sp. Desf. Flor. Atl, $t$. 235. f. 1. Pectidis sp. Linn. Sehreber Nov, Act, Upsal. I, t, 5, f. 2 .

SUETIVISIC VI. BELLIDEAE DC. Prodr. V. 304. R a di us uniserialis, rarissime biserialis. P a p u s coroniformis v. nullus.

2348. Bellis LINN. Capitulum multiflorum, heterngainum, floribus radii uniseriatis, ligulatis, femineis, disci tubulosis, hermaphroditis. Involuc ri campanulati, uni-biseriati squamae foliaceae, obtusae, aequales. R e e p taculum conicum, nudum. Corollae radi i lignlatae, disci tubulosae, limbo quadri-quinquedentato. Antherae eeaudatae. Ach en i compressa, obovata, hispidula. Pap p s nullus _ Herbae e u ropeae, in America boreali rarae, annuae v. perennes, caulescentes v. acaules; foliis omnibus radicalibus $v$. caulinis alternis, oblong is $v$, obovatis, plerumque dentatis, in petiolum atlenuatis, disco luteo, ligulis albis, extus roseis $v$. subviolaceis, primum in globum conniventibus.

B ell1 s Lìn, gen, $n$, 962, Gärtn, II, 419, $t, 168$, Cassini in Dict. sc. nat. XXXYIT. 493. Lessing Synops. 192. DC. Prodr. V. 304.

a. KYBERLA Necker elem. n. 81. Annuae, caulescentes. (Viviani Fragm, t. 10, f, 8.)

b. BELLIS Necker elem, $n, 82$. Perennes, subacaules. (FI. dan. $t, 502$. E. B. $t, 424$. Schkuhr $t$. 251. Cyrillo Neap. II, $t, 4$.)

2345. Irachyeome CASS, C a p i $t$ u I u multiflorum, heterogamum, floribus radii uniseriatis, ligulatis, femineis, disei tubulosis, hermaphroditis. Involneri campannlati squamae pauciseriales, margine membranaceae. Receptacul n m conicum, subalveolatum. Corollae radii ligulatae, d i s c i tubulosae, limbo quinquedentato. Antherae ccaudatae. A chenia plano-compressa, erostria. Pappus brevissimus, setoso-coroniformis. - Herbae Novae-Hollandiae perennes, erectae; foliis alternis, glabris, parce dentatis, pinnatilabatis $v$. trifidis, capitulis solitariis ramos apice aphyllos terminantibus, disco luteo, radio albo.

Brachyeome Cassini in Diet. sc, nat, XXXYII, 464 . et 491, Lessing Synops. 192. exel. sp. DC. Prodr, V. 305. Brachyscome Cassini in Bullet. soc. philomat. 1816. p. 199. Dict, sc, nat, V. suppl, 63. Bellid is sp. Labillard. Nov, Holl, t, 206, 207.

2350. Paquerina CASS. Capitulum multiflorum, heterogamum, fleribus radii uniseriatis, ligulatis, femineis, disci tubulosis, hermaphroditis. Involueri campanulati squamae subuniseriales. R e c e pt a culum conicnm, breviter paleaceo-fimbrilliferum. Coroll a e radii ligulatae, disci tubulosac, limbo quinquedentato. Anthe ra e ecaudatae. Achenia plano-compressa, erostria, margine crassiusculo, basi receptaculi scrobiculis immersa. Pappus nullus. - Herba NovaeHollandiae austro-occidentalis, glabra, gracilis, simplex v. ramosa; foliis alternis, linearioblongis, integerrimis, basi attenuatis, ramis foliosis apice monocephalis.

P a querina Cassini in Dict. sc. nat. XXXVIT. 16/.et 492. Lessing Synops, 192. DC. Prodr. $V .306$. B ellis gr aminea Labillard Nov. Holl, $t, 204$.

2351. Lagemoplnora CASS. C a p itu$1 \mathrm{um}$ multiflorum, heterogamum, floribus radii uniseriatis, ligulatis, femineis, disci tulublosis, hermaphroditis v. masculis, Involu cri subbiseriati, discum aequantis squamae acntac, basi eoriaceae, adpressae, apice submembranaceac. $\mathbf{R} \mathrm{e}-$ ceptaculum planum, nudum. Corolla e ra dii ligulatae, dis ei tubulosae, limbo quinquefido. Antherae ecandatae, subliberae. A chenia radi i plano-compressa, oblonga, rostro colliformi, disci abortiva. Pappus nullus. - Herbae perennes, graciles, in Nova-Hollandia et NovaZeelandia, nec non in America untaretica indigenae; foliis radicalibus obovatis, in petiolum angustatis, dentatis, scapo squamalo, monocephalo, capitulorum disco luteo, radio albo v. purpureo.

Lage n o plio ra Cassiui in Bullet. soc.philomat. 1818. p. 34. Lessing in Tinnaea VI. 131. Synops. 193. Pöppig et Endl. Nov, gen, et sp. $t$, 26. DC. Prodr. T. 307. Las era Cassinl in Bullet, soc. philomat, 1816, p, 199. M i rocalia A. Riehard Elor. Nov. Zeel. 231, t.30, Calen$\mathrm{d}$ u I a sp. Forst. Thouars Flor. Agnanat. 2, 9. B ellidis p. Labillard. Nov, Holland. $t$, 20S. A s t e r i s sp. Commers. Lam. t. 681. $f .4$.

235\%. Ixauelhenus CASS. Ca p it a lum multiflorum, heterogamum, floribus radii biseriatis, ligulatis, femineis, disci tuhulosis, hermaphroditis v. abortu masculis. Involu eri subhemisphaerici, discum aequantis squamae pluriseriatae, laxe adpressae, foliaceae. Re cept a c u lum nudum, latum, planum. Corolla e radi $i$ ligulatae, ligula elongata, disci tubulosac, limbo quinquefido. Antherae ..... A chenia ovali-oblonga, compressa, glabra, in collum brevem glutinosum attenuata. Pappus nullus. - Herba Novae Hol landiae, non satis nota, glabra; caule basi foliato, caeterum aphyllo, scapiformi, monocephalo, foliis subradicalibus, alternis, semiamplexicaulibus, sublyratis, valde inaequalibus, disco flavo, radio albo.

I $x$ a u he nus Cassiul in Dic2, sc, nat. SVT. 176. DC. Prodr. V. 308. I x i u chenus Lessing Synops. 193.

2853. NIyriactis LESS. Capitulum multiflorum, heterogamum, floribus radii bi-pluriseriatis, ligulatis, femineis, disci tuluulosis, hermaphroditis. Involu cri uni-biseriati squamae lineares, acutae. Receptaculam convexum v, planum, alveolatum. Corolla e radii lignlatae, ligula late-elliptiea, integerrima, dis e i tnlulosae, limbo quinquefido. An the rae ecaudatae. Achen i a plano-compressa, glalura, erostria v. apice sulbattenuata, superne glandulifera. P a p p us nullus. - Herbae indicae, erectae, subdichotome ramosae foliis alternis, ovatis $v$. lanceolatis, dentato-serratis, supra scabriusculis, pedunculis elongatis, monocephalis, subpaniculatis, capitulis globosis, albis $v$. flavescentibus.

M y ria et is Lessing in Linnaea VI, 127, Synops. 193. DC. Prodr, $V, 308$.

a. DISTICHACT1S. $R$ a d i us subbiserialis, $A$ e he ni a ai. ce subattenuata. - Indiae australis et insulae Javae indisenae.

M y riactis seet. I. DC. l. c. Bellidis sp. BInm. b. MYRIACTIS. Radius muttiserialis. A chenia omnino erostria. - Species nepalenses ot persicae.

Myriact is Lessing in Linnaea $V l$. $t$. 2. $f_{\xi}$. $E$. M y riactis sect. 2. DC. $l$. c. Bot ry adenia Fiscl. et Mey, Iudex Sen, hort. petropolit.

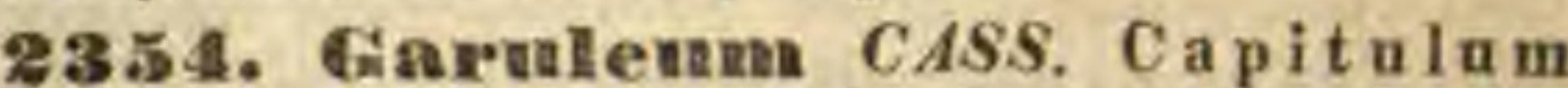
multiflorum, heterogrammm, floribus radii nniseriatis, lignlatis, femineis, disci tubulosis, ovario efoeto masculis. I n vol n eri squamae biseriales. Rece ptaculum convexum, nudum. Corolla e radii ligulatae, ligula Ionga, angusta, d is c i tubulosae, limbo quinquefido. Ant he ra e ecaudatae. A e h enia radii obovato-oblonga, tri-quadricostata, erosiria, sicco-coriacea, pericarpio tenui, rugosoaspero, disci aborliva, plano-compressa, laevia. Pa p pus nullus. - Herbae capenses, suffrutes- 
centes, erectae, glabrae v. subviscido-pubescentes; foliis alternis, pinnatisectis, lobis plus minus dentatis $v$. incisis, capitulis terminalibus pedunculatis, radio caeruleo, disco luteo, corollis basi puberulis.

G a r u l a m Cassini Diet. sc. nat, XYIIT, 162, XXXX,324. Lessing Synops, 194. excl. syuou. Tourn. DC. Prodr, $Y, 309$. Os te os perm am pinnatifid um Thunb. Heritier Stirp. nov. t. 6. 0, c a e rule u m Ait. Jaeq. Ic. rar. $t .179$.

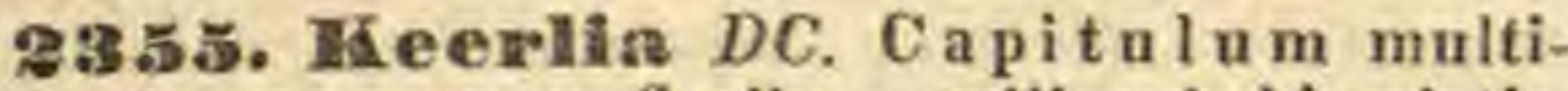
florum, heterogamum, floribus radii uni-biseriatis, ligulatis, femineis, disci tubulosis, hermaphroditis v. abortn masculis, I nvol u eri late campanulati, imbricati squamae pluriseriales, lanceolatae, acuminatae, margine submembranaceae. Reeeptaculu m planum, nudum. Corolla e radii ligulatae, ligula anguste lineari, dis ci tubulosae, tubo brevi, limbo quinquefido. Antherae $\ldots . .$. A chenia glabra, olppyramidata v. eylindracea, saepius longitudinaliter sulcata. $\mathrm{Pap}$ us paleis pluribus brevissimis, acutis, basi in coronam minutissimam subconcretis. - Herbae mexicanae, glabrae v pube brevi velutino-villosulae, erectae, parce ramosae; foliis alternis, oblongis v. cuneatis, sessilibus v. semiamplexicaulibus, integerrimis aut apice dentatis, ramis apice nudis, monocephalis, floribus albis aut flavis.

Keerlia DC. Prodr. $V$. 309. ?Braehycome xanthecomoides Less.

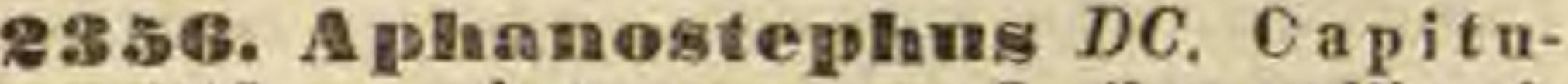
l $\mathrm{m}$ multiflorum, heterogam $\mathrm{mm}$, floribus radii uniseriatis, ligulatis, femineis, disci tubulosis, hermaphroditis. Involueri biseriati squamae lanceolatae, acuminatae, margine membranaceae. $R$ eceptac ulum conico-convexnm, nudum. Corolliae radii ligulatae, dis c i tubulosae, limbo quinquefido. Antherae ..... A $\mathbf{c h e n i a}$ teretia, striatula. P a p p s coroniformis, parvus, integer.

Herba mexicana, erecta, ramosissima, pubescens; foliis alternis, sessilibus, inciso-dentatis $v$. sublobatis, ramis apice nudis, monocephalis, ligulis albis, involucro duplo longioribus, disco flavo.

Aphanosteplus DC. Prodr. $V, 310$.

DUVIS ID IR. CHRYSOCOMEAE DC. prodr.V.310. R e cept a cu I um epaleatum, nudum, alveolatum v. fimbrilliferum. Cap it uI a lutea, homogama, corollis omnibus tubuIosis, hermaphroditis; $\mathbf{v}$. heterogama, floribus radii ligulatis femineis $\mathrm{v}$. neutris, disco homochromis.

SUEDIDUET I. GYMNOSPERMEAE DC. Prodr. V. 310. Papp us nullus.

235\%. Xanthecona $H . B . K$, C a pituI $\mathrm{m}$ multiflorum, heterogamum, floribos radii uniseriatis, ligulatis, femineis, disei tubulosis, hermaphroditis. Involucri campanulati squamae hási imbricatae, apice subfoliaceae, laxinsculac. Receptaenlom vix convexum, subfoveolatum. Coroll a e radii ligulatae, ligulis discum duplo superantibus, dis ci tubulosae, limbo quinquefido. Antherae ecaudatae. A $\mathrm{c}$ h e $\mathrm{n}$ i a compressa, P a p p a s nullus. - Herba mexicana, caes pitosa, glabra; foliis alternis, linearibus, integerrimis, capitulis terminalibus solitariis, corollis omnibus flavis.

$\mathrm{X}$ a $\mathrm{uth}$ oe om a Kunth in Humb. et Bonpl. Nov, gen. et sp. IV, 311, t, 119. Lessing Synops, 192, DC. Prodr. V. 3to.
2358. Xerothammus $D C$. $C$ a p itu 1 um multiflorum, monoienm (?), floribus radii uniseriatis, ligulatis, femineis, disci tubulosis, sterilibus. Involucri imbricati squamae lanceolato-subulatae, rigidulae, apice subdivergentes, R e ce p tac u l um nudum, areolatum. C orolla e radii ligulatae, ligula revoluta, quadrinervi, disci tubulosae, tubo brevi, angustissimo, limbi cylindrici quinquedentati dentibus erectis, acutis. Antherac ecandatae, A ch e $n$ i a ra di i subtrigona, dorso convexo curvato, areola terminali ad mediam lateris interioris longitudinem, disci abortiva, recta, obovata, mucrone brevi superata. P a p p u s nullus. - Suffrutex capensis semipedalis, erectus, rigidulus, ramosus, Stypheliae facie, affinitatis obseurae; foliis alternis, confertis, subtriquetris, acutis, dorso versus apicem et margine muricato-scabris, siccis, patulo-squarrosis, pedunculis versus apices ramorum solitariis $v$. paucis, remote pauci-squamatis, monocephalis, floribus luteis.

Xerothamin us DC. Prodr. $V .311$.

a359. Anaglyplan $D C$. C a pitulum multiflorum, heterogamum, floribus radii uniseriatis, ligulatis, femineis, disci tubulosis, hermaphroditis. Involucri biseriati squamae aequales, disco paullo longiores, acuminatissimae. Recepta culnm planum, alveolatum. Corolla e radii ligulatae, ligula quadrinervi, di s e i tubulosae, tubo hirsutulo, limbo quinquefido. A n the ra e ...... A chenia obovata, puberula. Pappus nullus. Suffrutex capensis, caule et praesertim ramorum apicibus pube brevi conferta glanduloso-subvelutinis; foliis alternis, linearibus, apice recurvis, acuminatis, utrinque suleato-striatis, cilitis rigidis, margine et versus apicem in nervis seaberrimis, capitulis parvis, terminalibus, solitariis, floribus disci et radii flavis.

Anagly pha DC. Prodr. $V .311$.

2360. Gymmosperma LESS. Ca p itu$1 \mathrm{um}$ pauciflorum, subheterogamum, floribus radii subquinis uniseriatis, ligulatis, femineis, quandoque nullis, di s e i ternis v. denis tubulosis, hermaphroditis v. masculis. Involucri oblongi squamae imbricatac, adpressac, scarioso-coriaceae. Re c epta culum nudum, angustum. Corollae ra di ligulatae, ligula angustissima, minima, disei tubulosae, limbo quinquefido. Anth er a e ecaudatae. A ch enia subeompressa, erostria, omnino calva. Pa p pus nullns. - Suffrutices mexicani et brasilienses, glabri, ereeti, corymboso-ramosi; foliis alternis v. oppositis, sessilibus, integerrimis, oblongis v. linearibus, acutis, punctatis, sacpe glutinosis, capitulis oblongis, ad apices ramulorum ternis $v$. aggregatis, saepius corymboso-fastigiatis, floribus luteis.

G y m os perma Lessing Synops, 19h. DC. Prodr. V. 311. Sell o a Spreng. Pugill. 36. Bot. Reg, t. 468. Nuttall $i \pi$ Sillim. Journ, 1828. p. 300, non H. B. K.

SUEDTVISID 耳. ACHYRIDEAE DC. Prodr. V. 312. P a p p u multipaleaceus.

2361. Iraelhyris NUTT. Capitnlum pluriflorum, heterogamum, floribus radii quinis v. denis uniseriatis, ligulatis, femineis, disei ternis denisve, tubulosis, hermaphroditis. Involueri ovati $v$, cylindracei squamae arete imbricatae. Recept acu lum nudum. Corol la e radii lignlatae, dise i tubulosae, limbo quinquefido. Anthera e ceandatae. A $\mathrm{e}$ h e $\mathrm{n}$ i a obconica, erostria. P a p p s paleis quinis-octonis, oblongis, persisten- 
tibus. - Herbae in America occidentali, boreal $i$ et a ustrali indigenae, rhizocarpicae v. subfruticosas, erectae, glabrae; foliis alternis, linearibus sive lanceolatis, integerrimis, capitulis solitariis v. ternis, ad apices ramulorum corymbosis, involucri squamis pallidis, apice macula viridi notatis, corollis luteis.

B rachy r is Nuttall gen. 21 . 163. Lessing Synops. 191. DC. Prodr. $V .312$, B racby achy ris Sprengel Syst. $I I T$. 574.

a. EUBRACHYRIS DC.FIores disci numero floribus radii aequales v. pauciores. Papp us acheniorum discl et radii conformis.

E ubrachyris DC. Prodr. Y.312, Haok. Ic. t. 142, 147. b. AMPHLCHYRIS DC. FIores disei floribus radii plures. A ch e u ia radii pappo brevissimo v. uallo.

Amphiachyris DC. Prodr. $V$. 313. Brachyris dracuaculo ides DC. Nol, pl. hort. Genev, NII, t, 1 .

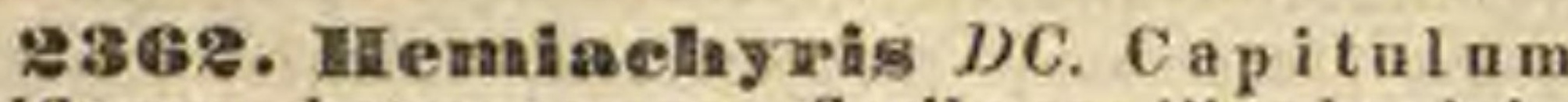
pluriflorum, heterogamum, floribus radii subquinis, ligulatis, femineis, disci septenis v. octonis tubulosis, hermaphroditis. Involucri ovati squamae oblongae, adpresse imbricatae. Recepta $\mathbf{c u} \mathbf{I} \mathbf{u m}$ nudum. Corollae radii ligulatae, disci tubelosae, limbo quinquefido. Anthera e ....... A c he nia obovato-teretiuscula, villosula. Pa ppus radii nullus, dis ci squamellis ovatis, acutiuseulis, brevibus. - Herba suffruticosa texan a, erecta, ramosissima, glabra; ramis junioribus sulcato-angulatis, adultis teretibus, foliis alternis, $l_{i-}$ nearibus, integerrimis, uninerviis, summis fere subulatis, capitulis parvis, ramos terminantibus, solitariis, floribus luteis.

H emiachyris DC. Prodr. V. 313.

Z363. Teplatoplingllum CASS. Capi$t \mathbf{u l n} \mathrm{m}$ pluriflorum, heterogamum, floribus ratii binis v, ternis, ligulatis, femineis, disci quaternis v. senis, tubulosis, hermaphroditis. Involucri oblongo-cylindracei squamae paucae, obtusae, imbricatae. R c c p ta culu m parvum, nudum. Corolla e radii ligulatae, disci tubulosae, limbo quinquefido. Antherae ecaudatae. Achenia oblonga, striata. Pap p u 8 disei et radit conformis, uniserialis, setis paleaceis confertis, inaequalibus, margine subfimbriatis. - Frutex magellanicus ramosus, glaber; foliis opposilis, quadrifariam imbricatis, ovato-subtrigonis, coriaceis, parvis, integerrimis, capitulis ramos terminantibus sessilibus, solitariis, corollis flavis.

Lepidophyllum Cassini in Bullet, roc, philomat. 1816. p. 199. Dict, sc, nat, XXVI. 36. Lessing Synops. 191. DC. Prodr. V. 314. Conyza cupressiformls Lam. t. $697 . f .3$.

2364. Grindelia $W I L L D$. C a p itu $1 \mathrm{~nm}$ multiflorum, heterogamum, floribus radii uniseriatis, ligulatis, femineis, rarissime nullis, disci tubulosis, hermaphroditis. In v o l u c ri basi hemisphaerici squamae pluriseriales, imbricatae. R e e e $\mathrm{p} t$ ac u lum foveolatum. Corolla e $r$ adi ligulatae, di s e i tubulosae, limbo quinquefido. An the rae ecaudatae. A chenia obovata v. subangulata, glabra. P a p u s disci et radii conformis, pauciaristatus, deciduns, aristis crassis, rigidis. - Suffrutices v. herbae americanae, imprimis mexicanae, ad apices imprimis glutinosae; foliis alternis, integerrimis $v$. saepius serratis, radicalibus plerumque spathulatis, caulinis sessilibus v. semiamplexicaulibus, capitulis ad apices ramorum solitariis, floribus flavis.

Grindelia Willdenow in Berl. Magaz. 1807. p. 261. Danal in Mlem, Afus, V. 48,t,1_3. Bit. Reg. t.248, 781. DC. Prodr. V. 314. Demetria Lagasca Nov. Gen, 30. Don ia R. Brown in Ait, Hort, kew. IT. 5. 82, Bot. Mag. 1. 1706.
Grindelia et A urelia Cassini in Dict, sc, nat, XXXYII. 468. G riudelia et Do ni a exel. sp. Lessing Synops. 163. 199. As teris sp. Cavanill. Ic, $t, 168$.

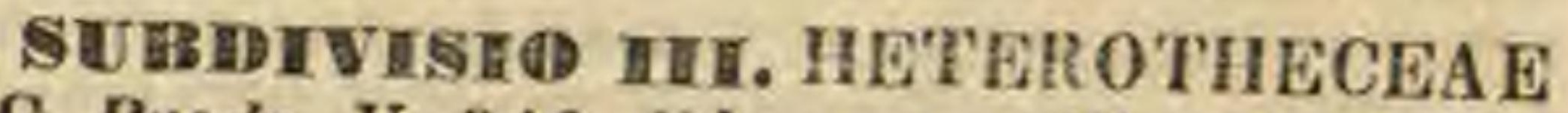
DC. Prodr. V. 316 . F I ores radii uniseriales. Pa p pus disci et radii diversus.

2365. Heterotheca CASS. C a p it ulum multiflorum, heterogamum, floribus radii nniseriatis, ligulatis, femineis, disei tubulosis, hermaphroditis. Involueri pauciseriati squamae imliricatae, lineares, adpressae, apice patnlae. R ecepta culum planum, alveolatum. Corollae radi ligulatae, disei tubulosae, limbo quinquefido. Anthera e ecaudatae. Stigmata ralii teretiuscula, glabra, disci apice lanceolata, hispida. A c henia radii oblonga, laevia, disei cuneiformia, villosa. Pappus radii nullus v. simplex, paucisetus, disci duplex, uterque setosus, exterioris setis brevissimis, interioris longis, subseabris. Herbaemexicanac et boreali-americanas, erectae, paniculatim ramosae, villosae v. pilosae; foliis caulinis sessilibus, integerrimis v. rarius dentatis, floribus flavis, pappi serie exteriore alba, interiore rufa.

He ter ot he a Cassini in Bullet. soc, philomat. 1817, 13\%. Dict. "c, nat, XXI, 130, LI, 460. DC. Prodr, V. 316. a. CHAETACTIS $D C$. A chenia radil pappo simpliei, pauciseto.

Chaetactis DC. $t$. c.

b. GYMNACTIS DC. A chenia radii pappo omnino nullo. G y anactis DC. $l$. $c$. Heterothe a Cassini $\| l$. cc. Caly e in m Ertiat Carolin, TK. 339, non Alior, Diplocom a Dou in Sweet Fl. Gard. I. $t$, 246, Lessing in Linnaea $V$. 144. t. 2. $f$. 17 , Dorouici sp. Liak et Otto Abbild, t. 22.

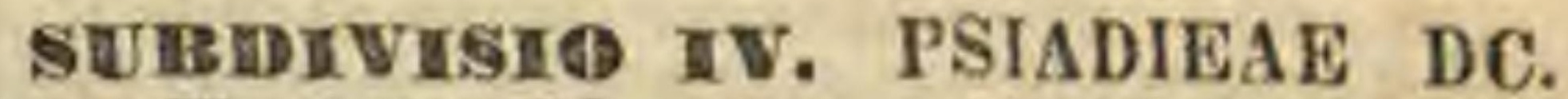
Prodr. $V, 317$. Flores radii pluriseriales. $P$ a p us in disco et radio conformis, saepius uniserialis, v. setis in biseriali similibus.

236s. Erato DC. Ca pitulam multiflorum, heteroganum, floribus radii pluriseriatis, ligulatis, femineis, disei tubulosis, hermaphroditis. Involucri imbricati squamae lanecolatae, exteriores rigidule ciliatae, interiores paulo Iongiores, nudiusculae. Rec e $t$ a cul 1 m planum, nuím. Co rolla e radii ligulatae, secus tubum brevissime puberulae, ligula angusta, disci tubulosae, fance dilatata, limbi quinquedentati dentibus apice rigide pilosis. Antherae ceaudatae. Achenia tetragona, glabra. Pa P p us radii et disci conformis, uniserialis, setiformis, subseaber. - Herba orinoccensis erecta, Polymniae facie; caule glabro, tetragono, foliis oppositis, adultis supra glabris, subtus seeus nervos adpresse puberulis, petiolis basi late auriculatis, auriculis in vaginam connatis, lamina late ovato-acuminata, grosse inciso-dentata, basi quinque-septemnervia, capitulis in corymbum terminalem compositum, densum dispositis, floribus flavis, disci intensius coloratis.

Erato DC. Prodr. V.317.

236\%. Wकodvillea DC. Capitnlum multiflorum, heterogamum, floribus radii snbtriseriatis, ligulatis, neutris, disei tubulosis, hermaphroditis. Involucri campanulati squamae hi-triseriales, lineari-oblongae, aequales. Receptac aI $\mathrm{m}$ nudum. Corollae radii ligulatae, tubo longo, hispido, ligula lineari, dis ei tubulosae, limbo quinquedentato. A n th e r a e ecaudatae. 
Achenia villosa, radi i linearia, sterilia, dis ci oblonga, compressa. Pa p p s pluriserialis, setis tenuissimis, subscabris, aequalibus. - Herba californica, spithamea, Calendulae facie, glanduloso-villosa, caule adscendente, tereti, foliis alternis, oblongis, basiattenuatis, sessilibus, obtusis, integerrimis, triveniis, capitulis terminalibus.

Woodvillea DC. Prodr. V. 318.

2368. IP ginadia $J A C Q$. C a p it u $1 \mathrm{u} \mathrm{m} \mathrm{mul-}$ tiflorum, heterogamum, facie disciforme, floribus radii pluriseriatis, brevissime ligulatis, femineis, disci paucis, tubulosis, hermaphroditis v. abortu masculis, interdnm nullis. Involucri imbricati squamac pauciseriales, margine subscariosae. Receptaculum subalveolatum. Corolla e radi ligulatae, ligula brevissima, integerrima, dise tubulosae, limbo quinquefido. Antherae ecaudatae Achenia oblonga, glabra. Pappus uniserialis, coroniformis, setosus, scabriusculus.

Frutices mauritiani et madagascarienses, juniores vix non semper glutinosi v. viscosi; foliis alternis, peliolatis, oblongis, integerrimis $v$. grosse dentatis, corymbis terminalibus compositis, polycephalis, subaphyllis.

P s i a di a Jacquin Hort. schönbr. IT. 13. Lessiag Synops. 190. DC. Prodr. V.318. Ps iadia et Elphege a Cassini in Diet. sc. nat, XLIII. 503, Tho u a $\mathrm{r}$ s ia Vent, msc. A I ix et Glutinaria Commers. mse. Conyzae et Baceha$r$ id is sp. Lam.

a. GLUTiNARIA DC. Prodr, $V, 318$, Fr utices mauritiani, glutisosi, foliis glandulosis, saepius triplinerviis, floribus flavis, radit plurimis, pluriserialibus, brevissime ligulatis. - Jacq. op. cit. $t, 138$. S o I idago vi s c 0$\mathrm{s}$ a Schrader Sert. hannov. $t, 6$. B a c charis vis cosa Lam. Journ, I. t. 3.

b. GLANDULARIA DC, Prortr. $Y$. 320 . He r b a madagascariensis, nou glutinosa, foliis sessilibns, paucinerviis, subtus minute glanduliferis, pedunculis axillaribus, floribus purpurascentibus, radii paucis, uniseriatis, ligula ob. longa. - Conyza madagaseariensis Lam.

2369. Frofvaldia. Capitul um multiflorum, heterogamum, floribus radii pluriseriatis, minutissime ligulatis, femineis, disci pancis, tubulosis, abortu masculis. Invol u cri imbricati squamae lanceolato-lineares, subscariosae, ereetae. $\mathbf{R}$ eceptac 1 am nudum. Corolla e radii ligulatae, ligula lineari pappo breviore, dis ci tubulosae, limbo tri-quinquefido. A $n t h$ e $r$ a e ecaudatae. A chen i a ohlonga, compressa (?), glahra. Pa ppus pilosus, uniserialis. - Frutices indici et a fricani, interdum arborescentes, saepius erecti, nonnunquam subvolubiles, glabriusculi, apice ramosi; foliis petiolatis, ovatis, acuminatis, integerrimis v. subserratis, subtus pubescentibus et glandulosis, adultis subglabratis, corymbis terminalibus aphyllis, fastigiatis, divarica! is, floribus luleis, pappo rufo.

Microglos a DC. Prodr. $V$. 320, non Ornitholog. Co дуz a e sp. Wallieh, Bojer.

2370. Niderella CASS. Ca pitu In multiflorum, heterogamum, floribus radii uni-bipluriseriatis, minutissime ligulatis, femineis, disci tubulosis, hermaphroditis, centralibus interdum sterilibus. Involucri campanulati squamae adpresse imbrieatae. R e c p ta $\mathbf{c u l} \mathbf{I} \mathbf{m}$ alveolatum. Corolla e rait ligulatae, ligula minima, di 8 ci tribulosae, limbo quinquefido. Antherae ecau datae. A chen i a oblonga, teretiuscula v, subcompressa, glabra v. minute puberula. P a p p us uniserialis, setis subscabridis, basi in annulum subconnatis. - Herbae v. suffrutices capenses, species una arabica; caulibus erectis, foliis alternis, capitulis corymbosis $v$. solitariis, corollis omnibus favis, disci interdum pallidioribus.
Nidorella Cassini in Diet, sc. nat, XXXII. 459. es 469. LVI. 166. DC. Prodr. $V .321$. E r i g'e r o u t is sp. Linn. et Auet.

23\%1. Homedaroman $D C$. C a p itulum multiflorum, heterogamum, floribus radii uniseriatis, ligulatis, femineis, disci tubulosis, ovario efoeto masculis. Involueri bi - triseriati squamae lineares, acuminatae, adpressae. Re e e $t$ a cu I n m convexum, subfoveolatum. Corollae radii ligulatae, dis e i tabulosae, limbo quinquefido. Anthera e ecaudatae. A $\mathrm{c}$ henia radii plano-compressa, obovata, villosa, dis ci filiformia, glabra. Pappus uniserialis, setosus, setis radii circiter quindenis, disci subdenis, omnibus imprimis ad apiecm plumosis. - Frutex capensis, ramosus, hirtellus; ramis foliosis, apice nudis, monocephalis, glanduloso-hispidulis, folits alternis, sessilibus, oblongo-linearibus, inlegerrimis, ciliatis, capitulis fla vis.

\section{H om oc hroma DC. Prodr. $\mathcal{V} .324$.}

8378. Neja D. DON. CapituIum multiflorum, heterogamum, floribns radit uni-triseriatis, ligulatis, femineis, disci tubulosis, hermaphroditis, Involuc ri late hemisphaerici squamae triseriales, imbricatae, lineari-subulatae, Recept a $\mathbf{c} \mathbf{u} \mathbf{l} \mathbf{u} \mathbf{m}$ planum, favosum. Corolla e radii ligulatae, ligrula angusta, dis ci tubulosae, limbo quinquefido. Antherac ecaudatae. A $c$ henia lineari-oblonga, compressa, sericeo-villosa. P a p u s duplex, exterior brevis, anguste paleacens, interior longior, pilosus, scaber. - Suffrutices mexicani et brasilienses, pilis longis, sparsis, patulis hispidi; foliis sparsis, linearibus, subacerosis, calloso-mucronatis, integerrimis, ramis foliosis v. apice nudis, monocephalis, involucris hirtis, corollis omnibus flavis.

Nej a D. Don in Sweet Fl, Gard, II, n, 78, DC, Prodr. V. 325.

a. PODONEJA DC. $l$. c. L I g u 1 a e pluriseriales. R e e ptac a I um vix favulosum. Cor olla e paplloso-pilosae. - Capitula longe pedunculata. Folia impunctata. Don op. cit, $t, 78$. Loddig Bot, Cab. t. 1814.

b. PHYLLONEJA DC. $t$, c. Ligulae plariseriales. Recep t a culum alveolatum. Co rolla glabrae. - Ca. pitula sessilia. Folia punctata.

e. MONOGYRIA DC. $l$. c. Ligula e uniseriales. Receptaculum... Corollae glabrae. - Capitnla ad apicem rami foliati v. nudi solitaria. Foli a impunctata.

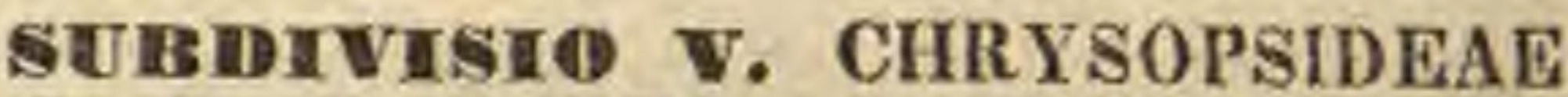
DC. Prodr. V. 326. F lore s radii uniseriales, rarissime bi-triseriales. $\mathrm{P}$ a $\mathrm{p}$ p u s duplex, exterior brevis, subpaleaceus, interior setosus.

23\%3. Charysopsis NUTT. Cap itulum multiflormm, heterogamum, floribus radii uniseriatis, ligulatis, femineis, disci tubulosis, hermaphroditis. In volneri imbricati squamae lineares, acnminatae. Recéptacul l um planum, subalveolatum. Corollae radii ligulatae, disci tuhulosae, limbo quinquefido. An the ra e ecaudatae. A che$\mathrm{n}$ i a obovata, compressa. $\mathrm{P}$ a p p $\mathrm{s}$ in disco et ra. dio conformis, duplex, exterior brevis, subpaleaceus, interior setiformis, elongatus, seaber. Herbae boreali-americanae, rhisocarpicae, saepius ramosae, villosae; foliis alternis, integerrimis $v$. dentatis, capitulis ramos terminantibus, solitariis, floribus omnibus luteis.

Chrysopsis Eliott Carolin. II. 333, excl. sp. DC. Prodr. $V, 326$, C h r y s op s i s sectio Iaulae Nuttall gen. II. 130. Diplago a Rafin. in New York Monthl, Magaz. 1818. D iplop appi sp. Less. In uIa e sp. Pursh. 
2384. Fresenta $D C$. Capitulum multiflorum, homogamum. Involu $\mathrm{eri}$ subtriserialis squamae imbricatae, lineares, margine submembranaceae, dorso glandulis uni-triseriatis notatae. R e c p tacul a m angustum, areolatum. Cor olI a c tubulosae, glabrae, fauce haud ampliata, limbo quinquedentato. An therae ecaudatae. A $\mathbf{c}$ he $\mathbf{n}$ i a compressa, erostria, sericeo-villosa. Pa p a s dnplex, exterior brevis, paleiformis, interior setaceus, scabridus, longus. - Suffrutices ca penses, glabri; ramis oppositis, apice nudis, monocephalis, foliis oppositis, linearibus, aculis, fere subulatis, integerrimis, saepe in axillis fasciculatis, corollis pallide flavis.

Freseuia DC. Prodr. V. 328.

SUIBIDITISIO VI. SOLIDAGINEAE DC. Prodr. V. 328. Capitula discoidea v. radiata, radio uniseriali. $\mathbf{A} \mathbf{c h}$ en i a plerisque angulata seu teretiuscula, nec compressa. $\mathrm{P}$ a pp u s disci et radii conformis, uniserialis, pilosus.

23 ร5. IBigelowia $D C$. Capitulum triquinqueforum, homogamum, v. flore unico ligulato heterogamum. Involucri oblongi squamae paucae, imbricatae, crectae. R e c e $t$ a $\mathrm{cul} \mathbf{\mathrm { um }}$ angustum, squama setacea, basi latiuscula, achenia aequante, inter flores centrali. Corollae tubnlosae, glabrae, limbo quinquefido. Antherae ecaudatae. A c h e ni a oblonga, subangulosa, pubescenti-villosa. $\mathbf{P}$ a p p u s uniserialis, pilosus, rigidus, scaber. - Herbae perennes, bor eali-americanae; foliis alternis, integerrimis, caulinis oblongis $v$. linearibus, capitulis corymbosis, floribus flavis.

Bigelowia DC. Prodr, $V, 329$, non Alior. C bry soc o m a e sp. americanae Auct.

23ร G. Solidago LINN. C a p i $t$ a $1 \mathrm{n} \mathrm{m}$ pluri-multiflornm, heterogamum, floribus radii nniseriatis, quinis-quindenis, saepe distantibus, liznlatis, femineis, disci tuhulosis, hermaphroditis. Involncri ut plurimam oblongi squamae plurimae, adpresse imbrieatae. R eсе p ta c n $1 \mathrm{~nm}$ epaleatum, nunc omnino nudum, nune alveolatum v. fimbrilliferum. Corollae radii ligulatae disci tubulosae, limbo quinquefido. An the rae ecaudatae. A chenia teretiuscula, multicostata P a p pus uniserialis, pilosns, scabridus. - Herbae in America boreali copiosissime provenientes, in Europa et Asia rarae, basi saepius suffruticosae; foliis alternis, integerrimis v. serratis, racemis terminalibus $v$. axillaribus, erectis, patentibus v. reflexis, pedicellis secundis, cymas scorpioideas formantibus $v$. vere racemosis, radio concolore, rarissime discolore.

Solidag o Linn. gen, n, 955, Gärtn. II. 447. $t, 170$ DC. Prodr. $V$. 330. Vi rga.A a re a Toarnefort inst. 483 Dor la Adanson Fam. II. 124.

a. VIRGAURRA DC. Involu cri imbrieati squamae liberae. Recept a c u I u m nudum v. alveolatua, haud fimbrilliferum. Flores radii paueiores quam disei. - Hace mi simplices v. paniculati, hasd corymbosi, capitulis ad apices pedicellorum solitariis.

Virgaurea DC. l. c. Solidago Nattall gen. $I T$. 159. Cassini in Dict, sc. nat. XXXVII. 459. et 472. Lessing Synops. 163.

b. EUTHAMiA DC. Nutt. In rolue ri imbrienti squa mae subadglutiuatae. Re e e $t$ a e u lum fimbrillifernm. Vlores radii floribus disei numerosiores. - Capilula ad apices ramulorum sessilia, in corymbum disposita.

F th a $i$ a Nuttall gen, II, 169. Cassini in Dict.sc, nat, XXXVII. $471, \mathrm{C}$ hrysecomae sp. Linn.
2รรซ. Anplatrlaapis $D C$. C a pitulum multiflorum, hetero lis, denis-vicenis, figulatis, femineis, disci tubulosis, hermaphroditis. Involucri pauciseriati squamae exappendiculatae, imiricatae. R eceptac $\mathbf{~} 1 \mathbf{u m}$ alveolatum. Coroll a e radii ligulatae, ligula angusta, dis e i tubulosae, limbo quinquefillo. Antherac ecaudatae. Achenia linearioblonga, subeompressa, villosa v. pubescentia, villis ad basim pappi ealyculum exteriorem, pilosum saepius simulantibus. Pap p us uniserialis pilosus, scabridus. - Herbae in dica e, inter Asteres et Solidagines ambiguae; foliis alternis, denticulatis, capitulis corymbosis, floribus omnibus luteis.

Amphirhapis DC. Prodr. $V .343$. Solldaginis et Asteris sp. Wallich.

23ร8. Conamislendirum $B U R C H$. C apitu I u m multiflorum, heterogamum, floribus radii uniseriatis, ligulatis, femincis, disci tubulosis, hermaphroditis. Invo / n eri pauciseriati squamae lineares, acuminatae, imbricatae, $R$ ecep $t$ a $\in \mathbf{n} I \mathbf{~ m ~ m}$ nudum. Corolla radii ligulatae, disei inbulosae, limbo quinquefido. Ant herae ecaudatae, appendiculatae. A $\mathrm{e}$ henia compresso-plana, erostria, glabra. Pa p p s uniserialis, pilosus, scaber. - Arbusculae gummiferae, in insula S't. Hel en a e indigenue; ramis foliorum cicatricibus crassis, callosis notalis, foliis allernis, obovalo-v. lanceolato-cuneatis, integerrimis $v$, denticulatis, utrinque glabris $v$. subtus tomeniosis, pedunculis corymbosis, polycephalis, ex axillis supremis $v$. apice ramo. rum ortis, floribus albis.

Com midend r um Barchell ex DC. Prodr. V. 344. Conyzacet Solidaginis sp. Roxb.

23\%9. Steiraetis $D C$. Capitulu m multifloram, heterogamum, floribus radii uniseriatis, ligulatis, neutris, disei tubulosis, hermaphroditis. Invol ucri cylindracei, imbricati squamae pluriserialcs, lincares, margine membranaceae, interiores longiores. Re cepta $c \mathbf{a} \mathbf{~} \mathrm{m}$ parvam, nudum. Corolia e radii ligulatae, disci tubulosae, limbo quinquefido. An the rae ecandatac. A chenia teretiuseula, pilosa. P a p p $\mathrm{s}$ uniserialis, fimbriatopilosus. - Frulex arborescens Novae-Zeelandiae, non satis notus; foliis alternis, petiolatis, ovali-orbiculatis, glabris, repandis, sublus albidopurpureis, capitulis paniculatis.

Steiractis DC. Prodr. $V$. 345. Solidago a rborescens Forst. A. Riehard Fl. Nov. Zeel. 252.

2380. IBgelhonia $D C$. C a p it 1 u m multiflorum, heterogamum, floribus radii uniseriatis, ligulatis, neutris, disci tubulosis, hermaphroditis. Invo I u cri inbricati squamae subscariosae, lineares, uninerviae. Recepta $\mathrm{cul} \mathbf{u} \mathrm{m}$ alveolatofimbrilliferum. Coroll ae radii ligulatae, disci tubulosae, limbo quinquefido. An therae ecaudatae. A chenia teretiuscula, subvillosa. Pap pus uniserialis, setosus, subseaber. - Frutices madagascarienses; ramulis foliisque subtus canescentibus, foliis alternis, sessilibus, coriaceis, integerrimis, uninervits, capitulis paucis $v$. solitariis ramulos terminantibus, floribus omnibus flavis.

Rochon ia DC. Prodr. $V$. 345. Co nyzae sp. Bojer.

2381. II 1 plopappus CASS. CapituI $\mathrm{m}$ multiflorum, heteroramum, floribus radii uniseriatis, ligulatis, femineis, rarissime nullis, disci tubulesis, hermaphroditis. Involneri im brieati squamae lineares, acutae. R e cep $f$ a $\mathrm{e} u \mathrm{l}$ u m planiuseulum, foveolatum 8 . alveolato-subfimbrilliferum. Corolla e radii ligulatae, disci tubu- 
losae, limbo quinquefido. Anthera e ecandatae. A e he nia oblonga, teretiuseula v, turbinata, dense sericea ant rarins glabra. PaPp u s setosns, unipluriserialis, setis conformibus, subinaequilongis. - Herbae perennes $v$. suffrutices, per onnem $A$ mericae continentem, in australi extratropic o copiosius provenientes; foliis alternis, integerrimis $v$. dentatis, capitulis terminalibus, floribus radii concoloribus $v$, rarissime discoloribus, albis seu purpurascentibus.

A plop app us Cassini in Dict. sc, nat, LVT, 169. DC. Prodr. $V$. 395. Diplo pap a $\mathrm{s}$ Lessing in Linnaea VI. 110. Synops, 163.

a. LEIACHENIUM $D C$. A che $\mathrm{n}$ ia glaberrima, elongata. Lelacheaium DC. Prodr. $V_{\text {. }} 346$ - ?Hoorebe $\mathrm{k}$ i a Cornelisseu in Musshe Bort, gandav, 1817, p, 120. c. ic.

b. BLEPHARODON DC. A c he nia sericeo-villosissima, brevia, turbinata.

B lepharodon DC. Prodr. V. 346. - ? Side ranth h s Fraser.

c. BUAPLOPPUS $D C$. A c hen i a sericeo-villosa, elongata. E u a 1 o p a p u s DC. Prodr. $\mathscr{V} .347$. D ip I o p pa. pi sp. Lessiug, Pöpp. Gria deliae sp. Bertero.

d. LEUCOPSIS $D C$. A c he u i villosa v, hirsuta, elongata. Pa p u s radii corollis disci longior.

Le u co ps is DC. Prodr. $\boldsymbol{F}$. 348 .

e. PYRoChaETA DC. A chenia radii abortiva, pappi selis paucissimis; dis c i turbinata, sericeo-villosissima, p a p p o multiseto, scabro, rigidulo.

Pyroeh a eta DC. Prodr. V. 349.

f. INULOPSIS $D C$. C o rolla e radii plurimae, ligulis linea. ribus. A che nia villosa, brevia, teretiuscula. $\mathrm{P}$ a p p us? Inulops is DC. Prodr. $V_{\text {. }} 349$.

g. HAPLODISCUS $D C$. Capit u 1 u m discoideum. A cheu ia villosa. Pa p p us ....

A plodise us DC. Prodr. V. 350 .

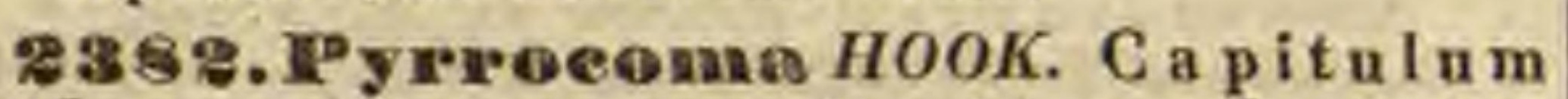
moltiflorum, homogamum, discoideum, In v o lncri squamae plures, laxe imbricatae, plns minus 8quarrosae. R e eptac $\mathbf{l}$ um epaleatum. Corollae tubulosae, fauce hand ampliata, limbi quinquedentati dentibus brevibus, erectis. A n thera ecaudatae, subinclusae. A chenia oblonga, teretiuscnla, glabra. $\mathrm{P}$ a p и 8 uniserialis, setis seabris, fulvis. - Herbae perennes v. suffrutescentes, in America boreali et australi extratro$\boldsymbol{p}$ ic a indigenae, simplices, erectae; foliis alternis, lanceolatis $v$. oblongis, coriaceis, subpubescentibus, parce dentato- $v$. spinoso-serratis, saepe punctatis, floribus luteis.

Pyrroeom a Hooker Flor. Bor. Amer. I. 306. DC. Prodr. $V .350$.

a. EUPYRROCOMA DC. I n v o l u c r i squamae squarrosae, apice subreeurvae. Folia punetata. - Herbae borealianericanae.

E a py rocom a DC. $t$. c. (Hooker op, eit, t. 107.)

b. CHROMOCHAETA. DC.I a v l u cri squamae adpresse imbricatae, haud squarrosae. Folla impanctata. - Suf-
frutices chilenses.

Chromochaeta DC, $l, c$.

2383. 耳hessing gîn CHAM. C a p itulu m multiflorum, homogamum, radiatiforme, floribus omnibus tubulosis, radii majoribus, In volucrum imbricatum. ReceptacuI um nudum. Corolla tubnlosae, radii majores, obconicae, profunde quinquelobae, dis e i cylindrico-tubulosae, limbo quinquedentato. Anth era e eaudatae, inclusae. Achenia compressa, erostria, serieen-villosa. $\mathbf{P}$ a p p s uniserialis, setis rufis, scabridis, rigidulis. - Herba californica, procumbers, ramosa, adulta glabrata; foliis alternis, crassiusculis, infimis pinnatifidis, superioribus apice dentatis, capitulis solitariis, terminalibus et ramorum elongatione alaribus, floribus flavis.
Lessing i Chamisso in Linnaea IV. 203. $t$ 2. f. 2. Lessiug Synops. 388. Cassini Opuse, phytolog. III. D6. DC. Prodr. $Y .35 t$.

9394. Hinosyris LOBEL. C a pitalum multiflorum, homogamum, discoideum. Involucri panciserialis squamae imbricatae. Receptac u l u m planum, alveolatum, alveolarnm marginibus carnosis, dentatis. Coroll a e tubulosae, limbo profunde quinquefido. Antherae ceandatae, exsertae. A c h en ia oblonga, compressa, sericea, erostria. P a p p ns pilosus, biserialis, selis scabris. Herbae perennes, erectae, in Europ a imprimis mediterranea et Asia boreali indigenae; foliis alternis, confertis, linearibus v. oblongis, subintegerrimis, capilulis ad apices ramorum solitariis, saepe corymbum formantibus, floribus luteis.

Lin osyris Lobel. Histor. 283. DC. Prodr. V. 351. Crinitaria Lessing Synops, 195. Crinitaria et Lino. s y $\mathrm{ris}$ Cassini in Dict. sc. nat. XXXVIT, 475, 476. C rinita Monch Method, 378. exel. sp. Ch r ys o e o m a sp. Lian. Sehkuhr $t$. 238. Waldst. et Kitaibel $P i$. Hung. $t$. 58 , Delile Aegypt. t. 46. f. 2.

2385. Chrysoeoma CASS, Cap it $1 \mathrm{um}$ multiflorum, homogamum, discoidenm. In voluc ri eampanulati, floribus brevioris squamae oblongo-lanceolatae, imbricatae. R e ceptacul um nudum, subalveolatum. Corolla e tnbulosae, limbo quinquefido. A $n t h$ e r a e ecaudatae, exsertae. A ch en i a lateraliter plano - compressa, vix hispidula, erostria. Pappus setaceo-pilosus, uniserialis. - Frutices capenses; foliis alternis, linearibus, saepius integerrimis, ramis apice plus minus denudatis, monocephalis, capitulis subglobosis, floribus luteis.

Chrysocom a Cassini in Dict, sc, nat. XxxVII, 477. Lessing Synops, 195. DC. Prodr. $Y$. 3J3. C b r y 8 o co mate sp. Thunb. Linn.

2386. Fteronia LINN. Capitulum homogamum, discoideum, saepius multiflorum, rarius tri-v. uniflorum. In v o Iu eri pluriserialis squamae imbricatae, adpressae. $R$ e c e p $t$ a $\mathbf{e} u \mathbf{l} \mathbf{u m}$ alveolatum, alveolorum marginibus parum prominulis, v. plus minus in fimbrillas productis. Corolla e tubulosae, limbo quinquefido. Antherae ecaudatae. Ac henia compressa v. turbinata, glabra aut villosa, apice interdum in collum brevem attenuata. Pap pus multiserialis, setaceo-paleaceus, setis crassiusenlis, dense et breviter barbellatis, liberis $\mathbf{v}$, basi in cupulam concretis. _ Fruticuli c a p en se s, rigidi, ramosi; foliis alternis $v$. saepius oppositis, integerrimis $v$, rarissime subdentatis, glabris v. hirsutis, saepe eiliatis, eapitulis terminalibus, solitariis v. corymbosis, floribus luteis aut rarius purpureis.

P ter on ia Lina, gen, n. 937. Thuuberg Flor, cap, 629. DC. Prodr, $Y, 356$.

a. SCEPINIA DC. Prodr. V.356. C a p it $n 1$ u m multi- v. paueiflorum. Receptaculum alveolatum, breviter fim. brilliferun. A e h e $\mathrm{a}$ i a teretia v, subeompressa, villosa, apice minime in collum attenuata. Pappi paleae basi distinctae. - Folia alterna v, opposila.

S cepin i Necker elem, $n, 140$. Cassini in Dict.sc. nat. XXXVII.475. XLVIII.44. P te $\mathrm{r}$ on i a et $\mathrm{H}$ en ant hus Lessing Synnps. 195. (Gärta, t. 167, f. 2.3

b. PACHYDERRIS DC. Prodr. $V$. 360 , C a p i tul $\mathrm{nm}$ mul. thflorum. Recepta c u I um alveolatum. A c he $\mathrm{f}$ a com. pressa (exteriora saepe trigona) sub pappo in collum brevem. crassum, glabrum, villis occultatum attenuata, P a p p paleae basi distiuctae. - Eolia opposita, rarius alterna.

$\mathrm{P}$ a c h y der ris Cassini in Dicl.sc. nat. LVI, p, $t 70$. Lessing Synops, 196.

e. PTEROPHORUS DC. Prodr. Y.364. Ca pitulu m muttiflorum. Receptae u 1 um fimbrilliferum. A chenia plano-conipressa, glaberrima, erostria. P a p p u s sub. uniserialis. setis basi in auaulum coneretis. - Follia 
sparsa, linearia, capilula solitaria in ramis fore ad apicem foliosis.

Pte rophorus Vaillant in Aet. Academ. Paris. 1719. p. 289. Cassini in Dict.sc, nat. XXXVII. 474. Lessing Synops. 195. P t er o $p$ h or a Necker elem, n, 139. (Lam. t. 667. f. 1.)

DIVISID I $\mathrm{W}$. SOLENOGYNEAE DC. Prodr. V. 365. Cap it ulum discoideum, heterogamum, floribus radii pauciseriatis, tubulosis v. vix ligulatis, tenuissimis, subtridentittis, femineis ; disci hermaphroditis, quinquedentatis.

238\%. Denaldea $D C$. Ca p it $\mathrm{n} 1 \mathrm{um} \mathrm{mul}$ tiflorum, discoideum, heterogamum, floribus tubulosis, radii pancis femineis, disci pluribus, hermaphroditis. Involn eri ovati, imbricati squamae triseriales, lineares, exteriores dorso subtomentosae, interiores glabrae, discum subaequantes. $R$ eceptaculum planum, nudum. Corollae tubulosae, ra d i minimae, dis ci fauce longa, limbo quinquedentato. A n $t h$ e $r$ a e ecaudatae. A $c$ h en i linearia v. teretiuscula, villosa. Pa p p us uniserialis, setis subrigidulis, acntis, scabris. Suffrutex sinensis, ramosus; ramulis subcorymbosis, conferte villosis, teretibus, adultis glabratis, foliis alternis, superioribus subsessilibus, ellipticis, obtuse mucronulatis, penninerviis, integerrimis $v$. parce calloso-denticulatis, supra sparse pilosis, subtus sericeo-canis, capitulis in apice ramulorum axillarium confertis, breviter pedicellatis, floribus favis.

Duhaldea DC, Prodr. $V .366$.

2389. Nierotaielaia DC. Capitu I u m multiflorum, discoideum, heterogamum, floribus tubulosis, radii uni-biseriatis femineis, disci hermaphroditis. Involnerum uni - biseriale disco brevius. Receptac $\mathbf{n} \mathbf{l n m}$ globosum, nudum. Corolla e tubulosae, radii minimae, disci quin. quedentatae. Antherae ..... A chenia sessilia, turbinata, erostria, glabriuscula. Pa p pus disci uniserialis, pilosus, brevissimus, radii conformis v, nullus. - Suffrutex sen eg a mbicus, diffuse ramosissimus, cinereo-hirsutus; foliis alter. nis, sessilibus, oblongis, basi subcuneata integerrimis, apice latiori grosse dentatis, acutiusculis, floribus flavis.

Microtrie hia DC. Prodr. $V .366$.

2389. Nolletia CASS. C a p it ulum multiflorum, discoideum, heterogamum, floribus tubulosis, radii uniseriatis femineis, disci hermaphroditis. Involucri bi-triseriati squamae imbricatae, lineares, acuminatae, floribus vix breviores, demum reflexae. R e e p ta e u lum planum, nudum. Corolla e tubulosae, $r$ a $\mathbf{i} i$ filiformes, d i s c i limbo quinquedentato. A n th e ra e ecaudatae. A chenia compresso-plana, erostria. Pap pus uniserialis, setis corollas subaequantibus, scabris. - Frutex mauritanicus, ramosissimus; foliis alternis, linearibus, integerrimis, utrinque strigilloso-subvillosis, ramis apice breviter denudatis, monocephalis, floribus flavis.

Nolletia Cassini in Dict, sc, nat, XXXVIT, 479, Lessing Synops. 187. DC. Prodr. $V$. 366. Conyza chry's acomoldes Desfout. Flor. att. t. 232.

2390. Sareanthemum CASS. C a pitul u m nultiflorum, heterogamum, floribus radii uniseriatis, subligulatis, femineis, disci tubulosis, hermaphroditis. Invol ucrum hemisphaericum, imbricatum, floribus paullo brevius. Rece $p^{t}$ ae ul um planum, paleaceo-fimbrilliferum. Corol-
I a e tubo inferne crasso, ampliato, $r$ a dii in ligulam minimam productae, disci limbo quinquedentato. Antherae ecaudatae. Achenia radii compresso-obovata, pap po brevi, coroniformi, squamato, dis ei abortiva, ad callum basilarem reducta, $\mathrm{p}$ a $\mathrm{p}$ p o uniseriali, setoso-paleaceo, irregulari. - Frutex m a uritianus, glaber; foliis alternis, anguste oblongo-lanceolatis, basi attenuatis, apice serratis, obscure triplinerviti, corymbo composito terminali, capitulis ad apices pedunculorum confertis, subsessilibus, floribus flavis.

Sareanthe mum Cassini in Bullet. soc, philomat. 1818. p. 74. Dict, sc, nat. XLVII. 349. Lessing Synops. 191. DC. Prodr. $V$. 367, Conyza Cor on opus Lam.

23\%1. Heptothannass $D C$, C a p ituln m multiflorum, discoidenm, heterogamum, floribus tubulosis, radii uniseriatis, femineis, disci (stylo indiviso?) hermaphroditis. I n v o l u e r i subtriserialis squamae floribus paulo breviores, imbricatae, acuminatae. Receptaculum planum, epaleatum, vix subalvenlatum. Corolla tubulosae, $r$ a d i i filiformes, truneatae, disci limbo quinquedentato. A n t h e r a e ecaudatae. A $e_{\text {h }}$ nia radii gracilia, glabra, disei obovato-oblonga, pubescenti-villosa. P a p p u s pilosns, deciduus, radi i nniserialis, d i 8 e i aequaliter biserialis v. saltiu copiosior. - Suffrutex capensis, erectus, gracilis, ramosus; foliis sparsis, erecto-adpressis, lineari-subulatis, nervo subtus prominente, rigide ciliolatis, ramis apice breviter aphyllis, monocephalis, hispido-scabris, involucris monocephalis, corollis e flavo purpurascentibns.

Le p toth am a s DC. Prodr. K. 367.

23\$2. Sollenogyne CASS, Cap itu lu m multiflorum, radiatiforme, heterogamum, floribus tubulosis, radii pluriseriatis, femineis, disei subdenis, ovarii abortu masculis. Invol u cri subhemisplraerici, flores aequantis squamae subtriseriales, inaequales, obtusae, subimbricatae, adpressae. Ciorolla e tubulosae, $r$ a dii tri- dis ci quinquedentatae. Anthe ra e eaudatae. A chenia oblongoobovata, compressa, erostria, apice tuberculo terminata. Pa p us nullus. - Herba Novae-Hollandiae, parva, Bellii facie, basi foliata, caeterum aphylla; foliis alternis, inaequalibus, spathulatis, apice dentatis, caulibus filiformibus, scaposis, monocephalis, capitulis parvis, floribus luteis (?).

Sole nog y ne Cassini in Dict, se, nat, LVT. 175. Lessing Synops, 193. DC. Prodr. K. 367.

\section{SUITTEIBUS II. BACCHARIDEAE} Lessing Synops 200. Capit u la heterogama v. dioica, nunquam radiata, floribus omnibus tubulosis, femineis in ambitu filiformibus. Keceptaculum epaleatum. Antherae ecaudatae._Folia allerna.

DIVISI T. CONYZEAE Lessing Synops. 200. Capitula heterogama, monoicas

SUBDIVISIO I. SPHAERANTHEAE DC. Prodr. V. 368. C a pit ula in glomerulos sphaericos congesta, ad bractearum axillas sessilia. - Species omnes gerontogaeae.

23D3. Flepharispermam WIGHT. Capitula plurima, in glomerulum globosum coacervata, biflora, flore altero femineo, altero masculo. Invo lu cr am commne glemeruli bracteae foliaceae $\mathbf{v}$, membranaceae, proprium capituli 
squamae subbinae breves, oratae. Receptacul $\mathbf{u m}$ angustissimum, palea lineari cuivis fluri adjecta, altera sub flore femineo plana, altera sub maseulo conduplicata. Cor o lla e tubulosae, floris feminei tri-, masculi quinquedentatac. Antherae apice appendiculatae, hasi ecaudatae. Sty I u 8 floris feminei hrevis, inclusus, apice vix bifidus, infra emarginaturam subtumidulus, puberulus. A che. nin floris feminei obovato-oblongum, obcom pressissimum, subtetragonum, angulis duobus nerviformibus lateribusque glaberrimis, duobus marginalibus longe ciliatis; floris masculi sterile, elongatum, gracile, glabrum. P ap p u 8 achenii feminei e paleis tribus v. quinque scariosis, acuminatissimis, masculi nullus. - Suffrutices ind $i c i$, glaberrimi; ramis teretibus, gracilibus, foliis aller$n i s$, ovatis $v$. ovalibus, integrerrimis, penninerviis, glomerulis ramos terminantibus. V. 368 .

B lepharis perm u might Contribut.11. DC. Prodr.

2394. Athroisman DC, Capitula plurima, in glomerulum ovatum conferta, bracteis concavis interstincta, pluriflora, heterogama, floribns tubulosis, exterioribus quaternis v. quinis femineis, interioribus paucis masculis. Involucrum commune glomeruli nullum, partialia capilulorum oligophylla, bracteis paleiformibus vix distincta. Receptaculum nudum. Coroll a e tubulosae, femine a e tenues, quadri-quinquedentatae, $m$ a sc ulae apice latiores, quinquedentatae. An $t$ h era e..... Stylus in flirribus femineis apice bifidus, glabriusculus. A chenia nigra, obcompresso-ovalia, hinc plana, illine convexa, ad angiulum marginatem apice ciliata, eaeterum glabra. Papp us parcus, villum referens, subsetosus - Herba indica, basi suffruticosa, erecta, ramosa, parce subpuberula; foliis alternis, petialatis, lyrato-pinnatipartitis, lobis oblongis, obtusis, dentatis, glomerulo terminali, subsessili, stramineo.

Athroisma DC. in Guillem. Arohiv. Bot, II. 516 . Prodr. V. 368.

2395. Splhaeranthus VAILL. C a p it 1 la plurima, in glomerulum subglobosum dense aggregata, bracteis interstincta, pluriflora, heterogama, floribus tubulosis, exterioribus femincis pluriseriatis, centralibus stylo imperfecto masculis, Invol u crum commune glomeruli varium, partialia capitulorum uni - bi - triseriata, polyphylla. R e c p ta culum nudum. Corolla e tubulosae, femineae indurato-dilatatae, saepe tridentatae, ma s cula quinquedentatae. Anthera e ecaudatae. Stylus in floribus femineis bifidus, in centralibus indivisus. A $\mathrm{ch}$ en ia erostria, pilosiuscula v. glabra. Pa P p us nnilus.-Herbae int er tropicos veteris or bis obviae; foliis alternis, longe secus caulem decurrentibus, pedunculis alatis $v$. apte ris, monocephalis, glomerulis densis, corollis violaceis.

Sphaeranthus Vaillant in Act. Academ. Paris. 1719. p. 289, Linu. gen, $n$, 998. Gärtn. IT. 413. Cassini in Dict. sc. nat, L. 208. Lessing Synops. 201. DC. Prodr. $V$. 369.

a. EUSPhaERANTHUS DO. G 1 o meru 11 axis solida. C apitulorum bracteae omaes lineares, molles, floribus subaequales, exteriores commune glomeruli involucrum haud constituentes, - Species indicae.

Rusphaerantbus DC. Prodr. V.369. (Lam,t.718. f. 1.?)

b. CUSPIDELLA $D C$. Glo meruli axis solida. C a pitu1 or um braeteae aeuminato-pungentes, exteriores commune glomerull involucrum distincte formantes, interiores flores vix aequantes. - Species africanae.

C uspidella DC. Prodr, $Y .370$. c. POLYCephalos $D C$. GI om er u li axis solida v. eavo-Incunosa. Ca pitulor u m bracteae ovato-lanceola. tae, cuspidatae, rigidae, floribus longiores, exteriores commune glomeruli involucrum haud formantes. - Spe. cies asiaticae, africanae, australasicae.

Polycephalos DC. l. c. Poly cephalos Fors. kael Aegypt.154. Oligo 1 ep is Cassini in Dict.se.nat. L. 212. (Lam. t. 718. f. 2. Gärtn. t. 164.)

SUEDIVISID II. GRANGEINEAE DC. Prodr. V. 371. C a p it ul a heterogama, monoica, in glomerulum haud congesta. P a p u s nullus v. subnullus.

2396. Dielurocephala $D C$. CapituI $\mathbf{~ m ~ m u l t i f l o r u m , ~ h e t e r o g a m u m , ~ f l o r i b u s ~ o m n i b u s ~}$ tubulosis, marginalibus multiserialibus, femineis, centralibus paucis, abortu masculis. Involueri subuniserialis, expansi squamae ovatac, subaequales. Receptaculum conicum, nudum. CorolI a e tubulosae, marginis cylindricac, obsolete triquadridentatac, centrales fauce campanulata, limbo quadridentato. Antherate ecaudatae. Stylus inclusus. A chen i a compressa, erostria; marginalin pap o nullo, centralia abortiva, $p$ a p po nnibiseto, brevissimo._-Herbae annuae, per Africam australem et $A$ siam dispersae, hirsutiusculae $v$. subglabrae, ramosae, adscendentes $v$. erectae; foliis alternis, dentatis, cuneatis aut petiolatis, petiolo nudo $v$. appendiculato, capitulis globosis, parvis, in racemos v, paniculas dispositis, pedicellis propriis nudis brevioribus.

Dichroeephala DC. in Guillem. Archiv, Bot. 11 . 517. Wight Contribut. 11. DC. Prodr, $V$. 371 . C entipeda Lessing Synops. 200. non Loureir. Cot u lae sp. Roxb. Blume. G rangea e sp. Lam. $t$, 699. $f$. 1 . Ethuliae sp. Schkuhr $t$, 235 .

239\%. Grangen $A D A N S$. Cap itu I um multiflornm, heterogamum, floribus omnibus tubulosis, radii bi-pluriseriatis, femineis, disci hermaphroditis. In vo I u cri biseriati squamae oblongae, obtusae. R e ce p ta c u lum hemisphacrieum, nudum. Corolla e tubulosae, femineae angustissimae, tridentatac, hermaphroditae quinquedentatae. An thera e ecaudatae. Stylus radii bifidus, disei indivisus. A chenia obovata, lateraliter subcompressa, apice truncata $v$. in rostrum cupnlatim expansum producta. Pap p us brevissimus, pilosodentatus, cupulae margini insidens. - Herbae annuae, in Asia tropica et Africa indigenae, plus minus villosae; foliis alternis, semiamplexicaulibus, sinuato-pinnatifidis, lobis obtusis, capitulis solitariis, subglobosis, in pedunculis oppositifoliis v. terminalibus.

Grange a Adanson Fam. II. 121. DC. Prodr. $V, 372$,

a. CRASSICOLLA DC. $\boldsymbol{l}$. c. Flores radii pluriseriales. Rostrum achenii promisens, albidam, celfulosum, se. mine fere crassius. - Herba Indiae australis.

Grange a Adans. 2. c. Cassini in Dict. sc. nat, XIX. 304. Lessing Synops, 201. A r te mis 1 a maderas at a a a Linn.

b. LEPTODERRIS DC. $\boldsymbol{l}$. c. Flores radii pluriseriales. Rostrum achenii compressi, ovalis, utrinque attenuati gracile, in cupulam expansum. - Herba aegyptiaca.

Ta nacetu m a e g p ti a c u m Jacq. Hort. Vindob. IIT, t. 88, (Lam. t, 699. $f .3$, )

c. PYRARDA DC. $l$. c. Flore 8 radii biseriales. A che, ni и v. nullo. - Herbae senegambicae.

P y rarda Cassini in Dict. so, nat, XLI, 120. Lessing Synops. 202- non Adans.

2398. Cyathoeline CASS. C a pitulum multiflorum, heterogamum, floribus omnibus tubulosis, marginalibus multiseriatis, femineis, centrali- 
bus plurimis, masculis. I nvo I nerum pluriseriale, discum subacquans. Reeeptaculum nutum, supra involucri basim elevatum, copuliforme. Corolla e tubulosac, femincae tenuissimae, limbo parvo, tridentato, masculae tubo obeonico, limbo quinquedentato. Antherae ..... Stylus.... A chenia glabra, oblonga, ntrinque attenuata, rostro brevi, pellncido. Pap u s nullas. - $\boldsymbol{H}_{\mathrm{c}}$ bac indicae, erectac, ramosac, viscoso-puberulac, odoratae; foliis alternis, pinnatipartitis, lobis obovatis linearibusve dentatis, dentibus lobulisve secus rhachim immixtis, caulinis basi in auriculas dentatas, magnitudine varias dilatulis, capitulis parvis, subglobosis, albidis, in raccinos corymbosos, nudos, terminales disposilis.

Cy athocline Cassini in Annal. sc, nat. 1829. p. 34. Dict. sc. nat. LX. 581, et 595. Lessing Synops, 202, DC. Prodr. $\nu, 373$, T a a a e tum vi seos un Wallich.

2399. Testadia KUNTH. Ca p itulum multiflorum, heterogamum, floribus omnibus tubnlosis, marginalibus pluriseriatis, femineis, centralibus masculis, In v o I u erum imbricatum. Receptacu I um planum, nudam. Corolla tubulosae, limbo quinquedentato, femineae tenuiores. Antherac ...... Stylas ..... A chenia oblonga, rostrata. Pa p pus nullus. - Fruticulus austro-americanus, quadipollicaris, ramosissimus; foliis confertis, linearibus, hirsutis, capitulis solitariis ramos superne aphyllos terminantibus. V. 374.

E stadia Kunth in Lessing Synops. 203. DC. Prodr.

8400. Gymmariolnewa DESF. C a p it u lum multiflorum, heterogamum, floribus omnibus tubnlosis, marginalibus multiseriatis, femineis, centralibus denis duodenisve, ovario efoeto masculis. I n v o l u cri uniserialis squamae paueae, v. is deficientibus bracteae foliaceae binae v. solitariac. Receptaculum convexum, in ambitu paleas flores femineos primum involventes, demum increscentes, in centro fimbrillas, floribus interjectas gerens. Coroll a e tubulosae, femineae basi incrassatae, demum increscentes, tri-quadridentatae, masculae fauce dilatata, limbo quadridentato. Antherae ecaudatae. Stylus floris feminci bifidus, ramis longis, gracilibus, semiteretibns, masculorum simplex, subelavellatus, acutus, grosse papillosns. Achenia in ambitu villosa, oblonga, in centro teretia, glabra, inania. Pappus acheniorum perfectorum pluriserialis, setosus, seaber, abortivorum uniserialis, setis quinis senisve, basi inter se connatis. - Herba persica, annua, humilis, rumosa; foliis alternis, paucis, confertis, oblong is, capitulum bracteantibus, floribus flavidis.

G y ma $\mathrm{r} r \mathrm{~h}$ e $\mathrm{n}$ a Desfont. in Mém Mus. IV. 1, $t, 1$. Cas sini in Dict, sc, nat. $X X I$, 111, XXIII. 566. Lessing Synops. 419. DC. Prodr. V. 374. G y m a rhe a Steudel Nomencl.

\section{SURDIVISID HL. EUCONYZEAE} DC. Prodr. V. 375. Capitula in glomerum haud congesta. Pap us pilosus, unibiserialis.

2401. Thespis $D C$. Capit u In multflorum, heterogramum, floribus omnibus tubulosis, marginalibus multiscriatis, femineis, centralibus paucis, masculis. Involueri pluriserialis squamae oblongae, acutae, disco subbreviores. R e c e $\mathrm{r}$ ta culn m planum, nudum, punctulatum. Corol 1 a e tubulosae, femineae tenuissimae, subconicae, stylum includentes, masculae tuho brevissimo limbo campanulato, quinguedentato. Antherac ecaudatae, inclusae. A $\mathrm{c}$ h $\mathrm{cn}$ i a compressa, glabra. Pap p s achenio brevior, setis $7-8$, crassiusenlis, barbellatis. - Herbae indica c, annuae, erectae, ramosae, glabrae; caule tereti, foliis alternis, oblongis, basi angustatis, apice dentatis, pedunculis axillaribus et terminalibus, capitulis paucis, parvis, subcorymboso-congestis, floribus flavidis, pappo juniore albo, demum subrufescente.

Thespis DC. in Guillemin Archiv. Bot. IT. 517. Prodr, $V, 375$. Cotula e sp. Wallich.

2402. Karelinia LESS. Capitulnm multiflorum, heterogamum, floribus omnibns tubulosis, marginalibus multiseriatis, femineis, centralilsus octonis-denis, hermaphroditis. Invo I u c ri cyindrici squamae wvato-lanceslatae, rigidae, adpressac. Recepta c a l u m planum, nudum. Coroll a e femineae filiformes, truncatac, hermaphroditae tuinlosae, quinquefidac. Anther a e ecandatae. Stylus in floribus femincis gracilis, glaber, stigmatibns divergentibus, elongatis, in hermaphroditis inelusus, longe hispidulus, lobis brevibus, erectis. A e heni a cylindracea, erostria. Pappus in femineis uniserialis, setis tenuissimis, capillarilus, elongatis, in hermaphroditis pluriserialis, setis apice barbellatis. - Herba caspica, perennis, erecta, ramosa, glabra; foliis sessilibus, oblongolanceolatis, integerrimis, margine subscabris, capitulis corymbosis, cylindricis, floribus purpurascentibus.

Karelinia Lessing mse. ex DC. Prodr. $V .375$. Serratula caspia Pallas Voy. $\pi$. $t, 13$.

2403. IBerthelotia DC. Ca pitulum multiflorum, heterogamum, floribns omnibus tubulosis, marginalibus pluriseriatis, femincis, disei paueis, hermaphroditis v. ovario efocto maseulis. Involucri ovati, pluriserialis squamne imbrieatae, adpressae, exteriores latae, breves, obtusae, intimae lineares, discum aequantes, acutae, seariosae. $R$ e e p ta $\mathrm{cn} I \mathbf{~ a m}$ planum, nudam, punctatum. Cor olla e tubulosae, marginales tenuissimae, hi-tridenticulatae, disci majores, limbo quinquedentato. Antherae ecaudatae. Sty Ins in floribus femineis gracilis, glaber, exsertus, bifidus, in hermaphroditis papillosns, subinelusus, stigmatibus ablreviatis, papilloso-hispidis. A chenia sessilia, teretinseula, glabra, erustria. Papp us uniserialis, marginis setis tenuissimis, vix scabridis, basi snbdistinetis, centri setis rigidis, basi subpaleaceis, concretis, apice harbellato-seabris. - Fruticulus in India orientali et in Senegambia observatus, erectus, ramosus, pube brevissima, subadpressa molliter canescens; foliis alternis, sessili. bus, lanceolatis, mueronatis, rigidulis, intererrimis $v$, interdum acute serratis, nervosis, capitulis oblongis, ad apices ramorum dense corymbosis, floribus puipurascentibus.

Berthelotia DC. Prodr, $\nu$. 376, Conyzae sp. Wallich, Perrotet.

2404. Laenuecia CASS, Capitnlum multiflorum, heterogamum, floribus omnibus tubulosis, marginalibus pluriseriatis, femineis, centralibus hermaphroditis. Involucri campanulati sqnamae imbricatae, lineares, apice subulato-acuminatae, coloratae, glabrae. Receptaeuln m nudum, punctulatum. Coroll a e tubulosae, marginales tenuissimae, bi-tridentatae, centrales majores, quinquedentatae. Antherae ecaudatae. A chenia oblongo-obovata, compressa, villusa, erostria. Pappus conformis, biserialis, setosus, 
serie exteriore brevi, multiseta, interiore longa, pilosa. - Herbae americanae tropicae, lanatae, habitu gnaphalioideo; foliis atternis, oblongolinearibus, dentatis $v$. incisis, capitulis ad apices ramulorum axillarium saepius solitariis.

L a en neei a Cassini in Diet sc. nat. XXV. 91. XXXVIr, 462. et 489. Lessing Synops. 203, DC. Prodr. V. 376. C o n y2 a g a phatioides hanth in Humb. et Bonpl. Nov, gen. et sp. t. 327 .

2405. Comyza LESS. C a p it u 1 u m multiflorum, heterogamum, floribus omnibus tubulosis, marginalibus multiseriatis, femineis, centralibus paucis, herma phroditis v. masculis. Involncri squamae pluriseriales. Receptaculum epaleatum, punetulatum v. fimbrilliferum, planum v. con vexum. Co rolla e tubulosae, marginis filiformes, truncatae $\mathbf{v}$. brevissime bi-tridentatae, centri majores, limbo quinquedentato. An $\mathrm{th}$ e $\mathrm{r}$ a e ecauda tae. A cheni a compresso-plana, plerumque glabra, basi attenuata, erostria. P a p us uniserialis, setis filiformibus, vix scabris. - Herbae in regionibus tropicis et temperatis totius orbis provenientes, in America rariores; caulibus erectis, ramosis, teretibus, foliis alternis, variis, integris $v$, varie incisis, semiamplexicaulibus, capitulis pedunculatis, corymbosis v. subpaniculatis, floribus flavis, pappo rufo $v$, rufescente.

C o ny za Lessing Synops. 203. DC. Prodr. V.377. C on y $z$ a e sp. Liun.

a. ANDRYALOIDES DC. ReceptacuIum alseolare, alveolorum uarginibus integris. A e b e $\mathrm{a}$ i a pappum manifeste scabrum aequantia v, subsuperantia. - Herba indica, subacaulis, lanato-tomentosa, scapis monocephalis.

A d d ryalo ides DC. Prodr. V. 377.

b. DIMORPHANTHES Cass, Receptaculam planum, nudun v. brevissime alveolato - subfimbrilliferum. A $\mathbf{c}$ h $\mathrm{e}$ n i a pappo setiformi muito breviora.

D int orph a th thes Cassini in Dict. sc, nat. XIII. 254. XXV. 93, XXXVII, 461, et 481. DC. Prodr. $V, 377$. Eschenbachia Mönch Meth, 573. Krigerontis sp. Liun. Jacq. Hort. Vindob, I. t.79, IIT, t, 19. (Kunth in Humb. et Bonpl. Nov. gen, et sp. t. 336. Ledebour Ic. t. 100.)

c. TUBIFEra $D C$. Receptacul um fimbrilliferum, fimbrillis elougatis, aequalibus. A $\mathrm{c}$ h en i a pappo setiformi multo breviora. - Species mauritiana.

T u bifera DC. Prodr. $Y .386$. C. I a u rifoli a Lam.

d. FIMBRILlaria Cass. Re e p ta $\mathrm{cu}$ I u m fimbrillifernm, fimbrillis centri longioribus, saepe setiformibus. A chen i a pappo setiformi multo breviora. - Species capenses.

FImbrillarla Cassini in Dict, sc, nat, XVIr. 54 . DC. Prodr. $V, 387$, Eriger ontis sp. Liun.

840S. IPhas multiflorum, heterogamum, floribus omnibus tubalosis, marginalibus pluriseriatis, femineis v. ovario efoeto neutris, centralibus hermaphroditis. InvoJucri imbricati squamae plus minus scariosae. Receptaculam plenum, nudum. Corollae tubulosae, marginis tenuissime filiformes, centrales ampliores, limbo quinquedentato. Antherae ecaudatae. A $\mathrm{e}$ he $\mathrm{n}$ ia teretinscula, adpresse villosa, erostria. Pa p pus conformis, uniserialis, pilososetaceus, sctis paucis, subseabris. - Fruticuli mediterranei et canarienses; ramis teretibus, tomentosis, foliis sparsis, linearibus $v$. lanceolatis, inlegerrimis $v$. subdentatis, subtus tomentosis, saepe marginibus revolutis, capitulis ramos ut plurimum apice aphyllos terminantibus, plerumque solitariis, ebracteatis, floribus luteis v. lutescenlibus.

P li ag na lon Cassini in Bullet. soc, philomat. 1819 p. 174. Dict,sc, nat, XIX, 118. XXIII, 561. XXXIX. 400, Les sing Synops, 402. DC. Prodr, V. 397. Couy z a e $\mathrm{G}$ a phatii sp. Lian. et Auct.
240\%. CInionolaena $D C$. Capitu $\mathrm{lum}$ mnltiflornm, heterogamum, floribus omnibus tubulosis, marginalibus pluriseriatis, femineis, disei pancis, ovario efoeto masculis. In v o l u c ri pluriserialis squamae lineares, siceae, albae, glabrae, demum deciduae. R e e p $t$ a c a l $\mathbf{a}$ m nudum, punctatum, post involucri lapsum persistens. CorolI a e tubulosae, marginales tenuissimae, truncatae v. bidentatae, centrales ampliores, quinquedentatae. An th era e caudatae. A $\mathrm{ch}$ en ia teretiuscula, graeilia, villosa, erostria. P a p $\mathbf{p}$ s uniserialis, setosus. - Suffrutex brasiliensis, arboris imaginem minutam referens; trunco nudo, ramis foliosis, apice sericeo canis, mox glabris, foliis alternis, confertis, patulis, linearibus, acutis, supra glabris, sublus sericeo-canis, enerviis, capitulis ramos terminantibus solitariis, sessilibus.

\section{Chi on ol a e na DC. Prodr, $\mathscr{V}, 397$.}

2408. Flaclaotlanmmos $D C$. CapitnI $\mathrm{m}$ multiflorum, heterogamum, floribus omnibus tubulosis, marginalibus pluriseriatis, femineis (?), centralibus paucioribus, hermaphroditis. I n v o l ue $r$ i tri-quadriseriati squamae imbricatae, lineares, acutae. Receptaculum nudum. Corollae tubulosae, marginis tenuissime filiformes, centri ampliores, limbo quinquedentato. Antherae... $A$ chenia teretiuscula. Papp us marginis pluriserialis, setosus, setis conformibus, centri biserialis, squamellis exterioribus paleaceis, acutis, interioribus paucioribus, setiformibus. - Frutex $\mathrm{No}$ vae-Hollandiae, Mesembryanthemi facie, bipedalis, erectus, ramosus, glaber; foliis sparsis, teretiusculis, carnosis, integerrimis, acutis, erectis, ramis apice squamellalis, monocephalis.

Elachothamnus DC. Prodr. Y. 398.

SUIBDIVISIT IV. EUBACCHARIDEAE DC. Prodr, V. 398. Ca pitula dioica.

2409. Polypappens LESS. C a pitula dioica, homogama, floribus tubulosis. Invol u cri campanulati squamae imbricatae. $R$ h a $\mathrm{ch}$ is plana, nuda. Cor oll a e tubulosae, femineae filiformes, masculae ampliores, quinquedentatae. Anthe rae..... Stylus...... A chenia teretiuseula. Pappus femineis et masenlis floribns conformis, pluriserialis, setis plurimis, apice clavellatis.- Fruticuli brasitienses et mexicani; ramulis pubescentibus, demum glabratis, foliis alternis, sessilibus, oblongro-subcuneatis, triplinerviis, capilulis ramos terminantibus solitariis, majusculis, floribus purpurascentibus.

Poly pap p us Lessing in Linnaea $I V .314 . V I .149$. Synops, 204. DC, Prodr. $V .398$.

2410. IBaceharois LINN. Capitula dioica, homogama, floribus tubulosis. Invol u cri subhemisphaerici v. oblongi squamae pluriseriales, imbricatae. Recepta culum nudum, v. rarissime subpaleacenm. M a s c. Cor oll a e tubulosae, fauce dilatata, limbo quinquefido. A $\mathrm{n} t \mathrm{~h}$ e ra e exsertae, ecaudatae. St y l u s plus minus imperfectus. A ehen i a efoeta. Pap p us pilosus, uniserialis, saepius tortuosus v. subplumoso penicillatus, involucrum subaequans. Fem. Corolla e filiformes, subtruncatae. Antherae omninonullac. Stylus bifidus, exsertus. A ch enia sulcato-costata, v, rarius terelia. $\mathbf{P}$ a p p 8 uni-pluriserialis, setis apice attenuatis, involuero longioribus. - Herbae v. saepius frutices, interdum arborescentes, per omnem $A m \mathrm{e}$ ricam, frequentius inter tropicos provenientes, sacpius glabri et resinoso-viscosi, interdum villosi; fo- 
liis alternis $v$, rarissime oppositis, plerumque utrin que in nervulum $v$. alam decurrentibus, integerrimis v. dentatis, capitulis varie dispositis, floribus saepissime albis.

B a c c har is Linn. gen, n. 949. excl. sp. Lam, $t$, 698. L. C. Riehard in Michaux Flor. Bor. Amer. II. 125. Duhamel Arbr. ed. II, t, 60, Kunth in Humb. et Bonpl. Nov. gen, et sp. $322-325$. R. Brown in Linn. Transact. XII, 115. DC. Prodr V. 398. M of ist a Ruiz et Pav. Prodr. III. t, 24. B a ccharis et Sergilus Gärti, Il. 409, t, 174. Bacehar is et Molitua Lessing Synops. 204, 205. B a c charis Cassini in Dict, sc, nat.XVIT, 3. S e rg 11 as Citss, op, cit, XXVI. 431. P in. graea Cass, op. cit. XII. 68. Tursenia Cass. op. cit. XXXVIr. 480. A r r h e n a e h ne Cass. op. cit. LII. 253.-S te. $\mathrm{p}$ h a $\mathrm{n}$ at $\mathrm{t}$ th u s Lehmann Index sem, hort. Hamb. 1826. p. 18.

SURTEIBUS III. 'TARCHONANTIIEAE Lessing Synops, 205. C a p it ul a dioica v. heterogama, nunquam radiata, floribus omnibus tubulosis, marginalibus pluriseriatis, tennissimis, femineis ; centralibus paucioribus, majoribns, hermaphroditis v. masculis. An ther a e ecaudatae. - Eolia alterna.

ID VISID I. EUTARCHONANTHEAE DC. Prodr. V. 429. C apit ul a dioica.

24 1 1 B Brachylaena R.BR. Capitula multiflora, dioica, homogama, floribus tubulosis. Involueri imbricati squamae siccae, corollis breviores. Rece $t$ a $c \mathrm{ulnm}$ angustum, nudnm. Mase, Coroll ae tubulosae, limbo inaequaliter quinquedentato. Antherae connatae, basi bisetae. Sty ins filiformis, simplex, Ovarinm efoetum, hispidum. Pa p p u s paucisetus. Fe m. $\mathrm{Co}_{0}$ rollae ut in maribus, sed angustiores. Antherae liberae, efoetae. Stylus apice breviter bifidns, stigmatibus latis. A e henia glanduloso-pubescentia. P app us biserialis, setis scahridis. Frutices v arbusculae capenses; foliis alternis, breviter petiolatis, coriaceis, integerrimis $v$, dentatis, utrinque glabris $v$. subtus tomentosis, capitulis in racemos subpaniculatos dispositis, corollis luteis.

B rach y lae n a R. Browa in Linn. Transact. XIT, 115. Lessing Synops. 208. DC. Prodr. $\nu, 429$. 01 ig o e a r p ha Cassini in Dict, sc. nat, XXXYT, 21, B a c charid is sp. Lín. Tarehonant bis sp. Thunb. Willd.

2412. Tarehonamthus LINN. C a p itul a saepins multiflora, disica, homogama, floribus tubulosis. Masc. In volucri squamae quinque, uniseriales, ad medinm coalitae. Rece p tacul u m epaleatum, hirsutum. Coroll a e tubuloso - campanulatae, quinquedentatae, extus viscosohirsutae, intus glabrae. Antherae in tubum coalitae, exsertae, breviter appendicnlatac, basi longe bisetae, filamentis glabris, Ovarinm abortivum. Nectarium amplam, callosum, apice concavum, ovarium intra corollam libernm mentiens. Stylus fitiformis, apice obsolete bilohus. Fem. Involueri biserialis squamae plurimae, distinctae. Receptaculam et corollae ut in masculis. St amina abortiva. Ne etari um nullum. S t y lus exsertus, apice bilobus, lobis arcnatorevolutis, A chen ia lanato-hirsutissima. Papp us nullas. - Arbusculae capenses; foliis alternis, petiolatis, coriaceis, supra reticulato - areolatis, demum glabris, subtus tomentosis, capitulis terminalibus paniculatis $v$, rarius ad axillas solitariis.

T a re ho na athus Linn, gen, n, 301. Gärtn. It, 392, Cassini in Dict. sc, nat. LIT, 245. Lessing Synops, 208. DC. Prodr. V. 431, noa Vaill.

2. EUTARCHONANTHUS DO. C a $\mathrm{it}$ a 1 a femineatri-quinqueflora, involucri squamis late ovatis. A chenia lifrsutissima. - Folía indivisa.
E utare hou an thus DC. Prodr. $V_{.431}$. (Lam. $t$. 671. Gärta. t. 166.)

b. HENOTOGYNA $D C$. Capitula feminea uniflora, in. volucri squamis linearibus. A $\mathrm{c}$ he a ia paree hirsuts. Folia cuneata, basi subsinuata, apice obtuse trifida. lobo medio minore.

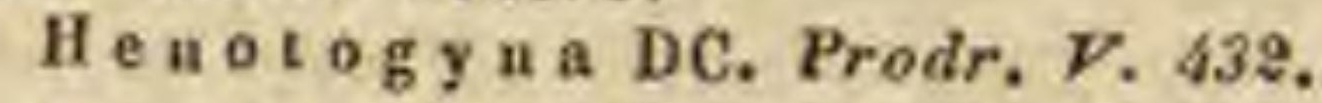

DIVISEO II. PLUCHEINEAE DC. Prodr. V. 432. Capitula heterogama v, monoica.

2413. Blumea DC. Capitulum multiflorum, heterogamum, floribus omnibus tubulosis, marginalibus pluriseriatis, femineis, centralibns pancis, maseulis. Involucri pauciserialis squamae subimbricatae, lineares, acuminatae. $\mathbf{R}$ e e e pta cu I um planum, omnino nudum, v. interdum tenuissime fimbrilliferum, hirsutum. Coroll a e tubulosae, femineae tennissime filiformes, trnncatae v. obsolete bi-tridentatae, masculae cylindrieae, fauce aequali v. vix dilatata, limbo quinquedentato. Antherae basi tenuissime caudatae. A ehenia teretiuscula. Pappus nniserialis, setis capillaribus, vix subscabris. Herbae v, suffrutices, inter tropicos Asia ce copiosissime provenientes, in Africa rarae; foliis alternis caulibusque sacpissime villosis, capitulis paniculatis v. laxe corymbosis, floribus flavis $v$, purpurascentibus.

B I ume a DC. in Guillem. Archiv, Bot, 11, 51\%. DC. Prodr. V. 432. non Alior, Erigero a Don nepal. 171, nов Linn. C on yz ae sp. Blume, Wallich.

2414. Firuelhea CASS, Capit u lu m multiflorum, heterogamum, floribus omnibus tubulosis, marginalibus pluriseriatis, femineis, centralibus paucis, hermaphrodito-sterilibus v, masculis. Invo I u cri pluriserialis squamae imbrieatae, ovatae. R c e e p ta cu 1 u m planum, nudum v. hirsuto-fimbrilliferum. Corolla e tubulosae, femineae tenuissime filiformes, truncatae v. obsolete bi-tridentatae, masculae ampliores, limbo quinquedentato. A ntherae bicaudatae. A chenia cylindracea v. sulcato-angulata. Pap p s uniserialis, setis filiformibus, vix scabris. - Herbae v. suffrutices, in America, Asia et Afrioa calidiore provenientes; foliis alternis, variis, saepe pubescenti-glandulosis, capitulis pedicellatis, corymbosis.

Pl u che a Cassini in Bullet, soc, philomat, 1817, p.3t. DC. Prodr. V. 449.

a. STYLIMNUS DC. Prodr. $V$, 450. Re eeptaculam nadum.

Stylimnos et Gymnema Rafin, Journ. Phys. p. 100. et Ann. nat. p. 15. L e p to g y e Blli ot Carolin, II, 328. non Less. PI ue he a et Ch Iae. nobol us Csssini in Diot. sc, nat. XLIT. 1, B a $\mathrm{c} \mathrm{ch}$ a. ridis et Co a yzae sp. Lian. et Auet. Jacq. Ic, rar. 2. 585. Kunth in Humb. et Bonpl. Nov. gen, et sp. t. 328. - ? P la c us Loureiro Flor, cochinch, II, 606.

b. HeBephoka DC. Prodr. V. 453. Re ce pta culum birsutum.

2413. Pteroeaniom ELL. C a p it n 1 un multiflorum, heterogamum, floribus omnibus tubulosis, marginalibus pluriseriatis, femineis, centralibus pauris, masculis, Involueri oblongi, pluriserialis squamae imbricatae, adpressae $\mathbf{v}$. apice subsquarrosae, caducissimae. Receptaculum planum, tenuissime fimbrillifero-hirsutum, rarius nudum. Co rolla e tubulosae, femineac filiformes, tridentatae, masculae ampliores, quinquedentatae. Antherac basi subulato-bicandatae. A $c$ henia angulata, adpresse pilosa. Pa p p us pluriserialis, setis filiformibus, aequalibns, involuero longioribus. - Herbae interdum basi suffruticosae, in $A m e$ rica boreali calidiore et tropica provenientes; rhizomate tuberoso, sacpe lignoso, caule 
tomentoso, sexfariam foliaceo-alulo, foliis alternis, lanceolatis, integerrimis $v$. denticulatis, supra glabris v. juniwribns araneosis, subtus tomentesis, utrinque in caulis alas productis, capitulis sessilibus glomeratis, in spicus v. thyrsos spicaios dispositis.

Pterocaulon Elliot Carolin. II. 323. DC. Prodr. V. 453. Chla e nobolus Cassiut in Dict, sc, nat, XLIX, 337. Pl ucheae sp. Less.

a. CHLAENOBOLUS DC, $l$. c. R e e p taculum hirsu tam. - C o n y z a e sp. Linn. Swartz.

b. PTEROCAULOPSI: DC. $l, c$, R e cep t a culum nudum.

24 16. Fionenteles $L A B I L L$. C a p itu$1 \mathrm{~nm}$ pluriflorm, heterogamum, floribus omnibus tubulosis, marginalibus bi-triscriatis, femineis, cen tralibus paucissim is v.unice hermaphrodito, interdum ovario effocto maseulo. Involucri oblongi squamae biseriatac, subaequales, persistentes. 12 e e pta $\mathrm{c}$ ln $\mathrm{m}$ planum, angustum, nudum. Corollae tubulosac, femineae filiformes, apice subdentatae, hermaphroditae cylindricae, extus subglandulosac, limbo quinquedentato. Anth er a basi subulatobicaudatae. A e h e n i oblonga, subcompressa, par ce villosa. Pa p u s uniserialis, setis filiformibus, ima basi subeoneretis, involueram vix superantibus, - Herbae habilu gnaphalioideo, in Asiae tropicae insulis indigenae; foliis oblongis v. lanceolatis, denticulatis, utrinque secus caulem in alas longas integerrimas decurrentibus, capitulis sessilibus, ad axillas foliorum floralium fasciculatis, spicas interruptas formantibus.

M o uenteles Labillard. Nov, Calod, t. 43. 44. Cassini in Dict,sc.nat, LIII, 236. DC. Prodr, $V$, 455. T e s s a $\mathrm{r}$ l a e sp. Lessing.

241\%. Tessaria RUIZ et $P A V$. C a p ituI $\mathrm{m}$ multiflorum, heterogamum, floribus omnibus tuhulesis, marginalibus pluriseriatis, femineis, centralibus pancis v. unico hermaphrodito, nune ovario efocto masculo. In vo In eri oblongi squamae im bricatae, scariosae, exteriores breves, ciliatae, persistentes, interiores elongatae, acutae, integerrimae, deciduae. R e c p t a c a l u m tenniter fimbrilliferum, hirsulum. Coroll a e femineac filiformes, truncatae v. bi-tridentatae, centrales majores, apice dilatatae, quinquefidac. An $\mathrm{t}$ h era e basi brevissi me eaudatae. A chenia brevia, teretiuscula, glabra. Pappus uniserialis, setis filiformibus. Frutices Americae a ustralis; foliis ramulisque adpresse cano-villosis, foliis alternis, ovali-oblongis $v$. lanceolatis, integerrimis $v$. dentatis, corymbis terminalibus ramosis, corollis centri purpureis, marginis pallidioribus.

Tes saria Ruiz et Pav. Prodr. 112, t. 24. Cassini in Jiet, sc. nat, LIII, 233, DC. Prodr. $\boldsymbol{V}$. 456, G y nhe ter ia Willd, in Berl. Magaz. 1807. p. 110. G y n ete r la Spreng. Neue Enideck. II. 135. G y n h eteria et Tessaria $\mathrm{T}$. Lessing Synops. 207. 208. - ? P ha la crom es u m Cassini in Dict. sc. nat. LIII, 235. LVIT, 339, LX, 586.

2418. NI onathenus CASS. C a pitula pluriflora, heterogama. florilus omnibus tubulosis, marginalibus subbiseriatis, femineis, centrali unico hermaphrodito v. ovario efocto mascalo. In vol ue ri campanulati, floribus paullo brevioris squamae oblongae, obtusae, apice subtomentosae. IR e c ptaculnm planum, parvum, nudum. Corollae tubulosae, femineae filiformes, tri-quadrilobac, mascula cylindriea, extus subglandulosa, limbo quinquedentato. Antherae apice longe appendiculatae, basi breviter caudatae. Achenia oblongo-cylindracea, supcrne subhispidnla, callo basilari, crasso. Pap pus uniserialis, setis seabris. Frutices mauritiani; foliis alternis, linearibus v. sublanceolatis, integerrimis, supra scabridis, sub- tus tomentosis $v$. sericeis, capitulis ad apices pedun. culorum confertis, subsessilibus, corymbum compositum formantibus, floribus luteis.

Monarrhenus Cassini in Bullot. soc.philomat.1817. p. 44. Dict. sc. nat. XXXIT. 433. LIIT. 236. DC. Prodr. V. 457. M a ho bre t a DC, mse. 1802, C ony z a e sp. Lam, Tes. Sariae sp. Lessing.

24 D. Cyllindroeline CASS. Capitul u m pluriflorum, spiciforme, heterozamum, floribus inferioribus femineis, terminalibus pantis, stylo abortivo masculis. Involuerum oblongum, squamis secns receptacul um spicaeforme, apice suiconcavum imbricatis, wislongis, inferiorilıs sterilibus, ad dorsum apice tomentosis, snperioribus fistoriato-ciliatis, in axilla floriferis. Co rollae tuhnlusac, femineae filiformes, masenlae quinque. dentatac. Achenia oblongo-cylindracea, basi attenuata, subarcuata, octocostata, pilosiuscula. P'a p u 8 uniserialis, paleis axi corneis, pectinatobarbellatis. - Fruticulus mauritianus; ramis basi glabratis, inter folia dense et longe sericeohirsutis, foliis ad apices ramorum confertis, rosulalis, integerrimis, ovalibus, bas $i$ atlenuatis, supra ad basim sericeo-hirsutis, ad ajicem breviter strigilloso-scabris, subtus albo-tomentosis, corymbo composito, conferto, ramis longe sericeo-hirsutis, aphyllis, folia vix aequantibus, floribus cueruleis.

Cylindrocline Cassini in Bullet. soc. philomat. 1817. p. 11. Dict. sc, nat. XII, 318. Lessiug Synops. 207. DC. Prodr. V. 458. Le pid o po g on Tauselh in Flora 1829. p. 37. 1831. p. 224. Conyz a hirsuta Commers.

24:0. Evax GARTN. Capitnlum subspicaeforme, multiflorum, heterogamnm, floribus omnilus tubulosis, inferioribus multiscriatis, femineis, supremis paucis, masculis. Invol ue ri unibiserialis squamae adpressae, seariosac, ovales, aristato-acuminatae. R e e p $\mathrm{ta}$ e $\mathrm{n} \mathrm{n} \mathrm{m}$ elongatum, subulatum, inferne inter flores femineos paleolis scariosis, acuminatis obsessum, superne inter flores masculos nudam. Corolla tubulosae, femineae graciliores, limbo quadricrenato. Antherae... A chenia obcompressa, obovalia, glabra. Pa ppus nullus. - Herbae in Europa australi et in Oriente indigenae, nuper etiam in $\mathrm{America}$ b oreal $i$ reperlae, pusillae, subacaules, cano-tomentosae; foliis allernis, integerrimis, circa capitulorum glomerulum rosulatis, capitulis plurimis, confertis, subumbellatis, medio majore.

Evax Gïrtn. IT, 393. DC. Prodr. P.458. Fil a g o Willd. sp. $I I T$. 2387. Cassini in Dict. se, nat. XVIT. 2. G a phali um Vaillant in Act. Acadom. Paris. 1719. p. 314. Filagin is sp. Linn. Mi eropodis sp. Desfont.

a. EUEVAX DC. l. c. I n vol a e ri squamae et receptaculi palea planae, scariosae, abrupte aristato-acuminatae. Capitula dense umbellata, bracteis foliaceis haud di. stincla, foliis foralibus oirca umbellam radiantibus. - (Gärtn. $t$, 165, Lam. t. 694. Cavauill. Ic. t. 36.)

b. PSEUDEYAX DC, l.c. I n v o I u c r i squamae exteriores lanatae, interiores receptaculi paleae oblongae, chartaceae, obtusae. - Capitula sparsa v. congesta, bracteit foliaceis intermirlis, foliis foralibus inordinale glomorulum cingentibus. - (Delle Aegypt. $2,47 . f$. 2.)

2481. Nilieropsis DC. C a p itu $\mathrm{l}$ u m pluriflorum, heterogamnm, floribus omnibus tubulosis, marginalibus bi-friscriatis, femincis, centralibus subternis, maseulis. In v o I n er i bi-triserialis squamae apice membranaceac, oblongae, subacutae, glabrae. R e e p ta culum angustum, nudum. Corollae tubulosae $\ldots \ldots$ An therae ...... A chenia oblonga, villosa. Pappus parvus, squamellosus. - Herba clilens is, Micropodis facie, non satis nota, multicaulis, vix pollicem longa; foliis alternis, obovatis, adpresse cano-villosis, integerrimis, 
obtusis, mucronatis, superioribus congestis, subverticillatis, in axillis capitula parva, sessilia foventibus.

Micropsis DC. Prodr. $V .460$.

2421. Mieropuss LINN. C a p itul um pluriflorum, heterogamum, floribus marginalibus quinis-septenis uniseriatis, femineis, centralibus totidem masculis. Involucri biseriati squamae interiores flores et fructus radii involventes. $R$ eceptaculu m angustum, nudum. Corollae tubulosae, femineae filiformes, masculae quinquedentatae. Antherae inclusae. Achenia lateraliter compressa, obovata, involncri squamis interioribus inclusa, cum isisdem decidua. $P$ a p p $\mathrm{n} s$ nullus. Herbae in Europa imprimis meridionali, et in America oceidentali indigenae, pusillae, lanato-tomenlosae; foliis allernis, integerrimis, capitulis glomeratis.

M i cr opu s Linn. gen. n. 996. Gärtn. IT. 386. Cassini in Dict. sc. nat. XXXI. 39. Lessing Synops, 205. DC. Prodr. V.460. G n a phalo de s Tournefort Inst. 439.

a. ACANTHOLAENA DC. $l$. $c$. Involucri squamae interiores achenia involventes, derso rigiae aculeato-echinatae. - (Gärtn. t, 164. Cavanill, 1c, t, 36. Lam, t. 694. f. 1.)

b. BOMBYCILAENA DC. l,c. Involucri squamae achenia involventes, inermes, lanatae. (Lam, $t, 694, f$. 2.)

24.2. Epaltes CASS. Ca pitula m multiflorum, heterogamum, floribus omnibus tubulosis, marginalibus pluriseriatis, femineis, centralibus paucioribus, ovario efoeto masculis. Involucri eampanulati squamae bi-pluriseriales, imbricatae. Re e pt a c u lum convexum, nudum. Coroll ae femineae tenuissime filiformes, limbo subintegerrimo, masculae obconicae, quinquedentatae, extus parce glandulosae. Anthera e inclnsae. A chen ia obovato - subangulata, glabra, centralia abortiva. $P$ a p p u s nullus. - Herbae annuae, ramosae, in India orientali, Nova Hollandia et America tropica observatae; foliis alternis, oblongis $v$. obovatis, integerrimis v. vix dentatis, sessilibus aut decurrentibus, pedunculis oppositifolits, capitulis solitariis v. geminis pedicellatis, subpuniculatis.

Ep a It es Cassini in Bullet. soc, philomat, 1818. p. 139. Dict, sc. nat. XV, 6, XXXVIT.339. Lessing Synops, 206. DC. Prodr. F. 461. Et huli a Gärtn. I1. 389, t. 16\%, non Cass. Ethuliae sp. Linn.

2423. Demekin THUNB. Ca pitulum multiflorum, heterogamum, floribus radii pluriseriatis, bilabiatis, femineis, disci tubulosis, hermaphroditis. Involucri campannlati squamae biseriales, discosuhaequales. Receptaculu m planum, nudum. Corolla e radi i bilabiatae, labiis exiguis, aequalibns, integerrimis, d is c i tubulosae, limbo quinquedentato. Antherae ..... A chenia sessilia, erostria, Pa p p s radi nullus, di sci paleaceus, palea una majore, apice palmatisecta, reliquis brevioribus, integerrimis. - Herbae c a$p$ enses, erectae, debiles; foliis alternis, semiamplexicaulibus, oblongis, undulatis, subtus araneosotomentosis, supra glabris, mucrone apiculatis, omnibus integerrimis $v$. superioribus sinuato-dentatis, capitulis paniculato-corymbosis, subconfertis, parvis, floribus albis, involucris glanduloso-hirtellis.

Denekia Thunberg Flor. cap. 665. Willd. sp. III 1912. Cassini in Dict. sc, nat. XIII. 65. Lessing Synops. 206. DC. Prodr. V. 462.

2424. Dipteroeome FISCH. et MEY. $\mathrm{C}$ a p i $\mathrm{tu} \mathrm{lum}$ pauciflorum, heterogamum, floribus radii bilabiatis, uniseriatis, femineis, disei tubulosis, masculis. Involuerum subimbricatum. Receptaculum ...... Corollae radii infundibuliformi-subbilabiatae, dis $\mathrm{c}$ i tubuloso-filiformes, quinquedentatae. Ant herae ecaudatae. St y lus glaber, stigmatibus teretinsculis, patentibus, glandulosis, glabris. Achenia radii cylindracea, curvata, bicornia, cornubus recurvatis, ramosis, d is ci efoeta. Pappus setacens, disci brevissimus. - Herba persica, annua, affinitatis valde dubiae, minuta, subglabra; foliis oppositis $v$, alternis, subsessilibus, linearibus, integerrimis, capitulis uxillaribus, sessilibus.

Dipterocome Fischer et Meyer Inder Sem. hort. Petropolit. 1835, I, 26 .

SURTERIRUS IV. INULEAE Cassini in Annal. sc.nat. 1829. 20. Capitula nunquam dioica, rarius homogama discoidea, plerumque heterogama, floribus radii femineis ligulatis, ligulis disco concoloribus. An the ra e caudatae. R ecepta culum epaleatum, rarissime paleatum. - Folia alterna. Omnes gerontogeae.

DIVISIO I. EUINULEAE DC, Prodr. V. 463. C a pitula pluri-multiflora, haud in glomerulum concreta.

2485. Clanterium DESF. C a pitaI $\mathbf{~ m ~ m u l t i f l o r u m , ~ h e t e r o g a m u m , ~ f l o r i b n s ~ r a d i i ~ u n i - ~}$ seriatis, ligulatis, femineis, disei tubulosis, hermaphroditis. Involueri ovati squamae basi concavae, imbricatae, apice in appendicem rigidam, uncinato-reflexam productae. Rec epta $\mathbf{c u l u m}$ paleaceum, paleis et involneri squamis interioribus flores amplectentibus. Corollae $\mathrm{r}$ a di i ligulatae, dis c i tubulnsae, limbo quinquedentato. Antherae apice acute appendiculatae, basi caudatae. A chenia ovali-subpentagona, glabra, erostria. Pappus radii nulíns, disei e paleis quinque cadueis, basi integerrimis, apice utrinque dense barbellatis. - Suffrutex mauritanicus, rigidus, parce foliosus; ramis tomentosis, apice monocephalis, foliis alternis, lanceolatis, argute serratis, glabriusculis, floribus luteis.

$\mathrm{R}$ h a n t e ri um Desfont. Flor, Atlant, Ir. 291, $t, 290$, Cassini in Dict. sc, nat. XLV. 312. Lessing Synops. 199. DC. Prodr. ${ }^{2}, 463$.

24:6. Invia GÄRT. Capitn $1 \mathrm{~nm}$ multiflorum, heterogamnm, floribus radii uniseriatis, ligulatis v. subtubulesis, femineis v. abortu sterilibus, disei tubulosis, hermaphroditis, Invo I u eri pluriseriati squamae imbricatae. Recepta culum planum v. subeonvexum, nudum. Corolla e radii ligulatae $\mathbf{v}$, subtubulosae, trifidae, dis c i tubulosae, limbo quinquedentato. Antherae basi bisetae. A ch en i a teretiuseula v. tetragona. $P$ a pp u s disci et radii conformis, uniserialis, setis capillaribus, subscabris. - Herbae perennes, rarius biennes v. annuae, in $\bar{E} u r o p a$ et $A$ sia media indigenae; foliis alternis, saepe amplexicaulibus, indivisis, integerrimis $v$, serratis, capitulis ad apices pedunculorum solitariis, saepe corymbosis, flavis.

In u 1 a Gärtner 1 r, 449. Lessing Synops, 198. DC. Prodr. V. 463. In u late et Con y z a sp. Lian.

a. CORvisartia DC. Prodr. V. 463 . In volucri siua. mae exteriores late ovatae, follaeeae, interiores obovatospathulatae, obtusae. Flores radii ligulati. A c he a ía glaberrima, tetragona v. teretiuscula. 
Corvisartia Merat Flor. Paris, edit, 1K, 2. 261. Cassini in Dict. sc. nat. X. 572. I u u a H le u i u Liun. Flor. dan. t. 728. Gärto. t. 170.

b. Bubonium $D C$. Prodr. $V$. 4h4. Invo 1 u er i squamae lineares v. lanceolatae, apice appendiculo parvo foliaceo anetae, exteriores subbreviores. Flores radii ligulati. A che i i teretiuseula.

En I a Duby Bot. gall. 1. 267. Inula e sp. Linn. Jacq. Flor. Austr, $t, 134,162,358$, Append, 19. Hort. Vindob. III. t.5t. Schkuhr t. 247. Flor. dan. t, 4t3.786, Bot. Mag. $t, 1907$. Bot. Reg. t.334. Reichenb. Ic. crit. $t$. 346. Con y z a e sp. Linn. Flor, dan. t. 622. B, B. t. 1195.

c. CAPPA DC. Prodr. $Y$. 469. Involucri squamae multiseriales, obtusiusculae, regulartter imbricatae, exteriores brevissimae, interiores sensim longiores. Flores radii (uniseriales) subtubulosi, bi-tridentati v- brevissime ligulati. A c he n i teretinscula. - Suffrutices indici.

Conyza Don nepal. 176.

d. LIMBARDA DC. Prodr. $\nu$. 470. Involueri squamae paueiseriales, omnizo exappendiculatae, adpressae, acuminatae, interiores paullo longiores. Flores radii ligulati. A c b e n ia teretiuscula, villosa.

L i m b a $\mathrm{r}$ a Adanson Fam. II. 125. Cassini żn, Diet. se, nat. XXIII, 565. XXVT. 437. In u I a e sp. Linn. E. B. t. 68. Eriger o ntis sp. Linn. Jacq. Hort. Vind, $t, 165$.

242\%. Selnizogyme CASS. Capitulum multiflorum, heterogamnm, floribus omnibus tnbulosis, marginalibus paueis, uniseriatis, femineis, centralibus hermaphroditis. Involucri oblongoobconici squamae imbricatae, colorato-scariosae, oblongae, acutae, serrulatae, ciliolatae, glabrae. Recepta $\mathbf{c} 1 \mathrm{um}$ nudum, angrastum. Coroll ae tubulosae, marginales tenues, bidentatae, centrales ampliores, quinquedentatae. An th era e basi breviter bisetae. A chen ia oblongo-cylindracea, glabriuscnla. P a p u s uniserialis, setosus, scabridus. - Frutex canarien $i$ s ramosissimus; foliis al ternis, sessilibus, linearibus, integerrimis, corymbis terminalibus subpaniculatis, polycephalis, pedicellis squamulosis, involucris cilrinis, floribus intensius luteis.

$\mathrm{Sebizog}$ y o Cassini in Dict. sc. nat. LVT. 23. Les sing Synops. 123. DC. Prodr. $P$. 473 . Conyza sericea Ait. Chrysocoma sericea Linn. f.

2485. Varthemia DC. Capitulum multiflorum, homogamum, floribus omnibus tubulosis. Invol ucri obovati, imbricati squamae adpressae, acutiusculae, interiores sensim Iongiores, intimae discum aequantes. Receptaculum alveolatum. Corolla e tubulosae, limho quinquedentato. Ant herae basi bisetae. Stigmata brevia, inclusa. A ehenia oblonga, compressa, pubescentia. Pap p us uniserialis, setis subscabridis. Suffrutex persicus, erectus, ramosissimus, glaberrimus, foliis paucis, sparsis, linearibus $v$. oblongo-linearibus, integerrimis, patulo-deflexis, capitulis ad apices ramorum solitariis, floribus luteis.

Varthemia DC. Prodr. V. 473.

24:3. Vieos CASS. Ca pitul um multiflorum, heterogamum, floribus radii uniseriatis, ligulatis, femineis, disci tulunlosis, hêrmaphroditis. Involucri imbricati squamae lineari-subulatae. Receptac $\mathbf{n} \mathbf{l} \mathbf{m}$ epaleatum, areolatum, planoconvexum. Corolla e radii ligulatae, ligula angusta, disci tnbulosae, limbo quinquedentato. Anthera e basi setoso-appendieulatae. A chenia erostria. Pappus radii nullus, disci eapillaris, uniserialis. - Herbae indicae, annuae, erectae, ramosae; foliis alternis, sagittato-auriculatis, semiamplexicaulibus, lanceolatis $v$. linearibus, integerrimis $v$, parce dentatis, ramis parce foliosis, apice monocephalis, floribus flavis.
Vien a Cassini in Annal. sc, nat, 1829. p. 33. Diet. 8c. nat. LX. 394. Lessing Synops. 199. I n ula e sp. Linn. Wallich.

2430. Fentamema CASS. C a p it ul u m multiflorum, hetcrogamum, floribus radii uniseriatis, ligulatis, femineis, disci tubulosis, hermaphroditis. Involneri subglobosi squamae lineares, imbrieatae, villis longis, mollibus hispidae. Receptaculam epaleatum, subconvexnn. Corollae radii ligulatae, ligula angusta, pubernla, iridentata, disci tubulosae, limbo quinquedentato. Antherae ..... A chen i erostria, hispidula. $P$ ap $p$ us in disco et radio conformis, setis quinque, eapillaribus. _ Herba orientalis, annua, erecta, gracilis, molliler hispida; ramis divaricatis, rubentibus, foliis allernis, obovatis v. oblongis, obtusis, integerrimis, membranaceis, parce villosis, capilulis oppositifoliis, pedunculatis, subglobosis, floribus flavis.

P e ntanema Cassini in Bullet. soc. philomat. 1818. p. 75. Dict. 3c, nat. XXIII. 555. XXXVIII. 373, Lessing Syn. ops. 198. DC. Prodr. $V$. 474.

Z431. Fromeoevaris CASS. CapitnI $\mathrm{m}$ multiflornm, heterogamum, floribns radii uniseriatis, ligulatis, femineis, disci tubnlosis, hermaphroditis, Involucri campanulati squamae imbricatae, lineari-subulatae. $\mathbf{R}$ e e p $\mathbf{t}$ a $\mathbf{c} \mathbf{l} \mathbf{u} \mathbf{m}$ planum, nudnm. Coro 11 a e radii ligulatae, ligula brevi, disci tubulosae, limbo quadridentato. A ntherae basi setoso-appendiculatae. A chen i erostria. Pappu 8 in disco et radio conformis, eaducus, setis uniseriatis, inferne subscabris, superne barbellato-subplumosis, basi conferrmminatis in annulam brevissimnm, setulis paleolisve minimis cornnatum. - Suffrutex parvus, erectus, ad ostia Nili, Gambi et Gangis observatus; foliis alternis, semiamplexicaulibus, oblongis, dentatis, ramis teretibus, monocephalis, floribus flavis.

Francoenria Cassini in Dict. sc. nat. XXXIV. 44. XXXVIII. 374. Lessing Synops. 198. DC. Prodr. $\mathscr{Y} .475$. D uchesnia Cassini in Dict. sc, nat. XIII. 505. A ster e r is pus Forsk. Inu la crispa Delile Aegrpt, $t$. 45. $f$. 2 .

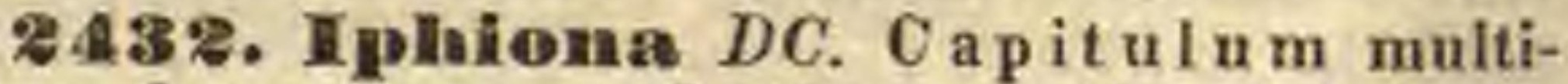
florum, homogamum, floribus omnibus tubulosis, hermaphroditis. I n v o l u e r i obovato-oblongi squamae imbricatae, adpressae, acuminatae $v$. ovales, mucronatae. R e cepta e u lum angustum, alveolatum. Co ro 11 a e tubo nullo, fance longa, cylindrica, limbo quinquedentato. Antherae basi hreviter setoso-eaudatac. A chenia subeylindracea, striato-sulcata, parce hispida. Papp n s rigidns, multiserialis, subseaber, setis exterioribus brevioribus, intimis sensim longioribus, corollam aequantibus. - Fruticuli a g yptiaci, ramosissimi, glabri; folïs paucis, sparsis, subulatis, rigidis, pungentibus, basi biauriculatis, capitulis solitariis ramos apice subnudos terminantibus, floribus luteis, pappo rufescente.

Iphiona DC. Prodr. . 775. Iphio nae sp. Cassint. Chrysocoma e sp. Forsk. Delite $A_{g} g p t, t, 46, f$. 3 . Conyzae et $\mathbf{S t a}$ e helinae $s p$. Auet.

2433. Jasonia DC. C a pitulum multiflorum, homogamum, floribus omnibus tubulosis, hermaphroditis; v. heterogamum, floribus radii uniseriatis, ligulatis, femineis. Involucri imbricati, discum aequantis squamae lineares, acntae. $\mathrm{Re}$ ceptacul um planum, nudum, subalveolatum. Corolla e omnes tubulosae, quinquedentatae, $v$. radii ligulatae. Antherae basi setis eandatae. A chenia villosa, oblongo-cylindracea, basi atte nuata. Pa p p s biserialis, setis filiformibus, bar bellatis, exterioribus brevissimis, interioribus co- 
rollam aequantibus. - Herbae v. suffrutices humiles, in regione mediterranea et in insulis Can ariis provenientes, saepius pilosiv. glandulosi, ramosi; ramis patentibus, apice monocephalis, foliis alternis, sessilibus, oblongis $v$. linearibus, integerrimis aut dentatis, floribus luteis.

Jasonia DC. Prodr. $D$. 476.

a. CHILIADENUS Cass, Capitula discoidea, homogama. A che nia basi villosa, apice glandulosa. P a p p u s in. terior multisetus. - Caules herbacei.

Chiliadenus Cassini in Dict, sc, nat. XXXIV. 34. Myriadenus Cassini $O \rho$, oil. XXIII. 565. non Desv. Orsin i a Bertoloni in Giornale delle seienze Bolongn. 1829. . 362, Rrigeron glatinos um Linn. Inula s a atilis Lam.

b. EUJASONIA $D C$. Ca pitula radiata v. subdiscoidea. A chen Ia teretiuscula, undique villosa. Papp n 8 interior unulisetus. - Caules herbacei v. suffruticosi.

Eujas onia DC. Prodr. V. 476. Jas onia Cassini in Dict, sc, nat. XXIV, 200. E rigeron siculum et E. $\mathrm{t} u$ beros a a Lina. Inulae sp. Auct. Lam. $t$. 680. f. 3 .

c. AllAgopappuS Cass. C a itula discoidea, homogama. A eli enla angulata, ad angulos villosa. P a ppus uterque paneisetus, setis filitormibus, scabris. Caules fruticosi, folia glandulosa.

Allagopappus Cassini in Dict. sc, nat. LVI.21. Lessing Synops. 197. C on y a canariens is Willd. Chry sacom a diehotoma Jacq. Ic. rar. t. $17 t$.

d. DonIOIDES $D C$. Capitula radiata. A $c$ henia sub. angulata, hispida. P a p $\mathrm{i}$ interioris setae paucae, cras sae, cillato-scabrae, exterioris plures, brevissimae.

Donioides DC. Prodr, $V$, 477. B uphthal mum laevigatum Broussonet. D o n i canariensis Lessing.

2434. Pullenria GARTN. Ca pitulum multiflorum, heterogamum, floribus radii uniseriatis, ligulatis v, anguste tubulosis, femineis, disci tubulosis, hermaphroditis. Involueri laxe imbricati, pauciseriati squamae lineares. ReeeptacuI u m planiusculum, areolatum, nudum. C oro II a e radii ligulatae v. anguste tubulosae, bi-trifidae, dis ei tubulosae, limbo quinquedentato. Anthera e basi setis candatae. A chenia teretiuscula, puherula, erostria. P a p p s in disco et radio conformis, biserialis, serie exteriore coroniformi, dentata, brevissima, interioris setis denis v, vicenis, seabridis. - Herbae ut plurimum europea e, paucae africanae et indicae, plerumque loca uliginosa incolentes, villosae, odoralae, erectae, ramosae; foliis alternis, cordato-sagittatis, lanceolatis, integerrimis v, dentatis, pedunculis apice monocephalis, floribus flavis.

Pulie aria Gärtn. $I T$. 461. DC. Prodr. V. 477. In ul a e sp. Línn. et Auct.

a. PULICAR1A Cass. F 1 o r e s radil anguste ligulati.

A chen ia puberula.

Pulicaria Cassini in Dict. sc. nat, XXIII, 365 . XLIV. 93. Lessing Synops. 197. I n u l a e sp. Libn. Flor. dan. $t$. 410, 613. E. B. t. 1115, 1196. (Gärta. t, 173.)

b. TUBILIUM Cass. Flores radil tri-quinquefidi, stepe antheris efoetis donati. A chen ia glabriuscula.

T ubili um Cassini in Bullet, soc, philomat. 1817 p. 153. Dict. sc, nat. XXITr. s65, LVT. 19. Lessing $S y n$ ops. 197.

2435. Strabonia $D C, C$ a pitulum mul tiflorum, heterogamum, floribus radii uniseriatis subligulatis, femineis, disci tubulosis, hermaphro ditis. Involucri pauciseriati squamae lineares disco dimidio breviores. Re e p ta cul u m planum, nudum. Corolla e radii subligulato-difformes, minimae, dis ci tubulosae, limbo quinquedentato. Antherae basi bisetae. A chenia compressa, villosa, apice obtusa, basi subangustata, P a p p us collo vix manifesto ab achenii apice distinctus, duplex, exterior brevissimus, subcoroniformis, dentatus, interioris setis pluribus, uniseriatis, dense et crasse barbellatis. - Herba pers i c a, multicaulis, erecta, dense albo-lanuginosa, pedicellis et involueris subglabratis $v$. pubescentibus; foliis obovatospathulatis, obtusissimis, semiamplexicaulibus, undulatis, capitulis ad apices ramorum solitariis, floribus flavis.

Strabonia DC. Prodr. $V$. 481. Inula gnaphalodes Vent. Cels, t. 75.

2436. Perolletin CASS. Capitulum multiflorum, homogamum, floribus omnibus tubnlosis, hermaphroditis. Involucri bi-triseriati squamae imbricatae, Jineari-subulatae, floribus breviores. Receptaculum epaleatum, punctatum, planum. Corolla e tubulosae, quinquefidae, subringentes. A n t h e $\mathrm{r}$ a e basi longe bicaudatae. A chenia cylindracea, sulcata, subangulata, erostria. Pappus biserialis, paleis seriei exterioris brevibus, interioribus elongatis, filiformibus, barbellatis, fere plumosis. - Fruticuli $v$. herbae $c$ apenses et sene gambicae; folits alternis, ellipticis $v$. linearibus, punctatis, capitulis ad apices ramorum solitariis, floribus flavis.

$\mathrm{Pe}$ golettia Cassial in Dict, sc, nat. XXXVIII. 230. Lessing Synops. 200.

243\%. Geigeria GRIESS. Capitulu m multiflorum, heterugamum, floribns radif uniseriatis, ligulatis, femineis, disei tubulosis, hermaphroditis. Involucri imbricati squamae exteriores laxae, bracteaeformes, foliaceae, interiores adpressae. Receptaculam conicum, epaleatum, piloso-fimbrilliferum. Corolla e tubulosae, limbo regulariter quinquedentato, An th e r a e ......... A ch en i a subtrigona, erostria, basi attennata, pilosa. Pa p us biserialis, paleis octonis v. duodenis obovatis, obtusis. - Herba capensis, humilis; rhizomate lignoso, simplici, caule brevissimo, subdichotomo, folits linearibus, confertis, integerrimis, capitulis fasciculatis sessilibus, floribus luteis,

Geigeria Griesselich in Linnaea V. 411. DC, Prodr. . 482. G eigera Lessing Synops, 199. Z e y heria Spreng. f. Suppl. 92, Dizanium Willd. msc.

SUEIDIVISIO II. CAESULIEAE DC. Prodr. V. 482. Ca pitula uniflora, in glomerulum aggregata, involucro proprio bivalvi, demum cum achenio concreto.

243s. Caesulia ROXB. Ca pitul a plurima, uniflora, in glomerulum aggregata. Invol ucrum com mune glomeruli folia floralia 2_3, orbiculata, colorata, bracteolis paucis, parvis adjectis, propria capitulornm bivalvia, valvis membranaceis, carinatis, basi inter se et demum cum fructu concretis. Recepta culum punctiforme. C o r oll a e tubulosae, fauce ovata, limbi quinqueIobi lobis patulis. Antherae rigidae, hasi setis laevibus caudatae. A $\mathbf{c}$ h e $\mathrm{n}$ i m compressum, valvis involneri acretis, pappum bipartitum simulantibus bialatum. Pappus nullus. - Herba in $d i$ ca, glabra, adscendens; foliis alternis, lancerlatolinearibus, remote serratis, ramulis floriferis axillaribus brevissimis, floribus pallide violaceis $v$, albis, a centro ad peripheriam glomeruli evolutis.

C a es ulli a Roxb. Corom, 1. 64, t. 93. Andr, Bot, He. posit. $t$. 431. Cassini in Dict, se. nat. VI. Suppl. \&. R. Brown in Linn, Transact. XII. 94. Lessing Synops, 200. DC. Prodr, Y. 482. 
SUBTREIBUS $v$. BUPHTHALMEAE Lessing Synops. 209. Capit ula rarissime homogama, saepissime heterogama, floribus radii ligulatis rariusve tubulosis. R e ce p taculum totum paleatum. Antherae longe v. brevissime caudatae, interdum ecaudatae. Papp us coroniformis, lacerus v, piloso-dentatus. - Folia alterna.

2439. Ruplhthalmaum $N E C K$. C a $\mathrm{p}$ tulum multiflorum, heterogamum, florilus radii uniseriatis, ligulatis, femineis, disci tubulosis, hermaphroditis. Involueri pauciseriati squamae longe acuminatae. Recepta $\mathrm{culam}$ totum paleatum, paleis discum aequantibus. Corolla e radii ligulatae, di s c i tubulosae, tube tereti, basi angustate, limbo quinquefido. A $\mathrm{ch}$ e $\mathrm{n}$ i a $\mathrm{r}$ a d i i triquetra, anguste trialata, dis ci plano-compressa, margine interiore unialata. P a p p us in radio et disco conformis, scariosus, coroniformis, piloso-dentatus._Herbae perennes, glabriusculae, in Europa indigenae; foliis alternis, lanceolatis, subintegerrimis, capitulis terminalibus, solitariis.

Bu phtha $1 \mathrm{mum}$ Necker elem, n.34. Cassini in Dict. sc, nat, XXXIV, 276. Lessing Synops. 209. DC. Prodr. $V .483$. Bu phth a Im i sp. Linn. Jacq. Flor. Austr. t.370. Schkulir t. 257. B ustiae sp, Adanson. Asteroidis sp. Tournef.

2440. Telekia BAUMG. C a pitu $\mathrm{lum}$ multiflorum, heterogamum, floribus radii uniseriatis, ligulatis, femineis, disci tubulosis, hermaphroditis. Involncri pauciseriati squamae mucronatae $v$. acuminatae. Recept a c a lum totum paleatum, paleis discum aequantibus. Coroll a e rad i i longe ligulatae, dis c i tubulosae, tubo inferne angustato, limbo quinquefido. Antherae basi caudis elongatis. A ch enia conformia, linearia, elongata, multicostata, triquetro-obcompressa, aptera. Pap pus in disco et radio conformis, coroniformis, subcartilaginens, dentatus, - Herbae in Europa orientali indigenae, erectae, puberulae; foliis alternis, cordatis, amplexicaulibus v. petiolatis, serratis, capitulis terminalibus, solitariis.

Telokia Baumgartn. Flor. Transylv, IIr. 149. exel. eharact. Lessing Synops. 209. DC. Prodr. V. 485, M ol p ad i a Cassini in Bullet. soc. philomat, 1818. p. 166. Dict. sc. nat. XXXII. 400 . B u p h th a I m i sp. Linn. Waldst. et Kitaib. Pl. Hung. t, 113. Reiebenb. To, crit. t, 349. Aster oid is sp. Tournef.

2441. Asteriseus $M O ̈ N C H . C$ a p it $\mathrm{lu}$ m multiflorum, heterogamum, floribus radii uniseriatis, ligulatis, femineis, disei tubulosis, hermaphroditis, Involucri pluriseriati squamae exteriores foliaceae, inermes, obtusae, disco multo longiores. Receptacul um totum paleatum, paleis discum aequantibus. Corolla e radii ligulatae, tubo brevi basi biauriculato, ligula cuneiformi apice tridentata, dis e i tubulosae, tubo inferne incrassato, exalato, limbo quinquefido. An $t$ her a e basi longe caudatae. A ch en ia conformia, triquetro-obcompressa, aptera. Pa p p $\mathrm{s}$ in disco et radio conformis, coroniformis, irregulariter dentatus. Herbae basi suffruticosae, ramosae, plus minus hirsutae, in regione mediterranea imprimis occidentali indigenae; foliis alternis, obovatis, oblongis $v$. linearibus, integerrimis, capitulis terminalibus, demum saepius lateralibus, floribus flavis.

Asteriscus Möuch Method. 592. Lessing Synops. 209. DC. Prodr. $\mathcal{D}$. 486, Na uplius Cassini in Dict, sc, nat. XXXIV. 272. B u p ht hal ni sp. Linn. Gárti. $t .169$. Sehkulir t. 257. Vaht $S_{y m b} t$. 19. Bot. Mag. $t$. 1836. A s ter is ci sp. Tournef. Asteroidis sp. Vaill.
244\%. Pallenis CASS. Capitu $\mathrm{lum}$ multiflorum, heterogamum, floribus radii biseriatis, ligulatis, femineis, disci tubulosis, hermaphroditis. In v ol la cri pluriseriati squamae exteriores foliaceae, patentes, apice spinosae. $R$ e c e p ta c n ln m cutum paleatum, paleis discum aequantibus. $C_{0}$ rolla e radii ligulatae, tubo crasso, bialato, ligula angnsta, apice tridentata, dis c $i$ tubulosae, tnbo crasso, hine marginato - alato, limbo quinquefido. Antherae caudatae. Achenia radii obeompressa, orbieulata, alata, disei subtriquetra, villosiuscula. Pa p p us denticulato-ciliaris, radii dimidiatus, externus, dis c i integer, coroniformis. Herba mediterranea, annua; caule erecto, hirsulo, foliis obovato-aut oblongo-lanceolatis, integerrimis, capitulis terminalibus, solitariis.

$\mathrm{P}$ alle $\mathrm{n}$ is Cassini in Dict. sc. nat. XXXYIT. 275. Les. sing Synops. 210. DC. Prodr. V. 487. A t h a I m u mecker elem. $n$. 33. Buphthal a um spinosum Lian. Sehkuhr t. 257 .

2443. Anvillea $D C$. Capitulu m multiflorum, homogamum, floribus omnibus tubulosis, hermaphroditis. Involu eri campanulati squamae exteriores foliaceae, spathulatae, patulae, interiores biseriatae, adpressae, imbricatae. ReceptacuI $\mathrm{m}$ totum paleaceum. Co roll a e tubulosae, tubo tereti, limbo quinquedentato. A n th e r a e ecaudatae. A chenia conformia, tetragona. Pappus coroniformis, durus, brevis, integerrimus. - Herba persica, erecta, v. multicaulis, diffusa, ad summitates velutino-canescens, ad basim fruticosa; foliis alternis, obovatis spathulatisve, basiattenuatis, grosse et obluse dentatis, capitulis sessilibus terminalibus, v.ramis sub iisdem ortis lateralibus, floribus aureis.

Anvillea DC. Prodr. $V$. 487. B u p th tha $1 \mathrm{~m} i \mathrm{sp}$. Delile in Laborde voy, $t$. 4. Vent, Cels, $t$, 25.

2444. Cervana FORSK. Capitulum multiflorum, heterogamum, floribus omnibus tubulosis, marginalibus pluriseriatis, femineis, centralibus hermaphroditis. I n vol u e r um campanulatohemisphaericum, subbiseriale, bracteis foliaceis cinctum. Receptacul um convexum, totum paleatum. Coroll a e tubulosae, femineae graciles, tridentatae, hermaphroditorum tubo ampliore, lim. bo quinquedentato. An thera e ecaudatae. A cheni a conformia, oblongo-obovata, bicostata, compressa, callo apicali annulari, brevissime rostrata. P a p p 8 coroniformis brevissimus, piloso - dentatus. - Herbae $v$. fruticuli a egyptiaci, hirsuti; foliis alternis, subsemiamplexicaulibus, grosse dentatis $v$, inciso-pinnatifidis, capitulis cymosis, floribus luteis.

Cervan a Forskaël Aegspt, 153. Cassini in Dict. sc. nat. VIIT. 22. Lessiag Synops. 202, DC. Pradr. $V .488$. Buphthalmum pratease Vahl, Delile Flor. Aegypt. $t$. 48. $f .6$.

SUBTRIBUS VI. ECLIPTEAE Lessing Synops. 210. Ca pitula heterogama, floribus radii ligulatis. Receptaculum paleatum. Antherae ecaudatae. Pappus nullus v. aristatus, nunquam setosus. - Folia opposita.

2445. Borxiehia ADANS. C a $\mathrm{i} t \mathrm{tr}$ u m multiflorum, heterogamum, floribus radii uniseriatis, ligulatis, femineis, disci tubulosis, hermaphroditis. Involueri hemisphaerici squamae imbricatae, exteriores foliaceae, acutae, interiores obtusissimae, margine membranaceae. $R$ e c e p t a c uI u m planum, paleis lanceolatis obsitum. C o rolla e radii ligulatae, dis c i tubulosae, fauce subdilatata, limbo quinquefido. An the rae ecaudatae 
nigricantes, A chenia radii cuneata, compressoangulata, corticata, di s c i subdifformia. Pap p u s radii coroniformis, brevissimus, dentatus, dis ci nullus. - Frutices v. suffrutices, in America tropica littorei ; foliis oppositis, oblongis, coriaceis, utrinque mediante ligula triangulari adpressa subconnatis, capitulis terminalibus pedicellatis, floribus luteis.

B orrich ia Adanson Fam, IT, 130. DC. Prodr. $V .488$. D i o m ed e a Cassini in Bullet, soc, philomat. 1815. p. 175. 1817, p. 70. Jict. sc, nat, XIIT. 283. Kunth in Humb. et Bonpl. nov. gen. et sp. IV. 212. Lessing Synops. 240. non Ornitholog. $-? 0$ do ut os permum Neeker elem. n. 36. B uphthalmi sp. Linu.

2446. Eelfpta $L I N N$. Ca p it $\mathrm{l} \mathrm{um} \mathrm{mul-}$ tiflorum, heterogamum, floribus radii uniseriatis, ligulatis, femineis, disci tubulosis, hermaphroditis. Involucri biseriati squamae ovato-lanceolatae, acuminatae. Re cepta cul u m e plano convexum, paleis lineari-filiformibus, apice ciliatis, achenia aequantibus. Corolla e radii ligulatae, ligula brevissima, angusta, dis c i tubulosae, limbo qua dridentato. Antherae eeaudatae. A chenia radi i triquetra, dis ci compressa, ad latera muricatotuberculosa, apice mntica v. brevissime uni-tridentieulata, juniora ad apicem puberula. Fap pus nullus. - Herbae in regionibus tropicis subtropicisque totius orbis provenientes, in America frequentius abviae, ramosae, erectae $v$. prostratae, plus minus scabrae aut hirsutae; foliis oppositis, penninerviis, integerrimis v. serratis, pedunculis axillaribus, solitariis, geminis $v$. ternis, monocephalis, floribus albis.

Eelipta Linn. mant, 157. Gärtn. IT. 441. Cassini in Dict. sc. nat. $X I V$. 231. XLVI. 399, et 410. Lessing Synops. 212. DC. Prodr. $r .489$.

a. EUECLIPTA $D C$, $l$, $c$, A cheni a omaia murieato-tu. berculosa, calva aut vix aristulata, $r$ a d i i triquetra, $d$ is c i subcompressa, oblonga.

Feliptac sp. Auct. Gärtn. $t$. 169. Micrelium Forskael Aegypt. 158. Eu pat orio phalacron Vail lant in Act. Academ. Paris. 1720. p. 32\%, exel. sp.

b. PLATEClipta DC. 1. c. A e he n la laevia v. partim muricata, aristis 2-3 coronata, lateraliter in alau latam complanata, $r$ a dii subtrigona, dis ci compressissina, subrotunda.

244\%. IBlainvillea CASS. Ca pitu I um pauciflorum, heterogamum, floribus radii paucis, uniseriatis, ligulatis, femineis, disci pluribus tubulosis, hermaphroditis. In vo In cri ovato-cylindracei, uni-biseriati squamae erectae, exteriores ovalioblongae, foliaceae, interiores paleiformes. Receptacul $\mathbf{~ n m}$ angustum, planum, paleis flores amplectentibus concavis, submembranaceis, apice dentatis. Co rolla e radii ligulatae, ligula brevi, lata, tridentata, subirregulari, dis ei tubulosae, limbo quinquedentato. A n $\mathbf{t} \mathbf{h}$ e $\mathbf{r}$ a e ecaudatae. A chenia radii triquetra, glabriuscula, ad angulos hispidula, d is c i lateraliter compressa. $P$ a $\mathbf{P}^{-}$ pus aristatus, radii aristae tres, persistentes, rigidae, ciliatae, dis ci geminae, rarins ternae $\mathrm{v}$ quaternae. - Herbae erectae, scabrae v. hirsutae, inter tropicos Asiae, Africae et Americae observatae; foliis oppositis, petiolatis, ovato-rhombeis $v$. lanceolatis, triplinerviis, dentatis, pedunculis ex axillis foliorum $v$. ramorum solitariis v. pluribus, nudis, monocephalis, floribus albis.

B la invill e Cassini in Journ, Phys, 1823. 216. Dict. sc. nat. XXIX. 493. XLVIT. 90, LIX, 138. Lesslag Synops. 912. DC. Prodr, $\mathcal{Y}$. 492. Ue a ce a Cassini in Dict. sc, nat. XXVIT. 9. excl, synon, Ecliptae sp. Lian. Verbesinao sp. Roxb. Walliel.
2448. Salmea DC. C a pitulum multiflorum, homogamum, floribus omnibus tubulosis, hermaphroditis. I nvo I u crum imbricatum. Rece pt a culum conicum, paleatum, paleis convoIntis, flores amplectentibus. Coroll a e tubulosae, fauce vix dilatata, limbi quinquelobi, lobis revolntis. Antherae sagittatae. A $\boldsymbol{c}$ hen $i$ a obcompressa, linearia, aptera, marginibus ciliatis. Pappi aristae geminae, angulis achenii continuae, persistentes. - Frutices erectiv. scandentes, a m e r $i$ c a $n i$, imprimis antillani, affinitatis obscurae; ramis teretibus, foliis oppositis, petialatis, ovatis, acutis, penninerviis, dentatis $v$. subintegerrimis, capitulis paniculato-corymbosis, floribus albidis.

$\mathrm{S}$ a $1 \mathrm{~m}$ e a DC. Catalog. hort. Monsp. 1813. p. 140. Prodr. 7. 493. R. Brown in Linn, Transact, XIIT, 112. Cassini in Dict. sc, nat, XLVIT, 87. Lessing Synops, 218, non Allor. Hopkirkia Spreng. Nov. Prov. 23. Jacq. f. Eclog.t, 139. B i d e n tis sp. Linu. Bot. Mag. t. 2068.

2449. Dahlia $C A V A N$. Capitulum multiflorum, heterogamum, floribus radii uniseriatis, ligulatis, femineis v. neutris, disci tubulosis, hermaphroditis. Involucrum duplex, exterioris squamae foliaceae subquinae, uniseriatae, patulae v. reflexae, interioris duodenae v. vicenae subbiseriatae, longae, apice membranaceae, basi crassiusculac et inter se coalitae. R e ceptaculi plani paleae membranaceae, oblongae, indivisae. C oro ll a e radi i ligulatae, dis c i tubulosae, quinquedentatae. Anth erae appendiculatae, ecaudatae. A ch en i a conformia. oblongo-obovata, obcompressa, apice obsolete bicornia. P a p p a nullus. - Herbae mexicanae, elatae, anno 1790 a Sessè, Mopino et Cervantesio in Europam introductae, ob habitum eleganter spectabilem, et florum autumnalium, coloribus speciosissimis mire in hortisludentium admirandam pulchritudinem, solerter ab adonistis e radicibus fasciculat is multiplicatac, etiam botanicis gratae, omnibus partibus glabrae; foliis oppositis, pinnatipartitis v, rarius bipinnatipartitis, segmentis ovatis, acutis, serralis, ramis elongatis, apice nudis, monocephalis, capitulis amplis, versicoloribus, facile et delicate plenis, disco luteo, radio purpureo, roseo, albo $v$ flavo.

Dab1i a Cavanilles Te. 1,57, c, 80, et 265. 266. Thonia in Annat Mus, III, t. 3. Salisbary Parad. $1,16.19$. Bot. Mag. t. 767. DC. Prodr. $V$. 494. G e org in a Willd. sp. III. 2124. Hort. Berol. t. 93_96. DC. in Annal, Alus, XY. 368. Cassini in Dict. se. nat. LIX. 320.395. Lessing Synops, 211. Ge org ia Spreng. Syst. IIT. 363. excl. sp.

2450. Teptoearpha DC. Capitulum multiflorum, heterogamum, floribus radii uniseriatis, ligulatis, neutris, disci tubulosis, hermaphroditis. Involucri biseriati squamae aequales, lanceolato-lineares. Re ceptaculi subconvexi paleae paucae, lineares, angustissimae, deciduae. Corolla e radii ligulatae, disei tubulosae, tubo cylindrico, extus puberulo, fauce vix dilatata, limbo quinquedentato. Anth e ra e ecaudatae, fuscae. A chenia compressa, obovata, membranacea, pubescenti-subglandulosa. P a $\mathbf{p}$ p i aristae duae, breves, tenues, achenii angulis continuae. Suffrutex chil ensis, a Pöppigio repertus, erectus, glabriusculus; foliis inferioribus oppositis, superioribus alternis, membranaceis, penninerviis, petiolatis, ovato-lanceolatis, dentato-serratis, basiobtusis, apice acuminatis, capitulis pedicellatis, paucis, subcorymbosis, floribus luteis.

Leptacar pha DC. Prodr. $V, 495$.

2451. Siegesbeekia LINN. CapituI $\mathrm{m}$ multiflorum, heterogamum, floribus radii uni- 
seriatis, ligulatis, $\mathbf{v}$. difformibus femineis, disci tubulosis, hermaphroditis. Involueri biseriati squamae exteriores quinque, lineari-spathulatae, patentes, pilis capitatis glandulosae, interiores achenia radii semiinvolventes, erectae, dorso piloso-glandulosae. Receptaculi plani paleae ovali-oblongae, achenia involventes. Ant herae ecaudatae. Cor oll a e radii ligulatae, ligula plana v. irregulari, bi-tridentata, di s e i tubulosae, quinquefidae, pentandrae, v. trifidae, triandrae. A ch en i conformia, obovato-oblonga, subtetragona, introrsum subarcuata. $\mathrm{P}$ a $\mathrm{pp}$ u s nullus. Herbae inter tropicos totius mund, in regione caucasica, America austral $i$ temperata et in Nova-Hollandia observatae, erectae, dichotomae, superne glanduloso-pilosae; foliis oppositis, saepius in petiolum angustatis, ovato-triangularibus, grosse dentalis, subvillosis v. pilosis, pedunculis ex alis ramorum monocephalis, subcorymbosis, floribus luteis.

Siegesbeckia Liun. Hort, cliffort. 412. Heritier Stirp, 37, Gärth. II. 424. Lessing Synops. 211. DC. Prodr. V. 495.

a. PENTAMeranthes $D C$. $t$. $c$. Flores $\mathrm{r}$ a di i ligula plana, disci quinquedentati, pentandri. A chenia areola sive collo brevissimo, integerrimo asperata, ant subealva.

S i eges be ckia Mönch Mrethod. s66. Cassini in Dict. sc. nat, XLIX, 114. LIX. 237. (Lim. Hort. Cliffort. $t$. 23. Cavanill. Ic. t, 253. Bot, Reg. t, 1061.)

b. TRIMERANTHES $D O, t$. c. Flores $\mathrm{r}$ ad $\mathrm{i} i$ ligula brevi, difformi, bi - tridentata, disci tridentatae, triandrae. A c he a i a collo terminali plane destituta.

Trimerauthes Cassini in Dict. sc, nat. XLIX, 114. IIX, 237. Schk $u$ hria Mönch Method, 566. (Heritier Stirp, nov. t. 19.)

2452. Sabazia CASS. Capitul n m multiflorum, heterogamum, floribus radii uniseriatis, ligulatis, femineis, disci tubulosis, hermaphroditis. Invo I u eri subglobosi squamae septem v. octo, biseriatae. Receptaculi conici paleae lineares v. setiformes, glabrae, achenia subsuperantes, intimae ad apicem receptaculi persistentes. CorolI a e extus pilosae, $r$ a d i i ligulatae, ligula cuneata, grosse tridentata, sexnervi, dis e i tubulosae, limbo quinquedentato. A che n i a conformia, pentagona, striata, cnneata, apice mutica. Pap pus nullus.

Herbae Americanae $t$ ropicae, ramosae; foliis oppositis, petiolatis, oblongris, dentatis, glabris, pedunculis alaribus et terminalibus, elongatis, monocephalis, radio albido, extus purpurascente, disco luteo.

Sa baz ia Cassini in Diet. se, nat, XLVT. 480. LV.26 et 273. Lessing Synops. 211, DC. Prodr. $\mathcal{V} .496$.

a. ECI.iptoIDES. Receptacalam conicum. Achenia glabra.

Eclipta hum Il is Kanth in Humb. et Bonpl. Nov. gen. el sp., 394 .

b. VIBORGIOLDES. Receptac u I u m convexum. A chen i a hispidula.

Viborgla urticaefolla Kunth Op. cit. $t .389$.

2453. Cryphiospermum PALIS. C a pitulum multiflurum, heterogamum, floribus intra receptaculi paleas complicatas omnino inclusis, radii pluriseriatis, ligulatis, femineis, disci tubulosis, stigmate imperfecto masculis. Involneri tetraphylli squamae foliaceae, duae oppositae majores. Receptaculi hemisphaerici paleae coriaceae, subglandulosae, apice pilos articulatos pancos gerentes. Cor olla e basi latiores, corneae, apice angustatae, limbo brevissimo in floribus radii subligulato, tri - quadridentato, in diseo campanulato, quinquedentato. An therae ..... Stigmata brevia, extus arcuata, obtusa. A ch e nia obcompressa, basi attenuata, erostria, receptaculi paleis incluss. Pappus nullus. - Herba Africa tropica incola, aquatica, glabra, oppositifolia, dichotoma, procumbens, Enhydrae facie; folits oblongis, remotis, integerrimis v. subserratis, capitulis axillaribus solitariis, sessilibus.

Cryphios perm u in Palisat Flor. Owar. II, 24. t, 74. (deseript. exel.) Cassiat in Dict. sc, nat. XII. 78. Lessing Synops. 210. DC. Prodr. $V$, 497, W a b len ber gi a Schumacher in Act. soc. Hafn, 1829.161. non Alior.

TURIBUS IE. SENECIONIDEAE Lessing Synops. 218. S t y li apice cylindracei, in floribus hermaphroditis superne bifidi, rami longiusculi, lineares, apice penicillati v. truncati, nunc ultra penicillom in conum brevem aut appendiculam elongatam, angustam et hispidam producti. G 1 an d a l a r u m stigmaticarum series latiusculae et prominnlae, usque ad pennicillum seu coni $v$. appendicis originem productae. Corolla disci regulares, pellucidae. Pollen globosum, echinulatum.

\section{SUBRTRIBUS T. MELAMPODINEAE}

DC. Prodr. V.500. Flores omnes unisexuales, in diversis v. iisdem stirpibus, in iisdem v. in distinctis capitulis. Receptaculum vix non semper paleatum. An $t h$ er a e ecaudatae. Pappus nullus v, subcoroniformis aut aristatus, nunquam setosus. St $\mathrm{i}$ mat a pilis collectoribus saepissime deficientibus, interdum deformati $v$, apice barbati.

DIVISID I. EUXENIEAE DC. Prodr. V. 501. Capitula dioica, discoidea, multiflora. Achenia ecorticata.

2454. Fuxenia $C H A M$. C a p itul a multiflora, dioica, homogama, globosa, floribus omnibus tubulosis. Involucri uniseriati, patuli, demum reflexi squamae decem, liberae, aequales, $r$. duae oppositae majores. Receptaculi convexi paleae oblongae, obtnsac, deciduae. Corolla e tubo angusto, fance eampanulata, extus hirsuta et glandulosa, limbo quinquedentato. Antherae ecaudatae, nigricantes, leviter cohaerentes, in floribus femineis efoetac, liberae. S $\mathrm{tig} \mathbf{m}$ a $\mathrm{ta}$ crassa, ohtusa, exserta, in floribus masculis abbreviata, inclusa, dorso hispidula. A ch eni a olpyramidata, tetragona, glabra v. circa areolam apicis minutissime pilosa. Papp a nullus v. brevissimus, auriculiformis. - Frutices chilenses, dichotome ramosissimi; ramis teretibus, junioribus adpresse pubescentibus, foliis oppositis, breve petiolatis, ovatis v. ovali-lanceolatis, triplinerviis, acutis, serratis, utrinque scabriusculis, pedunculis e dichotomiis solitariis v. pluribus, monocephalis, floribus flavis.

$\mathrm{E}$ uxe $\mathrm{i}$ a Chamisso in Hor. phys. Berol. 75. t. 16. Cassini in Dict. sc. nat. XXXY. 446. L. 478. Lessing Synops. 216. DC. Prodr. $Y, 301.0$ g ie ra Spreng. sjst. III. 6z4. non Cass. P o d a n th us Lagasea Nov, gen. 24. Cassini in Dict. sc. nat. XLVI. 404. Lessiug Synops, 419 . non Haw.

2455. Petrobium $R$. BR. Ca pitula pluriflora, dioica, homogama, floribus omnibus tubulosis. Invol u eri campanulati squamae paneae, biseriatae, ovali-oblongae, glabrae, floribus breviores. Rec e taculi convexiusculi paleae invo- 
lucri squamas referentes inter flores. Corolla e tubo brevi, tereti, limbi quadripartiti lohis ovalioblongis. Antherae exsertae, appendienlatae, in floribus femineis efoetae, distinctae. Stigm at a acuta, reeurva, in floribus masculis hispidula. A chenia linearia, compressa, medio utrinque nervigera, sparse hirtella. $\mathbf{P}$ a $\mathbf{P} \mathbf{p}$ u s biaristatus, aristis erectis, strigulosis, subeiliatis, nervis achenii continuis, interdum arista tertia aceessoria.

Arbor triorgyalis, in insula $S t$. Helenae indigena; ramulis alternis, foliis opposilis, petiolatis, late obovalibus, apice serratis, supra glabris, subtus sparse puberulis, paniculae terminalis oligocephalae ramis oppositis, capitulis longe pedicellatis, erectis, albidis.

Petrobla u R. Brown in Linn, Transact. XIT, 113. DC. Prodr. Y. 501. L a $\mathrm{x}$ m a $\mathrm{u} \mathrm{n}$ i a Forst. gen. t. 42. D ri. myphyllum Burehell msc. Spilanthi sp. Forster in Comment, Goitting. IX, 66 .

2456. Astemma LESS, C a p it u I a pluriflora, dioica, homogama, floribus omnibus tubulosis. Invo I u cri tubuloso-campanulati squamae lineares, obtusae, subimbricatae. Re e ptac u I paleae membranaceae, ciliatae, involucri squamas referentes. Corolla e tubulosae, limbi quinquedentati dentibus revolutis. Antherae $\ldots . .$. Stigmata ........ A e henia linearia, breviter stipitata et rostrata. Papp u s nullus. - Arbor quitensis, vix nota; ramis angulatis, puberulis, foliis alternis, subtriplinerviis, subdenticulatis, panicula terminali ramosissima, fastigiata, foliata.

A stem a Lessing Synops, 216. DC. Prodr. V. 502. Monactis dubia Kunth in Humb. el Bonpl. Nov. Gen. et sp. IV. 287.

DIVISIO II. MILLERIEAE DC. Prodr. V. 502. Ca pitula monoica, pauciflora, heterogama, floribus femineis paucis, ligulatis $\mathbf{v}$. trifidis. Recept aculum saepius epaleatum.

245\%. Elvira DC. Ca pitulum biflorum, flore altero masculo, altero femineo. Involuc rum di-tetraphyllum, foliolis duobus oppositis, altero majore orbiculato, basi subcordato, crenato, altero minore, tertio quartoque dom adsunt oblongis, acutis. Receptaculnm minimum, sudum. I a s c. Corolla e tubulosae, limbo quinquefido. Antherae inclusae. Stylus abortivus, breviter bifidus. F em. Coroll a subligulata, tabo longo, ligula brevi, integerrima. Stylus apice bifidus. A cheni um plano-compressum, ovale, involuero immutato tectum, nec inclusum. P a p a s nullus.

Herba americana tropica, annua, trichotoma; foliis oppositis, petiolatis, ovatis v. oblongis, acuminatis, triplinerviis, serrulatis, pubescenti-subscabridis, pedicellis in axillis supremis aggregatis, monocephalis, subumbellatis.

EIvira DC. Prodr. $V .502$. EIvira et Meratia Cas. sini in Dict, sc, nat, XXX. 65 et 67. Delilira Spreng. in Bullet. soc. philomat. 1823. p. 54.t. 1 , nou Kunth. E ug a meli a Flor. Mexic. inedit. Mille ria biflor a Linn. Hort. Cliffort, $t, 28$. Gärtn. $I I, 423 . t, 168$. Lam, $t, 710$.

2458. Milleria CASS. Capitnla panciflora, heterogama, flore unico ligulato, femineo, tubulosis paucis, masculis. Involu erum tri-pentaphyllnm, foliolo uno majore, cneullato. R eс сpta culum parvum, nudum. Masc. Corolla e tubulosae, limbo quinquedentato. A $\mathrm{n} t \mathrm{~h}$ e $\mathrm{r}$ a $\mathrm{e}$ subexsertae. F e m. Co ro Il a ligulata, ligula profunde trifida. Stylus apice bifidus. A chen ium nitidum, plano-compressum, areola laterali, involucro demum carnoso - inilurato, irregulariter gibbo inclusum. P a p p us nullus. - Herbae a mericanae tropicae, annuae, trichotomae, subvillosae; folitis oppositis, petiolatis, ovato-rhombeis, tenere membranaceis, triplinerviis, dentatis, aurieulis stipulaeformibus utrinque inter folia ovatis, saepe reflexis, pedunculis terminalibus dichotomis, pedicellis e dichotomiis et apice rumorum monocephalis, corollis luteis.

Mille ria Cassini in Dict sc, nat. XXX, 67. L,IX, 235. Lessing Synops. 215. DC. Prodr. $Y$. B03. Milleria quin. q u e fl or a Lian. Gärtn. $I$. 423, $t, 168 . f$. 5 . Tam. $t .710$. f. 2. M. die hotom a Cavauill. Ic, $t, 82$.

2459. Tiencourtia CASS. Capitula quadri-septemflora, discoideo-heterogama, floribus omnibus tubulosis, unico femineo, reliquis masenlis. Involucri oblongi, diseo brevioris squamae octonae, biseriatae, aequales, adpressae, coriaceae. Receptacul um parvum, nudum. M a sc. C orolla e tubus brevis, faux ampla, limbus ynadriquinquedentatus, dentibus apice fasciculato-pilosis. Antherae nigricantes. Stylus indivisus, exsertus, F e m. Corolla e cylindricae, limbus tridentatus. St ylus bifidus. A ch enium obcompressum, ovale v. orbiculatum. Pappus nollus. Herbae guianenses, erectae, ramosae; foliis oppositis, petiolatis, lanceolatis, trinerviis, pilosis, subdentatis, capitulis spicatis $v$. ad apicem rami superne aphylli glomeratis.

Rie n c o r tia Cassini in Bullet. soc. philomat. 1818. p. 76. Dict, 5c. nat. XLN. 466. Lessing Synops, 215, DC. Prodr. V. 503. Tetrantha Poitean msc.

2460. Latrelliea $D C$. C a pitula multiflora, heterogama, floribus omnibus tubulosis, marginalibns paucis femineis, centralibus masculis. Invo l a eri uni - triseriati squamae exteriores (bracteae) breves, interiores majores, concavae. R ecepta culi subspicaeformis paleae lateovales, sulorbiculatae, eiliatae, inter flores sitae. Co roll a e tubulosae, marginales tubo brevi, extns pilis articulatis vestito, limbo truncato, centrales glabrae, limbo quinquefido. Ant herae concretae, ecaudatac. Stylus bifidas, stigmatibns crassis, glabris, acuminatis, intus suleatis, in floribus masculis simplex, inclusus. A ehen ia marginis grossa, obeompressa, glabra, centralia aborliva, Pappus nullus. - Herbae brasilienses; rhizomate lignoso, caule herbaceo, basi striato, glabro, apice puberulo $v$, hispido, folitis oppositis, sessilibus, oblongis, subtus glabris, superne hirtellis, corymbo breviter trifido, hirto, capitulis circiler tribus $v$, quinque ovatis, lupulaceis.

Latreille a DC. Prodr, V. 504.

2461. Iehthyothere $M A R T$. C a p itula multiflora, heterogama, floribus omnibus tubulosis, marginalibus subquinis, femineis, reliquis masculis. Involner um minimum, cupuliforme, persistens. Receptaculi paleae singulos flores stipantes. Corolla e tubulosae, marginalium limbus in fimbrias tenuissimas laciniatus, centralinm quinquefidus. Anthera e intus denticulo auctae. Stylus bifidus. Achenia intra receptaculi paleas extimas, increscentes obovata. Pappus nullus. - Herba brasiliensis, perennis, pisces inebrians; folits oppositis, argute serratis, petiolis breviter vaginantibus, capilulis terminalibus pedunculatis, aggregatis, rhachi post grossificationem per dichotomiam exerescente, involucris tunc increscentibus.

1elithyothere Martius Arzneipfl. 27. DC. Prodr. V. 504 .

2462. Clibadium $L I N N$. Capitulum multiflormm, heterngamum, floribus omnibus tubu- 
lesis', marginalibus paucis, uniseriatis, femineis, centralibus hermaphrodito-masculis. In volucri ovati squamae conniventes, ovatae, concavae, interiores saepe achenia marginis in parte concava semifoventes. Receptaculi plani discus nudus, ambitus involueri squamis interdum biseriatis paleatus. Corolla e tubulosae, limbo quinquefido. Stylus bifidus, stigmatibus divaricatis, subrevolutis, glabriusculis, obtusis, in floribus masculis indivisus, apice clavatus, hispidulus. Achenia grossa, ohovata, intus obcompressa, extus convexa, apice pilis articulatis villosa, disci abortiva, gracilia, linearia, villosissima. $\mathrm{P}$ a p p u s nullus. - Herbae $v$. suffrutices americani tropici; ramis teretibus, saepius subvillosis, foliis oppositis, petiolatis, ovatis $v$. lanceolatis, serratis, plerumque asperis, capitulis parvis, ovatis, albidis, in paniculam saepius corymboso-fastigiatam dispositis.

C 1 i b a d i um Linn. Mant. 161. DC. Prodr. $V .505$.

a. EUCLIBADIUM $D C$. A chenia drupacea, succo viscoso scatentia, radii uniserialia. Pa I e a e receptacull nullae.

Euclibadium DC, $l$. c. Clibadium Linn. $l$. c. Cassini in Dict, sc, nat. IX, 395. XXIX. 176. et 181. LIX. 324.

b. OSWALDA Cass. A chenia sicea, villosa, radii uniserialia, obeompressa, obovata, dorso convexa, disc I gracilia, linearia, apice hispida. $P$ a 1 e a e receptaculi nullae.

0 s w a Id a Cassini in Dict, sc, nat, LIX, 319 et 322. Lessing Synops. 215, DC. Prodr. 2. c. Balllieria Aublet guian. II, 805. t.317. Trixis Swartz Flor. Ind, occid. 115. pro parte.

c. TRIXIDIUM DC. A chenia sieca, apice villosa, radi biseriata, exteriora squamis, interiora paleis squamas aemulaatibus extus semilinvoluta, dis ci abortiva, epale ata.

Trixidinm DC. Prodr. N. 506. Baillieria Cassiui in Dict. sc, nat. LIX.324. Lessing Synops, 215. non Aubl. Trixis ros ea Swartz.

2463. Unxia $L I N N$. Capitulum pluriflorum, heterogamum, floribus radii subquinis, ligulatis, femineis, disci totidem tubulosis, masculis. Involueri subglobosi squamae quinque, ovatae. Receptaculum nudum. Corollae radii ligulatae, ligula parva, ovata, disci tubulosae, limbo quinquedentato. An $t$ h e ra e ecaudatae. StyIus ....... A chenia ovata, dura, compressa, laevissima, areola laterali. Pappus nullus.

Herbae guian enses, dichotomae, Camphoram redolentes; folits oppositis, oblongo-obovatis, acuminatis, basi rotundatis, quinquenerviis, villosis, capitulis axillaribus breviter pedunculatis.

Un $x$ i a Linn. fil. Suppl. 56. Jussieu gen. 186. Lessing Synops, 220. DC. Prodr. Y.s07.

3464. Trapalus DC. Capitulum plurillorum, heterogamnm, floribus radii pancis, uniseriatis, ligulatis, femineis, disei pluribus, tubulosis, masculis. I n v olu eri uniseriati squamae quinque v. septem, ovatae. Receptaculum angustum, nudum. Coroll a e radii ligulatae, ligula ovali-oblonga, integerrima, dis ci tubulosae, tubo tereti, fauce campanulata, limbo quinquedentato. Antherae ....... Stylns in floribus femineis bifidus, stigmatibus teretibus, extrorsum arcuatis, A ch enia oblonga, erostria, suleato-angulata, glandulosa, brevia, crassa, velutino-hirtella, disco epigyno superata. - Herba chilensis, tenella, annua, erecta, glabra, versus apicem subvillosa; foliis, alternis, semiamplexicaulibus, basi lineari-petioliformi integris, apice pinnatipartitis, lobis oppositis linearibus, integerrimis, ramis apice pedicelliformibus, monocephalis, corollis flavis.:
Hapalus DC. Prodr. $\mathcal{V}$. 508. Unxia anthemifo. Ii a Bertero msc.

2465. Promaerom CASS. Ca pitu lu m multiflorum, heteroganum, floribns radii quinis, uniseriatis, ligulatis, femineis, disci subduodenis, tubulosis, masculis. Involueri subglobosi, discum aequantis squamae septem, biseriatae, duae exteriores majores, rutundatae, villosae, quinque interiores membranaceae, glabrae. Rec eptaculi plani paleae paucae, inaequales, subulatae. Coroll a e radii ligulatae, tubo glanduloso, ligula elliptica, subintegerrima, disci tubulosac, limbo quinquedentato. Anthera e .... Stylus... Achenia radii lateraliter plano-compressa, Ienticularia, crassa, truncata, laevia, disci efoeta, gracilia. Pappus nullus. - Herba gu ianen$s$ is, annua, ramosissima, villosa; foliis oppositis, lanceolatis, subdentatis, capitulis terminalibus pedunculatis, floribus flavis.

Pronacron Cassini in Dict. sc, nat, XLIII, 370. Lessing Syrops. 214. DC. Prodr. V. 508.

2488. Aiolotheca DC. Capitulum multiflorum, heterogamum, floribus radii pancis, uniseriatis, ligulatis, femineis, disci pluribus, tubulosis, femineis. Involucri biseriati squamae exteriores oblongae, erectae, octonae v. denae, disco breviores, interiores paleas achenia radii semiincludentes referentes. Recepta culi parvi, convexi paleae membranaceae, cuneatae, apice dentatae, acutae, achenia involventes. Co rollae ra di i ligulatae, ligula brevi, obtusa, tridentata, disei tubulosae, limbo quinquedentato. Antherae..... Stylus..... A ehenia radii villosa, subtrigona, villis subcoronata, intra involncri squamas interiores et paleas receptaculi exteriores inclusa, disci gracilia, efoeta, ealva. Pappus nullus. - Herba mexicana, incana, apice corymboso-ramosa; caule tereti, basi glabrato, foliis allernis, sessilibus, oblongis, obtusis, sinuatis, capitulis corymboso-fastigiatis, floribus luteis.

\section{Alolotheca DC. Prod. $V$. 508 .}

\$48\%. 'Trigonospermum LESS. Capitula m pluriflorum, minntum, heterogamum, floribus radii tribus, lignlatis, femineis, disei pluribus, tubulosis, hermaphroditis. Involucri hexa-octophylli squamae lineares, acutae, uninerves, alternae majores, orbiculatae. R e e pta e uli paleae scariosae, difformes, exteriores majores, erosae, interiores lineares. Corolla e radii ligulatae, ligula parva, profunde tri-quadriloba, disci tubulosae, limbo quinquedentato. Antherae ..... Sty $\mathbf{l u s}$ radii bifidus, disci indivisus, inclusus, abortivus. A $\mathrm{c}$ he n $\mathrm{ia}$ radii laevissima, lucida, involucri squama interiore et receptaculi palea exteriore cincta, di s ci nulla. Pa p p u nullus. - Herba m exicana, annua, erecta, dichotoma; foliis oppositis, triplinerviis, rhombeo-ovatis, breviter acuminatis, ad basim petioli cuneato-decurrentibus, utrinque hirsutiusculis, capitulis cymoso-paniculatis, ramis glanduloso-hirsutis, floribus luteis.

Trigon os per m a m, Lessing Synops, 214, in Linnaea IX, 267. DC. Prodr, $\nu, 308$.

2468. Xenismia $D C$. Capitulum pluriflorum, heterogamum, floribus radii quinis-septenis, ligulatis, femineis, disci denis v. duodenis tubnlosis, mascnlis. Invol u eri uniseriati squamae oblongae. R e ceptacul u m epaleatum. Corolla e radii ligulatae, ligula obtusa, basi ciliata, dis c i tubulosae, limbo quinquefido. An th er a e 
..... Stylus ..... A glabra, aculeis rigidis, crassis undique echinata, dis ci nulla. Pappus nullus. - Herba capen$s i s$, annua, subpuberula, erecta, multicaulis; foliis alternis, oblongo-cuneatis, basi angustatis, apice dentatis, capitulis ad ramorum apices pedicellatis, solitariis, parvulis.

\section{Xenis mi a DC, Prodr. $V, 509$.}

2469. Seolospermunn LESS. Capit u I a m pluriflorum, heterogamum, floribus radi uniseriatis, ligulatis, femineis, disci tubulosis, masculis. Involueri triseriati squamae in seriebus duabns exterioribus septenae, subaequales, R e c pta $\mathrm{e}$ uli paleae breviter reclinato-acuminatae, superne ciliatae. Corolla e radii ligulatae, ligula late ovali, disci obconico - tubulosae, limbi quinquedentati dentibus extus hirsutinsculis. An $t h$ erae obtuse appendiculatae, basi ecaudatae. Stylus radii bifidus, disci indivisus, exsertus, teretiuscule clavatus, apice hirsutiusculus. A chenia triquetra, versus apicem tuberculata, receptaculi paleis intimis, capsulatim inclusa; embryonis conformis cotyledonibus conduplicatis. P a p p $\mathbf{x}$ nulIns. - Herba mexicana, erecta, dichotoma, Baltimorae facie; foliis oppositis, petiolatis, ovato-lan ccolatis, acuminatis, serratis, triplinerviis, capitulis in alis dichotomiarum terminalibusque, pedunculatis, floribus luteis.

Scolospermum Lessing in Linnaea $V$. 152, t. 2. f. 19_31. Synops, 219. DC. Prodr. $V_{.}, 509$

24 8. D. HaItimarea $L I N N$. C a pitulum pluriflorum, heterogamum, floribus radii quinque, ligulatis, femineis, disci tubulosis, masculis. Involueri biseriati squamae lanceolatae, adpressae, extcriores foliaceae. Recepta $\mathrm{culi}$ plani paleae amplectentes, membranaceae, apice eiliato-fimbriatae. Corolla e radii ligulatae, disci tubulosae, extus hirsutinsculae, limbo quinquedentato. Antherac ecandatae. A $\mathrm{ch}$ e $\mathrm{n}$ i $\mathrm{r}$ a di juniora subtrigona, obrompressa, pappo coroniformi, dentato, decidno, adulta trigona, laevia, omnino calva, d is ci ahortiva, elongata, compressa, papulosa. - Herbae mexicanae, erectae, annuae; caule abtuse tetragono, scabriusculo, folits oppositis, petiolatis, ovatis, acutis, serratis, trinerviis, subscabridis, capitulis alaribus pedicellatis $v$. rarius in iisdem individuis oppositifoliis, floribus pallide flavis.

B al ti mo ra Línn. Mant. 288. Gärtn. IT. 443. $t$. 169 Schkular $t$. 261. Lam. $t$, 709. Fougerouxía DC. Prodr. V. 509. Niebu hria Seop. Introduct. 134. Baltimoi a et Fougeri a Mönch Method. 592. et Suppl. 243. Cassini in Dict, sc, nat. XXVII, 283. XLVI. 399. et 418.

247 1. Chry somomam LINN. Cap it a I $\mathbf{m}$ multiflorum, heterogamum, floribus radii subquinis, uniseriatis, ligulatis, femineis, disei tu bulosis, hermaphroditis. Invo I u eri pentaphylli foliola oblonga, radium subaequantia. R e ce pta culi plani squamae lineares, obtusae. Coro Il a ra dif ligulatae, dis ci tubulosae, glabriusenlac, tubo brevissimo, limbi quinquedentati dentibus obtusis. A chen ia radii obcumpressa, vix subtrigona, glabra, di s ci abortiva, linearia, elongata. $P$ ap p 8 in radio et diseo conformis, coroniformis, persistens, dentatus. - Herbae perennes, bo reali-americanae, humiles, hirsutae, multicaules, stoloniferae; foliis caulinis oppositis, petiolatis, ovatis, crenatis, capitulis solitariis breviter pedunculatis, floribus luteis.

Chrysog on um Linn. gen, n, 988. Gärtn. $\pi t .436$. Lessing Synops, 220. DC. Prodr.,+510.

a. CHkysogonum Cass. P a p p us corouifornis, ad latus interius fissus, apice crenatus.
C h r y 8 og on u m Cass, in Dict.sc, nat, $X L V 111,543$ Ch. virginian u m Lian. Gärtu. t. 174. $f$. 8. Lam. t. 713. f. 6 .

b. DIOTOSTEPHLS Cass. P a p p s biauritus.

Diotostephus Cassini Op. cit. XLVIIX. 543. C h. virgia ia nu m Michaux, Lam. $t$. 713. f. a.

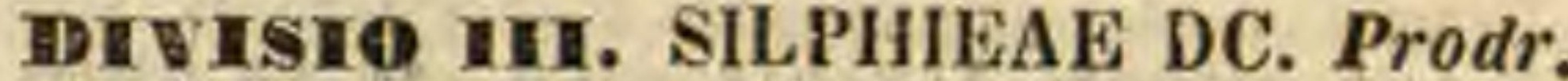
V. 510. Capitula multiflora, heterogama, floribus radii ligulatis, disci tubulosis. It eceptaculi paleae v. squamae nunquam cum acheniis concretae. Achenia ecorticata, calva v, biaristata.

24 2. Guaruliola $H$. et $B$. Ca p itu $1 \mathrm{um}$ pluriflorum, heterogamum, floribus radii ternis $\mathbf{v}$. quinis, ligulatis, heteruchrois, femineis, disci subduodenis, tubulosis, masculis. Involucri triphylli squamae ovales, erectae. Re cepta $\mathbf{c} \mathbf{u} \mathbf{m}$ planum, angustum, paleacenm. Corollae radii ligulatae, tubo longo, basi hispido, ligula brevi, tridentata, dis si tubulosae, tubo elongato, glabro, limbo quinquedentato. Antherae nigricantes. Stylus ...... Achenia radii obcompressa, laevia, disci abortiva. Pap u s nullus. - Herba mexicana, glubra, trichotoma; foliis oppesitis, longe petiolatis, ovato-lanceolatis, acuminatis, serratis, basi subcuneatis, capitulis tern is, pedicellatis, corymbosis, terminalibus, disco flavo, radio albo.

Gua rdiola Humb. et Bonpl. Pl. aequinoct, I, 1at. t. 4t. Nov, gen, et sp. IV. 247. Casxini in Dict, se, nat. $X X$. 12. LIX. 319. Lessisg Synops. 419. DC. Prodr, V. 511. Guandiola Ste.

2473. Ifilalgon LESS. C a pitu I u multiflorum, heterogamum, floribus radii quinis, ligulatis, femineis, disci tubulosis, abortu masculis. Invo lueri cylindraceo - campanulati, disco brevioris squamae biseriatae, integerrimae, obtusae. Re ce p ta culi plani paleae membranaceae, lineares, Córolla e radi ligulatae, dis ci tubulosae, limbo quinquedentato. Stylus radii bifidus, stigmatibus semilanceolatis, disci indivisus, clavatus. A $c$ h en ia dis ci linearia, radii valde compressa, laevia, elliptica, anguste bialata. Pap p u aristato-bicornis, aristis achenii alas continuantibus. Herba mexicana, scandens; foliis alternis, petiolatis, pedati- v. ternatisectis, segmentis lateralibus plus minus bilobis, capitulis terminalibus solitariis, longe pedunculatis, floribus aurantiaceis.

Hidalgo a Lessing in Linnaca VI. 406. Synops. 213. DC. Prodr. $V$. Sit, non Llav. et Lexarz.

2474. Silpiniam $L I N N$. Capituln m multiflurum, heterogamum, floribus radí uniseriatis, ligulatis, femineis, disei tubulosis, marginalibus hermaphroditis, centralibus styli abortu mas culis. Invo I u eri eampanulati squamae imbrieatae, basi adpressae, strictae, apice foliaceae, laxae. R e c e $\mathbf{t}$ a c u l u m subconvexum, paleaceum. Corolla e radii ligulatae, dis ci tubulosae, tubo brevissimo, fauce cylindracea, limbi quinquedentati dentibus superne puberulo-hirtis. Stylus radii bifidus, disci indivisus, apice hispidus. A $\mathrm{eh}$ en ia ra d i i plano-obcompressa, bialata, apice emarginata. Pa p pi dentes v. aristae duae, nunc liberae, nune cum achenii alis utrinque coneretae. Herbae $b a$ reali-americanae, ut plurimum elatae, nonnunquam gummiferue; caule lereti v. tetragono, foliis alternis, verlicillalis v. oppositis, basi saepius connatis, capitulis pedicellatis, floribus luteis.

S ilp h 1 m L Linn. gen. n, 1334. Cassini in Dict, sc. rat. I.IX, 319. Lessing Synops. 213, DC. Prodr. $r$. 311 . 
a. SILPHIA TERETICAULIA DC. $l, c, \mathrm{C}$ a ul is teres v. obsolete hexagonus. Folia alterna v. ternato-verticillata. A che u i a apice biaristata v. bidentata. - Gärtner t. 17t. Jacq. Hort. Vindob, I. t. 43. Jaeq. f. Eclog. $t .90$. Bot. Mag. $t$. 3355 .

b. SILPHIA TETRAGONA DC, $l$, c. C a u lis tetragonns, apice interdum teretiusculus. Folfa opposita, superiora saepe connata. A c benia aristis cum ala omnluo con natis. - Bot. Mag. t. 3354.

94\%5. Polymuia LINN. Capitnlum multiflorum, heterogamum, floribus radii uniseriatis, ligulatis, femineis, disci tubulosis, hermaphroditis, styli abortu maseulis. Involueri duplicis squamae exteriores quinque, magnae, foliaceae, patulae, ovato - Ianceolatae, interiores plures, exteriorilus breviores, sed disco longiores, adpressae, achenia amplectentes. R e cepta culum planum, paleaceum. Corolla e radii ligulatae, dis ci tubulosae, limbo quinquefido. Stylus disci superne pubescens, apice bifidus. A chenia glabra, radii obovata, erassa, subeompressa, laevia, ap tera, disci abortiva, terelia. Pa p us nullus. Herbae erectae, americanae; foliis alternis $v$ oppositis, asperis, semiamplexicaulibus, capitulis subcorymbosis, luteis, disco saepe fusco-purpurascente.

Pol y m n i a Linn, gen, $n$, 987, Gärtn. $I T$, 499. Lessing Synops. 213. DC. Prodr, V. 514.

a. UVEDALIA DC. t. c. Ligu la e elongatae, involucrum superantes.

Poly $\mathrm{m}$ ia Necker elem, $n, 58$, Lam. $t$. 711. Cas. sini in Diet. sc. nat. LIX. 246.

b. ALYMNIA DC. l. c. Ligulae obovatae v. lineares, involuero breviores.

A I y m ni a Necker elem, $n, 57$. Polymnis stru Lan. $i, 711$. Cassini $l$. o.

24r6. Dspeletia MUT. Capitulum multiflurum, heterogamum, floribus radii plurimis, uniseriatis, ligulatis, femineis, disci tubulosis, abortu masculis. Involucri campanulati squamae plurimae, imbricatae. Ke e p ta culi planiuseuli paleae membranaceae, obtusae. Corollae radii Jigulatae, dis c i tubulosae, limbo quinquedentato. Antherae exsertae, breviter caudatae? Stylus radii bifidas, gracilis, dise i indivisus. A $\mathrm{e}$ hen ia ra di i obovata, angulata, disei abortiva (?). Herbae in Andium regione frigida perennantes, dense lanato-tomentosae, resinosae; foliis oppositis, integerrimis, capitulis ramos terminantibus corymbo sis, floribus luteis.

Es peletia Mutis in Humb. et Bonpl. Pl. aequinoct. II, 11. t, 70_72. Kunth in Humb. et Bonpl. Nov. gen, et sp. IV. 280, DC. Prodr. V. s16.

24\% . Berlandiera $D C$. Capitulum multiflorum, heterogamum floribus radii uniseriatis, ligulatis, femineis, disci exterioribus uniseriatis, tubulosis, masculis, centralibus filiformibus, abortivis. Involucri triseriati, foliacei squamae exteriores subternae, oblongae, mediae quaternae v. quinae majores, obovatae, aentinsculae, intimae senae v. octonae maximae, subrhombeac, subdentatae. Receptaculi turbinati, obconici paleae foliaceae, exteriores ad basim squamarum involucri intimarum geminatae, cuenllatae, apice dilatatae, obtusae, interiores in margine et disco receptacnli minores, cuculliformes, flores abortivos foventes v. vacnae. Corollae radii ligulatae, disei tubulosae, limbo quinquedentato, Anthera e.... Stylus ...... A ehenia radii obcompressa, obovato - orbiculata, coriacea, aptera. P a P P u s brevissimus, subaristatus. - Suffrutex texanus; ramis teretibus, hirsutis, foliis alternis, sessilibus, cordatis, ovato-sublanceolatis, crenatis, supra strigilloso-villosis, subtus villoso-canescentibus, capitulis ad apices ramorum ternis $v$. quinis, longe pedunculatis, corymbosis, involucris et receptaculi paleis pubescentibus, floribus flavis.

Berlandiera DC. Prodr, V. 517.

DIVISIQ IV. MELAMPODIEAE DC. Prodr. V. 517. Capitula monoica, hetero. gama, floribus radii pluribus, ligulatis. R eceptaculum paleaceum. Achenia corticata, i. e. cum receptaculi paleis concreta. Pa pus nullus.

2485. VIelampoaliman LINN. Capita. I $\mathrm{m}$ multiflorum, heterogamum, floribus radii quinis v. denis, uniseriatis, ligulatis, femineis, disci tubulosis, masculis. Invo In crum duplex, exterioris squamae quinque, rarius tres, planae, patalae, interiores tot quot flores radii, eosdem involventes. R e ce ptaculi convexo-v. subulato-conici paleae diaphanae, deciduae. Corolla e radii ligulatae, d i s e i tubulosae, limbo quinquefido. A chenia disci abortiva, radii obovata, subcurvata, laevia, involucri squamis interioribus plus minus inclusa, externe tubereulosa v, rugulosa. Pap p u nullus. - Herbae $v$. suffrutices a mericani; caulibus dichotomis, foliis oppositis, pedunculis inter dichotomias monoeephalis, floribus omnibus flavis $v$. radio rarius albo.

Melu ni p od i u m Linn. gen. n. 989. R. Brown in Linn, Transact. XII. 104. Kunth in Humb. et Bonpl. Nov, gen, et sp. IV. 272, Lessing Synops, 217, DC, Prodr, V. S17.

a. EUMELAMPODIUM $D C$. I a vol ucri squamae interio. res achenia radii involventes, extus tuberculosae v, muricatae, nersoso - costulatae, superne il cucullum truncatum desinentes, $v$. in aristam uncinatam productae.

Eumela un podium DC. $l$. c. Melampodium Linn. l. c. Gärtn. IT. 436. t. 169. Cassini in Dict, oc, nat, LIX. 232.

b. ZARABELliA Cass. Invol ucri squamae interiores achenia radif invulventes rugosae v. tuberculatae, super. ne truncatae $\mathbf{v}$. in muerones dentesve $1-3$, antice sub hiantes, et achenii apicem denudatam monstrantes productae.

$\mathrm{Z}$ a r a belli a Cassini in Dict. sc, nat, LIX, 240. DC. Prodr, l. o. Dy sodium L. C. Richard in Pers. Ench. II. 489. Colla in Act, Taurin, 1827, p.323. A I c in a e sp. Lagasea, Jaeq. f. Elog. t. 78 . M e la m pod ii s p. Kuutit Op. cit. $t$. 399 . Reicheub. Ic, exot, $t$. 12.

c. ALCINA Cav. Invol u eri squamae interiores achenin radil iuvolveutes ovali-oblongae, laeves, apice tubercula minima, 2-4 gerentes, inter tubercula foramine miaimo aperta. A c he a i a striata.

A l ci n a Cavanill. Ic. I, 10, t. 15. Cassini in Dict, sc, nat, LXIX, 242, DC, $l$, c, C a muti a Bonat.- ? Hid a I g a Llav, et Lexarz. Nov, veget, I. 15. non Less.

2479. Acanthospermum $S C H R A N K$. C a p i tu I u m pluriflorum, heterogamum, floribus radii uniseriatis, ligulatis, femineis, disci tubulosis, hermaphroditis. Involueri uniseriati squamae quinque, elliptieae, coneavae. Receptaculi plani paleae exteriores ovaria radii involventes, extus aculeis herbaceis nncinatis muricatae, interiores flores masculos stipantes conravae, apice dentatae. Coro 11 a e radii ligulatae, ligula eucullata, disci tubulosae, limbo quinquedentato. A n thera e ecandatae, appendiculatae. Styli bifidi, stigmatibus recurvatis, apice glabris. Achenia dis ci abortiva, radi paleis aculeatis arete invoIuta, compressa, obtusa, basi subattenuata. P a pp s s nullus. - Herbae americana e, humiles, ramosac, diffusae, trichotomae; foliis oppositis, sublus 
punctatis, capitulis parvulis, ad apices $v$, in dichotomiis ramorum solitariis, corollis luteis.

A canthos permum Schrank Hort. monac. II. $t .53$. DC. Prodr. $V$. 521. Centrospermum Kunth in Humb. et Bonpl. Nov. gen, et sp. IV.271. Cassini in Dict, sc, nat. LIX, 235. et 244. Lessing Synops. 217. E chinodiu m Poiret msc. M ela upodil s p. Liun. R. Brown.

a. XANTHIOIDES DC. 1 . $c$. Receptacall paleae exte. riores achenia radii involventes longitudinaliter suleatostriatae, secus nervulos aculeatae, apice obtusae.

Me I a modi um a us trale Linn. (Kunth Op. cit. t. 397.)

b. CERATOLAENA DC. l. c. Recepta cull paleae exteriores acheuia radii involventes exsulca, apice elongato - bicornia.

Mela mpod I n h $\mathrm{nmile}$ Swartz. Moris in Act. Academ, Taurin, XXXVI, 193.

DIVISTO v. AMBRosieAE DC. Prodr. V. 522. Capitula sexu distincta, monoica. Involucra saepius gamophylla, mascula multiflora, feminea uni-pauciflora. Coroll a e tubulosae, breviter quinquedentatae, in floribus femineis saepius nullae. An the rae ecaudatae, approximatae nec revera connatae. A chenia calva.

2480. Xauthium TOURNEF, Capitula heterocephala, monoica. Mase. Involueri subglobosi, multiflori squamae liberae, uniseriatae. Receptaculam cylindraceum, paleatum. Corolla e clavato -tubulosae, pilosiusculae, limbo breviter quinquelobo. Staminum filamenta corollae vix adnata; antherae liberae, ecandatae. Stigmata 2 , concreta. F e m. Involueram ovatum, gamophyllum, biflorum, hamato-aculeatum, rostris 1-2 superatum. Coroll a e filiformi tubulosae. Stamina nulla. Stigmata 2 , linearia, divergentia, ad latera papillifera. A $\mathrm{eh}$ en i a compressa, involucri demum indurati, bilocularis, loculis inclusa. - Herbae annuae, ramosae, in ruderatis climatis temperati et culidi totius orbis obviae; foliis alternis, incisis, capitulis irre gulariter glomerato-spicatis, spica terminali, superne mascula, inferne feminea.

$\mathrm{X}$ a a thi u mouraefort inst, $t$, 252. Linn, gen, $n, 1056$. Gitrtu. II. 418. Cassini in Diet, sc, nat. XXV, 195. Lessibg Synops. 219. DC. Prodr. V. 522.

a. EUXANTHIUM DC, $\boldsymbol{l}, c$. Involu cri fructiferi rostra duo, apice plus minus uncinato-incurvata, raribs recta. - Spinae ad basim fotiorum nullac. Folia cordata, in sinu cuncata, triloba, dentata. (Sehkuhr t.291. Gärtn. $t$. 164. Cavanill. Ic. $t$. 221. Lam. $t, 665, f$. 1 . Flor, dall. t. 270. E. B. $t$. 2544. Reichenb. Icon, $t, 323$, Flor, Flum. X. t. 23.)

b. ACANTH OXANTHIUM DC. $l$. c. Involucri fenctiferi rostrum saepius unicum, semper rectum. - Spinae ad basim foliorum validae. Folia basi cuneata, nunquam cordata. (Lam. t, 665, f. 2, Flor. Flun. $x, t, 24$.

8481. Franseria $C A V$. Capitula he terocephala, monoica. Masc. Involnernm hemisphaericum, gamophyllum, octo-duodecin dentatum, multiflorum. Receptaculam planiuscn. Ium, paleis filiformibus inter flores. Corolla tubulosae, quadrifidae, Stamina imae corollae inserta, tobo vix adnata; antherae liberae. Ova ri rudimentum. Fem. Involuerum ovatum, extus aculeatum, apice in cornua $3 \ldots 4$ cava desinens, uniflorum, $v$, intus in loculos $\overline{3}-4$ unifloros divisum, Corolla nulla v. stylo adpressissima. Antherae nullae. Stylns filiformis, inter involucri cornua exserius, hifidus, stigmatum apice obtuso, A c heni a calva, in involucri loculis nidu-
Iantia. - Suffrulices v. herbae americanae; foliis alternis, grosse dentato-lobatis, uni-bipinnatisectis, capitulis spicatis, masculis superioribus, femineis inferioribus, saepe aggregato-spiculatis.

Franseria Cavanilles Ie. 1T. 78. Willdenow Spec, 1V. 378. Cassini in Dict, sc, nat, XVII, 364. Lessiug Synops, 219. DC. Prodr, $\boldsymbol{V} .524$.

a. XANTHIOPSIS DC. l. c. Invol u c $r$ a fruetigera acu. leis mollibus, uncinatis hispida. - (Cavanill. Ic, 6. 200. Willd. Hort. Berol. $t$, 2.)

b. CENTKOLAENA DC. 2 , c. I a voluera fructigera acnleis spinescentibus echinata. - CLessing in Linnaea PI. 807.$)$

248\%. Ambresin TOURNEF. Capitu la hetcrocephala, monoica. Masc. Involucra distincta, pluriflora, squamis uniseriatis, plus minus in cupulam connatis. Receptaculum nudam. Coroll a tubnlosa, brevis, limbo quinquedentato. St a minum filamenta brevissima, distincta, antherae liberae. Ovarii rudimentum. Fem. Invo I u cra uniflora, gamophylla, aggregata, invoI uero comnuni libero cincta, bracteolis interpositis distincta. Corolla nulla. Stamina nulla. Stigmat a clongato-filiformia, exserta. A ehe$n$ i $\mathrm{m}$ involucro persistente angulato, rostrato v. in cornua excrescente inclusum. - Herbae $v$. suffrutices, in regionibus mediterraneis, in Asia et Africa tropica parce provenientes, in America imprimis tropica copiose crescentes; foliis inferioribus oppositis, superioribus alternis, pinnatilobatis $v$. trilobatis, rarius indivisis, ramis in spicam, basi compositam femineam, apice simplicem masculam desinentibus.

A $n$ b ros i a Tournef. inst, $t$. 239. Linn, gen, $n, 1057$. Gärtn. $I I .417, t$, 164. Lam. $t$. 765. f. 1. Cassiai in Dict, sc. nal, $X X Y$. 203, Lessing Sjnops, 219.

DIVISIO VI. IVEAE DC. Prodr. $\boldsymbol{V}$. 527. Ca pitula heterogama, discoidea. C oroll ae omnes tubulosae, interdum in floribus femineis nullae. Antherae liberae, approximatae. Styli in floribus masculis apice incrassati, in floribus femineis bipartiti $v$, simplices, elongati, fere subulati, hispiduli.

2483. Pinillosia OSSA. Capitulum heterogamum, quadriflorum, floribus duobus masculis, tubulosis, cum totidem femineis, apetalis alternantibus. Invo I n $\mathrm{eri}$ tetraphylli, extas brat:teolis duabus linearibus brevibus stipati squamae cruciatim oppositae, trinerves, basi subeoneretae. Receptaculum planum, epaleatum (?). Flores masculi ante involucri squamas minores siti. Corolla tubulosa, tulo tereti, fauce aperta, limbi quinquelobi lobis ovatis, papilloso-puberis. Anthera exsertae, ovato-oblongae, utrinque obtusae, approximatae, liberae. Ovarium abortivum. Sty Ins antheras paullo superans, apice bilobus, incrassatus, glaher. Flores feminei ante involucri squamas majores siti. Corolla nulla. St y Ii rami ad basim fere distincti, elongati, graciles, apice subhispidi, A ch e ni a obnvata, subeuneata, juniora praeter apicem mucroniformem instructa p a p o quadriaristato, aristis crassis, retrorsum aculeolatis, apice capitellatis, adulta quadricornuta, cornubus conicis, nudis, patulis. $\mathbf{E}$ b ry on is erassi cotyledones obovatae, extus convexae - Herba antillana, elegans, repens, gla. berrima, Linnaeam parvulam quasi referens; fotiis oppositis, orbiculatis, longe petiolatis, integerrimis, pedunculis axillaribus petiolos superantibus monocephalis, floribus albis.

Piuillosia Osaa ex DC. Proulr, V. s2s. 
2484. Tetranthas SWARTZ. C a p itu$1 \mathrm{u} \mathrm{m}$ heterogamum, quadriflorum, floribus omnibus tubulosis, masculis duobus cum totidem femineis alternantibus. In vo I u cri tetraphylli, extus bracteolis quatuer v. quinque linearibus, ciliatis, acentis stipati squamae ovales, obtusae, duae exteriores paullo majores. R e e p ta culi plani paleae convolutae, amplectentes. Flores masculi ante involueri squamas minores siti. Corolla e tubo gracili, fauce infundibuliformi, limbi quinquelobi, lobis oblongis, subpuberulis, subinaequalibus. Antherae oblongae, apice breviter mucronatae, approximatae nee concretae. Flo res fem in e i ante involucri squamas majores. C o ro $\mathrm{Ll}$ a e tubulosae, limbo quinquedentato. Stig mat a longa, gracilia, exserta, apice divergentia, hispidula, Achenia oblonga, substriata, receptaeuli paleis involnta. P a p us brevis, coroniformis, ciliolatus. - Herbae damingenses, repentes; foliis oppositis, petiolatis, ovatis, mucronulatis, pedunculis axillaribus nudis, folia superantibus, monocephalis, floribus ulbidis.

Tetra uth as Swartz Prodr. 116. Flor. Ind.occid. IIT. 1885, t. 27. Cassini in Dict, sc. nat, LVII. 343. Lessiug Synops. 480. DC. Prodr. V. 528.

2485. Iva LINN. C a pitu lu m heterogamum, multiflorum, floribus omnibus tubulosis, marginalibus paucis, uniseriatis, femineis, disci pluribus masculis. In vo l n crum saepius tri - tetraphyllum, campanulatum, squamis ovatis, subuniseriatis, basi plus minus connatis, rarius imbricatum, squamis pluribus, tri-quadriseriatis. R eceptaculi plani paleae lineares v. lineari-spathulatae. Flores in asculi centrales. Corolla e tubulosae, obconicae, limbi quinquedentati dentibus revolutis. Anth erae exsertae, muticae, distinctae. Stig m a ta hrevia, incrassata. A e h eni a abortiva. Flores feminei marginales, uniseriati. Corolla tubulosae v. eampanulatae, limbo quinquedentato. A ch en i a obeompressa, mutica. Pa p pus nullus. - Herbae v. frutices, in America, imprimis boreali provenientes; foliis oppositis $v$. superioribus alternis, trinerviis, integerrimis v. serratis, capitulis in foliorum superiorum axillis solitariis $v$. ternatis, breviter pedicellatis, deflexis, semiglobosis, racemos terminales, foliatos formantibus, corollis albidis, antheris luteis.

I v a Linn. gen, n. 1059. Gärtn. II. 394, t. 164. Selımiedel Ic, t. 16. Cassini in Dict, sc, nat. XXIV, 43, LIX, 176. Lessing Synops. 219. Hooker Flor. Bor. Amer, t, 106. DC. Prodr $V$. 529, D e n i r a Adans. Fam. II. 118.

2486. Euphrosyne DC. Capitulum heterogamum, multiflorum, floribus marginalibus uniseriatis, apetalis, femineis, disci tubulosis, masculis, centrali abortivo filiformi, apice penicillato. Involucri uni-biseriati squamae obovatae, mar gine submembranaceae, patentes. Re c e p t a c u Ii planiusculi paleae obovatae, membranaceae, exteriores majores, intimae multo minores. F lo res mas culi. Cor o II a e tubulosae, brevissimae, limbo quinquedentato. A n $\mathbf{t h}$ e $\mathbf{r}$ a e distinetae. Fem. Corolla nulla. Stigma ta teretia, glabra, obtusa. A chenia obeompressa, margine ealloso cincta, laevia, inter involucri squamas et paleas receptaculi exteriores sita, mutica. $P$ a $p$ p u s nullas. - Herba mexicana, erecta, glabra, habitu inter Ambrosiam et Parthenium ambigen's; foliis alternis, petiolatis, pinnatipartitis, lobis oblongis, pinnatilobatis, sinuatis, lobulis secus rhachin parvis, sinuato - dentatis, capitulis breviter pedicellatis, paniculam ramosissimam formantibus, floribus albidis.

Euphrosya e DC. Prodr, $V .530$.
DIVISID VI. PARTHENIEAE DC. Prodr. V. 530. Capitula lieterogama, floribus radii uniseriatis, ligulatis, femineis, ligulis subcoriaceis, persistentibus v. sero deciduis, disci tubulosis, quinquedentatis, masculis. R eceptaculum saepius paleatum. Achenia radii obcompressa, margine calloso cincta $v$. rarius trigona.

348\%. Coniothele DC. Capitulum multiflornm, heterogamam, floribus radii septenis v. denis uniseriatis, ligulatis, femineis, disei pluribus, tubulosis, maseulis. Invol a c ri campanulati squamae septem $\mathbf{v}$, decem, subuniseriales, oblongae. Rec e p ta eulum convexum, epaleatum. Corolla e radii ligulatae, disei tabulosae, fauce ampliata, limbo quinquedentato. Anther a e ...... Stigmata.... A chenia disci nulla, radii teretia, papillis minutis confertis pulverulentovelutina. Pap p us nullus. - Herba ca lif orn $i$ c a, tenella, annua, erecta, glabra, subsimplex; foliis alternis, pinnatipartitis, rhachi lobisque bi-trijugis, remotis, linearibus, capitulis terminalibus pedicellatis, solitariis.

Conit othele DC. Prodr, V. S31.

2488. Leptosyne $D C$. C a p it u 1 u m multiflorum, heterogamum, floribus radii uniseriatis (?), ligulatis, femineis, disci tubulosis, abortu masculis. Involneri biseriati squamae exteriores paucae, lineares, foliaceae, discum subsuperantes, interiores ellipticae, vix acutae, submembranaceae, disco aequales. R e e p ta euli paleac membranaceae, laneeolatae, persistentes. Coroll a e radi i ligulatae, ligula late ovato - subrotunda, di sc i tubulosae, fauce obconica, basi subbarbellata, limbo quinquedentato. Anthera e ecaudatae. Stylus bifidus, radii vix exsertus, obtusus, dis ci inclusus, ramis cono hispido, brevi, lato eapitellatis. A chenia (immatura) obeompressa, margine subalata, glabra. Pap p u s nullus v. minimus, coroniformis. - Herba californica, annua, tenuis, glabra; radice simplici, gracili, foliis subradicalibus erectis, angustissime linearibus, aliis integerrimis, aliis lobis parcis linearibus pinnatipartitis, canle tereti, gracili, nudo, monocephalo, folia triplo $v$. quadruplo superante, floribus flavis.

Leptosyne DC. Prodr. $\nu .531$.

2489. Parthenium LINN. C a pitulum multiflorum, heterogamum, floribus radii quinque, uniseriatis, ligulatis, femineis, disei pluribus, tubulosis, styli abortu masculis. Invol u cri hemisphaerici squamae biseriatae, exteriores ovatae, interiores suborbiculares. R e ce pta culi conici v. cylindracei paleae semiamplectentes, membranaceae, apice latiores. Corolla e radii ligulatae, ligula oheordata brevi, dis ci tubulosae, limbo quinquedentato. Stamina imo corollae tubo inserta, antherae juniores vix cohaerentes. StyI s s disci indivisus, radi $i$ bifidus, stigmatibus semiteretibus, obtusis. A chenia oheompressa, laevia, margine calloso, utrinque basi squanis contiguis adhaerente, et demum ab ovario secedente eineta, Pappus bisquamellatus, squamellis aristaeformilus v, suborbiculatis. - Herbae v, suffrutices hirsuto-canescentes, in America cis a equatore $m$ indigeni; foliis alternis, capitulis fastigiato. paniculatis, albidis.

Parthenium Lian, gen. $n$, 1058. Gärta. IT. 489. Cas sini in Dict. sc. nat. XXXVITI. 14. Lessing Synops. 319. DC. Prodr. $V$. 331 . Parthe is iastrum Nissol in Let, 
Aoadem. Paris. 1711. H ysterophor us Vallaat in Act. Aoadem. Paris. 1720, p. 335. Tricbospermum Palisot misc.

a. PARTheniastrum DC. $l$, c. Pappi squamellae te nues, brevissimae v. nullae. - Folia integra. (Gärtu. t. 168. WHld. Hort. Berol. t, 4.)

b. PARThenichaeta DC. $l$. c. Pappus biaristatus, aristis longis, rigidis: - Folia obtuse sinuato pinnatifida. (Humb. Bonpl. et Kunth Nov. gen. et sp. t.391.) c. ARGYR0CHAETA DC. $l$. c. Pappi squamellae ovalioblongre, obtusae, membranaceae. - Folia bipinnatipartita. - Arg y r o elo a eta Cavanill, Io, IV. 54, t. 878. Villa no va Ortega Decad. 48. t, 6.

2490. VIendezía $D C$. Ca pita lum mul tiflorum, heterogamum, floribus radii paucis, uniseriatis, ligulatis, femineis, disci tubnlosis, ovario efoeto masculis. Involueri imbricati squamae paucae, bi-triseriales, ovales, obtusae. Rece p taculi parvi, conici paleae membranaceae, oblongae, complicatae. Corolla e radii lizulatae, tarde deciduae, ligula elliptica, dis ei tubulosac, tenues, glaberrimae, limbo quinquedentato. Stig mat a disci summo apice hirtella. A $\mathrm{chen}$ ia dis ci compressa, abortiva, radii obcompresso-plana, elliptico-cuneata, apice emarginata, breviter biaristata, utrinque glabra, margine snbtuberculata, tuberculis fasciculato-pilosis - Herba mexie a na, annua, trichotoma; foliis oppositis, oblongo-linearibus, integerrimis, puberulis, capitulis terminalibus, solitariis, disco intense croceo, radio pallido.

$\mathrm{M}$ endezia DC. Prodr. $\boldsymbol{V}, 532$.

2491. Tragoceras LESS. Capitu 1 u m pluriflorum, heterogamum, floribus radii senis octonis ligulatis, Pemineis, disei quinis-senis tubulosis, masculis. Involueri ovati squamae quinque v. septem, imbricatae, membranaceae, obtusae. Receptacnlum minutum, pateatum. Corollae radii ligulatae, dis ei tubulusae, limbo quinquedentato. Stigmat a capillacea, patentia. Ach enia disci abortiva, ra dii oblongo-obovata, apice truncata, corolla persistente, magna coronata. Pappus nullus. - Herbae mexicanae, annuae, humiles, graciles, ramosissimae; foliis oppositis, integerrimis, capitulis solitariis, ramos superne aphyllos terminantibus.

Tragoeeras Lessing Symops. 220. DC, Prodr. $V .533$. Trag o ceros Kusth in Humb. et Bonpl. Nov. gen. et sp. IT. 248.

a. EUTRAGOCERAS DC. $l$. c. A chenia radii eeostata. (Kunth Op. cit, t. 385.)

b. SKIRHOGLYPHIS DC. l. c. A chenia radii eostis tribus eallosis, nedia uinore, lateralíbus crenato-tuberenlatis.

SURTTIBUS II. HELIANTHEAE Lessing Synops. 221. Capitula saepins heterogama, floribus radii ligulatis, femineis, disci hermaphroditis, rarius discoidea, homogama, floribus omnibus tubulosis, nunquam monoica v. dioica. Coroll a e floris hermaphroditi lobis crassis, saepius superne papillosis. Antherae nigricantes, ecaudatac. Stigmata floris hermaphroditi divergentia, nune truncata, apice penicillata, nune saepius cono acuto v. appendiculo lineari terminata. A chenia saepius tetragona, nunc teretia ant obcompressa. Pap p us nullus, v. coroniformis, aristatus aut partim paleaceus, nunquam nec omnino setosus, nec cmnino paleaceus. Folia saepius opposita.
DIVISIO I. HELIOPSIDEAE DC.Prodr. $\boldsymbol{V}$. 534. Capitula heterogama, floribus radii femineis, rarius homogama, discoidea. Achenia saepius crasse corticata, cortice (calycis tubo) a pericarpio solubili $\mathbf{v}$, arcte eidem adhaerente, obovata, angulata v. compressa, nunquam obcompressa. Pap p n s nulIus $v$. coroniformis, aut setis paucis, rigidulis, irregularibus constans.

2492. Philactis SCHRAD, Capitulum multiflorum, heterogamum, floribus radii uniseriatis, octonis v. denis, lignlatis, femineis, disci tubulosis, ovario efoeto masculis. Invo lncri campanulati, imbricati squamae biseriales, adpressae. $R$ e e p ta cu $\mathbf{~ u ~ m ~ e l o n g a t o - c o n i e u m , ~ s u b o r b i c u l a - ~}$ tum, paleis oblongis, acutis, complicatis. CorolI a e radii ligulatae, cum ovario continuae, oblongae, amplae, obtuse tridentatae, disci tubnlosae, extus parce glandulosae, limbo quinquedentato. Anthera e ecaudatae. Stig in a $\mathrm{ta}$ a $i \mathrm{i}$ exscrta, dis ci saepius inclusa, ramis cono brevi snperatis. A ehenia radii trigena, obpyramidata, glabra, extus ligula persistente, intus arista crassa, acuta, subciliata cormata, d is ci compresso-subtetragona, efoeta (?), aristis quatuor, cruciatiminacqualibus, scabris, ex angulis ortis, basi snleoneretis superata. - Herba mexicana, basi suffruticosa, dichotoma; ramis teretibus, junioribus villosis, folïs oppositis, petiolatis, late ovatis, acuminatis, triplinerviis, serrulatis, utrinque adpresse viltosis, pedicellis inter dichotomias ortis, apice mo. nocephatis, folitis brevioribus, ligrulis flavis, demum rufescentibus, disco luteo.

Philaetis Selurader Index Sem, Hort, Görting, 1831. DC. Prodr. V. 534.

\&93. Zimnia LINN. Capitu1u multiflornm, heterugamum, floribus radii uniseriatis, ligulatis, femineis, disei tubulosis, hermaphroditis. Involueri imbricati squamae ovato-rotnndae, nigro-marginatae. Recepta culi conici v, cylindracei paleae oblongae, complicatae, flores disci involventes, Corolla e $\mathrm{r}$ a di $\mathrm{i}$ ligulatae, ligula obovata r. ublonga, coriacea, reticulata, cum achenii apice continua, persistente, disci tubulosae, super ovarium articulatae, tubo extus relntino, limbo quinquedentato. A n $\mathbf{t h}$ e $r$ a e eeaudatac. Stigmata exserta. A $e$ hen ia curticata, membranacea, subulata, $r$ a dij snbtrigona, calva, disci exteriora sulitrigona, interiora compresso-plana, apice ex angulo interiore uniaristata $\mathrm{v}$. biaristata, arista interiore longiore, $v$, bidentata aut motiea. - Herbae mexicanae et austro-americanae, annuae; ramis foliisque tri-quinquenerviis, integerrimis, oppositis, capitulis ramos terminantibus solitariis, speciosis, diu persistentibus.

Z, i n ia Limu. gen. n, 974. Gärtn. Ir. 459. Cassini in Diet. sc. nat. LIX 315. Don in Tinn, Transact. XVI, 155. Lessing Synops. 294, DC. Prodr. V. 334,

a. EUZINNIA. Pale a e receptaeuli integerrimae, obtusae. A c benia disei intus noiaristata, rarius aristis binis. exteriore brevissima superata. - Linn, f. Decad. t, 12. Jacq. Ic, rar, t, 390. Cavanill. Ic. t. 25i. Gärth. t. 172. Andr. Bot. Reposit, t, 189, Lejica Hill Exot. 29. C rassina Serpin. Dissert.

b. PSEUD0ZINNIA. $\mathrm{P}$ a I e a e receptaculi integerritmae, acutae. A ehenfa disei apice biaristata, bideatata $r$. mutica. - (Bot. Mag. $t$, 2123.)

c. CAlozinNiA, Paleae receptacull acuminatae, apice serrato-eristatae. A chenía disci matlca $v_{\text {, subbidentir- }}$ ta. - (Jucq. Ic, rar, t, 589, Cavanill. Ic, t. 81. Andr. Bol, Reporil. t. 55 Bot. Mag. t, 527.) 
2494. Helieta CASS. Ca pit ul um multiflorum, heterogamum, floribus radii uniseriatis, ligulatis, femineis, disci tubulosis, hermaphroditis. Involucri campanulati, biseriati, disco longioris squamae exteriores quinque spathulatae, apice foliaceae, interiores mineres, oblongae. R e c e ptaculi convexi paleae flores disci amplectentes. Corolla e radii ligulatae, ligula fere ad basim fissa, disci campanulatae, tubo nullo, limbo quinquedentato. Anthera e subdistinctae, nigricantes, ecaudatae, appendice terminali grosse tuberculata. Stigmata exserta. A ehenia omnia conformia, erostria, compressa, obovato-oblonga, superne hispidula, utrinque margine calloso cincta. Pa p p us coroniformis, brevis, eartilagineus, dentatus. - Frutex sarmentosus, incertae originis, in horto paris ino cultus; ramis teretibus, junioribus hispidulis, foliis oppositis, subconnatis, ovalibus, obtusis, remote subdentatis, crassiusculis, lucidis, pedicellis solitariis, terminalibus et axillaribus, floribus luteis.

He II ct a Cassini in Bullet, soc. philomat. 1818. p. 167. Dict, sc, nat. XX, 461, XLVI, 399, et 406, DC. Prodr. $V$. 537. non Lessing.

2495. Alareconia $D C$. $C$ a $p$ i $t$ u $\mathrm{u} \mathrm{m}$ multiflorum, heterogamum, floribus radii uniseriatis, ligulatis, femineis, disci tubulogis, hermaphroditis. In vo l a cri campanulati, bi-triseriati squamae laxe foliaceae, hirsutae, oblongae, disco aequalesv. longiores, intimae minores, receptaculi paleas simulantes. Receptaculi plani paleae flores subaequantes et semiamplectentes. Co rollae $r$ adii ligulatae, ligula ampla, apice tridentata, disci tubulosae, tubo brevi, coriaceo, fance cylindrica, longa, quinquenervi, limbi quinquedentati dentibus vix extus apice subbarbatis. Stigmata radi i glabra, di s c i longa, densissime hispida, acuta, exserta, revolnta. A chenia conformia, crassa, elongata. Pap p us coroniformis, quinquedentatus v. truncatus, aut in aristam elongatam productus. - Herbae californicae, perennes, villosae, spectabiles, Inulae Helenii facie; foliis alternis, oblongis aut elliptico-oblongis, inferioribus basi attenuatis, superioribusque semiamplexicaulibus integerrimis, capitulis terminalibus, solitariis, amplis. A lareonia DC. Prodr. $V .537$.

a. EUALARCONIA. Involueri squamae disco Jongiores. A ehen i a glabra, dentibus 5 lanceolatis, acutis, sericeo. elliatis, crassis coronata. - A. helenioldes DC. $l$. $c$. b. TRACHINGA. I n v 1 u e ri squamae disco aequales. A ch en I a apice villosa, truneata $v$. iu aristam setosam, seabram, elongatam producta. - A. a ug ustifolia DC. $l$. c.

2496. Wedelia JACQ. Ca pitulum multiflorum, heterogamum, floribus radii uniseriatis, ligulatis, femineis, disei tubulosis, hermaphroditis. Invol n cri bi-trigeriati squamae exteriores foliaceae, intimae membranaceae. Receptac aI u convexum, paleatum. Corollae radii ligulatae, ligula late ovata, disci tubulosae, limbo quinquedentato. Antherae ecandatae. Stigmata disci cono superata, Achenia obovata v. compressa, erostria. P a p p us coroniformis v. ca. Iyeiformis, saepius substipitatus, e squamellis concretis, dentatis eiliatisque constans, - Suffrutices v. herbae, ut plurimum americanae, in Asia et Australasia rarae; foliis oppositis, breviter petiolatis, serrutis rariusve trifidis, pedicellis termina. libus saepius solitariis, plerumque e ramorum dichotomia, rarius e foliorum axillis ortis, floribus luteis.

We de li a Jaeq. Amer. 217. L. C. Riehard in Persoon Ench. II. 290. DC, Prodr. $\boldsymbol{V}$, 338, nou Adaus. We delia sp. Lessing. a. CXATHOPHORA $D C$. A chenia omnia aptera, aplee calyculam dentatum gereatia, nee in tubercula callosa producta.

Cyathoploora DC. Prodr. D. 538. Wedella, Stem modoutia et? Trichostemma Cassini in Dict, sc, nat. XLVT. $407-409$. T r i c bos t e p h u s Cassini Op. cit. LX. 618. T ri ch os te p hi a m Cassini Op. phylolog. IIT. 59. Silphit, Buphthalmi et Verb e s i u a sp. Linn. Cavanili, To. $t$, 167.' (Bot. Reg. $t$. 543 . Kunth in Humb. et Bonpl. Nov. gen, ot sp. t, 471.)

b. CALLOPHORA DC. A ehenia omuia aptera, apice producta in tubercula duo callosa, obtusa, inter quae pappus brevissimus, coroniformis, subserrulato -, ciliatus sedet.

Callo phor a DC, Prodr. V. 548 .

c. ACTINOPTERA $D C$. A ch on i a radii ala angusta, non membranacea margiuata, disei aptera, ounia in pappum cyathiformem membranaceum, obllquum, dentatum produeta.

A etinoptera DC. Prodr. V. 543. Wedelib he. 1 ianthoides Kunth $O p$. cit, $t$. 372 .

d. ? AglossA DC. Ca p itu I u m homogamum, discoldeum. Invo I u c r u uniseriale, pentaphyllum. A che a i a ad angulos tuberculosa. - Verosiniliter suí generis.

Aglossa DC. Prodr. $V$. 543 . Wedella discob. de a Schlechtend.

2497. Уägeria H. B. K. Capitulum multiflorum, heterogamum, floribus radii uniseriatis, ligulatis, femineis, disci tubulosis, hermaphroditis. Invo I u eri campanulati, oligophylli squamae aequales, florum femineorum basim et demum achenia involventes. R e c e $\mathrm{t}$ a $\boldsymbol{c}$ u li parvi, conici paleae carinatae, diaphanae, persistentes. Corolla e radii ligulatae, dis ci tubulosae, limbo quinquedentato. S $\mathbf{t} \mathbf{i} \mathrm{g}$ a $\mathbf{t}$ a recurvata. A chenia compressa, tri tetragona, oblonga, laevia, disco epigyno minuto. Papp a s nullus v. minimus, coroniformis. - Herbae a mericanae tropicae, annuae, erectae, pilosiusculae, simplices $v$, ramosae; ramis foliisque oppositis, subsessilibus aut breviter petiolatis, ovalibus, subserratis, capitulis parvis, pedicellatis.

Jägeria Kunth in Humb. et Bonpl. Nov, gen, et tp. IV. 277. $t$. 400. Cassini in Dict. sc, nat. XXIV. 125. Lessing Synops, 283. DC. Prodr: V. 543.

2498. Iipotriehe R. $B R$ Cap itulum multiflorum, heterogamum, floribus radii uniseriatis, ligulatis, femineis, disci tubulosis, hermaphroditis. Involueri squamae biseriatim imbricatae, subaequales. Receptaculi convexi paleae foliaceae, distinctae. Corolla e radii ligulatae, tridentatae, dis ci tubulosae, quinquedentatae. Stig$\mathrm{m}$ a $\mathbf{t}$ a appendice acuta, hispidula. A $\mathrm{ch}$ enia subuniformia, turbinata. Pa P p u s setaceus, cadncus, setis octo v. decem nniseriatis, denticulatis. Herbae africanae tropicae; foliis oppositis, indivisis, pedunculis terminalibus ternis, floribus flavis.

Lipot riche R. Brown in Linn, Transact, XII, 118, in not. DC. Prodr. V. 5ht. non Lessing.

249s. Mellanthera ROHR. Ca pit olum multiflorum, homogamum, floribus omnibus tubalosis. Invo i u e ri biseriati squamae aequales, diseo breviores. Receptaculi convexi paleac persistentes, flores amplectentes. Corolla e tubs brevi, limbi quinquefidi lobis supra papillosis. Stigin a ta ..... A cheni a compressa, subtetragona, basi incrassata, apice truncata, P a p p n s setosus, setis binis-denis, rigidulis, caducis, irregulariter dispositis. - Herbae americanae tropicae, interdum suffrutescentes, ramosae; caulibus tetrago. nis, foliis oppositis, rarius ternato-verticillatis, petiolatis, triplinerviis, ovato-deltoideis v. trilobis, dentato-serratis, scabris v. subcanescentibus, capi- 
tulis terminalibus longe pedunculatis, solitariis $v$. ternis, corollis albis, antheris nigricantibus.

Melanthera Rohr in Kiobenh. nat. hist, Selskab. Skrift, 1. 213. Cassiut in Journ, Phys, XCVI. 207. Dict. sc. nat, XXIX, 483. LIX, 158. De. Prodr, V. 544. Melauthera Richard in Michaux Flor. Bor, Amer. II. 106. R. Brown in Linn. Transact, XIV, 117, Lessing Synops, 221. Amellus P. Browne Jam. 317, Bide nt is s p. Lins, Ca. 1 e a $\mathrm{s}$. Jacq. Ic. rar. $t .583$.

2500. Dopiera CASS. Ca pitulum suboctoflorum, homogamum, floribus omnibus tubuJosis. Involucri biseriati squamae subdenae, exteriores foliaceae, majores, interiores paleas referentes. R e cepta cul im parvum, planum, paleatum. Corolia tubulosae, limbo quinquedentato. Stig mata in appendicem hispidam producta. A ch en ia oblonga, gracilia, subtetragona, apice in collum brevissimum attenuata. P a P $\mathbf{P} \mathbf{s}$ nullus. - Herbae in America tropica cis a equatorem observatae, piloso-hispidae; foliis oppositis, petiolatis, ovalibus, subdentatis, triplinerviis, subtus plus minus glandulosis, capilulis parvis, pedicellatis, floribus luteis.

$\mathrm{Og}$ fera Cassiul in Dict. sc. nat, XXXV. 445. XLIH. 371. Opuse, phytolog. IIT. 61. DC. Prodr. V. 566. $\mathrm{C}$ h a 1 a ri u moiteau msc. We deli a e sp. Lessing.

2501. MTomaetis H. B, K. C a p itu $l u m$ quinque-undecimflorum, heterogamum, flore radii unico, ligulato, femineo, disci pluribus, tubulosis, hermaphroditis. Involucri cylindracei, subimbricati squamae lanceolato-lineares. Receptaculi plani paleae squamas involucri referentes, carinatae. Corolla e radii ligulatae, disci tubulosae, limbo quinquedentato. S $\mathrm{t} i \mathrm{~g} \mathrm{~m}$ a $\mathrm{ta}$ disci exserta, revoluta. A chen ia compressa, breviter rostrata et stipitata, glabra. P ap p a s nullus.

Arbor Americae a equinoctialis, glabriuscula; ramis angulatis, subflexuosis, foliis alternis, petiolatis, ovato-oblongis, subdenticulatis, triplinerviis, panicula terminali ramosissima, foliata, floribus flavis, involucri squamis et receptaculi paleis demum spiraliter tortis.

It o a $e$ t is Kunth in Humb. et Bonpl. Nov, gen. et sp. IV. 286, 1,403 . excl. sp. Lessing Synops, 211. DC, Prodr. V. 596 .

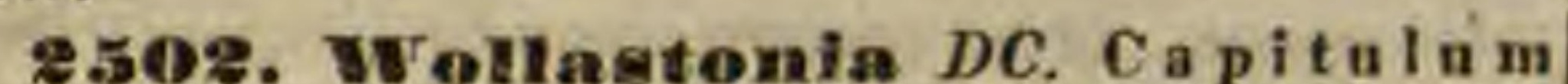
multiflorum, heterogamum, fluribus radii uniseriatis, ligulatis, femineis, disci tubulosis, hermaphroditis. Involncri bi-triseriati squamae exteriores oblongae, foliaceae, internae minores, membranaceae. R e ce pta c u l u m planum v. convexum, paleatnm. Coroll a e supra ovarium articulatae, ra dii lignlatae, disci tubulosae, limbo quinque dentato. Stigmat a disci cono superata, A $\mathrm{c}$ h enia crassa, obovala, turbinata $v$. compressa, apice umbilicata. Pappus nullus v. aristaeformis, arista solitaria v. quinis, tenuilus, rigidulis, deciduis.

Suffrutices $v$, rarius herbae, in India orientali, Moluccis et Australasia indigenae, Wedeliae facie, saepius hispidae; foliis oppositis, breviter petiolatis, ovatis, acutis, triplinerviis, dentatis, pedicellis ad apices ramorum saepius ternis, monocephal is.

W oll a st on ia DC. ex Decaisne in Nouv. Annal. Mus.

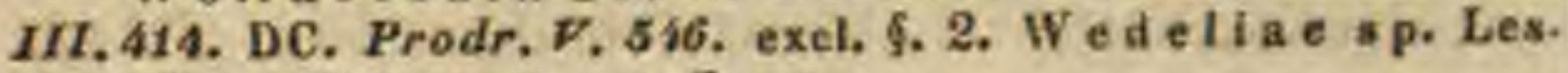
siug. B ap ht halani sp. Forst.

2503. Tilesia F. W. MEY. Capitulum multiflorum, homogamum, floribus omnibus tubu losis, v. heterogamum, floribus radii uniseriatis ligulatis, femineis, disci tubulosis, hermaphroditis. Invol u eri imbricati squamae bi-triseriatae, co riaceae, ovatae, apice squarrosac. Ree ptacul hemisphacrici paleae involucri squamas referentes, amplectentes. Corolla e radii ligulatae, bifidae, d i s c i tubulosae, quinquedentatae. S $t$ i g m a t a setacea, plumosa. A chenia ohpyramidata, tetragona, immarginata, cortice separabili. $\mathrm{Papp} \mathbf{\mathrm { u }}$ nullus. - Herba guianensis, scandens, scabra; foliis oppositis, petiolatis, ovatis, crenato-serratis, utrinqae scaberrimis, capitulis ad apices ramorum solitariis $v$. ternis, congestis, corollis croceis. ข. 340 .

Tilesi a C. W. Meyer Flor. Essequeb. 252. DC. Prodr.

2504. Pasealia ORTEG. Capitul um multiflorum, heterogamum, floribus radii uniseriatis, ligulatis, femineis, disci tubulosis, hermaphroditis. Invol acri discum aequantis squamae subbiseriatae, lineares, subfoliaceae. Receptaculi convexi paleae lanceolatae, semiamplectentes. Corolla e radi $i$ ligulatae, dis ci tubulosae, limbo quinquedentato. Stigmata $\ldots . .$. A chenia matura carnosa, drupacea, $r$ a dii triquetra, invoIncri squamis haud inclusa, disci tetraquetra, obovata, paleis receptaculi semiinvoluta. $\mathrm{P}$ a p p u 8 coroniformis, brevissimus, irregulariter dentatus.

Herba chilensis, scabriuscula, parce ramosa, Pini strobilos redolens; foliis oppositis, lineari-lanceolatis, subtriplinerviis, integerrimis, inferioribus irregulariter dentatis, capitulis terminalibus, solitariis, corollis luteis.

P a s call a Ortega Decad. $T V$. 39, $t, 4$. Willdenow $S p$. IIT. 2298. Cassini in Dict. sc, nat, XIVI. 406. Lessing $S y n$. ops. 223. DC, Prodr. V. 549.

2505. Fumfordia $D C$. CapituInm multiflorum, heterogamum, floribus radii subdenis, uniseriatis, ligulatis, femineis, disei tubulosis, hermaphroditis. Involueri duplicis squamae exteriores quinque, patulae, foliaceae, ovali-oblongae, disco breviores, interiores subdenae, complicatae, ovatae, mueronatae, dorso glanduloso-puberae, achenia radii involventes. Receptaculi plano-eonvexí paleac squamas involucri interiores referentes. Co roll a e basi puberae, super ovarium articulatae, ra dii ligulatae, dis ci tubulosae, limbo quinquedentato. S ty li radi longi, apice bifidi, glabriusculi, disci exserti, stigmatilins semiteretibus, apice puberulis, cono brevissimo su peratis. Achenia radii et disci conformla, obo rato-compressa, glabra. P a p p ns nullus. - Frutex mexicanus, glaber; ramis teretibus, foliis oppositis, amplis, sessilibus, late ovalibus, basi attenuatis, apice breviter acuminatis, ad quartam suae longitudinis partem triplinerviis, basi integerrimis, apice serrulatis, capitulis pedicellatis, corollis radii pallide flavis, disco obscurius luteo.

$\mathrm{R}$ u mifordi a DC. Prodr. $V$. 549.

2506. Heliopsis PERS. Capitu $1 \mathrm{~nm}$ multiflerum, heterogamum, floribus radii uniseriatis, ligulatis, femineis, disci tubulosis, hermaphroditis. Involueri bi-pluriseriati squamae exteriores saepius foliaceae, interieres subimbricatae. R e ceptaculi coniei paleae oblongo-lanceslatae, achenia amplectentes. C o rolla e radi ligulatae, d isci tubulosae, limbo quinquedentato. Acheni a angulato-compressa, glabra, disco epigyno parvo. Pappus nullus. - Herbae americanac perennes, erectae; foliis oppositis, dentatis, capitulis solitariis, pedunculatis, floribus flavis.

Heliopsis Persoon Ench. $\boldsymbol{I}$, 473. Dunal in Memt. Mus, V. 54. Lessing Synops. 223. DC. Prodr, V. 550, -? Helepta Rafia. Mov gen, 1825. p. 3.

a. EUHELIOPSis DC. $l$, c. In vol u e r u m bi-triseriale. Co rollae ounes glabrae, radil soper ovariari articu-

latac. A c he n i laevin, - Herbae boreali-americanael folits serratis. 
$\mathrm{Heli}$ ops is Cassini in Dict, sc. nat, XXIV.333. Dunal Op. cit. t. 4. Bot. Mag. t. 3372. Bot. Reg. t. 592. Buphthal $m a m$ helian thoides Ling. Herit, Stirp. t. 45 .

b. KALLIAS DC. $l$, c. Invol a $\mathrm{crum}$ bi-quadriseriale, imbricatum. Corolla e omues glabrae, radii ovario continaae, persistentes. A che a i a subdrupacea, rugosa. Herbae austro-americanae; folits serratis,

Kall l a s Cassini in Dict. sc, nat, XXIV. 326. XLFI. 406. A them is buphthalmoides Jacq. Hort. schönbr, t, 151.

c. BALSAMORHLA DC. l. c. Capitula fere Helianthi. A chenia compresso-tetragona, calva. $R$ a dix crassa, balsamifera. - Folia radicalia petiolata, pinnatilobala.

B a Is a mor hiza Hooker Flor, Bor. Amer. I. 310 .

250\%. Guizotia CASS. C a p it u $1 \mathrm{u} \mathrm{m}$ multiflorum, heterogamum, floribus radii uniseriatis, ligulatis, disci tubulosis, hermaphroditis, In volucri biseriati squamae exteriores quinque, late ovatae, foliaceae, interiores superantes. $R$ eceptaculum conicum, paleis oblongo-lanceolatis, achenia amplectentibus. Co roll a e super ovarium articulatae, ima basi et ad medium tubi pilis crassis, subarticulatis annulatae, ra dii ligulatae, disci tubulosae, limbo quinquedentato. A $\mathrm{che-}$ n i a angulato - compressa, laevia, disco epigyno minuto. $\mathbf{P}$ a p p us nullus. - Herba annua, in India orientali et Abyssinia ob semina oleifera culta; folits semiamplexicaulibus, subcordato- $v$. ovato-lanceolatis, remote serratis, subscabridis.

$\mathrm{G}$ uizot i a Cassini in Bullet soc philomat. 1821.p. 187. Dict. sc. nat. LIX, 247. DC. Prodr. V. 531, Not. Plant. rar. Hort, Genev, VIT, t, 2. 3. R a m tilla DC. in Wight Cantribut, 18. Poly $\mathrm{m}$ n ia a b ys $8 \mathrm{i} u \mathrm{ica}$ Linn. f. Ve r be sina sativa Roxb. Bot. Mag. 2 . 1017.

2508. Tetragomotheea DILLEN. $\mathrm{Ca}$ pituln m multiflorum, heterogamum, floribus radii uniseriatis, ligulatis, femineis, disei tubulosis, hermaphroditis. Involu crum duplex, exterioris squamae quatuor, maximae, late ovatae, acuminatae, basi in cupulam tetragonam concretae, interiores octo, ovali-lanceolatae, parvae, achenia radii semiamplectentes, R e e pta c uli convexo-conici paleae membranaceae, lanceolatae, acuminatae. Corollae super ovarium articulatae, secus tubum hispidae, radii ligulatae, ligula lata, multinervi, disci tubulosae, limbi quinquedentati dentibus erectis. Stigmat a exserta, hispida. Achenia in disco et radio conformia, obovata, vix angulata, crassa, laevia, areola terminali latiuscula, nectario elevato. Pap pus nullus. Herba borea li -a mericana, annua; caule tereti, hirtello, ramis foliisque oppositis, dentatis, parce villosis, pedunculis terminalibus monocephalis, capitulis amplis, floribus luteis.

Tetragonotheca Dillenins Eltham 378. Linn. gen. n. 976, Herit. Stirp. 177. Cassini in Diet, sc. nat. LIX. 319. Lessing Sjnops. 420. DC. Prodr. $V$. 552. P o I y m i a T etragonotheca Lisa. Stlphium Tetragonotheea Gärtn. 11 , t. 171, f. 2 .

2509. Ferdinanda LAGASC. C a p it nI um multiflornm, heterogamum, floribus radii uniseriatis, ligulatis, femineis, disei tubulosis, hermaphroditis. Involucri hemisphaerici, disco brevioris squamae bi -triseriatae, adpressae. R eceptaculi conici paleae oblongae, submembranaceae, ampleetentes. Corolla e radii ligalatae, d i s c i tubulosae, limbo quinquedentato. S $t$ i g mata puberulo-hirta, cono brevi superata. A ch e n ia ra di obeonica, angulata, disci oblonga, compressa, subquadricostata. Pappus radii e sqnamellis binis-quinis eoroniformis, minimns, interdum obsoletus, disci nullus. - Frulices mexicani; foliis alternis, ovatis $v$. oblongis, basi attenuatis, apice obtusis, integerrimis $v$. crenatis, triplinerviis, supra pubescentibus v. scabris, subtus argenteo-velutinis v. pubescentibus, corymbo terminali ramoso, polycephalo, foliis floralibus coloratis, floribus luteis.

Ferdin a u d a Lagasca Nov, gen, et sp. 3t. Cassini in Dict, sc, nat. XX, 499. XLVI, 404. Lessing Synops, 221. DC. Prodr. V. 552.

2510. Chrysophamia KUNTH, C a p it $\mathrm{l}$ a m multiflorum, heterogamum, floribus radii uniseriatis, ligulatis, femineis, disei tubulosis, hermaphroditis. Involuerum subuniseriale. Recepta culi conici paleae oblongo-ellipticae, obtusae, multinerves. Corollae radii ligulatae, ligula parva, rotunda, disci tubulosae, basi obsolete puberulae, limbo quinquedentato. S $\mathrm{t}$ ig mat a puberula, cono brevi terminata. A chenia in disco et radio conformia, quadrangula $v$, subeompressa, quadricostata, disco epigyno parvo. Pa ppus nullus. - Fruticulus mexicanus, dichoto. mus; foliis alternis, ellipticis, grosse inaequaliter crenatis, petiolatis, secus petiolum obsolete decurrentibus, supra canescentibus, subtus incanis, panicula terminali fastigiata, parce ramosa, capitulis luteis.

Chrys ophania Kunth in Lessing Synops. 224. DC. Prodr. $V .563$.

2511. Zaluzamia PERS. Cap itulum multiflorum, heterogamum, floribus radii quinis. septenis, uniseriatis, ligulatis, femineis, disci tubulosis, hermaphroditis. Invol u cri biseriati, patuli squamae sericeae, interiores breviores, cuneatae, trilobac. Receptaculi conici paleae membranaceae, amplectentes, cuneatae, apice trilobae, involueri squamas interiores referentes. $\mathrm{Co}$ rolla e radii ligulatae, ligula ovali, disci tubulosae, hispidae, tulo fanci aequali, hasi achenium obtegente. Stigmata pulierula, conn brevi terminata. A ch en ia radii subtrigona, hispida, disci compressa, glabra, laevia, exangulata. Pa Ppus nullus. - Herba mexicana, perennis, basi suffruticosa, ramosa, villoso-tomentosa; foliis infimis oppositis, reliquis allernis, petiolatis, pinnatipartitis, lobis paucis, obtuse sinuato-repandis, saepius trilobis, capilulis pedicellatis, corymbosis, laxe subpaniculatis, floribus luteis.

Zaluz ania Persoon Ench. II. 473. Cassini in Dict. sc, nat. LVI. 239. Lessing Synops. 224. exel.sp. DC. Prodr. V. 333. A nthemis triloba Orteg.

2517. Chiliophyllum DC. Capitu$1 \mathrm{u} \mathrm{m}$ multiflorum, heterogamam, fluribus radii biquadriseriatis, ligulatis, femineis v. ahortu neutris, disci tubulosis, hermaphroditis Involucrum biseriale, squamellis plurimis, linearibus, inter squamas majores et flores radii sitis. Receptaculi convexi paleae acuminatae, achenia superantes. Corolla e radii ligulatae, ligula angusta, saepins bifida, irregulari, disci tuhulosae, ima basi barbellatae, limbo quinquedentato. St ylus radii profunde bifidus, stigmatibus hirtellis, disci inclusus, brevissime bifidus, stigmatibus truncatis, apice subbarlatis. A chenia compressa, glabra, incurva et cuneata. P a p p u s nullus. - Herba mexicana, perennis, parce pilosa; foliis allernis, bitripinnatipartitis, lobis inaequalibus, linearibus, acutis, ramis nudis, apice monocephalis, capitulis globosis, luteis.

Chiliophyllum DC. Prodr. $\mathcal{V}$. 554. Hybridella Cassini in Dice, sc, nat. XXII. 86. A $n$ them is g lobos a Ortega, Jacquil, Hort Schünbr, $t, 37 t$. 
Heliopsideis adnumeratur genus a cl. Lindley latroduct. edit. II. p. 443. paueis indicatum:

SCALESIA Arnott msc. Capitulum homogamum. Invol n с $\mathrm{r}$ m biseriale. Ant herat nigricantes, exsertae, ecaudatae, alis cordato-oblongis. Stylus Tagetis. A chen i a compressa, obeordata, omnino ealva, conformia, glabra, disco epigyno inconspicuo. - Frutex in insu, is Gallipagos repertus; foliis atternis, lineari-lanceolatis, ntrinque angustatis, supra scabriusculis, subtus pubescentibus, integerrimis, capitulis axillaribus, breve pedunculatis, basi in. trusis. - Nonne capitulum sphalmate homogamum vocatur, quia achenia conformia dícuntur?

DIFISI II. RUDBECKIEAE Lessing Synops.225. Capitula heterogama, floribus radii ligulatis, neutris. Achenia erostria, calva v. pappo coroniformi superata.

2513. Celhimacea MÖNCH. Capitulnm mnltiflorum, heterogamum, floribus radii uniseriatis, ligulatis, neutris, disci tabulosis, hermaphro. ditis. Invo In cri triseriati squamae lanecolatae, eiliatae. Receptaculi ovati paleae rigidae, superne cartilagineae, flores disci superantes. Coroll a e radii lignlatae, lignla elongata, bi-tridentata, disci tubulosae, tubo subnullo, fauce nuda, limbi quinquefidi laciniis erectis. $\mathbf{S}$ ta min u m filamenta imae corollae inserta. Stigmat a appendicnlis semilanceolatis superata. Achenia tetragona, obpyramidata, crassa. Pappus irregulariter lacerus, subcoroniformis, deciduus. - Herbae boreali-americanae, perennes; foliis ra. dicalibus petiotatis, caulinis alternis, sessilibus, in tegerrimis v. serratis, ramis superne nudis, monocephalis, capitulis amplis, ligulis purpureis, uni-bipol licaribus, disco obscure virescente.

$\mathrm{E}$ e hinace a Mönch Method, 591. Cassini in Dict, sc. nat. XXXV. 274, XLVT, 397. et 400, Lessing Synops. 225. DC. Prodr. V.554, B ran neria Necker olem, n, 301. B o. bartia Petiver Herb. 473. non Linn. Heliehroa Rafinesque Nov. gen. n. 35. Ru d b e c ki a e s p. Linn. Schkulir t. 259. Bot, Nag, t. 2. Sweet Fl, Gard, t. A, Co reop s idis s p. Cavanili, Ic. $t, 268$.

2514. IBublbeckia LINN. Ca pitulum multiflorum, heterogamnm, floribus radii uniseriatis, lignlatis, nentris, disei hermaphroditis, tubulosis. Involacri biseriati squamae foliaceae, patentes. Receptaculi conici paleae acntae, planae v, naviculares. C or olla e radii ligulatae, genitalium rudimento nullo, disci tubulosae, tubo brevi, limbo quinquedentato. S $t$ ig $\mathrm{m}$ a $t$ a cono hrevissimo superata. A chenia tetragona, obpyramidata, areola laterali, disco epigyno nullo. $\mathrm{P}$ a pus brevissimus, coroniformis, irregulariter dentatus v, nullus. - Herbae boreali-americanae, ut plurimum perennes, hispido-scabrae, ramosae; fo liiis alternis, aliis pinnatilobatis, aliis dentatis $v$. in tegerrimis, ramis nudis, elongatis, monocephalis, ligulis luteis, disco fusco-violaceo.

R udbecki a Linn, gen, n, 980. excl, sp. Gärtn. $\pi$. 435, t. 172 . Bot. Mag. $t$. 1996. Bot. Reg. $t$. ses. Casstui in Dict. sc. nat, XLVI. 398. Lessing Synops, 226. Sweet Fl. Gard, IT, $b, 8 z$, Obelliscothe $e$ a Vaillant in Act. Academ, Paris, 1720, p. 329. Helioph thal mam Rafin, Flor. Iudovic, 72.

25. multiflorum, heterogamum, floribus radii uniseria tis, lignlatis, neutris, disci tubulosis, hermaphroditis. Involueri biseriati squamae exteriores senae-ocionac, lineares, patulae, interiores parvae adpressae. Re ceptaculi conici paleae involucri squamas interiores referentes. Corollae radii lienlatae, disci tubulosae, tubo subeylindraceo, limbi quinquedentati dentibus reflexis. S $t$ ig $m$ a $t$ a appendice lineari superata. Ach en i a teretia, basi attenuata, areola laterali. $P$ a p p us coroniformis, hrevissimus, integerrimus. - Herba borealia mericana, annua, glabra, ramosa; caule ramisque striato-sulcatis, foliis alternis, cordato-amplexicaulibus, laevibus, integerrimis, acutis, capilu. lis terminalibus, solitariis, radio fiavo, disco luteo.

Dra e op is Cassini in Dict. se. nat, XXXV. 273, XIVX. 400. Lessing Synops. 226. DC. Prodr. $V$. 558. Rudbe. chla amplexicaulis Yahl in Aot, soc, $h, n$. Hafn. II, t. 4. Sclikuhr t. 259. R. a mplexifolla Jacq. Io, rar, III. t. 592. R. perfolia ta Cavauill. Le, t. 252.

2516. Dbelisen rias CASS. Capitulum multiflorum, heterogamum, floribus radii uniseriatis, ligulatis, nentris, disci tubulosis, hermaphroditis, Involucri uni-biseriati squamae exteriores paucae, lineares, patulae, interiores parvae, obtusae, a receptaculi paleis vix distinctae. Rece p taculi elongate-spicaeformis paleae complicatae, apice hirsutae, achenia disei amplectentes. Corol. la e ra di i ligulatae, dis ci tululosae, limbo quinquedentato. Stig mata lirevia, in appendicem se. milanceolatam, parce barbellatam producta. A c h enia radii trigona, hispida, abortiva, dis ci bilateraliter compressa, ovalia, antice margine subulata, v, apice unidentata. Pa p p us nulins. - Herbae boreali-americanac, erectae, glabriusculae; caule striato-sulcato, foliis alternis v. irregula. riter subverticillalis, pinnatisectis, petiolo striato, lobis indivisis $v$. pinnetisectis, ramis apice longe denudatis, monocephalis, ligulis flavis $v$. croceis, disei cylindrici floribus plurimis, minutis, fuscis.

Obeliscaria Cassini in Dict, sc. nat. XLPT, g0t. DC. Prodr. $V$.558. Le pach y 8 Lessing Synops. 295.

a. LEPACHXS $D C, l$. c. Involueri biseriati series interior brevissima. Ligula e angustae. A chenia antice subulata, apice calva.

Le pachys Rafinesque in Journ.Phys.LXXXIX, p.100. Rudbeekia pinnata Veutenat Cels, $\ell$, 71 . Smitb Exot. Bot, $t, t, 38$. Bot. Mag. t, 2310.

b. RATIBIDA DOC, l, c. Inv of n $\mathrm{c}$ u la e elougatae, anguatae. $\Delta$ clie nia sntice subulata, apice calva.

Ratibida Rafinesque l. c. Rudbeckia colum. a a r is Parsh. Bot. Mag. $\ell$, 1601.

c. MONODONTA DO. l. c. Invalucri biseriati series interior brevissima. Lign Ja e obovatae. Achenia ex. alata, ad margioem inferiorea aplce anidenlata.

251\%. Analleuxia DC. Capitulum multiflorum, heterogamum, floribus radii subvicenis, uniseriatis, ligulatis, femineis, sterilibus, disci tubulosis, hermaphroditis. Involu cri biseriati squamae oblongae, foliaceae, vix acutae, apice patentes. R e ceptac uli convexi paleae membranaceae, acutae, subconrolutae, floseulos semiinvolventes. Corolla e radii ligulatae, subcoriaceae, cum ovario continuae, di s c i cylindraceae, glabrae, limbo quinquedentato. Stylus radii profunde bifidus, glaber, dis ci stigmata subrevoluta, apice summo barbata aut cono brevissimo superata. A ehenia trigona, radii abortiva, pubeseentia, disci angustiora, glabra. Papp us nullus. Herba mexicana, erecta, parce ramosa; caule angulato, hinc inde subserratim piloso-hirsuto, basi glabro, foliis oppositis, petiolatis, ovatis, acutis, serratis, pubescentibus, exulis apice pedunculiformi, monocephalo, sub capitvlo obcomico, velutino, foribus luteis.

Andrieuxha DC, Prodr. $\boldsymbol{V} .559$.

2518. A 150 mosteplaium $D C$. Ca pituI $\mathrm{m}$ multillorum, heteroganum, floribus radî uni- 
seriatis, lignlatis, nentris, disci tubulesis, hermaphroditis. In volucri campanulati, pluriseriati v subnniseriati, disco brevioris v. subaequalis squamae exterinres ovatae, acutae, foliaceae, laxe erectae, interiores oblongae, membranaceae, obtusae, exterioribns angustiores, sed aequilongae. $\mathbf{R}$ e c e pta culi plani paleae membranaceae, apice rufae, subrotundae, caeterum eonvolutae et achenia in volventes. Corolla e radii ligulatae, tubo gracili, longo, ligula ovali, dis e i tubulosae, tubo brevi, fauce longa, campanulata. Antherae exsertae. Stigmat a puberula, radii obtusa, dis ci cono acutissimo snperata. A $\mathrm{e}$ h enia lineari-subtetragona, gracilia, radii glabra, apice breviter bicornia, disei adpresse villosa, pa p po irregulari, coroniformi superata. - Herbae in Bra silia et in Antillis observatae, basi suffruticosae, erectae; caule subsimplici, hispido, tereti, foliis oppositis, sessilibus, utrinque sparse et adpresse piloso-scabris, capitulis ad apices caulis et ramorum paucis, subsolitariis, pedicellatis, corollis luteis, antheris nigricantibus.

\section{Anomostephinm DC. Prodr. $V, 360$.}

2519. Aspilia THOUAR. Ca pitulum mnltiflorum, heterogamum, floribus radii quinisdenis, uniseriatis, ligulatis, neutris, disci tubulosis, hermaphroditis. Involu eri biscriati squamae oblongae, discum aequantes. R e e p ta euli planiuseuli paleae oblongae, complicatae, achenia includentes, apice acuminatae. Cor oll a e radii ligulatae, ligrula apice denticulata, disci tubulosae, limbo quinquedentato. Stig $\mathbf{m}$ a $t$ a cono brevi superata. A chenia conformia, linearia, adpresse villosa. Pap p u coroniformis, dentato-ciliatus. Herbae madagascarienses, procumbentes; caulibus gracilibrs, puberulis, foliis oppositis, subsessilibus, lanceolatis, integerrimis v. subdentatis, supra sparse, subtus ad nervos setoso-scabris, capitulis e dichotomiis longe pedicellatis, solitariis, floribus flavis.

A spili a Thonars Gen, madagase, 40. Cassini in Dict. rc. nat. Suppl, III, s7. DC. Prodr. V. S61.

2530. Tymmopsis DC. Capitulum multiflorum, heterogamum, floribus radii uniseriatis, ligulatis, neutris, disei tubulosis, hermaphroditis. Involucri biseriati squamae exteriores subfoliaceae. Receptaculum planum, convexum v. subconienm, paleatum. Co rolla e radii ligulatae, $\mathrm{d}$ i s c i tubulosae, limbo quinquedentato. Stigmata disci appendiculata. A chen ia sicca. P a p u s coroniformis, brevissimus, dentatus.

Herbae v. suffrutices, in $A$ merica tropica provenientes; foliis oppositis, petiolatis, tri-v. triplinerviis, dentatis, capitulis pedicellatis, floribus radii et disci concoloribus,

G y mo psis DC. Prodr. V. 561. Hooker Ic, $t, 145$. G y mofomia Kunth in Humb. et Bonpl. Nov. Gen. et op. IV. 127. t. 373. non Ker - ? Al d a ur a Llave et Lexarz Nov. Veget, I. 14. Lessing Synops. 227.

25 2 1. Wulffin $N E C K, C$ a pitulum maltiflornm, saepius heterogamum, floribus radii uniseriatis, ligulatis, nentris, rarius homogamum, floribus omnibus tubulosis, hermaphroditis. In v 0 l u cri subhemisphaeriei squamae laxe imbrieatae, sublanceolatae. Rece ptac uli subconvexi paleae lanceolatae, snbearinatae v. planae, persistentes. Corolla e radii ligulatae, disci tubulosae, limbo quinquedentato. Stig m at a cono superata. A che nia radii abortiva, dis ci crassa, hebetate tetragona, plus minus carnosa, obtnsa, apice umbilicata, ealva, glabra $\checkmark$. superne velutino-villosa.
Pap pas nnllus. - Herbae Americam tropica $m$ incolentes; caulibus erectis v. subsarmentosis, saepius scabro-asperis, ut plurimum maculatis, foliis oppositis, petiolatis, late ovatis, acuminatis, serratis, subtriplinerviis, capitulis pedicellatis, terminalibus v, axillaribus, saepe ternis, post anthesin subglobosis, floribus flavis.

W u Iffi a Neeker elem. n, 66. Cassini in Dict, sc, nat. XLVI. 398. et 403, DC, Prodr. V. 563. Chakiatella Cassini in Diet. sc, nat. XIITI, 37, et XLVT, 402. Chy. Io dia Richard ex Cassini in Journ. Phys, 1823, 214. non R. Br. Gy mo olomia Ker in Bot. Reg. t, 669. Lessing Synops. 22s, non Kunth. Crod is perma Polteaumsc. Co. reopsis baceata Linn. f.

2522. Nontagnaea $D C$. Capitulum multiflorum, heterogamum, floribus radii quinis $\mathrm{v}$. denis, uniseriatis, ligulatis, neutris, disei tubulosis, hermaphroditis. Involucri biseriati squamae exteriores quinque oblongae, patulae, interiores subdenae, paleas receptaculi referentes. $R$ e ceptac u li convexi paleae basi latac, apice spinoso-mueronatae, achenia plus minus involventes. Corolla e $r$ adii ligulatae, dis ci tubulosae, limbo quinquedentato. Stigmat a cono brevi v. longiusculo superata. A chenia radii abortiva, disei subcompressa, obovata, cuneata, calva, nectario interdum prominalo. Pa p p $\mathbf{s}$ nullus. - Suffrutices v. frutices americani, potissimum mexicani; ramis teretibus, apice saepius hirsulis, foliis oppositis, petiolatis, ovatis $v$ cordatis, serratis aut lobatis, saepius subtus subtomentosis, capitulis corymbosis, radio albo $v$. interdum ut videtur roseo, disco albido.

Montagnaea DC. Prodr. V. 564. Er io com a Kunth in Humb, et Bonpl. Nov, gen, et sp. IV. 267. Cassini in

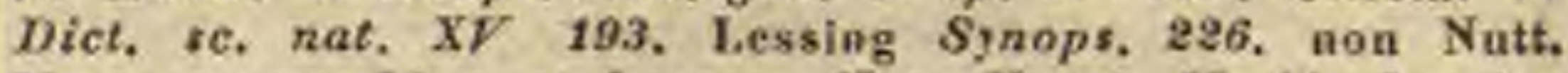
Montanea Llav. et Lexarz. Nov, Veget. IT, 11. Lessing Synops. 420. Erlo e a r ph a Cassini in Dict, sc, nat. LIX, 236. Pristle y a Flor. mexie. inedit.

a. ERI0CARPHAR DC. l, c. F to res radil quinque. Pale a e hirsutissimae. - Kunth $O p$, cit. $t, 396$. Sweet $F t$, Gard. II. $t$. 44 .

b. ACANTHOCARPHAE $D c$. $t$, e. Flo res radii cireiter decers. Pale a e parce villosae, evidentius mueronatae, demum spinescentes.

2523. Selleroearpus $J A C Q . F$. C a p it u $l$ u m multiflorum, heterogamum, floribus radii tribus, ante involucri squamas interiores sitis, minimis, neutris, disci oetonis v. denis, tubulosis, hermaphroditis, centralibus saepe abortivis. Involncram duplex, exterioris squamae foliaceae, subpetiolatae, majores, interioris tres minores, distantes. Recepta c uli parvi, convexi paleae flores disci involventes, iisdem breviores, CorolI a e radii ligulatae, ligula irregulari, d is ci tubulosac, pubeseentes, persistentes, limbo quinquedentato. An the rae vix connatae, apice in appendicem subulatam productae. Stig $\mathrm{m}$ a t a subulata, hispida. A ehenia radii abortiva, tenuissima, di s c $i$ obovata, laevia, intra paleam curvato-subcomplicatam, induratam, intus hiantem, apice in collum contractam inclusa. Pappus nullus. Herba africana tropica, erecta; caule seabro, tereti, imprimis apice ramoso, folits alternis, petiolatis, ovatis, acuminatis, serratis, triplinerviis, supra villosis, scabris, subtus puberulis, eapitulis ad apices ramulorum solitariis, subsessilibus, floribus flavis.

$\mathrm{S}$ eI e r o carpus Jacq. fil. in Act, Helv, IX, 34. $t .2$. f. 1. Jacq, Ic. rar. t. 176. Cassini in Dict, sc, nat, XLVITK. 148. DC. Prodr. $\mathscr{V} .566$.

2524. Encelia ADANS. Capitulum multiflorum, heterogamum, floribus radii uniseriatis, lignlatis, neutris, disci tubulosis, hermaphroditis. Invol e ri biscriati, discum aequantis squa- 
mae snbimbricatae, Receptac nli plani paleac membranaceae, naviculares. Corolla e radii ligulatae, disci tubulosae, limbo quinquedentato. Stigmata cono superata. Achenia plano-compressa, margine albo-lanata, emarginata, villosa. Pap p s nullus. - Suffrutices a mericano-tropici, ramosi, plus minus canescentes; foliis alternis, petiolatis, ovatis $v$. oblongis, tri- v. triplinerviis, integerrimis aut repandis, capitulis paucis, pedicellatis, paniculatis, floribus fiavis.

E a e 11 a Adanson Fam. II. 128. Cavavill. Ic, t, 61. 210. Bot. Reg, t. 909. Cassint in Dict, se. nat, XIV. 447. LIX, 139. Lessing Synops. 298. DC. Prodr. $Y .566 . \mathrm{P}=1$. la s i a Heritier mse, Aiton Hort, kew. I. 3, 253. Willd. sp. III. 2960 , Core op 8 is lime ns is Jacq. Ic. rar. $t$. E94.

2525. Philoglossa DC. Capitulum multiflornm, heterogamum, floribus radii plurimis, uni-bi- (?) seriatis, ligulatis, neutris, disci tubulosis, hermaphroditis. In volu eri quadri-quinqueseriati squamae exteriores inter se alternae, biseriatae, lanceolatae, foliaceae, eiliatae, interiores triseriatae, membranaceae, albidae, glabrae, lanceolatae. Re e e ptaculi plani paleae lineari-subulatae, scabridae, caducissimae. Coroll a e radii ligulatae, ligula angustissima, hirta, disei tubulosae, tubo brevi, limbi profunde quinquelobi lobis aenminatis, Anther a e nigricantes. Stylus apice subbifidus, longe hispidus. A chenia obovata, laevia, areola terminali minima. Pappus nullus. - Herba limensis, verosimiliter annua, villoso-hispida; caule adscendente, foliis ovalibus v. obovatis, basi cuneatis, sessilibus, tenuissime triplinerviis, integerrimis $v$. subdentatis, pedicellis filiformibus, hispidis, axillaribus et terminalibus monocephalis, demum folia superantibus, floribus luteis.

Phfloglos a DC. Prodr,, 567.

2ะ $t u l u m$ multiflorum, heterogamum, floribus radii nniseriatis, ligulatis, neufris, disci hermaphroditis, tubulosis. In vol n cri biscriati squamae foliaceae, basi coadunatae, exteriores pancae, parvae, lineares, patentes, interiores erectae, ovali-oblongae, margine subscariosae. R e cepta eu li plani paleae lineares, angustissimae, fere filiformes. Corolla e radi ligrlatae, di sei tubulesae, limbo quinquedentato. Stigmat a cono superata, pube reversa. A chenia plano-obcompressa, wbovato-elliptiea, angulis albido-alata, glaberrima, apice emarginata, disco epigyno minute. $\mathbf{P}$ a p $\mathbf{p}$ s coroniformis, la cerus. - Herba boreali-americana, erecta, nitida; foliis oppositis, petiolat is, infimis subpedatopinnatijidis, superioribus trisectis, segmentis lanceolatis, inlegerrimis, pedunculis subgeminis, mongcephalis, capitulorum radio luteo, disco brunneo.

Chrysostemma Lessing Synops. 222, DC. Prodr, $x$ : 567. Coreopsis tripteris Linn. A nacis sp. Schrank.

252\%. Calliopsis REICHEN $B$, CapituI $\mathrm{m} \mathrm{m}$ mnltiflorum, heterogamum, floribus radii uniseriatis, ligulatis, neutris, disci tuluulosis, hermaphroditis. Involueri biseriati squamae exteriores breves, єquarrosae, interiores majores, ereetae, cuadunatae. Receptaculi plani paleae dinearcs, decidnae, floribus breviores. Corullae $r$ a d i ligulatae, Jigula grosse tri-quinquedentata, d is ci tubulosae, limbo quinquedentato. Stig mata truncata, apice penicillata. A $c$ hen i a wieompressa, incurra, truncata, diseo epigyno minuto. Pap pus nullus. - Ilerbae borea $i$-a mericanae, elegantes, glalvae; foliis oppositis, uni-bipinnatisectis, lobis integris, capitulis remos terminanti- bus, radio luteo, basi fusco-purpureo, maculato, disco luteo $v$. subpurpureo.

Calliopsis Reichenbach Magas, $t, 70$. Cassini in Dict, sc. nat. LIX. 321. Lessing Synops. 298. DC. Prodr. V. 568. D iplos a s tra Tausch Hort. Canal. fasc. 1. Co. reopsis tinctoria Nutt. Bot. Mag. $t$. Zst2. Bot. Reg. t. 846.1376 .

PERAMIBUS Rafinesque Ann, nat, I, 14. Cassini in Dict. sc, nat. XXXVIII, 416. DC. Prodr. $V$, 568. Core o p. sis a cuita Pursh. gents borealt americauum, vix notum, a Coreopside achenis triangularibus, lacvibus, nudis differre dicitar.

DIUISIT NII. COREOPSIDEAE Lessing Synops. 228. Capitula heterogama, floribus radii neutris. Ach en ia erostria. Pappus nunc ex aristis binis - quaternis, nunc ex aristis et squamellis constans.

2528. Agarista DC. Capitulum multiflorum, heterogamum, floribus radii uniseriatis, ligulatis, nentris, disei bermaphroditis, tubulosis. Involucri campannlati, duplieis squamae acutae, exteriores quatuor late ovatae, basi subconcretac, interiores oeto, ovali-oblongac, duplo fere longiores, sulmembranaceae. Re ce $p t$ a $c u l i$ plani paleae lineari-lanceolatae, subhyalinae, acheniorum lateri exteriori applicitae, simul deciduae. Cor olla e radi lignlatae, ligula obovato-truncata, multinervi, disei tubulosae, limbo quinquedentato. Stigmat a cono superata. A chenia obcompressa, radii ovalia, inania, glabra, di s ci oblonga, sub palea glabra, margine utroque et facie interiere villosissima. $P$ a p pus radii nullas, disci bisquamellatus, squamellis elengatis, men.branaceis, corolla pareum brevioribus, ex angulis achenii ortis. - Herba californica, annua, crecta, glaberrima, Calliopsidis v. Correopsidis facie; caule tereti, ramoso, foliis alternis, multifidis, rhachi lobisque linearibus elongatis, ramis apice nudis, monocephalis, capitulis erectis, aureis.

Agarist a DC. Prodr. $V .569$.

2529. Coreopsis LINN. Capitulum multiflorum, heterogamum, floribus radii suboct6nis, lignlatis, neutris, disei hermaphroditis, tubnIosis. Involueram duplex, utramque suboctophyllum, ima basi coadunatum, exterioris squamis foliaceis, angustioríbns, subpatulis, interioribus latioribus, submemlanaceis Receptaculi plani paleae persistentes. Corollae radii lipulatae, dis ci tubulosae, limbo quinquedentato. Si $\mathrm{g} \mathrm{ma-}$ ta apice hispida, cono superata. Achenia obcompresso-plana, rarius incurva, margine plus minus alata, apice bidentata v. biaristata, aristis Jacvilius v. sursum ciliato-serratis. - Herbae boreali-americanae, interdum suffrutescentes, ut plurimum glabrae; foliis oppositis, rariusve alternis, indivisis $v$, partitis, pedunevlis monocephalis, solitariis v, corymbosis, capilulorum disco luteo, radio concolore $v$, rarius albo.

Coreopsis Lina. gen. n. 981. Selikuhr t,260. 6. Bot. Mag. $t, 156,348$. . Sweet $\mathrm{Fl}$. Gard, $11, t, 175$, Lessiag $S_{y n}$. ops. 298. DC. Prodr. $\nu$. 569. C or e o poldes Müach method. 594. A c is p e r m u $\mathrm{N}$ eher elem. $n$. 64. Lechea Cassim in Dict. sc. nat. $\mathrm{X}$. 419. XXV. 388. L.1X. 320. 321. Chrysometea Tausch Hort. Canal. fasc. 1. A na $\mathrm{c}$ is sp. Schrank.

2530. Aetinemeris NUTT. C a pitu$1 \mathrm{u} \mathrm{m}$ multiflorum, heterog amum, floribus radii uniseriatis, paucis, ligulstis, ncutris, disci tubulosis, hermapliroditis. Involneri uni-triseriati squamac subinacquales, fuliaceac, acsminatac. Recep- 
t a e u I i convexi paleae acheniorum marginem amplectentes. Corollae radii ligulatae, dis c? tubulosae, limbo quinquedentato. Stig mata appendiculata, acuta. A chenia bilateraliter planocompressa, anguste alata, a ris ti s binis, triquetris, sublaevibus coronata. - Herbae boreal $i$-amer $i$ canae, scabrae, biennes v. perennes; caule erecto, ramoso, tereti, foliis longe decurrentibus alato, foliis alternis, rariusve suboppositis, ovatis $v$. lanceolatis, serratis, capitulis corymbosis, corollis flavis, radio interdum pallidiore.

A etinomeris Nuttall Gen. $I T$. 13t. Lessing Synops. 228. DC. Prodr. V. 575. Rida n Adanson Fam. II. 130. P terophyton Cassini Bullet. soc. philomat. 1818, p. 76. Diet. sc. nat. XLIV. 48, LIX. 139. A c time $\mathrm{r}$ is Rafinesque 1820. C o re o p s id is s p. Linn. Jacq. Hort, Vind, t. 110. Cavanill, Ie, $t$. 260.

253 1. A ronamia BERTER, C a p itulu m moltiflorum, heterogamum, floribus radii uniseriatis, ligulatis, neutris, disci hermaphroditis, tubulosis. Invol u eri triseriati squamae imbricatae, adpressae. Recepta $\mathrm{culum}$ planum, epaleatum. Corolla e radii ligulatae, dis ci tubulosae, tubo brevi, fance lato-cylindrica, limbo quinquedentato. Stigmat a brevia, truncata, apice barbata, exappendiculata. $\Delta \mathbf{c h}$ e n i obcompressa, elliptica, cartilaginea, adpresse pubescentia, $s$ et is duabus rigidis, antice scabris coronata.-Frutex a ustroamericanus, adpresse villosus; ramis teretibus, foliis alternis, petiolatis, ovatis, acuminatis, subcrenatis, penninerviis, capitulis terminalibus paucis, pedicellatis, floribus luteis.

Armania Bertero msc. ex DO. Prodr. $V$. 576 .

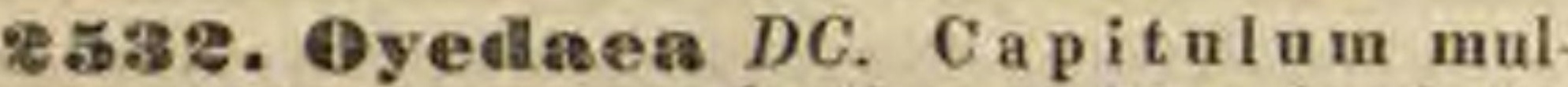
tiflorum, heterogamum, floribns radii nniseriatis, lignlatis, nentris, disci tubulosis, hermaphroditis. Invol a cri triseriati squamae subaequales, foliaceae. R e ceptacu I n m planum, paleis complicatis, mucronatis, acuminatis, coriaces-subscariosis. Corollae radii ligulatae, disci tubulosae, tu. bo gracili, fauce cylindrica, limbi quinquedentati dentibus erectis, extns puberulis. Stigmata graeilia, appendice hispida. $A c h$ en i a $r$ a $i \mathrm{i}$ abortiva, linearia, p a p pe bi-triaristato, aristellisque minimis superata, dis ci compressa, alata, subeuneata, apice hine saepe gibba, pap po vario, ex aristis duabus elongatis, caducis, aliisque pluribus, brevibus constante. - Frutices a mericani tro$p$ ic $i$, Verbesinae facie; ramis teretibus, adpresse villoso-subhirtis, foliis oppositis, in petiolum attenuatis, ovatis, acuminatis, dentatis, supra sparse villosis, subtus villoso-subcanescentibus aut tomentosis, inferioribus grosse triplinerviis, summis subpenninerviis, capitulis pedunculatis, corymbosis, floribus luteis.

\section{O y ed a a DC. Prodr, V. 376 .}

2533. Simsina PERS. Ca pitula m multiflorum, heterogamum, floribus radii uniseriatis, paucis (quinis-duodenis) ligulatis, neutris, disci tubulosis, hermaphroditis. Involu eri bi-triseriati squamae erectae, lineares, subaequales. Ree pta culi plani paleae membranaceae, complieatae. Corolla e radii ligulatae, dis ei tubulosae, limbo quinquedentato. Stigmat a appendiculata. A chenia plano-compressa, glabriuscula, exalata, aristis duabus superata. - Herbae mexicanae, ut plurimum hispidue; foliis inferioribus oppositis, superioribus alternis, trinerviis, petiolatis v. sessilibus, saepe basi auriculato-amplexicaulibus, capitulis pedicellatis, laxe corymbosis, floribus tuteis.
S i m s ia Persoon Ench. IT. 478. Cassini in Dict, se. nat. LIX. 136. DC. Prodr. V. 577, non R. Br. Ximenesi a e s p. Kunth in Humb. el Bonpl. Nov. gen, et sp, 6. 380. Lessing. Co reops id is s p. Cavauill. Ic, . 77 .

2534. Ehguleren $H . R, K, C$ a p itulum multiflorum, heterogamum, floribus radii uniseriatis, ligulatis, neutris, disei tubulosis, hermaphroditis. In v o I u cri semiglobosi squamae uni-biseriatac, subaequales, in appendicem foliaceam productae. Receptaculi plani paleae persistentes, achenia ampleetentes. Coroll a e radii ligulatae, dis c i tubulosae, limbo quinquedentato. St i $\mathrm{g} \mathrm{ma-}$ t a exserta, subulata, hispida. A $\mathbf{c}$ h en i a compressa, obovato-cuneata, pubescentia, squa mell is quatuor ovatis, obtusis, a ristis que duabus ex angutis ortis coronata. - Herbae ramosae, in $A m e$ rica calidiore trans a equatorem indigenae; caulibus glabris $v$. rarius villosis, foliis oppositis $v$, alternis, petiolatis, triplinerviis, ovato-lanceolatis, superne scabris, capitulis pedicellatis, laxe paniculato-corymbosis, floribus luteis.

Viguiera Kunth in Humb, et Bonpl. Nov, gen, et sp. IV. 224. t. 379. DC. Prodr. $V$. 379. Vigniera Lessing Synops. 578. H eli a $\mathrm{th} \mathrm{i} \mathrm{sp}$. Cavanill. Ic, $t, 220$.

2535. Leiglnia CASS. Capitn I um multiflorum, heterogamum, floribus radii uniseriatis, ligulatis, neutris, disci tubulosis, hermaphroditis. Involueri imbricati squamae oblongae, in appendicem foliaceam, patulo-squarrosam prodnctae. Receptaculi convexi paleae lanceolatae, achenia amplectentes. Corollae radii ligulatae, disci tubulosae, tubo brevi, fance ampla, cylindracea, limbo quinquedentato. St $\mathrm{g} \mathrm{m}$ a $\mathrm{ta}$ appendiculata. A ch en i compressa, hispidala, squamellis deabus aristaeformilus, ex angulis achenii ortis, et quatuor intermediis ovalibus, brevibus, denticulatis coronata. - Herbae v. suffrutices, in America tropica provenientes; foliús alternis $v$. oppositis, capitulis Helianthi, sed minoribus.

Le ig hi a Cassini in Diet, sc, nat, $X X V$. 435. DC. Prodr. V. 580. Helianthis p. Cavan. Ic. . 218, Bot. Reg. t. 323. Kunth in Humb. et Bonpl. Nov, gen, et sp. $\ell$. 3z7.

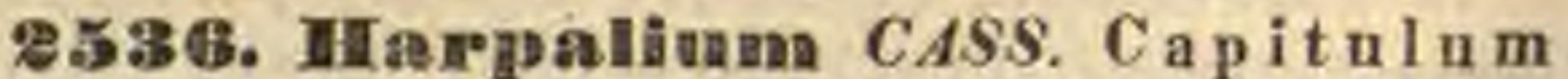
multiflorum, heterogamum, floribus radii uniseriatis, ligulatis, neutris, disci tubulosis, hermaphroditis. Involucri imbricati squamae ovatae, inappendiculatae, obtusae. R e e ptaculi convexi paleae oblongae, achenia amplectentes. Cor oll a e ra di i ligulatae, dis ci tubulosae, tubo brevi, fauce ampla, cylindracea, limbo quinquedentato. Stig m a ta appendieulata. A $\mathrm{c}$ h e n i compressa, parce villosa, squa mellis duabus aristaeformibus ex angulis achenii ortis, et quatuor brevibus, obtusis, intermediis coronata. - Herbae perennes, in $A m e$ rica boreali et tropica observatae; foliis alternis $v$. oppositis, facie Helianthi.

H a rpatium Cassiui in Dict. sc, nat, $X X$. 299. XXV. 437. DC. Prodr. V. 583, H ell a nth i sectio Lessing.

a. EUHARPALIUM $D C$. $t$. $c$. $A$ ch e ni a radii calva,

b. HARPALIZIA DC. $l$. c. A ehe nia radii pappo coronaeformi, amplo, dentato superata.

253\%. Tht Ihonia DESFONT. Capitulu m multiflorum, heterogamum, floribus radii uniseriatis, ligulatis, neutris, disei tubulosis, hermaphroditis. Involueri bi-triseriati squamae ovatae, basi intus striatae, subeallosae, apice foliaceo-appendiculatae, obtusae. R e e pta culi convexi paleae lanceolatae, membranaccae, achenia plus minus amplectentes. Corolla $\mathrm{radii}$ ligulatae, dis ci tubulosae, tube brevissimo, fance inflata, multinervi, limbo quinquedentato. S ti g m a $t$ a ex- 
serta, sulunlata, hispida, revoluta. A chenia radi i obcompressa v. triquetra, p a p po brevissimo, parco, disci subtetragona, compressa, laevia, p a p o uniseriali, sqnamellis pluribus denticulatis, setisque interdum solitariis v. geminis, ex fructus angulis najoribus coronata. - Herbae mexicanae, perennes; foliis alternis, triplinerviis, serratis, ramis apice pedunculiformibus, monocephalis, subnudis, corollis flavis v. croceis.

T ith o $\mathrm{n}$ i a Desfont. in Jussieugen, 189. Annal. Mus, $I$. 46. $t$. 4. Bot. Reg. t, 591, Cassini in Dict. sc, nat. XXXY. 877. LIV. 451. LIX, 147. Lessing Synops. 299. DC, Prodr. V. s84. Heliautlif sp. Jacq. Hort. Schönbr. $t$, 37s, Bot. Mag. 1519. Cavaaill. Ic. $t$. 219 .

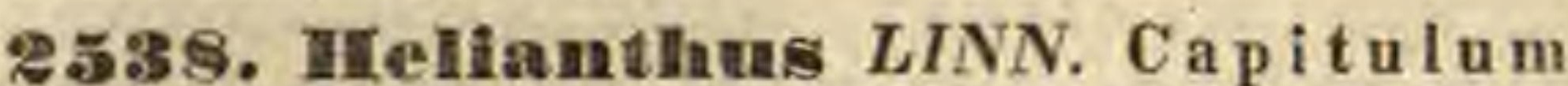
multiflorum, heterogamum, floribus radii uniseriatis, ligulatis, nentris, disei tubulosis, hermaphroditis. In v o I u cri irregulariter imbricati squamae exteriores foliaceae, acutae, appendiculatae, laxiusculae, intimae minures, paleiformes. R e c c pt a culi plani v. convexi paleae semiamplectentes, oblongae, acutae. Corolla e radii lirulatae, d i s c i tubulosae, tubo brevi, fauce ampla, cylindracea, limbo quinquedentato. Stig m a $t$ a appendieulata. A e h en i a lateraliter compressa v. subtetragona, parce villosa v. glabra, squame 11 is duabus aristaeformibus, angulis achenii continuis, rarissime quaternis, conformibus, duabus tune ex angulis lateralibus ortis. - Herbae annuae v. perennes, interdum suffrutescenles, in America boreal $i$, rarius inter $t r o p i c o s$ indigenae, ut plurimum scabrae v. villosae; foliis oppositis, superioribus interdum alternis, integerrimis $v$. dentatis, saepius triplinerviis, capitulis amplis, solitariis $v$. interdum corymbosis, radio luteo v. subaurantiaco, disco luteo $v$, fusco.

Helianthus Linn, gen. n. 979. excl. sp. Sehkulir t. 258, Jaeq. Hort. Vindob, t, 161. 162. Willd. Hort, Berol. t. 70. Cavanill. Ic. $t$, 272, But. Mag. t. 227, 2020. 2778, Bot, Reg. $t$. 508. 524. 1265, Sweet Fl. Gard. II, t. 75. Humb, et Boupl. Nov. gen. et sp. $t, 376$. Cassini in Dict. sc, nat, XX. 351. $L I X, 140$. C h ry sis Reneala. 84, $t, 83$. C a rona SoIis Touruef, inst. 489. Voc as a n Adanson Fam. II. 130. Dis com ela Rafinesque Nov, gen, 1825. p. 3.

25B. Fleurensia $D C$. CapituIam multiflorum, homogamom v. heterogamnm, floribus radii uniseriatis, lignlatis, neutris $v$. femineis imperfectis, disci tubulosis, hermaphroditis. In v o lucri bi-triseriati squamae oblongae, subaequales. R e e pta c uli subconvexi paleae complica tae, deciduae, flore breviores. Cor ollae radii ligulatae, disci tubulosae, tubo brevi, fauce vix dilatata, limbo quinquedentato. Stig m at a exserta, elongata, fere linguiformia, obtusa, extus parce hispida. A cheni a compressa, basi attenuata, villosissima. Pap $\mathbf{p} \mathbf{i}$ aristae quatuor, membranaceae, lineari-subulatae, ciliato-fimbriatae, duae laterales minores, interdum obsoletae - Suffrutices $v$. frutices, in America australi extratropica et in temperatis Mexici observati, glaberrimi, saepius glutinosi, nonnunquam resiniferi; foliis alternis, sessilibus, oblongo-lanceolatis, coriaceis, plerumque penninerviis, reticulatis, pedunculis axillaribus et terminalibus corymbosis, floribus luteis.

Floureasia DC. Prodr. V. 592 . Diomedeac sp. Bertero, Coila in Act. Academ. Taurin, XXXVIII. $t .31$. Hell a n thi sp. Molina, Pöppig.

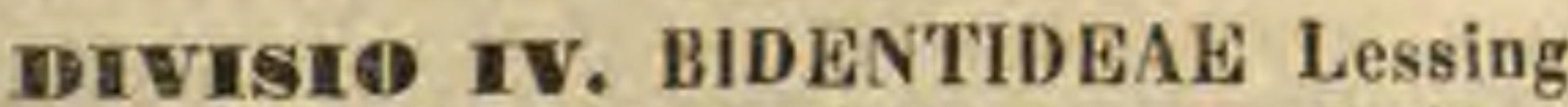
Synops. 229. Capit u la heterogama, floribus radii ligulatis, neutris, rarissime homogama, discoidea. Ach enia rostrata, plerumque in aristas $1-4$, saepissime retrorsum aculeatas producta, rarius calva.

8540. Canapylotheen CASS. Capitu I u m multiflorum, heterogamum, floribus radii uniseriatis, ligulatis, neutris, disci hermaphroditis, tubulosis. Involucri squamae pauciseriatae, oblongo-ellipticae, demum reflexae. Lecepta $;$ u lu in planum, paleatum. Corollae radii lirulatae, ligula multinervi, dis ei tubulosac, tubo brevi, fauce longissima, decemnervi, limbo quin quedentato. A $\mathrm{e}$ he nia elongata, subeontorta $\mathrm{v}$. curva, subtetragono-obeompressa, angustissime alata, alis apice in mucrones minimos, saepe deciduos v, fere obsoletos abeuntibus. - Frutices sundwicenses, erecti, trichotomi; foliis oppo sitis, ternatim biternatimve sectis, segmentis ovalo lanceolatis, integerrimis $v$. dentatis, capitulis pedicellatis, luteis.

Ca a py lotheca Cassini in Diot, sc. nat. LI. ar5. Lessing in Linnaea VI. 508. Synops. 230. DC. Prodr. P. 593. B I de ntis s p. Gaudich. ad Freyc. $t$. 85.

2541. Eideng $L I N N$. Capitulum ho nogamum, discoideam, nune heterogamnm, floribus radii uniseriatis, ligulatis, neutris, disci tubalosis, hermaphroditis. Involucri biseriati squamae exteriores interioribus conformes v, dissiniles.

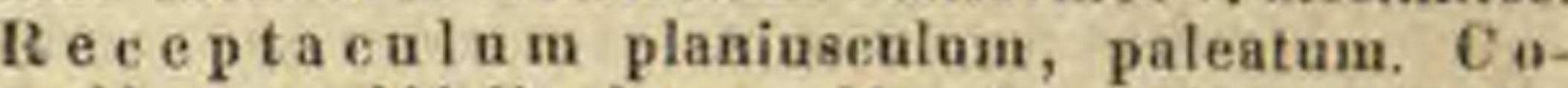
rolla e radii ligulatae, di s ci tubulosac, limbu quinquedentato. Stigmata cono brevi superata. Ach enia plus minus obcompressa, aeuleata, ru. stro ab achenio vix diverso superata, in aristas binas-quinas retrorsum piloso-scabras producta.Herbae cosmopolitae, in America copiosac, ut plurimum annuae; caule tetragono $v$, tereti, sacpius opposite ramoso, foliis oppositis, supremis interdum alternis, indivisis, partitis $v$. sectis, Lobis incisis v. serratis, capitulis plerumque flavis, rarius radio albo, rarissime corollis omnibus purpureis.

B i de ns Linn. gen. $n$, 932, Gîrtn. 11 . 419, $t$, 167. Lessing Synops, 230. DC, Prodr, $V$, 893. Bidens et Kerue. $\mathrm{r}$ i a Mosch Method. 569. et 595. Cassini in Diot, sc, not. XXIV. 397, 409, LT, 673. LIX, 321, 328, 399. PIu riden et $\mathrm{E} d \mathrm{w}$ ards ia Necher elem.n.156.157. Deratoce p thau s Vaillunt in Act, Academ. Paris, 1720, p. 325.

a. PLATYCARPAEA DC. Prodr. $P$. s94. Capitula discoidea latea, v. radiata, ligulis Aavis $v$. interdam al. bis. A e benia ovalia v. obovato - enueiforaia, obcoupresso - plana, setulis omnibus v. saltim superioribus re. trorsis ad margines eiliata, ima basi vix in areolam dilatata. - Folia saepissime indivisa, rarius dissecta. (Sebkuhr t, 234, Flor dan. t. 312, 481, E. B. t, 1t13. 1114.)

b. PSILocarpaea $D C$, Prodr, $V$, 596. Ca pitula dis. coidea, flava v. saepios radiata, radio plerumque flavo, Interdum albo. A clienia liueari-tetragona, glabra v, uiargine sursum eiliata, basi vix in areolam subdilatata. - Eolia saepissime dissecta, rarius indivisa. (Cavanill. Ic. t. 13, 219. Hamb, et Boupl, Nov. gen, ot ip. t, 381. Jacq. t. Elclog. t. 54. Bot. Mag. t.3155. Bot. Reg. t. 684. C or e o p s i i is s p. Jacq. Hort. Schönbr. t. 375. Bot. Mag. t. 2059. C os me a s p. Bot. Mag. t. 1689.)

c. DISCOPODA DO. Capitula radiata, radio discoque purpureis. A che a ia liaeari - subtetragona, utriaque at. tenuata, inferne in areolam orbicularem, obliquam dilatata. Ar is t a e patulae. - Folia pinnatisecta.

254\%. Cosmos $C A V A N$. Capitulnm multiflorum, heterogamum, floribus radii uniseriatis, lignlatis, neutris, disci tubulesis, hermaphroditis. Invol u crum duplex, utriusque squamae octo $v$, decem, basi plus minus concretac, apice acuminatac. Receptaculi plani paleae membranaceae, in filum elongatum productae. Co 
rolla e radii ligulatae, dis ci tubulosae, limbo quinquedentato, Antherae appendice scariosa, cordata superatae. Stigm a ta apice incrassata, hispida, in conum subulatum producta. A ehenia tetragona, exalata, rostrata, interdum stipitata, a $\mathrm{r}$ is $\mathrm{t}$ is binis-quaternis retrorsum pilosn-scabris, deciduis superata. - Herbae a merieano-tropi. cae, annuae, elatae, ramosae, glabrae $v$. parce pilosulae; foliis bipinnatisectis, lobis linearibus, lanceolatis, saepius integerrimis, capilulis ad apices ramorum longe denudatorum solitariis, disco intense luteo, radio versicolore.

C o s mo s Cavanill. Ic. I. 9. t. 14. 79. Kunth in Humb. et Bonpl. Nov. gen, et sp. IV. 239, t, 382. Cassini in Dict. sc, nat. XI. 4. DC. Prodr. $V$. 606. Cosmea Willdenow sp. IIT, 2250. Lessing Synops. 230. C o $8 \mathrm{~m} \mathrm{n} \mathrm{s}$ Pers, Ench, II 477. Core opsidis s p. Jacq. Ic, rar. $t .595$.

25.43. A themolle ais LESS. C a pitu $\mathrm{l} \mathrm{um}$ pluriflorum, heterogamum, floribus radii circiter quatuor, ligulatis, neutris, disci tubulosis, hermaphroditis. I n v o l u e r i eylindracei discum aequantis squamae biseriatae, lineares, interiores foliaceae, glandula magna terminatac. R e c e p t aculnm planum, paleatum. Corollae radii ligulatae, ligula subelliptica, emarginata, disci tulublosae, limbi basi inflati dentibus quinque revolutis. Antherae exsertae, ecaudatae. Achenia conformia, subtriangulato-obeompressa, exalata, lreviter rostrata $v$. apice attenuata, ealva, disci nonnulla interdum linearia, sterilia. - Herba sandwicensis, anmua, gracilis, parvula, apice puberula; foliis oppositis, petiolat is, ternatisect is v. superioribus sessilibus, trilobis, capitulis terminalibus, solitariis, parvis, luteis.

A denolepis Lissing in Linnaea NI. 510. t.6. f. 610. Synops. 230. DC. Prodr. I. 607.

DI VESTO V. VERBESINEAE Lessing Synops. 230. Ca pitul a heterogama, floribus radii ligulatis, femineis; rarius homogama, discoidea. A ch eni a cortice tenui, fere semper compressa $v$. obcompressa, rarius trisul cata $v$, trigena, nune calva, nune in aristas rigidas, numera angulorum producta, rarissime pappo vaginaeformi $v$, setis rigidulis, fragilibus superata.

2544. Easianthaea $D C$, C a pit $\mathrm{u}$ in m multiflorum, heterog amum, floribus radii uniseriatis, ligulatis, femineis, disci hermaphroditis, tubulosis. Invol ueri campanulati squamae pluriseriales, imbricatae, ovatae, obtusae, exteriures eiliatac. Recepta $e$ u li plani paleae membranaceae, complicatae. Corollae radii ligulatae, dis ci tubulosae, tubo tongo, limbi quinquelobi lobis superne pule crassa hirsutissimis. Antherae ap. pendice lineari-lanceolata superatae. Stigmata disci apice summo barbata, exappendiculata. A chen i a glabra, ra di i triquetra, trialata, triaristata, d is ci compressa, bialata et triaristata, a ristis omnium hasi alato dilatatis, - Frutex mexica$n u s, d i$-trichotomus; ramis teretibus, puberuloasperis, foliis oppositis, breviter petiolatis, ovatis, sublanceolatis, vix dentatis, supra sparse strigilloso puberulis, subtus subvelutino-villosis, reticulato-nervosis, capitulis ad apices ramerum circiter quinque, breviter pedieellatis, umbellatis, crassis, floribus luteis.

L. as inatbaca DC. Prodr, r. 607. Lasiantlrus Zucearini msc.
2545. Peryatenium SCHRAD. Capit u I n m multiflorum, heterogamum, floribus radii uniseriatis, ligulatis, femineis, disci hermaphroditis, tubulosis. Invo lucri ovati v. campanulati squamae inbricatae, ovatae, obtusae v. subacutae. Re e c p a c uli planiusculi paleae membranaceae, complieatac. Corollae radii ligulatae, disei tubulosae, limbo quinquedentato. Stig ma ta disci breviter appendiculata, seu cono terminata. A e henia subconformia, subeempressa v. marginalia obcompressa, mutica $v$, apice subemarginata, exaristata. Pappus nniseriatns, setis octo v. decem, rigidulis, fragilibus, inaequalibus. - Suffrutices $v$. frutices mexicani, setulis adpressis scabridi; foliis opposilis, plus minus petiolatis $v$. triplinerviis, ovatis v. oblongis, dentatis, capitulis pedicellatis, solitariis $v$. corymbosis, floribus croceo-flavis.

Pery me i i m Schrader Index Sem. Kort. Gött, 1830. DC. Prodr. $Y$. 608. S $\mathrm{ch}$ is $\mathrm{t}$ o $\mathrm{ca} r \mathrm{ph}$ a Lessing in Linnaea VI. 387, Synops, 387 .

2546. Psaturochaeta DC. CapituI $\mathrm{nm}$ multiflorum, heterogamum, floribus radii uniseriatis, ligulatis, femineis, disci tubulosis, hermaphroditis. Involucri disco brevioris squamae uni-biseriatae, aequales. Rece ptaculi convexi palcae lanceolato-lineares, acuminatae. Coroll a e $r$ a dii ligulatae, dis e i tubulosae, limbi quinquedentati lobis puberulis. Stigmata disei cono elongato-acuminato, hispido terminata. Achenia brevia, acuta, tetragona, subcompressa. Pa p p u dis ci setis octonis-denis, inaequalibus, fragilibus, deciduis, ra di i paucioribus, brevioribus, - Herba capensis, Verbesinae facie; caule teretiusculo, sexsulco, foliis oppositis, petiolatis, utrinque scabris, trinerviis, saepius trilobis, lobo medio longiore, longius acuminato, pedunculis ad apices ramorum alternis, subternis, monocephalis, nudis, corollis intense flavis.

$$
\text { Fs at urochaeta DC. Prodr. } V .609 .
$$

254\%. Lipoehaeta DC. Capitulum mu!tiflorum, heterogamum, florihus radii uniseriatis, ligulatis, femineis, disci tubulosis, hermaphroditis. Involucri ovati v. eampanulati squamae hi-triseriatae, ovales, adpressae. Rece $\mathrm{P}$ ta e u li planiusculi paleae membranaceae, complicatae. Corolla e radii ligulatae, disei tubulosac, limbe quinquedentato. Stigmata disei apice appendiculata. A chenia radii triquetra, vix subulata, angulis saepius tribus in a ristas persistentes productis, dentibus setiformibus, paucis interjectis; disci compressa, uni-biaristata, ad latus interius subulata. - Herbae perennes $v$. suf frutices, in terris mexicanis et in insulis Sandwicensibus provenientes; foliis oppositis, breviter petivlatis $v$. sessilibus, ovato-lanceolatis, subserratis, triplinerviis, capilulis pedicellatis, soli tariis $v$. corymbosis, floribus luteis.

Li pochaet a DC. Prodr. $\mathscr{X}$. 610. Lipotriche Les. sing $S_{2}$ nops 231. Linnaea ${ }^{2} T, 310$, non R. Browb. ? Z ex in en i a Llav. et Lexarz. Nov, veget. $I, 13$. Verbesinae s p. Gaudich,

2548. Hiplothrix DC. Capitulum multiflorum, heterogamm, floribus radii subquinis, uniseriatis, ligulatis, femineis, discitubulosis, hermaphroditis. Involueri orati squamae imbrica. tae, ovatae. Ree e taculi plani paleac eomplicatae, flores involventes. Corollae radii ligula tae, ovaris continuae, persistentes, ligula ovata. disci tubulosac, limbo quinquedentato. Stigmata cono superata. A ch en ia radi obcompressa v. triquetra, calra sive denticulis minimis superata, 
disci compressa, exteriora subealva, centralia biaristata. - Suffrulices mexicani, ramosissimi; foliis oppositis, confertis, acerosis, acutis, integerrimis, vix subpuberulis, uninerviis, marginibus subcallosis, capitulis ad apices ramorum solitariis, breviter pedicellatis.

Diplothrix DC. Prodr. $\nu .611$.

25.4\%. Selloa H. B. K. Ca pitula m multiflorum, heterogamum, floribus radii denis-quindenis, uniseriatis, ligulatis, femineis, disci herma phroditis, tubulosis. In v o I u e r i bi-triseriati syuamae denae-quindenae, exteriores ovato-elliptieae, interiores oblongae, acutae. Receptaeuli convexi paleae lineari-setiformes, Corollae radii ligulatae, ligula novemnervi, apice trilıba, disei tubulosae, limbo quinquedentato. Stig m a $\mathrm{ta}$ cono superata. $A \mathrm{c}$ h e ni a cuneata, pentagona, laevia, setulis tribus hispidulis, caducis, corollae tubo adpressis superata. - Herbae mexicanae; caule bssi folioso, apice longe denudato, subseapiformi, mono- v. rarius tricephalo, foliis oppositis, petiolatis, ovalo-ellipticis, subintegerrimis, triplinerviis, glabris.

Selloa Kunth in Humb, et Bonpl. Nov. gen, et sp. IV. 265. t. 395. Cassini in Dict. sc. nat. I.V. 273. Lessing Synops. 231. DC. Prodr, V.612, non Spreng. Fe a e a Spreng. cyst, $H T, 581$,

2550. Werbestna LESS. Capitul u multillorum, plerumque heterogamum, floribus radii ligulatis, femineis, rarias homogamum, floribus omnibus tubulosis, hermaphroditis. Involu er i bi-pluriseriati squamae aequales $\mathbf{v}$. imbricatae. R ee e p ta culi plani v. convexiusculi paleae plus mi nus complicatae, flores amplectentes. Co rolla radii ligulatae, dis ei tubulosae, limbo quinquedentato. Stigmata appendieulata. A $\mathbf{c h}$ e $\mathbf{n}$ a erostria, plano-compressa, ad angulos alata, in aristas binas, rigidas desinentia. - Herbae $v$. suf frutices, in America imprimis tropica crescentes; foliis oppositis $v$. alternis, petiolatis aut sessilibus $v$. decurrentibus, dentatis pinnatilobisve, capitulis pedicellatis, solitariis $v$, corymbosis, floribus luteis rariusve albidis, disci interdum flavis, radi albis.

Verbesia a Lessing Synops, 231. DC, Prodr. V. 012. Verbesinae et Sieges beckiaesp. Linu. Verbesi. na et Loehería Necker elem. $n, 6 t$ el 71 .

a. Verbesinaria DC. Prodr. $V$. o12. C a pitula lie terogama, floribus radii uniseriatis, ligulatis. A $\mathrm{c}$ h en i aristae rectae, saepissime binae aequales, una interdum breviore v, plane deficieote.

Ver bes $\mathrm{i}$ a a Cassini in Dict, sc. nat, LIX, $142 . \mathrm{Ca}$ vanill. Ic, t, 100. 214. 275. Jacq. Ic, rar, t. 175. Hort. Schönbr, t, 305. Colla Hort, Ripul, t, 31. Link et Otto Absild, t, 49. W ed elf a e $8 \mathrm{p}$. Hooker Bot, Mag.t.3381. Pallasiae s p. Huab, et Boupl. Plant, aequinoct. $t$ 111. Sleges beckia Gronov, Virgin. 128. P ha $t$ us a Gärte, $I T .465$. c. 169.

b. HAMULIUM $D C$, Prodr, $\mathscr{V}, 617, \mathrm{C}$ a pitu 1 a heteroga. $\mathrm{ma}$, floribus radil subbiseriatis, ligulatis, A $\mathrm{ch} \in \mathrm{n}$ i aristae binae inaequilongae, altera minore reeta, altera majore apice uncinata.

H a muti u Cossinj in Dict. sc. nat.Xx. 260. Ver be sin a a lata Linn. Bot. Mag, $t, 1216$.

e. PLATXPteris DC. Prodr. $Y .617$, C a pitula homogama, discoidea.

Platypteris Kunth in Humb. ct Bonpl. Nov.gen. et sp. IV. 200. Cassini in Dict. sc. nat. L. 959. B idens crocata Cavan. Ie, $t, 99$. Sptla athes croca ta Sims in Bot, Mag. $t$. 1697,

2551. Dhtrielnum CASS. Capitu $1 \mathrm{um}$ pluriflorum, homogamum, floribus omnibus tubulosis, hermaphroditis. Involucri biseriati, ey- lindracei, fluribus longioris squamae exteriores brevissimae, laxae, interiores longae, erectae, coriaceae, acuminatae. $R$ e cept a $\mathbf{c}$ u i plani paleae in appendicem subulatam productae. Corollac tubulosae, extus pilosae, limbo quinquedentato. A ch e ni a compressa, obovata, glabra. Pap p us biaristatus, aristis ex angulis ortis, crassis, subharbulatis. - Herbaulvidelur americana, elata; caule tereli, pubescente, foliis alternis, sessilibus, subdecurrentibus, oblongo-lanceolatis, irregulariter sinuato-lobatis, scabris, fere pedalibus, capitulis paniculato-corymbosis, floribus flavis.

Ditriehum Cassini in Bullet. soc. philomat, 1817. p. 33, Diet, sc, nat, XIII, 272. DC. Prodr, V, 619. S p il a nthi sp. Less.

255\%. NIferaetis $D C$, Capit u I m multiflorum, heterogramum, floribus radii minutissiuse ligulatis, fenineis, discitubulosis, hermaphroditis, centralibus fortassis sterilibus. Involueri unibiseriati squamae oblongae, subeoneavae, dorso subpuberulae. Receptaculi plani paleae complicato-concavae, glabrae, achenia semíavolventes. Corollae radii ligulatae, lignla brevissima, integra, concava, dis ci tubulosae, limbo quadridentato. Antherae quadricaudatae. St y lus radii exsertus, disei inclusus. A chenia tetragono-compressa, fere obovata, glabra omnino calva. - Herba madagascariensis, obscurae affinitatis, annua, erecta, minutissime puberula; foliis opposilis, oblongis, acutis, vix subcrenatis, scabris, superioribus integerrimis, capitulis ad apices ramorum ternis, congestis, breviter stipilatis, floribus minutissimis, flavis.

Mieraetis DC. Prodr. V. 619.

2353. Spillanthes $J A C Q$. Capitulum multifiorum, nune heterogamum, floribus radii ligulatis, femineis, disci tubulosis, hermaphroditis, nunc homogamum, floribus omnibus tubulosis, hermaphroditis. Involneri biseriati, adpressi, disco brevioris squamae exteriores subfoliaceae, interiores submembranaceae, complicatae. $\mathbf{R}$ e e pt a u li convexi v, conici paleae complicatae. Curolla e radii ligulatae, disci tubulosae, limbo quadri-quinquedentato. Antherae nigricantes. S $t$ i g $\mathbf{m}$ a $t$ a disci apice truncata et penieillata. A chenia erostria, disci compressa, ad latera ciliata, exaristata, radii dum adsunt triquetra $v$. obeompressa, apice emarginata, in aristulas doas, piliformes desinentia, - Herbae ut plurimum annuae, rarius perennes $v$. suffruticulosae, inter tropicos totius orbis, imprimis Americae obviae, gustu plerumiue fervidae et salivariae, dichotomae $v$. vage ramosae; foliis oppositis, subintegerrimis, pedunculis terminalibus $v$. $e$ dichotomiis ortis, erectis, monocephalis, capitulis ovatis $v$. conicis, floribus flavis $v$, rarius albis, radio concolore $v$. rarius discolore.

SpHanthes Jacq. Amer. 212. Schrebergen, 1266. DC. Prodr. $V .620$. S pila in th us Lian, mant. II. 167. Lessing Synops. 232. P y r eth rum Medicus Act. Academ. Palat. III. 237. Ceruch is Gärtner msc.

a. ACMklla DC. Prodr, $V, 620$. C a pitula radiata, lignlis basi hispidis. A che nia radii saeplus trigona, triaristati seu rarius calva, v. augulo interiore uodo biaristata, v, augulo interiore obliterato fere obeompressa.

Acmella Richard in Persoon ench, IT.472. Cassioi in Diot. sc, nat. XXIV. 531. A th ronia Necker elem. $n, 59$.

b. SAlivaria DC, Prodr, $\boldsymbol{V}$. 624. C a p itula diseoidea. A che n 1 a omnia conformia, compressa.

$\mathrm{S}$ pila $\mathrm{nt}$ thes Jaeq. Amer. $t$. 126, Hort, Vindob. $t$. 135. Ic, rar. t. 584. Heritier Stirp.t.4. Kuntb in Humb. 
et Bonpl. Nov, gen, et sp.t.370. B identis s p. Lam. t. 668 .

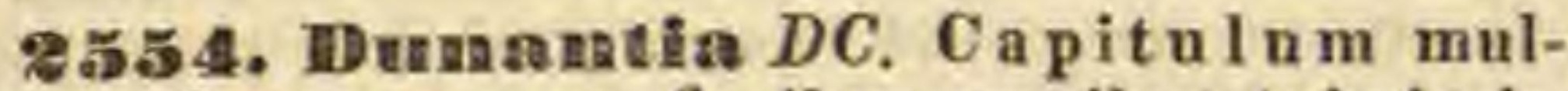
tiflorum, homogamum, floribus omnibus tubulosis, hermaphroditis. Involucri uniseriati squamae adpressae, Ianccolatae v. oblongae. Receptaculi elongati paleae exteriores involueri squamis simillimae, interiores sensim tenuiores, submembrana ceae. Corolla tubulosae, limbo quinquedentato. Stigmata exserta, in appendicem filiformem, hispidam longe producta. A $\mathbf{c h}$ en ia tetragona, gracilia, erostria, glabra, ealva. - Herbae mexicanac, perennes; caule erecto, tereti, pubescente, ramis saepius oppositis, subdivaricalis, apice nudis, foliis oppositis, brevissime petiolatis, lanceolatis, basi acutis, triplinerviis, pubescentibus, integerrimis, capitulis ovatis, ad apices rumorum solitariis, binis $v$. ternis, lateralibus ubi adsunt subsessilibus.

Dunautia DC. Prodr. $V, 626$.

2555. Ximnenesia $C A V A N$. C apitu $\mathrm{lnm}$ multiflorum, heterogamum, floribus radii uniseriatis, ligulatis, femineis, disci hermaphroditis, tubnlosis. Involueri biseriati, discum subsuperantis squamae foliaceae, patulae, angustae, acutae, subaequales. Receptac ali plano-subconici paleae membranaceae, lanceolatae, amplectentes. Corolla e tubo hispido, radii ligulatae, disci limbo quinquedentato. Stig $\mathrm{m}$ a $\mathrm{ta}$ disci apice appendiculata. A chenia radii plano-compressa, ulata, apice profunde emarginata, subpilosa, biaristata, a ristis cum lateribus alarum subconeretis. - Herbae annuae, ut plurimum mexicanae, plus minus canescentes; foliis oppositis v. alternis, in petiolum saepias subalatum et basi auriculatum attenuatis, cordatis, ovatis v. oblongis, dentalis, capitulis laxe et irreguluriter corymbosis, floribus luteis.

Ximenesia Cavanill. Ic. II, 60, t, 178. DC. Prodr. V. 627 .

P.556. Samvitalla GUALT. Capitulum multiflorum, heterogamum, floribns radii uniseriatis, ligulatis, femineis, disci hermaphroditis, tubulosis. Involucri bi-triseriati squamae adpressae, subimbricatae, interiores paullo longinres, disco aequales. Re e e ta culi conici v. convexi paleac oblongae, semiamplectentes. Corollae radii ligulatae, persistentes, dis ei tubulosae, piliferae, super ovarium artienlatae, limbo quinquedentato. Stigmata cono superata. A chenia radii grossa, triquetra, laevia, arist is tribus crassis, laevibus, conicis, divergrentibus coronata, disci compressa, biformia, exteriora muricata, fere calva, interiora alata, ciliata, aristellis duabus minimis superata. - Herbae mexicanae, annuae, trichotomae, saepius villosae; foliis oppositis, ovatis, integerrimis, triplinerviis, in petiolum ciliatum attenuutis, capitul is terminalibus, solitariis, inter folia bractealia sessilibus, disco convexo-conico, atropurpureo, radio luteo.

Sanvitalia Gualter in Lamarck Journ. Hist, nat, II, 176. t. 33. Illustr. t. 686. Cavanill, Ic, t, 351. Cassini in Dict, se, nat. XLVIT. 294. Lessiag Synops, 232. DC. Prodr. T. 628. L o re a te a Ortega Decad. $I V .42, t$. 5 . nou Less.

\$55\%. Anatis DC. Capitulum multiflorum, heterogamnm, floribus radii ligulatis, femineis, disei hermaphroditis, tubulosis. I n v o I acri campanulati, bi-triseriati squamae imbricatae, obtusae. Re e pta culi convexi paleae decidnae, complieatae, calloso-acaminatae. Corollae rad i i ligulatae, persistentes, ligula multistriata, disei tabulosae, ...... Stigmata radi i bre- vissime exserta, dis ei ...... A ehenia glabra, minutissime et parce muriculata, radii trigona, rostrata, calva, di sci plano-compressa, subulata, emarginata v, bidentata, - Suffruticulus a capulc ensis, non satis notus; ramis teretibus, divaricatis, junioribus pubescentibus, foliis oppositis, oblongis, basi attenuatis, integerrimis, pubescentibus, ramis apice longe aphyllis, monocephalis, floribus radii luteis, disci subfuscis.

\section{Auaitis DC. Prodr. $V$. 629.}

\$558. Diligosyne $D C, C$ a pitulum plnriflorum, heterogamum, flore radii unico v. quinis, ligulatis, femineis, disci senis-octonis, tubulosis, hermaphroditis. Invo I ucri uniseriati, erecti squamae quinque, ovali-oblongae, foliaceae, R e e ptaculi plani palcae lineari-lanceolatae, planae. Corollae radii ligulatae, dis ci tubulosae, limbo quinquedentato. St ig m a t a d i s ci exserta, hispida. A ch en i obcompressa v. teretiuscula, sulimnrieulata, glabra, a ristis duabus v. quatuor conicis, rigidis superata. - Herbae mexicanae et brasilienses, Sanvitaliae habilu, diffusae, puberulae; foliis oppositis, petiolatis, ovatis, serratis, subtriplinerviis, pedicellis axillaribus monocephalis, capitulis parvis, floribus flavis.

\section{Oligogy ne DC. Prodr. V. 629.}

3559. Syeacilrella GIRTN. C a p itu$1 \mathrm{u} \mathrm{m}$ pluriflornm, heterogamnm, floribus radii suboctonis, subbiseriatis, ligulatis, femineis, disei totidem hermaphroditis, tubulosis. Invo lu e ri oblongi, oligophylli squamae erectae. Recepta cu1 u m parvum, planum, paleatum. Corollae rad ii ligulatae, dis ci tululosae, limbo quinquedentato. A chenia radii obcompressa, ovalia, biaristata v. mutiea, margine alata, alis laciniatis, d is ci linearia, snbtriquetra, integra, bi-triaristata. - Herba entillana, erecta, dichotoma; caule tereti, glabriusculo, foliis oppositis, petiolatis, ovalibus, utrinque attenuatis, integerrimis, parce villosis, capitulis in ramorum et foliorum superiorum axillis sessilibus, subglomeratis, floribus luteis.

$\mathrm{S}$ y ne d rell a Gärtner $I T .456, t$. 171. Rlehard in Per. soon Ench. IT. 472. Cassini in Dict. sc, nat. LI. 470. Lessing Synops. 233. DC. Prodr. $V$. 699. Verbesina nodi. fl o r a Linn. (Sloane Jam. t, 154.)

2569. Caly ptecarpons LESS. Ca p ituIn m multiflorum, heterogamum, floribus radii uniseriatis, ligulatis, femineis, disei hermaphroditis, tubulosis. Involuc ru m pentaphyllum. Recepta c ulum paleatum. Corulla e radii ligulatae, d is e i tubulosae, limbo quinquedentato. Siig mata ..... A ch e nia conformia, erostria, planoobcompressa, biaristata, interrupte et anguste alata. - Herba mexicana, gracilis, dichotoma, annua, procumbens; foliis decussatis, petiolatis, scabris, dentatis, capilulis solitariis, luteis, brevissime radiatis, pedunculatis, terminalibus, demum alaribus.

Calyptocarpus Lessing Synops, 221. Linnaea $V$. 269. DC. Prodr. $V$. 629.

2561. Eleetra DC. Capitulum pluriflorum, heterogamum, floribns radii subquinis, ligulatis, femineis, disci octonis-denis, tubulosis, hermaphroditis. Involu cri duplicis squamae exteriores quinque, lineares, distantes, interiores totidem inter se et cum exterioribus fere concretae. Receptaculi angusti, plani paleae oblongo-Tineares, coloratae, persistentes, flores subsuperantes. Corollae radi i ligulatae, di s c i tubulosac, glabrae, abrupte in faucem dilatatae, limbo quinquedentato. Stigmat a radit glabra, disci co- 
no hispido terminata. A chenia obcompresso-plana, elliptico-oblonga, utrinque subangustata, apice obtuse truncata, glaberrima, calva.-Fruticulus mexicanus, glaber, erectus; ramis junioribus tetragonis, adultis teretibus, foliis oppositis, in petiolum brevem angustatis, oblongo-lanceolatis, acu. minatis, grosse serratis, penninerviis, capitulis pedi cellatis, saepius ternis, corymbosis, ovali-oblongis, corollis et receptaculi paleis luteis.

Electra DC. Prodr. V. 630.

2562. Chrysanthellum RICH. Capi $t \mathbf{u l ~ u m}$ pluriflorum, heterogamum, floribus radi uniseriatis, ligulatis, femineis, disei tubulosis, her maphroditis. Involucri biseriati squamae exte riores quinque, paullo breviores, erectae, interiores decem, coloratae. R e e p ta $\mathbf{c} \mathbf{u}$ li plani paleae lineares. Corolla e radi i ligulatae, ligula lineari, bidentata, d is ci tubulosae, limbo quinquedentato. Stig $\mathrm{m}$ at a disei in appendicem hispidam producta, Achenia calva, oblonga, truncata, emarginata v. ntrinque ala minima, crassa, cartilaginea ancta. - Herbae annuae, glabrae, parvulae, in Antillis, Senegambia et India orient ali observatae; foliis radicalibus petiolatis, ovalibus, basi cuneatis, caulinis superioribus sessilibus, oblongo-linearibus, apice tridentatis, ramulis subnudis, apice monocephalis, capitulis parvis, floribus luteis.

Chrys anthell u michard in Persoon Ench, IT. 471. Cassini in Dict. sc. nat. $1 X$. 150. Lessing Synops. 234. DC. Prodr. $V$ 630. Chrysanthellina Cassini in Diet. sc. nat. $X X V \cdot 390$, S e ba s tian ia Bertoloni Opusc, 1822, p. 37. non Spreng. Coll ate a Spreugel Syst, III, 628. A n them idis, Bidentis et Verbesinae sp. Linn.

2563. Neuractis CASS. Capitulum pluriflorum, heterogamum, floribus radii tribus, ligulatis, femineis, discitubulosis, hermaphroditis Involucri biseriati, diseo multo brevioris squamae oblongae, exteriores breviores. R e c e t a culi plani, centro nudi, paleae marginales oblongolineares, planae. Corolla e radii ligulatae, ligula ampla, ultra medium trifida, dis c i tubulosae, limbo quinquedentato. Stig $m$ a $t$ a disci exserta, revoluta, in appendicem longissimam gracilem desinentia. Achenia obcompressa (?), oblonga, glabra, in collum breviter producta. $P$ a P p $\mathbf{s}$ s nullus v. margo incompletus, dentatus. - Herba $j a$ vanica, glabra, diffuse ramosa; foliis alternis, petiolatis, bipinnatilobatis, lobis oblongis, integerrimis, mucronatis, capitulis pedicellatis, solitariis, corollis flavis, ligulis fusco-lineatis.

Nen ractis Cassini in Dict. sc. nat, XXXIV.496. Les. sing Synops, 232. DC. Prodr. V. 631.

2564. Glossocardia CASS. Capitu$1 \mathrm{u} \mathrm{m}$ pluriflorum, heterogamum, floribus radi duobus v. unico, (interdum nullo) ligulatis, femi neis, disci tubulosis, hermaphroditis. Involucri oblongi squamae paucae, subimbricatae, exteriores brevissimae, Receptaculi angustissimi paleae inter flores plurimae, membranaceae, deciduae. Corollae radii ligulatae, disci tubulosae, limbo quadridentato. Stigmata disci appendiculata. A chenia disci plano-obcompressa, angulis quatuor villosissima, subbialata, a ristis binis rigidis, laevibus, angulis lateralibus continuis. Herba Indiae orientalis, annua, multicaulis, diffusa, edulis, odore et sapore Foeniculi; foliis al ternis, linearilobis, capitulis solitariis, pedunculos breves, nudos terminantibus, floribus flavis.

GIossoeardia Cassini in Dict. sc. nat. XIX, 62. Lessing Synops. 233. Verbe $\mathrm{sina}$ B o 8 walle a Linn.
9565. Heterospermum $W I L L D, C$ apitulu m pluriflorum, heterogamum, floribus radii ternis v, solitariis, ligulatis, femineis, disci quinis-quindenisve, tubulosis, hermaphroditis. Involucri duplicis squamae paucae, erectae, oblongae, exteriores ciliatae. Reepta $\mathrm{culi}$ angusti paleae oblongo-lineares, planae, obtusae. Corollae radii ligulatae, di s $\mathrm{e}$ i tubulosae, limbo quinquedentato. Stig m a $\mathrm{t}$ appendiculata. A chen i a oheompressa, glabra, alis incrassatis cincta, diflormia, radii ovalia, erostria, calva, disei lineari-ublonga, rustrata, biaristata, a ris tis retrorsum aculeolatis. - Herbae a mericanae tropicae, annuae, opposite ramosae; caulibus glabris, bifariam pilosis, foliis oppositis, dentatis, lobatis $v$. pinnatipartitis, glabris, pedunculis alaribus terminalibusque gracilibus, monocephalis, fioribus flavis.

Heterosperm um Willdenow sp. HI. 2129. Kunth in Humb. et Bonpl. Nov. gen. et sp. IV. 245. t. 383.384. Cas. sini in Dict. sc, nat. XXI, 128. Lessing Synops. 233. DC. Prodr. V. 638. Heteros p e r m a Cavanill. Ic. III. 34, t.267.

2566. Allossogyne CASS, Ca pitulun multiflorum, heteroganum, floribus radii uniseriatis, ligulatis, femineis, disci tubulosis, hermaphroditis. Involueri biseriati squamae breves, adpressae. Receptaculam planum, demum convexum, paleolatum. Corolla e radii ligulatae, di s c i tubulosae, limboquinquedentato. Stig mat a disci elongata, hirta. A $\mathbf{c h e n i a}$ linearia, angulata, aristis duabus retrorsum setosis. - Herbae in Australasia tropica et in India orientali indigenae, erectae, basi interdum suffruticosae, dichotomae, nunc fruticosae, pedunculis plurimis, nudis, simplicibus; foliis alternis, ad collum confertis, brevibus, pinnatipartitis, lobis linearibus, acutis, integerrimis, summis paucis, parvis, linearibus, indivisis, capitulis erectis, ebracteatis, floribus luteis.

G los sog y ne Cassini in Dict. sc. nat. Lr. 475. DC. Prodr. V, 632, non Less. B id e at is s p. Wallich, Labillard. Nov, Caled. t. 45.

258\%. IBelucia DC. Capitnln multiflorum, heterogamum, floribus radii uniseriatis, ligulatis, femineis, disci tubulosis, hermaphroditis. Involucri duplieis, subaequalis squamae linearilanceofatae, erectae, exteriores foliaceae, interiores coloratae. Curollae radii ligulatae, disci tubulosae, limbo quinquedentato. Stigma ta cono superata. A $\mathrm{eh}$ e nia conformia, obeumpressa, linearia, a ristis tribns, retrorsum hispidis superata. - Herba mexicana, subsimplex, vix pedalis, glabra; folius oppositis, petiolatis, trisectis, segmentis ovatis, utrinque acutis, grosse dentaloserratis, capitulis solitariis, longe pedunculatis, floribus luteis.

Deluela DC. Prodr. $\nu .632$.

2568. Narvalina CASS. Capitulum plnriflorum, heterogamum, floribus radii ternis v. solitariis, ligulatis, femineis, disci suboctonis, tubulosis, hermaphroditis. In v o I u $\mathrm{eri}$ biseriati squamae exteriores subternae, foliaceae, acutae, interiores quinque, longiores, disco breviores, oblongac, erectae, apice coloratae. Re e e ta culi plani paleae squamas interiores referentes. Cor ollae radij ligulatae, dis ei tubulosae, limbo quinquedentato. Stigmata ... A c h en ia obcompressa, ovalia, ampla, late marginata, ciliata. Pappus caducus, biaristatus, aristis erassis, fragilibus, coloratis, triquetro-subalatis, secus angulos spinnloso-strigosis. - Frutex demingensis, non satis nolus, glaberrimus; foliis oppositis, breve petiu53 
latis, obovatis, serratis, coriaceis, capitulis corymbosis, floribus luteis.

Narvalina Cassini in Dict. se, nat, XXXYTIT, 17, LIX. 320. Lessing Synops. 234. DC. Prodr. $V$. 633. Ne edhami a Cassini in Dict. sc. nat. XXXIV. 335.

z569. Thelesperma LESS, C a p itu I $\mathrm{m}$ multiflorum, homogamum, floribus omnibus tubulesis. Invol ucrum biseriatum, utriusque squamae suboctonae, exteriores breves, lanceolatae, subdistinctae, interiores campanulato-concretae, striatae. Re e pta culi plani paleae oblongae, medio nervigerae, marginibus late albomembranaceis. Coroll a e tubulosae, limbo quin quedentato. Stigmata appendiculata. A chenia obcompresso-teretiuseula, erostria: P a p p s biaristatus, aristis oppositis, retrorsum fimbriatis, trigono-conduplicatis, subulatis, persistentibus. Herba brasiliensis, perennis, bipedalis, glabra; caule tereti, opposite ramoso, rigido, foliis oppositis, biternatim $v$. bipinnatim-sectis, lobis linearibus elongatis, acutis, integerrimis, capitulis ramos apice nudos terminantibus, involucris glandulosis, corollis obscure luteis.

Theles perma Lessing in Linnaea VT. 511. Synops. 234. DC. Prodr, V. 633.

25\%0. Isostigma LESS. Ca pitul um multiflorum, heterogamum, floribus radii uniseriatis, ligulatis, femineis, disci hermaphroditis, tubulosis. Involueri campanulati, bi-triseriati squamae liberae, exteriores breviores, angustiores. Receptaculum planum, paleatnm. Corollae ra dii ligulatae, ligula oblonga, di s c i tubulosae, limbo quinquedentato. St $\mathrm{g} \mathrm{m}$ a $\mathrm{t}$ a in disco et radio conformia, in appendicem lineari-filiformem, longissimam, hispidam producta. A chen i a linearia, striata, plano-obeompressa, subalata, in rostrum achenio simile producta, alis in mucrones vel aristas duas, laeves, divergentes desinentibus. - Herbae brasilienses, perennes, glaberrimae; rhizomate lignoso, subhorizontali, foliis ad collum conferte alternis, linearibus, integris $v$. saepius biternatim v. bipinnatim sectis, segmentis filiformibus integerrimis, caule erecto, simplicissimo, nudo $v$. parce squamato, monocephalo, eapitulo magno, sordide fusco.

I s o stig m a Lessing in Linnaea VI. 513. Synops. 235. DC. Prodr. $\boldsymbol{V} .634$.

SUE'THERS TII. FLAVERIEAE Lessing Synops. 233. C a p it u la varia, nunc unipanciflora, dense aggregata, heterogama (flore unico femineo, reliquis hermaphroditis) homogamis mixta, nunc multiflora, floribus femineis pluriseriatis, reliquis masculis. Receptacn$1 a$ in capitulis paucifloris nuda, in multifloris paleata. Stig mata floris hermaphroditi saepissime exappendiculata. A ch en ia calva, exalata, teretiuscula, basi longe attenuata.

Herbae glabriusculae, in A meric a trop $i$ ca indigenae; foliis oppositis, tri-v. multiplinerviis, Roribus flavis.

25\%1. FIaveria JUSS. Capitula pau ciflora, fasciculato-conglomerata, nunc homogama, nune heterogama, flore unieo lignlato, femineo, reliquis tubulosis, hermaphroditis. Involucr oblongi, tri-tetraphylli squamae conniventes, aequilongae, extima major, subconcava. R e ceptaculum parvum, epaleatum. Corollae femineac ligulatae, hermaphroditae tubulosae, limbo qquin- quedentato. Stigmata exappendiculata, A $\mathrm{Ch}$ n ia oblonga, calva, striata, glabra. - Herbae annuae, austro-americanae, glabrae v. juxta ramos parce puberulae; foliis oppositis, sessilibus, interdum basi attenuatis, dentalis $v$. integerrimis, saepius trinerviis, capitulis secus ramos unilateralibus, plus minus in cymas v. glomerulos confertis, floribus luteis.

Fiave ria 3ussieu gen, 186 , Cassiai in Dict, sc, nat, XVI. 127. Bot. Mag. $t$, 2400. Lessing Synops, 233, DC. Prodr, $V$. 635. Ver mifng a Ruiz et Pav. Prodr, t. 24. Syst, 210. Mille $r$ ia e s p. Cavanill. Ie, $t, 4.223$.

25ร2. Broteroa $D C$. C a pitula in glomerulum ovatum dense spicato-conferta, sessilia, alia biflora, heterogama v, homogama, alia uniflora, feminea v. hermaphrodita. Involucri squa mae nunc solitariae, concavae, amplae, nunc binae v. ternae, aliae amplae concavae, aliae parvae. Receptac a lum punctiforme, nudum. Corolla e $\mathrm{fem}$ inea e filiformes, subligulatae (?), mas. cula e tubulosae, extus pilis articulatis, confertis hispidae, limbo quinquefido. Stig $\mathrm{m}$ a $\mathrm{ta}$ in floribus hermaphroditis exappendiculata. Achenia obcompressa, obovato-oblonga, glabra, calva, floris feminei majora. - Herba carac as an a, glabra, parce divaricato-ramosa; foliis oppositis, sessilibus, ovali-lanceolatis, acuminatis, trinerviis, integerrimis aut serratis $v$, subrepandis, glomerulis ad apices ramorum $v$, in axillis superioribus paucis, subumbellatis, floribus flavis.

Broteroa DC. Prodr. F. 635. Brotera Sprengel in Schrader Journ. 1800, II. 186. t. 5. excl. synon. Persoon Ench. II. 498. Cassini in Dict, sc. nat. XXXIV. 304. LIX. 236. nou alior. $\mathrm{N}$ a u e a brgía Willdenow $s p . I 11.239$. Hoffmansegg Vers. 237. Lessing Synops. 232. non Mönch. Plaveria s p. Lagasc.

25\%3. Clairvillea $D C$. Capitula fas. ciculato-capitata, pluriflora, heterogama, floribus radii subquinis, uniseriatis, ligulatis, femineis, disci totidem tubulosis, hermaphroditis. In vol uc ri ovati squamae ovales, arete imbricatae. $\mathrm{Re}$ c e p ta c nli angusti margo paleis oblongo-linearibus onustus, discus epaleatus. Coroll ae radii ligulatae, dis ci tubulosae, limbo quinquedentato. St ig $\mathbf{m}$ a $t$ a disei appendiculata, hispidula. A $\mathrm{ch}$ en ia ovata, glabra, calva. - Frutex peruvianus; ramis teretibus, junioribus albo-tomentosis, adultis glabris, foliis oppositis, connato-vaginantibus, ovatolanceolatis, acuminatis, serratis, serraturis distantibus calloso-spinellosis, supra quinquenerviis, junioribus araneosis, adultis rugosis, glabriusculis, subtus dense albo-tomentosis, capitulis subsessilibus, in glomerulum ovatum, terminalem dense aggregatis, centralibus praecocioribus.

Clairvillea DC. Prodr, V. 636.

25ร 4. Enlny dra LOUREIR. Ca pitulum multiflorum, heterogamum, floribus singulis palea receptaculi involutis, exterioribus pluriseriatis, ligulatis, femineis, centralibus tubulosis, hermaphrodito-masculis. Involueri tetraphylli squamae foliaceae, duae oppositae majores. R e c e $t a-$ culi parvi, planiuseuli paleae complicatae, conniventes, coriaceae, apice hirtellae. Co roll a e radii tubo filiformi, limbo subligulato, tri-quadrifido, di s c i obconicae, limbo infundibuliformi, quinquefido. Stig mata exserta, revoluta, apice hispidala. A chenia obcompressa, erostria, ealva, paleis omnino involuta. - Herbae aquaticae, radicantes, oppositifoliae, in Asia et America tropica indigenae ; foliis oblongis, interdum biauriculatis, capitulis ad axillas superiores solitariis, floribus albis. 
E n h y d ra Loureiro Flor, cochinch. II, 624. DC. Prodr. V. 636. Me y era Setreber gen, $n, 1318$. Lessing Synops. 236. Ruizet Pav. Prodr. 109, f. 24. Rn h ydra, Me yera et Sob r y a Persoon Ench, II. 498. Hi a geh a Roxhurgh Flor. 8nd. III. Tetractis Reinwardt in Blume Bijdr. 892. P thyllinema Blume msc. Me yerae sp. R. Browa. Eahydrate s p. Cass.

SUIBTHEDS IV. TAGETINEAE Cassini Opusc. III. 54. Capitula multiflora, nune heterogama, floribus radii femineis, plerumque ligulatis, nunc homogama, discoidea. Invo luer um nunc uniseriale, squamis plus minus concretis, nunc pluriseriale, squamis exterioribus bracteiformibus, liberis, interioribus concretis, Recepta culum planum, epaleatum. A chenia erostria, striata, elongata, basi attenuata. P a P p u s ex aristis, squamellis v. setis constans. Herbae ut plurimum annuae, rarius suffruticosae, omnes Americanae, glandulis pellucidis, grossis in omnibus partibus foliaceis inslructae, saepius odoriferae, foliis oppositis v. alternis.

DIVISIO I. TAGETEAE DC. Prodr. $\boldsymbol{V}$. 638. Capitula saepius heterogama, radiata. In v o lu cri squamae saltim interiores omnino inter se connatae. Co rolla disci regulariter quinquedentatae. St i g mat a cono superata. $\mathbf{P}$ a p u s inaequalis, uni-biserialis, ex aristis v. squamellis constans.

25\%5. Ademopliyllum PERS. Capitulum multiflorum, heterogamum, floribus radii ligulatis, femineis, disci tubulosis, hermaphroditis. Invol uerum gamophyllum, squamis linearibus, concretis, apice in aristam subulatam, basi uniglandulosam productis, bracteis subuniseriatis, ari stato-subulatis, basi uniglandulosis cinctum. $\mathbf{R}$ ece p ta cu l u m alveolatum v. fimbrilliferum. Co rolla e radii ligulatae, disci tubulosae, limbo quinquedentato. A chenia elongata. P a p p u 8 duplex, exterioris paleae breves, truncatae, interiores elongatae, apice acute trifidae. - Herbae $m$ exicanae, Tagetis facie; foliis inferioribus oppositis, superioribus alternis, omnibus pinnatisectis, segmentis ovatis $v$. fere linearibus, aristato-dentatis, rhachi hine inde inter segmenta aristas gerente, pedunculis monocephalis, sub capitulo incrassatis, corollis croceis $v$. coccineis, disci dilutioribus, interdum monstrose sex-octofidis, stylo tunc tripartito.

A de no phy 11 a m Persoon Ench, II. 458. DC. Prodr. V.638. Will den owa Cavanilles Ic. $t, 89$. Lam. t. 685. Hon Thunb. Scblechtendali a Willd. sp. III. 2125. non alior. Dys sodae sp. Lagasc. $\mathrm{T}$ age $t \mathrm{i}$ s sp. Less.

25\%8. Tebetina CASS. Ca pitulum multiflornm, heterogamum, floribus radii lignlatis, femineis, disci tubulosis, hermaphroditis. In v ol u c ru m cylindraceo-campanulatum, squamis subvicenis, uniseriatis, inferne connatis, apice varie liberis, cinctum bracteis uni-biseriatis, pinnatipartitis, lobis apice subulato-piliformibus. Receptaculum convexum, fimbrilliferum. Corolla e radii ligulatae, disci tubulosae, limbo quinquedentato. A chenia cylindracea, minutissime pubes centia. Pa p p a s duplex, exterioris paleae decem, oblongae, integerrimae, interioris setae totidem, basi paleaceo-cuneatae, apice ramoso-pinnatae, filiformes. - Herba erecta, ramosa, glabra, 'Tagetis facie; foliis alternis, pinnatipartitis, lobis serratis, serraturis in pilum longum desinentibus, ramis apice subnudis, foliis supremis paucis bracteaeformibus, monocephalis, corollis flavo-aurantiaceis.

Le betina Casslui in Dict, sc. nat, XXV.394. LIX. 68, DC. Prodr. V. 639. B o e ber a Lessing Synops. 237. non Willd. D ys s o dia Willdenow enum, 900, uon Cav.

$25 \%$. Dysedia $C A V$. Capitulum multiflorum, heterogamum, florilsus radii ligulatis, femineis, disci tubulosis, hermaphroditis, rarius homogamum, discoideum. Involucrum squamis uniseriatis, plus minus inter se connatis, rarius nudum, plernmque bracteolis uni-biseriatis calyculatnm. Rece ptac nl um planum, brevissime hirsuto-fimbrillifernm v. subalveolatum. Corollae ra dii ligulatae, dis c i tubnlosae, limbo quinquedentato. S $\mathbf{t} \mathbf{~ g ~ m}$ a $\mathbf{t}$ a cono puberulo superata. A chenia elongata, tetragono-compressa. P a pp u s uniserialis, paleis ima basi integerrimis, in pilos setaceos, scabros aut palmatim fissis. - Herbae mexicanae, Tagetis facie; foliis oppositis $v$. rarius alternis, indivisis $v$. saepius pinnatipartitis, serraturis acutis, $v$. in pilos atlenuatis.

Dysodia DC. Prodr, $V$. 639. nou Lour. Dyssodia Cavanilles Annal, sc, nat, VI.334. Cassiat in Dict, sc. nat. XXY. 396. LIX. 61. Lessing Synops. 388. B o e b e r a Willdenow sp. III. 2125. Cassini in Dict. sc, nat. V. Suppl. 2. non Less.

a. EUDYSODIA DC. l. c. Involucrum braeteatua, bracteis piunatipartitis, lobis in pilos abeuntibus. $\mathrm{R} e$ ceptaculnm dense hirsuto-fimbrilliferum. - Folta alterna, pinnatisecta.

Dysodia porophylla Lagase. Ptoroniae sp. Cayanill. Ic. t. 225 .

b. BoEBERA DO. $l$. c. I n vol u e rum bracteatnm, brac. teis oblongis linearibusve, indivisis. Receptacu In m brevissime fimbrilliferum v. subsudam. - Folia oppo. sita, pinnatisecta.

B o ebera Willd, l. c. Lindl, in Bot. Heg. t. 1602. A s te ris sp. Cavanill. Ie, t. 212. T a getis s p. Vent. Cels. $t, 36$.

c. BOEBERIOIDES DC. l. c. Involucr u m bracteatua, bracteis ovatis, acutis, subserratis. Receptaculum ......- Eolia opposita, indivisa.

d. GYMNOLAENA DC. t. c. I $\mathrm{z}$ vol u er u m ebracteatum, omaino nudam. R e e p ta cula m subalveolatum. - Fo. lia opposila, indivisa.

e. ACIPHYLLA DC. l. c. Involaerum nudum, inter folia suprema neerosa, subbracteiformia sessile. R e cep. tac $\mathbf{l} 1 \mathrm{um}$ minate alveolatum. - Folia opposita, inte. gerrima. Habitus a genere alienus.

25\%8. Clomemoeoma CASS. Cap itu$1 \mathbf{~ m ~ m ~ m u l t i f l o r u m , ~ h e t e r o g a m u m , ~ f l o r i b n s ~ r a d i i ~}$ uniseriatis, lignlatis, femineis, disei tubulosis, hermaphroditis. Involueri imbricati squamae lineares, dorso versus apicem glandula grossa instructae. R e cepta $\mathrm{cul} \mathbf{l} \mathbf{m}$ tenuiter fimbrilliferum. Co rolla e radii ligulatae, disci tubulosae, limbo quinquedentato. Stig m a ta....... Achenia elongata, multistriata, glabriuscula. $\mathrm{P}$ a p p s squamellis decem, uniseriatis, basi varie connatis, superne lineari-setiformibus. - Herbae a us tro-american a e, subdubiae, Tagetis facie; foliis oppositis, pinnatisectis, capitulis terminalibus, pedunculatis, solitariis, floribus aurantiaceis.

C 1 ome nocoma Cassini in Diot. sc, nat, IX. 416 . LIX. 61. 66. DC. Prodr. V. 04t. B a r toli n a Adauson Fam. II. 24. nou R. Brown. A st er is sp. Lina. Houston Relíq. t. 18. - ? Cavanill. Ic. $t, 212$.

25\%9. IIImematherrmm CASS. Capitulu m multiflorum, heterogamum, floribus radii subdenis, uniseriatis, ligulatis, femineis, disci tubulosis, hermaphroditis. Involucrum turbina tum, campanulatum, disco brevius, squamis decem $53 *$ 
v. quatuordecim, uniseriatis, eonnatis, grosse glandulosis. Receptae a l um planum, omnino nudum. Corollae radii ligulatae, ligula ovali, superne velutina, dis ci tubnlosae, limbo inaequaliter quinquedentato. Stig mata elongata. A chen ia gracilia, striata. P a pi paleae decem v. rarius quinque, subuniseriatae, inferne indivisae, membranaceae, nunc superne trifidae, lobis v, omnibus rigidulis, aristatis, scabris, v. lateralibus membranaceis, medio aristato, nunc alterne trifidae, aristatae, alternae oblongae, membranaceae. Herbae mexicanae v, chilenses, annuae, diffusae; caulibus angulatis, foliis inferioribus oppositis, superioribus alternis, omnibus pinnatisectis, capitulis ramos terminanlibus, luteis.

H y men a the r u a Cassini in Bullet. soc. philomat. 1817. p. 76, et 1818, p. 21. Dict. sc, nat. XXII. 313, Lessing Synops, 236. DC. Prodr. V. 64t.

2580. Tagetes TOURNEF, C a p it u l u m multiflorum, heterogamum, rarissime subdiscoideum, plerumque radiatum, floribus radii ligulatis, femineis, disci tubulosis, hermaphroditis. In v o I uer i squamae uniseriatae, in cupulam campanulatam v. cylindraceam, apice dentatam concretae. R eceptaculum subalveolatum. Corollae radii ligulatae, ligula ut plurimum bilabiata, dis ci tubulosae, limbo quinquedentato. Stig mata elongata. A chenia elongata, basi attenuata, compresso-tetragona. P a p p a simplex, paleis inaequalibus, aliis obtusis, subconcretis, aliis aristatis, elongatis, liberis. - Herbae a mericanae, annuae, saepius foetidae $v$, rarius svaveolentes, glandulis foliorum subrotundis, pellucidis, involucri $b i$ nearibus, foliis oppositis v. alternis, indivisis, serratis $v$. pinnatisectis, segmentis integerrimis $v$, serratis, capitulis solitariis $v$. fasciculatis, plus minus longe pedicellatis, corollis croceis $v$. flavis.

T a getes Tournefort inst, 488, $t$. 278. Linn. gen, $n$, 964. Gärtn. IT. 43\%, t, 179. Cavanill, Ic. $t, 169.264 .352$. Humb, et Bonpl. Plant, aequinoct. t,73. Sehrank Hort, monac. $t$. 5i. Jaeq. f. Eclog. t, 80. Bot. Mag, t. 150. Sweet Fl. Gard, $I, t .151 . I I, t$ 35. Lessing Synops. 236. DC. Prodr. V.642. Tagetes, Diglossus et Enalcida Cassini in Dict, sc. nat, LIX. 62. $69-70$.

2584. 'Thymoplaylla LAGASC. C a pituln multiflorum, homogamum, discoideum. Involucri campanulati, apice dentati squamae concretae. Receptaculam nudum. Corolla e ....... Stigmata...... A ehenia ...... Pappi paleae quinque, nniseriatae, truncatae, breves, - Suffrutex mexicanus; ramis foliisque oppositis, confertis, subsetaceis, minutissimis, pedunculis terminalibus, monocephalis, mono-diphyllis, villosulis, involucro extus pulvereo-tomentoso achenia aequante, corollis atro-purpureis. 7. 647 .

DIVISIT II. POROPHYLLEAE DC. Prodr. V. 647. Ca p it u l um homogamum, discoideum. Involucri squamae liberae v. vix basi connatae. Cor oll a e disci inaequaliter fissae, subbilabiatae. Stigmata in appendicem subulatam producta. Pap $\mathrm{p}$ us setosus, pluriserialis.

258Z. Poroplayllume VAILL, C a p itu l u multiflorum, homogamam. Involueri uniseriati squamae quinque, rarius novem v. duodecim, oblongo-lineares, junieres basi subconnatae. R eceptac u l um Rudum, punctatum. Coro II a e tubulosae, limbo regulariter quinquedentato v, ra rius dente unico profundiore bilabiato. Stig mat a exserta, seriebus stigmaticis intus binis, apice acuto, undique hispido. A chenia elongata, angulata, saepissime scabra, apice plus minus in rostrum attenuata. $\mathbf{P}$ a p p ns pluriserialis, pilosus, scaber. - Herbae v. suffrutices, in A merica tropica et in India orientali provenientes; foliis alternis $v$. rarius oppositis, saepius glaucis, ovatis v. oblongis, integerrimis $v$. dentatis, ut plurimum glandulis pellucidis, amplis, oblongis notatis, pedicellis elongatis, monocephalis, involucris saepe caeruleo $v$. purpureo coloratis, glaucescentibus, corollis sordide purpureis.

Por o phy $11 \mathrm{u}$ m Vaillant in Act. Academ. Paris. 1819. p. 407, Linn. Hort. Oliffort. 494. Adans, II. 122. Cassiui in Dict. sc, nat, XLIIT, 56. DC. Prodr, V. 647. K I e I n I a Jacq. Amer. 215. Willd. sp, III. 1738. Lessing Synops. 196. non Juss.

a. EUPOROPHYLlUM DC. Prodr, $V, 648$, Involneri squanae quinque. - Folia plerumque poris notata. Americanae.

c. T s in o ma Hernand. Mexic. 434, f.3. Capit aI a ey. lindracea, einggata. In v o l u c r i squamae muerone cal loso apiculatae. Co roll a e regulariter quinquedentatae. A e he n ia evidentius rostrata. - Ca calia e sp. Linn. Cav. Ic. t. 222, K le i n lae sp. Jacq. Amer. t. 127. Kunth in Humb. et Bonpl. Nov. gen. et sp. 2,356 .

B. Hunteria Flor. Mexic, inedit. Capitula ovali-ob. longa, brevia. I nvolucri squamae obtusae, margine scariosae. Corolla e lobo nno profundiore subbilabia. tae. A chenia apice vix attenuata. - Kleiniaesp. Kunth. Martius Amoen. Mronac. $t, 15$. Loddig. Bot. Cab.
t. 1561.

b. Cusimbua DC. Prodr. $\nu, 650,1$ n v ol u e ri squamae novem v. duodecim. - Folia poris glandulosis destitula? - Species indicae.

Cacaliae sp. Doa, Willd. Kleinfae sp. Lessing.

c. KUGAIA DC. Prodr. $V$. 650. Involueri ealyculati squamae ...... Folia pinnatifida.

Senecio japonicus Thunb. Kleinta japoni$c$ a Lessing.

SUBTERES \%. HELENIEAE Cassini Opusc. III. 36. C a p it ul a saepius heterogama, floribus radii uniseriatis, femineis v. neutris, ligulatis v. interdum ampliato-tubulosis, reliquis hermaphroditis, rarius homogama, nunquam dioica. In volucri squamae liberae v. rarius connatae, uni-pluriseriales. $R$ e ce ptac u l u m nudum v. paleatum. A n th erae saepe nigricantes, basi subproductae, neque tamen caudatae, articulo antherifero tereti. S tig m at a nune apice truncata, nunc cono v. appendice superne piloso superata. A $\mathrm{c}$ h e $\mathrm{n}$ i a erostria. Pappus multipaleaceus, squamellis planis, distinctis, uniseriatis, scariosis, obtusis sive acuminatis, rarissime abortı nullis $\mathbf{v}$, in vaginulam connatis. - Folia plerumque alterna, rarius opposita.

DIVISIO I. GAILLARDIEAE DC. Prodr. V. 651. Pa p pi paleae membranaceae, saepissime integerrimae. R eceptaculum epaleatum, nndum sive alveolatum fimbrilliferumve. Americanae.

SUIDIVISI O TUGAILLARDIEAE DC. Prodr. V. 651. Flores radii ligulati, neutri. 
2583. Gaillardia FOUG. Capitulum multiflornm, heterogamnm, lloribus radii uniseriatis, ligulatis, neutris, disci tubulosis, hermaphroditis. Involueri squamae bi-triseriatae, appendice foliacea, discum superante auctae. $R$ e $\varepsilon$ e $t a-$ cul u m convexum, fimbrilliferum. Co roll a e ra. dii ligulatae, ligula multinervi, glandulosa, apice palmato-trifida, dis c i tubulosae, tubo brevi, limbo pilis articulatis hispido, quinquefido. $\mathrm{Sti} g \mathrm{~m}$ a ta in appendicem longam, subulatam, hispidam desinentia. Ach enia oblonga, villosa. Pappi paleae uninerves, in aristam longe aeuminatae. Herbae boreali-americanae, erectae, pilosiusculae; foliis alternis, superioribus integerrimis, sessilibus v. semiamplexicaulibus, ramis longe denudatis, monocephalis, capitulorum disco fusco v. flavo, ligulis flavis $v$, basi croceis.

G a ill a rd i a Foug. in Mém. Academ. Paris. 1786, p.1. Cassinf in Dzet. sc, nat. XVIIT, 17. LV. 264. DC. Prodr. V. 651. Bot. Mag. ᄂ. 1602. 2368. 2940, 3368, 3551. Bot. Reg. t. 1186. G a lard a Lam. Illustr. t. 708. Lessing Synops. 237. Colo un a Buehoz Icon, $t, 126$. Virgili a Heritier mse. non allor. G a I ordi a Reusehel Nomencl. 251.

2584. Balduima NUTT. Capitulum multiflorum, heterogamum, floribus radii uniseriatis, ligulatis, neutris, disei tubulosis, hermaphroditis. Invol ucrum imbrieato-campanulatum. Rece ptaculam convexum, alveolato-fimbrillifernm. Coroll a e radii ligulatae, lignla apice tridentata v. trifida, disci tubulosae, basi corneac, extus glanduliferae, limbo quadri-quinquedentato. A ntherae basi breviter bisetosae. Stigmata inclusa, apice vix appendiculata. A $\mathrm{eh}$ e $\mathrm{n}$ i a receptaculi foveolis immersa, obeoniea, sericea. Pa ppi paleae membranaceae, hreves. - Ilerbae boreali-americanae, perennes, glabriusculae; caule tereti, simplici v. ramoso, ramis apice nudis, monocephalis, foliis alternis, sessilibus, integerri. mis, corollis flavis.

Bal d u in a Nuttall gen, II. 175. Elliott Carol. II. 4i7. Lessing Synops, 238. DC. Prodr. V. 652.

a. BALDUINA Elliott l. $c$. I a volucrum pluriseriale. Pappi achenium aequantis paleae biseriatae, interiores acutae, exteriores sublimbriatae.

b. ACTINOSPERMUM Elliote $l$, $\sigma$. Involu $\mathrm{erum}$ biseriale. Pappi paleae duodecim v. quatuordecim, in capulam patentem dispositae, breves, obtusae.

2555. Leptopoda NUTT. Capitulum multiflorum, heterogamum, floribus radii circiter vicenis, ligulatis, neutris, disci tubulosis, hermaphroditis. Invol ueri biseriati squamae exteriores lineari-subulatae, interiores sublanceolatae. Receptacul am convexum, nodum. Corollae radii ligulatae, ligula trifida, dis ei tubulosae, limbo tri-quinquedentato. Stig mat a brevia, exappendiculata. Achenia subeylindracea. Pappi paleae suboctonae, membranaceae, breves, fimbriatae, in aristam haud productae. - Herbae boreali-americanae, erectae, simplices, monocephalae; foliis alternis, lineari-lanceolatis, subdentatis, capitulis terminalibus, solitariis, floribus flavis.

L e pt opod a Nuttall gen. IT. 174, Elliott Carolin, II. 445. Cassini in Dict, so. nat. XXVI. 79. LV. 264, 278, Lessing Synops, 238, DC. Prodr. V. 653.

SUEIIVISIO II. EUHELENIEAE DC. Prodr. V. 653. Flores radii nulli, v. ligulati feminei.

2586. Cutierrezia LAGASC, C a p itu$1 \mathrm{u} \mathrm{m}$ pluriflorum, heteroganum, floribns radii ternis, ligulatis, femineis, disei quinis, tubulosis, her- maphroditis. Involucri imbricati squamae apice reflexae. Re cep tac u I um favosum, dentato-paleaceum. Corollae radi ligulatac, disci tubulosae, limbo ....... Stig ma $t$ a $\ldots . . . A$ ch enia ..... Pap pus paleaceus, polyphyllus.

Planla mexicana, vix nota, suffruticosa, glabra, resinosa; foliis sparsis, sessilibus, linearibus, acutis, integerrimis, corymbo terminali, oligocephalo.

\section{Gutierrezia Lagasea Elench. hort, Madrit. 30.}

s5S\%. Alny ropappess $H, B, K, \mathrm{C}$ a $\mathrm{i}-$ tul u m multiflorum, heterogamum, floribus radii ternis v. quinis, ligulatis, femineis, disci tubulusis, hermaphroditis. Involucri uniseriati squamae quinque, ovales, obtusissimae. Receptaculum parvum, alveolatum, nudum. Corollae radii ligulatae, d is s: i tubulosae, quinquefidae, pappo vix longiores. Stigmat a breviter appendienlata. A ch en a lineari-cuneata, tri-tetragena. Pa p p i paleae senae-octonae, membranaceae, obovatomuticae. - Herbae mexicanae, annuae, erectue, vix puberulae; folitis oppositis $v$, superioribus alternis, multipartilis, lobis pinnatipartitis, oblongis $v$. linearibus, oblusis, capilulis longe pedicellatis, laxissime carymbosis, corollis omnibus flavis. - Genus vix a sequente distinctum.

A eh y rop a p p s Kusth in Humb. ot Bonpl. Nov. gen. et sp. IV. 257. t. 390. Liuk et Otio Abbild. t. 30. DC. Prodr. $V$. 364. nou Bielerst. A e h y r o pap p I s e ctio Lessing $S y n$ ops. 239. C hama estephanum Willeaow in Berl. Magaz. 1807. p. 140. S chkuhria e sp. Nees.

2598. Selakuluria ROTH. Capitulum pluriflorum, heterogamum, floribus radii binis v. solitariis, ligulatis, femineis, dissi quinis-octonis, tubulosis, hermaphroditis. Involueri uniseriati squamae subquinae, obovatae, apice membranaceocoloratae. R e ce p t a cul a m parvam, nudum. C oroll ae radii ligulatae, dis ci tubulosae, breves, limbo quadri-quinquedentato. Stig m a t a breviter appendiculata. A eh en ia tetragona, basi attenuata. Pappi paleae octo, quatuor achenii angulis continuae acuminato - aristatae, quatuor alternae, iisdem conformes $v$. breviores et obtusiores, margine subfimbriatae. - Herbae mexicanae et peruanae, annuae, ramosissimae, glabrae; foliis alternis tri- v. pinnatisectis, segmentis linearibus, tenuissimis, integerrimis, capitulis ovatis, solitarïs, longe pedunculatis, floribus luteis.

Schkuhria Roth Catalect, . . 116. Schkulir t. 250. $b$.

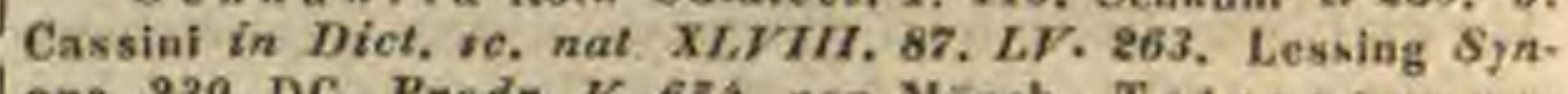
ops, 239. DC. Prodr. $V$. 634. non Mönch. Te trae a rp u u Mönch. Suppl. 24t. M i e ria Llav, et Lexarz. Nov. Veget. II. 9. nou Liak. Pe ctidis s p. Lamarch Journ. hist, nat. II. t. 31 .

2589. Florestima CASS. Capitulum hoinogamum, discoideum. Invol n e ri uniseriati squamae oeto, floribus breviores, oblongae, obtusae Receptaculum parrum, planum, subalveolatum. Co roll a e tubulosae, tubo brevi, limbi quinquelobi lobis inaequalibus, papilloso-hirtellis. S $t$ g m a ta in appendicem subulatam, hirtam produeta. A ch e n i a subtetragona, oblonga. Pap p i paleae octo v. duodecim, uniseriatae, scariosae, suborbiculatae, nervo saltim basi opaco. - Herbae mexicana e, Steviae facie, pube adpressa, brevissima canescentes; foliis alternis, pedatipartitis $v$. indivisis, capitulis laxe corymbosis v. subpaniculatis, corollis albidis v. purpurascentibus.

Florestin a Cassini in Bullet, soe, philomat, 1815. p. 175. Dict, sc, nat, XVIT, 155. LV. 266, Opusc, I, 197, t, 8. DC. Prodr, $V$. 655. Lepido pappus Flor. mex. inedit. H ymenopappi sectio Lagase. Achyropappi sect lo Lessing. Stevia pedata Cavanill, $I c, t, 3 s 6$. 
3590. Actinolepis DC. Capitu $\mathrm{Im}$ multiflornm, heterogamtam, floribus radii ternis v. quinis, ligulatis, femineis, disci tubulosis, hermaphroditis, stylo abortivo masculis. Involuer ovato-oblongi, bracteis feliaceis paucis eineti squamae paucae, obtusac, adpressae, dorso molliter tomentosae. R e c e p t c u $1 \mathrm{um}$ angustum, nudum. Corollae radii ligulatae, ligula lata, brevi, bi-tridentata, dis ci tubulosae, tubo tereti, fance dilatata, limbo quinquedentato. Stylus radii bifidus, exsertus, dis c i simplex, apice capitellatus v. subnullus. Achenia oblonga, subangulata, radii pubescentia, dis ei glabra. Pappus radii e squamellis subquinis, seariosis, acuminatis, disci nullus. - Herba californica, annua, tenella, multicaulis; caulibus apice araneosis, foliis oppositis, parvis, late obovatis, basicuneatis, integerrimis, apice obtusissimo quinquedentatis, capitulis in axillis supremis approximatis, solilariis, subcongestis, parvis, floribus flavis.

Actinolepis DC. Prodr. $V .655$.

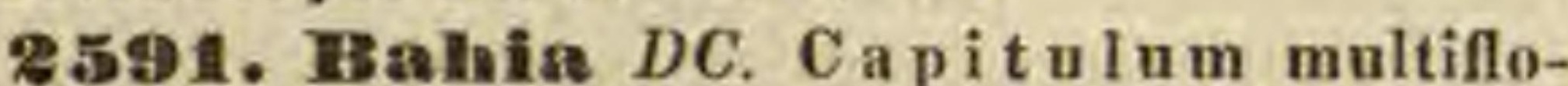
rum, heterogamum, floribus radii quinis-denis, ligulatis, femineis, disci tubulosis, hermaphroditis. Involucri ovati v. campanulati squamae adpressae, uni-biseriatae. R e cepta $\mathrm{cul}$ u m epaleatum, nudum v. parce alveolato-fimbrilliferum. C o rolla e $r$ a di i ligulatae, dis c i tubulosae, extus glanduloso-subsetosae, limbo quinquedentato. Stigmat a obtusa, exappendieulata. A chenia turbinato- v. lineari-tetragona, ut plurimum glabra. $P$ a p pi paleae quatnor v. octo, ovales aut oblongae, obtusinsculae, membranaceae. - Herbae $v$. suffrutices in America, imprimis boreali-occidentali provenientes; foliis oppositis $v$. alternis, integris partitisve, supra glabris aut araneosis, subtus tomentosis, pedunculis nunc elongatis, monocephalis, nunc corymbosis, corollis luteis.

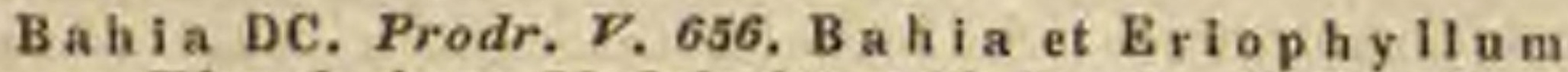
Lagasea Elench, hort. Madrit, 28. et 30. Lindley in Bot. Reg. t. 1167. Lessing Synops, 238. Trichophy il u m Nuttall gen. $I T, 166$, won Ren. Phialis Spreng. gen. n. 631. Hei euiis sp. Spreng.

259\%. IHymenopappens HERIT, C apitulum multiflorum, homogamum. Involueri bi-triseriati squamae elliptieo-oblongae, obtusissimae, interiores interdum majores, petaloideae. Receptaculum parvum, nudum, foveolatum. Corollae tubo basi dilatato, extus glandulososetigero, limbo campanulato, quinquefido. An therae exsertae. Stigma $\mathbf{t}$ a apice breviter appendiculata. A che nia turbinata, striata, basi attenuata, subpedicellata, matara subtetragona. Pap pi paleae duodecim ad sedecim, nniseriatae, membranaceae, breves, elliptico-oblongae, obtusae. - Herbae carolinianae, perennes; caule sulcato-angulato, ramoso, inferne glabro, superne tomentoso $v$. velutino, foliis alternis, pinnatipartitis, lobis saepe incisis v. multifidis, capitulis carymbosis, pedicellatis, involucri squamis interioribus et corollis albidis.

Н у m e u p a p p us Heritier Dissert, inedit. Cassini in Diet. sc. nat. LV. 266. et 279. Lessing Synops. 238. DC. Prodr. $\nu$. 05s. R o th i a Lamarek in Journ. $h, \pi, I, 16, t .1$. rllustr. $t, 667$.

2593. Chaenaetis DC. C a p it $\mathrm{u} 1 \mathrm{um}$ multiflorum, homogamum, radiatiforme. Involneri campanulati squamae circiter viginti, uni-biseriatae, lineares, acutiusculae. $R$ e e e p ta $\mathbf{c} \mathbf{~ l} \mathbf{u m}$ epaleatum, alveolatum. Corolla e radii amplae, basi tubulosae, sursum subbilabiatae v, subpalma tae, dis ei regulares, tubo glabro, limbi obtuse quinquedentati lobis hirsutulis. Stigmat a disei hispida, cono obtuso, brevi superata. Achenia lineari-tetragona, basi attenuata, subpedicellata, adpresse pnbescenti-villosa. $P$ a $\mathrm{p}$ i paleae quinque v. sex, membranaceae, $r$ adii breves, obtusae, d is ci longiores, subacutae, tubi corollini dimidiam longitudinem aequantes. Herbae californicae, erectae; foliis alternis, pinnatipartitis, lobis linearibus, integris, ramis upice nudis, monocephalis, floribus luteis.

\section{C baeuactis DC. Prodr. $V_{\text {. }} 639$.}

2594. Folypteris NUTT. Capitulum multiflorum, homogamum. Involucri squamae biseriatae, foliaceae, ovali-lanceolatae, breviter acuminatae, primum erectae, demum reflexae. R eceptaculum hemisphaericum, omnino nudum. Corolla e tubo brevi, fauce ampla, inflata, limbi quinquelobi lobis subulatis, hirtellis. Stig mata in appendicem linearem, hirtam longe producta. A chenia turbinata, sericeo-villosa. Pap pi paleae novem, membranaceae, achenium subsuperantes, basi attenuatae, valide uninerves, nervo in aristam longam, rigidam producto. - Herba boreali-americana, erecta, ramosa, pubeseentiscabra; foliis alternis, integerrimis, oblongo-linearibus, sessilibus, capitulis ramos terminantibus solitariis, corollis fuscis v. pallide flavis, achenii setis et pappi paleis fuscescentibus.

Polypteris Nuttall gen. Ir. 139. Elliott Carolin, II. 313. DC. Prodr. V. 659.

2595. Espejoa DC. Capitulum septemflorum, homogamum. Involueri octophylli squamae quadriseriatim oppositae, late ovatae, imbricatae, apice mucronatae. Re ceptac ulum alveolatum. Corolla e tubulosae, glabrae, limbo quinquefido. Stigmata obtusa, parce puberula. A ch en i a obcompresso-cuneata, confertissime rufo-sericeo-villosa, disco epigyno lato, orbienlari. Pap i paleae subsedenae, uniseriatae, membranaceae, ovali-ohlongae, uninerves, mucronatae, corollam subaequantes, basi achenii villis cinctae. - Herba mexicana, glabriuscula, erecta, dichotoma, caule subangulato, versus apicem pilosiusculo, folits oppositis, ovali-oblongis, sessilibus, integerrimis, pedunculis axillaribus monocephalis, floribus flavo-subpurpurascentibus.

Es pejoa DC. Prodr. V. 660.

2596. Cercostylos LESS. Ca p itulum multiflorum, homogamnm. Invo I u eri campanulati squamae biseriatae, longe acuminatae, $\mathrm{Ke}$ c epta c I n m convexum, epaleatum, dense paleaceo-fimbrillifernm. Co rolla e tubnlosae, limbo quinquedentato. Stigmat a appendice lineari, angastissima. A chen i a turbinata, villosa. $P$ a p pi paleae decem, uninerves, apice lacerae, in aristulam acuminatae. - Herba brasiliensis, basi lignescens; folits alternis, sessilibus decurrentibusque, integerrimis, pilosiusculo-canescentibus, capitulis solitariis, caulem ramosque elongatos, superne aphyllos terninantibus, floribus luteis.

Cercostyl os Lessing Synops. 239. DC. Prodr. $K$. 660. Poly pte ris Lessing in Linnaea VI. 518, non Nutt.

25อร. Hopkirkia $D C$. C a pit ulum triflorum, homogamum. Involucri oblongi, tetra-pentaphylli, basi bracteolis minimis duabus v. tribus stipati squamae ovato-oblongae, subscariosae. Re eeptacnlum angustum, nudum. Corolla e tubulosae, pappo breviores, limbo inaequaliter quadri - quinquedentato. Stigma t a brevia, apice capitellata. A chen i tetragona, basi 
attenuata, substipitata. P a p p i squamellae octo, scariosae, medio uninerves, apice subtrifidae, nervo in aristulam producto. - Herba mexicana, glabra, adscendens, ramosa; foliis alternis, pinnatipartitis, lobis uni-bijugis cum impari, anguste linearibus, elongatis, integerrimis, capitulis terminalibus, pedicellatis, solitariis, parvis, floribus luteis.

fl o pkirkia DC. Prodr, V. 660. non Spreng.

2598. HFmenoxys CASS. Cap itn lum multiflorum, homogamum, discoideum v. heterogamum, floribus radii octo v. decen, ligulatis, fe mineis, disci hermaphroditis, tubulosis. Involue ri biseriati squamae rigidulae, adpressae, interiores longiores. Rec e $\mathrm{tacul}$ um conicum, epaleatum, alveolatum, glandulis parvis subonustum. Corollae radi i dumadsunt ligulatae, dis c i tubulosae, limbo quinquedentato. St ig $m$ a $t$ a disei apice truncato - barbellata. A ch enia conformia, turbinata, villis sericeis, erectis villosissima. Pa pp i palcae quinque v, octo, inaequales, membranaceae, ovali-lanceolatae, aristato-acuminatae, erectae. - Herbae in America tropica indigenae, erectae, ramosae, glabriusculae; foliis alternis rariusve in eodem caule oppositis, in lobos lineares multipartitis, ramis apice nudis, pedunculiformibus, monocephalis, floribus luteis.

H y m e $n$ oxy 8 Cassini in Dict. sc, nat, LV. 278. DC. Prodr, V. 661.

a. EUbYMENOXYS DC. $l$. c. Capitula homogama, dis. coidea.

b. OXYPAPPUS $B C$. $l$. c. C a pitula heterogama, radiata. - Cephalophorae seetio Lessing Synops, 240. A etine a s p. Kunth in Humb. et Bonpl. Nov. gen. et tp. $t, 411$.

2599. Ceplualophora $C A V$. C a p itu$1 \mathrm{u} \mathrm{m}$ sphaericum, multifiorum, homogamum v. heterogamum, floribus radii ligulatis, disci tubulosis, femineis. Involucri biseriati squamae reflexae, lineari-lanceolatae, floseulis aequales $\mathbf{v}$, breviores. Receptaculum nudum v, foveolare, Corolla e radii dum edsunt ligulatae, ligula tridentata, d is c i tubulosae, extus hispidulae, tubo brevissimo, fauce obovoidea, limbo quinquedentato, connivente, subcalloso. Stigmata exserta, patulo-revoluta, apice hispidnla, exappendiculata. A $\mathrm{ch}$ enia turbinato-tetragona, pilis squamosis, adpressis tecta. Pappi paleae quinae-octonae, membranaceae, margine erosae, apice apiculatae. - Herbae $v$, suffrutices chilenses, erecti, glauci; caule striato ramoso, brevissime puberulo, foliis alternis, oblongolinearibus, acutis, capitulis ramulos nudiusculos terminantibus sphaericis, corollis flavis, apice fuscis, floribus exterioribus interdum cum involucri squamis interioribus mixtis.

Cephal ophora Cavanill. Ic. $V I$. 79. DC. Prodr, $V$. 661. Cephalo phorae sectio 1 et 2. Less. Synops. 240.

a. EUCEPHALOPHORA DC. $t$. c. C a pitulum homogamum.

Gra em i a Hooker Exot. Flor. II. t. 189. Sa n taIlno Ides Poquill, Feuillé Observ, III, $t$. 45, $f$. 2 , (Cavanill. Ic. そ. 599.)

b. ACTINELLA DC. l. c. Capitulum heterogamum , floribus radii ligulatis, femiaeis.

A ctinelta Persoon Ench. IT, 469. A ctinea Jas. sien in Annal. Mus. $I$. 426. t. 61. f. 2. A ctinea et D uga l de a Cassiai in Dict. sc. nat. LV. 270.

:GDD. Wammea PERS. C a $\mathrm{p}$ i $\mathrm{t}$ a 1 u $\mathrm{m}$ mnltiflorum, homogamum, discoidenm. In v o l ucri lati, patentis squamae subrotundae, triseriatim imbricatae. R e cepta cul um nudum. Coroll a tubulosae, limbo quinquedentato. A n th e $r$ a c ceandatae, apice in appendicem ovato-lanceolatam productae. Stigmata obsolete papillosa, cono brevi terminata. A $\mathbf{c}$ he $\mathbf{n}$ i terctiuscula, costis minimis longitudinalibus notata. Pa p pi squamellae octonae-denae, breves, inaequales, denticulatae, aeutae. - Suffrutex bonariensis, glaber; foliis oppositis, connatis, linearibus, integerrimis, carnosis, capitulis terminalibus, solitariis, nutantibus.

J a u me a Persoon Ench. II. 397. DC. Prodr. $V$. 663. K 1 e iu i a Jussieu in Annal. Mus, IT, 424, $t, 61, f, 1$.

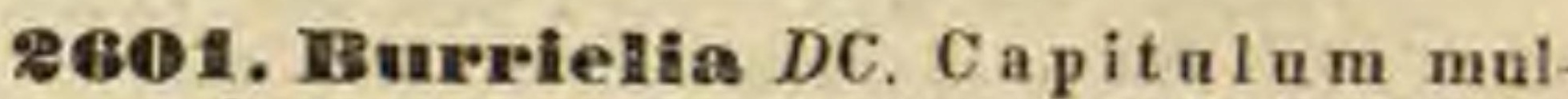
tiflorum, heterogamum, floribus radii ligulatis, femineis, disci plurimis, tulublosis, hermaphroditis v. abortu sterilibus. I n vol n e r i patentim campanulati squamae ovales, acuminatae, diseo paullo longiores, uni-biseriatae, subalternae, aequales. Receptaculam epaleatum. Corolla e radii ligulatae, ligula obovata, disci tubulosae, quinquelobae, lobis extus tenue barbellatis. Stigm a t a cono brevi terminata. A chenia gracilia, lineari-subtetragona, radii fere obcompressa. P a ppus radii longe bi-triaristatus, dis ci paleis ternis v. quaternis lanceolato-aristatis, corollam $8 \mathrm{ub}$ aequantibus. - Herbae californicae, annuae, graciles, parce puberulae $v$. glabrae, erectae, subsimplices ; foliis opposilis, linearibus, longis, integerrimis, capitulis caulem ramosque apice nudos terminantibus, floribus aureis.

B urifelia De. Prodr, $V .663$.

2BQD. Hieradenia HOOK. Ca p itu In m multiflornm, heterogamum, floribus radii octonisdenis, ligulatis, fenineis, disci hermaphroditis, tubulosis. Involucri subhemisphaerici squamae imbricatae, exteriores basi subeoadunatae. Re e ptaculum conicum, nudum. Corollae radii ligulatae, lignla obovato-oblonga, grosse tridentata, dis ei tubulosae, extus glandulosae, limbo quinquedentato. Stig $\mathbf{m}$ a ta brevinscula, inclusa, apice incrassata, dorso hirsuta. A e he n ia oblonga, villosa. P a pi paleac sex v, septem, erentae, ovatae, acuminatissimae, nudae, membranaceae, Herba bor eali-americana, radice crassa; foliis alternis, lineari-filiformilus, rigidis, pinnatifidis, glanduloso- et pellucido-punctatis, capitulis terminalibus flavis, glandulis corollarum disci amarissimis.

Picradenfa Hooker Flor, Bor. Amer. $T, 317,4,108$. DC. Prodr. $V, 665$.

2603. Jir lenteam $L I N N$. C a p itu $1 \mathrm{um}$ multiflorum, heterogamum, floribus radii uniseriatis, ligulatis $\mathbf{v}$, tubnlosis irregularibus, femincis, disci tubniosis, hermaphroditis. Involueri biseriati squamae exteriores plurimae, foliaceae, elongatae, sublineares, reflexae $v$, patentissimae, interiores pauciores, breviores, acuminatae, receptaculi paleas simulantes, sed extra flores sitae. Recepta e $\mathbf{I} \mathbf{m}$ convexum, globosum v, oblongram, nudum. Corollae radii ligulatae v. tubulosae, irregulariter tri-quinquefidae, $d$ is e i tubulosae, brevissimae, quadri - quinquedentatae. Stigmata obtusa, exappendieulata. Achenia turlsinato-obovata, multifariam villosa. Pa p p i paleae quinque $v$. sex, membranaceae, plus minus apiculatae. - Herbae boreali-americanae et mexicanae, glabrae v. pubescentes; foliis alternis, decurrentibus, subtus punctatis, inlegerrimis, dentatis $v$. subpinnatifidis, capitulis ad apices caulis et ramorum solitariis, corollis luteis, extus pube. rulis.

He I e ilum Lias. gen, n, 961, DC. Prodr. V. 665. H ele ni a Linn. Hort, Olfffort. 418. Mönch Method, 589. Gärtn. II, 438. 
a. HELENIA DC. l. $c$. Receptaculum convexum v. globosum. Corollac dixei quinquedeutatae. Pappi paleae aristatae v. distincte apiculatae.

H ele n i $\mathrm{m}$ Cassini in Dict. sc. nat. LV. 269. Les. ximg Synops. 240. He le n i a Linu. Gärtil, $t, 169$. Schkuhr t. 250. Lam. Journ. hist, nat, II, t.35. Bot. Mag.t, 2994.

b. TETRODUS DC. l. c. R e e e ta $\mathrm{eulum}$ ovatum v.oblangum. C orolla e disei quadridentatae. Pappi paleae breves.

Tetrodus Cassini in Dict. sc, nat. LV. 262. Les. sing Synops. 250. Mes o detra Rafin. Flor. Ludov, 141. Rudbeckiae sp. Jacq. Io. rar, $t$. 593 . Helen i i sp. Labillard, Act, soc. h, n, Paris, I, t. 4. Bot. Reg. t, 598 .

2604. Amblyolepis DC. Capitulum multiflorum, heterogamum, floribus radii uniseriatis, ligulatis, fenineis, disci tubulosis, hermaphroditis. Involucri biseriati squamae exteriores sex v septem ovatae, acutae, foliaceae, adpressae. disco aequales, interiores obovato-rotundae, obtu sissimae, hyalinae, enerves. Receptaculum planiusculum, alveolatum. Corolla e radii li gulatae, apice trifidae, disci tubulosae, tubo bre vi, fauce ampla, limbi lobis quinque lanceolatis, ealloso-apiculatis, nervo marginatis. Antherae longe et acute appendiculatae. Stig mata exappendiculata. Achenia turbinata, adpresse villo sissima. Pappi paleae quinque, uniseriales, ener. ves, corollae tubum aequantes. - Herba $m$ e $x \boldsymbol{i}$. cana, erecta, annua, simplex, secus caulem et margines foliorum et squamarum involucri pilis longis ciliato-pilosa; foliis alternis, semiamplexicaulibus, haud decurrentibus, ovali-lanceolatis, subintegerrimis, capitulis terminalibus, solitariis, flavis.

A mblyole pis DC. Prodr. $V .667$.

2G05. Hogilla LESS. Ca pitulnm he terogamum, floribus radii ligulatis, femineis .... Involucri cylindracei squamae scariosae, exte riores sublineares. Receptaculum epaleatum. Corolla e ....... Stigmat a appendiculata. A chenia obcompressa, basim versus angustata, Pa pi paleae plumoso-fimbriatae. - Herba mexicana, annua, vix nota, floribus luteis.

R osill a Lessing Synops. 245. DC. Prodr. V. 668.

2BOG. ITecabaen $D C$. Capitulu m mul tiflorum, heterogamum, floribus radii uniseriatis, ligulatis, femineis, disci tubulosis, hermaphroditis. In v o l u cri biseriati squamae exteriores foliaceae, patulae, radium aequantes, interiores breviores, lineares, discum subsuperantes. Re cept a c $\mathbf{l} \mathbf{u} \mathrm{m}$ planiuseulum, nudum. Corolla e radii ligulatae, tri-quinquefidae, di s c i tubulosae, limbo quinquelobo. S $\mathrm{t}$ ig $\mathrm{m}$ a $\mathrm{t}$ a truneata, subeapitata, hispidula. A $c$ h en i a angulata, glabra, glandulosa. P р p и 8 nullus. - Herba mexicana, glabra, pedalis, simplex, caule tereti, ad medium folioso, apice nudo, pedunculiformi, monocephalo, pedunculo sub capitulo obconico, fusco-subvilloso, foliis alternis, decurrentibus, oblongo lanceolatis acuminatis, integerrimis, ligulis flavis, diseo fusco-purpurascente.

Hecubaea DC. Prodr. $V, 665$.

200\%. Taeria FISCH. et MEY. C a p it u I $\mathbf{n m}$ multiflorum, heterogamum, floribns radi uniseriatis, ligulatis, femineis, disci hermaphroditis, tubulosis, I nvol u cri biseriati squamae sub denae, aequales, planae, late-ovatae, erecto-patalae. Re ceptac ulum conicum, nudum. Corol la radii ligulatae, disci tubulosae, limbi quinquedentato. Stigma ta cono superata, A c h enia conformia, fusiformia, compresso-subtetragona, laevia, glabra, obtusa, areola parva, terminali. Pa p p us nullus. - Herba Californiac, annua, gracilis, erecta, ramosa, pilis simplicibus adspersa, subglabra, ramis elongatis, apice nudis, foliis oppositis, sessilibus, linearibus, integerrimis, capitulis terminalibus, solitariis, floribus aureis.

B a eri a Fiseher et Meyer Index sem, hort. Pelropolit. II. 1835. p. 29

\$608. Callieloroa FISCH. et MEY. C a pituln multiflorum, heterogamum, floribus radii uni-biseriatis, ligulatis, femineis, disci tubulosis, hermaphroditis, In vo I u eri biseriati squamae vicenae erectae, achenia radii obtegentes. R e ce pt a c u 1 u m planum, pubescens, ambitu squamosum. Cornlla e radii ligulatae, ligula apice bi-trifida, disci tubulosae, limbo quinquedentato. Stig mata ...... A chenia fusiformia, subcompressa, apice truncata, radi i glabra, disci pubescentia. Pap pus radii nullus, disei setis numerosis, uniseriatis, serrulato-scabris, persistentibus, Herba californica, annua, gracilis, ramosa, pilis simplicibus, albis, elongatis et pube brevi canescens; foliis plerumque alternis, linearibus, integerrimis v. paucidentatis, floribus flavis.

Calli ebroa Fiseher et Meyer Index II. Sem. hort. Petropolit, 1835, p. 31.

2699. Lastlaenia $L I N D L . C$ a it $\mathrm{lum}$ multiflorum, heterogamum, floribus radii uniseriatis, ligulatis, femineis, disci tubulosis, hermaphroditis. Invo I ucrum campanulatum, gamophyllum, quindecimdentatum. Receptacul um conicum, papillosum. Coroll a e radii lignlatae, dis ci tubulosae, limbo quinquedentato. Stig mat a cono superata. A ch en ia conformia, compressa, adpresse pubescentia, apice mueronata. P a pp us nullus. - Herba Californiae, annua, erecta, tenuissime pubescens; foliis oppositis, linearibus, subintegerrimis, capilulis solitariis ramos apice nudos terminantibus.

La sthenla Lindley in Bot. Reg. $t$. 1780. non Cass. Lastheniaesp. DC.

2610. Teneagua PÜPP. et ENDL. Capitulum pluriflorum, homogamum. Involucru m gamophyllum, campanulatum, quinque-octodentatum, dentibus acutis, ciliatis. Re cep $t$ a c uI um conicum, papillosum. Coroll a e tubulosae, fance inflata, limbo quinquedentato. Stig mata cono brevi superata. A $\mathrm{e}$ h e n i compressa, adpresse pubescentia, areola basilari cava, cornea. $\mathbf{P}$ a ppi paleae decem, bi-trifidae v. inciso-serratae, persistentes. - Herbae chilenses, uliginosae, erectae $v$. procumbentes, parce ramosae; foliis oppositis, linearibus, integerrimis, ramis monocephalis, sub capitulo inverse conicis, cavis.

R a n e agu a Pöppig et EndI. Nov. gen, et sp. I. 15. $t$. 24. 25. L a s the ni a Cassini Opuse. phyl. III. 88. non Lindl. Las the ulae sp. DC.

2611 1. Argyroxîplaiuan DC. C a pitu1 a m multiflorum, heterogamum, floribus radii uniseriatis, ligulatis, femineis, disci hermaphroditis, tubulosis. Invo l u cri campanulati squamae bi-triseriatae, lanceolato-lineares, subaequales, disco paullo breviores. Re cepta culu m nudum, planum. Corolla e radi i ligulatae, ligula obovato-cuneata, apice lata, incisa, di s c i tubulosae, limbo tridentato. Antherae eeandatae, apice appendiculatae. Stigmata divergenti revoluta, subfiliformia, disci apice pilosiuseula, A chenia elongata, glabra, compressa, ad angulos dnos vix subciliata, latere uno $v$. altero nervo sive angulo subexserto instructa. Pap p s persistens, unise- 
rialis, paleaceus, radii auricularis, ad latus exterius situs, acuminatus, integer, dis e i paleis binisquinis irregularibus, serratis, subfoliaceis, rigidis. - Herba sandwicensis, Tussilaginis v. Cinerariae textura; foliis aliis e basi subrigida elongatis subensiformibus, integerrimis, villis sericeis, adpressis, copiosissimis argenteis, aliis basi tenerioribus, virescentibus, pube glandulosa instructis, pedunculis fere ex axillis foliorum ortis, solitariis, subglanduloso-hirtis, subaphyllis, monocephalis, involucris hirtis, foliis supremis textura similibus, capitulis subglobosis, nutantibus.

Argyraxiphium DC. Prodr. V. 668.

TIVISIO II. GALINSOGEAE DC.Prodr. V. 668. I nvolucri squamae planiusculae, achenia radii haud involventes. $R$ e $\mathbf{c e p} t$ a $\mathbf{c u -}$ $1 \mathrm{um}$ paleatum. Pappus uniserialis, e paleis integris v. plumosis constans, rarissime nullus.

SUIBIUISID I. EUGALINSOGEAE DC. Prodr. V. 668. Flo res radii dum adsunt ligulati, feminei. Pap pi squamellae planiusculae, nec aestivato-contortae.

9612. Temmatium DC. Cap it $1 \mathrm{um}$ sex-septemflorum, heterogamum, floribus radii circiter tribus, ligulatis, femineis, disci tribus $\mathrm{v}$ quatuor tubulosis, hermaphroditis. Involucri cylindracei squamae imbricatae, oblongae, exteriores subfoliaceae, interiores membranaceae, $R$ ece pta culum angustum, paleis convolutis, lineari-oblongis, flores involventibns et aequantibus. Corollac radii lignlatae, dise i tubulosae. limbi quinquefidi lobis longinseulis, acutis, glabris St ig m a ta exappendiculata, A chen i a trigonoprismatica, ad angulos villosa. P a p $\mathbf{s}$ s membra naceus, vaginans, apice dentatus, corollae faucem aequans. - Frutex brasiliensis; caule dense et breviter hirsuto, tereti $v$. obtuse angulato, foliis oppositis, sessilibus, suborbiculatis, basi cordatis, crenato-dentatis, coriaceis, supra puberulis, subtu tri-v. quintuplinerviis, reticulatis, villoso-scabris, capitulis subsessilibus, in corymbum amplum, valde compositum, fastigiatum dispositis, braeteis aliquo foliaceis interstinctis, floribus luteis.

$\mathrm{L} e \mathrm{~mm}$ a ti u m DC. Prodr. $V, 669$. Ca le a cte Lessing in Linnaea $V$. 158, Synops, 248, non $\mathrm{R}$. Br.

2613. Calydermos LAGASC, C a p it nIum multiflorum, homogamum. Involucriob longi, imbricati squamae subseariosae, obtusissimae. Rec e ta culum angustum, conicum, paleis linearibus, acutis. Coroll a e tubulosae, quinquefidae. Stigmata cono terminata. Achenia tetra-pentagona, pilosa. P a p p i paleae uniseriatae, lineares, obtusae, uninerves v. nullae. - Herbae mexicanae, humiles, erectae, scabrae v. pilosae, ramosae; folitis oppositis, sessilibus, ovatis $v$. ellip tico-acuminatis, grosse serratis, trinerviis, ramis longe aphyllis, apice breviter trifidis, capitula fasciculato - corymbosa gerentibus, involucris flavescentibus, floribus luteis.

C alydermos Lagasca Nov, Ben. 24, DC. Prodr. $V$. 669. C a lea e s p. Kunth.

a. EUCALYDERMOS $D C$, l, c. P a p p $\mathrm{s}$ nullus.

Cal Iy dermos Cassini in Dict, sc. nat, $L V .265$. I.essing Synops. 2as. (? Cale a e peduneularis var. epapposa Kunth in Humb. et Bonpl. Nov. gen. et sp. t. 408, f. 5.)

b. Calebrachys $D C, l$. c. P a p pi paleas $10 \_12$.
Calebraehys Cassini in Dict, sc, nat, LV. 277. Lessing Synops, 241. Calea peduacularis Kunth op. cit. t. 408. excl. f. 5 .

2614. DIeyeria $D C$. Capitnlum mul tiflorum, heterogamum, floribus radii uniseriatis, ligulatis, femineis, disci hermaphroditis, tubulosis. Involueri eampanulati v, ovati squamae pluriseriales, adpresse imbricatae, ovatae. $R$ e c e p $t$ a $e$ uli planiusculi paleae apice saepe tridentatae, complicatae, flosculos amplectentes. Corolla e radi ligulatae, dis c i tubulosae, limbo quinquedentato. Stigmata cono terminata. A $\mathrm{ch}$ enia prismatica, villosa. Pa p pi squamellae plurimae, uniseriales, oblongae v. ellipticae, obtusae, membranaceae. - Frutices $v$. suffrutices brasilienses; foliis oppositis, sessilibus $v$. brevissime petiolatis, integerrimis v. grosse et obtuse crenatis, capitulis solitariis $v$. rarius corymbosis, floribus luteis.

Meyeria DC. Prodr, V. 6ro, non Sehreb.

a. HOLOPHYLLAEA DO. l. c, C a pitula terminalia, so. litaria. I avoluerum campanulatum. - Folia! inte. gerrima,

b. GLYPHIPHYLLAEA DC, l.c. Capitula in corymbum oligocephalum cenferta. I a voluc r u m oratum, laxum. - Folia grosse et obtuse crenata.

2615. Callilepis DC. Capitu $\mathrm{l}$ a m multiflorum, heterogamum, floribus radii plurimis, uniseriatis, ligulatis, femineis, disci hermaphroditis, tubulosis. Involucri campanulati squamae pluriseriales, lanceolatae, subaequales. R e ce p $t a-$ c nli plani paleae coriaceo-scariosae, complieatae, acuminatae, flores includentes. Corolla e radii ligulatae, ligula plana, dis ei tubulosae, limbo quinquedentato. Stigmat a cono brevi terminata. A ch enia glabra, ra di trigono-compressa, dise i plano-compressa. Pap pi squamellae tres scariosae, acuminatae, inaequales, persistentes, adjecta in disco hinc inde una alterave minima. Suffrutices in regione capensi orientali indigeni, erecti, pedales; caulibus e basi plurimis $v$. solutariis, ramis apice monocephal is, folits inferioribus oppositis, superioribus alternis, lanceolatis, acuminatis, integerrimis.v. subserratis, capitulorum diametro pollicari.

$$
\text { Callile pis DC. Prodr, } V . \text { Grt. }
$$

9616. CuIea R. BR. Ca pitulam paucimultiflorum, homogamum v. heterogamum, floribus radii ligulatis, femineis, disci tubulosis, hermaphroditis. I n v o 1 u e r i ovati v. campanulati squamae imbricatae, saepius obtusae, siccae. $\mathbf{R}$ ec epta c alum plus minus conicum, paleatum. Corollae radii dum adsunt ligulatae, disci tubulosae, limbo quinquedentato. Stigmat a disci exappendiculata. A ch enia teretia v. compressa, angulata. Pa p i paleae quinae-vicenae, saepius subdenae, lineari-lanceolatae, scariosae, acuminatae, uninerves, subaequales. - Frutices rariusve herbae, in America tropica provenientes; foliis oppositis $v$. rarissime ternis, saepius trinerviis, scabris, integerrimis v. dentatis, capitulis terminalibus v. axillaribus, floribus luteis.

C al ea Lessing Synops. 24t. DC. Prodr. V.67t. C aI e a e s p. Linn. et Auct.

a. AMPhicalea DC, l. c. Capitn $\mathrm{l}$ m quadeiflorum, diseoideum. Recep tacul um epaleatum.

b. DISCOCALEA DC. l. c. C a pitulam multiflorum, discoideum.

C a le a R. Browa in tinn, Trazsact. XIIT, 109. Cas. sini in Dict. sc, nat. LV. 265. (Kunth in Humb, et Bonpl. Nov, gen, et sp. $t$, 406, 40\%.) 
c. CALEACTE DO. l.c. C a p itu $1 \mathrm{a} \mathrm{m}$ multiflorum, radiatum, ligulis 5-10. In volucri squamae siccae, ex!eriores braeteiformes nullae.

C al ca ete R. Brown l. c. Cassini $l$, c, non Lessing. Mo cinna Lagase. Nov. Gen, 31.

d. LEONTOPHTHALMUM Lessing Synops, 24t. C a p it a$1 \mathrm{um}$ multiflorum, radiatum, ligulis 15 -25. In voluc r u m basi bracteis foliaceis, puberis cinctum.

Leon to phthal m u milldenow in Berl. Magaz. 1807. p. 140. Kunth in Humb. et Bonpl. Nov. gen. et sp. IV. 296, t. 409. Cassini in Dict, sc. nat, XXV. 471. LV. 265.

261\%. Alloearpus $H, B, K$. Capitu$1 \mathrm{u} \mathrm{m}$ multiflorum, heterogamum, floribus radii subquinis, ligulatis, femineis, disci tubulosis, hermaphroditis. Involucri hemisphaerici squamae subdenae, laxe imbricatac, scarioso-membranaceae. $R$ ecepta c u li planiusculi paleae lanceolatae, persistentes, scariosae. Corollae radii ligulatae, disci tubulosae, limbo quinquedentato. S $\mathrm{tigma-}$ ta exappendiculata. A chenia radii cuneata, compressa, disei cuneato-cylindrica. Papp as radii nullus, dis c i multipaleaceus, paleis uniseriatis, acuminatis, pectinatis. - Herbae a mericana e tropicae, erectae, ramosae; foliis oppositis, breviter petiolatis, tripli-quintuplinerviis, ovalibus, utrinque acuminatis, integerrimis, villosis, capitulis pedicellatis, flavis v. sordide albis.

Alloca rpus Kunth in Humb. et Bonpl. Nov. gen. et sp. IV. 291. to 405. Cassini in Dict. sc. nat, LV. 265. Les. sing Synops, 242. All o Is permum Willdenow in Berlin. Magaz, 1807, p. 139.

2618. Vargnsin $D C$. Capitulum multiflorum, heterogamum, floribus radii paucis, uniseriatis, ligulatis, femineis, inter involucri squamas interiores et receptaculi paleas exteriores occultatis, disci tubulosis, hermaphroditis. Involueri hemisphaeriei squamae subbiseriales, ovales, mucronulatae. R e e p ta culi convexi paleae membranaceae, angustissimae, exteriores majores. C orolla e radii ligulatae, ligula brevi, obovata, apice tridentata, dis ci tubulosae, limbo quinquedentato. Stylus brevis, inclusus; stigmata cono brevi terminata? A $\mathbf{c}$ h enia basi attenuata, subpuberula, radii obeompressa, inter involucri squamas interiores et paleas receptaculi exteriores inclusa, disci subtrigona. $\mathbf{P}$ a p i paleae variae, radii setiformes, parvae, dis ci quinque, ovatae, erectae, serrato-ciliatae, acutac, corolla triplo longiores. - Herba caracasana, erecta, annua, gracilis, parce dichotome ramosa, sparse hispida; foliis oppositis, brevissime petiolatis, ovatis, acuminatis, dentato-serratis, pedunculis e dichotomiis monocephalis, ebracteat is, capitulis subglobosis, involucro glabro, floribus pallide purpurascentibus.

Vargasia DC. Prodr, V. 676.

2819. Cialimsoga $R U I Z$ et $P A V$. C a pit n l u m pluriflorum, heterogamum, floribus radii quaternis v. quinis, ligulatis, femineis, disci hermaphroditis, tubulosis. Involucri pentaphylli squamae uniseriatae, ovatae, margine hyalinae. Receptaculi conici paleae lineari-lanceolatae, acutae, integrae v, trifidae. Corollae radi i ligulatae, ligula suborbiculata, dis ci tubulosae, limbo quinquedentato. Stig mat a acuta, vix appendiculata. A chenia angulata, adpresse hispidula. Pap pi uniseriati paleae oblongae, breves, plumoso-fimbriatae. - Herbae in America tropica et australi extratropica provenientes, annuae, trichotomae, ramosissimae; foliis oppositis, ovatis, triplinerviis, serratis, pedunculis axillaribus et terminalibus, mono-tricephalis, capitulis parvis, disco luteo, radio flavo.
Galin soga Ruiz et Pav. Prodr, 110, $t$. 24. Cavanill. Ic. $t$. 281, excl. reliq. Cassini in Dict, sc. nat, XVIII, 96. DC. Prodr. $\mathcal{V}$. 677. Galins og a e Zucearini in Flora 1821. p. 612. Wiborgia Roth Catalect, II, 112. Lessing Synops, 275. nou alior.

2620. Sogalgina CASS. Capitulum multiflorum, heterogamum, floribus radii uniseriatis, bilabiatis, femineis, disci tubnlosis, hermaphroditis. Involucri hemisphaerici, pauciseriati squamae submembranaceae, ovales, obtusissimae. Receptaculi convexi paleae ovali-acuminatae, flores amplectentes. Co ro 11 a e radi i bilabiatae, labio exteriore amplo, apice dentato, interioris lobulis duobns linearibus, diseretis v, connatis, disci tubulosae, tubo hrevi, fance cylindrica, limbo quinquedentato. Stig $\mathrm{m}$ a $\mathrm{ta}$ in appendicem filiformem longe producta. A $\mathrm{e} h \mathrm{en}$ i a teretiuscula. $P$ ap i paleae uniseriatae, conformes, pinnatipartitae v, plumoso-fimbriatae._Herbac mexicanae, annuae, trichotomae, pilosiusculae $v$, glabrae; foliis oppositis, lateraliter incisis, capitulis terminalibus, pedunculatis, floribus luteis.

Sogalgina Cassini in Bullet, soc, philomat, 1818. p. 3t. Dict, sc, nat, XLIX, 397. LV, 265. DC. Prodr, V. 678. Galinsogea et $\mathrm{Sog}$ a $I_{\mathrm{g}} \mathrm{i}$ in Lessing Synops. 245, G a. Ii nsoge a s p. Cavanill. Ic. 1. 282, Kunth in Humb, et Bonpl. Nov. gen, et sp. t. 386. Sog a lig n a Steud.

3621. Ptilostephinm $H, B, K$, C a pit u l u m multiflorum, homogamum, floribus omnibus tubulosis, exteriornm limbo subirregulari. Involucri campanulati squamae paucae, imbricatae, margine scariosae, Recepta culi plani paleae oblongo-lineares, scariosae. Coroll a e tubulosae, centrales tubo brevissimo, fauce tumidiore, elongata, limbo regulariter quinquedentato, marginales majores, inaequaliter quinquelobae, lobis exterioribus majoribus. Stigm at a breviter appendiculata. A $\mathbf{c}$ h e $\mathbf{n}$ i a villosa, basi attenuata. P a p p i nniseriati paleae quindenae-vicenae, ciliatoplumosae. - Herbae mexicanae, annuae, trichotomae, pilosiusculae; foliis oppositis, irregulariter palmati- v. pinnatilobatis, lobis linearibus, acutis, capitulis longe pedunculatis, floribus luteis.

Ptilost ephi um Kunth in Humb. ot Bonpl. Nov. gen. et sp. IV. 255. DC. Prodr. $Y$. 679.

a. CARPHOSTEPHIUM Cass. In volu cri squamae exteriores plurimae, emarginatae. P a p i squamae membranaceae, ciliato-fimbriatae.

C a r phosteph $1 \mathrm{um}$ Cassini in Dict. sc, nat. XLIY. 62. Lessing Synops. 246. (Kunth Op. cit. 6. 388.)

b. PTIlostephium Cass. I n volucti squamae exteriores obtusae v. muerouatae. $\mathbf{P}$ a p p $i$ paleae medio nervigerae, margine plumosate.

Ptlloste phi um Cassini 2, c. Lessing l.c. (Kunth Op. cit. t. $38 \%$,)

R68\%. Treldax LINN. Capitnln m multiflorum, heterogamnm, floribns radii lignlatis, femineis, disci tubulosis, hermaphroditis. In vo 1 ucri ovati squamae laxe imbricatae, exteriores sex v. octo ovales, foliaceae, dorso villosae, interiores membranaceae, glaberrimae, paleas referentes sed latiores. Rece p ta c u li paleae lanceolato-lineares. Corolla radii ligulatae, ligula ovata, trilobata, disci tubulosae, limbo quinquedentato. Stigmata appendice filiformi terminata. Achenia villosa, dis ci obpyramidata, radi i obovata, obcompressa. Pap pi nniseriati paleae quindecim v. sedecim, pinnatisectae, radii minores. - Herba in America tropica cis a equatorem indigena, procumbens, hirsuta, ramosa; foliis oppositis, petiolatis, ovatis, inciso-dentatis, ramis apice nudis, elongatis, monocephalis, floribus disci luteis, radii pallide flavis. 
T r id a x Linn. Hort. cliffort, 418. Gen, n.972. R. Brown in Linn. Transact, X11, 103. Lessing Synops, 246. DC. Prodr. ข. 629 .

2683. HIeplanuipappans HOOK, Ca pitul u m multiflorum, heterogamum, floribus radii pancis, ligulatis, femineis, disei tubulosis, hermaphroditis. Involucri uniseriati squamae aequales, oblongae $v$. ellipticae, $R$ e ce p ta cu I u m paleatum. Corolla e radii ligulatae, ligula latecuneata, profunde trifida, d is ci tubulosae, limbo quinquedentato, apice longe piloso. Stig mat a dis ci linearia, longe recurva, glanduloso-pubescentia, $\mathbf{r}$ a di i brevissima. A chenia clavata. $\mathbf{P}$ a $\mathbf{P}$ pi paleae circiter octo, lineari-acuminatae, fim briatae, ciliatae. - Herbae boreali-america n a e, annuae, ramosae; foliis alternis, linearibus, integerrimis, capitulis terminalibus, solitariis, disco flavo, radio albo.

B lepharipappus Hooker Flor, Bor. Amer. I. 316. DC. Prodr. $V .679$.

2624. Mirselhallia SCHREB. Ca p itulu m multiflorum, homogamum. Invol ucri unibiscriati squamae lineari-lanceolatae, discum aequantes. Recepta culi convexi paleae lineares, acutae. Corolla e tubulosae, extus hirsutae, limbo quinquedentato. S $\mathbf{t} \mathbf{i} \mathbf{g} \mathbf{m}$ a $\mathbf{t}$ a exappendiculata. A $\mathbf{c}$ h en i turbinato-subpentagona, pubescentia $v$. villosa. Pa p p i paleae quinque, enerves, ellipticae, acuminatae, integerrimae. - Herbae borealiamericana e, perennes; foliis alternis, integerrimis, capitulis terminalibus, solitariis, purpurascentibus, scabiosaeformibus.

Marschallia Sehreber gen, $n, 1762$. Cassini in Dict. sc. nat. LV. 263. Lessing Synops. 241. DC. Prodr. $V$. 680. Persoonia Michaux Flor, Bor. Amer. IT, 104, $t$, 43, non Smith. Trattiniekia Persoon Ench, 1I. 403. non Willd. A than asia Walter Carolin, 201. nou Linu. Phyte um. opsis Jussieu msc.

26ะ5. Tabautia GAUDICH. Capitul $\mathrm{um}$ octo-decemflorum, homogamum. Involucri campanulati squamae circiter octo, liberae, uniseriatae, sibi mutuo incumbentes. Receptacu$1 \mathrm{um}$...... Corollae tubulosae, limbo quin quedentato. Antheras ecaudatae, breviter appendiculatae. Stigmata dilatata, acnta, ciliata. A $\mathrm{ch}$ e nia hirsuta, oblonga v. obpyramidata, areola terminali. Pappi paleae uniseriatae, angustae, ciliato-plumosae. - Suffrutices sandwicenses; ramis teretibus, strigilloso-pilosis, apice foliosis, inferne cicatrisato-annulatis, foliis oppositis, sessilibus, rigidis, subparallele venosis, dentalis, capitulis in racemos paniculatos aggregatis.

D u b a u ti a Gaudichand ad Freyc. 468, t.84. Hooker et Arnott ad Beech, 88. Lessing Synops, 247. DC. Prodr. V.680.

SUBIDUISIO II. SPHENOGYNEAE DC. Prodr. V. 681. Flores radii ligulati, neutri. Pappi paleae obovatae, obtusissimae, contorto - convolutae.

2626. Sphenogyne $R$. BR. C a pitu$1 \mathrm{u} \mathrm{m}$ multiflorum, heterogamum, floribus radii uniseriatis, ligulatis, nentris, disci tubulosis, hermaphroditis. Involueri campanulati, multiseriati squamae imbricatae, interiores majores, apice ample seariosae. Receptaculi paleae scariosae, flores amplectentes, saepins apice truncatae. Coroll a e radii ligulatae, disci tubulosae, limbo quinquedentato. $\boldsymbol{A} \mathrm{n}$ the ra ecandatae, appendice terminali subeordiformi. Stigmat a apice truncata, fere cuneata. A chenia cylindracea, inferne vix angustata, pilis mollibus, e basi ortis cincta.
Pap p i uniseriati paleae obovatae v, cuneatae, ob. tusae, juniores pellucidae, spiraliter contortac, adultae opacae, lacteae. - Herbae $v$, suffrutices c $a$ penses, Anthemidis facie; foliis alternis, saepius pinnatilobis, rarius trifidis $v$. integerrimis, ramis apice pedunculiformibus nudis, monocephalis, corollis flavis aut apice fuscis, ligul is interdum subtus rubris.

$\mathrm{S}$ phenogyne R. Brown in Ail. Hort, Few. IT. 3 . p. 142. Cassini in Dict. sc. nat, L. 204. Lessing Synops, 249. DC. Prodr. $Y$. 681. Olig a e rio n Cassini Op. cit. IT. 75. XXIX, 187. Thely tha mnos Spreng. fil. Suppl. 25. S permophylla Necker elem. I. 2. excl. sp. Aretotidis s p. Lina, et Auct, Ursiniae sp, Lam.

a. THELYTHAMNos $D C$. l. c. Involueri squamae ex. teriores absque margine scarioso manifesto.

c. Anthemoides Lessing Synops, 248. Species anmuae. Aretotidis s p. Linn. Jaeq. Hort. Schonbr. 2. 156. Bot. Mag. $t, 544$.

ק. Thelythan nos Lessing Synops. 243. Species perennes v. suffrutescentes. A retotidis $s$ p. Liun.

b. XEROLEPIS DC. $l$. c. Involueri squamae omnes margine late scariosae, - Herboe perennes v. frutices.

Xer olepis Lessing Synops. 244. Aretotidis s p. Linn. Jacq. Hort, Schönbr, $t$, 155.

262\%. Urginia GẌRTN. Capitulum multiflorum, heterogamum, floribus radii uniseriatis, ligulatis, neutris, disci tubulosis, hermaphroditis. Invol u c ri eampanulati, multiseriati squamae imbricatae, interiores majores, pleraeque apice in appendicem scariosam productae. $R$ e $c$ e $p-$ $t$ a $\mathbf{c}$ li paleae scariosae, flores amplectentes. C orollae ra dii ligulatac, dis c i tubulosae, limbo quinquedentato. Antherae ecaudatae, apice appendiculatae. Stig mat a apice truncata. A $\mathbf{c h} \mathrm{c}$ nia obovato-turbinata, basi distincte attenuata, glaberrima, nervulis quinque minimis subcostata Pa p p us duplex, exterioris paleae quinque, amplae, obovatae, lacteae, spiraliter aestivato-contortae, interioris fila totidem, concoloria, angustissima, ima basi subconcreta. Herbae $v$. frutices c apenses; foliis alternis, uni-v. bipinnatisectis, ramis apice nudis, monocephalis.

Ursinfa Gírtner II. 462, t. 172. Lessing Synops. 244. DC. Prodr. $V .688$. A r c to tid is s p. Auet.

DIVISI III. MADIEAE DC. Prodr. $V$. 691. Involucri squamae uni-biseriales, convolutae v. complicatae, achenia radii includentes. Receptaculum margine $v$. fere totum paleatum. Achenia radij semper calva, dis ci pappo paleaceo donata v. interdum calva, fertilia v. sterilia. - Folia allerna, flores flavi.

2628. IIadia MOLIN. Ca pitu Ium muItiflorum, heterogamum, floribus radii denis v. duodenis, nniseriatis, ligulatis, femineis, disci tubulosis, hermaphroditis. In v ol u e ri subglobosi squamae uniseriatae, dorse carinatae, complicatae, achenia radii involventes. Receptaculi plani, centro nudi paleae inter radium et discum nni-biseriatae, subeonnatae. Corolla e radii ligulatae, ligula basi glabra vix involucro longiore, interdum monstrose ample et irregulariteritubulosac, dis c i regulariter tubulosae, limbo quinquedentato. Stigmat a disci apice pilis rigidis, erectis onnsta. A ch enia conformia, compressa, recta, basi attenuata, glabra, utrinque in medio nervo longitudinali aucta, ideo tetra - pentagona. $\mathbf{P}$ a $\mathbf{p}-$ pus nullus. - Herba chilensis, annua, erecta, villosa, apice glanduloso pilosa; folits infimis oppo54 * 
sitis, superioribus alternis, semiamplexicaulibus, oblongis, integerrimis, capitulis breviter pedicellatis, in racemum dispositis, foliis parvis, saepius bracteatis, corollis luteis, seminibus oleosis.

M a dia Molina Chil, 113. Cavanill. Ie. IT. 50. t. 298. Jacq. Hort. Schönbr. $t$, 302. DC, Mém, soc. 4. n. Génèv, VIT. 277. Prodr. $V$. 691. Mad i a et B latia Cassini in Dict. sc, nat. XXXIV. 308.

2689. THadaria $D C$. C a pitul u mul tiflorum, heterogamum, floribus radii denis v, duodenis, uniseriatis, ligulatis, femineis, disci tubulosis, ovario efoeto masculis. Invo I u cri subglobosi, uniseriati, torulosi squamae complicatae, achenia radii omnino involventes. Recepta $\mathrm{e} u \mathrm{li}$ subconvexi, centro epaleati, dense et breviter fimbril lifero-hirsuti paleae inter radium et discum nni-biseriatae. Corollae basi puberulo-hirtellae, radii ligulatae, involuero daplo longiores, disei tubulosae, limbo quinquedentato. Stigm a ta apice hispidula. A ehen a radii compressa, nervis utroque latere aucta, subtetra-pentagona, basi rostello incurvulo donata, dis e i omnino abortiva. Pap p $\mathrm{s}$ nullus. - Herbae californicae, annuae, erectae, villosae, saepe glanduloso-pilosae; foliis oppositis, sessilibus, lanceolatis $v$. linearibus, integerrimis, capitulis laxe corymbosis, longius pedicellatis, ebracteatis, floribus flavis.

M a daria DC. in Mém. soc. h. n, Génèv. MII. 280. Prodr. V. 691. Bot. Mag. $t$. 3548. Ma dia elegans Don in Bot, Reg, t. 1458.

2630. Hemizonia DC. Capitulu m multiflorum, heterogamnm, floribus radii uniseriatis, ligulatis, femineis, disci tubulosis, ovario efoeto masenlis. Involueri nniseriati squamae concavae, achenia radii involventes. $R$ e ce p $t$ a $c \mathbf{u} l \mathbf{u ~ m}$ planum, paleatum $v$ disco nudum, paleis inter radinm et discum uniseriatis. Corolla e glabrae, $\mathrm{r}$ a di i ligulatae, involucro paullo longiores, dis ci tubulosae, limbo quinquedentato. Stigma $t$ a obtusiusenla. A $c$ he nia ra dii obovata, fere obcompressa, extus convexa, intus plana, glabra, disci nulla. P a p p s nullns. - Herbue californic a e, erectae, ramosae, basi suffruticosae, pilosiusculae, interdum glanduliferae; foliis alternis, confertis, lanceolatis $v$, linearibus, integerrimis v. serratis, capitulis terminalibus, solitariis $v$. paucis, bracteis foliaceis, plurimis cinctis.

He mizo nia DC. Prodr, $V$. 692.

a. MADARIOIDES DO, l. c. Ree ptaculi disens nudus, planus, punctatus, paleae inter ralium et diseum uniseriatae.

b. OLOCARPHA DC. $l$, c. Receptaculum totum paleatum.

2631. Tollatia. Capitulum multiflorum, heterogamum, floribus radii denis v. duodenis, uniseriatis, ligulatis, femineis, disci tubulosis, hermaphroditis, centralibns plurimis abortivis. Involueri squamae uniseriatae, basi rigide ciliatae, convolutae, achenia radii omnino involventes, superne in appendicem linearem, foliaceum productae. Receptaculum totum paleis membranaceis inter flores onustum. Corolla e radii ligulatae, ligula hasi pubescente, apiee grosse dentata, disci tubulosae, tubo obcompresso, limbo quinquelobo, pubescente. Ant herae nigricantes, Stigmata disei in appendicem hispidam, aeutissimam producta. A chen ia obcompressa, obovatooblonga, glabra, centralia saepe abortiva. - Herba c alifornica, annua, erecta; caule tereti, purpurascente, glabra, foliis alternis, pinnatifidis, lobis quinque-octojugis, integerrimis, ciliatis, capitulis ramulos apice nudiusculos, hirsutos terminantibus, bracteis paucis, ciliatis, floribus flavis,

0 x y ur a DC. Prodr. $\nu, 693$.

263\%. Flitatmannia DC. Capitulum pluri-multiflornm, heterogamum, floribus radii uniseriatis, ligulatis, femineis, disci tubulosis, hermaphroditis. In vo I u eri extus bracteis aliquot linearibus cincti squamae oblongo-lanceolatae, acutae, convolutae, flores radii semiamplectentes. $R$ eceptaculnm totum paleatum, paleis involneri squamas referentibus sed planiusculis. Corolla e ra di i ligulatae, ligula apice grosse dentata, di sci tubulosae, limbo quinquedentato vix puberulo. Antherae nigricantes. Stigmata disci cono acuto superata. Achenia radi tri-tetragona, obovata, subpedicellata, dorso subconvexa, areola terminali obliqua, introrsa, interdum papillosn-exserta, disci ovali-oblonga, obcompressa. Pappus radii nullus, disci paleaceus, paleis quinque membranaceis, enerviis, obtusis, corolla dimidio brevioribus, rarissime defieientibus. - Herbac californicae, erectae; caule simplici, apice corymboso-ramoso, pilis patulis hispido, foliis allernis, infimis nonnunquam oppositis, sessilibus, lineari-oblongis, pinnatifidis v. serratis, pubescentibus, capi tulis ad apices ramorum corymbosis v. fasciculatis, floribus fluvis.

\section{Hartmannia DC. Prodr. $V .693$}

2633. DIradaroglossa DC. C a pitulum multiflorum, heterogamum, floribus radii uniseriatis, ligulatis, femineis, disci hermaphroditis, tubulosis. In volu e ri uniseriati squamae acuminatae, basi convolutae. Rece p taculu m paleis lineari-lanceolatis, submembranaceis onustum. C orolla e radii ligulatae, disei tubulosae, limbo breviter quinquedentato. Stig $\mathrm{m}$ a $\mathrm{ta}$ disci inclusa. A chenia radii linearia, basi attenuata, disci lineari-clavata. Pappus radii nollus, disci ex aristis octonis-denis, basi ciliato-plumosis, apice seabris. - Herbae californicae, erectae, pilososcabrae; caule tereti, foliis alternis, sessilibus, oblongis, acutis, inciso-dentatis $v$. integerrimis, capitulis ramulos terminantibus subcorymbosis, floribus flavis.

Madaroglossa DC. Prodr, $Y .694$.

2635. Calyeademia DC. Ca pitulum multiflorum, heterogamum, floribus radii ternis v. quinis, tubuloso - irregularibns, femineis, disci tubulosis, regularibus, ovario efoeto masculis. In v 0I u c ri bracteolati, uni-biseriati squamae basi coneavae, achenia radii semi-includentes. IR e c e p taculi medio nudi paleae inter radium et discum uniseriatae. Corolla e radii irregulariter ampliatae, introrsum fissae, dis ci tubulosae, limbo quinquedentato. Stig mata ........ A $c$ h e nia radii trigona, subobcompressa, glabra, disci linearia, abortiva. Pa p p as nullus. - Herbae californicae, erectae, strictae; caule tereti, simplici, foliis inferioribus oppositis, superioribus alternis, rigidis, linearibus, margine revolutis, integerrimis, ramulorum confertis, apice glandulam Calycium referentem gerentibus, capitulis in ramulorum apice solitariis $v$. in caulis apice congestis, floribus luteis.

$$
\text { Cal ycadeuia DC. Prodr. } \mathscr{V}, 695 .
$$

SUETTERS VI. ANTHEMIDEAE Cassini Opusc. III. 61. DC. Prodr. VI. 1. Capitula monoica, rarius homogama, plerumque heterogama, floribus radii uni-pluriseriatis, femineis $\mathbf{v}$. rarissime neutris, ligulatis, tubu. 
losis $\mathbf{v}$. interdum bilabiatis, disci tubulosis, quadri - quinquedentatis, hermaphroditis $\mathbf{v}$. rarius masculis. Antherae ecaudatae. Stigmat a apice barbata $v$. truncata, rarissime cono superata. A chenia angulata, teretia, v. in radio plano-obcompressa. Pappus nullus v. parvus, coroniformis, rarius auriculaeformis. - Folia saepissime alterna. Species, paucis exceptis, gerontogeae.

DIUISIO I. EUANTHEMIDEAE DC. Prodr. VI. 1. Capitula radiata, rarius discoidea, floribus radii uniseriatis, ligulatis, femineis rariusve neutris, disci hermaphroditis. Receptaculum paleatum.

2635. Dederia DC. Capitula in glomerulum bracteatnin umbellatim aggregata, cylindracea, heterogame, floribus radii paucis, ligulatis, in ambitn glomernli elongatis, disci tubulosis, hermaphroditis. Invol u cri pauciseriati squamae scariosae, adpressae. Receptaculi angusti paleae scariosae. Corolla e radii ligulatae, disci tubulosae, quinquedentatae. An the ra e ecaudatae, appendice truncato. Stigmat a disci exappendiculata. A chenia exalata, angulato-cylindracea, glabra, pappo brevi, scarioso, coronaeformi $\mathbf{v}$. paleaceo-piloso. - Frutices c a p enses; foliis oppositis aut rarius ternis $v$. spiralibus, imbricatis, approximatis, integerrimis, margine scabris, glomeru lis terminalibus, foliis floralibus bracteaeformibus latioribus cinctis, pseudo-radiatis, ramulis saepe in ter capitula nascentibus, floribus luteis.

Dederia DC, Prodr. VT, 1, O edera Linn. gen, $n$, 1325. Gärtn. IT, 464. Cassini in Dict, sc, nat. XXXV. 400. Lessing Synops. 247.

a. EUORDERIA DC. Prodr. $V T$, 2. C a pitula inter bracteas sessilia. Ligulae $5-8$ exteriores elongatae, glomerulum radiatum mentientes. $\mathrm{P}$ a p $\mathrm{p}$ s brevissimus, radi et disci conformis. (Laa. $t, 720$. Gärtn. $t$, 172,)

b. ERIOPODA DC. Prodr. $P I$. 2. Ca pitula inter lracteas peduaculo brevi insielentia. Ins of u erj squanae exteriores brevissimae. Ligulae brevissimae, capitulum fere discoideum sistentes. Pappus radii brevissimus v. uullas, disei membranaceus, npice dentatus, corollae tubo longior.

2636. Wunorphia $D C$. C a pitnlum multiflorum, heterogamum, floribus radii uniseriatis, ligulatis, femineis, disci hermaphroditis, tubnlosis. Involuerum imbricatum. Receptaculi convexi paleae flores involventes. Corollac radii ligulatae, disci tubulosac, quinquedentatae, eglandnlosae, basi super ovarii appendicem dilatatae. Antherae ecatidatae. Stigmata disci divergentia, breviter exserta, obtusa, radi i longiora, acuta, A c h en ia glabra, prismatica, tri-quadriangulata, corollae basi quasi operculata, P a P p u nullus. - Frutex capensis, glaber, ramis superne puberulis; foliis oppositis, linearibus, brevibus, obtusis, dorso sulcatis, erectis, in axillis saepe gemmuliferis, capitulis ad apices ramorum ternis, breviter pedicellatis, floribus radii albis, dorso purpurascentibus, disci luteis.

E um or phta DC. Prodr, NI. 2.

263\%. Aganippea DC. C a p i $\mathrm{tulum}$ multiflorum, heterogamum, floribus radii uniseriatis, ligulatis, femineis, disci hermaphroditis, tubulosis. Involucri biseriati squamae exteriores snbquindecim, lanceolatae, basi subconnatae, interiores tot quot flores radii membranaceae, breves, paleas referentes, achenia radii involventes. R eceptaculi plani paleae membranaceae, achenia involventes. Corollae radi i ligulatae, disci tubulosae, limbo quinquedentato. An th era e ecaudatae. Stigmata cono brevi superata. Achenia oblonga, erostria, exteriora imprimis paleis involuta. Pappus nullus. - Herbae mexicanae, erectae $v$. adscendentes; foliis oppositis, dentatis $v$. integerrimis, pedicellis monocephalis, nudis, ex axillis supremis orlis, floribus radii albis, subtus roseis, disci flavis.

A g a i p pea Flor. Mexic. inedit. ex DC. Prodr, VI. 3.

2638. Wpallage DC. Cap itulum multiflorum, heterogamum, floribus radii uniseriatis, ligulatis, femineis, disei hermaphroditis, tubulosis. Involucri bi-triseriati squamae oblongae, erectac. Receptaculi angusti, planiusculi paleae lanceolatae, rigidae, mucronato-spinescentes, demum deciduae. Corollae radii ligulatae, tubo longo, tereti, ligula angusta, integra $\mathbf{v}$, breviter tridentata; dis ci tubulosae, teretiusculae, limbo quinquedentato. Antherae ecaudatae, eglandulosae. Stigm a ta exappendiculata. A c henia conformia, erostria, angulato-8ulcata, oblonga v. subturbinata, paleis semiinvoluta, P a p p us coroniformis, brevis, denticulatus v. subinteger.Suffrutices $v$. herbae madagascarienses; folitis alternis, petiolatis, integerrimis $v$. dentatis aut incisis, capitulis terminalibus, pedicellatis, flavis.

EpaIIage DC. Prodr. VI. 3. A at he midis s p. Bojer. Helletae s p. Lessing.

2639. Anthemis $D C$. C a pit u $1 \mathrm{~nm} \mathrm{mul}$ tiflorum, heterogamm, floribus radii uniseriatis, ligulatis, femineis, rarius subtubulosis v. nullis, disci tubulosis, hermaphroditis. In v o I n eri squamae imbricatae, pauciseriatae. R e e pta cu I n m convexum, oblongum $v$, conicum, paleis membranaceis onustum. Corollae radi ligulatae, dis c i tubulosae, limbo quinquedentato. A nt herae ecaudatae. S $\mathbf{t}$ i g $\mathbf{m}$ a $\mathbf{t}$ a exappendiculata. A ehenia teretiuscula v, obtusissime tetragona, striata v. laevia. Pap u s nune nullns, nune membrana brevissima, integra $\mathbf{v}$, dimidiata, nune aurienlaeformis, introrsum lateralis. - Herbae rarius basi suffrutescentes, ramosae, in Europa et Asia temperata indigenae, in regione medit er rane a orientali imprimis copiosae, odoratae; foliis uni-bipinnatipartitis, lobis varie incisis, ramis apice aphyllis, monocephalis, capilulis ebracteatis, radio saepius albo, rarius flavo, rarissime nullo, pappi forma in eodem saepius capitulo varia.

A $n$ the $\mathrm{m}$ is DC, Elor.fr. A98, excl. sp. Prodr. VI, 4. A nthe as id is sp. Linn.

a, CHamakmelum $D C$. $l$, $c$, C ap $i t \mathrm{n}$ la radiata. $\mathrm{P}$ a pp us uullus.

C h a m a e $\mathrm{mel}$ u m Cassini in Dict. sc.nat. XIX. 279. Lessing Synops, 248. (E. B. t. 602,950. Fl, dan, t, 1179. - Marcelia Cassini Op. cit, $X X X I V$, 107. quate A a. eyclus a a e s Lina. Iigulis brevissimis, stylum nempe haud superantibus, vix alia nota clifert.

b. EUANTHEMIS DC. $l$. c. C apitula radiata v. rarissi. me discoidea. P a p p a s coromila cireularis v, unilateralis. An them is Cassini $O p$, cit, $X \times I X, 179,185 \times x \times I V$. 105. Lessing Synops. 248. Jaeq. Fl. austr, $t$. 4 H. E. B. t. 1472. 1370. Selikulie t. 25\%. Vahl Symb. II. $t$. a6. Desfont. $F l$, atl, $t$, 239. Delile Fl. aegspt. $t$. 45. f. I. t.37, f. 3. Tenore Fl. neap. $t .82$, Gussoue Pl, rar. $t, 60$. Bot. Reg. $t .527$.

2840. Waruta CASS. Capitulum multiflorum, heterogamum, floribus radii ligulatio, abrque genitalinin rudimento neutris, disci tubu. losis, hermaphroditis, In v o I u $\mathrm{c}$ r i hemisphaerici, 
squamac paciseriatae, disco breviores. Re cept a c $\mathrm{l}$ um conicnm v, convexum, totum v. apice tantum inter flores paleatum. Corollae tubo plano-obcompresso, bialato, basi exappendiculato; $r$ adi $i$ ovario sterili continuae, ligula oblonga; d is ci cum ovario articulatae, limbo quinquedentato. Antherae ecaudatae. Stignata exappendiculata. Achenia costata, glabra, disco epigyno parvo, areola terminali. Pap p u s nullus, Herbae annuae, europeae, in Americam transfugae, foetidae, ramosae, glabriusculae v. parce pilosae; folits alternis, tripinnatisectis, lobis lineari-subulatis, ramis apice denudatis, monocephalis, radio albo, saepe deflexo.

Maruta Cassini in Dict. sc, nat. XXIX 174. Lessing Synops. 248. DC. Prodr. DI. 13. A a themis Cotula Linn. FI. dan. t. 1179. Sclikuhr t, 254.

2641. Huger $D C$. C a p it u lum multiflorum, heterogamum, floribus radii nniseriatis, ligulatis, femineis, disci tubulosis, hermaphroditis. Involucri pauciseriati squamae imbricatae. $R$ e. c e p $t$ a c u l u m convexum, paleis inter flores onnstum. Coroll a e radi i ligulatae, disci tubulosae, limbo quinquedentato. Antherae... Stigmata exappendiculata. A chenia anguste obpyramidata, tri-tetra-pentagona, angulis nerviformibus, sulcis totidem fuscis separatis. Pa p pi dentes tot quot anguli achenii, isdem continui, submemliranacei.-Suffrutex canariens is ; foliis alternis, pinnatilobatis, supra scabris, subtus velutinis, lobis oblongis, obtusis et obtuse lobatis, marginibus revolutis, inflorescentia corymbosa, pedunculis nempe quinque $v$. sex subracemosis, ad apicem caulis ortis, radio albo.

Lugoa DC. Prodr. VT. 14. Anthemis fruticosa Chr. Smith. A. revol ut a Link.

264. Tyonmetia CASS. C a pitnlum multiflorum, homogamum, discoideum. In v o l acri campanulati squamae pauciseriatae, imbricatae. Receptac u I um conicum v. convexum, paleatum. Coroll a e tubo plano-obcompresso, biaato, basi exappendiculato, limbo quinquedentato. Antherae ecandatae. Stigmat a exappendicnlata. A chenia teretia, suleata, obovata, exalata, conformia. P a p p 8 aurienlaris, introrsum lateralis. - Herbae pusillae, in maris mediter ranei ora orientali et insulis indigenae; foliis alternis, varie pinnatipartitis, caulibus apice nudis, monocephalis, capitulis luteis.

L y o n netin Cassini in Dict. sc. nat. XXXIV. 106. Les sing Synops, 259. DC. Prodr. VI. 14. A n a y eli s p. Lim Desfont. in Annal. Mus. XI, t, 22. Cot ula et Sa utoli nae sp. Auet.

2643. Anaeyelus PERS. Ca p itu 1 u m multiflorum, heterogamum, floribus radii ligulatis subligulatisve, rarissime tubulosis, femineo-sterilibus, discis tubulosis, hermaphroditis. Involucri subeampanulati squamae pauciseriatae, disco breviores. Receptaculum conicum v. convexum, paleatum. Coroll a e tubo obcompresso, bialato, exappendiculato; $\mathrm{r}$ a dii ligulatae, di s ci limbo calloso quinquedentato. Antherae ecaudatae. Stigmat a disei exappendiculata. Achenia plano-obcompressa, alis latis, integerrimis marginata. Pap p u 8 brevis, irregularis, denticulatus, introrsum lateralis, alis continuus. - Herbae mediterraneae; foliis alternis, pinnatilobatis, pedunculis monocephalis, raro corymbosis, ligulis nunc albis, nunc fere nullis.
An acyclus Persoon Ench, IT. 464, Cassini in Dict. sc, nat, XXXIV, 103. DC. Prodr. VI, 15, A u a c y ell et Anhe uid is s p. Linn. Cotulae s p. Tournef.

a. PYRETuRARIA DC. op. cit. VI. 15. Capitula am. ple radiata, ligulis albis v, subtus purpureis. Corot. la e disci lobis quinque aequalibus. - Species perennes. A n the mis P yreth $\mathrm{r}$ u Lian. Lam. t.683.f.4. b. DIORTHODON DC, op. cit. $V I, 16$, C a pitula ample radiata, rarius subdiseolden. Cor olla a disci, impri. mis centrales biaristatae; nempe lobis duobus longioribus, magis callosis, ervetis. - Species annuae, pedun. culis demum cavis. - (Lan, t. . $00 . f$. 1.)

e. HIORTHIA Neck. elem, n. 176, DC. op, cit, VI. 17. Flores radil feminei, minutissime ligulati, fere tu. bulosi. Corolla e disei lobis quinque aequalibus. Herba perennis, multicaulis. - Anaey clus orien$t$ a lis Lisu.

2644. Cyrtelepis LESS. Capitulum multiflorum, homogamum, discoidenm. Invo I aeri campanulati squamae uniseriatae, subrotundo-obovatae, curvilineo-acuminatae. R e e p tac $\mathbf{u} / \mathbf{u m}$ convexum, paleatum. Corollae tubnlosae, tubo tereti, gracili, limbo campanulato, quinquedentato. Anth er a e ecaudatae. St i $\mathrm{g}$ mat a exappendiculata. A $\mathrm{ch}$ e n a plano-obcompressa, bialata, alis lacero-dentatis. Р a p и в brevis, coroniformis, fissus, cum alis confluens. - Herbac a eg $y p$ tiaca c, annuae, parvulae; foliis alternis, bipinnatipartitis, lobis linearibus, capitulis flavis.

Cyrtolep is Lessing in Linnaea VI.166. Synops. 258. C. Prodr, $V I$. 17. Tauacetum monanthos Linn. et Anacyclus alexandrinus Willd. Delile Fl, aegzpt. t. $48 . f .3$.

2645. Drenenis CASS. Capitulum multiflorum, heterogamum, floribus radii uniseriatis, ligulatis, femineo-sterilibus, disci tubulosis, hermaphroditis. Involucrum subhemisphaericum, nni-biseriatum, disco sub anthesi aequale, dein brevins. R e e ptac uli ampli, cylindraceoconici paleae carinatae, acutae, achenia a tergo involventes. Co rolla e radi i tubo obcompresso, basi bilcalearato, cum ovario continno, ligula oblonga; disci tubo compresso, intus alato, ala super achenium in ealcar producta, limbo quinquedentato. An the ra e ecaudatae. Stigmat a disei exappendiculata. A ehen ia exalata, teretinscula, hine palea receptaculi, illine caleare corollino obtecta. - Herba europa ea, Anthemidis facie, annua, ramosa ; foliis sessilibus, alternis, pinnatifidis, rhachi lata, lobulis integris subdentatisve, brevibus, ramis superne aphyllis, monocephalis, ligulis albis, basi flavescentibus.

$0 \mathrm{rmen}$ is Cassini in Dict. sc. nat, $X X X V T$, 355. Les. sing Synops. 249. DC. Prodr. VI. 18. A athem is mixta Lina. et A. coronopifolia Willd.

2646. Cladantlargs CASS, C a p it u $1 \mathrm{um}$ multiflorum, heterogamum, floribus radii uniseriatis, ligulatis, styli abortu et ovario efoeto neutris, disci tubulosis, hermaphroditis. In vol u cri uniseriati squamae ovatae, apice scariosae. R e $c$ eptaculi conici paleae tot quot flores, membranaceae, acutae, fimbrillis filiformibus is aequalibus intermixtis. Corolla e radii ligulatae, tubo obcompresso, imae squamae inserto; $\mathrm{d} i$ s ci tubo tereti, basi ampliata ovarium obtegente, limbi quinquedentati dentibus callosis. Anth e ra e ecaudatae. Stigma ta disci exappendiculata. A $\mathbf{c h}$ en ia compressa, exalata, glabra. P a p us nullus. Herba mauritanica, annua, ramosissíma, glabra; ramis infra capitula ortis, foliis alternis, pinnatipartitis, lobis linearibus, trifidis, capitulis ad ramorum axillas et fapices sessilibus, solitariis, bracleatis, floribus luteis. 
Cladanthas Cassini in Bullet, soc, philomat, 1816. p. 153. Dict, sc. nat. IX, 342. Opusc, 1 . t.9. Lessing Syn. ops. 249. DC. Prodr, VI, 18. A it he mis a rab ic a Linn. Smith Spicileg. $t .16$.

264\%. Irepidoplooruma NECK. Cap itu I $\mathbf{u} \mathbf{m}$ multiflorum, heterogamum, floribus radi uniseriatis, ligulatis, neutris v. interdum femineis, disci tubulosis, hermaphroditis, quandoque unisexualibus. Involueri late campanulati, pluriseriati squamae imbricatae, subrotundae, apice fusco-scariosae. Re cepta $\mathrm{e}$ I um convexum, paleis inter flores acuminato-aristatis, sub anthesi corollas superantibns. Coroll a e ra dii ligulatae, disci tubulosae, tubo basi aequali, limbo quinquedentato. Anthera e ecaudatae, appendi. culatae, inclusae. St $\mathbf{l} \mathrm{I} \mathrm{s}$ intra tubum antherarum inclusus. Stigmat a brevissima, truncata, vix barbata. A chenia glabra, tetragona, erostria. Pappus radii paleae quatuor, quarum duae acuminatissimae; $\mathrm{d}$ is $\mathrm{c} i$ conformis $v$. saepissime nullus. - Herba lusitanica, glabra, simplex, monocephala; foliis alternis, crenato-dentatis, sessilibus, radicalibus spathulatis, caulinis oblongis, capitulis luteis.

Lepidophorum Necker elem.n. 28. DC. Prodr. PI. 19. Anthemis repanda Linn. Brotero Phytogr. t. 27.

\$648. Ptarmiea TOURNEF. C a $\mathrm{p}$ it nl $\mathrm{u} \mathrm{m}$ multiflorum, heterogamum, floribus radii uniseriatis, quinis - vicenis, ligulatis, femineis, disci tubulosis, hermaphroditis, Involu eri campanulati squamae margine fusco-scariosae. R c cepta c u lum latum, planum vix convexum, paleatum. Corolla e radii ligulatae, ligula plana, expansa, involucro multo longiore; disci tubo obeompresso, limbo quinquedentato. An th e ra e ccaudatae. Stigmata exappendiculata, A chenia obcompressa, exteriora margine saepius subalata. Pap pus nollus. - Herbae in Europa indigenae, in $S i b$ iria rarae; foliis serratis $v$. pinnatis aut pinnatipartitis, lobis interdum incisis, radio albo, disco albido v. ochroleuco.

Ptarmie a Tournefort inst. $t$. 283. excl. sp. Necker elem. $n$. 26. DC. Prodr. VI. 19. A n the midis s p. Limn. Jaeq. Fl. austr. App. t. 30. Tenore neap. t. 81. A chll. Le ne $s \mathrm{p}$. Liba. Jacq. Ft, austr, $t .76,77,4 p p, t .33$. Allioni Fl. pedemont, $t, 9.5 .3$. Flor. dan, $t, 643$, Waldst, et Kit. Pl. Hung, t. 2.

264\%. Achiliea NECK. Ca pitulum multiflorum, heterogamum, floribus radii quaternis-senis, ligulatis, femineis, disci tubulosis, hermaphroditis. Involucri ovato-oblongi squamae imbricatae, rarissime margine fusco. Receptac. $\mathrm{l}$ i angusti, nunc planiuseuli, nune (in eadem specie) elongati, rhachidiformis paleae oblongae, hyalinac. Corolla e radi ligulatae, ligula abbreviata, saepe diflormi, rarius nulla; dis c i tubo ohcompresso, limbo quinquedentato. Anth er a e ecaudatae. Stigmata exappendiculata. Acheni a oblonga, glabra, obcompressa, exalata, subnerviformi-marginata. Pa p p us nullus._Herbae perennes, pleraeque in Europa, paucae in Asia et America boreali v. in Africa mediterranea nascentes; foliis alternis, variis, capitulis corymbosis, radio albo, purpureo, flavo v. ochroleuco.

A chille a Necker elem, n, 25. DC. Prodr. VI, 24. Achille ae 8 p. Linn. Selikulir $t$, 255. Jacq. Colleot. 1. t. 2t. Allioni $F l$. pedemont, t. 53. f. 1. 2. Flor. dan, t, 737. E, B, $t, 758,2531$. 2532. Waldst. et Kitaibel Pt. Hung. t, 66, 80. Jaeq. f. Eclog. t. 4. 88. Labillard. Syr. dec. IIT. $t .9$. Ventenat Cels, $t$, 53. 95. Tenore $E l$, neap, $t, 83$.

2650. Diotis DESFONT. Capitulum multiflorum, homogamum, tliscoideum. In vo I t - cri campanulati squamae oblongae, imbricatae, adpressac. Receptac ul n m planum, paleatum. Cor o Il a e tubo plano-obcompresso, bialato, basi obtuse bicalcarato, calcaribus supra ovarium productis, limbo quinquedentato. $\boldsymbol{A}$ n th e r a e ecandatae. Stigmata exappendiculata. A $c$ henia angulata, exalata. P a p p us nullus._Herba erecta, tomento denso candida, in Europae littore occidentali et mediterraneo crescens; foliis alternis, semiamplexicaulibus, ovalibus v. oblongis, obtusis, capitulis ad apices ramulorum foliatorum solitariis, corymbum formantibus, floribus luteis.

D iot is Desfont. Fl. atl. II. 26t. Cassini in Dict. sc. nat, XIII. 295. XXIX, 179. ot 185. DC. Prodr. VI. 34. non Sehreb. G n a p halli um Tournefort inst. 261. Gartn. $\boldsymbol{I I}$. 301. $t$. 165. uou Linn. Otanthus Link Flor. Portug. $I$. 364. Lessing Synops. 259. A than as iae et Filagiuis 8 p. Lian. Santolinae sp. Lam.

2651. Santolina TOURNEF. C a p itul $\mathrm{u}$ multiflorum, homogamum v. heterogamum, floribus radii subligulatis, abortu femineis, disci tubulosis, hermaphroditis. Involucri saepius campanulati squamae imbricatae, adpressae. R eceptaculi convexo-hemisphaerici paleae oblongae, subamplexantes. Corolla e radii subligulatae; disci tubnlosae, saepius inferne in annulum v. cucallum ovarii verticem cingentem productae. A n th er a e ecaudatae. Stig mat a exappendiculata. A chenia oblonga, subtetragona, glaberrima. P a p us nullus. - Suffrutices v. rarius herbae, in regionibus mediterraneis crescentes, aromatici; ramis apice plerumque nudis, monocephalis, foliis alternis, margine dentato-tuberculatis $v$, pinnatilobatis, capitulis ebracteatis, floribus flavis $v$. rarius albidis.

S a ntoli a a Tournefort inst, 260, Linu. gen, n. 348. Gärtner II. 398. Cassiui in Dict, sc, nat, XLVIT, 298. DC. Prodr. $2 T .35$.

a, CHAMAECXPARISSUS DC. op. cit. NT. 35. C a pitu1 u m globosum v. hemisphaericum. Corolla e tabus basi supra ovarii verticem plus miaus productas. Gärtu. , 165. Lall. t, 671. f. 3.4. Smith Exot, Bot, It. t. 62. Viviani Fragm, $t$, 1. Gussone Plant, rar. t, 58.)

b. BABOUNYA DC. op.cit, VT, 36. C a p ital um ovatum. Corolla e tubus graellis, hasi supra ovarium hand productus. - (Delile Fl, aegypt, t. 42. f. 3. Lam.t.67t. f. 5.)

2653. Nablominam CASS. Capituln multiflorum, homogamum. Invo l ueri hemisphacrici, floribns brevioris squamae bi-triseriatae, aequales, adpressae, exteriores ovales, intimae apice bi-trifidae, lobis subulatis. Receptaculi planiusculi paleae apice trifidac. Corolla e tubnlosac, basi snpra ovarium articulatae, limbo quinquefido. Antherae ecandatae. Stigmata truncata. Achenia obcompressa, lata, nitida, apice producta in cornua duo rigida, spinescentia, intus canaliculata, divergentia. - Herba $\mathrm{No}$ vae-Hollandiae meridionalis, pusilla, gracilis, saepe stolonifera; caule ima basi foliato, simplicissimo, monocephalo, superne squamato, foliis glabris $v$. tomentosis, lanceolatis, petiolatis, integerrimis.

Nablonium Cassini in Diet. sc, nat, XXXIV. 101. Lessing Synops. 259. DC, Prodr. VI. 37.

2653. Lasiospermuna $L A G A S C$. Capitulum mnltiflornm, heterogamum, floribus radii femineis, nune tubulosis, minimis, nunc ligulatis, dieci hermaphroditis, tnbulosis. Involueri late campannlati squamae imbricatae, disco snbbreviores. R e c e pta $\mathrm{cu}$ I $\mathrm{n}$ m latum, paleatum. Corolla $\mathrm{radi}$ i ligulatae, exsertae $\mathbf{v}$, tubulo- 
sae, minimae; dis : i tubnlosae, limbo quinque dentato. An the ra e eaudatae. Stigmat a exappendiculata. A $\mathrm{c}$ he nia exalata, juniora hirsuta, adulta lana densissima involuta. P a P p u nullus. - Herbae v, suffrutices capenses, glabri; foliis alternis, varie pinnatisect is, lobis linearibus, ramis superne longe aplyyllis, capitulo solitario terminatis, floribus disci flavis, ligulis dum adsunt albis.

L a sios perm um Lagase. nov. gen. et sp. 31. Cassini in Diot, so, nat, XXV, 304. Treviran, in N. A. N. C. XIII. $t$. 205. Lessing Synops. 250. DC. Prodr. VI, 37, non Raf. nec Fiscl.

a. EUlasiospermom DC. Prodr. $P 1.38$. C a p it ul um discoideum, floribas radil tulualosis, minimis.

Lasios perm um Lagasc. 1.c. Santolina crec. ta Law, t. 67t. $f$. 4. S, erios perma Pers. Schrauk Hort, Monac, $t$, 67 .

b. LANIPILA DC, Prodr. VI. 38. Capitulum radiatum, ligulis fenineis exsertis.

L a nipila Burchell Trav. I. 259. M a tax a Spreng. Syst. $I V .303$. Lidbeckiae sp. Thunb, Lancis iae $8 \mathrm{p}$. Pers.

DIVISI0 II. CHRYSANTHEMEAE DC. Prodr. VI. 38. C a pitul a radiata, floribus radii uniseriatis, ligulatis, femineis $\mathbf{v}$. rarius neutris, disci hermaphroditis. B e ce pt aculum epaleatum.

2654. Steinoglossa DC. Capitul um multiflorum, heterogamum, floribus radii uniseriatis, ligulatis, neutris, disci tubulosis, hermaphroditis. In vo I u c ri uni-biseriati squamae discum aequantes. Recepta $\mathrm{culam}$ convexum, epaleatum. Corollae radii ligulatae, ab ovario facile secedentes; disci tubulosae, limbo quadriquinquedentato. Antherate ecandatae. Stigmat a exappendiculata. A $\boldsymbol{c}$ h e $\mathrm{n}$ ia radii abortiva, disci obpyramidata, glabra. Pappus nullus v. multipaleaceus, brevis. - Herbae Novae-Hollandiae, dubiae affinitatis, glabrae, caulescentes, ramosae, v. scapiformes simplices; foliis alternis, pinnatipartitis, lobis integerrimis, capitulis pedicellatis, ligulis caeruleis.

Steirogloss a DC. Prodr. VT. 38.

2655. Lidbeekia $B E R G, C$ a $\mathrm{p}$ t $\mathrm{n} \mathrm{lnm}$ multiflorum, heterogamum, floribus radii uniseria tis, ligulatis, neutris, disci tubulosis, hermaphroditis. Involn eri bi -triseriati squamae discum aequantes. R e e ptacul um planiuseulum, epaleatum, fimbrillis fitiformibus, paneis. Corolla radii ligulatae, ovario sterili continuae; disci tubulosae, limbo quadridentato. An th era e ecaudatae. Stigmata exappendiculata, Achenia ra di ahortiva, disei costata, glabra, nectario cylindraceo superata. Pa p p 8 nullus. - Herbae capenses, basi suffrutescentes, Chrysanthemi fere facie; foliis alternis, pinnatilobatis, lobis linearilanceolatis, integerrimis, ramis apice parce foliosis, monocephalis, floribus radii albis, disci luteis.

Lidbeckia Berglus El. cap. 307, t, 5. f. 9. Cassiai in Dict. sc. nat. XXVI. 275. Lessing Synops. 250. DC. Prodr. VI. 39. L a nclisi ae s p, Lam, i. 701, f, 2,3, C otuIae sp. Linn.

2656. Camolepis LESS. Capitnlum multiflorum, heterogamum, floribus radii uniseriatis, ligulatis, femineis, dis ci tubulosis, hermaphroditis. Involucri squamae plurimac, uniseriatae, nitra medium inter se concretae. R e ceptac $\mathrm{l}$ I um convexum, nudum. Corollae radii ligulatae, di s c i tubulosae, limbo quinquedentato.
Antherac ecaudatac. Stigmata disci cono superata. A chenia conformia, exalata, glabra, areola terminali $\mathrm{P}$ a p us nullus, - Frutices ra riusve herbae, in Capite bonae spei indigeni, glabriasculi; foliis allernis, varie pinnatisectis, rarius integris, plerumque coriaceis, ramis apice denudatis, elongatis, pedunculiformibus, monocephalis, floribus luteis.

G a molepis Lessing Synops, 251, DC. Prodr. VT, At, a. PSILOThONA E. Meyer ex DC, $t$. c. I u volu c'r I cylindracei squamae paullo ultra medium concretae. Herba annua, - Othou a Tagetes Lian.

b. PSH osteUM DC, $l$, $c$, l n vo I u e ri campanulato-rotati squanae vix ad medium concretae. - Caules fru. ticosi. - 0 th ounae 8 p. Llun. Thuab.

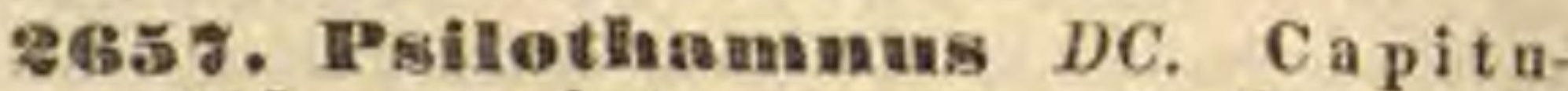
l n m multiflorum, heterogamnm, floribus ratii uniseriatis, ligulatis, femineis, disci tubulosis, hermaphroditis. Involneri uniseriati squamae decem lanceolatae, liberae, persistentes. R e e pt a cul um convexo-conicum, alveolatum, alveolis oblongis, margine exsertis, subscariosis. Corollae radii uni-biligulatae, dise i tubulosae, limbo quinquedentato. Antherae ecaudatae. Stigmat a divergentia, reflexa, apice capitellato - hispidula. A c h enia ovato-teretiuscula, rugosa v. hine inde suberistulata, disco epigyno majusenlo. Pappus nullus. - Suffrutices capenses, trichotome ramosi, rigidi, tenues; foliis sparsis, parvis, subulatis $v$. acerosis, pedunculis monocephalis, aphyllis, gracilibus, erectis, longis, glabris, inter trichotomias ortis, capitulis parvis, luteis.

Psilotbamnus DC. Prodr. VI. 41. Jacquemontia Belanger $V_{o y}$. $t$. s. n, non Choisy.

265S. Coinosyane LESS. C a pitu $1 \mathrm{um}$ multiflorum, heterogamum, floribus radii uniseriatis, ligulatis, femineis, disei tubulosis, hermaphroditis. Involu eri paneiseriati squamae adpressae, multinerves, obtusissimae. Re eptacnlum conicum, nudum. Corolla e radii ligulatae, ligula brevi; disci tubulosae, limbo quinquedentato. Anthera e eaudatae. St igmata cono superata. A c h e $\mathrm{n}$ a oblonga, multieostata, glaberrima, areola laterali, colloque basilari, semilunari. - Herba californica, multiculis, glabra, facie fere Poroplyylli fruticosi; foliis oppositis, carnosis, ligulatis, integerrimis, capitulis terminalibus, solitariis.

Coinogyne Lessing in Linnaea VT, 520. t. 6. f. c. Sjnops. 261. DC. Prodr. VT. 41.

265\%. Egletes LESS, C a pitulum multiflorum, heteroganum, floribus radii uniseriatis, ligulatis, femineis, disci tubulusis, hermaphroditis. Involucri hemisphaeriei squamae pauciseriatae, lanceolatae, imbrieatae. Re ce p ta cuI u m convexum, nudum. Coroll a e radi i ligulatae, disei tubulesae, limbo tri-quinquedentato. Antherae ecaudatae. Stig mata cono superata. A $c$ henia subturbinata, exalata. Papp u s coroniformis, brevissimus, crassus, callosus, subintegerrimus v. subdentatus. - Herbae am ericanae tropicae, Matricariae fere facie, plus minus hirsutae, saepius prostratae; caulibus dichotomis, folits alternis, dentato-pinnatifidis, semiamplexicaulibus, capitulis solitarits, lateralibus $v$. oppositifolits, pedicellatis, disco flavo, radio albo v. albido.

Kg letes Lessing Synops. 259. DC. Prodr. VI. 32. E gle tes et $\mathrm{Xerobius} \mathrm{Cassini} \mathrm{in} \mathrm{Bullet.} \mathrm{soc.} \mathrm{philomat.}$ 1817. 153. Dict. sc. nat, XIV. 265. LIX, 128. Ey seli a Reichenb. Yc. exot. t. 252, M a tricariae s p. Swartz, P y.
rethri sp. Willd. 
2680. Venegasia DC. C a pitulum multiflorum, heterogamum, floribus radii uniseriatis, lignlatis, femineis, disci tubulosis, hermaphroditis. Involuer i eampanulati, pluriseriati squamae exteriores circiter quinque, cordatae, acutae, subfoliaceae, mediae subdenae, ovato - orbiculatae, obtusissimae, subcoloratae, intimae circiter quindenae, minimae, lanceulatae. R e ce pt a c u $\mathbf{l}$ u m planum, nudum. Corollae radii ligulatae, dis ci tubulosae, tubo glanduloso-piloso, basi quasi ciliato et supra ovarium stellatim subexpanso, fere operculiformi, limbo quinquedentato. A nthe ra e ecaudatae. Stigmat a connlo brevi terminata. Ach enia angulata, subcylindracea, muricata, erostria. Pa p pus nullus. - Herba cali fornica, a basi ramosa, erecta, glabriuscula; ramis teretibus, foliis alternis, petiolatis, late ovatis, acutis, dentatis, basi fere truncatis, capitulis pedunculatis, cernuis, floribus flavis.

Venegas i a DC. Prodr. VI. 43.

2661. Heueopsidium $D C$. Capitu l $\mathrm{m}$ multiflorum, heterogamum, floribus radii tricenis v. quadragenis, ligulatis, femineis, disci tubulosis, hermaphroditis. Involucri squanae imbricatae, ovato-lanceolatae, margine membranaceae, apice calloso-subsphacelatae. R e $c$ e p taculum convexum, demum subhemisphaericum. Corollae radii ligulatae, disci tubulosae, tubo tereti, demum basi indurato, calloso, limbe quinquedentato. Anthera e ecaudatae. S t i $\mathrm{gma}$ ata cono brevi superata. A chenia, imprimis ra. dii subcompressa, omnia sulcata, glabra. P a P p $\mathbf{~} 8$ disci et radii conformis, coroniformis, brevissimus, regulariter multipartitus. - Herba b or e ali.americana, Leucanthemi facie, pube brevissima, conferta, molli subvelutina, erecta, ramosa; foliis alternis, radicalibus oblongis, basi attenuatis, obtuse et parce sinuato-dentatis, caulinis semiamplexicaulibus, lanceolatis, integris, mucronulatis, ra mis apice nudis, monocephalis, involucris albidis, subvillosis, disco luteo, ligulis albis, rubore parco suffusis.

\section{Leucopsidium DC. Prodr. VT, 43.}

\section{ager. Xanthocephalume WILLD. C a} pit u I $\mathrm{m}$ multiflorum, heterogamum, iloribus radii uniseriatis, ligulatis, femineis, disci tubulosis, hermaphroditis. Involucri campanuiati squamae pauciseriatae, imbricatae. Re cepta $c \mathbf{u l u m}$ subconvexum, nudum. Corollae radii ligulatae, ligula lineari-oblonga, d i s c i tubulosae, limbo quinquedentato. An the ra e ecaudatae. Stigmat a cono superata. A chenia conformia, compressa, glabra. P a p P u s coroniformis, brevissimns, membranacens, irregulariter lacero-dentatus. Herbae mexicanae, basi suffruticulosae, mullicaules, glabrae; ramis teretibus, foliis alternis, linearibus v. lanceolatis, inciso-denlatis, capitulis terminalibus, solitariis, breviter pedicellatis, disco radioque flavis.

$\mathrm{X}$ a th o e e phal a m Willenow in Berl. Magaz. T. 140. Lessing Synops. 252. DC. Prodr. VI, 43. P y r et h r u m B on p I a ad i a n u Kunth.

2663. Phymaspermum LESS. $\mathrm{C}$ a $\mathrm{p}$ itulum multiflorum, heterogamum, floribns radii neutris, difformibus, lignlatis $\mathbf{y}$ filiformibus, disei tubulosis, hermaphroditis. Involnerum campanulatum, arcte imbricatum. Receptacuin m planum, nudum. Wo rollae radii ligulatae v. filiformes, dis ci tubulosae, teretes, limbo quinquedentato. A nthera e... Stig mat a....
A chenia obovata, papillosa. Pap us nullus. Fruticulus eapensis, ramosissimus; foliis sparsis, sessilibus, coriaceis, linearibus, margine revolulis, integerrimis, demum nilidis, cupitulis parvis, solitariis, terminalibus, involucri squamis tomentosis, oblusis, mucronatis, rudio albo.

Phymaspermum Lessing Synops. 253. DC. Prodr. VI. 44. Oste os permum janceum Thubb.

2684. Irisutsma $D C$. C a p it $u 1 \mathbf{n m ~ m u l - ~}$ tiflorum, heteroganum, floribus radii uniseriatis, ligulatis, femineis, disci tubulosis, hermaphroditis. Involueri bi-triseriati, imbricati squamae subaequales, subfoliaceae, vix acutae. $R$ e cep $t$ aculum convexum, nudum. Corollae radii ligulatae, ligulae lineares, integerrimae, hine inde subtus glandulosae; disci tubulosae, parce pubescentes, limbo quinquedentato. Antherae $\because$. Stigmata.... A ehen ia radii triquetra, dis ci obcompressa, ovalia. Pa p p s nullus.

Herba cant oniensis, caespitosa, erecta, pube minima scabrida, Boltoniae facie; folits lanceolatis, inferioribus serratis, superioribus integerrimis, radio caeruleo, disco luteo.

Hisutsua DC. Prodr. $\mathscr{Y} T$. 44. Matricaria can. toniensis Lonreir.

2685. Irachanthemum $D C$. C a p it u l u in multiflorum, heterogamum, floribus radii quinis v. senis, ligulatis, femineis, disci tubulosis, hermaphroditis. Involncri imbricati, pauciseriati squamae interiores obtusissimae, margine lato, hyalino cinctae. R e cepta c u l u m subeonvexum, alveolatum. Coroll a e radii ligulatae, ligula brevi, obovata, obtuse tridentata, disci tubulosae, tubo teretiusculo, limbi dentibus quinque profundis, reflexis. Antherae ecaudatae. Stigmata exappendiculata, Aehenia conformia, subtrigona, disco epigyno parvo. Pa p p s nullus. - Fruticulus a lta icus, basi decumbens, ramosissimus, foliis alternis, carnosulis, incano-subsericeis, trijidis, lobis integerrimis, mucronatis, capitul is terminalibus, conferte subcorymbosis, floribus disci radiique aureis.

Brachanthemum DC. Prodr. VT. 4t. Chrysan. them иm frutfeulos um Ledebour Ic. $t, 495$.

26B8. Wamanthea DC. Capitulum decem-quindecimflorum, floribus radii uniscriatis, ligulatis, femineis, disei tubulosis, hermaphroditis. Involucri octo-enneaphylli squamae subuniseriatae, ovales, apice et margine membranaceae. R e ce p t a culum angustum, nudum, Co rolla ra dii ligulatae, dis ei tubulosae, obconicae, quadrifidae. Anth erae ecaudatae. Stigma ta crassiuscula, oblonga, ebarbata, A chenia ovalia, subcompressa, glabra. $\mathbf{P}$ a p p us nullus.-Herba perpusilla in insulis maris ligurici vegetans, glabra, e basi ramosa, caespitosa, saepe radicans; foliis alternis, petiolatis, pinnatipartitis, lobis utrinque duobus v. tribus cum impari, oblongis, obtusis, integerrimis, pedunculis capillaribus monocephalis, folia vix superantibus, capitulis minimis, involucri squamis margine albis, floribus radii albis, disco luteo.

Nananthea DC. Prodr, VI. 45. Chrysanthemu perpusill u m Loisleur in Desvanx Journ, bot, 1809, $\boldsymbol{I I}$. 369. $t, 13 . f .3$. Not. 128, t. 4. f. 3. Flor. Gall. $t, 27$.

286\%. Leueanthemum TOURNEF. C a p it u ln m multiflorum, heterogamum, floribas radii uniseriatis, ligulatis, femineis $v$. rarissime neutris, disci tubulosis, hermaphroditis. In v o $1 \mathbf{n}$ с ri late campanulati squamae imbricatae, margine 
subscariosae. R e ce ptac u l u m planum v. convexum, nudum. Corollae radii ligulatae, dis c i tubulosae, tubo carnoso, plano-obcompresso, subbialato, limbo quinquedentato. Anthera e ecaudatae. Stig in a tappendiculata. A chen i a conformia, exalata, teretiuscula, striata, disco epigyno magno terminata. Pap u s disei nullus, $r$ a dii nullus $v$. anriculaeformis. - Herbae perennes, in Europa media et mediterranea copiose provenientes, in $A s i a$ et $A m e r i c a$ arc$\boldsymbol{t}$ ica rarissimae; foliis alternis, dentatis $v$, pinnatilobatis, capilulis ad apices caulis et ramorum solitariis, disco flavo, ligulis albis $v$, subrubentibus.

Le $u$ ea the $\mathrm{mu}$ m Tournefort inst. 492, excl. sp. DC. Prodr. DI. 45. Chrysanthem nm et Phalacrodiscus Lessing Synops. 253. Chrysanthem i s p. Liun.

a. PHAlacroglossum DC. Prodr. VI. 45. F 1 o re s radii feminei. A che nia omnia epapposa.

Chrysanthem um Lessing l. c. B. B. t. 601. FI. dan. . 994. Sehkuhr Handb. $t$. 253. Waldst. et Kitaibel Pl. Hung. t. 236.

b. PHALACRODISCUS DC. Prodr. NT. 47. Flo res radii feminei. A che aia dis ei epapposa, radii pappo coroniformi, saepius unilaterali superata.

Phalacrodis cus Lessing $l$.c. Chrysanthemi p. Lian, Jacq. Observ. IV, $t, 91-93$.

c. ENUCh0GLossum DC. Prodr. $V T$, 48. Flo res radii neutri. A chen i disci epapposa, $r$ adi i efoeta, pappo unilaterali superata.

Chrysanthemus pectinatum Linn. et Cb. palud os u mesf.

d. PHALACROCARPUM DC. Prodr. $V I, 49$. F I o res radil feminel fertiles, disci masculi steriles. A chenia omnia epapposa.

Chrysunthemum anomalum Lagase.

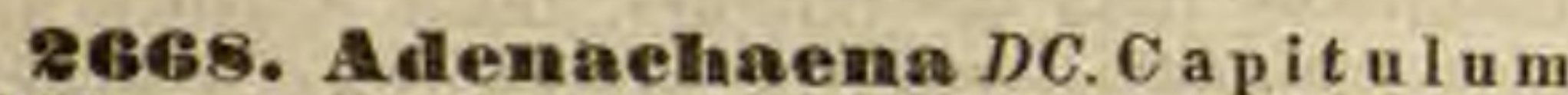
multiflorum, heterogamum, floribus radii uniseriatis, ligulatis, femineis, disci hermaphroditis. Involn eri bi-triseriati squamae disco brevio res, subaequales, lineari-lanceolatae, intimae obtusiusculae. R e e e ta e u l a m plano-convexum, demum interdum subglobosum, minute papillosum. Corollae radii ligulatae, dis ci tubulosae, tabo teretinsculo, limbo quadri-quinquefido. A nthe ra e ecaudatae. Stig m a t a exappendiculata. A chenia conformia, teretia, obtusa, granulis glandulosis obtecta. Pap p u nullus. - Suffruticuli capenses, erecti, ramosi, glabri; foliis alternis, rigidulis, trifidis v. utrinque dente grosso notatis, rarius apice nudis, monocephalis, capilulis fere Matricariae, radio albo, reflexo.

Adena chaena DC. Prodr. Pr. 49.

a. Le ucanthemolies DC. Z. e. Capitula multi. flora, foribus disci circiter triginta, flavis. Receptaculuu convexum. A chenla vix striata. - Folia acuta, acute triloba.

b. EUMORPEOIDES DC. $t$. c. Capitula pauciflora, floribus disci circiter duodecim v. quindecim, flavis v. purpureis, antheris fluvis. A che ui a manifeste stria ta - Folia obtusiuscula, pauca, abtase triloba.

2689. MTatrienria LINN. Capitulum multiflorum, heterogamum, floribns radii uniseriatis, ligulatis, femineis, rarissime nullis, disci hermaphroditis, tubulosis. Involueri imbricati, pauciseriati squamae subaequales, Receptacu $\mathbf{c}$ um amplum, ovato-conicum, nudum. Coroll a e $\times$ adii ligulatae, d is ci tubulosae, tubo teretinseulo, limbo quadri-quinquedentato, Antherae ecaudatae. Stigmata exappendiculata. A chenia conformia, exalata, angulata, disco epigyno magno. $P$ ap pus nullus v, brevis, coroniformis, - Herbae annisae, in Europa, in $A$ sia media et Ameri- ca boreali, nec non in Capite bonae spei indigenae, glabrae, ramosae; folïs alternis, multipartitis, lobis lineari-setaceis, ramis apice nudis, monocephalis, subcorymbosis, radii floribus albis, disci luteis.

M atrica ria Linn, gen. n, 967. DC. Prodr, VI, 50 .

a. ANACTIDEA DC. Prodr. $\boldsymbol{Y I}$. So. C a p it u la discoi. dea. Corolla e quadrideutatac. Papp us uullus v. marginiformis, integer, vix conspicuus. - Herba cali: fornica.

b. Sphaeroclinium DC, Prodr. VT. 50 . Capitula radiata. Co ro II a e disei quadridentatae. St y 1 us basi bulbosus. A c he n i a epapposa, margine calloso superata, exteriora obcompressa, interiora tetragona. Recepta. cal u m globosum. - Herba capensis.

c. Chamagmela DC. Prodr, VI. 50. C a pitula radia. ta. Corolla e disci quadridentatae, radif ligulatae, stylo minimo subneutrae. A che n $i$ a omaia pappo eoro. niformi v. auriculari superata. R e ceptac u I u un ovato. globosum. - Herbae capenses.

d. PSEUdo-CHAMomilla DC. Prodr. $V I$. 51. Capi. $t u l a$ radlata. Cor olla e disei quinquedentatae. A $\mathrm{c}$ be. n $f$ a omnino epapposa. - Herbae orientales.

e. CHAMomilla DC. Prodr. VI.S1. Ca pitula radiata. Co roll a disci quinquedentatac. A che a i a pappo co. roniformi superata. - Herbae europeae et astaticae. (Schkuhr t. 253. Curt. Fl, Lond, V. t, 63, Fl, dau, t.696. Hayne Arzneigew. (. 4.)

26\%D. Fyrethrum G $A ̈ R T N$. CapituI $\mathrm{m}$ multiflorum, heterogamum, floribus radii uniseriatis, ligulatis, femineis, rarissime nullis, disci tubulosis, hermaphroditis. Involueri campanulati squamae inbricatae, margine scariosae. Rec epta culum convexum, nudum, v. planum, interdum paleolatum. Cor oll a e rad ii ligulatae, dis ci tubulosae, tubo saepius obcompresso, bialato, rarius tereti, limbo quinquedentato. A n $t$ h era e ecaudatae. S t i g m a t a disei exappendiculata. A chenia conformia, exalata, angulata. Pap p us coroniformis, saepius dentatus, interdum auriculaeformis, achenii diametro. - Herbae ut plurimum perennes, rarius frutescentes, interdum annuae, per veteris orbis regiones temperatas sparsae, in Europa copiosiores; foliis alternis, dentatis $v$. va. rie lobatis, capitulis solitariis $v$. corymbosis, disco flavo $v$, rarissime albido, radio albo v. saepius flavo.

P y reth rum Gärtn. 1I. 430. Smith Fl, brit. III, 900. De. Prodr. VT. 53. Py rethrum et Gy moeline Cass. Less. Chrys ant he mi sp. Linn.

a. LEUCOGLOSSA DC, Ligula e albae, rarius roseae, elongatae. Discus flavus. Receptaculum semper nudam.

Leucoglossa DC. Prodr. VT. 53. Chrysan. the mi sp. Linn. Jaq. Fl. Austr, t. 379. Observ. IV. t. 90. Allioni $F l$. pedemont. $t$. 37. $f$. 1 . Desfont. Fl, all. t. 217. Veat. Cels, t. 43. Loisl, Fl, gall, t, 18. Yisiani Dalmat. $t$. 8. Matri eari ae s p. Linn. FI. dan. $t, 674$. (E. B. t. 979. Bieberst. Pl. ross. IT. t. 78, Reichenb. Hort. bot. t. 36. Tenore Fl. Neap, t, 80. Heyne Arzneigew. VI. $t$. 20. Ledebour Ic. $t, 81$. Bot. Mag, $t, 2706$. Bot. Reg. $t$. 1084.)

b. GXMNOCLINES $D C$. L ig a la albae v, flavae, paucae. breves, subdifformes, rarius nullae. Receptaculum semper uudum, subangustum, planum.

G ym noclines DC. Prodr. VT. 58. G y mnocline Cassini in Dict. so. nat. XX. 121. Lessing Synops. 253. Chrys anthemi sp. Waldst. et Kitaibel Pl. Hung. t. 94. A chillea s p. Desf. Lam.

c, XANTHOGLOSSA Do. Ligulae elongatae, plurimae. flavae. Recept a $\mathrm{cuI}$ um omnino nudum.

Xanthoglossa DC. Prodr. VI. 60. Coleosteph us Cassini in Dict, sc, nat, XLI, 43. Chy 8 a nthe. mi i p. Auet. Jacq. Observ. IF. 2. 94. Desfont. Fl. atl. $t$. 235. f. 2. Viviaui $E l, L, b i c, t, 10, f, 4$. (Labillard. $S y r$. Dec, III : i. 8.) 
d. TRIDACTYLINA DC. I ig a la e flavae, steriles, eorol. lae disci tubo obcompresso. A che ai a disci trigoua, pappo coroniformi superata, $\mathbf{r a d i i}$ abbreviata.

Tridact yliua DC. Prodr, VI. 61.

e. DENDRANTHEMA DO. Inrolu cra scariosa. C ap itula facillime omuino v. partim, ligulis multiplicatis plena, bracteolis scariosis in reeptaculo tunc inter ligulas sparsis. - Caules fruticosi.

Dendranthema DC. Prodr. VI. 62. Chrysanthe $\mathrm{m} \mathrm{um}$ ind $\mathrm{i} e \mathrm{um}$ Auet. Bot. Mag. t. 327. 20.42. Bot. Reg. $t$. 4. 455. 616. Sabine in Horticult. Transact, IV. t. 12,14 .

f. BALSAMITAE DO. Capitulum nune homogemum, discoideum, aune radiatum, ligulis femineis, corollis dis ei teretibus, quinquedentatis. Pappus brevissimus, subdentatus, undique aequalis, nec unilateralis

B at Is a mitae DC. Prodr. $D I$. 69. B als am it ae $s$ p. Desf. Chrysant hemum Bals a mita Lian. Jaeq. Observ. $I V \cdot t .89$. Tanacetum BaIs am ita Linn.

2681. Chrogsmenthernum $D C$. C a p i t $\mathrm{a} / \mathrm{um}$ multiflorum, heterogamum, floribus radii uniseriatis, ligulatis, femineis, rarissime nullis, disci tubulosis, hermaphroditis. Invol ucri campanulati squamae imbricatae, margine seariosae. Receptaculum nndnm. Corollae radii ligulatae, dis c i tubulosae, tubo tereti v. obcompresso, bialato, limbo quadri- v. quinquedentato. Anthera e ecaudatae. Stigm a $t$ a exappendienlata. A c henia radii triquetra v. trialata, angulis alisve dnabus lateralibus, tertia introrsa, disci ala brevi introrsum exserta, Pappas nullus v, coroniformis. - Herbae $v$. frutices, per regiones temperatas vet eris orbis dispersi; foliis alternis, habitu vario.

Chry s a the mum DC. Prodr, VI. 63. non Cass. et Less. Ismelia, Pinardia et Glebionis Cassini in Dict. so. nat. XLI. 38. I $\mathrm{s}$ elia et P in a rdia Lessing Synops. 225.

a. GLebionis DC. Prodr. VI, 64, A chenia ra dii tri. gona, aptera v, brevissime alata, disci turbinata $\mathbf{v}$ subcompressa, striato-costata, ala brevi apice interdub dentiformi donata. P a p p 8 nallus. - Herbae annuae, Europam et Asiam incolentes, capilulis favis, radio interdum ochroleuco.

G I e bion is Cassini in Dict.sc.nat. XI.I.38. Chry. santhemis p. Linn. E. B. t. Gso. Curtis Flor. Lond. t. 60. Lam. t. 678. f.6. P y rethri s p. Roxb. Bot. Mag. t. 1591. Pinardiae 5 p. Less.

b. PINARDIA DC. Prodr. VI, 64. A ehenia radit tria. lata, apice trispinosa, dis e i unlalata, apice anispinosa. Pap us nullus. - Herba hispanica, annua, capitulis flavis.

P I n a rdla Cassini in Dict. sc, nat, XLI. 39. C e n. tros perm um Spreng. Nov. Prov. 19, non Kunth. H e. teranthemis Sehott in Isis 1818, p. 821. Centrichacua Sebottmsc, Chrysanthem um riscosum Desfont.

c. ISMELIA DC. Prodr, $P T$. 65. A c he nia radii ample trialata, disci compressissima, angulis lateralibus vix nerviformibus, interno in alam amplam, dorsali in alam mediocrem productis. $\mathrm{P}$ a p p us coroniformis, deutatus. - Herba ma uritanica, annua, ramosa, foliis multifidis, subcarnosis, ligulis albis, basi flavis, disco alropurpureo.

Is mella Cassint in Dict, sc. nat, XLI, 40, Chr, c arin a $\mathrm{tum}$ Schousb. Maroce, $t, 6$. Chr. versicolor Andr. Bot. Reposit. 2.109.

d. ISMELIOIDES DC. Prodr. NT, 65. A chen ia $\mathrm{r}$ adii trialata, disci tetraquetra, angulo interiori late alato, lateralibus et dorsali anguste alatis. Pa p p s brevis. coroniformis. Co roll a e disci quadridentatae. - Suffrutices capenses; folitis crasciusculis, lobatis, ligulis albis v. Javis.

Is melia Lessing Synops. 235. P In a di a Lessing in Linnaea VI, 168. Arctotidis et Chrysanthe$\mathrm{mi}$ s p. Thunb.

e. SPERMOPTERA DC. Prodr. VI. 65. A e h e $\mathrm{i}$ i a radil et disci obconipressissima, utrinque ample alata. $\mathrm{P}$ a P p u coronifornis, amplus. Corolla e discl quinctuedentatae. - Suffrutex capensis, verisimiliter e genore eli. minandus.

f. MAYARSA DC. Prodr, $V T, 65$, A chenia radii an. ple trialata, dis c i subcompressa, angnlo interno breviter alata. Papp us coroniformis, subdeatatus v. nullus. - Frutices canarienses et madeirenses, folits pinnalilobatis, capilulis fere Leucanthemi, ligulis albis. Is meli a e s p. Sweet Fl. Gard. II, $t$. 342.

267\%. 1Dimorphotheca VAILL. Cap it u I u m multiflorum, heterogamum, fleribus radii ligulatis, femineis, disci tubulosis, exterioribus hermaphroditis, intimis abortivis, masculis. Invo lncri uniseriati squamae lineares, acuminatae. Rec ept a culi plani, demum eonvexi paleae nullae v. paucae, decituae. Corollac radii ligulatae, disci tubulosae, quinquedentatae, ad lobos extus appendiculatae. Anthe rae ecaudatae. Stig mata radii lenga, glabra, disei brevia, areuata, apice rotundata, margine glandulifera, extus pilosa. A chenia recta, radi i exalata, obeonica, subtriquetra, tuberculata, dis ci plano-compressa, bialata, alis semine latioribus, margine incrassatis. $\mathrm{P}$ a p p us nullus. - Herbae $v$. suffrutices c a penses; foliis alternis, plus minus scabridis, capitulis terminalibus, solitariis, disco luteo $v$. fusco, radii ligulis supra albis, subtus purpureis $v$. utrinque luteis.

Dim or phothee a Vaillant in Act. Acad. Paris, 1720. p. 279. Mönch Method. 585. DC, Prodr. VI, 70.

a. METEORINA DC. Prodr. VI, 70. Flares disci exte. riores hermaphroditi, fertiles, iateriores masculi, steriles. A e he nia disei margine laevia. - Herbae annuae, caule ramoso.

Meteorina Cassini in Dict, sc, nat, XXX, 320. Gatten ofia Necker elem, $n, 76$. Cardis permu Traut. Act. Acad. Paris. 1724.p. 279. Cale nd ula pluvialls et C. hy b r ida Lias. Schkuhr $t$, 264. Miller IC. t. 75. f. 1. t, 79. f. 2. Sweet Fl. Gard, I, t, 39, D i mor. photheca anua Less.

b. LESTIBODEA DC. Prodr. VI, 71. Flores discl exte. riores hermaphroditi, fertiles, jntimi maseuli steriles. A c ben i a disci margine scabra. - Herbae perennes, caule subnudo $v$. folioso.

Lestiboder Neeker elem. $n$. 77 . Dimorpho. theca perennis Less. Calendulaesp. Linn. Jacq. Hort. Schönbr. 2. 153. Miller Ic. t, 76. f. 1. Bot. Mag. t. 1981. Bot. Reg. t, 289.

c. BLAXIUM DC. Prodr, VI, 7I, Flores disci omnes aterlies maseuli, corollis ad lobos appeadiculatis. - $S u f$. frutices, caulibus ramosis, fotiosis.

B I a xium Cassiul in Dict, sc, nat, XXX, 328. C a. le udula frutfeos a Lian. Miller. Ic. $t .283$.

d. OSTEOSPERMOIDES DC. Prodr. VI. 71, Flores discl omnes steriles. A che a ia $r$ ad if ovali oblonga, trigona, laevia v. apiee summo subtuberculata, d Is c i angusta, plano-obcompressa, inaaia. - Suffrutices, foiits lanceolato-linearibus, aeutit, integerrimis $v$. denticulatis.

e. CASTalis DC. Prodr. VT, 72. Flo res disci fertiles, (intimi interdum steriles) tubo brevissimo, lobis exappeadiculatls. A chenia radil trigona, interrupte et crasse trialata, tuberculosa, dis el obovata, plana, Jaevia, bialata. - Suffrutices, radio flavo v, aurantia. co, disco concolore.

C a $\mathrm{t}$ a lis Cassini in Dict. sc, nat, XXX. 332, Opusc. II. 80. Lessing Synops. 257. non Salisb. Cal e a d i a e 5 p. Thunb. Vent. Malm, t.20. Andr. Bot, Reporit. $t, 412$, Aretotidis 5 p. Bot, Mag. $t, 1343$.

f. RUTidocarpaEA DC. Prodr. $P T$, 78, Flores disci steriles. A be a i a $r$ a $i$ i compresso-trigona, transver. sim iugosa, disci plano-compressa, exteriora majora, margine callosa. Interiora angusta, pellacida. - Suffrutex. foltis bipinnatipartitis, radio purpurascente.

g. ARNOLDIA DC. Prodr. VI. 73, Flores disci bisexuales, sed plerique ovario efoeto steriles. A chenia $r$ adif trigona, laevia, disci plano-conipressa. - Frutex 
glaber; foliis inciso-sublryatis, foribus radii et disci concoloribus, flavis.

A rnoldia Cassini in Dict. sc. nat. XXX. 330. Les. sing Synops. 257. Calendula chrys anthemifo$1 \mathrm{i}$ a Veut. Malm. $t, 56$. Bot. Keg. $t$. 40, Bot. Mag. $t .2218$.

h. TRIPLOCARPAEA DC. Prodr. VI. 73. Flores disci exteriores fertiles, intimi steriles. A $\mathrm{c}$ h $\mathrm{e}$ i a trimorpha, radii trigooa, tuberculata, angulis interrupte lobatis, disci exteriora plano-compressa, fertilia, obovata, ealloso-alata, intima oblonga, sterilia, pellucida.

2673. Acanthotheea $D C$. C a pitulum multiflorum, heterogamum, floribus radii uniseriatis, ligulatis, femineis, disci tubulosis, ovario efoeto masculis. In v o I u cri uniseriati squamae lineares, acuminatae, disco longieres. Recepta culnm planum, nudum. Corolla e radii ligulatae, ligula basi ciliato - hispida, dis ci tubulosae, limbo quinquedentato. An the rae ecaudatae. Stylus ra di i bifidus, glabriusculus, $d$ ise $\mathrm{i}$ indivisus, apice capitato-hispidulus. A chenia radii trigona, ad angulos et praesertim versus apicem aculeis erassis, pungentibus onusta, dis ci omnino abortiva. $\mathbf{P}$ a p $\mathbf{p} \mathbf{s}$ nullus. _ Herbae ca penses, annuae, puberulo glandulosae $v$, rarius glabrae; foliis alternis, integris $v$. pinnatisectis, floribus flavis, ligulis saepe basi fusco-maculatis.

\section{A canthotheca DC. Prodr. VI. 73.}

26r4. VIonolopia DC. Capitulum multiflorum, heterogamum, floribus radii uniseriatis, ligulatis, femineis, disci tubulosis, masculis? Involucri uniseriati squamae octo v, decem, ad medium concretae. R e c p ta $\mathbf{c} \mathbf{l}$ um convexum v. subconicum, epaleatum. Coroll a e radii ligulatae, interdum bilabiatae, disc i tubulosae, tubo tenui, hispidulo, fauce dilatata, limbo quinqueden tato. An the ra e ecandatae. Stigmat a cono brevi superata. A ehenia glabra, radii obeompressa v. subtrigona, dis ci compressa. Pappus nullus. - Herbae californicae, annuae, erectae, albo-tomentosae; foliis alternis, oblongo-linearibus, integris v. parce dentatis seu lobulatis, capitulis ad apicem caulis et ramorum terminalibus, ebracteatis, floribus luteis.

Monolopia DC. Prodr, VT, 74 .

2685. Steinodiseus LESS. C a pituln multiflorum, heterogamum, floribns radii nniseriatis, ligulatis, femineis, disci tubnlosis, ovario efoeto masculis. Involuerum ventricosum, polyphyllum. Receptac $\mathbf{l u m}$ nudum. Corollae radi i ligulatae, dis ci tubulosae, tubo tereti, limbo quinquedentato. A nth e ra e ecaudatae. St i g mata disei (?) cono brevi superata. A ehenia exalata, linearia, glabra, disei semper sterilia. P a ppus nullus. - Herba capensis, erecta, annua; foliis uni-bipinnatisectis, segmentis linearibus, capitulis terminalibus, luteis, radio circiter quinquefloro, revoluto.

Steirodiscus Lessing Synops. 251. DC. Prodr. VI. 74. Cineraria capiflacea Thubl.

25\% 8. Selhistesteploimm KREBS. Cap it $\mathbf{l} \mathbf{u}$ m multiflorum, heterogamum, floribus radii ligulatis, femineis, disci...... Invo l u crum ...... Receptaculnm epaleatum. Corollae ra i i lignlatae, ligula obsoleta, profande trifida, tubo brevissimo, fisso, d is ei ........ Antherae ....... Stigmata conformia. A chenia radi exalata, longe hirsuto-villosa, disci sterilia, glabra. Pappus nullus. - Fruticulus capensis, non satis notus; facie foliisque Pentziae flabelliformis, capitulis luteis, parvis, discoideis, fastigiatopaniculatis.
Sehistostephium Krebs ex Lessing Synops, 251. DC. Prodr. VI. 74.

26\%ซ. Chlamyspermà LESS, Ca pi$t \mathbf{n} l \mathbf{n}$ m subsexflorum, heterogamum, floribus radii tribus, femineis, ligulatis, disci tubulosis, hermaphroditis. Involu cri campanulati squamae quinque, uniseriales. R e ce pta $\mathbf{c} \mathbf{~ I ~} \mathbf{m}$ minutum, nndum. Corollae ra di ligulatae, disei tubulosae, teretes, quinquedentatae. Anth er a eeaudatae. Stig ma ta exappendieulata. A $\mathbf{c h}$ en ia $r$ adii tuberculata, intus alis duabus oppositis, latis, margine valde incrassatis aucta; disci scabra, triquetra, aptera. P a p p s nullus. -. Herba me. xicana, pubescens; foliis oppositis, deltoideo-ovatis, grosse serratis, capitulis parvis, terminalibus et alaribus, flavis.

ChI a mysperma Lessing Synops. 256. DC. Prodr. VI. 75. Unxia prateasis Kunth in Humb. et Bonpl. Nov. gen, et sp. $t, 401$.

2685. Willanova $L A G A S C$. C a p itul u m panciflorum, heterogamum, floribus radii quinisdenis, ligulatis, femineis, disci tubulosis, hermaphroditis. Invol u cri campanulati squamae paucae, uniseriatae. R e ceptacul um planum, nudum. Coroll a e radi i ligulatae, ligula obovata, apice dentata, disci tubulosae, teretes, limbo quinquedentato. Anth era e ecaudatae. Stig mata disci cono superata. Achenia obpyramidata, exalata, punctata, glabra, disco epigyno minuto. Pap as nullus. - Herbae americanae tropicae; foliis oppositis $v$. alternis, pilosis, profunde crenatis $v$. pinnatifidis, capitulis terminalibus et alaribus, radio albo $v$. disco flavo concolore.

Vill a n v a Lagasea Nov. gen, et sp. 21, Lessing $S_{y n}$. ops. 256. DC. Prodr. VI. 75. Unxia anemonatofia Kunth in Humb. et Bonpl. Nov. gen. et sp. $t$, 402.

26\%9. Brachymeris $D C$. Capitulum octo-sedecimflornm, homogamum. Involueri campanulato-ovati squamae imbricatae, adpressae, ovali-oblongae. Recepta $\mathbf{c} \mathbf{l} \mathbf{l} \mathbf{m}$ nudum. Corolla extus pubescentes, tubo brevi, limbo quinque. fido. Antherae ecaudatae. Stylus filiformis, stig matibus vix exsertis, apice summo barbellatis. A $\mathbf{c}$ h en i tereti-subcompressa, striata, erostria, tenuissime puberulo-scabrida. Pa p p u s nulIns. - Frutex ca pensis, ramosus, subcinereus, ramis striatis fere Ephedram referentibus; foliis spar. sis, parvis, oblongis, obtusis, integerrimis, utrinque adpresse pubescenti-villosis, capitulis ex axillis supremis brevissime pedicellatis, in racemum oligocephalum subconfertis.

B rachymeris DC. Prodr. VI, 76. Brachystylis E. Meyer in Herb. Dreg.

8680. Jacosta $E$. MEY. Ca p itu $1 u$ m pluriflorum, heterogamum, floribus radii binis $v$. unieo, ligulatis, femineis, disci duodecim v. quindecim tubulosis, hermaphroditis. Involu e ri bitriseriati, imbricati squamae interiores apice subscariosae, ciliolatae. Receptaculum nudnm. Cor olla e ra dii ligulatae, d is e i tubulosae, limbo quinquedentato. Anth era e ..... Stigma ta exappendiculata. A chenia teretiuscula, costis obtusis octo v. decem striata, glanduloso-subscabrida, apice truneato suberenulata. Pap pus nullus. - Suffrutex capens is, glaber, multicaulis; ramis erectis, apice laxe corymbosis, foliis linearisubulatis, erectis, integerrimis, superne remotioribus, capitulis pedicellatis, obovato-oblongis, luteis.

Jaeosta E. Meyer in Herb. Dreg. DItgoglossa DC. Prodr. NI. 26. 
DIVISIO III. COTULEAE Lessing Synops. 260. C a p it u l a homogama v, heterogama, disco semper hermaphrodito, floribus radii uni-pluriseriatis. Receptaculum epaleatum.

2681. Tapeyrousfa THUNB. Capitu$1 \mathrm{~m} \mathrm{~m}$ mnltiflorum, discoideum, homogamum, Involueri campanulati squamae $2-3$, inter se subaequales, disco longiores. Receptaculn m planum, epaleatum. Co rolla e tubo obcompresso, bialato, limbi brevis, tri-quadrilobi lobis subcallosis. An $t h$ e ra e caudatae. Stigmat a exappendieulata. A chenia subtetragono-obcompressa, exalata, erostria. P a p p s nullus. - Suffrutices c apenses, parce ramosi; foliis sparsis, lanceolatis, sessilibus, mucrone calloso acuminatis, integerrimis, utrinque sericeo-tomentosis, pedunculis brevibus, monocephalis, subumbellatis, floribus flavis.

Lapeyrousia Thunberg Fl. Cap. 700. Cassini in Dict. sc. nat. XXV. 251. Lessing Synops, 260, non Pourr. Peyrousea DC. Prodr. VI. 76. Cotula et $0 \mathrm{smit}$ is sp. Linn. f.

268\%. Dtoelhlamys $D C$. Capitulum multiflorum, discoideum, heterogamum, floribus radii paucis, femineis, disci hermaphroditis (?), centralibus sterilibus. Invo I u crum duplex, utrumque pentaphyllum, exterioris squamae laxiusculae, rufae, ovato-subrotundae, interiores scarioso stramineae, subrotundae, disco aequales, flores arcte cingentes. R e c p ta cul u m planum, epaleatum, echinis callosis, grosse ovatis exasperatum. Corolla e tubo obcompresso, late bialato, basi dilatato, deorsum producto in auriculam achenium omnino vestientem, limbo in floribus femineis nul1o, in hermaphroditis quadridentato. Antherae ........ Stylus radii bifides, disei ........ A e hen ia obovata, obcompressa, laevia. Pa p p us nullus. - Herba capensis, annua, bipollicaris, simplex, erecta, glabriuscula ; radice exili, foliis oppositis, lineari-subulatis, erectis, integerrimis, capitulo terminali, breviter pedunculato, globoso, flavo.

0 tochlamys DC. Prodr, VI. 77.

2683. Cotula GARTN. Ca pitu $\mathrm{lnm}$ multiflorum, discoidenm, heterogamum, floribus radii uniseriatis, apetalis, femineis, disci tubulosis, hermaphroditis. Invol u erum ....... Rece ptaculum planum, epaleatum, post acheniorum lapsum plus minus distincte papillosnm. Cor o1lae radii nullae, disci tubulosae, tubo planoobcompresso, saepe basi breviter bicalcarato, limbo quadricrenato. An therac ecaudatae. Stigmat a exappendienlata. A chenia plano-obeom pressa, marginata, glabra, radii stipitata, disci saepius sessilia, angustiora. Pap p us nullus.

Herbae annuae, specie una mediterranea et altera cosmopolita exceptis, omnes e Capite bonae spei ortae, parvae, ramosae; foliis dentatoineisis $v$. pinnati-aut bipinnatipartitis, lobis angustis, ramis apice aphyllis, pedunculiformibus, monocephalis, capilulis parvis, flavis.

C ot u l a Gírtner $I T .388, t, 165$. Cassini in Dict. sc. nat. XXYI. 283. Lessing Synops, 260. DC. Prodr. VI. 77. An ant hocyclus Vaillant in Act. Academ. Paris, 1219. p. 289. L a n ci si a Adanson Fam. IT. 126. B a I di ageria Necker elem, n, 158. Cotula s s. Lian. Fl, dan, t, 341. Lam, $t, 700$.

3684. Strongylosperma LESS. C a p itulu m multiflorum, heterogamum, floribus radif pluriseriatis, ligulatis, femineis, disci tubulosis, centralibus abortivis. Involucri campanulati squamae panciseriatae. Rec epta c u l u m planum, nudum. Corolla e radii ligulatae, tubo gracili, eum ovario continuo, persistente, ligula angustis sima, tubo breviore, disci tubulosae, teretes, limbo quadricrenato. A $\mathrm{ch}$ e ni a obcompressa, radii rotundata, bialata, alis callosis, disei obova. ta, exalata. Pap pus nullus. - Herbae Novae Hollandiae, Cotulae v. Ceniae habitu; foliis pinnatilobatis, ramis apice longe aphyllis, monocephalis, capilulis luteis.

\section{Strongylosperma Lessing Synops. 261.}

2685. Cemin COMMERS. Capitulum multiflorum, rarius homogamum, saepius heterogamum, floribus radii uniseriatis, Iignlatis v. bilabiatis, femineis, disci tubulosis, hermaphroditis. Involucri squamae latae, biseriatae. Re c e ptaculum convexum, nudum, supra pedunculum apice turbinatum, vacuum. Corolla e radii li gulatae v. bilabiatae, labio exteriore ligulaeformi, interiore multo minore, tridentato, dis ci tubulosae, teretes, quadridentatae. A chenia exalata, obcompressa, orbicularia, bicostata, costis marginalibus. Pappus nullus. - Herbae capenses, pusillae; foliis alternis, bipinnatipartitis, lobis linearibus, ramis longe aphyllis, monocephalis, apice turbinato-inflatis, nervoso-striatis.

Ce a fa Commers. ex Jussieu gen, 183. Cassiai in Dict. sc. nat. VII. 367, XXV1, 283. DC. Prodr. VI. 82. Cotula Vaillant in Act. Academ. Paris. 1219, p. 288. Cot ulae s p. Linn.

a, DISCOCENIA DC. Prodr. VT. 83 . C o rolla e radiit abulosae. - Cotala n udieaulis Thunb.

b. ACTINOCENIA DC. Prodr. VI, 82. Corolla e radii ligulatae v. bialatae. - Lancisia Gärtner $I I$. 429 . Lam. t. 701. $f$. 1, Lid be cki a e s p. Thunb.

2886. Homalotes DC. Capitulum multiflorum, discoideum, heterogamum, floribus radii uniseriatis, femineis, disci hermaphroditis. Invol a eri campanulati, panciseriati squamae adpressae, acuminatae. R e cepta culum convexnm, nudum. Cor o Il a e tubulosae, ra di i plano-obcompressae, bialatae, tricrenatae, dis ei teretes, quinquedentatae. An the rae ..... Stigmat a.... A chen i a conformia, exalata, tetragona. Pa p p $\mathbf{s}$ coroniformis, repandus. - Herba californica, Santolinae tomentosae facie; caule tereti, ramoso, foliis allernis, breve petiolatis, bipinnatisectis, capitulis solitariis $v$. corymbosis.

Ho malotes DC, Prodr. VI, 83, 0 malantlous Les. sing Synops. 260, non Adr. Juss.

DIVISI0 IV. ATHANASIEAE Lessing Synops. 262. DC. Prodr. VI. 84. Cap itula lomogama, corollis omnibus tubulosis, teretibus. Receptaculum paleatum. Achenia angulata v. teretia, nunquam obcompressa. P a p p us nunc nullus, nunc minute squamellatus, v. e pilis simplici serie cellularum formatis constans.

268\%. Lomas $A D A N S$, Capitnlum muItiflorum, homogamum. Invo lu e ri campanulati squamae imbricatae. R e e pta $\mathrm{cu} \mathbf{I} \mathbf{u m}$ conico-angulatum, paleatum. Coroll ae tubulosae, teretes, limbo quinquedentato. A n th e ra e eandatae. S tigmata exappendiculata. A ehenia angulata, exalata, apice hinc inde glandulosa. Pappus oblique coroniformis, membranaceus, parvns, integer. Herba mediterranea, annua, glabra; foliis alternis, pinnatipartitis, lobis acuminatis, capilulis 
ad apices ramorum cymoso-umbellatis, $v$, in ramis lateralibus subsolitariis, floribus luteis.

L o na s Adanson Fam. II. 118. Gärtn. IT. 396, $t$. 165 Cassini in Dict. sc, nat, XXVIT. 166, Lessing Synops. 263. DC. Prodr. VI, 84, Athanasia an nu a Linn. et $\mathrm{A}$ ehillea inodora Lina.

268S. Comospermumn LESS. C a p it uI $\mathbf{~ m}$ multiflorum, discoidenm, homogamum. Involucri oblongi v. ovati squamae pauciseriatae. Re ce pta culum planum, epaleatum. Corolla e tubulosae, teretes, limbo quinquedentato. Anthe$\mathbf{r}$ a e ecaudatae. Stig $\mathbf{m}$ a $\mathrm{t}$ a exappendiculata. A $\mathbf{c h}$ enia exalata, quadri-quinquecostata, P a p i paleae minutae, semilanceolatae. - Frutices canarienses, Tanaceti facie; foliis alternis, membranaceis, pinnatiparlitis, lobis dentato-incisis, junioribus pubescentibus $v$. subtomentosis, adultis glabris, capitulis in corymbos terminales dispositis, floribus luteis,

Go nos perm um Lessing Synops. 263. DC. Prodr. VI. 84. Hy me nole pidis s p. Cass. Tan acetis p. Auct.

2635. PHetagnamthus. $C$ a pit u I u m pauciflorum, discoideum, homogamum. Invo I u eri oblongi squamae paucae, imbricatae, adpressae, exteriores breviores, interiores discum haud aequantes. Receptaculum planum, angustum, paleatum. Corolla e tubulosae, teretes, limbo quinquedentato. Antherae ccaudatae. Stigmata exappendiculata. A ehenia cylindracea, sulcata, exalata. Pappi paleae minutae, acntae. - Fruticuli capenses, Athanasiae facie; foliis pinnatisectis, lobis linearibus, integerrimis, corymbis decompositis, polycephalis, involucris glabris, floribus luteis.

H ymenolep is Cassini in Dict. sc. nat. XXIT. 315. (nee XXXIII. 61.) Lessing Synops. 263. DC. Prodr, VI. 85. non Kaulf.

a. MICRORHACHIS DC, $t$. $c$, R e e p ta culu m planum, angustum. Capitula oblonga, tri-septemflora. - Fru. tices, folitis pinnatipartitis. - Athanasia parvi. flo r a Lian, Jacq. Hort. Schönbr, t, 149.

b. ? PLANORHachis DC.l.c. Recepta e u $1 \mathrm{n}$ m planinsculom. Capitula obovata, cireiter quindecimflora. A chenia subangulata. Pappl paleae parvae, apice inciso-serratae, subinaequales. - Herbae integrifoliae.

c. ? COENORHACHIS DC. l.c. Re e pt a e u l a m conicum, cavum. Capit uIa multiflora, ovato-globosa. A cli e n i a angulis octosuleata. P a p $\mathrm{i}$ paleae octo, breves, distinctae, obtusae v, hine inde piliformes. - Herbae integrifoliae.

2690. Foloplayllumn LESS. C a pituI $\mathrm{n}$ m multiflornm, discoideum, homogamum. Invo Iu eri campanulati squamae exteriores foliaceae, interioribus et disco aequilongae. 12 e e e p ta c u I u m plannm, paleatum. Coroll a e tubulosae, tubo tereti, limbo quinquedentato. Anth e rae ecaudatae. Stigmat a exappendiculata. A ch en i a pentagona, angulis alatis, aequalibus, integerrimis. $P$ a $\mathbf{p} p \mathbf{s}$ pilosus, fragilis, deciduus, pilorum cellulis uniseriatis. - Fruticuli capenses, plus minus imprimis apice villosi, rariusve glabri; foliis sparsis, confertis, punctatis, sessilibus, ovalibus v. oblongis, integerrimis rariusve hinc inde dentatis, capitulis ovatoglobosis, inter folia ad apicem caulis subsessilibus glomeratis $v$. interdum solitariis, floribus luteis.

Hol o ph y 11 u m Lessing Synops. 262. DC, Prodr. VI. 80. Pristocarpha E. Meyer in Herb. Dreg. A than a. 8 i a e s p. Linn. Cavanill. Ic, $t, 3$.

2691. Athamasia CASS. Capitulum multiflorum, discoidenm, homogamum. In vol u cri squamae siccae, arcte imbricatae, exteriores breviores. Recepta $\mathbf{c} \mathbf{u} \mathbf{I n m}$ planum, paleatum. Coro 11 a e tubulosae, teretes, limbo quinqueden. tato. Antherae ecaudatae. Stigmata exap pendiculata. A $\mathrm{e}$ he n i teretia, exalata. $\mathbf{P}$ a p p u s pilosus, brevis, cadueus, fragilis, pilorum cellulis uniseriatis. - Fruticuli capenses; foliis sparsis, integerrimis, dentatis $v$. lobatis, capitulis corymbosis, oblongo-ovatis $v$, globosis, saepius ebracteatis, floribus luteis.

A th a n a s i a Cassini in Dict. sc, nat, XXII, 315. XXVII. 168. $X X I X$, 179. Lessing Synops, 262. DC. Prodr, VI. 86, A thanasiae sp. Liun. Thunb. Miller Ic, $t$. 2ag, $f .2$, Jaeq. Hort. Schönbr. $t, 148$.

2692. Salntmorygia. Capitu Inm pauei-multiflorum, discoideum, homogamum. Involucri squamae siccae, imbricatae, interiores longiores, disco breviores. Recept a $\mathrm{c}$ u lum planum, paleatum. Corollae tubulosae, teretes, limbo quinquedentato. A $\mathbf{n} \mathbf{t}$ h e $\mathbf{r}$ a e ecaudatae. Stigm at a exappendiculata. A chenia teretia, suleata, exalata. Pap p u s nullus. - Fruticuli c apenses, Athanasiae facie, a quibus solo pappi defectu differunt, charactere fortassis nimis artificiali ab iisdem separatae.

M or y s i Cassint in Dict, sc, nat. XXXIII. 39. Lessing Synops. 263. DC. Prodr. VI. 90.

a. ATHANASIOIDES DC. $l$. c. C a p itu 1 a ovali-oblonga, novem-duodecimflora. - Athanasiae et $\mathbf{T}$ anaceti sp. Lisn. Thunb.

b. STILPNOIDES DC, $l$. c. Capitula ovato-globosa vigintiquinque - quadragintiflora.

DIVISIO V. ARTEMISIEAE Lessing Synops. 263. DC. Prodr. VI. 92. Ca pitula discoidea, homogama v. heterogama, floribus radii interdum femineis, uni-pluriseriatis, disci hermaphroditis, corolla tereti, styloque bifido donatis. A chen i a exalata, nunquam (?) plano-obcompressa. Receptacul um epaleatum.

2693. Stilpnoploytum LESS. Capit n l u m multiflorum, discoideum, homogamum. Invol u cri campanulati, imbricati squamae disco breviores. Receptac $\mathrm{lum}$ planum, nudum. Corolla e tubulosae, teretes, limbo quadri-quinquefido. Antherae ecaudatae. Stigmata exappendiculata. A $\mathrm{ch}$ en ia cylindracea, sulcato-angulata, recta. Pa p pus nullus. - Fruticuli ca penses, ramosi, glabri, nitidi; foliis linearibus, integerrimis, sparsis $v$. oppositis, capitulis in corymbum compositum dispositis, floribus luteis. VT. 92 .

Stilpnophytum Lessing Synops. 264. DC. Prodr.

a. EUSTILPNOPHXTUM DC. l. c. Capitula globosa, triginti - quadragintiflora, A che $\mathrm{n}$ i a exteriora oblongocylindracea, obtase quinquesuleata, centralia gracillima, sterilia. - T a n a e t i $\mathrm{sp}$. Thunb.

b. MESOSTEIRUS DC. l.c. Ca pitu l a ovata, quindecimvigintiflora. A chenia exteriora acute pentagona, eentralia gracillima, sterilia,

2694. Artemisia $L I N N$, Capitulum pluri-multiflorum, homogamum v. heterogamum, floribus radii uniseriatis, femineis, disci hermaphroditis v, ovario efoeto masculis. Involucri imbrieati squamae siccae, margine scariosae. Rec e p t a $\mathbf{c}$ l um planiusculum v. convexum, epaleatum, nudum v. hirsuto-fimbrilliferum. Co r o 11 a e tubulosae, teretes, radii tridentatae, dis ci quinquedentatae. Anthera e caudatae. Stigm at a d i s ci elongata, exserta, ra dii saepius abortiva, inclusa. A e h enia obovata, disco epigyno minuto. Pa p pus nullus. - Herbae $v$, suffrutices, in hemisphacrae borealis regionibus temperatis copiosi, ob qualitates aromatico-amaras cele- 
brati; foliis alternis, varie pinnatilobatis, capitulis ut plurimum parvis, inconspicuis, spicatis v. racemo. sis, spicis racemisve saepissime in paniculam dispositis, corollis luteis v. purpureis.

Artemisia Linn. gen. n. 945. Besser Monograpk. inedit. DC. Prodr. VI. 93. A rtimis i a Roxburgh Flor. Ind. IIT. 418.

a. DRACUNCulus Bess. Ca pitul u m heterogamum, floribus radih uniseriatis, femineis, disci bisexualibus, ovario efoeto. R e ceptacul um nudum.

Dracuneulus Besser in Bullet, soc. h. n. Mosc. VIII. 1 -97. DC. Prodr. VI. 93. $011 \mathrm{~g}$ o s p or us Cassini in Bullet. soc. philomat. 1817. p. 33. Dict. sc. nat. XXXVI. 25. Lessing Synops. 264. (Allioni Flor. pede. mont. $t$, g. $f .1$. Fi. dan. $t$, 1175, 1585. E. B. $t$. 338. Waldst. et Kitaibel Pl, Hung. t. 65. Delile Fl. aegypt. t. 43. f. 1. Ledebour Ic. t, 473. 475.)

b. SERIPHIDIUM Bess. Capitulam homoganum. Receptacul um nudum.

Seriphidinm Besser in Bullet. soc. h. n. Mose. I. 222, DC. Prodr. VI. 100. Seriphida Lessing Synops, 264. (Asso Fl. Arrag. t, 8. f. 1. E. B, t, 1001, 1706. 2426. Waldst. et Kitaibel Pl. Hung. t. 75. Delile Fl.aegypt. t. 43. f. 2. Sieber in N. A. N. C. XIII. t. 43. Ledebour Fl. $A(t, t, 478$.

c. ABROTANUM Tournef. Capitula m heterogamum, floribus radii femineis, disci heruaplroditis, omnibus fertilibus. Receptacula m nudum.

Abrotanum C. Bauh. Pin. 136. Besser in Nouv. Mém. soc. $h$, n. Mosc, IIT. DC. Prodr. VI. 105. A r t emisia Cassini, Lessing $l l$. cc. (Allioni Fl, pedemont. t. 60. f. 3. t. 70. f. 2, E. B. t, 978. Jacq. Fl. austr. t. 99. 100. App. t. 34. Ic. rar, t, 172. Hort, Schänbr. t. 467. Desfont. Corollar, t. 36. Reichenb. Ic. exot. t. 4. 5. Plant, orit, t. 310, Roehel Banat, t. 73. Ledebour Ic. t. 174. 452. 467. 469. 472.)

d. ABSINTHIUM Tournef. Capitulum subglobosum, floribus radii femineis, disci hermaphroditis, omnibus fertilibus. Recep $\mathbf{a}$ a $\mathrm{c}$ I $\mathrm{um}$ pilosum.

A bs i uth i u mournefort inst, 260. Gärtn. II. 393. t, 164. DC, Fl. fr. IV. 189. Besser in Bullet, soc, $h, n$. Mose. VIIT. 225. Lessing Synops, 264. DC. Prodr. VI. 120. (Jacq. Collect. II. t. 7. E. B. t. 1230. Ledebour Ic. $t$. $458,459,468,463,465,466$.

2695. Crossosteplainm LESS. Ca p i t $\mathbf{n}$ ln m multiflorum, discoideum, heterogamum, floribus radii pluriseriatis, femineis, disei hermaphroditis, fertilibus. I n vo lu er um campanulatum, pluriseriatum. Recepta $\mathrm{cu} 1 \mathrm{um}$ conicum, nudum. Corollae radii filiformes, basi ampliatae, ore vix denticulatae, dis e i cylindricae, amplae, limbo quinquedentato. A $\mathrm{n} t \mathrm{~h}$ er a e ....... S $\mathrm{t}$ i $\mathrm{g} \mathbf{m}$ a $\mathrm{ta}$ ....... Achenia conformia, angulata, exalata. Pap pi paleae complures, minutae, semilanceolatae, inaequales. - Frutex albo tomentosus, in $M a$ nilla et circa Cantonem Sinarum observatus, Artemisiae chinensis facie; foliis alternis, firmis, inferioribus cuneatis, apice trilobatis, capitulis glo bosis, racemosis, luteis.

Cross astephia m Lessing in Linnaea VI. 220. Byn. ops. 266. DC. Prodr. VI. 127. Artemisia chinensis Vahl, non Linn.

2856. Tamacetums LINN. Ca pitu $1 \mathrm{um}$ multillorum, discoidenm, homogamum v. heterogamum, floribus radii uniseriatis, femineis, disei hermaphroditis, sterilibus. In v o l u er um campanulatum, imbricatum. Receptacalum convexum, nudum. Corolla e tubulesae, radii triquadridentatae, dis c i quadri-quinquedentatae. A nthera e ecaudatae. Stigmata exappendiculata. A chenia conformia, sessilia, angulata, glabra, disco epigyno magno. Pa p p as nunc nullus, nunc membranaceus, coroniformis, integer $\mathbf{v}$, aequaliter dentatus, v. subinaequalis, extrorsum subunilateralis. - Herbae v, suffrutices, per totum orbem dis- persi in Europa et in Asia media imprimis copiosi; foliis alternis, varie dissectis, capitulis solitariis $v$. corymbosis, subglobosis, luteis.

T a n a c e t u m Lina. gen, n, 944. exel. sp. Gärta. II. 395. Lessing Synops. 264. DC. Prodr, VI, 127.

a. EUtanacetum DC. Prodr. VI. 128. Capitulum heteroganum, floribus radii tridentatis, disci quinque. destatis. - Herbae europeae, asiaticae et bo. reali-amoricanae, folits uni-bipinnatipartitis.

T a a a cetu m Necker elem, n, 160. Tan a ceti sec. tio IV. Lessing Synops, 265. (Gärtn. i, 165. Lam. t. 696. f. 1 . Ledebour Ic, $t$. 38.)

b. PSANACETUM DC. Prodr. VT. 130, Ca pitu $1 \mathrm{um}$ homogamum, floribus omnibus quadridentatis $v$, saepius quinquedentatis. - Herbae europeae et as $i a t i c a c$.

Ps a n a cetum Necker elem. n. 161. Lessing Syn. ops. 265. (Miller Ic, t, 227, $f$. 1.)

e. MATricarioides DC. Prodr. VX. 131. Capitu In homogamum, floribus omnibus quadridentatis. R e c e p tacul u m conicum. - Herba arctica.

Matricarioides Lessing Synops. 265. T. pat. cif lo r u michardson.

d. BROCCHIA DC. Prodr. VI. 131. Capitulum homo. gamum v, rarius heterogamnm, floribus omnibus quadri. deatatis. A ehenia radii nngulata v. compressa, nec obcompressa. - Species capenses et boreali.af. ricanae.

B rocehla Visiani Pl. Aegypt. 35. Cotulae s p. Thunb. Less. Delile Fl. Aegypt, $t, A 1, f, 4$.

e. HIPPIOIDES DC. Prodr. $V I, 134$. Capituluth hete. rogamum, floribus disci quadridentatis, aininis. A c h e. nia radii obcompressa. - Species capenses, sui verisimiliter generis.

2698. Plagias HERIT. Capitulum multiflorum, homogamum, discoidenm. In v o Inc rum campanulatum, imbricatum. ReceptacuI u m latum, planum, nudum. Corolla e membranaceae, tubulosae, terctes, limbo quinquedentato. Anth e rae ecaudatae. St $\mathrm{igm}$ a ta exappendiculata. A $\mathrm{c}$ henia conformia, angulata, callo basilari crasso elongato-stipitata. $\mathbf{P}$ a p p $\mathbf{s}$ membranaceus, aurieularis, achenio brevior, ad latus interius productus, ad latus exterius plus minus incisus. Herbae mediterraneae, perennes v. basi suffrutescentes, Chrysanthemi facie, sed capitulis discoideis facile distinguendae; foliis allernis, obovatis, dentatis, ad basim caulis confertioribus, capitulis solitariis magnis, v. paucis corymbosis, paullo minoribus.

Plag i us Heritier msc. DC. Prodr, V1, 135. B a Is a. mita Lessing Synops, 263. Bals a mittate sp. Desfont. in Act, soc, h. n, Paris. 1791, $t, 1$, et Anct. Cotula is p. Linn. Jaeq. Observ. $I V, t, 81$. Chr y $s$ a ut hemi s $p$. Lian. Allioni Flor. pedemont. c. 11. f. 1. Chrysocomac sp. Jacq.. Hort. Schönbr. t, 363.

2858. Ademosolen $D C$, Capitulum multiflorum, homogamum. Involucri subtriseriati squamae imbricatae. R e ceptaculum convexum, nudum v. rarissime uni-bipaleatum. C orolla e tubo glandulifero, basi dilatato, cum ovario arete cohaerente, fauce dilatata, campanulata, limbo quinquefido. Anthera ecandatae, exsertae steriles, subinclusae fertiles. Stigmata exserta, apice capitellata. A chenia teretia, glabra. P a p p 8 nullus. - Suffrutex capensis, ramosus, glaber; foliis alternis, sessilibus, lineari-subulatis, acuminatis, inlegerrimis, capitulis ad apices ramorum paucis, pedicellatis, subcorymbosis.

Adenosolen DC. Prodr, VT. 136.

2695. VIarasmodes $D C$. Capitulum pluriflorum, homogamum. In v o I n e ri ovati, imbricati squamae exteriores apice scarioso-appendiculatae. R e ce p ta c 1 um angustum, nudum. C orolla e tubo brevi, limbo quinquedentato. A n- 
thera e ecaudatae. Stigmat a exserta, apice capitellata. A chenia teretia, erostria. Pap pi paleae plures, distinctae, membranaceae, obtusae, Suffrutices capenses, rigidi, ramosi, divaricati, glabri; foliis alternis, sessilibus, crassiusculis, siccis, ericoideis, apice submucronatis, capitulis saepius ad apices ramorum sessilibus aggregatis, floribus flavis.

Marasmodes DC. Prodr, VI. 136.

\& ร60. Fentaia THUNB. C a p itul um multiflorum, homogamum. Invol u eri obovati, discum aequantis squamae imbricatae, margine scariosae. Rece pta $\mathbf{c} \mathbf{l} \mathbf{~ u m}$ angustum, planum, demum convexum, parce fimbrilliferum. Co r o lla e tubo tereti, limbo quinquefido. Antherae ecaudatae. Stig $\mathbf{m}$ a $\mathbf{t}$ exappendicnlata. A $\mathbf{c}$ hen ia sessilia, angulata, exalata. Pa p p s membranaceus, breviter tubulosus, irregulariter lacerus, exteriore latere sinu incisus, hinc quasi introrsum auriculaeformis, - Fruticuli capenses, rigidi, ramosissimi, plus minus incani; foliis alternis, confertis, varie incisis aut dentatis, capitulis terminalibus luteis, solitariis $v$. corymbosis.

Pentzia Thunberg Prodr. 145. Willdenow sp. III. 108. Cassinl in Dict. sc. nat. XXXVIII. 386. Lessing Synops, 266. DC. Prodr. VI. 136.

a. OOMORPHAEA DC. Prodr. VI, 136. Capituila ovata, in corymbum umbellatum disposita. Involucri squamae omes hyalinae, subrufescentes, obtusae. Guaphalii sp. Linn. Tanaeti s p. Heritier Sert. t. 21 .

b. EREMOCEPHALA DC. Prodr. $V T$. 137. C a pitula campanalata v. subglobosa, ad aplees ramorum solita ria. In volueri squamae saltim exteriores nou scariosae. - Cotulae, Osteospermi et Chrysan. themi sp. Thunb.

2ซ01. Chlamydophora EHRENB. Ca pit a $1 \mathrm{~nm}$ multiflorum, homogamum. Invol u cri campanulati, bi-triseriati squamae imbricatae. Receptaculam conicum, nudum. Coroll a e tubulosae, tubo demum incrassato, limbo tubo angustiore et breviore, quadri-quinquedentato. Antherae.... Stigmata.... Achen ia sessilia, oblique cylindracea, nervulis albis striata. Pa p p s membranaceus, corolla longior, achenio fere major, auriculaeformis, ad latus exterius sinu profundo incisus. - Herba a egy ptiaca, annua, glabra, erecta; foliis linearibus, carnosis, saepius apice tridentatis, capitulis ramos terminantibus solituriis, flavis.

Chlamydophora Ehreaberg ex Lessing Synops.

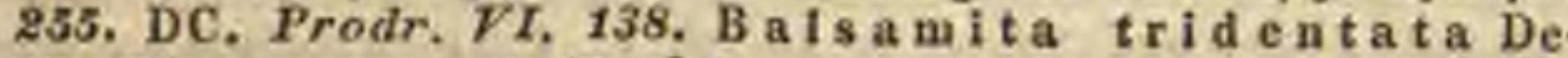
lile Flor. aegypt. t. 47, $f, 1$.

2ร03. Myriogyne LESS. Capitulum multiflorum, heterogamum, discoideum, fleribus marginalibus uniseriatis, femineis, centralibus paucis, hermaphroditis. Invol n $\mathrm{crum}$ expansum, subcampanulatum, floribus brevius, squamis subbiseriatis, ovatis, aequalibus. Co rolla e tubulo sae, femin ea e limbo subintegerrimo, hermaphrodit a e tubo brevissimo, limbo campanulato, quadridentato. Antherae ecaudatae, Stigmata exappendicnlata. A $\mathrm{c}$ h e $\mathrm{n}$ i a conformia, angulata, exalata. P a p p us nullus.- Herbae ramosissimae, acres, sternutatoriae, per regiones extratropicas hemisphaerae a ustralis et inter tropicos Asiae et Oceaniae dispersae; foliis alternis, confertis, oblongo-ovatis, apice dentatis, capitulis globosis, parvis, primum terminalibus, demum lateralibus, oppositifoliis, floribus luteis.

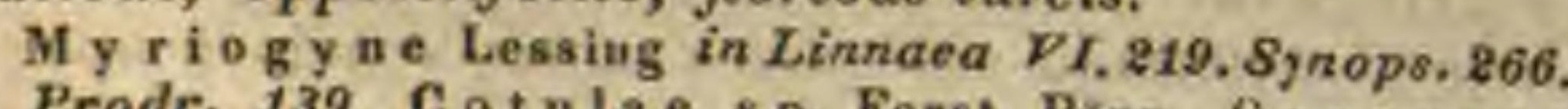
DC. Prodr. 139. Cotula e s p. Forst. Pöpp. Qrange a s p. Poir. Dichrocephalae sp. Herit.
2ร03. Sphaeromorplaaea $D C$. Cap it u l a m multiflorum, heterogamum, discoideum, floribus marginalibus multiseriatis, femineis, centralibus paucis hermaphroditis. In volu e ri eampanulati, floribus panllo longioris squamae bitriseriatae, obtusae, apice conniventes. Recepta culum planum, nudum. Corollae femin e a e tubuloso-conicae, apice vix dentatae, h e rma phodita e tereti-tubnlosae, limbo quadridentato. Antherae ecaudatae. Stylus basibulbosus; stigmata exappendiculata. A chenia conformia, eylindracea. Pap p us nullus. Herbae in Asia tropica et in Nova-Hollandia extratropica indigenae, aeres, decumbentes $v$. prostrato-radicantes, glabrae v. lanuginosae; foliis alternis, obovato-cuneatis, dentatis, in petiolum plus minus angustatis, capitulis globoso-depressis, axillaribus, solitariis $v$. geminis, brevissime pedicellatis $v$. sessilibus.

S phaeromorphaea DC. Prodr. VT. 140. Artemis i a miniasa Linn. Burm, Ind. $t .38, f, 3$.

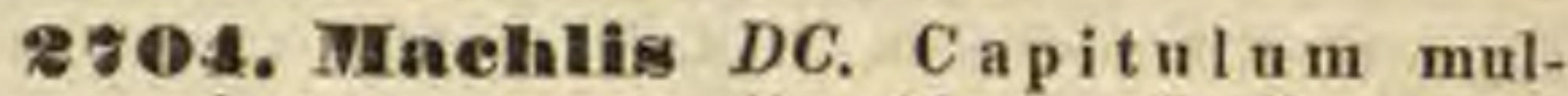
tiflorum, heterugamum, discoideum, floribus marginalibus multiseriatis, femineis, apetalis (?), centralibus pluribus tubulosis, masculis $\mathbf{v}$, hermaphroditis (?) Involucri biseriati squamae ovales, apice membranaceae, subincurvae, disco paullo longiores. Receptacul a m latum, planum, nodum, punctulatum. Corollae femineae nullae, (an fortassis minimae?) maseula e tabulosae, limbo obconico, quadridentato. Anth erae .... Stylus floribus femineis brevis, nudus (?) bifidus; stigmata apice subbarbata. A $\boldsymbol{c}$ henia teretia, subangulata, subglandulosa, radii apice bidentata, disci apice truneata. Pap us nullus. - Herba indica, annua, multicaulis, erecta, ramosa, glabra, ad summitates ra. morum villosa; foliis alternis, pinnatim multifidis, lobis linearibus, acute mucronatis, capilulis solitariis, pedicellatis, axillaribus terminalibusque, subconvexis, floribus ut videlur fulvis,

Machlis DC. Prodr. VI. 140. Cotala hemisphaerica Wallich, Artemisia hemisphaerica Roxb.

DIVESI0 VI. HIPPIEAE Lessing Synops. 267. DC. Prodr. VI. 141. C a p itula heterogama, floribus marginalibus femineis, centralibus masculis. Stylus disci simplex clavatus, apice truncatus.

2r05. Abrotanella CASS. Ca pitulnm subquinqueflorum, heterogamum, floribus tribus exterioribus femineis, interioribus duobus styli abortu masculis. Involucrum pentaphyllum, uniseriale. Rec ept a $c u l$ um nudum, Coroll ae omnes tubulosae, femin eae cum ovario articulatae, tridentatae; mascula e quadri-quinquedentatae. Antherae ecaudatae. Stylns mas culus indivisus, femineus bifidus; stigmatilo us brevibus, divergentibus. A chenia com. pressinseula. Pa p p us nullus. - Herba maclo. vian a caespitosa, musciformis, glaberrima; foliis alternis, imbricatim confertis, coriaceo-carnosis, emarginatis, capitulis terminalibus, parvis, solitariis, sessilibus.

A brotanelln Lessing in Dict. sc, nat, XXXVI. 27. Opusc, phyt, IT. 42, Lessing Synops. 267, O1I g o sp or us e marginatus Cassini ex Gaudich, in Annal. sc, nat. V. 104. $t .3$. f. 4.

2\%06. Leptinella CASS. Capitulum quindecim-trigintiflorum, heteroganum, floribus 
radii femineis, ligulatis, disci tubulosis, masculis. Involueri hemisphaerici, bi-triseriati squamae cirriter decem, orbiculatae, adpressae. R ee.p taculum planum v. subeonicum, nudum. Corolla e radii ligulatae, tubo longo, ligula minima, v. irregulariter tubulosae; disci tubulosae, grosse quadridentatae. Stylus disci indivisus, apice rotundatns, truneatus; radii bifidus; stigmatibus latis, brevibus, divergentibus. A h e n i a r i $i$ obcompressa, obovata, bicostata, glabra, disci abortiva. Pappus nullus. - Herbae americanae, tenues; folits alternis, confertis, pinnatifidis, lobis integris $v$. lobatis, capitulis terminalibus, in ramis superne aphyllis solitariis, parvis, flavis.

Leptinelia Cassini in Bullet, soc. phitomat. 1822 , p. 127. Dict. sc. nat. XXVI. 67. Lessing Synops, 268, DC. Prodr. VI, 141. - ? Hippia e sp. Kunth.

2 \% D. Flagioclineileas $A R N O T T$. Ca p i$t \mathbf{u l} \mathrm{um}$ multiflorum, heterogamum, floribus radii uniseriatis, irregularibus, femineis, disci regularibus, masculis. Invol u eri floribus brevioris, bitriseriati squamae obovato - oblongae. Receptaculnm hemisphaericum. Corollae radii lobis inaequalibus, integerrimis, interiore minore; $\mathrm{di}$ sci tubo brevi, limbo quadridentato. Antherae .... Stigmata .... A chenia radii compressa, oblonga, erostria; $d$ is c i abortiva. Pappus nullus. - Herbae austro-americanae; foliis alternis, pinnatisectis, segmentis incisis lobulatisve, capitulis pedicellatis, nudis.

Plagiocheilus Arnott mse. ex DC, Prodr, PY. 148.

2\%OS. Solliva $R U I Z$ et PAV. Capitnl $\mathrm{n} \mathrm{m} \mathrm{multiflorum,} \mathrm{heterogamum,} \mathrm{floribus} \mathrm{radii}$ pluriseriatis, apetalis v. filiformibus femineis, disci paucis, tubulosis, femineis. Involucri campanulati squamae quinque $\mathbf{v}$, decem, uniseriatae. Receptae u lum plannm, nudum. Coroll a radii nullae v. filiformes, tenuissimae, persistentes; disci tubulosae, limbo tri-sexdentato. Anthera e ecaudatae. Stylus masculus simplex, apice Iate orbiculatus, truneatus; femineus persistens, rigidus, apice vix bifidns. Achen ia $\mathrm{r}$ ad i i obcompressa, mucronata, margine alata $\mathbf{v}$. callosa. Pap p us nullus. - Herbae in America tropica et a us trali temperala indigenae, etiam in Lusitania observatae, parvac, erectae v. prostratae; foliis petiolatis, impari-pinnatisectis, lobis integerrimis v. pinnalipartitis aut multifidis, capitulis sessilibus $v$. pedunculatis.

Soliv a Ruiz et Pavon Prodr, 113. t, 24. R. Brown in Linn, Transact, XII. 101. Lessing Synops, 268. DC. Prodr, VI. 142. G y mu os $t$ yl es Jussieu in Annal. Mus. IV. 260, $t, 61$. Cassini in Dict. sc, nat. XX, 153. Sollvae a Cassini in Dict sc. nat. $\mathrm{XX} T \mathrm{X}$. 127. Sollva et Gymnostyles Per. soon Ench. HI. 491. 497. It ip pla e sp. Linn. Brotero.

2ช (D). IIfppia $L I N N$. Ca p it n ln multiflorum, heterogamum, discoidenm, floribus radii uniseriatis, filiformilus, femineis, disci tubulosis, masculis. Involucri subuniseriati squamae ellipticae, margine scariosae, R eceptaculum parvum, convexum, epaleatum. Corolla e radi i filiformes; dis ci tubulosae, quinquedentatae. Antherae ecaudatae. Stylus ..... A chen ia radii subrotunda, plano-obeompressa, margine bicostatav. bialata; dis ei abortiva. Pappns nullus. - Herbae v. frutices capenses, odore anthemideo; foliis alternis, saepius pinnatilobatis, rarius integerrimis, capitulis corymbosis, parvis, luteis.

H i p p i a Lino. gen. $n$, 1324. Gärtner $I T .390 . t, 164$. Cassini in Dict. sc. nat. XXI. 268. T a n aceti sp. Linn. Berg.
DIVISID VII. ERIOCEPHALEAE LeSsing Synops. 268. DC. Prodr. VI, 145. Capitula multiflora, heterogama, floribus radii paucis, ligulatis v. tubulosis, femineis; disei tubulosis, stylo simplici, clavato-truncato masculis. A chenia obcompressa, exalata. Pappus nullus. Receptaculum paleatum. - Erutices capenses.

28 10. Eroloceplaalms LINN. C a p ituI $\mathrm{um}$ multiflorum, heterogamum, floribus radii ligulatis v. subtubulosis, femineis, disci tubulosis, masculis. I n vo I n c rum duplex, exterioris campanulati squamae quatuor v. quinque, ovatae, liberae, interioris plures, inter se concretac, extus lanigerae. Receptaculum paleatum. Corolla e radii ligulatae, ligula obovata, apice dentata, v. subtubulosae, limbo integro, oblique truncato; dis ci tubulosae, limbo quinquedentato, Anthera e ecandatae. Stylus radii bifidus; disci simplicissimus, clavato-truneatus. A chenia radii obcompressa, exalata; disei abortiva, $P$ a ppu s nullus. - Frutices capenses, ramosissimi; foliis allernis v. oppositis, linearibus, crassiusculis, nunc indivisis, nunc apice trifidis, saepius sericeovillosis, pubescentibus, rarius glabris, capitulis pedicellatis, nunc racemosis, nunc umbellatis, nunc solitariis, subglobosis, post anthesim lana albida $v$. rufescente dense vestitis.

E riocephal u s Linn. gen, $n .815$. Gärtner $I T$. 428. Lessing Synops. 268. DC. Prodr. VI, 145, non Vaill.

a. PHAENOGYNE DC. Prodr, VT, 145. C o rolla e radii stylo et involucro longiores, ligulatae, obovatae v. euneatae, apice obtuse tridentatae.

Rriocephalus et Monochlaena Cassini in Dict. sc. nat. $X Y$. 188, et L. 491 . (Gürtn, $t, 168$. Lamarck 1,717 .)

b. CRYPTOGYNE DC. Prodr, VT. 147. Corolla e radif stylo breviores, intra involuerum subocultati, tubulosi, apice subintegri aut oblique truacati $v$, subligulati.

Cryptogyne, Mierogyne, Brachygyne, Selenogyne, Siphogyae v. Stenogyne Cas: sini in Dict. so. nat. L. 493.

SUBTIIBUS VIT. GNAPHALIEAE Lessing Synops. 269. DC. Prodr. VI. 149. C a pitul a homogama sive heterogama, multi-pauciflora, rarius uniflora. Co rolla e tubolosae, quinquedentatae, florum femineorum filiformes, rarissime ligulatae. An the ra e caudatae. Stylus floris hermaphroditi ramis exappendiculatis, masculorum saepe indivisus. Pa p p u s pilosus v. setaceus, rarissime nullus. - Herbae v. suffrutices, potissimum gerontogei, foliis ut plurimum alternis.

DIVISIO $\mathrm{I}$. ANGIANTHEAE DC. Prodr. VI. 149. C a pitula uni-pauciflora, in glomerulum involucro generali cinctum dense aggregata.

7911. Styloneerus LABILLARD, C apitula paueiflora, homogama? Inv olucri flores superantis squamae elliptico-oblongae, obtusae. Recepta eulum nudum? Corollae tnbulosae, basi dilatatae, limbi quinquedentati dentibus brevilus, erectis. Anthera e ecaudatae? Sty lus basi valde incrassatus. A chenia obennica, papillosa. Pappus coroniformis, e paleis 
quinque basi concretis, a medio serrato - fimbriatis, acuminatis, extus fortassis membranula annulari minima stipatis. - Herba Novae-Hollandiae austro-occidentalis, pusilla, prostrata, in vivo recognoscenda; foliis sparsis, linearibus, integerrimis, glabris, capitulis in glomerulum ovato - globosum, terminalem dense aggregatis.

S t y 1 o ne er as Lablllard Nov. Holland. IT. 57. $t, 209$. (splialaate Siloxerus) Cassiai in Dict. se. nat. XXIII. 563. Lessing Synops.269. DC. Prodr. VT. 149. Ogeerost y I us Cassini in Dict. sc. nat. XXIII. 563. XLIX, 221.

2812. Ifyalolepîs $D C$. Capitula uniflora, in glomerum dense aggregata, involucri communis multiseriati squamis ovato-lanceolatis, integris $\mathbf{v}$. apiee bifidis, nervo opaco, ceterum hyalinis. Receptaculam commune nudum. InvoI uc ra partialia supra receptaculum sessilia, mo nophylla, (fortassis e squamis tribus concretis) teretia, basi indurata. Corolla filiformis, apice subelavellata, tri-quinquedentata, An ther a e..

Stigmata apice subbarbellata. Acheninm teres, elongatum, sericeo-subpubescens. P'a p p us seta filiformis, corolla parum brevior. - Herba Novae-Hollandiae, pygmaea; caulibus e collo plurimis, brevissimis, foliis fere radicalibus, linearisubulatis, integerrimis, basi dilatato-amplexicaulibus, glomerulo inter folia ad apicem cujusque cauliculi sessili, albido, basibus foliorum et involucri generalis laxe et parce lanuginosis.

H y a lolepis DC. Prodr. Fr, 149.

2813. Plinyllocalymma $B E N T H$. C a pitnla biflora, homogama, in glomerulum subglobosum aggregata, involue $r i$ communis squamis herbaceis, linearibus, glomerulo longioribus. Reveptac nlum commune nudum Involuf: $r$ a partialia pleiophylla, oblongo-cuneata, scariosa, exappendiculata. Antherae $\ldots \ldots$ st $\mathbf{y}$ I $\mathrm{s}$ inclusus $\cdots \cdots$ A $\mathrm{ch}$ e $\mathrm{n}$ a clavato - linearia, hirsuta. P a p i paleae subquinae, basi ovatae, in setam corollam subaequantem, laevem v. scabram productae. - Herba Novae-Hollandiae austro-occidentalis pusilla, ramosissima, superne albo-tomentosa; foliis linearibus, basi amplexicaulibus, integerrimis, glomerulis lateralibus et terminalibus subglobosis.

P h y llo e al $1 \mathrm{~m} n$ a Bentham in Enum. plant. Hügel.p. 61 .

2\% 14. Angianthus $W E N D L$. C a p itu la biflora, homogama, in glomerulum spieaeformem, ovato- cylindraceum dense conferta, involucri communis squamis quatuor ovatis, albido-tomentosis, glomerulo multo brevioribus. R e cep tacu1 u $\mathrm{m}$ angustissimum, tomentosum. In v o l u cra partialia tetraphylla, squamis ovatis, scariosis, duabus planis, duahus alternis convolutis, flores singulos involventibus. Corolla tubulosae, quinquedentatae. Anther a e caulatae. Stigma ta exserta, truncata, divergentia, apice pilosa. A cheni a oblonga, glabra. P a p p u s biaristatus, aristis basi membranaceo-dilatatis, serratis, apice plumnso-penieillatis. - Herba Novae-Hollan diae annua, tota cano-tomentosa; foliis alternis, oblongo-spatleulat is, enerviis, integerrimis, capitulis ad apicem ramorum in spicam ovatam, involucri communis foliolis albis tomentosis quadribracteatam confertis, involucris partialibus et corollis aureis.

Anginnthus Wendland Collect. IT. 31.t.48. R. Brown in Linn. Transact, XII, 103, DC. Prodr. VT, 130. Cassinia R. Brown in Aiton Hort. Kew. 2, $P$. 184. Cassini in Diet. sc. nat, VIT, 299. nee alib. Hirneli a Cassini in Bullet. soc. philomat, 1820, Dict. sc. nat. XXI, 199. XXIII. 508. Lessing Synops. 269.
2815. Skirrlhophoress $D C$. C ap it u la biflora, homogama, in glomerulum ovatum dense conferta, in vo l u c ri communis biseriati squamis exterioribus lanatis, interioribus longioribus scariosis, glomerulo brevioribas. Re e ptac $\mathbf{c}$ / um commune papillosum. In v o I u cra partialia sessilia, squa mis subhyalinis, oblongis, deciduis. Corollae tubulosae, minutae, tubo basi in tuberculnm skir rhosum, subrugulosum et ovario latiorem dilatato, limbi quinquedentati dentibus reflexis. An therae ... Stigmata brevia, apice capitellata. A c h e nia glabra, oblonga, basi attenuata. Pappus nullns. - Herba Novae-Hollandiae austra. lis, suffruticulosa, ramosissima, dense tomentosa; foliis alternis, linearibus, integerrimis, crassiusculis, glomerulis ramulos terminantibus ovatis, involucri communis bracteis exterioribus lanatis, interioribus capitulisque flavo-scariosis.

Skirrhophorus DC, Prodr. Ml. 150.

\% 16. IIyrideepla alus BENTH. C a $\mathrm{p}$ itula quadri-quinqueflora, homogama, in glome. rulum depresso-subglobosum densissime aggregata, involucri communis polyphylli squamis lineari bus, dorso lanatis, appendice seariosa, ovata radiantibus. R e e p t a e u a nuda. Involueri partialis squamae paucae, scariosae, minute appendiculatae. Co rolla e tubulosae, tubo brevi, basi aequali, limbo quinquedentato. Anthe ra e ..... Stigmata exserta, brevia, opice subincrassata. A chenia linearia, glabra. Pappus nullus. Suffruticulus Novae Hollandiae a ustro-occidentalis; caule erecto, glabro v. apice puberulo, foliis alternis, linearibus, integerrimis, basi amplexicaulibus, utrinque viridibus, fere glabris, glome rulis terninalibus.

M y rioeephal us Bentham in Enumerat.plant. Hügel.

2817. Cinephosis CASS. C a p i t a I a uni - quadriflora, homogama, intra bracteas scariosas, inferne cuneatas, superne obtusas, subdentatas, in spicam ovatam dispositas solitaria. Invol ucri proprii octophylli squamaebiseriatae, exteriores persistentes, membranaceae, superne coloratae, interiores longae, caducae, appendicula radiante superatae. Receptaculum angustissimum, nudam. Corolla tubulosae, graciles, limbo obeonico, quinquefido. A $\mathbf{n}$ thera e ....... ma, laevia. Pap p ns coroniformis, brevissimus, lacerus, cadueissimus. - Herba Novae-Hollandiae australis, annua, glaberrima, ramosa; ramis gracilibus, flexuosis, saepe nudis, foliis paucissimis, alternis, linearibus, scabridis, integerrimis, capitulis ad apices ramorum in spicam obovatam glomeratis, bracteis scariosis, flavescentibus interstinctis.

Guephos is Cassini in Bullet. soc. philomat. 1820. p. 43. Dict. sc. nat, XIX, 127. Lessing Synops. 270. DC. Prodr. VI. 151.

28 18. Caloeephalus $R, B R$. C a $\mathrm{p}$ it u 1 a triflora, homogama, in glomerulum globosum, exinvolucratum dense aggregata. Invol u eri squamae fluribus sublongiores, apice obtusae, seariosae. Recepta culum nuilum. Corolla e tubulosae, quinquedentatae. Antherae ...... Stig. ma $t$ a ....... A chenia obovoidea, sessilia ve pedicellulata, Pap pi uniseriati setae paucae, apice plumoso-penicillatae. - Herbae Novae-Hollandiae orientalis, erectae, parce ramosae, graciles, tomentoso-canescentes; foliis oppositis, basi in 
vaginam brevissimam connatis, linearibus, integerrimis, glomerulis terminalibus.

C al a ce phal us R. Brown in Linn. Transact. XIT. 109. Cassini in Dict, sc, nat. XXIII, 563. Lessing Synops, 271. Bronguiart ad Duperr. t. 60. DC. Prodr. VI, 151.

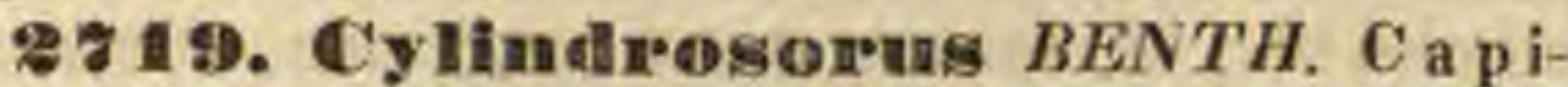
$t \mathrm{n} I$ a billora, homogama, in glomerulum oblongocylindrieum dense aggregata. Involucri communis biseriati squamae paueae, lineares, scariosae, exteriores brevissimae, interiores glomernlum subaequantes. Recepta $\mathbf{e u} \mathbf{l u m}$ nudum. Involucra propria squamis paucis, oblonge-cuneatis, scariosis, exappendiculatis. Corolla e tubulosae, limbo quinquefido. Anthera e caudatae. Stig$\mathrm{m}$ at a inclusa, brevissima. A ehenia linearia, glabra. Pap p i paleae paueae, basi ovatae, in setam corollam subaequantem, supra mediom breviter plumosam productae. - Herba Novae-Hollandiae erecta, ramosa, laxe tomentosa; foliis alternis, linearibus, semiamplexicaulibus, glomerulis terminalibus, oblongo-cylindraceis, involucri proprii squamis apice citrinis.

C y lindros or us Bentham in Enumerat. plant. Hügel. p. 62 . DC. Prodr. VT. 132.

28 30. Heucophyta $R \cdot B R$. Capitula triflora, homog ma, in glomerulum globosum, bracteis interstinctum aggregata. Invo I n eri communis foliola uniseriata. Receptacula nuda. Invol u cri proprii squamae subdenae, submembranaceae, obovato-oblongae, flores aequantes. Co rolla e tubulosae, quinquedentatae. Anth era e basi bisetae. Stigmata ..... A chenia pedicellata, obovoidea, glandnlosa. P a p p i uniseriati setae longae, a basi ad apicem plumosae. Herba Novae-Hollandiae a ustro-orientalis, suffrutieulosa, ramosa, tota tomento adpresso incuna ; foliis alternis, sessilibus, linearibus, erectis, glomerulis terminalibus, rhachi conica, corollis flavis.

Le ue o phyta R. Brown in Linn. Transact. XII. 106. Cassini in Dict, sc. nat. XXVI. 158. Lessing Synops. 271. DC. Prodr, VI, 158.

2821. Craspedia FORST. Capitula quinquefora, homogama, in glomerulum subrotundum, bracteis sub singulis capitulis sitis cinctum aggregata, receptaculo communi cylindraceo, lanato insidentia, substipitata. Involucri proprii squamae membranaceae, hyalinae, ellipticae, floribus aequales. Receptac $\mathbf{u} \mathbf{l} \mathbf{m}$ angustum, margine paleis hyalinis, integris onustum. Corolla e tubulosae, late quinquedentatae. Antherae basi bisetae. Stigmata inelusa. A chenia oblonga, villosa. P a p p i uniseriati setae filiformes, plumosae. - Herbae ferennes, Novae-Hollandiae et Novae-Zeelandiae incolae; foluis in partecaulis inferiore confertis, alternis, lanceolato-linearibus, integerrimis, caule erceto, subnudo, apice monoce phalo, floribus sulphureis.

Cras pedia Forster Prodr. 326. R. Brown in Linn. Transact. XII. 105. Cassiai in Dict. sc. nat. XI. 353. Les. sing Synops, 271. Bot. Reg. t. 1908. Bot. Mag. t. 3415. DC. Prodr. VI. 159. Rich a Labillard, Voy, I, 187, $t, 16$, Cassini in Dict. se. nat. XXIII. 503. noa alior. C arto di um Solander msc.

2\% 2. Pyenosorus BENTH. C a pitula pauciflora, heterogama, flore uno neutro, reliquis hermaphroditis, in glomerulum globosum . exinvolucratum dense conferta. Invol u cri proprii squamae pancae. Recepta $\mathbf{c} \mathbf{u} \mathbf{u} \mathrm{m}$ paleis inter flores involucri squamas referentibus. Co roll a e tubulosae, limbi quinquedentati dentibus erectis. A n therae ...... Stigmata..... Achenia pi- losa. Pappus floris nentri setae paueae, apice plumosae, hermaphroditoram plurimae, inferne subdilatatae et a basi plumosae. - Fruticulus $\mathrm{No}_{0}$ vae-Hollandiae, erectus, albo-lanatus; foliis alternis, oblongo-linearibus, pedunculis longis, rigi. dis, nudis.

P y e nos orus Bentham in Enumerat, plant. Hügel. p. 63. in not. DC. Prodr. VT. 153.

\section{DIEISH(1) CASSINIEAE Lessing} Synops. 271. DC. Prodr. VI. 153. C a pitula haud glomerata. Receptaculum totum v. margine paleatum.

2828. A manatolotuman $R$. BR. C a p itul u m multiflorum, homogamum. In v o I u c r $\mathrm{i}$ hemisphaerici, flores aequantis squamae imbricatae, coriaceae, margine membranaceae, appendice scariosa, lata, concava, patente terminatae. Receptac ulnm latum, conicum, paleis oblongis, snbconcavis, apice denticulatis, acuminatis inter flores. Corolla tubulosae, tubo carnoso, virescente, limbo quinquelobo. Antherae basi bisetae. Stigmata exserta, arcuata, apice pilosa. Achenia obcompresso-tetragona, apice quadridentata, dentibus duobus majoribus in setulam $v$. aristam productis. - Herba Novae-Hollandiae orientalis, erecta, ramosa, villoso-canescens; foliis radicalibus oblongis, longe in petiolum attenuatis, caulinis in alum secus caulem decurrentibus, capitulis ad apices ramorum solitariis, involucris albis, floribus flavis.

A m m o bium R. Browa in Bot, Mag. t. 2459. Cassini in Dict, sc. nat. XLVI. 524. Gaudichaud ad Freycinet, 467. t. 90. Lessing Synops. 377. DC. Prodr. VI. 153.

28 24. Ixodia $R, B R$. C a pitulu m multiflorum, homogamum. Involuer n m cylindraceo-campanulatum, floribus longins, squamis basi adpressis, coriaceis, in appendicem petaloideam, scarioso - albam, obovatam, patentem productis. Receptaculum conicum, paleis flores subsuperantibus, involueri squamas referentibus, basi latis, denticulatis, fructum involventibus, apice oblongis, albo-coloratis. Corolla e tubulosae, quinquedentatae, extus glandulis stipitatis obsitae. Antherae bisetae. St i g mat a apice truncata, papillosa. A chenia oblongo-cylindracea, papilloso-pilosa. Pappas nullus. - Suffrutex Novae-Hollandiae orientalis, glaberrimus, viscoso-virens; folits alternis, linearibus, crassis, acutiusculis, integerrimis $v$ subdentatis, uninervïi, glanduloso-punctatis, capitulis corymbosis, involucris albis, radiantibus, floribus flavis.

Ix odia R. Browa in Aiton Hort. Kew. 12, IV, 517. Bot. Mag. t, 153\%. Cassini in Diot, sc, nat, XXIV. 36. Les. sing Synops. 272. DC, Prodr. VI, 153. non Solander.

2 *3. Fhymea $D C$. Capitulum multiflorum, heterogamum, floribus radii quinis, filiformibus, femincis, disci circiter quindecim, tubulosis, hermaphroditis. In v ol u c ri imbricati squamae exteriores pubescentes, obtusae, interiores in appendicem oblongam, patulam, obtusam, albam productac. R e e p ta $\mathrm{e}$ u l paleae lineares, deciduae. Corolla e f em incae filiformes, hermaphroditae tubulosae, limbo quinquedentato. An the rae basi lreviter bisetae. Stig in a ta truncata. A chenia obosato-oblonga, erostria, minute puberula. Pa p pi uniseriati setae vix scabridae. - Suffrutex capensis, erectus, ramosus; ramis foliisque sublus tomento albido, adpressissimo tenaci canis, foliis alternis, sessilibus, decurrentibus, lanccolat is, apiculatis, uninerviis, superne glabris, pallidis, corymbo compo- 
sito, subpaniculato, foliis parvis interstincto, involucri squamis interioribus et paleis apice albis.

A hignea DC. Prodr. VI. 154.

298E. Cassinia R. BR. C a p itu $\mathrm{nm}$ pauciflorum, homogamum, floribns omnibus hermaphroditis, tubulosis, rarius heterogamum, floribus paucissimis femineis, angustioribus in ambitu. Involuerum imbricatum, scariosum. Receptaculi paleae distinctae, intimas involueri squamas referentes. C or oll a e tubulosae, limbo quinquedentato. Antherae inclusae, basi bisetae. Stigmat a apice obtusa, subtruncata, hispidula. A c henia obovata, erostria. Pappi uni-biseriati setae plurimae, filiformes v. apice penicillatae. Suffrutices, in Nova-Hollandia orientali et in Nova-Zeelandia indigeni; foliis sparsis, saepius linearibus, rarius oblongis $v$. lanceolatis, integerrimis, margine saepe revolutis, corymbosis $v$. paniculatis, terminalibus, involucris hemisphaericis, oblongis $v$. turbinatis.

C a s $\mathrm{s}$ in i a R. Brown in Linn. Transact. XIT. 126. (non Hort. Kew.) Cassini in Dict, sc, nat, XXXIV. 504, Lessing Synops. 2r8, excl. Angiantho.

a. GLossophylla DC. Prodr. $V T$. 135. In v o 1 u e r u m squamis intimis apice patulis breviter radians. P a p p s persistens. - Suffrutices ramosissimi.

Cas s in a Cassini in Dict, sc, nat. LVT, 219, Cassintae sect. 1. R. Brown l. $c$. Craspediae s p. Forst.

b. ANACTILAKNA DC. Prodr. VI. 135. Involn er um connivens . squamis corlaceo-seariosis. Pa p pus deciduas. - Fratices.

Chromoebiton et Achromolaena Cassini in Dict. sc. nat. LVI, 220. Cassinia sectio II. R. Brown $l$. e. C a l e a e sp. Labillard. Nov. Holl. $t .185$. (Bot. Reg. t. 764.)

DIVISID TH. HELICHRYSEAE Lessing Synops. 272. DC. Prodr. VI. 157. Capitula haud glomerata. Receptaculum epaleatum, nudum v. fimbrilliferum.

aร 9 . Humea SMITH. Cap itnlum triquadriflorum, homogamum. In volu eri cylindracei, imbricati squamae oblongae, margine late scariosae, infimae secus pedicellum minores, bracteiformes. Recepta $c u l u m$ angustissimum, nudum. Corolla tubulosa, quinquedentata. Antherae hasi bisctae. Stigmata....A A chenia erostria, glandulosa, glabra. Pappus nullus. - Herba Novae-Hollandiae orientalis, biennis, resinoso-odorata, erecta, biorgyalis, parce ramosa; foliis alternis, auriculato-amplexicaulibus, ovali-lanceolatis, acuminatis, sparse pilosis, paniculae amplae ramis dependentibus, involucris purpureis v. roseis, corollis purpureis.

H u me a Smith exot. Bot. I. t. 1. Cassini in Dict. sc. nat, XXIX. 39. Lessing Synops, 272. DC. Prodr. NT. 157. C a I o m er i a Venten. aralm, $t, 73$. A g a $t$ h omeris Delau. ne Jard. Bot, 1805. Oxy p heria Hortulanor. Raz u movia Sprong. mse. non Syst.

OBSERVATI0, Hae loco collocatur a ef. De.Candolle ge. nus a Lessingio inter Angiantheas poite Gaephosin paucis verbis indieatum, nobís plane dubiuu

CRossolepis Lessing Synops, 270. ${ }_{n}$ Capitulum peirciter decemflorum. Rhach is ebracteolata. Pappus nnullus. - Herba Novae-Hollandiae, annua, gra. ncillinta, lana mox evaniala vestila; falits angustissime "tinearibus, follolis involueri vix biserialibus, floribus "parum brevioribus, scariosis, fimbriato-laceris." -Ge. nas etiam ex alterins speciei capitulis blfloris donatae, a cl. Bentham Enumerat, pl, Hügel. p. 61, bue relatae, fortassis tamen minime congeneris specimine almodum manco haud stabiliendum, verisiuiliter cnm aliquo praecedentinm condunandum. 2ซas. Quinetia CASS. Capitulum bitriflorum, homogamum. Invol u crum eylindraceum, tetraphyllum, achenia vix superans, squamis linearibus, alternis planis, alternis concavis. Receptacu I um angustum, nudum. Corollae tubulosae, ad faucem haud ampliatae, limbo triquadridentato. An the ra e inclusae, appendice terminali acuta, candis subnullis. S $\mathbf{t}$ ig m a $t$ a exserta, elongata, divergentia, subpiliformia, glabra, in appendicem brevem, diaphanam desinentia. Ach en i a teretiuscula, in stipitem subsericeum attenuata, apice subsericea, caeterum glabra. Pa p pi paleae quinae - octonae, uniseriatae, persistentes, basi membranaceae, ovatae, in aristam longam, subscabridam productae. - Herba Novae-Hollandiae a ustro-occidentalis, annua, erecta, pusilla, tenella, simplicissima, glabra; foliis obovatis, mucronatis, integerrimis, longe petiolalis, petiolo basi dilatato, amplexicauli, capitulis ad axillas foliorum solitariis, breviter stipitatis, secus cauliculos racemoso - spicatis

Quinetia Cassini in Dice. sc. nat. LX, 579. et 590. DC. Prodr. Pr. 158.

2 \% 29. IEytidosis DC. Cap itulum multiflorum, homogamum. Involncri bi-triseriati squamae scarioso-hyalinae, transversim rugosae, serrato-ciliatac, breviter unguiculatae, $R$ e c e p tacul um alveolatum. Coroll a e tubulosae, quinquedentatae. Anth era e ......S Stigmata brevia, cono superata. A chenia ..... areola basi disciformi. Pappi squamellae quinque, paleaceae, ovatae. - Herba Novae-Hollandiae orient alis, araneoso-canescens, Helichrysi facie; foliis alternis, sessilibus, linearibus, calloso-acuminatis, ramis paucis, nudis, apice monocephalis, involucris flavis.

Rytidosis DC. Prodr. VT. 159,

2930. IEhodianthe LINDL, C a p it u I u m multiflorum, homogamum. Invol u e ri turbinati, imbricati squamae membranaceae, ovatae, acutae, extimae secus pedicellum bracteiformes argenteae, mediae adpressae, intimae stellatim patentes, roseae Receptaculum nudum. Corolla e tubulosae, quinquefidae. Antherae ..... Stigmata.... A chenia erostria, lanata. Pappi uniseriati setae distinctae, plumosae. - Herba Novae-Hollandiae austro-occidentalis, erecta, annua, ramosa, glabra; foliis alternis, amplexicaulibus, obtusis, integrerrimis, capitulis terminalibus, solitariis, elegantissimis.

Rhodanthe Lindley in Bot. Reg. $t$. 1703. Hooker in Bot. Mag. \&. 3483. D. Don in Sweot Fl. Gard. IT. $t .295$. DC. Prodr. VI, 159.

2ร31. Podetheca CASS. Capitulum multiflorum, homogamnm. Invol u crum floribus aequale, cylindraceum, squamis subimbricatis, lineari-acuminatis, subfoliaceis. Recepta $c \mathbf{u l u m}$ epaleatum. C orolla e tubulosae, graciles, quinquedentatae. Antherae basibisetae. Stigmata longa, apice obtusa. Achenia subcylindracea, hispida, areola laterali, stipiti gracili e centro alveolorum orto insidens. Pappi paleae quinque, longissimae, nniseriatae, basi concretae, longe plumosae. -Herba Novae-Hollandiae austroocc identalis, annua, glabra; foliis alternis, am plexicaulibus, lineari-semilanceolatis, integerrimis, acuminatis, capitulis solitariis, ramos aphyllos forminantibus, involucris subaraneosis, floribus flavescentibus.

Pod otheca Cassini in Dict. sc. nat. XXIII, $\$ 6 t, 569$. Lessiug Synops, 973. DC, Prodr, VT. 159. Pod ospermit 
Labillard. Nov, Holl, IT. 35. t. 117. non alior. P ha e n o p od a Cassini in Dict. sc. nat. XLII. 84.

2ร3\%. Heptorlaynelnus LESS. C a p itulum multiflorum, homogamum. Involucri multiseriati squamae imbricatae, adpressae, acuminatae, siccae, apice scariosae. R e e p ta c n l u m planum, nudum. Co roll a e tubulosae, quinquedentatae. Antherae basi bisetae. Stigmata apice capitellata. A ch enia compressa, subpappnlosa, gracilia, apice in rostrum continuum, breve v. elongatum desinentia, areola terminali. Pap p i setae denae-duodenae, uniseriatae, basi subconcretae, serrato-scabrae. - Herbae Nova e-Holl andiae graciles, adscendentes; folits alternis, sessili. bus, oblongo-linearibus, margine plus minus revolutis, integerrimis, capitulis solitariis, ramos aphyllos terminantibus $v$. subcorymbosis, involucris subtomentosis, corollis flavis.

Leptorhy achus Lessing Synops. 273. DC. Prodr. $V I$. 159. Vir a y a Gaudich. ad Freye. 466. Mo o n a Lindley in Bot, Heg. n. 1941. 1944, Rhyt idanthe Bentham in Enzmerat, plant. Hügcl. 63.

a. APHANORHYNCHUS Lessing Synops. 273. Ae henia breviter rostrata, C a pit u la in ramis solitaria. C h rysocoma s qu am at a Labillard. Nov. Holl, $t$. 184.

b. MORNA Lindley in Bot. Reg. t. 194t. A $\mathrm{c}$ h e n f a longe rostrata. Capitula corymbosa. - Viraya Gaudich. Op. cit, t. 89 . Rhy thd a in the Bestham 7 . $c$.

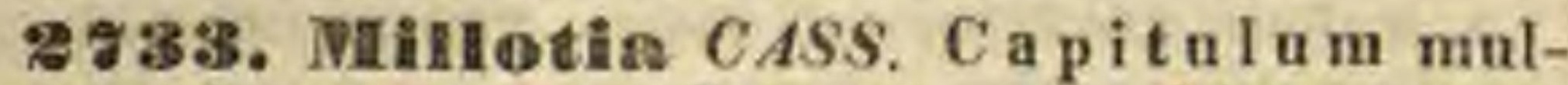
tiflorum, homogamum. In volu c ri oblongo-cylindracei squamae octo $\mathbf{v}$. decem, uniseriatae, apice acuminato-subulatae. Receptacul n m planum, nudum. Corollae tubulosae, quadridentatae. Antherae basi bisetae. Stigm at a glabra, appendice conica, minima snperata. A e henia oblonga, compressa, scabra, rostro tenui, longo. Papp us uniserialis, pilosus, tenuis, scaber, corolla longior. - Herba Novae-Hollandiae austro-occidentalis, annua, tenuis, erecta, tomento arachnoideo inducta; foliis alternis, tenuissimis, acutis, integerrimis, capitulis terminalibus solitariis, corollis flavis, pappo rufescente.

Mill ofia Cassini in Annal. sc, nat. XVIT, 416. Dict. sc. nat. LX. 592. Lessing Synops. 273. DC, Prodr. YT, 161.

2834. Hxiellaena BENTH. Cap it a $\mathrm{um}$ multiflorum, homogamum. Involucri cylindracei squamae plurimae, virides, margine scariosae, erectae, apice lamina parva, petaloidea radiantes. Receptacul u m alveolatum, breviter fimbrilliferum. C o rolla e tubulosae, breviter quadri-quinquedentatae. Anthera e basi bisetae. Stig mata apice penicillata. A $\mathbf{c}$ heni a glandulae insidentia, teretiuscula, hispidnla, erostria. Pap p i setae plurimae, scabrae. - Herba Novae-Hollandiae a ustro-occidentalis, erecta, dura, ramosa, laxe lanata, viscosissima; folits inferioribus oblongo. spathulatis, in petiolum attenuatis, superioribus lineari-spathulatis, subdecurrentibus, capitulis in ramis ternis v. quaternis, viscoso-pubescentibus, squamarum involucri marginibus niveis.

Ixlola e n a Bentham in Enumerat, plant. Hügel, p. 66 .

2ระ5. Fanaetia CASS. Capitulum inultiflorum, heterogamum, floribus tubulosis, radii paucis femineis, disci hermaphroditis. I n v o l ue.ri hemisphaerici, flores aequantis squamae imbricatae, intermediae petiolatae, appendice lata, scariosa, fimbriato-dentata, extimae ad appendicem redactae. Coroll a e tubulosae, radii limbo tripartito, lobis linearibus; disci longe tubulosae, quinquefidae. Anthera $\ldots . . .5 t i g m a t a . . .$.
A $c$ h enia eonformia, oblonga, erostria. Pa p i setae tenuissimae, superne plumosae, radii binae, disci tres v. quatuor. Herba Novae-Hollandiae austro-occidentalis, annua, parvula, erecta, gracilis; caule sparsim piloso, apice in ramos monocephalos diviso, foliis alternis, sessilibus, oblongis, acutis, integerrimis, subtus albido-tomentosis, capitulis solitariis, luteis.

Pan a ti a Cassini in Annal. sc. nat. XVI. 417. Dict, sc. nat. LX. 580. 593. Lessiug Synops. 273. DC. Prodr. VI. 162.

2836. Podiolepits LABILLARD. C a p i$t \mathbf{n} l \mathbf{u m}$ multiflorum, heterogamum, floribus radii ligulatis v. irregulariter tubulosis, femineis, disci regularibus, hermaphroditis. In v o lu $\mathrm{r}$ i campanulati squamae multiseriatae, extimae sessiles, scarioso-diaphanae, intimae ungue lineari angusto stipitatae. Receptaculam paleatum. CorolI a e radii ligulatae, integrae v. vix dentieulatae, v. irregulariter tubulosae, profunde tri-quinquefidae; dis ci regulares, quinquedentatae. An the rae basi bisetae. Stigmata glabra, apice capitellata. Achenia oblonga, subpapillosa, apice vix attenuata, areola laterali $\mathbf{v}$. subterminali. $\mathbf{P}$ a ppi setae uniseriatae, pilosae, scabro-serratae, basi in annulum subconeretae. - Herbae Novae-Hollandiae, erectae, parce ramosae; foliis alternis, sessilibus, subdecurrentibus, oblongo-linearibus, acuminatis, integerrimis, capitulis terminalibus, soli tariis.

Pod ol e pis Labillard. Nov, Holl. 1I. 57. R. Brown in Aiton Hort, New, 2. V. 82. Cassini in Dict, sc, nat, XLII, 62. Lessing Synops. 367. DC, Prodr, VI, 162.

a. SCALlA Sims. Flores radil ligulati v. difformes, incisuris 3-5, irregularibus, profundis, Pa p p I setae basi in tubulum brevem connexae. Involucri squama stipite eglanduloso. - Flores lutei.

Sealia Sims in Bot. Mag. t. 956. DC. $t$, c. (LabilIard. Op. cit. t. 28.)

b. STYLOLEPIS Lehm. Flores radii ligulati, integri v. vix denticulati. Pa p pi setae basi vix connatae. I v o: 1 u eri squamae stipite glandulifero. - Flores violacel.

St ylolep is Lehmann Catalog. Sem, hort, Hamburg. 1528, p. 17, DC, l. c, (Bot. Mag. t. 2904. Sweet Fl. Gard. $t$, 285.)

R. DORATOLEPIS Benth. F I o res radil subtabulosi. Pappi setae lasi vix connatae. Involu crí squamae stipite glanduloso. A chen for um areola subterminalls.

Dor atolepis Bentham in Enumerat, plant. Hügel. p. 6i. DC. $l$. c.

2ร3ร. Swamunerdamia DC. CapituI $\mathbf{n m}$ multiflorum, heterogamum, discoidenm, floribus marginis pancissimis femineis, disci hermaphroditis. In volucri squamae imbricatae, lineari-oblengae, obtusae, ochraceo-subscariosae. R ecepta $\mathrm{cuI}$ um angustum, nudam. Corollae femineae subtrilentatae, hermaphroditae quinquefidae. Antherae subexsertae, basi breviter caudatae. Stigmata apice capitellata, feminea exserta, hermaphroditorum demum reflexa. Achenia teretinscula, callo basilari, crasso. P a p p u s conformis, uniserialis, setis apice elavellatis, - Suffrutex insulae Diemen; ramulis angulatis, folits alternis, obovato - cuneatis, brevissime subpetiolatis, obtusis, inlegerrimis, uninerviis, coriaceis, subtus subcandicantibus, capitulis in paniculas breves, oligocephalas, bracteolatas, ramos terminantes dispositis, floribus pallidis.

Sw ammerdatnia DC. Prodr. NT. 164.

2\%38. Dzothamans $R$. BR. Cap itu. I $\mathrm{m}$ pauci-pluriflorum, homogamum. Invo Iucri imbricati squamae scariosae, saepius obtusae, inti- 
mae saepe coloratae. R e e pt a c n ln m epaleatum, alveolatum v. saepius omnino nudum. Corolla e tubulosae, quinquedentatae. Anthera e basi bisetae. Stigmata apice subinerassata. A chenia obovata. Pa p pi uniseriati setae filiformes, scabrae, barba apicis longiore facie prima subelavatae. Frutices Novae-Hollandiae et insulae Diemen; foliis alternis, confertis, sessilibus, coriaceis, saepius elongatis, margine revolutis, subtus tomen tosis, corymbis terminalibus compositis, involucris ulbis v. subferrugineis, corollis luteis, pappo albo.

$0 \mathrm{z}$ ot ha mu $\mathrm{s}$ R. Brown in Linn, Transact, XII. 125. DC. Prodr, VT. 164.

a. FAestula DC. $l$. c. Capitnlum submultiflorum. Receptacul um epaleatum, alveolato-fimbrilliferum. Involucrum florihus aequale, imbricatum, squamis adpressis, lanatis, appendice scariesa, glabra. A chenia obovoidea, pilis longis, nitidis, apice bifidis onusta.

$\mathrm{F}$ a u $\mathrm{s} \mathrm{t}$ u $\mathrm{l}$ a Cassini in Dict. se. nat, XVT, $25 t$. Chrysocoma reticulata Labillard. Nov. Holl. t. 183.

b. PETALOLEPIS DC. l. c. Capitulum pauciflorum. Receptaculum angustum, nudum. Involucrum imbricatum, seariosum, floribus panllo longius, squamis intimis apice coloratis, obtusis, radiantibus.

Petalolep is Cassini in Bullet. soc. philom.1817. p. 138. Dict, sc, nat. XXIII, 562, XXIX, 194, non Lessing. R u pat orif s p. Labillard. Nov. Holl. t.180,181. Chrys oc om a e s p. Labillard. Op. cit. t, 189.

c. EUOzoThamNUS DC. $\boldsymbol{l}$. c. C a pitul u m paueiflorum. Re e ptaculum angustum, nudum. I avolucri sub. glohosi squamae apice conniventes.

0 o oth a m n s Cassini in Dict, sc. nat. XXIII.569. XXXIX, 196.

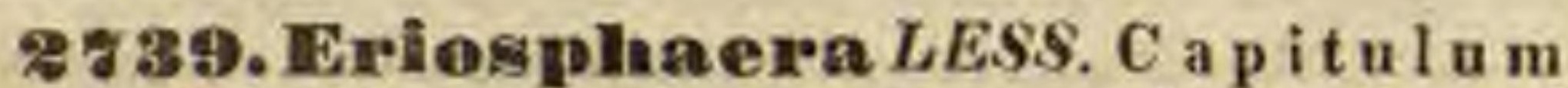
decem-vigintiflorum, homogamum. I n vo I u c r i pauciseriati, tomento densissimo involuti squamae lineares, integrae. Co roll a e tubulosae, teretes, glabrae, limbo quinquedentato. Anth era e basi bisetae. Stigm a $t$ a apice subinerassata. A $\mathbf{c h}$ en i obovato-subangulata, minute papulosa. P a p pi piliformis, cadueissimi setae apice longius barbellatae fere dolabriformes. - Herbae capenses, suffruticosae, dense lanatae; foliis obovatis v. spathulatooblongis, planis, obtusis, submucronatis, capitulis congestis, lana intermixta obvallatis, corollis luteis.

Eriosphaera Lessing Synops. 270. DC. Prodr. VI. 166. Gnaphalinm 0 eulas Cati Lina. f.

अ 40 . Theomtonyx CASS. Cap itn $1 \mathrm{~nm}$ viginti-trigintiflorum, discoideum, homogamum v. heterogamum, floribus marginalibus paucis, femineis, reliquis hermaphroditis. Invo Ineri ovatocylindracei, imbricati squamae exteriores tomentoso-lanatae, interiores elongatae, sicco-membranaceae, rigidae, uncinato- v. spiraliter flexae, coloratae. Re e p t a e $\mathrm{tum}$ planum, nudum. CorolIa e tubnlosae, limbo quinquedentato. A n thera e basi bisetae. Stigm at a ..... A ehenia sessilia, erostria, scabra, areola terminali. $\mathbf{P}$ a p p u biseriatus, eapillaris, tenuissimus, corollam aequans. Fruticuli sive herbae capenses, humiles, lanatotomentosae; foliis alternis, sessilibus, basi angustatis, membranaceis, capitulis ad apices ramorum glomeratis.

Le ontony $\mathrm{x}$ Cassini in Diet. se. nat, $\mathrm{XX} Y$, 466. Ises. sing Synops, 325. DC, Prodr, VT, 167. S piratepis Don in Mém, Wern. soe, $V$. 551. G a ph alli sp. Linn. Jaco. Fragm. $2,3, f .4$.

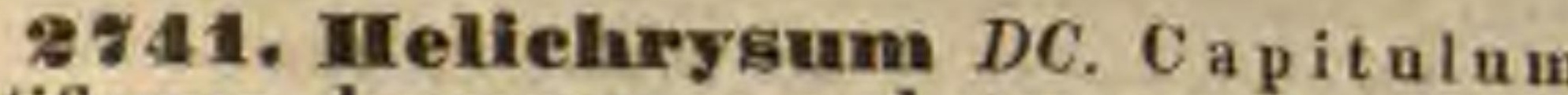
multiflorum, homogamum v. heterogamum, floribus marginalibus nniseriatis, saepe paucissimis, gracilibus, femineis, reliquis hermaphroditis. In- vol ucri imbricati squamae scariosae, interiores conniventes v. radiantes. Recepta e $\mathbf{l} \mathbf{u}$ m planum, epaleatum, nunc nudum v. areolatum, nune fimbrilliferum. Corolla e tubrlosae, femineae fere filiformes, limbo quinquedentato. An therae basi bisetae. Stigmata exserta, apice vix incras sata. A ch en ia sessilia, erostria, areola terminali. P a p i uniseriati setae subscabrae $\mathbf{v}$. apice barba tae, nunc liberae, nunc basi aequaliter eoncretae, nunc inaequaliter subcoadunatae $v$. ramosae.

Herbae v. suffrutices gerontogei, imprimis c ape $n$ $s e s$; foliis alternis, involucris albis, purpureis $v$ flavis, corollis luteis v. purpureis.

Helichrysum DC. Prodr. VI. 169. Heliehrysum et Lepfeline Cassini in Dict, sc. nat, XX, 4i9. XXVT. 19 . He I i. e bry si s n bgenera $1-3,5,9$, Lessing Synops, 274_324. Helichrysisp. Vaillaut et Auct. Guapha Iii sp. Liun. a. EuHelichrysum DC. Prodr. VT, 169. Re ceptac u. lum nudam. P a p i setae subseabrae.

Heli c hry s u m Gärtuer II. 404, Cassini in Dict. sc. nat. XX. 449. Don Mém, Wern, soc. V. 17. Lessing Synops. 274. A n a xe to n Gärta. II. 406, t. 166. Lam. t. 0992. Argyrucome Gärtn. 11 . 410. t. 167. Lam. t. 693. Guaphalif s p. Auet. Audr. Bot. Reposit. t. 489. Bot. Mag. $t, 1987,2328$, Bot. Reg. $t$. 243, Xe ran $t$ hem i s p. Jarq. Ic. rar. $t, 173$. Lahillard. Syr. Dec, $I T, t, t_{\text {. }}$ Audr. Bot. Reposit, t. 387. Vent. Malm, II. t, 2. Bot. Mag. t. 414. A stelmatis s p. Bot. Reg. t. 726. (Labillard. Nov. Holl, t. 190. 192. Bot. Mag. t. 1773. 1814.)

b. BLEPhAROLEPIS DC. Prodr. DI. 193. R e e p ta e uI u nudum. Pappi setae per totam longitudinem scabrae v. apice barbatae.

G n a p halli sp. Labillard. Nov, Holl, t, 187. 188. Bot. Reg. t. 29o. (Labillard. Op. cit, t. 191.)

e. TAXOSTICHE DC. Prodr. VI, 196. Re ceptaculum fimbrilliferum v. areolatum. P a p pi setae seabrae.

Pentataxis Don in Mem. Wern. soc. $V$. 550.

d. LEPICLINE DC. Prodr. VI. 197. R e e ptacula m paleaceo-fimbrilliferum. P a p pl setae scabrae.

Le pieline Cassini in Bullet. soc, philomat. 1818. p. 31, Dict. sc. nat. XXVI. 49. L ep icli n e et E recie i ph y 11 u messing Synops. 296 et 312. Euehloris Dou in Mém. Wern. soc. $\nu$. sas.

e. Chionostemia DC. Prodr. $V I$. 209. Receptaculi fimbrillae paleaceae liberae, ovaria superantes. P a p pi paleae basi varie inter se coneretae, seabrae, apice vix crassiores.

Le ucostem a Don in Mém. Wern. soc. $\mathcal{T}$, sio, non Benth. - Lessing Synops. 314. Xeranthemi s p. Linn. Andr. Bot. Reposit, t, 384.

2\% 4. Helipterum $D C$, Cap itu $1 \mathrm{um}$ multiflorum, discoifleum, homogamum, floribus omnibus hermaphroditis, rarissime floribus centra. libus abortivis heterogamum. Involu er i imbricati squamae seariosae, interiores conniventes $v$. radiantes. $R$ ece ptac $\mathbf{l} \mathbf{l} \mathrm{m}$ nudum $v$. alveolatum sive fimbrilliferum. Co roll a e tubulosae, limbo quinquedentato. Anthera e basi bisetae. Stigm a ta exserta, obtusiuscula. A chenia sessilia, erostria, areola terminali. $\mathbf{P}$ a p p setae uniseriatae, plumosae, liberae v. basi connatae. Herbae v. suffrutices, in $C$ a $p$ it $e$ bonae spe $i$ et in Nova-Hollandia indigeni; facie Helichrysi, involucris albis $v$. flavis.

Helipteram DC. Prodr. VI. 211. Argyrocome Gärtuer $I T$. 410. quoad charact. exel. sp. nec alíor. Helie brys i s p. Auct.

a. ASTELMA DC. Prodr. NT, 211. C a pit u la homogama. I avolucrum imbricatum, coanlveus v, radians. R eceptaculu a convexum, alveolatum. Antherarum setae plumosae. Stigmata lineari-ligulata, obtusa. Pa p p us radiis plumosis, basi counatis. - Capenses.

AsteIma Lessing Synops. 315. Argyracome Schrank in Act. Academ, Monac. VIII, 146. non Cass. 
D a mirou i a Cassini in Dict. sc. nat. LVT. 224. LX. 588. Astel un atis 8 p. R. Brown in Bol. Reg. $t$. 539 . Don in Mém. Wern. soc, $\mathcal{V}$. s42, Xera nthem i $s \mathrm{p}$. Liun. Andr. Bot. Heposit, t, 51. G a a p hallit s p. Linn. Bot. Mag. 2 . 300. He li c hrys i s p. Willd. Audr. Bot. Reposit. $t .262$.

b. SYNCARPHA DC. Prodr. VI. 213. Capitula homo. gama. Involueri ovati squamae imbricatae, apice in ligulam membranaceam, triangularem, acuminatam, reflexam productae. Receptacu I u m planum, alveolatum, alveolis ovaria subsuperantibus, e fimbrillis coria. ceis, inter se connatis. A $n$th er a $r$ am caudae barbatae. $\mathrm{S} t \mathrm{i} g \mathrm{mat}$ a longa, extus arcuata. A $\mathrm{ch}$ en $\mathrm{i}$ a papillosa. - Capenses.

$\mathrm{S}$ y nearpha DC. in Annal. Mus, XVI. 225. $t .8$. f. 13. Cassini in Dict. sc, nat. LI. 462. - Lessiug Synops.321 -? Ro e cardi a e s p. Necker elem, n, 132. Staehelinag naphaloides Linn. Gnaphaliam modestum Hooker in Bot. Mag. $t$. 2710.

c. EDMONDIA DC. Prodr. VI, 214. Ca pitula homogaua. I nvol u eri eampanulati squamae imbricatae, seariosae, radiantes. R e cep $t \mathrm{ac} u \perp \mathrm{a} m$ planiusculum, fimbrilis paleaceis v, setiformibus, deciduis persistentibusve, liberis nec in alveolos concretis. Antberarum setae plumosae. P a p p a s dense et breviter barbellatus. - Capenses.

$\mathrm{E} d \mathrm{moudia}$ Cassiai in Dict. se. nat. XIV. 288. Lessiug Synops. 321. A phelexis Don in Mém, Worn. soc. V.546, non Boj. X e raut h e u $\mathrm{m}$ Necher elem, $n$. 150. Xera nt he m i s p. Linn. Andr. Bot. Heposit, t.242. 279. 659. Bot. Mag. $t$. 425 . Helichrysi sp. Willd. Loddig. Bot. Cab. t. $59,1954$.

d. LEUCOCHRXSUM DC, Prodr. VI, 215, C a pit a Ia homogama. Invol u cri squamae stipitatae, ad apicena stipitis lanato-ciliatae. R e cept a cu l um nudum. A chen ia glabra. P appus plumosus. - Suffrutices a $u s$. tralasici.

LEIOCHRYSUM DC. Prodr, VI. 216. Capitula homogama. Involucri squamae basi hyalinae, haud ciliatae nec angustatae. Re c e pta cu l u m nudum. A che. ni a puberula, - Herbae a ustralasicae, annuae, Glabrae.

f. SERICOPHORUM DC. Prodr, VI, 216. Cap it u la floribus marginalibus fertilibus, centralibus interdum abortivis heterogama. I nvol u cri imbricati, scariosi squa. mae intimae elongatae, petaloideae, coloratae, ciliatae. A ntherarum setae imberbes. A ehenia adpresse sericea, villis superioribus pappum exteriorem calyeulfformem nentieutibus. Pa p pi setae dense plumosae. Herbae $v$. suffrutices a stralasiei.

Heliehry $8 \mathrm{um}$ Gaudichaud ad Frejc. 465. $t$. 87. 88.

27 43. Aplielexis BOJ. Ca pitulum homogamum, panci-multiflorum. Invol neri pauciseriati squamae disco longiores, basi virescentifuscae, in appendicem lineari-lanceolatam productae. Receptaculum vix alveolatum. Corollae tubulosae, limbo quinquedentato. Anthera e basi breviter bisetae. St igmat a ....... A chen ía sessilia, erostria, areola terminali. P a p p i setae filiformes, apice summo paucilyarbellatae, basi distinetae v. subeonsretae. - Fruticuli madagascarienses, ericoidei; capitulis terminalibus, solitariis v. pluribus.

Aphelexis Bojer mse. ex DC. Prodr. VI. 217. Freeu a $\mathrm{i}$ i Bojer msc.

2844. Stenoeline DC. Capitulum uni-quinqueflorum, homogamum, oblongum. Involncri squamae paucae, erectae, oblongae, hand imbrieatae. Recepta $\mathrm{cu}$ l $\mathbf{n} \mathrm{m}$ angustissimum, nudum. Co rolla e tubulosae, quinquedentatae. A nthe ra e basi bisetae. Stigmat a obtusa. A chenia oblonga. Pap u s uniserialis, setis filiformibus v. sublamellatis. - Herbae v. suffrutices, madagascarienses et brasilienses; foliis alternis, lanceolatis $v$, linearibus, capitulis ut plurimum ternato-fasciculatis, fasciculis in corymbum compositum dispositis, involucris albis v. subjlavescentibus.
Stenocline DC. Prodr. VT. 218.

a. TRiCephaLUM DC. $l$. c. Capitula uni-triflora. Involueri squamae interiores snbscariosae. A chenia oblonga. Pappus pilosus. - Herbae mada as carienses; folits oblongis $v$. lanccolatis, capitulis parvis, albido-subflavidis, ad apices ramulorum co. rymbi compositi ternis, sessilibus, ovalibus s. obova. tis, bracteis extus subinvolutis $v$, nudis.

b. EUSTENOCLINE DC. $l$. $c$. C a p it $\mathrm{l}$ a tri - quadriflora. Involucri squamae oblongae, erectae, subaequales. obtusiusculae. A chenia oblonga v. obovata. Pappi setae superne plano-lamellatae, subeiliatae. - Herbae madagasoarienses, erectae; folitis linearibus $v$. lanceolatis, capitulis confertis, subglomerato-corymbosis, involueris niveis.

c.? CHIONOLEPIS DC. $l$. c. Capitula quadri-quinqueflora. Involucri squamae oblongae, niveae, haud vere imbricatae. A chenia oblonga. Pappus pilosus. Herba brasiliensis; caule tomentoso, folits lan. ceolatis, supra glabris, subtus tomentosis, capitulis corymbi compositi fascieulato-congestis, bracteis ca. pitulis proximis involucri squamas referentibus.

8ร 45. Aclayroeline $D C$. CapituIum subquinqueflorum, tenue, cylindricum, heterogamum, floribus exterioribus tribus v. quatuor femineis, intimis duobus v. unico hermaphroditis. Invel u eri imbricati squamae scariosae. Coroll ae tubulosae, quinquedentatae. Anthera e hasi bisetae. Stigmata obtusa. A e he $\mathrm{n}$ i a oblonga. Pa p u s uniserialis, scabridns. - Suffrutices a mericani tropici; foliis allernis, sessilibus v. decurrentibus, linearibus v. oblongo-lanceolatis, saepius tomentosis, capitulis in corymbum compositum dispositis, involucris flavescentibus $v$. rufis.

A eb yracline DC. Prodr. VI. 219. Gnaphalii sp. sectio 1. Kunth in Humb. et Bonpl. Nov, gen,el sp, t, 329.

2 \% 46. Gmaplaaliomen DON. Ca p it u l u m multiflorum, heterogamum, discoideam, floribns marginis uni-pluriseriatis, tennissimis, femineis, centralibus hermaphroditis. Involucri ovati, discum aequantis squamae imbrieatae, adpressae, subhyalinac. Receptaculum planum, nudum. Cor o 11 a e femineae tenuissimae, hermaphroditae tubulosae, limbo quinquedentato. Anthera e basi bisetae. Stigmata obtusa. A ehenia teretia v. teretiusenla, rarins obcompressa, subpapillissa. P a p p s conformis, uniseriatus, setis filiformilus, vix scabridis. - Herbae rarissime suffrutescentes, plus minus lanatae $v$. tomentosae, per $t$ ot $u m$ or be $m$ dispersae, in America et in Capite bonac s pei ut videtur frequentiores; foliis sessilibus v. decurrentibus, saepissime mollibus, capitulis in glomerulos terminales $v$, axillares, fasciculatos, corymbosos v. spicatos dispositis, involucri squamis albidis, rufis, purpureis $v$. flavis.

G napha ll a m Don in Mém. Wern. soc. $V .563$. G n a. plia IIi sect. Lessing Synops, 328. Griaphalium et 0 malotheca DC. Prodr. VI. 221, et 245.

a. EUgNapHalium DC. Prodr. VT, 228, Fla re 8 feminei pluriseriales. A chen ia teretiuscula.

G naph a li um Cassini in Dict. sc. nat, XIX, 119 (FI. dan. t. 254. $859,1229$. E. B. $t$. 923. 1194. Delile Ft. aegypt, $t, 44$. f. 1. 2. Selirank Hort. Mtonac, $t, 84$.)

b. EUCHITON DC. Prodr. DT, 235. Flo res feminei plu riseriales. A c hen ia subcompressa.

Euchiton Cassini in Dict. sc, nat, LVT, 214, (Lsbillard. Nov, Holl, $t, 189$, Bot. Mag. $t$. 2582.)

c. HomalothecA, Fiores feminei uniseriales. A cheni a obcompressa, obovoidea.

0 malotheca Cassini in Dict. se. nat. LVI. 218. DC. Prodr. VI. 245. G naptralium supisum VIII. E. B. $t, 1193$.

2ร4ช. Cladoelhaeta $D C$. Capitulum multiflorum, homogamum. Inv o l ueri eylindracei 
squamae obtnsae, dorso velntinae, margine scariosae, intimae discnm aequantes. Re e p tacul u m planum, brevissime fimbrilliferum. Corollae tubulosae, quinquedentatae. Antherae basi bisetae. Stigmata apice hispidula. A chenia teretiuscula. $\mathrm{Pap}$ p $\mathrm{i}$ setae uniseriatae, basi in fasciculos seorsim deciduos concretae. _Herba caucasica, gracilis, niveo tomentosa; foliis alternis, sessilibus, oblongis, obtusis, enerviis, integerrimis, summis linearibus, corymbo terminali polycephalo, capitulis breviter pedicellatis.

Cladochaeta DC. Prodr, VI. 245. Graphaliam candidiss im a m Bieberst.

28.48. Fteropogon $D C$. Capitulum panciflorum, heterogamum, floribus omnibus tobulosis, exterioribus duobns femineis, centralibus duobus v. tribus ovario efoeto masculis. Involuori oblongi squamae septenae-octonae, oblongae, glabrae, scariosae, conniventes, intimae paullo longiores. Receptaculum angustum, epaleatum. Corollac tubulosae, quinquedentatae. Anthera e..... Stigmata ....... A chenia exteriora obovata, tecta villis sericeis confertissimis, superioribus achenio longioribus, pappum exteriorem simulantibus, interiora abortiva. $\mathrm{P}$ a $\mathrm{p}$ pi uniseriati setae paucae, dense et conferte plumosae. - Herba Novae-Hollandiae orientalis interioris; caulibus e collo pluribus, erectis, tenuibus, apice pubescentibus, foliis infimis oppositis, reliquis alternis, lineari-subulatis, acutis, sessilibus, superioribus araneoso-pubescentibus, capitulis in corymbum terminalem, foliis cinctum confertis, sessilibus, involucri squamis exterioribus fuscis, intimis apice lacteis.

Pteropogon DC. Prodr. VT. 245.

2848. IAasiopogon CASS. C a p itu lum mnltiflorum, heterogamum, floribus omnibus tubulosis, marginalibus uni-pauciseriatis, femineis, centralibus hermaphroditis. Involueri bracteis foliaceis stipati squamae uni-biseriatae, apice subhyalinae, disco paullo longiores. Rece ptacu $1 \mathbf{n}$ m planum, nudum. Co roll a e tubulosae, femineae tennissimae, hermaphroditae ampliores, quadriquinquedentatae. Antherae basi bisetae. Stigmat a obtusiuscula. A chenia obovalia, subcompressa, glabra. P a p i uniseriati setae longissime plumosae. - Herbae in Africaboreali et a ustrali indigenae, diffuso-ramosissimae, caespitosae, pusillae, annuae; foliis sparsis, anguste spathulatis v. linearibus, capitulis confertis, glomeratis.

L a 810 pogon Cassini in Bullet. soe. philomat. 1818. p. 75. Diet, sc, nat. $\mathrm{XX} V .302$. DC. Prodr. VI. 246 Gnam platii sectio 3. Lessing Synops. 332. Gnaphalium muscoides Desfont. Flor, atl. $t, 231$.

ะชัด. Amplaidoxa $D C$. C a p itulum multiflorum, heterogamum, floribus omnibus tubulosis, marginalibus pluriseriatis. femineis, centralibus hermaphroditis. In vol u ex i campannlati squamae imbricatae, exteriores adpressae, hyalino-rufescentes, interiores in appendicem albam, ovalem, obtusam productae, parce radiantes. R eceptaculnm planum, nudum. Corollae femineae tenuissimae, hermaphroditae, amplius tubulosae, quinquedentatae. Antherac basi bisetae. Stigmata...... A e henia oblonga. Pappus radii nullus, di 8 ci setosus, setis quinis-senis cadu. cissimis, apice barbellatis, subelavellatis. - Herba capensis, ramosa, basi indurata, apice lanata; folits alternis, sessilibus, oblongis, apice obovatis, muerone calloso superatis, complicatis, subundulatis, utrinque lanato-sericeis, capitulis ad apices ramorum subcongestis, breviter pedicellatis.

Ampli i oxa DC. Prodr. FI. 246.

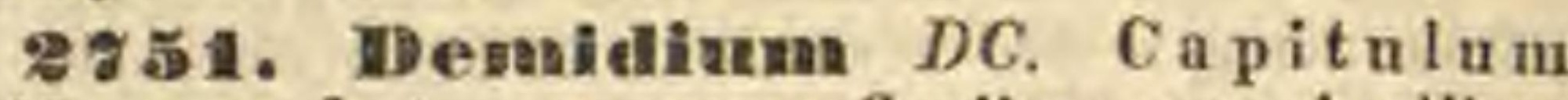
multiflorum, heterogamum, floribus marginalibus pluriseriatis, filiformibus, femineis, disci tubulosis, masculis. Involueri campanulati squamae unibiseriatae. Receptacula m planum, nudum. Corolla e femineae filiformes, masculae tubulosae, quinquedentatae. Antherae .... St ig mata...... A $c$ lienia radii oblonga, tetragonoteretinscula, pilis minimis submuriculata; disei gracilia abortiva. P a p us nullus. - Herba madagascariensis, humillima, multicaulis, molli. ter hirsutula, Filaginis gallicae facie; foliis alternis, linearibus, acutiusculis, capitulis parvis, fuscis, in axillis superioribus $v$, in apice ramorum subsessilibus, parce aggregatis.

Demidium DC. Prodr, $\nu x, 246$.

ะ ร5\%. Fillagอ TOURNEF. Ca pitulum multiflorum, heterogamum, receptaculo elongato-filiformi, vix apice dilatato, in vo I u eri squamis imbricatis, nee a receptaculi paleis distinctis, exterioribus dorso lanatis, reliquis scariosis. Flo$r$ es intra receptaculi paleas axillares, solitarii, feminei, terminales plurimi, exteriores feminei, centrales hermaphroditi v, abortu masculi. Coro Il a e femineae filiformes, apice vix dentatae, hermaphroditae tubulosae, quadri-quinquedentatae. An $\mathbf{t}$ h erae caudatac. Stigmata obtusiuscula. A $\mathrm{ch}$ enia te. retia, subpapillosa. Pap p us florum centralium setis filiformibus, marginalium nullns v. dissimilis.

Herbae europeae, annuae, plus minusve tomentosae, saepius ramosae; foliis alternis, integerrimis, capitulis in axillis foliorum $v$. ad apices ramorum aggregatis.

Filago Tournefort inst.259. Vaillant in Act. Academ. Paris. 1719. p. 296. Linn. sp. 1311. excl. sp. 1, et 7. Gärtuer II. 404. Mónch Method. S76. DC. Prodr. VI. 247, non Cass. et Less. G n a ph a I ii s p. Auct.

a. GIFOLA DC. Prodr. VI. 247. C a pitula subpentagona. Flores feminei inter squamas quintuplici ordine dispositas siti. Pappus florum extimorum nullus, terminalium tam femineorom quam hermaphroditorum uniserialis. - Capitula in glomerulum globosum coacer. vata.

G if ol a Cassini in Bullet. soc. philomat. 1819. p. 143. Dict. sc. nat. XVIII. 531. Lessing Synops. 433. I up i a Dodon. Pempt. 67. Bluff et Fingerli. Flor. germ. II. 349. Gnaphalii sectio 2. Reichenb. Flor. Germ. II. 293. (Gärtner t, 166. Gussone Plant, rar, t. 69.)

b. OGLIFA DC. Prodr. VI, 298. Capitula pyramidata v, ovoidea. Flores feminei exteriores uni-biseriales, inter squamas involucri dispositi. P a p p us florum exteriorum caducissimus, úniserialis, centralium tam fe. mineorum quam hermaphroditornm pluriserialis. - $\mathrm{Ca}$. pitula aggregata, subspicata $v$. fasciculata, rarius solitaria.

$0 \mathrm{~g}$ I if a Lessing Synops. 333. O glifa et Logfia Cassini in Bullet, soc, philomat. 1819. p. 143. $\Lambda \mathrm{c} \mathrm{h}$ ariteri u m et Xerotiu m Bluff et Fingerh. Flor. germ. II. 343. et 345. G n a p a lil s e ctio 1. Reichenb. Flor. germ. II. 228. Gu a h alli sp. Flor. dan. $t$. 1275. E. B. $t, 1157.2369$.

2\%53. Fletalasia $R, B R$. Capitulnm pauciflorum, homogamum. Involucri pauciseriati squamae imbricatae, intimae longiores, apice saepe dilatatae, coloratae. Receptacul um totum nudum. Corolla tubulosae, limbo quinquedentato. Antherae basi bisetae. Stigmata obtusiuscula. A e he nia juniora utrinque basi in stipitem, apice in rostrum attenuata, pellueida, maiura subsessilia et erostria, semper glabra. $\mathbf{P}$ a $\mathbf{p}^{-}$ 
p n s uniserialis, paucisetus, setis seorsim deciduis, apice incrassatis, subdenticulatis. - Frutices capenses, erecti; ramis teretibus, saepe tomentosis, ad capitula usque aequaliter foliatis, foliis sparsis, sessilibus, coriaceis, linearibus v. oblongis, supra marginibus involutis concavis, subtus convexis, nitidis, glabris, plerisque spiraliter tortis, capitulis cy lindricis, in glomerulos corymbosos aggregalis, involucri squamis interioribus albis, purpureis $v$. rarius flavis, corollis purpureis v. albidis.

M eta lasia R. Brown in Linn. Transact. XII. 124. Don in Mem. Werner. Soc. $\nu$. 556 . Lessing Synops. 334, exel. sp. Eadole uca et M etalasia Cassini in Dict. sc. not. XIV. 474, XXX. 229. Hellehrysi sect. Lessing in Lin. naea $V T$. 223. G a a phalif sp. Linn. Thuab.

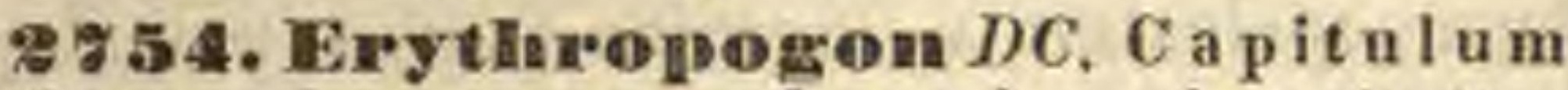
pluriflorum, homogamm. Invo l u eri ovato-turbinati squamae pluriseriales, imbricatae, linearilanceolatae, appendice scariosa, colorata subradiantes. Recepta $\mathrm{eu} I \mathrm{~nm}$ planum, nudum. Coroll a c tubulosae limbo quinquedentato. Antherae basi hisetae. Stigmata obtusiuscula. A chenia etiam juniora, sessilia, erostria, glabra. P a ppi uniseriati setae scabrae, apice haud incrassatae. - Suffrutices capenses; folits alternis, coriaceis, parvis, mucronatis, supra cano-tomentosis, subtus glabris, enerviis, capitulis tribus ad septem, pedicellatis, umbellatis, involucrorum appendicibus et corollis purpurascentibus v. albis, pappo intense purpureo.

Erythropogon DC. Prodr. VI. 25\%. Metalasiae sp. Don. Xeranthemi sp. Lam. Argyrocomes sp. Lam. $t .693 . f .3$.

2 855. Laelnmospermann $W I L L D, \mathrm{Ca}$ pitulum multiflorum, homogamum. Involucri turbinati squamae imbricatae, adpressae, ovales, acumine subpungente, erectiusculo. R e c pt a c uli ambitus paleis paucis, linearibus onustus. Corollae tubulosae, quinquedentatae. Antherae eaudatae. Stigmata apice penicillata. A chenia obloaga, angulata, juniora ad angulos tantum villosa, demum tota fere hirsuta. P a p p s biserialis, setis pilosis, corollam paullo superantibus. - Frutex capensis; ramis divaricatis, rigidis, tomentosis, foliis parvis, ad axillas fasciculatis, teretiusculis, obtusis, tomento supra obduct is, ut in Metalasia fortilibus, sed brevioribus, capitulis terminalibus, solitariis, rarius geminatis $v$. ternis, breve pedunculatis.

L a ch no s perm u m Willenow $S p$. HI. 1787. Cassini in Dict. sc. nat. XXV. 51. Lessing S)nops. 349. DC. Prodr. VI. 255. C a r phol o m a Don in Mem. Werner. Soc, V. 855. Staehelinae sp. Thunb. Serratulae sp. Poir.

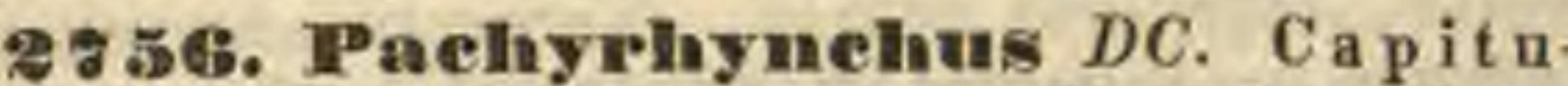
l u m decemflorum, homogamum. Invol u cri tereti-oblongi, bracteis brevibus foliaceis, villosocanis stipati squamae elongatae, scariosae, nitidae, glabrae, lineares, acutae, demum patulae. R eceptacnI um planum, nudum. Coroll a e tubulosae, limbo quinquedentato. Antherae ...... Stig $\mathrm{m}$ a $\mathrm{t}$........ A chenia sessilia, ovata, villosissima, rostro glabro, crasso superata, Pap p as pi loso-setaceus, setis vix scabris, pluriserialibus, co rolla longioribus. - Suffrutex capens is, ramosus, erectus, totus capitulis exceptis villoso-tomentosus, canescens; foliis sessilibus, lanceolatis v. oblongis, calloso-apiculatis, integerrimis, confertiusculis, subimbricatis, involucris stramineis.

P a cb y rhynehus DC. Prodr. V1. 285.

285\%. Elytropappas CASS. Capitu$1 \mathrm{um} \mathrm{bi-octoflorum,} \mathrm{homogamum.} \mathrm{Involucri}$ squamae oblongae, pauciseriales, mucronatae $\mathbf{v}$. seuminatae. Receptaculum planum, nudum. Corolla e tubulosae, limbo quinquedentato. A ntherae caudatae. Stigmata apice penicillata. A chenia sessilia, erostria. Pappi setae plures, basi in annulum deciduum connatae, margine co roniformi, brevi, subintegerrimo calyculatae, infra nudae, apice plumosac. - Fruticuli capenses, ramosissimi, erecti; foliis sparsis, saepe spiraliter tortis, pilis glandulosis plus minus exasperatis, intus semper tomento persistente vestilis, marginibus plus minus inflexis, capitulis ad axillas foliorum superiorum sessilibus $v$, subsessilibus, solitariis v, paucissimis, spicato-racemosis.

Elytropappus Cassini in Bullet, soc, philom, 1816. p. 199. Dict. sc. nat, XIV. 376. Lessiug Synops. 369. DC. Prodr. VI. 256, Guaphalii, Stoebes et Seriphii sp. Auct.

2ร ร. Disparago $G \ddot{A} R T N$. Cap itulu m biflorum, heterogamum, flore altero ligulato, femineo v. neutro, altero tubuloso, hermaphrodito. Inv o lucri oblongi squamae pauciseriales, sublineares, mucronatae, scariosae, glabrae. R e c e p t a c u$1 \mathrm{um}$ angustum, nudum $\mathrm{v}$, inter flores paleolatum. Corolla e ligulatae, tubo longo, ligula brevi ovali, integerrima v. bidentata, tubulosa, limbo quinquedentato. Anthera e brevissime bicaudatae. Stigmat a obtusa. A $\mathbf{c h}$ enia oblonga, erostria. Papp u q quinque-multisetus, setis basi coriaceis, nudis, apice plumosis, rarius basi margine coroniformi cinctus, florum ligulatorum saepe depanperatus v, nullus. - Fruticuli capenses, ericoidei; foliis spiraliter dispositis, saepe tortis, confertis, sessilibus, lineari-subulatis, acuminato-mucronatis, intus et saepius utrinque tomentosis, capitulis in glomerulum terminalem subrotundum, bracteatum dense aggregatis, corollis purpureis $v$. albis.

D i s p a r a go Gärtner II. 463. Cassini in Dict. sc, nat. XIIT, 348, XXIII. 563. XXXIV. 42. DC. Prodr. VI. 257. WIga n di a Necker elem, $n$, 172. non Kunth.

a. DISPARELLA DC. l. c. R e e p ta culi squamae v. pa. leae inter flores plures. $F$ los ligulatus femineus. A c h enIa glabra. Pappus conformis, quinquesetus, submarginatos.

Disparago Gärtaer t. 173. Lessing Synops. 362.

b. LEIACHENA DC. $t$. c. Recepta $\mathrm{c}$ a 1 u m nudum. FIos ligulatus neuter, A o be n i glabesrima. Papp ns floris hermaphroditi quinquesetus, neatri nullas.

c. STEIRocoma DC. l. c. Receptaculum nudum. Flos ligulatus neuter. A che nía tomentosa. Papp us floris hermaphroditi multi- $(15$-20) setas, basi nudus, neutri depauperatus, quadri-quinquesetus.

d, STEIROSTILPNA DC. $l$. $c$, Re e p tacu $\mathrm{l}$ m nudum. Flos ligulatus neuter. A e h e f a tomentosa, villis pappi basim cireumdantibus. Pa p p us floris hermaphroditi multi- $(15-20)$ setus, neutri nullus.

W i g a u dir Lessing Synops. 362.

2959. Amplniglossa $D C$. Capitu $\mathrm{um}$ tri-multiflorum, homogamum v. heterogamum, floribus radii paucis, ligulatis, femineis, disei tubulosis, hermaphroditis. Invo I u eri cylindracei squamae imbricatae. Re e p ta $\mathbf{c u l u m}$ nudum. Corolla ra di ligulatae, ligula angustissima, discum saepius haud superante; dis ci tubulosae, limbo quinquedentato. Antherae ...... Stigmata.... A chenia sessilia, erostria, glabra. Pappus conformis, uniserialis, deciduus, basi margine brevissimo cinctus, setis a basi ad apicem longe et. confertim plumosis. - Suffrutices ca p ens es, ramosissimi, erecti $v$. decumbentes; ramis interdum spinescentibus, glabriusculis, foliis sparsis, confertis, coriaceis, extus convexis, glaberrimis, laevibus, intus subconcavis, albo-tomentosis, capitulis parvis, ramos terminantibus, supra ultima folia sessilibus. 
A mp higlossa DC. Prodr, VI, 258.

a. AGLOSSA DC. l. c. C apitula tri-quinqueflora, homogama.

b. LEPTOGLOSSA DC. 1 . o. C a pit u 1 a sex-duodecimflora, heterogama, floribus radii duobus v. tribus, minutissime ligulatis, disenm haud supesantibus.

c. PHAENoglosSA DC. $l$. $c$. C a p it u 1 a novemflora, floribus radil tribus, ligulatis, revolutis, discum superantibus.

DIVISID IV. SERIPHIEAE DC. Prodr. VI. 259. Capitula uniflora, libera v. in glomerulum, involucro generali nunquam tamen cinctum, aggregata.

2\% BD. Stoeloe LESS. Capitulnm uniflorum. Involncri squamae oblongae, imbricatae, siceo-membranaceae, florem aequantes. $R$ eceptaculum punctiforme. Corolla tubulosa, limbo quinquedentato. Antherae basi bisetae. Stigmata apice solo penicillata. A eheni $\mathbf{u m}$ oblongum v, cylindricum. P a p $\mathrm{i}$ extus margine coroniformi brevissimo, persistente stipati paleae plurimae, longae, uniseriales, basi annulatae, inferne nudae, apice plumosae. - Fruticuli c a penses; ramis terelibus, foliis confertis, spiraliter dispositis saepiusque spiraliter tortis, corcavis, subulatis, junioribus imprimis supra tomentosis, adultis glabratis, capitulis in glomerulos densos, subglobosos $v$. spiciformes collectis.

S to ebe Lessing Synops. 345. DC. Prodr. VI. 259. Stoebes et Seriphil sp. Auct.

a. EUSTOEBR Cassiai in Dict, sc, nat, LI, 60. A the $\mathrm{n}$ ia oblonga, subteretia v. subtetragona, glabra v. brevissime tomentosa, nunquaw in angulis dentato-serrata. - Capitula in glomerulum globosum v. oblongum dense congesta.

b. ALOPECUR01DES DC. Prodr. $V T$. 260. A e benta eylindracea, suleati, glabra, eminentiis apice argute serratis. $\mathrm{P}$ a p pi setae basi magis distinctae. - Glomeruli longe spicati.

2\%61. Serplphimun LESS. Capitulum uniftorum. Involucri squamae imbricatae, interiores longiores, sicco-membranaceae. R e e p t acul um punetiforme. Corolla tubulosa, limbo quinquedentate. Antherae basi bisetae. Stigmat a apice solo penieillata. A chenium oblon gum v, eylindricum, P a p i uniserialis paleae basi subconcretae v. liberae, inferne nudae, apice pilosae, margo exterior nullus. - Fruticuli, unico bor bonico excepto capenses, Stoebes facie; foliis sparsis, sessilibus, junioribus supra, rarius utrinque tomentosis.

Seriph i um Lessing Synops. 349. DC. Prodr. VT. 261 . Seriphit et stoebes sp. Auct.

a. EREMANTHIS DC, $l$. c. Capitula ad apicem ramulorum solitaria, nee congesta. Pa p pi paleae basi subconcretae et annulatae. - Species borbonica.

Eremanth is Cassini in Dict, so, nat, Lr, 63. sub Stoebe.

b. EUSERIPHIUM DC. l. e. Capitula in glomerulum subrpicatum v. globosum congesta. P a p p i paleae basi vix concretae. - Species capenses.

Pleurocephalum et A eroeephalum Cassini in Dict, so. nat. XLVIIT. 509.510. Lessiag Synops. 350 . 351. (Gärtn. $t, 157, f .2$.

2\%68. Ferotriehe CASS. Capitulnm uniflorum. Involucri pauciseriati squamae oblongae, mucronatae, adpressae. Re ceptaculnm nudnm. Cor o 11 a tubulosa, limbo quinquedentato. Antherae basi bisetae. Stigmata apice solo penicillata. A cheninm cylindraceum, glabrum. Pap pus nullus. sparsis, rigidis, confertis, linearibus, acuminatis, spiraliter tortis, supra tomentosis, capitulis in glomerulum, Pisi mole, bracteis parvis stipatum aggregatis,

Perotriche Cassini in Bullet, soc, philomat. 1818. 75. Dict. se, nat. XXXVIIT, 525. Lessiag Synops. 353, DC. Prodr. VI. 264. G y m na chae a Reichenb. in SieberHerb. cap. $n, 23$.

DIVISI0 V. ANTENNARIEAE Lessing Synops. 353. DC. Prodr. VI. 264. C a p itula haud in glomerulum aggregata, multiflora, dioica v. subdioica, seu monoico-heterogama, floribus masculis stylum simplicissimum, apice clavato-truncatum gerentibus. Receptacu$1 \mathrm{um}$ epaleatum v. margine tantum paleatum.

2 r63. Triehogyne LESS. C a p it u lum pluriflorum, heterogamum, floribus inter involucri squamas intimas et receptaculi paleas paucis, filiformibus, femineis, centralibus pluribus tubulosis, masculis. Involueri pauciserialis squamae laxe imbricatae. R e c p tacul am margine paleolatum, caetera nudum. Corollae femineae filiformes, masculae tubulosae, basi attenuatae, Jimbo quinquedentato. Anthera e basi bisetae. Stylus marium simplicissimus, apice snbdilatatus, puberulus, feminarum apice bifidus. A $\mathrm{ch}$ e $\mathrm{n}$ i a sessilia, erostria, centralia abortiva. Pa p pus feminarum nullus, marinm nniserialis, setis capillaribus, apice plumosis. - Suffrutices capenses humiles, v, herbae mediterraneae; ramis alternis, undique foliatis, foliis sessilibus, sparsis, membranaceis, tenuibus, muticis, saepe inflexis $v$, involutis, supra dense tomentosis, subtus glabrioribus, capitulis terminalibus glomerato- $v$, spicato - congestis, rarius axillaribus verticillatis.

Trich og yne Lessing in Linnaea VI, 231. DC. Prodr. $V I$. 264. Stoebes, Seriphii et Graphalis sp. Auet.

a. EUTRICHOGYNE DC. l.c. F1 ores pauci, feminei 1-4. - Caulis fruticosus.

Triehogyne Lessing Synops, 359.

b. IFLOGA DC. I.c. F1ores 6_12, feninei 4_6. _ Caules herbacei.

If I og a Cassini in Dict. sc, nat. XXXVII. 13. Les. sing Synops. 333. G n a phalli sp. Desfont. Labillard. Syr. Dec. IV. L. 2. $f$. 1. Fresenius in Mus. Senkenberg. t. 4. $f .1$.

2\%64. Planenocoma DON. Ca p it u $\mathrm{lum}$ multiflornm, heterogamum, floribus omnibus tubulosis, marginalibus uniseriatis femineis, centralibus masculis. In rolncri imbricati squamae basi lanatae, exteriores breves, adpressae, acuminatae, intimae in appendicem scariosam, coloratam, radiantem productae. Receptaculum totum epaleatum. Co rolla e tnbulosae, limbo quinquedentato. Anthera e..... Sty lus marium clavatns, indivisus, feminarum apice breviter bifidus. A chenia glabra, centralia abortiva. Pappus uniserialis, setosus, seaber, corollam aequans, feminarum setis varie coalitis ramosus, marium clavatus, Fruticulus capensis, ramosissimus; ramis tomentosis, abbreviatis, ramulis axillaribus elongatis, foliis caulinis et ramorum acuminatis, rigidis, deciduis, ramulorum granuliformibus, obtusis, confertis, supra tomentosis, cupitulis terminalibus, solitariis.

$\mathrm{Ph}$ a $\mathrm{nocom}$ a Don in Mem. Herner, soc. V. 554. Lessing Synops. 358. DC. Prodr. VT, 266. Xeranthemum proliferum Lian. Helichrysam proliferum Willd. Bot. Mag, t. 2365. Bot, Reg, t, 21. Andr. Bot. Reposit. $t$. 374.

2765. Petalacte DON, C a pitulum decem-vigintiflorum, heterogamum, floribus omnibus 
tubulosis, marginalibus intra receptaculi paleas pancissimis femineis, reliquis maseulis. Inv o I uc ri imbricati squamae exteriores scariosae, fuscae, acutae, interiores scarioso-petaloideae, coloratae, obtusae. Receptaculnm margine paleatum, centro nudum. Corolla e tubulosae, limbo quinquedentato. Antherae basi bisetae. Sty l u s marium simplicissimus, clavatus, feminarum breviter bifidus. A c h en i a glabra, centralia abortiva. P a ppus uniserialis, capillaris, tenuis, marium apice subplumosus v. clavatus. - Fruticuli c apenses, erecti, lunati; foliis sparsis, sessilibus, coriaceis, capitulis in glomerulos breve pedunculatos et corymbosos dispositis, involucri extus pube rufa lanati lamina petaloidea alba, corollis purpureis.

Petalacte Don in Mem. Werner. soc. V. 553. DC. Prodr. VT. 267. Petalolepis Lessing Synops. 350?. non Cass.

a. EUPETALACTE DC. $l$. $c$. Involucri squamae exteriorex basi in stipitem attenuatae. Pappi setae apice subplumosae. - Gnapha li um coronatum Linu.

b. AMPHILASIA DC. l.c. Involucri squamae basi fere latiores. P a p $\mathrm{i}$ setae apice incrassato-clavatae.

2rG6. Anaxetom CASS. Capitulum panciflorum, heterogamum, floribus omnibus tubulosis, uno alterove femineo, reliquis masculis. Involucri squamae multiseriatae, siecae, laxe imbricatae, intimae unguiculatae, spathulatae, lamina subrotunda, nivea, radiante. Recepta $\mathbf{c u} \mathbf{l} \mathbf{u m}$ planum, totam epaleatum, lanato-tomentosum. Corolla e tubulosae, limbo quinquedentato. Antherae basi bisetae. Stylus marium simplicissimus, feminarum apice breviter bifidus. Achenia receptaculi lana involuta. Pap p s pancisetus, setis capillaribus corolla brevioribus, seabris v. breviter plumosis._Fruticuli capenses, flexuoso-erecti, ramis teretibus, sub floribus parcius foliosis; foliis alternis, coriaceis, integerrimis, sessilibus, mucronulatis, nervo unico supra impresso-sulciformi, margine revolutis, capitulis in corymbum dense confertis, cylindraceis,

A naxeton Cassini in Diot. sc. nat. XXVT.53. XXXIV. Lessing Synops. 225, non allib. DC. Prodr. VI. 267. A n a x etI sp. Gärtn, exel. sp. Lam. t. 692. $f$. 2. G naphallii s p. Linn. Thunb.

2ซตร. Antenmaria $R . B R$, Capitula multiflora, dioica v, subdioica. Involueri imbricati squamae apice coloratae v. subscariosae. R eceptaculum convexum, alveolatum. Corolla e tubulosae, femineae filiformes, limbo quinqueden tato. Anthera e semiexsertae, basi bisetae. Stylus feminarum apice bifidns, marium simplex v. rix bifidus, abortivus. A e h e $\mathrm{n}$ a teretiuscula. P a ppus uniserialis, setis feminarum filiformibus, marium apice clavatis. - Herbae perennes $v$. interdum suffrutescentes, in he mispha era e bor e alis temperatis et frigidis obviae, inter tropicos Asiae rarae; foliis alternis, integerrimis, subtus tomentosis, capitulis corymbosis, involucris albis, roseis $v$. rufo tinctis, nunquam flavis, corollis flavescentibus.

A nte unaria R. Brown in tinn. Transact. XII. 122. Lessing Synops. 353. D. Don in Mem, Werner. soc. $V .560$. DC. Prodr. VI. 269. non Link. Antennariae sp. Gïrtn. G naphaliisp. Linn. Elichrysisp. Tournef.

a. CATIPES DC, $l$. c. Capitula omnino dioica, Pap pus florum sterilium evidenter clavatns. - Caules collo plurimi, casspitosi, alii surculosi, foliosi, diffusi, alii erecti, simplices, foridi. Individua feminea masculis frequentiora. - Guaphalii 8 p. Linn. Reichenb. Pl. crit. $t$, 750 . B. B. $t$. 267. Wablenb. Fl, carpath. t. 3. Disynanthus Rafinesq. msc. (Gürtner t. 167. f. 3.)

b. MARGARIPES DC. t, c, Capitula dioiea, mascula saepe flosculos paucos neutros in ambita gerentia, $\mathbf{P}$ a p- pus florum sterilium obseure clavatus. - Caules erecti, basi simplices, apice summo corymboso-ramosi. Indi vidua mascula femineis frequentiora. - G n a p h a li i sp. Linu, Wallich. K. B. t. 2018. (Bot, Mag. \&. 2468. Bot. Reg. t. 605.)

2\%63. Anaplanifs $D C$, Capitulum multiflorum, heterogamum, floribus radii filiformibus, pauci-pluriseriatis, femineis, disci tubulosis, hermaphrodito-sterilibus. Involneri imbricati squamae niveo-scariosae, lanceolatae, radiantes, exteriores sessiles, mediae longiores, fusco-stipitatae, intimae angustae, brevissimae, paleiformes. Receptaculum subconvexum, alveolatum. Corolla e radii filiformes, dis $\mathrm{ci}$ tubulosae, quinquedentatae. Antherae semiexsertae, basi bisetae. Stylus radii longe exsertus, bifidus, dise i indivisus, obtusus. Achenia glabra, subobcompressa. Pappus conformis, uniserialis, setis a basi ad apicem seabris, filiformibus. - Herbae as iat ic a e, alpicolae, cano-lanatae $v$. tomentosae; caulibus simplicibus, plerumque monocephalis, foliis oblongis $v$, linearibus, superioribus apice scariosis $v$. mucronatis.

A a phalis DC. Prodr. VI. 271. Gnaphalii sp. Wallich. He lichrysi sp. Don.

2r65. Leontopodhom $R, B R . C$ a $\mathrm{i}$ t u l $\mathbf{~ m ~ m u l t i f l o r u m , ~ h e t e r o g a m u m , ~ f l o r i b u s ~ r a d i i ~}$ uni-pluriseriatis, filiformibus, femineis, disci tubulosis, hermaphrodito-sterilibus. Involucri imbricati squatnae adpressae, extus lanatae. $\mathbf{R}$ e $\mathbf{c}$ e pta cula m convexum, foveolatum. Corollae rad i i fliformes, tri-quadridenticulatae, dis ci infundibuliformi-tubnlosae, limbo quinquedentato. Antherae basi caudatae. Stylus radii bifidus, dis e i indivisus, apice clavatus. A ehen ia cylindracea, compressa. Pa p p u uniserialis, setis basi subconcretis, $r$ a dii filiformibus, barbellatis, $d$ ise i saepius apice incrassatis. - Herbae in Europa et Asia alpicolae, lanato-tomentosac, caule florente simplici; foliis alternis, oblongis $v$. infimis obovatis, integerrimis, capitulis ad apicem caulis umbellatocorymbosis, corymbi capitulo centrali sessili, ebracteato, praecociore, radio uniseriali, lateralibus brevissime petiolatis, radio pluriseriali donatis, singulis bractea lanata, foliacea subtensis, glomerulo ideo foliis floralibus radiantibus cincto.

Le on topodium R. Brown in Linn. Transact. XXI. 124. Cassini in Bullet. soc, philomat. 1819. p. 144. Dict, sc, nat, $X X V$, 473. Lessing Synops. 354. Don in Mem. Werner. soc. V. 561. DC. Prodr. VI. 275. Gnapballi sp. Jacq. Fl, austr. $t$, s6, Reichent. Pl. crit, $t, 961$. Filag i n is s p. Linn. Antennaria e sp. Gărtn.

IDVISIO VI. LEYSSEREAE Lessing Synops. 336. DC. Prodr. VI. 276. Capitula multiflora, radiata, ligulis femineis. Receptaculum epaleatum. Pappus nunquam coroniformis, squamellis aliis paleiformibus, aliis setiformibus. - Frutices capenses.

\&รซ 0. Athrixia $K E R$. Ca pitulu m multiflorum, heterogamum, floribus radii uniseriatis, ligulatis, femineis, disci tubulosis, hermaphroditis. Involueri turbinato-campanulati squamae plurimae, imbricatae, apice aristato-acuminatae, recurvae, Receptaculum nudum. Corollae radii uni-biligulatae, disci tubulosae, limbo quinquedentato. Antherae caudatae. Stigma $\mathbf{t}$ a exappendiculata. A chen ia oblonga, sessilia, erostria, ima basi nuda v. pilis fasciculatis stipata, caeterum glabra. Pappus uniserialis, setis filiformibus, subscabris, v. setis cum paleis apice serratis alter- 
nantibus. - Suffrutices capenses et madagascarienses, Asteris $v$. Vernoniae habitu; folits alternis, longe decurrentibus, plerisque linearibus, mucronatis, rigidis, margine revolutis, subtus tomentosis, supra spinelloso-scabris, capitulis terminalibus, solitariis, radio patente, purpureo v. lilacino aut albido, disco luteo.

A t hrixia Ker in Bot. Heg. n.681. Lessing Synops.364. excl, sect. 1. DC. Prodr. VI. 276. A ste ris s p. Linn. Thunb.

\&. EUATHRIXIA DC, $l$. c. Pappus totus e setis scabris constaus.

Athrixia Lessiag Synops. 365 . (Bot. Reg. 2. 681.)

b. PSEUDATHRIXIA DC. 2. c. Pappi paleae breves, apice subserratae, cum setis longis subscabris alter nantes.

Asteropsis Lessing Synops. 366. non 188.

25 1. Antithrixia DC. Capitulum multiflorum, heterogamum, floribus radii uniseriatis, ligulatis, femineis, disci tubulosis, hermaphroditis. Involucri imbricati squamae lineari-oblongae, apice scariosae, obtusae. R e ce p t a c u l a m nudum. Corolla e radi i ligulatae, planae, disei tubulosae, cylindricae, limbo quinquedentato. Antherae candatae. Stigmat a exappendiculata. A ch enia teretiuscula, glabra, stipite pubescente, brevi, calloso, apice subrostrata, $P$ a p p s uniserialis, setis rigidis, subscabris, plurimis, basi inter se subconcretis. - Fruticulus capensis; ramis junioribus araneosis, mox glabris, foliis oppositis, linearibus, brevibus, superne tomentosis, subtus glabriusculis, convexis, saepe gemmuliferis, capitulis terminalibus, solitariis, flavis.

Antithrixia DC. Prodr. VI. 2z7.

28\%\%. Leysgera $L I N N$, Capitulum multiflorum, heterogamum, floribus radii uniseriatis, ligulatis, ovario efoeto nentris, disei tubulosis, hermaphroditis. Involucri imbricati squamae exteriores breviores. Receptacul um epaleatum, subfimbrilliferum. Coroliae radii ligulatae, ligula brevissima v. discum superante, disci tubulosae, limbo quinquedentato. Anthera e caudatae. Stigmata exappendiculata. A ehenia sessilia, breviter rostrata, areola terminali. $\mathbf{P}$ a p$\mathrm{pus}$ uniserialis, setis $\mathrm{radii}$ brevibus, inter se conformibus, disci longis, plumosis, cum paleis alternantibus. - Suffrutices v. herbae, in Africa a ustrali et boreali obvenientes; ramis gracilibus, apice nudis, monocephalis, foliis sparsis, sessilibus, linearibus, saepe in axillis fasciculatis, floribus luteis.

Le y s sera Liun. sp. 1279. Lessing Synops. 367. DC. Prodr. YT. 278.

a. ASTEROPTERUS DC. $l$. $c$. Involucri squame intimae intus ad basim non replicatae nec achenía foven. tes. L ig ula e disco et involuero longiores. Pappus disci selis a basi plamosis. - Suffrutices capenses.

Aster opter as Valliant in Act. Acad,Paris, 1720. p. 720. Gärtn, $I T, 460, t, 173$. C a lli cota I a Burmann Prodr, cap. 24. Ley ssera Cassini in Dict, sc. nat. XXYT. 185. (Jacq. IC, rar, t. JS8.)

b. LONGCHAMPIA DC. $l$. $c$. I nvol ucri squamae intimae basi haud replicatae. Li g u J a e minimae, diseo aequales. P a p p a s disei setis apice tantum pluauosis. tlerba maurilanica, annua.

L a g c hampla Willdewow in Berlin, Magaz. $V T$. p. 160. Le ptop hy tus Cassini in Dict, sc, nat, XXYI. 77. Ga phalium leysscroides Desfont.

. LEPTOPHYTA DC. Prodr, VT, 279. In volu cri squa. make intimae iatus ad hasim replicatae, achenia arete foventes. Pappas radii paleis quiaque oblongis, sub. dentatis, disci paleis quinque obrtsis, setisque totidem apice plumosis.
28 ร3. Pterothefx $D C$. C a p it u 1 u m nunc quinqueflorum homogamum, nunc decemflorum heterogamum, floribus radii tribus v. quatuor ligulatis, femineis. In v o I u cri cylindrici squamae imbricatae, exteriores acuminatae, interiores in appendicem subscariosam, oblongam, acutam, erectam productae. R e c p ta c a I u m angustum, nudum. Corolla e radii breviter ligulatae, dis ci tuhulosae, cylindricae, quinquedentatae. An thera e caudatae. Stig ma ta exappendiculata. A chenia oblonga, sessilia, erostria, glabra. P a p pi setae subdenae, uniseriales, usque ad basim distinctissimae, valde plumosae, cadneae. - Suffrutices c apen ses, Relhaniae facie; ramis usque ad apicem foliosis, interdum in spinam nudam desinentibus, foliis sparsis, confertis, semipatentibus, coriaceis, involuto-subcomplicatis, supra sulcato-concavis, subtomentosis, subtus convexis, glabris, capitulis parvis, ad apices ramulorum solitariis v. glomeratis, supra folia sessilibus.

Pterothrix DC. Prodr. 280.

a. RELHANIOIDES DC. l.c. Capitalum quiaqueflorum, homogamam.

b. LUCILIOIDES DC. l, c. Ca pitulnm decemflorun, heterogamum, radiatum.

Lucflioides Athrixiae sect. Lessing Synops. 364. ReIlania tomentos a Thunb.

2ร ร4. TRosenia THUNB. Capitu I n m multiflornin, heterogamum, floribus radii ligulatis, femineis (?), disei tubulosis, hermaphroditis. Invo 1 u cri eylindraceo-campanulati squamae imbricatae, margine scariosae, exteriores ovatae, acutae, intimae oblongae, emarginatae. R e c e $t$ a c u l u m totum paleolatum, paleis conduplicatis, scariosis. Corolla e radii ligulatae, disci tubulosae, limbi quinquedentati dentibus erectis. Antherae caudatae. Stigmat a exappendiculata. A ch en ia sessilia, erostria, glabra, ra di triquetra, tricostata, di s c i cylindracea, sulcata. Pappus dis c i biseriatus, squamellis exterioribus brevibus, linearibus, intimis binis setaceis longis, ra di i simplex, ut disei interior. - Frutices capenses, ramosissi$m i$; foliis decussatis, oblongo-obovatis, obtusis, conferlis, uninerviis, subtus tomentosis, demum glabris, punctato-scabris, supra albo-tomentosis, floribus luteis,

Rosenia Thuaberg $F l$. cap. 692. Lessing Synops.369. DC. Prodr, YT, 280, excl, sp. 2.

DIVISID VIE. RELHANIEAE Lessing Synops, 370. DC. Prodr, VI. 280. Capitula multi- (rarius 3 _ 5) flora, homogama v, radiata, ligulis femineis v. neutris. Receptacul u m nudum, fimbrilliferum v. paleatum. A $c$ hen i a erostria v. rostrata. Pa p us nullus, v. e squamellis distinctis $v$. basi plus minus connatis, coroniformis v. multipaleaceus. - Fruticuli capenses; folis alternis $v$. oppositis, interdum dentatis.

28 ร5. Carpesiom LINN. Ca p it u I u m multiflorum, heterogamum, floribes radii plariseriatis, femineis, disci tuhulosis, hermaphroditis. Involueri squamae pluriseriatae, imbricatae. $\mathbf{R}$ eceptaculum planum, nudum. Corolla radi ligulatae, disci tubulosae, quinquedentatae. An thera e cadatae. Stigmata teretiuscula, obtu sa, glabriuscula, saepius exserta. A ch eni a elongata, striata, glabra, rostrata, rostro et basi glan dulis papulieformibus obsita, areola terminali cupulaeformi. Pap pus nullas. - Herbae crectac, 
ramosae, in Europa rarissimae, in Asia meridionali obviae; foliis alternis, petiolatis, ovatis v. oblongis, saepius dentatis, capitulis ad apices ramorum solitariis, v. lateralibus subracemosis, floribus flavis.

Carpes i u m Linn. Act. Upsal, 1741. 81, Gen. n. 948. Gïrtner II, 387. Cassini in Dict, sc, nat, VIT, 146. Lessing Synops. 37t. DC. Prodr, VI. 28t, Conyzoides Tournef. in Act. Academ. Paris. 1706. p. 237.

a. CONXZOLDES DC. l. c. Involucri squamae exteriores foliaceae, plus minus refiexae. C a p itu la bracteis foliaceis, amplis, patulo-reflexis stipata. - (Jacq. $F l$. austr. $t$. 204. Schkuhr $t$, 244. Lam, $t, 696, f$. 1. Gärtn, t. 164.)

b. ABRotanOIDES DC. $l$. c. In volucri squamae omnes erectae, adpressae. C a pit ula ebracteata, ad axil. las foliorum florallum breviter pedicellata. - (Lam. t. 696. f. 2.)

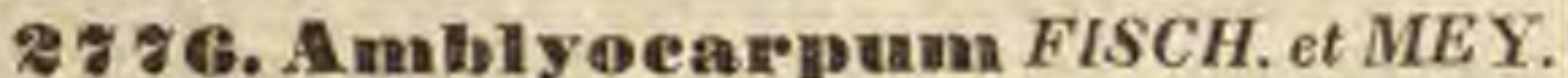
Cap it u $1 \mathbf{m} \mathrm{m}$ multiflornm, heterogamum, florihus radii uniseriatis, ligulatis, femineis, disci tubulosis, hermaphroditis. Involueri imbricati squamae bi-triseriatae, exteriores foliaceae. Receptacu$1 \mathbf{n ~ m}$ hemisphaericum, nudum, punctatum. Corolla e radii ligulatae, ligula lineari, disci tubulosae, quinquedentatae. An therae caudatae Stigmata ..... A chenia subfusiformia, quin quangularia, erostria, obtusa. P a P p n s nullus. Herba cuspica, annua v. biennis, Pulicariae vulgaris facie, glabra; foliis sparsis, capitulis in apice caulis et ramorum solitariis, floribus flavis.

A mblyoearpum Fischer et Meyer Index sem. hort. Petropolit. III. 1837. p. 30.

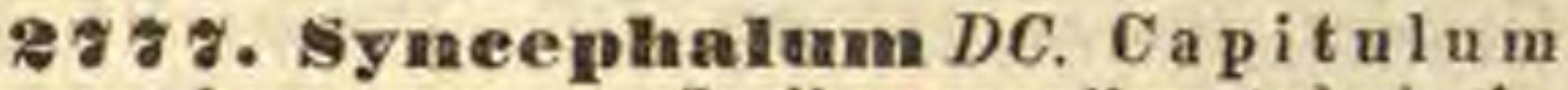
triflorum, homogamum, floribus omnibus tubulosis. Involucri oblongi squamae septem v, octo, oblongae, acuminatae, scarioso-diaphanae. R e e e ta $\mathbf{c} \mathbf{~} \mathbf{l} \mathbf{u}$ angustissimum, nudum. Corolla e tubulosae, quinquedentatae, lobis extus ad apicem glandulosis. Antherae caudatae? Stylns tenuis, inclusus, ramis brevibus, approximatis. A chen i a oblongo-pyramidata, erostria, glabra, P a ppus nullus. - Suffrutex madagascariensis, pedalis, Relhaniae facie; ramis teretibus, subtrichotomis, foliis conferte alternis, ovalibus, sessilibus, subcrenulatis, coriaceis, erecto-subpatentibus, ramis floriferis corymbum compositum, fastigiatum formantibus, capitulis in axillis foliorum extremorum a caulinis parum diversorum sessilibus, floribus flavis.

Sy ucephaJum DC. Prodr. VI, 289.

2ร ร 9. DIigodora DC. C a p i $t$ u I u m quinqueflorum, homogamum, floribus omnibus tubulosis. In vo I u eri subtrigoni squamae imbricatae, adpressae, intimae margine replicatae, achenia exteriora foventes. Receptaculum angustum, paleaceo-fimbrilliferum, paleis complicatis, achenia quasi intra loculos foventibus. Co roll a e tubuiosae, quinquefidae. Antherae caudatae? Stigw a ta inclusa, obtusa, apice pilosa. Achen a cylindracea, laevia. P a p i squamellae quinque, ovatae, breves, ciliato-dentatae. - Suffrutex c a pensis, erectus, ramosus, glaber; foliis alternis, crassiusculis, sessilibus, dentatis, dentibus utrinque duobus v. tribus et terminali mucromulatis, capitulis ad apices ramulorum brevissime pedicellatis, corymbulosis, squamis sive bracteis secus pedicellum brevibus, acutis, subpatentibus, corollis albidis.

oligodora DC. Prodr. TT. 28.

ร ร ร. Nestlera SPRENG, Ca p itulum multiflorum, heterogamum, floribus radii uniseriatis, ligulatis, femineis, disci tubulosis, hermaphro ditis. Involucri imbricati squamae adpressae, interiores longiores, membranaceo-scariosae. $\mathbf{R}$ ecepta e ulum epaleatum, alveolatum. Corolla e ra di i ligulatae, d is c i tubulosae, quinquedentatae. Antherae ecaudatae. Stigmata inclusa, obtusa. Achenia conformia, erustria. Papp n. coroniformis, dentatus. - Herbae v, suffrutices capenses, humiles; foliis allernis v. oppositis, sublinearibus, integris, capitulis aliis terminalibus, aliis in dichotomiis ramorum sessilibus.

Ne s t l er a Sprengel Syst. III. 589. Lessing Synops. 372. DC. Prodr. VI. 283.

a. STEPHANOPAPPUS DC. $l, c$, Involucri squamae acuminatae. A c b e a i a elougata, longitudiualiter sulea ta, subtetragona. - Herbae.

Stephanopappus Lessing in Linnaea $V I .234$. Col th melle a Jacq. Hort. Schönbr. III, 28, t, 301, non alior.

b. STRONGYLOLEPIS DC. 1. c. Involucri squamae apice scariosae, stramineae, obtusissinae. A che nia hine inde subpuberula, longitudisaliter suleata. - $S u f$. frutices humillimi.

Relhaniace Pteroniaesp. Auct.

2\% 80. Polyclanetia LESS, Ca p it u I um multiflorum, heterogamum, floribus radii paucis, ligulatis, femineis, disci hermaphroditis, tubulosis. Involueri ovati, arcte imbricati squamae intimae apice breviter et acute appendicnlatae. $\mathbf{R e}$ ceptaculum fimbrilliferum, fimbrillis alveolos, achenia saepius superantes constituentibes, nune apice fissis, nunc ad basim in setas plurimas multipartitis. Corolla e radii anguste ligulatae, ad basim ligulae secus margines glanduleso-punctatae, d is c i tubulosae, quinquefidae, lobis extus glanduloso-pilosiuseulis. Antherae caudatae? basi barbatae, apice longe appendienlatae. Stig mata ra di elongata, dis e i subadglntinata, vix apice libera. A chenia setis adpressis, sericeis plus minus villosa, exteriora angulata. $P$ a p p u s paleaceus, uniserialis, paleis nune ad basim fere liberis, nune: in tubulam apiee dentatum concretis. - Herbae cap enses, basi suffruticulosae, glaberrimae, erectae $v$. subadscendentes; ramis angulatis, foliis sparsis, sessilibus, oblongo-linearibus, inlegerrimis, mucronatis, uninerviis, nune utrinque impresso-punctatis, nunc utrinque tomentosis, capitulis ovatis, ad apices ramorum solitariis $v$. cymosis, ramorum infra capitulum elongatione cauli arcte continua axillaribus $v$. lateralibus, floribus flavis.

Poly e ba etia Lessing Synops,381. DC. Prodr, VI. 285. a. STICTOPHXLLA DC. l.c. Folia glabra, utrinque glan. duloso-punctata.

b. EUPOLYCHAETIA DC. l. c. Folia superne, rarins utrinque cano-tomentosa.

\& 81. Bellanuia HERIT. Cap itulum multiflorum, heterogamum, floribus radii uniseriatis, ligulatis, femineis, disci tubulosis, hermaphroditis. Involueri ovati v. eylindracei squamae imbricatae. Receptaculum planum, paleolatum. Corolla e radii ligulatae, disc i tubulosae, limbo quinquedentato. Antherae caudatae. Stigmata radii exserta, disci abbreviata, inclusa. A c h en i conformia, linearia, erostria. $P$ a $p$ a s coroniformis, brevissime dentatus. - Fruticuli capenses, erecti, ramosi; foliis sparsis, sessilibus. integerrimis, capitulis terminalibus, solitariis $v$. co. rymbosis, floribus luteis.

Relh a n a Heritier Sert. 22, excl. sp. Lessing Synops. 374. DC, Prodr, VI. 286. non Gmel, Rell haniac sectio 1. Cassini in Dice, sc, nat, XLV. 29. Relban bae $5 \mathrm{p}$. Herit. Thus:b. Willd. 
a. METALASIOIDES DC. 1. c. Capitula ovata v. caapanulata, solitaria. - Folia superne tomento denso, persistente inducta, subtus laxe velutina.

Relhaniae sectiol. Lessing $l$.c. Leys serae sp. Lìn. Gärtn. $t$. 172, f. 9.

b. PSiLOPHYLlUM DC. $l$. c. Capitula cylindracea, cymoso-corymbosa. - Folia glaberrima v. vix pubescentia, encrvia $v$. uninervia, excavalo-punctatu.

Psilophyllum Lessing Synops. 376.

2ช8\%. Eelopes GÄRT. Ca pitnlum multiflorum, saepius heterogamum, floribus radii ligulatis, femineis, rarius discoidenm, homogamum. Involueri imbricati squamae multiseriales, obtusae, scariosae, aridae. $\mathrm{R}$ e c e p $\mathrm{t}$ a $\mathrm{c} \mathrm{l} \mathbf{\mathrm { u }} \mathrm{m}$ planum, paleolatum. Corolla e radii ligulatae, disci tubulosae, quinquedentatae. Antherae caudatae. Stigma ta obtusa. A chenia conformia, erostria, nunquam obcompressa. P a p us multipaleaceus, brevis. - Fruticuli c a penses, erecti, ramosi; foliis alternis $v$. oppositis, sessilibus, integerrimis, capitulis terminalibus solitariis v. corymbosis, sessilibus aut pedicellatis, floribus luteis.

E clopes Girtner II. 440. Lessing Synops. 378. DC. Prodr. VI. 287. Relh an i e sect. 2. Cassini in Diot. se. nat, XLV. 30.

a. EUECLOPES DC. $t$, c. Invol u e rum diseo brevius v. vix aequale. Capitula radiata v. discoidea, parvula. solitaria v. corymboso-pedicellata ant sessilia.

Eclopes Lessiog Synops. 378. Atbanas iaesp. Liвn. (Gärta. t. 169.)

b. ODONTOPHYLLum DC. $l$. c. A e henia triguetra, bialata, alis radil ciliatis.

Odontophyllum Lessiog Synops. 379. Athanasia uniftora Linn.

c. RIGIOPHYLLUM DC. 7 . c, Involucrum floribus disci longís. Capitula radiata, terminalia, solitaria, ses. silla, majuscula.

Rigiophyllum Lessing Synops, 380. Relthaniae 8 p. Herit. Bot. Reg. $t .587$.

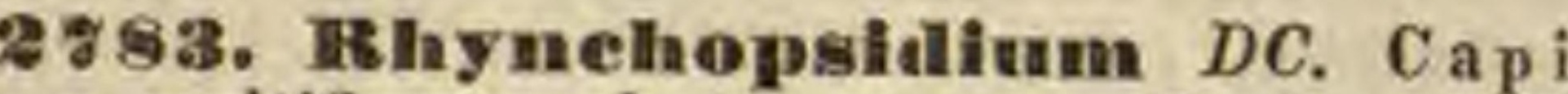
tu 1 n m multiflorum, heterogamum, floribus radii uniseriatis, ligulatis, femineis, disei tubulosis, hermaphroditis, intimis abortivis. Involnernm arete imbricatum. Recept a c $\mathbf{l}$ i plani paleae seariosae, acuminatae, amplexiflorae. Corolla e radii li gulatac, disci tubulosae, tubo apice puberulo, limbo quinquedentato. A n the ra e ecaudatae. $\mathbf{S t}$ ig. mata obtusa, A chenia brevirostria, elongata, teretia, pilis adpressis villosa, intima saepius abortiva, glabra. P a p p $\mathbf{s}$ multipaleacens, brevissimus. - Herbae capenses, annuae, graciles; foliis alternis, sessilibus, linearibus, integerrimis, pilis capitatis obsessis, capitulis terminalibus, interdum ramulorum evolutione demum lateralibus, saepius sessilibus, floribus luteis,

R hynehopsidium DC. in Mém. soc. h. n. Génèv. $P$. 283, $t$, 4. Prodr, VI. 290. Nan o pbytum Eelopis sectio Lessing Synops. 382, R hy n choe a r p us Lessing Synops. 382, Relbatiae s p. Thunb. Athanastaesp. Linn.

28 84. Dsmites CASS. Ca p itu I u m multiflornm, heterogamum, floribus radii ligulatis, femineis v, rarius nentris, disci tubulosis, hermaphroditis. Involucri campanulati squamae pluriseriales, subaequales. R e cepta c u I u m plannm epaleolatum. Corolla radii ligulatae, dise tubulosae, quinquedentatae. Anthera e eaudatae. Stigmata obtusa. A chenia sessilia, erostria, glabra v, puberula, subtetragono-obeompressa, Pap p us multipaleaceus. - Fruticuli capcnses; foliis allernis, confertis, sessilibus, ovalibus, obovalis, lanceolatis $v$, linearibus, serratis, punctato-glan- dulosis, capitulis ad apices ramorum solitariis, disco luteo, ligulis albis, crassiusculis.

$0 \mathrm{smites}$ Cassinf in Dict. sc, nat. XXXVII, 5. DC. Prodr, VI. 290. Bellidia strum Vaillant in Act. Acad. Paris. 1790, p. 316. non Miehel. 0 s m it e s $8 \mathrm{p}$. Linn. Thunb.

a. EUOSMITES DC. l. c. Corolla e radil ligulatae neu trae. Pappus brevis.

0 suites Lessing Synops, 383.

b. BELLIDIOPSIS DC. $l$. $c$. C o roll a e ralii ligulatae fe mineae. Pappus brevis.

Bellidiastrum Lessing Synops, 383. (Gärtner 174. $f$. 3.)

c. SPANOTRICHUM DC. $l$. c. Corolla a radii ligulatae, femineae. $\mathrm{P}$ a p $\mathrm{pi}$ palea inaequales, nonnullae in setam elongatae,

Spanotrichum E. Meyer msc.

2\%85. Osmaitopsis CASS. Ca p itulum multiflorum, heterogamum, floribus radii ligulatis, neutris, disci tubulosis, hermaphroditis. I nvo I neri campanulati, pluriseriati squamae imbricatae. Receptaculum planum, epaleolatum. CorolI a $\mathrm{radii}$ ligulatae, dis ci tubnlosae, basi dilatatae, quinquedentatae. A n t h e r a e caudatae. Stigm ata obtusa. A $c h$ en i conformia, areola terminali margine calloso cincta. Pap u s nullus. _Suffrutex capensis, Camphoram redolens; folitis confertis, punctatis, capitulis sessilibus.

osmitops is Cassini in Dict. se. nat. XXXVIT, 5. Lessing Synops. 386. DC. Prodr. VI. 292. Osmites $\mathrm{c}_{\mathrm{a}} \mathrm{m}$ phorina et $0 \mathrm{smites}$ as terieoides Linn. Gairto,t.173.

SUERTEIBUS VHTI. SENECIONEAE Cassini Opusc. III, 69. DC. Prodr. VI. 292. C a pitula homogama v. saepius heterogama, nunquam dioica, discoidea v. radiata, ligulis saepissime uniseriatis. Rece ptaculum plerumque epaleatum. An th e $\mathrm{r}$ a e ecandatae. A chenia pappo piloso v. setaceo coronata, exteriora interdum calva. - Folia alterna,

DIVIST6 I. NEUROLAENEAE Lessing Synops. 387. DC. Prodr. VI. 292. R e e ptac ul u m paleatum.

28 86. Neurolnema $R . B R$. C a pitulum multiflorum, homogamum, floribus omnibus tubulosis. Involucri imbricati squamae oblongae, trinerves, obtusae, subfoliaceae. Recepta enli planiusculi paleae involueri squamas referentes. Corolla e tubulosae, limbo quinquedentato. Anthe r a e inclusae, ecaudatae. S $t i g m a t a$ recurva, cono brevi superata. Ach enia puberula, teretisubturbinata, erostria, stipitulo calloso, subobliquo, cavo insidentia, Pap p i nniserialis setae rigidulae, scabrae, persistentes. - Suffrutex antilianus, ramosus, subpuberulus; foliis alternis, ovato-lanceolatis, denticulatis, utrinque acuminatis, inferioribus subtrilobis, superioribus indivisis, ramis in corymbos congestos, compositos desinentibus, corollis albidis.

Ne u rola e n a R. Brown in Linn. Transact. XII. 120. DC. Prodr. VI. 292. Ne u r o ch I a e u a Lessiog Synops. 388. C a l e a Gärner $I T .408, t$, 174, non Linn. C o n y z 10 b a. t a Linn.

DIVISIO II. ERECHTITEAE DC. Prodr. VI. 293. Receptaculum nudum v. alveolato-fimbrilliferum. C a pit $\mathrm{u}$ la discoidea, heterogama, floribus radii tubulosis femineis, v. subdioicum, floribus femineis etiam tubulosis. 
2ซ8\%. Farujasia CASS, Capitulum multiflorum, discoideum, subhomogamum, floribus omnibus tubulosis $\mathbf{v}$, exterioribus staminum abortu femineis. Involucri subcylindracei, bracteolis parvis calyculati squamac decem v, duodecim, uniseriales, lineares, acutae. Recept a culum planinsculnm, nudum. Corollae tubulosae, tubo basi dilatato, ovario latiore, limbo quinquedentato. Anthera e ecaudatae. Stig mat a truncata (?). A $\boldsymbol{c}$ henia oblongo - cylindracea, striata, glabra. Pappi setae quatuor filiformes, subscabrae, elongatae. - Frutex mauritianus, glaber; foliis spiraliter dispositis, conferlis, erectis, lineari-subu latis, acutis, rigidulis, dorso convexis, striatis, corymbi conferti pedunculis plurimis, mono-oligocephalis, bracteolalis, floribus flavis.

F a ujasia Cassini in Bullet. soc. philomat. 1819. p. 80. Dict. sc. nat. XVI. 267. XLVIII, 457. Lessing Synops, 249. DC. Prodr. VI. 293. Con y z $\mathrm{p}$ i u ifoli a Bory.

2788. Eriothrix LESS, Capit u n m multiflorum, subhomogamum,floribus marginalibus nonnullis femineis. Involu e ri subhemisphaerici, nnipluriserialis squamae folia omnino referentes. R ecepta e i um planum, nudum. Corolla e tubnlosac, basi aequales, quinquedentatae, exteriores subfiliformes. Antherate ecaudatae. Stigmat a truncata. Achenia cylindracea, gracilia, striata. $\mathbf{P}$ ap pi pluriserialis setae filiformes, crispato-flexuosae, subbarbellatae. - Suffrutex mauritia$n u s$, glaber, rigidus, ramosissimus, Lycopodii $v$. Juniperi facie; foliis subulatis, acutis, dorso triangularibus, erectis, usque ad apices ramorum imbricais, capitulis sessilibus, terminalibus, pappo demum exserto globum hirsulum referentibus, floribus luteis.

Eri othrix Lessing Synops. 394. DC. Prodr. VI. 293. Eriotrlx Cassini in Bullet. soc. philomat. 1817. p. 32. Dict. sc. nat. $X V .200$. Con y $z$ a ly e o podioides Lam. t. 697. f. 2 .

28 89. Stilpmogyme DC. Capitulum septem - octoflorum, heterogamum, discoideum, floribus marginalibus tribus femineis, centralibus quatuor v. quinque hermaphroditis. Involucri uniseriati squamae quinque $v$, septem, disco aequales. Recepta $\mathbf{u} 1 \mathrm{um}$ angustam, nudum. Corolla e tubulosae, femineae hermaphroditae, tri-quinquedentatae. Antherae ..... Stigmata florum hermaphroditorum brevia, apice summo barbellata, femineorum longiora, teretiuseula, subpa berula. A c h e ni a oblonga, utrinque subattenuata, globulis rotundatis, subglandulosis punctata, florum femineorum ealva, hermaphroditorum $p$ a $p$ po uniseriali, multiseto, scabrido, corollam fere superante coronata. - Herba capensis, annua, glabra, demissa; foliis alternis, petiolatis, quinqueseptemlobis, lobis ovatis, obtusis $v$. acut is, caulis ramosi ramis in pedicellos nudos, monocephalos, caule longiores divisis, involucris oblongis, corollis flavis.

Stllpnogyne DC. Prodr. VT. 294.

2r DD. Ereelntites RAF. Capitulum multiflorum, heterogamum, discoideum, floribus marginalibus multi-pauciseriatis, femineis tenuissimis, centralibus hermaphroditis, In volucri cylindracei squamae uniseriatae, lineares, acutae. Receptacul $\mathbf{l} \mathrm{m}$ nudum, subpapillosum, hand fimbrilliferum. Cor olla e femineae tenuissimae, subtri-quinquedentatae, hermaphroditae ampliores, quadri - quinquedentatae. Anthera e ecaudatae. S $t$ i $g$ m a $t$ a cono sursum puberulo terminata. A chenia oblonga, striata, apice subattenuata, saepius seabrida. Pa p p i pluriseriati setae tenuissime capillares, vix scabrae. - Herbac america- nae et australasica e, erectae, annuae, glabrae, scabridae $v$. subtomentosae; foliis alternis, lanceolatis, integerrimis $v$. dentatis, rarius pinnatifidis, corymbi terminalis compositi pedicellis saepius bracteolatis, corollis flavis $v$. albidis.

Erechtites Rafinesque Ludov. 65. DC. Prodr. VT. 296. N e o c els Cassini in Bullet. soc. philom. 1820. p.90. Dict. sc. nat. XXXIV. 386. Erechtites et Crossocephali sp. Lessing Synops. 395. Se ne e i o n is sp. Linn. Labillard.

a. NEOCEIS DC. l. c. A chenia oblonga, apice nec atte nusta, nec margine ealloso superata. - Species ameri canae.

Neoceis Cassini $l$. c. Erechtites Rafinesq. $l$. c. S e neelon is sp. Auct. Bory in Annal, gen. sc. phys. I. $t$. 12. Reiehenb. Ic, exot, $t, 85$.

b. MICRODERRIS DC. l. c. A e hen i a rostrata, rostrum. que tenue pubernla. - Species Novae-Hollandiac.

Senecionis sp. Labillard. Nov. Holl, $t, 194$.

c. TYLODISCUS DC. $l$. $c$. A che a i erostria, apice vix attenuata, superne in marginem eallosum, prominulum, pappigerum dilatata. - Species Novae-Hollandiae et Novae-Zeelandiae.

Senecionis s p. A. Richard Sert. Astrolab, $t, 94$.

d. ? PLAGlotome DC. $l$. $c$. Corollae radil integrae, oblique truncatae, in ligulam ninimam, stylo breviorem desinentes. - Species Novae-Hollandiae et Novac. Zeolandiae.

Sene cionis sp. A. Richard, Sert, Astrolab, $t, 36$.

2ร91. Cremoee ghalum CASS. Capitul $\mathbf{n} \mathrm{m}$ multiflorum, heterogamum, discoideum, floribus marginalibus pauci-v. interdum uniseriatis, femineis, centralibus hermaphroditis. I n v o I nc rum polyphyllum, uniseriale, diseo paullo brevins, squamellis calyculatum. Receptaculum fimbrilliferum, cum involucri basi demum incrassatum. Corolla e tubulosae, femineae angustiores, tridentatae, hermaphroditae quinquedentatae. A ntherae ecaudatae. Stigmata cono brevi, hispidulo superata. A chenia teretinscula, decemcostata, glabrinsenla. P a p p s pilosus, mullis, pluriserialis. - Herba in India orientali et in Africae australis insulis indigena, erecta, ramosa, subpubescens; foliis alternis, ellipticis, basi attenuatis et saepius incisis, apice dentatis, acutis, ramis elongatis, nudis, monocephalis, capitulis cernuis, purpureis,

C remoeephatum Cassini in Diet. se. XXXXI. 390. DC. Prodr. VI. 29\%. Crassocephalum Möch Method. 516. Crassoeeplrali sp. Less. Senecio eernuas Linn. S, rube as Jacq. Hort. Vindob. III, t. 98.

DIVISI(1) III. EUSENECIONEAE DC. Prodr. VI. 298. C a p itulum homegamum, discoideum, v. heterogamum, radiatum, ligulis femineis v. rarissime neutris. Receptacu$1 \mathrm{u} \mathrm{m}$ nudum v. alveolato-fimbrilliferum. Cotyledones planae.

2ซg\%. Cynura CASS. Capitulum multiflornm, homogamum. Involucri cylindracei, basi squamulis subulatis calyculati squamae uniseriatae, lineares, ad margines, praeter apicem aentum membranaceae. Re c e p ta cu $\mathbf{~ u m ~ p l a n u m , ~}$ alveolatum, alveolorum marginibus nunc brevissimis, nune in fimbrillas elevatis. Corolla e tubu. losae, tubo basi corneo, limbo quinquedentato. Antherae ecaudatae. Stigmata in appendicem longam, hispidam, saepius exsertam producta. A ch enia teretinscula, striata, erostria. Pap pi multiseriati setae filiformes, vix barbellulatae. Herbae perennes, basi interdum suffrutescentes, in Asia tropica et in Africae australis in- 
sulis indigenae; foliis alternis, integris, dentatis $v$. pinnatilobatis, capitulis corymbosis.

G youra Cassini in Diet. se, nat. XXXIV, 391, XLVHI. 448. et 458. DC. Prodr. VI. 298. C rassocephali sp. Livn. S eneeionis et Ca caliae sp. Auct. Salisbury $P a$. rad, $t, 25$. Bot. Reg. $t, 110$.

2ร93. Fmsilla CASS. Ca pitulum multiflorum, homogamum. Invo I u cri ovato-cylindracei, ecalyculati squamae lineares, nniseriatae, post anthesin reflexae. $R$ e c e $t$ a c u l $\mathbf{u m}$ planum, vix alveolatum. Corolla e tubulosae, quinquelobae, lobis linearibus, elongatis. Antherae ecaudatae. Stigmata cono brevi hispido terminata. A ehenia oblonga, pentagona, angulis ciliatohispidis. Pappi pluriseriati setae filiformes, vix barbellulatae. - Herbae annuae, ramosae, in India orientali et in Africae australis in$s u l i s$ indigenae; foliis infimis saepius obovatis, petiolatis, caulinis cordato-sagillatis, semiamplexi. caulibus, capitulis paucis, subcorymbosis, pedicellatis, floribus croceis, purpureis $v$. citrinis.

$\mathrm{E} \mathrm{m}$ ill a Cassini in Dict. sc. nat, XIV. 405. XXXIV. 393. XLVIIT. 449. 461. DC. Prodr. DI. 30t. C ras soce phall $8 \mathrm{p}$. Lessing. C a c a li a e $8 \mathrm{p}$. Auct. Bot. Mag. $t$. 564 .

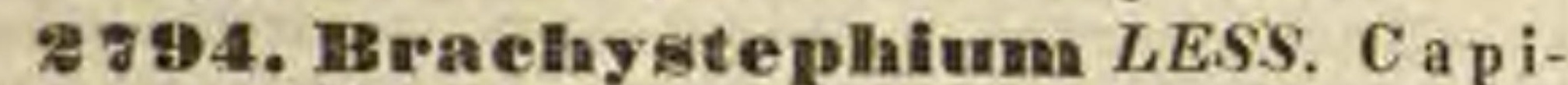
$t \mathrm{u} l \mathrm{um}$ multifloram, heterogamum, floribus radii uniseriatis, ligulatis, femineis, disci tubulosis, hermaphroditis. Involncri campanulati squamae pauciseriatae, ovales, subaequales, R e c e p t a c uIum nudum, subfoveolatum, Corollae radii longe ligulatae, dis c i tubulosae, quinquedentatae. Antherae ecaudatae. Stigm a ta discicono longiusculo, pube sursum decrescente obsesso superata. Ach enia conformia, exalata, tetraquetra, ad angulos duos oppositos ciliata. Pa p p ns setaceus, uniserialis, brevissimus, aequalis. - Herbae $\mathrm{No}$ $v$ a e-Hollandiae; foliis alternis, lanceolatis, integris $v$, pinnatifidis, capitulis terminalibus, solitariis, ebracteatis, radio albo, disco luteo.

Brachystephinm Lessing Synops. 388. DC. Prodr. VI. 303. Pyrethrum divers ifolium Graham. Hooker Erot, Bot. t. 215. LindI. Bot. Reg. 1026.

2ซง5. Oligothorix CASS. Capitu I n multiflorum, heterogamum, floribns radii quinis, ligulatis, femineis, disci tubulosis, hermaphroditis. Involucri campanulati, ecalyculati squamae duodenae-quindenae, uniseriatae, basi concretae. $\mathbf{R}$ ecepta cul um planum, nudum. Corollae radii ligulatae, dis ci tubulosae, limbo quinquedentato. Anthera e ecaudatae, exsertae, stylum includentes, Stigmata ....... A chenia obtuse pentagona, erostria, imprimis secus angulos papulososcabra. P a p u s circiter quinquesetus, caducissimus, setis subcrispis, barbellatis, - Herba capen$s i s$, annua, saepius multicaulis, glaberrima; cauli bus erectis, teretibus, laxe dichotomo-corymbosis, foliis caulinis obtuse auriculato-amplexicaulibus, lanceolatis, apice dentatis, floribus flavis.

01 igothrix DC. Prodr. VI. 304 .

2 รง . DI multiflorum, heterogamum, floribus radii uniseria tis, ligulatis, femineis, disci tubulosis, hermaphroditis. Involucri uniseriati, basi squamula una alterave aucti squamae circiter viginti, acuminatae, discnm subaequantes. Receptacul a m planum, nudum. Corolla e radii ligulatae, ligula revoluta, disei tubulosae, quinquedentatae, dente nervo medio validiore percurso. Anth erae ecaudatae. Stigmata inclusa, apice barbata. A e he. n ia juniora compressa, adulta pentagona, secus angulos ciliata, rostro brevísimo, setis erassis, brevibus, pappum exteriorem simulantibus onusto $\mathrm{P}$ ap pus uniserialis, setiformis, tenuissimus, deciduus, radii pauci- disci multisetus. - Herba capensis, basi suffruticosa, ramosa, glabra; caulibus teretibus, foliis alternis, petiolatis, pinnatipartitis, lobis lanceolatis, dentatis, ramis apice in pedicellos quinos-septenos elongatos, subsquamellatos, monocephalos, subcorymbosos divisis, corollis pallide flavis, nervis opacis, subrubentibus.

A esogr a mma DC, Prodr. NT. 304.

2ร5ซ. Cinceraria LESS. Capitulum multiflorum, rarius homogammm, discoideum, plerumque heterogamum, floribus radii ligulatis, femineis, disci tubulosis, hermaphroditis. Involu cri subealyculati squamae uniseriatae, margine scariosae. Receptaculam planum, nudum, Corolla e radii dum adsunt ligulatae, di s c i tubulosae, limbo quinquedentato. A $\mathrm{n} t \mathrm{~h}$ e $\mathrm{r}$ a e ecaudatae. Stigmata disci cono brevissimo, pube adseendente superato obsessa. A $\boldsymbol{c}$ h e $\mathrm{n}$ i a plano-obcompressa, erostria, saepius, exteriora saltem margine alata, Pap p s conformis, uni-pluriserialis, capillaris, aequalis, caducus. - Herbae $v$. suffruticuli capenses; foliis alternis, variis, capitulis luteis.

Cin eraria Lessing Synops. 390. DC. Prodr. V1. 305. $\mathrm{X}$ enocarpus Cassini in Diet. sc, nat, LIX, 108, Cinerariac sp. capenses. Linn.

2ร98. Senecillig GARTN. Capitulum multiflorum, heterogamum, floribus radii subduodenis, ligulatis, femineis, disci tubulosis, hermaphroditis. Invol n eri cylindrici squamae uniseriales, aequales, demum stellato-patentes. R e e e $\mathbf{p}$ ta culum planum, nudum, foveolatum. Antherae ecaudatae. Stigmata disci cono brevi hispidnlo superata. A c he ni ablonga, sulcata, angulata, glaberrima. P a pi brevissimi, uniseriati paleae margine aculeato-plumosae, vix faucem corollae aequantes. - Herba perennis, glabra, glau$c a$, in campis sibiriae et Podoliae indigena; caule simplici, apice racemoso, foliis inferioribus late ovatis, in petiolum alatum angustatis, caulinis subcordato-amplexicaulibus, oblongo-ellipticis, foribus flavis.

Senecillis Gärtner II, 433. $t, 173$. Lessing Synops. 420. DC. Prodr. VI. 313. C Ineraria gi uea Linn. Solidagi a is s p. Gmelin Sibir. $I T . t$. 74 .

2899. Higularia CASS. C a pitu I um multiflorum, heterogamum, floribus radii uniseriatis, lignlatis v. bilabiatis, staminibus efoetis v.nullis femineis, disci tubulosis, hermaphroditis. Involucrum campanulatum, subuniseriale. R e e e ptaculum planum, nudum. Corollae radii ligulatae v. bilabiatae, disci tubulosae, quinquedentatae. Anthe ra e ecaudatae. Stigmata disci obtusa, pube longe descendente utrinque obsessa, cono brevissimo superata. A chenia erostria, sulcata, teretiuscula, exalata, haud ciliata. Pa pP u s pluriserialis, pilosus, conformis - Herbae perennes, in Asia media et India borealicopiose provenientes, in Europa orientali et media rarae; foliis alternis, variis, capitulis amplis, flavis, in racemum thyrsumve dispositis aut solitarits, longe pedunculatis.

Ligularia Cassini in Bullet. soc. philomat. 1816. p. 108. Dict, sc. nat, LXVI. 401. Lessing Synops. 390. DC. Prodr. VI. 313, Royle Himalay, $t .60, f .2 . \mathrm{H}$ op pea Reichenb. Hort. Bot. 8, $t, 10$, non alior. Cinerariate s p. Auct. Waldst. et Kilaibel Plant, Hung. $t, 16$. Lapeyr. Pyren, t. 5. Bot. Reg. t. 812, Ledebour Ic. $t$. 157, 354. 367. \$SO0. Armiea $L I N N$. Ca pitul um mul-
iflorum, heterogamum, floribus radii uniseriatis, 
ligulatis, staminibus nullis $v$. interdum efoetis femineis, disci tubulosis, hermaphroditis. Invo I uc ri campanulati, biseriati squamae lineari-lanceolatae, aequales. Recepta $\mathrm{c}$ u $\mathrm{I}$ m fimbrilliferum, pilosiusculum. Corolla e radii ligulatae, disci tubnlosae, tubo hirto, limbo quinquedentato. A ntherae ecaudatae. Stigmata disci longa, pube descendente obsessa, truncata v. cono brevi superata. A chenia subeylindracea, utrinque attenuata, subcostata, hirsutiuscula, P a p us uniserialis, pilis confertis, rigidulis, barbellato-scabris. - Herbae in hemisphaerae borealis regionibus frigidiusculis crescentes, perennes, subhirsutae; foliis oppositis, integerrimis, capitulis ad apices caulium et ramorum oppositorum solitariis, magnis, luteis.

A r n I c a Linn. gen. n. 958. excl. sp. Gïrtner $I T, t$. 173. Sclikuhr t. 248. FI. dan. $t$. 63. 1524. Cassiai $t n$ Dict. sc, nat, LI, 459. Lessing in Linnaea VT. 253. Synops. 390. DC. Prodr, YI, 316.

2901. A romieum NECK, Capitul um multiflornm, heterogamum, floribns radii uniseriatis, ligulatis, femineis, disci tubulosis, hermaphroditis. Involucri pauciseriati squamae lineares, acuminatae, subaequales. R e e ptacnlum subconvexum, epaleatum. Corolla e radii ligulatae, dis ci tubulosae, limbo quinquedentato. Antherae ecaudatae. Stigmata disci truncata, apice solo penicillata, radii brevia, obtusa. A $\mathrm{ch}$ enia erostria, exalata, oblongo-turbinata, sulcata. P a ppus setosus, disci pluriserialis, radii subuniserialis. - Herbae in Europa media et in Asia centrali alpicolae, habitu et foliis alternis Doronici.

Aronic um Necker elem. n. 49. Reichenbach Flor. excurs. II. 233. DC. Prodr. VI. 319. Gr a m in a rthro n Cassini in Bullet, soc, philomat. 1817, p. 32. Dict, se, nat, $X I X$, 294. A r nic a e s p. Linn. Jaeq. Flor, austr. $t, 82,349$. Ic, rar, $t, 586$, Loisleur Flor, gall, $t, 20$.

2898. Doronieum LINN. Capitulum multiflorum, heterogamum, floribus radii uniseriatis, ligulatis, staminibus nullis v, efoetis femineis, disci tubulosis, hermaphroditis. Involucri paueiseriati squamae lineares, a cuminatae, subaequales. Receptaculum subconvexum, epaleatum. Corolla e radi ligulatae, disci tubulosae, limbo quinquedentato. Antherac ecaudatae. Stigmata disci truncata, apice solo penicillata, $\mathrm{r}$ a di brevia, obtusa. A ehenia oblongo-turbinata, snlcata, erostria, exalata. Pap p u s ra dii nullus v. rarissime uni-trisetus, disci setosus, pluriserialis. - Herbae europeae et caucasicac, subhirsutae v. glabrae; rhizomate saepius tuberoso v. repente, foliis alternis, radicalibus petiolatis, caulinis alternis, plus minus amplexicaulibus, capitulis solitariis $v$. pluribus pedunculatis, floribus flavis.

D o r o n ie u m Linn. gen, n. 959. Gārtaer $I I$, t. 173. Cas. sini in Dict. sc. nat. XIIT. 454. Lessing Synops, 390. DC. Prodr. VI, 320.

a. EUDORONICUM DC. $l$. c. I n vo I u erum pauciseriale. P a p p u albidus. - Eolia radicalia cordata v. ovala. (Sehkuhr t. 249. Jaeq. Flor. austr. 1. 130, 350. E. B. 2654. Hayne Arsneigew, WT.t, 21. 22. Tenore Flor. Neapolit, $t, 79$. Bot. Mag, $t, 3143$.

b. CHRomochaeta DC. $l$. c. Involuctum subuniseriatum, demum reflexum. P a p as intense cinnamomeo. rufus. - Folia linearia. - Aster odontophyllus Wall. mes.

2S03. Wernexia H. B. K. Capitulum multiflorum, heterogamum, floribus radii uniseriatis, ligulatis, femineis, disci hermaphroditis, tubulosis. Invol ueri campanulati, ecalyculati squamae ligularum numero uniseriatae, plus minus inter se concretae. Rece p tac a l u m nudum. Co- roll a e radii ligulatae, dis ci tubulosae, quinquedentatae. Ant her a e inclnsae, ecaudatae. Stigmat a apice truncata, penicillata. A $\mathrm{cheni}$ turbinata, erostria, villosa. Pa p p u pluriserialis, setacens, subscaber, longus. - Herbae in $A m e-$ rica a equinoctiali alpicolae, caespitosae, humiles; foliis subradicalibus confertis, lineari-oblongis, integrerimis, coriaceis, subenerviis, glabris, basi subvaginante lanatis, capitulis solitarits, breviter pedunculatis, disco luteo, radio concolore v. albo.

Werneria Humb. Bonpl. et Kunth Nov. gen, et sp. IV. 191, t. 368. 369. Lessing Synops, 393. DC. Prodr, VI, 323. Oresigonia Willd, msc. $0 \mathrm{rib}$ a $\mathrm{i}$ a Flor. mexic. inerit. Euryopis sp. amerie. Cass.

2804. Culeitium HUMB. et BONPL, C apit u I u m multiflorum, homogamum, floribus omnibus tubulosis. Invol u cri campanulati, nudi v, bracteolis paucis stipati squamae biseriales. $\mathbf{R}$ ec e p t a $c \mathbf{n} l \mathbf{u m}$ latissimum, planum, foveolis tetrapentagonis regulariter areolatum. Coro Il a e ta bulosac, fauce longa, tereti, limbo quinquedentato. Staminum articalus superior elongatus, antherac ecaudatae. Stylus basi bulbosts; $8 \mathrm{tig}$ a t a apice subglaboso-capitata, hispidula. Achenia teretiuscula, striata, glaberrima, erostria, apice in marginem subdilatata. Papp us e margine ortas, pluriserialis, setiformis, subscabridus. - Herbae in America a equinoctiali et australi alpicolae, tomentoso-lanatae; caule simplici monocephalo, rarius ramoso oligocephalo, foliis alternis, integris, capitulis amplis, luteis.

Culcitium Humb. et Bonpl. Plant, aequinoct, $1 T$. 1 . t. 66. 67. Kusth in Humb, et Bonpl. Nov. gen. et sp. IV. 170. $t$. 362, 363. Cassini in Dict. sc. nat, XVIIJ, 210. Lexsing Synops.393. DC, Prodr, VI, 324, 0 r e s i g o a i a Schleeh. tend, msc.

2805. Aymoxys CASS. C a p itulum multiflorum, heterogamum, floribus radii uniseriatis, ligulatis, femineis, disci tubulosis, hermaphroditis. I nvo I u r n m uniseriale, saepius bracteolis paucis subcalyeulatum, disco brevius. Re eepta $\mathrm{cu}$ lum planum, alveolatum. Corollae radii ligulatae, disci tubulosae, limbo quinquedentato. Anthera e ecaudatae, Stigmat a disei in conam hispidnm, elongatum, acutissimum producta, deorsum saepe hispidula. Achenia teretiusenla, erostria, exalata. Pa p p u conformis, pilosus, pluriserialis. - Plantae in America a equinoctiali indigenae, aliae arborescentes, opposilifoliae, aliae scandentes, alternifoliae; foliis petiolatis, capitulis corymbosis, flavis.

G y nox y s Cassini in Dict. sc, nat. XLVIIT. 455. Les. sing Synops. 390. DC. Prodr. VI, 325.

2806. Caealia DC. Capitnlum pluririflornm, homogamum, floribus omnibus tubulosis. Invol a crum uniseriale, penta - polyphyllum, bracteolis pancis basi subcalyculatum. R e e e p tac u l u m epaleatum. Co roli a e tubulosae, limbo quinquedentato. Ant hera e ecaudatae. S $t$ ig mat a cono brevi, basi snbhispidulo terminata. A c h cn i a oblonga, erostria, glabra. P a p u s uniserialis, multisetus, setis rigidulis, scabridis. - Herbae perennes, in America cis a equatorem, in Asia media et Africa australi indigenae; foliis alternis, saepius petiolatis, dentatis $v$. lobatis, capitulis paniculatis $v$, corymbosis, corollis albidis, roseis $v$, ochroleucis.

Caenlia DC. Prodr, VI. 327, Ca enliae sp. et Pe $\mathrm{r}$ icalia Cassini in Dict. se. nat, XLVIII. 459.

a. EUCACALIA DC. $l$. c, Receptaculum plaaum, audum. - Specics asiati ae et anericanac, Roribus al. 
bis v. albidis. (Kunth in Humb. et Bonpl. Nov. gen. et sp. $t$. 360.)

b. CONOPHORA DC. $l$. c. Receptaculam medio in conum angustum, sterilem productum. - Species borealiamericanae.

? e. AULACOPHORA DC. 2 . c. Invol u erum ecalyeula tum, deca-dodecaphyllam. R c e p $t a c$ a a m fimbrillife. rum, conicum, undique floriferum v, planiusculam. Species mauritianae et madagascarienses, dubiae of. finitatis, corollis flavis, antheris lilacinis.

?d. CISSAMPELOPSIS DC. $l$. c. Capitula decemflora, a nthera e louge exsertae, stigmata cono brevi, acuto superata. - Suffrutices capenses v. javanici, scandentes. floccoso-araneosi, folits alternis, petiolatis, orbi. culatis.

280\%. Parealimm $D C$. C a pitulum pluri-multiflorum, homogamum, floribus omnibus tubulosis. Invol u eri ample bibracteati v. ealyculati squamae octonae-sedenae, disco breviores. Receptacu I a m planiusculum, nudum. Corollae tubulosae, quinquedentatae. Antherae ecandatae. Stigmat a elongata, praeter nervos marginales medio uninervia. Achenia striata, erostria, glabra. Pa p p $\mathbf{s}$ uniserialis, pilosus. - Herbae $v$. frutices in $A$ merica a equinoctiali indigeni, habitu vario.

Psacalium DC. Prodr. NI. 334.

a. PSACALIUM Cass. Herb a foliis peltatis

P s a cali um Cassini in Dict. sc, nat, XLVIII, 461 . Cacalia peltat a Kunth in Humb. et Bonpl. Nov. gent, et sp. $t, 361$.

b. PENTACALIA Cass. Frutices, interdum arborescentes, foliis haud peltatis.

Pentacalia Cassint in Dict, se, nat. XLDIIT. 461, Cacaliae s p. Kunth Op. cit. t. 358.359.

2809. Lopholaena DC. Ca pitulum multiflorum, discoideum, subheterogamum, floribus marginalibus antheris abortivis interdum femineis, centralibus styli abortu nonnungnam masculis. Involucri pentaphylli squamae liberae, foliaceae, dorso eristam longitudinalem exserentes, margine late alatae. Receptaculum alveolatum. Coro 11 a e tubulosae, tubo tereti, centralium indurato, integro, marginalium interdum ad latus interius longitudinaliter fisso, limbo quinquefido. St a $\mathrm{m}$ i$n \mathbf{m}$ articulus antherifer longus, crassus, an $t h e-$ $r$ a e candatae. Stigm a $t$ a elongata, inferne intus biseriatim stigmatosa, dorso puberula, apice in appendicem elongatam, undique hispidam, vix acutam producta. A $\mathbf{c h}$ e $\mathrm{n}$ i a angulata, erostria, gla. briuscula, ad angulos ciliata, centralium nonnulla abortiva, compressa. P a p u s multiserialis, setosus, vix scaber. - Suffrutex capensis, erectus, glaber; foliis alternis, sessilibus, basi utrinque in nervos tenues subdecurrentibus, elliptico-v. oblongo. lanceolatis, obtusis, integerrimis, trinerviis, subcoriaceis, ramis foliosis, monocephalis, in corymbum dispositis, corollis pallide flavis.

L o pbolaen a DC. Prodr. VI. 335.

2809. Kuleinia LINN. Cap ituln m multiflorum, discoideum, homogamum v. rarissime heteroganum. Involuerum bracteolis parvis calyculatum v. rarissime nudum, uniseriale, polyphyllum. R e epta e u l um plannm, nudum, Corolla e tubulosae, limbo quinquedentato. Ant hera e ecaudatae. Stigmata cono brevi, basi ciliato terminata. A chenia erostria. Pappus setosus, subscaber, plnriserialis, - Frutices africani, carnosi, interdum subacaules, saepius glauci; ramis teretibus v. angulatis, cicatrisat is, foliis alternis, saepius integerrimis, floribus albis v. saepius flavis.
K l e inia Linn. Hort. cliffort.395. Haworth Plant, suc. cul, 313. DC. Prodr, VI. 336. non alior. C a c a II a Cassini in Dict. sc. nat. XLVITY. 459. Lessing Synops, 395. non alior. C a c a li ant hemum Dillen. Hort. eltham, $I, 54 . \mathrm{C}$ a $\mathrm{ca}$. I i a e sp. Linn.

a. CACAlianthemum DC, $l$, c, Capitulum homogamum, ftoribus omaibus hermaphroditis. - Cacallac s p. Linn. Gärtn. t. 166. f. 1, Jacq. Ic, rar, t. 68. DC. Pl. gr. t. 12. 18. 42. 90.

b. ERECHTITOIDES DC. l.c. C a p it u l u m heterogamum, discoideum, floribus radii uniseriatis, femineis, filiformitubulosis, bi-tridentatis v. oblique truncatis, ligulam minutissimam monstrantibus. - C a e ali a a caulis Lian. f.

2810. Aeleia $D C$. Capitulum multiflorum, homogamum, floribus omnibus tubulosis. I n v I u cr n m uniseriale, cylindraceo-globosum, squamulis paucissimis ad apicem pedicelli substipatum. Receptaculum planum, nudum. Corella tubulosae, limbo quinquedentato. Anthera e ecaudatae. Stigmat a $\ldots \ldots \ldots$ A $c$ henia laevia, plano-compressa, apice in collnm breve $\mathrm{nr}$ ceolum disciformem sustinens dilatata. P a p p u s pilosus, subdenticulatus, decidaus._Herba a e g y ptiaca, annua, ramosa, erecta, glabra; foliis inferioribus petiolatis, ovalibus, crenatis, caulinis amplexicaulibus, inciso-dentatis, capitulis paucis, laxe corymbosis, corollis luteis, demum fusco-violaceis.

A eleia DC. Prodr. DI. 340. Senecio Belbeysius Delile Flor, aegrpt, $t, 45 .$, f. 3.

2S11. Senecio LESS. C a p it ulnm multiflorum, homogamum, discoideum, v. heterogamum, floribus radii uniseriatis, ligulatis, femineis, disci tubulosis, hermaphroditis. In vo l u e r i nune nudi, nunc squamellis accessoriis calyculati squamae uniseriatae, saepius apice sphacelatae, margine subscariosae, dorso plerumque binervatae. $R$ ecepta $c \mathbf{u} \mathbf{l} \mathbf{u}$ epaleatum, nudum v. alveolatum. Corolla e radii ligulatae, d is e i tubulosae, limbo quinquedentato. A n $\mathbf{t}$ h e r a e ecaudatae. Stigmat a disci truncata, apice solo penicillata. A ch n i a teretiuscula v. sulcato-angulata, erostria, exalata. Pa p p us pilosus, pluriserialis, caducus, setis rectis, subaequalibus, tenuissimis, vix scabris. - Genus totius regni vegetabilis ut videtur vastissimum, nondum rite quo ad subdivisiones stabilitum, speciebus herbaceis $v$. fruticosis polymorphis, per totum orbem obviis, plerisque endemicis, foliis alternis, capitulis solitariis, corymbosis $v$. paniculatis, corollis disci plerumque luteis, rarissime purpureis, nunquam nisi in stirpibus cultis albis, ligulis flavis, rarissime purpurascentibus $v$, albis.

Seneclo Lessing Synops. 391. DC. Prodr. VI, 3 40. Senecio, Cacaliacet Ciuerariaesp. Linn. Seneeio et Anecio Necker elem, $n, 174$ et 52. Sene cio et $\mathrm{J}$ ae o bae a Tournef. inst. 436 . 485 . J a c o bae a, $\mathrm{S}$ e ne e jo et Doriae 8 p. Thunb. Jacobaca, Obaejaca, Eudorus, A etheolaena, Carderina, Dorobaea, Synar. thrum, Selerobasis, Pithosillum, Aspelina, Senecio, Scrobicaria et Cineraria Cassini Opusc. phyt. III. 70. 71. Dict, se, nat, XLVIIT. 45t. ss. S e n e c i o et RoIdana Llav. et Lexarz. Senecio et Perieallis D. Don.

1. CAUCASICI DC. Prodr. VI, 341. Species in Europa, Africa mediterranea, Oriente et Sibiria sponte naseentes. a. 0 b a ejacae DC. Prodr. V1. 341. Lig ulae nullae tune flores radil interdum feminei, v. ligulae brevissimae, revolutae, involucrum vix superantes. A c h enia teretiuscula, striata, saepias puberula. Pappns corollas disei subaequans. - Herbae annuae, involuer is ovato-cylindraceis, calyeulatis, floribus luteis.

* Senecio Cass. Ligulae nullae. - Senecio Vaill. Adans. Gärtn. $I T$. $t$. 166. Cassini in Dict. sc. nat. XLVIrT. 454. Se ne ci o ty p a s Dumort. Flor. belg. 65. (Jacq. Hort. Vindob, I. $t, 3$. Flor. dan. t. 513. E. B. t. 742.) 
** $O$ baejaca Cass. Ligula e minimae, revolutae. 0 b t e $\mathrm{j}$ a c a Cassini in Dict. sc. nat. $X X I V .113$. $X X X Y, 270, X L V I T I, 448$. (FI. dan, $t, 869,1230, \mathrm{E} . \mathrm{B}$. t. 32. 748. 2515. Tenore Flor, neap, II, $t, 78$.

b. 0 baejacoide ae DC. Prodr. VI.343. Capit ula radiata, ligulis planis, exsertis. - Herbae annuae, involucro calyculato, floribus luteis. - (Vahl Symb. II. t. 45. E. B. t.600. Waldst. et Kitaibel Plant. Hung. $t, 24$. Desfont. Fl, atl. t. 233. Dufour in Annal. sc. nat. $\nu$. t, 11. Viviani Fl, lybic, t, 11, f. 3. Ledebour Ic, t, 493. Cinerariae s p. Cavanill. Ic. t. 33. f. 3. Ortega Do. cad. t, 10. f. 2.)

e. Ecalyeulati DC. Prodr. VI, 367. Capitula radiata. - Herbae perennes, involuero ecalyculato, floribus luteis, folits varie pinnatilobatis v. dentatis, glabriusculis. - (Hooker Fl. Bor. Amer, t, 112. C i. nerarlae s p. Jaeq. Fl, austr. t. 167. 177.)

d. Jacobaca DC. Prodr. VI. 348. Capitula ra. diata. - Herbae perennes, involucro calyeulato, folits pinnati- $v$. bipinnatilobis, glabris $v$, glabriusculis. (Jacq. Fl. austr. t. 79. Desfont. Flor. atl. t. 23\%. Vahl Symb. $I$. t. 18. Fl. dan. $t$. 784. E. B. $t .574 .1130,1131$. Waldst, et Kitaibel PI. Hung. t. 128. J a c o b a e a Gärtn. t. 170. $f$. 1. Herb i ch i a Zawadzky Flor. Galic, 198.)

e. S a rracenici DC. Prodr. VI. 352. Capitula plerumque radiata. - Herbae perennes, involucro calyoulato, floribus luteis, folits integris $v$. dentatis, glabriusculis. - (Jacq. Fl, austr. t, 184 - 186. Fl. dan. t. 385. E. B. t. 650. 2211. Waldst, et Kitaibel Pl. Hung. c. 210. Far o ba a Schrank ex Colla Hort. Ripul. Ap. pend. IV. 19. $t, 9$.

f. Fruticulosi DC. Prodr. VT. 354. Capitula radiata. - Caules fruticosi, folits integerrimis $v$, den tatis, glabriusculis, floribus luteis. (Forskal Ic. t. 19.)

g. In c a ni DC. Prodr. NI. 355. C a pitula radiata, ligulis 5-12, planis. Pap p us disci tubum corollae superans. - Herbae perennes $v$. suffrutices; folits to mento denso utrinque $v$, subtus canis, varic pinnatilo batis, lobis obtusis, capitulis favis, corymbosis v. rarissime solitarits. (Allioni Flor. pedemont, t, 17, f. 3 . t. 38. f. 3.)

h. Crociserides DC. Prodr. VI. 357, Capitula radiata, ligulis planis. A $\mathrm{e}$ h enia glaberrima. Pappus disci corollaw aequans. - Herbae perennes, involucro bracteolis paucis calyculato, folits integerrimis $v$. parce dentatis, capitulis solitariis $v$, paucis, longe pedicellatis, flavis. - (Jacq. Flor, austr. append, t. 45. Hooker Fl. Bor. Amer. $t$. 113. C inerariae $\mathrm{sp}$. Ledebour Ic. t. 94 . Cinerariae sectio Crociseris Reichenb. Flor, excurs, 242.)

i. Tephroserides DC. Prodr. VI. 359. CapltuIa radiata, ligulis 15 _20, rarius nullis. A e be n $i$ a gla. bra v. pubescentia, angulato-subcostata, costis aequalibus, parum exsertis. Pa p p us parcior. - Herbae perennes, caule simplici, corymbis oligo-polycephalis, simplicibus, nune subracemosis, nune umbellatis, involucro polyphyllo, ecalyculato, ligulis flavis v, aurantiaceis. (C in er a ria e 8 p. Jaeq. Fl, austr. $t, 178.179$. 181. Trattinick Archiv, t. 48. Waldst. et Kitaibel Plant. Hung. $t$. 239. Bot. Mag. $t$. 2262. Cinerariate sectio Te phroseris Reiehenb. Fl. excurs. 241.)

k. Heloserides DC. Prodr. VI, 362. Capitula radiata, ligulis circiter 20 . A c h e $\mathrm{n}$ i a glabra, uniticostata, eostis subinaequalibus, angustis, exsertis. P a pp us multisetus. - Herbae biennes, subhirsutae, involucro ecalyculato, esphacelato, polyphyllo, corymbis subcompositis, ligulis pallide flavis. - (C i ne r a ria e s p. Linn. F1. dan. t.753. E. B. t. 151. Schkuhe t. 246.a. Cinerariae sectio Heloseris Reichenb. Fl. excurs. $I T$. 241. Cinerariae sectio Eriopappus Dumort. $F l$. Belg. 65.)

II. ChInENSES DC. Prodr. VT. 363. Species in China media et australl, nec non in Japonia sponte nascentes. T u s s flagin is s p. Linn. Banks Ic. Kämpff. $\iota, 27.28$.

III. INDICI DC. Prodr. $V T$. 364. In Indiae continente et insulis indigeni.

IV. AUSTRALASICI DC. Prodr. $7 I, 370$. In Nova-Hollan dia et insulis vieinis crescentes. - (A. Riehard Sert, Astrolab. $t, 37.38$.

V. SANDWICENSES DC. Prodr, VI. 375, In insulis Sand. wicensibus habitantes.
V1. MAURITIANI DC. Prodr. VT. 375. In insulis Mauriti et Borboniae nascentes. - (Lam, t. 6r6, f, 6, 7.)

H a bertia Bory Voy. t. 14. f. 1. t, 14. bis. Pithos $f 11$ u m Cassini in Diet. sc. nat. XLT. 165. S y n a rthrum Cassini Op. cit, XLVIIT, 455. LI. 457.

YII. MADAGASCARiENsES DC, Prodr, VI.376, In insula Madagascar spontanei.

VIII. CAPENSES DC. Prodr. $V I$, 379. In Africa australi extratropica indigenl.

a. A n nu i DC. Prodr. VI. 371. C a pitula radiata, lutea. - Caules horbacei. Hadices annuae. Folia va. ria. - (Jacq. Collect. V. t. 6. f. 2. Fragm, t. 1. f. 3.)

b. Gymnorbizi DC. Prodr. VI. 383. Capitula radiata, lutea $v$. discoidea. - Species perennes. Caules herbacei, nudiusculi, ad collum non lanuginosi, folia nec decurrentia nec subtus dense tomentosa.

c. Lasiorhizi DC. Prodr. VI. 387. Capitula radiatn, latea v. discoidea. - Herbae perennes, collo lanuginoso.

d. Decurrentes DC. Prodr. VI. 388, Capitula radiata, lutea. - Herbae perennes, foliis caulinis de. currentibus.

e. Verbascini DC. Prodr. VI. 389. Capitula radiata, luten. - Species perennes, caulibus herbaceis folitsque utrinque plus minus incano-tomentosis. (Jacq. Hort. Schönbr. t. 150.)

f. Hy pole uci DC. Prodr. VI. 389. Ca pitula ra. diata, lutea, v. discoidea. - Caules suffruticosi, folia linearia $v$. lanceolata, integra $v$. hine inde sublobata, margine saepe revoluta, subtus (rarius etiam supra) plus minus tomentosa.

g. Rigidi DC. Prodr, VI. 392. C a pi t ula radiata, lutea. - Caules plus minus saltim ad basim fruticosi, foliosi. Folia ovata $v$. lato - lanceolata, orosse dentata. - (Jacq. Hort. Schönbr, t, 304. Collect, V. t. G. $f .1 . \bar{S}$ cl e r o bas is Cass. in Diet. ec, nat, $X L V I I T .455$.

h. Serratuloidei DC. Prodr. VT,394. Capitula radiata, lutea. - Caules suffruticosi, foliosi. Folia lyrato-pinnatisecta, lobis lateralibus parvis, integris, oblongo-linearibus, terminali maximo, dentato.

1. Leptolobi DC. Prodr. VI. 395. C a pitula radiata, lutea v. discoidea. - Caules fruticulosi. Folia pinnatiloba, lobis angustis. - C C e a ll a e s p. Jacq. Ic. rar. t. s81.)

k. Carderini DC. Prodr. VI, 397. C a pitula ra. diata v. diseoidea, Intea, ad basim involucri squamellis pluriserialibus, subimbricatis instructa. (Heritier Stirp. t. 5. Jacq. Ic, rar. t, 180, Ca rderina Cassini in Dict, sc. nat, XXXN. 272.)

1. Pinifolii DC, Prodr. VT, 399, Ca pitula radiata v. discoidea, Intea. - Caules fruticosi, folia acerosa, integerrima, glaberrima.

m. Leptopbylli DC, Prodr. FT. 399. Capitula radiata v. discoidea, lutea. - Caules suffruticosi. Folia linearia $v$, oblongo-linearia, integerrima $v$, dentata, aut vix hinc inde sublobata, Glabra v, Airtella, nunquam tomentosa. (Jacq. Ic. rar. $t, 587$.

n. Kleinioidei DC. Prodr. NI, 401. Capitula radiata, lutea. - Caules fruticoso-subearnosi, folia carnosa, glabra, integerrima, rarius lateraliter in. ciso-dentata.

o. Glaberrimi DC. Prodr. VI, 403, Capitula radiata v. discoidea, lutea. - Suffrutices $v$. saepius her. bae glaberrimae, volubiles v, erectae. Folia plerumque petiolata, saepius tri-quinquelobata, palmato-angulata.

p. Erythraei DC. Prodr. VI. 405. Flores omnes v. saltim radii purpurei, rarius variantes albi. (Jacq. Ic. rar. t. 580. Andr. Bot, Reposit, t. 291. Bot. Mag. t. 238. Bot. Reg. t. 41. 901.)

1X. CANARIENSES DC. Prodr. VT. 409. In Insulis Canariis, Azorieis et Madera erescentes.

a. Pericallides DC. Prodr. VI. 409. Invola. c r a m uniseriale, polyphyllum, eealyculatum. L I gu 1 a e plures, planae. - Erutices v. herbas canarienses et madeirenses ; foliis caulinis petiolatis, palmatinervits, angulato-lobatis, basi cordatis, saepe subtus tomentosis, ad basim petioli non raro aurito-stipulatis, capitulis tomentosis, pedicellis bracteoligeris, floribus pur. 
pureis, albis $v$, rarius flavis. - Cinerariae sp. Heritier Jacq. Colloct. III. t. 19. $f$. 3. Vent, Malm. t. 99. 101. Jacq. f. Eclog, $t, 105$. Bot. Mag, t.53.1786.)

b. Bethencourtii DC. Pradr, VI. 411. Involuc r u m pentaphyllum, oblongum. Flo res 7 - 8 , lignlati 2-3, tubulosi 4-5. - Caules fruticosi, folia longe cuncata, apice incisa, glabra. - Bethencourtia Cholsy in Buch Canar. 148. non St. Hilaire. Cinera. $\mathrm{r}$ i a palmens is Nees in Hor, phys. berolin. $t .22$.

X. CARIBAEI DC. Prodr. $V I$. 411. Frutices in insulis caribaeis spontanei. - Cineraria e s p. Swartz. Bot. Mag. t. 2647. G y noxys $8 \mathrm{p}$. Less.

XI. PATAgoniCI DC. Prodr. VI. 412. In Patagonia, insolis Maclovianis et terra Magellanica vegetantes.
Cacaliae $8 \mathrm{p}$. Vahl Symb. III. t. 71 . Cinerariae s p. Lam. $t$. 675. $f$. 4. Smith Exot. Bot. $I T$. $t$, 65 .

X11. CHILENSES DC. Prodr. VI. 413. Species in agro Chilensi spontanel. - D a n a Colla in Mém. Academ. Taurin. XXXVIII, t. 28. Heterolepis Bertero msc. A denotriehia Lindley in Bot, Heg. t. 1190.

XIII. BRASILIENSES DC. Prodr, VI. 418, In Brasilia, imprimis meridionali, et in Bonaria spontanei.

XIV. PERUViani DC. Prodr. VT. 420. In Perusia, Bolivia et Columbia crescentes. - Cacaliae $\mathrm{sp}$. Kunth in Humb, et Bompl. Nov, gen, et sp. $t, 357$, S enecion is s p. Kunth $O p$. cit. t. 369. S ta ehelinae sp. Linn. Smith Iv. inedit. III. $t, 71$. $\mathrm{S} \mathrm{cr}$ o bi c a ria Cassini in Dict. se, nat, XLVIIT. 456. A e the ol a ena Cassini Op. cil. XLVIIL. 453. D o r o ba ea Cassini $l$, $c$.

XV. MEXICANI DC. Prodr. VI. 426. In terris Mexici, California et Louisiana australiore indigeni. - (Kunth in Humb. et Bonpl. Nov. gen, et sp. $t$, 365. Hooker in Bot. Mag. t. 3487. C inerariae sp. Cavanill. Ic. t. 24\%. DC. Hort. Genev, t. 7. Schrank Hort. Mtonac. t. 95. Colla Hort. Ripul. App. 2, t. 12. Rold a na Llav. et Lexarz. Nov. Veget, II. 10.

XVI. BOREALI - AMERICAN1 DC. Prodr, VI. 431. In America boreali, exelusis provineiis anstralioribus et California erescentes. - (Hooker Flor. Bor. Amer, t, 114._116.)

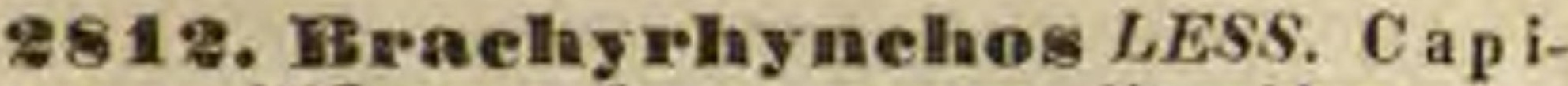
tu I n m maltiflorum, homogamum, discoiden, v. heterogamnm, floribus radii uniseriatis, ligulatis, femineis, disci tubulosis, hermaphroditis, Involucrum nniseriale, squamellis paucis calyeulatum. ll ceepta $\mathrm{c} \mathbf{n} \mathbf{l} \mathbf{m}$ planum, nuilum. Corollae ra di ligulatae, disei tubulosae, limbo quinquedentato. Antherae ecaudatae. Stigmata apice snmmo puberula. A ehenia elongata, striata $v$, angulata, exteriora subcompressa, apice in rostrum breve producta. Pap p u pluriserialis, setis piliformibus, ima basi subconcretis. - Herbae ca$p$ en ses habitu vario, fortassis vix rite in genus consociatae $v$, non satis a Senecione diversae.

Brachyrhy a ehos Lessing Synops. 392. DC. Prodr. VI. 437. Cinerariae s p. Auct.

a. EUBRACHYRHYNCHOS DC, $l$. c. Capitula radiata 12_15flora, ligulis 5, oblongis. A ehe nia striata, laevia, glabra.- Rami aplizlit, flores lutei, capitula par. ce calyculata.

b. TRACHYCARPUS DC. $l$. c, Capitula radiata v. discoidea. A eh e n i a papillis piliformibus v. pilis brevibus plus minus aspera, - Herbae perennes, ad collum sae pe subtuberosae, glabrae $D$, araneoso-lanatae; folits petiolatis, nune pinnatisectis sublyratis, nune ovato. cordatis, inciso -dentatis, pedunculis elongatis, mono. cephatis, squamellis longis, subulatis instructis, involucro ecalyculato.

2813. Mradaraetis DC, Capitulum multiflorum, heterogamum, floribus radii uniseria tis, ligulatis, stylo nullo $v$. rudimentario neutris, disci tubulosis, hermaphroditis. Involueri polyphylli, squamellis pancis calyculati squamae uniseriales. Recepta $\mathbf{c} \mathbf{L} \mathbf{l} \mathbf{m}$ planum, nudum. C 0 roll a e radi ligulatae, dis ci tubulosae, limbo quinquedentato. An th e rae ecaudatae. Stig mata disci apice truneato-penicillata. A c he nia $\mathbf{r a -}$ dii cylindrica, disci breviora. Pappus radii nullus v. paucisetus, di s ci pluriserialis, pilosus. - Herbae indic a e, saepe basi suffruticulosae, plerumque pubero-scabrae, Senecionum habitu; folits alternis, dentatis $v$, pinnatijidis, capilulis solitariis v. corymbosis, longe pedicellatis, floribus luteis.

$M$ adaractis DC. Prodr. VI. 439.

2814. Tetradymia DC, Capitulum quadriflorum, homogamum. In vol a eri tetraphyli squamae biseriales, cruciatim oppositae, ovali-oblongae. Receptaculum angustum, nudum. Corolla e tubulosae, quinquefidae, lobis linearibus. Anthera e ecaudatae. Stigmata teretiuscula, apice capitellata, A ch enia erostria, villosa. Pappus pluriserialis, deciduus, setis rigidulis, dense et Ionginseule serratis. - Herba in America boreali-occidentali indigena, tomentoso-cana; caule tereti, folioso, foliis alternis, sessilibus, linearibus, integerrimis, mucrone rigidulo terminatis, capitulis quinis-octonis pedicellatis, in racemum terminalem confertis, floribus luteis.

Tetradymia DC. Prodr, VI. 440.

2815. IRaillarala GAUDICH. Capitnlu m quadri-sexflorum, homogamum. Involuer um cylindraceum, tetra-pentaphyllum, floribus aequale, basi bibracteolatum $v$. nudum. R e ce p $t$ ac $\mathbf{l} \mathrm{lum}$ angustum, nudum. Coroll a e tubulosae, tubo obconico, limbo quinquedentato. St a min u m filamenta superne incrassata, an $t$ h e $r$ a e ecaudatae. Stigmata arcuato-divergentia, plana v. semifiliformia, acuminata, ciliata, exserta. A $\mathbf{c}$ he $\mathrm{n}$ i a tereti-angulata, turbinata $\vee$. basi attenuata, hirsuta v. glabra. Pappus uniserialis, plumosus, setis basi subcorneis. - Frutices Sandwicenses; ramulis teretibus, ternatis, foliis alternis v. ternatoverlicillatis, linearibus v. lanceolatis, integerrimis, subcoriaceis, nitidis, capitulis in racemum v. corymbum paniculatum dispositis, involucris extus subscabris, floribus luteis, pappo rufescente.

R a illarda Gaudichaud ad Freyc. 469. $t .83$.

2816. IBedifordia $D C$. Cap i $t u l u m$ mnltiflorum, homogamum. Involucri ovati, basi bracteolis binis v. ternis subulatis stipati squamae imbricatae, aequales, distinctae, bi-triseriales. Receptac ulum favosum, alveolorum marginibus dentatis. Corolla e tubulosae, tubo gracili, limbo abrupte dilatato, quinquepartito. An $t$ h er a e ecaudatae, apice appendiculatae. Sty lu s basi bulbosus; stigmat a linearia, arcuata, obtusa, apice hispidula, dorso subpapillosa. A c b e nia glabra, tereti-angulata, apice margine dilatato. $P$ a p p us uniserialis, pilosus, setis basi scabridis, apice Iongius barbellatis. - Frutices Novae-Hollandia e; ramis teretibus, junioribus tomentosis, foliis alternis, saliciformibus, subintegerrimis, lanceolatis $v$. linearibus, coriaceis, supra glabris, subtus tomentosis, capitulis ad axillas solitariis $v$. breviter racemoso-corymbosis, floribus luteis.

Bedfordia DC. in Guillem. Archiv. Bot. II, 332 . Prodr. VI. 401. C a c a lia e $s p$. Labillard, Nov, Holl, $t, 178$. 179. Lindl. in Bot. Neg. t. 923.

281 \%. Notomia DC. Capitulum multiflorum, homogamum. Invol u e rum cylindricum, uniseriale, floribus brevins, ecalyculatum, bracteolis nallis v. secus pedicellum paucissimis instructum. Recept a $c$ u lum planum, alveolatum, alveolorum marginibus productis fimbrilliferum. Corolla e tubulosae, quinquedentatae. $\mathrm{S}$ t ig $\mathbf{m}$ a $\mathbf{t}$ in conmm brevem, hispidum producta. $A \mathbf{c h}$ e nia teretia, multistriata, glabra. Pappus multi- 
serialis, setis filiformibus, hine inde barbellatis, Suffrutices indici, carnosi, glabri, Kleiniae facie; ramis teretibus, cicatrisatis, foliis oblongis $v$. obovatis, planis, subcarnosis, integerrimis, corymbis pau cifloris, capitulis majusculis.

Noton i a DC. in Guillem, Archiv, Bot, II. 514. Prodr. VI. 441. non Wight et Ara. C ac a li a e sp. Wallich.

2818. Taelhanodes DC. C a p it $\mathrm{u} \operatorname{lnm}$ pluriftorum, homogamum, floribus omnibus tubulosis, v. rarius heterogamum, floribus radii uniseriatis, ligulatis, femineis, disci tubulosis, herma phroditis. Invol u crum uniseriale, squamis quinis-septenis, margine submembranaceis, erectis, bracteolis ad apicem pedicelli minimis, pancis subcalyculatum. Recepta cu lum angustum, epaleatum, alveolare. Coroll a e radii dum adsunt ligulatae, ligula obovata, disci tubulosae, tubo basi corneo, conico, incrassato, lobis quinque, lanceolato-linearibus, medio uninerviis. Antherac eeaudatae. Stylus basi bulbosus; $s$ tigmata longa, revoluta, lineari-filiformia, hermaphroditorum apice in conum brevem subpuberulum desinentia. A chenia oblonga, glabra, sessilia, erostria, demum striata. P a p p 8 pilosus, pluriseriaIis, subaequalis, tubo corollae brevior, subscaber. - Arbores insula e $\boldsymbol{S} t$. Helena e, cortice crasso, ligno tenero, albo; foliis alternis, breviler petiolatis, penninerviis, dentatis, ovali-lanceolatis, capitulis in corymbum compositum dispositis, floribus albis.

$\mathrm{L}$ ach a nodes DC. in Guillem. Archiv. Bot, II. 332. Prodr. VT. 448.

a. EULACHANODES. C a pit n 1 a pauciflora, homogama - Mikania arborea Roxb.

b. PLADAROXXLON. Ca pitula pluriflora, heterogama, radiata. - Solidago Leucadendron Willd.

2815. Euryops CASS. C a p itu ln multiflorum, heterogamum, floribus radii uniseriatis, ligulatis, femineis, disci tubulosis, hermaphroditis. Involucri uniseriati squamae marginibus plus minus concretae, per aestivationem valvatae. $\mathbf{R} e-$ c e p t a cu ln m convexum, nudum, alveolatum. Coro 11 a e radii ligulatae, disei tubulosae, limbo quinquedentato. Antherace ecandatae. Stig mata hermaphroditorum truncata, apice solo penicillata. A c h e n i a teretinscula, erostria, exalata. Pa p u s pluriserialis, setaceus, cadueus, flexuosus, pilis exterioribus saepe deorsum flexis. - Frutices capenses, ramosi; foliis alternis, sparsis, plus minus coriaceis, varie sectis $v$. integris, pedunculis nudis, monocephalis, solitariis v. approximatocorymbosis, floribus luteis.

Euryops DC. in Bullet. soc. philomat. 1818, p. 160. Dict. sc. nat, XVI. 49. (exct. Werneria), Lessing $\mathcal{S}$ ynops. 393. ? Hertia Necker elem. $n$. 11, von Less. Eua ntiotrich u m E. Neyer in Herb. Dreg. O th on na e sp. Linn. Thumb. Jacq. Itort. Sehönbr. t, 239, 269, 308. Bot. Mag, t.306. Bot. Reg. t, 108. Loddig. Bot. Cab. t, 728, 1698.

THVISI0 IV. BALBISIEAE DC. Prodr. VI. 447. Capitulum homogamum discoideum, v, radiatum subdioicum. R ece p tacul $\mathrm{nm}$ nudum. Cotyledones involutae. Frulices insulae Si. Juan Fernandes.

2820. Balbisia $D C$. C a pitulum triflorum, homogamum. Involueri triphylli, cylindrici, basi braeteolis paucis, minimis subcalyculat squamae erectae, glabrae, apice summo albo-ciliatae. Receptaculum angustum, nudum. Corolla e tubulosae, coriaceae, quinquelohae, lobis erectis, linearibus, subconvolutis. Anther a e liberae, ecaudatae, appendiculatae. S ty In s crassus, durus, exsertus, stig matibus crassis, revoluto-divaricatis, sulco medio exaratis, vix apice summo puberulis. A e h e nia elongata, compresso-teretiuscula, subangulata, pube rufa, adpressa, apice pappi basim cingente inducta. Pap p us candidissimus, subuniserialis, inaequalis, pilosus, scabridus, corollae longitudine. Embryonis cotyledones involutae. - Frutex speciosus, in insula $\boldsymbol{s}$ t. Juan Fernande $z$ indigenus, resinifer; ramis teretibus, cicatricibus notatis, foliis sparsis, spiraliter dispositis, lineari-lanceolatis, basi attenuatis, sessilibus, integerrimis, apice summo serratis, uninerviis, coriaceis, panicula terminali, ramosissima, myriocephala, floribus fiavis, fortassis dioicis, nempe femineis tantum ut videtur observatis.

B a I b is i a DC. in Guillem. Archiv, Bot, II.333, Prodr. VT. 447. Decaisue in Nouv, Annal, sc. nat, I. 26. t. 1. f. A. nou alior. Ing e $\mathrm{n}$ h o u z i a Bertero msc. non alior.

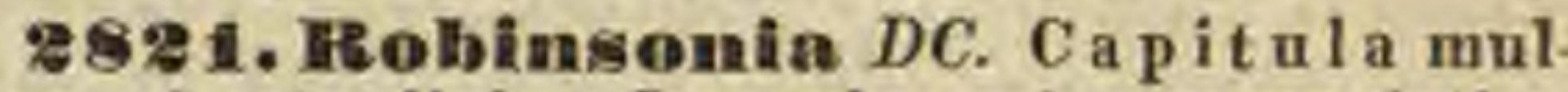
tiflora, abortu dioica. Invol u cri campanulati v. ovati, basi interdum bracteolati squamae uniseria tae, plns minus coalitae v. subliberae, saepius apice summo barbatae. Re ce p ta c u I n m planum, nudum. Flor. masc. Corolla e membranaceae, tubulosae, quinquedentatae. Ant h era e concretae, inelusae. Pollen echinatum. Stigmata cono piloso-papilloso terminata. A ch e n ia efoeta. F lor. fem. Corollae coriaceae, radii uniseriatae, breviter ligulatae, integrae v. tridentatae, dis c tubulosae, quinquedentatae. Stamina inclusa, antheris liberis, exappendieulatis, polline laevi. Stylus basi bulbosus; stigmata crassa, brevia, truncata, glabra, supra sulco notata. Achen ia teretia v. costata. P a p p u s uniserialis, setis nunc liberis, nunc in vaginam concretis. $\mathbf{E}$ bryon is cotyledones saepins involutae, interdum fere planae. - Arbores insulae $\boldsymbol{S} t$. Juan Fernande biorgyales, resinifluae; foliis alternis, lanceolatis, indivisis, subcoriaceis, floribus flavis.

Robinsonia DC. in Guillem. Anchiv. Bot, II, 333. Prodr. VI. 4n7. Decuisne in Nouv. Annal. sc. nat, 1. 27. nou Schreb.

a. SYMPHYOCHAETA DC. l.c. In v ol uc ri squamae ferc ad apicem concretae. Ligula e brevissimae. Pappi setae fere ad mediam longitudinem in vagloam membranaceo-rigidnlam concretae. - (Decaisne l. c. t, 1, f, 13.)

b. ELEUTHEROCHAETA DC. $l$. $c$. I n v o I u eri squamae fere ad apicem coucretae. Lig n la e brevissimae. P a ppi setae liberae. - (Decaisue . c, $t$, 1. f. C.)

c. ELEUTHEROLEPIS DC. $l$. $c$. Involn cri squamae liberae. Ligulae majusculae. Pappi setae liberae.

TRIBUS V. CYNAREAE Lessing Synops. 4. Styli hermaphroditorum superne nodoso-incrassati et saepe ad nodum penicillati, ramis concretis v. liberis, extus puberulis. Glan d u lar u m stigmaticarum series haud prominulae, usque ramorum apicem pertingentes, ibique confluentes. Corolla e pellucidae, regulares $\mathbf{v}$. subregulares, marginales rarissime ligulatae. Polle n globosum, echinulatum, rarius ellipticum, laeve. R e ceptaculum nudum v. alveolato - fimbrilliferum.

SUE'TRIBUS I. CALENDULACEAE DC. Prodr. VI, 451. Ca pitula multiflora, heterogamo-monoica, floribus radii ligulatis, femineis, disci tubulosis, quinquedentatis, ovario efocto masculis. Invo I u crum uni-pauci- 
seriali. Recept aculum nudum, alveolatum, rarissime setulosum. Antherae disci basi brevissime caudatae. Corollae fere omnes basi barbatae. Stylus radii bifidus, stigmatibus elongatis, disci subindivisus, nodulosus, pilorum zona barbatus, superne conicus, bifidus, stigmatibus valde approximatis seu concretis. A chen i radii fertilia, saepe difformia, disci plerumque abortiva. - Herbae v. suffrutices, omnes in veteri orbe indigeni, plus minus glandulosi et odore gravi donati.

DIVISI I. CALENDULEAE Lessing Synops. 89. DC. Prodr. VI. 451. C a p it ul a multiflora, heterogama, floribus radii uni - triseriatis, ligulatis, femineis, disci tubulosis, ovario efoeto sterilibus. Invo lucri uni-biseriati squamae liberae. Antherae breviter caudatae. A chenia radii fertilia, rostrata, epapposa, saepius curva, inter se formis disparia.

2522. CalenduIa NECK. Capitulum multiflorum, heterogamum, floribus radii bi-triseriatis, ligulatis, femineis, disci tubulosis, masculis. Involucri pauciseriati squamae distinctae. Receptaculum planum, nudum. Corollae basi hispidalae, rad ii ligulatae, dis ci tubulosae. A ntherae breves, candatae, subulatae. Stylus in conum nodosum, hispidulum, apice bifidum desinens, radii brevis, stigmatibus longis, gracilibus, inferne glabris, superne glandulosis. 0 varia $r a-$ di i arcuata, disei abortiva, Achenia disci nulla, radii bi-triseriata, heteromorpha, nempe exteriora plus minus in rostrum elongata, media apice truncata, dorso echinata, plus minns incurva, lateribns in membranam integram, coneavam v. planam, inciso-dentatam productis, intima annularia v. incurva, dorso muricata, omnia, sed imprimis intima fertilia. Pap p us nullus. - Herbae annuae $v$, perennanti-suffruticosae, in regione mediterranea indigenae, pube subglandulosa consitae, graveolentes; foliis oblongis v. obovatis, integris $v$, sinuato-dentatis, capitulis terminalibus, solitariis, ebracteatis, erectis, corollis flavo-croceis v. flavis.

Calendula Necker elom, n, 75. Cassini Opusc. phyt. II. 75, Dict, sc, nat. XXX, 327. Lessiag Synops, 90. DC, Prodr, VI. 461. Calendula e s p. Linn. Gartn. t. 168.

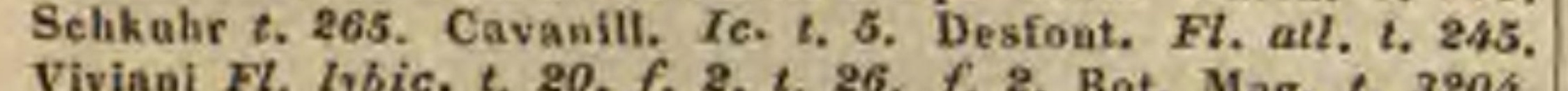
Viviani Fl. Iybic. $t, 20$. f. 2. $t$. 26. f. 2. Bot. Mag. $t$. 3204 . I. a Itha Vaillant in Act, Academ. Paris, 1720. p. 288. Mönch Method. 885.

2823. DIîgo enrpurs LESS. C a p it 1 i m multiflorum, heterogamum, floribus radii uniseriatis, ligulatis, femineis, disci tubulosis, masculis. Invo iu cri nniseriati squamae acuminatae, $\mathrm{R} e-$ e eptac u I um nudum. Corollae radii lignlatae, dis ci tubulosae, limbo quinquedentato. A ntherae caudatae. Stigmata ….. Achenia disci abortiva, radii sessilia, reeta, subtrigena, squamellosa v, transverse rugosa, omnino exalata v. pareissime alata, rostrata, rostro nunc urceolato, cavo, nune solido, brevissimo $v$. in iisdem saepe eapitulis elongato, laevi, coroniformi. P a P p $\mathbf{z}$ s nulIns. Herbae ca penses, basi suffruticulosae, multicaules, puberulae $v$, araneoso-tomentosae; foliis alternis, sessilibus, oblongis v. lanceolatis, pau- cidentatis, capitulis solitariis pedicellatis, minutis, luteis.

Oligocarpus Lessing Synops. 90. DC. Prodr. VT. 455, O s te ospermum calend u l a ce um Lisn. fil.

2824. Tripteris LESS. Capitulum multifloram, heterogamum, floribus radii uniseriatis, ligulatis, femineis, disci tubulosis, ovario efoeto hermaphrodito-masculis. In vo I u eri nni-biseriati squamae liberae, saepius margine scariosae. $\mathbf{R}$ eceptac alum nudum, planum, demum subconvexum. Corolla e radii ligulatae, disci tubulosae, limbo quinquedentato. Anthera e basi bisetae. Stylus radii bifidus, disci indivisus. A chenia disci abortiva, radii trigona, angulis in alas saepe inaequales productis, lateralibus laevibus v. echinatis, recta, substipitata, rostrata, rostro cavo, membrana hyalina, fenestraeformi clauso, interdum teretia, elongata, aptera, rostro solido. P a p pn s nullas. - Herbae v. suffrutices capenses, unicus ar abicus, saepius glandulososcabridi, Calendulam redolentes; foliis alternis $v$. oppositis, incisis, dentatis $v$. integerrimis, capitulis ramos terminantibus, radio flavo, albido v. purpurascente, disco luteo.

Tripteris Lessing in Linnaea VT. 95. Synops. 90. Calendula e s p. Auct. Jacq. Ic, rar, $t, 5900$.

DIUISIO II. OSTEOSPERMEAE DC. Prodr. VI. 459. Capitula multiflora, heterogama, floribus radii uniseriatis, ligulatis, femineis, disci tubulosis, ovario efoeto hermaphrodito - masculis. Involucri pauciseriati squamae liberae. Antherae breviter caudatae. A chenia disci abortiva, saepius teretia, radii fertilia, forma varia, semper erostria, epapposa.

2825. Dsteospermum LINN. Capitu $1 \mathrm{u} \mathrm{m}$ multiflorum, heterogamum, floribns radii uniseriatis, ligulatis, femineis, disci tubulosis, hermaphrodito-sterilibus. In v o l a eri pauciseriati squamae liberae. R eceptac $\mathbf{n} l \mathbf{u} m$ nudum $v$, rarius setiferum. C o rolla e radi ligulatae, d i sci tubulosae, limbo quinquedentato. Ach en ia disci abortiva, radii baccata v. nncleata, crassa v. durissima, glabra, erostria, teretia, laevia v. trigona, transversim rugosa. P a p p us nullus. - Fruticuli $v$. suffrutices capenses; foliis integerrimis, dentatis $v$. pinnatifidis, capitulis luteis.

Osteospermun Linn. gen. n. 992. Jaeq. Hort. Schönbr. t. 377. Berkh. Comp. t. 1. a. f. 7. Lam. t. 714. Lessing Synops. 89. DC. Prodr, $Y 1$. 459. Chry s a themoides Tournef. in Act. Academ. Paris, 1705. p. 237. Dillen. Nov, gen. 151, t. 9, Mösch Method, 485 , excl. sp. Osteosperm am et Erioclia e Cassini in Dict. sc. nat, $\mathrm{X} Y, 191, X X X, 333$.

\section{DIVISI0 III. OTHONNEAE Lessing} Synops. 88. DC. Prodr. VI, 468. Capitula multiflora, heterogama, floribus marginalibus ligulatis v. tubulosis, femineis, centralibus tubulosis quinquedentatis (v. bilabiatis?), stylo abortivo masculis. Involucri uni-pauciseriati squamae liberae v. plus minus inter se concretae. Antherae caudatae. Achenia papposa, pappo setoso, radii saepius multiseriali, disci uniseriali v. nullo.

8826. Heteractis DC. Capitalnm multiflorum, heterogamum, floribus radii subbise- 
riatis, aliis ligulatis, neutris, aliis tubulosis, femineis, disci aeque tubulosis, masenlis. Involucri biseriati squamae aequales, lineares, marginibus subconvolntae, acutae. R e c p ta cul um convexum, alveolatum. Corollae radii aliae anguste ligulatae, aliae discique tubulosae, quinquedentatae. A chenia disci linearia, glabra, abortiva, radii plano-compressa, ligularun oblonga, glabra, efoeta, tubulorum obovata, glandulis parvis muriculata. P a p $\mathbf{z}$ s omnium conformis, uniserialis, setosus, setis paucis, scabridis, eaducissimis. Suffrutex capensis, glaber; caule tereti, ramoso, erecto, folïs sparsis, sessilibus, linearibus, acuminatis, basi rigide ciliatis, integerrimis, subfulcatis, pedunculis parce puberulo - glandulosis, monocephalis, subnudis, in corymbum dispositis, floribus pallide flavis, ligulis parvis, subpurpurascentibus.

Heteractis DC. Prodr. VI. 468.

282\%. Cymmodiseus LESS. C a pitu1 u m pluriflorum, heterogamum, floribus radii quinis-septenis, ligulatis, femineis, disci tubulosis, hermaphroditis. Invol u cri squamae quinque v. novem, ovatae, basi concretae. Rece ptaculum nudum. Coroll a e radii breviter ligulatae, dis ei tubulosae, limbo quinquedentato. A chenia glaberrima, obovata v, ovata, laevia. Pap p us radii nniserialis, setosus, disci nullus. - Herbae capenses, glabrae, annuae, simplices, ima basi tantum foliatae, graciles, Capsellam bursam v. Androsacem septemtrionalem habitu simulantes; foliis obvvatis, lyratis v. linearibus, integerrimis, capilulis parvis, corymboso-paniculatis, floribus luteis.

G y mnodis cus Lessing in Linnaea VI. 95. Synops. 89. Othon na eapillaris Linn. t.

2898. Dthomma $L I N N$. C a p i $\mathrm{n} l \mathrm{u} \mathrm{m}$ multiflorum, heterogamum, floribus radii uniseriatis, ligulatis v. truneatis, femineis, disci tubulosis, stylo imperfecto masculis. Involucri uniseriati squamae lateribus inter se plus minus concretae, aestivatione valvatae. R e ce $\mathrm{p} t$ a $\mathrm{cu}$ I u $\mathrm{m}$ convexum v. subconicum, foveolatum, interdum pilosinsculum. Corolla e radi i ligulatae v. tubulosae, truncatae, involucro breviores, dis ci tubulosae, limbo quinquedentato. A chenia radii fertilia, ovalia, hirta v. glabra, papillosa, d isci abortiva, cylindracea, glabriusenla, $\mathbf{P}$ app us pilosus, $\mathrm{radi}$ multiserialis, densus, disci uniserialis, depauperatus. - Frutices $v$, herbae ca penses; foliis varie incisis aut integris, carnosis v. membranaceis, capitulis ad apices pedunculorum solitariis, flavis $v$, rarissime cyaneis.

Ot ho n a Linn. gen. n. 993. Cassini in Dict. sc, nat. L.PIII. 462. Arist otela Adanson Fam, II, 125. non alior Calthoides B. Juss.

a. DORIA Less. Capitula discoidea, floribus femineis tubulosis, truncatis, involucro brevioribus.

Do r ia Lessing in Linnaea VI. 94. Synops. 89. DC. Prodr. VT. 469, non Dill. (Jacq. Hort. Schönbr. t, 238. 376.)

b. EUOTHONNA. C a pitula radiata, floribus femineis ligulatis.

Othoun a Lessing Synops, 88. DC. Prodr. VT. 473. (Jacq. Hort, Schönbr, t, 240, 241. Bot. Mag, t, 168, 1312. 1979. Bot. Reg. t. 266. Cacalla e s p. Thusb. DC. Pl. gr. $t .48$, ,

? e. HERTIA Less. Capitula radiata, floribus femineis, Ifgulatis v. bilabiatis, floribns disei bilabiatis! labio exteriore tridentleulato, interiore profuade bifido. - $A n$ slatus monstrosus?

II e r t I Lessing in Linnaea YI. 94. Synops. 88. DC Prodr. PT. 483, non Neck. Ottron na crass ifolia Lion.
2899. Herekeria $D C$. C a pitu 1 a m multiflorum, heterogamum, floribus radii ligulatis, femineis, disci tubulosis, styli abortu masculis. Involu cri uniseriati squamae acutae, vix ima basi subconcretae $v$, liberae. Rec e $t a c$ ulum subconvexum v. areolatum. Corolla e radii ligulatae, di s c i tubulosae, limbo quinquedentato. Stylu s disci indivisus, inclusns, apice hispidus. A ch enia radi i oblonga, teretiuscula, disci tenuia, abortiva, pubescenti-velutina. Pap p a s subconformis, pluriserialis, earducus, setis flexuosis, barbatis, de-mum lanuginem copiosam referentibus. - Herbae c a penses, perennes; caulibus e collo frutescente pluribus, brevibus, basi foliosis, pedunculis scapiformibus elongatis, monocephalis, foliis crasso-coriaceis, pube rigida albentibus, uni-bipinnatipartitis, lobis planis v. teretiusculis, acutis, floribus flavis, ligulis intense striatis.

Ruckeria DC, Prodr. PI. 483.

SUETIEIBUS II. ARCTOTIDEAE Cassini Opusc. II. 47. DC. Prodr. VI. 484. C a p it u la multiflora, nunc homogama, discoidea, nunc heterogama, radiata, floribus radii uniseriatis, ligulatis, femineis $v$. neutris, disci tubulosis, hermaphroditis, centralibus interdum pressione sterilibus. Inv 0l u c r i squamae inermes v. spinosae. R eceptaculum epaleatum. Antherae breviter candatae. Stylus disci superne nodosus, pilis verticillatis instructus, lobis concretis, extus minutissime hispidis, apice summo liberis, obtusis. Achenia erostria, turbinata, areola terminali instrncta, saepius villosa, calva v. papposa. Pappus margine prominulo haud cinctus, squamellis late paleaceis $v$, rarius subsetiformibus. - Herbae $v$, suffrutices, unico australasico excepto capenses.

DIVISIO I. ARCTOTEAE DC. Prodr. VI. 484. In v ol u cri squamae omnes inermes, inter se distinctae. Capit ula radiata, ligulis femineis v, rarius neutris. A chenia plerumque alata.

2830. Aretotis GARTN. Capitulum multiflorum, heterogamum, floribus radii uniseriatis, ligulatis, femineis, disci tubulosis, hermaphroditis, intimis interdum abortu sterilibus. In v o lucri campanulati squamae multiseriales, liberae, exteriores parvae, subfoliaceae, interiores longiores, apice obtusae, scarioso-membranaceae. R e e e p tacul um alveolatum, fimbrilliferum. Corellae radii ligulatae, di s c i tubulosae, limbo quinquedentato. St am in um filamenta, laevia. Achenia stipitata, basi villosa, ovata, dorso trialata, alis lateralibus margine inflexis, integris $\mathbf{v}$. dentatis, intermedia recta, angnstivre. Pap p us biserialis, paleaceus, paleis seriei interioris saepius octo, aestivatione spiraliter dispositis. - Herbae c a pen$s e s$, inermes, subacaules $v$, caulescentes; foliis alternis, petiolatis, membranaceis, nervis primarüs supra planis, capitulis pedunculatis, solitariis.

A retot is Gitrtaer II. 439. R. Brown Hort, Kew. II, s. 169. Lessing Synops, 15. DC. Prodr. V1. 484. A ret o the c a Vaillant in Act. Acadent. Paris, 1720. p. 330. A r c t o. tis, Odontoptera et Stegonotus Cassini in Dict. so. nat. XXV. 270. XX1X, 456. XXXV. 396. A retotidis s p. Linn. et Auet. 
a. FUARCTotis DC. Prodr, VI, 48z. A ehenta longe et dense ad basim villosa, alis dentatis. (Jaeq. Hort. Schönbr. t. 158_162. 165_177. 307. 378_382. Jacq. f. Eclog. t. 51, 58. Bot. Mag. 2. 2182. Bot. Keg. t. 32.)

b. PSEUDARCTOTIS DC. Prodr. VI. 485, A ehe nia nndique minute pubescentia. (Jacq. Hort, Schönbr. $t .163$. 160.)

283 1. Cymalo onaters CASS. Capitulum multiflorum, heterogamum, floribus radii plurimis, ligulatis, femineis, disci tubulosis, hermaphroditis. Invol ucri hemisphaerici squamae multiseriales, imbricatae. R e cepta $\mathrm{e} \mathbf{l} \mathbf{~ n ~ m}$ alveolatum, alveolis margine subfimbrilliferis, Corolla e radii ligulatae, disci tubulosae, limbo quinquedentato. Stam in $\mathbf{t}$ m filamenta laevia. A $\mathrm{chen}$ i a glabra, subhemisphaerica, dorso bialata, alis inflexis, margine suberenatis. - Herba Novae-Hollandiae, acaulis; foliis petiolatis, ovalibus, subspathulatis, remote denticulatis, subtus albo-lanatis, scapis pluribus monocephalis, petiolis brevioribus.

C y m bo not u s Cassini in Dict, sc. nat, XXXV. 397. Opuse. phyt. II. 65. Gaudich. ad Frejc, 462, t, 86. Lessing Synops. 28. DC. Prodr. NI. 491 ,

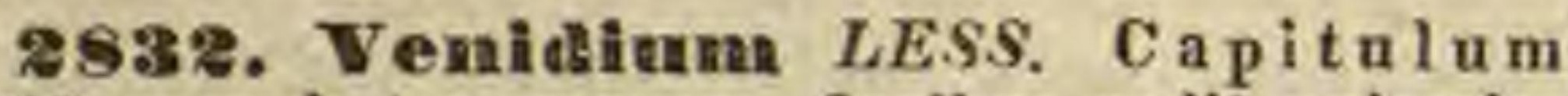
multiflorum, heterogamum, floribus radii uniseriatis, ligulatis, femineis, disci tubulosis, hermaphroditis. Involucri campanulati squamae pluriseriales, exteriores angustae, subfoliaceae, interiores scariosae, obtusae. R e e pt a cul u m alveolatum, saepius nudum. Corolla e radi ligulatae, dis. c i tubulosae, limbo quinquedentato. S t a m in u m filamenta laevia. A chenia glabra, dorso trialata, alis lateralibus margine inflexis, intermedia recta latioribus. P a p u s nullus v. dimidiatus, dorsalis, quadrisquamellatus. - Herbae capenses, Arctoiidis habitu, glabriusculae v. plerumque plus minus lomentosac.

Ven idiu m Lessing in Linnaca $V T$. 91. $t .2, f . d$. Synops. 29. DC, Prodr, VI, 491. CleItria Schrader Index sem. hort. Götting. 1831. A r etotidis s p. Liun. Thuab. Jacq. Hort. Schönbr. t. 168. Oste os permi s p. Lian. Thusb.

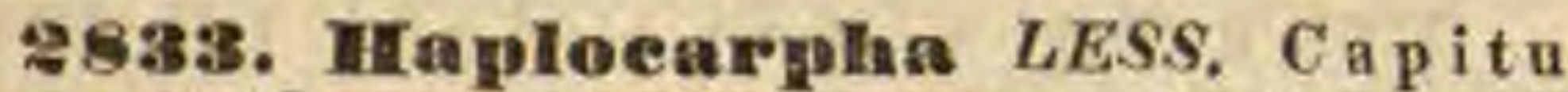
I $\mathrm{m}$ multifornm, heterogammm, floribns radii uniseriatis, ligulatis, femineis, disci tubulosis, hermaphroditis, centralibus saepius abortu masculis. Involucri campanulati squamae multiseriales, inbricatae, exteriores acuminatae, interiores margine scariosae. Corolla e ra di ligulatae, dis e i tubulosae, limbo quinquedentato. Sta min $\mathbf{~} \mathbf{m}$ filamenta seabra. A chenia exalata, turbinata, villosa. Pappus uniserialis, paleacens, paleis tenerrimis, diaphanis. - Herba capensis, perennis, acaulis ; rhizomate ad collum crasso, foliis radicalibus breviter petiolatis, oblongo-obovatis, tri-quinquenerviis, subintegerrimis, supra scabridis, subtus tomentosis, scapis monocephalis, foliis duplo v. triplo longioribus, nudis, tomenlosis, pilosiusculis, floribus flavis.

H a $\mathrm{I}$ o e a r pha Lessing in Linnaea YT. 90, t. 1. $f$. a. Synops. 36, DC, Prodr. VT. 495. Arctotls 1 anata Thunb.

2834. Thandina LESS, Ca p ituI u m maltiflorum, heterogamum, floribus radii uniseriatis ligulatis, femineis, disci tubulosis, hermaphroditis. InvoIucri squamae pauciseriatae, multinerves, exteriores acuminatae, squarrosae, interiores siccae, obtusae. Receptacn 1 a m planum, nudam. Corollae radii ligulatae, disei tubulosae limbo quinquedentato. S $\mathbf{t}$ a $\mathrm{m}$ in $\mathbf{n} \mathbf{m}$ filamenta laevia. A chenia exalata, prismatico-tetragona, sulcata, ima basi hirsuta, Pap p 8 nniserialis, pa- leaceus, paleis tenerrimis, diaphanis. - Herbae c a pens es, perennes; rhizomate ad collum crassiusculo, foliis radicalibus petiolatis, oblongo-ellipticis, penninerviis, subtus niveo-tomentosis, scapis monocephalis, foliis brevioribus, floribus luteis.

L a ndita Lessing Synops. 37. DC. Prodr. DI. 494. Perdicii s p. Thuab.

2835. Aretothees WENDL. Capitul $\mathbf{~ m ~ m u l t i f l o r a m , ~ h e t e r o g a m u m , ~ f l o r i b u s ~ r a d i i ~}$ uniseriatis, ligulatis, neutris, disci tubulosis, hermaphroditis. Inv ol u cri campanulati squamae pluriseriales, exteriores lineares, foliaceae, interiores majores, scariosae, obtusissimae. Receptacal $\mathbf{m}$ m fimbrilliferum. Corolla e radii ligulatae, dis c i tubulosae, limbo quinquedentato. St a m in um filamenta papillosa. A ehenia exalata, ovata, subtetragona. Pappus nullus. - Herba capensis, repens, perennis; caule albo-tomentoso, foliis petiolatis, lyrato-pinnatifidis, supra scabriusculis $v$. glabris, subtus albo-tomentosis, pedunculis axillaribus, monocephalis, folio paullo longioribus, floribus flavis.

A retotheca Wendland Hort. Herrnh. 8, t. 6. R. Browa Hort. Kew. II. 5. 141, Cassini in Dict, sc. nat. IT. Suppl, 116, XXIX. 454. Lessing Synops. 35. DC. Prodr. VI. 495. non Vaill. A retotis repens Jaeq. Hort. Schönbr. t. 306 .

2836. Cryptostewama $R . B R$. Capitu l u m multiflorum, heterogamum, floribus radii uniseriatis, ligulatis, neutris, disci tabulosis, hermaphroditis. Involneri squamae pluriseriales, liberae, interiores apice membranaceae, obtusae. Receptaculum alveolatum. Corollae radi i ligulatae, saepe difformes, palmatipartitae v. biligulatae, disci tubulosae, quinquedentatae. St amin n m filamenta seabra. A e he nia exalata, densissime lanata. Pappus nniserialis, paleacens, scariosus, Iana achenii absconditus. - Herbae capenses, annuae, acaules v. caulescentes, plus minus cano-tomentosae; foliis pinnatilobatis, lyratis $v$. rarius indivisis, capitulis vix Asteris alpini magnitudine, disco nigricante, radio flavescente.

Cryptostemma R. Brown in Ait. Hort. Hew. II. 5 . 141. Cassini in Dict. sc. nat. XIr. 125. Lessing Synops. 38. Bot. Mag. t. 2252. DC. Prodr. VX. 495. C y no tis Hoftmansegg Verz. 1826. p. 99. A r ctotid is sp. Linn. Thuab. Jacq. Hort. Schönbr. t. 157.

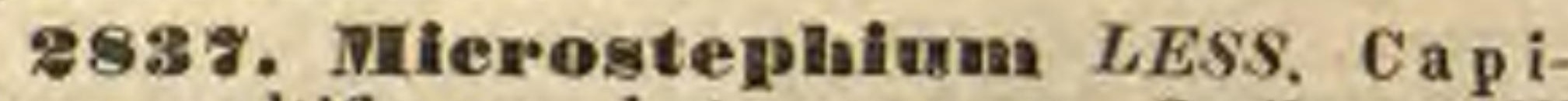
tulu m multiflorum, heterogamum, floribus radii uniseriatis, ligulatis, neutris, disci tubulosis, hermaphroditis. In v ol u cri campanulati squamae pluriseriatae, imbricatae. Receptacul nm obiter alveolatum. Corolla e radii ligulatae, disci tubulosae, limbo quinquedentato. S $\mathrm{t}$ a min a m filamenta scabra. A ch e n i a exalata, tomentosa. $P$ a $p-$ p u s uniserialis, coroniformis, crenatus, basi callo. sus, apice membranaceus, demum introversus. Herba capensis, ramosa, niveo-tomentosa, inermis, reptans; foliis longe petiolatis, ovato-orbiculatis, subrepandis, pedunculis petiolos aequantibus, monocephalis.

Microstephium Lessing in Linnaea VI. 92. $t$. 2. f. e. Synops. 55 . Ost e o s p e mum niveum Linn. f.

2838. Heterolepis CASS. Cap itulum multiflorum, heterogamnm, floribus radii biligulatis, femineis, disci tubulosis, hermaphroditis, centralibus abortu masculis. Invo I u cri squamae liberae, bi-triseriatae, exteriores lanceolatae, acuminatae, extus subtomentosae, interiores Iongiores, ovales, apice membranaceae, obtusae, subfimbriatae. Co roIla e basi hispidulae, $r$ a di i biligulatae 
ligula exteriore ampla, quadrinervi, interiore minima, cirrhiformi, dis ci tubulosae, limbo regulariter quinquelobo. St a $\mathrm{m}$ in $\mathbf{u m}$ filamenta laevia, etiam in floribus radii obvia, antherae radii nullae, disci breviter eaudatae. Stylus laevis, radii profundius bifidus $v$, interdum trifidus, A ch eni a breviter cylindracea, villosissima. P a p p i setae biseriatae, quindenae-vicenae, crassae, dense barbellatae, inaequales, interiores longiores. Suffrutices capenses; ramis junioribus tomentosis, foliis confertis, sessilibus, linearibus, rigidulis, supra glabris, subtus tomentosis, marginibus revolutis, vix subdentatis, capitulis terminalibus, solitariis, floribus luteis.

Heterolepis Cassini in Bullet. soo. philomat, 1820. p. 26. Dict. sc. nat. XXI. 120. Opusc. II. 50. Lessing Synops. 58. DC. Prodr. VI. 496. H e te $r$ o mo r p ha Cassiai in Bullet. soc. philomat. 1817, p. 12. O e d e ra a ti e na Linn. f. Jacq. Hort. Schünbr, t, 15\%, Fragm, t. 2. f. 9. A rnica inuloides Vahl. Leyssera arctotoldes Thunb.

DIVISID II. GORTERIEAE Cassini Opuse, III. 53. DC. Prodr, VI. 497. In volucri squamae saltim exteriores et mediae in spinam productae, saepius lateraliter dentatospinosae, basi plus minus inter se concretae. Capitula radiata v. discoidea, ligulis dum adsunt semper neutris.

2839. Steplnanocoma LESS. C a p itu$1 \mathrm{um}$ multiflornm, homogamum, discoideum, v. heterogamum, floribus radii uniseriatis, ligulatis, neutris, disci tubulosis, hermaphroditis. In v o I ucri squamae multiseriales, pleraeque basi coneretae, ciliis spinnlosis, uniseriatis. Corolla e radi dum adsant ligulatae, d i se i tubulosae, quinquedentutae. St a m i n u filamenta laevia. A che nia exalata, nitida. Papp a uniserialis, coroniformis, irregulariter crenatns. - Herbae c apenses; foliis decurrentibus, pinnatifidis, spinoso-dentatis, floribus luteis. 497.

Step h a n oc om a Lessing Synops, 5s. DC. Prodr. VI.

a. CARDU OIDES Lessing l. c. Capitula discoidea, Ree e p tacul a m fimbrillis elongatis, rigidis. - Stobaea decurrens. Thunb.

b. BERKHEXOIDES Lessing t. c. Capitula radiata. Receptaculum leviter alveolatum. - Rohria de. currens Thumb.

2840. Cullumia $R$. BR. Cap itulum multiflorum, heterogamum, floribus radii uniseriatis, ligulatis, nentris, disci tubulosis, hermaphroditis. Involucri pluriseriati squamae basibus inter se concretae, exteriores pectinato-spinulisae, foliis similes, interiores integrae v, subfimbriatae, apice spinescentes. Recepta $\mathrm{culum}$ alveolatofavosum, alveolorum marginibus elevatis, achenia includentibus, apice setigeris. Corollae radii ligulatae, dis ci tubalosae, limbo quinquedentato. A che ni a angulata, glabra, plura abortiva. P a $\mathrm{p}^{-}$ p $\mathbf{s}$ nullus. - Fruticuli capenses, erecti, ramosi, spinosi; ramis usque ad apicem dense foliosis, foliis sparsis, sessilibus v. decurrentibus, ciliis spinosis, distantibus instructis, caeterum intcgerrimis, capitulis terminalibus, solitariis, floribus luteis.

$\mathrm{Cu} I 1$ u ma R. Brown in Aiton Hort. Kew. II. 5. 137. Cassini in Diet. sc. nat. XII. 213. Lessing $\mathcal{S y n a p s , ~ 8 1 . ~ D C . ~}$ Prodr. YI, 497. Gor te r la e s p. Lina. Jacq. Hort. Schönbr. t. 371, Berkbe y a s p. Willd. Schrak Hort. 3Lon. t.97.

2841. Gorteria GARTN. Ca pituin multiflorum, heterogamum, floribus radii uniseria- tis, ligulatis, neutris, disei tubulosis, marginalibus paucis antheris efoetis femineis, reliquis stylo imperfecto masculis. Involucri squamae pluriseriales, in tubum urceolatum, demum clausum concretae, apice lineari-subulatae, liberae, demum squarrosae. R e e pta c n l u m brevissime alveolatum v, nudum. Coroll ae $r$ adii ligulatae, dis ci tubulosae, acutissime quinquedentatae. St a min $\mathbf{m}$ filamenta laevia. A ch en ia obovato-triquetra, basi attenuata, apice bäbata, caeterum glabriuscula, cortice externo membranaceo, a fructu facile secedente. Pa p p us coroniformis, brevis. Herbae capenses, annuae, radice involucrum nuciforme ad collum retinente; foliis allernis, oblongis, integerrimis v. dentatis, superne setoso-scabris, subtus cano-tomenlosis, uninerviis, capitulis ramos terminantibus, solitariis v. approximatis, corymbosis, corollis luteis, ligulis subtus purpurascentibus $v$. virescentibus.

Gorteria Gïtner II. 427, $t, 171$. R. Browa in Aiton Hort. Hew. II, 5, 140. Gassini in Dict. sc, nat. XIX. 23t. XXX. 453. Lessing Synops, 51, DC. Prodr, VT, 500, non Lam. Pers o naria Lamarck t.716. Gorteriae s p. Lfun. Jaci. Collect. IV. $t$, 21, $f$. 1 .

2848. Mirrpieinan CASS, Ca pitulum multiflorum, heterogamum, floribus radii uniseriatis, ligulatis, neutris, disci tubulosis, hermaphroditis. Involueri squamae basibus coneretae, multiseriales, Reseptaculum leviter alveolatum. Corolla e radii-ligulatae, disci tubulosae, limbo quinquedentato. Sta min u filamenta laevia. A ch enia exalata, longe lanata. Pa p p s uniserialis, coroniformis, in setas divisus. - Fruticuli capenses, ramosissimi, erecti; foliis sessilibus, linearibus, subcoriaceis, eapitulis terminalibus, solitariis.

Hirpicium Cassini in Bullet. soc. philomat, 1820. p. 27. Dict. sc. nat. XXI. 238. XXIX, 448. 450. Lessing Synops. 53. DC. Prodr, YI. 508. Gorteria Integrifolia Thunberg in $A c t$. soc. $H a f n$. $I V$. t. 2. $f$. 2. et 0 ed exa a li exat a Thunb.

2843. Dielelta LESS. C a p itu lu m multiflorum, homogamum, discoideum, v. heterogamum, floribns radii uniseriatis, ligulatis, neutris, disci tubalosis, hermaphroditis. Involueri squamae biseriatae, basi coneretae, seriebus valde inaequalibus, nune extimis, nune vero intimis majoribus. ReceptaenI in alveolatum, alveolorum marginibus rigide fimbrilliferis, Cor oll a e radii lignlatae, dis e i tubulosae, limbo quinquedentato. S taminu m filamenta laevia. A chen ía exalata. Papp u s uniserialis, paleaceus, paleis acuminatis, fimbriato-plumosis, - Suffrutices v. herbae capenses; foliis oppositis $v$, alternis, integris $v$. sinuato-dentatis, inermibus v. spinulosis, capitulis terminalibus, pedunculatis, solitariis, floribus luteis.

D f de It a Lessing Synops. 59. DC. Prodr. VI. 503.

a. CHORISTEA DC. $l$. c. Involucrl segmenta extima amplissima, rotundato - ovata. R e ce p ta e uli alveolae parum profundae, - Caules fruticosi.

Cho riste a Thanb. Prodr. 163. Dide It a Heritier Stirp. 55. t. 28. Wendland Observ. t, 4. f. 32. F a von i u na Gätner II. 431. t.174. Cassial in Diet. se. nat. $X V I$. 295. Didelta et $\mathrm{F}$ a v on $\mathrm{i} u \mathrm{~m}$ Cassini in Dict. sc. nat. XXXIX. 448. B rete uilli a Buchoz.

b. CUSPIDIA DC. l. c. Involucri segmenta intima maxima. Receptaculi alveolae profundae. - Caules herbacei, radices capilulum annotinum, ut in Gorteriis ad collum retinentes.

Cuspldia v. Aspidalis Gärtaer It. 454. t. 171. Cassini in Bullet, soc. philomat, 1880, p. 171. Dict, sc. nat, XII. 25t. XXIX, 448. G or teri a cern u a Linil. f. 
2844. Berkheya EHRH. Capitalam mnltiflorum, heterogamum, floribus radii uniseriatis, ligulatis, neutris, disei tubulosis, hermaphroditis. Invo I u eri multiseriati squamae liberae v. basi vix inter se concretae, apice spinescentes: Receptaeulum alveolatum. Corollae radi ligulatae, dis c i tubulosae, limbo quinquedentato. Staminnm filamenta laevia. A chenia sericeovillosa v, rarius glabra. Pap p ns biserialis, paleis fimbriatis, oblongis, Ionge acuminatis. - Herbae v. frutices capenses; foliis alternis, plus minus ciliato- v. dentato-spinosis, capitulis terminalibus, solitariis, floribus luteis.

Berkhey a Ehrhart Beitr. III, 137. Willd. sp. III. 2269. Lessing Synops. 69. DC. Prodr. VT, 504. B e rk h ey a et $\mathrm{E} v o \mathrm{p}$ is Cassini in Dict, sc, nat, $\mathrm{XXIX}$, 448. Crocodilodes Adausou Fam. II. 141. uon Vaill. Basteria Houttayn Pfanz. Syst. IT. t.34. nou Mill. A g r iph y 11 u m Jassieu Gen. 190. R o h ri a Vahl et Thunb. in Act, soc. $h, n$. Hafn, IIT. 97. IV. 1. G or te ri a Lam. Illustr, n. 702, Z a. rabellia Necker Elem, n, 14. non Cass. Gorterlae sp. Linn.

a. EVOPIS DC. $l$, c. In 8 ol u erl squamae siecae, liberae, sibi invicem adpressae, margine subintegerrimae, inermes. - Herba perennis, foliis alternis, ad basim confertis, superne remotiusculis.

$\mathrm{E}$ vop is Cassini in Bullet. soc. philom. 1818. p. 32. Dice. sc, nat. XVI. 65. Opusc. 11 . 49. et 56. Gorteria herbate a Linn. f. Rohr ba eynarodes Thunberg et Vahl in Act, soc. h, n. Hafn, I. t. 8.

b. AGRIPHYLLUM DC. 1 . c. Involucri squamse basi vix subcohaerentes, margine spinoso-ciliatae, exteriores foliaceae, interiores rigidae, scariosae, subeoloratae. - Herbae perennes, simplices $v$. parce ramosae, alternifoliae.

Agriphy 11 um Lessing Synops, 70. Gorteriae sp. Linn. f. Robritue sp. Thunb. et Vahl Op. cit, $I$. t. 7. 9. II, $t$, 6. III. 4. 8, C a rth a mi \& p. Burmann.

c. BASTERIA DC. $l$. c. Involuer I squamae foliaceae, squarrosae. A cheuia saepins subglabrata. - Frutices ramosi, folits alternis, profunde pinnatifidis.

Basteria Lessing Synops.73. Rohriae sp. Thunberg et Vahi Op. eit. III. $t, 13$,

d. EUBERKHEYA DC. l. c. Involu cri squamae folia. ceae, squarrosae, basibus concretae, dentato-lobatae, deatibus spinosis. A c h e a i a sericeo-villosa. P a p p i squamellae paleaceae, breves, submembranaceae, clliato fimbriatae, acutae. - Erutices ramosi, folits alternis v. oppositis, indivisis, spinoso-serratis, spina ter minatis.

Berkheya Lessing Synops, 76, Gorteriae 8 p. Linn. Jacq. Ic, rar, $t, 591$. Ro hriae s p. Vahl Op. cit, II. $t, 7, I I T, t, 10_{-1}$. C a rth a $\mathrm{mi} \mathrm{s}$. Lam. A p a le j a e sp. Gärtn. (Bot. Mag. t. 1844.)

e. TRICHODES DC. $l$. c. I nvolu cri squamae foliaceae, squarrosae, dentato-lobatae, deatibus spiuosis. A e h eni a villosa. Pa p pi squamellae setiformes, elongatae, scabrae. - Frutices, folits alternis, indivisis v. pin. natifidis, dentibus $v$, lobis in spinas productis.

Gorteria spinosa Lim. to Basteria acu Lea ta Houttuyn Pflanz. Syst. II. $t$. 34. f. $\mathbf{8}$.

f. TRICHOCOMA DC. $l$, $c$, Invol u er $i$ squamae adpres sae, nec squarrosae, ciliatae v, ciliato-spinosae. C a p i t a la Interdun disenidea. A che n i a parce vilfosa. Pap pi squamellae lineares, acuminatae, ovario tongiores. setifurmes, margiae seabrae. - Herbae basi fruticosae, Cardui facie; folits saepius scabris, superne selosohispidis.

2845. Cazamia GARTV, Capitulum multiflorum, heterogamm, floribus radii uniseriatis, ligulatis, neutris, disci tubulosis, hermaphroditis. Involueri squamae bi-multiseriales, basibus inter se concretae, urceolum apice lobatum constituentes. Receptacul $\mathbf{~ m}$ alveolatum, alreolis brevibus. Cor olla e radi i ligulatae, d i s. c i tubulosae, limbo quinquedentato. S $\mathbf{t a ~ m ~ i ~ n ~} \mathbf{~ m}$ filamenta laevia. A e henia villosissima, exalata.
Pa p pi biseriati paleae tenerrimae, saepe scariosae, denticulatae, saepius pilis achenii absconditae. - Herbae capen ses, basi interdum suffrutescentes, rarius annuae; foliis nunc ad collum congestis, nunc per caulem sparsis, in eadem stirpe indivisis et pin. natilobis, pedunculis nudis, monocephalis, prope collum $v$, in axillis ramorum ortis, capitulis saepius amplis, speciosis, ligulis flavis v. aurantiaceis, saepius ad basim nigro-maculatis.

G a z a n I a Gãrtuer IT. 45t. Mönch Suppl, 209. R. Brown in Aiton Hort. Kew. II, 15, p. 140, Lessing Synops. 41. DC, Prodr. VI. 508. M ussinia Willd. $s p$, III. 2263. Mo ehu i a Necker elem. n, 13. Mela n cbrysum et Gazan ia Cassini in Dict, sc, nat. XXIX. 441, XVIII. 243, Opusc, II. 48. 58. Gorteriate sp. Linn.

a. MELANCHRYSUM DC. $l$, $c$. P a p p i squamellae parvac, inter villos ovarii elongatos absconditae. - Species ple. raeque perennes, folitis subradicalibus.

c. Brachylaenae DC. $l$. e. Involuerum eampanalatum, brevissimua, tabo subnullo, squamis ima basi concretis, a basi involucri subliberis.

$\beta$. Oocephalae DC. 1 , c. Involueru un ovale v. eampanulutum, basi obtusum, squanis ad medium v. ul. tra medium in tubum coneretis. Gorteriae sp. Auct. Thunb, in Act, soc, $h, n, M a f n, I V, t, 5$. Andr. Bot. Reposit, t. 523, Bot. Mag. t. 90. (Bot. Reg. t.35.)

$\gamma$. I utrusae DC. $l$, c. I uvoluerum obovatum v. cyliadraceam, basi truacatum v. iatrusum, squamis ad medium v. oltra medium in tubum coneretis. - Gorteri a e s p. Lina. f. Thunb. Op. cit. IV, t. 1. (Bot. Mag. t. 2280.)

b. LEPTOMORPHA DC. $l$. $c$. P a p pi squamellae elonga. tae, scariosae, villos ovarii longe superantes.- Herbae annuae.

3846. Stoluaen THUNB. Capitulum multiflornm, homogamum, discoideum, v. heterogamum, floribus radii uniseriatis, ligulatis, neutris, disei tubulosis, hermaphroditis. Invol ne ri pluriseriati squamae basi concretae, in spinam acuminatae, margine spinulas aliquot gerentes. R ec e p t a e u lu m alvenlatum, alveolis elongatis, achenia foventibus, apice in lacinias setiformes fissis. Coro 11 a e radii lignlatae, dis ci tubulosae, limbo quinquedentato. S $t$ a $\mathrm{m}$ in u m filamenta laevia. A eh e n i a olopyramidata v. turbinata, glabra, puberula v, villosa. P a p i squamellae uni-biseriales, aequales $\mathbf{v}$. alternae angustiores, ovales, obtusae, apice denticulatae. - Herbae $v$. rarius suffrutices capenses, Carduacearum habilu; foliis alternis $v$. rarissime oppositis, plus minus pinnatijido-lobatis, margine ciliato-spinellosis, lobulis in spinam productis, caulinis sessilibus $v$. decurrentibus, capilulis ramos terminantibus, floribus luteis v. rarissime purpureis.

Stobaca Thunberg Prodr. 8. Fl. cap. 620. Lessing in Linnaea VI, 109. DC, Prodr. VT. 514 . S tabaca et A pule ia Lessing Synops. 63. ot 63. A puleia Gärtu. $I I$. 439. $t, 171, f, 1$, son Mart. - ? A reli n a Necker elem, n. 199 .

SUE'TEREUS IIII. ECHINOPSIDEAE Lessing Synops. 13. DC. Prodr. VI. 522. Capitula uniflora, in glomerulum globosum, foliolis plurimis involucratum, capitulum multiflorum referentem aggregata, supra receptaculum commune globosum articulata, sessilia. Involucri proprii squamae multiseriales, inter se et cnm ovario concretae. Flores omnes hermaphroditi. Cor olla e tubo tereti, abrupte ad fancem inflato, limbo inaequaliter quinquelobo. Stigmata laevia, nitua. A cheni um sericeo-villosum. Pap pi setae breves, liberae v. in coronam plus minus connatae. Species 
in hemisphaera boreali veleris orbis indigenae.

284r. Eelhimops LINN. Capitula uniflora, plurima, supra receptaculum globosum, nudum aggregata, summa praecociora, in vol u c ri communis squamis paucis, parvis, reflexis. Invo lucrum proprium polyphyllum, persistens, triplex, foliolis exterioribus brevioribus, piliformibus, seariosis, penicillum constituentibus, mediis vix longioribus, subspathulatis, breve acuminatis, in timis elongatis, lineari-acnminatis, carinatis. Co rolla e tubulosae, tubo brevissimo, limbo inaequaliter quinquefido. St a m in u m filamenta glabra, usque ad originem laciniarum corollae concreta, antherae ecaudatae v. basi subbarbatae. Stig $\mathbf{m}$ a ta libera, arcuato-divergentia. A $\mathbf{c}$ henia $\mathbf{c y}$ lindracea, sericeo - villosa. P a p p u brevissimus, subeoronaeformis, pilis fimbriatis. - Herbae ge rontogea bo reales, erectae, ramosae, spinu losae; foliis uni-bi-tripinnatipartitis, lobis dentibus que apice spinescentibus, glomerulis sphaericis, cae ruleis $v$. albidis, capitulis areola cornea, circulari super receptaculum insertis.

Echin ops Linn. gen. n. 999. A. Riehard, in Dict. class. VI. 38. Lessing Synops, 13. Trautwetter, de Echinope genere capila duo, Mitav. 1833. 4. DC. Prodr. FT.522. E chino pus Touruef. inst. 463. Cassini Tabl, synopt. 10. E chinanthus Necker elem. $n, 166$.

a. TERMA. Pap p a s coroniformis, setis in cupulam sub integerrimam coalitis. In volueri squamae omnes di. stinctae. - (Schkulir t, 268. Bot. Mag. Trautw. Echinop. $f, 1$, )

b. RITRO. Pappi setae basi conferruminatae, apiee dis. tinctae, cupulam fimbriatam formantes.

c. S phae rocephali. Involucri squamae omnes distinctae. - (Miller 1c. t. 130. Jacq. f. Eclog. t. 9. Bot, Reg. t. 356. Reichenb, Pl. crit, t. 450. Rochel Pl. Banat. t. 39. Trautw. Echinop. f. 3. 6. 9.)

$\beta$. Horridi. Involncri squamae interiores circl. ter ad mediam longitudinem in tubum coneretae. - (Royle Himalag t. 5. 6. f. 1.)

c. PSECTRA. Pa ppi setae a basi liberae. Invol ucri squamae omnes liberac. - E. strigosus Linu.

2848. A eantholepis LESS. C a p itula uniflora, in glomerulum, foliis apice et margine remote spinosis cinctum aggregata. In v o I u crum proprium compressum, pluriseriale, squamis margine fimbriato plumosis, apice spinosis. Co roll a e tubulosae, quinquefidae. A nt her a e breviter caudatae, caudis laceris. Sty I u 8 brevissime bifidns. A chenium villosum, obovato-oblongum. P a pp u s uniserialis, brevissimus, paleacens, paleis fimbriatis, ellipticis, - Herba persica, annua, pu silla; radice simplici, caule erecto v. adscendente lanato, foliis lanceolato-ellipticis, spina terminatis sublus imprimis tomentosis, summis sparse spinosociliatis.

A ca utholepis Lessiug in Linnaea $V X$. 88. Synops. 13. DC. Prodr. VI. 527.

SUTHTRIBUS TW. CARDOPATEAE Lessing Synops. 14. DC. Prodr. VI. 527. Capitula pauciflera, homegama. Involucri cylindracei squamae exteriores v. bracteae pinnatifido - spinosae, interiores integrae, subpungenti-mucronatae. Corollae palmato-quinquefidae. Anthera e caudatae, caudis retrorsum hirtis. A ch enia rostrata, villosa, areola terminali. P a p us uniserialis, paleaceus, longus, basi margine prominulo haud cinctus, paleis integris.
2849. Carraprotium JUSS. CapituI a m submultiflorum, homogamam, aequaliflorum. Invol u cri oblongi foliola imbricata, pauciseriata, coriacea, exteriora margine spinosa, apice in appendicem subulatam, spinosam subrecurvam producta, interiora subscariosa, apice denticulata et spinescentia. Receptacul a m angustum, fimbrillatum. Corolla e palmato-quinquefidae, tubo basi gibbo, subcorneo, lobis apice induratis. St a minum filamenta glabra, a $\mathrm{n}$ h e ra e appendice terminali acnta caudisque duabus longis, retrorsmm hirtis. Stig m a ta brevissima, obtusa. A $c$ h en i um subovoideum, hasi attennatum, apice in collum productum, sericeo-villosum. Pap pi squamellae octonae-denae, uniseriatae, inaequales, subdentatae, colli longitudine. - Herba perennis, in regione mediterranea orientali indigena, ramoso-co. rymbosa, spinosissima; foliis pinnatipartitis, lobis inciso-pinnatifidis et inciso-spinosis, capitulis plurimis, floribus caeruleis.

Cardopatium Jussien in Annal. Mus, VI. 324. Cassini in Dict. sc. nat. VII, 93, XLVII. 505. DC. Prodr, VI, 627. Cardopatum Persoon Ench. IT. 500. Lessing Synops, 14. Brotera Willdenow $S p, I 1 I$. 2399. non alior. C hatua eleon C. Baubia Pin, 350. Eehinops eory ubas us et Carthamus corymbosus Ling.

SUBTRIIBUS $\%$. XERANTHEMEAE Lessing Synops. 14. DC. Prodr. VI. 528. Capitula multiflora, heterogama, discoidea, floribus marginalibus femineis, reliquis hermaphroditis. Invol ucr um multiseriale, scariosum, radians, squamis distinctis, paleaceis, Receptaculum paleatum. Corollae hermaphroditae quinquedentatae, femineae tridentatae v. bilabiatae. Achenia turbinata, hermaphroditorum villosa, feminarum glabra, disco epigyno magno, areola terminali. Pap p us margine prominulo haud cinctus, paleis longis, semilanceolatis, paucis, integris.

2850. Xeranthemum TOURNEF. Cap it u $1 \mathrm{um}$ multiflorum, heterogamum, snbaequaliflorum, floribus marginalibus paucis femineis, reliquis hermaphroditis. I n volu $\mathrm{erum}$ imbricatum, multiseriale, scariosum, squamis interioribus saepe longioribus, radiantibus. Re e e ta c ali paleae scariosae, tripartilae. Co rolla e hermaphroditorum acqualiter quinquedentatae, inferne coriaceae, feminarum bilabiatae, labio exteriore longiore bitridentato, interiore breviore bipartito. St a min um filamenta corollae haud adnata, glabra, anthera e lineares, bicandatae. Stigma ta hermaphroditorum demum lihera, feminarum brevissima. Achenia exalata, pilis sericeis tecta. Papp p paleaceus persistens, feminarum rarior. Herbae annuae, in Europa australi et orientali, nec non in As ia contermina indigenae, Helichrysi facie, erectae, ramosac, inermes; folits linearibus v. oblongis, integerrimis, margine revolutis, subtus tomentosis, capitulis terminalibus, solitariis, involucris corollisque albidis $v$, pallide roseis.

Xera n the mum Tournefort inst. 284. Gärtn. 21. 399. t. 165. Scbkuhr t. 243. Jacq. Flor. austr. $t$. 388. Sehrank in Act. Academ. Monac, VIII, 146. Don in Mém. Werner. soc. V. 538, Gay in Mém, soc, h. n. Paris H11. 357. t. 7. Reichenb. Pl. cril, 2, 690. 641. Fischer et Meyer in Nont. Hem. sos. h, n. Mosgu, IV. 333. DC. Prodr. VI. 388. Xe. rant lre $m$ um et Xerol om a Cassini in Diet.so, nat. LIX. 112. et 120. Hariso nta Neeker elem. $n, 151$. non allor. Xerant the ai s p. Liau.

$59 *$ 
2551. Chardinia DESF. Capitulum multiflorum, heterogamum, aequaliflorum, floribns marginalibus paucissimis femineis, reliquis hermaphroditis. Involueri imbricati squamae membranaceae, interiores longiores, haud radiantes. Receptaculi plani paleae membranaceae, exteriores longiores, abrupte acuminatae, interiores brevieres, angustae, bipartitae. Corolla e tubulosae, hermaphroditae basi crassa, conica, limbo quinquedentato, femineae cylindraceae, tridentatae. St a min $\mathrm{m}$ filamenta glabra, tubo adnata, superne monadelpha, an $t$ h er a e auriculis subnullis. Stigmata primum erecta, demum divergentia. Achenia hermaphroditorum compressa, aptera, striata, feminarum compressissima, intus unicostata, margine alata, costa alisque saepe in cornua productis. P a p p i hermaphroditorum squamulae subdenae, uniseriatae, scariosae, persistentes; feminarum unica v. subternae, $\mathbf{v}$, interdum nullae. Herba orientalis, annua, Xeranthemi facie.

C hardiu ia Desfont, in Mem, Mus, III, 454, t, 21. Gay in Mém. soc. h, $n$. Paris. III, 365. t. 8, Cassini in Dict. sc, nat. LIX, 124. Dou in Mem. Werner. soc, $V$. 539 . Lessing Synops. 16. Fiseher et Meyer in Nouv. Mem. soc. h. n. Mosq, $I V, 341$. DC. Prodr, VI, 531. Xeranthemum ล ฉ $\mathrm{x}$ u m $\mathrm{p}$. Linn.

2852. Siebera GAY. Capitul n m multiflorum, heterogamum, aequaliflorum, floribus marginalibus paueissimis, femineis, reliquis hermaphroditis. I n vol u cri imbricati foliola scariosa, ovata, in spinam producta, interiora longiora, flosculos superantia. Re e e t a e uli paleae subulatae. Coroll a e tubulosae, hermaphroditae quinquedentatae, femineae bilabiatae, labiis inaequalibus, bilobatis. Stam ina...... S ty 1 a s hermaphroditorum inclusus, feminarum exsertus. A chen ia .. P a p p i squamulae quinque, corollam superantes, apice subulatae, scabrae. - Herba orientalis annua, habitu Xeranthemi; caule a basi ramosissimo, capitulis terminalibus $v$, ad collum sessilibus.

S i e be ra Gay in Mém. soc. h, n. Paris, 111. 343. Cassini in Diet, sc, nat. LIX, 125. DC. Prodr. VI. 531, non alior. Xeranthem um pungens Lam. t. 692. f. 2 .

SURTRERES VI. CARLINEAE Cassini Tabl. 5. DC. Prodr, VI. 531. C a pitula multiflora, homogama v. heterogama, nunquam dioica. Involueri multiseriati squamae distinctae, saepe spinosae. Corolla e hermaphroditae quinquefidae, femineae $v$. neutrae varie difformes, omnes saepius extus subrecurvae. St a min um filamenta libera, nuda, laevia. Antherae basi caudatae, caudis saepius longis, barbatis, subconnexis. A chen i a saepius villosa. Pap pus uni-biserialis, plumosus v. pilosus, nunquam paleaceus, pilis interdum varie concretis, prima fronte ramosis.

2853. Saussurea $D C$. C a p itulu m multiflorum, homogamum, aequalifloram. In vo I u e r i multiseriati, saepius imbricati squamae muticae v. apice appendiculatae. Re e e ta e ul $1 \mathrm{~m}$ planum, fimbrilliferum v. paleatum, paleis liberis v. cohaerentibus, persistentibus, rarissime nudum. Coro1I a tubo graeili, fance ventriensa, limbo quinquefido. Si aminum flamenta glabra. Antherae apice longe et acute appendieulatae, basi bisetae, setis ciliatis v. villoso-lanatis. Stigmata stylo continua, longa, apice divergentia. A $c$ henia glabra, P a p p s duplex, exterior subfiliformis, sca- ber, plerumque persistens, interioris setae longe plumosae, basi in annulum deciduum subconcretae. - Herbae in Europa alpicolae, in Sibiria a ustraliore copiosissime obviae, in India bore al $i$ rarae, habitu vario; foliis alternis, integris, $v$. in eadem stirpe incisis aut pinnatifidis, capitulis saepius corymbos caules ramosque terminantes formantibus, corollis purpureis v. atro-violaceis,

S a as urea DC. in Annal, Mus, XVI, 197, Prodr, VI. 331. Ledebour IC, I. 14, Lessing in Linnaea $V I .87$. H ete. rotrich um Bieberst. Suppl.S5t, non DC, B e nue tia Gray Brit. pl. II. 490. Lagurostemon et Sa us a rea Cas. sini in Diet. sc. nat. LIIT. 466. XLVIT. 494. Lessiug Synops. 11, 12. Saussurea et Cyathidium Royle Himalay, 251 . Serratulae sp. Linn.

a. LAGUROSTEMON DC. $\boldsymbol{l}$. $c$, Iavol u $c$ ri squamae om. nes foliaceae, inappendiculatae. A i thera $\mathrm{r} u \mathrm{~m}$ caudae lanatae. P a p u s biserialis, dispar.

C y a th 1 d i u Cass, in Dict, sc, nat, LIII. 466. L a gurostemon Wydler in Linnaea $V .425$. Less. Synops, 11 .

C. C y at hidium Lindl. In volu cri turbinati squamae laxae. - C y athidium Lindley in Royle Hima. lay. 25t. t. 56. f. 2. Lagurostem on C. A. Meyer msc. Serratula e s p. Jaeq. Fl. austr. $t$. 440. (Ledebour Io. $t$. 59.)

B. Laguranthe a C. A. Meyer msc, Involucri cylindriei squamae imbricatae. (Ledebour Ic. $t .75$ 78. 80.)

b. BENEDICTIA DC, $l$, $c$. I u rolucri squamae exappendieulatae. A n therar u m caudae ciliatae v. rarius fere glabrae.

S a us surea Cassini in Dict, sc, nat, XLVII, 494. Eus a us urea C. A. Meyer msc. (DC. in Annal. Mus. XVI. $t, 10$. Ledebour $\left.I c, t, 60 \_62,69 \_74,\right) \mathrm{S}$ er r a t uI a e s p. Linn.

c. THEODOREA DC, $l, c$, Involucri squamae apice appendiculatae. A n therarum caudae ciliatae.

Theodorea Cassini in Diet. sc. nat, LIIT. 453. (DC. in Annal, Mtus, XVT, t. 13. Ledebour IC, $t, 63-$ 68.) Serratulae s p. Lina. Bot. Mag. $t$. 2389.

2854. Haplotaxis DC. Capitulum multiflorum, homogamum, aequaliflorum. I n v oI neri multiseriati squamae imbricatae. Recepta cu I um fimbrilliferum v. paleatum. Corollae tubo gracili, fauce ventricosa, limbo quinquefido. St a in in filamenta glabra. Antherac apice appendiculatae, basi bicaudatae, eaudis ciliato-villosis v. subnudis. Stigm at a stylo continua, apice divergentia. A chen i glabra. Pa p p u s uniserialis, plumosus, setis basi in annulum plus minus coneretis, achenii margine circulari einctis. - Herbae in Indiac orientalis montibus indigenae, in Sibiria rarissimae, Cirsii v. Serralulae habitu.

H a plotaxis DC. in Guillem. Archiv. Bot. II. 330. Prodr. VI. 538. Eiriostemo n Lessing Synops, 12, nou alior. Frolovia Ledebour msc. Saussureae, Centa u. reae et Cuicisp. Don, Wallieh, Ledebour.

a. Frolovia Ledeb. msc. C a u I e s monocephali. - S a us. s urea e s p. Wall, Ledebour Ic. $t .352$.

b. CIRSIoldes DC. l. c. Capitula plurima, laxe co. rymbosa. - ? H e misteptia Bunge in Fisch. et Mfey. Index sem. horl. Petropolit, II. 1835. p. 38.

c. ERIOCORYNE Wall, msc. CapituIa corymboso - conferta, bracteata. S a s s urea es p. Wallich Pl. $A s$. rar. t. 138. (Royle Himalay t. 59. f. 1.)

2855. Dolomiaca DC. Capitulum multiflorum, homogamum, aequaliflorum. In vol a cri ovati squamae pluriseriales, imbricatae, lanceolatae, acuminatae, erectae, inermes. R e e ept a c u I u m planum, fimbrillis in alveolos cohaerentibus. Corolla e tubo gracili, basi subdilatato, limbi quinquelobi Iobis linearibus, aequalibus, Staminum filamenta glabra. Antherae apice appendiculatae, basi caudatae, caudis incurvo tortis, 
ciliatis. Stylus apice subincrassatus, villosus. Stigmata apice libera, teretiuscula. A $\mathbf{c h}$ e ni a glabra, subtetragona. P a p p $\mathbf{n} 8$ longus, rufescentiviolaceus, setis plurimis, scabris, basi in annulum ab achenio solubilem coneretis. - Herba nepalen$s i s$, inermis, humilis; foliis radicalibus pinnatipartitis, lobis oblongis, obtuse inciso-sinuatis, dentatis, subtus cano-tomentosis, capitulis e caule brevissimo ortis, breve pedunculatis, axillaribus, in caput irregulare, folits intermixtum aggregatis, corollis purpureis, pollicem longis.

Dolomiae a DC, in Guillem. Archiv, bot. II. 330 . Prodr. VI. 562. Royle Himalay. 251. $t$. s7.

2856. Anetium LAM. Ca pit a I m multiflorum, homogamum, aequaliflorum. In v o I u cr i campanulati squamae pluriseriales, subaequales, lineares, apice subulatae. R e e p ta $\mathrm{c} \mathbf{~ l u m}$ alveolatum, alveolis subfimbrillatis. Coro 11 a e tubo vix ad faucem dilatato, limbo breviter quinquefido. Staminum filamenta glabra, antherae basi bicaudatae. Stylus ad apicem vix incrassatus; stigmat a brevia, divergentia, obtusa. A $\mathrm{ehe}$ ia glaberrima, angulato-compressa, areola terminali destituta. P a p u s pluriserialis, persistens, setis scabridis, saepe spiraliter ineurvis. - Herba in schistosis Galliae meridionalis crescens, subacaulis, undique lanuginosa; foliis rosulatis, petiolatis, ovalis, crenato-dentatis, capitulo solitario breviter pedunculato, corollis albido-ochroleucis, foliis radicalibus post germinationem infra cotyledones lateraliter ortis.

A reti u u Lamarek Fl. fr, II, 70, Illuslr. $t, 664, \mathrm{Jus}$ sieu gen. 172. Lessing Synops, 11. DC. Prodr. VI. S52, non Linn. A r c t io Lam. Dict, 1.235. A r e tío n Cassini in Dict. sc. nat. XLI, 311, L. 443. V III a r si a Guettard Mém. min. I. 170, t. 19. B e $\mathrm{r}$ a $\mathrm{r} d \mathrm{i}$ a Villars Delphin. II. 27. $t .22$. non Brongn. O nopordon rotundifolium Allioni Pedemont, t. 38, f. $t$.

385\%. Steelhmammia $D C$. Capitulum pluriflorum, homogamum, aequaliflorum. In vo I ucri cylindracei squamae imbricatae, adpressae, in spinain productae, inferiorum spinis patulis, superiorum erectis. Rece p taculum ..... Corolla e tubo ad faucem vix dilatato, limbo inaequaliter quinquelobo. Staminnm filamenta glabra, a ntherae appendicula terminali coriacea, caudis longis, vix apice incisis. St ig m at a libera. A $\mathrm{che}$ nia glabra, obovata. Pappi pluriserialis setae lineares, plumosae, exteriores breviores, omnes distinctae. - Suffrutex libanoticus, humilis, multicaulis, ramosus; caulibus tomentoso-lanatis, foliis linearibus, margine revolutis, integerrimis, capitulis terminalibus, ebracteatis, corollis fere Arctii.

Stechmannia DC. Prodr. VT. 543.

3858. Staelaelima $D C$. Ca pitulum pluriflorum, homogamum, aequaliflorum. In v o l u $\mathrm{c} \mathrm{i}$ cylindracei squamae imbricatae, adpressae. Keceptaculi plani paleae angustae, persistentes, basi vix subconcretae. Coroll a e tubo limbo quinquefido nune breviore, nunc longiore. St a m in u m filamenta glabra, antherae apice longe appendicnlatae, basi bicaudatae, caudis plus minus barbatis v. Iaceris. Sty Ins apice tumido-barbellatus; st i $m$ at a basi concreta, apice libera, obtusa. A chenia oblonga, apice areolata. Papp us uniserialis, pilis quaternatim quinatimve basi in fasciculos ramosos concretis. - Suffrutices mediter rane $i$; foliis alternis, subtus plerumque canis v. se riceis, capitulis terminalibus.

Sta ob li ia a DC, in Annal, MLus, XVI, 192. Prodr. VI. 543. Gessing Synops. 5. St a e helln a e sp. Linn, gen, ed 176\%, n. 938, nec edit. 1842. a. STAEHELINA Cars. A chenia glabra. Pappi setae laeves.

Staehelina Cassini in Dict. se, nat. XLVIT. 439. Serratulae 8 p. Lam. t. 666. $f .4$.

b. HIRTELliNa Cass. Ova rium villosum. Pap pi setae scabrat.

Hirtellin a Cassini in Dict, se, nat. L. 46t. (La. billard. Syr, Dec. IV, $t, 1$. DC, in Annal, Mas, XVI. t. 1. $f .30$.) S e r a tula e s p. Lam. $t, 666, f .3$.

c. BARBELLINA Cass. Ovarium glabrum. Pappi se tae scabridae $\mathbf{v}$. barbellatae.

B a $\mathrm{rbelli}$ a Cassini in Dict. sc, nat, L. 440. (Schre. ber Decad. I. t. 1. DC. Op. cit, t. 1. f, 29.)

2859. Carlina TOURNEF. Ca pit u lu m multiflorum, homogamum, aequaliflorum. In v ol u c r i squamae exteriores foliaceae, dentato-spinosae, patentes, intimae elongatae, radiantes, scariosae, coloratae. R e ceptaculi plani fimbrillae basi concretae, alveoliformes, apice inaequaliter multifidae. Corolla e tubulosae, glabrae, quin quefidae. Sta min um filamenta glabra, an $t h e-$ ra e apice longe appendiculatae, basi bicaudatae, caudis plumosis. Achenia oblongo-cylindracea, pilis sericeis, biapiculatis, adpressis vestita. Papp u s uniserialis, lamellis basi ternatim quaternatimve concretis, caeterum plumosis, - Herbae spinosae, durae, in Europa media nec non in tota regione mediterran ea obviae, habitu vario.

C a rli n a Tournefort inst. 285, Linn. gen, n, 929, Gärt. ner $I I, 384$. DC. Prodr. VI. 545 .

a. HERACANTHA DC, $l$. c. Involuerum duplex, squa. mis exterioribus foliaceis et interioribus radiautibus eoloratis contiguis, nullis allis intermixtis. - Herbae acaules $v$. caulescentes, monocephalae.

Her a c a th a Tabaernemont. Rrduterb. 398. C a r. $1 \mathrm{i}$ a Cassini in Dict. sc, nat, VII. 108. Lessing $S y^{n}$ ops. 12, subgen. 1. E. B. t. 1144. Schkuhr $t$. 232. f. 2.

b. MITINA DC. t. c. I nvol a erum triplex, squamis extimis foliaceis ab intimis radiantibus serie intermedia diutinctis. - Herbae caulescentes, pleiocephalae.

M itina Adanson Fam. IT. 116. Cassini in Diet, $6 C$. nat, XLVII. 498. et SOz. Lessing Synops, 12. (Gärta, $I I$. t. 163. f. 1, Schkuhr t. 232. f. 1. Desfout. Fl, all, $t, 22 \%$. Reichenb. $\mathrm{Pl}$. crit. $t, \mathbf{2 6 1 \text { .) }}$

c. CHAMAELEON DC. l,c. In volucri duplicis squamse exteriores foliacene, dentato-spinosae, interiores vix longiores, lanceolato-lineares, integerrimae, apice acuminatae, submembranaceae, uec radiantes, nec coloratae. - Herbae subacaules, caespitosae, monocephalae.

Chat a e le on Cassini in Dict. se, nat, XLVIT, 509 . L. 59. A tractylis s p. Lina. Cavanill. Ie, t, 288. Des. font. Fl. alt. $t$. 226, A c a r a a e s p. Willd.

d. CARLOWIZIA DC.l.c. In vol u crum bemisphaericua, Imbricstum, squamis intimis apice seariosis, breviter radiantibus, extus einetum foliis patulis, indivisis, serrato-spinosis. Frutices o anarionses; caulibus junioribus tomentoso-albidis, folits coriaceis, indivi. sis, oblongis $v$. linearibus, serraturis spinescentibus, capitulis terminalibus, corollis ochroleucis.

Carlowizia Mōnch Method. 225.

2860. Atractylis LINN. CapituIum multiflorum, nune homogamum, aequaliflorum v. radiatiforme, nunc heterogamum, radio neutro, disco hermaphrodito. Invo I u c r n m duplex, exterioris foliola conferta, dentato-spinosa, interioris squamae adpressae, integrae, membranaceae $v$. scariosae. R e epta e uli plani fimbrillae basi in alveolas concretae, apice multifidae. Corolla dis ei tubulosae, regulariter quinquefidae, $r$ a di $i$ conformes v. falso-ligulatae seu palmatae, quinquelobae. Staminnm filamenta glabra, an therae apice appendiculatae, basi bicaudatae, caudis barbatis. Stigmat a fere omnino concreta. A $\mathbf{c h c -}$ nia tecta villis sericeis, copiosis, summis quasi 
pappi basim involuerantibus, P a p p s uni-biserialis, setis basi coriaceis, subconcretis, nudis, apice plumosis. - Herbae mediterraneae et orientales, durae, spinosae, Carlinam v. Cirsium habitu referentes; foliis alternis, dentatis $v$. pinnatifidis, capitulis terminalibus.

At raetylis Linn. gen. n,930. excl, sp. DC, in Annal, Mus. XVI, 157. Prodr. VT, 549. non Vaill. C $\mathrm{x}$ o codilo des Vaillant in Act. Academ. Paris. 1718, p. 172. non Adans.

a. CHALCEIOS DC. Capit u 1 a m homogamum, aequaliflorum. I a volucrum daplex, exterioris erecti squamae foliaceae, pinnatipartitae, lobis spinosis, interioris squamae uembranaceae, oblongae, obtusae, non radiantes. Cor oll a e quinquefidae, subregulares. An the $r$ a. r u m aprendices acutae, caudae lougae, subintegerrimae. A che nia oblonga, sericeovillosissima, villis supremis pappum breviter calyculantibus, nee tamen cum eo coneretis. Papp u 8 uniserialis, setis plumosis, basi corneís, concrelis. - Herbae caulescentes, simplices, mono-oligocephateac.

Chalcelos DC. Prodr. VT, 549.

b. ACARNA Cass. Capit a $1 \mathrm{um}$ homogamum, aequaliflorum. Involucrum duplex, exterioris squamae foliaceae, dentato-spinosae, fere pectinatae, interiores aequantes v. superantes, iuterioris imbricati squamae lineares, adpressae, acuminatae, istimae longiores, aplce scarioso. appendiculatae, vix thme⿰ radiantes. Cor olla e quit. quefidae, subregulares. A $\mathrm{n}$ the $\mathrm{rar}$ u $\mathrm{m}$ appeadices aeuminatae. A eh e nia obovata, sericeo-villosissima, villis supremis pappi basim calyculantibus. Pap p us unise. rialis, plumosus. - Herbae caulescentes; foliis linearibus v. oblongis, subtus tomentosis, margine ciliatospinosis, involucri exlerioris spinis ramosis, corollis purpurascentibus.

A carna Cassini in Dict, se, nat. L. 57. A. c a ncellata Allion. Cirselliam cancellatum Gärt. ner $I I, 45 \%, t, 163 . f$. 2. Lam. $t, 662 . f, 1$. C a r th a m u s cancellat as Lam.

c. ANACTIS Cass. Capitulum homogamum, aequaliflorum. I nv o I п с r u m duplex, exterioris squamae folia. ceac, spinoso - dentatae, interioris brevioris squamae adpressae, ovatae, truneatae, nervo medio in spianan producto. Ant herarum appendix terminalis acuminaia. Papp us nniserialis, setis basi corneis, nudis, apice plumosis. - Herbae durae, caulescentes, folitis sessilibus.

A n a ctis Cassini in Dict. sc, nat, L, 56, A c a $\mathrm{r}$ a c a espitos a Desfont. Fl. Atlant, $t$. 225.

d. CirselliUm $D C$. Oa $\mathrm{p}$ it u $\mathrm{I} \mathrm{m}$ homogamum, inaequa. liflorum, subradiatiforme. In volu $\mathrm{crum}$ duplex, exte rioris squamae foliaceae, dentato-spinosae, interioris brevioris squamae adpressae, ovatae, truneatae, nervo medio in spinam producto. Corolla e exteriores liermaplicoditae, paluatae, ligulam simulantes Anthera. $r u m$ appendix terminalis acuminata. Pappus nuise rialis, setis basi nudis, apice plumosis. - Herbac caulescentes, durae, oligocephalae.

Cirsellium DC. Prodr. VI, 550. Atractylis Cassini in Dict. sc, nat, XLVII, 510, L, 55, A tra e ty11 is h umillis Linn. Cavanill. Ic. $t$, 54. Lam. $t$. 660 . Cirsellium humile Gärtn, $I$. 455 .

e, SPADACTIS Cass, Capit ulum heterogamum, radiatum, ligulis neutris, disco hermaphrodito. Involu. c r u m duplex, exterioris squamae subuaiseriatae, follaceac, dentato-spinosae, capitulo longiores, interioris squamae imbricatae, adpressae, ellipricae, acutae, apice subspiacscentes. Corolla e dis e i regulares, quiluque. fidae, antheris in appendicem tacutam productis, $r$ adi $i$ ligulae elongatae, quinquefidae, genitalibus subabortivis. Pappus disci nal. triserialis, setis plumosis, radii Imperfectus. - Herbae caulescentes, durae, ramosae; folits pinnatifido-dentatis, spinosis.

$\mathrm{S}$ padactis Cassiaj in Diet. se. nat, XLVIT. 510 . L. S1. A tra etylis flava Desfont. Fl, Atlant, t. 262.

2861. Thevemotia DC. Ca pitu I u m multifloram, homogamum, aequalifloram. I n v o I ueri ovati, inter folia bracteiformia sessilis squamae multiseriales, adpressae, imbricatae, exteriores breviores, interiores sensim longiores, lineares, ener- ves, obtusae, spinula longa, erecta apiculatae, intimae subscariosae, hand radiantes. R e e p ta euI $\mathrm{m}$ planum, fimbrillis basi in urceolos coalitis. Cor ofl a e tubulosae, quinquefidae, lobis angustis, aequalibus. Staminum filamenta glabra, a $n$ thera r a m candae barbato plumosae. St y lus indivisus, A ehenia dense et adpresse sericeo-villosa. Pappus uniserialis, setis basi subcorneis, superne longe plumosis. - Herba persica, annua, canotomentosa; folits infimis obovatis, spinoso-subdentatis, floralibus sublyratis, brevissime petiolatis, lubis dentibusque validius spinosis, capitulis ad axillas bractearum sessilibus, involucri appendicibus spinosis, squamarum exteriorum flavidis, interiorum fuscis, corollis ochroleucis.

\section{Thevenotia DC. Prodr, VI. 551 .}

2862. Cousinia CASS. Capitulum multiflorum, homogamum, aequaliflorum. InvoIn eri squamae imbricatae, coriaceae, spinosae. Recepta en li plani fimbrillae setosne, liberae. Coroll a e tubulosae, glabrae, limbo quinquefido tubum superante. Sta min $\mathbf{m}$ m filamenta glabra, a $\mathbf{t}$ h e $r$ a $\mathbf{u} \mathbf{m}$ appendices terminales longae, corneae, caudae barbato-plumosae. Stig m a ta libera, extus cum styli parte superiore pubescentia. A ch en i a subcompressa, sulopentagona, glabra, firma, areola subobliqua. P a p p u 8 brevis, serrulato-seaber, caducus, uniserialis, interdum subnullus, margine circa pappum elevato v. obsoleto. - Herbae in Asia me dia copiose obviae, perennes $v$. biennes, ramosae, tortuosae, Carduifacie; foliis plus minus decurrentibus, sinuato-dentalis, dentibus spinosis, capitulis ternis,

Cousinia Cassini in Diet. sc, nat, XLVIT, 53. C. A. Meyer Enumerat, plant, Caucas, 230. Belanger Voy. Bot. Ic. DC. Prodr. VI. BJ2. Cardui, Oa buromatis et Carthami sp. Auet.

2863. Aneathin $D C$. Capitulu m multiflorum, homogamum, aequaliflorum. In volu cri ovato-globosi squamac imbricatae, exteriores et mediae spinosae, intimae scariosae, coloratae. Recep $t$ a c u l u m paleaceo fimbrilliferum. Corolla tubulosae, limbo oblique quinquefido. St a m in n m filamenta glabra, an th e ra r um caudae penicillatae. Ach enia glaberrima, oblonga, angulata, longitudinaliter striata, areola laterali, margine crenato. Pappus subbiserialis, setis basi in annulnm deciduum conferruminatis, aequalibns, plumosis. Herba a ltaica, rupicola; caulibus ramosis, ramis villoso-tomentosis, monocephalis, foliis lanceolato-linearibus, subtus villoso-tomentosis, supra glabris, subintegerrimis, hinc inde ad latera spinulas geminatas gerentibus, involucri squamis spinosis, palulo-recurvis, intimis rectis, purpurascentibus.

An cat hia DC. in Guillem. Archiv. Bot. II. 331. Cir. 8 i um Ig niarium Spreng. Ledebour Ic. $t$, 477.

2864. Auelhera $D C$. C a pitnlum maltiflorum, homogamum, aequaliflorum. In v ol a cri ovati squamae arete imbricatae, mnerone ealloso, uncinato, rigido terminatae. Receptac $\mathbf{u} \mathbf{l} \mathbf{u m}$ longe fimbriliferum. Co ro Il a e tubo brevissimo, fauce longa, cylindracea, lobis quinque erectis. Stamin um filamenta glabra, an $t h e r a e$ basi bicaudatae. $\boldsymbol{A}$ e he $\mathrm{n}$ i a glabra, compressa, margine bidentato superata, areola basilari, $\mathbf{P}$ a p p $\mathbf{s}$ sub. uniserialis, setis paucis, rigidis, vix dentieulatis, cadtucissimis. - Herba persica, erecta, bipedalis, rlaberrima; radice longe cylindracea, foliis radicalibus sub anthesi evanidis, caulinis pinnatipartitis, rhachi lobisqus linearibus margine revolutis, integer. 
rimis, mucronatis, capitulis in paniculam laxam subnudam dispositis, corollis flavidis.

A ucher a DC. Prodr. VT. 557.

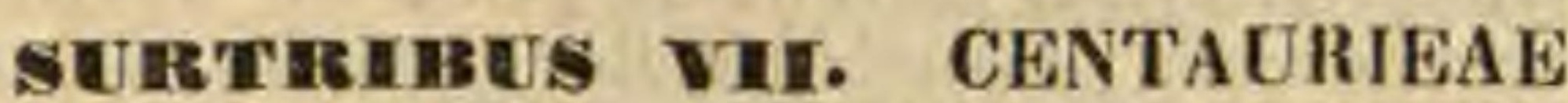
DC. Prodr. VI. 557. Capitula heterogama, radiatiformia. Involncri squamae imbricatae, varie appendiculatae, rarius exappendiculatae. Flo res radii saepissime neutri, corolla ampliata, irregulariter quinquefida, discum saepius superante. Sta m in u m filamenta distincta, saepius papillosa. A ch e n i saepius compressa, rarius cylindracea, plerumque areola antice laterali notata. Pap p us rarissime deficiens, pilosus v. paleaceus, saepius multiserialis, nunquam plumosus.

2865. Auberboa PERS. C a pitulum multiflorum, homogamum v, heterogamum, radia tiforme, floribus marginalihus neutris, disei her maphroditis. Involueri squamae varie appendiculatae $v$, rarius exappendienlatae, muticae $v$, in terdum spinescentes. Receptaculum setosum, Corolla e tubulosae, quinquefidae, marginales ampliatae, subirregulares, disco saepius longiores. S t a m in u m filamenta puberala v. papillosa. A e h e n i a compressa v. turbinato-tetragona, areola laterali $\mathbf{v}$ basilari. P a p p s paleaceus, paleis oblongis v. obovatis, basi attenuatis, omnibus subhomogeneis, rarissime minimns vel nullus. - Herbae mediterranea et orientales. habilu Centuurearum, a quibus pappo paleaceo diversae.

A uther bou Persoon Encheir. II. 48t. exel. sp. DC. Prodr. VI. 558. A mberbol Isnard in Act. Academ. Pa ris. 1219, $t, 10$. Adaus. Fam. IT, 117, C is ry $\mathrm{xe}$ is et $\mathrm{A}$ m. be $\mathrm{x}$ b a a Lessing Synops. 6 . et 8.

A. CHRYSEIDEAR DC. Prodr. VI, 558, In vol ueri squa mae exappendiculatae $\mathrm{v}$. appendice haud pectinato-ciliata aucthe.

c. GONIOCAulon DC. Prodr. VI. 558. Involucti ey lindracei squamae aupressie, imbricatne, aentie, coriaceae, margiue nembranaceite. Floseuli paci, omnes aequales, hermaphroditi. S ta a nther he appendice longa, cornea termiaatue. Stig mata distineta. Pa p us longus, paleis multiseriatis fubricatis, seariosis, lineari-oblougis, interioribus lougioribus, basi angustatis. - Species indicae.

Goniocaulon Cassini in Bullet soc. philomat. 1817. p. 34. 18t8. p. 184. Dict. se. nat. XIX. 201 XIIV. 39.

B. CXanopsis DC. Prodr. VI. 358. Invola eri ovati squamac lanceolatae, integerrimae, prodictae in appen dicem subdecurrentem, membranaceam, acutan, exteriorum saepe patulum, spiaiformem, interiorum subscariosam, erectam. Stig mata concreta. A che nia villosa, costata. P a p pi palese oblengae, basi angustatae, apice serrulatie, exteriores breviores, intimae lougiores. IIerbae annuae, capitulis longo pedunculatis, radio caeruleo v. purpureo, disco oroceo v. pallido.

Cyanopsis et Volutarella Cassini in Dict. sc. nat. XLIY. 39 .

1. C y a astrum DC. Prodr, VI. 558. Inveluer subhemispbaerici squanae exteriores et mediae in ap peudicem longau, patulam, subspinescentem prodactae. Corolla e radil longissimae. A ele nia inter costas transverse ragosa. Pappi series 6. - C y a no $\mathrm{pis} \mathrm{ct}$ C y a nastr at Cassibi in Dict, sc, nat, LVI. 39. C e u. t a urea muricata Lial.

2. Lacellia DC. Prodr. VT, 359, Involucri ob. longi squamae apice nigro-spliacelatae, exteriorum ap peudice brevi, inermi, saepe patula. Corolla e radii mediocres, saepe discolores. Achenia inter costas transversim rugosa. Pappi series $3-4$. - L a cellia Viviaui Flor. Libic, 22. f. . . C en taurea erupinoi. des Desfont. DC. in Annal. Mus, XVI, t, s. f. \&, Volu. tarella e sp. Cass.

3. Volutaria DC. Prodr. DT. 539. Involacri obovati squamae apice et margine membranaceae, acutae, exteriorum appendice erecta. Corolla e radif mediocres, disci saepe ad apicem tubi villosae, lobis glabris, introrsum volutis. A elhenia vix costata, nec transversim rugosa. Pappi series......-Voluta ria Cassini in Dict, sc, nat, $\mathrm{XXXIX}, 500$. Volut a rell a Cassini Op. cit. XLIV.39. C e u ta urea Li ppii Liau. Schkuhr t. 261 .

$\gamma$. CHRYSEIS DC. Prodr. VI. 559. Involnori ovato. globosi squamae inermes, obtuxae, exappendiculatae 8 . intiorae apice scarios?-membrauaceae. A n the rat basi ealcaratae. Styli apice liberi. A eh en ia villosa, bilo laterali. Pap pus nullus, v, simplex pluriserialis, paleis interioribus apice dilatatis, subdentatis. - Herbae orlen. tales, annuae, erectae, ramosae, floribus odoratis.

Ch r y se is Cassiofi in Dict. sc, nat. IX, 154, XLIV. 39. Ceutauren mosehata Linn. Schkuhr t. 261 .

f. PARARHYSIS DC. $l$. c, Involucri ovati squamae adpressae, basi interdum uni-bidentatae, appendice subspiniformi, lineari-subulata, glaberrima, subintegerrima, patula. C o r o Il a e radii paucae, tennes, trifidae, disco breviores. Stig a at a concreta. A chenij areola basi. laris. Papp us disci multiserialis, paleis exterioribus linearibus, obtusis, interioribus fere setifornibus, sutciliatis. - Horba persica, perennis v. biennis, ra. dice fusiformi.

B. AMBLyopsideae DC, Prodr. VI. 560. In volueri squamae appendice pectinato - eiliata.

๙. PHAEOPAPPUS DC. Prodr, NI, 560. In vol neri ovati squamae adpressae, imbricatae, exteriores et mediae in appeudicem nou decarrentem, erectam, elliatan expast. sae, ciliis nunc palmatim, nune pinnation dispositis, lobo medio plus minus spinescente. Corolla e radi $i$ discum haud superantes. Stig mat a conereta. A e he u i a glabra. Pa p p s extimus brevis, paleacens, imbricatus, albus, medius et intimus setis subfitiformibus, rufis, subaequalibus, intimis haud distinetis. - Flores Iotel. Psophelius Fiseh. et Mey. msc. Centaureat Bats a m it a Don in Sweet Fl. Gard. II, t. 355, non Lam.

B. AMBLYOPOGON DC. Prodr. VI. 56t. Involueri ovalis squamie imbricatae, breves, in appendicem am. plan, scariosau, ovato-Ianceolatam, marglne pectioatoeitiatam, apice aristatam expansae, C o rolla e radit discum hand superantes. A utherae basi submuticae. Stig mata concreta. A c he a fa areola basilari. P a pp us simplex, palencens, paleis apice dilatatis. denticulatis. - A mbi yopogon Fischer et Meyer msc.

$\gamma$. XANTHOPSIS DC. Prodr. VX. Sot. In vol u eri ovati squamae extimae et mediae breves, in appendicem membrancesm, ovalo- ianceolatam, acumhatam, pectinatociliatam, laxe fmbricatam expansae, intimae lineares, acutue, vix cillatae. Corollae radfi diseum non supecautes, hermaphroditae, sed fortassis steriles. S $t i g$ ma ta connata. A chen I a compressa, dorso gibba, glaberrima. Pappus disel brevissimus, paleis obtusis, subserratis, basi angustatis. - Flores lutei, involuera flaveseentia, pauciflora. - Psephelli sp. Fischer et c. A. Meyer.

2886. Zoegea LINN. C a pitulum multiflorum, heterogamum, radiatiforme. In vo l u cri ovati squamae exteriores in appendicem seariosam, adpressam, profunde pectinato ciliatam productae, intimae longiores, scariosae, lineari-lanceolatae, integerrimae, apice summo serrato-incisae. $\mathbf{R}$ ecepta en lum setosum. Corollae radii neutrae, magnae, irregulares, subligulatae, di sei regulares, quinquefidae, hermaphroditae. Sta m in um filamenta laevia, glabra, an the ra e caudatae. A $\mathrm{ch}$ en i compressa, areola laterali. Pap pi paleae exteriores membranaceae, imbricatae, obtusae, mediae pilosae, longissimae, intimae pilosae, brevissimae. - Herbae orientales, erectae, annuae, ramosae; foliis infimis petiolatis, lyratis, lobo terminali majore oblongo, subdentato, superioribus linearibus, integerrimis, mucronatis, involucri squa- 
mis interioribus fere radium simulantibus, floribus croceo-fulvis.

$\mathrm{Z}$ oege a Lian. Mant, 13. Heritier Stirp, $t$. 29, Jaeq. Ie. rar, $t, 77$, Cassini in Dict. sc. nat. XLIV. 36, LX, s60. Lessing Synops, 7. DC. Prodr, VI. 562, Ce nt a u re at caIendulacea Lam.

\%86\%. Mierolloneluus $D C$. Ca pitulum multiflorum, heterogamum, radiatiforme. I n ₹ oIu eri ovati squamse adpressae, coriaceae, apice productae in appendicem spiniformem, nunc brevem, reflexam, deeiduam, nune longam, duram, erecto-patulam, persistentem. R e ce p ta c u 1 u m setosum. Coroll a e radi neutrae, plus minus ampliatae, subligulatae, dis ci regulares, quinquefidae, hermaphroditae. St am in um filamenta papillosa, antherae ecaudata. Achenia compressa, areola laterali. Pa p p u duplex, interioris paleae latae, vel in squamam unilateralem, apice subacuminatam, pappum exteriorem subsuperantem concretae. - Herbae perennes, mediterranea $e$, orientales et indicae, glabrae v. glabriusculae; ramis floridis apice aphyllis, monocephalis, corollis nunc purpureis v, variantibus albis, nunc flavidis.

Microlonehus DC. Prodr. VT. 562. Mantisale a A. Microlon eh us Cassini in Bullet. soc. philomat. 1818. p. 142. Dict. sc, nat. XXIX, 80.

a. MANTISALCA Cass, l. c. Inv olucri squamae in mu. cronem spinulosum v. spinam productae. Flo res radii magis ampliati, purpurel vo albi. P a p p i paleae interiores setas exteriores aequantes. - C entaure a s a I mantie a Linn. Jacq. Hort, Vindob, $I, 64$. Sehkuhr $t, 261$.

b. URALEPIS DC. $l$, c. Involueri squamac inermes, in appendicem scariosam, subrotundam productae. Coroli a e radif vix ampliatae, flavesceutes. Pappi squamellae interiores exterioribus breviores.

2888. Trielnolepis $D C$. Ca pitulum multiflorum, homogamum. In vo I u cri hemisphaerici squamae imbricatae, numerosissimae, lineari setaceae, apice criniformes, subrecurvae, inermes. Receptaculi fimbrillae in setas tenuissimas fissae. Coroll a e tubulosae, quinquefidae, subreguJares. St a mi $\mathbf{n} \mathbf{~ m}$ filamenta papilloso-pilosiuscula, antherae apice acute appendiculatae, caudis parvis, sublaceris. Stigmata plus minus divergentia. A chenia oblonga, areola laterali, apice margine circulari coronata. P a p i setae nunc lense scabrae, multiseriales, basi in annulum deciduum coneretae, nune distinctae, nanc interdum nullae. - Herbae indicae, glabriusculae, inermes; foliis sessilibus, indivisis, lanceolatis v. oblongis, serratis, capitulis ebracteatis, corollis ochroleucis $v$. pallide rubentibus.

Trichole pis DC, in Guillem, Archiv. Bot, II. 331. Prodr. V1, 563. A ehy ropappus Bieberst. mse.

a. EUTRICHOLEPIS. P a p p i setae basi in annulum deciduum concretae.

b. OCHANOPAPPUS. Pappl setae paleaceae, margine scabro.elliolatae, in anuulam eoneretae. - Folia punetata. (Hook. Bot, Mag. Compan. I. 2.4 .)

c. ANAPHALANTIAS, Pap a s aullus.

2869. Tomantlaea DC. Ca p it ul u m multiflorum, heterogamum. I n ₹ o I u c r i ovati squamae adpressae, appendice ampla, orbiculata, rigide membranacea, ad margines longe eiliata, apiee in spinam tenuem, ciliis vix longiorem producta. Receptaculam fimbrilliferom. Corolla e $r$ a di i trifidae, steriles, diseum vix aequantes, dis e i quinquefidae, post anthesim infra faucem transverse marcescentes et secedentes, tubo inter pappi setas persistente. Staminum filamenta papillosa, brevia, contorta, an therae appendice terminali cornea, caudis nullis, Stig m a $t$ a con. ereta. A chen ia cylindraceo-subpentagona, gla- berrima, areola basilari, apice extra pappi originem in marginem orbiculatum, brevissimum dilatata. Pa p p s radi i paneisetus, disei multiserialis, setis exterioribus brevioribus, paleaceis, linearibus, obtusiusculis, eaeteris rigidis, elongatis, omnibus integerrimis. - Herba perennis, persica, subacaulis; foliis canescentibus, pinnatipartitis, petiolo et rhachi marginatis, lobis oblongo-lanceolatis, integerrimis, summis oblongo-lanceolatis, integerrimis, capilulis terminalibus, sessilibus, corollis pallide purpurascentibus, pappo violaceo.

Tomant be a DC. Prodr. VI. 564.

28\% D. Crapina CASS, Ca pitulum pauciflorum, heterogamum. In v ol to c ri ovati squamae lanceolatae, adpressae, acutae, inermes, integerrimae, exappendiculatae, $R$ e e e p ta e $\mathbf{u}$ I n m setosum. Corollae marginales neutrae, tri-quinquefidae, reliquae hermaphroditae, quinquefidae, ad apicem tubi barbatae. Stamin um filamenta papillosa, antherae ecaudatae. A chenia crassa, ovato - teretia, sericea, areola basilari, umbone terminali elevato, concavo, crasso, corollae basi persistente cincto. Pap p s radii nullus, dis ei triplex, exterioris paleis brevibus, imbrieatis, medii setis longis, rigidis, intimi paleis denis, brevibns, ovalibus, subtridentatis. _ Herba mediterranea, annua, erecta, simplex v. parce ramosa, glabra; foliis pinnatipartitis, lobis linearibus, distantibus, denticulatis, inferioribus pinnatilobatis, capitulis oblongis, glabris, nudis.

Crupina Cassini in Dict, sc, nat, XLIV, 39, L, 239. Lessing Synops, 7. DC. Prodr. VI. 565. C е и t a u r e a Crupina Linn. Crupinae sp. DC. in Annal. Mus. XVI. t. 1. f. 1 .

2881. Cemtaurea LESS. C a p itulum multiflorum, heterogamum, plerumque radiatiforme. Involucri squamae imbricatae, exappendiculatae v. varie appendiculatae, mutieae v. spinosae. Co rolla e radii ut plurimum steriles, ampliatae, quinquefidae, rarius discum non superantes $v$. hermaphroditae. S $\mathbf{t a m}$ in $\mathbf{n}$ m filamenta papillosa, an $t$ h e ra e ecaudatae. A $c$ h en i compressa, areola prope basim antice laterali. P a p $\mathbf{i}$ setae subfiliformes, seabrae, saepissime multiseriatae, intimae minores, subconniventes, rarius exteriores aequantes v. superantes. Herbae in veteris orbis hemisphaera boreali ingentiformarum numero degentes, in $A m$ erica rarae, nonnullae late a mortalibus agricolis diffusae, nunc cosmopolitae.

Centaurea Lessing Synops, 7. DC. Prodr. VI, 565. Centaureac sp. Linn. Centaurieae prototypae Cassini Tabl. 7. excl. pauc. Crocadilitum, Caleitrapa, Cyanus et Centaurium DC. in Annal. Mus. XVI. t. 5. Calcitrapa, Centaurea et Cyanus Baumgarta. Flor. Transylv. II, 69_81. C y a as, Phrygia, Hy pophoestam. Poly acaniha et Le ucautha Gray Brit. pl. II. 441_444.

1. HAPLOLEPIDEAE DC. Prodr. VT. 565. In volucri squamae aut appendiculatae, sut appendice scariosa, non eiliata, raro breviter spinulosa donstae.

a. HYALEA DC. Prodr. VI. 565. Involueri oblongi squamae imbricatae, apice et ad marginem in parte superiore hyalino-membranaceae, obtusae, mutieae, intimae longiores. Flores radii pauei, steriles. A $\mathrm{ch} e$ it $i$ glabra. Pap p u s duplex, exterioris setae longae, teanes, subseabrae, interioris paleae octo, breviores, oblongae, basi subattenuatae, apice setoso-scabrae. - Flores purpurei. - (Ledebour Ic. t. 39.)

b. CENTAURIUM DC. Prodr. VI. $566.1 \mathrm{n}$ vol u $\mathrm{cri}$ ovatoglobosi squamae late ovatae, dpressae, obtusae, inermes, apiee imprimis interiores membranaceae. A cli en i a glabra. Pa p p u s duplex, exterioris paleae extimae breves, sensia elongatae, setiformes, interiores breves, distinetae. - Herbae erectar, glabrae, simplices v. $r a$ - 
mosae, capitulis ad apicem caulis superne nudi v, ramorum aphyllorum solitarits, corollis luteis $v$, rarius fuscis.

Centanri um Cassini in Dict. sc, nat. XLIV. 39 non Pers. (Desfont. Flor. atl, t. 241. Brotero Phytogr. lusit. $t, 3$.

c. MiCRolophUS DC. Prodr. VI. 567. I n v $1 \mathrm{n} \mathrm{er} \mathrm{i} \mathrm{ava-}$ to-conici v, ovato-oblongi squamae adpressae, imbricatae, coriaceae, integerrimae, mediae acutae v. mucrone brevissimo, recto, spinuloso, saepius deciduo, interdom utrinque uni-bidentato v. paimatim quinqne-septemaristato superatae, intimae lineares, apice et paullo etiam margine searioso-membranaceae. Co rolla e radit steriles, bi-trifidae, discum non superantes. A ehenia ovalia, eom. pressa, glabra. P a p p a s duplex, interioris paleae bre ves, liberae. - Herbae, folits caulinis decurrentibus, indivisis, corollis favis.

Microlophus et Piptoceras Cassini in Dict. sc, nat, XLIV, 37. L, 248, et 469. LIV. 487, et 490 . S e r.

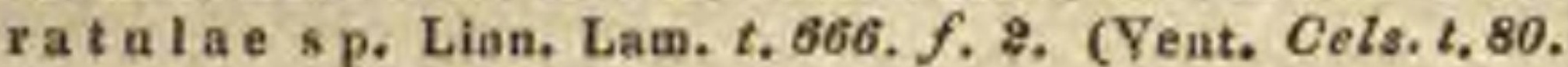
Nees Hor. phys, berol, $t, 25.26$.

d. Chartolepis DC, Prodr, NI, 568. I avol u e r i ovoidei squanae adpressae, productae in appendicem non decurrentem, suborbiculatam, seariosam, margine subinte gerrimam, apice fissam, ligulam subalatum proferentem. Corolla e marginales neutrae, disco fere breviores. Papp us duplex, setis intimis paucis, brevibus. - Flores iutei.

Chartolepis Cassini in Dict. sc, nat. $X L I P, 36$. LIV, 492. (Bot. Mag. $t$. 62, 1248.)

e. PHALOLEPIS DC. Prodr. VI, 568. In volueri ovati v. globosi squamae in appendicem non decurrentem, sub. rotundam, margine late scariosam, apice in aristam mucroniformen desinentem productae. F I o res radii neutri, disco vix v. paullo majores. P a p u s duplex, rarius nullas, - Flores purpurei v, rarius albi.

Phalolep is Cassini in Dict. sc. nat. L. 248, C a 1. $1 \mathrm{c}$ e p halu s C. A. Meyer Enumerat. plant, Caue. 66. (Tenore Flor, neap. $t$, 84.)

11. JACEINEAE DC. Prodr. VI. 580 . I n voln e ri squamae mediae apice in appendicem scariosam, ciliato-serratam, non v. vix decurrentem productae.

f. JACEA DC. Prodr. VI. 570 . I n v o 1 u cri ovato-globosi squamae inferiores appendice ciliata, basi dilatata, superíores appendice suborbiculata, scariosa, sublacera. Flores radil nunc steriles, diseum superantes, une omnes hermaphroditi, aequales. P a p p u s nullus v. sub. nullus. - Herbae ramosae, floribus purpurascentibus $v$, rarius albir.

$\mathrm{J}$ a ce a Cassini in Dict, sc, nat, XXIV. 88. J a cea et Platylop hus Cassini Op. cit. XIV. 36.

ct. J a ce a Cassini Op. cit.XLIV. 36. C or olla e radii steriles, diseum superantes. - (Fl, dan. t. 519 . Reichenb. Pl. crit. $t$. 963 .)

B. Platylophus Cassini Op. cit, XLIV. 36. Co. rolla e omes hermaphroditae, aequales. - C e $u t$ a are a $\mathrm{n}$ ig $\mathrm{r}$ a Linn. Fi. dan. $t, 906$. k. B. t. 278. Reichen bach $P l$. crit. t. 985.

g. PterolofhuS DC. Prodr, VI. 581.1 a volucrl ovato-globosi squamae inbricatae, dorso striatae, appeadice saepius fusco-maculata, non v, vix decurrente, margine ad basim utrinque ala scariosa menibranacea aucta, supra longe pinnato-ciliata, apice apiculo inermi $v$, spinnso terminatae. P a p p us nullus $\mathbf{v}$. brevis. _ Flores pallide purpurei $v$. flavo mixti.

c. E a pterolophus DC, l,c. Pterolophus Cas sinf in Diet. sc, nat. XLIV. 34, L, 249. P a p p u s nullus. I n o o u cri squamae exteriores et mediae appendice basi scarioso-alata, apice ciliata. - C en t a u rea s piu $u$ lo s a Rochel Plant. Banat. t. 36. $f$. 76.

B. Iacaeoldes DC. $l$. c. Pappus brevis. InvoI ueri squamae externae appendice omnino pectinatoeiliata, internae appendice basi searioso-alata, apiee ei liata, Centa urea mutabilis St. Amand in Mem. Mus, $\bar{T}, t, 24$.

h. LEPTERANTHus DC. Prodr, $D I, 572$. Involucri squamae mediae et exteriores produclae in appendieem linearem uon decurrentem, protunde pectinato . ciliatam, rigidan, siccitate recurvam, humiditate erectam, barbel- lis distantibus gracilibus, intimae apice seariosae, snb. dentatae. A c h e ni a oblonga, areola laterali. Pa p u $s$ duplex, brevissimus v. subnullus. - Flores purpureo. violacei, albo variantes, nunguam favi.

Lepteranthus DC. in Annal. Mus. XVI. 158, Cas sini in Dict. sc. nat. $X X V I$. 65. L ep te ra $n t$ h i s p. Necker. S te n olo ph us Cassini Op. cit. XLIY.36. L. 499. exel. sect. 3. Phrygi a s p. Pers. (Flor. dan, $t, 520$, Reichenb. Plant, crit. t.362,372.374.375.376,642,964.)

i. AETHEOPAPPUS DC. Prodr. VI. 57t. Involucri ovato-globosi squamae extimae ab ipsa basi seariosac, ovato-lanceofatae, irregulariter clliato-lacerae, mediae ovales, pluristriatae, immarginatae, in appendicem seariosam, ovato-lanceolatam, eiliato-pionatam productae, intimae oblongae, appendice concavat apice ciliata. $\mathbf{C} 0$ rollae radif disco longiores. A e h e $\mathrm{i}$ a glabra. Pappus radii subnullus, disci simplex, setis filifor. mibus, basi barbellatis, distantibus, hirtellis. - Flores purpurei, capitula ebracteata.

A e the opappus Cassiui in Diot. se. nat. $x$. 250 . LI. 53. Centaurea pulcherrima Willd. Reichenb. Plant, orit. $t, 216$.

k. STIZ0L.OPHUS DC. Prodr. V1. 574, I n v o I u eri ovali squamae imbricatae, coriacene, apice in appendicem scarioso-subcoriacean, Janceolatam, aristato - acuminatau, pectinato-ciliatam productae. Co rolla e $r$ ad $i i$ staminibus castratis donatae, tubo subtorto, discum non superantes. A chenia glabra. Pappus $r$ adil saepins nullus, dis ci duplex. - Herbae glabrae, ramosae; caulibus albis, folits caulinis sessilibus, integris, capilulit terminalibus, ebracteatis.

Stizolophus Cassint in Dict, sc, nat, XLIF. 36 . LI, 49. Centanrea Balsamita Lam. et C. coro. nopifolla Lam.

1. PLECtocephalds DC. Prodr. VT. 575. I a v a u eri subglobosi squamae exteriores in appendicem seariosocoriaceam, pectinato - ciliatam productae, intinaae longio. res, apice scariosae. Co roll a e radi discua louge superantes. A $c$ he $n$ i o $\mathrm{r}$ m areola subteruinalis. P a ppi setae homogenere, scabrae, rigidae, caducae, subunise. riales. - Species americanae.

Plectocephalus D. Don in Sweel Fl, Gard. II. t. 51. (Colla Hort, Ripul. t, 6. Mem. Aeadem. Turin, XXXVIIT. t. 28.)

m. PSEPHELlUS DC. Prodr. $V T$. 575. Involu c ri subglobosi squamae exteriores et mediae apice in appendi. cem lanceolatam $\mathrm{v}$. subrotundam, pectinato-ciliatam productae, interjores appendice ovali erosa v. subintegra. Corollat radii subregulariter quinquefidae, discum superantes. A chenia glabriuscula. Pappus in radio et diseo couformis, rufescens, scabridus, setulis globu* lisque paucis saepe intermixtis maltiserialis, uniformis, serie futima vix dissinill. - Corollae purpureae, invo. lucra glabra.

Psephellus et Heteroloph o cassini in Dict, sc, nat.XLIII. 488, L, 250. (Gmelin Sibir. II, t, 42, f, 2.)

घ. CHeinolophos DC. Prodr, VI. 577. I avolacri ovati squamae adpressae, coriacese, margine membranaceae, iutegrae, apice in appeulicem scariosam, saepius palnato-ciliatam productae. C o roll a e radii staminibus eastratis donatae, discum haud superantes. A eltenia glabra, areola vix obliqua. P a p pus radii nullus, disei setis aultiserialihus filformibus, vix barbellatis, interin. ribus nullis. - Herbae suffruticosae, mediterraneo-ocoidentales et canarienses, ramosae, glabriusculae, capitulis ebracteatis, foribus purpureis v. albis.

Chefrolophns Cassini in Dict, sc. nat. L. 250. LI. 55 .

III. CYANEAE DC. Prodr. DI, Sz7. In v of u cri squama. rum mediarum appendix plus minus scariosa, secus squamam decurress, rarius in spinam simplicem desinens.

o. MELANOLOMa DC. Prodr. VI. 577. 1 n vo I u cri ovati squamae fanceolatae, membrana nigra, suherosa marginatae, apice in appendice in cosiaceam, pinuatisectam. recurvam, lobis distautibus productae. Corolla e radii disco longiores. Pa ppus radil uullus, d i s ei duplex, Interior minimus.

Mela noloma Cassint in Dict, sc, nat, XXIX. 472. $X$ L.IV. 37. L. 258, (Mtiller Ic. E. 159. Reichenb. Plant. crit. t. 373.) 
p. CYANUS DC. Prodr. $\not r$. 578. Involueri ovati v. subglobosi squamae usque ad apicem margibe serratomembranaceo, ciliato cinctae. C o r olla e radii discum superantes. Stigat a libera. Pappus duplex, mediocris v, brevis. - Capitula ebracteata.

C y a n s. Cassini in Dict. sc. nat. XI.IV. 37. L. 291. (Bulliard Herb, t. 221. Jacq. Fl. austr. t. 371. Waldst, et Kitaibel Plant, Iung, t. 178. 219. Bot. Mag. t. 77.)

q. ODONTOLOPHU3 DC. Prodr. VI, 379. Invol a eri oblongi squamae arete adpressae, angustissime albo-marginatae, appendice ovata, membranacea, ciliato-denticulata, adpressa terminatae. F Iores radii diseum superantes. A chenia pubescentia. $P$ a p a s $r$ a di nullus, dis ci paleis numerosissimis, imbricatis, crassiusculis, dense et breviter barbellatis.

Odontolophus Cassini in Dict. sc. nat. L. 252. Centaurea trinervia Steph.

r. LOPHOLOMA DC. Prodr. $\boldsymbol{T}$. 580. Involueri ovati v. subglobosi squamae $\tau$ d,ressae, appendice decurrente, coriaceo-meubranacea, fnsea v, nigra, dentato-ciliata, Inermi apiculatac. P a p и s duplex, interior brevis. Flores purpurei, rarissime albi.

L o pho $10 \mathrm{ma}$ Cassiui in Dict, sc, nat. XLIV.37. (E. B. 1. 36. F1. dan. t. 1231. Jacq. Hort. Vindob. I. t. 92. Waldst, et Kitaibel Plant. Hung. $t$. 195, Reichenb. Plant. crit. $t, 424.956$.

s. SPILACRON DC. Prodr. YT. 581. I n vol u eri oblongi squamae imbricatae, adpressac, appendice subdecurrente membranacea, breviter ciliata, inermi, intimae longiores. obtusae, non dilatatac. P a p p i paleae subsetosae, multiseriales, aequales $\mathrm{v}$. interiores paullo longiores.

Spila eron Cassiui in Dict, sc, nat, I. 238. C. wolgens is DC.

t. ACROLOPHUS DC. Prodr. YT. 581. I n v ol u $\mathrm{x}$ i ovati squamae imbricatae; appendice terminali breviter decurreste, margine plus minus elliata, apice acuta, inerui v. subspinosa. Pap $\mathrm{p}$ s brevis, rarius nullus, rarissime achenium longitudiue aequans. - Flores purpurascentes, rarius albi $v$, albido-flavescentes, rarissime flavi.

A e rolo $\mathrm{ph}$ us Cassiai in Dict. sc, nat. I. 253.

6. Pterolophoides DC. . c. A p pendices ba. si membraua scarissa, irregulari, parce slecurrente auctae, apice ciliatae. - (Reichenb. Plant, crit. 6, 811. Gussone Plant, rar, t, 61.)

P. A erolophoides DC. l. e. A p pendices cilla. tae, breviter flecurrentes, membrana non sensim auctae. - (Reichenb. Plant, crit. 4. 443. Cavauill, Ic. t. 320,)

$\gamma$. Aerocentraides DC.l. c. Appendices sub decurrentes, utrinque ciliatae, in spinam duriuseulam distinctissimam productae. - (Bot. Mag. 九. 2493.)

ii. ACRoCENTRON DC. Prodr. VT. 586 . Invol neri ovati squamae adpressae, margine ad apicem membranaceat, ciliatae, medio productae in spinam rigidam, basi ciliato spiuulosam, caeterum uudam, intimae appendice scariosa, ciliato-serrata, saepius suborbleulata.

A erocentron Cassini in Diet. sc, nat, TLIY. 37. I. 253 .

r. Lo photomaides DC. $l$. c. I avolucri squamae coriaceae, plus minus subspinoso-acuminatae, nec tamea spina vera terminntae. - Flores favi v. igneoatropurpurei. - (Walilst, et Kitaibel Plant. Mung. $t .116$. Reicheab. Plant, crit, $t$. 465. 447.)

B. Euacrocentron DC. . c. Involncri squamae splua vera, rigida terminatac. - (Desfont. Flor, all. t. 243. Bot. Mag. $t$, 494.)

v. HYMENOCENTRON DC. Prodr. VT. 59t. Involu eri squamae adpressac, appendice subdecurrente scariosth, palarato-lacera, squamarum exteriorum medio in spinulam producta, mediarum medio eallosa et spina abortiva do, aata, intimarnm subrotusda, saepe inflato-tumila. C o. $r 0.11$ a e radil discum superantes. Papp as acheniorum radil abortivorum nullus, disci duplex, interior mininus.

H y menooentro a Cassini in Diet. sc. nat, X.IY. 37. $I$ LV. 351 .

w. CROCODYLIUM DC. Prodr. PT. 591. Invo 1 u ert ova10. globosi squamae imbricatae, coriaecae, margine late scariosae, appendice ovato-lauceolata marginatae, in spinam simpli issimam productae. Co rollae radif ampliatie, disce longiores. A ćl e u la sericeovillosa. Pap. pus duplex, exterioris paleae imbricatae, hatimis longioribus, setosis, interior brevis, connivens, paleis ob. loagis v. linearibus, - Corollae purpureas.

Crocodylium Vaillant in Academ. Paris, 1718. p. 161. Cassini in Dict, sc, nat, XII. 19. (Veut. Malm. t. 9.)

IV. CALCitrapkAE DC. Prodr. $V I$. 892 . Sq u a ma r u m inyolucri appendix cornea, pungens, apice spinis pinaatilobatis donata.

x. VERUTINA DC, Prodr, YT, 692, Involuer i subglobosi squamae imbricatae, mediae ovatae, productae in spinam patulam, longissimam, corneam, medio lateraliter utriuque spinulis $1-2$ auctam, intimae oblongae, maticae. Corolla e radii discum nonsuperantes. A e he n I a ob. loaga, compressa, pubescentia, areola laterali. Pa p p us duplex, interior vix ab exteriore distinetus. - Corollae luteae.

Verutina Cassini in Dict. sc. nat, XLIV, 38. C ent a rea Ver utum Linn. Jacq. Ic. rar. $I, t, 178$.

y. MESOCENTRON DC. Prodr. VI. 392. In v ol u e r l ovati squama imbricatae, coriaceae, mediae ovatae, productae In appendicem spinosam, Iongam, utrinque in parte inferiore spinulis lateralibus 2_3 distantibus piunatim onu. stam, apice nudam, interiores oblongae, spina simpliel v. nulla. Co rolla e radil tri-quadrifidae, disco breviores. A che nia compressa, areala laterali. Pa p p s duplex, exterior rigidus, multiserialis, interior lorevis, regularis, connivens. - Corollae luteas v. rarissime purpureae.

Mesocentron et Triplocentron Cassint in pict. sc, nat, XLIV, 38, LVI. 348, 349, (E. B. t. 243 . Delile $B l$, aeggpt, $t .49 . f$. 1.)

x. CORETHROPSIS DC. Prodr. VT. 396 . I n volu eri squamae exteriores et mediae in spiuam nunc simplicem, nunc basi utrinque spinala atuctam productae, interiores in. ermes. Corallate radii discum non suprantes. P a ppus pluriserialis, subeonformis. - Suffrutices orienta. les, scoparii, ramosissimi; folitis caulinis parvis, ses. silibus, linearibus, integerrimis, corollis purpuras. centibus.

aa. CALCITRAPA DC. Prodr. MT, 596. Invol ueri squa. mae mediae h spinam basi spinulis pinoatam productae, Intimae apice seariosac, $\mathrm{C}$ o r o ll a e radil disco aequales v. longiores. A chenia glabriuscula, areola laterali. Pappus nullus v. brevis, rarius setoso-elongatus. Corollae purpureae.

C a leitrapa Cassini in Diet. sc, nat, XLIV. 38. (B. B. t. 125. Delile Elor, aegypt, t. 49. f. 3. DC. Ic. plant. Gall, rar. t. 23.)

V. SERIDIEAE DC. Prodr. $V T, 598$. I n voluc $\mathrm{I}$ squamae adpressae, imbricatae, aplce ju appendicem corneam, pat. mato-spiuosam productae.

Calcitrapeac Serideae Cassini Tabl. 8. Seridi a Jussieu gen. 173. P a d a Necker elom, n. 127. C a 1. e itra poides Vall. in Aot. Aoad. Paris, 1718, p. 167.

bb. PHIL.OSTIZUS DC. Prodr, VI, 598. Involueri ovatoglobosi squamae exteriores et mediae in appeadicem patulam, spinosissinam productae, spina terminali majore, rigida, lateralibus utrinque 3 - 4 brevioribus, patulis. 5 6 aliis, supra appendicis paginam erectis, subfasciculatis. St Ig a ta coucreta. A cheila tenuissime pubescentia. $\mathbf{P a p p u s}$ radii uullas, disel duplex.

Philostizus Cassini in Dict. sc. nat, XXXIX, 498. XIIV. 38. XLVIII. 500 . Cen a u r a f $r$ ox Desfont. FYor. altant. $t .242$.

ce. SERIDIA DC. Prodr. PI. 598. In voluçri subglobosi squamae in appendieem palmato spinosam productac, spinis $3-11$, saepius 5 divergentibus. A chen ia saepius glabra. Corolli e radif discum superantes. Stigmata coucreta. Pappus duplex. - Corollac purpurascen. tes, disci interdum albidae

Seridia s p. Cassini in Dict. sc, nat. XLIF. 38. XLVITT. 498. (Viviani Flor. Lybic. t, 24. f. 3. Bot. Mag. t. 2551. )

dd. PECTINASTRUM DC. Prodr. V1, 600, Involucri ovoidet squamae adpressae, productae in appendicem coriaceo-corneam, erectam, orbiculatam, pectinata-spinosan, spinis $5-7$ subaequalibus, parallelis v, vix divergeutibus. - Corollae purpureae.

Peetinastrum Cassini in Diet,sc. nat. XXXIY.38. XLYII, 500 , Ce a tarea ua pifolia Linn. 
ee. SERIDIOIDES DC. Prodr. PI, 600, I n volucri oblongi squamae apice productae is appendicem parvam, palmato-spinosam, spinis $3-5$ vix divergentibus. C orolla aequales. Stig mat a brevia, libera, divergentia. - Corollae pallide gavae.

Centaurea glomerata Vahl. C. prolifera Vent, Cels. $t, 10$. C. e ontracta Viviaui Elor. Lybic. t. 24. f. 1.

ff. ALOPHIUM DC. Prodr. VT. 601. Involneri ovati squamae adpressae, exteriores ovales, spiuula minima simplici, mediae spinulis 3 erectis, intimae oblongae, obtusae, apice scariosae. Co roll a e disei glabrae, radi vix ampliatae steriles. A che ni a disei pubescentia, radil glabra. $P$ a p p s $\mathrm{r}$ a dii nullus, dis el brevis, paleis exterioribns oblongis, brevibus, medils linearibus denticulatis, intimis filiformibus, brevioribus.

A. 1 o p hi u m Cassini ín Dict, sc. nat. LIV. 493.

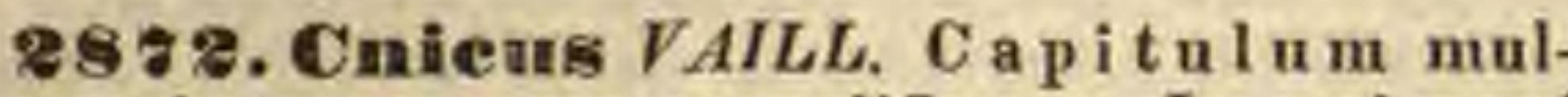
tiflorum, heterogamum, aequaliflorum. In v o l u c r i bracteati, ovati squamae adpressae, coriaceae, in appendicem longam, duram, spinosam, pinnatam productae, spinis lateralibus conicis distantibus. Receptaculi plani setae confertae, achenia aequantes. Corolla e tubulosae, quinquefidae, marginales steriles, disco subaequales, tenues. Antherae ecaudatae. A chenia longitudinaliter et regulariter striata, glabra, areola lata, prope basim laterali. Pappus triplex, exterior margo fructus brevissimus, corneus, crenatus, interior setae decem, rigidae, longae, intimus setae totidem breves, exterioribus alternae. - Herba in region e mediterranea orientali indigena, nune per omnem Europam a ustraliorem diffusa, eliam in Americam transvecta, annua, ramosa, villoso-sublanugi nosa ; foliis amplexicaulibus, subdecurrentibus, semipinnatifidis, capitulis terminalibus involucrato-bracteatis, corollis flavis.

C u icus Vaillant in Act. Academ. Paris. 1718. p. 163. Giirtner $I T .385, t, 162$, DC, in Annal. Mus, XVT. 158, $t, 1$. f. 23. Cassini in Dict. sc, nat, IX, 457, XLIV. 37, L." 254. DC. Prodr. YI, 606, non Linn. C a r b en i Adauson Fam. II. 116. Cardus benedictus Auct.

28\%3. Tetromorplinea $D C$. Ca pitulu m multiflorum, heterogamum, aequaliflorum. In volueri subglobosi, foliis spinisque intermixtis irregularis squamae exteriores breves, appendice non decurrente foliacea, oblonga, pectinatoserrata, apice breviter mucronato-spinulosa auctae, mediae integerrimae, breves, productae in spinam terminalem longam, duram, patulam, supra sulco notatam, interiores lanceolatae, apice spinescentes, intimae lineares, apice scariosae, obtusae. R e c e pta $\mathrm{culnm}$....... Flores radii nentri discnm non superantes, disci hermaphroditi. Staminum filamenta laevia, glabra, an $t$ he ra e coriaceae, in tubnm laevem, duriusculum concretae. Stylus indivisus. A chenia ...... - Herba persica, non satis nota, el fruclu incognito etiam quo ad affinitatem dubia, ramosa; caule albo, hispidulo, foliis infimis petiolatis, lyratis, subdentatis, caulinis et rameis sessilibus, cordatis, margine cartilagineo, pectinato-serrato, floribus purpurascentibus.

Tetramorphata DC. in Guillem, Archiv. Bot. II. 331. Prodr, VI, 609.

SUBTIE TUUS VIII. CARTHAMEAE DC. Prodr, VI, 609. C a p it ul a multiflora, homogama, rarissime floribus marginalibus pattcis sterilibus heterogama. Involucri squamae multiseriales, saepius spinosae, externae bracteiformes, foliaceae. Cor olla e quinquefidae, extus curvae, subinaequaliter fissae. St a- m in u m filamenta saepius fasciculatim v. sparse pilosa. Achenia glaberrima, tetragona, areola laterali. Pa p p us nullus v. multiserialis, paleaceus v. rarius pilosus, scaber.

28\% 4 . ICentroplay llam NECK. C a p itul um homogamum, mnlti- et aequaliflorum. Involucri ovati squamae exteriores foliaceae, pinnatilobatae, spinosae, interiores oblongae, vix subdentatae, acuminato-subspinosae. Recepta e uI $\mathbf{~ m}$ crassum, fimbrillatum. Cor olla e regulares, quinquefidae, marginales nonnunquam paucissimae, filiformes, steriles. Sta min $\mathbf{n m}$ filamenta medio pilorum fasciculo hispida, anther ar $\mathbf{n} \mathrm{m}$ appendix terminalis obtusa. Stigm a ta concreta. A $\mathrm{ch}$ enia crassa, obovato-subtetragona, glabra, rugulo$\mathbf{s a}$, apice denticulato-crenata, areola obliqua. $\mathbf{P}$ a $\mathbf{p}$ p 8 floram marginalium nullus v. subnullus, reliquorum paleae exteriores margine ciliatae, obtusae, imbrieatae, sensim longiores et acutiores, multiseriales, intimae saepins brevissimae, uniseriales, truncatae, dentatae. - Herbae in Europa australiore et regione mediterranea indigenae, erectae, ramosae; foliis alternis, semiamplexicaulibus, ovato-lanceolatis, inciso-dentatis, apice incisuris dentibusque in spinam validam productis, capitulis terminalibus, corollis flavis, albidis v. purpureis.

Kentrop hy 11 u m Necker elem n, 155. DC, in Annal. Mus, XVI, 158. Cass, in Dict. sc, nat, XXIV.381. Lessiug Synops. 7. DC. Prodr. VI, 610. Hohenwarta West in Flora 1820. p. 1. Cassini Op. cit, XXT. 273. He ra cantha Link Flor. portug. II. 205. A tra ety lis Vaillant in Aot, Academ. Paris. 1718. p, 170. Gärtner II. 38t. $t$, 16t. non Link. Carth a mus Berkh. Comp. t. 1. A. f. 8. Car thami s p. Linn.

a. ATRAXYLE DC. $l, c$, In vol u c $\mathrm{i}$ foliola interiora lanceotata, subintegerrima, non dilatata. Pap pi series intima exterioribus multo brevior, apice truncata. - Spe. cies herbaceae._C arth a m i s p. Lian. Bot. Mag. t, 2172.

b. ODONTOGNATHIA DC. $l$. c. I a volueri squamae mediae et interiores npice dilatatae in appeodicem ciliatoserratam. P a p pi paleae exteriores breves, obtusae, ceterae sensim longiores, acuminatae, series intina deficiens v. exteriores superans. - Herba annua, - Carth amus dentatus Vahl $S y m b, t, 17$.

c. THAMNACANTHA DC. $t$. c. 1 nvoluerl squamae in. teriores lanceolatae, integerrimae, apice woa dilatatae. PappI series intima a caeteris vix distineta, paleolae omnium angustae, ciliatae, fere setiformes. - Frutices, floribus flavis. - Carthau us ar borescens Lisn. (Bot. Mag. $t, 3302$.) et C. mareotieus Delile Flor. aegypt, t. 48. $f, 1$.

28\%5. Cartlanmats TOURNEF. Ca pit $\mathbf{l}$ l u m homogamum, multi- et aequaliflorum. Involueri squamae exteriores foliaceae, patulae, mediae erectae, ovales, apice in appendicem ovatam, margine spinulosam expansae, intimae oblon gae, integrae, acuminato-pungentes. $R$ e ce p tac uli plani fimbrillae lineares, confertae. Co rolI a e quinquefidae, regulares, subglabrae, tubo supra discum expanso. Stam in um filamenta gla Iriuscula, antherae appendice terminali obtusa. S tig mata vix distincta. A $\mathrm{c}$ he $\mathrm{n}$ i a obovato-tetragona, glabra, laevissima. P a p a s nullus. - Herbae orientales, annuae, ramosae; foliis glabris, lanceolatis, serrato-ciliatis spinosisve, corollis croceis, Croci veri in usu tinctorio succedaneis.

Carthamus Tournefort inst. 258. Adanson Fam. 11,

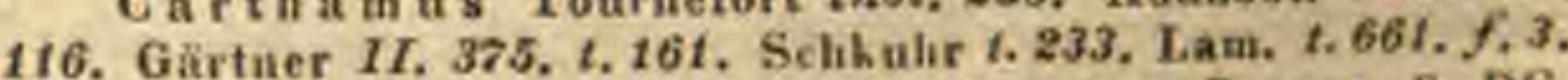
Cassiui in Dict, se, nat. XXIV, 38. Lessing Synops, 8, DC. Prodr. VI, 611, C a r th a m i sp. Lian. 
28\%G. Dnebroma DC. Capitulum multiflorum, heterogamum, floribus marginalibus nentris, subradiantibus. Involueri ovati squamae exteriores lateraliter spinoso-dentatae, omnes in spinam acuminatae. Rec e p tac u l u m fimbrilliferum. C o roll a e tubulosae, aequaliter quinquefidae, marginales disco paullo longiores. S $\mathrm{ta}$ m inum filamenta glabra, antherae apice appendiculatae. Stigma ta subconcreta. A chenia subtetragona, glabra. $P$ a p p u s $r$ a di i nullus, dis e $i$ multiserialis, paleolis linearihus, margine seabridis, exterioribus brevioribus. - Herbae orientales, annuae, erectae, spinosae; foliis semiamplexicaulibus, dentato-spinosis, capitulis terminalibus, solitariis, favis.

Onobroma DC. Prodr. VI. 613. non alior. Carthamus flavescens Willd.

asร ซ. Carduneellus ADANS. Capitul um homogamum, inulti- et aequaliflorum. In voIucri squamae exteriores appendieulatae, foliaceae, spinosae, interiores imbricatae, erectae, intimae oblongae, apice scariosae, subdentatae, obtusae. Receptaculi fimbrillae subulatae, breves. Corolla c quinquefidae, subregulares. S t a min n m filamenta medio pilorum torqne instructa, pilis imbricato-concretis submonadelpha, antherae apice appendiculatae. Stigmata summo apice libera. Achenia tetragona, glabra, areola terminali margine subdentata, basilari subobliqua. $\mathbf{P}$ app u m multiserialis, achenio longior, interdum tulum corollae aequans, setis hasi in annulum subconeretis, inaequalibus, suberispis, barbellatis, barbellis longiusculis, distantibus. - Herbac mediterraneae, perennes, acaules v, caulescentes, monocephalae; foliis pinnatilobatis, serratis, serraturis plus minus spinosis, capitulis ovatis, floribus caeruleis, rarissime albo-variantibus.

Carduncellus Adanson Fam. II. 116. DC. Fl. fr. $I T$. 72. Annal. Mus. XVT. 154. Prodr. YT. 614. Lessing Synops. 5. Cartba m i sp. Linn. Cavanill. Ic. t. 128. Desfont. Flor, atlant, $t$. 228, 229. Bot. Mag. $t, 2993.0$ u o b r o m a ti s $8 \mathrm{p}$. Gärtuer 2 . 160.

SUE'TREUS EX. SILYBEAE Lessing Synops. 10. DC. Prodr. VI. 615. Capitula multiflora. Involucri squamae multiseriales, apice spinosae. Flo res omnes hermaphroditi, atequales, v. marginales neutri, ampliores. S t a$\mathrm{m}$ in um filamenta monadelpha, a $n t h$ e $r$ a e ecaudatae. A ch en ia glabra, compressa. Pa pp u s multiserialis, pilosus v. plumosus. - Fofia albo-maculata.

2898. Silybum VAILL, Capitulum homogamum, multi et aequaliflorum. Involueri avoidei squamae foliaceae, exteriores dilatatae in appendicem ovatam, longe spinoso-acuminatam, in parte rotundata spinoso-serratam, interiores lanceolatae, integerrimae. Receptaculn m earnosum, fimbrilliferum. Co roll a e inaequaliter quinquefidae, obringentes, limbo tubo dimidio breviore. St amin um filamenta monadelpha, papillosa, antherarum appendices breves. $A \mathrm{ch}$ e $\mathrm{ni}$ a eompressa, glabra, areola exacte basilari lata, terminali annnlum corneum pappifernm gerente. P a p p a s mulliserialis, setis breviter barbellatis. _ Herba $m e-$ diterranea, nunc per orbem diffusa, annua, erecta, ramosa; folïs amplexicaulibus, sinuato-spinosis, albo pictis, utrinque glabris, capitulis terminalibus, corollis purpureis,
S Ily bu m Vall lant in Act, Academ. Paris. 1718 p. 172. Gărtner $Y I, 378$, t. 168. DC. in Annal. Mus. XVI. 155. Cassini in Dict, se. nat. XLI. 326. Lessing Synops. 10. DC. Prodr. VI. 616. Carda us Mariauas Liun. E. B, $t, 976$.

28\% 9. Calactites MÖNCH, Ca pitulum multiflorum, heterogamum, floribus disci hermaphroditis, radii neutris, ampliatis, radiantibus. Involucri ovati squamae imbricatae, adpressae, apice spinescentes. Re e pta cu Ii plani fimbrillae tenuissimae, pacae, deciduae. Corolla dis ci aequaliter quinquefidae, radii majores, subobringentes. Stamin u m filamenta monadelpha, papilIulosa, antherarnm appendix terminalis uncinata. Stylus apice indivisus. A e hen ia glabra, areola basilari haud obliqua, terminali subeornea. P a p i setae plumosae, basi in annulum a fructu separabilem concretae. - Herba mediterranea, lactescens, ramosa, Cirsiihabitu; caule, ramis foliisque subtus tomentosis, supra glabris, albo-maculatis, pinnatifidis, lobis spinosis, corollis purpureis, roseis v, albis.

Gral a etites Mrnel Method, s58, DC. Fl. fr, IIT, 110. Annal. Mus. XVT. 195. t. 9. Cassini in Diet. se. nat. $X V I I T$. 34, XLI, 334. Lessing Synops. 11, DC. Prodr. VI, 616. C enta a rea Ga I a ctites Liun.

2896. Tyeimans CASS. Capitulum multi- et aequaliflorum, floribus marginalibus saepins neutris heterogamum. I $n$ vo i n e r i ovati squamae imbricatae, lanceolatae, spinula recta appendiculatae. $R$ e $\boldsymbol{c}$ e p $t$ a $\boldsymbol{c} \mathbf{n} \mathbf{I} \mathbf{~ m}$ fimbrilliferum. Corollae tubo brevi, limbo quinquefido, obringente, laciniis apice subcorneis, obtusiusculis, margine sub lente denticulatis. St a mi $\mathbf{n}$ u in filamenta monadelpha, apice glaberrima, basi subpilosinscula, a $n$ h erar $\mathbf{n m}$ appendix terminalis lineari-subnlata. A e he nia oblonga, compressa, glabra, nitida, areola basilari subobliqua, terminali annulo cartilagineo cincta, nectario indurato, persistente. $\mathbf{P}$ a pp us multiserialis, setis filiformibus, basi annulatis, apiee subscabris. - Herba medit er ran ea, erecta, simplex v. ramosa; caule arachnoideo, ramis elongatis, tomentosis, foliis oblongo-lanceolatis, sinuatis $v$. subpinnatifidis, decurrentibus, supra albo-maculatis, subtus plus minus tomentosis, margine alisque dentato-spinosis, capitulis erectis, corollis purpureis $v$. albis, loborum apicibus purpurascentibus.

Tyrimuls Cassini in Bullot. soc. philomat. 1818. p. 168. Dict. sc. nat. XLI, 335. Lessiug Synops. 11, DC. Prodr. VI, 617. Cardu us leucographus Linn. Jacq. Hort. Vindob. III, t, 23. Allioni Pedemont, $t, 73$. Gärtner t. 162 .

SURTEI BUS $x$. CARDUINEAE DC. Prodr. VI, 617. Ca pitul a homogama, multiet aequaliflora, floribus interdum dioicis. Inv ol u cri multiseriati squamae liberae, saepins apice spinosae. Co roll a e quinquefidae, extus arcuatae, lobis exterioribus paullo profundius incisis. St a m in u m filamenta distincta, pilosa, papillosa v. rarius glabra, an the ra e ecaudatae v. brevicaudatae. Achenia glaberrima, erostria, areola terminali. Pa p p us pilosus $\mathbf{v}$. plumosus, setis saepius basi in annulum concretis, nunquam tamen achenii margine prominulo cinetis.

2881. Dnopordon VAILL. Capitn In homegamum, multi-et aequaliflorum. Involueri ovato-globosi squamae imbricatae, coriaceae, in appendicem lanceolatam, apice spinescentem pro- 
ductae. R e e p ta c ul u m carnosum, alveolatum, alveolis membranaceis, sinuato-dentatis. CorolI a e quinquefidae, obringentes, ad basim limbi incrassatae. St a minnm flamenta glabriusenla, antherae appendice lineari-subulata, caudis brevilus. Stig $\mathbf{m}$ a $\mathrm{ta}$ fere ad apicem concreta. A $\mathbf{c h}$ n i a obovato-compressa, tetragona, transverse rugosa. P a pi squamellae pluriseriales, basi in annulum corneum concretae, filiformes, barbellulatae v. barbato-plumosae. - Herbae in E uropa et in Asia media obviae, saepius durae, magnae, ramosae, rarius acaules; caulibus saepe foliis decurrentibus spinoso-dentatis alatis, foliis pinnatilobatis, dentatis, dentibus lobisque valide spinescentibus, capitulis magnis, spinosis, corollis purpureis $v$, rarius albo-variantibus.

O nopordou Vaillant in Act. Academ. Paris. 1718, p. 158. Linn. gen, $n, 987$. Gärtner $I I, 376 ., t$. 161. Sebkuhr t. 230. Jaeq. Hort. Vindob. $t$. 148, 149. Fl. dan, t.909. E. B. t. 927. Cavanill. Io, $t, 88$. Sehultes Observ, 197. DC. in $A n$. nal. Hus. XVI, 154, Cassini in Dict. sc, nat, XLI, 31t, 329. Bot. Mag. t. 3299. DC. Prodr, VI. 617. A a nos Adanson Fam. IT. 116.

2882. Cymara VAILL, C a p itu $1 \mathrm{~nm}$ homogamum, multi- et aequaliflorum. Involucri ovati squamae imbricatae, coriaceae, in appendicem lanceolatam, apice spinescentem productae. Receptae u l um planum, fimbrillatum. Coroll a e quinquefidae, obringentes, limbi basi incrassati, dimidiam tubi longitudinem aequantis laciniis valde inaequalibus. Sta minum filamenta papilIosa, antherae appendice obtusissima. Stigmata concreta. A ehenia obovato-compressa, tetragona, dura, glabra, areola lata, subobliqua. $\mathbf{P}$ ap pus pluriserialis, plumosus, setis basi inter se liberis, annulo deciduo adhaerentibus, Herbae mediterraneae, perennes, spinosae; foliis plerumque pinnatilobatis, nunquam decurrentibus, capitulis amplis, receptaculo carnoso, in specie culta eduli, sapido, corollis caeruleo-violuccis.

C y n a ra Vaillant in Act. Academ. Paris, 1718, p. 155. Linn. gen, $n$, 928. excl. sp. Sehkuhr t.231. Bot. Mag. $t, 2868$. 3241. DC. Prodr, YT, 620. C in a ra Tournef. inst. 283. Jussieu gen. 173. Cassini in Diet. sc, nat, XLI, 328, Ca r d u i s p. Liun.

2883. Spanioptilon LESS, C a pitn$1 \mathrm{~nm}$ heterogamum, multi-et aequaliflorum. Invo. I ucri squamae siccae, pungenti-mucronatae. R eceptaculum ....... Corollae ....... Staminum filamenta papillosa, antherae ........ A eh enia erostria, glaberrima, areola terminali. P a p u s uniserialis, paleaceo-setaceus. - Herba japonica, non satis nota, basi lignosa, erecta, glabra; foliis confertis, linearibus, spinoso-dentatis, capitulis nutantibus.

Spanioptilon Lessing Synops. 10. DC. Prodr. PI. 621. Cardu us linearis Thub.

2884. Caralmas GARTN. Capitu $1 \mathrm{um}$ homogamum, multi- et aequaliflorum. Involueri squamae imbricatae, lanceolatae $\mathbf{v}$, lineares, margine haud scariosae, saepius apice spinosae v. acuminatae. Recepta $\mathbf{c} \mathbf{I} \mathbf{u} \mathrm{m}$ fimbrilliferum. $\mathrm{C}_{\mathbf{o}}$ ro Il a e tubo brevi, fauce oblonga, limbo quinquefido, obringente. Stamin um filamenta tibera, pilosa, antherae ecaudatae, appendice linearisubulata. St igmat a concreta. A chen ia oblonga, compressa, glabra, areola terminali subearno. sa, basilari vix subobliqua. P a p u s multiserialis, setis filiformibus, scabris, basi in annulum a fructu secedentem concretis. - Herbae in Europa et in regione mediterranea obviae, in Asia media rurae, erectae, simplices, monocephalae, $v$. in ramos monocephalos divisae; foliis caulinis decurrentibus, pinnatilobatis $v$. indivisis, capitulis subglobosis $v$, oblongis, erectis aut demum nutantibus, corollis purpureis $v$. rarius albo variantibus.

C a r d u u s Gärtuet II. 377. t. 162. DC. in Annal. Mrus. $X V T, 155$. Cassini in Dict, sc, nat, XLI, 314.336. DC. Prodr. VI. Ge1. C a r d u i s p. Linn. Jacq. Fl, austr, t. 89. 249, 348, Hort. Vindob. I, t, 44, II, t. 92, Ic, rar, $t, 166$. Fler, dan. t. 621. 653. B. B. t. 112, 412. 973. Waldst, et Kitaibel Plant, Hung. t. 83. 232. 267. Reichenb. Plant, crit. t. 426. C ar d u us et Clom io u Adanson Fam. $I T, 116$.

9855. Claveaa DC. Capitulum homogamum, multi- et aequaliflorum, InvoIucri squamae imbricatae, saepius apice spinosae, omnes wargine late scariosae. Re e pta $\mathbf{c u l u m}$ fimbrilliferum. Co r o Ha e subregulariter quinquefidae. St a minum filamenta libera, hirsutissima, anth e ra e ecaudatae, appendice sulbulata. Ach enia oblonga, compressa, glabra, areola terminali. $\mathbf{P}$ a ppi setae plurimae, multiseriales, barbellatae, apice in clavulam serrulato-ciliatam dilatatae. - Herbae c anarienses, simplicicaules, araneosae, foliis decurrentibus, dentato-spinosissimis alatae, habitu Carduorum, a quibus involucri squamis margine scariosis, et pappi setis clavatis facile distinguuntur.

Clavena DC. Prodr. VI. 633, non Necher. Cardu us clavajatus link.

2886. Pienemon LOBEL. Ca p it ulum homogamum, multi- et aequaliflorum. In volucri ovato-conici, bracteis foliaceis, flores subsuperantibns eineti squamae imbricatae, adpressae, in appendicem subulatam, pinnato-spinulosam, reflexam desinentes, intimae exappendiculatae. Corolla e subregulariter quinquefidae. S $\mathrm{ta}$ in u $\mathrm{m}$ filamenta libera, hirsuta, antherae ecaudatac, appendice subulata. Stig mata libera, divergentia. A ch enia oblonga, compressa, ecostata, neetario stipitato, quinqueradiato. P a P p a multiserialis, longus, plumosus, setis basi in annulum conferruminatis. - Herba mediterranea, annua, Kentrophylli habitu; foliis decurrentibus, lineari-lanceolatis, tomentoso-canis, dentatis, spinosis et spinulosociliatis, summis capitula involucrantibus, floribus purpurascentibus.

Pien om on Lobel $I c, I T$, t. 14. f, 2. Adanson Fam, IT. 116. Cassini in Dict, se, nat. XXV, 225, XXVIT, 184, XL. 187. XLI, 313. et 331, Lessing Synops. 9. DC. Prodr, VI. 634. A carna Vaillant in Aet. Academ. Paris, 1718. p. 163. non Willd. Pien acomon Dalechamp 1456. C. A. Meyer non Liak, C n i c u 5 A cara Lian. Cavanill, Ic, $t, 53$.

288\%. Cinesinem TOURNEF. Ca pitu $\mathrm{Ium}$ homogamum, multi- et aequaliflorum, floribus hermaphroditis v, dioieis. Involueri squamae inbricatae, apice plus minus spinesae. ReceptacuI $\mathbf{~ m}$ fimbrilliferum. Co rolla e tubo brevi, fauce oblonga, limbo quinquefido. S $\mathbf{t}$ a $\mathbf{m}$ i $\mathbf{n}$ u $\mathbf{m}$ filamenta libera, saepe pilosiuscula, an ther a e eandatae, appendice lineari-subulata. Stigmat a concreta. A chenia oblonga, compressa, glabra, membranacea, ecostata, areola terminali subcarnosa. P a p u s multiserialis, setis basi in annulnm deciduum coneretis, plumosis, apice saepius snbdentienlatis v. subelavellatis. - Herbae in Europa, in Asia mediu et in America boreali indigenae, Cardui habitu; foliis decurrentibus $v$. sessilibus, variis, saepius spinosis, floribus purpureis $v$. ochroleucis.

Cirs i u in Tournefort inst. 255. Gärtner 11.383 . exct. fig. DC. Fl. fr. IV, 110. Annal. Mus. XVI. 155 Prodr, VI. 634. non Less. Cnicus Sehreber gen, n. 1255. Willd. sp. $I I T$ 1662, exel. sp. B reea et C a rd u i s p. Lessing Syops. 9. Lophiolepis, Eriolepis, Onotrophe et Cirstum Cassini. Cnici et Cardul sp. Lien. 
a. LOPHOLEPIS DC. Prodr. VT. 634. In volu er i ovato. globosi, ebracteati $\nabla$. vix bracteati squamae imbricatae, adpressae, in appendicen lineari-subulatam, apice spinosam et margine spinuloso-serratam desineutes. Flores marginales, saepius masculi, subabortivi. - Capitula magna, subrotunda. Species pleraeque caucasico-tauricae.

Lopliolepis Cassini in Dict. sc. nat. XLI, 313. Lo phiolepidis s p. Cassint Op. cit. XXVII, 180.

b. ERIOLEPIS DC. Prodr. PI. 635. 1 nvolueri ovati v. globosi squamae imbricatae, in appendicem subulatam. spinosam, integerrimam desinentes. Flores omnes hermaphroditi. - Folia superne seabra, subtus tomentosa, sessilia v. rarius decurrentia. S Species plurimae e regione mediterranea et Asia media, paucae indicae nonnullae mexicanae et boreali-americanae.

$\mathrm{E} \mathrm{riolep}$ is Cassini in Dict. sc. nat. $\mathrm{X} X \mathrm{X} \nu .172$. XXXVI, 146, XLI, 313. et 331. L. 470. L o p hiolep idis sp. Cassini Op. cit. XXVIT. 183. Epitrach y s DC, in Duby Bot.gall. I, 286. Erioce pali sp. Vaill. Cardui s p. Lian. Jacq. Flor. austr, $t$, 171. Allioni Flor.pedemont. $t, 50$. FI. dan. $t, 1173$. E. B. $t, 107,386$. Desfont. Flor, allant. t. 221. C nici s p. Auct. Humb. Bonpl. et Kunth Nov. gen, et sp. $t, 310$. Reieheub. Plant. crit, $t, 359$.

e. ORTHOCENTRUM DC. Prodr. PT. 641. Involncri ovati squamae ovali-oblongae, saepe molliter eiliatae, imbricato-adpressae, apice saepissime in spinam subulatan, reetam productae. Corolla e subaequaliter quinquefidae. St a m i u m filamenta glabra. Pap u $\mathrm{s}$ rufescens. - Herbae mediterraneae, folits decurrentibus spinosis.

Orthocentrum Cassini in Dict, sc. nat, XXVIT. 184. $X X X V$. 173. $X X X V I$. 480, C a rd n i s p. Linn.

d. CORYNOTRICHUM DC. Prodr, VI. 649, Involucri semiglobosi squamae imbricatae, adpressae, lanceolatae, in spinan rectam productae, intinae elongatae, apice longe seariosae, acuminatae. Pa p $\mathbf{i}$ setae rufescentes, plumosae, apice in clavulam minimam dilatatae. - Her bae nepalenses et californicae, follit sessilibus v. vix decurrentibus, floribus purpureis.

e. CEPHalonoplos DC. Prodr. VT. 643. Capitula abortu dioiea. Involucri ovati squamae imbricatae, Janceolatae, adpressae, exteriores apice subspinosae, intimae apice subscariosae, inermes. S $t a m$ in u milamenta subscabra. - Herbae europeae et asiaticae, radice repente; folits sessilibus vix subdecurrentibus, plus minus pinnatifilis, ciliato-spinosis, foribus sordide et pallide purpureo-lilacinis.

Cephalonoplos Necker elem.n, 118. Cirsium Cassini in Dict, sc. nat. XXVIT. 185. XXXV. 178. XLI. 332. Breeae $s$ p. Lessing $\mathcal{S}$ ynops. 9. Serratula ar. ven is Lian. FI, dan. $t$. 644. E. B. $t .975$.

f. ONOTROPHE DC. Prodr, $Y I$, 644. I nvoluc 1 ovati v. globosi squanae ant mueronatae v. spinula inermi, brevi terminatae, intimae semper inermes. Corolla subregulariter quinquefidae. Sta m in a m filamenta pl. losiuscula. - Species per hemisphaeram borealem dif. fusae, plurimae hybridae.

Onotrophe Cassioi in Dict. sc, nat. XXXVT, 145. Card a i 8 p. Lina Jacq. Flor, ausir, $8 ., 5.42,43,90$. 310. Hort. Vindob. III. $t$. 5. C n i c i s p. Willd. Waldst. et Kitaituel Plarit. Mung, $t, 161 . \mathrm{Cu}$ ici sp. Auct.

2858. Erythrollacan SWVET. C a p ii I I m homogamum, multi- et aequaliflorum. Involucri conici squamae lanceolatae, acuminatae, exteriores foliaceae, dentato-spinulosae, reflexae, intimae erectae, coloratae, elongatae, integerrimae. Receptac ul um convexum, piloso-fimbrilliferam. Corolla e quinquefidae, regulares, lacinis apice incrassatis, tubo brevioribus. Staminnm filamenta glanduloso-pilosa, an thera e basi bisetae. Stylus Iongissime exsertus, stigmatibus subliberis, approximatis. A $\mathrm{c}$ h e nia obtusissime tetragona, glabra. Pappas plumosus. - Herba mexicana, ramosa; foliis sessilibus, pinnatifidis, spinuloso dentatis, atro viridibus, subpubescentibus, involucris pollicaribus, croceo-rubris, capilulis solitariis, ramulos
terminantibus.
Eryt hrola e na Sweet Ft. Gard. IT, t, 134. DC. Prodr. VI. 657. Carduts polychroos Lessing.

2889. Clanumeperace $A L P I N$, Ca p it . In homogamum, multi- et aequaliflorum. Invo I ceri ovati squamae multiseriales, imbricatae, basi adpressae, in appendicem integerrimam, lanceolatam, acuminatam, plus minus pungentem productae. Recepta $\mathbf{c}$ lum fimbrilliferum. CorolI a e quinquefidae, subaequales v. ringentes. S $t$ am in $\mathbf{n}$ flamenta plumosa $v$. hirsuta, a $\mathrm{t}$ herarum appendices oblongae, acutae, caudae longae, lacerae. Stig m a ta concreta, vix apice summo libera. A chenia obovata, vix subcompressa, basi attenuata, ecostata, laevia, cortice duro. $\mathbf{P}$ a p pi setae plumosae, uni-bi-pluriseriales, basi in annulum subcorneum, demum deciduum concretae. Herbae $v$. suffrutices, in regione mediter ranea et $t a u r i c o-c a u c a s i c a$ provenientes; foliis alternis, spinoso-dentatis, sessilibus $v$. rarius decurrentibus, capitulis terminalibus $v$. in axillis subsessilibus, corollis purpureis, saepissime albo-variantibus.

Cham a epeuce Prosp. Alpin. Exot, z7. DC. Prodr. VT. 657. Cirsiam et Ptilostem on Lessing Synops. 9. et 5. Ptilostemon, Lamyra et Platyrhaphium Less. Cardui, Caici et Staehelinae sp. Auct.

a. PTILOSTEMON DC. Prodr. PT. 657. I n v o I u e r I squa. mae in appeudicem angustam, vix ab ipsa squama distinctam productae. Corolla e obringentes. S tam in u m filamenta eleganter plumosa. - Suffrutices, ramis tomentosis, apice oligocephalis; folits sessilibus, plus minus confertis, langix, linearibus, margine revolutis, subius tomentosis, integerrimis, v. utrinque ima basi uni. bidentatis.

Ptilostem o n Cassini in Dict. sc. nat, $X X X Y .137$. $X L I V$. 58. Lessiug Synops. 5 . Sta ehe $\mathrm{Sin}$ a $\mathrm{C}$ ha $\mathrm{m}$ a epeuce Limn. Cardu i s. Cyrillo Pl. rar. $I$. t. 9.

b. LAMYRA DC. Prodr. VI. 658. Invo 1 neri squamae in appendicem spinosam, lanceolatam, intas basi plus minus tumidam v. tubercnlosam produetae. Corolla e subaequales. S $t$ a m i n u m filameata hirsuta. - Herbae annuae $v$, perennes, interdum suffrutescentes; foliis sessilibus rariusve decurrentibus, plus minus spinoso. dentatis, margine plani's v. vix revolutis.

La m y ra Cassini in Dict, sc, nat, XXXV, 173, L a. m y ra e sp. Cassini Op. cit. XXV. 218, Cirs il sp. Lessing Synops. 9. Cardu i s. Linn.

c. PLATXRHAPHIUM DC. Prodr. $V I$. 659. Involuerl squamae in appendicem spinosam, lato - Ianceolatan, intus basi subtumidam, patulam v. erectam productae. $C_{\text {o- }}$ roll a e obriagentes. Stami a a m filamenta hirsuta. Herbae ut videtur biennes, caulibus ramosis, tomen. tosis; folits sessiltbus, subtus tomentosis, incisis $v$. pinnatifidis, spinis validis, geminatis ternisve instruc. tis, capitulis terminalibus.

PInty rhaphi um Cassini in Dict. sc. nat. XXXV. 173. $X L Y$. 305. Lam y ra e 8 p. Cassini Op. cit. XXV. 218. Cirsil s p. Lessing 2.c. Desfont. Corollar, $t .33$. Cardui s p. Jacq. Hort. Schönbr. t. 145. Labillard. Syr. II. T. 3 .

28401. Notolbasta CASS. C'apitulum multi- et aequaliflorum, heterogamum, floribus marginalibus ovario efoeto masculis. In v o I u c r i ovato - globosi, bracteis spinosis, pinnatipartitis cincti squamae coriaceae, adpressae, apice nervo medio in appendicem subtriquetram, spinosam, patulam productae. Receptaculi paleae lineares, liberae. Corolla e obringentes. Stamin un filamenta hirsuta, anthera e ecaudatae, appendicibus acutis. Achenia marginalia efoeta, centralia glaberrima, compressa, eicatrice dorsali lineari inserta, ideo ineurva, caeterum subcornea. Pap p us acheniorum centralium annularis, setis longe plumosis, biserialibus, marginalium paucisetus, setis haud plumosis, vix denticalatis. _ Herba mediterranea annua; caule hispidulo, foliis amplexi- 
caulibus, oblongis, dentato-spinosis, albo-venosis, summis pinnatipartitis, lobis validius spinosis, nervis albis, crassioribus, capitulis terminalibus et ad axillas sessilibus, corollis purpureis $v$, albo variantibus.

Not o basis Cassini in Dict. sc. nat. $X X V .225$. $X X X V$. 170. DC. Prodr. VI. 660. Cardu us s yriacus Lian. Cirsium syriaeum Gartner $t, 163$. Cuicus syriac u s Willd. Schhulir $t$. 899 .

2891, Eelnemais CASS. Capitulum homogamum, multi- et aequaliflorum. Involueri hemisphaerici squamae imbrieatae, oblongac, apice in appendicem scariosam, sublaceram, spinescentem, exteriorum lanceolatam, interiorum orbiculatam expansae. R eceptaculi fimbrillae liberae. Corolla e quinquefidae, obringentes, limbo tubnm duplo superante. Staminum filamenta libera, piloso-asperula, a $\mathbf{t}$ herar $\mathbf{u} \mathbf{m}$ appendices terminales acutae, eaudae breves, membranaceae, sublacerae. St i g m a $t$ a fere ad apicem concreta. A $\mathbf{c}$ he n i abovato-compressa, glabra, multistriata. Pa p p s biserialis, plumosus, setis exterioribus breviuribus, interioribus apice in clavulam planam v. discum membranaceum subdilatatis. - Herba ca ucasica, erecta, ramosa, Cardui facie ; foliis pinnatifidis, dentatis, lobis dentibusque spinescentibus, capitulis nucis Juglandis magnitudine, nutantibus, corollis albidis.

E e hena is Cassini in Bullet, soc. philom. 1818. p. 33. 1890. p. 4. Dict. se, nat. XIV. 170. XXV. 226, DC. Plant rar, Jard. Génèv. t. 22, Prodr. VI. 660. Carliua Echi n us Bieberst.

299\%. Happar TOURNEF, Ca pitulum homogamum, multi- et aequaliflorum, Involu $\mathrm{er}$ globosi squamae coriaceae, imbricatae, basi adpressae, superne subulatae, apice corneo uneinatoinflexae. Receptac u li subearnosi, plani fimbrillae rigidae, subulatae. Corollae quinquefidae, regulares, tubo decemnervi. S $t$ a $m$ i n u filamenta libera, papillosa, a $\mathbf{n}$ h e $\mathrm{r}$ a $\mathbf{r} \mathrm{m}$ appendices terminales filiformes, candae subulatae. A $\mathrm{c}$ hen ia oblonga, lateraliter compressa, glabra, transverse rugosa, areola basilari vix obliqua. P a p p s brevis, pluriseriatus, pilis in annulum haud coneretis, caducis, filiformibus, scabris. - Herbae in Europae et $A$ siae ruderatis crescentes, ramosae; foliis petiolatis, cordatis, subundulatis, subtus plus minus tomentosis, capilulis terminalibus subcorymbosis $v$. solitariis, corollis purpureis $v$. albo variantibus, involucro aequalibus.

L a p p a Tournefort inst, 156. Jassieu gen. 173. Gärtner IT. 379. $t$. 169. Lam. t. 665. DC. in Annal. Mus. XPI, 154. Cassini in Divt. sc, nat. XXV. 256. XLI, 310. et 324. Lessing Synops. 8. DC. Prodr. VI. 661. Arctium Lappa Liuu. Schknhr $t, 227$.

\section{SEMTTEIBIS XI. SERRATULEAE} Synops. 6. DC. Prodr. VI. 662. Capitula multiflora. Involucri multiseriati squamae distinctae, vix spinescentes. Flores omnes hermaphroditi v. dioici, rarius pauci in ambitu capituli feminei. Corolla e quinquefidae, exfrorsum arcuatae. Sta min um filamenta papillosa v. pilosa. An therae caudatae v. ecaudatae. A chenia glabra. Pappus uni-v.saepius multiserialis, pilosus v. plumosus, mar gine achenii annulari cinctus.

28\$3. A curoptioliom CASS, Capitulam homogamum, pluri-et aequaliflorum. In vol u cri ovati squamae imbricatae, exteriores et mediae $\mathbf{s u b}$ rotundae, concavae, margine et apice late seario- sae, membranaceae, intimae lineari-lanceolatae, margine seariosae, apice ciliatae, fere plumosae. Receptaculi fimbrillae confertae, lineares. Corolla e glabrac, quinquefidae, subregulares. Stamin um filamenta glabrinscula, antherarum appendices terminales obtusa naceae. Stigmata apice tantum libera, extrorsum areuata. A chenia obovato-oblonga, glabra, areola exacte basilari. $P$ a $p$ p u 8 albus, pluriserialis, caducus, setis dense barbellatis, intimis quinque reliquas duplo superantibus. - Herbae ramosae, caucasica et orientales, Centaureae fere facie; radice repente, caule subangulato, folits alternis, oblongo-linearibus, margine subscabris, inferioribus saepe sinuatis, caeteris serratis v. integerrimis, apice mucronulatis, capitulis ovato-oblongis, corollis purpurascentibus.

A eroptilio n Cassini in Diet, sc, nat, L, 464. DC. Prodr. VI. 662. Centaurea Picris Pallas.

2894. Thapontiemm $D C$. Ca p itu I u m homogamum, malti- et aequaliflorum. Invol u e ri squamae multiseriales, adpressae, in appendicem totam v, margine scariosam, integram, dentatam, acuminatam $v$. rotundatam desinentes. Re ceptacu $1 \mathrm{~nm}$ fimbrillis linearibus onustum. Corolla quinquefidae, subregulares. St a m in u filamenta papillosa, antherarum appendices terminales obtusae. A ch e nia oblonga, bilateraliter compressa, glabra, areola basilari valde obliqua. P a p p u s rufescens, multiserialis, setis rigidis, scabris, exterioribus sensim decurrentibus. - Herbae in Europa australiore et in regione taurico-caucas $i$ ca indigenae, perennes, monocephalae $v$. oligocephalae; foliis indivisis v. varie pinnatilobatis, saepius subtus cano-tomentosis, capitulis magnis, subglobosis, corollis purpureis.

Rhapontieum DC. Prodr. VI. 663. Hookia Necher elem, $n$, 122. Centa u ri um Haller Ifelv, $I, 69$, R ti a o a. ticum et Serratulae s p. DC. in Annal. MIns, XVI, 184. 188. Rhapoutieum, $S t e m$ meantha et Cestrinus Cassini in Dict. sc, nat. XLI, 309, et 320 , L. 460. R h a p а в. tici sectio 3 . Lessing Synops. 6. R hacomaesp. Adans, Serratula $5 \mathrm{p}$. Gärtn. Ceutaureac, Caici et Cy. narae sp. Lion.

a. STEMMACANTHA DC. $l$. c. I v v lu e $\mathrm{i}$ squamat in appeadiceu longam, acuminatissizan, mavgine tanfum scariosatin desinentes. A che a ta margine subdentato circa basion pappi coronata.

S temmacant ha Cassiui $t$. $t$. c. c. C n i c us centaurofies Lina. et Cardus atriplieifolius Treviran. Reíchenb, Hort, bot. $t, 18$.

b. EURhAPONTICUM DC. l. c. Invo I u eri squamae exteriores in appendicem amplam, ohlongam $\vee$. subrotundam, omnino scariosam, subintegram v. demum disrupto. laceram desinentes, interiores angustiores lineari-lanceo. Jatae, acuminatissimae.

$\mathrm{R}$ baponticu m DC. in Aanal. Mus, XVI, 168. Cas. sini in Dict sc. nat. XII. 309. Poiret in Dict.sc, nat. XLV. 315. Cnicisp. Linn.

c. CESTRINUS DC. l. c. I n vol u cri squamae oblongae, apice summo in appendicem ovalem, seariosam, laceram expansae.

Cestrinus Cassiui in Dict. sc. nat. DITI. 24. C yn a r a e a lis Linn. Desfont. Flor. allant. $t$. 223.

d, CESTRINOIDES DC. . c. Involucri squamae ovalioblongae, in appendicem lanceolatam, acuminatas, chartaceo - subscariosam, integerrimam desinentes.

28\$5. Hevzea DC. Capitulum homogamum, multi - et aequaliflorum. Involucri squamae imbricatae, multiseriales, apice in appendicem seariosam expansae. Receptaculi fimbrillae lineares, Corollac quinquefidae, sobregulares. St a min um filamenta papillosa, a n th $\mathrm{B}$. 
rarum appendices terminales obtusae, caudae breves. Stig mata apice libera. A c hen ia oblonga, bilateraliter compressa, glabra, areola basilari subobliqua. P a p p u s longus, pluriserialis, plumosus, setis basi in annulum concretis, interioribus sublamellatis, ciliatis. - Herbae mediterraneae, orientales, sibiricae et australasicae, tomentosae, saepius monocephalae; foliis in eadem stirpe saepius variis, pinnatilobatis, capitulis ovatoglobosis, terminalibus, corollis purpureis.

Le uzea DC. Fl, fr. 4. 109. Annal. Mus. XVI. 203. DC. Prodr. VI. 665. Le uz e a t Forale in m Cassini in Dict, sc, nat, XVIT, 249. XXVI. 179, XLI, 319, L. 464. $\mathrm{Rhapontici}$ sect. 1. Lessing Synops.6. Rh a comate sp. Adans. Cent a u reat $s$ p. Linn.

a. RHACOMA DC. $l, c$. Involucri squamae in appendicem orbiculatam, subconcavam, saepe demum irregulariter fissam expansae, intimae longae, angnstae, appen. dice laneeolata. A che n i a subtuberculata, margine haud manifesto.

L e z e a Cassini in Diet. sc, nat. L, 320. C en t a u. rea con ifera Linn. (DC, in Annal. Mus, XVI, t, 10. Gaudich. ad Fregc, $t$. 92.)

b. FORNICIUM DC. $t$. $c$. Involucri squamae in appendicem integram, lanceolatam v. subulatam, planam expansae, A chenia laevia, margine manifesto, crenato coronata.

Fornicium Cassini in Dict. sc. nat. XYIT. 249. MaIa cocephalus Tauseh in Flora 1820, p, 481.

c, CYNAROIDES DC. l.c. Involucri squamae in appendicem seariosam, ovatam, acnminatam expansae. A ch eni a striata, margine erenato coronata.

C yn a r a pusilla Labillard. Syr. Dec, III, t. 7 .

2596. Alfredlia $D C$. Capitulum homogamum, multi- et aequaliflorum. Involncri hemisphaerici squamae scariosae, oblongae, appendiculatae, exteriores lacerae, apice spinescentes, intimae apice orbicnlatae, eoncavae. R e c p taculi fimbrillae liberae. Coroll a e quinquefidae, regulares, limbe tubum duplo superante. $\mathrm{St}$ a $\mathrm{m}$ in $\mathrm{n} \mathrm{m}$ filamenta libera, subaspera, antherae appendice terminali longa, acnta, caudis longis, subplumosis. Stigmat a lere ad apicem concreta. Achenia obovato-compressa, multistriata. P a p p s biserialis, longus, setis barbellnlatis, exterioribus brevioribus. - Herba sibirica, perennis, erecta, ramosa ; foliis subtus niveo-tomentosis, margine spinulosis, inferioribus cordatis, petiolo marginato, superioribus sessilibus, semiamplexicaulibus, capitulis cernuis, corollis flavescentibus.

A If e dia Cassini in Bullet, soc, philom, 1815. p. 175. Journ. Phys. 1816, p. 145. Diet, sc. nat. I. Suppl. 115. $X X I, 429$. XIT, 311. et 324. Reichenb. Plant, crit, $t, 448$. DC. Prodr. VI, 666. Rhapontici sect. 5. Lessing $S y n-$ ops. 6. Caicus cerauas Linn. Silybu in cernu ua Gärtner $t, 162$.

289 tiflorum, saepius homogamum, interdum aborto unisexuale v. margine femineum. In vo I u eri subovati squamae imbricatae, exteriores breviores, acutae, muticae $\mathbf{v}$, in spinulam subinermem desinentes, interiores longiores, apice plus minus scariosomembranaceae. Rece ptacul a m fimbrilliferum. Corollae quinquefidae, subregulares. Sta minum filamenta papillosa, antherae apice obtuse appendiculatae, ecaudatae, Stig $\mathrm{m}$ a $\mathrm{ta}$ divergentia. Achenia oblonga, compressa, glabra, laevia, hilo subobliqno. Pappus pilis mnltiserialibus, rigidnlis, scalbridis, subrufescentibns, inaequalibus, exterioribus brevioribus, seorsim deeiduis, nee tamen basi annulatis. - Herbae in Europa et in $A s i a$ media indigenae, inermes $v$, subinermes, mono polycephalae, glabrae $v$. subscabrae aut tomentosae; corollis purpureis $v$. albo variantibus.

Serratula DC. Prodr. VI. 667. Serratulae sect. 1. DC, in Annal. Mus, XVI. 184. Se r ratulae et C enta ureae sp. Lian. Kla a sea, Mastrucium et SerratuI a excl. sp. Cassini in Dict, sc, nal. XXXV. 173. XLI, 310 . L. 468. Serratula et R hapontiel sect. 2. Lessing $S y n$ ops, 4. ef 6 .

a. SARRETA DC. 1. c. Capitula sexu uno castrato dioiea.

Serratula Cassini et Lessing l. l. c. c. Serratula tinctoria Linn. Fl. dan. $t$. 28t. E. B. $t .38$, Sehkuhr Handb. t. 234.

b. MASTRUCIUM DC, $\boldsymbol{l}$. c. Flo res radii pauci feminei, discum superantes, tri-quadrifidi, stamina castrata ge. rentes.

M a strueium Cassini in Dict. sc, nat, XXXV. 173. Pereuphora Hoffuansegg Verz, 174. R h a phontic sect. 2. Lessing $l$. c. Cent a u rea coronata Linn.

c. KLASEA DC, $l$. c. FIores aequales, omues hermaphroditi et papposi.

K I a s e a Cassini 2 . c. Rh a pon ti e i sect, 1. Lessing l. c. Cehtaurea e s p. Lian. Card ui s p. Cavanill. Ic. t. 46, 83. 165, 226. Waldst. et Kitaibel Plant. Hung. t. 11. (Desfont. Flor, atl. t. 219, Ledebour Ic, t. 32. Bot. Mag. $t$, 1871.)

d. OLIGOCHAETA DC. FIores omnes hermaphroditi, marginales saepe pappo destituti, pappus omnium paucisetus, setis vix scabris.

Serratula divarieata Fisch. et Meyer,

2898. Jurinea CASS. Cap it ul um mul. tiflorum, homogamum. Involueri subglobosi, obovati v. cylindracei squamae saepins inermes, imbricatae, squarroso-patulae v. adpressae. Ree eptaculi fimbrillae in setas lineares partitae. Corolla involncro longiores, quinquefidae, obringentes. $\mathrm{S}$ t a min $\mathbf{m}$ m filamenta subpapillosa, a $\mathrm{n}$ the rae apice obtase appendiculatae, basi bicaudatae, caudis apice tantum incisis. Stig mat a distincta. A c h e ni a olpyramidata, tetragona, areola apieulari demum in umbonem ambitu pappigerum, deciduum excrescente. P a p u 8 intra marginem minutissimum, calyciformem ortus, paleis pauciseriatis, subinaequalibus, crassis, regulariter et conferte barbellatis. - Herbae in regione mediterranea, taurico-caucasica et in Oriente indigenae, plerumque perennes, acaules $v$, caulescentes, simplices $v$. ramosac; foliis variis, semper subtus cano-tomentosis, rarius vage pubescentibus, floribus purpureis.

Ju rin ea Cassini in Bullet. sac. philom. 1821. p. 140. Dict. se. nat, $X X I V$. 287. XLI. 321. Lessing Synops. 45. DC. Prodr. VI, 673. S e r a tula e seet. 2. DC, in Annal. Mus, XVI. 185. S e r a tul a e s p. Auct. Desfont. Flor. atlant. t. 220. Bieberst. Plant, ross, $X, t .39$. Steven in Linn, Transact, XI, t, 37, 38. Ca rd u i s p. Linn. Jacq, Fl. atustr. t. 18. Doit in Sweet Fl. Gard. II. t, 103.

SUIBERID II. LABIA'TIFLORAE. F10res hermaphroditi plerumque bilabiati, unisexuales ligulati v. bilabiati.

TIRIBUS VI. MUTISIACEAE Lessing Synops. 92. Capitula uni-multiflora, homogama v. heterogama, aequaliflora v. inaequaliflora, floribus marginalibus uni-pluriseriatis, femineis $\mathbf{v}$, neutris, rarissime dioica, R ece pta culum epaleatum, nudum v. piloso-fimbrilliferum, rarius alveolatum. Corollae saepissime plus minus crassae et impellucidae, marginales bilabiatae $v$. ligulatae, rarissime filiformes, centrales saepissime bilabiatae, rarius 
subregulares v. regulares, laciniis longis divergentibus. Ant herae caudatae v. rarius ecaudatae, alis longis. Stylus hermaphroditorum superne cylindraceus v. subnodosus, $\mathrm{s} t \mathrm{igma-}$ tib us saepius obtusis v. truncatis, subtus val de convexis, superne pube minuta, aequali, rarius nulla vestitis. - Species pleraeque in America trans aequatorem, extratropicam frequentius indigenae, in America cis aequato rem, et in Capite bonae spei, in India boreali et Asia media rarissimae, alibi uon visae.

SURTRIEUS I. MUTISIFAE Lessing Synops. 93. Capitula homogama v: heterogama, floribus femineis uniseriatis, reliquis hermaphroditis. Corolla e staminigerae bilabiatae v. regulariter quinquefidae, laciniis longis, revolutis. Stylus saepissime crassus, stigm a t a obtusa v. acuta, extus convexa, hermaphroditorum brevia, extus cum styli parte superiore puberula, v. Jongiora et tunc glaberrima. - Arbores v. frutices, rarius herbae superne aphyllae.

DIVISID I. GERBER EAE DC. msc. Antherae ecaudatae.

2899. Selulechtendalia LESS. C a pitulum homogamum, multi- et aequaliflornm. Involucri campanulato-turbinati, multiseriati foliola multinervia, exteriora subfoliacea, mucronatoacuminata, subpungentia, intima coriacea, linearia. R e c e p $t$ a $\mathbf{c} \mathbf{l} \mathbf{u} \mathrm{m}$ paleaceo-fimbrilliferum, C oro 11 a e coriaceae, sericeo-villosae, palmato-quinquefidae, laciniis tubum brevissimum longe snperantibus. Sta in in $\mathbf{m}$ filamenta plana, distincta, aintherarum alae breves, integrae, obtusae, caudae nullae. Ach enia turbinata, erostria, longe denseque villosa. Pap pi paleae latae, subuninerves, subintegerrimae, longe acuminatae, inaequales. - Herba rhizocarpica, pulcherrima, in Brasilia meridionali indigena, plus minus villosa; caule simplici, ima basi dense, caeterum sparse foliato, foliis Luzulae albidae, coriaceis, linearibus, integerrimis, capitulis caulem ramosque terminantibus, involucris stramineis, corollis aurantiaceis.

S chlechte $n d a l i a$ Lessing in Linnaea $v, 242, t, 3$. f. so_55. Synops. 93, nou alior.

2900. Diaeantha LESS. Capitulum homogamum, multi- et aequaliflorum. Invol n cri ovato-cylindracei, disco brevioris squamae multiseriatae, arcte imbricatae, coriaceae, uninerves, ex teriores breviter mucronato-spinosae, interiores elongatae. R e ce p t a c u l u m piloso-fimbrilliferum. Coroll a e membranaceae, extus villosae, bilabiatae, labio exteriore ligulaeformi quadridentato, in teriore filiformi, breviore, torto. Stamin u m filamenta plana, in tubum connata, antherarum alae breves, integrae, obtusae, caudae nullae. A $c$ h enia turbinata, dense villosa, nectario alveolari. $\mathbf{P}$ a p p u s plumosus, uniserialis, paleis aequalibus, basi connatis. - Arbor quitensis; ramis tetrago. nis, spinis ad basim ramulorum geminis, foliis confertis, obovato-oblongis, integerrimis, utrinque tenuissime pubescentibus, capitulis terminalibus, solitariis, sessilibus.

Di a c a $\mathrm{t}$ b a Lessing in Linnaea $\gamma$. 243, t. 3, f. 56, 37 . Barnadesia arborea Kunth.
2901. Barmadesia LINN. F, Ca p it u $1 \mathrm{um}$ homogamum, multi-et inaequaliflorum, heterocarpum. Involueri turbinati, radio brevioris foliola multiseriata, imbricata, coriacea, uninervia, interiora teneriora, linearia, elongata. Rece pta cuI u piloso-fimbrilliferum. Co rolla e membranaceae, bilabiatae, ad tubi apicem villosae, radii uniseriatae, tubo gracili, longo, limbi bilabiati labio exteriore longiore, quadrifido, quinquenervi, interiore angustissimo binervi, dise i paucae (1-3) tubo brevissimo, amplo, limbi labiis subaequilongis. Staminum filamenta glabra, plana, radii connata v. distincta?, disci distincta, antherarum alae breves, integrae, obtusae, eaudaenullae. A chen ia turbinata, densissime sericeo-villosa, oblonga, angusta, disci breviora, crassiora. P a p u s uniserialis, paleis radii setaceis, gracilibus, plumosis, dis c i corneis, rigidis, integerrimis, - Frutices $v$. arbusculae Americae meridionalis; ramis alternis, basi bispinosis, adultis aphyllis, annotinis abbreviatis, folia alterna, integerrima, plana, glabra v. pilosa, oblongo-obovata, basi longe cuneata, aculeis geminis deciduis suffulta, subfasciculatim conferta gerentibus, capitulis solitariis sessilibus v, pluribus, corymbosis, corollis atro-purpureis.

B a r n a desia Linn. fil. Suppt. 348. Hunb. et Boppt. Plant, aequinoct. II. 176. Don in Linn. Transact. XVI, 223. Lessing in Linnaea $V$. 244. $t$. 3. $f$, s8_62. Synops. 94. -? B a c a 2 i a Ruiz et Pav, Prodr, 105. Lagasea Amen, nat,,-71 . D i a ca ut h a Lagasca Amen, nat. $\boldsymbol{I}$, 4f.

a. EUBARNADESIA. Flaseuli disci subterni. F il $\mathrm{a}$ me n t a radii counata. - (Humb. et Bonpl. Plant, aequinoct, t, 138.)

b. BACAZIA. Flosculns disci unicus. Filamenta radil consata. - B a cazla Ruiz et Pav. Prodr. $z$. 22.

c. PENThea. Floseulas disei unicus. Filamenta omnia libera. - Barnadesía (Penthea) Iaxa Dou l. c.

2908. Dasyphyllam $H, B, K$. C a pitul $\mathbf{n m}$ homogamum, multi- et aequaliflorum. InvoI ucri ovato-hemisphaerici squamae multiseriatae, arcte imbricatae, subaequales, pungentes. R e c e pt a $\mathrm{c}$ I l um piloso-fimbrilliferum. Corolla e regulares, tubo brevi, limbi quinquefidi laciniis linearibus, aequalibus, patentibus. St a $\mathbf{m}$ in u $m$ filamenta filiformia, libera, an $t$ h erarum alae breves, obtusae, integrae, candae nullae. Sty I us indivisus. A ch enia oblonga, compressa, sericeo-hirsuta. Pa p p s uniserialis, plumosus, - Arbuscula quitensis; ramis sparsis, spinosissimis, spinis geminis, foliis conferte alternis, subsessilibus, elliptico-oblongis, coriaceis, integerrimis, utrinque sericeo-hirsutis, pungentibus, capitulis terminalibus, sessilibus, congestis.

D a s y phyllum Kuath in Humb. et Bonpl. Nov. gen. et sp. IP, 17, $t, 308$.

2903. Nardoplayllwam HOOK, et $A R N$. Capitulum homogamum, pauciflorum. InvoI u crum involueratum (?), foliolis scariosis, acnminatis. li eceptaculum epaleatum. Corollae tubulosae, regulares. St am in um filamenta laevia, glabra, anther a e ecaudatae. A chenia sericeo-villosa. P a p p a pluriserialis, subplumosus. - Frutices chilenses, vix noli; ramis junioribus albo-tomentosis, foliis linearibus, rigidis, margine revolutis, capitulis terminalibus, solitariis.

Nardophy 11 a m Hooker et Arnott in Compan. Bot. Mag. II. 44. Go e hnatia revoluta Don mse.

2904. Fullealdea POIR. Capitulum uniflorum. I nvol u c ri cylindracei folisla coriacea, obsolete plurinervia, exteriora mucronata, intima 
longiora, flore breviora acuminata, inermia, su perne ciliata. R ce p ta c u l $\mathbf{u} \mathbf{m}$ punetiforme. C o ro 1 l a coriacea, limbo a tubo haud distincto inae qualiter quinquefido, lacinia una profundiore, ex tus torta. S ta min a m filamenta glabra, distineta, ant herarum alae breves, integrae, caudae nul lae. A ch enium cylindraceum, oblongum, sericeovillosum. Pap p us uniserialis, plumosus, aequalis, paleis angustis, acuminatis, flavescentibus. - Frutices andicol $i$; foliis alternis, petiolatis, integerrimis, capitulis terminalibus, aggregatis.

Fulcaldea Poiret Dict. $\nu .375 . \quad t, 989$. Lessing in Linnaea $V$. 247. $t$. 3. $f, 63$ 65. Synops. 95. T u r pinia Humb. et Boapl. Plant, aequinoct. 1 . 113. t. 33. Vo ig ti a Sprengel Syst. IIT. 6r3. Doliehos t ylls Cassini in Dict. tc. nat. LVI. 139.

OBSERVATIO. A r row $\mathrm{m}$ ith in $D O$. a cl. Lindley $I n$ zroduct. edit. 2, 262. post Fulcaldeam collocata, nobis proh dolor! peuitus incognita est.

2905. Terbera BURM. Cipitulum heterogamum, multi- et aequaliflorum, radiatiforme. Involucri pluriseriati, discum aequantis squamae plurinerves, arpressae, interiores longiores margineque scariosae. Receptac u I $\mathbf{n}$ m piloso-fimbrilliferum. Co roll a e bilabiatae, glabrae, labiis in radio exteriore ligulaeformi tridentato, interioris hipartiti laciniis angustissimis, cirrhiformibus, in dis co aequilongis, exteriore latiore tridentato, interiore bifido. Stamin um filamenta glabra, teretia, distineta, an ther a e radii nullae, disci alis lanceolatis, laceris. A $\mathrm{e}$ h e n ia compressa, rostrata, paucieostata, sparse papulosa, nectario alveolari. Pap pi biseriati paleae setaceae, serratae, aequales. - Herbae capenses, pulcherrimae, rhizomate repente perennantes; caule unico v. pluribus, erectis sive adscendentibus, teretibus, striatis, simplicissimis, ima tantum basi foliatis, caeterum aphyllis, foliis petiolatis, conferlis, petiolis intus canaliculalis, basi ampla imum caulem amplexante lana longa, sericea cinctis.

Gerber a Burm Afr. 135. Cassiai in Bullet, soc. philomat. 1817. p. 34. Dict sc. nat. XVIIT. 459. Opusc. phyt. IT. 98. Lessing in Linnapa $V$. 290. Synops. 118. A p hyllocat ulo o Lagase. Amen. nat. $I$. 36.

a. GERBERA Lessing l. l. e. c. I a v a I n $\mathrm{cr}$ a m eampanuJatum, floribus radii multo brevius, foliolis coriaceik.

Folia cariacea, adulia supra nitida. - A r n i e a e s p. Yino. Burm. Afr. $t, 36, f, 1,2$. Lam. $t, 679 . f, 5, \mathrm{D}_{0-}$ ronicisp. Auct.

b. PILOSELlOIDES Lessing $l$. $l$, e. c. In turbiuatum , radio paullo longius, foliolis berbaceis. Folia membranacea, supra hirsuto-pilosa, equles graciles, nuali, nutantes, pappus rufescens. - A r $\mathrm{n}$ ie a e $s p$. Linn. Thunb. (Lessing in Linngea $V, t, 4 . f .115$. 116. 118, 119.)

OBSERVATIO. Oreoseris DC. ex Lindl, introduet. edit. 2, p.268, hoe loco collocanda, nobis peuitus incoguita.

254B. Bermiera $D C$. C a pitulum homogamum, multi- et aequaliffornm, discoideam Involucri turbinato-campanulati, multiseriati squamae multinerves, punctatae, intimae margine scariosae. Receptaculum ...... Corolí. bilabiatae, pilosiusculae, labiis aequilongis, exteriore tridentato, interiore angustiore, bipartito, revoluto. Staminum filamenta ...... a $\mathrm{t}_{\mathrm{h}}$ e $\mathrm{ra}$ rum alae longae .... A che nia rostrata? Pap p a s multiserialis, setoso-paleaseus .... - Herba nepalensis, perennis, non satis nota; caule tereti, simplicissimo, uni-bipedali, laxe lanato-tomentoso, ima tantum basi foliato, caeterum aphyllo, esquamato, folits ad basim caulis confertis, subdel toideis, profunde hastato-sagillatis, acuminatis, re motc et obsolete mucronulato-denticulatis, sustus to- mento albo, tenero vestitis, nervis prominentibus glabris, petiolis longis, striatis, basi valde dilatata imum caulem amplectentibus, capitulo terminali solitario, primum nutante, demum erecto.

B ern ie r a DC, msc. ex Liudley Introduot. edit. IT, p. 269. Is a n th us 0 noserid Is sect. Lessing in Linnaca $V .338$. t. 4.f.125. Sjnops. 119. Chaptalia maxima Dou.

2S0ร. Hastopres CASS. C a p it u I u heterogamum, multi- et aequaliflorum, radiatiforme, floribus marginalibus femineis biseriatis, seriei exterioris longioribus, disci hermaphroditis. In v o I ne ri turbinati, multiseriati, florihns longioris squamae lineari-lanceolatae, acuminatae, purpureae, extus lanatae. Re e p ta $\mathbf{c} \mathbf{I} \mathbf{u m} \ldots .$. CorolI a bilabiatae, labiis hermaphroditorum aequilongis, exteriore tridentato, interiore hipartito, laciniis apice gibbis, feminarum inaequalibus, exteriore ligulaeformi tridentato, stylum superante, interiore bipartito. Sta min $\mathbf{~ m}$ filamenta distineta, plana, glabra, a n therae alis truncatis, in floribus femineis nullae $v$. efoetac. $A$ c h e $n$ i a rostrata. P a p us pluriserialis, angustissime paleacens, serrulatus, aequalis. - Herba capensis, perennis; omnibus partibus praeter involucrum et genitalia Gerberae piloselloidi simillima.

Las iopus Cassini in Bullet. soc. philomat. 1817. p. 139, Dict. sc. nat. $\mathrm{XX} V$, 298. Lessing in Linnaea $V .352$. Synops. 121.

DIVISE II. EUMUTISIEAE DC. $m s c$. Antherae caudatae.

2\$08. Flotovia SPRENG. C a pitu I utu homogamum, multi- et aequaliflormm, discoideum. Involueri campanulato-turbinati, pluriseriati, flores aequantis squamae coriaceae, multinerves, mucronatae, intimae inermes, demum squarrosoreflexae. Re e p ta $\mathrm{c} \mathbf{1} \mathrm{nm}$ angustum, planum, piloso fimbrilliferum. Corolla e coriaceae, palmatac $\mathbf{v}$. inaequaliter profunde quinquefidae, laciniis aeutis, apice extus barbatis. Stamin num filamenta distineta, plana, glabra, an the ra e breviter eaudatae, alis apice bifidis, brevibus. Stylus glaber. A che nia obconico-cylindracea, brevia, erostria, hirsuta. Pappus uniserialis, paleaceus, persistens, paleis angustissimis, longis, acuminatis, plumosis, acqualibus. - Arbores $v$. frutices brasilienses et chilenses, aculeati; aculeis ad basim petiolorum geminis, stipularibus, ramis alternis, divaricatis, striatis, teretiusculis, lenticellis petiolorumque delapsorum cicatricibus notatis, foliis conferte alternis, petiolalis, triplinerviis, reticulato venosis, integerrimis, petiolis supra canaliculatis, cum ramis articulatis.

Flot ovia Sprengel Syst. IIT. 359. Lessing in Linnaea V. 248. t. 3. f. 66 68. 95. Synops. 95. Prppig et Endlicher Nov. gen, et sp. $X$. 20. $t .32$. Erinesa C huquiragae se ct. Don in Linn. Transact XVI. 288. - P iptocarpha Hooker et Araott in Comp. Bot. Mag. I. 110. Reperiuntur in plerisque F. diacanthoides et aliarum etian specierum brasiliensium ineditarum capitulis, aelienits fertilibus aduixta ovaria efoeta, fertilibus une pressim adhaerentia, uune plas minus distincta, receptaculi "paleas angustissime "lineares, superne plumoso-elliatas," quales in Piptocarphis suis clarissimi anetores deseribunt, simulantes.

2ง09. Serin LESS, C a pitula multiflora, homogama, diseoidea, v. heterogama, radio uniseriato femineo, disco hermaphrodito. Involucri pluriseriati, flores aequantis squamae coriaceae, hneares, acuminatae, adpressae, interiores longinres. Receptaculu in nudum. Cornllate extus imprimis inferne sparsin pilosae, hermaphroditoram regulares, limbi quinquefidi laeiniis revolutis, 
apice gibbis, linearibus, tubo brevioribus, feminarum ligulatae $\mathbf{v}$, bilabiatae. S $\mathbf{t}$ a $\mathbf{m}$ in $\mathbf{~} \mathbf{m}$ filamenta distincta, plana, laevia, an thera e caudis laceris, alis hrevibus mucronato-acuminatis, in floribus femineis abortivae. Stylus glaber. A chenia oblongo-cylindracea, villosa, erostria, nectario alveolari. $\mathbf{P}$ a p p $\mathrm{s}$ uniserialis, paleaceus, paleis angus tissime linearibus, serratis, longis, aequalibus. Herbae brasilienses, perennes; caulibus erectis, simplicibus, teretibus, lanato-tomentosis, foliis alter nis, inferioribus petiolatis, superioribus sessilibus $v$. nullis, omnibus coriaceis, integerrimis, penninerviis, reticulato-venosis, subtus punctalis.

Willd.

$\mathrm{S}$ e $\mathrm{r}$ is Lessing in Linnaea $V$. 253. Synops. 99, non

a. ACTINOSERIS. C a pitula radiata, involuero subhemisphaerico, pauciseriali, - onoseris brevifolia Don. (Lessing in Linnaea $\boldsymbol{V}$. c. 3. f. 76 - 81.)

b. DISCOSERIS, C a pitula discoidea, involucro turbinato-campanulato, pluriseriali.

2910. Lyeoseriss CASS, C a p itulum multiflorum, heterogamum, radio uniseriato, femi neo, disco hermaphrodite. Involacri multise riati, floribus brevioris squamae coriaceae, oblon gae, acuminatae, adpressae, interiores longiores. Receptaculam ..... Corollae glabrae, hermaphroditorum subregulares, quinquefidae, laciniis reflexis tnbo brevioribus, feminarum ligulatae, ligula truncata, tridentata, tubum brevissimnm longe superante. Staminum filamenta distincta, laevia, plana, a n therae caudis integris, alis longiusculis, obtnse lanceolatis, in floribus femineis abortivae. Stylus radii glaber, dis ci superne hispidus. Achenia conformia, erostria ....... Pappus uniserialis, paleis angustissimis, longe acuminatis, serratis, longis, aequalibus. - Herbae Novo-Granatenses, basi suffruticosae; foliis alternis, breve petiolatis, subcoriaceis, reticulato venosis, integerrimis, supra nitidis, capitulis solitariis, purpureis.

L ycoseris Cassini Opusc. phyt. IT. 96. et 112. excl. sp. Lessing in Linnaea $V$. 255, $t, 3, f .82 .83,85$. Synops, 98. On oseridls s p. Willd. Atractylis s p. Suith Io, inedit. II. $t$. 66. - ? D I a z e $\mathrm{x}$ is Don in Linn. Transact. XVT, 259. Lessing Synops, 92. L a ng $s$ dorfia Willd mic,

2911. Centroelíniuan DON. Capitu $1 \mathrm{um}$ multifiorum, heterogamum, radio uniseriato, femineo, diseo hermaphrodito. Involucri sub globosi v. cylindracei, multiseriati squamae coria ceae, lanceolato-acuminatae, adpressae, interiures longiores. Receptaculum planum, spinulosofimbrilliferum. Corollae glabrae, disci suliregulariter quinquefidae, laciniis reflexis, tubo bre vioribus, radii bilabiatae, labie exteriore lignlae formi, tridentato, interiore breviore, bifido, laeinii filiformibus, revolutis. $\mathbf{S} t$ a $\mathrm{m}$ i $\mathrm{num}$ filamenta di stincta, glandulosa, plana, a ntherae candis integris, alis obtnse lanceolatis, in floribus femineis efoetae. Stylus radii glaber, disci superne papillosus. A $\mathrm{ch}$ enia conformia, pentagona, erostria, demum glabrata. Pa p p u s pluriserialis, de ciduus, setaceus, setis exterioribus brevioribus, $\mathrm{pi}^{\mathrm{i}}$ liformibus, interioribus apiec dilatato-complanatis, denticulatis. - Suffrutices peruviani; ramis te retibus, foliis alternis, breve petiolatis, supra demum glabratis, subtus niveo-tomentosis, integerrimis $v$ grosse dentatis, capilulis terminalibus longe pedun culatis.

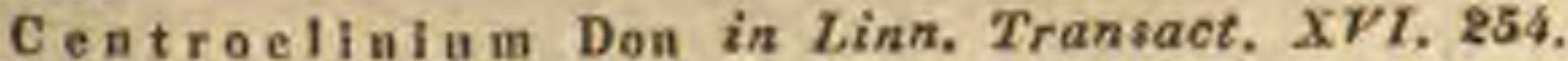
Hooker Bot. Mag. 1.3114. 3115. Hi p pos e ridis s p. Cas sini Opusc, $p h y$. II, 97 . O noseridis s p. Lessing $S y n$ ops. 119.
291 2. Chretaelalaema DON, CapituI $\mathrm{m}$ multiflorum, heterogamum, radio uniseriato, femineo, disco hermaphrodito. I n vol u eri hemisphaerici squamae pluriseriatae, imbrieatae, lanceolatae, apice in setam longam, recurvato-patentem productae. Receptaculnm favosum, dentatoscabrum. Corolla e glabrae, disci tubulosae, tubo infra medium angustato, fauce cylindrica, limbi subaequaliter quinquedentati dentibus linearilus, obtusis, ra dii ligulatae, ligula apice triloba, tubum brevissimum longe snperante. St am in um filamenta ..... an the ra e candis setiformibus, alis lineari-lanceolatis, acutiusculis, in floribus femineis rudimentariae. Stylus radii indivisus, clavatus, dis ci emarginatus. A chenia conformia, cuneato-oblonga, erostria, pilosiuscula. P a ppu s pluriserialis, persistens, setaceus, setis exterioribus brevissimis, piliformibus, interioribus compressis, rigidis, serrulatis. - Herba peruviana, annua, Cryptostemmatis calendulacei habitu, caulibus decumbentibus, simplicibus v. ramosis; foliis alternis, membranaceis, petiolatis, ovatis, sinuato-dentatis v. sublyralis, dentibus inaequalibus, mucronatis, subtus dense lanatis, radicalibus longius petiolatis, capitulis solitariis, pedunculos filiformes, adsurgentes, lanuginosos, squamula unica setacer munitos terminantibus.

C haet a $\mathrm{ch}$ la ena Don in Linn. Traneact, XVI. 256.

9913. Chauduinaga JUSS. C a p itnln m homogamum, mn!ti- et aequaliflorum, discoideum. Invol ueri campanulato-turbinati, flores aequantis, pluriseriati squamae coriaceae, uninerves, acutae, exteriores mucrunatae. Recept a e u l um planum, piloso-fimbrilliferum. Co roll a e coriaceae, villosae, inaequaliter profunde quinquefidae, laciniis acutis, basi intus barbatis. S $t$ a $m$ in u m filamenta distincta, plana, glabra, a n therae caudis laceris, alis lanceolatis, obtusiusculis, integris. StyI us superne hispido-pubescens. A ebenia turbinata, erostria, hirsuta. P a p pus uniserialis, paleaceus, persistens, paleis angustissimis, lungis, acnminatis, plumosis, aequalibus, basi coadunatis. Fruticuli, in America a ustrali tropica et extratropica alpicoli, ramosissimi; foliis confertis, sessilibus, coriaceis, lucidis, margine incrassato integerrimis, plerumque glabris, pungenti-mueronatis, capitulis solitariis, magnis, speciosis, ramos usque ad apicem foliis dense tectos terminantibus, involucri foliolis pilis flavescentibus longe denseque ciliatis, exterioribus fuscis, interioribus aureis, corollis atropurpureis.

Chuquiraga Jussieu gen. 178. Humb. et Banpl. Plant. aeguinoct. $T$. 151, $t$. 43, Lam. $t$, 691. Lessiug is Linnaea $V$. 258. t. 3. f. 84. 86. Sjnops. 96. J a ha a u ia Willdenow $s_{p}$. IIIT. 1705.

2914. Spadonia LESS. Ca pitul a dioica, pauciflora, homogama. Involu e ri campanulato-turbinati v, subcylindracei squamae pluriseriales, imbricatae, coriaceae, plurinerves, acutae. Receptaculum planum, nudum. Corollae mem branaceae, glabrae, quinquefidae, regnlares, laciniis tubo multu longioribus, apice gibbis. S $\mathrm{tam}$ inum filamenta...... anthe sae candis integris, alis ellipticis, acnminato-mucronatis. St y lus glaberrimus. A chenia eylindracea, erostria, hirsuta. Pap p s biserialis, setaceus. - Frutices brasilienses, non satis noti; foliis allerris, petiolatis, integris, subtus tomentosis, capitulis pauciftoris, minusculis, aggregatis.

Sp a do nia Lessing Synops. 99. 
2915. Goelnmatia $H . B, K, C$ apitula pluri-multiflora, homogama, discoidea, v. heterogama, floribns marginalibus abortu femineis, disci hermaphroditis. Invol u eri turbinati, campanulati v. cylindracei squamae multiseriales, coriaceae, plarinerves, imbricatae. R e e p t a c u l u m planum, nudum. Corolla glabrae, hermaphroditorum regulares, limbo a tubo vix distincto, quinquefido, feminarum bilabiatae, labio exteriore ligulaeformi, apice tridenticulato, interiore bipartito. S $\mathbf{t a m i -}$ n a m filamenta distincta, laevia, a $\mathrm{n} t \mathrm{~h}$ erarum caudae longae, integrae v. lacerae, alae ellipticae, breves, mueronulato-aeuminatae. Stylus glaber. A c h e n i a cylindracea, erostria, villosa. Pap p u s pluriserialis, longus, inaequalis, setaceo-paleaceus, paleis apice paullo latioribus, profundius serratis v. breviter plumosis. - Frutices $v$, herbae, in Ame$r$ ica a ustral $i$ crescentes; caulibus teretibus, foliis alternis, reticulato-venosis, subtus involucrisque tomientosis.

Go eb natia Kunth in Humb. et Bonpl. Nov. gen. et sp. IV. 20. Lessing in Linnaea $V .260$. Synops, 102. excl. sp.

a. EUGoCHNATIA. Capitula homogama, solitaria vo aggregata. - Frutices austro-americani.

Go hnatia Lessing Synops. 102.

re. Cyclolepis Don. Capitula solitaria, multi. flora. A u therar um caudae lacerae.

C y clole pis Don in Edinb. philosoph. Mag. April. 1832. p. 392, ot in Compan. Bot. Mag. T. 109.

P. Anastraphia Don. Capitula solitarin, mul. tiflera. Antherarum caudae int.grae.

A nastraphia Don in Linn. Transact. XVI. 295. (Kunth Op. cit. t. 309.)

y. Pentaphorus Don. Capitula aggregata, pauciflora. A a thera $r u m$ caudae integrae.

Pentaphorus Don in Linn. Transact. XVI, 296. Compan, Bot, Mag. II, 108.

b. HEDRAIOPHYLLUM Less. Ca pitu I a heterogama. A nthe raru m caudae lacerae, - Herbae brasilienses.

Hedraio phy 11 u m Lessing Syrops. 103.

25 16. Augusta LEANDR. C a p itu $1 \mathrm{um}$ multiflorum, homogamum, discoideum. Involue ri turbinati, floribus multo brevioris squamae arete imbricatae, coriaceae, multinerves, obtusae. R eceptac u I n m planiusculam, nudum. Corolla subcoriaceae, glabrae, regulares, limbi quinquefidi, ubo multo brevioris laciniis revolutis. S $t$ a $\mathrm{m}$ in u m filamenta distincta, glabra, plana, a $\mathbf{n}$ h e rae longe exsertae, eaudis elongatis, integris, alis oblongis, acuminatis, brevibus. Styl us glaber. A che n i a lanceolata, breviter rostrata, obsolete costata glabra. P a p p us multiserialis, paleaceus, longus, paleis angustis, linearibus, inaequalibus, serratis, apice parum crassioribus. - Frutices in Brasilia tropica indigeni; foliis conferte alternis, petiolatis, integerrimis, glabris, nitidis, capitulis solitariis, magnis, speciosissimis, v. paniculato-confertis, parvis.

A a u u ta Leandro de Sacramento in Münchner Denkschrift, VII. 235. $t$, 14. $f, 1$, 2. StIfftia M.kan Delect, 1 t. 1. Cassiui in Diet, se, nat. XLI. 9. Lessing in Linnaea v. 263. t. 3. f. 91. 92. 94, 111. Synops, 103. S a n hila ria Leandro msc. Mocina DC. mac.

2917. Mutisia LINN. F, Capitulum multiflorum, heterogamum, inaequaliflorum, radiatum. Involueri floribus brevioris squamac multiseriatae, imbrieatae, integerrimae, planae, interiores longinres. R e cep ta culum planum, nudum. Corollae radii ligulato-bilabiatae, la. bio exteriore lignlaeformi, integerrimo $\mathbf{v}$, obsolete tridentato, interiore minimo, bifido, dis ei tubulosac, limbo a tubo haud distincto, bilabiato, tabin altero bi-altero trimero, utroque revoluto.
S t a min um filamenta distincta, papillosa, plana, an $t$ her a e disci exsertae, longissime candatae, alis obtusiusenle acuminatis, longis, $r$ a d $i \mathrm{i}$ abortivae. Stylus glaber. A $\boldsymbol{c}$ h e nia rostrata, costata, glabra. Pap p us biserialis, paleis angustis, linearibus, aequalibus, longis, plnmosis, basi in annulum cohaerentibus, simnl caducis. - Frutices in America australi, tropica et extratropica indigeni, speciosi, habitu vario; ra. mis foliisque alternis, capitulis solitariis, magnis, pulcherrimis,

Mutisia Lina. fil. Suppl, 57. Ruiz et Pavon Prodr. 107. Lessing in Linnaea $Y$. 265. Synops. 103.

a. EUMUTISIA Lessing $\boldsymbol{l}$, c. Involucri foliola exappendiculata, adpressa, obtusa v. acuta. - Species pe. $r u v i a n a e$, scandentes; folits pinnatisectis, in cirrhum ramosum desinentibus, segmentis integerrimis. (Humb, et Bonpl. Plant, aequinoct. t. 80 . Cavanill. Ic. t. 491. 492.)

b. MUTISIASTRUM Lessing $l$. c. Invol u e $\mathbf{i}$ foliola exteriora foliacea, squarrosa, acuminata. - Species brasilienses; folits pinnalisectis in cirrhum ramosum desinentibus, segmentis integerrimis, membranaceis. (Lessiug in Linnaea $V$. t. 4. f. 99. 100, 102. Bot. Mag. t. 2705.)

c. GUARIRUMA Lessing $\boldsymbol{l}$, c. Invol ueri foliola extima foliacea, acuminata, squarrosa. - Species peruvia. nae et chilenses; folits pinnatifils $v$. dentatis, in cirrhum desinentibus $v$. ecirrhosis. - Guarlr u. m a Cassiol Opuse, phytolog. II. 109. Cavanili. Ic. t. 493. 495. 498. 499. Hooker Bot, Míscell. t. 4. 5. 7. Püppig et Endl. Nov. gen, et sp. t, 87 _ 29.)

d. HOLOPHYLLUM Lessing $l$. $c$. Involueri foliola exteriora foliacea, acuuinata, squarrosa. - Species chi. lense s. folits integerrimis. (Cavanill. Ic. t. 409.490. Hooker Op. cit. $t$ 6. Püppig et Endl. Op. cit. $t .30,31$. Lessing in Linnaea $V . f$. 87, 93.)

e. HAPLOPHYLLUM Lessing $t$. c. Invol u er f foliola exappendieulata, adpressa, obtusa v. acuta. - Species chilenses, folits integerrimis. - Apla phyll u Cassint Opusc. phytolog. IT. 107. (Cavanill. Ic. $t .497$. 500. Hooker Op. cit, t. 8. 9.)

2918. Promstia LAGASC. C a p it u 1 u m subquinqueflorum, homogamum, discoideum. Involueri turbinati, floribus multo brevioris squamae coriaceae, adpressae, obtusissimae, extimae minimae. Recepta c a l a m planum, piloso-fimbrilliferum. Corolla glabrae, bilabiatae, labiis aequilongis, revolntis, exteriore latiore apice tridentato et interiore bifido, $v$. exteriore quadridentato, interiore indiviso, integro. S $\mathbf{t a} \mathbf{m}$ in $\mathbf{~} \mathbf{m}$ filamenta distincta, glabra, plana, a $\mathbf{t}$ h er a $\mathbf{r} \mathbf{~ m}$ candae lacerae, longae, alae breves, lanceolatae. Stylus superne hispido-pnberulus. A ehenia oblonga, teretiuscula v. trigona, erostria, pilosa, callo apieali. Pa p p ns biserialis, aequalis, paleaceus, paleis angustissime linearibus, apice paulIum incrassatis et profundius serratis. - Arbusculae chilenses et peruanae; folits alternis, petiolatis, coriaceis, integerrimis $v$. denticulatis, capitulis paniculatis.

Proustia Lagasea Amen. nat. 1 , 33. DC. in Annal. Mus. XIX, 67. et 70. Cassini in Dicl, sc. nat, LV. 395. Don in Linn. Transact, XVI. 198. Lessigg in Linnaea $V$. 280. Synops. 110

a. BUPROUSTIA. A c he a ia pilosa. Pa p p u s coloratus. - Flores thyrsoidei, purpurei. (DC. Op. cit. t. 13.)

b. LEUCORYPHE. A $\mathrm{c}$ h en i a papilloso-seabra. teretinscula. P a p us atbus. - Flores fasciculato-corymbosi, albi.

e. HARMODIA. A c be n i a cuneato trigona villosa. Pa p. pus fusco-purpurens. - Flores lare spicati, rosei. Harmodia Don $O p$, eit, $X V 1.202$.

291 9. Iryalis DON. Capitulum subquinqueflorum, homogamum, disevideum. In vo- 
lucri pluriseriati squamae adpresse imbricatae. Receptac $\mathbf{l} \mathbf{1}$ um fimbrillis callosis, brevibus sub singulo achenio instructum. Cor oll a e bilabiatae, labio exteriore maximo, ligulaeformi, tridentato, interioris profunde bipartiti laciniis linerari-acuminatis, revolutis. S $\mathbf{t}$ a $\mathbf{m}$ in $\mathbf{u}$ filamenta distincta, glabra, plana, a ntherarnm caudae plumosolacerae, alae lanceolatae, acuminatae. S t y $1 \mathbf{u} 8$ glaberrimus. A ehenia ovato-oblonga, ventricosa, erostria, decemeostata. Pa p p u s triserialis, inaequalis, paleis angustissime linearibus, versus apicem profundius dentatis, ima basi subconnatis. Herba patagonica, perennis, multicaulis, tota pube copiosa, implexa argentea; radice repente, caulibus erectis, simplicibus, angulatis, circiter pedalibus, foliis sessilibus, lanceolato-linearibus, acuminatis, integerrimis, nervosis, basi attenuatis, subtripollicaribus, capitulis terminalibus, oblongis, paniculato-corymbosis, corollis pappoque albis.

Hy alis Don ex Hooker Compan, Bot. Mag. I. 103.

2920. Eracliyelados $D O N$. C a p itu$1 \mathrm{um}$ heterogamum, radiatum, radio femineo, disco hermaphrodito. In vol u e ri pentaphylli, basi bracteolati foliola ovato-Ianceolata, acuminata, carinata. Re cepta culu m nudum. Corolla e glabrae, bilabiatae, labiis in disco aequilongis, exteriore tridentato, interiore bifido, revolutis, in radio exteriore ligulaeformi, interiore bifido, laciniis linearibus, revolutis. S $t$ a $m$ in u m filamenta distincta, laevia, antherae caudis plumosis, alis ...... Sty l u s glaber. A c hen a cuneato-pentagona, erostria, dense papillosa. P ap us plariserialis, persistens, capillaris, seaber, cinereus. Frutex patagonicus, rigidus, ramosissimus; foliis fasciculatis, linearibus, mucronatis, margine revolutis, integerrimis, capitulis terminalibus, solitariis, pedunculatis. I. 106.

B rachyelados Don in Hooker Bot. Mag. Compan.

292 1. Clanetsmthera $R U I Z$ et $P A V . C$ a pitul u m pluriflorum, heterogamum, radiatum, radio femineo, disco hermaphrodito. Invol u crum campanulatum, pluriseriatum, foliolis omnibus siccis, adpressis, v, exterioribus foliaceis, patentibus. Receptaculam nudum. Corolla e glabrae, limbo a tubo vix distincto, bilabiato, labiis in disco fastigiatis, exteriore tridentato, in radio inaequalibus, exteriore ligulaeformi amplo, apice tridentato, interiore cirrhiformi, indiviso $\mathbf{v}$. bifido, interdum obsoleto. St a minum filamenta distineta, laevia, plana, an $\mathbf{t h}$ e $\mathbf{r}$ a $\mathbf{r} \mathbf{m}$ caudae lace rac, alae obtusae, oblongo-ellipticae. Stylus superne hispidulo-pnbescens. A $\mathrm{c}$ h en i a turbinata, oblonga, erostria, papulosa. P a p p us pluriserialis, setaceo paleaceus, serratus, longus, subaequalis. - Herbae ch ilenses, humiles; foliis sessilibus, membranaceis, uninerviis, aveniis, integerrimis, dentatis v, rarissime pinnatifidis, capitulis terminalibus, solitariis, luteis.

C.ha etant hera Ruiz et Pav. Prodr. 106. DC. in An. nal. Mus. XIX. 65. Lagasca Amen, nat. I. 37. Cassini in

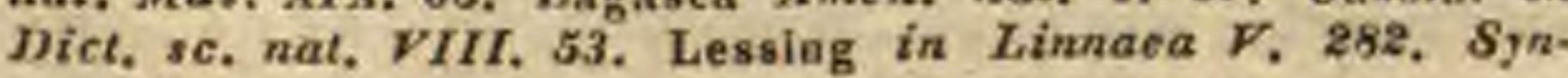
ops, 111.

a. BICHENIA Don. Involueri foliola omia sicea. Folia radicalia pinnatifia, subfus tomentosa, caulina nulla.

B i e he n i Don in Linn. Transact, XVI, 237.

b. CHERINA Cass. Invol u eri foliola fere omnia sicea , extima minima. interiora sensim majora. - Folia $l i$ nearia, integerrima $v$. denticulata.

Cherina Cassiui in Dict, sc, nat. VIIT. 456. Enthrixia Don in Linn. Transact, XVI. 259. test, Hoo. ker et Aruott in Compan. Bot. Mag. 1,104 . C h a e ta ntherae sect, Liniphyllum Lessing Synops. 112.

c. EUCHAETANTHERA. Invo I u cri foliola extima foliacea, patentia, Interioribus longiora. - Folia lincaria $v$, obovato - Iinearia.

Cha et a $\mathrm{t}$ he rate sect. 3. Lessing Synops. 113. Pro. 8 clia Don in Linn. Transact, XVI, 235.

d. PRIONOTOPHXLLUM Less. Involueri foliola extima foliacea, patentia, interioribus longiora. - Folia sputhulata, serrala.

Prionotoph y 11 a m Chaetantherae sect. 4 . Lessing Synops. 118.

e. TYLLOMA Don. Involueri follola extima foliis eaulinis simillima. - Fotia spathulata, margine incrassato integerrima.

T y $110 \mathrm{~m}$ a Don in Linn. Transact. XVT. 230.

2523. Paelnylaema DON. Capituln m multiflorum, heterogamum, radiatum, radio femineo, diseo hermaphrodito. In vol u e ri subglobosi, multiseriati foliola coriacea, oblonga, adpressa, interiora longiora radiantia. Rece p taculum nn. dum. Corollae glabrae, bilabiatae, labiis in diseo aequilongis, revolutis, exteriore tridentato, interiore bifido, in radio inaequalibus, exteriore ligulaeformi, elongato, interioris bipartiti laciniis setaceis. Sta min um filamenta distincta, laevia, plana, antherarum caudae lacerae, alae lineari - mucronulatae. Stylus glaberrimus. A cheni a cuneata, erostria, glabra. Pappus paleaceus ...... Herba chilensis, caespitosa, prostrata, multicaulis, glauca; caulibus teretibus, rubicundis, foliis alternis, petiolatis, late ovatis, obtusis, eroso-denticulat is, coriaceis, glaberrimis, subtus purpurascentibus, petiolis longis, dilatatis, complanatis, capitulo terminali, solitario, magno, floribus albis.

$\mathrm{P}$ a e hy I a e n a Don in Bot. Mag. Compan, I. 106.

2923. Trielhoeline CASS. Ca $\mathrm{p}$ it $\mathrm{I} \mathrm{um}$ multiflorum, heterogamum, radiatum, radio femineo, disco hermaphrodito. Involucri campanulati, pluriseriati foliola plana, exteriora foliacea, longiora, patentia, interiora membranacea, linearia, erecta. R e cep $t$ a c a l n m piloso-fimbrilliferum. Corolla e glabrae, limbo a tubo hand distincto, bilabiato, labiis in disco aequilongis, exteriore latiore tridentato, interiore bidentato, in radio inaequalibus, exteriore ligulaeformi amplo, apice truncato, tridentato, interiore spiraliter torto, bifido $v$. indiviso. S $\mathrm{ta}$ m in $\mathrm{um}$ filamenta distincta, plana, papillosa, a $\mathrm{n}$ h erarum caudae longae, lacerae, alae obtnsiusculae, breves. S tyIns superne puberulus. A chenia turbinata, erostria, papulosa. Pa p p s multiserialis, setosopaleaceus, serratus, Iongus, subaequalis. - Herbae brasilienses, rhizomate perennantes; caulibus pluribus, simplicissimis, ima basi conferte foliatis, caeterum nudis $v$. squama una alterave instructis, capitulo terminali solitario, corollis croceis.

Trichoclia e Cassini in Dict. sc. nat. LV. 216. Les. sing in Linnaea $V .286 . t$. 4 . f. 113. 114. Synops. 117. Doronici sp. Lam. $t$. 679. $f$. 3 , C hap talla e sp. Doa.

2924. A mblysperma BENTH. C a p itul u m multiflorum, heterogamum, radiatum, radio femineo, disco hermaphrodito. Involucri campanulati, pluriseriati squamae imbricatae, latolanceolatae, interiores longiores. R eceptacuI n m planum, subalveolatum. Coroll a e glabrae, disci tubulosae, limbo quinquefido, laciniis duabus interioribusaltius connatis, ra di ligulato-bilabiatae, labio exteriore amplo, oblongo-lineari, apice breviter trifido, interiore brevi, subulato, 
profunde bifido. Staminum filamenta distincta, laevia, plana, antherarum caudae glabrae, alae breves. Stylus superne pubernlus. A $\mathrm{che}$ n i a turbinata, obtusissima, papulosa. P a p p u s mul tiserialis, setoso-paleaceus, subscaber, longas, subaequalis. - HerbaNovae-Hollandiae austro occilentalis, scapigera; foliis radicalibus lon giuscule petiolatis, oblongis, sinuato-dentatis, sublo batis, membranaceis, supra glabris, subtus laxe albo lanatis, scapo uno-bipedali erecto, imprimis versus apicem laxe albo-lanato, squamis subfoliactis remote vestito, capitulo solitario magno, terminali.

A m b 1 y sperm a Bentham in Enumer. plant. Hü̈gel. 67

2925. Dnoseris DC. Capitulum mul tiflorum, heterogamum, radiatum, radio femineo diseo hermaphrodito. Involueri turbinato-campanulati, pluriseriati foliola sicca, lineari-acuminata, margine scariosa. R e ce p ta cul u m nudum. Co$\boldsymbol{r}$ olla e glabrae, limbo a tubo haud distincto, bilabiato, labiis in diseo aequilongis, exteriore triinteriore bifido, utroque revoluto, in radio in aequalibus, exteriore ligulaeformi, amplo, interio ris bifidi laciniis angustis, spiraliter tortis. S t a min um filamenta distincta, plana, pupillosa, a $n$ therarum caudae filiformes, integrae, alae acuminatae. A ch enia angulata, multicostata, rostro crassiusculo terminata. Pa p p n s multiserialis, setoso-paleaceus, serratus, valde inaequalis.

Herbae Novo-granatenses, perennes, ima basi foliatae; fotiis confertis, membranaceis, reticulatovenosis, petiolatis, serratis $v$. lyrato-pinnatifidis scapis simplicissimis $v$, rarius subramosis, remote squamosis, eapitulis terminalibus solitariis, magnis.

Onoseris DC. in Annal. Mus. XII. 65. $f$. 4. Kuntl in Humb. et Bonpl. Nov. gen, et sp. t. 304, 305. 0 nos e$r$ id is sectio 0 no seris et C I ad os eris Lessing in Lin naea $V, t, 4, f, 120,121,126.127,0$ no $s$ er id is et $\mathbf{B}$ i p po seridis s p. Cassiai Opusc. phyt. IY. 97. Atractylidis $s$ p. Lius. Smith $I c$, inedit, $t$, 65 .

2926. Isetypus. H. B. K. Capitulum multiflorum, homogamum, discoideum. InvoI u cr u m campanulato - tarbinatum, floribus brevins, squamis laxe imbrieatis, lanceolato-linearibus, membranaceis, margine scariosis, interioribus sensim longioribus. Rece ptaculum piloso-fimbrilliferum. Corollae glabrae, limbo a tubo multo longiore haud distineto, aequaliter quinquefido. St a min n m filamenta distincta, laevia, antherarum caudae filiformes, alae aentiusculae. S tylu s glaber. A chenia pilosa, lineari-penta gona, costata, rostrata, rostro crassiusculo, necta rio alveolari, areola terminali. $\mathbf{P}$ a p p $\mathbf{n}$ s pluriserialis, setoso-paleaceus, longus, aequalis, serratus. Herba $A$ merica e trop $i$ ca e, facie Onoseridis purpureae; foliis radicalibus pinnatifido-lyratis, subtus argenteo-lanatis, scapo corymboso ramoso, pedicellis bractsis squamaeformibus, adpressis dense obsitis, floribus roseis.

Is of y pus Kunth in Mumb. et Bonpl, Nov. gen, et sp. IV. 9. t. 307. Lessing in Linnaea V. 345. t. 3, f. 89 $90,1,4,96$-98. Se ris Willdenow in Berl, Magaz, 1807, p, 139.

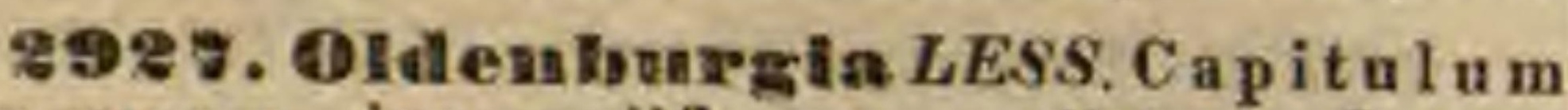
homogamum, inaequalifforum, radiatum. Invo1 u eri foliola inermia, plana, interiora longiora, acuminata, Receptac u I u m ..... Corollae glabrae, limbo a tnbo hand distincto, disci regulares quinquefidae, laciniis apice gibbis, v. aequaliter bilabiatae, lobis semper tubo longioribus, $r$ a di inaequaliter bilabiatae, labio exteriore lignlaeformi, amplo, interiore breviore bifidov, biden tatu. Stamin um filamenta distincta, laevia, pla- na, antherarum caudae integrae, basi subtruncatae, alae ovato-oblongae, breviter acuminatae. Stylus glaber. Achenia turbinata, brevia, erostria, villosa. Pap p us paleaceus, breviter plumosus, paleis aequalibus, longis, angustissime linearibus, acuminatis. - Fruticulus ca pensis, Vernoniae villosissimae facie; foliis conferte alternis, oblongo-linearibus, oblusis, coriaceis, margine revolutis, integerrimis, subtus tomentosis, capitulis terminalibus magnis, solilariis, inter folia sessilibus,

OI den burg i a Lessiag in Linnaea $V$. 252. t. 3. f. 69 -75. Synops. 99.

2928. Tencomeris $D O N$. Capitulnm quadriflorum, homogamum. In vo I u e ri cylindraceo turbinati, floribus multo brevioris squamae pluriseriatae, arcte imbricatae, ovato-oblongae, interiores longiores. R e e ptaculum serobienlatum. Coroil a e glabrae, limbi a tube multo longiore haud distincti, quinquefidi laciniis revolutis. Sta in in um filamenta distincta, laevia, plana, a $n$ therarum eaudae retrorsum plumosae, alae acuminatae. Stylus glaber. A che nia oblongoubconica, erostria, dense et longe villosa. P a p p us pluriserialis, setaceus, setis longis, subplumosis. Frutex nepalensis; ramis junioribus tomentosis, foliis alternis, petiolatis, oblongo obovatis, acutis, integerrimis, supra laevibus, lucidis, subtus subfloccoso-tomentosis, capitulis in fasciculos terminales, convexos, polycephalos aggregatis.

Le ucomeris Don Nepal. 169. G o chnatiae sectio Le ucomeris Lessing Synops. 103.

AINSLLAEA DC, quae Liatris Iatifolia Don. Nep. 169. ex el. Liadley Introduct. edit. IT. p. 262. post Leucomerim collocanda, nobis prorsus est incognita.

2929. Myripmois BUNGE, Capitula dioica, subquinqueflora. Involucrum nniseriale, pentaphyllum, foliolis oblongis, obtusis, aequalibus, trinerviis. Recepta e al am parvum, nudum. Ma se. Corolla e bilabiatae, labii superioris bipartiti lobis bifidis, inferiore integro, lobis omnibus demum revolutis. An thera e basi bisetae, in tubum subcurvatum cohaerentes. Orarii rudimentum. F e m. Coroll a e bilabiatae, labio exteriore quadrifito, interiore indiviso, laciniis $\mathrm{i}$ nearibus, demum revolutis. Stamin um filamenta sterilia, libera. Sty las inclusus; stig ma infundibuliforme, bilamellatum. A c h en i a lineari-oblonga, villosa. P ap pu s pilosus, scaber. - Frutex bipedalis in China bor a li rupicola; ramis virgatis, foliis oblongis, integerrimis, acutis, viscidulis, fragrantibus, floribus e gemmis ortis, solitariis, subpraecocibus, masculis albis, femineis purpureis.

\section{Myripnois Bunge Enum, pl. Chin. boreal. 38.}

2930. Dieoma CASS. Capital a multiflorum, homogamum, discoideum, v. heterogamum, radiatum, radio neutro, disco hermaphrodito. Invol a eri eampanulati, disenm subaequantis foliola coriacea, sicea, rigida, lncida, obsolete multinervia, pungenti-acuminata. R e ceptacuI m paleaceo-fimbrilliferum, fimbrillis basi in alveolos subconnatis. Corolla e pilis crassis, brevibus obsitae, ra di bilabiatae, dis ci regulares, limbi distincti, quinquepartiti laciniis tubo longioribns. St a min um filamenta distincta, plana, glabra, a ntherarum eandae laecrae, laciniis piliformibus, sursum spectantibus, alis oblongoelliptieis, acuminatis. Stylus apice hispidulus. A chenia turbinata, brevia, erostria, longe vil- 
lesa. Pappus bi-multiserialis, paleaceus, paleis inaequalibus, corollam subaequantibus. - Fruticuli $v$. suffrutices capenses et senegambic $i$, dichotomi ; foliis alternis, aveniis, capilulis solitariis, ramos teretes, fere ad apicem aequaliter foliatos terminantibus.

Die om a Cassini in Butlet. soc, philomat, 1818, p. 47. Dict. se. nat, XIII. 194. XLVIT. 503. Lessing in Linnaea Y. 276. Synops. 109 .

a. LEUCOPHXTON Less. Capitula,homngama, discoidea. A chen la decemcostata, basi imprimis villosa, costis versus apicem magis prominentibus. P ap u s biserialis, paleis anguste linearibus, interioribus basi utrinque ala scariosa auctis. - Suffrutices capenses el senegambici; folits oblongo.obovatis, niveotomentosis.

Leueophyton Lessing Synops. 109. D ic o m a Cassini $2 . c$.

b. RHIGIOTHAMNUS Less. Cap it a la beterogama, radiata. A c h e n ia ecostata, undique villosissima. Pa p p us multiserialis, paleis angustissimis, conformibus. gerrimis, supra glabris, subtus albo-tomentosis.

Rhigiotham us Lessing Synops. 109.

c. MACLEDIUM Less. Capitula homogama, discoidea. A e he u i a ecostata, undique viflosissima. P a p p s pluriserialis, pateis latis. acuminatis. - Frutices capenses; folits subintegerrimis.

Ma cledium-Cassini in Dict. sc. nat. XXXY. 39. Nitelium Cassini Op. cil. XXXV. 12. Elichrysum spinosum. Thusb. Xeranthemum spinosum Liun. Burmann Afric. $t$. 67. $f$. 3 .

258 1. Fintzina CASS. C a p i t u $1 \mathrm{um}$ multiflorum, heterogamum, radiatum, radio femi neo, diseo hermaphrodito, Invol neri campanu lati, tomentoso - viscidi, floribus brevioris foliola basi conduplieata, semilanceolata, interiora paulto breviora. Receptacul a m nudum v. leviter alreolatum. Corollae radii bilahiato-ligulatae, labio exteriore amplo, ligulaeformi, interiore brevissimo v. obsoleto, dis $\mathrm{i}$ i regulares quinquefidae, laciniis tubo brevioribus, revolutis. Sta $\mathrm{m}$ in $\mathbf{n m}$ filamenta distincta, plana, glabra, a n th e rae di s c i exsertae, candatae, alis brevibus, r a dii obsoletae. Stylus puberulus. A e henia villosa, cylindracea, erostria. P a p p a pluriserialis, setnso-paleaceus, longus. - Frutices c apenses; foliis alter nis, confertis, sessilibus, membranaceis, integerrimis, mucronatis, tomento supra plus minusve obso leto, subtus persistente vestitis, capitulis solitariis, ramos usque ad apicem dense foliatos terminantibus,

Printzia Cassint in Dict, sc. nat. XLITT. 324. Lessing in Linnaea $V$. 274. Synops. 108. Inula c a erule a Linu. et l. aromatica Linn.

2D3\%. Perdieivan LAGASC. Ca pituI $\mathbf{~ m}$ heterogamum, multi- et aequaliflorum, diseoideum, fluribus marginalibus uniseriatis, femineis reliquis hermaphroditis. Involucri cylindracei squamae foliaceae, multiplinerves, acuminatae, interiores majores, $R$ ecepta $\mathbf{c u} / \mathbf{n} \mathbf{m}$ breviter paleacco-fimbriliferum, fimbrillis in areolas superficiales connatis. Corolla e bilabiatae, labiis in disco aequilongis nunc, exteriore bidentato et interiore trifido, nuns, interiore bipartito et exteriore tridentato, in radio inaequalibus, exteriore lignlacformi, apice tridentato, interiore bipartito. Staminum flamenta distineta, plana, glabra, a $\mathrm{n}$ b era caudatae, alis obtnsis, in radio nullae, Stylus apice pilusulus. A shenia papulesa, olcompressa, multicustata, erostria, callo apicali annuliformi pappi basim eingente, nectario alveolari. P a p p s multiserialis pilosus, scaber, demum invelucro longior, cum callo an- nulari caducus. Herba capensis, perennis, humilis, simplicissima, demum glabrata, ima basi foliata; foliis membranaceis, runciratis, floribus albis.

Perdicium Lagasca Amenit, nat. I. 39. DC. in Annal. Mus. XIX. 66. Cassini in Dict. sc. nat. LY. 393. Lessing in Linnaea $V$, 348. Synops. 120. P a r d is $\mathrm{i}$ u m Burmann Flor. cap. 26. P. s e miflos culare Linn. P. T a$r$ ax a ci Vahl in Act, soc. h, n. Hafn. X. 9. $t .1$.

2933. A ma alleta SIEGESB. Ca p it u $\mathrm{l}$ u m heterogamum, multi- et aequaliflorum, discoideum, floribus marginalibus uniseriatis, femineis, reliquis hermaphroditis. Invo In eri turbinati v. subeoaici squamae foliaceae, pauciseriatae, interiores majores. Receptaculum nudum. Corolla e glabrae, bilabiatae, limbo haud inflato, labiis in hermaphroditis aequalibus, exteriore in femineis majore. S $\mathrm{ta-}$ m in un filamenta distincta, plana, glabra, antherae candatae, alis obtusis, in radio nullae, Stylus apice puberulus. A chen i a pilosa, rostrata, rostro lato, areola terminali. $\mathrm{Pa}$ P $\mathrm{p} u \mathrm{~s}$ pluriserialis, eapillaris, scaber, longus, subaequalis. Herbae sibiricae, perennes; caulibus teretibus, erectis, simplicissimis, nonnisi ima basi foliatis, foliis membranaceis, obovato-oblongis, sinuato- v. lyrato-dentatis, sublus plus minus tomentosis, capitulo terminali solitario, parvo.

A n a d ria Siegesbeck in Linn. Amoen, acad, $T$. $16 t$. Lessing in Linnaca V.346.t, 3.f.88, t, 4. 101. 103-110. Synops. 120. L ef $\mathrm{n}$ itzi a Cassini in Dict, sc, nat, XXV. 920 . T us. silaginis s p. Linn. Hort. Upsal, t, 3. Gmelin Sibir. t, 67 . f. 2. $t, 68 . f .1$, Perdieii s p. R. Browa.

SUETERE II. LERIEAE Lessing Synops. 120. Capitula multiflora, heterogama, floribus marginalibus uni-pluriseriatis, femineis, reliquis masculis $v$. hermaphroditis. Corollae radii bilabiatae v. ligulatae, disci bilabiatae v. regulariter quinquedentatae. Antherae caudatae. Stylus tenuior; stigmatibus aequalibus, truncatis, extus superne aequaliter puberulis. - Herbae tomentosae, scapigerae, foliis membranaceis, capilulo terminali solitario, inconspicuo.

2934. Chaptalia VENT. Ca p it ul u m multiflorum, heterngamum, radiatum, radio biseriato femineo, disco masculo. In volucri campanulati, diseum aequantis foliola linearia, acuminata, uninervia, extus albo-tomentosa. R e c e p tacuI u nudum. Corollae radii ligulatae, ligulis seriei exterioris involucro styloque longioribus, seriei interioris atroque brevioribus, disci bilabiatae, labiis aequilongis, exteriore profunde tridentato, interiore bipartito, laciniis apice giblis. Staminnm filamenta pubescentia, antherae caudatae, alis obtusis, radii nullae. Stylus conformis, basi attenuątus, ovariis disci inanibus. A chenia glabra, multicostata, rostrata, rostro valido, $\mathbf{P}$ a p p $\mathbf{s}$ biserialis, capillaris, longus, aequalis. - Herbae perennes, in America boreali et a ustrali, nec non in India orientali observatae; caulibus simplicissimis, nonnisi ima basi foliat is, folits conferte alternis, spathulato-oblongis, mucronulato-dentatis, subtus albo-tomentosis, capitulo terminali, solitario.

Cha ptalia Venten. Cels. $t$. 61. DC. in Annal. Mus. XIX. 66. Cassini in Dict. sc, nat. VIIT, 161. XXVI, 40t, Lessing in Linnaea $V$. 351. Synops. 121. Rogle Himalay. l. 59. Tus 8 ilagiaia s p. Linn. Michaux. 
2935. Leria DC. Capitul um multiflorum, heterogamum, radiatum, radio pluriseriali, femineo, diseo hermaphrodito. Involucri campanulato-cylindracei, disco paullo longioris foliola linearia, acuminata, uninervia, extus albo - tomentosa. Receptaculam nudum. Corollae radii ligulatae, ligulis seriei extimae stylo pappoque longioribus, apice tridenticulatis, interiorum fere obsoletis, brevioribus, disci bilabiatae, labiis aequilongis, exteriore tridentato, interiore bipartito, laciniis apice gibbis. Sta min um filamenta glabra, a ntherae caudatae, alis obtusis $v$, truncatis, radii nullae. Stylus basi aequalis. Achen ia sparse papulosa, elliptico-Ianceslata, quinquecostata, rostrata, rostro longissimo, filiformi. $P$ a pp us capillaris, pluriserialis, brevis v. mediocris. Herbae in Antillis et Americae continente intratropico vulgatae, acaules; foliis radicalibus spathulato-oblongis, integerrimis v. sinuato-ly ratis, subtus albo-tomentosis, scapis nutantibus.

Lerla DC. in Annal. Mus. XIX. 68. excl, sp. Cassini in Dict. sc, nat. XXYT. 101. Lessing in Linnaea $V, 353$. Synops. 121. T ussilagi $\mathrm{n}$ is sp. Linn. et Auet.

2536. Theberkuhnia CASS. C a pitu$1 \mathrm{um}$ multiflorum, heterogamum, radiatum, radio biseriato, femineo, disco masculo. Involucri turbinati, radium aequantis foliola lineari-acuminata, trinervia, margine scariosa. Receptacu I um obsolete alveolatum. Corollae ra dii ligulatae, ligulis seriei exterioris lineari-ellipticis, stylo tuboque longioribus, interioris multo brevioribns obsoletis, di $\mathrm{ci}^{\mathrm{b}}$ bilabiatae, labiis fastigiatis, exteriore trifido, interiore bipartito. St a min um filamenta glabra, a n th e ra e caudatae, alis obtusis, in radio nullae. St y lu s basi attenuatus, ovariis disci inanibus. A ch e nia basi ima papulosa, quinquecostata, rostrata, rostro tenui, filiformi. Pap p us capillaris, pluriserialis, brevis, aequalis. - Herba montevidensis, pusilla, scapigera, Hieracii Pilosellae habitu; foliis radicalibus oblongoobovatis, basi in petiolos planos angustatis, margine dentalo-runcinatis $v$. subintegerrimis, scapis pluribus, basi squamosis, caeterum aphyllis, filiformibus, flexuosis, niveo-tomentosis, capitulo solitario terminatis.

Lieberkuhnia Cassini in Dict. sc. nat. XXVI. 286. Lessing in Linnaea $\nu$. 355. Synops. 122. P erd fe i u m p iJosell oides Vabl in Act. soc, $h, n$, Hafn. $I T, 38, t$, s.

293 \%. Dxy don LESS. C a p itul a m multiflorum, heterogamum, radiatum, radio biseriato, femineo, disco masculo. In vol u cri turbinati, flores superantis foliola lineari-lanceolata. Re ceptaculum nudum. Corollae radii lignlatae, ligulis seriei exterioris obovato-linearibus, involucro stylisque longioribus, seriei interioris brevioribus. fere obsoletis, dis ci regulares, limbo tubo parum ampliore, quinquedentato. St $\mathrm{am} \mathrm{in} \mathrm{u} \mathrm{m}$ filamenta glabra, an the rae caudatae, alis obtusis, superne rigido-ciliatis, in radio nullae. Stylus basi attenuatus, A ch e ni a glabra, quinquecostata, rostrata, rostro longissimo, filiformi. P a p p us capillaris, pluriserialis, brevis, aequalis. - Herba NovoGranatensis, andicola, gracilis, parvula; foliis radicalibus petiolatis, obovatis, runcinato-dentatis, sublus niveo-tomentosis, scapo simplicissimo, remote squamoso, capitulo solitario terminato.

$0 \mathrm{x} y \mathrm{~d}$ an Lessing in Linnaea $\nu$. 357. Synops. 122. Chaptalia runciuata Konth in Humb, et Bonpl, Nov. gen. et sp. $t, 303$, Lox od ont is $s$. Cass.

2938. Loxodon CASS. Cap itu $\mathrm{um} \mathrm{mul}$ tiflorum, heterogamum, discoideum, floribus mar- ginalibus pluriseriatis, femineis, reliquis hermaphroditis. Invo I c cri turbinato-campanulati, floribus longioris foliola oblongo-ovata, obtusa, multinervia, margine anguste scariosa, glabra, Receptaculum nudum. Corollae femineaje ligulatae, ligulis brevissimis, serierum interiorum sensim decrescentibus, $h$ erma $p$ h rod it a e regnlares, limbo quinquedentato. S $\mathrm{ta} \mathbf{m} \mathrm{inm}$ filamenta glabra, a nthera e caudatae, alis obtusis, in floribus marginalibus nullae. $S^{t}$ y I n s basi aequalis. A che ni a papuloso-pilosa, oblongo-obovata, erostria. P ap p us capillaris, multiserialis, longus, inaequalis. - Herba in America austra. li extratropica indigena; folitis radicalibus oblongo-obovatis, plus minus sinuato-dentatis, subtus albo-tomentosis, scapo simplicissimo, brevissimo, capilulo solitario terminato.

L o x od on Cassini in Dict, sc, nat. XXVIT. 254. excl. sp. Lessing in Linnaea $V$, 358. Synops, 122. L ex i a ex$8 \mathrm{capa}$ DC.

2939. Chevreulia CASS. Capit $\mathrm{ln}$ m multiflorum, heterogamum, discoideum, floribus marginalibus pluriseriatis, femineis, centralibus hermaphroditis. Invo l u cri primum cylindraceooblongi, demum turbinati, flores aequantis foliola ovata, lucida, nninervia, margine scariosa, interiora multo longiora. R e c e p ta cul u m nudum. C orollae tenues, femine a ligulatae, ligula angustissima, apice dentata, tubo multo breviore, m a s a la e regulares, limbo quinquedentato. St aminum filamenta glabra, an the rae caudatae, alis obtusis, in floribus marginalibus nullae. Stylus basi attennatus. A chenia paberula, obcompressiuscula, bicostata, costis angularibus, rostro longo, filiformi, P a p us capillaris, uniserialis, corollam aequans. - Herbae aguanatica et brasiliensis, pusillae, ramosae; foliis oppositis, confertis, semiamplexicaulibus, sublinearibus, integerrimis, subtus albo-tomentosis, capitulis parvis, ramos filiformes, superne aphyllos terminantibus.

Che v reuli a Cassini in Dict. sc, nat. VIII, 516. Lessing in Linnaea $V .360$. Synops. 128. Xeranthenum c a es pitos u m Thouars Elor. aguanat, $t .8$.

SUBTRIBUS HII. FACELIDEAE Lessing Synops. 123. Capitula multiflora, heterogama, floribus marginalibus uni-pluriseriatis, femineis, centralibus paucis, hermaphroditis v. neutris. Corollae radii uniseriati obsolete ligulatae, pluriseriati filiformes, dis c i regulariter quinquedentatae. Antherae calldatae. S t y l u s tenerrimus, stigmatibus truncatis, inclusis, extus superne puberulis. Herbae gnaphaliodeae, tomentosae, humiles, capitulis inconspicuis, oblongis, caulem ramosque usque ad summum apicem dense foliatos terminantibus, solitariis v. spicatis.

2940. Iueblia CASS. Capitul $\mathrm{m}$ multiflorum, heterogamum, brevissime radiatum, radio uniseriali, femineo, disco hermaphrodito. In v oI u cri radium aequantis foliola exteriora ovata, scariosa, interiora lineari-elongata, membranacea, margine scariosa. R e ceptacul a m nudum. Corolla e radii ligulatae, ligula angustissime lineari, apice dentata, tubo breviore et angustiore, di sci longe tubulosae, limbo brevi, quinquedentato. An th er a eaudatae, alis ellipticis, obtusis. A ch en $\mathrm{i}$ a dense villosa, obovata, obcompressiuscula, 
erostria, areola terminali. $P$ appus setaceo-capillaris, uniserialis, setis longis, aequalibus, basi inter se conferruminatis ramosus. - Herbae $B$ ra. siliae meridionalis; cauliculis ex eodem rhisomate plurimis, tomentosis $v$. subvillosis, foliis al. ternis, sessilibus, confertis, membranaceis, linearibus v. sublinearibus, integerrimis, planis, uninerviis, aveniis, utrinque incanis, capitulis terminalibus, solitariis $v$. simpliciler breviterque spicatis.

L u cili a Cassini in Dict. sc, nat. XXV1T. 263. Lessing in Linnaca $V .362$, t. 4. f. 128 - 132. Synops. 123.

2\$41. DIigranallea LESS. CapituIum multiflorum, heterogamum, discoideum, floribus marginalibus pluriseriatis, femineis, centralibus paucis, masculis. Invol u eri cylindracei foliola scarioso - nitida, exteriora breviora. $R$ e $c$ ep $t$ a $\mathbf{c u}$ I u m nudum. Corollae glaberrimae, graciles, filiformes, femineae stylo breviores, masculae crassiores. Antherae ..... A ehenia villosissima, ovoidea, erostria. Pappus biserialis, serie exteriore ramosa et setacea, interiore pilosa. - Fruticuli brasilienses, humiles; caulibustomentosis, foliis alternis, confertis, nunc membranaceis, oblongo-ellipticis, erecto-patentibus, nunc parvis, triangularibus, adpresse imbricatis, supra argenteo- subtus niveo-tomentosis, capitulis terminalibus, solitariis $v$ in apice caulium spicatim aggregatis.

0 Iig a ndra Lessing Synops. 103.

2948. Facelis CASS. Capitulum multiflorum, heterogamum, discoideum, floribus marginalibus pluriseriatis, femineis, centralibus paucis, hermaphroditis. I n vol u cri flores aequantis squamae exteriores ovatae, scariosae, interiores lineares, membranaceae, margine scarioso cinctae. Rece pta cul um nudum. Corolla glabrae, graciles, femineae breves, masculae paullo erassiores, longiores, limbo brevissime quinquedentato. A ntherae caudatae, alis ovato-lanceolatis. A chenia villosissima, ovoidea, erostria. Pa p p u uni serialis, plumosus. - Herba Brasiliae meridio $n$ a $l i s$; caulibus erectis $v$, adscendentibus, simplicibus $v$. ramosissimis, lanato-tomentosis, foliis alternis, confertis, sessilibus, membranaceis, flaccidis, obovato-linearibus, integerrimis, apice obtusis $v$. retusis, saepius obsolete tricrenatis, utrinque tomentosis, capitulis in spicam terminalem, confertam approximatis.

F a cells Cassini in Dict. se, nat, XVI. 104. Lessing in Linnaea $V .364$. t. 4. f. 133_135. Synops. 125. $6 \mathrm{n} \mathrm{a-}$ p lialím retus um Lam.

TERIBUS VIr. NASSAUVIACEAE Lessing Synops. 396. Ca p i t u la pauci-multiflora, homogama $v$, rarissime subheterogama, aequaliflora, radiatiformia, nunquam dioica. R e c e ptacul um saepissime epaleatum, rarius totum v. margine tantum paleatum. C or olla e tenerae, pellucidae, bilabiatae, labiis apice revolutis, exteriore multo majore ligulaeformi, tridentato v. rarius trifido, interiore bidentato $v$. bipartito. Antherae caudatae, alis oblongis, latis. Stylus aequalis, nec nodoso-inerassatus, stigmatibus linearibus, longiusculis, truncatis, apice solo penicillatis. - Species omnes americanae, paucissimae inter tropi cum cis aequatorem provenientes, longe plurimae in regione extratropica australi indigenae.

\section{SUBTEIIBUS I. POLYACHYRIDEAE.} Capitula biflora, homogama?

F943. Pollyaelaynas $L A G A S C$, C a p it uI a biflora, homogama, subheterucarpa, flore altero achenio minore pappoqne breviore donato prins evoluto, in glomerulos subglobosos congesta. Involucri tri-pentaphylli foliola membranacea, inermia, florihus breviora, extimum saepius basi glandulosam. Rece pta e uli bracteola unica, involueri fuliolis simillima, florem serius evolutum amplectens, Corolla e conformes, bilabiatae, labiis subaequilongis, exteriore latiore tridentato, interiore bifido. An $t$ hera e caudatae, in flore serius evoluto inelusae. A chenia erostria, pilosa, floris praecocioris brevius, efoetum (?) Pap p i uniseriati paleae plurimae, angustissime lineares, subplumosae, floris praecocioris longiores, rariores et inaeynales. - Herbae chilenses, basi foliatae, superne aphyllae et obsolete tomentosue; foliis alternis, basi auriculato-semiamplexicaulibus, pinnatisectis, laciniis divergentibus, capitulis plurimis, dense glomeratis, cum lana intermixta in glo. merulos subglobosos, ramos superne aphyllos terminantes confertis.

P o l y a e h y u s Lagasea Amen, nat, $I$. 37. DC. in An. nal. Mus. XVI. 68. Lessing in Linnaea V. s. t. 1. f, G, 9-14. Synops. 400. Don in Linn. Transact. XVX. 230. Pöppig et Erdlicher Nov. gen. et sp. I. 14. $t$, 23. B ridges i a Hooker in Bot. Mircell. IT. 222, t.92. Dia $\mathrm{ph}$ or a $t$ h u s Meyeu Reise 1 . 406. Cephaloseris Póppig msc.

SUBTTERES II. NASSAVIEAE Lessing Synops. 396. C a p it ul a subquinqueflora. Involucri foliola subbiseriata, interiora amplexiflora. Receptaculum epaleatum.

2944. Nassavia COMMERS, Capitul $\mathrm{m}$ quadri-quinqueflorum, homogamum. Involucri subliseriati, flores subacquantis foliola membranacea, apice subspinescentia, exteriora breviora. R c c eptaculam epaleatum, nudum. C or oll a e glabrae, bilabiatae, labio exteriore triinteriore bidentato. An the ra e caudatae. Achen ia erostria, oblongo-obovata, compressa, glabra. Pappus nniserialis, paleaceus, paleis quatuor $\mathbf{v}$. quinque, anguste linearibus, planis, serratis, caducissimis. - Herbae perennes, caespilosae, ramosae, Americam australem extratropicam frigidam incolentes; foliis imbricatim confertis, integerrimis $v$. inciso-dentatis, parvis, capitulis in spicam terminalem subglobosam, foliis intermixtam confertis.

Nas savia Commerson ex Jussieu Gen, 197. Lam, t, 721. DC. in Annal. Mus. XIX. 67. Cassini Opusc. phytolog. II. 176. Lessing in Linnaca V. 4. $t, 1, f$. 8. Sysops. 399. Pöp. pig et Endlicher Nov. gen. et sp, $t$. 21. 22. Brouguiart ad Duperr. t. 86. N as 5 ovia Pers, Ench, II, 499.

2945. Mastigophorus CASS. C a $\mathrm{p}$ itu lu m quinqueflorum, homogamum. Invol u eri floribus brevioris foliola sulbquina, uniseriata, aequalia, coriacea, rigida, spina brevi terminata. R ecep ta cu lam epaleatum, nudum. Corollac glabrae, bilabiatae, labio exteriore tri- interiore bidentato. Anth era e caudatae. A chenia erostria, turbinata, glabra. P a P p u s biserialis, paleis duodenis quindenis, obovato-lanceolatis, planis, apice fimbriatis, inferne longe attenuatis. - Herba in insulis Maclovianis indigena, diffusa, ramosissima, subglaberrima; foliis imbricatim confertis, amplexicaulibus, coriaceis, ciliatis, integerrimis tecta, capitulis terminalibus, solitariis, sessilibus. 
Mastigophorus Cassini Opusc. phytolog. II. 178. Annal.sc, nat. V. p. 103, t. 3.f. 5. Lessing in Linnaea V. 2. t. 1 . f. $1-3$. Synops. 396. Nas 8 avia Ga ud ichaudil Cass.

2946. Triachne CASS. Capitulum quinqueflorum, homogamum. Invo I u e r i biseriati foliola interiora quina, mucronata, exteriora breviora, mutica. R ecepta c $\mathbf{l} \mathbf{l} \mathbf{m}$ epaleatum, nudum. Corolla e glabrae, bilabiatae, labio exteriore tri- interiore bidentato. Anth er a e caudatae. A ehe nia erostria, obovata, glabra. Pappi longissimi paleae tres v. quinque latae, oblongoobovatae, basi angustatae, canalieulatae, glabrae, medio crasso-coriaceae, margine scariosae. Planta magellanica, bipollicaris, lignescens, diffusa, ramosissima, tota foliis imbricatim confertis, semiamplexicaulibus, inferne cilato - dentatis, superne coriaceis, integerrimis tecta, capitulis terminalibus, glomeratis.

Triachue Cassini in Bullet. soc. philomat, 1817. p. 11. 1818, p. 48. Dict. sc. nat. LV. 181. Opusc, II, 176. Lessing Synops. 392 .

2945. Triptillon RUIZ et PAV. C a pit u $1 \mathbf{~} \mathrm{m}$ quinqueflorum, homogamum. Involucri biseriati, floribus brevioris foliola decem, carinata, spinula terminata, exteriora patentia, coriacea, interiora erecta, margine scariosa. $R$ e e p ta $\mathbf{c} \mathbf{u}-$ I um epaleatum, piloso-fimbrilliferum. Cor olla e bilabiatae, labio exteriore multo latiore tridentato, interiore bidentato v. bifido. Anthera e caudatae. A eh enia erostria, obpyramidata, costato-tri-tetraquetra, pilosa v. glaberrima. $P$ a p p i uniseriati, longi paleae ternae-quinae, latae, subconduplicatae, apice recurvo longe fimbriatae v. ciliatae, intus saepius pilosae. Herbae chilenses, erectae, humiles; foliis rigide membranaceis, alternis, sessilibus, varie pinnatifidis, lobis spinescentibus, superioribus semiamplexicaulibus, capitulis fasciculatis $v$. glomeratis, caerulescentibus,

Triptilion Ruiz et Pav. Prodr. 102. DC. in Annal. Mus. XIX. 67. Kuath in Humb. et Bonpl. Nov. gen. et sp. IV. 362. Cassini Opusc. IT, 174. Don in Linn. Transaet, XVI. 220. Lessing in Linnaea $V .3$. Synops, 397 . N a 8 s a v la e sect. 2. et 3. Don in Edinb. new philosoph. Magaz. 1832. Apr, p. 399.

a. EUtriptibios. Receptac u l um villosum. Achen i a glaberrima, pappi paleis tribus.

Triptilio a Ruiz et Pav, Op cit. t. 22. DC. Op. cit. 1.3. f. 3, Lessing in Linnaea V. 1. 1, f. 4. 57. Bot. Mag. 2. 853. Nas s a via e sectio 3. Don in Edinb, now. philos. Magaz. 1832. Apr. p. 399. Triptilii seet.1. et 2, Don in Linn. Transact, XVI, 220, et 229.

b. ACANTHOPHYLLUM. R e cepta cul u m subvillosum. A che $\mathrm{x}$ ia villosissima, pappi paleis tribus va quinque.

A ca a thophy $1 /$ um Hook. et Aruott in Bot. Mag. Compan. T. 32. N a \& savilae seetio 2. Don in Edinb. new philosoph. Magaz. 1832. Apr. p. 399. Triptilil sectio 3. Don in Linn. Transaet, XVI. 283.

2948. Famargyenm LAGASC. C a pit ulum quinqueflorum, homogamum. Invelu eri biseriati, floribus brevioris foliola subdena, carinata, spinula terminata, exteriora patentia, coriacea, interiora ereeta, longiora, margine seariosa. Receptaculum epaleatum, nudum. Corolla e bilabiatae, labio exteriore multo latiore tridentato, interiore bifido, revoluto, Antherae candatar. A ch e n i erostria, oblonga, glaberrima. Pa p p i uni-biseriati, longi paleae plurimae, subpersistentes, angustissime lineares, acuminatae, serrulatae. Fruticuli chilenses, Triptilii habitu; folits alternis, aridis, aculeato-pinnatifidis, capitulis solitariis v. fasciculatis.

P a u $\mathrm{rg}$ yru w Lagasea ex $D C$, in Annal. Mus, XIX, 67. Doa in Edinb. new. philosoph Magaz, 1832, Apr, p. 390 , Peata at hits Lessing Synops. 397. a. PIPTOSTEMma Don. Papp us uniserialis. - Piptoste $\mathrm{mma}$ Don l. c. Pe nt a a thus Lessing $l$. c. Nassavia a e uleata Pöppig et Endlieher Nov. et sp. $t .20$.

b. PANargXrum Don. Pappus biserialis. - Panar. g y ri sect. 1. Don $l$. $c$.

9949. Caloptilizam LAGASC. Ca pituI $\mathrm{m}$ quinqueflorum, homogamuın. Involuc ri biseriati serie quavis pentaphylla, foliolis exterioribus angustissime linearibns, interioribus ovatis. Receptacu I um minimum, nudum. Coroll a e bilabiatae, labio exteriore majore, tridentato, interiore bifido. Antherae eandatae. A chenia erostria. Pappus longus, plumosus. - Herba chilen sis, pygmaea, Nassaviae nivalis habitu; folïs undique imbricatis, coriaceis tecta, capitulis glomeratis, glomerulis sessilibus.

Calo ptiflum Lagasea Amen, nat, $I$. 402. Lessing Synops. 400. Sphae rocephalus Lagasca ex DC. in $A n$. nal. Mus, XIX, 67. Portalesta Meyen Reise I, 316.

SIIB'TRIEUS III. TRIXIDEAE Lessing Synops. 400. Capitula quinque-multiflora. Involucri foliola bi-pluriseriata. Receptac ul $\mathbf{u m}$ epaleatum v. paleatum.

2950. IP am plasulea $L A G A S C$. C a p itnI $\mathbf{m}$ pluriflorum, homogamum, aequaliflorum. Involucrum campanulatum, uniseriale, floribus brevins, basi saepius foliolis carinatis, truncatis, denticulatis, margine seariosis auetum. $\mathbf{R}$ ecepta culu m planum, totom epaleatum, minutissime fimbrilliferum. Co roll a e pilis brevissimis, carnosis obsitae, bilabiatae, labiis revolutis, exteriore ampliore, apice tricrenulato, interiore bidentato. A n thera rum eaudae integrae, alae obtusiusculae, longae. A ch en ia erostria, obcompresso - tetraquetra, costata, obovata, papillosa, callo basilari, disco epigyno parvo, areola terminali. Pappus nullus. - Herbae brasilienses, paludosae, lucidae, fragiles, glaberrimae v. asperae; foliis infimis petiolatis, petiolis dilatatis caulem amplectentibus, superioribus sessilibus, omnibus teneris, reticulato-venosis, caulibus dichotome ramosis, capitulis solitariis parvis, ramos elongatos, divergentes terminantibus.

Pa mphale a Lagasca Amen. nat. I. 34. Cassini in Bullet. soc. philomat, 1819. p. 111. in Dict, sc, nat, XXXVII. 345. Lessing in Linnaea V. 6, t. 1. f. 15-17. Synops. 6. Ceratolepis Cassini msc.

2951. Cepha lopappus NEES et MART. Ca pitul um pluriflorum, homogamum, aequaliflorum. Involueri hemisphaerici, floribus bre. vioris foliola triseriata, oblonga, obtusa, exteriora breviora. Receptac ulum planum, totum epaleatum, minutissime papillosum. Corollae pilosae, bilabiatae, labio exteriore erecto, tridentato, interiore patente, bifido. Anther arum caudae integrae alae obtusae. A ch en i rostrata, lanceolata, disco epigyno capitiformi magno, areola terminali. Pappus nullus. - Herba brasili en sis, subacaulis; foliis radicalibus ovato-oblongis, acutis, dentatis, subtus sublanatis, scapiselongatis, dicephalis, rufo-lanuginosis.

C ep balop a p p u s Nees et Martius in Nov. Act. N. C. $X I I .5, t, 1$.

2552. Pleocarplaus DON.C a p it u 1 u m pluriflorum, homogamum. Invol u cri imbricati squamae triseriatae, squamis membranaceis, lanceolatis, acnminatis, interioribus sensim longioribns. R e e pta e u li plani paleae rigidae, carinatae, margine scariosae, lanceolatae, acutae vel 
truncatae, Cor olla e glabrae, bilabiatae, labiis revolutis, exteriore latiore, ligulaeformi, tridentato, interiore bifido. An the rarum alae lanceolatae, obtnsae, caudae integrae. A chenia erostria, anguste pentagona, papilloso-scabra. P a pp u s biserialis, eapillaris, scaber. - Frutex $c h i$ lensis; foliis alternis, linearibus, sessilibus ramisque undique glandulis pedicellatis obsessis, primariis basi alia, stipulas geminas mentientia, sublunata, persistentia gerentibus, capitulis paniculatis, luteis, pappo cinereo.

Ple oca p p us Don in Linn. Transact. XVI. 228. Le5. sing Synops. 417.

2953. Pentantlaris HOOK. et $A R N$. Capitulum quinqueflorum, homogamum. Invol u c ri cylindracei, mniseriati squamae quinque, floribus oppositae, oblongae, obtusae, basi callosae, margine interiore scariosae. R ecept a c ul um epaleatum, nudum. Coroll a e bilabiatae, labio exteriore trifido, interiore profunde bifido. Ant hera e eaudatae. A ch en ia erostria, glabra, callo basilari. Pap p a s pluriserialis, setosus, seaber. - Suffrutex peruvianus, ramosissimus, Jungiae habitu; caule ramisque glaberrimis, subglaucis, foliis alternis, longe petiolatis, exstipulatis, cordato-subrotundis, quinqueangulato- $v$. septangulato-lobatis, hinc inde apiculato-dentatis, supra glabris, reticulato - venosis, subtus subpubescentibus, ramis floriferis axillaribus, apice corymbosis, corollis albis, pappo sordide fulvo.

Pentanthus Hooker et Arnott in Bot. Mag. Compan. 1. 32. in not, non Less.

2954. Jumgia LINN. F. Ca pitulum multiflorum, homogamum, radiatiforme. InvoI u cri campanulati, polyphylli, flores subaequantis squamae foliaceae, biseriatae, exteriores inaequales, planae, patentes, interiores longiores, erectae, aequales, margine scariosae, amplexiflorae. R e ceptac ul n m planum, paleis membranaceis, oblongis, achenia amplexantibus. Corol. I a glabrae, bilabiatae, labio exteriore majore, tridentato, florum marginalium ligulaeformi, interiore bifido. Antherar um alae lanceolatae, longae, caudae integrae. A chen i a breviter rostrata, oblonga, hispido-pubescentia, multieostata, diseo epigyno magno, neetario styliformi, callo basilari, areola terminali. P a p pi uniserialis paleae angustissime lineares, plumosae, aequales. Herbae v. suffrutices, in America australi crescentes, plus minus pubescentes; foliis alternis, longe petiolatis, tri-quintuplinerviis, subrotundis, quinque-septemlobis, petiolis saepissime basi stipulis geminis, sessilibus, foliis simillimis, sed multo minoribus instructis, capitulis varie paniculatis $v$, racemosis,

J u n g i a Linn. f. Suppl. 58. Lagasca Amen, nat. I. 36. DC. in Annal. Mus. XIX, 67. Cassini in Dict. sc, nat, XXIV. 283. Lessing in Linnaen $\nu$. 35. Synops. 407. Trinacte Gärtn. IT. 415. $\mathrm{R}$ h $\mathrm{i}$ n a e $t \mathrm{i} \mathrm{n}$ a Willdenow in Berl. Magaz. 1807. p. 139. - D nmerilia Lagasca ex $D C$. in Annat. MLus, XIX, 64, $2,15,16$. Cassini $O p$. cit, XIII, 553, Martrasia Lagase. Amen. nat. I. 36. Cassini Op. cit. XXIX. 294. Opusc. II. 152.

2955. TIoselnaria RUIZ et PAV. Capitulum multiflorum, radiatiforme, heterocarpum. In vo In eri uniseriati, eampanulati, floribus brevioris squamae foliaceae sex, ovatae, acuminatae, concavae. Receptaculi plani, centro subalveolati paleae membranaceae, extimae condnplieatae, obliquae, subpenninerviae, reliquae plus minus planae, lineari-lanceolatae, uninerves.
Corolla tenerrimae, sparsim pilosae, bilabiatae, labio exterivre apice tridenticulato, marginalinm ligulaeformi, interiore bifido. An $\mathbf{t h}$ era $\mathbf{r} \mathbf{m}$ alae lanceolatae, longae, caudae integrae. A chen ia interiora sterilia, calva, seriei extimae fertilia, receptaculi paleis omnino involuta, compressa, obovata, obliqua, breviter rostrata, rostro inaequali extrorsum gibbo, callo basilari, disco epigyno magno. P a p p u s uniserialis, paleacens, plumosus, brevis, aequalis. - Herba chilensis, annua, superne in paniculam dichotomam divisa; folits alternis, amplexicaulibus, pilosiusculis, pinnatisectis, inferioribus confertis,

Moscharia Buiz et Pavon Prodr. 103. Lessing in Linnaea $P$. 39. $t$. $1 . f .39-49$. Synops. 417. M o s c b if e r a Molina. - Mosiegia Spreng. syst. IIT. 661. Gastroc a rpha Don in Linn. Transact. XVI, 232. Sweet Fl, Gard, IT. t. 299.

2956. Teulueria $L A G A S C$. Ca pitulnm pluriflorum, homogamum, radiatiforme. Invoi cri campanulati, flores subaequantis squamae biseriatae, membranaceae, exteriores acutae. R eceptaculi plani, centro nudi paleae marginales uniseriales, scariosae, late ellipticae, mueronatae, serrulatae. Corolla glabrae, bilabiatae, labio exteriore latiore, florum marginalium ligulaeformi, tridentato, interiorum bifido. An th era r nm caudae lanceolatae, obtusae, alae integrae. A c h enia erostria, turbinata, hirsuta. Pappus uniserialis, breviter plumosus. - Herbae chilenses, erectae, annuae; caulibus teretiusculis, foliis alternis, inferne confertis, tenere membranaceis, pinnatifidis, superioribus subintegris, omnibus tomento, supra tenero et fugaci, subtus persistente albo vestitis, capitulis paniculatis.

L e ceria Lagasca Amen, nat. $\boldsymbol{X}$. 32. DC. in Annal. Mus. XIX. 66. Le u ch a eria Lessing Synops. 401. Mar. tr a s i a Spreng. Gen, $n, 3110$. nou Lagasca. Le uceria e sect. 1. Dou in Linn. Transact. XVI. 213. Le u cha eriate sect. E u le u c ha e r i a Hook. et Arnott in Bot. Mag. Com. pan. $T$. 35. Trixidis s p. Hooker Exot, Flor, t. 101.

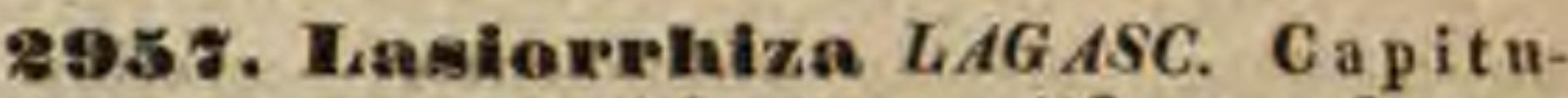
I $\mathbf{m}$ homogamum, multi- et aequaliflorum. In voI u eri subbiseriati, floribus brevioris foliola aequalia, membranacea, plana, adpressa. R eceptaculum planum, totnm epaleatum. Corollae glabrae, bilabiatae, labiis revolutis, exteriore ampliore, ligulaeformi, tridentato, interiore bidentato. Antherarum caudae integrae, alae longae, obtnsiugculae. A $c$ h en i a erostria, papillosa, basi attennata, disco epigyno magno, areola terminali. Pap p u uniserialis, plumosus, longus, aequatis, anguste paleaceus, paleis linearibus. Herbae magellanicae et chilenses, simplices, superne subaphyllae; folits alternis, membranaceis, inferioribus plerumque pinnalifidis v. pinnatisectis, capitulis purpurascentibus.

Lasiorrhiza Lagasea Amen. nat. $I$, 32. Cassini Opusc, phytolog. II, 132, 158, Dict. sc, nat, VIII, 46. $X$ LIII, 80, Lessing in Linnaea $V, 10, t, 1 . f .21,23-26$. Synnps. 40s. Chabraea DC. in Annal. Mus. XIX. 65. Bertolouia DC. Op. cit. t. 14. Frageria DC. msc. Perdicii s p. Vahl in Act, soc. h. n. Hafn. I, 9. t. 3. Le uceriae sectio C assiopea Don in Edinb, new, phi. losoph. Magaz. 1832. Apr. p. 389.

2958. Pulluress DON. Capitulum hnmogamum, multi- et aequaliftorum. Involncri biseriati foliola subaequalia, ovato-lanceolata, apice membranaceo acuminato-radiata. R e e p taculam planum, totum epaleatum. Corollae bilabiatae, labio exteriore ampliore ligulaeformi, tridentato, interiore bifido, demum revolnto. A n- 
therarum alae lineari-lanceolatae, acutae, candae integrae. A c h enia breviter rostrata, ellipticooblonga, compressa, papilloso-glandulosa, disco epigyno parvo. P a p us biserialis, plumosus, paleis basi dilatata imbricatis, deciduis. - Herba peruviana, perennis, humilis, caespitosa, Dauci $v$. Athamanthae facie, setulis erectis, glanduliferis, confertis obsessa; foliis supradecompositis, petiolis vaginantibus, capitulis magnis, albis, ternis, brevissime pedunculatis, involucris lanatis.

Ptilurus Don in Linn. Transact. XVT, 218.

2959. Dumenoilia LESS. C a p ituln $\mathrm{ln}$ quinqueflorum, homogamum, subaequaliflorum. Invol a eri cylindracei, floribus brevioris squamae imbrieatae, triseriatae, coriaceae, adpressae, planae, interiores sensim longiores. Receptaculnm totum epaleatum. Corollae glabrae, bilabiatae, labiis florum marginalium aequilongis, exteriore latiore tridentato, interiore bifido, Anthe ra $\mathbf{r} \mathbf{m}$ alae breves, caudae integrae. A chenia papillosa, rostrata, areola terminali, disco epigyno magno, nectario styliformi. $\mathrm{P}$ a p p s uniserialis, paleaceus, longus, aequalis, paleis linearibus, serrulatis. - Frutex mexicanus, inermis; foliis rigido-membranaceis, alternis, confertis, scabris, inferioribus amplis, rotundis, semiamplexicaulibus, profunde cordatis, dentatis, capitulis fasciculato-corymbosis, albidis.

D n merilia Lessing in Linnaea V. 13, t. 1. f. 27. Synops. 407. non Lagase. DC. Proustia mexieana Don.

2960. Treixh $P$. BR, C ap itu I um multiflorum, homogamum, radiatiforme. Involuc ri teretis, floribus brevioris squamae uni-biseriatae, laxe imbricatae, planae, interiores longiores. $R$ ec e p t a c n I n m epaleatum, nudum v. saepins pilosofimbrilliferum. Cor oll a e pilosae, bilabiatae, labio exteriore latiore ligulaeformi, tridentato, interiore bifidov. bidentato, revoluto. A $\mathrm{n} t \mathrm{~h}$ e $\mathrm{ra} \mathbf{r} \mathbf{m}$ alae longae, caudae integrae. A $\mathrm{c}$ h e $\mathrm{n}$ i a breviter rostrata, multieostata, hispido-pubescentia, teretiuscula, oblongo-ovata v. ovato-lanceolata, disco epigyno magno, neetario styliformi, callo hasilari, areola terminali. P a p p s bi-pluriserialis, piliformi-paleacens, subaequalis, serratus v. snhplumosus. Herbae $v$. frutices, erecti $v$. volubiles, in In $\bar{i} \bar{a}$ orientali et in Americae australis ora orientali crescentes; foliis alternis, membranaceis, penninerviis, capitulis laxe paniculatis $v$. corymbosis, albis $v$. luteis.

T r is is P. Browne Jam, 312. Lagasea Amen. nat, 1.35. DC. in Annal. Mus, XIX, 66, Lessing in Linnaed $V .24$, Syn. aps. 113.

a. Cleanthes. Receptaculum nudum. - Herbae simplices, superne aphyllac.

Cle an thes Don in Linn. Transact. XVT. 195. P erdicil sp. Linn. (Lessing in Linnaea $V . t, T . f .31-36$. ? Platycheilus Pereziae sect. Lessing in Linnaea V. 29. Synops.413. P l at y cheilus Cassiai Opase phy. tolog. It. 133. et 168. Holo chell as Cassini in But. let. soc. philomat, 1818, p. 73. Dtet, sc, nat, XXI, 306.)

b. EUTRIXIS. Recepta c u 1 a m piloso- fimbrilliferum. Herbae $v$. frutices.

ec. OIf gophyilon Lessing Synops. 413. - Herbae simplices, superne aphyllae.

B. Poly phyllon Lessing Synops. 413, - Herbae usque ad inflorescentian dense foliatae.

$\gamma$. Prionathes Selirank Hort, monac. II. $t, s 1$. Prutices ramosi. - Te no ria Bertero msc, Peridici s p. Lian. Las. t, 677. Gairtn. II, 450. t, 150. f. 9. Kunth in Humb. et Bonpl. Nov. gen. et sp. t, 355. Bot. Mag. c. 2765 .

f.? Al cit b o é Dou Op. eit. t. 191. Frutlees. Invofucri foliola quíaque exteriora ampla, bracteiformia.
2981. Doliehlasimm $L A G A S C, C$ a $\mathrm{p}$ t u l u multiflorum, homogamum, disciforme. Involu c ri oblongi, laxe imbricati squamae biseriatae, acuminatae, interiores longiores. Rece p $t$ a $\mathbf{c u l} \mathbf{~ u m}$ epaleatum, nudum. Coroll a e bilabiatae, labiis subacquilongis, tnbo triplo brevioribus, exteriore tridentato, interiore bifido, revoluto. An therar $\mathbf{~ m}$ alae lanceolatae, breves, eaudae integrae. A ch enia rostrata, hirsuta, rostro brevi, glabro, glandulis pedicellatis obsito, diseo epigyno magno, areola terminali. Pappus uniserialis, paleis linearibus, apice breviter plumosis. - Herba peruviana, perennis, conferte glandulosa; caulibus erectis, tereliusculis, flexuosis, monocephalis, foliis alternis, petiolatis, pinnatisectis, lobis ovatooblongis, mucronatis, subintegerrimis, rigidis, terminali majore plerumque trilobo, capitulo magno, albo.

Dollehlasium Lagasca Amen, nat, I, 33. DC. in Annal. Mus. XIX. 66. Don ex Hook. et Arnott in Bot. Mag. Compan, I, 34.

2962. Perezia LAGASC. Capitulum pluriflorum, homogamnm, radiatiforme. InvoIn cri teretis, floribns brevioris foliola pluriseriata, interiora longiora. Recepta $\mathbf{c} \mathbf{u} \mathrm{lum}$ epaleatum, nudum v. piloso-fimbrilliferum. Corollac glabrae, bilabiatae, labio exteriore latiore, tridentieulato, florum marginalium ligulae forme, interioris bifidi laciniis filiformibus, spiraliter tortis. Anthe ra rum alae longae, caudae integrae. A $\mathrm{che-}$ n i a erostria, piloso-villosa, disco epigyno magno, areola terminali. Pa p pus bi-pluriserialis, piliformi-paleaceus, serratus, longus, snbaequalis, flavidus. - Herbae austro-americanae, annuae $v$. perennes; caulibus crectis, teretibus, stria tis, foliis alternis, glabris v. subglabris, inferioribus petiolatis, confertis, petiolis striatis, planis, basi dilatata caulem amplexantibus, superioribus sessilibus, minoribus, saepissime rarioribus.

Per ezia Lagasca Amen, nat.1.29. Lessing in Linnaea V. 14. Synops. 408 . non DC. - C haet a $\mathrm{n}$ thera Hamb. et Bonpl. Plant, aequinoct. $t$. 135. 136. non Ruiz et Pav. H omolanthas Boopl. msc. Homanthis Kunth in Humb. ot Bonpl. Nov. gen. et sp. II. 357. Clarionea et Homoi a n tbus DC. Prodr. inedit,

a. Clarionea DC. R ecepta e ul u m nuam.

$\boldsymbol{c}$. Euclarinnea. Involneri pauciseriati foliola foliaque cautina pinnatisecta, inermia. Petioli foliis longiores v, aequales. Flor es sulphurel, - Caules sim. plicissimi. - Herba magellanica.

Clarionea DC. in Annal. Mus. XrX. 65. Pere $z i$ a e seet. 5 . Perezia Lessing in Linnaea $V$. 23. Synops. 413. Perdicinm magella a c um Lian. Forst. Vaht in Aol. soc. h, n, Hafn. I. t. 4.

$\beta$. Droz i a Cass. Invol u eri multiseriati foliola spinoso-mucronata, exteriora spinoso-dentata, foliacea, patentia. Folía dentata v. pinnatifida, spinoso-ciliata. Capitula solitaria. Flores caerulei. - Herbae pe. ruvianae et chilenses.

Drozia Cassini in Dict, sc, nat. XXr. 413. Opusc. phyt. II, 171, Pereziae sect, Drozia Lessing Syn. ops. 410. Chaetanthera pungens Boupl. Plant. aequinoct, $t, 12 \pi$.

$\gamma$. Stenoph y 11 um Less. Involucri eampanula. ti, multiseriati foliola spinoso-mucranata, exteriora squar. rosa, spinoso-deutata. Folla linearia, integerrina, margine revoluta, spiuoso-ciliata. Ca $\mathrm{p}$ it $\mathrm{u}$ I a solitaria. F I ores caerulei. - Herbae chilenses ot magellanicae.

Pereziae sect. 3. Stenophyllum Lessing Synops. 412. Perdicium recurvatum Valal Op. cit. t. 7. Clarioncae s p. Cassini Opusc, phyt. II. 166.

b. HOMOIANTHUS DC. Recepta e a I a a piloso-fimbrilliforum.

d. Asteroseris. Involueri pauciseriati foliola foliaque integerriua, ineraia, Petioli foliis longtores. 
Flores sulphurei, Caules simplicissimi. - Herba magellanica.

Clarionea Pereziae sect. I.essing in Linnaea V.22. Synops, 413. Clarioneac sp. Cassini Opusc. phyt, II.166. Perdicium lactucoides Vahl Op. cit. t. 5 .

ع. Scolymanthus Willd. Involueri pauciseriati foliola mueronato-spinosa, integerrima. Folia spinoso-eiliata, membranacea, penninervia. $C$ a $u 1$ is simplex, in inflorescentian dichotomam divisus. Corolla e caeruleac. - Herbae peruanae, brasiliensos ot chilenses.

Scolymanthus Willdenow msc. Homoranthus DC. in Annal. Mus. $X I X, 65$. Ho mo a $\mathrm{nt}$ th u s seet. 1. Perexfae Lessiag in Linnaea $V$. 15. Synops. 408. Homotanthus et Clarioneac sp. Cassini $l$. $o$. $\mathrm{C}$ b a etanthera e $8 \mathrm{p}$. Humb. et Bonpl. Plant. aequi. noct. $t, 135$. Pe rd i cli sp. Vahl op. eit, $t, 6$.

observatio. Pereziae species a el. Llave et Le. xarz. Nov, veget. . 25. indicatac, nobis incogaitae, fide cl. Lindley Introduct, $I T$. $p, 263$, genus $\mathrm{P}$ crez $\mathrm{I}$ a DC. constituunt.

2983. A courtian $D O N$, C a p i t u l u m multiflorum, homogamum, radiatiforme. In y o. I n e ri turbinati, pluriseriati squamae imbricatae, lanceolatae, mueronatae, adpressae, deciduae. Recepta cul am epaleatum, scrobiculatum. Corolla bilabiatae, labio exteriore latiore, ligulaeformi, obtuse tridentato, interiore bipartito, revoluto. Antherarum alae lineari-lanceolatae, acutae, caudae integrae. A c h e n ia erostria (?) teretiuscula, undique papilloso-scabra, disco epigyno parum dilatato, planinsculo. P a p u s uniserialis, setis apice penicillatis, deciduis. - Fruticulus $m$ e $x i$ canus, sesquipedalis v. tripedalis, erectus, rigidus, paniculatim ramosus, glaucescens, Serratulue facie ; ramis sulcatis, glabris, viridibus $v$, sanguinolentis, foliis alternis, amplexicaulibus, cordatooblongis v. subspathulatis, spinuloso-serratis, cartilagineo - rigidis, laevibus, reticulato - venosis, summis minoribus, saepius integerrimis, capitulis in apice ramorum corymboso - glomeratis, involucris saepius sanguineo-coloratis, floribus purpureis, pappo niveo.

\section{A courtia Don in Linn. Fransact, XVT. 203.}

2964. Calopappua MEYEN. CapituI $\mathrm{m}$ sexflorum, homogamin. Inv o I n e ri campanulato-cylindracei, polyphylli foliola exteriora ovata, apice attenuata, dentata, acutissima, interiora lanceolata, acuta, glabra, rigida. R e c e ptaculum squamosum. Corollae bilabiatae Iabio exteriore apice tridentato, interiore bifido revoluto. Anth er a caudatae, exsertae. A che ni a ...... Pa p p s biserialis, paleaceus, paleis longis, latis, lucidis, serratis. - Planta chilen $s i s$, andicola; caule procumbente, ramosissimo, omnino folioso ; foliis dense imbrioatis, acerosis, acutis, basi semiamplexicaulibus, glabris, rigidis, capitulis terminalibus, solitariis, floribus sanguineis, pappum et involucri folia aequantibus.

Calopa p us Meyen Reise $I$. 315 .

OBSERVATIO, C a diseus E. Mey, et Pog on u ra DC. genera a el. Liadley Introduct. edit. II. p. 263. Illud in capite, hoc ad calcem Trixidearum commemorata, mili inco guita sunt.

SURO HED III. LIGULIFLORAE. F10res omnes hermaphroditi, ligulati.

TIE IISUS TIE. CICHORACEAE Juss. gen. 168. Cap itula homogama, radiatiformia, aequaliflora, homocarpa v. heterocarpa, smnquam dioica. Cor oll a e omes ligulatae, quinquedentatae, quinquenerves. Stylus superne cylindraceus, superne $s t i g m a t a q u e$ plus minus longa, obtusiuscula aequaliter pubescens, glandularum stigmaticarum series ante medios ramos desinentes, nuspiam confluentes. - Herbae lactescentes, rarius suffrutices, rarissime arborescentes, in hemisphaerae borealis temperatis copiosiores.

SUBTREBE I. SCOLYMEAE Lessing Synops. 126. Receptaculum paleatum. Papp us coroniformis v. paleaceus.

2965. Seolymars CASS. Capitulnm multiflorum, homocarpum. Involu e rum imbricatum, spinosum, bracteatum. R e ce p ta cu Ii pla. ni paleae carinatae, acheniis angustiores. Corolla e ligulatae. A $c h$ enia brevissime rostrata, libera. Papp $\mathbf{8}$ brevis, coroniformis, - Herba mediterranea, perennis; foliis alternis, margine cartilagineo cinctis, spinoso-dentatis, ala aequaliter spinosa per caulem decurrentibus, capitulis in caule ramisque terminalibus, subternis.

$\mathrm{S}$ e ol y u u $\mathrm{s}$ Cassini in Dict. sc, nat. XXV.60, XXXIV. 86. Lessing Synops. 126. S e o I y mus maeulat us Desfont. S. gу mи s p e r m u Gärta. $t, 15 \%$. $f$, 4 .

2985. Inyseolus CASS. Capitulum multiflorum, homocarpum. Invol a crum imbricatum, spinosum, bracteatum. Receptaculi subglobosi paleae membranaceae, obovatae, marginibus introflexis conduplicatae, achenia includentes. Corolla e ligulatae, A ehenia erostria, receptacnli paleis capsulatim inclusa et partim connata. $P$ a $\mathbf{p}$ i paleae binae, angulares, aequales, longae, una alterave minore accedente, omnes caducissimae. - Herbae med it erranea e, perennes, Scolymi facie; foliis ala deorsum attenuata decurrentibus, caule subracemoso, capitulis axillaribus, solitariis $v$, congestis.

M y $s$ col us Cassint in Dict, sc. nat, XXV, 60. XXXXIV. 83. Scolymus hispanicas et Sc. grandifloras Desfont, Flor, allant, $t, 218$. S e. a ng i os p e rmas Gärta. t. 157. f. 5. 8 c, maeulatu s Sehkubr t, 197 .

SUBTERIBUS IT. LAMPSANEAE Lessing Synops. 127. Receptaculum epaleatum. Papp us nullus.

2967. Champsana VAILL. Capitu $1 \mathrm{um}$ multiflorum, homocarpum. Invol u c ru m sinplici serie octo-decemphyllum, basi squamis brevibus calyculatum, fructifernm hand mutatum, erectum. Receptaculum planum, epaleatum, punctatum. Corollae ligulatae. A $\mathrm{chenia}$ erostria, compressa, striata, decidna. P a p p s nullus. Herbae e ur opeae, annuae, tenerae, glabrae, caulescentes; foliis inferioribus lyratis, superioribus dentatis, capitulis parvis, luteis.

$\mathrm{L}$ a m p s a in Valltant in Act. Acad. Paris, 1721, p, 180. Juss, gen. 168. Cassini in Dict, sc. nat. XXV. 209. Lessing Synops. 126. L $\pi$ p 8 a n a Tournef. inst. 272 , Gärta. $I I$. 354. 2. 157. Lapsana communis sp. Lian. Fi. dan. t. 500 . Sehkuhr $t$, 225 .

2968. SoldeviHa $L A G A 9 C$. Ca pit u $\mathrm{l}$ m multiflorum, homocarpum. Invo I a e ri basi ventricosi squamae lineares, uniseriatae, inferne connatae, apice demmm conniventes. R e c eptacuI $\mathbf{~ m}$ epaleatum, alveolato-fimbrilliferum. Corolla e ligulatac. A chenia uniformia, oblonga, striata. Pappas nullus - Herba hispanica, annua, humilis, pilis ramosis hispido-setosa; folüs integris, pedunculis clavatis, capilulis aureis. 
Soldevilla Lagasea ex Don in Edinb. new philo. roph. Journal 1829, p. 310. Lessing Synops. 127. His pidell a Barasdes in Lam. Dict. IIT. p. 134. Cassini in Dict. sc. nat, $\times x x$. 248 .

2969. A posom ELLIOTT. Capitulum pauciflorum, homocarpum. Involuc rum duplici serie octophyllum. Re e p ta $\mathbf{c} \mathbf{~ l} \mathbf{u m}$ planum, epaleatum, nudnm. Co roll a e ligulatae. A e henia uniformia, lanceolata, sulcata, transversim striata. Pa p u s nullus. - Herba caroliniana annua, glauca, glabra; folits sessilibus, integris, capitulis terminalibus, umbellatis.

$\Delta$ pogon Elliott Carolin, IT, 267.

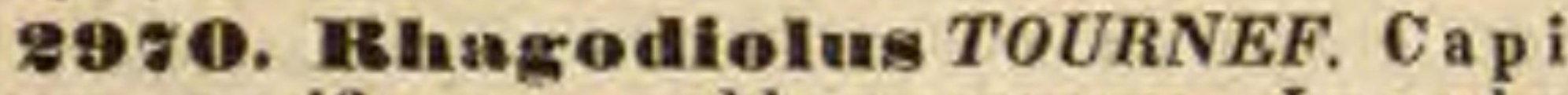
tulum pauciflorum, subhomocarpum. Involu c r u m simplici serie penta-octophyllum, basi squa mis hrevibus calyculatum, floriferum erectum fructiferum patens. Re e p ta $\mathrm{culum}$ angustissimum, epaleatum, nudum. Corollae ligulatae. Achenia erostria, arcuata, exteriora involucr foliolis involuta, et cum iisdem patentim persistentia, interiora breviora, decidua. P a P p u s nullas. Herbae mediterraneae, tenerae, annuae; foliis alternis, sessilibus, lyratis $v$. integris, oblongis, denticulatis, basi attenuatis, capitulis parvis, luteis.

$\mathbf{R}$ bagodiol us Tournefort inst, 272, Gïrtn. II. 354. t. 157. Cassini in Dict, sc, nat. $X L V$. 302, Lessing 8 jnops. 127. Lapsara edulis et Lapsaua stellata Linn. Schkuhr $t$, 225.

29\%1. IKةpinia PALL. Capitulum paneiflorum, homocarpum. Invol nernm simplici serie subpentaphyllum, basi squamis brevibus calyculatum, floriferum erectum, fructiferum patens. Recepta c $\mathbf{l} \mathbf{n}$ m angustissimum, epaleatum, nudum. A chenia uniformia, erostria, apice incnrva, latere exteriore spinosa, patentissima P a p p s nullus, - Herba da urica; foliis linearilanceolatis, integerrimis, capitulis lateralibus pedunculatis, solitariis.

K $8 \mathrm{I}_{\mathrm{p}} \mathrm{n}$ i a Pallas Reise ITT. 755. $t$. L. $t$. f, 2. Lessing Synops. 127. La ps a n K

SUATIEIRUS III. HYOSERIDEAE Lessing Synops. 127. Receptaculum epaleatum. Pap pus coroniformis v. paleaceus, paleis integris, latiusculis, saepissime brevibus.

29\% 2. Arnoseris GARTN. C a p it n $1 \mathrm{n} \mathrm{m}$ multiflorum, homocarpum. Involuerum simplici serie polyphyllum, basi squamis brevibus calyculatum, fructiferum torulosum, globose connivens. R eceptac $\mathbf{a}$ I u m planum, epaleatum, foveolato-punctatum. Cor ol ta e ligulatae. Achen i a erostria, obpyramidata, suleato-angulata. Pa pp us brevissime coroniformis, coriacens, integerrimus. - Herba europa a, annua, scapigera; foliis radicalibus obovato-oblongis, dentatis, scapis monotricephalis, pedunculis superne clavato-incrassatis, fistulosis, cupitulis luteis.

Arnoseris Gärtner $I T .355, t, 157$. Cassini in Dict. sc. nat. II, 135. Lessing Synops, 127, H y os eris miaim a Lisn. Schkuhr $t$. $22 i$.

29 33. Hedy pmois TOURNEF, Capitu$1 \mathrm{~nm}$ multiflorum, subhomocarpum. Invo In eni simplici serie octo-decaphylli, basi squamis brevi. bus calyculati foliola achenia marginalia involventia. Recepta $\mathbf{c}$ I $\mathbf{~ a m}$ planum, epaleatum, exeavato-punctatum. Corolla e ligulatae. A ehenia conformia, rostrata, teretiuscula, incurva. Pa $p$ р и s biformis, acheniis exterioribns coroniformis, dentatis, interioribus biseriatim multipaleacens, paleis longissime acuminatis, interioribus brevioribus. - Herbae mediter ranea e, annuae, diffuse ramosae, hirsutae; foliis alternis, radicalibus sinuato-dentatis, capitulis solitariis, luteis, ramos superne aphyllos, clavato - incrassatos terminantibus.

Hedypnois Tournefort inst, 271. Hyoseris Gärt. ner II. 37\%, t. 160, Lessíng Synops, 127. H. e retic a Sehkuhr i. 224.

2974. IIroseris $L I N N$. C a p i t a $1 \mathrm{am}$ multiflorum, heterocarpum. Involucri simplici serie octo - decaphylli, basi squamis brevibus calyculati foliola achenia marginalia involventia. Rece p ta c u l n m planum, epaleatum, excavato-punctatum. A ehenia rostrata, biformia, extima involucri foliolis involuta, teretia, suberosa, interiora membranaceo-alata. $\mathbf{P}$ a $\mathbf{p} \mathbf{p}$ s biserialis, paleaceus, acheniis exterioribus copiosior, angustior, inaequalis, interioribus rarior, brevis, paleis longissime aenminatis. - Herbae mediterraneae, annuae, glabriusculae, scapigerae; foliis radicalibus runcinato-pinnatifidis, scapo monocephalo, superne clavato-incrassato, capitulo luteo.

H yos eris Linn. gen, n. 916. exel. sp. Hedy pnois Gärtn. II. 372, $t, 160$. Lessing Synops, 128. A e h y ras t r u m Necker elem, $n, 104$.

8975. A poseris NECK. Capitulum multiflornm, subhomocarpum. Involueri simplici serie octo decaphylli, basi squamis brevibus calyeulati foliola achenia marginalia involventia. Receptacu l um planum, epaleatum, excavatopunctatum. Coroliae ligulatae. Aehenia confornia, rostrata, alata, obcompressa. P a p p u s biformis, acheniis marginalibus brevissimus, aequalis, reliquis submediocris, paleis longissime acuminatis, interioribus quinis, exterioribus pluribns, angustioribus, inaequalibus. - Herbae in Europa media et mediterranea indigenae, scapigerae; foliis radicalibus runcinatis, scapis apice incrassatis, capitulis parvis, luteis.

A poser is Necker elom, n. 105. Cassini in Dict. sc. nat. XLVITI. 427. Lessing Synops. 128. H yoseris foetida Linn. Waldst. et Kitaibel Plant. Hung. $t$. 49. H y o se ri s I u cida Linn.

29\%5. Catamamelhe TOURNEF. C a p itul um multifforum, homoearpum. Invol u eri squamae scariosae, nitidae multiseriatim laxe imbricatae, interiores majores. Recepta $\mathrm{en} / \mathbf{u} \mathbf{m}$ planum v. subconvexum, epaleatum, conferte setosum. Corollae ligulatac. Achenia uniformia, erostria, turbinata. Pa p p u s conformis, paleacens, paleis quinque, longissime acuminatis, aequalibus, denticulatis. - Herbae mediterraneae, annuae, glabrae $v$, incano-villosae, inferne foliosae, superne aphyllae; foliis lineari-lanceolatis nervosis, integerrinis $v$, apice incisis aut basi pinnatifidis, pedunculis nudis v, squamis scariosis involucri folia extima referentibus conspersis, capitulis magnis caeruleis, $v$. parvis luteis.

C a ta n a n e he Tournefort inst. 27t. Linn. gen. n. 290. exel. sp. Girtner IT. 356. $t$. 157. Schkuhr $t$, 226, Cassini in Dict. tc. nat. VII. 265 . Lessing Synops. 128.

2ง ร ซ. A eanthoplayto an LESS. C a p itulum subsexflorum, homocarpum. Involucri cylindracei, imbricati squamae subaequales. R ec e p t a c n l u m planiusculum, epaleatum. C or o 1 l a e ligulatae. A c he $\mathbf{n}$ i a uniformia, erostria, turbinata, transversim rugulosa. $\mathbf{P}$ a p p i uniformis, brevissimi, multipaleacei, basi margine achenii prominulo eineti paleae ellipticae, obtusae, remotiusculae. - Herba mediterranea, 
biennis, foliis alternis, runcinato-dentatis, caule dichotomo, ramis divaricatis, nudis, spinescentibus, capitulis axillaribus, solitariis, luteis.

A ean thoph y $t$ o a Lessing Synops. 128. Cichorium s pi о о $x$ u Lian.

258 8. Chelhoritum TOURNEF. Cap itu$1 \mathrm{um}$ multiflorum, homoearpum. Invo I u eri eylindrici, biseriati squamae exteriores breviores, adpressae, interiores basi subconnatae, demum patentes. Re cep ta c u l u m planiusculum, epaleatum, foveolatum v.setosum. Co roll a e ligulatae. A $c$ h enia conformia, erostria, turbinata. Pa p pi uniformis, brevissimi, aequalis, biseriati paleae ellipticae, obtusae. - Herbae in Europa media et in regionibus mediterraneis indigenae; foliis denticulatis $v$. runcinatis, capitulis axillaribus, glomeratis, sessilibus $v$. pedunculatis, caeruleis $v$. luteis.

Cichorium Tournefort inst. 272. Linn. gen, $n, 357$. Gärtner II. 357. t, 157. Schkulir t. 226. Flor. dau. $t$. 907. Lessing Synops. 129.

ะยรง. 'Tolpis $A D A N S$. C a p itu $1 \mathrm{n} \mathrm{m} \mathrm{mul-}$ tiflorum, subhomocarpum. Invoin erum biseriatim polyphyllum, aequale, squamis setaceis, demum falcato-patentibus calyculatum. R e c e p tac ul u m planum, epaleatum, alveolatum, alveolorum marginibus denticulatis. Corolla e ligulatae. A chenia uniformia, erostria, turbinata, striata. $\mathbf{P}$ a pus biformis, in acheniis marginalibus subpaleaceus, brevissimus, paleis nniseriatis, basi in annulum connatis, in acheniis centralibus coroniformis, brevissimus, erenulatus, setas duas v. quatuor longissimas exserens. - Herba mediterranea, annua, diffusa, dichotome ramosa; foliis alternis, lanceolatis, inferioribus dentatis, pedunculis monocephalis, superne incrassatis, fistulosis, capitulis speciosis, floribus marginalibus luteis, centralibus atro-violaceis.

Tolp is Adanson Fam, II. 112. Gärtner IT. 371, t. $1 \partial 0$. Lam, $t$. 651. Bivona-Beraardi Tolpid, $t, 3$, exel. reliq. Les. sing Synops. 129. Drepan i a Jussieu gen. 169. Desfont. Flor. atlant. $I I, 239$. S wertía Ludew, $C$ ha telan ia Necker elem, n. 96. Crepis b a r ba t a Linn.

2980. Selumidtia MÖNCH. Ca pitulum maltiflorum, homoearpum. In volucri biseriatim polyphylli squamae lineares, exteriores breviores, adpressae v. laxiusculae, subpatentes. R e ce pt a c n 1 u m planum, epaleatum, alveolatum, alveoIorum marginibus denticulatis. Corolla e ligulatae. Achenia uniformia, erostria, turbinata. $P$ a p us uniformis, uniserialis, inaequalis, setacens, setis basi valde dilatatis, subeallosis, saperne scabris, aliis minimis interjectis. - Herbae perennes, ramosae, $v$. fruticuli in regioni bus mediterraneis provenientes; foliis alternis, lanceolatis, dentatis, pedunculis monocephalis, superne vix incrassatis, involucris farinoso-incanis, capitulis luteis.

Sclimidtia Mrneh Method. suppl. 1802. Cassini in Dict. sc nat. XLVITI. 433, Lessing Synops, 199. A ethioni a Don in Edinb. philosoph. Journ, 1829, p. 309. Polychaetia Tausch non Cass. Hieracti sp. Willd. Tol. pidis s p. Bivona-Bernardi Tolpid, t. 1. 2. Sehrank Hort. Monae, $t$, 46. C r e p id is s p. DC. Desfont.

3981. Irofigia SCHREB. Capitulum multiflorum, homocarpum. Inv o lueri squamae subdenae, uniseriatae, aequales, erectae. Recepta c n l um planiusculum, epaleâtum, foveolatum. Corolla e ligulatae. A $\mathrm{ch}$ enia conformia, erostria, turbinata, Pap u s conformis, biserialis, serie exteriore coroniformi, brevi, interiore quinque-pluriseta, longa. - Herbae boreali-ame- icande, anruae, glaucae, glabraev. glanduloso-pilosae, basi foliatae, superne nudae, simplicissimue $v$. dichotomae; foltis runcinatis $v$. integris, capitulis terminalibus, solitariis,

Krig i a Schreber, gen, n, 1244. Nuttall gen. II, 126. Reiehenb. Ic. exot, $I, t, 87$. Lessing Synops. 129. H yos er is virginica s p. Linn.

2983. Troximon $G \not ̈ R T N$, $C$ a pitúlum multiflorum, homocarpum. Involu e ri polyphylli squamae biseriales, exteriores breviores. Recept a culum planiusculum, epaleatum, foveolatum. Corolla e ligulatae. A chenia uniformia, erostria, quadrangula. Pap p 8 uniformis, multiserialis, inaequalis, serie extima brevissima, persistente, multipaleacea, interioribus piliformibus, cadneis. - Herbae perennes, bore a $i$-a mericanae, glaucae, glaberrimae, obligocephalae; folitis alternis, infimis lyratis, superioribus amplexicaulibus, inlegerrimis, capitulis terminalibus, luteis.

Trax I m on Gärtner 1 r. 360 . exel. sp. non Nutt. Don, Cy $\mathrm{t}$ h hi a Don in Edinb, new pbilos. Journ. 1829, p. 309 . A dopogon Necker elem, $n, 101$, L u tlie r a C. H. Seluultz in Linnaea $X, 256$.

2983. Microseris DON. CapituInm multiflorum, homocarpum. Iñ volueri polyphylli $s q u a m a e$ biseriatae, exteriores breviores, R e c e p $t$ ac u I u planum, epaleatum, foveolatum. Corolla ligulatae. A chenia uniformia, erostria, turbinata. Pa p p s uniformis, uniserialis, squamis membranaceis, apice emarginatis, seta longissima serrato-subplumosa terminatis. - Herba ch $i$ lens is, tenella, scapigera; foliis radicalibus runcinato - pinnatifidis, scapis simplicissimis, monocephalis, capitulis ante anthesim nutantibus, luteis.

Mi cros e ris Don in Edinb. philosoph. Magas. XI, 388. Hooker Bot, Mag. Compan, II, 30. Lepid o n e m a Fischer et Meyer Index sem. Hort. Petropolit. 1835. p. 31. Fie h te a C. H. Sebultz in Linnaea $X$, 255.

SUBTRIBUS IV. HYPOCHAERIDEAE Lessing Synops. 130. Receptaculum paleatum. Pa p us paleaceus, paleis angustissime semilanceolatis, interioribus $\mathrm{v}$, in acheniis interioribus plumoso-pinnatisectis.

2984. Dreoplitin DON, Capitulum multiflorum, homocarpum. Involueri polyphylli squamae pluriseriatim imbricatae. Receptaculi plani paleae membranaceae, setaceo-acuminatae. C o ro 1 l a e ligulatae. A $\mathbf{c}$ h en ia uniformia, erostria, compressa. P a p u s uniformis, uniserialis, paleis plumosis, inaequalibus, basi crassiore persistentibus, - Herba peruviana, andicola, acaulis, exscapa; radice fusiformi, folits rosulatis, petiolatis, linearibus, coriaceis, sinuato-dentatis, supra glabris, subtus pilosis, flore inter folia solitario, sessili, magno, aureo.

Ore ophila Don in Linn, Transact, XVI, 178, -? Hypochaeris sessiliftora Kunth.

2985. Typoehaeris LINN. CapituI $\mathrm{m}$ multifloram, heterocarpum. Invol u cri polyphylli squamae pluriseriatim imbricatae. Re: ceptaculi plani paleae membranaceae, lineariacuminatae. Corolla e ligulatae. Achenia biformia, striata, scabra, rostrata, rostro marginalium brevissimo, centralium elongato, setíformi. P a pus uniformis, biserialis, serie exteriore breviore subsetacea, interiore plumosa. - Herbae annuae, glabriusculae, in Europa et in Capite bonae $s p e i$ indigenae, dichotomae, basi tantum foliatae; folits alternis, oblongis v. lanceolatis, sinuato- 
dentatis v. subintegerrimis, capitulis terminalibus, luteis.

H y p o eh a e $\mathrm{r}$ is Linn. gen. n. 918, excl. sp. pl. Gärtner II. 374. 2.160 . Lessing Synops. 130. S e riola Cassini in

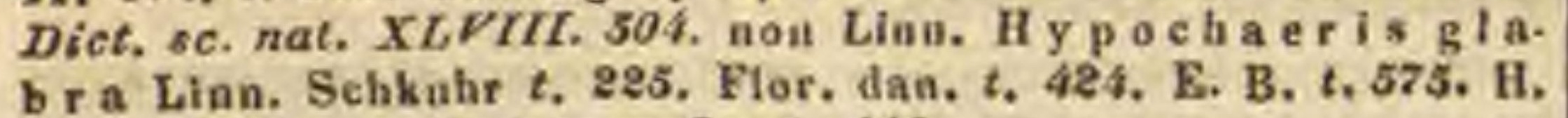
$\mathrm{g} \mathrm{r}$ a nd ifl or a Ledebour Ic. t. 440.

2986. Aeloyroplinorans SCOP. Capitu$1 \mathbf{m}$ multiflorum, homocarpum. Involncri polyphylli squamae pluriseriatim imbricatae. R e c e ptaculi convexinsculi paleae membranaceae, lineari-acuminatae. Corollae ligulatae. Achenia conformia, rostrata, striata, scabra, rostro elongato, setiformi. Pa p p u s uniformis, biserialis, serie exteriore breviore subsetacea, interiore plumosa. Herbae perennes, in Europa et Asia media indigenae, hirsutae v, scabrae, simplices v. ramosae, basi tantum foliatae; foliis oblongis, sinuato-dentatis $v$. runcinatis, capitulis terminalibus solitariis, luteis.

A c h y r o p h o r a s Seopoli Flor, carniol, IT, n, 987, Gärtn. II. 370, t. 159. Lessing Synops. 130. P o r cellites partim Cassiai in Diet, sc, nat, XLIIT. 42. H y poc hat e ridis $\mathbf{s}$. Linn. Schkuhe $t$. 225. FI. dan. $t$. 149. 150. B. B. $t .225 .831$. Jacq. Ic. rar. $t, 165$. S corzonerae $*$ p. Jacq. Op. cit. t. 106 ,

298\%. Seriola GÄRTN. Capitulum multiflorum, homocarpum. Involncri polyphylli squamae uniseriales, aequales. $R$ e cepta c $\mathrm{u}$ li convexi paleae membranaceae, lineari-lanceolatae. Corolla e ligulatae, A $\mathrm{c}$ henia conformia, rostrata, striata, scabra, rostro setiformi. Pa ppus uniformis, nniserialis, paleis angustissime semilinearilanceolatis, plumosis, plumulis persistentibus v. caducis. - Herbae mediterraneae, chilenses et brasilienses, annuae, dichotomae, plus minus hirsutae; foliis sinuato-dentatis v. runcinatis, capitulis terminalibus, solitariis, luteis.

Serlola Ling. gen, n, 917. Gärn, IT. 370, t. 159. Schkuhr t. 224. Rodigi a Spresgel Syst. III, 654. P ip to. pogon Cassini in Dict. sc, nat, XLFITI, 507. A ge nor a Don in Edinb, new philosoph. Journ, 1899, p.310. P o r e e I. 1 ites partim Cassini in Dict. sc, nat. XLIIT. 42. Por celiitis s p. Lessing in Linnaea VI. 102.

2988. ISobertia DC. Capituln m mul. tiflornm, homocarpum. Involneri polyphylli squamae uniseriales, aequales. Rece ptaculi convexiusculi paleae membranaceae, lineari-lanceolatae. Corolla ligulatae. Achenia conformia, rostrata, teretia, laeviuscula, rostro brevi, vix ab achenio distincto. Pappus uniformis, uniserialis, paleis angustissime semilanceolato-linearibus, apice plumosis, - Herba mediterranea, glabra, acaulis ; foliis radicalibus runcinatis, scapo monocephalo, capitulo luteo.

Robertia DC.Fl. fr. V. 453. Lessing Synops, 131, S eriolataraxacoldes Loisl. S. unifiora Bivon.

SUE'TRIBUS v. SCORZONEREAE Lessing Synops. 131. Receptaculum epa leatum. Pap pus paleaceus, paleis angustissime semilanceolatis, saltim interioribus $\mathrm{v}$, acheniorum centralium plumosis, rarissime omnibus scabris.

2989. Thrineía ROTH. Capituln m multiflorum, subhomocarpum. In voIucri squamae pluriseriatim imbricatae. Rec epta c n lum planum, epaleatum, favosum. Coroll a e ligulatae. Achenia conformia, rostrata, rostro brevi, continuo. P a p u 8 biformis, acheniorum marginalium brevis, coroniformis, dentatus, centralium pluriserialis, plumosus, paleis basi latioribus, scariosis, plumulis tandem deciduis. - Herbae in Europa media et in regionibus mediterra$n$ eis indigenae, scapiferae; radice fibrosa $v$. napiformi, foliis oblongo-obovatis, integris, scapis monocephalis, capitulis luteis.

Thrincia Roth Catalect, I. 97. Lessing Synops, 131. Reicheab. Plant, erit, f. 990 -995. Co l o b i um Roth. Le on. to dont is s p. Lins. Curtis Flor. Lond, II. t, 160. A p a rg i a e s p. Selikahr $t$. 220 . Hed y p no is s p. E. B. $t$. $s 50$. Streckera Sehultz in Flora 1834. p. 483.

2990. Heontodom LINN. Capit u l u m multiflorum, homocarpum. Involueri polyphylli squamae pluriseriatim imbricatae. Recepta $\mathbf{c} \mathbf{u}-$ I $\mathbf{~ m}$ convexiusculum, epaleatum, punctatum v. scrobiculatum. Corollae ligulatae. Achenia uniformia, teretia, transversim ragulosa, sensim in rostrum breve, continuum attenuata. $\mathbf{P}$ a $\mathbf{p} \mathbf{p} 8$ conformis, uniserialisiv. biserialis, plumosus, paleis basi scarioso-dilatatis, aequalibus, v. exterioribus piliformibus nudis. - Herbae in Europa et Asia me di a indigenae, etiam in $A$ merica observatae, scapigerae; foliis radicalibus oblongo-obovatis, dentatis $v$, pinnatifidis aut sacpius runcinatis, scapis simplicissimis, monocephalis, capitulis luteis.

L e o n to d o n Linn. gen, n.912. exel. sp. pl. Koch Elor. germ. 418. $\Lambda$ parg i a Willd. sp. III, n, 1408. exel. sp.

a. VIREA Adans. P a p i series exterior piliformis, seabra, joterior plumosa, paleis basi searioso-dilatatis, serratis.

Vir e a Adansou Fam, $I T, 112$. Gärtn, $I T, 365 . t, 159$. Le ontodon Jassieu gen. 170. Lessing Sjnops. 131. Taraxaconoides Vaillant in Act. Academ. Paris. 1721, p. 170. A n tod o n Neeker elem, n, 107. L e ontodontis sp. Linn. Jaeq. Fl. austr. 1. 93. 164. Apargi a s p. Willd. Sehkuhr $t, 220$. exel. $f$. 2.

b. APARGiA Less. Pap pi series utraque plamosa, interioris paleae basi serrulatae.

Apargia Lessing Synops, 132. Hieracium incan u m Lian. Jacq. Fl, austr, $t, 287$.

c. ASTERothriX Cass. Pa p I series utraque plumosa, paleis a basi aequaliter plumosis, exterioribus brevioribus.

A ste rothrix Cassini in Dict, sc, nat, XLVII, 434. A pargia crispa Willd. A. a spera Waldst. et Kitaibel Plant. Hung. t, 110. - ? Fi de li a Schultz in Flora 1834. p. 481.

d. OPORINiA Don, Pappus uniserialis, plumosus, paleis basi scarioso-dilatatis.

0 porin i a Don in Edinb. nex philosoph. Journ, 1829. p.309. Lessing Synops. 132. S c o r z o ne r o ldes Mönch Mothod.569. Le on tod on a $u t u m n a l i s$ Linn. A pargia a utuma allis Willd. Schkahr $t, 220$.

2S91. DIIILna CASS, Capitulam multiflorum, homocarpum. Invol ueri subuniserialis foliola conduplicata. Receptaculum planum, epaleatum, foveolatum. Co r o 11 a e ligulatae. A chenia uniformia, rostrata, transverse striata, rostro longo, gracili, ab achenio distincto. P a p p n 8 uniformis, uniserialis, setaceo-paleacens, plumosus. _Herba incertae originis, soli Cassinio nota; caule basi ima foliato, simplicissimo, monocephalo, adscendente, squamis subulatis obsesso, apice inflato, foliis runcinatis, pilis simplicibus adspersis, capitulo luteo.

Mill in a Cassini in Dict. sc. nat, XXXI. 90. Lessing Synops. 132.

299\%. Ceropogon $L I N N$. C a pitulum pauciflorum, subhomocarpum. Involucri uniseriati foliola aequalia, basi ennnata, floribus longiora. Receptac n I um planum, epaleatum, setosum. Corolla e ligulatae. A ehen ia uniformia, rostrata, rostro continuo, longo. P a p p s biformis, acheniis exterioribus nniserialis, quinquepaleatus, paleis semilanceolatis, serrulatis, interioribus pluriscrialie, plumosus. - Herba mediterra- 
nea, ramosa, glabriuscula, Tragopogonis facie; foliis alternis, gramineis, integerrimis, capitulis terminalibus, solitariis, roseis.

Ge ropog o n Linn, gen, $n$, 904. Sehknhr t. 231. Jaeq. Hort. Sohönbr. $t$. 33. Gärtuer II. 374, t, 160. Lessing $\mathcal{S}_{j n-}$ ops. 132.

2993. Podespermum DC. Ca p it a $1 \mathrm{um}$ multiflorum, homocarpum. Involueri pluriseriatim imbricati foliola margine scariosa. $R$ e e ptac $\mathbf{l}$ u m convexiusculum, papillosum. Corolla e ligulatae. A chenia uniformia, erostria, su perne aequalia, callo basilari, inflato, achenium subaequante stipitata. P a p u s uniformis, uniscrialis, plumosus. - Herbae in Europa media et in regionibus mediterran eis indigenae, glabrae foliis alternis, pinnatifidis, capitulis terminalibus, solitariis, octangularibus, floribus luteis, margina libus involucrum superantibus v. vix subaequantibus.

Podosperm um DC. Fl, fr. IV. 61. Podosperma Lessing Synops, 133. Re i chard ia Roth Beiträge. 35, non Nov. sp. Monch Method. S45. Scorzonera lacinfata Linn. Jacq. Fl, austr. t. 356. Sehkuhr 1, 215. Gärtn. t. 159.

2994. Urospenmuran JUSS. C a p itu l u m pluriflorum, homocarpum. Involucri oe tophylli foliola uniseriata, basi connata. R e cep taculum convexiusculum, epaleatum, foveolatum. Coroll a e ligulatae. A ehenia uniformia, sessilia, rostrata, muricata, rostro longo, inani, basi inflato, intus septo transversali ab embryone separato. P' a p us uniformis, uniserialis, plumosus, plumulis liberis. - Herbae mediterraneae, annuae, dichotomae, glabraie; foliis alternis, semiamplexicaulibus, plus minus pinnatifidis, capitulis longe pedunculatis, luteis.

Ur o s p e r m u m. Jussieu gen. 170. Desfont. Catalog 90, Lessing Synops. 133. A r no pog o n Willdenow $S p . I I I .1496$. excl. sp. Tragopogon picroides et Tr. Dalechampi i Lind. Gärtuer $t$, 159. Schkuhr $t$. 159.

ஓ\$S. 'Tragopogan $L I N N$. C a p itu $1 \mathrm{um}$ pluriflorum, housocarpum. Invol ueri octododecaphylli foliola uniseriata, basi connata. Receptaculum convexiusculum, epaleatum, nudum v. fimbrilliferum. Co rolla e ligulatae. A $\mathbf{c h}$ enia uniformia, rostrata, sessilia, muricata, rostro continuo, longo. Pap p us uniformis, pluriserialis, plumosns, paleis subcorneis, nonnullis longioribus, apice nudis, plumulis intertextis. - Herbae in Europa et $A$ sia temperata indigenae, erectae, simplices $v$, ramosae, aequaliter foliatae; foliis alternis, lineari-semilanceolatis, inlegerrimis, semiamplexicaulibus, capitulis terminalibus, solitariis, luteis $v$, purpurascentibus.

Tragopogon Linn, gen, $n$, 905. exel. sp. Gïrtn. Ir 386. t. 159, excl. fig. 2. 3, Schkuhr $t$, 214. exel. fig. Jacq. Fl. austr, $t$, 29. Ic, rar, t, 159, E. B, $t$ 434. 638. Fl. dan. t. 424. 797. 906. Waldst, et Kitaibel Plant. Hung. t. 112, Lessing Synops. 133.

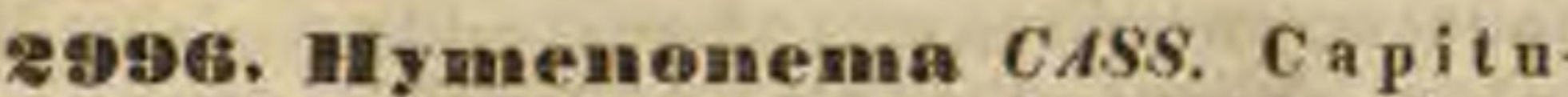
I u m multiflorum, homocarpum. Involneri polyphylli squamae pluriseriatim imbricatae. $\mathbf{R}$ e c e $\mathbf{p}$ t a $c$ u $1 \mathrm{~nm}$ planiusculum, epaleatum, nudum. Corolla e ligulatae. A $\boldsymbol{c}$ henia nniformia, erostria, turbinata. Pappi nniformis paleae decem, suhuniseriales, aequales, basi scarisso-dilatatae, superne plumosae. - Herbae perennes, in regione mediterran ea orientali indigenae, simplices, basi tantum foliatae; foliis oblongis, varie pinnati lidis, saepe asperis, capitulis terminalibus, magnis, speciosis, luteis.
H y men on em a Cassini in Dict, sc, nat, XXII,31. Lessing Synops. 134. Cat a a n che g rae ca Linu. S corzonera as pera Desfont.

2998. Seorzonera LINN, Capitulum multiflorum, homocarpum. Invol u cri polyphylli squamae pluriseriatim imbricatae, margine plerumque scariosae. Receptacul n m convexinscolum, epaleatum, papillosum. Coroll a e ligulatae. Ach enia uniformia, erostria, glabra v, villosa, callo basilari areolam lateralem cingente brevissimo. P apps uniformis, pluriserialis, plumosus, paleis nonnullis interioribus longioribus, apice nudis, plumulis intertextis. - Herbae perennes, in Europ a imprimis australiore, et in Asia media indigenae, nonnullae etiam ob radices qui. busciam in opsoniis gratas cultae, simplices v. dichotome ramosae, basi tantum $v$. aequaliter foliatae; foliis semiamplexicaulibus, lanceolatis, integerrimis, capitulis terminalibus solitariis, luteis v. purpurascentibus.

S corzonera Linn. Gen. n, 906, excl, sp. DC. Fl. fr. IV. 59. Lessing Synops, 134, excl, sect, 2, Koch FI. Germ. 423.

a. SCORZONERA Cass. A che nia glabra. - Scorzone. $\mathrm{r}$ a Cassini in Dict, sc, nat, XXY, 65. 264. (Girtn, t, 159 . excl. fig. super. Jaeq. Fl, austr, $t, 35.36,305$. Fl. dan. t. 816. 1653. Lapeyr. Pyren. t. 156. Waldst, et Kitaibel Plant, Hung. $t$. 121.)

b. LASIOSPORA Cass. A chenia villosa. - L a s i o spo$r$ a Cassini in Dict, sc, nat, $X X V, 306$, L a sios per$\mathrm{m} u \mathrm{~m}$ Fiselier Index Hort. Gorenk. 1812. p. 34. S corzonerae s p. Bieberst. - ? Fleis cheria Steudel et Hochst. mse.

2998. Callasia CASS. Capitulum multiflorum, homocarpum. Involucri polyphylli squamae pluriseriatim imbricatae. Receptacu lum convexinseulum, epaleatum, papillosum. Corolla e ligulatae. A chenia uniformia, erostria, ses. silia, murieata. Pappus uniformis, pluriserialis, scaber, paleis exterioribus piliformíbus, intimis laneeolato-dilatatis, intus intrieato-villosis. Herba in Europa orientali indigena, multicaulis, adscendens, ramosa; foliis alternis, amplexicaulibus, linearibus, carinatis, villosis, capiculis terminalibus, solitariis, floribus vix involucro longioribus, subtus purpurascentibus.

G al a s i a Cassisi in Dict, sc. nat, XVIIT. 285, XIIt. 81. Koeb F2. Germ, 426. S corzonerae sect. 2. Lessing Synops. 134. S corzonera villos a Sinp. Carniol. t. 46. Se, an g ustifoli a Waldst, et Kliaibel Plant, Hung. t.122.

29S5. Pieris $L I N N$. Capitnlum multiflorum, homocarpum. Involueri polyphylli squamae imbrieatae, extimae patentes. Recepta cu1 n m planum, epaleatum, alveolatum. Corollae ligulatae. A ch en i uniformia, transversim rugosa, sensim in rostrum brevissimum attenuata $v$, apice constricta. Pappus uniformis, biserialis, deciduus, paleis basi in annulom connatis, exterioribns pauciorilus, piliformibus, interioribus basi latioribus, plnmosis. - Herbae in Europa, regione mediterranea et Asia media indigenae, ramosae, hispidae; foliis alternis, integris $v$. pinnatifidis, capitulis terminalibus, solifariis, luteis.

Pic ris Limn. gen, n. 907, excl. sp. Gärtner II. 366 . t. 159. Schkulir $t$, 2i6, exel. fig. sup. Fl. dan, $t$. 216. DC. Plant. Gall. rar. $t$, 20. Lessing Synopz, 134. - M edicusia Mónch Method.536. Crepis rhagodioloides Lun. Jacq. Hort. Schönbr, t.144. S pitze li a Selinitz in Flora 1833. p. 723. - Dech e r a Schultz Ibid. 1834. p. 478.

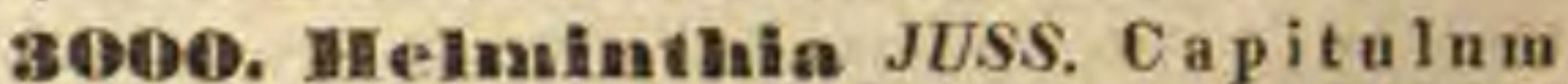
multifloram, homocarpum. Involucri duplicis foliola exteriora quinque, cordata, latiora, patentia, interiora octo erecto-conniventia. R ceep 
ta e ul um planum, epaleatum, papillosum. Corolla e ligulatae. A $c$ h enia uniformia, rostrata, plano-obcompressa, elliptica, transversim ruguIosa, apice laevi rotundata, rostro longo, gracili, fragilissimo superata. P a p us uniformis, pluriserialis, plumosus, persistens. - Herba annua, hispi. dissima, dichotome ramosa, in Europa a ustrali et in Ang lia indigena; foliis alternis, semiamplexicaulibus, oblongis, repando-dentatis, capitulis terminalibus, solitariis, luteis.

$\mathrm{HeIm}$ int hia Jussien gen. 170. Gärtner II, 268. t. 159. Lam. $t, 648$. H e $1 \mathrm{~m} \mathrm{in} \mathrm{th}$ o $\mathrm{t}$ he a Vaillaut in Act, Acad. Pa. ris, 172t, p. 205. P i cris e th lo 1 d es Linn. Curt. Fl. Lond. I. $t, 179$. Schkuhr $t, 172$.

30OA. IKalb Passia SCHULTZ. Ca pita. I u m multiflorum, heterocarpum. I n v o I u c r i polyphylli squamae subimbricatae, adpressae, exteriores breviores. R e c e $\mathrm{t}$ a $\mathbf{c} \mathbf{u} \mathbf{I} \mathbf{u}$ convexiuseulum, epaleatum, alveolatum. Coroll a e ligulatae. Achenia biformia, erostria, exteriora breviora, involucri squamis intimis semiinclusa, scabra, interiora substipitata, transversim tuberenlata, pappigera. P a p us in acheniis marginalibus nullus, centralibus uniserialis, plumosus, persistens. Herba atlantica, annua; foliis radicalibus pinnatijidis, caule ramoso, capitulis terminalibus, soli tariis, luteis.

\section{Ka Ibfussia Sehultz in Elora 1833, p. 723.}

SUTRTEIIBUS VE. LAC'TUCEAE Lessing Synops. 135. Receptacul am epaleatum v. rarissime paleatum. $\mathbf{P}^{\mathrm{a}} \mathrm{p} \mathrm{p}$ us piliformis, plerumque inaequalis, argenteus, mollissimus, fugax, nunquam plumosus, pilis exactissime linearibus, nec basi manifeste complanatis v, dilatatis.

30OR. Pieridinne DESFONT. Cap ituI n m multiflorum, homocarpum. Involucri urceolati squamae plnriseriatim imbricatae, margine scariosae. Rec e pta e $\mathbf{l}$ um planum, epaleatum, foveolatum. Coro 11 a e ligulatae. A c henia uniformia, erostria, tetragono-prismatica, transversim tuberculata, summo apice sulscontracta. $P$ a p p a s uniformis, pluriserialis, pilosus. Herbae in Europa media et in regione med $\bar{i}$ terranea indigenae, dichotome-ramosae; foliis alternis, amplexicaulibus, inferioribus sinuatopinnatifid is, capitulis terminalibus, solitariis, luteis, pedunculis clavatis.

Pieridium Desfont. Flor. allant, $I$. $t$. 221. Lessing Synops, 160. Sonch us picroides Allioni Pedemont,t, 16. f. 1. Garta, $t, 158$. S e r zo u or a $t$ ingit a na Linu. Schkulir 1. 275 .

3003. Sonelnas LINN. C a p it n $\mathrm{l}$ u multiflornm, homocarpum. In vo I n er i squamae pluriseriatim imbricatae. Reeeptaculam planum, epaleatum, foveolatum. Corolla ligulatae. A ehenia uniformia, erastria, plano-compressa, transversim rngulosa, apiee truncata. P a pp us uniformis, pluriserialis, pilosus, setis basi fascieulatim connatis. - Herbae cosmopolitae, poly. morphae, saepius hirsutae; foliis alternis, pinnatifidis, capitulis aggregatis, luleis.

Son chus Linn. gen. n, O0s, exel. sp. Cassini in Diet. sc. nat. XXV. t5̆t. Synops. 140, F. dau. t. 60G. 803. 1109.

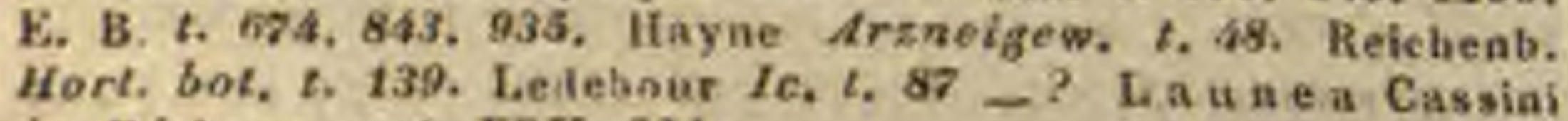
in Dict. sc. nat. $X X Y$. 321 .

3004. Trachodes DON, Capituln m multiflorum, homocarpum. I nvol u cri polyphylli squamae pluriseriatim imbricatae. Receptacul u m planum, epaleatum, laeve. Co rolla e ligulatae. A chenia uniformia, erostria, fusiformia, transversim rugosa, P a p p s uniformis, triserialis, pilosus, pilis omnibus distinctis, intimis nonnihil crassioribus. - Herba mexicana, biennis, viri. di-caerulescens; caule paniculatim ramoso, tereti, aculeis minutissimis scabro, basi purpureo-maculato, foliis radicalibus spathulatis; sinuato-runcinatis, spinuloso-denticulatis, caulinis amplexicaulibus, lobatis, floribus paniculatis, citrinis.

Trachodes Dou in Linn. Transact. XVT. 182.

3005. Fremanthes GIRTN. Capitul u m quinque - decemflorum, homocarpum, floribas uni-biseriatis. In vo I u c r um cylindraceum, pentaphyllum, squamulis brevibus ealyculatum. Receptacuium epaleatum, foveolatum. Corolla ligulatae. A chenia uniformia, erostria, teretia, prismatica v, compressa, laevia, Pa p p ns uniformis, plnriserialis, pilosus, pilis intimis interdam scabris. - Herbae v. frutices in Europa media et mediterran ea, in Asia temperata et A me rica bo reali indigeni; foliis alternis, pinnatifidis $v$. integris, capitulis terminalibus, solitariis.

Prenanthes Gärtuer $I I$. 3a8. Lian. exel. sp. Lessing Synops. 137.

a. EUPRENANTHES. Capitula 5flora. Achenia pris. matica. Pappi albi plif omnes conformes. - Herbae europeae; foliis oblongo-lanceolatis, amplexicaulibus, basi cordatis, denticulatis, capilulis paniculatis, purpureis.

Prenanthes purparea Linn. Jacq. Fl. austr. t. 307. Gärtn. t, 14\%7.

b. NABALUs Cass. Ca pitula 5_10flora. A c be n ia sub. cyliudracea, striata. P a p p a s coloratus, seaber - Her. bae boreali-americanae; foliis alternis, amplis, plo. rumque petiolatis, integris, sinuatis $v$. pinnatifidis.

$\mathrm{Nabatus}$ Cassini in Dict. sc. nat. XLITK. 28t. Haoker Flor, bor. Amer, 293. t. 102. Harpalye Don is Edinb. new philosoph, Journ. 1829. p. 308. (Willdenow Hort. berol, t, 25. Pursh Fl. Bor. Amer. t, 24, Bot. Mag. t. 1079.)

c. LYGodesma Don. Capitala 5flora. A chenia li. nearia, compressa, sulcata. $P$ a p p a coloratus, denti. culato-seaber. - Suffrutices v. herbae, in America boreali ot in regione meditorranea orientali proveniontes; folits abortivis, squamaeformibus.

L y godes m i a Don in Edinb, new philasoph. Journ. 1829. p.31t. Hooker Fl, Bor, Amer, 295. $t, 103$. (Labil. lard. Syr. Decad, IIT. $t$. 2.)

c. Atalanthus Don. Capit ula 10flora. Ac he a ia linearia, compressa, sulcata. P a p pi nivei plli inaequales. - Suffrutices mediterranei ot canarienses, ramo. sissimi; folits pinnatifilis.

Atalanthus Don in Edinb. new philosoph. Journ. VT. 311. Preaanthes pinata Lina. P. spinosa Yahis.

30108. Cherisana DON. Capitulnm pauciflorum, homocarpum, floribus bi-triseriatis: InvoIncrum oetophyllum, basi squamulis aliquot ovalibus calyculatum. R e e e p t a e u I a m epaleatum. Cor o I l a e ligulatae. A c he ni a nniformia, brevissima, rostrata, subfusiformia, eompressa, sulcata. P a p p s uniformis, pilosns, pluriserialis. - Herba in America arctica indige. na, sarmentosa, repens; caulibus filiformibus, ad arliculos radicantibus, folits remotis petiolatis, profunde tripartitis, capitulis solilariis, pedunculatis, pallide caeruleis.

Chorisma Don in Edinh, new philosoph. Journ. VT. 308. Prenanthes repeos Lian.

300\%. PPlaenixopus. KOCH Ca pitu$1 \mathrm{~cm}$ quinqueflorum, homoearpum, floribns uniseriatis. Involu c r u m suboctophyllum, foliolis 
exterioribus hrevierilus subimbrieatum, v. brevissimis calyculatum. R eceptacu I n m epaleatum, obsolete scrobiculatum. C o r o 1 I a e ligulatae. A chenia uniformia, rostrata, plano-compressa, rostro filiformi, P a p u $s$ nniformis, pluriserialis, setosus. - Herbae in Europa, Asia et America boreal $i$ indigenae; foliis amplexicaulibus, decurrentibus, lyrato-v. sinuato-pinnatifidis, capitulis paniculatis, luteis.

Phoenixopus Koch Fl. germ, 430. Phoenixopus et $\mathrm{M}$ y c elis Cassini in Dict, sc. nat, XXXIIT. 483. P ho enixopus et Lactucae sp. Lessing.

a. PHOENIXOPUS Cass. $l$. c. Invol u crum subimbrica. tum, fusiforme. A clte niorum rostrum breve. - P rena thes viminea Linn. Jacq. Flor, austr, $t .9$.

b. MYCELIS Cass. $\boldsymbol{l}$, $c$. I n vol n crum calyculatum, demum coutortam. A chenior u m rostrua longus. Prenantlies muralis Linn. Scbkuhr $t .218$. FI. dan. $t$, 509. R. B. $t$, 457. Ledebour Ic. $t$, 158, 498. C i e rbit a e sp. Walls. Lactaca e sp. Lessing.

3009. liacterea LINN. Ca pitulum pauciflorum, homocarpum, floribus bi-triseriatis. Involucri oblongo-cylindracei squamae pluriseriatim imbricatae. Receptacu $\mathbf{c} \mathbf{n}$ m planum, epaleatum, scrohiculatum. Corolla e ligulatae. A chenia nniformia, rostrata, plano-obcompressa, rostro filiformi. Papp n s uniserialis, pilosus, margine tenui, plus minus prominulo, laevi v. brevissime setuloso cinctus. - Herbae per Europ a m, regionesmediterraneas, Asiammediam et $A$ mericam boreale $m$ divulgatae; foliis inferioribus runcinato- $v$. sinuato-pinnatifidis, superioribus saepius integerrimis, basi plerumque sagittatis, carina $v$. margine aculeatis, capitulis luteis $v$. interdum caeruleis.

L a c tu c a Linn. gen. $n$. 909. Gärtaer $I T .361 . t$, 158. exel. sp. Lessing Synops. 135.

a. SCARIOLA. A che a i m strils elevatis utrinque plari. mis. FIores flavi. - Lactucae genuInae Koch Fl. germ. 431. Selikuhr t. 217. Jaeq. Fl. austr, $t$. 230. E. B. t. 268. Flor, dan. t. 1227. Waldst. et Kitaibel Plant. Hung. $t, 1$. 48 . Hayne Arsneigew. $t .46 .47$. - ? R h a bdo the ca Cassinl in Dict. se, nat. XLVIII. 494.

b. CYANOSERis, A c beni um utrinque linea unica elevata. Flores caerulei. - Cyau aseris Koch $l$. $c$. Lactuca pereson is Ling. I., u udulata Ledebour Ic. $t$. 129 .

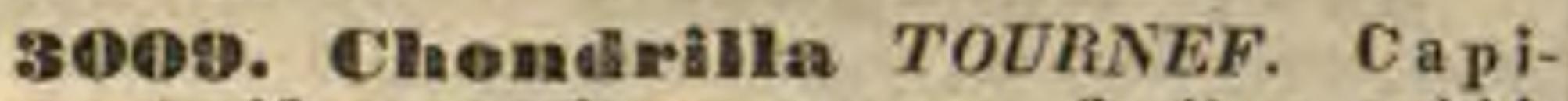
tulum pluriflorum, homecarpum, floribus subbiseriatis. Involucrum cylindracenm, subdecaphyllam, squamis brevibus calyeulatnm. R e cept a $\mathbf{c}$ I um planum, epaleatum, exeavato-punctatnm. Coro Il a e ligulatae. A e he n ia unifurmia, rostrata, teretia, apice muriculata, rostro pili formi fragili, basi dentieulorum coronula rincto. Pa p p $\mathbf{s}$ nniformis, pluriserialis, pilesus. - Herbac biennes $v$. perennes, in Europa media et in $r e$ gionibus mediterraneis, nec non in terris mexicanis indigenae, dichotome rumosue, vir gatae; foliis infumis runcinatis, superioribus integris, capilulis lateralibus solitariis v. pluribus, rarius terminalibus, inconspicuis, luteis.

Chond rilla Tournefort inst, $t, 268$. Liun, gen, $n$. 910. Cassipi $\Gamma \mathrm{X}$. 64, Lessiug Synops. 135, Doa in Linn. Transact. XVT. 179 .

a. EUCHONDRILLA. I a y o 1 u c ri calyealus adpressus, foliolis aequalibns. F lores panei, subbiseriati. Herbae gerontogeae, biennes, caulibus ramosis, multifloris. Jacq. Fl. austr. $t$. 427. Gärtu. II. 362, t, 158, Setikuhir t. 218. F. das. $t$. 1652. Ledebour Ic. t. 37.

b. CRINISSA. I a o l u eri calyculus patentissimus, squamis lineari.selaceis, iuaequalibus. Flores plurimi. Herbae mexicanae, perennes, caulibur nudiusculis. subuniforis. - Criniss a Don $l$. c.
3010. 'Taproxacum JUSS. Capitulum multiflorum, homocarpum. Invol u cri oblongi squamae imbricatae, interiores aequales erectae, extimae breves patentes, umnes tandem reflexae. $R$ ec e p t a c u um planum, demum pulvinatum, epaleatum, excavato-punctatum. Co ro 11 a e ligulatae. A chenia uniformia, rostrata, sulcompressa, superne squamoso-muricata, abrupte in rostrum filiforme contracta. Pa p p s uniformis, pluriserialis, pilosus. - Herbae perennes, nemini non notae, in Europa et Asia temperata vulgares; folitis omnibus radicalibus polynorphis, inlegerrimis v, runcinato-pinnatifidis, scapis monocephalis, fistulosis, capitulis luteis.

T a r a х а $\mathrm{cum}$ Jussien gen. 169. DC. Fl. fr. IV. 45. Lessing Synops. 135. L e o u to d on Adanson Fam. II. 112.

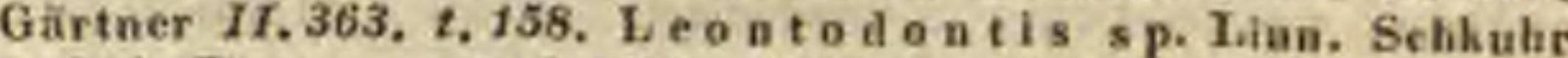
t, 219. FI. dat. t. 254.1708. Waldst, et Kitaibel Plant. Hung. t. 114. 115. Ledebour Ic, t. 33. 34. 132. 497.

30 1. WiHemetia NECK. C a pita $1 \mathrm{~nm}$ multifloram, homocarpum. Involueri polsphylli squamae imbricatae, exteriores breviores. R e e pt a e u lum planum, epaleatum, excavato-punctatum. Corolla e ligulatae. A chen ia nuiformia, restrata, teretia v, angulata, coronula rostri elongati, filiformis, fragilis basim cingente. $\mathbf{P}$ app u s uniformis, pilosus, uniserialis. - Herba in Europa media alpicola, perennis, spithamea, simplex; foliis radicalibus oblongo-obovatis, dentatis, glabris, caulinis lineari-lanceolatis, caule angulato, oligocephulo, inferne scabro, pedunculis involucrisque hispidis, fioribus luteis.

Willemetia Necker elem. n. 90. Cassini in Dict. sc. nal. LIX. 228. Mounier Hierac, 80. Lessing Synops, 136. Ca I y cosorus Selimidt. Wibelia Hoppe. Pelitidium Zollikofer in Nat. Anz, 1820, Zollikotera Nees Com. pend. Fl. germ, $I 1,306$. Literacium stipitat u macq. El. austr. t. 293.

30 A2. Ixeris CASS, Capitulum multiflorum, homocarpum. Invo In cri biseriati folfola exteriora quinque, minima. R e e pta $\mathrm{c}$ l um epaleatum. Coro I la e ligulatae. A chenia uniformia, rostrata, decemalata, teretia, rostro ovario breviore, laevi. Pa p p 8 uniformis, pluriserialis (?) pilosns. - Herba nepalensis, erecta, subglaberrima; caule ramoso, foliato, foliis semiamplexicaulibus, lineari-subulatis, capitulis flavis, irregulariter corymbosis.

I xe r Is Cassini in Bullet. soo. philomat, 1821, p, 173. Dict, sc, nat, $X X I V$. 49. Lessing Synops. 136.

3013. Zaeymtha TOURNEF. Capitulum pauciflorum, homocarpum. Involneri demum earnosi, angulato - torosi squamae interiores conduplieatae, arete conniventes, exteriores membranaceac, patentes. Receptaculam planum, epaleatum. Corolla e ligulatae. A ehenia subuniformia, exteriora involucri squamis inclusa subincnrva, brevissime rostrata, plano-compressa, exalata. Pappus uniformis, pilosus, uniserialis, scaber. - Herba mediterranea, dichotoma, glabra ; fuliis inferioribus runcinatis, ramis junceis, capitulis terminalibus et lateralibus sessilibus, luteis

Z a c y n tha Teurnef. inst. 269. Gïrtner $I T$. 358. t. 157. Cassini in Dict. sc. nat, LIX, 228. Lessirg Synops, 138. $\mathrm{L}$ a p s a i a $\mathrm{Z}$ acy in tha Libn.

3014. Nemavelhenes CASS. C a pituI в m multiflorum, heterocarpum. Involncrum campanulatum, uniseriatum, basi squamis brevi-

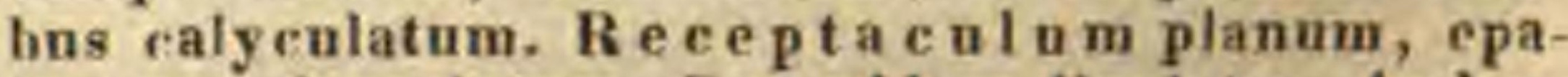
leatum, foveolatum. Corolla e ligulatae. Ach e- 
nia biformia, erostria, extima involucri foliolis involuta, pubescentia, intus nnialata, ala ultra discum epigynum in cornu producta, interiora subeylindracea, spinuloso - exasperata. Pa p p u s uniformis, pilosus, pluriserialis, inaequalis, gracilis. - Herbae orientales erectae, ramosae, longe pilosae; foliis alternis, semiamplexicaulibus, cordatis v. sagittatis, irregulariter dentatis, capitulis parvis, corymboso-paniculatis, luteis.

Ne ma tu he nes Cassini in Diot. se. nat. XXXIV. 362. Lessing Synops. 138. Crep is a s p e r a Limn.

3015. Gatyona CASS. C a pitul um pauciflorum, heterocarpum. Involuerum demum globoso-connivens, uniseriatum, basi squamis brevibus calyculatum. R e e pta c a l u in convexiusculum, epaleatum, alveolatum. Cor olla e lignlatae. A chenia biformia, brevissime rostrata, extima trigono-compressa, margine interiore alata, reliqua fusiformia, sulcata, scabra. P a p p u nniformis, pilosus, pluriserialis, seaber. - Herba Europae australis, erecta, ramosa; foliis inferioribus runcinato-lyratis, caulinis amplexicaulibus, oblongis, basi incisis, auriculatis, pedunculis elongatis, apice parum incrassatis, involucris farinosotomentosis, floribus flavis, subtus aurantiaceis.

$\mathrm{G}$ a t y o na Cassini in Diet. sc, nat. XVIIT. 162. XXV. 62. Lessing Synops. 138. Crepis Diostoridis Lian. Schkuhr t. 292. DC. 1c. plant, Gall, rar. t. 18.

3016. Lomatolepis CASS. Cap ituI $\mathbf{m}$ multiflorum, homoearpum. Involu cr i polyphylli squamae adpressae, margine late scariosae. Reeptaculum planum, epaleatum, alveolatum. Coroll a e ligulatae. A chenia uniformia, brevissime rostrata, glabra, complanata, quadrisuleata, bialata, alis oppositis, rostro vix manifesto. P a p p us uniformis, pilosus, multiserialis. Herba a e g y tia ca, ima basi foliata; foliis runcinatis, caule superne paniculato, capitulis luteis.

I, o mat olepis Cassini in Dict. sc, nat, XfVITI. 422. exel, sp. Lessing Synops, 138. Choudrill a capit at a Sieber, Sonchus capitat as Lian.

301\%. Anamoseris LESS Capitul um multiflorum, homoearpam. In v o I n eri polyphylli squamae adpressae, margine seariosae. R e e p ta e ulam planum, epaleatum, alvenlatum Corol la e ligulatae. A chenia uniformia, brevissime rostrata, glabra, angulata, quinqueenstata, costis callosis, subaequalibus, crassiusculis, rostro vix manifesto. P a p u s uniformis, pilosns, multiserialis. - Herba a gyptiaca, decumbens, diffusa, glaberrima; foliis runeinatis, paniculae dichotomae rumis divaricatis, capitulis luteis.

Mierorhynehus Lessing Synops, 139. non Zoolog. Choudrilla a adicaulis Linn. Lomatolepidis sp. Cass.

3018. Treolnoseris $P O ̈ P P$. et ENDL. C a pita I u m multiflorum, homoearpum. In vol a c r eampanulati squamae imbricatae, exteriores squarrosae. R e cepta $\operatorname{col}$ I m planum, epaleatum, alvenlatum. Co roll a e ligulatae. A ch e ni a uniformia, rostrata, glabra, oblonge elliptiea, plano-obcompressa, multicostata, costis suberoso-callosis, rostro longo, gracili, areola intus laterali. $P$ app us uniformis, pilosus, pluriserialis. - Herba chilensis, pusilla, multicaulis, villoso-canescens; foliis radicalibus oblongis, pinnatifidis, hirsuto villosis, caulibus simplicissimis, monocephalis, capitulis majusculis, luteis.

Trochoseris Pöppig et Rudl, msc. Macrorliy a ch th s Lessing Synops. 139. non Zoolag.
30 19. Thagoseris BIEBERST. C a p i tuI $\mathbf{m}$ multiflorum, heterocarpum. Involucri eampanulati, calyculati squamae uniseriatae, margine membranaceae. R e c e p t a $\mathbf{c} \mathbf{u} \mathbf{u m}$ planum, paleaceo fimbrilliferum. Corolla e ligulatae. A che nia biformia, marginalia derso convexa v, subcarinata, earinis filiformibus, obtusis v. membranaceo-alatis, centralia linearia, teretia, rostrata. $\mathrm{P}$ a p p u s capillaris, acheniorum marginalium parcus, caducissimus, centralium pluriserialis, persistens. - Herbae in Europa a ustraliore, in Asia mediterranea et in regione taurico-caucasica indigenae, basi foliatae, superne aphyllae; foliis pinnatifidis, capitulis paucis $v . p l u$ rimis, luteis.

L a g o s e ris Bieberst. Flor. III. S38. Lessing Synops,139. Koch Fl.germ. 435. P te ro the a Cassiui in Díct. sc, nat. $X X Y .68, X L I V .56$.

a. PTERothrca Cass. A e hen in marginalia latere interiore tri-quinqnealata, centralia omnia glaberrima.

Pterotheea Cassini $l$. o. Andryala nema $u$ se u s is Villars Delph, $t$. 26.

b. TRICHOCREPIS Visian. A chenia marginalia Iatere interiore tricarinata, cariuis filiformibus, obtusis, centra. lium extima muricata, interiora subtilissime soabra.

Triehoerepis Visiani Stirp. Dalmat, 18. $t$. 7 . Crepinia Reicheab. $F l$. ercurs. 269. $n$. 1786. in not, Lagoseris bifida Koch, I atybellia Cassini in Dict. sc. nat. $\mathrm{XXV}$. 124, M y os e ris Liuk Handb. $I I$. 798.

3030. Prelayleniक LESS. Ca p it u ln m mnltiflorum, heterocarpum. Involueri polyphylli squamae subimbricatae, rigidae, subcarinatae. Re ce pta e ul u m planum, paleaceum. Corolla e ligulatae. A chenia biformia, gibberosoincurva, breviter rostrata, compressinscula, marginalia calva, truneata, extus striata, intus unialata, interiora pappigera, longitudinaliter et trans. versim striata. Pap p n s acheniorum marginalium nullus, centralinm plnriserialis, pilosus, subdenticulatus. - Herba boreali-americana, ereca; foliis sessilibus, lanceolatis, serratis, capitulis luteis, subumbellatis.

Pachylepis Lessing Synops. 139. Solerolepis

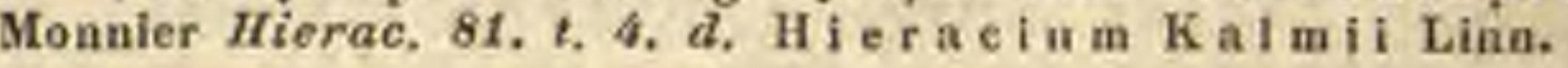

30? 1. Earklhaugia $\mathrm{MöNCH}$. C a p itu$1 \mathrm{um}$ multiflorum, homocarpum. I n v o l u c r ; pluriseriati squamae exteriores breves, laxae, interiores aequales, rectae. $R$ e e p $t$ a $c$ u $I \mathbf{~} \mathbf{m}$ planum, piloso-fimbrilliferum. Corolla e ligulatae. A chenia snbuniformia, rostrata, exalata, transversim rugulosa, rostro exteriorum saepius brevi, interiornm longo, gracillimo, subulato. Pap pas uniformis, pilosus, pluriserialis. - Herbae in Europa et Asia media, et in regionibus mediterraneis obviae, in America australi extratro. pica rarae, Crepidum, a quibus vix diversae, habitu, capitulis luteis $v$. purpurascentibies.

Barkhausia Monch Method. 536. Griesselich in Lin. naea V. 417 . Lessing Synops. 136. B n r k ha us i it Bobtamer 43. Hostia Mónch Method. Suppl. 1802. Crepldis s p. Linn. et Anct. Gartn. t. 158. E. B. t. 406. Ledebonr Ic. t. 36. $\mathrm{P}$ a ley a Cassini in Dict. so. nat, XXXIX, 393. Crepis al. bida Villars Delph, t. 33. Pferidilsp. DC. - Delode ri u Cassini in Dict, sc. nat. $x$ LVIII. 434.

30\%?. Crepis LINN. C a p it n l u m pacimultiflorum, homocarpum, floribus uni-multiseriatis. Involucrum polyphyllum, imbricatum v, squamulis plurimis ealyeulatum. R ecepta cu I $\mathbf{c} \mathbf{m}$ epaleatum, punctato-foveolatum. Corollae lignlatae. A che nia nniformia, exalata, teretia, stria. ta, sensim in rostrum breve attenuata. $P$ a $P$ P s 
uniformis, pilosus, pluriserialis. - Herbae in temperatis utriusque hemisphaerii obviae, utplurimum annuae; foliis plerumque pinnatifidis, capitulis parvis, luteis.

Crepis Linn. gen, n, 914, excl, sp. Lessing Synops. 136. Koch $\mathrm{Fl}$. germ. 437 . exel. seet. 2. et 4.

A. BUCREPIS. A the n ia 10_-13 striata.

C rep is sect. 1. Koch l. c.

1. Intybus. Scapus aphyllus, apice polycephalus. Capitula parva. Involacrum calyculo brevi, adpresso.

In t y b us Fries Novit. edit. 2. p. 244. exel, sp. Inty bellia Monier Hierac, 28. excl. sp. Geracil sp Reicheab. H ie ra eil s p. Linn. Jacq. Ic, rar, $t, 878$.

2. Aetheorhiza. Scapus aphyllus v. basi sub. foliatus, apice monocephalus, simplex $\mathrm{v}$. basi ramo uno alterove folio suffulto, apice monocephalo auctus. C a pitula majora. Involucrum hirtum.

A etheorhiza Cassini in Dict. se. nat. XLVIIT. 425. Le ontodon bulbosum Lian. - Calliopea Don in Edinb. new philosaph. Journ, VT, 309. L e onto do a a u re u m Linn. Jaeq. Fl, austr. $t$. 297. - Hie. racium a l pestre Jacq. Fl. austr. $t, 191$, - ? T ro$x$ imon Don in Edinb new philosoph. Jaurn. VI. 309. Tr. gla ucus Pursh. Tr. cuspidatus Pursh. Ago se $\mathrm{r}$ is Rafinesg. in Journ, Phys.

3. Berinia. Ca ulis foliatus, apice corymbosus.

Berinia Brignoli, Andryala chondrlllofdes Scopoll Carniol. $t$. 52 . - B rachyderea Cassini in Dict. sc, nat, XXVII. 4. C repis $\mathrm{rigida}$ Waldst. et Kiraibel Plant. Hung. $t, 19$. - P h a e c a s in m Cas: sini in Dict. sc. nat. XXXIX, 387. Scler ophy $1 /$ a m Gandin Hclv, 48. Crepis pulchra Linn. - Crepis Cassini in Dict, se. nat. XI. 395. Crepis tecto rum L. Cr. biennis L. Cr. virens L. Sehkuhr t. 222. VI. dan. $t$. 501 . E. B. $t$. 149. 1111. Waldst, et Kitaibel Plant, Hung. $t, 220$.

B. HOMALOCLINE. A e be ni a 20 striata.

$0 \mathrm{mal}$ ocline Cassini in Dict, se, nat, XLVIII. 425. Monnier Hierao, 78 . H i e r a eli s p. Linn. Waldst. et Ki taibel Plant. Hung. t. 218. Crepidis $s$ p. Waldst. et Kitaibel $t, 70$.

SUIBTRIBE VIIT. HIERACIEAE Lessing Synops. 140. R e ceptacul u m paleatum v. epaleatum. Pappus piliformis, rigidiusculus, fragillimus, demum saepe sordidus v, flavescens, nunquam plumosus, pilis exactissime linearibus, basi aequalibus.

3023. Fethia SCHREB. Capitulu m multiflorum, heterogamum. Invo I c ri poly phylli squamac uniseriatae. Receptacul um planum, margine paleatum, centro fimbrilliferum. Corolla e ligulatae. Achenia uniformia, erostria, cylindrica, striata, marginalia receptaculi paleis involuta, calva, centralia pappigera. Pa p p u setaceus, multiserialis. - Herbae in $E$ u ropa a us trali indigenae; foliis integris $v$ pinnatifidis, capitulis terminalibus, solitariis v. corymbosis.

Roth i a Sehreber gen. n, 124t. Gärtuer IT. 371. t. 174. Selikuhr t. 223. Cassiai in Dict, so, nat. XLVI. 311. Lessiag Syops. 141. Voig tia Roth in Usteri Annal, 1790, X. 17. A "1dry al a e sp. Lian.

302s. Heteracia FISCH, et MEY. Ca pitulum multiflorum, heterocarpum. Invol u er um octopartitum, basi squamosum. Re ce ptaculum plannm, epaleatum. Corolla e ligulatae. A chenia biformia, abrupte rostrata, exteriora compresso-tetragona, suberoso-corticata, calva, interiora teretiuscula, pappigera $\mathbf{P}$ ap p us setaceus, pluriserialis, setis serrulato-scabris, Herba annua, in Asia e rossicae salsis indigena, non satis nofa, dubie hue relata, humilis, glabra, ramosa; foliis sagittatis, runcinatis, eapitulis flavis
Heterncia Fischer et Meyer Index Semin, hort. Peropolit. $1835, p .31$.

3025. Andryala LINN. C a p it a $1 \mathrm{a} \mathrm{m}$ multiflorum, homocarpum. In vol ucri polyphylli squamae biseriatae. Receptaculum epaleatum, alveolorum marginilus longe fimbrilliferis. Corol1 a e ligulatae. Achenia uniformia, erostria, omnia pappigera. Pappus setaceus, pluriserialis, setis ima basi connatis, simul deciduis. - Herbae in Europa austro-orientaliet in insulis Canariis indigenae, dichotome ramosae, pilosoincanae; foliis integris $v$. pinnatifidis, semiamplexicaulibus, capitulis terminulibus, luteis.

A n d r y a l a Linn. gen, n, 915. exel. sp. Gärtner $I I, 36 t$. t. 158. Selhuhr t. 223. Cassini in Diot, sc. nat. II. 130 , Lessing Synops. 141. Erioph o rus Vaillant.

3026. IIleraeium TOURNEF, Capituln multiflorum, homocarpum. Involueri polyphylli squamae imbricatae, inaequales. $\mathrm{Re}$ ce pta $c$ a I am epaleatum, villosum valveolatum. Corolla e ligulatae. A chenia uniformia, erostria, striata v. subprismatica. Pap pus uniformis, setaceus, uniserialis, achenii margine brevissimo annulari, crenulato cinctus. - Herbae perennes, polymorphae, in temperatis totius or bis repertae, in hemisphaera boreali, inprimis in alpestribus copiosae, pilis dentatis, glandulosis $v$. stellatis obsessae, caulescentes v. scapigerae; capitulis luteis $v$, rarius aurantiaceis.

H beracium Tournefort inst, 267. Linn. gen, n, 913. excl. sp. Gärtner II, 360, t. 158. Monaier Hierac, 80. Cassisi in Dict, sc. nat. XXr. 156. Don in Linn. Transact, XYI. 175. Lessing Synops. 143. Jacq. El, austr, $6,8,189,286$. 410. Ic, rar, $t, 163$. Fi. dan, $t, 27,680,1110=1113$. E, B. t. 349. 1093, 2079. 2333, 2379. 2383. Waltst. et Kitaibel Plant, Hung. t, 85, 127, 145, 193, 209. 216. 917, 273. Reichenb. Plant. crit. icc. Ledebour 1e, $t .380,456,461 .-$ Míegla et Pla a cla Necher elem. n. 88, 89.

302 \%. Aracium NECK. C a p i $t$ u 1 o m mnltiflorum, homocarpum. Invo Iu eri polyphylli squamae subuniseriales, lineares, acuminatae. Rec e p ta culu m epaleatum, alveolatum. Coroll a e ligulatae. Achenia uniformia, rostrata, teretia, striata, rostro achenio breviore. Pap p u s unifoxmis, setaceus, uniserialis, achenii margine acscssorio nullo. - Herbae eитореаe, perennes, apice aphyllae; foliis inferioribus pinnatifidis, capitulis terminalibus paucis, luteis.

A racium Necker elem, n. 87. Lessing Synopa, 14t. li i e ra ci um pal u dos $\mathrm{um}$ Linn. Selikuhr $\ell$. $28 t$. Fi. dan. t, 928. E. B. $t$, tog4. H. ch on drillo ides Jaeq. Fl. austr. t. 429. Aracil et $\mathrm{S}$ o y erae $\mathbf{p}$. Monnier. Ge ra ci i s p. Reichenb. - Stenothe e Monnier Hierac, 7t, H, mariaa $\mathbf{m}$ L. H, venos um L.

3018. Muigedium CASS, C a pitulum multiflorum, homocarpum. In volu eri polyphylli squamae imbricatae. Receptaculum epaleatun, alveolatum. Corolla e ligulatae. A chenia uniformia, rostrata, plano compressa, rostro brevissimo. Pap p us uniformis, setaceus, pluriserialis, rostri margine brevissimo, setuloso cinnlus. Herbae perennes, in hemisplaterae borealis alpestribus et frigidiusculis crescentes; folits inlegris $v$. runcinatis, capitulis corymbosis, caeruleis.

Mulgedinm Cassiai in Dict. sc. nat. XXXIrr. 296. XLVITI. 426. Lessing Synops, 142. Royle Himalay. t. 61. Ag athyrsus Don in Edinb, new philosoph. Journ. VT. 310. Sonehus al pinas Linn. Fl. dan. t. 182. S. sibiricus Liau. S, azureus Ledebour Ic, t, 699. A raci i s p. Munaier.

3089. Soyeria MONN. C a p it u 1 u m multiflorum, homocarpum. Involueri bi-triseriati squamae lineares, exteriores minores et pa- 
tentes. Receptaculam epaleatum, alveolatofimbrilliferum. Corolla ligulatae. Achenia uniformia, rostrata, ancipiti-compressa, rostro achenio breviore. P a p us uniformis, setaceus, pluriserialis. - Herbae europeae et borealiasiaticae; foliis superioribus semiamplexicaulibus, sinuato-dentalis, capitulis magnis, corymbosis, luteis.

Soyeria Monnier Hierac. 74. Lessing Synops, 142. Catonia Mönch Method. 535. La pi caune Lapeyr. Pyren. 478. exel. sp. H a palostep hi um Don in Edinb. new philosoph. Journ. VI. 307. Hieraeil et Crepidis s p. Linu. et Aut. Jaeq. El, austr, $t, 190$.

3030. Pierosia DON, C a pitul u m mul tiflorum, homoearpum. Involueri eylindracei squamae uniseriatae, margine undulato-scariosae. Receptac n lum planum, epaleatum, nudum. Corolla e ligulatae. Achenia uniformia, rostrata, rostro achenio longiore. Pappus uniformis, setaceus, pluriserialis. - Herba chilensis, laevis, glauca; caule erecto, parce ramoso, foliis lanceolatis, integerrimis $v$. remote dentatis, radicalibus basi angustatis, caulinis semiamplexicaulibus, capitulis ramos terminantibus, solitariis, luteis.

Pierosia Dos in Linn. Transact. XVT, 183. Lessing Synops, 143. Tragopogon f ritillarioides Lessing in Linnaea $V I_{*} 101$.

3031. Pinaropappus LESS. Ca p it n I um multiflorum, homocarpum. Invol a eri polyphylli squamae imbricatae, margine apieali latissime scariosae. R e c e p t a c u l u m planum, pa leatum. Corolla e ligulatae. A chenia uniformia, rostrata, sulcata, laevia, achenio rostro longiore. $\mathbf{P}$ a p p s uniformis, setaceus, pluriserialis. - Herba mexicana, erecta, glauca, glaberrima, superne aphylla; folits inferioribus pinnatifido-dentatis, capitulis terminalibus, solitariis, roseis.

Pinaropappus Lessiag Synopt. 143. A chyroph n$r$ us roseus Lessing in Linnaea $V .134$.

303\%. Denalloseris DON. Capitu$1 \mathrm{n} \mathrm{m}$ multiflornm, homocarpum. Involucri campanulati, polyphylli squamae imbricatae. R e e p$t$ a $: u l u m$ coneavum $v$, planum, alveolatum, alveuloram marginibus nudis $v$. lacero-fimbrilliferis. Corolla e ligulatae. A chen i aniformia, erostria, basi et apice emarginata, alato-trigona $v$. compressa, Pappus uniformis, multisetus, setis inaequalibus, scabriusculis - Arbores insulae s. Juan Fernandes, decem-viginti pedales, divaricato-ramosissimae $v$. rarius inferne subsimplices; ligno in aliis durissimo, gravi, in aliis fragili, cortice laevi, inciso lac glulinosum effundente, foliis alternis, nunc integerrimis, nunc varie lobatis $v$ bipinnatis, chartaceis, petiolatis, petiolis limbo decur. rente saepe alatis, rarius subnullis, suprem is sessilibus, sensim in bracteas transeuntibus, bracteis flarum minimis, setaceis, nunc subfoliaceis v. membranaceis, paniculis terminalibus ramosissimis, interdum divaricatis, e foliorum confertorum congerie erectis, corollis albis $v$, rarius croceo-fulvis.

Dendroseris Don in Edinb, new philosoph. Journ. VI. 388. Hooker in Rot. Mag. Compan. I. 32. Rea Bertero ef Decaisne in Guillem. Archiv, bot, I. 513. $t, 9.10$.

APPENDIX. GENERA PENITUS DUBIA.

1. APATANTHUS Viviani Elor, L,bic, 5t, t, ?. f. 3. C a. p it u I u m sultiflorum, heterogamum, floribus radii ligulatis, femineis, disei hermaphroditis, tubulosis. I n vo i c ri eylindrici, setis nigricantibus teeti squamae septem, lineares, intus concavae. R e e ept a e u i i paleae ii neares, acutae. Co rolla e radii ligulatae, ligula liueari, trancata, quadridentata, dis ci tubulosae, tubo basi filiformi, supra mediuar ampliato, limbo truncato, obsolete dentieulato. A e b e $\mathrm{i}$ a conformia, linearia, ero. stria. Pa p u s pilosus. - Herba cyrena $i c a$, annua; folits amnibus radicalibus, obovatis, in petiolum an. gustatis, integerrimis, utrinque pilis setulosis consper. sis, scapo monocephalo, versus apicem conferte setu. loso, setulis in involuerum transeuntibus.

2. ABASOLOA Llav. et Lexarz. Nov, veget, I. 11, C a p I$t \mathrm{u} I \mathrm{u}$ m multiflorum, heterogamum, floribus femineis bi. triseriatis, ligulato-capillaribus, disci tubulosis, quadridentatis, hermaphroditis. I n vol u cri biseriati squamae aequales. Receptaculi plani paleae lineares, acutae, ciliato-serratae. A c h e $\mathrm{n}$ i a tetragono-rhomboidea, apicis centro papilla umbilicata. P a p p ns nullus. - Herba? mexicana, tripedalis, ramosissima, dicholoma; foliis oppositis, lineari.laneeolatis, asperulis, remote dentatis, capitulis solitariis, e dicholamiis longe pedunculatic.

3. AlLENDEA Llav, et Lexarz, Nov, veget, I, 10, C a pit al u m multiflorum, heterogamum, floribus femineis multiseriatis, ligalato-filitormibus, hermaphroditis paueis, tubulosis, limbi quinquetidi laciniis revolutis. I nvo I ue ri imbricatísquamae acutae. Re e e ta culi convexi paleae minutae, apice subaristatae, centrales longiores. Achenia ...... Pappus pilosus, uniforms. Herba mexican a, virgata, ramulis striato-teretibus. tomentoso-sericeis; folits oppositis, connatis, late lanceolatis, in petiolum brevem decurrentibus. saepius inaequilateris, supra late viridibus, subtus trinerviis, tomento argenteo sericeis, una alterave papilla denticulatis, capitulis corymbosis, flavescentibus.

4. GALRANa Llav, et Lexarz. Nov, veget, 12. C a pituI a m paneiflorum, heteroganum, floribus radil tribus. brevissime ligulatis, bifidis, femineis, disci eireiter quinque tubulosis, quinquedentatis, hermapbroditis, $1 \mathrm{nvo-}$ lueri pentaphylli foliola aequalia, carinata. Recepta.

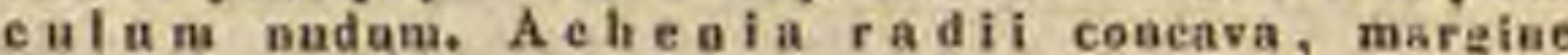
subdentato, dis ci prismatica. Pap pus nullus. - Her. ba me ricana, caule procumbente, striato, dichotome ramoso; foliis oppositis, breviter petiolatis, ut plurimum glabris, succulentis, hastatis $v$. sagittatis. capitulis e ramorum dichotomiis solitariis, longe pe. dunculatis ot in summilate ramorum breviter race. mosis.

5. ROSALESIA Llav, et Lexarz. Nov, veget. 9. Ca pit nI u m multiflorum, homogamum, discoideum. Invola cri floribus brevioris, biseriatim imbricati foliola apice re. voluta, glauduloso-viscosa. R e ce pt a c u l u m nudum. Corolla e tubulosae, tabo filiformi, ore constricto, limbo brevissime quinquedentato. A $\mathrm{n}$ the $\mathrm{r}$ a $\mathrm{e}$ in fundo eorollae. $\mathrm{S}+\mathrm{i} \mathrm{g} \mathrm{m}$ a $t$ a elongata, clavata, divarieata. A $\mathrm{ch}$. n i a cylindracea, striata, villosa. Pa p pus villosus. Frutex mexicanus, biorgyalis, virgato-ramosus; ramis junioribus striatis, pubescentibus, forigeris superne viscosis, folits oppositis, ovato-subcordutis, petiolatis, supra asperis, subtus subtomentosis, crenato-serratis, capitulis in corymbos axillares of terminales dispositis.

OBSERVATio. Genera Gomezia Llav. et Osteiza Llav, a elariss. Lindley Introduct. edit. IT. p. 264. commemorata, sobis prorsus ignota sunt.

6. MNESITEON Rafio. Ludov, 67. C a p itu $1 \mathrm{um}$ radiatum, floribus hermaphroditis quadrifidis, tetraudris. In $v 01 \mathrm{n}$. e r l turbinati, quadrifidi laciuiae radiatae, foliaceae, radio longiores. Reeeptaculum ntidum. A e he uia compressa, abata, membranacea, apice margiue crasso coronata. P a p p us?...... Plantae bore al $i$ a mericanae, scabrae v, pubescentes; folits alter. nis, linearibus, integerrimis, v. oppositis, serratis.

7. MicrospermuM Lagasea Nov, gen, 25. Capitu. I u m multifloram, homogamum, radiatiforme, floribus marginalibus majoribus subbilabiatis, I и vol u erum . Receptacul am ...... Pap pi dentes brevissimi et aristae 2 3, elongatae, - Herba mexicana; foliis oppositis.

8. Platzia Ruiz et Pav, Prodr, 104, C a pitulu m multiflorum, hэmoganum, radiatiforme, floribus marginalibus bilabiatis, labio exteriore maxino, tridentato, interiore bipartito, laciniis linearibus, revolutis, centrales infuadibuliformes, quinquefidl. Involucri ovati foliola plurima, lanceolata, erecta, Receptac u I u in nudum, P a p p us pilosus. 
9. PLACUS Loureir. Cochinch, 606. Ca pitulu m multiflorum, heteroganum, discoideum, floribus marginalibus plariais femineis, centralibus paucis hermaphroditis. i n vol u cri obturbinati, inbricati squamae lineares, temues, erectac. Recepta c u l u convexum, nudum. Co. roll a e bermaphroditae tubulosae, quinquefidae, femineae piliformes, trunchtae. A chen la oblonga, marginis tenuiora. Pappus pilosus. - Herbae cochinchi$n e n s e s$, erectae, ramosae; foliis ovatis, serratis, ucuminatis, glabris. v. oblusis, utringue tomentosis, capitulis tutvis $v$. violaceis, paniculatis.

10. GalophthalmuM Nees et Mart. in $N . A, A$. $C$. XII. 7. t. 2. CapituIn as panciflorum, heterogamun, fioribus radii unilaterafibas, subterais, ligulatis, femineis, disef tubulosis, hermaphroditis. Involucri cylindracei, biseriatios octophylli squamae aequales, interiores nembranaceae. Receptacufum nudum, punctatum. A chenia compresso-tetragona, obcosica. P a p pi spiaae 2-4, breves, divergentes, e latiori basi acuissimae. - Herba brasiliensis; caule faccido, procumbente, sparsim hispidulo, folits subquaternis, longe petiolatis, petiolis basi dilatata subconnatis, obtuse serratis, utrinque tuberculoso-setosis, capitulis parvis lutels, e dichotomitis breviter pedunculatis $v$. in axillis superioribus sessilibus.

11. DAMATRIS Cassini in Dict, sc, nat. XIT, 472. C a pit u $1 \mathrm{um}$ multiflorum, heterogamum, floribus radil uniseriatis, ligulatis, femiaeis, disci tubulosis, masculis. I nvolueri hemisphaerici squamae imbricatae, exteriores appendice foliacea, Interiores scariosa auctae. R e e ptaculi convexiuscull paleae inter radium et discum uniseriatae, flores femiueos amplectentes. Corollae $r$ a d i ligulatac, dis c i tubulosae, limbi quinquelobi lobis eallo triangulari, nigricante terminatis. A c h e i a dis e i abortiva, r $r$ d i i cylindracea, rufo-pilosa. Pa p pi achenio longioris squamellulae biseriatac, inaequales, paleiformes, latae, obovales, nembranaceo-scariosae. Herba capensis, annua; caule brevissimo, pedunculis scapiformibus, monocephalis, foltis alternis, semiamplexicaulibus, lineari-lanceolatis, sinuatis, tomentosis, subtus albidis, floribus flavis.

12. DimerostemMA Cassini in Dict, sc, nat, XIII. 253. Ca pit u I u m multifloroun, homoganusa, discoideum. I n. vo I c eri subglobosi squamae pauciseriatae, inaequales, exteriores majores bracteifornes, ovales, dentatae, interiores oblongae, integerrianae. Receptaculi planius. culf paleate oblongae, acutae, apice subspineseentes, achenia amplexantes. A che u fa liuearia. Pappi paleolae duae coriacese, nagnae, semilanceolatae, basi connatae, saepias irregulariter ineisae. - Herba $r_{a s i}$. liensis villosa; foltis alternis, breve petiolatis, dentate-crenulatis, subtriplinervizis, capitulis flavis, terminalibus, solitarits.

13. GLYPHIA Cassiai in Diet. se. nat. $X I X$, 108. Capi$t \mathbf{l} \mathbf{l} \mathrm{m} \cdot \mathrm{mnitifiorum}$, heterogamum, floribis radi nnise. riatis, ligulatis, femineis, disei tubulosis, hermaphroditis, Involucri squamae biseriales, imbricatae, submembranaceae. Receptaculum planum, fimbrilliferum, finbrillis brevibus, inter se conatis, subutatis, membranaceis. A e h e i i a oblonga, subeylindracea, striata, hispidula, callo basilari cartilagimeo. Pap pi longi squamellae plurimae, inaequales, filiformes, barhellulatae. - Planta madagascariensis, glaberrima; caule lignoso. flexuoso, fortassis volubili, folits alternis, subsessi. libus, ovato-acuminatis, integerrimis, membranaceis, pellucido-glandulosis, capitulis in ramis terminalibus, paniculatis.

14. GÜNTHERIA Spreng. Syst. $I I T$. 356. Involuerum monopliyllum, mulipartitum, multifloram. Receptaca$1 \mathrm{um}$ paleaceum, paleis fissis, aristatis. Pap us paleaceus, paleis corollae tubum isivalventibus. - Herba brasiliensis cubitalis, monocephala, pubescens; folits alternis, oblongis, utrinque attenuatis, integer rimis, floribus flapis.

OBSERVATI0. Genera Aganippea Flor. mex. et Tri. metra Flor. mex. a cl. Lindley Introduct. edit. II p. 264. commemorata, penitus ignota manent.

\section{Drdo CXXI. Calycereate.}

CALXCEREAE R. Brown in Linn. Transact, XII, 139 148. L, C. Richard in Mems. Mrus, YI, 77. Bartling Ord, nat.
133. DC, Prodr, V. 1. BOOPIDEAE Cassini in Journ, Phys, 1818. p. 113. Opusc. phytolog. II, 344.

Herbae annuae v. perennes, rarius suffrutescentes, succo aqueo, rarissime scapigerae, plerumque caulescentes, caule ramisque teretibus v. angulatis. Folía alterna, sessilia, integra, integerrima v. dentata, saepius pinnatifida, exstipulata.

F tores hermaphroditi, v, ovarii et styli struetura imperfecta unisexuales, in capitulum multiflorum, terminale, v. rami axillaris in caulem succrescentis elongatione oppositifolium, supra receptaculum rarissime planmm, plerumque subglobosum v, convexo-conicum, foliolis unipluriseriatis involucratum collecti, sessiles.

Capituli nune flores omnes fertiles, nune steriles, ovario efoeto donati, fertilibus mixti, vel in receptaculo conico inferiores (marginales) perfeeti, mediantibus calycibus inter se connati, superiores (centrales) steriles, distincti.

Invouvcri foliola plura, uni-biseriata, libera v. basi plus minus inter se connata.

Receptacolum commune paleis inordinate floribus intermixtis, in nonnullis fere obsoletis, rarissime in alveolos concretis obsessum.

Catyx tubo cum ovario connato, limbo supero, quinquepartito, laciniis plerumque plus minus inter se inaequalibus, in floribus sterilibus ut plurimum squamaeformibus, brevissimis, in fertilibus plus minus elongatis, acntis, maturitate induratis, coniformibus, persistentibus.

ConoLta disco epigyno inserta, gamopetala, regularis, tubo elongato, gracili, recto, limbo campanulato v. infundibuliformi, tubo multo breviore, ampliore, quinquefido v rarins quadrifido, laciniis linearibus, nervo medio duobusque submarginalibus instructis, per aestivationem valvatis.

Stamina quinque, corollae laciniis alterna, imo tubo inserta, fil a ment a juxta totam longitudinem tubi corollini arctissime eidem adnata, ad faucem a tubo distincta, monadelpha, per totam longitndinem in tubum connata v. apicibus brevissime distincta. Antherae introrsae, biloculares, erectae, lineares, exappendiculatae, basibus inter se in tubum connatae, apicibus distinctae, connectivo filamentis continuo, filiformi, loculis parallelis, longitudinaliter dehiscentibus.

Ovariem inferum, uniloculare, uniovulatum. O vulum apici loculi appensum, anatropum. Discus epigynus conoideus, styli corollaeque basim connectens, intra tubum corollae in laminam tenuissimam, ad faucem in areolas quinque glandulares tumentem produetus. Stylus terminalis, simplex, exsertus, apice clavato-incrassatus, glaberrimus. Stig ma ter- 
minale subcapitatum, integerrimum, glandulosum.

Achenia limbo calycis saepius aucto, rigescente v. spinescente, et corolla emarcida coronata, libera $\mathbf{v}$, in globum echinatum coadunata, epicarpio (calycis tubo) crasso, fungosocoriaceo $\nabla$. sublignoso, ab endocarpio (pericarpio proprio) solubili.

Seren unicum, inversum, test a membranacea, $r h a p h$ e lineari et $\mathbf{c h}$ al aza apicali notata. $\Lambda$ lb um en carnosum.

Емвкхо orthotropus, axilis, albumine parum brevior, cylindricus. Cotyle do nes oblongae, obtusae, plano-accumbentes, $r$ a d i c ula umbilicum spectante, supera plus minus brevioribus. Plu $\mathrm{mala}$ inconspicua.

Boopideae a Compositis semine inverso albuminoso, a Dipsaceis staminibus synantheris et corollae lobornm nervatione distinctissimae, in America australi extratropica parvo adhucdum specierum numero observatae fuerunt, in Brasilia tropica et in Antillis rarissimae.

3033. Camoearplua $D C$. Capituli multiflori flores omnes fertiles. Involncri biseriati squamae foliaceae, exteriores quinque v. sex basi ad mediam connatae, interiores totidem alter. nae, liberae. Recepta $\boldsymbol{c}$ uli planiuseuli fimbrillae acutae, in alveolos concretae. Flores distincti. C a ly x tubo brevi, cylindrico, cum ovario connato, limbo snpero, brevissime quadri-quinquedentato. Corolla supera, tubo brevi, fauce inflata, limbo campanulato, quadri-quinquefido. S $\mathrm{t}$ a $\mathrm{m}$ in a quatuor $\mathrm{v}$, quinque, fauci corollae inserta, inclusa; fil ame $\mathrm{n}$ ta basi monadelpha, apice libera, a $\mathrm{nt}$ h era e inferne in tubum connatae, superne distinctae, muticae. 0 vari um calycis tubo connatum, uniloculare. Ov u I n unicum, apici Joculi appensum, anatropum. Sty I u s exsertus, indivisus, apice clavato-incrassatus; $\mathrm{sti} \mathrm{g} \mathrm{m}$ a terminale, subcapitatum. A e h e n i a ..... - Herba pusilla, Valeriunae Saliuncae habitu, in andibus Antucensibus Chili a ustralis degens; foliis radicalibus confertis, obovato-ellipticis, in petiolum attenuatis, inte. gerrimis, glaberrimis, scapis monocephalis.

Gamocarpha DC. Prodr. V. 2. Boop is alpina Pöppig et Endlfch. Nov. Gen, et sp, t. 33.

3034. Boopiss JUSS, Capituli multiflori flores omnes fertiles v. fertiles sterilibus mixti. Involucri demum patentis squamae septenaeoctonae, basibus membranaceo dilatatis, denticula tis connatae, apice lineari-acuminatae. R e ce p $t$ ac u $1 \mathrm{um}$ convexiusculum, parvum, paleis spathulaeformibus onustum. Flores distincti. Calyx tubo obeonico, angulato, cum ovario connato, limbi superi quinquepartiti laciniis brevibus, Іапceolatis, integris v. inciso-dentatis. Corolla supera, tubo filiformi longo, fauce subaequali, limbo campanulato, quinquefido. St a $\mathrm{m}$ in a quinque, fauci corollae inserta, inclusa; filamenta monadelpha, apice brevissime distincta, antherae basi in tuhum connatae, superne distinctae, muticae. Ovarium calyeis tubo connatum, uniloculare. Ovulum unicum, apici loculi appensum, anatropum. St yl as exsertus, indivisus, apice clavatoincrassatus; s t i g ma terminale, subcapitatum.
A $\mathrm{e}$ henia turbinato - prismatica, calycis limbo et corolla persistente superata. Semen inversum. Embryo in axi albuminis carnosi orthotropus, radicula supera. - Herbae chilenses et bonarienses, perennes, humiles, puberulae, ramosae; foliis alternis, sessilibus, patentiusculis, profunde pectinato-pinnatifidis, laciniis linearibus, integerrimis, capitulis terminalibus, hemisphaericis.

B oo p is Jussieu in Annal. Mus, II, 350, t. 58. $f .2$. Cassini in Journ. Phys, 1818, p. 11i. Opusc, phytolog. II. 355. L. C. Richard in Mem. Mus. YI. 78. t, 11. Pijppig et Eudlicher Nov, gen. et sp, $t, 34$. DC. Prodr, V. 2.

3035. Calyeera $C A V A N I L L$. Capituli multiflori flores fertiles sterilibus mixti. Involncri demum patentis squamae foliaceae quinae-septenae, basi vix connatae, inaequales. R e c e p ta $\mathrm{e}$ uI $\mathbf{~ m}$ subglobosum, paleis tenuissimis, setaceo-subulatis onustum. Flores distincti. Cal y cis tubns oblongo-turbinatns, angulatus, linbi superi, quinquefidi laciniae in aliis floribus brevissimae squamiformes, ovales, obtusae, in aliis elongatocorniformes, induratae, acuminatae. Corolla supera, tubo filiformi, longo, fauce abruptim inflata, limbo campanulato, quinquefido. St a $m$ in a quinque, fauci corollae inserta, inclusa; fi la me nt a basi monadelpha, apice libera, a ntherae inferne in tubum connatae, superne distinetae, muticae, O va. r i u m calycis tubo connatum, uniloculare. OvuI $\mathbf{m}$ unicum, apici loculi appensum, anatropum. S tylus exsertus, indivisus, apice clavato-incrassatus; st igma terminale, subcapitatum. A $c$ hen i a turbinato-pentagona, calycis limbo in aliis floribus brevissimo, squamaeformi, in aliis elongato, corniformi et corolla persistente superata. S e m e n inversum. E mbryo in axi albuminis carnosi orthotropos, radicula supera. - Herbae chilen$s e s$, perennes, glaberrimae $v$. subpilosae; foliis alternis, pinnatifido-dentatis, capitulis terminalibus, solitariis.

Cal y e ra Cavanilles Ic. IV. 34. $t$, 358. (sphalmate Calicera) Cassini in Dict. sc. nat. VI. Suppl. 36. Journ. Phys. 1818. p. 113. Opusc. phytolog. II. 353. L. C. Richard in Mem. Mus. II, 27. t. 10. DC. Prodr. V. 2. S c a bios a s y m paga n the ra Ruiz et Pav. Flor. peruv. $t$, 76. $f$. $a$.

3036. A eicarpha JUSS. C a p it ul i multiflori flores marginales (inferiores) hermaphroditi, centrales (superiores) ovario efoeto masculi. Invo I u c ri patentis squamae foliaceae quinque, spathulatae, basi plus minus inter se et cum receptaculo connatae v. liberae. Recepta $\mathrm{culum}$ conicum, paleis inter flores vix manifestis. F I ores fertiles calycibus inter se connati, superiores steriles distincti. CaI y x tubo brevi, obconico-pentagono, cum ovario connato, in floribus sterilibus subnullo, limbi superi quinquefidi lobis inaequalibus, acuminatis, demnm spinescentibus. Corolla supera, tubo filiformi, longo, fauce sabinflata, limbo infundibuliformi, quadri-quinquefido. $\mathrm{S} t \mathrm{a} \mathrm{m}$ i $\mathrm{n}$ a quatuor v. quinque, fauci corollae inserta, inclusa; fil a menta juxta totam longitudinem monadelpha, a n ther a e inferne in tubum connatae, apice distinctae, muticae. Ovarium calycis tubo connatum, uniloculare. Ovulum unicum, apici loculi appensum, anatropum. Stylus exsertus, indivisus, apice clavato-incrassatus; stig ma terminale, subeapitatnm. A chen ia in globum, calyeum laciniis demum conico-spinescentibus echinatum conferruminata. S e $\mathbf{m}$ e $\mathbf{n}$ inversum. E $\mathbf{m}$ b r yo in axi albuminis earnosi orthotropus, radieula supera. - Herbae v. suffrutices, brasilienses et bonarienses; foliis allernis, spathulatis v. ob- 
longo-cuneatis, integerrimis v. sinuato-dentatis, capitulis opposilifoliis.

A cicarpha Jussiea in Annal. Mus, IV. 347. $t$. 58 . f. 1. Cassini in Diet. sc. nat, I. Suppl, 32. L. C. Richard in Mem, Mus. VI. 77. $t, 11,12$ Lessing in Linnaca VI. 587. DC. Prodr. $V$. 3. Cryptocarpwa R. Brown in Linn. Transact, XI1. 131. Cassini in Diot. so. nat. XII. 85. Opusc. phytolog. IT. 357. Hoin Radd. So mme a Bory in Annal. gener. sc. phys. VI. 92, t, 87. A c a uthosper ma Arrabo Flor. Flumin. VIII, $t$, 159. E е h i u ole m a Jacq. f. mse.

\section{Classis XXX更. Campanulinae.}

Herbae v. frutices, rarius arbores. Folia alterna $v$. opposita. Stipulae nullae. Flores hermaphroditi, inflorescentia varia. Calyx tubo cum ovario connato, limbo supero, rarius liber, corollae tubo tunc saepius cum ovario connato. Co roll a perigyna v. rarissime hypogyna, regularis $v$. irregularis. St a mina cum corolla inserta, ab ejusdem tubo vix non semper distincta. O va rium rarius uniloculare, plerumque pluriloculare. 0 v u 1 a rarissime definita, e basi erecta, saepissime in placentis e loculorum angulo centrali plurima, adscendentia, anatropa. Fructu s capsularis, baceatus v. nucamentaceus, mono-polyspermus. S e mi$\mathrm{n}$ a albuminosa, rarissime exalbuminosa. E $\mathbf{m}$ bryo intrarius, orthotropus, radicula infera.

\section{Drdo CXXIE. Brumomiaceae.}

BRUNONIACEAE R. Brown in Edinb. new philosoph. Magas. 1839, Sept, Lisdley Introduct. edit, II. p. 266.

Нвквав Novae-Hollandiae, perennes, subacaules, Scabiosae facie, pubescentes, pilis simplicibus, eglandulosis. F o li a radicalia conferta, integerrima, spathulata. Sca pi ex eadem radice plures, simplicissimi, erecti, monocephali.

Fuones hermaphroditi, regulares, in capitulum hemisphaericum, lobatum, involucratum congesti, lobis bractea foliacea, foliis involucrantibus simili subtensis, singuli bracteolis quatuor verticillatis, membranaceis, et quinta parum dissimili distincti.

Calyx tubo brevi, turbinato, extus puberulo v. villoso, ab ovario distincto, limbi quinquefidi laciniis tubo longioribus, subulato-setiformibus, plumosis, apice simplicibus v. glandula colorata terminatis, sub anthesi erectis, demum patulis.

Coвоци hypogyna, gamopetala, infundibuliformis, azurea, marcescens, tubo calycis lacinias aequante, demum fissili, limbi quinquefidi laciniis spathulatis, patentibus, duabus superioribus paullo profundius distinctis.

Stamixa quinque, hypogyna, inclusa. FiI a enta ovarii stipitnlo brevissimo inserta, plana, linearia, distincta. Anthera e oblongae, lineares, biloculares, in tubum stylo pervium cohaerentes, loculi introrsi, paralleli, longitudinaliter dehiscentes. Pollin is granula sphaerica.

Ovaniom liberum, stipitulo brevissimo, nonnisi demum manifesto impositum, uniloculare. O $\vee \mathrm{Ium}$ unicum, basilare, anatropum. StyI us terminalis, simplex, crassiusculus, exsertus, superne piloso-hispidns. Stigma cuneiforme, carnosum, retusum, indusio aequaliter bifido, ore nudo inclusum.

Utriceles monospermus, inclusus tubo aucto et indurato calycis superne patuli, laciniis plumosis.

Simes erectum, ovatum, testa simplici. A 1 b um en nullum.

Enввуо orthotropus; cotyledunibus plano - convexis, radicula brevissima, plumula obsoleta.

Brunoniace ae, unico adlucdum genere comprehensae, a reliquis Campanulinis ovario libero, staminum insertione hypogyna, et albuminis defectu differunt, Goodeniaceis propter peculiare stigmatis indusium proxime accedentes.

803\%. Brumomia SMITH. Flores capitati, involucrati, singuli quadribracteati. Cal y x tubo brevissimo, limbi quinquefidi laciniis plumosis. CorolI a hypogyna, infundibuliformis, limbi quinquepartiti lacinis duabus superioribus profnndius distinetis. Sta $\mathrm{m}$ in a quinque, hypogyna; $\mathrm{f}$ lamenta distincta, antherae connatae, Ovari um unilocnlare. $O_{\text {v }}$ I n m unicum, basilare, anatropum. Stylns simplex; stigmatis indusium bivalve. Utric ul us monospermns, ealyeis tubo indurato, superne patulo, laciniis plumosis inclusus. Semen erectum. Embryonis exalbuminosi radicula brevissima, infera. - Herbae Novae-Hollandiae perennes, scapigerae, pubescentes; foliis radicalibus confertis, spalhulatis, integerrimis, scapis simplicissimis, monocephalis.

B ra n a $\mathrm{n}$ a Smith in Linn. Transact, $x$, 367, t, 28. 29. R. Brown Prodr, 589. Linn, Transact, XIT, 139. Ferd, Bager Flustr, Plant, t, 10. Bot, Reg. t, 1833. Guillemin Ic, Ii. thogr. t. 15.

\section{Drdo CXXIII. Goodeniacene.}

GOODENOVIAE R. Brown in Flinders Voy, $I I$. 559 . Prodr. 573. G00DENOVIEAE Bartling Ord. nat. 147. G00. DENOVIACEAE et SCAKVOLACEAE Liudley Introduct, edit. II. p. 241, 242.

Herbae v. suffruticrs, succo aqueo, calle erecto $v$. rarissime volubili, tereti $v$, irregulariter angulato, interdum nudo scapiformi, nunc aequaliter foliato, pube dum adest simplici v. rarius glandulosa, ant interdum stellata. F oli a sparsa, nonnunquam omnia radicalia congesta, extipulata, simplicia, saepins indivisa, integerrima $\mathbf{v}$. saepius dentata, rarius lobata.

Fuones hermaphroditi, irregulares, flavi, caernlei v. purpurascentes, rarissime rubicundi, nxillares v. terminales, varie dispositi. 
Calyx tubulosus, tubo cum ovario connato, v. rarissime ab eodem distincto; limbus superus, interdum obsoletus, plerumque manifestus, quinquefidus, laciniis subaequalibus ; rarius calyx liber, triphyllus v. pentaphyllus, foliolis subaequalibus, ima basi cohaerentibus.

Corolra gamopetala, plus minus irregularis, decidua v. marcescenti persistens, imo calyci libero, vel summo tubi cum ovario connati margini inserta; $\mathbf{t} \mathbf{u}$ b u s postice fissus $\mathbf{v}$. quinquepartibilis, dum calyx liber ab eodem plane distinctus, sed ovario adnatus, $l \mathrm{imb}$ us quinquepartitus, laciniis plus minus inaequalibus, uni - bilabiatim dispositis, laciniarnm discolanceolato, plano, saepe pubescente, marginibus (alis) plus minus latis, texturae tenerioris, cleratis, aestivatione induplicatis, raro obsoletis v. nullis.

Stauiva 5, epigyna, a corolla et stylo libera, illius laciniis alterna. Filamenta filiformia, distincta $\mathbf{v}$. interdum apice cohaerentia. Antherae distinctae $v$. in tubulum leviter cohaerentes, erectae, lineares, biloculares, introrsae, loculis longitudinaliter dehiscentibus. Poll in is granula simplicia v. rarissime e granulis quaternis composita.

Ovariem inferum, v, calyci superum et corollae inferum, nunc uniloculare, nunc saepius septo incompleto $\mathrm{v}$. completo subbiloculare $\mathrm{v}$. biloculare, rarius septo secundario quadriloculare. $0 \mathrm{v}$ u l a nunc in loculis solitaria, rarissime intra ovarium uniloculare gemina collateralia, e basi ereeta, nunc plurima, utrinque in placentis dissepimentum occupantibus imbricatim adscen dentia, anatropa. G la n d u I a epigyna inter stamina duo anteriora, saepissime deficiens. $S \mathrm{ty}$ Iu s unus, rarissime duo, ima basi connati, simplex $v$. interdum trifidus. S $t i g m$ a carnosum, indivisum v. bilobum, ind us io (disci epigyni cum stylo connati margine libero) submembranaceo, cyathiformi, integro v. bilabiato, labiis horizontalibus ve verticalibus, cinctum.

Froctus nune drupaceus v. nucamentaceus cum seminibus definitis, nunc capsularis cum semiuibus indefinitis, plus minus complete biJocularis v. interdum quadrilocularis, septifrago bivalvis, valvis dissepimento parallelis $\mathrm{v}$, contrariis, nune iisdem bifidis quadrivalvis.

S e m i n a erecta, solitaria, v. adscendentia, imbricata; testa saepius crassiuscula, interdum nucamentacea, in capsularibus plerumque margine v. ala membranacea cincta. Alb u men carnosum, semini conforme.

Euszyo in axi albuminis orthotropus, ejusdem fere longitudine; cotyledonibus mediocribus, saepe foliaceis, radicula umbilico proxima, infera, pl umula inconspicua.

Gooden iacea maxima copia in NovaHollandia inter et extra tropicos indigenae, rarius in Capite bonae spei gignuntur, una species per Anstralasiae et Americae littora antarctica divulgata, paucissimae inter tropicos Asiae, Oceaniae et Americae reperiuntur.

Affinitate proximae sunt Lobeliaceis, a quibus tum habitu in plurimis peculiari, tum indusii stigmatici fabrica, tum corollae aestivatione et tubo ejus postice fisso facillime distinguuntur.

TRIBUS I. SCAEVOLEAE R. Brown Prodr.582. Fructus drupaceus v. nucamentaceus. Semina definita.

3038. Sesevola $L I N N, C$ a ly $x$ tubo ovato v. subgloboso, cum ovario connato, limbi superi, quinquefidi laciniis aequalibus, interdum obsoletis, Corolla supera, tubo hine longitudinaliter fisso, genitalia exserente, limbi inde secundi, quinquepartiti laciniis alatis, conformibus, aestivatione induplicatis. Stamina 5 , cum corolla inserta, filamenta et antherae apice interdum barbatae liberae. 0 vari um inferum, biloculare, rarius quadriloculare v. uniloculare. Ovula in loculis solitaria, in ovario uniloculari interdum bina collateralia, e basi ereeta, anatropa. Stylus simplex; $8 \mathrm{tigmat}$ is indusium imberbe. Drupa baccata v, exsueca, calycis limbo coronata v. nuda, umbilicata, uni-quadrilocularis. Se mina in loculis so. litaria, erecta. Emb r yo intra albumen tenue carnosum rectus; cotyledonibus carnosis, radicula brevissima, infera. - Suffrutices $v$. herbae inter tropicos veteris orbis, in insulis Oceani et Novae-Hollandiae littoribus vulgares, in Antillis rarae; foliis alternis $v$. rarissime oppositis, integris, saepissime dentatis, pube dum adest simplici, floribus axillaribus $v$. in spicam foliatam dispositis, calyeibus basi bibracteolatis, corollis albis, caeruleis v. rarissime luteseentibus, alis luciniarum basi, rarius juxta totam longitudinem fimbriatis, fim. briis apice floccoso - ramosis, tubo intus villoso, ad faucem saepe ramentifero.

Searvola Linn. gen. n. 224. Jussieu gen. 165. R. Browa Prodr. 582. Lo be li a Plumier gen. t. 31 . Gärtaer I. 119 .

a. SARCOCARPA Don syst. $T I T$. 727. Dr a pa baccata, bilocularis, disperma. - Frutices littorei, folits alter. nis, ad axillas barbatis, pedunculis axillaribus triflo. ris, rarius unifloris. - C e r be r a Loureir. Flor. co. chinch. 168. uon Linn. G I y p h a Loureiro mse. L o b eI i a e s. Plumier. Catesby Carolin. $t$. 29. Gartn. t. 25. (Jussieu in Annal. Mas. XVIIT. $t, 1$. f. 4. Labillard. Nov. Caledon, $t$. 49. Gaudich, ad Frejcinet $t .81$. 82. Bot. Mag. t, 2732,)

b. XER0CARPA Don Syst, IT, 72s. Drupa saepius exsueca, uui-quadeilocularis, mono-tetrasperma. - Erutices v. herbae Novae-Hollandiae, spica forum terminali $v$, axillari, bracteis foliaceis, bracteolis persistentibus, - Goodenia e s p. Smith Bot. Mag. t. 287 . Audr. Bot. Reposit, t, 28. (Cavanill. Tc. t, 509. Labillard. Nov, Holl. t. 78 -80.)

c. POGONANTHERA Don $S y s t$ IIL, 729. D r u p a exsucea, disperma (?). Anthera e barbatae. C a l y $x$ longitudine ovari. - Herbae Novae-Hollandiae pedunculis axil. laribus elongatis, unifloris, apice diphyllis. - Seae. vola hispida Cavanill. Ic, $t, 510$. Goodenia ra. uos is sin a Saith Nov. Holl, $t, 5$.

d. Crossotoma Don $S y s t, I I T, 230$, D r u p a $\ldots .$. Cal yx obsoletas, Corolla alis laciniaram longitudi. naliter fimbriatis. - Frutex Novae-Hollandiae meri. dionalis, sui persimiliter geaeris, pedunculis axilla. ribus uniforis, bracteolis deciduis. - Pogouetes Lindley Introduct. edit. IT, $p$. 242. absque elaract. Scaevolaspinescens R. Brown. 
3039. Diaspasis $R, B R, C$ al $\dot{y} x$ tubo brevi cum ovarii basi connato, limbi semisuperi, quinquefidi laciniis aequalibns. Corolla supera, subregularis, hypocraterimorpha, tubo quinquepartito, genitalia includente, limbi laciniis late alatis, duabus snperioribus panllo dissimilibus, aestivatione induplicatis, $\mathrm{S}$ t a $\mathrm{m}$ in a 5, cum corolla inserta; fi l amenta et antherae imberbes libera. Ovarinm semiinferum, uniloculare. O vula gemina, collateralia, e basi erecta, anatropa. St ylus simplex; 8 tig matis indusium semibivalve, imberbe. $N$ ux corticata, monosperma. S e men erectum. E mbryo ....... Herba in Novae-Hollandiae ora a us tro-occiden tali observata, subramosa, glabriuscula, pube rara, simplici; foliis alternis, teretiusculis, pedunculis axillaribus unifloris, apice diphyllis, flore cernuo, corollae unguibus basi arctius connatis, superne pube brevissima, capitata connexis.

Diaspasis R. Brown Prodr. 587.

3040. Danopiera R. BR. C a ly $x$ tubo cum ovario connato, limbi superi, quinquefidi laciniis aequalibus, saepe obsoletis. C orolla supera, bilabiata, tubo hine fisso, laciniis alatis, labii superioris margine interiore auriculatis, omnibus aestivatione, unguibus etiam per anthesim induplicatis. S $t$ a m in a 5 , cum corolla inserta; fil a menta libera, antherac arcte in tubum cohaerentes. Ovari u m inferum, uniloculare. $O$ v u l u m unicum, e basi erectum, anatropum. Sty I u s simplex; 8 tig matis indusinm imberbe. N $\mathrm{n} \times$ corticata, monosperma. Se men erectum. Embryo... - Suffrutices v. herbae perennes Nova e-Hollandiae, aridae, pubescentes, pilis saepius biformibus, aliis longioribus plerumque ramulosis, subplumosis, aliis brevioribus, stellatis; foliis alternis, indivisis, subdentatis, coriaceis, floribus axillaribus v. terminalibus, solitariis $v$. subspicatis, bracteis parvis $v$. nullis, corollis caeruleis v. purpureis, laminis extus hirsutissimis.

Da mplera R. Brown Prodr. 587. Jussieu in Annal. Mus. XVIIT, 18, t. 2, f. 1, 2.

TRIIBUS Ir. GOODENIEAE. Fruetus capsularis. Semina indefinita.

3041. Cyphia BERG. Caly $\mathrm{x}$ tubo turbinato, cum ovario connato, limbi superi, quinquepartiti laciniis subaequalibus. Co rolla supera, pentapetala, petalorum unguibus in tubum postice apertum, antice aequalem $\mathbf{v}$, gibbum conniven tibus rarinsve subconnatis, laminis subaequalibus, bilabiatim patentibns, angustissime alatis, aestivatione induplicatis. S $\mathrm{t}$ a $\mathrm{m}$ in a 5 , cnm corolla inserta ; fil a $m$ e $n t$ a pilosa, superne sub anthesi cohaerentia, demum discreta, an therae liberae. Ovarin m inferum, biloculare. Ovala plurima ...... StyI a s simplex; stigmatis indusium brevissimum, barbatum. Cap 8 ul a bilocularis, polysperma. Herbae capenses, erectae $v$. volubiles; radice in pluribus tuberosa, foliis rarius omnibus radicalibus integris, caulinis alternis, plerumque digitatis v. lobatis, floribus terminalibus, spicatis v, racemosis.

C y phia Bergius El. eap. 173. Jussteu gen. 165. Presl in E. Mejer Comment. Pl. Afr, austr. 292. Lo be Ii a e s p. Linn.

a. RUCXPHIA Pres! l. c. Cor o lla bilabiatae, basi gibbae petala libera. (Bot, Reg. t, 625.)

b. Isomerta Prest. $t$. c. Corolla bilabiatae, basi aequalis petala libera. c. CYPhiRLla Presl. 2. c. Corolla gamopetala, hypocraterimorpha, tubo cylindrico, Incurvo, deasum bisc is. de irregulariter fisso, limbo patente, aequali.

3042. Selliera CAVANILL. C a l y $\mathrm{x}$ tabo cum ovario connato, limbi superi, quinquepartiti laciniis aequalibus. Corolla supera, quinquefida, aequalis, postice fissa, laciniis unilabiatis, apteris, aestivatione valvatis. Sta m in a 5 , cum corolla inserta; filamenta et antherae liberae. Ovari nm inferum, vertice subexsertum, biloculare. Ovul a plurima, adscendentim imbricata, anatropa. Stylus simplex; stigmatis indusium horizontaliter bilabiatum, imberbe. Caps a la bilocnlaris, carnusa, indehiscens. S e min a plurima, adscendentim imbricata, compressa, membranaceomarginata. Embryo ....... - Herba pusilla, glabra, in littoribus Novae-Hollandiae et Americae australis extratropicae observata; caule lignescente, prostrato, radicante, foliis ad nodos congestis, spathulato-lanceolatis, carnosis, integerrimis, pedunculis axillaribus unifloris, bibracteatis.

Selliera Cavanillis in Anales de fienc. nat. I, 41. $t, 5$, Ic, $V, 49, t, 474 ., f$, 2. Gooden ba repens La. billard. Nov. Holland. t. 76. R. Brown Prodr. s79.

3043. Goodenta SMITH. C aly $\mathrm{y}$ tubo cum ovario connato, limbi superi, quinquepartiti laciniis aequalibus. Corolla supera, aequalis $\mathrm{v}$. antice in gibber nectariferum producta, postice fissa, limbi quinquefidi, uni-bilabiati laciniis alatis, aestivatione induplicatis. $\mathrm{St}$ a $\mathrm{m}$ in a 5 , cum corolla inserta; filamenta et antherae liberae. Ovari um inferum, vertice breviter exsertum, biloculare $v$. septo abbreviato subuniloculare, rarius septo secundario quadriloculare. Ov u la plurima, ads:endentim imbricata, anatropa. Stylus simplex; $8 t i g m a t i s$ indusinm horizontaliter v. verticaliter bilabiatum, barbatum. C a p \& $\mathrm{l}$ a bi-quadrilocularis, septifrago-bivalvis, valvis integris v. demum bifidis. S e m in a plurima, adscendentim imbricata, compressa, membranaceo-marginata. $\mathbf{E} \mathbf{m}$ hryo in axi albnminis carnosi orthotropus; cotyledonibus foliaceis, radicula umbilico proxima, infera.

Herbae in Nova Hollandia indigenae, plerumque caulescentes, nonnullae etiam suffrutescentes; foliis alternis, inlegerrimis, dentatis $v$. incisis, floribus axillaribus $v$, terminalibus, pedicellis bibracteatis $v$, ebracteatis, corollis saepius flavis, nunc caeruleis $v$, purpurascentibus, antheris ante anthesim leviter cohaerentibus, imberbibus v. rarissime apice subbarbatis, capsulae figura varia.

Goodenia Smith in Linn. Transact, II. 347. exel. sp. Labillard. Nov. Holl. I, 59. R. Browu Prodr. 575. excl. sect. 5.

a. OCHROSANTHUS Don Syst, ITT. 224. Co rolla bilabiata, flava. Stig a atis indusium horizontaliter bilabiatum. Ca ps ula bilocularis v. dissepimento abbrevia. to noilocularis. (Cavanilles Ic. $t, 506$-508, Labillard. Nov, Holl, t. 75. Andr. Bot, Reposit, $t$, 68. Venten. Cels. t. 3. Bot. Mag, t. 890. 1137. Loddig. Bot. Cab. t. 1032.)

b. TETRATHYLAX Don Syst. $T I T$. 725. C a roll a bilabiata, flava. Stig a a $t$ is indusiam horizontaliter bllabiatum. Capsula quadrilocularis. - G. quadrilocu. Ia ris R. Brown $l$. $c$.

c. PORPHYRANTHUS Don Syst, IIT. 725. Corolla bilabinta, caerulea $v$. purpurea. $S t i g \mathrm{~m}$ a $t$ is indusium ho. rizontaliter bilabiatum. C a p $\mathrm{u}$ I a bilocularis $v$. semibiloealaris. - Gooden fa sect, III. R. Brown $l$. c.

d. MONOCHILA Don Syst. IIT. 725. C or o Il a nullabiata. $\mathrm{Stigmatis} \mathrm{indusinm} \mathrm{verticaliter} \mathrm{bilabiatam.} \mathrm{Caps} \mathrm{a-}$ Ia bilocularis. - Goode a ia set. IV. R. Brawa 7 . $c$.

3044. Calogyne R. BR. Calyx tubo ovato, cum ovario connato, limbi superi, quinque- 
fidi laciniis aequalibns. C or oll a supera, postice fissa, limbi quinquepartiti, bilabiati laciniis subaequalibns, alatis, aestivatione induplicatis. S $\mathbf{t}$ a $\mathbf{m}$ i na 5 , cum corolla inserta; fil amenta filiformia et antherae liberae. Ovarium inferum, vertice breviter exsertum, dissepimento abbreviato incom plete bilocolare. Ovula plurima, juxta dissepi mentum utrinque adscendentim imbricata, anatro pa. Stylus linearis, apice trifidus, lobo medio erecto, lateralibus longioribus deflexis; $s \mathrm{ti} \mathrm{gma}$ tu in indusia horizontaliter subbilabiata. GIan du I a epigyna inter stamina duo anteriora. Cap sula incomplete hilocularis, septifrago-bivalvis. Se min a pauca, adscendentim imbricata, compressa. $\mathbf{E}$ in b ryo ...... - Herba pilosa, annua, in Nova-Hollandia tropica indigena, sicca Anthoxanthi odore; foliis alternis, dentatis $v$. incisis, foralibus basi auriculatis, pedunculis axillaribus, unifloris, ebracteatis, fructiferis reflexis.

Calogy ne R. Brown Prodr. 579.

3045. Tistylis $G A U D I C H$. Calyx tubo ovato, cum ovario connato, limbi soperi, quinquepartiti laciniis aequalibus. Corolla supera, tubo hinc lougitudinaliter fisso, limbo inde secundo, quinquepartito, laciniis aequalibus, alatis, aestivatione induplicatis. Sta min a 5, cum corolla inserta; filamenta et a $\mathrm{n}$ h herae liberae. Ovarium inferum, dissepimento abbreviato incomplete biloculare. Ovula juxta dissepimentum utrinque adscendentim imbricata, anatropa. Styli 2 , ima bas connati, convergentes; st $\mathrm{igm}$ a $\mathrm{t} \mathrm{m}$ indusia integra, barbata. C a psula incomplete bilocularis, septifrago-bivalvis. Sem in a plura, atscendentim imbrieata, compressa, membranaceo-marginata. Embryo .... - Herba Novae-Hollandia occidentalis, annua, multicaulis, pilosa; foliis radicalibus confertis, pinnatifido-incisis, caulinis re mote alternis, dentatis, floribus axillaribus solitariis, longe pedunculatis, racemosis, ebracteat is, flavis.

D ist y $1 \mathrm{i} s$ Gaudichaud ad Fregcinet $460, t, 80$.

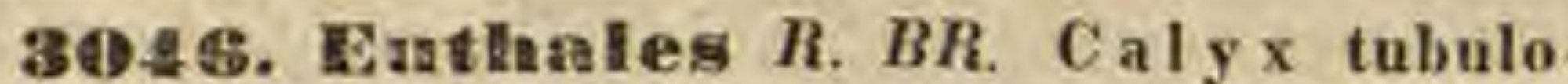
sus, tubo libero, limbi quinquefidi laciniis inaequafibus. Corolla calycis basi inserta, tubo inferne ovario adnato, a calyee distineto, superne hine fisso, limbi quinquepartiti, bilabiati laciniis aequalibns, alatis, aestivatione induplicatis. St a mina 5 , epigyna; filamenta filiformia et antherae libe. rae. Ovarium ealyei superum, corollae inferum, dissepimento abbreviato incomplete biloculare. O v u l a plura, juxta dissepimentum utrinque ad seendentin imbrieata, anatropa. S ty I u s simplex; sti g matis indusium horizontaliter bilabiatum. Ca psul a basi bilocularis, quadrivalvis, valvis septum nudantibus. Se mi a pauca, adscendentim imbricata, coupressa. E mb ryo..... Herba in Nova-Hallandia meridionali indigena; foliis radicalibus spathulatis, subdentatis, pubesccn tibus, cuulibus adscendentibus, dichotomis, pedun. culis unifloris, strictis.

Euthales R. Brown Prodr. 435. Velleja triner vis Labillard. Nop. Holl. $t$. 77 . Go odenia te tella Andrews Bot. Reposit. t. 466. Bot. Mag. t. 1137.

3048. Velleja SMITH. Caly x tri-pen taphyllus, liber, foliolis inaequalibns. Curolla calycis basi inserta, tubo inferne basi ovarii adnato, antice gibbo $\mathrm{r}$ calearato, apice hine fisso, limbi quinquefidi, bilabiati laciniis subaequalibus, alatis, aestivatione induplicatis, St a m in a 5 , epigyna; filainenta et a ntherae liberae, Ovarinu ealsei superum, corullae seminferum, dis- sepimento abloreviato incomplete biloculare, O v ula juxta dissepimentum utrinque adscendentia, imbricata, anatropa. Stylus simplex, tetragonus ; stigmatis indusium maximum, cyathiforme $v$. verticaliter bilabiatum. G 1 an dula epigyna inter stamina duo anteriora. Ca p 8 u la basi bilocularis, bivalvis, valvis septum nudantibus, demum bipartitis. Se min a adscendentim imbricata, compressa. Embryo ...... - Herbae acaules, in NovaHollandia indigenae; foliis radicalibus subspathulatis, saepius dentatis v. lyratis, scapis dichoto$m$ is, axillis plerisque floriferis, bracteis oppositis, foliaceis, quandoque maximis, interdum connatis, calycis foliolo postico latiore, basi saepe dentato, corolla flava.

Vellej a Smith in Linn. Transact, IV, 217. R. Brown Prodr, 580 .

a. MENOCERAS R. Brown $l$. c. Calyx peataphyllus. Coroll a basi ealcarata, calcare persistente. - (Bot. Reg. t. 971 . Guillen. Ic. lithogr, t. 4.)

b. VELLEJAE VERAE R. Brown $l$. c. $\mathrm{C}$ a 1 y $\times$ triphyllus. C o r ull a basi hine gibbosiuseula. - (Bot. Reg. t. 551 . Jussieu in Annal. Mus, XVITI. t. 1. f.5. Hooker Exot. Flor, t. 24.)

3618. Heeloemaultia $R, B R, C$ al y x tubo ablongo v. lineari, cum ovario connato, limbi superi, quinquefidi laciniis aequalibus. Cor o II a supera, tubulosa, postice fissa, limbi quinquepartiti laciniis subaequalibus, conniventibus, v. inaequalibus, uni-bilabiatis, labii superioris connatis $\mathbf{v}$. di stinctis, omnibus alatis, aestivatione induplicatis. Stamina 5, cum corolla inserta; filamenta libera, a $n t h$ erae sub anthesi cohaerentes. O varium inferum, biloeulare. Ovula juxta dissepimentum utrinque biseriata ...... Sty I us sim. plex; 8 tigma in fundo indusii horizontaliter bilabiati obsoletum, Ca p 8 ula prismatica, biloenlaris, quadrivalvis, valvis oppositis medio septiferis. Semina cubica v. cylindracea, nueamentacea. E mbryo ..... Fruticuli ericoidei, in $N_{n} v a-$ Hollandia indigeni, rarius herbae; foliis angustis, integerrimis, floribus axillaribus $v$. terminalibus, subsolitariis, rubris, pollinis granulis e sphaerulis quatuor coalitis compositis.

Lechena ultia R. Browa Prodr, $88 t$.

a. LATOURIA. Capsula tardius valvata, valvis collo coarctato coliaereutibus. Sem i n a cyliudracea. - Herba Novae.Hollandiae tropicae; folits alternis, compresso-filformibus, floribus oppositifolits, - L. filiformis. R. Br.

b. LeChenaUlTia. Capsula valvata. Semina cabica. - Fruticuli ericoidei, in Novae-Hollan. diae ora meridionali indigeni, floribus axilla. ribus v. terminalibus. - (Bot. Reg. t. 916. Bot. Mag. t. 260\%. Sweet Flor. australas. $t_{\text {. 26. 26.) }}$

3649. Anthotimm $R$. BR. C a ly x tubo cum ovario connato, limbi superi, quinquepartiti laciniis subaequalibus. Cor oll a supera, linc fissa, quinquepartibilis, bilabiata, unguilus margine inflexis, laciniis exalatis, aestivatione valvatis, dnabus superioribus margine interiore aurieulatis. Sta m in a 5 , cum corolla inserta; fil a m e $\mathrm{n}$ a libera, a ntherae sub anthesi cohaerentes. Ovarium inferum, bilonulare. Ovula ..... Stylus simplex; st ig mat is indusium verticaliter bilabia $t a m$, imberbe. Capsula ..... _ Herba in NovaeHollandiae ora meridionali reperta, humilis, acaulis, glabra; foliis radicalibus teretiusculis, basi parum dilatatis, scapis pluribus, patulis, indivisis, floribus fasciculatim congestis, subviolaceis, bracteis subtendentibus foliaceis, pollinis granulis simplicibus.

Anthotium R. Biown Prodr. so2. 
3050. Pentaphragma $W A L L$. Caly $x$ tubo ovato, basi cum ovario connato, superne libero, processubus quinque septiformibus ovario adhaerente, limbi scmisuperi, quinquelobi lobis aequalibus, obtusis. Corolla summo calycis tubo inserta, rotata, tubo brevissimo, limbi quinquefidi lobis oblongis, eum calyeis laeiniis alternantibus. $\mathrm{S} t$ a min a 5 , septis ovarium cum calycis tubo jungentibus inserta, ejusdem lobis opposita; fil a m en ta brevia, a $\mathbf{t h e r a e ~ l i n e a r e s . ~ O v a r i u m ~ i n f e - ~}$ sum, tri-quadriloculare. Ovula in placentis e loculorum angulo centrali prominulis plurima ..... Stylus brevis, crassus; stigma in fundo indusii carnosi, trilobi concavum. C a p 8 u la oblonga, triquadrilocularis ....... S e m in a plurima ...... Herba indica, non satis nota, et dubiae admodum affinitatis; caulibus procumbentibus, villosis, villis fasciculatis, foliis alternis, petiolatis, semicordatis, inaequilateris, acutis, grosse subspinescenti serratis, subtus villosis, adultis supra glabratis, ex. stipulatis, pedunculis axillaribus v, supraaxillaribus, floribus securdis, in spica recurva distiche subsessilibus, bracteis cuneiformibus, obtusis.

Pentaphragma Wallich Catalog. n. 1313. Phyte uma begoniaefolfum Roxburgh Hort. bengal. 85. Wal. lieh in Roxb. Fl, ind. II. 108. Jack in Malay. Miscell. cx Hooken Bol. Miscell. I. 276. $t, 57$.

\section{Ordo CXXII: Lobeliaceae.}

Campantlaceae \$. 2. R. Brown Prodr. 562, LobeliaCEAR exclusis Stylideis et Goodentels, Jussieu in Annal. Mtus, XVIIr, 1. LOBELIACEAE Bartling Ord, nat, 150. Don Syst, IIT, 797, Lindley Introduct. edit. HI. p, 235. C. B. Presl, Prodromus Monographiae Lobeliacearum, Pragae, 1836. 8 .

Нвввав annuae v, perennes, saepe suffrutescentes, rarius frutices v. ARBon Es, plerumque lactescentes, caule ramisque teretibus $\mathbf{v}$. irregulariter angulatis. Foli a alterna, radicalia saepe conferta, simplicia, integra v, Jaciniata unt pinnatipartita, plerumque dentata $v$, serrata, rarius integerrima. $S t i p u l$ a e nullae.

Flores hermaphroditi v. rarissime dioici, plus minus irregulares, rarissime regulares, racemosi v. spicati, rarius corymbosi v. subcapitati, nunc axillares, solitarii, sessiles $v$. pedicellati, pedicellis nudis $\mathbf{v}$. bibracteolatis.

CaLYX lubo vario, cum ovario v. toto v. ejusdem basi connato, rarius supra ovarii verticem adnatum producto, limbo supero v. semisupero, quinquefido, subregulari v. laciniis duabus inferioribus minoribus, persistente v. deciduo.

Corolla summo calycis tubo inserta, e petalis quinque, cum limbi calycini laciniis alternantibus, rarissime omnibus distinctis et aequalibus regularis, plerumque iisdem varie inter se connatis irregularis, nempe nunc petalis duobus inferioribus liberis et tribus superioribus in unicum apice trilobum cohaerentibus. ad speciem tripetalo-bilabiata, nunc petalis inferioribus inter se distinctis et cum superioribus cohaerentibus unilabiata, ve petalis omuibus in tubum coalitis tubulosa, tubo integro, v. petalis duobus inferioribus plus minusve inter se distinctis antice (pedicelli torsione postice) interdum fere usque ad basim fisso, limbi quinquefidi laciniis inaegualibus v. subaequalibus, saepissime bilabiatis, aestivatione valvatis.

Stauisa quinque, cum corolla mediante annulo, interdum in diseum epigynum effuse inserta, ealycis lobis opposita. Fil a me n ta ima basi plerumque distincta, superne in cylindrum stylo pervium, liberum v. basi corollae adhaerentem, rarissime hinc eidem adnatum coalita. Antherae in cylindrum, apice saepissime incurvum connatae, introrsae, biloeulares, loculis appositis, longitudinaliter dehiscentibus, nunc omnes conformes, nudae v. apice aut rarius etiam basi barbatae, nunc tres superiores nudae, duae inferiores apice barbatae $\mathrm{v}$, in mucronem setasve productae. Pollinis granula ovoidea.

Ovariom inferum v. vertice plus minus exserto semisuperum, rarissime ima tantum basi cum ovario connatum et fere totum liberum, e carpidiis duobus v, rarius tribus conflatum, nunc bi- v. triloculare, placentis dissepimento utrinque adnatis v. loculorum angulo insertis; nunc septo incompleto margine placentifero, v. septo nullo, placentisque duabus parietalibus, carpidiorum duorum nervo medio adnatis, carpidio tertio minore sterili, uniloculare. Ovula plurima, sessilia, plerumque horizontalia, anatropa. Stylus terminalis simplex, inclusus v. rarius ultra antherarum tubum breviter exsertus. Stig $\mathrm{m}$ a rarius indivisum, plerumque emarginatum v. divaricato-bilobum, lobis pilorum annulo cinctis.

Frnctos baccatus, carnosus v. sicciusculus, indehiscens, bilocularis, v. capsularis, nunc bi-trilocularis, apice loculicido, interdum ultra verticem exsertum bi-trivalvis, nunc unilocularis, juxta totam longitudinem trivalvis, valvis duabus medio placentiferis, tertioque minore sterili revolntis, v. basi et apice cohaerentibus, rarissime operculo apicis dehiscens.

Semina plurima, parvula, testa laevi v. scrobiculata, umbilico basilari, excavato-orbiculari, rhaphe obsoleta. A I bum en carnosum.

Еиввуо in axi albuminis orthotropus, ejusdem fere longitudine; cotyled on ibus obtusis, radicula umbilico proxima, saepissime centripeta, plumula inconspicua,

L, obeliaceae ab affinibus Campanulaceis corollae irregularitate et staminum symphysia, a Goodeniaceis laciniarum corollae aestivatione et indusii stigmatis defectu, a Stylideis staminibus cum stylo haud connatis facillime distinguendae, in regionibus tropiris subtropieisque totius orbis magno numero generantur, in America tropica et in regionibus subtropicis hemisphaerae australis, videlicet in Capite bonae 
spei et Nova-Hollandia imprimis copiosae, parcius in hemisphaerae borealis regionibus temperatis vegetant, versus Oceani atlantici oras paullo frequentiores. Insulae Sandwicenses generum arborescentium copia superbiunt.

L obeliaceae plurimae suspectae, nonnullae acriter venenatae, aliquibus qualitates antisyphiliticae et anthelminthicae tribuuntur.

Ordinis in tribus divisionem classicam, a cl. Presl ex ovarii et fructus indole propositam totam recepi, in circumscribendis et nominandis generibus a sententia hujus auctoris paullo recendum esse putavi.

Tremisus r. Clin'tonieae Presl Monogr. 43. O v a ri um uniloculare, placenta in dissepimento incompleto late diffusa, v. placentis duabus parietalibus. Capsula unilocularis, operculo apicis v. valvulis tribus, quarum duae medio placentiferae, dehiseens.

3051. Crammatotheca PRESL. Ca$1 y \times$ tubo lineari - triqnetro, cuin ovario connato. limbo supero, quinquepartito. Corolla summo calycis tubo inserta, tubulosa, tubo apice hinc longitudinaliter fisso, limbi quinquefidi, bilabiati lobis inferioribus tribus majoribus pendulis. S t amina 5, eum corolla inserta; filamenta et antherae apice barbatae in tubum connatae. Ovarium inferum, uniloenlare. Ovula in placentis duabus parietalibus, linearibus plurima, anatropa. Sty In s inclusus; st ig ma bilobum, lobis demum exsertis, divaricatis. Capsula linearitriquetra, unilocularis, trivalvis, valvis basi et apice cohaerentibus, duabus medio placentiferis. Semin a plurima, minima ...... - Herbae capenses tenellae; caulibus ramosis, diffusis, foliis alternis, linearibus, dentatis $v$. serrulatis, apice callosis, floribus axillaribus, solitariis, sessilibus.

Grammatotheca Pres1 Monogr. 43. C11ntoniae sp. Cham.

3052. Clintonia DOUGL. Caly $\mathrm{x}$ tubo lineari-triquetro, conterto, cum ovario connato, limbo supero, quinquepartito. Corolla summo calycis tubo inserta, tubo brevissimo, limbi bilabiati labio inferiore cuneato-trilobo, superiore erecto, bipartito. Stamina 5, cum corolla inserta; filamenta et antherae, quarum duae inferiores apice setigerae, in tubum connatae. Ova rinm inferum, uniloculare. $O \mathrm{vula}$ in placentis duabus parietalibus, linearibus plurima, anatropa. Styln s inclasus: sti $\mathrm{gma}$ exsertum, conicum, barba papillosa einctum. Cap 8 u I a lineari triquetra, unilocularis, trivalvis, valvis linearibus, revolutis, duabus medio placentiferis. Semin a plurima, m in i m a...... Herbae annuae, procumbentes, in America occidentali extratropica, boreali et australi observatae; foliis sessilibus, anguste lanceolatis, integerrimis, floribus axillaribus, solitariis, sessilibus.

Cuinto u ia Douglas in Bot. Reg. t. 126t, Don Syst, IIT. 717. Presi Monogr. 45, absq. charaet.

3053. Lysipomia $H, B, K, \mathrm{C}$ aly $x$ tubo turbinato v. obeonico, quinquenervi, eum ovario connato, limbo supero, quinquepartito, subbilabiato. C o rolla summo calycis tubo inserta, infundibuliformis, tubo integro, ad fancem inflato, limbi bilabiati labio inferiore trifido, superiore bipartito, erecto. Stamina 5 , cnm corolla inserta; filamenta et antherae, qnarnm duae inferiores apice setigerae, in tubum connatae. O ari $u$ m inferum, vertice brevissime exsertum, unileculare. O vula juxta placentam unicam parietalem bi-triseriata, anatropa, adscendentia (?) St y lu s inclusns; s tig ma exsertum, bilobum, lobis rotundatis, pnbescenti-ciliatis. C a p s u I a unilocularis, operculo nmbonato aperta. S e m in a plura, minima, umbilico basilari, orbieulari. Embryo in axi albuminis carnosi orthotropus; r a d i e u l a umbilicum speetante, infera? - Herbulae andic ol ae, acaules v, caulescentes, caespitosae, Montiae v. Aretiae facie; folits alternis, linearibus aut spathulatis, integerrimis, rigidis et caespitoso-congestis, $v$. subcarnosis et remotis, floribus parvulis, axillaribus, solitariis, pedunculatis, albis.

Lysipom in Kunth in Humb, et Bonpl. Nov, gen, et sp. IIT. 319. t, 266. f. 2. (exel, f, 1,) t, 267, f. 1, 2. Don Syst. III. 716. Prest Monogr. 45. absq. charact.

3054. Hypsela PRESL: C a I y $\mathrm{x}$ tubo subgloboso, enervi, cum ovario connato, limbo supero, quinquepartito, aequali. Corolla summo calyeis tubo inserta, infundibuliformis, tubo integro, ad faucem inflato, limbi bilabiati labio inferiore trifido, superiore bipartito. St am in a 5, cum corolla inserta; fi lamenta et ant herae, quarmm duae inferiores apice setigerae, in tubnm connatae. Ovarium inferum ..... Stylus inclusus; stig ma exsertum, bilobum, lobis demum divaricatis, orbiculatis. C a p s u la semibilocularis, operculo umbonato dehiscens, dissepimento incompleto, basi et apice inserto, margine libero, plano, undique placenta tenui obtecto. S emina ...... Herbula andic ola, repens, Violae palustris facie; foliis alternis, orbiculato-reniformibus, emarginatis, subcarnosis, floribus axillaribus, solitariis, pedunculatis, albis.

H y p sela Presl Monogr. 45. Ly si pomiae sp. Kunth in Humb. et Bonpl. Nov. gen. et sp. t. 266. f. 1 .

TEIIBUS II. LOBELIEAE Presl Mo, nogr. 9. O v a ri u m bi-trilocnlare, placentis dissepimento longitudinaliter adnatis. C a p s ula bi-trilocularis, loculicido-bi-trivalvis.

3055. Metzleria PRESL. Calyx tubo hemisphaerico, cum ovario connato, limbo supero, quinquefido. C o roll a summo calyeis tubo inserta, pentapetala, regularis, petalis aequalibns, lanceolatis, patentilus. S tam in a 5, cum corolla inserta; fi lamenta filiformia, libera, antherae in tubum apice leviter incurvum connatae, duae inferiores apice setuleso-aristatae. Ovarium inferum, apice breviter exsertum, biloculare. 0 va 1 a in placentis dissepimento ntrinque adnatis plurima ...... Stylus ..... Ca psula bilocularis, apice breviter exserto loculicido-bivalvis. S e m in a ...... Herbae capenses; caule decumbente, radicante, foliis alternis, confertis, ovato-spathulatis, in caulem decurrentibus, in petiolum brevem angustatis, integerrimis $v$. calloso-dentatis, pedicellis axillaribus solitariis, unifloris. Linn.

$$
\text { Metzleria Presl Monogr. 9. Labelia depressa }
$$

3056. Dobrowslkya PRESL, C a 1 y $x$ tubo hemisphaerico v. turbinato, enm ovario connato, limbo supero, quinquepartito. Corolla summo calyeis tubo inserta, bilahiata, petalis dnobns superioribus distinetis, nnguiculatis, inferioribus in unicum trifidum cohaerentibus. $\mathrm{S} t$ a $\mathrm{m}$ i $\mathrm{n}$ a $\mathbf{5}$, cum corolla inserta; filamenta et antherae 
basi et apice barbatae, in tubum connatae. $0 \mathrm{v}$ ari um inferum, biloeulare. $O \mathrm{vula}$ in placentis carnosulis, dissepimento utrinque longitudinaliter adnatis plurima, horizontalia, anatropa. Stylus per staminis tubum exsertus; stigmata 2 , li. nearia, demum spiraliter revoluta. Ca psula bi locularis, loculicido-bivalvis. Semina plurima, minima. Embryo in axi albuminis carnosi ortho tropus; radi $e$ ula umbilico proxima, centripeta. Herbae capenses, annuae v. perennes; foliis alternis, oppositis aut quinato-verticillatis, linearibus $v$. oblongo-lanceolatis, integerrimis $v$ dentatis, scabris, pedunculis terminalibus scapiformibus, $v$. axillaribus solitariis, unifloris, floribus caeruleis.

D a browsky a Presl Manogr. 10. Lobella uniden$t$ at a Aiton. Bot. Mag. $t, 1484$. P a r as $t r a n t h I s$ p. Doa.

305\%. DIonopsis SALISB. Caly x tubo obconico v. hemisphaerico, cum evario connato, limbo supero, quinquefido. Co ro ll a summo calycis tubo inserta, gamopetala, tubo line joxta totam longitndinem fisso, limbi quinquefidi laeiniis subaequalibus. Stamina 5, cum corolla inserta; fila$m$ enta et a $\mathbf{t}$ he ra e imberbes (?) in tubum eonnatae. Ovari um inferum, biloculare. Ovula in placentis carnosulis, dissepimento utrinque adnatis plurima ......Sty lus inclusus; stig ma indivisnm, barbatum. C a ps ula bilocularis, loculieidobivalvis, Semina plurima, minima ..... Herbae perennes, in Capite bonae spe $i$ et in Nova Hollan dia tro pic a observatae; caulibus
debilibus, foliis alternis, linearibus, dentatis rariusve integerrimis, floribus hermaphroditis $v$. interdum dioicis, axillaribus solitariis longe pedicellatis, $v$. terminalibus corymbosis.

Monopsis Salisbury in Transact. Hortic, soc. II. excl. sp. Presl Mtonogr. 10. absque charaet.

a. EUMONOPSIS. Co rolla e limbus rotatus, lobis ovatis, obtusis. Flores hermaphroditi axillares, longe pedicellati. Mo nops is Salisb. l.c. Don Syst, IIT. 717. S pe e uI r $\mathrm{r}$ a Solander msc. Lobelia Speculua Andr. Bot Reposit. t. 664. Bot. Mag. t. 1499.

b. Holostigma. Corolla e limbu* dimidiatus, lobis linearithus. Flores dioici v. hermaphiroditi, terminales, curymbosi, teminel axillares, solitarii.

Halostigma Don $s y s t, I I X, 716$. Lo belia dioica R. Brown et L. cory mbos a Graham in Bot, Mag. t. 2693.

3058. Lobelia LINN. CaIy $x$ tubo obco nico, turhinato $\mathrm{v}$. hemisphaerico, cum ovario connato, limbo supero, quinquefido. Co roll a summo calycis tubo inserta, tubulosa, tubo hine apice fisso, limbi quinquefidi, uni-bilabiati laciniis tribus inferioribus pendulis, duabus superioribus pendulis v. cum inferioribus conniventibus. Stam in a 5 , cum corolla inserta; filamenta et antherae, umnes $v$, saltim dnae inferiores barbatae, in tubum connatae. $O$ varium inferum, vertice brevissine exsertum, bi-triloculare. $0 \times \mathbf{v} 1$ a in placentis earnosulis, dissepimento utrinque adnatis $\mathbf{r}$. e loculorum angulo centrali porrectis plurima, anatropa. Stylus inclusus; stigm a demum exsertum, bilobum, lobis divaricatis, orbiculatis, subtus pilorum annulo cinctis. Ca p $\mathbf{u} \mathrm{l}$ a bi-trilocularis, ultra verticem exsertum loculicido-bi-trivalvis. S e m in a plurima, minima, scrobiculata. E m by ro in axi albumis carnosi orthotropus, cotyledonibus bre vissimis, obtusis, radicula umbilico proxima, centripeta. - Herbae perennes $v$, rarius annuae, in regionibus tropicis subtropicisque totius orbis observatae, in America a equinoctiali imprimis copiosae, in Europa media rarissimae, habitu et inflorescentia admodum variae.
L o belia Linn. gen. n, 1006. exel. sp. pl. non Plua. nec Presl. R a p untium Touraef. inst. 51. Gärti. I. 151. Presl Monogr. 11.

a. XANThomeria Presl-Monogr. 11. Flores sessiles bibracteolati, axillares, eapitati v. spicati. C a I y e is tu bus eylindracens v. obeonieus. Curolla flava. Cap. s u la biloeularis. - Parastranthi sp. Don. (Bot. Mag. t. 1319. 1692.)

b. STENOTIUM Presi Monogr. 12, Fl or es pedicellati, racemosi. C a l y eis tubus ubcoaicos, lineat is $\mathrm{v}$. oblongus v. turbinatus. Co rolla caerulea v. alba. C a p5 u la bilocularis. - (Jacq. Hort. Schönbr. t, 178. Cavanill, Ic, t. 512. f. 2. Curtis Flor. Lond, DI, $t$, 33 Hooker Exot, Flor, t. 44. Labillard. Nov, Holl, t, 73. Bot. Mag. t. 514. 901, 2287. 3292. Bot. Reg. t.773, 1896. 2014. Poht Plant, bras. t. 165. Wallich Plant. As, rar. t. 152.)

c. DORTMANNA Rudbeck Aot. Upsal, 1720, p. 97, t. 2. Flores racemosi. Calyeis tubus lineari-obenicus. Corolla caerulea. Capsula trilocularis. Doa $S_{y} s$. III. 715. Lobelia Dortuanna Lina.

d. SPHAERANGIUM Presi Monogr. 19. Flores pedicel. lati, racemosi. C al y eis tubus hearsphaerieus. Corol. 1 a alba, caerulea v,ruber. C a p s ul a bi-triloeularis. (Cavauill. Ic, t, 511, f. 2, t. 518. 521_523. Willdenow Hort, berol. t, 30, 85, 86, Bonpl. Mtalm. t, 7. Bot. Mag. t. 320. 644. 2137, 2251, 2277. 3292. 3550, 3600. Sweet Fl. Gard. I. t. 99. Pobl Plant. Bras. t. 166, 167.) T u pa Don Syst, IIT, 700. (Cavanill. Ie. t. 516. Bot. Mag. t. 1325. 2550.3207. Bot. Reg. t.973. 1325. 1612.) T y l am i u m Presl Monogr. 31. cujas typi Lob. conglo. bata Sieb. et Lam. L. robusta Grah. in Bot. Mag. t.3138. et L. assurgeus Liall. nealyeis tube in sammo apice de. „mum anuulum callosum, persistentem, margine liberum ngerente, tubo stamineo deciduo, seminibus ovall-subnglobosis, umbilica oblique excavato, foveaeformin dif. ferre dicitur.

3059. Sîphoeampylas $P O H L$. C a l y $x$ tubo obeonico, turbinato $\mathbf{v}$, hemisphaerieo, cum ovario connato, limbo supero, quinquefide. $\mathrm{C}_{0}$ rolla summo calycis tubo inserta, tubulosa, tubo integro, incurvo v, rarius recto, limbi quinquefidi, bilabiati laciniis subaequaelibns v. duabus superioribus paullo longioribus. Stamina $5, \mathrm{cum}$ corolla inserta; fil a m e $n$ t a et a $n$ thera e, quarum duae inferiores $v$, omnes apice barbatae $v$. mueronatae connata, $O \mathbf{v}$ ari $\mathbf{u} \mathrm{m}$ inferum, vertice breviter exsertum, biloculare. Ovu 1 a in placentis carnosulis, dissepimento atrinque longitudinaliter adnatis plurima, anatropa. St $\mathbf{I} \mathbf{u}$ s inclusns; $8 \mathrm{tig}$ ma exsertum, bilobum. lobis divaricatis, orbiculatis. Ca p 8 u I a bilocalaris, vertice exserto locnlicido-bivalvis. S emin a plurima, minima, scrobiculata. L mbryo in axi albnminis earnosi orthotropus, radi c u la umbilico proxima, centripeta. Suffrutices americani tropici; foliis alternis v. oppositis, petiolatis, serratis, floribus axillaribus, solitariis, perlicellatis, rarius in racemum v. corymbum approximatis, rubris.

Siphocam pylus Pahl Plant. Brasil. 11. 109. t. 168 172. Lobelia Presl Monogr. 33. Lo belia e sp. Lian. Smith Ic. inedit, $I, t$. 22. Cavanill. Ic. $t, 512, f, 1, t, 513$. 514. 319. Presl $S$ jmb. $t$. 40, Kunth in Humb. et Bonpl. Nov. gent ot sp. $t, 268$ _az1.

OBSERVAT10. Canonanth us Don Syst, IIT. 718. Lobelia campanulata Cavanill. Yo. t. 517 , genus e manca Cavanillesfl icone et descriptioue insufficieate exstruetum, a Siphocampylo corolla regulari campauulata, vix alia nota differre videtur.

3080. Tamarentia NECK. C a l y $\mathrm{x}$ tubo ovato, cum ovario connato, limbo snpero, quinquefido, CornIla summo calyeis tubo inserta, tubulosa, tubo recto, integro, limbi quinquefidi laciniis subaequalibus $v$. bilabiatis, erectis v. patentibus. St a $m$ in a 5, enm corolla inserta, filam e n$t$ a et antherat, quarum duae superiores apice barbatae v. mucrunatae, in tubnm connatae. O va- 
ri um inferum, vertice brevissime exsertum, bi loculare. Ovula in placentis oblongis, dissepimento utrinque aduatis plurima, snatropa. Sty I u 8 brevissime exsertus; stigma bilobum, lobis divaricatis, orbiculatis. Capsula bilocularis, vertice exserto loculicido-bivalvis. S e mina plurima, minima, scrobiculata. E mb r y o in axi albuminis carnosi orthotropus, $r$ a di $\mathrm{e}$ a la nmbilico proxima, centripeta. - Herbae ut plurimum annuae, acaules, scapigerae, $v$, caulescentes, plerumque prostra tae, in regione mediterranea, Capitebonae spei et Nova-Hollandia extratropi ca indigenae; foliis radicalibus confertis, caulinis dum adsunt alternis, parvis, scapis racemoso-paucifloris, floribus in caulescentibus axillaribus, solitarits, plerumque longe pedunculatis, corollis caeruleis, roseis $v$. albis.

L a urentia Necker elom. n. 224.

a. SOLENOPSIS Presi Monogr. 32. Corolla e bilabiatae laciniae inferiores altius infer se connatae. - Lobeli a e sp. Linn. Sibtliorp Fl. graec. $t$. 221. Presl Symb. 1. 20. Bot. Mag. t. 2077. 2590.

b. ENCHYSIA Presl Monogr, -40, Cor oll a e infundibuliformis laciniae erectae, subaequales. - Lobella e rinoides Linn.

e. ISOTOMA R. Brown Prodr. 565. Corollae hypocraterimorphae laeiniae patentes, subaequales. - Bot. Reg. t. 964. Bot. Mag. t. 3075.

d. HIPPOBROMA Don Syst, IIt, 717, Lobeli a Iong iflor a Jacq. Amer. pict, t, 200. Hort, Vindob, I, t. 27 Bot. Reg. $t, 1200$. habitu et corollae tubo longissimo magis recedit, sed ovarium et fructus a nobis plane ignorantur.

3061. Is yrsanthes PRESL. Calyx tubo ima basi ovario adnato, limbo quinquepartito. Corolla ealycis tubo inserta, infundibuliformis, coriacea, tubo integro, limbi quinquepartiti laciniis ereetis, aequalibus. Sta min a 5 , cum corolla inserta; fila menta et a $\mathbf{t h}$ e rae, omnes v. dnae inferiores apice barbatae, in tubum connata. $0 \mathrm{va}$ r i $\mathbf{m}$ basi adnatum, biloculare. Ovula in placentis bilobis, dissepimento utrinque adnatis cristaefor-

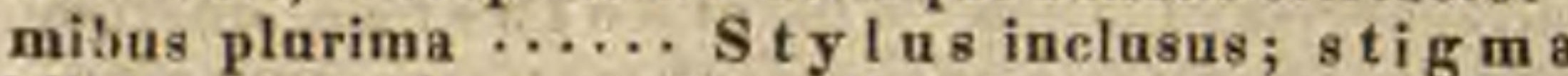
bilobum, lobis exsertis, divaricatis, orbiculatis, subtus pilorum annulo interrupto einctis. C a p 8 ula ....... Frutices andicoli, niveo-tomentosi, vix noti; foliis integerrimis, pedicellis axillaribus folio longioribus. Willd.

Byrsanthes Presl Monogr. 41. Lobelia niven

30S\%. Heterotoma ZUCCAR. Calyx tubo hemisphaerico, cum ovario connato, limbo supero bilabiato, labii snperioris apice trifidi laciniis erectis, inferioris horizontaliter producti, a pice bifidi lacinits inflexis. Corolla summo calyci inserta, tubulosa, tubo basi valde inaequaliter dilatato et in calycis labio inferiore ad lacinias nsque in calcaris speciem extenso, sursum cylindrico, quinquefido, tandem longitudinaliter fisso). Stamina $5, \mathrm{cum}$ corolla inserta, filamenta et antherae, quarnm duae inferiores apice barbatae, connatae. $O$ v a ri um inferum, biloculare. Ovula plurima ...... Stylus simplex; s ti g ma emarginato-bilobum ...... F ruetus .... - Herba mexicana, circiter tripedalis; foliis alternis, petiolatis, e basi rotundata ovatis, oblique acuminatis, inaequaliter dense dentatis, utrinque pubescentibus, floribus in racemos terminales simplices, multifloros dispositis, magnis, purpureis.

Hete rot o ma Zuecarial in Flora 1832. Beiblalt. p. 100. M yop sia Presi Monogr. 8. ex quo nstigma aunulo inae nqualiter multipartito, erecto, indusifformi ciactum, bilobum. nlabis demum exsertis, divaricatis, orbiculatis," quod in spe. cimine Zuecariaiano nequaquau video.
Teribus Irit. DELISSEACEAE Pres] Monogr. 46. O va r i m biloculare, placentis dissepimento utrinque adnatis. Fructus bilocularis, indehiscens, siccus $v$. baccatus.

3063. Pratia GAUDICH. Caly x tubo hemisphaerico v. obeonico, cum ovario connato, limbo supero, quinquedentato v. quinquefido. Coroll a summo calycis tubo inserta, gamopetala, tnbo hinc fisso, limbi quinquefidi laciniis aequalibus $v$. bilabiatis. $\mathbf{S}$ tam in a 5 , cum corolla inserta; filamenta et a $\mathbf{t}$ herae, quarum drae inferiores apice setigerae, in tubum connatae. O vari $\mathbf{m}$ inferum, biloculare. $O v \mathbf{v}$ la in placentis subglobosis, dissepimento utrinque adnatis plurima, anatropa. Stylus inclusus; $8 \mathrm{tig} \mathrm{m}$ a emarginatobilobum, subexsertum. B acca subglobosa, calycis limbo coronata, bilocularis. S e m i n a plurima, ovata. Embry o in axi albuminis carnosi orthotropus, ra d i e u la umbilico proxima, centripeta. - Herbue pusillae, in America australi intra et extra tropicos, nec non in Ne palia observatae; caulibus repentibus, radicantibus, foliis alternis, petiolatis, cordato-orbiculatis, crassiusculis, pedicellis axillaribus solitariis, unifloris.

Prat i a Gaudich, ad Freyc. 456. Lindley in Bot. Reg. n. 1373 .

a. BERNONIA. Caly cis laciniae subulatae. Ca rolla e limbus bilabiatus, labil superioris bifidi laciniae lineares, labium Inferius trilobum. - Herba nepalensis. (Lindl. in Bot. Heg. $t .1373$. L o bellia bego n ia efolia Wallich.)

b. EUPRATIA. Caly cis dentes breves, acuti. CorolI a c limbus aequaliter quinquefidus. - Herbae chilen. ses et brasilienses. (Gaudich. ad Fregc, t, 79.)

3064. Delissea GAUDICH. Cal y x tubo hemisphaerico, cnm ovario connato, limbo supero, brevissime quinquedentato. C o r o ll a snmmo calycis tubo inserta, tubulosa, tubo integro, limbi bilabiati labio superiore bifido, laciniis erectis, in. feriore trilobo, patente. Sta min a 5 , cam corolla inserta; filamenta et antherae, quarum duae inferiores apice barbatae, in tubum libernm connatae. $O$ vari um inferum, bilocnlare. Ovn I a in placentis carnosis, dissepimento utrinque adnatis plurima, anatropa. Stylu s brevissime exsertus; stig ma bilobum, pilis cinctum. B a cea snbglobosa, calycis limbo coronata, bilocularis. Som in a plurima ......- Frutices $v$, arbusculae $s$ an $d-$ wicenses, lactescentes; foliis alternis, integris $v$. pinnatifidis, racemis axillaribus erectis, folio brevioribus, pedicellis basi unibracteatis, floribus albido.roseis.

Delis se a Gaudichaud ad Freyc. 457, $t, 76 \_78$.

3065. Cyamea GAUDICH. Calyx tubo ovato, decemsulcato, cum ovario connato, limbi superi, quinquepartiti lacinitis foliaceis, oblongis, margine reflexis, nndulato-crispis. Corolla summo calycis tubo inserta, tubulosa, tubo integro, limbi quinquefidi lariniis subaequalibus, duabus superioribus erectis, inferioribus patentiusculis, St a m in a 5, cum corolla inserta; fil amenta et antherae apice omnes harhatae in tubum liberum connatae. $\mathrm{O}$ v a ri u m inferum, biloeulare. O vnla in placentis carnosis, emarginato-bilobis, dissepimento ntrinque adnatis plurima, anatropa. Stylus inclusus; stigma orbieulatum, annulo piloso cinctum. B a c ca sulcato-decagona, calycis limbo foliaceo coronata, bilocnlaris. S e m in a plurima ......-Arbor sandwicensis, lactescens, ramis ramulisque tuberculoso-aculeatis, folits alter- 
nis, pinnatipartitis, lubis serratis, racemis axillaribus strictiusculis, pedicellis basi unibracteatis, flo ribus cyaneis.

C y a n e a Gaudichaud ad Frege. 457, 4.85.

30BG. PIneroelailus PRESL. Calyx tubo obconico, eum ovario connato, limbi superi, quinquepartiti laciniis foliaceis, oblongis, margine imbricatis. Corolla summo calycis tubo inserta, tubulosa, tubo elongato, hamato-incurvo, superne hine fisso, limbi quinquefidi, unilabiati laciniis aequalibus, linearibus, conniventibus, pendulis. Stamina 5, cum corolla inserta; filamenta et a $n t h$ era $e$, quarum duae inferiores apice longe barbatae, in tubum liberum connatae. Ovarium inferum, biloculare. Ovula ..... Stylus brevissime exsertus; stigma bilobum. Fruetus ....... Arbor sandwicensis, palmaeformis, trunco stricto, biorgyali, comam foliorum et pedunculorum extollente; foliis glabris, oblongo-obovatis, acuminatis, undulatis, denticulatis, pedunculis tomentosis, folio longioribus, nutantibus, multi-bracteatis, florum adscendentium capitulo globoso, compacto, bracteis dense imbricato terminatis.

Macrochilus Presl Monogr. 47. Lobelia superb a Chamisso in Linnaea VIII, 223.

306\%. Hellandia GAUDICH. C a I y x tubo ovato, cum ovario connato, limbi superi, quinquepartiti laciniis brevibus, obtusis. Coroll a summo calycis tubo inserta, tubulosa, tubo compresso, arcuato, integro, limbi quinquefidi laciniis subaequalibus, superioribus in inferiora patentia conniventibus $\mathrm{S}$ t a mina $5, \mathrm{cum}$ corolla inserta; fil am enta et antherae, quarum duae inferiores apice barbatae, in tubum basi corollae postice connatum coalita. Ovarium inferum, biloculare. Ovula plurima ..... Stylus inclusus; stigma bilobum, pilis cinctum. Ca p$8 \mathrm{ula}$ baceata, calycis limbo coronata, bilucularis, indehiscens. Semin a plurima ...... Fru. tices sandwicenses; folits alternis, integris, racemis axillaribus paucifloris, erectis, folio brevioribus, pedicellis basi unibracteatis, floribus albidis.

R oll a ndia Gaudichaud ad Eregc. 458. $t, 74$.

30BS. Clermentis GAUDICH. Calyx coloratus, inferne cum ovario connatus, tubo arcuato, longe supra ovarism produeto, apice quinquefido, corollam aequante, demum circninscisse deciduo. Corolla calycis tubo pone ovarii verticem inserta, tubulosa, tubo compresso, integro, limbi quinquefidi laciniis subaequalibus, duabus superioribus erectis, inferioribus patentibus. S ta $m$ in a 5 , cum corolla inserta; fil amenta et a $\mathrm{th}_{\mathrm{m}} \mathrm{rae}$, quarum duae inferiores apice barbatae, in tubum liberum coalitae. Ov a ri $\mathbf{m}$ inferum, bilocnlare. Ov 1 a in placentis carnosis, bilobis, dissepimento ntrinque adnatis plnrima, anatropa. Stylus brevissime exsertus; stigma bilobum, pilis einctum Cap 8 ula baceata, umbilicata, bilocularis, indehiscens. Semina plurima $\ldots .$. - Frutices $v$. arbores lactescentes, in insulis sandwicensib $u s$ indigen $i$; folits alternis, serratis, racemis axillaribus, folio brevioribus, pedicellis basi unibracteatis, floribus speciosis, albidis $v$, roseo-violaceis.

Clerm ontia Gaudichaud ad Freyc. 459. t, 71 - 73.

3069. Centropogon PRESL. Caly tobo subgloboso, eum ovario connato, limbi superi, quinquefidi laciniis subulatis, patentibus. C oro 11 a summo calycis tubo inserta, tubo cylindraceo, medio incurvo, integro, limbi quinqnefidi laciniis faleato-galeatis, inferioribus patentibus.
S t a $\mathrm{m}$ in a 5 , inter corollam et annulum perigy num carnosum, quinquedentatum, persistentem inserta; filamenta et antherae, quarum duae inferiores aculeo ovato - triangulari, cartilagineo, solitario terminatae, in tubum liberum coalitae. 0 varin inferum, biloculare. 0 v 1 a in placentis magnis, carnosis, dissepimento utrinque adnatis, medio cristatis plurima $\ldots . . .5$ Stylus inclusus; stigma exsertum, bilobum. Bace a globosa, bilocularis, pericarpio tenui, placentis carnosis. S e m i n a plurima ....... Suffrutices Americae tropicae; foliis alternis integris, serratis, floribus axillaribus solitariis, longe pedunculatis.

Centropogon Presl Monogr. 48. Lobelia suri$n$ a me $n \times$ is Linn. Bospl. Navarr. t. 39. Andr. Bot, Heposit. t. 502. Bot. Mag. t. 225. L. h irta Cavanill. Ic. t. 520. L obellia e s p. Hamb. et Bonpl.

30\%9. Trimeris PRESL, Calyx tubo anguste turbinato, cum ovario connato, limbi 8uperi, quinquefidi laciniis nervo medio crasso donatis. Corolla summo calycis tubo inserta, petalis duobus superioribus linearibus liberis, inferioribus in labium trilobum, ereetum connatis. Stamina 5, cum corolla inserta; filamenta et anth erae, quarum duae inferiores apice barbatae, in tubum connatae. Ovari um inferum, biloculare. Ovula ...... Stylus inclusus; $8 \mathrm{tigma}$ bilobum, lobis demum exsertis, divaricatis, orbiculatis. Fruetus indehiseens. - Frulex insulae St. Helenae; foliis allernis, oblongis, racemis axillaribus.

Trimeris Presl Monogr, 46. Lobelia scaevolacfolla Roxb.

\section{Ordo CXXV. Campanulacede.}

CAMPANULAE partim Adanson Fam, $\boldsymbol{T}$. 132. CAMPA NU LACEAE exel. plur. Jassieu gen. 164. Annal, Mus, XVIII. 1. CAMPA NULACEAE sect. 1. R. Brown Prodr. 559. CAMPA. NULEAE Alph. DC. Monographie des Campanulees. Paris, 1830. 4. CAMPANULACEAB Bartling Ord. nat. 151, Lindley Introduct. edit, II. p. 237.

Herbar annuae v. perennes, saepissime lactescentes, rarius suffrutices, canle ramisque teretibus v. irregulariter angulatis. Folia alterna $v$, interdum opposita, sessilia v. in petiolum, plerumque plus minus marginatum angustata, simplicia, integra v. nonnunquam lobata, rarius integerrima, plerumque dentata v. crenata, radicalia saepe a caulinis diversa, plerumque majora et longius petiolata. $\mathrm{Stipulae}$ nullae.

FLOBEs hermaphroditi, regulares, axillares v. terminales, racemosi, spicati v. glomerati, interdum paniculati, plerumque nudi, rarissime involucro libero v. cum calycis tubo connato cincti, ut plurimum caerulei v. albi, rarius purpurei v. lutei.

Calyx tubo cum ovario v, cum ejus basí connato, li mbo supero v. semisupero, persistente, plerumque quinquefido, rarius trisex- v. octofido, rarissime truncato, lobis margine planis v. inflexis, in lobulum sinum obtegentem decurrentibus, per aestivationem valvatis. 
Corolla gamopetala, annulo inter summum calycis tubum et ovarium protruso, rarius in discum epigynum efuso, rarissime inter androecium et stylum in tubulum nectariferum styli basim vaginantem producto, inserta, marcescens $v$. rarius decidua, campanulata v. tubulosa, limbo plus minus profunde partito, laciniis numero loborum calycis, iisque alternis, aestivatione valvatis, sub anthesi erectis $v$. patentibus, interdum apice in tubum cohaerentibus.

Stavisa cum corolla inserta, rarissime ejusdem basi subadhaerentia, ejusdem lobis numero aequalia et alterna, rarissime pauciora, inclusa v. interdum subexserta. Fil amenta aequilonga, libera, basi rarissime aequalia, plerumque inferne plus minus membranaceodilatata, ciliata, conniventia v. subcohaerentia, apice attenuato-filiformia. An therae introrsae, filamentis breviores $\mathbf{v}$, interdum longiores, biloculares, basi insertae, liberae $v$, in tubum stylo pervium cohaerentes, loculis oppositis, parallelis, contiguis $\mathbf{v}$, rarissime connectivo interposito, in cuspidem excurrente subdiscretis, longitudinaliter ante anthesim dehiscentibus. Pollen sphaericum, papillosum.

Ovariou cum calycis tubo connatum, inferum v. semiinferum, bi-octoloculare, loculi, dum calycis lobis numero congrui, iisdem oppositi v. alterni. $O \mathrm{v}$ u $\mathrm{la}$ in placentis dissepimento ovarii bilocularis adnatis, $\mathbf{v}$. ex angulo interiori loculorum ovarii plurilocularis prominulis, plus mintus carnosis, integris v. bilobis plurima, plerumque horizontalia, anatropa. Stylus terminalis, simplex, inclusus v. exsertus, in alabastro pilis pollen colligentibus, in series tot quot antherarum loculi dispositis, cito caducis hirsutus. Stigma nudum, rarissime capitatum, plerumque in lobos numero loculorum ovarii divisum, Jobis in alabastro erectis, conglutinatis, dorso pilosis, per anthesim divergentibus, recurvatis, glabris.

Capsula bi-octolocularis, polysperma, nune vertice subexserto loculicide dehiscens, pedicello tunc plerumque erecto, nunc tota infera, loculis prope basim v. medio, ant pone calycis limbum poro v. valvula parietali, sursum revoluta apertis, rarissime fissuris plurimis transversis dehiscens, pedunculo tunc plerumque reflexo.

Semina plurima, minima, loculorum angulo centrali affixa, ovoidea v. angulata, interdum compressa, saepe aspera, rhaphe et chalaza apicali rix manifestis.

Finвхо in axi albuminis carnosi orthotropus, ejusdem fere longitudine, subcylindricus : cotyled onibus brevissimis, obtusis, radi cul la umbilico proxima, plerumque centripeta.
Campan ulace a e Lobeliaceis proxime affinibus praeter notas leviores, floribus regularibus et polline sphaerico distinctae, frequentissime in hemisphaera boreali veteris orbis proveniunt, inter $36^{\circ}-37^{\circ}$ L. B. imprimis copiosae, in hemisphaera australi in regione capensi obviae, inter tropicos rarae. Ca m panuleae omnes hemisphaeram borealem incolunt, Wahlenbergieae frequentius trans aequatorem habitant. Succo turgent plurimae lacteo, acri sed innocuo. Radices et folia juniora nonnullarum inter obsonia eduntur.

TRIBUS I. WAHLENBERGIEAE. C aps $\mathrm{l}$ a apice dehiscens. - Genera in hemisphaera australi frequentius obvia.

SUR'TREDS I. JASIONEAE. An $\mathrm{t} h \mathrm{e}$ rae connatae. Capsula apice valvatim dehiscens.

30ร 1. Dasiome LINN. Caly $x$ tubo cum ovario connato, limbo supero, quinquefido. Co roll a summo calycis tubo inserta, profunde quinquepartita, St amina 5, eum corolla inserta; filamentis tenuibus, liberis, antheris basi in tubum cohaerentibus, apice distinctis. Ova ri um inferum, biloculare. Orula in placentis prope basim locuIorum centralibus plurima, anatropa. Stylus a medio ad apicem dena serie pilosus; stigmat a 2 , brevia. Ca psula sphaeroidea v. ovoidea, bilocnlaris, apice brevissime bivalvis, foramine lato hians. Sem i na plurima, minima, nitida. Embryo in axi albuminis carnosi orthotropus; cotyledonibus brevissimis, radicula umbilico proxima, centripeta. - Herbae annuae v. saepius perennes, humiles, lactescentes, Scabiosae facie, in Europa imprimis a ustro-oceidentali provenientes; foliis radicalibus interdum rosulato-congestis, caulinis alternis, angustis, integerrimis $v$. sinuatis, floribus parvulis, in capitula terminalia bracteato-involucrata congestis, inflorescentia in quovis capitulo centripeta.

I a s io ne Linn, gen. n. 100z. Jassieu gen, 166. Lam. t. 724. Gärtn. I. 149. t. 30 e Flor. dan. t. 319. E. B. t. 882. Cavanill. Ic, $t, 168$, Bot. Mag, $t, 2198$. Bot. Reg. $t .585$. Alph. DC. Camp. 101. 0 vill a Adanson Fum. I1. 134. A p h yllan thes Dalechamp Hist. 864 .

\section{SET BTTEIBUS IR. LIGHFOOTIEAE.}

Antherae distinctae. Capsula apice valvatim dehiscens,

307 2. Light footia HERIT. C a 1 y $x$ tubo cum ovarii basi connato, limbo semisupero, quinquefido. Co r oll a summo calycis tubo inserta, quinquepartita $v$. interdum quinquefida. $\mathbf{S} t$ a $\mathbf{m}$ in a $\mathbf{5}$, cum corolla inserta; filamentis basi dilatata ciliatis antherisque cadacis liberis. Ovarin m semiinferum, tri-v. quinqueloeulare, loculis lobis ealyeinis oppositis. Ovula in placentis prope basim loculorum centralibus plurima, anatropa. Stylus imberbis; stigmat a loculorum numero brevia, filiformia. C a p s u la pyramidata, tri quinqueloeularis, apice loenlicido tri-quinquevalvis, S e min a plurima, ovoideo-trigona, minima. E m bryo in axi albuminis carnosi orthotropus; cotyledonibus brevissimis, radic ula umbilico proxima, eentripeta, - Suffrutices $v$. rarius herbae perennes, 
specie unica madagascariensi excepta capenses; foliis alternis v. interdum oppositis, linearibus, integerrimis $v$. denticulatis, floribus ut plurimum racemosis, breve pedunculatis.

L I g t footia Heritier Sert, angl. 3. $t$. 4. 5 . Smith Exot, Bot. 11. 2. 69. Loddig. Bot. Cab. t. 1038. Alph. DC. Camp. 107. t. 3. f. B. Ca m p a ulae $\mathrm{sp}$. Thunberg in Mem. Academ. Petropolit, IV, t, s., f, t, t. 6, f., t, t. ?. f. 2. 3 .

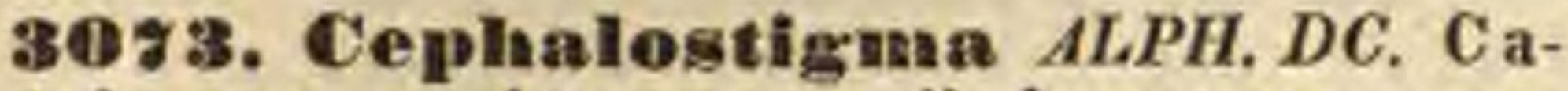
lyx tubo cum ovario connato, limbo supero v. semisnpero, quinquefido. Co rolla summo calycis tubo inserta, quinquepartita. Sta m i n a 5, cum corolla inserta; filamentis basi dilatatis antherisque liberis. O vari um inferum $v$. semiinferum, bi-triloculare. Ovula plurima $\ldots .$. Stylus filiformis; stigma simplex, capitatum, pilosum. Ca ps u la bi-trilocularis, apice loculicido-bi-trivalvis. Semina plurima, ovoideo-triquetra, minima. $\mathbf{E} \mathbf{m b} \mathbf{r} \mathbf{y}$ o ....... Herbae in senega mbia et in regno Birmanico observatae; foliis alternis, linearibus $v$. lanceolatis ovatisve, floribus racemosis $v$, paniculatis.

Cephalostigma Alph. DC. Camp. 117.

a. EUCEPhalostigma. Sty 1 us lacinias corollae sub. superans. Caps ula bilocularis, infera. - Herbae senegambicae; foribus racemosis $v$, paniculatis.

b. TRITAMIDIUM. Stylu s lacinias corollae vix aequans. Ca p s i I a trilocularis, semisupera. - Herba birmanica; floribus lase paniculatis.

3084. Campantamaea $B L U M$. In vola erum quinquepartitum, liberum v. cum basi calyeis connatum. C al y $\times$ tubo hemisphaerico, cum ovario connato, limbo truneato. Co rolla summo caly cis tubo inserta, quinquepartita v. quinquefida. Stam in a 5, cum corolla inserta, involueri lobis opposita; filamentis basi sublatioribus antherisque liberis. Ovari $\mathbf{m}$ inferum, triloculare. Ov nla in placentis a loculorum angulo centrali plurima...... Stylns inclusus; $s \mathrm{tigmata} 3$, ovata, crassa. Capsula globosa, trilocularis, umbilico lato, plano, quinquangulari, multivalvis? Se$m$ in a plurima, ovoideo-cylindrica, leviter punctata. Embryo ...... Herbae javanicae et indicae, glaberrimae, lactescentes; radicibus tuberosis, caule ramisque teretibus, foliis oppositis, petiolatis, ovato-cordatis v, oblongo-linearibus, subintegerrimis $v$. serrulatis, subtus glaucescentibus, floribus solitariis, sparsis $v$. subcorymbosis.

C am par u maea Blume Bijdr. 726. Alph. DC. Camp. 118. Codonopseos seetio 11. Alph. DC, Op. cit. 128.

30\%5. Codonopsis $W A L L . C$ a ly $x$ tubo hemisphaerico, cum ovario connato, limbo semisu pero, quinquelobo. Co rolla summo ealycis tubo inserta, earnosula, campanulata, apice quinqueloba. Stamina 5, cum corolla inserta; filamentis basi sublatioribus antherisque liberis. O va ri u m inferum, trilocnlare. $O v$ u Ia in placentis ex angulo centrali loculorum plurima, anatropa. Stylus inclusus; stigmata 3 , ovata, crassa. Capsula hemisphaerica, trilocularis, apice acnto loculicido trivalvis. Sem ina plurima, ovoideo-cylindrica. Embryo in axi albuminis carnosi orthotropus cotyledonibus brevissimis, radicula nmbilico proxima, eentripeta. - Herbae in India sept em trion al i monticolae, saepius glaberrimae; caulibus e caudice lignoso adscendentibus, plerumque volubilibus, foliis alternis $v$. oppositis, petiolatis, crenatis, subtus glaucescentibus v, incanis, floribus axillaribus terminalibusque pedunculatis, luteo- $v$. cateruleo-virescentibus v, purpureis.
Codonopsis Wallich in noxburgh Flor. Ind. II. 103, Alph. DC. Camp. 120. Royle Himalay. i. 62. f. 2. Glossoco mia Don Nep. 158.

368 8. Cumarima JUSS. Caly $\mathrm{x}$ tubo obconico, cum ovario connato, limbo supero, sexfido. Coroll a annulo perigyno inserta, campannlata, maxima, apice sexloba. Stamina 6 , cum corolla inserta ; filamentis basi crassioribus antherisque liberis. Ovarinm infernm, sexloculare, loeulis lobis calycin's oppositis. Ovula in placentis e loeulorum angulo centrali bilobis plurima, anatropa. Sty In s inclusus, superne pilis duodecimseriatis hispidus; stig m a t a 6 , demum stellatopatentia, C a p s u la obovato-hexagona, sexlocularis, apice retuso loculicido-sexvalvis. Semina plurima, minuta, angulata. E m bryo ......

Herba canariensis, tri-quadripedalis, glaberrima, glauca ; radice fusiformi-tuberosa, succo lacteo scatente, caule adscendente, ramoso, ad foliorum originem incrassato-subarticulato, foliis oppositis $v$. rarius ternatis, petiolatis, hastato-subcordatis, irregulariter dentatis, supra nitidis, subtus pallidioribus, peduneulis unifloris, solitariis, ramos axillares foliosos terminantibus, nutantibus, corollis carnosulis, luteo-purpurascentibus.

C a n a ri n a Jassieu gen. 164. Lan. 2 , 259. Gärtn. f. III. 163. t. 121. Bot. Mag. $t$. 444. Alph. DC. Camp, 123, t.4. f,6, Ca nar i a Linn. Mant, 198. Pe r u e t t y a Scopoli Introduct. 150.

30\% \%. Platyeodon $A L P H . D C$. Caly tubo obconico v. turbinato, eum ovario connato, limbo supero, quinquefido. Co rolla summo calycis tubo inserta, maxima, infundibuliformis, apice quinqueloba. Stamina 5 , cum corolla inserta; filamentis basi latioribus antherisque liberis, $O \mathrm{va-}$ $\mathbf{r}$ i $\mathbf{~ m ~ i n f e r n m , ~ q u i n q u e l o c u l a r e , ~ l o c u l i s ~ l o b i s ~}$ calycinis alternis. Ovula in placentis e loeulorum angulo centrali plurima, anatropa. Stylus basi incrassatus, apice pilosus; $8 \mathrm{tigmata} \mathbf{3}$ v, 5 , stellato-patentia, Ca p s u la ovoidea, tri-quinquelocularis, apice loculicido-tri-quinquevalvis. S emina plurima, ovoidea, nitida. Em hryo in axi albuminis carnosi orthotropus; coty led on ibus brevissimis, radie ula umbilico proxima, centripeta. - Herbae perennes, glaucescentes, in As i a boreali indigenae, etium in regione mediterrane a observatae; foliis alternis $v$. suboppositis, sessilibus, ovato-v.lineari-lanceolatis, serratis, subtus pallidioribus, superioribus minoribus, floribus paucis, terminalibus, solilariis, pedunculatis.

Platyeodon Alph. DC. Camp. 125. Campanula grandiflo ra Jaeq. Hort, Vindob. III. $t$. 2. Bot. Mag. t. 252.

30\% 8. Mierocoden $A L P H . D C . \mathrm{C}$ al y tubo sphaerico, cum ovarii basi connato, hispidissimo, limbo semisnpero, quinquefido. C oroll a summo calycis tubo inserta, minima, eylindracea, apice quinqueloba, persistens. St a mina $\mathbf{5}$, $\mathbf{c u m}$ corolla inserta ; filamentis tenuissimis, basi aequalibus antherisque liberis. Ovarium semiinfernm, quinqueloculare, loculis lobis calycinis alternis. Ovula in placentis prope basim loculorum centralibus plurima, anatropa. Stylus filiformis, inclusus; stigmata 5 , brevia. Ca psula sphaeroidea, hispidissima, apice loculicido-quinquevalvis. S e min a plurima, minima, ovoidea, nitida. E mbryo in axi albuminis carnosi orthotropus; cotyledon i bus brevissimis, radienla umbilico proxima, centripeta. - Herbae c a p ens es, annuae, humiles; foliis allernis v. suboppositis, anguste-lanceolatis, parvis, sessilibus, superioribus paullo lon- 
gioribus, floribus terminalibus brevissime pedicellatis,

\author{
Mierocjodon Alph. DC. Camp, 127, t. 19.
}

30ร9. Wallembergia SCHRAD. C a1 y $x$ tubo ovoideo v. obconico, cum ovario connato, limbo semisupero, tri-quinquefido. Corolla summo calycis tubo inserta, campanulata, apice v. interdum usque ad medinm tri-quinqueloba. Stamina $3-5$, cum corolla inserta; filamentis basi subdilatatis antherisque liberis. Ovari um semiinferum, bi-tri- v. quinqueloculare, loculis lobis calyeinis oppositis. Ovula in placentis e loculorum angulo centrali plurima, anatropa. St y1 us inclusus, superne pilosus; stigmat a $2-5$, brevia, patula. Ca psula ovoideo-oblonga v. subsphaerica, bi-tri-quinquelocularis, apice valvis loculicidis dehiseens. - Herbae ut plurimum annuae, rarius perennes, interdum suffrutescentes; in hemis phaerae borealis regionibus extratropicis rarae, in hemisphaera a ustrali, imprimis in Cap ite bonae spe $i$ obviae; foliis alternis $v$. interdum oppositis, sacpius in inferiore caulis parte congestis, floribus ut plurimum longe pedunculatis, pedicellis floriferis nutantibus, fructiferis erectis.

Wa hle n berg i a Schrader in Comment. Göting. VI.123. Alph. DC. Camp. 129. Campanulae seetio Codouia Sprengl Syst. $T$. 735.

a. EDRAIANTHA $A l_{p} h, D C$, Flores pentameri. Fructus bi-trimerus. S e mi na ovata, plana. - Herbae perennes, humiles, in Europa australi indigenae; folits alternis, angustis, radicalibus confertissimis, caulinis subamplexicaulibus, floribus sessilibus, saepius capitatis.

Edrafantha Alph. DC. Camp. 130. Campanulae s p. Sibthorp Flor. graec, $t, 206$, Waldst. et Kitaibel $\mathbf{P l}$. Hang. t. 15\%. 156. Portenschlag Dalmat. 1c.

b. AIKINIA Salisb. Flores pentameri. Fructus tripentamerus. Semina ovoidea. - Herbae plerumque annuae, in Capite bonae spei, Australasia et India orientali indigenae, in Europa occidentali rarissimae; foliis allernis v. rarius oppositis, angustis, floribus plus minus longe pedunculatis et pedicellatis.

A ikinia Salisbury ex $A l p h, D C$. Op. cit. 135. S c hultes ia Roth Enumerat, 1. Campanulae seetio Campanopsis R. Brown Prodr, 561. Campanulae s p. Thunberg in Act. Academ. Petropolit. IV. t. 6. f. 3. t. 5. f. 3. 4. t. 7. f. 1. 4. Venten. Malm, t, 12. Bot. Mag, $t, 69 t, 789$. Wallieh in Asiat. Heisearch. XII. 371. c. ic. Hooker Flor. Lond. t. 93. R o ell a e s p. Andr. Bot. Reposit. t, 238. - (Alph. DC. Op. cit. t.15, 16. 18. 19. $f$. 1.)

c. CERviciNa Del. Flores tri-tetrameri. Fruetus dimerus. S emina triquetra, una extremitate acuta, altera truncata. - Herba humilis, annua, Aegyptum ot Senegambiam incolens; foliis alternis, sessilibus, angustis, floribus breve pedicellatis.

Cervieina Dellie Flor, aegypt, 7. t. F. f. 2. Alph. DC, Op. cit. 156.

d. LOBELIOIDES Alph, DC. F 1 o r e s tri-pentameri. F r u etus dimerus. Se m in a ovoidea, nitida, - Herba tenuis, annua, Madeiram, Canarias et Novam Hollandiam incolens; folits alternis, sessilibus, poribus longe pedunculatis.

Lobelioides A!ph, DC. Op. cit. 157, t, 17, C a mpanula lobelioides Lian.

c. LINARIOIDES $A l p h, D C$. Flores peistamert. Fractus dimerus. Se nt in a lentieularia, nitida. - Herba in America australi extratropica indigena, perennis; faliis alternis, sessilibus, angustis, floribus longe pedicellatis.

Liuarioides Alph, DC. Op. oit. 138. Campanu. la filiformis Ruiz et Pav. Flor. peruv. t. $200, f . c$.

f. NESOPIILA Alph, DC. Flores pentameri, Proctus bi-trimeras. Semin i ovata, plana. Suffrulices, insulas St. Hetenae, Ascensionis et $S$. Juaz Fernandez incolentes; folits allernis, sessilibus, firmis, latis, argute serratis, floribus pedunoulatis.

Nes ophil a Alph. DC. Op. cit. 160.

SUETEIBUS IIT. PRISMATOCARPEAE. Capsula elongata, apice rupta v. poro dehiscens.

3080. Frismatoenrpiss $A L P H . D C$. Cal y x tubo cylindraceo, elongato, cum ovario connato, limbo supero, quinquelobo. Corolla summo calycis tubo inserta, infundibuliformis, apice quinqueloba. S tamin a 5 , cum corolla inserta; filamentis basi latissimis, apice filiformibus antherisque liberis. Ovarinm inferum, biloculare. Ovula in placentis dissepimentum totum oceupantibus plurima, pendula, anatropa. St y I u s brevis, basi persistente; stigmata 2 , brevia. C a ps u l a elongata, prismatiea v. cylindracea, bilocularis, als apice versus basim quinquefariam rupta. S e mina ovoideo-subeompressa, obtusa, punetata. E m b r y o in axi albnminis carnosi orthotropus; cotyledonibus brevissimis, radicula nmbilico proxima, supera. - Herbae sublignosae v. suffrutices c a penses; foliis alternis, sessilibus, angustis, ciliatis $v$. integerrimis $v$, dentato-serratis, foribus in axilla folii $v$. bracteae sessilibus, solitariis $v$, approximatis, rarissime subpaniculatis.

Prismatoearpus Alph. DC, Camp. 164. t. 20, non Heritier. Pris mato carpi sp. Heritier Sert. angl. $t$. 3 . C a mp a nulae s p. Aiton, Thunb. Bot. Mag. $t .2733$.

3081. Itoella $L I N N$. C a ly $x$ tubo cylindraceo, cum ovario connato, limbo supero, quinquefido. Coroll a summo calycis tubo inserta, infundibuliformis v. tubulosa, apice quinqueloba. St a mina 5, cum corolla inserta; filamentis basi latis, apice filiformibus antherisque liberis. Ovari a m inferum, biloculare. Ovala in placentis juxta totum dissepimentum plurima, pendula, anatropa. Stylus brevis, basi persistente; stig mat a 2, brevia. Ca ps u la eylindracea, bilocularis, styli basi demum operculatim secedente foramine lato aperta. Semin a plurima, angulosa, scabra, crassa. E m b r yo filiformis, in axi albuminis carnosi orthotropus; cotyledonibus brevissimis, radicula nmbilico proxima, supera. Plantae ca pens es, suffruticosae v. rarius herbaceat, perennes; foliis alternis, plurimis, per caulem ramosque sparsis, rigidis, saepius angustis, dentatis v. serratis, ut plurimum ciliatis, floribus sessilibus, terminalibus $v$. interdum axillaribus.

Roella Lian. Hort. cliffort. 492, t, 35. Gen, n, 219. Gartn. T. 154, t. 31, Lam. t. 123. Heritier Sert, t. 6. Bot. Mag. t. 378. Alph. DC. Camp. 172. A e u leos a Plucknet Almag. 8, t. 259. $f$. 4. C a m p a n u l a e s p. Thunb.

TEIBUS II. CAMPANULEAE. Cap$\mathrm{s}$ u la latere $\mathrm{v}$. basi poris dehiscens.

3092. Phyteuma LINN. Calyx tubo ovoideo v. obcenico, cum ovario connato, limbo supero, quinquefido. C oroll a summo ealycis tubo inserta, quinquepartita, laciniis linearibns, apice din v. pertinaciter in tuhum stylo pervium cohaerentibus. St a m in a 5, cum corolla inserta; filamentis basi latioribus antherisque longis liberis. 0 vari $\mathrm{um}$ inferum, bi-trilocnlare. $O \mathrm{v}$ il a in placentis e loculorum angulo centrali plurima, anatropa. Stylus filiformis, apice pilosns; stigmata 2-3, filiformia, brevia. Capsal a ovoidea, bi-trilocularis, loculis basi v. prope medium rimu- 
la parietali longitudinali valvatim apertis. S emin a plnrima, ovoidea v. subcompressa, interdum nitida. E mbry o in axi albuminis carnosi orthotropus; cotyledonibus brevissimis, divaricatis, rad icula umbilico proxima, centripeta. Herbae perennes, in Europa temperata et in Asia finitima indigenae; foliis alternis, radicalibus petiolatis, majoribus, caulinis saepius sessilibus, floribus sessilibus $v$. brevissime pedicellatis, subspicatis $v$, capitatis,

P hy te u ma Linn. gen, n, 298. Gärtn. $I$, 149. Alph. DC. Camp. 180. R a рине ulus Touruef. Inst, 113, R apun t i um Lohel. Hist. 178.

a. PHYSOPLEXIS, Co rollae laciniae apice counatae. S ta min un filameota basi vix dilatata. S $t \mathrm{igmata} 2$. C a psu I a bilocularis. - Flores brevissime pedicella. ti, laxe fasciculati. - P h y te u m a c o m os u m Linn. Jacq. Flor. austr. $\ell, 50$.

b. RAPUNCULUS. C o r o I la e laciniae apice demum distinetae. S ta m i u u filamenta basi dilatata. Stigmata 2_3. C a p s u I a bi-trilocularis. - Flores sessiles v. brevissime pedicellati, laxe spicativ, dense approximati. (Gärta. t. 30. Schkuhr t. 39. Lan. t. 124. Jacq. Flor. austr. t. 437. Ic. rar. t 333. Sibthorp Flor. graec. t. 217_219. Willdenow Phytogr. $I$. $t$. 4. $f$. 2. Waldst. et Kitaibel Plant, Hung. $t, 14$. Hooker Flor, Lond, $t, 56$. Gussone Plant, rar. t. 19. Reichenb. Icon, erit. t. 249. 250. 348. 363-365. Bot. Mag. t. 1015. 1466. 1797. 2066. 2145. 2972, 1347.)

3093. Petromarula $A L P H . D C$. C a I y x tubo ovoiden, cum ovario connato, limbo supero, quinquefido. Cor o 11 a summo calycis tubo inserta, quinquepartita, lobis linearibus, demum reflexis. St amina 5, cum corolla inserta; filamentis basi dilatatis antherisque brevibus, liberis. Ovarin m inferum, triloculare. Ovula in placentis e localorum angulo centrali plurima, anatropa. Stylus cylindricus, glaberrimus; stigma crasse capitatum, indivisum, pilosiusculum. C a p s ul a sphaeroideo-trigona, trilocularis, loculis prope medium foramine parietali apertis. S em ina plurima, minima..... - Herba cretica, rupicola; foliis radicalibus petiolatis, ovatis, acutis, demum petiolo lobis lateralibus aucto pinnatis, caulinis paucis, alternis, serrato-lacinatis $v$. irregulariter pinnatis, demum in bracteas lanceolatas, serralus transeuntibus, floribus in racemum olongatum, multiflorum dispositis, caeruleis v. albidis, capsulis erectis.

Petromarula Alph, DC. Camp. 209. Phytenma pinnatum Ventenant Cels. $t$. 52. Sibthorp Flor. graec. t. 226. Reiehenb. Hort, Bot, $t, 137$.

3084. Dielnawxia HERIT. C a ly x tubo obeonico, cum ovario connato, limbo supero, octo fido, laciniis in lobos reflexos, sinus obtegentes decurrentibus. Co rolla summo calycis tubo inser ta, octopartita, laciniis lanceolatis, demum reflexis. St a mina 8, cum corolla inserta; filamentis membranaceis, ovato-acuminatis antherisque libe ris. Ovarin m inferum, ostoloculare, loculis lo bis calycinis oppositis. Sty I u s brevis, sedena serie pilosus; $8 \mathrm{tigmata} 8$, filiformia, brevia. O va 1 a in placentis carnosis, e loculornm angulo cen trali peltatis plurima, anatropa. C a ps ula turbinata, octocostata, octolocularis, loenlis prope basim valvula parietali sursum revoluta dehiscentibus. Semin a plurima, minima..... - Herbae orientales, biennes, glabrae v. pilosae; foliis radicalibus petiolatis, irregulariter lobatis, caulinis alternis, subamplexicauli-sessilibus, grasse lobatis, floribus paniculatis fructibusque nutantibus.

Micha usia Heritier Monograph. inedit. Lam. t. 295. Gärin, f. III. 162. 4. 211. Bo: Mag. , 219. Venten. Cels. 6. 81. Alph, DC. Camp. 211, t, i. f. c. Bot. Mag. 6. 3128. Mi a d a m Adansou Fam, $I T, 134$. Jussieu gen, 164.
3085. Campamula LINN. Ca ly x tubo ovoideo v. subsphaerico, cum ovario connato, limbo supero, quinquefido, laciniis margine planis $\mathbf{v}$. in lobos sinus obtegentes decurrentibus. Corolla summo calycis tubo inserta, plus minus campanulata, apice quinqueloba v. quinquefida. Stam in a 5, cum corolla inserta; filamentis basi late membranaceis antherisque liberis. Ovarium inferum, tri- v. quinqueloculare, loculis lobis ealycinis oppositis. Ovula in placentis e loeulorum angulo centrali plurima, anatropa. $S t y l$ n $s$ pilis mox deciduis tectus; $8 \mathrm{t}$ ig mata $3-5$, filiformia. C a psu la ovata v. turbinata, tri-quinquelocularis, loculis prope basim v, apicem valvula parietali sursum dehiscentibus. Se min a plnrima, plerumque ovata, complanata, rarius ovoidea et minima. Embryo in axi albuminis carnosi orthotropus; cotyledonibus brevissimis, radicula umbilieo proxima, centripeta. - Herbae perennes $v$. annuae, nunc humiles et caespitosae, nune erectae, elatae, multiflorae, per omnes hemisphaerae borea $i$ is regiones temperatas et frigidiusculas diffusae, pratisque et lucubus miro decori; foliis radicalibus saepissime majoribus, longiusque petiolatis et obtusioribus, caulinis alternis, variis, floribus plerumque pedunculatis, racemosis, rarius spicatis v. glomeratis, saepe majusculis, caeruleis $v$. in eadem specie interdum candidis.

C a mp a nula Lina. gen. n, 290. Gürta. I. 153. Alph. DC. Camp. 213.

a. MEDIUM AIph. DC, Op. eit, 214. C aly els sinus loborum appendicibus retroflexis obtecti. C a s u la triquinquelocularis, loculis valvula prope basim parietali dehiscentibus.

Medi um Tournef. inst. I. 109. Marianthe in um Sehrank msc. Rapu ut i a m Chevalier Flor. Paris. $I$. 596. (Jacq. Flor, austr, t, 118, 200, Observ, II, t, 37. Sibthorp Flor. graec. $t, 208$ 213. Waldst. et Kitaibel Plant. Hung. $t, 64$. 258, Desfout. Flor. atl. $t, 5 t$. Annal. Mus. XI, t, 15_17. Labillard, Syr. Dec, $V, t, 4$. Bieberst. Plant, ross, t. 209. Vent. Cols. $t$, 18. Andr. Dot. Reposit. t, 385. Salisb. Parad, t. 26. Bot. Reg. t. 237, Bot. Mag, t. 404. 659. 811. 912, 057, 1258, 1723. 2019. Reielienb, Ic. crit, t, 401, Alph. DC. Op, cit. t. 9. 10. 11. $f$. 1.)

b. EUCODON Alph. DC. Op, cit. 214. C a I y cis sinus Inbis margine planis uudi. Caps a la triloeularis, loculis valvula prope apicem parietali dehiscentibus.

C a manula e s p. Jaeq. Flor, ansir, t. $285,411$. Tc. rar, t. 334. Hort. Vindob, t, 57. Flor. dian, $t, 373$. 789. 787. 1026, 1086. 1326, 1397. 1328, 1512, Sibthorp Flar. graec. $t$. 203_207. Waldst. et Kitalbel Plant. Hung, t, 136. 263. Brotero Phytogr, t. 18, 20. Desfont. Flor, all. $t$. 50. Link et Hoffanusegg Flor. Porlug. IT e. 79. Lubillardi, Syr. Dec. II. t. 6. V, t. 3. 5. Bieberst. Plant. ress, t. 10. 42 . Tenore Flor. Neap. t. $15-18$. Hooker Elor Lond t. 81 . Nees Amoen, bot, II. $t$, 4. Bat. Reg. t, 211, 620. Bot. Mag. t. 1257, 1973. 2492. 2649. Relicleab Io. cril, L.77. et seq. Alph. DC. Op. eit, t,11. f. a. t. 12, f. 6. t. 13 f. 6. - Ron e el a Dumortier Comment. bot, 14. (Sibthorp Flor. graec, t, 214. 215.)

308B. Specalaria HETST. Cal y tubo elongato prismatico v. Ionge obconico, cum ovario connato, limbo supero, quinquelobo. Co rolla summo calycis tubo inserta, rotata, quinqueloba. $\mathrm{S}$ t a $\mathrm{m}$ in a 5 , cum corolla inserta; filamentis memhranaceis, pilnsis, antherisque longioribus liberis. Ova ri um inferum, triloculare. Ovula plurima Stylus inclusus, dena serie pilosns; st ig mata 3 , filiformia. Capsula longe prismatiea, triloenlaris, loeulis prope apicem $v$. supra medium valvula parietali, sursum revolnta dehiscentibus. S e m in a plurima, ovoidea v. lentienlaria, sulscompressa, nitidissima. E m b r y n - Herbae annuae, humiles, in Europa mediter- 
ran ea imprimis indigenae, una per o $m n \in m A m e$ ricam diffusa; folits allernis, inferioribus subdis. similibus, floribus axillaribus et terminalibus sessilibus, erectis, corollis caeruleis, roseis $v$. ex albo et caesio variegatis, sole splendente in rotam expansis.

Speenlaria Heister gen. 8. Alph. DC. Camp, 344. $\mathrm{Pr}$ is matocarpus Heritier Sert. 2. exel. sp. capensibus, non Alph. DC.

a. APENULA Neck. Caly $\mathrm{c}$ is tubus elongato-prismaticus, angulosus. Capsula prope apiceu versus calycis limbua dehiscens. S e mi na ovoidea. - Folia ovato - ob. longa $v$. lanceolata, subintegerrima, sessilia v. petiolata. Species in veteri orbe indigenae.

A pe a ula Necker elem, n, 397. Legouzia Durand Flor. Bourg. II. 26. Prismat o e a r pi s p. Heritier, Tenore Flor. Neap. t. 20 . C a mpanula e s p. Linn. Sibthorp. Flor. graec. t. 216. Desfout. in Annal. Mus. XI, t, 18. Bot. Reg. t. 56. Bot, Mag, t. 102.

b. DYSMICODON. Caly cis tubus longe obeonicus, laevis. Cap 8 ula versus mediam partem dehiscens. S em i u a sublenticularia. - Folia ovato-rotundata, amplexicaulia, crenato-dentata. Species americana.

C am pa a n 1 a e sp. Linn. Ruiz et Pav. Flor. peruv. t. 200. f. 6. Kunth in Humb, et Bonpl. Nov. gen. et sp. c. 265.

308\%. Traelaeliome $L I N N$. C al yx tubo ovoideo, cum ovario connato, limbi superi, quinquefidi lobis subulatis, erectis. Corolla summo calycis tubo inserta, hypocraterimorpha, tubo longo, angustissimo, limbo quinquelobo. S $\mathbf{t}$ a $\mathbf{m}$ in a 5 , cum corolla inserta; filamentis filiformibus, basi aequalibus, antherisque liberis. Ovari um inferam, triloculare. $O \mathrm{vu} l \mathrm{a}$ in placentis e loculorum angulo centrali peltatis plurima, anatropa. StyI s filiformis, exsertus, apice incrassato inordinate pilosus; stigmata 3 , minima, obtusa. Ca p s u a sphaeroideo-trigona, trilocularis, loculis valvula prope basim parietalidehiscentibus. S em in a plurima, ovoidea, minima, spadicea, nitida. E in b r yo in axi albuminis carnosi orthotropus; cotyledonibus brevissimis, obtusis, radicula umbilico proxima, centripeta. - Herba perennis, in regione mediterranea occiden $t$ al $i$ indigena; caule erecto, glaberrimo, simplici, foliis alternis, petiolatis, ovato-aculis, grosse serratis, subtus pallidioribus, corymbo terminali multi floro, floribus violaceis.

Trach e: i u m Linn. gen, n, 293. Gärtner I. 155, $t, 31$. Lamarck t. 126. Sehkube t. 40 . Alph. DC. Camp. 354.

3083. Adenoplhora FISCH. Caly x tu bo ovato $v$. hemisphaerico, cum ovario connato, limbo sapero, quinquefido. C o rolla summo ealy cis tubo inserta, campanulata $v$. infundibuliformis, apice quinqueloba. St am in a 5 , cum corolla inserta; filamentis basi membranacea, dilatata arcte conniventibus, apice filiformi antherisque discretis. Ovari u m inferum, triloculare. Ovila in placentis e loculoram angulo centrali plurima, anatropa. T u bulus epigynas cylindricus, nectarifer, styli basim vaginans. Stylus saepius exsertus, apice dena serie pilosus, mox glaber; stigmata 3 , linearia. Ca p s ula ovoidea $v$. subsphaerica, trilocularis, loculis prope basim valvula parietali dehiscentibus, Sem in a plurima, ovata, plus minus complanata. E m b r yo in axi albnminis carnosi orthotropus; cotyledonibus brevissimis, obtusis, radieula umbilieo proxima centripeta. - Herbae perennes $v$. interdum fortassis biennes, una specie excepta in Europa or ientali indigena, Sibiriam, Dahuriam et Chinam borealem incolentes, Campanularum fueie; radice saepirs eduli, canle erecto, foliis alternis $v$. rarius sub. verticillatis, radicalibus petiolatis, rotundatis, caulinis saepius sessilibus, superioribus angustioribus, brevioribus, floribus racemosis v. paniculatis, terminalibus et axillaribus, pedicellatis, nutantibus.

Adenophora Fischer in Act. Mosqu, VI, 165. Rel chenb. Ic. crit, t. 480. Alpli. DC. Camp. 354. t. $1 .$, . 6, t, 6. FI b r k a Sprengel Anleit. II. 523. non alior. C a m p a n al a e s p. Lian. Jaeq. Hort. Schönbr. $t$. 335. Waldst. et Kitaibel Plant, Hung. $t, 247$. Bot. Reg, t, 149.

3089. Symplayamallen $A L P H . D C, \mathrm{C}$ a 1 y x tubo obconico, cuin ovario connato, limbo supero, quinquefido, laciniis margine planis v. in lobos sinus obtegentes decurrentibus. Co r o 11 a summo calycis tubo inserta, campanulata v. infundibuliformis, saepius velutina, apice quinqueloba. St a mina 5 , cum corolla inserta; fil a mentis basi dilatata membranaceis, ciliatis, liberis, antheris in tubum longum, cylindricum, stylo pervium, apice quinquedentatum connatis, O varium inferum, triloculare. Oval a in placentis e loculorum angulo centrali plurima, anatropa. Stylus eylindricus, pilosus; stigmata 3 , filiformia. Capsula sphaeroidea, trilocularis, loculis prope basim valvula perietali dehiscentibus. S e m in a plurima, ovata, plus minus complanata, nitida. Emb ryo in axi albuminis carnosi orthotropus; $\cot$ le $d$ on i b us brevissimis, obtusissimis, $r$ ad i $c$ a $I_{a}$ umbilico proxima, centripeta. - Herbae perennes, herbaceae $v$. sublignosae, in insula Creta et in regione caucasica observatae; foliis alternis, petiolatis, cordatis, crenato-dentatis, inferioribus petiolatis et majoribus, floribus terminulibus et axillaribus, pedicellatis, saepius racemosis.

S y mphyandra Alph. DC. Camp. 365. Campanula e s p. Sieber, Stev.

a. MELANOCALYX. Cal y els sinus nudi. Corolla glabra. - Herba glabra, cretica. (Alph. DC. Op. cit, t. 8.)

b. SERICODON. Cal y cis siuus appendicibus obtecti. Co. roll a velutina. Herbae pilosae, caucusicae. (Sweet Ft. Gard. IT. t, 66.$)$

3090. Vinsselha DUMORT. C a l y x tubo obconico, decemnervi, cum ovario connato, limbi superi, quinquefidi laciniis erectis. Coroll a summo calycis tubo inserta, profunde quinquefida, laciniis lineari-lanceolatis, patentibus. St a m in a 5 , cum corolla inserta; filamentis basi sublatioribus antherisque apice connectivo excurrente cuspidatis liberis. Ov a r i n m inferum, quinqueloculare, loculis lobis calycinis alternis. Ovula in placentis e loculorum angulo centrali bilobis plurima, anatropa. Stylus cylindricus, glaber; stigmat a 5 , linearia, stellato-patentia. Cap 8 u la obconica, decemnervis, quinquelocularis, loculis fissuris plurimis parietalibus, transversis dehiscentibus. Sem in a plurima, minima, ovoidea, nitida. E m bryo in axi albuminis carnosi orthotropus; c oty led onibus brevissimis, obtusis, radieula umbilico proxima, centripeta. - Suffrutex canariens is, sempervirens, lactescens; caudice pedali, erecto, cicatrisato, nudo, subcarnoso, superne comoso-foliato, ramis floriferis e foliorum conıa pyramidatim paniculatis, annuis, foliis alternatim confertis, maximis, ovato-lanceolatis, duplicato- $v$, triplicato-serratis, laete virentibus, nitidis, firmis, floribus plurimis pyramidatim racemosis, aureis.

M usschia Dumortier Comment. bot. 28. Alph. DC. Camp. 368. 2. 4. f. a. C a m pa nu 1 a a u rea Linn. Venten. Malm. t. 116. Jacq. Hort, Schönbr. $t$. 472, Bot. Reg. $t$. 57.

309 1. Merciera $A L P H ., D C$. Caly x tnbu ovoideo, cum ovario connato, limbo supero, 
quinquefido. Co ro Il a summo caly cis tubo inserta, longe tubulosa, tubo angustissimo, limbo quinquelobo. Sta min a 5, cum corolla inserta; filamentis tenuissime filiformibus, basi aequalilıus antherisque multoties brevioribus liberis. Ovarium inferum, uniloculare? O v u la 4 , basilaria? ...... Stylus filiformis, saepius exsertus, glaber; st $\mathbf{t g} \mathbf{m}$ a $\mathbf{t}$ a 2 , brevissima. Caps a la indehiscens? ...... Suffrutices c a penses, Roellae ciliatae habitu, propter ovarii et fructus fabricam nondum rite perspectam quoad affinitatem veram, et locum in ordine dubii; caule erecto, ramoso, ramis valde foliosis, sublignosis, puberulis, rubescentibus, folits sessilibus, alternis, confertis, linenribus, subulatis, plus minus ciliatis, rigidis, floribus axillaribus, solitariis, sessilibus, spicam foliosam, deorsum florentem constituentibus, calycis tubo hispidissimo, limbi lobis lanceo latis, acutis, glabriusculis, corolla longissime tubu losa, fere Trachelii.

Merciera Alph. DC. Camp. 369, t, 5,

\section{* PONGatiEAE.}

3092. Pongation JUSS. Caly $\mathrm{x}$ tubo obpyramidato, cum ovario connato, limbi superi, persistentis, quinquepartiti lobis obtusis, carinatis, conniventibus. Corolla supera, brevissime tubulosa, quinquefida, lobis maryine auriculatoinflexis. An therae $\overline{5}$, subrotundae, intra tubum corollae sessiles, laciniarum marginibus inflexis velatae, biloculares, loculis longitudinaliter dehiscentibus. O va r i um inferum, biloculare. Ovu1 a in placentis eylindricis, ex apice dissepimenti pedicellatis, descendentibus plurima, anatropa. Stylus brevissimns; $s$ tig ma obsolete bilobum, glabrum. Capsula membranacea, calycis limbo coronata, bilocularis, operculo apicis dehiseens. Se min a plurima, minutissima, teretiuscula. Emb r yo in axi albuminis parci, carnosi cylindricus; cotyledonibus breyissimis, obtusis, radic u la umbilicum attingente. - Herba indica, dubiae affinitatis, paludosa, glabra; foliis alternis, angustis, integerrimis, stipulis nullis, floribus in capitulum terminale subcylindricum dense congestis, sessilibus, basi bibracteolatis.

Pong a t i um Jussieu Gen, 483, Lindley Introd. edir, II. p. 239. S pheno ele a Gärtuer $\boldsymbol{I}$. 113.2 . 24. Gä́rt nera Retz Observ, t. VI. 15. R a pin i a Loureir. Flor. cochinch. t. 156. P o ng a ti Rheede Malab. II. t. 24,

\section{Ordo CXXVI. Stylidene.}

StYLIDEAE R. Brown Gen, Rem, 561. Prodr, 565. Jussieu in Annal. Mus. XVII. 7. Bartling Ord, nat, 148, STY LIDIACEAE Liudley Introduct edit. II. p. 240.

Herbae annuae v. perennes, interdum suffrutescentes, succo aqueo. Caules saepe abbreviati, scapos exserentes, ramique teretes v. irregulariter angulati, pube dum adest simplici, glanduloso-capitata v. acuta. Folia sparsa rariusve verticillata, radicalia in scapigeris conferta, simplicia, integra, saepius integerrima, marginibus nudis v. ciliatis.

Flores hermaphroditi, asymetrici, spicati, racemosi v. corymbosi, interdum solitarii, et tunc terminales, rarius axillares, pedicellis saepius tribracteatis.

Calyeis tubus cum ovario connatus, nune ovato-oblongus v. sphaericus, basi iuterdum hinc gibbus, nunc linearis, elongatus, teres v. compressus, apice aequalis $v$. in collum contractus, limbus superus, persistens, rarissime regularis, sexfidus, plerumque irregularis, bilabiato - pentamerus, labio inferiore bidentato v. bifido, superiore tridentato $\mathrm{v}$. trifido.

Corolla summo calycis tubo inserta, gamopetala, rarissime tubo campanulato et limbo sexfido regularis, plerumque irregularis, tubo brevissimo, fauce nuda v. denticulis glandulisve coronata, limbi quinquefidi laciniis quatuor majoribus patentibus, geminatim approximatis v. rarius cohaerentibus, contiguis saepe minoribus, quinta infima (antica), torsione tubi mox laterali (labello), dissimili, minore, tubo continua v. interdum cum eodem articulata, articulo írritabili, patente v. deflexa.

Stamina 2, epigyna, parallela. Filamenta cum st y lo longitudinaliter in columnam arcte connata, c ol u m n a cylindrica v. linearis, erecta et continua, v. duplici flexura, quarum inferior subtus irritabilis, reclinata, plerumque longe exserta et a tubo corollae libera, rarius brevis, basi tubo pone labellum adnata. Antherae juxta columnae apicem duae, stigmati incumbentes, simplices v. didymae, loculis demum divaricatis, longitudinaliter dehiscentibus. Po 1 le n globosum, simplex, quandoque angulatum. Stigma obtusum, indivisum, inter antheras occultatum, v. bifidum, lobis capillaribus, apice capitato - glandulosis.

Ovariom inferum, dissepimento limbi calycini labiis parallelo completo bilocularis, v. dissepimento abbreviato semibilocularis, loculis aequalibus $v$, antico interdum angustiore. $0 \mathrm{v} u$ Ia in placentis dissepimenti centro utringue adnatis plurima, adscendentia, anatropa. G I a nd n la epigyna una antica v. duae oppositae.

Capsura formis inter sphaericam et linearem, teretem v. compressam variis bilocularis, v. septo abbreviato aut interdum sub maturitate a valvularum marginibus introflexis soluto unilocularis, septifrago-bivalvis, v. rarius loculo altero minore, interdum effoeto, indehiscente, altero (postico) majore fertili, rima longitudinali loculicide aperta.

Szmrsa axi dissepimenti adnata, sessilia $v$. breviter stipitata, adscendentia, minima, subglobosa, laevia v. longitudinaliter suleata.

Eмввуо (in unica specie observatus) in basi albuminis carnoso-oleusi, prope umbilicum minimus, indivisus (?).

Stylidea insolita staminum cum stylo symphysi distinctissimae, et eum nullo plantarum ordine facile confundendae, in Nova-Hollandia, imprimis extratropica gignuntur, in Nova-Zeelandia, Moluccis et Indiae continente rarae, in America antarctica rarissimae. 
3093. Stylidium SWARTZ. Calyx tubo sphaerico, oblongo v, lineari, eum ovario connato, limbo supero, bilabiato, labio inferiore bidentato $v$. bifido, snperiore tridentato $v$, trilido. Coroll a summo calycis tubo inserta, gamopetala, irregularis, tubo brevissimo, fauce nuda v. denticulis glandulisve coronata, limbi quinquefidi laciniis quatuor conformibus, patentibus, geminatim approximatis v, rarius cohaerentibns, contiguis saepe minoribus, quinta infima (labello) dissimili minore, patente v. deflexa, simplici v. basi utrinque lacinula appendieulata. Col um a genitalium epigyna, linearis, labello longior, duplici flexura, exteriore subtus irritabili reclinata; a n ther a e duae, bilobae, lobis verticalibas, subpatentibus, de. mum divaricatissimis, longitudinaliter dehiscentibus. St $\mathrm{ig} \mathrm{m}$ a inter antheras obtusum, indivisum. Ovari u m inferum, biloculare v. septo incompleto semibiloculare, glandula epigyna antica, rarius obsoleta. O v u I a in placentis dissepimenti axi utrinque adnatis plurima, adscendentia, anatropa. $\mathbf{C}$ a ps u la bilocularis v. semibilocularis, septifrago - bivalvis, nunc loculo altero minore interdum efoeto indehiscente, altero majore loculicide fisso. Semin a plurima, erecta, ovata v, subglobosa. E mbryo in basi albuminis carnoso-oleosi minimus. Herbae scapigerae $v$. caulescentes, interdum suffrutescentes, in Nova-Hollandia copiosae, in Moluccis et India e continente admodum rarae; foliis radicalibus confertis, in petiolum nonnunquam angustatis, caulinis sparsis v. verticillatis, saepe minoribus, bracteaeformibus, rarius apice cirrhosis $v$. basi solutis, floribus racemosis, spicatis v. corymbosis, rarius subsolitariis.

Stylidium Swartz in Berl. Magaz. I. 47. t, 1, 2, Labillard. Nov, Holland, II. 63. R. Browa Prodr. 566. Jussieu in Annal. Mus. XVIIT. 7. V e n t e a a $\mathrm{i}$ a Smith Exot. Bot. 1I, 13. C a n d oll e a Labillard, in Annal, Mus. VI. 414 .

a. TOLYPANGIUM. C a p s u la ventricosa, subovata, interdum sphaeriea v. oblonga. - V enten a ti a Suith $O p$. cit, $t, 66,67$. Ca ndolle a Labillard. Op. cit. $t .64$. (Labillard. Nov. Holl. $t$. 213_217. Salisbury Parad. t. 77. Bot. Reg. t. 90. 550. Bot. Mag. t. 2249. 3136. 3194. Richard in Annal. Mus, XVIIT. t, 3. Hooker Exot. Flor, $t$. 53. Link et Otto Ic, rar. $t$. 26. Ferd. Bauer $I l$ lustr, t. 14. t. 15. $f$. 1.)

b. NITRANGIUM. C a p s u 1 a linearis v- linearl-Ianceolata. $A$ a ders o a i a König msc. (Bot. Reg.t,914, 1459. Ferd. Bauer Illustr. t. 15. f. 2.)

3094. Tevenhookia $R$. BR. C al y x tubo ovato, basi antice gibbo, limbo supero, bilabiato, labio inferiore bifido, superiore trifido, Coroll a summo calycis tubo inserta, gamopetala, irregularis, tubo lirevissimo, fauce nuda, limbi quinquefidi laciniis quatuor conformibus, patentibus, geminatim approximatis, contiguis panllo minoribus, quinta infima (labello) dissimili minure, eum tubo artieulata, articulo irritabili, lamina fornicata, basi utrinque lacinula deflexa appendiculata. Col n mn a genitalinm epigyna, labello brevior, ereeta, basi tubi corollini laterali pone labellum adnata; an the ra e dnae, bilobae, lobis uno super alterum divarieatis, longitudinaliter dehiscentibus. Stigm a retro antheras bifidum, laciniis capillaribus, apice glandulosis. 0 va $r$ in $m$ inferum, septo abbre viato uniloeulare, glandula epigyna nulla. Ovula in placentis septo ntrinque adnatis panca, adscendentia, ....... Caps ula unilocularis, septifragobivalvis, S e mina pauca, ereeta, subglobosa. Herbae Novae-Hollandia e meridionalis, pusillae, Rhodiolae facie; foliis alternis, petiolatis, ra. morum summis confertis, floribus fasciculatis interstinctis.

Le ve uhookia R. Brown Prodr. 578. Ferd. Bauer Il. Instr. $t$. 15. $f .3$.

3095. Forgtera $L I N N$. C a l y $x$ tubo ovato $v$. obconico, cum ovario connato, limbo supero, sexfido, laciniis aequalibus, nonnullis interdnon obsoletis v. tubo demissius adnatis (?). Corolla summo calycis tubo inserta, gamopetala, regularis, tubo campanulato, fauce nuda, limbi sexfidi laciniis aeqnalibus, patentibus. Co 1 u $\mathbf{m} \mathbf{n}$ a genitalinm epigyna, cylindrica, recta, exserta. Anth era e dnae, simplices, parallelae, longitudinaliter dehiscentes. $S t i g m$ a retro antheras bilobum (?). Ova ri u m inferum, biloculare, glandulis epigynis duabus oppositis. Ovula in placentis dissepimenti axi utrinque adnatis plura, adscendentia ...... Fructus .... - Fruticuli demissi, in Nova-Ze elandia a ustrali et in America antarctica observati, non satis noti; foliis densissime imbricatis, floribus terminalibus solitariis, sessilibus $v$. longe pedunculatis, nonnullis antherarum abortu fortassis femineis.

Forstera Linnée Nov, Aot. Upsal, III, 184. Swartz in Schraders Journ, 1799. p, 31.

a. PHYLLACHNE Forst. FIo res in apice ramorum solitaril sessiles, foliis floralibus calyce longioribus, lacinils ealycinis saepius obsoletis?

P h y 11 a c h a Forst. Char. gen, 58. Lamarck Journ. h. n. I. 190. t, 1. Jussieu in Annal. Mus. XVIIT. t. 2. f. 3. S t 1 b a s Commers. msc.

b. FORSTERA Linn. $f$. Flores in apice ramorum solitarii, longe peduneulati, pedunculis pone calycem breviter pauci - bracteolatis.

Forster a Linn. Nov, Act, Upsal. III, t, 9. Swartz Op. cit. t. 1. 2. f. 2.

\section{Classis Xxxum. Caprifolia.}

Arbores v. frutices, rarius herbae, succo aqueo. Foli a opposita v. verticillata, simplicia, integra, saepissime integerrima. Stipulae variae v. rarius nullae. Flores hermaphroditi aut rarius per abortum unisexuales. Calyx cum ovario connatus. Corolla supera, gamopetala, plerumque regularis. St a mina corollae inserta, ejusdem lobis alterna, et numero aequalia, rarissime pauciora. 0 va ri um inferum, bi-pluriloculare. 0 vala in loculis solitaria v. plurima, situ varia, directione amphitropa $v$. anatropa. F r u c t u s capsularis, baccatus v. drupaceus. Se min a in loculis solitaria v. plurima. Embryo intra albumen carnosum v. cartilagineo-corneum homotropus, saepissime foliaceus.

\section{Ordo CXXVII. Rubiacene.}

RUBiaceae Jussieu gen, 196. Annal. Mus. X. 313. Mem. Mus. VI. 365. Dict. sc. nat, XLVI. 385. A. Richard in Mem, soc. $h, n$. Paris, $V, 8 t$, ss. DC. Prodr. IV. 341. LYGODYSODEACEAE et REBIACEAE Bartling Ord, nat, 207. 208. CINCHONACEAE, LYGODYSODEACEAE et STELLA. TAE s. GALIACEAE Lindley Introduct, edit. IT. p. 293. 247. 249.

Arbores v. prutices, rarius herbae, caule ramisque teretibus v. saepius tetragonis, nodoso-articulatis. Folia simplieia, integerrima, margine nerviformi aueta, sessilia v. pe- 
tiolata, opposita v. rarissime verticillata, bistipulata. Stipula e variae, nunc inter se et a foliis omnino distinctae, nunc inter se liberae sed foliis adnatae, nunc contiguae diversorum foliorum inter se plus minus connatae (interpetiolares integrae v. bifidae), nunc ejusdem folii inter se concretae (intrafoliaceae), nunc omnes inter se coadunatae (intrafoliaceae vaginantes), nune basi connatae et apice multisetae v. in ligulas foliis omnino consimiles expansae, folia verticillata, gemmae axillaris defectu a foliis veris distinguenda, simulantes.

Flones hermaphroditi v. rarissime abortu unisexuales, regulares $v$. interdum subirregulares, varie dispositi, saepius cymosi v. paniculati, nunc capitati, inter se distincti $\mathbf{v}$, basi connati.

Calyx tubo cum ovario connato, forma vario, limbo supero v. semisupero, tubuloso v. partito, nunc integerrimo truncato, nunc bisexfido v. dentato, in fructu persistente v. deciduo ant obsoleto.

Corolda summo calycis tubo inserta, gamopetala, e petalis $4-6$, varie inter se coalitis, rotata, infundibuliformis, hypocraterimorpha v. campanulata, intus glabra v, ad faucem saepius pilosa, limbo quadri-sexfido, regulari v. interdum vix subirregulari, lobis aestivatione valvatis v. contorto-imbricatis.

Stamiva corollae tubo, plerumque ad faucem, rarius demissius v. prope basim inserta, ejusdem lobis numero aequalia et alterna, rarissime (in Opercularieis) pauciora, exserta v. inclusa. Fil a ment a filiformia v. subulata, saepius brevissima $\mathbf{v}$. subnulla, libera $\mathbf{v}$. rarissime inter se coalita. Antherae introrsae, biloculares, erectae v. incumbentes, loculis appositis v. parallelis, longitudinaliter dehiscentibus, distinctae $\nabla$, rarissime coalitae.

Ovarium inferum, e carpidiis duobus v. pluribus conflatum, rarissime e carpidio unico constans, dis co epigyno carnoso, vario, urceolari v. pulviniformi, nunc obsoleto coronatum. 0vula nunc in loculis solitaria, e basi erecta $v$. ex apice pendula, ant saepius medio angulo centrali peltatim inserta, rarius gemina collateralia v. fortassis etiam superposita, nunc in placentis e loculorum angulo centrali plurima, adscendentia, pendula v. subhorizontalia, v. peltatim inserta, anatropa v. amphitropa. Stylus simplex; stigma bifidum v. interdum loculorum numero plurifidum, lobis distinctis v. inter se cohaerentibus.

Fructus capsularis, baccatus v. drupaceus, apice nudus, umbilicatus v. saepius calycis limbo persistente coronatus, bi-plnrilocularis, rarissime abortu unilocularis, loculis mono - polyspermis, indehiscens v. varie apertus.
Semina situ varia, erecta, inversa, horizontalia v. peltata, dum solitaria saepius dorso convexa et facie plana, dum plura plerumque compressa et membranaceo-marginata, testa laevi v. rugosa, Albumen dense carnosum, cartilagineum v. corneum, rarissime parcum v. subnullum, solidum $\mathbf{v}$. interdum testae plicis subruminatum.

Emвгxo orthotropus v. homotropus, rectus v. curvatus, nune in axi albuminis v. subdorsalis, fere seminis longitudine, nunc in basi albuminis brevissimus. Cotyledones nunc semicylindricae angustae, nunc latae, saepissime foliaceae. R a di cula plus minus longa, teres $v$. interdum incrassata, umbilico proxima $v$. parallela, directione supera v. saepius infera.

Rubiaceae ob stirpium plurimarum insignes virtutes, radicum nempe in aliis tinctorias, in aliis emeticas, purgativas et diureticas, corticis febrifugas, albuminisque in quibusdam praeclare tonicas, oeconomis medicisque imprimis celebratissimae, maximo numero in regionibus intertropicis utriusque hemisphaerii gignuntur, in America imprimis copiosae et nobiles, extra tropicos, imprimis polyspermae rarae.

SUROIRDO I. COFFEACEAE. Orula in loculis solitaria $\mathrm{v}$, rarissime gemina. Fru ctu s loculi monospermi v, rarissime dispermi.

TERTES T. OPERCULARIAE Jussiet in Annal. Mus. IV. 418. X. 32s. Flores hermaphroditi, plures inter se in capitulum concreti. Co roll a e tubulosae, tri-quinquefidae. Stamina $1-5$, imo corollae tubo inserta. Ov aria unilocularia, uniovulata, ovulo erecto, anatropo. Stylus brevissimus; stigmata 2 , elongato-filiformia. Fruet us connati, demum dehiscentes. - Herbae v. suffrutices australasici; foliis opposilis, stipulis utrinque binis, distinctis v. connatis, floribus in capilula pauciflora, pedicellata el umbellata, v. sessilia et in capitulum generale coadunata collectis.

30DB. Pomax SOLAND. C a p itula tri flora, flores tubis calycinis inter se connatis, calycem communem, turbinato - campanulatum, tubo costato, limbo supero, breviter et obtuse septemdecemlobo formantibus, axi centrali triquetra inter flores transeunte in diseum epigynum communem planem effuso. Corolla disco epigyno impositae, tubulosae, limbi breviter tri-quinquefidi lobis erectis. S $t$ a mina $1-5$, imo corollae tubo inserta, exserta v. rarius inclusa; fil a m enta filiformia, a $n t h$ erac lineares, erectae. Ov aria intra calycis communis tubum coadunata, uniloenlaria, nniovulata. Ovula e basi locnlorum erecta, anatropa. Stylus brevissimus; stigmata 2 , elongato-filiformia, hispidula, crure altero saepius breviore $\vee$. interdum obsoleto. Syncar pi um coriaceum, calyeis communis limbo coronatum, trilocnlare, trispermum, disco epigyno cum axi centrali operca- 
latim secedentibus aperta. Sem in a erecta, oblonga, granulata. Embryo in axi albuminis dense carnosi orthotropns; e ot yledonibns foliaceis, radieula eylindrica, infera. Herbae NovaeHollandiae, annuae v, suffrutescentes; foliis oppositis, utrinque stipula subfolifformi stipatis, pelunculis terminalibus umbellatis, monocephalis, basi fo liis floralibus geminis stipulisque subquaternis invotucratis.

$\mathrm{P}$ o m a X Solander ex Gärtner 1,112 . A. Richard in Mem. soc. h. n. Paris. V. 145. t. 13. f. 1. DC. Prodr. IV. 615. 0 pereulariae umbellatae Gärtner t, 24. Lam. $t$. 58. f. 1 . Jussieu in Mem. Mus. IV. 426 .

309\%. Dpereularia A.RICH. Capit u l a multiflora, flores tubis ealycinis circa axim cen tralem connati, limbis distinctis, bi-quinquepartitis, laciniis erectis, subcarnosis, cornuformibus, persis tentibus. Cor o lla e superae, subinfundibuliformi campanulatae, limbo breviter tri-quinquefido. $\mathbf{S}$ a mina 1 - 5 , imo corollae tubo inserta, exserta; filamenta filiformia, antherae lineares, erec tae. Ov a $\mathrm{r}$ i a infera, unilocularia, nniovulata, $\mathrm{O}$ v la e basi erecta, anatropa. Sty lus brevissimus, stig $\mathrm{m}$ a $\mathrm{ta}$, elongato-filiformia, hispida. $\mathrm{C}$ a $\mathrm{p}$ sula e in synearpium limbis calycinis echinatum coalitae, uniloculares, monospermae, bivalves, valvis exterioribus patentibus, interioribus $\mathbf{c u m}$ ax communi coalitis, simul deciduis. S e m in a erecta, dorso convexinseula, facie plana, laevia. E m b ryo in axi albuminis dense carnosi orthotropus; c oty led onibus foliaceis, radieula cylindrica, infera. Herbae Novae-Hollandiae, basi suffru ticulosae, diffusae; foliis oppositis, basi stipulis in tegris v. bijidis junctis, capitulis globosis, terminalibus $v$. in ramorum dichotomiis ortis, pedunculatis $v$. subsessilibus, involucratis involucellatisque.

0 pereularia A. Richard in $\mathrm{Mem}$, soc, $h$, n. Paris, $D$. 144, t, 13. f. 2. DC. Prodr. $I V .615$. R u bi oid es Solander msc. Cryptosp e r m n $\mathrm{m}$ Youg in Linn. Transact. III. 30. t.5. O pereulariae enpitatae Gärtner t. 24. Jussieu in Mem. Mus. IV. 487. $t$. 70. 71. Labillard. Nov. Holl. t. $46-48$.

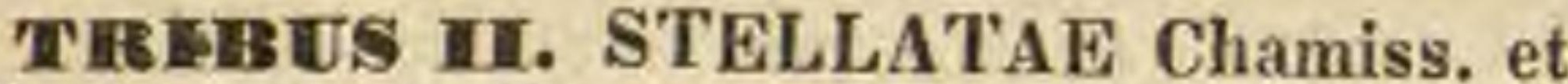
Schlechtend. in Linnaea III. 220. Flores hermaphroditi v. interdum diclines. Corolla e rotatae $\mathbf{v}$. infundibuliformes, plerumque quadrifidae, lobis per aestivationem valvatis. 0 v aria bilocularia, loculis uniovulatis. St yli duo, distincti v. plus minus coaliti; sti g mat a capitata. Ca rpidia sicca v. rarius baccata, secedentia, indehiscentia, monosperma. A I b umen corneum. - Herbae v. suffrutices; $r a$ dicibus saepissime rubentibus; foliis oppositis, in axilla gemmam foventibus, stipulis foliifor mibus utrinque solitariis, duabus v. tribus, gemmis axillaribus desticutis, verticillum foliorum mentientibus. Species pleraeque regiones temperatas et frigidiusculas utriusque hemisphaerii incolunt, in regione mediterranea praepri mis copiosae, aliquae extremum septemtrio nem petunt, usque ad $80^{\prime \prime}$ L. B. observatae. Paucae inter tropicos repertae fuerunt.

3098. Valllantia $D C$. Flores terni medio hermaphrodito, lateralibus masculis, pedicellis conereti. Ma s c. C alyx obsoletus. CorolIa trifida, laciniis erectiusculis. St a min a 3 , inclusa. Herma phr. Caly $x$ tubo subgloboso, cum ovario connato, limbo supero, irregulariter rigide multidentato. Coroll a supera, rotata quadrifida. St a mina 4, corollae tubo inserta, subexserta: f $\mathrm{i}$ I amenta filiformia, antherae erectae. Ovari a m inferum, biloculare. $O \mathbf{v a} 1$ a in loculis 80 litaria, amphitropa. St y li duo distincti; stig mata capitata. Fructus floribus tribus coneretis tricornis, cornubus lateralibus sterilibus, interme. dio seminifero, dispermo v. abortu monospermo. Sem en peltato-curvatum. Emb ryo intra albumen cartilagineum homotropus; cotyledonibus foliaceis, ra dicula elongata. Herbae annuae, ramosae, in Europa australi indigenae; caulibus tetragonis, foliis opposilis, ovalibus, cum stipulis utrinque solitariis verticillum tetraphyllum constituentibus, floribus ex quavis axilla tribus, pedicellis fere ad apicem connatis, parvis, albis sen flavidis.

Vaillautia DC. Fl, fr. IV. 266. Prodr. IV. 613. A. Ricluard in Mem. soc. h. n. Paris, V. 134. t. $11, f$. \&. VaI antia Tournef. in Aot. Academ. Paris. 1705. p. 234, Mi. eheli Gen. 13. 2,7 . Mönch Methad, 639. Valantia muraI is Linn. et V. hispida Linn.

3095. Callipeltis STEV. Flores omnes hermaphroditi. Cal yx tubo oblongo, eum ovario connato, limbo obsoleto. Coroll a supera, campanulata, limbi lobis quatuor, brevissimis, obtusis. S t a min a 4, corollae tubo inserta, inclusa; fil am enta brevissima, a $\mathrm{t}$ herae erectae. Ovari um inferum, biloculare, loculo altero efoeto, altero uniovalato, ovulo amphitropo. Stylus bifidus; stigmata capitata. Frue tus loculo altero abortivo unilocularis, monospermus, oblongus, supra axim incurvus. Semen a pericarpio haud distinctum, incurvum. Embryo intra albumen cartilagineum homotropus, curvatus; cotyle donibus foliaceis, radicula elongata, infera.

Herba in Oriente et in Hispania observata, annua, erecta, ramosissima, gracilis, glabra; foliis oppositis, oblongis, cum stipulis conformibus verticillum tetraphyllum constituentibus, floribus minimis ex axilla singula tribus, breve pedicellatis, verticillis ideo sexfloris, bractea ampla, membranacea, fructum apice hispidum cuculli instar includente.

C allipeltis Steven Observ, pl. ross, 69. DC. Prodr. IV. 613. Cucullaria Buxbaum Cent. I, 13. t. 19. $f .2$. non alior. Valantia $\mathrm{C}$ a cullaria Linn. Lam, $t, 8 / 3$. $f .2$.

3100 . Galliuman $L I N N$. C a 1 y $\mathrm{x}$ tubo ovatosubgloboso v. oblongo, cum ovario connato, limbo supero, integerrimo, obsoleto. Co ro 11 a supera, rotato-stellata, quadrifida $v$. rarius trifida. S ta min a 4 , v. rarius 3 , corollae tubo inserta, exserta; fil amenta filiformia, anthera e ereetae. $0 \mathrm{ra}$ ri um inferum, biloculare. Ovula in loculis solitaria, amphitropa. St y $\mathbf{l}$ i 2 , breves, ima basi connati; stigmata capitata. Fruetus globoso. didymus, siccns v. subearnosus, tuberculosus $\mathrm{v}$. hispidus, bilocularis, dicoceus, coccis dorso convexis, facie planis, indehiscentibns, monospermis. $\mathrm{S}$ e $\mathrm{m}$ in a a pericarpio haud distincta, erecta. E mb ry $\theta$ intra albumen corneum subcurvatus; cotyledonibus foliaceis, radicula elongata, infera. - Herbae annuae v. perennes, rarius basi suf fruticosae, cosmopolitae, inter tropicos rarae; foliis oppositis, cum stipulis foliiformibus verticillatis, floribus axillaribus terminalibusque subpaniculatis.

Gali um Scopoli Carn. edit, 2, 1. 94. A. Richard in Mem. soe. h. $n$. Paris, $V .133$. Galium et Valantise sp. Linn. Galium, Aparine et Aspera Möech Mothod. 486. 640. Galium, Eyselia et A parine Necker elem. n. 332.333. 335. Gallum, Aparine et Cruciata Tournef. inst. 39. G a $1 \mathrm{i}$ u m et $\mathrm{K}$ ubia c sect. 2 , et3. DC. Prodr. 
a. ASPERA Mönch Mothod. 641. FI o res hermaphroditi. Fruetus oblongi, hispidi, corcis angustis, elongatis. Herbae annuae, verticillis tetraphyllis v. rarius hexa. phyllis, inflorescentia laterali. - Sherardiae s p. Linn.

b. EUAPARINE DC, $l$, $c$. Fl ore s hermaphroditi v, rarius polygami. Frtuet us didymo.globosi, granulati v, hispidi. - Herbae annuae, caulibus scabris, verticillis tetra-octophyllis, inflorescentia axillari. - (Cavan. Ic. t. 191. f. 1. Sib thorp Ft. graec. $t .133$-135. B. B. $t .816$. 1641, 2173. Waldst. et Kitalbel Plant, Hung. t. 202. DC. Ic. plant, Gall, rar, t. 26.)

c. LEIAPARINE DC. l. c. Flores hermaphroditi, albi. Fructus glabri. - Herbae annuae, verticillis tetra. octophyllis, inflorescentia cymoso-paniculata. - (Sibthorp Fl, graec. t. 126. DC. Io, plant. Gall, rar. t, 24.)

d. XANTHAPARINE DC. l. c. Flo res hermaphroditi, lutel. Fruetus glabri. - Herbae annuae, verticillis tetra-octophyllis, inflorescentia cymoso-paniculata. (Desfont. Flor, atlant. $t, 40$. )

e. CRUCIATA Tournef, inst, 115. DC. l. c. FIores polygami, Intei, masculi hermaphroditis mixti. Fructus glabriuseuli ve pilosi. - Herbae annuae, verticillis te traphyllis. - Val enti a e s p. Linn. Lam. t. 843. $f$. 1 . (5., B. $t, 143$.

f. MASCHALIGALIUM DC. l.c. Fl o res polygami, ochroleuei. - Herbae perennes, verticillis tetraphyllis, inflorescentia axillari. - (Sibthorp $t .125$. V a la ntia s p. Waldst. et Kitaibel Plant, Hung, t. 32.)

g. ERICOGALIUM DC. $l$. c. Flore s hermaphroditi, lutei. - Herbae perennes v. suffrutescentes, americanae, verticillis tetra-hexaphyllis, inflorescentia axillari.

h. XANTHOGALIUM DC. $\boldsymbol{l}$. $\boldsymbol{c}$. F 1 o res hermaphroditi, latei. - Herbae perennes, verticillis hexa-decaphyllis, inflorescentia paniculata, - (Flor, dan. $t$. 1146.)

i. ERYTHROGALIUM DC. $l$. c. Flores hermaphroditi, purpurei. Fructus glabri. - Herbae perennes, verticillis hexaphyllis, inflorescentia cymoso-paniculata. (Nocca et Balbis Flor, ticin, t, 3. 4.)

k. COCCOGALIUM DC. $l$.c. FI o res bermaphroditi, longe pedunculati. Fruct as grasulati. - Herbae perennes, verticillis tetraphyllis.

1. TRICHOGALIUM DC. $l$. c. Flores hermaphroditi, al. bi v.rarius lutel. Fructus hispidi. - Herbae perennes, verticillis tetra-decaphyllis, inflorescentia cymoso-paniculata. - (Sibthorp Flor. graec. t. 136. Flor, dan. t. 1024. B. B. t. 103. Willd. Hort. berol, t. 66, Kunth in Humb. et Bonpl. Nov. Ben, et sp, t. 278.)

m. PLATXgaliUM DC. l, c. Flores hermaphrodit, albi, rarissime purpurei v. subochroleaci. Fru et us glabri. Herbae perennes, verticillis tetraphyllis, folits latis, inflorescentia eymoso-paniculata. - (Valantiac $s \mathrm{p}$ Lam. $t$, 843. $f, 3$, )

n. LEIOGALIUM DC. $l$. $c$. FIores hermaphroditi, albi Fructus glabri. - Herbae perennes, verticillis hexa decaphyllis, rarissime tetra-pentaphyllis, inflorescentia cymoso paniculata. - (Jaeq. Fl. austr. t, 80. Cavanill. Ic. t. 206. f. 1. Flor. das. t. 48. 423. 425. 609. E. B. t.74. 1623. 1857, 1972. 2206. Sibthorp Fl. graec, t. $127-130$ DC, Ic, plant. Gall, rar. t, 25.)

o. RELBUNIUM. Flores hermaphroditi. Fructus subcaraosi. Pedunculi axillares apice gerentes bracteas quatuor verticillatas; involuerum constituentes, flores intra involucrum solitarii v. terni, sessiles v. pedieellati. - Herbae perennes, diffusas v. prostratae, omnes americanac. - (R u b i a e s p. DC. Kunth Op. cit, t.280.)

3101. IBubia TOURNEF. C a ly $\mathrm{x}$ tubo ovato - globoso, cum ovario connato, limbo supero, integerrimo v. plane obsoleto. Corolla supera, subeampanulata $v$, rotata, quinquepartita. S $t$ a $m$ in a 5 , corollae tubo inserta, subexserta; fil a m e nta brevia, antherae erectae. Orari um inferum, biloculare. Ovnla in loculis solitaria, amphitropa. Sty li 2 , breves, ima basi connati; stigm a $t$ a capitata. B a c $c$ a didymo - subglobosa, succosa, bilocularis, rarius loculo altero abortivo unilocularis, laevis. S e m in a in loculis solitaria, erec ta, a pericarpio haud distincta, dorso convexa, facie plana. E mbryo intra albumen corneum subcurvatus; cotyledonibus foliaceis, radicula elongata, infera. - Herbae perennes $v$. suffrutescentes, saepius hispidae, gerontogea extratro. p ic a e, interdum basi suffrutescentes; foliis oppositis stipulisque foliiformibus plerumque verticillum constituentibus, floribus varie dispositis, axillaribus $v$, terminalibus.

Rubia Tournefort inst, 113. Linn. Ben, n, 127. Lam. t. 60. Schkuhr t. 23. Gärta. f. 1II, 85, $t, 195$. Jaeq. Ic. rar. t. 25. Cavanill. Ic. t. 195. Tenore Flor, neap. t. 10. Liuk et Hoffwansegg Fl, portug. t,85. A. Ricliard in Mem, soc, $h, n$. Paris. V. 132.

3 f (D2. Crimelamella LINN. Ca Iyx tubo ovato, eum ovario connato, limbo distincto nullo. Co roll a supera, infundibuliformis, tubo elongato, limbi quadri-quinquelobi lobis saepius in ap pendicem setaceam, inflexam productis. Anthera e 4_5, inclusae, intra corollae faucem subsessiles, lineares. Ovarin m infernm, biloculare. Ovala in loculis solitaria, amphitropa. Stylus apice bifidus, inclusus; stig $\mathrm{m}$ a $t$ a eapitata. Fruct u s subglobosus, siccus, vertice nudus, bilocularis, dicoceus, coccis dorso convexis, facie planis, indehiscentibus, monospermis. Sem in a a pericarpio haud distincta, erecta. Embryo intra albumen corneum rectus; cotyled onibus foliaceis, r a di cula elongata, infera. - Herbae basi suffrutescentes, in Europa et Asia temperata, non ul tra $45^{0}$ L. B. obviae; foliis oppositis, lanceolatis $v$. linearibus, stipulis utrinque conformibus, solitariis v. pluribus adjectis, florum spicis nunc elongatis, subcontinuis, nunc capitatis, nunc floribus fasciculalis, pedunculatis interruptis, calycibus unibracteatis bibracteolatisque, bractea bracteolisque calycem superantibus, calyculum exteriorem simulantibus.

C rucia nella Linn. gen. n, 126. Gärtner $I, 111$, t.24. Lam. t. 61. Smith exot. Bot.t. 109. Sibthorp FI. graec, t, 139 Bleberst. Plant, ross. II. $t$. 65. Labillard. Syr. Doc, I. $t$, 3. Trinius in Mem. Petrop. 1818. t, 11. 12. Jussieu in Mem. Mus. VI, 370. Reichenb, Plant, crit, $t$, 262. A. Richard in Mem. soo. h. n. Paris. V. 131. DC, Prodr. IV. 586. R ube ola Mörch Method. 325 . Laxmannia $\mathcal{S}, G$, Gmelin.

3103. Aspervala LINN. C a ly $x$ tnbo ovato-didymo, cnm ovario connato, limbo supero, hrevissime quadridentato, deciduo v, obsoleto. Corolla supera, infundibuliformis v. rarius campanulata, fance nuda, limbo quadrifido, rarissime trifido. Stam in a 4, corollae tubo inserta, subexserta; filamenta filiformia, antherae oblon. gae, erectae. O va ri um inferum, biloculare, 0 v $\mathbf{u}$ la in loculis solitaria, amphitropa. Sty li 2 , ima basi $v$. fere ad apicem conereti; $8 \mathrm{tigmata}$ capitata, Fructus globoso-didymus, siceus v. vix sulscarnosus, vertice nudus, bilocularis, dicoceus, coccis dorso convexis, facie planis, indehiscentibus, monospermis. Sem in a a pericarpio haud distineta, erecta. E m b ryo intra albumen corneum subincurvus; cotyledonibus foliaceis, radicula elongata, infera. - Herbae v. suffrutices gerontogeiboreales, imprimis mediterranei; foliis oppositis, supremis estipulatis, inferioribus cum sti. pulis conformibus utrinque solitariis, binis $v$, trinis verticillum tetra-octophyllum formantibus, floribus terminalibus $v$. axillaribus fasciculatis.

A s perula Linn. gen, n, 121. Lam, t, 61. Jaeq. Flor. austr, t. 84. Gärtner f. III. 89, t. 95. Fl, dan, $t$. 569. E. B. t. 33. Waldst, et Kitalbel Plant, Hung, t. 150. Vear. Cels. t. 60. Sibthorp Fl, graec, $t, 117-124$. Tenore Flor. neap. t. 9. Bot. Mag. t.2146. Ledebour Ic. t. 301. Reichent. Plant. crit. t. 93. A. Riehard in Mem. soe. h. n. Paris, V. 130. t. 11. f. 1. DC. Prodr. IV. 581 . 
3104. Sherardita DILLEN. C a y $\mathrm{x}$ tubo ovato, eum ovario connato, limbo supero, quadrisexilentato, persistente. Coroll a supera, infun dibuliformis, tubo tereti, limbo quadrifido. S $t$ amina 4, corollae tubo inserta, exserta; filamenta capillaria, antherae ovoideae, erectae. Ovarium inferum, biloculare. Ovula in loculis solitaria, amphitropa. St ylus apice hifidus; stig mat a capitata. Fructus globoso-didymus, siccus, calycis limbo coronatus, bilocnlaris, dicoceus, coceis dorso convexis, facie planis, indehiscentibus, monospermis. S e min a periearpio hand distine ta, erecta. E $\mathbf{m}$ b r y o intra albumen corneum subincurvus; cotyledonibus foliaceis, radieula elongata, infera. - Herba annua, in agris Euro pae et Tauria passim obvia; foliis oppositis, lan ceolatis, acutis, scabris, cum stipulis plane conformibus utrinque solitariis verticillum tetraphyllum for mantibus, floribus terminalibus parvis, caeruleis $v$ roseis, intra involucrum verticillatum sessilibus.

$\mathrm{S}$ h e r a rd i a Dillenius Gen. 3. Linn. gen, n. 120. Gïrt. ner $I, 110, t, 24$, Sehkuhr $t$. 22, Curtis Flor. Lond, D. t. 13. Flor. dan. $t$. 439. A. Richard in Mem. soc. h. $n$, Paris, $V$. 129. DC. Prodr. IV. S81. D III a i a Heister hort. Helmstad. 435. A parines s p. Tournef,

TEIIEUS I耳. ANTHOSPER MEAE Cha miss. et Schlechtend. in Linnaea III. 309. Corollae quadrifidae, rotatae, lobi aestivatione valvati. Ovari a bilocularia, loculis uniorulatis. Styli duo distincti; s $\mathrm{t}$ i g $\mathrm{m}$ a $\mathrm{t}$ a elongata, hispida. Fructus dicoccus, coccis monospermis, indehiscentibus, $\mathbf{A} 1 \mathrm{~b}$ u m en carnosum v. subcorneum. - Suffrutices $v$. herbae; foliis oppositis $v$, verticillatis, medianti. bus stipulis parvis uni-tridentatis, petiolo utrinque subadnexis, floribus saepius dioicis. - Anthospermeae pleraeque capenses, Phyl. lis in insulis Canariis, Coprosma genus ad Coffeeas transitum faciens, in Australasia habilant.

3 105. Anthospermam LINN. FIo res dioici, rarius polygami v. hermaphroditi, C a1 y $\times$ tubo obovato, cum ovario connato, limbe supero, minimo, quadri-quinquedentato, C o r oll a supera, in floribus masculis et hermaphroditis rotata, tubo brevissimo, limbi tri - quinquepartiti lobis ovato-oblongis, aestivatione valvatis, sub anthesi revolutis; in floribus femineis minutissima, subeampanulata, limbi breviter quadrifidi laciniis erectis. St am in a $3-5$, imo corollae tubo inserta, exserta; fil am enta filiformia, an th era eblongae, erectae. Ova ri um inferum, biloculare, diseo epigyno subcarnoso. Ovula in loculis solitaria, e hasi erecta, anatropa. Styli 2, elongato-filiformes, ima basi vix coaliti, undique hirsuti v, patentim-pilosi, stigmatosi. Fructus ovatus, apice denticulatus, crustaceus, bilocnlaris, dicoccus, coccis dorso convexis, facie planis, indehiscentibus, monospermis. S emina erecta, Embryo intra albumen cartilagineum exeentricus, subdorsalis, orthotropus; cotyledonibus foliaceis, radicu I a elongata, infera. - Suffrutices $v$. herbae capenses; caulibus ramosis, foliis oppositis v, verticillatis, mediante stipula interposita, in dentem brevem producta connatis, floribus axillaribus sessilibus, verticillatis $v$, oppositis, rarius paniculatis, ad basim vyarii bi-tribracteolatis.
A nthosperm um Lina. gen, n, 1164. Jussieu gen, 197. Gartuer f. III. 87. 2. 195. Cruse Rubiac. Cap, 7, tab. 1. f. 1 . 2. Linnaea $V T$. 4. A. Rlehard in Mem. soc. h. n. Paris. $V$. 138. t. 12. f. 1. To u $\mathrm{r}$ efortia Ponteder. Epist. 11. A nsbra ri a Heister hort. Helmstad. 438. non Cruse.

310B. Ambraria CRUSE. F lores dioici. Ca $1 \mathbf{y x}$ tubo in masculis brevissimo, in femineis obovato, cum ovario connato, limbo supero, brevissime quadri-quinquedentato, persistente. Cor ol la supera, in floribus masculis rotata, quadriquinquepartita, tubo brevissimo, lobis ovato-oblongis, aestivatione valvatis, sub anthesi revolutis; in floribus femineis minutissima, subcampanulata, laciniis erectis. Stamin a $4_{-} 5$, imo corollae tubo inserta, exserta; fil amenta filiformia, a nt hera e oblongae, erectae. Or a ri $\mathbf{~ m}$ inferum, diseo epigyno subcarnoso, quadriloculare, loculis duobus vacuis, duobus oppositis ovuliferis. Ovula solitaria, e basi erecta, anatropa. St y 1 i 2 , elongatofliformes, ima basi vix coaliti, nndique hirsuti v. patentim pilosi, stigmatosí. Fruetus ovatus, crustaceus, calycis limbo obsoleto coronatus, indehiscens, loculis duobns sterilibns in cavitatem centralem amplam coalitis, duobus oppositis monospermis. Semina erecta. E mbryo intra albumen cartilagineum orthotropus; cotyledonibus foliaceis, rad i cula elongata, infera. - Suffrutices capenses; foliis ternato-verticillatis, angustis, mediante stipula dentiformi interposita connatis, floribus axillaribus, sessilibus.

A mbraria Cruse Rubiac. Cap, 16. t. 1. f. 3. 4. Lin. naea VI. S. A. Bichard in Mem, soc. h, n, Paris. V. 139. t. 12. f. 2. DC. Prodr. IV. 580 . Nenax Gärta. I, 165, $t .32$. Cllffortiaesp. Lina.

310\%. Callopina THUNB. Caly $\mathrm{x}$ tubo obovato, a dorso compressiusculo, cum ovario connato, limbo supero, aequali, minutissimo v, obsoleto. Corolla supera, rotata, profunde quadripartita, tubo subnullo, lobis lineari-lanceolatis, obtusis, aestivatione valvatis, sub anthesi reflexis. Stamina 4, imo corollae tubo inserta, exserta; fil a menta filiformia, an $t$ herae oblongae, erectae. Ova $\mathrm{rium}$ inferum, biloculare, disco epigyno carnoso. Ovula in loculis solitaria, e basi erecta, anatropa. Styli 2, elongato-filiformes, ima basi vix coaliti, undique hirsuti v. patentim pilosi, stigmatosi. Fru ctu s ubovato-didymus, apice nudus, suberustaceus, bilocularis, dicoceus, coccis. dorso convexis, gyroso-verrucosis, facie planis, indehiscentibus, monospermis. Semin a erecta. Emb r yo intra albumen cartilagineum orthotropus; cotyled onibus foliaceis, radicula elongata, infera. - Herba capensis, glabra, Circeae facie; caule tereti, lineis e foliis decurrentibus biangulato, foliis oppositis, ovato-lanceolatis, acuminatis, stipulis trifurcatis, floribus parvis, in paniculam terminalem, laxam dispositis.

Gat op in a Thunberg Dissert, nov, gen, T. 3. Jussieu in Mem. Mus, VI, 371. Cruse Rubiac, Cap. 18. A. Richard

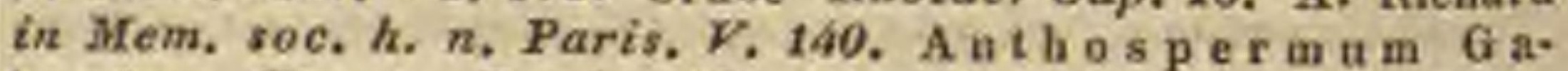
lopina Thunb. Prodr. 32. P hyllis Galopina Cruse in Linnaea VT. 20. - 0 x y 8 permum Eeklon et Zeyher Enumerat. 364 .

3105. Playllis LINN. F lores hermaphrodito-polygami. Cal y x tubo obovato, a dorso compresso, cum ovario connato, limbi superi, bilobi laciniis inaequalibus, deciduis. Co rolla supera, subrotata, quinquepartita, tubo brevi, lobis lineari-lanceolatis, a estivatione valvatis, sub anthesi patentiosculis. St amin a 5 , imo corollae tubo inserta, exserta; filam en $t$ a filiformia, an $t h$ erae oblongae, erectae. Ova ri um inferum, biloculare, 
disco epigyno carnoso. O vula in loculis solitaria, e basi erecta, anatropa. Styli 2 , elongato-filiformes, ima basi coaliti, undique hirsnti, stigmatosi. Fructus obovatus, compressinsculus, apice obsolete bidentatus, bilocularis, dicoccus, coccis dorso convexiusculis, laevibus, facie planis, indehiscentibus, monospermis. S e mina erecta, compressa. E mbryo in axi albuminis cartilaginei orthotropus; cotyledonibus foliaceis, cordatis, radicula clongata, infera. - Suffrutices c anarienses; foliis oppositis $v$. ternatim aut quaternatim verticillatis, acuminatis, stipulis membranaceis, petiolis adnatis, in setas plurimas filiformes productis, floribus parvis, albo-virescentibus, in paniculam terminalem, compositam dispositis.

P hyllis Linn. gon, n, 328. Gärtner I. 123. t, 25. Jussieu in Mem. Mus. VI. 370. A. Richard in Mem. soc. $h, n$. Paris. V. 140, t. 12. $f$. 3. DC. Prodr, IV. 828. Nobula Adansod Fam, II. 145. B a ple uroides Boerh.

3109. Coprosma FOBST. F lores hermaphrodito-polygami. Calyx tuho ovato, cum ovario connato, limbo supero, brevissimo, quadrisexdentato. Corolla supera, subeampanulata, tubo brevi, ventricoso, fauce nuda, limbo quadrinovemlobo, patente. S ta m in a $4-9$, imo corollae tubo inserta, longe exserta; fil am en t a filiformia, anther a e oblungae, erectae. Ovarium inferum, bi-triloculare, disco epigyno carnoso. O v a I a in loeulis solitaria, e basi ereeta, anatropa. Styli 2 , elongato-filiformes, ima basi coaliti, undique piloso-stigmatosi. B a e c a ovata, umbilicata, pulposa, nuculis 2 -3 evalvibus, monospermis. S e $m$ in a ereeta, dorso convexa, facie plana. Embryo in axi albuminis dense carnosi orthotropus; cotyledonibus foliaceis, radicula elongata, infera, - Frutices v. arbusculae, in Nova-Zeelandia et Nova-Hollandia indigeni; foliis oppositis, stipulis petiolaribus utrinque solitariis, persistentibus, floribus terminalibus $v$ axillaribus, solitariis aut in eodem pedunculo paucis, basi bibracteolatis.

Copros ma Forster gen, 69. Lam. t. 186. et 854. Labillard. Nov. Holl. 6. 95. Jussieu in Mem. Mus. VI, 381. Gärtn. f, III. 17. I. 182. (alabastrum floris mase. ot antherae,) A. Riehard in Mem. soc. h. n. Paris. V. 137. DC. Prodr, IV, s78, Endlieh. Prodr, Fl, Norfolk, 61.

TRIRES IV. SPERMACOCEAE Chamisso et Schlechtend. in Linnaea III. 309. Corollae saepissime quadrifidae lobi per aestivationem valvati. O varia bi quadrilocnlaria, loculis uniovulatis, rarissime biovulatis. Stigma bilamellatum. Carpidia sicca v. parce carnosa, secedentia, indehiscentia v. varie dehiscentia, monosperma, rarissime disperma. A Ib u men carnoso-subcorneum. - Herbae v. frutices; foliis oppositis, vagina stipulari petiolos nectente apice saepe seloso-lacera, floribus in cymis trichotomis, saepe in capitula interdum depauperata contractis.

Spermacoceae per regiones tropicas totius orbis et extratropicas calidiores dispersae, in America aequinoctiali abundantius gignuntur. Cephalantheae in India orientali frequentius habitant, et paucissimae Americam, a Brasiliae plagis australiorilus ad Canadam incolunt, Putoriearum partes octavae quinque in India orientali vivunt, unica species per regionem mediterraneum et Orientem diffusa, allera in insulis Caribaeis reperta, sed Euspermacocearum duae fere terliae in Ameri. ca calidiore generantur, reliquae in Asia ec Africa observatae fuerunt.

\section{SUB'TRE EUS I. PUTORIEAE DC. Prodr.} IV. 575. Fructus subcarnosi, haud bipartibiles.

3110. Putoria PERS. Cal y $\mathrm{x}$ tubo ovato, cum ovario connato, limbo supero, breve tubuloso, minute quadridentato. Coroll a summo ca. lycis tubo inserta, hypocraterimorpha, tubo longo, tereti, fauce glabra, limbi quadrilobi lobis acntiusculis, patulis. Stamina 4 , corollae tubo prope apicem inserta; filamenta brevia, anth era e lineares. Ova ri um inferum, biloculare. O v u Ia in loculis solitaria .....Sty $\mathbf{l}$ us simplex; stigm a bifidum. Bace a subexsucea, ovato-oblonga, umbilicata, bilocularis. Semina in loculis sulitaria, oblonga ..... E m b r y o..... Frutcx mediterraneus, rigidus, ramosissimus; ramis velutino-pubescentibus, foliis oppositis, oblonga-linearibus, obtusis, contritis foetentibus, stipulis utrinque solitariis, floribus ad apices ramorum fascicula. tis, sessilibus, purpureis.

Putoria Persoon Ench. r. 524. A. Richard in Mem. soc, $h, n$. Paris. $V$. 160. DC. Prodr. IV. 577. A s perula c a la bric a Lian, f. Heritier Stirp. $t$. 32. Pa vetta fetidis sima Cyrill. Neap, $t$. 1 . Er nodea montana Sib. thorp Flor. graec, $t, 143$.

311 1. Ploesma $A I T, \mathrm{C}$ a 1 y $\mathrm{x}$ tubo ovatogloboso, eum ovario connato, limbo supero, brevissimo, sinuato - quinquedentato. Co roll a summo calyeis tubo inserta, campanulato-infundibuliformis, fauce nuda, limbi quinque-sexlobi laciniis erectiusculis. S t a m i na 5-6, corollae fauci inserta; filam enta nulla, an the rae lineares. Ovari um inferum, bi-triloculare. Ovula in loculis solitaria, erecta, anatropa. Ba c ca calycis limbo coronata, apice minute areolata, bi-trilocularis, endocarpio tenuissime membranaceo. Semina in loculis solitaria, erecta, dorso convexa, facie exeavata, longitudinaliter rimata. E mbryo intra albumen parcum, cartilagineum subdorsalis, orthotropus; cotyledonibus planis, radicula clavata, subincurva, infera. - Suffrutex canarien$s i s$, ramosissimus, glaber; ramis teretibus, gracilibus, virgatis, foliis oppositis, lineari-filiformibus, stipulis cum petiolis connatis, membranaceis, brevibus, obtuse dentatis, floribus ad axillas supremas et in apicibus ramorum solitariis $v$. ternis, breve pedunculatis, albidis.

P 1 o c a ma Aiton Hort, kew, ed.1. p. 292, Gärtn. f, III. 96. t. 196. Jussien in Mem ALus, VI. 371. A. Richard in Mem, soc. h. n. Paris. V. 161. DC. Prodr. V. s77, Placo. ma Persoon Ench, I, 210. Bartllngi a Reichenb. in Flo. ra 1824. p. 241. Ic. exot. t. 11. non Brong. Plocama et Bartilingia Spreng. Syst, $r, n, 815,793$. Plocama et Placoma Gmelin Syst. I. p. 296, 390 .

311 . Seyphiphora $G \ddot{A} R T N$. $F, C$ a 1 y $x$ tubo ovato, cum ovario connato, limbo supero, breviter tubulato, subintegerrimo. Co rolla summo calycis tubo inserta, infundibuliformis, tubo intus hirsnto, limbi quadrifidi laciniis lanceolatis, patentibus. Stamina 4 , corollae fauei inserta, exserta; fil amenta subulata, a n thera e lineares, introrsum incumbentes. 0 va rium inferum, biloeulare. Ovula in loculis solitaria, infra apicem peltatim affixa, amplitropa. Stylus simplex; stig ma bifidum, lobis approximatis. Drupa bac:cata, octosulcata, calycis limbo coronata, dipsrena, 
pyrenis osseis, dorso suleato-angulatis, facie planis. Sem ina intra pyrenas solitaria, oblongo reniformia; nmbilico supra medium ventrali. E mb ryo in axi albuminis carnosi homotropus, subincurvus; cotyledonibus oblongis, radicula conico-teretinseula, infera. - Frutex in maritimis Mo luc c a rum proveniens; foliis oppositis, obovalibus, aveniis, floribus axillaribus, subcorymbosis.

$\mathrm{Sey}$ phiph or a Gärtner f. IIT. 21, t.195. Blume Bijdr. 955. A. Richard in $\mathrm{Hem}$, soc. h, n. Paris, V. 159. t, 4. f. 1 . DC. Prodr, IV. 577 .

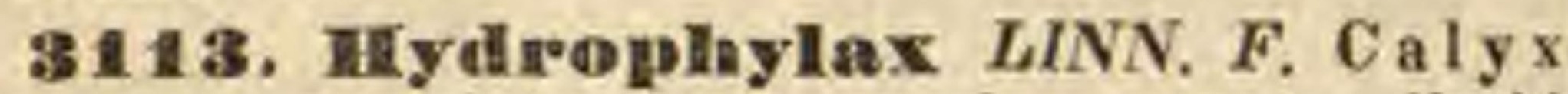
tubo ovato, angulato, cum ovario connato, limbi superi, quadripartiti, persistentis dentibus acutis, erectis. Corolla supera, subcarnosa, infundibuliformi-campanulata, tubo intus annulato-piloso, limbo quadrifido. S $t$ a $\mathrm{m}$ i $\mathrm{n}$ a 4 , corollae fanci inserta, exserta; filamenta brevissima, antherae lineares, erectae. Ovarinm inferum, biloculare, disco epigyno carnoso. Ovula in loenlis solitaria, peltatim affixa, amphitropa, Stylus filiformis, simplex; stigma obtusum, obsolete bilobum. B a c c a suberosa, oblonga, acute quadrangula, calycis limbo coronata, bilocularis. Semina in loculis solitaria, oblonga, dorso convexa, facie bisulca adnata. Embryo intra albumen cartilagineum subdorsalis, rectus; cotyletonibus lanceolatis, foliaceis, radicula teretiuscula, longa, infera. - Herba in arenosis maritimis Indiae orientalis repens, glabra; ramis adscendentibus, teretiusculis, foliis oppositis, obovato-oblongis, carnosis, stipulis petiolos in vaginam cupularem integerrimam $v$. dentatam combinantibus, floribus axillaribus sessilibus, solitariis v. subbinis, pallide lilacinis.

H y draphylax Linn. f. Suppl. 126. Lam. t. 76, f. $t$. Roxburgh Pl. Carom, $t$, 223. DC. Prodr. IV, 576. Wight et Arnott Prodr. Flor. Pen. Ind. 1 . 441. Sa r is s is Gärtner I. $118 . t, 25$.

31 1. Cumcen HAMLT. Caly x tubo cum ovario connato, limbo supero, minimo, quadridentato. C o ro I I a supera tubo brevi, fauce villis elausa, limbi quadrifidi laciniis rotundatis. Anthera e 4 , lineares, sessiles, inclusae. O v a r i n in inferum, biloculare. Ov ula ...... Stylus simplex; stigma bifidum, exsertum. B a $e$ a calycis limbo coronata, bilocularis. Semina in loculis solitaria. - Herba nepalensis perennis, erecta, ramosa; cauletereti, subtomentoso, foliis oppositis, petiolatis, nervosis, utrinque pubescentibus, inferioribus ellipticis, superioribus lanceolatis, mucronat is, stipulis tripartitis, lobis selaceis, cymis terminalibus compositis, multifloris, floribus parvis, luteis.

C un ce a Hamilton in Don Prodr. 138. A. Richard in Mem. soc, $h, n$. Paris. $\mathcal{V}$. 157. DC. Prodr. IV. 576.

31 15. Eragalea $S W A R T Z$. Calyx tubo ovato, tereti, enm ovario connato, limbi superi, quadri-sexpartiti lacinits oblongo-linearibus, acntis, erectis, persistentibus. C o r o 11 a supera, hypocraterimorpha, tubo tereti-subtetragono, face nuda, limbi quadri-sexfidi laciniis linearilanceolatis, revolutis. St a m in a $4-6$, infra fancem corollae inserta; filamenta linearia, anthera lanceolatae, ereetae. Ovarium inferum, biloculare, disco epigyno carnosa. Ovula in loculis solitaria, peltatim affixa, amphitropa. Stylus simplex, staminibus longior; stigma incrassatum, emarginato-bilobum. Dru p a baceata, subrotunda, calyeis limbo coronata, bisulea, dipyrena, pyrenis cartilagineis, dorso convexis, facie suleatis, bipartibilibns. Semina in loculis solitaria, oblonga, peltatim affixa, Embryo in axi albuminis cartilaginei rectus; $\operatorname{cotyledoni}$ b us cordatis, foliaceis, radieula conica, infera. - Suffrutex littoralis antill anus, decumbens, diffusus; folitis oppositis, subsessilibus, lanceolatis v. ellipticis, stipulis vaginantibus, multipartitis, basi connatis, floribus axillaribus solitariis, sessili. bus, pallide lutescentibus, baccis luteis.

Brnodea Swartz Prodr, 29. Flor. Ind. accid. r. 223. t. 4. Selureber Gen. n. 1718. Vaht Symb. II. 28. Jussieu in Mem. Mus, DI. 373. Gärta, f. III. 94. t. 196. A. Rieliaril in Mem, soc. h. n. Paris. $V$. 156. $t, 15 ., f$. 2. DC. Prodr. IV. 573 .

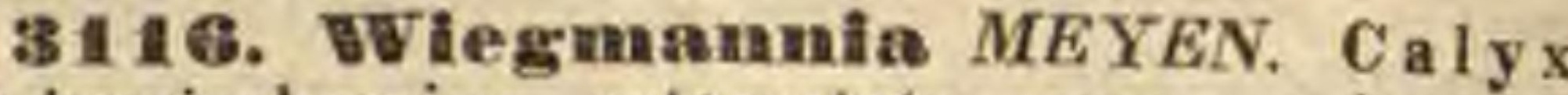
tubo hemisphaerico, octocostato, cum ovario connato, limbi superi, quadrifidi laciniis majusculis, foliaceis, sinu sejunctis. Cor oll a supera, infundibuliformis, tubo intas glabro, limbi quadrilobi lobis aestivatione valvatis. St a m ina 4 , corollae infra fancem inserta, inclusa; fil amenta brevissima, subnulla, antherae ovatae, erectae. Ovari u m inferum, biloculare, disco epigyno carnoso. Ovula in loculis solitaria, peltata, amphitropa, mieropyle infera. St y I us filiformis, inclusus; s ti g ma bifidum, lobis linearibus. B a c c a subglobosa, octocostata, calycis limbo foliaceo coronata, bilocularis. S e min a in loculis solitaria, peltata ..... Suffrutex s andwicensis, glaber; fuliis oppositis, elliptico-lanceolatis, in petiolum subangustatis, acuminatis, stipulis triangularibus, integerrimis, summis cymae multiflorae contractae radios involucrantibus, subcordatis, calycibusque glaucis, corollis purpureis.

Wiegmannia Meyen Reise II. 139.

311\%. Serissa COMMERS. Calyx tubo obovato, eum ovario connato, limbo supero, quinquefido v. rarius quadrifido, lobis brevibus, dentibusnonnullis interdum interjectis. Corolla supera, infundibuliformis, tubo interdum hirsuto, limbo quinquelobo $v$, rarius quadrilobo, lobis aestivatione induplicatis, apice interdum brevissime trifidis. St a min a $5-6$, corollae fauci inserta; filamenta brevissima, subnulla, antherae lineares, exsertae. Ovarinm inferum, biloculare, diseo epigyno carnoso. O vula in loculis solitaria, peltatim affixa, micropyle infera. St y lus filiformis, inclusus; st i gma bifidum, lobis linearibns. B a ce a subglobosa, caly cis limbo coronata, bilocularis. Semina in loculis solitaria. ..... Frutex indicus, glaber; ramis novellis puberulis, foliis oppositis, subsessilibus, in axillis saepe fasciculatis, tritis foetentibus, stipulis cum petiolis connatis, margine ciliato-fimbriatis, floribus subfasciculatis, terminalibus, subsessilibus, albis.

S eriss a Commers. in Jussieu gen, 209. Mem. Mus. $V T$. 395. Lam. t. 15t. $f, 3$. Blume Bijdr. 969. A. Riefiard in Mem. soc, h. n. Paris. $V$. 161. DC. Prodr. IV. 375 . D y sod a Loureiro Fl. coehinch. I. 181. B u choz i a Heritier Dis. sert, inedit. L y c i i s p. Thunb. Bot. Mag. t. 361 .

SUB'TRIIBUS II. EUSPERMACOCEAE DC. Prodr. IV, 540. Fructu s sicci, bi-triquadripartibiles.

3118. Demoeritea $D C$. Flo res ..... Fructus calycis tubo turbinato, subangulato et pericarpio membranaceo, inter se connatis, demum ruptis constans, limbi quinquelobi lobis acutis, rigidulis coronatus, junior bilocularis (?) demum septo evanido unilocularis, dispermus. Semina intra pericarpium libera, dorso convexa, facie 
plana. Embryo in axi albuminis carnosi rectus; radicul a infera. - Frutex chinensis, flore ignoto maximopere dubius, Serissae habilu, a qua fructu abunde diferre videtur, ramis teretibus, albidis, junioribus subpuberulis, foliis oppositis, vaginis brevibus cum petiolis subconnatis, trisetis, rigidis, floribus ad apices ramulorum fasciculatis.

\section{D e moerite a DC. Prodr. IV. 540 .}

3119. Detodon THONN. Caly $\mathrm{x}$ tubo clavato-obovato, cum ovario connato, limbi superi dentibus octo, brevissimis, ohtusis. Corolla supera, campanulata, quadrifida, lobis acutis, intus pilis apice glandulosis adspersa. $\mathrm{S} \mathrm{t}$ a $\mathrm{m}$ n a 4, imo corollae tubo inserta; fil am enta.... a ntherae $\ldots . .$. O varium inferum, biloculare. Ovula ..... Stylus simplex; stigma globulosum, obsolete bifidnm. Ca p sula turbinata, obsolete tetragona, bilocularis, septicido-dicocea, coccis intus semibifidis, monospermis. S e min a oblonga ...... Herba guineensis, erecta, pedalis, ramosa. glabra; caule tetragono, foliis oppositis, filiformibus, elongatis, acutis, stipulis vaginantibus, utrinque breviter tri-quinquesetis, florum capilulis terminalibus, paucis, verticillatis, subrotundis, subaequalibus.

$0 \mathrm{ctod}$ on Thonning ex Schumack, in Ael. soc, $h, n$, Hafn, III. 94. DC, Prodr. IV. 540 .

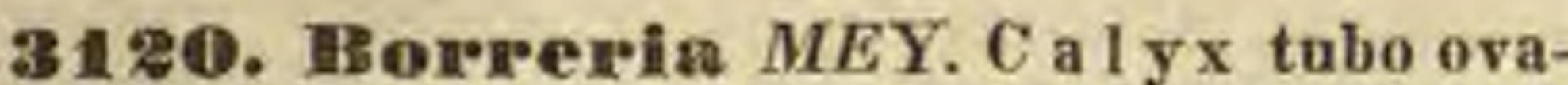
to, cum ovario: connato, limbo supero, in dentes laciniasve duas aut quatuor persistentes partito. Corolla, supera, hypocraterimorpha v. infundibuliformis, tubo intus nudo $v$, ad fancem piloso, limbo quadrilobo, Stamina 4 , corollae fanci v. tubo demissius inserta, exserta $v$, in clusa; filamenta subulata, antherae ovatae v. lineares, erectae. Ovarium inferum, biloculare, disco epigyno carnoso. 0 v u 1 a in localis solitaria, peltata, amphitropa. S t y l u 8 sim plex; stigma bifidum $v$. indivisum. Capsula calycis limbo coronata, bilocularis, ab apice septieido-dehiscens, dissepimento libern nullo, coccis intus aequaliter rima longitudinali apertis, monospermis. S e min a ovato-oblonga, dorso convexa, facie plana, sulco longitudinali. Emb ry o in axi albuminis dense carnosi rectus; cotyle. donibus foliaceis, radicu I a infera. - Herbae v. suffrutices, in Americ a calidiore obvii, inter tropicos Asiae et Africa e rari; caule ramisque saepe tetragonis, foliis oppositis v. axillaribus novellis fasciculatis, pseudoverticillatis, stipulis cum petiolis connatis, plus minus vaginantibus, utrinque multifido-setoso-fimbriatis, floribus in axillis $v$, ad apices ramulorum verticillato-capitatis, rarius cymosis $v$. corymbosis, parvis, albis aut caeruleis.

B or er i Meyer Essequeb. 79. Cham. et Schlechtend. in Linnaca III, 310. Spreng. N. Entdeck. IT. 144. DC. Prodr. IV. 5.0. non Achar. B I ge I o w i a Sprerg. Syst. I. 394. non alior. Chlorophytum Pohl msc. - ? GuhImanola Necker elem. $n$, 338. Spermacoees s p. Auet. Aablet Guian. t. 29. f. 6. 7. Rniz et Pav. Flor. peruv. t, 91. St. Hilaire Plant, usuell. Bras, t. 12, 13.

3121. Spermacoce LINN. C a I y x tubo ovate $v$, turbinato, cum ovario connato, limbo supero, in dentes duos $\mathrm{v}$, quatuor, interdum accessoriis nonnullis partito, persistente $\mathbf{v}$. demum obliterato. Coroll a supera, hypocraterimorpha $v$. infundibuliformis, tubo intus nudo v. ad faucem piloso, limbo quadrilobo. $\mathrm{S} t \mathrm{a} \mathrm{m}$ i $\mathrm{n}$ a 4 , corollae fauci v. tubo demissius inserta, exserta v. inclusa; fil amenta sobulata, antherae ovatae $v$, lineares, erectae. $0 \mathbf{v}$ a $\mathbf{r} \mathbf{i} \mathbf{~ m}$ in- ferum, biloculare, disco epigyno earnoso. Ovula in loculis solitaria, peltata, amphitropa. Stylus simplex; stigma bifidum v. indivisum. Cap8 ula calycis limbo saepius obliterato coronata, bilocularis, ab apice dehiscens, cocco altero septo adnato clauso, altero septo rupto aperto, ambobus ab apice bipartibilibus, monospermis. $\mathrm{S} \mathrm{e}$ min a ovato-oblonga, dorso convexa, facie plana, suleo longitudinali. E m bryo in axi albuminis dense carnosi rectus; cot yledonibus foliaceis, radicula infera. - Herbae $v$, suffrutices, inter tropicos totius orbis provenientes; caule ramisque saepe tetragonis, foliis oppositis, slipulis cum petiolis connatis vaginantibus, in setas plurimas fimbriato-fissis, floribus axillaribus sessilibus, confertis $v$. semiverticillatis, parvis, albis $v$, caeruleis.

S permacoce Linn. gen, $n$. 119. exel, sp. Gärtner $T$. t. 25. Lam. t, 62. f. 2, Jacq. Hort. Schonbr, $t$. 322. Meyer Essequeb. 79. Chan. et Schlechtend, in Linnaea IIT. 355. DC. Prodr. IV. 552. Spermacoce, Cavelia et Chenoc arpus Necker elem. n. $337-339-$ ? T a d avel Adans. Fam. II. 145.

312. Dexasepaltum BARTL. Calyx tubo oblongo-obpyramidato, eum ovario connato, limbi superi sexpartiti lobis, angustis, subaequalibus, acutis, persistentibus. C o r o I l a supera, campanulato - infundibuliformis, tubo obeonico, intus nudo, limbi quadrifidi lobis lanceolatis, acutis. Stamina 4 , corollae infra faucem inserta, breviter exserta; fil amenta subulata, antherae oblongae, erectae. Ovarium inferum, biloculare, disco epigyno carnoso. Ovnla ...... Stylus simplex; stigma obsolete bilobum. Ca p sula oblonga, costata, calycis limbo coronata, septicido-bipartibilis, coccis septo clansis, monospermis. Semina. ..... - Frutex mexicanus, adscendens, ramosissimus, glaber; ramis compressis, diffusis, flexuosis, foliis oppositis, elongato linearibus, acutis, vix margine scabris, stipulis vaginantibus, in setas plurimas, vaginae aequales, ciliis brevissimis intermixtas fissis, floribus axillaribus solitariis, sessilibus, inter contribules maximis.

Hex as epalum Bartling $e x D C$. Prodr, IY. 861 .

3183. Dioula LINN, Calyx tubo ovato v. obovato, nervoso, cum ovario connato, limbo supero, persistente, bifido $v$. quadrifido, laciniis aequalibus $v$. alternis inaequalibus, rarius pluribus. Corolla supera, infundibuliformis, tubo intus hirsuto, limbi quadrilobi laciniis lanceolatis, acutis. Stamina 4 , snmmae corollae fauci inserta; filamenta subulata, antherae lineares, versatiles. Ovarium inferum, biloculare, disco epigyno carnoso. Ovula in loculis solitaria, peltata, amphitropa. Sty I us plus minus bifidos; stigmata subcapitata. Capsula calycis limbo coronata, bilocularis, axi nulla inter coccos disjunctos, indehiscentes, monospermos. Semina ovato-oblonga, dorso convexa, facie plana, sulco longitudinali. Emb r y o in axi albuminis dense carnosi rectus; coty ledonibus foliaceis, radi e al a elongata, infera. - Herbae $v$. suffrutices, omnes, specie unica africana tropica, in America calidiore crescentes; caule ramisque teretibus v. tetragonis, foliis oppositis $v$. fasciculis axillaribus accedentibus spurie verticillat is, floribus parvis, albis, varie dispositis.

Di o dia Linn, gen. n, 122. -Gärtner $I, t, 12 t$. Meyre Essequeb. 81. Chamiss. et Sehlechtend, in Linnaea IIT. $3 \mathrm{ht}$. exel, sect. 2. DC. Prodr. IV. s61.

a. EUDIODIA DC. Prodr. $T V$. 5ä. C a ps ula crustacen v. subearnosa, coccis indehlscentibus. - Flores axill. 
lares sessiles, oppositi v, utrinque duo v. plurimi verticillati. - (Jacq. 1c. rar. 1, t, 29. Lam. t, 63. Gärtner t. 25.)

b. DASYCEPhaLA DC. Prodr. IV. 565. Capsula membranacea, coecis demum intus dehiscentibus. - Flores capitati.

3124 . Troioston $D C$. C a Iy x tubo turbinato, cum ovario connato, limbo supero, persistente, bi-quadridentato, denticulis nonnullis interdum accessoriis. Co rolla supera, infundibuliformis, tubo brevi, intus hirsuto, limbi quadrifidi laciniis lanceolatis. Stamina 4, summae corollae fanci inserta, exserta; fil amenta subnlata, antherae lineares, versatiles. Ovarium inferum, bilocnlare, disco epigyno carnoso. O v n I a in loealis solitaria, peltata, amphitropa. Stylus simplex; $8 \mathrm{t} \mathrm{i} g \mathrm{~m}$ a bifidum, laciniis linearibus. Ca p su la chartacea, calycis limbo coronata, bilocularis, bipartibilis, axi persistente cum nervis duabus spermaphoris tridentem formante inter coccos disjunctos, indehiscentes, monospermos, Seun in oblonga, dorso convexa, facie plana, sulco longitudinali. E mbryo in axi alhuminis dense carnosi rectus; cotyled onibus foliaceis, radie ula elongata, infera. - Frutices brasilienses, ramosissimi, glabriusculi; foliis oppositis $v$. spurie verticillatis, oblongis $v$. linearibus, floralibus minimis, floribus ad apices ramulorum axillaribus $v$. terminalibus, spicatis fasciculatisve, parvis.

Triodon DC. Prodr. IV. 366. Diodiae sectio 2. Chamiss. et Sehlechtend, in Linnaea III, 343.

3125. Crusea CHAM, et SCHLECHTEND. Caly $x$ tubo ovato - didymo, cum ovario connato, limbi superi, basi supra ovarium constricti, quadrifidi laciniis lineari-subulatis, elongatis, hirtis, denticnlis minimis interjectis. Corolla supera, hypocraterimorpha, tubo longo, apice obeonico, fauce intus nulla, limbi quadrilobi laciniis lanceolatis, acutis. Stamina 4 , summae corollae fanci inserta, exserta; filamenta subulata, anthera e lineares, versatiles. Ovarium inferum, biloculare, disco epigyno carnoso. Ovula ...... Sty In s simplex; s tig ma bifidum, laci niis linearibus Ca psula coriacea, didyma, bipartibilis, axi persistente plano membranaceo, caly eis limbum retinente, inter coccos sejunctos, in dehiscentes, monospermos. Sem ina

Herbae $m$ exicanac, basi suffruticulosae, erectae $v$. adscendentes; folitis oppositis, ovato-lanceolatis stipulis vaginantibus, ciliato-setosis, floribus termi nalibus capitato-umbellatis, involucratis, rubris.

$\mathrm{C} r$ us e a Chamisso et Sehlechtend. in Linnaea $V .165$. DC. Prodr. IV. 566, non A. Rich, S permacoce rubra Jacq. Hort. Schönbr. t. 256. S. strig os a Bot. Mag, t, 1558

3126. Istelnaratsonia KUNTH. C a ly $x$ tubo sulggloboso, cum ovario connato, limbi su peri, basi supra ovarium constricti, quadri-septempartiti, dentibus subaequalibus, accessoriis nullis interjectis, Cor olla supera, infundibuliformis, tubo obeonico, intus nudo, limbi patuli, triquinquelobi laciniis lanceolatis, acutis. St a mina 3 - 5, summae corollae fauci inserta, exserta; filamenta lineari-subulata, antherae ovatae, versatiles. Ovari n m inferum, tri - quadriloculare, disco epigyno obsoleto. O $\mathbf{v} \mathbf{~} 1$ a in loculis solitaria, peltata, amphitropa. Stylus simplex; stigma tri-quadrifidum, lobis erassiusculis, subelavatis, C a p 8 I a membranacea ealyce demum circumscisse deciduo nuda, tri quadripartibilis, axi distineta nulla, coccis indehiscentibus, monospermis. Semina oblonga, durso convexa, facie plana, longitudinaliter bisulea. E m. b ryo in axi albuminis dense carnosi rectus; cotyledonibus foliaceis, ra dícula elongata, infera. - Herbae in America tropica indigenae, decumbentes, diffusae, hispidae v. villosae; radice subsimplici, sublignosa, crasse corticata, transversim rugosa, in plerisque emetica, foliis oppositis, ovatis, mediante stipula multiseta combinatis, floribus ad apices ramorum capitatis, capitulis foliis summis quadribracteato-involucratis.

$\mathrm{R}$ i ehardson i Kunth in Humb. ot Bonpl. Nov. Gen, et sp. III, $t, 350$. St. Hilaire Plant, usuell. t.7. 8. Martius Mat, Medic. t, 9. A. Richard in Mtem, soc. h. n. Paris. V. 15t. t. 14. f. 5. DC. Prodr, IV. 566, non Neck. R i e h a rd i a Lian. gen, $n$. 439. Gärta. $I$. 123. $t$, 25, non Kunth. $\mathrm{S}$ chi ed ea Bartliug mse.

318\%. Nitaracarpum ZUCCAR. Caly x tabo cum ovario connato, limbi superi, quadridentati, persistentis dentibus duobus saepissime majoribus, duobus minimis, interdum obsoletis. Corolla supera, hypocraterimorpha, tubo tereti, intus prope basim pilorum annulo, fauce nuda, limbi quadrifidi laciniis patentibus, obtusis. Stam in a 4, corollae fauci inserta, exserta $v$, inclusa; fil amenta filiformia, antherae ovatae, erectae. Ovari um inferum, biloculare, disco epigyno carnoso. Stylns simplex; stigma bifidum. C a p s u la membranacea, calycis limbo persistente coronata, bilocularis, infra medium circumscis. sa. Semina in loculis solitaria, dissepimenti parti persistenti affixa, dorso convexa, facie plana, suleo longitudinali. Embryo in axi albuminis carnosi rectus; cotyled onibus foliaceis, radicula elongata, infera. - Herbae $v$, suffrutices, Spermacoces facie, in Am erica tropica, rarius in insulis Philippinis et Mariannis, rarissime in Senegambia crescentes; foliis oppositis, stipulis breviter cum petiolis connatis, in setas plurimas solutis, floribus in capitulo basi tetraphyllo dense verticillatis, albis.

Mitracarpum Zuccarint in Schultes Mantiss. III. 210. Chamiss. et Sehlechtend, in Linnaea IIT, 358. t. 3. f.1. 2. A. Riehard in Mem. soc. $h, n$, Paris, $V$, 15t, t. 14. f. 4 . DC. Prodr. IV. 57t. Crusea Chamiss. mso. Sehizang i u m Bartling msc. St a u rospermum Thonaing ex Schumach, in Act, soc. h, n. Hafn. III. 93. S p e r m a co. ces s p. Jacq. Ic. rar. t. 308.

31\%8. Permena $A U B L, \mathrm{C}$ a 1 y $\mathrm{x}$ tubo turbinato, brevissimo, cum ovario connato, limbi superi, bipartiti laciniis anticis elongatis, foliaceis, posticis nullis. Co rolla supera, infundibuliformis, fauce villosa, tubo intus squamulis tribus, minimis aucto, limbi tri-quadrifidi laciniis subovatis, acutis. St a $\mathbf{m}$ in a $3-4$, summo corollae tubo inserta, subexserta; fil am enta brevissima, antherae lineares, basi barbatae. Ovarinm infe$\mathrm{rum}$, triloculare. $\mathrm{O} \mathbf{\mathrm { nl }}$ a in loculis solitaria, amphitropa. Stylus capillaris; stig ma bidentatum. Capsula obpyramidata, membranacea, calycis limbo persistente coronata, trilocularis, snpra medium circumscissa. Se min a in loeulis solitaria, dissepimenti parti persistenti affixa, triquetra. E mb $\mathbf{y} \mathbf{o}$ in axi albuminis carnosi rectus, subcylindricus; cotyledonibus brevissimis, radicula elongata, infera. - Herbae americanae tropicae, annuae, simplices $v$. ramosae, hispidulae; caule ramisque terelibus, foliis oppositis v. ternatis, sessilibus, ovalo-oblongis v. linearibus, basi connatis, margine stipulari angustissimo, fere obsoleto, floribus in capitulum terminale globosum v. cylindricum, nudum $v$. foliis superioribus bracteatum congestis, parvulis. 
Pera ma Aublet Guian. t, 5h. t. 18. St. Hilaire Voyage Distr. Diam. II. 419. Mattus chkea Sehreber Gen. n, 1712. Kunth in Humb. et Bonpl. Nov. Gen, et sp. II, 271.

31 29. Strelia $C H A M, \mathrm{C}$ a ly $\mathrm{x}$ tubo ovato, cum ovario connato, limbi superi, persistentis dentibus duobus subulatis, accessoriis subnullis. Corolla summo calycis tubo inserta, infundibnliformis, tubo gracili, intus nudo, limbi quadrilobi lobis erectiusculis, acutis. Stamina 4 , fauci corollae inserta, exserta ; filamenta filiformia, antherae lineares, versatiles. Ovarin in inferum, biloculare, disco epigyno obsoleto. O vula in loculis solitaria, peltata, amphitropa. C a p s uI a membranacea, bilocularis, bivalvis, valvulis concavis, dente calycino superatis, linea declivi a dissepimento integro persistente circumscisse solutis. Semina in Iocnlis solitaria, dissepimento affixa, dorso convexa, facie plana suleo longitudinali. Embryo in axi albuminis carnosi rectus; cutyledonibus foliaceis, radicula elongata, infera. - Herbae brasilienses; caule tereti, foliis oppositis, linearibus, glabris, axillaribus fasciculatis, stipulis membranaceis, angustis, multiset is $v$. acute trilobis, capitulis axillaribus sessilibus, verticillatis, et terminalibus globosis.

S ta ell a Chamisso in Linnaea III. 364. $t, 3, f, 3 . \mathrm{DC}$. Prodr. IV. 573.

3130. Tessiera $D C$. C aly x tubo ovato, eum ovario connato, limbi superi, quadrilobi, persistentis lohis subaequalibus, accessoriis nullis. Corolla supera, infunilibuliformis, fance glabra, limbo quadriluho. St a m in a 4 , corollae fauci inserta, brevissime exserta; fil a m e n t a filiformia, anth erae lineares, incumbentes. Ovarium inferum, biloculare, disco epigyno ubsoleto. Ova la in loculis solitaria, peltata, amphitropa. Sty I us simplex; stigma obsolete bilobum. Capsula membranacea, bilocularis, septifrago-bivalvis, valvis concavis, dentibus calycinis coronatis, seorsum deciduis, septum ovale seminigerum denudantibus. Semina in locolis solitaria, medio dissepimento affixa, dorso convexa, facie plana. E m b r y o.... - Herbae a merican a e tropicae, lana vel tomento praeter corollas tectae; foliis opposilis, lineato-ner. vosis, mediante stipula multiseta combinatis, floribus axillaribus, sessilibus, paucis, verticillatis, bracteolatis.

\section{Tessiera DC. Prodr. IV. 574.}

3131. Psyllocarpass MART. C a ly x tubo turbinato, cum ovario connato, limbi superi, persistentis dentibns octo, sex brevissimis, doobus oppositis linearibus, elongatis. Corolla supera, infundibuliformis, tubo ad fancem barbato, limbi quadrilobi lobis acutiusculis. Antherae 4 , intra tubum corollae sessiles. Ovarium infernm, bi loculare, diseo epigyno ohsuletn. Ovula in loen lis solitaria, amphitropa. Sty I $\mathrm{s}$ brevis, simplex; 8 t i r m a emarginato-bilobum. Ca p 8 u la membranacea, dentibus calycinis coronata, a dorso compressa, bilocularis, septifrago-bivalvis, valvis concaviusculis, dissepimentum planum parallelum nudantibus, S e m in a in loculis solitaria, ovalia $\mathrm{v}$ orbiculata, compressissima, membranaceo-marginata, dissepimento peltatim affixa. Embryo in axi albuminis carnosi tenuis, rectns; c ot y l ed oni bus orbiculatis, foliaceis, ra dicula eylindrica, infera. - Frutices brasilienses, humiles; ramis virgatis, tetragonis, folits oppositis, linearifiliformibus, mediante stipula ciliato-setosa combinatis, axillaribus fasciculatis, saepius spurie verticillatis, floribus axillaribus et terminalibus caeruleis.
Ps y llocarpus Martius et Zuccar. Nov. 6en, ot sp. I. 44. t. 28. DC. Prodr. IV. 570. Diodo is Pohl in Flora 1825. p. 183

3132. Canthionia $A$. RICH. C a 1 y x tubo ovato, cum ovario connato, limbi superi, acute quinque-septemdentati dentibus inaequalibus, acutis. Coroll a supera, infundibuliformis, tubo tereti, intus nudo, limbi quinque-septemlobi lobis oblongis. St a min a $5 \ldots-7$, corollae fauci inserta, subexserta; fil ament a filiformia, antherae ovatae, erectae. Ovari $\mathbf{n}$ inferum, biloculare, disco epigyno carnoso. Ovula in loculis solitaria, e basi erecta, anatropa. Stylus filiformis, apice incrassatus; stigna bilobum. Capsula ovata, membranacea, apice denudata, dicocca, coecis indehiscentibus, monospermis. S e $\mathrm{m}$ i $\mathrm{n}$ a erecta, convexa, facie plana. Em bryo in axi albuminis carnosi orthotropus; cotyledonibus foliaceis, radic ula elongata, infera. - Herbae persicae, durae, opposite ramosae, totae etiam in corollis pube tenui subvelutinae; folits oppositis, linearibus, apice calloso-mucronatis, utrinque gerentibus stipulas binas, nune breves stipuliformes, nunc lingiores foliaceas, floribus aliis in ramorum dichotomia sessilibus, solitariis, nudis, aliis in apice ramorum inter folia duo suprema sessilibus, Asperulae facie.

Galllionia A. Richard in Mem. soc. h, n. Parts, $V$. 153. t. 15, f. 3. DC. Prodr. IV. 574.

3133. Dtioplaora ZUCC. Calyx tubo ovato-globoso, cum ovario connato, limbi superi, inaequaliter quinquedentati dente infimo valde elongato, foliaceo, lateralibus brevioribus, summis abbreviatis, setaceis. C o rolla supera, hypocraterimorpha, tubo filiformi, intus nudo, limbi quadrifidi laciniis lineari-lanceolatis. St a mina 4 , corollae tubo infra faucem inserta, exserta; filam enta filifurmia, anthera e elliptieae, erectae. Ovarium inferum, biloculare, disco epigyno obsoleto. Ovula in loculis solitaria, e basi ereeta, anatropa. Sty lus filiformis; $8 \mathrm{tigma}$ bifidum, lobis linearibus, elongatis. Capsula membranacea, calycis limbo persistente coronata, bilocularis, diencea, coccis indehiscentibus, monospermis. S e min a erecta, elliptica, compressa. E m b ryo in axi albuminis carnosi orthotropus; cot y l ed onibus suborbiculatis, foliaceis, radie uía elongata, infera. - Frutex madagascariensis, setoso-hispidus; fuliis oppositis, sessilibus, stipulis setaceo-laciniatis, floribus spicatis, geminis, ebracteatis.

Oti oph o r a Zuecariai Nov. Plant, fase. $1 ., p, 316$.

3134. Kmoxia $L I N N$. Calyx tubo ova to, subeostato, cum ovario connato, limbi superi dentibus quatuor, valde inaequalibus, persistentibus, demum conniventibus. Corolla supera, hypocraterimorpha, tubo tereti, fauce saepius barbata, limbi quadrilobi lobis lanceolatis. Stamin a 4 , corollae fauci inserta; fil a m en ta subnulla, a ntherae inclusae. Ovarium inferum, bilaeulare, disco epigyno carnoso. Orula in loculis solitaria, apici apensa, anatropa. Sty lu s simplex, exsertus; 8 t igma bilobum. Cap $\$$ ula membranacea, calycis limbo coronata, bilocnlaris, dicocca, coceis basi primnm ab axi filiformi persistente soIntis, demnm divaricatis, indehiscentibus, monospermis. S e mina inversa, ovato-triquetra. $\mathbf{E}$ bryo in axi albnminis carnosi orthotropus; cot yledonibus foliaceis, radicula elongata, supera. - Herbae $v$, suffrutices ind $i$ ci; caule tercti v. tetragono, folits oppositis v. fasciculis axillaribus psetulo verticillatis, stipulis integerrimis v. pau- 
cisetis, petiolorum bases jungentibus, cymis terminalibus, sessilibus $v$. pedunculatis, ramis post anthesim elongato-spiciformibus.

K n ox i a Linn. gen, n. 123, Gärtuer $I .121$ t, 25. (rad, situ male deseript,) Lam. $t$. 59. A. Richard in Mem. soc. h. n, Paris, $V$. 152. $t$. 15, $f, 1$. Wallich Plant, asiat, rar. t. 32. DC. Prodr. IV. 569.

3135. Traelanonia HUMB. et BONPL. Cal y x tubo obovato, cum ovario connato, limbo supero, breviter quinquefido. Corolla supera, infundibuliformis, tubo brevi, fauce villosa, limbo quinquefido. Stamina 5 , corollae fauci inserta; filamenta filiformia, a ntherae subcordatae, erectae. Ovarinm inferum, biloculare, disco epigyno carnoso. $O \vee v 1$ a in loculis solitaria, apici appensa, anatropa. St y lu s simplex; stigm a bipartitum. C a p s u I a oblongo-cuneata, subtetragona, calycis limbo coronata, bilocularis, dicocea, coccis indehiscentibus, lignoso-coriaceis, trigonis, demum infra apicem ex axi lineari persistente pendulis, monospermis. Semin a inversa, ovatotriquetra. Embryo in axi albuminis carnosi orthotropus; cotyledonibus foliaceis, radicula elongata, supera. - Frutices $v$, arbores in $A m e-$ ric a tropic a provenientes; foliis oppositis, petiolatis, acuminatis, stipulis interpetiolaribus utrinque solitariis, paniculis terminalibus, subcorymbosis, floribus albis, magnitudine florum Asperulae.

M a cha o n I a Humb. et Bonpl. Plant, aequinoct, I. 101 t. 29. Kuath in Humb. et Bonpl. Nov. Gen. et sp, ITI. 350. Jussieu in Mem. Mus. VI. 382. Chamisso et Schlechtend, in Linnaea IV.2. A. Richard in Mem, soc, h, n. Paris, V. 161. DC. Prodr, IV, 874.

3136. Deppea CHAM. et SCHLECHT. C al y $\times$ tubo hemisphaerico, cum ovario connato, limbo supero, breviter quadridentato. Coroll a supera, subrotata, quadrifida, lobis erectiusculis. Stamina 4, corollae tubo inserta; filamenta brevissima, subulata, a ntherae lineares, exsertae. Ovarium inferum, vertice breviter exsertum, biloculare, $O$ vula in loculis solitaria, peltata, amphitropa, micropyle supera. Stylus filiformis ; st $\mathrm{ig} \mathrm{m}$ a indivisum, subclavatum. C a psula membranacea, ellipsoidea, dentibus calycinis coronata, bilocularis, loculicido-bivalvis. S e$\mathrm{m}$ i $\mathrm{n}$ a in loculis solitaria, peltata. Em bryo.....

Fruticulus mexicanus, Hedyotidum habitu; radice, ligno et cortice interiore rubentibus, folitis oppositis, petiolatis, ellipticis, utrinque acuminatis, supra et margine subpilosis, stipulis triangularibus, subdeciduis, cymis axillaribus et terminalibus pedunculatis, tri-quadriradiatis, floribus flavis.

De p pea Chamisso et Sehlechtend. in Linnaca $\nu .167$. DC. Prodr, IV. 618. Endlicher Atakt, 25, t. 24.

$$
\text { ** }
$$

$313 \%$. Cruekshanksia $H O O K$, et $A R N$. C a ly $\mathrm{x}$ tube globoso-subdidymo, cum ovario connato, limbi superi, tetraphylli foliolis Ionge petiolatis, cordato -subrotundis, papyraceis, reticulatis, petiolis basi anriculato-bistipulatis. Co rolla supera, hypocraterimorpha, extus pubescens, tubo elongato intus fauceque glabro, limbi quinquefidi laeiniis patentibus. S $\mathrm{t}$ a mina 5 , corollae fauci inserta, breviter exserta; fil am enta compressa, utrinque angustata, a $n$th e ra e oblongae, erectae. Orari um inferum, biloculare. Ovuia in loculis gemina, collateralia, peltatim adscendentia, amphitropa. Stylus filiformis; stigma bifidum, lobis linearibus. C a psu la membranacea, globosodidyma, ealycis foliolis coronata, bilocularis, bi- valvis, valvis cymbiformilus a septo membrana. ceo solntis, demum bifidis. S e m in a in loculis gemina, collateralia, arcuata, ad nubilicum ventralem exeavata. Embryo intra albumen corneum areuatus, teres; cotyle don ibus brevissimis, radicula elongata, infera. - Herba chilensis, perennis, hispidulo-pubescens; caulibus herbaceis, adscendentibus, teretibus, flexuosis, ramosis, foliis oppositis, obovato-lanceolatis, acutis, in petiolum angustatis, stipulis intrapetiolaribus late subulatis, discretis $v$. plus minus coadunatis, floribus terminalibus capitato-umbellatis, involucrato-bracteatis, flavis.

Cruckshanksia Hooker et Arnott in Bot. Miscell. III. 361. Rotheria Meyen Reise $I$. 402.

SUBTIRIBUS III. CEPHALANTHEAE DC. Prodr. IV. 538. Flores et fructus supra receptaculum globosum dense aggregati, sessiles. Fruct u s bi - quadripartibilis.

3138. Cephalanthus LINN. C a 1 y 8 tubo obpyramidato, cum ovario connato, limbo supero, angulato, quadridentato. Corolla supera, tubulosa, gracilis, limbi quadrifidi lobis erectiusculis. Stamina 4 , summo corollae tubo inserta, subinclusa; fi l am en ta filiformia, a nth era e cordatae, erectae. Ov ar i u m inferum, biquadriloculare. Ovula in loculis solitaria, apici appensa, anatropa. St y l us simplex, longe exser tus; stigma capitatum. Fructus coriaceus, obpyramidatus, calycis limbo coronatus, bi-quadrilocularis, a basi bi-quadripartibilis, loculis indehiscentibus, monospermis, duobus in fructu tetramero saepissime inanibus. Sem in a inversa, oblongo-triquetra, epiphysi ad umbilicum callosa. E mb r yo in axi albuminis subcartilaginei orthotropus; cotyledonibus oblongis, foliaceis, radicula brevi, supera. - Frutices americani; ramis teretibus, foliis oppositis v. ternatis, stipulis brevibus, distinctis $v$, subconcretis, pedunculis ex axillis supremis et ex apice ramorum nudis, capitulis globosis, floribus supra receptaculum piligerum sessilibus, dense aggregatis sed distinctis, ochroleucis.

C e phal a $t$ h u s i Linu. gen, n. 113, Gïrtn. $I I, 4 t, t, 86$. Lam. t. 59. Schkuhr t, 5. 6., t. 21. Duhamel Arbr. t. 84. Hamb. et Bonpl. Plant. aequinoct, $t$. 98 . Jussieu in Mem. Mus. VT, 402. Barton Flor. medic. $t .91$. A. Richard is Mem, soc, h. n. Paris, D, 155. DC. Prodr. IV. 538. P I ata nocephalus Vaillant in Act. Acad. Paris, 1722. 191.

TRIBUS v. PSYCHOTRIEAE. Flores hermaphroditi, varie dispositi, interdum capitati, involucrati, nunquam tamen connati. Coroll a e tubulosae, lobis per aestivationem valvatis. Ovarium biloculare, loculis uniovulatis. Fructus baccatus, bilocularis, dipyrenus, pyrenis osseis v. crustaceis, monospermis, nunc abortu unilocularis, monopyrenus. Semin a dorso convexa, facie plana et medio sulco longitudinali exarata, rarius depressa. Alb u men corneum. - Arbores v. frutices, rarissime herbae; foliis oppositis, stipulis interpetiolaribus geminis, connatis $v$. distinctis. - Psychotrieae in America calidiore copiosissime generantur, a Chili al Floridam observatae. Multae in India orientali degunt, pauciores in Senegambia et Africae australis insulis vigent, paucae Austra- 
Iasiam, paucissimae Caput bonae spei et Arabiam felicem inhabitant.

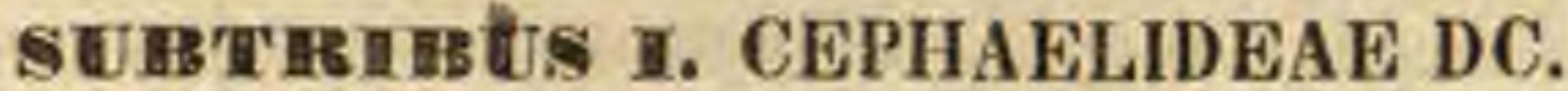
Prodr. IV. 532. Flores capitato-fasciculati, involucrato - bracteati.

3139. Geoplaila DON, Calyx tubo obovato, cum ovario connato, limbi superi, quinquepartiti laciniis linearibus, patentibus. Corolla supera, tubulosa, fauce pilosa, limbi quinquelobi lobis ovatis, subrecurvis. Stamina 5 , corollae infra faucem inserta; filamenta subnulla, anthera e lineares, erectae. Ovarium inferum, biloculare, disco epigyno depresso. Ovula in loculis solitaria, e basi dissepimenti adscendentia, anatropa. S t y l u s simplex; s t i g m a bifidum. B a cea ovoidea, costata, calyeis limbo coronata, bilocularis, loculis monospermis. $\mathrm{S}$ e m in a erecta ...... - Herbae perennes, depressae, repentes, in America tropica rariusque in India orientali indigenae, Violae fere facie; foliis oppositis, petiolatis, cordatis, stipulis utrinque solitariis, indivisis, pedunculo e supremi folii axilla solitario, apice plurifloro, floribus umbellato-subsessilibus, bracteis flore brevioribus involucratis.

Geophila Don Prodr, nepal, 136. DC, Prodr. IV, 537. Ps ye hotria s p. Linn. Jaeq., Amer. $t$, 46. Tusare $F l$ Antill. $t, 8$. Ruiz et Pavon Fl, peruv, $t, 211, f$. 6. c.

3140 . Cephadils $S W A R T Z$, Caly $\mathrm{x}$ tubo obovato, cum ovario connato, limbo supero, brevissimo, quadri-quinquedentato. Corolla supera, infundibuliformis, fauce nuda v. villosa, limbi quadri -quinquelobi lobis brevibus, obtusiusculis. Stamin a 4 -5, corollae infra faucem inserta, inclusa; fil amenta brevissima, anthe$r$ a e lineares, incumbentes. Ovarium inferum, biloculare, disco epigyno depresso. Ov u la in loeulis solitaria, e basi dissepimenti adscendentia, anatropa. S ty lus simplex, inclusus v. subexser. tus; stigma bifidum. B a ce a obovato-oblonga, succulenta v. subsicea, calyeis vestigio coronata, dipyrena, pyrenis osseis, costatis, monospermis. S e m ina erecta. Em bryo in axi albuminis cornei orthotropus; cotyledonibas foliaceis, radicuIa cylindrica, infera. - Herbae suffrutescentes $v$. frutices, in America calidiore crescentes, ob radices emeticas celebratae; foliis oppositis, petiolatis ovalibus, acutis, stipulis utrinque geminis, liberis $v$, in unicam bifidam v. bidentalam concretis, capitulis terminalibus $v$, axillaribus, sessilibus aut pe dunculatis, bracteis binis-octonis cruciatim oppositis involucratis, floribus in capilulo bracteolis inter. stinctis.

C ephäli is Swartz Prodr. 45. Fl. Ind. occid. 435. t. 10. A. Richard in Mem. soc. h. n. Paris. $V$. 172. DC. Prodr, IV. 532, Cephateis Vahl Eelog, I. 19. Callic acca Schreber gen. 316. 1 p e c a c u a a ha Arrada Dissert. 44. T a pog ome a et Eve a Aublet Guian, I. 100. et 157. Jussieu gen. 258. C e pli a ëli is et $\mathrm{B} v$ e a Jussieu in Mem. Mtus. VI. 402. excl. synon.

a. CALLICoCCA DC. 1, c, CapituIa bracteis distinelis, ovatis v. oblongis, erecto-adpressis involuerata. $-T$ apogomeae sp. Aublet Guian, t. 60. 62. 63. Even Aublet t. 39. Lam, $t$. 59. Sehraderae 5 p. Rudge Guian, t. 85. Morfind a e s p. Jacq. Amer. $t$. 35. (Rudge Guian, t. 43. 44. Martius Mat, medic, t. 1. St. Hilaire Plant, us. Brasil, t, G, Hooker ad Beechey t, 13.)

b. TAPOGOMEA DC. 2 , e. Capitula bracteis duabus connatis, magnis, patentibus, coloratis involuerata. Aublet $O_{p}$. cit, $t, 61$.

3141. Carapiehea $A U B L$. Caly $\times$ tubo obovato, cum ovario connato, limbo supero, bre vissimo, quinquedentato. C or oll a supera, infundibuliformis, fance villosa, limbi quinquelobi lobis brevibus, obtusis. S ta min a 5, corollae infra faucem inserta, exserta; filam enta filiformia, a nthera e lineares, incumbentes. Ovarium inferum, biloculare, disco epigyno depresso. Ovula in loculis solitaria, e basi dissepimenti adscendentia, anatropa. Stylus simplex, exsertus; stigma bifidum. B a c ca exsucea, sulcato angulata, calycis limbo obsoleto coronata, dipyrena, bipartibilis, pyrenis osseis, laevibus, monospermis. S e m in a erecta... - Frutices guianenses, glabri, fortassis a Cephaélide haud satis distincti; ramulis subnodosis; foliis oppositis, ovali-acuminatis, petiolatis, stipulis utrinque geminis, in unicam bidentatam connatis, capitulis e supremis axillis breve pedunculatis, nutantibus, bracteis quatuor acutis cinclis, corollis albis.

Carapiehea Aublet Guian, 1. 167, t, 68. DC. Prodr. IV. 536. Eurothia Necker elem, $n, 348$, C e phatilidis sp. Willd. Juss. A. Riehard.

3142. Tatabea $A U B L$. Caly x tubo obovato-globoso, cum ovario connato, limbo supero, brevissimo, integerrimo $\mathbf{v}$, obsolete quadri-sexdentato. C orolla supera, tubo brevi, tereti, limbi quadri-8extobi lobis oblongis, patulis. Anther a e 4_6 lineares, intra faucem corollae sessiles. Ovarium inferum, biloculare. Ovula in locnlis solitaria, erecta? ...... Stylus simplex; stigm a obtuse bifidum. B a c ca globosa, calyce sub. clauso coronata, laevis, bilocularis, disperma. S emina ...... - Frutices guianenses, glabri; foliis oppositis, breve petiolatis, ovalibus ovatisve, acuminatis, stipulis e basi lata subulatis, floribus in axillis foliorum $v$, in apice ramorum capitatoconfertis, bracteis quatuor, cruciatim oppositis, parvis stipatis.

Pat a be a Anblet Guian, I. 111, $t, 45$. Jussien gen. 208. Mem, Mus. VT. 401, excl. synon. Lans, $t$. 65. Kunth in Humb. et Bonpl. Nov. gen. ot sp. III. 375. DC. Prodr. IV. 537. Ce phälidis s p. Walld. Spreng.

3143. Salzmannia $D C$. Calyx tnbo ovali cum ovario connato, limbo supero, cupulari, obtusissime quadridentato v. sinuato. Corolla supera, tubo brevi, limbi quadrilobi lobis oblongis. St a m in a 4, corollae fauci (?) inserta ; $\mathrm{fila-}$ ment a brevissima, antherae lineares, elongatae. Ovarium ...... Stylus indivisus ant lobis concretis. B a c c a exsucca, calycis limbo coronata, adulta abortu nnilocularis, compressa, ovalis, monosperma. Semen compressum.

Frutex brasiliensis, glaberrimus, non satis notus et dubiae etiam affinitatis; ramulis junioribus subtetragonis, adultis teretiusculis, foliis oppositis, ovatis, breve petiolatis, supra nitidissimis et quasi vernicosis, stipulis truncalis, brevissimis, pedunculis axillaribus oppositis, capilulum densum, decem-duodecimflorum, bracteis foliaceis binis - quaternis involucratum gerentibus, floribus intra bracteas sessilibus, albis.

Salzmann i a DC. Prodr. IV. 617,

3144. Suteria DC, C a lyx tubo brevissimo, ovato, cum ovario connato, limbo supero, longissime tubuloso, angulato, apice inaequaliter quinquedentato. Corolla supera, hypocraterimorpha, tubo tereti, fauce nuda, limbi quinquefidi lobis ovali-oblongis. Anthera 5 , intra fancem corollae sessiles, oblongae, erectae, $0 \mathrm{va}$ ri n m inferum, biloculare, disco epigyno carnoso, pulviniformi. Ovula in loculis solitaria, e basi erecta, anatropa. Stylus simplex, exsertus; stig $m$ a bilamellatum, obtusum. Fructus ..... 
Frutex brasiliensis, glaberrimus, nitidus; foliis oppositis, subsessilibus, oblongo-lanceolatis, stipulis ovatis, deciduis, capitulis axillaribus, subsessilibus, subsexfloris, bracteis foliaceis, ovatis involucratis, bracteolis inter flores linearibus, corollis albis, fere Jasmini.

Suteria DC. Prodr. IV. 536. C epha Ëlis ealy cin a Liadley Collect. $t .21$.

SUETRIBUS II. COFFEEAE DC. Prodr. IV. 472. Fl ores distincti, haud involucrati.

3145. Chasalia COMMERS. C a 1 y $x$ tubo ovato, cum ovario connato, limbo supero, integerrimo v. apice quinquedentato, dentibus linearibus, demum auctis. C o rolla supera, tubo elongato, tereti, aequali, fauce nuda, limbi quinquelobi lobis brevibus, acutiusculis, ereetis v. patulis, saepe callosis. Antherae 5, lineares, in me dio v. summo tubo peltatim sessiles, inclusae v. ad faucem subexsertae. O v a r i u m inferum, biloculare, disco epigyno earnoso, pulviniformi. $O$ v uIa in locnlis solitaria, e basi erecta, anatropa. Stylas simplex; stigma bifidum, lobis linearibus. B a c ca ovata, calycis limbo demum aucto coronata, subcostata, dipyrena, pyrenis coriaceis v. subcorneis, dorso convexis, crista longitudinali versus basim productiore notatis, monospermis. Semina erecta, sectione transversali lunata. Embryo in basi albuminis cornei orthotropus, linearis; cotyledonibus subfoliaceis, radicu la cylindrica, infera. - Frutices borbonici, glabri; foliis oppositis v. ternato-verticillatis, stipulis ovatis, indivisis $v$. in vaginam quadrifidam concretis, floribus ad apices ramorum congestis, sessilibus, $v$. paniculato-corymbosis.

C h a s alia Commerson ex Jussieu in Mem. Mus, VI. 379. A. Richard in Mem, soc. h. n. Paris, V. 166. t. 16. f. 1. DC. Prodr. IV. 531.

3146. Palleourea $A U B L$. C aly $\mathrm{x}$ tubo ovato, cum ovario connato, limbi superi, breviter quinquedentati, dentib ns subinaequalibus. C o r o 11 a supera, tubulosa, subcylindrica, basi hinc gibba v. curvula, intus infra medium barbata, limbi brevis. sime quinquefidi lobis erectis. S $\mathrm{ta}$ m in a 5 , corollae tubo inserta, inclusa v. exserta; fil a m e $n$ ta filiformia, a $\mathrm{nthe}$ rae lineares, incumbentes. Ovarium inferum, biloculare, diseo epigyno carnoso, pulviniformi. Ovula in loculis solitaria, e basi dissepimenti adscendentia, anatropa. Stylu s simplex; s tig ma breviter bifidum. B a c c a carnosa, costata, calycis limbo coronata, dipyrena, pyrenis dorso convexo quinquecostatis, facie planis, monosper mis. S e m i na erecta, cavitati conformia. $\mathbf{E} \mathbf{m}$ br y o brevissimus, in basi albuminis cornei orthotropus; cotyledonibus subfoliaceis, radicula cylindrica, infera. - Frutices in America tropica indigeni, plerumque glabri; foliis oppositis v. rarius verticillatis, saepius amplis, stipulis diversimode connexis, paniculis terminalibus, nunc elongatis, nune thyrsoideis, nunc cymosis, sessilibus $v$. saepius pedunculatis, corollis luteis v. albis.

Pallicourea Aublet Guian. 1 . 173. $t$. 66. Kunth in Humb. of Bonpl. Nov. gen. et sp. III, 367. t. 285. Radge Guian. $t$. 42. St. Hilaire Plant, remarq. Brasil. $t$. 22. A. Richard in Mem. soc, h, n. Paris. $D$. 174. DC. Prodr. 1V. 524. Galvania Vandelli in Hömer Seript. 89. t. 6. f. 7 . S tep han i um Selureber gen, $n$, 308. Coll a d o $\mathrm{a}$ ta Spreng. Syst, I, 757. Ps y chotri a e s p. Jussieu, Swartz, Lam, $t$. 161, $f, 3$. Ruiz et Pavaa. Flor. peruv. $t, 201 . f . a$, t. 203, f. a. b. t, 204. f. a, b. t. 208, f. b. $t, 218, f, b$. t. 213. f. a. b.
314\%. Psychotria LINN. C a lyx tubo ovato, cum ovario connato, limbo supero, brevi, subintegro v. quinquelobo aut quinquedentato. Corolla supera, infundibuliformi-tubulosa, tubo tereti, basi aequali, fauce glabra v. barbata, limbi quinquefidi $\mathbf{v}$, rarius quadrifidi lobis patentibus $\mathbf{v}$. recurvis, aestivatione valvatis. S ta m in a $4-5$, corollae tubo inserta, inclusa v. rarius subexserta; fi l amenta filiformia, brevia, anthera e lineares, incumbentes. O vari u m inferum, biloculare, diseo epigyno carnoso, pulviniformi. Ovula in loculis solitaria, e basi dissepimenti adscendentia, anatropa. S t y l a s simplex; s t i g m a bifidum. B a eca carnosa, calycis limbo coronata, costata v. laevis, dipyrena, pyrenis dorso convexo costatis v. rarius laevilus, facie planis, monospermis. Semina erecta, eavitati conformia. Embry o brevis, in basi albuminis cartilaginei orthotropus; cutyled on ibus foliaceis, lanceolatis, radicnla cylindrica, infera. - Arbusculae $v$. frutices, rarius herbae perennes, inter tropicos totius mundi, imprimis tamen America e crescentes; foliis oppositis, petiolatis, stipulis varie connexis, pedunculis rarius axillaribus, plerumque terminalibus, floribus paniculatis $v$, corymbosis.

Ps y eho tría Lina, gen, $n$, 229. Jacq. Amer, $t, 174$. f. 22. Hort, Schönbr, t. 260. Gurtner $I ., 120 . t$. 25. Ruiz et Pav, Flor. peruv. t. 202. $f, a, t, 205 . f . a, t, 206, f . a . b$. t. 207. f. $a$ b. $t, 208$, f. a, t. 209. f. a. b. t. 210. f. $a . b$. $t$. 212. $f . b$. Humb. et Bonpl, Plant, aequinoct, $1 \dot{1}$. 142. t. 126. Kunth in Humb. et Bonpl. Nov. gen. et sp. III. 354. $t$. 282. 284. 288. Bot. Reg. $t$, 607. Labillard. Nov. Ca. ledon. $t$, 47. St. Hilaire Plant, remarq. Brasil, $t, 21, f . a$, A. Richard in Mem, soc. h, n. Paris. $V$. 171. excl, sp. DC. Prodr. IV. 304. excl. sp. Wight et Arnott Prodr. Flor. Penins. Ind. or. I. 432. P s y e b t r o p h u m P. Browne Jam. 160. My rt ip h y $11 \mathrm{um} \mathrm{P.} \mathrm{Browne} \mathrm{Jam.} 152$.

3148. Tonabea $A U B L$. C a I y x tubo brevissimo, ovato, cum ovario connato, limbo supero, minimo, quinquedentato, in fructu obsoleto. C oro 11 a supera, infundibuliformis, tubo tereti, fauce nuda, limbi quinquefidi laciniis lanceolatis, patentibus. St a m in a 5, medio tubo inserta, inclusa; filament a filiformia, brevissima, antherae oblongae, erectae? Ovarium inferum, biloculare. 0 v u 1 a ...... S t y l a s simplex; stigma bilamellatum. B a c c a ovata, umbilicata, laevis, dipyrena, pyrenis dorso convexo laevibus, facie planis, monospermis. S em in a ..... - Frutices guianenses, glabri, non satis noti, fortassis a Psychotria non distincti; foliis oppositis, ovalibus, acutis, breve petiolatis, stipulis utrinque solitariis, acutis, pedunculis axillaribus apice bisexfloris, petiolo brevioribus, floribus parvis, albis, basi bibracteolatis.

Ronabea Aublet Guian. I. 154, $t$. 59. Lam. $t$, 166. Jassieu gen. 205. Mem, Mus. VI. 380. A. Richard in Mem, soc. h. n. Paris. $V$. 170, DC. Prodr. $I V$. 503. Viscoides J seq. Amer. 75. $t .51, f, 1$.

3149. Mapouria A. RICH. Ca I y x tubo ovato, cum ovario connato, limbo supero, bre. vissime quinquedentato, in fructu obsoleto. C 0 roll a supera, brevis, subcampanulata, fauce pilis erectis, densis obturata, limbi quinquepartiti laciniis reflexo-patentibus. S tam in a 5 , fauci eorollae inserta, exserta; fil am enta filiformia, antherae ovato-cordatae, erectae. Ovarinm inferum, biloculare, disco epigyno carnoso, pulviniformi. Sty I n s simplex; stigma bilamellatum, obtusum. Ovula in loculis solitaria, e basi dissepimenti adscendentia, anatropa. B a ce a ovoidea, subcarnosa, umbilicata, dipyrena, pyrenis osseis, dorso convexis, costatis, facie planis, mo- 
nospermis, S e mina erecta, cavitati conformia. Em b r y o brevis, in basi albuminis cartilaginei or. thotropus; cotyledonibus lanceolatis, foliaceis, radie n la eylindrica, infera. - Frutices $v$. arbores, in Guiana et in Antillis crescentes; foliis oppositis, stipulis interpetiolaribus integris, subcaducis, floribus in racemum terminalem saepius cymosum dispositis.

Mapouria A, Richard in Mem, soc. h, n. Paris. V. 173. M a p o ri a Aublet Guian, I. 175. t. 67. et Simira Aublet Op. cit, $I$. 170. $t$. 65 .

3150. Antherura LOUREIR. C a lyx tubo cum ovario connato, limbo supero, brevi, acute quadridentato. Corolla supera, rotata, quinquepartita, laciniis acutis. St a mina $5, c 0-$ rollae inserta; filam enta brevissima, anthera e sagittatae, apice in caudam longam, reflexam productae. $O$ vari um ....... Stylus subulatus, corolla longior; $s t i g m$ a simplex. B a c c a corticosa, decemsulcata, dipyrena, pyrenis monospermis. Semina ...... _ Arbuscula cochinchinensis et moluccan $\bar{a}$, vix nota, glabra; ramis diffusis, foliis oppositis, breve petiolatis, ovato-lanceolatis, stipulis ...... paniculis terminalibus erectis, laxis, corollis albis, filamentis rubris, bacca ovata, fusco-rubra.

Antherura Loureiro Flor, cochinch. I. 144. DC. Prodr. IP. 503, C a r yo phyllas ter ruber Rumph. $\mathbf{A m}$ boin, III, t, 136. P s y e hotriate s p. Willd, Juss.

3151. Trualigea SALISB. C a l y x tubo ovato-globoso, cum ovario connato, limbi superi, quinquepartiti laciniis acutis. Co r o ll a supera, subinfundibuliformis, tubo elongato, gracili, fauce nuda, limbi quinquepartiti laciniis reflexo - patentibus, angustis, basi subconcavis, apice triquetris, abruptim deflexis. St a in in a 5 . corollae fauci inserta, inclusa; fil am enta brevissima, a n th erae oblongae, erectae. $\mathbf{O}$ a ri $\mathbf{m}$ inferum, biloculare. Ovula...... - Stylus simplex; stigma bilamellatum, B a ce a? bilocularis, disperma .... Arbores $v$. frutices $g$ uianenses; ramulis petiolisque cinereo-pubescentibus, folitis oppositis, petiolatis, magnis, glabriusculis, stipulis interpetiolaribus magnis, ovatis, fimbriatis, deciduis, paniculae terminales, densae, bracteolatae, ramulis oppositis, floribus in sicco nigricantibus.

$\mathrm{R}$ u d g e a Salisbury in Linn. Transact. VIII. 328, $t .18$. 19. Jussieu in Mem. Mus. VI. 38t. A. Richard in Mem. roc. h. n. Paris. V. 169. DC. Prodr. IV. 503.

315.. Coffea LINN. Caly $x$ tubo ovato, globoso v, turbinato, limbo supero, brevi, quadriquinquedentato. Co rolla supera, infundibuliformi - tubulosa, limbi patentis, quadri-quinquepartiti lobis oblongis, aestivatione contortis. Stamina 4 _. 5ummo v. medio tubo inserta, exserta v. inclusa; fil amenta filiformia, antherae oblongae, erectae. O vari a m inferum, biloculare, disco epigyno pulviniformi v. ureeolari. Ovula in Joculis solitaria, dissepimento inserta, amphitropa. Stylus simplex; stigma bipartitum, lobis revolutis v. rarius cohaerentibus. Ba c c a umbilicata, nuda v, calyeis limbo coronata, dipyrena, pyrenis chartaceo - membranaceis, dorso convexo laevibus, facie planis, sulco exaratis, monospermis. Semina cavitati conformia, dorso convexa, faciei marginibus arcte involutis. $\mathbf{E} \mathbf{m}$ b r y o in basi albuminis cornei dorsalis, erectus, brevis; cotyledonibus cordatis v, oblongis, foliaceis, ra di e u l a cylindrica, infera. - Arbusculae v. frutices, inter tropicos totius orbis indigenae; folits oppositis, breve petiolatis, stipulis interpetiolaribus, inflorescentia varia.

C offea Linn. gen, $n$, 230. Gärtner $I$, 118, Jussieu in Mem. MLs. VI 379. DC. Prodr. IV. 498.

a. COFFE DC. l. o. Flores plernmque quiaquefidi, ra. rius quadrifidi, nonaunqaam per excessum sex-septem. fidi. C a l y c is limbus brevissians, post authesim haud mutatus, fere semper demum evanidus. C or olla e faux nuda. Stig m a bifidum. B a c ca ovata v. globosa. S e$\mathrm{m}$ i u u margo interior manifestius involutus. - Arbo. res v. frutices gerontogei et americani, stipulisutrin. que solitarits, indivisis, integerrimis, haud oiliatis.

Coffe Rai Hist, plant. II. 1691. Jussieu in Act, Aca. dem. Paris. 1713. $t$. 7. C offe a A. Richard in Mem. soc. h, n. Paris. V. 168. t. 16. f. 2. - (Lam. t. 160 . Gärtuer $t$. 25. Bot. Mag. t. 1303 . Tussac Flor. Antill. t. 18. - ? Aublet Guian. $t$. 57. 58. Ruiz et Pavon Flor, peruv. $t$. 214. $f . a$

b. HORNIA DC, l. $c$. Flores pentameri. Caly cis limbus post anthesim excrescens, baceam collo coronans, denticulis evanidis. Co rolla e faux uuda. Stig ma bifidom. B a c c a ovata v. globosa, saepius abortu monosperma. - Frutices peruviani, inflorescentia axil. lari v. terminali, stipulis utrinque solitariis, inte.

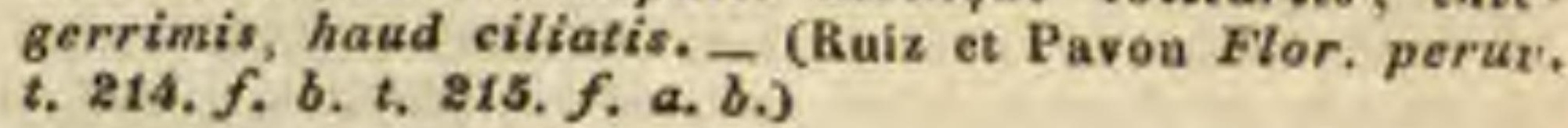

c. PANCRAsia DC. $l$. o. Flores pentameri. Calycis limbí vestigia supra baceam persistentia. Co roll a e faux barbata. S $\mathrm{t} \mathrm{g} \mathrm{g} \mathrm{m}$ a bifidum. B a c c a subglobosa. - Fru. tices peruviant, glabri, racemis v. corymbis terminalibus, stipulis saepius ciliato- $v$. fimbriato-dentatis. nune bidentatis. - (Ruiz et Pavon t. 216_218. Kunth in Humb. et Bonpl. Nov, gen. et sp. t. 286.)

d. STRAUSSIA DC. l. c. Flores tetra-hexameri. C aly. e is tubus turbinatus, If mbi vestigia in fruetu persis. tentia. Corollae faux nuda v. liarbata. Stig ma bifi. dum. B a c ca globosa v, ovalis, saepius ahorta mono. speras. - Frutices sandwicenses et manillenses, cy. mis terminalibus, stipulis ovatis, deciduis, cicatricis margine inferiore ciliato.

3153. Strempelin A. RICH. Caly x tubo obovato-globoso, eum ovario connato, limbo supero, campanulato-tubuloso, quadri-quinquedentato, persistente. Cor oll a supera, tubulosa, tubo tereti, fauce nuda, limbi quadri-quinquepartiti laciniis lanceolatis, acutis, patentibus. St a m ina 4_5, medio corollae tubo inserta, inclusa; fil amenta filiformia, basi breviter pilosa, an $t h \mathrm{e}$ ra e lineares, erectae. Ovari um inferum, biloculare. $O$ v ula in loculis solitaria, e basi ereeta, anatropa. Stylus simplex; stigma bifidum, laciniis linearilus. B a c ca ovoidea, striata, limbo calycino coronata, dipyrena, pyrenis osseis, dorso convexo laevihus, facie plana medio anisuleis, monospermis. Semina erecta, cavitati conformia. Emb ryo intra albumen cartilagineum orthotropas, subteres; coty led o nibus brevissimis, radienla infera. - Frutex guianensis; foliis oppositis, ellipticis, stipulis fimbriatis, floribus in pedunculo terminali umbellatis, flabellato-serrulatis.

Strempeli a A. Richard in Ment. voc, h. n. Paris, $V$. 180. $t$. 18. $f$. 3. DC. Prodr. IV. 498.

3154. Faramea $A$. RICH. Calyx tubo turbinato-globoso, cum ovario connato, limbo supero, brevissime subtubuloso, integerrimo v. quadridentato. Coroll a supera, tuluilosa, tubo brevi, tereti, fance nuda, subinflata, limbi quadrifidi lobis oblongis linearibusve, acutis, aestivatione contortis, sub anthesi patentibus, tubo lengioribus. $\mathrm{S}$ ta $\mathrm{m}$ in a 4 , corollae summo tubo inserta, inclusa; fil am enta brevissima, antherae oblongae, apices subexserentes. Ovarium inferum, biloenlare v. dissepimento interdnm evanido uniloculare, diseo epigyno carnoso, pyramidali v. depresso. Ov u la in loculis solitaria, $v$, in ovario uniloculari 
gemina collateralia, basilaria, amphitropa. Stylus simplex; st i gma bifidum. B a c a sicciuscula, depresso-globosa, umbilieata, abortu unilocularis, monosperma. S e m en depresso-globosum, hasi concava affixum. E m bryo intra albumen cartilagineum minimus, lateralis, horizentalis; $r$ a di $\mathrm{e}$ ul a centrifuga. - Arbusculae $v$. frutices a mericani, dichotomi, glabri; foliis oppositis, coriaceis, ovalibus $v$. oblongis, acuminatis, stipulis interpetiolaribus utrinque solitariis, basi latis, apice acutis $v$. setaceocuspidatis, floribus terminalibus corymbosis v. umbellatis, pedunculis sub flore dilatatis, corollis albis.

Faramea A. Richard in Mem, soc, h, n. Paris $V, 175$. DC. Prodr. IV. 496.

a. EUfaramea DC. l. c. Ped n nenli terminales, solitaril v. terni, apice umbellam simplicem gerentes. Flo. res bracteis caducis involucrati.

F a ra me a Aublet Guian, I. 102, t, 40, Lam. t. 63. Jnssieu in Mem. Mus. VI. 376. F a marea Virtmann Summ. pl. I. 257. (A. Richard Op. cit. t. 17, f. 1.)

b. TETRAMERIUM DC. $l$. $c$, C o ry mbi terminales, trichotomi, Flores nudi.

Tetramerium Gärtner $n I$. 90 . $t$. 196. Kunth in Humb. et Bonpl. Nov, gen, et sp, III. 373. t. 287. Jus. sieu in Mem. Mus. VI. 376. P ot im a Persoon Ench. $I$. 209. D a r I u c a Rafin. Annal. gen, sc, phys, VI. 87. C of. feare s p. Jaeq. Amer. $t$. 47 . 1 x or a e s p. Linn.

c. FARAmeoIDES DC. 2 . c. Panicula e terminales thyrsoideae.

3155. IEytidea DC. Calyx tubo globo80, cum ovario connato, limbi superi, brevis, quinquepartiti lobis ovatis. Co rolla supera, infundibuliformis, tubo tereti, fauce subdilatata, nuda, limbi quinquefidi lobis ovalibus, patentibus. Antherae 5, ad faucem corollae sessiles, exsertae, oblongae. Ovarium inferum, ....... Stylus simplex; stigma clavatum, bisuleum. B a c c a subexsucea, globosa, limbo calyeis stellato coronata, v, rarius nuda, unilocularis, monosperma. Se men globosum, basi depressa affixum, erectum, extus rugosum. E $\mathrm{m}$ bry o in albumine eartilagineo, testae processubus ruminato lateralis, subarcuatus, tenuis; radicula centrifuga. - Frulex africa$n u s$ tropicus; ramis teretibus, junioribus hispidis, foliis oppositis, breve petiolatis, ad nervos petiolisque hispidis, stipulis interpetiolaribus utrinque binis, ad medium concretis, apiee subulatis, spica terminali racemosa, interrupta, floribus in fasciculos oppositos, subsessiles congestis, bracteis calycibusque hispidis, corollis glabris, in sicco nigricantibus, fructibus glabris.

Rutide a DC. in Annal. Mus, IX. 219. Prodr, IV. 495. Jussieu in Mem. Mus. VI. 378. A. Richard in Mem, soc. h. n, Paris. V. 179.

3156. Crumilea GARTN. Caly $\mathrm{x}$ tubo obovato, cum ovario connato, limbo supero, bre. vissime urceolari, integerrimo v. quinquedentato. Corolla supera, infundibuliformis, tubo brevi, fauce villosa, limbi quinquepartiti laciniis apice incurvis, aestivatione valvatis. S tamin a 5 , corollac tubo inserta, breviter exserta; fil a m ent a brevia, antherae oblongae, erectae. Ovarinm inferum, bi-triloculare, disco epigyno carnoso, rylin drico v. quinquelobo. Ovula in loculis solitaria, e basi dissepimenti adscendentia, anatropa. Stylus simplex; stig ma bi-trifidum, lobis incrassatis. B a c c a subcoriacea, ovato - globosa, calycis limbo connivente coronata, bi-trilocularis, rarissime abortu unilocularis. S e min a in loculis solitaria, erecta, cavitati conformia, rugosa. Em b r yo in basi albuminis cartilaginei, testae processubus ruminati subdorsalis, brevis, rectiusculus; coty- ledonibus lanceolatis, subfoliaceis, radicula infera. - Frutices indici, glabri; foliis oppositis, petiolatis, basi angustatis, stipulis interpetiolaribus utrinque solitariis, basi intus pilosis, saepe caducis, florum corymbis terminalibus.

Gr umile a Gürtner I. 138, t. 28. DC. Prodr. IV. 495. Wight et Aruott Prodr. Flor. Penins, Ind, orient, 1. 432. G rumile a Poiret Supplem, II, 857.

315\%. Polyozas LOUREIR. C a ly x tubo turbinato, cum ovario connato, limbo supero, obsolete denticulato, deciduo. Co roll a supera, infnndibuliformis, tubo brevi, cylindrico, fauce villosa, limbi quadri-quinquefidi laciniis tubo longioribus, patentibus. Stamin a $4-5$, corollae tubo inserta, inclusa; fil amenta brevissima, antherae oblongae, erectae. Ovarinm inferum, biloculare, diseo epigyno coronatum. O vula in loculis solitaria. Stylus brevis; $s t i g m a$ bifidum. B a c c a subglobosa, nuda, dipyrena, pyrenis coriaceis, facie excavatis, dorso gibbis, monospermis. Semina....$E$ mbryo in basi albuminis cartilaginei minutus, rectus; $\mathrm{r}$ a dicula infera.

Arbusculae asiaticae et mauritianae; foliis oppositis, stipulis interpetiolaribus, florum cymis trichotomis, axillaribus et terminalibus.

Poly ozus Loureiro Flor. cochinch. I. 94. exel, sp.1. Blume Bijdragen. 947. DC. Prodr. MF. 494. P o l y o s u s A, Riehard in Mem, soc, $h, n$, Paris. $\nu, 185$.

3159. Coussarea $A U B L$, Caly x tubo ovato, cum ovario connato, limbo supero, breviter tubuloso, sinuato quadridentato, persistente. Coroll a supera, infundibuliformis, tubo tereti, fauce vix inflata, glabra, limbi quadrifidi laciniis lanceolatis, tubo brevioribus, aestivatione valvatis, sub anthesi patentibus. St a mina 4 , summo corollae tubo inserta, inclusa; filamenta subnulla, antherae lineares, erectae. Ovarium inferum, biloculare, disco epigyno carnoso, conico. Ovnla in loculis solitaria, medio dissepimento peltatim affixa, amphitropa. Stylus filiformis; stigma bifidum, lobis linearibus, subexsertis. B a c ca vix carnosa, subglobosa, limbo calycis tubuloso coronata, abortu unilocularis, monosperma. S e m e n subglobosum, parietale. E in b ryo in albuminis cornei foveola basilari parvus, recius; cot yle dunibus foliaceis, radicula incrassato-napiformi, infera. - Frutices guianenses et antillani, glabri; foliis oppositis, coriaceis, breve petiolatis, stipulis interpetiolaribus utrinque solitariis, acutis, floribus terminalibus paucis, confertis, breve pedicellatis, albis.

Co us a re a Aublet Guian. I, 98, $2,38$. Lame $t, 65$. A. Richard in Mem, soc, h, n. Paris, V. 177. t. 18, f. 1.2. DC. Prodr. IV. 493. B 111 a rd i e r a Vahl Eclog. I, 13, t. 10. f.3. F röhli ehia Vahl Eclog.pracfat. 3, P e che y a Scop. Introduet. $\pi, 830$.

3159. Saprosma BLUM. C alyx tubo ovali, cum ovario connato, limbo supero, parvo, quadridentato, persistente. C oroll a supera, quadrifida, hirsuta. S t a m in a 4, corollae fauci inserta, filamentis brevibus. Ovari um inferum, ...S $t$ igma bifidum. Ba ce a ovalis, laevis, umbilicata, ealyce coronata, unilocularis, monosperma. S emen ...... E m bryo in albumine carnoso erectns. Arbores $v$. frutices, in insula Java indigeni, non satis noti, nec fortassis a Coussarea sufjicenter diversi; foliis oppositis, glabris, utrinque angustatis, floribus confertis, terminalibus $v$, rarius axillaribus, sessilibus, baccis et ligno foetidissimis.

$\mathrm{S}$ a pros m a Blume Bijdrag. 256. A. Riehard in Mem. soc. h, n. Paris. V. 178, DC. Prodr. IV. 493. 
3160. Pavetta LINN. Calyx tubo turbinato, cum ovario connato, limbo supero, brevi, quadri-quinquedentato, C o r o 11 a supera, hypocraterimorpha, tubo gracili, cylindrico v. superne subinflato, fauce nuda v. barbata, limbi quadri-quinquepartiti laciniis tubo brevioribns, obtusis v. acutis, subinaequalibus, aestivatione contortis, sub anthesi patentibus. Antherae 4_5 lineares, fauci insertae, subsessiles, exsertae v, rarius inclusae. Ova rium inferum, bi - triloculare, disco epigyno carnoso. Ovula in loculis solitaria, medio dissepimento peltatim inserta, amphitropa. Stylus longe exsertus; stigma clavatum, indivisum. B a c c a globosa, ealycis limbo coronata, di-tripyrena, rarius abortu monopyrena, pyrenis subchartaceis, dorso convexo laevibus, facie plana sulco longitudinali exaratis, monospermis. S emina cavitati conformia, umbilico ventrali. $\mathbf{E} \mathrm{m}$ b ry o intra albumen cartilagineum dorsalis, homotrope incurvus; cotyledonibus foliaceis, radicula elongata, infera. - Frutices in Asia tropica et in Africa tam intertropica quam australi extratropica crescentes; foliis oppositis, stipulis interpetiolaribus mucronatis, corymbis e supremis axillis v. terminalibus, saepius trichotomis, floribus albis.

Pa vetta Linn. gen. n. 132. Jussieu gen. 203. Mem. Mus. VI. 375, Gärtner 1 . 116, $t, 25$. Palisot Flor. Owar. t.52. Bot. Reg, t, 198. Bot. Mag. t. 3580, A. Riehard in Mem. soc, h. n. Paris, V. 180. excl, sp. DC. Prodr. IV. 490. Prodr. Flor. Penins. Ind. or. I. 430. Pavet ta e ver a e Wight et Arnott Blume Bijdr.951. C rinita Houttuyn Pflanz. Syst. $V .357 . t$. 40. f. 1, P a va te Ray Hist, plant, II, 1581. Ixorae sp. Auet.

3161. Ixora LINN. Cal yx tubo ovato, cum ovario connato, limbo supere, brevi, quadriquinquedentato. Co rolla supera, hypocraterimorpha, tubogracili, cylindrico, fance nuda v. barbata, limbi quadri-quinquepartiti laciniis tubo brevioribus, acutis v. obtusis, aestivatione convolntis, sub anthesi patentibus. St a min a $4-5$, corollae fauci inserta, subexserta; f il a m e n t a brevissima v. subnulla, anth erae oblongae, erectae. Ova ri um inferum, biloculare, disco epigyno carnose. O v $\mathbf{u} \mathrm{a}$ in loculis solitaria, medio dissepimento peltatim inserta, amphitropa. Stylus simplex, vis exsertus; $8 \mathrm{tig} \mathrm{m}$ a bifidum, Iaciniis patentibus $\mathbf{v}$. revolutis. B a c e a globosa, calycis limbo coronata, dipyrena, pyrenis ehartaceis, dorso convexo laevibus, facie concavis, monospermis. S e min a cavitati conformia, umbilico ventrali. $\mathbf{E m b r y o}$ intra albumen cartilagineum dorsalis, homotrope incurvus; cotyledonibus foliaceis, radicula elongata, infera. - Frutices $v$, arbusculae, in $A s$ ia et parcius in Africa tropica crescentes; folits oppositis, petiolatis, stipulis interpetiolaribus utrinque solitariis, e basi lata acuminatis $v$, in aristam setaceam desinentibus, corymbis terminalibus, saepius trichotomis, floribus coccineis, roseis rariusve albidis, saepe fragrantibus.

Ix o $\mathrm{r}$ a Liau. gen. n. 131. Jassieu gen, 203. Mem. Mas. VT. 375. Gärtner I, 117. t. 25. Andrews Bot, Reposit. t. 78. Bot. Mag. $t$. 169. 2428, 2505. Bot. Reg. $t, 100,145.573 .788$. DC. Prodr. IV. 485. WIght in Hooker Bot, Mriscell. Suppl. t. 34. 35. Wight et Arnott Prodr. Flor. Penins. Ind, or. I. 427. P a vet tae seet. 1 x o ra Blume Bijdr.949. Pavettae * p. A. Richard.

B 162. İaconia $D C$. Caly $\times$ tubo brevissimo, cum ovario connato, limbi superi, quadrifidi lobis obtusiusculis, erectis. Co r oll a supera, infundibuliformis, tabo tereti, brevi, fauce barbata, limbi quadrifidi lobis oblongis, tubo longioribus, per aestivatienem contortis, sub anthesi reflexo- patentibus. Stamina 4, fauci corollae inserta, exserta; filamenta brevissima, antherae lineares, erectae, lobis paullo breviores, post anthesim spiraliter tortae. O va ri um inferum, biloculare, disco epigyno conico, crasso, ovarium liberum mentiente. Ovula in loculis solitaria, medio dissepimento peltatim inserta, amphitropa. StyI s filiformis, exsertus; st ig ma clavatum, indivisum v. brevissime bilobum. B a ce a exsucea, depresso-globosa, umbilicata, dipyrena, pyrenis crustaceis, fragilibus, dorso convexo laevibus, facie plana exsulcis, monospermis. S e m in a semiglobosa, umbilico ventrali, excavato-orbiculari. $\mathbf{E}$ mb r y o intra albumen cartilagineun dorsalis, rectinsculus; radienla infera. - Frutex africanus tropicus, glaber; foliis oppositis, petiolatis, ovalibus, utrinque acuminatis, stipulis connato vaginantibus, brevibus, corymbis terminalibus trichotomis, floribus albidis.

B a conia DC. in Annal. Mus. IX, 219. Prodr, IV. 485. Jussien in Mem. Mus. VI, 374. A, Richard in Mtem, soc, h. n. Paris. V. 18\%. Verulamia DC. msc. Poiret Dict. VIII. 543.

3163. Chomelia $J A C Q$. Calyx tubo turbinato, cum ovarie connato, limbi superi, persistentis, ad medium quadripartiti laciniis linearisubulatis. Corolla supera, hypocraterimorpha, tubo gracili, fauce glabra, limbi quadrifidi lobis tubo brevioribus, acutis, patentibus. S $\operatorname{tam}$ i n a 4 , corollae fauci inserta, inclusa; fil a me $n$ ta subnulla, a $\mathbf{t h}$ erae oblongae, erectae. Ovarinm inferum, biloculare, disco epigyno carnoso, $O \mathrm{v} u-$ Ia in loculis solitaria, apiei appensa, anatropa. Stylus simplex, inclusus; stigma bifidum. B a c c a ovata, calycis limbo coronata, dipyrena v. abortu monopyrena, pyrenis monospermis, Semen inversum. Embry o..... - Frutices americani tropici, saepius spinescentes, pubescentes sive glabri; foliis oppositis, brevissime petiolatis, rigidis, coriaceis, stipulis interpetiolaribus brevibus, pedunculis axillaribus, uni-paucifloris, brevibus, floribus albidis, fragrantibus, ad basim calycis bracteolis duabus setaceis stipatis.

C ho mell a Jacquin Amer. 18. $t$. 13. Jussieu in Mem. Mus. PI. 375. Chamisso et Sehlechtend. in Linnaea IV, 185. A, Rlehard in Mem, soc, $h, n$, Paris. $V$. 182. DC. Mrodr. IV. 484. non Linn. Ix o ra e sp. Jam.

3164. Scolosenthus VAHL, C alyx tubo ovato, brevi, cum ovario connato, limbi superi, persistentis, quadrifidi lobis lineari-lanceolatis, acutis. Coroll a supera, infundibuliformis, tubo apice quadrangulo, fauce nuda, limbi quadrifidi lobis tubo brevioribus, ovatis, acutis, aestivatione valvatis, sub anthesi revolntis. S tamin a 4 , imo corollae tubo inserta, inclusa; fila. menta subulata, pilosa, a nth erae oblongae, erectae. Ovarium inferum, bilocalare. Ovula ...... Stylus simplex, vix exsertus; stigma bifidum, lobis obtusis. B a ce a subglobosa, ealyce coronata, dipyrena $\mathbf{v}$. aborta monopyrena, pyre. nis monospermis. Semina ...... Frutices antillani, glabri, spinescentes; foliis oppositis, subsessilibus, parvis, oblongis $v$. obovatis, coriaceis, in axillis saepius fasciculatis, stipulis interpetiolaribus parvis, pedunculis axillaribus nune brevibus uni-quadrifloris, nunc excrescentibus in spinam simplicem $v$. bi-trifidam, sacpius nudan, rarius floriferam, floribus parvis.

Scolos a n thus Vahl Eclog. $I, 11, t, 10$. Jusstea in Mem. Mus. VT. 377. A. Richard in Mem. soc, $\hbar, n$. Paris. V. 205. DC. Prodr. 1V. 485. A n ta e a n (ha \& L. C, Richard msc. Cates baea parvillora Lau. $t$, 67. $f$. 2 . 
3 165. Saldinia $A$. RICH. Caly $\mathrm{x}$ tubo cum ovario connato, limbo supero, brevi, subcampanulato, obsolete repando. Co roll a supera, tubo brevi, fauce pilosa, limbi quadripartiti lobis oblongis, acutis, patentibus, St a mina 4 , corollae fauce inserta, vix exserta; a $n$th e r a e oblongae, subsessiles. Ovarium ..... Stylus.... Fruetus parvulas, ovoideo-compressus, limbo calycino umbilicatus, drupaeens, abortu unilocularis, monospermus. S e m e n erectum, oblongnm. $\mathbf{E} \mathbf{m b r y o}$ in axi albuminis carnoso oleosi subteres; radicula infera. - Frutex? madagascariensis; foliis oppositis, breve petiolatis, el liptico-acuminatis, acutis, coriaceis, glabris, stipulis subulatis, acutis, floribus parvulis, quaternis v. enis, in axillis congestis, subsessilibus.

Saldinia A. Richard in Mem, soc. h, n, Paris, $V$. 206. DC. Prodr. IV. 483.

3166. Mllargaris $D C$. Calyx tubo globoso, cum ovario connato, limbi superi, persistentis, semiquinquefidi dentibus acutinsculis. Corolla supera, infundibuliformis, tubo obconico, apice obtuse quinquedentato $\mathbf{v}$. breviter quinquelobo. St a mina 5, medio corollae tubo inserta; filamenta corolla breviora, antherae ovatae. Ovarium ...... Stigma capitatum, indivisum v. subbilobum. B a c c a globosa, ealycis limbo coronata, bilocularis, disperma. S em in a semi-ovata, hine acuta. ..... Frutices mexicani; ramis gracilibus, foliis oppositis, ovatis, glabris, parvulis, fere Myrticommunis, stipulis parvis, utrinque solitariis, pedicellis axillaribus, oppositis, brevibus, uniftoris, floribus albis, saepius secundis, sub calyce bibracteolatis, baccis albis.

Margaris DC. Prodr. IV. 483. Descliea Flor. mexie. inedit.

316\%. Chioedeen P. BROWN. Calyx tubo ovato, cum ovario connato, limbi superi, persistentis dentibus quinque, acutis. Corolla supera, infundibuliformis, tubo obconico, fauce nuda, limbi quinquefidi laciniis patulis. Sta mina 5, imo corollae tubo inserta, inclusa; filamenta barbata, antherae lineares, erectae. Ov a ri u m inferum, biloculare, disco epigyno carnoso. Ovula in loculis solitaria, apici appensa, anatropa. Stylus simplex; stigma clavatum, indivisum $\mathbf{v}$. obsolete bilobum. B a $c$ c a subdidy. mo - compressa, dentibus calycinis coronata, dipyrena, pyrenis chartaceis, compressis, monospermis. S e min a inversa, cavitati conformia, E mbryo in axi albuminis earnosi orthotropus; radic ul a elongata, supera. - Frutices americani tropici, saepius scandentes; radice emetica alexi. teria, folits oppositis, ovatis v. oblongis, acutis, glabris, stipulis basi lata acuminatis, persistentibus, racemis axillaribus oppositis, simplicibus v. paniculatis, floribus pedicellatis, ex albo flavidis.

Chiococea P. Brawne Jam, 174. Lian. gen. n. 231. Gärtner $X$. 185. $t$. 26 . Hooker Exot. Flor. t, 93. Martius Mat, Medic. Brasil. $t$. 3 . 6. Nees Plant. offic. Suppl. $I$. t. 20. 21. A. Richard in Mem, soc. h. n. Paris, V. 186, DC. Prodr. IV. 482 , exel. sect. 2.

3189. Tertrea DC, Calyx tubo ovato, cum ovario connato, limbi superi, persistentis, quinquepartiti lacinitis ereetis, ovalibus, obtusis, ciliatis. C o rolla supera, brevis, infundibuliformis, fauce longe pilosa, limbi quadrifidi lobis bre. vibus, obtusis, subpatentibus. S ta mina 4 , sum. mo corollae tubo inserta, exserta; filamenta brevia, a $\mathrm{th}$ er a eblongae, erectae. Ovarin m inferum, biloculare, disco epigyno carnoso. O v n
Ia in loculis solitaria, apiei appensa, anatropa. S tylu s simplex, inclusus; st i g ma breviter bifidum, lobis obtasis. B a c $c$ a oblongo-compressa, bisulea, calycis limbo coronata, dipyrena, pyrenis chartaceis, compressis, monospermis. S e m in a inversa, cavitati conformia. $\mathbf{E}$ mb r y o...... - Frutex martinicensis; ramulis saepius apice spinescentibus, foliis oppositis, breviter petiolatis, ovalibus, acutis, membranaceis, glabris, stipulis interpetiolaribus acuminatis, floribus parvis, in racemo terminali opposite ramoso.

Tertrea DC. Prodr. $1 V$. $481 . \mathrm{S}$ eh le dea A. Richard in Mem, soc. $h, n$. Paris, $V .186$.

3169. Deelieuxia H. B. K. C a ly $x$ tuba obovato, cum ovario connato, limbo supero, persistente, quadrifido. Co roll a supera, infundibuliformis, fauce barbata, limbi breviter quadrifidi lobis reflexo-patentibus. Sta min a 4 , corollae fanci inserta; fil a me nt a filiformia, a n therae lineares, versatiles. Ovari um inferum, biIoculare. Ovn I a in loculis solitaria, medio dissepimento inserta, amphitropa? Stylu s simplex, inclusus; stig ma bifidum. Bace a subexsueca, calycis limbo coronata, didyma, compressa, dipyrena, pyrenis chartaceo-compressis, monospermis. Se m in a lenticularia $\ldots .$. E m b r y o $\ldots . .$. Suffrutices $v$, rarins herbae, in America tropica crescentes; caulibus erectis, junioribus tetragonis, foliis opposilis $v$. verlicillatis, subsessilibus, stipulis interpetiolaribus parvis, corymbis terminalibus tripartitis, bracteatis, dichotome ramosis, floribus albis, alaribus v. sessilibus pedunculatis, bibracteolatis.

Declie uxia Kunth in Humboldt et Bonpl. Nov. gen. et sp. IIT. 352. t. 28t. Martius et Zuccarin. in Römer et Schult. Mantiss. III. 112. Chamisso et Schlechtend, in Linnaca IV. 4. A. Richard in Mom, soc. h. n. Paris. V. 193. DC. Prodr. IV. 479. Ps y 11 a carp us. Pohl mse. non Mart. - Anne genus non obstante fructu subbaccato ad Sperma-

31\%๑. Eumaehia $D C$. Calyx tubo obovato, cum ovario connato, limbo supero parvo, quadridentato, deciduo. Co rolla supera, infundibuliformis, tubo brevi, fauce nuda, limbi qua. dripartiti lobis rotundatis, reflexo-patentibus. Stamin a 4, imo corollae tubo inserta, inclasa; filamenta brevia, antherae oblongae. Ovarium ...... St ylus simplex; stig ma bifidum, lobis longiusculis, acutis. B a ce a globosa, apice nuda, bilocularis, loculis monospermis. S e mi na dorso convexa, umbilico ventrali, meniscoideo. Album e n cartilagineum. E m bry o ....... Arbor in insulis Namoka observata, glabra; ramis teretibus, foliis oppositis, petiolatis, laevibus, oblongolanceolatis, cymis terminalibus axillaribusque trijidis, corollis incarnatis.

$\mathrm{E}$ a macbia DC. Prodr. IV, 478. Petes la earnea Forst. Gïrtner f, $I I I$. 66, $t, 192$.

31\%1. Siderodendron SCHREB. Ca1 y $x$ tube subgloboso tetragono, eum ovario connato, limbe supero, subnullo v quadridentato. C orolla supera, tubo longo, tereti, fance subinfata, intus glabra, limbi quadrifidi lobis ovalibus, obtusis, patentibus. Anthera e 4, ad fancem corollae sessiles, subexsertae, ovatae. Ovarin m inferum, biloculare, disen epigyno carnoso. O vuIa in loculis solitaria, medio dissepimento inserta, amphitropa. Stylus simplex; stigma bifidum. B a c c a sicca, subglobosa, apice nuda, bilocularis, Inculis monospermis. Semina dorso convexa, nubilieo ventrali, late orbiculari, concavo. Ent- 
bryo intra albumen eartilagineum subdorsalis, rectiusculus; cotyledonibus foliaceis, cordatis, radieula longiuscula, infra. - Arbores $A m e$ ricam tropicam cis a equatorem incolentes; ligno duro, ramis teretibus, junioribus pedicellisque tetragonis, foliis oppositis, petiolatis, ovalioblongis, acutis, subcoriaceis, stipulis utrinque solitariis, breve apiculatis, pedunculis axillaribus trifidis $v$, trichotomis, floribus extus roseis, intus albis.

Siderode ndron Schreber gen, n. 691. Vahl Eclog. $t$. 10. Jussien in Mem. Mus. VI. 374. A. Richard in Mem, soc. $h$. $n$, Paris. V. 183, t. 16. f. 3. DC, Prodr, $1 \mathcal{V}, 478$. Sideroxy to ides Jacquin Amer. 19. t. 175. f. 9.

317. Neseidia A. RICH. Caly $\mathrm{x}$ tubo eum ovario connato, limbo supero, subnullo, integerrimo. Coroll a supera, tubo brevi, fauce nuda, limbi quinquefidi lobis incumbentibus. S tamina 5, corollae fauci inserta, inclusa; filam enta brevissima, antherae lineares, acutae. Ovarinm inferam, biloculare. Ovula in loculis solitaria, medio dissepimento inserta... S ty 1 us brevis; stigmata duo, linearia, acuta, facie interiore coalita. Fructus...... - Frutex mauritianus, glaberrimus; foliis oppositis, petiolatis, myrtoideis, coriaceis, vix acutis, stipulis brevibus, interpetiolaribus, floribus axillaribus solitariis, basi calyculo bidentato cinctis.

Nescidia A. Richard in Mem, soc, h, n, Paris, V. 192. DC. Prodr. IV. $47 \%$.

31\%3. Pleetronia LINN, Calyx tubo obovato-oblongo, cum ovario connato, limbo supero, quinquedentato, dentibus brevissimis, acntiusculis. Corolla supera, subinfundibuliformis, tubo brevi, fauce barbata, limbi quinquepartiti laciniis acutis, reflexis. St a mina 5 , corollae fauci inserta, subexserta; fil am en ta brevissima, a ntherae erectae. Ovarium inferam, biloculare, loculo altero saepe minore. $O \vee \mathrm{u} l$ a in loculis solitaria, medio dissepimento inserta, amphitropa. Stylns simplex; stigma lamellis binis approximatis subeapitatum. B a ce a sicea, apice nuda, emarginata, obovato-oblonga, compressa, didyma, dipyrena, v. abortu monopyrena, pyrenis coriaceis, monospermis, altera saepius efoeta. S e mina..... - Arbusculae capenses et africanae tropicae; ramis oppositis, subspinosis, foliis oppositis, petiolatis, ellipticis, utrinque acutis, subcoriaceis, subtus pallidis, stipulis utrinque solitariis, apiculatis, pedunculis axillaribus brevibus, solitariis, racemosis $v$. corymbosis, pedicellis gracilibus.

Plectronia Lina, mant, 6 . Lam. $t, 146$. Cruse Rubiac, cap, 21, t. 2. A. Richard in Mem, soc. $h, n$, Paris, $Y$. 189. DC, Prodr. $I V .475$, non N, Burm, nec Loureir.

31 4 . Pghlontoma KLOTSCH. C a ly $\mathrm{x}$ tubo obovato, cum ovario connato, limbo supero, brevi, persistente, quinquedentato, dentibus acutiusculis, patentissimis. C o rolla supera, subcampanulata, tulo brevi, angulato, fauce nuda, limbi quinquepartiti laciniis lanceolatis, acutis, reflexis. Stamina 5 , corollae fanci inserta, subexserta; filamenta brevissima, antherae ovatae, erectae. Ov a ri um inferum, biloculare, loculo altero saepins minore. Ovula in loculis solitaria, medio dissepimento inserta, amphitropa. Stylus simplex; stigma lamellis binis approximatis subcapitatum. B a c c a exsucea, dentibus calycinis coronata, oblonga, compressinacula, bilocularis, loculo altero monospermo. S emen inversum. E mbryo intra albumen corneum or- thotropus; cotyled on ibus subfoliaceis, $r$ ad e u la elongata, supera. - Frutex capensis, opposite spinosus, a Plectroniis vix nisi corollae fauce nuda, et limbo calycino in fructu persistente diversus; ramis teretibus, glabris, ramulis divergentibus, pube brevi, stellata dense tectis, foliis oppositis, subcoriaceis, ovatis, subtus pallidis, stipulis interpetiolaribus utrinque solitariis, apiculatis, floribus axillaribus, longe pedunculatis. 368.

Psil o stom a Klotsch in Ecklon ot Zegher Enumorat.

3175. Canthium LINN. C a 1 y $x$ tubo ovato, cum ovario connato, limbo supero, brevi, persistente, quadri-quinquedentato, Coroll a supera, tubo brevi, fauce barbata, limbi quadriquinquefidi lobis patentihus. An th e ra e 4-5, ad fancem corollae subsessiles, vix exsertae, 0 varinm inferum, biloculare. Ovula in loculis solitaria, medio dissepimento inserta, amphitropa. Stylus simplex; stigma indivisum, crassum, ovato-globosum v. mitraeforme, rarius apice bilobum. B a c c a globosa v. didyma, carnosa, dentibus calycinis coronata, v. iisdem obsoletis umbilicata, laevis v. transversim rugosa, bilocularis, v. ahortu unilocularis, loculis monospermis. Semina inversa, ineurva. $\mathbf{E} \mathrm{mb}$ ryo intra albumen dense carnosum homotropus, subarcuatus; cotyledonibus subfoliaceis, radicula elongata, supera. - Frutices asiatic $i$ et africani; ramalis spinosis $v$. inermibus, foliis oppositis, petiolatis, coriaceis, stipulis interpetiolaribus utrinque solilariis, pedunculis axillaribus brevibus, pluriftoris.

Canthium Lam. dict, 1. 602. Jussieu gen, 204, Mem. Mus, VI, 380. Gârtner f, III, 93, B!ume Bijdr, 699. Wight et Arnott. Prodr. Fl. Penins. Ind. or. I. 425. P s y. d rax Gärtaer I, 12z. Canthium et Ps ydrax DC. Prodr. IV. 473, el 476 .

a. BUCANTHIUM DC. $l$, c. B a e a limbo calycino coronata, laevis, bilocularis. (Cavanlll. Ic. $t$. 436. Gărtner t. 196. Roxburgh Corom, t. 51.)

b. PLEUROGASTER DC. l. c. B a e a abortu unilocularis, cicatrice florali ad basim fruetus rejecta.

c. PSYDRAX Gärtuer t, 26. B a c e a limbo ealycino obsaleto umbilicata, rugoso-tuberculata, bilocularis.

31\% 18. Diplospora $D C$. Calyx tubo obovato, cum ovario connato, limbo supero, brevissime campanulato, breviter quadridentato. Corolla supera, tubo lato, fauce pilosa, limbi quadrifidi lobis tubum subsuperantibus, patentibus, carnosis. Antherae 4 , ad faucem corollae sessiles, semiexsertae. O varinm inferum, biloculare. Ovula in loculis gemina, collateralia, adscendentia. Stylus brevis; stigma bifidum. Fruetus...... Frutex chinens is, glaber, fructu incognito magnopere quoad affinitatem dubius; ramis tetragonis, foliis oppositis, petiolatis, oblongo-lanceolatis, utrinque acuminatis, stipulis interpetiolaribus utrinque solitariis, persistentibus, ovatis, acuminatis, floribus axillaribus congestis, subsessilibus, basi bracteolis concretis calyculatis, $e$ flavo pallide virescentibus.

Diplospora DC. Prodr. IV. 477. Canthium du. b i u m Lladley in Bot. Heg. $t$. 1026.

31\%ซ. Marquisia $A$. RICH. Calyx tubo ovato, cum ovario connato, limbo supero, brevi, acute quinquepartito. Coroll a supera, tubo brevi, fance nuda, limbi quinquefidi lobis oblongis, obtusiusenlis, tubo longioribus, patulis, $A$ ntherae 5, ad fancem corollae sessiles, ovatae. Ovarium ...... Stylus filiformis, tubi longitudine; stigma quadri-sexfidum. B a c c a ovata, 
carnosa, calycis limbo coronata, biloenlaris, loculis monospermis. Semina erecta, dorso convexa, facie plana, sulcata. Embryo ..... Frutex Novae-Hollandiac australis, non satis notus, glaber; ramulis spinosis, foliis oppositis, subpetiolatis, lanceolatis, utrinque attenuatis, parvis, sti pulis utrinque solitariis, petiolis adnexis, pedicellis axillaribus solitariis, unifloris, deflexis, e vagina jissa erumpentibus, floribus parvis, bractea calyciformi quadrifida stipatis.

$\mathrm{M}$ a $\mathrm{r} q \mathrm{u}$ is i a A. Riehard in Mem, soc, h. n. Paris. $V$. 192. DC. Prodr, $I V$, 4a7.

318. Damnseanthus GARTN. FIL, Fl os ..... B acca globosa, calycis limbo supero parvo, quinquedentato coronata, bilocularis, disperma. Scmin a e basi loculorum erecta. E mbry o in basi albuminis cartilagineo-carnosi minimus; radieula brevi, infera - Frutex ind $i$ cus, vix notus; spinis oppositis.

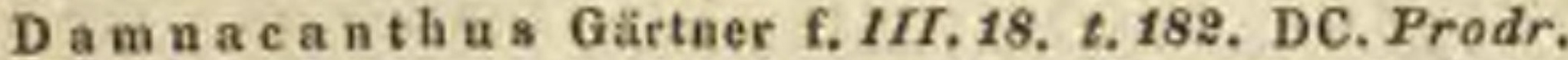
IV. 473. - ? 0 y a cantha javanic a Rumph. $\lambda$ mboin. VII. t. $19, f .3$.

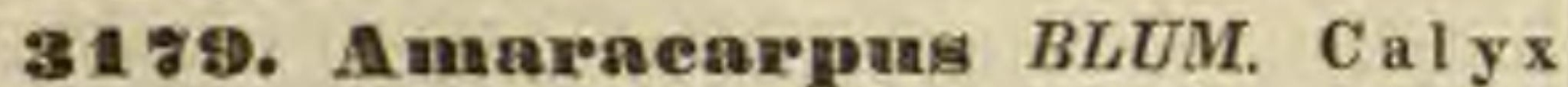
tubo ovali, cum ovario connato, limbo supero, quadrifido, inaequali, Co roll a supera, infundibuliformis, fauce villosa, limbo profunde quadrifido. $S$ ta min a 4 , fauci corollae inserta. $O$ vari $\mathrm{um}$ inferum ..... Stylu s simplex; sti $g$ ma bilobum. D r u a baceata, calycis limbo coronata, dipyrena, pyrenis osseis, dorso suleatis, monospermis. S e mina .... - Frutex javanicus, parvus, ramosus; ramulis pubescentibus, foliis oppositis, breviter petiolatis, lanceolatis, supra glabris, subtus pallidioribus et in venis subpubescentibus, stipulis basi connatis, apice bifidis, deciduis, floribus parvis, in axillis foliorum solitariis, rarius terminalibus, sessilibus, basi bracteutis.

A maracarp u Blume Bijdr. 954. A. Ricliard in Mem. soc. h, n. Paris. V. 198. DC. Prodr. $V$. 478.

TUEI BUUS vi. PAEDERIEAE DC. Prodr. IV. 4Fo. Flores hermaphroditi. Coroll a e lobi per aestivationem plicati. Ovarium biloculare, loculis uniovulatis. Stylus simplex. Fructus indehiscens, siccus v. subcarnosus, dicoccus, calyce facile a fructu solubili, cocc is compressis, saepe marginatis, monospermis, ex axi filiformi pendulis. S e min a erecta. A l b u m e n carnosum, quandoque fere nullum.

Suffrutices $v$. frutices scandentes, foliis oppositis, stipulis interpetiolaribus. _ Paederieae Indiam orientalem potissimum inhabitant, paucissimae Americam tropicam incolunt.

3180. Faedileria LINN. C a ly x tubo ovato, cum ovario connato, limbo supero, parvo, persistente, quinque-v, rarius quadridentato. Co rolla supera, infundibuliformis, campanulata, intus hirsuta, limbi quinque - v, rarius quadrifidi lobis aestivatione plicatis. Antherae 5 v. 4, oblongae, in medio corollae tubo sessiles, interdum abortivae. Ov ari $\mathbf{m}$ inferum, biloeulare. Ovala in loculis solitaria, e basi erecta, anatropa. Sty I u s simplex, inclusus; st ig m a bifidum. B a c c a ovato-globosa, calycis limbo coronata, dicocea, cortice demum fragili, coccis dorso convexis, facie planis, membranaceo-marginatis, monospermis. S em ina execta. Embryo in axi albuminis carnosi ortho- tropus; cotyledonibus planis, foliaceis, maximis, radicula brevi, tereti, infera. - Frutices in dic $i$, sarmentosi $v$. rarius erect $;$; foliis oppositis, petiolatis, lanceolatis, ovatis v. cordatis, acutis, stipulis interpetiolaribus utrinque solitariis, pedunculis axillaribus et terminalibus ramosis, subcorymbosis, floribus parvis, alterius sexus abortu saepius dioicis.

Pa ederia Linne Mant. 2. Jussieu gen. 205. excl. Danaide. Mtom. Mus. VI. 38t. Lam. $t, 166 . f$. 1 . Gărtuer f. III. 86, $t, 195$. Wallieh Plant, As, rar, $t, 165$. A. Rieliard in Mem. soc. h. n. Paris. V. M21. DC. Prodr. IV. 47. Hondbessen Adanson Fam. IT, 158.

3181. Hecontea $A$. RICH, Cal y x tubo obovato, cum ovario connato, limbi snperi, quinquepartiti laciniis subulatis, persistentibus. Coroll a supera, subinfundibuliformis, tubo longiusculo, tereti, fauce nuda, limbo quinquepartito. Stamina 5, corollae fauci inserta; filamenta brevissima, anther ae oblongae, subexsertae. Ovari um inferum, biloculare, disco epigyno depresso. Ovula in loculis solitaria, e basi erecta, anatropa. Sty lus simplex; stig ma t a 2 , linearia, recurvata. Fru ct us compressus, calyeis limbo coronatus, dicoccus, epicarpio membranaceocoriaceo, e basi rupto, coceos compressos, monospermos, ex apice axeos centralis filiformis pendulos obtegente. S em ina erecta. Embryo in axi albuminis carnosi orthotropus; c oty led onibus compressis, obtusis, foliaceis, radicula parva, tereti, infera. - Suffrutices madagascarienses, scandentes; foliis oppositis, petiolatis, tomentosis, stipulis interpetiolaribus utrinque solitariis, floribus subsessilibus, spicatis, spicis in apice pedunculi communis axillaris fasciculatis, nunc longis erectis, nunc brevibus recurvis.

Lecontea A. Riehard in Mem, soc. $h_{0} n$. Paris. $V$. 19s, t. 20. f. 1. 2. DC. Prodr. V. 420.

3182. Hygodysodea RUIZ et PAV. C a l yx tubo ovato-subgloboso, cum ovario connato, limbi superi, quinquedentati dentibus acntis, persistentibus, Coroll a supera, subinfundibuliformis, tubo calycinos dentes longe superante, fance hirsuta, limbi quinquefidi lobis revolutis. Antherae 5 , intra corollae tubum sessiles, oblongae, inclusae. O vari u m inferum, biloeulare, disco epipyno depresso. Ovula in loculis solitaria, e basi erecta, anatropa. Stylus simplex; stigmat a 2, graeilia, exserta. Fructus ovalis, compressus, calycinis dentibus coronatus, dicoccus, cortiee crustaceo, fragili, a basi quadrifariam rupto, coceis lenticularibns, margine nerviformi cinctis, ex axi centrali filiformi bifida pendulis. S e mina ereeta. E m b r y o subexalbuminosus, orthotropus; cot yledonibus magnis, cordatis, planis, foliaceis, radicula brevi, tereti infera. - Frutices peruani et mexicani, scandentes, glabriusculi; caulibus teretibus v. compressis, foliis oppositis, petiolatis, cordatis $v$ ovatis, acuminatis, stipulis brevissimis, subtruncatis, petiolos jungentibus, paniculis paucifloris, laxis, ramulos axillares, paucifolios terminantibus, $v$. axillaribus, foliosis.

Lygodysodea Ruiz et Payon Prodr, 3, $t$. 5. Flor. Peruv. II. 48. t. 188, Bartling Ord. nat. 208. DC. Prodr. IV. 47o. D is a d e a Persoon Ench. I. 210. Jussieu in Mem. Mus. VI, 381 .

THE BUS VII. GUETTARDEAE Kunth in Humb. el Bonpl, Nov, gen, et sp, III. 419. Flores hermaphroditi. Corollae lobi per 
aestivationem saepissime contorti. $0 \mathrm{varium}$ bi-multiloculare, loculis uniovulatis. Fructus drupaceus, di-polypyrenus. Semina saepissime teretia, elongata. Album en carnosum. - Arbusculae $v$. frutices, foliis oppositis v. rarius ternis, stipulis interpetiolaribus solitariis. - Guetlardeae inter tropi$\cos$ totius orbis obviae, in veteri continente paullo copiosiores, in regionibus extratropicis borealibus Americae rarissimae.

SUERTEIBE I. MORINDEAE DC. Prodr. IV. 446. Flores fructusque dense in capitulum aggregati, connati.

3183. Norinda $V A I L L$. F 10 res in capitulum globosum conferti, saepissime mediantibus tubis calycinis connati, Calyx tubo obovato v. obpyramidato, eum ovario eonnato, limbe supero, brevi, obsolete dentato. Corolla supera, infundibuliformis, tubo subtereti, limbo quinquelobo v, rarissime quadrilobo, patente. $\$ \mathbf{t a ~} \mathbf{m}$ n a 5 v. 4 , tubo corollae inserta, inclusa v. rarissime exserta; filamenta brevia, antherae erectae. Ovari um inferum, bi-quadriloculare. Ovula in loculis solitaria, e basi erecta, anatropa. Stylus filiformis, exsertus $v$, interdum inclusus; stig ma bifidum, rarius indivisum. B a ce a e di-tetrapyrenae, pressione mutua angulatae, saepins in synearpium carnosum, calyeum vestigiis areolatum coneretae, pyrenis monospermis. Semina ereeta, rhaphe interdum fungosa. Embryo in axi albuminis carnosi orthotropus; cotyledonibus semicylindricis, radicula tereti, infera. - Frutices $v$, arbusculae, inter tropicos totius orbis crescentes; foliis oppositis rariusve ternatim v, qualernatim verticillatis, stipulis intrafoliaceis, saepius oblusis, membranaceis, pedunculis axillaribus $v$. terminalibus, simplicibus aut ramosis, floribus supra receptaculum subglobosum, nudum sessilibus, dense aggregatis.

Morinda Vaillant in Act. Acad, Paris, 1729. p, 275. Linn. gen. n. 235. Jussieu gen. 209. Mem. Mrus. VT. 402. Gartwer 1. 144. A. Richard in Mom, soc. h. n. Paris. V. 211, DC, Prodr, IV, 446.

a. R010C Plumier gen, 11, t,26. Flores pentameri, pentandri, $S t i g$ a bifidum. B acca e di-tetrapyremae. -

(Gürtner $t$, 29. Jacq. Horl. Vindob, $t, 10$. Roxbargh Corom, t, 237.)

b. PADAVARA Rheede MaLab. VH. 51, $t, 2$, Flores tetrameri, tetrandri. Stigma bifidum. Ba cea tetrapyrena. (Bot. Mag. $t$. 3351.)

c. PHXLliRA EASTRUM DC. Pradr. IV. 449, F I o res tetrameri, tetrandri, $S \mathrm{tig}$ a clavatum, indivisum. B a cca tetrapyreas. - Morinda phylliraeoides Labillard. Nov. Caledon. ใ. 49.3

d. ? CHRYSORHIZA DC. Prodr, $I X$. 450. Flores pentameri, peatandri. Bace a bilocularis, loculis dispermis. Capitala oppositifolia. - Morinda ehrysorbi$z$ a Sehumach.

SUBTEIRUS II. EUGUETTARDEAE DC. Prodr. IV. 450. Flores distincti.

318. Myrmeeoulia $J A C K, \mathrm{C}$ a $\mathrm{y} \mathrm{x}$ tubo ovato, cum ovario connato, limbo supero, tubuloso, integerrimo. Cor oll a supera, infundibuliformis, fauce pilis squamulisve clausa, limbi quadrifidi lobis ereetis, obtusis. S t a min a 4 , coroll a e fauci inserta, inclusa ; fil a menta brevissima, antherae ovatae, erectae. Ovarium infe- rum ...... disco epigyno carnoso. O v ul a ..... Stylus simplex; stigma bifidum, lobis incisis. D r up a baceata, calycis limbo annulari coronata, tetrapyrena, pyrenis chartaceis, triquetris, monospermis. Semina erecta. Embryo in axi albuminis carnosi orthotropus; radicula incrassata, infera. - Frutices moluccani, pseudo-parasilici; basi tuberosa, inermi v. aculeis seriatis obsessa, foliis oppositis, confertis, petiolatis, glabris, stipulis peltatis, ciliatis, floribus axillaribus, ses. silibus.

M y $\mathrm{r}$ m e codia Jack in Linn. Transact, XIV, 122, Blu. me Bijdr. 1001. A. Richard in Mem, soc. h. n. Paris. $Y$. 224. excl. sp. Gaudichaud ad Ereyc. t. 95. 96. DC. Prodr. IV. 450. Nidas germina us Rumph. Amboin. $Y T$. 199. t. 55. $f$. 2. L a s io s $t 0 \mathrm{~m}$ atis s p. Spreng.

3185. Fryduephytum JACK. Calyx tubo ovato, cum ovario connato, limbo supero, brevi, integerrimo. Co rolla supera, tubo brevi, intus hirsuto, limbo plano, quadrilobo. St a m in a 4, corollae fauci inserta; i ilamenta brevissima, antherae erectae. Ovarium inferum, biloculare, disco epigyno carnoso. O vala in loculis solitaria ..... Stylas filiformis; stig ma bilobum. Bacca succosa, dipyrena, pyrenis coriaceis, dorso convexis, facie planis, monospermis. Se mina erecta. Em b ryo in axi albuminis rectus; radicula incrassata, infera. - Frutices moluccani, pseudo parasitici, basi tuberosa, cava, a Formicis habitata; foliis oppositis, breve petiolatis, ovalibus, stipulis parvis, linearibus, floribus axillaribus, parvis, albis.

H y d nophyt n m Jack in Linn. Transact, XIV, 124, Blume Bijdr. 955. DC. Prodr. $I V$. 450. Ni as germianas formicarum nigrarum Kunph. Amboin, VI, 119. $t, \xi 5 . f$. 1 . Lasiostomatis sp. Spreag. Il yruecodiae sp. A. Rich.

3186. Hypobathrum BLUM, CaI $y \mathrm{x}$ tubo eum ovario connato, limbo supero, parvo, quadridentato. Co roll a supera, parva, subcampanulata, fauce villosa, limbo patente, quadrifido. S t am in a 4 , corollae fauci inserta; fil am enta brevissima, o va ri um inferum ..... disco epigyno styli basim cingente. Stylus brevis; stig ma bifidum. D rupa calycis limbo coronata, biloeularis, loeulis dipyrenis, pyrenis coriaceis, oblique sibi incumbentibus, superne affixis, monospermis. S e min a ...... E m b r yo intra albumen inversus. - Frutex javanicus, Coffeae habitu; ramis divaricatis, foliis oppositis, distichis, floribus in receptaculis axillaribus, hemisphaericis, sessilibus, dense confortis, umbellatis, sessilibus, bracteatis, fructibus pedicellatis.

H y abathrum Blume Bijdr. 100\%. A. Richard in Mem. soc, h, n. Paris, V. 198, DC. Prodr. $V .451$.

318\%. Nertera BANKS. Ca I y $x$ tubo ovato, cum ovario connato, limbo supero, minimo, quadridentato. Coroll a supera, infundibuliformisubcampanulata, intus glabra, quadriloba. Stamina 4, imo corollae tubo inserta, subexserta; fil amenta filiformia, libera, antherae subrotundae. Ovarium inferum ..... Ovula ...... Stylus filiformis; stigmata 2 , hirsuta. B a c c a subrotunda, umbilicata, di-tetrapyrena, pyrenis coriaceis, monospermis. S emina erecta, dorso convexa, facie plana, suleata. $\mathbf{E m -}$ bryo in axi albuminis cornei rectus; cotyledonibus brevissimis, radicula teretiuscula, infera. - Herba in hemisphaerae australis regionibus tropicis et extratropicis obvia, repens; foliis oppositis, petiolatis, ovalibus, carnosulis, sti68 * 
pulis minimis, floribus terminalibus sessilibus, solitariis, albis, baccis rubris.

Nertera Banks ex Gärtner 1. 124. t. 26. Jussieu in Mem. Mus, VT. 373. A. Richard in Mem, soc, $h, n$. Paris. V. 219. DC. Prodr. IV. 451. Nerteria Smith Ic. inedit. 11. 28, t. 28. G o m e z i a Mutis in Linn, f. Suppl. 17. Ruiz et Pavon Flor. Peruv, t. 90. E r y throdan u m Thouars Flor. Aguanat. 41, t, $10,11$.

3189. Diftelnella $L I N N$, Cal y ces saepins bini inter se cohaerentes, tuho ovato-globoso, cum ovario connato, limbo supero, quadridentato, $\mathrm{Co}$ rolla supera, infundibuliformis, tubo tereti fance limbique lobis quatuor patentibus, intus hirtis. S $t$ a min a 4 ; fil a m en ta corollae tubo usque ad faucem adnata, anthera e ovatae, vix exser tae. Ova ri u m inferum, quadriloculare. Ovu I a in loculis solitaria, e basi erecta, anatropa. Sty lus filiformis; $8 \mathrm{tigmata} 4$, inclusa. Ba eca subglobosa, calycis limbo coronata, tetrapyrena, v. saepissime baccae geminatim connatae, octopy renae, pyrenis corneis, monospermis. Semina compressiuscula, erecta. Embryo in basi albnminis subcartilaginei minimus, subglobosus; c otyledonibus brevissimis, radicula incrassata, infera. - Herbae boreali-americanae, Nerteriae facie, glabrae, repentes; foliis oppositis, pe tiolatis v. subrotundis, stipulis utrinque solitariis, minimis, floribus axillaribus $v$. terminalibus, nuno geminis ad apicem pedunculi concretis, nunc solitariis, sessilibus.

Mitc he 11 a Linn. gen, n, 134. Jussieu gen, 205. Mem. Mus. VI. 373, Lam. t, 63. Gartner f. III, 70, $t, 192 . \mathrm{A} . \mathrm{Ri}$ chard in Mem, soc, h. n. Paris, V, 220, DC. Prodr, IV, 452. Cham aedaphne Mitehell gen, 17, non Buxb.

3189. IBsumamian $D C$. C a l y x tubo ovato-globoso, cum ovario connato, limbo supero, brevi, quadrilobo. C o roll a supera, infundibuliformis, tubo tereti, fauce limbique lobis quatuor patentibus, intus hirtis. Sta mina 4 ; fil ament a corollae tubo usque ad fancem adnata, an $\mathbf{t h}$ erae ovatae, inclusae. Ovarium inferum, quinqueloculare, disco epigyno urceolari. Ovula in loculis solitaria. Stylus filiformis, exsertus; $s \mathrm{tig} \mathbf{m}$ at a 5 , linearia, revoluta. Fruct us .... - Suffrutex ut videtur a siaticus, dichotome ramosissimus, glaber; foliis oppositis, ovatis, mucronatis, stipulis spinescentibus, floribus axillaribus, subsessilibus, geminis, albis.

B a umannia DC. in Mem, soc. phys. Genev. IV. 583. $t$. 1 .

3190. IIeplitidia REINW. Cal y $\mathrm{tu}$ bo cum ovario connato, limbo supero, tri-sexpartito $\mathbf{v}$. dentato. Corolla supera, infundibuliformis, regnlariter quadri-sexfida, plernmque hirsuta. Stamina $4-6$, corollae fauci inserta; fil aIn ent a brevissima, antherae lineares, exsertae $\mathbf{v}$. inclusae. Ovari $\mathbf{~} \mathrm{m}$ inferum ...... Ovula ..... Stigmat a $4-9$, linearia, crassa. D r u a calycis limbo coronata, tetra-enneapyrena, pyrenis coriaceis, triquetris, monospermis. S e m i$n$ a ....... Frutices v, suffrutices in $d i c i$, saepissime foetidi ; floribus confertis $v$. dense capitatis, axillaribus aut terminalibus, bracteatis, drupis plerumque cyaneis.

Mephitidla Reinwardt mse, DC. Prodr. IV. 459 Las i a thus Jack in Linn. Transact. XIV. 125. Blume Bijdr. 995. A. Richard in Mem. soc. h. n. Paris, V. 210. nou Linn.

3191. Tangueria COMMERS. Ca lyx tubo brevi, obovato, eum ovario connato, limbo supero, minimo, quinquedentato, patente. Co rol-
Ia supera, campanulato-globosa, quinquefida, ad faucem hirsuta, lobis ovatis v. lanceolatis, acutis, recurvis. Stamina 5 , corollae fauci inserta, vix exserta; filamenta brevissima, antherae oblongae, erectae. $\mathrm{O}$ v a $\mathrm{r}$ i $\mathrm{m}$ inferum, quinquelocalare. Ovula in loenlis solitaria, anguli centralis medio inserta, amphitropa. St yl u s filiformis, corollae longitudine; $s$ t $\mathbf{g} \mathbf{m}$ a exsertnm, mitraeforme, pentagonum. B a $\mathrm{c} c$ a succulenta, apice nuda, areola quinquesinuosa notata, pentapyrena, pyrenis osseis, basi obtusis, apice acutis, monospermis. S emin a oblonga, umbilico ventrali medio anguli interioris pyrenae affixa. E m br yo in axi albuminis carnosi magnus, rectus; cotyled onibus oblongis, plano-convexis, ra di $e$ u la brevi, obtuse cordata, compressa, supera. - Arbusculae ma dagascarienses, indicae et capenses; foliis oppositis, petiolatis, stipulis utrinque solitarits, lanceolatis, cymis ramosis, subpaniculatis, axillaribus $v$. infra folia e cicatribus annotinis ortis, corollis virescenti-albidis, baccis pomiformibus, nonnullarum specierum edulibus.

Vangaerla Commerson in Jussieu gen. 206. Mem. Mrus. VI. 396. Lam. t. 159. Gârtner IIT. 75. t. 193. Jacquin Hort. Schönbr, t. 44. A. Richard in Mem, soc. h, n. Parlis. V. 217. DC, Prodr. IV. 484. Wight et Arnott Prodr. Flor. Penins. Ind. orient, $I$. 42t. Van g u i r a Persoon Ench, $I$. 459. V a v a $\mathrm{g}$ a Rohr in Act, soc. h, n. Hafn. Il. 1. p. 208. t. 7. M e y nia Link Jahrb. I. 3. p. 32. ex Schlechtend, in Linnaea $I V .516$.

3192. Guettarala $V E N T$. C a I y x tubo ovato v. globoso, cum ovario connato, limbo supero, tubuloso, persistente $\mathbf{v}$, deciduo, trnncato $v$. irregulariter subdentato. Corolla supera, hypocraterimorpha, tubo cylindrico, fauce nuda, limbi quadri-novemfidi lobis ovali-oblongis. An $t h$ e $r$ a e 4_. 9, intra corollae faucem sessiles, inclusae. $O$ vari u m inferum, quadri-novemloculare. Ovu 1 a in loeulis solitaria, e basi erecta, anatropa. Stylus simplex; stigma capitatum v. rarius bilobnm. D rupa evata $v$, subglobosa, limbo calycino coronata $v$. apice nuda, putamine osseo, obtuse quadrinovem-angulato, quadri-novemloculari, loculis monospermis. Se min a e basi loculorum erecta, teretiuscula. Embryo lae, inter tropicos America e copiose, rarius in Asia crescentes; foliis oppositis, ovalis $v$. lanceolatis, rarius cordatis, stipulis lanceolatis, deciduis, rarissime vaginantibus, truncatis, pedunculis axillaribus bifidis, rarius bis bifidis, floribus in dichotomiis solitariis, sessilibus, secus ramos unilateralibus.

Guet tarda Ventenat Choir n. A. A. Richard in Mem. soc. h. n. Paris. V. 201. DC, Prodr. K. 455.

a. CADAMBA Sonner. Calycis limbus post anthesim deciduus. Drupa e nucleus loculis gnomonice curvatis. $\mathrm{C}$ a d a mba Sonnerat Voy. II. 228. $t, 128$. Rava Pon Rheede Malabar. IV.t. 47. 48. (Lam, t, 154, f. 2.)

b. GUETTARDARIA DC. Calye is limbus saepius persistens, truncatus v. irregulariter subdentatus. C or ol. la extus sericeae lobi plani. Drupa e locali recti.

Guettardaria DC. 2. c. Halesia P. Browne Jam, 205. M at $t$ hiola Plumier edit. Burm, $t, 173$. f. 2 . Lian. Gen, $n, 1231$. E d e c h I Losfling $r t, 259.271$. D i. crobotryon Wildenow es Schultes syst. $V .221$. La ugeria Jacquin Amer. $t$. 127. $f$. 21. (Lam. t. 15\%. f. 1. 3. 4. Vent. Choix t, 1.)

e. ULLOBUS $D C$. C a I y cis limbus brevis, fere ad basim quinquepartitus, persistens. Cor olla e extus sericeae lobi margine crispi. D r u p a e nucleus loculis rectis.

UIlobus DC. 2 . c. La ugeria Ruiz et Pavon Flor. peruv. IT. 22, t. 145. (Vahl Eclog. I. t, 6.)

d. LAUGERIA Vahl. C a ly cis limbus truneatus v. dentatus. Co rolla glabrae lobi plani. D r u pae aueleus loculis rectis. 
L a ugeria Vahl Eclog. I. 26. t. 10, f. 6. Viviania Rafinesque $s$ pecch. $I$. 117. Terebraria Sessé msc.

3193. Malanea $A U B L$. C a ly x tubo brevissimo, cum ovario connato, limbo supero, brevi, quadridentato. Co roll a supera, parva, subrotata, tubo brevissimo, limbo quadrilobo, patente. St amina 4, corollae fauci inserta, exserta; fila menta filiformi - subulata, antherae subrotundae. Ovarium inferum, biloculare. Ovula in loculis solitaria, apiei appensa, anatropa. Stylus simplex; stigma bifidum. Dr up a sicca, tenuis, ovata, limbo calycis coronata, nueleo biloeulari. $\mathbf{S}$ e $\mathbf{m}$ in a in loculis solitaria, inversa, oblongo-linearia, teretia. E m b r y o.....-Frutex guia nensis, sarmentosus, subscandens; foliis oppositis, petiolatis, ovatis, acutis, stipulis interpetiolaribus ovalibus, obtusis, deciduis, pedunculis axillaribus folio multo brevioribus, racemoso-paniculatis, ramis oppositis, inferioribus longioribus, floribus parvis, secus ramos sessilibus, caerulescentibus.

M a la ne a Aublet Guian. I. 106. t. 4t. Lam, t, 66. f. 2. Jussieu in Mem. Mus, VI. 376. DC. Prodr. IV. 459. C и nning ha mi a Sehreber gen, n, 1720.

3194. Antirlhoea COMMERS. $\mathrm{C}$ al y $\mathrm{x}$ tubo ovato $\mathrm{v}$. oblongo, cum ovario connato, limbo supero, persistente, brevi, campanulato, quadriden tato. Corolla supera, subinfundibuliformis, tubo tereti, fauce nuda, limbi quadrifidi lobis tubo brevioribus, subacutis. Antherae 4 , ad faucem corollae subsessiles, oblongae, inclusae. Ov a riu m inferum, biloculare. Ovula in loculis solitaria apici appensa, anatropa. Sty I us simplex; stig ma bifidum. Drupa subbaccata, ovata v. oblon ga, calycis limbo coronata, nucleo biloculari. S e$\mathrm{m}$ in a in loculis solitaria, oblongo-teretia, inversa. Embryo...... - Arbusculae mauritianae; foliis oppositis $v$, ternatis, petiolatis, oblongis $v$. obovatis, glabris, in axillis venarum saepe glanduloso-pilosis, stipulis interpetiolaribus acutis, deciduis, pedunculis axillaribus folio brevioribus, bifidis, floribus secus ramos unilateralibus, sessilibus, parvis, albidis, interdum abortu dioicis.

Antirhoea Commerson ex Jussien 6en. 204. Mem. Mus. PI. 377. DC. Prodr. IP. 459. Malanea e s. Lam. t. 66. f. 1. A. Richard. Cu uni g $\mathrm{ghamiae} s \mathrm{p}$. Sehreber. Willd. - ? Neuropora Commers.

3155 . Stenostomum GIRTN. FIL. Caly x tubo obovato, cum ovario connato, limbo supero, persistente, parvo, quinquedentato, dentibns demum conniventibus, subinaequalibus. Corolla supera, infundibuliformis, tubo superne subam. pliato, fauce nuda, limbi quinquelobi lobis lanceo. latis, obtusiusculis. Stamina 5 , corollae fauci inserta, subinclusa; fil amenta brevissima, antherae oblongae, erectae. Ovarium inferum, biloculare. O vula in loculis solitaria, apici appensa, anatropa. Stylus simplex; stigma obtuse bilobum. Drup a ovato-oblonga, calycis limbo connivente coronata, nucleo lignoso, biloculari. $\mathrm{Se} \mathrm{mina} \mathrm{in} \mathrm{loculis} \mathrm{solitaria,} \mathrm{inversa,} \mathrm{clavata,} \mathbf{E} \mathbf{~ m}$ b т $\mathbf{y}$ in centro albuminis carnosi minimus; $\cot \mathbf{y}$ ledonibus ovatis, compressis, radicula brevissima, supera, - Arbusculae antillanae; foliis oppositis, breve petiolatis, ovalibus v oblongis, stipulis demum deciduis, pedunculis axillaribus in cymam bifidam divisis, floribus parvis, albidis, centrali lateralibusque secus cymae ramos secundis, ses. silibus.

Stenostom a märtner f. $I I I, 69$. DC. Prodr. IV. 460. S a r i Gasieu in Mem, Mus, VI, $37 \%$, M a I ne a $s \mathrm{p}$. A. Richard in Mem. soc. h, n. Paris. V, 202, Laugeriae sp. Swartz, Vahı Symb. t. 57 .

313 S. Saceonia. Cal y $x$ tubo obovato, cum ovario connato, limbo supero, persistente, repando-quinquedentato. Co roll a supera, subinfundibuliformis, tubo brevi, fauce nuda, limbi quinquelobi lobis planiusculis, obtusis. St amin a 5 , corollae tubo inserta, exserta ; fil a m enta filiformia, an the rae lineares, incumbentes. O var i u m inferum, bilocnlare, disco epigyno carnoso. Ovula in loculis solitaria, apici appensa. Sty $\mathbf{l u}$ \& simplex; s tig ma bilobum, lobis brevissimis, obtusis. D rupa olivaeformis, subcarnosa, calycis limbo coronata, siccatione leviter sulcata, nucleo osseo, biloculari. S e min a in loculis solitaria, inversa, subteretia. E m b ry o ..... Arbor insulae Tortosa, glabra; foliis oppositis, petiolatis, coriaceis, basi vagina stipulari integerrima junctis, cyma terminali pedunculata, floribus albis.

C r us e a A. Richard in Mem, soc, h. n. Paris. V, 204. t. 19. $f$. 1. non alior. Chiou e DC. Prodr. $I V$. 461, non Zoolog. Ps yehotria megalosperma Vabl Eclog. III. t. 21 .

315\%. Timonius $R U M P H . C$ a $1 \mathrm{y} \times$ tubo ovato, cum ovario connato, limbo supero, persistente, tubuloso, truncato, bi-sexdentato. Corolla supera, hypocraterimorpha, tubo superne angustato, fauce nuda, limbi quadri-sexpartiti lobis ovalibus, obtusis, patentibus. An the ra e $4-6$, ad faucem corollae sessiles, oblongo-cordiformes, inclusae. 0 varium inferum, indefinite multiloculare, disco epigyno annulari. Ovala in loculis solitaria .... Stylus simplex; $8 \mathrm{tigm}$ a $\mathbf{t a} 2$, exserta, digitato-quinquefida, lobis linearibus. Dr n pa globosa, laevis, limbo calycino coronata, polypyrena, pyrenis distinetis, osseis, monospermis. Se$\mathrm{m}$ in a inversa, linearia. Em b ry 0 in axi albuminis carnosi teres; cotyledonibus brevissimis, rad i cula longa, crassa, supera. - Arbores moluccanae et oceanicae, glabrae; foliis oppositis, petiolatis, stipulis interpetiolaribus aculis, integris, pedunculis axillaribus folio brevioribus, apice trifloris, flore medio sessili, lateralibus pedicellatis, singulis basi bractea cupuliformi, biloba, persistente cinctis.

T im o n i s Rumph Amboin, IrT, 216, t, 140. DC. Prodr. IV. 461. B o b e a Gaudichaud ad Ereyc. $t .93$. B o b a e a A.

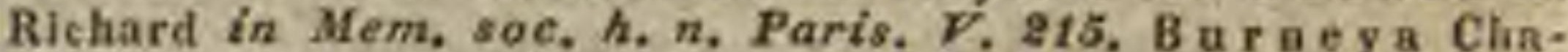
misso et Schlechtend. in Linnaea IV. 188, E rithalis Forst. Prodr. n. 101, aon Liau.

31DS. Cupyrena WIGHT et $A R N$, CaI y x tubo obovato, cum ovario connato, limbi su. peri, persistentis, brevis dentibus quatuor, triangulari-acuminatis. Co rolla supera, infundibuliformis, extus hirsuta, tubo tenui, limbo quadrifido. Anthera e 4, lineares, corollae fauci medio dorso insertae, inclusae. O v a r i $\mathbf{m}$ inferum, sex-duodecimloeulare. Ovula in loculis solitaria, e basi erecta, anatropa? Stylus filiformis, tubo corollae brevior; stigma simplieissimum. D r u p a globosa, calycis límbo coronata, sulcata, hexa-dodecapyrena, pyrenis distinctis, osseis, subincurvis, monospermis. S emina eylindriea, erecta. Album e $\mathbf{n}$ carnosum. Embry o...... - Arbusculae v. frutices Indiae orientalis; folits oppositis, breve petiolatis, stipulis e basi lata acuminatis, pedunculis juxta ramulorum apices axillaribus, oppositis, bifidis $v$. bis bifidis, floribus secus ramulos seysilibus, secundis, bracteis solitariis, angustis stipatis.

Eupyrena Wight et Arnott Prodr. Elor. Penins. Ind. orient. $r$. 429. P y ro stria Roxbargh Flor. ind. $I_{\text {. }} 430$. non Commers. 
3199. Srontia WIGHT et ARN. Calyx tubo obovato, cum ovario connato, limbi superi, persistentis, brevis dentibus quinque subulatis, duobus approximatis v. basi connatis. C orolla su pera, hypocraterimorpha, tubo brevissimo, fauce villosa, limbi quinquefidi Jobis oblongis, tubo multo longioribus, patentibus. Stam in a 5 , corollae fauci inserta, exserta; fil ame nt a brevissima, antherae oblongae. Ovarium inferum, tri-v. rarissime quadriloculare, disco epigyno crasso, carnoso. Ovula in loculis solitaria, e basi erecta, anatropa? Stylus pilosus, superne inerassatus; s t i g m a capitatum, tri-quadrilobum. Dr u p a sub. globosa, calycis limbo coronata, tri-tetrapyrena, pyrenis osseis, rugosis, oblongis, subincurvis, monospermis. S e min a erecta, teretiuscula, subincurva. Embryo in axi albuminis carnoso-gelatinosi cylindricus; radicula infera? - Frutex indicus; ramis junioribus pilosis, foliis oppositis, breve petiolatis, elliptico-oblongis, acuminatis, supra glabris, subtus ad nervos hirsutis, nervis utrinque venis copiosis transversis, imprimis supra prominentibus, stipulis triangulari-acuminatis, brevibus, cadu cis, cicatricem annularem, pilosum relinquentibus, pedunculis axillaribus brevibus, apice tri-quadrifloris, calyce et interdum etiam corolla pilis rigidulis conspersa.

S antia Wight et Arnott Prodr. Flor. Ponins. Ind. orient, 1. 422.

3200. Psathyra COMMERS. Calyx tubo ovato, eum ovario connato, limbo snpero, persistente, campanulato, quinque-sexdentato. Co roll a supera, infundibulifermis, tubo brevi, intus barbato, limbi quinque-sexlobi lobis acutis, aestivatione valvatis, sub anthesi patentibus. Antherae 5, ad fancem corollae sessiles. Ova $r$ i $\mathrm{m}$ inferum, quinque-sexloculare. $O \mathrm{val}$ a in loculis solitaria, e basi erecta, anatropa. Stylus simplex; $8 t \mathrm{igma}$ quinque- $\mathrm{v}$. sexlamellatum. Drupa subglobosa, calycis limbo coronata, penta-hexapyrena, pyrenis osseis, monospermis. S emina erecta. A lb u m en carnosum. Embry o...... - Arbusculae mauritianae, glabrae; ramis nodosis, fragilibus, foliis oppositis, petiolatis, lanceolatis, laevibus, stipulis ovatis, caducis, cicatrice elevata petiolos coadunante, pedunculis e foliorum supremorum axillis laxe paniculatis, folio brevioribus.

Ps a thura Commers. in Jussieu gen, 206. Mem. MLus. $V T$. 396. Lam. $t$, 260. Gartner f. IIT. 82, t. 194. A. Riehard in Mem. soe, h. n. Paris. Y. 214. DC. Prodr. IV. 469. C h i coln a e Commers. mse. Psat ura Poiret Dict. VI. 587. P s a th y r a Spreagel Syst. $I T$. 127 .

3201. II Imiltonia $R O X B$. C al y x tubo ovato, cum ovàrio connato, limbi superi, quinquepartiti, persistentis laeiniis subulatis. Coroll a supera, infundibuliformis, tubo longo, recto, limbi quinquefidi lobis oblongis. S ta min a 5 , corollae fauci inserta, inclusa, filamenta brevissima, antherae erectae. Ovarium inferum, quinqueloculare. Ovul a in loculis solitaria, e basi erecta, anatropa. StyIns simplex; stigma quinquefidum, laciniis acutis. Caps a l a calyeis lobis coronata, unilocularis, pentapyrena, apice dehiscens, pyrenis triquetris, monospermis. $\mathrm{S}$ e m in a erecta, epidermide laxa, reticulata. E mb r y o intra albumen parcum orthotropus; cotyled on ibus cordatis, foliaceis, radicula oblonga, infera. Frutices indic $i$; folits oppositis, breve petiolatis, lanceolatis, stipulis brevibus, e basi lata acutis, adpressis, floribus fasciculatis v. umbellatis, suaveolentibus.
H a wilto a a Roxburgh Flor. Ind. IT. 223. DC. Prodr. IV. 462. S permadyetion Roxburgh Plant, Corom. IIS. 32. t. 2.36. Bot, Reg. $t$. 348, 1235 .

3202. Leptodermais $W A L L$. Caly $\mathrm{x}$ tubo cum ovario connato, involucro ealyeiformi diphyllo constricto, limbi superi, brevis, persistentis lobis quinque, rotundatis, adpressis. Corolla supera, infundibuliformis, papilloso-scabra, tubo tereti, intus piloso, limbi lobis quinque, ovatis, cuspidatis, aestivatione involuto-valvatis. S $\mathrm{tam}$ ina 5, corollae prope fancem inserta, inclusa; filamenta brevissima, anth erae erectae. Ovari u m inferum, quinquelocnlare. Ovala in loculis solitaria, ...... Stylus filiformis; stigma quinquefidum. Fruetus oblongus, quinquelocnlaris? quinquevalvis? pentaspermus. Semina ........ - Frutex nepalensis, distinctissimus, sed non satis notus; ramulis decussatis, tetragonis, foliis oppositis, lanceolatis, attenuato-acutis, breve petiolatis, membranaceis, villosis, stipulis petiolos aequantibus villosis, acutis, adpressis, persistentibus, floribus ad apices ramorum ternatim sessilibus, inodoris, albis.

Leptodermis Wallich in Roxburgh Flor. Ind, IT. 191. A. Richard in Mem. soo, h. n. Paris, V. 221. DC. Prodr. IV. 462. Hamiltouia frutieos a Don Nepal, 137.

3203. Myomima COMMERS, Calyx tubo globoso, eum ovario connato, limbo supero, minimo, obtuse octodentato. Corolla supera, tubo brevi, limbo obtuse quadripartito. S ta mina 4, corollae fauci inserta, exserta; fil a m e nt a brevia, antherae oblongae, ereetae. Ovarium inferum, quadriloculare. Ovula in loculis solitaria, medio angulo centrali inserta, amphitropa. Stylus simplex; stigmat a 4 , linearia, brevia, crassiuscula, approximata v. cohaerentia. B a c ca globosa, apice nuda, tetrapyrena, pyrenis carni adhaerentibus, monospermis. Semina umbilico ventrali meniscoideo, Em b ryo intra albumen carnosum dorsalis, arenatus; cotyled onibus cordatis, obtnsis, radicula teretiuscula, infera. Frutices $v$ arbusculae ma liis oppositis, petiolatis, coriaceis, stipulis parvis, acutissimis, deciduis, pedunculis axillaribus et terminalibus folio brevioribus.

M y o im a Commerson in Jussieugen, 206. Hem. Mus. VI. 397 . Lam. $t .68$. Gärtaer f. $I I T .86, t, 195$. A. Ricliard in Mem. soc, $h, n$. Paris, $V .211$, DC. Prodr. $I V .493$.

3204. Pyrostria COMMERS. Calyx tubo obovato, cum ovario connato, limbo supero, minimo, obsolete quadri quinquedentato. Corolla supera, subcampanulata, patens, quadri-quinquefida, fauce tomentosa, lolis lanceolatis, acntis. $\mathrm{S} t$ a min a $4-5$, corollae infra fancem inserta, semiexserta; fil a menta subnulla, a nther a e subcordiformes, erectae. Ovarium inferum, quadrioctoloculare. O v ula in loculis solitaria, apici appensa, anatropa. Stylus apice incrassatus; stigma bifidum, lobis approximatis. Drupa pyriformis, subsuberosa, striata, apice nudo umbilicata, tetra-octopyrena, pyrenis osseis, angulo interiore coalitis, monospermis. S e m in a inversa. $\mathrm{Km}$ bryo in axi albuminis carnosi orthotropus; radic u I a supera. - Arbores v. arbusculae mauritianae, glabrae; folits oppositis, breve petiolatis, stipulis lanceolatis, acuminatis, petiolo fere longioribus, pedunculis axillaribus uni-trifloris, floribus bracleis duabus oppositis involucratis.

Pyrostria Commerson in Jussieu gen. 206. Mem. Mrus, VI. 397, Lam. $t, 65$. A. Richard in Mem. soc. $h, n$. Paris V. 216. DC. Prodr. IV. 464. 
3205. Detavia $D C$. Ca ly $x$ tubo globoso, cum ovario connato, limbo supero, subnullo, trun cato. Corolla ...... S $\mathrm{s}$ amina ...... ova ri um ..... disco carnoso, lucido, persistente, medio perforato. St y ln s ...... Drup a globosa, carnosa, laevis, apice nuda, octopyrena, pyrenis verticillatis, monospermis. S e min a ....... A lb umen.... - Frutex guianensis, glaber; foliis oppositis, petiolatis, ovalibus, longe acuminatis, membranaceis, superne lucidis, stipulis ovatooblongis, acuminatis, erectis, petiolo multo brevioribus, tarde deciduis, floribus in axillis superioribus $v$. in apice ramulorum sessilibus, solitariis, ebracteatis.

Octavia DC. Prodr. IV. 464.

8206. Hithosanthes BLUM. C a lyx tubo cum ovario connato, limbo supero, minimo, quadridentato. Corolla supera, globosa, fauce villosa, limbo brevi, patente, quadrifido. S t a m ina 4 , corollae infra faucem inserta, inclusa; $\mathrm{fi}$ lamenta brevissima, anthera e lineares. Ovarím inferum, quadriloculare, disco epigyno carnoso, a stylo perforato. Ovula in loculis solitaria, erecta? Stylus inclusus; stigma subclavatum, apice quadridentatum. D r u p a succulenta, obovata, umbonata, inflata, unilocularis, sultetrapyrena, pyrenis crustaceis, hasi axi centrali incompletae affixis, monospermis. $\mathrm{S}$ e $\mathrm{m}$ in a erecta, incurva? Embryo in axi albuminis incurvas; radicula infera. - Frutex javanicus, Ferneliae facie; foliis oppositis, subsessilibus, trapeziformibus, parvis, pedunculis axillaribus filiformibus, apice bifloris.

L ithos an thes Blume in Flora 1825. p. 189. Bijdr. 994. A. Richard in Mem, soc. $h$, n. Paris. V. 213, DC. Prodr. IV. 465.

320\%. Erithalis $P$. BROWN. C alyx tubo ovato, cum ovario connato, limbo supero, persistente, brevi, subtruncato, obsolete quinquedecemdentato. Corolla supera, tubo subnullo rotata, quinque-decempartita, lobis lineari-oblongis, patentibus. St a mina 5-10, imae corollae inserta; fil amenta subulata, anthera e lineares. $O$ v a ri u $m$ inferum, quinque-decemloculare. Ovnla in loculis solitaria, ex apice pendula, anatropa. Stylus simplex; stigma bilamellatum, lamellis approximatis, adglutinatis. Drupa globosa, sulcata, calycis limbo annulari coronata, penta-decapyrena, pyrenis distinctis, osseis, monospermis. S em in a e funiculo pendula, compres. siuscula. Em bryo in basi albuminis carnosi minimus; cotyledonibus brevissimis, radicula incrassata, supera. - Frutices antilla $n i$, glabri; foliis oppositis, petiolatis, stipulis latis, brevibus, mucronatis, vaginantibus, persistentibus, pedunculis axillaribus paniculatis, folium subsuperantibus.

Erithalts P. Browne Jam, 165, t. 17. f. 3. Linne gen, n. 238. Jacquin Amer, $t, 173, f .23$. Jussleu gen, 206. Mem. Mus. FT. 396. Lam, t. 159. Gärta. I. 129. t. 26. A. Riehard in Mem, soc, $h, n$, Paris, $\nu, 213$. DC. Prodr, IV. 465. Herrera Adanson Fam, II. 158. non Ruiz et Pav.

3208. Retiniphyllum $H U M B$, et $B O N P L$, Ca ly x tubo subgloboso, eum ovario connato, limbî superi, persistentis, tubuloso-campanulati, quinquefidi lobis acutis. Co roll a supera, hypoeraterimorpha, tubo tereti, limbi quinquelobi lobis linearibus, obtusis, patentibus. St am in a 5, corollae fauci inserta, longe exserta; fil a m enta subulato-filiformia, a n th era c oblongae, erectae. Ovarium inferum, quinqueloculare, O vula .... Stylus exsertus; stigma indivisum, incrassa- tum. Drupa globosa, sulcata, calycis limbo coronata, peritapyrena, pyrenis osseis, monospermis. Se min a ...... - Arbuscula glabra, resinosa, in umbrosis Orinocci ripis observata; foliis oppositis, coriaceis, obovatis, obtusis v. emarginatis, basi cuneatis, subtus pubescentibus, stipulis vaginantibus, spicis ad apices ramorum axillaribus, pedunculatis, secundifloris, floribus bracteatis, carneis.

Retiniphyll um Humb. et Bonpl. Plant. aequinoct. r. 86. $t$. 25. Kunth in Humb. et Bonpl. Nov. gen. ot sp. III. 421. A. Richard in Mem. toc. h. n. Paris. V. 208. DC. Prodr. IV. 466.

3209. Nonatelia $A U B L . C$ al yx tubo ovato, cum ovario connato, limbo supero, persistente, quinquedentato. Co roll a supera, infundibuliformis, tubo longo, fauce nuda, limbo quadri - quinquepartito. An the rae $4-5$, intra corollae faneem sessiles, oblongae, dorso affixae. O v a r i u inferum, quadri-quinqueloculare, disco epigyno carnoso, depresso. O vu 1 a in toculis solitaria, medio anguli centralis inserta, amphitropa. Stylus simplex; stig ma bifidum, tobis obtusis, approximatis v. cohaerentibus. D ru pa globoso-depressa, calycis limbo coronata, suleata, tetra-pentapyrena, pyrenis distinctis, osseis, compressis, monospermis. Semina compressa, incurva, umbilico ventrali subfungoso. $\mathbf{E} \mathrm{m}$ b $\mathrm{r}$ yo in axi albuminis dense carnosi homotropus, teretiusculus; radicula infera. - Frutices v. arbusculae guianenses; foliis oppositis, stipulis interpetiolaribus, saepius basi in vaginam connatis, floribus terminalibus racemosis, spicatis $v$. conglomeratis, saepius basi squamatis, albidis.

Nonatell a Aublet Guian, I, 182, t, 72. exel, reliq. A. Richard in Mem, soe. h. $n$. Paris, $D^{206, t}, 19$. DE. Prodr. IV. 466, exel. sp. 0 rib a s i a Schreber 6en. $n$, 30 ,

3210. Gymoelntodes BLUM. Calyx tube cum ovario connato, limbe supero, brevi, integerrimo. Cor olla supera, quadri-quinquepartita, intus villosa, laciniis inferne conniventibus, superne patentibus, ad apicem ungue inflexo instructis. St amina 4_5, imae corollae inserta, inclusa. Ova ri $\mathrm{n} m$ inferum ..... S tylus..... stigma bifidum, verrucosum. Dru p a carnosa. globosa, umbilicata, tetrapyrena, pyrenis triquetris, chartaceis, monospermis. S e min a $\ldots .$. E mb ryo intra albumen; radicula infera. - Frutex javanicus, scandens, glaber; foliis oppositis, oblongo ovalibus, acutis, coriaceis, stipulis utrinque binis, approximatis, erectis, persistentibus, demum marcescentibus, floribus axillaribus, confertis.

G y n o b to des. Blame Bijdr. 993. A. Richard in Mem, soc. h. n. Paris. V. 208. DC. Prodr. IV. 477.

321 1. Coelospermum BLUM. Cal y $\mathrm{x}$ tubo cum ovario connato, limbo supero, urceolato, integerrimo, deciduo. Corolla supera, tubo brevi, limbi quadri-quinquefidi lobis oblongolinearibus, patentibus. St a m in a $4 \ldots 5$, corollae fanci inserta; fil amenta exserta, a ntherae longe lineares, incumbentes. Ovarium inferum quadriloeulare, disco epigyno styli basim vaginante. Sty I us simplex; st ig ma bifidum, exsertum. Drupa globosa, umbilicata, tetrapyrena, pyrenis chartaceis, doren gibbis, facie concavis, monospermis. S emina ...... E mbryo intra albumen; radicula infera. - Frutices javanici, scandentes, glabri; ramisteretibus, folits oppositis, petiolatis, stipulis latis, brevibus, truneatis, corymbis v, umbellis axillaribus simplicibus, $v$, terminalibus compositis. 
Coelospermum Blume Bijdr. 994. A. Richard in Hem, soc, h. n. Paris, V. 209, DC. Prodr. IV. 468.

3\% 1 8 . A meylanthas DESFONT. C a l y x tubo cum ovario connato, limbi superi, quinquepartiti laciniis laneeolatis. Co rolla supera, tubulosa, subineurva, tuho ad basim intus pilorum annulo eineto, fauce ampliata, nuda, limbi inaequaliter quinquefidi lobis duobus superioribus longrioribus, omnibus erectis, apice calloso-subulatis. An the rae 5 , ovatae, intra faneem corollae sessiles. Ovarium inferum, quinqueloculare. Ovnla in loculis solitaria, medio anguli centralis inserta, amphitropa? Sty Ins simplex, corollae longitudine; s t igma crassum, teres, basi apiceque truncatum, hine obsolete quinquelobum, illine ad insertionem styli exstinctoriiforme. F ruetus ..... - Frutex angolensis; ramulis villosis, foliis oppositis, breve petiolatis, ellipticis, obtusis, puberulis, subtus reticulatis, stipulis coriaceis, acutis, basi vaginantibus, floribus axillaribus breve pedicellatis, solitariis $v$. ternis, bracteolatis, patentibus $v$. nutantibus, hirsutis.

A ncy 1 anthus Desfontaines in Mem. Mus. IV. 5. $t$. 2. Jussieu in Mem. Mus. VI. 396. A. Richard in Mem. soc, $h$. n. Paris, D. 209. DC. Prodr. IV. 468.

3213. IKylaeinam $P A L I S$. Cal yx tubo brevi, hemisphaerico, cum ovario connato, limbo supero, quinquedentato. Coroll a supera, infundibuliformis, tubo longo, limbi quinquefidi lobis rotundatis, reflexis. A nth e r a e 5 , intra faucem corollae sessiles, $O \vee$ a $r$ i $\mathbf{~} \mathbf{m}$ inferum ...... Ovula ..... Stylus basi crassus, quinquesulcatus; stigma cylindricum, basi et apice trun. catum, quinquesulcatum. Dr u p a sicea, n u c le o biloculari, compresso, rugoso, loculis monosper. mis. Semina ...... - Frutex owariensis, pessime descriptus ; foliis oppositis, breve petiolatis, ovato-oblongis, utrinque attenuatis, glabris, stipulis ....., corymbi terminalis pedicellis $b i$-triftoris, floribus albis.

H y 1 a ci u m Palisot Flor. Owar, 83, t, 113. DC. Prodr. IV.619. Ps y ehotria s p. Jussieu in Mem, Mus. $Y I .379$.

3214. Plhallaria SCHUMACH. Caly x tubo globoso v. turbinato, cum ovario connato, limbo supero, acute quinquedentato, Corolla supera, tubulosa, quinquefida, laciniis acutis, patulisv. reflexis. Anthera e 5, ad fancem corollae sessiles, ovales. Ov a ri um inferum, dispermnm. Stylus filiformis; stig ma phalliforme. Fructus ..... Frutices guin e en ses, glabri, pessimedescript $i$; ramis teretibus, inermibus $v$. spinosis, foliis oppositis, subpetiolatis, ovato-ellipticis, stipulis interpetiolaribus, acuminatis, pedunculis axillaribus.

$\mathrm{P}$ h a ll a ri a Schumacher in Act, soc. h, n, Hafn. III. 132. DC. Prodr. IV. 619.

3215. Cuvieren $D C$. Calyx tubo brevi, enm ovario connato, limbi superi, quinquepartiti lobis linearibus, acutis, foliaceis, patulis, tubo triplo longioribus. Corolla supera, campanulata, quinquefida, Iobis linearibus, acutissimis, induratospinescentibus. St a mina 5 , corollae fauci inserta, inelusa; fil am enta brevissima, a n the rae ovatae, erectae. Ovari n m inferum, quinqueloculare, diseo epigyno obsoleto. Ovula in loculis solitaria. Styl us simplex; stigma magnum, dilatatum, marginibus reflexis exstinctoriiforme, obtusum, pentagonum. B a c c a quinquelocularis, loculis monospermis. Semina ...... Frutex glaber, in Africae ora tropica occidentali indigenus; ramis divergentibus, foliis oppositis, subsessilibus, ovali-oblongis, acutis, stipulis in vaginam brevem, bidentatam connatis, panicula terminali corymbosa, corollae tubo intus membrana separabili instructo.

C u vi era DC, in Annal. Mus, IX, 222, t. 15. Jussieu in Mem. Mus. VI. 396. A. Riehard in Mem, soc, h. n. Pa. ris, V. 210. DC. Prodr. $I V .468$.

321 6 . Domalista $D C$. Cal y $x$ tubo turbinato, cum ovario connato, limbo supero, brevissimo, vix quinquedentato, Cor olla supera, tubo brevi, lato, intus pilis rigidis, scariosis, retrorsis, nniseriatis vestito, limbi quinquefidi lobis acuminatis, aestivatione valvatis, sub anthesi patulis. Stamina 5, corollae fauci inserta; filamenta brevia, tenuia, antherae ..... Ovarium inferum, uniloculare? Ovul a plurima? ..... St $\mathbf{y}$ l u s filiformis, medio tumidus et hispidus; st ig m a ovatum, basi truneatum, subexstinctorifforme. Fructus....... Frutex indicus, glaber; ramulis tenuibus, foliis oppositis, brevissime petiolatis, oblongis, acuminatis, basi acutis, stipulis acutis, brevibus, deciduis, racemulis tri-quadrifloris, brevibus, axillaribus, $v$. ex ramulis brevissimis axillaribus ortis, bracteolatis, foliis multo brevioribus.

Dondisia DC. Prodr. IV. 469. non alior.

321\%. Stigmantlhus LOUREIR. C aly x tubo brevi, cum ovario connato, limbi superi, quinquepartiti laciniis filiformibus. Cor olla supera, infundibuliformis, tubo longo, limbi quinquefidi lobis ovato-oblongis, patentibus. S t a $\mathrm{m}$ in a 5 ; $\mathrm{fi}$ I amenta brevissima, antherae reflexae. 0 varium ...... St y lus filiformis, corolla longior; stigma ovatum, sulcatum, maximum, B a c ea exsucea, tuberculosa, compressa, nnilocularis. Semin a plurima, ossea. - Frutex cochinchinen$s i s$, scandens ; foliis lanceolatis, glabris, cymis amplis, axillaribus et terminalibus.

$\mathrm{S} t \mathrm{f} g \mathrm{~m}$ a $\mathrm{t}$ th us Loureiro Flor. cochinch. $T$. 181. Jus. sleu in Mem. Mlus, DI. 390. DC. Prodr. IV. 469 . S $t \mathrm{ig}$ m atanth us Römer Schult. Sjst. $V_{.} p, 15$.

3218. Strumpifa $J A C Q$. Caly x tuho ovato, cum ovario connato, limbi superi, campanulati, ultra medium quinquefidi lobis acutis, erectis. Corolla supera, subcampanulata, profunde quinquepartita, tubo vix ullo, lobis erectiusculis, lanceolatis, apice subreflexis. Stamina 5 , imo corollae tubo inserta; fil amenta brevissima, connata, anthera e quinqueloculares, loculis tribus extrorsis, duobus introrsis regularibus, in tubum ovoideo-oblongum, stylo pervium, apice quinquedentatum coalitis. O varium inferum, biloculare. Ovula in loculis solitaria, e basi erecta, anatropa. Sty lus simplex, antherarum longitudine; stig m a breviter bifidum, lobis erectis, obtusis, Drup a pisiformis, umbilieata, n u cl eo globoso, biloculari, rarius abortu uniloculari. S e mi$n$ a in loculis solitaria, erecta. Al bumen carnosum. E mbryo ....... Suffrutex antillanus ma ritimus, in ordine valde anomalus, etiam quoad locum subdubius; caule brevi, quasi articulato, trichotomo, folitis ternato-verticillatis, carnosis, linearibus, obtusis, margine revolutis, stipulis interpetiolaribus, floribus minimis, in racemos axillares, breves, subsimplices dispositis, bracteis duabus oppositis sub singulo flore.

Strumpfia Jacquin Amer, 218. Lam, $t$, 731 . A. Richard in Mem. soc. $h$. $n$. Paris, $\nu .218, t, 19$. f. 3 . DC, Prodr. IV. 469. Strump hia Persoon Ench, II. 211. 
*it.

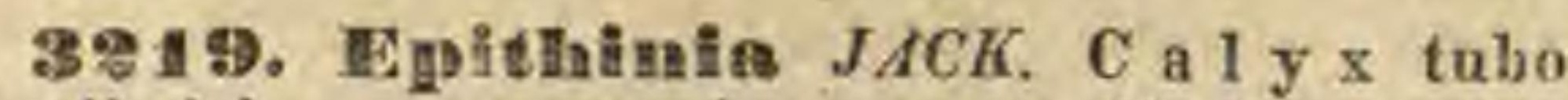
subcylindrico, cur ovario connato, limbo supero, membranaceo, urceolato, integerrimo v. obsulete quadridentato. Co rolla supera, hypocraterimorpha, tubo calycis limbum dnplo v. triplo superante, intus piloso, limbi quadrifidi lobis ovatis, recurvatis, aestivatione imbricato-subcontortis. Sta in ina 4 , exserta; a $t$ hera e lineares, acutae. Ovarium inferum, biluculare. $O$ vala in loculis gemina, superposita, superius ex apice loculi penduIvm, inferius ...... Stylas filifurmis, glaber; $s t$ i $\mathrm{m}$ a hifidum, Lobis linearibus, divaricatis. $\mathrm{B}$ a cca oblongo-clavata, compressiuscula, octusulcata, limbo calycis corunata, dipyrena, pyrenis lignosis, distinctis v, in unam cohaerentibus, dispermis v. abortu monuspermis. Semina lineari-oblonga, superposita. Embryo intra albumen tenue, carnosum magnus; cotyledonibus oblongis, planiusculis, radieula supera. - Frutex indicus, glaber; ramis junioribus apice gummiferis, foliis oppositis, petiolatis, obovatis, oblusis, subcarnosis, enerviis, stipulis adpressis, connato-vaginantibus, truncatis, cymis supraxillaribus, pedunculo horisontali, bifido, peliolo breviore, floribus albidis,

Epithin ta Jack in Malay. Miscell. I. n. \&, p. 12. DC. Prodr. IV. 477. Wight et Araott Prodr, Flor, Penins, Ind. arient. 1.423.

TREI UES VIII. CORDIEREAE A. Richard in Mem. soc.h. n. Paris. V.107. et222. Flores hermaphroditi v. monoici, axillares glomerati, v, terminales involucrati. O v a ri u m bi - quinqueloculare, loculis uni - biovulatis. Fructus baccatus, bi-plurilocularis, A 1 bum en carnosum. - Frutices, folits oppositis, stipulis latiusculis junctis, a Guel ardeis fruclu loculos veros nec pyrenas gerente distincti, sed allerius generis fructus ignolus, et major fortassis cum Diplospora inter Cof feeas affinilas. Fortassis tamen expulsa Tricalysia, reoocatis pluribus generibus supra incer Guetlardeas recensitis, cribus stabilienda.

B290. Cardiera $A$. RICH. F $10 \mathrm{r}$ e s unisexuales, in diversis ramis. II a sc. Gal y x cupuliformis, solidus, limbo integro. Coroll a hypo. craterimorpha, tubo longo, versus apicem sensim attenuato, subincurvo, coriaceo, nitente, quasi corneo, fauce angustissima, nuda, limbi plani, quadri-quinquepartiti, stellatim patentis lobis obJongo-acntis. Anth er a e $4-5$, oblongae, in medio corollae tubo sessiles. Styli rudimentum e fundo calycis, F e m. C a I y x tulio subgloboso, cum ovario connato, limbo supero, brevissimo, integro. Co rolla supera, hypocraterimorpha, tubo recto, apice vix attenuato, limbo quadri-quinquepartito, patente. Stamina parva, ahortiva. Ovarium inferum, quadri-quinquelocnlare, diseo epigyno medio depresso. Ovula in loculis solitaria, medio anguli centralis inserta, amphitropa. Stylus simplex; stig mata 4-5, subulata. Ba eca carnosa, depresso-globosa, umbilicata, quadri-quinquelocularis. Semina in loculis solitaria, umbilico ventrali, lineari. Embry o in axi alluminis carnosi rectus; cotyledonibus subcordatis, foliaceis, $\mathbf{r}$ adicula infera. - Frutex guianen$s i s$, dumosus, quadri-quinquepedalis; folits oppo- sitis, elliptico-acuminatis, glabris, mediantibus stipulis acutissimis basi inter se subcoalitis, floribus candidis in ramulis terminalibus, masculis ternis, sessilibus, bracteis qualuor squamaeformibus cinclis, femineis solitariis, quadribructeatis.

Cordiera A. Riehard in Mom. soc. h. $n$, Paris, $V$ 930, t. 10, f. 2. DC, Pradr. IV. 405.

329 A. Treicalygin A. RICII. C a I y $\mathrm{x}$ basi calyculo duplici, utroque quadritentato munitus, tubo cum ovario connato, limba supero, subampliato, quinque-sexdentato. Coro 11 a supera, tubo brevi, fauce nuda, limbi quinque-sexpartiti laciniis angustis, patulis. Stamina $5-6$, corollace fauci inserta, exserta; filamenta brevia, an $t h$ erac lineares, $O_{\text {r a }}$ in m inferum, biloculare. $O_{\text {y }} \mathrm{u}$ la in loculis gemina, collateralia, facie intern medio dissepimento inserta. ..... Stigma $t$ a 2 linearia, brevia, subrecurva, exserta. Fruetus ..... - Frutex angolensis, non satis notus. foliis oppositis, basi sensim angustalis, mediantibus stipulis latis, acuminatis conjunctis, floribus subsessilibus, in axilla foliorum conglomeratis, pubescentibus.

Tricalys ia A. Richard in Ifem, soc. $h, n$, Paris, $\gamma$. 224. DC. Prodr. IV, 445 .

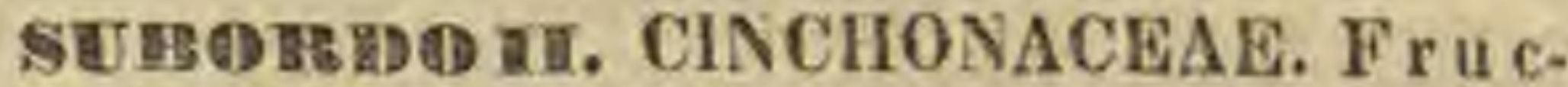
tus luculi polyspermi.

TIE II IV. 438 . Fructus baccatus, multilocularis, loculis polyspermis. Semina albumine carnoso.

33\%2. Evasmais $H U H B$, ct BONPL. C $\mathrm{a}$ ly $x$ tubo ovato, cum ovario conuato, limbo supero, brevissimo, quatridentato. Coroll a supera, sulorotata, ultra medium quadrifida. St a mina 4 , corollae fauei inserta, subexserta $v$. inclusa; $f_{i-}$ lamenta brevissima, antherae oratae. Ova$\mathrm{ri}$ u inferum, quadriloculare. $O$ v u 1 a in placentis e loculoram angulo centrali plurima, horizontalia, anatropa. St y I u f filiformis; $8 \mathrm{tigma}$ incrassatum v. quadrilobum. B a ce a ovata, calycis limbo coronata, quadrilocularis. Semina in loenlis plurima, minima, Ineida, punetata. E m b ryo in axi albuminis carnusi orthotropus; cot y led onibus brevissimis, radicnla crassa, centripeta. - Frutices $v$ arbusculae in America tropica crescentes; foliis oppositis, petiolatis, ovalibis, utrinque acutis, membranaceis, stipulis brevibus, ovatis, acutis, deciduis, racemis ex axillis inferioribus geminis $v$. ternis, pedicellis elongatis, capillaribus, floribus rubris, baccis junioribus odoratis.

Evosmia Humb, et Bonpl. Plant, aequinoct. IT, 165. t. 134. Kuath in Humb. et Bonpl. Nov. gen. et sp. IIT. 418. Jussieu in Mem. Mus. VI. 398. A. Richard in Arem, soc. $s$. n. Paris, $V$, 232. DC. Prodr, IV. 138. E vos ma Willdenow mse. Othigginsia aggregata Ruiz et Pav. Flor. peruv, f. 83, $f, 6$.

3223. Tepesia G:RRTN. FIL. Calys tubo oblongo, cum ovario connato, limbo snpero, quadridentato, dentibus carinatis; duobus oppositis exterioribns majoribus ereetis, duobus minoribus conniventibas, C oro ${ }_{1}$ a ...... Stamina.... O varium inferum ..... B acca oblonga, calycis limbo coronata, quadrilocularis. $\mathrm{Scmina}$ in foculis plurima, in pulpa nidulantia, minuta, angulata, punetata. Em br yo in axi albuminis carnosi orthotropus; eot yled onibus brerissimis, radicula crassa, umbilico proxima. - Frulex 
chilensis, excepto fructu ignotus, fortassis ab Fvosmia non satis distinctus.

Te pes i a Gärtner f. $I I L, 72, t, 199$. DC, Prodr. IV. 438.

3\%24. Sabicea $A U B L . C$ aly $\mathrm{x}$ tubo oblongo v. turbinato, cum ovario connato, limbo supero, persistente, quadri-quinquepartito. Corolla supera, hypocraterimorpha, tubo longo, gracili, fauce hirsuta, limbi quadri-quinquepartiti lobis acutis. Stamina $4-5$, corollae fauci v.tabo infra faucem inserta, inclusa $v$. subexserta; fil amenta brevissima, antherae lineares, incumbentes. Ovarin $\mathrm{m}$ inferum, quadri-quinqueloculare, ureeulo epigyno carnoso. Ovnla in placentis e loculorum angulo centrali plarima ...... Sty I n s filifermis; s tig mat a $4-5$, filiformia $v$. subclavata, patentia. B a c c a subglobosa, calycis limbo coronata, quadri-quinquelocularis. Semin a in loculis plurima, minuta, angulata. E m b ryo ..... - Frutices $v$. suffrutices a mericani tro$p i c i$, scandentes; folits oppositis, breve petiolatis, ovalibus, acutis, stipulis utrinque solitariis, persistentibus, floribus axillaribus, fasciculatis, sessilibus, v. corymbosis, breve pedunculatis, albis, corollis pilosis.

$\mathrm{S}$ a b i e e A Aublet Guian, I. 192. $t$. 75. 76. Lam. t. 165. Jussieu in Mem. Mus, VI. 400, A. Richard in Mem. soc. $h$. n. Paris, $V$. 297. DC. Prodr. IV. 439. Se hwe nk felda Schreber gen, n, 306. S $\mathrm{ch}$ we akfeldia Willdenow sp. I. 982 .

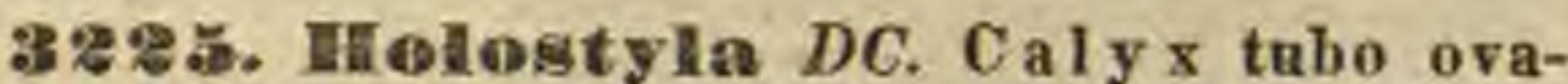
to, cum ovario connato, limbo supere, brevissimo, quinquedentato. Coroll a supera, subrotata, tubo brevi, intus piloso, limbi quinquefidi lobis linearilanceolatis, margine inflexis. Sta mina 4, corollae fauci inserta; fil am enta brevissima, antherae lineares, exsertae. Ovarinm quadriloloculare, urceolo epigyno carnoso. Ovula in loculis plurima ..... Stylus filiformis; stigma elavatum, indivisum. B a e c a glabra, calyeis limbo et urceolo epigyno coronata, quadrilocularis. S e$\mathrm{mina}$ in loculis plurima, minuta, elliptiea, in pulpa nidnlantia. Embryo $\quad$ m.... Frutex Novae-Caledoniae, inermis, glaber; foliis oppositis, breve petiolatis, obovato-oblongis, coriaceis, stipulis latis, brevibus, acuminatis, floribus in corymbum terminalem subthyrsoideum dispositis.

Holostyla DC. Prodr. IV, 440 . Stylocoryna Labillard. Nov. Caled, 47. t. 48. - ? G ard a ia cor y mbo\& a Reichenb. Ic. exot, t. 106.

32\%G. Axwatines $B L U M$, Flores hermaphroditi v, abortu dioici. Ca ly $x$ tubo cum ovario connato, limbo supero, nrceolato, subintegerrimo. Corolla supera, rotata, tubo brevi, cylindrico, fauce fasciculis quinque villornm instructa, limbi quinquefidi lobis patentibus. Stamina 5 , fauci corollae inserta, vix exserta, Ovari $\mathbf{m}$ inferum, quinqueloculare, disco cpigyno sulcato. Orula in loculis plurima ...... Stylus simplex; stig m a quinquelobum, lobis primum conniventibus. B a c ca globosa, calycis limbo coronata, quinquelocularis, placentis carnosis, S e m i$\mathrm{n}$ a in loculis plurima, minuta, depresso-punctata - Frutices v, arbores javanicae; folits oppositis, floribus axillaribus subcapitatis, cymosis $v$, rarius corymbosis.

Axanthes Blume Bijar, 1002. DC. Prodr. IV. 440. Masclialanthe Blume Flor. Jav. Praef. VII. Walli. eli ia Reinwardt in Flora 1825. p. 107, non alior.

329\%. Unophyllam JACK et WALL. Calyx tubo ovato, cum ovario connato, limbo supero, brevi, campanulato, subquinquefido. $\mathrm{C}_{0}$ ro II a supera, infundibuliformis, fauce bar- bata, limbi quinquepartiti lobis wvatis, aestivatione valvatis. Stamina 5 , corollae fauci inserta; fil amenta brevia, antherae lineares, incumbentes. Ova r i u m inferum, quinqueloculare, disco epigyno glanduloso. Ovula in loculis plurima ...... St y lus simplex; $8 \mathrm{tigma}$ cras. sum, quinquelobnm. B a c c a globosa, calyeis limbo coronata, minuta, lucida, poris pentagonis notata. - Frutices in India a us traliore indigeni, erecti; foliis oppositis, breve petiolatis, oblongo-lanceolatis, in acumen longissimum angustatis, stipulis oblongis, acutis, deciduis, pedunculis axillaribus brevibus, flores verticillato-capitatos gerentibus, bracteis plurimis, acutis, capitulum involucrantibus, floribus virescentibus

U rop b y $11 \mathrm{am}$ Jaek et Wallich in Roxburgh Flor. Ind. TI. 184. Wallichi a Boxbargh msc. non alior.

3228. II anelia $J A C Q$. Caly $x$ tubo ovali, cum ovario connato, limbo supero, brevi, quinquelebo, lobis erectis, acutis. Coroll a supera, tubulosa, tubo subpentagono, fauce nuda, limbi breviter quinqnelobi lobis aequalibus, vix patentibus. St a mina 5 , medio corollae tubo inserta, inclusa; filamenta filiformia, antherae oblongo- lineares. Ovariu m inferum, quinqueloculare, disco epigyno conico. O v u a in placentis e loculorum angulo centrali bilobis plurima, horizontalia, anatropa. Stylus simplex; stigma indivisnm, obtusum, subpentagonum. B a c c a ovalis, quinquesuleata, calycis limbo coronata, quinquelocularis, dissepimentis membranaceis. Sem in a in loculis plurima, minima, compressa, areolata. Embry o in axi albuminis carnosi orthotropus; cotyledonibus obtusis, radicula tereti, nmbilico proxima, centripeta. - Frutices America e tropicae; foliis oppositis v. ternatim aut quaternatim verticillatis, petiolatis, ovali-oblon. gis, utrinque angustatis, stipulis utrinque solitariis, lanceolato-subulatis, cymis di-trichotomis, in corymbum v. paniculam saepius terminalem dispositis, bracteis minimis, floribus croceo-rubentibus.

$\mathrm{H}$ a m el i a Jacq. Amer. 71. t. 50. Ic. rar. t. 335. Gärtner f. III. 63. t. 191, 196. Smith Exot, Bot, t. 24, Ruiz et Pavon Flor, peruv, $t, 221$. $f, a$, et $b$. Heritier Sert. $t .7$. Salisbury Parad. t, 65. Bot. Reg, 6. 1195. A. Richard in Mem. soc, h, n. Paris. V. 227. DC. Prodr. IV. 441. D u h a melia Persoon Ench. X. 203. T a n g a r a e a Adauson Fam, II. 16́7. Lonicera Plumier Gen, 17. t. 33.

322马. Altbertian $A$. RICH. Flores ab. ortu incomplete unisexuales $\mathrm{C}$ a Iy $\mathrm{x}$ tubo subgloboso, cum ovario connato, limbo supero, tubnloso, quinquedentato. Co roll a snpera, tubulosa, tubo tereti, fauce nuda, limhi quinquepartiti, patentis laciniis ovali-acutis. An the rae 5 , in corollae fance sessiles, lineares, inclusae, $O \mathrm{v}$ a $\mathrm{r}$ i $\mathrm{m} \mathrm{m}$ infernm, quinqueloculare. Ovula in toculis plurima, horizontalia, anatropa. St y I n s simplex; sti $\mathrm{g} \mathrm{m}$ a in floribus masculis indivisum, acntam, femineis profunde quinquefidum, laciniis linearibus. B a c c a globoso-depressa, subcorticata, calycis limbo persistente coronata, quinquelocularis. Semina in loculis plurima, compressa, pnlpa tenui involuta. Em b $\mathbf{r} \mathbf{y}$ in axi albuminis carnosi orthotropus; cotyledonibus brevibus, obtusis, radicula tereti, nmbilico proxima, centripeta. - Arbuscula guianensis; foliis oppositis, oblongo-acuminatis, coriaceis, stipulis subconnatis, integerrimis, acutis, floribus ramos terminantibus solitariis, v. pluribus fasciculatis, subsessilibus.

Alibertia A. Richard in Kem. soc, h, n. Paris. $V$. 234. $t$. 21. f, 1. DC. Prodr, IV. 443, Melanop sidium 
Peiteaumsc. Genipella L. C. Bieliard msc. Genipa ed u. Iis L. C. Richard.

330. Selaranilera $V A H L$, Calyx tubo obovato, cum ovario connato, limbo supero, trun cato v. subdenticulato. Corolla supera, infundi buliformis, tubo tereti, fauce pilosa, subdilatata, limbi quinque-oetofidi lobis patentibus, carina in crassatis, interdom intus denticulo calloso, retrorso auctis. An the rae 5_8, lineares, intra faucem corollae sessiles, apieibus subexsertis, O va ri u m inferum, bi quadriloculare. Orala in loculis plurima. Stylus brevis; stigma bi-quadrifidum. $\mathbf{B}$ a c c a pisiformis, tri tetraquetra, calycis limbo coronata, bi-quadrilucularis. Semina in loculis plurima, minntissima, in pulpa nidulantia. $\mathbf{E} \mathbf{m}$ bryo..... - Frutices Americae tropicae pseudoparasitici, radicantes, glabri; foliis oppositis, petiolatis, ovalibus $v$. lanceolatis, coriaceis, sti. pulis ovali oblongis, caducis, ad basim pedunculo rum diutius persistentibus, bracteiformibus, pedunculis terminalibus solitariis $v$. rarius pluribus, petiolo longioribus, floribus capitatis, involucro $e$ bracteis duabus connatis orbiculato, lobato v. subintegro.

Sehradera VabI Eclog. I. 35. t. 5. Jussien in Mem. Mus. VI. 403. A. Richard in Mem, soc, h. n. Paris, V. 299. DC, Prodr, IV. 443. Fu elt si a Swartz Prodr. 62. U rce ola ria Willdenow in Coth. Disposit. p. 10. non alior.

32: 1. Froignolía $D C$. C a l y x tubo subsemigloboso, cum ovario connato, limbi superi, quadridentati dentibus inobus oppositis majoribus. Co rolla supera, tubo brevi, fauce limbique tubum superantis, sexlobi lobis lineari oblongis, ob tusinsculis, intus hirsutissimis. St a mina 6 , tubo corollae inserta, inclusa; fil am enta brevissima, antherae lineares. Ovarinm infernm ...... Stylus filiformis; $s t i g m$ a capitatum, indivisum. Fruetus carnosus, globosus, ealyeis limbo eoronatus. Semin a plurima ...... - Frutex var bor insulae Trinitatis; ramis teretibus, villosis, foliis oppositis, petiolatis, ovali-oblongis, basi obtusis, apice acuminatis, ad nervos puberulis, ceterum glabris, stipulis utrinqne binis, Lanceolatis, acuminatis, in unicam interpetiolarem primum coadunatis, mox a basi ad apicem disjunctis, corymbo terminali pedunculato, rhachi brevi, hirsuta, ramis conferlis, puberulis, trichotomis, bracteis ciliatis, floribus in dichotomiis et ad apicem pedicellorum sessilibus.

Brignolia DC. Prodr. IV. 4 id.

3232. Fatima $A U B L E T$. C alyx tubo ovato, cum ovario connato, limbo supero, tubu loso, laxo, subpentagono, brevissime quinque sinuato. Corolla supera, tubulosa, tubo tereti, fance subdilatata limbique quinqnepartiti laei niis longissime acuminatis, intns dense sericeis. Stamina 5 , corollae fauci inserta, inclusa; $f i$ I a m enta brevissima, antherae ovato-oblon gae, erectae. Ova riu m inferum, quinquelneula re, disco epigyno carnoso. Oru $\mathrm{I}$ a in inculis plu rima ...... Stylus simplex; stigma brevissi me bilobum. Ba cea subglobosa, ealycis fimbu coronata, quinquelocularis, placentis carnosis, bilobis. Sem in a in loculis plurima, minutissima. Embryo.... - Suffrulex guianensis, gla. ber, erectus; ramis terolibus, foliis oppositis, petinlatis, ovato-oblongis, utrinque angustatis, stipulis solitariis, brevibus, latis, aculis, porsistentibus, pedunculis axillaribus, uni-paucifloris.

P a tim a Aublet Guian, 1. 196. t. 77. Jussieu in Mem. Mus VI 401. A. Richaesi in Mem. soc, h. n. Paris. r. 230. . 25. $f$. 2. DC. Prodr. IV. 440.
3233. Polly phragmen DESFONT. Cal y $x$ tubo ovato, cum ovario connato, limbo snpero, brevi, integerrimo v. quinquedentato $C_{u-}$ rolla supera, hypocraterimorpha, tubo tereti, limbi decempartiti lobis elliptico-oblongis. Antherae 10 , lineares, in medio corollae tubo ses siles. Ovarium inferum ...... Stylus incras. $8 a t u s$, longitudinaliter sulcatus; $8 \mathrm{t}$ i $\mathrm{g} \mathrm{m}$ a $\mathrm{ta} 6-7$, acnta. B a e e a globosa, calycis limbo coronata, decem-vigintilucularis. S e min a oblonga, in quovis loculo plura, uniseriata, deorsum inbrieata, septulis transversis distincta. Embryo .... Frutex $t$ imorensis; foliis oppositis v, ovali-lanceolatis, utrinque acuminutis, subtus adpressc sericeis, stipulis deciduis, pedunculis axillaribus brevibus, unifloris, calycibus corotlisque setosis.

Poly p ragmon Desfont. in Mem, Mus, Yr, 6, t, 2, ot a bis. Jussien in Mem. Mus. VT, 399. A. Richard in Ment. soc, , n. Paris. V. 231. DC. Prodr. IV. 445. Erithalis uniflora Gartuer f, III. 93. 4, 196.

THIBUS $\mathbf{x}$. ISERTIEAE A. Richtard in Mem. soc. h. n. Paris. V. 235. D rupa pleiopyrena, pyrenis polyspermis. - Frutices $v$. herbae archipelagum indicum el Americam tropicam, pari fere specierum numero incolentes; foliis oppositis, stipulis interpetiote. ribus.

3234. Isertia SCHREB, Caly $\mathrm{x}$ tubo subgloboso, cum ovario connato, limbo supero, brevi, persistente, quadri-sexdentato. Carolla supera, longe tubulosa, tubo medio angustato, limbi sexlobi lobis brevibus, ereetis, obtusis, intus lanuginosis, sinubus in eristas exsertis. A n therae 6, ohlongae, intra corollae faucem sessiles, inclusae. Ovarin m inferum, sexloculare, disco epigyno carnoso. Ovula in loculis plurima, placentis ex angulo centrali prominulis inserta, horizontalia, anatropa. Sty tns simplex; stigin a $t$ a 6 , linearia, erectu-stellata. B a cea globosa, calycis limbo coronata, hexapyrena, pyrenis triquetris, fragilibus, polyspermis. S e min a sub. globesa, basi truneata. Embryo in axi albuminis carnosi orthotropus; cotyledonibus semicylindricis, radicula tereti, centripeta. - $\mathrm{A}$ busculae guianenses et mexicanae; folitis op positis, breve petiolatis, ovalibus, utrinque acuminatis, subtus velutino-villosis, stipulis utrinque geminis, subulato-lanceolatis, thyrso terminali multifloro, spicaeformi v. panicutaeformi, pedunculis opposilis, floribus cocoineis.

Is ertia Selireber gen. $n$, 602. Vahl Eclog. 27. ᄂ. 15. Gïrtn. f. III. 60, $t, 191$, Kunth in Humb. et Bonpl. Nov. gen, et sp. III. 415. Jassieu in Mem. Mtus. VI. 399. A. Richard in Mem, soc, h, n, Paris, V. 235, t. 21. f. 2. DC. Prodr. IV. 437. Guettardae sp. Aublet Guian, t, 123. Lain, 250. Plios a uthus Rafinesque in Annal. gen. se. $p h y s$. 1., 88 .

3235. Gomzallea PERS. Calyx tubo subglobuso, cam ovario connato, limbo supero, persistente, quadridentato v. quadripartito. Carolla supera, infundibuliformis v. hypocraterimorpha, tubo cylindrico, longo, fance pnbescente $v$, hirsuta, limbi quadrifidi lobis brevibus, ovatis. Stamina 4 , corollae fauci inserta, inclusa; filamenta brevissima, antherae lineares. Ova $r i n$ inferum, bi-quadriloculare. Ovala in loculis plarima $\ldots . . S$ s $\mathbf{y} 1$ u g filiformis; stig n a bi-quadripartitum, lobis patentibns $v$, in globum cohaerentibus. D rupa globosa, ealyoía limbo coronata, di-tetrapyrena, pyreniz ogseis $\mathbf{y}$, $69 \div$ 
chartaceis, polyspermis. Sem ina minuta, angn lata, punctata. Embryo ..... - Frutices in Americatropica cis aequatorem et in Pe$r u$ via indigeni; ramis teretibus, villosis, foliis oppositis, petiolatis, ovali-lanceolatis, acuminatis, stipulis utrinque solitariis v. geminis, spicis terminalibus $v$. ex axillis supremis elongatis, villosis, flori bus subsecundis, solitariis $v$. fasciculatis.

G оп zalea Persoon Ench. T. 132. Jussien in Mem. Mus. VI. 400. A. Richard in Mrem. soc, h, n, Paris, V. 236. DC. Prodr. $I V .436$.

a. GoNZALAGUNIA Ruiz et Pav. Prodr. 12, $t, 13$. B a cea carnosa, tetrapyrena, pyrenis osseis, - Stipulae utrinque binae. - (Ruiz et Pav. Flor. peruv, I. 56 . t. 86 . Suppl. Quinolog. 84. t. 1. f. a.)

b. LYGISTOIDES DC. Prodr. IV. 436, B a eca subexsueca, di-tri-tetrapyreua, pyrenis chartaceis. - Stipulac utrinque solitariae. - B u e n a Cavanill. Anal. cien, nat, II, 279. Ic. VI. 50, t. 571. non Pohl. L y g is $t \mathrm{i}$ s p. Lam. Coeency pseli 8 p. Kanth. (Humb. et Boupl. Plant, aequinoct, t. 64.)

323 B. Anthoeptialins $A, R I C H$. C a l y x tubo cum ovario, connato, limbo supero, persisten te, quinquepartito, Corolla supera, longe tubalosa, limbo quinquepartito. $\mathrm{St}$ a $\mathrm{m}$ in a 5 , inclnsa. Ovarium inferum, quadrilocnlare. Ovula ...... Stylus longe exsertus; stigma bilo. bum, lobis approximatis. Frnetus limbo calycino coronatus, tetracoccus, coccis ovoideis, coriaceis, extus parce carnosis, basi truncatis, indehiscentibus, tetra-pentaspermis, S e m in a .... Arbuscula chinensis; foliis oppositis, stipulis interpetiolaribus solitariis, floribus terminalibus in globum densum, supra receptaculum commune sphaericum dispositis, subpedicellatis.

Anthocephalus A. Richard in Mom. soo. h. n. Pa. ris. $V$. 237 . Cephalanthus chine 8 is Lam.

323\%. IIetabolus $B L U M$. Cal y x tubo obovato - subgloboso, cum ovario connato, limbo supero, quadri- $v_{\text {s }}$ rarius quinquefido aut partito. Corolla supera, infundibuliformis, limba quadri-quinquefido $v$, partito. $S t$ a $m$ in a $4-5$, corollae fauei inserta … O vari nm inferum, bi-quadriloculare. Orula in loculis plurima .... Styins filiformis; stigma incrassatum, bi-quadrilobum. Bác c a exsucea, calycis limbo coronata, partibilis, di-tetracocca, coccis pelyspermis. Sein in a angulata, placentis prominulis affixa. Embryo .... Herbae suffruticosae, $j$ avan icae et manillenses; caule tetragono, foliis oppositis, parallele venosis, stipulis geminatis, incisis, floribus verticillatis $v$. capitatis, axillaribus.

Metabolus Blume Bijdr. 990. A. Richard in Mom. sac, $h, n$, Paris, D. 237. DC, Prodr. ID. 435. S cle roco ecus Bartling msc.

TIREIBUS $\mathrm{x}$. IIED Y OTIDEAE Cham. et Schlechtend. in Linnaea IV. 150. Fructu s capsularis, bilocularis, loculicido-dehiscens, rarius indehiscens. Semina plurima, aptera. Albumen carnosum. - Frutices v. herbae, folitis oppositis, stipulis interpetiolaribus.

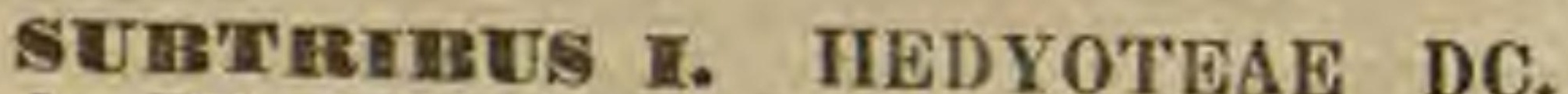
Prodr. IV. 419. Stipulae utrinque cum petiolis in vaginam integerrimam, $\nabla$. saepius in setas plures desinentem connatae. Hedyoteae in Indiae terra continente et insulis mag. no

numero crescunt, pauciores

Americam tropicam, Africam tropicam et australem extratropicam, nec non Oceani pacifici insulas inhabitant. Paucissimae in America boreali reperlae, nonnullae per regiones tropicas 10. tius orlis divulyatae.

3238. Dentella FOBST. C a I y x tubo subgloloso, hispido, cum ovario connato, limbi superi, quinquefidi laciniis lanceolatis, acutis, Corolla supera, infundibuliformis, tubo calycem superan. te, fauce inflata, limbi quinquefidi, patentis laeiniis medio utrinque acute unidentatis. Stamina 5, corollae tubo paullo supra basim inserta, inclusa; filam enta brevissima, antherae oblongae, erectae. Ovarium inferum, biloculare. Orula in placentis carnosis, dissepimento utrinque adnatis plurima, horizontalia, anatropa. St ylus brevis; stigma bifidam, lobis crassis, obtusis, subcohaerentilus. B a c ca exsucea, hispida, calycis lobis conniventibus coronata, bilocularis, indehiscens. Semina in loculis plurima, parra, cuneata. - Herbae in India et Oc e ania trapica indigenae, paludosae, annuae, caespitosae, repentes ; caulibus filiformibus, glabris, foliis oppositis, breve petiolatis, oblongis, basi ciliatis, stipulis petiolorum bases jungentibus acutis, inciso. serratis, pedicellis axillaribus solitariis, unifloris, floribus parvis, albis.

De atella Forster Char, gen. 26, $t, 13$. Lam. $t, 118$. Jussieu in Mem. Mus. NT. 385. Chamisso et Seltechteis. in Linnaea IIT. 150. A. Richard in Mem. soc. h. n. Paris. $V$. 270. DC. Prodr. IV. 418. Wight et Arnott Prodr, Flor. Pe. nins. Ind. orient. 405. Lip a y a Eadlielier Alakt. 13.

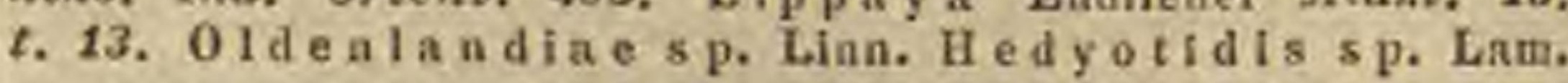

3239. Gonotheea BLUM. Calyx tubo ovato, tetraptero, cum ovario connato, limbo supero, tubnloso, amplo, quadridentato. Corolla supera, tubnlosa, tubo calycis limbum vix supo. rante, basi inflato, fauce villosa, limbi quadrifidi lobis patentibus, carinatis. Anthera e 3-4, ovatae, ad basim tubi corollini sessiles, Ovarium inferum, biloculare. Ovn I a in placentis dissepimento utrinque adnatis plurima, horizontalia, anatropa. Stylus subnullus; stigmata 2 , linearia, obtusa, Capsula membranacea, compressa, utrinque ala duplici in pedicellum decurrente marginata, limbo calycis late tubuloso cornnata, bilocularis, inter stylos dehiscens. Semin a plurima, ovata, scrobiculata. E mbryo in axi albuminis carnosi orthotropus; c ot yle d o n ib a s semicylindricis, obtusis, radicula tereti, umbilico proxima, centripeta. - Herba moluc cana, erecta, glabra; caule quadrangulari, divaricato, foliis oppositis, lanceolatis, subsessilibus, stipulis inciso dentatis, cymis axillaribus et terminalibus pedunculatis, paucifloris.

Go nothee a Blume in DC. Prodr. IV. 429. Eadlicher Atakt. 23. t. 22.

3240. JiLedyotis $L A M$. Caly $\mathrm{x}$ tubo ovato v. globoso, cum ovario v. ejus basi connato, limbo supero, persistente, quadrifido, denticulis interdum interjectis. Co r o I I a supera, infundibuliformis v. rotata, quadrifida, laciniis aestivatione imbricatis. Sta m in a 4 , corollae fauci inserta, exserta $v$. inclusa; fil a m en ta filiformia, brevissima $v$. subnulla, an therae oblongae $v$. sublineares. Ovarium inferam v. vertice plus minus exserto semisuperum, biloculare, discu epigyno tenui. O v u I a in placentis dissepimento utrinque adnatis plerima v. pauea, horizontalia, anatropa. Stylus filiformis; stigma bifidum, 
lobis obtusis, divaricatis v. subcohaerentibus. C ap sula ovata, obovata v. subglobosa, calycis limbo coronata, bilocularis, vertice plus minus complete loculicido-dehiscens, valvis saepins demum septicido-bifidis. Semina in loculis plurima, rarius pauca v. subsolitaria, angulata, reticulatopunctata. Embryo in axi albuminis carnosi orthotropus; cotyled onibus semicylindricis, obtusis, radicula umbilico proxima, centripeta, Herbae $v$, suffrutices inter tropicos $t$ ot $i u s$ orbis provenientes, in America borealirari; caule tetragono $v$. tereti, ramis saepius compressis, foliis oppositis, stipulis petiolos connectentibus plurisetis $v$, rarius inlegerrimis, inflorescentia varia.

Hedyoti's Lamarck Dict, $t$. 62. A. Richard in Mrem. soc. h, n. Paris, V. 266. Wiglit et Arnott Prodr. Flor. Pen. ins. Ind, orient, I. 405 .

a. DiPLOPHRAGMA Wight et Aruott Op, cit, I, 406, C a1 y cis quadripartiti laciniae sion obtuso-sejunctae. Ca ro Ila infundibuliformis, tnbo limbum calyeis paullo superante, fauce dilatata limbique lobis oblongis, tubum subnequantibns, margine pilosis. St a mina exserta; a ntherae oblongo-lineares. Ovariam vertice breviter exserfum. C a p $\$$ ula apice loculicido-dehiscens, deman usque ad basim septicido-dicocea. S emina pluriua, minuta, angulata. - Suffrutices $v$. frutices indic $i$; stipulis ovatis, acutis, margine denticulato-setosis, floribus in paniculas $v$, thyrsos terminales, $v$, $\theta$ su. premis folits axillares dispositis, rarius in capitula terminalia $v$, axillaria, sessilia collectis.

Hed yotidis s p. DO.

b. MACRANDRIA Wight et Arnott. C aly cis quadripar. titi laciniae oblongo-lanceolatae, reeurvatae, sinubus sub rotundatis sejuactae. C o r ofla late infundibuliformis, chartacea, tubo brevissimo, dimidiam limbi calycini longitudinem vix aequante, limbi quadrifidi laciniis lineari bus. Stamina longe exserta; a $\mathrm{n}$ therae oblongo-lineares. 0 varin m vertice breviter exserto conferte setosum. C apsu I a apice septicido-dicocea, coccis crustaceis, intus apertis. Semina plurima, minima.

Suffrutex ohinensis, molliter pubescens; folits su. pra scabris, stipulis truncatis, brevibus, setoso-ciliatis, foribus breviter pedicollatis, in carymbos termi. nales, capituliformes, pedunculatos confertis.

Macrandria Wight et Aruatt Op. cit, $I$. 406. in not. Hedyotis macrostemma Hook. et Arn. ad zecchey 192 .

c. DIMETIA Wighlet.Arnou. Caly e is quadridentati deates carinati, rigidi, erecti, ia fruetu distantes, sinu ro tundato disjanetl. C o roll a late lufundibulfformis, chartacea, tubo brevissiono, fauce limbique Jaeiniis linearibus, tubum superantibus margine barbatis. Stam in a longe exserta; filamenta filifornia, a utherae oblongae. 0 varium vertice breviter exserto pubescens, turbinatum, subqnadrangulum. Cap $8 \mathrm{u}$ la coriacea, non ultra verticem breviter exsertum, compressum, loculicido dehiscens. S e m in a plurima. - Herbae suffruticosae, scandentes, indicae, glabrae $v$, molliter pubescentes; stipulis in vaginam brevem, laxam, utrinque in cuspidem productam connatis, floribus breviter pedicella. tis, corymbosis.

D im etia Wight et Araatt Op. cit, I. 406. in not. Hedyotidis sp. Roxburgh, Wall.

a. ANOTIS DO. Calyeis quadripartiti v. quadridentati lobi v. dentes in fruetu erecti v. recurvi, distantes, sinu acuto. Corolla infundibuliformis v, hypoeraterimorpha, fauco glabra v. pilosa, limbi fobis ovatis, tubo brevioribus. Stamina exserta; filamenta brevia, a ra e oblongo-lineures. O va ri um faferum v. semisuperum. Capsula coriacea v. suberustacea, plus minus complete loculicida-bivalvis. S emina plurima v. pauca. - Herbae v. suffrutices; stipulis indivisis $\mathrm{N}$, multise tis, floribus terminalibus, solilarils $v$. laxe corym. bosis.

Anotis DC. Prodr. IV. 431. Wight et Araott Op. cit. $I .431$.

a. Didymotoce. Orarium inferam. Capsutas semiorbicularis, spice Dhero emargibata, usqune ad basim loculicido dehiseens. Se min a in loculis gemiear superpo. sita, adscendentia. - Herba indica adscendens; fo. liis ovalibus, obtusis $v$. acutis, breve petiolatis, pe dunculis dichatomis. - H. R heedii Wight et Arnott. (Rheede Malab, 10, 1. 25.)

ק. Ambloma. 0 varium inferun. Capsnla sub. orbicularis, compressissima, bisulea, apice brevisnime Iibero loculicido-dehiscens. Semin a in loeulis gemina, leuticularik, superposits, superius adscendens, inferins peudaluar, alterum pleramque abortivam. - Herba in dioa, diffusa, pilosa; foliis ovalibus, brove potia latis, floribus in capitula axillaria ot terminalia. sessilia collectis. - H. Wightian a Wall.

$\gamma$. Eurhaphe. Orarlum loferum. Capsula vis compressa, vertice breviter exserto loeulieida-dehiscens. Se mia a ia loculis pauca v. solitaria, dorso convexa facic plana, rhaphe percursa. - Horbae indicae, pro. cumbentes.

$\delta$. Panetos Rafinesq. in Ann. gen, sc, phys, $D .227$. 0 varium semisuperum. Caps a la loculicido-bivalvis. Semia panca. Herbae americanae, aragal. lideae $v$. suffrutices prostrati aut repentes; foltis ovala-rofundalis $v$. oblongo.Ianceolatis, foribus axil. Laribus $v$, terminalibus, solitariis $\nu$, in corymbum tri. ohotomum dispositis.

Housto aia Linu, gen, $n, 124$. Poiretia Gmell syst. 263. Hed yotid is s p. Kunth in Humb, ot Bonpl. Nov, gen, et sp. t. 289. A mphiotis et Panctos Anotidis sect. DC, Prodr. IV. 433.

E. Erefeotis DC. Prodr, $I V, 433,0$ varium inferum. Capsu I a ultra mediutu loculicido-bivalvis. - Her bae $v$, saepius suffrutices ericotalei, in $A$ merica tropica indigeni; folis oppositis, linearibus, mu. eronalis.

Hed y otidis s p. Ruiz et Pavon Flor, peruv, $t, 87$. f. a, b. c. t. 88, f. a. Cavanill. Ic, t. 575. f. 1. 2.,

c. RUHRDYOTIS Wight et Arn. C aly e Is quadripartiti Iaciniae in fructu patestes, sinu angusto separatae. C o. rolla breviter tulublosa, tubo vix limbum calycis nequante, fauce pilosa. Stamia exserta; fila menta bre via, antherae ovatae. Ovarium fuferum. CapsuI a sutiglobosa, nucasentacea, vertice breviter exserto styli basí persistente uucrouata, iadeliscejas ? S e m i a a pauca. - Suffrutices indic $i$; ramis procumbentibus, divaricatis, foliss venoso-linoatis, stipulis uni pluri. setis, Roribus axillaribus, corymbosis 》. capitatis, pedunculatis $v$. sessilibus.

E a hed y ot is Wight et Arnott Op, cit. I, AtI, He dyotis Linn. gen. $n, 118$.

f. SCLRROMITRION Wighe et Arnott, Ca I y c is quadridentati dentes in fructu erecti, sinu angustissimo acuto se. fancti. Co rolla tubulosa, tulo brevissimo, limbom ea. lycis subaequante, fauce pilosa. S $t$ a m ina exserta ; $f i$ lamenta brevia, autherae ovatae v. rotundatae Ovariu a luferum. Caps ula subglobosa, vertice bre vissime exserto rimula localiclda dehiscous. So min a pauca v. plurima. - Herbae saepius euffrutescentes, a mpkige aej stipulus multisetis, foribar axillaribus, subsessilibus, rarias in corymbos dichotomos, foliosos dispositis.

Sclerom Itrlon Wight et Aruatt Op. cir. $I, 412$. Hed y otis Roxburgh Flor. Ind, I. 368. Cluamisso et Schlechtend, in Linnaea IV. 153. DC. Prodr. IV. 419. Hed yotidis \& p. Auct. (A. Kichard Sert. Astrol,t.23.)

g. OLDENLANDIA tinn. Cal y eis quadridentati v. qua. drifidi lobi $v$. dentes in fructa erecti, sinu lato sejuncti. Corolla breviter tubulosa, infandibuliformis $\$$. subro. tata, fance glabra v. villosa. S I s m ina exserta; $f$. Iamenta brevia, antherae ovatae v. orbiculatae. Oy a ri um inferum. Caps ul a ovato-subglobosa, apice breviter exserto rimula loculicha aperta. S e mina plurima. - Herbae ge $r \circ n t o b$ o $a$, alsinoideac, rarissime fruticulosae; folits oppositis, mediante ottpula uni-pauciseta voadunatis. pedunoulis axillaribur v.terminalibas, uni bi-multifloris, saopitus clongatis. gracilibus.

01 denlandfa Liap, Ben, n, 154. Roxburgh Flor. Ind. I. 444. Plant. Corom, t. 3. DC, Prodr. IV, 484. nos Saith nec fioth. Ge r o nt o ge a Chamisso of Seblechtead. in Linnaca IV. 154. Hed yotis et Olden In o. di a Gärth, I. 147, 148, T, 30, 01 is en la in d ia et Lis Le. ria Necker etem, $m$, 34b. 392 . Listerín thafiaesque 
in Annal. gen. so. phys. VT, 81. non R. Br. He d yot i. d is 5 p. Auct. Cavanill, Ic. $t, 573.574$. Gaudichaud ad Freje. t. 94.

h. KOAAUTIA Cham. et Sehlecht. Caly eis quadridentati dentes acuti, sinu tandem latissimo sejuneti. C o r ol 1 a hypocraterimorpha, tubo lougo, tereti, lobis ovali. lanceolatis, saepe mucrone euspidatis. A a therae futra faucem eorollne sessiles, inelusae. Ovari um inferun. C a p s u la subglobosa, membranacea, loculieido-dehiscens. S e m in a plurima. - Herbae indicae et a fric a nae, ereotae, virgatae, ramosae, Asperulae facio; folits linearibus $v$, lineari-lanceolatis, stipulis uni plurisetis, cymis terminalibus, corymbosis v. laxe subspicatis.

$\mathrm{K}$ o b a u $t$ i a Chamisso et Schlechtend. in Linnaea $I V$ 156. DC. Prodr. IV. 489. Eadlicher Atakt. 24. $t .23$. Royle Himalay. 2,53 . Knoxiae et Hedyotidis sp. Auct.

i. KADUA Cham, et Schlecht. C a I y $\mathrm{c}$ is tubus hemisphaeriens, limbus quadrifidus v. quadridentatas. Corolla córiacea, hypocraterimorpha, intus glabra, tubo longo, limbo quadrifido. A a the $r$ a o lineares, fatra faucem corollae subsessiles, inclusae. O varium semiinferum. Ca p s u la globosa v. breve ellipsoidea, calycí exsuceo v. carnoso semiadnata, vertice exserto loculicide hians. Semina plurima. - Suffrutices sandwicenses, glabri; folits oppositis, stipulis utrinque solitarits, acutis, integris, floribus terminalibus oymosis, v, axillaribus solitarits, pedunculatis.

$\mathrm{K}$ a d u a Chamisso in Linnaea IT, 157. DC. Prodr. IV. 430 .

k. RHACHICALLIS $D C$. C aly $\mathrm{x}$ tubo hemisphaerico, limbi dentes quatuor, dentieulo uno v. tribus inter lobos singulos interjectis. Coralla tubo lougo, tereti, fauce glabra, limbi lobis brevibus, patentibus, obtusis. An thera e intra faucem corollae sessiles, iuclusae. Ovari u m inferum. C a p s u la subdidyma, loculieido - bivalvis, val. vis deutibus ealycinis coronatis. Se mina plurima. Suffrutices americani lropici, rupestres, Pas. serinae facie; folits oblongis, carnosis, margine re. volutis, sessilibus, stipulis connatis, integerrimis $v$. tridentatis, floribus solitarits, sessilibus.

Rhachicallis DC. Prodr. IV. 433. Hedyotidis sp. Swartz, Kunth.

t. LUCYA DC. C aly eis tubus hemisphaericus, limbi dentes quatuor bifidf persistentes. Corollae tubus brevissimus, limbus brevissime quadrilobus, lobis obtu. sis. Stam in a corolla breviora. C a psula globoso-di dyma, loculicido- et semistpticido-dehiscens. unde apice quadrivalvis. Sem in a pauea. - Herba antillana, pusilla, Peplidis facie; radice fibrosa, fibris interdum tuberosis, caule brevi, glabro, folits subsessilibus, cordato-ovatis, subtus pubescentibus, summis subquaternis, floribus axillaribus et subterminalibus, solitarits, brevissime pedicellatis, albis, parvis.

Lueya DC. Prodr. IV. 434. D unalia Sprengel Pugill. 1. 25. Hed yot is $t u$ ber os a Swartz Observ. bot. $t$. 1. f.2. P eplis tetrandra Linn. Jacq. Amer. t. $180, f .29$.

3241. Folypremum LINN. Caly $\mathrm{x}$ tulo o brevissimo, imo ovario adnato, limbi quadripartiti lobis subulatis. Corolla summo calycis tubo inserta, tubo brevissimo, fance barbata, limbi quadripartiti lobis ovalibus. Stamina 4 , cirellae tubo inserta, inclusa; fil a me n t a subnulla, antherae ovatae. Ovarium imn ealyei adhaerens, caetera liberum, bilocutare. $O$ vula in placentis basi dissepimenti utrinque insertis, adscendentibus plurima ..... Stylus filiformis; 8 tig ma indivisum. Ca p sula ovata, compressa, calyce stipata, toculicido bivalvis. Se min a plurima, minutissima, angulata, diaphana. Em li r yo in avi albuminis carnosi rectus ...... - Herba boreali-americana, glabra, Buffoniae v. Galii habitu, dubiae affinitatis; faliis oppositis, lineari-subulatis, mediante vagina stipulari subinlegerrima basibus connatis, corymbis terminalibus dichotomis, cymosis, floribus parvis, in dichotomiis et apice ramulorum sessilibus, bracteis duabus $v$. quatuor stipatis, corollis albis.

Palypremam Linn. in Act. Academ, Upsal. 1741. t. 78, Gen, 137. Gärtner I, 994, t, 62. Lam. t, 71. Jussieli in Annal, Mus, $V$, 255, Mem, Mus, VI, 382, DC. Prodr. IV. 435.

SUETTEIIES IT. RONDELETIEAE DC. Prodr, IV. 401. Stipula e utringue binae, distinctae v. connatae, haud tamen vaginantes nec setosae. - Rondeletieae pari fere specierum numero Americam aequinvctionalem et Indiam orientalem incolunt, paucissimae in Africa tropica, Madagascaria et Australasia hucdum observatae fuerunt.

3242. Tula ADANS. Caly x tubo cum ovario connato, limbo supero, qninquedentato. $\mathrm{C}_{0}$ rolla supera, tubo oblongo, limbo quinquefido, obtuso, dentato-crispato. Antherae inclusae. Ovarinm ...... Capsula bilocularis, loculis polyspermis. - Herba peruana, annua, procumbens, ramulosa, quasi caespitosa, soli Feuilleo nota, Nerteriae facie, a qua fortassis, etsi loculi fruclus polyspermi dicantur, non diversa.

T n I a Adanson Fam, II. 500. Jussieu in Mem, Mus, VI. 385. Römer et Schult. Syst, $I V . X X V$. DC. Prodr. IV, 418.

3243. Spiradielis BLUM. Caly $\mathrm{x}$ tubo oblongo-turbinato, cum ovario eonnato, limbo supero, persistente, quinquedentato. Corolla supera, tubo brevi, limbo quinquepartito, patente. S tamin a 5 , corollae tubo inserta, inclusa. O v a r ium inferum, biloculare, disco epigyno quadriglanduloso. Ovula in loculis plurima. Stylus simplex; stigma bilobum. Capsula oblonga, calycis limbo coronata, bilocularis, bivalvis, valvis bipartitis, demum intortis. Sem in a plurima, angulata. ...... - Herba javanica, Nerleriae facie, caespitosa; foliis oppositis, ovatis, subundulatis, glabris, spica lerminali v, axillari pauciflora, floribus unibraoteatis, secundis, parvis.

$\mathrm{Spir}$ adtelis Blame Bijdr. 975. A. Richard in Mem. soc, $h, n$, Paris, V. 288. DC. Prodr. IV. 418.

3244. Argostemama $W A L L$. C a ly x ta bo brevi, obconico, cum ovario connato, limbi superi, tri-quadri-quinquefidi lobis acutis, persistentibus. C o r oll a supera, rotata, tri quadri-quinquefida, patens. St a m in a $3-5$, corollae fauci inserta, exserta; filamenta filiformia, anth erae magnae, lanceolato-oblongae, arcte conniventes, loculis apice rimula brevi, obliqua dehiscentibus. Ovarium infernm, biloculare, diseo epigyno ear nose, operculiformi. Ovula in placentis convexis, dissepimento utringne adnatis plurima. Stylus simplex; stigma globosum, indivisum. Capsula calyeis limbo et diseo operculiformi coronata, bilocularis, vertice radiatim fatiscens. S e m in a plurima, angulata. - Herbae indica e, humiles, pube brevi hirsutae; foliis oppositis, petiolatis, altero saepius minore, rarius quaternat im verticillatis, pedunculis terminalibus aut subaxiltaribus, apice fiores plurimos, fasciculato-umbellatos gerentibus, rarius unifloris, floribus albis.

A rgoste a ma Wallich in Fosburgh Flor. Indic. II. 32a. Plant. As. rar t. 185. Blume in DC. Prodr. IV. 4it. Pom a $\mathrm{g}$ i n m Reinwardi msc.

3245 . Dphlorrhiza LINN. C a ly $x$ tube brevi, turbinato, eum ovario connato, limbo smpero, quinquefido, persistente. C orolla snpera, infundibeliformis, tabo amplo, calycis limbum 
superante, fauce barbata, limbi quinquefidi lobis brevibus, ovatis, obtusis. Sta $\mathrm{m}$ in a 5 , corollae tubo inserta, inelusa; fil am enta brevia, antherae lanceolatae, erectae. Ovari $\mathbf{m}$ inferum, biloculare, disco epigyno carnoso. Ovula in placentis cylindricis, liberis, e basi loculorum erectis plurima, anatropa. St ylu s brevissimus, inclusus; st ig m a bilobum. Caps u la lata, compressa, bilobo-mitraeformis, limbo calycino coronata, bilo. cularis, vertice rimula lorulicida dehiscens, Sem ina plurima, minima, subhexagona. Embryo in axi albuminis dense carnosi orthotropus, cylindrieus; radienla nmbilico eontigua. - Herbae indic a e, perennes, humiles; foliis oppositis, petiolatis, membranaceis, saepius magnitudine inaequalibus, stipulis utrinque geminis, minimis, pedunculis axillaribus et terminalibus solitariis, apice cymosis, ramulis subumbellatis, floribus secus ramulos unilateralibus, sessilibus.

Oph lor r hiza Linn. Flor. Zeylan, 402. Gärtner I.264. t. 55. A. Richard in Mem. soc, h. $n$. Paris. I. G7. $t$. 2. V. 269. Blume Bijdr. 976. Gaudich. ad Fregc, t, 92, DC. Prodr. IV. 415. Ophiorrhiza e sp. Linu. gen, $n, 210$.

3248: Lipostomase $D O N$. Cal yx tubo ovato, angulato cum ovario connato, limbi superi, quadripartiti laciniis linearibus, erectis, deciduis. Corolla supera, subeampanulata, tubo prope faucem barbato, limbi quadrifidi lobis ovatis, patulis. Stamina 4 , corollae tubo inserta, inclusa; fil amenta filiformia, antherae lincares, versatiles. Ovarium inferum, biloculare, apice brevissime exsertum, disco epigyno planiuseulo. Ov u$1 \mathrm{a}$ in placentis subglobosis, e dissepimenti basi pedicellatis plurima..... Stylus filiformis; stigma bifidnm, lobis subulatis. Capsula globosa, biloenlaris, operculo apieis dehiscens. Semina plurima, minuta, angulata, scabra. Embryo in axi albuminis subcornei rectus; cotyledonibus oblungis, plano-eonvexis, radicula cylindriea, infera. - Herbae brasilienses, diffusae, pilosae; folits oppositis, petiolatis, ovatis, stipulis interpetiolaribus subulatis, floribus in pedunculo axillari, solitario dense cupitatis, bracteolatis, corollis caeruleis.

Lipostom a Don in Edinb. new. philosoph. Mragas. 1830. Jan, p. 168. Hed y ot is $\mathrm{c}$ a m pa $\mathrm{n}$ u $\mathrm{l}$ if 1 o r a Hooker in Bot. Mag. t, 2840. C o c cocyps ell s p. DC.

324\%. Wireeta $D C$. C a lyx tubo brevi, ovato, cum ovario connato, limbi superi, quinquefidi lobis lineari-setaceis. Corolla supera, infundibuliformis, tubo oheonico, limbum calycis aequante, fance nuda, limbi quinquefidi lobis lineari-oblongis, ciliatis. St a m in a 5 , corollae fanci inserta, longe exserta; filamenta filiformia, an $t h$ erae lineares, basi bifidae, versatiles. 0 rari um inferum, biloculare. Ovala in loculis plurima ...... Stylus filformis, staminum longitudine; st i $\mathrm{g}$ a indivisum, vix incrassatum. C a p sula subglobesa, limbo calycis tandem deciduo nnda, bilocularis, loculicido-bivalvis. S e m in a plurima, tetra - pentagona, submuriculata. - Herbae africanae tropicae, molliter hispidae, opposite ramosae; foliis oppositis, ovali-oblongis, stipulis utrinque binis, lanceolatis, floribus albis, dense cymoso-corymbosis, ramulis post anthesim elongatis.

Virecta DC.Prodr. $W .414$. Phyteuto tdes Smeathnan msc. Vi rectae $8 \mathrm{p}$. Suith.

32 \&8. Sipanea $A U B L$. C aly $\times$ tubo turbinato, cum ovario connato, limbi superi, persistentis, quinquepartiti lobis lanceolato-subulatis. Corolla supera, infundibuliformis, tubo tereti, limbum calycis longe superante, fance barbata, limbi quinquepartiti lobis ovatis. Antherae 5 , lineares, intra faucem corollae sessiles, inclusae. Ovarium inferum, biloculare. Ovala in placentis carnosis, semiglobosis, dissepimento medio utrinque adnatis plurima, anatropa. Stylus simplex, inclusus; $8 \mathrm{i} \mathrm{g} \mathrm{m}$ a bifidum, lobis acutis. $\mathrm{C}$ a $\mathrm{p}-$ s ula subglobosa, limbo ealycis coronata, bilocularis, losulicido-bivalvis. S e m in a plurima, angulata, reticulata. E $\mathrm{m}$ b r yo in axi allonminis earnosi orthotrupss, eylindricus; radieula umbilicum spertante. - Herbae annuae $v$. perennes, in $A m e$ rica tropica indigenae, laete virentes; foliis oppositis, ovatis, stipulis utrinque solitariis, linearibus, acuminatis, floribus axillaribus $v$. terminalibus.

S i p a uea Anblet Guian. I. 147, t.56. Kunth in Humb. et Bonpl. Nov. gen. et sp. IIT. 397. A. Richard in Mem. soe, h, n. Paris, V 275. DC. Prodr. IV. 414. Eadlicher Atakt. 7. t, 7. Virecta Linn. f. Suppl. 17. Vaht Eclog. II. 11. Gastoer f. IIT. 31. t. 184. P t g e hode a Willd. msc.

3\%49. Carplinalea JUSS. Calyx tubo turbinato, cum ovario connato, limbi superi, qua dripartiti lobis amplis, ovali-oblongis, subspathnlatis, scariosis, persistentibus. Corolla supera, tubo longo, filiformi, fauce ventricosa, intus hirta, limbi quadripartiti lobis oblongis, acutis. Anthera e 4, oblongae, intra corollac faucem subsessiles, inclusae. Ovari u m inferum, biloculare. Ovala plurima $\ldots$. Stylus filiformis; stigma bifidum? C а p sula biloealariz, limbo calycis coronata, loculicido-bivalvis, valvis medin semiseptiferis. Sem in a plurima....... Frutex mada gascariensis, Serissae habitu, non satis notus et propter semina ignota quo ad locum in ordine subdubius, aridus, glaber, hyssopifolius; foliis oppositis, sessilibus, lincaribus, acutis, stipulis

floribus lerminalibus, corymbosis.

Carphalea Jasieu gen. 198. Mem. Mus. VT. 383. Lam, t. 59. A. Richard in Memt soc, $h, n$. Paris, V. 274. DC. Prodr, IV. 413.

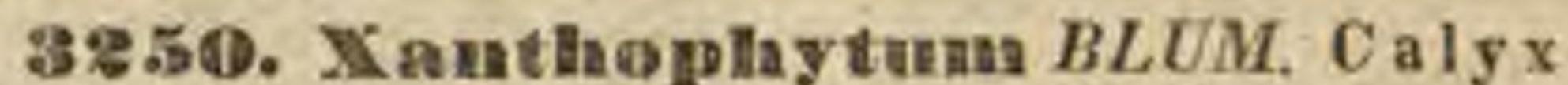
tubo ovato, eum ovario connato, limbo supero, persistente, quadri-quinquefido. Coralla supera, infundibuliformis, tubo brevi, fauce villosa, limbo quadri-quinquefido, patente. St amina $4-5$, corollae fanci inserta; fil amenta conniventia, antherae..... O Orarium inferum, biloculare, disco epigyno carnoso, styli basim cingente. Ovula in placentis dissepimento medio ntrinque affixis plurima. Stylus subelavatus; $8 \mathrm{tigma}$ crassum, bilobum. Dr n a didyma, calycis limbo coronata, bilocularis, dicocea, coccis indehiscentibus. Semina plurima, minuta, angulata.

Suffrutices ja vanic $i$, glabri v. rufo-villosi; foliis oppositis, oblongis, stipulis utrinque binis, subulatis, basi connatis, spicis axillaribus et terminalibus. interruple glomeratis, nutantibus, v. pedunculis axillaribus, trichotomis, multifloris.

$\mathrm{X}$ a nthoph yt um Blume Bijdr.989. A. Riehard in Mem. soc. h. n. Paris. V. 2a5. DC. Prodr. V. 413.

3251. Creenia WIGHT et $A R N$. Caly $x$ tubo globoso, cum ovario connato, limbi quadripartiti, persistentis laciniis erectis. Corolla supera, infundibuliformis, pnbescens, fauce glabra, limbi quadrifidi lobis anguste ovatis, acutis, aestivatione contortis. Antherae $\}$, lineares, intra faucem corollae peltatim sessiles, apicibus brevissime exsertis. Ovarium inferum, bilsculare, disco epigyno crasso, carnoso. Ovula in placentis hemisphaericis, medio dissepimento vtrinque insertis plurima ...... Stylus filitormis, sub. exsertus; stigma bifidum, lacinits linearibus, re- 
curvis. Cap sula ealycis limbo coronata, bilocularis, dicocca, eoccis apice dorso fissis, demum a calyeis tubo solutis. Semina plurima, minuta, angulata .... - Frutices indici; foliis oppositis, acuminatis, basi angustatis, stipulis magnis, membranaceis, linguaeformibus, corymbis terminalibus, divaricalo-trichotomis, ramis hirsutis, pedunculis dichotomis, floribus albis, juxta ramulos introrsum secundis, sessilibus, approximatis, singulis bractea subulata stipatis, calycibus brevissime setulosis.

Greenia Wight et Arnott Prodr. Flor. Penizs, Ind. Orient. 1 . 404. Rondeletia spicata Wallicb. WendLandiae sp. DC.

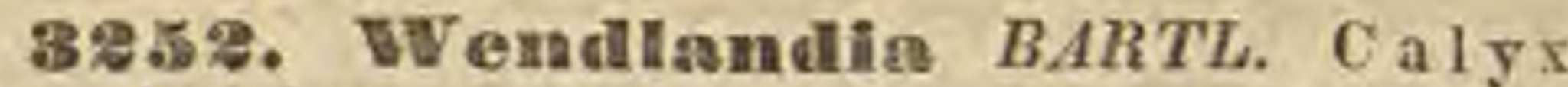
tubo subgloboso, saepius striato, cum ovario connato, limbo supero, persistente, brevissime quinquedentato. Corolla supera, tubo tereti, fauce ampliata, glabra, limbi quinquefidi lobis oblongis v. lanceolatis, acutis v. obtusis, aestivatione im. bricato-subcontortis. Stam in a 5, summo corallae tubo inserta, exserta; filamenta brevia, a $\mathrm{ntherac}$ lineares, versatiles. Ovari um inferum, biloculare, disco epigyno carnoso. Ov uIa in placentis hemisphacricis, dissepimento utrinque insertis plnrima...$\ldots$. S t y 1 u s filiformis, exsertus; stigma bifidum, lobis lato-ovalibus, crassiusculis, Capsu I a globosa, calyeis limbo coronata, bilucularis, apice loculicido-bivalvis. Scm i na plurima, minuta... - Arbores $v$. frutices, in India orientali crescentes; foliis oppositis, coriaceis, ovalibus v. lanceolatis, petiolatis, stipulis utrinque solilariis, e basi lata acuminatis, puniculis terminalibus, thyrsaideis, mulifloris, floribus albis, parvis.

We nd la n di a Bartling mse. DC. Prodr. IV. 411. Wight et Aruott Prodr. Flor. Penins, Ind, orient. . A08. R on deletiae sp. Rox3. et Wallich.

3.253. Adteñsacrae WALL. C a 1 y x tubo ovato, cum ovario connato, limbi superi, quinquefidi, persistentis laciniis lanceolatis, margine utrinque et interdam etiam apice glandula globosa stipatis. Co roll a supera, infundibuliformis, tubo cylindrieo, extrus puberulo, intus villoso, fance subampliata, nuda, limbi quinquefidi, patentis laciniis angusto-ovatis, aeutis, aestivatione valvatis. Stamina 5 , imo corollae tubo inserta, inclasa; fil am enta brevissima, a $\mathrm{nth}$ erae oblongae. Ovarium inferum, biloculare. Ovala in placentis carnosis, dissepimento utrinque insertis plurima ...... Stylus filiformis; stigma bifidum, lohis linearihus, erectis. Cap s n la ovata, limbo calycis recurvato coronata, bilocularis, apice rimula loculicida dehiscens. Semina plurima, minnta..... - Frulex nepalensis; ramis laxis, epidermide secedente; foliis oppositis, elliptico-oblongis, acuminatis, basi acutis, subtus villosis, stipulis lanceolatis, basi bidentatis, panicula dichotoma, latevi, bracteis glandulosis, corollis umplis, flavis.

Aden os a eme Wallich Catalog. n.6280_6282. R ondeletia $10 n g$ if olia Wallich in Roxburgh Flor. Ind. or. II. 138. Wend la a diae $5 \mathrm{p}$. DC.

3\%54. IBondeletia BLUM. Caly $x$ tubo subgloboso, cum ovario connato, limbi superi, persistentis, quadri-quinquefidi laciniis oblongolinearibus, acutis. Corolla supera, infundibuliformis, tubo eylindrico, fauce subampliata, limbi quadri-quinquefidi, patentis lobis ovatis, obtusis, aestivatione imbrieatis. An the ra e $4-5$, intra fau cem corollae sessiles, inslusae. Ovarium infe- rum, biloenlare. $O \vee \mathrm{v}$ a in placentis dissepimen. to utrinque insertis plurima, anatropa. Sty $\mathrm{lu}_{\text {z }}$ filiformis; stigma bifidum, lobis obtusis. Capsula globosa, calyeis limbo coronata, bilocularis, apice rimula loculicida ajerta, rarius juxta totam longitudinem loculirifo-v, septiciso-hivalvis, valvis apies demum bilidis. Semina minuta, plurima, v. ovuloram aborta pauca. Embryo ...... - Erutices v, arbusculae, in Americu tropic a indigenae, verisimiliter in plura genera divellendae; foliis oppositis, peliolatis v. sessilibus, stipulis utrinque solitariis, delloideis $v$. lanceolatolinearibus, integerrimis, inlerdum intus hirsutis, pedunculis axillaribus saepius trichotomis, $v$. in paniculam corymbosam terminalem dispositis, rarius tri-v. interdum unifloris.

Rondeletin Plumier Gen, 15. t, 12, Jaeq. Amer. c. 42. Lam. $t$. 168. Vahl Symb. IIT. 2, 54. Gäriaer f. III. 38. t. 184. Kunth in Humb. et Banpl. Nov- gen. et sp. 6. 290. 291. A. Riehard in Mem. soe. h. n. Paris, $\mathcal{Y}$, 221, DC. Prodr. IV. 406. Petes ta P. Browne Jam. 143, $t$. 2. non alior. Lightfo otia Schreber gen. n. 303. Hon Herit. Willd e now ia Gmelia Syst. 368. nou Thuab. A ra e b n imo r p la Desvaux in Ilamilton Prodr. Flar. Ind, oceid, is.

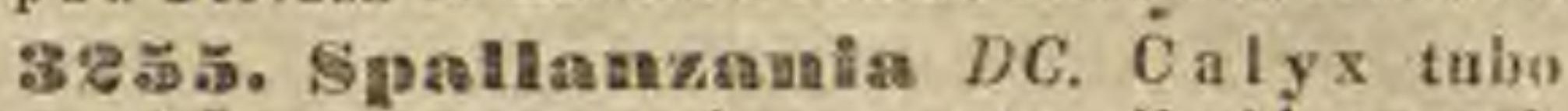
ohpyramidat, enm uvario cunnato, limbi snperi, quinquepartiti, persistentis tobis foliaceis, linearibus, distantibas, acutis, erectis, tubo longioribas. Corolla supera, infundibuliformis, tubo tereti, gracili, calycis limbum superante, fauce nuda, limbi quinquefidi lolis ovalibus, patentibus. Stamina $\mathbf{5}$, corollae fauci inserta, exserta; $\mathrm{fi}_{-}$ I a $m$ en $t$ a filiformia, an thera e oblongae, Ovari $\mathrm{nm}$ inferum, biloeulare. Ovula in placentis dissepimento utrinque insertis plarima .... S $t y-$ I us filiformis; stigma bifidm, laciniis linearibus, elongatis. Ca $\mathrm{p}$ u la ovato-glohosa, calyeis limbo coronata, bilocularis, apice loculieido-bivalvis valvis demum bifidis. Se m in a plurima, ovata, rugoso-tuberculata. Emb ryo .... - Arbor $m a$ dagascariensis, glabra; ramulis teretibus, apice compressis, foliis oppositis, petiolatis, obovatis, coriaceis, stipulis utrinque solitariis, ovatis, apice breviler bifidis, corymbi terminalis multiflori ramis angulatis, basi bracteatis.

\section{Spallanzania DC. Prodr. $I V$. 406, non alior.}

3256. Hsidorea $A, N I C H$. C a ly x tubo turbinato - pentagono, cum ovario connato, limbi superi, quinquepartiti, persistentis laciniis erectis, carinatis, lanceolato-subulatis. Corolla supera, tubalosa, tubo pentagono, fauce nuda, limbi brevissime quinquefti lobis triangularibus, acatis, patentibus. Sta mina 5, imo curallac tulo inserta; fil am enta filiformia, tubum aequantia, basi villosa, in tubnm brevissimum connata, a $\mathrm{n} t$ herae oblongac, erectae. Ovari um inferum, biloculare, disco epigyno carnoso. Ovula in placentis dissepimento utrinque adnatis plurima, horizontalia, anatropa. St y 1 u 8 filifurmis, subexsertas; stig ma breviter bilobum, lobis obtnsis. C a p s u la subgloboso-pentagona, calycis limbo coronata, bilocularis, dicocca, coccis facie demum bifidis. Semina plurima, polyedra, basi membranula enpulacformi lacera cincta. - Frntex antill an us, rigidus, Ernodeae facie; foliis oppositis, linearibus, rigidis, margine revolutis, slipulis junioribus integris, subulatis, demum bifidis, floribus subterminalibus, solitariis, subsessilibus, interdum hexumeris.

Is idorea A, Richard in stem, soe, h. n. Paris, $\mathscr{V}$.

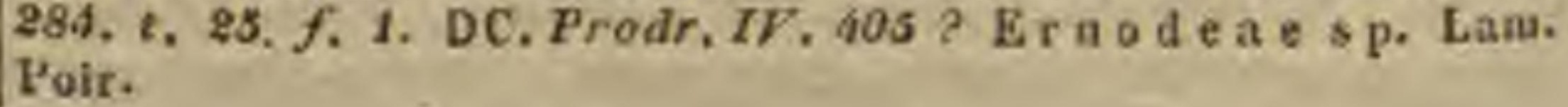


325\%. Thk hia $R E I N W$, Calyx tubo turbinato-oblengo, cnm ovario connato, costis octo filiformibus, Jimbi superi, quadripartiti laciniis lineari-lanceolatis. Coroll a supera, clavato-tetragona, limbo quadripartito. Stam in a 4 , corollae tubo prope basim inserta; fil amenta filiformia, a $n t$ herae elongato-lineares, erectae. Ovarium inferum, bileculare. Ovula in placentis dissepimento utrinque insertis, anguste bilobis plurima ...... Stylus simplex, inclusus; stigma...... Capsula ovata, apice dehiscens, calyce solnto demum denulato, bilocularis, valvolarum marginibus involutis fere quadrilocularis. Semin a plurima, minima, compressa, cristis membranaceis secus marginem echinata. Albumen carnosum. E m bryo .......-Arbuscula moluccana, glabra; folitis oppositis, obovatis, obtusiusculis, basi cuneata petiolatis, praeter nervum medium subaveniis, stipulis brevibus, truncatis, concretis, vaginantibus, pedicellis axillaribus solitarïs, unifloris, nudis, floribus albis.

B ik kia Reinwarit in Blume Bijdr. 1017. DC. Mem. Umbellif. 10. Prodr. IV. 405. A. Richard in Mem. soc. A. $n$. Paris, V. 230. Cormigonns Rafinesque in Annal. gen. š, phys. VT. 83. Portlandia tetrandra Forst. Hoffma и и a A micorum Spreng.

3259. Fortlandia $P, B R, C$ a $1 \mathrm{y} \times$ tubo obovato, cum ovario connato, quinquenervi, limbi superi, persistentis, quinquefidi lobis oblongis, foliaceis, magnis. Cor oll a snpera, maxima, pentagono-infundibuliformis, fauce ampliata, nuda, limbi quinquefidi lshis obtusis. St a m in a 5 , imae corollae fauci inserta; filamenta filiformia, antherae lineares, semiexsertae. Ovarium inferum, biloculare. O $\mathrm{v} n \mathrm{la}$ in placentis e dissepimento utrinque porrectis plurima, horizontalia, anatropa. Stylus filiformis, subexsertus; stigin a indivisum, haud inerassatum. Capsula obovata, costato-pentagona, apice retusa, calycis limbo patente coronata, apice loculicido bivalvis. Semina plurima, elliptica, compressa, punctatoscabra, umbilico earnoso-incrassato, E mbryo in axi albuminis carnosi orthotropus; coty ledonib us semicylindricis, obtusis, radicnla tereti, umbilico proxima, centripeta. - Arbuscula antillana, glabra; foliis oppositis, breve petiolatis, lanceolato-ellipticis, nitidis, stipulis latis, triangularibus, pedunculis axillaribus, brevibus, uni-trifloris, floribus albidis, maximis.

Portl a ndia P. Browne Jam. 164. Linn. gen, n. 297. Jacq. Amer, t. 44. Gärtner I. 153, t, 31, Smith Ic, pict, I. t, 6. Bot. Mag. t. 286. A. Richard in Mem, soc, h, n. Paris. T. 286, DC, Prodr, IV, 404.

3259. Selnreibersia $P O H L$. Calyx tubo oblongo, cum ovario connato, decemnervi, Iimbi quinquefidi laciniis aenminatis, ereetis, Corolla supera, infundibuliformis, magna, tulıo e basi angusta sursum ampliato, subincurvo, limbi quinquefidi laciniis oblongis, acutis, patentibus. Antherae 5, oblongae, inter limbi corollini la einias sessiles, subreflexae. Ovarinm infernm, biloculare. 0 v n 1 a in placentis e dissepimento ntrinque porrectis plurima, horizontalia, anatropa. Stylus filiformis, basi hirsutus; $8 \mathrm{i}_{\mathrm{g}} \mathrm{ma}$ bifidum, lobis crassinsculis, obtusis. Ca p s n la oblonga, decemnervis, limbo calycis coronata, bilocularis, loculicido-bivalvis, valvis demum $e$ salycis tubo solutis, denudatis, plus minus profunde bifidis. Semina plurima, tetragona. $\mathrm{Em}$ bryo........ Arbores $v$, frulices brasilien. ses, glabri; folitis oppositis, oblongis, acutis, co- riaceis, stipulis e basi lata cuspidatis, deciluis, pedunculis axillaribus uni-trifloris, basi bibracteolatis, floribus purpureis, speciosis.

Sehrefbersia Pohl in Flora 1825. p. 183. A u g sta Pohl Plant. Mrasil. $I I$. 1, $t, 101$-105, non Leaudr. A ugustea DC. Prodr. IV. 404.

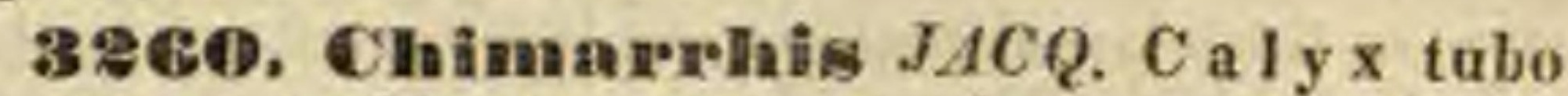
obovato v, tarbinato, cum ovario connato, limbo subnullo, integerrimo. Corolla supera, tubo brevi, limbi quinquefidi, patentis lobis extus medio hirsutis. St am in a 5, sumuo corollae tubo inserta; fi lamenta basi hirsuta, antherae ovales. Ovarium.....Stylns..... Caps u la obovata v. turbinata, calycis limbo marginali coronata, ligneo-coriacea, bilocularis, usque ad basim bivalvis, valvis semibifidis. Semina plurima, pendula.....-Arbores America e tropicae, glabrae, non satis notae, vix hujus loci; foliis oppositis, breve petiolatis, stipulis inlerpetiolaribus utrinque solitariis, corymbis v, cymis terminalibus, floribus albis.

Chimarihis Jacq, Amer. t. 61. Jussieu gen, 204. Mem, Mus. VI. 381. DC. Prodr. IP. 403. Macrocne u i s p. A. Richard.

3261. Maeroenemuma $P$. BR. C a ly $\mathrm{x}$ tubo turbinato, cum ovario connato, limbo supero, persistente, brevi, quinquedentato. Corolla supera, tubulosa, tobo pentageno, fauce ampliata, nuda, limbi quinquefidi lobis ovatis, acutis, suberectis. S tam in a 5, imo corollae tubo inserta, inclusa; filam enta filiformia, libera, supra medium hirsuta, antherae oblongae, incumbentes. Ovarium inferum, biloculare. Ovala in placentis dissepimento utrinque adnatis plurima Stylus filiformis; stigma bilobum, lobis obtusis, Capsula turbinata, limbo ealyeis coronata, bilocularis, bivalvis, valvulis lateribus externe dehiscentibus? Se min a plurima, intbricata, acuta... . - Arbuscula ja ma icensis, glabra; foliis oppositis, approximatis, oblongis, breve acuminatis, stipulis utrinque solitariis, pedunculis terminalibus et subaxillaribus solitariis, superne trichotomo-corymbosis, floribus majusculis, luteo-virescentibus.

Macrocuem a m P. Browne Jam. 165. Lien. Amoon, V. 413. Swartz Observ. 6s. 6. 3. f. 1. Jussieu in Mem. Mus. VI. 386. DC. Prodr. IV. 402,

3262. Condaminea $D C$. Caly $x$ tubo cyathiformi-campanulato, cum ovario eonnato, limbo supero, quinquecrenato $v$. quinquedentato, circumscisse deciduo. Corolla supera, infundibuliformis, tubo brevi, subeurvato, fauce dilatata, limbi quinquepartiti lohis ovatis, acutis, patentibns, apice incrassatis, Stamina 5 , corollae tulo supra medium v. prope faucem inserta; fil a m e nta filiformia, inclusa, a $n$ the rae oblongo-lineares, hasi bifidae, subexsertae. Ovarium inferum, biloculare. Ovula plurima ......Stylus filiformis; $s t \mathrm{igm}$ a bilobum. Capsu la turbinata, compressa, truncata, umbilicata, bilocularis, loculicido-bivalvis, S emina plurima, minima, cuneiformia, aptera. - Frutices peruani; foliis oppositis, breve petiolatis, amplis, stipulis intrafoliaceis, bipartitis, acuminatis, adpressis, sacpe connatis, corymbis v. racemis terminalibus multifloris.

Condaminea DC. Prodr. 1 . 408. Macroenemi s. p. Ruiz et Pav, Flor, peruv, t, 188, f. a. $t, 189,190, f . b$. Kunth, A. Rich.

Treinus xuI. CINCHONEAE. Fructus capsularis, bilocularis. Semina alata. 


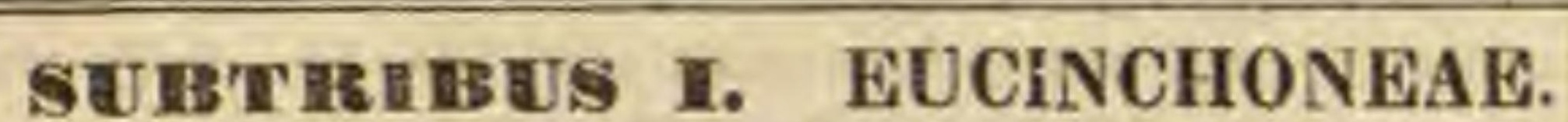
Flores distincti, pedicellati.

3:63. Calyeoplayluan $D C$. C a 1 y x tubo ovato-oblongo, cum ovario connato, limbo supero, truncato $v$. obtuse quinquedentato, dente uno in folium petiolatum, membranacenm, coloratum expanso. C o rolla supera, campanulata v, breviter infundibuliformis, limbo quinquepartito. $\mathrm{St}$ a $\mathrm{m}$ in a 5, corollae faci inserta; filam enta filiformia, limbum aequantia, anthera evales, exsertae. Ovariu inferam, biloculare. Ovula in placentis linearibus, dissepimento utrinque adnatis plurima ...... Stylus brevis; $8 \mathrm{tigm}$ ata 2, filiformia, reflexa, Capsula bilocnlaris, apice dehiseens ..... Sem in a plurima, oblonga, imbricata, membranacea, subalata. E mbry o ..... - Arbusculae antillanae, glabriusculae; foliis oppositis, petiolatis, membranaceis, supra glabris, subtus ad venas villosis, stipulis brevibus, latis, deciduis, floribus corymbosis, axillaribus et terminalibus, pedunculis trichotomis, compressis.

Caly cophy 11 am DC. Prodr. IV, 367. Macrocnent i s p. Vahl symb, II, 38. t. 29. 30.

3864. Pinlumeya L. C. RICH. Caly tubo oblongo-turbinato, eum ovario connato, limbi superi, quinquepartiti, erecti lobis quatuor oblongis, quinto in folinm coloratum, amplum expanso. Corolla supera, infundibuliformis, tubo cylindraceo, limbi quinquepartiti lobis oblongis, recurvo-patentibus. Stamina 5 , imo corollae tubo inserta ; filamenta setacea, exserta, antherae oblongae, ineumbentes. Ovarium inferum, biloculare. Ovula in placentis bilobis, dissepimento utrinque insertis hiseriata, horizontalia, anatropa. Stylu 8 filiformis; $8 \mathrm{tigma}$ obtuse bilobum. C a p s u la subgloboso-didyma, vertice nuda, bilocularis, loctlicido-bivalvis, S e m in a in loculis plurima, biseriata, horizontalia, compressa, incumbentia, epiflermide laxa, membranacea, ad umbilieum emarginata, E mb r yo in axi albuminis carnosi orthotropus; cotyledonibus foliaceis, radicula conica, umbilico proxima, centripeta. - Arbuscula caroliniana, ramosa; foliis oppositis, ovalibus, utrinque angustatis, subtus ramisque subtomentosis, stipulis deciduis, floribus majusculis, pubescentibus, pallidis, in supremis foliorum axillis fasciculatis.

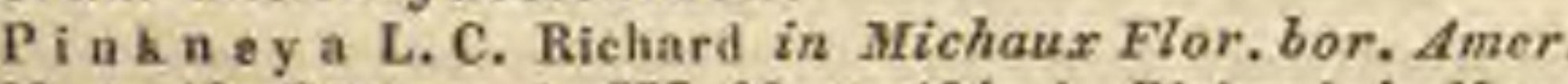
1. $103, t .13$. Gärtner f. $I T T .80 . t, 194$. A. Ricliard in Mem. soc. h, n. Paris. $V$. 2z7, DC. Prodr. IV. 3e6. P in knea Persoon Ench. T, 197.

: 265 . Bow bo subgloloso, eum ovario connato, limbi superi, quadripartiti lobis lineari-subulatis, dentibns interilum interjectis. Co rolla supera, infundibuliformi-tubulosa, elongata, extus velntino-papillosa, intus glabra v. barbata, fauce nnda, limbo quadripartito, patente, brevi. Stam in a 4 ; fi I a m e n ta brevissima v, subnulla, ant herae lineares, inclusae. Ov ari u m inferum, vertice subexsertum, biloculare. Orula in placentis orbicularibus, dissepimento utrinque insertis plurima, amphitropa. Stylus filiformis; stigma bilamellatsm, exsertum. Caps a la membranacea, globoso-compressa, bilocularis, apice septírrago-bivalvis. S e m in a plurima, compressa, peltata, imbricata, ala membranacea eincta. E m b r y o ..... Fru tices mexic ani; foliis oppositis $v$. verticillatis, stipulis angustis, acutis, petiolis utrinque adnatis, pedunculis terminalibus, triftoris v. trichotomis, co rymbosis.
B ou v a dia Salisbury Parad, II, 88, $t, 88$. Kuath in Humb. et Bonpl. Nov. gen. et sp. III.383. Jussieu in Mem. Mus, VI. 383. Bot. Reg. $t$. 107. 245. A. Richard in Mem, soc, h. n. Paris. V. 271. $t$. 23. f. 3. exel. sp. DC. Prodr. IV. 365. Ho us toni a Aadr. Bot. Reposit. $t$. 106. Chris tim a Rafi. nesque in Annal. gen, sc.phys, V. 224. A eg I ueti a Cavanill, Ic. VI. $5 t, t .572$, non Linn. I $\mathrm{x}$ o r a e $\mathrm{s}$, Jacq. Hort, Schönbr. t. 257 .

3266. FInettia MUTIS, Calyx tubo turbinato, cum ovario connato, limbi superi, quadri-quinquepartiti lobis lineari-lanceolatis, accessoriis dentibus totidem saepins inter lobos. $\mathrm{C}_{0}$ rolla supera, infundibuliformis, tubo tereti $\mathbf{v}$. tetra-pentagono, fauce ampliata, pilosa, limbi brevissime quadri-quinquefidi lobis obtusis, patentibus v. revolutis. Sta m in a $4 v$. 5 , corollae fauci inserta; filamenta filiformia, subexserta, anthe rae ovatae, incumbentes. Ovarium inferum, biloculare. Ova I a plurima, placentis cylindricis, e basi dissepimenti utrinque adscendentibus undique inserta, amphitropa. Stylus filiformis; stigma obtuse bilobum, subexsertum. Capsula membranacea, calycis limbo coronata, bilocularis, septicido-bivalvis. Sem in a plurima, compressa, peltata, imbricata, ala membranacea cincta. $\mathbf{E}$ mbryo in axi albuminis carnosi orthotropus; cotyledonibus ovatis, subfoliaceis, radicula cylindrica, infera. - Herbae v. suffrutices volubiles, in America tropica crescentes; ramis gracilibus, foliis oppositis, brevissime petiolatis $v$. sub. sessilibus, ovato-oblongis v. subcordatis, stipulis latis, brevibus, acutis, saepius cum petiolorum basi subconcretis, pedunculis axillaribus, uni-multifloris, nudis $v$. medio bibracteolatis.

Manettia Mutis in Linn. Mantiss. 556. Schrebergen. n. 181. Ruiz et Pavon Elor. peruv. t, 89. 90. $f$. a. Kunth in Humb, et Bonpl, Nov. gen. et sp. III. 387. Murtius Mat. Medio. Brasil. t. 7. Bot. Reg. t. 693. 1866. DC. Prodr. IV. 362, non Adans. N a ci be a Aublet Guian. I, 96. 2.37. Gārtner f. III. 102. t, 197. Jussieu in Mem. Mus. VI. 384. excl. synon. Bo a vardiae sp. et Conotrichia A. Richard in Mem. soc. h. n. Paris. $V$. 277. $t$. 24. f. 1. Lyg istam P. Browne Jam, 142, Lam. t. 67. f, 2.

326\%. Damais COMMERS. F lores abortu dioici. Caly x tubo brevi, obovato, cum ovario connato, limbo supero, brevissimo, quinque dentato. Corolla supera, infundibuliformis, tube gracili, fauce villosa, limbo quinquepartito. Sta$m$ in a 5 , corollae fauci inserta, marium exserta, feminarum inclusa, abortiva. $O$ v a $r i \mathbf{~} m$ inferum, biloculare. $O \mathrm{vula}$ in placentis dissepimento utrinque adnatis plurima, amphitropa. Stylus simplex; 8 tigma bifidum, laciniis linearibus, exsertis, in floribus mascnlis inclusis. Ca psula subglobosa, limbo calycis coronata, coriaceo-chartacea, bilocularis, loculicido-bivalvis. Se m in a plurima, peltata, compressa, imbricata, ala membranacea cincta. Embryo ..... - Frutices ma uritiani, scandentes, glabri; radicibus succo aurantiaco scatentibus, folits opposilis, oblongis $v$. ovatis, stipulis utrinque solitariis, latis, brevissimis, pedunculis axillaribus, corymbosis, multifloris, ramulis oppositis, floribus aurantiaceis, fragrantibus, interdum hexameris.

D a na Is Commerson ex Venten. Tab7. II. 584. Jussieu Mom, Mus. VI. 385. Gärtner f. III. 83, t. 198. A. Richard in Mem. soc. h. r. Paris, V. 274. DC. Prodr, IV. 361. P aede $r$ i a s p. Jussieu gen, 204. Lam. l. 160. $f$. 2.

3868. Alseis SCHOTT. Flores abortu monoici. Calyx tubo obconico, cam ovario connato, limbi superi, quinquepartiti laciniis lanceolatis. C o r o I I a supera, subcampanulata, brevis, limbo late quinquedentato, erecto. S $t a$ 
min a 5 , ino corollae tubo inserta, exserta, in femineis inclusa; fil a menta subulata, basi pilosa, antherae ovatae, erectae. Ovarium inferum, biloculare. Ovula in placentis dissepimento utrinque longitudinaliter adnatis plurima, pendula, imbricata, marginata, anatropa? Stylu s simplex, basi pilosus, exsertus; s tig ma bifidum, laciniis linearibus, patentibus. Fruetus.. - Arbuscula brasiliensis; foliis oppositis, breve petiolatis, ovato-acuminatis, venosis, utrinque pilosiusculis, stipulis late triangularibus, brevissimis, spicis terminalibus et e summis foliorum alis ramosis, floribus confertis, sessilibus, inferioribus hermaphroditis, superioribus femineis, corollis ochroleucis, pilosis.

A $1 \mathrm{se}$ is Schott in Sprengel Cur. post. 404. DC. Prodr. IV. 620. Rudlieher Alakt, $t .33$.

3269. Exostemma L.C. RICH. C a ly x tubo ovato, cum ovario connato, limbo supero, quinquedentato. Co rolla supera, infundibuliformis, tubo tereti, limbi quinquefidi laeiniis linearibus, patentibus v. revolntis. S $t$ a m in a 5 , imo corollae tubo inserta, longe exserta; filamenta filiformia, libera $v$. tubo ad faucem usque adnata, antherae lineares, erectae. Ovarium inferum, biloculare. Ovula in placentis linearibus, dissepimento utrinque insertis plurima, pendula, anatropa. Sty lus elongato-filiformis, apice subclavatus; stig ma indivisum, subunilaterale v, breviter bilobum. Cap 8 ula coriacea, calycis limbo coronata v. demum subnuda, bilocularis, septicido-bivalvis, valvis integris v, demum bifidis. Semina plurima, e placenta demuın libera pendula, imbrieata, compressa, ala membranacea, angusta, ad nmbilicum emarginata cincta. E $\mathrm{m}$ bryo in axi albuminis carnosi orthotropus; cotyledonibus ovatis, subfoliaceis, radicula tereti, elongata, umbilico proxima, supera. - Arbores v. frutices, in America tropica indigeni, plerumque glabri; foliis oppositis, ovalibus $v$. lanceolatis, breve petiolatis, stipulis utrinque solitariis, pedunculis axillaribus v, terminalibus, floribus candidis v. rubentibus.

Exost em ma L. C. Richard in Humb. et Bonpl. Plant. aeguinoot. 1 . 151. St. Hilaire Plant. Hsuell, Bras, 3. A. Biehard in Mem, soc. h. n. Paris. V. 280. DC. Prodr. IV. 358.

a. PITONIA DC. l. c. C alycis limbus usque ad basim in dentes longitudine varios divisus. Corollae glabrae, tabus lacioiis Iongior. Stig ma indivisum. - Species antillanae, cortice febrifugo, subemetico. - C f nchonae s p. Jaeq. Amer. $t, 179$. f.65. Observ. 2.t.17. Gärtner $t$. 33. f. infer. Lambert Cinch. $t, 4.6-9$.

(A. Richard in Mem. soc. $h, n$. Paris. $V, t$. 24.)
BRACHYANTHEMUM DC. $l$. c. Caly c is limbus usque

b. BRACHYANTHEMUM DC. . C. Caly c is limbus usque brevior v. vix aequalis. Stig ma indivisums v, subbilobum. - Species peruanae, manillenses et oceanicae. - Cin c ho na e sp. Forst. Cavanill. Ic, 2, 329. Lambert Cinch. $t .5$. Portlandiae sp. Ruiz et Pav. Flor. peruv. t. 190. f. a, (Humb. et Bonpl. Plant, aequinoct. 2. 78.)

3ะช (D. 面ymenodyetion WALLICH. C al y x tubo ovato, cum ovario connato, limbo supero quinquedentato. C o roll a supera, infundibuliformis, fauce nuda, limbi quinquefidi lobis aestivatione plicatis, sub anthesi erectis. St a m in a 5 , fauci corollae inserta, inclusa; fil a m en t a brevissima, antherae oblongae, erectae, Ovarium inferum, biloculare. Ovula in placentis linearibus, dissepimento utrinque insertis plurima, adscendentim imbricata. Stylus simplex, longe exsertus; s ti g m a clavato-capitatum, sublobatum. Ca p 8 ula coriaceo-lignosa, apice nuda, bilocularis, loculicido-bivalvis. Semin a plurima, in placenta"de- mum libera adscendentim imbricata, compressa, ala membranacea, reticulata, ad umbilicum bifida cineta. E m b r y o-in axi albuminis carnosi rectus; cotyledonibus cordatis, radicula tereti, infera. - Arbores indic a e, umbrosae; ramulis compressis, foliis oppositis, petiolatis, coriaceis, stipulis interpetiolaribus solitariis, glanduloso-ciliatis, deciduis, floribus parvis, inconspicuis, virescentibus, pubescentibus, fasciculatis, in racemos pedunculatos, paniculam terminalem formantes dispositis, bracteis sub racemis longe petiolatis, lanceolutis, aridis, convexis, venosis.

Hymenodyetion Wallich in Roxburgh Flor, Ind. IT, 148. Tent. Flor, nepal. I. 31. t.22. Plant. As, rar, t.188. DC. Prodr. IV. 358. Don in Linn. Transact. XVII, 112. Cinchonat 8 p. Roxburgh Plant. Corom, $t, 106$.

329 1. Luenlia SWEET. Calyx tubo turbinato, cum ovario connato, limbi superi, quinquepartiti laciniis lineari-subulatis, aequalibus, deciduis. Corolla supera, hypocraterimorpha, tubo ad faucem vix ampliato, limbi quinquefidi laciniis aestivatione valvatis, sub anthesi patentibus, obovatis, obtusissimis. Antherae 5, lineares, ad corollae faucem spbsessiles, subinclusae. Ovarium inferum, biloculare. Ovula in placentis linearibus, dissepimento ntrinque insertis plurima, adscendentim imbricata. Sty Ins simplex; stig m a ta 2, carnosa. Ca psu la obovato-oblonga, apice nuda, bilocularis, septicido-bivalvis, S e m ina plurima, in placenta demum libera adscendentim imbricata, compressa, ala membranacea, dentata, ad basim angustata cincta. Em b r yo $0 .$. Arbuscula n epalensis; ramis teretibus, pubescentibus, foliis oppositis, ellipticis, breve acuminat is, petiolatis, supra glabris, subtus ad nervos villosis, stipulis utrinque solitariis, e basi lata acuminatis, petiolos superantibus, corymbi terminalis multiflori ramulis oppositis, ultimis apice trifloris, corollis roseis, carnosulis.

Luculia Sweet Fl, Gard, I, t, 145. DC. Prodr. IV. 357. Don in Linn, Transact, XVIT, 143, C inchon a g rat. tissima Wallich Tent, Flor. nepal, t. 21. Mussaeuda L u culi a Hamilt.

32\%3. Hasionema $D O N$. Calyx tubo obovato, cum ovario connato, limbo supero, persistente, brevissime quinquedentato. Corolla supera, tubo brevi, Jimbi quinquefidi laciniis aestivatione imbricatis, sub anthesi patentibus, oblongis, obtusis. Stamina 5, corollae tubo infra faucem inserta, subexserta; fil a menta filiformia, medio barbata, antherae oblongae, incumbentes, basi bifidae, $O$ va ri u m inferum, biloculare. $O \mathrm{vula}$ in placentis dissepimento utrinque insertis plurima, peltata. Stylns simplex; stigma bifidum, lobis obtusis. Cap s ula bilocularis, calycis limbo coronata, loculicido-dehiscens, septo integro. S e m in a plurima, peltata, membranaceo-marginata. E mbryo ….. - Arbor peruana, Cinchonae facie, floribus paniculatis.

$\mathrm{L}$ a si o n ema Don in Linn. Transact, XVIL, 142. C inchou a rose a Ruiz et Pav. Flor, peruv, $t, 199$. ? Exa. stemmatis sectio III. Ps e ados tem ma DC. Prodr. IV. 358. (St, Hilaire Plant, usuell, Bras, $t, 3$. )

3\%ซ3. Femijia DC. Caly $\mathrm{x}$ tubo obovato, cum ovario connato, limbo supero, persistente, quinquefido. Cor o 11 a supera, infundibuliformis, tubo tereti, limbi quinquepartiti laciniis aestivatione valvatis, sub anthesi patentibus, linearibus, acutis. S t a m in a 5, medio corollae tubo inserta, inclusa; fil am enta brevia, inaequilonga, a $n$ thera lineares, erectae. Ovarium inferum, bilo$70^{\circ}$ 
culare. $0 \mathrm{vula}$ in placentis linearibns, carnosis, lissepimento utrinque insertis plurima, adscendentim imbricata. Stylus simplex; stigmata 2 , linearia, inclusa. Cap sula ovata, calycis limbo coronata, bilocularis, ab apice ad basim septicidobivalvis, valvis demum bifidis. Sem in a in placen. tis demum liberis plurima, adseendentim imbricata, compressa, peltata, ala membranacea, integra, basi emarginata cincta. E $\mathbf{m}$ b r $\mathbf{y} 0$ in axi albuminis carnosi rectus; cotyledon ibus brevissimis, subcordatis, radicula tereti, infera. - Frutices brasilienses, graciles, vix ramosi, a Cinchonis vix nisi habitu, inflorescentia et capsulae valvis demum bifidis, nec viribus diversi; foliis oppositis v. ternatis, oblongis $v$. ovatis, coriaceis, superne profunde sulcatis, marginibus revolutis, subtus ramulisque nonnullis villoso-ferrugineis, stipulis lanceolatis, basi connatis, deciduis, racemis axillaribus elongatis, interruptis, florum fasciculis oppositis, corollis extus tomenlosis.

Remijia DC, in Biblioth. Univ. Genev, 1829. Ir. 185. DC. Prodr. IV, 357. M a с r o c u e u u a Vellozo in Vandelli Fl. bras, 14, non Linn. Cin ch o u a s p. St. Hilaire Plant. us, Bras, $t, 2$.

3984. Cinelioma LINN, C a ly x tabo turbinato, cum ovario connato, limbe supero, quinquefido, persistente, Coroll a supera, tubo tereti, limbi quinquefidi lobis per aestivationem valvatis, sub anthesi patentibus, oblongis. Stamina 5 , medio corollae tubo inserta, inclusa; filamenta brevissima, aequalia, a $\mathrm{t}$ h e rae lineari-oblongae, erectae, subexsertae. Ora ri um inferum, biloculare. $O \mathrm{vula}$ in placentis linearibus, dissepimento ntrinque insertis plurima, adscendentim imbricata. Sty lus simplex; stig m a breviter bifidum, subclavatum. C a p s u la ovata v. oblonga, calycis limbo coronata, bilocularis, a basi ad apicem, rarius ab apice ad basim septicido-bivalvis. Semina pluri ma, in placentis demum liberis adscendentim imbricata, compressa, ala membranacea, apice latiore, dentata, basi angustata, emarginata cineta. E mbryo in axi albuminis carnosi rectus; cotyledonibus subcordatis, radicula tereti, infera. - Arbores v. arbusculae peruanae et brasilien$s$ es, ob corticis qualitates febrifugas quam in contribulibus nobiliores celebratissimae; foliis oppositis, breve petiolatis, margine planis, stipulis ovatis $v$. oblongis, foliaceis, liberis, deciduis, floribus paniculato-corymbosis, terminalibus, albis $v$. roseo-purpurascenlibus.

C i u ho n a Linn. gen, n. 227. exel. sp. Humb. et Bonpl. Plant. aequinoct., , 33. Lambert Cinch, Lond. 1797, 4. Ruiz, Quinologia, Madrid, 1792, 4. DC. in Biblioth. univ. Genev. 1829. IT. 14i. Prodr, 1P. 351. Don in Linn. Tranzact. XVIT, 140, K i n k in a Adauson $I T .147$.

4. QUINRUINA. Capsula a basi ad apicem dehiscens. (Gürtn. t. 33. fig. sup. Ruiz et Pavon Flor. peruv. t. 193-195, 197. 195, 823, 224. Humb. et Bonpl. Plant. aequinoct, $t, 10,19.39,47$.

b. CASCARILLA. Caps u la al apiec ad basim dehiscens. 2. 196. 295.)

3275. Cosmilouema RUIZ et $P A V . \mathrm{C}$ aly $x$ tubo oblongo, cum ovario connato, limbo supero, campanulato, quinque-sexdentato, deciduo. Cor oll a supera, infundibuliformis, tubo tereti v. ad faucem subdilatato, limbi quinque-sexpartiti lobis aestivatione imbricatis, sub anthesi patentibus, ovali-oblongis. Antherae 5-6, ad faucem corollae subsessiles, oblongo-lineares, subexsertae. $O$ v ari $\mathbf{u}$ inferam, bilocnlare. Ovnla plurima, pla. centis latis, carpidiorum marginibus e dissepimento introflexis utrinque adnatis inserta, adscendentim imbricata, amphitropa, micropyle infera. Stylus simplex; stigma bifidum. Capsula oblonga, teretiuscula, apice nuda, bilocularis, ab apice ad basim septicido-bivalvis, carpidiis demum e calyce solutis. Se m in a plurima, in placentis maximis, demum a dissepimento solutis peltata, adscendentim imbricata, compressa, ala membranacea, apice lacera, basi emarginata cincta. E m bry o ....... Arbores peruanae et brasilienses, glabriusculae; foliis ovatis, coriaceis, breve petialatis, stipulis ovalibus, amplis, obtusis, erectis, deciduis, floribus terminalibus, cymosis $v$. paniculatis, albis $v$. ochroleucis.

Co $8 \mathrm{mib}$ u e a Ruiz et Pavon Flor, peruv, IIT. 3. t, 296. Don in Linn. Transact. XYI, 141. B nena Pohl Plant. Brasil. I. 8, t. 8. DC. Prodr. IV. 350, non Cav. C inehona s p. Ruiz et Pav. Fl. peruv. $\ell, 198$.

32 B. Dy yanenopogom $W A L L$. Cal y tubo obovato, enm ovario connato, limbo supero, quinquepartito, persistente. C o ro 11 a supera, hypocraterimorpha, tubo elongato, ad facem subinflato, limbo quinquepartito. An therae 5 , intra faucem corollae sessiles, inclusae. Ovari $\mathrm{m}$ inferum, biloculare. Ovula plurima, in placentis linearibus, dissepimento ntrinque insertis adscendentim imbricata. Sty l us simplex; stigma oblongum, bilobum, lobis linearibns. Ca p 8 I a oblongo-clavata, decemnervis, calycis limbo coronata, bilocularis, apice septicido incomplete bivalvis, valvis demum superne medio bifidis. Semina plurima, in placentis angustissime linearibus, demum liberis imbricata, compressa, linearia, ntrinque membranaceo-appendiculata. E mb r y o .... - Frutex indicus, super arbores pseudo-parasiticus, parvus, incurvus ; foliis oppositis, approximatis, acuminatis, membranaceis, superne pubescentibus, subtus villosis, stipulis membranaceis, ovatis, acutis, ciliatis, persistentibus, corymbis subterminalibus trichotomis, bracteatis, floribus longissimis, inodoris, pubescentibus.

H y m e no pog o n Wallich in Roxburgh Flor. Ind. II. 156. DC. Prodr. IV. 351. non Palis.

3ะซร. Hillia $J A C Q$. Cal y $x$ basi involucello di-tetraphyllo cinctus, tubo obovato, eam ovario connato, limbi superi, bi-quadripartiti laciniis angustis, acutis, persistentibus. C orolla stipera, hypocraterimorpha, tubo elongato, tereti, ad fancem inflato, limbi quadri-sexpartiti lobis patentibus, planis, ovalibus. Anth e ra e 4 - 6 , intra corollae faucem sessiles, inclusae. $O$ v a $r$ i $\mathbf{m}$ inferum, biloculare, $O \mathbf{v u l a}$ in placentis dissepimenta utrinque insertis plurima, adscendentia, anatropa. Stylus filiformis, simplex; sti gma crassum, bifidum. Ca p 8 u la elongata, calycis limbo coronata, bilocularig, loculicido-bivalvis. S emina in placentis septum marginantibus plurima, adscendentim imbricata, compressiuscuia, testa laxa, apice in caudam penicilliformem fatiscente, basi attenuata, nucleo centrali. Embryo in axi albuminis parei, carnosi orthotropns; cotyledon ib u s ovatis, plano-convexis, radieula brevi, crassa, infera. - Frutices v. suffrutices, in A merica tropica indigeni, parvi, glabri, saepius super arborum truncos pseudo-parasitici; foliis opposilis, obovatis, laete virentibus, subcarnosis, stipulis ovalibus, membranaceo-foliaceis, deciduis, summis floris terminalis solitarii involucellum constituentibus, corollis longissimis, capsulis folliculiformibus.

H illia Jacquin Amer. 96, t,66. Linn. gen, n. 448. Lau. t. 257. Swartz Observ. $t$. 5. f. 1 . Flor. Ind, occid $t, 1 t$. 
Gilrtuer f. IIT. 97. t. 197. Jussieu in Mem. 3Lus. VI. 388. A. Rirhard in Mem, soc. h. n. Paris. V. 287. DC. Prodr. IV. 350 . Fer eiri a Vandelli in Römer Script. 98, $t$. 6 .

3\%89. Coutarea $A U B L$. C al y $\mathrm{x}$ tubo turbinato-oblongo, cum ovario connato, limbi superi, sexpartiti laciniis subulatis, deciduis. Co r oll a supera, magna, infundibuliformis, tubo brevi, fauce obconica, ventricosa, nuda, limbi breviter sextobi lubis acstivatione induplicatis, sub anthesi patentinsculis, obtusis. St am i a 6, corollae tubo inserta, exserta; fi lamenta filiformia, anthera e lineares, erectae. Ova ri nm inferum, biloculare. $O \mathrm{vula}$ in placentis orbicularibus, medio dissepimento utrinque insertis plurima, horizontalia, anatropa. Stylus filiformis; $s t i g m$ a indivisum, sulcatum. C ap sula coriaceo - chartacea, obovata, compressa, costata, bilocularis, loculicidobivalvis, valvis semibifidis. Semin a in placentis dissepimento demum libero ntrinque insertis plurima, horizontalia, a latere compressa, reniformia, ala membranacea lata, ad umbilicum exeisa cincta. Embryo in axi albuminis carnosi orthotropus; cotyledonibus cordatis, planis, radieula elongata, tereti, umbilico proxima, eentripeta.

Arbores in America tropica orientali indigenae; foliis oppositis, breve peliolatis, ovatis, acuminatis, stipulis latis, brevibus, acutis, pedunculis axillaribus et terminalibus saepius trifidis, floribus albidis, interdum heptameris.

C o u ta r c a Aublet Guian. I. 314. t. 122. Lam. $t$. 157. Jussieu gen. 202. in Mem. Mus. VI. 388. Gärtner f. III.79. t. 194. A. Richard in Mem, Mus. soc. h. n. Paris. V. 287. DC. Prodr, IV, 350. Portlan di a e s p. Jaeq. Amer. $t, 182$. f. 20 .

32 ร9. Stevensia POIT. Caly $\mathrm{x}$ involucello brevissimo, inaequaliter quadrilobo cinctus, tubo subgloboso, cum ovario connato, limbi superi, bipartiti lobis acutis, deciduis. C or oll a supera, hypocraterimorpha, tubo brevi, limbi sex-septempartiti lobis patentibns, obtusis. Antherae 6 - $\gamma$, ovato-lanceolatae, intra fancem corollae sessiles, inclnsae. O varium infernm, biloculare. Ovula in placentis hemisphaericis, medio dissepimento ntrinque insertis plurima, horizontalia, anatropa. Stylus filiformis, inclusus; 8 tigma bilamellatum. Cap sula globosa, apice areolata, areola pubescente, dicocea, coceis osseis, dorso fissis, facie basi mediantilus placentis cohaerentes. Semina plurima, elliptica, compressa, horizontaliter imbricata, margine membranaceo, angustissimo, apice latiore, denticulato, basi attenuato eincta. E $m$ bryo in axi albuminis carnosi orthotropus; cotyl ed onibus ovatis, subfoliaceis, radi cula obtuse conica, umbilico proxima, eentripeta. - Frutex domingensis, ramosissimus; ramulis resinosis, foliis oppositis, ovalibus, subtus al. bidis, tenuiter reticulatis, stipulis in vaginam brevem concretis, floribus axillaribus, solitariis, albis, breve pedicellatis, bracteis quatuor in involucellum concretis cinctis.

Stevensia Poiteau in Annal, Mus, IV. 235. t, 60. Gärtner f. III. 99. $t, 197$. Jussieu in Mem. Mus, VI. 389. A. Richard in Mem. soc, h, n. Paris. V. 285. DC. Prodr. IP. 349. non Neek.

SUBTRIBUS IT. NAUCLEEAE DC. Prodr. IV. 343. Flores capitati, supra receptaculum globosum aggregati.

3280. Nauelea LINN. F lores supra receptaculum commune globosum aggregati, sessiles v. pedicellati, bracteolis interstincti. Cal $y_{x}$ tubo oblongo, cum ovario connato, limbo supero, brevi, truncato v. quinquepartito, lobis linearibus. Corolla supera, infundibuliformis, tubo gracili, fauce nuda, limbi quinquefidi lobis aestivatione valvatis, sub anthesi patentibus, ovali-oblongis. St a mina 5 , corollae fauci inserta, inclusa $v$. subexserta; filamenta brevissima v, subnulla, a $n$ therae oblongae, erectae. Ovarinm inferum, bilocnlare. Ovula in placentis oblongis, dissepimento utrinque insertis pauca v. plurima, amphitropa. Stylus filiformis, exsertus; st ig ma oblongum v. ovatnm, tumidum, indivisum. $C$ a ps u la e nunc sessiles, inter se distinctae v, connatae, nune pedicellatae, biloculares, dicoccae, cocris ex axi filiformi pendulis, apice elastice bisalvibus. $\mathrm{S}$ emin a plurima v. subdefinita, ovata, parva, excentrice peltatim inserta, membranaceo-marginata, apice setaceo attenuata. Embryo in axi albuminis carnosi rectus; cotyledonibus ellipticis, radicula oblonga, supera. - Arbores $v$. frutices scandentes, inter tropicos totius orbis cres. centes; foliis oppositis $v$. vertieillatis, petiolatis $v$. sessilibus, coriaceis, stipulis interpetiolaribus, capitulis globosis, pedunculatis, axillaribus aut terminalibus.

Na uelea Linn. gen, n. 223. Gïrtner 1 , 151.

a. PLATANOCARPUM. FI ores supra reeptaculum commuae sessiles, calycis lobis brevilus acutis v, subaullis, deciduis. Ca psula e connatae, polyspermae, - Arbo. res indieae, inermes.

Nancleac sectio Nauclearia 5. 1. DC. Prodr. IV. $3 / 3$.

b. NAUCLEARIA. FIores supra receptaculam commune sessiles, calycis lobis brevibus aentis v. subnallis, dect. duis. Ca p s u I a e distinetae, polysperaae. - Arbores v. frutices inermes, in Asia et rarius in Africa tro. pica crescentes.

Naucleace sectio Nauclearia §. 2. DC. Prodr. IV. 344. В a a c a lus Rumph. Amboin, III. 55. f. 1 . Lam. t. 133. f. 1. Gürta. t. 30, Roxb. Plant. Corom. t. 82. - ? A crodry a в Spreug. Syst. $I, 384$.

c. PENTACORYNA. Flores supra receptaculam commune subsessiles, calyeis lobis elongato-clavatis, deciduis. Capsula distinetae, oligospermae. - Arbores indicae, inermes.

Naucleac sectio Pentacoryna DC. Prodr. IV. 346. (Roxb. Plant. Corom. t. Sh,)

d. UNCARIA. FI ores supra receptaculam commane laxe aggregati, calycis tubuloso-urceolatí lobis brevilus, per. sistentibus. Capsufae pedicellatae, polyspermae. Frutices scandenter, in Asia ot America tropica in. digeni, pedunculis senescentibus $v$, inferioribus sterilibus in spinam axillarem compressam, uncinatam conversis.

U n с a ri a Sehreber gen, n, 311. Wallich in Roxburgh Flor. Ind, orient, II. 125. Plant. As, rar. t. 170. DC, Prodr, IV, 347, Delessert Ic, select, III, t, 81. non Burch. A g ylophora Necker elem, $n$, 252. On nou. paria Aublet Guian, $I, 177$. (Huater in Linn. Trans. act, IX, t. 22. Nees Plant, offio. Suppl, I, t, 7.)

e. ADINA. Flores supra receptaculum commune confertim sessiles, calycis linbo campanulato, quinquepartito. persistente. C aps ulae distinctae, loculis di-tetraspermis. - Suffrutices chinenses, inermes.

Adina Salisbury Parad. $t, 115$. Jussieu in Mem. Mrus, VI. 403. (Bot. Reg. t, 895, Bot. Mag. 2. 2613.)

TIRIBUS XIIT. GARDENIEAE A. Richard in Mem. soc. h. n. Paris. V. 108. Fructus baceatus, bi- v. abortu unilocularis, loculis polyspermis. Semina aptera. Album e n carnosum. - Arbores $v$. frutices; $s t i-$ pulis inlerpetiolaribus. 
SUB'TRIEUS T. SARCOCEPHALEAE DC. Prodr. IV. $36 \boldsymbol{6}$. Flores in receptaculo communi sessiles, in capitulum bracteatum collecti, fructibus inter se concretis v. distinctis.

3281. Sarcocephalus $A F Z E L, F$ lo r e super receptaculum sessiles, cum illo et inter se tubis calyeinis in massam carnosam arete concreti. Calycum limbi margines brevissimi, superi. Corolía e infundibuliformes, quinque-sexfidae. Antherae 5-6, intra faucem corollae sessiles. Ovaria infera. ...... Styli exserti; stigmata oblongo-capitata, indivisa. B a c c a e uniloculares (?), in massam calyeum limbis aerolatam concretae. S e m in a parva, subreniformia. E mb ryo ... - Frutex scandens, in Africa tropica occidentali observatus; foliis oppositis, breve petiolatis, ovalibus, supra nitidis, subtus ad venarum axillas pubescentibus, stipulis utrinque solilariis, triangularibus, indivisis, basi subconcretis, capitulis terminalibus, breve pedunculatis $v$, sessilibus, floribus subroseis, syncarpiis Persicce magnitudine, edulibus.

Sarcecep ba 1 us Afzelius msc. Sabine in Horticull. Transaet, V. 4i2. $t$, 18, Liadley Ibid. VII. 56. A. Richard in Mem. soc. A. n. Paris. V. 2s1. DC. Prodr. IV. 367. Cephalina Thooning ex Schumach, in Act. soc. h, n. hafn. III. 125 ,

3282. Zuecarinia BLUM. Flores supra receptaculum hemis phaericum aggregati, sessiles, bracteati. Caly $\mathrm{x}$ tubo ovali, cum ovarin connato, limbo supero, quinquedentato. Corolla supera, tubulosa, tubo brevi, limbo quinquelobo, erecto. Anth er a e 5, lineares, corollae tubo insertae, inclusae. Ov a ri u m inferum, biloeulare, disco epigyno depresso. Ovula ...... Stylus simplex; sti gma bifidum, vix exsertum. Bacca ovalis, stipitata, calycis limbo coronata, bilocularis. Semin a in loculis plurima, biseriata, compressa, testa fibrosa Em b ryo albuminosus; radic ula centripeta. - Arbor javanica, pulchra; ramulis compressis, foliis distichis, elliptico-oblongis, ultrapedalibus, acuminatis, undulatis, glabris, stipulis geminatis, carinatis, capitulis pedunculatis, axillaribus, solitariis.

Z uecarinia Blume Bijdr. 1006. A. Richard in Mem. soc, h, n. Paris, $V$, 262. DC. Prodr. IV. 368.

3293. Luelanea $D C$. F 1 o res in capitu lnm dense concreti. Cal y cum margines superi, integri. Corolla e superae, infundibuliformes, intus dense villosae, quadripartitae. S $t$ a min a quatuor, corolla breviora; fil amenta brevia, antherae lineares. Ovaria ..... Stylus simplex; stigma bifidum. Baccae concretae, bilocnlares. $\mathrm{S}$ e $\mathrm{m}$ in a in loculis plurima, angula ta. E mbry o...... - Frutex nitidus, glaber; subdichotomus; folits oppositis, petiolatis, ovatis, acuminatis, coriaceis, laevibus, stipulis interpetiolaribus, brevibus, pedunculis axillaribus, oppositis, v. terminalibus subumbellatis, capitulis paucifloris.

Lueianea DC, Prodr. IV.368. Morinda polys perma Jack.

3284. Canepluora JUSS, Flores in apice pedunculi dilatati aggregati, sessiles, involucro brevi eineti, squamis distineti. C a ly x tubo obovato, cum ovario connato, limbi superi, quinque-sexdentati dentibus lanceolato-triangularibus, subobtusis, subeoncavis. Corolla supera, subeampanulata, limbo quinque-sexlobo, erecto. Anthe rae $5-6$, subexsertae. Ovarium inferum, biloculare. Ovula in loculis plurima, compressa imbricata, placentae eentrali fungosae inserta. St yI as simplex; stigma oblongum, bipartitum. B a c c a e coriaceae, dense in capitulum congestae, biloculares. Semina in loculis abortu gemina, pendula. E m br yo ..... - Frutices madagascarienses, glabri; foliis oppositis, ellipticis, coriaceis, glabris, stipulis utrinque solitariis, triangularibus, acutis, pedunculis axillaribus, solitariis.

C a nep hora Jussieu gen. 208. Mem. Mus. VI, $40 t$. Lam. t. 15i, f. 1. exel. f. 2. A. Richard in Mem, soc. h. n, Paris, V. 261, DC, Prodr. IV, 617, C ephallidi um A. Richard $O_{p}$, cit, 280.

3285. Breomia A. RICH. Flores in capitulum globosum eollecti, involucro spathaeformi, hinc fisso, apice longe rostrato, deciduo. CaIy x tubo cum ovario conato, limbi superi, quinquepartiti laciniis truncatis, subcuneatis, C o roll a supera, tubulosa, tubo tereti, limbi quinquepartiti, patentis lobis planis, ovali-lanceulatis. Stamina 5, corollae fanei inserta, semiexserta. Ovarium inferum, biloculare. Ovula in loculis septem v. octo, placentae membranaceae, subcordiformis, utrinque ex apice dissepimenti pendulae faciei externae inserta. S $t$ y I a s simplex, longissime exsertus; stigma oblongum, bipartitum, laciniis approximatis. Fructus suberustaceus, bilocularis, indehiscens. Se m in a plurima..... - Arbor madagascariensis; foliis oppositis, amplissimis, stipulis connatis, capitulis axillaribus salitariis, longe pedunculatis.

B re on a A. Richard in Mem. soc, $h, n_{0}$ Paris, V. 290. DC. Prodr. $I V \cdot 620$.

SUM'TREIBUS TR. EUGARDENIEAE DC. Prodr. IV. 368. Flores in capitulum hand collecti.

3286. Catesbrea LINN. Calyx tubo obovato, cum ovario connato, limbo supero, quadridentato v. quadripartito, persistente. Co rolla supera, infundibuliformis, tubo elongato, ad faucem sensim dilatato, limbo quadrilobo. $\mathrm{S} \mathrm{t} \mathrm{a} \mathrm{m} \mathrm{i-}$ na 4 , imo corollae tubo inserta; fil a menta filiformia, a ntherae lineares, exsertae. Ovarium inferum, biloculare. Ov u la plurima, in placentis dissepimenti apici ntrinque affixis biseriatim pendula, anatropa. Stylns filiformis, inclusus; sti g m a bidentatum. B a eca globosa v. oblonga, calyeis limbo coronata, bilocularis. S e mina in loculis plurima, biseriatim imbricata, pendula, compresso-syuamaeformia. $\mathbf{E} \mathrm{mb} \mathbf{r} \mathbf{0}$ intra albumen carnosum minimus; ra di $\mathrm{c}$ u la nmbilico proxima, supera. - Frutices antillani glabri; spinis supraaxillaribus, simplicibus, foliis oppositis, parvis, ovalibus, saepe fasciculatis, stipulis utrinque solitariis, deciduis, pedicellis axillaribus, unifloris, floribus albidis.

C a te s b a e a Lian, gen, n, 130. Jussieu gen, 199. Mem. Mus. VI. 393. Lam. $t$, 67. Vahi Eclog. t, 10. f. 1 . Gärtner f. III. 67. t. 192. Bot. Mag. t. 131. Bot. Reg, t. 858. A. Ri. chard in Mem, soc, $h$, n. Paris, V. 256. DC. Prodr, IV, 400.

325\%. Hofranamia $S W A R T Z$. Calyx tubo oblongo-tetragono, cum ovario connato, limbi superi, quadridentati dentibus erectis, acutis. Corolla supera, hypocraterimorpha, tubo brevissimo, limbi quadripartiti lobis lanceolatis. Antherae 4 , in fauce corollae sessiles, lineares, acutae, erecto-conniventes. Ov a riu m inferum, biloculare. $\mathbf{O} \mathrm{vula}$ in loculis plurima $\ldots . . \mathrm{Sty}-$ lus simplex; stigma obtusum, vix emarginatum. Cap su la baceata, ealycis limbo coronata, bilo- 
cularis. Semin a plurima, minuta, subrotunda. E in bryo ...... Herba jamaicensis, monticola, basi suffruticosa, ramosa; ramis hirsutis, foliis oppositis, ovato-acuminatis, supra punctatoasperis, subtus hirsutis, stipulis brevissimis, acutis, pedunculis axillaribus petiolos superantibus, multifloris, corollae tubo rubro, lobis basi sanguineostriatis, apice luteis, baccis coccineis.

Hoff manni a Swartz Prodr. 30. Flor. Ind, occid. $x$. 241, $t$. 1. Sebreber gen, $n$. 1719. Jussieu Mem, Mus, VT. 383. A. Richard in Mem, soc. h. n, Paris, V.259. DC. Prodr. IV. 400 .

3285. Mrigginsia PERS. Caly $\mathrm{x}$ tubo brevi, obovato, cum ovario connato, limbo supero, persistente, ad basim quadridentato. Corolla supera, infundibuliformi-subcampanulata, tubo brevi, fauce nuda, limbo quaripartito, patente. St amina medio corollae tubo inserta, inclusa; filamenta brevia, antherae ovatae, erectae. Ovarium inferum, biloculare. Ovala in placentis septo utrinque adnatis plurima.... s $t \mathbf{y}$ lus brevis; stigma bifidum, exsertum. Bacca calycis limbo coronata, oblonga, subtetragona, bisulea, biloeularis. Semin a plurima, parva....

Suffrutices peruani, tri-quadripedales; ramis hebetate tetragonis, foliis oppositis v. verticillalis, obovatis v. oblongis, acutis, stipulis utrinque solitariis, parvis, acutis, deciduis, pedunculis axillaribus racemosis, pedicellis brevibus, unilateralibus, corollis rubentibus.

H ig g in sia Persoon Ench, I. 133. A. Richard in Mem. soc. $h$. n. Paris. V. 255. DC. Prodr. IV. 399. 0-H iggiusi a Ruiz et Pavon Flor. peruv, 1, 55, $t, 85, f, a, b$. exel. sp. Evosmiae sp. Spreng. Nacibeae sp. Juss.

3289. Petumga $D C$. Caly $\mathrm{x}$ tubo ovato, cum ovario connato, limbo supero, persistente, quadridentato. Co roll a supera, infundibuliformis, tubo brevi, obconico, fauce villosissima, limbo quadripartito. Stamina 4 , corollae tubo inserta; filamenta brevia, antherae subexsertae. Ovarium inferum, biloculare. Ovula ..... Stylus filiformis, villosus; stigma subexsertum, bidentatum. Ba e c a globosa, depressoumbilicata, bilocularis. Semina in loculis 2-4, squamiformia, pendula. $\mathbf{E} \mathrm{m}$ br y o intra albumen cartilagineum rectus; cotyledon ibns linearibos, radicula supera. - Frutices indici, inermes, erecti, glabri; ramis decussatis, horizontali. bus, foliis oppositis, oblongis, utrinque attenuatis, stipulis longis, acuminatis, deciduis, spicis axillaribus, solitariis v. geminis, simplicibus, multiftoris, folio brevioribus, bracteis brevibus, unifloris, floribus distichis $v$. tetrastichis, secus rhachin sessilibus, ex albo virescentibus.

Petunga DC. Prodr. IV. 398. Higginsia Blume Bijdr. 988. non Pers. Randia racemos Roxb. - ? Spicillaria A. Richard in Mem, soc, $h, n$, Paris, $V, 252$.

3290. Fernelia COMMERS. Caly $\mathrm{tu}$ bo obovato, cum ovario connato, limbi superi, persistentis, quadrifidi lobis apice subulatis. Corolla supera, parva, tubo brevi, fauce nuda, limbo quadrilobo, patente. Stamin a 4 , corollae tubo inserta, inclusa v. semiexserta; fil amenta filiformia, antherae ovatae, ereetae. Ovarium inferum, bilocnlare, dissepimento incompleto, basi semilunari-fenestrato. 0 vula in placentis dissepimenti parti superiori integrae, et marginibus utrinque adnatis plurima, horizontalia, anatropa. Stylus simplex; stigma bifidum. B a cc a calycis limbo coronata, dissepimento incompleto semibilocularis. S e min a plurima, subcompressa, ru- gosa. $\mathbf{E m}$ bry o in basi albuminis cartilaginei subdorsalis, rectus; cotyledonibus planis, subrotundis, radicu la crassiuseula, umbilico parallela, centripeta. - Arbusculae maurilianae, ramosissimae, glabrae, Buxi facie; foliis oppositis, obovatis, rigidulis, stipulis utrinque solitariis, brevibus, acutis, pedicellis axillaribus brevissimis, bracteolatis, uniftoris.

Fernelia Comarerson ex Jussieu gen. 199. Mem. Mus. VI. 3!r3. Lam. $t$. 67. $f$. 1. Gitrtier f, $I I I .61 . t$. 191. et 197. A. Richard in Mem. soc, h, n. Paris, $Y$. 257. DC, Prodr. IV. 398 ,

32D1. Coceocypelum SWARTZ. Caly x tubo ovato, cum ovario connato, limbi superi, quadripartiti, persistentis laciniis angustis. Cor olla supera, infundibuliformis, fance glabra, limbo quadripartito. Stamina 4 , corollae tubo inserta, inclusa; filamenta brevissima, anthera e oblongo-cordiformes. Ovarium inferum, biloculare. Ov $\mathbf{l}$ a in placentis dissepimento utrinque adnatis plurima, horizontalia, anatropa. S ty I us simplex; stigma bifidum. B acc a ovata, calycis limbo coronata, bilocularis. Semina plurima, lenticulari-angulata. Em bryo .... Herbae americanae tropicae, repentes; foliis oppositis, breve petiolatis, stipulis utrinque solitariis, subulatis, pedunculis axillaribus, alternis, solitariis, capitulo paucifloro, breve involucrato terminatis, corollis baceisque caeruleis v. purpureis.

C pecocy s ela m Swartz Flor. Ind. occid, I. 245. Kunth in Humb, et Bonpl. Nov. gen, et sp. III. 403, Chamisso et Scblechtend. in Linnaea $I V$. 138. A. Richard in Mem. soc, h, n. Paris. $V$. 259. DC. Prodr, IV. 396, C o c. cocypselum et Siceliam P. Browse Jam. 146. To ntanea Aublet Guian. I. 108. t, 408. Coecoey ps el u u et Tontanea Jussieu in Mem. Mus. VI. 394. Coceo. cy psel um et Bellardia Schreber t5en. $n .172 t$ et 1723. Condalia Ruiz et Pavon Prodr, II, $t$. 2. uon Cav.

329:. Fetesia $B A R T L$. Cal y $x$ tulo subglohoso, cum ovario connato, limbo supero, bre vi, quadri-quinquedentato, deciduo. Co rolla supera, infundibuliformis, fauce nuda, limbo aequaii, quadri-quinquefido. S $t$ a m in a 4 -5, corollae tabo inserta, inclusa; fil amenta subnulla, antherae oblnngae, erectae. Ovarium inferum, biloculare. Ovula...... Stylas simplex; st igma bifidum. Ba c $c$ a subglobosa, apice nuda, bilocularis. Semina plurima, subangulata, crustacea …-Arbores $v$. frutices mexicani et luzonenses; foliis oppositis v. ternis, breve petiolatis, saepe coriaceis, stipulis interpetiolaribus utrinque solitariis, indivisis, pedunculis axillaribus folio brevioribus, cymam corymbosam, paueifloram gerentibus.

Petesia Bartling ex $D C$. Prodr. $I P$. 395. non Gärtn. an P. Browne, Jacq.?

3293. Stylocoryne $C A V . \mathrm{C}$ aly $\mathrm{x}$ tuba turbinato, cum ovario connato, limbo supero, quinquedentato v. quinquepartito, persistente. $\mathrm{Co}_{\mathbf{0}}-$ rolla supera, infundibuliformis v. hypoeraterimorpha, fauce glabra, limbi quinquepartiti lobis patentibus v, recurvis. St a m in a 5 , corollae fauci inserta; fil a menta brevissima v. subnulla, antherae longe lineares, exsertae. Ovarium inferum, biloculare. Ovnla in placentis parvis, medio dissepimento utrinque inserlis gemina v. plnra, amphitropa. S t y la s filiformis, exsertus st ig ma incrassatum, elavatum v. fusiforme, indivisum. B a ce a globosa, ealyeis limbo coronata, bilocnlaris, pleiosperma, v. rarissime abortu unilocnlaris, monosperma. S em in a panca v, pluri- 
ma, angulata, umbilico ventrali rugeso. E m b r y o in albumine subeartilaginea subdorsalis; cotyledonibus foliaceis, parvis, radicula cylindrica, in diversis infera, centrifuga $\mathbf{v}$, centripeta. - Arbores $v$. frutices in dic $i$, inermes; foliis oppositis, petiolatis, oblongo-lanceolatis, stipulis intrafoliaceis, latis, breve acuminatis corymbis $v$. cymis terminalibus, axillaribus aut oppositifoliis, floribus albis, fragrantibus.

S t y loc or y ne Cavanil. Ic. IV. 45. A. Richard in Mem. soc. h. n. Paris. V. 248. Wight et Arnott Prodr. Flor. Penins. Ind. or. I. 400.

a. STYLOCORYNE $D O$, C alyeis limbus breve tabulosus, quinquedentatus. Semina plurima. $\mathbf{E}$ mbryo dimidio alburaiue longior.

S ty lo co ry n e Cavanill. Op. cit. $t$. 368. Gầrner f. IT. 100, t, 197. Blume Bijdr, 982. DC. Prodr. IV, 37\%. W a hle n berg la Blume Cat, hort. Buitensorg. 14.

b. CUPIA $D C$. Caly cis limbus quinquepartitus, Semin a panca. E mb r y a dimidio albumine brevior.

C upia DC. Prodr. IV. 393. exel. sp. C u pi Rheede Malab. II. 37. Adanson Fam. II. 168. C h o meli i Linn. gen, edit. 1737. n, 167. non Jacq. We be r a Schreber gen. $n, 1733$, exel. charact. Gärtuer f. III, 71. t. 192. Noxlourgh Flor. Ind. II. 533. Bot. Reg. t. 126. non Hedw. C anthii sectio Cupia Romer et Schultes Syst. IV. 306. Z a m aria Rafinesque in Annal. gen. sc. phys. VI. 85. T a renna Gärtner $I, 139.2 .28$, DC, Prodr. IV. 395.

3294. Pouehetia $A, R I C H . \mathrm{C}$ al $\mathrm{y} \times \mathrm{tu}$ bo ovato, cum ovario connato, limbo supero, parvo, quinquedentato, persistente. Corolla supera, tubo brevi, obconico, fauce glabra, limbi to bis quinque, ovali-oblongis, per aestivationem contortis. Antherae 5, lineares, intra corollae tabum sessiles, $O$ y a $\mathbf{r}$ i $\mathrm{m}$ inferum, biloculare. $0 v$ ula ..... Stylus filiformis; stigma $t a 2$, lincaria, acuta, suldivergentia, vix exserta. B a cca obovata, exsucea, calyeis dentibus conniventi. bus coronata, bilocularis. S e $\mathrm{m}$ i n a in loculis 4 _6, pressione difformia, oblonga, pube adpressa sericea. Al bn men carnosum. Embryo .... Frutex africanus tropicus, glaber; ramis teretiusculis, foliis oppositis, breve petiolatis, ovatis, atuminatis, stipulis utrinque solitariis, ovatis, breve cuspidatis, pedunculis oppositis axillaribus, supremis foliis sensim minoribus in bracteas muta tis in paniculam dispositis, floribus parvis, glabris.

Pouchetia A. Riehard in Mem. soc. h, n. Paris, $\nu$. 251. DC. Prodr. IV. 393.

3295. Bertiera $A U B L, \mathrm{C}$ a $1 \mathrm{y} \times$ tubo snbgloboso, cum ovario connato, limbo snpero, hrevissimo, quinquedentato, persistente, Corolla supera, infundibnliformis, tubo tereti, fance glabra, limbi quinquepartiti laciniis patentibus, ovalibus, acutis. Antherae 5, oblongae, intra corollae faucem sessiles, inclusae. Ovari um inferum, biloculare. Ovula in placentis medio dissepimento utrinque insertis plurima, horizontalia, amphitropav, anatropa. S tylus simplex; stigma bilamellatum, lamelis acntis. B a cea subexsucea, subglobosa, calycis limbo coronata, bilocularis. Semina plurima, angulata, muricata. Embryo intra albumen carnosum rectus $v$, areuatus; $r$ a dicula vaga, - Frutices americani tropici, borbonici et indici; foliis oppositis, petiolatis, ovali-oblongis, acuminatis, villosis, stipulis utrinque solitariis, basi concretis, acuminatis, thyrsis terminalibus racemoso-paniculatis, bracteolatis, floribus parvis, albidis.

Bertier a Aublet Guian. I. 180. Gärtner f. III. 198. 1. 73. Jassien in Mem, Brus, VI. 390. A. Riehard in Mem, roe, h, n. Paris, V. 253. DC. Prodr. IV. 391. a. BERTIERA Aubl. Fructus saepius striatus, dentibus calyeinis erecto-conaiventibus, subulatis coronatus. $\mathrm{E} \mathrm{m}$. bryou is radicula umbilieo proxima. - Species guia. nenses, inflorescentia terminali. - B e rt le r a Aublet Op. cit, $t, 69$. Lam, $t, 165$, Gärtn. f, $t, 192, f, 7$, A. Richard $O p$. eit. $t$, 23. $f .1$.

b. ZaLUZaNia Commers. Fruct ns laevis, dentibus calycinis patentibus ant ereetis, nec conniventibus corona. tas. E m bryon is radicula ab unbilieo remota. - Spe. cies borbonicae, inflorescentia racemoso-thyrsoidea. terminali, - Z aluzania Coumers, msc. (Gïrtn. $\mathrm{f}$. t. 192. $f .6$.

c. MYCETIA Reinw. Fructus intus erustaceus, dentibus calyeinis patentibas coronatus. - Species javanicae, racemulis axillaribus subeorymbosis. - M y c e t i a Reiuwardt msc, B erti e r a Blume Bijdr. 987.

3296. Pomatium GARTN. FIL. C a lyx tubo subgloboso, cum ovario connato, limbo supero, obtnse et breviter quinquedentato. C o rolla supera, parva, tubo tereti, limbo quinquepartito. Antherae 5, intra faucem corollae sessiles, inclusae. O vari um inferum, biloculare, disco epigyno urceolari. Ovula in placentis tumidulis, dissepimento utrinque insertis plurima, horizontalia, anatropa. Stylus simplex; stigm a bifidum, laciniis oblongis. B a c c a globosa, didyma, subsitca, calyeis restigio eroso et diseo urceolari coronata, bilocularis. Se m in a plurima, angulata. Emb ry 0 in axi albuminis carnosi orthotropus ; cotyledo nibus planis, ovatis, radicula crassinscula, umbilieo proxima, centripeta. - Frutex africanus tropicus; ramis teretibus, junioribus hispidis, adultis glabratis, foliis oppositis, subsessilibus, oblongo-lanceolatis, acuminalis, stipulis foliaceis, utrinque solitariis, oblongis, acuminatis, basi concretis, pollicaribus, thyrso spicaeformi terminali.

Pomatium Gărtner f. III. 259. t. 225, DC. Prodr. IV. 391. Bertierae sp. A. Rich.

329\%. IItppotis RUIZ et PAV. C a lyx tubo obovato, cum ovario connato, limbo supero, spathaeformi, apice hinc fisso, inde in auriculam, mucrone acuminatam producto. Coroll a supera, infundibuliformis, tulo subincurro, limbo obtuse quinquelobo. Stamina 5 , medio corollae tabo inserta, inclusa; fil amenta brevissima, anthera e ovatae, erectae. Ovari u m inferum, biloculare, disco epigyno urceolari, quinquecrenato. Ovula in loculis plurima.... Sty I us simplex; s $\mathrm{t} \mathrm{igm}$ a bilobum, lobis adpressis. B a c ca ovata, calyeis limbo coronata, bilocularis. S e min a plurima, minnta..... - Frutex peruanus, inermis, villosus; foliis oppositis, petiolatis, ovato-oblongis, acuminatis, stipulis utrinque solitariis, ovatis, acutis, extus villosis, caducis, pedunculis axillaribus, vix dimidium folium aequantibus, apice tri. floris, corollis et baccis villosis, purpureo rubris.

Hippotis Ruiz et Pavon Prodr. 33. Flor. peruv. II. 55. $t$. 201. Jussieu in Mem. Mus. VI. 393. A. Richard in Mem. sac, h, n. Paris, V. 255, DC, Pradr. 1V. 391.

3298. Helospora JACK. Calyx tubo globoso tetragono, cum ovario connato, limbo supero, subeampanalato, quadridentato, persistente. Coroll a supera, tubulosa, limbo ealycino multo longior, fauce nuda, limbi lobis quatuor, per aestivationem valvatis, sub anthesi patentibus, oblongis. Antherae 4, lincares, intra corollae tuhum sessiles, inclusae. O v a rium inferum, .... S tylus quadrisulcus; stig m a quadrifidum, lobis brevibus, patentibus. B a c ca tetragona, ealycis limbo corenata, unilocularis. S emin a plurima, duplici serie erueiatim disposita, nidulantia, linearia, pa- 
rum incurva. Embryo $. . . \cdots-$ Arbuscula sumatrensis, glabra, non satis nota; foliis oppo. silis, breve peliolatis, ovato-lanceolatis, stipulis deciduis, intus ciliorum seriem gerentibus, peduncu. lis axillaribus unifloris, folio brevioribus, calycibus basi bibracteolatis, corollis flavescentibus. f. 3 .

He 1 o s p or a Jaek in Linn. Transaet. XIV. 127, $t$. 4 .

32D8. Menestoris DC. Calyx tubo globoso, cum ovario connato, limbi superi, quinquepartiti laciniis linearibus, fere subulatis, distantibns, deciduis. Co rolla snpera, infundibuliformis, tubo longo, tereti, fauce nudiuscula, limbi quinquefidi lobis ovalibus, acutis, brevibus. Antherae 5 , oblongae, intra corollae tubum sessiles. Ovarium inferum, biloculare. Ovula in placentis septo utrinque adnatis plurima ...... Stylus filiformis, inclusns; stig th a lifidum, lobis linearibus. B a ce a subexsucea, calfcis limbo deciduo apice areolata, bilocularis. S em in a plurima, minima ...... - Frutices nepalenses, inermes; foliis oppositis, stipulis utrinque solilariis, demum deciduis, corymbis terminalibus. Don.

Menestoria DC. Prodr. IV. 390, Gardealaesp.

3300. Ifeinsia $D C$. C a ly $\mathrm{x}$ tubo ohovato, cnm ovario connato, limbi superi, quinquepartiti lobis foliaceis, oblongis, persistentibus. Corolla supera, hypocraterimorpha, tubo tereti, limbo calycino longiore, intus hirsntissimo, limbi lobis quinque, ovalibus, undulatis. Antherae 5 lineares, acutae, in apice tubi corollini sessiles, inclusae, faucis pilis occultatac. Ovarium inferum, biloculare. Ovula in placentis crassis, carnosis, dissepimento utrinque adnatis plurima. Fruetus globosus, calycis limbo coronatus, siccus, durus, indehiscens, bilocularis. S em in a plurima, in placentarum superficie nidulantia ..... - Arbuscula africana tropica, ramosissima, inermis, sed ramulis persistentibus, spinas simulantibus horrida; foliis oppositis, breve petiolatis, ovali oblongis, acuminatis, stipulis utrinque binis, minimis, acutis, floribus ad apicem ramorum tribus v. quatuor subracemosis, pedicellalis, albis.

If el usia DC. Prodr, IV, 390.

3391. Chapeliferia A. RICHI. C a I y $\mathrm{x}$ tnbo cum ovario connato. limbi snperi, quinquepartiti laciniis erectis, acutis, persistentibus. C orolla supera, tubulosa, tubo gracili, fance villosa, limbi quinquepartiti laciniis subobliquis, patentibus, lanceolato-acatis. Antherae 5, medio corullae tolso insertac, subsessiles. O varium in. ferum, biloculare. O v u la plarina .... - Sty lus simplex, brevis, inclusns; st $\mathrm{i} g \mathrm{ma}$ biparti tum, lobis approximato-coalitis. Fructus ovoideus, coriaceo-carnosus, limbo ealycino ampliato, erecto coronatus, bilosalaris. Sem in a plurima, distincta, subpolyedra, adpresse anreo-sericea. Embryo in axi albuminis cornei orthotropus, linearis, teres. - Frutex madagascariensis; foliis oppositis, curiaceis, elliptico-acutis, glaberrimis, stipulis interpetiolaribus, integris, caducis, floribus in axilla foliorum congestis, breviter pedicellatis.

Chapelierla A. Riehard in Mem. soc. h, n, Paris. V. 258. DC. Prodr. IV. 389.

3330\%. Greifrithis WIGHT et $A R N$. Ca lyx tubo obevato, brevi, cum ovario connato limbo supero, campanulato, quinquedentato, de cidno. Coroli a supera, infundibuliformis, fauce villosa, limbi quinquefilli laciniis aestivatione subcontertis, sub anthesi patentibus, oblongis, acutis, tubo longioribus. St a in in a 5 , corollae fauci inserta; fil amenta subnulla, antherac elongato-lineares, acutae, dorso affixae. Ovarium inferum, biloculare, disco epigyno crasso, carnoso. Ovula in loculis plura ..... Sty $\mathbf{s}$ s filiformis; stigma exsertum, indivisum, fusilorme, striatum. Ha c c a globosa, limbi calycini cicatrice areolata, bilocularis. Semina in loculis $8-10$, angulata, mueilagine invelnta. $\mathbf{E}$ m b r y o albuminis cartilaginei longitudine ..... Frutex indicus, glaber, inermis $v$. saepius spinis oppositis armatus; foliis oppositis, petiolatis, obovatis $v$. oblongis, basi cuneatis, coriaceis, subtus ad nervorum axillas glandulis perforatis instructis, stipulis interpetivlaribus utrinque solitariis, $c$ basi ovata cuspidatis, deciduis, florum corymbis terminalibus umbellatis, pedicellis basi bibracteatis, corollis albis, baccis rubris.

Griffithia Wiglut et Aruott Prodr. Flor. Penins. Ind, orient, T, 399. G a rde a i a frag raus Roxbargh Plant. Corom, t. 197. Stylocoryae Pandani DC.

3303. Hyptianthera $W I G H T$ et $A R N$. C a ly x tubo brevi, ohovato, cum ovario connato, limbi superi, profunde quinquefidi laciniis oblongis, acuminatis, persistentibus, Corolla supera, rotata, tubo brevissimo, intus piloso, limbi quinquepartiti laciniis aestivatione contortis, sub anthesi patentibus. Antherae 5, oblongae, summo tubo corollae peltatim insertae, apisibus exsertis. Ovariu m inferum, biloculare, disco epigyno carnoso, crasso. O v u la in singulis loculis circiter sex, pendula ... Stylus brevissimus; st ig matis incrassati, bipartiti lobi approximati. B a c c a globosa, calyeis limbo coronata, bilocularis. Semi$\mathbf{n}$ a in toculis biseriatim pendula, panca. E m br y o - Frutex indicus, inermis, glaber; foliis oppositis, breve petiolutis, oblongo-lanceolatis, acuminatis, basi cuncalis, slipulis interpetiolaribus utrinque solitariis, integris, triangularibus, acuminatis, rigidis, adpressis, floribus bractealis, parvis, in fascientos subglobosos, in foliorum uxillis sessiles collectis.

H grtianther a Wight et Araot; Prodr, Elor, Penins. Ind. or. I. 390.

3304. IRamalla HOUST: Cal y $x$ tubu obovato, cum ovario connato, limbo enpero, quinquefido v. quinquedentaco, porsistente. Corolla supera, hypocraterimorpla, inbo brevi v. Iongo, limbo quinquepartito. Antherae 5 , infra eorollae faucem sessiles, ohlongo-lineares, inclusae. Ovarium inferum, biloculare, disco epigyno carnoso. Orula in placentis dissepimento utrinque adnatis plnrima, deorsum imbricata ...... St y 1 u s brevis; st ig ma crassum, bilobum, glabrum. B a c ca calycis limbo coronata, snbsicea, corticosa, bilocularis. Semina in loculis plura, in pulpa nidalantia, crassiuscula, angulata. E mbryo intra albumen cartilagineum rectus; c otyled onibus subfoliaceis, radicula longiuscula, tereti, vaga. - Arbusculae $v$. frutices, in ter tropicos amphigci, ramosissimi; spinis axillaribus opposilis v. subverticillatis, folits oppositis, sessilibus $v$. breve petiolatis, stipulis interpetiolari. bus utrinque solitariis, floribus axillaribus, plerumque solitariis et sessilibus.

R n ndia Houston ín Linn. Hort, cliffort, 485. Gen, $n$. 911. Jussieu in Mem. Mus, YI.399. DC, Pradr, IP. 384, exel. sp. Wight et Arnott Proilr, Elor, Pentus, Ind, or. I. 346. 
a. OXYCEROS DC. t. c. Coroll a e faux haud ditatata. Frutices spinosi.

$0 x$ y e eros Loureiro Flor. cochinch. 186. Garde. n ia Gärtn. I. 480. C exi s c u s Gärtn. I. 140,t.28. G a rden a e s p. Roxburgh Plant. Coram. $t, 135,136$, Kunth in Humb. et Bonpl. Nov, gen, et sp, t. 293. Bot. Mag. t. 1841. M uss a e nda e s p. Jacq. Amer. $t$, 149. (Ruiz et Pav. Flor. Peruv, t. 120, f. 6. Lam, t. 156, f. 1, et 4.)

b. EUCLINIA DC. $l$. c. Corollae tubus ad faucem saepís ampliatus, obeonicus. - Frutices inermes.

Euclinia Salisbury Parad. $t$, 93, R othmannia Salisb. Op. cit. t. 65. (G a r denia e s p. Ruiz et PavOp. cit, t, 219. M us s a e ndae sp. Jaeq. Amer, $t$, 48.)

3305. Caradlenia ELLIS. C aly $\mathrm{x}$ tubo ovato, laevi v. costato, cum ovario connato, limbo supero, tubuloso, truncato, dentato, fisso v. partito. Corolla supera, infundibuliformis v. hypocraterimorpha, tubo calycem longe superante, fauce glabra, limbi quinque - novempartiti laciniis aestivatione contortis, sub anthesi patentibus. Anthe rae $5-9$, lineares, ad fancem corollae sessiles, subexsertae. Or a $\mathbf{r}$ i m inferum, dissepimentis $2 \ldots 5$ ad axim deliquescentibus uniloculare. Ovula in placentis dissepimentis insertis plurima, horizontalia ...... Stylus simplex; stigma clavatum, bidentatum v. bifidum, lobis in crassatis, erectis. B a c ca carnosa, calycis limbo coronata, intus chartacea $v$. nucleata, incomplete bi-quinquelocularis. S emina plurima, minuta, placentis parietalibus carnosis immersa. E m bry o in axi albuminis carnosi rectus; e otyled on ibus foliaceis, radic ula tereti, vaga. - Arbores $v$. frutices, inermes $v$. spinescentes, inter tropicos Asiae et Africae, nec non in Capite bonae spe $i$ crescentes; foliis oppositis rariusve verticillatis, ovalibus, stipulis interpetiolaribus integris, floribus axillaribus $v$, terminalibus, plerumque solitariis, albis, demum flavescentibus, saepius odoratis.

Ga rdenia Ellis in Linn, gen, n. 296. Gärtner f. 111 . 79. Blume Bijdr. 1014. DC. Prodr. IV. 379.

a. GARDEniA. C a I y e is tabus lacinilis decurrentibus cos. tatus. C or oll a e tubus cylindracens.

G a rde n i E Ellis in philosoph. Transact. LI. t, 23. Solander Ibid. LIT, t. 20. Miller Ic, t. 180. Andr, Bot. Reposit. $t$. 491. Bot. Reg. $t$. 73. 449. Gärtner f. $t$. 194.

b. KUMBAYA. Calyefs tubus laevis, limbus aequaliter dentatus v. partitus, rarius truacatus. Corollae tubus cylindraceus.

G a rde n i a e $s$ p. Roxburgh Corom, t, 134. Bot. Mag. t. 1904. Gärtner f. $t, 193$.

c. PIRINGA. Cal y $\mathrm{c}$ is tubus laevis, limbus tabulosus, costatus, quinque-sexfidus, lateraliter fissus. C orollas tubus cylindracens.

Piring a Jussieu in Mem, Mus, VT, 399. Thunbergla Montin in Act. Holm, 1773, t. 11. S a h l ber gla Necker olem. n. 418. B erg kias Sonnerat Voy. t. 17, 18. Journ. phys, III. 299. t. 3. Chaquepiria Gmelin Syst. 651. (Bot. Mag. t. 1004. Salisbury Parad. t. 46.)

d. RothmanNia. Calyeis tubus costatus v. Iaciniis decurrentibus angulatus. Corolla e tubus fauce dilatata obconicus.

Roth mania Thubberg in Aot. Holm, 1786, p.65. c. ic. (Bot. Mag. 2, 690.)

3306. Fenipa BLUM. Caly $x$ tubo orato, laevi, cum ovario connato, limbo supero, tubuloso, truncato v. subdentato. C o roll a supera, hypocraterimorpha, tubo calycis limbum haud superante, fauce glabra, limbi quinque-sexpartiti laciniis ovatis, acutis, tubo corollae longioribus. Anthera e 5_6, lineares, ad faucem corollae sessiles, exsertae. Ovari um inferum, biloculare. Ovula in placentis dissepimento ntrinque adnatis plurima, amphitropa. Stylu s simplex; s ti g ma indivisum, clavatum, obtusnm. B a e e a ntrinque attenuata, calycis limbo coronata, corticata, pulposa. S em in a plurima, in pulpa nidulantia. Einb ryo intra albumen cartilagineum obliquus; coty ledonibus foliaceis, radicula tereti, vaga. Arbores $A$ merica tropicae; folits opposilis, ovalibus $v$, oblongis, stipulis interpetiolaribus ovatis, acuminatis, deciduis, floribus axillaribus $v$. terminalibus, solitariis aut paucis, albis, demum flavidis.

Gen i p a Plumier Cat, 20. Lina. gen, n, 2s0. Jussieu gen, 201. Mem, Mus. VI. 391. Gärtuer f. III. 55. t. 190. Ruiz et Pav. Flor. Peruv, $t$, 220. f. a. A. Richard in Mem. soc. h, n, Paris. V. 244, t. 29. DC. Prodr. IV. 378. Pres! Symb, t, 160. D u roi a Liun. f. Suppl. 30. Gar deuiae s p. Swartz.

330\%. Dxyamtlatss DC. Caly x tubo obovato, cum ovario connato, limbo supero, nrceolato, acute quinquedentato. Co roll a supera, hypocraterimorpha, tubo gracili, longissimo, fauce aequali, glabra, limbi quinquepartiti, regularis lacinits oblongis, acnminatis. Antherae j, lineares, acuminatae, corollae fauci insertae, exsertae, Ov a r i u m inferum, biloculare, disco epigyno carnoso. Ovula in placentis dissepimento utrinque adnatis plurima. Stylus filiformis, exsertus; stig m a clavatum, brevissime bilobum. B a ce a bilocularis .... - Frutices Africae tropicae; foliis oppositis, breve petiolatis, ellip. ticis, acuminatis, stipulis oblongo-triangularibus, subfoliaceis, demum deciduis, pedunculis axillaribus racemoso-corymbosis, corollis semipedalibus.

$0 \times$ y a thu \& DC. in Annal. Mus. IX. 218. Jussieu in Men, Mus, VT. 390. Lindley Collect, t. 13. Bot. Mag. t, 1992. DC. Prodr, IV.376. Garde a ine s p. Andr. Bot. Reposit. t. 183.

3308. Posequeria $A U B L, \mathrm{C}$ a l y $\mathrm{x}$ tubo obovato, cum ovario connato, limbo supero, bre vi, quinquedentato. Co ro Il a supera, infundibuliformis, tubo tereti, longissimo, fance vix dilatata, villosa, limbi quinquepartiti laciniis patentibus, obtusis, subaequalibus, alabastro hine gibbo. St amina 5, corollae fauci inserta, exserta; filamenta filiformia, brevissima, apice infracto. geniculata, antherae oblongae, acutae. Ovari u m inferum, biloculare, disco epigyno carnoso. $\mathrm{Ovula}$ in placentis dissepimento utrinque adnatis plurima .... Stylus filiformis, inclusus; $8 \mathrm{tig}$ $\mathrm{m}$ a brevissime bifidum, lobis gracilibus. B a $\mathbf{c}$ a ovata, calycis limbo coronata, succulenta, bilocularis. S e min a plurima .... - Frutices $v$. arbusculae, guianenses et antillanae, glabrae ramis teretiusculis, foliis oppositis, breve petiolatis, coriaceis, stipulis oblongo-triangularibus, demum deciduis, floribus terminalibus, albis, longissimis, corollis nutantibus.

Posoqu eria Aublet Guian, I. 134. 1, 51. Jussien in Mem. Mus. VI. 389. DC. Prodr. IV. 375, non Alior. C y rtant hus Schreber gen. n. 302. non Ait. Ky r t anthus Gmelin Syst, 362. Solen a Wildenow $s p, r$, 961. Rudge Guian, t. 40. 41. P os o r i a Rafinesque in Annal. gen. sc. phys. VI, 80. To coyena e sp. A. Rich.

3309. Tocoyema $A U B L$. C a ly x tubo turbinato, cum ovario connato, limbo supero, brevissime tubuloso, quinquedentato. Co roll a supera, infundibuliformis, tubo filiformi, longissimo, fauce dilatata, nuda, limbi quinquepartiti laciniis brevibus, obtusis. Antherae 5, ad faucem corollae brevissime exsertae, ovatae, acutae. 0 vari $\mathbf{~ m ~ i n f e r u m , ~ b i l o c u l a r e . ~} \mathrm{O} \mathbf{v} \mathbf{u}$ a in placentis dissepimento utrinque insertis plurima ..... StyI $\mathrm{g}$ filiformis, apice fusiformi pilosus; $g \mathrm{tigma}$ 
clavatum, bilamellatum. B a e c a subcarnosa, calycis limbo coronata, bilocularis. S e min a plurima, rotundato-ovata, in pulpa molli nidulantia. - Frutices $v$. suffrutices inermes, in America tropica indigeni; foliis oppositis, breve petiolatis, stipulis triangularibus $v$. ovatis, floribus terminalibus corymbosis.

To co y e n a Aublet Guian. I. 131, $t$. 50. Jassleu in Mem. Mus, VI. 390. Kunth in Humb. et Bonpl. Nov, gen. et sp. III, 411. DC, Prodr, IY, 374, U cria n a Willdenow Sp. . .961 .

3310. Cymopachys $B L U M$. Caly $\mathrm{x}$ tubo turbinato, cum ovario connato, limbo supero, urceolato, subintegerrimo, deciduo. Cor o 11 a supera, tubo brevi, fauce setosa, limbo quinquepartito, patente. Stamina 5 , corollae fauci inserta; fil amenta brevia, anthera e lineares, incumbentes, exsertae. 0 v a r i nm inferum, biloeulare. Ovula ...... Stylus brevis; 8 tig ma crassum, subbilobnm, exsertum. B a c c a globosa, umbilicata, calycis basi cireulari coronata, bilocularis. S e mina in placentis carnosis, membranaceo-stipitatis, transversim lamellatis plnrima, compressa. Embryo ..... - Frutices javanici, scandentes; folitis distichis, stipulis interpetiolaribus indivisis v. geminis, subconcretis, floribus ex axillis dense corymbosis v. subcorymbosis, unilateralibus.

Gynopachys Blume in Flora 1825. p. 134. Bijdr. 933. DC. Prodr. IV. 324.

33 11. Casgupa $H U M B$. et BONPL. C aly $x$ tubo globoso, cum ovario connato, limbo supero, brevissimo, integerrimo. Corolla supera, tubulosa, extus rugosa, fauce villosa, limbi sexpartiti, brevis lobis acutiusculis, vix patentibus. Antherae 6 , oblongae, intra corollae faucem subsessiles, villis occultatae. Ova ri um inferum, biloculare. Ovula in placentis medio dissepimento utrinque insertis plurima $\ldots . . .5$ stylus inclusns; stig ma bifidum, gracile. Bace a subglobosa, calycis limbo brevissimo coronata, bilocularis. S e m in a plurima, minima. E m b r y o ....

Arbor Americae tropicae; folitis oppositis, longe petiolatis, obovato-oblongis, coriaceis, subtomentosis, pedalibus, stipulis lanceolatis, persistentibus, thyrsis terminalibus paniculatis, oppositifloris, bracteolis sub flore duabus $v$. tribus, interdum calyci adnatis, corollis uni-bipollicaribus, pallide rubris.

C a 8 s u p a Hamb. et Bonpl. Plant, aequinoct. T. 43. t. 12. Kunth in Humb, et Bonpl. Nov. gen, et sp. MII.412. Jussieu in Mem. Mus, VI. 389. A. Richard in Mem. soc. $h$, n. Paris. V. 250. DC. Prodr. IV. 373.

331\%. I watehubaea FISCH. C a I y x tubo turbinato, cum ovario connato, limbo supero, tubulose, ovarium superante, truncato. Cor oll a supera, tubo cylindrico, calycis limbum longe superante, fauce villosa, limbi octopartiti laciniis lanceolatis, acuminatis, aestivatione contortis. Anthera e 8, oblongae, acutae, inter villos faucis sessiles. 0 v a ri u m inferum ...... Stylus filiformis; stigma grossum, clavatum, lobis duobus applieitis, extus convexis, hirsutis, intus planis, glabris. Frnetus .... Arbor gu ine ensis glabra; ramulis teretibus, folitis oppositis, breve petiolatis, obovatis, obtusis, stipulis ovatis, latis, brevibus, breve coneretis, persistentibus, interdum bifidis, floribus terminalibus, subcorymbosis, pedicellatis, ebracteatis, amplis, corollis basi purpureis, apice pallidis, tripollicaribus, coriaceis.

K a te hub a a Fineker ex DC. Prodr. IV. 373.
3313. Nirssaenda $L I N N$. Caly $\mathrm{x}$ tubo oblongo-turbinato, cum ovario connato, limbi superi, quinquepartiti, demum decidni lobis erectis, acutis, uno exteriorum interdum producto in folium petiolatum, amplum, reticulato-venosum, coloratum. Cor olla supera, infundibuliformis, fance villosa, limbo quinquepartito. An th e r a e 5 , intra corollae faucem sessiles, lineares, inclusae v. subexsertae. Ovarium inferum, biloculare. Ov $\mathbf{l}$ a in placentis e medio dissepimento utrinque stipitatis, revoluto-bilobis plurima, horizontalia, anatropa. B a c ca subglobosa, apice denuda. ta, bilocularis. Semina plurima, parva, lenticulari-compressa, scabrida. Em bryo in basi albuminis dense carnosi minimus; $r$ ad i cula crassa, umbilico proxima, centripeta. - Arbusculae $v$. frutices, inter tropicos ve teris orbis indigeni, in Am erica rari; foliis oppositis, petiolatis, ovatis, villosis v. glabris, stipulis utrinque binis, liberis $v$. basi concretis, acuminatis, floribus terminalibus, corymbosis, bracteis sub pedicellis et corymbi ramis parvis.

Mus s a enda Linn. Ben. n, 2at. Gïrtner $I$, 140. Jussieu in Mem. Mus. VI. 386. Hamilt, in Linn, Transact. XIV. 198, et 203. A. Richard in Mem. soc. h. n. Paris. V. 370. DC. Prodr. IV. 370. Wight et Aruott Prodr, Flor, Penins, Ind. or. I. 393.

a. BELILLA DC. 1. c. Caly cis lobus unus in folium maximum, petiolatum, venoso-reticulatum, bracteiforme pro. ductus.

Belitl a Rheede Malab. II, 27, t. 17. Macroenemi s p. Jacq. Hort. Schünlr. $t$. 13. (Lam. $t$. 157. $f$. 1 . Gírtt. t. 28. Bot. Mag. t, 2099. Wallich Plant. As. rar. t. 150.) - M. I u te ol a Delile in Caillaud Vog. 65. $t$. $1 . f, 1$. quae Manettia 1 a n ceolata Vabl, a cl. Dc. hue relata, genus Neuroearpaea R. Brown ad Salt. 64. et in Tuckey Cong. 448. constituit, quod quo charactere stabiliatur, botanici hactenus ignoraut.

b. LANDIA DC. $t$. c. $\mathrm{C}$ aly $\mathrm{cis}$ lobi omnes aequales $\mathrm{v}$ vix inaequales, nec in lobum expansi, decidul. - Folia opposita.

Landi a Commers. msc. (Lam, $t, 157, f$. 2.)

c. CAANTHE DC. l. c. Caly cis lobl omnes aequales, li neares v, setacei, persistentes. - Specier madagas. carienses, vix congeneres; folits ternata-verticil. latis, stipulis basi latis, apice aculit, adpressis, co. riaccis.

3314. Amaiona $A U B L$. Caly 1 tubo ovato, cum ovario connato, limbo supero, tubnloso, tereti, sexdentato, demum deciduo. Corolla supera, hypocraterimorpha, tubo tereti, ealyeis limbnm superante, linbi sexpartiti, patentis lobis oblongis. Antherae 6, lineares, intra corollae faucem sessiles. Ovarium inferum, bitriloculare. Ovula in loculis plurima, biseriata, horizontalia, anatropa. Stylus simplex; stig. ma clavatum, indivisum. B a c c a obovato-oblonga, corticata, apice areolata, bi-trilocularis. Semina in loculis biseriata, depresso-plana, suborbiculata, septulis membranaceis horizontalibus distincta. E m b r y o ....... Arbores v. frutices, in America tropica indigeni; foliis oppositis $v$. ternatis, breviter petiolatis, nervosis, glabris, stipulis oblongis, deciduis, floribus ad apicem ramorum corymbosis, subsessilibus.

A mai o ta Aublet Guian. Suppl. 13. t, 375, DC, in Annal. Mus. IX. 218. Desfont in Mem, Mus. VI, 11, 1.4-6. Jussieu Ibid. VI. 391. Kanth in Humb. el Bonpl. Nov, gen. et sp. t, 294. A. Richard in Mem, soc, $h$. $n$. Paris. $V$. 249. DC. Prodr. $I Y, 369$. Hexactina Willd. mse.-? Ebreaberg i a Spreng. Syst, $n, 1318$.

3315. Frrelnellia $R$. BR, Caly $x$ tubo obovato, cum ovario connato, limbo supero, tnbuloso, ultra medium quinquefido, persistente, 71 
Corolla supera, clavato-infundibuliformis, fance nuda, limbi quinq̨uefidi lobis abbreviatis, aestivatione imbricato-contortis. Stamina 5, supra mediun tubo corollae inserta, inclusa; fil a men$\boldsymbol{t}$ a subnulla, a nthera e lineares. Ovari um inferum, biloculare, disco epigyno carnoso. O v ula in placentis dissepimento utrinque adnatis plurina, anatropa. Stylus filiformis; stigma exsertum, clavatum, indivisum, bisulcum. B a c ca snbglobosa, calycis limbo coronata, bilocularis. S e m in a plurima, angulata. E $\mathbf{m}$ br $y o$ in axi albuminis cartilaginci orthotropus, dimidia ejusdem longitudine; radi $\mathrm{eu}$ I a ad umbilieum direeta, centripeta, - Frutices capenses; foliis oppositis, breve petiolatis, ovalis, acutis, basi subcordatis, stipulis interpeliolaribus e basi lata cuspidatis, deciduis, floribus ad apices ramorum capitatis, supra receptaculum villosum sessilibus, bracteolis minimis distinctis, foliorum pari ultimo subinvolucratis, coccineis.

Bu reltellia R. Brown in Bot, Reg. t. 466, 891. Bot. Mag, $t, 2339$. A. Fichard in Mem. soe. h, n. Paris, V. 260 . DC. Prodr. IV. 368. B a b a li u a Rafinesque in Annal. gen. sc. phys. VI, 86. Louleera bubalina Linn. Canae. phora capitata Lam, t. 15t. f. 2.

\section{GENERA DUBIAE TRIBUS.}

3316. Sempaneñ SCHLECHT. Calyx tubo cum ovario connato, limbi superi, quinquefidi laciniis magnis, persistentibus. Corolla supera, tubo ealyeis limbum haud superante, subeampanulato-eylindraceo, utrinque, imprimis intus praeter basim nudam villoso, limbi quinque fidi laciniis brevibus, aestivatione valvatis, sub anthesi margine revolutis. Antherae 5 , anguste ellipticae, in medio corollae tubo sessiles, inclusae, Ovarium inferum, biloculare. Ovnla in placentis dissepimento utrinque insertis plurima. Sty lus simplex; sti $\mathrm{g}$ ma bifidum, laciniis linearibus, acutis, erectis. B a ce a (?) ealyeis limbo coronata, bilocularis. Semina plurima.

Arbuscula mexicana; foliis oppositis, petiolatis, stipulis interpetiolaribus, elongatis, integerrimis, deciduis, cymis axillaribus, tri-quinqueftoris, pedicellis bibracteolatis.

Somm e ra Scblechtend. in Linnaea IX. 602.

$331 \%$. Seepseothamums CHAM. F $10-$ res polygamo-dieiei, Masc. Calyx tubo brevissimo, cum ovarii rudimento connato, limbo supero, truncato. Corolla supera, hypocraterimorpha, tubo brevi, panllulum inflato, fance villosa, limbi quinquefidi laciniis late ovatis, brevilus. Antherae 5, lineares, intra corollae faucem sessiles, inclusae. Ovarii rudimentum inferum. Stylus inclusus, apice attennato pilosus stig mate obsoleto. Fem, v. $\mathrm{Herm}$ a $\mathrm{ph}, \mathrm{Ca}$ 1yx et corolla maris. Ovari um inferum, biloculare. Orula in loculis solitaria, dorso convexa, facie plana, medio dissepimento peltatim inserta. ...... Stylus teres, lrevis; stigma crassum, prismatico obtuse pentagonum, nigrum. Fructus ...... Frutices brasilienses, inermes, $r a-$ mosissimi; ramulis compressis foliisque oppositis, stipulis interpetiolaribus integris, parvis, floribus masculis in apicibus ramulorum, saepius ternis, sessilibus, femineis solitariis.

S e pscothaimuns Chamisso in Linnaea $\mathrm{IX}, 248$,

3318. Cardeniola CHAM. F lo r es polygamo-dioici. Ma s c, C a ly x tubo brevissimo, cum orarii rudimento connato, limbo supero, truncato. Corolla supera, hypoeraterimorpha, tubo brevi, paullulum inflato, fauce villosa, limbi quadrifidi laciniis late ovatis, brevibus. Anthera e 4, lineares, intra corollae fancem sessiles, inclusae. O varii rudimentum inferum Stylus inclusus, apice attenuato pilosus; $8 \mathrm{ti} \mathrm{g} \mathbf{m}$ a te obsoleto. Fem. v. Herma phr. Flos.... B acca globosa, umbilicata, bilocularis. Se mina in loenlis $33_{-} 5$, arillata (?) ovoidea, angulata, nitida, acie umbilica lineari. Embryo in cavo axili albuminis subcornei, violaceo-nigrescentis parvus, ambilico proximus; radicula umbilicum spectante. - Frutex brasiliensis, inermis, ramo. sissimus; ramulis compressis foliisque oppositis, stipulis interpetiolaribus, parvis, integris, parum conspicuis, floribus masculis in apice ramulorum tribus v. quinque sessilibus, baccis totidem pediccllatis, Pisi mole, nigris.

Gardeuiola Chanisso in Linnaea $I X$, 2fr.

3319. Thileodoxa CHAM. Flores polygamo-divici. Mas c. Calys tubo cum ovarii rudimento connato, limbo supero, truncato v. olsolete dentato. Coroll a supera, hypoeraterimorpha, fauce villosa, limbo quinquepartito. Anther a e 5, lineares, intra corollae tobum sessiles, inelusae. Ovarii rudimentum inferum. Stylas simplex, teres, apice attenuato glaber; stigma obsuletum. F e m. Ca ly $x$ tubo globoso, subeostato, cum ovario connato, limbo supero. Corolla $\ldots . .0$ variu m inferum, triloculare. Ova$1 \mathrm{a}$ in loculis gemina, angulo interiori aflixa, alterum saepius abortivum. Stylus teres, brevis; stigma crassum, prismaticum, obtuse pentagonum, nigrum. B a cea globosa, umbilicata, pulposa, trilocularis v, abortu unilocularis. S e mina in loeulis solitaria, arillata (?) triquetro-sulglobosa, irregularia, basi acutiora, nigra, umbilico punctiformi, vix conspicuo. Embryo in axi albuminis cornei, violaceo-nigrescentis intensius coloratus; radicula exserta, tereti, crassiore, umbilico proxima. - Arbores brasilienses; folitis opposilis, breviter petiolatis, stipulis membranaceis interpetiolaribus, triangularibus, aculis, in vaginam arcte adpressam connatis, ramulis supraaxillaribus, floribus terminalibus, sessilibus.

Thile od ox a Chamisso in Linnaea $I X, 251$.

8320. Amisoments PRESL. Calyx tubo obovato, cuḿ ovario connato, limbi superi, quadripartiti laciniis patentibus, valde inaequalibus. Co rolla supera, hypocraterimorpla, tubo gracili, limbi quadrifidi laciniis ovatis, acutis, aestivatione valvatis. An the rae 4, lineares, in fauce corollae sessiles, subexsertae. Ova rium inferum, biloculare. 0 vula ..... Stylus filiformis, exsertus; s $\mathrm{ti} \mathrm{g} \mathrm{m}$ a bifidum, lobis patentibus, obtusis. D rup a ealycis limbo coronata, hilocnlaris, loculis' monospermis, altero minore saepins vacuo. Semina …. - Arbor v. frulex bras $i$ liensis; ramis oppositis, divaricalis, altero ra. mulisque spinescentibus; foliis oppositis, breve petiolatis, ovali-acuminatis, coriaceis, stipulis inlerpetiolaribus, integris, ovatis, floribus in pedunculo axillari capitatis, involucro diphyllo minuto suffultis, albis.

A nis omeris Presl $S_{y m b}$.IT. 5. 1. 54. Cl, auctor se. mina linearia, teretia, pendula, embryonem vero in axi atbominis ereç̧um dieit.

3391. Psilobium cum ovario connato, limbo supero, quinquepar- 
tito, patente. Coroll a supera, tubo brevi, limbo quinquepartito, lobis aestivatione valvatis. Stamina 5 , basi corollae inserta. Ovarinm infe rum, biloculare $\ldots . . S t y l u s$ simplex; $8 \mathrm{tigm}$ a clavatum, decemalatem, exsertum. Fruetus cylindricus, siliquaeformis, ealycis limbo persistente coronatus, bilucularis. Sem in a in loculis plarima, axi biseriatim inserta. - Frutices in dici; caulibus obluse telragonis, foliis oppositis, petiolatis, lanceolatis, stipulis latis, carinatis, floribus axillaribus, bracteatis.

Psilo bi u m Jack in Malay. Misc, II. ex Roxburgh Flor. Ind. edil. Wall, II. 320. et ex Hooker Comp. Bot. Mag. I, 255.

338\%. Flatymaeriam BARTL. C a 1 y $x$ tubo brevi, cum ovario connato, limbo supero. rotato, quinque $-v$, rarius quadripartito, Iobis planis, obtusis. Coroll a supera, infundibuliformis, coriacea, tubo brevi, intus lanato, limbo quinquev. rarius quadripartito, lobis planis, obtusis, per aestivationem dextrorsum contortis. A $\mathbf{n} \mathbf{t h}$ e$r$ a c $4-5$, lineares, intra tubum corollae sessiles, Ovarium inferum, biloculare, disco epigy no tectum. Ovula ...... Stylus clavatus, spiraliter decemcostatus. Fructus..... - Frutex manillensis, vix notus, Psilobio ex auctore affinis; ramulis gracilibus, teretibus, foliis oppositis, breve peliolalis, coriaceis, lanceolatis, acumi. natis, subtus ramulisque pubescentibus, floribus in axillis plurimis, glomeratis, breve pedicellatis, caly cibus cano-tomentosis.

Plat y merium Bartling msc, ex DC, Prodr, IP, 619.

3383. Theeanantlarus JACK, $\mathrm{C}$ al $\mathrm{y} \times$ tubo cum ovario connato, limbo supero, eampa. nulato, dilatato, colorato, irregulariter diviso Corolla supera, tubo brevi, limbi quinquefidi lobis per aestivationem valvatis. Anth, rae 5 , magnae, corollae tubo insertae. Ova $r i n$ infe. rum, biloculare. $O_{\mathrm{y}} \mathrm{Ja}$ in placentis semicylindricis plurima. Sty I us bifidus; stigmata linearia. Fructus...... - Frutex indicus, radieans; caule tetragono, angulis duobus magis exscrtis, foliis oppositis, breve petiolatis, stipulis ligulatis, floribus pallide rubescentibus, in capilula terminalia, involucrata dense aggregatis.

Leeanathus Jich in Malay. Mise, II, ex Wallich in Roxburgh Flor. Ind. II. 319. et ex Hooker Bot. Mas. Comp. I. 254. A. Rlchard in Mem, soc. h, n, Paris, V. 293. DC. Pradr. IV. 620.

3384. Marelia A. RICH, Calyx tubo cum ovario connato, limbo supero, marginali, erecto, sabintegerrimo. Co rolla supera, tubo brevi, limbi quincuepartiti laciniis lanceolatis, aestivatione imbricatis, sub anthesi patulis, Stamina 5 , corollae fauci inserta, exserta; anthe$\mathrm{r}$ a e lineares. Ovari um inferum, quadri-quinqueloculare. $0 \times 4 \mathrm{la}$ in loculis $3-4$, loculorum angulo centrali affixa. Stylus simplex, apice incrassato - fusiformis; stigma bifidnm, lobis approximatis. Fructus carnosus, collo calyee brevi coronatus, quadri-quinquelocularis. Sem in a in foculis duo v. tria ..... - Frutex sene gra $m b i$ cus, glaber, Baconiac facie; ramis terelibus, einereis, folits oppositis, ellipticis, coriaceis, stipulis inlerpetiolaribus deciduis, foribus axillaribus racemosis, racemo subtrichotomo.

Morelia A. Richard in Mems, roc, $h, n$. Paris, $V, 232$, DC. Prodr, IV. 617 .
3325. Neurealyx HOOK, Ca I y x tubo obconico-pentagono, cum ovario connato, limbi superi, quinquepartiti laciniis ovato-lanceolatis, foliaceis, nervosis, persistentibus. Corolla supera, rotata, quinquepartita, calycis limbo multo brevior. Antherae 5, magnae, in fance corollae sessiles, in tubum pyramidalem stylo pervium coalitae. Ovariu m inferum, quinqueloculare, disco epigyno orliculari tectum. O vala plurima. Stylus simplex; stigm a indivisum. Fru ctus .... - Herba seylanica; caule simplici, abbreviato, folitis ad basim caulis congestis, lanceolatis, acuminatis, membranaceis, basi longe attenuatis, stipulis mullijidis, racemis axillaribus, folio brevioribus.

Nourocaly $x$ Hooker Ic, 2, 174.

3836. Enameorlaiza $P O H L$. Caly x tu bo turbinato, eum ovario connato, limbo supero, quadridentato, persistente. Coroll a supera, rotata, fance barbata, limbi quadrifidi lobis obtusiusculis, patentibus. St a m in a 4 , corollae fauci inserta, exserta; filamenta filiformia, a $\mathrm{n}$ thera e lineares. Ovari um inferum, vertice brevissime exscrtum, biloculare. O v u 1 a in loculis solitaria, placentae ellipticae, tenuissimae, membranaceae, e medio dissepimento utringue peltatae inserta, amphitropa. Stylus filiformis, exsertus; stigma bifidnm, lobis clavatis. Capsula oblonga, ealycis limbo coronata, bilocularis, ab apice septicido dicocea, dissepimento libero nullo, coccis intus aequaliter rima longitudinali dehiscentibus. S e m in a ovata, compressiuseula, placentae membranaceae simul decidnae centro peltatim inserta, ejusdem marginibus, imprimis basi et apice quasi alata, Embryo ..... - Suffrutex brasiliensis, volubilis, fortassis Borreriae nimis affinis, a Cinchonaceis certissime longe alienus; ramis oppositis, ancipitibus, foliis oppositis, breve petiolatis, lanceolalis, acutis, stipulis basi vaginantibus, apice multisetis, floribus terminalibus, parvis, paniculato-corymbosis, in umbellas multifloras aggregatis, distincte pedicellatis.

$\mathrm{Bm} \mathrm{meofhlz} \mathrm{a} \mathrm{Pohl} \mathrm{in} \mathrm{Flora} \mathrm{1825,} \mathrm{p.} \mathrm{183.} \mathrm{Fadil.}$ chera Presi Symb. 1.73. 8. 49.

238\%". Alberta $E$. MEY. Oaly x tubo turbinate, cusu ovario connato, decemeostato, limbi superi, quinquefidi laciniis tribns acutis, duabus oppositis majoribus obtusis, in fruecu amplia tis. Eorolla supera, clavato-infundibuliformis, tubo incurvo, fance nuda, limbi quinquefidi lobis brevissimis, erectis, imbricatis. S t a min a 5 , corollae tubo supra medinm inserta; an $t$ herae subsessiles, inclusae. Ov a ri $\mathbf{m}$ inferam, biloculare. Ovala in loculis solitaria, apici appensa, anatropa. Sty Ius subfusiformis, exserias; stig$\mathrm{m}$ a attennatum, brevissime bifidum. Fructus ovato-oblongas, suleato-decemcostatus, calycis laciniis duabus oppositis foliaceo-dilatatis, membranaceis, reticulato-venosis, coloratis coronatus, bilocularis ...... S e mina ..... - Arbor (?) capensis; foliis oppositis, subsessilibus oblongis, obtusis, coriaccis, glabris, stipulis in vaginam la$x a m$, truncatam, subciliatam concretis, paniculis lerminalibus corymbosis, corollis pollicaribus, bordid purpurcis, scriceo-pubescentibus.

Alberia k. Meyer moe. in Drege Herb. eap. 
3388. Melanopsiditum CELS. C a I y x tubo cum ovario connato, limbo supero, quinqueseptempartito. Coro I l a supera, hypucraterimorpha, tubo intus barbato-setoso, limbo quinqueseptempartito. Antherae 5 insertae. Ov a ri u m inferum, .... disco epigyno urceolari. Stylus simplex; stigma quadrifidum. Drup a abortu monosperma .... - Frutex incertae originis, glabriusculus; folïs oppositis, petiolatis, ellipticis, acutiusculis, petiolo nervis subtus marginibusque villosis, stipulis ad nodum quemvis solitariis, quatuor nempe concretis in vaginam hinc fissam, apice denticulatam, juniorem pubescentem, adullam subfuscam, basi circulariter deciduam.

Melanopsidium Hort. Cels, non Poit. Viviania Colla in Annal. soc. Linn. Paris. IV. 25. t. 2. non alior. Billiottia DC. Prodr. IV. 618, non Coll. nec R. Br.

3329. Iackia $W A L L$. C a ly $\mathrm{x}$ tubo ovato, cum ovario connato, limbo supero, nnilatera$\mathrm{li}$, apice trifido. Coroll a supera, infundibuliformis, tubo filiformi, limbi campanulati, quinquepartiti lobis lanceolatis, aestivatione valvatis. Antherae 5, ad fancem corollae sessiles, semiexsertac, filiformes. $O$ varium inferum ...... Stylus corolla dnplo longior, medio pilosus; stigma bilobum. Capsula (?) alis tribus unilateralibus, amplis coronata, unilocularis, monosperma ....... - Arbor Indiae australis excelsa; foliis oppositis, brcve petiolatis, ellipticoobovatis, cuspidatis, subtus ramulisque ferrugineo. villosis, stipulis connato-vaginantibus, fimbriatis, paniculae pendulae, villosae spiculis subdichotomis, pedunculis compressis, bracteis connatis, floribus albis.

$J$ a $\mathrm{ck}$ i a Wallich in Roxburgh Flor. ind. II, 312. Plant. As. rar. t. 293, A. Richard in Mem, soc, h. n. Paris, $V$. 199. DC. Prodr. VV. 612. non Blum, Zu cearinia Spreugel Syst, c, p. n. 50, non Blum.

3330. III imatantlaus WILLD. Caly tubo turbinato, cum ovario connato, limbi superi, laxi, persistentis, quinquepartiti laciniis ovatis, acuminatis, duabus paullo minoribus. Corolla supera, infundibuliformis, tubo calycem longe superante, superne parum dilatato, limbi quinquefidi laciniis oblongis. St a m in a 5 , imo corollae tubo inserta; fil a m ent a brevissima, capillaria, antherae lineares, erectae, tubo breviores. Ov a ri u m inferum, biloculare. Ovula in loculis solitaria $\ldots .$. . St y lus truncato-clavatus; $8 \mathrm{tig}$ m a subulatum. Fructus..... Arbor brasiliensis, in provincia Para Sucuba dicta; foliis elliptica-lanceolatis, petiolatis, integerrimis, glabris, floribus spicatis, sessilibus, ante anthesim bractea magna, decidua involucratis.

H im a tanthus Wildenow msc. ex Rümer et Schultes syst, $Y, 13$.

3331. Andis LOUREIR. Ca I y x tubo eum ovario connato, limbo supero, quinquedentato, erecto. Corolla supera, hypoeraterimorpha, fauce lanata, limbi quinquepartiti laciniis lanceolatis. Antherae 5, lineares, corollae incisuris insertae. Ovari um inferum ...... St y I us stamina aequans; st igma ovato-oblongum. B a $\mathbf{c}$ c a ovata, umbilieata, monosperma ...... Arbor c o chinckinensis, magna, ligno albo, gravi, du- rabili; ramis patentibus, foliis oppositis, lanceolatis, integerrimis, glabris, stipulis? .... racemis axillaribus, brevibus, laxis, floribus albis.

A id i a Loureiro Elor. cochinch. 1, 177.

\section{GENERA VIX NOTA.}

1. SICKINGIA WII.L.D. Caly $\mathrm{x}$ quiaquedentatus, per. sistens. Corolla campanulata, quinquedentata, dentibus oblongis. Fila menta 5 , melio tubo inserta, antherae fineares, exsertae. Stigma 1. Capsula liguosa, bival. vis. Semina alata. - Arbores caracasanae; folits oppositis, profunde et remole dentatis, floribus termina. libus, trichotomis, panioulatis, odoratis.

siekingia Willdenow in nov, act, nat, cur. $I I T$, 445, Sehrader Journ, 1800, II, 291. Jussieu in Mem. Mus, VI. 387. DC. Prodr. IV. 621 .

2. STIPULARIA PALIS. Cal y $\times$ parvus, tubulosus, ore quínquedentato. Coroll a tubulosa, gracilis. S $t$ a $m$ in a 5 ? - Planta ovariensis; caule quadrangulo, folits op. positis, petiolatis, ovalibus, apice acutis, basi acumina. tis, slabris, supra obscure viridibus, subtus favidis, tactu mollibus, stipulis interpetiolaribus amplis, late ovatis, acutis, glabris, capitulis axillaribus subsessilibus, involutro magno, calyeiformi, quinquedentato, villoso, floribus pallide flavis.

Stipulazia Palisot Flor. Owar. II. 26, t, 75. DC. Prodr. IV. 619.

3. BENZONIA SCHUMACH. $\mathrm{C}$ al $\mathrm{y} \times$ tubo globoso, limbo minimo, quinquedentato, dentibus erectis. C or olla tubulosa, coriacea, quinquefida, lacinilis coneavis, cyathíformibus. A n the $\mathrm{r}$ a e triquetrae, ad faucem sessiles. $S$ t y I a s filiformis; stig ma ovato-globosum, acutiuseulum, suleis $6 \ldots 7$ longitudinalibus. - Erutex guineensis; ramis teretibus, superne pilis basi papillosis absitis, folits oppasitis, ovato-oblongit, acuminatis, glabris, pedunculis arillaribus dichotomis, corymbosis pedicellisgue bifidis hirsutis.

B e nz on ia Schumach. in Nov, act. soc. $k, n$, Hafn. III. 333. DC. Prodr. IV. 620.

OBSERyATI0. Genera My rione n ron R. Br. in Wall. cat. n. 6223. N e u r o е а r pa a R. Br. (Cfr. supr. n, 3313.) Pl eo the a Wallich. catalog. n, 6215. E geri a Nerand apud Gaudich., ad Freyc. p. 28. et Meretric i a Neraud. . c. c, peaitus iguota nobis sunt.

\section{Ordo CXXIIII. Lonicenecte.}

CAPRIFOLIA sect. 1. 3. Jussieu gen. 210. CAPRIFo LIACEAE A. Richard in Dict. class. ITI. 172, DC. Prodr. IV. 321. Lindley Tntroduct, edit. 2, p. 247. CAPRIFOLIACEAE et SAMBUCEAE Kunth in Humb. et Bonpl. Nov. gen. et sp, IIT. 424. CAPRIFOLIACRAE et VIBURNEAF. Bartling ord, nat. 213. 214. (Coll, R. Brown in Clarke Abel Voy. Chin. 376. et in Wallich Pl. 1s. rar. I. 15.)

Suffrutices v. Frutices, interdum volubiles, rarius hвRвав perennes, ramis teretibus, nodosis, sueco aqueo, medulla in nonnullis valida. F 0 lia opposita, nunc sessilia, interdum connata, saepius petiolata, simplicia, penninervia, integra, integerrima v. crenata aut serrata, rarius incisa v. palmatiloba, $\mathbf{v}$. impari-pinnatisecta. Stipulae nullae, earum loco interdum appendices ad basim petiolorum eiliformes v. glandulares.

Flores hermaphroditi, regulares v. subirregulares, varie dispositi, nunc in pedunculis axillaribus at terminalibus solitarii v. gemini, interdum connati, v. plures, capitati, involucrati, nunc breviter spicati $\mathbf{v}$. in axillis foliorum glomerati, verticillati, nunc in cymas terminales compositas dispositi, exteriores cymae 
interdum steriles, ampliati, radiantes, pedicellis uni-bibracteatis.

CALYX tubo cum ovario connato, limbo supero, quinquefido $\mathbf{v}$. quinquedentato, persistente v. deciduro.

Corolia epigyna, gamopetala, tubulosa v. infundibuliformis, rarius rotata; limbo quinquefido, laciniis aequalibus regulari, v. interdum inaequalibus ringente, per aestivationem imbricatis.

Stamixa corollae tubo inserta, eiusque laciniis numero aequalia et alterna, rarissime unius defectu pauciora, exserta v. inclusa. Filamenta filiformia, aequalia $v$. in androecio tetramero didynama. A n the ra e introrsae, biloculares, oblongo-lineares, incumbentes, versatiles, loculi appositi, longitudinaliter dehiscentes. Pollin is granula laevia, globosa v. oblonga.

Ovarium inferum, bi-quinqueloculare, disco epigyno carnoso, v. vertice breviter exserto, nudo. Orula in loculis nune solitaria, ex apice anguli centralis, v. plurima ex angulo interiore biseriata, in ovario pluriloculari saepius in uno loculo solitaria et fertilia, dum in reliquis plura et abortiva, rarius omnium loculorum plurima, omnia v. pleraque fertilia, semper pendula, in generibus corolla rotata donatis extrorsum anatropa, in generibus corolla tubulosa instructis introrsum anatropa. Stylus terminalis, nunc filiformis, simplex, inclusus v. exsertus, stigmate subcapitato, indiviso v. brevissime bilobo; nunc brevissimus v. subnullus, s $t \mathbf{i g m}$ atibus $3 \ldots 5$, sessilibus, obtusis $\nabla$. acutiusculis.

Frvetus baccatus, calycis limbo coronatus v. vertice nudus, pulposo-succosus v. coriaceus, siccus, nunc plurilocularis, nunc septis demum evanidis unilocularis, loculis mono-polyspermis, v. interdum loculo uno monospermo, reliquis ovula plura sterilia gerentibus.

Semina inversa, test a crustacea, dura v. interdum ossea, $r$ haph e dorsali v. ventrali.

Emвryo in axi albuminis carnosi, plus minus densi orthotropus, nune brevissimus, nunc fere albuminis Iongitudinem aequans. Cotyledon e semícylindricae, brevissimae et obtusae, v. lineares. R a dicula cylindrica, umbilico proxima, supera.

L onicereae a Rubiaceis vix visi stipularum defectu diversae, in hemisphaerae borealis regionibus temperatis maxima copia gignuntur, inter tropicos rarae. Sambuci species perpaucae in Nova-Hollandia et America australi extratropica observatae fuerunt.

Ordo verisimiliter iterum dividendus, $\mathbf{L}$ onicereis veris magis Rubiaceis arcte con- terminis, a Loranthaceis staminum situ cum corollae lobis alternante certe longius alienis, $S$ a m bucine is habitu, corollae forma, styli stigmatisque figura et rhapheos situ bene distinctis, ad ordines eleutheropetalos, Corneas imprimis Araliaceasque magis accedentibus.

Baccae Lonicerarum et Sambucorum nonnullorum edules, flores fragrantes, in quibusdam sudorifici, folia nonnullarum foetida, omnium fere drastica, purgativa, cortex plurimarum adstringens.

\section{SUBOIRDO I. LONICEREAE VERAE} R. Brown in Wallich Plant. As, rar. I. 15. Corolla tubulosa, limbo regulari v. irregulari. Stylus filiformis. Seminum rhaphe extrorsa.

3338. Hinmaea GRONOV. Calyx tubo ovato-subgloboso, cum ovario connato, limbi superi, quinquepartiti laciniis lanceolato-subulatis, deciduis. Co roll a supera, turbinata, subcampanulata, limbo subaequaliter quinquelobo. Stamin a 4 , corollae tubo prope basim inserta, didynama, inclusa. Ovarium inferum, triloculare, loculis duobus pluriovulatis, abortientibus, tertio uniovulato, fertili. O vula ex angulo centrali loculorum pendula, anatropa. Sty I 8 subexsertus; $8 t$ ig m a capitato-subglobosum, B a ce a apice nuda, ovato-globosa, inaequilatera, coriacea, trilocularis, loculis duobus minoribus, sterilibus, tertio fertili, monospermo. S em en inversum. E m b r yo in axi albuminis carnosi, mollis brevissimus, orthotropus; cotyledonibus obtusis, radicula umbilico proxima, supera. - Herbula borealis, amphigea, sempervirens, repens, subvillosa; surculis ascendentibus, apice nudis, $b i$ floris, folits oppositis, petiolatis, ovalibus, subdentatis, floribus ex albido roseis, nutantibus, bracteolis sub flore geminis, calyculum simulantibus.

L i u n a e Gronovius in Linn, gen, $n$, 774. Jussieu gen. 211. Schkulir t. 176. Flor, dan. t. 3. E. B. $t$, 433, Wahleaberg Flor. Lapp. 170. 2, IX, f. 3. Hooker Flor. Lond, IC. DC. Prodr. IV. 340, 0 b ol a ri a Siegesbeck Prim, 79.

3333. Abelta $R$. Br. Calyx tubo cum ovario connato, lineari-oblongo, cempressiusculo, hine uninervi inde quinquenervi, apice in collum subangustato, limbi superi, quinquepartiti laciniis foliaceis, spathulato-oblongis, persistentibus. C orolla supera, infundibultiformis, limbi quinquefidi, patentis laciniis ovatis, obtusig, subaequalibns. S $t$ a $m$ in a 4 , corollae tubo inserta, sulnd idy. nama, inclusa v, breviter exserta. $O \mathrm{v}$ a $\mathbf{r}$ i $\mathrm{m}$ in. ferum, triloculare, loculis duobus plnriovulatis, abortientibus, tertio uniovulato fertili. Ovula angulo centrali loculorum inserta, sterilinn uniseriata, inferiora pendula, supremum adscendens, loculi fertilis gendulum, anatropum. Sty I us sulexsertus; stig ma depresso-capitatum, indivisum. B a c e a coriacea, exsucea, ealycis limbo coronata, trilocularis, loculis duobus sterilibus minoribus, tertio fertili monospermo. Sem en inversum, sub. cylindrieum. Embry o in axi albuminis carnosi brevis, orthotropus; cotyledonibus obtusis, radicula umbilieo proxima, supera. - Frutices chinenses et indici, decumbentes $v$. ereeti, debiles, glabri; foliis oppositis, peliolatis, dentatocrenatis, pedunculis modo axillaribus trichotosis v. 
trifidis, modo terminalibus indivisis, involucro uni-bi-multifloro, foliolis sex v, pluribus.

$\Delta$ belia R. Browa in Clarke Abel Voy. Chin, 376. c. ic. et in Wallich Plant. As, rar. 1 . 14. $t$. 15. DC. Prodr. IV. 339.

3334. Symepladeicarpas DILLEN, $\mathrm{C}$ a1 y $x$ tubo globoso, cum ovario connato, limbo supero, quadri-ģuinquedentato, persistente, Corolla supera, infundibuliformis, limbi quadriquinquelobi lobis subaequalibus, obtusis. Stamina $4_{-} 5$, coroliae tubo prope fancem inserta, inclusa, aequalia. Ora riu inferum, quadriloculare, loculis dnobus pluriovulatis sterilibus, duobus oppositis uniovulatis, fertilibus. $O \mathrm{v}$ u la ex apice anguli centralis loculorum pendula, anatropa. StyI us inclusus; $8 \mathrm{tig} \mathrm{m}$ a depresso-capitatum, indirisnm. B a c c a subslobosa, succosa, ealyeis limbo coronata, quadrimealaris, loculis duobus filiformibus, vacuis, duobus oppositis monosperuris. S e$\mathrm{mina}$ inversa, ossea. Embryo in axi albuminis carnusi brevissimus, orthotropus; cotyled on i= bus obtusis, radicula umbilico proxina, supera. - Frutices boreali-americani et me$x i$ c a $\bar{n} i$, erecti, dumosi, opposite ramosissimi; foliis oppositis, brevissime petiolatis, ovalibus, integerrimis, pedunculis axillaribus brevibus, uni-mulifforis, floribus parvis, brevissime pedicellatis, bibracteolatis, albis $v$, roseis.

S y mphoricarpus Dillen. Hort. eltham. 371. Jussieu gen. 211. Mömch Method. S02. Kunth in Humb. et Bonpl. Nov. gen, ot sp. IIT. 424. t. 295, 296. DC. Prodr. 1V. 338. S y m ploricarpa Neeker elem. n, 220. S y mphoria Persoon Ench. 1, 214. Bot. Mag. $t$. 2211. A $n$ i. n a athus Willdenow msc. R8m. et Schult. Syst. $\boldsymbol{P}$. 223. Loniceraes p. Lian.

3535. Theyeestria $W A L L$. C a I y $\mathrm{x}$ tubo ovato-subgloboso, cum ovario connato, limbi saperi, quinquepartiti lobis linearibus, subinaequalibns, persistentibus. Cor oll a supera, infundibuliformis, tabo basi hine gibbo, limbi campanulato-quinquepartiti lobis ovatis, subaequalibus. Stamina 5 , corollae tubo inserta, breviter exserta. Ovari nm inferum, quinqueloculare, localis pluriovulatis. Orula in loenlorum angulo centrali biseriatim pendula, anatropa. Stylus breviter exsertus; stigma capitatum, indivisum. Ba c ca subglobosa, succosa, calycis limbo cororata, quinquelocularis, polysperma. Semina in localis biseriata, ovata, pendula v. subhorizonta lia. Embryo in axi albuminis earnosi brevissi. uns, orthotropus; cotyled onibus semicylindrieis, radieula nubilico proxima, supera. Frutex nepalensis, elegantissimus; ranis elongatis, leretibus, e gemma squamosa ortis, folitis oppositis, petiolatis, ovato-lanceolatis, acuminatis, brevibus, petiolo piloso, floribus sessilibus, fasciculatis, subverticillatis, racemum terminalem brevem formantibus, bracteis lalis, foliaceis, purpureis, pubescentibus, basi subconnatis, corollis ex albo purpurascentibus, baccis intense purpureis.

Ley cestria Wallich in Roxburgh Flor. Ind, or, II. 181. Plant. As, rar. t, 120. DC. Prodr. IV. 338.

3338. Hienviln TOURNEF, Calyx fubo cum ovario connato, oblongo, apice in collum angustato, limbi superi, quinquefidi laciniis lineari subulatis, decidais. Corolla supera, infundibuliformis, limbi quinquefidi, patentiuscnli lavinis acutiuseulis, subaequalibus. Sta $\mathbf{m}$ in a 5 , corollae tubo inserta, subexserta. Ovari $\mathbf{m}$ inferum, biloculare, diseo epigyno carnoso, calycis collum replente. Ovula in loeulis plurima, juxta disse- pimentum utrinque biseriatim pendula, anatropa. Stylus subexsertus; stigma capitatum, indivisum. B a e c a coriacea, sicea, oblonga, acuta, apice nuda, bilucularis, polysperma. Semina biseriatim pendula, ovata. Embryo in axi albuminis carnosi hrevis, orthotropus; cotyledonibus semicylindricis, obtusis, radic ula umbilico proxima, supera. - Frutices erecti, in $A \mathrm{~m}$ : ricaboreali et Japonia indigeni; foliis op positis, breve petiolatis, ovatis, acuminatis, ar gute serratis, pedunculis axillaribus bibracteatis, saepius dichotomis, bi-tri-quedrifloris.

Di ex villa Tournefort in Aet. Academ. Paris, 1z06. t. 7. f. 1. Linn, Hort, eliffort. 63, t. 7. Jussieu gen, 211 . Duhamel Arbr. I. t. 87. Lo n i cerae s p. Lian. - Wei-

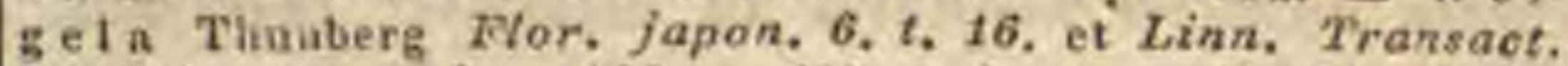
II. 331, Act. Holms. 1780, p. 137, t, 5, Lam, t. 105. W e igelia Persoon Ench. 1. 176. teste R. Brown in Wallich Plant, As. rar. I. 13.

333\%. Honicera DESFONT. Cal y $\mathrm{x}$ thbo ovato v. subgloboso, cum ovario connato, limbo supero, brevi, quinquedentato, persistente $\mathrm{v}$. deciduo. Corolla supera, tubulosa campanulata v, infundibuliformis, tubo aequali v. basi hin: gibbo, limbo quinquefido, regulari v, ringente. Stam in a 5, corollae tubo inserta, exserta v. inclusa. Ova rium inferum, tri-bilvenlare 0 v u la in loculis plura, ex angulo centrali pendula, anatropa. Stylus filiformis; stigma capitatum. Ba cea carnosa, trilocularis v, dissepimertis demum obliteratis unilocnlaris, oligosperma. Sem in a inversa, crnstacea. E mb ryo in axi albuminis carnosi brevis, orthotropus; cotyledonibus cllipticis, radicula umbilico proxima, supera. - Frulices erecti $v$ scandentes, in hemisphaerae borealis rc. gionibus extratropicis temperatis et calidioribus obvii, inter tropicus $A$ sia e et $A$ merica e rari; foliis oppositis, petiolatis $v$. sessilibus, interdum connatis, integris $v$. in eadem specie subruncinatis, floribus axillaribus varie dispositis.

L a ni cer a Desfont. Flor. ALI, I. 183. BC. Prodr. IV. 330. Lonicerae sp. Lial. Caprifolinm et $X y l a$. steum Juss. gen. 212. Xy $10 x$ tsou, Caprifollum, Chamaecerasus et Perielymenum Tournef, inst. t. 328. 379. Caprifoljum et $L$ on ic e r a Rum. et Schult. Syst. F. p. XIX. L n nicera et Xylosteusa Torrey Flor. unit. stat, $I$. 202, ss.

A. CAPRIFOLIUM Juss. B a c ca e solitariae, calycis limbo co:onatae, dissepimentis obliteratis unitoculares. - Caules scandentos, folia saepins connata, flores capitato. verticillati.

Caprifoli um Jussien gen, 212. Rōmer et Schult. t. c. DC. l. c. Lanicera Torrey $l$. $c$.

c6. Caprifolinm Touracf. inst. 608. Flores ria. geates. (E. B. t. 799. 800. Jaeq. Fl, austr, t. 357. Bot, Mag. t. 640, 1318. Bot. Reg. t. 1/57. 1761, Hook. Exal. Flor, t. 28.)

B. Periely menum Tournef, inst. 608, Fi ores sutbrezulares. (Bot. Mag, 2. 781. Bot. Reg. t. 781. Kuath in Mumb. et Bonpl. Nov. Gen, et sp. t. 298.)

B. XVLOSTEON Juss. B a ee a e gemiane, distiactae v. eodnatae, calycis limbo deciuno apice nudae, bi-trilo. eulares. - Caules erefi vo scandentes, folia nunquam comata, pedicclli arillares, apice bibracteati, biflori.

$\mathrm{X}$ ylost $\mathrm{tum}$ Jussieu gen. 212. DC. 2. C, Lonieera Röm. et Schuli. 1. c, X y loste on et $\mathrm{C}$ h a ma ece. rasus Touruef, inst, 609. Xylosteam et isikn Adins. Fam, II, 501. C o b в е a Necker elem. n, 219.

a. NINTOOA DC. $t$. c. Ovaria et baceae ounino distinetae. - Caules scandentes.

Ninto o a Sweet Hort, Brit, edit, M. p. 258. (Desfont. Flor, Alt, $t$, 59. Bot, Reg. t. 70, 712, 1232, Andr.

- Bot, Reposit. t. 383. Bot. Mag. t, 3310.) 
b. Cha uaceerasus DC. l. c. Bace a e liberac s. sacpias bani inter se subeoneretae, upice divergentes. Corollae basi aequales v. vix sfbbae. - Caules erecti, dumosi. - (Jaeq. Fl ausir. t. 314. Ic. rar. t. 37. Gärtu. t. 27. f. 6, a E. B. t 916. Bot. Reg. t.31 Bot. Mag, t, 2469 Royle Himalay, t, 53.)

c. Cuphaut ha DC. l. e. Buccae liberae v. coneretae. C or oll a e basi hinc manifeste gibbae. - Cau les erecti $v$. demissi, nunquam scandentes. - Kuuth in Humb el Banpl. Nov. gen. et sp. t. 297. Bot. Reg. t. 1179. Hooker Flor. Bor, Amer, , 100.)

d. Is ika DC. l. c. Bacea e in unicam biumbilicatam omuino coneretae, - Caules erecti, dumosi. Is ik म Adaus. 2. c. Is ie a Mónch Method, s04 (Jaeq. Fl. austr, t. 17, 274. Gïrtia. t. 27, f. 6. $b$. Bieberst. Ross, I. t, 13. Bot. Mag. t. 1965 )

3335. Troiosterana LINN, C aly x tubo ovato, cum ovario connato, limbi superi, quinquepartiti lobis lineari lanceolatis, foliaceis, persistentibus. Corolla supera, calyce paullo lon gior, tutsulosa, tubo basi gibbo, limbi subaequaliter quinquelobi lobis obtusis. S ta m i n a 5 , corol lae tubo inserta, aequalia, inclusa. Ovarium inferum, triluculare, rarissime quinqueluculare. Ovula in loculis solitaria, ex apice anguli centralis pendula, anatropa. Sty $\mathbf{I}$ s inclusus; $8 \mathrm{ti} g-$ ma oblongo-incrassatum, indivisum. B a $\mathrm{c} c$ a coriacea, obovato-triquetra, calycis limbo foliaceo coronata, tri-quinquelocularis. S e m in a in locu lis solitaria, inversa, elliptica, ossea. E m br yo in axi albominis carnosi minimus, orthotropus; $c$ otyledonibus obtusis, radicula umbilico proxima, supera. - Herbae perennes v. suffrutices, in Americaboreali et in Asiae mediae montibus crescentes; foliis oppositis, basi subconnatis, subsessilibus $v$. brevissime petiolatis, floribus axillaribus, sessilibus $v$. brevissime pedicellatis, solitariis v. confertis, rarius sublerminalibus, racemosis.

Trios te u minne gen. n. 23t. Gärtaer $T$. 129. $t .26$. Selikuhr $t$. A1. Lan. $t$. 150. Bigelow Med. bot. $t$. 9. Sweet Fl. Gard. II. t, 45. Wallich in Roxburgh Flor. Ind. or. II. 180, DC. Prod. IV. 329.

\section{GENUS DUBIUMI.}

3:339. Calysplayruana BUNG. CaIyx tubo cum ovario connato, lineari pentagono, decemstriato, limbi superi, subeampanalati, profunde quinquefidi laciniis lanteolatis, subaequalibus, acutis, erectis, deciduis. Co roll a supera, infundibuliformis, tubo calycis lacinias aequante, fauce ampliata, glabra, limbi ampli, quinquepartiti, patuli laciniis rotundatis, aestivatione imbricatis, quinta paullo minore. Sta $m$ in a 5 , imo corollae tubo inserta; filamenta $\ldots .$. a ntherae lineari oblongae. Ova $\mathbf{r i m}$ inferum, biloeulare. Ovula in placentis medio dissepimento utrinque adnatis plurima, biseriatim pendula, compressa .... Stylus filiformis, exsertus; stigma peltatum. Fruetus...... - Frutex e Chinaboreali relatus; foliis oppositis, subsessilibus, oblongis, acuminatis, dentatis, floribus in ramis terminalibus binis v. quaternis, sessilibus, corollis purpureis, Rhododendri daurici fere forma et magnitudine.

Cal ys phyrum Bunge Enumerat, plant. Chin. boreal. $3^{\text {th }}-$ Genus a cl, anctore dubie inter Rubiaceas col. locatam, eodem monente Lobeliaceis fortassis adnumerandum, nobis ob folia dentata et stipulas aullas, saltim in descriptione non commemoratas, et ob stamina libera ab utroque ordine alienum, hoc potius loce enumerandum vide tar, Diersillae fortassis uimis affine.

SUEOIRID 1. SAMBUCEAE Kunth in Humb, et Bonpl. Nov. gen. el sp. III. 381 .
Co roll a regularis, rotata v. breviter tubulosa. Stigmata tria, sessilia. Seminum rhaphe introrsa.

3340. Viburnum LINN. Calyx tubo ovato cum ovario connato, limbo supero, parvo, quinquefido, persistente. Corolla supera, rotata, campanulata v. breve tubnlosa, quinquefida, patens. Stamina 5, corollae tubo inserta, exserta, aequalia $O$ vari u m infernm, triloculare. Ovula in loculis solitaria, ex apice anguli centralis pendula, anatropa. Stigmat a 3 , sessilia, obtusa. Ba c ca ovata v. globosa, ealycis limbo coronata, abortn unilocularis, monusperma. Se$m$ e $n$ inversum; $t$ e $8 \mathrm{ta}$ erustacea, dura. $\mathbf{E} \mathbf{m}$ bryo in axi albuminis dense carnusi brevissimus; cot $\mathbf{y}$ ledonibus obtusis, radicula umbilico proxima, supera. - Frutices erecti, in regionibus temperatis hemisphaerae borealis, in America et In dia montana copiosius obvii, inter tropicos Asiae et $A$ merica e rari; foliis oppositis, petiolatis, serratis $v$. incisis, rarius integerrimis, $p l e$ rumque pubescentibus $v$. villosis, interdum glaber rimis, corymbis terminalibus, floribus albis $v$. subroseis.

Viburnum Linn. gen, n. 370. Jussien gen, 214. Sebkuhr t. 81. Gärtuer 1 . 133. DC. Prodr. IV, 323. $0 \mathrm{p} \mathrm{a-}$ lus, Viburaum et Tinus Touruefort inst, 607. Vibur. "n u m et Opulus Möach Method. 505.

a. SOLENoTinus DC, $l, c, \mathrm{C}$ or y m bi flores omnes fertiles, aequales. Corolla e ohconicae v. cylindraceotubulosae. S e m en ovali-oblongum. - L o n i cera mon. gollic a Pallas Flor, ross, I. t. 38. et, t. 58.

b. LENTAGO DC. l. c. Corymbi flores omnes fertiles, aequales. Cor oflla rotatae v. vix subcaupaniformes. Seme n ovale.

Viburnum Móneh Method. 505. Viburnum et T i nus Touraef. $l$. c. Borkhaus, in Römer Arch. I, 20. (Jaeq. Flor. austr, t, 341. Hort, Vindob, I. t, 36. Bot, Mag. t. 38. 2082. Bot. Reg. t. 376, 456, 1630, Wallich Pl. As, rar, t, 61, 160.)

c. OPULUS DC. $l$, $c$. C ory m b i flores exteriores steriles, malto majores, radiantes Co roll a e rolatae. S e me obeordatum.

Op ulas Tournef. I. c. Möuch l. c. (Gürtn, t, 27. E. B, $t$. 339. F1. dau. $t, 661$, )

3344. Sarabsuers TOLRNEF, C a ly x tubo ovato-subgloboso, cum ovario connato, limbo supero, parvo, quinquefido, demum obsoleto. Corolla supera, rotato-urceolaris, quinquefida. Stamina 5 , corollae tubo inserta, aequalia. $O$ var $\mathbf{i} \mathrm{m}$ inferum, tri-quinqueloculare. Ova 1 a in loenlis solitaria, ex apice anguli centralis pendula, anatropa. Stig m at a $3-5$, sessilia, obtusa. Ba ce a subglobosa, calycini limbi rudimento coronata, pulposa, dissepimentis obliteratis unilocularis, tri-pentasperma. Semina e funieulis filiformibus in axi baceae combinatis pendula, oblonga, hebetate triquetra; t e s t a crustacea, dnra. Embryo in axi albuminis carnosi orthotropus, ejusdem fere longitudine; cotyledonib us linearibus, ra di c n I a umbilico proxima, supera. - Herbae perennes, graveolentes, $v$. frutices arborescentes, per regiones temperatas et calidas totius orbis sparsi; folits opposilis, impari-pinnatisectis, segment is dentatis $v$. pinnatisect is aut laciniatis, basi bistipulatis v. biglandulosis, floribus corymbosis terminalibus, corymbis planis $v$. in thyssum dispositis, corollis albis v. rubentibus.

$\mathrm{S}$ a mb ucus Tournefort instit. $t$, 376, Linn. gen, $"$. 322, Jussieu Ben, 214. Gürtaer I. 137, t, 27, Lam, t. 211. Schkuhr t, 83 . Miller Ic, t. 296, E, B, t. 475, 476, Jicç. 
Ic. rar. 1, t, 59. DC, Prodr, IY, 321, P hyte u ma Loureiro Flor, cochinch, 172.

\section{GENERA VIX NOTA.}

1. VALENIIANA Rafin. Spece, $1,87, \mathrm{C}$ al y $x$ tubo cum ovario conuato, liabo supero, octofida. Corolla supera. tubulosis, limbo quiaquefido, subrequali. S $t$ a m in a 4 , co-

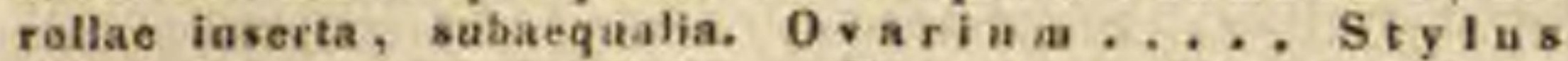
filformis; stigua bilobna. Fructus bilocularis? Frutex $a b y s s i n i c u s$, volubilis, ex auclore Linnaeae af. Anis, sed vix notus, fortassis commentitius; folits oppositis, petiolatis, subsagitlatis, subserratis, arutis, flori bus axillaribus, solitarits, bibracteatis, bracteis corda. tis, extus alatis.

2. KARPATON Rafin. Flor, Ludow. 78. Caly $\mathrm{x}$ tubo cum ovario counato, limbo supero, quadridentato. C o r o lIa supera, tubulasa, quadrifida, bilabiata. $S$ ta m i a a 2 , antheris bilobis, labis remotis. Ovarinm... Stylus sub corollac labio superiore; $8 \mathrm{ti}$ g ma simplex. Capsula calycis liabo enronata, unilncularis (?), tetrasperma. Planta ludoviciana, Diervillae ex auclore affinis; caule herbaceo (?) anguloso, ramis fastigiatis, folits op. positis, sessilibus oblongls, hastatis, basi inaequaliter dentatis, acuminatis, glabris, floribus verlicillatis, sessi. libus, parvis.

\section{Classis XXXIV. Contortae.}

Arbores, frutices $v$, herbae, succo aqueo v. saepius lacteo. Folia opposita v, interdum verticillata, rarissime subalterna, simplicia v. interdum pinnata, plerumque integerrima. Stipulae saepissime nullae, rarius vaginales v. liberae. Flores ut plurimum hermaphroditi. Calyx liber. Coroll a hypogyna, gamopetala, regularis. Stamina corollae inserta, ejusdem lobis numero aequalia, nunc panciora. Ovarium dimerum. Ovula solitaria v. plurima, amphitropa v, anatropa. Fructus capsularis, follicularis, baceatus v, rarius drupaceus: Sem i n a solitaria v. plurima. Emb r y o intra albumen homotropus, nunc exalbuminosus, cotyledonibus saepius foliaceis.

\section{Ordo CXIXI. Iasmineare.}

JASMINEAE R. Brown Prodr. 520. Bartling Ord. nat, 216. JASMINACEAE Lindiey Introduct. odit. II. p. 308 ,

Arbuscular v. Frutices, saepius volubiles. Folia opposita, plerumque composita, ternata v. imparipinnata, nunc simplicia, petiolo in plerisque cum lamina articulato, integerrima $v$, rarius incisa. Stip ula e nullae.

Flores hermaphroditi, regulares, axillares v. terminales, pedunculis trichotomis, subtrifloris, v. repetito tri-dichotomis, multifloris.

Catxx liber, gamophyllus, quinque-octofidus v. dentatus, persistens.

Conowla hypogyna, hypoeraterimorpha, tubo tereti, limbi quinque-octofidi lobis aequalibus, Iateraliter incumbentibus, aestivatione imbricatis et tortis.

Stramiva 2, corollae tubo inserta et inclusa. Filamenta brevissima v, subnulla.
Antherae biloculares, basi fixae, loculis oppositis, parallelis, rima longitudinali dehiscentibus.

Ovariux liberum, absque disco cingente, ovatum v. subdidymum, biloculare. Ovula in loculis solitaria, v, rarissime gemina collateralia, ex ima dissepimenti hasi adscendentia, anatropa. S t y l u s terminalis, brevissimus; s $t \mathbf{g} \mathbf{m}$ a indivisum v. bilobum aut bifidum.

Froctes nunc b a c ca didyma, disperma, v. lobo altero abortiente monosperma, nunc capsula obcordata, septicido-bipartibilis v. interdum circumscissa.

Senisa in loculis solitaria, v. rarissime gemina collateralia, e basi erecta, subcompressa; test a coriacea v. reticulato cribrosa, arillaeformi, end ople ura plerumque tumidula.

Albumen initio copiosum, sub maturitate penitus consumtum, v. ad laminam tenuissimam redactum.

Gimano orthotropus; cotyledonibus plano-convexis, carnosis, r a di c u la brevi, infera. Plumula vix conspicua.

$\mathrm{J}$ asmineae ob florum formam et miram odoris suavitatem celeberrimae, in regionibus tropicis subtropirisque veteris orbis indigenae, in America rarissimae, Oleineis proxime affines, ovulorum situ, seminis structura et co. rollae aestivatione distinetae, Contortarum hine seriem incipiunt, inde Verbenaceis Ebenaceis que conterminae.

334\%. Jasminum TOURNEF, Calys tubulosus, quinque octo-dentatus v. partitus, persistens. Cor olla hypogyna, hypoeraterimorpha, tubo elongato, limbi quinque-octopartiti laciniis aestivatione contorto-imbricatis, sub anthesi patentibus. S $t$ a min a 2 , corollae tubo inserta, in clusa. Ovarium bilocnlare. Ovula in loculis solitaria, e basi dissepimenti adscendentia, anatropa. Stylus brevis; stigma bilobum v. bifidum. B a ce a didyma, disperma, v. tobo altero saepius abortiente monosperma. S emina ereeta, compressiuscula; t e st a coriacea v. reticulato cribrosa, endoplenra tumida. Em b ryo exalbuminosus, orthotropus; cotyle don ibus plano convexis, earnosis, radienla brevi, infera. - Frutices erecti v. saepius valubiles, inter tropicos veteris orbis, in regione medilerranca, Africa australi et Australasia ex lratropica indigeni; foliis oppositis, ternatis $v$, imparipinnatis, nunc integerrimis, petiolo arliculato, floribus corymbosis, plerumque suaveolentibus.

Jasminz Tournefort inst, 368. Lien. gen, $n, 17$. Gïrtner T. 196, t. 42. Jacquln Horl, Schönbr. t. $321,490$. Smith exol. Bot. 2. 118. Audrews Bot. Reposit, t. 127. 497.

R. Brow и Pradr, 721. Bot. Reg, t, 1. 98, 91, 128, 264. 250, 436. 521, 690.918, 1296. 2013. Bot. Mag. t. 31. 985.461 .980$. 1785. Labillard, Nov. Caledon, $t, 27$, Wallieh Plant, As, rar. $t$. 224. 275. Jas minum et Mogorium Jussieu gen, n. 106.

3343. Nyetanthes LINN. Calyx tubulosus, obsolete quinquedentatus. Corolla hypogyna, hypocraterimorpha, limbi quinque-octopartiti 
lacinis aestivatione oblique tortis, sub anthesi patentibus. Stamina 2, corollae tubo inserta, inclusa. Ovarium biloculare. Ovula in loculis solitaria, e basi dissepimenti adscendentia, anatropa. Stylus brevis; $8 \mathrm{tigma}$ capitatum. Ca p s uIa chartacea, obcordata, compressa, septicido-bi partibilis, loculis monospermis. Semina erecta, compressiuscula; te $8 \mathrm{ta}$ coriacea, endopleura $t u$ mida. E m bryo exalbuminosus, orthotropos; $c 0$. tyledonibus foliaecis, ellipticis, radicula brevi, infera. - Frutex in Asia tropica indigenus; ramulis tetragonis, foliis oppositis, petiola. tis, ovatis v. ovato - oblongis, acuminatis, basi sub cordatis, scabris, umbellis axillaribus et terminali. bus, involucratis.

Nyctanthes Lian. gen, $n$, 16. excl. sp. Bot. Reg 8. 399. Blume Byjdr. 680. S c a b $\mathrm{r}$ it a Lian. Mant, 37. Giartner $I I$. 265. t. 138. P a rili um Gärtnee 1 . 234. t. 51.

3344. IVIengalora HUMB, et BONPL. Cal y $x$ subeampanulatus, quinque-ortopartitus, persistens. Corolla hypogyna, infundibuliformis, tubo abbreviato, limbi quinque-octopartiti lobis aestivatimne contorto-imbricatis, snb anthesi erec1iusculis. S tamina 2 , corollae tubo inserta, inclusa v, subexserla. O varium obcordatum, bi loculare. Ovula in loculis gemina, collateralia, e basi dissepimenti adscendentia, anatropa. St yIn s filiformis; stigm a capitatum, obsolete bilobun. Capsula eartilaginea, didyma, bilucularis, circnmscissa, locnlis dispermis. Semina erecta, trigona; testa spongioso-reticulata, laxa. Embryo exalbuminosus; cotyledonibus planoconvexis, crassiusculis, ra di $\mathrm{c}$ u la brevi, infera, - Suffrutices $v$. frutices, in America orientali a provincia cisplatina ad Texas sparsim observati; ramulis tetragonis, foliis oppositis, subsessilibus, glabriusculis v. piloso-scabris, integerrimis $v$, in eadem stirpe intertum lrisectis, floribus axillaribus terminalibusque solitariis, pedunculatis,

M e n'o d or a Humb. et Bonpl. Plant, aeguinoct. II. 98. t. 110. Kunth in Humb. el Borpl. nov. gen. et sp. VII. 199. Bolivaria Chamisso. et Selieelitend. in Linnaca $I$ 20\%. t. A. f. 1. Calyptros peru a m Dietrieh spec, $I$. 226.

\section{GENUS DUBILM.}

3345. Chond rospermanan WALL. Caly urceolatus, acute quadridentatus. Corolla hypogyna, infundibuliformis, carnosula, tubo calycem superante, limbi quadripartiti, tuho Iongioris laciniis lineari-elavatis, aestivatione valvatis, sub anthesi patentibus. St a m in a 2 , corollae tubo supra basim inscrta, inclusa. Ovariu m ovatum, biloculare. Ovn la in loculis solitaria, e hasi erecta ..... Stigm at a 2 , sessilia, acnta. Fruetus ..... - Frutex indic us, scandens; ramis telragonis, foliis oppositis, petiolatis, ovalibus, ucuminatis, trinerviis, reticulato-venosis, glaucis, paniculis terminalibus et axillaribus, ramosis, brachiatis.

Chondros per m u m Wallich Catalog. $n, 2837$. Ch i a n. a thus s milacifolia Wallich in Roxburgh Flor, ind. I, 108 ,

\section{Drdo CXXX. Dleacene.}

OLEINEAE Hoffuansegge et Link Flor. Porlug. I. 385. R. Brown. Prodr, s22. Bartling Ord, nat. 217. OLEACEAE Lindley Introduct, edil, $I, p, 307, \mathrm{~J}$ a $8 \mathrm{~m}$ i n e a r um genera Juss.

Arbores v. Frutices, ramis oppositis, nodosis, ramulis tetragonis $\mathbf{v}$. compressis. Folia opposita, petiolata, simplicia, integra, petiolo cum lamina hand articulato, rarius impari-pinnata, fuliolis integerrimis v. serratis. Stipula e nullae.

Flores hermaphroditi $v$. interdum abortu unisexuales, racemosi $v$. trirhotome paniculati, nunc pedicellis abbreviatis subfasciculati, pedicellis oppositis, unibracteatis.

CALYX gamopliyllus, quadridentatus $\mathbf{v}$. divisus, persistens, rarissime nullus.

Conolsa hypogyna, e petalis quatuor, nune mediantibus staminibus basi cohaerentibus, quasi tetrapetala, nunc perfecte gamopetala, infundibuliformis v. subcampanulata, limbi quadripartiti lobis per aestivationem valvatis, rarissime nulla.

Stamisa 2, hypogyna, filamentis corollae tubo adhaerentibus. Antherae biloculares, dorso aflixae, loculis oppositis, longitudinaliter dehiscentibus.

Ovariem liberum, biloculare, absque disco cingente. $0 \mathrm{vula}$ in loculis ut plurimum gemina collateralia, ex apice dissepimenti utrinque pendula, rarius terna collateralia, lateralibus abertiris, nune biseriatim plura. Stylus brevissimus. Stig ma indivisum v. bifidum.

Froctus varius, nune drupaceus, abortu saepius unilocularis, monospermus, nunc baccatus v. capsularis indehiscens, superne in alam membranaceam productus, nunc capsularis loculicido - bivalvis.

Semuxa in loculis ut plurimum abortu solitaria, rarius gemina, rarissime plura, semper pendula, saepissime compressa, interdum ala membranacea cincta.

Embryo in axi albuminis dense carnosi v. subcornei rectus, ejusdem fere longitudine; cotyledonibus foliaceis, radicula tereti, supera.

Ole a ce a e, quarum nonnullae ob lignum durabile, aliae ob druparum putamen oleo scatens et fructus edules, nonnullae ob florum elegantiam et odorem inter mortales celebratae, in temperatis calidioribus veteris orbis maximo numero gignuntur, inter tropicos rariores, in America aequinoctiali rarissimae. Frax i$\mathrm{n} \mathbf{i}$ in America boreali abundant.

Ordinis diagnosis a Jasmineis facilis, sed affinitas subdubia. Corollae elementa in pluribus subdistincta transitum ad ordines polypetalos indigitant.

SUBoreme I. OLEINEAE. Fructus drupaceus v, baccatus.

3346. Chionanthus LINN. C a lyx abbreviatus, quadripartitus. CoruIl a hypogyna, infundibuliformis, tubo brevissimo, limbi quadri- 
partiti laciniis linearibus, elongatis. St am in a 2 v. 4 , corollae tubo inserta, inclusa. Ova rium biloculare. Ovula in loculis gemina, collatera. lia, ex apice septi pendula. Stylus brevissimus; stigma emarginato-bilobum. Drupa bac. cata, abortu monosperma, putamine osseo, suleatostriato, uniloculari. S e men inversum. Embryo exalbuminosus; cotyled onibus plano-convexis, crassis, radicula brevissima, supera. - Arbores $v$. frutices, in America boreali et tropica, nec non in Asia calidiore indigeni; ramulis superne compressis, foliis oppositis, simplicibus, in tegris, racemis simplieibus v. compositis, terminalibus v. axillaribus, floribus luteis.

Chion anthus Linu. gen. $n$. 2t. excl. sp. Vah Enumerat. 1. 44. Watson Dendrolog. t. 1. R. Brown Prodr. 523.

334 . Tinoeiera $S W A R T Z$. Caly $\mathrm{mi}$ nimus, quadrifidus. Corolla hypogyna, tetrapetala, petala linearia, elongata, basi mediantibus staminibus per paria connexa. Stamin a 2 v, rarissime 4 , petalorum bases jungentia, inclusa. Ovarium biloculare. Ovula in loculis gemina, collateralia, ex apice septi pendnla. Stylus brevissimus; s t ig ma emarginato - bilobum. Dru pa baceata, ahortu monosperma, putamine tenui, suleato - striato, uniloculari. S e m e $n$ inversum. Embryo exalbuminosus; cotyledoaibus plano-convexis, crassis, radicula brevissima, supera. - Arbores $v$, frutices in America et Asia tropica indigeni; foliis oppositis, simplicibus, integris, floribus in pedunculo terminali $v$. axillari, racemosis aut glomeratis, albis, luteis $v$. rarius purpureis.

Linoeiera Swartz Flor, Ind, occid, I, 94, t. 2. Valil Enumerat. I. 46. Gätner f. III, 192. t. 245. R. Browa Prodr. 523. Pobt Plant. Brasil. II. 97, t. 164. Th o u i a ta Swartz Prodr.p. 15, uon Alior. M a y e p e a Aublet Guian. $I$. 81. t. 31. Ceranthus Selureber gen, n. 27. Chjonan. th i s p. Lina. Jacq. Collect, II, $t$, $6 . f$. 1 . Gärtuer $I$. 189. $t, 39$.

3348. Norominia $S T A D T M$. Calyx minimus, quadrifidus, persistens. Coroll a hypogyna, globulosa, crassa, profunde quadrifida. A ntherae 2, imo corollae tubo insertae, subsessiles. Ovarium biloculare. Ovula in loculis gemina, collateralia, ex apice septi pendula. Stigma subsessile, truncato-capitatum. Drupa baccata, abortu monosperma, patamine osseo, semibiloculari. S emen inversum. Em bry o exalbuminosus; cotyled on ibus plano-convexis, crassis, radicula brevissima, supera. - Arbuscula madagascariensis et mauritiana; foliis oppo. sitis, chartaceis, integerrimis, petiolis brevibus, lignosis, crassis, floribus axillaribus, racemosis, ochroleucis.

Norouhla Stadtmann ex Thouars Gen, madagasc, $n$. 24. Bojer in Hooker Bot. Miscell. II. 167. t. 88. Bi in i a Noronli, mse. 0 le a $\mathrm{e}$ u argi n a t a Lam, $t, 8$. $f$. .

3345. Dlea $L I N N$. C a ly $x$ abbreviato-tu bnlosus, quadridentatus, Co roll a hypogyna, breviter campanulata, limbo quadrifido $v$, quadripartito, plano, rarissime nulla. St a $\mathrm{m}$ in a 2 , imo corollae tubo inserta, exserta, in apetalis hypogyna Ova ri $\mathbf{m}$ biloculare. OvuIa in loculis gemina, collateralia, ex apice septi pendula. Stylus brevissinus; $8 \mathrm{t} \mathrm{i} \mathrm{g} \mathrm{m}$ a bifidum, laciniis integris v. emarginatis. D rup a baceata, abortu mono-disperma, putamine osseo v. chartaceo - fragili, uni-biloculari. Semina inversa. $\mathbf{E} \mathbf{m}$ bryo in axi albuminis carnosi v. subfarinacei rectus, ejus. dem fere longitudine; coty ledonibus foliaceis, radieula supera. - Arbores $v$. frutices, in $E u$ ropa mediterranea, Asiatropica, Capite bonae spei et Australasia extratropica, rarissime in America boreali crescentes, ob florum fragrantiam, drupae carnem gustui gratam et putamen oleo scatens, inde a generis humani incunabulis celebres; foliis oppositis, integerrimis, coriaceis, floribus axillaribus, fasciculatis, racemosis paniculatisve.

Ole a R. Brown Prodr. 523.

a. GYMnelaka. Corolla nulla. S tamina hypogyna. D r u p a e putamen osseum. A I b u me n subearuosum.

Gy muelae a Endlicher Prodr. Flor, Norfolk, 156. 01 a a petala Vabl. non Alior.

b. OLEASTER. Corolla limbo quadrifido. Stamina corollae basi iaserta Drupa e putamen osseum. Al. b u m en subearnosum.

01 e a Tournefort inst. 370. Lian. gen. $\pi, 20$. Sebkular t. 75. Girtuer II. 75.t. 93. Jacq Hort, Seh̆b̈nbr. t. 2. 251. Sibthorp Flor. graec. t. 3. Miehaux Arbr. III. t. 6. But, Mag. t, 1552, 3089. Bot. Reg. t. 613. Royle Himalay, t. 65.

c. PHillyraeA, Corolla limbo quadripartito. Stam in a corollae basi inserta. D r u pa e putamen chasta. ceum, fragile. Alb u m e n subfariaaceum.

Philly raca Tournefort inst. 367. Lim. gen, n. 19. Gïrtuer IT, 71. t. 92. Sibihorp Flor. graec. $t$. 2. Link. Jahrb. I. 174. Os a a uth us Loureiro Flor. co. chinch, 35 .

3350. Notelaea $V E N T$. Caly q quadri fidus, Corolla hypogyna, tetrapetala, petala ova. ta, fornicato-concava, basi mediantibus staminibus per paria connexa. S $\mathbf{t}$ a $\mathbf{m}$ i a 2 , petalorum bases jungentia, inclusa. Ovari um biloculare. Ovula in loculis gemina, collateralia, ex apice septi pendala. St y l a s subnullus; stigma emar ginato-bilobum v. indivisum. Drupa baecata, abortu monosperima, putamine chartareo, nervoso, uniloeulari, bipartibili. S e $\mathbf{m}$ e $\mathbf{n}$ inversum. $\mathbf{E} \mathbf{m}$ bryo in axi alhuminis dense carnosi reetus ejusdem fere longitudine; cotyledonibus foliaceis, ellipticis, radicula brevi, supera, - $A r$ busculae v. frutices Novae-Hollandiae, Oleae habitu; foliis oppositis, ovatis v. lineari-lanceolatis, integerrimis.

Notela ea Ventenat Choix t, 25. R. Brown Prodr. 593. Rh y s o s permum Girtuer f. III. 232, to 224, $01 \mathrm{ea}$ a petala Andrews Bot. Reposit. $t .315$.

3351. Stereoulerma BLUM. Caly x obsolete quadridentatus. Corolla hypogyna, gíobosa, coriacea, limbo semiquadrifido. St a mina 2 , corollae supra basim inserta, inclusa. Ovari um biloculare. Ovula in loculis gemina, collateralia, ex apice septi pendula. Stigm a subsessile, obtnsum. Bacea exsucea, abortn monosperma. Se $m$ e $n$ inversnm. E $m b \mathbf{r} o$ in avi albuminis carnosi rectus; cotyledonibus..... radicula supera. - Arbor javanica; folitis oppositis, breviter petiolatis, oblongo-lanceolatis, acuminatis, basi acutiusculis, integerrimis, glabris, subvenosis, paniculis terminalibus brachiatis, foliorum longitudine.

Stereoderma Blume Elor. Jav. Praefat, VII. Pa. ch yderma Blume Bijdr. 682.

335\%. Wigustrem TOURNEF. Caly $x$ abbreviato-tubulosus, quadridentatus, deciduus. Cor oll a hypogyna, infundibuliformis, tubo calycem superante, limbo quadripartito. Stamina 2 , corollae tubo inserta, inclusa. Ovarium biloculare. $O \times \mathbf{a}$ a in loeulis gemina, collateralia, ex apice septi pendula. Stylus brevis- 
gimus; stigma bifidum, obtusum. B a ce a globosa, bilocularis, loculis dispermis v. abortu monospermis. S e mina inversa, ovata v. angulata. $\mathbf{E} \mathbf{m b} \mathbf{r y}$ " in axi albuminis subcartilag ine $i$ rectus, ejusdem fere longitudine; cotyledoni b u s subfoliaceis, ovato-lanceolatis, radicula teretiuscula, supera. - Frutices $v$. arbusculae in Europa media et boreali, nec non in $A s i a$ orientali temperala crescentes; foliis oppositis, petiolatis, ovato-oblong is $v$. lanceolat is, integerrimis, glaberrimis rariusve subtus villosis, floribus terminalibus, paniculatis $v$. thyrsoideis.

L ig a st $\mathrm{rum}$ Tournefort inst. 367. Linn. Gen. n, 18. Sehkuhr $t$. 2. Gärtaer II. 72. t. 92. Flor dan. $t$. 11a1, B. B. 764. Bot. Mag, t. 2565. 2921. Wallich Plant. As. rar. 2. 271 .

9UE DRED II. FRAXINEAE. Fru ctus capsularis, indehiscens samaroideus v. sep ticido-bivalvis, loculis mono-pleiospermis.

3353. Fraximtas TOURNEF. Flores polygami. Caly $\mathrm{x}$ quadripartitus v. nullus. Coroll a hypogyna, quadripartita v. nulla. Stamina 2, hypogyna. Ovari am biloculare. Ovala in loculis tria, collateralia, e funicnli dissepimento ntrinque adnati, in apice liculi liberi, nutantis, trifurei cruribus pendula, intermedium fertile, lateralia abortiva. S $t$ ig $\mathrm{m}$ a subsessile, bifidum. Ca p s a la coriacea, ovato-oblonga, compressa, superne in alam foliaceam expansa, bilocularis v. abortu unilocularis, indehiscens. $\mathbf{S}$ e $\mathbf{m}$ i $\mathbf{n}$ in loculis solitaria, ex apice funiculi pendula, ovulis abortivis stipata. E mb r yo in axi albuminis carnosi rectus, ejusdem fere longitudine; cotyledonibus subfoliaceis, radi $c$ ula tereti, supera. - Arbores saepius excelsae, rarius frutices, in $A m e r i c a$ boreali copiose, parcius in Europa et Asia media et mediterranea, rarissime in India boreali crescentes; foliis oppositis, simplicibus v. impari-pinnatis, foliolis oppositis, dentalis v. serratis.

Fraxinus Tournefort inst. 343. Linn. gen, n. 116. Gärtuer I. 229.

a. BUMELIOIDES Flores calyce et corolla destituti. (Sclikulir $t$. 375 . Flor. dau, $t, 969$. Gärtner $t$. 49. $f, 1$. )

b. MELIOIDES. P I o $\mathrm{r}$ e $s$ ealyeulatf, corolla iestituti. (Sehkuhr t. 375. Michanx Arbr. t, III. t, 8-13. Girtner t. 49, $f, 2$.

c. ORNUS. Flares calyce et corolla instructi. - Ornus Persoon Synops I. 9. (Sibthorp. Flor, graec, t, 1. Wallich Plant. As. rar, $t, 2 \pi 7$.

3354. Fontanesia $L A B I L L \quad \mathrm{C}$ al y $\mathrm{x}$ ab. breviato-tubulosus, quadripartitus, persistens. Corolla hypogyna, tetrapetala, petala obovata, per paria hasi mediantibus staminibus connexa. S $t$ amina 2, petalorum bases jungentia, filamentis setaceis, corolla longioribus. $O$ varium bi-triloculare. Ovala in loculis gemina, collateralia, ex apice dissepimenti pendula. St y 1 n s brevis; g $t$ i g ma bifidum, laciniis filiformibus, Caps ula chartacea, obovata, utrinque emarginata, stigmatibus superata, compressa, bi-trilocularis, margine membranaceo anguste bi-trialata, indehiscens. Semina in localis solitaria, inversa. Embryo in axi albuminis carnosi orthotropus, ejusdem fere longitudine; cotyledonibus plano-convexis, obtusiusculis, radicula tereti, su pera. - Frutex syriacus, opposite ramosus; fo liis oppositis, breve petiolatis, lanceolatis, integer rimis, margine ciliatis, scabris, pedunculis axilla ribus racemoso-cymosis, folio brevioribus, floribus albis.
Fon ta nes i a Labillard. Syr. Decad, I. 1, t, I. Lam, t 22. Duham. Arbr, edit, nov. t. 5. Gírtuer f. III. 193. t. 215. Turpia Allas IV. t. 37.

3355 Syringa $L I N N$. Calyx abbreviato tubulosus, quadridentatus, persistens. Cor olla hypogyna, infundibuliformis, tubo calycem longe superante, limbi quadripartiti laciniis aestivatione valvatis. Stamina 2 , corollae tubo inserta, inclusa. Ovarium biloculare. Ovula in loculis remina, collateralia, ex apice septi pendula. St y l a s filiformis, inclusus; st $\mathrm{f}$ m a crassjusculum, bifidum. Cap 8 u Ia ovato-lanceolata, cumpressiuscula, coriacea, bilocularis, loculicidobivalvis, valvis navicularibus, medio septiferis. Semina in loculis gemina, pendula, compressiuscula, ala membranacea, angusta cincta. $\mathbf{E}$ mbryo in axi albuminis carnosi, tenuis rectus, ejusdem longitudine; cotyledonibus foliaceis, rad i cula tereti, supera. - Frutices $v$ arbusculac, in Asia media et occidentali sponte nascen. tes, jam per Europam omnem diffisi, gratissimo regionibus nostris decori; foliis oppositis, peliolatis, cordatis $v$, ovato-lanceolat is, integerrimis, glaberrimis $v$. subtus villosis, florum thyrso terminali, corollis lilacinis $v$, albo-variantibus, suaveodoris

Sy ríga Liun. gen. $n$ 29. Schkuhr $t$. 2. Gärtner $I$. 224. t. 49. Bot. Mag. c. 783. 486, 3278. Bot. Reg. t, 1733. Reichenb. Iconogr. $t$. 780, Royle Himalay, $t, 65$, Lilac Tournef. inst. 601. t. 372, Juss. gen, 105.

3356. Forsythia VAHL. Calyx brevissime eampanulatus, quadripartitus, deciduus. Corolla hypogyna, subeampanulata, quadripartita, tubo brevissimo, lobis aestivatione contortis. Stam in a 2, ino corollae tubo inserta, inclusa. O varium biloculare. Ovnla in loculis plurima, e placentis medio dissepimento ntrinque insertis plariseriatim pendula. St y 1 us brevis; s tigma capitato-bilobum. Capsula ovata, compressiuscula, sublignosa, cortieata, bilocularis, loculicido-bivalvis, valvis planinseulis, medio septiferis. Se mina in loculis pauca, pendula, compressa; testa membranacea hine in alam angustam, inde in marginem angustissimam expansa. $\mathbf{E m -}$ b $\mathbf{r y o}$ in axi albuminis earnosi, parci rectus; co. tyiedonibus foliaceis, radicula brevi, cylindrica, supera. - Frutex chinensis, in Japonum hortis passim cultus; ramis oppositis, sacpius pendulis, gemmis perulatis, foliiferis a floriferis distinctis, foliis oppositis, ternis v. quaternis, simplicibus, serratis, integris v. ternato-pinnatisectis, floribus praecocibus, e quavis gemma solitariis, luteis, rubro-striatis.

Fors y th ia Vabl. Enumerat, I. 39. Bunge Enumerat. Plant. Chin, boreal. 42, Zuccarini in Siebolll Flor, Japon. I. 11. t. 3. Syringas sus pens a Thubberg.

\section{GENUS DUBILM.}

335\%. TTetrapilna LOUREIR. Flores dioici. Cal y $x$ campanulatus, miniuns, quadrifidus, laciniis acutis, persistens. Coroll a eampanulata, tubo brevi, quadrisulco, limbi quadrifidi laciniis plicato-cuenllatis. Stamina 2 ; fil a menta crassa, brevia, antherae ovatae, biloculares, ereetae. Ovarium ovatum ...... Stylus brevissimus, crassus; stigma crassiusenlum, bifidum. Bacea ovata, bilocularis Semina subrotnnda, pauca. - Arbuscula cochinchinensis; ramis patentibus, brachiatis, foliis opposilis, ovato-lanceolatis, subserratis, incurvis, glabris, racenis axillaribus brevibus, floribus parvis, albis.

Tetrapit us Loureiro Flor. cochinck, 750 . 
3358. Nyyxepyrum BLUM. C a 1 y x parvns, quadrifidus, persistens. Coro II a globosa, coriacea, intus plicata, limbo quadrifido, St a mi$n$ a 2 , medio corollae tubo inserta, inclusa. O $\mathrm{va}$ ri a m hiloculare. Ovula in loculis $3 \ldots \ldots$. Stigma crassum, sessile, latere angulatum, saperne bicuspidatum. Drupa coriacea, uni-bilocolaris, nucleis 1_4, angulatis, nunospermis, mu cilagine obvolutis. E m b r yo intra albumen cor nenim erectus. - Fratex javanicus, scandens, Noronhiae ex $\mathrm{cl}$. auclore maxime afjenis; ramulis tetragonis, foliis oppositis, elliptico-oblongis, superne interdum serralis, trinerviis, glabris, floribus paniculatis, uxillaribus lateralibusve.

M yxopyrum Blume Bifdr. B83.

\section{Ordo CXXXI. Logganiaceare,}

LOGANEAE R. Brown in Flinders Voy, 11,504 Tuckey Congo 448. Martius Nov, Gen, et sp. IT. 133. P0TALtEAR Mart us Op. eit, II, 91, ex 133. STRYCUNKAE DC. Theoric elem. 218. SIRYCHNACGAE Blume $k i j d r$ 10/8. LOGA. XIACEAE, POTALIACEAE et APOCYNEARUM pars Lindley Introduct, edit. II. p, 306.

Arbores r. pretichs, rarissime hbrbae, suceo aqueo. Folia opposita, petiolata, simplicia, integerrima, petiolis basi, nisi stipulae adsint, in marginem brevissimum amplexican lem, interdum fere obsoletum combinatis. Sti$\mathrm{pul}$ a e rariae, nunc petiolis utrinque adnatae, nunc interpetiolares liberae $\mathbf{v}$. in vagin im coalitae, quandoque axillares, dorso petioli basi adnatae.

FLOREs hermaphroditi, regnlares, interdum anisomeri, axillares, solitarii, racemosi v. corymbosi, nunc terminales corymbosi aut paniculati.

CaLyx liber, gamophyllus, lobis aestivatione valvatis, v. tetra-pentaphyllus, foliolis imbricatis, interdum squamis multiseriatis tectus.

Conolta hypogyna, gamopetala, rotata, campanulata v. infundibuliformis, limbo quadriquinque-v. decemfido, laciniis aestivatione convolutivis $\mathbf{v}$, valvatis.

Stamixa corollae tubo $v$. fanei inserta, inclusa v. saepius exserta, ejusdem lobis numero aequalia, in flore tetra-pentamero iisdem alterna, in decamero opposita. Filamenta filiformia v. subulata. A n ther a e biloculares, erectae $v$. incumbentes, loculis longitudinaliter dehiscentibus.

Ovaricm liberum, biloculare, v. rarissime carpidiorum marginibus involutis quadriloculare. $0 \mathrm{v} \times 1 \mathrm{a}$ in placentis dissepimento utringue adnatis v. $\mathrm{e}$ basi adscendentibus plurima, rarissime in loculis solitaria, peltatim inserta, directione amphitropa, rarissime $\mathrm{e}$ basi loculorum erecta, anatropa,

Strues filiformis, simplex. Stig ma eapitatum v. peltatum, indivisum $\mathrm{v}$, obsolete bilobum, rarissime bifidum.
Fructus varius, nunc capsularis, bilocularis, septicido-bivalvis, carpidiis intus placentas liberas v. adnatas retinentibus, v. septifrago-apertus, carpidiorum marginibus introflexis a placenta persistente sclutis et cum valvulis deciduis, nunc bace a t u s, bilocularis, seminibus placentae adhaerentibus, in pulpa nidulantibus, rarissime $d i_{\text {p y }}$ ren us, pyrenis chartaceis, indehiscentibus, monospermis.

Semixa plurima, rarissime solitaria, peltatim inserta, plus minus compressa, saepius alata, interdum solitaria et e basi loculorum erecta. Albumen varium, carnosum, cartilagineum v. subcorneum.

Euвryo in axi $\mathbf{v}$, in basi albuminis rectus, umbilico ventrali parallelus, v. rarissime orthotropus umbilico basilari. Cotyled ones plano-convexae v. foliaceae. Radicula cylindrica, saepissime infera $v$, vaga.

Loganiaceae, quales a nobis Potalia et Strychno Logaviae et Usteriae adjectis considerantur, sistunt plantarum ordinem, e generibus naturali necessitudine conjunctis, sed multiplici affinitate aliis ordinibus conterminis conflatum, et in plures tribus, totidem fere $R$ ubia ce a r um sectionibus analogas abeuntem. Diagnosis ab A pocyneis absoluta dari nequit, tum ob limites utriusque ordinis vacillantes, tum ob characterum omnium in tanta generum diversitate inconstantiam. Log a nieae, quo nomine genera corollae aestivatione convolutiva donata in subordinem colligimus, stipularum in plerisque praesentia, et floce in nonnullis anisomerio ab auctoribus distinguntur, a Rubiaceis ovariolibero solum diversae; sed superioris characteris sim stipularum in nonnulis Loganiae specicbus defectus infringit, posterioris pondus debilitant flores in plurimis generibus isomeri, calyx multiplici serie imbricatus cum corollae aestivatione valvata in Antonia, et loborum corollae et staminum numerus in Polypheagmo genuina Rubiacearum stirpe. Strychneae corollae aestivatione valvata donatae, ob genus stipulis manifestis donatum, et aliud calycis elementis cum corollae partibus haud congruis a Loganieis difficulter avellandae, succi lactei defectu optime ab Apocyneis baccatis distinguerentur, nisi eadem succi qualitas in nonnullis Apocyneis dabia, certe etiam quibusdam Echitis speciebus deesset, ut taceam Strychni speciebus americanis corticem succo croceo tragidum a nonnulis auctoribus tribui. Neque corollae aestivatio charactere constanti ab Apoeyneis easdem segregat, cum etiam in Lyonsia genuino Apocynearum genere, capsulae oeconomia mirum in modum Loganiae accedente, corollae lobi morginibus sese haud contingant. Calycis foliolorum porro multiplex st- 
ries, quali Antonia est insignis, in Apocynearum generibus pluribus squamulis inter calycem et corollam sitis abunde indicatur. Optime adhuc definietur ordo stipularum praesentia, quae ubi desunt corollae aestivatio valvata et succi qualitas aquea accedunt. Cortex in pluribus amarus, in aliis inspidus. Semina in quibusdam insigniter renenata.

Genera per regionestropicas As iae, $\mathbf{A f}$ ricae et $A$ mericae, nec non per Novam Hollandiam extratropicam dispersa sunt.

SUBAIDID I. STRYCHNEAE. C o rollae aestivatio valrata.

TREUS 1. EUSTRYCHNEAE. B ac c a bilocularis, polysperma. Semi na peltata, aptera.

3359. Stryelnos $L I N N$. Cal y x quadri quinquefidus, lariniis imbricatis. Coroll a hypo gyna, tubulosa, faure nuda v. barloata, limbi qua dri-quinquefidi laeiniis aestivatione valvatis, sub anthesi patentibus. Stamina $4 \ldots 5$, corollae fauci inserta; fil a $m$ e $n t$ a brevissima, antherat suhexsertae Ovariom lilocnlare Ovala in placentis earnosulis, dissepimento utrinque adnatis plurima, amphitropa, micropyle infera. Stylus filiformis; st $\mathrm{g} m$ a capitatum, indisisum. B a cea corticata, unilocularis, polysperma v, abortu mo nosperma. Semina in pulpa nidulantia, discoideocompressa, umbilico ventrali. $\mathbf{E} \mathrm{mb} \mathbf{r} \mathbf{0}$ in basi albnminis cartilaginei, subbilamellati subexcentricus, rectus, brevis; cotyled onibus foliaceis, radicula tereti, vaga. - Arbores $v$. frutices scandentes, inter tropicos Asiae et Americae crescentes; foliis oppositis, breve petiolatis, integerrimis, nervosis, petiolis basi connatis, altero saepius aborlivo, ex axilla ramulum simplicem, cirrhiformem exserente, floribus cymoso-corymbosis rariusve pa niculatis, axillaribus et terminalibus, virescenti-albidis, saepius fragrantissimis.

Strychnos Linn. gen. n. Roxburgh Plant. Corom. t. 4. 5. Leschenault in Amat. Mas, $X V I, t, 23$. Colebrook, in Linn. Transact. XIT. $t$, 15. St. Hilaire Plant, zs, brasil. 1. t. 1. Blume Bijdr. 109. Rumptia I. 66, t. 94. 25. Ro uh a mo a Aublet Guian, I. 93, t.36. Las ios to ma Schreher gen. n. 180. K a $\mathrm{i}$ r a m Thowars in Dict, sc. nat. et in Desvaux Joura. bot. 1808. p. 2t7.

3369. Ig nulatus, quinquedentatus. Corolla hypogyna, infundibuliformis, tubo filiformi, elongato, limbi quinquepartiti laciniis oblengis, obtnsis, acstivatione valvatis, S $t$ amina 5 , imo corollae tubo inserta, inclusa; fil amenta filiformia, a $t$ hera e conniventes. Ovarium ovatum..... Stylus filiformis; stigma bipartitum, laciniis filiformibus. Drupa lignasa, unilocularis. Semin a plarima, angulata, nmbilico ventrali. Embryo in axi albuminis cartilaginei rectus, ejusdem fere longitudine; cotyledonibus plano-convexis, radieula eylindrica, vaga. - Frulex manilensis; ramis longis, teretibus, glaberrimis, sarmentis scandentibus, folitis oppositis, petiolatis, ovatis, integerrimis, acutis, venosis, pamiculis axillaribus parvis, pedunculis tri-quinquefloris, floribus longissimis, nutantibus, albis, odore Jasmini.

Ignatia Lina. f. suppl. 20. Camelli in Philosoph. Transact, XX, $, 1,1$ g a a tia a a Loureiro Flor, cochinch, 155.
THR BUS II. GARDNERIEAE. B a ce a bilocularis, disperma. S e m in a peltata, aptera.

3361. Cardineria $W A L L$. Calyx turbinatus, quadri-quinquefidus, persistens, Co ro 11 a hypogyna, subrotata, quadri-quinquefida, fance nuda, laciniis aestivatione valvatis. S $\mathbf{t}$ a $m$ in a 4_ 5, corollae fauci inserta; fil a m en $t$ a sulnulla, a $n$ therae conniventes, liberae $v$. in tubum cohaerentes. Ovarinm biloculare. Ovala in loculis solitaria, medio dissepimento inserta, amphitropa. Stylus filiformis, inclusus; stig ma obsolete bilobum. B a c c a carnosa, bilueularis. S emina in loculis solitaria, dorso convexa, facie plana, nmbilico ventrali. Embry " in axi albuminis cornei leviter incurvns; cotyled onilus lanceolatis, foliaceis, radicula cylindrica, infera. - Frutices nepalenses, scandentes, glaberrimi; foliis oppositis, petiolatis, lanceolatis, acuminatis, integrerrimis, peliolis basi dilatata in marginem amplexicaulem angustissinum commissis, ciliis axillaribus, floribus ex axillis foliorum solitariis $v$. corymbosis.

Ga rdneria Wallich in Moxburgh Elor, indic. I. 100. 1I. 318. Plant, Asiat, rar, t, 231. 281 .

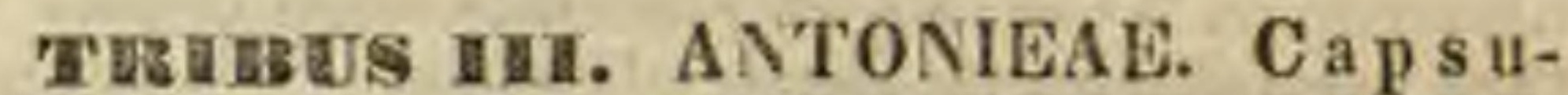
la bilocularis, bipartibilis, disperma. Semina peltuta, alata.

3362. Antomia POHL, CaIyx peniaphyllus, squamis conformibus, pluriseriatim imbricatis teetus. Corolla hypogyna, infinndibuliformis, fance pilosa, limbi quinquefilt laciniis aestivatione valvatis, sub anthesi revolutis. Sta. mina 5, corollae fanci inserta, exserta. Ovariu un biloculare. Orala m in quovis loculo unicum, centro placentae e basi loculi adnato-stipitatae, in laminam orbicularem, peltatam, liheram, inferne subtus lobulo spongioso auctam expansae insertum, amphitropum. Stylas filiformis, exsertus; stigma brevissime bilebum. Capsula oblonga, coriacea, bilocularis, septicido-bipartibilis. Se mina in loeulis solitaria, umbilico ventrali placentae peltatae inserta, oblonga, plano-compressa, hasi et apice in alam membranaceam producta. Embryo in asi albuminis carnosi rectus; cotyledonibus rotundatis, subfoliareis, $r$ adie u la cylindrica, infera. - Arbusculde brasilienses el guianenses, glabrae v. pilosae; foliis oppositis, ovatis, integerrinis, brevissine petinlatis, peliolis basi dilalatis, in marginem brevissimum stipularem commissis, corymbis terminalibus trichotomis, floribus albidis.

A ntonia Pobl Plant, brasil. 11, 14, t, 109. Hooher Ic. 2,60 .

TUEIBES IV. LABORDIEAE. Capsul a trilocularis, polysperma. Se min a ....

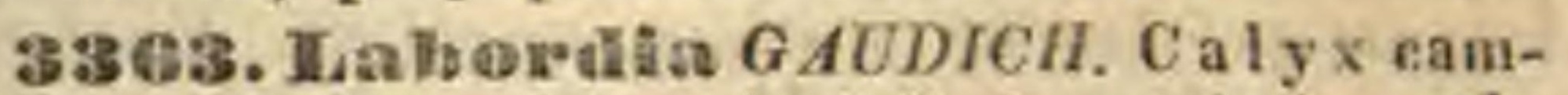
panulatus, quinquefidus, laciniis lanceolatis, subinaequalibus. Corolla hypogyna, infundibuliformis, basi ventricosa, limbi quinquefidi laciniis lanceolatis, aestivatione valvatis, sub anthesi patulis, intus fauceque villosulis. Stamina 5 , corollae fauci inserta, inclusa; filamenta brevissima, antherae cordatae, erectae. Ovarium trigonum, triloculare. Ovala in placentis carnosis, oblongis, loculorum angnlo centrali insertis plarima..... s'tylus brevis, crassus; stigma triangulari-conicum, pubescens. Cap 8 ula? trila- 
cularis, polysperua. ...... Frutex s and $w i$ censis, glaber; ramis oppositis, teretibus, folits uppositis, petiolatis, integerrimis, stipulis axillaribus, dorso petioli basi adnatis, floribus terminalibus pedunculatis, umbellatis, pedunculis medio bibracteatis, bracteis lineuribus, calycibus flavido-virescen tibus, corollis flavido albis.

$\mathrm{L}$ a bordia Gaudichaud ad Freycinet 449, $t$. 60.

SUBEGEO II. LOGANIEAE. C o r o 1 . I a e aestivatio convilutiva.

THIEUS v. EULOGANIEAE. Capsu la bilocularis, polysperma. S emin a peltata, aptera.

3354. Thegania $R \cdot B R$. C a lyx quinque partitus. Corolla hypogyna, subeampanulata fauce villosiuscula, limbi quinquepartiti laciniis aestivatione convolutivis. Stamina 5 , corollae tubo $v$. fauci inserta, subinclusa v. exserta. $O$ variu m biloculare. Orula in platentis septo utrinque adnatis plurima, amphitropa. Sty las simplex; stigma clavato-capitatum, indivisum. Cap s u la coriacea v. sublignosa, bilocularis, septicidobipartihilis. Sem ina in placentis intra cuceos su tura ventralidemum apertasliberis plurima, minima, peltata, aptera. $\mathbf{E} \mathbf{m}$ b r yo in axi albuminis carnosi rectus, radieula infera. - Frutices $v$. herbae Novae-Hollandiae; foliis oppositis, integerrimis, stipulis in vaginam intrapetiolarem connulis, v. distinctis, interpetiolaribus lateralibusve, nune plane nullis, floribus terminalibus v. axillaribus, opposite-corymbosis $v$, racemosis, nunc solitariis, corollis albis interdum venosis.

Loga nia R. Brawu Prodr. 454. E u os at a Andrews Bot, Reposit, 520.

a. LOGANIAE VERAER. Br. $l, c, \mathrm{C}$ a 1 y $x$ obtusus, $\mathrm{S}$ a m i. II a medio cornllae tubo inserta, inclusa. - Frutices vaginula stipulari intrapetiolari, - Exacum va giuale Labillard. Nov. Holl, t, 51 .

b. EUOSMA R. Br. I. c. Caly $x$ obtusus. Stamina medio corollae tubo inserta. inelusa. - Erutices stipulis setaceis, lateralibus, distinetis $v$. nullis. (Andrew Bot. Reposit, (., 520.)

c. STOMANDRA R. Br, $l$, c. Caly $x$ aentus. Stam ina corollae fauel inserta, seaiexserta. - Herbae v, suffru tices, stipulis interpetiolaribus v. nullis.

3365. Geniostoma FORST. C a ly $\mathrm{x}$ turbinatus, quinquefidus. Co roll a hypogyna, urceolato-infundibuliformis, intus villosa, limbi quinquefidi lobis aestivatione convolutis. St a m i na 5 , corollae fanci inserta, exserta, 0 va $\mathbf{r}$ i u m biloculare. 0 vula in placentis angustis, dissepimenti axim constituentibus plurima, amphitropa? Stylu * brevis; stigma sulcatum, didymam. Capsula coriacea, bilocularis, septicido-bivalvis, valvis de. cidais, margine introflexo angusto. Semina in placenta centrali doplici connata, post valvarum lapsum persistente plurima, angulosa. E m b r y o ...... Frutices in Moluccis et Nova-Zeelandia indigeni; foliis oppositis, petiolatis, integrerrimis, stipulis in vaginulam intrapetiolarem commissis, floribus axillaribus, corymbosis.

Ge nístoma Forster Char, gen. t. 12. R. Browa Prodr. 455. in not. A a as s e r Jussieu gen, 150, non Rumph. - ? Haemospermu a Reiswardt in Blume Bijdr. 1018.

TREDES Vu. US'TERIEAE. Capsula bilocularis, bipartibilis, polysperma. S e m in a peltata, alata.
3366. Csteria WILLD. Cal y $x$ brevis, quadrifidus, lacinia antica majore, petaliformi, persistens. Corolla hypogyna, hypocraterimorpha, tubo basi ampliato, intus villoso, limbi quadripartiti laciniis anticis paullo majoribus, divergentihus. St amen anicum, eorollae tubo insertum, inclusum. Ovarium biloculare. Ovula in placentis eylindricis, e basi loculorum erectis plurima, amphitropa. Stylus brevis, inclusus; $s \mathbf{t}$ ig ma bifidum. Ca psula coriacea, ovato oblonga, com. pressiuscula, bilocularis, septisido-bipartibilis. Sem in a in placentis cylindricis, intra coceos sutura ventrali tandem apertos liberis plurima, pel. tata, compressa, imbricata, margine membranaceo cineta. Embryo intra albumen carnosum, tenue rectus; cotyledonibus suborbiculatis, foliaceis, radicula brevi, infera. Frulex guineensis, ramosus; foliis oppositis, petiolatis, ovalibus, breve acuminatis, glabris, margine stipulari inter petiolos obsoleto, paniculae terminalis ramulis pubescentibus.

Usteria Willdenow in Beobachtung. der Gesellsch. natf. Fr. Berl. 1692. IV. p. 51. l. 2. Atzelius Gen. Guin, 1. Konig in Annal. of Bot, I, 263. $t$. 7. f. 5. M o a od y a aun is Gmelin Syst. I, 10.

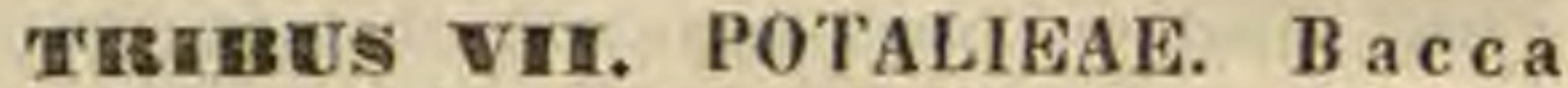
bilocularis, polysperma. S e m i n a peltata, aptera.

336\%. Fagraen THUNB. Caly x quin quepartitus, basi bibracteolatus, laciniis obtusis, imbricatis. Corolla hypogyna, infundibuliformis, tubo superne ampliato, limbi quinquefidi lobis ob. liquis, aestivatione subcontorto-imbricatis, sub anthesi patentibus. Stamina 5, medio corollae tubo inserta, ejusque lobis alterna, exserta; filamenta filiformia, an therae incumbentes, Ovariu $\mathbf{m}$ disco annulari cinctum, biloculare, dissepimenti marginibus utrinque in placentam bilobam involutis, v. carpidiornm marginibus axim haud attingentibus,placentisque subparietalibus uniloculare. $O$ vala plurima, peltata, amphitropa. Stylus filiformis; stig ma peltatum, indivisum, B a c ca ovalis, cortieata, placentis pulposis centralibus v. subparietalibus bilocularis $\mathbf{v}$. subunilocularis. Se min a plurima, minuta, placentae foveolis peltatim immersa, crustacea. Embryo intra albumen corneum minutas; cotyledonibus brevissimis, obtusis, radicula vaga. - Arbores Asiae tropi. ca $a$; folits oppositis, petiolatis, oblongis $v$. ovatis, integerrimis, petiolis basi dilatatis, in vaginam stipularem integram $v$, auriculato-bilobam commissis, floribus terminalibus corymbosis.

F a g r a e a Thunberg in Act. Holm, 1782, $p, 125$ t. 4 Lam. t. 167. $f$. 2. Wallich in Noxburgh Flor. Indic. 11 . 31. Plant, As. rar. t. 229. Blume Bijdr. 1020. Humphia II. t. 72_81, absq. text. C y $\mathrm{r}$ t o ph y llum Reinwardt in BIu. me Bijdr, 1028. Will a g b b fale s p. Spreng.

3368. Plerophlotens $B L U M$. C a ly $x$ quinquepartitus, laciniis imbricatis. Corolla hypogyna, tubo brevi, limbo quinquepartito, aestivatione imbricato. Sta mina 5 , imae corollae inserta, brevia. Ovarium ....... Stylus brevis; stigma obtusum, emarginatum. Ba cea bilocularis, crustacea, polysperma. Semina plurima, minnta, angulata, reticulata, placentis carnosis, ex introflexis dissepimentorum marginibus in utroque loculis geminatis inserta. Al b am en cartilaginenm. - Frutex $j a v a n i c u s$, non satis notus, vix hujus loci, et fortassis nisi corollae aestivatio revera imbricata, prope Strychnon collocandus; cortice amaro, foliis oppositis, oblongis, coriaceis, 
subvenosis, glaberrimis, corymbo terminali, trichotomo.

Pierophloeus Blume Bijdr, 1019.

3369. Potalla $A U B L$. C al y $x$ quadripartitus, urceolatus, lobis rotundatis, imbricatis, interioribus minoribus. Corolla hypogyna, tubnloso-campanulata, tubo subcylindrico, limbi decemfidi laciniis subcontorto-imbricatis, erectis. Stamin a 10, tubo corollae inserta, ejusdem lobis opposita, inclusa; fil am enta subulata, brevia, antherae lineares, erectae. Ovarin disco annulari cinctum, biloculare. $0 \mathrm{vu} 1 \mathrm{a}$ in placentis earnosis, dissepimenti basi utrinque adnatis plurima, amphitropa. Stylus filiformis; stigma peltatum, obsolete quinquelobum. B a c e a turbinata, mollis, bilocularis. Semina placentis carnosis, dissepimenti basim ntrinque occupantibns immersa, plurima, angulata; tes t a crustacea, areolata, umbilico ventrali. Embryo in axi albuminis cartilaginei rectus, ejusdem fere longitudine; cot yledoni bus brevissimis, obtusis, radic nla conica, infera. - Frutices Americae tropica e, subsimplices; foliis oppositis, deoussatis, elongato-obovatis, petialatis, petiolorum basibus dilatatis in vagi$n a m$ intrapetiolarem commissis, panicula terminali corymbosa, squamato-bracteata.

Potalia Aublet Guian. II. 394. 2. 151, Lam. 2. 348. Martius Nov. gen. et sp. IH. 89. t, 170. Ni e a ndra Schre. ber gen, $n$, 714. non alior.

OBSERVATIO. Gen us Potaliae proximum sistit arbor guine ensis: A $\mathrm{t} t$ ho ele is $t$ a Afzelius msc, $e x \boldsymbol{R}$. Brown in Tuckes Cong. 449. ealyce quadrifido, corolla et androeeio decamero cum Potalia conveniens, fructu e carpidiis duobus quadrilocnlari diversum.

TIRIBUS VIII. GAERTNEREAE. B a cc a dicocea, coccis monospermis. S e min a e basi erecta.

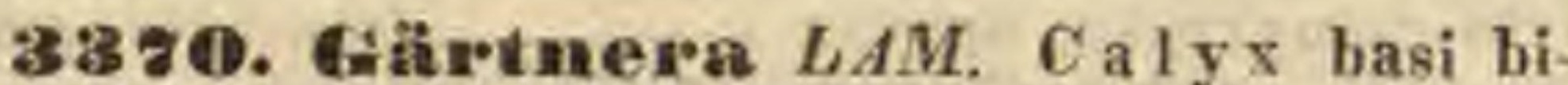
bracteolatus, abbreviato-campanulatus, quinque dentatus, persistens. Corolla hypogyna, infundibuliformis, limbi quinquefidi laciniis aestivatione convolutis, 8 bl anthesi patentibus. Stam ina 5 , eorollae fauei inserta, inclusa; fil a menta brevissima v, subnulla, anthera e oblongae, erectae. Ovarinm biloculare. Ovul a in locnlis solitaria, e placenta minima, basi dissepimenti utrinque adnata erecta, anatropa. Stylus filiformis, exsertus; $8 \mathrm{t} i \mathrm{~g}$ a bifidum, laciniis setaceis, patentibus, $\mathrm{B}$ a $\mathrm{c}$ ca sicca, dipyrena, pyrenis ehartaceis, dorso convexis, facie planis, monospermis. S emina erecta, umbilieo prope basim ventrali. Embryo in basi albnminis cartilaginei orthotropus, rectiusculus; cotyledonibus e basi tumida subulatis, radie:u la turbinata, umbilico contigua, infera. - Arbores madagascarienses et maxritianae; foliis oppositis, petiolatis, coriaceis, oblongis, integerrimis, stipulis vaginantibus, cylindricis, integerrimis $v$ apice filamentosis, floribus terminalibus, paniculatis $v$. corymbosis.

Gintn era Lamarek Nlustr, n, 506, t. 167. Gärtner f. III. 58, t, 191. A nde rso n ia Willdenow muc. - $5 \mathrm{y} k \mathrm{e}$ $\times$ i a Aruott in N. A. N. C. XVHI. 351.

338 1. Fagamea $A U B L$, Cal y x brevis, turbinatus, quadridentatus, persistens. Cor olla hypogyna, urceolata, intus villosa, limbo quadrifido. St am ina 4, corollae fauci inserta, inclusa. Ovarinm biloculare. Ovula ...... Stylus bifidus, laciniis filiformibus. Ba ce a-carnosa, dipyrena, pyrenis osseis, dorso convexis, facie planis, dispermis $v$, abortu monospermis. S e m ina
....... Frutex guianensis, vix notus, ramosus; foliis oppositis, petiolatis, lanceolatis, integer. rimis, glabris, stipulis in vaginam intrafoliacean laxam connatis, floribus oppositis, laxe spicatis. axillaribus et terminalibus.

Paga me a Aublet Guian, I. 112. $t$. 44.

oBSERVATI0. Tribum inter Loganieas distinctam sistere videtar geans ineditum africauum tropicam, a cl. R. Brown in Tuckey Congo 448, eommemoratum, seminlbus erectis et fructu capsulari, forma et dehiscentia Bursariae similina insigue.

\section{Ordo CXXXIT. Apocynacene,}

APOCYNEARUM pars Jussieu gen. 143. Annal. Mus. $Y$. 261. X $N$. 345. APOCYNEAE R. Brown Prodr. 465. Mem. Werner. soc. $T$. 59. Bartling Ord. nat. 203. excl. pl. VIN. CEAE Apocynearum sect. DC. et Duby Bot. gall. 384. APO CYNACEAE Lindley Introduct, edit, $T$. p. 299.

Arbores interdum excelsae, $\nabla$. Frutices saepius volubiles, rarius Herbar perennes. succo in plerisque lacteo, nonnutiquam copioso, caule ramisque teretibus v. tetragonis, saepius nodoso-articulatis. Folia plerumque opposita, rarius ternatim v. quaternatim verticillata, rarissime sparsa, simplicia, integra et integerrima, glabra $\vee$. pubescentia.

Stripolas nullae $\nabla$. interdum interpetiolares, rudimentariae, glanduliformes $v$, cili. formes.

Froues hermaphroditi, regulares, saepius speciosi, terminales $\mathrm{v}$. interpetiolares, cymosi v. subcorymbosi, rarius solitarii axillares, albi, rosei, purpurei v. flavi, rarius caerulei.

Casyx liber, quinquefidus v, quinquepartitus, rarissime quadrifidus, plerumque parvus, rarius foliaceus, saepius intus squamularum v. ciliorum serie anctus.

Corolsa hypogyna, decidua, gamopetala, infundibuliformis v. hypocraterimorpha, tubo fauceque nudis, v. saepins squamulis numero variis, integris v. partitis auctis, limbo quinquefido $v$, quinquepartito aut rarissime quadripartito, laciniis saepissime obliquis, inaequilateris, per aestivationem contortis $\mathrm{v}$, rarissime valvatis.

Stauiva 5, rarissime 4 , corollae tubo $v$. fauci inserta, inclusa v. exserta. Fil a m ent a saepius brevissima v. subnulla, interdum superne dilatata. An therae introrsae, biloculares, ovatae, saepius acuminatae v. interdum mucronatae, nunc sagittatae, loculis juxta totam longitudinem polliniferis, v. appendicibus basilaribus effoetis, liberae, erectae v. conniventes, nunc marginibus inter se paullulum, medio stigmati pertinacius cohaerentes, longitudinaliter dehiscentes. Pollen granulosum, stigmati immediate applicitum.

Ovariom e carpidiis duobus, distinctis rel connatis, simplex biloculare, v. duplex, placentis ad carpidiorum suturam ventralem; rarissime simplex uniloculare, placentis ad sutu- 
ras parietalibus. Ovula rarissime solitaria, plerumque indefinita, amphitropa v. anatropa. Stylus unicus, superne plerumque incrassatus, saepissime in discum stigmati suppositum expansus. Stigma bifidum $\nabla$. rarius indivisum.

Froctus varius, saepissime follicularis, folliculis binis v. alterius abortu unico; rarius capsularis, bilocularis, nempe e folliculis binis ad axim cohaerentibus conflatus, nunc drupaceus $v$. baccatus, mono-polyspermus, rarissime capsularis unilocularis, bivalvis.

Semina varia, saepissime compressa, mar. gine nunc aequalia $\mathbf{v}$. ala membranacea cincta, umbilico ventrali $\nabla$. basilari et tunc plerumque coma sericea retrorsa cheto, rarissime ad extremitatem umbilico oppositam comosa. A lb u m e n carnosum v. cartilagineum, interdum parcissimum $v$, nullum.

Eмrryo intra albumen rectus, saepissime foliaceus; c oty le d o nib u s planis v. rarissime convolutis, $\mathbf{r}$ a di cula situ et directione varia.

Apocynaceae mediantibus generibus baccatis et drupaceis Rubiaceis, Oleineis et Loganiaceis proximae, per genera fructu folliculari seminibusque comosis donata Asclepiadeis arcte conterminae, et vix nisi pollinis indole di versae, maximo numero inter tropicos utriusque orbis generantur, in Asia trans aequatorem paullo copiosiores, in regionibus extratropicis calidioribus temperatisque rarae.

Succus plurimarum venenatus, aliarum innocuus. Fructus generum baccatorum plurium edulis, nonnullorum semina perniciosissime virulenta. Lac aliarum gummi elasticum praebet.

Genera baccata et ảrupacea (quarum fructus in hortis et museis passim desiderantur) denuo sub incudem revocanda, plura ab auctoribus obiter descripta, verisimiliter olim coadunanda $\mathbf{v}$. aliter collocanda.

SUEARTO I. CARISSEAE. O v a ri u m unum, biloculare, placentis dissepimento insertis, $\nabla$. uniloculare, placentis ad suturam parietalibus. Fruetus baceatus v, rarissime capsularis.

337\%. Carissa LINN. Cal yx quinquepartitus. Corolla hypogyna, infundibuliformis v, hypocraterimorpha, limbo quinquepartito, fauce nuda v, villis clausa. Stamina 5 , medio corollae tubo inserta, inclusa. $O$ vari u m biloculare, $O$ v ula in placentis dissepimento utrinque adnatis panea, amphitropa. Stylus filiformis; stigma e basi dilatata bifidam. B a e $\mathrm{c}$ a bilocnlaris, oligosperma, rarius abortu monosperma. S e m in a peltata, compressa. E $\mathrm{m}$ bryo in axi albuminis subcornei rectus; cotyledonibus cordatis, foliaceis, radicula cylindrica, supera. - Frutices lactescen. tes, in Asia et Australasia tropica, neo non in Africa a ustrali indigeni; foliis oppositis, setulis interpetiolaribus, pedunculis axillaribus $v$. terminalibus multifloris, sterilibus passim spinescentibus.

Cariss a Linn. gen, n. 1251. Lam, $t, 118$. Correa in Annal. Mus. TIYI. $t$. 32, $f$. 2, Roxburgh Corom. $t$, 77 , R. Brown Prodr. 468. Wight in Hooker Comp. Bot. Mag. t. 13. Ard uin a Linn. Gen, $n$, 1250, Miller Ic. 1I. $t .300$. - A nt ur a Forsk, Descript.63. (Delile ad Cail. t. 2. f.1.)

33\%3. Traneornia GOMEZ. C a $1 \mathrm{y} \mathrm{x}$ quinquepartitus. Corolla hypogyna, hypocraterimorpha, tubo angusto, superne ventricoso, intus villoso, limbi quinquefidi laciniis patentibus. Sta$\mathrm{m}$ in a 5 , medio corollae tubo inserta, inclusa; $\mathrm{fi}$ I a me $n t$ a brevissima, an $t h$ er a e cuspidatae, conniventes. Ovari n m biloculare. Ovula in placentis dissepimento utrinque adnatis plurima, amphitropa. Stylus filiformis; stigma conicum, apice bicuspidatum. B a c c a carnosa, orata, unilocularis. Semina plurima, in pulpa nidulantia, ovata, compressa, umbilico ventrali. Embryo intra albumen suh corneum rectus...... Arbo. res brasilienses; foliis oppositis, ellipticis, costatis, glabris v. pubescentibus, floribus suaveolenti bus, fructu eduli.

II a neornia Gomez fot. Uttisipon, 1812, IIT. p. SI Mang a 1 b a Maregrav. Brasil, $t$. 128. Piso Brasil. $t$, 76 .

33\% 4. Ambelania $A U B L$. CaIy $\mathrm{x}$ quin quepartitus. Coroll a hypogyna, hypocraterimor pha, tubo cylindrico, superne angustato, fauce nuda, limbi quinquepartiti laciniis obliquis, undu. latis. St a min a 5, imo corollae tubo inserta, inclusa; antherae sagittatae, subsessiles. Ovarium biloculare. Ovula plurima, dissepimento ntrinque inserta .... Sty Ius tetragonus; stig ma basi orbiculatae impositum, ovatum, apice bicuspidatum. B a c ca coriacea, ovata, bilocularis. Semina plurima, dissepimento gracili inserta, lato-compressa, aspera ..... - Arbuscula guia. $n$ ensis, non satis nota; folitis oppositis, saepissime naequalibus, pedunculis axillaribus $v$. terminalibus, ri-quadrifloris, unibracteatis.

A m be la n ia Aublet Guian. I. 265, t. 104. Jussieu gen, 148. Lam, t. 169. Willug h bei a Sehreb. $n$. 417 .

33\%5. Pacouria $A U B L$. C a lyx subquinquepartitus, persistens, Coroll a hypogyna, infundibuliformis, tubo brevi, limbi quinquepartiti laciniis obliquis, undulatis. Stam in a 5 , imo corollae tubo inserta, inclusa; an $\mathbf{t h}$ e ra e cuspida tae, subsessiles. O vari um ..... Stylus tetragonus; s $\mathrm{t} \mathbf{i} \mathrm{g} \mathrm{m}$ a e basi dilatata bicuspidatum. B a c c a carnosa, unilocularis ..... Semina plurima, in pulpa nidulantia, magna, angulata, sub. ossea..... - Frutex guianensis, vix notus, lactescens; ramis sarmentosis, nodosis, foliis ad no. dos oppositis, floribus racemosis, albidis, pedunculo longo, cirrki instar volubili.

Pacouria Aublet Guian, I, 292. t, 105. Juss, gen. 148. Willug hb ei a s p. Auct.

33\% 6. Colloplinera $M A R T$. C a l y q quinquefidns. Corolla hypogyna, tubuloso-hypocraterimorpha, fauce nuda, limbo quinquefido. St amina 5 , corollae tubo inserta; fil amenta brevia ...... O varin m ...... Stylns filiformis; stigm a cylindrienm, apieulatum. B a c ca globosa, uniloeularis. Semin a plurima, oblonga, compressa, in pulpa nidulantia, epidermide molli, hyalina ..... - Arbor brasiliensis, vix nota, succo lacteo spisso scatens; foliis oppositis, floribus corymbosis. 
C o 11 o phor a Martius in Buchner Aepertor, der Pharmac, 1828.

335\%. Handelphia PALIS. C a I y penta-hexaphyllus, foliolis subimbricatis, coriaceis, interioribus minoribus. Coroll a hypogyna, tubulosa, fauce villis clansa, limbi quinquefidi laciniis obliquis. Sta $\mathrm{m}$ in a 5 , corollae tubo infra faucem inserta, inc:lusa; anther a e sagittatae, subsessiles. Ovari um decemstriatum .... Sty lus apice incrassatus; $8 \mathrm{tig} \mathbf{m}$ a subbifidum. Bacea carnosa, subglobosa, apice compressa, unilocularis. Sem in a pauca, ovata, compressa. - Frutex ow ariensis, vix notus; ramis teretibus, foliis op. positis, petiolatis, ovato-lanceolatis, acutis, floribus terminalibus paniculata-corymbosis, brevissime pedicellatis.

Land olp hi a Palisot Flor, owar, I. 54. t. 34.

\$3 8 8. II elodimus FORST. Cal y x quinquepartitus. Co roll a hypogyna, hypocraterimorpha, tubo eylindrico, fauce squamulis quinque bifidis v. vicenis biseriatis clausa, limbi quinquefidi laciniis obtusis, obliquis. Stam in a 5 , medio corollae tubo inserta, inclusa; a therac oblongae, acutae, subsessiles. Ovari u m conicum, bilocuJare. Ovula in placentis septo utrinque adnatis plurima, amphitropa. Stylus brevis; stigma incrassato-conicum, apice brevissime bicuspidatum B a c c a carnosa, globosa, intus pulposa. S e m in a plurima, nidulantia, compressa, umbilico ventrali. Embryo in axi albuminis carnosi rectus; cotyledonibus oblongis, subfoliaceis, radienla cylindrica, vaga. - Frutices in Asia tropica et in Oceani australis insulis extratropi$c i$ is indigeni, sarmentosi; foliis oppositis, breve petiolatis, glaberrimis, nitidis, cymis axillaribus.

Melod $i \mathrm{n} u \mathrm{~s}$ Forst. char. gen, 19. Bot. Reg. $t$. 834 . Bot. Mag. t, 2597. Labillard Nov, Caled. $t, 33$. Blume Bijdr. 1026.

33\%9. Couman $A U B L$. Caly $\mathrm{x}$ quinquepartitus. Corolla hypogyna, subinfundibuliformis, tubo eylindrico, medio subinflato, fauce pilis adpressis subclausa, limbi quinquefidi laciniis angustis, subobliquis, patulo deflexis. Stamina 5 , medio corollae tubo inserta, inclusa; $f$ il a menta brevissima, an therae cordato-sagittatae. Ovari um globoso. depressum, striatum, uniloculare. Ovula in placentis duabus parietalibus plurima, minima. Stylns subulatus; stigma oblongum, bipartitum, basi appendice squamaeformi obtuso cinctum. Bacea globosa, carnosa, unilocularis. Semina tria ad quinque, in pulpa nidulantia, orbiculate-oblonga, planiuscula ...... Arbor gu ianens is, non satis nota, succo lacteo scatens; ramis erectis, ramulis subtetragonis, foliis ternatoverticillatis, glabris, atro-viridibus, subtus pallidis, in petiolum brevem, membranaceum, canaliculatum attenuatis, floribus roseis, in paniculis axillaribus ramosis, pedicellis articulatis, subtrigonis, basi tribracteolatis, fructu eduli.

C о и ш a Aublet Guian. suppl. 39. t. 392. A. Richard in Annal. sc. nat. I. 36. C e r b e r a triphylla Rudge Guian, t. 48 .

3380. Clailoenrpus BLUM, C a I y $\mathrm{x}$ quinquepartitus. Corolla hypogyna, hypocraterimorpha, tubo medio incrassato, limbi quinquefidi laciniis obliquis. Stamina 5, medio corollae tubo inserta; antherae subsessiles, inclusae, sagittatae. Orarium ...... Stylus ...; s tigma eapitatum, antheris inclusum. Ca ps nla corticata, unilocularis, pulpa granulari repleta, demum la tere dehiscens. Semina plurima, compressa, altero latere convoluto-sulcata, membranis e capsulae parietibus orinndis obvoluta. Embryonis intra albumen corneum recti cotyledones fo. liaceae, radie ula ... _- Plantae javanicae, fruticosae (?), scandentes; foliis oppositis, venosis, cymis axillaribus.

Chilocarpas Blume Bijdr. 1025.

3351. Willughbeia ROXB, $\mathrm{C}$ a $1 \mathrm{y} \mathrm{x}$ quinquepartitus. Co rolla hypogyna, hypocraterimorpha, tubo medio incrassato, fauce nuda, limbi quinquefidi laciniis obliquis. S $\mathrm{ta} \mathbf{m}$ in a 5 , corollae tubo inserta, inclusa; antherae ovatae. Ovari m uniloculare. Ovala in placentis duabus parietalibus plurima ....... Stylus didymus; stigm a obtusum. B a c c a corticata, pulposa, pseudo-bilocularis. S e min a plurima, seriata. E mbryo exalbuminosus; cotyledonibus planoconvexis, radicuta brevissima, plumula conspicua. - Frutices indic $i$, scandentes, saepius cirrhiferi; foliis oppositis, venosis, pedunculis axillaribus cymosis, fructu eduli.

Will ug h be i a Roxburgh Plant. Corom, III.77, t. 280. Blume Bijdr. 1023. non Scop. An cylocladus Wallich Plant. As. rar, IIT. 45, t. 272.

338\%. Teuconotis $J A C K, \mathrm{C}$ a l y qua dripartitus. Corolla hypogyna, tubulesa, tubo superne angustato, fauce nuda, limbi quadrifidi laciniis ovatis. Stamina 4 , imo corollae tubo inserta, inclusa; fil amenta brevia, antherae sagittato-lineares, Ovari um biloculare, Ovula in loculis $2 \ldots .$. Stylus brevis; stigma annulatum, apice conico. B a e e a ovata, earnosa abortu mono-trisperma. S e mina elliptico-oblonga. Em bryo exalbuminosus; cotyledonibus plano-convexis, rad ic u la retracta, supera. - Fru. lex sumatranus, lactescens; foliis oppositis, petiolatis, oblongis, acuminatis, basi rotundatis, supra nitidis, floribus axillaribus, dichotome corymbosis.

Leuconotis Jack in Linn. Transact. $X I V, 191$, t. 1. $f .2$.

3383. Allamamala $L I N N$. Caly $x$ quinquepartitus. Coroll a hypogyna, infundibuliformis, tubo cylindrico, fauce squamis quinque eiliatis aucta, limbi campanulati, ampli, quinquefidi laciniis obtusis, subinaequalibus. Stamina 5 , corollae fauci inserta, inclusa; an therae sagittatae, subsessiles, conniventes. Ovarinm uniloculare, compressum. Ovula in placenta marginali ambiente plurima, e funienlis Ionginsculis pendula. C a p s u la coriacea, subrotundo-elliptica, lenticulari-compressa, echinata, unilocularis, longitudinaliter bivalvis. Semina plurima, funiculo umbilico ventrali inserto, e valvularum marginilus pendula, deorsum imbricata, compressiuscula, ala membranacea late cincta. $\mathbf{E}$ m b r y o intra albumen parcum, cartilaginenm rectus; cotyledonibus foliaceis, ovato-cordatis, $\mathbf{r}$ a dicula lineari - acuminata, centrifuga. - Frutices $v$. suffrutices $A \mathrm{~m} e$ ricae tropicae, erectiv. scandentes; foliis verticillatis, pedunculis terminalibus et interpetiolaribus multifloris, floribus speciosis, luteis.

All a m anda Linn. Mant. 214. Jussieu gen. 148. Lam. $t .171$, Gürtner $I$. 293. $t .61 . f$. 4. Schrader et Weadl. Sert. Hannover, $t$, 22. Bot. Mag. $t, 338$. Kunth in Humb. et Bonpl. Nov, gen, et sp. III, 229. Pohl Plant, Bratil. 1. 70, $t, 37-59$. $0 \mathrm{r}$ eli a Aublet Guian, I, 281, t, 106.

SUBOBDQ II. OPHIOXYLEAE. O vari u m duplex. Fru c tus drupaeens. 
3394. Vallesia RUIZ et PAV. Calyx quinquepartitus, persistens. C orolla hypogyna, hypocraterimorpha, fauce subinflata, pilosa, limbi quinquefidi laciniis obliquis. Sta $\mathrm{m}$ in a 5 , corollae fauci inserta, inclusa; fi l amenta brevissima, anth erae ovato-acuminatae. Ovaria 2 . Ovula ..... Stylus unus, filiformis; stig ma sub. clavatum. D r и p a e 2 , altera saepissime abortiens, putamine coriaceo, sulcato, demum retieula tim solubili. Semen unicum, erectum (?), suleatum, apice tuberculato-crispatum. E mbryo intra albumen tenue, carnosum rectns; coty 1 e don ibus plano-convexis, carnosis, ra di cula tereti, erassa, infera. - Arbusculae $v$. frutices $A$ merica tropicae; foliis alternis, petiolatis, ovatis $v$. oblongis, saepissime conduplicatis, pedunculis oppositifoliis, dichotomis, multifloris, floribus albis.

Vallesia Ruiz et Pavon Prodr. t. 5. Plor. Peruv. IT. 26. t. 15t. Kunth in Humb, et Bonpl. Nov. gen. et sp. IIK. 233. $t$. 241, - ? R a u wolfiae $8 \mathrm{p}$. Cavanill. Ic. t, 297.

3385. Dplnioxylon $L I N N$. C a 1 y x quinquefidus, persistens. Coroll a hypogyna, infundibuliformis, tubo longo, medio inerassato, limbi quinquefidi laciniis patentibus, obliquis. St a m ina 5, medio corollae tubo inserta; antherae subsessiles. Ovarium didymum. Ovula intra lobos solitaria, pendula ...... St y l us filiformis, inclusus; stig ma capitatum. Drupae baccatae geminae v. abortn solitariae, nucleo rugoso, monospermo. S e m i n a inversa, compressinscula. Embryo in axi albuminis carnosi, mollis subcurvatns; cotyledonibus foliaceis, orbiculatis, radicula teretinscula, supera. - Fruticulus indicus; folïs ternatim v. quaternatim verticillatis, cuneato-oblongis, acutis, glabris, subtus pallidioribus, cymis axillaribus, longe pedunculatis, densifloris.

$0 \mathrm{phi}$ oxylon Linn. gen. n. 1142. Jussieu gen. 149. Gïrtner 1T. 129. t. 109. Wendl. in Römer Archiv I. 53. t. 7. f. 2. Jaeq. Hort. Schünbr. t. 389. Bot. Mag. t. 784. Blume Bijdr. 1034.

3386. Tanglainin THOUARS. C a I y $\mathrm{x}$ quinquepartitus, patens. Corolla hypogyna, hypocraterimorpha, fauce squamulis 5 fornicatis, staminibus oppositis clansa, tubo glandulis totidem staminibus subjectis aueto, limbi quinquefidi laciniis obliquis, patentim-reflexis. St am in a 5, corollae fauci inserta, inclusa; a n thera cordatae, subsessiles, stigmati incumbentes, $O$ v a $\mathrm{rinm}$ bilobum, lobis didymis ..... Ovula ..... StyI us filiformis; stig $\mathrm{m}$ a depresso-capitatum, apice bituberculatum. D r ap a e 2 , altera plerumque abortiente, putamine fibroso, semibivalvi. Semen unicum; testa fibris endocarpio adhaerens. Emb r y 0 intra endopleuram tumidam exalbuminosus; eotyledonibus carnosis, plano-convexis, $r a$ dieula brevi, supera. - Arbor madagaseariensis, trigintapedalis; foliis sparsis, ad apices ramulorum approximatis, oblongis, acutis, coriaceis, nitidis, paniculis terminalibus subcorymbosis, pedicellis carnosis, basi articulatis, bracteatis, floribus roseis, drupis luteis, rubro-striatis, veneno perniciosissimo scatentibus.

T a ng hin ia Thouars Gen. madagasc. $n, 31$. Bojer in Hooker Bot. Mise. III, 290. 2,110 . C erbera Tanghi a Hooker in Bot. Mag. t. 2968.

$338 \%$. Thevetin $L I N N$. Caly $x$ quinquepartitus, patens. Coro 11 a hypogyna, infundibuliformis, fauce ampla, intus quinquedentata, limbi quinquefidi laeiniis obtusis, obliquis. Sta mi na 5 , corollae tubo inserta, inclusa; a $n t h$ e rae subsessiles, conniventes. O vari u m depresso-didymum, biloculare. Ovula ....... Stylus filiformis; st igma lamellato-bilobum. A n n u l u hypogynus carnosus. Drup a depresso-conica, subbiloba, putamine lignoso, quadrivalvi (?). S e m i na in loculis solitaria, placentae lamellari, loculos bipartienti hine adnata. Em bryo exalbuminosus. Arbores Americae tropicae, quo ad intimam fructis structuram non satis notae; foliis alternis, saepius confertis, ovatis $v$. elongato-linearibus, floribus cymosis.

The vetia Linn, gen, edit, $1, n, 177$. Jussieu in Annal. Mus. XV. 346. C exber a Juss. gen, 149. A hou a i Tournef. inst, $t .434$. Cerbera e s p. Ltun. Lam. $t$, 170. Rnix et Pav. Flor. Peruv, $t$. 127. Andrews Bot. Reposit, $t, 231$. Jacg. Amer, t. 34 .

3388. Cerbera LINN, C a I y $x$ quinquepartitus, patens. Corolla hypogyna, infundibuliformis, fauce quinquedentata, limbi quinquefidi lobis obliquis. St a mina 5 , corollae tubo superne inserta, inclusa; antherae subsessiles, mucronatae, stigmati incumbentes. O va ri $\mathbf{m}$ didymum, biloculare. $0 \mathrm{vula}$ in loculis gemina $\mathrm{v}$, quaterna, placentae plano-compressae, dissepimentum bipar tienti utrinque adnata, amphitropa. Stylus fili formis; stigma discoideum, margine inferne crenulatum, superne convexum et emarginatum. D ru p a e 2, distinctae, altera saepius abortiente, pu tamine fibroso, semibivalvi, placenta lamellari basifixa, mobili, loculum bipartiente. S e mina ab ortu solitaria, placentae adnata. E mbr yo exalbuminosus; cotyledonibus plano - convexis radieula brevi, supera. - Arbores Asiae tro. picae; foliis sparsis, cuncato-oblongis, acutis, glabris, floribus terminalibus, corymbosis.

C erbera Linn gen, edit, 1, n. 178, Gärtner II. 198. t. 123. 124. Blume Bijdr. 1031. M a ng has Burmanu Zey lan, 150, t. 70.f. 1 , 0 do 11 a m Rheede Malab, I, 71, t. 39.

3385. Delarosia JUSS. C a 1 y $x$ quinque. partitus. Corolla hypogyna, infundibuliformis, tubo medio ventricoso, fauce nuda, limbi quinquefidi laciniis obliquis. S $t$ a min a 5 , medio corollae tubo inserta, inclusa; an thera e subsessiles, ovato lanceolatae. Ovaria $2 \ldots \ldots$ Orula $\ldots \ldots$. Sty Ius unicus; stigma bicuspidatum. Drup a e 2 , follieuliformes, oblongae, subtriquetrae, quadriloculares, loculis duobus centralibus vacuis, lateralibus mono-dispermis. S emin a oblonga, planiuscula ....... Frutices $v$, arbusculae, in insula Borbonia et in Nova-Caledonia observatae, non satis notae; foliis ternatim $v$. quaternatim verticillatis, corymbis terminalibus et axillaribus, corollis ochroleucis.

Oe h r a sia Jussieu gen. 145. Labillard. Nov. Caledon. t. 30. Eschseholtz in Mem. Academ. St. Pelersb, X. 281. Ophioxylon Persoon Ench. 1, 266. Diderota Comwers. msc.

3390. Kopsin BLUM. Cal y $\mathrm{x}$ quinquedentatus, persistens. Corolla hypogyna, hypocraterimorpha, tubo superne ventricoso, fauce coarctata, villosa, limbi quinquefidi laciniis patentibus $v$. reflexis. Stamina 5 , corollae tubo in serta, inclusa. Ovari $\mathbf{u} \mathbf{m} \ldots .$. St y l as filiformis, inclusus; $8 \mathrm{ti} \mathrm{g} \mathrm{m}$ a oblongum, indivisum, superne pubescens. Drupae 2 , altera saepissime abortiente, intus dissepimento incompleto divisae, monospermae. Sem en ..... - Emb ry o exalbuminosus, inversus. - Arbores $v$. frutices javanicae, lactescentes, charactere parum a Cerbera di- 
versae; foliis oppositis, cymis pedunculatis, terminalibus $v$. alaribus, bracteolatis.

Ko p s i a Blume Bijar. 1030.

3391 . Favwolfa PLUM. C a Iy quinquedentatus, persistens. Corolla hypogyna, infundibuliformis, tubo brevi, fauce barbata, limbi quinquefidi laciniis obliquis. $\mathrm{S} t$ a $\mathrm{m}$ in a 5 , corollae tubo inserta, exserta v. inclusa. $O$ v a ri $\mathrm{n} m$ bilobum. Ovula in loculis gemina (?). Stylus brevis; stigma emarginatum. Annulus hypogynus, ovarii basim cingens. Drupa subglobosa, didyma, dipyrena, pyrenis distinctis v. axi cohaerentibus, septo secundario, e media axi protenso incomplete bilocellatis, monospermis. Semina inversa, conduplicata, extremitate inferiori reflexa. Em b ryo intra albumen carnosum, molle homotropus; cotyledonibus foliaceis, sursum recnrvatis, rad i c u I compressiuscula, Ionga, supera. - Frutices americani tropici; foliis oppositis v. ternatim quaternatimve verticillatis, floribus corymbosis, saepius terminalibus.

R a uwolfia Plumier gen. $t, 40$. Linn. gen, $n, 293$. Jussieu gen. 148. Jaeq. Amer, h7, Observ, II, $t$. 35. Gürtner $I$. 242, t. 52. Cavanill. Ic, $t, 526$. Ruiz et Pav. Flor. Peruv. t, 109,

3392. Cordyloearpon DFSFONT. Ca1 y x quinquepartitus, persistens, Corolla ...... Stamina ...... Ovarinm ..... Follicn1i 2, elongati, compressi, evalves, articulati, lo mentis duobus $v$. quatuor, demum secedentibus, monospermis. S e m in a inversa, lineari-elongata, sulco ventrali septulo membranaceo inserta. $\mathrm{E}$ mbryo in axi albuminis carnosi rectus; cotyledo nibus subulatis, radicula filiformi, supera,

Frutex v, arbor guianens is; foliis ternatoverticillatis, elliptico-lanceolatis, glaberrimis, nitidis, corymbis laxis, axillaribus et terminalibus. 4. 11 .

Condylocarpon Desfont, in Mem. Mus, VIII. 119.

33형. Aly $x$ ia $B A N K S$. $C$ a l y $x$ quinquefidus. Corolla hypogyna, hypocraterimorpha, fauce esquamata, nuda v. barbata, limbi quinquefidi laciniis obliquis. St a $\mathrm{m}$ in a 5 , corollae fauci inserta, inclusa; antherat ovatae, subsessiles. Ovaria 2, ovulis ad suturam ventralem introflexam paucis, superpositis. Styli subcohaerentes; stigma obtusum, nudum v. rarius barbatum. D ru pae 2, altera saepius abortiente, pedicellatae, simplices monospermae, v. catenatim compositae lomentiformes, putamine dissepimento e sutura prominulo semibiloeulari. S e m in a snlco ventrali dissepimento commisso bipartita. Embryo in axi solida albuminis cornei, ruminato-lobulati rectus v, curvatus; cotyledonibus oblongis, obtusis, radicula infera. - Arbusculae v. frutices, glabri, lactescentes, in Asiatropica et in Australasia extratropica crescentes; foliis verticillatis v. rarius op positis, coriaceis, compactis, sempervirentibus, floribus axillaribus v. terminalibus, quandoque spicat is, albis, saepe suaveolentibus.

Al y $\times$ is Banks ex R. Brown Prodr. 469. Blume Bifdr. 1030. Cuaningh. in Bot. Mag. t. 3312. 3313. G y a op og on Forst. Char, 3b, t, 18, Labillard, Nov, Caled, t, 3t,

SURORDO III. EUAPOCYNEAE. 0 varium duplex. Fructus follicularis, folliculis interdum carnosis, pulposis.

TRLBUS L. PLUMERIEAE. Se $\mathrm{m}$ in a ecomosa, saepissime peltata.
3394. Ir mutealn ROXB. Calyx quinquepartitus. Corolla hypogyna, infandibuliformis, tubo basi et apice subdilatato, fauce nuda, limbi quinquepartiti laciniis obliquis. Sta m in a 5 , summo corollae tubo inserta, inclusa; a $\mathrm{t}$ herae ovatae, snbsessiles. Ovarium bilobum. Ovnla intra lobos gemina, subbasilaria. Stylus filiformis; stigma ovatum, apice bieuspidatum. Annul a s hyogynus carnosus. B a e ca e 2, distinetae, subpedicellatae, ovatae, dispermae. Se mina ....

Frulex bengalensis; foliis oppositis, breve petiolatis, oblongo-lanceolatis, obtusis, floribus terminalibus corymbosis, albis, parvis.

Huteria Roxburgh Flor. ind. edit. Wall. II. 531.

335. Uneeola $R O X B$. Caly 1 quinquedentatus. Corolla hypogyna, urceolaris, fance coarctata, nuda, limbo quinquedentato. S $t$ a $m$ in a 5 , imo corollae tubo inserta, inclusa; antherae sagittatae, subsessiles. Ovaria $2 \ldots$ OvnI a ..... Sty 1 us unus; stig ma ovatum, margine annulari, Annul us hypogynus ovaria includens, Folli culi coriacei, subglobosi, compressiusculi, semibivalves. S e m in a plurima, reniformia, pulpae carnosae immersa. - Frutex Asiae tropicae, scandens, lacte spisso scatens; folits oppositis, oblongis, scabriusculis, paniculis terminalibus ramosissimis, floribus minutis, corollis sordide virescentibus, extus pilosis.

U r ce ol a Roxburgh in Asiat. Research, $\nu, 169, c$, ic.

339B. Tabernaemontana $L I N N$, C al y x quinquepartitus, lobis basi intus glandula anctis, persistens. Corolla hypogyna, hypocraterimorpha, fauce nuda, limbi quinquepartiti laciniis obliquis. S t a $\mathrm{m}$ in a 5 , medio corollae tubo inserta, inclusa; antherae sagittatae, subsessiles. Ovaria 2 , ovulis ad suturam plurimis. Stylus unus, filiformis, stig ma e basi dilatata bifidum Squamu lae hypogynaenullae. Folliculi 2 , oblongi v. subglobosi, carnosi, pulposi, divaricati v, adpressi, abortu saepe solitarif, demum fatiscentes. Sem in a plurima, intra pulpam cellnlosam nidulantia, compressiuscula, angulata. E mbryo in axi albuminis carnosi rectus; cotyledonibas foliaceis, radicala cylindrica, vaga. - Arbus. culae in America et Asia tropica indigenae; folits oppositis, stipulis interpetiolaribus, infra adnatis, apice solutis, cymis subdichotomis.

T a ber a a e u a ta n a Lian, gen, n, 298. Juss. gen. Jaeq. Amer. $t, 31$. 175. 181, Ic. rar. $t, 52.320$, Lam, $t, 171$ Aubl. Guian, t: 103. Raiz et Pas. Flor. Peruy, t. 143. 144. Bat. Reg, t. 1064. 108d. 1273. R. Brown Prodr. 467. Blume Bijdr, 1027. R ejoni a Gaudichaud ad Freye, 450, $t, 6 t$ -? P a a daca Thouars Gen, madagase. n, 33.

335\%. Woneanga THOUARS. C a I y quinquefidus, persistens. Cor o I a bypogyna, suls infundibnliformis, tubo ad faucem nudam ventricoso, limbi quinquefidi laciniis obliquis. Sta min a 5, corollae fanci inserta, semiexserta; anth era e sagittatae, conniventes. Ovaria 2 , ovulis at suturam ventralem plurimis. Stylus unus, superne in cupulam, appendicibus binis retrorsum hamatis auctam inerassatus; $s \mathrm{tigma}$ bilobum. Annulus hypogynus integer. Folliculi 2 , baceati, corticati. Semina plurima, ovoidea, in pulpa nidulantia .... - Arbores $m a d a g a s c a-$ rienses et capenses; foliis oppositis, stipulis interpetiolaribus, floribus cymosis.

Voacang a Thouars Gen, madagane, n, 32. E. Meyer Comment, plant. Afric. austr. 189.

3398. Drehipeala $B L U M$. C a 1 yx tuhinlosns, obtuse quinquefidus, deciduus. Ó or 011 a 
hypogyna, snbinfundibuliformis, tubo medio inflato, fauce intus annulo tumido semiclausa, limbo quinquelobo, patente. St a min a $\mathbf{5}$, corollae tubo inserta, inclusa; antherae sagittatae, stigmati cohaerentes. Ovaria 2 , ovulis ad suturam ventralem plurimis. Stylus unicus; stigma conicnm, pentagonum, apice bicrenulatum. AnnuI и hypogynus, ovaria cingens. Drup a e 2 , carnosae, globosae, uniloculares, intus pulposae, demum latere fatiscentes. S e $\mathbf{m}$ in a plurima, rugosa, altero latere convolnto-biloba. Embryonis intra albumen carnosum recti cotyle don es foliaceae. - Arbor javanica; foliis opposilis, oblongis, glabris, pedunculis axillaribus v. terminalibus bifidis, pauciftoris.

\section{Orchipeda Blume Bijdr. 1026.}

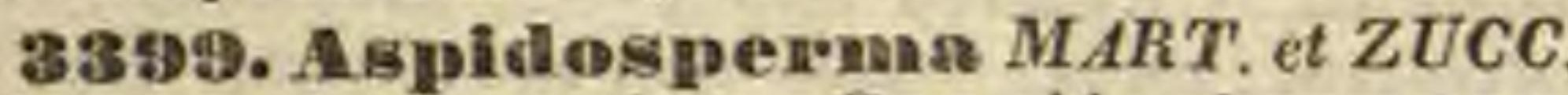
C a I y x quinquepartitus. Coroll a hypogyna, subinfundibaliformis, tubo basi ventricoso, fauce nuda, limbi quinquefidi laciniis lanceolatis, obliquis. Stamina 5, medio corollae tubo inserta, inclusa; antherae ovatae, subsessiles. Ovaria 2 , ovulis ad suturam in funiculis longinsculis plurimis. Stylus unus, cylindricus; stigma clavato-incrassatum, apice umbonatum, nudum v. barbatum. S q u a m $\mathrm{l}$ a e hypogynae nullae. F olliculi 2, altero plerumque abortiente, lignosi, obovati, compressi, semibivalves. Sem in a plurima, imbricata, suborbiculata, compressa, funiculo longo umbilico ventrali affixa, ala membra nacea, radiato-striata cincta. Embryo exalbuminosus; cotyledonibus planis, orbieulatis, basi emarginatis, radicula brevi, suturam spectante. - Arbores brasilienses; ramis patentibus, saepe squarrosis v. refractis, cortice interdum suberoso, foliis sparsis, sessilibus v. petiolatis, ovatis, floribus terminalibus, cymosis.

Aspidosperma Martius et Zuccarinl NVov, gen, et sp. $Y$. 57. $t, 34-36$.

3400. Tlanmeria LINN. C a ly $\mathrm{x}$ quinquefidus. Co r o 11 a hypogyna, infundibuliformis, tubo tenui, tereti, fauce nuda, limbi quinquepartiti laciniis obliquis, $\mathbf{S} \boldsymbol{t}$ a $\mathrm{m}$ i $\mathbf{n}$ a $\boldsymbol{b}$ imo corollae tubo inserta, inclusa; a $n t h$ e$r$ a e conniventes. Ovaria 2 , ovulis ad suturam ventralem plurimis. Sty lus brevis; stig ma incrassatum, apice emarginatum. Annulus hypogynus carnosus. Folli culi ventricosi, teretes, demum deflexi. S e m in a plurima, compressa, hine membranaceo-alata. Embryo ...... - Arbores $v$. arbusculae Americae tropicae; folits alternis, magnis, floribus terminalibus corymbosis, speciosis, incarnatis, roseis, albis $v$. lutescentibus.

Pl a merfa Lian. gen, n, 296. Jussieu gen. 158. Jacq. Amer. t, 174. Ruiz et Pavon Flor. peruv. t, 137_141. Bot. Mag. 2. 279.

3401. Cameranias $P L U M, \mathrm{C}$ a l y $\mathrm{x}$ quinquefidus. Corolla hypogyna, hypocraterimorpha, tubo basi et apice inflato, fauce nuda, limbi quinquefidi laciniis obliquis. Stamina 5 , summo corollae tubo inserta, inclnsa; an therae subsessi. les, acuminatac, in filum productae, conniventes. Ov a ri a 2 , basi ntrinque gibba, ovalis ad suturam ventralem plurimis. Stylus unus, brevis; stigma capitatum, bilobum. Folli i uli divarieati, basi utrinque inflato-gibbosa quasi trilobi, lobo intermedio majore. Semina plurima, compressa, apice membranaceo-alata. Embryo ....... Arbores $v$, frutices Americae tropicae; foliis oppositis, saepius costatis, floribus axillaribus et terminalibus, corymbosis.
Camerari a Plumier gen. 2 . 29. Linn, gen, $n, 297$. Jussieu gen. 145. Aublet Guian, t. 102. Jacq. Amer, $t, 182$, Lam. t. 173. Andrews Bot. Reposit, t, 715.

34D2. Gomioma $E . M E Y$. C a 1 y x quinquefidus. Corolla hypogyna, hypocraterimorpha, tubo intus hirsuto, superne angulato, limbi quinquefidi laciniis subcordatis, aestivatione obliquis. S $t$ a m in a 5, medio corollae tubo inserta, inclusa; antherae subsessiles, sagittatae, conniventes. Ovaria ..... Stylus ..... Follienli 2 teretiuseuli, patentes. Semina pendula, imbrieata, ala oblonga, retieulata cincta. E m b r y o intra albumen brevis, bicruris.... - Frutex $c a-$ pensis, non satis notus; folits oppositis $v$, ad apices ramulorum ternatis, cymis terminalibus, floribus parvis, corollis coriaceis, luteolis.

Go nlom a E. Meyer Comment, plant. Afr. austr, 188.

3403. IBlhazya DECAISN. C a l y x quinquepartitus. Corolla hypogyna, hypocraterimorpha, tubo intus piloso, ad faucem contracto, limbi quinquefidi laciniis aequilateris. $S t$ a $m$ in a 5 , medio cor,llae tubo inserta, inclusa; antherae ovatae, obtusae, liberae. Oraria 2 , ovulis ad suturam ventralem plurimis. Sty I us filiformis; stig ma rotundato-depressum, appendiculo conoideo, bifido. F ollieuli lineari-teretes, erecti, laeves. Semina plurima, oblonga, basi et apice mutua pressione membranacea ...... - Fruticulus in Arabia felic $i$ et in Asia finitima observatus, Daphnes Laureolae habitu; foliis alternis, lineari-oblongis, acutis, subpungentibus, utrinque glaberrimis, corymbis ad apicem ramulorum axillaribus et terminalibus, pedunculatis, floribus subsessilibus, basi bracteolatis, albis, suaveolentibus, vix semipollicaribus.

$\mathrm{R}$ h a z y a Decaisue in Nouv. Annal. sc, nat, IV. 80 .

3404. Amsonia WALT. Caly $\mathrm{x}$ quinquefidus. Cor olla hypogyna, infandibuliformis, tubo cylindrico, fauce dense barbata, limbi quinquefidi laciniis subobliquis. Stamina 5 , medio corollae tubo inserta, inclusa; antherae ovatae, obtusae. Ovaria 2 , ovulis ad suturam ventralem plurimis. Stylus simplex; stigma peltatum. Follicali teretes, erecti. Semina plurima, subeylindriea, utrinque truncata, umbilico ventrali. Em b r yo ..... Herba perennis, $b a-$ reali-americana; foliis oppositis, ovali-lanceo. latis $v$. linearibus, venosis, glabris $v$. pubescentibus, floribus terminalibus corymbosis.

A ms on ia Walter Flor. Carolin. 28. L. C. Richard in Michau,x Flor. Bor. Amer. I. 121. Bot. Reg. $t$. 151. T a bernaemontana s p. Linn. Vent. Choix, $t, 29$.

3405. Whaca $L I N N$. Cal y $x$ quinquefidus. Corolla hypogyna, infundibuliformis, fauce ampliata, membrana annulari quinqueplicata coronata, limbi qninquefidi laciniis obtusis. S ta mina 5 , medio corollae tubo inserta, inclusa; fil a m enta basi geniculata, apice dilatata, antherae stigmati incumbentes, apice membrana barbata terminatae. Ovaria 2 , ovulis ad suturam ventralem plurimis. Stylus filiformis, superne incrassatus, in discum nudum dilatatus; stigma fimbriatopentagonum. Glandulae 2 , hy pogynae, ovariis alternae, obtusae. Folliculi teretes, marginibus introflexis semililoculares. Se min a plurima, ovato-oblonga, tuberculata, umbilico ventrali. E mb ryo intra albuminis erassi, earnosi extremitatem superiorem minimus; cotyledonibus brevissimis, radic ula supera. - Fruticuli v. herbae decumbentes, sarmentosae, in Europa media ef 
australi indigenae; foliis oppositis, pedunculis axillaribus solitariis, unifloris, floribus caeruleis.

Vin c a Lian. gen, $n$. 293. exel. sp. Gärtner $I T, 172$. t. 117. Schkulur $t .51$, E. B. $t, 514,917$. Waldst. et Kitaibel Plant. Hung. t. 9. Bot. Mag. t. 2008. Bot. Reg. t, 301. Per vinc a Tournef. Inst, 45, Dumort. Fam, p. 26.

3.108. Thellomera REICHENB. C alyx quinquefidus. Corolla hypogyna, hypocraterimorpha, fauce contracta, membrana annulari ciJiata, obsoleta, limbi quinquefidi laciniis obliquis. St a m in a 5, summo corollae tube inserta, inclusa; filam enta brovissima, filiformia, an $t$ herae stigmati ineumbentes, apice simplices. Ov a ri a 2, ovalis ad suturam ventralem plurimis, $\$$ ty 1 us filiformis, superne in discum subtus vaginula membranacea auctum dilatatus; $8 \mathrm{tigma}$ obtuse pentagonum. Gland nla e 2, hypogynae, lanceolatae, ovariis alternae et aequales. Follieuli teretes. Semina plurima, subcylindrica, utrinque truncata, umbilico ventrali. E mb ryo..... - Suffrutex erectus, inter tropicos $A$ siae et $A$ merica e obvius; foliis oppositis, petiolatis, petiolis basi biselis, floribus axillaribus sessilibus, geminis $v$. pluribus, roseis.

Loehnera Reichenbach Consp. n. 2353. b. Vinea Dumort. Fam, p. 26. Vinc a r o s e a Lim. Medicus Beobacht. 83. Bot. Mag. $t, 186$.

340\%. Fleetanein THOUARS. Calyx urceolaris. Coroll a tubo brevi, ventricoso, limbo contorto atque coarctato. Stamina 5 ; antherae sessiles, sagittatae. Ovarium unicum ..... Stylus brevis; stigma capitatum. Cap s ula siliquaeformis, subtetragona, longissima, e duobus folliculis connatis bilocularis, marginibus introflexis seminiferis, maturitate dehiscentibus. Se $\mathrm{m}$ in a marginibus affixa, funicnlo tenui, compressa, alata. $\mathrm{Em}$ b ry o intra albumen tenue rec. tus; cotyledonibus planis. - Frutex madagascariensis, lactescens; folitis oppositis, floribus parvis, corymbosis.

Ple etaneia Thouars Gen, mailagasc, $n, 36$.

TRIBUS FI. ALSTONIEAE. F oII i c u 1 coriacei. S e m i n a peltata, ciliata, ciliis elongatis utrar, extremitate comosa.

3408. Alstonia R. BR. Calyx quinque. fidas. Corolla hypogyna, hypocraterimorpha, fauce tuboque esquamatis, limbi quinquefidi laci niis obliquis. S $\mathbf{t}$ amin a 5 , medio corollae tabo inserta, inclusa; a ntherae subsessiles, lanceolatae, liberac. Ovaria 2 , ovulis ad suturam ventralem plurimis. Stylus unus, filiformis, apice dilatato; stigma subconicum, Squamulae hypogynae nullae. Folliculi teretes, elongati. S emin a plurima, peltata, linearia, compressa, ciliata, eiliis utriusque extremitatis elongatis comosa. Embryo ....... - Arbores, saepius pro cerae, lactescentes, in Asia et Oceania tropi $c a$ indigenae; foliis oppositis $v$. verticillatis, costatis, glabris, eymis terminalibus paniculatis, floribus ut plurimum albis.

Alst o n i R. Brown in Mem. Werner. Soc, I. 28, t. 32. Labillard. Nov. Caled, $t$. 32. Ee h It is s p. Linn. Forst.

Tremes InI. ECHITEAE. Foli $\mathrm{c}$ ul $\mathrm{i}$ coriacei $v$. membranacei, distincti $v$, rarius in expsulam connati. Semina ad umbilicum comosa.
3409. Wehites $P$. BROWN. C a $1 \mathrm{y} \times$ quinquepartitus. Co roll a hypogyna, hypocraterimorpha v. infundibuliformis, fauce tuboque esquamatis, limbi quinquepartiti laciniis inaequilateris. Stamina 5, corollae tubo v, fauci inserta, inclusa; antherae sagittatae, medio stigmati cohae rentes, appendicibus polline destitutis. Ova ria 2, ovulis ad suturam ventralem plurimis, Stylu s unus, filiformis; sti $\mathrm{gm}$ a pentagonum, apice conico. S qua mula e hypogynae 5, liberae v, rarius connatae. Folliculi graciles. Semina plurima, ad umbilicum comosa. - Frutices saepius volubiles, rarius suffrutices erecti, plerumque lac. tescentes, in America et Asia tropica crescentes; foliis oppositis, ciliis in nonnullis interpetiolaribus glandulosis, floribus ut plurimum speciosis, albis, luteis $v$. purpureis.

E chites P. Browne Jam, 181, t, 16. f. 2. Linm. gen. n. 295. excl. sp. pl. Jacq. Amer. $t, 21.23,26-28$. Ic. rar. t, 53. Ruiz et Pavon Elor. Feruv, t. 131. f. 6. t. 134. f. a. t. 136. R. Brown in Mem. Werner Soc. 1. 59, Desfont. in Mem, Mus. V. 274. 4. 20. Bot. Mag, t, 1064, 1910, Bot. Reg. 2. 1664. 1774. Wallich Plant. As, rar, t. 49.

3410. Telhnoearpuss $R, B R$. Calyx quinquefidus. Corolla hypogyna, hypocraterimorpha, fauce tuboque esquamatis, limbi quinquefitli laciniis dimidiatis. Stamin a 5 , corollae tubo inserta, inclusa; an therae sagittatae, a stigmate distinctae. Ovaria 2 , ovulis ad suturam ventralem plurimis. Stylns unus; stigma ovatum, acuminatum. Filame n ta 5 , hypogyna, staminibus alterna. Folliculi graciles, polyspermi. Semina plurima, ad umbilicum comosa, - Frutex indicus, ramosus; foliis oppositis, panicula terminali, brachiata, floribus parvis.

I e h noc arpus R. Brown in Mem. Werner, soc. I.61. A poeynum frutescens Burmann Thesaur. Zeylat. t. 12. $f .1$.

3411. Beaumontia WALL. Calyx pentaphyllus, patens, foliolis latis, Corolla hypogyna, campanulato - ventricosa, maxima, fauce tuboque esquamatis, limbi breviter quinquefidi laciniis subaequilateris. S tamin a 5 , summo corollae tubo inserta; an therae subexsertae, sagittatae, circa stigma cohaerentes, appendicibus polline destitutis, O varinm biloculare, ovulis juxta axim utrinque plurimis. S tylus unus; stigm a crasso-fusiforme, apice bicuspidatum. An nulus hypogynus quinquelobus, lobis cum staminibus alternantibus. Folliculi maximi, ad axim eohaerentes, polyspermi. Semina plurima, ad umbilicum comosa. - Frutex indicus, scandens; ramulis pubescentibus, foliis oppositis, petiolatis, oblongis, obtusis, integerrimis, corymbis terminalibus $v$, axillaribus, multifloris.

B e a mon ti a Wallieh Tent. Flor. Nepal. I, 13,t, 17. Bot. Reg. t. 901, Bot. Mag. t, 3213. E chites g ra n difl or a Roxburgh Plant. Corom. t. 281.

3412. Hilarrohena R. BR. C alyx quinquepartitus, laciniis subulatis, C o rolla bypogyna, hypocraterimorpha, fauce tuboque esquamatis, limbi quinquefidi lobis subaequilateris. Stamina 5 , imo corollae tubo inserta, inclusa; an ther a e a stigmate liberae, lanceolatae, integrae, longitudinaliter polliniferae. Ovaria 2 , ovalis ad suturam ventralem plurimis. Stylus unus; stigma cylindracenm. Squa mae hypogynae nullae. Follic nli graciles, polyspermi. S e min a pluriua, ad umbilicum comosa. - Frutices in dici, crecti, glabri; foliis oppositis, petiolatis, membranaceis, inlegorrimis, cymis terminalibus et lateralibus. 
H olarthen a $\mathrm{R}$. Browu in Mem. Werner, soc, $I$. 62. Carissa uitis Vahl Symb. III. 6. 59 .

34.13. Paelaypodilum LINDL. C a I y x quinquepartitas, laciniis acutis. Corolla hypogyna, hypocraterimorpha v, subinfundibuliformis, lance tuboque esquamatis, limbi quinquepartiti lobis aequilateris. Stam in a 5 , medio corollae tubo inserta, inclusa; antherae a stigmate liberae, sagittatae, appendicilus polline destitutis, subsessiles. Ovaria 2 , ovulis ad suturam ventralem plurimis. Stylus unus; stigma oblongum, basi annulato-inerassatum. Squ a m a hypogynae nullae. Folli e u I i ovati, compressiusculi, polyspermi. Semin a plurima, ad umbilicam comosa - Frutex capensis; caudice basi sphaerico, tuberoso, laevi, ramis teretibus, succulentis, foliis sparsis, sessilibus, oblongis, obtusis, carnosis, subtus tomentosis, spinis infrapetiolaribus bi-trilobis, subulatis, planis, floribus axillaribus et terminalibus subaggrega. tis, breve pedunculatis.

Paeky podiam Lindley in Bot, Reg. $t, 1321$. B elo. nites B. Meyer Comment. plant. Afr. austr. 187. E c h i tes sucoulenta Thunberg in Nov. Act. Academ. Petropolit. XIV. 505, t. 9. $f$. 2. et E elit es bispinos a Thuub.

OBSERVAT10. Pa e hy p od i o fortassis affine v. congener: Nerium obesum Forsk. Descript. 205. Vabl Symb, II. 45. a. cI. R. Brown e Neril genere exclusnm:

ADENIUM Röm. et Schult. Syst, IV. p. XXXY. , Calyx quinquepartitus, Iaciniis lanceolatis, Coroll a e tubus inferne angustatus, dein ampliatus, pubescens, intus lineis qquinque longitudinalibus, villosis, limbi laciniis rotuadatis. , S $t \mathrm{am}$ in u fil a me n tabrevissima, superne in tabi parte wangustiore, antherae sagittatae, superae cum stigmate "coliaerentes, apice seta pilosa longitudine corollac. $0 \mathrm{va}$. wria 2, globosa. Stylus usicns, longitudine antherarum. nStigma capitatum, apice bídentatum, lateribus quinque"dentatani," - Planta a rabica, indigenis Aden dicta. caudice molli, bulbum epigaeum referente, capitis human mole, ramis lignosis, foliis sparsis, ad apices ramorum ap. proximatis, oblongis, basi angustioribus, mucronatis, subtus villoso-tomentosis, setis axillaribus rigidis, corymbis terminalibus multifloris.

B4t4. Isomeman $R$. BR. Caly $\mathrm{c}$ is quinquefidi foliola basi intus squamula duplici aueta. Corolla hypogyna, hypocraterimorpha, fance tuboque cylindraceo, intus medio barbato esquamatis, limbo quinquepartito. Sta $\mathrm{m}$ in a 5 , corollae fauci inserta, exserta; fil am enta apice simplicia, antherae sagittatae, medio stigmati cohacrentes. Ovaria 2 , ovulis ad suturam ventralem plurimis. Stylus unus, filiformis; stigma incrassatnm, obtusum. Squamae hypogynae nullae. Folliculi..... Frutex Africae tropicae, erectus (?) oppositifolius, pilosus; panicula terminali brachiata, floribus corymbosis, scmiuncialibus.

Is o ue ma R. Brown in Mem. Herner, soc. $T$. 63 .

34 45 . Thenaselta $H, B, K, C$ aly $x$ quinquepartitus. Corolla hypogyna, rotata, tubo qubnullo fauceque esquamatis, limbi quinquefidi lobis inaequilateris. Stamina 5 , corollae tubo inserta, exserta; fil am enta basibus membranaceis cohaerentia, apice filiformi, antherae sagittatae, medio stigmati cohaerentes. 0 va ria 2 , ovulis ad snturam ventralem plurimis. Stylus unus, filiformis; $8 \mathrm{tig}$ ma pentagonum, tuberculo clavato terminatum. Sq $\mathbf{n}$ a m $\mathrm{l}$ a e quinque hypogynae, liberae. Folliculi ..... - Frutex mexicanus, volubilis, glaber; folits oppositis, ovatooblongis, acuminatis, pedunculis interpetiolaribus, clongatis, subtrichotome ramosis, floribus umbellato- congestis, longe pedicellatis, bracteatis, facie florum Solani tuberosi, corollis virescenti-albis.

Then a rdia Kunth in Humb. ot Bonpl. Nov. gen. et sp. $I I T .209$. . 240.

3416. Wallarig N. L. BURM, C a lyx quinquepartitus. Co rolla hypogyna, hypocraterimorpha, fauce tuboque esquamatis, limbi quinquefidi lobis obtusis. Stamina 5 , corollae fauci inserta, exserta; fil amenta brevissima, apice extus gibbere earnoso, anth er a e sagittatae, medio stigmati cohaerentes. Ovarium biloculare, ovulis juxta axim utrinque plurimis. Stylus filiformis; $8 \mathrm{tigma}$ conico-ovatum. Squa ma quinque hypogynae, basi connatae, apieibns ciliatis. Follic uli ..... Frutices indici, volubiles, oppositifolii; pedunculis interpetiolaribus, dichotomis, floribus corymbosis, suaveolentibus.

Vallaris N. L. Burmanu Ind. 51. R. Browa in Mem. Werner. soc. $I, 63$. Hooker Ic, $t, 133$. E merici a Romei et Schultes Syst. IV. 401. - ? FIos pergulanus Rumph Amboin. V. 51, t. 29. f. 2. Houttuyu Syst, III. t, 20. f. 1 , Pergulariaesp. Linn. Peltanthera Roth Nov, sp. 132.

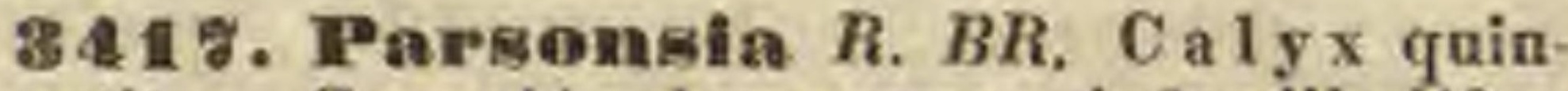
quepartitus. Corolla hypogyna, infundibuliformis, fauce tuboque esquamatis, limbi quinquepartiti, recurvi laciniis aequilateris. Stamina 5 , medio v. imo corollae tubo inserta, exserta; filamenta filiformia, anthera e sagittatae, medio stigmati cohaerentes, appendicibus polline destitutis. Ovaria 2 , v, unieum biloculare, ovulis at suturam ventralem v. juxta axim utrinque plurimis. Stylus unicus; stigma incrassatum. Squamae quinque hypogynae, distinctae $v$. connatae. Folliculi 2, distineti v. axi cohaerentes. Semina plurima, ad umbilicum comosa. - Frutices volubiles, in America et Australasia tropica indigeni; foliis oppositis, floribus cymosis v. racemosis, racemis saepe compositis, terminalibus $v$, interpetiolaribus, parvis.

Parsonsia R. Brown in Mem. Werner, soc, I. 64. Prodr, 465.

a. Porsteronia $C$. F. W. Meger, Ovaria 2. Folli. c uli distincti. - Species americanae.

Forsteronla C. F. W. Meyer Essequeb, 133. E c hit is s p. Amer, t. 29. 30. Edit. pict. t. 36. 37.

b. PARSONSIAE VERAE. Ovarium blloculare. Follif c uli cohaerentes. - Species australasicae.

Periploca eapsularis Forst.

3418 . Eedysanthern $H O O K$ et $A R N$. Cal y x quinquepartitus. Corolla hypogyna, sub. campannlata, fance tuboque esquamatis, limbi quinquefidi, patentis lasiniis aequilateris, aestivatione contortis. St amina 5 , medio corollae tubo inserta, subinclusa; fil am enta brevissima, antherae sagittatae, medio stigmati cohaerentes, appendicibus polline destitutis. Ovaria 2 , ...... Sty I us unicus; stigma conico-capitatum, acutum. Annulus hypogynus carnosus, ovariorum basim cingens. Folliculi .... Frutex cantoniensis, ut videtur erectus; foliis oppositis, longiuscule pelialatis, ellipticis, acutis, glabris, paniculis axillaribus elongatis, laxe cymosis, floribus parvis, roseis.

Ecd y s a n t her a Hook, et Arnott ad Beechey 198, $t$. 42.

3419. Theligme $B L U M$. C al y x quinquefidus. Corolla hypogyna, rotata, tubo brevi ventricoso fauceque esquamatis, limbi quinquefidi laciniis obliquis. S $t$ a m in a 5 , corollae tubo inserta, exserta; filamenta stylo spiraliter circumvolnta, antherae sagittatae, stigmati colaerentes. 
Orarium biloculare; 0 vulis juxta axim utrinque plurimis. Stylns unus; stigma clavatum. S qua. in a e hypogynae quinque. Folliculi cohaerentes, placentis adnatis. Semina plurima, ad nmbilienm comosa. - Frutex javanious, volubilis; foliis oppositis, ovato-ellipticis, glabris, corymbis axillaribus, dichotomis.

Heligme Blume Flor. Jav. Praef, PIT, Helygia Blume Bijar. 10 is.

5az0. Ilyersia $\boldsymbol{R}, \boldsymbol{B R}$. Ca I y $x$ quinquefidus. Corolla hypogyna, infundibuliformis, fauce tuboque esquamatis, limbi quinquepartiti, recurvi laciniis aequilateris, aestivatione valvatis. St a mina 5, medio corollae tabo inserta, exserta; filamenta filiformia, antherae sagittatae, medio stigmati cohaerentes, appendicibus polline testitntis. $O \mathrm{v}$ a ri $\mathbf{n} \mathrm{m}$ biloculare; o v $\mathrm{a} \mathrm{l}$ is juxta axim utrinque plurimis. Stylus fliformis, apice dilatatus; 8 tigma subconicum. Squa ma e quinque hypogynae, connatae. Cap s ula cylindracea, bilocularis, valvis folliculiformibus, dissepimento parallelo libero, utrinque seminifero. Semina plurima, ad umbilicum comosa. - Frutex NovaeIlollandiae extratropicae, volubilis; foliis oppositis, cymis terminalibus trichotomis, floribus $e$ ninoribus, limbo barbato.

Lyonsia R. Brown in Mem. Merner. soc, $T$. 66 . Prodr. 466.

3421. Pottein HOOK, et $A R N$. C alyx quinquefidus. Corol a hypogyna, infundihuliformis, fauce tuboque esquamatis, limbi quinquepartiti, recurvi laciniis aequilateris, aestivatione valvatis. Sta mina 5 , corollae fauci inserta, exserta; filamenta filiformia, brevia, a nt herae sagittatae, medio stigmaticohaerentes, appendicibus polline destitutis. O varia $2, \ldots$. . Stylus e basi crassiore attenuatus; stigma subglobosum, pentagonum, acutnm. Folli is uli .... - Frutex chinens $i s$, erectus, Lyonsiae ut videtur nimis affinis; ramis puberulis, foliis opposilis, glabris, petiolatis, ovalibus, basi subcordalis, cymis axillaribus et terminalibus longe pedunculatis, irichotomis, laxis, paucifloris, floribus parvis.

Potts ta Hooker et Araott ad Beech, 198, 2 , 43.

34.2. A poeynum LINN, Caly x quinquefidus. Corulla hypogyna, campanulata, quinquefida, tubo intus denticulis quinque acntis, inclusis, limbi lobis oppositis, fauce nuda. St am in a 5, imo corollae tubo inserta, inclusa; fila. menta brevissima, antherae sagittatae, medio stigmati cohaerentes, appendicibus polline destitutis. Ovaria 2 ; ovulis ad suturam ventralem plurimis. Styli subnulli; 8 tigma dilatatum, apice conico. Squama quinque hypogynae. Folliculi graciles, distincti. Semina plurima, ad umbilicum comosa. - Herbac perennes, erectae, in $A$ merica el Asia boreali, rarissime in Eupa austrati erescentes; folitis oppositis, nembranaceis, glabris, floribus cymosis.

A p o су nu mi Linn. gen. $n, 302$, excl, sp. Selikuhr t. 53, Lam. t. 176. f. 1. Jaeq. Hort. Vindob. IIT, t. 66. Bot. Mag. $t, 280$. R. Brown in Mem. Werner. soc. I. 67.

3483. Wetadifum $E, M E Y$. C a 1 y $x$ quinquefidus. Coroll a hypogyna, hypocraterimorpha, limbi quinquefidi laciniis subaequilateris, tubo intus processibus quinque lanceolatis, compressis, inclugis, laciniis alternis. Stamina 5 , imo corollae tubo inserta, inclusa; anther a e medio stigmati cohaerentes, extns sursum dense hirsutae. Ovaria $2 ; 0$ vulis ad suturam ventralem plurimis.
Stylus unus; stigma peltatum. Squamulae hypogynae? ...... Folliculi graciles, divaricati. S emin a plurima, ad nubilieam comosa. Suffrulex capensis; ramis erectis, virgatis, junia. ribus cano-puberulis, foliis oppositis, anguste linearibus, rigidis, subpungentibus, cymis in ramulis axillaribus abbreviatis, paucifloris, cano-pubescentibus, floribus parvis, luteis.

E c ta di u m F. Meyer Comment. plant. Afr. austr. 188.

3424. Cryptolepis $R$. BR. Cal y $\mathrm{x}$ quinquefidus. Corolla hypogyna, infundibuliformis, quinquefida, tubo intus squamulis quinque obtnsis, inclusis, limbi laciniis alternantibus, fauce nuda. Stamina 5, imo corollae tubo inserta, inelusa; antherae sagittatae. Ovaria 2 ; ovulis al suturam ventralem plurimis. St y I u s mulius; st i g ma dilatatum, apiento conico. Squ a mula e quinque, hypogynae. Follic uli ...... Frutex Indiae orientalis, volubilis; foliis oppositis, paginis discoloribus, inferiore venosa, corymbis interpetiolaribus, subsessilibus, brevissimis.

Cryptolepis R. Browa in Mem. Werner soe, I. 69.

3425. Prestomia R. BR. Calys quinquefidus, laciniis basi intus squamula instruetis. Corolla hypogyna, hypocraterimorpha, limbo quinquepartito, fance eoronata tubulo annulari indiviso, squamisque quinque interioribus cum limbi laciniis alternantibns, Stamina 5 , corollae tubo inserta; antherae semiexsertae, sagiltatae, medio stigmati adhaerentes, appendicilus polline destitutis, Ovaria 2; ovalis ad suturam ventralem plurimis. Stylus nnus, filiformis, apice dilatato; stigma irhinatum, apiculo angusto. Urceolus hypogynus, gamophyllus v. quinquefidns. Follieuli ..... Frutices a mericani trapici, volubiles, tomentosi; foliis opposilis, corymbis interpetiolaribus congestis, calyce foliaceo.

Prestoni a R. Browa in Mem. Worner. soc. I. 69. Kunth in Humb. of Honpl. Nov. gen. of sp. III, 221, 1, 212.

34R6. EBalrowria $R$. BR. Calyx quinquepartitus, intus foliolis decem stipa! us. C or o 11 a hypogyna, infundibntiformis, limbi quinquefidi laciniis rectis, aequilateris, fauce tulublo creauiato coronata. Sia mina 5 , corollae fanci inserta, $\mathbf{8 e -}$ miexserta; antherae sagittatae, mucronatae, medio stigmati cohaerentes. Ovari u m biloculare; ovulis juxta axim utringue plurimis. St y I us unus, filiformis, apice dilatato; 8 L i $g \mathrm{~m}$ a angulatum. Squamulae hypogynae nullae. Follie ali ....... - Arbor Novae-Hollandiae tropicae, biorgyalis; foliis oppositis, lanceolato-tinearibus, falcatis, denticulis interpetiolaribus, cymis lateralibus terminalibusque, trifidis.

Balfouria R. Brows in Fem. Werner, soc. I. 70 Prodr. 467.

34\%\%. Neriman $R$. BR. Calys quinquepartitus, intus denticulis auctus. Corolla hypogyna, hypoeraterimorpha, limbi quinquefidi laciniis tortis, inaequilateris, ecaudatis, fauce foliolis lacero-multifidis coronata. Stamina 5 , medio corollae tubo inserta, inclusa; an $t$ herae sagittatae, aristatae, medio stigmati cohaerentes. Ovaria 2 ; 0 valis ad suturam ventralem plurimis. Stylus unus, filiformis, apice dilatato; st igma obtusum. Squamula e hypogynae nullae. F olli e uli cylindracei Semina plurima, ad umbilicum comosa. - Frulices Indiac orientalis, erecti, glabri; foliis ternis, elongatis, coriaceis, venis numerosis parallelis, corymbis terminalibus. 
Neri u m R. Browa in Mem, Werner. soo. $T$, 7t, Ne rif 3p. Lina. Sethkulir 6, 52. Duham. Arbr. II, $t, 12$.

3498. Strophanthus DC. C al y $\mathrm{x}$ quinquepartitus, C o r o Il a hypogyna, infundibuliformis, limbi quinquefidi laciniis caudatis, fauce squamulis decem indivisis coronata. S $t$ a $m$ in a 5 , medio corollae tubo inserta, inclusa; an the ra e sagittatae, aristatae v. mueronatae. Ovaria 2 ; orulis ad suturam ventralem plurimis. Stylus ungs, filiformis, apice dilatato; $\mathbf{s t} \mathbf{i} \mathbf{~ m a}$ subcylindraceum. Squamulae quinque, hypogynae. Folliculi divaricati, obtusi. S em in a plurima, ad nmbilicum comosa. - Frutices sarmentosi, in Africa et Asia tropica indigeni; foliis opposilis, floribus terminalibus, glomeratis.

Strophanthus DC. in Bullet. soc. philomat. III. 122. t. 8. Desfont, in Annal. Mus. 1, 410, t. 27. R. Browa in Mem. Worner. soc. I. 72. Bot. Reg. E. 409. Reichenb. Hort, Bot, t, 159. Blume Bijdr, 10h4. E chites ca ad at a Llua.

TRIBUS IV. WRIGHTIEAE. S e $\mathrm{m}$ in a ad extremitatem umbilico oppositam comosa.

3429. Wrightia $R \cdot B R$. C a l y $x$ quinquepartitus, intus squamis quinque v. decem auctus. Corolla hypogyna, hypocraterimorpha, limbo quinquepartito, patente, fauce squamis decem, divisis coronata. Stamina 5 , corollae fauci inserta, exserta; an the rae sagittatae, medio stigmati cohaerentes. Ovaria 2 , cohaerentia; ovu$\mathrm{li} s$ ad suturam ventralem plurimis. Stylas filiformis, subelavatns; stig m a obtusum, emarginatum. Folliculi distincti v. cohaerentes, placentis adnatis. S emin a plurima, ad extremitatem umbilico oppositam comosa. E m b ry o exalbuminosus; cotyled on ibas longitudinaliter involutis, radienla umbilico proxima, supera. - Frutices v. arbusculae erectae, in Asia et Nova-nollandia tropica crescentes; foliis oppositis, corymbis subterminalibus, foribus albis.

Wrightia R. Brown in Mem. Werner. soc. I. 73. Prodr. \$67. Blume Bijdr, 1045 Wallich Plant. As, rar. t. 146. Bot. Reg. t. 933 . N e ri u m Gärtner 11 , 172, t. 117. Nerium ze y lanieum Linn.

3430. Kaxia BLUM. C a l y x quinquepartitus. C o rolla hypogyna, subinfundibuliformis, tabo medio coarctato, fauce nuda, limbo campanulato, quinquepartito, torto. S ta min a 5 , corollae fauci inserta, exserta; a n the ra e cuspidatae, dorso callosae, medio stigmati cohaerentes, Ovaria 2, annulo carnoso cincta; ovulis ad suturam ventralem plurimis. Stylus filiformis; stig m a clavatum. Folliculi distineti, elongati. S e min a plurima, ad extremitatem umbilico oppositam coma stipitata. Embryo exalbuminosus; cotyled on ib u s longitudinaliter involutis, $r$ adicula umbilieo proxima, supera, - Arbor javanica, pulchra; folïs oppositis, avalibus, utrinque acutiusculis, supra glabris, subtus pallidioribus puberulisque, floribus axillaribus fasciculatis, magnis, albido-flavescentibus.

K ix ia Blume Flor, Lav, Praef, $p$, VIT. Hasseltia Blume Bijdr, 1045, non alior.

\section{GRNERA DUBIA.}

1. ALAFIA THOUAR. C a I y x parrus, quinquelobus. $\mathrm{C}$ o. foll a tubulosa, ventricosa, limbo quinquepartito, contorto, lacinils hine integris, Inde plicato-sinuatis, Stam ina 5 , fil a menta brevia, infra a theras acutas, distinetas sed conniventes pistillo alligata. Ovaria 2. Stylus filiformis, appendicibus quinque filameatis adnatus; $8 \mathrm{ti} \mathrm{g} \mathrm{m}$ a capitatua, acuminatum, inter antheras laciusum. Fr u c ta.....
Frutex madagascariensis, debilis, scandens; folits oppositis, floribus terminalibus, numerosis, purpurascen. tibus.

Al a fia Thouars Gen, marlagasc, $n$, 34.

2. SYSTREPHA BURCH. C al y x pentaphyllus, foliolis subulatis. C orolla tubulosa, basi globoso-isflata, tubo cylindrico, nigro-purpureo punctato, limbi quinquefidi laci. viis longissimis, erectis, clegantissime in formam corouae inperialis contortis. Nectaria 5 , bifida, erecta, linearia. obtusa. Filamenta 5 , nectaríis longiora, apice conai. ventia, germen orbiculatum depressum tegentia; $a$ utherae ad basim filamentorum. St y $l$ u s et $s t i g m a$ igcanspicua. Herba capensis; radice fasciculata, tuberibus fusifor. mibus, succulentis, albis, caule volubili, filiformi, pe. dunculo axillari bifloro.

S y strepha Burchell Travels I. 546. Lindleg Intro. duct. edit. II. p. Aiks.

3. ANABATA WILLD. C al y $x$ eampanulatus, brevissime quinquedentatus. Co roll a caupanulata, limbo quínquefido, lacinifs lanceolatis, acuminatis, patentibus. A n therae 5 , intra tubum corollae sessiles. 0 variua.... Sty 1 as exsertus; s tI gma simplex. Capsula tetragona, stylo persistente coronata, valvis placentiferis. - Frutex or $i$. nocensis, scandens; folits oppositis, floribus albth, Jasminum spirantibus.

A uabata Willenow mse. Sprengel Gen, pl.n. 742. Sulzeria Römer et Schult, syst. $I V$. XX. R a uwolfia oppositifolia Sprengel N, E, IIT, 33 .

4. DISSOLENA LOUREIR, C al y $x$ fubalosis, quinque. fidus, laciníis subulatis, erectis. Corolla infundíbulifor mis, tubolongo, inferne erassiore, pentagono, superne cy. lindrico, limbo quiaquefido, patente. Sta min a 5 , iuferiori tubi corodlini parti inserta; fil a m e a ta capillaria, brevia, antherae ovatae, erectae. Ovarium ovatum. Stylas filiformis, staminibus brevior; $s t i g$ a subovatum, eras. sum, seabrum. D r u p \& parva, ovata, nuce compressa, seabra, nucleo simpliel. - Arbuscula cantoniensis; ramis patentibus, folits inferioribus oppositis, summis ternatim quaternatimve verticillatis, racemis subdivisis, terminali. bus, floribus albis, drupulis nigris, glabris.

D is s ole n a Loureiro Flor, cochineh, 171.

5. VABEA LAM. Caly $\times$ minimus, quinquefidus. Cor ofI a infundibuliformis, tubo elongato, basi ventricoso, limb quinquefidr laciahis tortis. $\mathbf{S} t a \mathrm{~m}$ i u a 5 , medio corollae tubo inserta; fllamenta brevissima, a utherae sagittatae. Ovari $n$ m ovatum, acutum. St y lus subulatus; $\$$ i g main disco orbiculari carnoso bieuspidatum. ...... Arbor madaga oc ariensis, an frutex? ramis glabris, tere. tibus, folits oppositis, petiolatis, coriaceis, subellipticis. nervosis, floribus terminalibus cymosis, ochroleucis, pe. dicellis bracteolatis.

V a he a Lam. t. 169. Poiret suppl. V. 409.

OBSERVATLO. Genera Cercoc om a Wallich Calalog. n. 1623. Cryptolobus Wallich ex Lindl. introduet. edit. II. p. 302. et Syringosma Zuecar, ex Reichenb. consp. n. 3.526. nobis ignota sunt.

\section{Ordo CХХХराH. Asclepiadeat.}

APOCYNEARUM pars Juskieu gen, 143. ASCLEPIADEAK Jacquin Miscellan. austr. I. 1. 35. De genilalibus Ascle. piadum controvorsis Vindobon. 1811. 8. Jussieu in Annal. Mus. V. 261. XV. 345, R. Brown in Mem. Merner. saciet. 1. 12. Prodr, 4ES. Observations on the organs and mode of fecundation in Orchideae. London. Octob. 1831. Supple. mentary Observations. July 1833. Linn. Transact. XXI. 685-745. t. 34-36. Verm. Schrift, V. 117-193. C. L. Tre. viranus, Zeitschrift fär Physiolog. II. 230_2A1. Brongniart in Annal. sc, nat. XXIV. 113-130. Ehrenberg in Linnaed IV. 94. Ueber das Pollen der Asclepiadeen, Berlin, 1831. 4. Bartling Ord, nat. 201. Wight et Arnott Contribut, 77. ss. E. Meyer Comment, Plant. Afric, austr, 193. ASCLE. PIADEACEAE Lindley Introduct, edit, II, p. 302.

Frutices v, rarius herbar, saepissime volubiles, plerumque lactescentes, caule ramisque teretibus, nodoso-subarticulatis, rarius carnosis. 
Foura opposita, rarius verticillata v. alterna, in succulentis saepe abortiva v. rudimentaria, nonnullarum in ascidia conversa, petiolata, simplicia, integerrima. Stip ula e nullae, earum loco interdum setae interpetiolares.

Flones hermaphroditi, regulares, in pedunculis interpetiolaribus $v$. rarius axillaribus varie dispositi, saepissime umbellati v. fasciculati, rarius cymosi $v$. racemosi, rarissime solitarii.

Ca Lyx quinquepartitus v, quinquefidus, ut plurimum parvus, rarissime corollam superans, laciniis per aestivationem imbricatis.

Conocla hypogyna, gamopetala, decidua, quinquepartita v. quinquefida, campanulata, urceolata, hypocraterimorpha v. saepius rotata, laciniis cum calycis lobis alternantibus, per aestivationem contorto-imbricatis $\mathrm{v}$, rarissime valvatis, interdum denticulo interjecto separatis, tubo intus fauceque interdum squamulis aucto.

Stamisa quinque, imae corollae inserta, ejusque lobis alterna. Fil a m en t a complanata, rarissime libera, plerumque in tubum connata. $\mathbf{T u b}$ us stamineus postice rarissime nu. dus, plerumque foliorum varie efformatorum, distinctorum v, connatorum corona auctus. Antherae extrorsae, biloculares, saepissime connectivi processu membranaceo apiculatae, rarius apice pilosae v. omnino nudae, in tubum coalitae v, rarissime subdistinctae v. distinctae; loculi appositi, paralleli, interdum septo longitudinali bilocellati, rima longitudinali v. apicali, rarius transversa ante anthesim dehiscentes. Bursae polliniferae (pollinia) in singulis loculis singulae, membranaceae, sutura cartilaginea clausae, polli nis granula fusiformia, materia oleosa involu ta, e sutura provenientia includentes, loculorum contignorum ad diversas antheras pertinentium, per paria stigmatis processubus glandulosis apice $v$, latere affixae, erectae $v$, transversae sive pendulae; rarius pollin is mas. s a e bursiculatae, granulosae, e granulis quatuor compositae, solitarie $v$. quaternatim stigmatis glandulis adplicitae.

Ovaria duo follicularia, sessilia v, pedicellata, distincta $v$. interdum primitus ima basi subcohaerentia. $0 \mathrm{v} u 1 \mathrm{a}$ in placentis nerviformibus, ad suturam ventralem sitis plurima, pluriseriata, pendula, anatropa. Styli duo, ovariis continui, plerumque brerissimi, arcte approximati. $\mathrm{S} \mathrm{t} \mathrm{i} \mathrm{g}$ a stylis duobus commune, dilatato - pentagonum, rarissime lacero multifidum, apice muticum v. rostratum, indivisum v. bifidum, rarissime multifidum, angulis baseos cum antheris alternantibns, corpuscu- lis plicaeformibus, cartilagineis, bursas polliniferas arcte retinentibus, v. glandula pollinis massas glandulosas affigente auctis.

Foldicul erecti $v$, patentes aut divaricati, saepius ovario altero abortivo solitarii, laeres v. spinis innocuis echinati, sutura dehiscentes, placenta simul soluta, libera.

Sevixa plurima, compressa, deorsum imbricata; t e s t a membranacea, ut plurimum cartilagineo-marginata, margin e prope umbilicum in comam sericeam, fructus verticem spectantem, rarissime deficientem soluto. Albumen tenue, carnosum, rarissime nullum.

Embryo orthotropus, axilis. Cotyledones planae, foliaceae. R a dicula umbilico proxima, fructus verticem spectans. PlumuÍa inconspicua.

Asclepiadeac arctissime Apocyneis affines, singulari plane genitalium fabrica, et miris fructificationis phaenomenis, iterum iterumque scrutandis ab omnibus plantarum ordinibus distinctissimae, et solis fortassis Orchideis analogae sunt.

Frequentissime proveniunt in regionibus tropico circulo inclusis v. vicinis, in novo continente in hemisphaera boreali, in reteri in australi frequentiores, inter $59^{\circ} \mathrm{L}$. B. et $58^{\circ}$ L. A. inclusae.

Plurimarum radices emeticae, diaphoreticae. Succus proprius acris v. amarus, mitis tamen nec venenatus, Calotropeos inspissatus antisyphiliticus.

Genera nimis fortassis nuper multiplieata, serie artificiali e corollae forma et coronac stamineae indole, per tribus ut videtur satis naturales, disposita sunt.

SUEOREO I. PERIPLOCEAE R. Brown in Mem. Werner. soc. I. 56. Filamenta subdistincta v. omnino libera. Ant herae uniquadriloculares. Pollinis massae 5-20, granulosae, solitariae v. quaternatim apicibus dilatatis corpusculorum stigmatis applicitae. Omnes yerontogeae, ut plurimum cropicae, paucae medilerraneae.

3431. Cryptostegia $R, B R$, $C$ a 1 y x quinquepartitus, lasiniis elongatis, lanceolatis, margine undulatis. Co roll a campanulato-infundibuliformis, quinquefida, tube intus squamulis 5 inclusis, angustis, bipartitis, antheris oppositis, easque fegentibus. St a m in a 5 , imo corollae tubo inserta, inclasa; fil amenta brevissima, distineta, antherae muticae, hasi stigmatis margini adhaerentes. Pollinia solitaria, granulosa, stigmatis glandulis $\mathbf{5}$ spathulatis, angulatis applieita. Styli distineti; stig ma globoso-conicum, apice obsolete bieuspidatum. Fo il i c uli disaricatissimi, acute triquetri, apice ohtuse attennato, incurve. Semin a ad umbilieum eomosa. - Frutex Indiae orientalis, volubilis, glaber; foliis oppositis, $74 *$ 
breve petiolatis, ellipticis, obtuse acuminatis, utrinque nitidis, subtus minute fusco-reticulatis, corymbis lerminalibus, trichotomis, floribus magnis, speciosis, rubellis, corollae aestivatione contorta.

Cryptostegia R. Browa in Bot. neg. t. 435. Wight et Arnott Contribut, 65. Nerium graud iflorum Roxb.

343\%. Fintlaysonta $W A L L$. C a l y $x$ quinquepartitus. Co roll a rotata, quinquefida, fauce tuberculis 5, staminibus oppositis, aristatis, aristis capillaribus, erectis, apice uncinatis. $\mathrm{Sta}$ in a 5 , corollae fanci inserta, exserta; fil ame nta di. stincta, a $n t h$ erae apiculo late ovato terminatae, imberbes, basi medio stigmatis adglutinatae. Pollin i a 20, granulosa, stigmatis appendiculis dilatatis quaternatim applicita. Stigma magnum, ovatum, basi pentagonum. F olli c ali divaricatissimi, ventricosu-ovati, apice uncinato-rostrati, laeves, Semina ...... - Frutex indicus, volubilis, carnosus, glaber; foliis oppositis, petiolatis, obo vatis, obtusissimis $v$, retusis, corymbis multifloris, majusculis, folio brevioribus, fructiferis valde elongatis, floribus parvis, corollae extus glabrae laciniis ovato-rotundatis, intus hine nudis, inde albido-villosis.

Pinlays onia Wallich Plant, As, rar, II. 48, t, 162. Wight et Arnott Contribut. 65.

3433. Feriploea LINN. Caly $x$ quinquepartitus. Corolla rotata, quinquefida, fauce tuberculis 5, staminibus oppositis, aristatis, aristis narnosis, erectis, apice uncinatis. Stamina 5 , corollae fanci inserta, exserta; fil am enta distincta, a $\mathbf{n}$ h er a e apiculo acuto terminatae, dorso barbatae, basi medio stigmatis adglutinatae. Pollinia solitaria, granulosa, apicibns dilatatis glandularum stigmatis applieita. S $\mathbf{t} \mathbf{g} \mathbf{m}$ a obtuse pentagonam, muticum, Follic uli cylindracei, divaricatissimi, laeves. Se m in a plurima, ad umbilicum comosa. - Frutices in regionibus mediterraneis et in Africa tropica indigeni, saepius volubiles, glabri; foliis oppositis, nitidis, floribus interpetiolaribus subcorymbosis.

Periploca Linu. gen, n, 300. exel. sp. R. Brown in Mom, Morner, soc, $I$, s9, Cayanill. Io, $t, 217$, Labillard Syr. Decad, IT. t, 7, Bot. Reg. t. 803.

3434. Streptocanilom WIGHT et $A R N$. Caly $x$ quinquepartitus. C orolla rotata, quinquefida, fance squamis 5 brevibus, staminibus oppositis, aristatis, aristis flexuoso-erectis, filiformibus, apice rectis. Sta $\mathrm{m}$ in a 5 , corollae tubo inserta, exserta; fi lameata distincta, anth erae apice simplices, imberbes, basi margini stigmatis cohaerentes. Pollinia solitaria, granulosa, apicibus dilatatis glandnlarum stigmatis applicita. Stigma obtuse pentagonum, muticum. Folliculi cylindracei, divaricatissimi, laeves. Semin a piurima, ad umbilicum comosa, - Plantae in $d i$ cae, volubiles $v$, rarissime decumbentes, saepius pubescentes $v$. tomentosac, rarius glabrae; foliis oppositis, cymis interpetiolaribus, saepius patentibus ot ramosissimis, floribus parvis.

Streptocaulou Wight et Aruott Conbribut, 64.

3435. Gymmanthera $R$. BR. C a lyx quinquefidus. Co rolla hypoeraterimorpha, fauce squamis 5 staminibus oppositis, aristatis, limbo guinquefido. Stamina 5 , corvllae fauci inserta, exserta; filament a distincta, antherae acuminatae, imberbes. Pollinia 20, granulosa, apicibus dilatatis glandularum stigmatis quaternatim applicita. Stigma apieulo bifido. Folliculi ey- lindracei, divarieati, laeves. S e m in a plarima, ad umbilicum comosa, exalbuminosa. - Frutex Novae-Hollandiae tropica e, volubilis, glaberrimus; foliis oppositis, nitidis, pedunculis laleralibus subdichotomis, floribus albo-virescentibus, imberbibus, squamis quinque incisis, intus sub sinubus calycis insertis.

Gymnanthera R. Browa in Mom. Therner, soc, $I$. 58. Prodr. 464.

3436. Deealepis $W I G H T$ et $A R N$. C a I yx quinquefidus. Cor olla subrotata, quinque partita, fauce squamis 5, oblongo-ovalibus, planis, muticis, staminibus oppositis, tabo intus ad basim squamis totidem linearibus, obtusis, iisdem alternis. Stamina 5, corollae fauci inserta, exserta; filamenta distincta, squamis faucis ad medium cohaerentia, an $t \mathrm{~h}_{\mathrm{i}}$ erae appendiculo sulsdilatato terminatae, imberbes, basi margini stigmatis adglutinatae, Pollinia solitaria, granulosa. apicibns dilatatis glandularum stignatis applicita. Stigma muticum. Folliculi ...... - Frulce indicus, volubilis? glabriusculus; foliis oppositis, obtuse ovalibus, acuminatis, cymis parvis, longius cule pedunculatis, foliis brevioribus, ramis racemiformibus, floribus parvis, corollac limbo inlus villoso.

Decalepis Wight et Aruott Contuibut. 64.

343\%. 呫rachylepis WIGHT et $A H N$. Caly $\mathrm{x}$ quinquefidus. CoroIl a subeampantata, quinquefida, fauce squamis 5 , brevibns, truneatis, planis, mutieis, staminibus oppositis, tubo brevi intus annulo lato, earnoso, adnato penitus vestito. Stamina 5, summae corollae fauci inserta, exserta; fil am enta brevissima, lata, distincta, anthera e apice simplices, imberbes, basi margini stigmatis adglutinatae. Po 11 in ia 20 , granulesa, apicibns dilatatis glandularum stigmatis quaternatim applicita. Stigma muticum. Follienli $\mathrm{cy}$ lindracei, divaricatissimi, laeves. Sem in a ...... - Frutex indicus, volubilis; ramulis pubescentibus, foliis oppositis, ovalibus, abrupte acuminatis. junioribus subpubescentibus, adultis glabris, supra nitidis, subtus parallele nervosis, cymis interpetiolaribus parvis, tomentosis, foliis brevioribus, floribus parvis, congestis, corollae extus hirsutae, inlus gla. brae segmentis patentiusculis,

Brachylepls Wight et Arnott Contribut. 63.

3438. IItemidesmus $\boldsymbol{R} . \quad B R, \mathrm{C}$ al $\mathrm{y} x$ quinquefidus. Co ro 11 a rotata, quinquefida, squamis 5, sub sinubus muticis. St a mina 5, corollae tubo inserta, exserta; fil a m enta basi connata, superne distincta, antherae inter se cohaerentes, a stigmate liberae, imberbes, apice simplices. Pollinia 20, granulosa, appendicibus reniformibus glandularum stigmatis quaternatim applicita. Stig ma planinsculam, muticum. Follic uli cylindracei, divaricatissimi, laeves. Semin a plurima, ad umbilicum comosa. - Frutices indici, volubiles, glabri; folits opposilis, supra nitidis, cymis interpetiolaribus, floribus parvulis, corollis carnoso-coriaceis.

He mides mus R. Brown in Mem, Werner, soc. $I$. 56. Wight et Arnott Contribut, 62, Periploca indica Linu.

\section{PERIPLOCEAE DUBIAE.}

3439. Lepistoma $B L U M$. C a i $\mathrm{x}$ turbinatus, quinquedentatus. Corolla rotata, tubo medio inflato, intus squamis 5 , carnosis, genitalilos acumbentibus, limbe quinquepartito, obliqquo. 
Antherae 5, tubo corollae supra basim insertae, inclusae, ovatae, dorso pulsescentes, stigmati incumbentes. Pedieelli polliniferi 10, lineares, cornei, extus longitudinaliter dehiscentes, erecti, basi corpusculis suffulti, stigmatis sulcis appliciti, Pollen granulosum. Ovarinm didymum. Stylus unus, crassus; stigma pentagonum, suleis quinque exaratum. Follie uli ..... - Frutex javanicus, volubilis; foliis oppositis, elliptico-oblongis, acutiusculis, venosis, glabris, subtus pallidioribus, pedunculis interpetiolaribus, bifidis.

Lepistoma Blume Flor, Jav, praefat, VII. L e posma a Blume Bijdr, 10:8.

3440. Playllanthera BLUM. C a ly $\mathrm{x}$ parvas, quinquefidus. Coroll a profunde quinquepartita, earnosa, basi intus discoidea, tubo fauceque esquamatis. Stamin a $5 \ldots \ldots$; filament a ereeta, distineta, a $\mathrm{n}$ therae conniventes, dorso nudae, apice foliaceo-dilatatae. Pedicelli polliniferi 5, elavati, erecti, extns dehiscentes, basi corpusculis suffulti, stiginati incumbentes. Pollen granulosum. Ovarium didymum. Stylus unus, basi bisulcatus, Stigma capitatum, maticum. Folliculi ..... - Frulex javanicus, volubilis; foliis oppositis, lanceolatis, glabris, tenuissime transverse venosis, pedunculis axillaribus, solitariis, bifidis.

Phylla a thera Blume Bijdr. 1048.

SUEDIEDO IE. SECAMONEAE. FiI a m enta connata. An the rae quadriloculares. Pollin ia 20, laevia, quaternatim (ad duas antheras pertinentes) apici corpusculorum exsulcorum stigmatis applicita. - Frutices indici el africani.

34.1. Seeamone R. BR. Calyx quinquefidus. Co rolla rotata, quinquefida. Column a genitalium exserta. Co r o n a staminea pentaphylla, foliolis lateraliter compressis, margine longitudinali affixis, aversis, simplicilus. Pollinia 20, laevia, erecta, apicilus corpusculornm atigmatis exsulcorum quaternatim affixa. $\mathrm{Sti}_{\mathrm{g}} \mathrm{ma}$ apice coarctato. Follie uli laeves. Sem in a plurima, ad umbilicum comosa. - Frutices ereeti $v$. volubiles, glabri, in India orientali, in Nova Ilollandia tropica et in Africa tropica crescentes; folits oppositis, cymis interpetiolaribus, dickotomis, floribus minutis.

Secamane R. Browa in Mem. Werner, soc, 1. 55. Prodr. 464. Blume Bijdr, 1049. Wight et Arnott Contribut. 60. Periploca Secamone. Lina. et Periploca emetic a Retz, Willdenow Rhytogr. T. 6 t. S. f. 3.

3442. Toxocarpus WIGHT et $A R N$. $\mathrm{C}$ a $1 \mathrm{y} \times$ quinquefidus. C o rolla rotata, quinquefida. Columna genitalium exserta. Cor o n a staminea pentaphylla, foliolis dorso planiusculis, intus lacinula auctis. Pollinia 20, laevia, erecta, apicibus corpusculorum stigmatis exsulcornm quaternatim affixa. Stig ma rostratum, rarius apiculatum, indivisum. Folliculi laeves, divaricati, Semin a plurima, ad umbilicum comosa. - Frutices indici, volubiles; foliis oppositis, corymbis interpetiolaribus, saepius opposilis, dichotomis, patentibus, multifloris.

Toxacarpus Wiglt et Arnott Contribut, 81.

3443. Goniostemma WIGHT et ARN. Cal y 8 quinquefidus. Corolla ro'ata, quinquepartita. Columna genitalium exserta, Corona staminea gawophylto-tubulosa, quinquangulata, quinqueloba, columnae basi adhaerens. Pollin ia 20, laevia, erecta, apicibus corpusculorum stigmatis exsulcortum quaternatim affixa. $S$ tig m a rostratum. Follieuli...... Frutex indicus, volubilis; cortice verruculoso, foliis oppositis, oblongoellipticis, basi et apice acuminatis, utrinque glabris, supra nitidis, cymis interpetiolaribus, paniculaeformibus, laxis, multifloris, corollae laciniis ligulatis, intus medio pubeseentibus, superne glabris.

Go onios temma Wight et Aruott Contribut, 62 .

SUROIBID IR. ASCLEPIADEAE VERAE. R. Brown in Mem. Werner, soc. I, 21 . Filamenta connata. Antherae biloculares. Pollin i a 10 , per paria stigmatis processubus sulco longitudinali bipartitis affixa.

TerreUs I. CYNANCHEAE. Pollinia pendula, apice $\mathbf{v}$. supera medium lateris affixa. - Per totum orbem sparsae, in regio. nibus tropicis subtropicis veteris orbis paullo frequentiores.

\section{\$. 1. ISTEPHANEAE. Corona staminea nulla. Corolla tubo fauceque esquamata.}

344A. Hybanthera $E N D L$, C a I y quinquefidus. C o rulla rotata, quinquefida, tuho brevissimo fauceque esquamatis, Coron a staminea nulla. Ant her a e torso gibbosie, appendice inembranacea terminatae. Pollinia ventricosa, apice attenuato affixa, pendula. Stig ma muticum. Follieuli ...... - Suffrutex insula: Norfolk, volubilis, glaber; foliis oppositis, petiolatis, ovato-oblangis, subcoriaceis, basi biglandulosis, umbellis inlerpetiolaribus, racemosis.

H ybanthera Eadlicher Prodr. Flor. Norfolk. 59 Ic. $t, 7 s$.

3445. Astephanass $R$. BR. Caly $x$ quínquefidus, Co roll a eampanulata, limbo quinquepartito, fauce tuboque esquamatis. Cor on a staminea sulla. A n therae appendice membranacea terminatae, Pollin ia apice attenuato affixa, pendula. Stigma muticum v, caudatum. Folliculi ...... - Plantae capenses, olubiles; folits oppositis, umbellis interpetiolaribus, floribus parvis.

Asteptanus R. Browa in Mem, Merner. voc, 1.55. Apocyirisp. Thisib.

3446. IInemax E. MEY. C a I yx quin quefiluz. Corolla urceolata, limbo brevissime quinquefido, tubo fauceque retrorsum hispida esquamatis. Eorona staminea nulla. Anthera e appendice membranacea terminatae. Pollinia apice attenuato affixa, pendula. Stigm a conoideum, obtasum. Folliculus abortu solitarius, gracilis, laevis. Semina piurima, ad umbilicum comosa. Fruticuli c apenses; ramis spinescentibus, foliis oppositis, cordatis, minutis, caducis.

H a e m a $\times$ E, Meyer Comment, plant. Afric, austr, 228. A steplianlsp. R. Browa.

\$. 2. METASTELMEAE. Corona staminea nulla. Corolla tubo fauceve squamis instructa.

344 \%. Mieroloma R. BR. C a l yx quinquefidus. Coroll a urceolata, limbo quinquefido fauce nuda, tubo angulato, medio intns squamis 5 inelusis, sul, sinubus insertis, totidem fascieulis 
villorum alternantibus, C orona staminea nulla. Antherae appendice membranacca terminatae, sagittatae. Pollinia compressa, apice affixa, pen dula. Stigma npiculatum. Follienli ...... Suffrutices capenses, volubiles; folits oppositis, linearibus, glubris, v sagiltatis, subtomentosis, umbellis interpetiolaribus, calycibus interdum corolla longioribus.

Microloma R. Browa in Mem. Werner, soc. I. 53. Ceropegiae s p. Lian. Jacq. Hort, Schänbr. t, 38. Lam. t. 179 ,

3448. Parapodium E. MEY. Calyx qninquefidus. C o r oll a subcampanulata, quinquepartita, ad fancem coronata squamis 5, rotundatis ante sinus positis, utrinque in tubum brevissimum decurrentibus. Coron a staminea nulla. Anthe$r$ a e appendice membranacea terminatae. Pollinia compressa, apiec attenuato affixa, pendula St ig ma pyramidale, quinquesulcatum, apice obtnso. Folliculi ....... - Herba capensis, erecta, glabra; foliis oppositis, lanceolato-oblongis, acutiusculis, subcoriaceis, costatis, umbellis inlerpetiolaribus, floribus sordide violaceis. 221.

Parapodi u a E. Meyer Comment. plant. Afr. austr.

3449. Detastelma $R . B R$. C a lyx quinquefidus. Corolla subcampanulata, quinquepartita, fance coronata dentibns 5 exsertis, ante sinus positis, in tubum decurrentibus. Cor o n a staminea nulla. Antherae appendice membranacea terminatae. Pollinia compressa, apice attenuato affixa, pendula. Stigma muticum. Folliculi ...... - Herba antillana, perennis, volubilis, glabra; foliis oppositis, ellipticis, mucronatis, um bellis inlerpetivluribus, subsessilibus, floribus parvis.

Metastel ua R. Brown in Mem. Werner. soc. I. s3 C g ва п c li um paevifloram Swartz. Periploca Plu wier Ic, 215, $f, 1$.

3450. Selumbertia $M A R T$. et $Z U C C$. C aly $\mathrm{x}$ quinquepartitus. Corulla infundibuliformis, limbo quinquefide, tnbo basi globoso, medio squamis 5 lanecolatis, conniventibns, inclusis, decur rentibus, per callos quinque antheris adhaerentibus aucto. Anthera e appendice membranacea terminatae. Pollinia compressa, apice attenuato aftixa, pendula. Stigma muticum. Folliculi ... - Frutices Americae tropicae, volubiles, hirsuli; foliis oppositis, petiolatis, cordatis, floribus umbellatis, subearnosis, intus saepius barbatis.

Schuberti is Martius et Zucc. Nov. gen. et sp. I. 5 s. c. 33. C y a a $\mathrm{n} \mathrm{hum} 1$ o a g iflo $\mathrm{rum}$ Jaeq. Amer, edit. piet.

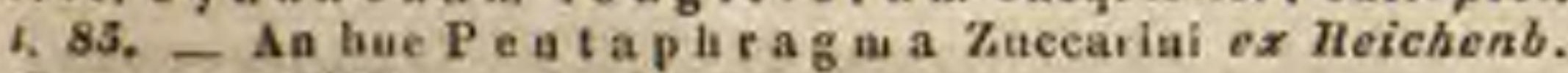
Consp. n. 3432 .

3451. 'Tweedia HOOK et $A R N$. C a lyx quinquefidas. Co rolla eampinulata, quinquefida, fauce coronata squanis 5 earnosis, retusis $\mathbf{v}$, bilidis, ante sinus positis, exsertis. Coruna staminea nulla. Antherae appendice membranacea terminatae. Pollinia ventrieosa, apice attenuato affixa, pendula. Stig ma elongato-acuminatum, bipartitum Follienli ..... - Suffrutex ch $i$ lensis, volubilis; foliis opposilis, subcoriaceis, ob longis, acutissimis, glabris, basi cordalis, ciliatis, umbellis inlerpetiolaribus, floribus majusculis, speciosis, corollis extus hirsutis, intus glabris.

Twe edia Hooker et Armott Journ. of Bot. I. 261. Bot. Mag. t. 3630.

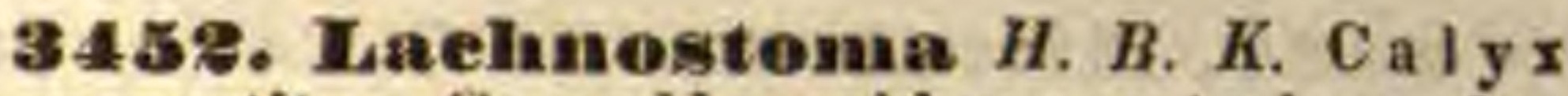
quinquepartitus. Coroll a subhypoeraterimorpha, quinquefida, fauce barbata coronata squamis 5 lnnato-bilobis, ante sinus positis, exsertis. Corona staminea nulla. Antherae appendice membranacea terminatae, Pollinia ventricosa, apice attenuato arfixa, pendula. Stigma mutieum. Foll iculi... - Suffrutex Americae tropicae, volubilis; ramis ferrugineo-hirsutis, folits oppositis, elliptico-oblongis, membranaceis, utrinque pilosis, racemis interpetiolaribus, floribus geminis, umbellatoapproximatis.

La chnos to m a Kunth in Humb. of Bonpl. Nov. gen. et sp. III. 198. t. 232.

3453. Maeroseepis $H, B, K, \mathrm{C}$ aly $x$ quinquefidus, corollam superans, basi bracteatus. Coroll a tabo globoso-ventricoso, limbo quinquefido, fauce coronata squamis 5 subcucullatis, ante sinus positis, inelusis, Corona staminea nulla. Antherae appendice membranacea terminatae. Pollin ia ventricosa, compressa, apice affixa, pendula. Stigm a depressum, mnticum. Folli culi ....... - Suffrutex America e tropicae; caule volubili, ramis foliisque oppositis, obovatis, cordatis, hirsuto-pilosis, pedunculis inlerpetiolaribus bifloris, floribus pedicellatis, pedicellis involucrato-bracteolalis.

M acroscepis Kunth in Humb, et Bonpl. Nov. gen. et sp. III, 200. t. 233.

3454. Pamtasaelnane WALL. Calyx quinquefidus. Co roll a subrotata, profunde quinquefida, laciniis anguste linearibus, aestivatione valvatis, fauce coronata squamulis 5 , ante sinus positis. Corona staminea nulla. Antherae liberae, apice simplices $\mathbf{v}$, acuminatae. Pollin i a pendula, supra medium affixa, apice coaretato pellucido. Stigma muticum v. apiculatum. Folli e ali ..... - Merbae indica e, erectae, graciles, subramosue; foliis oppositis, lanceolatis, mentbranaceis, planis, umbellis paucifloris, subsessilibus.

Pantas ach ine Wallich es Wight ot Arnott Contri. but. 60 .

\section{§. 3. DITASSEAE. Corona slaminea com- posita, seriebus $2-3$ insertione distinctis.}

3455. Eustegia $R . B R$. Cal y $x$ quinque fidus. Corolla rotata, quinquepartita. Corona triplex, singula pentaphylla, extima fauci inserta, limbi laciniis opposita, reliquae antheris oppositae, foliolis mediae tripartitis, intimae indivisis. Anther a e appendice membranacea terminatae. $P(b)$ I inia apice attenuato affixa, pendula. Stigma submuticum. Folliculi ........ Herbae capenses, llumiles, decumbentes; foliis oppositis, lineari-filiformibus, subhustatis, floribus subumbellalis.

Eustegia R. Browa Mom, Werner. soc. I. S1. Spreagel N. E. 1. t. 1. f. 5_10. A po c y u i s. Thunberg in Act. Academ, Petropolit, XIV, t, 9. f. 1 .

3456. Sarcostemma $R$. BR. C al y x quinquepartitus, C or oll a rotata, quinquepartita. Corona staminea duplex, exterior eyathiformis v. annularis, erenata, interior summo filamentorum tubo inserta, pentaphylla, exteriorem superans, foliolis carnosis. Anthe rae appendice membranacea terminatae. Pollinia apice attenuato affixa, pendula. Stigm a apienlatum v, muticum. Folliculi graciles, laeves. Semina plurima, ad umbilicum comosa. - Frutices volubiles $v$. decumbenles, inter tropicos totius orbis et in Africa extratropica observati; caulibus articulatis, aphyllis, v. foliis oppositis, distantibus instructis, floribus umbellatis, lateralibus v. terminalibus. 
Sa reostem m a R. Browa in Mem. Werner. soc. I, 50. Kunth in Humb. et Bonpl. Nov. gen, et sp. IIT, 194. $t$, 299. Wight et Aruott Conlribut, 89. Cynanehi 8 p. Jacq. Amer. t. 60, f. 2, Edit, pict, t. 87. - ? Delile Flor, aegzpt. t. 20, f. 3.

345\%. Philhbextia $H$. B. K. Calyx quinquepartitus. Corolla urceolato-rotata, sinuato-quinqueloba, lobis acutis, denticulis totidem interjectis. Cor on a staminea duplex, exterior in fundo corollae annuliformis, carnosa, integra, undulata, interior summo filamentorum tubo inserta, pentaphylla, exteriorem superans, foliolis carnosis. Antherae appendice membranacea terminatae. Pollinia clavato-cylindracea, infra apicem affixa, pendula. Stigma biapienlatum. Folliculi .... - Frutices America tropica e, volubiles; foliis oppositis, cordatis, umbellis interpetiolaribus, nultifloris.

Ph illbertia Kuath in $H u m b$. et Bonpl. Nov. gen, et sp. III. 195. t. 230. Hooker et Aruott Journ. of Bot. I. 290. Bot. Mag. t. 3616. - Corona exterior in speciebus brasilien. sibus saltim satis manifesta.

3458. Doemia $R$. BR. Caly $\mathrm{x}$ quinquefidus. C o roll a rotata, quinquepartita, tubo brevi. Co ron a staminea duplex, exterior brevis, decempartita, laciniis alternis nanis, interior pentapliylla, foliolis basi solutis, apice subulatis. Anthe rae appendice membranacea terminatae. Pollinia compressa, apice affixa, pendula. Sti g ma muti cum. Follicali ramentacei. Semina plurima, ad nmbilicum comosa. - Suffrutices volubiles, in India orientali et in Africa tropica indi geni; foliis oppositis, cordatis, floribus umbellatis.

Doe mia A. Browa in Mem, Werner. soc. I. so. Wight et Arnott Contribut. 59. Dim in Sprengel Syst. T. 526. C y. n a nehi sp. Forsk. Jacq. Io, rar, t. Si. Andrews Bot. Reposit, t, 562. Palisot Flor, Owar, t, 56. P e r gularia e s p. Lam, t. 176 .

345y. Ditassa $R, B R$. Caly $\mathrm{x}$ quinquepartitus. Co rolla subrotata, quinquepartita. Corona staminea duplex, exteriorquinquepartita, laciniis acuminatis, interior pentaphylla, exteriori antherisque opposita. Antherae appendice membranacea terminatae. Pollinia ventricosa, infra apicem attenuatum affisa, pendula. Stig ma apiculo obtuso. Folliculi teretiusculi. S emina plurima, ad umbilicum eomosa. - Suffrutices br asilienses, erecti $v$. volubiles; foliis opposilis, sessilibus $v$. breviler petiolatis, umbellis lateralibus, ftoribus ut plurimum minutis.

Dit assa R. Brown in Mem. Werner. soo, I. 49. Martius Nov, gen, et sp. I, 50, 2. 31, 32,

\section{\$. 4. CYNOCTONEAE. Corona staminea simplex, gamoplublla.}

3460. Holostemma $R, B R$. C a I y $x$ quinquepartitus. Coroll a subrotata, quinquefida. Corona staminea imo filamentorum tubo inserta, simplex, annularis, obsolete quinqueloba. Ant herae appendice membranacea terminatae. Pollinia compressa, apice attenuato affixa, pendula, Stig m a muticnm. Folliculi ventricosi, laeves. Se min a plurima, al umbilicnm comosa. - Frutices indici, volubiles, glabri; foliis oppositis, latis, umbellis interpetiolaribus, breviter pedunculatis, floribus speciosis.

Hol o s tem ma R. Brown in Mem, Ferner. soc. I, 42 , Wight et Arnott Contribut, 55. Royle Himalay, t. 66.

3461. Cynanchum LINN. C a l y $x$ quinquepartitus. Corolla subrotata, quinquepartita. Corona staminea tabulosa, columnam inclndens, ore quinque decemfido, laciniis 5 interioribus an theris exterioribusque oppositis et parallelis, $A \mathrm{n}$ therae appendice membranacea terminatae. $P_{0} 1$ linia ventricosa, infra apicem attenuatam inserta, pendula. Stigm a apiculo semibifido. Follic uli cylindracei, divaricati. S e m in a plurima, ad umbilicum comosa. - Herbae mediterraneae, volubiles; folitis oppositis, cordatis, umbellis interpetiolaribus.

C у и a c hum Lima. gen. n. 30t, exel. sp. Gärtner Ir. 171. t. 117. f. 3. Jacquin Miscell,.,$t .1$. Ic. rar. t. 340. Cavanill. Io, $t$, 60. Sibthnrp Flor. graec, $t$, 250, 25t. C y c hi sect. 1. R. Browa tin Mem, Werner, soc. $T$. 44.

3462. Endotropis. Cal y $x$ quinquepartitus. Coroll a subrotata, quinquepartita. Co ron a staminea tubulosa, columnam includens, ore quinque-decemfido, earinis decem interioribus simplieibus v. supra in lacinulas productis. An therae appendice membranacea terminatae. Pollini a ventricosa, infra apicem attennatum inserta, pendula. Stig $m$ a apiculo emarginato. Folliculi ventricosi, angulati, patentes S emin a plurima, ad umbilicum comosa. - Frutices Novac-Hollandiae et Indiae orientalis volubiles; foliis oppositis, cordatis, umbellis interpetiolaribus.

C y u a nehi sectio II. R. Browa in Mem. Merner. soc 1. 45. Pe riplo cae s p. Retz. Whild. Phylogr. $1, t, 5, f .3$,

3463. Selnizoglosgum $E, M E Y$. Ca I y x quinquepartitus. Cornlla subrotata, quinquepartita. Curona staminea quinquepartita, sinubus nudis $v$. lacinula minutissima interjecta auctis, Jaciniis intus e basi processum adversam, Iigolatum v. bierurem, stigmati incumbentem exserentibus. Antherae appendice membranacea terminatae. Pollinia ventricosa, infra apicem attenuatnm affixa, pendula. Stig m a muticum. Follieuli abortn solitarii, rostrati, spinis innocuis echinati. - Herbae capenses; caule ereclo, pubescente, foliis oppositis, pedunculis interpetiolaribus, floribus umbellatis.

Schizoglossum B. Meyer Comment. plant. Afr. autr. 218.

3464. Cymoetonum $E, M E Y$. Calyx quinquepartitus. Co rolla subrotata, quinquepartita. Co rona staminea tubulosa, simplex, ore quinque-decemfido, laciniis carinisve interioribus nullis. Antherae appendice membranacea terminatae. Poll in ia obelavata, apice attenuato inserta, pendula. Stigma apiculo bifido. Follieuli graciles, laeves, reflexi. S e mina plurima, ad umbilisum comosa, - Herbae capenses, valubiles; foliis opposil is, subcordalis, umbellis interpetiolaribus

C y a o to a um E. Meyer Comment. plant, Afr, austr. 215. $\mathrm{c}$ y $\mathrm{n}$ a $\mathrm{n}$ ch i sect. III. R. Brown in Mem, Werner, Aoc. $I$. 46. C ya anch1 sp. Linn. Andrews Bot. Reposit. t. 557. Jacq. Miscell. t. 1. f. 3. - C yna a chum rosenm R. Brown $l$. c. quod A selepias daurica Willd. C ynan. chi sect. 1V, a cl. Meyer dubie hue relata, geuus videfur sistere diversum stigmatis apiculo integro, caule erecto, foliisque lanceolato liacaribus.

3465. Vincetoxieum $M O ̈ N C H$. Cal y x quinquepartitus: Co roll a subrotata, quinquepartita. Corona staminea scutelliformis, carnosa, quinque-decemloba, intus simplex. Antherae appendice membranacea terminatae. $P$ ollin $i$ a ventricosa, infra apicem attenuatum affixa, pendula. Stig m a apiculo brevissimo, integro. Follieuli ventricosi, laeves, patentes. Semina plurima, ad umbilicum comosa. - Herbae in Europa a $l i$ et boreali usqque ad $59040^{\prime}$ indigenae; caule 
erecto $v$, superne volubili, foliis oppositis, umbcllis interpetiolaribus.

Vincetaxieum Möreh. Method. 317. Cynaneb setet. V. R. Browa in Mem. Merner. soe $I$. 47. A s cle pla dis s p. Lina. Schiular 4. 54, 55. Flor. Dait. \&. 849.

3486. Cenedylogyne $E$, MEY. C alyx quinquefidus. Co rolla subrotata, quinquefida, yatens. Co rona staminea quinqueparita, laciniis antheris oppositis, oblongis, obtusis, intus carinatis. Anthera e appendice membranacea terminatae. Pollin ia apice attenmato affixa, pendula. $\mathrm{Stigma}$ longe rostratum, apice clavatum, compressum. Follic nli abortu solitarii, graciles, laeves, erecti. Semina plurima, ad umbilicam eomosa. - Jlerba capensis, multicaulis, glabriuscula; caulibus simpliciusculis, erectis, virgatis, foliis opposilis, ungustissime linearibus, erectis, marrine revolutis, umbellis terminalibus et axillaribus longe pedunculatis, subglobosis, floribus luteo-virentibus.

Cordylogyne B. Meyer Comment, plant, Afric. austr. 218 .

346\%. Solenostemana $H A Y N$. C a $y x$ quinquepartitus. Co rolla rutata, quinquefida. Corona staminea quinquepartita, laciniis antheris oppositis, obtusis, carinato-complicatis. Ant he$r$ a e appendice membranacea terminatae, $P$ ollin i a apice attenuato affixa, pendula. St igma muticum. Follie uli abortu solitarii, ventricosi, laeves. S emin a plurima, ad umbilicum comosa. - Suffrutex in Africa boreali indigenus, erectus; foliis oppositis, ovalibus, umbellis axillaribas multiftoris.

$\mathrm{S}$ ol e noste m a a Hayne Arzneigew. IX. $t$, 3s, C y n $\pi$ nof u a A rghel Delile Aegypt. t. 20. $f$. 2. Rr. Nees Pla'at. officin. suppl, I. t. 13 .

3468. GHossosteplasums $E, M E Y$. C al y x quinquefidus. Coroll a subrotata, quinqueparlita, Cor on a staminea ime flamentorum tubo adnata, profunde quinquepartita, laeinits antheris oppositis; oblongo-laneeolatis, apiemlatis, planis. Antherae appendice memiranacea terminatae. Pollinia apice attenuato affixa, pendula. Stigm a pyramidatum, emarginatum. Folliculi - Herba capensis, volubilis, glabra; foliis op posilis, lineari-lanceolatis, margine revolutis, umbellis terminalibus lateralibusque, floribus albis.

Glossostepbau us E. Meyer Comment. plant. Afr austr. 217. A poc у и и m li a eare Thunb.

3489. Iretrolexis $R$. BR. C a ly $\mathrm{x}$ quinquepartitus. Corolla subrotata, quinquepartita. Corona staminea quinquepartita, laciniis nanis, cucullatis, cum antheris alternantibus. Pollinia ventricosa, latore affixa, pendula. Stigma rostro elongato, indiviso. Follic n $1 \mathrm{i} \ldots .$. . Frutex China e borealis, volubilis, glaber; foliis oppositis, cordatis, racemis interpetiolaribus, pedunculatis, corollae limbo barbato.

Metaplexis R. Brown in Mem. Werner, soo. I. 48 - ? Urost e Im a Bunge Enumerat, plant. Chin.bor, 44.

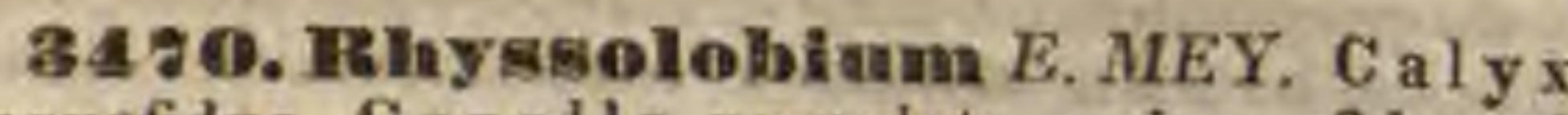
quinquefidas. Co r oll a ureeolata, quinquefida, ad faucem pilosa. C oron a staminea summo filamentorum tubo inserta, brevissime quinquesinuata, carnosa. An $t$ he ra e appendicemembranacea terminatae. Pollinia apiee affixa? pendula. Stigm a depressum. Folliculi breves, turgidi, corticosi, demum rugoso-suleati, Se min a plurima, marginata, ad umbilicum comosa. - Fruticulus c a p ensis, spithameus, ramosissimus, rigilus, pubescenti-canus; foliis superioribus oppositis, in ferio ribus fasciculatis, crassiusculis, margine revolutis, obtusis, subsessilibus, floribus axillaribus pacis, bre vissime pedunculatis, minimis.

Rhyssolobium E. Meyer Comment. plant. Afrie, austr, 217.

\section{§. 5. CALOTROPIDEAE. Corona staminea} simplex pentaphylla. Corolla subcampanulala.

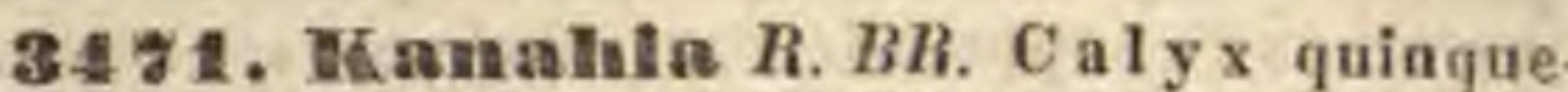
fidus, Cor oll a campanulata, limbo quinquepartito. Colum na genitalium semiinclusa. Corona staminea summo tuho filanentorum imposita, pentaphylla, foliolis e basi incrassata subulatis, indivisis. Antherac appendice membranacea terminatae. Pollinia ventricosa, apice affixa, pendula. Stigma mntieum. Follieuli graciles, striati. Semina plurima, ad umbilicum comosa. - Frulex arabicus, erectus; foliis oppositis, planis, lanceolato-ellipticis, acutis, pedunculis interpetiolaribus, apice fasciculatim multifloris, pedicellis imbrioalis, basi unibracteatis.

$\mathrm{K}$ a a h ia R. Brown in Mem. Wernor soc. I. 39. As cle pias Ianiflora Vahl Symb. 1, t, 7, Calliand Meros $t, 64$.

349\%. Isaglhistemma $W A L L, C$ aly quinquefidus. Co rolla campanulata, limbo quinquepartito. Col a mn a genitalium exserta. Corvn a staminea pentaphylla, foliolis elongatis, compressis. Anthera e appendice membranacea terminatae. Pollinia sub apice affixa, pendula. Stigma obtuse conicnm. Folliculi saepius solitarii, subventricosi. Semina plnrima, ad umbilieum comosa. - Frutex indicus, volubilis, glaber; foliis opposilis, majusculis, cordatis, floribus corymbosis, albidis.

R a phiste m ma Wallich Plant. As, rar. II. 50, t. 163. Wight et Aruott Contribut. 54.

34\%. Seuterpa REICHENB. C a I y $x$ quinquepartitus. Corolla campanulata, quinquepartita. Corona staminea pentaphylla, foliolis planis, obtusis. Antherae appendice membranacea terminatac. Pollin i a apice affixa, pendula. St ig u a conicum, bifidum. Folliculi laeves. Semin a plurima, ad umbilieum comosa. - Herba boreali-americana, littoralis, volubilis; foliis oppositis, sessilibus, linearibus, subcarnosis, margine revolutis, umbellis interpetiolaribus, paucifloris.

Seutera Reicheabach Consp, n. 3438. L yo ni a Eliott Carolin. I. 316, non Nutt. C ex op egia palustris Pursh.

3484. Sonminir REICHENB C a ly quinquepartitns. C o ro 11 a tubo brevi, urceolato, limbo quinquepartito. Corona staminea pentaphylla, foliolis obtnsis, squamula interiore auctis. Antherae appendice nembranacea terminatac. Pollinia ventricosa, juxta apicem affixa, pendula, Stigma rostro elongato, indiviso. Fulliculi..... - Planta chilensis, volubilis, ramosa, glaberrima; foliis oppusitis, oblongo-lanceolatis, margine revolutis, subtus pallidis, corymbis paucifloris, foliis subbrevioribus, floribus majusculis, corollae laciniis acuminatis, supra pubescentibus.

Sonninia Reichenbach Conspect. 151. Diplotepis R. Browu in Mem. Merner. sac, $I$, 42. Hook. et Aruott Journ, of Bot. 1. 290. non Zoolog.

34) quepartitus. Co roll a tabo brevi, ventricoso, limbi quinquepartiti laciniis ligulatis. Corona sta- 
minea pentaphylla, foliolis subrotundis, obtusis $\mathrm{v}$. truncatis, carnosis, intus simplicibus. Antherae appendice membranacea terminatae. Pollinia linearia, processuum demum adscendentium curvaturae affixa, pendula. Stigma acumine elongato, bipartito. F olli euli oblongi, compressiusculi, laeves. Semin a plurima, ad umbilicum comosa. - Suffrutices Americae tropicae volubiles, $v$. herbae erectae; folits oppositis, floribus interpetiolaribus, solitariis $v$, corymbosis, suaveolentibus.

0 x y petalum R. Brown in Mem. Werner, soo. $I$. 41. Kuath in Humb. et Bonpl. Nov. gen. sp. III. 197. $t .231$. Martias et Zuecarini Nov, gen, et op, 1, 47, $4,29,30.60-$ thofred a Vent. Choix 36. t, 60.

34 6. Sellatstogy me HOOK, et $A R N$. C a ly $\mathrm{x}$ quinquepartitas. Curolla rotato-campanulata, limbi quinquepartiti laciniis elongato-acuminatis. Corona staminea pentaphylla, foliolis oblongis, obtusis, membranaceis, intus simplicibus. Pollinia ventricosa, ovata, infra apicem affixa, pendala. S $t$ i g m a subseptempartitum, laciniis subulato-filiformibns. Folliculi $\ldots \ldots \ldots$ - Fru. ticulus Brasiliae australis, volubilis, glaber; foliis oppositis, ovato-oblongis, acutis, basi subcordatis, corymbis interpetiolaribus, umbellatis, pedunculo foliis breviore.

Schistogy ue Hooker et Araott Journ. of Bot. 1. 292.

348\%. Playsinuthus MART. et ZDCCAR. Cal y $x$ quinquepartitus. Co roll a campanulata, tubo basi ventricoso-inflato, limbo quinquefido, connivente. Coron a staminea pentaphylla, foliolis tubo stamineo insertis, dorso corollae adnatis, sursum liberis, cucullatis. Antherae appendice membranacea terminatae. Pollinia compressoclavata, processubus deflexis affixa, pendula. Stig-

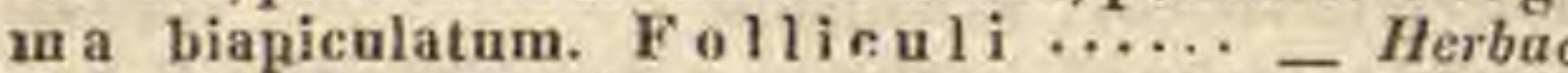
Americae tropicae volubiles; folits oppositis, pedunculis interpetiolaribus, cymosis.

Physianthus Martius et Zuccarini Nov. gen, et sp. I. 50. t. 32. Bot. Mag. t. 3201. Bot. Reg. t. 1759. - $\mathrm{A} \mathrm{r}$ a u$\mathrm{f}$ a Brotero in Linn, Transact. XII. 68, $t, 4.5$. cui ex auctore: „folliculi patentes, subovales, coriaceo-fungosi, placeunta maltilamellata et semina plurima, ad umbilicum comow5a" juxta descriptionem distiugui nequit.

34 8. Calotropis $R$. BR. Cal y $x$ quinquepartitus. Coroll a subcampanulata, tubo angulato, angulis intus saceatis, limbo quinquepartito. Corona staminea pentaphylla, foliolis carinaeformibus, tubo filamentorum longitudinaliter adnatis, basi recurva. Ant herae appendice membranacea terminatae. Pollin i a compressa, apice attenuato affixa, pendula. St $\mathrm{ig}$ ma muticum. Folliculi ventricosi, laeves. Semina plurima, ad umbilicum comosa. - Frutices in India orientali et Persia indigeni, erecti, glabri; foliis oppositis, latis, umbellis interpetiolaribus, floribus speciosis.

Calotropis R. Browa in Mem, Werner, soc, $I, 39$. Fr. Hamilt, in Linn. Transact. XIV. 248. Wight et Arnott Contribut. 53. As clepias ig ante a Ait. Andrews Bot, Heposit. $t, 271$. Bot. Reg, $t, 28$.

\$. 6. EUASCLEPIEAE. Corona staminea simplex, pentaplyylla. Corolla subrotata.

3485. Fentatropis $R$. BR. C a I y x quinquepartitus. Cor olla rotata, quinquefida. Corona staminea pentaphylla, foliolis antheris oppositis, tulso stamineo verticaliter adnatis, aversis, apice solutis, Anthera e appendice mem- branacea terminatae. Pollin i a rentricosa, infra apicem affixa, pendula. $\mathbf{S}$ ti $g$ m a muticum. F o lliculi laeves, obsolete trigoni, hine planiusculi. Semina plurima, ad nmbilicum comosa. Suffrutices volubiles, in $A$ sia et $A f r i c a$ tropica indigeni; foliis oppositis, subcarnosis, planis, umbellis interpetiolaribus.

Pentatropls R. Browa in Salt Abysin, LXIV. Wight et Arnott Contribut. 52. Asclepias microphylia Roxb.

3480. Tribista $W I G H T$ et $A R N$. C a ly 8 quinquepartitus. Corolla rotata, quinquefida. Coron a staminea pentaphylla, foliolis carnosis, apise abruptim angustatis. An $t$ h era appendice membranacea terminatae. Pollinia ventricosa apice inserta, e processum adscendentium, filiforminm apicibus penduls. Stig ma muticum. Folli e u $1 i$ rostrati, laeves. Semina plurima, ad unbilicam comosa. - Herbae $v$. suffrutices I $n$ diae orientalis, erecti v. volubiles; foliis oppositis, umbellis interpetialaribus, simplicibus, aggregatis $v$, ad flexuras pedunculi subsessilibus.

Ip his ia Wight et Arnott Contribut. 52.

3481. Oxystelana $R$. BR. Calyx quinquepartitus. Corolla subrotata, quinquefida. Corona staminea pentaphylla, foliolis acutis, integris. Antherate appendice membranacea terminatae, Pollin ia compressa, apice attenuato affixa, pendula, Stigma muticum. Follieuli laeves. Semin a plurima, ad nmbilicum comosa. Suffrutices Indiae orientalis, volubiles, glabri; foliis oppositis, racemis $v$. umbellis interpetiolaribus.

Oxystelma R. Brown in Mem. Werner, soc. I. 40. Prodr. 462. Wight et Aruott Contribut, 54, Periploca esculenta Lina. Roxbargh Plant. Corom, $t$. 11.

348\%. Braclinglepils HOOK et $A R N$. C aI y $x$ quinquepartitus. C o ro 11 a rotata, quinquefilla. C o r o n a staminea pentaphylla, foliolis brevissimis, obtusis, integris. An the $\mathrm{r}$ a e appendice membranacea terminatae. Polli $n$ ia clavatucylindracea, apice affixa, pendula. Stigm a elongatum, subfiliformé, apiee bifidum. Folliculi …. - Frutex peruanus, subvalubilis, pubescens; foliis oppositis, membranaceis, cordatis, pedunculis axillaribus, corymbosis.

B rac hylep is Hooker et Arnott Journ. of Bot. 290 .

3483. Enslemia NUTT. C alyx quinquepartitus. Corolla subrotata, quinquepartita. Corona staminea pentaphylla, foliolis planis, bifidis, laciniis acnminatis. Antherae appendice membranacea terminatae. Pollinia cylindrica, infra apicem attennatum aflixa, pendula. Stigm a conieum, snbbilamellatum. Folliculi cylindrici, laeves. Semin a plurima, ad umbilicum comosa. - Herba boreali-americana, volubilis; foliis oppositis, cordato-ovatis, acuminatis, corymbis axillaribus, multifloris.

Enslen la Nuttall Gen, amer. T. 165, $\Lambda$ m pelanus Rafinesque in Amer. Monthl. Mag. 1819.

3484. Gomplno earpins R. BR. Caly $x$ quinquefidus. Corolla quinquepartita, reflexa. Co rona staminea pentaphylla, foliosis eucullatis, intus simplicibus, basi plerumque utrinque nnidentatis. Anther a e appendice membranacea terminatae. Pollinia compressa, apice attenuato affixa, pendula. Stigma depressum, muticum. Folliculi abortu plerumque solitarif, ventricasi, spinis innocuis echinati. Sem in a plurima, ad umbilicum comosa. - Frutices b. suffrutices 
capenses, erecti; foliis oppositis, margine saepius revolutis, umbellis interpetiolaribus, multifioris.

Gomphocarpas R. Browa in Mem. Wernor, soo. I, 38. Bot. Mag. $t$. 1628. Reielienb. Magaz, $t$. 28. A s clepiadis s p. Lima. Jaeq. Hort. Schönbr. t. 50, Vahl Symbol, $I, t, 8$.

3485. Hagarintlaus $E, M E Y$. C a lyx quinquefidus. Corol I a quinquepartita, subrotata, ad margines undulata. Corona staminea pentaphylla, foliolis encullatis, intus simplicibus. A n the $r$ a e appendice membranacea terminatae. PolI in ia compressa, apice attennato affixa, pendula. Stigma depressum, muticum. Follicali abortu plerumque solitarii, graciles, laeves, basi turgidali, rostrati. S e m in a plnrima, ad umbilicum comosa. - Herbae v. suffrutices capenses, erecti $v$, adscendentes, graciles; foliis oppositis, angustis, margine saepe revolutis, umbellis interpetiolaribus, multifloris.

Lagrinthus E. Meyer Comment. plant. Afr. austr. 202.

3486. Pacliyearpus $E$ MEY. CaIy x quinquefidus, Coroll a quinquefida patens, v, rarius quinquepartita reflexa. Coron a staminea pentaphylla, foliolis eucullatis, intus simplieibus. Antherae appendice membranacea terminatae. Po 1 I i n i a obclavata, apice compresso affixa, pendula. Stigma depressum, muticum. Follicali abortu solitarii, ventricosi v. turgidi, septemeostati, parietibus spongioso - incrassatis, laevibus? Se min a plurima, ad nmbilicum comosa. - Herbae capenses, basi suffrutescentes; foliis latioribus, duriusculis, floribus nonnunquam maximis, maculatis $v$. subluridis.

Pach y carpus E. Meyer Comment. plant. Afr. austr. 909. X y 5 malobium grandifloram R, Br.

348\%. Xysmabobiume $R$. BR. Caly x quinquepartitus. Cor o $1 /$ a quinquefida, laciniis intus dense papilloso-barbatis, Corona staminea simplici serie decempartita, laciniis quinque antheris oppositis carnosis, subrotundis, intus simplieibus, totidem alternis, nanis. Anthera e appendice membranacea terminatae. Pollin ia compressa, apice affixa, pendula. Stigma muticum. Folliculi abortu solitarii, ventricosi, ramentis plumosis tecti. Semina plurima, ad umbilicum comosa. - Frutices capens es, erecti; foliis oppositis, umbellis interpetiolaribus, majusculis.

Xysmalobium R. Brown in Mem. Werner, soc, 1 . 39. excl. sp. R. Meyer Comment. plant. Lfr. austr. 215. Ascle piadis $8 \mathrm{p}$. Linn. Thumb. Commelyn Ic, rar. $t .16$.

34.88. A eerntes ELLIOTT. Caly $\mathrm{x}$ quinquepartitus, C o r o I I a quinquepartita, reflexa. Corona staminea pentaphylla, foliolis brevissimis, concavis, integris. Antherae appendice membranacea terminatae. Pollini a compressa, apice attenuato affixa, pendula. Sti g ma muticum. Folli euli cylindrici, laeves. $\mathrm{S}$ emin a plarima, ad umbilienm comosa. - Herba borea $l i$ am erican $a$, erecta $v$. decumbens, pubescens; folits alternis, lineari-lanceolatis, scssilibus, umbellis interpetiolaribus, erectis.

Acerates Elliott Flor, Carolin. 1, 316, Ascleplas Iong ifolia Miclix.

3489. Peilostigma ELLIOTT. C a ly $\mathrm{x}$ quinquepartitus. Co r olla subrotata, quinqueparita. Cor on a staminea pentaphylla, foliolis carinaeformibus, inflexis, apice intus septo versus basim deliquescente bilocellatis. Anthera appen- dice membranacea terminatae. Pollin ia apice Innge attenuata, pendula. Stigm a mutieam. Folli $c$ u $1 \mathrm{i}$ cylindrici, laeves. S e m in a plurima, ad umbilicum comosa. - Herbae boreali-americanae, erectae; foliis oppositis, umbellis terminalibus et interpetiolaribus.

Podostig ma Elliott Flor. Carolin. I. 326. Sty 1. andra Nattall Gen. dmer. I. 170-? A a a $\mathrm{t}$ th rix Nuttall Op. cit. I. 169 ,

3490. Aselepias $L I N N$. Calyx quinquepartitus. Corolla quinquepartita, reflexa. Corona staminea pentaphylla, foliolis cuenllatis, e fundo processum corniformem aversum exserentibus. Antherae appendice membranacea terminatae. Pollinia compressa, apice attenuato af fixa, pendula. Stig ma depressum, mutieum. Follieuli laeves. Semina plarima, ad umbilicum comosa, - Herbae boreali-americanae et tropicae; foliis oppositis, alternis verticillatisve, umbellis interpetiolaribus $v$, rarissime lerminalibus.

Ascle pias Linn. gen. n. 303, exel. sp. R. Browa in Mem. Werner, soc. I. 37. (Jacg. Observ. I. 1. 33. Ic. rar. t. 345. Hort. Vindob. $t$. 107. Jaeq. f. Eolog. $t$. 28. Cavanill. Ic, t. 57, 58, Bot. Mag. t. 1181, 1189. Bot. Reg. t, 76. 81. 2s0. Kuath in Humb. ot Bonpl. Nov. gen. et sp. IIT. 289. 1. 227. Turpín Atl, III. $t, 58.59$.

3491. Dtaria $K U N T H . C$ a ly $x$ quinquepartitus. Corolla quinquepartita, reflexa. Co rona staminea pentaphylla, foliolis cucullatis, e fundo processum cornifurmem aversum exserentibus, basi interiore bianrieulatis. Antherae appendice membranacea terminatae. Pollinia compressa, apice attennato affixa, pendula. Stigma depressum, muticum. Folliculi .... - Herba mexicana, erecta; ramis tomentoso-pubescentibus, foliis opposilis, oblongis, acutis, glabris, umbellis interpetiolaribus, multifloris.

Otaria Kunth in Humb. et Bonpl. Nov, gen. et sp. IIT. 191. in not. Asclepias auriculata Kunth Op. cit, $t, 228$.

349\%. Fentarrininum $E$. MEY. C aly $\mathrm{x}$ quinquepartitus. Corolla quinquepartita, reflexa, Corona staminea pentaphylla, foliolis subeuneatis, truncatis, complicatis, processum aversum, rostratum exserentibus. Antherae appendice membranacea terminatae. Pollin ia oblongo-teretia, apice obtuso affixa, pendula. Stigma depressum, muticum. Folli c u $1 \mathrm{i}$ abortu solitarii, turgidi, spinis innocuis, uneinatis echinati. Semina plarima, ad umbilicum comosa - Suf frutex eapensis, volubilis, glaber; foliis opposiis, cordatis, acuminatis, umbellis axillaribus, pedunculatis, alternis.

Pentarrhinum E. Meyer Comment, plant, Afric. austr. 200.

3493. Aspidoglossam E. MEY. CaI y $x$ quinquepartitus. Corolla quinquepartita, subrotata. Coron a staminea pentaphylla, foliolis e lata basi attennato-subulatis, duplicatis, seu processn conformi adverso auctis. Anth e rae appendice membranacea terminatae. Pollin ia compressa, apice attenuato affixa, pendula. Stigma depressum, muticum. Folli e uli ...... - Herbae c apenses, crectae, angustifoliat ; pedunculis axillaribus alternis, fasciculatis, nutantibus.

Aspldoglossum E. Meyer Comment. plant. Afric. austr. 200.

THE HUS. H. GONOLOBEAE. PoIli$\mathrm{n}$ is massae transversae, extremitate exteriori affixae, sub stigmate occultatae. _ Americae 
borealis et tropicae, nec non Capitis bonae spei indigenae.

3454. Dregen $B$. MEY, Caly x quinquepartitus. Corolila tubo urceolato, limbo rotato, quinquepartito. Cor on a staminea quinquepartita, laciniis ovalibus, obtusissimis. Antherae appendice membranacea terminatae, transversim dehiscentes. Po 1 I i n i a transversa, extremitate exteriori affixa. Stigma conicum, subbilobum. Folliculi divaricati, pyramidales, laeves, tetrapteri, alis superne angustatis. S e m in a plurima, ad nmbilicum comosa. - Suffrutex capensis, volubilis; foliis opposilis, petiolatis, ovatis, obtusis, glabris, umbellis axillaribus, oppositis, pedunculatis, multifloris, floribus minutis, pallide badiis.

Dregca E. Meyer Comment, plant, Afr. austr. 199.

3495. Nomollobus $L, C, R I C H$. Calyx quinquepartitus. Coroll a subrotata, quinquepartita. Coron a staminea scutelliformis, lobata. A nthe ra e appendice membranacea terminatae, transversim dehiscentes. Pollinia transversa, extremitate exteriori affixa. St $i_{g m a}$ depresso-planius culum. Folliculi patentes, ventricosi, subcostati. Semin a plurima, ad umbilicum comosa. Suffrutices volubiles, in America boreali et tropica crescentes; foliis oppositis, latiusculis, umbellis interpetiolaribus.

Gonolobus L. C. Riehard in Michaux Flor, bor. Amer. I. 119. R. Brown in Mem. Trerner. soc. 1. 35. Kunth in Humb. et Bonpl. Nov, gen. el sp. IIT, 207, t. 238, 209. Barton Flor. Bor. Amer. t. 99. Bot. Mag. t. 2799. Bot. Reg, $t$. 252, 93t, 1053. 1126. Gon ol oblum Pursh. Flor. Amer, septembr. I. 179. C y na ne hi s p. Linn. Jacr. Amer. t. 54_60. Cavanill, Te. t. 7. 21, 159, 310. Bot. Mag. t. 1273. Andrews Bot. Reposil, t. B15.

34D6. Datelea $A U B L, C$ aly $\mathrm{x}$ quinquepartitus. Corolla rotata, quinquepartita. Cor on a staminea scutelliformis, lobata. A $\mathrm{n}$ the $\mathrm{r}$ a e appendice membranacea terminatae, transversim dehiscen. tes. Pollin ia transversa, extremitate exteriori affixa. Stig m a depresso-planinsenlum. Folli $\mathrm{e}$ uli ventricosi, costati. Se min a plurima, calva. _ Frutex guianensis, erectus; foliis oppositis, basi supra biglandulosis, floribus lateralibus, racemosis.

Matele a Aublet Guian. I. 278. t. 109. R. Brown in Mem. Werner. societ, I. 36. Hos te a Willdenow Spec. I. 1274.

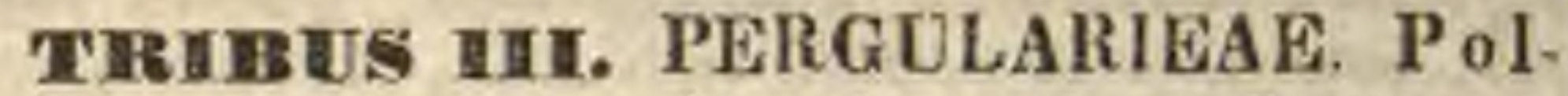
lin ia erecta $v$. conniventia, stigmati incumbentia, basi v. infra medium latere affixa. In reyionibus tropicis sublropicisque veteris orbis copiosae, in America rarissimae.

SUBTREUST. HOYEAE. An therae appendice membranacea terminatae.

\section{§. 1. SARCOLOBEAE. Corona staminea nulla.}

349\%. Sareolobus $R$. BR. Cal y $\mathrm{x}$ quinquepartitus. Corolla subrotata, quinquelida, fauce nuda, Coron a staminea nulla. Antherae appendice membranacea terminatac. Pollinia basi affixa, ereeta. Stigma muticum. Follienli abortu subsolitarii, ventricosi, earnosi v. coriacei. Semina plurima, marginata, umbilico nudo. - Frutices indici, volubiles, glabri; foliti oppositis, latiusculis, coriaceo-carnosis, floribus interpeliolaribus, umbellatis v, corymbosis.

$\mathrm{S}$ arcolobas R. Brown in Mem. Werner. soc. 1. 35. Wallich in Asiat, Hesearch. XII. 367. t. 4. 5. Wight et Aruott Contribut. d7.

3498. Gymanema $R$. BR. Calyx quin quepartitus. Corolla suburceolata, quinquefida, fauce squamulis $v$. denticulis quinque sinubus insertis coronata, rarius nuda. Corona staminea nulla. Anthera e appendice membranacea terminatae. Pollinia basi affixa, ereeta, Stigma muticum. Folliculi graciles, laeves. Semina plurima, marginata, ad umbilieum comosa. Frutices v, suffrutices indici, sacpius volubiles; foliis oppositis, membranaceis, planis, umbellis interpetiolaribus, cymaeformibus.

G ym nema R. Browa in ILom. Werner, soc. I. 33 . Wight ef Aruott Contribut. 44.

a. EUGYMNEMA. Coroll a e tubas iatas pilosus, fauce denticulis $v$. squanalis 5 decurreatibus coronata. Asclepias laetifera Linn. Periploea sylvest $\mathrm{r}$ is Willd. Phytogr. . 5. f. 3.

b. BIDARA. Corolla o faux lineis 5 pilosis decarrentibus. - Asclepias tingens Roxburgh Plant. Co. rom, $t, 239$.

c. GONGRONEMA Corolla ventricosa , fauce edentula, tubo intus nado. Fil is me ta saepius tuberculo carnoso ad basim instrueta. Pollin i a cosmpressa, spathulata. Flores laxe coryubosi v. umbellati. $-G$ y m-

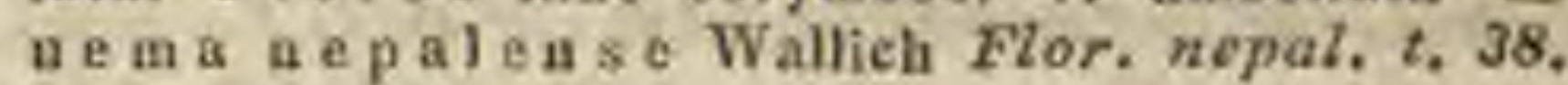

\section{\$.2. TYLOPHOREAE. Corona staminea pen- taphylla.}

3495. Belostemma $W A L L$. C a 1 y $x$ quinquepartitus. C o r olla rotata, quinquefida. C oron a staminea pentaphylla, foliolis lineari-oblongis, carnosis, tubi stauinei medio verticaliter affxis, aversis, patentibus. Antherae appendice membranacea terminatae. Pollin ia globosa, subadscendentia, $\mathbf{v}$, transversim sub stigmatis margine dilatato sita, Stigma muticum. Folliculi ... - Suffrutex nepalensis, volubilis, laxe pubescens; foliis opposilis, cordalo-ovatis, subcecuminatis, umbellis simplicibus, paucifloris, folio brevioribus, floribus purvis.

Belostem a Wallich ex Might el Arnout Contribat. 58 .

3500. Tylopladra $R$. BR. Caly $x$ quinquepartitus, Cor olla rotata, quinquefida. Co r ona staminea pentaphylla, foliolis depressis, carnosis, angulo interiore simplici, edentulo. Anthera e appendice membranacea terminatae. Pollinia basi affixa, erecta, marginibus simplicibus. Stigna muticum. Fulliculi laeves. Semina plurima, ad umbilicum comosa. - Herbae v. suffrutices volubiles, in Asia, Africa et NovaHollandia tropica crescentes; foliis oppositis, membranaceis, umbellis interpetiolaribus, floribus saepius minutis.

Tylophora R. Browa in Mem. Werner soc. 1.28. Colebt, in Linn. Transact, XII, $t, 16$.

3501. Elloya $R, B R$. C a I y x quinquepartitus. Corolla rotata, quinquefida. Corona staminea pentaphylla, foliolis depressis, carnosis, angulo interiore in dentem antherae incumbentem producto. An th era e appendice membranacea terminatae. Pollini a basi affixa, conniventia, compressa. Stigma muticum v. subapiculatum. Fo 1liculi laeves. Semina plurima, ad umbilieum comosa. - Suffrutices in Asia et Nova-Hollandia tropica indigeni, volubiles $v$. decumbentes, 
saepe radicantes; foliis oppositis, earnosis v. membranaceis, umbellis interpetiolaribus, multifloris.

H o y a R. Brown in Mem. Forner. soc. 1 , 26. Prodr. 459. Wight et Aruott Contribut, 35. S chollia Jacq. fil. Eclog. 2. Sperling ia Vaht in ect. soc. Hafn, VI. 112. Asclepiadis sp. Linu.

a. HOYAE VERAE. Coroua stamineae foliola subtus suleata. - Caulos volubiles v. decumbentes, folia carnosa. (Bot. Mag. t, 788. Bot. Reg. t. 951. Wallich PIant, As, rar. t. 75. Jacq. fil. Eclog. t, 2.)

b. WATTAHAKA. Corona stamineate follola subtus exsulca. - Caulis volubitis, folia membranacea. (Wight in Hook. Miscell. Suppl. $t$. 1. As elepias volubi. Iis Linn.)

3502. Fterostelluna WIGHT. C a l y $\mathrm{x}$ quinquepartitus. Co rolla rotata, quinquefida. Corona staminea pentaphylla, foliolis membranaceis, lateribus reflexis, conniventibus, angulo interiore in dentem subulatum, erectum producto. Antherae appendice membranacea terminatae. Pollinia dorso corpuseuli basi inserta, approximata, erecta. Stig ma apieulatum. Folliculi ...... Frutex indicus, volubilis an decumbens? foliis oppositis, oblongis, acuminatis, carnosis, floribus majusculis, corollae laciniis lineari lanceolatis, tubo piloso, coronae foliolis latiusculis, marginibus arcte reflexis Papilionis sedentis alas simulantibus.

P terostel ma Wight Contribut, 39.

3503. Plhysostelman WIGHT. Calyx quinquepartitus. Co ro 11 a rotata, patens, repande quinquedentata. C or on a staminea pentaphylla, foliolis inflatis, antheris oppositis. Fil a m e n t a bipartita, cruribns vicinis diversorum staminum in filamenta antheris alterna, corpusculis stigmatis opposita connatis. Ant herae appendice membranacea terminatae. Pollin ia subcylindracea, basi affixa, erecta, Stigma depressum. Folliculi ...... - Frutex indicus, volubilis; foliis oppositis, ovato-lanceolatis, acuminatis, carnosis, glabris, umbellis interpetiolaribus, longiuscule pedunculatis, paucifloris, floribus magnis.

P hy sostelma Wight Contribut. 39.

3504. Tenaris $E, M E Y$. Calyx quinquepartitus. Co ro II a subrotata, quinquepartita, laciniis anguste spathulatis. Corona staminea quinquepartita, laciniis ovatis, apice bidentatis. Antherae appendice membranacea terminatae. Pollinia basi affixa, erecta. Stigma ....... Folliculi graciles, laeves, erecti. Semina plurima, ad umbilicum comosa. - Herba capensis; radice tuberosa, caule subsimplici, virgato, caerulescente, foliis oppositis, angustissime linearibus, planis, cymis terminalibus, parvis.

T enaris E. Meyer Comment. plant. Afr, austr. 198.

35ด5. Heterostemma WIGHTet ARN. C a ly $\mathrm{x}$ quinquepartitus. Coroll a rotata, quinquepartita. Corona staminea pentaphylla, foliolis dilatatis, intus processu auctis. Antherae appendice membranacea terminatae. Pollinia erecta, obsolete tetragona, margine hine pellucido. Stigma ..... Folliculi laeves, Semina plarima, ad umbilicum comosa. - Frutices in dici, volubiles; foliis oppositis, supra versus basim glandula minuta instructis, umbellis parvis, interpetiolaribus, breve pedunculatis.

Heterostemma Wight et Arnott Contribest, de.

3508. Cosmestigna WIGHT. Calyx quinquefidus. C o r o 11 a rotata, quinquepartita, Coron a staminea pentaphylla, foliolis compressis, bifidis. $\mathbf{A} \mathrm{t}$ h e ra e ventricosae, appendice membrana- cea terminatae. Po 1 i i n a ereeta, appendiculo stigmatis longo, pendulo basi affixa. Stig m a mutienm, ala angusta, flexuosa, repanda coronatum. F o $11 \mathrm{i} e \mathrm{c}$ Ii magni, oblongo-lineares, obtusi, laeves. Sem in a plurima, ad umbilicum comosa. - Frutices $i n$ dici, volubiles; foliis oppositis, membranaceis, corymbis saepius geminatis, longe pedunculatis, floribus parvis.

Cosmostigma Wight Contribut, 41. Asclepias racemosa Roxb.

35ด8. Mnessulenia $R, B R$. Caly $x$ quin quepartitus. Co roll a urceolata, quinquefida, nune subrotata. Corona staminea pentaphylla, foliolis compressis, indivisis, intus simplicibus. Anth e $\mathrm{r}$ a e appendice membranacea terminatae. Stigma inuticum v. rostratum. Pollinia basi affixa, erecta. Folli enli laeves. Sem ina plurima, ad umbilicum comosa. - Suffrutices volubiles $v$, rarius erecti, in India orientali et Nova-Hollan$d i a$, rarius in $A m$ eriea meridion ali crescentes; folits oppositis, latiusculis, planis, cymis v. thyrsis interpetiolaribus.

M a r s de in a R. Browa in Mem, Worner. soc, I. 29. Prodr. 460.

a, MARSDENIAF VRRAE R. Browa l. c, $\mathrm{S}$ tig m a mati cum. (Rudge in Linn, Transact. $X, t, 21, f$. 21. Guil. lemin Ic. lithograph, $t$, 9. Bot. Reg. t. 489. Bot. Mag. t. 3289.)

b. NEPHRANDRA R. Brown $l$. c. Stigm a rostratum. C y a n $\mathrm{chum}$ ere t $\mathrm{um}$ Linn. Jaeq. Hort. Vindob. t. 38 , a. cl. Brown huc relatum, eodem moneate verisi. militer sut generis. - M. t en a c is sima Wight es Arn. Contribut. 4t. quae As clepias te nacis $\mathrm{s}$ ima Roxburgh Plant. Corom, $t$. 240. coronae stamineae foliolis latis, apice truncatis, subiategris v. bifurcatis diversa videtur. M. C alesiana Wight $l$. $c$. coronac stamineae foliolis profunde bifilis, lobo uno lougiore antherae facumbente, altero hreviore versus basim carinaeformi diversissima. An M. cla us a R. Browa reversa congener?

3508. Disellaidia $R$. $B R$. Calyx quin quepartitus. Cor oll a urceolata, quinquefida. Corona staminea pentaphylla, foliolis bifidis, lobis patentibus, apice recurvis. An th e ra e appendice membranacea terminatae. Pollin i a basi affixa, erecta. Stigma mutieum. Folliculi laeves. Semin a plurima, ad nmbilicum comosa. - Herbae in Asia et Australasia tropica indigenae, in arboribus parasiticae; caule ad genicula inferiora radicante, foliis oppositis, crassis, carnosis, interdum in ascidia conversis, floribus parvis, subumbellatis.

Dis chidia R. Brown in Mem. Merner. sac, $I$, 32. Prodr. 461. Colebr, in Linn. Transaet, XIT. L. 15. Wallich Plant. As. rar. II. 35. t. 142. Hooker in Bot. Mag. t. 2914. Decalsue in Nouv. Annal.Mus, III. 377. 1. 17. Wight et Ar. nott Contribut, 43, Coly ris Vabl in Aet, soc. h, n. Hafn. VI. 111. - C onchophyllum Blume Bifdr. 1060. Num. mularia lactea Rumph Amboin. $V$. 470 . $t$. 176. $f$. 1 . Pustula arborum Rumph $l$. c. $t, 175 . f .3$.

3503. 耳eptostemma BLUM. Calyx quinquedentatus. Corolla tubulosa, fauce constricta, nuda sive squamulis v. fasciculis villorum clausa, limbo semiquinquefido. Coron a staminea pentaphylla, foliolis cordatis v. sagittatis, indivisis. Antherae appendice membranacea terminatae. Pollinia basi affixa, erecta, Stigma mnticum. Folli euli laeves. Semina plurima, ad umbilicum comosa. - Herbae javanicae, in arboribus radicantes; foliis oppositis $v$, verticillatis, carnosis, floribus umbellatis.

Le p tost e m a a Blume Bijdr. 1057. 
3510. Steplnanotis THOUARS, Calyx quinquepartitus, Coroll a hypocraterimorpha, fauce nuda, limbo quinquepartito. Co ro n a staminea pentaphylla, foliolis ovatis v. lanceolatis, indivisis. Antherae appendice membranacea terminatae. Pollinia basi affica, erecta. Stigma conicum, acutam. Folliculi laeves. Semina plurima, ad umbilicum comosa. - Frutices madagascarienses, volubiles; folits oppositis, coriaceis, laevissimis, floribus ternatis v, umbellatis, pedunculis interpetiolaribus.

Ste phanotis Thouars Gen. madagasc. n. 35. Brongniart in Nouv, Annal. se, nat, VII, 30. Delessert Ic. seZect. III. $t .89$. 83. Is a a a Commers. ex Poiret Suppl. ITI, 188 .

3511. Pergularia LINN. Calyx quinquepartitus. Coroll a hypocraterimorpha, tubo ureeolato, fauce hirsuta, limbo quinquefido. $\mathrm{Cu}$ rona staminea pentaphylla, foliolis compressis, apice indivisis, intus lacinula auctis. Antherae appendice membranacea terminatae. Pollinia basi affixa, erecta. Stigma muticum. Folliculi ventricosi, laeves. S e min a plurima, ad umbilicum comosa. - Herbae volubiles, incertae originis, in India et Chin a ob flores suaveolentes cultae; foliis oppositis, membranaceis, latiusculis, cymis interpetiolaribus, floribus flavescentibus.

Pergularia Liun, gen, n, 1253. exel. sp. R. Brown in Mem. Werner, soc. I. 31. Smith Ic. piot. t. 16. Andrews Bot. Reposit. 2, 185. Bot. Mag. t. 755. Bot. Reg. t. 412 .

351 2. Baxtera REICHENB, C a y x quin quepartitus. Coroll a urceolata, fanee nuda, limbo quinquefido, erecto. Corona staminea pentaphylla, foliolis carnosis, intus dente auctis. An ther a e appendice membranacea terminatae. Pollini a basi affixa, erecta. Stigma ...... Follieuli..... - Frutex brasiliensis, erectus, non satis notus; foliis oppositis, cordato-ellipticis, coriaceis, umbella terminali, floribus rubicundis.

B axtera Reichenb. consp. n. 345t. Harrisonia Hook, in Bot. Mag. t. 2699. non alioe.

SUBTTERE IIS. STAPELIEAE. Anthe rae apice simplices.

\section{§. 1. LEPTADENIEAE. Corona staminea nulla.}

3513. Drthanthera WIGHT. Calyx quinquepartitus. Coroll a urceolata, tubo subventricoso, fauce nuda, limbo quinquefido, aestivatione valvato. Coron a staminea nulla. Anther a liberae, erectae, apice simplices, acutae. Pollinia hasi affixa, erecta, apice coarctato, pellucido. Stigma apiculatum. Folli e ul i ..... - Frutex hindostanieus, aplyllus, tomento impalpabili teclus; umbellis breve pedunculatis, paueifloris. 2. 66 .

Orthanthera Wight Contribut. 48. Royle Himalay.

3514. Heptadenia $R . B R$. C a ly $\mathrm{x}$ quinquepartitus, Coroll a subrotata, quinquefida, tubo brevi, fance squaruis quinque, eum limbi quinquefidi laeiniis aestivatione valvatis alternantibus coronata. C orona staminea nulla, Antherae liberae, erectae, apice simplices, acutae. Pollinia basi affixa, erecta, apice coarctato, pellucido. Stigma muticum v. rariug apiculatum. Folli- culi laeves. Semina plurima, ad umbilicum comosa. - Frutices volubiles, in Ind ia o rien tali et in Africa tropica et boreali indigeni, tomento cinereo impalpabili pulverei; folits opposi. tis, planis, umbellis interpetiolaribus, interdum cymosis.

Leptadenta R. Brown in Mem, Werner. soc, I, 34 . Wight et Arnott Contribut. 47.

\section{§. 2. CEROPEGIEAE. Tubus stamineus ex- us appendiculatus.}

3515. Fiselneria $D C$. C a $\mathrm{y} \times$ quinquepartitus. Corolla rotata, quinquepartita, lobis undulato - crispis. Co I u m na genitalium exserta. Cor on a staminea gamophylla, carnosa, truncata, basi annulo nectarifero cincta. Anth era e apice simplici, uncinato, intus replicato. Pollin i a medio lateri inserta, stigmati incumbentia. Stigma mutienu. Follie uli $2 \ldots .$. - Frutex seandens, incertae originis et dubiae affinitatis; ramis tenellis foliisque oppositis, pube tenuissima molliter velutinis, floribus e flavo virescentibus.

Fischeria DC. Catalog. Hort. Monsp. 18ss. p. 112. Römer et Sehultes Syst. VI, so.

3516. Nilerestemma $R, B R$. Calyx quinquepartitus. Coroll a rotata, quinquepartita, Col u m n a genitalium exserta. Cor on a staminea quinqueloba, lobis carnosis, cum antheris alternantibus. Anther a apice simplices. Pollinia medio lateri inserta, stigmati incumbentia. Stigma muticum. Folliculi graciles, laeves. Semina plurima, ad umbilicum comosa. - Herba Novae-Hollandiae tropicae, erecta, glabra; radice tuberosa, caule inferne simplici, folits minutis, superne ramoso, foliis oppositis, linearibus, umbellis lateralibus et terminalibus subsessilibus, corollis nigro-purpureis, intus barbatis.

Microstem ma R. Browa in Mem. Werner. sac. I. 25. Prodr. 459.

351\%. Brachystelma $R$. $B R$. Calyx quinquepartitus. C o rolla campannlata, quinquefida, ampla, sinubus angulatis. Colum na genitalium inclusa. Co ron a staminea quinquefida, Iobis antheris oppositis, simplicibus. An th era e apice simplices. Pollinia basi affixa, erecta. Stigma mulicum. Folliculi graciles, laeves. Semina plurima, ad umbilicum comosa, - Suffrutices capenses; radice tuberosa, foliis oppositis, membranaceis, pedunculis axillaribus aggregatis.

B rachy s t el ma R. Browa in Bot. $3 a_{B}$, 4. 2345. 3016. Bot. Reg. $t$. 728, 1113. E. Meyer Comment. plant. Afr. austr. 195.

3518. Sisyranthus $E$. MEY, C al y $\mathrm{x}$ quinquepartitus. C o roll a eampanulata, quinquefida, sinubus angulatis. Col $\mathrm{n}$ m a genitalium inclnsa. C o r o n a staminea quinquefida, Iaciniis ovatis, intus sub apice apiculatis, apiculo verrucaeformi. Antherae apice simplices. Pollinia basi affixa, erecta. Stigma depressum. Follic uli graciles, laeves. S emina....$-H e r b a$ capensis, glaberrima; caule simpliciusculo, gracili, virgato, foliis oppositis, angustissime linearibus, carinatis, strictis, ima basi semiamplexicaulibus, umbellis axillaribus pedunculatis, paucifloris, corollae extus rugulosae, flavescenti-viridis fauce subcontracta, limbi laciniis erectis, intus strigillosobarbatis, barbis in tubum decurrentibus.

Sisyranthus E. Meyer Comment. plant, Afric, austr. 192. 
3519. Ceropegia LINN. C alyx quinquepartitus. Cor olla e basi ventricosa infundibuliformis, limbi quinquefidi laciniis ligulatis, apice cohaerentibns. Colu m na genitalium inclusa. Coron a staminea quinque-quinilecimloba, lobis unibiseriatis, interioribus antheris oppositis, ligulatis. Antherae apice simplices. Pollinia basi affixa, erecta. Stigma muticum. Follienli cylindracei, laeves. S em in a piurima, ad umbilieum comosa. - Herbae v. suffrutices Indiae orientalis, voIubiles; radice tuberosa, foliis opposilis, umbellis interpetiolaribus, pauci-multifloris.

C e ropegia Linn. gen. n. 299. R. Browa in Mem, Werner, soc, I. 21. Roxburgh Plant. Corom. t. 7-to. Wallich Plant, As. rar. $t, 73.193$. 187. Bot. Mag., 3015. 3267. 3330, 3301. Bot. Reg, t. 626. 1706. Link et Otto Ie. rar. t. 18. Wight in Hool, Bol, Misc, Append, t. 2. Contribut. 30. Royle Hinalay, 2. 66.

35:0. Eriopetalum WIGHT. Caly $\mathrm{x}$ quinqueparlitus. Co rolla subcampanulata, quinquefida, laciniis anguste linearibus, sinu lato. Columna genitalium vix exserta. Coron a staminea quindecimloba, lobis quinque interioribus antheris oppositis et incumbentibus, exterioribus decem per paria approximatis, interiorum dorso adhaerentibus, Antherac apice simplices. 1'ollinia juxta luasim affixa, erecta, stigmati incumbentia, margine hinc pellucido. Stigm a muticum, Follicu. ii graciles, laeves. Sem in a plurima, ad umbilicum comosa, - Herbae indic a e, ereclae, subramosae; caulibus teretibus, foliis minutis, squamae. formibus, adpressis, floribus parvis, umbellatis, umbellis lateralibus v. terminalibus, sessilibus, corollae laciniis tubo longioribus, inlus sacpius dense villosis v. lanalis.

Erio p ctalum Wight Contribut. 35.

3521. EBuecrosia HIGHT et ARN. C aly $x$ quinquepartitus. Corolla subcampanulata, quinquefida, laciniis late triangularibus, sinu acuto. Col um na genitalium subinclusa. Cor un a staminea quindecimloba, lobis quinque interioribus antheris oppositis et incumbentibus, exterioribus decem per paria approximatis, erectis $\mathrm{v}$, apice sub. incurvis, interiorum dorso adhaerentibus. Ant herae apice simplices. Pollinia erecta, tetragona, margine pellucido. Stigma muticum. Folliculi lacves, teretes, rostrati. S e min a plnrima, ad umbilicum eomosa. - Planlae indic a e, carnosae, aphyllae, erectae, tetragonae; angulis dentalis, foribus plurimis, terminalibus, umbellatis.

Bucerosia Wight et Arnott Contribut. 3d. Stapelia umbellata Roxburgh Plant, Corom, t, 2it. Ca$\mathrm{rall}$ u ma creaulata Wallich Plant, As, rar, $t, 7$.

352. Hiluteloina WIGHT et ARN. Ca1 yx quinquepartitus. Corolla subcampanulata, quinquefida. Colamna genitaliam subinclusa. Corona staminea vigintiloba, laciniis biseriatis. interioribus quinque antheris oppositis et incumbentibus, exterioribus alternis, ternatim approximatis, lateralibus intermedio majoribus, Ant hera e apice simplices. Pollinia basi affixa, erecta, margine hinc pellueide. Stig ma ...... Folliculi.... - Plantae in dicae, carnosae, aphyllac, erectae, tetragonae, ramosae; angulis dentatis, floribus terminalibus plurimis, subumbellatis, corolla intus pilosa.

Hutehinfa Wight et Aruott Contribut. 34.

3533. Caralluma $R, B R$. Caly $x$ quinquepartitus. Corolla rotata, profunde quinquefida. Col u mna genitalium exserta, $C_{0}$ ron a staminea simplici serie decemloba, lobis quinque an- theris oppositis carnosis, iisdem incumbentibus, alternis ligulatis, bipartitis. An the ra e apiee simplices. Pollinia basi affixa, erecta, tetragona, margine hine pellucido. Stig ma mutieum Folliculi graciles, laeves. Semina plurima, ad umbilieum comosa. - Herbae indicac, carnosae, aphyllac; caulibus crectis, tetragonis, secus angulos denlatis, pedunculis e dentium summorum axillis solitariis, unifloris.

Caralluma R. Brown in Mem. Terner. soc. $I$, 25 . Wallich Plant. As. rar. $t$. 8. Wight et Arnott Contribut. 33. Stapelia adscendeas Roxburgh Plant. Corom, $4,30$.

35z4. Stapelia $L I N N$. Cal yx quinquepartitus. Corolla rotata, quinquefida, carnosa. Col a m n a genitalium exserta. Co r o na staminea duplex, exterioris foliolis v, laciniis integris v. partitis, interioris corniculiformibus, simplicibns v. bifidis, Antherae apice simplices. Pallinia basi affixa, erecta, margine hine cartilagineo pellacido. S ti g ma muticum. Folliculi subcylindracei, laeves. S emin a plurima, ad umbilieum comosa. - Plantae capenses, aphyllac, carnosae, angulatae, saepissime tuberculatae, floribus ut plurimum speciosis, sed odore nauseoso, stercorario.

Stapelia R. Browa in Mrem. Werner. soc. 1. 23. St a peliae sp. Linn. Massau, Stapeliae novad. Londini, 1796. fol. Jaequia, Stapeliae cullae. Vindob. 1806. 4.

a. STAPELTONia. Corou a stamiaea exterior quinquepartita, lacialis indivisis, interioris corniculis sinplicibus v. bipartitis. Sta pelf a Haworth Synops. suceul. 15. (Masson Stapel. t. 11-13, 17-19. 39. Jaeq. Stapel. t. 47-39. Bot. Mag. t. 536. 585, 1240, 1890. Bot. Reg. t. 756.

b. GONOSTEMON Haworth $o_{p}, \mathrm{cil}, 27$. Corona staminea exterior pentapbylla, foliolis ligulaeformibus, interioris corniculis siaplicibus uacinatis. - Jaeq. Op. cit. t. 20-23. Wendl. Collect, t. 51. Bot. Mag. t, 1002, 2037.

c. PODANTUES Haworth $O p$, cil. 32 . C oron a staminea exterior quinquepartita, laciniis emarginatis, interioris coraiculis brevissimis, simplicibus, infractis. - Masson Op. cit. t, 8. 9. 34, 36. Jacq. Op. cit. t. 18, 19. Bot. Mag. t. 786.

d. TRIDENTEA Haworth $O p$. cit, 34. Corona stamina exterior quinquepartita, laciuiis tridentiformibus, interioris corniculis bifidis, ramulo interiore longiore. Masson Op. cit. $\ell$. 15. 16. Jacq. Op. cit. 24_28. Bot. Mag. t. 1234. 1839.

e. Tromotriche Haworth $O p$. cit. 36 . C o r o n a staminea exterior quinçepartita, laciniis horizontalibas, emar. ginatis v. serratis, intevioris cornieulls bifidis, ramulo interiore lougiore elavato, - Masson $O_{p}$, cit. $t, 1$. Jateq. Op. cit. $t$. $44-46$.

f. Caruncularia Haworth $O p$. cit. 334 . Corona staminea exterior pentaphylla, foliolis patulis, emarginatis, interioris corniculis bifidis, torosis, clavatis; cArunculatis. - Masson $O p$, cit. $t, 21.37$, Jacq. Op. cit. t. $60-63$, Bot. Mag. $t$. 793 .

g. ORBEA Haworth Op. cit. 37. C or o n a staminea exterlor pentaphylla, foliolis patalis, bi-\{ridentatis, interiorls corniculis bifidis, ramo interiore longiore, clavato. Masson Op. cit. t.38. Jacq. Op. cit. $t \cdot 29$ - 43. Bot. Mag. 1169. 1676. 1833. Bot. Reg, $t$, 755.

h. OBESIA Haworth $O p$. cit. 42. Corona staminea exterior gamophylla seutiformis, interioris corniculi bifidI, ramo exteriore patulo, interiore ia stigma incumbente, - Masson Op, cit. t. 38. Jacq. Op, cit. t, 2943. Bot. Mag. t. 26. 1196. 1676. 1833. Bot, Reg. t. 75s.

i. DUVALIA Haworth $O_{p}$. cit, 44 . Corolla Iaciniae replieatae, faux in orbieulum solidum elevata. Corona staminea exterior gamophylla, scutiformis, iuterior corniculis siaplicibas, stigmati iacumbentibus. - Mas. son Op. cit. $t$. 29. Jacq. Op. cít. t. $10-15$. Bot. Mag. e. 1184,1397 .

PECTINARIA Haworth suppl. (Masson Op, cil, t. 30.) et HOODIA Sweet Hort. brit. 395. (Masson Op. eit. $t$, 40.) quo eharaetere distinguantur, neseio. 
DESMIDORCHIS Elireub. in Linnaea. IV. 94 . quae Stapelia qua ufaugula Forsk. utrieulis poltinis fusciculatis, meabraua inclusis insigue geaus, descriptum noudum est.

3525. Apteramthes MIK. Caly x quinquepartitus. Cor o 11 a rotata, quinquefida. Co $\mathrm{la} \mathrm{m}$ n a genitaliun exserta, Co ron a staminea simplex, quinqueloba, lobis subtriangularibus planis, sub truncatis, stigmati incumbentibns. Antherae apice simplices. Pollinia basi affixa, erecta, margine hine earlilagineo-pellneido. Stigm a muti eum, Follie uli ......-Herba Stapeliae habitu, in insula Lampedusa noslris diebus a Gussoneo detecta; floribus umbellatis, parvis, inodoris.

A pteranthes Mikan in N.A.N.C. XVIT. 594. t. $4 x$.

35\%6. Piaranthoss $R$. BR. C aly x quinquepartitus. Co rolla campanulata, quinquefida, carnosa. Colu m na genitalium inclusa. Co ro na staminea simplex, pentaphylla, foliolis dorso dentatis. An th erae apice simplices. Pollinia basi affixa, erecta, margine hine cartilagineo-pellacido. Stigma muticum. Folliculi.... Herbae capenses, Stapeliarum habitu, a quibus corona staminea simplici diversae.

Piaranthus R. Brown in Mem, Werner, soc, $T$. 23. St a peliae sp. Masson Stapel. $t$. 23. 24, 31. 32. 35. Bot. Mlag. t. $16 \mathrm{is.}$

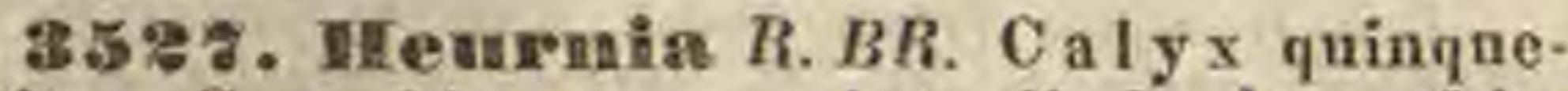
partitus. Coroll a campanulata, limbo decemfido, lacinis alternis nanis, dentiformibus. Col u m n a genitalium inclusa. Co rona staminea duplex, exterior quinquefida, laciniis bifidis, interior pentaphylla, foliolis e basi gibbosa subulatis, indivisis, laciniis exterioribus alternantibus. Antherae apice simplices. Pollinia basi affixa, erecta, margine hinc cartilagineo pellucido. Stigma muticum. Folliculi cylindracei, laeves. Semina plurima, ad umbilicum comosa. - Herbae c a penses, Stapeliarum habitu.

Heuruia R. Brown in Mem. Werner. soc. 1,23 , S ta.

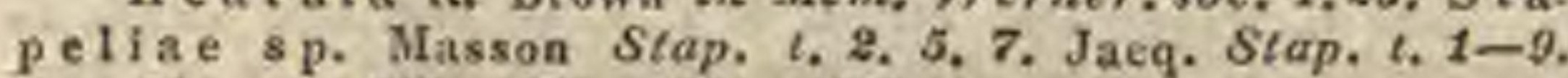
Bot, Mag. $i, 506,1227.1661,1662$.

\section{Orda CXXXIE: Gentianeae.}

GENTIANEAE Jussieu gen. 111. R. Brown Prodr. 440. Martits Nov, sen. et sp. MI. 132. Bartling Ord, nat, 199. Grieseback, Observations quaedam de Gentianearum familiae characteribus. Berolini, 1836, 8. GENTIANACEAE Lindley Introduct, edit, 1 I. p. 296.

Herbae annuae $\nabla$. perennes, rarius suffrutescentes, rarissime frutices, interdum volubiles, ut plurimum glabrae, rarissime pube, interdum glandulosa v. viscidula conspersae, caule ramisque teretibus, compressis v. interdum tetragonis, succo in omnibus aqueo.

Folia opposita v. interdum verticillata, rarissime alterna, radicalia saepius congesta, omnia simplicia, integerrima (in Menyanthearum subordine ternata, saepius dentata), plerumque nervosa, sessilia $v$. in petiolum attenuata. Stipulae nullae.

Fuones hermaphroditi, regulares, rarissime irregulares, terminales v. axillares, solitarii v. fasciculati, nunc corymbosi, racemosi v. cymosi.

Cal y $\mathrm{x}$ liber, persistens, e foliolis quatuor v. quinque, rarius sex-octo, liberis v. plus mi- nus connatis compositus, foliolis aestivatione valvatis v. contortis, planis $\mathbf{v}$. carinatis, angulatusv, interdum alatus, rarissime foliolorum suturis in alas productis.

Corolla hypogyna, decidaa v. marcescenti persistens, nunc supra capsulam contorta, petalis numero foliolorum calycis iisque alternis composita, gamopetala, infundibulilormis v, hypocraterimorpha, fauce nuda v. annulo subtilissino, fimbriato instructa, laciniis basi nudis $\mathrm{v}$. foveolis glanduliferis, solitariis v. geminis, nudis, ciliatis v. squamula propria tectis, rarius in calcar fundo glanduliferum productis, rarissime extus glandula instructis, aestivatione dextrorsum contortis $\mathbf{v}$. in subordine Menyanthearum induplicativis.

Stamixa corollae tubo v. fauci inserta, ejusdem lobis numero aequalia et alterna, exserta v. inclusa. Filamenta plerisque filiformia, libera, aequalia v. subinaequalia, rarissime basi dilatata et in annulum connata, interdum basi dilatata et distincta, utrinque in dentem producta.

Antherae introrsae, biloculares, forma variae, erectac v. incumbentes, cornectivo brevi v. loculos superante, apice poro genuino v. rimulis brevibus, saepius juxta totam longi. tudinem dehiscentes, post anthesim immutatae v. spiraliter convolutae aut involutae.

Ovariva e carpidiis duobus conflatum, carpidiorum marginibus valvatim connatis $v$. parum introflexis uniloculare, nunc isdem intus Iongius productis semibiloculare, v. intus discretis pseudo-quadriloculare, v. placentam centralem attingentibus complete biloculare. Placentae suturales solitariae v. geminae, plus minus distinctae, nunc carpidiorum parietibus adnatae, rarius centrales solitariae, maturitate saepius solutae. O vula plurima, pluriseriata, horizontalia, anatropa.

S t y I u s terminalis, ovario continuus, nune brevissimus $v$. nullus. Stig m a bilidum v. bilamellatum, rarius indivisum, rarissime per suturas decurrens.

Capsula unilocularis v, plus minus complete bilocularis, bivalvis, valvis margine placentiferis, v. placentis demum solutis liberis, rarissime epicarpio carnoso subindeliscens $v$. maceratione tandem apertum.

Semina plurima, rarissime subdefinita, minima, globosa v. angulata; test a areolata, nunc compressa, margine membranaceo cincta.

Albumen carnosum copiosum, nunc cavum seminis explens nunc minus.

Eurryo in basi albuminis orthotropirs, minimus, Cotyledones subdiscretae v. co- 
haerentes. Radicula umbilico proxima, in plerisyue centrifuga.

Gentianeae ab Apocyneis arcte affinibus habitu, fructus structura et succo aqueo optime distinctae, per totum terrarum orbem diffusae, et e nullo climate omnino exules, in hemisphaerae borealis montibus et alpibus, in subtropicis hemisphaerae australis, et in regionibus Americae aequinoctialis situ supra mare elato temperatioribus maximo numero gignuntur. Omnes et nonnullae insigniter amarae, magni in medicina usus. In recensendis generibus, paucis exceptis cl. Grieseba $\mathrm{ch}$, cujus monographia ordinis a botanicis expectatur, secutus sum.

SUEBTREO 耳. GENTIANEAE VERAE. Corollae laciniae aestivatione dextrorsum contortae. Albumen cavum seminis explens.

Tremed . CHIRONIEAE. Capsula unilocularis v. plus minus complete bilocularis, placentis suturalibus.

35\%8. Gentiama LINN. Calyx quadridecemfidus v. partitus, rarissime dimidiato-spa thateus. Corulla hypogyna, infundibuliformis, campanulata v. rotata, fauce nuda v. barbato-fim briata, limbo quadri-quinquefido, rarius decemfido, laciniis alternis nanis. S $\mathrm{ta}$ m in a $4 \mathrm{v}$. 5 , corollae tubo inserta; fil amenta basi aequalia, a n the rae erectae, immutatae, longitudinaliter dehiscentes. Ovarium uniloculare. Ovnla juxta sutaras plurima. Stylas brevissimus v. nullus; stig ma bipartitum, obtusum. Capsula unilocularis, bivalvis. S emina plurima, minima, compressa, saepius margine membranaceo eineta. Herbae perennes, habitu vario, in Europa et Asia imprimis a lpestri magna formarum copia obviae, in America boreali et in summis Andium jugis rarae, in regionibus antarctic is rarissimae.

GENTIANA Liun. gen, $n, 319$ excl, pl, Gürtn. II. 149, $t, 115$. Prölich, Dissert. de Centiana, Erlangae, 1796. 8. Bunge in Mom, soc. h. n. Mosq. VIT, 209. Griesebach Observat. 14. Asterias, Eurythalea, Ericala, Thylacites, Cyauea, Dasysteptiaus, Tetrorbiza Renealm. sp. Asterias, Coilantha, Dasystephana, Ciminalis, Erieoila, Eurythalia. Geatiana et Ge a fia nelia Borklansen in Römer Archiv. $I, 25$. P в e umonanthe. Hippion, Gentiana et Chirouia parItin Sehmidt Flor, bohem. II. 18-35.

A. ASTERIAS Renealm. C or o 11 a rotata, fance nuda. As ter 1 a s Renealm, $t .63$. Barkhausen in Römer $A r c h$. t. 25. Bunge in Hem. soc, h, n. Mosq. VIT. 209. (G. Intea L. Mill. Ic, $t, 139$. G. liybrida DC.) - ? H e $\mathrm{a}^{-}$ rice a Lemalre-Liseacourt in Bullet, soe. Philomat. 182d. p. 121. G. Chirayta Roxb. ex Flemming in Asiat. Research, $X I, 167$. Wallieh Plant. As, rar, 2, 132.

b. Coklantua Frölich $O p$. cit. 15. Cor olla campanulata, fauce nuda. - Coelantha Bunge Op. oit. 210. - Colla a tha Borkt. Op. eit. $t$, 8s. G. purpurea L. For, dan. 4 . So. Aadrews Bot. Reposit, t, 117, - G. biloba DC, Ic. plant. Gall. rar. t. 13. - P n e umouanthe Borkh. $l$. e, G. pannonica Scop. Jacq. Flor, austr, , $136,-\mathrm{D}$ a s y s t ep h a na Benealm. $t, 68$. Borkh. Op, cit, 1, 27, G, puistata L, Jacq. Flor, austr. App. $t, 28$. G. campaunlata Jaeq, $l, c, t, 29, \mathrm{G}$. Gebleri Bunge $O$ p. cit. t. \&. $f$, $t$, G. decumbens L. G. adseenleis Pallas Flor. Hoss, II. 8, 9k. Bot. Mag. t, 705. 793, G. daurica Fiselier in Mem. soc. h, n. Mosq. III. 6. 12 . G. algida Pallas- $O_{p}$. cil. $I T, t, 95, \mathrm{G}$. frigida
Hänk. Frölich Gent. t. 1. G. Romanzowif Bunge Op. cit, t. 11. $f$. 1. G. gelida Bieberst. G. septemfida Pallas $O p$ cit. $I$. $t$. 92. G. triflora Pallas Op. cit. IT. t. 93, f. 1 . G. angustifolia Michx. - Cutte ra Rafiesque in $N$. Fork Medic. Reposit. $\boldsymbol{I}$. Hex. $V$. 350. G. Saponaria L. Bot. Mag. t. 1039. G, ochroleuca Frölich Bot. Mag. t. 1551 .

c. PNEUMONANTHE Bang. Corolla infundibuliformis, fauce nuda. - Pneusu an the Bunge Op. cit, 220 . - Das yeeptala Borkh. Z. c. G. asclepiadea L. Jacg. Flor, austr. $t$, 328, Bot. Mag. $t$. 1078. - C im in a 11 s Borkh. Op. eit. $I$. 26. T b y la eites Renealm. $t .68$. G. Pueunonauthe L. Ft. dar, t. 269. Bot. Mag. $t$, 1101. - G. montaua Forst. in $A \mathrm{ct}$. Stokhotm, 1777, $t$. 5. G. saxosa Forst. G. contorta Royle Irimalay, c. 68. f. 3.

d. CrossocephaluM Frölich Op. cit. 109. Co rolla hy. pocraterimorpha, fauce nuda, límbl quadrifidi laclalis ciliatis. - C r o s s o peta 1 u m Koth. Bunge Op. cit. $p$. 299. Urananthe Gaudin Flor. Helvet. Den. cker Rufinesque $l$. c. Gentianella Borkh. $O p$. cit. I. 24. G. ciliata L. Jaeq. El. austr. 113. G. barbata Frö. Bot. Mag. t. 693. Buage Op. cit, t. 9. f. 1 . G. crinita Frăl. Bot. Mağ. t. 2031. Audrews Bot. Fepo. sit. t. 50t, G. detonsa Rotib. G. serrata Gunn. Flor. clan, $t, 317$. G. braeliypetala Bunge $0 p$, cilt, $t, 11, f .3$.

e, ERICALA Renealm. Corolla liypocraterimorpha, fauce auda, limbo quiaquefido. - $\mathrm{C}$ a la $t h \mathrm{i} a$ a a Frölieh Op. cit, 57. Rõm. et Schult. syst. $Y T$, 152. Bunge Op. cil. 226. Erieala Renealm. $t$. 68. Hippion Sehmidt in $R B m$. Archiv. 1. c. C in inalis Borkh. 2. c. G. acaulis L. Jacq. Flor. austr. \&. 136. Ericolla Borkh. l. c. G. alpiaa Villars Delph, t, 10. G. puwila L. Jncq. Fzor, austr. $t$. 302. G. earpathica Waldst. et Kit. G. bavarica L. G. imbricata Frôl. G. prostrata Hănke in Jacq. Collect, II. t. 17. f. 2. G. brachyphylla Vill. G. verua L. E. B. $t$. 493, G. aestiva Sehult. G. angulosa Bieberst. Plant, Ross. t. 47. G. ntriculosa I. Waldst. et Kit, Plant, Hung. $t$, 206. G, nivalis L. Flor. dan. $t, 17$. B. B. $t$, 896 . G. azurea Bunge $O_{p}$, cil. t. 10. $f$. 3 .

f. CHONDROPHYLLUM Bung. Carolla hypocraterimorpha, fauce nuda, limbo subdecemfido. C ho u d ro ph y IIa e Bunge $O p$. cit. 237. Hipplo a Sebmidt $t$. $c$. Fricoila Borkh, . c. c. G. altaica Pallas $O p$, cit. $t, 97$. G. pyreaaica L. Waldst. et Ritaib. Plant, Hung. t. 207. G. uutans Bunge $O p$. cit. $t$. 11. $f$. 2. G. squarrosa Ledeb. Bunge $O_{p}$. cit. t. 9. f. 3, G. humilis Stev. G. aqua. tica L. Bunge Op. cit. t. 9. $f$. 6. G. sedifolia Kunth in Humb. ot Bonpl. Nov. gen, et sp. 6. 325. - ? G. Kur. roo Royle Himalay. $t$. 68. $f$. 2 .

g. ERITHALIA Bung. Co rolla tubulosa, fauce nuda. Erithalia Bunge Op. cit. 237. Hippion Sehmidt 2. c. Tetrorhiza Renealm. t. 73 , Ericoila et Dasystephana Borkh. l. c. G. maerophylla Pallas Op. cil. t. 96. Bot. Mlag. t. 1414. G, crueiata Lims. Jacq. Flor austr. $t$. 378. G. glauca Pallas Op. cit. $t, 93$. C. surea L. Flor, dan, 1. 344, G. quinqueflora Lam. G. nualaceasis Busge. Op. cit. t. 9. $f .2$. G. unbellata Bieberst. G. setillora Bunge $O p$. cit. t. 9. $f$. 4 .

h. ENDOTRICHE Frólich $O p, c i t, 87, \mathrm{C}$ aro 11 a e faux barbata. - Endetriche Bunge Op. cil. 245. Rurythalia et Cyanea Renealm, $t, 68$. Eury $t$ ha lia et Ericoila Borkh. l. c. Hi p pi o n Sehmidt Op. cit. $t$. 2. f. 4. $t$. 3. f. 5-13. G, amarella L. Flor, dan, $t, 328$. G. campestris L. Flor. dan. t. 368. G. auriculata Pallas Op. cil, $t, 92$. G. caucaslea Pallas G. Biebersteinii Bunge Op. cit, $t, 10$. f. 1. G. pratensix FröL. G. uliginosa Willd, G. plebeia Cham. Bunge $O p$, cit, $t, 9, f, 5$. G. glacialis vill. G. borealis Bunge Op. cit. $t$. 9. $f$. 2. G. dichotoma Pallas G. nana Wuif, in Jacq. Miscell. . . t. 18. f. 3. G. aenta Michx, - ? G, coronata Royle Iimalay. t. 68. f. 1.

1. OREOPHYLAX. Corolla infundibuliformis quinque. fida, fauce barbata v. imberbi. - Spocies austra-amerioanae. Kunth in Humb. et Bonpl. Nov. gen, et sp. t. $120-124$.

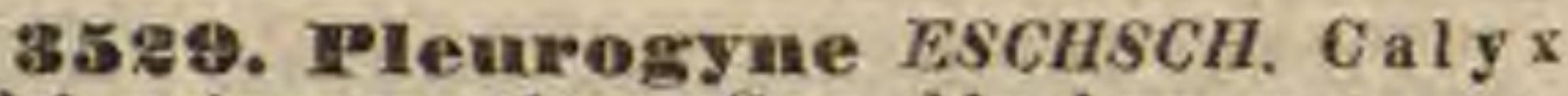
quadri-quinquepartitus. Corolla hypogyna, rotata, quadri-quinquefida, fauce squamoso-fimbriata, laciniis basi egrlandulosis. Stamina $4-50$, corollae fauci inserta; fila me n $t$ a basi aequalia, a therae immutatae. Ovarin m uniloculare. Ovn-
la juxta suturas plurima. Stigm a $\mathrm{ta} 2$, earpidio- 
rum suturis juxta totam longitudinem adnata Capgula unilocularis, bivalvis. S emina plurima, immarginata. - Herbae in Europa et $A s i a$ arctica, nec non in summis Europae mediae alpibus indigenae; caulibus ramosis, foliis oppositis, ovatis v. lanceolatis, obtusis, pedunculis elongutis, nudis.

Pleurogyne Eschseholtz in Linnaea $I$, 157. Griesebach Observ. 31. L o matog o n $\mathrm{i}$ u Alex. Braun in Flora 1830. p. 221. Reichenb. Flor. excurs, 421. G e it ti a un e sect. Troe ha a tha Bunge in Mem. soc. h, n. Mosqu. VII. 253. Swertia cariuthiaca Wulf. in Jacq. Misc. IT. 83. t. 6. S. rotata L. Pallas Flor. ross. II. $t .89$. f. 3 . S. suleata Rottb. (Elor. dan. 3. 343.) Gentianae sp. Frölich.

3530. Swertia $L I N N$, Calyx quinquepartitus. Co rolla hypogyna, rotata, quinquefida, faucis corona nulla, laciniis basi foveolis geminis glanduliferis, margine fimbriatis. Stamina 5 , corollae fauci inserta; fil a m enta basi aequalia, antherae immutatae. Ovarium uniloculare. Ovula justa suturas plurima. Sti $g$ ma terminale, sessile, emarginato-reniforme. Ca psula unilocalaris, bivalvis. Se m in a plurima, compressa, mem branaceo-marginata. - Herbae perennes, in Euro. $p a$ et Asia media, nec non in India boreal $i$ monticolae; foliorum radicalium vaginis alternis, caulinis oppositis.

S we r tia Liaa, gen, $n$, 321. excl, sp. Jaeq. Flor, austr. t. 243. Schkuhr $t$. 58, Gärtner $11.160 . t, 160$. (situ embryonis perperam depicto.) Reichenb, Iconogr, t. 419. Royle Himalay t. 67. Griesebach Observ. 39.

3531. Amagnillidimm GRIESEB, CaI yx quadripartitus. Co rolla hypogyna, rotata, quadrifida, faucis corona tenuissima, fimbriata, laeiniis basi foveolis geminis glanduliferis, squamulis haud fimbriatis tectis. Stamina fauci inserta; fil am enta basi aequalia, an the. rae immutatae. Ovarinm uniloculare. Ovala juxta suturas plurima. St y I u s terminalis, brevis; s tig ma emarginato-bilobum. Capsula unilocularis, bivalvis. Semin a plurima, compressa, marginata. - Herba Asiae mediae, perennis; caule dichotomo, ramosissimo, foliis oppositis, ovatis, obtusis, radicalibus longe petiolatis, caulinis subsessilibus, pedunculis unifloris.

An agallidi um Griesebach Observ, 32. S wertia dichotoma Pallas Flor, Ross. II, t. 9t. f. 3 .

353\%. (Dplaelia DON. C a 1 y x quadriquinquepartitus. Corolla hypogyna, rotata, quadri quinquefida, corona nulla, laciniis basi foveola nula, glandulifera. Stamina 4 v. 5 , corollae fauci inserta; fil am en ta basi dilatata submonadelpha, antherae immutatae. Ovarium uniloculare. Ovula juxta snturas plerima. Stigma terminale, sessile, bilobum. Capsu la unilocularis. Se min a plurima .....-Herbae indicae, erectae, ramosae; foliis oppositis, nervosis.

0 phella Don in Philosoph. Magaz. 1836. VIIT. 77. absq. charact. Griesebach Observ, 31. Swertía paniculat a Wallich Plant, As, rar. $t .205$.

3533. Agathodes $D O N$. C aly x quadripartitus. Coroll a hypogyna, marcescens, rotata, quadrifida, corona nulla, laciniis basi foveola glandulifera, squamula fimbriata tecta. Stamina 4 , corollae fauci inserta; fil amenta basi aequalia, antherae immutatae. Ovarinm uniloculare. Ovala in plaeentis suturalibus spongiosis plurima. Stig m a terminale, sessile, bilobum, C a ps u la subconica, unilocularis, bivalvis. Semina plurima, minima. - Herba indica; caule tetra- gono, foliis oppositis, lineari-lanceolatis, trinerviis, floribus paniculatis.

A g a thodes Griesebach Observ, 32, an Don in Philo. soph. Magaz. 1836. WIIT. 77 ? S wertia angustifolia Wallich Plant. As. rar. $t, 209$.

3534. Wrasera $W A L T$. Calyx quadripartitus. Corolla hypogyna, decidua, rotata, quadrifida, corona nulla, laciniis medio foveola glandulifera, squamula fimbriata tecta. St a mina 4 , corollae fauci inserta; filamenta basi aequalia, an therae immutatae. Ovarium unitoculare. $0 \mathrm{vul}$ a in placentis suturalibus plarima. $S t i g m$ a terminale, bilobum, lobis in suturas subdecurrentibus. Capsal a compressa, unilocularis, bivalvis. Se m in a pauca, compressa, late membranaceo-marginata. - Herba $b$ or e $a l i$ a mericana, biennis; caule orgyali ramisque tctragonis, foliis oppositis verticillatisque, oblongis, pedunculis axillaribus unifloris.

Frasera Walter Carolin. 87. L. C. Riehard in Michaux Flor. Bor. Amer. I.97, Gairtu. f. III. 233. $t$, 224. Nuttall Gen. I, 120. Griesebach Observ. 32.

3535. II allemia BORKH, C a I y quadripartitus. Co rolla hypogyna, zubrotata, quadrifida, corona nulla, laciníis basi in calcar fundo glandulifernm productis, Stamina 4 , corollae fanci inserta; fil am ent a basi aequalia, anthera e immutatae. Ovarinm uniloculare. Ovula in placentis suturalibns plurima. Stig ma terminale, bilobum. C a p 8 a 1 a compressa, uniloenlaris, bivalvis. Sem in a plurima, minima. - Herba sibirica, subramosa; caule tetragono, foliis oppositis, ovato-lanceolatis, trinerviis, pedunculis axillaribus et terminalibus, filiformibus, unifloris, nutantibus.

Ha len i a Borkhausen in Bömer Archiv. I. 25. Griese. bach Observ. 33. S wertla cornlculata Linn. Pallas Flor. ross, $\boldsymbol{I I}, t, 90 . f, 1$.

3538. Châromia $L I N N$, C aly y quinque fidus, laciniis subcarinatis. Corolla hypogyaa, tubo brevi, marcescente, limbi quinquefidi, subeampanulati laciniis deciduis. S tamina 5 , corollae fauci inserta; fil a menta brevia, declinata, anth e rae rectae $\mathbf{v}$, subrecurvatae, apice poro gemino dehiscentes. O vari u in valvularum marginibus introflexis semibiloculare. Ovula juxta introflexos valvularum margines plurima. Stylus terminalis, a staminibus divergens, apiee incurvus; stigma obconicum. Capsula semibilocularis, exocarpio subcarnoso, endocarpio membranaceo incomplete bivalvis. S emina plurima, minima. - Herbae v. suffrutices capenses; ramis alternis, foliis oppositis, lineari-lanceolatis, nervosis, floribus terminalibus, paniculatis.

Ch ir on ia Linn. gen. $n, 255$, Gärtner $I X, 156$. Thü berg in Linn. Transact. VII. 248. excl. Ch. frutescente. E. Meyer Comment, plant, Afr. austr. 177.

a. Hippochiron. C or olla e faux coarctata. C a ps u la oblouga. - Herbae perennes. (Thunb. Op. cit. VII. t. 12. f. 3.)

b. Euchironia. Corolla faux aequalis. Capsula oblonga v. ovata. - Suffrutices. (Lam. t. tos. f. 2, 3 , Thunb. Op. eit. $\overline{V I}, t, 12, f, 2$. Bot, Mag. t, si1.)

c. ROESLINIA Mönch Method. suppl. 211. Corollae faux coarctata. C a psul a subglobosa, vix dehisceas. Suffrntex. - Ch, baeeifera L. Bot. Mag. t. 233. Gärtacr $t, 114$.

$353 \%$. Ploeand ras $E, M E Y$. C al y x quinquefidus, laciniis earinatis. Coroll a hypogyna, tubo brevi, basi incrassato, mareescente, limbi qninquepartiti, subcampanulati laciniis decidais. St a mina 5, corollae tubo inserta; fil a meat a 
declinata, basi complanata, a nthera e contortae, Iongitudinaliter dehiscentes. Ovarium valvularum marginibus introflexis semibiloculare. $\mathrm{O}$ v u la juxta intruflexos valvularnm margines plurima. $S t$ yI us terminalis, a staminibus divergens, apice incurvus; stig ma bilobum, lobis conniventibus. Ca psula oblonga, semibilocularis, bivalvis. Semina plurima, minima. - Herbae capenses, suffrutescentes, inferne simplices, superne paniculatim ramosae; ramis foliisque oppositis, floribus paniculatis. 181.

Plocandra B. Meyer Comment. plant. Afric, austr.

3538. Drpindume $E . M E Y$. C a I yx quinquefidus, laciniis planis. D is c us hypogynus crenatus inter calycem et corollam. C o rolla hypogyna, marcescens, rotata, quinquepartita. Stanin a 5 , corollae tubo inserta; filamenta declinata, basi complanata, antherae contortae, longitudinaliter dehiscentes. Ov a rin m valvularum marginilons introflexis semibiloculare. $\mathrm{O}$ v u a juxta valvularum margines introflexos plurima. Stylus terminalis, a staminibus divergens, apice incurvus; stigma bilobum, lobis conniventibns. $\mathrm{C}$ a p $\mathrm{s}$ l a oblonga, semibilocularis, bivalvis. Sem in a plurima, minima. - Suffrutices capenses; ramis alternis, foliis oppositis, subtomentoso-pubescentibus, floribus paniculatis.

Orphiam E. Meyer Comment. plant. Afr. austr. t. 181. Chironja fsutes cens Linn. Bot, Mag, t. 37.818 . Veat. Cels. t. 3 t.

3539. Exnemm LINN. C a I y x quadrifidus, laciniis planis. Corolla hypogyna, subrotata, quadrifida, marcescens. St a m in a 4, corol lae tubo inserta; fil a menta basi aequalia, antherae apice poro gemino $v$. rimulis brevibus dehiscentes, immutatae. Ovari u valvularum marginibns introflexis biloculare. Ovala in placentis medio dissepimento utrinque adnatis plurima. Stylus terminalis, declinatus; $\mathrm{stigma}$ indivi. sum. Capsula bilocularis, septicido-bivalvis, placentis demnm liberis. Semina plurima, miniuna. - Herbae Asiae tropicae; foliis oppositis, trinerviis, floribus terminalibus et axillaribus.

Ex a e u m Liun. gen, n. 141. exel. sp. R. Brown Prodr. 458. in not. Wallich Plant. As, rar. $t$. 276. Griesebach $O b$ serv, 34.

3540. Woyme $A U B L$. C a I y x quinquefidus. C: rolla hypogyna, hypocraterimorpha, marcessens, tubo basi tumido, demum fisso, limbi quinquefidi laciniis patentibus. Stamin a 5 , summo corollae tubo inserta, inclusa; fil amenta brevissima, anthera e longitudinaliter dehiscentes, immutatae. Ovari a m valvularum marginibus introflexis semibiloculare. Ov u I a juxta valvalarum margines introflexos plurima. Stylus terminalis, filiformis; stigma depresso-capitatum. Capsula semibilocularis, bivalvis. Semina plurima, minima, testa utrinque membranaceo-acuminata scobiformia. - Merbae Americae tropicae, in truncis arborum vetustarum parasiticae; folits oppo. sitis, minutis, squamaeformibus quasi aphyllae, floribus terminalibus, solitariis $v$, paniculatis, calycibus nudis $v$, bracteolatis.

Vo y ra Aublet Guian, 1. 209. Griesebach Observ. 33. $V$ obiria Jussieu gen, 191. Hooker Bot, Miscell. I. A6. L 1 ta Scliveber gen, n, 1734, H u m bolat i a Necker Elem, $n, 630$. i. VOHIR1A. Caly $x$ basi squamulis tribus calyculatur. Capsula valvalis ab apice ad basim dehiscentibus. (Aublet Op, cit, t, 83.) b. LEIPHAIMOS. Ca 1 y $x$ basi nudus. Ca $5 \mathbf{z}$ I a valvulis medio dehiscentibus, apfee unitis fenestrata. L e i pha imos Schlechtead, in Linnaea $V T$. 387. Geutiau a p h ylla Jacq. Amer, t. 60, f. 3. (Hooker Op, cit, t, 25.)

354t. Cleendila ADANS, Calyx subcampanulatus, quadri-quinquedentatus v. partitus. Corolla hypogyna, infundibuliformis, demum supra eapsulam torta, tubo brevi, ventricoso, limbo quadri-quinquefido. S $t$ a m in a $4-5$, corollae tubo inserta; $\mathrm{f} i \mathrm{l}$ amen $\mathrm{t}$ a basi aequalia, a $\mathrm{t}$ herae immutatae, longitudinaliter dehiscentes. $\mathrm{O} v$ a $\mathrm{r}$ i u m uniloculare v. valvularum marginibus introflexis semibiloculare. Ovala in placentis suturalibus plurima. Stylus terminalis, rectus; $8 \mathrm{tig}$ ma capitatum, indivisum. Ca p s u la unilocularis v. semibilocnlaris, bivalvis. Se mina plurima, minima. - Herbae in Europa media el a ustrali indigenae, ramosae; folits oppositis, oblongis, nervosis, $v$. filiformibus, floribus lerminalibus paniculatis, v. axillaribus glomeratis.

Cleendia Adanson Fam, II, 503. Reichenbach Flor. excurs. 420. Griesebach Observ. 34. Ge atiana s p. Lian. Bx a ct 8 p. Smith.

a. MiCRoCALA. FI o res termiuales, tetrameri. Ca p s u i unilocularis.

Mierocala Liak et Hoffmannsegge Flor, Portug. I. 359. Franquevillia Gray brit. Plant, II. 338. Ge ntian a filiformis Linn. Flor. dan, $t, 324$. E x a c u fillfor me Smith. E. B. $t$, 235̆. Hooker Flor. Lond. 86.

b. HIPPOCENTAURBA, Flores terminales, tetramer: Capsu la semibilocalaris.

H i ppocentaurea Schultes Oesterr. Flor, I. 390. Ex a um p us 111 u m DC. Ic. plant. Gall. rar. t. 16. e. SLRVOGTIA. Flores axillares glomerati, pentameri. Ca p a la unilocularis.

Slevogtia Reichenb. consp, n. 3492, Hippion Spreng. Syst. n. 640 . excl. sp. Exacum viscosuu Smith Ic. piot. III. ᄂ. 18 .

3547. Centanuella L.C.RICH. C a I y quadrifidus. Cor oll a hypogyna, subinfundibuliformis, marcescens, tubo brevi, limbo quadripartito. St a min a 4, corollae tubo inserta; fil a m enta basi aequalia, antherae immutatae, longitudinaliter dehiscentes. Ovari um uniloculare, apice attenuato subconicum. $\mathrm{O} \times \mathrm{ula}$ in placentis suturalibus plurima. Stigma sessile, bilobum. C a p s n la uniloeularis, bivalvis. Semina plurima, minima, - Herbae boreali-americanae, annuae; foliis opposilis, subulatis, minimis, floribus terminalibus.

Centa urella L. C. Richard in Michaus Flor. Bor. Amer. 1. 98. t. 12. Pursh Flor. Bor. Amer. I. 100. Nuttall Gen. I. 101. Griesebach Observat. 34. B a rtoni a Muh. leuberg ex Willd. in Berlin. Verhandl, naturf. Er. III. 44d. Bartonia et Centaurium Persoon Encheir. $I$. 137. 142. Andrew s i a Spreagel Syst. $n$. 448.

3543. Wrythraea RENEALM. Calyx tubulosus, carinato-angulatus, quinquefidus. Coroll a hypogyna, infundibuliformis, demum supra eapsulam torta, tubo cylindrico, limbo quinquepartito. St a mina 5, corollae tubo inserta; fil a m enta basi aequalia, a n thera e longitudinaliter dehiscentes, demum spirales. O va rium uniloculare, v. valvularum marginibus introflexis semibiloculare. Ovu la juxta introflexos valvularum margines plurima. Sty la s terminalis, rectus; stigmata 2, subrotunda. Capsula linearis, uniloenlaris ₹. semiloiloeularis, bivalvis. S e min a plurima, minima, - Herbae cosmo politae, simplices $v$. ramosae; foliis oppositis, sessilibus, ftoribus corymbosis o. paniculatis. 
Erythra e Renealm. $S p$. 77, $t$, 76. Borkhausen in Römer Archiv. T. 28. L. C. Blehard in Persoon Ench. I. 283. R. Brown Prodr. 451. G. L. B. Sebmidt Dissert, de Ergthraea, Berolini, 1828. 8, Reicheubach Flor. excurs. 622. Griesebach Observ. 34. Gentianae sp. Linn. Chiron i a e s p. Smith.

a. ERYTHRARA Reichent. 2.c. Corolla persiefaa. St igim a $\mathrm{t}$ late ovata v. rotundata, stylo breviora. C a p s I a unilocularis. - Waldst. et Kitaibel Plant. rar, Hung. t. 258. 275. Link et Hoifmans, Flor. portug. $t$. 67, 68.

E. B. $t$, 417. 458. Sibthorp Flor. graec. 4. 238.

b. XANTHEA Reichenb. 1 . c. Corolla lutea. Stigmata lineari-oblonga, stylo longiora. Capsula semibiloctlaris. (Sibthorp Flor. graec. $t$. 237. Cavanill. Ic. c. 269. $f .1$.)

8544. Canseora $L A M$. C al y $\times$ tubulosus, quadridentatus, Corolla hypogyna, subinfundibuliformis, decidua v. marcescens, limbo bilabiato, labio superiore bilobo, inferiore emarginato. S $\mathbf{t}$ a $\mathrm{mi} \mathbf{n}$ a 4 , corollae tubo v. fauci inserta, superiora saepins castrata, infimum longius; fil amenta inaequalia, antherae immatatae, longitudinaliter dehiscentes. Ov a r i m uni loculare. $0 \mathrm{vula}$ in placentis suturalibus, spongiosis plurima. Stylus terminalis, rectus; $s t i g$ ma bilamellatum. Capsula unilocularis, bivalvis. S e mina plurima, minima. - Herbae indicae, annuae, simplices $v$. diffusae; foliis oppositis, nervosis, floribus subpaniculatis.

Ca a s cora Lamarck Dict. I. 602. Griesebach Observ. 35. Pladera Solander msc. ex Roxburgh Flor. ind. r. 416. Bot. Mag. t. 3066. Wight in Hooker Bot, Miscell. Append. $t$. 25 . H o p e a Willdenow in Berl. Vorhandl. naturf. Fr. III. 43s. Hayne Torm. bot. t. 30. f. 3. Vahl Enumerat. $I$. 3. Gen tiau a e Exaci s p. Lius.

3545. Drethestemen $R$. $B R$. Calyx tubulosus, quadridentatus. Co rolla hypogyna, subinfundibuliformis, limbo brevi guadrifido, marcescens. St a mina 4 , corollae tubo inserta, exserta; filamenta aequalia, antherae strictae, longitudinaliter dehiseentes. Ovari n m uniloculare. Ovula in placentis suturalibus plurima. StyI u $s$ rectus. St ig $\mathrm{m}$ a $\mathrm{t}$ a 2 , subrotunda. C a p $\mathrm{sul}$ a unilocularis, bivalvis. Semin a plurima, minima. - Herbae in Asia et Australasia tropica indigenae, flaccidae, ramosae; foliis oppositis, latius culis, nervosis, floribus terminalibus.

Orthoste in o n R. Brown Prodr. A51.

3546. Sabloatia $A D A N S$. Caly $x$ quinque-duodecimpartitus, laciniis linearibus lanceolatisve. Corolla hypogyna, subrotata, quinqueduodecimpartita, decidua. St a m in a 5-16, corollac tubo inserta; fil amenta aequalia, antherae demum revolutae, longitudinaliter dehiscentes. Ovarium uniloculare. $O \mathrm{vula}$ in placentis suturalibus plurima. Stylus filiformis; s ti $\mathrm{g} \mathrm{ma-}$ ta 2 , linearia, demum spiralia. C a p su la unilocularis, bivalvis. Semina plnrima, minima. Herbae boreali-americanae, annuae $v$. perennes; foliis oppositis, nervosis, floribus terminalibus, corymbasis.

S a b batia Adanson Fam, II, 503. Salisbury Parad. Lond. $t$. 32. Pursh Flor. Bor. Amer. I. 138. Nuttall Gen. I. 134. Griesebach Observ. 35. (C hir on ia e sp. Michaux.)

354\%. Chlores LINN. Calyx sex-oetopartitus, laciniis linearibus. Corolla hypogyna, subhypoeraterimorpha, tubo ventricoso, limbo sex-octofido, deciduo. St a m in a $6-8$, corollae fauci inserta; fil amenta aequalia, a $n$ therae immutatae, longitudinaliter dehiscentes, 0 v a r i u m uniloculare, $\mathrm{O}$ v u la in placentis suturalibus spongiosis plnrima. Sty Ins apice bifidus; $g \mathrm{tigmata}$ oblonga, obtusa. Capsu la nnilocularis, bivalvis. Se m in a plurima, minima. - Herbae annuae, in Europa media et australi indigenae; foliis oppositis, nervosis, sessilibus $v$, connato-perfoliatis, floribus terminalibus, corymbosis v. solitariis.

C h lo r a Linn. gen, n. 1258, Lam, t, 296. Sehknhr $t, 106$. E. B. t. 60 . Gärtn, f, IIT, 110, t. 198. Reichenb. Plant, crit. t. 349_351. Griesebach Observ, 35.

3548. Callopisma $M A R T$, C a ly x campanulatus, quadripartitus, laciniis carinatis. $\mathrm{C}_{0-}$ rolla hypogyna, hypocraterimorpha, marcescens, tubo aequali, cylindrico, limbo quadripartito. St amin a 4, summo corollae tubo inserta; fila m ent a basi aequalia, antherae exsertae, strictae, apice poro duplici dehiscentes. Ovarium uniloculare. Ovula in placentis suturalibus plurima. Stylus filiformis; stigma exsertum, bilobum. Capsula nnilocularis, valvularum marginibus introflexis, intus discretis semiquadrilocularis, bivalvis. Semina plurima. - Herbae brasilien. ses, campestres, subsimplices, glaberrimae; caule stricto, tereti, foliis oppositis, decussatis, sessilibus $v$. perfoliatis, margine pellucido cinctis, subtrinerviis, inflorescentia terminali paniculato-thyrsoidea, pedunculis opposite bracteatis, corollis roseis $v$, albis.

C all op is m a Martius Nov. gen. ot sp. IT, 107. t, 193 . 184. Dejanir a Chamisso et Schlechtend. in Linnaea $I_{6}, 95$. Grlesebach Observ. 35 .

3549. Selnultesia $M A R T$. Calyx tubulosus, quadrifidus, quadrialatus, alis in lacinias subulatas, erectas desinentibus. Corolla hypogyna, infundibuliformis, marcescens, tubo aequali, limbo quadrifido. Stamina 4 , imo corollae tubo inserta, inclusa; filamenta basi aequalia, antherae ereetae, immutatae, longitudinaliter dehiscentes. Ovari n uniloculare. Ovula in placentis suturalibus plurima. St y l n 8 filiformis ; stigma bilamellatum. Caps a la unilocularis, bivalvis. Semina plurima.-Herbae brasilien$s e s$, pratenses, tenerae, glabrae; caule tetragono, simplici v. dichotoma, folits oppositis, decussatis, sessilibus, lanceolatis v. linearibus, floribus tcrminalibus $v$. in dichotomiis alaribus, solitariis, roseis v. flavis.

S chultes ia Martius Nov, gen, et sp. 1T. 103. 6. 180 -182 . Griesebach Observ. 35.

3550. Higianthers $P, B R O W N E, C$ al $y x$ campanulatus, quinquefidus, laciniis erectis, margine membranaceo tenerioribus. Corolla hypogyna, infundibuliformis, marcescens, tubo hins: inaequali v, ventricoso, limbo quinquefido. Stamina 5 , imo corollae tubo inserta, inclusa $v$. limbum aequantia; fil a m en ta basi aequalia, saepissime inaequilonga, an thera e incumbentes, ple rumque apice demum revolntae, longitudinaliter dehiscentes. Ovari um valvularum marginibus introflexis plus minus complete biloculare. 0 v ula in placentis valvularum margines oceupantibus plnrima. Stylus filiformis; stigma bilamellatum. C a p s I a valvularum marginibus placentiferis in troflexis bilocnlaris v. semibilocularis, bivalvis. Semina plurima. - Herbae v. suffrutices Americae tropicae, erecti, glabri; caule tetragono, simplici $v$. superne ramoso, foliis oppositis, decussatis, breve petiolatis $v$, sessilibus, petiolis saepius in vaginam brevissimam commissis, saepe marginatis, tri-quinquenerviis, floribus axillaribus $v$, terminalibus, racemosis, racemis bifidis cum flore alari, v. dichotomis aut paniculatis, corollis purpureis, rubicundis, caeruleis $v$. luteo-viridibus. 
Lis iant has P. Browne Jam, 137, t. 9. Aublet Guian. t. 79_82, Jacq. Ic. rar. ${ }^{t}, 83$. Lam. $t .107$. Ruiz et Pavon Flor. Peruv, t, 122_ 127. Gärta. f. III, 23, t, 183. Martius Nov, gen, et sp. IT. 92, t. 171_178. Bot. Reg. t. 880. Bot. Mag. $t .3626$. Hooker Ic, $t, 195,196$. Griesebach Observ, 36.

3551. Irlbaehia MART. Calyx campanulatus, quinquefidus, laciniis erectis, margine membranaceo tenerioribus. Corolla hypogyna, infundibuliformis, decidua, tubo aequali, limbi quinquefidi laciniis apice utrinque glandulis pedicellatis tomentosis. S $\mathrm{tam}$ in a medio corollae tubo inserta, limbnm aequantia; fil amenta basi acqualia, antherae erectae, apice demum revolutae, longitudinaliter dehiscentes. O vari a m biloculare. Ovala in placentis suturalibus plurima. Stylus filiformis; stig ma bicrne, cruribus cylindricis, Ca p 8 u la biloenlaris, septicido-bivalvis, placentis in valvularum marginibns introflexis geminatis. Sem in a plurima. - Herba brasilien$s$ is, erecta, glabra; caule tetragono, fistuloso, foliis oppositis, decussatis, petiolatis, triplinerviis $v$. quintuplinerviis, floribus in panicula dichotoma alternis, caeruleis.

Iriba ohia Martius Nov. gen, et sp. IT. 101, t. 179. Griesebach Observ. 36 .

3558. Hella MART. Calyx campanulatus, quinquepartitus, laciniis erectis, margine membranaceo tenerioribus. Corolla hypogyna, hypocraterimerpha, marcescens, tubo cylindrico, medio inflato v. inaequali, limbo subobliquo, quinquepartito. St a mina 5 , corollae tubo supra hasi inserta, inelnsa; fil amenta basi subdilatata, antherae ereetae, immutatae, longituilinaliter dehiscentes. Ovarinm biloculare. Ovula in placentis cylindricis, medio dissepimento utrinque adnatis plurima. Stylus filiformis; stig ma bicrure, cruribus cylindricis. Cap $\&$ u la bilocularis, septicido-bivalvis, placentis ad valvalarum margines introflexos ntrinque solitariis. S em in a plurima. - Herbae Americae tropicae, campestres v. paludosae, glaberrimae; caule simplicissimo, tere$t i$, fistuloso, foliis oppositis, decussatis, sessilibus, basi subconnatis, marginatis, nervo medio excurrente, lateralibus evanidis, floribus ochroleucis $v$. virentibus, in panicula terminali, pauciflora coarctatis, bracteatis.

He li a Martins Nov. Ben, et sp. II, 123, t, 191. Griesebach Observ, 36. L is i a n t bi s p. Auct.

3553. Contoubea $A U B L$, Cal y $x$ brac teis calyculiformibus suffultus, campanulatus, quadripartitus. Corolla hypogyna, hypocraterimor pha, tubo eylindrico, aequali, limbo quadripartito, marcescens. St a m in a 4 , corollae tubo supra medium inserta, exserta; filamenta basi dilatata, bidentata, antherae erectae, immntatae, longitudinaliter dehiscentes. Ovari um valvularum marginibas introflexis semibilocnlare. Ovula in placentis valvularum marginibus introflexis adnatis plurima. Stylus filiformis, subdeflexus; stig m a bilamellatum, C a p s u I a bilocularis, septicidobivalvis. Semina plurima, minima. - Herbae $v$ suffrutices $A$ merical tropicae, erecti $v$, rarius volubiles; foliis oppositis, sessilibus, uninerviis, flo. ribus in spicis $v$. racemis terminalibus $v$. lateralibus densis $v$. laxis, tribracteatis, albis.

Co u to ub a Aublet Guian,, , 72, t, 27, 28, Griesebach Observ, 36. C u t u be a Martius Nov. gen. et sp. II, 110. t, 185. Pi crI u m Sebreber gen. n. 1726.

3554. Freprasa $M A R T$. C a l y x laxe campanulatus, coloratus, sexfidus, ad suturas alatus. Corolla hypogyna, tubo brevi, cylindrico, limbo campanulato sexfido, decidua. Di s cus hy. pogynus carnosus, corollae tubo adnatus, per sistens. St a m in a 6 , curollae fauci inserta; filam enta aequalia, antherae erectae, immntatae, longitudinaliter dehiscentes. Ovarium unilocuIare. 0 v 1 a in placentis suturalibas plurima. Stylus filiformis, rectus; $8 \mathrm{tig}$ a bilamellatum. Capsula unilocularis, bivalvis. Semina plorima, minima, - Frutex brasiliensis; ramis erectis, fastigiatis, foliis decussatis, superne congestis, racemis terminalibus foliosis, floribus speciosis, luteis.

Prepusa Martius Nov, gen. et sp. IT, 120. $t, 190$.

3555. Trelhin $A U B L$. C a I y x tubulosus, quinquangnlaris, quinquedentatus, Corolla by pogyna, infundibuliformis, fance ampliata, limbo quinquefido, decidua. St a m in a 5, imo corollae tubo inserta, exserta; filam enta basi aequalia, a ntherae erectae, immutatae, longitudinaliter dehiscentes. Discus hypogynns carnosns, imo corollae tubo adnatus. Ovarin $\mathrm{m}$ valvularum mar ginilus introflexis semibiloculare. $O$ vula in placentis ad introflexos valvularum margines plurima. Stylus filiformis, rectus; stig ma bilamellatum. Ca psula valvularum marginibus introflexis, demum discretis subquadrilocularis. S e mina plurima, minima. - Arbusculae et frutices Americae tropicae; folits oppositis, petiolatis, petiolis basi in vaginam commissis, floribus axillaribus, lateralibus et terminalibus, flavescentibus, majusculis, speciosis.

T a ch i a Aublet Guian. $T$. 15. $t$, 29. Martius Nov, gen, et sp. II, 118, t. 189. Griesebacl, Observ, 33. M y r me ci a Schreber gen. $n, 177$.

\section{*}

3556. Craw furrella $W A L L$. Caly $\mathrm{x}$ tu bulesus, quinquedentatas. Corolla hypogyna, marcescens, tubulosa v. eampanulata, limbo quinquefido, v. decemfido laciniis alternis nanis. Stamina 5 , imo corollae tubo inserta; fil am enta dilatata, an therae erectae. Ovarinm nniloenlare. Ovala in placentis suturalibns plarima. Stylus terminalis, rectus; stigma bifidum, lo bis oblongis, recurvis. Dis cus hypogynus quinquelobus. Ca p s u la stipitata, clavata, compressa, unilocularis, bivalvis. S e m in a plurima, verticalia, imbricata, membranaceo-marginata, hinc biloba. Herbae nep alenses, volubiles, glaberrimae; ramis elongatis, gracillimis, folits oppositis, trinerviis, floribus axillaribus, solitariis v. fasciculatis, magnis, speciosis, dilute caeruleis.

C raw f u r dia Wallich Tent. Flor, Nepal, $I, 63, t, 47$. 48. Griesebach Observ, 33.

TREIBUS 1T. SEBAEEAE. Ca p sula valvularum marginibus introflexis, placentam centralem unicam, demum liberam prehendentibus bilocularis.

355\%. IBelmontia $E$, MEY. C a I y x quinquepartitus, laciniis dorso alatis $\mathbf{v}$. carinatis. Corolla hypogyna, infundibuliformis, tubo subcylindrico, limbo quinquepartito, marcescens. S ta$m$ in a 5 , corollae tubo inserta, inclusa; anthera e apice glandulosae, longitudinaliter dehiscen tes, immutatae. Ovarium valvularum marginibus introflexis, placentam centralem prehendentibus biloculare. Ovula plurima. Stigmata 2, sessilia, clavato-semiteretia, conniventia. Capsula bilocularis, septicido-bivalvis, placenta centrali demum libera, quadripartibili. Semina pla- 
rima, minima. - Herbae capenses, Erythreae facie; foliis oppositis, subcordato-ovatis, floribus subcorymbosis, luteis.

B el montia E. Meyer Comment, plant. Afric, austr. 183. S e baea e s p. R. Browa. Exa c um c ordatam Linn. (Seba Mus. I, t, 22. f. 7.)

3558. Sebaea R. BR. Calyx quadriquinquepartitus, laciniis dorso carinatis. Coroll a hyporyna, iniundibuliformis, tubo cylindrico, limbo quadri-quinquepartito, marcescens. St a $m$ in a 4-5, corollae tubo inserta, exserta; a ntherae apice glandulosae, longitndinaliter dehiscentes, demum recurvatae. $O$ variu $m$ valvularnm marginibus introflexis, placentam centralem prehendenti bas biloculare. Ovula plurima. Stylus filiformis; stigmata 2, subglobosa. Capsula biloeularis, septicido-bivalvis, placenta centrali libera. - Herbae in Capitebonae spei et in No$v a-H o l l a n d i a$ extratropica indigenae; foliis oppositis, sessilibus $v$, decurrentibus, floribus corymbosis, luteis.

Sebae R Solander ex R. Brown Prodr. 451, excl, sp. Griesebach Observ, 37. B. Meyer Comment, plant. Afr. azstr. 182, Ex a ei 8 p. Lín. Lam, $t .80 . f$. 2. Labillard. Nov, Holl, t. 59 .

3559. Lagenias $E$. MFY. C aly x quinquepartitus, laciniis dorso subcarinatis. C orolla hypogyna, tubo subampullaceo, limbo quinquepartito, marcescens. St a min a 5 , corollae tubo inserta, inclusa; antherae hastatae, apice unibasi biglandulosae, immutatae, longitudinaliter dehiscentes. Ovarin $\mathrm{m}$ valvularum marginibus in troflexis, placentam centralem prehendentibus biloculare. Ovula plurima. Sty l us filiformis. Stigma suborbiculatum. Capsula bilocularis, septieido bivalvis, placenta centrali demum libera. S e min a plurima, minima, - Lerba capensis, perpusilla; foliis radicalibus congestis, caulinis op. positis, floribus subcorymbosis.

$\mathrm{Lageu}$ ias E. Meyer Comment, plant. Afr, austr, 186. Sebaea pusilla Ecklon.

3560. Selhibbleria $M A R T$. Cal yx quinquepartitus, laciniis dorso subearinatis. Corolla hypogyna, tubulosa, limbo quinqnefido, decidua. Stamina 5 , imo corollae tubo inserta, inclusa; antherae apice simplices v, apieulatae, immutatae, longitudinaliter dehiscentes. $O \mathrm{v}$ a ri $\mathrm{u} m \mathrm{val}$ vularum marginibus introflexis, placentam centralem prehendentihus biloculare. Ovula plurima. Stylus filiformis; st ig ma capitatum, indivisum. C aps n la bilocularis, septicido-bivalvis, placenta centrali demum libera, bipartibili. Semina plurima, minima. - Herbae brasilienses, annuae; foliis oppositis verticillatisque, sessilibus, floribus laxe paniculatis, roseis $v$. flavis.

$\mathrm{S}$ c hüb Jeria Martius Nov. gen. et sp. IT, 113, t.186188. Curtia Chamisso et Schlechtend. in Linnaea VIIT. 13. Thuratheissera Pohl mase.

3561. Exademus GRIESEB. C a 1 y x quadripartitus. Corolla hypogyna, subrotata, quadrifida, marcescens, laciniis basi extus glandula sessili $v$. pedicellata instructis. Sta m in a 4 , corollae tubo inserta; filamenta aequalia, antherae immutatae, longitudinaliter dehiseentes. 0 ₹ a ri u $m$ valvularum marginibus introflexis, placentam centralem prehendentibus biloculare. $O$ v u1 a plurima. Stigma sessile, bilobum, lobis obtusis. Capsul a bilocularis, apice septicido-bivalvis. Sem in a plurima, minima.-Herbae americanae tropicat, alpicolae; foliis oppositis, lineari- lanceolatis, floribus axillaribus et terminalibus, sessilibus v. paniculato-spicatis, geminis.

Exadeaus Griesebach Observ. 36, Swertia bre vicorais Kuath, et Swertía parviflora Kunth.

\section{GENERA DUBIA.}

3582. Hiniemstemma $B L U M$ Caly tubulosus, inaequaliter quinquefidns. Corolla infundibuliformis, quinquefida, aequalis. St a m ina 5, inclusa; fil amenta dilatato-fornicata. Stylus staminibus brevior; $8 \mathrm{ti} \mathrm{gm}$ a capitatum, subemarginatum. Ca p s u la oblonga, unilocularis, bivalvis, valvis margine utrinque inflexis seminiferis. Semina plurima, serobiculata. - Herba $j a$ va nica, fortassis Cicendiae subgeneri Hippion adscribenda ; foliis oppositis, amplexicaulibus, linearilanceolatis, capitulis axillaribus.

Henicoste m m a Blume Bijdr. 848 .

3563. Tripterosperman $B L U M . \mathrm{C}$ aI y x tubulosus, quinquefidus. Corolla tululosa, limbo quinquefido. St a min a 5 , inclusa; a $n t h e-$ ra e sagittatae. Ovari um pedicellatam, basi urceolo brevi cinctum. Stylus filiformis; $s \mathrm{tigma}$ bifidum, lobis revolutis. B a c c a carnosa, unilocularis, placentis tribus, parietalibus. Semina plurima, cristata. E mbryonis radicnla centrifuga. - Herba javanica, volubilis, Crawfurdiae fortassis affinis ; foliis oppositis, ovatis, acutis, trinerviis, integerrimis, glabris, pedunculis axillaribus unifloris, medio bibracteatis.

Tripterosperm um Blume Bijar. 849.

OBSERVATIO. Micraea Miers Trav. in Chili 11. 529. Gentianeis adoumerata, prorsus ignota manet.

SUBORDO IT. MENYANTHEAE. C 0rollae aestivatio induplicativa. Albumen cavo seminis minus.

3564. DIemy anthes LINN, C a l y $x$ quinquepartitus. Corolla hypogyna, infundibuliformis, quinquefida, laciniis in diseo longitudinaliter barbatis, marginibus induplicatis simplicibus. Stamina 5, corollae tubo inserta; filamenta aequalia, antherae basi bilohae. Ovarium uniloculare. Ovula juxta nervam medium valvularum uniseriata. Stylus filiformis; stigma bilobum. G I a nd alae hypogynae nullae. Ca p $\mathbf{8 u}$ Ia unilocularis, juxta valvularum suturam ruptilis, valvulis medio seminiferis. S e mina plurima, minima, - Herba in Europa media et in America boreali indigena, paludosa; caudice repente articulato, foliis alternis, longe petiolatis, basi vagina auriculata instructis, ternatis, foliolis ovalibus, scapo axillari, simplici, racemo abbreviato, bracteato.

M e y a $\mathrm{t}$ h es Linn. gen, $n$. 202, exel. sp. Schkuhr $\mathcal{\ell}, 35$. Elor. dan, t. 561, B. B, t. 495, Gärtn. f. III. 112. $t$. 198. Men 0 a $a$ t bes Haller Helvet, $n, 633$.

3565. Vhllarsia VENT. Calyx quinquepartitns. Co rolla hypogyna, subrotata, limbo patente, quinquepartito, laciniis disco plano, basi barbato v. squamulato, marginibus adscendentibus, aestivatione inflexis. St a m in a 5 , corollae tube inserta; filamenta aequalia, antherae cordatae. Ovarium uniloculare. Ovu $\mathrm{Ia}$ in placentis suturalibus pluriseriata. Stylus terminalis; stigma bilobum, lobis dentatis. G land ulae hypogynae 5, staminibus alternae. Cap 8 n la unilocularis, nune evalvis, nune bivalvis, valris 
medio seminiferis, tandem bifidis, S e m ina pluri ma v. subdefinita. - Herbae natantes $v$. paludosae, in Europa media et in America boreali admodum rarae, in Capite bonae spei, NovaHollandia et Asia tropica frequentius obviae; foliis alternis rariusve oppositis, petiolis basi dilatata semivaginantibus, integerrimis $v$. dentatis, subtus plerumque punctatis, floribus v. subumbellat is axillaribus, $v$. paniculatis terminalibus, corollis sae. pius flavis, laciniarum marginibus fimbriatis v. integerrimis.

Villarsia Ventenat Choix 9. R. Brown Prodr. 456.

a. NYMPHEANTHE Reichenb. C a p $\mathrm{s}$ l a bivalvis, valvis bifidis. - N y m phe a $\mathrm{n}$ the Reiehenbach Flor excurs. 420. in not. Villarsia Griesebach Observ. 37. Re nea $1 \mathrm{mi}$ a Houttnyn Pfl. Syst. $F T$. 319. $1.47 . f .1$. Trach y sperma Rafinesque in N, York. Medic. $n e$ posit. II, Hex, V. 356. $-\mathrm{C}$ a ma d a Jones in Asial. Research. IV. 249. M en y a nt his s p. Linn. Roxburgh Plant. Corom, t. 105. Hooker Bot. Miscell. $t$. 24. (Vent. Choix t. 9. Bot. Mag. t. 658. 1029. Wight in Hook Misc. Append, t. 30. Journ. of Bot, t. 123.)

b. LIMNANTHEMUM Gmel, Capsula evalvis, maceratione tandem aperta. - L i $m n$ a $n t h$ e $m n m$ S. P. Gme lin Act. Academ. Petropolit. 1769.XV. $567 . t, 17 ., f$. 2. Griesebach Observ. 37. N y m p ho id es Tournef. inst. 67. W ald s ch midi a Wigger. Primit. 20. S e h we y ckherta C. C. Gmelia Flor. Bad, I. 447. Villarsia Reichenbach Consp. n. 34rs. Me n y a $\mathrm{t}$ th is s p. Linn. Flor. dan. $t .339$. E. B, t, 217. Gârtn, t. 114. Hooker Flor. Lond. t. 164. Bot. Mag. t. 1328.

\section{GENERA GENTIANEIS AFFINIA.}

3568. Titrasacme LABILL. C a I y angulatus, quadrifidus, rarius bifidus. Corolla hypogyna, tubo angulato, limbo quadripartito, aequali, decidua. Stamina 4 , corollae fauci inserta, inclusa v, rarius exserta; fil amenta filiformia, aequalia, antherae sagittatae, extrorsae, biloculares, longitudinaliter dehiscentes. 0 va ri n m valvularum marginibus introflexis biloculare. $0 \mathrm{vn}$ I a in placentis juxta introflexos valvularum margines plurima, anatropa. S tyl u 8 basi bifidns, apice simplex; st ig ma indivisum v. bilobum. Cap $\mathrm{s} \mathrm{al}$ a bilocularis, inter styli divisuras dehiscens. S e m in a plurima, minima. - Herbae in Nova-Hollandia, imprimis tropica, rarius in Moluccis et in Indiae cont in ente crescentes; foliis oppositis, nune confertissimis radicalibus, caulinis nullis, nunc connatis, floribus terminalibus umbellatis, ra rius axillaribus solitariis.

Mit $r$ a s a c me Labillard. Nov. Holland, 1.36 . Mite a sacme sive Mitragyne R. Brown Prodr. 432.

a. ANISOMITRA. Cal y $\mathrm{x}$ bifidus. Stamin a medio corollae tubo inserta, inclusa. S ty 1 us jam sub anthesi basi bifidns. Stig m a bilobum.

b. MitraGYNE. Calyx quadrifidns. Stamina medio corollae tubo inserta, inclusa. S $t y l u s$ jam sub anthesi basi bifidus. Stig m a bilobum. (Labillard. $O p$. cit. t, 39.)

c. HoLOMiTRIUM. Caly $\mathrm{x}$ quadrifidus. $\mathrm{S} t \mathrm{n}$ mina medio corollae tubo inserta, Inclusa. S ty 1 u s sub anthesi basi indivisa. Stig ma integrum.

d. DiChelomitrium. Caly $\mathbf{x}$ plieatus, lobis concavis. S t a min a coroliae faucl inserta, exserta. Capsula demum semibivalvis.

356\%. NItreola $L I N$ V. Caly x quinquepartitus. Corolla hypogyna, tubo urceolato, fimbo quinquepartito, aequali, decidua. St a min a 5, corollae tubo inserta, inelusa; fil a m e n ta brevissima, antherae introrsae, biloculares. Ovarium valvularum marginibus introflexis biloculare. Ovnla juxta valvularum margines in- troflexos plurima. Stylus terminalis, brevis; stigma indivisum. Cap $8 \mathrm{ula}$ bilocularis, apice septicido-dehiscens, valvulis stylo indiviso junctis. Sem in a plurima, minima. - Herba perennis, in America tropica et boreali calidiore indigena; foliis oppositis, floribus spicato-corymbosis, minimis.

Mitreola Linn. Hort. Cliff. 492, R. Brown Prodr. 450. in not. A. Richard in Mem, soo, h. n. Paris, I. t. 3 , Cynoctonum Gaelia Syst. 443, Ophiorbiza MitreoI l Linn,

\section{Ordo CXXXI: Spigetiacene.}

SPIGELIACEAE Martius Nov, gen, et sp, $I T, 132$. Línd ley Introduct. edit. II. p. 298.

Il grbae v. strpantices, radicibus fibrosis, caule ramisque teretibus $\mathbf{v}$, obtuse tetragonis. Foli a opposita v. verticillata, subsessilia, integerrima, mediante petioli brevissimi basi dilatata, stipuliformi connata.

Flores hermaphroditi, regulares, in spicis secundis, interdum revolutis, rosel v. purpurei.

Calyx liber, persistens, brevissimus, campanulatus, quinyuefidus, laciniis angustis, erectis, per aestivationem imbricatis.

Corousa hypogyna, infundibuliformis, membranacea, decidua, tubo longo, intra calycem subpentagono, sursum tereti v. quinquesulco, sensim ampliato, nervis quinque percurso, limbo quinquefido, inter lobos triangulares, per aestivationem valvatos interdum plicato.

Stauina 5, medio v. summo corollae tubo inserta, ejusdem lobis alterna, aequalia, inclusa v. rarius exserta. Fil a m e nta erecta, subulata v. filiformia. Antherae introrsae, biloculares, basifixae, loculi appositi, basi sagittato-discreti, longitudinaliter dehiscentes. Pollen subtrigonum, angulis papillas diaphanas exserens.

Ovarium liberum, subglobosum v. compresso-suboblongum, basi calloso-incrassatum, e carpidiis duobus, marginibus in dissepimenta introflexis biloculare. Placentae e basi loculorum stipitatae, carnosae, subbilobae. $0 \mathrm{vula}$ sex ad quindecim, placentae foveolis immersa, excentrice peltata, micropyle infera. Stylus terminalis, cylindricus, rectus, superne infra stigma articulatus. Sti g $\mathrm{m}$ a terminale, horizontale v. nonnihil obliquum, circumscriptione ellipticum, concavum v. convexum, margine saepe ciliatum.

Capsula coriaceo - membranacea, didyma. compressa, dicocea, cocci subglobosi, marginibus introflexis dissepimentum duplicatum praebentibus, inferne e basi callosa elastice circumscissi, vertice transversim medio bivalres, basi cupuliformi persistente, placentis solutis, deciduis. 
Semina in loculis pauca, foveolis baseos placentae immersa, subcuneata, angulata, vertice planiusculo, areolato scabra, umbilico prope basim laterali. A l b u m en subcorneum.

Euвrxo in basi albuminis prope umbilicum axilis, minimus; cotyled on ibus vix conspicuis, radicnla infera.

Splabliacear genere unico americano tropico et subtropico comprehensae, a Gentianeis, quibuscum olim consociatae, distinguuntur stipularum praesentia, corollae aestivatione valvata, styli et capsulae structurae, nec non seminum numero, quibus simul notis etian a Scrophularineis, quarum fructus quodammodo aemulantur, recedunt, a Rubiaceis vix nisi ovario libero, a Loganieis plerisque fructus structura, et ab Euloganieis corollae etiam aestiva tione diversae.

Radices plurimum specierum catharcticae, anthelminthicae et narcoticae.

3588. Spigelia LINN. C a $1 \mathrm{y} \times$ quinquepartitus, persistens. Corolla hypogyna, infundibuliformis, limbi quinquefidi laciniis aestivatione valvatis. St am in a 5 , medio v. summo corollae tubo inserta, inclusa v. rarius exserta. Ovari u m biloculare. $O \mathrm{vula}$ in placentis basilaribus stipitatis plura, amphitropa. Stylus terminalis, infra stigma subcapitatum $v$, concavum articulatns. Cap su l a didyma, dicocea, basi circumscissa, coccis bivalvibus. Semin a pauca, cuneata, nmbilico prope basim Iaterali. Embryo in basi albuminis cornei minimus, rectus, - Suffrutices $v$ herbae, in America tropica et boreali calidiore crescentes; foliis oppositis, mediante petioli basi dilatata stipuitiformi connatis, floribus terminalibus, spicatis, secundis.

Spigella Lina. gen. n. 209, Lam. $t$, 107. Gărtner f. III. 113. t. 198. Kunth in Humb. et Bonpl. Nov, gen. et sp. III. 189. t. 226. Martius Nov, gen. et sp. II. 124. t. 192-194. Bot. Mag. t. 80, 209. 2359. A r a pa ba ca Plu. mier Gen. t. 3t. Can ala Poh1 Plant, Brasit. II. 62. $t$, 142. (placentis perperam pro seminibus descriptis.)

\section{Classis XXXV. Nueuliferac.}

Herbae, frutices v. arbores, succo aqueo. Fol i a opposita, alterna v. verticillata, simplicia. Stipulae nullae. Flores hermaphroditi. Cal y x liber. C o roll a hypogyna, gamopetala, regularis $\mathbf{v}$. limbo irregulari, bilabiato. Stamina corollae tubo inserta, ejusdem lobis numero aequalia v. saepius pauciora. 0 v a ri u m monomerum v. saepius tetramerum. $0 \mathrm{vula}$ in Joculis solitaria v. rarissime pauca, erecta $v$. inversa, anatropa v. amphitropa. Fruet u s nucamentaceus lobis distinctis $\mathbf{v}$. tandem discretis, axi centrali saepius nullo, rarissime utriculiformis. $\mathbf{E} \mathrm{m}$ b ry o intra albumen homotropus $\vee$. exalbuminosus.

\section{Dralo CXXXI. Labiatae.}

VERTICILLA TAE Limn, Ord, nat. 49. LABIATAE Jussien Gen. 110. R. Brown Prodr. 499. Mirbel in Annal Mus.
XV. 213. Bartling Ord, nat, 180. Bentham, Labiatarum ze. nera ot species. Lond. 1832-1836. 8. LABIATAE v. LA. MIACEAE Liadley Introduct. edit, II. p. 275.

Herbae, sUffrutices v. frutices, nunquam arborescentes; $\mathbf{r a m}$ is oppositis v. verticillatis, saepissime tetragonis. Foli a opposita v, verticillata, simplicia, integra v. divisa, reticulato-paucinervia. St i p u l a e nullae.

Flores hermaphroditi, irregulares, in cymas duas axillares, oppositas, dichotomas (verticillastros) unilaterales, centrifuge florentes dispositi, cymae varie digestae, interdum ad florem solitarium redactae, inflorescentiam polymorpham constituentes.

Calyx liber, gamophyllus, persistens, nunc regularis, quinquedentatus, nunc irre. gularis, obliquus, incurvus, v. dentibus inaequalibus et varie inter se coalitis bilabiatus, dente supremo interdum excluso $v$. squamaeformi.

Conolla hypogyna, gamopetala, decidua, irregularis, tubo vario, limbo quadri-quinquelobo, subeampanulato, bilabiato v. obliquo, lobis aestivatione imbricatis, lacinia infima intima, lateralibus tecta, supremis extimis.

Stamina tubo corollae inserta, ejusdem lobis alterna, adscendentia, erecta, divaricata v. declinata, duo inferiora semper fertilia, duo superiora nunc omnino abortiva v, sterilia, nunc perfecta, inferioribus breviora, subaequalia $v$. interdum longiora, supremum omnino abortivum $v$. rarissime in floribus monstrosis rudimentarium. Filamenta filiformia, nuda v. basi barbata, sive appendiculo dentiformi instructa. A $\mathbf{n}$ th e ra e normales biloculares, loculis basi connectivo insertis, parallelis v. apice divergentibus divaricatisve, rima longitudinali dehiscentibus, nune discretis, connectivo incrassato $v$. elongato-filiformi remotis, nunc contiguis $v$. in unum coalitis, infimo nonnunquam, superiore rarius casso v. abortivo, valvulis aut connectivo interdum barbatis v. appendiculato-calcaratis. A nn uI $\mathrm{s}$ intra tubum corollae sub staminum insertione, nunc completus e fasciculis pilorum v. squamis cum staminibus alternantibus, nune incompletus $\mathbf{v}$. omnino obsoletus.

Ovaвго quadriloculare, quadrilobum, gynophoro crasso, subcarnoso, disciformi, v, in lobulos glandulaeformes, loculis alternos, aequales v. inaequales expanso insidens, lobis aequaliter distinctis v. geminatim magis cohaerentibus. 0 v u 1 a intra lobos solitaria, e basi loculi erecta. S t ylu s inter lobos insertus, eorundem bases connectens, ut plurimum deciduus, saepissime apice bifidus, lobis subaequalibns v. superiore multo minore, rarissime integer, subclavatus. Stig mat a in styli lobis terminalia v. subterminalia, saepius inconspicua. 
Achenia quatuor v. abortu pauciora, calyce immutato v. rarius aucto, interdum subbaccato inclusa, epicarpio mne tenui, membranaceo, nunc duro, incrassato v. carnoso.

Semixa intra lobos solitaria, erecta.

Eмввуо intra albumen parcissimum carnosum orthotropus. Cotyled ones rectae v. apice recurvae, interdum axi florali contrariae. Radicula brevissima, infera.

Labiatae hine Verbenaceis proximae, indead Borragineas arcta affinitate accedentes, per totum fere terrarum orbem dispersae sunt, in hemisphaerae borealis regionibus extratropicis calidioribus, imprimis in regione mediterranea, nec non in elatioribus zonae tropicae jugis temperatis maximo numero vigentes, in regionibus arcticis et alpibus ventosis, aeque ac in regionibus intertropicis aestu ferrentibus rarae.

Folia et calyces in plurimis, in quibusdam etiam caules et corollae glandulis parvis, globosis, oleo aethereo aromatico repletis tecta. Plures amarae v. aromaticae, multiplici usu medico et culinario inter mortales celebratae.

In disponendis et circumscribendis generibus ordinis monographiam classicam, ab amicissimo Benth a m elaboratam, et nulli botanicorum ignotam secutus sum.

TEIBUS I. OCIMOIDEAE Benth. Labiac. 1. St am in a declinata. Coroll a subbilabiata, lobis quatuor superioribus planis subaequalibus, binisve supremis coalitis, infimo declinato, plerumque difformi, plano v. saepius concavo, cymbaeformi v. saccato. Anthe rae defloratae saepissime patelliformes.

SUETREUS I. MOSCHOSMEAE. C oroll a e laciniae subaequilongae, infima angustior, declinata, subplana. - Tropicae ampligeae.

3569. Deimum LINN. Cal yx ovatus v. campanulatus, quinquedentatus, dentis supremi ovati marginibus membranaceis decurrentibus alatus, demnm deflexns, fauce intus nuda v. pilosa, Corolla tubo ealyce subbreviere, intus exannulate, fauce saepius campanulata, limbi bilabiati labio snperiore quadrifido, inferiore vix longiore declinato, integerrimo, subplano. S $\operatorname{tam}$ in a 4 , declinata, inferiora longiora; fil a m enta libera, superiora basi dente $\mathbf{v}$. pilorum faseiculo appendiculata, rarius nuda, a n ther a evato-reniformes, loculis confluentibus. Stylus apice breviter bifidus, lobis subaequalibus, sululatis $\mathbf{v}$, complanatis; stig m a t a terminalia minuta v. marginalia. A $c h$ cnia 4, laevia, - Herbae v suffrutices, in regionibus tropicis Asiae copiosissime provenientes, in America et $A f r i c a$ tropica et subtropica rariores; verticillastris sexfloris, rarissime subdecemfloris, interrupte spicatis v, racemosis, racemis simplicibus v. basi subramosis, rarius thyrsoideo-paniculatis. biat. 1 .

0 e im um Linn. gen, $n$, 732 exel. sp. Benth, La a. OCIMODON Benth. Filame nta superiora basi dentículo aueta. - Verticillastri saepissime cexfori. Pcdicelli reflexi, calyce fructifero saepe breviores.

Ocimodon Benth. Op. eit. 3. (Jacq. Hort. Vindob. t. 12, 86. Ic, rar, t, 495. Herit. Stirp, t. 63, Pulis. Fl. Owar, t, 94. Bot. Mag. t. 2359.)

b. HIBROCIBUM Benth. Filamenta superiora basi fasciculo pilorum aucta. - Verticillastri sexfori, ra. cemos laxos, graciles formantes. Pedicelli patentes. caljecs nutantes.

Hierocim $\mathrm{n}$ m Benth. Op. cit. 11. (Burmaun Thesaur, Zeglan, $t$. $80 . f$. 2.)

c. GYMNocimuM Benth, Filamenta omnia basi-nuda. - Verticillastri sexflori, $v$, rarius decemflori. Pedi. celli calyce breviores.

G y m ао $\mathrm{cim}$ в menth. Op. cit. 12.

35\%0. Ceniosporam $W A L L, C$ al $\mathrm{y} x$ ovato-tubulosus, margine membranaceus, inaequaliter subquinquedentatus, dente supremo haud decurrente, lateralibus cum supremo et infimis in. vicem saepe connatis, froctifer suberectus $v$, declinatus, basi interdum transversim rugosus, fauce intus nuda. Corolla tubo calyce subbreviore, fanee campanulata, limbi subbilabiati labio superiore quadrifido, inferiore vix longiore declinato, integerrimo, subplano. St a m in a 4 , declinata, inferiora longiora; fil a m enta libera, edentala, ant herae ovato-reniformes, loculis confluentibus. St ylus apice breviter bifidus, lobis saepius complanato-dilatatis; $8 \mathrm{t}$ ig $\mathrm{m}$ a t a submarginalia. A chen ia laevia v, minútissime rugulosa. - Herbae annuae v. perennes, busi saepius procumbentes, in India orientali et in Africa tropica observatae; verticillastris multifloris, laxespicato-racemosis, racemis subsimplicibus, foliis floralibus basi saepius cartilagineis, albis $v$. flavescentibus, floribus parvis.

Genios porum Wallich msc. Benth, Labiat. 19.

a. GENIOSPORUM Benth. Cal y cis dentes duo infimi distincti.

Geviosporum Benth. l. c. Ocy wi sp. Lina. et Auet. (Burmann Thesaur. Zeglan, t. 70. f. 2.)

b. Platostoma Palis. Calyeis dentes in labia duo integra coaliti.

PI a tost o m a Palisot Flor, Owar, I1. 61, t. 05. f.2. Benth. Op. cít. 22.

3571. NIesoma BLUM. C a I y bilabiatus, labio superiore diviso, inferiore minimo, demum inflexo. Coroll a e labium superius fornica$\mathbf{t u m}$, inferius longius, indivisum. S $\mathrm{tam}$ in a 4 , didynama, declinata, breviora basi appendiculata. Anth e rae nniloculares, imberbes. - Herba $j a$ vanica, inodora; foliis ovato-oblongis, dentatis, rugosis, pilosiusculis, floribus dense verticillato-spicatis, verticillis bracteatis, pedicellis fasciculatis.

M es o a Blume Bijdr. 838. Benth. Labiat. 22.

35\% 2. A erocephalus BENTH. Calyx sub anthesi ovatus, fructifer elongatus, tubulosus, basi gibbus, bilabiatus, labio superiore subintegro, plano, inferiore integro $\mathbf{v}$. quadridentato, fauce intus nuda. Coroll a calycem subaequans, limbi subbilabiati labio snperiore quadridentato, inferiore integro, lobis omnibus subaequalibus. St a m in a 4 , declinata, inferiora longiora; fil a m en ta libera, edentula, antherae ovato-reniformes, loculis subconfluentibus. Stylus apice breviter bifidns, lobo inferiore subdilatato, complanato; stig mat a submarginalia. Ach enia glabra, laevia. - Herbae indica et madagascarienses; caulefoliisque piloso-hirsulis v. subglabris, floribus parvis, in capitula subglobosa terminalia dense imbricatis. 
A crocephalus Benth. Labiat, 23, 0 с y m um cap Itellatum Lian.

35\%3. III ovatus, quinquedentatus, dentis supremi majoris marginibus non decurrentibus, inferioribus subaequalibus, demum declinatus, fauce intus nuda. Corolla tubo calyce incluso, limbi subbilabiati labio superiore breviter quadrifido, inferiore integerrimo, subplano, lobis omnibns subaequalibus. St amina 4, declinata, inferiora longiora; fil amenta libera, edentula, antherae ovato-reniformes, loculis confluentibus. Stylus apice clavato-capitatus, brevissime bifidus; $s$ tigmat a minuta. Achenia ovato-compressa, laevia. Herbae annuae, graciles, glabrae v. hispidulae, in India orientali et Africa tropica observatae; verticillastris paucifloris, subsecundis, laxe racemosis, racemis axillaribus, subpaniculatis.

M oschosma Reichenbach Consp. p. 171. Benth. La. biat, 24. L u m nit z e r a Jaeq. f. Eclog. II. inedit. 0 e y. uum polystachy u m Linn. Murray Commont, Götting. III. $t, 3$.

35y4. Orthosiphon BENTH. C a l y ovato-tubulosns, quinquedentatus, dentis superioris ovato-membranacei marginibus decurrentibus alatus, demum deflexus, fauce intus nuda. Corolla tubo exserto, recto $\mathrm{v}$. incurvo, fance aequali v. rarius inflata, limbi bilabiati labio superiore triquadrifido, inferiore integerrimo, concavo. Stamina 4, declinata, inclusa v. exserta, inferiora longiora; filamenta libera, edentula, an the rac ovato-reniformes, loculis confluentibus. Stylus apice clavato capitatus, subinteger v. breviter emarginatus; stig mata in emarginatura subcon. fluentia, minuta v. incrassato-capitata. A $\mathrm{ch}$ h n ia minutissime punctulato rugosa. - Herbae perennes v. suffrutices, in India orientali obvii, in Americ a tropica rarissimi; racemis simplicibus, scepius elongatis, rarissime ovato-spiciformibus, verticillastris sexfloris, distantibus, laxis, foliis floralibus bracteaeformibus ovatis, acuminatis, reflexis, pedicellis saepius brevioribus, pedicellis fructiferis recurvis.

Orthosiph on Benth. Labiat, 25, Plectranth th 0 c y mi s p. Auct.

SUHBTERUS II. PLECTRAN'THEAE. Corolla e lacinia infima elongata, concava. - Tropicae gerontogeae.

35\%5. Pleetranthus HERIT, Calyx campanulatus, quinquedentatus, dentibus aequalibus v. supremo majore, fruetifer auctus, nunc deelinatus, rectus, incurvus v. inflatus, dentibus aequalibus v. varie bilabiatis, nunc erectus, tubulosus v, campanulatus, aequaliter quinquedentatus. Corolla tubo exserto, basi supra giblo v, calcarato, dein declinato, defracto v. subrecto, fauce aequali v. rarins inflata, limbi bilabiati labio superiore tri-quadrifido, inferiore integro, saepius longiore, concavo. St a min a 4, declinata, inferiora longiora; fil amenta libera, edentula, antherae ovato-reniformes, loculis confluentibus v. rarius snbdistinctis v, divaricatis. S t y lu s apice breviter bifidus, lobis subaequalibus, subulatis; stigmat a minuta, terminalia. Achenia laevia. Herbae, suffrutices v. frutices, inter tropicos Asiae, Africae et Novae-Hollandiae reperti; verticillastris laxis, saepius eymosis, multi. floris, laxe racemosis $v$, paniculatis.
Ple etranth us Herit. Stirp. I. 85. Benth. Labiat. 29. Ger a a ne a Lam. Diet, $11,682,-$ ? De nt 1 d ta Loureir. Fl. cochineh, 448.

a. GERMANEA Benth. $\mathrm{C}$ al $\mathrm{y} \times$ fruetifer declinatus, dente supremo ovato, quatuor Inferioribus lanceolatis. C or ofI a basi supra calcarata. - Frutex capons $i$ s; flori. bus paniculatis.

G erm anea Benth. Op, cit. 32. (Herit. Stirp, t.41.)

b. COLEOIDES Benth. C a I y $\mathrm{x}$ fructifer declinatus, deute supremo ovato, inferioribus angustioribus subaequalibus, v, infiutis longioribus, basi subconnatis. $\mathrm{C}_{0}$. rolla basi supra gíbba, nec calcarata, declinata. Herbae v. frutices, floribus racemosis v. subpaniculatis.

Coleoides Benth. Op, cit. 32. 0 c y m i sp. Linn. et Auct, (Herit, Op. cit, t. 49. Willd. Hort. berol, t. 63. Bot. Mag. t. 2460. Bot. Reg. t, 1093.)

c. HETERoCyLIX Benih. Caly $\mathrm{y}$ fructifer declinatus, bilabiatus, Iablis subintegerrimis, subaequalibus. $\mathrm{C}_{0}$. rolla basl supra gibba, nee calcarata, defracta. Herba africana tropica; Joribus racemosis.

Heterocy 11 x Benth. Op, cit. 39 . O $\mathrm{c} \mathrm{y} \mathrm{m} \mathrm{m}$ mo. nost a e liy u u Palis. Flor. Owar, $t, 95, f .1$.

d. MELISSOIDES Benth. Caly $x$ fruetifer declinatus, bilabiatus, labio superiore tridentato. C orolla basi supra calcarata. - Herba indica; cymis axillaribus, paucifloris.

Melis soides Benth. Op. cit. 39.

e. ISODON Schrad. C al y x fruetifor declinntus, dentibus ounibus aequalisus, $\vee$. in labia 2 , superius tri- inferius bidentatum divisus. C orolla basi supra gibba, nec calearata, decliuata v. defracta. - Herbae v. suffrutices; floribus paniculatis $v$. rarius racemosis.

Is o d o a Schrader mse. Benth. Op. eit. 40.

f. PYRAMIDIUM Benth, C a Iy $\mathrm{x}$ fruetifer erectus, tubuIosus, aequaliter quisquedentatus. C or oll a basi supra gibba, nee calcarata, defracta. - Herba indica; fo. ribus pyramidato-paniculatis.

Pyramidiun Benth. Op, cit, 44. Plectranthus ternifolius Don.

g. AMETHXSTOIDES Benth. Calyx fructifer erectus, campanulatus, aequaliter quinquedentatus. Corolla basi supra gibba, nec calcarata, defracta. - Horba chinensis; floribus lare paniculatis.

A a et hystofdes Benth. Op. oit. do.

358 6. Coleans LOUREIR. C a lyx ovatocampanulatus, quinquedentatus, dentis supreni ovati, membranacei marginibns interdum decurrentibus, inferioribus angustioribus, omnibus aeutis $r$. lateralibus ovato-truncatis, infimis saepe inter se connatis, fruetifer ereetus v. saepius declinatus aut reflexus, fauce intus nuda $\mathbf{v}$. hispida. Corolla tubo exserto, defracto, fauce inflata $\mathbf{v}$. aequali, limbi bilahiati labio superiore abbreviato, obtuse tri-quadrifido, inferiore integro, elongato, coneavo, saepius eymbaeformi, genitalia involvente. Stam in a 4, declinata, inferiora longiora; $\mathrm{fi}$ l a menta edentula, basi in tubulum stylum vaginantem connexa, anthera e ovato-reniformes, loculis confluentibus. Stylus apice subulatus, aequaliter bifidus; $\mathbf{s}$ t i g m a $\mathbf{t}$ a subterminalia. A $\mathbf{c h}$ enia compresso-subglobosa, laevia. - Herbae indicae, annuac $v$. perennes, interdum suffrutescentes; verticillastris sexfloris $v$. saepius multifloris, densissime v. laxe cymiformibus, pedunculo utriusque cymae ramisve utrinque binis plus minus elongatis, foliis floralibus bracteaeformibus, ante anthesim ad apicem racemorum plus minusve comosis, demum deciduis v. subpersistentibus, reflexis.

Coleus Loureiro Flor. cochinch. 452, Beath. Lat. biat. 47 .

a. CALCBOLus Benth. Cal y x frutifer reflexns, fauce intus villosa. - Verticillastri sex-decemflori. 
Calcoolus Beath. Op, cit. 49. Plectranthi et 0 o y m i 8 p. Auct. Bot. Mag. $t, 2036,2318$. Bot, Reg. t. 594.

b. ARomarla Benth. Calyx fruetifer vix declinatus, fauce intus auda, - Verticillastri densi, subglobosi, multiflori.

A r o maria Beath, Op. cit. 51. (Bot. Reg. t. 1520,) c. Solenostemon Schum. Caly x fructifer declinatus, fauce intus nuda. - Verticillastri laxi, multiflori.

Sole nos te mon Schumacher in Act, soc, $h, n, M a f n$. 1V. 45. Benth. Op. cit. 32. Mits a Chap. ox Bofer

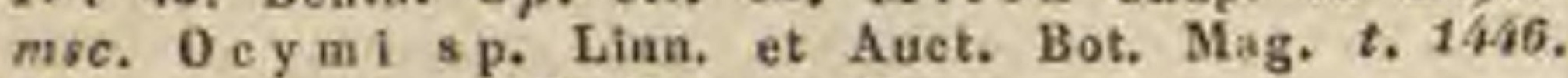
Plectranti sp. R. Brown. Blume.

35\% . Anisoelnilus $W A L L$. C a l $y \times$ ovatus, suberectus, bilabiatus, labio superiore integro, post anthesim inferiori truncato integerrimo $\mathrm{v}$. brevissime quadridentato incumbente clausus. C o roll a tubo exserto, defracto, fance subinflata, limbi bilabiati labio superiore abbreviato, obtuse tri-quadrifido, inferiore integro, elongato, concavo. Stamina 4, declinata, inferiora longiora; filamenta libera, edentula, an $\mathrm{t}$ erae ovato-reniformes, loculis confluentibus. Stylus apice subulatus, aequaliter bifidus; $8 \mathrm{t} \mathrm{i} \mathrm{g}$ m a $\mathrm{t}$ a subterminalia. A $\mathrm{e}$ he nia laevia. - Herbae indicae, annuae $v$. perennes; verticillastris in spicas oblongas, cylindricas dense imbricatis, foliis floralibus bracteaeformibus, imbricatis.

Anisochilus Wallich $P l$. As, rar. $I T$. 18, Bentl. La bial. 59. Plectranthi s p. Roxb. Lavand ula carno. sa Linu. Amoon. X. 56. t. 3.

3588. Aeolanthus MART. C a ly x ovato-campanulatus, dentibus obsoletis, fauce intus nuda, fructifer clausus, basi circumscissus, C oroll a tubo exserto, extra calycem decurvo, fauce dilatata, limbi bilabiati laljio superiore lato, obtuse quadridentato, inferiore integro, longiore, concavo. Stamina $k$, declinata, inferiora longiora; fil a menta libera, edentula, a $\mathrm{n}$ therae ovatoreniformes, loculis confluentibus. Stylus apice breviter bifidus, lobis subulatis; $8 \mathrm{tigmata} \mathrm{mi-}$ nuta, subterminalia. A chenia dorso concava, intus bifacialia - Herbae annuae, in planitiebus Caffrorum spontaneae, in hortis $\mathbf{S}$ inarum in Brasilia exulum cultae, tenuissime pubescentes; foliis obovatis, obsolete dentatis $v$. integerrimis, floribus secus cymarum ramos distichis, secundis, suaveolentibus.

A eolanthus Martius Amoen. monac. 4. t. 2. Benth. Labiat. 61. Orolan thus E. Meyer Comment, plant. Afr. austr. 230. sphalmate. - ? H p athronta Schrank in Syllog. pl. $I 1.85$.

35\%. Pyenostaelhys HOOK. C a ly ovatus, subaequalis, dentibus quinque subulatospinosis, fauce intus nuda. Coroll a tubo exserto, defracto, fance subinflata, limbi bilabiati labio superiore quadridentato, inferiore integro, concavo. Stam in a 4 , declinata, inferiora longiora; fil a m enta libera, edentula, antherae ovatoreniformes, loculis confluentibus. Stylus apice subulatus, brevissime et aequaliter bifidus; stig in a t minuta, subterminalia. A e he nia subglobosa, laevia. - Herbae madagascarienses, capenses et abyssinicae; foliis lanceolatis, remote serratis, verticillastris in spicas simplices, densas approximatis.

P y en o s tac hy s Hooker Exot, Flor, rt. $t, 209$. Benth. Labiat. 69. E chiaostathys E. Meyer Comment, plant. Afr. attstr. eds.

SUBT RIBUS III. HYPTIDEAE. Cor oll a e lacinia infima substipitata, transverse subcallosa, deinde saccata, per anthesim abrupte dejecta. - Pleraeque americanae.

35s0. Symeolostemon $E$. MEY. Calyx inflato-tubulosus, a equalis v. subincurvus, dentibus quinque aequalibus $v$. inferioribus lon gioribus. Corolla tubo recto, exserto, limbibilabiati labio superiore quadridentato, inferiore integro, concavo. S ta mina 4 , declinata, inferiora longiora; fil amenta inter se libera, edentula, corollac tubo adnata, a n the ra e oblongae, loen. lis confluentibus. S $\mathbf{t}$ y I u s brevissime bifidus. A $c$ h enia .... - Frutices capenses; foliis op. positis, parvis, subcoriaceis, ad axillas saepius fasciculatis, racemis terminalibus, simplicibus v, ramosis, foliis floralibus bracteaeformibus, deciduis, calycibus saepe coloratis.

S y n col o s t e m on Beuth, in E. Meyer Comment, plant. Afr. austr. 230.

3581. Peltodon POHL. Caly x campa nulatus, aequaliter quinquedentatus, dentibus erectis, subulatis, in appendicem peltatam subconea vam desinentibus, fauce barbata, fructifer auctus, membranacens, subinflatus. Cor o 11 a tubo recto, fauce subinflata, dentes calycinos subaequante, limbi subbilabiati labio superiore bifido, patente, inferioris longioris declinati lobis lateralíbus patentibus, oblongis, medio substipitato, basi angustato, transversim calloso, dein oblongo, saccato. acnto, integerrimo, per anthesim abrupte dejecto. St a mina 4, declinata, inferiora longiora; filamenta libera, edentula, an the ra e ovato-reni formes, loculis subconfluentibus. Stylus apice breviter bifidus; stigmata terminalia v. submarginalia. - Herbae in Brasilia interiore monticolae; floribus capitatis, involucrato-bracteatis.

Pe It o d o n Pohl Plant. Brasil. I, 66, t. 54-56. Benth. Labiat. 68 .

35S\%. II campanulatus, basi angustatus, aequaliter quinquedentatus, dentibus lanceolatis, erecto-patenti bus, fance intus nnda. Corolla tubo recto, fance vis inflata, dentes calycinos aequante, limbi subbilabiati labio superiore bifido et inferioris trifidi lobis lateralibus ovatis, erecto-patentibus, subaequalibus, infimo saccato, basi substipitato, apice acuminato, per anthesim abrupte dejecto St amina 4, declinata, inferiora longiora; fila menta libera, edentula, antherae ovato-reniformes, loculis subconflnentibus. Stylus apice breviter bifidus, lobis subcomplanatis; stigmata submarginalia. A ch en ia ovoidea, compressa, in tus concavo-eymbiformia, margine membranacee involuto, fimbriato. - Herba americana tropica, annua, procumbens, villosa, floribus capitatis.

Mars ypianthes Martius msc. ex Benth, Labiat. 6.3. H y ptidis sp. Willd. Poitean in Annal, du Mus, VIt. t. 27. f. 4. t. 31. f. 1 .

3ธ83. Hyptis $J A C Q$. Calyx ovatus $v$ tubulesus, ore recto $₹$. obliquo, limbi subaequali ter quinquedentati dentibus acutis $\mathbf{v}$, subulatoaristatis. Co ro lla tabo calyeem subaequante, lim bo subbilabiato, labii superioris lobis quatuor, in tegerrimis, planis, omnibus distinetis, labio inferiore indiviso, per anthesim abrupte deflexo, sac cato, ad basim contracto-subarticulato. $\mathrm{S} t$ a $\mathrm{m}$ in a 4 . declinata; fil ament a libera, edentula, anthera e ovato-reniformes, loculis confluentibus. Sty lus apice subaequaliter bifidus, lobis subulatis; stigmatibus loborum faciem internam omnem occupantibus. A chenia uvoidea, oblonga 
v. compressa, laevia v. rugosa, rarissime ala plana, membranacea marginata. - Herbae v suffrutices, habitu et inflorescentia multiformes, in America tropica, imprimis trans aequatorem copiosissime provenientes, extra tropicos rarissimae, nonnullae per regiones calidiores veteris orbis diffusac.

Hy pt is Jacq. Colloct, I. 101. Beath. Labiat. 64.

a. GYMNEIA Benth. Labiat. 77. Bracte a e numerosae, adpressae, subulatae. Verticillastri multiflori, spicati v. globosi, remoti. Calyees fructiferi apice recurvi.

1. SPICARIA Beath, Op. cî. 78. B r a cte a e numerosae, adpressac. Verticillastri multiflori, spicati v. inferiores subremoti, Calyces fructiferi recti. - Ne. Det a u a $x$ im a Sloase Jamaic, $t .108, f .1$.

t. APODOTES Benth. Op. cit. 79. Bractea e numerosae, adpressac, Capitula subdistinctu, sessilia. Verti. elllas tri omues remoti. C al y ces fructiferi recti.

d. PLAGiotis Benth. Op, eit. 80. B r a te a e numerosae, adpressae, ovatae. Capitula pedunculata, globosa, dense multillora. Caly $x$ fruetifer basi inflatus, ore incurvo, dentibus ovatis, inacqualibus.

e. CYRTA Beath. Op. cit. 81 . B r acte a e numerosae, adpressae, subulatae. Capitula peinaculata, globosa, dense multiflora. Cafyx fruetiter apiec recurvas. dentibns subulatis. - (Poitean in Annal. Mus. MII. i. 28. f. 2.)

f. CXanocephalus Pohl msc. Bracteas numerosae, adpressae, subulatae. C a pit ul a pedunculata, globosa, dense multiflora. Recep $\mathrm{a}$ c u 1 u m subsudum. Caly $x$ fructifer tarbinato-tubulosus, basi glaber, dentibus subulatis, rectis, molliter villosissimis. - Benth. Op. cit. 84.

g. ERIOSPHAFRIA Benth. Op. cit. 88. B racte a e numerosae, adpressae, lanceolatae v, lineares. C a p it u 1 a plerumque breviter peduaeulata, semiglobosa, dense multiflora. Receptaculum villosum v. lanatum. C'a$1 \mathrm{yx}$ campanulatus, rectus, apice lanato villosissimns, dentibus brevibus, rectis.

h. OOCEPHALUS Benth. Op, cit. 94. Bracteae numerosac, adpressae, ovatae. Capitula pedonculata, avoidea, dense pauciflora. Cal y $x$ campanulatus, reetus, dentibus subulatis, mollissime villosis, tubo longioribus.

TRICHOSPHAERIA Benth. Op. cit. 95. B ractea numerosae, adpressae, subulatae. C a pitula peduaculata, globosa, dense multiflora. Cal y $x$ eampanulatus, rectus, dentibus plamosis, filiformibus, tabo nualtoties longioribus.

k. XANTIOPHAEA Mart. mse. Bracteae numerosae, adpressae, subulatae v. liscares. $C$ a pitul a longe pedanculata, globosa, dense multiflora. Cal y $\times$ turbinatocampanulatus, fructifer medio v. basi inflatus, ore contracto, dentibus rigidis, subulatis, - Beath. $O p$. cit. 97 .

1. CEPHALOHYPTIS Benth. Op. cit. 98. B ractea utmerosac adpressae. C a pitula peduculata v, rarius subsessilia, semiglobosa, demum globosa, dense multiHora. Recepta e $\mathrm{I}$ I a m andum v. rarius lanatum. CaIy $x$ campanulatus v. tubulosus, glaber v. villosus, nunquam lanatus. - (Jacq. Ic, rar. t. 14i. Poiteau in Annal. MLus. YII. t, 27. $f .1,2$.

m. POLYDESMIA Benth. Op. cit. 114. B r acteac nume rosae, adpressae $v$. lanceolatae. Ca pitula subsessi. lia v. peduncnlata, racemoso-paniculata. Caly $\times$ fructifer nuac ore elougato, truncato, dentibus setaceis, strietis v. obsoletis, nunc tubuloso-campanulatas, dentibus lanceolatis.

n. MESOSPHAERIA Benth. Op, cit. 129. B ractea e minutae v. subulatac, laxae. Capitula laxe pauciflora, pedunculata, paniculata. C al y $x$ oblique campanulatus. ore truncato, dentibus setaceis, strietis, fauce intus plus minus pilosa. - B a 11 ot a e s p. Linn. Jaeq. Hort. Vindob. IIt, $t$, 42. (Poiteau in Annal, Mus. VII. t, 29. f. 2.)

o. PECTINARIA Benth, Op. cit, 127. B r a et e a e laxae, setaceae. C y m a e fruetiferae elongatae, peetiuatae, paniculatae. Cal $\mathrm{y} \times$ fructifer tubulosus, ore truneato. dentibus setaceis, strictis, fauce intas villosa. tera Spreng. in Linn. Transact, VI. 151. t. 4. Nepe. ta peetin at a Lian.

p. MINTHIDIUM Beath. Op. cit. 128. Bractea e minutae v, laxae, setaceae, Flares in verticillitstris axillaribus sessiles $\vee$. breviter pedieellati. C a ly $x$ fructifer fauce intus uuda. - (Jaeq. Ic, rar. $t, 113$. Poiteau in Annal, Mus. VII. $t, 31, f, 2.1$

q. BUDDLEIOIDES Benth. Op, cit. 139. B ractea minutae. Cy uae pedunculatae, subeapitatae, multiflorae,

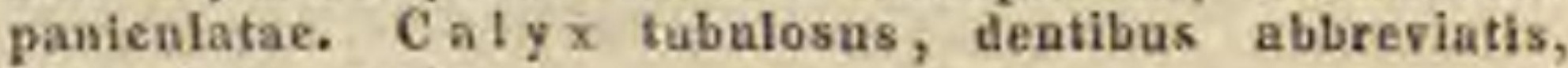
fauce latus nuda.

r. UMBELLARIA Beath. Op. cit.133. B r a ctea e minutae. C y u a e axillares, pedunculatae, umbellaeformes, plu. rillorae. C a I y $\times$ tabulosus, deatibus lanceolatis v. subu. latis, fauce intus nuda,

5. SIAGONARRHEN Mart. msc. Bractea e setaceae, minutae $\vee$. laxae, C y ma e regulariter dichotomac, racemosae v. rarius difformes, in paniculam elongatam. ccarctatam dispositae. Caly $x$ tabulosa - eampanulafns, incurvus, ore obliquo, dentibus lanceolatis, fauce latus nuda, Benth. Op. cit. 133.

t. HYPENIA Mart. mse. B ractea minutae v. laxae, setaceae. Flores subsolitarii, in paniculam laxe ramosissimam v, rarius coaretatam, glaberrimam, glaucam dispositi. C a I y $\times$ tubuloso-campanulatus, subacqualis, dentibus lasceolatis, acutis s. rarius obtusis, fauce intus anda. - Benth. Op, cil, 136.

3594. Eriope HUMB. et BONPL. Ca I y x turbinatus, florifer patens, aequaliter quinquedentatus, fructifer nutans, auctus, dentibus tribus superioribus membranaceo-dilatatis, duobus inferioribus vix mutatis bilabiatus, fance intus lana alba, densa clausus. Co rolla declinata, tubo subexser to, fauce valde dilatata, limbi bilabiati lobis qua tuor superioribus oblongis, subaequalibns, intermediis erectis, lateralihus patentibus, infims abrupte dejecto, saccato, apice acnminato-8ubbiden tato. S t a min a 4 , declinata, inferiora longiora fil amenta basi dense villosa, antherae ovato-reniformes, loculis confluentibus. St y Ins apice subaequaliter bifidus; $s t i g m$ a $t$ a subconfluentia. A e hen ia oblonga, subeompressa, laevia. Suffrutices fruticesve, rarius herbae perennes, in Brasilia indigenae; floribus secus axim racemi laxi, simplicis v. paniculato-ramosi solitariis, oppositis, foliis floralibus minutis, bracteaeformibus, per anthesim deciduis, bracteolis sub calyce duabus, minutissimis.

Eriope Humb. et Bonpl. mse, ex Benth. Labiat, 192.

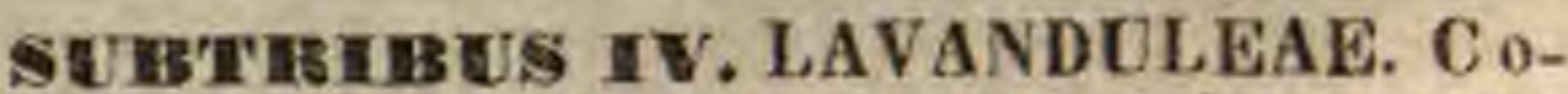
roll a bilabiata, labio superiore bilobo, inferiore trilobo. St a m in a corollae tubo inclusa. Genus mediterranewm.

3585. Lavanellula $L I N N$. C a I y x ovatotubulosus, subaequalis, uni-tri- rarius quindecim nervius, breviter quinquedentatus, dentibus quatuor inferioribus subaequalibns $\mathbf{v}$. duobus infimis angustioribus, supremo lateralibus parum latiore, $v$. apice in appendicem dilatatam producto, $\mathrm{Co}_{0}$ roll a tnbo exserto, fance dilatata, limbi oblique bilabiati labio superiore bilobo, inferiore trilobo, lobis omnibus subaequalibus, patentibus. $\mathrm{St}$ a m in a 4 , declinata, inferiora longiora; fil a menta glabra, libera, edentula, an therae ovato-reniformes, confluentes, uniloculares. S tylus apice breviter bifidus, lobis complanatis; stigmata marginalia, A ch eni a glabra, laevia, disci squamis quatuor coneavis postice adnata. - Herbae perennes, suffrutices $v$. fruticuli, in regione medit erran e copiose provenientes, specie una in India orientali observata; caule basifolioso, apice saepe nudo, bractsis utrinque uni-quinquefloris, op- 
positis $v$, rarius alternis, floribus in spicis terminalibus simplicibus v. basi ramosis, approximatis, bracteolis parvis setaceis $v$, nullis.

L a vand ula Linn. gen, n. 711. Gingins de Lassaraz, Histoiro naturelle des Lavandos. Génève, 1826. 8. Benth. Labiat. 146. Stoech as Tournef. inst, 201. Fabricia Adanson Fam. II. 188.

a. STOEchas Benth. Labiat. 147. B r a ctea e tri.quin. queflorae, in spicam densam imbrieatae, superiores ste. riles, comosae. C a ly cis dens supremus dilatato-appendieulatus. - Fruticuli; folits integerrimis v. pinnatodentatis. (Sibthorp Flor. graec, t. 399. Heritier Sert. t. 21. Link et Hoffmans. Elor. portug, t. 4. Bot. Mag. t. 400.)

b. SPICA Benth. Labiat. 148. B r a cte a e tri-quinqueflorae, in spicam laxani approximatae, superiores calyee breviores, fertiles. Caly cis dens supremus dilatatoappendiculatus. - Frutiouli; ramis superne nudis, folits integerrimis.

c. PTERostokchaS Ging, Lav. 158, B racte ae uniflarae, in spicam laxam dispositae, superiores aeque fertiles. Caly $\mathrm{x}$ tredecimnervis, subbilablatus, labio superiore tridentato, dente medio latlore non appendiculato, inferiore bidentato. - Herbae perennes v. basi sub. lignosne; folits dentatis $v$. inciso-mullifilis. (Benth. Trabiat. 149. Jacj. Ic. rar. t. 106. Bot. Mag. t. 401. Mirbel in Annal. Mus. $X V ., t .5 . f$. 5. Delile Plor. aesspt, t. 32, f. 1.)

d. ChaerostacuYs Benth. Labiat. 15t. B ractea uniflorae, alternae, In spicam laxíusculam, ramosan dispositae, superlores haud comosae. C al y x quindeciaineryis, subaequaliter quinquedentatus. - Herba perennis, indica; folits inciso-multifidis, Lavendula in ultifid a burm.

TRIIBUS II. MENTHOIDEAE Benth. Labiat, 152. S t a min a distantia, recta $v$. divergentia, nec per paria approximata. Cor ol1 a subcampanulata $\mathrm{v}$. infundibuliformis, tubo calyce breviore v. vix longiore, limbi quadriquinquefidi lobis subaequalibus.

SUB'TRE I. POGOSTEMEAE. Anther a e terminales, confluentim uniloculares. S t a m in a subdeclinata. - Genera gerontogea, subtropica.

3586. Fogestemon DESFONT. C a I y $\mathrm{x}$ ovato - campanulatus, quinquedentatus, acqualis, fauce nuda. Corolla tubo incluso, limbi quadrifidi, subbilabiati labio superiore trifido, inferiore indiviso, Lobis omnibus integerrimis, subaequalibus, patentibus. Stamina 4 , exserta, recta v. snbdeclinata; fila me nta nuda v. medio barbata, anth orae terminales, uniloculares. Stylus apice subaequaliter bifidus, lobis suhulatis; $8 \mathrm{tig} \mathrm{ma-}$ ta minnta, terminalia. A c he ni a laevia, - Herbae indicae; foliis oppositis, petiolatis, integris, dentatis $v$. subincisis, verticillastris multifloris, aequaIibus v. secundis, nunc glomerato-spicatis, bracteolatis, nune laxe racemosis.

Pogost em on Desfont, in Mrem, Mus, II, 154. t. 6 . Beath. Labiat, 159, Bot. Mag. t. 3238 .

3558. Dysoplnylla BLUM CaIy $\mathrm{x}$ ovato-campanulatus, quinquedentatus, aequalis, fauce nuda. Corolla tnbo incluso, limbi quadrifidi, subaequalis lobo supremo integerrimo v. emargi. nato, infimo subpatente. Stamina 4, exserta, recta v. vix declinata; fil a m en t a medio barbata, anth er a e terminales, uniloculares, rima transversali dehiscentes. Stylus apice snbaequaliter bifidus, lobis subulatis; stigmat a minuta, terminalia, A ehenia laevia, - Herbae indicae; foliis oppositis v. verticillatis, verticillastris multifloris, in spicas terminales dense approximatis $v$. imbricatis.

Dysophylla Blume Bijar. 896. Benth. Labiat, 156. Choteckia Opitz et Corda in Elora 1830. 1. 33. M entha s p. Limn. Roxb, Bot. Mag. $t, 290 \%$.

SUETIRIBUS II. ELSHOLTZIEAE. Antherae versatiles, loculis divaricatis, demum confluentibus. $S$ t a min a interdum subadscendentia. - Geronlogeae subtropicae.

3598. Elsholtzia WILLD. Cal y $\mathrm{x}$ ovatus v. campanulatus, quinquedentatus, aequalis, fance nuda, fructifer saepe elongatus. C o rolla tubo calycem aequante $\mathbf{v}$. rarius breviter superante, limbi breviter quadrifidi, subbilabiati labio superiore erectiusculo, subconeavo, emarginato, in feriore trilobo patente. $\mathrm{Stamina} 4$, saepius exserta, distantia, inferiora longiora; fil amenta nuda, a $n$ the $r$ a r nm loculi divergentes $v$. divaricati, demum confluentes. St y lns apice subaequaliter bifidus, lobis subulatis; stig mat a subterminalia. A cheni a laeviuscula, ovoidea.-Herbae v. suffrutices, in India orientali et in insula Java indigeni, in Asia media rarissimi; foliis oppositis, verticillastris mullifloris, in spicas laxas, graciles teretesque $v$. dense imbricatas disposilis, spicis saepius numerosis, paniculatis, floribus minutis.

E1s holtzia Willdenow in Usteri Magaz, II. J. Beoth. Labiat, 160.

a. APHANOCHILUS Benth. Antherarum locull divergentes $v$. divarieatl, demum confluentes. - Spicae saepius laxae, paniculatae, aequales v. subsecundae. braoteis lanceolatis $v$, subulatis, nunc dense imbricatae, aequales, bracteolis ovalis $v$. Laneeotatis.

Aphanochilus Beuth. in Wallich Pl. As. rar. I, 28. $t$. 33. 34. Labiat, 16t. Me nthate s p. DC. Pl, rar. hart. Genev, t. 8. Perilla s p. Don.

b. Cxclostegia Benth, A n thera e ovatae, loculis con. fluentibas. - Spica dense imbricata, bractcis conna. tis, mombranaceis, venosis, imbricatis, cyathiformibus, margine ciliatis.

Cyelostegia Benth. Labiat. 163.

c. ELSHOLTZia Filld. Antherarum loculi lineares. divaricati. - Spicae paniculatae, secundae, bracteis late ovatis.

Els holtzia Willd. Op. cit. t. 1. Bot. Mag. t. 2560. Benth. Labiat. 164. Mentliae sp. Cavarill. Ic. t. 360. f. 1. Lepechin in Act. Academ. Petropolit. I. $t .8$.

3589. Thetratemia BENTH. C a l y $x$ campanulatus, quinquedentatus, dente supremo latiore, fauce nuda. Cor olla tubo incluso, limbi campanulati, quinquefidi tobis subaequalibus, $S t$ amina 4 , aequalia, distantia; fil amenta nuda, a $n$ he ra $\mathbf{r} \mathrm{m}$ loculi confluentes, valvulis reflexis. Ovarii lobi sub disci glandulis quatuor aequalibus reconditi. S $t$ y 1 u $s$ apice breviter bifidus; s $t$ ig mat a ..... A ch enia ...... Suffrutex madagascariensis, tomentosus; foliis petiolatis, ovatis, crenatis, verticillastris in spiculas plurimas, racemoso-paniculatas dispositis.

Tetradenia Beath. in Bot. Reg. n. 1300. Labiat. 164. non Nees.

SUETRE US III. MENTHEAE. Anth e rae biloculares, loculis parallelis.

3550. Colleñrookia sMITI. Ca I y campanulatns, aequalis, quinquepartitus, laciniis plamosis, demum papposis, tubo cum acheniis 
maturis coalescente. C o rolla tubo calycem acquante, limbi brevissimi, subaequaliter quadrifidi lobo superiore emarginato. S t a $\mathrm{m}$ in a 4 , aequalia, distantia; fil amenta brevissima, a $n t h$ e $r$ a subsessiles, biloculares, loculis parallelis. $O$ va ri i discus aequalis, eglandulosus. Stylus profunde bifidus, lobis subulatis, prope apicem stigmatiferis. A $c h$ e $n$ ia oblonga, subtriquetra, apice villosa. Frutices indici, rufo tomentosi; ramis foliisque oppositis v. ternato-verticillatis, spiculis peduncula$t$ is, paniculatis, verticillastrorum cymis distinctis, capituliformibus, sessilibus, bracleis basi connatis involucratis.

Colebrook ia Smith Exot. Bot, II, $t, 111$, Roxburgh Corom. t. 24s. Benth, Labiat. 165.

3591. Perilla $L I N N$. C al y x campanulatus, quinquefidus, subaequalis, fauce nuda, demum nutans, bilabiatus, labio superiore dilatato, trifido, dente medio minore, inferiore bifido. Corolla tubo calycem subaequante, limbo brevissime quinquefido, subaequali. St a $\mathrm{m}$ in a 4 , subaequalia, distantia, erecta, corollam subaequantia; fil a menta nuda, antherae bilocnlares, loculis parallelis, demum divergentibus v, subdivaricatis. St ylus profunde bifidus; stig mat a terminalia. A chen i a sicea, laevia, - Herba indica, pilosa; foliis oppositis, longe petiolatis, ovatis, acuminatis, grosse serratis, floribus in spicas axillares terminalesque secundas dispositis.

Pe rilla Lisn. gen, $n$, 578. Benth. Labiat, 166. M eItis a $\mathrm{maxim} \mathrm{a} \mathrm{Arduino} \mathrm{Specim.} \mathrm{IT.} \mathrm{t,} 13$.

3592. Tsantlous $L, C . R I C H, C$ alyx campanulatus, aequalis, decemnervis, profunde quinquedentatus, fauce nuda. Corolla calycem vix superans, tubo brevi, recto, limbi campanulati lobis quinque aequalibus, rofundatis, patentibus. Sta mina 4 , subaequalia, distantia, erecta, corollam subaequantia; fil am enta nuda, a n the$r$ a e biloculares, loculis parallelis $v$. demum divergentibus. Sty I s apice breviter bifidus, Iobis subulatis; stigmata terminalia. A ehenia sicea, olovata, reticulata, lacunoso-rngosa. - Herba annua, boreali-americana, pubescenti-viscida; folits oppositis, breviter peliolatis, oblongo-ellipticis, integerrimis $v$, subsinuatis, trinerviis, pedunculis solitariis, axillaribus, folio brevioribus, unifloris, prope apicem saepe bibrateolatis.

Is a i th u s L. C. Richard in Whohaux Flor. Bor. Amer. II. 3. t. 30. Beuth. Labiat. 166.

3593. FPreshia OPITZ. Caly ovatus, aequalis, quadridentates, dentibus aristatis, fauce intus gubvilusa. Corolla tubo incluso, limbi quadripartiti lohis aequalibns, integris. Stamin a 4 , breviter exserta, aequalia, distantia, erecta; fil amenta glabra, antherae biloculares, localis parallelis. Stylus apice bifidus, Iobis subaequalibus; stigmata terminalia. Achenia oblonga, sicca, laevia. - Herba in uliginosis Europa e australioris crescens, prostrata, dura, glabra; foliis oppositis, sessilibus, lineari-lanceolatis, obtusis, integerrimis, punctatis, axillaribus subfasciculatis, floralibus conformibus, summis sterilibus, verticillastris multifloris, densis, distantibus, folio subbrevioribus, bracteis subfoliaceis, ovato-lanceolatis, basi in involucrum palmatifidum connatis.

Preslia Opitz in Flora 1824. p. 392. Fresenius in syllog. Plant. II. 238. Benth. Labiat. 16r. Me a th a ce r v in a Lius.

3594 . II latus $v$. tubulosns, quiuquedentatus, aequalis $v$. subbilabiatus, fauce intus nuda v, villosa. Corolla tubo incluso, limbi campanulati, quadrifidi lacinia superiore latiore, subintegra $v$. emarginata. St amina 4, aequalia, erecta, distantia; filamenta glabra, antherae biloculares, loculis parallelis. Stylus breviter bifidus; $s t i$ g $m$ a $t$ a terminalia. A chenia sicca, laevia. - Herbae saepius aromaticat, per omnem $E u$ ropam et Asiam me diam magna formarum inconstantia luxuriantes, et a mortalibus per orbem terrarum disseminatae, in America aequinoctiali, Capite bonae spei et India orientali sponte rarissimae; verticillastris sacpius multifloris, nunc omnibus remotis, ex axillis foliorum caulinis conformium, nunc in spicas terminales approximatis, foliis floralibus superioribus bracteaeformitus.

Me $n$th a Lino. Ben. n. 291. Sole, Menthae Britanicae Bath, 1798. fol. Smith E, B.f. 466, 449. 686,687, 1025, 1026. 2118, 2120, 2415. 2424. Ic. inedit, th 38, Jacq. Flor. austr. t. 430. Ic, rar. III. $t .87$, FI. daa, $t$. 484, 638, 1876. Flor. neap. 2, 35. 56, 156, 157. Hook. Fl. Lond. t, 166. Wahlenb. El. Lapp. t, 10 Benth. Labiat. 168. - A udiberti a Bonth. in Bot. Heg. $n$. 1228. non alib.

3595. Hyeopurs LINN. Cal y x campanulatus, aequalis, quadri-quinquedentatus, fauce intus nuda. Cor olla calycem vix excedens, campanulata, aequalis, quadrifida. Stamina superiora nulla, vel duo sterilia, filiformia, capitellata, corolla breviora, inferiora duo subexserta, fertilia, distantia; fil amenta nuda, antherae biloeulares, Ioculis parallelis, subdistinetis. Sty I $\mathrm{s}$ apice subaequaliter bifidus; stig $\mathrm{m}$ a $\mathrm{ta}$ terminalia, minuta. A chenia sicca, laevia, margine callosoincrassato, trigona, apice truneata, basi attenuata. - Herbae paludosae v. uliginosae, per omnem Europam, Asiam et Americam borealem diffusate, etiam in Nova-Hollandia observatae; foliis oppositis, acule dentatis $v$. pinnatifidis, floralibus conformibus, flores multo superantibus, verlicillastris densis, saepius multifloris, bracteis interioribus minutis, exterioribus in verticillastris inferioribus quandoque calyces excedentibus, floribus parvis, sessilibus.

L y copus Linn, gen, $n$, 13, E. B, t. 1108, Fl. dall. t. 1081. Sibthorp Fl. graec. t. 19. Benth. Lablat, 184.

SURTRIMUS IV. MERIANDREAE. Antherarnm loculi disjuncti, connectivo filiformi.

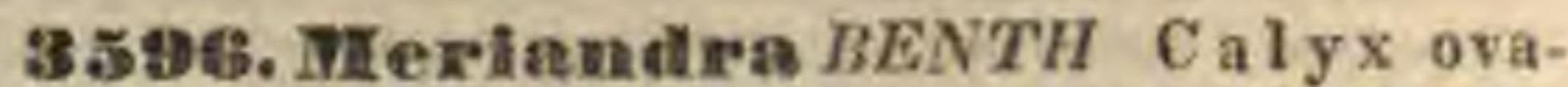
tus, bilabiatus, labio superiore concavo, integro $v$. brevissime tridentato, inferiore bifido, fauce nuda. Corolla tubo calycem aequante, limbi subaequaliter quadrifidi lobis planis, superiore integro v. emarginato. Stam in a fertilia plerumque duo inferiora, erecta, distantia, superiora abortiva, v. rarius uno alterove fertili inferioribus confurmi; filamenta glabra, an therae biloculares, 10 culis disjunctis, stipitatis, aequalibus, pendalis connectivo lineari, brevi, ad medium cum filamento articulato, utrinque erecto. Stylus apice subacqualiter bifidus; $8 \mathrm{tigmata}$ terminalia. Frutices indici, camphorati; floribus racemosis $v$. spicato-paniculatis.

Meriandra Benth. Labiet, 185, Salvia beughalensis Roxt.

TRERUS IIC. MONARDEAE Benth. Labiat. 190. Co roll a bilabiata. St a mina 2 fertilia, inferiora, adscendentia. Antherae 
nunc biloculares, loculis contiguis v. comnectivo lineari sejunctis, loculo altero saepius casso.

SUIBTIRETS T. SALVIEAE, Connectivum filiforme, cum filamento articulatum.

359\%. Salvia LINN. C a y x ovatus, tubulosus v. campanulatus, bilabiatus, labio superiore integro v. tridentato, inferiore bifido, fauce nuda. Coroll a tubo incluso $v$. exserto, varits, limbi bilabiati labio superiore integro $\mathbf{v}$. breviter emarginato, inferiore trilobo, lobo medio plerumque latiore, saepius emarginato. Stamina superiora nulla v. rudimentaria, clavaeformia, inferiora duo fertilia, prope faucem tubi inserta; fil am enta subhorizontalia $v$, rarius erecta, apice cum anthera articulata v. supra articulationem breviter producta, rarissime subcontinua, antherae dimidiatae, connectivo elongato antice adscendente loculum polliniferum gerente, postice deflexo loculo efoeto v. nullo, Ovarii discus antice glandulifer, glandula lobos subaequante. Stylus adscendens, apice bifidas, lobis aequalibus v, inaequalibus; itigmata terminalia ver lobos decurrentia. A chenia ovoideo-triquetra, sicca, glabra, plerumque laevissima. - Suffrutices $v$, herbae, per totum terrarum orbem diffusae, inter tropicos imprimis Americae copiosissime provenientes, labitu et inflorescentia varia.

Sal v i a Linn. gen, n, 39, Etlinger, Dissertatio de Salvia Erlang. 17r\%. 4. Benth. Labiat. 190. Ho r mi. u um, Selaraea et A ethiopis Tournefort.

a. EUSPHACE Benth. Cal y x eampannlatus, labio superiore tridentato, inferiore hispido, dentibus omnibus acutis, demum vix auctis. Corolla e tubas amplns, sabexsertus, intus piloso-annulatus, labium superius crectum, inferioris lobi laterales reflexa-pateates, mtdiius latus, emarginato-bifidus, laciolis subreflexis. An. the $r$ a $f$ u connectiva postice porrecta, loculum difformem, cassum v. rarius subpolliniferam gerentia, extremitate subcovvexa. - Herbae v, saepius suffrutices regionis mediterraneae; folits integris v, pin. natisectis.

$\mathrm{E}$ us p hace Benth. Op. oit. 202. (S.bthorp Flor. graec. t. 17. 18. Jacq, Hort. Schönbr. t. 195. Jacq. f. Eclog. t, 36. DC. Plant, rar. Genev, t, 3. Sweet El. Gard. t. 169. Bot. Mag. t. 1429.)

b. HYMENOSPHACE Benth. Cal y x campanulatus, labio superiore bi-trifido, inferiore bifido, lobis onnibus subaequalibus, demum membranaceo-dilatatis, venosis. Co. rollae tubus amplus, intus piloso-auaulatus, labium superiẹs subfalcatum, conipressum, inferioris lobi la. terales patentes. A a the r a rum connectiva postice porrecta, loculum difformem, eassum gerentia, extremitatibus subconnexa. - Suffrutices $v$, rarius herbae, saepius incanae, in regione mediterranea et in $\mathrm{Ca}$. pite $B$ ona $S_{p e i}$ indigenae.

H y me nosphace Benth. Op, eit. 214. Sehrade$r$ ia Mobeh Method. 378. (Miller Ic. $t$. 225. Sibthorp 27 , gracc. 2. 15. 16. Bot, Mag. $t$, 182.)

DRXMOSPHACE Benth. Cal $\mathrm{x}$ tubulosus v. campauu. latus, labio superiore subiategro, truncato v. rarissime ridentato. Corolla e tubus exsertus, intus piloso. annulatus, labium superius falcato-compressum, inferioris lobi laterales patentes, Antherarum conneetiva postice porrecta, loculam difformem, cassum gerentia, extremitatibus subeonexa. - Herbae europeae et ubiaticae, virides, subglutinosac; folits ut pluri. mum amplis, hastato-cordatis, floribus plerumque flavis, rarius caeruleis.

Dry mosphace Benth. Op. cit. 918. (Sweet Flor. Gard. II. t. 140.)

d. HORMINUM Benth. Ca I y x tubulosas, labio superiore truneato, subtridentato. Co rolla tubus sub fauce ampliatus $v$, veatricosus, intex exannulatus, labium su. perius rectum, concarum $v$, faleatum, compressum, inferioris lobi laterales oblongi, erecti, subtorti, inter medius rotundatus, patens. Antherarum connectiva postice deflexa, abrupte dilatata, extieaitatibus callosis connexa. - Herbae mediterraneae.

Horminum Benth. Op. cit. 220. (Sibthorp Flor. graec. $t, 19$-21. Desfout, $F l$, All, $t, 1$. Jacq. f. Eclog. t. 15. Bot. Mag. 2. 288)

e. AETHIOPIS Benth, C a ly $x$ campanalatus v. tubulosins, labio superiore tridentato, dentibus erectis, medio saepe minimo. C orolla e tubus sub fauce ampliatus v, ven tricosus, intus exannulatus, labium superius falcatum, compressum, luferioris lobi laterales oblongi, sub. erecti, subtorti, intermedius patens, rotundatus, plerumque concavus, emarginatus, creublutus. A n the. ra rum connectiva postice dellexa, abrupte dilatata. extremitatibus callosis connexa. - Herbae saepius albo. lanatae, in regione mediterranea oriental et $i \pi \quad A s i a e$ mediae montibus indigenae; folits foralibus persistentibus. erectis, verticillastros amplectentibus v. rarius pedunculo vix longioribus, pqnicula-ramosa, rarissime subsimplici.

Aethiopis Benth, Op. cit. 228. Stenarrhena Don Nop. 111. (Slbthorp Fl, graec. $t, 25-27$. Jacq. Fl, austr. t. 211. Hort, Schönbr. t. 6. Hort. Vindob. I. t. 78. Ic, rar. t. 7. Cavanill. Ic. t. 558. Vent. Cels. t. 59 . Link et Hoffmans. $F l$. poriug. $t, 20$. Jacq. f. Eolog. t, 16. Wallieh Pl. As, rar, t, 116. Bot, Mag. t. 295. 2320. Bot. Reg. t. 1003.)

f. PLETHosphace Benth. Caly $\mathrm{x}$ ovatus, labio supe. riore supra coneavo, bisnleato, tridentato, dentibus bre vissimis, conniventibus, inferius bifidum, lobis acutis. Corollae tubus sub fauce ampliatus v. ventricosus, jutus exannulatus, latium superius concavem v. faleato. compressum, inferioris lobi laterales oblongi, subereeti, subtorti, jatermedius patens, rotundatus, plerumque coneavus, emarginatus, crenulatus. A i thera r um conuectiva postice deflexa, abcupta, extremitatibes callosis connata. - Herbae in regiane mediterranea, Europa orientali ot Asiaboreali, nec non in capite bonae spei indigenae, foliis saepius eroso-dentatis $v$, incisis, racemis elongatic, simplicibus v. virgato-paniculatis.

Plethiosphace Benth. Op. cit. 230. (Sibthorp Fl. graec. t. 28. Jaeq. Fl, austr. t. 112. 212. Hort. Schönbr, t. 7. Hort. Vindob, T. t. 37. Ic, rar, t. 5. Desfout. $F l$, all, $t$. 2. 3. Link et Hoffmanns, $F l$. portug. t. 19. Waldst. et kitaibel Plant. Hung, $t$. 62. Jaey. f. Eclog. 2. 38. Bot. Mag. 4.1774. 2436. But. Reg. t. 1019.)

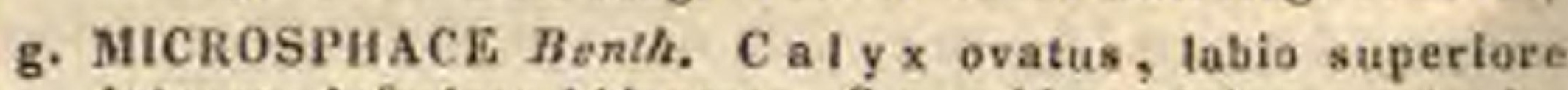
integro, iuferiore bidentato. C o roll a uinima, tubo incluso, iatus exannulato, labils brevissimis, superiote erecto, inferioris lobis lateralibus patentibus, An the $r$ a r u connectiva postice deflexa, linearia, longitudinaliter conaata, Styli lobus inferior complanato-dilata. tus, rotuadatus. - Herbae americanae tropi. cae, prooumbentes.

Mierosphace Benth. Op. eit. 2ai. (Ruiz et Pavon $F l$. peruv. $t, 39 . f . a$.)

b. CALOSPHACE Benth. Caly $\mathrm{x}$ ovatus, tubulosus v. canpanulatus, labio superiore integro $\mathrm{v}$. breviler trideutato. Corolla e tabus exsertus v. inclasus, intus ex. annulatus, interdum prope basim dentibus duobus anctus, labium superius reetum, eoneavum, integrum v. suepias breviter emarginatum. inferioris lobl patea. tes. A n therar u m conuectiva postice deflexa, linearia, tongitudinatiter connata. St y li lobus inferior subula. tus. - Herbae, suffrutices $v$. frutices, in $A m \in \mathbb{R} i c a$ tropica indigeni, habitu vario, folits integris, serratis, erenatis v. rarius integerrimis.

Calosphace Benth, Op. cit. 245. J a ng i Mö̀eh Method. 378. (Ruiz et Pavon Fl. peruv. t. 36, 34. Kunth in Humb, et Bonpl. Nov, gen. et sp. t. 138-158. Pohl Plant. Brasil. ' 189-196. Cavanili. Ic. $t, 23.27 .105$. 166. 317, 320. 457. 455. Smith Ic. t. 26. 27. Jacq, Hort. Schönbr, Ł. 252. 255. 318. 319. 381. Ic. rar, t. 3. 22. Jacq. f. Eclog. t, 13, 47. Vent. Cels. t, 50. Bot, Mag. t. 326. $808,1249,1728,2872$. Bot. Reg, t, 347. 359. 1356. 1370, 1429, 1384.)

i. ECHINOSPHACE Benth. C al y $\mathrm{x}$ ovatus, labio superiore tridentato, inferiore breviore bifido, dentibus omalbus 

spinosis. Cor olla e tubus intus piloso ansulatus, la-
bium superius rectum, emarginato-bifidnm, inferioris lobi laterales parvi, intermedius maximus, lacero- fun briatus. A n therar $\mathbf{m}$ m conuectiva medio affixa, remota, postice subporrecta, loculum subcosformem, pollini ferum gerentia. - Herba californica; folits flo ralibus et bracteis imbricatis, spinosis, floribus in verticillastris densissimis, multifloris glomeralis.

Echinosphace Benth. Op, cit. 302.

l., PYCNOSPHACE Benth. C aly x ovatus, Iabio superiore tridentato, inferiore bifido, dentibus omnibus subulatis. Corollac tubus intus piloso-annulatus, labium superius rectum, inferioris lobns medius integer v. emar. ginatus. Antherarum connectiva medio aifixa, postice remota, porrecta, loculum subeonformen, polliniferum gerentia. - Herba californica; fotils floralibus et bracteis imbricatis, muticis, floribus in verticillastris multifloris densissime glomeratis.

Pycaosphace Benth. Op. cit. 302. -? Leonia Llave et Lexarz. Nov, veget. $I$. 6 .

I. HBTERosphace Benth, C al y $\times$ tubulosus, labio superiore truncato, tridentato. Corollae tubus intus piloso-anuulatus, labium superius breve, rectum, inferioris tobi laterales parvi, subpatentes. An the rarum connectiva meilio affixa, postice porrecta, localum sub. conformem, polliniferum gerentia. - Horbae mediter. ranoae africanae, asiaticac ot borealia mericanac; foliis floralibus deciduis, floribus racemosis, vertiolllastris laxis, paucifloris, calyeibus saepe coloratis.

Heterosphace Benth. Op. cit. 303. (Jacq. Hort. Schöntbr. t. 8. Hort. Vindab. III. t, 98. Ie. rar. t. 6. Thub. Fl. japon, t. 5.)

im. NoTIOSPHACE Benth. Caly $\mathbf{x}$ ovatus, labio superiore iategro v. brevissime tridentato, dentibus conniventibus, inferiore bifido. C oroll a minima, tabo inclaso, labio superiore recto, inferiore subpatente. A n therarum connectiva medio affixa, postice remota, porrecta, locnIum subconformem. fertilem gerentia. - Herbao in Asia et Australasia tropica, neo non in Africa boreali-arientali observatae; folits floralibus bracteisque minutis.

Notiosphace Benth. Op. cit. 309. (Jacq. Hort, Vindob. IT. t, 108. Vivinai Flor, Lybic. t, 16. $f, 1$.)

n. GYMNOSPHACE Benth. CaI y $x$ ovato-tubulosus, labio superiore integro, recurvo, inferiore bifido. Corolla tubo brevi, umplo, fotus anaulato (?) labia brevia, su. perius erectum, infertoris lobl patentes. A nt he ra rum connectiva filamentis rectis subeontinas, postice remota, deflexa, filiformia, erecta. - Herba nepalensis, caespitosa.

G y m nosphace Benth $O_{p}$. cit, 310 .

a. HEMLSPHACE Benth. Cal y $\times$ tubulosus, labio superio. re truncato, tridentato, inferiore bifido. Corollac tubus intus piloso-anuulatas, labium superius erecto. patens, foruicatum, iuferioris lobis patentibus. A n ti e. r a $\mathrm{f} \mathrm{um}$ connectiva filamentis rectis subcontinua, postice remota, lirevissime producta, deflexa, acuta. - Herbae habilu Heterosphacium, in regione mediterra. nea orientali indigenae.

He un is phace Benth, Op, oit, 310. (Jacq. Hort. Vindob. II. 1. 152.)

3598. Audibertia BENTH. C a I y $x$ ovatus, bilabiatus, labio snperiore concavo, integro $\mathbf{v}$, breviter tridentato, inferiore bifido, fance nuda. Co roll a tubo calycem aequante $v$. exserto, limbo bilabiato, labii superioris bifidi lobis patentibns, inferioris trifidi lateralibus ovatis $v$, oblongio, patulis, medio latissimo, emarginato. S ta mina duo inferiora fertilia, adscendentia, saepius exserta, superiorum rudimenta minima, clavaeformia v. nulla; ant herae dimidiatae, connectivo lineari, cum filamento articulato, adscendente, apice loculum linearem gerente, postice haud producto $v$. brevissime acuminato. Stylus breviter gubulato-bifidus. A c he nia triquetra, glabra, -
Herbae californicae $v$. suffrutices villosi; racemo simplici v, composito.

A udibertia Beuth. in Bot, Reg. 1, 1469. Labiat.3t2.

SUETTEDUS IR. ROSMARINEAE. Connectiva parva. Sta mi n a 2 fertilia.

3599. Rosmu roinas $L I N N$. C a 1 yx ova to-campanulatus, bilabiatus, labio superiore integro, inferiore bifido, fauce nuda. Corolla tubo exserto, intus glabro, exannulato, fance subinflata, Iimbi bilabiati labiis subaequalibus, superiore erecto, emarginato, inferioris patentis, trifidi lobis Iateralibus oblongis, erectis, subtortis, medio maximo, concavo, dependente. Stam in a 2 , inferiora fertilia, adscendentia, e labio superiore exserta, saperiorum rudimenta nulla; fi I am enta ad fancem corollae inserta, prope basim dente brevi aucta, anthera e lineares, subbiloculares, loculis divaricatis, confluentibus, margine connatae. St yI $\mathrm{u}$ s apice bifidus, lobo superiore brevissimo; s $\mathrm{tig}$ m a ta terminalia, minnta. A chenia sicea, laevia. - Frutex tristis, in regione mediterranea rupicola; foliis oppositis, linearibus, integerrimis, margine revolutis, subtus canescentibus, floribus in racemis axillaribus paucis, approximalis, subsessilibus, corolla alba v. pallide caeruleo-purpurea.

R os marinus Linn. gen, $n$, 38. Sibthorp El. graec. t. 14. Benth. Labiat. 314 .

3600. NIomarda $L I N N$. C a I y 8 tubulosus, elongatus, quindecimnervis, subaequalis, quinquedentatus, fauce villosa $v$. rarius subnuda. $C_{0}$ ro 11 a tubo exserto $\mathbf{v}$. incluso, intus glabro v, pubescente, fauce subdilatata, limbi bilabiati labiis linearibus v. oblongis, subaequalibus, superiore erecto, integro v. emarginato, inferioris patentis, apice breviter trifidi lobis lateralibus ovatis, ob tusis, medio angustiore, oblongo, retuso,v. emarginato. Stam in a 2 inferiora fertilia, adscendentia, e labio superiore corollae saepius exserta, su periorum rudimenta subnulla; filament a ad faucem corollae inserta, edentula, anthera e lineares, subliloculares, loculis divaricatis, confluentibus, margine connatae. St ylu s apice subaequaliter bifidus; st ig mat a terminalia, minuta. A che nia sicea, laevia. - Herbae boreali-americanae; foliis integris, plerumque dentatis $v$. crenatis, floribus in verticillastros paucos densissime glomeratis, bracteis suffultis.

Monarda Linu. Gen, n. 37, excl. sp. Benth, La. biat, 315 .

a, EUMONARDA Benth. Labiat, 726. S ta m i u a longe ex serta. - (Pursh Fl. Bor. Amer. t, 1. Reichenb. Ic exot, t, 170, 171, 182. Hooker Exot. Flor. t. 130. Bot. Mag. $t$. 145. 546. 2513. 2958, 3310. Sweet Fl, gard. I. $t .98, I T, t, 166$.

b. CHEILYCTIS Benth. Labiat. 720. Stamina corollae labium superius aequantia v. breviora. - Cheily etis Rafinesque in Journ, Phys. LXXXIX. 99. C o ry a thu * Nuttall in Americ. Philosoph, Transact, V, 186.

3801. Flephilia $R A F I N$. Cal y $x$ ovato tubulosus, tredecimnervis, bilabiatus, labii supe rioris tridentati dentibus aristatis, inferioris bidentati muticis v. breviter aristatis, fauce nuda. Corolla tubo subexserto, intus glabro, fauce dilatata, limbi bilabiati labiis subaequalibus, superiore erecto, integro, inferioris patentis, trifidi lobis Iateralibus ovato-rotundatis, medio angustiore oblongo, retuso, emarginato. Stamina 2 inferiora fertilia, adscendentia, e labio superiore coroltac exserta, superiorum rudimenta filiformia 
parva $v$. nulla; filamenta ad faucem corollae inserta, edentula, an ther a e lineares, subbiloculares, loculis divaricatis, confluentibus, margine connatae. Stylus apice subaequaliter bifidns; $8 \mathrm{ti} \mathrm{gmata}$ terminalia, minuta. A $\mathrm{chen} i \mathrm{a}$ sicca, laevia. - Herbae boreali-americanae, habitu Monardae, floribus fere Zizyphorae; verticillastris plurimis, globosis, supremis in spicam subapproximatis.

Blephilia Rafin, in Journ, Phys. LXXXIX, 98, Benth. Labiat. 319. Monarda ciliat a Linn. et Auct.

3G0\%. Zizyplaora LINN. Caly x tubulosus, elongatus, tredecimnervis, bilabiatus, labii superioris tri-inferioris bidentati dentibus muticis, fauce villosa. Corolla tubo vix exserto, intus glabro, fance dilatata, limbi labiis subaequalibus, superiore erecto, intogro, inferioris patentis, trifidi lobis rotundatis, medio longiore, emarginato. St a m in a $\mathbf{2}$ inferiora fertilia, sub labio superiore adscendentia, eidem aequalia v. longiora, superio rum rudimenta subnulla; fi l amenta fauci corollae inserta, edentula, antherae lineares, subbiloculares, loculis divaricatis, confluentihus, margine subconnatae. Styli apice bifidi lobus superior brevissimus; s tigma ta terminalia, minuta. A c h enia sicea, laevia. - Herbae v. suffrutices, in $E u$ ropa australi et in Asia media provenientes; foliis oppositis, integerrimis $v$. minute paucidentatis, subtus lineatis, floralibus subconformibus, nunc la. tioribus, nunc angustioribus, verticillastris paucifloris, in apicibus ramorum saepius approximalis, pedicellis brevibus, complanatis, erectis.

Z iz y phora Linn. Gen $n$. 36. Sibthorp Fl. graec. t, 13. Rudolplt. in Mem, Academ. Petropolit. II. $t, 10-1 \mathrm{2}$, Bot. Mag. $t$. 906. 1093. Benth. Labiat. 320.

SUTRTERES IIT. HORMINEAE. Conne ctiva parva. Stamina 4 fertilia.

3803. T⿱ panulatus, tredecimnervis, bilabiatus, labio superiore tridentato, inferiore bifido. Corolla tabo exserto, intus piloso-annnlato, fauce elongata, ampliata, limbi subbilabiati labio superiore trun. eato-emarginato, inferioris trilobi laciniis brevibus, latis, rotundatis. S tamin a 4 fertilia, adscendentia, inferiora longiora; f i l a m e n t a nuda, anther a e per paria cohaerentes, lineares, biloculares, loculis divaricatis. Stylu s apice breviter bifidus, lubis subulatis; stigmata terminalia, minuta. A che nia laeviuscula. - Herba in Europae mediae subalpinis perennans; foliis fere omnibus rudicalibus, petiolatis, ovatis, profunde crenatis, basi truncalis $v$, subcordatis, glabris, utrinque viridibus, caulibus floriferis erectis, floralibus bracteaeformibus, brevibus, verticillastris distantibus, subsexfloris, secundis, floribus nutantibus, purpureoviolaceis.

H or $\mathrm{m} \mathrm{n}$ n m Benth. Labiat. 727. Horm inum p y rena $i$ cu m Linn. Sweet Fl. Gard. $I$. $\ell$. 252. Mellis a p yrenaíen Jacq. Hort, Dindob, $t, 183$.

THEHES IV. SATUREINEAE. Caly $x$ quinquedentatus, aequalis v. bilabiatus, labio superiore tridentato, inferiore bifido. CorolI a e tubus calycem vix aequans, limbus subbilabiatus, labio superiore integro $\mathbf{v}$. bifido, inferiore trifido. Stamin a distantia, recta, divergentia, aequalia v. postica breviora ant abortiva.
SUBTEREUS I. ORIGANEAE. C aly 10 -13nervis. Stamina 4 fertilia.

3694. IBystropogon HERIT. C a ly $\mathrm{s}$ campanulatus $v$, tubulosus, decem - v. tredecimnervis, aequalis, quinquedentatus, fance villosa. Corolla tubo incluso, limbo subbilabiato, labio superiore suberecto, bifido, inferiore patente, trifido, lobis omnibns planis, integris. St a m in a 4 , ereeta, distantia, corolla breviora, inferiora superioribns longiora; filamenta glabra, antherae biloculares, loculis parallelis. Ova rii discus aequalis, eglandulosus. St y lus apice breviter bifidus, lobis subacqualibns, linearibus subincrassatis, obtusis; stigma ta terminalia. A chenia sicea, laevia. - Frutices canarienses et a us tro-a meric a $n i$; floribus parvis, cymosis, v. dense spicatis, bracteis lanceolato-subulatis.

Bystropogon Heritier Sert. 19. exel. sp. Benth. Labiat. 324,

a. BYStropogon Beath. l. c. CaIyx campanulatus, decemuervis. Flores cymosi, cymae dichotomae, corymbosae v. laxe panieulatae. - Canarienses. (Heritier Op. eit, $t, 22,23$. Menthat s p. Liau.)

b. Mintostachys Benth. l, c. Caly $\times$ tabulosus, tredecimnervis. Vertieilla stri deasi, spicati. - Pera. viani.

3605. Pyemanthemunas BENTH. Caly $\mathbf{x}$ ovatus $\mathbf{v}$, tubnlosus, subtredecimnervis, quinquedentatas, dentibus subaequalibus, rectis v, tribus superioribus basi in labium eoalitis, C o rolla tubo calycem aequante, límbi subbilabiati labio superiore recto, plano, integro v. brevissime emarginato, inferioris plani, trifidi lobis omnibus ovatis, obtusis. Stamina 4, subaequalia v. inferiora parum longiora, recta, divergentia, exserta v. inclusa; filamenta glabra, antherae biloculares, loculis parallelis. St yl us apice subaequaliter bifidus, lobis subulatis; $8 \mathrm{tigmat}$ a terminalia. A eh enia sicca, laevia v. minute punctato-rngosa.-Herbae bor eali-americanae, perennes, rigidae, saepe canescentes, apice corymboso-paniculatae; verticillastris paucis, densis, multifloris, bracteatis, saepe capitula terminalia formantibus, corollis albidis $v$. purpurascentibus, labio inferiore plerumque purpureo - maculato.

P y c n a $\mathrm{n}$ h e m n menth. Labiat. 326.

a. TULLIA Benth. $t$, c. Cal y $x$ saepe bilabiatus, dentíbus subulato-aristatis. - Verticillastri saepius laxi, folia plerumque petiolata.

P ycnantbemum L. C. Richard in Michaux Flor. Bor. Amer, II. 7, $t, 33$, excl, sp. T ulli a Leavenworth in Silliman's Journ. $\mathrm{XX}, 3$ 3.3. $t .5$.

b. BRACHYSTEMUM Benth. 2 . c. Caly $\mathrm{c}$ is dentes breves, aequales, mutici. - Vertioillastri parvi, terminales, plerumguc capituliformes, rarius laxiusculi, subpaniculati. Folia plerumque sessilia.

Brachystem um L. C. Richard Op. eit, II. 6. t. 31. 32, Ko elli a Möneh Method. 406.

3606. DIonarallella BENTH. CaIy x ovato-tubulosus, saepe elongatus, decem- v. tredecimnervis, quinquedentatus, dentibus brevibns, subacqualibus, rectis, fance nuda. Cor oll a tubo calycem aequante v. breviter exserto, fance glabra, limbi subbilabiati labio snperiore bifido, inferioris trifidi lobis omnibus oblongis linearibusve, planis, subaequalibus. Stam in a 4 , subaequalia $v$. inferiora longiora, recta, divergentia, exserta; filamenta nuda, anth era e biloculares, loculis paralletis, demum divergentibus v, divaricatis. StyI 8 apice brevissime bifidus; $8 \mathrm{tig} \mathrm{m}$ a $t$ a terninalia, minuta. A chenia sicea, laevia. - Herbae 
boreali-a mericanae, perennes, verticillastris magnis, subglobosis, terminalibus, solitariis, bracteis latis suffultis.

Mo nardell a Benth. Labiat. 331. P y cna a t bem a m Monardella Michaux Flor, Bor. Amer, $t, 34$.

:BO 8 . Amarearis $M O ̈ N C H$. Ca I y x ovato-campanulatus, basi tredecimnervis, limbi labio superiore elongato, integro, erecto, inferiore truncato, subnullo v. brevissime bidentato, fauce nuda. Co rolla tubo exserto, limbi bilabiati labio superiore erecto, emarginato, subplano, inferioris patentis, trifidi lobis subaequalibus, integris. S $t$ amina 4 , erecta, adscendentia, vix distantia, inferiora longiora; filamenta glabra, antherae biloculares, loculis distinetis, divergentibus v. divaricatis. Styli apice bifidi lobus superior brevior; $s$ tigma ta terminalia, minuta. A $c$ henia ...... - Suffrutices cretic $i$, glabri $v$. densissime lanati; folits integrerimis, floribus in spiculas oblongas aggregatis, bracteis orbiculatis, membranaceis, coloratis, laxe imbricatis, calyce multo longioribus, corollae tubum aequantibus.

A mar a us Mönch Method. suppl. Benth. Labiat, 333. O rigan i sp. Linn. Sibthorp Fl. graec. t, 569. Bat. Mag. t. 298 .

3B08. Driganum $L I N N$. C a l y x ovato tubulosus, decem-v. tredecimnervis, striatus, dentibus quinque aequalibus $v$. tribus superioribus parum longioribus, fauce villosa. Corolla tubo calycem aequante $v$. vix superante, limbi subbilabiati labio superiore suberecto, emarginato, infe rioris patentis, trifidi lobis subaequalibus. Stamina 4 , exserta, distantia, inferiora paullo longiora; fil amenta glabra, antherae biloenlares, loculis parallelis. St ylus apice subaequaliter hifidus; stig mata terminalia, minuta. A $\mathbf{c h}$ en i a sieca, laeviuscula. - Herbae v. suffrutices, in regione medilerranea obvii, in Europa et Asia media, nec non in montibus Indiaesuperioris parce provenientes; foliis integerrimis $v$. subdentatis, floribus in spiculas cylindricas oblongasve aggregatis, bracteis coloratis, laxiuscule imbricatis, calyces obtegentibus.

Origan um Linn. Gen. $n$. 726 , excl. sp. Benth. La. biat. 337. Sibthorp $\mathbf{F l}$. Graec, $t, 570$. $\$ 7 x$. Link et Hoffmans. Fl. portug. t. 9 .

3EDD. IN brevissiuse campanulatus, limbo antice fisso, superne complanato-dilatato, integerrimo, orbiculato, margine basi subtus implicato, fance nuda. Coroli a tabo calycem aequante, limbi subbilabiati labio superiore suberecto, emarginato, inferioris patentis, trifidi lobis subaequalibus. St a m in a 4 , exserta, distantia, inferiora longiora; filamenta glabra, an thera e biloculares, loculis parallelis, divergentibus v, demum divaricatis. Sty 1 us apice subaequaliter bifidus; $\mathbf{s t} \mathbf{t} \mathbf{m}$ a $t$ a terminalia, minuta. A e henia sicea, laevia. - Herbae perennes v.suffrutices, saepe tomentoso-villosi, in regione mediterranea indigeni, etiam in Indiae al pibus observati; foliis integerrimis $v$. dentatis, floribus in spiculas breves, tetragonas aggregatis, bracteis orbiculatis, villosis, haud coloratis, calyces aequantibus, arcle imbricatis.

Majorna a Mösch Methoul. 406. Benth. Labiat. 328. Orig a $\mathrm{i}$ i $\mathrm{p}$. Lina. Sibthorp Ft, graec, t. 579. 573. Bot, Mag. $t .2605$.

3619. Thymaras LINN. Caly x ovatus, tredecimnervis, bilabiatus, Iabio superiore tridentato, inferiore bifido, laciniis ciliatis, subulatis, fauce villosa. Co roll a tubo incluso, intus nudo, limbi bilabiati labio superiore recto, emarginato, subplano, inferioris patentis, trifidi lobis aeqnalibus v. medio longiore. Stamina 4 , exserta $v$. rarius inclnsa, recta, distantia, aequalia $v$, inferiora longiora; filamenta glabra, antherae biloculares, loculis parallelis $\mathbf{v}$, demum divergentibus. Stylus apice subaequaliter bifidus, lolis subulatis; stig mata terminalia, minuta. A chenia sicca, laeviuscula. - Suffrutices $v$. fruticuli saepe canescentes, per omnem Europam, region em mediterranea $m$, et Asiam temperatam obvii; foliis parvis, integerrimis, venosis, margine saepe revolutis, verticillastris paucifloris, nunc omribus remotis, nunc in spiculas laxas, densas $v$. im bricatas aggregatis, bracteis minutis, floribus purpurascentibus $v$, rarius albis.

Th ym us Linn. gen, $n$, 797. excl. sp. Benth. La. biat, 340 .

a. MASTICHINIA Benth, $l$. $c$. Calycis dentes omines subulati.

b. SERPYLLUM Benth. $l$. c. $\mathrm{C}$ aly $\mathrm{c}$ is deates superiores lanceolati,- Folia foralia caulinis subconcolor a, - (Sib. thorp Fl. graec. 1 . $574-578$, Liak et Hoffuans. Fl, portug. $t$, 75-18, Waldist. et Kitaihel Pt. Hung. t. 71, 147. Bot. Mag. $t$. 2666. S a ture ia e sp. Sibthorp Fl. graec. t. 5\%4.)

c. PSEUDOTHYMBRA Benth. $l$. $c$. Caly $\mathrm{cis}$ dentes superiores lanceolati. - Folia floralia magna, colorata, mem. branacoa. - Th y mbra cilliat a Desfout, $\mathbf{F l}$, atlant. $t$. 122, et $\mathrm{T}$ h $\mathrm{y}$ m us e e phalotes Lina.

36141. Satureina $L I N N$. Caly $x$ campanulatus, decemnervis, aequalis, quinquedentatus v. obseure bilabiatus, fauce nuda v. parce villosa. Corolla tubo calycem aequante, limbi bilabiati labio superiore erecto, plano, integro v, emarginato, inferioris patentis, trifidi lobis planis, subaequalibus. Stam in a 4 , suberecta, divergentia, inferiora longiora, exserta; fi l a m e $\mathrm{t}$ a glabra, a nth e $r$ a e bilocnlares, loculis parallelis $v$, divergentibns. Stylus apice subaequaliter bifidus, lobis subulatis; stigmat a terminalia, minuta. A ch en i a sicea, laevinsenla. - Herbae $v$. suffrutices, in Europa imprimis mediterranea et in $A m e-$ rica boreali indigeni; foliis parvis, integerrimis, axillaribus saepe fasciculatis, verticillastris nune paucifloris, bracteis tune brevibus $v$. nullis, nunc multifloris $v$, in capitulum aggregatis, bracteatis.

Satureia Lian. gen, n, 707. Benth. Labiat. 351.

a. SATUREIA Benth. $l, c$, Verticillastri paucillori. B $r$ a c te a e parvae v. nullae. - (Jacq. Ie. rar. t. 494. Sibthorp Fl. graec. t. 5i3, S45.)

b. TRagoriganom Bentli. 1 . c. Verticillastri dense globosi, multiflori, remoti, bracteis suffulti, C al y x tubưm corollae subaequans. - (Sibthorp Fl. graec. t. 541 .)

c. PYCNothymus Benth. l. c. Verticillastri io capitulum oblongum aggregati, bracteis suffulti. C a l y $x$ minutus.

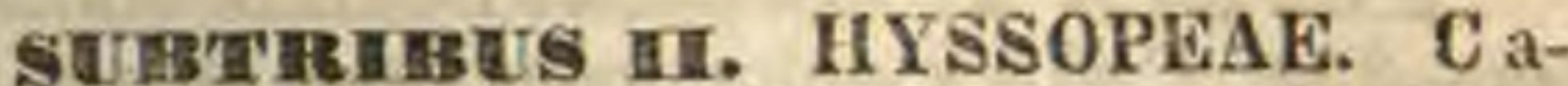
1 y $x$ quindecim nervis. Sta min a 4 fertilia.

3618. Myssopus LINN. C a I y $x$ tubulosus, quindecimnervis, limbi subobliqui dentibus quinque aequalibus, fance nuda. Cor oll a tubo calycem aequante, limbi bilabiati labio superiore erecto, plano, emarginato, inferioris patentis, trifidi lobo medio majore. Stamina 4 , exserta, divergentia, inferiora longiora ; fil a m e $\mathrm{n}$ a glabra, a ther a e biloculares, loculis linearibus, divaricatis. Stylus apice subaequaliter bifidus, lobis subulatis; stigmata terminalia. A $c$ hen i a ovoideo - triquetra, laeviuscula. - Suffrutex not issimus, 78 
per Europam et Asiam mediam diffusus; ramis virgatis, foliis oppositis, sessilibus, oblongolanceolatis, margine revolutis, utrinque viridibus, verticillastris multifloris, secundis, in spicam terminalem approximatis, foliis floralibus conformibus, bracteis lineari-lanceolatis, calyces subaequantibus.

H y s s o p u s Linn. gen, n, 709. Jacq. Fl. atustr. t, 502. Benth, Labial, 356.

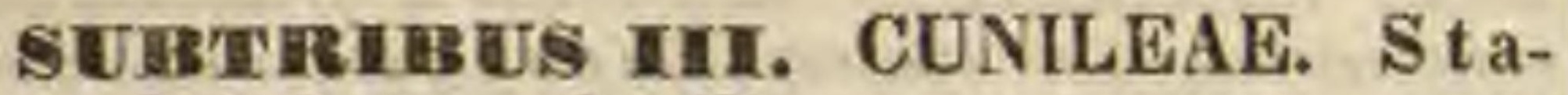
mina 2 inferiora fertilia.

38 13. Collinsonia LINN. Cal y $\mathrm{x}$ fructifer declinatus, ovatus, subdecemnervis, bilabiatus, labio superiore truncato, planiusculo, triden tato, inferiore bifido, fauce subnnda. C o r o Il a subcampanulata, tubo breviter exserto, fance ampliata, limbi subbilabiati lobis quatuor superioribus snbaequalibus, inferiore saepius longio$\mathbf{r e}$, declinato, subplano, dentato $\mathbf{v}$. fimbriato-lacero. Stamina 4, divaricata, longe exserta, superiora subbreviora $\mathbf{v}$, interdum ananthera; fi. f a menta nuda, antherae biloculares, loculis divaricatis, saepe confluentibus. Stylus apice subaequaliter bifidus; stig mata terminalia, minuta. A e hen i a sicca, laevia. - Herbae borealia merican a e, graveolentes; foliis caulinis magnis, floralibus parvis, bracteaeformibus, floribus pedicellatis, solitariis, in racemos simplices $v$. saspius $p a$ niculato-ramosos dispositis, calycibus sub anthesi minutis, demum valde auctis, corollis flavis v. Ravopurpurascentibus.

Collins on i a Lina. gen, n, 17. Hort. Cliffort, t. 5 . Benth. Labiat, 357. Bot. Mag. t, 1213.

36 4. Cumala $L I N N$. Calyx subtredecimnervis, ovato-tubulosus, aequalis, quinquedentatus, fauce villosa. Co rolla tubo calycem aequante, intus nudo, limbi bilabiati labio superiore erecto, subplano, saepius emarginato, inferioris patentis, trifidi lobis subaequalibus, integris vel medio parum majore, emarginato. S $t$ a $\mathrm{m}$ in a 2 inferiora fertilia, erecta, exserta, distantia, superiorum rudimenta nulla; fil a m e n t a glabra, edentula, a $n$ therae biloculares, loculis parallelis $v$. demum divaricatis. Sty $I$ us apice breviter bifidus, lobis subaequalibus, subulatis, apice minute stig matiferis, v. inferiore longiore, subcomplanato, margine stigmatoso. A chen i a sicca, laevia. Herbae, suffrutices $v$. fruticuli, in $A m e r i c a b o-$ reali et tropica indigeni; verticillastris nunc taxissime corymbosis, nunc axillaribus, paucifloris, foliis multo brevioribus, nitne dense multifloris, in spicas $v$. capitula terminalia approximatis, floribus parvis, albis v. purpurascentibus, corollis sacpius intus villosis, labio inferiore punctato.

Cunfla Lian. gen, n. 35. excl. sp. Beath. Labiat, 360.

TREIBUS W. MELLISSINAE Benth. Labiat. 365. C a ly $\mathrm{x}$ quinquedentatus, plerumque bilabiatus, rarius aequalis, decem- v. tredecimnervis. Corolla e tubus plerumque exsertus, limbi bilabiati labio superiore integro $v$. bifido, inferiore trilobo. St a m in a adscendentia, superiora breviora, interdum abortiva.

3615. Tredieema PERS. Calyx ovatotubulosus, basi infra subgibbus, tredecimstriatus bilabiatus, labio superiore tridentato v. subtrifido, inferiore bifido, fauce villosa. Cor o 11 a tubo caIycem aequante $v$. breviter exserto, limbi bilabiati labio superiore erecto, integro, emarginato v. sub- bifido, plano, inferioris patentis, trifidi lobis subaequalibus, v. medio parum latiore, integro v. emarginato. S t a m in a 2 inferiora fertilia, adscendentia, superiorum rudimenta brevia, subulata, capitata v, saepius nulla; filam enta nuda, anthera e biloculares, loculis divergentibus $v$. divarieatis. Stylus apice breviter bifidus, lobis subaequalibus $\mathrm{v}$. inferiore elongato, sulicomplanato, apice et margine stigmatifero, superiorem brevissimum basi involvente. A chenia sicea, laevia. Herbae v. suffrutices, in America tropica et boreali, nec non in Asiae mediae montibus provenientes; foliis parvis, integerrimis v. subdentatis, verticillastris axillaribus laxis, pauciftoris, in racemos terminales subapproximatis.

He deo ma Persoon Synops, II, 134. Benth. Labiat, 365. Cunila s p. Linn.

a. MIOSLA Hamilt. mse, $\mathrm{C}$ al $\mathrm{yx}$ ovatus, labio superiore patente, subplano, breviter tridentato. - Herbae folits dentatis.

b. Hedeoma Benth. 2 . c. Calyx tabulosus, teres, dentibus omnibus lanceolatis. - Suffrutices folits inte. Gerrimis,

3G16. Niferomeria BENTH. Calyx tubulosus, tredecim- $\mathbf{v}$. rarius subquindecimstriatus, quinquedentatus, dentibus subaequalibus, rectis v. vix subbilabiatis, fance saepins villosa. Corolla tubo aequali, recto, intus nudo, calyce plerumque breviore, limbi bilabiati labio superiore erecto, subplano, integro $\mathbf{v}$. emarginato, inferioris lobis planis, subaequalibns $\mathbf{v}$ medio latiore, integro v. emarginato. St am in a 4 , inferiora longiora, adscendentia, apice per paria approximata v. rarius subdivergentia; filamenta edentula, anthe rae liberae, biloculares, connectivo saepe incrassato, loculis distinetis, parallelis, divergentibus v. demum divaricatis. Sty $\mathbf{I} i$ apice bifidi lobi nune aequales, subulati, stig matib us terminalibus, minutis, nunc superior brevissimus, inferior elongatus, recurvus, complanatus, margine stigmatosus. A chen ia sicca, laevia, - Herbae v. suffrutices, in t em peratis calidioribus totius orbis ter. rarum, parcius in $A m$ erica tropica vegetantes; verticillastris axillaribus $v$. spicatis, rarius cymaeformibus subpaniculatis, floribus plorumque parvis, purpurascentibus $v$, albis.

Mi er o meria Benth, Labiat, 368 .

a. HESPEROTHYMUS Benth. Flores in pedicellis axilla. ribus utrinque solitarils $\nabla$. ternis, ealyce longioribus, pedunculo communi nullo v. rarius elongato. - Herbae boreali-amerieanae et mexicanae; folite saepe crenatis.

Hesperothy urus Benth. Op. cil. 371. Hedeomatis s p. Nutt. Th y mi s p. Swartz, Kunth.

b. PIPERELla Prest. Flores subsessiles v. in capitulis sessilibus peduneulatisque glomerati, pedicelli subaulli v. calyce breviores, vertieillastri axillares v. subspicati. - Suffrutices ve rarius herbae, in regione me. diterranea et Australasia tropica indige. nae, in Amerioa tropica rarae; foliis integer. rimis, venosis, saepo durts, folits floralibus caulinis subconformibus.

P i pe rell a Presl. Fl, sicul, XXXVT. Benth, Op. cit.1373. $\mathrm{X}$ en o poma Willd, in Borl, Magaz. V.339, Colla Hort. ripul. 197. t. 25. $\mathrm{Z}$ y $\mathrm{g}$ is Desvaux in Hamilt. Prodr. Flor. Ind. occid. 46 . S a t u re i a e 8 p Linn. Sibthorp Fl. graec. t. 340, 542, Desfont. Fl, atl, $t, 121$. Tenore $F l$, neap t, 151. Gussone Pl. rar. t. 42. Th y $\mathrm{mi}$ s p. Desfont. $F t$, atl, $t, 129$. Waldst. et Kitaibel Plant. Hung, t, 156.

c. PSEUDOMRLISSA Benth. Yerticilla a troruta cy mae elongatae, pedunculatae, subdiehotomae. - Herbae enopeae; folitis saepe rentatis.

Pse udomelissa Benth. Op. cit. 382. Melissat s p. Ling. Watdst. et Kitaibet Plant, Hung, t, 262. Ro- 
eliel Banat, t. 22, f. 8. Niepetac 8 p. Cavanill, Ic. t. s76. Bieberst. Plant. Lloss $I, t, 28$.

361\%. IIelissa BENTH. Ca I y tubulosus, tredecimnervis, saepius striatus, bilabiatus, labio superiore saepius patente, tridentato, inferiore bifido, fauce nuda $v$. villusa. Corolla tubo recto $v$. incurvo-adscendente, intas nudo, saepius exserto, fauce plerumque inflata, limbi bilabiati labio superiore erecto, subplano, integro v. emarginato, inferioris patentis, trilobi lobis planis, medio saepins latiore, integro v, emarginato. Stamina 4, inferiora longiora, adscendentia, apice per paria approximata v. rarissime distantia, superiora interdum sterilia; fil am enta edentula, antherae biloculares, connectivo saepe incrassato, loculis distinctis, parallelis, divergentibus v. demum divarieatis. St y li apice bifidi lobi nune aequales, subulati, stig matibus minutis terminati, nunc inferior elongatus, recurvus, complanatus, margine stigmatosus. A chenia sicea, laevia. - Herbae v. suffrutices, in Europa imprimis mediterranea et $A$ sia media indigeni, in America boreali et India orienta. $l_{i}$ parcissime crescentes; inflorescentia varia, floribus albidis, purpurascentibus $v$. flavis.

Meliss a Benth. Labiat, 383. Melis s a, Clinopo. dium et Thymi sp. Lins. Calamintha et Melis. s a Koch Synops, 859. 861. Benth. in litt.

a. CALAMINTHA Mo̊nch. Mothod, 608. C a I y x subteres, striatus, basi vix gibbus, fauce villosa. R a cem i laxi. subsecundi. Verticillastrorum cymae utrinque pedunculatae, dichotomae. - Benth. $O p$. cit. 386. T li y. ni $\mathrm{i}$ p. Linn. Sibthorp Fl. graec. $t$. 577. E. B, $t, 141 /$ 1676.

b. CALOMELISSA Benth. Op. cit. 388 . C al y x striatus, fauce villosa. Verticlllas tri multiflori, subaequales, condensati. B ra ete a e ovatae v, oblongae. - Thy m i sp. Michaux, Bot. Mag. ¿. 997.

c. ACINOS Mönch Method. 40\%. C a I y x hasi infra gibbus, subteres, profuade striatus, fauce villosa. Verticil. las tri subsexflori, pedicellis erectis, brevibus, rigidis. - Benth. Op. cit. 384. Th y m i s p. Linn. Jacq. Observ. t. 87. Sibthorp Fl. graec. t. 575. E. B. t, 411. Bieberst. Plant, ross. I. t, 38. Bot. Mag. $t$. 2152.

d. CLINOPODIUM Linn. gen. $n, 725$. C a $1 \mathrm{y} \times$ basi Infra gibbus v. subacqualis, fauce nuda v. parum villosa. Vertieillastri multillori v. laxe paucitlori, acquales, pedunculo communi subuallo, perlicellis filiformibus nec complanatis. B ra cte a e subulatae, mfautae v. calycem aequantes. - Benth. Op, cit. 391. E. B. t, 1901. Labillard. Syr. IV. t. 9. T h y m I s p. Ledebour Ic. $t .438$.

e. MELIPHYLLUM Benth. Op. cit. 393. C a I y x basi vix gibbus, pateus, labio superiore glabriusculo, fauce nuda v. pilis raris villosa. C or olla alba $\vee$. flavescens, tubo recurvo, adscendente. Verticill a s $t r i$ pauciflori, laxiusculi, secundi. B racte a e paueae. saepias ovatae. - Melissa Koch 7 . c. Benth. in litt. Sibthorp Fl. graec. 2.579.

f. MACROMELiSSA Benth. Op. cit. 394. Caly $\times$ fanee patentissima, subnuda, labifs profundis, divaricatis. Corolla elongata, purpurasceus, tubo dilatato. Stamin a apice subdistantia. Vertfelllas tri laxissimi, saepius pauciflori, cymis subumbellaeformibus, pedunculis elongatis, vix dichotomis. - Meliss a grandi. flor a Lina.

g. HETEROMELYSSON Benth. Op. cil, 395. C a 1 y x elongatus, basi haud gibbus, vix bilabiatus, dentibus setaceis, rectis, fauce subsuda. C or oll a elongata, purpurea, tubo subrecto. Verticillastri irregulares, pauci-v. multiflori, subsecundi, in ramos foliatos sacpe abeuntes. Bracte a subfoliaceae. $T$ h y mi $s p$, Don.

3618. Caradloumia RUIZ et PAV. C aly x tubulosus, tredecimnervis, subincurvus, ore aequali $v$. obliquo, dentibus brevibus, rectis, subaequalibus $v$ : subbilabiatus. Corolla tubo longe exserto, recto $v$. incurvo, intus nudo, limbi bila- biati labio superiore erecto, subplano, emarginato, inferioris subpatentis, trilobi lobis planis, medio latiore. S $t$ a m in a 4 , inferiora longiora, laxe adscendentia, apice subdistantia, superiora interdum sterilia; fil amenta edentula, antherae biIoculares, loculis distinctis, parallelis v. subdivergentibus. Styli apice bifidi lobi subaequales; stigmata terminalia, minuta. A chenia sicea, laevia. - Suffrutices $v$, frutices peruani et chilenses, in America boreali rarissimi, ramosissimi, foliosi, saepe procumbentes; flo. ribus speciosis, plerumque coccincis.

G a rd o q u i a Ruiz et Pavon Prodr. 148. Flor, peruv. t. 493-495. Benth. Labiat. 397. Bot. Reg. t. 1747. R i z o a Cavanill, Anal, eienc, nat. III. 133, t. 29. Ic. VI. 56. t. 578. C u nil a e s p. Hook, Exot, Flor, t. 163.

3619. Alechon $S P R E N G$. C a ly $\mathrm{x}$ ovatus v tubulosus, tredecimnervis, quinquedentatus, dentibus aequalibus v, subbilabiatis, duobus inferioribus saepe longioribus. Coroll a tubo ealyeem aequante, intus nudo, limbi bilabiati labio superiore emarginato v. semibifido, falcato, fornicato v, galeato, erecto $v$. inferius incumbente, inferioris patentis, trilobi lobis planis, integerrimis, lateralibus latioribus, basi labio superiori saepe adhaeren tibus. Stamina 2 inferiora fertilia, sub labis superiore adscendentia $\mathbf{v}$. inter ejusdem lobos breviter exserta, superiorum rudimenta nulla; fil ament a glabra, antherae biloculares, loculis linearilus, parallelis, divergentibus v. demum divaricatis. Stylus apice bifidus, lobo superiore brevissimo, inferiore elongato, complanato, margine stigmatoso. A ehenia oblonga, laevia, sieca. - Suffrutices $v$. fruticuli bra siliens es, sacpe canescentes; foliis plerumque parvis, floralibus conformibus $v$. raro minoribus, bracleaeformibus, verticillastris axillaribus $b i-s e x f l o r i s$, interdum versus ramorum apices breviter racemosis, corollis flavescentibus, carneis $v$. cacruleis.

Glechon Sprengel Syst. ID. 227. Bentl. Labiat. 405.

3820. Keithia BENTH. Cal yx tubulosus, subtredecimnervis, striatus, ore aequali v, olliquo, quinquedentato, dentibus subaequalibus, fauce nuda v, villosa. Cor o ll a tubo exserto, limbi bilabiati labio superiore erecto, emarginato, plano, inferioris patentis, trifidi lobis planis, subaequalibus. St a mina 2 inferiora fertilia, adscendentia, superiorum vestigia nulla; filamenta glabra, a nt hera e biloculares, connectivo crasso, loculis distinctis, divarieatis. Styli apice hifidi lobi subaequales, v. inferior longior, complanatus, margine stigmatosus, superioris basim involvens. A t henia sicca, ovoidea - Herbae, suffrutices $v$. frutices brasilienses; verticillastris axillaribus $v$, in spicas terminales approximatis, corollis plerumque coccineis.

Keithia Benth. Labiat. 409.

a. ERIOTHYMUS Beuth. Op, cit, $410, \mathrm{C}$ al y cis faux vil. losa. C o r olla e labium superius bifidum. C y ma e axillares. peduneulatae, pauciftorae, - Fruter, ramis divaricatis, foliosis,

b. KEITHIA Bentli. Op. cit. 410. C al y cis faux uuda. Corollac labium superins emarginatum. VerticilIa s tri axillares, pauciflori. - Suffrutices, ramisherbaceir, elongatis, procumbentibus.

e. RHABDOCAULON Benth. Op. cit. 411. C alyois acute dentati faux villosissima. C o roll a e labium superius enarginatum. Verticillastri in spicas terminales approximati. - Suffrutices $v$, herbae, ramis ereetib, virgatis, basi foliosis, apice longe denudatis.

d. GYMNOCYLIX Benth. Op. eit, 412, Cal y c is obtuke deutatl faux nuda. Co roll a e labium superins emargi78 
natum. Vertic ill a stri paueillori, distincti, subracemosi. - Herba, ramis erectis, strictis, subnudis.

369 f. Thymbra LINN. Caly x oblongus, supra deplanatus, bilabiatus, labio superiore tridentato, erecto, inferiore bifido, fance villosa. Corolla tubo subexserto, limbi bilabiati labio superiore erecto, emarginato, subplano, inferioris patentis, trifidi lobis planis, intermedio parum ma jore. Stamin a 4, sub labio superiore adscenden tia, inferiora longiora; fil amenta glabra, an therae per paria approximatae, biloculares, loculis distinctis, parallelis. Sty I u s apice breviter bifidus, lobis subulatis; 8 tigmata terminalia, minuta. Achenia sicea, laevia. - Suffrutex in regione mediterranea orientali indigenus, durus, rigidus, procumbens; ramis adscendentibus, foliis linearibus, rigidis, uninerviis, planis $v$. complicatis, ciliatis, vertivillastris multifloris, in spicam basi nonnunquam interruptam approximatis.

Th h m b r a Linn. gen, $n, 708$. Sibthorp $F l$, graec. $t$, 546 . Beath. Labiat, 413.

3628. Dicerandra BENTH. C a I y x tubulosus, subtredecimnervis, striatus, bilabiatus, lubio superiore patente, integerrimo v. breviter tridentato, inferiore bifido, fauce pilosa. Corolla tubo exserto, recto, intus nudo, limbi bilabiati labio superiore erecto, subplano, vix emarginato, inferiore patente, trifido. Stam in a 4 , adscendentia, approximata, inferiora longiora; fi la men t a glabra, an therae biloculares, lueulis divaricatis, apice aequaliter calearatis, calcare recto, acuto, loculum aequante. Stylus villosus, apice bifidus, lobis subulatis, aequalibus; $s t \mathrm{igm}$ a $\mathrm{t}$ a terminalia, minuta. A chenia sicea, laevia. - Suffrutex carulinianus, Hyssopi officinalis habitu; caulibus erectis, virgatis, pubescentibus, foliis sessilibus, an guste linearibus, integerrimis, glabris, axillaribus fasciculatis, verticillastris subsexfloris, in apice ramorum approximatis, pedicellis brevibus, bracteis setaceis, minutis.

Diceraudra Beath. Labiat. 413. Cerathera Elliott Carolin. II. 93. non Palis.

3833. Kogogyne BENTH. Cal y x campanulatus, subquindecimaervis, striatus, quinquedentatus, dentibus duobus inferioribus superiores duplo superantibus. Co roll a tubo exserto, intus ad faucem piloso, limbi bilabiati labio snperiore erecto, subplano, integro, inlerisris patentis, trifidi lobis planis, integris. Sta m in 7 , adscendentia, apice approximata, inferiora longiora; filaun enta glabra, antherae biloculares, loculis parallelis, distinctis, muticis. Sty l as villosus, upice bifidus, lobis aequalibns, subulatis; stigin a ta terminalia. - Herbae californica e; foliis petiolatis, oblongis, integerrimis v. superioribus dentatis, glabris, verticillis ad apices ramorum dense spicatis, foliis floralibus, bracteis calycibusque pilis longis, albidis ciliatis.

Pog o g y u e Beath. Labiat, 414 ,

TIE TBUS VI. SCUTELLA $H$ INEAE Benth. Labiat. 416. Cal y $\mathrm{x}$ bilabiatus, labio superiore truncato integro, v. subtridentato. C orolla tubo exserto, adscendente, intus annulato $v$. nudo. St ta m i n a 4 , sub labio superiore adscendentia, inferiora longiora.

362 4. Prumelta LINN. C a I y x tubulosoeampanulatus, irregulariter subdecemnervis, retieulato-venosus, supra planus, bilabiatus, labiu su- periore lato, truncato, breviter tridentato, inferio. ris semibifidi laciniis lanceolatis, fance nuda. $\mathrm{C}_{\mathbf{0}}$ roll ae tubus amplus, subexsertus, adscendens, intus prope basim piloso-v. squamuloso-annulatus, sub fauce subtus inflatus, ad faucem contractus, limbi bilabiati labium superins erertum, galeatum, supra subearinatum, integrum, inferius dependens, lobis lateralibus oblongis, deflexis, intermedio rotundato, concavo, crenulato. S $\mathrm{t}$ am in a 4 , adscendentia, inferiora longiora ; fil a me $\mathrm{n} t$ a basi edentula, glabra, apice, praesertim superiora breviter bidentata, dente inferiore antherifero, an the rae $8 \mathrm{ub}$ labio superiore per paria approximatae, liberae, bilveulares, loculis distinctis, divaricatis. Stylus glaber, apice bifidus, lobis subulatis; s tig mata terminalia. A chenia oblonga, sicca, laevia. Herbaec os mop olita e; folits integris v, inciso-pinnatifidis, floralibus bracteaeformibus, orbiculatis, persistentibus, imbricatis, verticillastris subsexfloris, dense spicatis.

Prunella Linn. gen, n, 735. Benth, Labiat, 417, Reicheub. Plant, crit. t. 238, 239.243.588. B r u u e 11 a Mönch Method, 414, Kunth in Humb. et Bonpl. Nov, gen, et sp. t. 162. Arthr. Hamilton Monogr. ex Seringe Bullet. bot. I. 153. ss. c. icc.

3G\%5. Cleomila LINN. Cal y x campanulatus, decemnervis, oblique bilabiatns, labio superiore lato, breviter tridentato, inferiore bifido, sinubus pilosis. Coroll a e tubus tenuis, exsertus, adscendens, intus nudns, fauce parum dilatata, limbi bilabiati labium superius erectum, galeatum, carinatum, integrum, inferioris breve dependentis, trilobi lobis lateralibus oblongis, suberectis, lobo intermedio patente, emarginato-bifido. Stamin a 4, adscendentia, inferiora longiora; fil a m enta basi edentula, glabra, apice breviter bifurca, dente superiore subulato, inferiore subcomplanato, antherifero, antherae per paria approximatae, biloculares, loculis divaricatis. St y 1 u s apiee breviter quadrifidus, lobis snbaequalibus, subnlatis; st ig mata terminalia, minuta. A che n i a magna, orbiculata, subcompressa. - Herba in regione mediterranea occidentali indigena, habitu Prunellae laciniatae; caule herbaceo, annuo, basi ramoso, foliis sessilibus, oblongo-lanceolatis $v . l i$ nearibus, obtusis, profunde dentatis v. semipinnatifidis, rugosis, subhispidis, floralibus minoribus aristatis, verticillastris sexfloris, in spicam laxam approximatis.

Cle o n i a Liun. gen, n. 236. Benth. Labiat, 419. P r uella intermedia Reichenb. Pl. crit. $t$. 205 . non Brot.

3636. Sentellaria $L I N N$. C a ly $\mathrm{x}$ campanulatus, bilabiatus, post anthesim clausus, demum usque ad basim fissus, labiis integris, superioris demum decidui lobo medio in squamam dorsalem dilatatam, concavam rejecto, inferiore persistente. Co ro $\mathrm{Il}$ a tubo longo, exserto, intus nado, recto $v$, saepins extra calycem recurvo-adscendente, superne in faucem dilatato, limbi bilabiati labio superiore galeato, apice integro v, emarginato, inferioris patentim-dilatati, convexi, apice emarginati lobis lateralibus nune liheris patentibus, nune cum labio superiore, rarissime cum inferiore coalitis. St a m i na 4 , sub Iabio superiore adscendentia, inferiora longiora; fil amenta edentula, a $t$ h erae per paria approximatae, eiliatae, staminum inferiorum dimidiatae, superiorum bilocalares, cordatae, loculis subdivarieatis, dorso oppositis. St y lus apice bifidus, labio superiore brevissimu, inferiore apice stigmatifero. A ehenia 
sicea, tubereulosa, glabra v. tomento adpresso pubescentia. - Herbae annuae $v$, perennes, rarius frutescentes, in extratropicis, rarius inter tropicos totius orbis indigenae, e regione capensi exules, inflorescentia varia.

Seutellaria Linn. gen. $n$, 734. Arth. Hamilton Monograph, in Seringe Bullet, bot, t.48, c. icc. Benth, Labiat. 119. Cassida Touraef, inst. 84. Moach Method. 413.

a. LUPUlinaria A. Hamilt. $l$. c. $1 t$. Plores tetragono. spicati v. subracemosi, vix secundi. Foli a floralia sae. pius membranacea. Beuth, Op. cit. 423. (Sibth. Fl. graec. t. 580 . Waldst, et Kitaibel. Pl. Hung. t, 137. Reichenb. Pl, erit. $t, 8$. Leidebour Ic, t, 183. Bot. Mag. t. 635. Bot. Reg. t. 1460. 1493.)

b. HETERANTHESIA Benth. Op. cit. 425. Flores raceuosi, secundi, omnes v. saltim superiores sparsi nee appositi. Folia floralia parva, herbacea. - (Venten. Choix. t, 39.)

c. STACHYMACRIS A. Hamilt. Op. cit, 17. Flores ra ceaiosi, secundi, oppositi. Folia floralia herbacea, parva, a caulinis diversa. Benth. Op. cit. 498. (Sibth. Fl. graec. t. $881-583$. Labillard. Syr. IV. t, 6. Waldst. et Kitaihel Pl. Hung, t. 125. Reicheub. Pl. crit. t. 488. Bot. Reposit. t. 494.)

d. Galericularia A. Hamilt. Op. cit. 31. Flores op positi, axillares, secundi v, supreni subracemosi. Fo i i a floralia lierbacea, caulinis conformia v. superiora seusiu minora. Benth. Op. cit. 436. (E. B. t. 823. 824. Jacq. Observ. t. 29. Hooker Exot, Fl, t, 106.)

e. MASCHALOSTACHYS Benth, Op. cit. 443, F 1 o res oppositi, secuadi, plerunque in racemos axillares termina lesque dispositi. Foli a floralia herbacea , inferiora caulinis conformia. (A. Hamilt, Op, cit, $t, 2, f, 1$.)

369\%. Perillomia $H, B . K$. Cal y x cam panulatus, bilabiatus, post anthesim clausus, demum usque ad basim fissus, labiis integris, superioris demum decidui lobo intermedio in squamam dorsalem rejecto, inferiore persistente. Cor oll a tubo longe exserto, recurvo adscendente, intus nudo, fauce subdilatata, limbi brevis, subbilabiati labio superiore suberecto, emarginato-bifido, in ferioris trifidi lobis lateralibus brevibus, subpatentibus, medio majore, patente, emarginato. S tam in a 4, adscendentia. inferiora longiora; fil ain enta edentula, antherae per paria approxiuatae, glabrae (?), staminum inferiorum dimidiatae, superiorum biloculares. Sty I us apice bifidus, lobo superiore brevissimo, inferiore apice stigmatoso. D is cus ovarii crassus, latere inferiore saepe dente auctus. A chenia sicea, margine membranaceo - alata. - Herbae v. frutices peruan i; foliis petiolatis, ovatis, crenatis, floralibus subconformibus, floribus axillaribus, solitariis.

Perilomi a Kunth in Humb. et Bonpl. Nov. gen, et sp. II. 327, t. 157. Beuth. Labiat. 445.

TRIEES vII. PROSTANTHEREAE Benth. Labiat. 447. Cal y $x$ campanulatus, bilabiatus v. aequalis, quinquedentatus. C orolla tubo brevi, amplo, fauce lata, limbo bilabiato. st a m ina 4, corolla breviora, inferiora nonnunquam abortiva, dum adsunt superioribus longiora. Achenia coriacea, rugosa, stylo subpersistente. - Frutices australasici.

3688. Clailodia $\boldsymbol{R}$. BR. Calyx campanulatus, tube brevi, tredecimstriato, bilabiatus, labio superiore integerrimo, inferiore emarginato, fauce nuda. Corolla tubo amplo, brevi, limbi campanulato-subbilabiati labio superiore erecto, subplano, emarginato-bifido, inferiuris trifidi lobo medio majore bifido, omnibus planis, patentibus. Stamina 4, subaequalia, corollae tubu breviora; fil amenta glabra, antherae biloculares, loculis parallelis, glabris, nuticis. Sty 1 us apice breviter bifidus, lubis subaeq̧ualibus; $s \mathrm{tigmata}$ terminalia. A chenia ...... Frutex NovaeHollandiae orientalis; ramis glabris $v$. tenuiter pubescentibus, foliis sessilibus, lincaribus, lanceolatis, acutis, coriaceis, margine subrevolutis, utrinque viridibus, floralibus conformibus, pedicellis axillaribus unifloris, sub calyce setaceo-bibracteatis.

Chilodia R, Browa Prodr. 507. Benth. Labiat. 44.

3629. Ciryplaia $\boldsymbol{R}$. BR. Caly x bibracteolatus, bilabiatus, clausus, labiis integris, aequalibus. Cor olla inclusa, tubo recto, limbi ringentis, bilabiati labio superiore galeato, brevissimo, inferioris trifidi lacinia medio parum majore. S $t$ imina 4 , subaequalia, inclusa; filam enta glabra, antherae biloculares, loculis parallelis, glabris, muticis. Stylus apice breviter bifidus, lobis subaequalibus; s t ig mat a terminalia. A ch enia ......-Fruticuli in Novae-Hollandiae o ra a us trali indigeni, glandulosi, graveolentes; folits Serpylli parvis, integris, pedunculis axillaribus, solitariis, unifloris.

Cryphia R. Brown Prodr. 508. Benth. Labial. 448. Bot. Mag t. 3405 .

3B30. Irpostrantinera LABILLARD. Cal y x campanulatus, bilabiatus, tubo brevi, tredecimstriato, labiis integris, subaequalibus, fructiferis clausis, fauce nuda. Cor olla tubo brevi, amplo, fance campanulata, limbi bilabiati labio superiore erecto, subplano, emarginato - bifido, inferioris patentis, trilobi lobo medio majore, integro v. bifido. Stamina 4 , adscendentia, inferiora sublongiora; filamenta glabra, antherae omnes approximatae, biloculares, loculis parallelis, connectivo subtus calcarato. Sty 1 us apice breviter bifidus, lobis subaequalibus; stig mata terminalia. A chenia nueamentacea, subbaecata, demum coriacea, reticulato-rugosa. - Frutices Novae-Hollandiae, glandulis sessilibus conspersi, graveolentes; foliis ovatis, oblongis v. linearibus, integerrimis v. crenatis, floribus nune racemosis, terminalibus, foliis floralibus caducis, nune in axillis foliorum caulinis conformium solitariis, bracteis sub calyce parvis.

Prostrant hera Labillard. Nov, Holl. IT. 18. t, 157. R. Brown Prodr. 508, Beath. Labiat. 498. Bot. Reposit. 6. 641. Bot. Mag. $t$, 2434. Bot. Reg. t. 143. 1072.

363 1. Flemiandira $\boldsymbol{R}, B R, C$ a $1 \mathrm{yx}$ campanulatus, bilabiatus, basi striatus, labiis planis, fruetiferis elausis, superiore erecto, integro, mucronato, inferiore semibifido. Cor oll a tubo brei, auplo, fauce campanulata, limbi bilabiati labio superiore bifido, inferioris trifidi lacinia intermedia emarginato-bifida, omnibus planis. Stamina 4 , laxe adscendentia, inferiora longiora; fil am ent a glabra, antherae dimidiatae, loculo fertili adscendente, sterili tenui, descendente. Stylus apice subaequaliter bifidus, lobis subulatis; stigu a ta terminalia. A c hen i obovoideo-8ubtriquetra, inter se et cum stylo connata, apice reticulata. - Suffrutices $v$. fruticuli, in Nova-Hollandia a ustro-occidentali indigeni. erectiv. dccumbentes; foliis lanceolatis v. linearibus, rigidis, integerrimis, pungentibus, uni-quinquenerviis, pedunculis axillaribus unifloris, solituriis, foliis joralibus cuulinis subconformibus.

Hem inu dira k. Brown Prodr. 502. Bentli. Labiat. 556. et in Hügel Bot. Arch, t. 4. 
3B3\%. Hemnigenis $R . B R$. C al y $\mathrm{x}$ subcampanulatus, profunde quinquefidus, aequalis. Corolla tabo brevi, intus nudo v. barbato, fance snbinflata, limbi bilabiati labio superiore subfornicato, bifido, inferioris patentis, trifidi lacinia media subbifida, omnibus planis. Stamina 4 , subadscendentia, inferiora longiora; fil am e nta glabra, an $t$ herae approximatae, loculo altero adscendente pollinifero, altero descendente difformi, efoeto, staminum superiorum subbarbato. St yI 8 apice brevissime bifidus, lobis subnlatis, subaequalibus, A chenia reticulato-rugosa. - Fruticuli australasic $i$; foliis sessilibus, confertis, $l i$ neari-subteretibus, acutis, floralibus conformibus, pedicellis axillaribus solitariis, unifloris.

H e migenis R. Brown Prodr. 502, Bentl. Labiat, 457.

3633. Westringla SMITH, Calyx campanulatus, decemnervis, aequalis, quinquedentatus, fauce nuda. Co rolla tubo brevi, intus nudo, fauce ampliata, limbi bilabiati labio superiore plano, subbifido, subpatente, inferioris patentis, irifidi lobo medio subbifido. St a m in a 4 , erecta, distantia, tubo corollae inclusa; fil am e n ta gla. bra, superiora fertilia, antheris dimidiatis, unilocularibus, glabris, inferiora sterilia, antheris bipartitis, lobis linearibus, dependentibus, efoetis. Sty 1 us apice subaequaliter bifidus, lobis subula. tis ; stigmat a terminalia. A ehenia coriacea, reticulato-rugosa. - Frutices Novae-Hollandia $e$; foliis perennantibus, ternatim v. quaternatim verticillatis, integerrimis, floralibus conformibus, in uxillis uniftoris, floribus ternatim verticillatis, distanfibus $v$. in racemum brevem terminalem approximatis, bracteis minutis, calyci adpressis.

Westriugia Smith Tracts. 977, $t$. 3. R. Brown Prodr. 501. Benth. Labiat, 457. Bot, Reposit, t, 421. Bot. Mag. t. 3307. 3308. Bot. Reg. t. 1581.

3634. Mierocorys $R$. BR. C aly x campanulatus, suludecemnervis, aequalis, quinquedentatus, fauce nuda. Corolla tubo calycem aequante, intus nudo, fauce ampliata, limbi subbilabiati labio superiore subplano, emarginato-bifido, erecto-patente, inferiore patente, trifido. St a mina 4, erecta, distantia, tubo corollae inclusa; fil a m enta glabra, superiora fertilia, an the ris dimidiatis, unilocularibus, barbatis, inferiora sterilia, an theris bipartitis, lobis linearibus, dependentibus, efoetis. Stylus apice subaequaliter bifidus, lobis subnlatis; stigmat a terminalia. A cheni a ovoidea, apice villosa. - Frutices Westringiae habitu, in Novae-Hollandiae orameridionali in digeni; foliis ternatim verlicillatis, floribus parvis, in axillis foliorum floralium caulinis conformium solitariis, cum iisdem ternato-verticillatis.

Microcory: R. Brown Prodr. 302. Benth, La biat, 460.

TIIBES VIII. NEPETEAE Benth. Labiat. 462. Caly $\mathrm{x}$ aequalis v. obliquus, subbilabiatus, dentibus superibus majoribus. Corolla inclusa v. exserta, fauce plerumque inflata, labio superiore subfornicato, inferiore patente. Stamina 4 , didynama, inferiora longiora, adscendentia v. divergentia.

3835. Loplananthas BENTH. CaI yx tubulosus, quindecimnervis, subincurvus, ore obliquo, quinquedentato, dentibus superioribus sublongioribus. Corolla tabs valycem aequante, intus nudo, limbi bilabiati labio superiore suberee- to, emarginato-bifido, inferioris subpatentis, trifidi lobo medio lato, crenato. St a min a 4 , distantia $v$. divaricata, inferiora breviora; fil a m e $\mathrm{ta}$ nuda, anthera e biloculares, loculis parallelis v. demum subdivergentibus. Sty Ins apice breviter bifidus, lobis subaequalibus, subulatis; $s t i g m$ a ta terminalia. A chenia sicea, laevia. - Herbae in America boreali et in Sibiria orientali indigenae; verticillastris in spicas terminales approximatis, v. cymis axillaribus laxe paucifloris.

Lo ple a $\mathrm{t}$ th as Benth. in Bot, Neg. n, 1982, Labiat. 463. non Forst.

a. CBIASTANDRA Benth, Stam in a snperiora declinata, inferiora adscendentia. - Verticillastri in spicam ter. minalem aggregati. - Vle ckla Rafin. in N. Y. medic. Reposit. II. Hex. $V .350$. Hys s o pl s p. bor, americ. Liua. Jacq. Hort. Vindob. 1. $t$. 69. (Bot, Reg. $t, 1282$.

b. RESUPINARIA Benth. Flor es subresupinati. S ta mia a inferiora subrecta, superiora adscendentia. - Cymae arillares laxae, pedunculatae, pauciforae.

Resupinaria Benth. Op. cit. 46i. Hyssopus Lo p ha uth a s Lina. Jacq. Hort. Vindob. II, $t$. 182.

3836. Nepeta BENTH. Calyx tubulosus, tredecim - quindecimnervis, plerumque incurvus, ore oblique quinquedentato, rarius ovatus, rectus, ore dentilsusque aequalibus. Cor oll a tnbo basi tenui, incluso v. exserto, intas nudo, fauce ampliata, limbi bilabiati labio superiore recto, subeoncavo, emarginato $\mathbf{v}$. bifido, inferioris patentis, trifidi lobo medio maximo, nune subbifido laciniis reflexo-patentibus, nunc integro, concavi, crenulato. St a min a 4 , adscendentia, inferiora breviora; filamenta nuda, antherae saepius per paria approximatae, biloculares, loculis divergentibus, demum divaricatis. Stylus apice subaequaliter bifidus, lobis subulatis; $8 \mathrm{tigm}$ a $\mathrm{t}$ a terminalia. A ehenia sicea, laevia, nuda. - Herbae in Europa et Asia temperata indigenae, in regione mediterranea orientali et taurico-caucasica imprimis copiosae, habitu vario.

Nepet a Benth. Labiat. 464. Nepeta et Glec hom a Linn. gen, $n, 710,714, \mathrm{C}$ a ta r i Mónch Method, 388.

a. SCHIZONEPETA Benth. Op, eit. 468. C al y x tubulosus, rectus v. saepius incurvus, ore aequali v. obliquo. S t a m in a subexserta, laxe adscendentia. - Perticillastri conferti, supremi in spicam terminalem, sub. interruptam approximati, cymis omnibus sessilibus. Bracteae variae. Folia dissecta v, lobata, - S a us ure a Mőneh Method, 388. (Gmelin Sibir. 111, 2. 55. Pallas Act. Petropolit. 1789, t. 12. Cavanill. Io, t. 49. Relehenb. $P l$, erit. $t .830$,)

b. PYCNONEPETA Bentli, Op, cit. 469. C al y $x$ tubulo. sus, rectus v. ineurvas, ore aequali v. obliquo. Verticillastri conferti, supremi $v$, omnes in spicam terminalem aggregati, cymis omnibus sessilibur. Bracteae saltem exteriores imbricatae, calycem ae. quantos. (Jacq. Observ. $t .75$. Desfont. Fl. atl. $t .123$. 124. Reiehenb. Pl. crit. $t$. 439. 440.)

c. STEGIONEPETA Benth. Op. cit, 474. Caly $\mathrm{x}$ uuuc elongatus, incurvus, ore obliquo, dentibus lanceolatis subulatisve, superioribus majoribus, nunc fere reetus, deatibus subaequalibus. C orolla tabo vix v. breviter exserto, fance inflata. - Cymae in verticillastros mul. tiflores condensatae, inferiores saepe pedunculatae, superiores subspicatac, Racemi simplices $v$. rariu, ramosi. Bracteae calycem subaequantes $v$. superan. tes. - Uacq. Hort, Vindob. II, t. 112. Sibthorp Fl. graec. t. 548. Reichenb. Pl. crit, $t$. 403.)

d. CATARIA Benth. Op. cit. 676. Caly $x$ elongatus, incurvus, ore obliquo, rarius subrecto, dentibus lances. latis, superioribus plerumque majoribus. Corolla tubo breviter exserto, fauce iuflata. - Cymae in verti. cillastris plerumque multiforis condensatae, inferiores pedunculatae. Racemi simplices v, paniculati, Bracteae calyce breviores, plerumque brovissimae. - (Reiehent. 
Plant. orit. 4. 261. 279. 305 585. 587. Ledebour Yo. t 412. Desfont. Corollar. $t$. 23. Bot. Mag. $t$. 932.)

e. MACrONEPETA Benth. Op. cit, 488. $\mathrm{Cal}$ y $\mathrm{x}$ elongatus, ore obliquo, dentibus lanceolatis v. ovatis, superioribus sublatioribus, Corolla tubo teuui, longe exserto, fauce inflata. - Cymae pedanculatae, pauciforae, ra. comi terminales, laxissini, subramosi. Folia floralia superiora $v$. ominia bracteaeformia. D raco cephali s. p. Lian. Pallas Fl, rost. t. 13. Bot. Mag. t, 2185. (Venten. Cels, $t, 66$. )

f. GLEChома Linn. gen, $\pi$, 743. Caly x tubulosus, subincurvus, ore obliquo, deutibus lanceolatis, aristatis, superioribus productioribus. Corolla exserta, tubo extra calycem dilatato. - Herba repens; verticillastris axillaribus paucifloris, foltis floralibus caulinis conformibus. Beuth. Labiat. 484. Hook. Fl. Lond. IT. t. 16. Waldst, et Kitaibel Pl. Hung, $t, 119$, $\mathrm{C}$ h a ma e. e I e m a Münch Method. 287.

g. OR'THONRPETA Benth. Op. cit. 485, C a I y x ovato - tubulosus, subrectus, dentibus subaequalibus, subulatis, rigidis nec pungentibus. Corolla exserta. - Herbae elatae; folitis subsessilibus. Flo rum oymae donsac, breviter pedunculatae. Verticillastri distantes, race mosi. Racemi simplices $v$. saepius paniculato-racemo. si. (Jacq. Flor. austr. $t, 24$, 129.)

b. OXXONEPETA Benth. Op. eit. 486. Cal y $\mathrm{x}$ tubulosus, subrectus, dentibus subaequalibus, subulatis, subpua gentibus. Corolla dentes calycinos aequans v vix superans. - Herbac humiles; foltis plerumque petio. Zatis, Roribus distinctis $v$, ad apices ramorum glomeratis, corymboso-paniculatis. (Ledebour Ic. t. 124.)

3838. IIrumeritis BENTH. C a $1 \mathrm{y} x$ tubuloso-campanulatus, tredecim quindecimnervis, profunde quinquedentatus, dentibus aequalihus, acutis. Corolla calyce brevior, labio superiore bifido, inferioris trifidi lobis lateralibus erectis, medio patente, lato, crenulato. Sta m in a 4 , adscendentia, inferiora breviora; fil am enta nuda, a $\mathrm{n} t \mathrm{~h}$ erae biloculares, loculis parallelis. St y lus breviter bifidus, lobis subaequalibus, subulatis; stigmata terminalia. A chenia sicea, laevia, nuda. - Herba himalayensis, pusilla; ramis procumbentibus, tomentoso-villosis, apice dense fotiosis, foliis petiolatis, reniformibus, crenatis, rugosis, utrinque tomento albo laxiusculo lanatis, verticillastris pauciftoris, in foliorum superiorum axillis secundis.

Marmoritis Benth. in Hooker Bot, Miscell. III. 377. Labiat, 489 .

3638. Wracoeeplatium $L I N N$. C a l y x inbulosus, tredecim-quinclecimnervis, rectus $v$, rarius incurvas, ore recto v. obliquo, quinquedentato, dente supremo latiore, saepius maximo, interdum tribus superioribus in labinm coalitis. Corolla tubo basi tenui, incluso v. saepius exserto, fance amplissima, limbi bilabiati labio superiore erecto, subconcavo, emarginato, inferioris patentis, trifidi lobo medio maximo, subbifido. Stamina 4, adecendentia, inferiora breviora; filamenta nuda, anther a per paria approximatae, biloculares. Iocnlis divaricatis. Stylus apice subaequaliter bifidus, lobis subulatis; s $\mathrm{ti}$ g mat a terminalia. A e he ni a sicea, laevia, nuda. - Herbae perennes, in Europa, imprimis orientaliet in Asia boreali obviae, in America boreali rarissimae; verticillastris plurifloris, axillaribus $v$. in spicam terminalem approximatis, bracteis sacpe foliaceis, aristato-dentatis, corollis saepius amplis, caeruleis $v$. purpurascentibus, rarius albidis $v$. fortassis etiam flavescentibus.

Dracocephal um Linn. gen. n. 729 . Benth. Labiat, 490. Moldaviea et Zornia Mönch Method. 410, R u y s e hia na Miller Diet. a. KEIMADRACON Benth. Op, cit. 492, C a Bles procumi bentes, ramosissimi. Foli a suborbiculata, inclso-crea ta v. subpalmato - pianatifida. Flores capitato-v. oblongo-spicati. An therae glabrae. - (Ledebour $I C$. t. 445.)

b. CALODRACON Benth. Op, cit, 494, C a n l e s basi cras. si. Rami floriferi erecti, paueifoliati. Foli a subradicalia, longe petiolata, crenata. Verticillastri capitato-v. oblongo-spicati. A u t bera e glabrae. - (Des font. Corollar. t. 26. Reichenb. Ic, exot. t. 96. Bot. Mag. t. 1009.)

e. CRYPTODRACON Benth. Op. cit. 495. Caules erecti, ramosi, follosl. Verticillastri eapitato-spicati. A ntherae glabrae, - D, parviflor am Nuttall.

d. MOLDAVICA Benth. Op. cit, 496. Caules erecti v. adscendentes, foliosi, Verticillastri distantes, sub. racemosi. A nt her a e glabrae. - (Bot. Mag. t, 1084. Bot. Reg. $t$. 841. Sweet Fl. Gard. I. t. 88.)

e. RUYSchlaNA Benth. Op. cit. 499. Ca ules ereeti, fo. liosi. Verticillastri subiaterrupte spieati. A u therate villosac. - Sweet Fl. Gard. I. $t$, i7.)

3639. Cedronella $M O ̈ N C H$. Caly x tu bulosus v. campanulatus, subquindecimnervis, ore subaequali v. obliquo, quinquedentato. Coro II a tubo exserto, intus nudo, fance dilatata, limbi bilabiati labio superiore reeto, subplano, emarginatobifido, inferioris trifidi lobo medio maximo. S tamina 4 , adscendentia, inferiora breviora; fil amenta nuda, a nth era e biloculares, loculis parallelis, Stylus apice subaequaliter bifidus, lobis subulatis; stigmata terminalia. A ehen ia sieca, laevia. - Herbac in America bareali et Mexico, fortassis etiam in insulis Canariis indigenae; verlicillastris in spicam v. racemum terminalem approximatis, foliis floralibus bracteaeformibus, bracteis parvis, selaceis.

Cedronella Mónch Method. 411. Dracoeeptali s p. Lina. Humb. et Bonpl. Nov. gon, et sp. t. 160.

TIIIBUS IX. STACHYDEAE Benth. Labiat. 503. Cal y $\mathrm{x}$ irregulariter venosus $v$. quinque-decemnervis, aequalis, obliquus $v$. rarius subbilabiatus, tri-decemdentatus. C 0rolla e tubus inclusns $v$. exsertus, intus saepe annulatus, limbi bilabiati labio superiore galeato v, plano, integro v. emarginato, inferiore varie trifido. St am in a 4 , adscendentia, superiora breviora, omnia fertilia v. inferiorum antherae interdum dimidiatae v. efoetae.

SUPTIBHES I. MELITTEAE. Cal y x post anthesim inflatus v. bi-quadrilobus. $\mathrm{C}_{0}$ r o ll a longe exserta.

3640. Melittis LINN. Cal y x campannlatus, membranaceus, irregulariter venosus, sub bilabiatus, labio superiore lato, rotundato, obsolete bilobo $\mathbf{v}$. breviter bi-tridentato, inferioris bifidi lobis rotundatis. C or oll a tubo amplo, exserto, exannulato, limbi bilabiati labio superiore or biculato, integro, subconcavo, patente, inferiore trilobo, patulo. Stamin a 4 , adscendentia, inferiora longiora; fil am en ta exappendiculata, antherae per paria approximatae, biloculares, Ioculis distinctis, divergentibus. Stylas apice breviter bifidus, lobis ovatis; $s \mathbf{t} \mathrm{g} \mathbf{m}$ a $\mathrm{t}$ a terminalia. A c h e nia sicca, laevia v. tenuissime reticulata. Herba in Europa media et a ustral $i$ indigena, hirsutiuscula ; foliis breve petiolatis, ovatis, crenatis, basi cordatis $v$, rotundatis, rugosis, floralibue con- 
formibus, verticillastris subsexfloris, axillaribus, bracteis subnullis, corollis magnis, rubris $v$, roseo-albis.

Melitt is Linu. gen. n. 731. Jacq. Fl. austr, t. 26. E. B. $t$. 636. S77. Hooker $F l$. Land, ic. Reicheub, Pl, crit. t. 24t, 242. Benth, Labiat. 503.

3641. Ilnysostegin BENTH. Calyx tnbuloso-campanulatus, mox inflato-campanulatus, obsolete subdecemnervis, subaequaliter quinquedentatus, v. truncatus, subintegerrimus. Corol la tubo longe exserto, intus exannulato, fauce inflata, limbi bilabiati labio superiore suberecto, subconeavo, integro $v$, emarginato, inferioris $\mathrm{pa}^{\mathrm{a}}$ tentis, trifidi lobis rotundatis, medio majore, emarginato. St a m in a 4 , sub labio superiore ad scendentia, inferiora paullo longiora; filamen ta edentula, antherae approximatae, biloculares, loculis parallelis, distinctis, nudis. Stylus apice subaequaliter bifidus, lobis subulatis; stig. mat a terminalia. A c henia sicea, laevia, - Herbae boreali-americanae, glaberrimae $v$. tenuissime pubescentes; foliis sessilibus, lanceolatis, acutis, argute serratis, racemo terminali simplici $v$. subpaniculato-ramoso, corollis purpureis, speciosis.

Ph y sos te g i a Benth, Labiat, 304, Bot. Mag. t. 3386. 3494. Dracoeephalum virginianum Lisn. et variet. Bot. Mag. t, 214. 567 . Vant. Cels, t, 4i, Sweet 57 . Gard. I, t. 93.

3648. Il campanulatus, membranaceus, irregulariter venosus, trilobus, lobo superiore oblongo, inferioribus rotundatis. Corolla tubo longe exserto, intus exannulato, fauce inflata, limbi bilabiati labio su. periore erecto, integro, subconcavo, inferioris paulIo brevioris, patentis, trilobi lobis rotundatis, me dio latiore. S $\mathbf{t}$ amin a 4 , sub labio superiure adscendentia, inferiora longiora; fil am en ta edentula, an therae per paria approximatae, bilocnlares, loculis divaricatis. Sty ins apice brevissime bifidus; stigmata...... A chenia ...... IIerba caroliniana, erecta, glabra; foliis petiola. tis, oblongo-ellipticis, obtusiusculis, obscure serratis $v$, sinuatis, basi rotundatis $v$. cuneatis, tenuibus, vix venosis, utrinque glaberrimis, v. supra parce pilosis, floralibus sessilibus, integerrimis, vix calycem ae quantibus, verticillastris ad apicem ramorum paucis, subsexfloris, bracteis nullis, coroll is subsesquipollicaribus.

Ma cbridea Elliott Carolin, 11, 86, Benth. Labiat, 505. Thymbra caroliniana Walt.

3643. Symand rea NUTT. C a 1 y $x$ inflato campanulatns, membranaceus, irregulariter veno sus, dentibns quatuor, subaequalibus. Corolla tubo longe exserto, superne fauceque dilatato, intus exannulato, limbi bilabiati labio superiore erecto, subconcavo, integro, inferioris patentis trifidi lobis ovatis, medio latiore, emarginato. S $t a-$ mina 4, adscendentia, inferiora longiora; fil amenta edentula, hirsuta, antherae per paria approximatae, glabrae, biloculares, loculis distinetis, divarieatis, superiorum loculis supremis connatis, obtusis, cassis, reliquis omnibus acutis, fertilibus. Stylas apiee bifidus, lobo superiore brevissimo, inferiore longiore, fere a basi stigmatife ro. A chenia sieea, magna, subinflato-compressa, laevia. - Herba boreali-americana, Lamii facie, hispidula; foliis ovatis, acuminatis, crenalis, verticillastris paucis, distantibus, bifleris.

S y nandra Nuttall Gen. IT, 29. L a mi um th is pidu1 u m Michx.

SURTRERUS 而. LAMIEAE. C a $1 \mathrm{y} x$ quinquedentatus, limbo haud dilatato. Corol- la subplana $\mathbf{v}$. fornicata. Stamina e tubo exserta.

3644. Wiedenammia FISCH. et MEY. C a ly x tubnloso-campanulatus, bilabiatns, labio superiore indiviso, lanceolato, inferiore porrecto, quadrifido, demum complicato faucem nudam reclndente. Corolla tubo exserto, basi annulato, fauce dilatata, limbi bilabiati labio superiore for. nicato, integro, inferioris trifidi lobis lateralibus dentiformibus. Stam in a 4 , adscendentia, inferiora longiora; filamenta edentula, antherae per paria approximatae, biloculares, loculis demum divaricatis, Stylns apice subaequaliter bifidus, lobis acutis. A ch enia sicca, trigona, laevia. - Herba annua, in Asia minore nuper reperta, Lamii purpurei facie, calycis structura singularis; folitis oppositis, subrugosis, inferioribus petiolatis, ovatis, acutiusculis, dentatis, superioribus sessilibus, basi cuneatis, acutis, inciso-serratis, verticillastris axillaribus, distantibus, subcapitatis, bracteatis, corollis intense sordido-purpureis, galea villis violaceis dense barbata.

Wiedemanuia Fischer et Meyer Index Sem. hort. Petropolit. IV. 1837, p. 58.

3645. Thamaiurn LINN. C a l y $x$ tubulosocampanulatus, subquinquenervis, ore aequali $\mathbf{v}$. saepius obliquo, dentibus quinque subaequalibus v. superioribus longioribus, apice subulatis. Coroll a tubo ineluse v. saepius exserto, intus nudo v. piloso-annulato, fauce dilatata, limbi bilabiati labio superiore ovato $\mathbf{v}$. oblongo, subfornicato $\mathbf{v}$. galeato, basi angustato, inferioris trifidi lobis lateralibus ad margines faucis truncatis v. rarius oblongis, appendicula dentiformi auctis v. muticis, medio lato, emarginato, basi contracto, substipitato. St a mina 4 , adscendentia, inferiora longíora; fil amenta edentula, antherae per paria approximatae, biloculares, loculis demun divaricatis, oblongis, hirsutis v. nudis. St ylus apice bifidus, lobis subaequalibus, apice stigmatiferis, $\mathrm{A} \mathrm{c} \mathrm{h}$ eni a sicca, triquetra, acutangula, apice truncata, laevia $v$. minute tuberculoso-rugosa. - Herbae in Europa,imprimis a ustraliet in Asia media indigenae, basi decumbentes; foliis infimis longe petiolutis, parvis, caulinis mediis majoribus, basi saepius cordatis, rugosis, plerumque duplicato- $v$. inciso-dentatis, floralibus subconformibus, superioribus minoribus, brevius petiolatis, omnibus calyces superantibus, verticillustris densis, axillaribus, inferioribus $v$. omnibus remotis, superioribus saepe approximatis, bracteis paucis, calyce brevioribus, subulatis $v$. rarius lanceolatis, corollis rubris, purpurascentibus, albis $v$. flavis.

L a u i u w Lian. gen, $n, 716$. Beath, Labiat, 502 .

a. ORVALA Linn. Corolla e tubus rectus, intus trans. verse aunulatus, faux amplissina, galea ovata. A utherae glabrae.

$$
\text { 0rvala Lius. gen, n, 808. (Bot. Mag. t, 172.) }
$$

b. LAMIOPSIS Dumort. Corollae tubus rectus, intus nudus v. transversim piloso-aunulatus, faux amplissima. A $n$ ther a e hirsulae.

Lamiopsis Dumort. El. Belg. 45. Erianthera Beuth. in Hook. Bot. Misc. III. 380. G a leo bdoln a Mouch Method. 393. Pollie hia Willd. Fl. Berol. 198. (Smith Exot, Bot, I. t, 48. E. B, t, 869. 770, 1933. Sibthorp Fl. graec, $t, 557$. Tenore Fl, neap. t. 153, f. 2 . Reichenb. Pl. crit, $t, 223$. 224, 707, 708, 721,

c. LAMLTYPUS Dumort, Corolla e tubus intus tiansversin anualatas, sub aaualo coatractus, sapra por. rectas, faux parum dilatata. A n the ra e hirsurae. La. mi oty pus Dumort, Fl. Belg. 45. (E, B, t. 765, 2550. 
Sibthorp Fl. graec, t, 856. Reicheub. Pl, crit, t. 215] - 217.)

d. GALEOBDOLON Huds. C or ollate tubus intus oblique anuulatus, sub anuulo contractus, supra anuulum dilatatus, subventricosus, subreeurvo-porreetus, faux parum dilatata, galea longa, basi longe angustata. A n the. rae glabrae. Galeobdolon Hadson Fl. angl, 2855 . Hooker Fl, Lond, IT. $t$, 16. E. B. $t$. 287. Polli $\mathrm{ch}$ ia Pers. in Usteri Ann. Bot, XIY, 39. C a rd ia c a Lam. Fl. fr. II. 384, part. Gal e o ps idIs s p. Linn. L e o. n uri sp. Scop. (Sibthorp Fl. gr, $t$. 855. Teuore Fl. neap, $t$, 52, Reichenb. Pl, crit, $t$, 706.)

3646. Inagoelnilus $B U \wedge G$. C a l y $x$ tu. buloso - campanulatus, subquinquenervis, ore ae quali v, obliquo, dentibus 5 subaequalibus v. superioribus longioribus, apice subspinosis. CorolIa tubo subexserto, intus annulato, limbi bilabiati labio superiore oblongo, apice bifido, inferioris trifidi lobis lateralibns brevibus, erectis, acutis, intermedio patente, late bifido. S $t$ a $\mathbf{m}$ in a 4 , adscendentia, inferiora longiora; fil amenta eden. tula, antherae per paria approximatae, loculis parallelis v. divergentibus, margine ciliato-hirsutis. Stylus apice bifidus, lobis subaequalibns, subulatis, apice stigmatosis. A chen i a sicca, triquetra, apice truncata, angulis acutis. - Herbae in Asia media indigenae, glaberrimae, rigidae; foliis oppositis, inciso-lobatis, lobis subspinescentibus, verticillastris axillaribus, paucifloris, bracteis subulatis, subspinosis.

L a gochil us Bunge ex Benth. Labiat, 6st. Yermo1 of $I$ a Belanger $V o y$. Ind. Bot io.

364\%. Heonurats LINN. Caly x turbinatus, quinquenervis, subaequalis, oris truncati dentibns quinque, apice sululatis, subspinosis, demum patentibus. Coroll a tubo incluso v, rarius exserto, intus nudo $\mathbf{v}$. oblique annalato, limbi bilabiati labio superiore oblongo, integerrimo, nunc: subplano, basi angustato, nunc fornicato, inferio ris patentis, trifidi lobis lateralibus oblongis, medio obcordato. Sta mina 4 , adscendentia, inferiora longiora; fil amenta edentula, antherae per paria approximatae, biloculares, loculis parallelis transversalibus, rarius divergentibus, valvalis nu. dis. Stylus apice subaequaliter bifidus, lobis subulatis, rarius brevibus, obtusis; $s t i g m$ at a terminalia. A ehenia sicca, laevia, triquetra, acntangula, apice truncata. - Herbae in Europa et Asia media et boreali indigenae; foliis oppositis, plerumque inciso-lobatis, inferioribus rotundatis, floralibus angustioribus, omnibus flores longe superantibus, verticillastris axillaribus, densis, distinctis, bracteis subulatis.

L e o и r us Linn. gen, n, 722. Beath. Labiat. 817.

a. CARDIACA Mónch Method, 601. C or olla tubo intus oblique annulato, supra annulum subventricoso, labio superiore subplano, basi angustato, inferioris patentissimi lobo medio integro. - Benth. Labiat, 518. (E., B. t. 286. Reichenb. Pl. crit. t, 338. Ledeb. Ic, t. 179).

b. CHAITURUS M8neh Method. 401, C o ra 11 a tubo reeto, intus nudo, labio superiore subfornicato, inferioris ereetinseull lobis subaequalibus, intermedia subiategro. Sta ni in a tubo vix lougiora, antherarua loeulis divergentibus. Plores minuti. - Benth. Labiat, 820. (L. M a rrubiastrum Lian. Jacq. El. austr. $t$. 405.)

c. PANZERIA Mönch Method. 402, Corolla tubo recto, lutus undo, labio superiore fornicato, inferioris erectiuseuli lobo medio saepius pateate, obeordato v. bifido. Stambina e tubo exserta. - Benth. Labiat, 520. (E., B. $t$, 94, Reichenb. Pl, crit, $t, 337.736$.

3648. Galeopsis LINN. Cal y x tubuloso-campanulatus, subquinquenervis, ore subaequali, dentibus quinque subaequalibus v. superioribus longioribus, apice subspinescentibus. Corvlla tubo exserto, recto, intus nudo, fance dilatata, limbi bilahiati labio superiore ovato, integro, fornicato, inferioris patentis, trifidi lobis lateralibus ovatis, medio obcordato v. subbifido, palato supra ad sinus loborum dente elevato aucto. Stam in a 4 , adscendentia, inferiora longiora; filamenta edentula, antherae biloculares, loculis oppositis, transversim bivalvibus, valvula interiore rotundata, margine ciliata, exteriore majore, nuda. Sty lus apice subaequaliter bifidus, lobis subulatis; stigmata terminalia. Achenia sicca, subrotundo-compressa, obsolete retieulata. - Herbae annuae, in omni Europa et Asia media indigenae, in Americamborealem transfugae, divaricato - ramosae, e basi decumbente adscendentes $v$. erectae, foliis floralibus caulin is conformibus, verticillastris pluri-multifloris, distinctis, fioribus rubris $v$. ochroleucis $v$, ex hisce coloribus variegatis.

Gale ops is Lian. gen, n, 171. E. B. t. 207. 669. 884. 2353. Reichenb, Iconogr. t. 46, 48. 57, 877, Beuth, Labiat. 522. Tetrahit Mönch Method, 395.

3649. Anisomeles $R . B R$. C aly $x$ ovato-tubulosus, suberectus, aequalis, quinquedentatus. Co rolla tubo calycem aequante, intus piloso - annulato, limbi bilabiati labio superiore oblongo, erecto, inferioris trilobi, majoris, patentis lobis lateralibus ovatis, obtusis, medio emarginatosubbifido. Sta m in a 4 , adscendentia, exserta, inferiora longiora; filamenta edentula, anthe$r$ a c per paria approximatae, staminum longiorum dimidiatae, inferiorum biloculares, loenlis parallelis, transversis. Stylus apice bifidus, laciniis subaequalibus. A e hen i a sicea, laevia, - Herbae v. suffrutices, in Nova-Hollandia et in Asia tropica indigenae, habitu Eriostachydum; verlicillastris nunc dense multifloris, floribus racemosis, nunc laxissimis, e cymis longe pedunculatis constantibus, nunc axillaribus, pauciftoris, floribus purpurascentibus.

A n 180 meles R. Brown Prodr. 503. Bot. Mag. t. 2021. Jacq. fil. Eclog. t. 86. Hooker Bot, Miscell, t. 19. Journ. of Bot, 1, 127. Benth. Labiat, 701. Ne petae et Ballotae s p. Lina. A jug a e sp. Roxb.

3850. Staelngs BENTH. CaIy x tubuloso-campanulatus, quinque-v. decemnervis, limbo aequali v. obliquo, quinquedentato, dentibus acqualibus v. superioribus majoribns, rarius basi in labium coalitis. Corolla tubo cylindraceo, aequali, incluso v. exserto, intus transversim piloso-annulato $\mathbf{v}$. nudo, superne saepe incurvo, fauce hand dilatata, limbi bilabiati labio superiore erecto $v$. subpatente, saepius subfornicato, integro v. vix emarginato, rarius elongato, subplano, emarginato-bifido, inferioris trilobi, saepins longioris, patentis lobo medio maximo, integro v. emarginato. Sta m in a 4 , adscendentia, inferiora longiora, deflorata saepe ad latera faucis dejecta; fil a m enta nuda, antherae approximatae, biloculares, loculis distinctis, parallelis, divergentibus v, divaricatis. St y lus apice bifidus, lobis subaequalibus, subulatis, apice stigmatosis. A chenia sicca, $\theta b-$ tusa, nec truncata. - Herbae, suffrutices $v$. frutices, $f$ ere in to to orbe, Nova-Hollandia excepta crescentes; habitu vario, verticillastris bimultifloris, saepius in racemos terminales, subsimplices dispositis.

Stachys Benth. Labiat, 895 . Stachys et Betonlc a Linn. gen, $n, 718,719$.

a. ALOPECUROS Benth. Op, cit. 331 . Herb it perennis, in Ruropa media et australl indigena, villosa, viridis; ver- 
ticillastris fasciculato-nultifloris, in spicam subinterruptam approximatis, bracteis cxterioribus calycem subaequantibus, corollae flavescentis tubo incluso, autherarum loculis parallelis.

Betonica Alopecuros Linn. Jacq. Fl. austr. t. 78. Reicheub. Iconogr, $t$. 719 .

b. BETONICA Benth. Op. cit. 532. Herbac perennes, in regione mediterranea et caucasica indigenae, pilosopubescentes v. villosae; verticillastris fascteulato-multifloris, in spicam interruptam approximatis, braeteis saltem exterioribus calycem aequantibus, corollis purpuras. contibus v, rarius oclsroleucis, tubo saepius exserto, antherarum loculis subparallelis.

Betonicae 5 p. Linn. Flor, dan, $t$, 726. E. B. 1142. Bot. Mag, $t, 700$, 2125. Reichenb. Iconogr. t. 710_715.

c. RRIOSTACHXS Benth. Op. cit. 534. Herbae biennes v. perenues, molliter villosae v. labatae, in Europa media, regione mediterranea, caucasica nec nou in India boreali erescentes; verticillastris multifloris, bractels saltem exterioribus calycem aequantibus v, vix dimidio brevioribus.

Eriostachys Reicheab. Flor. excurs. 319. part. E ri os tom um Liak et Hofmansegg. Flor. portug. 66. (Jacquin Flor. austr. t. 319. Ic. rar. t, 107. Russel Alepp. Ir. t. 10. Flor dan, t. 684. B. B. $t$. 829. Whldeuow Hort. berol, t. 60. Sibthorp Flor. zraec, t. 558. 360. Waldst. et Kitaibel Plant. Hung. $t$. 134. Lapeyr. Pyron. t. 8. Tenore Flor. Neapolit. t. 53, Bot. Mag. t. 1289. Sweet Fl. Gard, I. t. 100, Reichenb. Iconogr. c. 949.950.$)$

d. CALOSTACHYS Benth. Op. cil, 539. He $\mathrm{r}$ a e perennes, glabrae s. villosae, in America boreali-occidentall, Me xico, Asia arctica et in Capite bonae spel indigenae caulibus saepe ad angulos obverse pilosis v, aculeatis verticillastris subsexsloris, bracteis miautis, dentlbus calycinis acutissimis $\nabla$. subspinescentibns, corollis cocelneis v. purpureis, tubo longe exserto, antherarum loculis divergentibus $\mathrm{v}$. divaricatis. - (Jacq. Fort. Schänbr. t. 28\%. Andrews Bot, Reposit. t. 310. Bot. Mag. t. 666.)

e. STACHyotxpus Benth. Op. cit, $\tilde{5} 6 t$, Herbac cosmopolitae, вnnuae v. perennes, piloso-hispidae v, gla. bratae, rarius lanatae; verticillastris plerumque subsexfloris, rarius bi- quadri-v. decen-quindecimfloris, bracteis minutis, calyeibus saepius subspinescentibus, corollis parpurascentibus, rubris $y$. roseo-albis, nunquan ochroleacis, tubo incluso v. breviter exserto.

Stachydotypus Dumortier Flor. Belg. 45. Cam panistrum et Eriostachyos s p. Reichenb. Flor. excurs. 318. Trixag o et Sta e hy s Link et Hoffmans. Elor. portug. 66. (Jacq. Ic. rar. t, 108. Observ. 7. 77. Flor. dan. t. 587. K. B. 6. 416, 1154. 1675, 2089. Bot, Reg. t. 1080. 1538. Reichenb. Iconogr. t. 228. 646. 967.)

f, OLISIA Benth. Op. cit. 553 . He r b a e europere ct mediterraneae, annuae v. perenues, glabrae, pubescentes $\Delta$. pilosae, nunquam lanatae; foliis ovatis, verticillastris subsexfioris, bracteis minutis, calycibus saepius subspinescentibus, noununquam bilabiatis, eorollis ochro leucis.

OIls iat sp. Dumortier Flor. Belgic. 45. Tetrahit t m et $\mathbf{S t a}$ e by dis s p. Link et Hoffmans. Flor. portug. 66. Galeopstilis et Betonicates. Linn. (Jacq. Elor. austr. 2. 360. Hort, Vindob. I. t. 7o. Rei cheub. Io, exot, $t, 40$, Iconogr. t. 484.)

5. CHAMAESIDERITIS Benth. Op. cit. 556, He r b a e per ennes, in Europa media et in regione mediterranea spon taneae, glabrae v. pilosae, nunquam Isnatae; foliis oblongis, lanceolatis v. linearibus, verticillastris bi - sex. floris, bracteis minutis, ealycibus aequalibus, subspinescentibus, corollis ochroleucis $\nabla$. purpureis.

Chamaesideritis Reichenb. Fl. escurs. 318 , (Jaeq. Flor, eustr. t. 859. Desfont. Flor, atl. t. 126. Bot. Mag, t. 1959. Reichenb. Ic, exot, t, 28, Iconogr. t. 58, Sweet FI. Gard, II. $t$, 180.)

b. AMBLEIA Benth. Op. cit. 338. Suffruties v. fru. tice - in Capite bonae spel, Aegypto et Syria indigeni, tomentosi, rarius glabrati, nee pilosi ; verticillastris bi. sexfloris!, rarius subdecemfloris, brarteis parris v, pau. eis, calycibus tomentosis $v$. lanatis, dentibus mollibus, muticis.

A s pa s i a B. Meyer mso. (Lam. $t$. 509. $f$. 3. Jacq. Ic. rar. t. 493. Labillard. Syr. Dec, III. t. 5. Bot. Reg. t, 1697.)

i. ZIETENIA Benth. Op, cit. 563. Suffrutices medi. terranei et caucasiei, pilis mollibus albis lanati v. glabrati; bracteis parvis v. paucis, verticillastris bi-sexfloris, calycibus lanatis v. glabris, dentibus subulatis, saepissime spinosis.

Zietenia Gleditsch in Aet. Academ. Beroltn. 1706. p. 3. Sideritis ealycantha Bieberst. Reichenb. Iconogr, $t, 15$.

3651. Splnacele BENTH. CaI y x eampanulatus, fructifer saepius ampliatns, irregnlariter subdecemnervis, reticulato-venosus, ore aequali, intus nudo, profunde quinquedentato, dentibus subaequalibus v, vix snbbilabiatis. Co roll a tubo amplo, incluso v, exserto, basi intus piloso-annulato, limbi brevis, vix bilabiati lobis lato-rotundatis, erecto-patentibus, supremo subbifido, lateralibus integris, infimo majore, emarginato. $\mathbf{S t}$ a $\mathrm{mi-}$ n a 4, adscendentia, subaequalia v. inferiora longiora; fil a menta glabra, nuda, a ntherae subapproximatae, biloculares, loculis linearibus, distinctis, divergentibus. Sty 1 u 8 apice bifidus, lobis subaequalibus, subulatis, apice stigmatosis. A cheni a sicca, laevia. - Suffrutices $v$. frutices, in America occidentali a California ad Chili observati; foliis oppositis, bullato-rugosis, subtus saepe canescentibus, floralibus bracteafformibus $v$, rarius caulinis subconformibus, verticillastris bi-sexfloris, racemis terminalibus, simplicibus $v$, ramosis.

Sphacele Benth, Labiat, 567. Bot. Mag. t. 2993. Phyt oxys Molina Chili 309. Sideritidis s p. Humb. et Bonpl. Sta e hydis s p. Lindl. in Bot. $R e g$. t. 1226.

365:. Cumnenta COLLA. C a ly x campannlatus, decemnervis, ore aequali, profunde quinquedentatus, dentibus aequalibus. Co roll a tubo exserto, basi tenui, superne ventricoso, intus piloso annulato, limbi brevis, vix bilabiati lobis erecto patentibus, supremo late-rotundato, subbifido, lateralibus oblongis, intermedio integro aequalibus. St a m in a 4, erecta, distantia, superiora longiora; fil amenta basi villosa, antherae biloculares, loculis divaricatis. A $\mathrm{ch}$ e $\mathrm{n}$ i a sicea, laevia. - Fratex insulae St. Juan Fernande $\approx$, humilis, Bystropogenis punctati habitu; foliis serratis, supra viridibus, glabris, subtus vix tomentosis, cymis pedunculatis, corymbosis.

C u min i Colla in Mem, di Torino XXXVIIT, 139. t, M7. Benth. in litt. Bystropogon erlanthus Benth. Labiat. 227.

3653. Thepechlnia WILLD, C a Iy $x$ in flato-campanulatns, reticulato-venosus, apice truncatus, subbilahiatus, labio superiere bidentato, in ferioris tridentati dentibns omnibus aristatis, fauce intus nuda. Cornlla calycem aequans, tubo intus nudo, limbi bilabiati labio superiore recto, subplano, emarginato, inferioris trifidi lobis planis, integris, sulpatentilus. Stamina 4, adscendentia, inferiora longiora; filam enta glabra, anthe rae approximatae, loculis subparallelis. Stylns glaber, apice bifidus, lobis subaequalibus. $A \in$ heni a sicca, laevia, nigra. - Herbae mexi can ae: foliis oppositis, ovatis $v$, subcordatis, crenatis, ver ticillastris plurifloris, remotis $v$. spicatis, floribus parvis, flavescentibus.

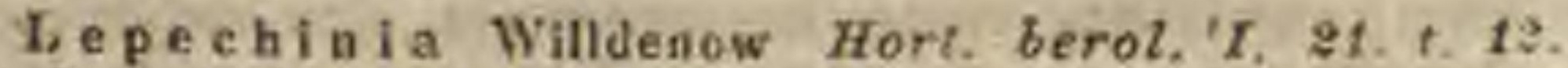
Bot. Reg. e, to2. Benth. Zabiat, bt3́. 
SUPTEIBUS III. MARRUBIEAE. Stamin a corollae tubo inclusa.

3654. Cranfotome REICHENB. Cal y x ovatus, aequalis, demum subglobosus, quinquedentatus, fauce coarctata, intus villosa. C o roll a tubo exserto, limbi bilabiati labio superiore brevissimo, concavo, integro, inferiore longiore, patente, trifido, laciniis lateralibus brevibus. St a min a 4 , adscendentia, inferiora longiora, corolla breviora. Sty I us apice bifidus, lobis subaequalibus; stigmatibus minutis. Aehenia sicca, laevia. - Herba nepalensis, erecta, ramosa; ramis gracilibus, patentim pilosis, foliis oppositis, petiolatis, ovatis, acuminatis, basi cordato-crenatis, utrinque piloso-hispidis, floralibus superioribus minoribus, supremis minutis, bracteaeformibus, cymis laxis, multifloris, pedunculatis, racemosis, racemis gracilibus, paniculatis, floribus minutis, eleganter roseo-albo et purpureo-variegatis.

Crani o t o w e Reichenb. Ic, exot. I. 39. $t$. 54. Benth. Labiat. 704. Nepeta vers icol ur Treviran.

3655. Sideritis LINN. Calyx tubulosus, quinque-decemnervis, dentibus quinque erectis, subspinosis, nune aequalibus, nune supremo latissino $v$. tribus superioribus basi in labium subconnatis. Corolla tubo incluse, intus nudo v. annulato, limbi bilabiati labio superiore erecto, subplano, integro v, emarginato-bifido, inferiore patente, trifido, lobo medio latiore, saepins emarginato. St a min a 4 , tubo corollae inclusa, superiora brevissima, antheris bilocularibus, loculis divaricatis; inferiora longiora, antheris dimidiatis, cassis $v$. difformibus, rarissime superioribus conformibus. St y $\mathbf{L}$ s apice bifidus, lobo superiore tereti, truncato, apice stigmateso, inferiore dilatato, basi superiorem ampleetente, apice et margine stigmatoso. A c he n i a sicca, obtusa. - Herbae, suffrutices $v$. frutices, in Europ a media, regione mediterranea, Asia temperata et in insulis Canariis crescentes; verticillastris sex-multifloris, axillaribus, racemosis $v$. spicat is foliis floralibus nunc caulinis subconformibus, superioribus minutis, nunc bracteaeformibus, dilatatis, flores amplectentibus, margine integerrimis $v$. spinoso-dentatis, corollis parvis, saepius flavescentibus.

Sideritis Linn. gen. $n, 712$. Benth. Labiat. 571 .

a. MARRUBIASTRUM Benth. Op, cit. 573. Frutices canarienses, molliter lanati, saepe nivei; foliis floralibus herbaceis, integerrimis v. erenatis, infimis subeonformibus sed multo brevioribus, supremis minutis.

Marrublastrum Mosnch Method, 39r. (Jacquin Hort, Vindob. III, t, 30.)

b. EMPEDOCLEA Benth, Op. cit. 514. Her b a e perennes v. suffrutices, basi lanati, in regione mediterranea crescentes; foliis floralibus integerrimis, flores sessiles amplectentibus.

Emped oclea Rafinesque Caratt, 78. Navieula ri a Fabricius. (Sibthorp Flor. graec. $t$. 550 . Bieberst. Plant. ross, 1. t. 39. Vent, Cels, t. 98. Labillard. Syr. Dec. IV. $t, 8$. Reichenb. Io. exot. t. 58, Iconogr. t. 384.

c. EUSIDERITIS Benth. Op. oit. 5a?. Suffrutiees me. diterranei, imprimis hispanici, villosi $\vee$. pills mollibus sublanati, rarius glabrati; follis floralibus bracteatermilus, sessilibus, latissime cordatis, flores amplectentibus, venoso-reticulatis, margine spinoso-dentatis, calycinis dentibus aequalibas, spinosis, corolla dentes calyefinos parum superante. - (Cavanill. Ic. $t$. 48,185 186. 209. 301, 304.)

d. HESIODIA Benth. Op, cit, 682. Herbae annuae, in Europa media et mediterranea indigenae, virides, pilis mellibus sublanatae; foliis foralibus caulinis subcon- formibus sed minoribus, subdentatis, dentibus muticis, calycinis dentibus nunc omnibus subaequalibns, tribus superioribas basi subcomexis, nunc dente supremo maxiuo, inferioribus muito angustioribus, fiter se atqua. libus, corolla dentibus calycinis plerumque breviore.

Hesiodia, Burgsdorffla et Marrnbiastri sp. Mönch Method, 391.392. (Murray in Nov, Comment. Gotting. 1378, t, 4. Jacquin Flor, austr, t. 434. Ca. vanill. Ic. t. 187. Sibthorp Flor. graec, t. 551. E52.)

3656. Aerotome BENTH. Calyx tubuloso-campanulatus, decemnervis, oblique quinquedentatus. Corolla tabo vix exserto, limbi bilabiati labio superiore erecto, integro, subfornicato, inferiore patente, trifido, lobo medio latiore. St a min a 4 , intra tubnm corollae inclusa. St yIns inclusus, apice bifidus, lobo superiore truncato, apice stigmatifero, inferiore dilatato, basi superiorem amplectente, apice et marginibus stig. matoso. A $c h$ enia sicca, acute triquetra, apice truncata. - Suffrutex capensis; foliis parvis, apice dentatis, floralibus subconformibus, verticilla. stris axillaribus distantibus, paucifloris, bracteis parvis.

$$
\text { A erotome Benth. in litt, 11, Mai, } 1838 .
$$

365\%. IInreubium $L I N N$. Caly x tubulosus, quinque-decemnervis, subaequalis, dentibus quinque $v$, decem acutis, aequalibus, erectis v. demum patentibus. Corolla tubo incluso, intus nudo v. subannulato, limbi bilabiati labio superiore erecto, subplano $\mathbf{v}$, coneavo, integro $\mathbf{v}$. breviter bifido, inferiore patente, trifido, lobo medio latiore, saepius emarginato. S t a m in a 4 , intra tubum corollae inclusa, inferiora longiora; antherae conformes, biloculares, loculis divaricatis, subconflnentibus. Sty l us apice bifidus, lobis brevibus, obtusis, apice stigmatiferis. A ch cnia sicea, apice obtusa, nee truncata. - Herbae perennes, in Europa media, regione medite rranea et $A$ sia temperata indigenae, nonnullae late per orbem terrarum diffusae, saepius tomentosae v. lanatae; foliis oppositis, rugosis, rarius basi cordatis, suepe incisis, floralibus conformibus, flores excedentibus, verticillastris axillaribus plerumque multifloris, bracteis subulatis calycem subaequantibus, rarius brevissimis v. subnullis.

Marrubium Linn. gen, n. 721. Beath. Labiat. Ess,

a. LaGopsis Benth. Op. oit. 386 . $\mathrm{C}$ aly $\mathrm{c}$ is dentes quia. que. Corolla e tubus exanuulatus, labium superius integrum. - Folia rotundala, inciso - pinnatifida.

Lagopsis Bunge msc. MoI ucella e sp. Steph. Ledebour $r_{c}, t, 150$.

b. MARRuBium Beuth, Op, oil. 587. Calyeis dentes quinque v. decem. Corolla e tubus subananlatus, la. bium superius emarginatum v, bifidum. - Folia rotur. data $v$. ovata, crenata $v$, rarius incisa. - (Jacq, For, austr, $t, 160$. Sibthorp Fl. graec. $t$, 561. Reichenb. Iconogr. t. 270, 288, 299, 300, 312, 313. Tenore Flor. neap. t. 154.)

SUBTIRTES IV. BALLOTEAE. Ca1 y $\mathrm{c}$ is limbus dilatatus $\mathbf{v}$. sex - decemdentatus, nunc ore truncato inter dentes submembranaceo, v. latissime membranaceo - campanulatus. C o r oll a e labium superius saepe compressogaleatum. St a min a corollae tubo exserta.

3658. IBallota LINN. Calyx subinfundibuliformis, tubo decemnervi, dentibns quinque $\mathrm{v}$. viginti, basi dilatatis $\mathrm{v}$, in limbum orbiculatum, patentem connatis. Corofla tubo subincluso, intus transversim piloso, annulato, limbi bilabiati labio superiore crecto, oblongo, subconcavo, apice $79 *$ 
emarginato, inferiore patente, trifido, lobo medio emarginato. Stamin a 4 , adscendentia, inferiora longiora; an therae e tubo corollacexsertae, per paria approximatae, biloculares, loculis demum divaricatis, subdistinctis. Stylus apice bifilns, lohis subulatis, apice stigmatosis. A ehenia sicca, apice obtusa, nec truncata. - Herbae perennes, in Eurapa et in regione mediterranea copiosae, in Capite bonae spei rarissimae, hirsutae, lanatae v. lomentosae; foliis rugosis, basi saepius cordatis, integerrimis $v$. crenatis, nunquam incisis, floralibus subconformibus, verlicillastris axillaribus, plerumque multifloris, bracteis copiosis, oblongis, subulatis, spiniformibus $v$. interdum brevissimis.

B a 11 o ta Lino, gen, n, 720. Benth, Labiat, 592 . M a $x$ r ubit et Molucella e sp. Lian.

a. BERINGERIA Benth. Op. cit, 594. Cal y $\mathrm{c}$ is limbus 6_20dentatus v. crenatus, - Bracteae oblongae $v$. subulatae, molles.

Beringeria Necker Elem. n. 489. Pseudodictam us Mónch Method, 399. M a r rubii s p. Linn. Sibthorp Flor. graec. $t$, 568 . Birona Manip. $T I$. $t$. 1.

b. BALlOTA Beath. Op. cit. 597 . C al y el s limbus 5deatatus. - Braoteae lineari-subulatae, molles. - (Reichenb. Kconogr. t, 773, 776.)

c. ACANTHOPRASIUM Benth. Op. cit, 598. C a ly e is limbus 5-10dentatus. - Bracteae subulatae, rigidae, spiniformes.

Molucell a s p. Llnn. Burm. Elor. indic, t. 38. $f$. 2. Sibthorp Flor. Braec, $t$. 586 ,

3659. Tusfocorys BENTH, Cal y x subcampanulatus, aequalis, decemnervis, dentibus quinque evatis, sinubus rarissime dentibus minutis auctis. Corolla tubo incluso, intus annulato, limbi bilabiati labio superiore integro, coneavo, erecto, extus hirsutissimo, inferiore patente, vix longiore, trifido, lacinia media subaequilata, emar ginata. St amina 4 , adscendentia, inferiora longiora; filamenta basi nuda, antherae sub labie superiore per paria approximatae, biloculares, loculis divaricatis. Sty lus apice bifidus, lobis subulatis, inferiore breviore $\mathbf{v}$. brevissimo, versus apicem stigmatoso. A chenia sicca, triquetra, apice obtusa. - Frutices capenses et abyssinici, candido-tomentosi v. pubescentes; foliis in ramis subfasciculatis, oblongis v. cuneiformibus, integerrimis $v$. apice dentatis, verticillastris bi-multifloris.

\section{L a s lo cor y s Benth. Labiat. 600 .}

36BO. IRoylea $W A L L, C$ a I y $x$ basi tubnlosus, decemnervis, limbi quinquefidi laciniis erectis, oblongis, membranaceis, reticulato-venosis, aequalibus. Co ro 11 a calyce brevior, tubo inclu. 80 , intus annulato, limbi bilabiati labio superiore crecto, integro, fornicato, inferiore patente, trifido, lobo medio integro. S $t$ a $m$ in a 4 , sub labio superiore adscendentia, inferiora longiora; antherae per paria approximatae, bilocalares, locnlis divaricatis, demum subconfluentibus. St y l u s apice bifidus, lebis subaequalibus, subulatis, apice stigmatosis. A ch eni a sicea, apice obtusa. - Frutex indicus, ramosissimus, cinereo-tomentosus; folitis oppositis, petiolatis, ovatis, obtusis, parce pilosis, supra viridibus, subtus incanis, floralibus sensim minoribus, verticillastris laxe sex-decemfloris, cymis breviter pedunculatis, pedicellis brevissimis, bracteis parvis, subulatis.

R o y le a Wallich Plant. As. rar. r. 57, t, 74, Benth. Labiat. 601, B all ot a cine re a Don.

3681. Dtostegila BENTH. Caly x basi tubulosus, decemnervis, limbi subbilabiatim mem- branaceo - producti labio superiore brevi, integrn v. triangulato, inferiore maximo, ovato, obtuso. Corolia tubo incluso, intus annulato, limbi bilabiati labio superiore oblengo, concavo, integro, erecto, extus hirsutissimo, inferiore patente, trifido, lobo medio latiore, emarginato. S $t$ a m in a 4 , adscendentia, inferiora longiora; fil a m enta basi nuda, antherae sub labio superiore per paria approximatae, biloculares, loculis divaricatis. StyI ns apice bifidus, lobis subaequalibus, subulatis, apice stigmatosis. A chenia sicca, apice obtusa. - Frutices arabici et abyssinici; foliis oblongis, integerrimis v. ovatis, dentatis, verticillastris laxe plurifloris.

Otostegia Benth. Labiat. 60t. Molucellae sp. R. Br. P h Iomis moluceoides Vahl Symb. I. C. 14.

3668. Letens R. BR. C a lyx tubulosus v. tubuloso-campanulatus, striatus, apice rectus v. incurvus, ore aequali $v$, oblique supra et infra producto, octo-decemdentato. Cor ol la tubo incluso, intus annulato v. nudo, limbi bilabiati labio superiore concavo, erecto, integro v. rarius emarginato, extus hirsutissimo, inferioris Iongioris, patentis, trifidi laeinia media maxima. Stamin a 4 , adscendentia, inferiora longiora; fi la ment a basi nuda, antherae sub labio superiore per paria approximatae, subbiloculares, loculis divaricatis, confluentibus. Stylus apice bifidus, lobo superiore brevissimo, inferiore subnlato, versus apicem stigmatoso. A chenia sicea, triquetra, apice obtusa. - Herbae v. suffrutices, in Asia et Africa tropica, rarius in Oceani pacifici insulis crescentes; foliis integerrimis v. saepius dentatis, floralibus subconformibus, verticillastris nunc paucifloris, nunc dense multifloris, corollis saepius albis, rarius purpurascentibus.

Le uce s R. Brown Prodr. 504. Benth. Labiat, 602.

a. HEMistoma Benth. Op. cit. 605. C a Iy $x$ tubulosus, ore obliquo, latere inferiore producto, supra fisso. Verticillastri globosi, multiflori, bracteae numerosae, Linu.

Hemistoma Ehreab. moc. Phlomis indica

b. LOXOSTOMA Benth. Op. cit. 600. C al y х tabulosus, ore obliquo, latere inferiore productiore. - Verticil. lastrí pauciflori, bracteae minutae.

c. ORTHOLEUCAS Benth. Op. cit. 606. Cal y $\times$ tubulosus v. subeampanulatus, striatus, ore aequali $v$. viz obliquo, fauce subnuda, dentibus decem erectis, subulatis v. brevissimis, setaceis - Vertioillastri laxiusculi, saepe pauciflori, bracteae minutae v. paueae, setaceae, rarissime calyces subaequantes. - (Desfont. in Mem, MLs. XI. t. 3.)

d. AsTroDON Benth, Op. cit. 611. Calyx tubulosus, ore aequall, fauce saepius villosissima, dentibus decem demum plerumque stellato - patentibus. - Verticillastri saepius globosi, multiflori, solitarii v. pauci, su. premi nunc capitati, bracteae calyeibus vix breviores. (Desfont. l. c. t. 1. 2.)

e. Plagiostoma Benth. Op. eit. 6t4, C al y x turbinatus v. tubulosus, ore obliquo supra productiore. Verticillastri saepius globosi, multiflori, solitarii v. pauci, supremi nunc capitati, braoteas ealyctbus aequales $v$. paullo breviores. P hlo midis s p. Jacq. Ic. rar. t, 110, 111. (Desfont. $t_{0}, c_{,} t, 4$,)

3663. Ieomotis PERS. Caly $\mathrm{x}$ ovatotubulosus, decemnervis, apice incurvas, ore obliquo, subdecemdentato, dente supremo majore. Corolla tubo saepius exserto, intus nudo $v$. incomplete annulato, limbi bilabiati labio superiore concavo, erecto, elongato, integro, inferioris brevis, patentis, trifidi lacinia media vix majore. Stamina 4, adscendentia, inferiora longiora; fila- 
me n ta basi nuda, an thera e sub labio superiore per paria approximatae, biloculares, loculis divarieatis, aentis. $S t y$ In $s$ apice bifidus, Jobo $8 u-$ periore brevissimo. Achenia sicea, apice obtusa. - Herbae $v$. frutices c apenses et guineen$s$ es; verticillastris multifloris, saepius densissimis, bracteis numerosis, lineari-subulatis, corollis speciosis, coccineis v. flavescentibus.

Le o not is Persoon Ench. Ir. 127. R. Brown Prodr. 504, in not. Bot. Reg. t. 281, 1850. Benth. Labiat.618. L e onu $\mathrm{r}$ us Tournef, inst, 87. Mönch Method. 400. P hl om i. d is s p. Linn. Bot. Mag. $t$. 478.

36G4. Phlomis $L I N N$. Cal y x tubulosus, quinque- $\mathbf{v}$. decemstriatus, saepius plieatus, ore aequali, truncato v. tridentato. Corolla tubo incluso $v$, vix exserto, intus sacpius annulato, limbi bilabiati labio superiore galeato, carinato, compresso, lato, integro $v$. emarginato, incumbente v. suberecto, inferiore patente, trifido. St a min a 4 , adscendentia, inferiora longiora; fil a m e $\mathrm{n}$ ta nuda, superiora adnata, basi saepissime in appendiculum producta, a $\mathrm{n}$ he rae sub galea per paria approximatae, subbilocnlares, loculis divaricatis, obtusis, confluentibus. Stylus apice bifidus, lobo superiore brevissimo, $v$. rarius inferioris subulati, apice stigmatosi dimidium aequante. A che nia sicea, triquetra, apice obtusa, glabra v. pubescentia. - Herbae $v$. suffrutices, in $r$ e gione mediterranea et Asia temperata crescentes, virides $v$. floccoso-lanati; foliis rugosis, verticillastris pluriftoris, axillaribus, bracteis suffultis $v$. rarius nudis, corollis luteis $v$. purpureis, rarius albis.

P hl om is Linn. gen, n. 723, exel, sp. R. Browu Prodr. 504, in not. Benth. Labiat, 620.

a. EUPHLOMIS Benth. Op. cit. 621. Corolla galea maxima, incumbente, labil inferioris lacinis lateralibus parvls, ovato-v. lanceolaso-appendiculatis, intermedia maxima, latissima, rotundata, saepius emarginata v. bifida. - Herbae v. suffrutices floccoso-lanati. Flo. res lutei v. purpurei. (Jacq. Hurt. Schönbr. t. 359. Sibthorp Flor. grace. . 563.564 . Desfont, El. Atlant, t. 127. Mem. Mus, XI, t. 5. Cavanill, Ic, t, 247. Labillard Syr. Dee. III. t. 10. Teuore Flor, neap. t. 75. Bot. Mag, $t, 999,1843,1819,2449,2542$. Royle Himalay. t. 75.)

b. PHLOMIDOPSIS Benth. Op. cit. 631. C o r o 11 a galea suberecta, pilosa, intus et margine pilis lougis barbata, Iabii inferioris lobo medio vix lateralibus majore. - Her. bae virides, floribus purpurascentibus v. albis.

Phlomoides Mönch Method. 403. Phlomldop 8 is Link Handb, 479. (Bot. Mag. t. 1355. Ledebour Ic. $t, 364$.

3665. Notoelnaete BENTH. C a ly x tubulosus, apice membranaceus, breviter quinquedentatus, nervis quinque sub apice calycis in aristas subulatas, rigidas, uncinato-revolntas produetis. Co rolla tubo incluso, exannulato, limbi bilabiati labio superiore galeato, pilosissimo, inferiore patente, subaequaliter trifido. St a m ina 4 , adscendentia, inferiora longiora; filamenta basi nuda, antherae per paria approximatae, biloculares, loculis demum divarieatis. Sty 1 us apice bifidus, lobis breviluns, aequalibus. A chenia sicca, apice truncata, nuda. - Herba nepalensis; caule erecto, ramoso, tetragono, brevissime pubescente, foliis oppositis, longe petiolatis, ovatis, acuminatis, serrato-crenatis, utrinque viridibus, glabriusculis, junioribus subtus tomentosis, verticillastris axillaribus remotis, globosis, dense multifloris, lappaceis, bracteis subulatis, rigidis ut dentes calycini apice uncinato-revolutis, corollas parvas superantibus.

N o to c ha e te Beath. Labiat, 635.
36B8. Eremosta elays BUNG. Calyx ample tubulosus, subeampanulatus $v$. infundibuli. formis, dentibus quinque spinosis, v. limbe maximo membranaceo mucroniformibus. Corolla tubo incluso, intus annulato $v$. nudo, limbi bilabiati hiantis labio snperiore elongato, galeato, subcompresso, basi attenuato, extus pubescente, intus margineque barbato, inferioris patentis, trifidi lobis omnibus rotundatis, medio latiore. Stamin a 4 , adscendentia, inferiora longiora ; fil a m e n$t$ a superiora in appendiculam obtnsam v. fimbriatam incrassata, antherae per paria approximatae, biloculares, loculis divaricatis. Stylus apice bifidus, lobis subulatis, aequalibus v. superiore vix dimidio breviore. A $\mathrm{e}$ henia sicca, apice densissime pilosa. - Herbae in Asia media indigenae, subramosae; foliis radicalibus caulinis amplioribus, integris $v$. dissectis, verticillastris multifloris, saepe ad apices caulis $v$. ramorum approximatis, bracleis adpressis, corollis suepius ochroleucis.

Eremostachys Bunge in Ledebour Flor, alt. II. 414. Ic. t, 122. 437. Benth. Labiat, 636. Belanger Voy. Bot. Ic. Rnyle Himalay. 6.74. P ht $10 \mathrm{~m}$ is 1 a cin ita ta Linit. Sweet Fl. Gard. $1, t, 2 t$.

366\%. Wrifoplingtom BENTH. C a $1 \mathrm{y} x$ membranaceus, ample campanulatus, aequalis, quinquedentatus, dentibus subspinosis. Corolla tubo inclnso, limbi bilatiati labio superiore maximo, galeato, compresso, incumbente, inferioris parvi, trifidi lobis rotundatis. Stam in a 4 , adscendentia, inferiora longiora; fil am enta superiora basi incrassato - appendiculata, antherae per paria approximatae, biloculares, loculis divaricatis. Stylus apice bifidus, lobis subaequalibus, subulatis, apice stigmatosis. A chenia sicca, nuda. - Herba in di ca, simplex, lana longissima, alba, laxa obtecta; foliis infimis parvis, superioribus et floralibus rhomboideis $v$. orbicularibus, basi subcuneatis, sessilibus, crenatis, mollissimis, bracteis nullis, verticillastris sexfloris.

Eriophy ton Beath. Labiat. 038.

3685. Niolucella LINN. Caly $\mathrm{x}$ basi oblique campanulatus, striatus, limbo amplo, dilatato, reticulato - venoso, quinque - decemdentato, dentibus mucronatis v. spinosis. Corolla tabo inelaso, intus oblique annulato, limbi bilabiati labio superiore erecto, integro $v$, emarginato- bifido, inferioris trifidi lobis lateralibus erectiusenlis, medio patente, lato, obcordato. Stam in a 4 , adscendentia, inferiora longiora; fil am enta basi nuda, antherae in apice filamenti lateraliter pedicellatae, biloculares, loculis subdistinctis, divaricatis. Sty lus apice bifidus, lobis subaequalibus, apice stigmatosis. Achenia sicca, acute triquetra, apiee truncata. - Herbae orienta$l i$-mediter $r a n$ ea $\mathrm{e}$, annuae, glaberrimae; foliis oppositis, petiolatis, profunde crenatis $v$. incisis, floralibus conformibus, verticillastris axillaribus plurifloris, bracteis subulatis, spinosis.

M ol ue ell a Linn, gen, $n$, 724. excl. sp. Benth. Labiat. 639. Mol u c c a Tournef. inst, 88 .

a. MOLUCCA. C al y cis limbus maximus, membranaceus. subpentagonus, brevissime quinquedentatus, dentibus mucronatis.

M. 1 a ev is Linn. Sibthorp Flor, graec, $t$. 566 . Bot, Mag. $t$. 43. 1825.

b. CHASMONE. C a 1 y cis limbus brevis, coriaceus, subbi. Jabiatus, octo-decemdentatus, dentibus spiaosis.

C has mo ue Presl Flor, vicul. xxxVII. Bot. Reg. t. 1294. M. sp in os a Linu. Sibtherp Fl. graec. t. 567. 
3669. Hilymemoerater FISCH, et MEY. Cal y x tube brevi, tredecimnervi, limbo maximo, membranaceo, patente, quinquefido, lobis ovatis. Corolla tubo exserto, limbi subbilabiati labio nuperiore bipurtito, inferieris tripartiti lacinia media majore, emarginata. Stamina inelusa, sub labio superiore adscendentia, inferiora longiora, antherae biloculares, loculis divaricatis. StyIns apice bifidus, lobis subaequalibns. A $\mathrm{c}$ h e ni a sicca, subovata, glabra, tuberculata. - Fruticulus persicus, humilis, glaber; foliis Nepetae pannonicase viscidulis, bitumen redolentibus, verticil. lastris quinque-septemfloris, confertis, foliis floralibus oblongis, subintegerrimis, corollis violaceis, $l i$ neis albis pictis.

H y men ocrater Fiseher et Meyer Index Som, Hort. Petropolil, II. 1835, p. 39.

36ร๑. Trolnskioldia RETZ. Calyx tubo brevissimo, limbo maximo, subrotato-campanulato, membranaceo - venoso, subintegerrimo. Corolla tubo elongato - incurvo, intus nudo, fauce subdilatata, limbi subbilabiati labio superiore bifido, laciniis erecto-patentibus, inferioris trifidi laciniis lateralibus parvis, reflexis, media ova$\mathbf{t a}$, patente, $S t \mathbf{a} \mathbf{m}$ in a 4 , exserta, adscendentia, inferiora longiora; fil amenta superiora dilataza, antherae biloculares, loculis parallelis. Sty Ius subindivisus v, lobo superiore brevissimo, apice minute stigmatosus. A chenia rugosa, per paria cohaerentia, subcarnosa. - Frutex ind $i$ cus; ramis divaricatis, tetragonis, glabris, saepe tuberculatis, foliis oppositis, petiolatis, ovatis, acuminatis, subintegerrimis, glabris, venosis, verticillastris bi-quadriftoris, racemulos axillares, petiolo vix longiores formantibus, calyce sanguineo, corolla rubra.

Holmskioldia Retz Observ. VT. 3t, Benth, Labiat. 669. Hastingia Smith Erot. Bot, IL. $t .80$, Platun i m Jassieu in Annal. Mus, PII. 76.

365 1. Aelnyrospermum BLUM. $\mathrm{C}$ a 1 y $\times$ amplus, subbilabiatus, labio superiore erecto, trifido, inferiore parum breviore, patente, bifido. C oroll a calyce longior, limbi bilabiati labio superiore abbreviato, erecto, emarginato, inferioris semitrifidi lobo intermedio majore, concavo. Stamin a 4, snbaequalia, adscendentia; fil a me nt a nuda, an therae loculis confluentibus uniloculares. St y l u s brevissime bifidus. A chenia dorso et apice paleis membranaceis coronata. - Herbae vel suffrutices javanici et madagascarienses; foliis oppositis dentatis, molliter pubescentibus, verticillastris in spicam terminalem aggregatis,

Achyrospermu m Blume Bijdr. 840. Bentham La. biat. 643. Sipho tox ys Bojer msc. La m pros ta eh y s Bojer msc.

36\%.. Colquhoumia WALL. Calyx tubuloso - campanulatus, decemnervis, subincurvus, suhaequaliter quinquedentâtus, fauce intus nuda. Coroll a tabo exserto, incurvo, intus nudo, fauce dilatata, limbi bilabiati labio superiore erecto, integro, subplano, inferioris subpatentis, trilobi lobis brevibus, ovatis, integris. Sta m ina 4, adscendentia, inferiora Iongiora; filamenta basi nuda, anthera e approximatae, biloculares, loculis demnm divaricatis. Stylus apice bifidus, lobis snbaequalibus, subulatis, apice stigmatosis. Achenia oblonga, sicea, laevia, apice membranaceo-produeta. - Frutices n ep alens es, volubiles, saepe tomentosi; foliis oppositis, petiolatis, ovatis, acuminatis, crenatis, supra atro- viridibus, junioribus subtus incano-tomentosis, verticillastris laxis, axillaribus $v$, in spicam terminulem approximatis, bracteis minutis, corollis coccineis.

Colqqu th ou i a Wallieh in Linn. Transact. XIIL. Gos. Tent. Flor. nepal, t, 6. Plant, As, rar, t. 267. 268. Benth. Labiat. 644,

TrEIBUS X. PRASIEAE Benth. L $a$ biat. 646. Caly $\mathrm{x}$ subaequalis. Co roll a bilabiata. Stam in a 4, adscendentia, inferiora longiora. A chenia subbaceata.

36r3. Complostenama WALL. $\mathrm{C}_{\mathrm{a}}$ ly $\mathrm{x}$ ovato - campanulatus $\mathrm{v}$. tubulosus, subaequalis, quinquedentatus, intus fauce nuda. Corolla tubo recto, saepins exserto, intus exannulato, supra medinm inflato, limbi bilabiati labiis subaequalibus, superiore erecto, integro, fornicato, inferiore patente, trifido. Stamina 4 , sub labio superiore adscendentia, inferiora longiora, antherae per paria approximatae, biloculares, loculis parallelis, transversis. Sty lus apice bifidus, lobis subaequalibus, subulatis, stigmatibus minatis. A chen ia carnosa. - Herbae indicae, perennes; caulibus saepius erectis, simplicibus, nunc basi procumbentibus, radicantibus, foliis saepius amplis, crassis, villosis $v$. tomentosis, floribus majusculis, verticillastris nunc spicatis, nunc axillaribus, remotis.

Gom phostem ma Wallich Plant. As. rar, II, 12. Benth, Labiat, 646.

36y 4. Plhyllostegía BENTH. Calyx campanulatus, ovatus v. tubnlosus, decemnervis, subaequalis, nunc quinquefidus, lobis ovatis, foliaceis, nunc breviter quinquedentatns. Corolla tubo ealycem superante, nunc longe exserto, saepius incurvo, intus exannulato, fauce subaequali, limbi bilabiati labio superiore subpatente, integro, sulbplano, inferioris longioris, patentis, trifidi lobis ovatis, medio majore integro. S $\mathbf{t a m}$ in a 4 , sub labio superiore adscendentia; an the rae biloculares, loculis divergentibus $\mathbf{v}$. demum divaricatis, Sty lus apice clavatus, subinteger v. breviter bifidns, lobis clavatis, divaricatis v. arcuatis, $8 t i g \mathrm{~m}$ a t a terminalia, saepe inerassata, capitata. Achenia carnosa. - Herbae sandvicenses, erectae $v$, adscendentes, subsimplices; foliis oppositis, petiolatis, ovatis, saepius dentatis, verticillastris sex decemfloris, in racemum, laxum terminalem disposilis $v$ infimis axillaribus, foliis floralibus superioribus parvis, bracteaeformibus, bracteis parvis, subulatis $v$. subnullis.

Phyll ostegi a Benth. Labiat, 650. Prasit sp. Gaudieliaud ad Freycin, $t, 64,6 s$.

36ร. Stenogyne BENTH. C a 1 y $x$ ovato - campanulatus, decemnervis, subaequalis v. oblique bilabiatus, nunc quinquefilus, lobis ovatis, foliaceis, nune quinquedentatus, dentibus tribus superioribus minus profunde distinetis. $\mathrm{Co-}$ roll a tubo calycem superante, incurvo, intus piloso-annulato, fauce dilatata, limbi bilabiati labio superiore erecto, emarginato, inferioris patentis, trifidi laciniis subaequalibus, integris. Sta mina 4, sub labio superiore adscendentia; anth $\mathrm{e}$ rae biloculares, locnlis demum divaricatis. Stylas apice bifidus, lobis subaequalibus, stig matibus minntis. A chenia carnosa. - Herbae sandwicenses, ramosae, procumbentes, adscendentes $v$. erectae; ramis divaricatis, subscandenti- 
bus (?), foliis saepius coriaceis, crenatis, verticillastris subsexfloris, axillaribus, distantibus $v$. ad apices ramorum approximatis, foliis floralibus caulinis conformibus, bracteis parvis, subulatis $v$. subnullis.

\section{Stenogyne Benth, Labiat, 654.}

36\%8. Prassinm LINN. C a lyz eampanulatus, decemnervis, irregulariter bilabiatus, labio superiore breviter trifido, inferiore profundius bifido, laciniis omnibus foliaceis, ovatis. CorolIa tubo incluso, intus pilis squamosis annulato, limbi subaequaliter bilabiati labio superiore ovato, integro, inferioris trifidi lacinia intermedia majore integra. Stamina 4 , sub labio supeifore adscendentia, anthera e biloculares, loculis demum divaricatis. Stylus apice bifidus, lobis subaequalibus, stigmatibus minutis. - Suffrutex medit er raneus, divaricato-ramosus; ramis herbaceis, junioribus hispidulis, foliis petiolatis, ovatis, acutis, serrato-crenatis, floralibus conformibus, verticillastris bifloris, distantibus, axillaribus, bracteis minutis $v$, nullis, corollis albidis $v$. pallide purpureis.

\section{Pras i um Linn. gen, n. 308. Benth. Labiat. 655.}

TERIBUS XI. AJUGOIDEAE Benth. Labiat. 657. Coroll a labium superius nune brevissimum, nunc fissum, laciniis abbreviatis, rarissime erectum, fornicatum, inferius elongatum. St a m i n a $2 \_4$, adscendentia, saepissime exserta, labio opposita. A chenia plus minus reticulato-rugosa.

36\% A Amethystea LINN. C a l y x subgiobosus, campanulatus, erectus, aequalis, quinquedentatus. Cor olla tubo ealyce breviore, intus exannulato, limbi declinati lobis quatuor superieribus subaequalibus, brevibus, inferiore ma jore. Stam in a 2 inferiora, adscendentia, inter corollae lacinias supremas exserta, superiorum redimenta minuta, filiformia, an $t$ hera e biloculares, loculis demum divarieatis, subeonfluentibns. Stylus apice breviter bifidus, lobis subaequalibus. A chenia reticulato-rugosa. - Herba annжa, per $A s i a$ mediam latissime diffusa, erecta, ramosa, glabra, saepe caerulescens; folitis oppositis, petiolatis, tri-quinquepartitis, segmentis oblongo-lanceolatis, inciso-dentatis, floralibus minoribus, supremis minutis, cymis pedunculatis, la$x$ is, racemoso-paniculatis, bracteis minimis, calycibus caerulescentibus, glaberrimis, corollis vix calycem superantibus, caeruleis.

A met hy st e a Linn. gen. $\pi$, 15. Benth. Labial. 657.

3689. Trielhostemma $L I N N$. C a I y nune campanulatus, subaequalis, profunde quinquefidus, nune depresso - campanulatus, obliguus, resupinatus, dentibus tribus superioribus elongatis, connatis, duobus inferioribus brevissimis. C oroll a tube tenui, saepius exserto, intus exannulato, limbi subaequaliter quinquefidi larínis oblongis, declinatis. Stamina 4 , inferiora longiora, longissime exserta; fil amenta interdum submonadelpha, antherae snbbiloeulares, loeulis divergentibus $v$. divaricatis. StyIus apice bifides, lobis subulatis; st ig mat $\mathrm{i}$ bu $s$ minutissimis. - Herbae bor eali-americanae; folïs integerrimis, inflorescentia axillari $v$. racemosa.

Trichostemua Linn, gen, $\pi$. 300. Beatl. Labiat. 658 . a. STREPTOPODIUM Bentl. Op. eit. 658. Caly $\mathrm{x}$ valde obliquus, pedicelli torsione resupinatus. - Pedicelli solitarii, opposili, uniflori. (Lam. 4. 515. Barton Flor. medic, $t_{0}$ 98.)

b. ORTHOPODIUM Benth. Op, cit, 659. C a 1 y $\mathrm{x}$ rectus, aequalis. - Cymae multiflorae.

36\% 9. Teacrium $L I N N$. C a ly x tubulosus v. campanulatus, rarius inflatus, quinquedentatus, dentibus aequalibus $\mathbf{v}$, supremo saepius latiore. Coroll a tubo hrevi, intus exannulato, limbi laciniis quatuor saperiorilus subaequalibus v. smpremis latioribus lnngioribusve, nune oblongis declinatis, nune brevissimis suberectis, infima maxima, rotundata $v$. oblonga, saepius concava. Stamina 4, inter lacinias snpremas exserta, inferiora longiora, a $\mathrm{n}$ th e rarum locali confluentes. Stylns apice bifidus, lobis subaequalibus; stigmatibus minutis. A $\mathbf{c}$ hen ia ples minusve rugosa. - Herbae v. frutices, per totum fere terrar $u m$ orbe $m$ erescentes, habitu et inflorescentia varia.

Teu crium Linn. Gen, n, 706. exel. sp. Benth. Labiat. 660. Chamaed ry s, Scorodonia, Scordium et Po. If a m Taursef. inst. 98. Dbuch Melhod. 401.

a. LeUCOSCEPTRUM Benth. Op. cit. 663. C a l y x turbinatus, incurvus, dentibus subaequalibus. Co rolla incurva, reflexa, lacinils superioribus brevissimis, latis, truncatis, erectis. - Frute.z indicus, cano-to. montosus; verticlllastris mullifloris, dense spicatis.

Le ucosceptrum Smith Erot. Bot. 113, $t$. 116.

b. TEUCROPSIS Benth, Op. cit, 664, C a 1 y $\times$ campaunatus, declinatus, dente supremo latiore, patente. Corolla extus tomentosa, laciniis superioribus brevissimis, latis, truncatis, erectis v. vix declinatis. - Fri. tices canarienses, incant; verlicillastris biflorls, axillaribus, $v$, in racemos terminales disposiks.

Te ncrops is Gingins msc. (Heritter Stirp. $t .49$. Jacq. Collect. I, t, 17. f. 2. Bot. Mag. t. 1114.)

c. TEUCRIS Benth, Op. cit, 665. Caly $\mathbf{x}$ eampnnalatns, erectus, aequalis, quisquedeatatus v. quinquefidas. Cor olla e laciuiae quatuor superiores oblongae, declinatae, infiua oblonga, concara. A e henla reticulaforugosa, glabra s. rarius villosissima. - Herbae, suffrutices $v$. frutices cosmopoltit; folits integer. rimis incirisve, rarissime erenatis, pedunoulis aril. laribus oppositis, unifloris $v$. lare cymosis, plariforis. (Sibthorp Flor. graec, t. $82 \%$. 529. Jacy. Aner. t. 183. f. 74. Observ. IT. t. 30. Bot. Reg. t, 1255.)

d. PYCNOBOTrXs Benth, Op. cit, 67t, Calyx Inflato. v. tubnloso-campanalatus, declinatus, dentibus subaequalibus v. supremis latioritus. Cor oltae laciaie supremae brevissimae, latae, truncatac, vix declinatae, laterales parvae, oblongae, declinatae, infina lata, concava. A c b a la rugosa, glabra. - Herbac v. frutices villosi v. glabri, nunquam incani; verictllastria quadri-multifloris, in spicam simplicem v. ramosam condensatir.

e. STACHYOBOTRYS Benth, Op. cit. 672, Calyx campasulatus, declinatus, dentibus superioribus, imprimis supremo laterioribus, rarius subaequallbus. Corollac laciniae superiores ollongae, declinatae, infima oblouga, coneava. A chenia valde reticulato - rugosa. glabra. - Herbae perennes, adscendentes $v$. ereciae, parum ramosae; vericillastris sex-multifloris, it spicam simplicem, teretem, terminalem dispositit. (Sibthorp Elor. graec. t. 531 . Bot. Mag. t. 2013. Desfont. Flor, atlant, $t, 120$.

f. SCORODONIA Benth. Op, cit. 614. C a I y $\mathrm{x}$ campanulatus, deelinatus, dentibus superioribus, imprimis gupremo latioribus. Co rolla laciniae superiores oblongae, declinatae. A $\mathrm{e}$ h e $\mathrm{n}$ l a parva, subglobosa, rugosa v. sublaevia. - Herbee perennes, europeae et asia. ticae, adscendentes $v$. erectac, ramosae; verticil. lastris bifloris, secundis, in racemor terminales. saepius ramosos dispositis, (Jacq. Hort. Pindab. $r$, $t$, 94, IIT. t. 4f. B. B. t. 15/3. Link et Hofrasascgge Flor, poriug. t, 2.) 
g. SCORDIUM Benth. Op. cit, 678. Caly x tubulosus, declinatus, basi infra gibbus, dentibus quinque subaequalibus r. supremo latiore. Corolla e laciuiae superiores oblongae, declinatae. A $\mathrm{c}$ he $\mathrm{n}$ ia valde $y$, vix rugosa. - Herbae annuae v. perennes, mediterra$n \in a \vec{e} ;$ verticillastris bi-sexfloris, distantibus, aril. laribus, folits foratibus caulinis conformibus. (E. B. t. 828, Sibthorp Flor. graec. t. 539 . Desfont. Flor. at. lant. $t$. 117. Link et Hoffuansegg. Flor, portug. t, 3.)

h. CHAMAEDRYS Benth. Op. cit. 680. Cal y x tubulosocampanulatus, decliuatus, basi obliquus, dentibus quinque subaequalibus v. superioribus vix latioribus. C or o 11 a e laciniae superiores oblongae, declinatae, A c b e. n la reticulata, leviter rugosa. - Suffrutices $v$. fru. ticuli, in Europa media et in rogionibus mediterraneis indigeni, erecti $v$, adscendentes; verticillastris bi-sexfloris, distinctis, in racemum terminalem, laxum dispositis. - (Desfont. in Annal. Mus. X. t, 22, Flnr, atlant. $t, 118$. E, B. $t, 580$. Sib. thorp Flor. graec, $t, 530,532,533$.

i. Polium Benth. Op, eit. 684. Caly $\mathrm{x}$ tubuloso-campanulatus, subdeelinatus, basi obliquus, dentibus quinque mbaequalibus $v$, superioribus vix Iatioribus. Coroll a laciniae superiores oblongae, declinatae, laterales minutac. A chenia rugosissima. - Herbae perennes v. suffrutices, in Europa media et in regioni. bus mediterraneis crescentes; caulibus basi Eaepius procumbentibus, ramosissimis, ramis floriferis adscendentibus, verticillastris paucis, in capitula substobosa, terminalia condensatis. - (Cavanill. Ic, t. 117. 119. 121. f. 1. t. 198. Sibthorp Flor. graec. t. 534. 538.)

3650. A juga $L I N N$. C a l y x ovato v. glo. boso - campanulatus, subaequalis, quinquedentatus. Coroll a tubo incluso v, exserto, intus saepius piloso - annulato, recto v. spiraliter semitorto, limbi bilabiati labio superiore brevi, saepius brevissimo, emarginato, inferiore elongato, patente, trifido, laciniis lateralibus oblongis, intermedia latiore, emarginata v. bifida. S ta min a 4, adscendentia, e labio superiore saepissime exserta, inferiora longiora; antherae subbiloculares, loculis divergentibns v. divaricatis, demnm confluentibus. Stylus apice bifidus, lobis subaequalibus; stig.matibus minutis. A chenia reticulato-rugosa. - Herbae gerontogeae et a ustralasicae, annuae, perennes $v$. basi suffruticosae, saepe procumbentes $v$. adscendentes, interdum stoloniferae; verticillastris bi-mullifloris, densis, nunc omnibus axillaribus, folits floralibus caulinis conformibus, nunc superioribus approximalis, spicatis, foliis floralibus minoribus $v$ difformibus.

A j u g a Linn. Gen, n. 705. Benth. Labiat, 690. B u gu. la et $\mathrm{Ch}$ a macpitys Tournef. inst. 98.

a. Bugula Benth. Op. cit, 692. Vertlelllastri sexv, saepius multiflori. Corolla e saepius caeruleae, roseae, purpuraseentes $\nabla$. albidae, nunquam flavac. (E. B, t. 477, 489, 1280.)

b. Chamaepitys Benth, Op, eit, 697. VertJeillastri bi-rarissime subquadriflori. C o roll a e roseae v. flavae, labio superiore brevissimo, truneato. - Phleboanthe Tansch in Flora 1828. p. 323. Te ueri is p. Lian. et Auct. Waldst, et Kitaibel Plant, rar. Hung. $t, 16$. (E. B, t, 77. Sibthorp. Flor, graec, t. 312, 326.)

e. PSEUDANISOMELES Benth. Op, eit, z00. Verticil. last ri bi-sexflori. C o rolla e labium superius inferiore vix triplo brevius. - Species australasicae.

3681. Cymarin BENTH. Caly x subglobosus, subdecemnervis, aequalis, quinquedentatus, fance coarctata, nuda. Corolla tubo subexserto, recto, limbi bilabiati labïis subaequalihus, superiore erecto, integro, fornicato, inferiore patente, trifido, lacinia intermedia integra. St a mina 4 , sub labio superiore adscendentia, inferiora longiora, anthera e biloculares, loculis demum divaricatis. St ylus apice bifidns, lobo superiore minuto, stigmata minuta. A chenia sicea, rugosa. - Frutices indic $i$; ramis tomentosis, folitisque crenatis subtus canescentibus, floribus parvis, cymosis, cymis racemosis.

C у ma ri a Benth. Labiat, 705. Deless. Ic. select, IIT, t, 86 .

\section{GENUS DUBIUM.}

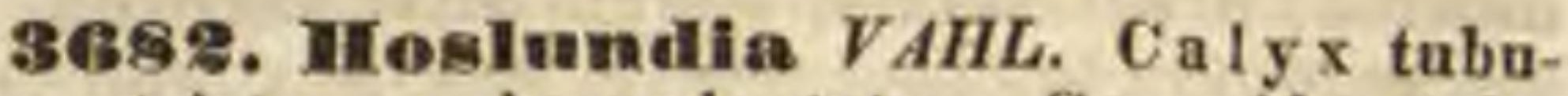
losus, striatus, quinquedentatus. Coroll a tubo exserto, fance compressa, limbi bilabiati labio superiore erecto, ovato, gibbo, inferiore trifido, recurvo. Stamin a 4 , quorum duo minima, sterilia, antherae reniformes. Stylns apice bifidus. A $\mathbf{c}$ h e $\mathrm{n}$ a calyce baceato, decangulo, apice dentibus umbilicato inclusa. - Frutices gu ineenses et senegambic $i$, ramosi, villoso-pubescentes; folits oppositis, serratis, basi et apice integerrimis.

H a 1 n n di a Vahl Enumerat, I. 212. Palisot Elor. Owar. I. 33. $t$. B2. Benth, Labiat, 706.

\section{Drdo CXXXVII. Terbenaceae.}

VITICES Jussieu Gen, 106. VERBENACEAE Jussleu in Annal. Mius. VII. 63. R. Brown Prodr. 510. Bartling Ord. nat. 179. Lindley Introduct, edit, 11. p. 877.

Неввав v. saepius frutices, interdum armores excelsae; caule ramisque plerumque tetragonis. Folia opposita, rarius alterna, interdum verticillata, nunc simplicia, integra, incisa, rarius integerrima, plerumque dentata v, crenata, nunc interdum composita, digitata v. impari-pinnata, petiolo in plerisque basi dilatato, semiamplexicauli. Stipulae nullae.

Flones hermaphroditi, irregulares v, rarius subregulares v. regulares, axillares v. terminales, rarius solitarii, plerumque spicati, eapitati, racemosi v. saepissime cymosi, unibracteati.

Calyx liber, persistens, gamophyllus, tubulosus, limbo partito v. dentate, aequali $v$. inaequali.

Corolla hypogyna, gamopetala, tubulosa, limbo quadri-quinquefido, plerumque plus minus inaequali, bilabiato, rarius aequali.

Stamina tnbov. fauci corollae inserta, ejusque laciniis alterna, rarissime omnia perfecta, posticum plernmque deficiens, didynama, duo superiora saepius castrata. Fil a m en $t$ a filiformia, plerisque brevissima, paucis elongata, simplicia, v, rarissime squamuloso-appendiculata. Antherae biloculares, erectae v. incumbentes, loculis parallelis, contiguis $v$. subdistinctis ant divaricatis, longitudinaliter dehiscentibus.

Ovariom e carpidiis duobus v. quatuor conflatum, carpidiorum marginibus nunc dissepimenta primaria praebentibus bi-quadriloculare, nunc iisdem in dissepimenta cavitatem bipartientia introflexis quadri-octoloculare. 0 y ul a 
in loculis solitaria v. gemina, collateralia, nunc e basi erecta, anatropa, nunc saepius adscendentim amphitropa, micropyle semper infera, puncto insertionis plerumque infra medium sito, situm erectum mentientia. Stylus terminalis, simplex; stigma indivisum, subcapitatum vel subobliquum, nunc bifidum.

Fructus drupaceus v. baccatus, drupae mono-di-tetrapyrenae, pyrenae uni-biloculares, saepius epicarpio ad maturitatem evanescente sponte secedentes; b a c c a e bi-quadriloculares, v. abortu interdum uniloculares.

SBmina in loculis solitaria, situm erectum monstrantia. Albumen nullum v. parcum, subcarnosum.

Emвryo rectus; cotyledonibus applicitis, germinatione foliaceis, radicula utplurimum brevi, infera.

Verben a ce a a Labiatis ovulorum insertione, ovarii et fructus fabrica, a Selagineis antheris bilocularibus, radiculae situ infero, a Stilbineis albuminis et embryonis proportione et corollae aestivatione, a Myoporineis ovulorum situ et radiculae directione diversae, maximo numero inter tropicos utriusque orbis generantur, imprimis in America copiosae. Paucae in regionibus temperatis et calidioribus extratropicis vivunt, in Asia media et boreali imprimis rarae. Regiones frigidas et alpium juga fugiunt.

Generum per tribus dispositio hoc loco tentata subartificialis.

TRIBEUS T. LIPPIEAE. Fructus drupaceus, maturitate in elementa carpica secedens.

3653. Buelhis H.B.K. C aly $\mathrm{x}$ bipartitus, laciniis acuminatis, carinato-concavis. Corolla hypogyna, basi extus pilis seriatis cincta, subinfundibuliformis, tubo cylindraceo, limbi quadripartiti laciniis aequalibus, erectiusculis. S ta min a 4, corollae fauci inserta, inclusa, 0 va ri u m depressoglobosum, acumine triplici terminatam, triloculare, loculis uniovulatis? Stylus filiformis; stigma tripartitum, laciniis capillaribus. Fructus calyce aucto inclusus, tricuspidatus, depresso-globosus, membranaceus, laevis, trilocularis. Semina in loculis solitaria. Em b r y o...-Herba or in oc. censis, erecta; foliis oppositis, breve petiolatis, elliptico-oblongis, integerrimis, nervosis, pedunculis terminalibus pluribus, polystachyis, spicis sessilibus, oblongo-cylindraceis, fasciculatim confertis, floribus minutis, dense imbricatis, ebracteatis? albidis.

B uch la Kunth in Humb. ot Bonpl. Nov. gen, et sp. II. 269. $t .132$.

3684. Lippla LINN. Cal y $x$ tubulosus v. compressus, bi-quinquedentatus, demum bivalvis. Coroll a hypogyna, tubo sursum ampliato, limbi bilabiati, plani labio superiore emarginatobilobo, inferiore trifido. S $\operatorname{tam}$ in a 4 , corollae tubo inserta, inelusa, didynama, omnia fertilia. Ova ri u m biloculare, loculis uniovulatis. Stylus terminalis; s ti g ma oblique capitatum v. lineare, sublaterale. Drupa sicea, calyce demum saepins bivalvi tecta, bilocularis, bipartibilis. S em in a in loculis solitaria. Embry $\mathrm{n}$ i s exalbuminosi radicula infera, - Herbae, suffrutices v. frutices, inter tropicos America copiose crescentes, in veteris orbis regionibus tropicis et extratropicis calidioribus rari, erecti, procumbentes v. repentes; foliis oppositis, simplicibus $v$, rarissime ternatis, saepissime serratis $v$. crenatis, interdum integerrimis, floribus in capitula axillaria, pedunculata, solitaria, verticillata v. paniculata, rarissime terminalia collectis, interdum in spicas axillares dispositis, bracteatis, saepissime albidis.

L ip pi a Lian. gen. n. 781. L. C. Richard in alichaux Flor. bor. Amer. II. 15, Kunth Synops. II. 82.

a. ZAPANIA JUSS. Cal y $x$ compressus, lacinils carinatis v. alatis. Flores eapitati.

$\mathrm{Z}$ a p a n a Jussieu in Annal, Mus, VII, 75. R. Brown Prodr. 514. P1 at on i a Rafinesque in N. York medic. Reposit. 2. Hexad, $Y$. 350. B e r tol o ni a Rafiuesque in Desvaux Journ. Bot. IV. 177. L i ppla, Ridelits et Dipterocaly x Chamisso in Linnaea $V I I .294$. 225. t. 7. f. c. d. B l a i ri a e s p. Gärtner t. s6. f. 2.3. Verben a e s p. Limn. Heritier Stirp. $I$. $t, 12$. (Jacq, f. Eclog. t. 85. Gärtner t. 56.)

b. ALOYSIA ORTEG. Caly x quinquedentatus, Flores spicati. Folia ternata v. simplicia.

A loys ia Ortega. Verbenae sp. Linn. Heritier Stirp. $1, t, 11$.

3685. Verbema $L I N N$, C a l y x tubulusus, quadri-quinquedentatus. Co roll a hypogyna, tubo cylindrico, recto $\mathrm{v}$, incarvo, limbo quinquefido plus minus inaequali. S $t$ a $\min$ a 4 , corollae tubo inserta, inclusa, didynama, omnia fertilia v, duo snperiora ananthera. O va $\mathbf{r} \mathbf{i} \mathbf{u m}$ bi- $\mathbf{v}$. quadriloculare, loculis nniovulatis. Stylus terminalis; s tig ma subeapitatum. D r n p a exsueca, bilocularis bipartibilis, v. quadrilocularis quadripartibilis. $\mathrm{Semina}$ in loculis solitaria. Embryonis exalbuminosi radicula infera. - Herbae v. suffrutices, per regiones calidiores et temperatas totius orbis diffusi, in America meridionali imprimis copiosi, in $A s i a$ media rarissimi, erecti, procumbentes $v$. adscendentes; folits oppositis, rigidis, saepissime serratis $v$. incisis, spicis axillaribus v. terminalibus solitariis, glomeratis v. paniculatis, floribus sessilibus, bracteatis, varie colorutis.

Verb e a Linn. gen, $n, 23$. exel, sp. St. Hilaire Plant. us, Bras, $n, 40$.

a. STACHXTARPHETA. Ovarium biloculare. Drupa bilocularis, bipartibilis. St a min a duo superiora anantliera. - Flores saepissime rhacheos carnosas exca. vationibus semiimmerit.

S t a ch y t a rphet a Vahl Enumerat. I. 206. Kunth Synops. II. 62. Bot. Mag. t. 976. 1848. 1860 . C y m b u. rn a Salishary Parad, $t$, 83 . A be na Necker Elem, $n$. 461. (Jacq. Observ. IV, t. 85. 86. Ic. rar. t. 20\%. 208. Hort. Schönbr, t. S. Vahl Eclog. II. t, 11. Ruiz et PRvon Flor. Peruv, 2. 34. Andrews Bot. Reposit. t. 435 . Veut. Malm. t. 36. St, Hilaire Plant, us, $t$, 39.)

b. BOUCHEA. Ovari am biloculare. Dru p a bipartibilis. Stamina omnia fertilla. - Spicae haud carnorae.

B o u c he a Chamisso in Linnaea VII. 252. Ve r be a a Pse udo.Gervao St. Hilalre Plant, us, bras. 8.40.

c. MElasanthus. O vari u m biloculare. Drupa bilocularls, bipartibilis. Stam ía a duo superiora anauthera. - Spicae haud carnosae.

Mela s a th us Pohl Plant. brasil, I, 75, 4. 60,65.

d. VERBENAE VERAE. Ova $\mathrm{r}$ u m quadriloculare. D $\mathrm{k}$. pa quadrilocularis, quadripartibilis. Stamia omaia fertilia, vel duo superiora interdum abortiva. - Spicae kaud carnosae. 
Verben a Jussieu in Annal. Mus. PII. 75. Kunth Synops. 1T. 57. E. B. t, 769. Sibthorp Elor. graec. $t .554$, Mirbel in Annal. Mrus, $\mathrm{X} V$. $t$. 14. $f .1-5$. Ruiz et Pavou Flor. Peruv. t, 33. Humb, et Boupl. Nov. gen, et sp. t. 133-137. Vent. Cels, t. 83. Hooker Bot, Miscell. t. 46-48. Bot. Mag. t. 308, 1976, 2200, 2910, 3127, 3333. Bot. Reg. t. 1102, 1184. 1748. 1768, 1935. Sweet Fl. Gard. $t$. 202. 295. $I T$. $t$. 9. 41. G I a nd u 1 a ri a Gmelin syst. 920. B 111 a rdier a Mönch Method. 369. (V. A u ble tia Jacq. Hort. Vindob. IT. t. 176.)

3686. Milonoelnilus FISCH. et MEY. C a ly x bilabiatus, labio superiore bi-, inferiore tridentato. Corolia hypogyna, tubulosa, limbo antice fisso, unilabiato, quinquefido, lobis lateralibus replicatis. St a min a 4 , subaequalia, fertilia, erecta. O variu m quadriloculare, loculis uniovulatis. St ylu s terminalis; stig ma punctiforme. D ru p a subbaceata, quadrilocularis, quadripartibilis. S e mina in loculis solitaria, erecta. E mbryo....-Herba brasiliensis, humilis; radice repente, carnosa, caule abbreviato, foliis confertis, magnis, oppositis, ovatis, serratis, pubescentibus, subtus purpurascentibus, Gloxiniae foliis simillimis, racemis axillaribus et terminalibus bractealis, pedicellis medio bibracteolatis, corollis albidis, fructibus niggrescentibus.

Monochilus Fischer et Meyer Index Sem, hort, Petropolic. 1835. I. p. 34 .

368\%. Chaseanum E. MEY. Calyx tnbulosus, quinquedentatus, demnm latere longitudinaliter fissus. Co roll a hypogyna, tubo cylindraceo, elongato, limbo quinquefide, subbilabiato. Stamina 4, corollae tubo inserta, inclusa, didynama. O varium quadriloculare, loculis uniovalatis. S tylus terminalis; s tig ma emarginatum. Dr u p a exsncea, ahortu bilocularis, dimidiato-subquadrangula, foveolis insculpta, mericarpio alteri abortivo, squamaeformi latere inferne adhaerens. Semina in loculis selitaria. Embry onis exalbuminosi radicula infera. - Herbae capenses, basi suffrutescentes, perennantes; foliis oppositis, dentatis v. incisis, floribus spicatis.

Chas a n a m E. Meyer Comment, plant. Afr. austr. 275. B u c h n er a ee r $\mathrm{n}$ a a Linn. Houttuyn $S y s t$. II, t, 58. f.2.

3688. Cassella NEES et MART. C a $1 \mathrm{yx}$ tubulosus, quinquefidns, demum longitndinaliter fissus. C oroll a hypogyna, tubo brevi, infundibuliformi, limbi quinquefidi laciniis posticis minoribus. Stamin a 4, corollae tubo inserta, inclusa, didynama. Ova rium biloculare, loculis biovalatis. Stylus terminalis; stigma capitatum, hinc concavum. Drupa submembranacea, biloenlaris, axi hians, tandem bipartibilis. Semina in loculis solitaria. Embryonis exalbuminosi radicula infera. Fruticuli brasilienses, humiles; folitis oppositis, petiolatis, integerrimis v. serratis, racemis axillaribus, paucifloris. 73. $t .6$.

C asselia Nees et Martius in N, $A, N, C, X I$.

3689. Dipyrema HOOK. Calyx tubulosus, quinquedentatus, dente antico longiore, demum latere longitudinaliter fissns, C or oll a hypogyna, infundibuliformis, tubo elongato, superne ampliato, limbo quinquefido, inaequali. St a m in a 4 , corollae tubo superne inserta, inclusa, didynama. Ovarium quadriloculare, loculis uniovulatis. Stylus terminalis, subexsertus; s t i gma dilatatum, subobliquum. D ru pa quadrilocularis, bipartibilis. Se mina in Ioculis solitaria. $\mathbf{E} \mathbf{m}$ bry on is exalbuminosi radicula in era. - Frutex andicola, glaberrimus, erectus, virgatus, habilu verbenae asperae; ramis subspinescentibus, fo- liis alternis $v$. in ramis junioribus fasciculatis, parvis, oblongo - spathulatis, crassiusculis, subcarnosis, uninerviis, sessilibus, floribus in spicam terminalem, laxiusculam digestis, bracteatis, odoratis.

D i pyren a Hooker Bot, Miscell. $T$. 365. Wil s onla Hooker Op. cit, $I, 172, t$, 49. non R. Br.

3690. Priva ADANS. C al yx tubulosoventricosus, quinquedentatns. Corolla hypogyna, tubo cylindraceo, limbo quinquefido, plano, subinaequali. S $\mathrm{t}$ a $\mathrm{m}$ in a 4 , corollae tubo inserta, inclusa, didynama. Ova ri u m quadriloculare, loculis uniovulatis. Stylus terminalis; stigma indivisum, laterale. Drup a calyce inflato inclusa, quadrilocnlaris, bipartibilis. S e m in a in loculis solitaria. Em bry on is exalbuminosi radicula infera.- Herbae hispido-scabridae, subdichotomae, in America tropica et subtropica obviae, in $A s i a$ et $A f r i c a$ rarae; folitis oppositis, integerrimis $v$, crenatis aut subserratis, spicis terminalibus et axillaribus, floribus subsessilibus, bracteatis, calycibus fructiferis hispidis $v$. villosis, reflexis.

Priva Adanson Fam. II. 505. Jussieu in Annal. Mas, VIT. 75. Kunth Synops, II, 61. B I a i ria Houston 277. Gärtner $t$. 56. $f$. 1 . exel, reliq. P h r y m a Liun. gen. n. 738. Leptost achya Mitchell gen. n. 9. C a stella Cavanilles in Anal. cienc, nat, III. 134. $t$. 30. Ic. $t .583$. Tortula Roxburgh in Willd, sp. $I I T$. 359. Strepti u m Roxburgh Plant. Corom. $M$. 25. $t$. 146. Flor. ind. IIT. 90. Hooker Journ. of Bot. t. 180.

3891. Chlonathes $R . B R$. C a ly $x$ campanulatus, quinquefidus, aequalis. Corolla hypogyna, tubulosa, fauce ampliata, limbi ringentis labio superiore bifido, inferioris tripartiti lobo medio longiore. St a m in a 4 , corollae tubo inserta, exserta, didynama. Ova riu m sexloculare, locnlis duobus intermediis efoetis, lateralibus utrinque dnobns uniovulatis. Stylus filiformis; $8 t \mathrm{igma}$ bifidum, acutum. D ru pa exsueca, dipyrena, pyrenis trilocularilius, loculo intermedio sterili, farcto. Semina in loculis solitaria, erecta. Embryonis subalbuminosi radicula infera. - Suffrutices N ov a e Hollandiae orientalis extratropicae, pubescentes; foliis oppositis, decurrentibus, linearibus, bullatis, pedunculis axillaribus, solitariis, unifloris, bibracteatis, calycis lacinits subfoliaceis, marginibus recurvis, corollis ochroleucis, siccitate virescentibus, pyrenis ventre bullato.

Chloanthes R. Brown Prodr. 513, Ferd. Bauer $I l$ lustr. Plant. Nov, Holl, $t, 4$.

369. Caryopteris BUNG. C al y $x$ campanulatus, quinquefidus, demum auctus. Co rolla hypogyna, tnbo superne ampliato, fauce villis clansa, limbi bilabiati labio superiore abbreviato, bipartito, inferioris trifidi lobis lateralibus oblongis, acutis, medio dilatato, subcucnllato, fimbriatomaltifido. Stamina 4 , corollae tubo inserta, exserta, didynama. O var i m quadriloculare, lecnlis uniovulatis. Stylus terminalis; $s t i g m$ a bipartitum. Cary op ses intra calycem ampliatnm quatuor, margine membranaceo cinctae, monospermae. S e min a ereeta, lnculo dimidio breviora. E m b ryo.... - Suffrutex mongolicus, leviter fragrans; foliis subintegerrimis, incanis, paniculis axillaribus oppositis $v$. alternis terminalibusque, floribus amoene cyaneis.

Car y opter is Bunge Plant, mongolico-chin. Dec, $I$. Casan, 1835 .

3693. Peronema $J A C K$. Calyx quinquepartitus, laciniis erectis, acutis. Coroll a hy 
pogyna, tabo brevi, limbi irregulariter quinquelobi laciniis secundis. Stamina 4 , corollae tubo inserta, duo superiora exserta, fertilia, duo inferiora inclusa, sterilia. Ova ri $\mathbf{n} \mathrm{m}$ quadriloculare, loculis uniovulatis. S ty lu s terminalis, exsertus; stigma simplex, refractum. Drupa sicca, villosa, quadrilocularis, quadripartibilis. S e m i na in loculis solitaria.... Arbor sumatrensis; foliis oppositis, impari-pinnatis, foliolis lanceolatis, integerrimis, subtus canescentibus, reticulalo-venosis, petiolo alato, panicula terminali, opposite corymbosa.

Peronema Jack in Malay. Miscell, II, $n, 7, p, 46$. ex Hooker Compan. Bot. Mag. I. 152.

TEIIBUS 11. LANTANEAE. Fruet us drupaceus, indehiscens.

3694. Spielmannia MEDIC. $\mathrm{C}$ a $1 \mathrm{y} \mathrm{x}$ quinquepartitus, persistens, laciniis linearibus. Coroll a hypogyna, hypocraterimorpha, tubo basi subgloboso, fauce vilis clausa, limbo quinquefide, sulaequali, patente. St amina 4 , corollae tubo inserta, inclusa, didynama. Ovari u m biloculare, loculis biovulatis. Stylus brevis, persistens; stigma uneinatum. Drupa globosa, monopyrena, putamine solido, biloculari v. abortu uniloculari. Semina in loculis solitaria v. gemina. Embryonis exalbuminosi radicula infera. Fruticulus capensis; foliis oppositis, ovato-oblongis, acutis, serratis, subdecurrentibus, hirsutiusculis, floribus axillaribus solitarïs, sessilibus.

Spielmannia Medicus in Act. Lcadem. Theodor. Palat. III. t. 10. Bot. Mag. t, 1899. Oftia Adanson Fam. II. 199. L a n tan a $\mathrm{f} r \mathrm{i}$ a a a Linn.

3695. Lantana LINN. C a ly x brevissime tubulosus, obsolete quadri-quinquedentatus C or olla hypogyna, tubo calyeem longe superante, incurvo, medio subinflato, limbo quadrifido, $\mathrm{pa}$ tente, inaequali. Stamina 4 , corollae tubo inserta, inclusa, didynama. Ovari u m bilocalare, loculis uniovulatis (?) Stylus filiformis; $8 \mathrm{tigma}$ obtusum v, uneinato-refraetum. D r u pa baecata, monopyrena, putamine biloculari, basí perforato, v. dipyrena, pyrenis unilocnlaribus, S emina in loculis solitaria. Embryonis exalbuminosi radicula infera. - Frutices $v$. rarius herbae, in $A m e$ rica tropica copiose, rarissime in India crescentes, inermes v. aculeati; ramis angulatis, foliis simplicibus, oppositis v. saepius ternatis, crenatoserratis, plerumque rugosis, rigidis, capitulis axillaribus pedunculatis, floribus bracteatis, bracteis exterioribus involucrantibus, corollis violaceis, aurantiaceis, flavis $v$, albis.

L a n t a n Linn. gen. n. 765. Jussieu gen. 109. Gärtner $I$. 276. Kunth Synops. $I T$. 49. Chamisso in Limaea VII. 122.

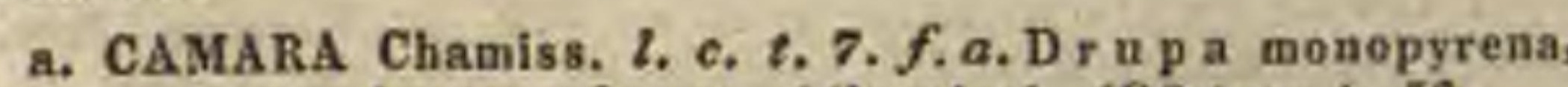
putamine basi perforato, biloculari. (Gấrtuer $t, \xi 6$.

b. CollioraAs Chamiss, $t, c . t .7 . f .6$. D r up a dipyrena, pyrenis unilocularibus, monospernis. (Jacq. Hort. Schönbr. t. 285. 360. Bot. Mag. t. 2981.)

3696. Tamonea $A U B L . C$ a 1 y $x$ tubulosus, quinquefidus, laciniis patentibus, acuminatis. Coroll a hypogyna, tubulosa, limbi bilabiati labio superiore integro $\mathbf{v}$. emarginato, inferioris trifidi lobis lateralibus minoribus. S $\operatorname{tam} \mathrm{m}$ a 4 , corollae tubo inserta, inclusa, didynama, minora saepius ananthera, filamenta medio squamula appendiculata. Ovarium quadriloculare, loculis uniovulatis. Stylus terminalis; stigma quadrifidum. Drupa baccata, calyce eincta, apice mutica v. patentim quadrispinosa, monopyrena, putamine axi perforato, quadriloculari. Se min a in loculis solitaria. Embryonis exalbuminosi radicula infera. Herbae Am erica e tr op ic a e, suffruticosae, erectae, ramosae; ramis tetragonis, folitis oppositis, serratis, superioribus interdum subpinnatifidis, spicis axillaribus, floribus alternis, pedicellatis, bracteatis, albidis $v$, caeruleis, drupis maturis nigris.

T a mone a Aublet Guian. IT. 660. $t, 268$. Jussieu Gen. 109. Gärtner f, III, $t$, 213, Kunth Synops. II. 65. G h in i a Sehreber gen. n. 42. Swartz Flor. Ind. occid. II. 1087. t. 21. L e p to carpus Willdenow msc, ex Link Jahrb. I. 3. p. si.

369\%. Illosta $J A C Q$. C aly x campanulatus, quadridentatus. Coroll a hypogyna, resupinata, labio superiore trilobo, lobis subaequalibus, inferiore emarginato. $\mathrm{S}$ t a $\mathrm{m}$ in a 4 , corollae tubo inserta, inclusa, didynama, duo minora ananthera. Ovarium quadriloculare, loculis uniovulatis. Stylus terminalis; $s t i g m$ a bifidum. Drupa baccata, monopyrena, putamine basi perforato, quadriloculari. Se mina in Ioculis solitaria. E mbryonis subalbuminosi radicula infera. - Frutices $A$ mericac tropica ; ramis tetragonis foliisque oppositis, simplicibus, integerrimis $v$. serratis, subtus canescentibus, paniculae terminalis ramis oppositis, dichotomis, corollis violaceis.

H os t a Jacquin Hort. Schönbr. I. 60. 1.114. R. Brown Prodr. 211. in not. Bot. Reg. $t$. 1204. Hostan a Persoon Encheir. II. 143. C or a u tia Gärtner f. III, 172, $t$. 213, won Plumier.

3GSS. Pyrostoma C.F.W.MEY. C a l y x tubnlosus, limbo ampliato, quinquelobo. C or o Il a hypogyna, resupinata, tubo subventricoso, limbi bilabiati labio superiore tripartito, lacinia media subrotanda, lateralibus oblongis, inferiore bifido. Stamina 4, corollae tubo supra basim inserta, exserta, didynama. Ovarium... Stylus filiformis; sti g ma bifidum. Fruetu s... Arbor an frutex? essequeboens is, vix notus; foliis oppositis, ternatis, foliolis integerrimis, utrinque glabris, corymbis terminalibus paucifloris, corollis sericeovillosis.

Pyrostoma G. F. W. Meyer Essequeb. 210.

3699. Walleothise ROTH. Caly x campanulatus, quinquedentatus. Co roll a hypogyna, resupinata, labio superiore trilobo, lobis lateralibus reflexis, medio cucullato, majore, inferiore bilobo. Sta min a 4, corollae tubo inserta, exserta, didynama, declinata. Ovarium quadriloculare, loculis nniovulatis. Sty ln s terminalis; stig ma bifidum. Drupa baccata, monopyrena, putamine quadriloculari v. abortu uniloculari. Se m in a in loculis solitaria, E mbry on is exalbuminosi radicula infera. - Arbores in dicae; foliis ternatis, subtus tomentosis thyrsoque terminali, $v$. foliis quinatis, utrinque glaberrimis, panicula axillari, dichotoma.

Wallrothia Roth Nov. spec. 317. Vitex LencoxyIo n Linn. - Genus recognoscendum, specles valde hetero. geneas complectitur.

3ร00. Vitex LINN, C a y x brevis, quinquedentatus. Coroll a hypogyna, bilabiata, labio superiore bifido, inferioris trifidi lacinia media majore. Stamina 4, corollae tubo inserta, subexserta, didynama, adscendentia. Ovari nm quadriloculare, loculis uniovulatis. Stylus terminalis; stigm a bifidum. Drupa baceata, monopyrena, putamine quadriloculari. S e mina in loculis solitaria. Embry on is exalbuminosi radicula infera. - Frutices, interdum arborescentes, inter tropicos veteris orbis obvit, in regionemediler80 * 
ranea rarissimi, in America aequinoctiali rari; foliis compositis, ternatis, digitatis $v$. pinnatis, raro simplicibus, pedunculis dichotomis, terminalibus $v$. axillaribus, saepe paniculatis.

Vitex Lian. gen. n, 790. Jussieu gen. 107. Gärtner $I$. 269. R. Brown Prodr. 511. Kuath in Humb. ot Banpl. Nov. gen. ot sp. II, 245. Chamisso in Linzaea VII, 107.

a. AGNUS CASTUS. Cy mae terminales, paniculatae. Species omnes gerontogeac. - Schkulir t. 177. Sibthorp Flor. graec, t, 609. Bot. Mag. t, 364, 2187. Wallich Plant. As, rar, t. 226.)

b. LIMIA. C yma axillares, saepe longe peduaculatae, interdum contractae, subcapitatae. - L $i m$ i a Vaadell, in Römer Script, 126, t, 7. f. 21. Nephra ndra Cothen Disposit, 8. (Vabl Eelog. II. t, 18.) - ? $\mathrm{C}$ h ry $80 \mathrm{~m} \mathrm{al}$. 1 u in Thouars Gen. Madagasc. $n .25$.

3701. Premina LINN, Caly x eyathiformi-campanulatus, quinquedentatus. Co roll a hypogyna, tubnlosa, limbi bilabiati, patentis labio superiore semibilobo, inferioris tripartiti lobis subaequalibrs. Sta mina 4, corollae tubo inserta, exserta, didynama, aequidistantia. O v a ri u m quadriloculare, loculis uniovulatis, D r u pa pisiformis, monopyrena, putamine axi perforato, quadrilocalari v, abortu bi-triloculari. S e mina in loculis solitaria. Embryonis exalbuminosi radicula infera. - Arbusculae v. frutices, in Asia et NovaHollandia tropica crescentes; foliis oppositis, stirpis junioris quandoque serratis, adultae integerrimis, saepe olidis, cymis terminalibus paniculatis, brachiatis, ramis dichotomis, floribus parvis, albicantibus.

P r em n a Linn, Gen, n, 1316, Jusslea Gen, 107. Gärt. ner I, 269, $t$, 56. R. Browa Prodr. 512. Roxburgh Flor, in. dic. III. 75. Blume Bijdr. 815. Co r n u ti a N. L. Burmann Flor. indic, $t$. $4 t$, nou Plum. Gumira 11 t II и m hir i и и ш Rumph Amboin. III, $t, 133.134$.

370?. Fityroulia $R, B R$. Caly x campanulatus, quinquefidus, aequalis. Corolla hypogyna, infundibuliformis, subregularis, limbi labio superiore semibilobo, inferiore tripartito, aequali. Stamina 4 , corollae tubo inserta, exserta, subdidynama, O vari n m quadriloculare, loculis nniovulatis. Stylus filiformis; stigma bifidum. Drupa apice exsucco semilaccata, monopyrena, putamine basi perforato, quadriloculari. S e m in a in loculis solitaria. Emb r y o n is subalbuminosi radicula infera. - Frutex Novae-Hollandiae tropicae, pube stellari squamulosa, furfuracea tectus; foliis oppositis, simplicibus, lanceolatis, integris, rugosis, graveolentibus, sapore fere Menthae, pedunculis axillaribus, oppositis, congesto-multifloris, floribus albis.

Pityrodia R. Brown Prodr, 513.

3*03. Teetonia LINN. FIL. Ca 1 y $\times$ campanulatus, quinquefidus, demum inflatus. Co ro 11 a hypogyna, infundibuliformis, tubo brevi, limbo quinquefido, aequali, patente. St a m i n a 5 , corollae tubo inserta, exserta, subaequalia, Ova ri um quadriloculare, loculis uniovalatis. Stylus terminalis; st i g m a bifidum. Dru p a monopyrena, hirsuta, spongioso-suberosa, calyce vesiculosoinflato, ore cearctato inclusa, putamine axi perforato, quadriloculari. S e m i n a in loculis solitaria. $\mathbf{E} \mathbf{m}$ b r y on is exalbuminosi radicula infera. - $\mathrm{Ar}$ bores indicae, excelsae, ob lignum leve, durabile celebratae; ramulis tetragonis, foliis oppositis v.ternatis, breve petiolatis, amplis, ovato-oblongis, integerrimis, asperis, paniculis terminalibus, floribus
albidis.
Te et o n ia Lion. fil. suppl. 151. Gärtner $r, 274, t, 57$. Roxburgh Plant. Corom, $Y$, 10, $t, 6$. Wallich Plant. As, rar. t, 294. The k a Rheede Malab, IV, 57. $t$. 27, Jussieu Gen. 108. J a t u Rumph Amboin. IIT, 34. $t, 18$.

3704. Cumelina LINN. Cal y x brevis, quadri-quinquedentatus. Co roll a hypogyna, obli que campanulata, limbi quadrifidi lobo supremo fornicato, infimo bilobo, lateralibus rotundatis. S t a m in a 4, corollae tubo inserta, exserta, didynama. Ova ri um biloculare, loculis uniovulatis. Stylus filiformis; stig ma inaequaliter bifidam. Drupa baceata, monopyrena, putamine basi perforato, biloculari. Semina in loculis solitaria. Embryonis exalbuminosi radicula infera. - Frutices $v$. arbores, interdum vastae in India orientali crescentes; ramulis saepius spinescentibus, foliis oppositis, integris v. lobatis, floribus terminalibus, paniculatis $v$. racemosis, brac. teatis, speciosis.

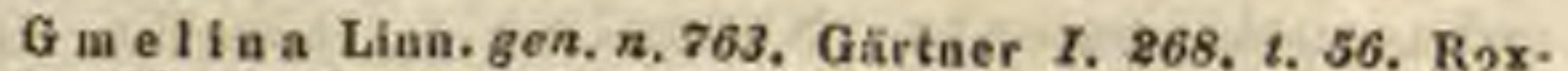
burgh Plant. Corom. t. 32, Flor. ind. IIT, 82, Blume Bijdr. 814 .

37D5. Fetitia $J A C Q$. C a ly $\mathrm{x}$ campanulatus, quadridentatus. C o rolla hypogyna, infundibuliformis, tubo calycem superante, limbo quadripartito, aequali. Stamina 4 , corollae tubo inserta, exserta, aequalia. Ova ri um biloculare, loculis uniovulatis? Stylns terminalis; $8 \mathrm{tigma}$ simplex. Drupa baceata, monopyrena, putamine basi perforato, biloculari. Se min a in loculis solitaria. Embryonis exalbuminosi radicula infera. - Arbuscula in America tropica indigena; ramis tetragonis foliisque oppositis, simplicibus, in. tegerrimis, paniculis axillaribus, oppositis,

Petitia Jacquin Amer. t. 189. f. 6. Kunth in Humb. et Bompl. Nov. gen, et sp. II, 248 .

3r06. Citharexylom LINN. C a ly campanulatus, brevissime quinquedentatus. Coroll a hypogyna, tubo calycem superante, fauce barbata v. rarius nuda, limbo quinquepartito, subaequali, patente. Stam in a 4 v. 5 , corollae infra faucem inserta, inclusa, subaequalia, Ova $\mathrm{r}$ i u m quadriloeulare, loculis uniovnlatis. Stylus ter minalis; st ig in a subcapitatum. D rupa baceata, dipyrena, pyrenis osseis, bilocularibus. S e m in a in loculis solitaria. Embry onis exalbuminosi radicula infera. - Arbores $v$. frutices $A$ m ericae tropicae; ramulis saepius spinescentibus, folits oppositis, simplicibus, integerrimis $v$. serratis, floribus axillaribus et terminalibus, laxe spicatis.

Cith a rexylon Linn. gen, n. V60. P. Browne Jam. t. 28. f. 2. Gärtner I, t. 56. Jaeq. Hort. Schönbr. $t .417$. Ic. rar. t, 118. 501. Veut. Cels. $t$, 47. Kunth in Humb, et Bonpl. Nov. gen. et sp. II. 256. Don in Edinb. new philosoph. Journ. Octob. 1830. p. 237. Rau wolf ta Ruiz et Pavon Flor. peruv. Ir. 26. t. 152. - Pöppigla Bertero es But. tet. sc. nat. 1830. p. 109. (Hooker ad Becheyt. 11.)

3รดร. Volkamerla LINN. Cal y $\mathrm{x}$ campanulatus, quinquefidus. Co ro 11 a hypogyna, tubo cylindraceo, limbi quinquefidi laciniis subsecundis. S tamin a 4, summo corollae tubo inserta, exserta, didynama. Ovari un quadriloculare, loculis uniovulatis. Stylus filiformis; stigma bifdum. Drup a baceata, dipyrena, pyrenis osseis, bilocularibus. S e mina in loculis solitaria. $\mathbf{E}$ m- 
bry onis exalbuminosi radicula infera. cula antillan a; ramulis spinescentibus, foliis op positis, oblongis, acutis, integrerrimis, corymbis axillaribus, trichotomis.

Volk a meria Linn. spec. 889. excl. pl, Jacq. Amer. 185. t. 117. Gärtner $I$. 267, $t, 56$. D u g las s i a Ammann Herb. 576 .

3\%08. Cleroollenalnon $R, B R O W N$. CaI y $x$ campanulatus, quinquefidns $\mathbf{v}$, quinquedentatus. Corolla hypogyna, tubo cylindraceo, saepins elongato, limbi quinquepartiti laciniis aequalibus. Stamina 4, summo corollae tubo inserta, longe exserta, didynama, secunda. Ovari u m quadriloculare, loculis uniovulatis. Stylns filiformis; $8 \mathrm{tigma}$ bifidum, acutum. Drup a baccata, tetrapyrena, calyce immutato $\mathbf{v}$, saepius ampliato cincta, pyrenis distinctis, uniloeularibus. Sem ina in loculis solitaria. Embryonis exalbuminosi radicula infera. - Arbores $v$. frutices, int e $r$ tropicos veteris orbis copiose, in America parce crescentes; foliis oppositis, simplicibus, indivisis $v$. lobatis, petiolorum basi persistente, corymbis terminalibus et axillaribus trichotomis.

Cle rodendron R. Brown Prodr, 510. Kunth Synops* 11. 39. Cl е ro de $\mathrm{n}$ d ro и LInn. gen. $n$. 798. Gärtner 1. 271. t. 57. Palisot Flor. Owar. t. 32. 62. Bot. Mag. t, 1805, 2536. 2959, Bot. Reg. t. 406. 629. 649. 945. 1035. 1307, II, t. 41. Wallich Plant, $4 s$, rar, $t$, 215. Vo $1 \mathrm{k}$ a me $\mathrm{f}$ a Lhn. gen, $n$. 788. exel. sp. Burmann Flor, ind. t. 44. 45. Jacq. Collect. cuppl. t. 4. 5. Ic, rar. $t$, 590. Si p h on a ut hu s Liul. gen. a. 129. Lam. $t, 79,0$ v i e da Linn. gen, n. 787. Gärtaer I. 278. $t$. 57. Burmanu Flor. Ind, $t$, 43, V a $1 \mathrm{~d}$ i a Plumier Gen. 14. To. t. 256. A g ricola Schrank in Regensb. Denkschr. 1808. p. 98. - T o r r e y a Sprengel Neue Entdeck, II. 121. Ita volente geueris conditore, supra inter Nyctagineas dubias, In observatione ad Tricyclam Cav. (n. 2007.) commemorata, monente el. Walker-Aruott in Jardine Journ, of nat, so, $\boldsymbol{I}$. 130. eat genuina Clerodendri generis species.

\section{$+$}

3\% (19. Cumanta $L I N N$. C a ly $\mathrm{x}$ campanulato-tubulosus, quinquedentatus, C or o 11 a hypogyna, subhypocraterimorpha, tubo calycem superante, incurvo, limbo quinquefido, patente, inaequali. Sta mina 4 , corollae tabo inserta, inclusa, didynama. Ova ri n m.... Sty In s terminalis; stigma capitatum, subobliquum, D rup a baccata, calyce apice constricto inclusa, tetrapyrena, pyrenis bilocularibus. Sem in a in localis solitaria. E $\mathbf{m b r y}$ on is exalbuminosi radicula infera. - Frutices Americae tropicae, inermes $v$. rarius spinis axillaribus armati; foliis oppositis $v$. ternatis, simplicibus, floribus laxe spicatis, bracteatis, spicis axillaribus et terminalibus, saepius paniculatis, corollis violaceo-caeruleis.

Duranta Linn. gen, n. 186, Jacq, Amer, 186, t. 176. f. 76, Ic. rar. $t$, 502. Gärtner $I$, 282. $t$. 5\%. Bot. Reg. $t, 244$. Kunth in Humb, et Bonpl. Nov, gen, ot sp. $I$. 253. EIII. sia P. Browne Jam. $t, 29 . f .1$. Cas a re a Plumier Ic, 79.

\section{$*$}

37 10. Petraen HOUST. Caly x campanulatas, fauce denticulis quinque, reflexis, cum limbi quinquepartiti maximi laciniis oblongo - lanceolatis, seariosis, saepe coloratis alternantibus. Corolia hypogyna, calyce brevior, tubo brevissimo, limbo quinquefido, subaequali, patente. S tamina 4 , corollae tubo inserta, inclusa, didynama. Ovarium biloculare. Ovala .....
Stylus terminalis, brevis; stigma capitatum. Pericarpi um coriaceum, calycis tubo inclasum, biloculare, dispermum. Se m in a erecta.... - Arbores v. frutices scandentes, in America tropica indigeni; foliis oppositis, simplicibus, integerrimis $v$. subserratis, sacpius glaberrimis, nitidis, racemis axillaribus et terminalibus simplicibus, pedicellis suboppositis, bracteatis.

Petrae a Houston Reliq. t. 11. Linn, gen, $n, 764$. Jacq. Amer. t. 114. Gärtner 11. 471. t, 177. Bot. Mag. t, 628. Kunth in Humb. et Bonpl. Nov, gen, et sp. II, 282.

\section{TRIBUS III. AEGIPHILEAE. Fruc-} tu s baccatus.

3711. Amasonia LINN. Calyx campanulatus, semiquinquefidus. Corolla hypogyna, tubulosa, fauce constricta, limbo quinquefido, subaequali. St a $\mathrm{m}$ in a 4 , imo corollae tubo inserta, exserta, didynama. Ovarium quadriloculare, loculis uniovulatis. Stylusterminalis; stigma bipartitum. B a c e a uniloeularis, di-tetrasperma. Semina erecta, ossea. Embryo...$-A r$ bores, frutices $v$, herbae, in America tropica cis a equatorem indigenae; foliis alternis, serratis, floribus terminalibus spicatis, bracteatis, bracteis magnis, coloratis, corollis luteis.

A m a 8 on i a Linn. fil. Suppl. 294. Vabl Eolog. II. 51. Kunth in Humb. et Bonpl. Nov. gen, et sp. II, 253. T a $1 \mathrm{i}^{-}$ $\mathrm{g}$ a le a Aublet Guian. II, 625, $t, 252$.

3718. Calliearpa LINN. C alyx campanulatus, quadrifidus, aequalis. Co rolla hypogyna, subeampanulata, quadrifida, regularis. $\mathbf{S}$ a$m$ in a 4 , corollae tubo inserta, exserta, aequalia. O v a $r$ i n m quadriloculare, loculis uniovulatis. Sty las filiformis; $8 \mathrm{tig}$ ma capitatum. Ba $\mathrm{cea}$ uniloeularis, tetrasperma v. abortu di-trisperma. S e mina erecta, subossea. Embryonis subalbuminosi radicula infera. - Frutices in Asia et Nova Hollandia tropica, rarius in America calidiore cis aequatorem crescentes, pube ramosa $v$. stellari furfuracei; foliis oppositis, simplicibus, cymis axillaribus, dichotomis, floribus parvis, albis v. purpurascentibus.

C allle a r p a Linn, gen, n, 135, Jussieu gen. 107. Lam, 6. 69. Gärtner II. 80, 2. 94. R. Brown Prodr. 813. Roxbnrgh Flor. Ind, edit, Wallich $I$. 405. Bot, Reg. $t$, 846. 883 . Hooker Exot, Flor, $t$, 133. B u rehardi a Duhamel $A r b, I$. IIT. 44. J ob ns a nia Catesby Carolin. $I I, 47, t$. $47, \mathrm{~S}$ h o nd ylo c o e c m Mitchel in Ephemerid. N, $C, V I I I, 218, \mathrm{P}$ orp h y a Loureiro Flor. cochinch, $I$. 78 .

3\%13. Aegiplaila $J A C Q$. Calyx campanulatus v. turbinatus, quadridentatus. Cor olla hypogyna, infundibuliformis v. hypocraterimorpha, tubo ealyce multo longiore, limbo quadripartito, aequali. Sta mina 4 , corollae tubo inserta, exserta, aequalia. Ovari $\mathbf{m}$ quadriloculare, loculis uniovulatis. Stylus terminalis, bifidus. B a ce a quadrilocularis v. abortu bilocularis. Semina in loculis solitaria ...... Arbores $v$. frutices Americae tropicae; foliis oppositis, simplicibus, corymbis axillaribus et terminalibus dichotomis, paniculatis, corollis flavis v. albis.

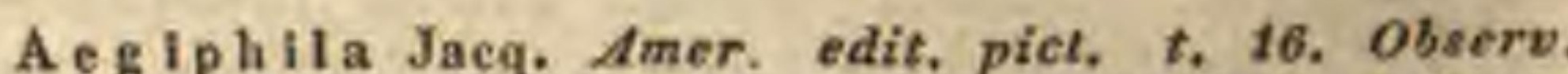
II. 3. t. 29, Lam. t. 70. Vahl Eelog. 1. t. 10. Rulz et Paven Flor. peruv, t. 76. Kunth in Humb, et Bonpl. Nov. gen, et sp. Ir. 249, $t$. 130. 131. M a a a b a Aublet Guian. I. 62. t. 23. $25.0 \mathrm{~m} \mathrm{p}$ b a lo e o c a Willdenow ex Homer et $5 \mathrm{chult}$. 
Mantiss, IIT. 10. (coll. Kunth in Abhandl. Berlin. Academ. 1831. p. 214.)

37 4. Cornetia PLUM. C a Iyx turbinatus, quadridentatus. Corolla hypogyna, hy pocraterimorpha, limbo quadripartito, inaequali. St a mina 4 , corollae tubo inserta, exserta, didy. nama. Ovari u m quadriloculare, loculis uniovulatis. Stylus terminalis, bifidus, B a c e a abortu unilocularis, monosperma. S e men reniforme.... - Arbuscula caribaea; ramulis tetragonis, foliis oppositis, ovatis, integerrimis, subtus canescentibus, panicula terminali elongata, pyramidata.

Cornut Ia Plumier Gen, 32. Ic. 106. f. 1. Lina, Hort. Cliffort. 319. Lam. $t, 55 t$, A g a a th us Vaillant in $A c t$. Academ. Paris, 1722. p, 273.

\section{*}

3\%15. Congea ROXB. Involnernm tri-hexaphyllum, pluriflorum. C a ly x tubulosus, quinquedentatus. Co rolla hypogyna, tubo caly cem superante, limbi bilabiati labio superiore elon gato, erecto, bifido, inferiore patente, trilobo. S $t$ a mi na $4-5$, corollae fauci inserta, longe exserta, didynama. Ovarium biloculare, loculis septo seeundario, incompleto bilocellatis. $O \vee v \mathrm{u}$ a in loeulis gemina, collateralia, septo secundario utrinque adnata. St y 1 u s filiformis; s $t$ i $g$ ma bifidum. B a c $\mathbf{c}$ a abortu monosperma. S e m en erectum $\mathbf{E}$ m b r y n i \& exalbuminosi radicula infera. Frutices indici, scandentes; foliis oppositis, simplicibus, integerrimis, tomentosis, paniculis axillaribus et terminalibus, floribus intra involucrum subfoliaceum sessilibus.

C o pgea Roxburgh Plant. Corom, IIT. 20. $t, 293$. R os coea Roxhurgh Flor. ind. III, 54. S phe nodes me Jach ex Hook. Bot. Miscell. I, 285.

37 16. Symplaorema ROXB. Involu e. r n m sex-octophyllum, pluriflorum. Caly x cam panulatus, sex-octodentatus. Co rolla hypogyna, tubulosa, limbi sex-octopartiti laciniis linearibus, reflexis. St a m in a $6-8$, summo corollae tubo inserta, exserta, aequalia. Ovarium ..... Styl u s terminalis, elengatus; stig m a bifidum. Caryopsis monosperma, ealyee inclusa ...... Frutex indicus, scandens; foliis oppositis, simplicibus, integerrimis, tomentosis, pedunculis axillaribus et terminalibus fasciculatis, floribus intra involucra foliacea, demum membranacea sessilibus.

S y m p h orem a Roxburgh Plant. Corom. II. 46. t.186. Flor, ind. $I$. 262 .

\section{GENERA DUBIA}

3\% 19. Ceumsia BLUME, Calyx turbinatus, obsolete quinquedentatus. Corull a hypogyna, tubo cylindrico, limbo quinquefido, revoIuto. $\mathrm{S}$ t a m in a 4 , imo corollae tubo inserta, exserta; a ntherae superne poris geminis dehiscen-

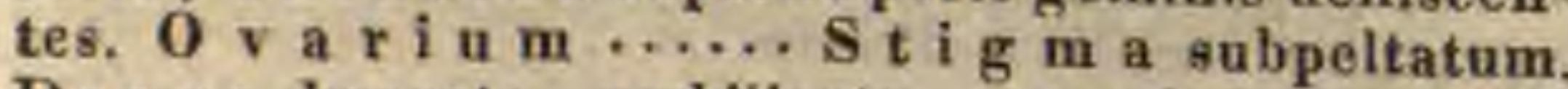
Drupa baceata, umbilieata, pntamine quadriloculari, loculis bipartibilibus, monospermis.

Plantajavanica; foliis oppositis v. alternis, ovato-oblongis, acuminatissimis, subtus reticulatis et farinoso-subtomentosis, cymis axillaribus, dichotomis, divaricatis.

Ge uns i a Blame Bijdr. 819 .
3\% 19. Quoya GAUDICH. Ca l y x subturbinatus, bilabiatus, labio superiore trilobo, inferiore bifido. Coroll a hypogyna, turbinato-cam. panulata, limbo quinquelobo, bilabiato, lobis quatuor acutiusculis, lateralibus minoribus, infimo maximo, subrotundo, concavo. S t a m in a 4 , medio corollae tubo inserta, exserta, didynama; a nther a e biloculares, loculis oppositis, parallelis, basi calearatis, calcaribus inferne connatis. $0 \mathrm{va-}$ rin m obovatum, emarginatum, quadriloculare, bipartibile. Ovu 1 a in loculis solitaria, angulo centrali loculorum inserta, adscendentim amphitropa. Stylus terminalis, filiformis, erectus; stig ma incrassatum, apice bilobum. Fruetus ...... Suffrutices Novae Hollandiac occidentalis, tomentosi, pilis stellulatis $v$, ramulosis; ramulis teretibus, foliis oppositis, sessilibus, obovato-cuneatis, crenatis, rugulosis, umbellis axillaribus, pedunculatis, simplicibus, paucifloris, bracteatis, floribus pedicellatis, caerulescentibus.

Q a o y a Gaudichaud ad Freyc. 453, t, 66.

37 30. Mrastacanthars. C a I y x quinquefidus, laciniis acutis, erectis, aequalibus, fructiferis conniventibus. Coroll a ringens, tubo calycem aequante, limbo quinquefido, labii snperioris laciniis quatuor ovatis, erectis, subaequalibus, labio inferiore magno, patente, incurvo, fimbria Ionga capillari terminato. St a mina 4 , didynama, dno longiora exserta; a therae subrotundae. Ovarium sulgglobosum, quadrisulcum. St $y$ I us bifidus, staminibus brevior; stigmata simplicia. A chenia (?) 4, subrotunda. - Frutex cantoniensis, pedalis, lignosus, graveolens; ramis adscendentibus, paucis, foliis oppositis, ovatooblongis, obtusis, serratis, basi integerrimis, lineatis, tomentosis, petiolis brevibus, floribus axillaribus, verticillis fastigiatis, corollis albis.

B a rbu I a Loureiro Flor. cochinch, 464.

OBSERVATIO I. Chiliantham Burchell Trav. $I$. 94. qui Scoparia arborea Thubb. ab omnibas auctoribus inter Verbenaceas relatam, a $\mathrm{N}$ uxia Commers. (vid. infra $n r$. 3972. inter Scrophularineas) non differre, et semina quatuor hoie stirpi, placentis nempe pro semi. nibus descriptis, perperam tribui, uronuit el. Bentham.

OBSERVATIO Il. Genera H y m e n o py r a m is Wallieh Cat, $n$. 774. Glossocarya Wallich t. c. n. 741. et $\mathrm{C}$ a. ehra nea Miers Travels in Chili $I T$. 599 . ab auetoribus ad Verbenaceas relata, nobis penitus ignota suat.

\section{VERBENACEIS AFFINES.}

\section{* AVICENNIEAE.}

3\%32. A vicemnia $L I N N$. C a $1 \mathrm{y} \times$ quadripartitus, aequalis, squamis imbrieatis tectus. C oroll a hypogyna, tubo brevi, campannlato, limbi quadrifidi, patentis lacinia postica paullo latiore. Stamina 4, corollae tubo inserta, breviter exserta, subdidynama. O va ri um biloeulare. Ov uI a in loculis gemina, collateralia, ex apice axeos compresso-tetragonae amphitrope pendula, micropyle infera. Fructu s coriacens, abortu nnilocularis, monospermus, bivalvis. Semen intra pericarpium germinans, E $\mathbf{m}$ b r y o erectus, exalbu- 
minosus; cotyledones latissimae, crassae, basi bilobae, condnplicatae, radicula infera barbata, plamula diphylla, scapo imposita. - Arbores littorales, in regionibus tropicis subtropicisque totius orbis cum hhizophoris crescentes; radicibus late repentibus, saepe super terram undique arcuatim expansis, e limo turiones erectos, copiosos, nudos, asparagiformes exserentibus, foliis oppositis, integerrimis, coriaceis, persistentibus, pedunculis terminalibus et e summis alis ternis, confertim multifloris, corollis subcoriaceis.

A vi ce n n I a Lian. gen. n. 1237. Jussieu Gen. 108. Jacq Amer. t. 112. Palis, Flor. Owar. t. 47. R. Brown Prodr. 518. Wallich Plant. As, rar, IIt. 44, t, 271. H a 1 od e ndru u Thousrs Gen. Madagasc. n. 26. S ceura Forsk. Aegypt. 37. Oe pat a Rheede Malab. IV. 59, t. 45. M a ng i u m a Ib a m Rumph Amboin. III, 115, $t, 76$. R a ck Bruce It. $t$. 34. Ovula ex observatione el. Brown pendula, micropyle in libera eorundem extremitate sita, deorsum spec. tante, eujus elongatione absque ulls ovuli inversione v. reclinatione semen in fruetu ereetum evadit. Ceternm Avicennia se hatet ad Verbanaceas sicut Aegiceras at Myrsineas.

\section{Drdo CXXXVIII. Stilfineate.}

STILBINEAE Kanth Handh, der Rot. 393, Abhandl. der Berlin. Academ. 1831. p. 201. so. R. Meyer Comment. plant, Afr. austr. 278. STILBACEAE Lindley Introduct. cdit. 11. p. 280.

Fruticul capenses, ericoidei; ramis alternis, ramulis verticillatis. Foli a verticillata, conferta, subacicularia, subtus bisulcata, integerrima, coriacea, rigida, basi articulata. Stip u la e nulla.

Flores hermaphroditi v. abortu interdum dioici, regulares, in summis ramis dense spicati, tribracteati, rhachi persistente, acuta, foveolata, villosa.

Calyx coriaceus, persistens, tubuloso-campanulatus, quinquefidus v. quinquepartitus, laciniis aequalibus, duabus inferioribus profundius distinctis, aestivatione induplicato-valvatis.

Corolua hypogyna, gamopetala, tubo infundibuliformi, fauce harbata, limbi quinquepartiti, patentis, subbilabiati, rarius quadripartiti, subaequalis laciniis aestivatione simpliciter v. induplicato-valvatís.

Stamixa 4_5, summo corollae tubo inserta, exserta, ejnsdem lobis alterna, quintum posticum castratum v. plane deficiens. Filam enta libera, filiformia, subaequalia. Anthe rae oblongae, introrsae, biloculares, dor so supra basim affixae; lornli oppositi, paralleli $v$. basi plus minus divaricati, longitudinaliter dehiscentes.

Ovariom libernm, biloculare. Ovula in loculis solitaria, e basi erecta, an itropa. Stylus terminalis, filiformis, rectus; stigma simplex, emarginatum. Discus hypogynus nullus.
Capsula bilocularis, disperma, apice quadrifariam dehiscens, v. utriculus abortu monospermus.

Semina erecta; t es ta laxe cellulosa.

Eмвкуо in axi albuminis dense carnosi orthotropus, brevis; cotyledones vix discretae, radicula infera.

Stilbineae a Verbenaceis calycis et corollae aestivatione, nec non embryonis et albuminis proportionibus optime distinctae, a Globularineis et Selagineis ovulorum situ erecto facillime distinguuntur.

3ร23. Campylostaelhys KUNTH. Calyx quinquepartitus, laciniis antieis profundius distinctis. Corolla hypogyna, infundibuliformis, fauce barbata, limbi quadri- v. quinquepartiti laciniis subcoriaceis, trinerviis, S $t$ a m in a 4, summo corollae tubo inserta, exserta, aequalia. Ovari n m biloculare. Ovula in loculis solitaria, e basi ereeta, anatropa. Stylus terminalis, filiformis; stigma emarginatum. CapsuI a bilocularis, subglobosa, tenuis, apice quadrifariam dehiscens. Semina in loeulis solitaria, erecta. E m bryo in axi albuminis dense carnosi brevis, orthotropus, radicula infera, - Frutices c apenses; folitis quaternis, linearibus, rigide coriaceis, integerrimis, spica terminali densa,'cernua, v. brevissima, erectiuscula.

C a mpylostac b y 8 . Kunth in Abhandl, Berlin. Aca. dem. 1831. p. 206. K. Meyer Comment, plant, Afr. austr. 287. Stilbe cernua Thunb.

3784. Stilbe BERG. C aly $x$ tubulosocampanulatus, quinquefidus. Corolla hypogyna, tubo infundibuliformi, fance barbata, limbi quinquepartiti, subbilabiati laciniis tenuissime membranaceis, duabns postieis altius connatis. St a min a 5, summo corollae tubo inserta, exserta, posticum anantherum. Ovar $\mathbf{i} \mathbf{m}$ biloenlare, locnlo altero minore. Ovula in loculis solitaria, e basi erecta, anatropa. Stylns terminalis, filiformis; stigma emarginatum. Utriculus tenuis, subturbinatos, quinquecostatus, monospermus. S em e $\mathbf{n}$ erectum. E $\mathbf{m b r y o}$ in axi albuminis dense carnosi brevis, orthotropus, radicula infera. Frutices capenses; foliis quaternis v. octonis, angustis, confertis, integerrimis, coriaceo-rigidis, floribus terminalibus dense spicatis.

Stilbe Bergias Flor. cap. 30, t. 4. f. 6. Lam. t. 856, Kunth in Abhandl, Berl. Academ 1831, p. 206. E. Meyer Comment. plant. Afr. austr. 279, L ü h e a W, Schaidt in Usteri Annal. X. 115. N e p a Petiver Sice. 246.

\section{Ordo CXXXIX. Globularieae.}

GLOBULARIEAE DC. Flor. fr. IrI. 427. Bartling Ord. nat. 127. excl. Stilhineis. Cambessedes in Annal. sc, nat, IX. 15. GLOBUlARIACEAE Lindiey Introduct. edit. $I$. p. 268.

Frotices v. supfreticks humiles, rarius HERBAF perennes; ramis teretibus, continuis. Folia simplicia, integra, alterna, ad basim ramorum aggregata, superiora magis remota, minora, in ramis lignosis sparsa, spathnlata, in petiolum marginatum angustata, subtripli. 
nervia, apice saepius tridentata, marcescentia. Stipula e nullae.

Flores hermaphroditi, irregulares, densissime supra receptaculum commune convexum, paleatum capitato - aggregati, capitulis terminalibus solitariis v. rarissime congestis, interdum axillaribus pedunculatis, involucro polyphyllo, pluriseriato, floribus breviore cinctis.

CaLxx herbaceus, gamophyllus, tubo demum tetragono, fauce pilis clausa $v$. rarissime nuda, limbi quinquefidi laciniis aequalibus $v$. rarius bilabiatis, labio superiore trifido, inferiore bifido.

Conolla hypogyna, gamopetala, tubo cylindrico, aequali, limbo bilabiato, labio superiore minore, saepissime bipartito, interdum bifido $\mathrm{v}$. indiviso, rarissime minimo, inconspicuo, inferiore longiore, tripartito, trifido $v$. tridentato.

Stamisa 4, summo corollae tubo inserta, ejusdem laciniis alterna, quinto inter labii superioris lobos deficiente. Fil a m ent a filiformia, exserta, superiora paullo breviora, in alabastro apice leviter incurva. Antherae reniformes, incumbentes, in alabastro biloculares, loculis sub anthesi confluentibus longitudinaliter univalves.

Ovariem liberum, uniloculare, Ovulum unicum, ex apice loculi pendulum, anatropum. Stylus terminalis, simplex, exsertus; stigm a simplex v. brevissime emarginato-bifidum.

Caryopsis calyce recondita, styli basi persistente mucronata.

\section{SEMEN inversum.}

Embryo in axi albuminis carnosi orthotropus, ejusdem fere longitudine; c ot yle d on ibus ovatis, obtusis, radicula umbilico proxima, supera.

Glo bu larie a e unico genere comprehensae, inter Stilbineas et Selagineas mediae, illinc ad Dipsaceas et Calycereas accedentes, Europam temperatam, imprimis austro-occidentalem inhabitant.

3ร25. Globularia LINN. C a I y x quinquefidus, aequalis v, bilabiatus. Corolla hypogyna, tubulosa, limbi bilabiati labio superiore biinferiore trifido. S $\mathbf{t}$ am in a 4 , summo corollae tubo inserta. Ovari nm liberum, uniloculare. Ovulum unicum, pendulum, anatropam. StyI $\mathrm{u}$ s terminalis; st i $\mathrm{g} \mathbf{m}$ a simplex $v$. emarginatum. Caryopsis monosperma. S e $\mathrm{m}$ e $\mathrm{n}$ inversum. Embryo in axi albuminis carnosi orthotropus; radieula supera. - Herbae perennes, frutices v, suffrutices; foliis alternis, integris, spathulatis, apice saepius tridentatis, floribus supra receptaculum paleaceum aggregato-capitatis, capitulis terninali- bus, solitariis $v$, interdum congestis, rarissime axillaribus, pedunculatis, involucro polyphyllo cinctis.

G l o b u la ri a Lino, gen, $n, 112$. Sehkuhr $t$. 21. Cambessedes in Annal. so, nat. 1X, 29. $t$. 40. 41. G I o b u larfa et Al y p um Touruefort Innt. 265. G I o b a larla et A b oI a $\mathrm{r}$ a Adanson Fam, II, 208.

\section{Ordo CXI. Selagineae.}

SELAGINEAE Jussien in Annal. Mus, VIT. F1, L. C. Richard in Persoon. Encheir. IT. 146. Choisy in Mem, soc. h. n. Genev. II, 2 71, ss. Bartling Ord. nat. 177, E, Meyer Comment. plant. Afr. austr, 245, SELAGINACEAE Lindley Introduct. edn, II. p. 289.

Fruticuli v. rarius herbae, omnes capenses. Folia alterna $v$. infima subopposita, nunc fasciculata, simplicia, integra, incisa v. dentata aut etiam integerrima, sessilia $\mathbf{v}$, in petiolum angustata. Stipu la e nullae.

Flores hermaphroditi, ut plurimum irregulares, in spicas terminales dispositi, approximati, unibracteati, rarius paniculato-corymbosi.

CaLYx liber, persistens, gamophyllus, spathaeformis $v$. tubulosus, tri-quinquedentatus v. tri-quinquepartitus, interdum diphyllus.

Coroula hypogyna, gamopetala, decidua, tubo brevi v. longo, integro $v$. hinc longitudinaliter fisso, limbo quadri-quinquelobo, nunc plus minus irregulari, uni-bilabiato, nunc subregulari, patente.

Stamina 4, corollae tubo inserta, ejusdem laciniis alterna, quintum posticum deficiens, rarius etiam duo antica penitus abortiva, didynama, inclusa v. exserta. Fil a mentalibera, filiformia, saepe brevissima. Antherae uniloculares, medio dorso affixae, erectae $v$. incumbentes, rimula longitudinali dehiscentes.

Ovarium biloculare. $0 \mathrm{vula}$ in loculis solitaria, apici cavitatis appensa, anatropa. StyI s terminalis, simplex; stigma indivisum, subcapitatum.

Acиenia duo, monosperma, cohaerentia v. ad maturitatem secedentia, aequalia v. inaequalia, alterum minus aeque fertile v. saepius sterile, laminaeforme, fertili adplicitum, nunc plane abortivum, loculo in fertilibus centrali v. parieti internae admoto, mesocarpio suberoso, solido v. loculis dnobus loculum seminiferum utrinque comitantibus inflatis hiante.

Semen in loculo unicum, inversum; te st a subcoriacea, chalaza apicali $r h a p h e q u e$ longitudinali manifestis. Al bu m en carnosum.

Exввхо in axialbuminis orthotropus, ejusdem fere longitudine, teres; cotyled ones 
semicylindricae, radicula umbilico proxima, supera.

Selagineae habitu, antheris unilocularibus, seminis situ et radiculae directione a reliquis ordinibus nuculiferis nullo negotio distinguuntur.

3726. Polyeenia CHOIS. Calyx spathaeformis, antice fissus. Coroll a hypogyna, tubo brevissimo, limbo antice fisso unilabiato, apice quadrilobo. S $\mathrm{t}$ a m in a 4, labii marginibus inserta, didynama; fil amenta brevissima, antherae uniloculares. Ovarinm biloculare, loculis utrinque canale filiformi, inani stipatis. Ov u 1 a in loculis solitaria, apici appensa, anatropa. Stylns terminalis, simplex; 8 ti g ma subclavatum. A ch enia duo, inter se aequalia, tandem secedentia, pseudo-trilocularia, loculis duobus lateralibus ma. joribus, inflatis, vacuis, intermedio monospermo. S e mina inversa. E mbry o intra albumen parcum, carnosum orthotropus; cotyled on i bus semicylindricis, ra di c ul a tereti, supera. - Herbae v. fruticuli capenses; foliis alternis, linearibus $v$. lanceolatis, nune cordatis, sessilibus v. decurrentibus, integerrimis $v$. denticulatis aut apice incisis, spicis terminalibus.

P'olycenia Choisy in Mom. soc. h, n. Genev, II. 91. $t$. 2. E. Meyer Comment. plant. Afr. austr. 245. H $\mathrm{e}$ benstreftine sp. Linn.

3\%ซr. Hebenstreitia LINN. Calyx spathaeformis, antice fissus. Corolla hypogyna, tubo brevissimo, limbo antice fisso, nnilabiato, apice quadril sbo. Stamin a 7 , labii marginibus inserta, didynama; fil amenta filiformia, anther a e uniloculares. $O$ vari am biloculare. $O \mathrm{vu}$ la in loculis solitaria, apici appensa, anatropa. St y lus terminalis, simplex; $8 \mathrm{tigma}$ subelava. tum. A cheni a duo inaequalia, secedentia, unilocularia, monosperma, anticum crassum, suberosofaretum, posticum tenuissime compressum, antico incumbens, saepins efoetum, rarius semine multoties minori, aeque fertili. S emina inversa. E mb ryo intra allumen parcam, carnosum orthotropus; cotyl edonibus semicylindricis, $\mathrm{radi}$ c ula tereti, supera. - Herbae v. suffrutices capenses; foliis alternis, linearibus, integerrimis $v$. dentato-pinnatijidis, floribus terminalibus spicatis, bracteatis.

H e be nstreitia Lian. gen. n, 770, exel. sp. Gairtner 1. 138, t. 51. Lam. t, 591. Bot. Mag. t. 1970. Choisy in Mem. soc. h, n. Genev. II. 92. excl. sp. Reichenb. Hort. bot. t. 133. E. Meyer Comment, plant. Afr. atustr. 246.

3728. Diselhisma $\mathrm{CHOIS}$. $\mathrm{C}$ a $\mathrm{l} \mathrm{y}$ bipartitus, laciniis lateralibus. C o rolla hypogyna, tubo brevi, limbo antice fisso, nnilabiato, apice quadrilobo. S $\mathrm{ta} \mathrm{m}$ in a 4 , labii marginibus inserta, didynama; fil amenta brevissima, antherae uniloculares. Ovari $\mathrm{mm}$ biloculare. Ovula in loculis solitaria, apiei appensa, anatropa. Stylus terminalis, simplex; st ig ma subclavatum. A chen i a dno, subaequalia, suberoso-fareta, vix secedentia, nniloenlaria, monosperma. S e m in a inversa. E mbryo intra albumen parcum, carnosum orthotropus; cotyled onibus semicylindricis, $\mathrm{ra}$ d icula tereti, supera. - Herbae v. suffrutices capenses; foliis allernis v. suboppositis, linearibus, integerrimis $v$, dentatis, spicis terminalibus bracteatis, plus minus villosis.

D is ch is m a Cholsy in Mem, soc, h. n. Genev. II, 93. t. 1. f. 2. (pessim.) E. Meyer Comment, plant. Mfr. austr. 250. H ebenstreitia e sp. Linn, Humb.

33 29. Agrathelpis CHOIS. Ca ly $\mathrm{x}$ tubulosus, plicatus, quinquedentatus, antice ad medium bracteae adnatus. Corolla hypogyna, tabo longissimo, cylindrico, incurvo, limbo hypoeraterimorpho, quinquepartito, aequali. S $t$ a in in a 2 , summo corollae tubo inserta, inclusa; $\mathrm{fil}_{\mathrm{l}} \mathrm{a}$ menta brevissima, antherae unilocnlares. Ova ri m biloculare. Ovu I a in loculis solitaria, apici appensa, anatropa. Sty 1 u s terminalis, simplex; 8 tigma acutum. A $\mathbf{c}$ h eni um abortu nnicum, semiteres, suberoso-farctum, monospermum. S e m e $\mathbf{n}$ inversum. E m bryo intra albumen parcum, carnosum orthotropus; cotyledonibus semicylindricis, ra dicula tereti, supera. - $\boldsymbol{S} u f$ frutices capenses; foliis alternis, lineari-filiformibus, spicis terminalibus, bracteatis.

Agathelpls Choisy in Mem, soc. h. n. Genev, II. 95. t. 1. f. 3. E. Meyer Comment, plant. Afr, austr, 252. E r a n them is p. Lian.

3830. Míenodon CHOIS. Caly $x$ tubulosus, plicatus, quinquedentatus, liber $v$, antice ima basi bracteae adnatus. Corolla hypogyna, tubo infundibuliformi, limbi bilabiati labio superiore bifido, erectiusculo, inferioris tripartiti laciniis lateralibus divaricatis, intermedia patente. S $t a$ mina 4 , corollae tubo inserta, didynama, duo longiora exserta; fil a m enta filiformia, anthera uniloculares. Ovari um biloculare. OvnIa in loculis solitaria, apici appensa, anatropa. S t yI u s terminalis, simplex; st i g ma acutum. A chen i u m abortu nnicum, semiteres, suberoso-farctum, monospermum. Sem en inversum. E mbry o intra albumen carnosum orthotropus; cotyle donibus semicylindricis, radicula tereti, supera. - Suffrutices capenses; foliis alternis, ovatis, integerrimis, spicis terminalibus bracteatis, bracteis latis.

Microdon Choisy in Mem, soc. h. n. Genev, II, 97. R. Meyer Comment, plant, Afr. austr. 253. D a I ea Giartner 1 . 235, $t, 5 t$. S e l ag $i$ is is $8 \mathrm{p}$. Linn. Lam. $t$. $521, f, 1$. Bot. Mag. t. 186. Vent. Malm, $t, 26$.

3731. Selago LINN. Calyx subcampanulatns, trifidus v. quinquefidus aut dentatus, interdum antice fissus. Corolla hypogyna, tubo infundibuliformi $v$, eylindrico, limbo quinquefido, inaequaliter patente, laciniis posticis saepius altius cohaerentibus. Sta m in a 4 , corollae tubo inserta, exserta v. inclusa, didynama; filamenta filiformia, a nthera e uniloculares. Ovarium biloculare. Ovu Ia in loeulis solitaria, apiei appensa, anatropa. Stylus terminalis, simplex; stigma obtusnm. A chenia duo, sponte secedentia, suberoso-farcta, monosperma. Semina inversa. E mb ry o intra albamen carnosnm, pareum orthotropus; eotyledonibus semicylindricis, radicula tereti, supera. - Herbae v. suffrutices c ap ens es; foliis latiusculis $v$. acicularibus, alternis, oppositis $v$. fasciculatis, floribus terminalibus spicat is, bracteatis v. subcorymbosis.

$\mathrm{S}$ el a go Linn. gen. $n, 769$. excl. sp. Jussieu gen. 110 . Gärtner $I, 238, t, 51$. Choisy in Mem, soc. $h, n$, Genev. IT. 98. E. Meyer Comment, plant. Afr, austr. 254. Nolt ea Eeklon msc.

a, EUSElAGo. Caly $\times$ pentamerus, laciniis dentibưve subaequalibus v. duobns antieis paullo longioribus, interdum fere ad basim ister se distinetis. (Jacq. Fragm. t. 3. f. 1. Choisy Op. cit. t, 3. 4.J)

b. MACRIA E. Meyer Op. cit, 268, Cal yx, trimerus, lacinia postica saepius minore, lateralibus integris $\mathbf{v}$. apice obsolete bidentatis. (Choisy Op. cit. t. 5.) 
3ร3\%. Walafridla $E$. MEY, C a l y x subbilabiato - quadripartitus, lacinia antica panllo longiore. Corolla hypogyna, tubo cylindrieo, incurvo, limbo subaequaliter quinquefido. Stamina 4, corollae tubo inserta, inclusa, didynama; filamenta brevissima, antherae uniloculares. $O$ va $\mathbf{r} \mathbf{i} \mathrm{m}$ biloculare. $\mathrm{Ovula}$ in loculis solitaria, apici appensa, anatropa. Stylus terminalis, simplex; stigma clavatum, incurvum. A che nia duo, inter se aequalia, tandem seceden. tia, pseudo-trilocularia, loculis duobus lateralibus majoribus, inflatis, efoetis, intus hispidulis, intermedio parieti interiori admoto, monospermo. S e m ina inversa, curvato-subtriangula. E mb туо... - Frnticulus capensis, pedalis; ramis erectis, subflexuosis, junioribus foliis decurrentibus angulosis, ad angulos hirtis, foliis ovatis, subcoriaceis, acutis et breviter acuminatis, basi subcordatis, spicis terminalibus, floribus sub anthesi subfastigiatis, tandem elongatis, cylindricis, bracteis lanceolato-acuminatis, calyce multo longioribus, corolla caerulea brevioribus. 278.

Walafridia E. Meyer Comment. plant. Afr. austr.

\section{Ordo CXL1. Myoporineae.}

MYOPORINEAE R. Brown Prodr. 514. Bartling Ord. nat. 176. MYOPORACEAE Lindley Introduct, edit. II p. 279.

Fritices glabri, v. rarius subpubescentes. Folia alterna v. rarius opposita, simplicia, integra, integerrima v. serrata, novella saepius fucata, viscida, nunc glandulis resinosis conspersa. Stipdzae nullae.

Flores axillares, solitarii, ebracteati, hermaphroditi, irregulares.

CALYX liber, quinquepartitus, persistens, fructifer immutatus, v. rarissime auctus, scariosus.

Corolla hypogyna, hypocraterimorpha, limbo subaequali, v. saepius ringens, bilabiata.

Stamixa 4, corollae tubo inserta, ejusdem lobis alterna, quintum posticum nullum v. rudimentarium, exserta v. inclusa, didynama. Fil amenta filiformia. Antherae bilocular es, incumbentes, loculis longitudinaliter dehiscentibus.

Ovarium liberum, e carpidiis duobus compositum, nunc biloculare, nunc loculis septo secundario, interdum incompleto ab axi ad peripheriam protenso bipartitis quadriloculare $\mathbf{v}$. semiquadriloculare. O v u l a cujusvis carpidii duo collateralia, v. rarissime quatuor per paria imbricatim superposita, ex apice anguli centralis pendula, anatropa, hinc in ovarii bilocularis loculis gemina, in quadrilocularis loculis solitaria, rarissime in ovarii incomplete quadrilocularis locellis geminatim superposita. Stylu s terminalis, simplex. Stigma indivisum, emarginatum v. rarissime bifidum. D iscus hypogynus nullus.
Dropa baccata v, exsucca; putamine biloculari, loculis collateraliter dispermis, v. quadriloculare, loculis monospermis, nunc biloculare, loculis semibipartitis, per paria superpositetetraspermis.

Semrxa inversa, teretiuscula v. oblonga; te st a subcoriacea, chalaza apicali et rhaphe longitudinali notata. $\Lambda$ I bu men carnosum, parcum.

Eмвrуo in axi albuminis orthotropus, ejusdem longitudine, teres. Cotyle do n es semi. cylindricae. R a d i c u 1 a umbilico proxima, supera.

M y oporineae in Nova Hollandia imprimis extratropica et in Oceani australis insulis obviae, in An illis rarissimae, nec alibi risae, osulorum inverso situ et radicula supera a Verbenaceis diversae, a Selagineis habitu et antheris bilocularibus facillime distinguntur.

3733. IIyoporum $B A N K S$ et $S O L$. C aly $x$ quinquepartitus, fructifer haud mutatus v. parum auctus. Corolla hypogyna, subhypocraterimorpha, tubo brevi, amplo, limbo quinquelobo, subaequali. St a mi na 4 , corollae tubo inserta, exserta $v$. inclusa, didynama. O va ri u m biloculare, loculis collateraliter biovulatis, v. quadriloculare, loculis uniovulatis, Ovula pendula, anatropa. St y lus terminalis; stig ma obtusum. Drupa baccata, bilocnlaris v. quadrilocularis, tetrasperma, loculis monospermis v, dispermis. Sem in a inversa. E $\mathbf{m}$ br yo in axi albuminis carnosi; radicula supera. - Frutices in Nova Hollandia, imprimis extratropica obvii, in insulis oceani rari; ramulis foliisque novellis saepe fucatis, viscidis, foliis allernis $v$ rarius oppositis, integerrimis, serratis, saepe pellucido-punctatis, pedunculis axillaribus fasciculatis, raro solitariis, unifloris, ebracteatis, floribus albis v. purpurascentibus, fauce sparsim barbata.

M y o p o rum Banks et Soland. ex Eorst. Prodr. 44. R. Brown Prodr. 215. Bot. Mag. t, 1691. 1830. Reichent. Ic. exot. t. 2. 26. Pogon la Andrews Bot, Reposit, $t$. 283. Labillard. Nov. Holl. $t .83$. A n drew sia Vent. Malm, 108.

3\%34. Plholidia $R$. $B R$. C a 1 y $x$ profunde quinquefidus, fructifer haud mutatus. Co rolla hypogyna, infundibuliformis, tubo calycem superante, fauce ampliata, hinc gibbosa, limbi brevis, irregularis labio superiore bilobo, recurvo, inferiore tripartito, aequali, patulo. S $t$ a m in a 4 , corollae tubo inserta, inclusa, didynama; a $n$ therae barbatae. Ovari um quadriloculare, loculis uniovulatis. Ovula pendula, anatropa. Stylns terminalis; stigma capitatum, emarginatum. Drupa exsucea, putamine quadriloculari, tetraspermo. S e min a inversa. Embryo intra albumen tenue teres; radicnla supera. - Frutex sparteus, in Nova Hollandia meridionali erescens; foliis oppositis, subulatis, pedunculis axillaribus solitariis, unifloris, ebracteatis, corollis caeruleis, extus squamulosis.

Pholldia R, Brown Prodr. 517.

3\%35. Eremoplina $R$. BR. Cal y $x$ quinquepartitus, fructifer mutatus, scariosus. C or olla ..... Stamina 4, didynama. Ovarium ..... stigma indivisum. Drupa exsucca, pu- 
tamine quadriloculari, tetraspermo. Sem in a inversa. … - Frutices spartei, in $\mathrm{NovaH} \mathrm{Hol}$ landia meridionali indigeni; foliis sparsis $v$. oppositis, semiteretibus, pedunculis axillaribus, solitariis, unifloris, ebracteatis.

Eremophila R. Brown Prodr. 518.

3ร36. Stemoelnilus $R$. BR. C a 1 y x quinquepartitus, fruetifer hand mutatus. Cor o il a hypogyna, ringens, tubo basi ventricoso, limbi Jabio superiore erecto, semiquadrifido, inferiore indiviso, angusto, deflexo. S ta min a 4 , corollae tubo inserta, exserta, didynama. O v a $\mathrm{r}$ i $\mathrm{m}$ quadriloculare, loculis uniovulatis. Ovula pendula, anatropa. Stylus terminalis; $s t i g m a$ obtusum, indívisum. Drupa baceata, quadrilocularis v. abortu bilocularis, tetrasperma v, disperma. Se mina inversa. Embryo..... - Frutices in Nova Hollandia meridionali indigeni, glabriusculi $v$. tomento tenuissimo cinerascentes; foliis alternis, saepius integerrimis, aveniis, pedunculis axillaribus solitariis, uniftoris, ebracteatis, floribus purpureis $v$. flavicantibus.

S teno chil us R. Brown Prodr. 517. Bot. Mag. t. 2930. Bot, Reg. $t$. 572.647.

3\%3\%. Bontia PLUM. C al y $\mathrm{x}$ quinquepartitus, fructifer haud mutatus. Cor o 11 a hypogyna, ringens, tubo elongato, limbi labio superiore erecto, emarginato, inferiore revoluto, semitri. fido. Sta mina 4 , corollae tubo inserta, exserta, didynama. Ovarium biloculare, loculis septo secundario incompleto semibipartitis, quadriovulatis. Ovula per paria imbricatim superposita, pendula, anatropa. Stylus terminalis; stigma bifidum, obtusum. Drupa baccata, putamine biloculari, loculis semibipartitis, tetraspermis. S emina inversa, subincurva. Embryo in axi albuminis carnosi, parsi orthotropus, subeylindricus; radieuIa supera. - Frutex antillanus; fuliis alternis, lanceolatis, subintegerrimis, glabris, peduncul is axillaribus, solitariis, unifloris, ebracteatis, corollis luteis, labio inferiore longitudinaliter purpureo-barbato.

Bont fa Plumier gen, t. 23. Dillen. Elth. t. 49. f. 57 . Linu. gon. n. 791. Jussieu gen, 127. Lam. $t$, 546. Gírtaer f. III, $168 . t$. 212 .

OBSERVATIO. Spartotham ni A. Canningh. in Loudon Hort, brit, Suppl, 600, characterea e specininibus de. floratis, a geueris auctore mecum humanissime commu nicatis eruere nequeo, ceterum genus Bremophilae et Pbolidiae propinquum videtur.

\section{Ordo CХй. Cordiacene:}

CORDIACEAE R, Brown Prodr. 492. Martius Nov. gen. et sp. II, 138. Liuk Hands. I. 569. Liudley Introduct. edit. II. p. 272.

Anвorbs v. Frutices. Foli a alterna, simplicia, integerrima v. incisa, rigide coriacea, scabra. Stipulae nullae.

FLores hermaphroditi $v$. interdum abortu diclines, terminales, paniculati v. corymbosi, nunc spicati, spica saepius contracta capitati, ebracteati.

Caryx liber, persistens, post anthesim plerumque plus minus anctus, nunc tubulosus, quinque $-v$. rarius quadridentatus, dentibus saepius setaceis, tubo laevi v. striato-nervoso, nune quadri-quinquepartitus.
Coroula hypogyna, infundibuliformi-tubulosa v. campanulata, tubo calycem aequante v. superante, saepius carnosulo, fauce nuda $\mathbf{v}$. pilosa, limbi quinquefidi, rarins quadrifidi, interdum septemfidi laciniis aestivatione imbricato-convolutis, sub anthesi patentibus $v$. erectis.

Sraurna corollae tubo inserta, ejusque la ciniis numero aequalia et alterna, rarissime plura, exserta v. inclusa. Filamenta filiformia v. subulata. Antherae incumbentes, biloculares, loculis longitudinaliter dehiscentibus.

Ovarium liberum, quadri - octoloculare. Ovula in loculis solitaria, apici cavitatis appensa, anatropa. St y I u s terminalis, apice dichotomus $v$. bis dichotomus. Stigmat a quatuor v. octo.

Drupa baccata, monopyrena; putamine osseo, quadri-octoloculari, v. abortu tri-uniloculari.

Skmisa in loculis solitaria, inversa. Testa membranacea, rhaphe manifesta, adnata $v$. soluta. Albumen nullum.

Embryo orthotropus. Cot y ledones crassae, carnosae, secus longitudinem plicatae, plicis plurimis, contiguis. Radicula brevis, supera.

Cordiaceae inter tropicos totius orbis obviae, cotyledonibus plicatis inter plantas gamopetalas drupiferas distinctissimae, hac nota ad Convolvulaceas aliquatenus accedere videntur, a quibus, revera distinctissimae, et seminum exalbuminosorum situ inverso facillime distinguendae.

Erycibe nuper huc relata, Iongius distat. Drupae caro in nonnullis succulenta, mucilaginosa, emolliens.

3738. Coralia $R$. $B R$. Caly $x$ tubulosus, quinque - v, rarins quadridentatns, laevis $v$. decemstriatus Coroll a hypogyna, infundibuliformitubulosa v. campanulata, Pauce pilosa v. glabra, limbo quinquefido, rarias quadri-septemfido. St am i n a tubo corollae inserta, ejosque lobis numero aequalia, raro plura. Ova ri n m quadriloculare. Ovula in loculis solitaria, pendula, anatropa. Stylus terminalis, dichotomus; stigmata 4 . Drupa baccata, monopyrena, putamine scrobicalato quadriloculari, v. aborto uni-triloculari, loculis monospermis. S e min a inversa; testa membranacea, rhaphe filiformi, soluta. Embryo exalbuminusus, orthotropus; cotyled on ib us crassis, secundum longitudinem plicatis, radicula brevi, supera. - Arbores v. frutices, inter tropicos totius orbis crescentes, plerique quoad fructus structuram ignoti; foliis integerrimis $v$. incisis, inflorescentia terminali, paniculata, corymbosa v. spicata, ebracteata.

Cordia R. Brown Prodr. 498. Cordia et Varron ia Linn. gen. n, 258, et 256. S e be s te a a Gärtaer 1 . 364. t. 76. Cerdau a Ruiz et Pavon Flor. Peruy. $I_{6} 47, t, 148$. 81 * 
a. Gerascanthus. Calyx decemstriatus. Flores co. rymbosi v. paniculati.

Gerascanth us P. Browne Jam. 170. t. 29. f. 3 . C e = d a u a Ruiz et Pavon Flor. Peruv. t. 184.

b. SEBESTENA. Cal y $x$ laevis.

c. M y $\mathrm{x}$ a. Flores eymoso panieulati. (Roxh. Plant. Corom. $t$. ss. Deltle Flor. Aegrpt. $t, 19,20$. Audrews Bot. Reposit. $t, 157$.

B. Varronia. Flores glomerati, eapitati v. spicati. Desvaux Journ. Bot, I. 257. t. 9. 10. (Kunth in Humb. et Boupl. Nov, gen, et sp. t. 207.)

\section{GENERA DUBIA.}

3ร39. Sacellium HUMB, et BONPL. Cal y $x$ persistens, fructifer auctus, inflatus, oblongo-ellipticus, membranaceus, reticulato-nervosus, ore quinquedentato, clauso. Corolla .... Stamina .... Drupa in fundo calyeis brevissime stipitata, stylo sujulato rostrata, e basi compressiuscula superne tetragona, suhquadriloba, nucleo sexloculari, loculis quatuor superioribus osseis, monospermis, duobns inferioribus maximis, vacuis, fragilibus. S e m in a inversa, ovato-pyramidata, triangularia. Embryonis exalbuminosi cotyledone $s$ secundum longitudinem plicatae; radicula subconica, supera, - Arbor peruana andicola, procera, inermis; foliis alternis, integris, exstipulatis, pedunculis supraaxillaribus et terminalibus, ramosis, multifloris, in paniculas dispositis, floribus polygamis.

Sacellin m Humboldt et Bonpl. Plant. aequinoct. I. 47. t. 13. Kunth in Annal. sc. nat. II. 80. Synops. IV. 228 ,

3740. Cordiopsis DESV. Calyx nrceolatns, setaceo-quinquedentatus. Corolla hypogyna, tubulosa, tuho elongato, limbo patente, subquinquelobo. St amina 5 , corollae tubo inserta, inclusa. Ovarium m.... Stylus columnaris; stig mata 8 . Dr upa subangulata, octolocularis, loculis monospermis. S e min a .... Frutex antillanus; foliis alternis, ovatis, acutis, longe petiolatis, grosse dentatis, utrinque rugoso-pubescentibus, pedunculis longis, apice bifidis, floribus subcymosis.

C ordiops is Desvaux in Hamill. Prodr. Flor. Ind. occid, 23. - ? Varronia mirabiloides Jacq.

3\%4. Patagomula LINN. Caly $\mathrm{x}$ minimus, quadri-quinquepartitus, mox excrescens. Corolla hypogyna, rotata, tubo brevissimo, limbì quadri-quinquefidi laciniis elliptieis, acutis. Stam in a $4-5$, corollae fauci inserta, O varium ..... Sty Ins terminalis, dichotomns; st $\mathrm{ig} \mathrm{ma}$ ta 4. Drupa suliglobosa, exsucea, monopyrena, putamine uniloculari. Semen ..... - Frutex Americae meridionalis, ramosissimus; foliis alternis, subcuneatis, versus apicem subserratis, inflorescentia paniculata, ebracteata, floribus parvulis, laciniis calycinis sub grossificatione pollicaribus.

Pat a g o u 1 la Linn. gen, n. 208. Lam. t. 96. Chamisso in Linnaea $\mathrm{IV}$. 499. P at agonic a Dillen Eltham, 304. t. 226. f. 293.

3748. Menais LINN. Cal y $\mathrm{x}$ triphyllus v. tripartitus, persistens, foliolis laxis, concavis. Corolla hypocraterimorpha, tubo calycem excedente, limbo plano, quinquepartito. Anthe$r$ a e 5, subulatae, in fauce corollae sessiles. O v a- rinm ...... Stylus simplex; stigmata 2 , oblonga. B a ce a globosa, quadrilocularis, loenlis monospermis. S emin a ovata, acuta. - Fru. tex Americae meridionalis; caule tereti, villoso, foliis alternis, ovatis, integris, asperis.

M e n a is Löfling IT. 306, Linn. gen, $n, 239$.

\section{Drdo CXE耳II. Asperifoliae.}

ASPERIFOLIAE Lina. Praeleot, edit. Gieseke 489. excl. gen. Lehuaun Plantae o familia Asperifoliarum nuciferae. Berolini, 1818. 4. Icones et deseriptiones novarum v. minus cognitarum stirpium. Hamburgi, 1821 - 1823. fol. fase. 1 -5. Martius Consp. 118. BorRagineaE Jassiea gen. 143. excl. gen. R. Brown Prodr. 492. Barlling Ord, nat, 196. Don in Edinb. new philosoph. Journ. XIII. 239. BORRAGINEAE et HELIOTROPICEAE Sehrader in Com. ment. Göting. IV. 15\%. ARGUZIEAE et BORRAGINEAE Lint Hands. 1 . 569. 571. EHRETIACEAE, HELIOTROPICEAE et ASPERIFOLIEAE Martius Nov. gen. ot sp. Ir. 136. EHRE. TIACBAE et BORRAGINACEAE Liadley Introduct. edit. IT. p. 273. 274,

Herbae, frutices v. arbores, succo aqueo, ut plurimum plus minus setosae v. pilis simplicibus aut interdum stellatis hispidae. Caules ramique teretes $v$. angulati.

Folia sparsa $\mathbf{v}$. interdum subopposita aut ternata, simplicia, integra, saepius integerrima, venosa. Stipulae nullae.

Flones hermaphroditi, v. interdum antheris efoetis diclines, regulares v. nonnunquam irregulares, nunc axillares, solitarii, nunc saepius paniculati v. corymbosi, saepissime in spicas v. racemos terminales, plerumque ebracteatos, secundos, apice ante anthesim circinatim revolutos dispositi.

CaLYX liber, persistens, fruetifer saepius auctus, gamophyllus, quinquefidus v. quinquepartitus, interdum quadrifidus, herbaceus v. rarissime petaloideo-coloratus.

Corolua hypogyna, gamopetala, decidua, infundibuliformi - tubulosa, subeampanulata v. rotata, limbo quinquedentato v. quinquefido, regulari v. interdum bilabiato, laciniis per aestivationem imbricatis, fauce nuda v. pilosa, laevi v. plicato intrursa, nune fasciculis pilorum, squamis v. fornicibus integris v. bilobis, limbi laciniis oppositis v. rarissime cum iisdem alternantibus instructa et saepissime clausa.

Stamina 5, corollae tubo v. fauci inserta, ejusdem lacinils alterna, exserta v. inclusa, faucis squamis dum adsunt interjecta v. alternatim subjecta, rarissime earundem dorso imposita. Fil amenta filiformia v. subulata, aequalia $\mathbf{v}$. interdum inaequilonga, simplicia $\mathbf{v}$. rarissime dorso basi appendiculata. Antherae introrsae, biloculares, incumbentes $v$. erectae, liberae v.interdum villis dorsalibus aut apicibus in acumina subulata desinentibus cohaerentes, loculis Iongitudinaliter dehiscentibus. 
Ovarivu e carpidiis quatuor, distinetis v. plus minus inter se coliaerentibus quadrilobum v. quadriloculare, carpidiis gynobasi v. columnae centrali styligurae adnatis. $O \mathrm{vula}$ in loculis solitaria, apici v. medio anguli centralis appensa, anatropa. Stylus terminalis, $v$. inter ovarii Jobos transiens, indivisus $v$, apice interdum bifidus. Stigma simplex $\nabla$. bifidum.

Deupa di-tetrapyrena, pyrenis uni-bilocularibus varie secedentibus, v. Nuces quatuor, distinctae aut rarissime per paria cohaerentes, basi sua plana v. impressa et annulo interdum tumido cincta receptaculo insertae, v. styli basi adnatae, monospermae.

Semina in loculis solitaria, inversa, recta v. plus minus arcuata. A l b u me n nullum v. parcum, lamelliforme, carnosum.

Esiв yo orthotropus v. homotrope curvatus, albumine dum adest inclusus. Co tyle dones per germinationem foliaceae. Radicula supera, recta v. descendens.

Asperifoltak Verbenaceis Labiatisque proximae, sed radiculae situ supero ab iisdem facillime distinguendae. B orragi ne a e in temperatis extratropicis totius orbis obviae, maximo numero in regione mediterranea et Asia media generantur, Ehreti a ce a majori numero inter tropicos habitant, extra tropicos rarissimae.

Qualitates emollientes, mucilaginosae in nonnullis laudatae. Radices in quibusdam tinetoriae. Genera denuo sub incudem revocanda.

SURORDO T. EHRETIACEAE. Stylus terminalis.

TRHB⿵⺆ I. TOURNEFOR'TIEAE. S emin a albuminosa.

3743. Fhretia LINN. Calyx profunde guinquefidus. Corolla hypogyna, infundibuliformis, limbo quinquepartito. St am in a 5 , corollae tubo inserta, exserta v. subexserta. Ovarium quadriloculare. $\mathrm{O} \mathrm{vala}$ in loculis solitaria, pendula. Stylus semibifidus; stigmata acuta v, obtusa. Drupa baccata, dipyrena, pyrenis bilocularibus, Loculis monospermis, v. tetrapyrena, pyrenis bilocularibus, localo majori vacuo. S e mi n a inversa. $\mathrm{Emb} \mathbf{r} \mathbf{y}$ in axi albuminis parci rectus $v$. homotrope arcuatus; cotyledonibus brevissimis, radicula supera. - Frutices $v$, arbores, inter tropicos totius orbis observati, olim in plura genera dispescendi, sed nondum satis noti; foliis alternis, oppositis v ternatis, integerrimis v. serratis, floribus lerminalibus aut axillaribus, paniculat is $v$, corymbosis.

Eli retia Lian. gon, n, 257. Roxburgh Plant. Corom. t. 85_57. R. Brown Frodr. 497 . Kunth in Humb. et Bonpl. Nov, gen, et sp. III. 63, t. 208. 209. Bot, Reg. t. 1097, - ? $\mathrm{C}$ a $\mathrm{r}$ म $\mathrm{u}$ a Cavanill. in Anal. cienc, nat. $I_{*} 38, t, 3$, Ic. t. 438 .

3844. Lhabdia MART. Calyx quinquepartitus. Corolla hypogyna, campanulata, limbo quinquefido, $\mathrm{S} t \mathrm{t} \mathrm{m}$ in a 5 , imo corollae tubo inserta, inclusa. $O$ vari $\mathrm{um}$ quadriloculare. OvaI a in loculis solitaria, pendula. Sty Iu s terminalis, simplex; stigma bilobum. Dru p a baccata, tetrapyrena, pyrenis chartaceis, unilocularibus, monospermis. S e m in a inversa. E mbryo in axi albuminis carnosi, parei rectus; cotyledonibus brevissimis, radicula supera. - Frutex brasiliensis, ramosus; ramis virgatis, pubescentihirtis, folits alternis, sessilibus, lanceolatis, obtusis, margine undulatis, subtus pubescenti-hirtulis, floribus axillaribus, $v$. in corymbis pauciforis, bracteatis.

R habd la Martius Nov, gen. et sp. Ir. 136, t, 195.

3ร45. Arabowsixya SCHLECHT, CaI y campanulatus, quinquedentatus. Corolla hypogyna, infundibuliformis, tubo brevi, limbi quinquepartiti, patentis v. reflexi laciniis aestivatione contorto-imbricatis. Sta $\mathrm{m}$ in a 5 , corollae tubo prope basim inserta, exserta; fil am enta medio villosa, antherae bilneulares, ovatae, incumbentes, longitudinaliter dehiscentes. Ovarin m quadriloculare. Ov $\mathrm{I}$ a in loculis solitaria, medio angulo centrali inserta, amphitropa? Stylus terminalis, simplex; st ig m a capitatum. D rup a baccata, calyce suffulta, dipyrena, pyrenis lignosis, bilocularibus, loculis monospermis. S e m in a dorso eonvexa, facie plana. E m b r yo intra albumen carnosum hamato-curvatus; cotyledonibus semieylindrieis, radicula supera (?) - Frutex brasiliensis, ramosissimus, spinis axillaribus horridus, Lycii habitu, dubiae affinitatis, Ehretiis fortassis tamen quam Solanaceis, a quibus fructu plane abhorret propinquior, sed revera quo ad seminis interiorem fabricam non satis notus; foliis alternis, obovatis, integerrimis, floribus oppositifoliis solitariis $v$, in summis ramis paniculatis.

G r a b ow s ky a Schlechtend, in Linnaea VIr. 72. Lindley in Bot. Reg. t. 1985. L y cium boe r havia efolium Lim L. hete ropley $1 /$ u mirray in Comment. Götling. 1783. p. 8.t. 2. Khretia halimifolta Heriter Stirp. I. 45. $t .83$.

3746. Beurreria $J A C Q$. Calyx campanulatus, subbilabiatus, quinquedentatas. $C$ oroll a hypogyna, infundibuliformis, limbo quinquepartito. S $t$ a m in a 5 , corollae tubo inserta, subexserta, Ovarinm quadri-octoloculare. OvuI a in loculis solitaria, ex medio anguli centralis anatrope pendula. Stylus terminalis, bifidus $\mathbf{v}$. indivisus; $8 \mathrm{tig} \mathbf{m}$ at a subeapitata. D rupa di-tetrapyrena, pyrenis bilocularibus, loculis monospermis. S em ina inversa. Embryo in axi albuminis carnosi rectas; cotyledonibus brevissimis, radieula supera. - Arbusculae $v$. frutices, in America tropica cis aequatorem crescentes; folitis alternis, integerrimis, corymbis subterminalibus, floribus albis.

B e urreria Jacquin Amer. 44, t, 173, $f$. 17. Observ. IT. 2. t, 26. Gärtner f. IIT. 170, t. 2t2. (embryonis situ perperam deseripto.) Kunth in Humb. et Bonpl. Nov. gen. et sp, III, 67, B o u r reria P. Browne Jam, 168,t,15,f. 2 ,

3\%4\%. Tournefortla $R, B R$, Calyx quinquepartitus, Co rolla hypogyna, hypocraterimorpha v. subrotata, limbi plicato-quinquefidi lobis obtusis v. acutis. S tam in a 5, medio corollae tubo inserta, inclnsa. O v a r i u quadriloculare. Ovula in loculis solitaria, pendula. Stylus terminalis, interdum nullus; st ig ma peltatum, subconicum, indivisum v. bifidum. Drup a baccata, dipyrena, pyrenis bilocularibus, inter loculos $\mathbf{v}$. dorso perforatis, loculis monospermis. S e min a in- 
versa. E m bryo in axi albuminis carnosi rectus; cotyledonibus ovatis, radicula supera. Frutices volubiles $v$, erecti, inter tropicos to tius orbis, in insulis Canariis et in Tauria crescentes; foliis alternis, integerrimis, scabris $v$. tomentosis, spicis secundis, ebracteatis, apice revolutis, saepius cymosis.

Tourn efortia R. Brown Prodr. 496. Römer et Schultes Syst, $I V, 533$. Tournefortiae seet. Pittonia Kunth in Humb, et Bonpl. Nov. gen, et sp. III. 80, t. 203. T o u r n e fortia et $\mathrm{M}$ es $\mathrm{se}$ r s c h mid ti a Linn. gen, n. 192. et 1245. Gärtner $t, 76 . f .2$. (situ embryouis perperam pieto) et $t, 109$ A rg uz i a Ammann Ruth. 38, Pitto n i a Plumier Ic, t. 230. Tournefortiae s p. Jaeq. Ic, rar, $t$. 31 . Ruiz et Pavou Flor. Peruv, $t, 149, b$, $t$, 150, $a$. Vent. Choix $t, 3$. Bot. Reg, $t$. 466. Bot. Mag, $t$. 3096. H eli otro pif s p. Jaeq. Amer. $t$. 173. $f_{*}$ 11. Ruiz et Pavon Flor. Peruv, $t, 110, f .2$.

3\%48. NIesserselnmidtia RöM. et SCHULT. Cal y x quinquepartitus. Corolla hy. pogyna, hypocraterimorpha, limbi quinquepartiti laciniis linearibus. Sta min a 5 , medio corollae tubo inserta, inclusa. Ova ri um quadriloculare. Ovula ..... Stylus subnullus; stigma peltatum, snbconicum. D rup a tetradyma, tetrapyrena, quadripartibilis, abortu mono-dipyrena, pyrenis nnilocularibus, monospermis. $\mathrm{S}$ e $\mathrm{m}$ in a arcuata. E mbry o subexalbuminosus, homotropus; cotyledonibus per dorsum, radicula per ventrem loculi descendente, infera. - Frutices americani tropici, volubiles; foliis alternis, integerrimis, scabris $v$. tomentosis, spicis secundis, apice revolutis, ebracteatis.

Mes ser $s \mathrm{chmidtia} \mathrm{Römer} \mathrm{ef} \mathrm{Schultes} \mathrm{Syst.} \mathrm{VI.} 541$ non Linn. Tournefortiae sect. Messersehmidtia Kunth in Humb, et Bonpl, Nov, gen. et sp. 1II. 78. $t, 201$ 202. Pittonta Plamier Ic. 209. Tournefortiae sp. Lian. Swartz. Ruiz et Pavon Flor, Peruv. $t$. 148, 149. a. 150. b. Vent. Choir t, 2. Gärtuer t, 76, f. 1 .

3ร.49. Coldenia LINN. Calyx quinquepartitus. Corolla hypogyna, infundibulifor mis, fauce ampliata, nuda, limbi quinquefidi laciniis aequalibus, patulis. Stam i na 5 , cerollae tubo inserta, inclusa. O varium quadriloculare Ovula in loculis solitaria, pendula. Stylus ter minalis, simplex; stigma bifidum. Drupa exsucca, tetradyma, tetrapyrena, quadripartibilis, pyrenis rostratis, angulo centrali cohaerentibns, nnilocularibus, monospermis. S e min a inversa. E m. b $\mathrm{ry} o$ in axi albuminis carnosi rectus; cotyledo n ibus tenuissime foliaceis, conduplicatis, ra. dicula brevissima, supera, - Herbae v. suffru tices in Asia tropica et in Peruvia crescentes; foliis allernis, integerrimis, lineatis, $v$. grosse serratis, plicatis, floribus axillaribus, solitariis v. congest is.

Cold e a i a Linn. gen. n, 173. Gärtner $I .329$. Lehmann ia Berlin. Magaz. VIIT, 91. Asporifol. I. 2.

a. COLDENIA Linn. Flores rxillares, subsolitarif. Foli a cuneitormia, petiolata. grosse serrata, plicata. D ru pa rugosa. - Herba zeslanica. (Lam. t. 98. Gartner i. 68.)

b. TIQUILLA Pers. Flores axillares, congesti. Foli a lanceolata, basi attenuata, lineata Drupa laesis. Suffrutex peruanus, - Tiquil i a Persoon Encheir I. 157. Lithosperman dishotomum Raiz et Pasvon Elor, peruv, t. 111.

TRIBUS II. HELIOTROPEAE. Semin a exalbuminosa.

3ร50. Sehleidenia. Ca l y $x$ quinquepartitus, inaequalis. Coroll a hypogyna, infundibuliformis, fauce squamalis quinque villosis, limbo quinquefido,dentibns interjectis introrsum conniventibus. S t a m in a 5 , corollae tubo inserta, inelusa, antherae conniventes, a picibus barbatis subcohaerentes. Ovarium quadriloculare. Ovala in loculis solitaria, pendula, Stylns terminalis, brevissimus; st ig m a conicum, bidentatum, diseo annulari insidens. Drupa exsucea, quadripartibilis, pyrenis unilocularibns, monospermis. Semina inversa. E mbryo exalbuminosus; cotyl edonibus foliaceis, medio complicatis, radicula brevissima, supera, descendente. - Herbae bras $i$ lienses, saepius prostratae; foliis alternis, parvulis, floribus spicatis, luteis $v$. albis.

Presle a Martius Nov, gen, et sp. IT, 75. $t, 164$. St. Hilaire Voy, Distr. Diam, II. 434. non Opitz.

3\%51. Heliotropium LINN. Calyx quinquepartitus. Co roll a hypogyna, hypocraterimorpha, fauce edentula, nuda v. barbata, limbo quinquefido, sinubus plicatis, simplicibns $\mathbf{v}$. dente instructis. S t a m in a 5 , corollae tubo iriserta, inclusa, Ovari u m quadriloculare. Ovula in loculis solitaria, pendula. Stylus terminalis, brevissimus; stigma peltatum. Drupa exsueca, tetrapyrena, quadripartibilis, pyrenis unilocularibus, monospermis, triquetris, angulo centrali carinatis. Se min a inversa. Em bry o exalbuminosus, rectus v. homotrope arcuatus; cotyledonibus earnosis, radicula tereti, supera. - Herbae $v$. suffrutices, inter tropicos et in reg ionibus subtropicis totius orbis magno specierum numero luxuriantes, in temperatis rarius crescentes; foliis alternis $v$. interdum suboppositis ternatisve, saepissime hispidis, integerrimis, spicis terminalibus et lateralibus, solitariis v. conjugatis, novellis saepius spiraliter revolutis.

Hell otropium Linn. gen. n. 179. Gärtner I, 329, R. Browa Prodr. 492. Lehmann Asperifol. I, 19.

a. ORThostachXS R. Brown l. c. Spicae solitariat, bracteis suboppositifloris, foliaceis, novellae haud spi. rales. C o roll a e faux barbata. E mb r y o homotrope arcuatus.

b. HRLIOTROPIA VRRA R. Brown l, c. S pic a e conjugatae v. dieliotomae, ebracteatae, novellae spiraliter re. volutae. Corollae faux imberbis. $\mathbf{E}$ mb r yo rectus. (Gärtuer $t$. 68, Schibuhr t. 29, Jacq. Flor, austr. t. 207. Desfout. Flor, atlant, $t$, 41. Sibthorp Flor, graec. t. 157. Boupl. Malmais. t. 32. Ruiz et Pavon Flor. Peruv. t. 107-111. Humb. et Bonpl, Nov. gen. et sp. t. 204. 206. Bot. Mag. t. 141, 1909.)

3ร5\%. Trarid dume LEHM. Calyx quinquefidus, Corolla hypogyna, hypocraterimorpha, tubo angulato, fauce nuda, quinqueradiata, limbo quinquelobo, undulato. St am in a 5, corollae tubo inserta, inclusa. Ovarinm quadriloculare. Ovula in loculis solitaria, pendula StyIn s terminalis, simplex; stigm a capitatum. Nux biloba, lobis bilocnlaribus, v. quadrilocularibus bipartibilibus, segmentorum loculo ventrali vacno. $\mathrm{Se} \mathbf{m}$ in a inversa. Em bryo exalbuminosus, rectus; cotyledonibas carnosis, radicula tereti, supera. - Herbae $v$. suffrutices, inter tropicos Asiae et Americae crescentes; foltis allernis, spicis lateralibus et terminalibus, solitariis v. geminatis, novellis spiraliler revolutis.

Tia ridi u mehmann Asperifol, $1,13$.

a. HieranthemUM. Nux biloba, bipartibilis, lobi biloculares, loculi angulo dorsali hinc cohaerentes. T. e $10 \mathrm{H}$ g a $t$ a m Lehm. (Chamiss, in Linnaea TV. $t$. 5. $f$. 1 , et Heliotropium tiarloides Chamisso $O p$. cit. t. $5 .$, . 3.$)$

b. EUTLARIDIUM. Nux profunde biloba, lobi quadriloculaes, bipartibiles, segmentorum locu'is ventralibus va- 
euis. - Heliotropiam indie u minn. Bot. Mag. t. 1837 .

SUEDIDD DI. BORRAGINEAE. S $t y$ I us inter lobos ovarii transiens.

TRERUS I. ANCHUSEAE. N u c e s receptaculo affixae. Semin a exalbuminosa.

3553. Cerinthe LINN. Calyx pentaphyllus, foliolis inaequalibus. Co roll a hypogyna, subcylindrica, fauce nuda, inflata, limbo quinquedentato. $\mathrm{S}$ t a m in a 5 , corollae tubo inserta, inclusa; a $n$ therae sagittatae, basi lobis connexae. Ovarium bilobum, lobis bilocularibus. Stylus simplex; stigma emarginatum. Nuc es 2 , biloculares, arceola basilari semicirculari, plana receptaculo affixae. - Herbae in Europa media et australi indigenae, glaucescentes, piloso-strigosae $v$. laeviusculae; foliis alternis, integerrimis $v$, denticulato-ciliatis, racemis terminalibus foliosis.

Cer In th e Lina. gen, n. 186, Gärtner $I$. 381.

a. CERANThE Reichenb. Flor. excurs, 339, Cor olla liabus inciso-quinquefdus. S ta m i a a m flamenta 8 bb. nulla. N u cula e loculi alterius abortu submonospermae. - (Jacq. Elor. austr. $\ell$, 194. Reichenb. Iconogr. t. 481. 488. 685.)

b. CERINTHE Reichenb. Elor. excurs, 340. Corolla e Iimbus subtruncalus, dentibus quinque brevissitnis, subreflexis. S $t$ a $m$ I $n$ m filamenta autheras subaequantia. Nucula e biloculares, dispermae. (Gïrtner $t$. 67. Sibthorp Flor, graec, $t$. 170, 171. Reichenb. Iconogr, t. $981-984$.

3754. Onosma $L I N N$. Caly $\mathrm{x}$ quinquepartitus. Corolla hypogyna, tubuloso-campanulata, fauce nuda, limbo obtuse quinquedentato. St amina 5 , corollae tubo inserta, inclusa; antherae sagittatae, basi lobis connexae. Orarium quadrilobum. Stylus simplex, inclusus; stig ma emarginatum. Nuce s 4 , distinctae, ovatae, lapideae, areeola basilari plana receptaculo affixae. - Herbae in regione mediterranea, Oriente et Asia media obviae, pilis stellatis v. simplicibus hispidae; racemis terminalibus.

0 n o 8 ma Linn. gen. $n$. 188. Glírtner $1.325 . \ell$. 67 . Schkuhr t. 31. Lehmann in Nov. Comment, Hafn, 1808. t. 1. 2. Asperifol. II. 358. Ic. t. 9-14. Jaeq. Flor. austr. t. 225. Sibthorp Flor. graec, t. 172_174. Desfont. Flor. atlant, $t$, 43. Labillard. Syr. Decad, III. 8 . 5. 5. Waldstein et Kita hel Plant, rar. Inng. $t, 173.279$. Ledebour Ic, $t, 24$. 196. 248. 280. Eichwald Plant, Caucas, . 3. Reichenb. Ico. nogr. t. 360 .

3\%5. Dnosmodium $L$. C, RICH, C alyx quinquepartitus Corolla hypogyna, subcampanulata, fauce nuda, limbi ventricosi, semiquinquefidi laciniis erecto-conniventibus. S $t$ a m ina 5 , corollae tubo inserta, inclusa; an therae sagittatae, distinctae. Ovarium quadrilobum. Stylus simplex, longe exsertus; stig m indivi. sum. Nuces 4, distinctae, turbinatae, areola basilari plana receptaculo affixae. - Herbae boreali. americanae, hispidae, molliter villosae; foliis alternis, sessilibus, integerrimis, nervosis, racemo terminali folioso.

$0 \mathrm{n}$ os mo di um L, C. Richard in Michaux Elor. Bor. Amer. $1.132 . t$ t. 15. Os m a dium Rafines fue in $N$. York Medic. Meposit. II. Hex, v, 330. P u r s h a Sprengel in Lehmann Asperifol. II, 382. Lithos peralu uirginian na Linn.

3\%56. DIolthia LEHM. C al y $x$ quinquepartitus. Corolla hypogyna, cylindrico-infundibuliformis, fauce nuda, limbo quinquefido, obtuso. Stamin a 5, corollae tubo inserta, exserta; antherac oblongae, incumbentes. Ovarium quadrilobam. Stylns simplex; stigma obtasnm. Nuces 4, distinctae, magnae, difformes, rugosae v. tuberculatae, areola basilari plana receptaculo affixae. - Herbae orientales, cano. pilosae; foliis radicalibus petiolatis, caulinis alternis, sessilibus, spicis lateralibus simplicibus, terminalibus conjugatis, bracteatis.

Moltk i a Lebwann in Act. Nat, scrut. Hallens, Ir. 2. p. 3. Asperifol. IT. 339. 1c. t, 43, 44. 0 no smat is s p. Willd. Non ne a e s p. Viviani Flor, Libye. t, 1.f. 3.

3\%5\%. Telhium TOURNEF, Caly $\mathrm{x}$ quinquepartitus. Corolla hypogyna, subcampanulata, fance nuda, limbo oblique quinquelobo, inaequali. Sta $\mathrm{m}$ in a 5 , corollae tubo inserta, exserta v. inclusa, inaequilonga, adscendentia. Ovarium quadrilobum. Stylus simplex; stig$m$ a bifidum. Nuce 8 4, distinctae, turbinatae, areola baseos triangulari, plana receptaculo affixae. - Herbae v, suffrutices, in Eu ropa med ia et mediterranea, nec non in Capite bonae spei obviae, intertropicos utriusque orbis rarae, hispidae v. strigosae; floribus spicatis $v$. spicato-paniculatis, in spiculis secundis.

Ech i m Tournefort inst, 54, Linn. gen. n, 191, Gärtner I. 320. t. 67, Lehmann Asperifol, II, 398. Ic, t. 1-5. 16_28. 31_38. 49. Jaeq. Flor, austr. t. 3. et Suppl, $t, 16$. Ic. rar. t. 30. 312, Hort. Sohönbr. 4. 34. 35, Hort, Vindob. t. 45. Jaeq. 61. Eclog. $t$, A1, 42, 63. Venten, Malmais, $t, 21$, 97. Desfont. Flor. atlant, $t$. 45. 46. Sibthorp Flor, graec. t. 179_183. Bot. Reg. t, 36. Bot. Mag, t. 1822, Andrews Bot. Reposit. t. 20. 154. 165. St. Hilaire Plant, us, Bra. sil. $t .25$.

3\%58. Eelhioelhilom DESFONT. C a Iy $x$ quadripartitus. Corolla hypogyna, tubo gracili, arcuato, fauce nuda, limbi bilabiati labio superiore bilobo, inferiore subtrilobo. Stam in a 5 , corollae tubo inserta, inclusa. 0 vari um quadrilobum. Stylus simplex; stigma bifidum. Nuces 4 , distinctae, tuberculatae, areola basilari plana receptaculo affixae. - Frutex atlanticus, ramasus ; foliis sparsis, linearibus, hispidis, inferioribus reflexis, superioribus adpressis, floribus axillaribus solitariis, sessilibus.

Echiachilon Desfont. Flor, atlant, $T$. 160. $t$, 47, Lehmana Asperifol, II. az7,

3ร Ћง. Pallmonaria TOURNEF. Cal y x quinquefidus, prismatico-pentagonus, fruetifer eampanulatus. Corolla hypogyna, infondibuliformis, fauce pervia, pilorum penicillis quinque, limbo inciso - quinquefido. S t a m in a 5 , corollae tubo inserta, inclusa. Ovarium quadrilobum. Stylus simplex; stigma emarginato-globosum. Nuces 4, distinctae, turbinatae, laeves, basi truncata receptaculo affixae. - Herbae in Europa me dia et a ustrali indigenae, hispidac $v$, pilosue; foliis radicalibus petiolatis, sacpius maculatis, caulinis sessilibus, floribus terminalibus subcorymbosis.

Pulmona ri a Tournefort inst. 55, Linn. gen, $n, 187$. Sehkuhr t, 30. Flor. dan. $t$, 482, k. B, t, 118, 1698. Lehmann Asperifol, 2. 973. Reichenb. Iconogr, 2, 501-506, B e s s e. r a Schultes Observ, $2 \%$.

3760. Steenlarmmera REICHENB. Cal yx quinquepartitus. Corolla hypogyna, tabo brevissimo, fauce nuda, limbo campanulato, repande quinquedentato. Stamin a 5 , corollae fauci inserta, inclusa. O va ri um quadrilobum. St y I us simplex; stigma obtusum. Naces 4, distinetae, subdrupaceae, laeves, basi truncata receptaculo affixae. - Herba littoralis arctica, glaberrima, glauca; caulibus ramosis, procumbenti- 
bus $v$, adscendentibus; folits ovali-spathulatis, carnosulis, inferioribus petiolatis, superioribus sessilibus, semiamplexicaulibus, floribus cymosis.

Steen h a mera Relchenb. Flor. excurs, 337. M e rte nsia Roth Catalect, I. B4. non Willd. Casselia Dumortier Comment. bot, 21. non Nees et Mart. P ulmon a. ria maritima Linn. Flor. dan, $t$. 25, E. B. $t$. 368. Lithospermum maritimu a Lehm.

8\% 61. Hithospermum TOURNEF. Ca1 y x quinquepartitus, Co roll a hypogyna, infundibuliformis, fauce nuda, gibboso-impressa, plicata $\mathbf{v}$. barbato-annulata, limbo quinquepartito. S t a$m$ in a 5 , corollae tubo inserta, inclusa, Ova ri um quadrilobum. Styl u s simplex; 8 tig m a bi-quadrifidum. Nu ces 4 , distinctae, osseae, laeves v. rugosae, basi truncata receptaculo affixae. - Herbae v. suffrutices, in regionibus extratropicis imprimis calidioribus obviae, inter tropicos rarae, strigosae $v$. glabrae; foliis alternis, racemis bracteatis.

L i th o s perm um Tournef. inst, 135. Linn. gen, n, 181 . exel. sp.

a, RHYTISPERMUM Link Handb. IT. 879. C o rolla e faux plicata, N a ces rugosae. - A e g on y c h I on Gray Arrangem, 11. 354. (Flor dan. t. 456. Jaeq. Ic rar. t.313. Sibthorp Flor, graec, t. 138.)

b. LITHOSPERMUM Link $l$, c. Co roll a e faux gibbosoimpressa. Nuc e 8 laevissimae. (Schkuhr $t$, 29. Flor, dan. t. 1048. E. B. $t, 134.1$

c. BATSCHIA Gmelia Syst. 315. C o ro Il a e fanx barbatoannulata, nuces laevissimae. - C y p h o $\mathbf{r} \mathbf{m}$ a Rafinesque in Journ. Phys. LXXXIX, 28. (Michaux Flor. Bor Amer. t. 14.)

d. MARgarospermuM Reichenb. Flor. germ, 337. C o. roll a e faux laevis, uuces laevissimae. (Jacq. Flor. austr. t. 14. Sibthorp Flor, graec, t. 161.) -? A rne bla Forshael Aegypt. 62, 63, (Vahl Symb. II, t. 28.)

3\% 62. MIacromeria $D O N$. C a ly x quin quepartitus, laciniis linearibus, subinaequalibus. Corolla hypogyna, tubo elongato, fauce dilatata, nuda, limbi quinquepartiti laciniis olslongis, erectis. Sta m in a 5, corollae fauci inserta, longe exserta; filamenta filiformia, antherae ob longae, incumbentes. Ovarium quadrilobum. Stylus filiformis, exsertus; $8 \mathrm{tigma}$ simplex. Nuces.... Herbae mexicanae, strigosae; caule erecto, simplicissimo, foliis alternis, sessilibus, lanceolatis, nervosis, racemo terminali, paucifloro, bracteato.

Macromeria Don in Edinb. new philoseph. Journ. XIII, 209.

3\% 63. Craniospermum LEHM. C a1 y oblongus, quinquepartitus. Corolla hypogyna, cylindrico - tubulosa, fauce nuda, limbo erecto, quinquedentato. St a $\mathrm{m}$ in a 5 , medio corollae tubo inserta, longe exserta; fil am enta filiformia, antherae oblongae, incumbentes. Ova rin m quadrilobum. Sty lus filiformis; stigma capitatum. Nuces 4 , hemisphaericae, basi perforata receptaculo affixae. Herba sibirica, dodrantalis, villosa; foliis alternis, spathulatis, racemis subcapitatis, floribus roseis. t. 50 .

Crani osperm am Lehmann Asperifol, If. 336, Is,

3764. Colsmammía $L E H M, \quad \mathrm{C}$ a 1 y $\mathrm{x}$ quinquepartitus, petaloideus, basi pentagonus. Corolla hypogyna, cylindrico - campanulata, fauce nuda, limbo obtuse quinquedentato. S $t$ a $\mathrm{m}$ in a 5, corollae tubo inserta, inclusa, a $n t h e r a e$ sagittatae. Ovarium quadrilobum. Stylus simplex; stigma subeapitatum. Nuces 4 , v. abortu geminae, ovato-triangulares, laeves, basi per- forata, margine tumido cincta receptaculo affixae. Herba orientalis, dense flavo-pilosa; foliis alternis, obovato-lanceolatis, racemo terminali, brevi, bracteato, calyce corollam superante.

Cols m annia Lebmann in Berlin, Magaz, VIII. 92. t. 1. Asperifol. II. 356 .

3765. Nonmea $M E D I C$. C a I y $x$ quinque fidus, fructifer inflatus, campanulatus. Corolla hypogyna, infundibuliformis, fauce harbata, pervia, limbo quinquepartito. Stam in a 5 , corollae tubo inserta, inclusa. O va ri $\mathbf{~ m ~ q u a d r i l o b u m . ~}$ Stylus simplex; stigm a subbifidum. Nuces 4 , distinctae, rugosae, basi exeavata, margine tumido cincta receptaculo affixae. - Herbae in $E u$. ropa et Asia media, nec non in regione mediterranea et oriente indigenae, pilosae; racemis terminalibus foliosis.

N o n ne a Mediens Philosoph. Bot. I, 31. Möneh Mrethod. 120. DC, Flor, frang. III, 626. $\mathrm{K}$ ch i o i d es Desfont. Flor. Allant. I. 163. L y cops is Lehmann Asperifol. II. 252. excl. sp. L y cops id is sp. Linn. Jacq. Flor. austr. t. 188. Gärtner $t, 67$.

3766. Ireneglhinia. Caly $\mathrm{C}$ quinquepartitus. Corolla hypogyna, infundibuliformis, tubo gracili, elongato, fance nuda, limbo quinquelobo, patulo. S t a min a 5, medio corollae tubo inserta, inclusa. Ovari um quadrilobum. StyIn s filiformis, apice bifidus; stig mat a 2, capitata. Nuces 4, distinctae, pyramidatae, basi perforata, margine tumido cincta receptaculo insertae. - Herba a gyptiaca, dodrantalis, ramosissima, verrucoso-hispidissima; foliis alternis, lanceolatis, racemis terminalibus foliosis, corollis ochroleucis, calyce multoties longioribus.

D f o c le a Sprengel Syst, $T$. 556. Gen. pl, n, 692, non Kunth. Anchusa asperrim a Delille. A. hispidissi. a Sieb. Lithospermu hispidiss im um Lehmann Ic. $t, 39$.

3\%6\%. Iyeopsis LINN. Caly x quinquepartitus. Co roll a hypogyna, tubo incurvo, fauce fornicibus clausa, limbo quinquefido, obliquo. $\mathrm{St}$ a m in a 5, corollae tubo inserta, inclusa. $0 \mathrm{va}$ rin m quadrilobum. Stylus simplex; stigma indivisum. Nuces 4 , distinctac, rugosae, basi excavata, margine tumido cincta receptaculo insertae. - Herbae pilosae, in $h \mathrm{em} i \mathrm{sph}$ a erae borealis temperatis et calidioribus indigenae; racemis bracteatis $v$. superne nudis.

L y oc ops is Linn, gen, $n, 190$, excl. sp. DC. Flor, fr. III. 6 j3. Sehkuhr t.31, Flor, dan, t. 435. Sibthorp Flor, graec. t. 178. A n elu us a e sp. Lehm.

3768. Amelhwsa LINN. Cal y $x$ quinquefidus. Corolla hypogyna, infundibuliformis v. hypocraterimorpha, fauce fornicibus clausa, limbo quinquepartito. St a $\mathrm{m}$ in a 5 , corollae tubo inserta, inclusa. Ovari um quadrilobum. Styl us simplex; stigma indivisum. Nuces distinctae, rugosae, basi exeavata, margine tumido cincta receptaculo insertae. - Herbae in hemis phaera e borealis temperatis et calidioribus indigenae, in regione mediterranea imprimis copiosae, inter tropicos Asiae et Americae, nec non in Capite b onae spei rarae; floribus axillaribus solitariis $v$, racemosis, racemis bracteatis.

A n e h $n$ s a Linn, gen, $n$, 189. excl. sp. Lehmann Asperifol. I. 211. excl. sp. B $\mathrm{g}$ I o $\mathrm{s}$ s um Tournef. inst. 63 .

a, BAPHORHIZA. Corolla e fornices abbreviati, staminibus subjecti.

Baphorhiza Link Hands. IT, 578. AItanna Trusch in Flora 1824, p. 226. Nees PIant, offic. Suppl. t.3. Os e a mpia Mönch Melhod. 420. A n e hus a $t i$ ucto ri a Linn. Sibthorp Flor. graec. $t .166$. 
b. ANCHUSA, C o r olla e fornices promianli, papillosi.

A n e hus a Tansch $l$. $c$. (Sibthorp Elor. graec, $t, 164$, Reichenb. Iconogr, $t$. $469-47 t$. Hooker Flor, lond, t,9t. Bot. Mag. ใ, 1608. 1897, 2349.)

e. BUGLOSSUM. Corolla e forvices exserti, penicillati.

B u glas: u m Gärtner 2. 67. Tauseh 2, c. (Sibthorp Flor. graec, $t$, 163. Reicheub. Ieonogr, $t, 96 \%$, Bot. Mag. $t$, 2197.)

d. BUGLossoldes. Corolla e fornices longe exserti, papillosi, fruetus deflexi.

Buglossoides Tausch $l$. c. Asperngin is sp. Jacq. Hort, Vindob, III, t, 21. (Sibthorp Flor. graec. t. 165. Bot. Mag. $t$. 2119.)

3\% 69. Flaglohothrys FiSCH. et MEY. Cal y x quinquepartitns. Corolla hypogyna, infundibuliformis, fauce plicis quinque intrusis clansa, limbo quinquefido. St a $\mathbf{m}$ in a 5 , corollae tubo inserta, inclusa. Ovarium quadrilobum. Stylus simplex; stigma capitato-bilobum. Nuces 4 , distinctae, subeonnatae, areola laterali semicirculari, perforata receptaculo hemisphacrico, elevato affixae. - Herba chilensis, annua, hirta, Lithospermi arvensis facie; foliis sublinearibus, sparsis, racemis terminalibus conjugatis, subaphyllis.

Plaglobothrys Fiseher et Meyer Index Sem, hort. Potropolit, 1835, II, p. 46,

3ร ช (D. Eritnoleitam SCHRAD. $\mathrm{C}$ a I $\mathbf{y x}$ quinquepartitus. Corolla hypogyna, hypocraterimorpha, fance fornicibns clausa, limbo quinquepartito, obtuso. St a min a 5 , corollae tubo inserta, inclusa. Ovarium quadrilobum. Styl us simplex; stigma subeapitatum. Nuces $t$, distinctae, triquetrae, antice planae, margine prominente aculeolato $\mathrm{v}$. laevi cinctae, angulo postico obtnso, umbilico dorsali punctiformi receptaculo affixae. - Herbulae in Europae mediae et $a$ ust $r a \bar{l} i$ s jugis excelsis crescentes, villosae, caespitosae; racemis bracteatis, pauciftoris, floribus laetissime cyaneis.

Eritriehiam Schrader in Comment. Qötting. $I V, 189$. M yos otis nan a Villars Delph. $t$. 13. M, terglo a ens is Hacquet Plant, alp. carn. 2. 2. f. 6. Sturm Flor. germ. 42.

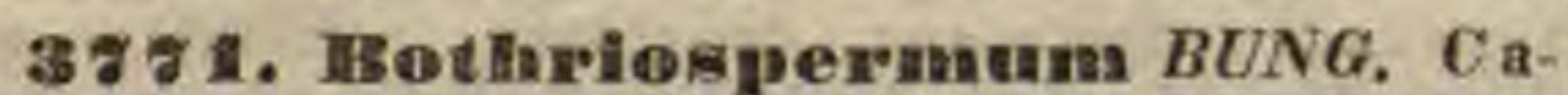
ly $\mathrm{x}$ quinquepartitus. Corolla hypogyna, hypocraterimorpha, tnbo brevi, fauce squamulis quinque bifidis, limbo quinquepartito. S $t$ a m i$\mathrm{n}$ a 5 , corollae tubo inserta, inclusa. Ov a rium quadrilobum. Stylus simplex; stigma eapitatum. Nuces 4, distinctae, reniformes, extrs granulatae, umbilico dorsali umbonato receptaculo affixae. - Herbae chinenses, annuae $v$. biennes, Myosotidis facie; floribus parvis, pedun. culatis, pedunculis lateralibus extrafoliaceis.

Bothriosperm a m Bunge Enumerat. Plant. Chin. bor, 67. Fiseher et Meyer Index som. hort. Petropolit. 1835. II. 23 ,

3\% \%. Dirosetis LINN. Caly x quinquepartitus. Coroll a hypogyna, hypocraterimorpha, tubo brevi v. calycem superante, fauce fornicibus clause, limbo quinquepartito, obtuso. Sta min a 5 , corollae tubo inserta, inclusa; a th era e peltatae. Ovarium quadrilobum. Sty In s siuplex; stigma capitatum. Nuces 4 , distinctae, laeves v. granulatae, rugulosae, umbilico basilari receptaculo affixae, - Herbae notissimae, in regionibus extratropicis totius orbis obviae; racemis simplicibus, ebracteatis.

M y o sofis Linn. gen, n. 180. Jussieu gen, n. 131. exel. sp. R. Brown Prodr. 694. Lehmann Asperifol. 1. 78. Sturn Flor, Germ, 48, E, B. 2. 480, 1973, 2558, 2559. Lede bour Ic, $t$. 215. E c h loides Mönch Method. 416. A nch h. $s$ a s p. Royle Himalay $t, 73$.

3ร ร. Exarrilhema $R$. BR. Calyx quinquepartitus. Corolla hypogyna, hypocraterimorpha, tubo calycem superante, fance fornicibus clausa, limbo quinquepartito, obtuso. St a m in a 5 , corollae tubo inserta, exserta; antherae peltatae. Ovarinm quadrilobum. Stylus simplex; $s t$ igm a subemarginatum. Nuces 4 , distinctae, basi umbilicatae. - Herba insulae Diemen, pilosa, Myosotidis facie; folitis decurrentibus, racemis conjugatis $v$. solitariis, ebracteatis, floribus albis, suaveolentibus.

Exarrbena R. Brown Prodr. 495. Lehmann Asperifol. $I, 76$. A. Richard Sort, Astrolab, $t, 29$.

ระร 4. Hobostemon LEHM. C a I y quinquepartitus. Cornlla hypogyna, infundibuliformis, fauce fornicibns quinque lanceolatis, erectis, durso staminigeris, limbi quinquefidi laciniis erecto patentibus. Stam in a 5, dorso fornicum faucis inserta, exserta; antherae subglobosae. Ovarium quadrilobum. Stylus filiformis; stig ma simplex. Nuce s a, distinctae, turbinatae, basi imperforata receptaculo affixae. Erutex capensis, humilis, ramosus; folizs sparsis, elliptico-lanceolatis, obtusis, supra glabris, subtus calloso-strigosis, spicis terminalibus coarctalis, bracteatis.

Lob o s tem on Lehmann in Limaea v, 378, $t, 5, f, 1$.

3\%ซ5. Stomotechinm LLHM. Calyx quinquangularis, quinquefidus. Corolla hypogyna, tubulosa, fauce fornieibus quinque, subrotundis, carnosis, extus muricatis clausa, limbi quinquefidi laciniis obtusis. St a corollae tubo inserta, inclusa. O va $\mathrm{r}$ ium quadrilobnm. Stylus fitiformis; stigma simplex. Nuc es 4 , distinctae, subrotundae, ragosae, umbilico basilari receptaculo affixae. - Frutex capen$s$ is, Echii facie; foliis alternis, semiamplexicaulisessilibus, papilloso-scabris, racemis terminalibus secundis, strictis, bracteatis.

St to o o te hin Lehmann Asperifol, IT, 390 .

3ร ซ 6. Sympllaytam $L I N N$. C a I y $x$ quin. quepartitns. Coroll a hypogyna, cylindrico-campanulata, fauce fornicibus quinque subulatis, in conum conniventibus clausa, limbo quinquedentato. St am in a 5, eorollae tubo inserta, inclusa, antherae acuminato-lanceolatae, cum fornicibus alternantes. Ovarium quadrilobum. Stylus simplex; stig m a obtusum. Nuces 4, distinctae, ovatae, rugosae, basi perforata, margine tumido eineta receptaculo affixae. - Herbae perennes, in Europa et Asiamedia indigenae; foliis alternis, sessilibus $v$. petiolatis, racemis terminalibus solitariis $v$. conjugatis.

$\mathrm{S}$ y zа p hy $\mathrm{ta} \mathrm{m}$ Tonrnefort inst. 56. Linn. gen, n, 185. Schkuhir t. 30. Gärtner $I$. 323. t. 67, Jacq. Flor, austr, t. 225. Jacquin f. Eclog. t. 8t. Waldstein et Kitablbel Plant, rar. Hung. t. 7. Flor. dan. $t$, 664. E. B. t. 817, Bot. Mag. t. 929, 1912. Reichenb. Iconogr. $t .280$.

3รซซ. Traelnystemon DON. Calyx quinquefidus. Co roll a hypogyna, tubulosa, fauce squamis quinque, abbreviatis, emarginatis v. $8 \mathbf{n}$ bulatis, integris instructa, limbi quinquefidi laciniis linearibus, revolutis. St a mina 5 , corollae fauci inserta, exserta; fil a m e n ta subulata, simplicia, antherae oblongae, incumbentes. Ovari um quadrilobum. Styins filiformis; stigma sim. plex. Nuces 4, distinctae, basi excavata, margine tumido cineta receptaculo insertae, - Herbae 
orientali-mediterraneae; foliis strigosis, floribus laxe racemosis, subsecundis, nutantibus.

Traeh y s te mo a Don in Edinb. new philosoph. Journ. XIIT. 239. B orrago orientalis et B. cretica Liun. Sibthorp. Flor. graec. $t$. 175. 176.

58\%8. Borrago TOURNEF. C a 1 y $\mathrm{x}$ quinquepartitus. Corolla hypogyna, rotata, fauce squamis quinque emarginatis instrueta, limbi quinquefidi laciniis ovatis, acuminatis, patentibus. Sta min a 5 , corollae fauci inserta, exserta; filam enta brevissima, dorso appendice cartilaginea, oblonga, erecta, an therae lanceolatae, acuminatae, in conum conniventes. Ovari u m quadrilobum. Stylus filiformis; stigma simplex. N n ce $s$, distinctae, basi excavata, margine tumido cincta receptaculo insertae. - Herbae mediterraneare et orientales; foliis strigosis, floribus laxe racemosis, subsecundis.

B orrag o Tournefort inst, t. 53. excl. sp. Linn. gen. n. 188. excl. sp. Sehkular t, 31. B. B, 2,36 , Desfont. Flor, atlant. t. 44. Ventea. Cels. t. 100, Bot. Mag, t. 1798.

TRRIIBUS II. CYNOGLOSSAE. Nuces styli basi adnatae. Semina exalbuminosa.

3รซร. Triehoilesma $R, B R$. Calyx quinquepartitus, C o roll a hypogyna, subrotata, fauce nuda, limbi quinquepartiti laeiniis] ovatis, mucronato-cuspidatis. S t a min a 5, corollae fauci inserta; a ntherac subsessiles, exsertae, acuminibus subulatis, tortilibus in conum conniventes, villis dorsalibus bifariis cohaerentes. O varium quadrilobum. Stylus simplex; stigma obsolete emarginatum. N u ces 4 , distinctae, styli baseos quadrangularis foveolis semiimmersae, juxta apicem adnatae. - Herbue strigosae, gerontogeae tropicae et capenses; foliis alternis, semiamplexicauli-sessílibus $v$. petiolatis, racemis bracteatis.

Trichodes ma R. Brown Prodr. 498. Lehmann Asperifol. 1. 192. Pollichia Mediens Philosoph. bot. I. 32. Cynoglossoides Isnard Act. Academ. Paris. $1718 \mathrm{p}$. 325. Borragiaoides Boerhave Lugd, Batav, I. 118. Borragiuis sp. Linn. et Auet.

a. CYNOGLOSSOIDES. C a 1 y e is laciniae simplices. (Jacq. Ic. rar, t, 314. Isnard $O p$. cit, t. 1t.)

b. BORRAGINOIDES. Cal y e is lacinise basi auriculatae. (Isnard $O p$. cit, t, 10. Gä̈tner $t$, G7.)

3780. Danplabloules TODRNEF. Ca ly x quinquepartitus. Corolla hypogyna, rotata, fance fornicibus clausa, limbo quinquelobo, obtnso. S $t$ a min a 5, corollae tubo inserta, inclusa, Ovarium quadrilobum. Stylus simplex; stigma obselete emarginatum. N a e es 4 , distinctae, depressae, margine membranaceo inflexo calathiformes, angulo dorsali styli basi adnatae. $-\mathrm{Her}$ bae mediterraneae, in Europa sparsimobviae, pilosae; racemis simplicibus $v$. conjugatis, nudis $v$. bracteatis.

$0 \mathrm{~m} \mathrm{phas}$ odes Touruefort inst, t, 58, Mäaeh Mothod, 419. Sehrank in Münchner Denkschrift. 1811,820, excl. sp. Liak et Hoffmansegg. Flor. portag. i. 25. Lehmann in Berlin. Magaz. VIII, 97, t. 2-4. Asperifol, $T$. 180. P i cot í a Römer

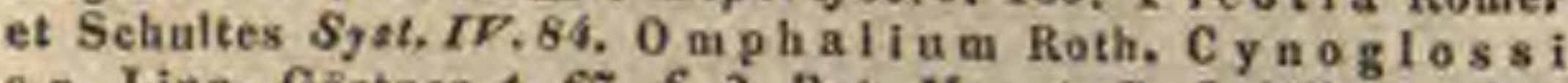
s p. Lía. Gärtaer $t, 67, f, 3$, Bot. Mag, $t, 7$. Labillard. $\$ y r$. Dec, IT. $t, 2$,

3r81. Findera $P A L L, C$ a lyx quinquepartitus. Corolla hypogyna, subinfundibuliformis, fance nuda, limbi quinquepartiti laciniis linearibus. Anthera e 5, in fauce corollae sessiles. $O$ va ri u m quadrilobum. Sty lus simplex; stigma subcapitatum. Nuc es 4 , distinctae, compres- sae, margine membranaceo circumalatae, angulo dorsali styli basi pyramidali adnatae. - Herba Asiae mediae; foliis inferioribus lanceolatis, superioribus ovatis, inflorescentia racemoso-corymbosa, dense cano-lanuginosa.

R indera Pallas It. I. App. 486. t.F. f. 1. 2, Ledebour Flor. Alt. r. 193. C y nog los 8 um R in d ex a Pallas Flor. ross. IT, t. 88. C. laevigatum Gärtner $t .67$.

3\%82. Nattia SCHULT. C a 1 y $\mathrm{x}$ quinquepartitus. Corolla hypogyna, infundibuliformis, tubo pentagono, fauce fornieibus emarginatis clausa, limbi quinquefidi laciniis linearibus. S t a min a $\mathbf{5}$, corollae infra fancem inserta, subexserta, O varin m quadrilobum. S t y l u s simplex; st igma obsolete emarginatum. Nuces 4 , distinetae, compressae, margine membranaceo circumalatae, angulo dorsali styli basi pyramidatae adnatae. Herba Europae a ustro-oc cidentalis, pedalis ; foliis lineari lanceolatis, cano-pubescentibus, inflorescentia umbellato-corymbosa, albo-lanata.

M a tifia Schultes Observ. 30. exel. sp. Syst. ID. 82 . C ynog loss um umbellatum Waldst. et Kitaibel Plant. rar. Hung, $t .148$.

3783. Solenamthus LEDEB. Caly quinquepartitus. Corolla hypogyna, tubulosa, tubo supra basim fornicibus quinque instructo, limbo quinquepartito, Stam in a 5 , corollae tubo supra basim inserta, exserta. Ovarium quadrilobum. Stylus subulatus; stigma simplex. Nuces 4, distinctae, depressae, eehinatae, styli basi tetragonae affixae. - Herba altaica, pilosa; foliis inferioribus petiolatis, superioribus sessilibus, subamplexicaulibus, racemis axillaribus, solitariis v. conjugatis, terminalibusque paniculatis, ebracteatis, unilateralibus, densis, ante anthesim et peractix florescentia spiraliter revolutis.

Solen an thus Ledebour Flor, alt, I, 193. Ic, t, 26.

3r84. Cynoglossum LINN. C al y $\mathrm{x}$ quinquepartitus. Coroll a hypogyna, infundibuliformis, fauce fornicibus quinque clausa, limbi quinquefidi laciniis obtusis. Ovari um quadrilobum. Stylus simplex; stigma subcapitatum. Nuces 4, distinctac, depressae, echinatae, umbilico dorsali styli basi pyramidatae insertae. Herbae in extratropicis, primis he misphasra e borealis obviae; racemis saepius ebracteatis, nunc bracteatis, bracteis interdum foliiformibus.

C y nog I o s s u m Linn. gen, $n$, 183. exel. sp. R. Brown Prodr. 495. C y nog 1 o s s I sect. 1. Lehuann Asperifol. $I$. 134. Schkuhr t, 30. Gírtner t, 67. f. 2. Flor. daa, t, 1147. E. B. t. 92t. 1642. Jacq. Hort. Schönbr. $t, 489$. Desfont, Flor. atlant, $t, 42$, Liak et Hoffuans. Flor, portug, $t, 24$. Bot. Mag. t. 2431. Reichenb. Iconogr. 2. 781. Nees Plant. offic. Suppl. IT, t, 13, 14.

3\% 85. Asperugo TOURNEF. C a 1 y x quinquefidus, fructifer auctus, compressus, lobis planis, parallelis, sinuatis. Corolla hypogyna, subinfundibuliformis, fauce fornicibus clausa, limbo quinquepartito. St a min a 5 , corollae tubo inserta, inclusa. Ovari um quadrilobum. Stylus subulatus; s tig ma simplex. Nu ces 4 , distinctae, compressae, verrueulosae, styli basi adnatae. Herba euro paea ; caulibus procumbentibus, angulatis, muricato-echinatis; folits oblongo-lanceolatis, floribus axillaribus breviter pedunculatis, purpureocaeruleis.

A s per u go Tournef. inst, 54. Linn. gen. n, 189. Schkuhe t. 31. Flor. dan. t. 558. B. B. t, 661. Sibthorp Elor. graec. t, 177. Lehmann Asperifol. I. 208.

3ร86. Felhinosperman SWARTZ. C a l y $x$ quinquefidus, C o r o I l a hypogyna, 
bypocraterimorpha v. infundibuliformis, tubo brevi, fauce squamis instructa, limbo quinque partito, obtuso. Stamina 5, corollae tubo inserta, inclusa. O varium quadrilobum. Stylns simplex; stig m a subcapitatum. Nuces 4 , distinctae, triqnetrae, marginibus muricatae, angulo dorsali stylibasi adnatae. - Herbae villosae, Myos. otidum facie, in temperatis hemisphaerae borealis et in America australiextratropi. $c a$, rarius inter tropicos Asia e crescentes; ra cemis ebracteatis, fructibus tunc deflexis, v. racemis bracteat is, fructibus erectis.

Echinospermum Swartz ex Lehmann Asperifol. $I$. 113. Sturm Flor. germ. fasc. 43. Ledebour Io, t. 27-29. 180_183, 302. Eichwald Plant. cauc. t, 6. L a p p n 1 a Mornch Method, 416. Rochella Römer et Schult. Syst. IV. 645. nou Reichenl. M yosotid is s p. Linn. Gârtuer $t$. 68. Flor. dan, $t, 692,1568$. Lehmann in Act. soc. h, n, Hall. 1IT, 2, t. 1. f. 1. t, 2. Cynoglossi sp. Scop. E chioidis sp. Mornch.

\section{GENUS ANOMALUM.}

3r8\%. Boehelia REICHENB. Calyx quinquepartitus. Co roll a hypogyna, infundibuliformis, fauce fornicibus clausa, limbo quinquelobo. St a mina 5 , corollae tubo inserta, inclasa. Ovari um biloculare, loculis uniovulatis. Sty. la s simplex; stigma obtusum. Nuces 2 , laeves v. verrucosae, styli basi rostratae adnatae et inter se connatae. - Herbae annuae $v$, biennes, in Europa australi et in Asia media indigenae, Echinospermi facie.

Roch ell a Reichenb. in Flora 1824. p. 243. Flor. germ. 346. Iconogr, t, 236, 237. Ledebour Flor, alt, I, 172, Ic, t. 244. Messerschmidia Asso Arragon. 162, $t, 1, f$. 2, non Linu. Lithosperm u d is perm a m Linn. Decad, $I, 7$. OBSERVATIO. A m s i k i a Lehmann Catalog. sem. hort. Hamburg. 1831. quae Be utha $\mathrm{m}$ i a Lindl. msc., genus cotyledonibus quatuor insigue, et Ktenosperm $\mathrm{Km}$ Lehuann Cat, cit. 1837. uobis ignota.

\section{Classis $\mathbf{X} \times \mathbf{X} \mathbf{I}$. Tubiflorae.}

Herbae, frutices v. arbores, succo in paucis lacteo. Foli a altern 3 , rarius opposita, integra v. lobata aut pinnatipartita. St $\mathrm{i}$ pulae nullae. Calyx liber. Corolla hypo. gyna, gamopetala, regularis. St a mina corollae tubo inserta, ejusdem lobis numero aequalia et alterna. Ovari um di-tetra-pentamerum. $O \mathrm{vula}$ in loculis rarius definita saepius plurima, erecta v. horizontalia, anatropa $v$. amphitropa. Fruetus capsularis v. baccatus. $\mathrm{E} \mathbf{m}$ b r y o intra albumen varium rectus $v$. saepius curvatus.

\section{Ordo CXIII: Comvolvulaceae.}

Convolvuri Jassieu gen, 133. excl. gen. coll. Annal. Mus. $V$. 257, XV. 339. CoNvolvULEAE Venten. Tabl. $I$, 394. R. Brown Prodr. 481. Bartling Ord. nat. 190. Choisy in Mem. soc, h. n. Genev. VI. 383. VIII. 43. Lindley Introduct, edit. II. p. 231.

Herbae v. sufrotetices aut frutices, caule saepissime volubili, rarius erecto, interdum arboreo, succo in aliis aqueo, in pluribus lacteo. Foli a alterna, sessilia v. petiolata, circumscriptione saepissime cordata, integra v. palmatiloba aut palmatisecta, rarius pinnatifida, marginibus semper integerrima. Stip ula e nullae.

Flores hermaphroditi, regulares, axillares v. terminales, pedunculis simplicibus v. trichotomis, pedicellis saepissime bibracteolatis, bracteolis interdum calyci adstantibus, interdum post anthesim auctis.

Calyx pentaphyllus, foliolis aequalibus v. inaequalibus, uni-bi-triseriatis, persistentibus et saepius post anthesim anctis; rarissime gamophyllus, quinquefidus.

Corolla hypogyna, gamopetala, campanulata, infundibuliformis v. interdum subhypocraterimorpha, limbo quinquefido, plano v. saepissime quinqueplicato, subintegerrimo, aestivatione contorto, rarius imbricato, post anthesim saepe involuto.

Stamina 5, imo corollae tubo inserta, ejusdem lobis alterna, inclusa v. exserta. Filam e $\mathbf{n}$ a aequilonga $v$. inaequilonga, basi saepissime ampliata et villosa, interdum in fornicem dilatata, apice filiformia. A n th er a e biloculares, erectae v. rarius incumbentes; loeulis parallelis, longitudinaliter dehiscentibus, defloratae saepius spirales.

Ovarium basi annulo carnoso hypogyno cinctum, nunc gamocarpum, e carpidiis saepius duobus, rarius tribus v. quatuor valvatim connatis, marginibus dissepimenta e columna centrali efformata contigentibus bi-tri-quadriloculare, v, columna centrali incompleta aut in nonnullis plane evanida nniloculare; nunc apocarpum, carpidiis seilicet unilocularibus dnobus distinctis, $v$. quaternis per paria connatis. $0 \mathrm{vula}$ in loculis solitaria $\mathrm{v}$, gemina collateralia, in ovario uniloculari quaterna, e columnae centralis basi erecta, exírorsum anatropa, secundinae marginibus induplicatis. Stylus in ovarils apocarpis basilaris, in gamocarpis terminalis, nune simplex, indivisus $\mathbf{v}$. bifidus aut bipartitus, nunc duplex. Stig ma simplex, acutum v. globosum, in stylo simplici saepissime bilobum, rarissime plurilobum.

Capsula uni-quadrilocularis, valvata, valvis columnam centralem, basi seminiferam nudantibus, nunc evalvis, epicarpio saepius transversim solnto, nune baccata, indehiscens.

SFmina ovulis saepissime pauciora, dorso plus minus convexa, erecta; testa coriacea $\nabla$. membranacea, saepe villosa. Albu men parcum, mucilaginosum.

Enвaxo plus minus curvatus. Cotyled on es foliaceae, conduplicato-corrugatae. Radicula umbilico proxima, infera.

Convolvulaceae habitu et characteribus distinctissimae, et cum nullo plantarum 
ordine facile confundendae, maximo numero inter tropicos utriusque orbis generantur, in America paullo copiosiores, versus polos, imprimis versus arcticum, numero minuuntur, in regionibus frigidis et in excelsis alpium jugis rarissimae. Nonnullae species latissime per orbem diffusae.

Radices plurium succo acri insigniter catharctico, et inter medicos celebratissimo scatent, allarum cultura edules.

Genera ad ordinis calcem rejecta, totidem ordinum distinctorum typos sistunt.

SUEOERO I. DICHONDREAE. Ovari a apocarpa.

3988. Fielnendrara FORST, Ca Iy $\mathrm{x}$ quinquepartitus. Coroll a hypogyna, subrotata, limbo quinquepartito, plano. S t a in a 5 , corollae tubo inserta, inclusa. O v a ri a 2 , distineta, biovalata. Styli 2, basilares; stigmatibus capitatis. Utrie ali duo, mono-dispermi. Semina erecta. Emb ry on i 8 mucilaginoso-albuminosi cotyledones contortuplicatae, radicula subspiralis, infera. - Herbae humiles, repentes, pubescentes, non lactescentes, in hemisphaerae australis regionibus extratropicis, in America tropica et boreali calidiore obviae; foliis reniformi-cordatis, petiolatis, integris, pedunculis axillaribus, unifloris, ebracteatis.

Die h on d r a Forster Char, gen, 39. t, 20. Smith, Ic, inedit. I. t. 8. Swartz Flor. Ind. occid. I. 556. t. 10. Willdenow Hort, Berolin, t. 81. R. Brown Prodr. 490. Steripha Banks et Soland. ex Gürtner $I$. 81 . 2. 94, D e un id of i a Gmelin Syst. 388 . Sibthorpiaesp. Lina.

3589. Falkis $L I N N$. $F$. C al y $\mathrm{x}$ quinquefidus. Corolla hypogyna, infundibuliformis, limbo quinqueplicato. S ta min a 5, corollae tubo inserta, inclusa. Ovaria 4 , mediantibus stylis per paria connexa, nniovulata. Styli 2 , basilares; stigmata capitata. Utriculi (?) 4, monospermi. S e min a erecta. Embry o ....... Fruticulus capens is, decumbens, ramosus, glaber; succo aqueo, ramis filiformibus, repentibus, foliis petiolatis, cordato-spathulatis, integris, pedunculis axillaribus unifloris, ebracteatis.

Falki a Lina f. suppl. 211. Thunberg Dissert. Nov. gen. I, 17. R. Browu Prodr, 490. in not. Andrews Bot, Reposit, t, $25 \%$.

SUIDIDID II. CONVOLVULEAE. 0 vari a gamocarpa.

3ร90. Whilsonia $R$. BR. Calyx urceolatus, pentagonus, quinquedentatus. Corolla hypogyna, infundibuliformis, aestivatiene imbricata. S tamin a ...... Ovarium uniloculare? biloculare? biovulatum. Capsula... - Suffrutex Novae-Hollandiae meridionalis, non satis notus, Cressae fere habitu, humilis, prostratus, ramosissimus, pubescens; foliiis disticho-imbricatis, parvis, crassiusculis, sessilibus, floribus axillaribus sessilibus, solitariis, ebracteatis.

Wils oula R. Brown. Prodr. 490 . Choisy in Mem. soe, $h, n$, Genev. $V I, 496$.

3ร21. Evolvulus LINN. Caly x pentaphyllus. Co rolla hypogyna, infundibuliformicampanulata v, subrotata. S $t$ a min a 5 , imo corollae tubo inserta, exserta. O v a ri u m biloculare, Toculis biovalatis. Styli duo bipartiti; gtigmata simplicia, Capsula bilocularis. Semina 4 , abortn interdum unicum, erecta. Embryonis curvati, mucilaginoso-albuminosi cotyle do o es corrugatae, ra d i cula infera. - Herbae prostratae v. repentes, rarius erectae, in regionibus tropicis subtropicisque totius orbis obviae; succo aqueo, foliis alternis, integris, pedunculis axillaribus uni-paucifloris, pedicellis bibracteolatis,

Evolv ulus Linn. gen, $n, 389$. Jacq. Amer, edit, pict. t. 260. $f$. 23. Laus, $t$, 216. Ruiz et Pav. Flor. perut, $t 252$. 253. R. Brown Prodr. 498. Kuath in Humb. el Bonpl. Nov. gen. t. 215. Labillard. Nov. Caled. t. 29. Bot. Reg. t. 401 , Morleasd Plant. Americ, $t, 33-37$. Choisy in Mem. soe. $h$. n. Genev. V1, 496, VIIT, 69. - C Iadostyles Humb. et Bonpl. Plant, aequinact. I. 202, $t, 57$. - S t y 1 i s at u 8 Ra. finesq. in Americ, Monthl. Magas, 1818.

3รจ2. Cressa LINN. C aly x pentaphyllus. C o rolla hypogyna, infundibnliformis, limbi qninquepartiti laeiniis planis. Stamina 5, imo corollae tabo inserta, exserta. O va rium biloenlare, loculis biovulatis. Styli duo; stigmata capitata. Capsula abortu unilocalaris, monosperma. S emen erectum. Embry on is curvati, mueilaginoso-albuminosi cotyled on es corrugatae, radicula infera. - Herbae humiles, pubescentes, in regione mediterranea et in Asia et America tropica sublittorales; succo aqueo, foliis sparsis, integerrimis, floribus in summis foliorum alis subspicatis, bibracteolatis.

Cress a Linn, gen, $n$, 179. Sibthorp Flor. graec. $t$. 936. R. Browa Prodr. 489, Cholsy in Mem. soc, h, n. Genev. PI, 495 .

3ร\$3. IBreweria $R$. BR. Caly x pentaphyllus. Corolla hypogyna, infundibaliformicampannlata, limbo quinqueplicato. $\mathrm{S} t \mathrm{a}$ min a 5 , imo corollae tubo inserta, inclusa. Ova riu m biloculare, loculis biovulatis. St ylns semibifidus; st ig mata capitata. Capsu la bilocularis. S emina 4, erecta. Embryo.... - Herbae v. suffratices, in Nova-Hollandia et Asia tropica, nec non in insula Madagascar crescentes, diffusi; succo aqueo, foliis alternis, integris, floribus axillaribus, solitariis.

B reweria R. Brown Prodr. 487. Chnisy in Mem. soc. h. $n$. Genev. VI. 493. $t$, 2. $f$. 14. Convolvali sp. Roxb. Wallich.

3ร94. Dufourea KUNTH. Calyx pentaphyllus, foliolis duobus exteriorilus maximis, involucrantibus, coloratis, Co rolla hypogyna, infundibuliformis, limbo quinquepartito. S $\mathrm{tam}$ ia a 5 , corollae tubo inserta, inelusa. Ovarium biloculare, loculis biovulatis. Stylus bipartitus; stig mat a capitata. Capsula bilocularis. S emina 4 , v. abortu pauciora, erecta $\mathrm{Embryo}$ ... - Suffrutices Americae tropicae, volubiles; foliis alternis, integris, pedunculis multifloris, axillaribus et terminalibus paniculatis, corollis albis.

D u fourea Kunth in Humb. et Bonpl. Nov, gen, et sp. III. 113. t. 314. non Bory. P revostea Choisy in Annal. sc, nat. IV. 496, Mem, soc. $h, n$, Genev. VI, 492, D e th a rd i ng I a Nees et Mart. in $N . A, N$. C.XT. 80 . Rein w a r d i a Spreng. Syst. I. 836. C a I y co b ol us Willdenow msc.

3ร95. Bønamia THOUAR, Caly $\mathrm{x}$ pentaphyllus, fructifer hand mutatus. Coroll a hypogyna, infundibuliformi - campanulata, limbo quinquepartito, plano. S t a m in a 5 , medio corolla tubo inserta, subexserta. O va ri u m biloculare, loculis biovulatis. Stylus bifidus, longe exsertus; stigmat a capitata, sublobata. Ca a su la bilocularis. S S m i na abortu 2 , erecta, arillo (?) 
carnoso. Em bry onis curvati, mueilaginoso-albuminosi e otyledones corrugatae, radicula infera. - Frutex madagascariensis, erectus; foliis alternis, coriaceis, integerrimis, undulatis, floribus in paniculum terminalem, brevem, contractam dispositis.

B on a m a Thouars Hist, Deg. Afr, atstr. 17, t. 6 ,

3\%96. Neuropellis WALL. C a $1 \mathrm{y} x$ pentaphyllus, immutatus. Co rolla hypogyna, infundibuliformis, limbo quinquepartito, plano. Stamina 5 , imo corollae tubo inserta, inclusa. Ovarium biloculare, Ioculis biovulatis. Styli duo, distineti; stigmata reniformia, carnosa, Capsula abortu unilocularis, monosperma, bractea florali, post anthesim dilatata, membranacea inclusa. Semen erectum. Embry onis curvati, mucilaginoso-albiminosi cotyl ed on es corrugatae, radisula infera. - Suffrutices Indiae orientalis, erecti; foliis alternis, ovatis $v$. lan. ceolatis, integris, racemis axillaribus plurifloris, pedicellis bractea decurrente, primum exigua, mox maxima instructis.

Neuropeltis Wallich in Roxburgh Flor, Ind, or. II. 43. Clooisy in Mem, soc, he n. Genev, P1, 491, t.2. f. 12.13.

8ร๖ร. Porana BURM. Calyx penta phyllus, foliolis demum auctis, scariosis. Corolla hypogyna, campanulata v. infundibuliformis, limbo quinquepartito, plano. Stamina 5 , imo curollae tubo inserta, inclusa. O culare, bi-quadriovulatum. St $\mathbf{l} \mathbf{l} 8$ indivisusv. semibifidus; stigmat a capitata, Capsula evalvis, unilocularis, abortu monosperma. Semen erectum. E mbryonis enrvati, mucilaginoso-albuminosi cotyledones corrugatae, radicula infera. - Herbae $v$, suffrutices volubiles, in $t$ er tropicos Asiae et Africae crescentes; foliis allernis, ovatis $v$, cordatis, floribus paniculatis.

Por an a Barm. Flor. Ind. st. Wallich in Roxburgh Flor, Ind. or. II. 39. Choisy in Mem. soc. h. n, Genev. VI. 487 .

a. DINETUS. CaIy cis pentaphylli foliola duo exteriora immutata, tria interiora post antliesiu aucta, Stylus simplex. - D in et us Sweet Hort. Lond, II, 289. exel, sp. (Roxburgh Plant. Coram, t. 235.)

b. EUPORANA. Calyeis pentaphylli foliola omnia post anthesim ateta. S tylus semibifidus. (Burm. Op. eit. t. 21. f. 1. Lam. t. 186. Palisot Flor. Owar, I. t. 49.)

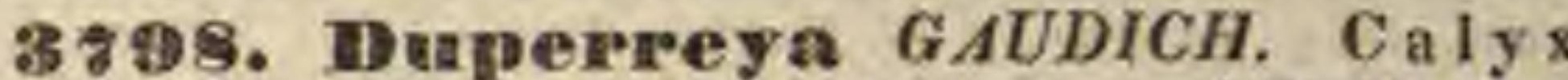
penfaphyllus, minute bibracteolatus, foliolis demum auctis, scariosis. Co roll a hypogyna, subcampanulata, limbo guinqueplicato. S $t$ a $m$ in a 5 , imo corollae tubo inserta, inclusa. Ov a rium uniloculare? .... Stylus simplex, exsertus; stig ma crassum, trigono-subeordiforme. Ca psu Ia unilocularis, monosperma Semen erectum. Embryon is curvati, mucilaginoso-albuminosi e otyl edones corragatae, $x$ adicula infera.

Fruliculus Novae-Hollandiae austro-occidentalis, erectus; foliis alternis, linearibus, sericeis, peduncul is axillaribus, solitariis, unifloris, subracemosis, floribus caeruleis.

D u perrey a Gaudichaud ad Freyc. 158, 4.63.

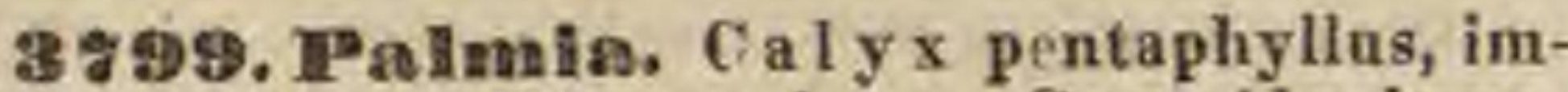
mutatus, minnte bibracteolatus. Corolla hypogyna, subeampanulata, limbo quinqueplicato. S $\mathrm{t}$ a$\mathrm{m}$ in a 5 , imo corollae tubo inserta, inelusa, $0 \mathrm{v}$ aria m unilocnlare, quadriovulatum. Stylas simplex; stigma bilobum, lobis capitatis v. ovatocomplanatis, Capsula uniloevalaris. Semina 4 v. abortu pauciora, erecta. E m b r y o n is curvati, mucilaginoso-albuminosi c ot y le d o n e s corrngatae, radicula infera. - Herbae Indiae arientalis, volubiles; folitis alternis, cortatis, integris $v$. sinuato-angulatis, pedunculis axillaribus, uni-multifloris.

Sh u terela Choisy in Mom, sac. h, n, Genev. DT, 485. t. 2. $f$, 11. non Wight et Arn. et S k inneria Choisy $O p$. cil. $487, t, 6$.

3800. Polymeria $R$. BR. C a l y x pentaphyllus, foliolis aequalibus $v$. duobus exteriorihus cordatis. Corolla hypogyna, infundibuliformis, limbo quinqueplicato. St a mina 5, imo corollae tubo inserta, inclusa. St y I 8 simplex; stigmata 4-6, acuta. Orarinm biloculare, loculis nniovulatis. Capsula abortn uniloenlaris, mono-disperma. Semina ereeta. Embryonis curvati, mueilaginoso-albuminosi cotyle dones corrugatae, ra dieu la infera. - Herbae Nova eHollandiae tropicae, diffusae v. repentes; succo aqueo, foliis alternis, oblongis $v$, cordatis, inlegris, pedunculis axillaribus, bibracteolatis.

Polymeria R. Browa Prodr. 488.

3801. Calystegia R. BR. Cal y x pentaphyllus, bracteis dababs foliaceis inclusus. C orolla hypogyna, campanulata, quinqueplicata. St a in a 5, imo corollae tubo inserta, inclusa. Ova ri um dissepimento ad apicem deliquescente incomplete biloculare, locnlis biovulatis, Stylus simplex; stigmata 2, obtusa, teretiav. globosa. Capsula unilocularis. Se mina 4 , erecta. Embryonis curvati, mucilaginoso-albaminosi e otyledones corrugatae, radienla infera. Herbae lactescentes, glabrae, volubiles $v$. prostratae, in regionibus extratropicis totius or $i$ is crescentes; foliis sagittatis $v$. reniformibus, pedunculis axillaribus, unifloris.

C al y s teg fa R. Browa Prodr. 683, Choisy in Mem. oc. h. n, Genev. VT. 485.

3802. Anniseîn CHOIS. C a l yx penta. phyllas, foliolis duobus exterioribus profundius insertis, in pedunculum subdecurrentibus, $C_{0}$ rolla hypogyna, campanulata, limbo plicatoquinquelobo. St a in a 5, imo corollae tubo inserta, inclusa. O a i um biloculare, loculis biovulatis. Stylus simplex; stig ma capitato-bilobum. Caps a I bilocularis. S emina 4 , erecta. Embryonis curvati, mueilaginoso-albnminosi cotyle dones corrugatae, radicula infera.

Herbae v. suffrutices, repentes aut diffusi, rarius volubiles, in Asia et America tropica crescentes; foliis alternis, oblongo-linearibus, basi integris v. sagittatis, pedunculis axillaribus, unifloris, bracteatis.

Anisei a Clioisy in Mem, soe. h, n. Genev, VI. 481. VIIT. 65. t. 4. Moricand Plant. Americ, t. 38. Convol. vull sp. Linn.

3S03. Contolvalias LINN. C al y x pentaphyllus. Corolla hypogyna, campanuiato-infundibuliformis, limho quinqueplicato. Sta min a 5, imo corollae tobo inserta, inclusa $v$, exserta, filamentis basi dilatatis. Ov a ri u m biloculare loculis biovulatis, septulo inter ovula collateralia nullo. Sty I u s simplex; stig mat a 2 , tereti-filiformia, complanato-ovata v, capitato-globosa, $\mathrm{C}$ a p8 u la bilocularis, bivatvis. Semina 4 , erecta. Embryonis curvati, mucilaginoso-albuminosi cotyled on es corrugatae, $r$ a di $c$ a $l$ a infera.

Herbae v. suffrutices, in temperatis calidis$q u$ e totius orbis obvii, volubiles $v$, rarius erecti; 
foliis alternis, saepius cordatis $v$. sagittatis, integris v. lobatis.

C o n olvulus Lina. gen, n. 214. excl. sp, C o n a I. v u lus et I pom a e a Jacq. Collect, III. 303. R. Brown Prodr. 482. 484. excl. 8p. - C o n volvalas, Jacquemont ia. I pom a e et $\mathbf{E} \times 0 \mathrm{~g} \circ \mathrm{nium}$ Choisy in Mem. soc, h. $n$. Genev. YI. 404.

a, convolvulus Choisy $O p$. cic. $V T$. 478. Stigmata lineari.cylindrica. Stamin a inclusa. (Sibthorp Flor. graec, t, 192. Cav, Ic. $t$. 48, Bot. Mag. t, 328 etc.)

b. JACQLEMoNT1A. Choisy Op, cit, VI, 476, VIIT, 6t, $t$. 3. S $\mathrm{tg}$ m a t a ovato complanata. S $\mathrm{tam}$ i a a inclusa. - Moricaud Plant, Americ. t. 27. 28. (Jacg. Ic. rar t. 316. Ruiz et Pavon Flor. Peruv. $t, 117, f$, a. Cavanill. Ic. t. 481, Bot. Mag, t. 2151. Bot. Reg. $t, 430$.

c. IPOMAEA Choisy $O p$. cit. $N I, 393$, et 444. Stigmat a capitato-globosa, $\mathrm{S} t \mathrm{am}$ in a inclusa. (Jaeq. Ic. rar. t. 317. Hort. Schönbr. t. 199. Jacq. f. Eclog. t. 89. Bot. Reg, t. 33. 86, 239. 279. 768, Wallich Plant. As. rar. t. 43. 155. 171. Wight in Hook, Bot. Miscell. Suppl. $t, 38$.)

d. EXOGONIUM thoisy Op. cit. VI. 443, VIIT, 49. $t .1$. Stigmata capitato-globosa. Stamina exserta. (Jacq. Amer, t, 19. Observ, t. 20, Cavauill. Io. t. 477.)

3804. Tepistemon BLUM. C a l y x pentaphyllus. Corolla hypogyna, tubulosa, tubo medio inflato, fance coarctata, limbo plicato-quinquelobo, patente. S ta mina 5 , imo corvllae tubo inserta, inclusa, filamentis basi in fornices super ovarinm conniventes dilatatis. O vari um biloculare, loculis biovulatis. Stylus simplex; stigm a capitato-bilobum. Cap $s$ u la bilocularis, bivalvis. Se mina 4 , erecta. Embryo.....-Herba indica, pilosa; caule volubili, foliis alternis, cordato-ovatis, integerrimis $v$. trilobis, cymis axillaribus densifloris, petiolo brevioribus.

Le pistemon Blume Bijdr. 722. Choisy in Mem. soc. h. n, Genev, VI. 443. 2. 2. f. 8. (abi ovarif bilocularis loculi perperam uníuvalati dienatur.) Convolvulus bi nectariferus Wall.

3805. Calonyetion CHOIS. Caly x pentaphyllas. Corolla hypogyna, subhypocraterimorpha, tubo elongato, limbo amplo, patente, quinqueplicato. S $\mathbf{t}$ amina 5 , imo corollae tubo inserta, exserta, filamentis basi dilatatis. 0 vari u m biloculare, loculis biovnlatis, septulo inter ovula collateralia incompleto pseudo-quadriloculare. St y I a s simplex; st igma capitato-bilobum. C a p$8 \mathrm{ula}$ incomplete quadrilocularis, quadrivalvis. Semina 4 , erecta. Embry on is curvati, mncilaginoso-albuminosi cotyledones corrugatae, radicula infera. - Herbae volubiles, inter tropicos Asiac et Americae obviae; foliis alternis, cordatis, pedunculis axillaribus, uni trifloris, fructiferis incrassatis, floribus maximis, speciosis.

Calonyetion Cholsy in Mem. soc, h. n. Genev. V1. 441. $t, 1, f, 4$. B o a a Nox Rafinesque. I p o m a e a bo a nox Linn. Bot. Mag. $t$.758. Convolvulus gran. diflor u s Jaeq. Hort. Vindob. III. $t, 69$.

3806. Duamoelit TOURNEF. C aly x pentaphyllus. Corolla hypogyna, subhypoeraterimorpha, limbo patente, plicato-quinquelobo. S t a min a 5, imo corollae tubo inserta, exserta, filamentis basi dilatatis. Ova ri u m quadriloculare, loculis uniovnlatis. Stylus simplex; 8 tigma capitato - bilobum. C a p 8 a 1 a quadrilocularis, quadrivalvis. Semina 4, erecta. Embryonis curvati, mueilaginoso-a buminosi coty led ones corrugatae, radicula infera. - Herbae volubiles, in America et Asia tropica crescentes; foliis alternis, cordatis, integris, lobatis $v$, pinnatifidis, pedunculis axillaribus, uni-multifloris, floribus rubris.
Q a moclit Tournef. inst. 39. Mönch Method. 453, Choisy in Mem. soo. h. n. Genev. VI. 433, t, 1. f. 1. C a I. b o Cavanill. Ic, $V$. $5 t, t$. 476. M a c ros te u a Persoon Encheir. I. 185. Exogoninm Moc. et Sesse msc, non Chois. M in a et Mo ren a Llav. et Lexarz. Nov, veget, 3 et 5. Couvolvull et I poma e a s p. Llan. et Auct. Bot. Mag, $t$. 40 .

380\%. Fatatas CHOIS. Calyx pentaphyllus. Coroll a hypogyna, campanulata, limbo patente, quinqueplieato. Sta $\mathrm{m}$ in a 5 , imo corollae tubo inserta, inclusa, flamentis basi vix latioribus. Ovarinm tri-quadriloculare, loculis uniovulatis. Stylus simplex; st $\mathrm{ig}$ ma capitato-bilobum. C a p s u la tri-quadrilocularis, tri-quadrivalvis. S e m ina $3_{-}$, erecta. Em b r y o $\mathbf{n}$ is curvati, mucilaginoso-albuminosi cotyled ones corrugatae, ra di cula infera - Herbae volubiles, inter tropicos totius orbis indigenae, in regione mediterran e a rarae, nonnullae ob radices tuberosas edules, in quibusdam insigniter catharcticas, in regionibus subtropicis cultae; foliis alternis, integris v. lobatis, pedunculis axiilaribus uni-multifloris.

Bat atas Choisy in Mem, soc. h, n. Genev, VI, 435. t. 1. f. 2, VIII. 45. Convolvuli et I pom a e a e s p. Auct. Operculina Silva do Mauso. (Jacq. Ic. rar. t. 319. Hort. Schönbr. t, 200. Cyrill. Plant, rar, I, t. S. Desfont. in Annal. Mrus. IT. t, 40. 41. Cavanill. Ic. t. 323. Bot. Reg. t. 75. 348. 621, Bot, Mag. t. 1790. Palisot. Flor, Owar. t. 105. Wight in Hook. Bot. Miscell. Suppl, t, 7. Nees Plant. offic. Suppt. III, t. 13.)

3803. Pharbitis CHOIS. C a l y $x$ pentaphyllus. Corolla hypogyna, campanulata v, infundibuliformis, limbo patente, quinqueplicato. St a mina 5 , corollae tubo inserta, inclusa, filamentis basidilatatis. 0 va ri u m tri-quadriloculare, loculis biovalatis. Stylus simplex; 8 tigma capitato-granulatum. C a p \& 4 l a tri-quadrilocularis, tri-quadrivalvis. S e mina $6-8$, erecta. Emb r y o n is curvati, mueilaginoso-albuminosi c otyle dones corrugatae, radic u la infera. - Her. bae volubiles, inter tropicos totius orbis in digenae; foliis cordatis, integris $v$. lobatis, pedunculis axillaribus, uni-multifloris, corollis saepissime caeruleis, albo purpureoque variegatis.

Pharbitis Choisy in Mem. soo. h, n. Genev, VI. 438, t. 1. f. 3. Bot. Reg. $t$. 198s. C onvolvuloides Mönch Method. 452, Convolvuli et I p m ea e sp. Linn. et Auct. Jaeq. Ic. rar, t, 36. Ruiz et Pavon Flor. Peruv, $t, 121$. f. a. Bot. Reg. t. 85. 276, Bot. Mag. t, 113. 1105. 1688.

3809. Hivea CHOIS. Caly x pentaphyllus. Coroll a hypogyna, infundibuliformis v. tubulosa, limbo quinqueplicato. Sta $\mathbf{m}$ in a 5 , corollae tubo inserta, inclusa. O va ri un quadriloeulare, loculis uniovulatis. St y l a 8 simplex; $s \mathrm{ti} g \mathrm{~m}$ a capitatum $v$ lamelliforme, bilobum. B a cc a quatrilocularis. Semin a 4 v, abortu panciora Em bryonis curvati, mueilaginoso-albuminosi cotyledones corrugatae, radicula infera. - Suffrutices Asiae tropicae, volubiles; foliis alternis, latis, cordatis, subtus pubescentibus $v$. tomentosis, floribus axillaribus $v$. terminalibus magnis, speciosis.

Rive a Choisy in Mem, soc. h, n. Genev, VI. tor. $t, 3$. Let ts omiaesp. Roxb. Courolvali et Ipomaeae sp. Auet.

3810. Argyreia LOUR. C a ly x pentaphyllus. Corolla hypogyna, eampanulata, limbo quinqueplicato v. quinqnefido $\mathrm{S} t$ a $\mathrm{m}$ i $\mathrm{n}$ a 5 , imo corollae tubo inserta, inclusa v. exserta. Ovarium biloculare, loculis biovulatis. Stylus 
simplex; stig ma capitato-bilobum. B a c ca biloeularis. Semina 4 v. abortu pauciora. Ein b r y on is eurvati, mucilaginoso-albuminosi cotyledon es corrugatae, radicula infera - Suffrutices Asiae tropicae, volubiles; foliis alternis, saepissime cordatis, amplis, integris, tomentosis v. sericeo-candicantibus, pedunculis axillaribus et terminalibus, uni-multifloris, floribus magnis, speciosis

A r g y rel a Loureiro Flor, cochinch, $I, 166$, Wallich Plant. As. rar. 2 , 76. Choisy in Mem. soc, h, n. Genev. VI. 411, L e $t$ s o m i Roxburgh Flor. Ind. edit. Wallioh IT. 95. exel. sp. Convolvuli et I pomate a s p. Auct.

a. SAMUDRA. Corolla e limbus plicatus subinteger. S t a m i a a inclusa.

Sam udra Stog a m Rheede Malab. Xr. 25t, $t, 6 t$. Convolvuli sp. Linn. Smith Ic, piet. $t$. 17. I p amate a p. Galiner $t$. 178. $f$. 1. Bot. Mag. 2170. 2446. 2688. (Bot. Reg, $t, 661$. Hook. Bot, Mag. Comp. t, 3.)

b. EUARGYRELA. Coralla e limbus quinquefidus. Stamin a exserta. (Wallich plant, As, rar, t, 76.)

3811. IBlinkworthio CHOIS, C a I y x pentaphyllus, calyculato tribracteatus. Co rolla hypogyna, cylindrico-urceolata, obsolete quinquedentata. Stam in a 5 , imo corollae tubo ingerta, inclusa, Ovarium biloculare, loculis dispermis. Stylus simplex; stigma capitatobilobum. B a c e a monosperma ..... - Suffrutex indicus, erectus; caule tereti, villoso, folits confertim alternis, linearibus, obtusis, mucronulatis, brevissime pelialatis, supra glabris, subtus subsericeis, pedunculis axillaribus, brevibus, unifloris.

Blink worthia Choisy in Mem, soc. h. n. Genev, VI. 430. 8.4 .

3818. II Iunabertia COMMERS. Calyx pentaphyllns. Coroll a hypogyna, urceolato-ventricesa, limbo subintegerrimo, quinqueplicato. St a mina 5, imo corollae tubo inserta, longe exserta. Ovarium biloculare, loculis biovulatis. Stylus simplex; stigma cavo-complanatum. B a ce a lignosa, bilocularis. Sem in a 4. ... Arbor madagas cariens is; foliis ramulorum confertim alternis, obovato-lanceolatis, emarginatis, pedunculis axillaribus, solitariis, unifloris, medio bibracteolatis.

H a mbertia Commers. mesc. ex Juss. gen. 133. Lam. t. 103. Choisy in Mem, soc. h. n. Genev, VR. 431. Th th u i$\mathrm{n}$ i a Smith Ie, inedit. I. 7, t. 7. S $\mathrm{mith}$ a Gmelin Syst. 389. Endra ch i u m Juss, gen, 133, Endrach Flacourt Madagasc, $137 . f, 100$.

38 is. Mloorerofia CHOIS. C a l y x pentaphyllus. Co rolla hypogyna, campanulata, limbo quinqueplicato. S $t$ a $m$ in a 5 , imo corollae tubo inserta, inclusa. Ovariu m.... St y lus simplex; stigma ..... B a ce a abortu unilocularis, raro bilocularis, monosperma. Semen .... - Suffrutices pinangiani, volubiles; folitis alternis, petiolatis, integris, subtus sericeis, pedunculis axillaribus, multifloris.

Mo or crofti a Choisy in Mem. soc. h, n. Genev, $V T$. 431. t. 8 .

38 14. VIaripa $A U B L . C$ a l y x pentaphyllas. Coroll a hypogyna, infundibuliformis, limbo plicato-quinquelobo. Stamina 5 , corollae tubo inserta, inclusa. O vari um biloculare, loenlis biovulatis Stylus simplex; stigma peltatum, decemsulenm. Fruetns... Frutex guianensis, sarmentosus; foliis allernis, petiolatis, ovatis, aculis, integerrimis, floribus terminalibus, paniculatis.

Ma rip a Aablet Guian, I, 230, 1. 91.

\section{GENERA CONVOLVULACEIS AFFINIA.}

\section{- erycibeae.}

3815. Wryeibe ROXB. Calyx quinquefidus. Corolla hypogyna, infundibaliformis, limbi quinquefidi lobis bipartitis. Stam in a 5, corollae tubo inserta, ejusdem lobis alterna, inclusa; filamenta brevissima, antherae pyramidatae, acutae. Ovari um uniloculare. OvuI a $3-4$, e basi erecta $\mathrm{Stigm}$ a sessile, radiatoquinquelobum. B a c c a monosperma. S e m en erectum. E m br y onis carnosi, mucilaginoso-albuminosi cotyledones contortuplicatae, $r$ adicula infera. - Frutices indic $i$, scandentes; foliis alternis, coriaceis, integerrimis, floribus axillaribus terminalibusve paniculatis.

Erycibe Roxburgh Plant, Corom, II. t. 154. Flor. Ind edit. Wall. IT. 284. Choisy in Nouv. Annal. sc, nat, $r$. 292. Erim atalia Rum. et Schult, Syst, P. p. XXYII, E rima-tali Rlieede Malab. VII. 73, t. 39.

\section{** CUSCUTEAE.}

3818. Cuseuta TOURNEF. Calyx quinquefidus, raro quadrifidus. C oroll a hypogyna, globoso-urceolata, intus nuda v. squamulis staminibus subjectis instructa, limbo quadri-quinquefido, marcescens Sta min a 4 -5, medio corollae tabo inserta, inclusa. Ovarinm biloculare. Ovula in loculis gemina, collateralia, e basi erecta. $\mathrm{Sty}$ I u s simplex v. bifidus; stigmata acuta v. capitata. Capsula bilocularis, circumscissa. S em in a in loculis gemina, collateralia, erecta. $\mathbf{E}$ mb r yo filiformis, indivisus, circa albumen carnosum spiraliter convolutus, extremitate radienlari incrassata, infera. - Herbae cosmopolitae, aphyllae, parasiticae, volubiles; floribus aggregatis, subcapitatis $v$. spicatis, unibracteatis.

Cuscuta Touraefort Inst. 492. Lian. gen, n. 170. Gärtuer I, 297. 1. 69. R. Browa Prodr. 491. Ruiz et Pavou Flor. Pertuv. $t$. 105. Hoaker Exot. Flor. $t .150$. Roxb. Plant, Corom. t. 104. Relchenb. Iconogr. $t, 495-300$. C a ssuta v. Cas sytha Gray Arrangm, Ir.345. Gramulca Loureiro Flor, cochingh. 17t. - De germinatione et erescen. di modo post Lius. sp. 180. Adanson Fam. II. 29i. Gouan Monsp. 16, et Mirbel in Annal. Afus. XIIT, 65. efr. impriwis Unger, in Annal, Miener Mus. II. 31.

\section{*** NOLANACEAE.}

381\%. NoIama LINN. Caly x campanulatus, quinquepartitus, persistens. Co rolla hypogyna, infundibuliformis, limbo plicato, quinquedecemlobo. Stam in a 5 , corollae tubo inserta, exserta. Ovaria plura, disco hypogyno carnoso inserta, libera, uni-sexlocularia, loculis nniovulatis. Stylus basilaris, simplex; stigma capitatum. Drupae distinctae, carnosae, putamine osseo, nni-sexloevlari. S e m in a in loenlis solitaria, reniformia, lenticulari-compressa. E m bry 0 filiformis, annularis, albumen carnosum cingens; $c 0$ ty le donibus semiteretibus, incumbentibus, $r$ ad i c u la infera - Herbaev. suffrutices $A$ mericae meridionalis, prostrati, subsuccosi, Convolvuli facie; foliis alternis, geminatis, integris, pedunculis extraaxillaribus.

Nol a n a Linn. gen, n, 193. Gärtner $n$. 262, $t, 132$. Rniz et Pavon Flor. Peruv, t, 112, 113, Bot. Reg. t, 565 . Bot. Mag. t. 731. 2604. W a l ker i a Ehret in Philosoph. Transaet. LIII, $t, 10 . \mathrm{Z}$ w ingera Hofer in Act. Helvet, $X, t, 1$. Teg a nium Sehmidel Analys. plant. 67, $t, 18$. Neudorffi a Arlaus. Fam, II. 325. 


\section{Ordo CXIE. Polemeniacene.}

POLRMONLA Jussieu gen. 136. coll. Annal. Mus. $V$. 250. $\mathrm{X} \nu$. 34t. POLRMONIACEAE Venten. Tabl, $I T .398$. Don in Edinb. Philosoph. Journ. VIT. 286. Bartling Ord. nat. 188, Lindley Introduct. edit. II. p. 232, COBAEACEAE Don in Edinb, philosoph, Journ, X.111.

Herbae v. rarius suffrutices v, Frutices, succo aqueo. Folia alterna $v$. inferiora opposita, sessilia v. petiolata, simplicia, indivisa $\mathbf{v}$. pinnatisecta $\mathbf{v}$. bi - tripinnatifida, in aliis palmatiloba. $S t$ i p u 1 a e nullae.

Flores hermaphroditi, regulares v. vix subirregulares, rarius solitarii, plerumque paniculati v. corymbosi, saepe subcapitati, bracteis involucrati.

Canyx liber, gamophyllus, e foliolis quinque, rarius herbaceis, plerumque nervo viridi prominente, marginibus membranaceis, inter se plus minus connatis compositus, quinquedivisus, saepe prismaticus, interdum foliorum marginibus extrorsum induplicatim connatis quinquealatus.

Corousa hypogyna, infundibuliformi-tubulosa v. subhypocraterimorpha, limbo quinquepartito, lobis aequalibus v, paullo inaequalibus, planis, patentibus, aestivatione imbricatis.

Stauina 5, imo, mediov. summo corollae tubo inserta, ejusque lobis alterna, inclusa v. exserta. Fil a ment a aequilonga $v$. inaequalia, recta v. interdum adscendentia. Antherae biloculares, incumbentes, oblongae, subsagittatae v. ovatae, loculis parallelis, longitudinaliter dehiscentibus.

Diseus hypogynus, carnosus, plus minus manifestus, ovarii basim cingens.

Ova ri um ovatum, v. apice subtrilobum, triloculare, carpidiis tribus, medio septo angusto, columnae placentiferae trialatae angulis commisso, et marginibus valvatim connatis triJoculare, rarissime carpidiis quinque et columna quinquealata quinqueloculare.

Ovnla in locnlis nunc solitaria, ex anguli rentralis basi erecta, anatropa, nune plura biseriata, adscendentim amphitropa. Stylus terminalis, simplex. Sti g ma bifidum v. rarissime quinquefidum, laciniis acutis, patentibus v, revolutis.

Capsula membranacea v. sublignosa, rarius subearnosa, tri-v. rarissime quinquelocularis, interdum abortu uni bilocularis, loculicido tri-quinquevalvis, valvis medio septo angusto, interdum fere obsoleto, a columnae placentiferae angulis plus minus complete soIuto instructis, eandem nudantibus, $v$, basi interdum cum ea pertinacins cohaerentibus, indivisis v. demum septicido-bifidis.

Semisa nunc in loculis solitaria, erecta, nune plura, biseriata, adscendentia, plano-convexa, angulata v. compressa; t es ta spongiosa, humectata mucilaginosa, in nonnullis vasis spiralibus scatens, in aliis undiyue v. superne in alam membranaceam producta, umbilico basilari v. ventrali. A I b u m e n carnosum, plus minus carnosum.

Emввуо rectus, axilis, albuminis longitudine. Cotyledones foliaceae. Radicula teretiuscula, brevis v. cotyledonibus longior, infera $\mathbf{v}$. in paucis vaga.

Polemoniaceae Convolvulaceis proximae, sed embryonis structura et habitu facillime distinguendae, in America extratropica occidentali, tam boreali quam australi maximo numero generantur, in Peruvia et Mexico multo rariores, paucissimae in veteris orbis temperatis et frigidis vivunt.

Co b a e a genuina nostri ordinis stirps, habitu et ovario, saltim in planta hortensi interdum pentamero, subanomala.

Cyananthus genus non satis notum, ovario pentamero, et fortassis corolla subperigyna differt.

3818. Caldagia WILLD, Calyx prismatico-tululosus, quinquedentatus, fructifer scariosus, auctus. Coroll a hypogyna, subinfundibuliformis, limbi quinquepartiti lobis cuneatis, emarginatis, subbilabiatim patentibus. Sta min a 5, medio corollae tubo inserta, exserta, deelinata, aequalia. Ovarium triloculare. Ovula in loculis solitaria, ex anguli centralis basi adscendentia, anatropa. Stylus terminalis, simplex; stig$\mathrm{m}$ a trifidum. Ca p s 1 a trilocularis, loculicido-triralvis, valvis columnam septiferam nudantibus. S emin a in loculis solitaria, e basi erecta, plano convexa; t es t a spongioso membranacea, faeie interiore rhaphe percursa. E m bryo in axi albuminis carnosi orthotropus; cotyledonibus subfoliaceis, ra dicula infera. - Herba mexicana, annua, ramosissima, glanduloso pilosa; foliis alternis, crenato-serratis, pedunculis axillaribus, geminis, unifloris, ebracteatis, corollis violaceo-caeruleis.

Caidasia Willdenow Hort, berolin, $r, 71, \ell, 71$, Kunth in Hrmb. ot Bonpl. Nov. gen, et sp. III, 166. Don in Edinb philosoph. Journ, VII, 288. B on p I a n i a Cavavill. Anal. cienc, nat, II. 131, t, 10. Ic. DI. 21. t. 339.

3815. Plalox LINN. Caly $x$ campanulato-prismaticus, quinquefidus. Co roll a hypogyna, hypocraterimorpha, tubo Iongo, limbo quinquepartito. Stamina 5 , medio corollae tubo inserta, inelusa, inaequilonga. O va ri n m ovatum, triloculare. O vula in loculis solitaria, ex anguli centralis basi adscendentia, anatropa. Stylus terminalis, simplex; stigma trifidum, Capsula ovata, triloenlaris, v, abortu uni - bilocularis, loenlieido-trivalvis, valvis columnam septiferam nudantibus. S emin a in loculis solitaria, e basi erecta plano-convexa; testa spongioso-membranacea 
facie interiore rhaphe percursa. L $\mathbf{m}$ bry o in axi albuminis orthotropus; cotyle donibus subfoliaceis, radicula teretinscula, infera. - Herbae perennes, interdum suffrutescentes, erectae $v$. prostratae, in America boreali obviae, in $A$ sia boreali rarae; foliis inferioribus oppositis, superioribus alternis, sessilibus, integerrimis, floribus terminalibus, paniculatis v. corymbosis, lilacinis $v$. roseis, rarius rubris, caeruleis $v$. albis.

$\mathrm{Phl}$ × Lian. gen, $n, 214$. Schkuhr $t$. 38. Gârtner $I$. 299. t. 61. Jacq. Hort. Vindab. II. t. 127. Smith Exot. Bot, II. t. 87. Cavanill. Ic, t. 527. Don in Edinb. philosoph. Journ, VII. 287. Bot. Mag. t. 163. 411, 415. 563. 1307. 1308 . 1344. Bot. Reg. $t$. 1351, 1949. - ? D u pratia Rafinesque Flon, Ludov, 54 .

3820. Collomia NUTT. Cal y x campanulatus, quinquefidus v. subquinquepartitus. C or oll a hypogyna, hypocraterimorpha, tubo longo, limbo quinquepartito. S t a min a 5 , medio corollae tubo inserta, inclusa, inaequilonga. Ova r iu m obcordato-trilobum, triloculare. $O \mathrm{vula}$ in loculis solitaria, angulo centrali inserta, anatropa. Stylus terminalis, simplex; stigma trifidum. Capsu la obcordato-triloba, trilocularis, loculicidotrivalvis, valvis columnam septiferam nndantibus. Sem in a in loculis solitaria, testa spongioso-membranacea, vasis spiralibus scatente, nmbilico ventrali lineari. Embryo in axi albuminis carnosi orthotropus; cotyledonibus foliaceis, radicul a teretiuscula, infera. - Herbae in America occidentali, boreali et australi indigenae; foliis alternis, rariusve inferioribus oppositis, integris, inciso-dentatis $v$. interdum pinnatifidis, floribus terminalibus, dense capitatis, bracteis late ovatis, integerrimis suffultis.

Collo mia Nuttall gen, 1 . 126, Benth, in Bot, Reg. $n, 1622$. Bot. Mag. $t, 2893$ 2994. 3469. Bot, Reg. $t, 1166$. 1174. 1622. Gill ia s p. Bot. Mag, $t$, 2924. Phlox $l i$ nea$r$ is et Ph, pinn at a Casanill. Ic. $t .582$.

382 1. Gilia RUIZ et PAV. Ca I y x tubulosus, quinquefidus. Co ro I l a hypogyna, infundibuliformis, tubo brevi v. longo, limbo quinquepartito. St amin a 5, corollae tubo supra medium v. prope fancem inserta, inclusa v. sulexserta. Ovar in m ovatum, triloculare. Oval a in loculornm angulo centrali biseriatim plura, amphitropa. Stylus terminalis, simplex; stig ma trifidum. Ca p $8 \mathrm{n} I \mathrm{a}$ ovata, trilocularis, loculicido-trivalvis, valvis columnam septiferam nudantibns. S emin a in loculis pauca, angulata, testa spongiosa, undique in alam angustissimam producta, umbilico ventrali. E m b r y o in axi albuminis carnosi rectus; cotyled onibus subfoliaceis, radicula teretinscula, vaga. - Herbae in America occidentali, boreali et australi indigenae; foliis alternis $v$. infimis oppositis, integerrimis, pinnatisectis v. palmatilobis, flaribus solitariis $v$. aggregatis, involucrato bracteatis.

Gili a Rulz et Pavau Flor. Peruv, Ir, 17, Don in Edinb. philosoph. Journ. VII. 287. I p o no p s is L. C. Riehard in Michaus Flor. Bor. Amer. I. 141. Navarretia Ruiz et Payon Flor, Peruv. IT. 8. H u g eli a, Linanth us, Leptosiphou, Fenzlia, Gilia et Aegoehloa Bentham in Bot. Reg. n. 162.

a. COLlomoldes. C a I y c is semiquinquefidi laeiniae subinaequales, lineares, subsphosae. Cor o 11 a e tubus breviter exsertus, limbi lacinlae oblongae, integerrimae. A ntberae inclusae, subsagittafae. Herbae plus minus albo-lanatae; folia alterna, linearia, integra $v$. pinnatifida, flores dense corymboso-capitati, bracteis involuti.

Hugelia Benth, t, c. Hooker Ic, t, 200, non Reichenb. nec R. BR. b. LINANTHUS. Cal yels membranacel, sewiquinquefidi laciniae subulatae, recurvae. Corolla e tubus brevis, limbi laciuiae abovatae, apice erenulatae. Antbera inclusae, lineares. - Nerba glaberrima; folii, oppositis, palmatisectis, floribus in dichotomits solitarits, subsessilibus, ebracteatis, versus apices ramarum plurimis approximatis.

Li in an thus Benth. $l$. $c$.

c. LEPTOSIPHON. C aly cis semiquinquefidi sinus memtranacei, laciniae lineari-subulatae. Corollas tubus longe exsertus, limbi laciuiae ovales, integerrimae. Anther a e inclusae, oblongae, basi sagittatae. - Herbao apice pubescentes; folitis oppositis, palmatisectis, flori. bus corymboso-capitatis, dense imbricato-bracteatis.

L e p to $s$ ip ho n Benth. $t$, c. Bot. Mag. $t, 3491$. 3578. Bot. Reg. t. 1710, 1723.

d. DIANTHOIDES. Calye is profunde quinquefidi sinus membranacei, lacisiae lineares. Co rolla o tubus bre. vls, limbi laciniae obovatae, crenatae. A n ther a e sub. exsertae, ovatae, saglttatae. - Herba pusilla, sub. simplex; folits oppositis, linearibus, integerrimis, floribus $t_{-3}$, pedunculatis.

Feuzll a Beath, $t$, c. Hooker $1 c, t, 199$, non Eadt. (Endl. Atakt, t. 29.)

e. DACTYLOPHYLLUM. $\mathrm{C}$ a 1 y $\mathrm{x}$ quinquefidus, margine sinubusque membranacels. C orollae tabus inclusus, limbi laciniae ovatae, integerrimae. A n the rae inclusae, ovatae, - Herbae; foliis inferioribus oppositis, omnibus palmatisectis, floribus solitarils, longe peduneulatis.

Dacty I ophy $1 /$ u m, Giliae sect. Beath. $l$. c. Findl. Atakt. t. 28.)

f. IPOMOPSIS, Caly $\mathrm{x}$ quinquefidus, margine sinubusque membranaceis. Co roll a e tubus elongatus, limbi laciniae ovatae, integerrímae. A n the ra e inclusae, ovatae. - Herbae; foliis alternis, pinnatisectis v. pinnatifidis, floribus solitarits $v$. subglomeratis

Ipomopsis L. C. Richard l. o. Smith Exot. Bot. I. t. 13. Bot. Reg. $t$. 128\%. I po m e ri a Nattall gen, I. 12/. B rick ellia Rafinesque in N. York Medic, Heposit, II. Hex. $Y$. 353. Gilia e sect. Ipomopsis Benth, $l$. $e$. (Bot, Reg. t, 1619.)

g. EUGILIA. Caly x quinquefidus, margine sinubusque nembranaceis. Corolla e tubus subinelusus, limbi Jaciniae ovatae, integerrimae. - Herbae; folits alternis, pinnatisectis $v$. pinnatifidis, foribus subsolitariis $v$. saepius glomeratis.

Eug filia, Gillae sect. Benth. l. e. (Ruiz et Pav. Flor. Peruv.t. 123. Smith Exot. Bot, I. t. 14. Bot, Mag, t, 2608. 2883. 2764. Bot. Reg. $t$. 1170, 1689, 1702.)

b. NAVARRETIA. Cal y e is basi membrancei, quinquefidi laciniae inaequales, rigidae, f́tegrae $v$. multifidae, spinosae. C or oll a e fubns subexsertus, limbt laciniae oblongae, integrae. A n thera e inclusae v, exsertae, ovatae. - Herbao plerumque glatinosae, foetidae: folits pinnatisectis, segmentis incisis, acutissimis, floribus dense capitatis, bracteis incisis, multifidis, spinosis involucratis.

N a varretia Raiz et Pavon Flor, Peruv. II, 8. A e go ehlo a Benth. I. e. (Bot. Mag. $t$. 2977. DC. in. Mem, soc. $h, n$. Genev, $Y I, t, 5$, )

3822. Polemomitam TOURNEF. Calyx urceolatus, quinquefidns. Coroll a hypogyna, rotato-subeampanulata, quinquefida. S $t$ a m in a 5 , corollae tubo inserta, exserta, subaequalia, adscendentia; fil ament is basi dilatatis, antheris incumbentibus. Ovarinm triloculare. Ovula in loculorum angulo centrali biseriata, anatropa, Stylus terminalis, simplex; stigma trifidum. Capsula trilocularis, apice locnlicidotrivalvis, valvis medio septiferis. Semina plurima, angulata, testa spongioso-membranaeea, umbilico ventrati. E mb r y o in axi albuminis carnosi rectus; cotyledonibus foliaceis, radicula teretiuscula, infera. - Herbae in Europa et Asia media, in America boreali et in Me- 
$x$ ic o indigenae; foliis alternis, pinnatisectis $v$. bipinnatisectis, floribus lerminalibus, corymbosis, ebracteatis, caeruleis v. albis.

Polem o $\mathrm{n} / \mathrm{um}$ Tournef, inst. 61. Lian. gen, $n$, 217. Schkulır t. 38. Gärtuer $I$. 299. $t$. 69. Dou in Edinb. Philosoph. Journ. VII. 287. Bot. Mag. $t$, 2989, 2800, Bot. Reg. t. 1303. 1304. Ledebour Ic, $t .20$.

3823. Hoitzia JUSS. Caly $\mathrm{x}$ tubulosoprismaticus, quinquefidus Corolla hypogyna, infundibuliformis, limbo quinquepartito, subaequali. Stamina 5 , medio corollae tubo inserta, exserta, subaequalia. Ova ri $\mathbf{m}$ triloculare. Ovula in loculorum angulo centrali pauca, amphitropa. St ylus terninalis, simplex; stigma trifidum. Cap s u la membranacea, trilocularis, apice lounlicido-trivalvis, valvis medio septiferis. Se$m$ in a intra loculos pauca, compressa, testa spongioso - membranacea, angustissime alata, umbilico prope basim ventrali. E $\mathbf{m b} \mathbf{r} \mathbf{y}$ in axi albuminis parci, dense carnosi rectus; cotyledonibus subfeliaceis, radicula teretiuscula, infera.

Suffrutices mexicani, rigidi, ramosi; ramis teretibus, pubescentibus $v$. viliosis, foliis alternis, brevissime petiolatis, ovatis $v$. lanceolatis, mucronatis, argute serralis, hirsutis, floribus axillaribus solitariis $v$. geminis, pedicellatis, calycibus bracteis quinque lanceolatis, mucronatis, serrato-aculeatis munitis, corollis magkis, speciosis, coccineis v. violaceis.

Hoitzi a Jussien gen. 136. Cavanill. IC. IV. 44. t.36E_367. Kunth in Humb, et Bonpl. Nov. Gen, et sp. III. 162. Don in Edinb. philosoph. Journ, TII. 288. L o e sel i a Linn. Gen, $n, 167$, Gärtuer $r, 295, t, 62, \mathrm{R}$ o y e n a Houston mse.

3824. Cuntua JUSS. C a lyx tubulosus, quinquefidas. Corolla hypogyna, infundibuliformis, tubo longo, recto v. subincurro, limbo quinquepartito, aequali. Stamina 5 , corollae tubo prope basim inserta, exserta, aequalia, Ov a r i $\mathbf{m}$ trileculare. Ovula in loculorum angulo centrali plura, adscendentim amphitropa. Stylus terminalis, simplex; stig ma trifidum. Capsa a lignosa, trilocularis, loculicido-trivalvis, valvis medio septiferis. Semina in loculis pauca, adscendentia, compressa, testa spongioso-membranacea, apice in alam producta, umbilico prope basim ventrali. Embryo in axi albuminis carnosi rectus; cotyledonibus subfoliaceis, radicula tere$t i$, infera. - Frutices peruviani, erecti, ramosi; foliis alternis, saepius fasciculatis, petiolatis, ellipticis, acuminatis v. cuneato-oblongis, integerrimis $v$. serratis, rariusve sinuato-pinnatifidis, floribus terminalibus, subsolitariis $v$, saepius corymbosis, erectis v. nutantibus, corollis magnis, speciosis, albis, flavis $v$. purpureis.

C an tu a Jussieu gen, 136. Annal. Mus. III, 117, $t, 7$. 8. exel. C. ligustrifolia. Cavanill. Ic. $t$. 363, 36t, Kunth in Humb. ot Bonpl. Nov. gen, et sp. HI. 161. Don in Edinb. philosoph. Journ, VIT. 289. Periph ras mos Ruiz et $\mathrm{Pa}$ von Flor, Peruy. 11. 17. t, 13t, et 133, exel. P. foetido.

3825. Cobrea $C A V$. C aly x foliacens, campanulatus, quinquangulatus, ad sutaras quinquealatus. Corolla hypogyna, campanulata, limbi quinquelobi lobis late rotundatis, aequalibus. Stamina 5, imo corollae tubo inserta, exserta, aequalia; fil a m enta declinata, demum spiratim torta, ant herae oblongae, incumbentes. Dis. e us hypogynus carnosus, quinquangularis, quinquefoveolat us. Ovarin $m$ tri-v, rarius quinquelo. culare. $\mathrm{O} v \mathrm{u} \mathrm{I}$ a in loculoram angulo centrali plu- rima, biseriata, amphitropa. St y lus terminalis, simplex; stigma tri-quinquefidam. Cap s n la pyriformis, subcarnosa, tri-quinqueloeularis, loculicido tri-quinquevalvis, valvis columnam centralem placentiferam, tri-pentagonam nudantibus. Semina in loculis pauca, biseriata, imbrieatim adscendentia, suborbiculata, compressa, testa spongiosa, undique in alam membranaceam angustam producta, umbilico prope basim ventrali, lineari. Embryo intra albumen pareum, carnosum rectus; cotyledonibus late cordatis, obtusis, planis, radicula brevissima, infera. - Frutex m exicanus, scandens; foliis allernis, sessilibus, paripinnatis, apice in cirrhum desinentibus, pedunculis axillaribus unifloris, medio bibracteolatis, floribus magnis, speciosis.

Cobae a Cavanilles $I c, I, 11, t, 16,17, V, 69, t, 500$, Andrews Bot, Reposit, $t$. 342. Kunth in Humb. et Bonpl, Nov, gen, et sp. IIT. 151. Don in Edinb, philosoph. Journ. VII. 111.

3826. Cyamanthus $W A L L$. Caly x tubuloso-campanulatus, semiquinquefidus. Co r o I I a perigyna (?), subinfundibnliformis, tubo amplo, limbo quinquefido. Sta in in a 5 , imo corollae tubo inserta, ejusdem lobis alterna, inclusa; filamenta subulata, aequalia, libera, anth erae ovatae, conniventes v, connatae. Ovari u m quinqueloculare. Ovula in loculorum angulo centrali plurima .... Stylus terminalis, simplex; stigm a quinquefidum. Ca p s u la oblongo-conica, quinquelocularis, loculicido-quinquevalvis. S e min a plurima, oblongo-linearia ....- Herbae nepalenses, annuae, parum ramosae, procumbentes $v$, adscendentes; folits alternis, ovato-oblongis, integerrimis v. serrulatis, $v$. cuneatis, inciso-lobatis, floribus paucis, solitariis, saepius terminalibus, calycibus nigro-villosis, corollis speciosis, caeruleis.

Cy a $\mathrm{a} n$th us Wallich Catalog, n, 1472.1473. Bentham in Royle Himalay. 304. $t$, 69.

\section{Ordo CXIVI. Hydrophylleae.}

HYDROPHYLLEAE R. Brown Prodr. 292. Bot. Heg. 2. 242. Append. to Erankl. Narrat. 764. Bartling Ord, nat. 195. Bentham in Linn, Transact, XVIT. 267. ss.

Herbar americanae, succo aqueo, caule ramisque angulatis. Foli a alterna $\nabla$. infima opposita, palmati- v. pinnatisecta v. pinnatifida, rarius integra. Stipulae nullae.

Fuores hermaphroditi, regulares, in racemos v. spicas unilaterales, scorpioideas, simplices $v$. dichotomas dispositi, rarius in pedunculis axillaribus solitarii.

CaLxx gamophyllus, liber, profunde quinquefidus, persistens, laciniis per aestivationem imbricatis, sinubus saepius reflexo appendiculatis, fructifer interdum auctus.

Corolta annulo hypogyno, ovarii basim cingenti extus inserta, gamopetala, decidua v. rarius persistens, campanulata, subrotata v. rarissime infundibuliformis, tubo intus nudo $v$. saepissime squamulis ligularibus, staminibus interjectis, integris $v$. bifidis aucto, limbo breviter quinquelobo, lobis integris v. emarginatis, per aestivationem imbricatis. 
Stamra quinque, imo corollae tubo inserta, ejusdem lobis alterma, inclusa v. exser ta. Fil a menta filiformia, libera, aequalia, saepe barbata, aestivatione inflexa. An the $r$ a e introrsae, biloculares, oblongae v. liueares, medio dorso affixae, versatiles; loculi oppositi, paralleli, basi discreti, juxta totam longitudinem dehiscentes.

Ovarium liberum, e carpidiis duobus valvatim connatis, placentis in semisepto medio carpellorum dorso adnato, angnste linearibus uniloculare; nune iisdem maximis, carnosis, linea dorsali angusta adnatis, caeterum liberis, versus axim porrectis, et ibi contiguis pseudobiloculare. $0 \vee \mathrm{vul}$ a nunc in placentis linearibus utrinque solitaria, v. ad marginem exteriorem plurima $\mathbf{v}$, subdefinita; nunc in interioribus placentarum late lamelliformium faciebus prope marginem gemina, diagonaliter opposita, iisdem faciei contiguae alterna, v. subdefinite plura, amphitropa, micropyle in plerisque vaga, in aliis supera. Stylus terminalis, elongatus, apice bifidus, crure singulo stigmate papilloso, subcapitato terminato.

Capsula globosa v. compressiuscula, membranacea $\mathbf{v}$. rarius subbaccata, unilocularis $\mathbf{v}$. incomplete bilocularis, valvis midio semisepta placentifera gerentibus, nunc placentis carnosis, sub maturitate a valvarum pariete solutis, liberis, capsulam interiorem simulantibus.

Semixa ad interiorem semiseptorum marginem nunc utrinque solitaria, nunc undique juxta margines subdefinita v. plurima, nunc intra placentas capsulaeformes subquaterna, rarius plura, saepius abortu solitaria, angulatosubglobosa $\mathbf{v}$, oblonge trigona. T' esta crustacea, areolata, umbilico excentrico, in nonnullis subcarnoso. A 1 b u m e $\mathbf{n}$ cartilagineum, copiosum.

Emвryo intra albumen excentricus v. subaxilis, rectus, brevissimus v. dimidiam albuminis longitudinem aequans aut raro superans. Cotyledones breves, obtusae. R adicula cylindrica, ab umbilico remota, situ vago v. rarius supera.

Hydrophylleae in Americae borealis temperatis et frigidiusculis copiosae, in America australi extratropica rarae, inter tropicos rarissimae, Polemoniaceis Hydroleaceisque proximae, ab his stylo, albumine et ovulorum directione, ab illis etiam placentatione distinctae; ab Asperifoliis, quibuscum olim confusae, longius distant, sola inflorescentia et perpaucarum specierum facie aliquatenus similes.

389\%. 1ify drophylium TOURNEF. C aI y x quinquepartitus, sinubus nudis v. reflexo-ap- pendieulatis. Coroll a hypogyna, tubulosa, tubo intus squamulis quinque linearibus, torso adnatis, apice marginibusque liberis, cum limbi quinquelobi lobis erectis alternantibus. St a min a 5 , imo corollae tubo inserta, longe exserta. O varium uniloculare, placentis duabus carnosis maxim:s, linea dorsali parieti adnatis, caeterum liheris, facie interiore ovuliferis. Ovala 4 , in cujusvis placentae facie gemina, diagonaliter opposita, iisdem faciei contiguae alterna, amphitropa. S $t$ y 1 u s terminalis, simplex; stigma bifidum. Capsula membranacea, ovata, unilocularis, bivalvis, placentis demum liberis, capsulam interiorem simulantibus. S emina 4 v. abortu pauciora, angulato - subglobosa, areolata. E m b ryo intra albumen cartilagineum excentricus, rectus, minutus ; cotyledonibus brevissimis, radicula crassiuscula, vaga, - Herbae boreal i-a mericanae, pilosae; folits radicalibus plurimis, caulinis paucis, alternis, latis, pinnatim $v$. palmatisectis, racemis scorpioideo - dichotomis, ebracteatis.

$\mathrm{H}$ y d ro phy $11 \mathrm{u}$ m Tournefort inst. 16, Linn. gen, n, 204. Lamark t. 27. Giirtner $I 1,133, t, 110$, L. C. Rehard in Mi. chaux Flor, bor. Amer. I. 133. Turpin Atlas Dict. sc, nat. IV. t. 46. Benthañ in Linn. Transact, XVII, 279. Bot. Reg. $t, 142.33 t$. D ecemin m Rafinesque msc. (H. appendieulatum Michx.)

3828. Ellisia LINN. Calyx quinquepartitus, sinubus nudis. Corolla hypogyna, subcampanulata, calyce minor, tubo intus nudo v. squamulis decem aucto, limbo quinquelobo, patente. Stamina 5, corollae tubo inserta, inclusa. Ovarium uniloculare, placentis duabus carnosis maximis, linea dorsali parieti adnatis, caeterum liberis, facie interiore ovuliferis. Ov ula 4 , in enjusvis placentae facie gemina, diagonaliter opposita, iisdem faciei contiguae alterna, amphitropa. Stylus terminalis, simplex; stigma bifidum. Capsula membranacea, ovata, unilocularis, bivalvis, placentis demum liberis, capsulam interiorem simulantibus. Semina 4 v. abortu pauciora, angulato-subglobosa, areolata. Em b r y o intra albumen cartilagineum exeentricus, rectus, dimidio ejusdem longior; cotyledonibus brevissimis, ra di e ula subeylindrica, vaga. - Herbae boreali-americana ; foliis inferioribus oppositis, superioribus alternis, omnibus pinnatisectis, pedunculis inferioribus oppositifoliis, superioribus in racemum laxum, unilateralem, simplicem dispositis.

Elli s i a Linn. gen. n. 193, Lam. t. 97. Gârtner f. $I I I$. 32. $t$. 184. Nuttall gen, $I, 118$. Beatham in Linn, Transact. $X V I I T, 273$. N y et el a e a Scopoli. Introduct, $n$, 775 .

3829. Nemophila $B A R T$. C a l y $x$ quinquepartitus, sinubns reflexis, appendiculatis. C orolla hypogyna, subcampanulata, tubo intus nudo $v$, squamulis decem brevibus instructo, limbo quinquelobo, patente. St a min a 5, corollac tubo inserta, subinclusa. O vari um uniloculare, placentis duabus carnosis, maximis, linea dorsali parieti adnatis, caeternm liberis, facie interiore ovuliferis. O v ula $4-12$, in placentarum faciebus sparsa, ejusdem faciei dissita, iisdem contiguae alterna, amphitropa. St y 1 u s terminalis, simplex; st igm a bifidum. Ca $\mathbf{p}$ n la membranacea, ovata, unilocularis, placentis demum liberis, capsulam interiorem simulantibus. Semina abortu pauca v. saepins solitaria, angulato-subglobosa, areolata. Embryo in axi albuminis cartilaginei rectus, ejusdem fere longitudine; cotyledonibus ellipticis, radicula cylindrica, vaga. - Herbae bor eali-americanae, annuae, diffusae, fragi- 
les; foliis inferioribus oppositis, superioribus alter-1 nis, omnibus pinnatifidis, pedunculis nunc axillaribus, unifloris, nunc paucis, ad apices ramorum in racemos breves dispositis.

Nemophila Barton Flor. bor. Amer. 61. Nuttall in Journ. Academ, sc, Philadelph. IT. 179. Bentham in Linn, Transact. XVII. 274. Bot. Mag. t. 2373. 3485. Bot. Reg t. $140,160 t, 1713,1940$.

3830. Datoea $R . B R$. Caly $\mathrm{x}$ quinquepartitus, sinubus nudis. Coroll a hypogyna, subcampanulata, tubo intus nuto v. squamulis decem auctu, limbo quinquelobo, patente. Sta min a 5 , corollae tnbo inserta, exserta. Ovarinm uniloculare, placentis duabus parietalibus, linearibus. Ovala indefinite plurima, amphitropa, Stylus terminalis, simplex; stigma bifidum. Ca p sula membranacea, unilocularis, bivalvis, valvis medio placentiferis. Semina plurima, angulata, areolata. E mb ryo intra albumen cartilagineum rectus, dimidia ejusdem longitudine; cotyled on ibus ellipticis, radicula cylindrica, vaga. Herbae boreali-americanae, annuae, saepius erectae, pubescentes, rarius diffusae $v$. divaricatoramosae; foliis alternis, pinnatifidis $v$, rarius indivisis, floribus racemosis, dense sessilibus $v$. laxe pedunculatis, cymis unilateralibus, simplicibus $v$. dichotomis.

Eutoca R. Browa in Franklin Narrat, 764, t. 27. Benthain in Linn, Transact. XVII. 276. Bot. Reg. $t, 1180$, Bot. Mag. t. 2985. 3003. H e te r y ta Rafinesque in Journ. Phys, LXXXIX, 10t. Polem о и um du b i am Lian.

3831. IPhacelia JUSS. Ca I y $x$ quinquepartitus, sinubus nudis. Cor oll a hypogyna, subcampanulata, tubo intus squamnlis decem instructo, limbo quinquelobo, erecto. $\mathrm{S} t \mathrm{a} m$ in a 5 , tubo corollae inserta, exsezta. O v a ri $\mathrm{m}$ dissepimento incompleto semibiloculare. 0 v u 1 a 4 , semisepti mar gini medio utrinque solitarie inserta, amphitropa. Stylas terminalis, simplex; \&tigma bifidum C a p sula membranacea, ovata, incomplete bilo. cularis, loculicido-bivalvis, valvis semiseptiferis. Semina 4, oblonga, suleata, $\mathbf{m} \mathbf{m}$ bryo in apice albuminis cartilaginei rectus, dimidio ejusdem longior; cotyledonibus ellipticis, radicula cylindrica, supera. - Herbae in America bor ea$l_{i}$ obviae, in Peruvia et Chili rarae, annuae $v$. perennes, erectae $v$. diffusae; folïs alternis, integerrimis, lobatis $v$. pinnatisectis, floribus racemosis, densis, sessilibus $v$. laxe pedunculatis, cymis unilateralibus, simplicibus $v$. dichotomis.

Phacellia Jussieu gen, 129. L. C. Richard in Michaux Flor. bor. Amer, I. 134. ᄂ. 16. Jaeq. f. Eclog. t, 91 . Bot. Reg. $t$. 1696. Bentham in Linn, Transact, XYIT. 279. A Ide a e Raiz et Pavon Flor. Peruv, II, 8, . 14. Endi plas Rativesque in Journ. Phys. LXXXIX, 99. Hy dr op bylli s. Lam.

3832. Emmenanthe BENTH. Caly x quinquepartitus, sinulus nudis. Corolla hypogyna, persistens! campanulata, tubo intus purpureo-maculato, basi squamis decem minutis instructo, limbo quinquelobo. Sta $\mathrm{m}$ in a $\mathbf{5}$, corollae tubo finserta, inclusa. Ovari $\mathbf{m}$ m dissepimento fere completo subbiloculare. $O$ v u I a ad septi margines interiores utrinque plura. Cap s n la oblonga, compressa, semidissepimentis ad axim incrassatis pseudo-quadriloculare ......-Herba californica, erecta, ramosa, subviscoso-villosa; foliis alternis, pinnatifidis, semiamplexicaulibus, basi haud auriculatis, racemis plurimis, gracilibus, ante anthesim circinnatis, pedicellis tenuibus, floribus nutantibus.

E m in u a nt he_Bea than in Linn. Transact. XVII. 281.

\section{Ordo CXII III. Hydroleacene.}

CONVOLVULORUM genera Jussien gen, 136. coll. Annat. Mus, $V$. 258, X $\nu$. 340. HYDROLEACEAE R. Browi Prodr. 489. ot in Tuckey Congo 451. Kunth in Humb. at Bonpl. Nov, gen. et sp. IIt, 125. Synops. 1T. 234. Bartling Ord, nat. 189. Choisy in Mem. soc. h, n. Genev, XI. 95129, c. ice, et in Annal. sce, nat. XXX, 225. Lindley Intro. duct. edit. II. p. 234 .

Herbar annuae v. suffrutescentes, succo aqueo, caule ramisque teretibus, haud articulatis, rarius glabrae, saepissime pube glandulosa viscidae, v. interdum pilis urentibus hispidae, nonnullae spinis axillaribus armatae. Foli a alterna, simplicia, integerrima $v$. dentata aut serrata, sessilia v. petiolata. S tip ula e nullae.

Flores hermaphroditi, regulares, axillares, solitarii v. congesti, nunc terminales, corymbosi v. in spicas secundas, scorpioideas dispositi.

Calyx liber, persistens, herbaceus, profunde quinquefidus v. subpentaphyllus, foliolis sive laciniis saepius apice spathulato-dilatatis.

Corolua hypogyna, gamopetala, decidua, infundibuliformis, subcampanulata v. subrotata, limbi quinquelobi lobis per aestivationem imbricatis, sub anthesi patentibus.

Staura 5, tubo corollae inserta, ejusdeı lobis alterna, exserta v. inclusa. Fil am e nta filiformi-subulata, basi aequalia et saepissime pilosa, v. interdum basi fornicato-dilatata. A ntherae incumbentes, biloculares, loculis parallelis, contiguis, longitudinaliter dehiscentibus.

Ovarium biloculare, v. dissepimentis e pariete centripetis, axim haud attingentibus incomplete biloculare, rarissime triloculare. Placentae nunc in quovis loculo solitariae, magnae, hemisphaericae, medio dissepimento adnatae, nunc geminae, juxta axim contiguae vel utrinque ad introflexos septi incompleti margines sitae. $0 \mathrm{v}$ u l a plurima, horizontalia v. pendula, anatropa. Styli duo terminales, distincti; stig mat a truncata v, depresso-capitata.

Capsura bilocularis v. subbilocularis, nune septifrago bivalvis, valvis dissepimentum placentiferum persistens nudantibus, nunc loculicido-bivalvis, valvis semiseptiferis, septulis utrinque $v$, ad margines introflexos placentiferis.

Semina plurima, minima, angulata, te s t a laxe membranacea, striata v. areolata. A l b umen carnosum, parcum.

Exвrxo orthotropus, axilis. Coty le dones planae. Radicula conica, umbilico proxima, in fructu eentripeta v. supera. 
H y dro le ace a e in America tropica et ex. tratropica frequentius obviae, inter tropicos veteris orbis rariores, Hydrophylleis Polemoniaceisque proximae, inde ad Solanaceas, a quibus imprimis embryone recto diversae, accedunt, a Convolvulaceis distinctissimae.

Romanzoffia stylo simplici anomala. Codon, genus capense nuper huc relatum, rectius fortassis inter Solanaceas militabit.

3833. Hy drollea $L I N N$. C a 1 y x quinquepartitus. Cor ol la hypogyna, rotato campanulata, limbo quinquefido, patente, $S t a m$ in a 5 , corollae tubo inserta, subexserta; fila m e n $t$ a basi fornieato-dilatata, an therae sagittatae. 0 vari nun biv. interdum triloculare. Ovula in placentis hemisphaericis, medio dissepimento v. loculorum angulo centrali adnatis plurima, anatropa, horizontalia v.pendula. St yli duo v. tres distineti; $8 \mathrm{tig}$ $\mathbf{m}$ a $\mathbf{t a}$ depresso - capitata. Ca ps u la bilocularis septifrago-bivalvis, dissepimento placentifero tandem lihero. Semin a plurima, minima, striata. Embryo in axi albuminis dense carnosi orthotropus. - Herbae suffruticosae, in $A$ merica tropica et boreali calidiore obviae, in Asia et Africa tropica rarae, ut plurimum paludosae $v$, ripariae, inermes $v$. spinis axillaribus armatae, piloso-glutinosae; foliis alternis, integris, floribus axillaribus et terminalibus caeruleis.

H y dra le a Lina, gen, $n$. 318, Gärtner $I .263, t, 55$. Aublet Guian. t. 110. Cavanill. Ic. t. 529. Bot. Heg. t. 566. Kunth in Humb.et Bonpl. Nov. Ben. et sp. IIT. 12\%, Choisy in Mem, soc, h: n, Genev, V1. 107. t, 1, Annal, sc, nat. XXX., 230. $t, 16 . f$. 1 , S te $\mathrm{r}$ is Burmann Flor. Ind, 73, t, 39 f. 3. Lius. Mant. 54. S a go ne a Aublet Guian, Y. 285, t, 111. Reiehelia Schreber gen. 512. Na mae 8 p. Linn. Flor. Zeylan, t.2. - ? н y drolla Thonars Gen, Afadagasc. n, 29.

3834. Vigandia KUNTU. Ca l y $\mathrm{x}$ quin quepartitas. Corolla hypogyna, infundibuliformis, limbo quinquepartito, patente. St a m in a 5 , corollae tubo inserta, exserta; fil a menta basi aequalia, antherae sagittatae. Ovari um biloculare. $O \nabla u 1$ a in placentis oblongo-linearibus, dissepimenti axi utrinque geminatim adnatis plurima, horizontalia. Styli duo, distineti; stigmata subpeltato-depressa. C a p $8 \mathrm{u}$ I a bilocularis, loculicido bivalvis, valvis semiseptiferis, septulis utrinque placentiferis. Se m in a plurima, minima, areolata. $\mathrm{Emb} \times \mathrm{yo}$ in axi albuminis carnosi orthotropus. - Herbae mexicanae et peruanae, elatae, saepius suffruticosae, pilis urentibus hispidae, caeterum inermes; foliis radicalibus quandoque amplis, caulinis allernis, integris, spicis terminalibus paniculatis, secundis, floribus sessilibus, ebracteatis, violaceis, albis $v$. flavis.

W I g a ndi a Kuath in Humb. et Bonpl. Nov. gen. et sp. IIT. 127. Choisy in Mem. soc. h. n. Genev. VT. 11s. Anzal. so. nat. XXX, 245. Hydrolea e sp. Ruiz et Paron Flor. Peruv, t. 203, 204. f. a.

3835. Nama LINN. Ca I y $x$ quinquepartitus. Corolla hypogyna, infundibuliformi-tubulosa, limbo quinquefido, patente. Stamina 5 , corollae tubo inserta, inclusa; filamenta basi aequalia, antherae reniformi-bilobae. Ova$r i \mathrm{~mm}$ dissepimento incompleto semibiloculare. $O_{v} \mathbf{1}$ a in placentis lineari-oblongis, dissepimenti incompleti marginibus introflexis utrinque adnatis plurima, auatropa, pendula. Styli duo, distineti ; stigmata obtusa. Cap sula incomplete bi- locularis, loculicido-bivalvis, valvis medio semiseptiferis, septulis margine utroque placentiferis. Semin a plurima, minima, areolata. Embryo in axi albuminis carnosi orthotropus. - Herbaev. fruticuli, in America tropica et australi extratopica crescentes; caulibus caespitosis, diffusis, glanduloso-pilosis, foliis alternis, integris, floribus axillaribus terminalibusque congestis $v$, laxe cymosis, corollis violaceis $v$. albis.

$\mathrm{N}$ a u a Linn. gen, n. 317. Kunth in Humb, et Bonpl. Nov. gen, et sp, III. 130, t. 218. Choisy in Mem. soc. h. $n$. Genev. VI. 111. $t .2$, f. 1. 2. Annal. sc. nat. XXX. 24t. t. 16. $f$. 2. H y drole a s p. Ruiz et Pavon Flor, Peruv. 204. $f . b$.

3836. TomanzofPia CHAM. Calyx quinquepartitns. Coroll a hypogyna, hypoeraterimorpha, limbo quinquepartitu, patente. S $t$ a m in a 5, corollae tubo inserta, inclusa; fil am enta basi aequalia, inaequilonga, an therac lineares, incumbentes. Ovariu m dissepimento incompleto semibiloculare. Ovula in placentis linearibus, dissepimenti incompleti marginibus introflexis utrinque adnatıs plurima, anatropa. Stylus terminalis, simplex; stigma capitatum. Cap s u la ovata, compressiuscula, ineomplete bilocularis, loculicido-bivalvis, valvis medio semiseptiferis, septulis margine utroque placentiferis. Semina plurima, minima, areolata. E $\mathbf{m}$ bryo in axi albuininis carnusi orthotropus. - Herbae Amerieae arctica e, humiles, multicaules, erectae, carnosulae, pilis patentibus obsitae; foliis radicalibus longe petiolatis, petialis basi dilatatis, caulem vaginantibus, reniformi-cordatis, sublobatis, caulinis paucis alternis, minoribus, racemo terminali, secundo, sub anthesi apice revoluto, fructifero stricto, elongato.

$\mathrm{R}$ o m a nzoffi a Chasisso in Hor. Phys. berolin, 71,t. 16 . Linnaea II. 007. Choisy in Mem. soc, $h, n$, Genev. PI. 118. t.3.f. 1. Bougard in Mom. Acaden. St. Petersb. n. s. It. t.4.

3837. Codon ROYEN, Calyx decemduodecimpartitus, laciniis subulatis, erectis, alternis minoribus. Coroll a hypogyna, campanulata, tubo costato, basi toruloso, limbo decen - daodecimfido, lobis oblongis, obtusis, earinatis, aestivatione imbricatis, alternis minoribns. Sta min a 10 v. 12, imo corollae tubo inserta; fi la ment a basi in fornices compresso-tetragonas dilatata, apice subulata, a $\mathbf{t}$ h er a e ineumbentes, biloculares, longitudinaliter dehiscentes. 0 va ri u m biloculare, valvarum marginibus intruflexis dissepimentum praebentibus, margine revoluto placentiferis. Ovula plurima...S tylus terminalis, semibifidus; stigm a t a dentata. Ca p 8 u l a ealyce persistente, connivente cincta, ovata, stylo mueronata, bilncularis, apice loculieido-bivalvis. S e m in a plurima, angulata, testa cartilaginea, dense papillosa. $\mathrm{E}$ m b r $y$ o in axi albumini dense carnosi subarcuatus, filiformis; cotyledonibus brevissimis, radienla elongata. - Herba capensis, annua, undique aculeis subulatis, albis consita; caule tereti, erecto, ra. moso, foliis alternis, petiolatis, ovato oblongis, subrepandis, subcarnosis, subtus nervosis, utrinque se. tosis, subtus margine et ad costas aculeat is, floribus extraaxillaribus salitariis, $v$, in apice caulis sub. racemosis, bibracteatis, corollis magnis, albis, purpureo-variegatis,

Do do n Royen ex Linn, gen, n, 1983. Gîrtaer II. 87. t. 95. Andrews Bol. Meposit. $t$. 325. Dou in Edinb. new philosoph. Journ. $X V$. 5 i. 


\section{Oxdo CXIIII. Solanaceae.}

I. URIDAR Linn. Praclect, edit. Giseke 384. exel. gen. SOLANEAE Jussieu gen. 124. coll. Annal. Mus. V. 255. R. Brown Prodr, 443. SOLANACEAE Bartling Ord. nat. 193. SOLANACEAE et CESTRACEAE Lindley Introduct. edit. 1I. p. 293, 296.

Herbae annuae v. perennes, aut suffritescentes, nune rRUTICEs v. ARBOREs, succo aqueo, caule ramisque teretibus v. angulatis. Folia alterna, sessilia v. petiolata, simplicia, saepe sinuato-dentata, lobata v. pinnatisecta, nunc integerrima, floralia et ramea saepits geminatim juxtaposita. Stipula e nullae, vel interdum e gemmae axillaris foliis primariis spuriae.

Flores hermaphroditi, regulares, varie tispositi, saepe alares v. extraaxillares, pe dicellis ebracteatis.

CaLyx liber, gamophyllus, quinque- rarius quadri-sexfidus v. partitus, persistens v. rarissime supra basim persistentem circumscisse deciduus, fructifer saepe plus minus auctus.

Conolla hypogyna, gamopetala, rotata, campanulata, infundibuliformis $v$. hypocraterimorpha, limbo quinque-rarius quadri-sexfido $v$. dentato aut partito, lobis per aestivationem plicatis v. interdum induplicato valvatis, rarissime simpliciter applicitis.

Stamisa 5, rarius 4 v. 6 , corollae tubo iıserta, ejusdem laciniis alterna, exserta v, inclusa. Fila ment a filiformia v. e basi latiore attenuata, aequilonga $v$. inaequalia, simplicia v. rarissime antice aut utrinque dente aucta. Antherae introrsae, biloculares, erectae $v$. incumbentes, conniventes v. interdum apicibus connatae, loculi appositi, paralleli, basi discreti, longitudinaliter dehiscentes v. rarius poro apicis apertae.

Ovarivm e carpidiis duobus, anticum et posticum ab axi floris latus occupantibus compositum, carpidiorum marginibus introflexis dissepimentum planum praebentibus biloculare, nunc septis secundariis a dissepimento primario procedentibus, apice deliqueseentibus incomplete $\mathbf{v}$. complete quadri - quinqueloculare, rarius carpidiorum numero per excessum aucto tri-quinqueloculare. $\mathrm{Pl}$ ac ent ae dissepimento utrinque lato dorso adnatae $r$. linea dorsali insertae, in loculis solitariae, nunc utrinque geminae, parieti plus minus admotae, et septo secundario discretae, $\mathbf{v}$. in angulo centrali sitae, lineares $v$. hemisphaericae. Ovula plurima, amphitropa. Stylus terminalis, simplex. Stig ma indivisum, v. loculorum numero obsolete lobatum.

Frictus capsularis v. baccatus, bi $-\mathbf{v}$. rarius plurilocularis. Capsulae nunc septicido bivalves, valvis margines introflexos a dissepimento placentifero solventibus, placentas coadunatas nudantibus, rarius easdem discretas inter margines longius introflexos retinentibus, indivisis v. plus minus bifidis, nuns evalves, infra apicem operculo circumscissae. Baccae pulposae v, exsuccae, coriaceae $r$. membranaceae, epicarpio in membranaceis nonnunquam irregulariter a septis persistentibus secedente.

Semixa plurima, nunc plus minus reniformia, a latere compressa, nunc ovata v. oblonga, a dorso compressa, umbilico ventrali. T esta plerisque crustacea, saepe tuberculata, in nonnullis pulpa carpica pertinacius adhaerente obducta, rarius membranacea. Albumen carnosum, copiosum.

Exrrayo in seminibus a latere compressis intra albumen subperiphericus, arcuatus, hemicyclicus v. spiralis; cotyledonibus semicylindricis, $\mathbf{r}$ a di cula tereti, ad umbilicum tendente, vaga: in seminibus a dorso compressis axilis, rectus; cotyledonibus orbiculatis, subfoliaceis, radicula tereti, ab umbilico remota, infera.

S ol a n a ce a e a Scrofularineis nullo certo limite distinctae, sed fiorum forma regulari et staminum perfectorum numero quinario a plerisque facillime dignoscendae, maximo numero in regionibus tropicis, imprimis Americae vigent, versus polos rarescentes, e regionibus frigidis et alpibus exules.

Vires omnibus magis minusve insunt narcoticae, hinc in medicina laudatae, et in philtris celebres. Nonnullarum fructus cultura innoxii eduntur. Solani tuberosi ingentes usus et laudes.

TRIBUS I. NICOTIANEAE. E $\mathrm{m}$ b $\mathrm{r}$ y 0 . nis plus minus arcuati cotyledones semicylindricae. Caps ula bilocularis, loculicidobivalvis.

3938. Fulbiama $R U I Z$ et $P A V$. Caly x tubulosus, semiquinquefidus. Corolla hypogyna, infundibuliformis, tubo sensim ampliato, limbo plicato, breviter quinquelobo. Stam in a 5 , imo corollae tubo inserta, inclusa, inaequilonga, apice incurva; antheris longitudinaliter dehiscentibus. Ovar i um biloculare, placentis dissepimento adnatis, multiovulatis. Sty 1 us simplex, apice incurvas; stigma obliquum. Capsnla calyce persistente inclusa, bilocularis, septicido-bivalvis, valvis apice bifidis, placentas coadunatas nudantibus. S e mina plurima, subglobosa. Em bryo intra albumen earnosum subperipherieus, arcuatus. Suffrutices a ustro-americani, viscosi v. resinosi; foliis alternis, sparsis $v$. imbricatis, pedunculis extraaxillaribus v. subaxillaribus, solitariis, unifloris.

F a biana Ruiz et Pavon Flor. Peruv, II. 12, t. 122, St, Hilaire Planl, remarq. Brasil, $220, t, 20$. 
3839. Nierembergia RUIZ et $P A V$. C a l y $x$ tubulosus v, subcampanulatus, subinaequaliter quinquefidus. Corolla hypogyna, infundibuliformis, tubo gracili, elongato, limbo amplo, patente, sabinaequaliter plicato-quinquelobo. S $t$ am in a 5, corollae fauci inserta, exserta, inaequilonga, libera et circum stylum conniventia, v. basibus plus minus connata; an the ris longitudinaliter dehiscentibus, sub stigmate reconditis. Ovari u m biloculare, placentis dorso dissepimento adnatis, multiovulatis. Stylus simplex; stigma reniforme, bilamellatum. Capsula calyce persistente tecta, bilocnlaris, septicido-bivalvis, valvis demum bipartitis, placentas coadunatas nudantibus. S e m in a plarima, triquetra, $\mathbf{E} m b r y o$ intra albumen carnosum rectus, axilis, $v$, arcuatus excentriens. - Herbae $v$. suffrutices Americae a ustralis, procumbentes $v$, repentes; foliis alternis, solitariis $v$. geminis, integerrimis, floribus extraaxillaribus $v$. oppositifoliis, solitariis, subsessilibus, albis.

Nierembergla Raiz et Pavon Flor. Peruv. II, 13. t. 123. Kunth in Humb. et Bonpl. Nov. Gen. et sp. MII. 8 t. 19s. St. Hilaire Plant, remarq. Brasil. 221, t. 21. f, $a$. Bot. Mag. $t$. 3108. 3370, 3371, Bot, Reg, $t$. 1649.

3840. Pretumia JUSS. C a ly $\mathrm{x}$ quinquepartitus, laciniis spathulatis. C o roll a hypogyna, infundibuliformis v. subhypocraterimorpha, tubo cylindraceo $\mathrm{v}$. ventricoso, limbo patente, inaequaliter plicato-quinquelobo. $\mathbf{S} \mathbf{t a} \mathrm{m}$ in a 5 , medio corollae tubo inserta, inaequilonga, inclusa. Ov arium biloenlare, placentis linea dorsali dissepimento adnatis, multiovulatis. Stylus simplex; stigm a capitatum, obsolete bilobum. C a psula bilocuiaris, septicido-bivalvis, valvis indivisis. S e m i $\mathrm{n}$ a subsphaerica. E $\mathbf{m}$ b r y o in axi albuminis carnosi rectus v. arenatas. - Herbae austro-a mericanae, subvicosae; foliis alternis, integerrimis, floralibus geminis, pedunculis axillaribus solitariis, unifloris.

Pet un i Jussieu in Annal. Mrs, II, 215, t. 47, Lindley in Bot. Reg. ᄂ, 1696, 1931. Bot. Mag. $t, 2552.3556$, S a I. piglassis s p. Hooker in Bot. Mag.t.3113. Nicotian a s p. Lebm.

384t. Nieotiana LINN. C a 1 y $\mathrm{x}$ tubuloso-campanulatus, semiquinquefidus. Corolla hypogyna, infundibuliformis v. hypocraterimorpha, limbo plicato-quinqueloho. Stam in a 5 , corollae tubo inserta, inclusa, aequilonga; a ntherae longitudinaliter dehiscentes. 0 varin m bileculare, placentis linea dorsali dissepimento adnatis, multiovulatis. Stylus simplex; stigma capitatum. Cap sula calyce persistente tecta, bilocularis, apice septicido-bivalvis, valvis demnm bifidis, placentas discretas retinentibus. S e mina plurima, minima. Embryo in axi albuminis carnosi leviter arcuatus. - Herbae interdum suffrutescentes, saepissime glutinoso-pilosae, in America tropic a copiosae, parcius in $A$ sia orientali calidi ore crescentes, plures ob fumi quem combustae spargunt, $v$. in pulverem contritae naribusque ingestae praebent illecebras cultae; folits alternis, inlegerrimis, floribus terminalibus racemosis aut paniculatis, albidis, virescentibus v. purpurascentibus.

Nic otian a Tournefort inst. 41. Linn. gen, n, 2is. Selikuhr t. 44. Gärtner 1. 864. 6. 65. R. Brown Prodr. 447. Kinth in Kumb. et Bonpl, Nov, gen. et sp. IIT. 1. Leh. mann, Historia Nicot. 1818, 4. $c$, ice. excl, sp. Mtiller Ic,, 185. Jacg. Fragm, t, 56, 84. Venten. Malmais, $t, 10$. Ruiz et Pa. von Flor, Peruv, t. 199. exel. $f . a, t$. 130. Audrews Bot, Reposit. , 484. Bot. Mag. t. 673. 1778. 2921. 2484. 2555.
2785. 2837. 2919. Bot. Reg. t. 833. 1057. 1592. C o d ylis Rafinesque in Americ. Monihl. Magas. 1819. Tabacus Möach Method. 348.

3842. Lehmannia SPRENG. Calyx tubuloso-campanulatus, inaequaliter bi-quinquefidus, Co rolla hypogyna, infundibuliformis, tubo brevi, limbo campanulato, suboblique truncato, inaequaliter plicato-quinquedentato. St amina 5 , corollae tubo inserta, exserta, adscendentia; a n the$r$ a e longitudinaliter dehiscentes. Ovarium biloculare, placentis linea dorsali dissepimento adnatis, multivvulatis. Sty Ins simplex, exsertus; st i g ma capitatum. C a p s u la ealyce persistente eincta, bilocularis, septicido-bivalvis, valvis indivisis, placentas discretas retinentibus. S e m in a plurima, minima. Embryo in axi albuminis earnosi subarenatus. - Suffrutex peruanus, subviscosus, apice ramosus; foliis alternis, decurrentibus, lanceolatis, acu. tis, integerrimis, subtus subtomentosis, venis purpureis, racemis terminalibus subsecundis, paniculatis, corollis sordide purpureis.

Lehuan ia Sprengel Anleit. II. 458. Nicotiana to meutos a Ruiz et Pavou Flor. Peruv, z. 199. $f$. 1 .

3543. Neetouxia H. B.K. Cal y $\mathrm{x}$ quinquepartitus, laeinils linearibus. Corolla hype. gyna, hypocraterimorpha, faucis corona cyathiformi truncata, limbo patente, plicato-quinquepartito. S ta m in a 5 , summo corollae tubo inserta, inclusa; antherae longitudinaliter dehiscentes. Ovarium biloculare, placentis dissepimento adnatis, multiovalatis. Sty Lus simplex, inelnsus; stig m a subemarginatum. F ructus ..... Herba mexicana, foetida, erecta; folits alternis, superioribus subgeminis, cordatis, integerrimis, pedunculis extraaxillaribus, solitariis, unifloris, corollis flavis.

Ne etouxia Kunth in Humb, et Bonpl. Not. Ger. et sp. III, 10, $8,193$.

3844. IRarekea C. C.RICH. CaIy $x$ tnbulosus, prismaticn-pentagonus, Coroll a hypogyna, infundibuliformis, limbo patente, quinquepartito, laciniis obtusis, subaequalibus, St a min a 5, imo corollae tubo inserta, inclasa; fil amenta filiformia, faucem aequantia; ant herae oblongae, longitudinaliter dehiscentes. Ova ri u m oblongo-conicum, bjloculare, placentis dissepimento adnatis, multiovulatis. Styl us simplex, filiformis; stig ma oblongum, indivisum. Capsala oblonga, subeylindrica, bilocularis, bivalvis ..... Semina plurima. - Frulex guianensis, non satis notus, scandens; ramis dependentibus, foliis allernis, petiolatis, ellipticis, acutis, integerrimis, subaveniis, glabris, nitidis, racemis axillaribus longe pedunculat is, nutantibus, corollis coccineis.

M a r eke a L. C. Richard in Act. soc. h. n, Paris. 10\%, A. Richard in Dict. class, X. 168, c. $i c$. L a m a r ck ea Persoon Encheir. I, 218.

TREIR⿴囗十 1 I. DATUREAE. E mbry 0nis plus minus arcuati cotyledones semicylindricae. Capsula v. ba c ca incomplete quadrilocularis, dissepimento primario medio $\mathbf{v}$. prope angulum parietalem utrinque placentilero.

3845. Datura LINN, Calyx tubulosus, saepe angulatus, apice quinquefidus $v$. hinc longit udinaliter fissus, supra basim peltatam, persis- 
tentem cirumscisse deciduus. C or o I la hypogyna, infundibuliformis, limbo amplo, patente, plicato, quinque-decemdentato. Sta $m$ in a 5 , corollae tubo inserta, inclusa v. subexserta; an therae longitudinaliter dehiseentes. $O$ va ri $\mathbf{m}$ incomple. te quadriloeulare, dissepimento altero supra medium deliquescente, altero completo, medio utrinque placentifero, placentis porrectis, multiovula tis. Stylus simplex; 8 tigma bilamellatum. Capsula ovata v. subglobosa, muricata v. aculeata, rarins laevis, semiquadrilocularis, incomplete ad septa quadrivalvis. Semina plurima, reniformia. Embryo intra albumen carnosum subperiphericus, areuatus. - Herbae virosae, annuae $v$, perennes, nunc suffrutescentes $v$, arborescentes, in America et Asia tropica indigenae, una nunc per orbem diffusa, aliae in hortis cultae; foliis alternis, petiolatis, oblongis v. ovatis, saepius angulato - dentatis, floribus alaribus, solitariis, saepius magnis, albis, violaceis $v$. coccineis.

D a tur a Linn. gen, $n$. 240. Kunth in Humb. et Bompl. Nov, gen. sp. III. 5, Berbhardy in Trommsdorf $n$, Journ. der Pharmac, XXVI. 146. S $\mathrm{t}$ amo $\mathrm{ni} \mathrm{am} \mathrm{Tournef.} \mathrm{inst.}$ 34. 44. Gärtner II. 234. B r u g m a $\mathrm{s}$ i a Pers. Encheir. I, 216.

a. BRUGMANSIA Bernh. . c. Caly $\mathrm{x}$ angulatus, apice quinquelobus. $S t a m$ in a incluss, a $\mathrm{n}$ h th a conglutinatae. S e mi n a obsolete trigona. B r ug m a $\mathrm{s}$ i a Pers. l. o. Bot. Reg. t. 1739. (Ruiz et Pavon Flor, Peruv. t. 123.)

b. STRAMONIUM Bernlt. l. c. $\mathrm{Ca}$ a $\mathrm{y} \times$ angulatus, apice quinquelobas. Corolla e limbus aente quinquangulus. Stamina inclusa, antherae distinctae. Semina reniformia. (Flor. dan. $t, 430$. Jaeq. Hort. Vindob, III, t. 82. Gärtner t. 132. Sweet Fl. Gard. II. t. 83.)

c. DUTRA Bernh. . $e . \mathrm{C}$ al $\mathrm{y} \times$ angulatus $\mathrm{v}$. teres, apice quipquelobus. C or o 11 a e limbus quinque-decemdentatus. Stamina subexserta, a $\mathrm{t}$ herae remotae. Semina reniformía, (Rumph $t$, 243.)

d. CrRatocaulis Bernh. l. c. Calyx teretiusculus, hinc fissus. Corolla e limbus decemdentatus. Sta mi. na exserta, antherae contiguae. S e mina subreniformia. (Jacq. Hort, Schonbr, t. 309. Bot, Reg. t. 1031, Bot. Mag. $t, 3352$, )

3846. Solandra $S W A R T Z$. C al yx tubulosus, tri-quinquefidus, persistens. Co r o 11 a hypogyna, infundibuliformi - ventricosa, limbo plicato, quinquefido, lobis undulatis. Stam in a 5 , corollae tubo inserta, adscendentia, erecta; antherae longitudinaliter dehiscentes, versatiles. Ovarium incomplete quadriloculare, dissepimento altero supra medium deliquescente, altero completo, prope angulum parietalem ntrinque placentifero, placentis porrectis, multiovulatis. Sty1 u s simplex; stigma subcapitatnm. Ba cca calyce demum hine fisso eincta, quadrilocularis, polposa. Semin a plurima, reniformia. Em bryo intra albumen carnosnm arcuatus, - Frutices Americae tropicae, sarmentosi; foliis in apice ramulorum confertim alternis, obovato-oblongis, integerrimis, subcarnosis, floribus terminalibus, solitariis, maximis.

Sol a ndra Swartz in Act. Holm, 1787, p. 300, t, 11 . Flor. Ind, occid, I. 387, t.9. Jacquin Hort. Schonbr. t. 95 . Salishury in Linn. Transaet. VT. 100. t. B. Correa in An. nat. Mus. VIIT. 389. t. 4. Bot. Mag. t. 1874. 1948. Bot. Reg. t. 1351. Lfnk et 0tte Ic, select, $t$. 87 . Swartzia Gme. Iin Syst. 360 .

TRIBUS III. HYOSCYAMEAE. Embryonis plus minus arcuati cotyledones semicylindricae. C a ps u la bilocularis, operculo circumscissa.
394\%. IIyoseyamus TOURNEF, $\mathrm{C}$ a I y urceolatus, quinquedentatus. C o roll a hypogyna, infundibuliformis, rarissime hine fissa, limbo plieato, quinquelobo, lobis obtusis, inaequalibus. St am in a 5, imo corollae tubo inserta, inclusa v. exserta, declinata; an the ra e longitudinaliter dehiscentes. Ov a ri u m biloculare, placentis linea dorsali dissepimento insertis, multiovnlatis. StyIns simplex; $s$ tig ma capitatum. Capsula caIyce persistente, saepius aucto recondita, e hasi ventricosa angnstata, membranacea, bilocularis, apice circumscissa, operculo biloculari. S e mina plurima, reniformia. E $\mathbf{m}$ b r $\mathbf{y}^{\mathrm{o}}$ intra albumen carnosum subperiphericus, arcuatus. - Herbae in Europa et Asia media, et in tota regione mediterranea indigenae, saepius viscosae, olidae; foliis alternis, dentatis $v$, angulatis, floralibus saepius geminis, floribus axillaribus, solitariis, in plerisque secundis.

H у о в с у а $\mathrm{m}$ u s Tournefort. inst. 42. Linn. gen, n. 247. Gärtner $t$, 369, t, 76. Flor. dan. $t$. 1458. E. B. $t, 891$. Sib thorp Flor. graec. t. 230. 231. Bot. Mag. $t$. 832, 2394, Bot. Reg. t. 180 .

3848. Anisodus $L I N K$. Caly $\mathrm{x}$ campanulatas, inaequaliter quinquefidus, Corol a hypogyna, campanulata, limbo plicato, quinquelobo, lobis obtnsis, inaequalibus. St a m in a 5 , imo corollae tubo inserta, inclnsa, resta; a nthera e longitudinaliter dehiscentes. Ovari u m bilocnlare, placentis dissepimento adnatis, multiovulatis. Stylus simplex; $s \mathrm{ti}$ g ma capitatum. Ca p8 u l a calyce inflato, costato, connivente inelusa, subglobosa, coriaceo-subearnosa, bilocularis, supra medium cirenmscissa, operculo mucronato, quadrivalvi. Semin a plurima, reniformia. Embryo intra albumen carnosum periphericus, semicircularis. - Herba nepalensis; radice fusiformi, crassa, foliis alternis, petiolatis, ovalibus, subrepandis, subtus subtomentosis, floralibus geminis, pedunculis axillaribus, solitariis, unifloris, nutantibus, corolla viridi-flava, demum purpurascente.

Anisodus Link Ic. select. p. 77 . Nees in Linn. Transact. XVII. 72. Whitle y a Sweet Fl, Gard. t. 125. Nicandra anomala Link $O p$. cit, $t, 35$. Physalis st $r$ a monifolia Walb.

3849. Seopolia $J A C Q$. C a ly $\mathrm{x}$ campanulatus, quinquefidus, aequalis. Coroll a hypogyna, cylindrico - campanulata, limbo plicato, quinquedentato. St amina 5 , imo corollae tnbo inserta, inclusa, declinata; ant h er a e longitndinaliter dehiscentes. O vari u m biloculare, placentis dissepimento adnatis, multiovulatis. St y l us simplex; stigma capitatum. Capsula calyce persistente basi stipata, subglobosa, coriaceo-subcarnosa, bilocularis, medio circumscissa, opercalo uniloculari. S e min a plurima. E m b r yo intra albumen carnosum periphericus, semicircularis. Herba in Europae orientalis subalpinis perennans, erecta, pedalis, di-trichotoma; foliis alternis, ovalibus, acutis, subrugosis, floralibus geminis, pedunculis axillaribus, solitariis, unifloris, filiformibus, nutantibus, corolla luride rufa, fundo flava.

S copoll a Jaeq. Observ. 1 . 32, t. 20, non alior. S c opolina Schultes Fi. Oesterr. II. $t$. 844 . H y os e y am us Seopolla Lina. Bot. Mag. $t$. 1126. At r opae s p. Scopoli.

TIRIBES IV. SOLANEAE. Em b r y 0 . $\mathrm{n}$ is plus minus arcuati cotyledones semicylindricae. B a cca bi-plurilocularis, placentis centralibus, rarissime c a p u la evalvis. 
3850. Nieandrea $A D A N S$. C a I $\mathrm{x}$ quinquepartitus, pentagonus, laciniis sagittatis. $C_{\text {o- }}$ rolla hypogyna, campanulata, limbo plicato, subintegro. Stamina 5, imo corollae tubo inserta, subexserta; filamenta basibns dilatatis conniventia, a n th erae longitudinaliter dehiscentes. $\mathrm{O}$ v a ri u m tri-quadriloculare, placentis intra loculos solitariis, dissepimento prope angulnm centralem insertis, multiovulatis. Sty I us simplex; stigm a subcapitatum. C a p sula calyce vesicario pentagono inclusa, tri-quadrilocularis, evalvis, epicarpio demum secedente, dissepimenta placentifera nudante. S e min a plurima, reniformia. Embryo intra albumen carnosum arcuatus. - Herba peruana, nunc per regiones temperatas et calidas totius orbis diffusa; foliis alternis, superioribus geminis, sinuato-angulatis, pedunculis extraaxillaribus alaribusque, solitariis, unifloris.

Nicandra Adanson Fam, II. 219. Jussieu gen, 125. Gärtner $I T$. 237, $t, 131$, non Schreb. C a l y d e r mo os Ruiz et Pavon Flor. Peruv, 1I. 44. A I k e k e a g Feuille Observ. 724. $t$. 16. A tropa physal odes Linn. Jaeq. Observ, $I V$. t. 98 .

385 1. Plnysalis LINN. Calyx quinquefidus, demum increscens, saepissime vesiculoso inflatus. Corolla hypogyna, campanulato-rotata, plicata, limbo quinquesinuato. S $t$ a $\mathrm{m}$ in a 5 , imo corollae tuho inserta, inclusa; antherae conniventes, longitudinaliter dehiscentes. Ovarinm biloculare, placentis subglobosis, dissepimento adnatis, multiovnlatis. Ŝtylas simplex; st i g ma capitatum. Ba eca calyce inflato, connivente recondita, bilocularis. Sem in a plurima, reniformia. E mbryo intra albumen carnosum subperiphericns, spiralis. - Herbae annuae $v$. perennes et frutices, in Asia, Africa et $A m e-$ rica tropica copiosius crescentes, in America temperata rarae, una species in Europa me dia et boreali indigena, nonnullae late per orbem disseminatae; folitis alternis $v$. geminatis, integris v. lobatis, floribus extraalaribus solitariis $v$. confertis.

P h y 5 a 1 i s Linn. gen, n, 250. Gärtner 11 . 238, t, 131. Jaeq. Hort. Vindob. $I$. $t, 136$, 1o, rar. $t, 38,39$. Fragm. $t, 8 \overline{.}$ f. a. Jacq. f. Eclog, t, 22, 23. Sibthorp Flor, graec, t. 293. 234. Cavanill. Io, t. 103. Herit. Stirp, $t$. 22, Andrews Bot. Feposit, t. 175. R. Brown Prodr. 44\%. Nees in Linnaea VI. 431-483. A I kekengi Tournef. Inst. 64. - HersebeIt Bowdich Madeir. p. 258. absq. charact. v. synon. quae Ph, edulis Bot. Mag. t, 1068. corollae Jaeinits basi glanduloso maculatis non satis differt.

385z. Sarraelna $R U I Z$ et $P A V$. C al $\mathrm{yx}$ quinquefidus. Co rolla hypogyna, rotata, tubo lorevissimo, limbo plicato, quinquefido, reflexo. Stamina 5, corollae fauci inserta, longe exser. ta; an therae distantes, longitudinaliter dehiscentes. Ovarium biloculare, placentis septo adnatis, multiovulatis. Stylns simplex; stígma capitatum. B a cea calyei aucto imposita, bilocularis, v. septis obliteratis placentisque coadunatis nnilocularis. Semina plarima, reniformia. Herbae peruanae, erectae $v$. procumbenles; foliis alternis $v$. geminis, pedunculis axillaribus solitariis $v$. confertis.

Sarracha Ruiz et Pavon Prodr. 31. $t$. 3f. FIor. Pe. ruv. t. 178-180. B elli a i a Römer et Sehult. Syst. IV. 687. A tr o pa e s p. Cavanill. 10, $t$, 72. Jacq. Hort. Seћönßr. t. 492, 493 .

3853. Whtheringia HERIT. Calyx quinquefidus. Corolla hypogyna, rotata, tubo brevi, limbo quadri-quinquefido, subvalvato. Stamin a $4-5$, corollae fauci inserta, exserta; a $n-$ the rae conniventes, longitudinaliter dehiscentes. Ova ri u m biloculare, placentis dissepimento adnatis, multiovnlatis. Styłus simplex, filiformis v. obconicus; s ti $\mathrm{g}$ ma simplex. B a c ca bilueularis, polysperma. S emin a plurima, reniformia. E m bry o periphericus, spiralis, albumen carnosum includens. - Herbae, frutices v. arbusculae, in America tropica trans a equatorem indigenae; foliis alternis $v$. geminatis, petiolatis, integris $v$. subsinuatis, pilosis, floribus alaribus $v$. extraaxillaribus, solitariis, racemosis v. subumbellatis.

Withering ia Heritier Sert. Angt. $x .33, t, 1$, Lam. 1. 82. Dunal Solan, 107. Synops. 1, Kanth in Humb. ot Bonpl. Nov, gen, et sp. III, 13. Bot. Mag. t. 2768. Martios Nov. gen. et sp. III. 73. t. 297_229. C y athostyles Sehott msc. S o J a n I s p. Lín. Cav, Ic. t. 359. f. 1. Ruiz et Pav. Flor. Peruv, $t$. 170. f. b. $t$. $171, f$. $a$,

3554. Capsieum TOURNEF. C a 1 y $\mathrm{x}$ quinque-sexfidus. Corolla hypogyna, rotata, tubo brevissimo, limbo plicato, quinque-sexfido. Stamina 5-6, corollae fauci inserta, exserta; filamenta brevissima, antherae conniventes, longitudinaliter dehiscentes. Ovarium bitri-quadriloculare, placentis dissepimenti $y$, anguli centralis basi adnatis, multiovnlatis. Stylus simplex, subelavatus; stigma obtusum, obsolete bi-trilobum. B acea exsucca, polymorpha, incomplete bi-trilocularis, placentis septisque superne deliquescentibus. S e min a plurima, reniformia. E mb r yo intra albumen carnosum periphericus, hemicyclicns. - Herbae annuae, perennes v, frutescentes, in Asia et America tropica indigenae, ob baccas acriter aromaticas ubique cultae, polymorphae; foliis alternis, solitariis v. geminatis, integerrimis $v$. sinuatis, pedunculis extraaxillaribus et alaribus unifloris, solitariis, geminis $v$ ternis, corollis sordide albis $v$, ochroleucis, baccis erectiusculis v. pendulis, ovatis, globosis v. oblongo-pyramidatis, multiformibus, aurantiaceis, coccineis $v$, purpureis.

C a ps i c m Tournef. inst. 66. Linn. gen. n, 259. Gärt. ner II. 201. t. 132. Fiagerhat Monographia generis Capsici. Ditsseldorp. 1832. 4, $c$, icc.

3855. Solanum $L I N N$. C a I y $\mathrm{x}$ quinquedecemfidus. Corolla hypogyna, rotata v. rarius campanulata, tubo brevi, limbo plicato, quinque-decemfido, rarius quadri-sexfido, $\mathrm{S} t \mathrm{a} \mathrm{m}$ in a 5 , rarius 4 v. 6 , corollae fauci inserta, exserta; $\mathrm{fil} \mathrm{a}^{-}$ menta brevissima, antherae aequales $v$. interdum inaequales, conniventes, apice poris geminis dehiscentes, O va ri u m bi-rarius tri-quadriloculare, placentis dissepimentis insertis, adnatis, multiovulatis. Stylus simplex; stigma obtusum. B a ce a bi-, rarius tri-quadrilocularis. S e mina plurima, subreniformia. Embryo peripheriens, spiralis, albumen carnosum includens - Herbae, suffrutices, frutices $v$, arbores, in regionibus tropicis et temperatis totius orbis crescentes, inermes $v$, aculeatae aut rarius spinosae, glabrae v. pilosae; pilis interdum stellatis; foliis alternis, solitariis aut geminis, integris $v$. varie partitis, floribus extraaxillaribus, lateralibus v. alaribus, rarius terminalibus, solitariis, geminis, umbellatis, fasciculatis, racemosis, cymosis, corymbosis aut rarissime paniculatis, corollis saepissime albis $v$. vio. laceis, rarius luteis.

Sol a n m Tournefort inst, 62. Linn. gen, n. 231. excl. 8 p. Gärtner $I X .939, t, 131$. Dubal, Histoire nafurelle des Solanum. Montpelier, 1813. 4. p. 115. Solano. rum synopsis. Monspelit, 1816, 8. p. 5. - Melange n a Tournef. inst. 65. - P seudo-ca p s f c a m Möacl. 
Method. 856. - D u I e a mara Möuch Method. 514. - N y ete ri um Ventea. Malmais, 85 . - A ndroeer a Nuttal gen. 1. 129. C e ra $\mathrm{t}$ he ra Rafinesque in Monthl. Reposit. 1819. A c quatia Jacquiu $2 m e r .15$. B a s ov i a Aublet Guian. I. 217. t. 85, S o I a $\mathrm{i}$ s p. Lam, t. 115. Flor. dan. t. 167. 160, Jacq. Amer. . 35. 36. 40. Edit, piot, t. 48-50. Hort. Pin. dob. I. t. $12-14$. II. t. 113. Ic. rar. t. 40-46. 322-332. Hort. Schönbr. t. 42, 333. 334. 369. 370. Aublet Quian. I. t. 48. Cavanill. Ic, t. 236. 243, 245. 259. 308, 309. 389. 439. 52\%. Ruiz et Pavon Flor. Peruv. t. 158-17\%. excl. nonnull. fig. Jussieu in Annal. Mus. IIT. 2. 9. Kunth in Hnmb. ct Borpl. Nov, gen, et sp. t. 195. DC. Morl, genev. t. 13. St. Hilaire Plant, us, Brasil, t, 21 . Hooker Exot, Flor. 6. 199: Bot. Mag, t. 369. 1801. 1921, 1928, 2173, 2567, 2568. 2618, 2697, 2708, 2739, 2888. 3385. 3672, 3684, Bot. Reg. f. 140, 17\%, 969, 1516, 1712. Reichenb. Iconogr, t, 963.954. 993 _997. Flor, Yluain, IT. $t, 98-133$.

3856. Hycopersicuma TOURNEF. Cal y x quinque-sexpartitus. C o roll a hypogyna, rotata, tubo brevissimo, limbo plicato, quinquesexfido. St a mina $5-6$, corollae fauci inserta, exserta; fil ament a brevissima, antherae oblongo-conieae, membrana apicis elongata connatae, intus longitudinaliter dehiscentes. O v a r i u m bi-triloculare, placentis dissepimento adnatis, multiovulatis. Stylus simplex; stigma obtusum, obsolete bilobum. B a c ca bi-trilocularis, S e min a plurima, reniformia, pulposo-villosa. E mbryo intra albumen carnosum subperiphericus, arcuatus; cotyledon ibus semicylindricis, radicuI a tereti, vaga, - Herbae $A m$ crica tropicae, nunc ob fructus si condiuntur admodum sapidos, in hortis ubivis cultae, ercetae $v$. procumbentes; foliis allernis, decompositis, impari-pinnatis, pedunculis extraaxillaribus multifloris, pedicellis sub flore articulatis, fructiferis reflexis, floribus in stirpe culta pluribus facile monstrose coalescentibus, corollam stylumque multifidum, antheras polyadelphas, baccam denique multilocularem, latam, torulosam praebentibus.

Lycopersicum Tournef. Inst, 93. Monneh Method. 515. Dival Solan, 109. t. 3. Synops. 3. Bot. Mag. t, 2814. Ly c opersicu in et Psol a u in Neeker Elem, n, z07, 708. Solani sp. Linn. Jacq. Ic. rar, t. 329, Hort, Vindob. I. t. 11 .

385\%. Atropar $L I N N$. Ca I yx quinquepartitus. C o r o ll a hypogyna, infundibuliformi-campanulata, limbo plicato, quinque-decemfido. S tam ina 5, imo corollae tubo inserta, exserta v. subexserta; filamenta filiformia, antherae lon ritudinaliter dehiscentes. O vari n m biloculare, placentis linea dorsali dissepimento insertis, multiovulatis. Stylus simplex; stigma peltato-depressum. B a ec a calyce patente suffulta, bilocularis. S e min a plurima, subreniformia. Em bryo intra albumen carnesnm subperiphericus, arcuatus v, annularis. - Frutices $v$, herbae caulescentes, in Eurupa media et in Peruvia crescentes; foliis alternis $v$. geminis, integerrimis, pedunculis extrauxillaribus, uni-bi plurifloris, corollis violaceis v., virescentibus.

A tropa Linn, gen; $n$. 249. excl. sp. Jussieu gen, 125. Schluhr $t$. 45, Gärtaer II, 240, $t, 131$. Jaeq. Flor. austr. t. 309. Flor. dan, t. F58. Ruiz et Pavon Flor. Peruv, t,181. Kunth in Humb ot Bonpl. Nov. gen, et sp. III. 11, $t, 196$. Hooker Bot, Miscell. t. 37, Ic, t, 106. 107. Pauquy Dissert. de Belladona, Paris, 1824. 4. Bellad on a Tournefort insl. 13. excl, sp.

3858. Wethanela $P A U Q . \mathrm{C}$ a 1 y $\mathrm{x}$ campanulatus, quinquedentatus. Co ro Il a hypogyna, campanulata, limbo quinquepartito. S t a m i na 5 , corollae tulo inserta, vix exserta; a n thera e longitudinaliter dehiscentes. Ovari u in biloenlare, placentis dissepimento adnatis, multiovulatis. Stylus sim- plex; stigma eapitatum. Bace a calyce aucto, angulato cincta, bilocularis. Semina plnrima, subreniformia. E m b r y o intra albumen carnosum subperiphericus. - Fruticuli hispanici et can arienses; folitis alternis $v$. geminatis, ovatis, obtusis, v. oblongis, acuminatis, pedunculis extraaxillaribus, -solitariis $v$, confertis.

Withania Pauquy Dissert. de Belladona. Paris, 1824, ex Ferrusac Bullet. se, nat. $V$. 25i. A trop a f ru tescens L.et A. aristata Poir. Physalis suberosa Cavanill. Ic. t. 102 ,

3859. Nandrogera TOURNEF. C a. I y $x$ turbinatus, quinquefidus. Co r o Il a hypogyna, campanulata, limbo plieatu, quinquefido. St a m ina 5 , imo corollae tubo inserta, subexserta; filamenta e basi dilatafa filiformia; antherae terminales, longitudinaliter dehiscentes. O v ar i m biloculare, placentis dissepimento adnatis, multiovulatis. Stylns simplex; stigma subeapitatum. Ba c c a calyce parum aucto suffulta, dissepimento obliterato placentisque coadunatis uni locularis. Se m in a plurima, subreniformia. E mb ryo intra albumen carnosum subperiphericus, arcuatus; e ot y le do $\mathrm{n}$ i bus semicylindricis, $\mathrm{ra}$ d ic u la tereti, vaga. - Herbae perennes, in $E u$ ropa a ustrali indigenae, acaules; radice crassa, carnosa, saepe bifida, apud strigas sagasque celebri, foliis radicalibus confertis, ovatis, basi atlenuatis, undulatis, integerrimis, saepe pedalibus, pedunculis radicalibus confertis, unifloris, apice in crassatis.

Ml a nd ragora Tournef, inst. 12. Jussier gen. 125, Gärtner. $I T$. 236. $t$. 131. A trop a M a ndrago ra Limn. Sibthorp Flor. graec, t. 232.

3869. Iilimeranthus. Ca ly $x$ quinquefidns. Corolla hypogyna, campanulata, limbo plicato, quinquepartito. St a m in a 5 , imo corollae tubo inserta, inclnsa; filamenta ligulaeformia, spathulato-oblonga, linea dorsali tubo adnata, caeterum libera, antherae dorso flamento infra apicem insertae, Iongitudinaliter dehiscentes. $\mathbf{O}$ va $\mathbf{r}$ i $\mathbf{~ m}$ biloculare, placentis dissepimento adnatis, multiovulatis. Stylus simplex; stigma globosum, obsolete bi-sexlobum. B a c c a calyce suffulta, bilocularis. Se m in a plurima, reniformia. E mbryo intra albumen carnosum subperiphericus, arcuatus. - Herba monte vid e en sis, inferne radicans, superne adscendens; foliis alternis, lyrato-sinuatis, pedunculis extraaxillaribus, solitariis, unifloris.

Jabor os a runcinat a Liak et 0tto Ic. select. $t$. 48 , an Law?

BS61. Iaborosa JUSS. C a I y quinquefidas. Corolla hypogyna, infundibuliformi-tabulosa, limbo plieato, quinquepartito. St a m i na 5 , corollae fauci inserta, inclusa; filamenta brevissima, antherae terminales, longitudinaliter dehiseentes. Ovarium bi-triloculare, placentis dissepimento insertis, multiovalatis. Sty I u simplex, inclusus $\mathrm{v}$. exsertus; $s \mathrm{ti} \mathrm{g} \mathrm{m}$ a clavatum, obsolete tri-quinquelobum. B a c $\mathbf{c}$ a calyce suffulta, bi-trilocularis. Se mi na plurima, subreniformia. Em bryo ..... - Herbae bon arienses, prostratae, radicantes $v$. adscendentes ; foliis geminatis, integerrimis $v$, runcinatis, pedunculis extruaxillaribus, solitariis, unifloris.

J a b o ros a Jussieu gen, 125. Lam. Dict. IIt. 189. t, 114. Hooker Bot, Miscell, I, 347, t, 71, Bot. Mag. t. 3489.

386:. Iuamulloa $R U I Z$ et $P A V$. C a I y $x$ coloratus, ovatus, inflatus, quinquefidus. Corol. I a hypogyna, tubulosa, fauce coarctata, postice 
gibba, limbo minimo, quinquepartito, patente. S t ain in a 5, corollae tubo inserta, inclusa; fil a m enta basi villosa; antherae sagittatae, longitudinaliter dehiscentes, 0 vari n m biloculare, placentis dissepimento adnatis, multiovulatis. B a cc a ovata, calyce inflato cineta, bilocularis. S em in a plurima, oblongo-reniformia. Embryo .... - Frutex peruanus, solis Ruiz et Pavon notus, vix hujus loci; foliis alternis, oblongis, acuminatis, integerrimis, racemis pendulis, dichotomis, floribus rubris.

Juanulloa Ruiz et Pavon Prodr. 27, t. 4. Flor Peruy, II. 47. t. 185. Ull o a Pers. Ench. I. 218.

3868. Tyefran $L I N N$. C a 1 y $x$ urceolatus aequaliter quinquedentatus, v. irregulariter triquinquefidus. C o roll a hypogyna, infundibnliformis v. tubulosa, limbo quinque-decemfido v, dentato, interdum plicato. St a min a 5 , medio v, imo corollae tubo inserta, inclusav. exserta; an $t h e r$ a longitudinaliter dehiscentes. $O$ v a $\mathrm{r}$ i u $\mathrm{m}$ biloculare, placentis dissepimento adnatis, multiovulatis. StyIns simplex; stigma depresso-capitatum v. obsolete bilobum. B a c a calyce suffulta, bilocularis. Se m ina plurima, reniformia. E mbryo intra albumen carnosum periphericus, hemicyclicns. - Arbusculae v. frutices, in regione mediterranea et in Americatropica transandina crescentes, plurimi quo ad seminis structuram nondum explorati, et fortassis olim e genere expellendi; folis alternis, integerrimis, interdum fasciculatis, pedunculis extraaxillaribus aut terminalibus, salitariis, geminis v. umbellatis, rarius corymbosis, co. rollis albidis, flavescentibus, roseis, purpureis $v$. coccineis.

L y ef a m Lian. Gen, n. 269. Gärtner $I I$. 242. Kunth in Humb, et Bonpl. Nov, et gen, sp. IIT. 50 . Sehlechtend. in Lin naea VII. 68.

a. EULYCIUM. C a 1 y $\times$ urceolatus, irregulariter tri - sexfidus. Corolla infundibnliformis, limbo quinquefido, patente. St a mina exserta. - Folia sparsa, flores extraaxillares, solitarii $v$. gemini. (Gïrtner t. 132. Selikuhr t. 46. Sibthorp Flor. graec. $t, 236$.

b. LYCLOBATOS. CaIyx urceolato-campanulatus, aequaliter quiàquedentatns. C o roll a infundibuliformis, lim. bo quinquefido, erecto. St a m in a inclusa. - Folic fasciculata, flores axillares, subsolitarii. (Miller Ie. t. $171, f(1)$

c. LXCLOTHAMNOS. Cal y $\times$ ureeolatas, inaequaliter quinquefidus v. quinquedentatas. C o ro 11 a tubulosa, limbo erecto, plicato, quinque-decemdentato. $\mathrm{S} t \mathrm{a} \mathrm{m}$ in a $\mathrm{sub}$ inclusa. - Folia sparsa, fores subaxillares v. termi nales, fasciculato-umbellati. (Humb. et Boupl. Plant. aequinoot, $t$. 42.)

3864. A enistus SCHOTT. C a l y x cam panulatus, quinquedentatus. Coroll a hypogyna, infundibnliformis, tubo brevi e basi dilatato, lim bo quinquepartito, patente $v$. reflexo, aestivatione imbricato. St amina 5 , corollae tubo supra basim inserta, exserta; fil am enta simplicia, antherae longitudinaliter dehiscentes. Ovarium biloculare, placentis subglobosis, dissepimento adnatis, pluriovulatis. Stylus simplex; stigma capitatum, subconeavam. B a c ea calyce cincta, bilocnlaris. Se min a pauca, reniformia, compressa. Embryo..... - Frutices Americae tropicae; foliis alternis, integerrimis, floribus in axillis annotis fasciculatis, corollis albis, odoratis, baccis rubris.

A c nistus Schott in Wiener Zeitschr. IV. 1180. Lin naea 1831. Litterat. Bericht. 54. Sehlechtend, in Linnaea $V I T, 66$. A tropa arborescens Linn. Cestrum $c$ a u. IIfi o rum Jaeq. Hort. Schünbr. $t$. 325. -? L y e il s p. Ruiz et Pavon Elor, Perive. $t, 182,183$.
TRTBUS v. CESTRINEAE. E m b ry 0nis recti cotyledones foliacéae, radicula infera. B a c c a bilocularis.

3865. Cestruana LINN, Calyx campanulatus, quinquefidns. Co rolla hypogyna, infundibuliformis, tubo elongato, superne ampliato, limbo quinquepartito, subplieato, patente $v$. revoluto. St a mina 5, medio corollae tubo inserta, inclusa; fil ament a simpliciav, intus dente ancta, an $t_{\text {h }} \mathrm{r}$ a e Iongitudinaliter dehiscentes. Ova rinm biloculare, placentis subglobosis, dissepiinento adnatis, panciovulatis. Siylus simplex; stigma subcapitatum, concavum v. obsolete bi obum. B a c ca calyce cincta $v$. inciusa, bilocuaris, v. dissepimento obliterato placentisque coadunatis unilocularis. Sem in a pauca, umbilice ventrali. E m b r y 0 in axi albuminis carnosi rec. tus v. retiusculus; cotyledonibus foliaceis, orbiculatis, radicula tereti, infera, - Frutices $A m$ ericae tropicae; folitis alternis, solitariis $v$. rarius geminis, integerrimis, gemmarum axillarium foliis extimis evolutis stipulas menientibus, floribus racemosis, racemis bracteat is, axillaribus, elongatis v. abbreviatis, in corymbum, spicam v. fasciculum contractis, floribus sacpe suaveolentibus, corallis luteis, baccis nigris v, nigro caeruleis.

Cestrum I.ina. gen, $n$, 961. Gïetner I. 378, $t, 75$ Smith Spicileg. t. 2. Heritier Stirp. t. 3t-36. Jacq. Hort. Schönbr. t, 32 r. 326-33t. 452, Ruiz et Pavon Flor, Peruy. 6. 154-157. Kuath in Humb, of Bonpl, Nov. gen. et sp. III. 55. t. 197. Sehtechtend, in Linmaea VIT, 5i. Bot, Mig. 6. 1729, 1770. 2999. 2974. Link et Otto Ic, rar, t. 6.

3866. Dunalis $H, B, K$. Caly $x$ urceo latus, quinquedentatus. Corolla hypogyna, in fundibuliformis, tubo elongato, subcylindraceo, limbo plicato, quinquefido. St a $\mathrm{m}$ in a 5 , corollae tubo inserta, inclusa; fil a menta tripartita, Ja ciniis eapillaceis, intermedia antherifera, anthera e longitudinaliter dehiscentes. Ovari $\mathrm{nm}$ biln. culare, placentis dissepimento adnatis, multiovu. latis. Stylus simplex, exsertas; stig ma emar ginato-capitatum. B a ce a globosa, calyce suffulta, bilocularis. Se min a plurima, lenticularia. Embryo ..... - Frutex novo-granaten. $s i s$; foliis alternis, solitariis, subintegerrimis, sub tus pilis stellatis floccoso-tomentosis, umbellis ex traaxillaribus, sessilibus, corollis albidis.

Dunali a Kunth in Hamb. et Bonpl. Nov. gen, et ap. III. $35, t, 194$. non Spreng. Dierbaclila Spreng, Syst. I, 676 .

386\%. IKahrothammus. C a I y x campa nulatus, quinquedentatus. Corolla hypogyna, clavato-tubulosa, tubo longo, limbo quinquedentato, contracto, S t a m in a 5, medio corollae tubo inserta, inclusa; fil am enta simplicia, anthe$r$ a e longitudinaliter dehiscentes. Ovari nm biloculare, placentis oblongis, dissepimento adnatis, pluriovulatis. Stylus simplex; stigma capitatum, obsolete bilobum. B a c ca calyce cincta, bilocularis. S em in a pauca, angulata, umbilico ventrali. E $\mathbf{m}$ b r yo in axi albuminis carnosi rectus; cotyledonibus foliaceis, radicula tereti, infera. - Frutices mexicani, glabri v. subtomentoso-pubescentes, pilis articulatis; foliis alternis, integerrimis, floribus inaequaliter cymosis, corollis baccisque rubris.

Me yenia Selilechtend. in Linnaea VIII, 251, nou Nees. 
ThIBUS VI. VESTIEAE. E mbry o$n$ is recti cotyledones foliaceae, radicula infera. Capsula bilocularis.

3868. Vestia WILLD. C a ly $x$ campanulatus, quinquedentatus. C orolla hypogyna, infundibuliforini-tubulosa, limbi quinquefidi, erectopatentis laeiniis ovatis, aestivatione induplicatovalvatis. Sta in in a 5 , medio corollae tubo inserta, exserta; a n the ra e longitudinaliter dehiscentes. Ovariu br biloculare, plaeentis dissepimento adnatis, multiovulatis, Stylus simplex, exsertus; stigma incrassatum, indivisum. C a p s u l a cylindracea, calyce stipata, bilocularis, loculicido-bivalvis, valvis demum bifidis, dissepimentum membranacenm medio placentiferum nudantibus. S e m in a plurima, oblonga, subcompressa, aptera, umbilico ventrali. $\mathrm{E} \mathrm{m}$ b ry o in axi albuminis carnosi reetus; cotyledonibus orbiculatis, subfoliaceis, radic ula tereti, infera. - Frutex chilensis, erectus, ramosus, Cestri v. Lycii-facie; foliis alternis, petiolatis, obovatis $v$. ellipticis, integerrimis, coriaceis, glabris; nitidis, floribus e summis alis solitaviis, pedunculatis, nutantibus, magnis, corollis flavis.

Vestia Willdenow Enumerat. I. 208. Don in Edinb. philosoph, Journ, VIT. 290. Schlechtend, in Linnaea VIT. 53. Periphragmos foetidus Ruiz et Pavon Flor. Pe. ruv. t. 132. excl. capsula. Cantua ligustrifolia Juss.

3869. Sessaea $R U I Z$ et $P A V, C$ a 1 y $x$ tubulosus, quinquedentatus. C o roll a hypogyna, infundibuliformi-tubulosa, limbi quinquefidi, erectopatentis laciniis ovatis, aestivatione plicatis? S tamin a 5 , corollae tubo inserta, inclusa; a n therae longitudinaliter dehiscentes, O va ri u m biloculare ..... St ylus simplex; st $\mathrm{i} g \mathrm{~m}$ a inaequaliter bilobum, Ca p s a 1 a calyce stipata, eylindriea, subarcuata, bilocularis, bivalvis, valvis demum bifidis. S e m in a plurima, imbricata, oblonga, compressa, margine membranaceo cincta, Embryo ..... - Arbores $v$. frutices per uani; foliis alternis, petiolatis, oblongis, basi cordatis, integerrimis, racemis terminalibus paniculatis.

S es s a e a Ruiz et Pavon Prodr, 21, t, 23. Flor. Peruv. $I I, 9 . t$. 115 . 116 .

\section{GENERA DUBIA.}

38\%0. Cotylanthera BLUM. Cal y campanulatus, quadrifidus, persistens. C o rolla hypocraterimorpha, quadripartita, mareescens, laciniis aequalibrs, patentibus. S t a m in a 4, aequalia; filam enta brevia, lata, antherae conniventes, apice poro nnico dehiscentes. Ovarium ..... Stylu s bisulcus; stigma capitatum, depressum. Capsula ovato-globosa, bilocularis, dissepimentis carnosis, utrinque inflexis. Semina plurima .... - Herba javanica, carnosa, inter minores, radicibus arborum innascens; scapo tereti, aphyllo, subramoso, hino illine stipulis parvis, geminatis instructo, pedicellis solitariis aut geminatis, medio bibracteatis, floribus dilute caerulescentibus.

Cotylanthera Blume Bijdr. 702.

3871. Imanthera NEES F1ores polygami. Herma phr, Calyx quinquefidus. C 0 rolla rotata, quinquefida, calyce brevior. $\mathrm{Sta}$ amina 5 , a nthe rae uniloculares, rima verticali longitudinali (?) dehiscentes, connectivam semicir culare amplectentes. Ovarium e carpidiis duobus ad axim communem inflexis, dissepimentum bilamellatum, diagonaliter recurrens, margine ovuliferum constituentibus. St y $\mathbf{l u} s \ldots . .$. stig ma truneatum. C a p s a I a bilocularis, receptaculis quatuor, lamelliformibus. S e m in a plurima, parva. .... Fem. Corolla nulla. Staminum rudimenta tuberculiformia. Ovari um ut in hermaphroditis. - Herba indica; caule erecto, medulla ampla farcto, cortice tenui, spongioso, candido, detergibili, dense ferrugineo-lanato, subtomentoso, pubescentia simplici, foliis alternis, obovato-cuneiformibus, acutis, in petiolum atlenuatis, costatopenninerviis, laxis, supra viridibus, lanugine sparsa, subtus lanuginoso-albicantibus, floribus in foliorum axillis fasciculato-glomerat is, nutantibus, calycibus extus valde lanatis; corollis glabris.

I santhera Nees in Linn. Transaet. XVIT. 82.

OBSERVATIO. Cotylanthera et is anthera, genera imperfectissime coguita, fortassis ad Cyrtandraceas pertineut.

38\%3. Dartus LOUREIR. Calyx quinquefidus, laciniis ovatis, membranaceis. Co rolla hypogyna, tubo subgloboso, calycem superante, limbi quinquefidi laciniis ovatis, patentibus. Stamina 5, medio corollae tubo inserta, inclusa; fil amenta filiformia, antherae incumbentes. Ova rium subglobosum, suleatum. Stylus brevissimus; stig ma quinquelobum. B a c e a parva, globosa, exeoriata, diaphana, unilocularis. Se mi$\mathrm{n}$ a plurima, subrotunda, minima, inaequalia. Arbuscula indica, sexpedalis ; radice aromatica, rubescente, ramis adscendentibus, flaccidis, foliis alternis, oblongo-ovatis, acuminatis, serratis, subtus tomentosis, mollibus, racemis axillaribus brevibus.

Dartus Loureiro Flor. cachineh. 152. P erlarius al te r Rumph Amboin. VI. $t$. 57.

38\%3. Doraena THUNB. Calyx quinquefidus, laciniis ovatis, concavis. Corolla hypogyna, subcylindrieo - rotata, limbi quinquefidi laciniis ovatis, obtusis, erectis. Sta m in a 5 , corollae tubo inserta, inclusa; fi l a ment a subnulla, antherae oblongae, subtetragonae. Ovarium liberum, squamis quinque nectariferis coronatum ..... Stylus simplex; stigma truncatum, emarginatum. B a c c a sicca, striata, squamulis nectariferis, stylo persistenti adpressis conice acuminata, unilocularis, placenta basilari libera, globosa, alveolata. Sem in a plurima, angulata, inverse pyramidata, testa membranacea, umbilico basilari. E mbr yo in axi albuminis carnosi orthotropus, teretiusculns; c oty I ed onibus brevissimis, ra di cula eylindrica, umbilicum respiciente. - Arbuscula japonica; ramis alternis, divaricatis, teretibus, glabris, cinereis, folitis alternis, petiolatis, oblongis, acuminatis, remote et obsolete serratis, glabris, patentibus, racemis axillaribus brevissimis, floribus albis, minutis.

Doraena Thunberg Nov, gen, 59. Flor, japon. 6. Gärtner f. III. 27. t. 184.

38\%4. Trigmera $G A V$. Caly $\mathrm{x}$ quinquepartitus, persistens, laciniis inaequalibus, lanceolatis. C o roll a hypogyna, tubo brevissimo, fauce ampliata, limbi plieati, quinquefidi, subbilabiati Iobis rotundatis, labio superiore breviore, reflexo, 
inferiore ventricoso, erecto-patulo. St a min a 5, urceoli perigyni, membranacei, basi meliflui, quinquedentati dentibus extus inserta, subaequalia, inclusa; fil amenta brevia, linearia, ant herae magnae, oblongo sagittatae, compressae, in conum conniventes. Ov a ri u $\mathrm{m}$ subglobosum, bisulcatum, urceolo staminigero cinctum et partim tectum. ..... Stylus subulato-filiformis; sti gma subcapitatum. Drupa calyce inclusa, sicea, membranacea, scarioso - rugosa, quadrilocularis, receptaculo subrotundo-tetragono, dissepimentis loculorum membranaceis, tenuissimis, evanescentibus. Semina in locnlis gemina, superposita, nucamentacea, subovato-compressa, aspernla, nucleo subrotundo, compresso ..... - Herbae hispanicae, annuae, narcoticae, muscum redolentes, Moradilla et Alm izquen a indigenis dictae, sed vix notae et obscurissime descriptae; folits alternis, sessilibus v. decurrentibus, obovatis, sinuatis, villosis, v, ovato-lanceolatis, integerrimis, laevibus, pedunculis axillaribus solitariis, bifidis, biftoris, nutantibus. t. 114 .

Triguer a Cavanill. Dissert. II. Append. I, Lam.

OBSERVATIO. Solanaceis adnumerari adhuc solet genus sequentibus circumseriptum:

STIGMATOCOCCA Willi, in Schult. Mantiss. III. 3.55. Caly $\mathbf{y}$ quadrifidus, persistens, Iaciniis ovatis, ereetiusen. lis. C o rolla rotata, quadrificla, tubo brevi, lacinlis ovali bus. Filamenta filiformia, an $t$ herae exsertae. St y I us subulatus; stig ma simplex. B a e ca globosa, monosperma. - Planta brasiliensis; caule frutesconte, ramoso, folits alternis, oblongis, basi attenuatis, petiolatis, crenulatis, glabris, foribus terminalibus paniculatis, pa. niculae ramis cymosis.

\section{TUBIFLORAE INCERTAE SEDIS.}

\section{* DESFONTAINEAE}

38\%5. Desfontainea $R U I Z$ et $P A V$. C al y $\mathrm{x}$ quinquepartitus, persistens, laciniis lanceolatis, erectis. Corolla hypogyna, tubulosa, subcartilaginea, tube calycem duplo superante, nervoso, nervis per medias limbi patentis, aequaliter quinquepartiti lacinias ovatas, aestivatione imbricatas decurrentibus. St a min a 5, corollae fauci inserta, ejusdem laciniis alterna, inclusa; fil am enta brevissima, complanata, anthera e biloculares, lanceolatae, longitudinaliter dehiscentes. Ovari um globosum, uniloculare? placentis parietalibus quinque, septiformilus, latere utroque ovuliferis, margine interiore nudis. Ovula plurima, horizontalia, anatropa. Stylus terminalis, filiformis; st $\mathbf{g} \mathrm{m}$ a eapitatum. B a c ca globosa, unilocularis, placentis parietalibus. S emina plurima, angulata, testa coriacea, hinc rhaphe prominula, callosa, umbilicum basilarem chalazae apieali dilatatae jungente pereursa. E mb ryo in basi albaminis dense carnosi, copiosi prope umbilicum minimus, subglobosus; cotyledonibus brevissimis, radicula crassa. Frutices peruani, inermes, non satis noti; ramis oppositis, foliis oppositis, petiolatis, coriaceis, spinoso-dentatis, amaris, petiolis cum ramo articulatis, floribus axillaribus et terminalibus solitariis, pedunculatis, pedunculis bibracteolatis, coroll is coccincis, limbo luteis, baceis albis.

Desfontaine a Ruiz et Pavon Prodr, 29, t. 5. (sitn staminum perperam ex hibito.) Flor, Peruv, II. 47. t. 186, (mal.) Humb, et Boept. Plant, aequinoct. $t, 45$. Kuath in Humb. et Bonpl. Nov. gen. et sp. YTI. 274. Don in Edinb, n.phi losoph. Journ. Octob. 1831 p. 274. Hooker Ic. 23. L i It. k i a Persoon Encheir. 1. 219.

\section{*** RETZIACEAE.}

38r6. Tetzia THUNB, C a lyx tubulo sus, quinquefidus, laciniis laneeolatis, inaequalibus Corolla liypogyna, tubulosa, tubo ealyce multo Iongiore, limbi quinquepartiti lacinis bre vibus, lanceolatis, aestivatione imbricatis, sub an thesi patentibus, St amina 5 , corollae fanei inserta, ejnsque lacinits alterna; fil a ment a brevissima, anth erae semiexsertae, biloculares, sagittatae, longitudinaliter dehiscentes. $0 \mathrm{v}$ ari a m biloculare. $O \mathbf{v}$ ula in loculis pauca, medio dissepimento inserta (?) Stylu s terminalis, filiformis, simplex, subexsertus; st $\mathrm{g}$ ma obsolete bilobum. Capsula compressa, bilocularis, bisulea, bivalvis .... S e mina subdefinita ..... E m b r y o intra albumen eariosum teretiusculns, reetus ..... - Frutex o apensis, non satis notus; ramis rigidis, foliis confertis, quaternatim verticillatis, lanceolato-linearibus, rigidis, margine revolutis, integerrimis, floribus in supremorum foliorum axillis solitariis, sessilibus, bracteis carinatis stipatis, inter folia fere absoonditis.

Retzia Thunberg in Act, soc, Lund, I. B5, t, t, f. 1 . Lam t, 103. R. Brown Prodr. 482, in not.

38r\%. Honehostoma WIKSTR. $\mathrm{C}$ aI $x$ pentaphyllus, bibracteolatus. C o rolla hypogyna, tubulosa, tubo calyce multo longiore, limbi quinquepartiti laciniis lanceolatis. $\mathrm{S}$ ta m in a 5, corollae fauci inserta, ejusdem laciniis alterna, inclusa v. breviter exserta; filamenta brevissima, antherae biloculares, sagittatae, longitudinaliter dehiscentes. 0 v a $\mathrm{r}$ i n m biloculare, placenta lineari dissepimento utrinque adnata, pauciovulata, ovulis pendulis. Styli 2 , terminales, subclavati v. filiformes, inclusi. C a p 8 u la bilocularis, dissepimento membranaceo, 'ntrinque placentifero. ... Semin a in quovis laculo 8 - 10 .... - Frutices capenses, vix noti; foliis confertim alternis, subimbricatis, sessilibus, ovalis, integerrimis, coriaceis, extus hirsutis, floribus in summis foliorum axillis solitariis, sessilibus, spicam foliatam formantibus.

Lo on ehos tom a Wikstrom in Act. Hotm, 1818. p.349. t. 10. Gnidia pentandra Thunb.

\section{Classis XXXVII. Personatae.}

\section{Herbae, frutices v. arbores, succo} aqueo. Foli a opposita, alterna v. verticillata, simplicia v. rarius composita, palmata $v$. pinnata, rarissime abortiva, squamaeformia. Stipulae nullae. Calyx liber v. cum ovarii basi connatus. Cor oll a hypogyna ve perigyna, gamopetala, rarius regularis, ut plurimum limbo irregulari, bílabiato. Stamina corollae tubo inserta, ejusdem lobis pauciora, rarissime aequalia. O va ri um dimerum, unibiloculare. Ovula plurima, anatropa v, amphitropa. Fru ctu s capsularis v. rarius baccatus. E m bryo intra albumen homotropus $v$, exalbuminosus. 


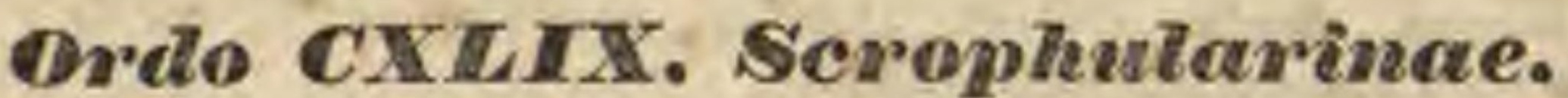

PEIDICULARES et SCROPHLLARIAE Jussieu gen. 99.117. IHINANTHOIDEAE et PERSUNATAE Venten. Tabl, II, 293. 351. RHINANTHACEAE et PERSONATAE Jussieu in $A n$ nal. Mus. $Y$. 235. $X I V$. 394. SCROPHULARINAE R. Browa Prodr. 433. Bartling Ord. nat. 169. Benthan, Scrophulari. nearum Revisio in Bot. Reg. Juni, 1835. Scrophularineae indicae Londini, 1835. 8. ot in Bot. Mag. Comp. . 198. 356. II. 13. 53. Don in Edinb. new philosoph, Journ. XIX. 108. SCRORHULARIACEAE Lindley Introduct. edit. $I I, p$. 288.

IIERBae v. sufpretices, rarins arbuscuLAB, caule ramisque teretibus, enodibus, v, tetragonis, nodosis. Folia alterna, opposita v. verticillata, simplicia, integra $v_{0}$ incisa aut pinnatipartita, sessilia $v$. petiolata, nunc in eaulem decurrentia. Stipula e nullae.

Fuones hermaphroditi, regulares v. saepis sime irregulares, axillares v. racemosi, rarius spicati, pedunculi oppositi v. alterni, nunc simplices, uniflori, nudi v. bracteolati, nune multiflori, dichotome cymosi.

Calxx liber, persistens, penta-v. tetramerus, saepissime gamophyllus, foliolis nunc fere ad apicem, nunc ima basi tantum coalitis, nune omnino liberis, aestivatione imbricatis, saepe inaequalibus, foliolo postico maximo, duobus anticis minoribus, duobus lateralibus omnium minimis.

ConoLLa hypogyna, gamopetala, pentamera, v. petalis duobus ad apicem usque coalitis specie tetramera, tubo brevi v. elongato, basi aequali $\mathbf{v}$. saccato aut calcarato, limbo rarius aequaliter $v$. subaequaliter partito, explanato, saepissime recto, bilabiato, labio superiore bi- inferiore trilobo, lobis aestivatione imbricatis.

Stauiva corollae tubo inserta, typice ejusdem lobis numero aequalia et alterna, abortu vis non semper pauciora, posticum omnino nullum v. rarius rudimentarium, rarissime fertile, sed semper brevius, duo lateralia inter se aequalia, antherifera, rarissime ananthera v. omnino deficientia, duo antica intêr se aequalia, nunc antherifera, posticis aequalia v. saepius longiora, nunc ananthera v. plane deficientia. Fil a m enta simplicia v, basi appendice dentiformi aut filiformi aucta, recta v. basi declinata. A nthe ra e biloculares, loculis parallelis $v$. divarieatis, saepe confluentibus v. dimidiatis uniloculares, longitudinaliter dehiscentes, saepissime per paria cohaerentes.

Ovarium liberum, e carpidiis duobus, an ticum et posticum ab axi floris latus ocenpantibus, marginibus in dissepimenta, columnam $v$. laminam placentiferam attingentia introffe$x$ is biloculare, rarissime placentis ad margines axim haud attingentes sitis uniloculare.
$0 \mathrm{vula}$ indefinita, anatropa, horizontalia, adscendentia v. pendula, rarissime subdefinita, amphitropa. StyIus terminalis, simplex v. rarius breviter bifidus; st $i g m$ a simplex, integrum, emarginatum v. bifidum, saepe complanatum, rarius stylo apice diviso duplex.

Capsula rarissime baccata, bilocularis, interdum apice incomplete valvatim v. operculatim aperta, saepissime bivalvis, loculicide septicide v. septifrage dehiscens, valvis integris $\mathbf{v}$. demum bifidis bipartitisve, dissepimento v. e marginibus valvarum introflexis duplicato, v. simplici integro valvis parallelo, nunc iisdem contrario bipartito, placentis centralibus coadunatis, septo adnatis v. tandem solutis.

Semra plurima v. rarissime definita, testa nunc solida, laevi $v$. saepius scrobiculata, interdum in alam expansa, nunc laxa, reticula$\mathrm{ta}$, solubili, umbilico basilari v. rarissime ventrali, rhaphe et chalaza obsoletis v. plus minus manifestis.

Eusryo in axi albuminis carnosi v, cartilaginei saepissime orthotropus, interdum homotrope curvatus. C otyle d on e s brevissimae, obtusae, rarius subfoliaceae. Radicula teretiuscula, umbilico proxima, v. rarissime ab umbilico ventrali remota.

Scrophularineae e nullo climate $v$. solo exules, in temperatis calidioribus utriusque hemisphaerii maximo numero generantur, inter ipsos circulos tropicos aliquantulum rariores, in frigidis rarae.

Diagnosis ordinis a reliquis Personatis perquam facilis, sed generum nonnullorum a Solanaceis capsularibus discrimen admodum lubricum, e corollae aestivatione, staminum imminuto numero et ovulnrum directione petendum.

Qualitates insunt plerisque acridae vol amarae.

In generibus distribuendis et circumscribendis dissertationes a cl. Bentham editas, notasque manuscriptas ab eodem benevole mecum communicatas secutus sum.

TREDUS I. VERBASCEAE Benth. Scroph. ind. 16. C or oll a tubo abbreviato ve subgloboso, limbo explanato, quadri - quinquefido v. bilabiato, non ringente. Sta $\mathrm{m}$ in a fertilia 2 v. 5, saepius declinata. Anth erae approximatae v, cohaerentes, uniloculares v. subbiloculares, loculis divaricatis, confluentibus. Capsula septicide bivalvis, valvis saepe bifidis, placentas coadunatas nudantibus. is eminu m testa solida.

3858. Verlbaseram $L I N N$, C alyx quinquepartitus, subaequalis. Corolla hypogyna 
tubo brevissimo, limbi subrotati, explanati, quinquepartiti laciniis subaequalibus $\mathrm{v}$, antica majore. Stamina 5 , corollae tubo inserta, exserta, declinata, antica longiora; fil amenta omnium $v$. trium posticorum bariata, an $t h$ erae adnatac v. medifixae, loculis confluentibus uniloculares, $O$ ₹ ari u m biloculare, placentis dissepimento utrinque adnatis, multiovulatis. Sty I us simplex, apice incrassatus; $8 \mathrm{t} \mathrm{i} \mathrm{g}$ m a indivisum v. bilamellatum. Ca p sula ovata v. globosa, bilocularis, septicide bivalvis, valvis apiee bifidis, placentis septo adnatis. Sem ina plnrima, lacunoso-rugosa. - Herbae in Europa media et australi, nec non in Asia temperata indigenae, erectae, durae, tomento $v$. lana floccosae, rarius glabratae; folitis alternis, saepe decurrentibus, floribus fasciculatis $v$. rarius solitariis, in racemos simplices $v$, paniculato-ramosos dispositis, corollis flavis v. phoeniceis.

Ver ba s e $\mathrm{m}$ Tournef, inst, 61 . Linn. gen, $n$, 245. Gärtner I. 262, t. 55 . Sehrader Monogr. 1813 - 1823.4. Nees in Linn. Transact. XVIT. 79. Benth. Scrophularin. ind.16. Revis. 1 . Nees Jun. Gen, plant, XVI, t, 19. Jacq. Flor. austr, $t, 125$. Waldst. et Kitaibel Plant, rar. Hung. t.79, 197. Link et Hof mans. Flor, portug, $t$. 26. 28. Sibthorp Flor, graec, $t$. $228-229$. E. B, $t, 58.59 .393,457,549,350$. Flor, dau, $t, 586,631$. 1058. 1810. 1811. Tenore Flor. neap, t. 21-33. Labillard Syr. Decad. IV. $t$, 5, Bot. Mag. t. 236, 885. 1037, 1226. 1777. Reichenb. Iconogr. $t, 998$.

38\%5. Celsia LINN. C a 1 y $x$ quinquepartitus, subaequalis. Corolla hypogyna, tubo brevissimo, limbi subrotati, explanati, quinquepartiti laciniis subaequalibus v. antica majore. Stamin a 4 , corollae tubo inserta, didynama, exserta; filam enta barbata, antica longiora, omnia fertilia, a $n$th erae adnatae v. medifixae, loculis confluentibus uniloculares. Ovarium biloculare, placentis dissepimento utrinque adnatis, multiovu latis. Sty lus simplex, apiec incrassatus; stigm a indivisum. Cap sula subglubosa, septicide bivalvis, valvis apice bifidis, placentis septo adnatis. Semina plurima, lacunoso-rugosa. - Herbae v. suffrutices, in regione mediterraneu imprimis orientali, Asia media et in $E m o d$ $j u g$ is crescentes; foliis alternis, inferioribus saepius lyrato-pinnatifidis, racemis terminalibus, subsimplicibus, pedunculis solilariis haud contortis, demum recurvis.

C els i a Linn. gen, $\pi$. 757. Gärtnee $I$. 269, $t$. 55, Benth. Serophularin. ind. 16.

a. PSEUDOTHAPSUS Benth, Op. cit. 5 . Stam $1 \mathrm{na} 2$ longiora glabra, antheris oblongls, adaatis, breviora barbata, antheris medifixis, locolis confluentibus.

Herbae. D D it a xia Rafin. Somiolog. 13. (Vent, Cels. t. 27. Bot. Mag. t. 964. Bot. Reg. t. 438.)

b. ARcturuS Benth. Op. eil. 5 . Stamiua 2, omnia barbata $\vee$. longiora glabra, antheris omnibus mediexis, loculis confluentibus. - Herbae. (Lim, . 532. Bot. Mag. t. 1962. Sibthorp Flor. graee. t. 605. Nees Jual Gen. plant, XVI, 1, 20,)

NEFFLEA Benth. Op. cit. 5. Stamina ombia bar bata, antheris terminalibus unilocularibus, valvilis dua bus aeutis dehisecntibus. - Suffrutex. - C. parsiffor Decaisue in Nouv. Annal. sc. nat. IT. 25i. - Sui ge neris monente cl. Benthau, sed fructus ignotas.

3580. Alemson RUIZ et $P A V . \mathrm{Caly}$ quinquepartitns, subaequalis. Corolla hypogyna, resupinata, tulo brevissimo, limbo subrotato, quinguefido, lobo antico superiore majore, omni bus rotundatis, Stamina 4 , corollae tubo inserta, exserta, didynama, declinata, adscendentia antherae biloculares, loculis divaricatis. Ov a riu $\mathbf{m}$ biloculare, placentis dissepimento utrinque adnatis, multiovulatis, St y I u s filiformis, simplex; stig ma subcapitatum, C a p s u la ovato-oblonga, acuta, bilocularis, apiee septicide bivalvis, valvis indivisis, placentis septo adnatis. Semina plurima, lacunoso-rugosa. - Herbae v. fruticuli, in Andibus Peruviae et in Chili crescentes; foliis oppositis $v$. ternatis, serratis $v$, interdum integerrimis, floribus axillaribus, subracemosis, pulcherrime miniatis, pedicelli torsione resupinatis.

Alons o a Ruiz et Pavon Syst. Flor. Peruv, 159. Benth. Revis. 1. Sorophularin. ind.5. H e m i m e r is Kunth in Humb. et Bonpl: Nov. gen. et sp, II, 37 6 , nou Linn. He m it o m us Heritier msc. H e m imeri s sp. americanae Auet. Cels ia e s p. Jacq. Ic, rar, t. 479. Bot. Mag, $t, 210,417$.

3881. Jovellama $1 R U I Z$ et $P A V$. Caly x quadripartitus, laciniis subaequalibus. Corolla hypogyna, tubo brevissimo, limbi bilabiati labiis patentibus, superiore breviore concavo-carinato, inferiore concavo, subcalceiformi. Stamina 2 , corollae tubo inserta, subexserta; a ntherae biloculares, loculis parallelis, adnatis. Orari $\mathbf{u m}$ biluenlare, placentis dissepimento utrinque adnatis, multiosulatis. Stylus simplex; stigma peltatosubcapitatnm. Ca 8 ula ovato-conica, bilecularis, septicide bivalvis, valvis bifidis, placentis ovatoconicis, dissepimento insertis. Se mi na plurima, striata. - Herbae chilenses, acaules; foliis radicalibus confertis scapisque unifioris, $v$. caulescentes, foliis oppositis, duplicato-serratis, floribus corymbosis.

Jovella na Rulz et Prvon Flor. Peruv, I. 12, $t, 18$. Cavanill. Ic. $t$. 453. Beuth. Kevis. 1.

388\%. Caleeolanola FEULLL. Calyx quadripartitus, laciniis aequalibus v. postica latiore. Corolla hypogyna, tubo brevissimo, limbi bilabiati labio saperiore abbreviato, truneato-ristundato, integro, inferiore maximo, porrecto, cal ceiformi, concavo. St amina 2, corollae tulop inserta, vix exserta; antherae biloculares, Joculis divaricatis, altero saepius sterili, Ovarium biloculare, placentis dissepimento utrinque insertis, multiovulatis, Stylas simplex; stigma acutiusculam. Cap 8 u la ovato-conica, bilocularis, septiciule bivalvis, valvis bifidis, placentis transversim olblongis, dissepimento insertis. Semina plurima, striata. - Merbac, sufficutices v. frutices, in Peruvia et Chili indigeni, acaules $v$. caulescentes; folits oppositis $v$. ternatis, rarissinu allernis, integerrimis, dentatis, crenatis v. serratis, nunc pinnatiparlitis $v$. pinnatis, pedunculis unimultifloris, alaribus, axillaribus $v$, terminalibus corymbosis, corollis flavis v. luteis, rarius albis v. purpurascentibus.

Calceolari a Feuillé Observ. IIT. t. 12. Lian. gen, n. 1288. Gitrtaer I. 296. \&. 62. Ruiz et Pavon Flor. Peruv. t. 19.31. Cavanill. Ic. t. 442-458. Kunth in Humb. et Bonpl. Nov, gen, et sp. IIT. 379, t. 170, 171. Bat. Mag. t. 41. 348. 2405. 2418. 2593. 2775. 2805, 2874. 2876. 2897 2915. 3036, 3094. 3218, 3255. Bot. Reg. t. 723. 744. 790. 1083. 1915, 1313, 1374, 1448, 1452. 1476, 1588, 1603. 18L, 1621. 1628. 1711. 1743 .

3883. Seropleularia TOURNEF. Ca I y $\mathrm{x}$ quinquefidus v. quinquepartitus, subaequalis. Corolla hypogyna, tubo ventricoso-subgloboso, limbo bilabiato, labio superiore longiore bi lobo, inferioris trilobi lobis lateralibus erectis, intermedio majore, patente v. deflexo, omnibus brevibus, obtusis, planis. St a m in a corollae tubo inserta, inclusa $r$. exserta, quatuor fertilia, didy nama; antheris adnatis, confluenti-uniloculari bus, quinto sterili, flamento adnato, anthera la melliformi v. emarginato-spathulata, rarius nullo. 
Ovarin disco annulari obliquo cinctum, biloculare, placentis medio dissepimento utrinque adnatis, multiuvulatis. Stylus simplex, apice intrassatus; stigma emarginatum. Capsula subglobosa v. ovoidea, saepe acuminata, bilocularis, septicide bivalvis, valvis integris $\mathbf{v}$. apice bifidis, placentis coadunatis, demum liberis. S e m in a plurima, rugosa. - Herbae v. suffrutices, in temperatis et calidioribus extratropicis hemisphaerae borealis, copiosius in regione mediterranea, parce in America boreali crescentes, saepius foetentes; foliis oppositis $v$. interdum alter$n i s$, integris $v$. inciso pinnatifidis, interdum pellucido-punctatis, inflorescentia thyrsoidea, pedunculis oppositis $v$. alternis, cymosis $v$. rarius unifloris.

S crop h u laria Tournef. inst. 24, Linn. Gen, $n, 312$. Gärtner I, 249. $t$. 55 . Wydler in Mem, soo, $h, n$. Genev. IV. 121-170, c. icc. Benth. Scrophularin. ind, 17. Nees jun. Gen. plant, XVI. t. 3. (Schkuhr t, 173. 174. Jacq. Hort, Schonbr. t. 209. 286. E. B. t. 567. 85/, 1504. 2209. Flor. dan. t. $41 t$, 507. 1167. Willd. Hort, Berolin, $t$. 55. 56, Desfout. Flor. atlant. t. 145, Hooker Flor, lond. t. 70. Delile Flor, aegypt. 1. 33. Waldst. et Kitaibel Plant, rar. Hung. t. 73, 170. 214. Sibthorp Flor. graec. $\ell$. $579-604$. Ledebour Ic, t, 121, 156 . Reichenb. Iconogr, $t, 98,258,728.729$.

TEIBUS 1r. HEMIMERIDEAE Benth. in Comp. Bot. Mag. II. 13. C a ly $\mathrm{x}$ quinquefidus v, pentaphyllus. Coroll a tubo brevissimo, limbo explanato, subrotato, bilabiato v. personato, late quadri-quinquelobo, basi saccato, bifossulato v. uni-bicalcarato. Stylus simplex; s t i g m a parvum, subcapitatum. Capsula bivalvis, valvulis integris, bifidis v. bipartitis.

3894. Tylaeantha NEES et MART. Calyx quinquepartitas. Corolla hypogyna tubo brevi, fauce fornicata, limbi subbilabiali plani labio superiore obtusissimo, bilobo, inferioris trilobi lobo medio basi saceato, longiore, rotundato. Stamina 4, corollae tubo inserta, inclusa, didynama; a $\mathbf{n}$ h erae biloculares, locnlis divergentibus. Ova ri $\mathrm{nm}$ biloculare, placentis dissepimento adnatis, multiovulatis. Sty lus simplex; stigma eapitatnm. Capsula globosa, bilocularis, evalvis. S emin a plurima, testa solida. Herba brasiliensis; caule tetragono, subpiloso, folüs oppositis, ovato-oblongis, apice serratis, floribus axillaribus solitariis, pedunculatis.

Ty 1 a e n tha Nees et Martius in $N, A . N, C, X 1,43$. Benth. in Bot. Mag. Comp. II. 15 .

3885. Angelonia HUMB. et BONPL. Cal $\mathrm{y} x$ quinquefidus v. quinquepartitus, Coroll a hypogyna, tubo brevi, fauce fornicata, limbi subbilahiati plani labio superiore obtusissimo, bilo. bo, inferioris trilobi lobo medio basi saccato, lon giore, rotundato. St a min a 4 , corollae tubo in. serta, inclnsa, didynama; anth erae biloculares. loculis divergentilius. Ovarium biloculare, pla. centis dissepimento adnatiz, multiovulatis. 's ty lus simplex; stigma capitatum, Capsula subglobosa, bilocularis, loculicide bivalvis, valvis medio septiferis, integris, placentas coadunatas nudantibus, S e min a plurima, testa laxa. - Herbae a ustro-americanae, erectae v procumbentes; foliis oppositis $v$. superioribus alternis, pedunculis uniftoris, solitariis, axillaribus v. racemosis.

A g gelonia Humb. et Bonpl. Plant. aequinoct. II 92, t, 108. Kunth Synops. 11. 132. Bot. Reg. $t$, 415. Bot. Mag. $t, 2478$. Benth. in Bot. Mag. Comp. II. 15. P hysi. di o m Sehrader in Göling. gel. Anzeig, 1821, p. 714. S c h el. veria Nees et Martius in Flora 1891. p. 299. et 328.

3886. Jhemingemis THUNB. C a $1 \mathrm{y} x$ pentaplyyllus. Corolla hypogyna, tubo brevissimo, limbi explanati, subbilabiati, quadrilobi lacinia suprema brevissime emarginata, basi bifossulata infimaque maximis, lateralibus brevissimis, latis, fauce appendicibns duabus dentiformibus genitalia cingentibus. Stamina 2 , corollae fanci inserta, patentia; antherae uniloculares. 0 varinm biloculare, placentis dissepimento adnatis, multiovulatis. Stylus simplex; stigma obtusum. C a p sula subglobosa, bilocularis, scpticide bivalvis, valvis saepius inaequalibns, demum bifidis, placentas coadunatas nudantibus. Se mi na plurima, testa solida. - Herbae capenses, annuae, diffusae; foliis oppositis, dentatis $v$. incisis, floribus interdum fasciculatis, pedunculis axillaribus unifloris, inferioribus solitariis, supremis subfasciculatis, demum reflexis, corollis flavis.

Hemimeris Tiunb. Nov, gen. 74. Linn, f. Suppl. 45. Jussieu gen, 120. Gärtner f. $I I T, 21, t, 183$. Benth. in Bot. Mag. Comp. 11. 16.

385\%. Diaseia $L I N K$. C a ly $\mathrm{x}$ pentaphyllus. Corolla hypogyna, tubo brevissimo, limbi explanati v. subconcavi, subbilabiati, quadrilobi labio snperiore bifido, basi hisaceato $\mathbf{v}$, bicalcarato, inferioris trifidi lobo medio integro v. emarginato lateralibusque latis, rotundatis, faucis glandula cordiformi, stamina deprimente, $\mathrm{Stam}$ in a $4, \mathrm{co-}$ rollae fauci inserta, declinata, didynama; fil amenta superiorum basi circumflexa, inferiorum medio appendieulata, antherae uniloculares, saepissime circa stigma cohaerentes. Ovarium biloculare, placentis dissepimento adnatis, multiovulatis. Stylus simplex; 8 tigma capitatum. Capsula subglobosa, ovoidea v. oblonga, teretinscula, bilocularis, septicide bivalvis, valvis saepius inaequalibus, indivisis (?) placentas coadunatas nudantibus. - Herbae capenses, annuae v. perennes; foliis inferioribus oppositis, superioribus subfasciculatis, pedicellis axillaribus racemosis $v$. fasciculatis, corollis coccineis.

D fascia Link et Otto Ic. select, $t, 2$. Benth. in Bot. Mag. Comp. II. 16. He m imeris s p. Auet.

3838. Nemesia VENT. Ca Iyx pentaphyllns. Coroll a hypogyna, tubo brevi, limbo personato, bilabiato, labio superiore quadrilobo, basi saccato $\mathrm{v}$, calcarato, inferiore integro $\mathrm{v}$. emarginato, palato convexo, fauce bicallosa. S $t$ a min a 4, corollae fauci inserta, declinata, didynama; fi 1 a $m$ e $n t$ a superiora basi circumflexa, an $t h$ e $r$ a uniloculares, saepins per paria cohaerentes. 0 var i u m biloculare, placentis septo adnatis, multiovnlatis. Stylus simplex; st $\mathrm{igma}$ subeapitatum. C a p su 1 a compressa, bilocularis, septicide bivalvis, valvis indivisis, placentas coadunatas nudantibus, navieularibus, apice oblique truneatis, angulo exteriore acnto v. breviter cornnto, rarius rotundato. S e min a plurima, compressa, ala membranacea cineta. - Herbae c apenses, annuae, rarius perennes $v$. suffrutices; foliis oppositis, dentatis $v$. incisis, floribus axillaribus solitariis, $v$, terminalibus racemosis.

Ne m e s i a Venten. Malmais. $t$. 41. Bentb. in Bot. Mag. Comp. II. 18. Bot. Reg, II. t, 39. A nt irrhini s p. Lian. Thaub.

3589. Dielis BENTH, Calyx pentaphyls. Corolla hypogyna, tubo:brevi, limbo peronato, bilabiato, labio superiore bifido, basi cal- 
carato, inferiore trifido. Stamina 4 , corollae fanei inserta, declinata, didynama; filamenta superiora basi eireumflexa, a nt h e ra e uniloculares, per paria cohaerentes. O vari nm biloculare, placentis dissepimento adnatis. S ty l u s simplex; stigm a capitatum. Capsula subglobosa, emarginata, bilocularis loculieide bivalvis, valvis integris v. vix fissis, medio septiferis, placentas coadunatas nudantibus. S emi n a pauca, ovoidea, striata. Herbae capenses et madagascarienses; caulibus repentibus, foliis oppositis, petiolatis, latis, dentatis, pedicellis axillaribus solitariis, unifloris.

Diclis Benth, in Bot. Mag. Comp. II, 23.

TIRIBUS IUI. ANTIRRHINEAE Chavannes Monogr. Antirrhin. Par, 1833. 4. Co rolla tubulosa, limbo personato v. ringente, bilabiato, rarius aequali. Stamina 4 , didynama. Antherae biloculares, per paria approximatae. Capsula bilocularis, dentibus v. operculis dehiscens, rarius pluriralvis, nunc irregulariter rupta. Sem in um testa solida, v. laxa, arilliformis.

3890. Anarrhinum DESFONT. C a ly $\mathrm{x}$ profunde quinquefidus. Coroll a hypogyna, tubo subineurvo, basi aequali v. breviter calcarato, fauce pervia, limbo bilabiato, labii superioris lobis erectis, demnm reflexis, inferioris patentibus, omnibus suhaequalibus, plus minus emarginatis. S $\mathrm{ta} \mathrm{m}$ in a corollae tubo inserta, inclusa, 4 fertilia subaequalia, quinto sterili brevissimo; antherae reniformes, uniloculares. Ovari u m biloculare, placentis dissepimento adnatis, multiovulatis. Stylus simplex, superne incrassatus; 8 ti g ma obtusum. C a p s l a chartacea, compresso-sphaerica, bilocularis, loculis aequalibus, sub apice poro oblongo, nnivalvulato dehiscentibus. S e m i n a plurima, ovalia, minima, testa tuberculata v. muriculata. Herbae mediterra neae, biennes $v$, perennes; foliis radicalibus saepe rosulatis, caulinis oppositis, palmatipartitis $v$, apice dentatis, superioribus integerrimis, floribus parvis, nutantibus, in racemum spiciformem, virgatum, nutantem dispositis.

A a arrhin am Desfont. Flor. atlant. IT. 51. $t$. 141. 142. Libk et Hoffanans. Flor. Portug. $t$. 32. 33. DC, Fl. Fr. IIT. 594. Chavannes Antirrh, 175.t. 10. Benth. Revis, 1. Nees jun. Gen. plant, XVI, $t, 13, \mathrm{Ca} r \mathrm{~d}$ i o th e e a Khrenb. msc. A ntirrhini sp. Lina. - ? S i m bulet a Forsk. Descript.116.

3891. Linaria TOURNEF, C a I $\mathrm{x}$ quinquepartitus. Coroll a hypogyna, tubo brevi, inflato, basi calcarato, limbo personato, palato pro minente $\mathrm{v}$. interdum depresso et faucem non claudente, plus minus barbato, labii superioris lobis basi plicatis reflexis, inferioris patentibus, intermedio plerumque minore. Stamina corollae tubo inserta, inclusa, 4 fertilia subaequalia, quintum sterile brevissimum, interdum nullum; a $\mathrm{t}$ h e r a e oblengae, biloculares. O va ri um bilocnlare, placentis dissepimento adnatis, multiovulatis. S tyl us simplex, apice inerassato v. bifido; st ig ma emarginatum v. bilobum. Ca p 8 u la chartacea v, membranacea, ovata, compressinscula, biloeularis, loculis subaequalibus $\mathbf{v}$. antico minore, valvulis tribus $\mathbf{v}$. quinque plus minus productis dehiscentibus, nune apice valvula unica apertis v. operenlo oblique eircumscissis. Semin a plarima, ovalia aut subprismatica, nunc compressa, discoidea, margine membranaceo cineta, - Herbae in $E$ ur rop a media, regione mediterranea et Asia fini tima magno numero crescentes, in India boreali et America temperata rarae, annuae $v$. perennes, rarius suffrutescentes; foliis alternis, verticillatis v. oppositis, integerrimis aut lobatis, floribus racemosis v. spicato-racemosis, rarius |axillaribus, solitariis.

L in a ri a Tournef. Inst, 168, exel, sp. Juss, gen, 120. DC. Fl. Fr. III. 582, Chavannes Antirrhin, 91, Benth. Revis. 1. Serophularin. ind, 19. E latine Dillen. Nov. gen. 116. . 6, non Linn. Antirrhini sp. Linn.

a. ChBnoRrhinum DC. $l$. c. exel. sp. Corolla palato plus minus depresso, labio superiore antice pro. dneto, calcare tubo breviore. C a ps ula chartacea, 10. culo postico saepins multo majore, apice univalvi, antico transversali, indehiscente v. rimula basim versus aper. to. Sem in a truncata, suleata, foveolata v. echinata. - Herbae plerumque pilosae; folitis oppositis et al. ternis, integerrimis, floribus axillaribus v. lase race. mosis. Antirrhini sp. Lian. Cavanill. Ie, t. 11 t. 180. (Desfont. Flor. atlant, $t$. 139. Chavannes $O p$. cit. t. s. f. 8. t. 6.)

b. MICRORRHINUM. C o rolla palato prominulo faucem haud claudente, labio superioze antice producto, caleare brevissimo. C a p s u I a membranacea, Ioenlis aequalibus, apice dentibus tribus dehiscentibus. S e m in a truncata, longitudinaliter suleata. - Herba ramosissima, pubes. cens; folits inferioribus oppositis, superioribus al. ternis, integerrimis, floribus axillaribus, laxe race. mosis. A n tirrhi num minus Linn. Flor dan, $t, 502$. E. B, $t, 20 t 4$. Gärtner $t, 83, f, 1$.

c. CYMBALARIA Chavannes Op, eit, 28, t. $5 . f .16$, C o. $r$ oll a palato fancem claudente, calcare obtuso, tubo aıul. to breviore. Capsula chartacea, loculis apice sexval. vibus. S e m i a oblonga, rugosissima. - Herbae per. enns, rupicolae, hypogaeocarpae; fotits longe pe. tiolatis, palminervits, saepissime lobatis, floribus axillaribus, longe pedicellatis. - Antirrhini s p. Linn. B. B. t. s02. Jacq. Observ, IT, $t$, 47 , Tenore Flor. neap. IT, $t, 59.159$. Bot. Mag. $t, 2941$.

d. ELATINOIDES Chavaunes Op, eit, 103, $t, 5, f, 9,10$. 19-21. C o rolla palato faucem claudente, calcare tubum aequante. C a psula subsphaerica, loculis вpice operculis obliquis eircumseissis, v. ovata, loculis apice univalvulatis. Semina ovato-truncata v. rotundata, irregulariter foveolata v, granuloso-tubereulata. - Her. bae procumbentes, annuae $v$. suffrutescentes; folits alternis, $v$, infimis interdum oppositis, caepius brevs petiolatis, penninervits, dentatis lobatisve, rarins integerrimis, foribus axillaribus, solitariis. - K ick$x \mathrm{i} \mathrm{a}$ Dumort. Flor. Belg. 35, jR la tin es sp. Mönch. Cymbalariae sp. Baumg. Antirrhinf sp. Linn. Plor, dan, 426. 913. Jaeq. Hort, Vindob, $r$, $t$, se. Valit symb. II, $t, 37$. (Desfont. Flor, atlant. $t, 32$, Link et Hoffmass. Flor. Portug, t. 34. Bory Pelopon, t. 21. Reichenb. Ieonogr. t, 81s. Wallich Plant, At, rar. t. 153.)

e. LINARIASTRUM. Chavannes Op, cit, 115, t. s. f, 10-13. f. $28-37 . t .7$. Co r oll a palato faneem claudente, ealcare tubum aequante v. superante. Caps ula ovata v. sphaerica, loculis apice dentibus v. valvulis $4-10$ de. biscentibus. S emina angulata v. discoidea, margine membranaceo ad umblilicum emarginato cincta. Herbae v. suffrutices; folitit sessillbut, alternit $v$. verticillatis, rarius oppositis, integerrimis, floribus terminalibus, racemosis, spicato-racemosis $v$. interdum subcapitatis. - Anti r r hin i sp. Linn. Gïrtner t. 53. Ag. super, Flor, dan, t. 982. Jaeq. Flor. austr. t. s8. 244. Ie. rar, t. 116, 117. 499. Cavanill. Ic, t. 39. 33. 59. 179. Sibthorp Flor. graec. t, 587_596. Venten, Malmais. $t, 11.18$. Cels. $t$, 49. Bot. Mag. $t, 200,207$. s9S. (Desfont. Flor. atlant. t. 134-138. 140. Link et Hoffonass. Fl. Portug. $t, 36$ - 99 . Jacq. f. Eclog. $t, 95$. DC. Ic. Plant, Gall, rar. $t$. 11-14. Ledebour Ic. $t, 91.491$, Reichenb. Ioonogr. $t, 421$-425, 431_438, 813. 814. Bot. Mag, $t, 2183,3474$.

389\%. Antirrininum JUSS. Caly quinquepartitus, obliquus. Corolla hypogyna, tnbo amplo, compressiusculo, basi saccato, intus antice biseriation piloso, limbo personato, palato prominente faucem claudente barbato, labii supe- 
rioris lobis deorsum productis, basi plicatis, reflexis, inferioribus patentibus, intermedio minore, concavo, erecto. S ta m in a corollae tubo inserta, inclusa, 4ffertilia didynama, quintum sterile brevissimum, interdum nullum; a n t h e r a e oblongae, biloculares. Ovarium biloculare, placentis dissepimento adnatis, multiovulatis. Stylus simplex, e basi crassiore attenuatus, apice subinflexus; stigma breviter bilobum, lobo postico productiore. C a psula bilocularis, nunc subovata v. pyriformis, basi saepe obliqua, loculo postico apice poro unico multivalvulato, antico geminis collateralibus dehiscente, rarius globosa, membranacea, loculis singulis poro singulo apertis. Semina plurima, minima, oblongo-truncata, foveolata $\mathrm{v}$. rugosa. - Herbae in Europa a ustrali et re. gione mediterranea indigenae, nunc in Indiam et Americamborealem transfugae, annuae, perennes $v$, rarius suffrutescentes; folits inferioribus oppositis $v$. interdum ternatis, nunc penninerviis integerrimis, nune palminerviis lobatisque, floribus racemosis $v$, axillaribus solitariis.

A n tir rli i a u Jussieu gen, 120. Chavannes Antirrhin. 79. Beath, Revis, 1. Scrophularin, ind, 20. 0 ro n t i u m Per. soon Encheir. I1, 158. Antirrhinum et Asarina Tour. nef. inst, 75. 76. A a ti r r hinis p. Linn.

a. ASARINA Touraef. t. c. Chavannes op. eit. 80, $t, 3$. $f .12, t, 4$. Caps it la membranacea, subglobosa, 10. culis singulis infra apicem poro singulo lato, irregulari apertis. - Folia opposita, palminervia, labata. A. A s a ria a Lina.

b. ANTIRrhiNASTRUM Chavannes Op. cit. 81, $t$. 3. $f$. 15-17. Cap 8 u la chartacea v. ligneseens, fere inverse pyriformis, basí obliqua, loeula postico poro unico, antico geminis collateralibus infra apicem aperto. - Folia in. feriora opposita $v$. rarius ternata, superiora plera. que alterna, penninervia, integerrima, (Gärtı.t. 53. fig. infer. B. B. $t$. 129. 1155. Link et Hoffmans. Flor. Portug, t, 50, 51.)

3S93. Maurandia ORTEG. C a l y $\mathrm{x}$ quinquepartitus. Coroll a hypogyna, tubo obsolete tetragono, basi saccato, antice ventricoso, limbo personato, palato prominulo fancem elaudente, $\mathbf{v}$. biplicato in tubum decurrente, labii superioris lobis erectis, inferioris patentibus, omnibus subaequalibus, integris v. emarginatis. Stamina corollae tubo inserta, inclusa, 4 fertilia didynama, quintum sterile minimum; an ther a eblongae, biloculares, O varium biloculare, placentis dissepimento adnatis, multiovulatis. S t y I u s simplex, subulatus ; s t igma obtusum, emarginatum. Caps a I a ovato-globosa, basi obliqua, compressiuscula, bilocalaris, loculis apice valvulis quinque dehiscentibus. S emina plurima, subovata, truncata, tuberculata. - Herbae mexicanae, rhizomate perennantes; ramis seandentibus, foliis alternis, longe petiolatis, petiolo volubili, lamina cordata, palmatinervia, floribus in axillis foliorum solitarits, longe pedunculatis, pedunculis volubilibus.

M a a ra nd i a Ortega Decad.Ir. 21.Jacq. Hort. Sohürbr. III. 20. $t$, 288. Willden. Hort. Berol. t. 83. Bot. Mag. t. 460. Bot. Reg. t. 1108, Chavaanes Antirrhin. 77. $t$. 2. Benth. Revis. 1. Us teria Cavanill, $I c, I I, 15 . t$. 126 . Andrews
Bot. Aleposit. t. 63. non Willd.

3894. Ealvezía DOMB. Ca l y $\mathrm{x}$ quinquepartitus. Corolla hypogyna, tubo subeylindrico, basi ventricoso, fauce nuda, limbo bilabiato, labii superioris lobis erectis, ovatis, inferioris patentibus, ovato-rotundatis, subaequalibus. S t amin a 4, corollae tubo inserta, inclusa, didynama, quintum sterile nultum; a therae biloculares, reniformes. Ovariumbiloculare, placentis dissepimento adnatis, multiovulatis. Stylus sim- plex, clavatus; stig ma emarginatum. Ca p su $\mathrm{I}_{\mathrm{a}}$ globoso-ventricosa, depressiuscula, biloeularis, loculis infra apicem foramine irregulari apertis. S em in a plurima, minima, oblongo-truncata, longitudinaliter costata, foveolata. - Suffrutex limensis; foliis oppositis et alternis, petiolatis, ovato lanceolatis, penninerviis, integerrimis, floribus axillaribus solitariis, longe pedunculatis, pedunclis capillaribus, medio inflexis.

Ga 1 vèzia Doubey of Juss. gen. 119. Benth. Revis, 1 . non Ruiz et Pavoa. Ag as $8 \mathrm{Iz}$ is Chavanues Antirrhin, 180. t, 11 . D odartiaes $\mathrm{p}$. Raiz et Pav.

3895. Hoplaospermum $D O N$. Cal y x quinquepartitus, laciniis foliaceis, amplis, ovato-lanceolatis, basi subauriculatis. Co roll a hypogyna, tubo campanulato, basi antice gibbo, intus biseriatim piloso, fauce dilatata, limbo bilabiato, labii superioris laciniis suberectis, ovatis, inferioris patentibus, intermedio minore. Stamin a corollae tubo inserta, inclusa, 4 fertilia didynama, quintum sterile brevissimum; a $\mathbf{t}$ he rae biloculares, reniformes. Ovarium biloculare, placentis dissepimento adnatis, multiovulatis. Sty 1 us simplex, sabulatus; $s$ tigma bilamellatum. Ca psula calyce tecta, membranacea, globosa, bilocularis, loculis infra apieem irregulariter rumpentibus. Semina plurima, ovato-truncata, tubereulata, subcompressa, margine membranaceo lato, reticulato, eristato, basi et apice emarginato cineta. - Herbae mexic an a e, rizizomate perennantes; ramis scandentibus, folits alternis, petiolatis, cordatis, saepe lobatis, foribus axillaribus solitariis, longe pedunculat is, pcdunculo volubili.

Lophosperm $\mathrm{m}$ m Don in Linn. Transaol. $X V .349$. Sweet El, Gard. IT. t. 68. Bot. Mag. $t, 3037$. 3038, 3630 . Bot. Reg. t. 1381, Chavanues Antirrhin, 75. t, 1. Benth. Revis. 1.

389B. IRhoulohitom ZUCCAR. Caly $\mathrm{x}$ membranaceus, coloratus, patentissime campanulatus, quinquefidus. Coroll a hypogyna, tubo cylindrico, intus nudo, fauce dilatata, limbi bilabiati laciniis subaequalibus. Stamina corollae tubo inserta, inclusa, fertilia 4 , subaequalia, quintum sterile brevissimum; a $\mathrm{t}$ he $\mathrm{r}$ a e biloculares, reniformes. Ovarin biloculare, placentis dissepimento adnatis, multiovulatis. Stylus simplex, filiformis; $8 \mathrm{tigma}$ indivisum. Ca psa la calyce cincta, membranacea, basi obliqua, depresso-obovata, inflata, bilocularis, loculis infra apicem irregulariter ruptis. Semina plurima, ovato - truncata, tuberculata, compressa, margine membranaceo lato, reticulato, irregulariter lacero, basi et apice emarginato cincta. - Suffrutex mexicanus volubilis; foliis alternis, petiolatis, cordatis, repando dentatis, floribus axillaribus longe pedunculatis, pe. culis petiolisque volubilibus.

Rhodochit on Zuecariat msc. Benth. Revis, 1. Bot. Reg. 1755, Bot. Mag, $t, 3367$. L. o pho s p e r m u m sanguineum Zucearial Plant. nov, $1.306, t .13$.

OBSERVAT10. Gasiromeria Don in Edinb. new philo. soph. Journ, 1835. XIX. 11t. inter Centrautheram $A . B r$. et Virgulariam nominatum, nullibi deseriptum, a cl. Ben. tham in Lindley Introduot, edit, $I 1$. p. 292, et Bot. Mas. Comp. II. 200, dubitanter ad ealcem Antirrhinearam collo. catur.

\section{GENUS ANOMALUM.}

389\%. Collinsia NUTT. Ca 1 y campanulatus, quinquefidus, aequalis. Co rolla hypogyna, personata, tubo postice gibbo, labio superiore erecto, bifido, inferioris trifidi lacinia media carinato-cucullata, stamina amplectente. Stam i- 
n a 5 , coroliae tubo inserta, inclusa, quatuor fertilia, didynama, antheris bilocularibus, loculis parallelis, quintam rudimentarium, anantherum, O $\mathrm{v}$ arinm biloculare, placentis carnosis, dissepimento utrinque adnatis. Ovula in loculis gemina, oblique superposita, peltatim amphitropa. Stylns simplex; stigma minutum, aequaliter bilobum. Capsula membranacea, bilocularis, 'septifrage bivalvis, val. vis apice bifidis, dissepimento placentifero parallellis. S e min a in loculis gemina, oblique superposita, convexo - concava, testa coriacea, umbilico ventrali, Embryo in axi albuminis cornei rectus, ejusdem longitudine, respectu umbilici transversus; cotyledonibus planis, foliaceis, radicnla tereti, vaga. - Herbue annuae, in $A m e r i c a b o$ reali-occidentali indigenae, erectae v. procumbentes, ramosae; folits oppositis $v$, ternatis, integerrimis $v$. dentato-incisis, pedunculis axillaribus unifloris, ebracteatis, oppositis verticillatisque.

Collinsia Nuttall in Journ. Academ. Philadelph, $r$. 190, t. 9. Lindley in Bot. Reg $t, 1082,1107.1734$. Bot. Mag. t. 3988 .

\section{TIRTIBUS IV.}

SALPIGLOSSIDEAE Benth. Revis. 2. Co r oll a tubo saepius elongato, limbo nunc bilabiato, nunc subaequaliter quinquelobo, plano. Stamina fertilia doo v. saepius quatuor, didynama, declinata, quintum sterile $v$. nullum; an the rae subbiloculares, loculis apice confluentibus. Capsu la bilocularis, septifrage bivalvis, valvis integris v. bifidis, dissepimento placentifero parallelis. Embryo rectus $v$. plus minus arcuatus. Tribus a Solanaceis capsularibus corollae aestivatione imbricativa, et stamine quinto imperfecto caute distinguenda.

3898. Selaizanthus $R U I Z$ et $P A V . C$ aIy quinquepartitus. C o roll a hypogyna, resu pinata, tubo brerissimo, limbo bilabiato, labio postico inferiore tripartito, lacinia media concava, emarginata, antico superiore quinquepartito, laciniis lateralibns bilobis, lobis integris v. incisis, intermedio obtuso v. emarginato, basi palato promi nulo. St a mina 4 , corollae fauci inserta, exserta, curu labii inferioris lobo medio declinata, didynama, duo sterilia, minima, fertilium an th e ra e biloculares, loculis divaricatis. Ovari u m biloculare, placentis dissepimento utrinque adnatis, multiovulatis, ovulis anatropis. Stylus simplex; stigma obtusum, indivisum. Capsula ovata, bilocnlaris, septifrage bivalvis, valvis membranaceis, indivisis, dissepimento placentifero parallelis. Semina plurima, plus minus reniformia, rugosa. E mbryo in axi albuminis dense carnosi homotrope arcuatus; cotyledonibus brevissimis, obtusis, radicnia tereti, umbilico prope basim laterali proxima. - Herbae chilenses, annuae, glanduloso-pilosae; foliis inferioribus oppositis, superioribus alternis, omnibus pinnatifidis, pedunculis oppositifoliis, unifloris, nune racemum simplicem v. paniculam efformantibus.

Schizanthus Rniz et Pavon Prodr. 5. t. 1. Flor. Peruv, $t, 17$. Hooker Exot, Flor, $t, 73.86$. Bot. Reg, $t, 725$. 1544. 1562. Bot. Mag. t. 2404. 2581, 3044. 3045. 3070.

3899. Salpiglossîs RUIZ et $P A V . C$ aI y $\times$ campanulatus, quinquepartitus, Iaciniis subaequalibus. Co rolla hypogyna, infundibuliformis, tubo superne ampliato, limbo quinquefido patente, laciniis subaequalibus, planis, emarginatis $\mathbf{v}$. bifidis. Stamina 5 , corollae tubo inserta, inclusa, quatuor fertilia didynama; a nth er is bilocularibus, loculis confluentibus, rimula unica transversali apertis, quintum minimum, anantherum. Ova rinm biloculare, placentis dissepimento utrinque adnatis, multiovulatis, ov u lis anatropis. St y I us simplex, apice incrassatu s; s t I gma obsolete bilobum. C a p su la ovata v. oblonga, bilocularis, septifrage bivalvis, valvis coria. ceis, apice bifidis, dissepimento placentifero parallelis. Semina plurima, subreniformia. Em. b ryo..... Herbae chilenses, glandulosa-visci dae; foliis alternis, sinuato-pinnatifidis, floribus terminalibus paniculatis, bracteis linearibus, subop. positifloris.

Salpigloss ls Ruiz et Pavon Prodr. 95. $t, 19$. Hooker Exot. Flor, t. 289. Bot. Mag. $t, 2811.3256,3365$. Bot, Rig. t. 1518.

3900. Aptosinamun BURCH. $\mathrm{Caly}$ campanulatus, semiquinquefidus, bibracteolatus. Corolla hypogyna, tubi parte inclusa contracta, exserta ampla, limbi quinquefidi, subbilabiati la. ciniis snbaequalibus, rotundatis, planis. St amina 4, corollae tubo inserta, inclusa, didynama, declinata; a nthe rae villosae, subbiloculares, loculis confiuentibus, rima transversali unica apertis, staminum postieorum minores, saepius efoetae. O va ri u m biloculare, placentis dissepimento utrinque insertis, multiovulatis. Sty I us simplex; stig ma hrevissime bilobam. Capsula brevis, basi subglobosa, apice compressa, obeordata, venoso rugosa, dissepimento contrario basi placentifero, apice breviter loculicide et septicide dehiscens. Sem in a plurima, trigona, rngosa. - Suffrutices capenses, rigidi, saepius prostrati v. densissime caespilosi; foliis alternis, confertis, integerrimis, petiolatis $v$. subsessilibus, nervo medio saepius valido, post laminae lapsum persistente, spinescente, floribus axillaribus, solitariis, sessilibus.

Aptos im nm Barehell Travels 1 , 260. Benth, in Bot. neg. t. 1889. Ohlendorfia Lehmana Index sem. Hort. Hamburg. 1835.

390 1. Fellostonanan BENTH. C a I y quinquepartitus. Co rolla hypogyna, tulo basi contracto, superne ampliato, limbi quinquefidi, suhbilabiati Iaciniis subaequalihus, rotundatis, planis. St a mina 4, corollae tubo inserta, inclusa, de clinata; a $\mathrm{th}$ erae villosae, subbiloculares, loculis confluentibus, rima transversali unica apertis, staminum posticorum minores, saepius efoetae. O va ri u mbilocnlare, placentis dissepimento utrinque adnatis, multiovalatis. Capsula ovatooblonga, acuta, apice subcompressa, sulcata, bilocularis, loculieide bivalvis, valis bifidis bipartitisve. Sem in a..... - Herbac $v$. suffrutices c apenses, rigidi, saepius viscosi; folits alternis, integerrimis, floribus axillaribus v. racemosis, sessilibus $v$. breviter pedicellatis, pedicellis saepe bracteatis.

Peliostom $\mathrm{nm}$ Benth. in Bot. Reg. n, 1882.

3903. Anthoeereis $L A B I L L A R D, \mathrm{C}$ al y $\mathrm{x}$ campannlatas, quinquefidas. Corolla bypogyna, campanulata, tubo basi coaretato, limbo quinquepartito, aequali, patente. Stamina 4, imo corollae tubo inserta, inclusa, didynama, cum rudimento quinti; filamenta basi latiora, an therae ovatae, biloculares. Ovarin m biloculare, placentis dissepimento ntrinque adnatis, multiovulatis, ovulis anatropis. Stylus simplex; stigma ca- 
pitatum, emarginatnu. Caps ala oblonga, bilocularis, septifrage bivalvis, valvis indivisis, columna placentifera libera. S e min a plurima, basi incurva, reticulata. $\mathbf{E} \mathbf{m b r}$ yo in axi albuminis carnosi; c otyle do nibus brevissimis, obtusis, radicula tereti, basi homotrope incurva, umbilico basilari proxima. - Frutices Nova e Hollandiae meridion alis; foliis alternis, petiolo basive attenuata cum ramo articulatis, crassis, interdum glanduloso-punctatis, floribus axillaribus subsolitariis, pedunculo minute bracteato, ad articulum saepe solubili, corollis albis v. flavis, speciosis, tubo intus striato, limbo quandoque sex-octopartito.

An th o cer eis Labillard. Nov. Holland, IT, 19, t. 158. R. Brown Prodr. 448, Bot. Reg.t. 212. 1624, Bot. Mag. $t$. 2961. Benth, Revis, 8.

3903. IBrowallia LINN. Calyx tubulosus, quinquedentatus, dentibus subinaequalibns. Cor oll a hypogyna, hypocraterimorpha, tubo calycem superante, superne inflato, limbo quinquepartito, plano, lobo postico paullo latiore, omnibus rotundatis, subemarginatis. St a min a 4 , corollae tubo inserta, inclusa, didynama, postica longiora, apice arcuata, cuneato dilatata, an therarum loculis superpositis, loculo superiore minere; antica breviora antherarum loculis divaricatis, confluentibus, rima transversali apertis. O varium biloculare, placentis dissepimento utrinque adnatis, multiovalatis, ovulis anatropis. Stylus simplex; stigma subquadrilobum. Capsula ovata, bilocularis, septifrage bivalvis, valvis apice bifidis, dissepimento placentifero parallelis. S emina plurima, scrobiculata, Embryo in axi albuminis carnosi rectus; cotyled onibus semicylindricis, brevissimis, radicula tereti, umbilico basilari proxima, - Herbae Am er ic a e tropicae, erectae, glabrae aut pubescentes v. viscosae; foliis alternis, petiolatis, ovatis, floribus extraaxillaribus v. terminelibus, caeruleis, violaceis $v$. rarius albis.

B r ow a 11 a Lian, gen, $n$. 773. Gärtner $I$, 246, $t, 83$, Bot. Mag. t. 34, 1136. Don in Edinb, philosoph, Journ, 1829. VII. 87. Benth. Hevis. 2.

3904. Franciscen POHL. Caly $\mathrm{x}$ campanulatns, quinquedentatus, dentibus subaequalibas. Corolla hypogyna, hypocraterimorpha, tubo calycem superante, apice ampliato, incurvo, limbo quinquepartito, lobis snbaequalibus, rotundatis, planis. S $\mathrm{ta}$ m in a 4 , corollae tubo inserta, inclusa, didynama; anther a e subbiloculares, loculis confluentibus, rima transversali unica apertis, O varium biloculare, placentis dissepimento utrinque adnatis, multiovulatis. Stylus simplex; st ig ma inaequaliter bilobum. Cap s u l a subglobosa, bilocularia, septifrage bivalvis, valvis coriaceis, integris, dissepimento membranaceo, utrinque placentigero parallelis. S emina pauca, angalata. Embryo in axi albuminis carnosi vix areuatus; cotyledonibus brevissimis, obtnsis, radicula nmbilico prope basim sublaterali proxima. - Frutices brasilienses, erectiusculi; folits al ternis, oblongis, integerrimis, floribus axillaribus et terminalibus conferte racemosis v. rarius solitariis, corollis violaceis $v$. lilacinis.

Franciscea Pohl Plant, Brasit. $T$. 1.t, 1_7, Bot. Mag. t. 2829. Beath. Revis. 2, B ru n felsia e s p. Don.

3905. Brounfelsía PLUM, Cal y x campanulatus, quinquedentatus, dentibus subaequalibus. Corolla e hypogyna, hypocraterimorpha, tubo elongato, apice aequali, recto, limbo quinque- partito, lobis subaequalibus, rotundatis, planis. S ta m in a 4, corollae tubo inserta, inclusa, didynama; a ntherae subbiloculares, loculis confluentibus, rima transversali nnica apertis. O v a ri $\mathbf{n} \mathrm{m}$ biloculare, placentis latis, dissepimento utrinque adnatis, multiovulatis, ovulis anatropis. St y l a s simplex; stig ma inaequaliter bilobum. C ap 8 ula globosa, subbaccata, bilocularis, septifrage bivalvis, placentis in massam globosam, liberam coalitis. S e m in a plurima, subarenata, rugosa. E m br yo in axi albuminis carnosi homotrope areuatus; $\mathrm{eo-}$ tyledonibus brevissimis, radicula umbilico ad basim sublaterali proxima. - Arbusculae in America tropica cis a equatorem indigenae; foliis alternis, oblongis, integerrimis, floribus axillaribus solitariis, v. terminalibus confertis.

B r u n fels i a Plumier Ic.t, 65, Liun. gen, n, 260, Swarta Flor. Ind. occid. II. 1035. Andrews Bol. Meposit, $t, 167$. Bot. Reg. $t$, 128. Gärtaer f, III, 167, $t, 212$.

3906. Duboisia $R, B R, C$ a 1 y $x$ bilabiatns, brevis. C o roll a hypogyna, infundibuliformicampanulata, limbo quinquepartito, subaequali. Stamina 5, imo corollae tubo inserta, inclusa, quatuor fertilia, didynama, quintum rudimentarium. Ov a r u m biloculare, placentis dissepimento ntrinque adnatis, multiovulatis. S ty lus simplex; stigm a capitato-emarginatum. B ace a bilocularis. S e min a plurima, subreniformia. $\mathbf{E}$ m b ryo.... - Arbuscula Novae Hotlandiae orientalis extratropicae, glabra, Myoporifacie; foliis alternis, cum ramulo articulatis, integerrimis, paniculis axillaribus, ad divisuras bracteis caducis, floribus albis, tubo intus striato, baccis parvis, ovalibus, nigris.

Dubols I a R. Brown Prodr. 468.

390\%. Diplanthera BANKS et SOL. Caly $x$ trifidus, lacinia postica integra, lateralibus bifidis. Corolla hypogyna, bilabiata, fauce compressa, labio superiore obeordato, inferiore tripartito, lobis rotundatis. Stamina 4 , imo corollae tubo inserta, exserta, subaequalia, adscendentia; a ntherae loeulis distinetis, divaricatis, aestivatione juxta latera filamentorum reflexis. 0 va riu m biloculare, placentis dissepimento utrinque adnatis, multiovulatis. S ty lu s simplex, staminum directione; sti $\mathrm{gma}$ bilamellatum. Fructus....-Arbor mediocris, in Nova Hollandia tropica observata; coma irregulari, diffusa, ramis teretibus, tomentosis, foliis quaternis, petiolatis, magnis, integris, basi superne biglandulosis, thyrsisterminalibus, subrotundis, depressis, pedunculis partialibus verticillatis, pedicellis trichotomis, floribus speciosis, calycibus semicoloratis, corollis flavis.

Diplanthera Banks et Soland. ex R. Brown Prodr. 448.

TRIBUS V. DIGITALEAE Benth. Revis. 2. Coroll a tubulosa, saepius ventricosa, limbo bilabiato. Stamina basi declinata, apice saepissime adscendentia, 4 fertilia didynama, quintum sterile v. nullum; antherae biloculares, loculis demum divaricatis, confluentibus. Caps u la dura, septicide bivalvis, valvis bifidis v. bipartitis, dissepimento e valvarum marginibus introflexis duplicato, demum bipartibili, placentis alnatis v. tandem solutis. 
3909. Chelome LINN. Caly x quinquepartitus. Corolla hypogyna, tubo postice convexo, limbi bilabiati labio superiore bilobo, lato, concavo, inferiore trilobo, basi barbato. St amin a corollae tubo inserta, quatuor fertilia didynama, exserta; a n ther a e biloculares, loculis divaricatis, quintum anantherum, Ovarium biloculare, placentis dissepimento utrinque adnatis, multiovulatis. Stylus simplex; stigma obsolete bilobum. Capsula bilocularis, septicide bivalvis, placentis adnatis. Semina plurima, compressa, late membranaceo - marginata. - Herbae bor a li-american ae; foliis oppositis, serratis, floribus terminalibus, spicatis.

Chelo ne Linn. Ben, $n$, 748, Gärtner 1 , 256, $t, 54$. Bot. Mag. t. 1864. Bot. Reg. 175. 1211. 1737. Nuttall gen. II. S1. Benth. Revis, 2.

3905. Pentstemon HERIT. Calyx quinquepartitus. Coroll a hypogyna, tubo teretinseulo, fauce subinflata, limbi bilabiati labio superiore emarginato-bilobo, inferiore trilobo, nudo v. basi barbato. Stamina corollae tubo inserta, quatuor fertilia didynama, exserta; a $\mathrm{t}$ h e $\mathrm{ris}$ bilocularibus, loculis divaricatis, quintum anantherum. O v a ri $\mathrm{n} \mathrm{m}$ biloculare, placentis dissepimento utrinque adnatis, multiovulatis. Stylns simplex; stigm a ohsolete bilobum. Ca $\mathrm{p}$ a I a bilocularis, septicide bivalvis, placentis adnatis. S e mina plurima, angulata, aptera. - Herbae perennes, in America borealiet tropicatrans a equatore mindigenae; foliis oppositis, integerrimis v. serratis, pedunculis axillaribus et terminalibus paucifloris, bracteatis, in racemos $v$. paniculas dispositis, corollis coccineis, purpurascentibus $v$, violaceis.

Pentste $\mathrm{m}$ o $\mathrm{n}$ Heritier msc. Lambert in Linn. Transact. X.t. 6. Nuttall gen. II. 51. Benth, Revis, 2. Bot. Mag. t. 1424. 1425. 1672. 1678, 2587, 2903, 9945. 2954. 3391. 3465.3466. 3645. 366t, B ot. Reg, 1121. 1129. 1139, 1138, 1245. 1260, 1268, 1270. $127 \%, 1280,1285,1236,1295,1309,1380,1270, I T, t, 3$, C h e10 nes 5 p. Cav, Ic.t. 29. Andrews Bot, Reposit. t. 40. Ellm igera Relcheab, Consp. n. 3177. (Chelone barbata Cav. It, t, 242. Andrews Bot. Reposit. $t$, 34. Bot.Reg. t. 116.) $\mathrm{D}$ as a nthera Rafin, in Journ. Phys, LXXXIX, 99.

3910. Fiusselia $J A C Q$. C a ly $\mathrm{x}$ quinquepartitus, laciniis acuminato-subnlatis, subaequalibus. Coralla hypogyna, tnbulosa, superne ventricoso-ampliata, fauce barbata, limbo bilabiato, labio superiore emarginato-bilobo, inferiore tripartito, laciniis subaequalibus. S $t$ a $m$ ina 4 , corollae tubo inserta, didynama, inclusa, declinata; anthera e biloculares, loculis divaricatis. Ovari um biloculare, placentis dissepimento utrinque insertis, multiovulatis. Stylus simplex; stigma obtusum. Ca p s al a subglobosa, attenuatorostrata, bilocularis, septieide-bivalvis, valvis bifidis, placentis coadunatis, demum liberis. S emina plurima, minima, aptera. - Herbae $v$. frutices, in Antillis et Mexico sponte crescentes; ramis angulatis, folits oppositis v. ternatis verticillatisve, integris, corymbis axillaribus, floribus coccineis.

R us seli a Jacq. Amer, 176, $t, 113$. Bot. Mag, $2,1328$. Kunth in Humboldt et Bonpl. Nov, gen. et sp. IIT, 358. Bot. Reg. t. 1773. Benth, Revis. 2.

3911. Phygelius E.MEY. CaIy x pentaphyllus. Corolla hypogyna, tubulosa, tubo declinato, apice recurvo-adscendente, limbo brevi, quinquefido, subbilabiato, laciniis planis, mnticis. Stamina 4 , corollae tabo inserta, exserta, didynama, declinata; a ntherae biloculares, loculis parallelis, muticis, adnatis. Ova rinm biloculare, placentis dissepimento ntrinque adnatis, multiovalatis. Stylus simplex; stig ma subincrassatum. Ca psul a ovata, obliqua, bilocularig. Semin a plurima, aptera. - Frutex capens is, praeter paniculae rhachin tenuiter pubescentem glaberrimus; foliis oppositis, petiolatis, ovatis, subcordatis, crenatis, crassiusculis, laevibus, paniculae pedalis laxae, secundae ramis tri-quinquefloris, bracteis ad basim ramorum et pedicellorum brevibus, pedicellis apice recurvis, calycibus nutantibus, corollis sesquipollicaribus speciosis, glaberrimis, capsula sesquipollicari, valde obliqua, submembranacea, bisulcata, glaucescente.

Phygelins E. Meyer ex Benth, in Bot. Mag. Com. pan, $\boldsymbol{I I}, \mathrm{SB}$,

3912. Colplas $E$, MEY. Cal yx pentaphyllus. Corolla hypogyna, tubo brevi, amplo, basi saccato - declinato, a pice adscendente, limbo quinquefido, subbilabiato, laciniis rotundatis, planis. S tamin a 4, corollae tubo inserta, inclusa, didynama, declinata; an therae biloculares, loculis divaricatis, demum confluentibus. O varium biloculare, placentis dissepimento utrinque adnatis, multiovulatis. Stylus simplex, brevissime emarginatus; stigmatibus parvis. Capsula bilocularis, septicide bivalvis, valvis coriaceis, apice bifidis. S emina ...... - Fruticulus capensis, divaricato-ramosissimus; ramis fragilibus, molliter pilosis, foliis oppositis, petiolatis, cordatis, semipollicaribus, acutis, inciso-dentatis v, palmatilobis, utrinque pilosis, peduneulis axillaribus, unifloris, folio longioribus, ebracteatis, corollis octo v. decem lineas longis, glaberrimis, capsula glabra, calycem aequante. IT. 53.

Colpias B. Meyer ox Benth in Bot. Mag. Compan.

3913. Fxianthes $E$. MEY. Calyx bilabiatus, labio superiore bi-tridentato, inferiore distincto, bipartito. Corolla hypogyna, tubo amplo, declinato, apice subadscendente, limbi quinquefidi laciniis planis. S ta min a 4 (?) corol. lae tubo inserta, inclusa, didynama, adscendentia; a ntherae biloculares, loculis erassís, divarieatis. Ovari a m biloculare, placentis dissepimento utrinque adnatis, multiovulatis. Sty lns simplex; stig ma brevissime emarginatum. Cap sula ovata, acuta, bilocularis, septicide bivalvis, valvis coriaceis, apice subbifidis, S e min a ...... Frutex capensis; ramis erectis, hirsutis, foliis confertis, quaternatim-quinatim verticillatis, subsessilibus, erectis, rigidis, lanceolatis, acutis, apice serratis, basi angustata integerrimis, coriaceis, glabris v. junioribus villosis, pedunculis axillaribus, unifloris, bibracteolatis, folio brevioribus, calycibus striatis, glabris, corollis decem lineas longis, valde obliquis, extus viscoso-villosis, capsulis semipollicaribus. II, 53 .

Ila nthe E. Meyer ex Benth. in Bot, Mag. Compan.

391 4. IRehmannia $L I B O S C H$. Caly $\mathrm{x}$ campanulatus, quinquefidus. Corolla hypogyna, ringens, tubo superne ampliato, limbi bilabiato-quinquelobi lobis subaequalibus, duobus superioribus reflexis, inferioribus patentibus. Stamin a 4, corollae tubo inserta, inclusa, didynama, recta; antherae biloculares, loculis subdivaricatis. Ovarinm incomplete biloculare, septis incompletis margine utroque placentiferis, multiovulatis. Stylus simplex; st $\mathrm{fgm}$ a late bilamellatam. C a p's n la ovata, incomplete bilocularis, bivalvis, valvis medio septa placentifera gerenti- 
bus. Semina plurima, ovata, testa laxa, spongiosa, reticulata. - Herba perennis, in China bor e al $i$ indigena, piloso-glandulosa; foliis radicalibus ovatis oblongisve dentatis, caulinis alter$n i s$, saepius parvis $v$. interdum nullis, petiolis axillaribus, solitariis, unifloris, folium subaequantibus, bracteolis nullis.

Rehmannia Liboschitz ex Fischer Ind, som. hort. Petropolit. 1835. I. 36. Lindley in Bot. Reg. t. 1960. Hooker Bot. Mag. t. 3653. Dig italis g 1 u t $\mathrm{in}$ o 8 a Gärtuer in Nov, Comment, Petropolit. XIV. $544, t .20$.

3915. Digitalis TOURNEF. Caly $\mathrm{x}$ quinquepartitus, subaequalis. Co rolla hypogyna, subeampanulata $\mathbf{v}$. infundibuliformis, ventricosa, limbi abbreviati labio superiore indiviso obtusissimo, v. bifido, inferioris trifidi lacinia intermedia aequali v. porrecta. Sta m in a 4 , corollae tubo inserta, didynama, inclusa, declinata; a n therae bilocalares, loculis divaricatis. Ovarium biloculare, placentis dissepimento utrinque adnatis, bilobis, multiovulatis. Stylus simplex; stigma bilamellatum, Capsula ovata, bilocularis, sep. ticide bivalvis, valvularum marginibus introflexis placentas coadunatas retinentibus. Semina plurima, rugosa. - Herbae perennes, in Europ a media et a ustrali, necnon in Oriente indigenae, in insulis $C$ anariis fruticosae; foliis alternis, integris, floribus terminalibus, spicatis $v$, racemosis.

Digitalis Touraef, inst, 73. Linn. gen, $n$, 758, Gärtner 1. 247 t. 53 . Lindley, Monographia. Lond.1821. fol. Nees jun. Gen, plant. XPI. 4.

a. Digitalis Lindley $l$. c. t. 1-26. Cor olla labium superlus multo brevius, ab inferiore imbricatum. - Species herbaceae. (Sibthorp Flor. graec, t, 506, 507. Reichenb. Iconogr, $t, 151$ - 160, Bot,Reg. $t, 1201$.)

b. Is op lexis Lindley l. c. $t$. 27, 28. C oroll a e labium superius inferiori aequale et aestivatione incumbens. - Species canarienses, fruticosae. (Smith Exot. Bot. II. $t$. 73. Heritier Stirp. $t$, 24, Bot. Reg, t. 48.)

3916. IPanlownis SIEBOLD et ZUCC. Cal yx coriaceus, campanulatus, quinquefidus. Co rolla hypogyna, infundibuliformi - campanalata, limbo quinquefido, bilabiato, laciniis subaequalibus. St a m in a 4 , corollae tubo inserta, inelusa; ant herae biloenlares, loculis divaricatis. Ova ri u m biloculare, placentis linea dorsali dissepimento utrinque insertis, multiovulatis. St ylus simplex; stigma truncatum. Capsula ovata, lignosa, bilocularis, septieide bivalvis. Sem in a plurima, parva, costis eristatis, margine in alam membranaceam, pellucidain, apice emarginatoexcisam expanso. - Arbor japonica; ramis horizontalibus, tortuosis, folits oppositis, petiolatis, cordatis, subtrilobis, integerrimis, subtus molliter villosis, floribus paniculatis, roseis, calycibus densissime ferrugineo-tomentosis.

Paulownia Siebold et Zuecariai Flor, Japon, 25. t. 10. BIg a onia tomeatosa Thunb.

321 1. Anastrabe E.MEY, Cal y $\mathrm{cam}$ panulatus, semiquinquefidus. Corolla hypogyna, tubo brevi, limbi bilabiati labio superiore bifido, laciniis planis, inferiore maximo, declinato, saccato, apice breviter trifido. Stamina 4 , corollae tubo inserta, didynama, declinata; an therae biloeulares, loculis parallelis v. divergentibus, $\mathrm{O}$ v a ri u m biloculare, placentis dissepimento utrinque insertis, multiovulatis. St y lus simplex; 8 tig $m$ a truncatum $v$. brevissime bifidam. Ca psula oblonga, coriacea, bilocularis, septicide bivalvis, valvis demum bifidis. Semina pauca, testa membranacea, reticulata. - Frutices ca penses, Freyliniae v. Buddleae habitu; foliis oppositis, breviter petiolatis, oblongo-ellipticis, supra nitidis, glabris, subtus incanis, floribus in corymbos cymasve axillares terminalesque, foliis plerumque breviores disposit is, calycibus et corollis extus to. mentosis. IT. 54 .

An astrab e E. Meyer ex Beuth. in Bot. Mrag. Compan.

TEEIEUS VI. GRATIOLEAE Benth. Scrophularin. ind. 20. C orolla limbo bilabiato v. subaequali, laciniis subplanis. St amina fertilia 2 v. 4 , adscendentia; an thera e biloculares, muticae. Capsula bilocularis, loculicide v. septicide aut septifrage bivalvis, valvis integris $v$. bifidis, dissepimento placentifero demum libero, rarius baccata. Semina aptera.

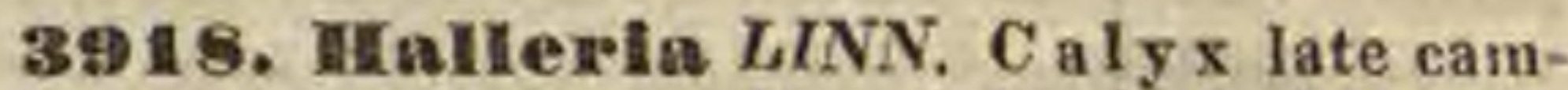
panulatus, tri-quinquepartitus, lobis latis, foliaceis. Corolla hypogyna, tubulosa, fauce dilatata, limbi obliqui, quinquefidi lobia brevibus, latis, planis. St am in 4 , corollae tubo inserta, didynama, adscendentia, erecta; anthera e biloculares, loculis parallelis, subbilobis, explanatis. O va $\mathrm{r}$ i $\mathrm{a} \mathrm{m}$ biloculare, placentis dissepimento utrinque adnatis, multiovulatis. Sty lus simplex; stigma punctiforme. Ba cea stylo superata, biloenlaris. Semin a plurima, compressa, punctata. Frutices capenses, glabri; foliis oppositis, sempervirentibus, ovatis, supra laevigatis, pedicellis axillaribus, solitariis v. fusciculatis, bibracteolatis, calycibus brevibus, subenerviis, laete virentibus, corollis rubentibus $v$. coccineis, nitidis,

Halleria Lian. gen, $n$, 761. Lau. $t$. 566. Bot. Mag. t. 174t. Giartner f. 111 , 41. . 185. Benth. Bot, Mag. Comp, II. $5 \dot{4}$.

3⿻19. Teedis RUDOLPH. Cal yx quinquepartitus, laciniis linearibus. C o roll a hypogyna, tubulosa, fauce barbata, limbi quinquefidi, subbilabiati laciniis planis. St a mina 4 , corollae tubo inserta, didynama, inclusa; antherae biloculares, loculis parallelis. Ovari $\mathbf{n} \mathrm{m}$ biloculare, placentis dissepimento adnatis, multiovalatis. Stylns simplex, brevis; stigma capitatum. B a c e a stylo superata, bilocularis. Sem in a plarima, oblonga. - Frutices capenses; foliis oppositis, basi angustatis, caulem dilatato-anılectentibus, pedunculis axillaribus $v$. terminalibus trifloris.

Te ed a Rudolphi ia Schrader Journ, II. 289. Bot. Reg. t. 209. 214. Benth. Revis. 4. Bot. Mag. Com, pan. IT. 5\%. B or $\mathrm{k}$ h a u s en a Roth Catalect. II. 56.C a p r r i a lucidaAit.

3920. Freyllinia BENTH. C a ly x pentaphyllus, foliolis subemarginatis. Co rolla bypogyna, tubulosa, limbi quinquelobi, subbilabiati laciniis planis. St a mina 4 , corollae tubo inserta, inclnsa, ditynama; antherae biloculares, loculis parallelis, contiguis. Ovarium biloenlare ..... Sty lus simplex; stigma incrassato-capitatum. C a p s a la ovata v. oblonga, bilocularis, septicide bivalvis, valvis coriaceis, apice bifidis, .... Semina pauca? ..... - Frutices c a penses; folits oppositis $v$. sparsis, integerrimis, coriaceis, nitidis, floribus in paniculas v. racemos terminales dispositis, bracteis ad basim ramorum paniculae et pedicellorum parvis.

Freylinia Benth. in Bot. Mag. Compan, IT. S5. an 
Colla? Capraria lanceolata Linn. Link et Otto Ic. select. $t$. 4 .

OBSERVATI0, Stirpes a cl. Bentham $t$. c. Freyliniae nomine indicatas, et plantam a cl. Colla Mort. Hipul. s6. et in Dis. sert, s, a. Fr e y lí i e a e nomiae descriptam esse conge neres, merito dubitanus, cum haie „drupa tetrapyrena, "pyrenis dispermis" diserte tribuatur.

3921. Caprearia LINN, C aly x quin quepartitus, aequalis, Corolla hypogyna, subcampanulata, tubo brevi, limbo quinquefido, subaequali. St a min a 4 , corollae tubo inserta, inclusa, didynama; antherae biloculares, locu lis parallelis, contiguis. Ovari n m biloculare, placentis medio dissepimento utrinque insertis, multiovulatis. Stylus filiformis; $8 \mathrm{tigma} s u b$. bilobum. Capsula ovata, bilocularis, septicide bivalvis, valvis coriaceis, apice bifidis, placentis coadunatis, demun liberis. Semina plurima, scrobienlata. - Herbae Americae tropicae; foliis alternis, oblongis, serratis, basi integerrima ciliatis, pedicellis axillaribus geminis, saepius elongatis.

Cn prarla Linn. gen, $n, 168$. Jacq. Amer. 182, $t, 115$. Swartz Observat. 239. Gärtner $I .250, t$. 53 . Kunth in Humb. et Bonpl. Nov. Gen, et sp. II. 354. Benth. Hevis. 3.

3982. Xunrezin RUIZ et PAV. C a lyx quinquepartitus, aequalis. Corolla hypogyna, subcampanulata, tubo brevissimo, limbo quinquepartito, aequali, patente. Stamina 5 , corollae tubo inserta, omnia fertilia, aequalia, subexserta; anther a biloculares, sagittato-bilobae. Ovari $\mathbf{m}$ biloculare, placentis dissepimento utrinque insertis, multiovulatis. St y I u s simplex, brevis; stigma bilamellatum. C a psula oblonga, obtusa, compressiuscula, bilocularis, septicide bivalvis, valvis coriaceis, bifidis, placentis enailunatis, demum liberis. Semina plurima, serobieulata. Frutex peruanus; ramis foliisque alternis, serra tis, pedicellis axillaribus, solitariis v. geminis.

Xuarezia Ruiz et Pavon Flor. Peruv. II. 13. $t .123$. f. $a$. Kunth Synops. II. 117. Capraria peruviau a Feuille observat. t. 48 ,

3923. Pogrostomes SCHR $A D$. C a ly x profunde quinquepartitus, laciniis tribus latiorihus, apice denticulatis. Corolla hypogyna, tabulosa, fauce liarloata, limbi quinquefidi, bilabiati lacinitis subaequalibus, planis. St a min a 4 , corollae tabo inserta, didynama, inclusa; a n th e$r$ a e biloculares, loculig divarisatis, confluentibns. Ovarinm biloculare, placentis medio dissepimento utrinque insertis, multiovulatis. Stylus simplex ; stigma depresso-capitatum. Cap s n la ovata, bilocularis, septieide bivalvis, valvis bifidis, placentis coadunatis, demum liberis. S e m in a plurima, serobieulata. - Herba mexicana; ramis hirsutis, foliis alternis, spathulalo-obovatis, cuneatis, duplicato inciso-serratis, pilosiusculis, peduneulis axillaribus subsolitariis, abbreviatis, hirsutis.

Pogosto m a Selurader Index semin. hort. Gotting. 1831. Caprarla saxifragaefolla Schlechtend. ia Lianaea $\nu .105$.

3924. Pterostionan BENTH. Calyx quinquepartitus $v$. quinquefidus, lacinia postiea majore. Coro 11 a hypogyna, bilabiata, labio superiore emarginato, inferiore trilobo. S ta m in a 4 , corollae tubo inserta, postica fertilia, an the $r$ is bilocularibus, loculis disjunctis, stipitatis; antica sterilia $v$. antheris dimidiatis. $0 \mathrm{v}$ ari um biloenlare, placentis medio dissepimento adnatis, multiovalatis. Stylas simplex; stigma subincrassatum, integrum, saepius ntrinque ala membra- nacea cinctum. Cap $s$ ula rostrata, bisulca, bilocularis, loculicide bivalvis, valvnlis bifidis, dissepimento e marginibus introflexis duplicato, demun libero, placentis adnatis v. tandem solutis. Se m in a plurima, striata. - Herbae indicae, durae, villosae, siccae saepius nigrescentes, odore aromatico Labiatarum ; foliis oppositis, rugosis, crenulatis, foribus capitatis, racemosis, sparsis $v$. inferioribus oppositis, pedicellis brevibus, apice saepius bracteatis.

P ter ostig m a Benth. Serophularin. ind, $20,1100 k$, ad Beechey 203, $t$. 45. S pathestig m a Hook, et Arn, mse.

39ร5. Hindenbergia $L I N K$ et OTTO.

Caly x campanulatus, breviter quinquefidus, laciniis ovatis, saepe foliaceis, Co r ol l a hypogyna, ringens, labio superiore emarginato, inferiore trilobo. Stamin a 4, corollae tubo inserta, omnia fertilia, didynama, inclnsa, postica breviora; a nthera e biluculares, per paria approximatae, liherae, loculis disjunctis, stipitatis, omnibus fertilibus. Ovarium biloculare, placentis medio dissepimento ntrinque adnatis, multiovulatis. St $\mathbf{y}$ l us simplex; stigm a subincrassatum, integrum, dilatatnm. Capsula oblonga, bisulea, bilocularis, loculicide bivalvis, dissepimento e marginilus inflexis duplicato, demum libero, placentis adnatis v. tandem solntis. Semina plurima, striata. - Herbae in Asia tropica et subtropica indigenae, ramosae, interdum scandentes $v$. divaricatae, villosae, siccatae saepe nigrescentes, inodorae; folits oppositis, dentalis, floribus sessilibus, nunc axillaribus oppositis, nunc in racemos v spicas interruptas, axillares et terminales dispositis.

Lindenberg ia Liak et 0ito Ic. select. 95. Benth. Scrophularin, ind. 21, Revis, 2. Bot. Reg. 1470, B r a. ch y c oris Schrader Catalog. Hort. Gätting. 1830. B ov e a Decaisne in Nouv. Annal, sc, nat, $M, 253, \mathrm{~S}$ tem od i a raderalis Vabl.

3528. Stemodira LINN. C al y $x$ tubuloso-campannlalus, quinquepartitus, subaequalis. Corolla hypogyna, ringens, labio superiore emarginato, inferiore trilobo. St a min a 4 , corollae tabo inserta, omnia fertilia, didynama, inelusa, postica breviora; anthera e biloculares, per paria approximatae, liberae, loculis disjunctis, stipitatis, omnibus fertilibus. Orarium biloculare, placentis medio dissepimento atrinque adnatis, multiovulatis. St y I us simplex; stigma integrum, subbilabiatum. Ca p s u Ia oblonga v. suhglobosa, bisulea, bilocularis, loeulicide v. septicide bivalvis, valvis bifidis, dissepimento e marginibus inflexis duplicato, demum libero, placentis adnatis. Se mina plurima, striata. - Herbae v. suffrutices, in Asia et America tropica crescentes; foliis opposilis $v$. verticillatis, sessilibus $v$. breviter petialatis, floribus axillaribus, v. superioribus in racemum v. capitulum approximatis.

Stemodia Lina. gen, $n$, 777 . St. Hilaire Plant, re. marq. Brasil. 216. Chamisso in Linnaea III. 4. Benth. Scraphularin, ind, 29, Revis. 2.

a. MODESTIA Chamiss. . c. C apsil la loculicidn. $-S p$ cies asiaticae. $\mathrm{C}$ y b b a $\mathrm{n}$ hera Hamilt. in Don $N 6$. pat. 87. (Roxburgh Plant, corom, $2,176$. )

b. DiAmoste Chamiss, $\boldsymbol{l}$. $c$. Capsnla septicida.-Species americanae. (Kuath in Humb, et Bompl, Nov, gon. ef sp. t. 175. Reicheab. Ic, exot. $t$. 1.)

398\%. Selnâstophromen $B E N T H$. CaIy $\mathbf{x}$ quinquepartitus. Corolla hypogyna, tabulosa, limbi bilabiati labio superiore breviter bifido, inferiore trifido, laciniis omnibus planis. Stamina 4, corollae tubo inserta, omia fertilia, didynama, inclnsa, postica hreviora; antherae 
biloculares, per paria approximatae, liberae, loeulis discretis, parallelis, omnibus fertilibus. $O$ vari um biloculare, placentis medio dissepimento ntrinque adnatis, multiovulatis. St y lu 8 simplex; st $\mathrm{gma}$ integrum, dilatatum. Capsula linearis, siliquaeformis, subcompressa, bisulea, bilocularis, septieide bivalvis, valvis navieularibus, indivisis, dissepimento placentifero, demum libero, apice hifido parallelis. S e m in a plurima, oblonga, lae via. - Herbula mexi cana, bipollicaris, ramosa; caulibus tetragonis, glabris v. ad angulos scabropubescentibus, foliis oppositis, pinnatisectis, segmentis linearibus subcuneatisve, integerrimis $v$. incisis, pedunculis axillaribus, brevibus, secundis, unifloris, ebracteatis, calycis vix duas lineas longi laciniis linearibus, rigidiusculis, acutis, scabris, subaequalibus, corolla calycem subduplo superante, glabra, capsula quinque lineas longa, tenui, acuta. $\mathrm{Sch}$ is to $\mathrm{phr}$ a gma Benth, in litter. 9, Jul. 1838.

3928. Ereimens $L I N N$. Calyx quinquepartitus, aequalis. Corolla hypogyna, hypocraterimorpha, limbo quinquepartito, lobis subaequa libus, patentibus, emarginatis. St a m in a 4 , co rollae tubo inserta, omnia fertilia, didynama, inelusa, postica breviora; antherae loculis confluentibus uniloculares. Ovarium bilocnlare, pla centis medio dissepimento utrinque adnatis, multiovulatis. Stylus subnullus; stigma subglobosum, utrinque ala dentiformi auctum. C a p s uI a ovata, bilocularis, septicide bivalvis, valvis demum bifidis, dissepimento placentifero parallelis. S e min a plurima, ovata, subrugosa. - Herba palmaris, caespitosa, pilosa, in alpibus $E u$ ropac mediae et australis perennans; folitis al ternis, spathulatis, profunde serratis, racemis terminalibus, laxe corymbosis.

Drinus Linn. gen, $n$, $77 t$, excl, sp. Schkuhr $t, 176$ Bot, Mag. $t .310$. Nees Jun. Gen, plant. $X V I, t$. 14.

3D29. Sutera ROTH. Cal yx quinque partitus, subaequalis. Corolla hypogyna, infundibuliformis, limbo quinquepartito, vix patente, laeiniis brevibus, aequalibus, integris. S $t a \mathrm{mi}$ n a 4 , corollae tubo inserta, omnia fertilia, didy nama, inclusa, postica breviora; antherae biloculares, loculis parallelis. Ov a ri $\mathbf{m}$ m biloculare, placentis medio dissepimento utrinque adnatis, multiovulatis. Stylus simplex; stigma obtasum. C a p su I a bisulea, bilocnlaris, septicide bivalvis, valvis demum bifidis, placentis coadunatis, liberis. S e nina plurima, laevia. - Herbae in India orientali, Aegypto et $A m$ erica boreali indigenae, basiramosissimae, diffusae; foliis oppositis, pinnatifidis, pedunculis axillaribus, solitarits, oppositis $v$. superioribus alternis, racemosis.

$S$ uter a Roth Nov. sp. 291, exel, spec. in Bemork, 172. descript. Benth. Scrophularin. ind. 42. Le u c os por a Nuttall in Annal, Lye. New-York. Caprariae 5 p. Nuttall, Delile Aegapt. $t .32$.

3930. Doulantia TOURNEF. CaIyx campanulatus, deeagonus, quinquedentatus. Corolla hypogyna, bilabiata, labio superiore breviore emarginato, adscendente, inferiore longiore trifido, biseriatim barbato, lobis integris. St a m ina 4 , corollae tubo inserta, inclusa, didynama; filamenta simplicia, antherae biloculares, distinctae, subglobeso-didymae. Ovarin m biloculare, placentis dissepimento utrinque adnatis, multiovulatis. Stylns simplex; 8 tig ma bilamellatum. Capsula subglobosa, bisulea, bilocularis, septifrage bivalvis, valvis indivisis, dissepi- mento placentifero parallelis. Semina plurima, angulata, laevia. - Suffrutex ramosus, in Asia minore, regione taurico-caucasica et Sibria orientali indigenus; caule ramisque tetragonis, foliis oppositis, linearibus, sessilibus, subdentatis, glabris, floribus racemoso-spicatis, purpureis.

Doda r tia Touruef. It. IIT. 208. Instit. 478. Linn. gen, n, 780. Gärtuer I. 245. $t, 53$. Bot. Mag, t, 2199. Benth. Revis, 2,

3931. Nazms LOUREIR. Calyx campanulatus, quinquefidus, subaequalis. Corolla hypogyna, bilabiata, labio superiore tridentato $v$. bifido, inferiore longiore trifido, basi bigibboso, lobis integris. S tam in a 4 , corollae tubo inserta, inclusa, didynama; fil am ent a simplicia, anthe ra e biloculares, per paria cohaerentes v. approximatae, loculis divergentibus v. divarieatis, demum confluentibus. O va ri um biloculare, placentis dissepimento utrinque adnatis, multiovulatis. St y l u s simplex; st ig ma bilamellatum. Ca ps n la bilocularis, loculicide bivalvis, valvis integris, medio septuliferis, dissepimento demum libero, placentifero contrariis. Semina plurima, striata. - Herbae in Asia tropica, Japonia et insula Diemen observatae, humiles, saepe procumbentes $v$. repentes; foliis radicalibus confertis, petiolatis, grosse dentatis $v$. lobatis, ramorum sterilium oppositis, floralium perpaucis, alternis, racemis terminalibus unilateralibus v. scapis paucifloris, floribus alternis, pedicellis nudis $v$. basi aut medio uni-bibracteatis.

M a z u s Loureiro Flor. oockineh. 385. R. Brown Prodr. 439. Benth. Scrophularin. ind, 26. Hornemannia Reichenb. Ic. exot, $t$. 37 . Willd. part.

3932. Limnophila $R, B R$. Caly $x$ tubulosus, quinquefidus, aequalis. Coroll a hypogyna, infundibuliformis, limbi subbilabiati Jabio superiore bilobo, inferiore trifido, lobis omnibus planis. Sta mina 4 , corollae tubo inserta, inclasa, didynama; filamenta simplicia, apice saépius abrupte ineurva v. dilatata, anth e $\mathrm{r}$ a e biloculares, per paria cohaerentes, loculis parallelis, distinctis. O vari um biloculare, placentis dissepimento utrinque adnatis, multiovulatis. St y l us simplex; stigma oblique dilatatum, bilamellatum. Ca p s ul a bilocularis, bisulea, loculicide bivalvis, valvis demnm bifidis, a placentis coadunatis tardins solutis. Semina plurima, rugosa, - Herbae in Asia et Nova-Hollandiatro$p i c a$ indigenae, paludosae $v$. aquaticae; foliis oppositis, inferioribus submersis, profunde multipartitis, laciniis capillaceo-multifidis, emersis integris, dentatis $v$. incisis, saepe tripartitis et hinc facie prima verticillatis, floribus solitariis, oppositis, sessilibus $v$. pedicellatis, axillaribus $v$. racemosis, pedicellis nudis $v$. apice bibracteolatis.

Lim no phila R. Brown Prodr. 442, Gaudich, ad. Freyc. t. 57. Benth. Serophularin. ind. 95. Rovis. 3. H y d r o plt y o a Gârtner $f$. IIT 19, $t$. 183. quo ad herbam exel. flor. et fruet. Hottonia indica Linn. C yrilla aquatiea Roxburgh Plant, Corom, 7.189.

3983. Jvedalia $R$. $B R$, C a ly $x$ tubulosus, prismatieus, quinquedentatus. Corolla hypogyna, bilabiata, labio superiore bilobo, inferiore trifido, lacinia media parum dissimili, basi bigibbosa. Stam in a 4 , corollat tubo inserta, inclusa, didynama; fil amenta simplieia, a n therae biloculares, loculis divaricatis. 0 vari u m biloculare, placentis dissepimento utrinque adnatis, multiovalatis. Stylus simplex; stig ma complanatum. Capsul a bilocnlaris, locnlieide bival- 
vis, valvis demum bifidis, marginibus inflexis a placentis coadunatis tardius solntis. Sem in a plurima... - Herba Novae-Hollandiae tropie a e; foliis oppositis, linearibus, pedunculis axillaribus et terminalibus unifloris, ebracteatis, corollis caeruleis.

Uvedalia R. Brown Prodr. 450.

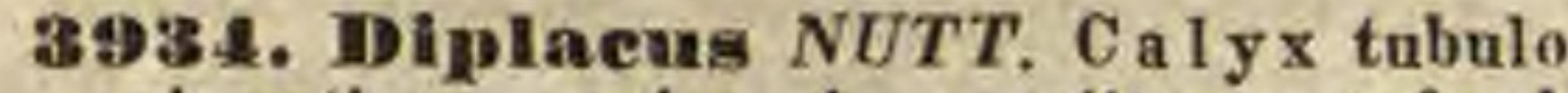
sus, prismaticus, apice inaequaliter profunde quinquedentatus. Corolla hypogyna, bilabiato quinquefida, lobis subaequalibus, plerumque emar ginatis. Stamina 4 , corollae tubo inserta, in clusa, didynama; filamenta simplicia, antherac biloculares, loculis divaricatis. $O$ va ri $\mathbf{n m}$ bi loculare, placentis dissepimento utrinque adnatis, multiovulatis. Stylus simplex; stigma bilamellatum. Capsn la oblonga, bilocularis, loculicide bivalvis, valvis medio septiferis, placentas adnatas anferentibus. Sem in a plnrima, minima, utrinque subulata, - Suffrutices californici, Mimuli facie; foliis opposilis, sessilibus, integerrimis v. serratis, plerumque viscosis, pedunculis axil. laribus, opposilis, unifloris, ebracteatis, corollis coccineis $v$. luteis.

D i pl a cu s Nuttall in Bot. Mag. $\mathrm{C}$. 3055. et in Jardine Annals of Nat. hist. I. 137. Mimulus glutinosus Winld, Bot, Mag. $t, 354$.

3935. DItmulus $L I N N$. Caly $\times$ tubulosus, prismaticus, quinquedentatus. Corolla hy pogyna, bilabiata, labio superiore bilobo, inferiore trifido, basi saepius bigibboso, lobis subaequalibus. Stam in a 4 , corollae tubo inserta, inclusa, didynama; filamenta simplicia, antherae biloculares, loculis divaricatis, demum confluentibus. Ovarin miloenlare, placentis dissepimento adnatis, multiovulatis. Stylu s simplex; stig$\mathrm{m}$ a bilamellatum. Ca p $\mathbf{s}$ u a bilocularis, Loculicide bivalvis, valvis integris, medio septiferis, placentae demum liberae contrariis. Semina plurima, minima, utrinque subulata. - Herbae in America extratropica occidentali,boreali et australi, in Andibus Peruviae, India boreali et Nova-Hollandia indigenae, erectae v. procumbentes, glabrae v. rarius villosae; caule plerumque tetragono, folits oppositis, dentatis $v$. rarius integerrimis, pedunculis axillaribus, oppositis, unifloris, ebracteatis, superioribus interdum racemosis, corollis coccineis, luleis, violaceis $v$, albis.

M i mulus Linn. gen. n, 783. Gärtner T, 245. $t$. 53 . Bonpl. Navarr. t. 60. R. Brown Prodr, 439. Kunth in Humb. et Bonpl. Nov, gen. et sp. II. 370. exel. sp. Pursh Flor. Bor. Amer. t. 20. Bot. Mag. t, 3353, 2560, 3563. Bot. Reg. 4. 874, 1118, 1125. 1330, 1591. Benth. Scrophutarin, ind. 27.

3938. Heuce earpus $D O N$. Cal y x campanulatas, prismaticus, quinquedentatus. CorolI a hypogyna, bilabiata, labio superiore breviore bilobo, inferiore trifido. Stamina 4 , corollae tubo inserta, inclnsa, didynama; fil amenta simplicia, antherae biloculares, loculis divaricatis, demum confluentibns. $O$ va ri $u$ biloculare, placentis dissepimento ntrinque adnatis, multiovulatis. Sty I as simplex; s ti g ma bilamellatum. B a e e a globosa, stylo mucronata, suceulenta, placentis carnosis. S e mina plurima, ovali-oblonga, utrinque mucronata. - Herba mexicana, erecta, annua; caule ramisque alato-quadrangulis, folits oppositis, semiamplexicauli-sessilibus, lanceolatis, argute serratis, cymis axillaribus multifloris, floribus sulphureis, baccis albis.
Leucocarpus Don in Sweet Fl, Gard, IT, $t$. 12i. Mimulus perfoliatus Bot. Mag, $t, 124$.

3937. Ellobum BLUM. C aly $\mathrm{x}$ quinquepartitus, aequalis. Co rolla hypogyna, bilabiata, labio superiore retuso, inferiose trilobo, majore, lobo intermedio angustiore. St a m in a 4 , corollae tubo inserta, didynama, exserta; filamenta simplieia, antherae biloculares, per paria cohaerentes. Orariam .....Stylas simplex; stig ma obtusum, emarginatum. Ca p s ula? siliquaeformis, subulata, bilocularis. Se min a plurima. - Herba javanica, radicans, pilosa; foliis oppositis, petiolatis, ovatis, serratis, racemis axil. laribus paucifloris, pedicellis fructiferis recurvis.

\section{EII o b u m Blume Bijdr, 747.}

3938. IIorgania $R$. BR, Calyx quinquepartitus, aequalis. Cor olla hypogyna, bilabiata, labio superiore breviore bilobo, inferiore trifido, lobis subaequalibus, obeordatis. S $t$ a m ina 4 , corollae tubo inserta, inclusa, didynama; filamenta simplicia, antherae biloculares, loculis divaricatis, demum confluentibus. O vari u m biloculare, placentis dissepimento utrinque adnatis, multiovalatis. Stylus simplex; stig ma bilamellatum. Capsula bilocularis, septifrage bivalvis, valvis margine inflexis, demum bifidis, dissepimento placentifero parallelis. S e m i n a plurima, scrobiculata. - Herbae Novae-Hollandiae tropicae; caule erecto, tetragono, folits oppositis, linearibus, integerrimis $v$. dentatis, pedunculis axillaribus unifloris, apice bibracteolatis, floribus caeruleis.

Morgania R. Browa Prodr. 461.

3939. Splnaerotheea $C H A M$, Caly $\mathrm{x}$ quinquepartitus, aequalis. Corolla hypogyria, bilabiata, labio superiore breviore bilobo, inferiore trifido, lobis subaequalibus, obtusis. Stamin a 4 , corollae tubo inserta, inclusa, didynama; fil a menta simplicia, antherae biloculares, loculis parallelis. Ovarium biloculare, placentis dissepimento ntrinque adnatis, multiovulatis. Styl us simplex; $8 t i g m$ a bilamellatam. Capsuia globoga, bilocularis, septifrage bivalvis, valvis margine planis, mox bifidis, dissepimento placentifero parallelis. Semina plurima, serobiculata. - Herba brasiliensig; caule erecto, tetragono, fistuloso, foliis oppositis, lanceolatis, argute cartilagineo-serratis, subpellucido punctatis, pedunculis axillaribus unifloris, apice bibracteolatis, floribus caeruleis.

Sph a e r o the Chamisso in Linnaea $11,606$.

3940. IIterpestes GARTN. C a ly x pentaphyllus, foliolo postico maximo, anticis angustioribus, lateralibus linearibus. Co rolla hypogyna, subbilabiata, labio superiore emarginato v. bifido, rarius indiviso, inferiore trifido, laciniis omnibus planis, subaequalibus. Stamina 4 , corollae tubo inserta, didynama, inclusa; fil a menta simplicia, antherae biloculares, per paria approximatae, locnlis divergentibns v. divarieatis, demum conflnentibus. O va ri u m bjlocnlare, placentis dissepimento utrinque adnatis, multiovulatis. Stylus simplex; stigma emarginatum $v$. bilamellatum. Capsula biloeularis, septifrage bivalvis, valvis margine planis v. vix inflexis, integris v, demum bifidis, dissepimento placentifern parallelis. Semina plurima, scrobieulata, - Herbae inter tropicos totius orbis, imprimis Americae obviae, repentes $v$, rarius erectae, glabrae v. villosac; foliis oppositis, integerrimis v. den- 
tatis; floribus axillaribus, sessilibus v. pedicellatis, solitariis $v$. glomeratis, pedicellis nudis $v$. uni-bibracteatis.

Herpestes R. Brown Prodr. 443. Beath. Scrophularin, ind. 29. ot Bot. Mag. Comp. II, 5s.

a. MAtoureA Benth. in Bot. Mag. Comp. Ir. 56. Coroll a e latíum superius integrum v. emarginatum. C a ps ula valvae integrae v. breviter bifidae, marginibus inflex is.

M a to n re a Aublet Guian, I. 641. t. 259. Chanisso in Linnaea III. 20. M e c a r do n i a Martius Nov, gen. et sp. III. 16. $t$, 209, an Ruiz et Pav. ?

b. CACONAPEA Beath. in Bot. Mag, Comp. It. 57. Co roll a e labium superius integrum v. breviter enarginatum. C aps u I a oblonga, acuta, valvis demua bifidis. C a l y c is foliola post anthesim vix aucta, posticum Ianceolatum v. oblougum.

Caconapea et $\mathrm{R}$ anaria Chamisso in Linnaed VTIT. 28-31.

c. BRAMIA Benth. in Bot.Mag. Comp. IT. 57 . Cor olla labium superius profunde emarginatum v. bifidua. C a p $s$ u l a subglobosa v, ovata, rarius oblonga, valvis bifidis. Caly c is foliola post anthesim aucta, extimum saepe cordatum.

B r a m I a Lam. Dict, I. 459. Mart. Nov, gen. et sp. IIT. 18. Amoen. Monac. t. 8 , M a n $\mathrm{n}$ ie ra P. Browue Jam. I. 296. t. 28. f. 1. Michaux Flor. Bor. Amer. II.22. Gärtner f. IIT. 187, t. 114. He rp e 8 t e s Gïrtner f. IIT. 186. $t$, 214. Palis. Flor. Owar. $t$, 112. Martius l. c. M ell a Vandelli in Römer Script, 187. t. 7. f. 22. C alytriplex Ruiz et Pavon Syst. 164. He inzeI manu i a Necker Elem, $n, 573$.

39 il 1. Curramga JUSS. C a l y x tetraphyllns, foliolis duobus exterioribns multo majoribus cordatis, postico latiore, duobus interioribus lateralibus linearibus, inclusis. Co r o Il a hypogyna, bilabiata, labio superiore emarginato, inferiore dilatato-trilobo. St a min a 4 , corollae tubo inserta, inclusa, antica sterilia, apicibus clavatis, postica fertilia; fil am entis simplicibus, antherarum loculis divergentibus. Ovarium bilocalare, placentis dissepimento ntrinque adnatis, multiovalatis. Stylus simplex; stigma spathulatum, inaequaliter bilamellatum. C a p s u l a ovata, compressiuscula, bilocularis, septifrage bivalvis, valvis integris, dissepimento placentifero parallelis. Se mi na plurima, scrobienlata.-Herba in dica; caule inferne repente, tetragono; foliis oppositis, petiolatis, ovatis, crenatis, basi cuneatis, pedunculis axillaribus folio brevioribus, apice subracemo sis, bi-quadrifloris, floribus pedunculatis.

Curanga Jussiea in Annal. Mus. IX. 319. Blume Bifdr. 746. C a r a n g VahiEnumerat, I.100, C u r a n i a Romer et Sehnlt. Syst. $I$. 178. S y n p h y 111 u m Griffiths in Madras Journ, of sc, $\boldsymbol{I}$. ex Benth, in litt. Grattol a a mara Roxb. Serratuta a mara Rumph A mboia. $\boldsymbol{V}$. 459 . $t$ 170. f. 1 .

394., Aelnetaria $C H A M$, C a I y $\mathrm{x}$ pentaphyllus, bibracteolatus. Coroll a hypogyna, bilabiata, labio superiore breviore erecto, integro, inferiore trilobo. St a min a 2, corollae tubo antice inserta, inclusa; fil a ment is simplicibus, an. ther arum loeulis parallelis, sterilia nulla. Ovariu m biloculare, placentis dissepimento utrinque adnatis, multiovulatis. Stylus simplex; 8 tigma emarginatum. Capsula bilocularis, septifrage bivalvis, valvis indivisis $v$. apice breviter bifidis, dissepimento placentifero parallelis. S em in a plurima, minima. _Herba brasiliens is, Melissae habitu, hirsutiuscula; caulibus tetraganis, foliis oppositis, breviter petiolatis, ovatis, acutis, crenulatis, pedicellis axillaribus solitariis unifloris, opposilis, corollis pubescentibus.

A e heta rI a Chamisso in Linnaec II. 567.
3943. IBeyrielala $C H A M$, F 1 o res resupinati, tribracteati. Cal y x pentaphyllus, foliolo antico (superiore) minimo, lateralibus postico (inferiore) majoribus. Co rolla hypogyna, bilabiata, labiis indivisis, subaequalibus. Sta mina 4 , corollae tubo inserta, antica (superiora) fertilia, exserta; fil amenti s simplicibus, an therarum loculis divaricatis; postica (inferiora) sterilia, inclusa. Ovarium biloculare, placentis dissepimento utrinque adnatis, maltiovulatis. Stylus simplex, apice incrassatus; stigma subcupuliforme. Capsula bilocularis, septicide bivalvis, valvis interris, placentis coadunatis demum liberis. S em in a plnrima, minima. - Herba brasiliensis, pubescens; caule erecto, tetragono, folits oppositis, breve petiolatis, ovatis, serratis, florali. bus brevissimis, spica terminali foliosa, densa.

Beyrichia Chamisso in Linnaea III. 21.

3944. Antielnaris. Cal y x ebracteola tus, quinquepartitus, aequalis. Co rolla hypogyna, bilabiato-quinquefida, lobis subaequalibus, $o b-$ tusis. Stamina 2 , coroliae tubo antice inserta, inclusa; fil amentis brevissimis, antherarum loculis divaricatis, demum confluentibus. Ovarium biloculare, placentis dissepimento utrinque insertis, multiovulatis. St y lus simplex; stigma obtusum, emarginatum. Capsula pyramidata, bilocularis, loculicide bivalvis, valvis demum septicide bifidis, placentis coadnnatis, liberis.

Herba a g yptiaca, subsimplex, obsolete glanduloso-pubescens; foliis alternis, petiolatis, ellipticis, integerrimis, pedunculis axillaribus, solitariis, uniftoris, petiolo brevioribus, infra medium minutissime unibracteatis.

Caprarla aegyptiaca Steudel et Hochst. msc.

3945. Irydretrele $Z U C C A R$. $\mathrm{C}$ a ly $\mathrm{x}$ ebracteolatus, quinquepartitus, aequalis. CorolI a hypogyna, infundibuliformis, limbo quinquefido, patente, aequali. S $t$ a $m$ in a 2 , corollae tubo postice inserta, inclusa; fil a m ent is simplicibus, atherarum loculis divaricatis, Ovarium biloculare, placentis dissepimento utrinque adnatis, multiovulatis. St y lus simplex; stigm a subinfundibnliformi-bilabiatum. C a p s u I a bilocularis, loculicide bivalvis, valvis integris, medio septiferis, placentis coadunatis, liberis. - Herba madagascariensis, aquatica; foliis inferioribus submersis, verticillatis, capillaceo-subulatis, setoso-serratis, superioribus oppositis, lanceolatis, obtusis, floribus in racemum pauciflorum dispositis.

Hydrotriehe Zuccarini Plant, nov, fasc. I. 109. Beuth. in Bot. Mag. Comp. II. 59.

3946. Gratiola $R$. BR. Calyx quinquepartitus, bibracteolatus, aequalis. Coroll a hypogyna, bilabiata, labio superiore emarginato $v$. bifido, inferiore trifido, aequali. S $\operatorname{tam} \mathrm{m} n \mathrm{a} 4$, corollae tubo inserta, inclusa, antica sterilia Iongiora, subelavata, postica fertilia; anth e $\mathrm{r}$ is cohaerentibus, bilocularibus, loeulis parallelis. $O$ variu m biloculare, placentis dissepimento utrinque adnatis, multiovulatis. Stylas simplex; stigma dilatatum, bilamellatum. C a psula bilocularis, loculicide bivalvis, valvis demum bifidis, dissepimento e marginibus introflexis soluto. Semina plurima, serobiculata. - Herbae perennes, uliginosae, in Europa media, America boreali et Nova-Hollandia extratropica indigenae; foliis oppositis, crenatis $v$. dentatis, pedunculis axillaribus solitariis, unifloris, oppositis v, alternis. 
Gratiola R. Browh Prodr. 435. Gratiolae sp. Lian. Gärtner t. 53. Flor. Daa. t. 363. Nees jun. Gon.plant, $X Y I, t, 6, \mathrm{~S}$ o ph=0 n a $\mathrm{the}$ Benth, in Lindley Introduct, cdit. II. p. 445. $\mathrm{N}$ i bor a Rafiuesq. Flor. Iudov, 36.

394\%. Dopatriven HAMILT, C a Iyx membranaceus, semiquinquefidns. Corolla hypogyna, limbo oblique quinquefido, subbilabiato, labio inferiore majore. S $\mathrm{t}$ a m in a 4 , corollae tubo inserta, inclusa, antica sterilia, minima, postica fertilia; fil a mentis simplicibus, antheris cohaerentibus, bilocularibus, loculis parallelis. Ovari u m biloculare, placentis dissepimento utrinque adnatis, multiovnlatis. Stylus simplex; st i g ma dilatatum, bilamellatum. Capsula bilocularis, septifrage bivalvis, valvis demnm bifidis, dissepimento placentifero parallelis. S e m in a plurima, minima, - Herbae indic a e, uliginosae, tenerae, glabrae; foliis opposilis, radicalibus et caulinis in. ferioribus paucis, obovatis, integerrimis, caulinis minutis, distantibus, pedicellis axillaribus salitariis, unifloris, oppositis $v$. alternis, corollis caeruleis.

Dopatriu m Hamilt. ex Benth. Scrophularin, ind, 30. Gratiola s p. Retz. Willd, Roxburgh Plant, Corom.. . 129.

39.8. Hommaya LINK et OTTO. $\mathrm{C}$ a1 y $x$ quinquepartitus, subaequalis. C oro 11 a hypogyna, tubo exserto, limbi bilabiato-quinquefidi labio superiore breviore. Stamina 4 , corollae tubo inserta, duo postica fertilia, inclusa; filamentis simplicibus, antheris cohaerentibus, antica sterilia, ad basim labii inferioris. O vari u m biloculare, placentis medio dissepimento utrinque adnatis, multiovulatis. Stylus simplex; stig un a complanatum, bilamellatum. Ca p 8 u la glohosa, oblonga v. linearis, bilocularis, septifrage bivalvis, valvis membranaceis, integris, margine planis, dissepimento placentifero, demum libero parallelis. S e mina plurima. - Herbae indicae, tenerae, glabrae v. rarius pilosiusculae, repentes $v$. suberectae; folïs oppositis, integerrimis v. dentatis, floribus axillaribus oppositis $v$, abortu alternis, saepius pedicellatis, superioribus interdum racemosis.

В о пи ау а Link et Otto $I c$, select. 25. Chamiss. et Schlecht, in Linnaea II. 568. Benth. Scrophularin, ind, 32. Revis. 1. G ratiola e 5p. Lian. Roxburgh.

a. SILIRUOSAE Benth. $l$. 0 . Capsulae Iineares, calyce multo longlores. G rat $t$ o I a e s p. Roxburgh Plant. Co. rom. $t$ 154. 135, 179. (Lfak et Otto Op. cil. t. 9.)

b. BRACHYCARPAE Benth. l. c. Capsulae ovatae, ealyce parum longiores. Gratiolae sp. Boxburgh Op. cit. t. 128.

. SPHAEROCARPAE Benth, $l$, c. Capsulae subglobosae, calyce breviores. Gratiolae sp. Roxburgh $O_{p}$. cit. t. 204 .

3949. IIteroearpaea $R, B R$. Caly tubulosus, pentagonus, quinquefidus. Corolla hypogyna, tubo calycem aequante, limbi bilabiati labio superiore bilobo, inferiore trifido, laciniis omnibus planis. Stamina 2 , corollae tnbo posti. ce inserta; filamentis basi gibbis, antheris approximatis, bilocularibus, loculis subparallelis, sterilia nulla. Ovari um .... Capsu I a biloeularis, loculicide bivalvis, valvis integris, dissepimento placentifero, demum libero contrariis. Ilerba pusilla, muscosa, glabra, in India orien tali et Nova-Hollandia tropica indigena; foliis oppositis, floribus axillaribus ebracteatis, minutis.

Microearpaea R. Browu Prodr. \$35. non Benth.

3950. Peplidium DELIL. Caly $x$ campanulatus, quinquedentatus Corolla hypogyna, tubo calycem aequante, limbi quinquefidi, vix bilabiati laciniis oumihus planis, subaequalibus. St a m in a 2, corollae tubo postice inserta; filame $n t$ is basi gibbis, subappendienlatis, incurvis, antheris approximatis, bilocularibus, loculis parallelis. Ovarin biloculare, plasentis dissepimento utrinque adnatis, multiovulatis, Sty lu s simplex; stigma complanato-dilatatum, indivisum. Capsula globosa, bilocularis, apice irregulariter v, subseptifrage rupta. Semin a plurima, minima. - Herba in $A$ sia et Africa calidiore littoralis, Peplidis habitu, repens, glabra; folitis oppositis, obovatis, integerrimis, floribus axillaribus oppositis, solitariis, brevissime pedunculatis.

Peplidiu m Delile Flor. Aegypt, 148, t. 4. f. 2. Benti. Scrophularin. ind, 32. Mierocarpaea cochlearifolia Smith. Hooker Bot. Miscell. suppl. t, 29. H e d yot is mariti m a Limt. suppl. 119,

3951. Miferanthemum $L, C, R I C H$ C a I $\mathrm{y} x$ campanulatus, quadridentatus, antice fissus. Corolla hypogyna, tubo stugloboso, fauce contracta, limbi bilabiati labio superiore brevissimo, truncato, inferioris tripartiti lacinia media lineari-ligulata, incurva, apice crenata. St amina 2, corollae tubo postice inserta, subexserta; fil a ment is medio appendice dentiformi anctis, a ntheris bilocularibus, loculis parallelis. O varinm biloculare, placentis dissepimento utrinque adnatis, multiovulatis. Sty I u s simplex; $8 \mathrm{tig} \mathbf{m}$ a bilamellatum. C a p 8 u la bilocularis, septifrage bivalvis, valvis margine planis, dissepimento placentifero parallelis. S e min a plurima, minima. - Herbae boreali-americanae, perpusillae, paludosae, repentes, glabrae; foliis oppositis v. verticillatis, subellipticis, subsucculentis, floribus axillaribus solitariis, breviter pedunculat is, minutissimis.

Micrantbemum L. C. Richard in Michaux Flor. Bor. Amer, 1. 10, Hemianth in 8 Nuttall in Journ. Academ. nat. sc. Phlladetph. I. 123. t. 6.

395ะ. Vandella $L I N N$. Calyx tubnlosus v. campanulatus, subaequalis, quinquedenratus v, quinquepartitus. Corolla hypogyna, tabo exserto, limbi bilabiato-quinquefidi labio superiore breviore, Stam in a 4 , corollae tubo inserta, omnia fertilia, didynama, postica breviora, filamentis simplicibus; antica ad basim labii inferiuris inserta, fil amentis elongatis, arcuatis, hasi appendice filiformi v. dentiformi auctis; a ntherae per paria cohaerentes, biloculares, loculis divergentibus $v$. divaricatis, apiee confluentibus. 0 vari um biloculare, placentis medio dissepimento utrinque adnatis, multiovulatis. StyIn s simplex; stigm a bilamellatum v. simplex. Ca p su la globesa, oblonga v. linearis, bilocalaris, septifrage bivalvis, valvis membranaceis, integris, margine planis, dissepimento placentifero, demum libero parallelis. Semina plurima. Herbae indicae et americanae, glabrae v. pilosae, Bonnayis v. Toreniis similes; foliis oppositis, saepius dentatis, floribus axillaribus, oppositis $v$. fasciculatis, superioribus saepe racemosis.

$V$ a nde 11 i a Linn. Mant. 89. Gärtner f. III. 35. Valit Eclog. II: 47. Chamisso in Linnaea HI. 20. Benth. Scro. phularin, ind. 35. Hevis 3. Tittma n nia Reielienb. Ic.

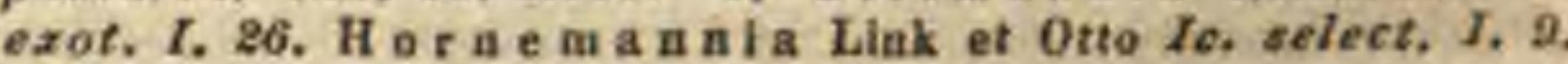
Willd. part.

a. BRACHYCARPAE Benth. I. C. Capsula subglobosa v. ovato-oblonga. calyce brevior v. vix longior (Gärth, $f$. $86 *$ 
8. 18\%. Link et Otto Op, cit. t. 3. Reichenb, Op. cit. t. 38, Gratiola e s p. Roxburgh Plant. Corom. $t, 202$.

b. SILlQuosAE Benth. $l$, c. Capsula oblongo-linearis, calyce longior.

3953. Toremia $L I N N$. C a ly $x$ tubulosus, tubo angulato v. alato, limbo oblique quinquedentato $v$, bilabiato, labiis bi-tridentatis. Corolla hypogyna, ringens, labio superiore bifido, inferiore trifido, laciniis subplanis. St amina 4 , corollae tubo inserta, omnia fertilia, didynama, postica breviora, filamentis simplicibus; antica ad basim labii inferioris inserta, f il amen $t$ is elongatis, arcuatis, basi appendice filiformi v. dentiformi auctis; antherae per paria cohaerentes v. approximatae, biloculares, loculis divergentibus v. divaricatis, apice confluentibus. Ovarium biloculare, placentis medio dissepimento utrinque adnatis, multiovulatis. Sty lus simplex; st $\mathrm{ig}$ in a bilamellatnm. Ca psula oblonga, calyce brevior, septifrage bivalvis, valvis membranaceis, integris, margine planis, dissepimento placentifero, demum libero parallelis. Sem in a plurima. - Herbae in Asia et Australasia tropica, neo non in $A m$ e rica e littoribus indigenae, racemosae, ba. si diffusae, glabrae $v$. villosae; foliis oppositis, saepius dentatis, floribus axillaribus, oppositis $v$. fasciculatis, interdum racemosis.

To re u i Linn. gen, n. 574, Gärtner f. IIT. 29. 2.184. Roxburgh Plant. Corom. $I$, 52. $t$. 161. R. Brown Prodr. 450. Benth. Sorophularin, ind. 38. Nevis 3. Norteria Thouars Gen. Madagasc, n. 27. Chamisso in Linnaea III, 18.

3954. Aelhimenes $V A H L$. C a ly $x$ quin quepartitus, subaequalis. Corolla hypogyna, infundibuliformis $\mathbf{v}$. campanulata, limbo quadrifido, subbilabiato, lacinia suprema latiore, tabo intus quadrisquamato. St a m in a 4 , corollae tubo inserta, omnia fertilia, didynama, postica breviora, filamentis simplicibns; antiea ad basim labii inferioris inserta, fil a mentis elongatis, arenatis, basi appendice obtuso brevi auctis; anthera e per paria cohaerentes, biloculares, loculis divaricatis, conniventibus. Ovari u m biloculare, placentis medio dissepimento ntrinque insertis, multiovulatis. Stylus simplex; stigma bilamellatum. C a psula subglobosa, bilocularis, septifrage bivalvis, valvis membranaceis, integris, margine planis, dissepimento placentifero, denum libero parallelis. Se min a plurima. - Herbae indicae, glabrae, Sesami facie; folits oppositis, subserratis, floribus in racemis terminalibus oppositis, breviter pedunculatis.

A himenes Vahl Symbol. IT. 71, non P. Bromie et Pers. Die eros Persoon Encheirid, IT, 166. A rtane ara Don ex Benth. Scrophularin, ind. 39. Roeis. 3, Col u m. nea e s p. Linn.

3955. Heteramthia NEES et MART. C a ly $x$ campanulatus, quinquefidus, subaequalis. Co roll a hypogyna, infandibuliformi-campanulata, limbi bilabiati labio snperiore breviore, oblongo, integro, inferiore concavo, trilobo, Iobo medio majore, emarginato. S $\mathbf{t a m}$ in a 4 , corollae tubo inserta, didynama, postica breviora; an therarnm loculis aequalibus, parallelis, connectivo simplici; antica ad basim labii inferioris inserta, a n$t$ he $r$ is stylum amplectentibns, connectivo postice glanduloso, loculis subinaequalibus, O variu m biloculare, placentis medio dissepimento utrinque adnatis, multiovulatis. St y lus simplex; st igma indivisum, obtusum. Capsula ovata, compressiuscula, bilocularis, septifrage bivalvis, valvis membranaceis, integris, margine planis, dissepi- mento placentifero, demum libero parallelis. S emin a plurima, rugosa. - Herba brasiliensis, perennis, repens; ramis adscendentibus, foliis alternis, suborbiculatis, obtusis, integerrimis, in petiolum decurrentibus, racemo terminali subsimplici, secundo.

Heteranthia Nees et Martius in N., A. N. $C, X r$. 69. t. 3. Benth. Revis. 3. Vrolle $\mathrm{k}$ ia Spreagel Syst. IIT. 165.

3956. IIydranthelimm $K U N T H, \mathrm{C}_{\text {a- }}$ ly $\mathbf{x}$ quadripartitus, laciniis duabus oppositis obtusis, trinerviis, duabus acutinsculis, uninerviis, C orolla hypogyna, infundibuliformis, limbo trifido, lobo uno duplo latiore, emarginato. S $t$ a m in a 3 , corollae fauci inserta, lobis alterna et breviora; antherae biloculares, oblongae. Ovari um biloculare, placentis medio dissepimento adnatis, multiovulatis. Stylus simplex; stigma bilobum. Cap s a l a calyce cincta, ovato-subrotunda, mucronata, bilocularis, septifrage bivalvis, valvis membranaceis, indivisis, margine pla. nis, dissepimento placentifero, demum libero parallelis. Semina plurima, cylindracea, subarcuata, striata. - Herbulae Americae tropicae, natantes, ad ramificationes radicantes, Callitriches facie; foliis oppositis, integerrimis, nervosis, floribus axillaribus, solitariis, alternis, pedunculatis, ebracteatis, minutis, albis.

Hydran thellum Kunth in Humb. ot Bonpl. Nov, gen. et sp. VIT. 203. t, 666, Williehia Mutis ex Liuu. Mant. 358.

395\%. IIyogetom. C a l y $x$ quinquepartitus, aequalis. Coroll a hypogyna, tubo calycem aequante $v$. snperante, labio superiore retuso, inferiore trifido, basi bicarinato. Stamina 4 , corollae tubo inserta, inclusa, didynama; filamenta simplicia, a $n t h$ er a biloculares, per paria cohaerentes, loculis parallelis, Ova ri um biloculare, placentis dissepimento utrinque adnatis, multiovulatis. Stylus simplex; stigma bilamellatum. C a p sula bilocularis, septifrage bivalvis, valvis integris, margine planis, dissepimento placentifero parallelis. S e m ina plurima, minima.

Herbae Novae Hollandia e tropicae, tenellae; foliis oppositis, in inferiore caulis parte subcongestis, superioribus remotis, floralibus minimis, pedunculis axillaribus et terminalibus ebracteatis, fructiferis deflexis, post capsulae dehiscentiam arrectis.

Lindernia R. Brown Prodr. 4at. non Allion.

3958. Hinderia $A L L I O N$. C a 1 y $\mathrm{x}$ quinquepartitus, aequalis. Corolla hypogyna, calyce brevior, tubo ventricoso, fance constricta, limbi bilabiati labio superiore brevi, bilobo, inferiore trilobo, lobo medio emarginato. Stamina 4 , corollae tubo inserta, didynama, inclusa; filamentis brevissimis, simplicibus, a n theris bilocularibus, loculis parallelis. Ovari um biloculare, placentis dissepimento mox obliterato insertis, multiovulatis. Stylus simplex; stigma bilobum. C a p s u I a oblonga, unilocularis, bivalvis, valvis integris, colum a placentifera fusiformi, libera. Semina plurima, minima, rugosa. Herba annua, in Europ a mediae inundatis crescens, procumbens; foliis oppositis, ovato-oblongis, integerrimis, trinerviis, sessilibus, pedicellis axil. laribus unifloris, ebracteatis.

Linder a ia Allion. Pedemont. III. 178. t. S. Schkahr t. 175. Gärtaer $f$. $I I I$. 34. t. 184. P y xida ri a Lindera. Alsat. 1. 152. IT. 267 . Caprar ia gratioloides Linn.

TIRABUS vU. BUCHNEREAE Benth. Bot. Mag. Comp. I. 357. C a ly x quinquefidus 
v. quinquedentatus. C or oIl a limbo quinquefido $\mathbf{v}$. inaequaliter quadrifido, nune bilabiato, laciniis omnibus planis. St am in a 4 , adscendentia, didynama, rarius duo approximata; antherae uniloculares. Stylus simplex; stigma parvum, subcapitatum. Capsula bivalvis, valvis integris $\mathbf{v}$. bifidis, rarissime carnosa, indehiscens.

SUB'TRTBUS I. EUBUCHNEREAE. Capsula loculicida, bivalvis, valvulis integris.

3959. Striga LOUR. Cal y x breviter tubulosus, quinque-quindecimcostatus, quinquedentatus v. semiquinquefidus, rarius quadridentatus. Corolla hypogyna, tubo tenui, medio v. supra medium infracto, limbi bilabiati labio superiore saepius breviore integro, emarginato v. bifide, inferiore trifido. Stamina 4 , corullae tubo inserta, didynama, inclusa; a n therae uniloculares. Ov a ri um biloculare, placentis septo adnatis, multiovulatis. Stylus simplex; stigma subclavatum. C a p sula recta, bilocularis, locnlicide elastice bivalvis, valvis subcoriaceis, integris, medio septiferis, placentas coadunatas nudantibus. S emina plurima, angnlata. - Herbae in Asia et Africa tropica indigenae, epigeae $v$. Orobanchearum more super radices parasiticae, scabrae, siccilute nigricantes; foliis infimis oppositis, superioribus alternis, nunc squamaeformibus, nunc linearibus, integerrimis $v$, paucidentatis, floralibus conformibus, sensim minoribus, floribus axillaribus solitariis, sessilibus, spicas terminales constituentibus, nudis $v$, minute bibraeteolatis,

Strig a Loureiro Flor, wockinch. 127. Benth. in Bot. Mag. Comp. I. 361. C a mpulei a Thouars Gen, madagase, n. 22. B u chu u ra esp. Linn, et Auct.

A. OROBANCHOIDES, Caly $\mathrm{x}$ quinquecostatus. Corolla e tubus supra medium infraetus. - Folia squamaeformia. Herba parasitica. - Bu ehnera orobanchoides R. Brown. Endlieher in Flor. 1839, t. 2. (Bentham Op. cil, t, 19,)

b. EUPHRASIOIDES. Caly $\mathrm{x}$ quinquecostatus. C orolla e tubus supra medium Jnfraetus. - Folta linearia. Buchnera asiatica Vahl.

c. EUSTRIGA. Calyx decem-quindecimeostatus. Co. rolla e tobus supra medium infractus. - Folia linearia. - C a mpuleia coceinea Hooker Exot. Flor. t. 203.

d. CAMpuleia. Caly $\mathrm{x}$ quinquecostatus. Corolla medio infraeta. - Folia linearia. - Bu chnera her. mo nthiea Delile. Flor, Aegypt, t. 34 .

3960. Buehnera LINN. C aly x breviter tubulosns, obsolete decemnervis, quinquedentatas. Corolla hypogyna, subhypucraterimorpha, tubo tenui, exserto, recto $\mathrm{v}$. sabineurvo, limbo patente, subaequaliter quinquefido, Iaciniis oblengis v. obovatis. Stamina 4, corollae tubo inserta, didynama, inclnsa; a n therae unilocnlares. Ovarium bilocolare, placentis dissepimento adnatis, multiovulatis. Stylus simplex; stigma subclavatum. Capsula recta, bilocularis, loculicide elastice bivalvis, valvis subcoriaceis, integris, medio septiferis, placentas coadanatas nudantibus. Semina plurima, angulata. - Herbae perennes, in Asia, Africa et Americ a tropica indigenae, scabrae, siceitate nigricantes; foliis inferioribus oppositis, infimis latioribus, saepe dentatis, superioribus angustioribus, remotis, plerumque integerrimis, floralibus bracteaeformibus, floribus solitariis, sessi- libus, bibracteolatis, in spicam terminalem dispo. sitis.

B u c hn era Linn. gen, n. 788, exel. sp. Gärtner $I .859$, t. s5. Benth, in Bot. Mag. Comp. I, 363. Piripe a Anblet Guian, 1I. 628, $t, 253$.

3961. Doratanthera BENTH. Calyx quinquepartitus. Coroll a hypogyna, tubulosa, limbi patentis, subaequaliter quinquefidi laciniis brevibus, rotundatis, planis. S ta m in a 2 , corollae tubo inserta, inclusa, sterilium rudimenta nulla; an therae approximatae, uniloeulares, triangulari-semihastatae. Ovari u m biloculare, placentis dissepimento adnatis, multiovulatis. Stylus simplex; stigm a subclavatum. Capsula ovoidea, rostro recto, obtuso, bisulca, bilocularis, loculicide bivalvis, valvis apice fissis, placentas coadunatas nudantibus. S em ina plurima, testa laxa, reticulata, - Herba seneg a mbica, annua, erecta, ramosa, pilis brevibus glandulosis hirta, siccitate nigrescens; foliis alternis, linearibus, uninerviis, integerrimis, floralibus conformibus, pedicellis axillaribus, filiformibus, solitariis, uniforis, secun. dis, calycibus basi bibracteolatis, glanduloso-kirtis, corollisque venosis.

Doratanthera Benth. in litt. 7. Jul, 1838,

3968. Fethamplhearpa BENTH. C aly $x$ campanulatus, quinquefidas. Coroll a hypogyna, tubo tenui, longe exserto, limbo patente, subaequaliter quinquepartito, laciniis obovatis, planis. St a min a 4, corollae tubo inserta, didy. nama, inclusa; antherae uniloculares. Ovari u m biloculare, placentis dissepimento adnatis, multiovulatis. Stylus simplex; stig ma subelavatum. Capsula oblique mucronata, rostrata, bilocularis, loculicide-livalvis, valvis coriaceis, integris, placentas coadunatas nudantibus. Semina plorima.... Herbae in Asia et Africa tropica, necnon in Capite bonae spei observa. tae, erectae, ramosae, glabrae, siccilate nigricantes; foliis inferioribus oppositis, superioribus alternis, angustis, integerrimis v. pinnatisectis, floribus breviter pedicellatis, racemosis, saepius ebracteatis.

Rhamphic a rpa Benth, in Bot, Mag. Comp. ., 368. Gerardia tubulosa Lian.

3963. Cyentum $E, M E Y$. Cal y $x$ longe tubulosus, quinquefidus. Corolla hypogyna, tabo cylindrico, recto, limbo patente, subaequaliter quinquefido, laciniis ovatis, integris. Stamin a 4, corollae tubo inserta, didynama, inclusa; antherae nniloculares. Ovarinm biloculare, placentis dissepimento adnatis, multiovulatis. Stylus simplex; stigma subclavatum. C a p8 ula carnosa, bilocularis, indehiscens? Semina....- Herbae capenses, rigidae, scabrae, siccitate nigricantes; foliis oppositis v. superioribus alternis, grosse dentatis, floribus axillaribus solitariis $v$, racemosis, calycibus basi bibracteolatis. I. 368 .

Cycninu E. Meyer mac. ex Benth, Bot, Mag. Comp.

SUBBTEREUS It. MANULEAE. Capsula septicida, valvulis bifidis.

3964. Zaluzianskya $J, W . S C H M$. C a lyx ovato - tubulosus, quinquedentatus, bilabiatus v. bipartitus. Corolla hypogyna, persistens, tubo elongato, basi demum fisso, fance aequali, saepe hispida, limbo patente, subaequaliter quinquepartito, laciniis bifilis $\mathrm{v}$, integris. Sta in in a 4, didynama, postica tabo inclusa, an the ris oblongis, erectis; antica fanci ingerta, an 
theris minoribns, transversis, saepe sterilibus, nune omnino abortiva. Ovarium biloculare, placentis dissepimento adnatis, multiovulatis. St $\mathbf{y}$ lus simplex; stigma subclavatum. C ap sula coriacea $v$, membranacea, bilocularis, septicide bivalvis, valvis apice bifidis, placentas coadunatas nudantibus. Semina plurima, serobieulata. nerbae v. suffrutices c a penses, plus minus viscosi, siccitate saepe nigricantes; foliis infimis oppositis, superioribus alternis, sacpius paucidentatis, floralibus minoribus integris, calyci adpressis $v$. interdum adnatis, floribus sessilibus, interrupte $v$. dense spicatis.

$\mathrm{Z}$ aluzianskya J. W. Selimidt in Usteri Annal. $\mathrm{X}$. 115. Tauseh in Flora 1830. $I T, 559$. N y e terin ia Don in Swoet Fl, Gard. II, t. 239. Benth. in Bot. Mag. Comp. I, 369. Erin i sp. Liuat. Thanb. Bot. Mag. C. 2504. Bot. Reg. t. 848 .

3965. Folyearena BENTH. Caly x membranaceus, bilabiatus, fruetifer bipartitus. Corolla hypogyna, persistens, tubo demum fisso, fauce latiore, limbo patente, subaequaliter quinquefido, laciniis integris. Sta mina 4, corollae tubo prope fancem inserta, didynama; a nthera e uniloculares, conformes, exsertae. Orari u m biloculare, placentis dissepimento adnatis, multiovulatis. Stylus simplex; stigma subelavatum. Capsula membranacea, bilocularis, septicide bivalvis, valvis apice bifidis, placentas coadunatas nudantibus. Semina plurima, seroliculata. - Herbae ca p enses, annuae, pusillae, plerumque ramosissimae, plus minus viscosae, siccitate nigricantes; foliis oppositis, obovatis, oblongis $v$. linearibus, paucidentatis, spicis terminalibus, floriferis saepe capitatis, fructiferis interdum elongatis, floribus subsessilibus, foliis floralibus pedicello brevissimo adnatis.

Poly caren a Benth. in Bot. Mag. Comp. X. 2z1. Maunlea plantaginea et capillaris Lim. Büch. uera capensis Lian.

3966. Playllepodium BENTH. Ca ly x subaequaliter quinquepartitus, laciniis basi margine membranaceo subconnatis. Corolla hypogyna, persistens, tubo ealyce breviore, limbo patente, subaequaliter quinquefido, laciniis integris. St am ina 4, corollae tubn inserta, didynama, exserta; a ntherae uniloculares, conformes. Ovari $\mathbf{u m}$ biloculare, placentis dissepimento adnatis, multinvulatis. Stylus simplex; stigma subclavatum. Ca p s n la membranacea, bilocularis, septicide bivalvis, valvis apice hifidis, placentas coadunatas nudantibus. S emina plurima, scrobiculata, - Herbae c apenses, annuae, durae, basi plerumque procumbentes, rarius erectae, siccitate saepe nigricantes; foliis oppositis, obovatis, ovatis $v$, oblongis, inciso dentatis, floralibus pedicello bre. vissimo adnatis, floribus parvis, sessilibus, aurantiaceis v. saepius purpurascentibus aut caeruleis, spicis terminalibus saepe capitatis, fructiferis plus minus elongatis.

Phyllopodium Benth. in Bot. Mag. Comp. 1. 372. Manulea capitata, M. euneifolia et M, hetero phylla Linn.

3Ф6\%. Sphenanatira BENTH. Calyx quinquepartitus. Corolla hypogyna, subrotata, tabo brevissimo, limbi quinquepartiti laciniis subaequalibns, rotundatis. Stamina 4 , eorollae fanci inserta, adscendentia; anthera uniloenlares, cuneatae, conformes. Ova rium biloculare, placentis dissepimento adnatis, multiovulatis. Stylus simplex; stigma obtusum, Capsula membranacea, bilocularis, septicide bivalvis, valvis apice bifidis, placentas coadunatas nudantibus. Semina plurima, serobiculata. - Suffrutex capensis, erectus, pedalis, viscoso-pubescens; foliis oppositis, lanceolatis, paucidentatis, florulibus pedicello multo brevioribus, liberis, ovatis, acutis, inte. gerrimis.

Spheuandra Benth. in Bot. Mag. Comp. I, 373, B u cbnera viseosa Ait. Bot. Mag, $t, 217$.

3985. Chaenostoma BENTH. C'al y x quinquepartitus, Corolla hypogyna, infundibuliformis v, hypocraterimorpha, rarius tubo brevissimo subcampanulata, fauce dilatata, limbo plano, subaequaliter quinquefido, laciniis obovatis v. rotundatis. Stamina 4 , corollae tubo inserta, didynama; antherae uniloculares, conformes, faucem aequantes v. breviter exsertae. Ov a ri u m biloculare, placentis dissepimento adnatis, multiovalatis. Stylus simplex; stig ma subelavatum. Capsula membranacea, bilocularis, septicide bivalvis, valvis apice bifidis, placentas eoadunatas nudantibus. - Herbae v. suffrutices capenses; foliis oppositis, dentatis $v$. rarius integerrimis, floralibus conformibus $v$. bracteaeformibus, a pedicello liberis, floribus axillaribus v, racemosis, longiuscule pedunculatis, siccatione haud nigrescentibus, capsulis glabris.

Cha enostoma Benth. in Bot. Mag. Comp. I, 37t. Manulea integrifolia L, Manuleae sp. Thunb. M. op positifoliaVeat. Malm. $t$. 15. B a chnera aethio. pie a Lín. B. foetid a Andrews Bot, Reposit. $t, 80$.

3969. Lyperia BENTH. C a lyx quinquepartitus, laciniis linearibus, subfoliaceis. Coroll a hypogyna, decidua, tubo elongato, viscoso, postice a pice gibbo v, incurvo limbo patente, sub. aequaliter quinquefido, laciniis bilabiatis. S $t$ am in a 4, corollae tubo inserta, inclasa, didynama; antherae uniloculares, conformes. Ovarium biloculare, placentis dissepimento adnatis, multiovulatis. Stylus simplex; stigma subclavatum. Ca psula membranacea, bilocularis, septicide bivalvis, valvis apice bifidis, placentas coadunatas nudantibus. S e m in a plurima, scrobiculata. Herbae, suffrutices v. fruticuli capenses; foliis inferioribus oppositis, superioribus alternis, integris, dentatis, inciso-pinnatifidis v. multifidis, ad axillas saepe fascieulatis, floribus sessilibus v. saepius pedicellatis, axillaribus, racemosis v. spicatis, corollis siccitate plerumque nigricantibus, capsulis plus minus viscosis.

Lyperia Benth. in Bot, Mag. Comp, I, 377. Erini et Ma nuleae sp. Linn. et Auet. Buchnera pedu u cu. I a a Andrews Bot. Reposit. $t .84$.

3) partitus, laeiniis linearibus v, subulatis. Corolla hypogyna, decidua, tabo elongato, glabro v. tomentoso, limbo quinquepartito, aequali v. laciniis quatunr superioribus approximatis, omnibus integris v. bifidis. Stamin a 4 , corollae tabo inserta, didynama, inclusa; a $\mathrm{t}$ he rae uniloculares, conformes. Orarium biloculare, placentis dissepimento adnatis, multiovalatis. Stylus simplex; stigma subclavatum. Capsula bilocularis, septieide-hivalvis, valvis apice hifidis, placentas coadunatas nudantibus. Sem in a plurima, scrohiculata. - Herbae v. rarius suffrutices c apenses; foliis saepe ad basim caulis approximatis, floralibus parvis, bracteaeformibus, floribus racemosis, racemis nunc simplicibus nudis $v$. minute bracteatis, nunc compositis, pedicellis multifloris, corollis saepe at- 
rantiaceis, siccitate haud nigricantibus, capsulis glabris.

M a n u I e a Linn. gen, $n, 1264$. excl. sp. plarim. Gärtner I. 258. t. 55. Benth. in Bot, Mag. Comp. I. 381, Link et Otto Ic. elelect, t. 2. 19. $\mathrm{N}$ e mi a Berg. Flor. cap. 160 .

TreI Scrophularin. ind. 42. C o r o 11 a tubo recto, limbo plano, patente, aequaliter quadrifido. St a m in a 4, omnia fertilia, aequalia, antheris distantibus, bilocularibus. Capsula bilocularis, septicide-bivalvis.

39) 1. IB tuddleia LINN. Cal y x campanulatus, brevis, quadridentatus v. quadrifidus, aequalis. Corolla hypogyna, campanulata v. tobulosa, limbo breviter quadrfido, aequali. St a$\mathrm{m}$ in a 4 , corollae tubo inserta, aequalia, inclusa; filamenta subnulla, antherae biloculares. O vari $\mathbf{n} \mathrm{m}$ biloculare, placentis dissepimento utrinque adnatis, multiovulatis. S $t$ y $l$ u s simplex; st $\mathrm{igm}$ a incrassatum, integrum. Capsula bilocularis, septicide bivalvis, valvis integris v. bifidis, placentis coadunatis, demum liberis. Sein in a plurima, minima, testa membranacea, utrinque relaxata. - Frutices $v$. arbores in America tropica et a ustrali, in India orientali et in Capite bonae spe $i$ indigeni, saepe tomentosi, foliis oppositis, integris, integerrimis v. dentat is, floribus saepissime sessilibus, glomeratis, glomerulis sessilibus $v$. pedunculatis, axillaribus $v$. in racemos simplices aut paniculatim ramosos dispositis.

B udd le ia Linn. gen, $n, 140$, Gärtner $I .296, t$. 49. Lam. t. 69. Jaeq. Ic, rar, t, 307. Ruiz et Pavon Flor. Pe. ruv, t. 80 -83. Bot. Mag. t. 174, 2713. 2824. 2853. Bot. Reg. t. 1259. Kunth in Huub. et Bonpl. Nov. gen, et sp. IT. 354. t. 182_187. Benth. Sorophularin, ind, 42. Bot, Mag. Comp. II. 60 .

3979. Nuxia COMMERS. C a lyx campanulatus, brevis, quadridentatus v. quadrifidus, aequalis. Corolla hypogyna, brevissime campanulata, limbo quadripartito, patente, aequali. St amina 4 , corollae tubo inserta, exserta; $\mathbf{f}$ I a m ent a filiformia, a $n t h$ e $r$ a e biloculares. O v a ri u m biloculare, placentis dissepimento ntrinque adnatis, multiovulatis. Stylas simplex; $8 \mathrm{tigma}$ incrassatum, integrum. Capsula bilocularis, septicide bivalvis, valvis integris subbifidisve, placentis coadunatis, demum liberis. S em i n a plurima, minima, testa membranacea, utrinque relaxata. - Frutices ca penses et $m a$ darasearienses, saepe tomentosi; foliis oppositis $v$. subverticillatis, integris, saepius dentatis, floribus stepius sessilibus, glomentatis, glomerulis sessilibus pelunculalisve, plerumque in paniculas terminales disposilis.

N axia Commerson ex Lam. Illustr, $t, 21$, Benth, in Bot. Mag. Comp, 1I, 59. Chilian th u m Barehell Travels f. gi. a Nuxía nou diferre, et loculos monospermos huic geuevi perperam tribuh, monet cl. Bentham.

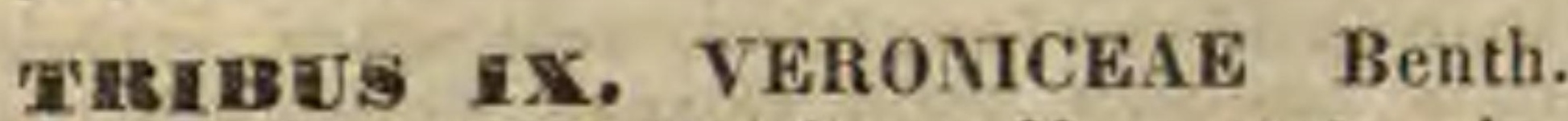
Scrophularin. ind. 43. Coroll a rotata, infundibuliformis v, rarius irregulariter bilabiata. Stamina 4 aequalia, fertilia, v. saepius 2 postica, sterilium rudimentis nullis. Capsula bilocularis, loculicide bivalvis, valvis saepissime juxta dissepimentum bifidis, nune septifrage bivalvis.
3983: Seoparia LINN. Calyx quadripartitus, aequalis. Corolla hypogyna, rotata, fance pilosa, limbo quadripartito, aequali, $S t a-$ min a 4, corollae fauci inserta, exserta, aequalia; antherae biloculares, loculis parallelis. Ovari u m biloculare, placentis dissepimento utrinque insertis, multiovulatis. Sty Ius simplex; stigm a obtusum. C a p s u la globosa, bilocularis, septifrage bivalvis, valvis indivisis, dissepimento placentifero parallelis. S e mi n a plurima, scrobienlata. - Suffrutex inter tropicos totius orbis obvius; foliis oppositis $v$. ternatim quaternatimve verticillatis, pedunculis axillaribus unifloris, subracemosis, floribus albis.

Scoparla Lian. gen. n, 143, Jacq. Amer. 17. Gärtaer r. 251. $t$, 53. Palisot Flor. Owar. $t$. 115. R. Brown Prodr. 445. Tupeicava Piso Brasil. $t, 108 f$. 2 .

3974. Creqelnorda CHAM, et SCHLECHT. Calyx quinquepartitus, aequalis. Corolla hypogyna, infundibuliformis, limbo quadripartito, subaequali. St am in a 4 , corollae tubo inserta, breviter exserta, aequalia; a $\mathbf{n}$ h era e biloculares, loculis parallelis. Ova ri um biloculare, placentis dissepimento utrinque insertis, multiovulatis, Stylus simplex; stigma subcapitatum. Capsula oblonga, acuminata, compressiuscula, bilocularis, loculicide bivalvis; valvis medio septiferis, columna placentifera libera. Semina plurima, minima. - Herba Brasiliae meridionalis; radice sublignosa, caulibus prostratis, flagelliformibus, ad nodos radicantibus, foliis oppositis, ternatis quaternatisve, obovato-cuneatis, in petiolum angustatis, lobatis, lobis crenatis, pedunculis axillaribus, solitariis, filiformibus, unifloris, ebracteatis, folio brevioribus.

Geochorda Chamisso et Sehlechtend, in Linnaea III. 11 .

39 ร5. Sibthorpia $L I N N$. C a ly x quinque-octopartitus. Co rolla e hypogyna, subrotata, quinque-oetofida, laeiniis aequalibus. Stamin a 4-8, curollae tubo inserta, inclusa; a nthera biloculares, loculis parallelis, apice confluentibus. Ovarium biloculare, placentis dissepimento utrinque insertis, multiovulatis. Stylus simplex; stigma capitato depressum. Capsu I a orbiculata, subcompressa, bilocularis, loculicide bivalvis, valvis medio septa placentifera gerentibus. Semina plura. - Herbae repentes, in Europa occidentali, insulis atlanticis et in $A m e r i c a$ tropica cis aequatorem indigenae; folits alternis, petiolatis, reniformibus, crenatis, pedunculis axillaribus solitariis v. pluribus, floribus carneis, violaceis. v. flavis.

S fbthorpla Kunth in Humb. et Bonpl. Nov. gen. et sp. $I L .390$. Sibthorpta et D is a ndra Linn. gen. n. 775. et Suppl. 32.

a. SfBTHORPIA Linn, Caly $x$ quinquepartitus, Corolfa quinquefida. Stam ina 4. S em in a teretia, umbilion basilari.-(E. B. $t$. 649. Gärfner $T .261 . t, 55$, Kunth, op. cit, $t, 176,177$.

b. DISANDRA Linn. C al $\mathrm{y} \times$ quinque-octopartitus. C o. roll a quinque - oetofida. S tamina 5-8. Se in $i$ na navleularia, umbilico basilari. - (Gärtner f. III, 46. t. 185. Bot. Mag. t. 218.)

3986. Glossostigma $A R N$. Caly $\mathrm{x}$ brevis, campanulatus, tridentatus. Corolla hypogyna, infundibuliformis, tubo calycem aequante, limbi quinquefidi laciniis subaequalibus, planis. Stamina 2, imo corollae tubo inserta, 
subexserta; a n thera e approximatae, bilocnlares, loculis parallelis. O va ri u m dissepimento columnam placentiferam utrinque contingente apice deliquescente incomplete biloculare, multiovulatum. Sty I us simplex; stig ma dilatatum, eomplanatum, linguaeforme. Caps u I incomplete bilo. cularis, loculicide bivalvis, valvis medio septiferis, indivisis, columna placentifera libera. Se mina plurima, rugosa. - Herba indica, pusilla, repens, Limosellae facie; foliis oppositis, subfasciculatis, spathulatis, petiolo basi dilatato, semivaginante, scapis solitariis, unifloris, ebracteatis, folio paullo longrioribus.

G $108 \mathrm{~s}$ ost $\mathrm{g}$ m a Arnott in N.A.N.C.XVIII. 355. Beath. in Bot, Mag. Comp. Ir. 59. M i cro e a rpa a Beath. Scrophularin. ind. 31. non R. Br. Mieroearpaea spathuJata Wight in Hooker Bot. Miscell. IT. 101. Suppl. t. 4.

39\% . Himosella LINN. Ca ly x brevis, quinquefidus. Corolla hypogyna, rotato-campanulata, tubo calycem aequante, limbi quinque fidi laciniis aequalibus, planis. St a mina 4 , medio corollae tubo inserta, subexserta, didynama; antherae distantes, uniloculares. Ovarium placenta columnari carpidiorum margine vix intro flexo libera uniloculare, multiovulatum. Stylus simplex; stigma capitatum, truncatum. Capg u la unilecnlaris, bivalvis, valvis margine planis, indivisis, columnae placentiferae parallelis. S e m i. na plurima, longitudinaliter suleata, transversim rugosa. - Herba europaea, pusilla, inundata, reptans, radicans; foliis confertis, spathulatis, subcarnosis, petiolo basi dilatato, semivaginante, scapis aggregatis, unifloris, ebracteatis, folio brevioribus.

L i mos e 11 a Linn, gen, $n$. 776. Sehkuhr $t, 176$. Hooker Flor, Lond, $t$, 62. Flor, Dan, $t, 69$, E. B. $t, 357$, A 1 s in e Tournef. Plantaginella Vaill.

3⿻) 8. Anphiamthus TORREY. C aI yx quinquepartitus, inaequalis. Co rolla hy pogyna, infundibaliformi-tubulosa, limbo quadrifido, subbilabiato, lobo inferiore paullo majore, S t a mina 2, corollae tubo inserta, inclusa; anthe ra e biloculares, loculis approximatis. Ovari u m biloculare, compressum, placentis dissepimento utrinque insertis, multiovulatis. Sty $\mathrm{I}$ s simplex; stigma breviter bifidum. Capsula obcordata, compressa, bilocularis, loculicide bivalvis, valvis indivisis, medio septiferis. Se m in a plurima, lineari-oblonga, laevia. - Herba bor e alia mericana, pusilla; foliis radicalibus linearibus integris, congestis, floribus minutis, aliis inter folia sessilibus, aliis in apice scapi simplicis inter bracteas oppositas solitariis.

A m p h lant h us Torrey in Annal, Lyc. N. York. IV. 82.

3งรง. অeromien LINN. C al y $\mathrm{x}$ quadriquinquepartitus v, compressus. Corolla hypogyna, subrotata, tubo calyce breviore, limbi quadripartiti laciniis integerrimis, planis, postica majore. Stam ina 2 , ad basim laciniae corollinae posticae inserta, divergentia; a $n t h e r a$ e biloculares, loculis apice confluentibus. O varium biloculare, placentis dissepimento ntrinque inser tis, panciovulatis. Sty Ins simplex; stigma indivisum, vix incrassatum. Capsula ovata v. obcordata, bilocularis, nune loculicide bivalvis, valvis medio septa placentifera gerentibus, integris v. demum bifidis bipartitisve, nune septifraga, valvulis dissepimento placentifero demum libero parallelis. Semina pauca, plano-convexa v. concavo-cupuliformia, umbilico prope basim laterali.
- Herbae, suffrulices v. frutices, in regionibus extratropicis temperatis et frigidis utriusque hem $i$ s ple a er $i$ crescentes; foliis oppositis $v$, verticillatis, rarius alternis, saepe dentatis $v$. incisis, inflorescentia axillari, racemosa v. spicata, floribus saepius caeruleis $v$, albis.

V e r o ni ca Linn. gen., n. 25. Gärtner 1. 257. $t, 57$. R. Brown, Prodr, 434. Duvau in Aanal. sc. nat. VIIT. t. 26. Beuth. Scrophularin, ind, 44. Nees jun. Gen, plant, XVI. $\ell, 17$. a. DIPLOPHYLLUM Lehm. C a I y c is diphylli foliola bilo. ha, in frueta compressa. Semina navieularia. - Di. plophyllum Lehmann in Berliner Magazin V $\vec{I} T$. 4. 2. Veron ica erista galli Steven in Linn. Trans. act. VI. t. 31 .

b. CochlidiospernuM Reichenb. C a l y $\times$ quadripartitus, fructifer saepe compressus. Semina coneavo-cupulf. formia. - Cocblldlospermam Reicheat. Flor. Germ. 365 . O mphalospora Besser Volhyn. 85 . (Flor. dan, t. 428. 627. E. B, t, 26. 784. Sibthorp Flor. graec. $t$. 8-10. Reichenb. Yconogr. $f$. 404. 405. 430. 631. 460. 867.)

c. VERONICA Reichenb. Caly x quidri-quinquepartitus. S e m in a plaao-eonvexa. - He be Juss. gen, 105. A i de I n s Spreng. Cur. post. 17. (E. B. t. 2. 25. 623. 655. 673. 734. 765. 766. 781, 782. 1092, 1098, 1075. Flor, dall. t. 16. 58. 209. 248, 252. 342, 448, 499. 511. 515. 903. 1201. 1961. Waldst. et Kitaib, Plant, rar, Hung. t. 108. 245. Ledebour Ic, $t$, 126, 127, 208_211. 217. Endl, in Annal. Wiener. Mus. I. t. 14. Bot. Mag. t. 2210.2975. 3653. Bot. Reg. t, 1930, Reichenb. Op. eit. 644, 645, 782. 783, 993_-205,)

3980. Paederota LINN. Cal y $\mathrm{x}$ qrisquepartitus, aequalis. C or oll a hypogyna, tabuloso-bilabiata, labio superiore erecto, integro v. emarginato, inferiore subpatente, trifido v. tripartito. Stamina 2, ad basim labii corollae poslici inserta, exserta; a n therae bilocnlares, loculis parallelis, apice confluentibus. O vari a!m biloculare, placentis dissepimento utrinque insertis, multiovulatis. Stylus simplex; stig ma capitato-bilobum. Capsula ovata, acuta, biloenlaris, loculicide-bivalvis, valvis medio septa placentifera gerentibus, demum bifidis. Se min a teretinscula, nmbilico basilari. - Herbae in alpibus Europae, in Sibiria et America boreali perennantes; foliis oppositis, serratis, racemo terminali, floribus caeruleis $v$. luteis.

Paederota Linn. Ben, n, 26. Jacq. Flor. austr. append. t. 39. Hort. Vindob, IT. t, 124. Sturm Flor, Germ. fasc. 6. Nees jun. Gen, plant. XVI. $t, 18$. B on a $r$ o t a Micheli Nov, gen, 19. t. 15. Le p t a n d ra Nuttall gen. I. ?. Callistac hy a Rafinesque in N. Y. Medic. Beposic. Y. 60. Eustacliy a Rafin. in Journ Phys, LXXXIX, 258. - Ve. ronicavirginica L, et V. sibirica Linn.

398 1 . Calorianbulos BENTH. Calyx quinquepartitus. Coro I I a hypogyna, tubulosa, tubo incurvo, limbo ereeto, oblique bi-trifido, lobo inferiore minore. Stamina 2, corollee fauei ad latera labii superioris inserta, exserta; a n th er a e biloculares, loculis parall lis, apice conflnentibus. O v a $\mathbf{r}$ i m biloculare, placentis dissepimento utrinque adnatis, multiovulatis. Stylus simplex; $s \mathrm{tig} \mathrm{m}$ a vix incrassatum. C a p $8 \mathrm{ula}$ bilocularis, loculicide bivalvis, valvis bipartitis. Semina plnrima, margine membranaceo crispo cineta. - Herba n e palensis, glabra, subsimplex, sesquipedalis $v$. bipedalis, folitis oblongo-lanceolatis, argute serratis, basi in petiolum brevem angustatis, spica semipedali, floribus sessilibus, glomeratis.

Calorbabdos Benth. Scrophularin, ind, 44. Ver a. nica B rounoniana Wallich.

3989. Wulfenia $J A C Q$. Cal yx quadriquinquepartitns, subaequalis. C o r o ll a hypogyna, tubulosa, tubo basi aequali $v$. postice subgibbo, limbo quadrifido subbilabiato, lacinia postica"emar- 
ginata v. bifida, lateralibus integerrimis, antica aequali v. latiore crenata. $\mathrm{St}$ a $\mathrm{min}$ a 2 , ad basim laciniae corollinae posticae inserta, inclusa; a ntherae biloculares, loculis demum divarieatis, confluentibus. Ovarium biloculare, placentis dissepimento utrinque insertis, multiovalatis. S tylu s simplex, exsertus; stigma capitatum. C a p8 u la ovata, obtusa, bilocularis, loculicide bivalvis, valvis medio septa placentifera gerentibus, demum bifidis. S e mina plurima, navienlaria, umbilico prope basim sublaterali, - Herbae perennes, in alpibus Carinthiae et Indiae borealis, nec non in excelsioribus Americae boreali-occidentalis montibus observatae, subacaules; foliis radicalibus petiolatis, oblongis $v$. reniformibus, duplicato-orenatis, scapis nudis, multifloris, erectis, floribus unilateralibus, pendulis, in axillis bractearum solitariis, breviter pedunculatis.

Wulfen i Jacq. Miscell. IT. 68. $t, 8, f .1$. Ic, rar. t. a. Nees jun. Gen, plant, XYI. $t$. S. Beath. Scrophularin. ind. 46.

3953. Campylanthus ROTH. Calyx quinquepartitus, inaequalis. Corolla hypogyna, infundibuliformis, tubo incurvo, limbo quinquefido aequali. Stamina 2 , corollae tubo postice inserta, inclusa; anther a e uniloculares, peltatae. (?) Ovarium..... Stylus simplex, apice incurvus; stig ma incrassatum. Capsula.... - Frutex insula e Teneriffa, vix notus; ramis teretibus, foliorum cicatricibus tuberculatis, foliis teretiusculis, filiformibus, carnosis, racemis in apicibus ramorum axillaribus, pubescentibus, pedunculis basi tribracteatis.

Campylanthus Roth Nov. sp. 4. Eranthemum s a $1 \mathrm{~s}$ ol o id es Linn. f. suppl. 89. quod monente el. R. Brown Prodr. 434, in not. genus Wulfeniae proximum, eul tamen a Rothio capsula trilooularis, quasi tricocca, columna centralis libera ${ }^{\alpha}$ tribuuntur.

3954. Gymmandra $P A L L$. Cal y $\mathrm{x}$ spathaceus, hinc fissus v, bipartitus, laciniis integerrimis v. dentatis. Coroll a hypogyna, tubulosa limbo subbilabiato, labio superiore integro, emar ginato $v$. bifido, inferiore bi-quadrifido, lacinii omnibus planis. St a mina 2, ad basim labii corollini postici inserta, exserta; an thera biloenlares, loculis apice confluentibns. O variu m biloculare, placentis dissepimento ntrinque insertis, panciovulatis. Stylus simplex; stigma truncatum v, incrassato-capitatum. Ca p 8 u la bilocularis, apice loculicide bivalvis, valvis medio placentiferis, indivisis v. subbifidis. S e $\mathrm{m}$ in a in luculis solitaria v, pauca, oblonga, suleata. - Herbae in Asia media et boreali indigenae, erectae, glabrae, siccatione nigricantes; caulibus e collo pluribus, simplicibus, foliis radicalibus petiolatis, caulinis minoribus, supremis saepe squamaeformibus, floribus in axillis bractearum sessilibus, spicam terminalem formantibus.

G y m n a nd ra Pallas It, IIT, 7I2, $t, A, f, 1$. Willdenow in Berl. Magaz. V. 389. 2.9. 10. Chamisso et Schlecht, in Linnaed II. 560. Benth. Scrophularin. ind, 46 Royle Himalay. t. 73. Lagotis Gärtuer in Nov. Commenc. Petro. polit, $\mathrm{X} I \mathrm{~V}, 534 . \mathrm{t}$. 18 .

3985. Pierorhiza ROYLE. Calyx campanulatus, quinquefidus, sulsaequalis. Corolla hypogyna, calyce brevior, campanulata, limbi quadrifidi laciniis subaequalibus, integris. St a mina 4, corollae fanci inserta, longe exserta, subaequalia, divergentia; a ntherae biloculares, loculis apice confluentibus. O vari u m biloculare, placentis dissepimento utrinque insertis, multio- vulatis. Stylus simplex; stig ma vix incrassatum. Cap su la ovata, bilocularis, loculicide bivalvis, valvis medio septiferis, apice bifidis. S emin a plurima, testa membranacea, vesiculosorelaxata. - Herba nepalensis, subacaulis; foliis radicalibus oblongis, basi in petiolum angustatis, apice serrato-crenatis, glabris v. pilosiusculis, scapis erectis, bracteatis, floribus sessilibus, dense spicatis.

P ieror hiz a Royle Himalay. .81 . Benth. Serophularin. ind. 47. Verouica Lind le yana Wallich.

3986. Durisia COMMERS. C aly $\mathrm{x}$ quinquepartitus, subaequalis v. bilabiatus. Corolla hypogyna, infundibuliformis, limbi quinquefidi laeiniis aequalibus, obtusis. Stamina 4 , corollae tubo inserta, inclusa, didynama, cum radimento quinti; a n th er a e reniformes, biloculares, loculis confluentibus. Ovarium biloculare, placentis dissepimento utrinque insertis, multiovulatis. S tyI s s simplex; stigma capitatum, emarginato-bilobum. C a p 8 u la bilocularis, loculicide bivalvis, valvis medio septiferis placentas auferentibns. $\mathrm{Se}$ m i n a plurima, testa relaxata, reticulata. - Herbae perennes $v$. suffruticuli, in America australi extratropica et in insula Diemen indigeni, repentes; foliis oppositis, pedunculis axillaribus et terminalibus solitariis $v$, corymbosis.

O u risia Commers. ex Juss. gen, 100. Gärtner f. IIT. 44. R. Brown Prodr. 438. Pöppig et Bndlicher Nov, gen. et sp. $T, 2$.

a. OURISIA Commers, C alyx bilabiatus, lablo superiore bidentato, iuferiore trifido. C or o 11 a e limbus erectus, tubi medio parum ampliatf et subcurvati vix sextam par. tem aequans, (Gärtner $t$, 185. Pöppig op. cit, $t, 4$. )

b. DiChroma Cav. Calyx aequaliter quinquepartitus. Co rolla e limbas patens, tubi reeti, cyllndrici tertiam v. dimidiam partem aequass. - Dichro ma Cavanill. Anal.ciene, nat, III, 233, t, 32, Io, VI, 59, t, 582. (Pöppig op. cit, $t, 5,7$.

398\%. Tilemiphragma $W A L L, C$ al y $\mathrm{x}$ quinquepartitus. Cor oll a hypogyna, tubulosa, limbo quinquefido, subbilabiato, laciniis anticis paullo latioribus. St a min a 4 , corollae tubo inserta, subexserta, snbaequalia; an therae biloculares, loculis parallelis. O va ri um dissepimento superne interrupto incomplete biloculare, marginibus liberis placentiferis multiovulatis. Stylus simplex; stigma indivisum, vix incrassatum. Ca psu la baceata, incomplete bilocularis, septiIrage bivalvis, valvis demum bifidis, dissepimento apice bifido marginibus placentifero parallelis. Sem in a plurima, ovata, punetata. - Herba $n$ epalensis, procumbens; ramis flagelliformibus, foliis sessilibus dimorphis, caulinis oppositis, orbiculatoreniformibus, crenatis, pilosiusculis, ramulorum axil. larium acerosis linearibus, integerrimis, ciliatis, floribus in axillis foliorum caulinorum et in apicibus ramulorum axillarium solitariis, subsessilibus, ebracteatis, corollis roseis, capsulis subglobosis, coccineis, lucidis.

Hemiphragma Wallich in Linn. Transact, XIII. 611. Elor. Nepal. 17. t. 8. Beath. Scrophularin, ind, 47.

3988. Theveoplhyllum HUMB. et BONPL, Caly $\mathrm{x}$ quinquepartitus, aequalis. Corolla hypogyna, tubuloso - campanulata, limbo bilabiato, labio superiore bilobo, inferiore trifido, lacinia intermedia maculata. Stamina 4 , corollae tnbo inserta, inclusa, didynama; a $\mathrm{t}$ h e $\mathrm{r}$ a e bilobae, locuiis divaricato - patulis. O varium biloculare, 
placentis dissepimento utrinque adnatis, multiovulatis. Stylus simplex; stigma indivisum. Fructus .... Frutex mexicanus, ramosissi. mus, densissime albo tomentosus; foliis alternis, petiolatis, ellipticis, integerrimis, floribus axillaribus solitariis, breviter pedunculatis, ebracteatis, calycibus incanis, corollis violaceis.

Le ueophyllum Humb. et Boupl. Plant, aeguinoct. II. 95. t, 109. Nov, gen, et sp, II. 360.

3989. Aragoa $H, B, K, C$ aly $x$ tetrapentaphyllus, aequalis. Corolla hypogyna, hypocraterimorpha, fauce nuda v. pilosa, limbo quadripartito, patente, aequali. S t a m in a 4 , corollae fauei inserta, exserta, aequalia, patentia; ant her a e biloculares, cordato-reniformes, loculis demum confluentibus, Orarium biloculare. Ovu la in loculis quaterna, per paria superposita, amphitropa, adscendentia. Sty Ius simplex; s tigin a subglobosum. Capsula ovata, bilocularis, septifrage bivalvis, valvis bipartitis, dissepimento libero seminifero parallelis. Semina utrinque quaterna $\mathbf{v}$. abortu. pauciora, per paria superposita, plano-convexiuscula, adscendentim peltata, testa laxa, reticulata, in alam angustam ambientem expansa, umbilico supra basim ventrali. $\mathbf{E} \mathbf{m b}$ r yo in axi albuminis dense carnosi rectus; c otyledonibus plano-convexis, carnosis, radicula brevi, crassa, infera. - Frutices bog otenses ramosissimi; ramis oppositis, confertis, densissime foliosis, folitis octofariam imbricatis, ovato-deltoideis, linearibus, carnosis, integerrimis, floribus axillaribus solitariis, subsessilibus, calycibus imbricato. bracteatis, corollis albis.

A rag o a Kusth in Humb, et Bonpl. Nov. gen, et sp. ITI. 153, t, 216. 217. Dou in Edinb. n. philosoph. Journ. $X I X, 113$.

TrEIBUS $\mathbf{x}$. GERARDIEAE Benth. Scrophularin. ind. 48. Co roll a campanulata, infundibuliformis v. tubulosa, limbo quinquefido, laciniis rotundatis, planis. Stamina 4 , omnia fertilia, adscendentia. An therae biloculares, loculis discretis, saepe acuminatis. Cap sula bilocularis, loculicide v. septicide bivalvis, valvis indivisis v. bifidis. Semina nucleo saepissime intra testam laxam, reticulatam, arilliformem minimo.

3950. Escobedia $R U I Z$ et $P A V . \mathrm{C}$ a $\mathrm{y} \mathrm{x}$ longe tubulosus, pentagonus, apice quinquefidus, lacinitis subpatentibus. Corolla hypogyna, infundibulifurmis, tubo longo, tenui, limbo ample quinquelobo, patente. S ta in in a 4, corollae tubo inserta, didynama, inclnsa; antherae omnes perfectae, loculis basi aristatis. Ovarium biloenlare, placentis dissepimento ntrinque adnat's, multiovulatis. Sty I us simplex; $8 \mathrm{tig}$ ma ligulatum, rugoso-undulatum. Caps a I a bilocularis, to culicide bivalvis. ..... S em in a .... - Herbae peruanae et mexicanae; foliis oppositis, ovatis, oblongis $v$. linearibus, scabriusculis, dentatis, pedunculis axillaribus, solitariis, unifloris, bibracteolatis, floribus magnis, albis.

E s e o be di a Ruiz et Paron Syst, 159. Kunth in Humb. el Bonpl. Nov. Gen. et sp. Mr. 371. t. 174. Sehlechtend, in

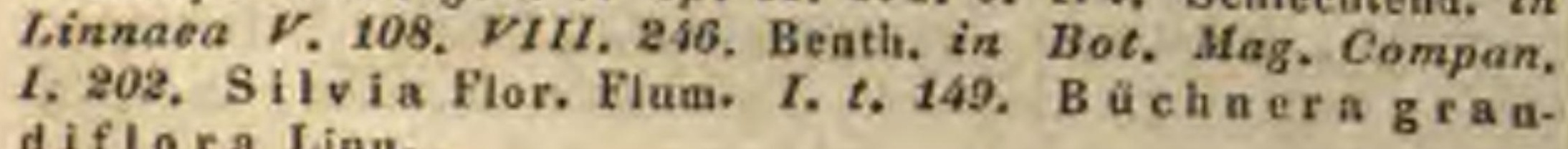
d iflo ra Linn.

399 4. Plnyseeniyx POHL. C a lyx coloratus, ovato-ventricosus, ore angustato quin- quedentatus. Corolla hypogyna, infundibuliformi - hypocraterimorpha, limbo subaequaliter quinquelobo. St a min a 4, corollae tubo inserta, didynama, inclusa; a n the ra e omnes perfectae, loculis basi breviter aristatis. Ova ri n m biloenlare, placentis dissepimento utrinque adnatis, multiovalatis. Stylns simplex; stigma subelavatum, indivisam. Caps ula bilocularis, loculicide bivalvis, valvis medio septiferis. S e m in a plurima, linearia, compressa, testa reticulata. - Frutices brasilienses, superne dense foliosi; foliis oppositis $v$, alternis, erectis, crassiusculis, integerrimis, pedunculis axillaribus unifloris, bibracteolatis, ad apices ramorum racemosis, calycibus corollisque splendide rubris.

Physocaly x Pohl Plant. Brasil, 1. 65. t. 53. Martius Nov. gen. et sp. IIX. 1. t. 201. 202. Benth, in Bot. Mag. Compan. IT. 203.

3998. Melasma BERG. C a 1 y $x$ foliaceus, laxus, demum inflatus, apice quinquefidus. Corolla hypogyna, infundibnliformis, limbi quinquelobi lobis brevibus, latis. St a m in a 4 , corollae tubo inserta, didynama, inclusa; anthera e omnes perfectae, loculis basi apiculatis. O v a $\mathbf{r} \mathbf{~ u ~ m}$ biloculare, placentis dissepimento utrinque insertis, multiovulatis. St y lus simplex; stig ma subclavatum. C a p s u la bilocularis, loculicide bivalvis, valvis medio septiferis. Se min a plurima, cuneiformia, compressa, testa reticulata. Herbae mexicanae et capenses; foliis oppositis, scabris, pedunculis axillaribus, solitariis, unifloris, medio bibracteolatis, subracemosis.

M e la s m a Bergius Elor. cap. 162. $t$. 3. f. 4. Gärtner I. 260, t. 35. Benth. in Bot. Mag. Comp. II. 202. Nigrina Linn. Mant. 42, non Thunb. L y nee a Cham. et Sehlechtend. in Linnaca $V$. 108. VIII. 24.

3993. Esterhazya $M I K, \mathrm{C}$ al y $\mathrm{x}$ campanulatus, quinquedentatus. Cornll a hypogyna, tubuloso-infundibuliformis, limbi quinquelobi lobis ovato-rotundatis, subaequalibus. St a m i n a 4 , eorollae tubo inserta, didynama, exserta; a nthe$r$ a emnes perfectae, loculis basi acutis, villosissimis. Ovarium biloculare, placentis dissepi. mento utrinque adnatis, multiovulatis. Sty $1 \mathrm{u}$ s simplex; stigma subclavatum. C a p sula bilocularis, loculicide bivalvis, valvis medio septiferis, demum bifidis. Se min a plurima, angulata, testa reticulata. - Frutices br a silienses, basi denudati, apice foliosi; foliis oppositis $v$. alternis, lanceolatis $v$. linearibus, integerrimis, floribus pedunculatis, versus apices ramorum breviter racemosis, pedunculis bracteatis.

Esterhazya Mikan Delect. $t$. 5 . Benth. in Bot. Mag. Comp. II. 203. Virgularia Martius Nov. gen, et sp. III. 5. $t$, 203, 204. exel. t. 205. nos Ruiz et Pav, L a s ios temo n Schott mse. Gerardiae seet. Dargeria Cham. et Schlechtend. in Linnaea III. 18.

3994. DIacranthers TORREY. C a I y x campanulatus, quinquefidus, laciniis tubo brevioribus v. longioribus. Corolla hypogyna, tubulosa, limbi quinquefidi laciniis brevibus, subaequalibus, patentibus. Stam in a 4 , corollae tubo inserta, longe exserta, subaequalia; antherae omnes perfectae, erectae. Ova ri u m biloculare, placentis dissepimento utrinque insertis, multiovulatis. Stylus simplex; $8 \mathrm{tigma}$ subclavatum. Capsula subglobosa, acuta, bilocularis, locnlieide bivalvis, valvis medio septiferis. Se in ina plurima .... Herbae in America borealis provinciis a $u s t r a l i o r i b u s$ indigenae; foliis oppositis, inciso-pinnatifidis, foribus racemosis, pedunculis ebracteatis. 
Ma cra athera Torrey ex Benth. in Bot, Mag. Comp. II. 203. Torrey in Annal. Lyo. New York. IV. 80. t. 4. Con radia Nuttall in Journ, Academ. nat. sc. Philadelph. PIT, 88, t, 12 .

35D5. Seymeria PURSH. Ca Iy x cam pannlatus, quinquefidus, laciniis linearibus, tubo longioribus. Coroll a hypogyna, tubo brevi, limbi quinquefidi laciniis oblongis, demum rotatopatentibus. Stamina 5, corollae tubo inserta, subexserta; antherae omnes perfectae, erectae. O varium biloculare, placentis dissepimento u trinque insertis, multiovalatis, Sty Ins simplex; $s t i g m a$ attenuatum. Capsula basi globosa, bi. locularis, loculicide bivalvis, valvis medio septiferis, demum bifidis. S e min a plurima, minima, alata. - Herbae boreali-americanae, pubescentes $v$, viscidulae; foliis oppositis, pinnatisectis, segmentis linearibus $v$. filiformibus, floribus parvis, subpaniculato - racemosis, luteis.

Seymeria Pursli Flor, Bor. Amer. II, 737. Benth, in Dot, Mag. Comp. IT, 203. A f z e $1 \mathrm{i}$ a Gaelin Syst. 927.

3996. Creraradia $L I V N$. C a ly $x$ campanulatus, quinquedentatus v. quinquefidus. Co rolla hypogyna, campanulata v. ventricoso-tubulosa, limbi quirquefidi laciniis rotundatis, semipatentibus, integris v. rarissime bifidis, St a mina 4 , corollae tubo inserta, inelusa, didynama $v$. rarins subaequalia; antherae nuns omnes perfectae, Ioculis aequalibus, nunc duae fertiles, duae minores efoetae. $O$ va $\mathbf{r}$ i $\mathbf{m}$ biloculare, placentis dissepimento utrinque insertis, multiovulatis. StyI u simplex; stig m a simplex, incrassatum, v. bilobum. Cap 8 u la acuta v. ubtusa, erostris, bilocularis, loculicide bivalvis, valvis medio septiferis, indivisis v. rarissime bifidis. Se m in a plurima, testa laxa, reticulata. - Herbae v. suffrutices in America tropica et extratropica, et in India orientali indigenae; foliis oppositis $v$. allernis, pinnatisectis $v$. pinnatifidis, raro integris, floribus solitariis, axillaribus, sessilibus $v$, pedunculatis, pedunculis saepius ebracteatis, corollis flavis $v$, roseo-purpureis.

Gerardia Lian. gen. $n_{*}$ 747, Gärtner f. $I 1 T$. 185. 6. 114. Beath. in Bot. Mag. Compan. II. 204, excl. sect, 6.

a. OTOPHYLLA Bentb. $l$. $c$. C $\mathbf{l} \mathbf{1} \mathbf{x}$ profunde quinquefdus. Corolla purpurea, campauulata. Sta uia di dynama, autherae longiorua fertiles, breviorum mino. res, cassae. - Herba boreali-americana; folizs basi aurioulato-lobatis. G. a u r f e u l a ta Michx.

b. CXRTOCODON Benth. , c. Caly $\mathrm{x}$ profuade quinguefi dus. Corolla flava, tubo saepius brevi, iacurvo, a $\mathrm{D}$ therae omnes fertiles, loculis maticis. - Species borcali-americanae el mexicanae.

c. PEDICULAROIDES Benth. l-c. Calyx semiquinquefi dns. Corolla flava, tubuloso-caupanulata. Stam in a didynama, anthera a e ounes fertlles, loculis basi calcaratis. - Herbae boreali-americanae, folits la. tiusculis, saepius inciris: - Pegesia Rafinesq. Flor. ludov. 48. Das y stoma Rafiaesr. in Journ. Phys. LXXXIX. 99 .

d. EUGRRARDIA Benth. $l$, c. $\mathrm{C}$ al y $\mathrm{x}$ quinquedentatus rarlus semiquinquefidus. Corolla purpurea, campanulata, rarius veatricoso tubulosa, au $t$ ber a e omes fertlles, loculis subaequal bus, muticis. - Horbae $v$. suffrutices, per omnem dmericam, calidam et tempe. ratam crescentes, folits linearibus $v$, rarissime lanceolalis inlegerrimis $v$. infinis interdum incisis. Virgularia Ruiz et Pav, Syst. 161. Martius Nov, gen. et sp. t. 205. (Banton Flor. Amer. t. 82. 97. Martias Op. cil. t. 206. 207.)

e. DARgRria Benth. . c. C al y $\times$ quisquedentatus. C orolla purpurea, lacinits emarginato-bifidis. Stamina didynama, a n ther a e omees fertiles, loculis aequalibus. - Herba indica, folits pinnatisectis, laciniti linearibus.
3998. Sopubin HAMILT. Caly $\mathrm{x}$ campanulatus, quinquefidus. Co rolla hypogyna, infundibuliformi-campanulata, limbi quinquefidi laciniis rotundatis, semipatentibns, integris. S $t$ am i na 4 , corollae tubo inserta, inclusa, didynama; antherae omnes fertiles, biloculares, loculo altero erecto, pollinifero, altero minore divergente efocto. Ovarium biloculare, placentis dissepimento utrinque insertis, multiovulatis. Stylus simplex; stigma incrassatum, obtusum. Capsula obtusa, bilocularis, loculicide bivalvis, valvis medio septiferis, bifidis bipartitisve. Sem ina plurima, testa laxa, reticnlata. - Herbae in $d i$ c a ; foliis oppositis, inferioribus inciso-pinnatifidis, superioribus integris, floribus solitariis axillaribus, breve pedunculatis, basi bracteolatis, corollis purpureo-roseis $v$. flavis.

Sopubia Hamilton ex Don Nep. 88, Gerardiae sect. So pubia Benth. Scrophularin. ind. 49, Bot. Mag. Comp. $I, 211, t, 9$.

3999. Harveya $H O O K . \mathrm{C}$ al $\mathrm{y} \mathrm{x}$ inflatocampanulatus, semiquinquefidus, laciniis latis, margine sinubusque recurvis. Co rolla hypogyna, ringens, tubo exserto, incurvo, fauce ampliata, compressa, limbi labio superiore erecto, bilobo, inferiore patente, trilobo, lobis obovatis, undulatis. Stamina 4 , corollae tubo inserta, inclusa, didynama; antherae biloculares, loculis subparallelis, altero fertili, ovato, basi acuminato, altero sterili elongato-subulato. Ovarium biloculare, placentis dissepimento ntrinque insertis, late bilobis, multiovulatis. St ylus simplex, subexsertus; stigma capitato-globosum. C a p $8 \mathrm{al}$ a bilocularis, loenlicide bivalvis, valvis medio septiferis, demum bifidis. Semina plurima, testa laxa, reticulata. - Herbae capenses, parasiticae, orobanchoideo habitu, simplices $v$. ramosae, pilis glandulosis subviscidae; foliis oppositis, squamaeformibus, floribus e supremis squamarum axillis solitariis, oppositis, brevissime pedunculatis, calycibus basi bibracteolatis, corollis magnis, roscis.

Harweya Hooker Ic. t. 118. Orobanches $s$ p. Drege, Eckl.

4009. Clossostylis CHAM. C a I y $\mathrm{x}$ eampanulatus, quadri-quinquedentatus. Co ro il a hypogyna, oblique campanulata, limbo breviter bilabiatim quinquelobo, lobo inferiore majore. St a mina 5, corollae tubo inserta, inelusa, didynama; anthera e biloculares, loculis parallelis, acutis. Ovarium biloculare, placentis dissepimento utrinque insertis, multiovulatis. Stylus simplex; $s t i g m$ a linguaeforme, incrassatum, recurvatum. Cap 8 u la obtusa v. emarginata, bilucularis, loculicide bivalvis, valvis medio septiferis, demum bifidis. Semina plurima, nueleo intra testam utrinque relaxatam, lincari-cuncatam, reticulatam minimo. - Herbae in Brasilia, India orientali et Ca $\bar{a}$ ite b on a e spei indigenae, asperae, ereotae, habitu fere Melampyri; foliis oppositis, sinuato-dentatis, floralibus basi latioribus, profundius dentatis, apice acuminutis, floribus subsessilibus, solitariis, alterne spicatis.

GI ossostylis Chamisso et Schlcehtend. in Linnaed II. 22. Benth. Scrophularin. ind. 49. Bot, Mag. Comp. I. 211, Ale etra Thunberg Nov. gen, 3,83, - ? St arbia Thouar. Gen, Madagasc. $\%$.

4001. Phtheirospermum BUNG. Cal yx campanulatus, quinquefidns. Corolla hypogyna, campanulato-ringens, labio superiore plano, bifido, Iubis replicatis, inferiore paullo 
longiore trifido, fauce hiante. Stamina 4 , corollae tubo inserta, didynama, rectinscula; a ntherae liberae, loculis parallelis, mucronatis. Ovarium biloculare.... Stylus simplex; stig ma bilobum. Caps u la rostrata, compressa, bilocularis, bivalvis ..... S e min a plurima, oblonga, angulata, membrana reticulata, spongiosa involuta. - Herba annua $v$. biennis, in China boreali indigena, habitu, foliis, calyce et capsula fere Pedicularidis palustris, corolla fere $\mathbf{M i}$ muli, sordide rosea, fauce lineis duabus flavidis notata.

Phtheirospermum Bunge ox Fisch. et Meger. Index sem, hort. Petropolit. 1835, I. p. 35.

4002, Centranthera $R, B R, \mathrm{Caly} x$ compressus, hine fissus, inde integer $\mathbf{v}$, demum bi-trifidus. Corolla hypogyna, tubulosa v. infundibuliformis, limbo patente v. bilabiato, lobis quinque rotundatis, inferioribus majoribus. $S t a-$ min a 4 , corollae tubo inserta, inclusa; anthe$\mathbf{r}$ a e per paria approximatae, biloculares, loculis parallelis, transversalibus, mucronatis v. calcaratis. Ova ri u m biloculare, placentis dissepimento utrinque adnatis, multiovulatis. Stylus simplex; $8 \mathrm{tig} \mathrm{m}$ a oblongum, incrassatum. Capsula ovoidea v. oblonga, bilocularis, loculicide bivalvis, valvis dissepimento placentifero, demum libero contrariis, integris v. bifidis. S em in a plurima, testa relaxata, reticulata. - Herbae in $A s i a$ et Nova-Hollandia tropica indigenae, erectae v. diffusae, rigidae, scabrae; foliis subsessilibus, oppositis, oblongis $v$. lanceolatis, integerri$m i s$. paucidentatis, floribus sessilibus, alternis v. inferioribus opposilis, saepius secundis, inferioribus remotis, superioribus interdum spicatis.

Centranthera R. Brown Prodr. 488. Wallich Plant. As. rar. 1, 39. t.45. Benth. Scrophularin. ind, 50. R a z u. movi a Sprengel Syst, II. 812. Gumteolis Hamilt. msc.

TIEIFUS XI. RHINANTHEAE Benth. Scrophularin. ind, 50. Corolla e limbus bilabiatus, labio superiore concavo, galeato v. lineari, integro v. emarginato, inferiore trifido. Stamin a 4 v. rarius 2 , adscendentia; anther a biloculares, loculis discretis, parallelis, saepe acuminatis. C apsula loculicide bivalvis, valvis medio septiferis, saepissime integris. S e minum testa solida, v. laxa arilliformis, nunc in alam expansa.

4003. Orthoearpus NUTT. Caly tubulosus, v. campanulatus, quadrifidus, aequalis. Co rolla hypogyna, personata, labio superiore minore compresso, marginibus reflexis, inferiore concavo, obsolete tridentato. St a min a 4, corollae tubo inserta, inclusa, didynama; anthera e biloculares, loculis divaricatis, inaequalibus. Ovarinm biloculare, placentis medio dis. sepimento utrinque insertis, multiovulatis. St yIus simplex; stigma vix incrassatam. Capsu I a ovato-elliptica, bilocularis, loculicide bivalvis, valvis medio septa placentifera gerentibus S e min a plurima, nucleo intra testam laxe membranaceam, reticulatam minimo. - Herbae annuae, in America boreali-occidentali indigenae; foliis integris $v$. laciniatis, floribus solitariis, sessilibus.

Orthocarpus Nuttall Gen, II, 56. Beath. Scrophularin, ind. 12, in not.
4004. Castilleja MUT, Caly x tubulosus, compressus, antice fissus, hine bi-quadrifidus. Coroll a hypogyna, ringens, tubo compresso, labio superiore lineari-canaliculato, integro, inferiore breviore, saepins brevissimo, tridentato v. trifido. Sta m in a 4, corollae tubo inserta, didynama, exserta; a n thera e biloculares, loculis divaricatis, inaequalibns. Ova ri um biloculare, placentis medio dissepimento utrinque insertis, multiovulatis. Stylus simplex; sti g ma capitatum. Ca p 8 ula ovata, compressa, bilocularis, loculicide bivalvis, valvis medio septa placentifera gerentibus. S emina plurima, nucleo intra testam laxe membrasaceam, reticulatam minimo. Herbae, suffrutices $v$. frutices, per omnem A m e ric a m, nec non in Asia boreali-orientali crescentes; folitis alternis, integris $v$, trifidis, floralibus bracteiformibus, heteromorphis, coloratis, floribus axillaribus solitariis $v$. terminalibus spicatis, corollis albidis $v$, virescentibus.

Castilleja Mutis ex Linn. fil. Sappl. 293. Smith Ic. inedit. $t$. 39. 40. Konth in Humb, et Bonpl. Nov. gen. et sp. II. 328. t. 163_165. Bot. Reg.t, 925. 1136. E u eh ro. m a Nuttall Gen, $I I$. 34 . - 20 n corhyne hus Lehmann Index Semin. Hort, Hamburg, 1832, n. 6 .

4005. Adenostegia BENTH. Cal y x bifidus, laciniis acutis, integris, corollam subsuperantibus. Coroll a hypogyna, bilabiata, labiis subaequalibns, superiore oblongo, galeato, erecto, breviter bifido. St am in a 4, corollae tubo inserta, inclusa, didynama; antherae biloculares, loculis disjnnetis, altero medifixo, terminali, altero filamento infra affixo..$\ldots$. C a $\mathrm{p}$ s $\mathrm{l}$ la bilocularis, loculicide bivalvis, valvis medio septa placentifera gerentibus. S e min a .... Herba Novae California e rigida, tenuiter glanduloso-pubescens; foliis anguste linearibus, saepius trifidis, floribus ad apices ramorum paucis, capitatis, bracteis adpressis, trifidis, glandulosis, ciliatis, filamentis antherisque villosis. p. 443 .

A denos te gi a Benth. In Lindley Introduot, edit, IT.

4006. Triplnysaria FISCH. et MEY. Caly x tubulosus, quadrifidus. Corolla hypogyna, ringens, tubo filiformi, labio superiore indiviso, subulato, inferioris tripartiti lacinits saccatis. S t a min a 4, corollae tubo inserta, didynama; ant her a e unilocnlares, lineares, muticae. Ovarium biloculare, placentis medio dissepimento utrinque adnatis, multiovnlatis. Stylus simplex; stig ma oblongum, bilobum, C a p s u la oblonga, bilocularis, locnlicide bivalvis, valvis medio dissepimenta placentae centrali cohaerentia gerentibus, S emin a plurima, oblonga, testa serobieulata, nucleo arcte adhaerente. - Herba californica, annua ; foliis elongatis, ima basi dilatatis, semiamplexicaulibus, apice pinnatilobato - incisis, infimis saepe oppositis, superioribus alternis, floralibus vix calyce longioribus, floribus axillaribus, solitariis, sessilibus, corolla alba, demum rosea, tubo filiformi calyeem duplo superante, labio superiore recto, subulato.

Triphysaria Fischer et Meyer Index sem, hort. Petropolit. $I T, 1835$, p. 58.

400\%. Selhwalloea LINN, C a lyx rentricoso-tubulosus, striatus, oblique quadrifidus, lacinia postica brevissima, antica lateralibus longiore, latiore, emarginata. Coroll a hypogyna, ringens, labio superiore fornicato, integro, inferiore trifido. Stamina 4, corollae tabo inserta, didynama, inclnsa; an the ra e biloculares, locu- 
lis divaricatis, aequalibus. Ovarium biloculare, placentis medio dissepimento ntrinque insertis, multiovulatis. Stylus simplex; stigma subincrassatum. Cap $\$$ u l a bilocularis, septicide bivalvis, columna placentifera demum libera. $\mathrm{S}$ e $\mathrm{m}$ in a plurima, nucleo intra testam membranaceam laxam, reticulatam, alaeformem minimo.

Herba in Americae borealis paludosis perennans, simplex, pubescens ; foliis oppositis, ovato-oblongis, acutis, integerrimis, floribus terminalibus racemosis, atro - purpureis, calycibus basi bibracteolatis.

$\mathrm{Sel}$ wa 1 b e a Linn. gen, $n, 744$. Gärtner 1 , 2s9. $t .58$. Nuttall Gen, J. 5 is.

4008. Tamourouxia H. B. K. C a $1 \mathrm{yx}$ campanulatus, subaequaliter quadrifidus, C or ol1 a hypogyna, ringens, tubo compresso, labio superiore galeato, integro, inferioris angustioris, trilobi, plicati lobis subaequalibus. S $t$ a min a 4, corollae tubo inserta, didynama, antiea exserta; antherae biloculares, reniformi-sagittatae, loculis basi saepissime mucronatis, staminnm posticorum efoetae, interdum nullae. O va ri u m compressum, biloculare, placentis medio dissepimento utrinque insertis, multiovulatis. Stylus simplex; st i $\mathrm{gma}$ clavatum, indivisum. Capsula compressa, bilocularis, loculicide bivalvis, valvis medio septa placentifera gerentibus. S emina plurima, nucleo intra testam laxe membranaceam, reticulatam minimo. - Herbae mexicanae et peruanae, erectae, ramosae; foliis oppositis, serratis $v$. pinnatijidis, floribus axillaribus, solitariis, oppositis, subspicatis, coccineis.

L a m o u rou xi a Kunth in Humb. ot Bonpl. Nov. gen. et sp. II, 335, t, $167-169$.

4009. Cymbaria MESSERSCHM. C aly $\mathrm{x}$ campanulatus, costatus, subaequaliter quinquefidus, laciniis linearibus, interdum minoribus interjectis. Corolla hypogyna, ringens, tubo superne inflato, labio superiore galeato, integro v. bifido, marginibus reflexo, inferiore trilobo, palato gibbo. Stamina 4 , corollae tubo inserta, antica galeam aequantia, postica inclnsa; an therae biloeulares, sagittatae, loculis basi mucronatis, omnes fertiles. Ovarium biloculare, placentis medio dissepimento utrinque insertis, multiovulatis. Stylus simplex; stigma capitatum, indivisum. Ca p s u la compressa, bilocularis, loculicide dehiscens, dissepimento utrinque placentifero contrario, indiviso, valvas connectente. S emin a pauca, compressa, angulata, testa spongiosomembranacea, in marginem irregularem producta. - Herbae sibiricae, humiles, basi suffruticosae, cano-villosae; caulibus teretibus, erectis, foliis oppositis, linearibus, lanceolatis, acuminatis, integerrimis, floribus axillaribus, solitariis, oppositis, subsessilibus, luteis, calycibus basi bibracteolatis.

$\mathrm{C}$ y $\mathrm{mb}$ a ri a Messersclimid ex Linn. Mant. 417. Gärtuer $T_{\text {. }}$ 258. Schlechtend, in Hor, phys. Berolin. 107.

a. CXMBOCHASMA. C a I y $\mathbf{x}$ quinquefidas, dentibus interjectis nullis. Co rolla e labium superius rectum, integrum. C ymbaria bory 8 thenica Pallas, Sehlechtend. Op. cit. $t, 21 . f .2$.

b. EUCYMBA. CaIy $x$ quinquefidus, dentibus minoribus interjectis. Corolla labium superias bipartitum. marginibus reflexis. Cymbaria daurica Lina. Amman Futh, t. 1, f. 2, Gärtner $\imath .53$. Sehlechtead, Op. cit. $f .1$.

4010. Dilontites HALL, Calyx campanulatus, subaequaliter quadrifidus. Co orolla hypogyna, ringens, labio superiore galeato, compresso, emarginato, inferiore paullo breviore, tri- partito, lobis aequalibus, integerrimis. $\mathrm{Stami-}$ n a 4, corollae tubo inserta, subexserta, didynama; a n th er a e biloculares, loculis aequalibus, parallelis, basi mucronatis. O varium biloculare, placentis dissepimento utrinque adnatis, multiovulatis. Stylus simplex, exsertus; stigma obtusum. Capsu la bilocularis, apice loculicide bivalvis, valvis medio septa placentifera gerentibus. S em in a plurima, ovata, costata, rhaphe valida percursa. - Herbae in Europa media et australi indigenae; foliis oppositis, sessilibus, lanceolatis, serratis, v. linearibus, integerrimis, floribus racemosis, rubentibus v. luteis.

0 dontites Haller Helv, 304, Persoon Encheir. 11 . 150, Nees jun. Gen, plant. XVI t, 8. E uphras iae sp. Linn. Flor. dan, t. 625. Schkuhr t, 169. Jacq. Elor, austr. t. 398 .

4011. Euphrasia TOURNEF, C a $1 \mathrm{yx}$ campanulatus, subaequaliter quadrifidus. C o r oll a hypogyna, ringens, labio superiore galeato, hifido, inferioris longioris laciniis emarginatis v. rarius integris. St a min a 4, corollae tabo inserta, inclusa v, exserta, didynama; a nth era e biloculares, loculis parallelis, mucronatis, loculi extimi inferiorum muerone longiore. O va rin m biloculare, placentis dissepimento utrinque adnatis, multiovulatis. Stylns simplex, inclnsus; stigma subcapitatum. C a psu la bilocularis, loeulieide bivalvis, valvis medio septa placentifera gerentibus, indivisis v. demum bifidis. Semin a plnrima, fnsiformia, costata, rhaphe valida pereurga. - Herbae in temperatis extratropicis totius orbis obviae, in hemisphaera australi frequentiores; foliis oppositis $v$, rarius alternis, saepissime dentatis $v$. incisis, floralibus plerumque latioribus, floribus sessilibus, subsolitariis, in apice ramorum subspicatis.

E u phrasia Linn. gen, $n$, 741, exel, sp. Gărtaer $r$. t. 54. Schkuhr t. 169. R. Browa Prodr. 456. Kunth in Rumb. et Bonpl. Nov, gen, et sp. II, 133, $t, 106$. Nees Jun. Gent, plant. XVI. e. 7. Pare a tucelli a Viviani Flor. Libje. 32. $t$. $21, f .8$.

401 . Siplnomostegia BENTH. Caly 5 infundibuliformis, tubo elongato, limbo quadriquinquepartito. Co rolla hypogyna, labio superiore incurvo, inferioris brevioris laciniis integris. S $t$ a $m$ in a 4 ; anth e rae biloculares, loculis parallelis, basi aentis, muticis, Ovarium..... st $\mathrm{igma}$ incrassato - capitatum. C a p sul a oblonga, recta, valvulis integris..... S emina ..... - Herba ad Macao Sinarum lecta, erecta; ramis virgatis, tenuissime pubescentibus, foliis inferioribus oppositis, superioribus alternis, pinnatifidis, laciniis incisis, acutis, lanceolatis, floribus sparsis, subdistantibus, subsessilibus, in spicas interruptas v. racemos terminales dispositis.

Siphonostegia Benth. Scrophularin, ind, 51. Hooker ad Becohey 203, $t$, 44. Pris mat an $t$ h us Hook, et Arn, mac.

4013. Bartein LINN. Calyx campanulatus v. tubulosus, subaequaliter quadrifidus. $\mathrm{C}_{0}$ roll a hypogyna, ringens, labio superiore galeato, compresso, integerrimo, inferiore trilobo, snbaequali, laciniis integerrimis. Stamin a 4 , corollae tabo inserta, galea inclusa, didynama; a nth e rae biloculares, loculis basi discretis, mucro. natis. Ov a r in m biloculare, placentis medio dissepimento utrinque insertis, multiovalatis. S tylus simplex; stigma subeapitatum. Capsula ovata, turgidula, bilocularis, loculicide bivalvis, valvis medio septa placentifera gerentibus. Semina plurima, curvula, umbilico prope apicem 
subventrali pendula. - Herbae simplices, annuae v. perennes, in Europa media et a ustrali in digenae; foliis oppositis, sessilibus, serratis $v$. in cisis, floribus axillaribus, solitariis, oppositis, sessilibus.

B a r ts i a Liau. gen, n. 739. Benth. Nevis, 1 .

a. BARTSCHiA. Semina mainscula, dorso convexo alis seais-octonis instructa. B a rtsia Reichenb. Flor. germ. 360. Nees jun. Gen, plant. XVI. t.9. B. a I pi n a Linne, Schkuhr $t, 160$. E. B. t. 361. Hooker Flor. lond. $t, 87$. Strehelin a Haller Hetv. 312 .

b. TRIXAGo. Semina miuima, laeviuscula. Trixago Steven in Mem, soc, $h, n$, Mrosqu, VI. 3. Reicheab. t. c. Nees jun. Op. cit. XYYI. t. 10. Lasiopera lisk et Hoffuans. Flor. Porlug. t, 58. Bellardia Allioni Flor. Pedemont. I, 61. Bartsia e R hi u a n thi et Euphrasia e s p. Lisa. E. B. t. 1045́. Hooker Elor. lond, t, 167. Siblhorp Flor. graeo, t. 585. 586.

4014. Hzungea C. A. MEY. C alyx tubulosus, subaequaliter quadrifidus. Corolla hypogyna, ringens, labio superiore galeato, tridentato, inferioris longioris, trifidi laeiniis lanceolatis. St a m in a 4, corollae tubo inserta, inclusa, didynama; antherae biloculares, loculis basi diseretis, mueronatis. Ovarinm placentis medio dissepimento insertis, revolutis subquadriloculare. Stylus simplex; stigma subcapitatum. Cap$\mathrm{s}$ u 1 a subquadrilocularis, apice bivalvis. S e mina plurima, compressa, rugusa, - Herba Asiae minoris; caule simplicissimo, subtomentoso, foliis oppositis, sessilibus, tripartitis, laciniis linearibus, pubescentibus, floribus oppositis, axillaribus, solitariis, sessilibus, calycibus basi bibracteolatis.

B un ge a C. A. Meyer Verseiehn. eaucas. Pflanz. 108. Rhinanthus trifidas Vahi.

4015. Fedicularis TOURNEF, $\mathrm{C}$ al $\mathrm{yx}$ subventricosus, inaequaliter quinquedentatus, nunc bilabiatus, labio superiore bidentato, v, integerrimo, inferiore tridentato. Co rolla hypogyna, ringens, labio superiore galeato, obtuso v. rostrato, inferiore trifido, patente v. clauso. S t a mina 4 , corollae tubo inserta, didynama; a nthera e biloculares, loculis obtusis, acutis v, calcaratis. $0 \mathrm{v}$ a ri $\mathbf{n m}$ biloculare, placentis dissepimento basi utrinque adnatis, multiovulatis. S ty lu s simplex; stigma capitatum. Capsula oblique rostrata v. rarius subglobosa, recta, bilocularis, loculicide bivalvis, valvis medio septa basi placentifera gerentibus. $\mathrm{S}$ e $\mathrm{m}$ in a ovata, angulata, rhaphe valida pereursa, chalaza rostelliformi. - Herbae in temperatis et frigidis, imprimis alpestribus he $m i$ s phaerae borealis obviae, saepius simplices; foliis alternis, oppositis v. verticillatis, inciso-denta tis v. pinnatifidis, floribus sessilibus, in spieas terminales densas $v$. interruptas dispositis.

Pedicularis Tournef. insh. 77. Linn. Gen, n. 746. Gärtner I. 246. $t, 53$ Steven in Mem. soc. h. $\pi$. Mosq. VI. p. 1. 55, eum icc, Benth. Serophularin, ind. 51 .

a. PEDICULARIS Reichenb. Flor. germ. 361, Corolla labium inferins deflexum. (Schkuhr $t, 171$. Jacq. Flor. austr. $t$. 139, 140. 205. 206, 258. Ic, rar. 4. 115. Collect. I. t. 14. Flor, dan. $t$. 225, E. B. t. 399. 400. B. M. 2506. Wall. Plant. As, rar, 154. Royle Himalay. 6.72. Reichesb. Iconogr, $4.81,314,587$, ) - E n s I e ni a Rafin.
Flor. Zudov. 35.

b. PROSOPIA Reichenb, Flor. germ, 363, Co ro II a e labium iuferius inflexum, faucem elaudens. (Flor. dan.

40 16. Rhimanthus BIEBERST. $\mathrm{C}$ a $\mathrm{y} \mathrm{x}$ bilabiatus, labio superiore galeato, brevissime bidentato, inferiore bipartito. C oroll a hypogyna, ringens, labio superiore angustissime galeato, recto $\mathrm{v}$. declinato, inferiore amplo, trilobo. S $\mathrm{ta}$ - mina 4, corollae tubo inserta, inclusa, didynama, longiora brevioribns spiratim circumvoluta; antherae biloculares, muticae. Ovarium biloculare, placentis linearibus, dissepimento utrinque adnatis, multiovulatis. Stylus simplex, a galea vaginatus; stigma capitatum. CapsuIa compressa, bilocularis, loculicide bivalvis, valvis medio septa placentifera gerentibus. Semina panca, compressiuscula, ovata, umbilico infra apicem ventrali pendula. - Herbae annuae, in Asia minore et regione taurico-caucasica indigenae; foliis oppositis, subsessilibus, ovato-lanceolatis, serratis, floribus axillaribus solitariis, pedunculatis, purpurascentibus.

R h in a thas Bieberst. Flor. Taur. caucas, $Y I$. 68. Ste. ven in Mem, soc. h. n. Mosqu. YT. 3. Reichenb. Icongr. t. 2 , E le phas Touraef. $I t, t, 299$. Beuth. Revis, 6 .

401\%. Aectorologhas HALL, C a ly x membranaceus, compresso-ventricosus, inaequaliter quadridentatus. Corolla hypogyna, ringens, labio superiore galeato, compresso, apice bidentato, inferiore subaequali trifido. St am in a 4 , corollae tnbo inserta, didynama, sub galea inclusa; an the rae horizontales, biloculares, villosae, muticae. $O$ vari u $m$ basi hine glandula stipatum, compressum, biloculare, placentis linearibus dissepimento utrinque insertis, pauciovulatis. Stylus simplex, subexsertus; stigma subeapitatum. C apsula compressa, bilocularis, loculicide bivalvis, valvis medio septz placentifera gerentibns. S e min a panca, saborbiculata, compressa, membranaceo marginata, umbilieo prope apicem marginali pendula. - Herbae annuae, in Europa media et australi, nec non in Asia finitima indigenae; foliis oppositis, sessilibus, lanceolatis, serratis, floralibus ovatis, floribus axillaribus solitariis, sessilibus, luteis.

Ale c torol o phus Hall. Helv, 314. Bieberst. Flor. Taur. caucas. II. 68. Steven in Mem. soc, h. n. Morq. VI. 3, Reichenb. Iconogr. $f$. 973 -976. Nees jun. Gen, plant. XVI. t. 5. Rhinanthus Benth. Revis. 6. Rhinanthus c $r$ is $t$ a galli Linn. Schkuhr $t$, 169 . Gärtner $t$. 54 .

4018. Melampyrum TOURNEF. C a1 y x campanulatus, haud inflatus, bilabiato-quadrifidus v. quadridentatus. Corolla hypogyna, ringens v. subpersonata, labio superiore galeato, compresso, emarginato, marginibus reflexo, inferiore tridentato $\mathrm{v}$ trifido, bigibboso. $\mathrm{S} \mathrm{tam}$ in a 4 , corollae tubo inserta, inclusa, didynama; a $t$ he$r$ a e biloculares, basi hifidae, loculis omnium $v$. staminum inferiorum basi mueronatis. Ovarium basi hine glandula stipatum, biloculare, ov $\mathrm{n} l$ is paueis, dissepimento utrinque affixis, semianatropis. Stylus simplex; stigma obtusum. Capsula ovata, acuminata, bilucularis, loculicide bivalvis, valvis medio septa prope basim seminifera gerentibus. Semina in loculis solitaria v, gemina, rhaphe filiformi, chalaza apicali earnosa, umbilico laterali. - Herbae annuae, in Europa media et australi indigenue; folitis oppositis, $l i$ neari-lanceolatis, integerrimis, floralibus dentatis v. pinnatifidis, saepe coloratis, spicis terminalibus, imbricatis $v$. secundis, saepe comosis.

M el a m p y r um Tournef. inst, 78 . Linn. gen, $n, 742$.

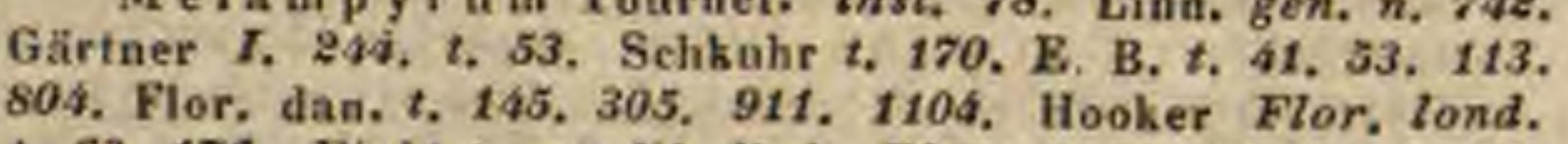
t. 63. 176. Waldst, et Kitaibel. Plant. rar. Hung. $t$. 86 . Nees jan. Gen, plant, XVI, t, 16.

4019. Tozzia MICHEL. Caly x quadriquinquefidus. Corolla hypogyna, tubo cylindrico, subinflato, limbo aequaliter quinquelobo, 
bilabiatim patente. $\mathrm{Stamina} 4$, corollae tubo inserta, didynama; a n therae biloculares, loculis basi mucronatis. Ovarium biloculare, loculis biovulatis, ovulis amphitrope pendulis. Stylus simplex; stigma obtusum. Fructus subdru. paceus, abortu unilocularis, monospermus, subbivalvis. S emen ovatum, umbilico laterali, dissepimenti reliquiis strophiolato, $\mathrm{Embryo}$ in apice albuminis carnosi minimus; radi cula supera. Herba in summis Europae mediae alpibus perennans, succosa, longe ramosa; foliis oppositis, sessilibus, ovatis, crenatis, racemis terminalibus brevibus, foliosis, corollae parvae, luteae labio rubro-punctato.

T o 2 f a Michell Nov, gen, t. 16 Lian. gen, $n, 7 i s$. Sehkuhr $t$, 17t. Jaeq. Flor. austr. 1. 165. Gärtuer f. III. 104. $t$. 198. St, Hilaire in Bullet, soc. philomat. Dec. 1826. p. 191 .

\section{GENERA DUBIA.}

4020. Comarea RUIZ et PAV. Caly quinquepartitus, laciniis aequalibus. Corolla tubo curvato, basi ventricoso, medio constricto, limbi bilabiati labio superiore quadrilobo, inferiore concavo, appendice urceolata, membranacea. Stamina 4 , didynama, brevia; antherae ovales. Stylus brevissimas, persistens; stigma capitatum. Capsula subtetragona, bilocularis, bivalvis, valvis bifidis. S e m in a plurima, oblonga. - Arbor peruana; foliis oblongo-lanceolatis, apice denticulatis, floribus racemosis.

Go mara Ruiz et Pav. Syst. 162.

4081. Samelhexia RUIZ et PAV. C a I y x quinqnepartitus. Co rolla hypogyna, longe tubulosa, tubo superne subconstricto, limbi quinquepartiti laciniis revolutis, duabns posticis panllo brevioribus. St a m in a 4 , corollae tubo inserta, duo ananthera, inclusa, duo fertilia exserta; antherac biloculares, loculis basi diseretis, aristatis. Ovarium biloculare, loculis multiovulatis. St $\mathbf{y}$ l us simplex; sti t ma bifidum. Capsula bilocularis, bivalvis. S e mina plurima. - Herbae peruanae, orgyales; caule tetragono, folitis oppositis, ovatis, crenatis, petialis basi connatis, floralibus bracteaeformibus calycibusque coloratis, ftoribus subverticillatis, sessilibus, corollis luteis.

$\mathrm{S}$ a nehezi a Ruiz et Pavon Prodr. $5, t$, 32. Flor. Pe. ruv. I. 7, t. 8.

4023. Lafuentea LAGASC. Calyx quinquepartitus. Co roll a bilabiata, labio superiore bifido, inferiore trifido. St a mina 4 , didy. nama, C a p sula bilocularis, polysperma. - Suffrutex Hispaniae a stralis, glanduloso-viscosus, graveolens; foliis decussatis, reniformibus, crenatis, spicis axillaribus pedunculatis, solitariis.

L a fuentea Lagasea. - Duriena Merat Dissert, Paris, 1829. 8. c. ic,

4023. Dieeros LOUREIR. C a l y $\mathrm{x}$ 'quinquepartitus, laciniis subulatis, erectis, subaequalibus, villosis. Coroll a campanulata, tubo intus villoso, limbi quadripartiti laciniis cordatis, una majore. Sta m in a 4, didynama, tubo inhaerentia, filamenta subulata, pilosa; antherae profunde bifidae, divaricatae, bicornes. Ova ri u m subulatum, breve, quadrisulcum. St y l u s corollae tubum aequans; stigma cochleariforme, infle- xum. Capsula subovata, bilocularis, bivalvis. S emina plurima, rotunda, minima. - Herba cochinchinensis, radice repente perennans; caule herbaceo, suberecto, tereti, villoso, foliis ternatim verticillatis, ovato-lanceolatis, serratis, carnosis, glabris, floribus axillaribus solitariis, pedunculis villosis.

Die eros Loureiro Flor, cochinch. 463, nou Pers.

OBSERVATIO. Adenostoma Blume in Flora 1826. $p$. 680. novum Serophularinearum genus javanieum, non: dum descriptam est. Palmstruekia Retz fil. a pla. ribus anctoribus inter Serophularineas nominata, nobls in. cognita.

\section{GENERA SCROPHULARINEIS AFFINIA.}

4024. Famondia C. L. RICH. Calyx quinquefidus. Corolla hypogyna, rotata, quinquepartita, lobis obtusis, subaequalibus, basi macula barbata. St a min a 5 , corollae tubo inserta, conniventia; fil a m enta brevissima, anther a e biloculares, cordatae, loculis oppositis, parallelis, longitudinaliter dehiscentibus, rimulae loculorum apice confluentes, porum mentientes. Ovarin m carpidiorum marginibus introflexis revolutis, facie interiore multiovulatis uniloculare. Stylus simplex; stigma obtusum. Ca p sula unilocularis, septicide bivalvis. S e m in a in revolntis valvarum marginibus plurima, hispidula, - Herba in al $p$ bus Europae occidentalis perennans; foliis radicalibus congestis, breve petiolatis, ovatis, incisocrenatis, rugosis, dense bruneo-hirsutis, scapo palmari nudo, corymbose bi-quadrifloro, corollis speciosis, lilacinis, fauce alba, flavo-maculata, antheris luteis.

$\mathrm{R}$ a mon dia L. C. Richard ex Persoon Encheir. $\mathrm{I}$, a16. M y co ni a Lapeyrouse Abreg. 115. C haixia Lapeyrouse Supplem. Verbas с и m M y o a i Lian. Trew Ehret. Plant. select. t, 57. Bot. Mag. t, 230.

4025. Haberlea FRIVALDSK, Calyx quinquefidus. Coroll a hypogyna, infundibuliformi-campanulata, limbi quinquefidi laciniis obtusis, duabus posticis paullo brevioribus. S ta min a 4, imo corollae tubo inserta, inclusa, didynama; filamenta apice inflexa, antherae per pariacohaerentes, biloculares, loculis ovatis, divaricatis. Ovarinm carpidiorum marginibus introflexis, margine multiovulatis uniloculare. Sty In s simplex; stig ma obtusum, Cap 8 ula unilocularis, septicide bivalvis. S emin a in introflexis valvarum margínibus plurima, laevia, - Herba perennis, in excelsioribus Rumeliae jugis crescens; foliis radicalibus congrestis, avato-oblongis, basi angustatis, crenatis, hirsutis, scapis palmaribus simplicibus, apice minute opposite bibracteatis, pedunculis subternis, brevibus, umbellatis, corollis speciosis, cyaneis.

H a be r le a Frivaldsky in Aet, soc, Hung, 1835, II, p. 249. t. 1 .

4026. Dbolaria LINN. Caly $\mathrm{x}$ diphylIns, bracteiformis. Coroll a hypogyna, campanulata, limbi quadrifidi laciniis suhineisis. Stamin a 4, inter corollae lobos inserta, subdidynama; fil amenta filiformia, brevia, antherae subglobosae, biloculares. O vari um uniloculare, placentis duabus parietalibus, multiovulatis. S t yIus brevissimus; stigma bifidum. Capsula ovata, bilocularis, bivalvis, valvis medio placen- 
tiferis. Semina plurima, minutissima. - Herba boreali-americana, subpaludosa, non satis nota, et dubiae affinitatis, fortassis ad Gentianeas depellenda, ab Orobancheis ut videtur aliena; caule simplici, foliis oppositis, sessilibus, subrotundis, carnosis, subtus purpureis, floribus terminalibus confertis, pallide caeruleis.

Obola ria Lian. gen. n, 778. Jussien gen, 101. Nuttall Gen. I. 103. Darlington Flor. Cestr. 112. S $\mathrm{ch}$ u I t z l a Rafiu, in N, Y. Med, Reposit. II. Hex. V. 350.

\section{Dralo CL. Acanthaceae.}

ACANTHI Jussieu gen, 102. coll, Annat, Mus, V. 251. IX, 231, XIV. 390. ACANTHACEAF, R. Brown Prodr, 479, Bartling Ord, nat. 183. Nees in Wallich Plant. As. rar. III, 70. s8. Lindley Introduct. edit. II. p. $28 t$.

Herbae basi suffruticosae, nune suffreTICES v. FRUTICEs, caule ramisque nodoso-articulatis, pube dum adest simplici, rarius capitata, rarissime stellata. Folia opposita, v. interdum geniculis abbreviatis ternatim quaternatimve verticillata, simplicia, integra, nunc integerrima, nunc crenata v. dentata, rarius spinoso-sinuata, sessilia v. petiolata, penninervia, ejusdem paris saepissime magis minusve inaequalia, singula basi plerumque nonnihil inaequilatera. Stipula e nullae.

Frones hermaphroditi, irregulares, axillares v. terminales, spicati, racemosi, fasciculati, rarius solitarii, in spicis ut plurimum oppositi, interdum alterni, singuli bractea bracteolisque geminis, nonnunquam obsoletis, quandoque maximis, calycis tune fere obsoleti vices gerentibus, stipati.

Calyx pentamerus, foliolis uno postico, dnobus anticis totidemque lateralibus, aequalibus v. inaequalibus, distinctis v. varie connatis, quinquefidus v. quinquepartitus, postico saepissime majore; nunc anticis duobus coalitis inaequaliter quadrifidus v. quadripartitus, interdum bracteolis inclusus, annularis, fere obsoletus, margine truncato, integerrimo v. irregulariter pluridentato.

Corolua hypogyna, pentamera, petalis cum laciniis calycinis alternantibus in tubum quinquenervem connatis, limbo rarius aequaliter quinquepartito, saepissime bilabiato, labio superiore dimero, in nonnullis obsoleto, inferiore trimero, lobis plus minus distinctis v. cohaerentibus, aestivatione contortis.

Stauiva corollae tubo diversa altitudine, nunc ima basi, nunc medio, interdum prope faucem inserta, exserta v. inclusa, quinto postico semper sterili, rudimentario, in plerisque penitus obliterato, nune quatuor didynama, antica breviora, nunc anticis anantheris v. penitus obliteratis nonnisi duo. Fil amenta filiformia v. subulata, basi interdum per paria connexa. Ant he rae nune biloculares, loculis oppositis, parallelis, aequalibus v. inaequalibus, valvulis contiguis saepius angustioribus ad speciem uniloculares, nune loculis inaequaliter insertis, obliquis, superpositis v. divaricatis, altero tunc, imprimis in staminibus anticis, abortiente v. rudimentario uniloculares, longitudinaliter dehiscentes.

Ovarium liberum, dimerum, dissepimento e carpidiorum marginibus introflexis duplicato, completo, v. ad axim deliquescente biloculare, loculis anticum et posticum axeos floralis latus respicientibus, saepius basi carpidiorum in unguem compressione obliteratis, medio ad apicem turgentibus, nunc apice in rostrum angustatis.

Ovuca in locnlis gemina, terna, quaterna v. interdum subindefinita, juxta medium dissepimentum biseriata, sessilia, processu placen= tari suffulta, amphitropa v. campylotropa. Stylus terminalis, filiformis, simplex. Stigma indivisum v. saepius bifidum.

Capsula membranacea, coriacea v. cartilaginea, sessilis v. unguiculata, obtusa v, rostrata, bilocularis (rarissime alterius loculi abortu unilocularis, indehiscens), elastice bivalvis, dissepimenti contrarii, integri v. medio deliquescentis, per axim bipartibilis segmentis valvis adnatis, persistentibus v. interdum ab iisdem dissilientibus, valvis nunc integris, nunc medio demum bipartitis.

Semina subrotunda, saepe compressa, in loculis gemina, quaterna v. subindefinite plura, interdum abortu solitaria, dissepimenti processibus subulatis v. uncinatis (retinaculis) subtensa, nune iisdem obsoletis v. in cupulam testae adnatam contractis suffulta. Testa coriacea, fibrosa v. laxa, saepissime tuberculata, nonnunquam pilosa. Alb u m e nullum.

Embryo curvatus v. rarius rectus. Cotyledones magnae, suborbiculatae, plano-convexae, v. interdum contortuplicatae. $\mathbf{R}$ a di c ula teres, descendens et simul centripeta, curvata v. recta. Plum ul a vix conspicua.

Acanthacea e magno specierum numero inter tropicos totius orbis luxuriantes, in regionibus subtropicis multo rariores, in hemisphaera boreali vix ultra $15^{\circ}$, in australi non ultra $12^{\circ}$ Isotherm. reperiuntur.

Affinitate inter Scrophularineas, mediante imprimis Melampyro, et Bignoniaceas mediae, notarum summa, albuminis defectu constanti, placentione in axi dissepimenti bipartiti et ad interiorem segmentorum ejusdem marginem, radiculae descendentis directione centripeta, capsulae in plerisque dehiscentia elastica, retinaculorum in plurimis apparatu, denique habitu quodammodo proprio optime distinctae.

Generum seriem, paucissimis ordinis stirpi- 
bus americanis accuratius adhucdum perpensis, incompletam, etian e nostri herbarii gazis brasiliensibus ab Acanthacearum indicarum sospitatore augendam, perficiendam speramus.

TRIBUS I. THUNBERGIEAE Nees in Wallich Plant. As. rar. III. 47. S e m in u retinacula in cupulam corneam dilatata, adnata.

402\%. Thumbergia LINN. Calyx basi bibracteolatus, lorevis, cupuliformis, truncatus $v$. pluridentatus. C or ol l a hypogyna, campanulatoinfundibuliformis, fance inflata, limbo quinquefido, patente, subaequali. Stam in a 4 , corollae tubo inserta, didynama; a nther a e biloculares, locnlis parallelis, ciliato-barbatis, altero breviore basi aristato. Ovarinm biloculare, loculis biovulatis, Stylus simplex; stigma infundibuliforme, transversim bilabiatnm. C a psula e basi globosa, biloculari in rostrum conicum angustata, di-tetrasperma, loculicide bivalvis, valvis medio septiferis. S e min a globosa, umbilico forato, annulo late calloso cincta. E mb r y on i s exalbuminosi cotyled ones foliaceae, conduplicatae, radi $c$ u la brevissima, infera. - Frutices indic $i$ et capenses; foliis oppositis, cordatis, angulatis, floribus axillaribus pedunculatis, solitariis v, race. mosis, corollis speciosis, luteis $v$. caeruleis, fauce plerumque saturatioribus.

Th u n be rg i a Linn. f. Suppl. 292. Gärtner f. III, 29. t. 183. Nees in Wallich Plant. As. rar. 1IT. 77. (Roxburgh Plant, Corom. $t$, 67. Hooker Exot. Flor, $t, 166,177$. Bot. Reg. $t$. 493. Bot. Mag. $t$, 3508.) D i ploc al y m m a Spreng. Syst. 1. 622. F I e m in gi a e p. Hamilt. msc.

4028. Meyenia NEES. Caly $\mathrm{x}$ basi bibracteolatus, brevis, quinquefidus. C o rolla hypogyna, infundibuliformis, tubo brevi, annulo piloso clauso, fauce sensim ampliata, limbo quinquefido, patente, subaequali. S t a min a 4 , corollae tubo inserta, didynama; a nthe rae bilocnla res, apice barbatae, loculi superiorum inaequales, altero divergente hinc tomentoso, interiorum subaequales, paralleli, basi mutiei. Ovarin m bilo. culare, loculis biovulatis. Stylus simplex; stigma membranaceo-dilatatum, bilabiatum, labiis bilobis. Capsula e basi globosa, bilocnlari in rostrum conicum angustata, tetrasperma, loculieide bivalvis, valvis medio septiferis. S e min a strophiola cupuliformi, spongiosa, solubili excep ta. Embryo .... - Frutex indicus, scandens; foliis oppositis, subsessilibus, cordatis, floribus axillaribus solitariis, pedunculatis.

Me yenia Nees in Wallich Plant, As, rar, III, 78. Thunbergia Hawtayneana Wallich Flor. Ncpal. 49. Plant. As. rar. II, 58, $2,164$.

4029. Hexacentris NEES. C a 1 y $x$ spathaceo-bibracteolatus, bracteolis postice connatis, brevis, pateriformis, inaequaliter dentatus $\mathbf{v}$. repandus. Co rolla hypogyna, infundibuliformicampanulata, fauce harbato-annulata, limbo oblique quinquefido, reflexo, subaequali. S $\mathrm{ta} \mathrm{m}$ in a 4 , corollae tabo inserta, didynama; a n th erae glahrae, biloculares, loculi paralleli, superiorum altero longissime calcarato, altero breviter mucronato, inferiorum utroque longe calcarato, calcaribus flexuosis. O vari um biloculare, loculis biovulatis. Sty ins simplex; stigma subbilabiatum, lobis truneatis, basi angustatis. Ca psula e basi globosa, biloculari in rostrum conicum angustata, tetrasperma, loculicide bivalvis, dissepi- mento solubili, ad axim bipartito. S emin a cristata .... Embryo... - Frutices indic $i$, scandentes; foliis oppositis, petiolatis, cordatis v. ovatis, dentatis, racemis axillaribus et terminalibus multifforis, bracteis parvis, floribus oppositis, solitariis $v$. fasciculatis, purpureis, bracteolis caducis.

Hexacentris Nees in Wallich Plant, As, rar. III. 78. Thunbergia coecine a Hooker Exot. Flor. t. 195. F te m m i g f a s p. Hamilt. ;mic.

4030. Iremdezia VELLOZ. Calyx spathaceo-bibracteolatus, bracteolis postice ennnatis, brevissimus, membranaceus, annularis, subintegerrimus. Corolla hypogyna, tubnlosa, limbo aequaliter quinquelobo. S $t$ a min a 4 , corollae tubo inserta, inclusa, didynama; a $\mathrm{t}$ h er a e biloculares, subulatae, loculis parallelis, altero saepius minore, muticis, glabris. Ovarium biloculare, loculis uniovulatis, altero saepins ninore. Stylus simplex; stig ma breviter bifidum. Drnpa sicea, putamine osseo, abortu uniloculari, monospermo. S emen ovatum. E mbry on is exalbuminosi cotyledones foliaceae, eonduplicatae, radicula brevissima, infera. - Frutices Amer cae tropicae, scandentes $v$. volubiles, plus minus hirti; folits oppositis, peliolatis, integerrimis, pedunculis axillaribus, unifloris, solitariis v. confertis, floribus speciosis, bracteolis ovatis v. lanceolatis, unicostatis, tomentosis.

Mendozia Velloz ex Vandelli in Nömer Seript. 126. t. 7. f. 22. Flor. Flum, VI, $t, 85,86$, Ruiz et Pav. Prodr, 89. t. 17. Martius Nov, gen, et sp. III, 20, t. 209-211.

TREIBUS II. NELSONIEAE Nees in Wallich Plant. As, rar. III. 74. R e t in a $\mathrm{cu}-$ la in papillam seminigeram contracta:

4031. Elytraria $V A H L$, Caly $\mathrm{x}$ quinquepartitus, lacinia postica latiore, anticis panllo altius connatis. Co r oll a hypogyna, infundibuliformis, limbo quinquefido, subbilabia to. Sta $\mathrm{m}$ i na 4, corollae tubo inserta, inclusa, duo antiea sterilia, postica fertilia; antherae biloculares, loeulis parallelis. Ovarium biloculare, loculis pluriovulatis. Sty ln 8 simplex; $8 \mathrm{t}$ i $\mathrm{gm}$ a bifidum. C a psula bilocularis, pleiosperma, loculieide bivalvis, valvis medio septiferis. Semin a in loenlis plura, retinaculis destituta. - Herba indica, acaulis; foliis radicalibus oblongis, crenatis, subtus villosis, spicis radicalibus, bracteis oppositis, unifloris, floribus parvis, bibracteolatis.

Blytra r1a Vahl Enumerat, $\Gamma_{\text {. }}$ 106, excl, sp. Nees in Wallich Plant. As. rar. IIT. 79. Justit ia a ca ulis Lion. Roxburgh Plant. Corom. $t, 127$.

4032. Nelisonia $R, B R$. C a $1 \mathrm{y} \times$ quadripartitus, inaequalis, lacinia postica majore, antica bifida. C o r o 11 a hypogyna, infundibuliformis, limbo quinquefido, subbilabiato. S $t$ a $\mathrm{m}$ in a 2, corollae tubo inserta, inclusa, sterilia nulla; a nther a e biloculares, Ioculis insertione aequalibns, divaricatis. Ovari u m biloculare, loculis pluriovulatis. Stylns simplex; stigma bifidum, laeiniis ovatis. Cap s u la bilocularis, pleiosperma, loculicide bivalvis, valvis medio septiferis. Semin a retinaculis destituta. - Herbae caulescentes, incanae, diffusae, in Asia et Nova-Hollandia tropica indigenae; foliis oppositis, latiusculis, integris, spicis terminalibus, densis, bracteis oppositis, latis, unifloris, floribus parvis, bibracteolatis $v$, rarius ebracteolatis. 
Nels onla R. Browa Prodr. 480. Nees in Wallich Plant. As. rar. III. 79. J u stici a e s p. Roxb.

4033. Adenosma $R . B R$. Cal y x quinquepartitus, lacinia postica majore $\mathbf{v}$, aequali. $\mathbf{C ~ o -}$ rolla hypogyna, ringens, labio superiore indiviso, inferiore trilobo, aequali. $\mathrm{S} t \mathrm{a} \mathrm{m}$ in a 4 , corollae tubo inserta, didynama, inclusa; a nt herae approximatae, biloculares, loculis parallelis. Ovari um biloculare, loculis multiovulatis. Sty. Ius simplex; stig m a bilabiatum, bilobum. Ca p$8 \mathrm{u} l$ a angusta, rostrata, bilocularis, polysperma, loculicide bivalvis, valvis medio septiferis. S e mi$\mathrm{n}$ a retinaculis destitnta. - Herbae annuae, in Asia et Nova-Hollandia tropica indigenae, glan. dulis conspersae, Menthae odore; foliis oppositis, ovalibus $v$. oblongis, crenatis $v$. denticulatis, floribus in axillis foliorum superiorum minorum sessili. bus, solitariis v. ternis, oppositis, spicam foliosam formantibus, calycibus bibracteolatis.

A de nosma R. Brown Prodr. 462. Nees in Wallich Plant. As. rar. III. 29. R uelli a ullig inos a Linn.

4034. Bbermeyera NEES. Calyx quinquepartitus, lacinia postica latiore, lateralibus angustioribus, Corolla hypogyna, infundibuliformis, limbo quinquefido, subaequali. S tamin a 4 , corollae tubo inserta, didynama, inclasa, omnia fertilia v. antica sterilia; a ntherae biloculares, loculis oblique transversis, divergentibus. 0 va ri u m biloculare, loculis pluriovulatis. Stylns simplex; stigma compressum, bilamellatum, lamella superiore latiore, truncata v. bifida. C a p s n l a oblonga, compressa, bilocnlaris, pleiosperma, loculicide bivalvis, valvis medio septiferis. Se min a retinaculis destituta.-Herbae indic ae; foliis oppositis, peliolatis, oblongis $v$. ovatis, racemis terminalibus abbreviatis, spiciformibus, floribus alternis, in bractearum axillis solitariis, bibracteolatis, pedicellis basi cum bractea connatis.

E bermeyera Nees in Wallich Plant. As. rar. IIT. 79. Endlieher Atakt. t. 28.

4035. Ery thracanthus NEES. C a l y $x$ profunde quinquepartitus, laciniis subaequalibus, ovatis, acuminatis. Coroll a hypogyna, infundi buliformis, limbo quinquefido, aequali, obtuso Stamina 4 , corollae tubo inserta, inclusa, didynama; antherae bilocnlares, loculis oblique divergentibas, muticis. Ovarium basi annulo constrictum, superne biloculare, loculis multiovulatis, ovulis horizontaliter patentibus, obtusis. Stylus simplex; stig ma bilamellatum, lamel lis angustis, superiore breviore, truncata. Capsula … - Fruticulus penangianus; caule foliisque oppositis, oblongo lanceolatis, pubescentiscabris, subtus rubicundis, racemulo terminali composito, bracteis floribusque subalternis, bracteolisque exiguis, setaceis, subaequalibus, calyce brevioribus. III. 80 .

E r ythracanthus Nees in Wallich Plant. As, rar.

4036. Cymmaeanthus NEES. $\mathrm{C}$ al yx magnus, coriacens, ultra medium quinquefidus. Corolla hypogyna, infundibuliformis, limbo quinquefido, aequali. S $\operatorname{tam}$ in a 4 , corollae tubo inserta, inclusa, didynama; a nthera e biloculares, sagittatae, loculis acqualibus. O varin m basi annulo einetum, biloculare, loeulis quadriovulatis, ovulis depresso-subrotundis. Styl a s simplex; stig ma compresso - bilamellatum, spirale. Capsula .... - Flanta mexicana, nondum descripta, floribus absque bracteis bracteolisque, e foliorum, in caulis et ramorum apicibus approximatorum axillis solitariis, oppositis, breve pedicellatis, pedicelis petiolisque basi connatis. p. 4 Gy.

G y $\mathrm{m} n \mathrm{a}$ a $\mathrm{n} t \mathrm{~h}$ a $\mathrm{s}$ Nees in Lindlef Introduct. edit, II.

TRIBUS IIT. ECHMATACANTHI Nees in Wallich Planc. As. rar. III. 75. R e tin acula uncinata, seminibus subtensa.

SURTEITUS H. HYGOPHILEAE Nees in Wallich Plant. As. rar. III. 75. Corolla ringens. Stamin a 4 v. 2 ; antherae biloculares, loculis parallelis, muticis. Cap su I a polysperma. Retina cula brevia.

403\%. Hemiadelphis NEES, Cal yx quinquefidus, lacinits inaequalibus. Cor oll a hypogyna, ringens, clausa, labio superiore bidentato, inferiore trifido. Stamin a 2, corollae tubo inserta, inclusa; filamenta basi dilatata, supra medium dente setaceo instructa, a n th er a e bilueulares, loculis parallelis, muticis, demum contortis. Ovari um biloculare, loculis multiovulatis. Stylus simplex; stigma bilobum, Capsula lanceolata, compressa, bilocularis, polysperma, loculicide bivalvis, valvis medio septiferis. S e m in a retinaculis subtensa. - Herba indica, repens, ramosissima ; foliis oppositis, elliptico-ablongis, glabris, spicis terminalibus, hirtis, corollis parvis, pubescentibus.

He $\mathrm{m}$ i a del $\mathrm{ph}$ is Nees in. Wallich Plant. As, rar. III. 80. Justicia polysperma Roxb.

4038. Physiehilus NEES. C a $1 \mathrm{y} x$ quinquepartitus, laciniis aequalibus, angustis. Corolla hypogyna, personata, labio superiore bifido, inferiore trifido, palato dense bullato. $\mathrm{S}$ t amina 4, corollae tubo inserta, inclusa, didynama, omnia fertilia, geminatim conjuncta; filamenta apice inflexa, a $\mathrm{n} t \mathrm{~h}$ era e biloculares, supra basim affixae, lineari.oblongae, loculis parallelis, contiguis, staminum breviorum minoribus. $O$ varium biloculare, loculis quadriovulatis. Stylus simplex; stigma indivisum, acutum. Ca p s u la oblonga, bilocularis, octosperma, loculicide bivalvis, valvis medio septiferis. S e min a orbiculata, compressa, retinaculis squamaeformibns subtensa. - Herba indica, humilis, diffusa, ramosa; foliis opposilis, subsessilibus, oblongo-lanccolatis, auctis, integerrimis, hirsutis, floribus axillaribus, subsessilibus solitariis, spicam terminalem subsecundam formantibus, bracteolis calycem aequantibus.

Physichilus Nees in Bot, Mag. Comp. 11, 310.

4939. Hy grophilla $R . B R$. C aly $\mathrm{x}$ tuhulosus, semiquinquefidus. Co r olla hypogyna, ringens, labio superiore bifido, inferiore trifido, medio convexo, ruguloso. Stamina 4 , corollae tubo inserta, inclusa, didynama, omnia fertilia; antherae biloculares, loculis parallelis, acutis v. breviter mueronatis. Ovarium bilocnlare, loculis multiovulatis. Stylus simplex; stigma indivisum, subulatum, incurvum. C a psula angusta, teretiusenla, sexstriata, bilocularis, polysperma, loculicide bivalvis, valvis medio septiferis. S e min a orbiculata, compressinscula, retinaculis brevibus, obtusis subtensa. - Herbae paludosae, caulescentes, in As ia et Nova-Hollandia tropica indigenae; foliis oppositis, lanceolatis $v$. oblongis, floribus axillaribus cymoso-glomeratis, versicillos integros $v$, dimidiatos formantibus, 
bracteis ciliatis, calycis demum quinquepartibilis laciniis hirtis $v$. barbatis.

H y grophila R. Brown Prodr, 479. Nees in Wallich Plant. As, rar, III, 80. Ru ellila ringens L. R. sa I i. eifolia Vahl R. barbata Vahl.

4040. Nomaplnilla $B L U M$. C a l y x quinquepartitus, inaequalis, lacinia postica majore. Corolla hypogyna, ringens, labio superiore fornicato, integro, inferiore trilobo, medio emargi. nato. Stamina 4 , corollae tubo inserta, exser. ta, didynama, omnia fertilia; an thera e bilocalares, oblongae, loculis parallelis, aequalibus, muticis. Ovarium biloculare, loculis multiovulatis. Stylus simplex; stig ma indivisum, acutum. C a p s u 1 a angusta, teretiuscula, bilocu laris, polysperma, loculicide bivalvis, valvis medio septiferis. S e m in a suborbiculata, compressa, retinaculis subtensa. - Herbae javanicae et $t i$ morenses; foliis oppositis, floribus axillaribus, cymosis, bracteolis calycibusque glanduloso-pilosis.

Nom a phila Blume Bijdr. 804, Decaisne in Nouv. An. nal, MLus. IIT, 387 .

SUIBTIEISUS 耳. RUELLIEAE Nees in Wallich Planc. As, rar. III. 75. Corolla limbo aequali v. subbilabiato. St a m in a $4 \mathrm{v}$. rarissime 2; anthera e biloculares, loculis saepissime parallelis. C a p su I a di-tetra-polysperma.

4041. Iyselnoriste NEES. C a l y x tabulosus, semiquinquefidus, aequalis. Co rolla hypogyna, infundibuliformis, limbo obliquo, quinquefido. Stamina 4 , corollae tubo inserta, inclusa, didynama; anthera e biloculares, loculis parallelis, aequalibus, basi mucronatis. Ovari u m biloculare, loculis biovulatis. Stylus simplex; stigma obsolete bilobum. Cap 8 ula oblonga, obcompressinscula, bilocularis, tetrasperma, apice Inculicide bivalvis, valvis medio septiferis. S e m ina ovata, obtusa, pellicula crassa, mucilaginosa involuta. - Fruticuli indic $i$, diffusi $v$. repentes; foliis oppositis, obovatis $v$. cuneiformibus, retusis, floribus in ramulo axillari brevissimo terminalibus, solitariis, sessilibus, bracteolis duabus foliiformibus stipatis.

Dyschoriste Nees in Wallich Plant, As. rar. III. 81. Ruellia littoralls Linn.

4048. Chaetaenntlaus NEES. C a lyx profunde quinquefidus, laciniis longis, setaceis, rigidis. Corolla hypogyna, infundibnliformis, tubo hine gibbo, limbo quinquefido. S $t$ a $m$ in a 2, corollae tubo inserta, inclusa; antherae biloculares, cordatae, loculis parallelis, muticis, 0 variu m biloculare, Ioculis biovulatis. Stylu 8 simplex; stigma bifidum. C apsula unguiculata, oblonga, depresso-tetragona, bilocularis, tetrasperma, loculieide bivalvis, valvis medio septiferis. Se min a ...... - Herba c apensis; foliis oppositis, ovatis, glabris, floribus axillaribus, solitariis, sessilibus, bibracteolatis, bracteolis calycibusque longissime setaceis, demum rigescentibus.

$\mathrm{C}$ h a et a $\mathrm{c}$ a $\mathrm{n}$ thus Nees in Lindleg Introduct. edit. IT. p. 445. Ruellia setigera Pers.

4043. Dipteraeanthus NEES. C a ly x profunde quinquefidus, a equalis. Corolla hypogyna, infundibuliformis, limbo quinquefido, subaequali. Stamina 4 , corollae tubo inserta, inclnsa, didynama; a ntherae biloculares, lineari-sagittatae, loculis parallelis, snhaequalibus.
Ovarium biloculare, loculis quadri-sexovulatis. Stylus simplex; stigma bilamellatum, basi nodulosum. Ca p su la unguiculata, subobcompressa, bilocularis, octo-dodecasperma, loculicide bivalvis, valvis medio septiferis, Semina orbiculata, compressa, margine tumido, discreto cincta, retinaculis uncinatis, praemorsis subtensa, - Herbae indicae, repentes, hirsutae; foliis oppositis, ovatis $v$, ellipticis, floribus axillaribus, solitariis $v$. fasciculatis, sessilibus v. breve-pedunculatis, bracteis duabus foliaceis, petiolatis, calyci $v$. fasciculo sub. jectis.

Dipteracanth us Nees in [Lindley Introduct, edit, II. p. 444.

4044. Apluragmia NEES. Cal y x quinquepartitus, laciniis inaequalibus, duabus angustioribus. Corolla hypogyna, infundibuliformis, limbo quinquefidu, aequali, obtuso. St a m in a 4 , corollae tuho inserta, didynama, inclusa; a ntherac biloculares, loculis angustis, parallelis, aequalibus. O va ri u m biloculare, loculis biovulatis. Stylns simplex; stigma bifidum. Ca psula unguisulata, dissepimento ineompleto subunilocularis, tetrasperma v, abortu disperma, loculicide bivalvis, valvis medio septiferis. S e min a retinaculis suffulta. - Herba mexicana; pedunculis axillaribus dichotomis, floribus in dichotomia sessilibus, bracteis divisionum foliaceis, foliis caulinis conformibus, bracteolis nullis.

A phragmia Nees in Lindley Introduct, edit. II. p. 404 .

4045. Petalialinm NEES. C a ly $\mathrm{x}$ quiaquepartitus, aequalis, bracteolis duabus valvatim inclusus. Corolla hypogyna, infundibuliformis, limbo quinquefido, aequali. $\mathrm{S}$ ta $\mathrm{m}$ in a 4 , corollae tubo inserta, inclusa, didynama; an therae biloculares, oblongae, sagittatae, loculis parallelis, aequalibus, basi aristatis. Ovarin m biloculare, loculis biovnlatis. Sty I u 8 simplex; stig ma bifidum, laciniis filiformibus. Ca p 8 u I a unguieulata, bilocularis, tetrasperma, loculicide bivalvis, valvis medio septiferis. S e mina ovata, acuta, compreasa, retinaculis uncinatis, subulatis subtensa. Frutex indicus, glaucescens; foliis oppositis, crenato-dentatis, floribus axillaribus, solitariis pedunculatis, $v$, in ramulo brevi fasciculatis, bracteolis magnis, corollis pollicaribus, extus glanduloso-pubescentibus, intus ad faucem hirsutis.

Petalidium Nees in Wallich Plant. As, rar. III. 82. Ruelli a barlerioldes Roth.

4046. Caloplaanes $D O N$. Cal y $x$ quin quepartitus, aequalis, laciniis setaceis, bracteolis duabus inclusus. Coroll a hypogyna, infundibuliformis, limbo quinquefido, subaequali. Sta min a 4 , corollae tubo inserta, subexserta, didynama; antherae biloevlares, oblongae, subsagittatae, loculis parallelis, aequalibus, basi aristatis. O va ri nm bilocnlare, loculis biovulatis. Sty I u s simplex; stigma indivisum, acutum. Ca p s n la teretiuscula, bilocularis, tetrasperma, loculicide bivalvis, valvis medio septiferis. S e min a ovata, acuta, compressa, retinaenlis uncinatis, subtens. Herbae boreali-americanae, erectae, sub. simplices; foliis oppositis, floribus axillaribus, solitariis, breve pedunculatis, corollis caeruleis, fauce maculata.

Calophanes Don in Sxeet Fl. Gard. II, 181, Rue I. Ii a blong if olla Miehx.

404\%. Taellia LINN. Caly $\mathrm{x}$ quinquepartitus, laciniis aequalibus v. subaequalibus. $\mathrm{C}_{0}$ 
rolla hypogyna, infundibuliformis, limbi quinquefidi, aequalis laciniis patentibus, obtusis. St amina 4 , corollae tubo inserta, didynama, inclasa; antherae oblongae, biloculares, loculis parallelis, aequalibus, muticis $v$. basi mucronulatis. Ovariu m biloculare, loculis tri-quadriovulatis. Stylus simplex; stigma subulatum, dorso canaliculatum, basi denticulo auctum. Ca p s u la oblongo-suhquadrangularis, bilocularis, sex-octosperma, loculicide bivalvis, valvis medio septiferis. S e min a retinaculis suffulta. - Herbae in Asia tropica, nec non in Nova-Hollandia tropica et $s u b t r o p i c a$ indigenae, caulescentes, pilosae; foliis oppositis, spicis axillaribus v. terminalibus, foliaceo-bracteatis, saepe in capitula contractis, bracteolis parvis $v$. nullis, floribus mediocribus.

R uelli a Liun. Gen, $n$. 784. exel. sp. R. Brown Prodr. 477. Nees in Wallich Plant. As, rar. III. 83.

4048. Plaleboplayllum NEES. C a 1 y $x$ quadripartitus, lacinia postica bifida. Corolla hypogyna, infundibuliformis, limbi quinquefidi lacinifs emarginatis, repandis. Sta m in a 2, corollae tubo inserta, inclusa; anthera e biloculares, loculis parallelis, muticis. Ovarium biloculare, loculis biovulatis. Stylus simplex; stigma subulatam, indivisum. C a psula unguieulata, bilocularis, tetrasperma ..... Planta indica, fruticosa; caule humili, quadrangulari, foliis oppositis, ovalibus, undato-serratis, supra lineolatis, hirtis, sublus venoso-reticulatis, albo-tomentosis, spicis axillaribus pedunculatis, alternis, ovatis, bracteis imbricatis, laxis, bracteolis geminis, angustis, corollis luteis. IIT. 83 .

Phleb ophyllam Nees in Wallich Plant, As. rar.

4049. Buteraen NEES. C a Iy $\mathrm{x}$ bipartitus, labio superiore breviore trifido, inferiore bifido v. bipartito. Corolla hypogyna, infundibuliformis, limbo subaequali, quinquefido, laciniis emarginatis. Stamina 4 , corollae tubo inserta, didynama, inclusa; antherae biloculares, loculis parallelis, aequalibus, muticis. Ovari um biloculare, loculis biovnlatis. Stylus simplex; stigma acutum. Capsula subunguiculata, tetragona, bilocularis, tetrasperma, loculicide bivalvis, dissepimento solubili, S em ina subrotanda, compressa, retinaculis subtensa. - Frutex indicus, ramosus; ramis novellis spicisque rufo hirsutis, foliis oppositis, petiolatis, inaequalibus, dentalo-crenatis, spicis axillaribus imbricatis, bracteis oppositis, latis, venosis, bracteolis parvis, corollis semipollicaribus, pallide violaceis, tubo gracili, incurvo, limbo ventricoso-campanulato.

Buterae a Nees in Wallich Plant, As, rar. III. 84. - P Ruellia rufescens Roth.

4050. Adenaeanthes NEES. C a 1 y x tripartitus, lacinia postica trifida. Corolla hypogyna, infundibnliformis, limbo subaequali, quinquefido, laciniis obtusis, Stamina 4, corollae tubo inserta, inclusa, didynama; anthera e biloculares, ovatae, magnae, loculis parallelis, Ovariu m biloculare, loculis biovulatis, ovu. lis compressis. Styius ..... - Herba birma$n i c a$; caule erecto, nodoso, ramis oppositis, gracilibus, foliis oppositis, inaequalibus, breve petiolatis, oblongo-laneeolatis, acuminatis, repandodentatis, glabris, utrinque glanduloso-punctatis, spica terminali pollicari, bracteis oppositis bracteolisque subconformibus, herbaceis.
Adenacanthus Nees in Frallich Plant. As. rar. III. 84.

4051. Steplanoplaysum POHL. CaIyx quinquepartites, aequalis. Corolla hypogyna, infundibuliformis, tubo gracili, limbo inflato-campanulato, quinquefido, laciniis subaequalibns, obtusis. St a min a 4 , corollae tubo inserta, subexserta, aequalia, basi per paria connatae; anthera e biloculares, oblongae, loculis parallelis. Ovari um biloculare, loculis quadrio. vulatis. Stylus simplex; stigma bifidum, laciniis acutis. Capsula unguiculata, lanceolatoelliptica, bilocularis, loculieide bivalvis, valvis medio septiferis. Sem in a ovata, compressa, retinaculis uncinatis subtensa. - Frutices brasilienses; foliis oppositis, oblongis, racemis axillaribus paucifloris paniculatis, bracteis bracteolisque exiguis, corollis rubicundis, speciosis.

Step ba no phy s u a Pohl Plant, Brasil, II. 83. 6. 155. 156.

4053. Stemosiplnonitum NEES. C aIy $\mathrm{x}$ aequalis, quinquefidas, marginibus membranaceis, demum quinquepartibilis, Corolla hypo. gyna, infundibuliformis, tubo gracillimo, limbo inflato-eampanulato, quinquefido, laciniis aequalibus, obtusis. Stamina 4 , corollae tubo inserta, inclusa, didynama; a th erae biloculares, anguste lineares, loculis parallelis, O vari n m biloculare, loculis quadriovulatis. Stylus simplex; $8 t$ ig m a dorso membranaceo-cristatum, apice subulatum. C a psula tetragono-columnaris, bilocularis, octosperma, loculicide bivalvis, valvis medio septiferis. S em in a lenticularia, mucronata, laeviuscula, retinacnla $\ldots \ldots-$ Frutices indic $i$; foliis oppositis, longe petiolatis, dentatis, spicis axillaribus et terminalibus, floribus oppositis, solitariis $v$, aggregatis, bracteis latiusculis, adpressis, rigidulis, bracteolis angustis, calyci consimilibus, corollis fauce maculatis. III. 84 .

Stenoslphonium Nees in Wallich Plant, As, rar.

4053. Strobilanthes BLUM. C a I y quinquepartitus, laciniis herbaceis. C or olla hypogyna, infundibuliformis, tubo sensim transennte in limbum campanulatum, quinquefidum, laciniis aequalibus v. subaequalibus, obtusis v, entarginatis. St a min a 4, corollae tubo inserta, inclnsa, didynama; antherae biloculares, loculis parallelis. Stylus simplex; stigma subulatum, incurvum $\mathbf{v}$, involntum, Ovari um biloculare, loculis biovulatis. C a ps u la subunguiculata, tetragono-colnmnaris, bilocularis, tetrasperma, locnlicide bivalvis, valvis medio septiferis $\mathbf{v}$. dissepimento soluto. S e m in a discoidea, angnlata, retinacnlis uncinatis subtensa. - Frutices $v$, rarius herbae, in Asia tropica crescentes; foliis oppositis, spicis axillaribus $v$. terminalibus, plus minus densis, bracteis foliaceis v. foliaceo-membranaceis, persistentibus $v$, caducis, bracteolis parvis $v$. rarius nullis, floribus majusculis, caeruleis $v$. albis.

Strobilanthes Blume Bijdr, 796. Nees in Thallich Plant. As. rar, III. 84.

a. Bustrobilanthes Nees $l, c, t$, 295, Capsula ses silis.

b. PTERACANThUS Nees $l$, c. C a p $s$ u l a unguiculatarRuellia alata Wallich op. cit. t. 31 .

c. SYMPAgIS Nees $l, c$, Stam in a basi la metubranau conflata, a n thera e breves, defloratas subquadratie, dipterae. 
4054. Stemsonall rimm NEES. C a 1 y $\mathrm{x}$ quinquepartitns, aequalis. Corolla hypogyna, infundibuliformis, tubo cylindrico, limbo brevi, quinquefido, laciniis subaequalibus, oblongis, obtusis. St a min a 4, corollae tubo inserta, didynama, faucem subaequantia; antherae uniloculares, lineares, durso et apice hirtae. Ova-ri um biloculare, loculis biovulatis. Stylus simplex; stigma acutum. Capsula oblonga, bilocularis, tetrasperma, loculicide bivalvis, valvis medio septiferis. S e mina echinata, retinaenlis suffulta.

Herba brasiliensis, inflorescentia Strobilanthi. p. 44i.

Stenandrium Nees in Lindley Introduct, edit. II,

4055. A echmanthera NEES. C a ly x quinquepartitus, aequalis. C oroll a hypogyna, infundibuliformis, limbi quinquefidi laciniis aequalibus. Stamina 4, corollae tubo inserta, inclusa; an thera e biloculares, apice mucronatae, loculis parallelis. Ovarium biloculare, loculis quadriovulatis. Stylus simplex; stig ma indivisum, dorso carinatum, C a p sula tetragona, bilocnlaris, octosperma, loculicide bivalvis, valvis medio septiferis. Semina lenticularia, laevia, retinaculis acutis subtensa, - Suffrutex indicus; caule ramisque novellis gossypino tomentosis, niveis, foliis oppositis, petiolatis, cordatis, crenato-dentatis, supra lineolatis, setoso-hirtis, subtus dense pubescentibus, incanis, capitulis bracteis bracteolisque subaequalibus cinctis, paniculato - v. corymboso-terminalibus.

A e chm ant bera Nees in Wallich Plant. As, rar. III. s7. Ruelliagossypina Wallich $O p, c i t, t$. 42 .

4056. Gold funsta NEES, C a l y $\mathrm{x}$ quinquepartitus, subaequalis. Corolla hypogyna, infundibuliformis, limbi quinquefidi laciniis aequalibus, obtusis. St amin a 4, corollae tabo inserta, inclusa, didynama, inferiora saepe brevissima, reflexa; antherae nutantes, biloculares, loculis in connectivo uncinato glanduloso obliquis, ovatis, membranaceis. O vari um biloculare, loculis biovulatis. S ty lus simplex; st ig ma subulatum, hine crenatum. Capsula sexangularis, bilocularis, tetrasperma, loculicide bivalvis, dissepimento solubili. S e m in a discoidea, retinacnlis subtensa. - Frutices indic $i$; foliis oppositis, penninerviis, floribus in capitulo paucis, bibracteolatis, bracteis deciduis, rarius spicatis, spica post bractearum delapsum elongata, capitulis pedunculatis, pedunculo simplici $v$. diviso.

Gold fus s la Nees in Wallich Plant. As, rar, III, 87. Bot. Mag. t.3404. R u elli a e s p. Roxb. Hooker Exot. Flor. $t, 191$.

405\%. Asystasia BLUM. Calyx quinquepartitus, aequalis. C o roll a hypogyna, subinfundibuliformis, limbi quinquefidi laciniis subaequalibus, postica concaviuscula. S tamina 4, corollae tubo inserta, inclusa, didynama; fil a m e nta basi per paria connata, an th era e biloculares, loculis angustis, parallelis, basi callosis v. appendiculatis. Ovarin m biloculare, loculis biovulatis. Stylus simplex; stigma capitatum, bilolum v. bidentatum. C a p su I a nnguieulata, tetragona, bilocularis, tetrasperma, loculicide bivalvis, valvis medio septiferis. S e min a discoidea, retinaculis subtensa. - Herbae v. fruticuli debiles, in Asia tropica crescentes; foliis oppositis, racemis spiciformibus, secundis, axillaribus v, terminalibus, bracteis bracteolisque exiguis, aequalibus.

Asystasia Blume Bijdr. 796. Nees in wallich Plant.
As. rar, III. 89. Ruelliae sp. Vahl, Roxb. Wallich $O_{p}$. cit, $t, 83$.

4058. Eehinaenthus NEES. Cal y $\mathrm{x}$ profunde quinquefidus, aequalis. Co rolla hypogyna, limbi quinquefidi laciniis aequalibus. St amina 4, corollae tabo inserta, inclusa, didynama; fil a m e nt a basi per paria connata, anth era e biloculares, sagittatae, oblongae, hirtae, loculis parallelis, basi calcaratis. O vari u m biloeulare, loculis multiovulatis. St ylu s simplex; st ig ma acntum. Capsula teretiuseula, bilocularis, polysperma, loculieide bivalvis, valvis medio septiferis. Semina cordato-subrotunda, retinaculis subulatis subtensa. - Herba nepalensis, simplex, erecta; foliis oppositis, petiolatis, basi cuneiformibus, subdentatis, superioribus sensim minoribus, cymis bifidis cum flore alari, ramis sursum secundifloris, in paniculam terminalem dispositis, bracteis angustis, bracteolis nullis.

Echinacanthus Nees in Wallich Plant, As, rar. 1II. 90. Ruellia at ten uat a Wall.

4059. Leptacanthus NEES. C a $\mathrm{y} x$ quinquepartitus, laciniis angustis, postica longiere, lateralibus brevioribus. C o rolla hypogyna , infundibuliformis, limbi quinquefidi laciniis inaequalibus, duabus posticis majoribus, adscendentibus. S ta m in a 4, corollae tubo inserta, inclusa, didynama; a $n t h$ e $r$ a e biloculares, cordatae, demum semiovales, loculis antrorsum parallele contiguis. O va rium biloculare, quadriovulatum, ovulis orbiculatis, retinaculis crassis sultensis. Stylus..... Capsula .... - Herbu indica; caule erecto, subsimplici, foliis oppositis, petiolatis, oblongis, floralibus ovato-acuminatis, minimis, floribus in panicula terminali trichotoma, ex axillis foliorum floralium pedicellatis, secundis, ebracteatis, corollis pollicaribus, speciosis.

Lepta e a th us Nees in Wallioh Plant. As, rar, III, 90. Ruellia rubie unda Wight.

SUIBTER in Wallich Plant. As, rar. III. 75. C aly x quadripartitus, laciniis antica et postica majoribus, lateralibus interioribus, nune bilabiatus v. quinquepartitus. Cor oll a infundibuliformis v. bilabiata. Stamina 4, pare altero brevissimo; a ntherae biloculares. Capsula ditetrasperma.

4060. Asterneantha NEES. Calyx quadripartitus, lacinia postica paulto majore, antica bidentata. Сото 11 a hypogyna, bilabiata, labio superiore bifido, inferiore trifido, basi bicalloso. Stamina 4, corollae tubo inserta, exserta, didynama; fil amenta per paria connata, anthera e biloculares, aequales, loculis parallelis, glabris, muticis. Ova rium biloculare, loculis quadriovulatis. Stylus simplex; stigma acuminatum. Capsula compressa, bilocularis, octosperma, Ioculicide bivalvis, valvis medio septiferis. Se mi na ovata, compressa, Jaevia, truncata, retinaculis parvis suffulta. - Herba indica, annua; foliis oppositis, lanceolatis, hirsutis, serrato ciliatis, spinis interpetiolaribus utrinque ternis, subulatis, floribus axillaribus sessilibus, bracteat is bracteolatisque, corollis pollicaribus.

Asteracantha Neen in Wallich Plant. As, rar. III. 90. Barleria 1 ongifolla Linn.

4061. Barleria LINN. Calyx tetraphyllus, foliolo postico et anties, interdum emar- 
ginato latioribus. Corolla hypogyna, infundihuliformis, tubo brevi v. elongato, limbo conice dilatato, quinquefido, lacinia postica breviore, S tamina 4, corollae tubo inserta, vix exserta, didynama; antherae biloculares, lineares, locolis parallelis, muticis, staminum breviorum saepe minores v. imperfectae. Ovarium biloculare, loculis biovalatis. Stylus simplex; stigma compresso-infundibuliforme, truncatum. C a p 8 ula subunguiculata, acuminato-eonica, bilocularis, tetrasperma $v$, abortu disperma, loculicide bivalvis, valvis medio septiferis. Semina ovata, testa floccosa, retinaculis crassis, concavis subtensa, - Herbae v. fruticuli, in Asia tropica crescentes; foliis oppositis, floribus axillaribus v. spicatis, bracteis latis v. angustis bracteolisque saepe ciliatis v. spinosis, corollis speciosis, caeruleis, albis v. lutescentibus, plus minus venosis.

B arleria Linn. gen, 785. excl. sp. Vahl Symb. $t .16$. Nees in Wallich Plant, As, rar. III. 91.

406\%. Hoplhostaehys POHL. Ca l yx quadripartitns, lacinia postica et antica, saepins bifida latiorilus. Coroll a hypogyna, tubulosa, bilabiata, labio superiore retuso, inferiore trifide. Stamina 4, corollae tubo inserta, exserta, didynama; antherae biloculares, oblongae, sagittatae, loculis parallelis, muticis. Ova ri um biloculare, loculis biovulatis. Stylus simplex; stigma emarginatum. Capsula bilocularis, te. trasperma, loculicide bivalvis, valvis medio septiferis. Semina ovata, retinaculis subtensa. Suffrutices brasilienses; foliis oppositis, petiolatis, spicis in apice caulis aggregatis, secundis, compressis, bracteis dorsalibus distiche incumbentibus, lutioribus, sterilibus, florigeris bracteolisque coloratis conformibus, subaequalibus, calyce colorato pallidiore brevioribus, corollis purpureis.

Lo phos ta eh ys Poht. Plant. Brasil. II. 93, t, 161163. Nees in Wallich Plant. As, rar, III, 94.

4083. Aetheilema $R, B R$. C a l y $\mathrm{x}$ quinquepartitus, lacinia postica maxima, hracteiformi. Corolla hypogyna, bilabiata v. ringens, labio superiore bidentato $\mathrm{v}$. bifido, inferiore trifido. Stamina 4, corollae tubo inserta, inclusa, didynama, per paria approximata; antherae biloculares, loculis parallelis, contiguis. Ovarium biloculare, loculis biovulatis. Stylus simplex; s t ig m a acutum. Cap s u la membranacea, bilocularis, tetrasperma, loculicide bivalvis, dissepimenti segmentis demum sponte bipartibilibus. Semin a compressa, retinaculis subtensa. - Herbae in Asia et Africa tropica indigenae; foliis oppositis, spicis $v$. racemulis axillaribus foliosis, bracteis in axillis foliorum alternis, secundis, biquinquefloris, venosis, bracteolis nullis.

A ctbeilem a R. Brown Prodr. 478. in not. Nees in Wallich Plant, As, rar. III. 94. Ruelli a imbricata Vahl.

4064. Geissomeria $L I N D L$. Cal $\mathrm{yx}$ pentaphyllus, foliolis imbricatis, postico majore. Corolla hypogyna, infundibuliformis, limbo quinquepartito, lobis subaequalibus, obtusis, antico barbato. St amina 4, corollae tubo inserta, subexserta, aequalia; an therae biloeulares, loculis parallelis, aequalibus, muticis, apicibus barbatis cohaerentes. Ovarin m unguiculatum, biloculare, loculis biovulatis. Stylus simplex; s tig ma infundibuliforme. Fructns ....... Herba brasiliensis; caule tetragono, foliis op- positis, spicis axillaribus terminalibusque, basi foliosis, dense imbricatis, bracteis nervosis, bracteolis subconformibus, brevioribus, corollis puniceis, velutinis, tubo longo, arcuato.

$\mathrm{G}$ ei s s o meria Lindley in Bot. Hez, $t, 1045$.

4085. Hepidagathis $W I L L D$. Calyx quadripartitus, lacinia postica maxima, antica minore bifida, lateralibus minimis. Co roll a hypogyna, bilabiata, labio súperiore integro, bidentato v, bifido, inferioreque trifido conformibus. $\mathrm{S} \mathrm{ta} \mathrm{m} \mathrm{i}$ n a 4 , corollae tubo inserta, inclusa, didynama, per paria approximata; an therae biloculares, loculis parallelis, contiguis. Ovarium biloculare, loculis biovalatis. S ty lus simplex; s tigma acutum. Ca p s I la membranacea, bilocularis, tetrasperma, loculicide bivalvis, valvis carina lignea septiferis, segmentis sponte haud bipartibilibus. S emina compressa, retinaculis subtensa. Herbae in Asia et Africa tropica, nec non in Antillis crescentes; foliis oppositis, spicis simplicibus v. glomerato-compositis, secundis, bracteis nervosis, unifloris, floribus bibracteolatis, corollis parvis.

Lep Id a g a th is Willdenow Spec. $I I T$. 400. R. Browa Prodr, 478, in not. Roxburgh Plant. Corom. $t$, 267. Nees in Wallich Plant. As, rar. III. 95. Delessert Ic. select. IV. t. 84. Ruelila fas cieulata Vahl.

4066. Newracanthus NEES. C a lyx bipartitus, labio superiore trifido, inferiore bifido. Cor olla hypogyna, bilahiata, sabringens, labio superiore bidentato, inferiore profunde trifido. S ta min a 4, corollae tubo inserta, inclusa, didynama; f il a ment a brevissima, a n ther a c parvae, biloculares, locnlis obliquis, ab apice filamenti pendulis, deorsum divergentibus, snperiore cristato piloso, staminum breviorum inferiore minore, incumpleto. Ovarin m biloculare, loculis biovnlatis. Sty lus simplex; stig ma laterale, oblongum. Capsula compresso-tetragona, bilocularis, tetrasperma, loculieide bivalvis, valvis medio septiferis. S e m ina ovato-subrotunda, compressa, laevia, retinaculis uncinatis subtensa, - Frutex indicus, ramosus, scaber; foliis oppositis, elliptico-oblongis, cuspidatis, in petiolum angusta. tis, venoso-reticulatis, spicis axillaribus oppositis, sessilibus, inaequalibus, telragonis, bracteis quadrifariam imbricatis, nervosis, bracteolis calyce duplo brevioribus, ciliatis, calycibus ciliato-plumosis, corollis parvis.

Neuracanthus Nees in Wallich Plant. As, rar. IIT. 97. Raelliatetragonostach ya Wall.

406\%. Corythaeanthus NEES. C a lyx bilabiatus, labiis aequalibus, integris. Coroll a hypogyna, ringens, labio superiore integro, inferiore amplo, trilobo. Stamina 2 , corollae tabo inserta; anther a e biloculares, subsagitta. tae, loculis parallelis, subaequalibus. Ova ri n m biloculare, loculis biovulatis. Stylus .... C a ps u la bilocularis, tetrasperma …. S a m in a compressa, retinaculis latis subtensa. - Planta brasiliensis, non satis nota; pedunculis axillaribus furcatim paucifloris, bracteis divisionum exiguis, bracteolis nullis.

Corythacanthus Nees in Lindley Introduct, edit. II. p. 448 .

SUITRIEUS IV. ACANTHEAE Nees in Wallich Plant. As. rar. III. 75. C a ly x quadripartitus, laciniis antica et postica majo- 
ribus. Coroll a unilabiata, basi cartilaginea. S tamina 4, subdidynama. Capsula di-tetrasperma.

4069. Blepharis JUSS. C al $\mathrm{x}$ quadripartilus, laciniis postica et antica bidentata majoribus. Corolla hypigyna, nnilabiata, labio antico, trifido, fauce cartilaginea, postice tridenticulata. S t a m in a 4, corollae basi inserta, sub. didynama; superiorum antherae uniloeulares, fil a mento adnatae, margine ciliato-barbatae, inferiorum oblique biloculares, in filamento obtaso laterales, sulstipitatae v. sessiles. Ovarium biloculare, loculis biovulatis. Stylns simplex; st ig ma bifidum. C a p 8 u l a bilocularis, tetrasperma v. abortu disperma, loculicide hivalvis, valvis medio septiferis. S e min a retinaculis subtensa. Herbae indicae, repentes, hispidae; folitis verticillatis, inaequalibus, mucronato-dentatis v. serrulatis, spicis imbricato-bracteatis, bracteis inferioribus vacuis, saepe aristato-ciliatis, flore terminali bibracteolato, bracteolis bracteisque conformibus $v$. difformibus.

Ble pharis Jussieu gen. 103. Nees in Wallich Plant. As, rar, III, 97. A canthl s p. Linn. Burm. Flor. ind. t. 48. $f$. 2. Vahl.

4069. IDIlivaria JUSS. Caly $\mathrm{x}$ quadripartitus, laciniis postica et antica paullo majoribus, basi callosis, omnibus integris. Corolla hypogyna, nnilabiata, labio trilobo, palato convexo, incrassato, margine postico integerrimo $\mathbf{v}$. tridenticulato. S t a m in a 4, corollae basi inserta, subdidynama; fil amenta conformia, anthe$r$ a e omnes uniloculares, adnatae, barbato-ciliatae. Ovarium biloculare, loculis biovulatis. Stylus simplex; st i $\mathrm{gma}$ bilobum. Capsnla memhranacea, compressa, bilocularis, tetrasperma, loculicide bivalvis, dissepimento ligneo, tandem soluto, apice dilatato, oblique truncato. S e m in a ovata, coimpressa, tuberculata, retinaculis crassis, obtusis, rectiusculis subtensa. - Frutices Asiae tropicae; foliis oppositis, repando-spinosis $v$. subintegerrimis, spica aphylla, bracteis subimbricatis, bracteolis geminis, subconformibus, mediocribus $v$, nullis, floribus speciosis.

D fllivaria Jussieu gen. 103. Nees in Wallich Plant. 18. rar. III. 98. A eanthis p. Linn. Vahl Symb. II. t, 40 . R. Brown, Waltich Plant. As. rar, $t, 178,-$ ? C heil op $x$ is Moquin Taudon in Annal. sc. nat. XXVII. 230. A ca n thus polystachius Delile in Caillaud Meroé t. 62,

40\% 0. BIEp harreant luus NEES, $\mathrm{C}$ a $1 \mathrm{yx}$ quadripartitus, laciniis antiea et postica oblongo-linearibus, majoribus. Cor oll a hypogyna, unilabiata, labio trilobo, basi interdum auriculato, margine postico integerrimo. St a $\mathrm{mina} 4$, corollae basi inserta; a n therae omnes uniloculares, barbato - ciliatae, staminum majorum adnatae, minorum in basi connectivi elongati, recti laterales, stipitatae. O v a r i a m biloculare, loculis biovulatis. Stylus simplex; stigm a bifidum. C'apsula.... - Frutices capenses, Acanthi facie; spicis terminalibus, $v$. propter ramulos brevissimos ad speciem axillaribus, bracteis imbricatis, spinosis, bracteolis linearibus, oppositis.

Blepharacanthus Nees in Lindley Introduct.edit. 1I. R. 444, A ca n thi s p. Thunb.

4021. Aeanthus TOURNEF. Calyx quadripartitus, lacinia postica et antica, apice bifida multo majoribus. Corolla hypogyna, unilabiata, labio trifido v. trilobo, basi interdom auriculato, margine postico integerrimo. $\mathrm{St}$ a $\mathrm{m}$ in a 4, corollae basi inserta, subdidynama; filamenta inferiora apice inflexa, antherae omnes uniloculares, eiliatae, staminum superiorum erectac, inferiorum in filamenti uneo transversae. Ovarium biloculare, loculis biovulatis. Stylus simplex; stigma bilobum. Capsula membranacea, bilocularis, compressa, tetrasperma, loculicide bivalvis, dissepimento ligneo, tandem soluto, apice dilatato, oblique truncato. S e mina ovata, compressa, tuberculata, retinacnlis crassis, obtusis, rectinsculis subtensa. - Herbae $v$. suffrutices, in regione mediterranea et in Asia tropica crescentes; folitis oppositis, inciso. v. repando-dentatis, dentibus spinosis, spica terminali aphylla, bractea dentato-spinosa v. setaceo-ciliata, bracteolis geminis.

A canthus Tournef. inst. 80. Linn, gen, $\pi$. 790, exct. 8p. Jussien gen. 103. Gärtner $r$. 253, $t$. 54. Sibthorp Flor. graec. $t$. 610, 611. Nees in Wallich Plant, As, rar. III, 98,

40\% \%. Aeanthodium DELILE, Calyx quadripartitus, laciniis postica et antica multo majoribus. Coroll a hypogyna, unilabiata, labio triloho, margine postico integerrimo. S'tamin a 4, corollae basi inserta, didynama; a $\mathrm{nth}$ c. ra e omnes uniloculares, ciliatae, ad bnsim connectivi elongati, reeti laterales, stipitatae. $\mathrm{O}$ varinm biloculare, loculis uniovalatis? Stylus simplex; stig ma bilobum. Capsula bilocularis, disperma, loeulicide bivalvis, valvis medio septiferis. Se min a compressa, sursum pilosa, retinaeulis uncinatis subtensa, - Suffrutex ae g y ptiacus, humilis ; foliis oppositis, ovatis, acutis, subsessilibus, dentato-spinosis, spicis quadrifariam imbricatis, rigidis, bracteis foliaceis spinosis, floręs superantibus, bracteolis setaceis.

A a a thodi um Delile Flor, aegypt. $t$. 33. $f$. 3.

SUBTRIBES v. JUSTICIEAE Nees in Wallich Plant. As. rar. III. 76. C al y $\mathrm{x}$ quinquefidus, rarius quadrifidus, lacinia postica saepe minore. Co rolla bilabiata v. ringens, rarius regularis. Stam in a 2 , antheris bilocularibus; v. 4, antheris omnium v. staminum breviorum unilocularibus. Capsula tetrasperma, rarius pleiosperma.

DIVISIO I. APHELANDREAE Nees $l, c$. St amina 2 v. varius 4 , antherarum loculis parallelis. C a p s u I a sessilis, tetra-polysperma.

4073. Crossandra SALISB. Calyx quinquepartitus, laciniis latis, interioribus brevioribus. Corolla hypogyna, subhypocraterimorpha, limbi plani, quinquepartiti laciniis snbsecundis. St a mina 4, corollae tubo inserta, inelusa, didynama; antherae nniloculares, hirtae, margine ciliatae. O vari um biloculare, loculis biovulatis. Stylus simplex; stigma ..... Capsula bilocularis, tetrasperma, loculicide bivalvis, valvis medio septiferis. Semina ovata, retinaculis subtensa. - Herbae indic a e; foliis ternatim v. quaternatim verticillatis, integris, saepissime punctatoscabris, spica terminali tetragona, bracteis oppositis, latis, membranaceis, bracteolis angustis, membranaceis, corollis speciosis, rubris.

C ros s and r a Salisbury Parad, 12, Bot. Reg. $t$. 69. Nees in Wallich Plant. As, rar, III, 98. H a r a $\mathrm{ch} i \mathrm{a}$ Jaeg, f, Eelog. 
t. 21. Justicla infandibuliformis Lina. R a ellia inf undibuliformis Andrews Bot. Neposit, $t, s i 2$.

40\% 4. Aplhelandra $R$. BR. C a I y quinquepartitus, inaequalis. Coroll a hypogyna, ringens, labio superiore subfornicato, bidentato, inferioris tripartiti laciniis lateralibus multo minoribus. St a m in a 4 , corollae tubo inserta, inclusa, didynama; an th era e uniloculares, muticae. Ovari um biloculare, loculis biovulatis. Styl us simplex; stigma bifidum. Ca p $\mathbf{s u l a}$ teretiuscula, bilocularis, tetrasperma, loculicide bivalvis, valvis medio septiferis. S e min a compressa, retinaculis subtensa. - Frutices America e tropica e; folius oppositis, spicis axillaribus et terminalibus tetragonis, bracteis oppositis, submembranaceis, bracteois angustis, corollis speciosis, rubicundis.

A phelandra R. Brown Prodr. 475. in not. Bot. Mag, t. 1578. Bot. Reg, t. 1477. Kanth in Humb, et Bonpl. Nov, gen. et sp. 11. 236. Hooker Ic. t. 113. S y n a ndr a Sebrad, in Neuwied Reise II. 343. H e $\mathrm{m}$ i to me Nees msc. J a s. ticia cristata Jacq. Hort. Schönbr. $t$. 320. J, p al. elier i m a Jacq. Ic, rar, t. 204.

40 5. The quepartitus, aequalis. Corolla hypogyna, bilabiata, fauce inflata, labio superiore lato, bifido, intus in canalem ntrinque barbatum decurrente, inferiore trifido. Stamina 2 , corollae tubo inserta; anthera e biloculares, loculis biovalatis. Stylus simplex; stigma bifidum. Capsula quadrangularis, suturis prominulis, dissepimento superne deliquescente incomplete biloeularis, tetraspermá, loculicide bivalvis, valvis medio septiferis. Semin a compresso-lenticularia, retinaculis subtensa. - Herbae indica ; foliis oppositis, dentatis $v$. crenatis, floribus spicatis, bracteis oppositis, latiusculis, imbricatis, bracteolis angus. tis, corollis speciosis.

End op og on Nees in Wallich Plant, As.rar, III, 98,

40\%6. Hoxamthus NEES. Cal y $\mathrm{x}$ quinquepartitus, aequalis, brevis Coroll a hypogyna, coriacea, tubulesa, tubo incurvo, limbi oblique quinquelobi lacinia infima profundius distincta. St a m in a corollae tubo inserta, duo fertilia; an $\mathbf{t h e r i s}$ bilocularibus, loculis aequalibus, paralielis, muticis, duo sterilia, brevissima, subulata, ananthera. Ov a ri $\mathbf{u m}$ biloculare, loculis multiovalatis. Stylus simplex; stigma bifidum. Cap\& ula bilocularis, polysperma, loculicide bivalvis, valvis medio septiferis. Se m in a retinaculis subtensa. - Frutex indicus, speciosus; ramis tetragonis, foliis oppositis, oblongo-cuneiformibus, integrerrimis, glabris, thyrso terminali, pedunculis bijidis, minute bracteolatis.

$\mathrm{L}$ o $\mathrm{x}$ a $\mathrm{n} \mathrm{t}$ h $\mathrm{u}$ Nees in Wallich Plant. As, rar. 11T. 89 .

4057. Phlogracantinus NEES. C a 1 y x quinquepartitus, aequalis. Corolla hypogyna, tubo trigeno, labio superiore latiore et longiore bifido, inferiore trifido. St am in a 2 , corollae tnbo inserta, duo fertilia; anthera biloculares, loculis parallelis, contiguis, demum hastato-divergentibus, muticis, duo sterilia, brevissima, ananthera, quandoque nulla. Ovarium bilocnlare, locolis quadriovulatis. Sty I us simplex; stigma bifidum. Ca p 8 ula compressa, unguiculata, bilocularis, octosperma, loculicide bivalvis, valvis medio septiferis. S e m in a retinaculis subtensa. - Fruticuli indici; foliis oppositis, supra minute papulosis, racemo terminali v. laterali, simplici $v$. trifido, spicaeformi, floribus verticillatoquaternis, bractea bracteolisque binis conformibus, angustis, elongatis, corollis speciosis, luteis $v$. fulvis.

$\mathrm{P}$ blog acanth us Nees in Wallich Plant. As. rar. IIT, 99. Justiciae sp. Roxb. Wallich Op. cit. $t$, 28. 112 .

40\%8. Cryptoplaragmitam NEES. Ca 1 y $x$ quinquepartitus, aequalis. Cor of l a hypogyna, bilabiata v, ringens, tnbo recto, labio superiore bifido, inferiore trifido. S $t$ a $m$ in a 2 , corollae tubo inserta; a n therae biloculares, loculis antice confluentibus. Ov a ri u m biloculare, loculis multiovulatis. Stylus simplex; stigma bifidum. Ca p 8 n la tetragona, bilocularis, polysperma, loculicide bivalvis, valvis medio septiferis. Se $\mathrm{min}$ a retinaculis subtensa. - Suffrutices indici; foliis oppositis, longe petiolatis, racemis $v$. spicis secundis aut glomerato-subverticillatis, bracteis bracteolisque parvis, subaequalibus.

Cryptophrag minm Nees in Wallich Plant. At. rar. III. 100, Bot. Mag. t. 3208. Justictavenu 8 ta Wallich Op. eit. $t, 66$.

Divisio II. GENDARUSSEAE Nees $l$. $c$. Stamina 2 v. rarissime 4 , antherarum loculis parallelis v. divergentibus. Capsula unguiculata, tetrasperma.

40\%9. Togtellaria NEES, C a 1 y $\times$ quadri-quinquepartitus, laciniis duabns superioribus saepe minoribus, quinta postica dum adest minima, Corolla hypogyna, bilabiata, labio superiore plano, truncato-bidentato, inferiore trilobo. Stamina 2 , corollae tubo inserta; antherae biloculares, loculis in connectivo apice incrassato obliquis, inferiore basi sterili in rostrum producto, superiore minore. Ovarium biloculare, loculis biovulatis. StyIns simplex; stigma bifidum. C a p s u la bilocularis, tetrasperma, loculicide bivalvis, valvis medio septiferis. Semina retinaculis brevibus, lamelliformibns subtensa. - Her. bae indica e, annuae $v$. perennes, saepe procumbentes, hirsutae; foliis oppositis, spicis terminalibus v. axillaribus, floribus decussatim solitariis, bibracteatis, bracteis calycis laciniis similibus is demque alternis.

Rostellaria Nees in Wallioh Plant. As, rar, III. 100. Justiciae sp. Auet.

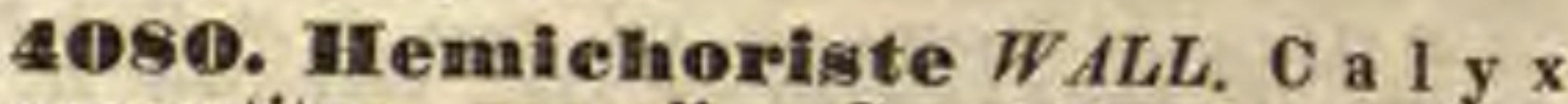
quinquepartitus, aequalis. Coroll a hypogyna, ringens, labio superiore integro, inferiore trifido, St a mina 4, corollae tubo inserta, didynama; an thera e longiornm biloculares, loculis connectivo dilatato diseretis, divergentibus, basi calcaratis, breviorum uniloculares, basi calcaratae v, rudimentariae. Ova ri u m nnguiculatum, biloculare, loculis biovulatis. Stylus simplex; stigm a obtusum, bifidum. C a p s $\mathrm{l}$ a ...... Herba indica, erecta, stricta, glabra; caule tetragono, fistuloso, foliis oppositis, oblongis, integerrimis, laete virentibus, thyrso elongato, e cymis oppositis subverticillato, bracleis bracteolisque latiusculis, remotis.

Hemichoriste Nees in Wallich Plant, As. rar. III. 108 .

4081. Graptoplayllum NEES. C a I y x quinquepartitus, aequalis. Coroll a hypogyna, ringens, labio superiore fornicato, recto, margine reflexo, inferiore trifido. Stamina 2 , corollae tubo inserta; anther a e biloculares, sagittatae, incurvae, locnlis parallelis, aequalibus, muticis, Ovarium biloculare, loculis biovulatis. Stylus 
simplex; st igma bifidum. Capsula rostrata, bilocularis, tetrasperma, luculicide bivalvis, valvis medio septiferis. S e $\mathrm{m}$ i n a retinaculis subtensa. - Suffrutex indicus; foliis oppositis, oblongis v. ovatis, cuspidatis, glabris, pictis, racemis axillaribus in racemum terminalem collectis, bracteis bracteolisque ad basim pedunculorum parvis, corollis laete purpureis.

Graptophyllum Nees in Wallich Plant, As. rar. III. 102. J usticia pieta Linn. Bot. Mag. $t$. 1870. Bot. Reg, $t, 1227$.

4082. Beloperome NEES. C a ly $x$ quinquepartitus, tubo aequali, laciniis latiusculis. Corolla hypogyna, ringens, tubo recto, labio superiore concavo, inferiore trifido. St a m i na 2 , corollae tubo inserta; antherae biloculares, loculis muticis $\mathbf{v}$, basi calcaratis, in connectivo semisagittato oblique divergentibus v. subcontigue superpositis. Ovarium biloculare, locnlis biovulatis. Stylus simplex; stigma subulatum. Capsula unguiculata, bilocularis, tetrasperma, loenlicide bivalvis, valvis medio septiferis. S em in a discoidea, colorata, retinaculis subtensa.

Herbae v. fruticuli, in Asia et America tropica crescentes; foliis oppositis, spicis axillaribus terminalibusque brevibus, secundis, floribus alternis, bracteis bracteolisque aequalibus, longis, angustis, corollis speciosis, coccineis.

Beloperone Nees in Wallich Plant, As, rar. III. 108. Justicia ob long a ta Liuk et 0tto Ic. select. $t$. 54 . J. pl um baginifolia Jaeq. f. Eclog. $t .12$.

4083. Gendarensen NEES.

$\mathrm{C}$ a 1 y $\mathrm{x}$ quinquepartitus, aequalis. Corolla hypogyna, ringens, tubo brevi, labio superiore fornicato, inferiore trifido, subaequali. Sta $\mathrm{m}$ in a 4 , corollae fauci inserta; antherae biloculares, loculis in connectivo rhombeo-lanceolato oblique superpositis, semiovatis, inferiore saepius calcarato. 0 v ari m biloculare, loculis biovulatis. Stylus simplex; stigma subulatum. Capsula unguiculata, bilocularis, tetrasperma, loculicide bivalvis, valvis medio septiferis. S e min a retinaculis subtensa. - Herbae $v$. frutices, interdum arborescentes, in Asia tropica et in Capitebonae spe $i$, rarius in $A$ me rica $t$ ropica indigeni; foliis oppositis, floribus spicatis.

Adhatoda et Gendarus sa Nees in Wallich Plant. As. rar. III. 102_-103.

a. ADHATODA Herm. Parad. 643, Bractea magnae, persistentes, calycem valvatim tegentes. Adbatoda Nees $l$. c. Jasticia Adhatoda Lian. Bot. Mag. t. 861. et J. B eto n i ca Linn.

b. GENDARUSSA Rumph Amboin. IV. $t$, 28. 29. B ractea plerumque parvae, deeiduae. Gendarussa Nees l. c. Justle la Gendar a s sa Lina. J, sp. Jacq. Hort. Schünbr. t. 3. Bot. Mag. t, 2266. Wallich Op, cit. $t$, 93. Jacq. f. Eclog, $t, 11$.

4084. Iillytiglossa NEES. C a 1 y $\mathrm{x}$ quinquepartitus, aequalis, Corolla hypogyna, ringens, labio superiore fornieato, incurvo, inferioris trifidi palato rugoso. St a min a 2 , corollae faci inserta, loculis transversim superpositis, discretis, mutieis. Orari n m biloculare, loculis biovulatis. Stylus simplex; stigma subulatum. Ca s sula unguiculata, bilocularis, tetrasperma, loculicide bivalvis, valvis medio septiferis. S e m in a retina culis sulitensa. - Suffrutices c upens es; foliis? op positis, spicis axillaribus et terminalibus, bracteis magnis, persistentibus, bracteolis parvis.

Rhytiglossa Nees in Linaley Introduct. edit. II. p. 444.
4085. Leptostaelaya NEES. Caly quinquepartitus, aequalis. Coroll a hypogyna, ringens, tubo brevi, fauce inflata, labio superiore late fornicato, inferiore convexo, trifido. Stamin a 2, corollae fanci inserta; an the ra e biloculares, loculis oblique superpositis, parallelis, muticis. 0 va ri n m biloculare, loculis biovulatis. Stylus simplex; stigma bifidum. Capsula unguiculata, snturis planis, apice compressa, bilocularis, tetrasperma, loculicide bivalvis, valvis medio septiferis. Semina muricata, retinaculis apice bifidis subtensa. - Fruticuli in Asia et America tropica crescentes; foliis oppositis, spicis gracillimis, e floribus distantibus, oppositis, glomeratis $v$. solitarïis, parvis, superioribus nonnunquam secundis, bracteis bracteolisque parvis, conformibus.

Le ptostachy a Nees in Wallioh Plant. As. rar. III. 105. J nsticiae s p. Jacq. Amer, t. 3, Edit, pict, t. 14 . Kunth, Wallich.

4086. Gymmostaelnyum NEES. CaI $\mathbf{x}$ quinquepartitus, lacinia postica breviore. Coroll a hypogyna, bilabiata, labio superiore angustiore bidentato, inferiore trifido. Stam i$\mathrm{n}$ a 2 , corollae tubo inserta, inclusa; a $\mathrm{n}$ ther a biloculares, loculis aequalibus, parallele contiguis, basi mucronatis. Ova rium oblongum .... S tylus simplex; stigma bifidum, laciniis compressis. Ca p sul a ...... - Herba indica; caule basi radicante, subtetragono, hirsuto, folits oppositis, oblongis, costatis, supra pilosis, racemo spicaeformi, gracili, subsecundo, floribus dissitis, brevissime pedunculatis, bracteis exiguis, subulat is, suboppositis, altera sterili paullo inferiore, bracteolis nullis.

G ymnos tachyum Nees in Wallich Plant. As, rar. IIT. 106.

DIVISE (1) III. ERANTHEMEAE Nees $l, c$. St amina 2, a n therae biloculares, loculis parallelis v. superposilis. C apsula longe unguiculata, di-tetrasperma.

408\%. Erantheman $R, B R \cdot C$ alyx quinquefidus, aequalis. Corolla bypogyna, hypocraterimorpha $v$, elongato-infundibuliformis, tubo gracili, longo, limbo quinquepartito, subaequali. Stam ina 2 , fertilia, corollae fauci inserta; antheris exsertis, bilocularibus, loculis parallelis, muticis, duo ananthera, inclusa. Ovarium biloculare, loculis biovulatis. Stylus simplex; tigma bifidum. Cap sula unguiculata, bilocularis, tetrasperma, loculicide bivalvis, valvis medio septiferis. S emina discoidea, retinaculis subtensa. - Herbae v. frutices gerontogei, tropici et subtropici, nec non in Antillis indigeni; foliis oppositis, floribus spicatis, dense $v$. laxe bracteatis, $v$. axillaribus, solitariis, bracteolis binis.

Era nthenam R. Brown Prodr. 476. Nees in Wal. ich Plant. As. rar. IIT, 106. Justictae $\mathrm{s}$, Lina. et Auet.

a. EURANTHEMUM. Spicne densae, bracteis snbfoliaceis. Species Indiae orientalis, Justicae sp. Vahl. Bot. Mag. t. 1358, Ruelli ia s p. Ventea, Cels. t. 46. (Andrews Bot. Reposit. t, 88,)

b. PLANETANTHEMUn. Spicae v. fascieuli laxi, bracteis parvis, sutulatis. - Species in Asia, Africa el Nova-Hollandia tropica et subtropica crescentes. Justiela e sp. Wallich $O p$, cit. $t, 92$. (Wallich $O_{p}$. cit. $t$, $2 t$. Bot. Reg. $t .876)$. 
c. HeSPERANTHEMUM. Pedunculi axillares, subuniflori. - Frutices antillani spinosi.

4088. Chameramthemum NEES. Ca I y $x$ quinquefidas, aequalis. Coroll a hypogyna, infundibuliformis, tubo gracili, longo, limbo quinquepartito, subaequali. S $t$ a in in a 4 , corollae fanci inserta, didynama, duo longiora subexserta; an theris bilocularibus, loculis parallelis, muticis, duo breviora inclusa, antheris unilocularibus, acutis. Ovari n m biloculare, loculis biovulatis. Stylus simplex; stigma bifidum. Ca p su ia unguiculata, bilocularis, tetrasperma, loenlicide bivalvis, valvis medio septiferis. Semina retinaculis subtensa. - Suffrutex brasiliensis; foliis oppositis, floribus laxe spicatis, bracteis bracteolisque parvis.

$\mathrm{C}$ h a merant he m $\mathrm{m}$ Nees in Lindley Introduct, edit. IT. p. 4 it5.

4089. Justieia NEES. Cal y $\mathrm{x}$ quinquepartitus, aequalis. Corolla hypogyna, infundibuliformi-bilabiata, tubo longo, labio superiore angusto, reflexo, inferioris trifidi laciniis aequalibus. Stamina 2 , corollae fauei inserta; a $\mathrm{n}$ the ris exsertis, bilocularibus, loculis parallelis, contiguis, basi subinaequalibus, mnticis. O $\mathrm{va-}$ ri n m bilocnlare, loculis biovulatis. St y lus simplex; stigma bifidum. Capsula unguiculata, cuspidata, bilocularis, abortu disperma, loculicide bivalvis, valvis medio septiferis. Semina cordata, compressa, tuberculata, margine elevato cincta, retinaculis uneinatis subtensa - Frutices Asia e tropicae; foliis oppositis, spica terminali, brateis herbaceis, latis, demum deciduis, floribus oppositis, solitariis, bracteolis parvis, subulatis.

Justici a Nees in Wallich Plant, As. rar, 1II. 108. Justici a Eebolium Lian. Bot. Mag. t, 1847.

4099. Ihhimaenthus NEES. Calyx quinquepartitus, aequalis. C orolla hypogyna, hypocrateriformi -subbilabiata, tubo longo, gracili, labio superiore angusto, integro, inferioris tripartiti laciniis aequalibus. St a min a 2, corollae fauci inserta; a ntheris subexsertis, bilocalaribus, Joculis serie lineari superpositis, muticis. Ovarinm bilocnlare, loculis biovulatis. Stylus simplex; stigma bifidum. C a p sn l a unguiculata, elavata, bilocularis, tetrasperma v. aborta disperma, loculicide hivalvis, valvis medio septiferis. Semina ovata, biconvexa, retinaculis suffulta. - Frutices indici; foliis oppositis, paniculis axillaribus in terminalem colleclis, trichotomis, ramis bijidis, floribus circa apices ramulorum glomeratis, albis.

Rhinacanthus Nees in Wallich Plant. As, rar, $I I T$. 108. Justicla nasuta Linn. J. calcarata Wallich Op. cit, t. 113.

TIREUS VI. DICLIPTEREAE Nees in Wallich Plant, As, rar. III. 76. C a 1 y $\mathrm{x}$ quinquepartitus, aequalis. Co r o 11 a bilabiata, saepe resupinata. Stamina 2 v. 4 , an thera uni-biloculares. Capsula tetra-octosperma.

4091. Blechuma $P . B R$, C al yx profunde quinquefidus, aequalis. Corolla hypogyna, infundibuliformis, tubo longo, limbi breviter quinquefidi lobis patulis, subaequalibus, rotundatis. St a mina 4, corollae tubo inserta, inclusa, didynama; a ntherae biloculares, ovales, loculis parallelis, muticis. Ovarium biloenlare, loculis quadri-pluriovulatis. St y las simplex; s tig ma bifidum. C a psu la ovata, subventricosa, bilocularis, dissepimento completo, octo-pleiosperma, loculicide bivalvis, dissepimentis demum a valvularum dorso solutis. S e m in a suborbiculato compressa, mucilaginosa, retinaculis subtensa. Herbae in America tropica et in Manillis crescentes; foliis oppositis, spicis subtetragonis, bracteis foliaceis, magnis, bracteolis geminis, parvis, corollis caeruleis.

B lec h и in P. Browne Jamaic. 261. Jassieu in Annal. Mus. IX, 269. Kunth in Humb, et Bonpl. Nov. gen. et sp. II. 238. Nees in Wallich Plant. As. rar. III. 109.

4092. Tungia NEES. C a $1 \mathrm{y} x$ quinque. partitus, aequalis. Coroll a hypogyna, bilabiata, labio superiore bidentato, inferiore trilobo, palato biplieato, Stamina 2 , corollae fauei inserta; a n therae exsertae, biloculares, loculis oblique snperpositis, inferiore basi appendice orbiculata lamellari. O variu m biloculare, loculis bievnlatis. Stylus simplex; st igma bifidum. Capsu la bilocnlaris, dissepimento mesubranaceo incompleto, tetrasperma, loculieide bivalvis, septis demum cum valvarum parietibus a carina persistente solutis. S e m in a compressa, concentrice rugosa, retinaculis subtensa. - Herbae v. suffrutices Asiae et Americae tropica ; foliis oppositis, spica quadrifariam bracteata, bracteis margine membranaceis, serierum duarum superiorum vacuis, inferiorum unifloris, bracteolis oppositis, linearibus, calyce vix longioribus, calycis laciniis linearibus, ciliatis, membranaceis.

R ungia Nees in Wallich Plant, As, rar. ITr. 109. Diclipterate seet. 3. Jussieu in Annal, Mus, IX, 268. Justicla repens Linn. J. peetinat a Roxburgh Plant.
Carom. $t$. 133.

4053. Diellptera JUSS. C a I y quinquepartitus, aequalis. C o ro 11 a hypogyna, resupinata, bilabiata, labio superiore (antico) integro v. bidentato, inferiore (postico) tridentato. S $\mathrm{ta}$ $\mathrm{m}$ in a 2 , corollae tubo inserta; antheris bilocularibus, loculis altero pone alterum positis, semiovatis, muticis. Ovarium biloculare, loenlis biovalatis. Stylus simplex; stigma bifidum. Ca ps u l a sessilis v. unguiculata, bilocularis, dissepimento incompleto, loculicide bivalvis, septis demum a dorso valvarum basi bifidarum solntis. S emin a discoidea, retinaculis uncinatis suffulta. - Herbae $v$. suffrutices Asia e et Americae tropica e; folitis oppositis, floribus in capitulis bractealis sessilibus, capitulis bracteis pluriseriatis, exlerioribus binis, oppositis, majoribus involucratis, in umbellas axillares terminalesque flabellatim dispositis.

Dieliptera Jussien in Annal. Mus. IX. 267. excl. sect. 3, et 4. Nees in Wallich Plant, As, rar. III, 111.
Dianthera Solander ex R. Brown Prodr. G76. Diantherae sp. Ruiz et Pavon Flor, Peruv. $t$. 14. Jus ticia chi uensis Vahl et Auct.

4094. Amplaiscepia NEES. C a ly quinquepartitns, aequalis. Coroll a hypogyna, ringens, labio superiore bifido, inferiore trifido. S $t$ amina 2, corollae tubo inserta; a ntheris bilocularibns, loculis muticis, connectivi elongati ernra terminantibus, altero sursum spectante. 0 vari um biloculare, loenlis biovulatis. Stylus simplex; $8 \mathrm{tig}$ ma indivisum. Cap $s \mathrm{ula}$ anguieulata, bilocularis, tetrasperma ..... S e min a retinaculis latis, truncatis subtensa. - Fruticulus brasiliens is, e basi repente adscendens; foliis oppositis, oblongis, utrinque acuminatis, spicis ter- 
minalibus compositis, secundis, bracteatis, bracteis floralibus latis, pedicello brevissimo connalis, oppositis exiguis, bracteolis parvis.

$A \mathrm{~m} p$ h i s e o p i a Nees in Wallich Plant, As, rar. III. 118.

4ODS. Feristroplne NEES, C a $1 \mathrm{y} x$ quinquedentatus $\mathbf{v}$, quinquepartitus, aequalis. $\mathbf{C}_{\mathbf{0}}$ rolla hypogyna, resupinata, tubo longo, limbi bilabiati labio superiore (antico) integro v. bidentato, inferiore (postico) tridentato. S $t$ a m in a 2 , corollae tubo inserta; antheris bilocularibus, loculis angustis, oblique altero pone alterum positis, diretione parallelis, maticis, demum contortis. Ovarium biloculare, loculis biovulatis Stylus simplex; stigma bifidum. Capsula unguiculata, compressa, bilocularis, tetrasperma, loculieide bivalvis, valvis medio septiferis. S e m ina discoidea, retinaeulis nneinatis subtensa. Herbae v. suffrutices Asiae tropicae; caule ple. rumque sexangulari, ad nodos carnoso, capitulis florum involucro bivalvi inclusis, in umbellas axil. lares et terminales, simplices $v$. compositas disposilis.

Peristrophe Nees in Wallich Plant. As. rar. III. 112. Justicia tinctoria Roxb. J. speciosa Roxb. Bot. Mag. . 1722. J. I a ue eola r I a Roxb. J. b I ealy cu Iat a Valt. J. Iigulat a Lam. t. 12. $f$. 2. Cav. Ic. t. 71 .

4096. Sautiera DECAISN. Calyx tu bulosus, quinquefidus, subaequalis, C oroll a hypogyna, infundibuliformi bilabiata, labio superiore fornicato-bilobo, inferiore trilobo. Sta min a 4, corollae tubo inserta, exserta, didynama; filamenta basi in tubulum connata, antherae biloeulares, locnlis aequalibus, parallelis. O vari um biloculare, loculis biovulatis. Stylu s simplex; stigma bifidum. Capsula unguiculata, compressiuscula, bilocularis, tetrasperma, loculicide bivalvis, valvis medio septiferis. Se mina discoidea, hirsuta, retinaculis uncinatis subtensa. Herba timorensis, suffruticosa; ramis teretibus, ad nodos incrassatis, foliis oppositis, cymis ad ramulorum apices axillaribus, subsessilibus, foliis delapsis spicam mentientibus, floribus majusculis.

S a utier a Decalsue in Nouv, Annal. Mus, III. 383.

40D\%. Hypoestess SOLAND. Invola c ru in tetraphyllum $v$. quadrifidom, tri-uniflorum. C a I y $x$ quinquefidus $v$. quinquepartitus, aequalis. Coroll a hypogyna, bilabiata, labio superiore angustiore, integro, inferiore trifido. Stamina 2 , corollae fauci inserta, exserta; antheris unilocularibus, in connectivo angusto gnblateralibus. Ovarium biloculare, loculis biovulatis. Sty lus simplex; stigm a bifidum. Ca p\& $\mathrm{l}$ a bilocularis, tetrasperma, loculicide bivalvis, valvis medio septiferis. S e min a ovata, compressa, tuberculata, retinaculis subulatis subtensa, Herbae v. suffrutices As ia e tropica e; foliis oppositis, capitulis florum tri-v. abortu unifloris, involucris tetraphyllis, foliolis cruciatim oppositis, liberis v. basi connatis, in umbellulas simplices $v$. compositas dispositis.

H y poestes Soland ex R. Brown Prodr. 474. Nees in Wallich Plant. As, rar. Irt. 114. Just le ia e p. Lina. Vahl. Mier a $\mathrm{t}$ hus Wendl. Obs.39. Pha glopsis Willd. $\mathcal{S}_{\text {P. }}$ III, $4 \mathrm{~S}$.

4098. Ehaphidespora NEES. Cal $\mathrm{x}$ parvas, quinquefidus, aequalis, Corolla bypogyna, resupinata, bilabiata, tubo reenrvo, labio
superiore (antico) concavo, inferiore (postico) lasuperiore (antico) concavo, inferiore (postico) la-
tiore, trifido. Stamina 2 , corollae fauci inserta, exserta; a ntherae biloculares, loculis su- perpositis, superiore breviore, inferiore basi calcarato. O va rium biloculare, loculis biovulatis. Stylus simplex; stigma bifidum. Capsula unguiculata, bilocularis, tetrasperma, loculicide bivalvis, valvis medio septiferis, S e min a discoidea, echinato-hispida, retinaculis nneinatis subtensa. - Herba indica, glabra, laxa; foliis oppositis, ovatis, longe acuminatis, obtusis, floribus ternato-capitatis, lateralium abortu solitariis, bracleis bracteolisque cinctis, corollis parvis.

$\mathrm{R}$ haphidospora Nees in Wallich Plant, As, rar. III. 11S. Justicia gla bra König.

TREIMUS VII. ANDROGRAPHIDEAE Nees in Wallich Plant. As. rar. III. 77. Calyx quinquefidus. Corolla bilabiata v. ringens, saepius resupinata. S t a min a 2 v. 4 , antherae uniloculares v. biloculares, loculo inferiore barbato. Capsula sessilis, pleiosperma.

4099. Erianthera NEES. C a l y $x$ quinquepartitus, aequalis. C orolla hypogyna, bilabiata, labio superiore latiore, integro, inferiore bifido. S $t$ a m in a 4 , corollae tubo inserta, exserta; antheraram loculo superiore pollinifero, inferiore in barbam lanosam soluto. Ovarium biloculare, loculis tri-pluriovulatis. S ty I u s simplex; stigma capitatum, parvum. Capsula oblonga, depressa, bilocularis, hexa-pleiosperma, locnlicide bivalvis, valvis medio septiferis. S emina angulata, retinaculis lirevibus suffulta. Suffrutices indici, humiles; foliis oppositis, pedunculis axillaribus, uni-bifloris, floribus ebracteolatis.

Erianthera Nees in Wallich Plant. As. rar. IIT. 115 .

410Q. Haplanthus NEES, $\mathrm{C}$ a $1 \mathrm{y} \mathrm{x}$ quinquepartitus, aequalis. Coroll a hypogyna, subinfundihuliformis, tubo incurvo, limbo quinquefido, subbilabiato. St a mina 2 , corollae tubo inserta, inclusa; fil amenta basi introrsum dilatata, antherae uniloculares, connectivo loculoque altero abortivo tomentosis. O varium biloculare, loculis multiovalatis. St y Ins simplex; stigma acutum. Capsula linearis, depressa, bilocularis, polysperma, loculieide bivalvis, valvis medio septiferis. Semin a parva, angulata, retinaculis suffulta. - Herba in dica, e basi procumbente adscendens, racemo terminali, tripartito, subspicato, bracteis bracteolisque parvis, subulatis.

H a p I a th us Nees in Wallich Plant. As, rar, III, 115.

101. Andrographis WALL, Cal $\mathrm{yx}$ quinquepartitus, aequalis, laciniis angustis. Corolla hypogyna, bilabiata, labio superiore integro v. bifide, inferiore trifido. S tamin a 2, corollae tubo inserta; anthera e biloculares, loculis parallelis, basi barbatis. Ovarinm bilocnlare, loculis bi-multiovulatis. Stylus simplex; stigma acutum. Capsula ovalis v. lanceolata, depressa, bilocularis, tetra-polysperma, locnlicide bivalvis, valvis medio septiferis. S e mina ovalia, obtusa, teretiuscula, basi oblique truncata, alveolato-scrobiculata, retinaculis pedicellatis, dilatato squamaeformilus, deciduis suffulta. - Herbae annuae v. perennes, interdum suffrutescentes, in As ia tropic a indigenae; foliis oppositis, racemis axillaribus, gracilibus, simplicibus v. di-tricholomis, secundis, bracteis duabus oppositis, calyce brevioribus, bracteolis nullis. 
A a drograp his Nees in Wallich Plant, As, rar, IIT. 116. Justicia paniculata Burm. J. e chioides Lina.

\section{GENERA DUBIA.}

4102. Clistax MART. C a ly $x$ intra bracteolas geminas coriaceas, valviformes minimus, membranaceus, annularis. Corolla hypogyna, ringens, labio superiore concavo, subemarginato, inferiore trilobo. St amina 2 , corollae tubo inserta; a n therae biloculares, loculis disjunctis. Ovarium biloculare, loculis biovulatis. Stylus simplex; stig ma obsoletum. C a p s n l a bilocularis .... S e min a retinaculis subtensa? - Herba brasiliensis, annua; foliis oppositis, petiolatis, cymis axillaribus paucifloris, pedicellis basi unibracteatis, medio bibracteolatis.

C 1i st a x Martius Nov. gen, et sp. III, 26.

4103. Staurogyne $W A L L$. Cal y $\mathrm{x}$ quinquepartitus, tribracteatus, laciniis aristato-acuminatis, inaequalibus. Corolla hypogyna, tubulosa, limbi breviter quinquelobi lobis obtasis, duobus inferioribus paullo minoribus. S $t$ a $m$ in a 4 , corollae tubo prope basim inserta, didynama, in clusa; a n therae biloculares, loeulis retroflexis, parallelis, basi connectivo brevi elavato conjunctis, superne distinctis. Ovarinm biloculare; ovala in placentis linearibus medio dissepimento ntrinque insertis plurima, patentia. Stylus filiforformis, simplex; stigma infundibuliforme, trilobum, lobis subulatis, patentibus. Fructus.... - Herba indica; caule carnoso ramisque oppositis teretibus, foliis oppositis, oblongo-v. lineari-lanceotatis, petiolatis, integerrimis v. obsolete crenatis, subtus argenteo-nitentibus, racemo terminali subcapitato, puberulo.

St a urogyne Wallich Plant, As, rar, II, 80, t. 186.

GENERA VIX NOTA.

BRILlANTAISIA Palis, Flor, Oxar, II, t. 100, C a l y x quinquepartitus, inaequalis. Corolla bilabiata, labio superiore fornieato, bidentato, inferiore tridentato, basi exteriore gibbo. Stamin a 4 , quoram duo longiora fertilia; anthe $r$ is oblongis, bast bifidis, divergentibus, duo bre. vlora antheris sterilibus. St y I us simplex; s tig m a bifidum. CapsuIa bilocularis, dissepimento adnato, loculis polysperais. - Planta Africae tropicae; caule erecto, quadrangulari, folits oppositis, basi in petiolum alatum attenuatis, ovato-lanceolatis. acutissimis, dentatis, ner vosis, floribus paniculatis, violaceis.

BANJOLEA Bowdich Madeir. 396. C a 1 y x quadrifidus unibracteatus. Corolla hypogyna, quadriteda, irregularis, lobis sinuatis. Stamina 2. Stylus unus, stig ma te simplici. Ca p su la bilocularis, polysperma. - Herba ma. deirensis, hirsuta; folits oppositis, ovatis, spicis axil. laribus, imbricatis, corollis violaceis.

Meiss a r rhe na R. Brown in Salt, Trav, LXIT, genus nondum deseriptum.

\section{Ordo CLI. Bignomiacene.}

BIGNONIAE Jussieu gen, 137. exel. gen. Annal, Mus. $\boldsymbol{X}$. 342. BIGNoniaCeAE R. Brown Prodr. 470 . Kunt in Journ. Phys. LXXXVII. A4A_454. exel, gea. Bartling Ord. nat, 185. Lindley Introduct, edit. II. p. 282.

Arbores v, frutices, saepe volubiles v. scandentes, rarius HERBAE. Folia opposita, interdum ternatim verticillata, rarius alterna, simplicia, conjugata, ternata, digitata, simpliciter v. composite impari-pinnata, nune abruptim pinnata, saepe petiolo in cirrhum simplicem aut ramosum producto, rarissime pinnatifida, plerumque integerrima. S tip ul a e nullae.

Flores hermaphroditi, plerumque irregulares, saepius speciosi, terminales, rarius axillares v. alares, interdum oppositifolii, paniculato-racemosi v. spicati, rarius solitarii.

Calyx liber, gamophyllus, subcampanulatus v. spathaceus, corolla multo brevior, persistens aut deciduus, limbo rarius truncato, integerrimo, plerumque plus minus profunde quinquediviso, interdum bipartito $\mathbf{v}$. bilabiato, rarissime bracteolis tubo adnatis duplici.

Coroula hypogyna, gamopetala, decidua, campanulata, infundibuliformis v. tubulosa, tubo brevi, fauce ampla, ventricosa, palato saepius punctato v. maculato, limbo quadri- v. quinquediviso, rarius regulari, saepissime bilabiato, labio superiore plerumque breviore, bilobo v. lobis connatis integro, erecto v. $r e-$ flexo, plano v. interdum fornicato, inferiore majore, rarissime minimo, trilobo, lobo medio plerumque majore, saepissime patente.

Stamina corollae tubo inserta, ejusque lobis alterna, inclusa v. rarius exserta, rarissime omnia fertilia, plerumque quinto postico rudimentario v, interdum penitus supresso quatuor didynama, rarius lateralibus abortivis duo. Fil a m ent a e basi plus minus lata angustata, filiformia. Antherae biloculares, loculis aequalibus, divaricatis, rarịus parallelis, basi tantum discretis, longitudinaliter dehiscentibus.

Ovarium annulo carnoso cinctum, e carpidiis duobus compositum, nunc carpidiorum marginibus planis, dissepimenti laminaeformis margini adnatis, v. dissepimenti marginibus mediis carpidiis insertis, eorumque marginibus valvatim connatis biloculare, nunc carpidiorum marginibus in dissepimentum introflexis, nervoque medio prominulo columnam centralem placentiferam contingentibus quadriloculare, rarius placentis carpidiorum nervo medio adnatis, marginibusque valvatim connatis uniloculare. Ovula plurima, dissepimenti marginibus v. paullo intra marginem utrinque inserta, horizontalia, rarissime pendula v. e dissepimenti basi adscendentia, anatropa. Stylus simplex; stigma bifidum v. bilamellatum, rarissime simplex,

Capsula coriacea v, lignosa, saepe compressa, siliquaeformis, nunc bilocularis, bivalvis, valvis planis v. rarissime navicularibus, dissepimento parallelis v. contrariis, rarius 
semisepta placentifera gerentibus; nunc quadrilocularis, septicide bivalvis, columna seminifera tandem libera; nunc unilocularis, bivalvis, valvis medio placentiferis.

Semrsa plurima, in generibus legitimis transversa, foliaceo compressa et saepissime undique $\mathbf{v}$. basi et apice in alam membranaceam, integram v. interdum papposo laceram expansa; in anomalis pendula- $v$. interdum adscendentia, alata $v$. etiam aptera, testa membranacea v. interdum coriacea, endopleura saepius tumida. A l b um en nullum.

Emвryo orthotropus, saepissime foliaceus. Cotyledones in legitimis reniformes, saepius emarginato-bilobae. R a dicula teretiuscula, umbilico proxima, centrifuga, rarius supera v. infera.

Bignoniaceae florum decore insignes, in regionibus tropicis totius orbis magno numero generantur, in America multo frequentiores; paucae regiones subtropicas Americae utriusque, Africae australis et Novae Hollandiae incolunt.

Ordo nisi Sesameas Pedalineis affines, et Eccremocarpeas Incarvilleasque ad Cyrtandraceas accedentes, invita natura excludere, et in proprios ordines erigere velis, vix definiendus; interim Sesameae fructus consistentia a Pedalineis, Eceremocarpeae et Incarvilleae habitu facile a Cyrtandraceis distinguentur.

Metternichia genus nulli cognitorum (nisi fortassis Ferdinandusae, seminum fabrica ignota summopere dubiae) cognatum, a Solanaceis et Convolvulaceis quibus a nonnullis adnumeratur, toto coelo differt. Wightia fortassis Scrophularineis aliquatenus accedit.

Genera quaedam dubia, ad ordinis calcem rejecta, olim cum melius fuerint cognita, anomalorum veras necessitudines uberius illustrabunt.

SUBORID I. SESAMEAE. Cap sula valvarum marginibus in dissepimenta introflexis, et nervo medio prominulo columnam centralem quadrifariam seminiferam attingentibus quadrilocularis, septicide bivalvis. Semin a adscendentia v. horizontalia, aptera v. membranaceo marginata. Ra dic ula infera v, centripeta. _ Pedalineis affines.

4104. Cerratotheea ENDL. Calyx quinquepartitus, lacinia postiea minore. Corolla lypogyna, tubo brevi, fance campanulata, limbi qninquelobo bilabiati lacinia antica majore. Stamina 4, corollae tabo inserta, quatuor didynama, absque rudimento quinti; antherae biloculares, loculis parallelis, bssi distinctis. O varium truncatum, compressum, carpidiornm mąrginibus introflexis et nervo medio prominulo coJumaam centralem attingentibus quadriloculare, ovulis e loculorum angulo centrali plurimis, uni- seriatis, adscendentibus, anatropis. Stylus simplex; stigma bilamellatum. Capsula planocompressa, truncata, apice angulis quadricornis, quadrilocularis, septicide bivalvis, columna seminifera libera. Senina plurima, erecta, compressa, cartilagineo-marginata. E m b r y o n is exalbuminosi, orthotropi radienla infera. - Herbae $A f r i$ cae tropicae, mucoso-pruinosae; caule erecto, tetragono, folits oppositis, petiolatis, angulatis, grosse dentatis, pedunculis axillaribus brevibus, oppositis, solitariis, unifloris, basi bibracteolatis, bracteolarum axillis glanduliferis.

Cerato the a Endlieher in Linnaea VIT, 1. $t .1,2$. Alakt, $t .5$.

4105. Sesamum LINN. C al yx quin-i quepartitus, lacinia postica minore. Corolla hypogyna, tubo brevi, fauce campannlata, limbi quinquelobo bilabiati lacinia antica majore. Sta$m$ in a corollae tubo inserta, quatuor didynama, cum rudimento quinti; a ntherae biloculares, loculis parallelis, basi distinctis. O varium acntum, teretiusculum, carpidiorum marginibus introflexis et nervo medio prominulo columnam centralem attingentibus quadriloculare, ovulis e loculorum angulo centrali plurimis, uniseriatis, adscendentibus v. horizontalibus, ŚtyIus simplex; stig ma bilamellatum. C ap sula linearioblonga, acuminata, compresso - tetragona, quadrilocularis, septicide bivalvis, columna seminifera tandem libera. S emin a plurima, erecta, horizentalia, compressa, aptera; v. angnlata, membranaceo-marginata. Emb ry o nis exalbuminosi, orthotropi radicula infera $v$, centripeta. - Herbae in Asia et Africa tropica indigenae; mucoso-pruinosae, una ob oleum quod e seminibus elicitur in regionibus subtropicis tropicisque culta, nunc per orbem divulgata; foliis oppositis v. alternis, petiolatis, integris v. trifidis, pedunculis axillaribus brevibus, oppositis, solitariis, unifloris, basi bibracteolatis, bracteolarum axillis glanduliferis.

S e 8 в m u m Linn. gen. n. 782. Gärtner II, 132. Kuath in Journ, Phys, LXXXVII, 452 ,

a. EUSESAMUM, $S \in \mathrm{m}$ in a eompressa, Immarzinata, (Gärt. ner t. 110. Bot. Mag. t. 1688. DC. Plant, rar. hort. Genev, t. 5.)

b. SESAMOPTERIS. $\mathrm{s}$ e mina nngulata, margine membra. naceo cincta. - S. pterosperm a m R. Br.

SUIBQIDO IT. ECCREMOCARPEAE. Ca psula uni-bilocularis, bivalvis, valvis medio semisepta margine interiore seminifera gerentibus. S emina horizontalia, alata. $\mathbf{R}$ ad i e u l a centrifuga. - Cyrtandraceis af fines.

4106. Calampelis DON, C a ly $\mathrm{x}$ brevis, campanulatus, quinquefidus. Corolla hypogyna, tubo brevi, fauce ventricosa, limbo constricto, brevissime quinquefido, revoluto. $\mathrm{St}$ a $\mathrm{m}$ in a corollae tubo inserta, quatuor didynama cum radimento quinti; antherae biloculares, loculis parallelis, basi divaricatis. Ovarium uniloculare, placentis duabus parietalibus, carnosis, margine utrinque multiovulatis, ovulis horizontalibas, anatropis. Sty ln 8 simplex; st ig ma bilamellatum. Ca psula coriacea, tuberenlato-muricata, nniloenlaris, bivalvis, valvis medio placentiferis. S emin a plurima, horizontalia, imbricata, compressa, ala membranacea undalata cineta. E mbry on is exalbuminosi, orthotropi cotyledones or- 
biculatae, radicula centrifuga, - Plantae chilen$s e s$, suffruticosae, scandentes; foliis oppositis, petiolatis, bipinnatis, cirrho composito spirali terminatis, pinnis primariis bijugis, foliolis inciso-serratis, racemis oppositifoliis, pedunculatis, multifloris, floribus subsecundis, calyce viridi, corolla coccinea.

C a lampelis Don in Edinb, now philosoph. Journ, VII. 89. E c e rem oc a r p s se a ber Kuiz et Pavoa, Bot. Reg. t. 939.

410\%. Eecremocarpans $R U I Z$ et $P A V$. C a l y $\mathrm{x}$ coloratus, laxe campanulatus, amplus, quinquefidus. Corolla hypogyna, tubulosa, tubo cylindrico, longo, limbi aequaliter quinguefidi laciniis patentibus. Stamina corollae tubo inserta, quatuor didynama cum quinti rudimento; antherae biloculares, lineares, incumbentes, loculis parallelis, connatis. Ovarium uniloculare, placentis duabus parietalibus, carnosis, margine utrinque multiovulatis, ovulis horizontalibus (?) anatropis. Stylus simplex; stigma bilamellatum. Ca p su la coriacea, laevis, unilocularis, bivalvis, valvis medio septiferis. Semina plurima, horizontalia, imbricata, compressa, ala membranacea, undulata cincta. E m b r y o n is exalbuminosi, orthotropi cotyledones orbiculatae, radicula centrifuga. - Frutices peruani, scandentes; foliis oppositis, tripinnatis, cirrho composito spirali terminatis, pinnis primariis bijugis, foliolis integerrimis, racemis laxis, oppositifoliti, floribus longe pedunculatis, pendulis, calyce rubicundo, corollae flavae limbo viridi.

Eecremocarpus Ruiz et Pavon Prodr, 90,t, 18, exel. sp. Humb. et Bonpl. Mlant. aequinoct. t. 65. Kunth in Humb. et Bonpl. Nov, gen. ot sp. III. 150. Journ, Phys, LXXXVIT. 452. Don in Edinb. new philosoph. Journ. VII. 88.

408. Fridericia $M A R T$, C a lyx coloratus, tubuloso - campanulatus, pentagonus, limbo constricto, quinquedentato. Coroll a hypogyna, infundibuliformis, tubo eylindrico, calyce parum longiore, limbi aequaliter quinquefidi laciniis patentibus $v$, revolutis. Stamina corollae tubo inserta, quatuor didynama cum quinti rudimento, inclusa; anther a e biloculares, loculis divaricato-patentibus. O v a ri u m subtetragono-oblongum, biloculare (?), ovulis ntrinque biseriatis, plurimis. Stylus simplex; stigma bilamellatum. C a psu l a compressa, coriaceo-lignosa, bilocularis (?) bivalvis, valvis medio semisepta margine interiore seminifera gerentibus. Se mina transversa, compressa, margine membranaceo cincta. Embry onis exalbuminosi, orthotropi cotyledones reniformes, radicula centrifnga. - Frutices brasilienses; foliis oppositis, ternatis, foliolis petiolatis, integerrimis, paniculis terminalibus, bracteatis.

Fridericia Martius in N. A. N. C. XIIT, 2. p. IX. t. A. B.

SUIB DIET III. INCARVILLEAE. C a psula hinc sutura dehiscens, dissepimento contrario intra margines seminifero. Se min a pendula, alata. Radicula supera. tandraceis affines.

4109. Amplateome $R O Y L, C$ a I y x campanulatus, quinquedentatus, sinubus nudis. Corolla bypogyna, infundibuliformis, limbi bila. biato-quinquelobi lobis obtusis, subaequalibus. S t a min a corollae tubo inserta, quatuor difyna ma, cum quinti rudimento subulato; fil a menta filiformia, apice convergentia, antherae bjloculares, per paria conniventes, connectivo appendiculato, loculis divaricatis, postice infra apicem processu subulato instructis. O va $\mathrm{ri} \mathrm{um} \mathrm{li-}$ neare, uniloculare, placentis duabus parietalibus, linearibus, oppositis, margine multiovulatis, demum ad axim concrescentibus, ovulis pendulis. Sty I us simplex; stigma bilamellatum. Capsula elongato-siliquaeformis, hine sutura dehiscens, dissepimento libero, contrario, intra margines utrinque seminifero. Se m in a plurima, suspensa, subfusiformia, compressa, testa membranacea, utrinque in comam fatiscente. $\mathbf{E}$ m b r y on is exalbuminosi, orthotropi cotyledones oblongae, plano-convexae, radicula brevi, supera. Suffrutex in India bore ali indigenus; foliis alternis, imparipinnatis, foliolis oppositis, breve petiolatis, bi-quadrijugis, lanceolatis, acuminatis, basi inaequilateris, dentalo-serratis, racemis axillaribus terminalibusque laxis.

A mphieome Royle Himalay. 295. $t$, 72. Lindley in Bot. Meg. II. t. 19. I a c a rville a e subgenus R. Browa apud Royle $\boldsymbol{l}$. c.

410 . Inerarvillea JUSS. Cal yx campanulatus, decemdentatus, dentibus alternis subulatis, elongatis, alternis membranaceis, abbreviatis, emarginatis. Co roll a hypogyna, infundibuliformis, limbi bilabiato-quinquelobi lobis obtusis, subaequalibus. Stamina corollae tubo inserta, quatuor didynama, cum rudimento quinti; fil am enta filiformia, apice convergentia, anthe rae biloculares, per paria conniventes, connectivo appendiculato, loculis divaricatis, basi in setam desinentibus. O varium lineare, uniloenlare? ..... Sty 1 u s simplex; 8 tig ma bilamellatum. Ca p s u la elongato-siliquaeformis, hinesutura dehiscens, dissepimento libero, contrario, intra margines utrisque seminifero. S e min a plnrima, suspensa, obovata, compressa, testa membranacea, undique in marginem integrum protucta. E m b ry o n is exalbuminosi, orthotropi cotyledones oblongae, plano-convexae, radicula supera. Herba chinensis, erecta; foliis alternis, bipinnatisectis, laciniis incisis, lobis linearibus, racemo terminali laxo.

In earville a Jussieu gen. 138, Lam. $t$, 527, Bunge Enumerat. Plant. Chin, bor. 45. In c a rvill e a e sect. R. Brown apud Rogle Himalay, 296. C a m p 8 is Loureiro Flor. cochinch, 458.

SUIB CIED I\$. TOURRETIEAE. C a psula dissepimento tetraptero quadrilocularis, bivalvis, dissepimenti alis oppositis angustioribus, valvis contrariis, intra marginem seminiferis. Semina pendula, alata. Polemoniaceis affines?

4111. Towaretia DOMB. C a ly x bilabiatus, labio superiore acuminato, integro, interdum postice processu corniformi aucto, inferiore apice dilatato, crenato. C or olla hypogyna, tabulosa, limbi bilabiati labio superiore maximo, galeato, inferiore minimo, dentiformi. St a min a 4, didynama, corollae tubo inserta, inclusa; antherae biloculares, loculis divaricatis. Ovari um carpidiornm marginibus dissepimenti tetrapteri lobos latiores, nervo medio ejusdem lobos minores attingentibus quadriloculare, ovulis intra lohorum dissepimenti angustiorum margines plurimis, uniseriatis, pendulis, prima facie parieta- 
libus. Stylus simplex; $s t i g m$ a indivisum, sub uncinatum. Ca p s ul a oblonga, compressa, coriaceo lignosa, spinis uneinatis echinata, quadrilocularis, bivalvis, valvis dissepimenti tetrapteri lobis angastioribus intra marginem utrinque semi. niferis contrariis. Sem in a compressa, membranaceo-marginata, pendula. Embryo $\ldots . .$. Herba peruan a, repens v. scandens; caule tetragono, dichotomo, foliis oppositis, corona ciliar caulem ambiente junctis, geminato-ternatis, cirrhosis, floribus axillaribus, spicatis, unibracteatis.

Tourretia Dombey ox Jussieu gen. 139. Kunth in Journ. Phys. LXXXVIT. 452. D o u b e y a Heritier Stirp. 33. t. 17.

SURDRED ॠ. BIGNONIEAE. Capsula bilocularis, bivalvis, valvis dissepimento marginibus utrinque seminifero contrariis $v$. parallelis. S emina transversa, alata, rarissime aptera. $\mathbf{R}$ adi cula centrifuga.

TUR IIBUS I. ARGYLIEAE. D i s s e p imen $\mathrm{t} u \mathrm{~m}$ valvis contrarium. Semina aptera.

41 1 A. Argylia DON. C a Iy x quinquepartitus. Co rolla hypogyna, basi tubulosa, fauce ventricosa, limbi quinquelobo bilabiati lobis subaequalibus, obtusis. St a m in a corollae tabo inserta, quatuor didynama absque quinti rudimento; antherae biloculares, loculis divaricato-patentibus. Ovarin m biloculare, ovulis intra dis sepimenti marginem utrinque paucis, horizontalibus, anatropis. Stylus simplex; stigma bilamellatum. C a p s la siliquaeformis, torulosa, bilocularis, bivalvis, valvis suberustaceis, dissepimento utrinque intra margines seminifero contrariis. S e mina transversa, compressa, horizontalia, subreniformia, testa coriacea, dorso conve$x a$, tuberculata, ventre concaviuscula, endopleura membranacea, laxa, E mbryonis exalbuminosi, orthotropi cotyledones lato-reniformes, bilobae, radicula brevissima, centrifuga, - Herbae chilenses, perennes; caule erecto $v$. adscendente, tereti, subviscido-pubescente, foliis alternis, petiolatis, peltato-digitatis, foliolis bi-tripinnatifidis, patentibus, laciniis cuneato-v. oblongo-linearibus, obtusis, integerrimis, floribus terminalihus, subracemosis, corollis luteis, fauce rubro punctalis.

Argylia Don in Edinb, philosoph, Journ, IX, 260. New Edinb, philosoph. Journ, VII, 6. Bign onia $\mathrm{r}$ a di at a Lian. Peuilé Observ. t, 22,

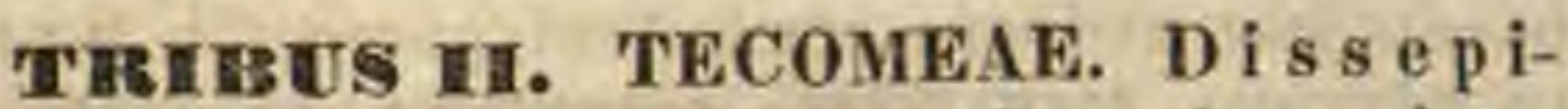
mentum valvis contrarium. Sem ina alata.

41 13. Catalipa JUSS. C a ly x bipartitus. Corolla hypogyna, tubo ventricoso-campanulato, limbi bilabiati labio superiore bilobo, inferiore trifido. Stamina corollae tubo inserta, duo fertilia, tria sterilia; an therae biloculares, loculis aequalibus, divaricato-patentibus. Ova ri um biloculare, ovulis ad dissepimenti margines utrinque plurimis, horizontalibus, anatropis. St yI us simplex; stigma bilamellatum. Capsula elongato-siliquaeformis, bilocularis, bivalvis, valvis dissepimento marginibus ntrinque seminifero contraris. Semina plurima, transversa, com pressa, utrinque in alam papposo-laceram expan sa. Embryon is exalbuminosi, orthotropi radicula centrifuga. - Arbores in America boreali calidiore et tropica indigenae; foliis ternato- verticillatis, simplicibus, cordatis v. oblongis, flo. ribus terminalibus, paniculatis.

C at a I p a Jussieu gen. 138, Bot. Mag. t, 1094, B ig a o. n i a e s p. Linn. Schikuls $t$, 175 .

414. Tecoma JUSS, Cal y x campanulatus, quinquedentatus. Co roll a hypogyna, tabo brevi, fauce campanulata, limbo quinquelobobilabiato. Stamina corollae tubo inserta, quatuor fertilia, didynama, cum quinti rudimento; an $t$ her a biloculares, loculis divaricato-patentibus. Ovarium bilocnlare, ovulis ad dissepimenti margines utrinque plurimis, horizontalibus, anatropis. St y l us simplex; $8 \mathrm{ti} \mathrm{gm}$ a bilamellatum. C a p su la elliptico-oblonga v, elongato-siliquaeformis, bilocularis, bivalvis, valvis dissepimento marginibus utrinque seminifero contrariis, Semina plurima, transversa, compressa, utrinque in alam membranaceam expansa. $\mathbf{E} \mathbf{m b}$ r y onis exalbuminosi, orthotropi radicula centrifuga. - Arbores $v$. frutices, interdum scandentes, in America tropica et boreali calidiore, rarius in Capite bonaespei et in Nova-Hol landia crescentes; foliis oppositis, impari-pinnatis v. interdum digitatis, foliolis serratis, incisis aut rarius integerrimis, floribus terminalibus, panicu. latis, flavis $v$. incarnatis.

Te c o m a Jussieu gen, 139. R. Browa ProsIr. 471. Kunth in Humb. et Bonpl. Nov. gen. et sp. III, 148 .

a. PANDOREA, Corolla subbilabiata, laciniis subaequalibus, obtusis. Ge uitalia inclasa. Capsula elliptico-obloaga. - Species Novae-Hollandiae.B ig noni a pandorea Andrews Bot, Reposit, $t, 86$. Vent, Malm, t, 43. (Bot. Reg. $t$. 2008.)

b. EUTECOMA. Corolla subbilablata, laciniis subaequalibus, obtusis. Ge a italia inclusav, exserta. Ca ps u la elongato-sillquaeformis. - Species amerieanae. - Bignon fa radicans Lios. Sclikuhr. $t, 175$. Bot. Mag. t. 485. 1398, B. 8 t a n s Lina.

c. TECOMARLA, C o r olla ringens, labio superiore erecto, emarginato, inferiorls trifidi lobis acutis, intermedio longlore. Ge uitalia louge exserta. Capsula elon. gato-sillquaeformis. - Species eapensis. - T e com a c a peasis Lindley in Bot, Reg. $t, 1117$.

4115. Jaenzanala JUSS. Caly $\mathrm{x}$ campanulatus, quinquedentatus, rarissime tobulosus, truncatus, Corolla hypogyna, tubo brevi, fauce dilatata, campannlata, limbi quinquelobi, bilabiati lobis subaequalibus, oltusis. Stamina corollae tubo inserta, quatuor didynama, cum quint: rudimento, inclusa; antherae biloculares, loculis divaricato.patentibus, rarissime aequalibus, altero plerumqne nano v, obsoleto. Ovari um biloculare, ovulis ad dissepimenti margines utrinque plurimis, horizontalibes, anatropis. Stylus simplex; stigma bilamellatum. Capsula suborbicularis, compressa, bilocularis, bivalvis, valvis lignosis, planiusculis, dissepimento marginibus utrinque seminifero contrariis. Semina plurima, transversa, compressa, ala membranacea eincta. Embryonis exalbuminosi, orthotropi radicula centrifuga. - Arbores saepius excelsae, Mimosae facie, in $A$ merica tropica, imprimis trans aequatorem indigenae; foliis oppositis, abrupte v, rarius impari-pinnatis, pinnis impari-pinnatis, floribus paniculatis, terminalibus $v$. interdum lateralibus, violaceis $v$. rarius luteis.

Jacaranda Jussien gen. 138. Kuath in Humb. ot Bonpt. Nov. gen. et op. III. 145. R. Brown in Bot. Mag. n. 2327. Don in Edinb. philosoph, Journ. IX. 264. B i g nia e sp. Liun.

a. COPAIA. Calyx tubulosus, truncatus. Antherae loculo altero abortiente subuailoculares, - Folia ab- 
rupte bipinnata, Bignonia Copaia Aublet Guian. z. 262, 265.

b. HEMLLOBOS. Cal y $\mathrm{x}$ campanulatus, quinquedentatus. A ntherae loculo altero abortiente subuniloculares.Folia imparipinnata. (Humb. et Bonpl. Plant. aequinoct. t. 17, 18. Bot. Mag. t. 2327. Bot. Reg. t. 631.)

c, DILOBOS. C a I y $\times$ eampanulatus, quinquedentatus, A a. ther a e loculis aequalibus, divaricatis. - Folia imparibipinnata, J. t o m e $\mathrm{t}$ os a R. Browa Bot. Reg, $t$. 1103.

416. Zeylneria MART. C alyx bipartitus, laciniis integris v. ineisis. Corolla hypogyna, tubulosa, tubo subeylindrico, limbi quinquelobi lobis subaequalibus, obtusis. St a mina imo corollae tubo inserta, quatuor didynama, cum quinti rudimento, inclusa; antherae biloculares, loculis divaricato-patentibus. O v a ri $\mathbf{m}$ biloculare, ovulis ad dissepimenti margines utrinque plurimis, horizontalibus, anatropis. Stylus simplex; stigma bilamellatum. Capsula substipitata, compresso-orbicularis, bilicularis, bivalvis, valvis navicularibus, dissepimento plano, marginibus atrinque seminifero contrariis. Se $\mathrm{m}$ ina plurima, transversa, compresso-orbiculata, ala membranacea cincta. E m bry on is exalbuminosi, orthotropi radicula centrifuga. - Arbuscula brasiliensis; folits oppositis, ternato- v. quinato digitatis, foliolis petiolatis, lato lanceolatis, integerrimis, supra glabris, subtus pulvereo-lepidotis, floribus terminalibus, paniculato-corymbosis, bibracteolatis, fulvo-tomentosis.

Z e y heria Martins Nov, gen, et sp. II. 65, t.159. -? Ch a $\mathrm{s}$ ia Schott ex Sprengel Cur. post. 409.

41\%. Chilopsis DON. Ca ly x membranaceus, ventrieosus, antice ad basim fissus, limbo obliquo, postice tridentato. Corolla hypogyna, basi tubulosa, fauce dilatata, campanulata, limbi quinquefidi, bilabiati lobis obtusis, undulatis, antico elongato, maximo. Stamina corollae tubo inserta, quatuor didynama, cum quinti rudimento; antherae biloculares, locnlis aequalibus, divarieatis. Ovari n m biloculare, ovulis ad dissepimenti margines utrinque plurimis, horizontalibus, anatropis. Stylus simplex; stigma bilamellatum. Capsula brevis, compressa, bilocularis, bivalvis, valvis dissepimento marginibus utrinque seminifero contrariis. S e m in a plurima, transversa, compressa, margine membranaceo eincta. Embryonis exalbuminosi, orthotropi radicula centrifuga. - Frutex mexicanus, erectus, ramosus; ramis teretibus, pubescentibus, foliis alternis, elongato-linearibus, planis, coriaceis, glaucescentibus, integerrimis, racemo terminali, spicaeformi, denso, tomentoso, pedicellis brevibus, bibracteolatis, corollis atro-purpureis.

Chil op $s$ is Don in Edinb. philosoph. Journ. IX. 269.

41 18. Spathoulea PALIS. Calyx spathaceus, antice fissus, postice integerrimus $v$. dentatus. Coroll a hypogyna, subinfondibuliformis, limbi quinquelobo bilabiati lobis subaequalibus. Sta mina corollae tubo inserta, quatuor didynama, cum quinto rudimentario, rarissime aeque fertili; antherae biloculares, loculis divaricato patentibus, 0 varium biloculare, ovulis ad dissepimenti margines atrinque plurinis, horizontalibns, anatropis. Sty I us simplex; stig m a bilamellatum. Capsula elongato-siliquaeformis, bilocularis, bivalvis, valvis dissepimento marginibus utrinque seminifero contrariis. S em in a plurima, transversa, compressa, utrinque in alam membranaceam expansa. Em b r y o n is exalbuminosi, orthotropi radicula centrifuga. - Frutices v. arbores, inter tropicos totius orbis crescentes; folits oppositis v. rarius alternis, conjugatis v. impari-pinnatis, interdum simplicibus, floribus subpaniculatis, aurantiaceis, flavis v. violaceis,

Spat hodea Palisot Flor. Owar. $T$. 46. exel, sp. R, Brown Prodr. 471. Kuath in Humb. et Bonpl. Nov. gen, et sp. IIT. 146. Blume Bijdr. 761. B i g n on i a e sp. Liun.

a. DOLICHANDRA Chamiss, in Linnaea VIT, 657. C a p. s u la compressa, dissepimento planiusculo, coriaceo.

b. SPATHODEA Chamiss, in Linnaea VIT, 657, C a p s u a teretiuscula, subfaleata, dissepimento suberoso. B ig. n on i a e s p. Roxb. Plant, corom. t. 144. (Palisot op. cit. $t$, 29, excl, reliq. Wallich Plant. As, rar, $t, 238$. Bot. Mag. $t$. 3681.)

TIEIIB US III. EUBIGNONIEAE. D issepimentum valvis parallelum.

419. Calossanthes BLUM. C a lyx tubulosus, truncatus, demum antice fissus. Curoll a hypogyna, tubo brevi, fauce campanulata, limbi quinquelobi, subbilabiati lobis obtusis. Stamina corollae tubo inserta, quinque fertilia, quorum duo longiora vix exserta; an therae biloculares, loculis divaricato-patentibus, mnticis. Ovarium biloculare, ovulis ad dissepimenti margines utrinque plurimis, horizontalibus, anatropis. Stylus simplex; stigma bilamellatum. C a p s u a elongato-siliquaeformis, bilocularis, bivalvis, valvis dissepimento marginibus ntrinque seminifero parallelis. Se mina plurima, transversa, compressa, utrinque in alam membranaceam expansa, Em br y on is exalbuminosi, orthotropi radicula centrifuga. - Arbor Asiae tropicae; foliis decomposito-pinnatis, foliolis subcordato-ovatis, paniculis terminalibus, multifloris.

C alosanthes Blume Bijdr, 760. Bignonia indie a Linn.

420. II 19ploloploium $C H A M$. $\mathrm{C}$ al $\mathrm{yx}$ campanulatus, tubo coriaceo, limbo membranaceo; amplo, undulato-crispo. C or o 11 a hypogyna, tubo brevi, fance dilatata, incurva, limbi bilabiato quinquelobi lobis subaequalibus, obtusis, antico emarginato. St a min a corollae tubo inserta, qua. tuor didynama, cum quinti rudimento, inclusa; a ntherae biloculares, loculis divarieato-patentibus, muticis. Ovarium biloculare, ovulis ad dissepimenti margines utringue plurimis, horizontalibus, anatropis. Sty lus simplex; stigma bilamellatum. Ca p su la elliptiea, compressa, echinata, bilocularis, bivalvis, valvis dissepimento marginibus utrinque seminifero parallelis. S e min a plurima, transversa, compressa, ala memhranacea cincta. E m bry on is exalbuminosi, orthotropi radicula centrifuga. - Frutices brasiliens es, scandentes, lepidoti; foliis conjugatis, foliolis ellipticis, acuminatis, panicula terminali abbreviata, floribus lateralibus saepius abortivis subspicaeformi, comoso-bracteata.

Haplol o phinm Chamisso in Linnaea VIT. 556.

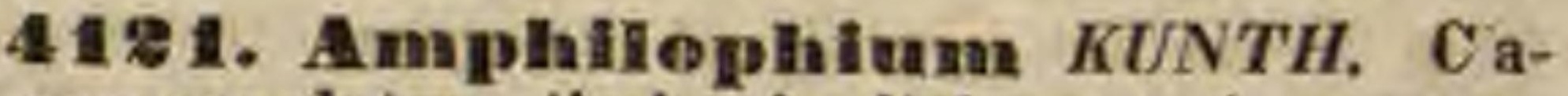
ly $x$ campanulatus, limbo duplici, exteriore membranaceo amplo, undulato crispo, patente, interiore bilabiato, lobis integris v. incisis, Cor oll a hypogyna, tubo brevi, fauce ampla, ventricosa, limbi bilabiati labio superiore majore, galeato, bidentato, inferiore recto, tridentato. Stamina corollae tubo inserta, quatuor didynama, cum quinti rudimento, inclusa; a $\mathrm{th}$ erae biloculares, loculis divaricato-patentilus, muticis. Ova- 
rium biloculare, ovulis ad dissepimenti margines utrinque plurimis, horizontalibus, anatropis. S ty I us simplex; stigma bilamellatum. Capsula ovata, compressa, lignosa, bilocularis, bivalvis, valvis dissepimento marginibus utrinque seminifero parallelis. Semina plurima, transversa, compressa, ala membranacea cincta, Embry o$n$ is exalbuminosi, orthotropi radicula centrifuga. - Frutices Americae tropicae, scandentes, cirrhosi; foliis oppositis, conjugatis, floribus paniculatis, roseis $v$. rubicundis.

A m phil op hi u munth in Humb, et Bonpl. Nov. gen. et sp. IIT. 149. $t$. 219. Bignonia pauleulata Linn. Jacq. Amer, $t, 116$.

4122. Delostoma DON. Calyx cam panulatus, trilobns. C o roll a hypogyna, infundibuliformis, fauce dilatata, patente, limbi bilabiati labio superiore breviore bilobo, inferiore trilobo, lobis subaequalibus, obtusis. St a in in a corollae tubo inserta, quatuor didynama $\mathrm{cum}$ quinti rudimento, inclusa; a n therae biloculares, loculis aequalibus, parallelis. Ovarium biloculare, ovulis ad dissepimenti margines utrinque plurimis, horizontalibus, anatropis. Stylus simplex; stig ma late bilamellatum. C a p sula lanceolata, eompressa, bilocularis, bivalvis, valvis coriaceis, subcarnosis, dissepimento marginibus utrinque seminifero parallelis. S e m in a plurima, transversa, compresso-plana, ala membranacea cincta. Embryonis exalbuminosi, orthotropi radicula centrifnga. - Arbores peruanae; folits oppositis, simplicibus, petiolatis, ellipticis, obtuse acuminatis, inlegerrimis, floribus terminalibus, racemoso spicatis, magnis, roseis.

De I o s to un a Don in Edinb, philosoph.Journ, IX. 263.

43:3. Astianthens DON. Caly x tubnlosns, quinquedentalus, aequalis. Corolla hypogyna, basi tubulosa, fance dilatata, campanulata, limbi quinquefidi, bilabiati lobis obtusis, undulatis, antico maximo. Stamina corollae tubo inserta, quatuor didynama cnm quinti rudimento; antherae biloculares, loculis aeqnalibus, confluentihus. Ovari a m biloculare, ovnlis ad dissepimenti margines utrinque plurimis, horizontali bus, anatropis. Stylus simplex; 8 tigma bila mellatum. Ca p $s$ a la elongato-siliquaeformis, biloenlaris, bivalvis, valvis coriaceis, dissepimento marginibus utrinque seminifero parallelis. S e mina plurima, transversa, compressa, utrinque in alan membranaceam papposo-laceram expansa. Embry on is exalbuminosi, orthotropi radicula centrifuga. - Frutex $m$ exicanus, erectus, ramosus; ramis teretibus, glabris, foliis ternatim verticillatis, simplicibus, late linearibus, elongatis, coriaceis, integerrimis, glabris, floribus terminalibus, paniculatis.

A st ianth us Donin Edinb, philosoph, Journ, $r X$, 262.

4124 . EBhgramia JUSS, C a lyx campanulatus, tri-quinquedentatus $v$. rarins integerrimus. Corolla hypogyna, tubo brevi, fauce dilatata, campanulata, limbi quinquelobo-bilabiati lobis obtusis, subaequalibus $v$. antico majore. Stam in a corollae tubo inserta, quatuor didynama, enm quinti rudimento interdum aeque fertili; a $n$ therae biloculares, loculis divarieato-patentibus, aequalibus, muticis. Ovarium biloculare, ovulis ad dissepimenti margines utrinque plurimis, horizontalibus, anatropis. Sty I u s simplex; $8 \mathrm{tig}$ m a bilamellatum. C a p s u la elongato-siliquaeformis, bilocularis, bivalvis, valvis coriaceis v. ligno- sis, dissepimento marginibus ntrinque seminifero parallelis. S e min a plurima, transversa, compressa, in alam membranaceam expansa. E m b r y on is exalbuminosi, orthotropi radicula centrifuga. - Arbores $v$, frutices, inter tropicos totius or $b i s$ crescentes, saepissime scandentes $v$. cirrhosi; foliis oppositis, simplicibus, conjugatis, ternatis, digitatis $v$, pinnatis, floribus axillaribus et terminalibus, saepe paniculatis, corollis albis, flavis v. rubris.

B ignonia Jussiea gen. 139. Kunth in Journ. Phys. LXXXVII. As0. Nov, gen, et sp. IHI. 133. Roxburgh Plant. Corom. t. 145. Wallich Plant. As, rar, t. 95, 96. 183. Bot. Mag. t. 2817. 2970. 3011. Bot. Reg. t. 249.418 714. 965. 1301. Oroxylum Vent. ex Funth 2 . c. Stenolobium Don in Edinb. philosoph. Journ, IX, 264.

4125 . IIthingtomia LINN. FIL. C a ly x brevis, campanulatus, aequaliter quinquedentatus, dentibus revolutis. Co rolla hypogyna, tubo infundibuliformi, gracili, longo, limbi bilabiati labio superiore erecto, semibifido, inferioris patentis tripartiti laciniis aequalibus. St a m in a corollae fauci inserta, exserta, didynama; anth erae terminales, biloculares, loculis parallelis, aequalibus, connectivo postice calcarato. $O \mathrm{v}$ ari $\mathrm{m}$ biloculare, ovulis ad dissepimenti margines ntrinque plurimis, horizontalibus, anatropis. St ylus simplex; stigm a bilamellatum. Ca p 8 u la elongato-siliquaeformis, bilocularis, bivalvis, valvis dissepimento marginibus utrinque seminifero parallelis. Semina plurima, transversa, compressa, ala membranacea cincta. Embry o n is exalbuminosi, orthotropi radicula centrifuga. - Arbor indica; folits oppositis, supradecompositis, foliolis cordatis, nitidis, integerrimis $v$. crenatis, floribus terminalibus paniculatis, albis.

Millingtonia Linn. fil. Supplem. 45. R. Brown Prodr. 472. in not. Bignonla suberosa Roxburgh Plant. corom, t. 214.

\section{GENERA ANOMALA,}

41.68. BViglitia WALL. Calyx campanulatus, quadrifidus, laciniis aequalibus, obtusis. Co rolla hypogyna, tobo infundibuliformi, limbi bilabiati labio superiore erecto, bifido, inferiore patente, trifido, subaequali. St a mina corollae tubo inserta, quatuor didynama absque quinti rudimento, breviter exserta; fil am enta subulata, anthera e biloculares, ovato-sagittatae, versatiles, loculis aequalibus, parallelis. O vari um biloculare, ovulis plurimis, placentae e dissepimenti margine stipitatae insertis, adscendentibus. Sty l u s simplex; stigma clavatum, indivisum. C a $\&$ ula coriacea, subcylindrica, acuta, valvarum marginibus introflexis septum placentiferum praehendentibus bilocularis, loculicide bivalvis, dissepimento angusto, utrinque placentifero, demum libero, parallelo. S e in in a plurima, oblonga, compressa, adscendentim imbricata, membranacenmarginata, basi et apice alata, umbilico paullo supra basim ventrali. Embryo exalbuminosus, cylindricus, rectus; cotyledonibus obtusis, radicula umbilico proxima, infera. - Frutex nepalensis, volubilis; foliis oppositis, petiolatis, simplicibus, ovatis, acuminatis, integerrimis, coriaceis pedunculisque pube stellata obtectis, racemis axillaribus, elongatis, pedunculis trichotomis, corollis pubescentibus.

Wig hti a Wallich Plant. As, rar, I, 7t, $t, 81$. 
42\%. Metterniehia MICK. Calyx brevis, campanulatus, inaequaliter quinquefidus. Corolla hypogyna, infundibuliformis, limbo amplo, plicato, breviter quinquefido, aequali. Stamina 5 , imo corollae tubo inserta, inaequilonga, subexserta; filamenta filiformia, anther a e biloculares, loculis parallelis, aequalibus. Ovarium biloculare, ovulis juxta dissepimenti basim utroque margine pluribus, adscendentibus, anatropis. Styln s simplex; stigma peltatobilamellatum. C a p s u la coriaceo-lignosa, ovatocylindrica, bilocularis, apice bivalvis, valvis dissepimento lamelliformi libero, apice bifido contrariis, demum semibifidis. S e min a panea, dissepimenti marginibus prope basim utrinque inserta, longe linearia, recta, dorso convexa, facie bisulca, testa coriacea, marginibus apiceque membranacea, umbilico basilari, endopleura tumida. $\mathbf{E}$ m. bryonis exalbuminosi, orthotropi cotyledones lineares, radicula longa, cylindrica, infera.

Arbor brasiliensis; foliis alternis, breve petiolatis, simplicibus, ovalibus, integerrimis, nitidis, floribus terminalibus racemosis, albis $v$, roseis.

Metternichia Mickan Delect.flor, et faun. Brasil. III. t. 1.

\section{GENERA DUBIA.}

4188. Ferdinamalusa $P O H L$, Calyx campanulatus, quadridentatus. Corolla hypogyna, infundibuliformis, tubo cylindraceo, elongato, fance ampliata, limbi quadrifidi laciniis aequalibus, inaequaliter inciso-bifidis, reflexo-patulis. Stamina 4, medio corollae tubo inserta, breviter exserta, didynama; a nth erae biloculares, incumbentes, loculis parallelis, connatis, basi et apice involntis. Ovarium apice obsolete quadrilobum, biloculare, loculis multiovulatis. Stylus simplex; stigma bilamellatum. Capou la ovata, lignosa, bilocularis, septicide bivalvis, valvis bifidis, columna seminifera libera. $\mathrm{Se}$ mina ....-Arbores brasilienses, mediocres; foliis oppositis, simplicibus, brevissime petiolatis, coriaceis, integerrimis, floribus terminalibus corymbosis, coccineis v. albo-virescentibus, speciosis.

Ferdin a d us a Pohl Plant. Brasil. II. 8, $t, 106-108$. Ferdiuandea Pohl in Flora 1826. p. 153.

429. Flatyearpuman HUMB. etBONPL. Caly x quinquepartitus, aequalis. Corolla hypogyna, tubo brevi, fauce infundibuliformi, limbo quinquefido, subaeqnali. Stam in a 5, corollae tubo inserta, inclusa; f il a m e $\mathbf{t}$ a filiformia, a $n$ therae oblongae, biloculares, dorso affixae. Ovariam basi glandnlis decem colnmnaribus villosis, cinctum, compressum, biloculare. $O$ vala .... Stylus simplex; stigma bilamellatum. C a psula didyma, lignea, compressa, bilocularis, bivalvis, dissepimento valvis contrario iisque adnato. S e min a in loculis gemina, lenticularia, membranaceo - alata. - Arbor crinocensis excelsa; foliis oppositis, simplicibus, breve petiolatis, obovato-oblongis, integerrimis, floribus terminalibus paniculatis, corollis roseis, extus pubescentibus.

Pl a ty a r p u m Humb, et Bonpl. Plant. aequinoct. II. 81. i. 104. Kunth Nov, gen, et sp. III, 151, Journ, Phys. LXXXYIT. 45i.
4130. Selurebera $R O X B$. C a ly $\mathrm{x}$ tubulosus, bilabiatus, labiis subaequalibus, emarginatis, sinubus inter labia minutis v. denticulo auctis. Corolla hypogyna, infundibuliformis, tubo brevi, limbi quinque- v. septempartiti laeiniis patentibus, cuneatis, obtusis. S t am ina 2 , medio corollae tubo inserta, inclusa; filamenta brevissima, a ntherae oblongae. ...... - 0 varium ovatum ..... St S lus simplex, exsertus; st $\mathrm{igma}$ bifidum. Capsula pyriformis, magna, lignosa, scabra, bilocularis, apice bivalvis. S em in a in loculis quaterna, irregulariter ovalia, compressa, sursum in alam membranaceam producta. ..... Arbor indica; folits oppositis, imparipinnatis, tri-quadrijugis, foliolis suboppositis, breve petiolulatis, cordatis, integerrimis, paniculis terminalibus, trichotomis, floribus parvis, albis, fuscovariegatis, noctu fragrantibus.

$\mathrm{S}$ chrebera Roxburgh Plant. Corom, II, 1, $t, 10 t$.

4131. Stereospermum CHAM. Caly $\mathrm{y}$ cupuliformis, coriaceus, late quinquedentatus. Coroll a hypogyna, tubo brevi, fauce campannlato-snbventricosa, limbi quinquelobo-bilabiati lobis obtusis, antico majore. $S t$ a $m$ in a 4 , didynama, cum quinti rudimento, corollae tubo inserta, inclusa; antherae biloculares, loculis aequalibus, divaricato-patentibus. O va ri n m eylindricum, disco hypogyno quinquelobo einctum. Stylas simplex; stigma bilamellatum. Fructus membranaceus, tetragono-subeylindricus, gracilis, elongatus, quadrinervins, tandem bivalvis, valvis dissepinento crasso, carnoso, utrinque alternatim hinc facie illinc margine seminifero parallelis. S e min a transversa, basi cuneiformi dissepimenti carni immersa, dorso convexo utrinque in alam membranaceam expanso, testae induplicatione bipartito. ..... - Arbor v. frutex Africae tropicae, foliis oppositis, impari-pinnatis, subquadrijugis, floribus axillaribus terminalibusve, paniculatis.

Stereospermu m Chamisso in Linnaea VII, 720, -? Fruit de la Spathodea Palisot Flor. Owar, t. 28.

43. Gelsemium JUSS. Calyx quinquepartitus, aequalis. C o rolla hypogyna, infundibuliformis, limbi quinquefidi, patentis lobis aequalibus, obtusis. Stamina 5 , imo corollae tubo inserta, aequalia, subexserta; fil a m e n t a subulata, a nt herae biloculares, oblongae, basifixae, loculis aequalibus, parallelis, basidiseretis. O va ri $n \mathrm{~m}$ biloculare, ovulis juxta dissepimenti axim utrinque plurimis, biseriatis, adscendentibus, anatropis. Stylus simplex; stigma quadripartitum, lobis oblongo-obovatis, complanatis. Capsula siliquaeformis, elongato-linearis, compressa, bivalvis, valvis niargine seminiferis. S emin a compressa, apice membranacea ...... Frutex boreali-americanus; foliis oppositis, petiolatis, simplicibus, lanceolatis, integerrimis, floribus axillaribus fasciculatis, pedicellis imbricatobracteolatis, corollis luteis.

GeIs emium Jussien gen. 150. Richard in Michaux Flor. Bor. Amer. I. 120. Nuttall Gen. I, 171. B ig a o n ia s empervireas Llua. Gelseminium Catesby Carolin. I. t. 53 . 
4133. (1xera LABILLARD. C a ly 8 quadripartitus, scariosus. C orolla hypogyna, tubo brevi, fauce dilatato - campanulata, limbo quadrifido, inaequali. Stamina 4 , corollae tubo inserta, duo postica sterilia inclnsa, antica exserta; fil a m enta declinata, filiformia, papillosa, a ntherae biloculares, adnatae. Ovarinm disco carnoso impositum, quadriloculare, quadrilobum, placentis intra loculos basilaribus, liberis, ovulis plurimis, striatis. Stylus inter ovarii lobos transiens, filiformis, declinatus; stig $\mathbf{m}$ a bifidum, laciniis acutis. Fructus.... - Frutex Novae Caledoniae; ramis verrucosis, foliis oppositis, breve petiolatis, ovali-oblongis, integerrimis, racemis axillaribus, oppositis, pedicellis subfasciculatis, nutantibus.

oxe r a Labillard. Nov. Caledon. $I, 83, t$. 28. O n e om a Spreng. Cur. post. 18.

OBSERVATio. Trig on o c a r pus Wallich Catalog. n.6520. genus Bignoniaceum indicum, nondum deseriptum, mihi penitus lncognitum. - R h igoz u m Burch. Trav, I.389. genus e cl. auctore Bignoniaceum genuinum, staminibus quinque perfectis, interdum septenis, follis in eadem stirpe simplicibus, trifoliatis v, fascieulatis, floribus luteis speciosis insigne, e speeimine Eckloniano nimis manco eruere nequeo.

\section{Ordo CLII. Gesneracene.}

GESNERIRAR Richard ex Jussieu Annal. Mus. $\boldsymbol{V}$. 428. Kunth in Humb. et Bonpl. Nov. gen. ot sp. IT. 392. GES. NEREAE Martius Nov, gen, et sp. III. 68. Bartling Ord, nat. 174. CYRTANDRACEAE Jack in Linn, Transact. XIV, 23. DIDYMOCARPEAE Don in Edinb, philosoph. Journ, VIr. 28. Prodr. $\beta$. Nepal. 12t. GESNERACEAR et CXRTANDRA. CEAE Lindley Introduct, edit, II. p. 283. 286.

Herbas annuae v. perennantes, erectae v. scandentes, rarius suffrutices v. FrUtices, caule ramisque tetragonis $v$. rarius teretibus. Foli a opposita v. verticillata, rarins alterna, (alterum ejusdem paris saepe minus, interdum minimum, stipulaeforme), petiolata v. interdum sessilia, simplicia, integra, quandoque integerrima, saepe inaequilatera. Stipulae nullae.

Fuones hermaphroditi, plus minus irregulares, cymosi, racemosi v. interdum spicati, quandoque fasciculati, nudi v. bibracteolati.

CaLyx persistens, liber v. rarius tubo cum ovario plus minus connato, limbo quinquepartito, lobis aequalibus v.postico anticisque majoribus inaequalis.

Corolla hypogyna v, perigyna, gamopetala, tubulosa, infundibuliformis, campanulata v. ringens, plus minus obliqua, basi nempe saepissime postice gibba, fauce aperta v. constricta, limbo antice productiore, quinquefido, bilabiato, labio superiore bi- inferiore trilobo, rarius subaequali, lobis per aestivationem imbricatis, lobo antico plerumque intimo.

Stamixa 5, corollae tubo inserta, ejusque lobis alterna, quintum posticum sterile, sae- pius omnino deficiens, lateralia et antica (in Gesnereis plerumque, rarius in Cyrtandraceis) fertilia, didynama, postica lateralia nune (in Gesnereis) breviora, nunc (in Cyrtandreis, nunquam in Gesnereis) ananthera, antica saepius longiora, rarissime (in Sarmienta el Aikinia) sterilia, omnia inclusa v. exserta. FiI amenta filiformia v. complanata, e basi latiore sensim angustata, recta $v$. arcuata aut interdum implexa. Antherae introrsae, biloculares, nune loculis confluentibus nune alterius, interdum demissius inserti abortu uniloculares, terminales v. in connectivo interdum bicruri sublaterales, longitudinaliter dehiscentes.

Ovariom liberum v. interdum cum calycis tubo basi connatum, rarius omnino inferum, disco pro varia cum ealyce cohaesione hypogyno, perigyno v. epigyno, integro, interrupto v. quinquelobo cinctum $\mathbf{v}$. coronatum, rarissime disco destitutum, dimerum, uniloenlare, placentis duabus, parietalibus, oppositis, dextrum et sinistrum ab axi floris latus occupantibus, nune in pariete sessilibus bilobis, carnosis, nunc e lamella parietali porrectis, in laminam latam axim attingentem, undique ovulis onustam v. ad axim nudam, ad margines revolutos, eavitatem in loculos quatuor spurios partientem ovuliferam expansis. Ovala plurima, in funiculis brevibus v. longiusculis anatropa. Stylus filiformis, simplex. Stigma capitatum, concavum v. bilobum.

Fruetus nunc baceatus, placentis duabus parietalibus pulposis, nune capsularis, ovatus v. subglobosus, aut (in Cyrtandreis) siliquaeformis, bivalvis, valvis rectis $\mathrm{v}$. tandem spiraliter contortis, medio placentas sessiles (in Gesnereis) v. e lamina porrectas, rarissime tandem solutas, rarius marginibus explanatas, saepius arcte revolutas, post dehiscentiam capsulas geminas ad margines rima apertas mentientes gerentibus, rarissime (in Epithemale) circumscissus.

Semisa plurima, minuta, e funiculis brevibus v. longiusculis pendula aut porrecta, interdum funiculo piliformi et chalaza in pilum desinente utrinque aristata. Testa coriacea, laevis v. rugosa aut punctata, interdum carnosula, laete colorata, endopleura saepius obsoleta.

Alb um en nullum (in Cyrlandreis) v, carnosum, plus minus copiosum (in Gesnereis).

Eмввуо orthotropus, in albuminosis axilis, albumine parum brevior. Cotyledones obtusae, semicylindricae, arcte sibi applicitae. R a di cula brevis, conica v, cylindrica, obtusa, umbilicum basilarem attingens.

Gesneraceae pro albuminis praesentia v. defectu in duos subordines, habitu aliisque $90^{*}$ 
characteribus vix distinctos, sed sedibus per orbem satis ut videtur segregatos, abeunt.

Gesnereae, seminibus albuminosis donatae, et calycis cum ovario in nonuullis generibus cohaesione a Personatarum typo recedentes, novi continentis regiones tropicas magno numero incolunt, sub ipso aequatore frequentissime crescentes, in regionibus subtropicis rarissimae, extra Americam nondum repertae.

Cyrtandreae, propter albuminis defectum a nonnullis in proprium ordinem segregatae, placentis e lamina porrectis et saepissime margine in dissepimenta spuria revolutis aliquantulum a Gesnerearum typo ad nonnulla Bignoniacearum genera vergentes, in Asia tropica imprimis insulari, et in Himalayae jugis ad anstrum declivibus generantur, in Africae capensis regionibus interioribus et in Australasia subtropica rarissimae. Unica generis indici species nuper e terris Mexicanis magno botanicorum miraculo relata fuit.

Gesnerearum characteres a Martio absoluti. Cyrtandrearum genera plurima imperfecte cognita, olim a R. Browneo illustranda, cuius curis nostrum hoc volumen nondum ornari, impensius doleo.

SUIBDERO I. CXRTANDREAE. S emin a exalbuminosa.

TIRIBUS I. DIDYMOCARPEAE. Fructus capsularis.

434. A esclatnantinass $J A C K$. C a $1 \mathrm{y} \times$ tubnlosus, quinquefitus, aequalis. Cor o 11 a hypogyna, tubo subinenrvo, fauce dilatata, limbi bilabiati labio superiore erecto, bilobo, inferiore trifido, laciniis subaequalibus. S $\mathbf{t}$ a $\mathrm{m}$ in a corollae tubo inserta, quatuor didynama, exserta v. inclusa; fil amentis filiformibus, anthe$r$ is basifixis, bilocularibus, per paria cohaerentibus, quintum posticum inclusum, anantherum. Ovarium annulo hypogyno carnoso cinctum, placentis duabus, lamina parietali stipitatis, latis, ad axim contiguis, ad margines revolutos multiovalatis pseudo-quadriloeulare. Stylns simplex; stigma clavato - bilanellatum. Capsula basi calyce stipata, elongato-siliquaeformis, psendoquadrilocularis, bivalvis, valvis medio placentas, demum explanatas, margine seminiferas gerentibus. S emina plarima, cylindrica, funiculo filiformi et chalaza incrassata in filum simplex v, bifidum excurrente utrinque aristata. E mbry on is exalbuminosi, orthotropi cotyledones breves, obtusae, radicula teretinscula, umbilicum basilarem attingens. - Frutices Asiae tropicae, volubiles $v$. scandentes, ad articulos tumidos radicantes; folitis oppositis, petiolatis, coriaceo-subcarnosis, integerrimis, pedunculis axillaribus solitariis, bifloris, rarius terminalibus, umbellatis, pedicellis bibracteolatis, floribus speciosis, aurantiaceo coccineis, viscoso-pilosis.

A e sch in a nt hus Jack in Linn. Transact. XIV. 12, t. 2, f. 3. Wallich Plant, As, rar, $t, 21$, T rich os por u m Don in Edinb. philosoph. Journ. PIT, 85. In carvila e a pa. rasitica Roxburgh Plant. Corom. $t$. 291. -? Orythia Blume Flor. Jav. praef. DII. A gal myla Blum. Bijdr. 766. A. sta min ea, cui e el. auctore stamina duo fertilia, fortassis ad Lysiouotum referenda.

4135. Lysiomotus DON. Calyx quinquepartitus, aequalis. Co ro 11 a hypogyna, infundibuliformis, fauce ampliata, antice bicallosa, limbi bilabiati labio snperiore breviore, bilobo, inferioris trifidi lobis subaequalibus. S ta mina medio corollae tubo inserta, inclasa; duo antica fertilia, filamentis complanato - subelavatis, infra apicem incurvum, papillosum antheriferis; a $\mathbf{n}$ he ris divarieato-bilobis, cohaerentibus, lateralia subulata, ananthera, posticum nullum. Ova ri u m basi attenuata disco annulari hypogy. no cinctum, cylindricum, placentis duabus lamina parietali stipitatis, latis, ad axim contignis, ad margines revolutos multiovulatis pseudo-quadriloculare. Stylus brevis, simplex; stigma orbieulatum, subtruncatum. C a ps a l a basi calyce revoluto stipata, substipitata, lineari-tetragona, psendo-quadrilocularis, bivalvis, valvis medio placentas demum explanatas, margine seminiferas gerentibus. Semin a plurima, minima, subulata, utrinque acuta et pilo longo hyalino aristata .... - Herba nepalensis, subcarnosa; caulibus ex eadem radice pluribus, cylindricis, simplicibus, foliis ternato - verticillatis rariusve oppositis, breve petiolatis, lanceolato-oblongis, acuminatis, serratis, utrinque glabris, subtus nervosis, corymbis axillaribus, oppositis verticillatisque, di-trichotomis, pedunculis basi bibracteatis, corollis dilute caeruleis.

L y s i o not us Dou in Edinb, philosoph. Journ, VIT. 86. Nepal. 124. Wallich Plant, As, rar, 1I. 20, 6. 118.

4138 . Tromadorfire BLUM. C a l yx tubulosus, quadri-quinquefidus, aequalis. Cor olI a hypogyna, infundibuliformis, fance ampliata, limbo inaequali, quinquelobo, subbilabiato. St a$m$ in a corollae tubo inserta, inclusa; duo antherifera, a ntheris bilocularibus, cohaerentibus, loculis insartione aequalibus, totidem sterilia apice villosa. Ovarium .... Stylus simplex; stigma subbilamellatum. Capsula elongatosiliquaeformis, pseudo-quadrilocularis, bivalvis, valvis medio placentas margine revoluto seminiferas gerentibus. S e m in a plurima, minima, pendula, basi in alam membranaceam expansa ... Frutices javanici, erecti v. radicantes; folïs oppositis v. alternis, serratis, pedunculis axillaribus confertis, bifidis $v$. dichotomis.

Tromsdorffia Blume Bijdr, 764.

4. branaceus, laxe campanulatus, quinquefidus, aequalis, decidass. Cornlla hypogyna, infundibuliformis, fauce ampliata, limbi bilabiati labio superiore breviore, bilobo, inferioris trifidi lobo medio majore. Stam in a corollae tubo inserta, inclusa; duo antica fertilia, filamentis medio complanato-dilatatis, a $\mathbf{t} \mathbf{h}$ eris divaricato-reniformibus, bilocnlaribus, cohaerentibus; lateralia et postienm ananthera, subulata. Ovarium basi attenuata annulo hypogyno cinctum, placentis duabus lamina parietali stipitatis, latis, ad axim contiguis, margine revoluto unultiovulatis preudoquadriloculare. Stylus simplex, cylindricus; stigma late bilamellatnm, ringens. Capsula substipitata, siliquaeformis, graeilis, pseudo-quadrilocularis, bivalvis, valvis medio placentas demum explanatas, margine seminiferas gerentibus. S emin a plnrima, minima, subulata. - Herbae 
nepalenses, subcarnosae; caule simplici, foliis oppositis, petiolatis, serratis, saepe inaequalibus, pedunculis axillaribus bibracteatis, uni-multifloris, corollis magnis, roseis, caeruleis $v$. luteis.

Chirit a Hamilton ex Don. Nepal. 89 . Wallieh Plant. As, rar. t. 50, 72. Royle Himalay. t. 70, f. 2. C al as a cme Wallich mse.

4138. Difly moearpus $W A L L, \mathrm{C}$ aly $\mathrm{x}$ campanulatus, quinquefidus, aequalis, persistens. Corolla hypogyna, infundibuliformis, fauce ampliata, limbi bilabiati labio superiore bilobo, inferioris trifidi lobo medio majore. Stamina corollae tubo inserta, inclusa; duo antica fertilia, filamentis filiformibus ineurvis, antheris divaricato-reniformibus, bilocularibus, cohaerentibus; lateralia ananthera, posticum nanum v. plane obsoletum. Ovarium oblongum, basi attenuata annulo hypogyno quinquelobo cinetum, placentis duabus lamina parietali stipitatis, latis, ad axim contiguis, ad margines revolutos multiovalatis pseudo-quadriloculare. S t y I u 8 simplex, filiformis; stigma subinfundibuliforme. Ca p sula ealyce basi stipata, substipitata, siliquaeformis, recta, teretiuscula v. compressa, psendo-quadrilocularis, bivalvis, valvis strictis, medio placentas arete involutas, margine seminiferas gerentibus. S e min a plurima, subfusiformia, testa membranacea. Embryonis exalbuminosi cotyledones breves, radicula teretinscula, nmbilicum basilarem attingens. - Herbae in As $i$ a tropica indigenae, perennes, acaules $v$. caulescentes; caule scapove simplici, folits oppositis, rariusve alternis, aequalibus, plerumque cordatis, crenatis, rugosis, hirsutis, floribus racemosis v. racemoso-paniculatis, pedunculis basi bibracteatis, bracteis distinctis $v$, interdum connatis, corollis roseis $v$. purpureis.

Didy mocar p a 8 Wallieh in Edinb. philosoh. Journ. t. 378. Plant, As. rar, t, 140. 141, Jack in Linn, Trans. act, XIV. 32, $t$, \&. $f$. 2. Don Nepal, 128, Royle Himalay. r. zo. $f$. 1. R dittle r a Vaht Enumerat, 1, 88, non alior. Henckelia Spreng. Syst. 1 . 70 .

4139. Streptoentopas LINDL. Cal y pentaphyllus, aequalis. C or olla hypogyna, infundibuliformi-tubulosa, fauce ventricosa, limbo oblique quinquefido, subbilabiato. Stam in a medio corollae tubo inserta, inclusa; duo antica fertilia, filamentis linearibus, incurvis, a n the$\mathbf{r}$ is divaricato - reniformibus, bilocularibus, cohaerentibus; lateralia sterilia tuberculiformia, posticum nullum. Ovarium diseo hypogyno annulari cinctum, subulatum, teres, uniloculare, placentis duabus lamina parietali stipitatis, latis, ad axim contignis, ad margines revolutos multiovulatis pseudo-quadriloculare. Styl us simplex, linearis; stigma late bilamellatum, lobis reniformibns, inaequalibus. Capsula basi calyce stipata, elongato-siliquaeformis, pseudo-quadriloenlaris, spiraliter contorta, bivalvis, valvis spiralibus, medio placentas arcte involntas, margine seminiferas gerentibus. Semina plurima, elliptico-oblonga, utrinque acuta, testa membranacea. Embryon is exalbuminosi cotyled o nes breves, $r$ a die ula teretiuscula, nmbilienm basilarem aitingens. - Herba perennis, acuulis, in Africa australi subtropica indigena; foliis radicalibus humifusis, oblongis, crenatis, villosis, imprimis subtus rugosis, scapis confertis, flacidis, unifloris, medio squamoso bibracteatis, corollis pallide caeruleis, fauce purpureo-striatis, majusculis, speciosis.
Streptoearpus Lindley in Bot. Reg. t. 1173. Did y moc a rpus Rexii Hooker Exot, Flor. t. 227. Bot. Mag, t. 3005 .

4140. IBaea COMMERS. Cal y p parvas, quinquepartitus, aeyualis. Corolla hypogyna, tubo brevi, subcampanulato, limbo inaequaliter quinquepartito, subbilabiato. St a mina 2 , corollae fauei inserta; antheris magnis, reniformibus, unilocularibus, apice cohaerentibus, O vari $\mathbf{~ m}$ lanceolatum, placentis duabus lamina parietali stipitatis, ad margines revolutos multiovulatis pseudo-biloculare. Sty lus simplex; sti gma brevissime bilobum. Ca psula siliquaeformis, elongata, bilocularis, bivalvis, valvis demum spiraliter contortis, placentis filiformibns geminis, liberis. Se mina plurima, minima. - Herbae acaules, in Nova-Hibernia et Chinaboreali observatae; foliis radicalibus obovatis, grosse crenatis, subtus dense albo-tomentosis, villosis, supra viridibus, pilosis, coelo sicco quasi exsiccatis, tempestate pluria explicatis, saxo adpressis, carnosulis, scapis debilibus, adscendentibus, glandulosis, paucifloris, floribus laxe paniculato-racemosis, laete caeruleis, antheris magnis, flavis.

B a e a Commers. ex Juss. gen. 121. Lam. t. 15. Vahl Enumerat. $I, 172$. Do r coceras Bunge Enumerat. Plant. Chin, bor, 6a. - B a e a e patria perperam terra Magellan indieatur, monente el. $R$. Browa ex Bentham in litt. verisimiliter in Nova Hibernia lecta.

411. Loxotis R, BR. Calyx laxe tubulosus, pentagonus, quinquefidus. Corolla hypogyna, personata, tubo subeylindrico, fauce clausa, limbi labio superiore abbreviato, bilobo, inferioris producti, semitrilobi lobis lateralibus nanis, St a mina corollae tubo inserta, inclusa, duo antica fertilia; a n theris bilocularibus, reniformibus, lateralia et posticum minimum ananthera. Ovariu m vaginula hypogyna incompleta cinetum, uniloculare, placentis duabus parietalibus e lamina angusta ortis, bilobis, utrinque multiovulatis. Stylns filiformis, simplex; stig. $\mathbf{m}$ a depresso-capitatum, indivisum. C a ps a l a subovata, calyee inclusa, unilocularis, bivalvis, valvis medio laminam fissilem, in placentam planam bilobaru, utrinque seminiferam expansam gerentibus. Se m in a plurima, elliptico-oblonga, ntrinque acuta, funienlo brevi crassiusculo, testa membranacea, endopleura obsoleta. E mbry on is exalbuminosi cotyledones breves, radicula teretiuseula, umbilieum basilarem attingens. Herba annua, glabriuscula, in Asiae tropicac continente et insulis crescens; caule erecto, suceulento, foliis alternis, petiolatis, integerrimis, hinc alte exciso - inuequilateris, racemis subsecundis, indivisis, pedicellis solitariis, unibracteatis, floribus deflexo-porrectis, caeruleis.

Loxolls R. Browa in Wallich Plant. As, rar. III, 65. in not, Plant, Jav, rar. Horsf. 102. $t$. 24. A n tonia R. Brown mse. Wulfenla obliqua Wallich Flor. No. pal. 45. 1.35. K n a p pla Ferd. Bauer misc. - ? R h i a chogloss um Blume Bijdr. 741.

4142. Cllosgrantinus KLEIN, C a 1 y x laxe tubulosus, basi inaequalis, pentapterus, quinquefidas. Corolla hypogyna, personata, tubo subcylindrico, fauce clausa, limbi labio superiore abbreviato, bilobo, inferiore producto indiviso $\mathbf{v}$. semitrilobo. S $t$ a m in a corollae tubo inserta, inclusa, quatuor fertilia, didynama, absque quinti rudimento; antherae bilocnlares, reniformes, in coronulam cohaerentes. Ovarium disco an- 
nulari completo cinctum, uniloculare, placentis duabus parietalibus, e lamina angusta ortis bilobis, utrinque multiovulatis. Stylus filiformis, simplex; stig m a depresso-capitatum, indivisum, Capsula ovata, calyce inclusa, unilocularis, bivalvis, valvis medio laminam fissilem, in placentam planam, bilobam, utrinque seminiferam expansam gerentibus. S e min a plurima, ellipticooblonga, sulcata, transversim rugulosa .... Herbae annuae, in Asia tropica et Mexico observatae, habitu, foliis hine excisis, racemo subsecundo indiviso corollisque caeruleis L o xot $i$ dis, a qua vix nisi staminibus quatuor fertilibus differunt.

Glossanthus Klein ex Benth. Serophularin. ind. 57. R. Brown Plant, Jav. rar. Horffield, 102, in not. W u lfenia Notoniana Wallich. - KI ugia Schlechtead. in Liwnaea VIII. 848.

414. Loxomia $J A C K$. Caly $\mathrm{x}$ quinquepartitus, laciniis subaequalibus, acutis. Corolla hypogyna, ringens, tubo brevi, ventricoso, fauce patnla, limbi bilabiati labio superiore emarginato, inferiore trifido, subaequali. Stam in a corollae tubo inserta, quatuor didynama; a $\mathrm{t}$ herae biloculares, reniformes, per paria cohaerentes. O vari $\mathrm{nm}$ disco hypogyno nullo (?), uniloculare, placentis duabus parietalibns, e lamina angusta, medio incrassata ortis, bilobis, marginibus utrinque multiovulatis. Stylus filiformis, simplex; stig ma depresso-eapitatum, obsolete emarginatum. Capsul a ovata, acuminata, calyee inclusa, unilocularis, bivalvis, valvis medio laminam demum liberam (?), in placentam planam, bilobam, facie nudam, marginibus utrinque seminiferam expansam gerentibus. S e min a plurima … - Herbae moluccanae, pubescentes; foliis sessilibus alternis, altero nempe opposito minimo stipulaeformi, oblongis, obliquis, serratis, pedunculis axillaribus racemosis, floribus caeruleis.

L ox on 1 a Jack in Linn, Transact, XIV. 40. R. Brown Plant, Jav. Horafield, t. 25. (absq. toxt.) $\rightarrow$ L Lox o ph y l.
1 a Blume Bijdr. 750 .

414. Epithema BLUM. Calyx tubnlosus, quinquefidus, aequalis. Corolla hypogyna, tubo cylindrico, limbo bilabiato patente, labio superiore bifido, inferiore tripartito, laciniis subaequalibus, Stamin a corollae tubo inserta, inclusa; duo lateralia fertilia, an th eris unilocularibus, filamenti apici obliquo basi adnatis, cohaeren tibus; antica ananthera, e basi subulata apice subdilatata, postici rudimentum nullum. Ov a riu m glandulis duabus hypogynis truneatis stipatum, uniloculare, placentis e pedicellis duobus parietalibus angustis, adnatis, in laminas subrotundas, solutas, compressas, ntrinque multiovulatas expansis. Stylus filiformis, simplex; stig ma peltatum, convexum. Ca p sula calyce cincta, unilo cularis, circumscissa, placentis duabus pedicellatis, liberis, undique seminiferis. S e m in a plurima, ovali-oblonga, funieulis praelongis, testa coriacea spiraliter striata, endopleura tumida. Embry onis subexalbuminosi, orthotropi cotyledones breves, semiovatae, radicula teres, nmbilieum basilarem attingens. - Herbae annuae, pilosiusculae, in Asia tropica indigenae, humiles; caule carnosulo, folits petiolatis, cordatis, subdenlatis, inferioribus, dum uno plura, alternis, terminalibus suboppositis, spicis unilateralibus, circinalibus, fructiferis corymbosis, pedunculatis, rhachi hinc pedi- cellis subduplici serie confertis, ebracteolatis, inde foliolo cucullato, subrotundo involucrata, floribus caeruleis fere Erini.

Epithema Blume Bijdr, 737. Aikinia R. Brown in Wallich Plant, As, rar, III, t. 65, $t$, 288, Gratiola Involuerata Ait.

4145. IRlabbolothamnus $A$. CUNNINGH. Cal y $\times$ tubo ovario inferne adnato, limbo profunde quinquefido, subbilabiato. Corolla hypogyna, tubulosa, limbo quinquelobo, bilabiato, subaequali, Sta m in a corollae tubo inserta, quatuor didynama; a ntheris bilocularibus, omnibus in discum lobatum eohaerentibus. Ovari $\mathrm{nm}$ ima basi calyci adnatum, annulo perigyno cinctum ..... Stylus simplex; stig ma bilamellatum. Capsula venosa, rostrata, unilocularis, bivalvis, valvis medio fissis, valvularum marginibus inflexis, placentis duabus lanceolato-lamellatis, pedicellatis, parietalibns, demum liberis. $\mathbf{S}$ m in a plurima....- Frutex Novae-Zeelandiae borealis, ramosissimus, dumosus; ramis virgatis, ramulis gracilibus, pallidis, pilosis, folitis oppositis, petiolatis, subrotundo-rhomboideis, subcuneatis, grosse serratis, venosis, scabris, pedicellis axillaribus unifloris, corollis sordide rubris v. rubiginosis, striatis.

Rhabdothamnus A. Cunningh. in Jardine Journ. of. nat. sc. $T$. 460 .

\section{TUEIBUS II. EUCYRTANDREAE. Fruc-} tus baccatus.

4146. Cyrtandra FORST. Calyx tubulosus, quinquefidus $v$, quinquepartitus, subaequalis. C orolla hypogyna, infundibuliformis, fauce ampliata, limbo quinquefido, subbilabiato. $S t$ a $m$ in a medio corollae tubo inserta, inclusa, duo antica fertilia; fil amentis complanatis, a $n$th e $r$ is bilocularibus, loculis aequalibus, parallelis v. divaricatis. Ov a ri um disco hypogyno quinquelobo cinctum, uniloculare, placentis duabus parietalibus late bilobis, lobis revolutis nndique multiovulatis. Stylus simplex; stigma obtusnm, capitatum v. bilobum. B a ce a oblonga, spongiosa, unilocularis, placentis parietalibus carnosis. S e m in a plarima, nidulantia, testa coriacea, punctata. E m bry on is exalbuminosi, orthotropi c ot yled ones obtusae, radicula teretinscula, umbilicum basilarem attingens. - Frutices $v$, herbae, in Molucc is crescentes; caule erecto $v$, procumbente, foliis oppositis, altero saepius nano $v$. abortivo, floribus fasciculatis v. capitatis, rarius solitariis, axillaribus, bracteatis, albidis $v$, sordide purpurascentibus.

Cyrtandra Forster Char. gen, 3. $t$. 3. Vahl Symb. 1I. 1. Jack in Linn. Transact, XIV. 25, t. 2. f. 1. Blume Bijdr. 768 . Gaudichaud ad Fregc. $\ell$. $88-56$.

414\%. Whitia BLUM. Calyx parvus, quinquefidus, aequalis. Corolla hypogyna, infundibuliformis, tubo sursum ampliato, limbo quinquelobo, subbilabiato. S $\mathrm{ta}$ m in a corollae tabo inserta, duo fertilia, vix exserta; antheris bilocularibus, loculis insertione inaequalibus, tria ananthera, setacea, inclusa. O va riu m ...... Stylus simplex; stigma infandibuliforme. Ba ce a siliquaeformis, pseudo-quadrilocularis, placentis parietalibus bilobis, margine revolnto seminiferis. S e min a plurima, striata, pulpa tenui eineta .... - Frutices javanic $i$, scandentes; 
foliis oppositis, integerrimis, obliquis, altero minore, fasciculis axillaribus, breviter pedunculatis, bracteatis.

Wh it i Blume Bijdr. $r$ 4.

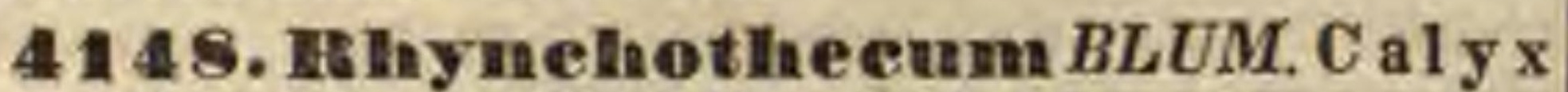
quinquefidus, aequalis. Co rolla hypogyna, tubo brevi, campanulato, limbo quinquelobo, inaequali. St a mina corollae tubo inserta, quatuor fertilia, didynama, inclusa; antheris unilocnlaribns, liberis. Ovarium … Stylus simplex, incurvus; stig ma obtusum. B a c c a globosa, calyce cincta, pseudo-quadrilocularis, placentis parietalibus bilobis, margine revoluto seminiferis, Semin a plurima .... - Frutex $j a v a-$ nicus; caule simplici, tereti, foliis oppositis, ob. longo-lanceolatis, serratis, subtus villosiusculis, corymbis axillaribus, dichotomis, pedicellis subfasciculatis.

Rhynehothecum Blume Bijdr. 775 .

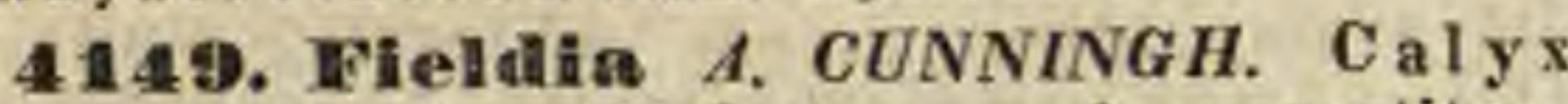
bractea spathaeformi stipatus, quinquepartitns, aequalis. Corolla hypogyna, tubuloso-ventricosa, limbo brevissime quinquefido, subbilabiato, obtuso. St a m in a imo corollae tubo inserta, limbum subaequantia, 4 fertilia, subdidynama; filam ent is e basi valde dilatata angustatis, a $n t h e-$ ris bilocularibus, subrotundis, quintum brevius, anantherum. Ovari $\mathbf{u m}$ uniloculare, placentis duabus parietalibus late bilobis, lobis (bifidis?) revolutis, undique multiovulatis. Stylus simplex; stigm a subcapitato-bilobum. B a cea oblonga, spongiosa, unilocularis, placentis parietalibus, carnosis. Sem ina plurima, nidulantia, testa coriacea, punctata, Embry on is exalbuminosi, orthotropi cotyledones obtusae, radicnla teretinscula, umbilicum basilarem attingens.

Fruticulus in Novae-Hollandiae montibus caeruleis super arborum truncis radicans; foliis oppositis, breve petiolatis, valde inaequalibus, ellipticis, integrerrimis $v$. serratis, pedunculis axillaribus solitariis, unifloris, nutantibus.

Fieldia A. Cunningh. in Fields Mem. N. S. W. 364. c. ic. Hooker Exot. Flor. t. 232.

4150. Centronala BLUM. Calyx spathaceus, hinc fissus. Corolla hypogyna, tubo infundibuliformi, limbi bilabiati labio superiore erecto, bilobo, inferiore trilobo, patente, lobis subaequalibus. Stamina corollae tubo inserta, 4 didynama, inclusa; antheris unilocularibus, dorso basi calcaratis, liberis. Ovarinm .... Stylus simplex, crassus; stigma capitatum. B a c c a siliquaeformis, pseudo-quadrilocularis, placentis parietalibus bilobis, margine revoluto seminiferis. Sem in a plurima, aptera. Herba javanica, pusilla, subcarnosa, in radicibus arborum parasitica; scapis aphyllis, squamis bracteisque unifloris instructis.

Centrouia Blume Bijdr. 776.

\section{GENERA DUBIA.}

414. Platystemana WALL. Calyx quinquefidus, aequalis. Coro 11 a hypogyna, explanato-rotata, tubo subnullo, limbo bilabiato, labio superiore emarginato, inferiore majore, trifido. Stamin a corollae tubo inserta, quatuor fertilia, subaequalia; filamentis brevissimis, antheris magnis, reniformibus, unilocularibus, quin- tum posticum anantherum. O vari um biloculare (?) multiovulatum. Stylns simplex, longissisimus, crassus; stigma capitatum, indivisnm. Fructus .... - Herba nepalensis, annua, rupicola, humilis, erecta, pilosa; caule mono-diphyllo, foliis sessilibus, cordatis, obtusis, supra atro-virentibus, subtus argenteis, venosis, floribus terminalibus paucis, azureis, pro ratione plantulae magnis.

Plat y ste m m a Wallich Plant. As, rar, IrT, 4t.t, 151 . Royle Himalay, $t, z 1, f .1$.

4158. Stamramathera BENTH, CaIyx subrotato - campanulatus, quinqueplicatus, latissime subdecemfidus. Corolla tubo brevissimo, ampla, obliqua, basi calcarata, apice subquinquefida. Stamina fertilia 4 ; antheris cordiformibus, cruciatim cohaerentibus. Ca p 8 u la circumscissa .... - Herba penangiana, ramificatione caulis et foliorum obliquitate Glossanthi; folitis amplis, rugosulis, racemis di-trichotome paniculatis.

Sta ura in ther a Benth. Scrophularin, ind, 57.

4153. Corysanthera WALL. Calyx pentaphyllus, aequalis. Corolla gamopetala, irregularis. Stamina 4 , imo corollae tubo inser. ta; antherae basifixae, erectae, liberae, oblongae, bilabiatae, quadrivalves, valvalis per paria cohaerentibus. O vari um uniloculare, placentis parietalibus replicatis, multiovalatis. Styl us ovario continuus; stigma .... - Herbae in dica $e$, nondum descriptae, a me non visae.

Cory $s$ a the r a Wallielt Catalog. $n, 6411$. Benth, in litt. 11. Mai. 1838.

4154. Tieria LOUREIR. C a Iy x tetraphyllus. deciduus, foliolis duobus oppositis, ovatis, planis, corolla longioribus, duobus linearibus, brevioribas. Coroll a tubulosa, ringens, tubo medio constricto, labio superiore spathulato, emarginato, inferiore ampliore, trifido, laciniis rotundatis, aequalibus. Stam in a 4 , duo superiora longiora, erecta, seorsim tubulis papillosis vaginata; antheris unilocularibus, curvis, distantibus, duo breviora, inflexa, antheris bilocnlaribus, connexis. Ovarium ovatum. Stylus co. rollam aequans; stig $\mathrm{m}$ at a 2 , lanceolata, erecta. B a c ca ovata, infera, bilocularis. S emina plarima, subrotunda. - Herba perennis, amarissima, in hortis sinarum culta; caule tetragono, erecto, ramoso, foliis oppositis, ovatis, serratis, floribus axillaribus et terminalibus pedunculatis, congestis.

Picria Loureira Elor. cochinch. 477.

SUBOBDD II. GESNEREAE. S e m i$\mathrm{n}$ a albuminosa.

TREIBS I. BESLEREAE. Ov a rium liberum. Fructus baccatus.

155. Sarmalenta $R U I Z$ et $P A V$. C a I yx liber, quinquepartitus, subaequalis, bracteolis duabns oppositis remotis. Corolla hypogyna, urceolato - campanulata, tubo ventricoso, limbo quinquepartito, subaequali. Sta mina corollae tubo inserta ; duo postica fertilia, longe exserta, filamenta filiformia, antherae biloculares, ovatae, tria sterilia, subulata, inclnga. Ovaria m liberum, disco quinquelobo cinctum, uniloculare, 
placentis duabus parietalibus bilobis, revolutis. Ov ula plurima.... Stylus simplex; stigma capitatum, depressum. В a c c a unilocularis, placentis duabus parietalibus pulposis, Sem in a plarima. - Herba chilensis, sarmentis ramosis in arborum truncis rupibusque radicans; foliis oppositis, petiolatis, ovatis v. orbiculatis, carnosulis, pedunculis axillaribus et terminalibus unifloris, corollis puniceis.

Sarmienta Ruiz et Pavon Flor. Peruv, $I, 8, \boldsymbol{t}, \boldsymbol{z}$. Martius Nov. gen, et $s p$. IIT. 66. $f$. 2. (mal.) U r c e ol a. I l a Feuillé Observ. IIT. 69, t, 43. Molina Chil. 277.

4156. Nitraria $C A V$. Caly x liber, quinquepartitus, subaequalis, bracteolis duabus oppositis, hine ad basim distinetis illine ad medium connatis inclusus. Corolla hypogyna, tubulosa, tubo superne ventricoso, limbo quinquefido, subbilabiato, patente. $\mathrm{Sta} \mathrm{m}$ in a corollae tubo inser$\mathrm{ta}$, quatuor didynama, longe exserta; fil a m e $\mathrm{nti}$ s filiformibus, a n theris bilocularibus, ovatis, liberis, quintum anantherum, inclusum. Ov a ri um liberum, disco obsolete quinquelobo einetum, uniloculare, placentis duabus parietalibus, bilobis. Ovala plurima ...... Stylus simplex; stigma obtusum. B a ce a globesa, unilocularis, placentis duabus parietalibus, pulposis. Semina plurima, oblonga, nitida .... - Fruticulus $c h i$ lensis, super arborum truncis radicans; caule ramisque tetragonis, debilibus, villosis, foliis oppo. sitis $v$. ternatis, breve petiolatis, ovatis, acutis, serratis, floribus axillaribus solitariis, oppositis, longe pedunculatis, corollis puniceis.

M i tra ri a Cavanilles Anal, eienc, nat, IIT, 230, t. 31. It. t. 579 .

45\%. Columnea PLUM, C alyx liber, quinquepartitus, sabaequalis. C orolla hypogyna, tubulosa, tubo basi postice gibbo, supra aequali, limbi ringentis labio superiore erecto, fornicato, integro v. emarginato, inferiore trifido, patente. $\mathbf{S} \mathrm{t}$ a $\mathrm{m}$ in a corollae tubo inserta, quatuor didynama, subexerta, cum quinti rudimento; a nthera e per paisia cohaerentes, biloculares, ovatae. Ovarium liberum, disco quinquelobo cinctum, uniloculare, placentis duabus parietalibus bilobis. Ovala plurima, in funiculis brevibus anatropa. Stylus simplex; stigma bilobum. Bac e a nnilocularis, placentis duabus parietalibus, pulposis. S e min a plurima, obovata. $\mathbf{E}$ mb ryo in axi albuminis carnosi cylindricus ; cotyledonibus brevissimis, obtusis, radicula umbilico proxima, centrifaga, - Herbae v, suffrutices Americae tropicae; caulibus flexilibus, erectis $v$. scandentibus, foliis oppositis, crassiusculis, hirsutis v. pubescentibus, subserratis, pedunculis axillaribus, solitariis $v$, confertis, corollis coccineis.

Col um ne a Plumier gen, 28. Ic, $t, 89$, Linn. gen, $n$, 292. Martius Nov, gen. et sp. IIT. 65. t. 296. f. 1. Bot. Reg. $t$. 805 , Bot. Mag. $t, 3081$. A chimenes P. Browne Jam. 271. $t, 30 .$, . 3, exel. sp.

458. Besleria PLUM. Caly x liber, quinquefidus, subaequalis, coloratus. C o rolla hypogyna, subcampanulata, tubo subaequali, limbo quinquefido, subaequali. St a min a corollae tubo inserta, quatuor didynama, inclusa, eum rudimento quinti; a n th er a e biloculares, distinetae, subglobosae. Ovari u m liberum, disco annulari cinctum, uniloculare, placentis duabes parietalibus bilobis. Ovula plarima, in funieulis brevibus anatropa, Stylus simplex; stigma bifidam
B a c c a nnilocularis, placentis parietalibus pulposis, demum irregulariter fasticens. S e m in a plnrima, obovata. Emb r y o in axi albuminis carnosi cylindricus; cotyledonibus brevissimis, obtusis, radicula umbilico proxima, centrifuga. Fruticuli in America tropica sylvicoli, erecti, ramosi; caule subtetragono, foliis oppositis, petiolatis, crassiusculis, supra puberulis, subtus nitidulis, nervis venisque prominentibus, pedunculis axillaribus, uni-paucifloris.

B e s l e r la Plumier Gen. 29. Yc. $t, 49 . f$. 1, Linn. gen. n. 755. excl. 8p. Giurtner $I, 24,8$. 52. Martius Nov. gen. et sp. III, 43, t, 218. E ri phi a P. Browne Jam. 270. St. Hi. laire in Mem, Mus. II. 158 .

4159. Irypoeyrta MART. C a ly x liber, quinquepartitns, aequalis. Corolla hypogyna, tubulosa, tubo basi postice gibbo, antice superne ventricoso, limbo quinquelobo v. quinquedentato, aequali. St a min a corollae tubo inserta, quatuor didynama, inclusa, cum rudimento quinti; a nthe rae per paria cohaerentes, biloculares, ovatae. O vari um liberum, disco annulari einctum, basi postice glandula stipatum, uniloculare, placentis duabus parietalibus, bilobis. O vula pluri$\mathrm{ma}$, in funiculis longis anatropa. Stylus simplex; st ig ma bilobum. B a ce a unilocularis, placentis parietalibus pulposis. Semina plurima, oblonga v ovata. $\mathbf{E}$ in b ryo in axi albuminis carnosi eylindricus; cotyledonibus brevissimis, obtusis, radie ula umbilieo proxima, centrifuga. - Fruticuli brasilienses, glabri v. hirsuti, procumbentes et radicantes $v$, rarius erecti, sparsim ramosi; foliis oppositis, crassiusculis, subtus saepe rubentibus, floribus axillaribus, solitariis v. aggregatis, coccineis, albis, ochroleucis v. roseis.

H y p o c y rta Martius Nov, gen, et sp. III. 48.

a. CODONANTHE Mart. t. c.t.220. 221. C oroll a e tubus subeampanulatus, antiee parum ventricosus, limbo Jasiuseulo, quinquelobo.

b. ONCOGASTRA Mart, l, e, t,222, C orolla e tubus antice gibboso-ventricosus, limbus erectus, quinqueden. tatus.

THRIBUS II. EPISICIEAE. C a l y $\mathrm{x}$ liber. Fructus capsularis.

4160. Drymonia MART. C aly x liber, pentaphyllus, obliquus, foliolis imbricatis, inaequalibus. Corolla hypogyna, obliqua, campanulato-subringens, tubo basi postice gibbo, fauce patula, limbi labio superiore bi- inferiore trilobo. St a min a quatuor, imo corollae tubo inserta, didy. nama, inclusa, quinti rudimento nullo; a n th era e conniventes, biloenlares, oblongae, subsagittatae. O vari u m liberum, disco annulari einctum, basi postice glandula stipatum, uniloculare, placentis duabus parietalibua, bilamellatis. $\mathrm{O} v \mathrm{u} \mathrm{l}$ a in funieulis longiusculis plurima, anatropa.: $S$ ty Ins simplex; st $\mathrm{gm}$ a bilobnm. C a $\&$ n 1 a unilocularis, bivalvis, valvis medio placentiferis. S emin a plurima, fusiformia. $\mathbf{E}$ m b ryo in axi albuminis earnoso-oleosi orthotropus, cylindricus; cotyledonibus brevissimis, obtusis, radicula ambilico proxima, rentrifuga. - Frutices Americae tropicae, super arbores scandentes, $v$. epigaei repentes; caulibus flexibilibus, epidermide nitida vestitis, foliis oppositis, petiolatis, serratis, crassiusculis, pedunculis axillaribus solitariis, brevibus, ebracteatis, corollis amplis, pictis.

D r y mogu i Mart. Nov. gen, et sp, III, s7, t, 224. 
Bot. Reg. II. t. 4. Besleria serrulata Jacq. Hort. schönbr. $t, 290$.

4181. Tapina MART. Calyx liber, quinquepartitus, obliquus, inaequalis. Coro 11 a hypogyna, infundibuliformi-subringens, tubo basi postice gibbo, antice superne inflato-ventricoso, fauce coarctata, limbi erecti labio superiore bi- inferiore trilobo. Stam in a 4 , corollae tubo inserta, subdidynama, inclusa, cum quinti rudimento; anthera e per paria cohaerentes, biloculares, ovatae. Ovarium liberum, disco annulari subquin. quelobo cinctum, basi postice glandula stipatum, uniloculare, placentis duabus parietalibus, bilamellatis. Ovula plurima, in funiculis brevibns anatropa. Stylus simplex; stigma capitatum, emarginato-bilobum. C a 8 u l a coriacea, unilo. cularis, bivalvis, valvis medio placentiferis. Semina plurima, oblonga. $\mathbf{E} \mathbf{m b r y o}$ in axi albnminis carnosi orthotropus, cylindricus; coty l edonibus brevissimis, obtusis, radieula umbilico proxima, centrifuga. - Herbae in Brasilia trop ic a sylvicolae; caulibus simplicibus v. ramosis, e tubere hypogaeo enatis, mollibus, carnosulis, foliis suboppositis, petiolatis, pedunculis axillaribus, solitariis $v$. geminis, unifloris.

T a pI n a Martius Nov, gen, et sp. III, 59. $t$, 295.

4 1 S9. Nematanthus SCHRAD. C a ly $x$ liber, quinquepartitus, obliquus. Co rolla hypogyna, infundibuliformi-campanulata, subobliqua, tubo basi postice gibbo, antice superne subventricoso, fauce patula, limbi quinquefidi laciniis subaequalibus. Stamina 4 , imo corollae tubo inserta, didynama, inclusa, cum quinti rudimento ; a therae per paria cohaerentes, biloculares, ovatae. Ovarinm liberum, diseo annulari einctum, basi postice glandula stipatum, uniloenlare, placentis duabus parietalibus, bilobis. Ov ula plurima, in funiculis brevibus anatropa. $\mathrm{Sty}$ lus simplex; stig ma subinfundibuliforme. Ca p8 ula coriacea, unilocularis, bivalvis, valvis medio placentiferis. Semina plarima, oblonga. E mbryo ..... - Frutices brasilienses, super arbores scandentes, radicantes, subramosi; ramis tetragonis, ad nodos subincrassatis, epidermide nitida, secedente, foliis oppositis, petiolatis, cras siusculis, pedunculis axillaribus, solitariis, ebracteatis, uniftoris, filiformibus, nutantibus, corollis amplis, puniceis.

Nemata nthus Schrader in Göttinger gel. Anzeig. 1821. I. p, 719. Martius Nov. gen. et sp. III. 46. t. 120.

4163. Alloplectus MART. Caly x liber, coloratus, pentaphyllus, foliolis inaequalibus, imbricato-conniventibus, Corolla hypogyna, infundibuliformi- v. elavato-tubulosa, tubo basi postice gibbo, antice superne saepius ventricoso, limbo quinquedentato v. breviter quinquefido. Stamina 4 , imo corollae tubo inserta, didynama, inclusa, cum quinti rudimento, filamenta circumplexa; antherae per paria approximatae, bilocnlares, ovato-oblongae. Ovari nm liberam, disco annulari cinctum, postice glandula stipatum, uniloeulare, placentis duabus parietalibus, bilobis. Ovula plurima, in funieulis longiusculis anatropa. Stylus simplex; stig ma hemisphaerieam, indivisum, medio concavum. Capsula coriacea, snbpulposa, nnilocularis, bivalvis, valvis medio plaeentiferis. Semin a plurima, oblonga v. fusiformia. E mbryo in axi albuminis earnosi orthotropus, cylindricus; cotyledonibus brevissimis, obtusis, radicuI a umbilienm spectante, centrifuga. - Frutices in America tropica super arbores scandentes; ramis subtetragonis, ad nodos nonnihil incrassatis, medulla ampla faretis, epidermide nitida, secendente, foliis oppositis, sacpe inaequalibus, petiolatis, subtus non raro rubentibus, coriaceo-subcarnosis, floribus axillaribus, nunc solitariis, pedunculatis, nunc aggregatis, sessilibus $v$, racemosis, bracteis interstinctis, bracteis calycibusque puniceis v. sanguineis, corollis flavis.

A II ople etus Martius Nov. gen. et sp. IIT, 53. $t, 223$. Crantzia Scopoli Introduct, n, 710. Dalbergia v, Dal. bergaria Tussac Flor. Antill, 1, 141, t. 30. T u s s a cia Reichenb. Conspect, 125. B e s I e r i a e s p. Linn. Jacq. Amer. t. 119. Aublet Guian, t. 225. O ro ba u chiae 8 p. Vellozo Vandell. $t, 7, f, 18$.

4 194. Episeia $M A R T$. Ca 1 y x liber, quinquepartitus. Coroll a hypogyna, infundibuliformis, tubo rectiusculo, basi postice gibbo, limbo quinquefido. Stamin a 4 , imo corollae tubo inserta, didynama, inclusa, cum quinti rudimento; antherae per paria approximatae, biloculares, suborbiculari-ovatae. O va ri um liberum, disco annulari tenui, postice in glandulam tumescente cinctum, uniloculare, placentis duabus parietalibus, bilobis. Ovula in funiculis longiusenlis plurima, anatropa. Stylus terminalis, simplex; stig ma bilamellatum. C a p $8 \mathrm{n} l$ a membranacea, bilocularis, bivalvis, valvis medio placentiferis. S e $\mathbf{m}$ in a plnrima, oblonga. $\mathbf{E} \mathbf{m}$ br yo in axi albuminis parci crassus, orthotropus; coty l ed onibus brevissimis, radicula umbilico proxima, centrifuga. - Herbae Americae tropicae, molles, succosae, glabrae $v$. pilis articulatis villosae, procumbentes, saepe radicantes; foliis oppositis, petiolatis, floribus axillaribus solitariis $v$, cymosis, bracteatis, varie coloratis.

E p is cia Martius Nov gen, et sp. III. 39. $t, 216.217$. Besle ría es p. Plumier gen. $t, 5.1 c, t, 48$. Linn. Smith Exot. Bot. I. t. 34. Sehrank Hort. Monac. t, 44.

TER IIBUS IIT. EUGESNEREAE, $0 \mathrm{v}$ ari u m inferum v. semiinferum. Fructus capsularis.

46.5. Gesmera MART. Calyx tubo cum ovarii basi eohaerente, limbo quinquepartito, subinaequali. Corolla perigyna, tubulosa, tubo ima basi quinquegibboso, limbi subbilabiati labio inferiore trilobo. St a m i n corollae inserta, quatuor didynama, inclusa, cum rudimento quinti; an ther a e biloculares, in discum cohaerentes, demum sulntae. $O$ v a $\mathbf{r}$ i $\mathbf{m}$ basi calyci cohaerens, glandulis quinque einctum, uniloculare, placentis duabns parietalibns, bilobis. Ovu la pluri$\mathrm{ma}$, in funiculis longiuscolis anatropa. Stylus simplex; stigma capitatum, obsolete bilobum. Ca s ula coriacea, unilocularis, bivalvis, valvis medio placentiferis, Semina plurima, subclavata. Embryo in axi albuminis carnosi orthotropus; cotyledonibus brevibus, obtnsis, $r a$ di cul a umbilicum spectante, centrifnga. - Her bae Americae tropicae, tuberibus hypogaeis perennantes; caule subsimplici v. opposite ramoso, medulla ampla fareto, foliis oppositis $v$, verticillatis, breve petiolatis, integerrimis, dentatis $v$. serratis, crassiusculis, molliter villosis $v$ subsericeis, floribus in cymulis oppositis, thyrsum terminalem constituentibus, rarius racemosis os spicatis, corollis 
coccineis, miniatis v. purpurascentibus, interdum virescentibus, maculatis, saepe pubescentibus.

Ge snera Martius Nov. gen. et sp. III, 27, $2,212$. 215. Amoen. Monac, t. 14. Gesneriac sp. Linu. Kunth in Humb. ef Bonpl. Nov, gen. et sp. t. 188 _192. Bot. Mag. t, 2725. 2776. 3576. 3602. 3612, 3659. 3664. Bot. Reg. t, 329. 363. 426. 1032, 1110, 1158, 1202. 1279. 1267, 1637. 1650. Link et Otto $I c$, select. t. 25 .

41 166. Trevingana WILLD. Calyx tubo cum ovarii basi connato, limbo quinquepartito, subaequali. Co r olla perigyna, infundibuliformis, tubo basi postice gibbo, subobliquo, limbo subaequaliter patente, quinquelobo, $\mathbf{S}$ t a $\mathrm{m}$ in a corollae tubo inserta, quatuor didynama, inclusa, cum rudimento quinti; antherae biloculares, in discum cohaerentes, demum solutae. Ova ri um basi calyci cohaerens, disco annulari cinctum, uniloculare, placentis duabus parietalibus, bilobis. Ovula plurima, in funiculis brevibus anatropa. Stylus simplex; stigma subcapitatum, obsolete bilobum. Capsula coriacea, nniloeularis, apice bivalvis, valvis medio placentiferis. Semina plurima, subclavata. Embryo in axi albuminis carnosi orthotropns; cotyledonibus brevibns, obtusis, radicula umbilienm spectante, centrifuga. - Herbae America e tropicae, pubescentes, stolonibus squamosis hypogaeis o. interdum axillaribus perennantes; foliis oppositis, ternatis, serratis, floribus axillaribus, solitariis, $v$. paucis aggregatis, corollis coccineis

Trevir a n a Willdenow Enumerat. II. 637. Martius Nov. gcn. et sp. IIT.65.t. 226. f. 2. C y ritl a Heritier Stirp. $t, 71$. Bot. Mag. $t$. 374. A c himenis s p. P. Brown. Pers. C o. I u m ne a e s p. Lam. B u chnerae s p. Seopoli Delic. insubr. II. $t . s$.

46\%. Cloximia HERIT. Calyx tubo tereti v. pentaptero, cum ovarii basi connato, limbo quinquepartito, aequali. Corolla perigyna, infundibuliformi- v. eampanulato - ringens, tubo basi postice gibbo, fance ampliata, antice ventricosa, limbi bilabiati labio superiore breviore bilobo, inferioris trilobi lobo medio majore. S $\mathbf{t a m i}$ na corollae tubo inserta, quatuor didynama, in clasa v. subexserta, cum rudimento quinti; a n ther a e biloculares, in discum cohaerentes. Orarium basi calyci cohaerens, glandulis quinque stipatum, uniloculare, placentis duabus parietalibus carnosis, bilobis. Ovula plurima, in funiculis brevibus, anatropa. Stylus simplex; stigma capitatum, subinfundibuliforme. C a ps u la calyce camoso tecta, apice bivalvis, valvis medio placentiferis. Se min a plurima, oblongo - fusiformia. E mbryo in axi albuminis carnosi orthotropus; cotyledonibus obtusis, radicula umbilicum spectante, centrifuga. - Herbae Americae tropicae, tubere hypogaeo pereninantes, acaules $v$. caulescentes; foliis oppositis, petiolatis, crassis, crenatis v. serratis, floribus axillaribus, solitariis $v$. paucis aggregatis, amplis, nutantibus, corollis violaceis, albis v. viridi-lutescentibus, interdum punctis $v$. maculis obscurioribus variegatis.

Gloxinia Feritier Stirp. $1.1 / 19$. Martlus Nov, gen, et sp. III. $6 \mathrm{~g}$,

a. PALiavana Velloz. Caly eis tabus teres.

Palíava a Vellozo apud Dardell. $t, 7 . f .17 . \mathrm{Mar}$ t y niae sp. Linn. Bot. Mag. $t .1191 .2690$. Bot. Reg. t, 213. 1004, 1127. Mart. Op, cit. t. 226. f. 1.)

b. SINNINGIA Nees, $\mathrm{C}$ a I y $\mathrm{c}$ is tubus angulatus ventapterus,
Sinningi a Nees in Annal. sc, nat, YI. 298. c. ic. Lindley in Bot. Reg. t. 997. 1134. (Mikan Delect. Flor. Brasil. t, 9.)

4168. IFytidopleylluma $M A R T$. C a ly x tubo subquinquecostato, cum ovario connato, limbo supero, quinquefido v. quinquedentato. Corolla supera, campanulata, medio constricta, limbo quinquefido, subaequali. Sta mina corollae tubo inserta, quatuor didynama, exserta, cum quinti rudimento; an th er a e biloculares, liberae v. per paria cohaerentes. Ovariu in inferum, disco annulari coronatum, uniloculare, placentis dnabus parietalibus, bilobis. Stylns simplex; $8 \mathrm{tig} \mathrm{m}$ a bifidum. Ca p 8 u la infera, unilocularis, vertice deplanato incomplete bivalvis, valvis medio placentiferis. Semina plurima, fusiformia, .... - Arbusculae $v$. frutices $A$ merica tro. picae; ramis alternis, hirtis, foliis oppositis, altero cujusvis paris nano, stipulaeformi, breviter petiolatis, subtus dense hirto-tomentosis, parenchy. mate supra in bullas apice in pilum desinentes elevato, pedunculis e supremorum foliorum axillis cymosis, corollis virescentibus, interdum sanguineo maculatis.

Rytidophyllum Martius Nov. gen, et sp. IIT. 39. Hooker in Bot, atag. $t, 3568$, C od o n o p ho $\mathrm{ra}$ Lindley in Bot, Reg. n, 1110. exel. sp. Ges nera to me ntos a Linn. Jacq. Amer, t. 175. f. 64, Gärtner II. 471, t. 177, Bot. Mag. t. 1023.

4169. Comnadia MART. C aly x tubo quinque- v. decemeostato, cum ovario connato, limbo supero, quinquefido v, quinquedentato. Coroll a supera, tubulosa v. campanulata, limbo quinquefido, aequali. Sta $\mathrm{m}$ in a corollae tubo inserta, quatuor didynama, exserta v. inclusa, cum quinti rudimento; anthera e biloculares, per paria v. omnes cohaerentes. Ov a ri u m inferum, disco epigyno nullo, nniloenlare, placentis duabus parietalibus, bilobis. Ov ula plurima ..... S tyI s s simplex; stigma bifidum. Capsula infera, unilocularis, vertice deplanato incomplete bivalvis, valvis medio placentiferis. S e min a plurima, scobiformia ..... - Frutices $v$. herbae, in $A m e-$ rica tropica indigenae; foliis alternis, petiolatis, dentatis $v$. rarius integerrimis, ut plurimum scabris, pedunculis e supremorum foliorum axillis cymosis, corollis rubris $v$. viridibus, sanguineo-punctatis aut interdum albidis.

Conradi a Martius Nov, gen. et sp. TIr. 38. Pentar h a phi Lindley in Bot, Reg, $n, 1110$. Gesneria Plumier Gen. t. 9. Ic. t. 133-137. G es neria e s p. Swartz.

\section{GENUS DUBIUM.}

4) ovato, cum ovarii basi connato, limbi semisnperi, quinquepartiti laciniis lanceolatis, patentibus. Co rolla perigyna, subrotata, tnbo brevissimo, limbi quinquepartiti laciniis ovatis, patentibus. Stamina 5, imo corollae tubo inserta; fila. $m$ en $\mathbf{t a}$ brevissima, a $\mathbf{t h}$ era e conniventes, $\mathbf{O}$ vari $\mathbf{n m}$ semiinferum, uniloculare, placentis parietalibus geminis, multiovulatis. Sty I us subulatus, persistens; stigma obtusum. Cap sula oblonga, acuta, stylo calycisque limbo connivente rostrata, unilocularis, bivalvis. Semina plurima, minima, oblonga, acuminata, rufa. - Frutices antillani, non salis noti, inermes $v$, spinis axillaribus setaceis armati; foliis decussatim oppositis, petiolatis, ovatis $v$. oblongis, angulatis, serratis, 
venosis, supra hirsutiusculis, pedunculis axillaribus solitariis v. corymbosis.

B ell on i a Plumier Gen. 42. Swartz Prodr, 42. Flor. Ind, occid. 3s2. Law. t, 179.

\section{* CREscentieae.}

11 1. Creseentia LINN. C a 1 y $\mathrm{x}$ bipartitus, aequalis, deciduus. Corolla hypogyna, subeampanulata, tulo brevissimo, fance ampla, ventricosa, limbo qninquefido, inaequali. $\mathbf{S} \mathrm{t}$ a $\mathrm{m}$ i $\mathrm{n}$ a corollae tubo inserta, quatuor didynama, exserta, cum rudimento quinti; fil a m enta subulata, antherae biloculares, loculis divaricatis. Ovarium substipitatum, uniloculare.... Stylus simplex; stigma incrassatum, bilamellatum. B a c c a maxima, ovata, obsolete quadricostata, corticosa, unilocularis, pulposa. S em in a plurima, in pulpa nidulantia, suborbiculata, compressiuscula, testa subcoriacea, basi incrassata, umbilico paullo supra basim ventrali, rhaphe sulciformi. E m bryonis exalbuminosi, orthotropi cotyledones suborbiculatae, bilobae, plano-convexae, earnosae, radicula brevissima, retracta, umbilicum spectans. - Arbusculae v, frutices Americae tropicae; folits alternis, solituriis aut saepissime fasciculatis, simplicibus, ternatis v. pinnatis, floribus e trunco ramisve subsolitariis, baccae pulpa eduli.

Cresceutia Linn. gen, n. 762. Jussieu gen. 127. Jaeq. Amer, $t$, 111. Lam. $t$. Bk7. Gärtner f. III, 229, $t$. 222, Kunth in Humb. et Bonpl. Nov, gen, et sp. $I I$, $157 . \mathrm{C}$ Jet te Plumier Ic. $\ell, 109$.

419. Tranaceium $S W A R T Z$. Calyx coloratus, globoso campanulatus, limbo truncato, integerrimo. Corolla hypogyna, tubo brevi, cylindrico, fauce elongata, inflata, limbi quinquefidi laciniis posticis panllo magis approximatis, brevioribus, $S \mathrm{ta} m$ in a imo corollae tubo in. serta, inclusa, quatoor didynama, cum rudimento quinti; an therae biloculares, didymae, loculis divaricatis. Ovari am globosum, sulcatum, biloculare. St y lus erassiusculus, adscendens; 8 tigm a bifidum, reflexum, B a c e a globosa, subpedicellata, corticata, fragilis, bilocularis. Se mina in placentis pulposis, medio dissepimento ntrinque insertis plurima, parva, angulato - oblonga ..... - Frutex antillanus, in truncis arborum para. siticus, radicans; cortice rugoso, cinereo, foliis oppositis, breve petiolatis, oblongis, obtusiusculis, integerrimis, coriaceis, nervosis, utrinque glabris, nitidis, pedunculis axillaribus brevissimis, subquadrifloris, floribus coccineis, nutantibus.

T a a ecium Swartz Flor. Ind oceid, 1053. $t .20$. f. 2. Jaequin Hort. Schōnbr. 2. 115. - Jaroba Marcgrav. Brasil. 25. Piso Brasil. 173, quae T a n a c lu m J a. ro b a Swartz Op. cit. 1050. $t$. 20. $f$. 1. ob habitum alienum, folia inferiora ternata, superiora bijuga cuns cirrho interJecto, eorollae et autherarum formam ut videtur diversam vix congener, an Crescentiae species?

4173. Tripinmaria PERS. C a lyx cyathiformis, quinqueerenatus, persistens. Coroll a hypogyna, subcampanulata, patens, tubo calycem superante, limbo quinquefido, laciniis ovatis, undulatis, villosis, summa majore. S t a m in a quatuor, didynama, corollae subaequalia; a nther a bicornes, incumbentes, 0 va rinm subrotundum. Stylus staminibus aequalis; 8 tig- ma acutum, bifidum. B a c ca ovata, carnosa, unilocularis, polysperma. S e m in a oblonga, compressa, pauca. - Arbor cochinchinensis, magna, ramis patentibus, foliis pinnatis, uni-plurijugis cum impari, foliolis ovatis, acuminatis, integerrimis, racemis terminalibus corymbosis, floribus magnis, luteo-rubris.

Tripinnaria Persoon Enchetrid 1I, 173. Tripinna Loureiro Flor, cochinch, 76 -? Ta a e ium pinnatum Jacquin Collect. III. $t, 18$.

\section{Ardo CLIII. Pealatineae.}

PEDAlineaE R. Brown Proir. 819. PEDAliACEAF Lindley Introduct, edit. IT. p. 281. exel. Sesameis. MARTYNiACEAE Personatarum sectio Link Handb. 1. 504.

Herbae interdum suffrutescentes, villosae, saepius viscidae, caule ramisque teretibus v. angulatis. Folia opposita v. alterna, simplicia, saepe angulatav. sinuata. Stipulae nullae.

Flores hermaphroditi, irregulares, axillares, solitarii v. spicati aut racemosi, saepissime bibracteolati.

Calyx liber, quinquefidus, subaequalis, interdum antice fissus, spathaceus.

Coroula hypogyna, gamopetala, fauce ventricosa, limbo bilabiato, quinquelobo.

Staniva corollae tubo inserta, inclusa, quatuor didynama, omnia fertilia v. breviora interdum castrata, quintum posticum rudimentarium. Fil amenta filiformia. Antherae biloculares, loculi aequales, paralleli, basi discreti v. divaricati, patentes, longitudinaliter dehiscentes, connectivo saepe in glandulam producto superati.

Ovarıum disco glanduloso cinctum, e carpidiis duobus v. quatuor conflatum, carpidiorum marginibus introflexis axim haud attingentibus uniloculare, nunc iisdem in dissepimentum introflexis biloculare, v. marginibus introflexis revolutis pseudo-quadriloculare v. octoloculare, apice saepissime carpidiorum marginibus productis, inter se cohaerentibus v. tandem solutis cornutum. Ovula juxta earpidiorum margines pauca, v. interdum in ovarii plurilocularis loculis solitaria, horizontalia, pendula v. erecta, anatropa. Stylus terminalis, simplex; stig$\mathrm{m}$ a bilamellatum.

Frvetus subcapsularis v. drupaceus, saepe carpidiorum apice indurato cornutus, angulisve in spinas productis armatus, uni-bi-quadri-octolocularis, septicide dehiscens, v. saepius cortice secedente, putamine lignoso valide fibroso, basi v. axi perforato, indehiscente.

Semra in loculis pauca, horizontalia v. pendula, nunc solitaria, erecta. Testa solida v. laxe membranacea, reticulata, et valvatim secedens, rhaphe filiformi, ab umbilico basilari 
ad chalazam apicalem inter testam et endopleuram percurrente Albumen nullum.

Exвryo orthotropus. Cotyledones plano-convexae, subcarnosae. R a dicula brevis, umbilico proxima, supera, infera v. saepius vaga.

Pedalineae inter tropicos totius orbis et in Capite bonae spei indigenae, hinc Gesneraceis mediante imprimis Craniolaria et Martynia conterminae, inde Bignoniaceis mediante Sesamo arctius affines, monente cl. R. Brown fructns structura, imprimis per J0sephiniam, ad Verbenaceas Myoporineasque accedunt.

41\% 4. Craniolaria LINN. C a I y campanulato-spathaeformis, hine fissus, inde quinquedentatus. Co roll a hypogyna, tubo longissimo, fauce campanulata, limbi bilabiati labio snperiore bi-inferiore trifido, lobo medio latiore. S tamina corollae tubo inserta, quatuor didynama, cum rudimento quinti; antherae biloculares, loculis parallelis, basi discretis, connectivo glandula terminato. Ovari $\mathrm{rm}$ carpidiorum marginibus dissepimentum constituentibus revolutis psendoquadriloculare, ovulis juxta margines paucís, anatropis. Stylus simplex; stigma bilamellatum. Drupa ovata, acuta, putamine lignoso, apice breviter bicorni, quadriloculari. S e min a in loculis quatuor, abortu interdum pauciora v. solitaria, ovata, compressiuscula... Herbae Americ ae tropica e, villoso-viscosissimae; foliis oppositis, cordatis, angulatis v. quinquelobatis, floribus axillaribus terminalibusve racemosis, corolla candida, fauce picta.

Cran iolaria Lina. gen. n. 752. Jaequin Amer. $t$. 110. Kunth in Humb, et Bonpl. Nov. Gen. of sp. HI, 153. Journ. Phys, LXXXVII. 453, Nees et Martís in N. A. N. C. XI, 67. t. 4. Hol ore $\mathrm{g}$ i a Nees in Flora 1821.p. 300,330. Neuwied Rieise $I I .239 .344$.

$41 \%$. Martymia LINN. Calyx quinquefidus, subaequalis. Corolla hypogyna, subcampanulata, límbo quinquelobo-bilabiato, lobo medio majore. Stamina corollae tubo inserta, quatuor didynama, fertilia $v$. duo minora eastrata, quintum rudimentarium; a $\mathbf{t} \mathbf{h}$ e ra e biloculares, loculis divaricatis, connectivo glandula terminato. Ovari u m carpidiornm marginibns dissepimentum constituentibus revolutis pseudo-quadriloculare, ovulis juxta margines paucis, anatropis. Stylus filiformis, simplex; stigma late bilamellatum. Drupa oblonga, acuminata, cortice coriaceo bivalvatim secedente, putamine lignoso, fibroso-scrobiculato, apice elongato-bicorni, qua driloculari, axi perforato. S e m in a in loculis pauca, superposita, pendula, testa spongiesa, crassa, tubereulato-rugosa. E $m$ b r y o n is exalbuminosi, orthotropi radic ula supera. - Herbae $A m e$. ricae tropicae; foliis oppositis v. alternis, an gulatis, floribus axillaribus $v$, terminalibus spicatis, bibracteolatis.

M a rt y n i a Linn. gen, $n, 753$. Gärtner $I I, 131$. t. 110, Miller Ic. $t$. 268. Gloxin Observ. t, 1. Jacquin Hort. Schönbr. t. 289. Bot. Mag. t. 1056. Bot. Reg. $t$. 934. Kunth in Humb. et Bonpl. Nov. Ben, et sp. III. 102. Journ, Phys. IXXXVII. 452, Turpin Atlas III. 2. 53, Probos cidea Selimidel Analys, 49, t, 12, 13.

4176. Carpoceras A. RICH. Calyx gquinquepartitus, lacinia postica breviore. C o r o J- la hypogyna, tubo basi postice gibbo, superne contracto, fauce campanulata, limbi quinquefidi laciniis subaequalibus. Stam in a corollae tubo inserta, quatuor didynama, cum rudimento quinti; ant hera biloculares, loculis parallelis, basi discretis, connectivo glandula terminato. O varium carpidiorum marginibus introflexis axim haud attingentibus uniloculare, ovulis ad suturas plurimis, anatropis. Stylus simplex; stigma bilamellatum. Capsula lignosa, ovato-pyramidata, basi utrinque in spinam horizontalem muticam producta, unilocularis. S e m in a plurima.... - Herba capensis; caule erecto, scabriusculo, foliis oppositis, petiolatis, ovatis, sinuatis, floribus axillaribus oppositis, solitariis, pedunculis basi biglandulosis.

Carpoceras A. Richard ex Ferrusac Bullet, $\mathrm{XX} T$, 98. Martyuia longiflora Linn. M. capensis Gloxin.

4 1 $\%$. IPedalioum $L I N N$. Calyx quinquepartitus, lacinia postica brevissima. C or o 11 a hypogyna, tubo brevi, fance campanulata, limbi quinquelobo-bilabiati lacinia antica majore. Stamin a corollae tubo inserta, quatuor didynama, cum rudimento quinti, fil a m e $\mathrm{t}$ a basi barbata; antherae biloculares, Jocnlis parallelis, basi discretis, connectivo glandnla terminato. Ovarium biloculare.... Stylus simplex; stigma bifidum. D r u p a exsucea, ovato-pyramidata, tetragona, angulis superne alatis, inferne in spinas quatuor horizontales desinentibus, cortice suberoso, putamine osseo, fibroso, basi perforato, superne biloculari. S e m in a in loculis gemina, superposita, pendula, testa membranacea, laxa, reticulata, valvatim secedente. Em b r y o n is exalbuminosi, orthotropi radi cula supera. - Herba indica, di-trichotoma, mucoso-pruinosa; foliis oppositis, petiolatis, ovatis, sinuato-dentatis, floribus axillaribus, solitariis, pedunculis basi biglandulosis, floribus flavis.

Pedali um Linn. gen, $n$, 794. N. L. Burmann Flor. ind. t. 45. Gärtner I. 276. t. 58. Kunth in Journ. Phys. LXXXXII, 453. Roxburgh Flor, ind, III. 114.

41 ร8. Unearia $B U R C H$. Calyx quinquepartitus, laciniis linearibus, acntis. Corolla hypogyna, infundibuliformis, tubo basi angustato, limbi quinquefidi laciniis rotundatis, aequalibus. St amina 4, didynama, corollae tubo inserta... Ovarium ..... Cap 8 u la lignosa, bilocularis, angulis lobato-alatis, lobis uncinatis. Se mina plurima, oblonga, angulata, rugosa .... Herba capensis, caulibus prostratis, parum ramosis, lota punctis numerosis albis conspersa. 529.)

Uncaria Burehell Travels $I$. p. 536. (ic. fruct. p.

4179. Hogeria $G A Y$. C a 1 y x quinquepartitus, lacinia postica brevissima. Corolla hypogyna, ringens, tubo cylindrico, basi postice gibbo, labio superiore longiore bilobo, inferioris trilobi lobis subaequalibus. Sta mina corollae tubo inserta, quatuor didynama, eum quinti rudimento; filamenta basi barbata, antherae biloeulares, loculis parallelis, basi dicretis, connectivo glandula terminato. Ovari um quadriloculare, loculis duobus posticis minoribus, ovulis plurimis, horizontalibus, anatropis. Stylas simplex; stig m a bilamellatum. C a p 8 ul a coria cea, ovato rostrata, hexa - oetogona, angulis medio in spinas horizontales, muticas desinentibus, incomplete quadrilorelaris, loculis duobus posterioribus multo minuribus, rostro apice bivalvi. Se min a 
in loculis majoribus plurima, imbricata, pendula, in minoribus gemina v. sulitaria, nucleo intra testam membranaceam laxam, reticulatain, valvatim secedentem parvo. E mb ry on is exalbuminosi, orthotropi radicula supera. - Herba Africae tropicae; caule tetragono, foliis oppositis, petiolatis, subrhomboideis, sinuato-dentatis, subtus glauco-pruinosis, floribus axillaribus ternis, oppositis, pedicellis exterioribus basi glandula stipatis.

Rogeria Gay in Annal. sc. nat. I. 457. Delite Centur. plant. voy. Cailliaud. Meroé, p, 78, t, 73. Badlich, in Linnaea VII, t. 3. f. 50-73.

4180. Hiceroearyam BOJ. C a $1 \mathrm{y} x$ quinquepartitus. Corolla hypogyna, extus his pida, campanulato-ringens, tubo basi postice gibbo, limbo late quinquefido, lobo antico majore. S t a m ina 4, didynama, corollae tubo inserta; antherae oblongae, incumbentes. Ovarium globosum, pone stylum bicorne ...... Stylus simplex; s tig ma bifidum. Nux basi convexa, laevis, superne depressa, marginata, obsolete quadriloba, exasperata, disco bicornis, nucleis quatuor, unilocularibus, mono-dispermis. E m b r y o minimus .... - Herba in Africae littore tropico a ustro-oriental $i$ indigena; caule procumbente, puberulo, colorato, foliis oppositis, petiolatis, ovatis, inciso-sinuatis, supra laete viridibus, subtus glauco-spruinosis, lobis spina herbacea nigra terminatis $v$. obtusis, pedunculis axillaribus oppositis, solitariis, unifloris, basi bibracteolatis, bracteolis axilla glanduliferis, floribus roseis, cernuis, corollis extus hispidis, lacinia antica rubro striata, fauce punctata.

Dicerocary u m Bojer in Nouv. Anzal. so, nat. IV. 268. t. 10. - ? Pretrea Gay in Annal, se, nat, I. 457. Martynia zanguebarica Loureiro Elor. coohinch. 769.

4151. Joseplinin VENT. C a ly $x$ quinquepartitus, aequalis v. inaequalis. Corolla hypogyna, tubo brevi, fance ampla, campanulata, limbi bilabiati labio superiore semibifido, inferioris trifidi lacinia media longiore. St a m in a corollae tubo inserta, quatuor didynama, cum quinti rudimento; antherae biloeulares, loculis parallelis, basi discretis, connectivo apiee glandula terminato. Ova ri n m quadri-octoloculare, ovulis intra loculos solitariis, e basi erectis, anatropis. Styln s simplex; stigma bifidum, laciniis emarginatis v. semibifidis. $\mathrm{N}$ ax ovata $\mathbf{v}$. subglobosa, echinata, quadri-octolocularis. $\mathbf{S}$ e $\mathrm{m}$ in a in loculis solitaria, erecta, testa dnriuscula, endoplenra tumida. E mbryonis exalbuminosi, orthotropi radicula infera. - Herbae diffusae, in NovaHollandia tropica et oceidentali, nec non in Moluce is indigenue; foliis oppositis, integris, pedunculis axillaribus solitariis, unifloris, bibracteolatis, floribus purpurascentibus, fauce maculatis.

Jose phinia Venten. Malm. $t$. 103. Mem. de IInstit. sc. phys, 1. sem, p, 71, R. Brown Prodr. 519. Blume Bijdr. 779. Endlicher in Linnaea DII, $t, 3 . f .74 \rightarrow 78$.

\section{Ordo CLIV. Drobancheae.}

OROBANCHEAE L. C. Riehard in Persoon Encheir. IT. 180. Jussieu in Annal. Mus. XII. 445. Waliroth, Orobanches generis diasceve. Francof. ad M. 1895. 8. Bartling Ord, nat. 173, C. A. Mever in Ledebour Flor. Alt. II. 450. in not. OROBANCHACEAE Lindley Introduct. edit. II. p. 287 .

Herbae fibrillis radiciformibus e caudice ortis aliarum stirpium radicibus adnatae, ca u- dice hypogaeo, perenni, nune incrassato, subtuberoso, nunc cylindrico, ramoso, squamis obtecto, apice scapum solitarium v. plures, simplices v. ramosos, nudos, pedunculiformes, v. saepius crassos, carnosos, squamis vestitos, semper coloratos exserente. Squ a mae foliorum loco scapo concolores, sessiles, sparsae v. imbricatae.

Flores hermaphroditi v. rarissime unisexuales, rarissime scapum aphyllum pedunculiformen terminantes, solitarii, ebracteati, plerumque in squamarum superiorum axillis solitarii, sessiles v. rarius subpedunculati aut racemosi, erecti v. nutantes, bracteolis praeter squamam floralem lateralibus geminis instructi v. ebracteolati.

CaLxx liber, persistens, tubulosus v. campanulatus, quadri-quinquefidus v. dentatus, nunc oblique truncatus, subunilabiatus, nune hine antice v. postice fissus, illine ad basim integer, nunc utrinque fissus, calycem diphyllum sistens.

Corolla hypogyna, tubo demum supra basim circumscisso emarcida persistens, tubulosa v. tubuloso-subcampanulata, bilabiata v. subbilabiata, labiis subaequalibus v. inaequalibus, superiore saepius fornicato, indiviso, bilobo v. bifido, inferiore trifido v. tridentato, quandoque obsoleto, fauce saepissime biplicata, lineis binis obliquis longitudinalibus, glabris v. villosis exarata.

Stamina quatuor, didynama, medio v. ilterdum imo corollae tubo, rarius prope faucem inserta, inclusa v. interdum subexserta. Filamenta e basi latiore angustata, teretia, recta $v$. incurva. Antherae biloculares v. rarissime uniloculares, coriaceae, persistentes, ovatae v. oblongae, apice obtusae, rotundatae v, emarginatae, basi sagíttatae, mucronatae $v$, rarins muticae, liberae $v$, apice cohaerentes, glabrae v. villosae, loculi oppositi, juxta totam longitudinem v. basi rimula dehiscentes, connectivum simplex, v, rarissime postice in appendicem calcariformem productum.

Ovarium sessile, liberum, disco carnoso, saepius obsoleto cinctum, v. glandula hypogyna postica stipatum, uniloculare, placentis parietalibus geminis, anticum et posticum ab axi floris latus spectantibus, simplicibus v. bilobis, v. quaternis, geminatim plus minus approximatis, nune biloculare, septo nempe plano, basi et apice inserto marginibus libero, placentis parietalibus opposito et ab iisdem distincto, $v$. placentis e pariete porrectis late bilobis, ad axim cum columna centrali apice deliquescente, tandem libera cohaerentibus. Ovula plurima, rarissime pauca, in funiculis brevibus v, inter- 
dum longiusculis anatropa. S tylus terminalis, simplex, persistens v. deciduus, apice inflexus v. rarissime rectus; stigma saepissime magnum, capitato-bilobum, rarius subclavatum, indivisum.

Capsura unilocularis v. rarius bilocularis, apice v. juxta totam longitudinem bivalvis, nunc valvis apice et basi cohaerentibus lateribus aperta, septo v. columna in bilocularibus libera, valvis axi v. juxta axim placentas solitarias v. geminas, filiformes v. dilatatas gerentibus.

Semixa plurima, minima, subglobosa, oblonga v. pyriformia, testa crassiuscula, fungosa, saepissime nitida, scrobiculata v. interdum tuberculata, $r$ haphe et chalaza obsoletis, endopleura tenuissima, albumini arcte cohaerente. Album en semini conforme, copiosum, album, transparens.

Emвryo in basi albuminis prope umbilicum excentricus, minimus, subglobosus.

Orobancheae habitu et vita parasitica insignes, a Gesneraceis albuminosis embryone minutissimo, placentis saepissime quatuor, et facie distinctae, maximo numero in hemisphaerae borealis regionibus extratropicis temperatis et calidioribus, imprimis in regione mediterranea generantur, in Capite bonae spei et Asia tropica rarae, e Nova-Hollandia, America tropica et australi ut videtur exules.

Ordinis descriptionem naturalem a cl. C. A. Meyer egregie elaboratam, paucis mutatis recepimus.

482. Epiplaegus NUTT. Fl o r es polygami, inferiores feminei, superiores hermaphroditi, steriles. Calyx bibracteolatus, urecolatus, quinquedentatus, dente postico majore, anticis sinu profundiore distinetis. Hermaphr, Corolla hypogyna, tubo compresso, labio superiore fornicato, integro, inferiore trifido, aequali, S t a$m$ in a 4 , corollae tubo inserta, inclusa, snbaequalia; antherae biloculares, loculis basi discretis, cartilagineo-mucronatis. O varium disco annulari, antice deliquescente cinctum, uniloculare, placentis duabus parietalibus, bilobis. $\mathrm{O} \mathbf{v} \mathrm{u} \mathrm{la}$ plu. rima, in funiculis longiusculis anatropa. S ty I n s simplex; stig m a capitatum, emarginatum. F e m. Coroll a brevis, obsolete quadridentata, mox basi soluta, ovarium sub grossificatione calyptratim degens. Ovarium ut in Hermaphrod. Stylus brevis; stigma emarginatum. Capsula brevis, ovata, apice incomplete bivalvis, valvis antice profundius distinctis, medio placentiferis. Semina plurima, oblosga, testa coriacea. Embryo in basi albuminis carnosi prope umbilicum minimus, subglobosus. - Herba bo reali-americana, in Fagorum radicibus parasitica; caule ima basi incrassato, radiculas copiosas emittente, e basi ramo so, squamis brevibus carnosis remotis vestito, gracili, stricto v. flexuoso, ramis basi esquamatis, superne floriferis, floribus laxe racemoso-spicatis, inferioribus fructiferis, corollis brevissimis, superioribus hermaphroditis, corollis semipollicaribus, angustis, haud fructificantibus, bracteis squamae- formibus, pedunculum brevem aequantibus, bracteolis calyci admotis bifidis, lobo antico minore, postico dimidio calyce longiore.

Epifegus Nuttall Gen, $I$. 60. Leptam ni um Ra. finesque in Americ. Monthl. Magaz. 1818. Mylanche WaIlroth Orobanch. 75 , Orobanche virginiana Linn. Morison 12, t. 16. $f .9$.

483. Plaelipaea DESFONT. F I ores hermaphroditi, bibracteolati. Calyx tubulosus, quadri-quinquefidus $v$. dentatus. C orolla hypogyna, ringens, labio superiore erecto, bifido, inferiore trifido, patente. S t a min a 4, corollae tubo inserta, didynama, inclusa; fil am enta basi complanata, antherae biloculares, loculis basi divarieatis, mueronatis, connectivo mutico v, mucronato. Ovarium postice glandula hypogyna stipatum, nniloculare, placentis parietalibus quatuor, geminatim approximatis. Ovula plurima, anatropa. Stylus simplex; stigma capitatobilobuin. Capsula unilocularis, apice bivalvis, valvis basi cohaerentibus, juxta axim placentas geminas gerentibus. S e m in a plurima, subglobosa, minima, testa fungosa, crassa. Embryo in basi albuminis carnosi prope umbilicum sublateralis, minimus, ovatns. - Herbae in Europa media et australi, nec non in Asia finitima super aliarum stirpium radicibus parasiticae, Orobanches habitu.

Pheli pa ea Desfont. Flor. atlant. $I T$. 60. C. A. Meyer in Ledebour Flor. Alt. 11. 459.0 ro ba a he s s p. Liun. Wallr. Phelipeae sp. Touruef.

a. TRIONYCHION $\mathrm{W}_{\mathrm{a}} \mathrm{ll}$. $\mathrm{C}_{\mathrm{a}} \mathrm{l}$ y $\mathrm{x}$ quadri-quinquefidus, lacinils elongatis, isaequalibus, acumluatis. A it the rae superfieie glabrae, valvalis villosis. - Scapus simplex v. ramosus.

Trionyehion Orobanches sect. Wallroth Orob. anch. 58. K o psia Dumortler Comment. 17. 0robanches sp. Linn et Auct. Schkuhr $t$. 176 . Jacq. Elor. austr. 276 . B. B. $t .184 .423$. Gürtner f. $t, 185$, f. 4. sinistr. Ledebour lc. $t$. 377. Vaucher Orob. t. 12-16. Reicheub. Iconogr. $f .928$-934.

b. CISTANCHE Link et Hoffmans. C a 1 y $x$ semiquinquefidus, lobis aequalibus, obtusis. An therat undique lanatae. Ca p su Ia stylo persistente, demum longitudinaliter secedente coronata.

Cis ta $\mathrm{u}_{\mathrm{c}}$ he Link et Hoffmans. Flor. Portug. 1, 319. t. 63. Haemodorum sectio Orobanches Wall. roth Orob, 69. (Desfont. Op. cit, $t$. 145, 196. Ledebour Ic. $t, 376$.

4184. Conopleolis WALLR. Fiores hermaphroditi. C a l yx bibracteolatus, ventricosotubulosus, spathaceus, antice ultra medium fissus, postice acutus, breviter quadridentatus, C or oll a hypogyna, ringens, tubo basi ventricoso, labio superiore fornicato, integro, inferioris brevioris trilobi lobis subaequalibus, patentibns, intermedio obtuso. Stamina 4 , corollae tubo inserta, subaequalia, exserta; an th erae biloculares, loculis basi divaricatis, mucronatis. Ovari u m uniloculare, placentis parietalibus quatuor, geminatim approximatis. Ovula plurima, anatropa. Stylus simplex; stig ma capitatum, bisulcum. C a psul a unilocularis, bivalvis, valvis juxta axim placentas geminas gerentibus. S e min a plurima, minima, testa fungosa, crassa. $\mathbf{E}$ mb ryo in basi albuminis carnosi prope umbilicum minimus, ovatus. - Herba in America boreali calidiore indigena; caule simplicissimo, carnoso, squamis succulentis, siccitate cartilagineis imbricatus, in spicam indivisam, conferle bractealam desinens, floribus subsessilibus, cauli concoloribus, luteis. 
Con opholis Walloth Orobanch. 78, Orobanche a merieana Linn.

4185. Droldameline LINN, Flores hermaphroditi, ebracteolati. Caly $\mathrm{x}$ diphyllus, foliolis distinetis $v$. basi hinc antice ant rarius postice connatis, integris $\mathbf{v}$. incisis aut dentatis. Corolla hypogyna, ringens, labio superiore erecto, bilobo v. bifido, inferiore patente, trifido. St a min a 4, corollae tubo inserta, didynama, inclusa; filam enta basi complanata, antherae biloculares, loculis basi divaricatis, mueronatis, connectivo mutico v. mucronato. Ovarium postice glandula hypogyna stipatum, uniloculare, placentis parictalibus quatuor, geminatim approximatis. Ovula plurima, anatropa. Stylus simplex; st i $\mathrm{gm}$ a capitato-bilobum. Ca p su la anilocularis, incomplete bivalvis, valvis basi et apice cohaerentibus, juxta axim placentas geminas gerentibus. Semina plurima, subglobosa, minima, testa fungosa, crassa. E mbryo in basi albuminis carnosi prope umbilieum sublateralis, minimus, ovatus. - Herbae in hemisphaerae borealis tem peratis super aliarum stirpium radicibus parasiticae; scapo simplici $v$, rarius ramoso, erecto, squamoso, floribus in squamarum axillis solitariis, sessilibus, erectis.

O roba nehe Linn. gen, n. 779. excl. sp. Gărtner IIT. 42. $t, 185 . f .4$. dextr. C. A. Meyer in Ledebour Flor, alt. Ir. 450. O robanches sect. Osproleon Wallroth Oro. banch. 29. (R. B, t. 421, 422. 568, 1786. Flor, dan. t. 1219. 133s. Curt. Flor. Lond, IV. t, 44. Hooker Flor, Lond. $t, 103$. Desfont. Flor, allant, $t$, 144. Link et Hoffmans. Flor. Portug. t. 62. Ledebour Yc, t. 385. 386. 389. 390. Vaucher Orobanch, $t, 1-10$, Reichenb. Iconogr, $f .876-923$. X. W. Schultz, Beiträge zur Kenntniss der deutschen Orobanchen, Mïnch. 1829. fol.

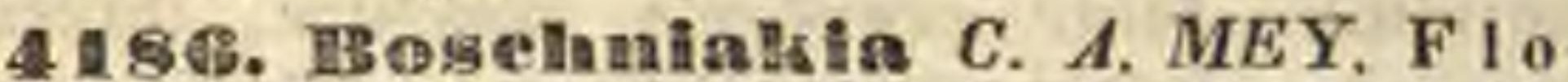
res hermaphroditi, ebracteolati. Caly x tubulosus, subtruncatas, inaequaliter quinquedentatns. Corolla hypogyna, ringens, labio superiore erecto, fornicato, bifido, inferiore abbreviato, subtrilobo. St a mina 4 , corollae tubo inserta, exserta, didynama; a n thera e biloculares, loculis basi discretis, muticis. Ovarinm uniloeulare, placentis parietalibus duabus ..... Stylus apice tubulosus, subbilabiatus, margine stigmat os o terminatus. Capsula unilocularis, incomplete bivalvis, valvis basi et apice cohaerentibus, medio placentam simplicem gerentibus. $S$ e m in a plarima ...... Herba Asiae aroticae; tubere hypogaeo nudo, multicauli, scapis crassis, simplici. bus, squamis ovatis, obtusis, mucronatis, racemo terminali, spicaeformi, denso.

B o sehn ia ki a C. A. Meyer msc, ex Bongard in Mem. Acalem. St. Petersb, n, s. II, 159, Orob is nethe $r$ ossi c a Cham. et Schlechtend. in Linnaea III. 132.

4IS\%. Clamalestina TOURNEF. Flores hermaphroditi, ebracteolati. Calyx campanulatus, quadrifidus. C o roll a hypogyna, ringens, labio smperiore galeato, inferiore breviore trilobo. Stamina 4 , corollae tubo inserta, didynama, subexserta; antherae biloculares, loculis discretis, basi mucronatis. Ovari nm glandnla hypogyna destitntum, uniloculare, placentis parietali bus duabus, linearibus. O vula pauca, nniseriata, anatropa. Stylus simplex; stigma capitato-bilobum. Capsula unilocularis, apice bivalvis, valvis medio placentam linearem gerentibns. Semina 4 v. 5, majuscula, angulata, testa coriacea, crassa, laevi, Embryo in basi albuminis prope umbilicum sublateralis, minimns, ovatus, Herba Europae australis, parasilica; caudice hypogaeo, ramoso, squamato, scapis brevissimis, floribus ex axillis squamarum solitariis, longe pedunculatis, strictis.

C I a ndestin a Tournef. inst, 958. I at h raea clan. destin a Linn.

4 48. Hathroea LINN. Flores hermaphroditi, ebracteolati. Ca ly $x$ campanulatus, quadrifidus, Corolla hypogyna, ringens, labio superiore subfornicato, integro, inferiore minore tridentato. St a min a 4 , corollae tubo inserta, subexserta, didynama; a n thera e biloculares, loculis basi diseretis, mueronatis. Ovarium glandula hypogyna postica stipatum, uniloculare, placentis parietalibus quatuor, geminatim approximatis, subconfluentibus, latis. Ovula plurima, anatropa. Stylus simplex; stigma magnum, capitato-bilobum. Capsula uniloenlaris, bivalvis, valvis juxta axim placentas geminas, latas, confluentes gerentibus. Se m in a plurima, subglobosa, minima, testa fungosa, areolata, E mbryo in basi albuminis prope umbilicum sublateralis, minimus, ovatus. - Herba in Europa media et a ustrali indigena; caudice hypogaeo, ramosissimo, squamis carnosis imbricato, squamis in scapo brevi paucis, alternis, racemo terminali denso, bracteato, secundo, cernuo.

L a thrae a Lina. gen, n. 743, excl. sp. Gärtner $I$. 243. t. 52. Selikulir $t$. 70, E. B. $t, 50$. Flor, dan, $t, 136, \mathrm{~S} q \mathrm{n}$ a m a ri a Haller Helv. 297. C I and estinae sp. Lam. (De modo crescendi cfr. Bowman in Linn. Transact. XVT. 399. t. 22. 23. et Unger in Annal, Wiener. Mus. IT. 23.

4189. Anoplavathus. Flores hermaphroditi, ebraeteolati. C a l y x subeampanulatus, quinquefidus. Coroll a hypogyna, tabulosa, tubo brevi ventricoso, v. longo basi subipenrvo, limbo aequaliter quinquefido, subbilabiato. S ta mi na 4 , corollae tubo inserta, inclusa, didynama; anther a e biloculares, Ioculis basi discretis, mucronatis. Ovarin m uniloculare, placentis parietalibus quatuor, remotis. O vula plurima, anatropa. Stylus simplex; stigma capitatum, obsolete bilobum, Ca psula nnilocularis, bivalvis, valvis intra marginem utrinque placentiferis, placentis convergentibus. S em in a plurima, minima ..... - Herbae parasiticae, in America boreali et regione taurico-caucasica obsorvatae, scapo basi squamis vaginato, apice nudo, unijloro.

Anoplou sect. Orobanches Walleth Orobanoh. 66. nou Zoolog. Phell peae s p. Auet.

a. BUANOPLON. C o r o lla tubo longo, incurvo, limbo patente. Seapus obsoletus, pedunculos elongatos, graciles, ubifioros, basi squama vagiantos promens. - Herbe boreali.americana. Oroba $n$ che un lf lo ra Lian.

b. ANBLATUM. Corolla tubo brevi, ventricoso, llmbo bifabiato. Scapus squamis majusculis, amplexicaulibos vagiastas, in pedunculum uniflorum desinens. Herba cancasica. - A n b lat a m Tournef. Cor. 48. P he1 i p a e foli at a Lambertin Linn. Transact. X, 260, t, 7.

4150. Aeginetia LINN. F lores hermaphroditi, ebracteolati. Calyx spathacens, laxus, antice fissus, postice acutus. Co rolla hypogyna, tubo cylindrico, calycem parum snperante, subineurvo, limbo subaequaliter quinquefido, bilabiato. St am in a 4, imo eorollae tabo inserta, inclusa, didynama; fil am enta teretia, convergentia, a n th e ra e per paria cohaerentes, ex apice connectivi incrassati pendulae, apice truncatae, basi acuta dehiscentes, staminum inferiorum postice in calcar conicum, obtusum prodnctae. Ova- 
ri um biloculare, placentis in quovis loculo geminis, divaricatis, crassis, undulatis, versus dissepimentum planum, basi et apice insertum, marginibus liberum porrectis. Sty 1 u s simplex; stigm a magnum, carnosum, peltato-cordatum. C a psula bilocularis, irregulariter hivalvis, valvis placentiferis. Semina plurima, minima. - Herbae indicae, parasiticae; scapo squamato, abbreviato, pedunculos unifloros nudos, scapiformes, solitarios.v. caespitose confertos exserente, floribus majusculis, speciosis.

A eg in e ti a Linn. Spec. edit, 1, p.632. Roxburgh Plant. Corom, I. 63, t. 91. Wallich Plant. As. rar. III, 13, t. 219. Orobanche ae a ulis Roxburgh Op. cit. t.292.

4191. IIyobanelae THUNB. Flores hermaphroditi, bibracteolati. C a ly x quinquepartitus, coloratus, laciniis linearibus, obtusis, C orolla hypogyna, ringens, tubo incurvo, labio superiore compresso, fornicato, integerrimo, inferioris lobis lateralibus nanis, reflexis, intermedio minimo, dentiformi. S $\mathrm{tam}$ in a 4 , corollae tubo inserta, didynama, inclusa; fil amenta e basi dilatata teretia, anthera e liberae, uniloculares, pendulae, basi acuta dehiscentes. Ovarium biloculare, placentis parietalibus porrectis, late bilobis, ad axim cam columna centrali apice deliquescente cohaerentibus. O v u la plarima, anatropa. Stylus simplex; stigma clavato-incrassatum, emarginatum, Capsula bilocularis, bivalvis, valvis medio placentiferis, colnmna centrali demum libera. Sem in a plurima, minima ..... Herba capensis, parasitica; scapo crassiusculo, imbricatim squamoso, sanguineo-villoso, floribus terminalibus rubicundis, in spicam laxe capitatam, am. plam confertis, bracteis latis, obtusis, calyce corollae tubum aequante paullo brevioribus.

H yobanche Thuoberg ex Lian. Mant. 263.

\section{GENUS DUBIUM.}

4192. Epirlhizanthus $B L U M$. C a ly x liber, turbinatns, quinquedentatus. Corolla gamopetala, ventricosa, trifida, bilabiata, labio supcriore concavo, bipartito, inferius hrevins, fornicatum, integrum amplectente. Stamen nnicum, inclusum; fil am ent um membranacenm, basi labii inferioris corollae adnatum, stylum semi vaginans, antherae quinque v. rarius quatuor, ellipticae, biloculares, in filamenti margine supe riore in orbem dispositae. Ovarium liberum, globoso-ellipticum. St y 1 a s longitndine filamenti; stigma capitatum. Ca p sula globosa, didy ma, bilecularis, bivalvis, dissepimento e valvarum marginibus introflexis. Se min a in loculis soli. taria, globosa, dissepimento adhaerentia. E $\mathbf{m}$ b ryo....- Herbae javanicae, in aliarum stirpium radicibus parnsiticae; caulibus squamosis, apice bi-trifurcatis, spicis terminalibus dense squamoso-bracteatis, bracteis unifloris.

Rpirhizanthus Blume Catalog, hort, Buitenzorg. ex Flora 1825. p. 133. Flor, Jav, Praef. VII.

\section{Drdo CLE. Utriculamiecte.}

LYSIMACHEIS AFFINES Jussieu Gen, 97. LENTIBULARIEAE L. C. Richard in Flor. Paris $I$, 26. R. Brown Prodr. 429, Bartling Ord, nat, 168. UTRICULARINAE Link et Hoffmansegg. Flor. Portug. I. 339. LENTIBULARIACBAE Lindley Introduct. edit. IT. p. 286.
Herbae aequaticae v. paludosae. Folia radicalia nunc conferta, rosulata, integra et integerrima, nunc sparsa v. verticillata, tenuissime dissecta, radiculas multiramosas filiformes referentia, saepissime vesiculis aëriferis instructa. Scapi saepissime indivisi, nudi v. squamulis minutis, stipuliformibus aut vesiculis verticillatis instructi, uniflori v. spicatim aut racemoso multiflori.

Flores hermaphroditi, irregulares, uni-tribracteati v. rarius ebracteati.

Calyx herbaceus, liber, persistens, diphyllus, foliolis integris, v. quinquepartitus, subbilabiatus, laciniis subinaequalibus.

Corolla hypogyna, decidua, gamopetala, personata v. bilabiata, tubo brevissimo v. subnullo, basi antice in calcar producto, labio superiore breviore bifido, inferiore indiviso $v$. trifido, palato convexo.

Stanina 2, imae corollae sub labio snperiore inserta, inclusa. Filamenta complanata, adscendentia v. convergentia, aut stricta. Anther a e terminales, adnatae, unilocnlares, transversim bivalves.

Ovariur liberum, uniloculare, placenta basilari, globosa. Ovula plurima, anatropa. Stylus brevissimus, crassus; stigma bilabiatum, labio superiore breviore, interdum obsoleto, inferiore lamelliformi, dilatato.

Capsura globosa v. ovata, acuminata, nunc evalvis, tandem irregulariter rupta, nunc bivalvis, juxta totam longitudinem dehiscens.

Semina plurima, placentae basilari globosae, liberae undique inserta, elliptica, minima, testa rugosa, nmbilic o basilari. Albumen nullum.

Eubryo orthotropus, subcylindricus, nune indivisus, nunc cotyledonibus duobus brevissimis, radicula elongata, umbilicum attingente.

Utriculariae per totum terrarum orbem ex aquis stagnantibus et lente fluentibus sub anthesi emergentes, v. in pratis paludosis epigeae, maximo numero in America boreali calidiore et in Nova-Hollandia observatae fuerunt, in veteri continente in regionibus tropicis subtropicisque frequentiores.

Ordo inter Personatas Scrophularineas, a quibus placentatione minus quam albuminis defectu recedit, et Primulaceas, corollae conformatione, staminum numero et ovulorum directione diversas, medius.

4193. Utrieulsoria LINN. Calyx diphyllus, foliolis aequalibus, indivisis. Corolla hypogyna, personata, tubo subnullo, basi antice calcarata, labio superiore breviore bifido, inferio- 
re longiore, palato prominente. $\mathbf{S} \mathbf{t}$ a $\mathbf{m} \mathbf{i} \mathbf{n}$ a 2, corollae labio snperiori inserta; fil a me $n t$ a conniventim incurva, apice intus antherifera, a $n t h$ e r a cohaerentes, uniloculares, simplices v. didymo-constrictae, longitudinaliter dehiscentes. Ovarium uniloculare, placenta basilari globosa. Ovu la plurima, anatropa? Sty I u s brevissimus, crassus; st igma bilabiatum, labio superiore brevissimo v, obsoleto, inferiore lamelliformi, dilatato. Capsula globosa, unilocularis, demum irregulariter rupta. Se mina in placenta basilari globosa, libera plurima, nmbilico basilari. E m b r y o exalbuminosus, indivisus....-Herbae cosmopolitae, in Americaboreali temperata et $\mathrm{No}$ va $\mathrm{Holl}$ andia imprimis copiosae, aliae aquaticae, libere natantes foliis radicalibus demersis, multifidis, vesiculis plurimis aëriferis instructis, aliae paludosae, radicantes, foliis radicalibus confertis, indivisis, vesiculis interdum radicalibus, scapis nudis, nunc squamulis paucis $v$. foliis vesiculiformibus instructis, floribus spicatis, racemosis v. solitariis.

Utrieularla Linn. gen. n, 3t. Schkuhr $t$, 2. Hayne in Schrader Journ, 1800. I. p. 17, t, 5. 6. E. B. t. 253. 284. Flor. dan. $t, 128,138,1262$, Gärtner f. IIT. 108, $t$, 198, R. Brown Prodr, 430. Roxburgh Plant. Corom, t, 180. Hooker Exot. Elor, t. 198. Leconte in Annal. Lyc. New-York I. 72. Wight in Hooker Bot. Miscell. Supplem. t. 27. Nees jun. Gen, plant. XII. t. 19. Le a ti b u I a ria Vaillant in Act. Academ. Paris, 1719.

4194. Gemlisea $S T, H I L, C$ a ly $x$ quinquepartitus, subaequalis. Corolla hypogyna, personata, tubo subnullo, basi antice calcarato, labio superiore breviore bifido, inferiore longiore, palato prominente. St am ina 2 , imae corollae inserta; fil a m en ta complanata, recta, a $\mathrm{n}$ h herae terminales, adnatae, uniloculares, transversim bi valves. Ovarium uniloculare, placenta basilari, globosa. Ovula plurima, anatropa. Stylus bre vissimus, crassus; stig ma bilabiatum, labio su periore breviore interdum obsoleto, inferiore la melliformi, dilatato. C a p s l a unilocularis, placenta basilari globosa ...... - Herbae paludosae, annuae, in Brasilia indigenae; foliis radicalibus rosulatis, petiolatis, spathulatis, integerrimis, glaberrimis, rarissime nullis, scapo solitario, erecto, squamulis paucis instructo, racemoso-paucifloro $v$. rarius unifloro, pedicellis tribracteatis.

G e 1 is e a St. Hilaire Vogage Distr. Diam, IX. 428.

4195. Fimguleula TOURNEF. Cal y x quinquepartitus, inaequalis. Corolla hypogyna, bilabiata, tubo brevi basi antice calcarato, labio superiore breviore emarginato v. bifido, inferioris trilobi lobo medio majore, omnibus integris v. emarginatis, palato subconvexo. St a min a imae corollae inserta; filamenta complanata, adscenden. tia, antherae terminales, adnatae, uniloculares, transversim bivalves. O va ri u m uniloculare, placenta basilari globosa. St y lus brevissimus, crassus, stig ma bilabiatam, labio superiore breviore, inferiore maximo, cristato v. lamelliformi. C a p 8 u l a ovata, acuta, unilocularis, bivalvis. S e mina plurima, placentae basilari globosae, liberae inserta, elliptica, rugosa. Embry on is exalbuminosi, orthotropi cotyled on es brevissimae, radicul a elongata, umbilicum basilarem attingens, - Herbae perennes, in paludosis et humidis Europae et America e bore a lis crescentes; foliis radicalibus rosulatis, integerrimis, subcarnosis, glaberrimis, scapo nudo unifloro.

Pinguicula Tournef. inst. 74. Linn. gen, $\pi, 30$. Schkuhr $t, 103$. Gärtner II, 140, $t, 112$. Hooker Flor. Lond. t. 104. Sibthorp Elor. graec. $t$. 2, Reichenb. Ioonogr. $t .168$.
171. 175. Bot. Reg. t, 126. Nees jun, Gen. plant. XII. t. 20. Brandon ia Reiehenb. Consp, 128. P. edentula Hooker Exot. Flor, t, 16.

\section{Classis XXXVIII. Petalanthae.}

Herbae, frutices v. arbores, succo interdum lacteo. Folia opposita, alterna v. verticillata, simplicia, integra. Stipulae nullae. Calyx liber v. rarissime ovarii basi adnatus. Corolla hypogyna, gamopetala, regularis. Stamin a lobis corolla numero dupla v. multipla, rarius aequalia et tune saepius isdem opposita. Anthera e biloculares, exappendiculatae, longitudiualiter dehiscentes. 0 variu m uniloculare, multiovulatum, v. pluriloculare, loculis uni-panciovulatis. Ovula amphitropa v. anatropa. Fruetus capsularis v. drupaceus. Embryo intra albumen homotropus.

\section{Ordo CLI'I. Prianulaceae.}

LXSIMACHIAR Jussien Gen. 95, excl. pI, primula. CEAE Veaten. Tabl, 1I. 285, R. Brown Prodr. 427. Bart. ling Ord, nat. 165. Liadley Introduct. edit, II, p. 293.

Herbar anuuae v. perennes, rhizomate saepius sublignoso, interdum tuberoso, rarissime suffruticulosae. Ca lis saepissime abbreviatus, hypogaeus, stipitiformis, ramis scapiformibus aphyllis, nunc epigaeus, foliatus. Folia nunc omnia radicalia, conferta, nune caulina, alterna, opposita v. verticillata, simplicia, saepius integra, rarius incisa v. Jobata, integerrima, serrata v. crenata, brevissime petiolata v. sessilia, semiamplexicaulia. Stipula e nullae.

Flores hermaphroditi, regulares $v$. rarissime subirregulares, nunc axillares, solitarii v. racemosi, v. terminales subspicati, nunc in apice pedunculi scapiformis solitarii v. saepius in umbellam simplicem, rarissime prolifero compositam dispositi.

Calyx liber v, rarissime (in Samolo) cum ovarii basi connatus, tubulosus, quinquefidus v.'quinquepartitus, rarius quadri-sex-septemfidus, persistens v. interdum deciduus.

Corolla hypogyna, deciduav. marcescens, gamopetala, rotata, campanulata, infundibuliformis v. rarissime (in Coride) subbilabiata, laciniis loborum calycis numero, iisdem alternis, integris, emarginatis $\mathbf{v}$. bifidis, interdum (in Soldanella) laciniatis, rarissime (in Glauce) nulla.

Stamiva corollae tubo v. fauei inserta, inclusa v. exserta, fertilia loborum corollae numero iisque opposita! sterilia nulla v. totidem, fornices corollae faucem circumsedentes, rarius (in Lysimachia et Samolo) fila subulata 
sistentia. Fil ame n ta filiformia v. subulata, saepissime brevissima v. subnulla. Anthe$r a e$ introrsae, biloculares, incumbentes $v$. erectae, interdum connectivo excurrente superatae, loculis parallelis, oppositis, longitudinaliter dehiscentibus. Pollin is granula angulata.

Ovarium liberum v. rarissime (in Samolo) basi calycis adnatum, e carpidiis tot quot lobi calycis conflatum, carpidiorum marginibus valvatim appositis uniloculare, placenta basilari globosa, sessili v. substipitata, rarius columnari, primum filis arachnoideis cum vertice ovarii cohaerente, mox libera. $0 \mathrm{vul}$ a rarissime definita, saepius plurima, peltatim amphitropa, rarissime (in Samolo et Hottonia) anatropa. Stylus terminalis, simplex; stigma acutum, obtusum v. subcapitatum, indivisum.

Fructus capsularis, unilocularis, apice v. juxta totam longitudinem (quandoque tam tarde ut fructum indehiscentem dicant) in valvas v. dentes, tot quot lobi calycis, iisdem oppositas, integras v, demum bifidas dehiscens, rarissime transversim operculo circumscisso apertus.

Semina plurima, saepe ovulis panciora, rarissime subdefinita, in placentae foveolis sessilia, dorso saepissime complanata, ventre convexo umbilicata, rarissime (in Samolo et Hottonia) umbilico basilari et rhaphe longitudinali instructa.

Eиввхо in axi albuminis dense carnosi v. subcornei umbilico parallelus, rectus, rarissime orthotropus, Cotyledones ellipticae, semicylindricae, germinatione foliaceae. $\mathbf{R}$ adicula vaga.

Primulaceac maximo numero in hemisphaerae borealis temperatis obviae, imprimis monticolae et alpium incolae, quibus lucisque collinis et planitierum maximo apud nos sunt ornamento. In hemisphaerae australis temperatis rarae, paucissimae, eaeque latissime per terrarum orbem diffusae inter circulos tropicos vegetant.

$0 \mathrm{rdo}$ e characteribus fructificationis solis Myrsineis, habitu facillime distinguendis comparandus, an revera naturali necessitudine affinis?

TiRiaUs I. PRIMUleae. C apsula valvatim dehiscens. S e min a amphitropa, umbilico ventrali. les.

SUBTRIBUSI.ANDROSACEAE.Acan-

4196. Douglasia $L I N D L . C$ aly $x$ tuho brevi, obconico, angulato, limbo quinquepartito, Cor oll a hypogyna, infundibuliformis, tabo ven- tricoso, limbi quinquepartiti, patentis laciniis basi utroque margine callo lineari, faucem claudente. Antherae 5, in fance corollae sessiles, limbi laciniis oppositae, inclusae, ovatae, biloculares, longitudinaliter dehiscentes. Ovarin m unilocnlare, placenta basilari pedicellata, fungilliformi, basi margine quinquedentata. Ovula quinque, placentae dentibus opposita, peltatim amphitropa. Stylus simplex; stigma obtusum. C a p. s u l a cartilaginea, unilocularis, quinquevalvis, valvis recurvis. Semina abortu duo, placentae basilari liberae inserta, dorso convexa, serobienlata, ventre coneavo umbilicata. E mbryo $\ldots .$. Herbae Americae arcticae, Androsaces facie, a quibus vix diversae, caespitosac, suffruticulosae; foliis lineari-lanceolatis, verticillatis, integerrimis, pedunculis umbellatis $v$. solitariis.

Douglasia Lindley in Brandes Journ. of. so. Jun. 1828. p. 383. Bot. Reg. $t$, 1886. Hooker Ic, $t .180$.

419'. Anthosace TOURNEF. Calyx quinquefidus $v$. quinquedentatus, demum saepins auctus. Corolla hypogyna, infundibuliformis v. hypocraterimorpha, tubo ealyeem vix superante ovato, apice contracto, fauce fornicilus brevibus instrncta. Stamina 5, corollae tubo inserta, ejusdem laciniis opposita, inclusa; filamenta brevissima, anth erae ovatae; bilocnlares, longitudinaliter dehiscentes. Ova rium uniloculare, placenta basilari globosa, substipitata. Ovula 5 v. indefinita, peltatim amphitropa. Sty I us filiformis, inclusus; stigma obtusum v. subglobosum. Ca p s u la unilocularis, apice $v$. juxta totam Iongitudinem quinquevalvis, Se mina 5 v, indefnita, placentae basilari glohosae liberae stipitatae inserta, dorso eomplanato rugulosa, ventre convexo umbilicata. Embryo in axi albuminis carnosi rectus, umbilico parallelus. - Herbae in temperatis et frigidis hemisphaerae borealis obviae, plurimae alpicolae, saepissime caespitosae, pedunculis solitariis $v$, umbellatis.

A ndrosace Tournef. inst. 46. DC. Flor. fr. III. 437. Duby Bot, I. 381. Koch Synops. 883 . A ndros a e et A retía Lina. gon, n. 195. 196.

a. ARETIA Linn. Ca ules ramosissimi, caespitosi, folits omnibus v. supremis in rosulam expansis. Pedunculi uniflori, nudi. 0 v a ri um 5 -8ovalatum.

A retia Linn. gen, $n$, 195. Sehkuhr t. 30. Jacq. Flor, austr. Append. t. 18. Gärtner f. III. 10z, $t, 198, f .4$. Nees jua. Gen. plant. XIT. t, 3. exel. fig. $11-17$.

b, ANDRASPIS Duby. Folia ad basin seapi rosulata. Pedunenli umbellati, involucrati. Ovari um 5 -multiovolatum. - A nd r aspis Duby l.c. (Jacq. Flor, aistr. t. 330. 333. 337. Collect, t. 12. $f, 3$ Wallich Plant. As. rar. t. 206. Reichenb. Iconogr. t. 579 . 580 . Ledebonr Ic. t. 15. 170. Nees jun. Gen. plant. XIT. t. 3.)

41DS. Cregerom DUBY. Calyx campanulatrs, quinquefidus. Co roll a hypogyna, hypoeraterimorpha, tubo snperne subinflato, fance pervia, fornicibus brevibus instructa, limbi quinquepartiti laciniis patentibus. Sta m in a 5 , corollae tubo inserta, ejusdem lobis opposita, inelusa; fi lamenta brevissima, antherae oblongae, biloculares, longitudinaliter dehiscentes. $0 \mathrm{va}-$ rium uniloculare, placenta basilari subglobosa, pedicellata. Ovula 5 , peltation amphitropa. Styi s simplex, inclusns; stigma obtusum. Capsula unilocularis, quinquevalvis. Semina abortu duo, placentae hasilari liberae, compressae inserta, dorso complanata, ventre subeonvexo umbilicata. $\mathbf{E m b r y o} \cdots+$ Herba pusilla, in $a l_{p} i-$ busigraniticis Europac obvia; cauliculis pluri- 
mis, prostratis, sublignosis, foliis anguste linearibus, acutis, imbricatis, flore subsolitario, sessili.

Gregoria Duby Bot. gall. 1. 383. A retia Gaudin Elor. Helvet. II. 95. non Linn. Vit ali a n a Sessi. Epit. t. 10. f. 1. Primula Vitallana Linn. Aretia Vita. lian a Willd. Nees jun. Gen. plant, XII, t, 3. f. 11-17.

4199. Primenta LINN. Cal y x subeampanulatus $v$. tubulosus, saepius angulates $v$. inflatus, quinquedentatus v, yuinquefidus. Corolla hypogyna, infundibuliformis v. hypocraterimorpha, tubo cylindrico, brevi v. elongato, ad faucem dilatato, nudo v. fornicibus instructo, limbi quinquefidi patentis v, erecti laciniis obtusis, emarginatis v. bifidis. Stam in a 5 , corollae tubo inserta, ejusdem laciniis opposita, inclnsa; filamenta brevissima, an th e ra e oblongae, biloculares, longitudinaliter dehiscentes. Ovari um uniloculare, placenta basilari substipitata, globosa. Ovula plurima, peltatim amphitropa. Sty lus filiformis; $8 \mathrm{tigma}$ capitatum. Ca p s $\mathrm{n}$ a unilosularis, apice quinquevalvis, valvis integris $v$. bifidis. S e m in a plurima, placentae basilari liberae globosae inserta, punctato-rugosa, dorso plana, ventre convexo umbilicata. E m bryo in axi albuminis carnosi restus, umbilico parallelus. - Herbae in Eur opa et Asia imprimis alpicolae, in America boreali rarae; foliis radicalibus, scapo simplici, floribus umbellatis, involucrutis, saepissime speciosis.

Prim ula Linn. gen, n, 197. Gärtner 1 . 223, t.50, Lehman Monographia generis Primul. Lips. 1817. 4. Nees jun. Gen. plant. XII, t. 1.

a. AURICULA. F a u $x$ corollae fornicibus destitnta. A re t i a Link Handb. II. 411. (Jacq. Flor, austr, 273. 327. 413. Append. 4. 26, Jacq, f. Eclog. 2. 43. Tenore Flor. Neapol. t. 14. Hooker Exot. Flor. t, 118. Bot. Mag t. 191, 942, 1922. 3167. 3414. Reichenb. Iconogr, t. 69. 70. $800-803.850-860$. Ledebour Ie. t. 218. 243. Royle Himalay, $t, 75,77$.

b. ALEURitiA. Fa u $\mathrm{x}$ corollae fornicibus distinetis v. confluentibus instructa. Primula et $\mathrm{A} \mathrm{u}$ g a n th n s Link Handb, II. 414. (Jacq. Flor, austr. Append, $t .46$. Schkular $t, 33$. Flor, dan, t. 125. 194, 194. 435. 1385. F. B. $t, 4-6,513$. Sibthorp Flor. graec, t, 184. Tenore Flor. Neap. t. 13. Reichenb. Iconogr. $f$. 660 . Lindley Colleot. t. 7. Hooker Exot. Flor, t. 68 , 105. Bot. Mag. t. 2564, 2842, 2973, 3020. Bot, Reg. 539.)

4800. Cortunsa $L I N N$. C a ly $x$ quinquefidus. Coroll a hypogyna, subrotata, fancis corona annulari, limbi quinquepartiti laciniis aeutis, integerrimis v. irregulariter incisis, S $\mathbf{t a m i n a} 5$, corollae tubo inserta, limbi laciniis opposita, inclasa; fil a menta brevissima, an therae cordatae, biloculares, connectivo excurrente acuminatae, longitudinaliter dehiscentes, O vari u m uniloculare, placenta basilari columnari, $O$ v 1 la plurima, peltatim amphitropa. Stylus filiformis, exsertus; stigma capitatum. Capsula ovata, unilocularis, apice quinquevalvis. S emin a placentae basilaris, liberae, columnaeformis foveolis semiimmersa, depresso-plana, umbilico ventrali. E mbryo in axi albuminis carnosi rectus, nmbilico parallelns. - Herba hirsutula, spithamea, in Eu ro pae alpibus perennans; foliis radicalibus longe petiolatis, reniformi-suborbiculatis, angulatis, incisis et acute dentatis, scapo simplici, umbella terminali, multiflora, acuta, corollis roseis $v$, rarius albis.

Cortus a Lisn. gen. n. 198. Jacq. Ic, rar. t. 32. Sehkuhr $t, 33$. Gïrtner $I$. 23t, $t, 50$. Andrews Bot, Reposit. t. 1. Bot. Mag. t. 987. Nees jun. Gon. ptant, XII. $t$. z.

4201. Cyelamen TOURNEF. C a 1 y $x$ quinquepartitus. Co rolla hypogyna, tubo brevi, subgloboso, fance incrassata, limbi refracti, quinquepartiti laciniis aequalibus, tubo longioribus. Stam in a 5 , imo corollae tubo inserta, ejusdem laciniis opposita, inclusa; fil a m en $t$ a brevissima, a $n t h$ e $r$ a cuspidatae, biloculares, longitudinaliter dehiscentes. Ovari um uniloculare, placenta basilari subglobosa, Ovula plurima, peltatim amphitropa. Stylus indivisus; stigma simplex. C a p s u la subglobosa, unilocularis, primum apice, demnm juxta totam longitudinem quinquevalvis, valvis reflexis. S e $m$ in a in placenta basilari libera, subglobosa plurima, angulata, umbilico ventrali. E m b r yo in axi albuminis cornei rectus, umbilico parallelus. - Herbae in Europa media et australi indigenae, tubere carnoso, subgloboso-disciformi, subtus radicellifero perennantes; foliis radicalibus petiolatis, cordato-reniformibus, angulatosinuatis, supra nitidis, subtus saepius purpurascentibus, scapis nudis, unifloris, floriferis strictis, frucliferis in spiram convolutis, humo adpressis, corollis roseis $v$, albis.

C y cla me n Tournef, inst. 68. Linn. gen, $n$, 201. Jacq. Elor. Austr, t, 401. Sehkuhr t, 35. Gïrtner f. III. 25. t. 183. (mal). E. B. $t$. 548, Sibthorp Flor. graee. $t$, 185. 186. Bot. Mag. t. 4. 1001. Bot. Reg, t, 1095, II. t, 49. Nees, Jun. Gen. plant. XII. 1. 7. - De germinatione efr. Trevirauus, Symb. phytolog. 86.

4201. Dodlecatleeon LINN. C a 1 y x quinquepartitus, reflexus. Corolla bypogyna, tubo brevissimo, fauce incrassata, limbi refracti, quinquepartiti laciniis aequalibus, tubo multoties longioribus. St a mina 5 , corollae fauci inserta. ejusdem laciniis opposita; fil a m e n ta brevissima, anthera e biloeulares, elongato-lineares, cuspidatae, in conum conniventes, longitudinaliter dehiscentes. Ovariu m uniloculare, placenta basilari ovata. Ovula plurima, peltatim amphitropa. Stylus indivisus, exsertus; stigma simplex. Ca p 8 ula subeylindriea, unilocularis, apice dentibns quinque dehiseens. Semina plurima, placentae basilari liberae columnari inserta, compresso-lenticularia, umbilico ventrali. Em bryo in axi albuminis carnosi rectus, umbilico paralleIns. - Herbae boreali amerieanae; folits radicalibus congestis, oblongis, inlegerrimis $v$, repando-dentatis, scapo simplicissimo, umbella terminali pauci-multiflora, pedunculis strictis v. nutantibus, corollis roseis.

D od e c a theo n Lian, gen, n. 200. Gärtner I. 232. t. 50. Sehkuhr t, 34. Bot. Mag, t, 12, 3622. Sweet Fl. Gard. II. $t$. 60. Me a dia Catesby Carolin. III. 1. $t$. 1. Ehret Decad, $t, 12$. Miller Ic, $t, 174$.

4203. Soldamella TOURNEF. C a 1 y $\mathrm{x}$ quinquepartitus, Corolla hypogyna, subcampanulata, fance nuda v. squamulis quinque emarginatis coronata, limbi quinquepartiti laeiniis fimbriato-multifidis. Stamin a 5 , corollae fanci inter squamas inserta, limbi laciniis opposita; filamenta brevissima, a $n$th er a e conniventes, cordatae, biloeulares, connectivo excurrente acuminatae, longitudinaliter dehiscentes. Ovari u m nniloculare, placenta basilari columnari. O v u la plurima, peltatim amphitropa. Sty I us filiformis, demum elongatus; stigma simplex. Capsula oblongo-conica, unilocularis, styli basi operculiformi circumscisse dejecta, dentibus quinque hians. Se min a placentae basilari liberae, columnaeformi inserta, abortu pauca, subreniformia, umbilico ventrali. E m b ry o in axi albuminis snbeornei rectus, umbilico parallelus. - Herbae pusillae, elegantissimae, in Europae al pibus crescentes; foliis ra$92^{*}$ 
dicalibus petiolatis, suborbiculato-cordatis $v$. reniformibus, integerrimis, scapo simplici unifloro, v. umbellatim plurifloro, floribus majusculis, cyaneis $v$. rarius albis.

Sold a nella Tournef. inst. 16. Linn. gen. n, 109. Schkuhr t, 53. Jaeq. Flor. austr. $t$, 13. Gärtner f. IIt. 24. t. 183. Bot. Mag. t. 49. 2163 . Sturm Deutschl. Flor. f. 41. Nees jun. Gen, plant. XII. t. 6 .

\section{SUETREBUS II. LYSIMACHIEAE. Caulescentes.}

4204. Glaux TOURNEF. Caly x coloratus, subcampanulatus, quinquepartitus. Co roll a nulla. S t a min a 5, imo calyci inserta, ejusdem laciniis alterna, inclusa v. vix-exserta; fil am en t a filiformia, a ntherae cordato-ovatae, biloculares, longitudinaliter dehiscentes. Ovarium uniloculare, placenta basilari globosa. O vu 1 a pauca, per placentam sparsa, peltatim amphitropa. StyIns filiformis; stigma late obtusum. Capsula globosa, unilocularis, quinquevalvis. S emina per placentam basilarem, liberam, globosam sparsa, dorso planinscula, ventre convexo umbilicata. Embry o in axi albuminis carnosi rectus, umbilico parallelns. - Herba in littoribus et campis salsis Europae et Asiae mediae obvia, ramosa, prostrata v. erecta, subcarnosa; foliis decussatis, lanceolatis, integerrimis, floribus axillaribus subsolitariis, sessilibus, albis.

G I a u x Tournef, inst, 60 . Linn. gen, $n, 291$. Gärtner f. III. 87. t. 187. Sehkuhr t. 50. E. B. t. 13. Flor. dan. t. 548. Hooker Flor. Lond. t. 188. St. Hilaire in Mem. Mas. II. 393, t. 4. $f .99,33$. Don in Edins. n. philosoph. Journ. 1829. III. 164. Nees jun, Gen. plant, XII. $t .17$.

42D5. Anterolinon LINKet HOFFMANS. C a l y x quinquepartitus. Coroll a hypogyna, ca lyce multo brevior, quinqnepartita, subrotata Stamina 5, corollae laciniis opposita et basi inserta; fila m en $t$ a filiformia, corollam superantia, calyce breviora, antherae biloculares, cordatae, obtusae, longitndinaliter dehiscentes. O va ri u m uniloculare, placenta basilari globosa, magna, carnosa. Ovula pauca, peltatim amphitropa. Stylus filiformis; st i $\mathrm{gma}$ capitatum. Capsula globosa, calyce et corolla persistentibus involaerata, unilocularis, juxta totam longitudinem quinquevalvis. S e m in a placentae basilari liberae globosae immersa, pauca, dorso rugosa, ventre plano umbilicata. E mbryo in axi albuminis carnosi rectus, umbilico parallelus. - Herba annua, bi-tripollicaris, in Eur op a e a ustra lis apricis crescens; caule erecto, simplici v. basi ramoso, foliis oppositis, lineari-lanceolatis, rigidulis, integerrimis, trinerviis, floribus axillaribus solitariis, pedunculis folio brevioribus.

Asteroliuon Link et Hoftmansegge Flor. portug. 332. Nees jun. Gen. Plant, XIT. $t, 11$, L y lia a ch i a L i. n $\mathrm{m}$ stell at a m Lina. Sibthorp Flor. graec. 1,189 . Gartner $t$, $s 0$.

4208. Naumburgla MöNCH. C al y quinque-sexpartitus. Corolla hypogyna, ad basim quinque-sexpartita, laciniis laneeolato-linearibus, denticulo minimo interjecto separatis, patentibus. Stamina $5-6$, imae corollae inserta, ejusdem laciniis opposita, exserta; fil a menta filiformia, a n th erae cordatae, biloculares, longitudinaliter dehiscentes. Ov a rium liberum, placenta basilari globosa. Ov u la plurima, peltatim amphitropa. Stylus filiformis; stigma obtasum. Capsula globosa, nnilocularis, quinquevalvis. S em in a placentae basilari globosae, libe- rae inserta, pauca, angulata, dorso complanata, ventre convexo umbilicata. E mbry o in axi albuminis carnosi rectns, umbilico parallelus. - Herba in fossis paludosis Europa e mediae et a us tralis crescens; caule erecto, uni-bipedali, foliis oppositis, pedunculatis, densis, abbreviatis, floribus parvis, luteis, glandulis rubris conspersis.

N a umburg i Mónch Method. suppl, 23. Nees jun. Gen. plant. XVI. t. 10. Th y rs a th u s Sehrank in Münchner Denkschrift. 1813. p. 75 . L ysiuach ia th y 8 iflo. $r$ a Lins. E. B, $t$, 176 . Flor. dan. $t, 517$.

420\%. Hys imaehia MÖNCH. C alyx quinquepartitus. Coroll a hypogyna, subrotata, tubo brevissimo, limbo quinquepartito, explanato v. connivente. Stamina $5 \mathrm{v}$. 10, corollae fauci inserta, quinque ejusdem laciniis opposita, fertilia, alterna breviora ananthera, saepissime nulla; fil amenta filiformia, libera $v$. ima basi in annulum cohaerentia, antherae oblongae, biloculares, longitudinaliter dehiscentes. Ovari n m uniloculare, placenta basilari subglobosa. Ov u la plurima, peltatim amphitropa. Stylus filiformis; stigma obtusum. Capsula snbglobosa, stylo persistente cuspidata, unilocularis, quinquevalvis, nunc bivalvis, valvis apice demum bi-trifidis. Sem in a plurima, orbicnlata v. angnlata, placentae basilaris globosae, liberae foveolis semiimmersa, dorso plana, ventre convexo nmbilicata. $\mathrm{E}$ mbry o in axi albuminis carnosi rectus, umbilico paralleIns. - Herbae perennes, in temperatis hemisphaerae borealis indigenae, erectae $v$, procumbentes; foliis alternis, oppositis v. subverticillatis, integerrimis, interdum punctato-glandulosis, floribus axillaribus solitariis $v$. racemosis, nune terminalibus spicatis $v$. spicato-racemosis, flavis v. albida-roseis aut purpurascentibus.

L ysimachia Möach Method. 311. Lysimachiate s p. Auet.

a. LYSIMANDRA. Sta m in a 10. alterna calycis laciniis opposita sterilia, auanthera. - Folia opposita et verti. cillata. Pedunculi axillares. L y $\mathrm{s}$ ma $\mathrm{ch}$ i a cilliat a
Lian.

b. LYSIMASTRUM. St a mi a a 5 , ima basi in annulam connata. Corolla pateas. Capsala quinqueval. vis. - Fotia opposita v. verticillata. Inflorescen. tia axillaris $v$ terminalis, simplex $v$. composita. Flo. res flavi, (Jaeq. Flor austr. $t$. 366 . Gïrtner $t .30, f .1$. Flor. dan, t. 689. 493. B. B. $t$. 588. 761. Bot, Mag. t. 104. 660. Ledebour Ic. t. 214. Nees juu. Gen. plant.
XVT. t. 8.)

c. LEROUXIA Merat Elar. paris.edit. 2, p. 149 . St a m in a 5 , libera. Corolla patens, Capsula bivalvis, valvis demum apice altera bi-, altera trifida. - Folia opposita. Flores axillares solitarit, favi. - Godivella Lestiboud. Ep hem er um Reicheab. Flor. Germ. 409. L y s imachia nemoram Lias. Flor. dan. t. 174. E. B. t. 397. Nees jun. Gen. plant. XVT, t. 9 .

d. EPHRMERUM. Stam in a 5 libera, exserta $v$. inelusa. Coro 11 a patens v. connivens. Ca p s a I a quinquevalvis, valvis indivisis v. demum bifidis. - Folia alterna. Elores terminales, spicati $v$. spicato-racemosi, albi, rosei v. purpurei. - L ysi machia E phemerum Lina. L. atropurpurea Lina. Sibthorp Flor. graec. t. 187. L. d a b i a Aiton. Slbthorp t. 188.

4208. Trientalis LINN. C a $1 \mathrm{y} x$ quinque-septempartitus, patens. Co roll a hypogyna, rotata, quinque-septempartita. St a min a $5-7$, corollae lacinis basi inserta et opposita; fila menta filiformia, patentia, a nth erae biloedlares, oblongo-ellipticae, longitudinaliter dehiscentes. O va riu m uniloculare, placenta basilari subglobosa. O val a pauca, peltatim amphitropa. S ty. Ius filiformis; stigma obtusum. Capsala globosa, unilocularis, quinquevalvis, valvis revolutis. 
Sem in a pauca, planiuseula, umbilico ventrali placentae liberae globosae inserta, compacta, epidermide membranacea cohaerentia. En bryo in axi albuminis carnosi subcurvatos, umbilieo parallelus. - Herbae spithameae, in Europa media et Americ a bore ali indigenae; caule erecto, inferne foliis alternis paucis, superne foliorum majorum, ovalium, integerrimorum vertillo unico, pedunculis solitariis $v$. pluribus unifloris, corollis albis, stellatis, seminibus atris, epidermide alba.

Trientalis Linn. gen. n. 46t, Gärtner $I$. 227. $\ell$. 50. Sebkuhr t. 103, E. B. t. 15. Flor. dan, t. 84. Hooker Flor. Lond, t, 159. Nees jun. Gen, plant, XIT, t, 15.

4\%क9. Coxia. Calyx quinquefidus. Coroll a hypogyna, infundibuliformis, tubo calycem aequante, limbi quinquepartiti tubo longioris laciniis spathulatis, aequalibns, obtusis, conniventierectis. Stamina 5, corollae fauci inserta, ejusque laciniis opposita, exserta; fil amenta subnlata, glandulosa, conniventia, antherae ovatae, incumbentes, biloculares, longitudinaliter dehiscentes. Ovarin uniloculare, placenta basilari globosa, carnosa. Stylus simplex, inclusus, sti g ma depressum. Ca p $\mathbf{s}$ I a unilocularis, evalvis? Semina in placenta basilari globosa libera plurima ..... - Herba capensis, radice stolonifera perennans; caulibus subsimplicibus, basi lignescentibus, angulatis, foliis inferioribus oppositis ternatisque, superioribus approximatim alternis, oblongolanceolatis, basi angustata subsemiamplexicaulibus, integerrimis, subtus discoloribus, epunctatis, racemis terminalibus congestis, nutantibus, bracteis pedicellos aequantibus, cum calycibus corollisque atropurpureis,

L ubin i a Link et Otto Ic. select. 61. t. 27. Don in Sweet Fl. Gard. II. $t$. 34. non Conmers. L y s im a $\mathrm{eh} \mathrm{i} \mathrm{a}$ a trop u r p urea Hooker Exot. Flor, t, 180, nou alior.

42 10. Tulbinia COMMERS. C a I y quinquepartitus. Corolla hypogyna, subhypocraterimorpha, tubo calycem aequante, fauce nuda, limbi quinquepartiti, patentis laciniis obtusis, duabus posticis paullo brevioribus. Sta min a 5 , imo eorollae tubo inserta, ejusdem laciniis opposita, filamenta crassa, adnata, apice brevissime libera, ant her a faucem aequantes, ovatae, obtusae, biloeulares, longitudinaliter dehiscentes. $O$ vari $\mathbf{~} \mathbf{m}$ uniloculare, placenta basilari globosa. O v ula plurima, peltatim amphitropa. Stylus filiformis, inclusus; st igma obtusum. Capsula ovata, mueronata, unilocularis, demum bivalvis, valvis apice bifidis. S e min a plurima, placentae basilaris globosae, liberae foveolis immersa, dorso plana, ventre convexo umbilicata. Embryo in axi albuminis carnosi rectus, umbilico parallelus. - Herba mauritiana, annua; caule adscendente fistuloso, ramis alternis, foliis approximato-alternis, spathulatis, integerrimis, basi semiamplexicaulibus, patentibus, uninerviis, subtus nigro punctatis, pedunculis axillaribus, solitariis, unifloris, ebracteatis, apice incrassatis, folio brevioribus, floribus flavis.

L u b In i a Commerson ex Venten. Cels, t. 69, uon alior. Lysima chí manritiana Lam.

4211. Comis TOURNEF. C a ly $\mathrm{x}$ tubulo8o-campanulatus, limbo duplici, exterioris dentibus spinescentibus, inaequalibus, patulis, interioris quinquefidi laciniis triangularibus, fructiferis conniventibus. Corolla hypogyna, tubulosa, limbi bilabiato-quinquefidi laciniis anticis brevioribus, omnibus bifidis. Stamina 5, corollae tubo inserta, limbi laciniis opposita, breviter exserta; fil a- menta filiformia, inaequilonga, basi glandulosa, a ntherae ovato-subrotundae, bilocnlares, longitudinaliter dehiscentes. O va ri n m obovatum, superne pentagonum et glandulosum, uniloculare, placenta basilari carnosa, snbglobosa, vertice depresso quinquedentata. Ovila quinque, inter placentae dentes inserta, peltatim amphitropa, micropyle supera. Stylus filiformis, simplex, basi glandulosus; st ig ma depresso-dilatatum. Ca p8 u la globosa, ealyce inclusa, unilocnlaris, quinquevalvis. Sem ina 5, placentae basilaris liberae vertici depresso inserta, conniventia, dorso plana, ventre convexiusculo umbilicata. Embryo in axi albuminis carnosi rectus, umbilico parallelns. Herba Europae australis, basi suffruticulosa, humilis; ramis adscendentibus, pubescentibus, folits conferte alternis, linearibus, coriaceis, integerrimis v. subsinuato-dentatis, margine revolutis, supremis basi bispinulosis, racemo terminali spicaeformi, denso, calycis limbo exteriore spinoso, rubente, corolla lilacina.

C or is Tournef, inst. 423. Linn, gen, n, 263, Lam, $t, 109$. Bot. Mag. t. 2131. Bot. Reg. t. s36. Necs jun. Gen, plant. XII. t. 16.

TRER II. ANAGALLIDEAE. Capsula transversim operculo circumscisse dehiscens. Semina amphitropa, umbilico ventrali.

4218. Centmineulas LINN, C a 1 y $\mathrm{x}$ quadri-quinquepartitus. C oroll a hypogyna, calyce brevior, suburceolata, marcescens, tubo subgloboso, brevissimo, limbo quadri-quinquepartito. Stamina 4 v. 5 , corollae fanci inserta, ejusdem laciniis opposita, exserta; fil a men t a complanata, imberbia, libera $v$. basi connata, antherae biloculares, ovatae. Ovari um uniloculare, placenta basilari, globosa. Ovnla plurima, peltatim amphitropa. Stylus filiformis; stigma obtusum. Ca p s n la globosa, operculo circumscissa. Se min a plurima, placentae basilaris liberae, globosae foveolis immersa, planiuscula, umbilico ventrali. Embryo in axi albuminis carnosi rectus, umbilico parallelus. - Herbae annuae, pusillae, erectae v. prostratae, cosmopolitae; foliis alternis, floribus axillaribus, solitariis, sessilibus v. pedunculatis, ebracteatis.

Centuncul us Linn, gen. n, 189. Flor. das. $t .177$. 1567. B. B. $t$. 531 . R. Browa Prodr. 427. Nees jun. Gen. plant. XIT. $t, 14$. A n ag allid is sp. Auct.

4213. Anagallis LINN. Calyx quinquepartitus. Corolla hypogyna, quinquepartita, subinfundibuliformis v, rotata. St a mina 5 , imo corollae tubo inserta, ejusdem laciniis opposita, exserta v. inclusa; fil a m e n t a filiformia, villosa, libera $v$. ima basi connata, anthera e ovatae, biloenlares, longitudinaliter dehiseentes. 0 v ari u m uniloculare, placenta basilari globosa. 6 vua plurima, peltatim amphitropa. Stylns simplex; stigma obtusum. Capsula globosa, unilocnlaris, operculo circumseissa. Semina plurima, placentae basilari liberae, globosae inserta, dorso plana, ventre conico-convexo umbilicata. E m b r y o in axi albuminis carnosi rectus, umbilico paralleIns. - Herbae perennes, in $E$ urop a et $\boldsymbol{A}$ sia media, nec non in Africa mediterran ea crescentes, erectae $v$. procumbentes; foliis oppositis, integerrimis, pedunculis axillaribus oppositis, unifloris, ebracteatis, corollis roseis, coccineis v. caeruleis, interdum albis. 
A nagallis Touruef, inst, 59. Lian, gen, n, 206. Gärtner $I, 230, t, 50$.

a. JIRASEKIA $W$. Schm. C orolla subinfuadibuliformis. S t a min a basi consata.

Jirase kia W. Sehmidt in Usteri Annal. IT. 124. t. 1. f. 2. Reichenb. Flor. Germ. 408. Nees jun. Gon. plant. XII. t. 13. (E. B. t. 530 . Cav. Ic, t. 193, f. 2. z. 306.f. 2. DC. Ic, plant, Gall. rar. t. 4. Curt, Flor. Lond, $t, 187$.

b. ANAGALlis $\mathbb{W}$. Schm. Corolla rotata. Stamina libera. (Gärtuer t. 50. Flor. dan. t. 88. Sebkuhr t. 36 . Hooker Flor. Lond. t. 169. Bot. Mag. t. 219. 2389. St. Hilaire in Mem, Mus. II. t. 4. f. 1. 4. Bot. Mag.t. 3380. Nees jun. Gen, plant. XII. $t .12$.

TRERES III. HOTTONIEAE. C a p s n1 a supera, valvatim dehiscens. S e m in a anatropa, umbilico basilari.

4214. Hifottonia LINN. Cal y $\mathrm{x}$ quinque. partitus. Corolla hypogyna, hypocraterimorpha, tubo calycem aequante, fauce inerassata, stellatim macnlata, limbi quinquepartiti laciniis obtusis v. retusis, patentibus. Stamina 5, corollae tubo inserta, limbi laciniis opposita, inclusa; fil a m e nta brevissima, antherae ovato-oblongae, biloculares, longitudinaliter dehiscentes, $O$ va $\mathbf{r i u m}$ uniloculare, placenta basilari globosa. Ovula plurima, anatropa. Stylus filiformis, exsertns; st ig ma obtusum. Ca p s n l a ovata, nnilocularis, demum quinquevalvis, valvis basi et apice cohae. rentibus. S e min a plurima, placentae basilari glo bosae inserta, ovato-elliptica, angulata, umbilico basilari. E mbryo in axi albuminis carnosi orthotropus, radi $c$ ula umbilico proxima, centripeta.Herbae aequaticae, in Eu rop a media et a ustrali, nec non in America boreali indigenae; foliis submersis, pectinato-multifidis, scapo emerso, flori bus albis $v$. lilacinis, verticillato-racemosis, internodiis verticillorum aequalibus $v$, inflatis.

Hottonia Linn. gen, n, 203. Schkuhr t. 25. E. B. $t$. 360. Flor, dan. $t$, 487. Gärtaer f. $I I T, 106, t$, 198. Nees

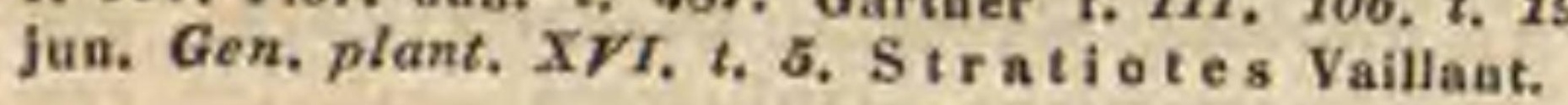

TrRaUS IT. SAMOLEAE. Cap sula semisupera, valvatim dehiscens. S e min a anatropa, umbilico basilari.

4215. Samolus TOURNEF. Ca ly $\mathrm{x}$ tubo cum ovarii basi connato, limbo semisupero, quinquefido. Corolla perigyna, subeampannlata, limbo quinquepartito. St am in a corollae tubo v. fanei inserta, quinque sterilia ejusdem laciniis alterna, filiformia v. squamaeformia, snbexserta, quinque fertilia laciniis npposita, inelusa, filamentis brevissimis, antheris biloenlaribus, cordatis, longitadinaliter dehiscentibus. O varium semiinferum, nuiloculare, placenta basilari globosa. O vula plurima, anatropa. Styl us bre vis, simplex; stig ma obtusum v. subcapitatum. Ca ps ula semiinfera, ovata, unilocularis, vertice exserto quinquevalvis. S e m in a plurima, placentae basilaris liberae, globosae foveolis immersa, depressiuscula, umbilico basilari. E mbryo in axi albuminis carnosi orthotropus, $r$ a dicula umbilico proxima. - Herbae cosmopotitae, in No. va-Hollandia copiosiores; folissalternis, inlegris, floribus terminulibus subracemosis v. corymbosis, al. bis, pedicellis medio v. basi unibrueteatis.

$\mathrm{S}$ a molas Tournef. inst, 60. Linn. gen, n. 222. Schkuhr t. 40, Gärtuer $I$. 146, $t$. 30. Flor. dan. $t$. 158. E. B.t.703. R. Brown Prodr, 488, Kunth in Humb, et Bonpl, Nov. gen, etsp. t. 129. St, Hilaire Mem, Mus, II, $t, 4, f, 35$. Nees jun. Gen. plant. XII. t. 18. S li effield i a Forster Char. gen. t. 9. Labillard. Nov, Holland. I, 40, $t$. 54 .

\section{GENUS PRIMULACEIS AFFINE.}

4216. Selawenkia LINN. C a 1 y $x$ tnbulosus, quinquefidus. Co roll a hypogyna, tubnlosa, limbo quinquedentato, erecto, glandulis elavatis, duabus v. quinque, dentibns interjectis. S $t$ am in a 5 , imo corollae tubo inserta, ejusdem laciniis oppesita, inclnsa, duo fertilia, reliqua ananthera; fil a menta subulata, an therae ovatae, biloculares, longitudinaliter dehiscentes, Ovarin m biloculare, placentis dissepimento adnatis, multiovulatis. St ylu s simplex; stigma suheapitatum. C a psuila bilocularis, bivalvis, valvis dissepimento membranaceo libero, utrinque placentifero parallelis. S e m in a pauca, angulata, scabriusenla, umbilico ventrali. $\mathbf{E} \mathrm{mb}$ ryo in axi albuminis carnosi rectus, umbilico parallelus. Herbae in America tropica indigenae, annuae, erectae, ramosae; foliis alternis, integris, floribus paniculatis, rarius in pedunculis axillaribus solitariis, geminis $v$. ternis.

Schwenkla Lín. gen. $n$, 293. Gärtner f. IIT, 182. t. 14. Kunth in Bumb et Bonpl. Nov. gen. et sp. II. 367. t. 178_181. DC. Plant, rar. Hart. Genev. 6 , 10 . C hat to: e hilus Vahl Enumerat. $I$. 102.

\section{GENERA VIX NOTA.}

MANAELIA Bowdieh Madeir. 38t. Cal y $\mathrm{x}$ pentagonus, quinquedivisus. Co rolla regularis, llmbo quinquediviso. Stamina 5 , lobis corollae opposita. Stylus unicus; st i ma simplex. Ca ps u la unilocularis, polysperma (?). - Herba madeirensis, hirsula; folis oppositis cum squamulis pluribus, floribus axillaribus solitarits, co-
rolla pallida.

FINDlaya Bowdich Madeir. 395. Calyx tubulosus, quinquefidus, persistens. Corolla tubulosa, limbi quia. quelobi regularis lobis mucronatis. Stam in a 5 , corollae Inserta, ejusque lobls opposita. Ovarium liberum. StyI u s simplex; stigma quinquefidam. Ca psula pentagois; caule suffrulicoso. folits alternis. Planta madeiren. lanceolatis, glabris, floribus axillaribus breve petiolatis, spicatis, tribracteatis, bracteis hastatis, calycibus hir. sutis, pilis basi dilatatis, glandulosis, viscosis, corollis
albis, antheris violaceis.

\section{Drdo CE VீII. Myrsineae.}

SAPOTIS AFPINES Inssieu Gen. 252, part. Annal, Mus. $V$. 266. OPHIOSPERMEAE Venten.Jard. Cels. 86. MYRSINEAR. R. Brown Prodr. 532. Tuckey Congo 464. Kuuth in Humb. et Bonpl. Nov, gen, et sp. III, 2d3, Alph, DC. in Linn, sc. nat, $V$. 193. ARDISLACEAE Jussieu in Annal. Mus, $X V$. 350 . Bartling Ord. nat, 163. MYRSINACEAR Lindley
Introduct, edit. $I 1 . p$. 22\%.

Arbores v. frutices, folitis alternis, rarius oppositis v. ternatis, simplicibus, integris, integerrimis v. serratis, coriaceis, saepe glanduloso-punctatis. Stipulae nullae.

FLORES hermaphroditi, saepius alterius sexus abortu polygami, regulares, ut plurimum axillares, fasciculati, umbellati, corymbosi v. paniculati, nune simpliciter racemosi, rarius terminales, ut plurimum parvi, saepius glandulis numerosis notati.

Calyx liber, v. rarissime cum ovarii basi 
connatus, quadri-quinquefidus v. partitus, lobis aestivatione v. etiam per anthesim imbricatis.

Corolua hypogyna v. rarissime perigyna, gamopetala $v$. rarissime fortassis eleutheropetala, plus minus profunde quadri-quinquefida v. partita, tubulosa, subcampanulata v. subrotata, laciniis cum lobis calycinis alternantibus.

Stamina corollae tubo $v$. fauci inserta, nune (in Ardisieis et Maeseis) simplici loborum corollae numero, iisdem opposita, omnia fertilia, antheris introrsis donata, nunc (in Theophrasteis) duplo loborum corollae numero, alterna iisdem opposita fertilia, antheris extrorsis donata, alterna sterilia squamas petaloideas cum corollae lobis alternantes sistentia. Filamenta saepissime brevia, libera, rarius basi aut juxta totam longitudinem in tubum coalita. Antherae biloculares, ovatae v. oblongae, erectae v. rarius incumbentes, distinctae v. conniventes, loculis parallelis saepissime adnatis, juxta totam longitudinem v. rarius solo apice dehiscentibus. Pollin is granula ovoidea, obtusissima.

Ovarion liberum v. rarissime basi calyci adnatum, uniloculare, placenta basilari globosa, sessili v. substipitata. Ovu la rarissime solitaria, plerumque pauca, subdefinita, v, indefinite plurima, amphitropa, nunc ejusdem foveolis immersa, puncto ventrali peltatim affi$\mathbf{x a}$, nunc in ejusdem superficie (in Theophrasteis) linea ventrali adnata. S tylu s brevis, simplex; stigma obtusum, acutum, indivisum v. rarius lobatum.

Froctus drupaceus v. baccatus, abortu saepissime monospermus, rarius oligo-v. polyspermus.

Semen intra pericarpium monospermum placentae basilaris apici insertum, dorso plus minus convexum, nonuunquam ventre impressoumbilicatum, in pericarpio polyspermo semina placentae plerumque stipitatae undique inserta, eidem ventre, prope basim micropyle impressa umbilicato, longitudinaliter adnata; te sta simplici, saepe mucilaginosa. A I bum en dense carnosum v. subcorneum.

Exвryo in fructu monospermo intra albumen umbilico ventrali et respectu pericarpii transversus, saepius arcuatus v. flexuosus, in fructu polyspermo excentricus, lineae ventrali qua semen adhaeret parallelus, directione carpica erectus, rectus v. parum inflexus. Cotyledones semicylindricae $v$. planae et subfoliaceat. Radicula teretiuscula, cotyledonibus longior, vaga $v$. infera.

Myrsineae inter tropicos totius orbis obviae, in regionibus subtropicis, Capite bonae spei,
Canariis, Japonia et Australasia rariores, in Africa tropica nondum observatae. Theophrasteae omnes americanae, Maeseae gerontogeae, Ardisieae amphigeae, in novo continente ut videtur frequentiores.

Ordo a Primulaceis habitu et fructu indehiscente diversus, mediantibus Theophrasteis ad Sapotaceas, ovarii et fructus oeconomia satis distinctas, accedit. Praeter lignum etiam floris et fructus partes in plurimis speciebus ductibus resiniferis instructae sunt. Maeseae a Samoleis ovulorum directione satis diversae.

A e gice re a e solo albuminis defectu, nota in stirpe littorali vivipara vix magni ponderis differunt, nam embryo respectu umbilici est transversus. - Le o n i a, si descripto quidem absoluta, longissime recedit, sed quo tandem referenda?

TIRIUE US I. ARDISIEAE. S $\mathrm{t}$ a $\mathrm{m}$ i $\mathrm{n}$ a sterilia nulla. Antherae introrsae. Ovarium liberum. Fructus monospermus.

421\%. Wallemia SWARTZ. C a $1 \mathrm{y} x$ campanulatus, quadridentatus. Co rolla hypogyna, tubulosa, limbi breviter quadrilobi lobis obtusis, imbricatis. St a mina 4 , imo corollae tubo inserta, ejusque lobis opposita, exserta; fil am enta crassa, ima basi cohaerentia, an therae ovoideae, breves, biloculares, longitndinaliter dehiscentes. Ovarinm uniloculare, placenta basilari subglobosa, Ovula pauca, peltatim amphitropa, Styl us brevissimns; st ig ma obtusum. Drap a subglobosa, monosperma. S e m en globosum, basi umbilicatum. E m bry o intra albumen corneum arcuatus, nmbilico transversus, ra dic n la vaga. - Arbusculae Americae tropicac; foliis alternis, suboppositis subternatisve, oblongis, obtusis, integerrimis, coriaceis, glabris, paniculis terminalibus multiforis, nudis, pedicellis in apice pedunculorum subumbellatis, corollae lobis punctatis,

Wallenia Swartz Prodr, 31. Flor. Ind. occid. 1. 248. t. 6. Jaeq, Hort, Sehönbr, t. 30. Martius Nov gen, et sp. $t$, 227, $f$. 11, exel. reliig. Alph. DC. in Linn. Transact. XVIr. 101. Petesioidex Jaeq. Amer.

4218. Concmorplaa $A L P H . D C . \mathrm{C}$ alyx campanulatus, quadrifidus. Corolla hypogyna, subcampanulata, limbi quadrifidi laciniis acutis, aestivatione valvatis, subanthesi subrevo. lutis. Stamina 4, summo corollae tubo inserta, ejusque laciniis opposita, breviter exserta; filament a brevissima, an $t h$ e $r$ a e ovoideo-triangalares, biloculares, longitudinaliter dehiscentes. Ovarinm uniloculare, placenta basilari subglobosa. Ovula pauca, peltatim amphitropa. StyI s brevis, subeonicns; stigma subcapitatum. Drupa globosa, monosperma. Se men snbglobosum, basi nmbilicatum. E m b ryo intra albumen corneum arcuatus, umbilico transversug, $r$ a di $\mathrm{cu}-$ la vaga.-Arbusculae brasilienses; foliis alternis, integerrimis, coriaceis, glanduloso-punctatis, racemis axillaribus, simplicibus, elongatis, pedicellis alternis brevissimis, minute bractealis, floribus punctatis, abortu saepe polygamis.

Conomorpha Alph. DC. in Linn. Transaet, XVIT. 102. Conostylas Pohl mse. Walleaia laxiflora Martius Nov, gen, ot sp. $t .237$. 
4215. Weigeltia $A L P H . D C . \quad \mathrm{C}$ a $1 \mathrm{y} \mathrm{x}$ quadripartitus. Co roll a hypogyna, quadripartita ..... St am in a 4, imae corollae inserta, ejusdem lobis opposita; filament a filiformia, libera, corolla breviora, antherae ovoideae, filamentis multo breviores, horizontales, biloculares, longitudinaliter dehiscentes. Ovarium ..... S tylus brevis, acuminatus. Bacea ...... Frutex surin a mensis; foliis alternis, obovatis, integerrimis, glabris, pellucido-punctatis, racemis axillaribus simplicibus, multifloris, patentibus, pedicellis brevibus alternis, corollae lobis obtusis, punctatis.

Weigeltia Alph. DC. in Linn. Transact. XVII. 103. Wallenia Myrianthos Reichenb.

4220. Cybianthus $M A R T$. Cal y $\mathrm{x}$ quadripartitus, patens. Corolla hypogyna, rotata, quadrifida, plana, circumscriptione subquadrata. St a m in a 4, corollae lobis opposita et basi inserta; filamenta subnulla, antherae transversim oblongae, biloculares, apice horizontaliter dehiscentes, Ovarin m minimum, quadrilobum ....S Stigma sessile, subcapitatum. Fructus ...... Arbusculae in Brasilia indigenae; foliis sparsis, versus apicem ramulorum confertis, petiolatis, glanduloso-tuberculatis, racemis filiformibus, pendu. lis $v$. erectiusculis, floribus parvis, unibracteatis, calyce et corolla fimbriato-pilosa, punctis lineolisque glandulosis, immersis notatis.

C ybianth us Martius Nov. Gen, et op. IIT. 87, t, 236. Alph. DC, in Linn, Transael, XVII, 103.

4721. Myrsine LINN. F lo res polyga mo dioici. C al yx quinquefidus, rarins quadri- v. sexfidus. Coroll a hypogyna, subrotata, quinquefida, rarius quadri-sexfida, laciniis aestivatione imbricatis. S ta min a 4_6, inuae corollae inserta ejusque laciniis opposita; filame nt a brevissima, antherae biloculares, erectae, longitudinaliter dehiscentes. Ovarium uniloculare, placenta basilari libera, subglobosa. Ov ula 4-5, peltatim amphitropa. Sty lus simplex; stig ma indivisum v. lobatnm aut fimbriatum. Drup a pisiformis, putamine crustaceo, abortu monospermo. S e m e n placentae basilari peltatim insertum, dorso convexum, ventre concavo umbilicatum. E m b ryo intra albumen corneum subarcuatns, umbilico transversus, ra di $c$ ul a vaga. - Frutices v. arbusculae in regionibus tropicis subtropicisque totius orbis obviae; foliis alternis, coriaceis, integerrimis, floribus axillaribus, fasciculato-aggregatis, subumbellatis, masculis majoribus, stigmate simplici, femineorum antheris minoribus, efoetis.

M yrsine Linn. gen. n. 269. Gärtaer $I, 281$. t. 59. R. Brown Prodr. 533. M y rsine et Badula Alph. DC. in Linn. Transact. XVII, 104. et 118.

a. MYRSINE $A l p h$, DC. Flores sessiles v, breve pedunculati, fasefeulati, fasciculi axillares, bracteis imbricatis, persistentibus, obtusis plas minus tecti.

Myrsine Jussieu Gen. 152. Ventea. Cels. 2.83. Kunth in Humb. et Bonpl. Nov. gen. et sp. IIT, 248, t, 243. Wallich Flor, Nepal, $t, 24$. 25 . Bot. Mag. $t, 8229$, Plot a Adans. Fam. II, $\mathrm{R}$ a p a n e a Aublet Guian, 1. 121. t. 46. M a g lilla Jussieu Gen. 151. C a balleria Ruiz et Pavou Prodr. R ó m er l a Thuaberg in Röm Arch, II. 2. S a mara Swartz Flor. Ind. occ, 261. Scler o. xylon Will. Berl. Mag. IIr, 58. A thruphyllum Loureiro Flor. cochinch. 148. Sutto n i a A. Richard Flor. Nov, Zeel. 394. $t$. 38. S ideroxy 11 s p. Lisu. Miller Ic, $t$, 299. Jacq. Hort, Vindob. I. $t, 71$.

b. BADULA Alph. DC. $t$, c. $t, 5$. FIores racemoso-paniculati v. umbellati. - Species mauritianae.

B a d a I Jussicu Gen, 290. B a rthesia Commers. moc. A a guillariae sp. Lina.
4222. Arelisia SWARTZ, Calyx quinquefidus v, quinquepartitus. C or oll a hypogyna, subrotata, limbi quinquepartiti laciniis aestivatione imbricatis, sub anthesi patentibus $v$. subreflexis. S ta min a 5, corollae fanci inserta ejusque laciniis opposita; fil amenta brevia, subulata, libera, a nth era e conniventes, liberae v. rarius connatae, filamentis aequilongae $\mathbf{v}$. majores, erectae, biloculares, triangulares, acutae v. acuminatae, longitudinaliter dehiscentes. O var i um uniloculare, placenta basilari libera, subglobosa. Ovula indefinita, peltatim amphitropa. S tylus simplex, persistens; st ig m a subulatum v. punctiforme. B a cc a abortu monosperma. S em en placentae basilari peltatim insertum, dorso convexum, ventre coneavo umbilicatum. E m b ryo intra albumen corneum arcuatus $v$. flexuosus, umbilico transversus, radi e ala vaga. - Arbores, frutices $v$. suffrutices, in Asia et America tropica, nec non in Japonia et insulis Canariis sponte crescentes; foliis alternis, rarius oppositis $v$. ternatis, punctatis, integerrimis v. saepius serrulatis, floribus paniculatis, pedunculis nunc in apice ramorum multifloris, foliis longioribus, nunc axillaribus, paucifloris, pedicellis in apice pedunculorum subumbellatis, corollis albis v. roseis, saepe punctatis.

Ardisla Swartz Prodr. 48. Flor. Ind, occid. 467. R. Brown Prodr. 533, in not. Roxburgh Elor. Ind. edit. Wallich II. 269. Kunth in Humb. ot Bonpl. Nov. gen. et sp. III. 243. Alph. DC, in Linn. Transact. XVII, 115. A ng ulllaria Gártaer $I$; 372.

a. EUARDISIA Alph, DC, Op, cit. 116. Anthera liberae, filamentis longiores. Sty lus subulatus, staminibus longior, - Bracteae pedicellis multo breviores.

c. P y rgus. Folla alteraa. - P y r g s Loureiro Flor. cochinchin, 149. I e c or a Aublet Guian. Suppl. 1. t. 368, Heberdeuia Banks msc. Anguillaria Giartner t. 77. Cavanill. Ic, t. 508. 503. (Swartz Flor. Ind. occid. $t$. 10. $f$. 1. Venten. Choix t. 5. Roxburgh Plant. Corom, t. 27. Andrews Bot, Reposit. t. 693, 630. Bot. Mag. t, 1657. 1950. 3292. Bot. Reg. $t, 323$, 638. 827. 1898. Alph. DC. Op. cit, $t, 6$, 8.)

B. B Iadhia. Folia opposita v. subternata. - Bladh i a Thunberg Flor, japon, $t, 18,19$. Gärtuer f. III. 195. $t$. 211. (Andrews Bot. Reposit. $t$, 623. Bot. Mag. t. 1950. Bot. Reg. t. 553.)

b. HYMENANDRA $A l p h$, DC. Op. oit. 126. A ntherate counatae. Stylus staninibus subaequilongus; stigma punctiforme. - Bracteae pedicellis multo breviores. - Ardisia hymenandra Wallich Plant. $A s$. rar. $t, 175$.

c. MiCranthera Alph, DC, Op, cit. 126, A n the rate liberae, filamentis elongatis multo breviores. Stylus stanínibus aequalis v. brevior, subulatus. - A. coriac e a Swartz. A. excels a Chr. Suith.

d. TYRBAEA $A l p h$. DC. Op. cit. 127 . Flores laxe paniculati, pedunculis alternis. Bracteas amplae, caducac, floribus alterais, subsessilibus majores.

4223. Hanbelia JUSS. CaI y x quinquepartitus. Corolla hypogyna, rotato quinquepartita, laciniis aestivatione valvatis. Sta mina 5 , corollae laciniis supra basim inserta et opposita, fil a menta brevia, antherae ovoideae, acutae. biloculares incumbentes, longitudinaliter dehiscentes, filamentis breviores. Ova ri u m uniloculare, placenta basilari subglobnsa. 0 v $\mathbf{l}$ u m unicum v. pauca, peltatim amphitropa. Stylus simplex, persistens; stigm a subcapitatum. Drupa baccata, monosperma. Sem en placentae basilari peltatim insertum, dorso convexum, ventre concavo umbilicatum. Eub r yo intra albumen corneum arcuato-subflexuosus, umbilico transversos, rad ic u la vaga. - Frulices Asiae tropica scandentes, petiolorum denticulis firmati; foliis al- 
ternis, coriaceis, integerrimis $v$. denticulatis, racemis axillaribus et terminalibus, simplicibus v. ramosis, pedunculis et pedicellis alternis, saepius pilosis aut velutinis, floribus parvis.

$\mathrm{E}$ m be li a Jussieu Gen. 497. Roxburgh et Wallich Flor. ind. II. 285. Alph. DC, in Jinn. Transact, XVII. 129. R i. bes foides Linn. Flor. Zeglan. 403. Ribes Burmann Flor, ind, 62, $t, 23$.

4\%24. Chorripetalum $A L P H, D C$. C aIyx quadrifidus. Coroll a hypogyna, tetrapetala, petalis aestivatione imbricatis, sub anthesi patentibus v. recurvatis, tandem separatim deciduis. St a mina 4, petalis opposita et ima basi adnata; fil a m ent a filiformia, antherae breves, lanceolatae, biloculares, longitudinaliter dehiscentes. Ovarium uniloculare, placenta basilari globosa. Ovula subgemina, peltatim amphitropa. Stylus simplex; stigma subinfundibuliforme. D rupa subglobosa, monosperma. Semen placentae basilari insertum, dorso convexum, ventre concavo umbilicatum. E m b r y o intra albnmen corneum arcuato-subflexnosus, rad $\mathrm{i} c \mathrm{u} l$ a vaga.-Frutices in $d i$ c $i$; foliis alternis, integerrimis, glabris, basi ovatis, in petiolos longos angustatis, floribus racemosis, pedunculis axillaribus, bracteis persistentibus, alternis, minimis, petalis glanduloso-ciliatis, $v$, maculis aurantiaceis notatis, floribus abortu saepe polygamis.

Choripetalum Alph. DC, in Linn, Transact, XVII. 131. Myrsine a uratiaca Wall. M. undulata Wall.

\section{*}

4ะ25. Dueostemam ADR. JUSS. C aly x quinquepartitus. Corolla hypogyna, rotatequinquepartita. St a m i n a coroliae fauci inserta, in tubum crassum, ovoideum v, cylindricum, apice quinquedentatum, dentibus corollae laciniis oppositis connata; antheris introrsis, bilocularibus. Ovarinm uniloculare, placenta basilari libera. O vula $2-4 \ldots \ldots$ Sty 1 us simplex; 8 tig ma subinfundibuliforme, subinteg errimum $\mathbf{v}$. denticulatum. Fructus..... Frutices madagascarienses; foliis alternis, petiolatis, integerrimis, pellucido punctatis, pedieellis in apice pedunculi axillaris umbellatis, unifloris.

Oneost e m n m Adr. Jussien in Mem, Mus, $X I X, 133$. t. 11. Alph. DC. in Linn. Transact, XVII. 115.

4226. Purkinyla PRESL. Caly x longe tubulosus, coriacens, decemnervis, apice attenuatoquinquedentatus. Coroll a hypogyna, in alabastro calyce multo brevior, profunde quinquefida, laciniis oblongis, acutis, aestivatione contortis. S $t$ am ina 5 , hypogyna, corollae laciniis opposita et breviora; fil a m e $\mathbf{t}$ a brevissima, planiuscula, anthe ra e lineares, obtusae, adnatae, biloculares. longitudinaliter externe debiscentes. Ovarium ovato-subglobosum, quinquesuleatum, nniosulatum, in styl zm teretem attenuatum; stigma globosum. Fruetus ..... - Frutex mexicanus, vix notus, ramosissimus; ramis apice tumido-incrassatis, ramulis subverticillatis, foliis sparsis, petiolatis, ellipticis, integerrimis, floribus secus paniculae terminalis ramos in fasciculos brevissime pedunculatos dispositis.

Purkinjia Presi Symb. IT. 17, t. 64.

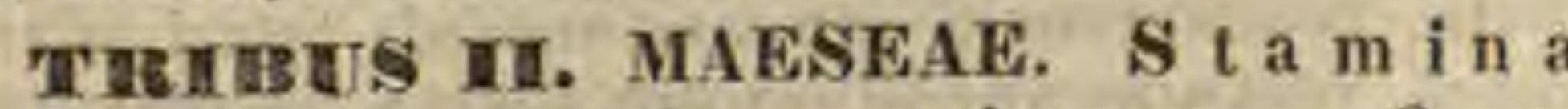
sterilia nulla. Antherae introrsae. Ovari m adnatum. Fructus polyspermum.
48\%8. NHaesa FORSK. C a Iy x bibracteolatus, tubo cnm ovarii basi connato, limbo quinquefido. Co ro 11 a perigyna, subeampanulata, quinquefida, laciniis aestivatione induplicato-valvatis. Stamina 5, corollae basi inserta, ejusdem laciniis opposita, inclusa; filamenta filiformia, a $\mathrm{t}$ h er a evoideo-cordatae, biloculares, longitadinaliter dehiscentes. O va ri u m uniloculare, placenta basilari, Ovula plurima, peltatim amphitropa. Stylus brevis; stigma obsolete tri-quin. quelobum. B a c e a calyce coronata, unilocularis. Semina plurima, placentae basilari globosae liberae inscrta, angulata, dorso complanata, ventre conico-convexo umbilicata. Embryo in axi albuminis carnosi rectus, radienla infera. - Frutices $v$. arbores, in Asia et Africa tropica et sub. tropica crescentes; foliis alternis, integerrimis v. dentatis, saepe pellucido-punctatis, floribus axillaribus, racemosis, racemis simplicibus v, ramosis, interdum terminalibus paniculatis.

M a e s a Forskael Descript. 66. Blume Bijdr. 869. Alph, DC, in Linn. Transact, XVIT, 132. t, 4. B a e o botrys Forst. Char, gen, t. 11. Vaht $S$ ymb, I, 19, t, 6. Gärner f. III. 131. 4. 210. Roxburgh Flor, ind. edit. Wallich II. 230. Martius Amoen. Monac, $t, 6$. Sibouratia Thouars Gen. Madagasc. n. 38.

\section{TUEIEUS III. THEOPHRASTEAE.} St am in a sterilia cum fertilibus alterna. A nthe ra extrorsae. Ovarium liberum. Fructus polyspermus.

42:8. Jacentuia $L I N N$. C aly $x$ quinquepartitus, laciniis obtusis, imbricatis. Cor olla hypogyna, subcampanulata, fauce squamis quinque, cum limbi quinquepartiti lobis obtusis, aestivatione imbricato-contortis, sub anthesi patentibus alternantibus. Stamina 5, imo corollae tabo inserta ejusque laciniis opposita, subexserta; fil a in en ta libera, complanata, basi subdilatata, antherae extrorsae, biloculares, ovatae, acutae, loculis adnatis, longitudinaliter dehiscentibus. Ovarin m uniloculare, placenta basilari subglobosa. OvuJa plurima, adscendentim amphitropa. Stylus brevissimus; stigma obtusum, indivisum. Bacca globosa, parva, unilocularis. Se min a pauca, angnlata, minima, placentae basilari liberae inserta, umbilico prope basim ventrali. Embryo intra albumen carnosum excentricus; cotyled on ibus ovatis, subfoliaceis, r adic n la longa, subinenrva, infera. - Arbusculae $v$. frutices $A m$ eric a e $t r o-$ picae; foliis sparsis, oppositis v. subverlicillatis, coriaceis, integerrimis, marginatis, muticis $v$, in acumen spinosum desinentibus, floribus terminalibus, solitarïs $v$, racemosis, albis $v$, aurantiaceis.

Jacquinia Linn. gen. $n$, 254. Jacquin Amer. 53. t. 39. Gärtaer f. HIT. 118. t. 201. Kanth in Humb. et Bonpl. Nov, gen, et sp. III. 230. t, 266. Bot. Reg. t, 1639. B o. a ellia Bertero msc.

48:5. Theopliwasta JUSS. C a 1 y $x$ profunde quinquefidus, Iaciniis obtusiusculis, imbricatis. Corolla hypogyna, eylindraceo-campanalata, quinqueloba, lobis obtasis, imbricatis, tubo intus corona e squamis quinque, cum limbi lobis alternantibus, dorso clypeatis, carnosis, infra medium connatis. Stam ina 5 , basi coronae intns inserta, corollae lobis opposita; fil a m enta brevissima, libera, ant he rae in connm conniventes, extrorsae, biloculares, loculis connectivo in acnmen producto adnatis, longitudinaliter dehiscenti- 
bus. Ovarium uniloculare, placenta basilari globosa. Ovula plurima, adscendentim amphitropa. Stylus brevis; stigm a subcapitato-bilobum. B a cea globosa, subpulposa, unilocularis, fragilis. S e m in a plurima, placentae basilariglobosae, liberae, stipitatae inserta, subcuneata, umbilico prope extremitatem latiorem ventrali, $t$ esta mueilaginea, tenui. $\mathbf{E} \mathbf{m}$ b r y o intra albumen cor. neum excentricus; cotyled onibus ovatis, planis, radicula cylindrica, infera. - Arbuscula domingensis; caudice simplici, apice comoso, foliis confertim subverticillatis, spinis acerosis interjectis, elongato-oblongis, spinoso-dentatis, rigidis, racemis terminalibus plurimis, subcorymbosis, abbreviatis, pedicellis bracteatis, supra medium bibracteolatis, floribus albis, nutantibus.

Theophrasta Jussieu Gen. 150. Lindley Collect. t. 26. Don in Edinb, new philosoph. Journ, 1831, X. 233. non Lian.

4230. Clavija RUIZ et PAV. C a 1 y x profunde quinquefidus, laciniis imbricatis, obtusis. Coro 11 a hypogyna, tubo brevi, fance in appendices carnosas, cum limbi quinquelobi laciniis obtnsis, aestivatione imbricatis, sub anthesi patentibus alternas tumente. $\mathrm{Sta}$ m in a 5 , imo corollae tubo inserta, ejusque lobis opposita, faucem vix superantia; fil amenta in tubum connata, a $n t$ her a e extrorsae, biloculares, trigonae, in capitulum decemradiatum conniventes, longitudinaliter dehiscentes. Ovarium uniloeulare, placenta basilari parva. Ovula pauca, adscendentim amphitropa. Stylus brevissimus; stigma abbreviato-bilobum. Bace a globosa, unilocularis. Semina pauca, placentae basilari globosae, liberae inserta, nmbilico prope basim ventrali, testa mucilaginosa, $\mathbf{E}$ mb r yo intra albumen corneum excentricus; cotyled onibus ovatis, planis, radicula infera.

Frutices $A m$ erica e tropica e; caule simplici, apice frondoso, foliis alternis, oblongis, coriaceis, integerrimis v. spinoso-dentatis, racemis axillaribus simplicissimis, strictis, folio brevioribus, bracteis minutissimis, floribus nutantibus, abortu saepe unisexualibus, albis $v$. aurantiaceis.

C Inv ija Ruiz et Pavon Prodr. 124. t. 36. Lindley Collectan, $n$. 26. Don in Edint, new philosoph. Journ. 1831. X, 234. Bot. Reg. $t$. 1764. Desfont. in Nouv. Annal. Mus. I. 398. t. 14. Hooker Ic, $t, 140$. The o p h ra $8 \mathrm{ta}$ Linn. Ben. n. 207. Jaeq. Hort, Schönbr, t, 116, non Juss. Eresia Plumier Gen. 8 .

\section{GENERA DUBIA,}

4as1. Leomia $R U I Z$ et $P A V$. C a I $\mathrm{y} x$ profunde quinquefidus, laciniis obtusis, imbricatis. Corolla hypogyna, subrotato-quinquepartita, laeiniis obovatis, aestivatione imbricatis, sub anthesi erecto-patentibus. Stamina 5 , imo corollae tubo inserta, ejusdem lobis opposita; fil amenta in tubum pentagonum connata, a nthe rae terminales, biloculares, globoso-didymae, adnatae, transversim dehiscentes. Ovari u m uniloculare, placentis parietalibus tribus $\mathbf{v}$. quinque, multiovnlatis. St ylus brevissimus; stigma minutum, obtuse conicum, indivisum. B a ec a globesa, unilocularis, polysperma. $\mathrm{S}$ e m in a in placentis parietalibus verticalia, oblonga v. obovata, pulpa invo. luta; test a sublignea, venosa, apice deraso - seabra. Embryo intra albumen carnoso-oleosum axilis. cotyledonibus foliaceis, nervosis, radicula eylindrica, umbilicum spectante. - Arbores perua. nae et brasilienses; folitis alternis, breve pe tiolatis, integerrimis, coriaceis, pellucido punctatis, glabris, racemis $v$, cymis axillaribus, compositis, floribus ochroleucis, compage molli, subgelatinosa, glanduloso-punctatis.

Le onta Ruiz et Pavon Flor. Peruv, II, 69, t, 229. Martius Nov. gen. et sp. 1I. 85. S te u d e li a Martius $O p$. cit. t. 168, 169, 200, f. 4 .

4232. Dneinus LOUREIR. C a ly $x$ liber, tubnlosus, breve quinquecrenatus. Corolla infundibuliformis, carnosa, faucis corona quinquefida, erecta, limbi quinquepartiti laciniis obtusis, omnibus hinc uneatis, emarginatis. St a min a 5, medio corollae tubo inserta; fil a m e n ta brevia, a $\mathrm{n}$ thera e simplices. Ovari a m rotundum.... Stylus inclusus; stigma acutum. B a ce a unilocularis. Semina plurima, subrotanda, nidulantia....- Frutex cochinchinensis, scandens; foliis oppositis, ovato-lanceolatis, integerrimis, glabris, nitidis, corymbis terminalibus racemosis, floribus albis, baccis globosis, pugni mole, nitido-rubris, cortice duriusculo, fragili, pulpa rubra, eduli, dulci, subadstringente.

0 ncin us Loureiro Flor. cochinch. 151.

\section{GENERA VIX NOTA.}

OTHERA Thunb. Flor. jap. 4. C aly $x$ quadripartitus, persistens, Iacinifs ovatis. Corolla tetrapetala, petalis obovatis, obtusis. Sta u in a 4 , imae basi petalorum inserta, iisque multo breviora, an ther a e didymae, quadri. sulcae. Ovarium liberum, glabrum. Stipma sessile. Fractus ....- Frutex $j a p o n i c u s$; ramis teretibus, striatis, purpureis, folitis alternis, petiolatis, ovatis, oblusis, coriaceis, glabris, integrix, floribus axilloribus aggregatis, brevissime pedunculatis.

ORIXA Thaub. Flor. jap. 3. Caly $\mathbf{x}$ quadripartitus, brevissimus. Corolla tetrapetala, virescens, petalis lanceolatis, patentibus. Stamina 4, petalis breviora, anthera e globosae. Ovarium liberum. Stylus erectus, simplex. Fructus.... - Planta faponica; caule frulescente, fexuoso, glabro, erecto, ramoso, ramis alternis, glabris, ultimis villosis, folits alternis, petiolatis, ovatis, integris, subtus pallidioribus, villosis, Ro. ribus racemosis, racemis alterisis, pallicaribus, bracteis sub pedicellis concavis, oblongis, glabris, pedunculis et pedicellis villosis.

\section{GENUS MYRSINEIS AFFINE.}

\section{* AEGICEREAE.}

4233. Aegiceras GAERTN. Flores hermaphroditi. Cal y $\times$ liber, qninquepartitus, persistens, laciniis oltusis, sinistrorsum imbricato tortis. C o r o ll a hypogyna, subhy pocraterimorpha, quinquefida, laciniis acutis, aestivatione dextrorsum imbricatis, sub anthesi patentibns. St a min a 5, imo corollae tubo inserta, ejusdem laciniis opposita, exserta; fil am enta subulata, basi in tubum connata, a n the rae sagittatae, incumbentes, biloculares, longitudinaliter dehiscentes, loculis septis transversis cellulosis, O ra ri u m liberum, conicum, uniloculare, placenta basilari, snbesnica. Ovula plurima, minima, peltatim amphitropa. Pericarpi u m folliculiforme, cylindraceo-arcnatum, coriaceum, hine fissum, monospermum. S emen erectum, cavitati conforme, intra pericarpium germinans; $t$ est a membranacea absorptione incompleta, fascia tenuis concavo seminis lateri adnata, supra medium vasculoso umbilicata, in calyptram ejusdem apicem obtegentem desinèns, A I bumen nullum. E mbryo erectus, arcuatus, cylindra- 
ceus; rad i cula brevis, obtusa, infera, c ot yledo $\mathrm{nes}$ in tubum cylindraceum crassum, plumulam subuliformem elongatam, indivisam includentem connatae, apice brevissime distinctae. $-\mathrm{Ar}$ busculae littorales, in $A s$ ia tropica et $O$ ce ea $n i a$ usque ad $34^{\circ}$ L. A. inter Rhizophoreas et Avicennias crescentes; foliis sparsis, obovatis, integerrimis, punctis glandulosis immersis, supra saepius excrescentiis salinis notatis, floribus axillaribus et terminalibus umbellatis, albis, fragantibus, pedicellis basi articulatis.

A eg feeras Gärtaer $r$. 216. $t$. 46. Känig in Annal. of Bot, $1.129 . t$. 3. R. Brown Prodr. 534. Blume Bijdr. 693. Nov, fam, exposit. 19. A. Richard Sert, Asterlab. t. 21. Wight in Hooker Bot, Miscell. Suppl, t, 21, Rhi. zopborae sp. Linn. - Malaspinea Presl in Roliq. Haenk. $I T$. 68. $t$, 61, certe congeuer, etsi ovarium uniovulatum dicatar, placeata verisimiliter pro ovulo descripta, nam stamina basi coadunata depiuguntur. Patria ${ }_{\text {regiones }}$ occidentales Mexiei" in tanta fasciculorum herbarit Haenkean quo ad locos uatales perturbatione, summe dubia.

\section{Ordo CL VIII. Sapotacene.}

SAPOTAE Jussieu Gen, 151. Annal. Mus, V. 417. SAP0TEAE R. Brown Prodr. 528, Bartling Ord, nat, 161. SAPOTACEAE Endlicher Prodr. Flor. Norfolk. 48. Lindley Introduct, edit. IT, p, 225.

Arbores v. frotices, ligno molli, plerumque succo lacteo scatentes. Folia alterna, coriacea, integerrima, breve petiolata, supra saepissime nitentia, transversim striata, subtus saepe pube seriacea vestita. Stipulae nullae.

Flores hermaphroditi, regulares, in peduneulis axillaribus simplicibus, solitariis $\mathbf{v}$. eonfertis.

Calyx liber, quadri-octopartitus, laciniis obtusis, imbricatis v. interdum biseriatis.

Corolla hypogyna, gamopetala, decidua, laciniis lobis ealycinis saepissime numero aequalibus et alternis, rarius duplis v. triplis.

Stamisa corollae tubo v. fauci inserta, inclusa, fertilia corollae laciniis numero aequalia et opposita, cum totidem anantheris alterna, rarissime sterilia nulla, quandoque fertilia laciniis corollae dupla v. plura, bi-pluriseriata. Filamenta subulata. Antherae biloculares, saepius extrorsae, erectae v. incumbentes, longitudinaliter dehiscentes.

Ovarium liberum, sessile, disco nullo, pluriloculare. Ovula in loculis solitaria, ex anguli centralis basi adscendentia, anatropa. Stylus simplex, saepissime exsertus; stig$\mathrm{ma}$ indivisum v. obsolete lobatum.

Bacca plurilocularis v. abortu unilocularis, loculis monospermis.

Semina nucamentacea (nauci), interdum in putamen pluriloculare connata, testa ossea, nitens, ventre plus minus deraso, opaco, ibique prope basin umbilieata. A Ib umen nullum v. carnosum.
Емввуо orthotropus, albumine dum adest inclusus, ejusdem longitudine, Cotyledones in albuminosis foliaceae, in exalbuminosis carnosae, plano-convexae. $R$ a d i cula recta v. paullulum incurva, umbilicum spectans, ideoque infera.

Sapotaceae in regionibus tropicis totius orbis obviae, in Australasia subtropica, Capite bonae spei, Africa boreali-occidentali, America boreali calidiore et australi extratropica multo rarius crescentes, hine mediante Jacquinia Ardisiaceis conterminae, illine Ebenaceis, succi lactei defectu, ligno durissimo, floribus saepius polygamis, ovulis seminibusque inversis, et stylo plerumque partito facillime distinguendis, affines sunt.

Plurimae ob fruetus sapidos et varios succi lactei usus, nonnullae ob corticis qualitates febrifugas celebres.

4334. Clnaysoplayllum $L I N N$. C a 1 y $x$ quinquepartitus, laciniis imbricatis. Coro 11 a hypogyna, campanulato-rotata, limbo quinquepartito, patente. S ta m in a 5 , eorollae tubo inserta, ejusdem laciniis opposita, sterilia nulla ; fil a m enta subnlata, anthera e extrorsae, incumbentes, biloculares, Iongritudinaliter dehiscentes. O vari n m quinque-decemlocnlare. Ovula in loeulis solitaria, in angulo interiori adscendentia, anatropa. Stylus brevis, exsertus v. subnullus, stigma depressum, obsolete quinque-decemlobum. $B$ a ec a quinque-decemlocularis, abortu saepius unilocularis. Semin a in loculis solitaria, nucamentacea, erecta, ventre derasa. E mb r y o intra albumen pareissimnm magnus, orthotropus; cotyledonibus crassis, subfoliaceis, radic u la brevi, subincurva, infera. - Arbores lactescentes, in America tropica indigenue; folits alternis, integerrimis, transversim multistriatis, subtus saepe sericeo-tomentosis, pedunculis axillaribus umbellato-confertis.

Chrysopbyll um Lian. gen. n. 203. Jnssieu Gen. 132. Jaequin Amer, 2. 37. 38. Edit, pict, t. 51. 55. 35. A ublet Guian, t. 92. Lam, t. 120. Gärtner f. IIt. 120, t, 201. 202. Kuath in Humb. et Bonpl. Now, gen. et sp. MIT. 238. Ny cteristium Ruiz et Pavon Flor. Peruv, IT, 46, t, 187. Finth op. cit, III. 238, t. 244. C a inito Tussac Flor. Antill. HIT, t. 9. Tarpin Attas II. $t, 63$.

4235. Siderexylon $L I N N$. C a lyx brevis, quinquefidas. Corulla hypogyna, subrotata, tubo brevi, limbi quinquepartiti laciniis simplicibus. Stamina corollae tubo inserta, quinque fertilia ejusdem laciniis opposita, cum totidem sterilibus petaloideis alterna; fil a ment a subulata, anthera e incumbentes, extrorsae, ovatae, bilocnlares, longitndinaliter dehiscentes. Ovari um quinquelocnlare. $O \mathrm{v}$ u 1 a in loculis solitaria, ex angulo centrali adscendentim anatropa. Stylus subulatus, exsertns; stigma obtusum. B a cea abortu bi-trilocularis. Semina in loculis solitaria, nueamentacea, ventre complanato derasa, prope basim umbilicata. Emb ryo intra albumen carnosum copiosum orthotropus; cotyledonibus magnis, planis, subfoliaceis, radicula brevi, infera. - Arbores v. arbusculae, in Capito bonae spe $i$ et India orientali erescentes; foliis alternis, coriaceis, integerrimis, pedunculis axillaribus et lateralibus unifloris, congestis. 
Sideroxylon Lian. gen. n. 264. excl. sp. Lam. t, 120. Gartner f. IIT. 123. $t$. 208. Roxbargh Plant. Corom, $t .28$. Hooker ad Becchey $t$, 41 , R ob e rtsi a Scopoli Introduct. n. 588 .

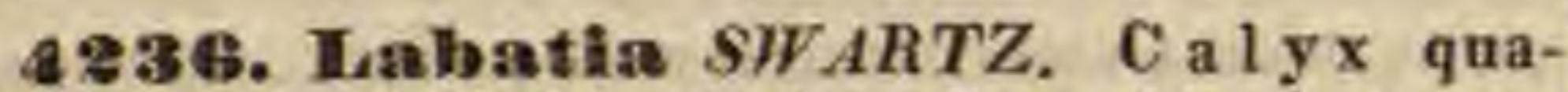
dripartitus, lacinis biseriatis. Corolla hypogyna, urceolato-tubulosa, limbo breviter quadrifido, erecto. Stamina quinque fertilia, imo corollae tubo inserta, ejusdem laciniis opposita, cum totidem sterilibns squamulaeformibus, fauci impositis alterna; fila m enta subulato-complanata, tubum aequantia, anthera e introrsae, biloculares, ovatae, longitudinaliter dehiscentes. O v a rium quadriloculare, 0 vu 1 a in loculis solitaria, ex angulo centrali adscendentim anatropa. St y I n s subulatus, inclusus; stig m a acutum. Bacea depressiuscule subglobosa, coriacea, quadrilocularis $\mathbf{v}$, abortu bilocularis. Se mina in loculis solitaria, erecta, ventre derasa. Em bry o exalbuminosus, orthotropus; cotyledonibus crassis, plano-convexis, radi cula brevi, subinenrva, infera. - Arbores $A \mathrm{me}$ ricae tropicae; foliis alternis, coriaceis, nitidis, integerrimis, pedunculis axillaribus unifloris, brevibus, confertis.

L a b a ti a Swartz Flor. Ind. occid, I, 283, Martius Nov. et op. Ir, 70, t. 160. 161. Ponter i a Aublet Gaian. I. 85. Gen, t. 33.

Q23\%. Gersallsta $R$. $B R$. C al y x quínquepartitus, Iaciniis imbricatis. Corolía hypogyna, subrotata, tubo brevi, limbi quinquepar titi laciniis simplicibns. Sta min a corollae tubo inserta, quinque fertilia ejnsdem laciniis opposita, cum totidem sterilibus petaloideis alterna; filamenta subulata, antherae extrorsae, bilocalares, subsagittatae, longitudinaliter dehiscentes. Ovarium quinquelocnlare. Ovula in loculis solitaria, ex angulo centrali adscendentim ana tropa. Stylus subulatus, exsertas; stigma acu tam. Bacea quinquelocularis, abortu saepins uni bilocularis, Semina in loculis solitaria, erecta, testa crustacea, ventre sulco longitudinali, $\mathbf{E}$ mbryonis exalbuminosi, orthotropi cotyled ones plano-convexae, crassae, radicula brevis sima, infera. - Arbores Novae Hollandiae tropicae, lactescentes; foliis alternis, obovatis, coriaceis, integerrimis, subtus sericeis, pedunculis axillaribus, unifloris, fasciculatis.

Sersalisia R. Brown Prodr. 599. A. Riehard Sert. Astrolab. $t, 32$.

4238. Bumelia $S W A R T Z$. Cal y quin quepartitus, laciniis imbricatis. Corolla hypogyna, subrotata, tubo brevi, limbi quinquepartiti laciniis basi utrinque lacinula auctis. Stamina corollae tubn inserta, quinque fertilia ejusdem laciniis opposita, enm totidem sterilihus petaloideis alterma; filamenta subnlata, antherae extrorsae, biloculares, subsagittatae, longitulinaliter dehiscentes. Ovarin quinqueloculare. Ovula in loculis solitaria, ex angulo centrali adscendentim anatropa. Stylus subulatus, exsertus; stig ma acutum. B a s c a aloortu nnilocularis, monosperma. Semen oxatum, testa cristacea, ventre plano. prope basim umbilieato. E mbryo nis exalbuminosi, orthotropi cotyledones crassae, planoconvexae, radicula brevi, suhineurva, infera. Arbores $v$. frutices lactescentes, in $A$ merica tro. pica et boreali calidiore crescentes; foliis alternis, integerrimis, pedunculis axillaribus v. lateralibus uniforis, saepissime fasciculato-congestis, floribus albis.
B umelia Swartz Prodr. 49. Flor. Ind, oceid, $I$, 488, Gärtner f. III. 127, $t, 102$. Veal. Choix t, 22, Kunth in Humb. et Bonpl. Nov. gen, et sp. III. 237, t, 647. Rudge Guian, $t$. 47, S t the rox y $1 \mathrm{f}$ s p. Linn, Jacq. Amer, $t, 120$, f. 2. Collect. IT, t. 17, f. S. Duhamel Arbr, t.68, C h r y so. phylli s p. Jacq. Observ. IIT. $t$, 5i. - ? Roste 11 a ria Qürtaer f. III. 135. $t$. 207.

4:35. Argania $S C H O U S B$. C aly $\mathrm{x}$ decempartitus, laciniis biseriatis. Corolla hypogyna, ovato-subeampanulata, quinquepartita, laciniis subemarginatis. $\mathrm{St}$ a m in a corsllae tubo inserta, quinque fertilia ejusdem laciniis opposita, cum totidem sterilibus petaloideis alterna; filamenta brevissima, subulata, anth erae extrorsae, biloculares, ovatae, Iongitudinaliter dehis. centes. Ovarium quinqueloculare. OvnIa in loculis solitaria, ex angulo centrali adscendentim anatropa. D ru p a aborta bi-trilocularis. Semina nucamentacea, subdistincta, v. ventre rhaphe percurso in putamen bi-triloculare connata. $\mathbf{E}$ m b r y o intra albumen carnosum, parenm orthotropns ; cotyledonibus planis, subfoliaceis, radicula brevi, infera. - Arbor marocean a; ramis spines. centibus, foliis alternis, lanceolatis, coriaceis, integerrimis, pedunculis lateralibus et axillaribus unifloris, confertis, brevissimis, fructu carnoso, succo lacteo, aëri exposito glutinoso.

A rganla Seliousbae Marooc.89. Sideroxylon spi. no $n$ m Linn. Hort. Cliffort. 69. Dryander in Linn. Transact. II. 225. Correa in Annal. Mus, YII. 393, t. 5.

48 40. A ehrass $P$. BROWN. Cal y $x$ quinque-sexpartitus, laciniis imbricatis. Co rolla hypogyna, subcampanulato-ventricosa, limbo quinquesexpartito, erecto. Sta m in a corollae fanci inserta, inclnsa, quinque $v$, sex fertilia, ejusdem laciniis opposita, cum totidem anantheris alterna; filam enta complanato-subulata, anthera e extror. sae, incumbentes, biloculares, Iongitudinaliter dehiscentes, 0 va ri $\mathrm{m}$ sex-duodecimlocnlare. 0 v u 1 a in loculis solitaria, in angulo interiori adscendentia, anatropa. Stylus subulatus, exsertus; s ti g$m$ a obtnsnm, indivisum. B a e $e$ a sex-duodecimlncularis, abortn saepe unilocularis. Semina in loculis solitaria, nucamentacea, erecta, a latere compressa, ventre derasa. Embryo intra albumen earnosum, parcum orthotropns; eotyledonibus magnis, planis, subfoliaceis, radicula infera. - Arbores lactescentes, in America tropiea et Australasia extratropica indigenae; foliis alternis, obovatis, integerrimis, nitidis, transversim multicostatis, pedunculis axillaribus, unifloris.

A chras P. Browne Jam. 200, t. 19, f. 3. Jaeq. Amer. 57. t. 41. Edit, pict, t. 4t. Jussient Gen. 15e, R. Brown Prodr. 530. Kuath in Hunb. ot Bonpl. Nov. gen, et sp. III. 239. S a pata Miller Dict, 1. Gitrtner $I I, 103$. 2. 104. III. 136. t. 207.

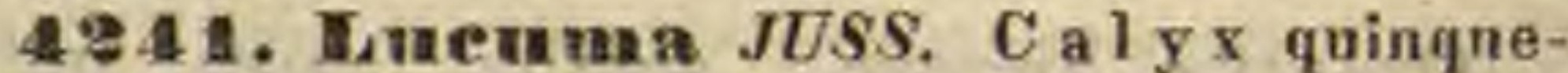
partitus, laciniis imbricatis. Coroll a hypogyna, subeampanulato - ventricosa, limbo-quinquepartito, erecto. St a min a corollae fauci inserta, inclnsa, quinque fertilia ejusdem lobis opposita, eum totidem anantheris alterna; fil a ment a complanatosubulata, a ntherae extrorsae, incumbentes, biloculares, longitndinaliter dehiscentes. $O$ varin m qainque-decemlosulare. $0 \mathrm{vnla}$ in loculis solita. ria, in angulo centrali adscendentim anatropa. Stylus subulatus, exsertus; stigma obtnsum, indivisum. B a $c$ a quinque-decemlocularis, aborfu saepe unifocularis. Semina in leenlis solitaria, nueamentacea, erecta, subglobosa, ventre derasa. Embryo exalbuminosus, orthotropus; cotyle- 
don e s magnae, carnosae, plano convexae, undulato-rugosae, radicula brevissima, infera. Arbores lactescentes, in Americatropica et a $u$ tralisubtropica indigenae; foliis alternis, obovato- $v$, oblongo-lanceolatis, nitidis, transversim costatis, pedunculis axillaribus, unifloris.

L u c u m a Jussieu gen, 152, Gärtner f. III, 199. t. 203. 204. Kunth in Humb. et Bonpl, Nov. gen. et sp. III. 239. A ch ra dis s p. Linn. Jacq. Amer. $t$. 182. $f$. 19. Edit. pict. t. 39. Ruiz et Pavou Flor. Peruv, t. 239 . - ? Vit. tellarla Gartner f. IIT. 13t. $t .205$.

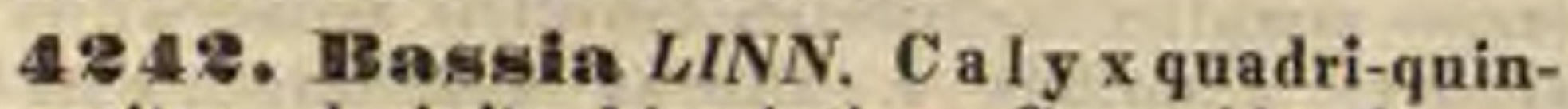
quepartitus, lacinis biseriatis. Corolla hypogyna, campannlata, limbo quinquepartito, erecto. Stamina corollae tubo faucique inserta, inclusa, ejusdem laciniis dupla v. tripla, bi-triseriata; filamenta brevissima, antherae introrsae, erectae, subsagittatae, biloculares, longitudinaliter dehiscentes. O va ri u m quinque-octoloculare. O vuIa in loculis solitaria, ex angulo centrali adscendentim anatropa. Stylus simplex, exsertus; $8 \mathrm{tig} \mathrm{m}$ a acutum, indivisum. B a $\mathrm{c}$ e a quadri-quinquelocularis. Semina in loculis solitaria, nueamentacea, erecta, ventre derasa. Embryo exalbuminosus, orthotropas; cotyled on es magnae, plano-convexae, ra dic ul a brevis, infera. - $A r$ bores Asiae tro picae, succo lacteo scatentes; foliis alternis, integerrimis, pedunculis axillaribus, unifloris.

Ba s s i a Linn. gen, $n$, 1347. Gärtner IT, 104. $t, 104$. Roxburgh Plant, Corom, t. 19. Asiat, Researeh. VITT. 477. Flor, ind, II. 523. Blume Bijdr. 674, Hooker Ie, $t$. 47.

4243. VImuseps LINN. C a 1 y x sexoctopartitns, laciniis biseriatis. Corolla hypogyna, subrotata, multipartita, laciniis biseriatis, exterioribus senis-sedecinis, integris v, divisis, patentibus, interioribus senis octonis, indivisis, erectis. Stamina imo corollae tubo inserta, sex v. octo fertilia ejusdem laciniis interioribus opposita, totidem anantheris alterna; filamenta subulata, fliformia, antherae sagittatae, extrorsae, biloculares, longitudinaliter dehiscentes. Ov a ri $\mathbf{~ m ~}$ octolocelare. $\mathrm{O} v \mathrm{n} \mathrm{I}$ a in loculis solitaria, ex angu lo centrali adscendentia. Stylns subulatus; stigma acutum. B a $\mathrm{c}$ e a aborin uni-bilocularis. S em in a in locnlis solitaria, nueamentacea, erecta, ventre derasa. Em b ry o intra albumen carnosum, parcum orthotropus; eotyledonibus magnis, crassinseulis, subcarnosis, rad i eula eylindriea, infera. -Arbores Asiae et Novae Hollandiae tropica lactescentes; folits alternis, integerrimis, nitidis, pedunculis axillaribus brevibus, confertis.

MIm usops Linn. Gen. 478. Jussieu Gen, 154. Gärtner I. 198. t. 42. IIT. 132. $t, 203$. R. Brown Prodr, 830 , -? Phlebolithis Girtuer $I .201 . t, 43$.

a. ELENGI. Corolta laciniae exteriores integrae. (Lam. t, 300. Roxburgh Plant, Corom, t. 14. 13. Bot. Mag. t. 3157.)

b. BINECTARIA. Corolla laciniae exteriores bis bifidae. B Inectaria Forskael Deseript. 89.

48 14. Inbbiearia COMMERS. C a ly octopartitus, laciniis biseriatis. Co rolla hypo. gyna, subrotata, multipartita, laciniis triseriatis, serium duarum exteriorum sibi invicem oppositis, tripartitis, cum interioribus integris alternis. Stamina imo corollae tubo inserta, octo fertilia, ejnsdem laciniis interioribus opposita, totidem anantheris alterna; fil a m en $t$ a filiformia, an $t h e-$ $r$ a e sagittatae, extrorsae, biloculares, longitudi naliter dehiscentes. Ova ri u m netoloculare. Ov ula in loculis solitaria, ex angulo interiori adscen- dentia, anatropa. Stylus subulatus; stigma acutum. B a cea octolocularis v. abortu quadrilocularis. Semina in loculis solitaria, nucamentacea, erecta, ventre derasa, dorso et ad nmbilicum prope basim ventralem cristata. Embryo intra albumen carnosum, parcum orthotrepus; cotyledonibus magnis, subfoliaceis, radicuIa brevi, incurva, infera. - Arbor ma uritiana, lactescens; folits alternis, in apice ramulorum confertis, obovato-oblongis, venosis, nitidis, pedunculis axillaribus confertis, nutantibus.

$1 \mathrm{mb}$ ricaria Commerson ex Jussieu Gen. 152. Lam. 2. 300. Gärtuer f. III. 133. t. 206. R. Brown Prodr. 531 , in not.

4245. Duaplaaloearpus PALIS. CaI yeis polyphylli squamae concavae, obtusae, pluriseriatim imbricatae. Corolla hypogyna, tubo brevi, limbi sex-septempartiti laciniis aequalibus, ovatis, margine undulatis, faucis squamis totidem, fimbriatis, eum iisdem alternantibus. Stamin a corollae tubo inserta, indefinita (?) (sena singulis laciniis opposita?) ..... O v a ri $\mathrm{n} \mathrm{m} \mathrm{mul-}$ tiloculare $\ldots .$. Stylus filiformis, simplex; stigma subcapitatum, indivisum. Fruetus lignosus, depresso - orbiculatus, eirea stylum persistentem umbilicatns, multilocularis, endocarpio concretionilsus lignosis, irregulariter angulatis, secedentihas scatente, loculis pulposis. S e mina in loculis solitaria, ossea, ovata, nitida, rhaphe longitudinali notata. E mbryo intra albumen carnosum rectus; cot y led on ibus magnis, planis, subfoliaceis, radieula brevi. - Arbor Africae tropicae; trunco elato, apice comoso, foliis alternis, lanceolatis, integerrimis, nitidis, floribus trunco innascentibus, sessilibus, solitariis $v$. confertis.

$0 \mathrm{mphalocarp}$ is Palisot Flor, Owar, 1 . 6. $t$, s.6. R. Brown Prodr. E29, in not.

\section{GENUS DUBIUM.}

4245. VIomroneda AURLET. Calyx quinquepartitas, laciniis imbricatis. Corolla hypogyna, infundibuliformis, limbi quinquefidi laciniis obtusis, patentibus. Stamina 5 , corollae fauci inserta, ejusdem laciniis opposita; filamenta subulata, antherae oblongae, ineumbentes. Ovarium eonienu, diseo einctum. StyI ns longus; stigma bilamellatum. Capsula ovato-oblonga, coriacea, fibrosa, bi-trilocularis, loculis monospermis. Semina dorso convexa, ventre plana. - Frutex guianensis, sarmentosus, vix notus, fortassis Convolvulaceis, a quibus tamen staminibus corollae lobis oppositis diferre videtur, adjiciendus; foliis alternis, breve petiolatis, ovatis, integerrimis, nitidis, floribus axillaribus corymbosis, caeruleis.

Mouroucoa Anblet Guian, $1,141, t, 5$. Maireria Scopoli Introduct, n, 831 .

\section{Drdo CLIX. Ebenaceas.}

GUAIACANAE sect. 1. part. Jnssien Gen, 156. EBENA. CEAE Venten. Tabl. 433. Jussleu in Annal. Mus. $V$, 417. R. Brown Prodr. 526. Bartling Ord. nat, 160. Liadley $\mathrm{In}$. troduct. edit. II. p. 226.

Arbores v. Fruticns, hand lactescentes, ligno denso, saepe durissimo. Fol i a alterna, coriacea, integerrima, latiusenla, petiolo obsolete articulato. Sti pula e nullae. 

Floses polygami, rarius hermaphroditi, re-|ideo plurium sede inter utrumque ordinem adgulares, axillares, pedunculis solitariis, masculis divisis, femineis saepissime unifloris, minute bracteolatis.

CaLrx gamophyllus, tri-sexfidus, subaequalis, persistens.

Corousa hypogyna, gamopetala, decidua, urceolata, subcoriacea, extus plerumque pubescens, intus glabra, limbo tri-sexfido, lobis aestivatione imbricatis.

Staura imae corollae inserta $v$. rarius hypogyna, definita, ejusdem laciniis numero dupla, rarius quadrupla, rarissime aequalia et tune alterna, inclusa. Fil amenta in floribus hermaphroditis simplicia, in polygamis dioicisque saepissime duplicata, crure utroque antherifero, interiore plerumque breviore. Anthe rae introrsae, biloculares, basi affixae, lanceolatae, Iongitudinaliter dehiscentes, glabrae v. interdum barbatae. Poll e n globosum, laeve.

Orarium sessile, absque disco hypogyno, tri-pluriloculare. Ovula in loculis solitaria v. gemina collateralia, ex apice anguli interioris pendula. Stylus divisus v, rarius simplex; stigmata bifida v. simplicia.

Bacca globosa v. ovalis, abortu saepe oligosperma, succulenta v. sicea, cortice tunc valvatim secedente.

Semixa inversa, testa membranacea, endopleura obsoleta. Al bum e n cartilagineum.

Exввхо intra albumen axilis v. subobliquus, ejusdem dimidio saepe longior. Cotyledones foliaceae, subvenosae, aceumbentes v. interdum subdiscretae. R a dicula teres, mediocris v. longa, umbilico proxima, supera. Plumula inconspicua.

E benacea e inter tropicos Asiae et Americae obviae, in Capite bonae spei, America boreali et in Europa mediterranea rarae, hinc Sapotaceis et Aquifoliaceis proximae, illine e sententia ill. R. Brown Oleineis propinquae, iisdem structura intima placentationeque seminum convenientes, foliis alternis, inflorescentia axillari, floribus saepe diclinibus et plerumque diplostemonibis diversae.

Genera ad ordinis calcem rejecta, novorum ordinum rndimenta, fructus indole, et embryonis albuminisque proportionibus imprimis recedunt, sed eorum inter se affinitatis gradus subdubius.

Aquifoliaceae ab Ebenaceis imprimis simplici staminum numero et corollae insertione ambigua diversae, infra pone Celastrineas collocantur, tum ob petalorum in pluribus distinctionem manifestam, tum ob seminum situm in pluribus nondum perspectum, generumqque huedum dubia.

Lignum nonnullarum specierum ob insignem duritiem et colorem atrum celebre, aliarum fructus edules.

424. Draba FORST. Flores dioici. Ca1 y $x$ semitrifidus. Coroll a hypogyna, urceolata, trifida. Masc. Stamina hypogyna, duplici v. rarins simplici laciniarum corollae numero; $\mathrm{fil}_{\mathrm{l}}$ menta simplicia v. alterna duplicata, a ntherae oblongae, erectae. Ovarii rudimentum. Fem. Stamina nulla. Ovarium triloculare. Ovula in loculis gemina, collateralia, pendula. Stylus brevissimus; st $\mathrm{g}$ ma tri-quadrifidum. B a c c a ovalis v. subglobosa, basi calyce cupuliformi cincta, trilocularis v, abortu bilocularis, loculis mono-dispermis. S e m in a inversa. $\mathrm{E} m$ b r yo in axi albnminis cartilaginei rectus; cotyledonibus foliaceis, radicula snpera. - Arbores v. frutices, in Asia et Nova-Hollandia tropica crescentes; foliis alternis, integerrimis, pedunculis axillaribus, uni-paucifloris.

Mah a Forster Char. gen. 6t. Jussieu in Annal, Mus. V. 418. R. Brown Prodr. 597. Labillard. Nov, Caledon, 1. 3i. $t$ 35. 36. F er re ol a Königex Hoxburgh Plant. Corom. I. 33. t. 45. P is a nia Rottboell Act. Hafn, II. 536. $t, 4$, f. 2. B be a ox ylo n Loureiro Flor, cochinch. 758.

4248. Cargillia $R$. $B R$. F lore s polygani. Caly $x$ semiquadrifidus. Cor oll a hypogyna, subeampanulata, quadripartita. Ma s c. S tamina imae corollae inserta, ejusdem laciniis dupla; fil amenta duplicata, anth era e oblongo-lanceolatae. Ovarii rudimentum. F e m. Stam in a efoeta, pauciora. Ovarium quadriloculare, Ovula in Ineulis gemina, collateralia, pendula. Stylus simplex v. tri-quadripartitus. B a c ca glohosa, basi calyce adpresso, cupulaeformi cincta, quadrilocularis v, abortu bilocularis, loculis mono-dispermis. Semina inversa. Embryo in axi albuminis cartilaginei rectus; cotyledonibus foliaceis, radicula supera. - Frutices in Nova-Hollandia tropica et orientali extratropica crescentes; foliis allernis, integerrimis, glabris, pedunculis axillaribus brevibus, paucifloris.

Cargillia R. Brown Prodr. 526. Bot. Mag. t. 3274 .

42 4\%. Tiospyres LINN. F I ores polygami. C a ly $x$ profunde quadri-rarius tri-sexfidus. Coroll a hypogyna, urceolata, quadri- nune trisexfida. M a s e. St a mina imae corollae inserta, ejusdem laciniis dupla v. rarius quadrupla ; fil ame nta duplieata, antherae lanceulatae, $0 \mathrm{va}$ rii rudimentum. Herma phrod. fem. Sta min a efoeta, pauciora. Ova ri um octo-duodecimloculare. Ovula in loculis solitaria, pendula. Stylus bi-plarifidus; stigmata simplicia v. bifida. B a c ca globosa, calyce patente, demum reflexo stipata, plurilocularis, loculis monospermis. Se $m$ in a inversa. E $m$ b ryo intra albumen cartilagineum obliquas v, axilis, rectus; cotyledonibus foliaceis, radieula supera. - Arbores $v$. frutices, inter tropicos totius orbis, rarissime in $A$ merica boreali et in regione mediterrane a crescentes; foliis alternis, integerrimis, pedunculis axillaribus, paucifloris.

Di ospyros Liua, gen, $n, 1161$. Jussieu gen, 136, R. Browa Prodr. Bes.

a. EBBNUS. S ta m i a a corollae laciniis dapla, fil a mea$t$ Is duplicatis. Ebea us Comners. ex Jussieu $l$. c. 
D i o s p y ros Gärtaer $I I, 478 . t, 179, I I I, 136, t, 208$, Jacq. Hort. Schönbr. t. 3t2. Rottboel Act. Hafn. II. t. 5. Watson Dendrolog. Brit, . 146. Roxburgh Plant, Corom, t. 46-50. Bot. Reg, t, 1138, Hooker Exot, Flor. t. 139. G u i a c a n a Tournef. Inst. 371 .

b. EMBRY OPTERIS. S a $\mathrm{m}$ i $\mathrm{n}$ a corollae lacinils quadrupla, filamentis duplicatis. Embryopteris Gärtaer $I_{\text {. }} 145$. $t$. 29. Roxburgh Plant. Corom, $t$, 20 . Cavanilla Desrouss, in Encycl, method. 2 , $45 \%$.

c. PARALEA. Sta m in a corollae laeiniis quadrupla, filamentis simplicibus. - P a rale a Aublet Guian,, , 576. $t, 231$,

4250 . IB ymaia. F l o res polygami. C a l y x semiquinquefidus. Co roll a hypogyna, urceolata, limbo quinquefido, revoluto, Ma $8 \mathrm{c}$. St a min a imae corollae inserta, ejusdem laciniis quadrupla; filamenta duplicata, antherae barbatae. Ovarii rudimentum. Fem. Stamina efoeta, pauciora. Ovari u m quadri-sexloculare. Ovu I a in loculis solitaria, pendula. Stylus bipartitus; stigmata bifida. Ba c c a ...... Arbuscula capensis; foliis alternis, subtus tomentosis.

Ro yen a poly an dra Linn. fit, suppl. 260, coll. R. Brown Prodr. 526. in not.

4:51. IB 1 yema LINN. Flores herma. phroditi. Caly $x$ semiquinquefidus, Corolla hypogyna, urceolata, limbo quinquefido, revoluto. St amina imae corollae inserta, ejusdem laciniis dupla; filamenta simplicia, antherae imberbes, Ovula in loculis solitaria, pendula. Stylns bipartitus ; stigma t a simplicia v. bifida, B a c ca globosa, calyce laxe cincta, cortice subvalvatim secedente, bi-plurilocularis, loculis monospermis. $\mathrm{S}$ e $\mathrm{m}$ in a inversa. E $\mathrm{m}$ b $\mathrm{ry} \mathbf{o}$ in axi albuminis cartilaginei rectns; cotyledonibus foliaceis, radicula supera. - Arbores $v$. frutices c apenses; foliis alternis, integerrimis, glabris v. hirsutis, pedunculis axillaribus, unifloris.

R o y e n Linn. gen, $n$. 555. Jussieu gen. 156. Lam. t. 370. Jacq. Collect. suppl, t, 13, f. 1. Fragm, t. 1. f. 2. Gärtner $I I$. 79, $t$. 94. Vent, Malmais. $t$. 17. Desfont. in An. nal. Mus. VI. 445, $t$, 62, R. Browo Prodr. 520, in not. Bot. Reg. $t, 500, \mathrm{D}$ i o s $\mathrm{p}$ y ri s p. Desfont, $l, c$,

\section{EBENACEIS AFFINES.}

\section{* STYRACEAE.}

4252. Styrax TOURNEF. Calyx liber, urceolato-campanulatus, quinquedentatus, C o rolI a perigyna, profunde tri-septemfida, saepius quinquefida. Stam in a imae corollae inserta, ejusdem laciniis dupla; filamenta juxta totam longitudinem connata, v. basi monadelpha, apice distineta, antherae erectae, adnatae, lineares, biloculares, longitudinaliter dehiscentes, loculis pilis stellatis conspersis. O varium liberum, triloculare. Ovula in loculis plura, angulo centrali subbiseriatim inserta, inferiora horizontalia $\mathbf{v}$. adscendentia, superiora saepius pendula, omnia anatropa. Stylus simplex; 8 tigma obsolete trilobum. Drupa exsucea, putamine rarissime triloculari, saepissime uniloculari, loculis monospermis. S e m en erectum v. inversum! Is m b r yo in axi albuminis carnosi orthotropus; cotyledonibus foliaceis, radicula umbilico proxima, infera $v$. supera, - Arbores v. frutices, in Mol uccis, Oriente, Japonia et Americaboreali rarae, in Americ a tropica copiosae, saepe pilis stellulatis tomentosae; foliis alternis, integerrimis, pedunculis axillaribus $v$. terminalibus, unimultifloris, floribus racemosis, bracteatis, albis.
S t y $\mathrm{rax}$ Tournefort inst, 369. Lam, gen. $n$, 595. Jussieu Gen. 156. Gärtner I. 284. Kunth in Humb. et Bonpl.
Nov. gen. et sp. III. 261.

a. EUSTYRAX. S tamin um flamenta basi connata, superne distineta. (Görtner t. 59. Cavanill, Dissert. t, 188 Andrews Bot. Heposit. t. 631. Hunib. et Bonpl. Plant. aequinoct. t. 101. Bot. Mag. t. 921. Pohl Plant, brastl, $t, 134-141$. Siebold et Zuecarini Flor. Japon, $t, 23$. Hooker ad Beochey $t$. 40. E pigen ia Flor. Elumin. IV. 37. Lithocarpus Blume Hort. Buitenz, non Flor. Jav. St, B e z o i n Dryand.

b. STRIGILLA. S tam in a juxta totam fere longitudinem connata. - Foveolaria Ruiz et Pavon Prodr. 57. t. 9. Strigili a Cavanill. Dissert. VII, 348, t, 201 . DC. Prodr. I. 621. Trein a $\mathrm{t}$ h $\mathrm{u}$ s Perseon Encheir. 1. 467. C y pellium Desvaux in Hamilt. Flor. Ind. occid, 28. Tr i ch og amila P. Browne Jam. 218.

4253. Dielidanthera $M A R T$. C a ly quinquepartitus, lacinis linearibus. Cor oll a hypogyna, infundibuliformis, limbi quinquefidi laciniis aequalibus, concaviusculis, linearibus, obtnsiusculis, aestivatione imbricatis, sub anthesi erecto-patentibus. Antherae 10, in fauce corollae una serie sessiles, inclusae, ovatae, biloculares, valvula unica ab apice ad basim revolnta dehiscentes. Ovarium liberum, globosum, quinqueloculare. Ovula in loculis solitaria, ex apice anguli centralis pendula. Stylus filiformis, simplex; stig ma depresso-carnosnm. B a c c a glo. bosa, quinquelocularis, loculis monospermis. S emina inversa, testa crassa, scabrinscula. Emb $\mathbf{r} \mathbf{y}$ in apice albuminis carnoso-cartilaginei minimus, rectus; cotyled onibus ellipticis, plano-convexis, radicula brevi, supera. - Frutices v. arbusculae brasilienses, ligno duro, rigido; ramis elongatis, saepe pendulis, foliis alternis, crassiusculis, integerrimis, floribus racemosis, bracteatis, corollis ochroleuco-albis, siccitate purpurascentibus.

D I clidanthera Martins Nov, gen, et sp, II, 139. t. 196.197.

4254. Thuraria MOLIN. Cal y x tubulosus, quinquedentatus, Corolla infundibuliformis, quinquefida. Stamina 10 , flamentis brevissimis, filiformibus, antheris didymis. Ovarium ..... Styli 2, setacei. Capsula bilocularis, disperma. - Frutex chilensis, multicaulis; cortice resinam thuri similem fundente, foliis alternis, rigidis, petiolatis, ovalibus, integerrimis, multifloris, floribus terminalibus, pedunculatis.

Thuraria Molina Chili 135.

4255. Cyrta LOUREIR. C a ly x liber, cyathiformis, quinquedentatus. Cor o 11 a campanulata, tubo brevi, calycis longitudine, limbo quinquepartito, magno, patente, laciniis lanceolatis. Stam in a 10, imae corollae inserta; fil a m en ta brevia, basi dilatata, ant herae oblongae, reflexocurvae, filamentis per totam longitudinem adnatae. Ovarin m subrotundum, acuminatum. StyI $\mathrm{s}$ subulatus, exsertus; $8 \mathrm{t}$ i gma simplex. Drup a oblonga, curva, ntrinque attenuata, tomentosa, putamine oblongo, sulcato, apice attenuato. - Arbuscula cochinchinensis; ramis patentibus, foliis alternis, ovatis, accuminatis, subserratis, glabris, pedunculis subterminalibus, multifloris, floribus albis.

Cy $x$ t a Loureiro Flor, cochinch. 341 . 


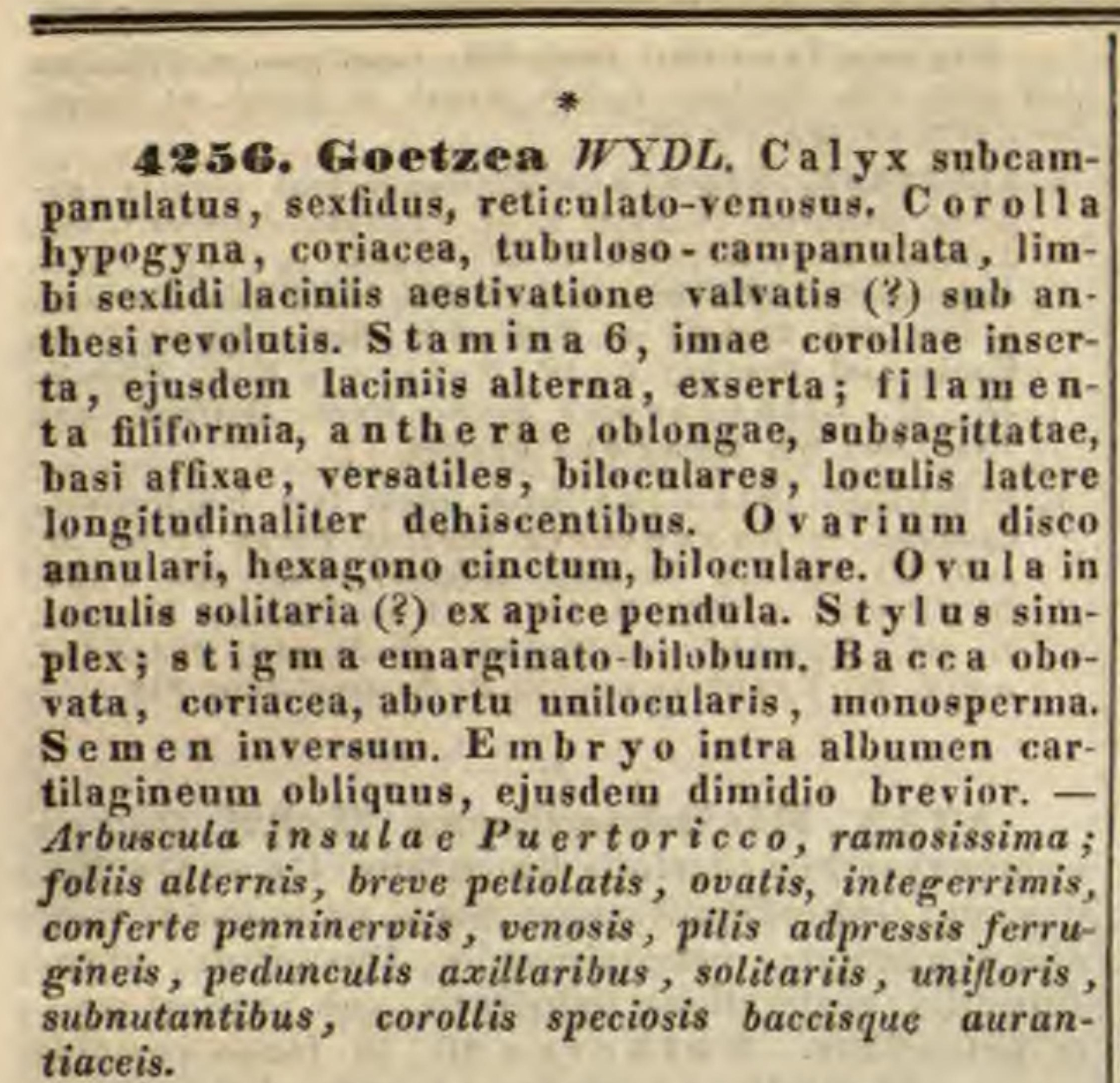

Goetze a Wydler in Linnaea $\nu .423, t .8$.

$425 \%$. Hornsehnehia NEES. C a l y $\mathrm{x}$ liber, brevissime campanulatus, truncatus, obsolete repandus. Corolla hypogyna, sexpartita, laciniis biseriatis, patentibus, exterioribus planinsenlis, paullo latioribus, interioribus carinatis. Stamina 6 , imae corollae inserta; fil amenta brevissima, ant hera e lanceolatae, extrorsae (?) biloculares, loculis adnatis, longitadinaliter dehiscentibus. Ovaria (effoeta?) tria, unilocnlaria, in corpus conicum, trigonnm approximata, in st y I u continua; stig mat $i b$ o s simplicibas... - Fruticuli brasilienses, erecti v, decumbentes; foliis alternis, integerrimis, venosis, pedunculis axillaribus solitariis, $v$. in ramulis e rhizomate ortis racemosis.

Horns e hu e hia Nees in Regensb. Denkschrift. II. 159. $t, 11,12 . N ., A . N$. C. XII. 22, Genus affinitatis admo. dum dubiae, a el. auetore Ehrenbergia Spreng. quae A in a jo va e sp. (supr. Nr. 334t. fnter Rubiaceas) aftine, ab eodem nunc Sapoteis nectario careatibas, aunc Ebenaceis, denique Sapindaceis adscriptum.

\section{** HALESIEAE.}

4258. Halesỉa ELLIS, C a $1 \mathrm{y} \times$ tabo campanulato, quadrinervi, cum ovario connato, limbo supero, quadridentato. Co rolla supera, subcampanulata, tubo brevissimo, limbi quadripartiti laciniis obtusis, imbricato convolutis. S $\mathrm{tamin}$ a 8_16, imae corollae inserta; filamenta basi monadelpha, subulata, antherae adnatae, lineares, biloculares, longitudinaliter dehiscentes. Ovarium inferum, quadriloculare, loculis ealycis nervis alternantibus. $O \mathrm{vula}$ in loculis quaterna, adscendentia (?).Stylus snbulatus; $\mathrm{st}$ ig m a sim plex. Drup a obovato-oblonga, sicea, calycis tubo nervis in alas membranaceas expansis tetraptero v. rarius diptero corticata, stylo apiculata, tetrapyrena, pyrenis inter sedistinctis, pericarpii parieti adnatis, monospermis. Semina e basi erecta, oblonga, testa tennissime membranacea. $\mathrm{Em}$ b r y o in axi albuminis dense carnosi rectus, einsdem longitudine; cotyledonibus lineari-obtongis, subfoliaceis, $\mathbf{r}$ adicul a elongata, lineari, infera. - Frutices boreali-americani; foliis alternis, integerrimis, pedunculis axillaribus, unifloris, nutantibus.

H a les i a Kllis in Philosoph. Transact, LI, 931, t. 22. Linn. gen, $n$, 596, Jussieu gen, 156. Sehkubr $t, 127$. Gürt. ner 1. 160, t. 32, Cavauilles Dissert. VI. 337, t. 186. 187. Nuttall Gen, 1I. 82. Bot. Mag, t. 916. Bot. Reg. t, 952. Loddig. Bot, Cab, t. 1172 ,

\section{** SYMPLOCEAE,}

4259. Symploces LINN. Caly $\mathrm{x}$ tubo eum ovario connato, limbo supero v. semisupero, quinquepartito. Coroll a perigyna, rotato-quinque-decempartita, laciniis patentissimis, alternis interioribus minoribus. Stam in a imae corollae inyerta, ejusdem laciniis tripla v. quadripla aut indefinita; fil a menta basi monadelpha v. polyadelpha, apice euspidata, ant herae erectae, subrotundo-ellipticae, biloculares, longitudinaliter dehiscentes. Orari um inferum v. semiinferum, tri-qninqueloculare. Ovula in loculis quaterna, angulo centrali diversa altitudine inserta, duo superiora horizontalia, inferiora pendula, anatropa, Stylus simplex; stigma subeapitatum, obsolete tri-quinquelobum. Dru p a baceata, ealycis limbo coronata, putamine tri-quinqueloculari, rarins abortu uniloculari, loculis monospermis. S emina inversa v, erecta? $\mathbf{E} \mathbf{m b} \mathbf{r y o}$ in axi albuminis carnosi orthotropus, cylindricus; cotyledonibus brevissimis, divaricatis, radicala elongata, umbilico proxima, supera v, infera? Arbores, in America tropica et borealicalidiore, nec non in Japonia et Indiae montibus crescentes; foliis alternis, obsolete crenatis $v$. dentatis, floribus axillaribus, sessilibus v. pedunculatis, solitariis, conglomeratis $v$. subracemosis, albis v. coccineis, basi imbricato-bracteolatis,

S y m pl oc os Heritier in Linn. Transact. I. 174. Kunth in Humb. et Bonpl. Nov, gen, et sp. III. 256. S y m pla. c o s Lina. gen, $n, 6 z 7$, Jussieu gen, 157. Swartz Observ, t. 7. Gärtner f. MIT. 141, t. 9. Humb. et Bonpl. Plant. aequinoct. $t$. 31 -35, Bot. Reg. $t, 710$. Siebold et Zuecarin, Flor. japon, t. 24. Alst o ni a Linn. Suppl. 264. H oppea Linn. Mant. 1270. Jussieu gen. 157. Gartner f. IIT. 140. t. 209. (Catesby Carolin, t.54.) C i pon im a Aublet Guian. 1.567. $t$. 226. Jussien gen. 157. Cavanill, Dissert. VII. 37O. 1. 217. Gärtaer f. III. 139, $t, 209$, an situ embryonis perperam deseripto?

4260. Selnöpfia SCHREB. C a I y $\mathrm{x}$ tubo basi calyeulato, eum ovario connato, limbo supero, integerrimo. Co roll a supera, tabulosa, limbo quin. quefido, rarins quadri-sexfido, lobis aestivatione valvatis, Stam in a numero lobornm corollae, iisque opposita; filamenta tubo adnata, an therae ovatae v, subrotundae, biloculares, loculis latere longitudinaliter dehiscentibus, Ovarium infe$\mathrm{rum}$, triloculare. Ovula in loculis solitaria, pendula. St y Ins erectus, trisuleus; stigma eapitatum v, trilobum, Drupa calyeis limbo coronata, nucleo triloculari, v. abortu uniloculari, loculis monospermis. Semina inversa. Embryo in apice albuminis earnosi minimus, radi cula turbinata, supera. - Arbores glabrae, in Antillis, Peruvia et Nepalia indigenae; foliis allernis, peliolatis, integerrimis, paucinervits, pedunculis axillaribus, uni-multifloris.

S chöpfia Sehreber Gen, n, 323. Don Nepal. 145. DC. Mem. Loranlh, VI 23. Prodr. IV. 319.

a. CODONIUM Vahl. Corolla e tubus ovatus, fanx nuda. - Species americanae.

Cod on i a Vahl in Act. soc. h, n. Hafn, II. I. 206. t. 6. Symb. IIT. 36. H a enkea Ruiz et Paron Flor. Peruv. HIT, 8. \&. 281, non Prodr. 
b. SchópFiA Wall. Cor oJla e tabus eylindricus, fauce ad antherarum originem pilorum fasciculo instructa. Species asiaticae.

$\mathrm{S} \mathrm{chäp} \mathrm{f} \mathrm{i} \mathrm{a} \mathrm{Wallich} \mathrm{in} \mathrm{Roxburgh} \mathrm{Elor.} \mathrm{ind.} T$. 188. Nepal. I, 18, $t, 9$.

* DIACAECARPIUM Blum. Bijdr. 657. Cal y x margige brevi calyculatus, cuu ovario connatus, limbo supero, decemdentato. Corolla .... Stamina ... Stigma obtusum, sessile ?.... D rup a baccata, oblonga, nucleo compresso, apice profunde eararginato, biloeulari v. abortu uniloeulari, loculis monospermis. - Frutex javanicus, vi.x notus, Schöpfiae e clarissimo auctore fortassis ni. mis affinis; folits alternis, ovato-oblongis, acuminatis, basi dimidiato-cordatis, integerrimis, subtus tomentosis, corymbis axillaribus, dichotomis.

42os 1. Dlorelosia $L L A V$. et $L E X$. C a Iy x tubo cum ovario cohaerente, ventricoso, coriaceo, limbo quinquefido. Corolla perigyna, quinquepartito-rotata, laciniis rotundatis, aestivatione convolutis, sub anthesi patentissimis. Stamina 5, corollae laciniis alterna, exserta; filamenta subulata, basi tomentosa, antherae subsagittatae, biloculares. 0 v a ri u $m$ adhaerens, conicum .... Stylus apice bifurcus; stigmat ibus duobus incrassatis. Drupa carnosa, coriacea, subglobosa, obsolete tetragona, basi (?) laciniis ealycis circumdata, putamine osseo, quadriloculari. S e m in a in loculis solitaria ..... Arbuscula mexicana; trunco scabro, ramis alternis, tortuosis, foliis ad apices ramulorum alternis, ovatis, longe petiolatis, integerrimis, nitidis, floribus terminalibus, corymbosis, cum apice peduncul articulatis, odoratissimis, albis.

Morelosia Llave et Lexarza Nov. Neget. descript. 1. 1. - H u anita Michuacanensium.

\section{GENERA DUBIAE AFFINITATIS}

\section{* NAPOLEONEAE.}

4262. Asteranthos DESFONT. C a ly x tubo brevissimo, turbinato, cum ovario connato, limbo explanato, moltidentato. Corolla supera, rotata, nervosa, limbo breviter multifido. S $\mathbf{t a} \mathbf{m}$ ina indefinita, imae corollae inserta; fil am ent a filiformia, basi subdilatata, corolla breviora, a $\mathrm{n} t \mathrm{~h}$ era e biloculares, basifixae, oblongae, obtusae, longitudinaliter dehiscentes. $O$ v a $r$ iu $m$ inferum, vertice radiis sex in styli basim procurrentibus. StyIus simplex; stig ma depresso-capitatum, obtuse sexlobum. Fruetus .... - Frutex brasiliensis; foliis alternis, exstipulatis, ovato-lanceolatis, acuminatis, integerrimis, breve petiolatis, pedunculis axillaribus, solitariis, unifloris, ebracteatis.

A steranthos Desfontaines in Annal. Mus, VI. 9 t. 3. R. Brown in Linn, Transact, XIII. 228.

4\%63. Napoleoma PALIS. Calyx tubo globoso, squamis imbricatis calyculato, inferne cum ovario connato, limbi quinquepartiti laciniis lanceolatis, Corolla calyci inserta, duplex, exterior subrotata, integerrima, nervosa, plicata, interior radiato-multifida. S $\mathrm{tam}$ in a 5 , imae corollae inserta; fil ame nt a petaloidea, lata, basi coalita, apice connivention inflexa, singula diantherifera, an thera e distinctae, erectae, biloculares. Ovarium basi calycis tectum. Stylas arevis; stigma peltatum, complanatum, quinquebngulare, angulis medio sulcatis. B a e $\mathrm{e}$ a mollis, sphaeriea, ealycis limbo coronata, unilocularis. Semin a plurima, in pulpa nidulantia, owariensis; foliis alternis, exstipulatis, breve petiolatis, ovato-oblongis, longe mucronatis, integerrimis $v$, apice inaequaliter bi-tridentatis, floribus per ramulos sparsis, sessilibus, corolla caerulea, staminibus purpurascentibus.

Napoleon a Palisot Flor. Owar. IT. 29. t. 78. B e1vis i a Desvaux Journ, Bot, IV, 130. R. Brown in Linn, Transact. XIII. 222.

\section{* Columelliaceae.}

4264. Columellia $R U I Z$ et $P A V . C$ a $I y x$ tubo turbinato, cum ovario connato, limbo supero, quinquepartito. Co roll a supera, rotata, quinquefida, laciniis aequalibus, obtusis, aestivatione imbricatis. St a m in a 2, imae corollae inserta, inter ejusdem lacinias duas postieas lateralesque sita; fil am enta brevia, compressa, superne in connectivum obsolete trilobum dilatata, a $n$ therae tres, singulae biloculares, loculis parallelis, connectivi sinubus circumplicatis, apice confluentibus, longitudinaliter dehiscentibus, in massam anfractuosam approximatis. Ovari um inferam, biloculare, placentis dissepimento utrinque adnatis, incrassato-bilamellatis, dextrum et sinistrum ab axi floris latus respieientibus. Ovula plarima, adscendentim anatropa. Sty I n 8 brevis, crassinsculus, bisuleus; s tig ma obsolete bilobum. C a ps u la sublignosa, calycis limbo coronata, vertice exserto semisupera, bilocularis, septicide bivalvis, valvis demum intus dersoque semibifidis. Se m in a plurima, adscendentia, obovata, compressa, testa coriacea, laevissima, umbilico basilari, chalaza apicali subeallosa, rhaphe obsoleta. Embryo in axi albuminis carnosi orthotropus, ejusdem fere longitudine; cotyledon es ovales, obtusae, radienla teretiuscula, cotyledonibus longior, infera. - Arbores $v$. frutices sempervirentes, in $\boldsymbol{P}_{e-}$ ruvia et Mexico crescentes; ramis ramulisque oppositis, compressis, foliis oppositis, exstipulatis, obovatis v. oblongis, basi in petiolum subangustatis, coriaceis, paucinerviis, integerrimis v. apice dentatis, floribus terminalibus breve pedunculatis, pedunculis basi bibracteolatis, corollis luteis.

Colnmelli a Ruiz et Pavon Flor. Peruv, I, 28, t, 8. f. a. t. 12. f. b. Kunth in Humb. et Bonpl, Nov. gen, ot sp. II. 388, Don in Edinb. new philosoph. Journ, VI, 46. Liadley Introduct, edit. II. p. 239, U I u x i a Jussien.

4865. Miloutabea $A U B L . \quad \mathrm{C}$ a 1 y $\times 1 \mathrm{l}-$ ber, tubulosus, limbi subbilabiato - quinquefidi laciniis ovatis, dextrorsum contortis. Corolla medio calycis tubo inserta, infundibuliformis, tubo brevi, hine fisso, limbi quinquepartiti laciniis ovatis, reflexo patentibus; fi lam en tu m conico-carinatum, corollae fauci postice adnatum, an $t h$ era per filamenti marginem decurrens, octoundulata. Ovarium subrotundum. Stylus subulatus, curvatus; st ig ma simplex. Po m u m subglobosum, obsolete angulatum, quinqueloculare. Se mina in loculo solitaria, oblonga, nitida, umbilico ventrali. - Frutices Americae tropicale, inermes $v$, ramis sarmentosis, spinis uncinatis, sparsis armatis, foliis alternis, exstipulatis, petiolatis, oblongis, acuminatis, coriaceis, nitidis, pedunculis axillaribus multifloris, confertim bracteolatis, fructu eduli.

M o u ta be a Aublet Guian. IT. t. 679. 274. Jussien gen. 420. M o nt a be a Pöppig Nov, gen. et sp. II. 62. $t$. 168. Cryptos to m u $\mathrm{m}$ Sehreber gen. $n$. 344. A cost a Ruiz et Pavon Prodr, 1. t. 1. Flor. peruv, I. J, t. 6. f. $a$, 


\section{Classis XXXX. Bicomes.}

Frutices v. arbores, rarius herbae. Folia alterna ve verticillata, rarius opposita, simplicia, saepius acerosa. Stipulae nullae. Ca lyx liber v. cum ovario connatus. Corolla annulo hypogyno v. epigyno inserta, regularis. Stamina cum corolla inserta, rarius eidem adnata, ejusdem lobis numero aequalia et alterna v. dupla. A $\mathrm{n}$ th e ra e simplices v. apice bifidae. Ovarium mono-pentamerum, placentis centralibus. S e mina indefinita v. rarius definita. E $\mathrm{mbry}$ o intra albumen rectus.

\section{Ordo CLX. Epacridene.}

ERICARUM genera Jussien Gen, 160, Annal. Mus, $V$. 428. EPACRIDEAE' R. Browa Prodr. 535. Ba*tliag Ord, nat. 157. BPACRIDACEAE Liudley Introduct. edit. IT, p. 222.

Frotices v. arbesculae, caule ramisque enodibus. Folia alterna, saepissime approximata, rarissime opposita, ut plurimum integerrima, rarius serrata, petiolata v. sessilia, basi nunc simplici, nune basibus latioribus imbricatis, cucullatis, semivaginantibus, saepius post lapsum circatricem semicircularem relinquentibus.

Flores hermaphroditi v. rarissime abortu unisexuales, spicati v. racemosi terminales, v. solitarii axillares, calycibus pedicellisve biv. multibracteatis, bracteis plerumque calycis textura, albi, purpurei v. rarius caerulei.

Calxx quinquepartitus v. rarissime quadripartitus, saepe coloratus, persistens.

Conoula hypogyna, decidua v. marcescens, gamopetala, tubulosa, campanulata, infundibuliformis $v$. hypocraterimorpha, tubo interdum quinquepartibili, basi intus nudo v. fasciculis villorum glandularumve cum staminibus alternantibus instructo, limbo quinquefido $v$. rarissime quadrifido, aequali, laciniis nudis $v$. barbatis, aestivatione valvatis v. imbricatis, interdum pertinaciter cohaerentibus, tubo transversim circumscisso, basi truncala persistente.

Staniva numero laciniarum corollae, isdem alterna, rarissime pauciora, hypogyna v. corollae tubo diversa altitudine adhaerentia, inclusav. exserta. Fil a m en ta filiformia v. subulata, rarius lato linearia. Antherae dorso affixae, simplices, receptaculo unico pollinifero, septum completum, interdum marginatum constituente, indivisae, longitudinaliter bivalves. Poll en nunc subglobosum, parum angulatum, nune e sphaerulis tribus connatis compositum.

Ovartem sessile, disco hypogyno cyathiformi, v, squamulis liberis aut connatis stipatum, bi-decemloculare, rarissime uniloculare.
Ovula in loculis solitaria, pendula v, in placentis loculorum angulo centrali adnatis plurima, anatropa. Stylus simplex; stigma obtusum, indivisum.

Froctus drupaceus, baccatus v. capsularis, bi-decemlocularis, rarissime abortu unilocularis, drupis mono-pleiopyrenis, loculis monospermis, capsulis septicide v. loculicide dehiscentibus, polyspermis.

Semiva in drupaceis inversa, solitaria, in capsularibus plurima, placentis loculorum angulo centrali adnatis v. solutis, ex eorundem apice pendulis inserta, testa membranacea, tenui, umbilico basilari, rhaphe filiformi et chalaza apicali notata. A l b u m en carnosum.

Емввуо orthotropus, axilis, teres, dimidio albumine longior; cotyledonibus brevissimis, radicula umbilico proxima, in drupaceis supera, in eapsularibus situ carpico vario.

E p a crideae ab Ericaceis insolita in hac classi antherarum simplicitate distinctissimae, Novam - Hollandiam imprimis extratropicam magno specierum numero incolunt, in NovaZelandia, archipelago Taitensi et Moluccis rarae. Nonnullae cis aequatorem in insulis Sandwicensibus habitant. Unica in America antarctica observata fuit.

TIREUS I. STYPHELIEAE, Ovarii loculi monospermi. Fructus ut plurimum drupaceus.

4\%G6. Comosteplutarn BENTH. C'alyx quinquepartitus, bracteolis quatuor v, plaribus. Corolla hypogyna, tubulosa, tubo ventricoso-conoideo, intus juxta basim villorum fasciculis quinque, cum limbi dentibus quinque erectis imberbibns alternantibus. St a m in a 5 , corollae tubo inserta, inclusa; filamenta brevissima, filiformia, anthe ra e oblongae, simplices, incumbentes. Ovarium quinqueloculare, loculis uniovulatis; ovn la pendula, anatropa, Sty Ins simplex; s $t$ ig m a obtusum. D r u p a exsucea, putamine osseo, solido, abortu uniloculari, monospermo. Semen inversum. - Frutex Novae Hollandiae meridionalis, erectus; foliis sparsis, oblongo-linedribus, pedunculis axillaribus, unifloris, recurvis.

Conostephlum Bentham in Enumerat. plant, Hil. gel. 76 .

428\%. Styplaelia SMITH. C a I y x quinquepartitus, bracteolis quatuor $\vee$. pluribis. Corolla hypogyna, elongato-tubulosa, tubo intus juxta basim villoram fasciculis quinque, cum limbi quinquefidi laeiniis revolntis, barbatis alternantibus. Stamina 5, medio corollae tubo inserta, longe exserta; fil ame n $t$ a filiformia, an $t h$ er a $e$ lineares, simpliees, incumbentes. S qua mulac hypogynae quinque, distinetae $\mathbf{v}$, rarius connatae. Ovarium quinqueloculare, loculis uniovulatis; ovulo pendulo, anatropo. St ylus simplex; stigma obtusum, quinquesuleum. Drupa subexsucea, putamine osseo, solido, quinqueloculari, Semina in Ioculis solitaria, inversa. - Frufices 
Novae Hollandiae orientalis et insulae Diemen; foliis approximato-alternis, brevissime petiolatis, mucronatis, floribus axillaribus, nutantibus v. divaricatis, speciosis, pedunculis unifloris, rarius bi-trifloris.

Styphella Smith Nov, Holl. 45. $t$. 14. excl. sp. R. Browu Prodr. 537. Andrews Bot. Reposit, t.72. 312. Sweet Austr. t. 50. Bot, Reg. t, 24. Bot, Mag. t, 1297.

4208. Asteoloma $R, B R . C$ al yx quinquepartitus, bracteolis quatuor v. pluribns. C oroll a hypogyna, tubulosa, tube calyce duplo longiore, supra medinm ventricoso, intus jnxta basim villorum fasciculis quinque, cum limbi brevis, quinquefidi laciniis patentibus, barbatis alternan tibus. Stam in a 5, summo corollae tubo inserta, inclusa; fil am enta late linearia, antherae oblongae, medio dorso insertae, simplices. Discus hypogynus cyathiformis, subinteger. Ovarium quinqueloculare, loculis uniovulatis; ovulis pendulis, anatropis. St y l us simplex; stigma capitatum. Dru pa subexsueca, putamine osseo, solido, quinqueloculari. S e m in a in loculis solitaria, inversa. - Frutices humiles, in Nova Hollandia meridionali, rarius in orientali et insula Diemencrescentes, saepius diffusi $v$. prostrati; foliis confertim alternis, lineari$v$. obovato-lanceolatis, saepe ciliatis, floribus axillaribus solitariis, erectis.

Astroloma R. Brown Prodr. 538. Bot, Mag. 1. 1439. Ventenatia humlfusa Cavanill. $I c, t, 348$. Ardisia p rocumbeas Gärtner f. $t .210$.

4269. Stenanthera $R . B R$. Ca1 yx quinquepartitus, bracteolis pluribus imbricatus. Corolla hypogyna, tubulosa, tubo ealyee duplo longiore, superne constricto, basi intus nudo, limbo brevi, quinquefido, laciniis patentibus, subbarbatis. Stamina 5 , summo corollae tubo inserta, inclusa; fil a m enta hrevia, carnosa, obovata, an thera e oblongae, medio dorso insertae, filam ento angustiores, simplices. D is cns hypogynus cyathiformis, integer. Ovarium quinqueluculare, loculis uniovulatis; ovulis pendulis. Stylus simplex; stigma subeapitatum. Drupa subexsucca, putamine osseo, solido, quinqueloculari. Semin a in loculis solitaria, inversa. Frutex Novae Hollandiae orientalis, erectus; foliis confertissimis, acerosis, floribus axillaribus, erectis, tubo coccineo, limbo flavo-virescente.

S ten anthera R. Brown Prodr. 538. Bot. Reg.t.218.

4z quepartitus, bracteolis pluribus imbricatus. Corolla hypogyna, rotata v. urceolata, tubo basi intus glandularum fasciculis quiaque, cum limbi quin quefidi laciniis semibarbatis alternantibus. S tam i na 5 , ime corollae tubo inserta, inclusa v. sub exserta; filamenta brevissima, subalata, an therae ovatae, simplices. Discus hypogy nus cyathiformis, integer v. quinquelobus. $O$ v a rinm quinqueloculare, loculis uniovulatis; ovalis pendulis. Stylus brevissimus v. nullus; stig ma oltusum. Drup a subexsucea, putamine osseo, solido, quinqueloculari. Semina in loculis solitaria, inversa. - Fruticuli erectiusculi v, procum bentes, in Nova Hollandia orientali et tropica crescentes; foliis approximato-alternis, lanceolatis, floribus axillaribus erectis.

Melichrus R. Brown Prodr. 539.

a, EUsIELICHRDS. C o rolla rotata. A in the ra e snbexsertae. Diseus hypoggaus subinteger. Stylus bre. vis. Ventenatia p pocumbeas Cavanill. Ic. t. 349. f. 1 . b. MELIDEPAS, Corolla urceolata. Antherae inclusae. Discus hypogynus quinquelobus. Stig ma sub. sessile.

4\%81. Cyatliodes R. BR. Ca ly quinquepartitus, bracteolis plurihus imbricatus. Coroll a hypogyna, infundibuliformis, tubo calycem vix superante, basi intus nudo, limbi quinquepartiti laciniis patentibus, barba rara v. nulla. Stam in a 5, corollae tubo inserta; filam enta filiformia, inclusa, antherae simplices, exsertae $v$, inclusae. Dis e u s hyogynus eyathiformis, quinquedentatus. Ov a $r$ i $\mathrm{m}$ quinque-decemloculare, locnlis uniovulatis; ovulis pendulis, anatropis. Stylus simplex; stigua subcapitatum. D r u a baceata, putamine osseo, solido, quinque-decemloculari. S e m in a in loculis solitaria, inversa. - Frutices erecti, ramosi, $v$, arbuseulae, in insula Dicmen, Moluccis, archipelago societatis et sandwicensi crescentes; foliis sparsis, subtus striatis, floribus axillaribus, erectis v. nutantibus, parvis.

C y athodes R. Brown Prodr. 539. Chamisso in Lin. naea I. 539 . Cy at hodis s p. Labillard. Nov. Holland. 81 . St y phelifa e $\mathrm{p}$. Labillard. Op. cit. $t, 68,69$. Ardis la aceros a Gartner $\pi$. $78, t .94$.

48. \%. Hissanthe $R, B R$. C a 1 y $x$ quinquepartitus, nudus v. bibracteolatus. Corolla hypogyna, infundibnliformis v. arceolata, tubo basi intus nudo, limbi quinquepartiti laciniis imberbilus. St a $\mathrm{m}$ in a corollae tuho supra medium inserta, faucem aequantia; fil am en ta filiformia, antherae ovatae, simplices. Discus hypogynus cyathiformis, quinquelohus. Ovarium quinqueloculare, loculis uniovulatis; ovulis pendulis. Stylus simplex; stigma subcapitatum, quinquesulcatum. Drup a baceata, putamine osseo, solido, quinqueloculari. S e m in a in loculis solitaria, inversa. - Fruticuli erecti, in Nova Hollandia orientali et in insula Diemen indigeni ; foliis approximato alternis, subtus lineatis, floribus inter minores albis, nunc in racemos axillares paucifloros dispositis, pedicellis tunc bibracteolatis calycibusque ebracteolatis, nunc in spicas axillares approximatis, calycibus tunc bibracteolatis, fructu nonnullarum specierum eduli.

L is s a n the R. Brown Prodr. 540. Bot. Mag. t. 3147 . Bot. Reg. $t$. 1275. S ty pheliac sp. Saith.

4ะร В. Hevcopogom $R, B R . C$ a 1 y x quinquepartitus, bibracteolatus. Corolla hypogyna, infundibuliformis, limbi quinquepartiti laciniis patentibus, plamoso-barbatis. S tamina 5, medio v. summo corollae tubo inserta, inclusa; filamenta filiformia, antherae dorso supra medium insertae, ovatae v. oblongae, simplices. Discus hypogynus cyathiformis, integer v, lobatus, interdum obsoletus. Ovari u m bi-quinqueloculare, loculis nniovulatis; ovulis pendulis. St yI us simplex; stigma subcapitatum, sulcatum. Drnpa baccata v. exsucca, nune erustacea, biquinquelocularis. S e m in a in leculis solitaria, inversa. - Frutices Novae Hollandiae; foliis sparsis $v$. interrupte confertis, spicis axillaribus $v$. terminalibus, rarius pedunculis axillaribus solitariis, bi-aut aborlu unifloris.

Le uc op og on R. Brown Prodr. 541, Labillard. Nov. Caled. t. 139. Guillemin Ic. lithogr. t. 10. Sweet Flor. austr. $t$, 47 . Bot, Mag, $t, 3162,3251$. Bot. Reg, $t, 1560$. P erojoa Cavanilles 1 c. IV. 29. t. 349. f. 2. Styphellae s. Audrews Bot. Reposit, $t$. 287, Veuten. Malm. t. 13. Labillard Nov, Holland, $t, 60,64-67$. Rudge in Limn. Trans. act, VIII, $t, s, \mathrm{E}$ p a cridts s p. Cayanill. Ic, $t, 347, f, t$. $94 *$ 
4284. Monotoea $R$. BR. Caly $\mathrm{x}$ quinquepartitus, bibracteolatus. C o roll a hypogyna, infundibuliformis, limbi quinquepartiti laciniis patentibus fauceque nudis. S t amin a 5 , corollae fanci inserta, subexserta; fil a me nt a filiformia, anth erae dorso supra medium affixae, ovatae, simplices. D i s e u s hypogynus eyathiformis, quinquelobus. O va ri u m uniloculare; ovulo unico, pendulo, auatropo. St ylus brevis; $\mathrm{sti} g \mathrm{ma}$ obtusum, subtrilobum. Drup a baceata, monosperma ...... - Arbusculae v, frutices, in Nova $\mathrm{Hol}$ landia orientali et in insula Diemen crescentes; foliis sparsis, spicis axillaribus v, rarius terminalibus paucifloris, floribus parvis, albis, abortu saepissime unisexualibus.

Monotoca R. Beowa Prodr. 54b. Sty phelia gl a u. c a Lab.llard. Nov, Holland. t, 6t, exel. ic. ovarii.

42 ซร. Aerotriche $R . B R$. C a ly $\mathrm{x}$ quinquepartitus, bibracteolatus. Corolla liypogyna, infundibuliformis, limbi quinquepartiti laciniis patentibus, apice barba deflexa. Sta m in a 5 , corollae fauci inserta, breviter exserta; fil a me nta filiformia, an therae ovatae, durso affixae, simplices. Dis'cus hypogynus cyathiformis, sublobatus. Ovarium quinqueloculare, loculis uniovulatis; ovalis pendulis, anatropis. St ylus simplex; stigma obtusnm. Drupa subbaceata, depressa-globosa, putamine quinqueloculari, cellu1oso. Semina in loculis solitaria, inversa.

Frutices Novae Hollandiae, humiles, ramnsissimi; ramis saepius divaricatis, foliis sparsis, spiois lateralibus et axillaribus brevibus, floribus parvis, albis,

Acrotriche R. Brown Prodr. 577. Bot. Mag. t. 317t,

4286. Trocluocarpa $R, B R, C$ a $1 \mathrm{yx}$ quinquepartitus, bibracteolatus, Co rolla hypogyna, infundibuliformis, limbi quinquepartiti, patentis laciniis barbatis. S t a in in a corollae tubo inserta, inclusa; fil am ent a filiformia, a ntherace infra apicem affixae, pendulae, simplices. Dis c us hypogynus cyathiformis, quinquelobus. Ov a ri u $m$ decemlosulare, loculis uniovalatis; ovalis pendulis, anatropis. Stylus simplex; stigma obtusum. Drupa depresso-globosa, baccata, pu tamine rotato-decemlobo, decemloculari, demum par tibili. Semina in loculis solitaria, inversa. Arbor parva Novae Hollandiae orientalis, ligno durissimo, glabra; foliis sparsis, breve petiolatis, laurinis, spicis terminalibus et axillaribus, floribus parvis, albis.

Trochoearpa R. Browa Prodr. 549, Bot. Mag. t. 3394. St yphelia I a u ria Rudge in Lian. Transact. VIII. 2.9 .

4zร. Deeaspera $R . B R$. Caly $x$ quinquepartitus, hibracteolatns. Co roll a hypogyna, eampannlata, limbi quinquepartiti laeiniis patentibus, laxe barhatis. Sta mina 5 , eorollae cubo inserta, breviter exserta; filamenta filiformia, antherae dorso supra medium insertae. Ovariu m decemloeulare, henlis uniovulatis. Stylins simplex; stig ma obtusum. Dr up a hascata, decempyrena, pyrenis munospermis. - Frutices insulae Diemen, speciosi; foliis sparsis, breve petiolatis, spicis terminalibus, nulantibus, floribus rubris, baccis violaceis.

Decaspora R. Brown Prodr. S4s. Cyatbodes di. at i ch a Labillard. Nov, Holland. $\iota, 83$.

4278. Pentachomalra $R, B R$. Calyx quinquepartitus, bractenlis quatuor $v$, pluribus im. bricatus. C orolla hypogyna, campanulata, limbi quinquepartiti laciniis patentiusculis, longitndinaliter dense barbatis. Sta $\mathbf{m}$ in a 5 , corollae fanei inserta; fil amenta brevissima, antherae oblongae, dorso supra medium affixae, simplices. Sq uamula e hypogynae 5, emarginatae. Ovari u m quinqueloculare, loculis uniovulatis. Stylus simplex; st igma obtusum. Drupa baceata, pentapyrena, pyrenis monospermis. - Fruticuli in insula Diemen et in Nova-Zeelandia monticoli; foliis sparsis, breve petiolatis, floribus terminalibus, solitariis, erectis, albis,

Pentachandra R. Brown Prodr. 549. Epacris p umila Forst.

4279. Needhamia $R$. $B R$, C a l y $x$ quinquepartitus, bibracteolatus. Coroll a hypogyna, hypocraterimorpha, limbo quinquefido, imberbi, sinubus elevatis, aestivatione plicato. Stamina 5 , inclusa. Disens hypogynus seutelliformis. O varium biloculare. Drup a exsueca. - Fruticulus Novae Hollandia e australis, pusillus, erectus; foliis oppositis, minutis, adpressis, spicis terminalibus erectis, solitariis, bracteis subtendentibus foliaceis, floribus albis.

Needham i a R. Browa Prodr. 549.

4280. Dligarihena $R$. BR. C a $I \mathrm{y} \times$ quadripartitus, bibracteolatns. Coroll a hypogyna, quadrifida, aestivatione valvata, persistens. Stamina 2, inclusa. Ovarium biloculare. S quamula e hypogynae 4. Capsula (?) bilocularis. - Fruticulus Nova e Hollandiae au. stralis, parvus, ramosissimus; foliis sparsis, imbricatis, minimis, spicis terminalibus, erectis, floribus parvis, albis.

01 ig arrhe a a R. Brown Prodr. 569.

TEIBUS II. EPACREAE. O v a $\mathrm{r} i \mathrm{i}$ loculi multiovulati. Fructus capsularis, polyspermus.

4281. Epaeris SMITI. Calyx quinquepartitus, coloratns, multibraeteolatas, bractenlis textura calycis. Corolla hypogyna, tubulosa, limbo quinquepartito, patente, imberbi. Sta mina 5, corollae tubo inserta, inclusa $v$. rarius exserta; fil amenta filifurmia, anther a e supra medinm peltatae. Squa mulae hypogynae 5. Ovarium quinquelocnlare, loculis multiovulatis. Stylus simplex; stigma obtusum. Capsala quinquelocularis, placentis columnae centrali adnatis. S e m i na plurima. - Fruticuli in Nova Hollandia obvii, in Nova $Z$ eelandia rari, saepius glabri; foliis sparsis, petiolatis v, basi simplici sessilibus, floribus axillaribus, saepius spicam foliatam formantibus, albis $v$. purpurascentibus.

Epaeris Smith Exot. Bot. 77, $2,39,40$. Cavauill. I0. t. 344. 345. Labillard. Nov. Holland. $t$. 55.88. R. Browa Prodr. 550. Bot. Mag. $t .844 .982,1170.3168 .3293,3253$. A. Richard. 3658. Bat. Reg. $t$. 153t. Sweet Flor, Austr, $t .4$. A. Richard Flor. Nov, Zcelard, $t, 29$.

428. Lysinema $R, B R$. Calyx quinquepartitus, coloratus, multibracteolatus, hractenlis textura calycis. Co roll a hypogyna, hypocraterimorpha, tobo nunc quinquepartibili, limbi quinquepartiti laciniis imberbibus, basi dextrursum imbricatis. Sta m in a 5, hypogyna, inclnsa; fil amenta filiformia, antherae supra medium
peltatae. S quamulae hypogynae 5 . O varium 
quinqueloeulare, loculis multiovulatis. Stylus filiformis; $s \mathrm{tig} \mathrm{m}$ a obtusum, C a p su la quinqueelocularis, placentis columnae centrali adnatis. S emi n a plurima. - Fruticuli, No v a e Holl andiae meridionalis et orientalis incolae, Epacridis habitu.

Lys inema R. Brown Prodr. 652. Epacridis sp. Cavanill. Ic, $t, 346$, Bot. Mag, $t, 1199$.

4283. Allodape. C a l y $x$ quinquepartitus, bracteolatus. Corolla hypogyna, campanulata, limbi quinquepartiti laciniis patentiusealis, imberbibus. St a min a 5, hypogyna, inclusa; filament a subclavata, ant herae filamenterum apicibus dilatatis adnatae. Dis e us hypogynus cyathiformis, quinquesinuatus. O va rium quinqueloculare, loculis multiovalatis. Sty Ins simplex; stigma inerassato-conicum. C apsula quinqueloenlaris, placentis columnae centrali adnatis (?) S e m in a plurima. - Fruticulus $A m$ er $i$ cae antarcticae, ex icone Hookeriana tantum nobis notus; foliis sparsis, sessilibus, ovatis, acutis, serratis, pedunculis axillaribus, solitariis, unifloris, multibracteolatis, nutantibus, floribus parvis.

Prionotes amerieana Hooker Ic, $t$. 30. Azalea bullata Forst.

4284. Prionotes $R, B R$. Caly $\mathrm{x}$ quin quepartitns, ebracteolatus. Corolla hypogyna, tubulosa, fance aperta, limbi quinquepartiti laciniis patentibns, imberbibus. S t a mi n a 5 , hypogyna; fil a me n ta tubo semiadhaerentia, inclusa, a n thera e exsertae, septo completo. Squa$\mathrm{mulac}$ hypogynae 5 . O v a $\mathrm{r} \mathbf{i} \mathrm{m}$ quinqueloculare; loculis multiovalatis. Stylus simplex; stigma subcapitatum. Ca s sula ..... Frutex insulae Diemen, ex icone Billardierii tantum notus, glaber, ramosissimus; foliis sparsis, petiolatis, serratis, pedunculis axillaribus, uniftoris, recurvis, basi minute bracteolatis, apice nudis, floribus speciosis, pendulis.

Prionotes R. Brawn Prodr. 559. Ep acris eerla tho id es Labillard. Nov, Holland, $t$, 59.

4285. Cosmelia $R \quad B R$. Calyx foliaceus, quinquepartitus, bracteolis foliaceis geminis v. pluribus imbricatus, Cor olla hypogyna, tnbulosa, limbi quinquepartiti laciniis patentiusculis, imberbibus. St a min a 5, corollae tubo inserta, inclusa; fil amenta complanata, antherae apicibus filamentorum adnatae, basi solatae. Sq $\mathbf{n}$ amulae hypogynae 5 . Ovarinm quinquelecalare, loculis multiovulatis. Stylus filiformis; stig ma eapitatum. C a p $8 \mathrm{ula}$ quinquelocularis, placentis columnae centrali adnatis, basi et apice solutis. Semina plurima. - Frutex Novae Holl andiae, paludosus, erectus, ramosus; ramis foliorum lapsu haud cicatrisatis, foliis basi cucullatis, semivaginantibus, floribus ramos laterales breves terminantibus, solitariis, cernuis, corollis rubicundis.

C o s melia R. Brown Prodr. 553.

4256. Andersonia $R$. BR. C a Iy $\mathrm{co}$ loratus, quinquepartitus, bracteolis foliaceis geminis v. plurihns imbricatus. C oroll a hypogyna, calycis longitndine, subcampanulata $\mathbf{v}$. hypocraterimorpha, limbi quinquepartiti laciniis patentihus, basi harbatis. Stamina 5 , hypogyna, fancem aequantia; fil a menta complanata, sulunlata, a $n$ therae dorso infra medinm insertae. Squamula e hypogyna 5 , distinctae v. connatae. Ovari u m quinqueloculare, tocolis multiovalatis. $\mathrm{C}$ a p-
8 n l a quinquelocularis, placentis e loculormm fundo erectis, columnae centrali adnatis. Semina abortu panea, erecta. - Fruticuli Novae Hollandiae meridionalis, squarrosi; ramis foliorum lapsu haud cicatrisatis, foliis alternis, basi cucullata semivaginentibus, floribus terminalibus, solitariis $v$, spicatis, ereclis.

A ndersonia R. Brown Prodr. 554.

428\%. Ponceletia $R$. BR. Caly x foliaceus, quinquepartitus, foliis minoribus imbricatus. Corolla hypogyna, breviter campanulata, limbi quinquefidi laciniis patentibus, imberbibus. Stamina 5 , hypogyna, inclusa; filamenta filiformia, antherae infra medinm peltatae, septo marginato. liberae, imberbes. S q a a m u la e hypo. gynae nullae. Ovarin quinqueloculare, losulis multiovulatis. Stylus simplex; stigma obtusum. Ca p s u la quinquelocularis, placentis coIumnae centrali adnatis. Semina ........ Fruticulus Novae Hollandiae orientalis, paludosus, erectus, virgatus; ramis foliorum lapsu haud cicatrisatis, ramulis floriferis fragilibus, foliis alternis, basi cucullata semivaginantibus, floribus ramulos terminantibus, solitariis, erectis.

Ponceletia R. Brawn Prodr. 555.

4288. Sprengelia $S M I T H, C$ a $y \times$ quinquepartitus, subeoloratus, foliis minoribus imbricatus. Corolla hypogyna, rotata, quinquepartita, imberbis. Stam ina 5 , hypogyna, exserta; filamenta subelavata, antherae oblongae, adnatae, basi solutae, septo immarginato, liberae imberbes, v, connatae barbatae. Squamulae hypogynae "nullae. O varium quinqueloculare, loculis multiovulatis. Stylus simplex; stigma obtusum, quinquesuleum. C a p sula quinquelocularis, placentis columnae centrali adnatis, basi et apice solntis. Se mina plurima. - Fruticuli Novae Hollandiae et insulae Diemen, erecti, ramosi; ramis post foliorum lapsum vix annulatis, foliis alternis, basi cueullatis, semivaginantibus, floribus ramulos laterales brevissimos terminantibus, corollae purpurascentis, calycis longitudine tubo brevissimo, demum quinquepartibili.

$\mathrm{S}$ prengelia Smith in Act. Holm. 1724. p. 200, t. 8 . Tract. p. 267. t. 2. Andrews Bot. Reposit. t. 2. R. Browa Prodr. 554. Bot. Mag. $t$, 1719. Polretia Cavanilles Ic. $I V, 378, t, 373$.

4289. Cystantlue R. BR. Caly x follacens, quinquepartitus. Corolla hypogyna, clansa, calyptraeformis, transversim dehiscens, basi traneata persistente. Stam in a 5, hypogyna, persistentia. Squa mu la e hypogynae nullae. Ovari u m quinquelocnlare, loculis multiovulatis. StyIn s simplex; stigma obtusum. Caps a la quinquelocularis, placentis ex apice colnmnae centralis pendulis. Semina ...... - Frutex in sulae Diemen, Sprengeliae, Ponceletiae v. Cosmeliae habitu, ramis foliorum delapsorum cicatricibus annulatis.

Cystanthe R. Brown Prodr. 855.

42D1. Pillitis LINDL. C a $1 \mathrm{y} \times$ foliacens, quinquepartitus, pungens. Corolla hypogyna, clausa, calyptraeformis, transversim dehiscens, basi trancata persistente. Stamina 5, hypogyna, persistentia. Squam a e hypogynae bilobae. Ovarium...... - Frutex ins ulae Diemen; ramis annulatim cicatrisatis, foliis glaberrimis, basi cucullatis, acerosis, capitulis florum terminalibus, ovatis, bracteis imbricatis, pungentibus.

Pilitis Lindley Introduct, edit, IT. p. 443. 
4291. IBelnea R. BR. Calyx membranaceus, quinquepartitus, ebracteolatus. C or oll a hypogyna, clausa, calyptraeformis, transversim dehiscens, basi truncata persistente. Stamina 5, hypogyna, persistentia. Squamula e hypogynae 5. Ovarinm quinqueloculare, locnlis multiovulatis. Stylus simplex; stigma obtasum. Capsula quinquelocularis, placentis ex apice columnae centralis pendulis, solutis. S emina plurima. - Frutex insulae Diemen, ramosus; foliis imbricatis, basi adpressis, dilatatis, amplectentibus, lamina ensiformi patente, pungente, floribus terminalibus, interrupte spicatis. t. 3 .

Richea R, Brown Prodr. 35s. Gulllemin Ic. lithogr.

4798. Draeoplayllema $L A B I L L$, C a l y x quinquepartitus, ebracteolatus. Corolla hypogyna, infundibuliformis, tubo subventricuso, fauce vix coarctata, limbi quinquepartiti laciniis patentibus, acutiusculis. St am in a 5 , corollae fauci inserta v. hypogyna, inclusa; fil amenta filiformia, anther a dorso supra medium insertae. Squamulae hypogynae 5 . O varium quinque. loculare, loculis multiovalatis. Stylus simplex; stigma obtusum. Capsula quinqueloenlaris, placentis ex apice colnmnae centralis pendulis, so lutis. Semina plurima. - Frutices $v$. arbusculac in Nova Hollandia orientali et in Nova $Z$ eelandia crescentes; ramis foliorum delapsorum cicatricibus annulatis, foliis basi adpressa dilatata amplectente, lamina ensiformi, patente, racemis terminalibus simplicibus $v$. compositis, bracteis pedicel los subtendentibus caducis.

Dracophy 11 um Labillardiere Voy. $t, I T$. 40. R. Brown Prodr. 556. exel. sect, $I T$.

a. DACRXANTHUS. S $t$ a m in a hypogyna. - Species Novae Hollandiae. D racophy 11 um seeundum R. Brown, Guillemin Ie. lithogr, t, 1. Bot. Mag. $t$. 3264.

b. EUDRACOPHYLLUM, $\mathrm{S} t \mathrm{a}$ a $\mathrm{i}$ a corollae inserta. Species Novae Zeelandiae. D rate o h y Il a m Labillard. Op. cit. $t$. 40. E p a c r I s Forster Char. gen, t, 10. Gărtner $I T, 77, t, 94$.

4293. Splnemotomas $R, B R$. C a I y x quinquepartitus, bibracteolatas. Corolla hypogyna, hypocraterimorpha, tubo gracili, fauce coarctata, limbo quinquepartito, obtusissimo, patente. Stamina 5, corollac tubo inserta, inclusa; filamenta filiformia, antherae dorso supra medium insertae. Squamulae hypogynae 5 . Ovari um quinqueloculare, loculis multiovulatis. Sty lus simplex; stigma capitatum. Capsula quinquelocularis, placentis ex apice columnae centralis pendulis, solutis. S e m in a plurima.- Frutices Nova Ho llandiae meridionalis; ramis foliorum delapsorum cicatricibus annulatis, foliis brevibus, basi cucullata vaginantibus, spica terminali simplici, saepius abbreviata, bracteis subtenden tibus persistentibus.

Sphenotoma, Dracophylli sect. R. Browa Prodr. 556. Bot. Mag, t, 2678. 7624. Sweet Elor. Austral. $t, 44$.

\section{Dralo CLXI. Ericaceare.}

RHODODENDRA et ERICEA Jussieu Gen, 158. 159. ERICEAE R. Browu Prodr. 557. Bartling Ord, nat. 154. RHo DORACEAE, ERICACEAE et VACCINIEAE DC. Theorie elem, 216. ERICACEAE et VACCINIACEAE Liadley Introd.
edit. $I$. $p$, 220. 29t.

Fritices, suffrotices v. Arbusculae sempervirentes. Folia alterna, opposita v. verticillata, saepissime acerosa, rarius coriacea, integra, integerrima v. dentata aut serrata, cum ramulo articulata. Stipula e nullae.

Flores hermaphroditi, regulares, saepissime elegantes v. speciosi, axillares v. terminales, solitarii v. aggregati, interdum involucrati.

Calyx nunc liber, quadri-quinquefidus v. partitus, nunc tubo cum ovario connato, limbo supero v. semisupero, quadri-sexdentato v. partito.

Corousa toro in annulum v. discum imo calyci adnatum, $v$, perigyne semisuperum, aut interdum epigynum tumenti inserta, gamopetala, forma varia, regularis v, rarissime subirregularis, persistens v. decidua, tri-hexamera, limbo diviso, rarius ad basim partita, elementis liberis seorsim deciduis, fere polypetala, lobis laciniisve aestivatione imbricatis.

Stamina cum corolla inserta, ejusdem basi saepe adhaerentia, laciniis numero aequalia et tunc alterna, v. dupla, inclusa aut rarius exserta. Fil ame n ta libera v. rarius basi aut tota longitudine inter se comnata. Antherae biloculares, dorso v. basi insertae, incumbentes, in alabastro saepissime extrorsae, demum reclinatae, loculi appositi, apice v. basi reclinatione supera discreti, in tubulos producti, ibique poro v. longitudinaliter dehiscentes, dorso nudi v. appendice setiformi caudati.

Ovariom superum v. inferum, e carpidiis saepissime calycis foliolis numero aequalibus et alternis, nune paucioribus, rarissime solitariis, circa columnam centralem placentiferam verticillatis compositum, carpidiorum marginibus columnae angulis plus minus productis adnatis, dissepimenta constituentibus. Ovula in placentis columnae centrali juxta totam longitudinem $v$. apice adnatis plurima, rarius e carpidii unici v. paucorum sutura solitaria, pendula, anatropa. Stylus columnae placentiferae continuus, cylindraceus. Stig m a capitatum v. peltatum, indusio annuliformi, discum glanduliferum, lobatum v. dentatum cingente.

Fructus in generibus ovario infero donatis baccatus v. drupaceus, in generibus ovario supero praeditis rarius baccatus, interdum calyce demum aucto carnoso inclusus, saepissime capsularis, loculicide v. septicide dehiscens, valvis margine v. medio septiferis, a columna placentifera tandem libera solutis, rarius in coccos monospermos indehiscentes, v. tandem dorso fissos secedens.

Semrva in loculis solitaria inversa, v. plurima; testa solida, saepissime serobiculata v. relaxata, reticulata, arillaeformis, nucleum multo minorem includens. A I bumen carnosum.

Embryo orthotropus, axilis. Cotyledones 
breves. Radicula umbilico proxima, supera v. vaga.

Eric a ceae habitu peculiari et florum eximio decore insignes, e nullo climate exules, plurimae gregariae, maxima formarum et individuorum copia Africam australem extratropicam inhabitant. Ovario infero donatae majori numero in America imprimis boreali generantur. In Nova Hollandia ubi Epacrideae earum vice luxuriantur rarissime vigent.

Baccae plurimarum edules, nounullarum subadstringentes et diureticae.

Ordinis divisio perquam difficilis et problematica. Generum plurimorum limites, imprimis ob antherarum morphosim nondum satis expensam, nimis vagi.

Pyrolaceae et Monotropeae ad Ericacearum calcem recensitae, ordines arcte affines sistunt.

SUIB (1)ID I. ERICINAE. An the ra e muticae v. dorso aristatae. Ovari um liberum. Fructus capsularis, locnlicide v. rarissime septicide dehiscens, rarius baccatus. Folia saepissime acerosa, rarius plana. Gemmae nudae. sistens.

TEREUS I. ERICEAE. Corolla per-

SUBTEIBES I. SALAXIDEAE Benth. msc. Ovarium loculis uniovulatis. Antherae muticae.

DIVISET I. COILOSTIGMEAE. Stigm a cyathiforme. Bracteac nullae v. minutissimae.

4294. Salaxis SALISB. Cal yx quadrifidus, lacinia antica majore subsoluta. Co rolla hypogyna, parva, subglobosa, limbo breviter quadrifido, erecto $v$, connivente. Sta min a $6 \mathrm{v}, 8,8 \mathrm{sub}$ disco hypogyno inserta; fil a m enta libera $v$. connata, an ther a e lateraliter connatae $v$, arcte approximatae, loculis ad apicem foramine laterali dehiscentibus. O va ri u m bi-tri-quadriloculare, loculis uniovulatis. Stylus brevis, deciduns; stigma magnum, peltato-cyathiforme. C a p sula globosa v. angulata, di tetracoeca, coccis indehiscentibus, monospermis. S e m in a compressa. - Fruticuli capenses, ericoidei; foliis ternatim-verticillatis, floribus parvis, herbaceis, ad apices ramorum in axillis foliorum sessilibus, solitariis.

S a la is Salisbury in Linn. Transact. VI, 317. Klotset in Linnaea IX, 351. Benth. Synops. msc.

a. EUSALAXIS Benth. Stamina 8, flamentis liberis. Salaxis Klotseh in Linnaea XII. 211.

b. Coccosperma rlotseh. Stamia a 6 , filamentis con. natis. - Coceosperma Klotsch in Linnaea XIT. 215.

4295. Lagenoearpus KLOTSCH, C alyx quadrifidus. Corolla hypogyna, parva, urceolato-subglobosa, limbo breviter quadrifido, erecto v. connivente. Stamina 8 , sub disco hypogyno inserta; fil a m enta connata, an therae lateraliter coalitae, loculis ad apicem foramine la- terali dehiscentibus. Ovarium lagenaeforme, uniluculare, ovulo unico e placenta parietali pendulo. Stylu s brevis; stigma magnum, peltato eyathiforme. Fructus ....... - Frutices capenses, ericoidei; foliis ternatim verticillatis, brevibus, erectis, floribus parvis, ad ramorum apices in axillis foliorum sessilibus, solitariis.

$\mathrm{L}$ a g n no $\mathrm{carp}$ u s Klotsch in Linnaca XII. 214. Benth. Synops. msc.

4296. Dunplanloenayon KLOTSCH. C al y x quadrifidus v. quadripartitus, lacinia antica majore v. profundius distineta. Cor o 11 a hypogyna, urceolato-subglobosa v. ovato-cyathiformis, limbo breviter quadrifido, erecto $v$. connivente. $\mathbf{S} t$ a $m$ in a $\mathbf{3}$ v. 4 , sub disco hypogyno inserta; fi lamenta libera v. eonnata, antherae lateraliter coalitae $\mathbf{v}$. arcte approximatae, loculis ad apicem foramine laterali dehiscentibus. O va ri $\mathbf{~ m ~}$ uniloculare, ovulo unico, ex apice placentae parietalis pendulo. Stylus simplex; stigma magnum, peltato-cyathiforme. Nucula ovatooblonga v. subglobosa, monosperma. - Fruticuli capenses, ericoidei, ramosissimi, tenues; foliis ternatim verticillatis, parvis, floribus minimis, axillaribus terminalibusque, solitariis v. ternatis, subsessilibus.

$0 \mathrm{mphalocaryon}$ Benth. Symops. mse. $0 \mathrm{mphal}$. caryon, Tristomon et Blepharophyllon Klotseh in Linnaea XII. 216. 243. 245.

a. TRISTEMON Klotsch $O p$, cit. XII. 245. S t a mina saepius 3 , rarius 4 ; fll a m e n t a libera, basi aequalia, a u the ra e liberae, approximatae.

b. OMPHALOCARYON Klotseh Op. cit. $X I T$. 243. Sta. mina 4; fila me n tis libera, basi saepe dilatata. A nthe rae approximatae, saepe cohaerentes. - B I a I I a m uscos a Willd.

c. BLEPHAROPHYLLUM Klotsels $O p$. cit. XII. 216. S ta. miua 4; filamenta connata, antherae cohaerentes.

429\%. Coalonostigma KLOTSCH. CaIyx eampanulatus, quadridentatus. Co rolla hypogyna, cyathiformi - globosa, limbo quadrifido erecto. Stam in a 4 , sub disco hypogyno inserta, exserta; filamenta libera, antherae terminales, loculis ad apicem foramine laterali dehiscentibus. Ovarium uniloculare, ovulo unico, ex apice placentae parietalis pendulo. Stylus exsertus; stigma parvum, cyathiforme. Fructus...... - Fruticulus capensis, ericoideus; foliis ternatim verticillatis, floribus in capitula terminalia, cernua aggregatis, calycibus ciliato - hispidis, corollis vix calyce longioribus.

Codonastig m a Klotsch moc. ox Benth. Synops, msc.

Az98. Coillostisma KLOTSCH. Cal y x quadrifidus, subaequalis v. lacinia antica majore. Co ro 11 a hypogyna, parva, ovato-globosa, limbo breviter quadrifido, connivente. Stam in a 4 , sub disco hypogyno inserta; fil am ent a libera, anthera e laterales, muticae, inclusae v. exsertae, loculis ad apicem foramine laterali dehiscentibus. Ova rium bi-quadriloculare, loculis uniovulatis. Stylns exsertus, persistens; stigma cyathiforme. Ca p s ul a di-tetracocca v. aberta monococca, coscis indehiscentibus, monospermis. S e m ina compressa. - Fruliçuli capenses, ericoidei; foliis ternatim verticillatis, floribus ad apices ramulorum subsessilibus, calycibus brevissimis, bracteis pratter folium florale duabus minimis $v$, nullis.

Coilostigma Beath, Synops; msc. Cailostigma t $T$ h a a um Klotsch in Linnaea XII. 283. 234.

a. ColLostigmA Klotseb $O p$, cit, XII, 234, A t th o r a e 
inclusac. 0 va rin m biloculare. Capsula abortu mo. nococca. - Bracteae saepius nullae.

b. THAMNIUM klotseh $O_{p}$. cit. $X I I$. 223. A n the rae inclusae. Ovarin un quadriloenlare. Capaula di-tetracocca. - Bracteae duae, minimae.

DIVISI0 HI. SYMPIEZEAE. Stig ma obtusum. Bracteae saepissime tres.

4295. Codonant lo emum KLOTSCH. Calyx campanulatus, quadridentatus, aequalis. Corolla hypogyna, campanulata, limbo quadridentato, erecto. S tamina 4, sub disco hypogyno inserta; f i l a m ent a libera, glabra, a $t$ h e r a e laterales, muticae v. aristatae, exsertae, loculis ad apicem foramine laterali dehiscentibus. O $\mathrm{va}$ ri um uniloculare, ovulo unico, ex apice placentae parietalis pendulo. Stylus exsertus, persistens; stigma obtusum, Nucula monosperma. - Fruticuli capenses, ericoidei, diffusi; ramis puberulis, foliis ternatim verticillatis v. sparsis, ad axillas fasciculatis, floribus ad apices ramulorum brevissimorum glomeratis, seeus ramos fasciculato. racemosis, bracteis tribus calyci approximatis.

Codouantbem $\mathrm{mm}$ Klotsch in Linnaea XIT. 2so. Benth. Synops, mse. B Iaíria paryiflora et Bi. pa. berula Klotsch in Linnaea VITI. 661. 665. A u o malanthas Klotsch in Linnaea XII. 238.

4300. Symdesmanthus KLOTSCH, C a 1 y x tubuloso-campanulatus $\mathbf{v}$, turbinatus, tetragonus, quadridentatus. Corolla hypogyna, obovato v. subclavato-tubulosa, limbo quadridentato, erecto v. connivente. St a min a 4 , sub disco hypogyno inserta; filamenta libera, glabra, anthera e terminales, exsertae, muticae, loeulis ad apicem foramine laterali dehiscentibus. Ovarium uniloculare, ovulo unico, ex apice placentae parietalis pendulo. Stylus exsertus, persis. tens; stig ma obtusum. C a p 8 ula unilocularis, bivalris, monosperma. - Fruticuli capenses, ericoidei; foliis ternatim verticillatis, floribus in capitula terminalia, saepe cernua aggregatis, subsessilibus, bracteis tribus, nunc calyci approximatis, nunc ad busim pedicelli brevissimi sitis, calycibus saepe ciliato-hispidis, herbaceis v. coloratis.

Sy ndesm anthus Beath. Synops. msc. S yndes man. thus et MacroIin $\mathbf{n}$ Klotsch in Linnaea XII, 240. 242.

a. Sy adesmanthus Klotsch $O p$. cil. XIIT, 24O. Caly x campinulatus, tetragonus. B r a ctea e nullae. - Fruticuli erecti, rarius decumbentes, virgato-ramosi. B I a e riae 8 p. Linn. Wendland Collect, $t, 31$, 44.

b. MACROLINUB Klotsch Op, oit, XII. 242, Cal y $x$ tur. Finatus v. subinfundibuliformis. B ra eteatidepressi, divaricato-ramosissimi. paueifolia Klotsch in Linnaea VIIT. 664.

4301. Sympieza LICHTENST, C a ly $\mathrm{x}$ crassiusculus, nune eompresso-bilobus, nune tabaloso-campanalatus, quadridentatus. C. o roll a hypogyna, obovato-v. elavato-tubulosa, obliqua, limbo bifido, connivente. Stamina 4, sub diseo hypogyno inserta; fil am enta libera, glabra, anthe ra e terminales, muticae, exsertae, loculis ad apicem foramine laterali dehiscentibus. O va$r$ i m m biloculare, loenlis nniovulatis. Sty $\mathbf{l}$ a
exsertus; exsertus; $8 \mathrm{tigma}$ obtusum. C a p sul a dicocea, coecis dorso ineomplete bivalvibus, monospermis. - Frutices capenses, ericoidei; foliis ternatim verticillatis, floribus in axillis folionum supremorum solitariis, subsessilibus, capitato-approximatis, bracteis nullis $v$. ternis, calyci approximatis, calycibus
glabris, margine ciliatis, coloratis.

S y m p i ez a Lichtenstein ex Röm, et Schult. Syst. III.
1V1. Bartling in Linnaea VII. 651. Kusth in Abhandl. Ber lin. Acalem. 1833. p. 13. Klotsch in Linnaea VIII. 655. Benth. Synops. msc.

a. SYMPIEZA Benth, msc. C a I y $x$ compressus, bi-quadri. lobus. Bractea nullae. Blaeria bracteata
Weadl. Collect. $t, 37$. b. MCROG0MPHUS Beoth. msc. Calyx campanulatus,
quadridentatus. B r a tea tres.

430\%. Sinnoellailma BENTH. C a 1 y x crassus $v$, crassissimus, ovato-campanulatus, quadridentatus. Corolla hypogyna, obovato-v, clavato-tubulosa, limbo quadrifido, connivente v. erecto. St a m in a 4, sub disco hypogyno inserta; fil a m enta libera, glabra, antherae terminales v. sublaterales, distinctae, loculis ad apicem foramine laterali dehiscentibus, O va r i n m bi-quadriloculare, loculis uniovulatis, Sty I us exsertus; stigma obtusum. Capsula bi-quadrilocnlaris, bi-quadrivalvis, di-tetrasperma, rarius abortu unilocularis, monosperma. - Fruticuli capenses, ericoidei; foliis ternatim-quaternatimve verticillatis, floribus subsessilibus, in capilula terminalia, sa epius cernua aggregatis, rarius subsolitariis, calycibus coloratis, saepissime tetragonis, subcarnosis, glabris v. apice breviter cilialo-hispidis, enerviis v. grosse
octocostatis.

Slmochilus Benth. Synops. msc. Pachyealyx, Plaglostemon, Thamnus et $S i m o c h e i l u s$ Klotsch in Linnaea $\mathrm{X} I T$. 230 -236.

a. PLAGlostemoN Klotsch Op. cit, XII. 232, $\mathrm{C}$ al y x tribracteatus, tetragono-campanulatus. A a the ra e sub. laterales. 0vari um biloculare. - B laeria bicolor Klotsch.

b. THAMNUS Klotsch $O p$. cit. $X Y I$. 235. Cal y x tribracteatus, subtetragono-campauulatas, basi obsolete octocostatus. A n th e ra e teruinales. Ovarium quadrilo. eulare. Capsula monosperma, quadrivalvis.

c. SIMOCHeILUS Klotsch $O_{p}$. cit. XIT. 236. Caly x tri. hracteatus, anguste tetragono-campanulatus, vix costafus. A thera terminales. Ovarium biloculare. Blaeriamultiflora et Bl. carne a Klotsch.

d. OCTOGONIA Klotsch $O p$, cit. $X I T$. 233. C al y x ebrae. tealus, ovatus v. subcampanulatus, crassissimus, tetragonus, basi oetocostatus. A a therae terminales v. sublaterales. O varin m tetragonum, bi-quadriloculare.
- B la eriae glabell a Willd.

e. PACHYCALYX Klotsch $O_{p}$. cit. $X I T, 230$. C aly x tribracteatus, ovato-conicus, crassissimus, tetragonus, basi octocostatus. A $\mathrm{n}$ therae subterminales. $0 \mathrm{vari}$ um biloculare.

4303. Aerostemom KLOTSCH, Cal y $x$ quadrifidus v. quadripartitus, aequalis, Corolla hypogyna, obovato-tubulosa, limbo quadrifido, connivente. Stamina 4, sub disco hypogyno inserta; filamenta libera, glabra, antherae terminales, distinctae, loculis ad apicem foramine laterali dehiscentibus. O v a r i $\mathbf{m}$ bi-quadriloculare, loculis uniovulatis. Sty $\ln s$ saepius exsertus; st ig ma obtusum. Capsula aborta uni-trilocnlaris, loculicide bi-trivalvis, di-trisperma. - Fruticuli capenses, ericoidei; foliis ternatim quaternatim verticillatis, saepe hirtis, floribus terminalibus, subsessilibus, capitatis, bracleis calyci approximatis, lateralibus minoribus, interdum nullis, calycibusque pilis longis, albis, rigidis obtectis, corolla calycem superante.

A crostemon et Comacephalus Klotseh in Lin. nae a XIT. 287 ot 284 .

4304. Grieselbaelaia KLOTSCH. Calyx tetragono-campanulatus, quadrifidas, aequalis. Corolla hypogyna, urceolata, limbo quadrifide, connivente. St a min a 4 , sub disco hypogy- 
ra e laterales, distinctae, loculis ad apicem foramine laterali dehiscentibus. Ovarin m biloculare, locolis uniovulatis. Stylus exsertus; stigma parvum, obtusiusculum. Capsula compressa, bilocularis, septicide bivalvis, disperma. - Fruticuli capenses, ericoidei; foliis ternatim quaternatimve verticillatis, hirtis, floribus terminalibus, subsessilibus, capitatis, bracteis calyci approximatis, lateralibus minoribus calycibusque plumoso-puberulis, corolla vix calycem excedente.

Griesebachia Klotseh in Linnaea $X I r$. 225. B 1 ae. ria eiliaris Liun, f.

4BO5. Finekea KLOTSCH. C a I y $\mathrm{x}$ quadripartitus, aequalis. Corolla hypagyna, cylin. drico tubulosa, limbo quadridentato, connivente. S t a m ina 4, sub disco hypogyno inserta; filam enta libera, villosa, a $\mathbf{n}$ h e $r$ a e laterales, distinetae, loculis ad apicem foramine laterali dehis. centibus, Ovari n m oblongum, biloculare, loculis uniovulatis. Stylns exsertus; $8 \mathrm{tigma} o b$ tusum. Nucula obovata, abortu unilocularis, monosperma. - Fruticuli capenses, ericoidei; foliis ternatim quaternatimque verticillatis, puberulis, floribus terminalibus subcapitatis $v$. umbellatis, bracteis ralyci approximatis, lateralibus minoribuscalycibusque pilosis, corollis puberulis, vix calyce longioribus.

Fine ke a Klotsch in Linnaea XII. 237.

43965. Eremia $D O N$. Calyx profunde quadrifidus v. quadripartitus, aequalis. C orolla hypogyna, urceolato-campanulata v. subglobosa, limbo quadrifido, erecto, connivente v. vix-patente. Sta $m$ in a 6 v. 8 , rarissime 5,8 ub diseo hypogyno inserta; filamenta libera, antherae distinctae v. cohaerentes, loculis latere foramine elongato dehiscentilus. Ovarin m bi-quadrilocnlare, loculis uniovulatis. Stylus rectus; $8 \mathrm{tigma}$ tenue, obtusum v. subcapitatum. C a psula ditetracocca, v, abortu monococca, coccis septicide secedentibus, monospermis. - Fruticuli capen$s e s$, ericoidei, divaricati; foliis ternatim quaterna timque verticillatis, patentibus v. reflexis, ciliatohispidis, floribus ad apices ramulorum glomeratis, brevissime pedicellatis, bracteis tribus calyci approximatis, calycibusque hispido ciliatis.

$\mathrm{E} r \mathrm{em}$ i a Don in Edinb. new philosoph. Journ. XPII. 156. G. Don Syst. III. 828. Benth. Synops mso.

a. HEXASTEMON Beatli. Ovarium biloeulare. - He. $x$ a stemou Klotsch in Linnaea XII. 220.

b. EREMIASTRUM Benth. 0 vari um quadriloculare. Eremia Don I. e. Klotsch Op. cit. XII, 218. Erica totta Thunb. E. ferox Salisb.

\section{GENERA DUBIA.}

439\%. Mierotrema KLOTSCH. Cal y x quadripartitns, aequalis. Corolla hypogyna, cyathiformis, quadrifida, limbo recto. Stam in a 6 , sub disco hypogyno inserta, exserta; anther ae Iaterales, aristatae, loculis foramine orbiculari minnto dehiscentibus. $O \mathrm{v}$ a $\mathrm{r}$ i $\mathbf{~} \mathrm{m}$ uniloculare, nniovulatum. Stylus exsertus; stigma obtusum. Fruet us...-Frutex capensis, Blaeriae facie; ramulis puberulis, foliis ternatim verticillatis, floribus terminulibus ternis, bracteis tribus calyci approximatis.

Mierotrema Klotsch in Linnaea XIT. 499.

4369 . Thoracosperma KLOTSCH, C a ly $x$ quadrifidus, aequalis. Corolla bypogyna, elongata, ampullacea, fere turbinata, limbo quadrifido, connivente. S ta $\mathrm{m}$ in a 4 , sub disco hypogyno inserta; fil amenta libera, an $t$ herae discretae, bipartitae, exsertae, ad apicem foramine unilaterali dehiscentes, Ovarium ....... Stylus fliformis, deciduus; stigma simplex. Ba $c$ ca exsucca, globosa, aspera, disperma, arillis (?) duobns putaminaceis crassis, ovalibus, favosis, vacuis ..... - Frutex ca pensis, Ericae facie; fo. liis ternatim verticillatis, linearibus, subjliformibus, longis, erectis, glabris, floribus lateralibus brevissime pedicellatis, brecteis tribus calyci approximatis, corollis elongatis, incarnato - albis.

Thor a eosperma Klotseh in Linnaea $I X, 350$. Eriea fasciculata Thubb.

SUETREDU II. EUERICEAE Benth. msc. Ov a rii loculi pluriovulati.

4309. B Ineria LINN. C a l y $\times$ quadrifidas v. quadripartitus, aequalis. Corolla hypogyna, campanulata v. suburceolata, limbo breviter quadrifido, erecto v. patente. Stam in a 4, sub disco hypogyno inserta, libera; antherae mnticae $r$. aristatae, loculis sub apice foramine laterali dehiscentibus, Ovari n m quadriloculare, loculis pluriovulatis. Stylus persistens; stig ma obtusum v. rarius peltatum. C a p s u I a gloloso tetragena, quadrilocularis, loculieide quadrivalvis, loculis oligospermis. - Fruticuli ericoidei, ca penses; foliis oppositis ternatisque, floribus terminalibus umbellulatis $v$. capitatis, majusculis, bracteis tribus, nunc a calyce remotis, parvis, nunc calyci approximatis, eundem aequantibus v. superantibus.

B I a e ri a Linn, gen, $n, 139$. Wendland Collect, $t, 25$. 38, 43, Klotseh in Linnaea VIII. 656, excl, sp. XII, 221, Beuth. Synops, msc.

4310. Ericinella KLOTSCH. CaIyx quadripartitus, lacinia antica majore. Corolla hypogyna, campanulata, limbo quadrifido, suberecto. Stam in a 4 v, rarius 5 , sub disco hypogyno inserta, libera; an the rae laterales, aristatae, loculis foramine unilaterali dehiscentibus, O v a ri u m tri-quadrilocalare, loculis pluriovulatis. Stylus persistens; stigma peltatum. Capsula tri-quadrilocularis, tri quadrivalvis, polysperma. - Fruticuli ericoidei, in insula Madagascar et in terra Caffror $u$ crescentes; foliis ternatim verticillatis, floribus terminalibus parvis, ebracteatis. Ericinell a Klotselt in Linnaea XII, 222. Benth. $S$ yn. ops, msc.

4311. Plhilippia KLOTSCH. CaIy quadrifidus v. quadripartitus, lacinia antica majore, saepius soluta. Corolla hypogyna, subglobosa, limbo breviter quadrifido. Stam in a 8 , sub disco hypogyno inserta; filamenta basi $\mathbf{v}$. longitudinaliter connata, a n th e ra muticae, connatae v. sub stigmate approximatae, loculis foramine laterali dehiscentibus. Ovarium quadriloculare, loculis multiovulatis. St y I a s subpersistens; stigma magnum, peltatum. C a p sula depresso-globosa, quadriloeularis, loculicide quadrivalvis, polysperma. - Fruticuli capenses, madagascarienses et mauritiani, ericoidei; folitis ternatim senatimque verticillatis, floribus parvis, ad apices ramorum breviler pedunculatis, umbellatis, rarius sessilibus $v$, subcapitatis, bracteis nullis $v$. rarius minutis, stylo incluso $v$. saepius exserto.

$\mathrm{P}$ hilip $\mathrm{p}$ ia Klotseh in Iinnaea $1 X, 353$. Benth, Synops. mse. 
a. EUPHILIPPIA Benth. Fila menta et a $n$ thera plus minus connatae. - Philippia Klotseh in Linnaea $\mathrm{X} I T .213$.

b. ELEUTHERostemoN Benth. Fila m e $\mathrm{nta}$ basi brevis sime monadelpha, apice a $\mathrm{t}$ heraeque liberae. Ble utherostem a Klotsch in Linnaea XII. 219.

4318. Haruelienthalia REICHENB. Ca lyx quadrifidus, subaequalis. Corolla hypogyna, subgloboso-campanulata, quadrifida. S $t$ amina 8 , sub disco hypogyno glanduloso inserta; filamenta basi connata, antherae liberae, muticae, loculis ad apicem foramine unilaterali dehiscentihus. Ova ri u quadrileculare, loculis multiovulatis. St y lus exsertus, persistens; stigma truncato-eapitatum, C a ps ula quadriloevlaris, loculicide quadrivalvis, polysperma, - Fruticulus ericoideus, in Europa austro-orientali indigenus; foliis ternatim-quinatim verticillatis $v$. sparsis, floribus pedunculatis, subverticillatis, ad apices ramulorum in spieulas dispositis, foliis floralibus parvis, bracteis nullis.

Brackenthalia Relehenbach Flor. germ. 414. Klotseh in Linnaea XrI. 216. Benth. Synops. msc. E ri e a spiculiflora Salisb. Sibthorp Flor. graec, $t, 353$, E. Bruekenthalii Spreng. Reichenb. Ieonogr. t. 300 . Men. ziesia Bruckenthalii Baumg.

4313. Eriea $L I N N$. C a lyx quadrifidus $v$. quadripartitus. Corolla hypogyna, varia, globosa, urceolata, tubulosa, campanulata v. hypoeraterimorpha, limbo quadrifido. Sta m in a 8 , sub diseo hypogyno inserta, inclnsa v. exserta; filamenta libera, a $n t h$ er a terminales $v$. laterales, distinctae v. basi cohaerentes, muticae, aristatae v. eristatae, loculis ad apicem foramine laterali dehiscentibus. O vari u m quadriloculare, loculis multiovalatis. St ylus filiformis; $8 \mathrm{tig} \mathrm{ma}$ capitatum, cyathiforme v. peltatum. Capsnla quadrilocularis, loeulicide quadrivalvis, valvis medio septiferis, septis columnae centralis placentiferae tetragonae $v$, tetrapterae angulis oppositis v. alternis, interdum adnatis. S e m i n a plurima, ovalia, reticulata. - Frutices in Eu ropa media et australi rarius obvii, in Capite bonae s $p$ e $i$ ingenti specierum et formarum numero luxu riantes, habitu proprio; foliis alternis, oppositis $v$. verlicillatis, acicularibus, floribus axillaribus v. terminalibus, bracteis tribus, calyci approxima tis $v$. ab eo remotis, pedicellis basi nonnunquam foliis involucrantibus instructis.

E rle a Lian. gen. n. 484. Wendland Collect, 1798. An drews Engravings of Heaths. London, 1809 . fol, 4 Vol. Klotseh in Linnaed $I X, 359-367,611$ 706. X, 319 $X I I .500$ 513. Tauseh in Flora 1837. p. 481 - $509 . \quad-\mathrm{G}$ y psoealis et Eremoealis Salisbury in Horticule. Transact, IL. Rriea, G y poeatis, Paehysa, Ceramia, DesmIa, Eurylepis, Eurystegla, Lophandra, Lamprotis, Callista, Euryloma, Chona, Syriagodea, Dasy anthrs, Eetasis, Rriodesmia, Óctopera D. Don in Edinb. new philosoph. Journ. XVII. 132156. coll. Klotsch in Linnaea Litteraturber. 1835. p. 67 78. Eriea generis species plurimas, corollae forma mirum in modum Iudentes, etiam antherarum insertione et eapsulae dehiscentia luter se diversas, in plures sectiones esse dispes. cendas etsi nullus Botanicorum hodie dubitet, tamea genera nec certis characteribus circumscripta, nec stírpes revera proxiue affines is uaum colligentia, qualia nuper proposita vidiuns, communi consensu repudiata fueruat, specierno per fauilias a aturales istra generís limites disponeadi negotio, experti cousilii mouographis, clarissimis Bentham et Klotsch uno omaium appleusu permisso, quorum curis non. dum ad nos perlatis v. seuifacta opera, geueris vastissimi et pulcherrimi sectlones nallae introducuatur is opere universi regni vegetabilis geuerua recensum praebeute, nee singulis praeter libri rationes diutius immoraute.

4314. Pentamers KLOTSCH, Ca I v quinquepartitus, aequalis. Corolla hypogyna, ovata, limbo quinquefido. St a min a 10 , sub disco hypogyno inserta; filamenta libera, anther a e distinetae, muticae, loculis ad apicem foramine laterali dehiscentihus $O \mathbf{v}$ ari um quinqueloculare, loculis multiovulatis. Stylus exsertus; stig ma incrassatum, obtusum. Caps a l a quinquelocularis, loculicide quinquevalvis, valvis medio septiferis, septis columellae placentiferae pentapterae angulis oppositis. Semina plurima, ovalia, reticulata. - Frutex ericoideus, in scopulis maritimis calcareis $\mathbf{S}$ icilia e vegetans, ab Ericis nonnisi quinario partium floris numero diversus; foliis quaternatim verticillatis, patentissimis, floribus terminalibus pedicellatis, bracteis tribus a calyce remotis, corollis puberulis.

Pentapera Klotsch in Linnaoa XrI. 497. Erica sicula Gussone.

43 is. Nacnabia BENTH. Cal y $\mathrm{x}$ quadripartitus, laciniis cruciatim oppositis, cartilagineis, duabus exterioribus carinatis, interioribus planinsculis. Corolla hypogyna, calyce multo minor, quadripartita. Sta min a 8 , sub diseo hy pogyno inserta; filamenta libera, ant herae distinctae, muticae, loculis sub apice rima laterali dehiscentibus. Ova ri um quadriloculare, loculis pluriovulatis. St ylus filiformis, uncinatus; s $t i g-$ in a simplex. C a p s u l a quadrilocularis, loculicide quadrivalvis, dissepimentis columnae centrali placentiferae adnatis. S e mina in loculis pauca, subrotunda, compressa, membranaceo alata. - Frutex c apensis, ericoideus, rigidus; foliis ternatim verticillatis, floribus ad apices ramulorum brevissimorum solitariis $v$. geminis, juxta ramos dispositis.

Ma cnabia Bentham Synops. msc. Nabea Lehmann Index Som, hort, Hamburg. 1831. Klotsch in Linnaea VIIT. 666.

43 16. Callouma SALISB. Cal y $x$ quadripartitus, laciniis cruciatim oppositis, aequalibus, scariosis, coloratis. C orol la hypogyna, calyce multo minor, subquadripartita. S tam in a 8 , sub disco hypogyno inserta; fila m en ta libera, a nth e $r$ a e distinctae, aristatae, loculis sub apice rima laterali dehiscentibus. O varium quadriloculare, loculis pauciovulatis. Stylus exsertus; stig $\mathrm{gma}$ peltato-infundibuliforme. Ca p s l a quadritocularis, septifrage quadrivalvis, columna centrali septifera, placentis apiei anguli centralis adnatis. Se mina in loculis panca v. solitaria, aptera. Fruticulus ericoideus, in Europa media et boreal $i$ erescens, nemini ignolus et omnibus gratus; foliis opposilis, pedunculis axillaribus v. in ramulis axillaribus terminalibus, bracteis sex, per paria oppositis, calyci approximatis, exterioribus herbaceis, interioribus basi dilatatis, scariosis.

C a II a n Salisbury in Linn, Transact. VI.317. Klotset in Linnaea VTr. 668. Benth. Synops, mse. E ric a v u I gai is Linn. Gärtner $t$. 63, Sehkuhr $t$. 107. $a$, Flor. dau. t. 678 .

TIRIBES II. ANDROMEDAE. C o r o1la decidua.

431\%. Dienziesia $S M I T H$. Ca I y quadri-quinquefidus $v$. partitus. Corolla hypogyna, campanulata v, subglobosa, limbo quadri-quinquefido $v$, reflexo. Sta $\mathrm{m}$ in a 8 v, 10 , hypogyna, inclusa ; fil a ment a filiformia v, subulata, a nthera e apice obtusae $v$. bicornes, dorso muticae v. aristatae. Ovarin quadri-quinqueloculare, loculis multiovalatis. Stylus simplex; stigma 
dilatatum. C a psu I a quadri - quinquelocularis, septicide quadri-quinquevalvis, colnmna centrali placentifera libera. S e min a plurima, laevia $\mathbf{v}$. serobiculata. - Fruticuli $v$. frutices bo reali a mphigaei, vix congeneres; foliis alternis, linearibus $v$. ovatis, floribus terminalibus, solitariis $v$. aggregatis.

M enziesia Smith 1e, inedit, Nr. 56, Swartz in Linn, Transact. X. 375 .

a. BRYANTHUS Gmel. CaIy x quinquepartitus, Corolla quinquepartita, patula. S tami in 10 , antheris obtusis, dorso muticis v. aristatis, - Fruticuli ericoidei, folits linearibus.

Bryanthus Gmelin Sibir. IV. 133. t. 57. $f .3$. Don in Edinb. new philosoph. Journ. XVIT, 160. A ud rom ed a e s p. Linn. Pallas Flor. ross. $t, 74 . f .1 .2$. (Swartz in Linn, Transact, $x, t, 30, f .6$. )

b. PHYLLODOCE Salisb. C a 1 y $\mathrm{x}$ quinquepartitus. Corol Ia globosa, limbo quinquedentato. St a m i na 10 . a $\mathrm{n}$. theris obtusis, muticis. Capsula quinquelocularis. - Frutices ericoidei, folits linearibus.

Phyllodoee Salisbury Parad. 36. Don in Edinb. new philosoph. Journ, XVIT. 139. A nd romed a e sp. Linn. Pallas. Flor. ross. $t$. 22. $f$. 2. (Swartz in Linn, Transaet, X, t, 30. f. a. E. B. t. 2469. Bot, Mag. t. 3176.)

c. DABOECIA. Don, Caly $\mathrm{x}$ quadripartitus. Corolla ovalis, limbo quadridentato. Stani ina 8 , antheris basi sagittatis, apice bicornibus. Capsula quadrilo. eularis. - Fruticulus ericoideus, foliis ellipticis.

D a boecla Dan in Edinb. new philosoph. Journ. XVIT. 160. C a n d o I I e a Baungarten Transylv. Eif c a D a b o e c i a Linn. E. B. $t$. 35.

d. ARCIMBALDA. Ca I y $\times$ quinquepartitus. C ofolla glo. bosa, limbo quadripartito. Stamina 8 , antheris obtusis, muticis. - Frutices azaloidei.

Menziesia Don Syst. III. 850. (Smith Ic. inedit. t. s6. Salisbury Parad. $t$. 44.)

4318. Andlromeda LINN. C a ly $x$ quinquefidus v. quinquepartitus. Corolla hypogyna, campanulata v. globosa, limbo quinquefido, refle$x 0$. St a $m$ in a 10 , hypogyna $v$. corollae basi inserta, inclusa; fil a m e n ta subulata, a n therae apice obtusae v. bicornes, dorso muticae v. rarius aristatae. Ov a ri u m quinqueloculare, loculis multiovulatis. Stylns simplex; stig ma obtusum, interdum dilatatum. C a p \& 1 a subglobosa, quinquelocularis, loeulicide quinquevalvis, valvis medio septiferis, indivisis v, demum bifidis, columna centrali apice placentifera. Semina plurima, laevia v. scrobiculata. - Fruticuli v. arbores, habitu vario, in America imprimis boreali, in Asia tropica et in regionibus areticis 8 ubarcticisque provenientes, olim in pluragenera sejungendi, interim characterum ex antheris valore et dignitate morphologica in Ericeis nondum rite perpensa, fructus dehiscentia, placentarum situ et seminum indole in paucis speciebus mihi cognita, ne erroribus errores adcumulem, sectionibus nuper introductis interim admissis, genus intactum hic relinquitur.

A n tr o meda Linn. gen, $n$, 549. Gärtner I. 304. Kanth in Humb. et Bompl. Nov. gen. et sp. III, 288.

a. CASSIOPE. Don. Caly $x$ qulnquepartitns, laciniis basi imbricatis. Corolla canpanulata. Antherae in alabastro extrorsae, demum introrsum reclinatae, loculis turgidis, basi (sursum spectante) foranine apertis ibigue postice aristatis. Stigma truncatum. - Erufi culiarctici et in Asia alpicoli; folits parvis, culiarctici et in Asia alpicoli; foltis parbis, solitarits, unifloris, ima basi bracteatis.

Cassiope Don in Edinb, new philosoph. Journ. XVIT. 157. A ndromeda hypuoides Linn. Flor. Lappon, t. 1. f. 3. Flor, dan, t, 10. Pallas Flor, ross. t. 73. f. 2. Bot. Mag. t. 2936. A. tetrag on a Linn. l. c. $t$. 1. f. 4. Pallas op. cit. t. 73. f. 4. Bot. Mag. t. 318t. A. 1 y copodioides Pallas op. cit, $t, 73$. f. 1. A. e ricoides Pallas op. cit. t. 73. f. 3. A. fastigiata Wallich Plant. As, rar, t. 284. A. M erten si a a Bongard in Mem, Academ. St. Petersb. n. s. II. t. s.

b. POLIFOLIA. C a I y $x$ quinquefidus. C or oll a subglobo sa. A n ther a e biaristatae. Stig m a truncatum. Semina laevia, rhaphe crassa! - Fruticulus arcticus; folits alternis, lineari-lanceolatis, mucronatis, margine revolutis, subtus glaucis, floribus terminalibus, umbellatis, bracteis ovatis, imbricatis.

Pol if olla Buxbaum Cent,, . 28, t,49. A nd romed a Don in Edinb. new philosoph. Journ. XVIT, 157. A. polifolia Linn. Flor. Lappon, t. 1 . $f$, 3. Flor dan. t. 54. B. B, t, 713. Heritier Stirp, II, t. 11. Pallas Flor, ross. $t, 1, t, 70, f, B$.

c. CASSANDRA Don. Caly $\mathrm{x}$ quinquepartitas, basi bi. bracteolatus. Cor olla tubulosa. A ut hera o maticae. $\mathrm{S} \mathrm{tig}$ m a peltato-dilatatum, disco quinquetuberculatum. Se mi na laevia, rliaphe crassa._Frutes borealis, a mphigaeus; folits alternis, coriaceis, elliptico. oblongis, denticulatis, lepidotis, peduneulis in apice ramulorum axillaribus, solilariis, uniflorit.

C a s s a $\mathrm{n}$ dra Don in Edinb, new philosoph. Journ. XVIT. 158. A. caly culata Lin. Pallas Flor, rose. t. 71, f. 1. Gärtner t, 63, Bot, Mag. $t .862,1286$.

d. ZENOBIA Don. Calyx quinquedentatus. Corolla campanalata, profunde quibquepartita. A n therae 10culis elongatis, tubulosis, apice biaristatis. Stig ma truncatum. Sem in a angulata. - Frutices boreali americani; foliis alternis, sempervirentibus, $l a$. tiusculis, dentatis, floribus racemosis, pedicellis so. litarits $v$. aggregatis.

$\mathrm{Z}$ e nobia Don in Edinb, new philosoph. Journ. XVII. 168. A. s peciosa Michx. A. cass inaefolia Vent, A. nitida Bot. Mag. $t$. 970. A. pulverulenta Pursh. Bot. Mag. 2 . 667. A. dealbat a Bot. Reg. t. 1010 .

e. LEUCOTHÖ̈. Caly $\times$ quinquepartitus, lacinils Imbricatis. C orolla tubulosa. A u thera e loeulis abbreviatis, truncatis, mutiois. S tigma late eapitatum. Frutices boreali-americani; folii, alternis, sempervirentibus, coriaceis, dentato-spinulosis, flo. ribus racemosis, axillaribus v. terminalibus.

L e u c ot ho e Don in Edinb, new philosoph. Journ. XVII. 159. A. a xillaris Sol. Bot. Mag. t. 2357. A. C a tesbaei Bot, Mag. $t$. 1955. A. a c um I ua ta Ait. Smith Exot, Bot. t. 89. A. I u e I d a Jacq. Ie, rar, t. 79. A. fl o r lb und a Bot. Reg. t. 807. Bot. Mag. t. 1566.

f. PIERIS Don, Caly $\mathrm{x}$ quinquepartitas. Ca rolla tabu. losa v. ovata. Fil ame n $t$ a apice bisetosa, a $n t$ herae loculis abbreviatis, longitudinaliter dehiscentibns, Stylus pentagonas; stigma truncatum. Se min a seobi. formia. - Arbusculae $v$. frutices nepalense $:$; foltis coriaceis, floribus terminalibus, racemosis.

P ie ris Don in Edinb. new philosoph. Journ, XVIT. 159. A $\mathrm{n}$ d $\mathrm{r}$ o m ed a $\mathrm{s}$. Wallich in Asiat, Researches XIII, t, 7.8. A. j a po n ie a Thunb. Flor. japon, t, 22, Gärtner $t .178$.

g. Agarista Don. Caly $x$ quinquepartitus. Corolla ovata. Antherae dorso mutieae, apice tubuloso-bicornes. Stylus teres; st $i_{g} m a$ capitatum. Sem f na angulata. - Frutices sempervirentes, in America tropica ot insulis borbonicis indigeni; folits coriaceis, sacpius integerrimis, reticulato.venosis, floribus terminalibus, racemosis.

A garlsta D. Don in G. Don Syst, III. 837. A. salielfoli a Commers. Suith Jo. inedit. 2.58 . Hooker Exot. Flor. $t$. 192. Bot. Mag. $t$. 3286. A. b u $x$ if ol i a Lam. Smith op. cit. $t$. 59. Bot. Mag. t. 2660. A n d romed a e sp. Kunth in Humb. et Bonpl Nov. gen, et sp. t, 263. Pohi Plant. Brasil. t. 121. 122.

4319. Hyomia NUTT. Caly $\mathrm{x}$ quinquepartitus. Corol la hypogyna, subglobosa, limbo quinquedentato. Stam in a 10 , imae corollae inserta; fi lamenta brevissima, basi dilatata, antherae muticae, longitudinaliter dehiscentes. 95 * 
Ovarinm quinqueloculare, loculis multiovulatis. Stylus simplex, fusiformi-pentagonus; s ti $\mathrm{g} \mathrm{ma}$ obtusum. Capsa la ovoidea v. subglobosa, qninquecostata, quinquelocularis, loculicide quinquevalvis, valvis medio septiferis, enm costis solutis alternantibus, placenta basilari quinqueloba. $\mathbf{S}$ emina plurima, acicularia. - Frutices bore a $l i$ americani; foliis alternis, sempervirentibus $v$. deciduis, pedunculis axillaribus v. lateralibus, paniculatis $v$. fasciculatis, ebracteatis, corollis saepe hispidulis.

L y o n i a Nuttall Gen, $t .266$, D. Don in Edinb, new phitosoph. Journ. XVIT. 158. Xoli s m a Rafinesq. in Americ. Monthl. Magaz. 1819. An drameda froudosa Pursh.

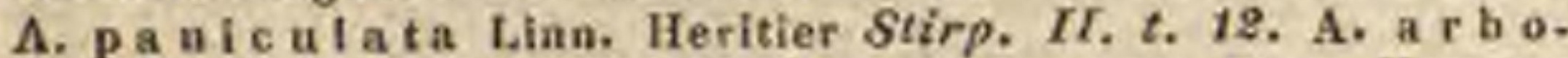
rea Lias. Bot. Mag. $t$. 905. A. ra ce m os a Linn. Heritier t. 13. A. mariana Linn. Ireq. Ic, rar. $t$. 465 . Bot. Mag. t. 1579. A. coriace a Willd. Bot. Mag. $t$, 1095. A. f e r$r u g i$ u e Walt. Vent. Malmats. $t, \delta 0$.

4320. Cletlera $L I N N$, C aly $x$ quinque partítus. Co r olla hypogyna, profunde quinque partita, laciniis spathulatis, conniventibus, seorsim decidnis. Stamina 10, hypogyna, inclnsa; fil am enta filiformia, anthera extrorsae, de. mum introrsum flexae, cordatae, apice mueronatae, dorso muticae. Ova ri um triloculare, loculis multiovalatis. Stylus filiformis, persistens; stig m a obsolete trifidum. Cap s u la calyce cincta, trilocularis, loculicide trivalvis, valvis medio septiferis, placentis e basi erectis, a columna centrali solntis. Semina plurima, testa fungosa, laxa. - Frutices v. arbores, in $A$ merica boreali et tropica crescentes; foliis alternis, serratis $v$. rarius integerrimis, racemis terminalibus bracteatis, albidis.

C Iethra Linn. gen, $n$. 553. Schkuhr t, 118. Gärtner $T$. 301. t. 63. Vent. Malm. t. 40. Duhamel Arbr. I.t. 71. Kuuth in Humb, et Bonpl. Nov, gen. et sp. III, 289, $t, 264$. Bot. Mag. t. 1057, C u ell ar la Ruiz et Pavon Syst, 103. T in us Liuv. gen, $n$, 504. Volkameria P. Browne Jam. 21j. t. $21, f, 1$.

432 1. Elliottia $M \ddot{U} H L E N B$. Ca I y x quadridentatus. Corolla hypogyna, profunde quadripartita, quadripartibilis. S $t$ a $m$ in a 8 , hypogyna ; filamenta glandulosa, antherae sagittatae. Ovarium quadriloculare, loculis multiovulatis. Stylus simplex; stigma clavatum. Capsula quadrilocularis ..... - Frutex boreali-americanus, non satis notus, vix a Clethra satis distinctus; foliis alternis, integerrimis, floribus terminalibus, racemosis.

Elli ottia Mühlenb. ex Nuthall Gen. Ir. add. p. 252.

43\%. Wpigaea LINN. Caly x basi tribracteatus, quinquepartitus, laciniis lanceolatis. Coroll a hypogyna, subhypocraterimorpha, tubo calyeem aequante, eylindrico v. ovato, intus villoso, limbo quinquepartito. St a m in a 10 , imae corollae inserta, tubum aequantia; fil am enta filiformia, antherae mutieae, longitndinaliter dehiseentes. Ovarinm quinqueluculare, loculis multiovulatis. Stylus simplex; stigma obtusum, obsolete quinquefidum. C a p s u la depresse subglobosa, pentagona, loculicide quinquevalvis, valvis medio septiferis, columna centrali placentifera quinqueluba. Semina plurima ....... Fruticuli boreali americani et antillan $\bar{i}$, procumbentes, hispiduli; foliis alternis, integerri mis, racemis axillaribus et terminalibus multifloris.

E pigaea Lian, gen, $\pi$. 550, Swartz. Flor. Ind. occid. II. 812. Lam. $t, 367$. Andrews Bot, Reposit. $t$, 102, Bot. Reg. $t .201$. Memecyloa Mitehel Gen, in A. N. C. 13.
4323. Gautiera $K A L M \quad C$ a l y $x$ quadriquinquefidus, fructifer pleramque baccatus, Coroll a hypogyna, ovata, limbo quadri-quinquefido. $S$ tam in a 8 v. 10 , imae corollae inserta, inclasa; filamenta subulata, antherae dorso mutieae, apice bifidae, Iobis bidentatis v, biaristatis. Squa mulae hypogynae 10 , liberae v. basi connatae. Ovarin quinqueloculare, Joculis multiovalatis. Stylus simplex; stigma obtusum. Capsula depresso-globosa, calyce saepins baccato, adnato, tecta, quinquelocularis, apice loculicide quinquevalvis, placentis imae columnae adnatis. Semina plurima, testa angulata, reticulata. - Frutices v, arbusculae, in America imprimis boreali, Asiae tropicae et $s u b$. tropicae montibus, nec non in Nova-Hollandia et Nova-Zeelandia indigeni; foliis alternis, floribus axillaribus et terminalibus racemosis, racemis solitariis, pedicellis bibracteolatis, bracteolis distinctis $v$, interdum connatis, calyci approximatis, filamentis saepius hirsutis.

Gantie ra Kalm in Mem. Acad, Paris, 1751, II. 378. Ga ulthiera Lina. gen, n. 851 . Gïrtner $I, 306 . t .63$. R. Brown Prodr.558. Kanth in Humb, et Bonpl. Nov. gen. et sp. III. 280 .

a. CHIOGRNES. $\mathrm{C}$ a $1 \mathrm{y} \times$ basi hibracteolatus, fructifer baecatus. Stamina 8 . - Chiogenes Salisbury in Horticult. Transact. Ir. Gly eyphylla Rafinesque in Americ, Monthl. Magaz, 1819. P hale roca rpus Don Syst. III. 841. Vaceinium hispidulnm Lina. Michaux Flor. Bor. Amer, $t$, 23. Gaultheria serpyllifolia Pursh Flor. Bor, Amer. $t .13$.

b. ? AMPHICALYX. C al y x basi bracteolis duabus connatis calyculatus, feuctifer baceatus. St a m in a 10 . A mphicalyx Blume Elor. Jav. Pracf. VIT. Dipli. cosia Blame Bijdr. 857. ( - ? G. trichophylla Royle Himalay, $t .63 . f .3$.

c. SHALLONIUM. C a l y $x$ ebracteolatus, fructifer baceatus, v. interdum siceus. Stamina 10 , - S hallo o i um Rafinesque in Journ. Phys. LXXXIX. 260. - ? A co st a Loureiro Flor. chochinch. 338, Gaultherlac s p. Lina. Duhau. Arbr. $T$. $t$. 113. Andrews Bot, Reposit, t. 116. Bot. Mae, t. 1966, 2843. Bot, Reg. t, 1411. A. Richard Flor, Nov, Zeel, t. 28. Hooker Ic. t, 66. Royle Himalay. $t$. 63. $f$. 2. A nd rom eda e s p. Auct. Venten. Choix I. 83. A. Richard Flor. Nov, Zeel. t. 27.

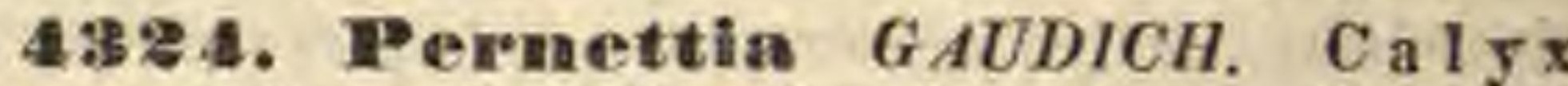
quinquepartitus, fructifer haud mutatos. Corolla hypogyna, ovata, limbo quinquefido. Stamina 10 , imae corollae inserta, inclusa; filamenta subulata, antherae dorso muticae, apice bifidae, lobis biaristatis. Squamula e hypogynae 10 , basi connatae. Ovari u m quinqueloculare, loculis multiovulat:s. St y I a simplex; stigma obtusum. B a c $\mathrm{ca}$ globosa, quinquelocularis, placentis angulo centrali adnatis. Se mi. n a plurima, testa crassa. - Frutices in $A m$ erica australi extratropica indigeni; foliis alternis, sempervirentibus, serratis, pedunculis axillaribus uni-paucifloris, bracteolatis.

Pernetila Gaudichaud in Annal. sc. nat. T. 102. Erejeinet 454, $t, 67$. Liudley in Bot. Reg, $t$, 16:5. A $\mathrm{r}$ h uti spee. Forst. Bot. Mag, t. 3093.

4325. A rolbutes TOURNEF. C a l y $x$ quinquepartitus. Corolla hypogyna, globoso-v, orato - campanulata, limbo quinquefido, reflexa. Stam ina 10 , imae corollae inserta; fil a m en$t$ a brevia, a nthera a latere compressae, dorso infra apicem aftixae et reflexo-biaristatae, apies biporosae. Ovarium diseo hypogyno cinctum $v$. semiimmersum, quinquelocolare, loculis multiovulatis. Sty ins simplex; 8 tigma obtusum. Ba $6-$ c a subglobosa, granulato-tubereulata quinquelocularis, placentis ex apice anguli centralis pendu- 
lis, solutis. Semina in loculis pauca, angulata, testa coriacea. - Arbusculae v. frutices, in Europa australi, in insulis Canariis, et in America boreali, Mexico et Chili crescentes; foliis alternis, integerrimis $v$. dentatis, $r a$ cemis terminalibus paniculatis, floribus pedicellatis, bracteatis, corollis albis $v$. curneis.

A r b ut us Tournef. inst. 368. Gïrtner T. 284. $t$. 59. Kunth in Humb, et Bonpl. Nov. gen, et sp. IIT. 289. t. 260. Une do Liak et Hoffmans. Flor. Portug. I. 415. A r but i s p. Linn. E. B. $t$. 2377, Bot. Reg. t. 113. 619. 1753. Bot. Mag. t, 2024. 3177. 3320. Sibthorp Flor. graec. t. 373.

4326. Tneyanthus LOUR. C a ly $\mathrm{x}$ quinquefidus, coloratas. Coroll a hypogyna, campanulata, limbo quinquefido, tubo quinquepartibili, basi foveolis nectariferis. S tam in a 10, imae corollae inserta, inclusa; fil amenta basi dilatata, an $t h$ era e tubuloso-bicornes. Ovari um quinqueloculare, loculis multiovulatis. Stylus simplex; st igma simplex. B a $\mathrm{c}$ c a quinquelocalaris. S e min a ovata, minima. - Frutices sinen$8 \varepsilon s ;$ foliis alternis, ad apices ramorum confertis, ovatis, integerrimis, nitidis, petiolo et costa, interdum etiam marginibus rubris, floribus terminalibus, involucri foliolis pluriseriatis, exterioribus herbaceis, nterioribus pedunculisque subclavatis nutantibus oloratis.

Encyanthus Loureiro Flor. cochinch. 339. Bot. Mag. $t$, 1649. Bot. Reg. $t$. 884. 885 . Meli dor a Salisbury in Horticult. Transact. 11. 156.

432\%. retostapliylos ADANS. CaIy x quinquepartitus. Co rolla hypogyna, globoso - v. ovato - campanulata, limbo quinquefido reflexo. St a min a 10 , imae corollae inserta; $\mathrm{fi}$ lamenta brevia, antherae a latere compres sae, dorso infra apicem affixae et reflexo biaristatae, apice biporosae. Ova rium disco hypogyno cinctum, quinqueloculare, loculis uniovulatis. S t y In s simplex; stigma obtusum. Drupa subglobosa, pentapyrena, pyrenis osseis, monospermis. Sem in a inversa, - Frutices $v$. suffrutices, in $\boldsymbol{E} u$ ropa media et boreali crescentes; foliis alternis, racemis terminalibus, pedicellis bracteatis.

Arctostaphylos Adanson Fam. Ir. 165. Uva Ursi Tournefort inst. 370 . M a irania Necker Elem. $n .363$. Desvaux Journ, Bot. I. 36. A rbuti sp. Lian, Flor, dan. t. 33. 37. E. B. $t$. $714,2030$.

4328. Comarostuplaylis ZUCCARIN. Caly $\mathrm{x}$ quinquefidus. Co roll a hypogyna, globoso-campanulata, limbo quinquefido, reflexo. Stam in a 10, imac corollae inserta; $f i l$ a me $n$ ta brevia, a ntherae a latere compressae, dorso infra apicem affixae, reflexo biaristatae, apice biporosae. Ovarium disco hypogyno einctum, quinqueloculare, rarius sex-novemloculare, locu lis nniovulatis. Stylus simplex; stigma obta sum. Drupa globosa, papillosa, monopyrena, putamine osseo, quinqueloculari, rarius sex-novemloculari, loculis monospermis. Semina inversa. - Frutices mexicani; foliis alternis, sempervirentibus, integerrimis $v$, argute serratis, racemis terminalibus simplicibus.

Comarostaplo ylis Zuccarini Nov. Stipp. fasc. $I I$ 24. - ? Arctostaphyli \& p. Kanth in Humb. ot llorpl. Nov. gen. et sp. $t$, 958.259.

SUBOIBDO HE. VACCINIEAE. C or olla decidua. Antherae semper bipartitae, aristatae v. rarius muticae. $0 \mathrm{v}$ ari u $\mathrm{m}$ inferum. Fruetus baccatus. v. Hupaceus. - Eolia plana, gemmae squamis imbricatae, rarius nudae.

4329. Gaylussacia $H, B, K$, Calyx tubo cum ovario connato, limbo supero, quinquepartito. C orolla calycis limbo inserta, tubulosa, basi ventricosa, limbo quinquefido. St a m ina 10, ealycis limbo inserta, inclusa; fil amenta brevia, anth erae dorso muticae, apice tubuloso-bicornes. Ovarinm inferum, decemlocalare, loculis uniovulatis, ovulis ex anguli centralis apice pendulis. Stylus filiformis, simplex; stig ma depresso-capitatum. D rup a subglobosa, calycis limbo coronata, decapyrena, pyrenis crustaceis, monospermis. Se min a inversa, testa solida, laevi, - Frutices $A$ merica e tropicae et nepalenses; folïs alternis, mucrone calloso terminatis, racemis axillaribus approximatis, floribus bracteatis, coccineis.

Ga y lus s a eia Kunth in Humb. et Bonpl. Nov, gen. et sp. 1IT. 257. Chamisso et Seblechtend. in Linnaca I. 528. VITI. 490. Poht Plant. Brasil. 2. 123_127, L u s s a cia

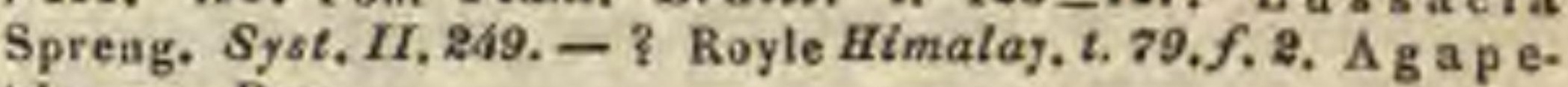
tis s p. Don.

4330. Sphyrospermum PÖPP, et ENDL. C a 1 y x tubo globoso, eum ovario connato, limbo supero, quadri-quinquedentato, CorolI a calyeis limbo inserta, urceolata, limbo quadriquinquedentato. St a mina 4 v, 5, calyeis limbo inserta, ejusilem dentibus opposita, inclusa; $\mathrm{fi}_{\mathrm{-}}$ I a $\mathrm{m}$ e n ta brevia, libera, a n therae dorso muticae, apice tubuloso-bicornes. Ovarium inferum, bi-quadriloculare, loculis multiovulatis, ovulis in placenta anguli centralis basi adnata adscendentibus. Stylus simplex; stigma obtusum. B a ce a globosa, calycis limbo coronata, bi - quadrilocularis, loculis polyspermis. S emin a cuneato - trigona, testa subearnosa, striata. - Frutices peruani, in vetustarum arborum truncis parasitici; foliis alternis, coriaceis, reticulato-venosis, pedunculis axillaribus, solitariis, unifloris.

Spbyrospermu m Póppig et Endlicher Nov, gon. et sp. $I$, 4, t, 8. Hooker Ic. $t$. 112.

4331. Dxyeoceos TOURNEF. Caly $x$ tabo cum ovario connato, limbo sopero, quadrifido. Coro Il a calycis limbo inserta, quadripartita, laciniis reflexe-patentibus. S $\operatorname{tam}$ in a 8 , calycis limbo inserta; filamenta libera, antherao dorso muticae, apice tabuloso-bicornes, $0 \mathrm{v}$ a $\mathrm{r}$ i $\mathrm{u} \mathrm{m}$ inferum, quadrilocnlare, loculis multiovnlatis, ovulis placentae ex angulo centrali prominulae insertis. Stylus simplex; stig ma obtusum. B a cc a glabesa, ealycis limbo coronata, quadrilocularis, polysperma. S e min a plurima, testa membranacea, retienlata. - Fruticuli decumbenies $v$. rarius erecti, in uliginosis Europae et Americae bore alis crescentes; ramis filiformibus, proliferis, foliis alternis, sempervirentibus, racemis axillaribus brevibus, basi hibernaculi squamis stipatis, pedicellis filiformibus, bibracteolatis, corollis roseis, baccis rubris v. rarius albis, grate acidulis.

$0 \times$ ycoceas Tournefort. Inst. 431. Persoon Encheir. r. 419. S eholler a Roth. Flor.germ. I. 170, Va e in il s p. Lian. E. B. $t$. 319 . Fior, dan, $t, 80$. Watson Dendrolog, $t, 3 t$, 122. Bot. Mag, $t$. 2506 .

4332. Vaceinium LINN, Caly $\times$ tubo cum ovario connato, limbo supero, quadri-quinquedentato, rarius integerrimo. Co rolla ealycis limbo inserta, urceolato-campanulata, qquadri-quinquefida، Stamina 8 r, 10, calycis limbo inserta, 
inclusa $v$. exserta; filamenta libera, anthera e dorso muticae v.bisetae, apice tubuloso-bicornes, O va riu m inferum, quadri-quinqueloculare, loculis multiovalatis, ovulis placentae ex angulo centrali prominenti insertis. S $t$ y l us filiformis, simplex; stigma obtusum. B a c ca calycis cieatrice umbilicata, quadri-quinquelocularis, loculis polyspermis. Semin a angulata, testa membranacea, reticulata. - Frutices $v$. suffrutices, rarius arbusculae, in America boreali maximo numero crescentes, rarius in $A m$ e rica tropica, $M a d a$. gascaria, India boreali, in archipelagi sandwicensis montibus, in Europa media et boreali, nec non in Asia subaretica prove nientes; foliis alternis, saepius sempervirentibus, integerrimis $v$. serratis, pedunculis axillaribus, solitariis $v$. confertis, unifloris $v$. racemosis, squamis e gemmarum hibernaculo saepe ad ramorum v. pedunculorum basim persistentibus.

V a e c i n i u Linn. gen, n. 483, excl. sp. Gärtner $I$. 142, t, 28. Schkuhr t. 107. B. B. $t, 581,598$. Flor. daa. t. 10. 231. Watson Dendrolog. $t .32-35.123-125$, A ndrews Bot, Reposit, t, 30, 105. 112. 138. 140. 181, 263.480. Kusth in Humb. et Bonpl. Nov, gen, ot sp. III, 263. t. 348-253, Poht Plant. Brasil. t. 123_125. Gandichand ad Freje. t. 68. Bot. Reg. t. 309. 600. 1354. Bot. Mag. t. 928. 974. 1106. 1152. 1288. 1550, 1607, 2586. Hooker Ic. t. 87, 131. 134. Vitis idea Tournefort Inst. 327. - ? A denaria Rafinesque Flor. Iudov. 56.

4333. Thibaudia PAVON. Cal y $\mathrm{x}$ tubo cum ovario connato, limbo supero, quinquedentato. Cor oll a calycís limbo inserta, tubulosoconiea, limbo quinquedentato. Stamina decem, imae corollae inserta, inclusa; fil am enta basi connata, apice distincta, an thera e dorso muticae, apice tubuloso-bicornes. Ova ri um inferum, quinqueloculare, loculis multiovulatis, ovulis placentae ex angulo centrali prominulae insertis. $S$ t ylu s filiformis, simplex; stigm a capitatum. B a cca calycis limbo coronata, globosa, laevis, quinquelocularis, loculis polyspermis. S em in a testa solida, laevi. - Frutices v. arbusculae, in Peruvia, Madagasearia, Moluccis et Himalayae jugis observati; foliis alternis v. rarissime oppositis, integerrimis $v$. interdum denticulatis, coriaceis, saepius nervosis, racemis axillaribus, so. litariis, ante anthesim bracteis squamosis imbricatis obtectis, strobiliformibus, floribus coccineis.

Thibaudia Pavon msc. ex Kunthin Humb. et Bonpl. Nov. gen, el sp. III. 268. t. 254-236 Ruiz et Pavon Flor. Perup, $t$, 384. inedit. Pöppig et Fudl ch. Nov. gen, et sp. t. 9. Royle Himalay. $t, 79$. Honker IC. $t .108$. t10. 111. Cavin ium Thouar. Gen. Madagase. $n$. 37. A g petis p. D. Don ex $G$ Don Syst. III. 868. - ? S y m ph y 8 i a Presl Epist. ad Jacq, 1827. Ta us chia Preisler in Flora. 1828. p. 43.

43334. Ceratostemana JUSS. Caly tubo cum ovario connato, limbo supero, quinque dentato. Coro 11 a calyeis limbo inserta, tubuloso conica, limbo quinquedentato. St amina 10 , calycis limbo inserta, inclusa; filamenta in urceolum connata, a $\mathrm{n}$ herae dorso muticae, apice tubuloso-hicornes. Or a rium inferum, quinqueloeulare, loculis multiovulatis, ovulis placentae ex angulo centrali prominulae insertis. S t y l us fliformis, simplex; $8 \mathrm{tig} \mathbf{m a}$ capitatum. Ba $\mathrm{c}$. coriacea, calycis limbo coronata, decemcostata, quinquelocularis, loculis polyspermis. Semina testa solida, laevi, - Arbusculae peruanae; foliis alternis, coriaceis, integerrimis, pedunculis unifloris, solitariis $v$. pluribus, e gemmis axillaribus perulatis.
Ceratostemma Jussien Gen, 163. Ruiz et Pavon Flor. Peruv. t. 383. inedit. Pöppig et Bndl. Nov. gen, of sp. $I, 6, t, 10$.

4335. Cavendislaia LINDL. Ca iyx tubo cum ovario connato, limbo supero, eampanalato-truncato, obsolete quadridentato. Corolla calyeis limbo inserta, tubuloso cylindrica, limbo quinquedentato. St a min a 8 , imae corollae inserta, inclusa; filamenta carnosa, monadelpha, connectivis alternis hastatis, auriculis rotundatis, alternis rhomboidalibus, a $\mathbf{t h}$ era e muticae, loculis sulco exaratis, apice liberis. Ovarium inferum, quadriloenlare, loculis multiovulatis. St igma simplex ...... - Frutex peruanus, sempervirens; gemmis magnis, imbricatis, foliis laurinis, floribus capitatis, involucratis, speciosis, purpureis.

Cavendis hia Lindley in Bot, Aeg. n. 1791.

4336. VIracleania HOOK. C al y $\mathrm{x}$ tubo cum ovario connato, pentaptero, limbo supero, obsolete quinquedentato. Coroli a calycis limbo inserta, tubuloso-eylindrica, limbo quinquedentato. Stamina 10, imae corollae inserta, inclusa; filamenta monadelpha, antherae muticae, apice in tubulum simplicem productae. Ovari u m infernm, quinqueloculare, loculis multiovulatis. Stylus filiformis, simplex; stigma obtusum. - Frutex peruanus; foliis alternis, pedunculis axillaribus unifloris, confertis, basi gemmarum squamis superstitibus stipatis.

M a cle a n i Hooker Io. t. 109.

\section{GENUS DUBIUM.}

433\%. Trossaea PLUM. Caly $\mathrm{x}$ tubo $\mathrm{cum}$ ovario connato, limbi superi, quinquefidi laciniis oblongis. C or olla conoidea, calyeis limbum aequans, apice angustata, truncata, integerrima v. crenulata. St a m in a 5 , inclusa. C a p 8 u a calycis limbo ampliato, connivente tecta, quinquelocularis. S emina plurima, minima. - Frutex antillanus, multicaulis; foliis alternis, floribus solitariis axillaribus, v. paucis terminalibus, pedicellis bibracteatis.

B ros s a e a Plumier Qen, 17. Linu. gen, n. 1299. Jus. sieu Gen, 161.

SUEQIED III. RHODODENDREAE. Corolla decidua. Anthera e muticae. Ovari u liberum. Fructus capsularis, septicide dehiscens. - Folia plana, gemmae squamosae, strobiliformes.

4338. Azalea LINN. Caly x quinquepartitus. Corolla hypogyna, subeampanulata, limbo quinquepartito, patente. St a m in a 5 , imae corollae inserta, ejusilem laciniis alterna, faucem aequantia; fil amenta filiformia, antherae ovatre, obtusae, longitudinaliter dehiscentes. Ovarinm bi-trilocalare, loeulis multiovalatis. Stylus simplex, cylindricns; stig ma depressum, annulo cinctum, disco bi-triglandulosam. Ca psula bi-trilocularis, apice septicide bi-trivalvis, columna placentifera fusiformi, compressa v. triquetra, libera. Semin a plurima, testa solida, scrobiculata. - Fruticulus in Europa e mediae et Americae borealis alpibus crescens, procumbens; foliis oppositis, breve petiolatis, ellipticolanceolatis, coriaceis, margine revolutis, nitidis, floribus terminalibus umbellatis, corollis carneis. 
A 2 a l a Linn. Flor, Lappon, 60, t, 6. $f$. 2. Flor, dan. †. 9. E. B. t. 865. Don in Edinb, philosoph. Journ. VI. 48. Lo is ele u ria Desvaux in Journ. Bot. $t$. 35. Turpin Ail. II. t. 71, C h a m a el ed on Link Enumerat, 1, 210.

4339. Kalmaia LINN. Caly $x$ quinquefidus, Corolla hypogyna, subhypocrateriformi infundibularis, tubo foveolis, antheras sub aestivatione recipientihus impresso, limbo quinquefido. St a m in a 10 , imae corollae inserta, limbum subaequantia; fil a menta filiformia, a n $t h$ erae loculis apice poro obliquo dehiscentibus. Ovar i $\mathbf{~ m}$ quinqueloculare, loculis multiovulatis. Stylns elongatus, persistens; stig ma capitatum. C a p s u la subglobosa, quinquelocularis, septicide quinquevalvis, placentis in columnam liberam connatis. Semina plurima, testa solida. Frutices boreali a mericani; foliis alternis $v$. ternato-verticillatis, sempervirentibus $v$. interdum deciduis, racemis terminalibus corymbosis, rarius pedunculis axillaribus, unifloris.

$\mathrm{K}$ a Imia Linn. gen, $n$, 545 . Schkuhr Hands, $t, 116$. Gärtner $T$. 305, t. 63. Bot. Mag, $t, 138.175,17 \%$.

4340. Fhodothamenus REICHENB. C a ly $\mathrm{x}$ quinquepartitus. Corolla hypogyna, rotato-quinqueloba, patentissima. S ta m i a 10 , hypogyna; fil ament a filiformia, patentia, anth era e muticae, loculis apice poro obliquo dehiscentibus. Ovarin m quinqueloculare, loculis multiovulatis. S t y l us filiformis; $8 \mathrm{t} i \mathrm{~g}$ m a capitatum. Ca p s u la globesa, quinquelocularis, loculicide quinquevalvis, placentis brevibus columnae tandem liberae adnatis. Semina plarima, scobiformia. - Fruticulus spithameus, in Europa media alpicola; ramis adscendentibus, foliis alternis, ovalibus, breve petiolatis, subtus albo-punctatis, ciliato serratis, flore terminali solitario, longe pedunculato, roseo.

Rhod ot ha m n us Reichenbach Flor. germ, excurs. 417 . Cham aecist $\mathrm{s} s$ Gray Brit. Plant, $I T$. G01, Rhodod en. dron Chamaecistus Lina. Jaeq. Flor, austr. 2. 217. Schkuhr $t$. 117.

434 1. IBthodiodemallaom LINN, Caly $\mathrm{x}$ quinquepartitus. Coroll a hypogyna, infundibuliformis $v$, subcampanulata, limbo quinquefido $v$. rarius septemfido, aequali $v$. subbilabiato. St am in a hypogyna $v$. imae corollae inserta, ejusdem laciniis numero aequalia $(5), \mathbf{v}$. saepius dupla (10 v. 14); fil am en ta filiformia, adscendentia, a ntherae muticae, locnlis apice poro obliquo dehiscentibus. Ovarium quinqne-decemloculare, loculis multiovalatis. Stylus filiformis; $s t \mathrm{~g} m$ a capitatam. Capsula globosa v. oblonga, quinque-decemlocularis, septicide quinque-decemval vis, columna centrali placentifera libera. Se min a plurima, testa laxa, reticulata, scobiformia. - Frutices v. arbores, in Europae et As iae mediae alpibus, in Americaboreali, in India e terra continenti et insulis sponta $n e i$, in hortis mutuo specierum commercio, et officio sae Adonistarum manus lenocinio formis plurimis hybridis multiplicutae; foliis alternis, integerrimis, sempervirentibus $v$, deciduis, floribus corymbosis, speciosis, luteis, roseis, purpureis v. albis.

R trododendron Lion. gen, n, 348. Gärtner I, 403. t. 63. Don in Edinb, philosoph. Journ. VT, 49.

a. ANTHODKNDRON Reichenb. C or olla pentamera, lim. bo snbbilabiato. Stamina 5. Ovariam pentamerum. Flores flavi. Species ung orientalis, rolinuae boreali.americanac. - Anthodeadron Rei.

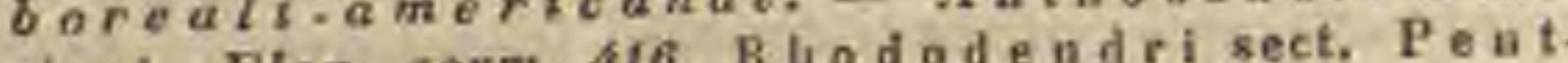
clienb. Flor. germ. 416 . R li 0 d o d e nd ri sect. Pet Auct. a ut hera Dou $S_{y}$ t. $I I I, 846$. Azalene sp. Linn, et Auct.
Andrews Bot. Reposit, t. 16. Bot. Mag. t. 172, 433. Bot. Reg, t. 414 .

b. RHODORA Linn. Co roll a pentamera, distincte bilabiata, labio superiore trilobo, inferiore bipartito. Stamín a 10. 0 varium pentamerum. - Flores rosei. Species boreali-americana. - Rhodora Linn, gen. S67. Heritier Stirp. I. t. 68. (Bot. Mag. t. 474.)

c. EURHODODENDRON. C orolla campauulata, pentame. ra. Stamina 10. Ovarium pentamerum. - Species gerontogeae et borealiamerioanae. Virey a Blume Bijdr. 854. (Jaeq. Flor. austr. t, 98. 255. 10. rar. $t$, 78. Bot. Mag. $t, 636,650,951,1458,1480.1671$. 2985. 2667. 3106. Bennett in Plant. favan. Horsfield. t. $19-20$.

d. BOORAM. C or olla pentamera, campanulata. Stam in a 10. 0 va ri um octo.decamerum. - Speoles indicae. (Smith Exot. Bot. t. 6. Hooker Exot. Flor, t, 168. Bot. Reg, t. 896. Sweet Fl. Gard. II. $t$, 241. Wallich Plant. As. rar. t. 123, 207.)

e. HYMENANTHES Btum, Co rolla campanulata, heptamera. Stamina 14. Ovarium pentamerum. - Species japonica. - H gmenanthes Blume Bijdr. 826 . Rhododendron Metternichii Siebold et Zuecariui Flor. japon, t. 9.

4342 . IBeforia MUTIS, C aly x sex-septemfidus. Cor oll a e petala sex v. septem, hypogyna, ereeta v. patentia. St a m in a 12 v. 14, hypogyna; fil amenta filiformia, antherae muticae, loeulis apice poro obliquo dehiscentibus. Ovari um sex-septemloculare, loculis multiovulatis. S ty l u g filiformis; $8 \mathrm{t}$ ig ma depresso-capitatum, radiatosulcatum. Capsula sex -septemloeularis, septicide sex-septemvalvis, placentis columnae centrali adnatis. Semin a plurima ..... - Frutices in America boreali a ustraliore et in al pibus peruanis crescentes; foliis alternis, saepe confertis, coriaceis, integerrimis, floribus terminalibus racemosis $v$. corymbosis, saepe purpureis.

B ef aria Mntis in Linn. Al. Suppl. 246. L. C. Riehard in Mtchaux Flor. Bor. Amer. t, 26. Venten. Cels, t. 51. Humb. et Bonpl, Plant, aequinoct, t, $118-121,177$, Kauth Nov, gen, et sp. III. 291. Pöppig et Eadl. Nov. gen. et sp, I, 24, $t$. 39. B e ja ri a Adr. Jussieu in Dict. class. II. 258. A c u a Ruiz et Pavon Prodr. 69. t. 19.

4343. Heioplinglam PERS. C a $1 \mathrm{y} x$ quinquepartitus. C o ro il a e petala 5, hypogyna, patentia. St a min a 10 , hypogyna; filamenta filiformia, patentia, a nth erae didymae, localis longitudinaliter dehiscentibus, O v a ri u m tri-quinquelocalare, loculis multiovulatis. Stylus simplex; s tig ma annulatum, diseo tri-quinqueglandulosum. C a p s u la tri-quinquelocularis, septicide ab apice ad basim tri-quinquevalvis, placentis coInmnae centrali adnatis. Se min a plurima, ovata, minima. - Fruticulus boreali-americanus; foliis alternis, ellipticis, utrinque glaberrimis, floribus terminalibus, fasciculato-corymbosis, albo-rubentibus.

Leio phy 11 um Persoon Encheir. , 477. Donia Edinb. hilosoph. Journ. VI. 50. A m m y r in e Pursh Flor. Bor. Amer. I. 301. Fis e her a Swartz in Mem, soc. h. n. Mosq. V. 14. $t$. 1. D e u d r i u mesvaux Journ, Bot, $I$. 36. L e d и un uxifolium Bergius in Act. Petropolit. 1777, p. I. t. 3. f. 2. Bot. Reg. $t, 531$.

4344. Thedum LINN. Calyx quinquedentatus. Corolla e petala 5 , hypogyna, patentissima. $\mathrm{S}$ ta $\mathrm{m}$ in a $10 \mathrm{v}$. rarius 5 , hypogyna; $\mathrm{fi}-$ lamenta filiformia, patentia, antherae muticae, loculis apice poro obliquo dehiscentibus. Ova $r$ i $\mathbf{~ m}$ quinqueloeulare, loculis multiovulatis. Stylns simplex; 8 tigma annulatum, disco quinqueradiatum. Ca p $\mathbf{s}$ u a quinquelocularis, septieide a basi ad apicem quinquevalvis, placentis e 
columnae centralis filiformis apice dilatato, valvas connectente pendulis. S e m in a plurima, testa relaxata, reticulata, scobiformia. - Fruticuli in paludosis frigidiusculis hemis phaerae borea$l i s$ crescentes; foliis alternis, coriaceis, linearibus v. ellipticis, subtus ferrugineo-tomentosis, floribus terminalibus, umbellato-fasciculatis.

Le d u m Linu. gen. n. 546. Gärtner II. 145. t, 112. Sehkuhr 2. 177, Jaeq. Ic, rar, t. 464. Flor, dan, t. 567, 1031. Hooker Flor, Lond. 1. 212. Don in Edinb. philosoph. Journ, VI. 50.

\section{ERICACEIS AFFINES.}

\section{"DIAPENSIACEAE.}

4345. Diapensia LINN. C a 1 y $\mathrm{x}$ imbricato-tribracteatus, pentaphyllus, foliolis herbaceis, duobus interioribus duplo minoribus. Co rolla hypogyna, subhypocraterimorpha, limbi quadrifidi laciniis aestivatione imbricatis. Stamina 5, corollae fauci inserta, ejusdem laciniis alterna; filam enta brevia, petaloideo dilatata, a $n t h$ e r a e biloculares, transversim bivalves, valvalis mnticis. Discus hypogynus nullus. Ovarium triloculare, loculis multiovulatis. Sty Ins filiformis, simplex; stigma obsolete tridentatum. Capsula cartilaginea, rotundato trigona, trilocularis, apice loculicide trivalvis, val vis basi cohaerentibus, medio septiferis, placentis fungosis, columnae centrali adnatis, basi solu tis. S emina plurima, sulscubiea, testa membranacea, areolata, umbilico infra apicem ventrali. Embryo in axi albuminis carnosi, mollis filiformis; cotyledonibus brevissimis, radicula elongata, umbilico parallele contigua. Suffrutices Europae et Americae arctica e, caudicibus hypogaeis, caespitosis, herbaceis, caespitulos dense foliosos, perennantes promentibus; foliis sempervirentibus, coriaceis, linearibus, margine re volutis, pedunculo solitario unifloro, erecto.

D I a p e nsia Linn. Flor. Lappon, s8, t. 1. f. 1. Flor dan. t. 47. Wahlenb. Flor, Lappon. 58. t. 9. S. Sensk. Bot t. 517. Lindley Introduct. edit. $11, p, 233,443$.

4346. Pyxidanthera $L$. C. RICH. Calyx imbricato-tribracteatus, pentaphyllus, foliolis membranaceis, subaequalibus. Coroll a hypogyna, subhypocraterimorpha, limbi quinquefidi laciniis aestivatione imbricatis. Stamina 5 , corollae fauci inserta, ejusdem laciniis alterna; $\mathrm{fi}$ lamenta brevia, petaloideo dilatata, antherae biloculares, transversim bivalves, valvula inferiore aristata. Discus hypogynus nullus. Ovarinm triloculare, loculis pauciovalatis. Stylus simplex; stigma brevissime tridentatum. Fru ctus ..... Suffruticulus boreali-a mericanus, repens; ramulis assurgentibus, foliis inferioribus oppositis, superioribus confertim allernis, coriaceis, cuneato-lanceolatis, basi interiore barbatis, integerrimis, in marginem ciliatum subdecurrentibus, flore terminali solitario, inter folia sessili. Pyxid an the ra L. C. Riehard in Michauz Flor, Bor,
Amer. I, 158, t, 17.

\section{** PYROLACEAE,}

134\%. Cladothamums BUNG. C a 1 y ab basim quinquepartitus, laciniis ellipticis, sub. inaequalibus. Corollae petala 5 , hypogyna, elliptica, obtusa, subinaequalia, ealyce duplo lon giora, patentia. St amin a 10, hypogyna, brevia; fila m e n t a basi dilatata, ant herae adnatae (?) biloculares, loculis apice obtuso rimula brevi sublaterali dehiscentibus. O var i $\mathrm{m}$ globosum, quin-
que -v. rarius sexloculare que - v. rarius sexloculare, loculis multiovalatis. Stylus filiformis, apice incurvus; stig ma globosum, subquinquelobum. Capsula subglobosa, quinque-sexlocularis, septieide quinque-sexvalvis, placenta centrali quinque-sexloba. S e m in a plarina, ovata, nucleo intra testam relaxatam, celinlosam ovali ...... - Frutex in America arctica occidentali indigenus, saepe orgyalis, ramosissimus; ramis teretibus, foliosis, junioribus albicantibus, glabris, foliis sparsis, sessilibus, ellipticis $v$. oblongis, basi angustatis, apice obtusiusculis cum cuspide brevi, integerrimis, glabris, junioribus margine tenuissime ciliatis, subtus glaucescentibus, nervosis, floribus axillaribus, solitariis , breve pedunculatis. C Iad ot ham n s Bunge in Mem. Academ. St. Po-
tersb. Nouv. Ser. II. 155, t. 1 .

4348. Chimoplaila PURSH. Calyx quinquefidus. Coroll a e petala 5 , hypogyna, patentia. St a min a 10, patentia; fila menta complanata, medio in discum dilatata, a pice angustata; a therae biloculares, dorso affixae, extrorsae, demum introflexae, loculis basi sursum spectante diseretis, tubulosis, poro dehiscentibus, polline violaceo. Ovariu in depresse-subglobosum, umbilicatum, quinqueloculare, loculis multiovulatis. Stylus brevissimus, ovario immersus; stigm a orbienlatum, disco quinquetuberculato. C a psula depresso-pentagona, quinquelocularis, apice locolieide quinquevalvis, valvis medio septiferis, margine nndis, placentis fungosis, columnae centrali adnatis. S e m i n a plurima, scobiformia, nueleo intra testam utrinque relaxatam, laxe cellnlosam subgloboso, minimo. E mbryo in basi albuminis dense carnosi minutissimus, umbilico extrali proximus, axi longitudinali integumenti externi transversus, centripetus. - Suffruticuli sempervirentes, in Eu ropa et Ame rica boreali indigeni; foliis sparsis $v$. verticillatis, coriaceis, lanceolatis $v$. cuneatis, serratis, pedunculo tereti, apice umbellato $v$. corymboso, pedicellis minute
bracteatis.

Ch Im op hil a Pursh Flor. Amer. bor. I. 300. Nuttall Gen. 1. 274. Radius Dissert. de Pyrota 33. t. 5. f. 2, Don Pseve Rafinesq. Obs, $\mathrm{P}$. 243 . Chimaza R. Brown misc. dan. $t, 1336$, P. Obs, P y rola $\mathrm{umbellata} \mathrm{Linn.} \mathrm{Flor.}$ dan. $t, 1336$. P. maculata Linn. Bot. Mag. $t$. 897 .

1345. Pyrola TOURNEF. C a I y $\mathrm{x}$ quinquefidus v. quinquepartitus. Coro 11 a e petala 5 , hypogyna, patentia v. campanulato aut subgloboso conniventia. Stamina 10, hypogyna, erecta v. adscendentia; filamenta complanata, apice angustata, a $t$ h era e biloculares, dorso affixae, extrorsae, demum introflexae, loculis basi sursum spectante discretis, tubulosis, poro dehiscentibus, polline luteo. Ovarinm angulato subglobosum, quinqueloculare, loculis multiovnlatis. Stylas filiformis, erectus v. declinatus; stig ma capitatum, annulatum, disco quinquetuberculatum, $\mathrm{C}$ a p$8 \mathrm{ula}$ globoso-pentagona, quinquelocularis, basi loculicide quinquevalvis, valvis medio septiferis, margine tomento tenui connexis, placentis fungosis, colnmnae centrali superne adnatis. Se mina plurima, scobiformia, nuclea intra testam utrinque relaxatam, laxe cellulosam minimo, subgloboso. E m b r yo in axi albuminis dense carnosi minutissimus, umbilico ventrali proximus, axi longitudinali integumenti externi transversus, centri-
petus. - Herbae biennes $v$. perennes, in $E$ urop $a$, 
in Asiae et Americae borealis umbrosis sylvaticis obviae, stoloniferae, acaules v. subcaulescentes; foliis radicalibus $v$. caulinis alternis, ovato-cllipticis $v$. suborbiculatis, coriaceis, sempervirentibus, crenatis $v$. serratis, pedunculis scapiformibus, squamis paucis adpressis, racemum simplicem, saepius secundum, pedicellis minute unibracteatis prominentibus, rarius unifloris.

P y ro la Tournefort inst. 132. Linn. gen, $n, 554$. excl. sp. Gïrtner I. 303. t. 63. Seringe Mus. Helvet. 3. 33, exel. sp. Radius Dissert, de Pyrola $\boldsymbol{I}$. $\boldsymbol{B}$.

a. PYROLA Salisb. Pedunculus racemosus. - Pyro 1 a Don in Mem. TVerner. Soc, $V$. 228. Schiuhr $t$. 119. Flor, das, t, 55. 110. 402.1693 .1816$. E. B. $t, 213.517$. 1945. 2543. Hooker Elor. lond. t. 26. 30, 153. 202. Radies $t, 1$ - 5 .

b. MONESES Salisb. Pedunculus unifloras. - Maneses Salisbury in Gray Brit. plant. I. 403. Don in Mem. Werner. soc. 242, Pyrol a aniflora Linn. Schkulir $t$, 119. Flor. dan. $t$. 8. E. B. $t, 1 / 6$, Hooker Flor. lond. t. 207.

4350. Falax $L I N N$. C a I y $\mathrm{x}$ quinquepartitus, subcampanulatus. Co r o 11 a e petala 5, hypogyna, subspathulata, campanulato-conniventia, apice patentia. Stamina 10 , hypogyna, in tubum cylindraceum apice decemfidum connata, laeiniis alternis petalis oppositis elongatis, spathulatis, anantheris, alternis brevissimis, crassinsculis, antheriferis; a ntherae introrsae, adnatae, uniloculares, rima transversa bivalves. O varium ovatum, apice attenuatum, tri-v. rarius quadriloculare, loculis multiovulatis. Styl us brevis; stigma subcapitatum. Ca p sula ovoidea, tri-quadrilocularis, apice loculicide tri-quadrivalvis, valvis medio septiferis, columella seminifera rarius persistente, plerumque tri-quadripartibili, lobis dissepimentorum margini adnatis. Semina plurima, angulata, utrinque mucronata, testa rugosa, laxa, nucleum minorem inclndens. Em b r yo in axi albnminis carnosi teres, curvulus, radic u la umbilieo basilari proxima, centripeta. - Herba boreali-americana, perennis, acaulis; radice repente, saturate rubra, folits radicalibus petiolatis, cordato-suborbiculatis, serratis, scapo gracili, ima basi squamoso, caetera nudo, racemo terminali spicaeformi, floribus albis, exiguis, pedicellis brevissimis, basi minute unibracteatis.

Q a l a x Linn. gen. n. 276. Bot. Mag. t, 750. Don in Edinb, new philoph, Journ, VI. 53. Erythrorhiza L. C. Richard in Michaux Flor. Bor. Amer. If. 35. t. 36. Gärtner f. III. 150. t. 210. Solen a udria Palisot ex Venten. Malmais. 1. 69. B I a udfordia Andrews Bot, Heposit. t. 343. Viticella Mitehell in A. N. C. 24.

\section{*** MONOTROPEAE.}

43ร1. Niomotropa NUTT. $\mathrm{C}$ alyx te traphyllus, foliolis squamaeformibus dissitis, a flore remotis, antico infimo duobus lateralibus oppositis approximato, postico supremo corollae admoto. Corolla e petala 5 , hypogyna, campanulatoconniventia, basi gibbo nectarifero. Sta m in a 10 , hypogyna, inclusa; filamenta subulato-compianata, a n thera e peltatae, horizontales, rimis transversis bivalves. Ovarium ovato-conicum, quinqueloculare, loculis multiovulatis. Stylus brevis, crassus, fistulosus; $s$ tig $\mathrm{m}$ a orbiculatum, quinquecrenatum, imberbe. $\mathrm{C}$ a $\mathrm{p} s \mathrm{u}$ la quinquelocularis, loculicide quinquevalvis, valvis medio septa axi placentifero inani adnata gerentibus. Se- m in a plurima, scobifurmia, nucleo intra testam relaxatam, eellulosam minimo. Embryo .... Herba b or e ali-americana, in arborum radicibus parasitica, inodora; radicibus intricatis, grumosis, scapo simplici, remote $v$. dense squamoso, unifloro

Monotropa Nettall Gen, $I$. 2at. M. u n ifl or a Linn. Hooker Exot, Flor, $t$. 8S. Turpin AU, II, $t, 76$.

435\%. Hypopithys DILLEN, C a ly tri-pentaphyllus, foliulis squamaeformibus, corollae admotis, C or olla e petala 4 v. 5 , hypogyna, in tubum conniventia, basi gibbo nectarifero. S $t$ am in a 10, hypogyna, inclusa; fi la menta subulato filiformia, an therae peltatae, horizontales, rima transversa dehiscentes, demum explanatae. O vari um ovatum, quinqueloculare, locnlis multiovulatis. Sty 1 n s filiformis, simplex, fistulosus; st ig m a dilatato-orbiculatum, margine barbatum. C a p s u l a quinquelocularis, loculicide quinquevalvis, valvis medio septa axi centrali inani adnata gerentibus. Semina plurima, scobiformia, nucleo intra testam relaxatam, laxe cellalosam minimo. - Herbae in Europa media et $A m e-$ rica boreali in Pinuum et Fagorum radicibus parasiticae; radicibus intricato-grumosis, scapo squamoso, apice racemose paucifloro, flore terminali pentamero, lateralibus tetrameris.

H y popith ys Dillen Gen, \%. Nuttall Gen, 270, M 0no tro pa e 8 p. Lian. Sehkuhr $t$, 16. E. B. $t$. 68. Flor. dan. $t$. 232. Gärtner $I I I, 45$, t. 185 . Hooker Flor. Lond. t. 105. Reichenb, 1conogr. $f$. 674. 675 .

\section{4\$53. Pterospera NUTT, C a $1 \mathrm{y} x$} quinquepartitus. Corolla hypogyna, campanulata, tubo subgloboso, demum quinquepartibili, limbo quinquefido, reflexo. St a $m$ in a 10 , hypogyna, inclusa; filamenta complanato-subulata, antherae biloculares, basi conduplicata biaristatae, longitudinaliter dehiscentes. Ovarium globoso-pentagonum, umbilicatum, quinqueloculare, loculis multiovulatis. Stylus brevis, crassus; stigma conicum, quinqueradiatum. C ap sula depresse globosa, pentagona, umbilieata, stylo persistente snperata, quinquelocularis, apice loculicide quinquevalvis, valvis medio sep. tiferis, placentis crassis, earnosis, axi centrali adnatis. Semina plurima, horizontalia, subglobosa, testa tenui, fragili, reticulata, apice in alam duplicem cristaeformem cellulosam expansa. A1. b umen carnosum, copiosum. Em b r yo ?.....

Herba canadensis, orobanchoidea, brunea, viscido pubescens; caule simplicissimo, stricto, squamis lineari lanceolatis, alternis vestito, racemo terminali, elongato, pedunculis brevibus, basi ninute unibracteatis, nutantibus.

P te r ospora Nuttall Gen. 1,269. Lindley Collect. t. 5 .

4354. Selnweinitzia ELLIOTT. Ca1 y $x$ pentaphyllus, foliolis concavis. Corolla hypogyna, campanulata, calycis longitudine, limbo quinguefido, tubo basi intus coronula nectarifera, quinqueloba. Sta m ina 10 , hypogyna, inclusa; fil am enta subulata, a ntherae adnatae, basi inversa poris duobus muticis dehiscentes. Ovar i $\mathbf{m}$ quinqueloculare, loculis multiovulatis. St ylns brevis, crassus; s $\mathrm{tig}$ m a subglobosum, quinquetubercnlatum. Ca p sula ...... - Herba $b$ o. reali-americana, parasitica, aphylla; scapo squamoso, floribus terminalibus, sessilibus, aggregatis, late bracteatis.

Schweinitzia Blliott ex Nuttall Gen. II. add. p. 270. Monots opsis Schweigitz in Elliott Carolin. $I$. 478. 


\section{COHORS IV. DIALYPETALAE.}

Perigonium duplex, exterius liberum v. cum ovario connatum, calycinum v. interdum coloratum, interius corollinum, elementis liberis v. rarissime staminum ope basi cohaerentibus, insertione hypogynis v. perigynis, interdum abortu nullum.

\section{Classis XL. Discanthate.}

Herbae, fruticesv. arbores. Folia alterna v. opposita, simplicia v. composita. Flores hermaphroditi v. abortu diclines. Calyx gamophyllus, tubo cum ovario v. ejus basi connato, rarius libero. Cor olla e petala distincta, disco perigyno v. epigyno, rarius hypogyno inserta, calycis laciniis numero aequalia et alterna, interdum nulla. S $\mathrm{ta}$ in a numc eum petalis inserta et iisdem numero aequalia et alterna, rarius iisdem inserta et opposita v. dupla. Ov a ri u m bi-quinqueloculare, loculis uniovulatis $v$, rarissime pluriovulatis; ovulis pendulis v. interdum erectis. Fructus loculis monospermis. Semina albuminosa. Emb ry o orthotropus.

\section{Ordo CLXI. Unebelliferce.}

UMBELLATAE Tournefort inst, $30 \mathrm{~s}$. Linne Praeleot, in Ord. nat, edit. Gieseke p. 308. Adanson Fam, II. 89. Gussone in Mem. soc, medic. Paris, 1788. SCIAD0. PHXTUM Necker Elem. I. 168. UMBELLIFBRAE Jussieu Gen. 218. Sprengel, Rlantarum Umbelliferarum denuo disponendarum prodromus, Hallae, 1813. 4. Species Umbelliferarum minus eognitae. Hallae, 1818. 4. Römer et Sehultes Syst. VI. p. XXIX. Hoffaann, Genera Umbelli ferarum, Alosq. 1814. 8. Edit. II. Ibid. 1816. 8. Vela in Lagasca Amenital. nat. 1821. IT. 61. Lagnsea Ibid. 87. ss Observac, aparasol. in Ocios Espagnol, emigrad. Lond 1826. p. 35_156. Koch, Generum Umbelliferarum nova dispositio in N. A. N. C. XII, 55. seq. Bartling Ord. nat. 234. DC. Memotre sur la Famille des Ombellifores. Parit. 1829. 8. Prodr. IV. 55. Tausch in Flora 1834, p.337. Meisner Gen. 139. (102.) UMBELLACEAB Lindley Feg n. 11 . UMBELLIFERAE v, APIACEAE Lindley Introduct. edit. 2 . p. 21.

Herbaf annuae v, rhizomate perennes, interdum sufrutescentes, radice varia, saepius fusiformi. Caul is teres v. angulatus, saepissime sulcatus, striatus, nodis ut plurimum perfectis, simplex v. alternatim ramosus, medulla saepius ampla farctus, interdum fibris per medullam sparsis caulem amphibryum mentiens. Foli a alterna, interdum omnia radicalia, rarissime infima opposita, simplicia, saepissime dissecta v. partita, petiolo basi plus minns dilatato, vaginante, superiorum lamina abortiva, saepins cueullata, v, omnium in phyllodium verticale mutato.

Fuores hermaphroditi, v. ahortu unisexuales, albi, rarius purpurascentes, ochroleuci v. flavi, umbellati, exteriores interdum radiantes. Umbella e simplices, multiradiatae v. capitatae, dichotomae aut irregulariter divisae $\mathbf{v}$. pauciflorae, nunc compositae, umbellulis nempe in umbellam dispositis, involucro generali involucellisque partialibus cinctae, alterutro saepius evanido, rarius utroque deficiente.

CaLYX tubo cum ovario connato, e foliolis quinque uni-plurinerviis conflato, limbo supero, truncato, obsoleto v. nullo, nunc quinquelobo, lobis dentiformibus $v$. foliolosis, persistentibus v. deciduis.

Coroluas petala quinque, dis e o summum calycis tubum vestienti $v$. distincte epigyno extus inserta, ejusdem lobis alterna, integra, emarginata v. biloba, apice plana v. in Iacinulam replicatam aut involutam producta, aestivatione subimbricata v, valvata, exteriora umbellae interdum majora, rarissime omnia abortiva.

Stanisa quinque, cum petalis inserta, iisdem alterna. Filamenta brevia, filiformia, aestivatione replicata. Antherae introrsae, biloculares, ovatae, subdidymae, loculis longitudinaliter dehiscentibus.

Ovaвium inferum, biloculare, rarissime abortu uniloculare. Ovula in loculis solitaria, pendula. Styli 2, terminales, simplices, basi plus minus in stylopodia ovarium tegentia inerassati, erecti, demum divergentes v. rarissime decidui, alter ambitum, alter centrum umbellae spectans.

Froctus (diachaena, polachaena, cremocarpium) saepissime calycis limbo stylisque persistentibus coronatus, e carpidiis (mericarpiis) duobus, maturitate cum calycis tubo secedentibus, ex apice columnae centralis duplicis, filiformis (carpopliori), saepissime plus minus in unicam connatae pendulis, rarius pertinaciter cohaerentibus v. alterius abortu solitariis constans, extus nervis primariis (jugis) decem, aliis nervos foliolorum calycinorum medios sistentibus (jugis carinalibus) in dentes calycinos productis, aliis ex eorundem sutura provenientibus in dentium sinus tendentibus (jugis suturalibus), interdum aliis secundariis Gugis secundariis) cum primariis alternantibus, e foliolorum calycinorum nervis lateralibus provenientibus. Mericarpiorum juga primaria quinque, dorsale unicum, intermedia dno, totidemque lateralia; mericarpii alterius jugo dorsali lateralibusque carina. libus, alterius homonymis suturalibus, omnibus plus minus productis v. obsoletis, saepissime symmetrice inaequalibus, plus minus approximatis $\mathbf{v}$, interstitiis (valleculis) remotis, lateralibus saepisse mericarpiorum plano commissurali approximatis v. impositis. C a n a les resiniferi (rillae) intra pericarpium coeci, ex 
apice ad basim directi, in valleculis v. commissura solitarii v. gemini aut plurimi, rarius sub jugis siti, interdum nulli v, obsoleti.

Semen in quovis mericarpio unicum, inversum, te st a cum pericarpio connata v. rarius distincta. Alb ume $\mathrm{u}$ copiosum, carnosum v. subcorneum, dorso plus minus convexum, facie carpophorum respiciente planum v. subconvexum (in Or(hospermis), v. lateribus involutum (in Campylospermis), aut rarius a basi ad apicem incurvatum (in Coelospermis).

Euвrxo in apice albuminis brevis, rectus. Cotyledones oblongae, subinaequales, germinatione in folia seminalia conversa. Hadicula supera.

Umbelliferae in regionibus mediterraneis et Asia media imprimis copiosae, inter tropicos rarae, singulari fructus fabrica el habitu facillime cognoscuntur, solis Araliaceis arctius affines.

Radices plurium carnosae, sapidae, aliarum herba edulis, aliarum cortex gummi resinoso, plurimarum fructus oleo aethereo v. resina aromatica scatens.

Generum limites et ordinatio problematica, discriminatio difficillima.

SUEORED I. ORTHOSPERMAE DC. Prodr. IV. 58. A I b u men latere interiore planum, nec convolutum nec involutum.

TREIBUS I. HYDROCOTYLEAE DC. Prodr. IV. 58. Fruetus a latere contractus. M ericarpia dorso convexa v. rarius acuta; juga primaria 5, interdum obsoleta, lateralia marginantia v. in commissuram rejecta, intermedia plerumque prae carinali lateralibusque prominula; jug a secundaria filiformia, subnulla v. penitus obsoleta. Al bumen antice planiusculum. Petal a patentia, integra, acuta, apice recto v. subinflexo. - Herbae saepius aquaticae, rarius suffrutescentes.

Hydrocotyleater $65^{\circ}$ L. B. et $55^{\circ}$ L. A. inclusae, frequentissime sub caelo tropico gignuntur. Nova Hollandia generum, America imprimis inter capricornum et aequatorem specierum est feracissima, inde trans circulum tropieum usque extremas novi continentis insulas suae generis plantae minori copia emergunt, boream versus in America non ultra $45^{\circ}$ L. B. repertae, europeae paucissimae, eaeque simul late per orbem vulgatae, ex Asia boreali plane exules. Capenses paucae, sed habitu proprio insignes, in Indiae continente et insulis rarae, nonnullae oceanicae, in Africa tropica et boreali nondum repertae.

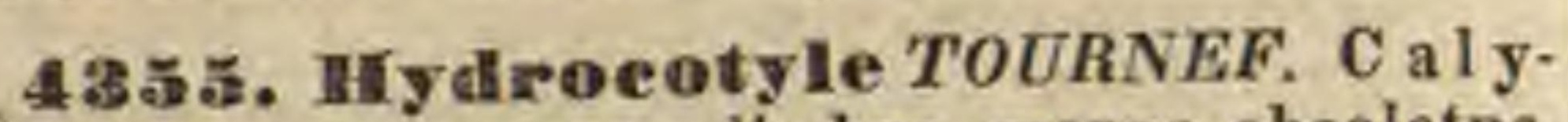
cis tubus compressus, limbus margo obsoletus.
P et a la ovata, integra, acuta, apice recto. Fructus a latere plano-compressus, biscutatus; mericarpia evittata, jugis filiformibus, carinali marginalibusque saepe obsoletis, intermediis duobus acretis. Se m e n carinato-compressum. Herbae v. rarius suffrutices, in regionibus tropicis temperatisque totius orbis crescentes, saepissime pusillae, tenellae, ut plurimum aquaticae; umbellis simplicibus, involucro oligophyllo, floribus sessilibus $v$, pedicellatis, albidis.

Hydracotyle Tournef. inst, 173. Thunberg Dissert. II. 4tO. A. Richard in Annal, sc, phys, 1820. IV. 164. Lagasca Amen. nat. II. 102. Koch Umbellif. 144. f. 64. 65. DC. Mem, V. 26, Prodr. IV. 59. Meisuer Gen, 140. (102.)

a. EUHYDROCOTYLE DC. Prodr. IV. 39. F r uetus cam. pressus, mericarpiis utriaque uni-bieostatis. - Caules herbacei, saepissime repentes, folia peltata v. basi cordata.

H y drocot yle Lina. gen, n, 325. Choudrocar. pus s. Gly ceria Nuttall Gen. I. 177. Trysanthus Loureiro Flor. cochineh, I. 219. Flor, dan, 1. 90. (Ruiz et Pavon Flor. Peruv, t. 296-248. Cyrill, Plant. Neap. I. t. 6. f. 6. Hooker Exot. Flor. t, 29. 30. A. Richard. Op, cit. t. 52-67. Link et Otto Ie, rar. 1. 21.)

b. CEntella DC. Prodr. IV. 68. Fructus vix compressos, mericarpiis utrinque plaricostatis. - Caules fruticosi, ereotiusculi, folits basi cunatis v. attenua. tis, rarissime cordatis.

Centella Liun. gen, n. 1051. Solaadra Lian. fil. Suppl. 176.

4356 . Crantzin NUTT. C a ly cis tubus s ubglobosus, limbus brevissimus, subnullus. P et a la subrotunda, integra, obtusa. Styli obtusi. F ructus subglobosus, commisura excavata, fere orbiculari; mericarpia inaequalia, jugis 5 filiformibus, lateralibus marginantibus, latioribus, intus crassis, albo spongiosis, valleculis univittatis, commissura bivittata, vittis rufis, distinctis. Seminis sectio transversa orbicularis. - Herbula boreali-americana, glabra, repens, non satis cognila, fortassis ad Ammineas referenda; foliis sessilibus, cuneato-linearibus, integerrinis, transversim lineatis, pedunculis axillaribus erectis, folii longitudine, umbella simplici, octo-decemflora, involucro penta-hexaphyllo, floribus pedicellatis, albis, uniformibus, hermaphroditis.

Crantzla Nuttall Gen. 1 . 17z. DC. Mem. $V$, 27. Prodr. IV, 70. Meisaer Gon. 140. (102.) H y drocotyle líne at a Michaux A. Richard in Annal. se, phys. 1820. IV. $t .68 . f .38$,

435 . Cesatia ENDL, Caly e is tubus compressus, suldidymas, limbus brevissime quinquedentatus. Pet a la ovato-lanceolata, acuta, integra, apice recto. Styli filiformes, patentes. Fructus a latere plano-compressus, basi subcordatus, apice emarginatus; mericar pi is sulerosis, evittatis, quinquejugis, jugo dorsali intermediisque obsoletis, lateralibus marginalibus productis, commissura bisulea. S e min is sectio transversa elliptica. - Herba Novae Hollandiae austro-occidentalis interioris; foliis superioribus tripartitis, lobis linearibus, acutis, umbellis lateralibus terminalibusque simplicibus, quinquefloris, involucri pentaphylli foliolis lancevlatis, integris, pedicellis paullo brevioribus.

Ces a ti a Endlicher in Annal. Wiener. Mtus. II. 200.

4358 . EBianetopia DC. Calyeis tnbas subglohosus, limbus obsoletus. Petala ovalioblonga, integra. Styli breves, Fructus didymas; mericarpia subglobosa, ad comissuram subcontracta, disparia, alterum muricatum, taberculis seriatis, compressis, obtusis, alterum 96 * 
echinatum, tubereulis conicis, in aculeos molles productis. S e min is sectio transversa elliptica Herbae Novae Hollandiae a ustro-occidentalis, annuac, pusillae, ramosae, pilis conspersae; foliis tripartitis, lobis cuneatis, lineari. oblongis, apice obtuse tridentatis $v$ trifidis, pedun. culis oppositifoliis folio longioribus, umbella simplici subquinqueflora, involucri foliolis quinque, lineari-lanceolatis, flores aequantibus, floribus albis.

Dimetopia DC. Prodr, IV, 71 . Beuth. in Enumerat. Plant. Hügel. 54. Meisner Gen. 140. (109.)

435\%. Enigenia NUTT. C a ly eis tnbns compressus, limbus obsoletus. Petal a obovata, expansa, integra, aequalia. Styli persistentes, elongati, subulati. Fructus ovalis, sublateraliter compressus; mericarpia gibboso-convexa, trijuga, commissura angusta, immarginata, plana. S em en ... - Herba pusilla, glabra, in inundatis America borealis crescens; radice tubero. sa, globosa, foliis radicalibus unico $v$. duobus pe tiolalis, biternatisectis, umbella irregulari, imperfecta, tri-quadriradiata, umbellulis tri-quinquefloris, involucro communi praeter folium breve, multifidum nullo, involucelli foliolis paucis, inaequalibus, corollis albis, antheris exsertis, atro-purpureis.

E rige n Ia Nattall Gen, I. 187. DC. Mem, V.27, Prodr. IV. 71 . Meisuer Gen, 140. (109.) H y d rocotyle couposita et a mbigu a Pursh, Spreng. Umbellif. sp. $t .5$. $f .9$. Sis on butbos un Michx.

4380. Difieroplemra LAGASC. C alyc is tubus compressus, limbus obsoletus. P et a la aenta, integra, ovalia. Fructus basi profunde cordato-bilobus, subfoliacens, apice emarginatus; mericarpia a latere compressa, oblique ovata, septemcostata, costis capillaribus, curvilineis, inferne ventricosis, marginalibus duabus rectilineis brevioribus, eommissura angustissima, mericar piis duplo brevior. S e m e n ......

sula e Chilo $\ddot{e}$, glabra, caulescens, Hydrocotyles facie; foliis petiolatis, petiolo basi dilatato, cordato-reniformibus, submembranaceis, sex-novemnerviis venosisque, crenatis, umbellis terminalibus pedunculatis, quadri-quinqueradiatis, involucro foliaceo monophyllo, umbellulis tri-quadriradiatis, involucello parvo, tri-tetraphyllo, floribus tribus, intermedio subsessili fertili, duobus lateralibus breviter pedicellatis, masculis.

Micropleura Lagasca in Oeios Espagn, emigr. 15. DC. Mem. V. 71. Meisner Gen, 140. (102.)

4361. Dinlisems DC. Calycis tubus compressus, limbus obsoletus. Petala ovalia, integra, obtusiuscula, aestivatione imbricata. Styli divergentes. Fru et a s basi emarginatus, sub. didymus; mericarpia a latere compressissima, evittata, murienlata v. punetato pilosa, quinquejnga, jugis filiformibus, lateralibns commissurae proximis, brevissimis, intermediis brevibus, curvilineis, dorsali subalato. Carpophoram indivisum. S e m e n compressissimum. - Herbae No. vae $H_{0}$ ll andiae; caule tereti, ramoso, foliis varie partitis ant lobatis, lobis subcuneatis, incisis, umbellis multifloris, simplicibus, involucri polyphylli foliolis basi concretis, corollis caeruleis $v$. albis.

Didiscus DC. in Bot. Mag, t, 2875. Mem, V. 28. t. 4. Prodr. IV. 72. Meisner Gen, 140. (102,) L a mpra Lindley msc. H ä ge li a Reiehenb. Ic. exot, t, 201, - ? Trac b y mene inclis a Radge in Linn. Transact. $X$. $t, 21$. f. 3 .
4369. Traehymene RUDG. Calyeis tubus compressus, limbas quinquedentatus. P et a l a elliptica, integra, acutiuscula, aestivatione subvalvata. Styli divergentes. Fruetus a latere compressus et contractus, didymus; meric a rpia gibbo-convexa, evittata, quinquejuga, jugis tribus dorsalibus valleculisque muricato-tubereulatis, lateralibus marginantibus. Carpophorum indivisum. Semen gibbo-convexum, antice planinseulum. - Herbae v. suffrutices, in Nova-Hollandia crescentes; folits integerrimis $v$. dissectis et minimis, umbella composita, pluriradiata, involucro polyphyllo.

Tra ehy me ne Radge in Linn. Transaet, X. 300. exel. sp. Koch Umbellif. 143. DC. Mem. V. 28. Prodr, IV. 72, Meisuer Gen, 140. (102.) A za rell a Lahillard. Nov, Hol, land. I. 74. A. Richard in Annal. so. phys. 1890. IV. 60. 4. 51.f. 6. not Lam, F i s e b e r a Spreng. Prodr, Umbellif. 27. exel. sp. Lagasea Amen. nat. $1 T$. 93. non alior. C a t e pha Leschen, msc.

a. Platymene DC. Prodr. IV. 72, Caules herbacei, compressissimi, subaphylli, foliis minimis, bi trisectis. A $z$ o rell a e sp. Labillard. Nop. Holland, t. 101.

b. DENDROMBNE DC. Prodr. $I V$. 73. C a ules fruticosi, folis intege rimis. - A $\mathrm{z}$ a $\mathrm{r}$ ell a e $\mathrm{p}$. Labillard. $O_{p}$. cit. e. 99. 100. (Bot. Mag, t. 3334,)

43633. Astrotrielas $D C, \mathrm{C}$ a l y e is tubus ovatus, limbus minimus, vix quinquedentatus, Petala persistentia, ovalia, subarenata, plana, extus pube stellata velutina. Styli filiformes, basi aequales. Fruetus calycis limbo petalisque coronatus; merie arpia ovato-oblonga, ad commissuram contracta, jugis obtusissimis, vix prominulis, primariis dorsalibus tribus, marginantibusque duobus acutioribus subobsoletis, secundariis quatuor, vittis dorsalibus nullis, commissuralibus duabns, pellieula spongiosa tectis, prominullis. Ca rpophor u m indivisum, Semen gibbo-convexum, antice carinatum. - Frutices Novae-Hollandiae, pilis stellatis albis obsiti, foliis alternis, petiolatis, integerrimis, supra glab. ris, pedunculis paniculatis, umbella simplici, multiflora terminatis, bracteis sub ramis ramulisque so=. litariis, involucri oligoplylli foliolis linearibus.

Astrotrich a DC. Mem. $V$. 29. t, 5. 6. Prodr. $I V$. 74. Meisner Gen, 140, (109.)

4368. Heacolaena $R$. BR. C a l y is tubus ovato-compressus, limbus quinquelobus, lobis subcoloratis, ovatis, acutis, v. orbiculatis, peltatis. Petal a unguiculata, ovalia, euspidata, v. carinata. Styli filiformes, e basi interna stylopodii erassi, villosi. Fructus compressus, striatonervosus; mericarpia ad commissuram contracta, septem-novemjuga, jugis duobus lateralibus marginantibus, valleculis et commissura angustissima evittatis. - Herbae v. suffrutices Novae-Hollandiae, saepius pilis stellatis hirti; foliis alternis, petiolatis, simplicibus $v$. tripartitis, umbellis axillaribus $v$, terminalibus.

$\mathrm{L}$ e ue o l a e n a R. Brown in Flinders Voy, IT, 557. Benth. in Enumerat. plant. Hügel. 55. X a nth os a Rudge in Linn. Transact. X, 361. DC. Mem. V.31. Prodr. 74. Meis. ner Gen. 140. (102.)

a. XANTHOSIA. U mbellac axillares, simplices $v$. bifidae, involueri foliola parva. Caly cis lobi ovati. Xanthosia Rudge $o_{p}$, cit, $t, 28$. $f, 1$. Xauthosiae seet. B a $x$ an thos ia DC. . $c$.

b. CRUCIELLA. U m bell a e terminales, tri-quadriradiatae, involucri foliolis magnis, albidis. Cal y cis lobt ovati. Cruciella Lesehenault msc. Xanthosiae sect. Le ucolaena DC. $\boldsymbol{l}$. $c$.

c. PENTAPELTIS. Umbella axillares et terminales, quadei-quinqueradiatae, involucri foliolis linearibus. 
Calyeis ${ }^{10}$ bi orbiculati, peltati. - Leucolaena peitigera Hook. Ic, $t, 45$.

436.ั. IBด tubo compresso, subtetragono, limbo quinquedentato. Petala elliptica, integra, acnta. Styli filiformes. Fructus ovatus, ad commissuram valde contractus, turgidus, subtetragonus, dorso utrinque planiusculus; mericarpia evittata, dorso impressione ovali notata, jugis quinque, obsoletis, dorsalibns tribus, duobus plano commissurali impositis. - Herbae austro-americanae, debiles, saepe pube stellata scabrae; foliis suboppositis, petiolatis, simplicibus, lobatis v. dentatis, umbellis axillaribus, simplicibus, paucifloris.

Bowlesia Ruiz et Pavou Prodr. 44. t. 34. Flor. Peruv, IIT, 28, t. 251, 268. f. 1. Spreng. Prodr. Umbellif. 24. Lagase, Amen. nat. II. 94. A. Richard in Annal, so. phys. 1820, IV.160, t. 31.f. 3. Koch Umbellif. 162. DC. Mem. V. 31. Prodr. IV. 7S. Link et Otto Ic, rar, t. 4. Meisuer Gen. 160. (108.)

4365. Azoreila $L A M$. C a ly $\mathrm{x}$ tubo compresso, limbo quinquedentato. Petala ovalia, integra. Styli breves. Fructus ovatus, ad commissuram contractus, subdidymus; $m$ e ri carpia evittata, a dorso subcompressa, jugis filiformibus obsoletis. - Herbae peruanae andicola e et magellanicae, humiles v. acaules, caespitosae; foliis integris v. tri quinquefidis, umbellis sessilibus $v$, pedunculatis, paucifloris, pedicellis involuerum aequantibus,

A z o rell a Lam, t. 484, f. 1. Cav. Ic. t. 482. f. 2. Gaudichiud in Annal. se, nat. V. 104. t. 3. f. 1. DC. Prodr. IV. 77. Meisner Gen, 140. (102.) non A. Rich. C th a m itis Solander ex Forster in Comment. Götting. IX, 45. Gärtner I. 94. $t$. 22. S i eber a Reichenb. Consp. 145. Fragos a Ruiz et Pavon Prodr. 43. t. 34. Flor. Peruv, t. 249. 250. Lagasea Amen. nat. IT. 93. Kunth in Humb. et Bonpl. Nov, gen, et sp. V. 27, t. 424. A. Riehard in Annal. sc. phys. 1820. IV. 160. t. 51. f. 4. DC. Prodr. IV. 76. Meisner Gen, 140. (102.) B ol a cis s p, Spreng. Koch.

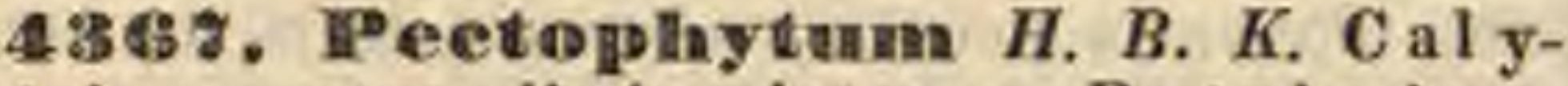
$e$ i s tubus ovatus, limbus integer. Petal a inaequalia, apice erecto, subinflexo. Styli breves, recti. Fruetus ovato-elliptiens; mericarpia evitfata, dorso subeonvexa, ovalia, a latere eompressa, quinquecostata, jugis filiformibus, commissura planiusenla. - Herba caespitosa, in $p l a$ nitie montis Antisanae ab Humboldtio lecta; foliis imbricatis, trifidis, petiolis superne suberoso tumidis, persistentibus, floribus in apice ramorum fasciculato-eongestis, albis, ad bractearum axillas solitariis, pedicellatis, bracteis dentato-ciliatis.

$\mathrm{P}$ ect op h y $\mathrm{t} \mathrm{m}$ Kunth in Humb. et Bonpl. Nov.gen. et sp. V. 28, t. 425. DC. Prodr. IV, 78. Meisner Gen. 140. (102.) Bolax peduneulatus Spreng. Umbellif. sp.10.

TYEIEUS IH. MULINEAE DC, Prodr. IV. 78. Fructus mericarpiis ad suturam valde contractis, evittatis, quinquejugis, dorso plano-compressis quadratus v, parallele biscutatus. Petala patentia, plana, plerumque integra. - Americae meridionalis extratropicae incolae, paucissimis, isque dubiis, inter tropicos repeptis. Drusae, generis canariensis huc relati, affinitas subdubia.

4363. IB olax COMMERS. Caly $\mathrm{c}$ is $\mathrm{lim}$ bus integerrimus, obsoletus. Petala ovata, in tegra. Styli breves. Fructus tetragonus, fa ciebus concavis; mericarpia evittata, quinquejuga, jugis nerviformibus, obtusis, laevibus, uno dorsali, duobus tetraëdri angulos formantibus, lateralibus filiformibus marginalibus, commissura angustissima. - Herba Americae antarcticae, caespilosa, Aretiae facie; foliis densissime imbricatis, trifidis, coriaceis, glabris, petiolis latis, basi suberoso-membranaceis, umbellis sessilibus $v$. pedunculatis, simplicibus, pauci-multifloris, involucro oligophyllo, fructu juniore pube stellata consperso adulto saepe calycis tubo soluto, resina repleto vesiculoso.

B olax Commerson ox Jussiou gen. 226. Gaudichaud in Annal. se. nat. V. 104. t. 3. f. 1. DC. Prodr. IV. 78. Hooker Bot. Miscell. t. 63. Meisner Gen. 141. (103.) $\mathrm{H} \mathrm{y-}$ drocotyle g u mifera Lam. $t$. 189. $f$. 21 .

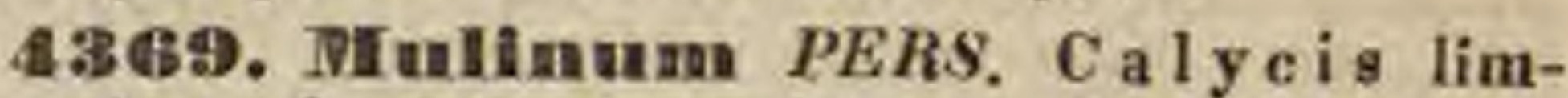
bus quinquedentatus, persistens. Petala ovata, integra, carinata, apice inflexa. Styli filiformes. Fruetus tetrapterus; mericarpia dorso concava, faciebus contiguis convexa, evittata, quinquejuga, jugis filiformibus, uno dorsali, intermediis angulos marginantibus, lateralibus intramarginalibus, commissurae angustissimae admotis. Herbae chilenses, caespitosae, suffruticosae; foliis saepius imbricatim confertis, tri-quinquefidis $v$. indivisis, petiolis vaginantibus, umbellis simplicibus, sessilibus $v$. pedunculatis, pedicellis involucro polyphyllo longioribus, floribus flavis.

M u li nu m Persoon Encheir. I. 309. excl. sp. Lagasca Amen. nat. II. 24. DC. Mem, V. 32. Prodr. IV. 79. excl. sp. Hooker Bot. Miscell. I. 327, $t$, 64. Sellin i s p. Cavanill, Ic. $t$. 486. f. 1. 2. $t .487 . f .2$.

4390. Asteriseium CHAM. et SCHL. Ca ly c is limbus late quinquepartitus, persistens. Peta la emarginata, lacinula inflexa, sinu callo8o. Styli filiformes. Fructus prismatico-tetrapterus; mericarpia dorso subeanalieulata, facie leviter convexa, evittata, quinquejuga, jugis nerviformibus, uno dorsali carinali, intermediis alas marginantibus, lateralibus intramarginalibns, commissurae angustissimae admotis. - Herbae ohilenses, rigidae, glabrae; caulibus ramosis, teretibus, paucifoliis, foliis subcoriaceis, simplicibus, petiolatis, cuneato-subrotundis, inaequaliter dentatis, subtrilobis, umbellis simplicibus, subglobosis, involucri polyphylli foliolis pedicellis brevioribus, floribus aliis longius prdicellatis masculis, aliis hermaphroditis.

Asteriscium Chamisso et Sehlechteud. In Linnaea I. 25i. $t$. S. f. 1. DC. Prodr. IV, 82. Hooker Bot. Miscell. I. 331, t. 67. bis. Meisner Gen. 140. (108.) Cassidoearpus Presl msc. - ? Dipterygla Presl msc. M ulini s p. DC.

4351. Haretia GILL, et HOOK. Cal ycis limbus quinquedentatus, persistens, P e ta la ovata, integra. Fructus elliptico-tetrapterus; merica r pia subconvexa, evittata, quinquejuga, jugis nerviformibus, dorsalibus tribus, duobus lateralibus alas marginantibus, commissura angustissima. - Herba chilensis, dense caespitosa, subacaulis; foliis rosulato-confertis, oblongis, cuneatis, integerrimis, basi amplexicauli-vaginantibus, umbella terminali pauciflora, sessili, involucro polyphyllo, brevi, fructibus pro statura plantulae maximis.

L a ret l a Gillies et Hooker Bot. Miscell. $I$. 329. t. 65, S e 1 in u m a caule Cavanill. Ic. $t$. 487, $f$. 2. M ul inum a ca a le Persoon. DC.

43\% \&. Dronsa DC. C a lyeis limbns integer, obsoletus. Petal a ovalia, integra. Styli filiformes. Fruetus biscutatus, tetrapterus; mericarpia compressissima, evittata, quinquejuga, 
jugo uno dorsali, lineari, vix prominente, intermediis productis in alas marginales, repando sinuatas, sinubus obtusis, angulis in spinulas uncinato-stellatas expansis, lateralibus intramarginalibus fere obsoletis, commissurae angustissimae admotis, - Herba canariensis, tenera, decumbens, pilosa, pilis aliis rigidis apice stellatis, uncinatis, aliis mollibus, sparsis $v$. stellato-fasciculatis; foliis oppositis, petiolatis, late trilobis, crenatis, umbellis axillaribus, pedunculis uni-biftoris, exinvolucratis.

Dr a 8 a DC. in Annal. Mus. X. 466. $t$. 38, Prodr. IV. 80. Sprengel Prodr. Umbellif. 15, $f$. 6 . Lagasca Amen, nat. II. 94. Meisner Gen. 140. (102). B ow I es i a op o s it if olli u Buch. Poiret Illustr. $t, 943$.

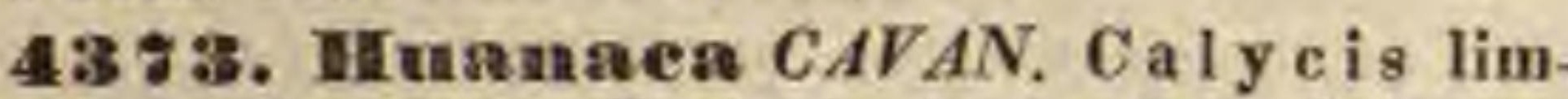
bus quinquedentatus. P e $t$ a I a lanceolata, integra. Styli divaricati. Fruetus ovatus, subacutus; m e ri car pi a dorso subconvexa, faciebus contiguis plana, unisuleata, evittata, trijuga, jugis dorsalibus vix prominulis, earpophoro bifido. - Herbae antaretamericanae et mexicanae, non satis notae; radice crassa, fotiis radicalibus petiolatis, palmato-quinquesectis, petiolis basi dilatatis et ciliatis, scapo nudo, umbella simplici, involucri polyphylli foliolis ciliato-spinulosis, ftoribus longiuscule pedicellatis, rubro luteis, exterioribus masculis.

H u a n c a Cavauill. Ic. IV. 18. $t$. 528. f. 2. DC. Mem. V.32. Prodr. IV. 80. Meisner Gen. 141. (103.) $\mathrm{S} p$ a na $\mathrm{n}$ th is 8 p. Lagase. Oe a a thes sp. Spreng.

43\% 4. Yiromaloearpus HOOK, et ARN. Ca l y cis limbus quinquedentatus. Petal a ovalia, concava, integra. Styli divaricati. Fructus subrotundo-ovalis; m ericarpia compresso-plana, evittata, quinquejuga, jugis filiformibus, immersis, uno dorsali, intermediis duobus marginalibus, lateralibus intramarginalibus, commis surae angustissimae admotis. - Herba chilen $s i s$, annua, erectiuscula, dichotome ramosa, pilis stellatis incana; foliis inferioribus alternis, superioribus oppositis, petiolatis, reniformibus, subseptemlobatis, lobis aequalibus, ovatis, obtusis, integerrimis $v$. lobato-incisis, pedunculis axillaribus et terminalibus petiolum subaequantibus, umbellis sim. plicibus, tri-sex/loris, dentibus calycinis pilosis, pilorum fasciculum simulantibus.

H om a lo a r u s Hooker et Arnott Bot. Miscell, III. 368. Meisaer Gen. 14t. (102.)

43 ร็. Dịpesis DC. Caly $\mathrm{c}$ is limbus obtuse quinquedentatus. Petala ovalia, integra, plana. Styli breves. Fruetus orbiculatus, bisentatus; is ericarpia a dorso eompresso-plana, evittata, quinquejuga, jng is filiformibns, uno dorsali, intermediis marginalibus, lateralibus intramarinalibus, commissurae approsimatis. Herba bonariensis, acaulis, glabra; folits radicalibus petiolatis, trisectis, lobis cuneiformibus, apice dentatis $v$. ineisis, lateralibus interdum bipartitis, scapo folia superante, umbella composita, sex-actoradiata, pedicellis involucro tetra-hexaphyllo multo longioribus, umbellatis, trijloris, ftore intermedio fertili, lateralibus duobus masculis.

Diposis DC. Mem. $V$. 33, t, 2, f. 0, Prodr. IV. 81. Meisuer Gen. 141. (102) Hy d r cotyle 3 a a icuI a e o I i a Lam. Cav. Ic, $t$. 488. $f .8$.

4386. Spamantlue JACQ. Calye is limbns quinquedentatus. Pet a l a elliptiea, integra, acutiusenla, apice recto. Fructus ovatus, biscutatus; meric arpia a dorso compressa, evittata, quinquejuga, jugis tribus dorsalibus, intermedio costaeformi, lateralibus extramarginalibus, commissurae approximatis. - Herba peruana, erecta, rumosa, glabra; foliis cordatis, dentatis, acutis, petiolis secus vaginam ciliatis, sub limbi origi. ne pilorum annulo cinctis, umbellis subcompositis, proliferis, involucris polyphyllis, floribus longe pedicellatis, albis.

$S_{p}$ an a n the Jacq. Collect. IIT, 247. Ie, rar. t, 350. Sprengel Prodr. Umbellif. 34. A. Rlchard in Annal. sc. phys. $1820, I V, 160$, t. 50. f. 2. Koeh Umbellif. 142. $f .66$ 68. DC, Prodr. IV. 81. Meisner Gen, 141. (102,) H y d ro. cotyle Spananthe Willd.

438\%. Pozon LAGASC. Calyeis limbus quinquedentatus, persistens. Petala ovata, integra, apice recta, carina callosa. Fructus oblongas, obtuse tetragonus; me ric arpia durso carinato-coneava, faciebus contiguis plana, evittata, quinquejuga, jugis costaeformibus, tribus dorsalibus approximatis, lateralibus remotis, marginalibus, valleculis convexinsculis - Herba ch $i$ lensis, glaberrima; foliis omnibus radicalibus, longe petiolatis, subcuneatis, flabellatim venosis, margine superiore crenato-dentatis, scapis demum elongatis, umbella simplici, involucro amplo, gamophyllo, hemisphaerico, membranaceo, venoso cincta, pedicellis brevissimis, in capitulum hemisphaericum congestis.

Pozoa Lagasea Nov. gen, et sp. 13. Amen, nat. II. 93. DC. Prodr. IV. 82. Hooker Bot. Miscell, 1. 330. t. 66. Meisuer Gen, 141. (103.)

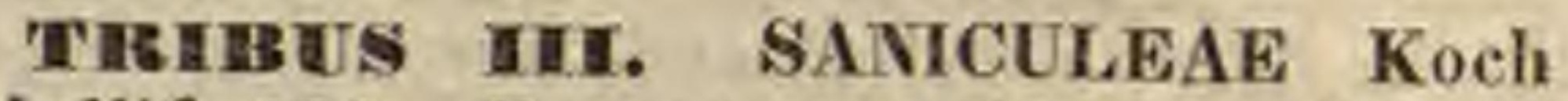
Umbellif. 138. Fruetus subteres. Meric arpia jugis primariis quinque, aequalibus, secundariis nullis v, omnibus obliteratis, squamis tectis, evittatis vittatisve. $\mathbf{S}$ e $\mathrm{m}$ e $\mathbf{n}$ sectione transversa semiteres, antice planiusculum. Petal a erecta, a medio infracto-emarginata. - Umbellae fasciculatae v. capitatae, simplices v. irregulariter subcompositae.

Saniculearum maxima copia reperitur in America inter $35^{\circ}$ L. B. et $40^{\circ}$ L. A. imprimis in regionibus cancro subjectis et trans capricornum sitis, deinde in Europa mediterranea, unde parce in Caucasum et Orientem evagantur. Paucae Europam mediam, imprimis alpestrem, et Novam-Hollandiam incolunt, paucissimae ex Asiae tropicae insulis, e Nepalia et Capite bonae spei relatae fuerunt.

4383. Aetinetas $L A B I L L$. Ca ly e is tubus ovatus, apice contractus, limbus quinquelobus, lobis ovali-oblongis. Petala nulla. Ovari u m uniovalatum. Styli 2 , basi incrassata villosi, apice setacei. Fructus ovatus, villosus, calycis limbo coronatus, quinquestriatus. - Herbae Novae-Hollandia orientalis, erectae, ramosae; foliis alternis, petiolatis, dissectis, umbellis simplicibus multifloris, capitatis, involucro polyphyllo, tomentoso $v$, serieco-villoso, radiante, fiores superante, pedicellis brevissimis.

A ctinotus Labillard. Nov. Holland, $T$. 67. $t, 92 . \mathrm{R}$. Brown in Flinders Voy. II. 557. DC. Prodr. IV, 83. Meisner Gen. 141. (103,) E rifocalia Smith Exot. Bot, II. 37. t. 78. 79. Sprengel in Schult. Syst, V1. 31. 639, Lagasca Amen, nat. IT. 105. P r o usti a Lagasea mse.

43\%. Holotone BENTH. Calycis tabns ovatus, apice contractus, limbus cupuli- 
formis, integerrimns. Petala 5, ovata, integra. Ovarinm uniovulatum. Styli 2, filiformes, apice conniventes. Fructus ovatus, compressus, villosus, calycis limbo coronatus, quinquestriatus. Herba Novae Hollandiaeoccidentalis, Aetinoti facie; foliis inferioribus petiolatis, superioribus sessilibus, tri-quinquepartitis, segmentis integerrimis $v$. tri-quinquefidis, laciniis linearibus, umbellis Actinoti Helianthi, floribus sterilibus longius pedicellatis, cum fertilibus subsessilibus mixtis.

Holofome, sect. Actinoti Benth. in Enumerat. plant. Hügel. 56 .

4380. Petagnia GUSS. U mbelln la e triflurae, floribus lateralibns masculis pedicellatis, pedicellis basi cum floris intermedii hermaphroditi sessilis calyce connatis. M a $8 \mathrm{c}, \mathrm{Ca} / \mathrm{y} \mathbf{x}$ tubo subnullo, limbo obsoleto, subquinquedentato. Peta la ovali-oblonga, ntrinque acuta, apice inflexa. Stamina 5, petalis alterna et longiora. Hermaphr. Calyx tubo ovato, compresso, limbo obsulete. Petala ut floribus masculis submembranacea, persistentia. $\mathrm{S} t \mathrm{a} \mathrm{m}$ i $\mathrm{n}$ a 5 , caduca. Ovaria m uniovulatunt. St sli 2 , filiformes, elongati, divarieati. Fruetus ovatus, compressus; mericarpiis concretis, octonerviis, jugis mericarpii cujusvis quinque, lateralibus marginalibns confluentibus, dorsalibus tribus magis promi nentibus. - Herba glabra, in nemoribus editiori bus Siciliae rhizomale oblongo perennans; folio radicali unico, longe petiolato, subpeltato, quin quepartito, segmentis ovali-cuneatis, apice subtrilo bis, dentatis, dentibus mucronatis, caule solitario, vix semipedali, apice diphyllo, foliis oppositis, sessilibus $v$. breve petiolatis, trilobis, lobis mucronatodentatis, ovatis, acutis, ramis duobus apice bifidis, basi bibracteatis, bracteis oblongis, acutis, mucronato-serratis, ramulis.brevibus, apice triftoris, basi minutissime bibracteolatis.

Petagnia Gussone Prodr. Flor. Sicul, $r$, 311. DC. Mem. V. 35̃. Prodr. IV. 83. Meisner Gen, 141. (103.) non alior. Heterosefadium DC. msc.

4391. Hollotselaia CHAM. Caly $\mathrm{x}$ tubo laevi, limbi lobis foliolosis. Pet a la conniventia, obovata, lacinula infracta, aequilonga. Styli conniventes. Fructus a dorso subcompressus, bipartibilis; mericarpia quinquejuga, jugis tribus dursalibus approximatis, evittatis, lateralibns marginalibus contiguis, univittatis, obsoletis, eommissura planinseula, carpophoro seminibus per totam longitudinem adnato, - Herba Brasilia e tropicae, annua, glabra; foliis radicalibus sub anthesi nullis, caulinis approximatis, petiolatis, pel, tatis, quinquelobis, lobis duplicato-serratis, supra obscure viridibus, subtus pallidioribus, venis anastomosantibus, prominentibus pulcherrime reticulatis, ramis paniculatis, basi bractea lanceolata suffultis, umbellulis paucifloris, floribus masculis pluribus ambientibus brevissime pedicellatis, centralibus unico $v$. tribus femineis sessilibus, involucelli polyphylli foliolis anguste linearibus, pedicellos florum masculorum aequantibus.

Klots chia Chamisso in Linnisea VIII, 327. Endlich. Atakt. 21. t. 19. Meisner Gen. 141. (103.)

438\%. Śanicula TOURNEF. Caly $\mathrm{x}$ tubo echinato, limbi lobis foliosis, persistentibus. Peta la eonniventia, obovata, in lacinulam aequilongam emarginato infracta. Ova ri m biovulatum. Styli filiformes. Fruetns snloglobosos; mericarpiis hemisphaerieis, concretis, ejuga- tis, multivittatis, dense uncinato-acnleatis. Herbae perennes, in Europa, in Americaboreali et australi extratropica, in Nepalia et insula Java monticolae; folits radicalibus petiolatis, palmatilobis, Lobis cuneatis, apice inciso-dentatis, caule nudo $v$. parce folioso, umbella generali pauciradiata, involucro oligophyllo, foliolis saepe divisis, umbellulis pluriradiatis, involucelli foliolis pluribus, integris, floribus hermaphroditis cum masculis in eadem umbellula mixtis.

Sanicula Touraefort inst. 173. Lian. gen, n. 326. Hoffuann Prodr. Umbellif. 6S. Spreng. Prodr, Umbellif. 24. Lagasca Amen, nat, IT. 105 Koch Umbellif. 139. DC. Mem. V. 35. Prodr. IV. 84. Meisuer Gen. 141. (103.)

a. SANICLA DC, $l, c, \mathrm{C}$ a ly ci s tubus echinatus. - Folia palmatiloba, - Tri cliu i u mafin. Flor. ludov, 79. (Schkulir t, 60. Lam, t, 191. Flor, dan. t. 283. Jaeq. IC. rar. t. 348. Hoffmann Prodr. Umbellif. t. 1. f. 1. Hooker Elor, Bor. Amer, t. 190-192.)

b. SANICORIA DC. $l$. c. Caly ci s tubus per anthesim Iaevis. - Folia bipinnatipartita. - Sanicula gra. ve al ens Pöppig.

4383. ISrequetia NECK. C a ly x tubo laevi, limbi lobis foliolosis, persistentibus. Peta la conniventia, obovata, a medio in lacinulam aequilongam infracta. Ovarium biovulatum. Styli filiformes. Fructus a latere contractus; me ric a rpia gibbo-convexa, connata, quinquejuga, jugis filiformibus, univittatis. - Herba in alpibus Europae mediae perennans; foliis radicalibus petiolatis, palmatisectis, segmentis tribus, cuneatis, bi-trifidis, mucronato-serratis, scapo solitario $v$. pluribus, apice umbellam simplicem gerentibus, involucri foliolis quinque $v$, sex obovatis, apice dentalis, umbella longioribus, floribus breve pedicellatis, flavis, maseulis cum femineis mixtis.

H a c que ti a Necker Elem, n. 406, DC. Prodr. IF. 85. Meisner Gen, 141. (103.) Dondia Sprengel in Btem, soc. h. n. Moso. V. 8. Prodr. Umbellif. 21. f. 2. Lagasca Ament. nat. II. 96. Koch Umbellif. 140. D on dis i a Reichenbach Consp. 144, non DC. Astrantia Epipactis Linn. f. Scopoli Flor, carniol, t. 6. Jaeq. Flor. Austr. Append. t. 11 .

4354. Astrantia TOURNEF. CaIy tubo tuberculato, limbi lobis foliolosis. Petala conniventia, oblongo-obovata, in lacinnlam sabaequilongam infracta. Sty $l i$ filifurmes. Fructas a dorso snbcompressns; mericarpia evittata, subeonnata, quinquejuga, jugis elevatis, obtusis, plicato-dentatis, inflatis, in eavitate juga minora fistulusa inclndentibus. - Herbae perennes, europea et caucasica $e_{;}$radice nigricante, aromatica, foliis radicalibus petiolatis, palmatilobatis, caulinis paucis sessilibus, umbella irregulari, pauciradiata, involucro vario, umbellulis regularibus, multifloris, involucello polyphyllo, floribus albis $v$. subroseis, sacpe polygamis.

Astrantia Tournef. inst, 166. Linn, gen, n, 397. Lam, t. 19t. Jacq. Flor. Austr. Append, t, 10. Sehkuhr t. 60. Suith Exot. Bot, IT, t, 76, 77. Salisbury Parad, t, 60, Bot. Mag. $t, 1553$. Nees jun. Plant, offic. XII, $t, 6$. Reichenb. Icanogr, t. 318. Lagasea Amen, nat. II. 97 . Koch Umbellif. 138. f. 42, 43. DC. Prodr. IV. 86. Meisner Gen, 14t, (103,)

4385. Aleplelea LAROCH, Flores $8 \mathrm{~m}-$ pra receptaculnm hemisphaerieum nudum sessiles. Cal y x tubo minute tuberenlato, limbi lobis folio. losis. Petala conniventia, oblonga, in lacinulam aequilongam infracta. Sty li filiformes. Fractus ovatus, teres, tuberculatus; m e ric a r p i a evittata, ejugata, semiteretia, carpophoro per totam longitudinem seminibus adnato. - Herbae capenses; foliis radicalibus petiolatis, setis spinescentibus ciliato 
dentatis, caulinis paucis, amplexicaulibus, minoribus, umbellulis fere Astrantiae, involucris involucellisque polyphyllis, foliolis basi subconnatis.

A Iepid e a Laroche Hist. Eryng. 19. t, 1. DC. Prodr. IV. 87. Ecklon et Zeyher Enumerat. 239. Meisner Gen, 141. (103.) Astraatia ciliaris Linn. fil. Jas ione capensis Berg. in Act. Upsal. III, 187, $t, 10$.

4386. Erymgimm TOURNEF. F Iore in receptaculo globoso v. cylindrico, paleato sessiles. Cal y x tubo squamulis vesiculisque aspero, limbi lobis foliolosis. P et a la conniventia, oblongo-obovata, in lacinulam aequilongam emarginato infracta. Styli filiformes. Fructus obovatus, teretiusculus, squamatus v, tuberculatns; m e ricarpia evittata, ejugata, semiteretia, carpophoro per totam longitudinem seminibus adnato. - Herbae cosmopolita e, annuae v. saepius per ennes, rarissime fructescentes v. arboreae, plerumque spinescentes; foliis radicalibus caulinisque, petioli plus minus vaginantibus, floribus in capitula sub rotunda v. oblonga aggregatis, bracteis inferiorum saepius majoribus involucrantibus, superiorum in paleas floribus intermixtas conversis.

E r y $\mathrm{ng}$ i $\mathrm{m}$ Touraef. inst, 173. Lian. gen, $n, 384$. Gärtner I. 27. t, 20. Lam. t, 187. Jaeq. Flor. Austr. t. 391. Ic. rar. $t$. 55. 347 . Flor. dan. $t .554$. Cavanill. Ic, t. 552 556. Desfont. Flor. Atlant. t. 53-55. Sibthorp Flor. graec. t. 258, 259. Bot. Mag. t, 928. Labillard. Nov. Holland. t, 98 Laroche, Hist. Eryng. Paris, 1808, fol. Koeh, Umbellif 139. DC. Prodr. IV. 87. Meisner Gen. 141. (103.) - Le s$s$ o $\mathrm{i}$ a Bertero in Annal. sc, nat. XXI. 348. Deless. Ic. se lect, III. t. 78. frutices v. arbusculae insulae S. Juan Fernandez, ramis dichotomis, inferne foliorum delapsorum cicatricibus notaris, ad extremitates dense foliosis, testibn Hooker et Arnott in Bot. Miscell. III, 351. ab Eiryngils non nisi habitu differunt. - Strebanth us Rafin. in Seringe Bullet, Bot, I. 218, Meisner gen. L. $c$. herba boreali-americana, soli generis auctori nota, Foliis oppositis, lanceolatis, uni-biaurieulatis, capitulis axillaribus pedunculatis, involucratis, monoieis, diferre dicitur : floribus tetrameris, mericarpis scro biculatis, dorso convexis, laevibus.

438\%. IHorgfiellia BLEM. Flores supra receptaculum paleatum dense capitati. Calycis margo integerrimus, obsoletus. Petala ovata, cuspidata, plana. Fructus compressus, villosus; meri carpia dorso trieostata. - Frutex javanicus, aculeatus, Eryngio teste generis auctore nimis affinis; foliis cordatis, quinquelobis, summis trilobis paniculisque terminalibus dense stelsato-tomentosis, capitulis sessilibus, involucro poly phyllo cinctis.

Horsfieldia BIame Bijdr. 884. ex emend, msc. DC. Prodr. ID. 87. Meisuer Gen, 141. (103.) Schubertia Blume $l$, c. non allor.

4358. Aetinamthas EHRENB. Fiores monoici, feminei capitati, masculi capitato-ambellati, floribus marginalibus in utriusque sexus capitulis abortivis coalescentibus et spinescentibns, receptaculo nudo. C a ly cis limbus quinquedentatus, persistens. Petala oblonga, apice complicato, inflexo, subcirrhoso. Styli clavati. Fructu 8 a latere compressns; meri carpi a suberosa, obovata, quinquejuga, jugis obtusis, lateralibus marginalibus contiguis, alternis carinalibus validioribus, valleculis angustis, univittatis, commis. sura plana, bivittata. Carpoph or a per totam longitudinem seminibus adnata. - Herba syriaca, pedalis, rigida, squarrosa; foliis inferioribus ternato-bipinnatisectis, involucris nullis, involucellis polyphyllis, adpressis, floribus albis, capitulorum floribus marginalibus in fasciculos lignosos, radios inaequales spinescentes, bipollicares formantes abeuntibus. I
A $\mathrm{ctin}$ a $\mathrm{n}$ th $\mathrm{n}$ s Ehrenb, in Linnaea IV, 398. DC. Prodr. 668. Meisner Gen, 141. (103.)

4389. Holnenaclicenia FISCH, et MEY Flores hermaphroditi capitati, paleolis et involucro nullo. Caly $\mathrm{c}$ is dentes subulati, patentes. Petal a subrotunda, cum lacinula inflexa. Styli subulati, reflexi. Frnetus laevis, a latere compressus, tetragono-pyriformis, rostro cylindraceo in dentes quinque subulatos patentes producto, bipartibilis; m eriea r pia apice gibba, spongiosocorticata, quinquejuga, jugis obtusis, solidis, valleculis angustis, evittatis. Carpophorum bipartibile, mericarpiis arcte adnatum. A / bu me n dor8o tricostatum, facie planum. - Herba armeniac $a$, pusilla, annua $v$, biensis, glabra, glaucescens, quasi in globum contracta; caulibus brevissimis, de.. cumbentibus, simplicibus $v$. dichotome ramosis, foliosissimis; foliis Bupleuri, elongatis, serrulatis, floribus in ramorum dichotomiis et in foliorum axillis aggregato-capitatis, sessilibus, involucris paleolisque nullis, petalis minutis, viridescentibus, antheris badiis, fructibus majusculis, flavescentibus.

Ho he nackeria Fischer et Mever Index, Semin, hort, Petropolit, 1835. II.p. 38. Bullet, soo. naturat. Mosc, 1838. p. 320. Cesati in Linnaea XI, 323, t, 7. f. 1_6. Vale. rianella exscapa Steven.

TREIBUS IV. AMMINEAE Koch Umbellif. 114. Fructus a latere compressus v. lateribus contractis subdidymus. Meric arpia quinquejuga, jugis filiformibus v. alatis, lateralibus marginantibus, omnibus aequalibus. Semen tereti v. gibbo-convexum, facie planiusculum v. undique teres. - Umbellae perfectae, compositae. - Ammineae copiosissime in regionis mediterranea ora utraque gignuntur, inde in Europam mediam, rossici imperii ditiones australes, Orientem, Asiam mediam, Sibiriam, Indiam borealem et insularem diffunduntur. Aliae Americam borealem inhabitant, unde paucae regiones tropicas ingrediuntur, paucissimae trans capricornum evagantur. Africae promontorium australe specierum ferax esse videtur, sed pleraeque vix cognitae. Unica species e Nova-Hollandia adlata fuit.

4390. If quinquedentatus. P et a la ovata, integra, patula, in lacinulam brevem, incurvam coaretata, F ructus subrotundus v, ovatus, didymus; mericarp i a solida, quinquejuga, jugis crassis, obtusissimis, gyroso-plicatis, valleculas univittatas, tuber. culis plicatis ornatas obtegentibus. Carpopho$\mathbf{r} \mathbf{m}$ bipartitum. S e m e $\mathbf{n}$ dorso gibbo-convexum, facie plannm. - Herbae taurico-caucasicae et sibiricae, glabrae; foliis decompositis, umbellis plurinis, involucro obsoleto v. oligophyllo, involucellis tri-octophyllis, floribus dioicis, flavis.

R u m i a hoffmann Umbellif, 171, f. 3. 4, 17, 21. Koch Umbellif. 129. DC. Mem, V. 36. Prodr. IV. 98, Meisner Gen. 148. (104.) C a c hry dis sp. Spreng. Artediao sp. Pallas. Trini a e s p. Ledehour Ic. $t .8$.

43\$1. Cieuta $L I N N$. Calye is limbng quinquedentatus, foliolosus. Petala obcordata, cum lacinula inflexa. Fructus subrotundus, a latere contractus, didymns; mericarpia quinquejuga, jugis planiusculis, aequalibus, laterali- 
bus marginantibus, valleculis univittatis, commissura sub membrana soluta livittata. Ca rpo ph oru m bipartitum. S e m e n teres. - Herbae perennes, aquaticae, virosae, in Europa, Asia media et America boreali indigenae; caule tereti, fistuloso, foliis tripinnati- $v$. ternatisectis, umbellis compositis, involucro obsoleto $v$. oligophyllo, involuccllis polyphyllis, floribus albis.

Cicuta Lins, gen, $n$. 354. Hoffmann Umbellif. 177. Spreugel Prodr. Umbellif. 19. Lagnsea Amen. nat. It. 96. Koch Umbellif. 129. $f$. 53 . 54. Flor. dan. $t$, 208. Nees Jun. Plant, offic, t, 12. Bigelow Mat, med, 1, t, 12. DC, Prodr. IV. 99. Meisuer Gen. 143. (104.)

4392. Zizia KOCH. C aly $\mathrm{c}$ is limbus obsoletus v. brevissime quinquedentatus. Petala elliptiea, in acumen longum, inflexum attenuata. Fruetus a latere eontractus, subdidymus, subrotundus v. ovalis; meriearpia quinguejuga, jugis filiformibus, prominulis, aequalibus, lateralibus marginantibus, valleculis univittatis, commissura bivittata. Carpophorum hipartitam. Semen tereti-convexum, facie vix planiusculum. - Herbae boreali-americanae, perennes; caule erecto, subsimplici, foliis ternativ. biternatisectis, segmentis oblongis cordatisve, umbellis compositis, involucro nullo, involucellis oligophyllis, variis, floribus flavis, albis $v$. atropurpureis.

Zixia Koch Umbellif. 129. DC. Prodr. IV. Meisner Gen. 142. (104.) $\mathrm{S}$ m y r $\mathrm{n}$ i u m Elliott Carolin. I. 357. $\mathrm{S}$ m y r.

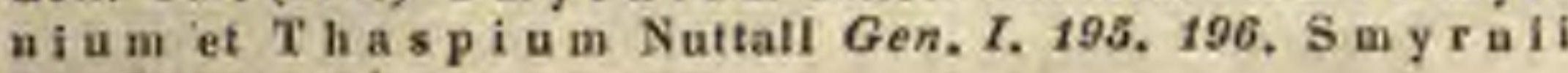
s p. Linn, et Auct.

4393. Apiman HOFFM. Calye is limbus obsoletus. Petala subrotunda, integra, apiculo inflexo v. involuto. Fructus stylopodio depresso, subrotundus, a latere contractus, didymus; meri $\mathbf{c}$ a $\mathbf{r}$ ia quinquejuga, jugis filiformibus, aequalibus, lateralibus marginantibus, valleculis interioribus univitatis, lateralibns bi-trivittatis. Carpophornm indivisum. Semen gibbo-convexum, facie planiuseulom. - Herbae perennes, in Europa, Asiamedia, in America andina et antaretica indigenae; radice ad collum incrassata, in stirpe culta sapida, caule sulcato, ramoso, foliis pinnatisectis, segmentis cuneiformibus, incisis, umbellis in ramulo axillari $v$, apice caulis sessilibus, involucro involucellisque nullis, floribus albo-virescentibus.

A p i u m Hoffmann Umbellif. 1. 75. t. 1.f. 8. Kocb Umbellif, 128. DC. Mem. V. 36. Prodr, IV. 100. Meisner Gen. 142. (104.) A p 1 i s p. Lisn.

a. CELLERI. Petal a apiculo arete involuto. A pit sect. Euapium DC. l. c. A p. graveolens Linn. E. B. t. 1210. Hayne Arzneigew, VII. t. 24. A p. Celle r i Gärta. $t$, 22.

b. OREosciadium DC. l. c. Pefal a apiculo inflexo dentieulata. A pi i s p. H. B. K.

4394. Petroselinum HOFFM. Ca Iyc is limbus obsoletus. Petala snbrotunda, incurva, vix emarginata, in lacinulam inflexam coarctata. Fructus ovatus, stylopodio brevi conico stylisque divergentibus coronatus, a latere contractus, subdidynus; mericarpia quinquejuga, jugis filiformibus, aequalibus, lateralibus marginantibus, valleculis univittatis, commissura bivittata. Carpophor um bipartitum. Semen gibbo-convexum, faeie planiusculum. - Herbae biennes, ramosae, glabrae, in Europa australi et insula Diemen sponianeae; foliis decompositis, laciniis cuneatis, involucro oligophyllo, involucellis polyphyllis, floribus albo-virescentibus, uni- formibus, disci saepe sterilibus, staminibus petala superantibus.

Petroselinum Hofimann Umbellif. $1.78, t, 1 . f .1$. Lagasea Amen, nat. Ir. 102. Koch Umbellif. 127. Nees jun. Plant. offic. XVI. t, 21. DC. Prodr. IV. 102. Meisner Gen. 142. (104.) A pii s p. Liun. Labillard. Nov. Holland. t. 103. Vent. Malmais, $t, 81$. Lig ustict sp. Linn. Jacq. Hort. Vindob. III, t. 18. Sis ou ís s p. Linn. Jacq. Op. cit, $t, 134$. E. B. $t .298$.

4395. Wyalleaia $D C$. C a ly e is margo obsoletus. Petala ovata, lanceolata, integra, acumine longo, incurvo. Fructus ovatus, stylopodio brevi stylisque reflexis coronatus, a latere subcontractus, vix didymus; mericarpia subsemiteretia, quinquejuga, jugis filiformibus, crassinsculis, obtusis, aequidistantibus, valleculis lais, univittatis, commissura angusta, bivittata, vittis angustissimis. Carpophorum bifidum. Semen subsemiteres, facie vix planiuscula. Herba caribaea, glabra; caule erecto, tereti, ramoso, foliis ternatisectis, segmentis multifidis, lobis cuneatis, involucro nullo v. monophyllo, involucellis polyphyllis, floribus albis.

W ydle ria DC. Mem. V. 63, t, 7. Prodr, IV. 103. Meisuer Gen. 142. (104.)

4398. Trimia HOFFM. Flores abortu dioici, rarius monoici. Calyeis limbus obsoletus. Petala floris masculi lanceolata, in lacinnlam involntam coarctata, floris feminei v. hermaphroditi ovata, breviter apieulata, apieulo inflexo. Fructus ovatus, a latere compressus; meric a r pia quinquejuga, jugis filiformibus, prominulis, aequalibus, lateralibus marginantibns, valleculis evittatis v, univittatis. Carpophorum planum, a basi bipartitum. Sem en gibbo-convexum, facie planiusculum. - Herbae biennes, ramosissimae, in Europa media et australi, in regione taurico-caucasica et in Capite bonae spei indigenac; caule angulato, foliis bipinnatisectis, segmentis triternatis, lobis linearibus, sacpe glaucescentibus, umbellis plurimis, in paniculam v. thyrsum dispositis, pluriradiatis, involucro nullo, umbellulis saepius exinvolucellatis, interdum proliferis $v$. subracemosis, floribus albis.

Tri ni a Hoffanan Gen. Umbellif. 92, Koch Umbellif. 197. DC. Prodr. IV. 103. Reichenb. Iconogr. $t$. 448. Meisner Gen. 142. (104,) Apinclla Necker Elem. n. 326. Spielmannia Gussone ex Jussien in Dict. so, nat. LV. 328. P impinella e s p. Linn. Jacq. Flor. Austr, t, 28, E. B, t. 1209. Waldst. et Kitaibel Plant, rar. Hung, t. 72.

4:398. Heloseindium $K O C H$. C a l y e is limbus quinquedentatus v. obsoletus, P e ta la ovata, integra, apice recta $v$. inflexa. Fractus a latere compressus, ovatus v. oblongus; $\mathbf{m}$ eric a r ia quinquejuga, jugis filiformibus, prominulis, aequalibus, lateralibus marginantibus, valleculis univittatis, Carp ophorum integrum, liberum. Semen gibbo v. tereti convexum, facie planiusculam. - Herbae in Europa, America om $n i$ et India boreali indigenae; umbellis compositis, involucris variis, floribus albis.

Helosciadium Koch Umbellif. 129. DC. Mem. $\nu$. 37. Prodr. IV, 10\%. Meisner Gen. 142. (104.) S i u m Adanson Fam. II. 97. Sli s p. Linn.

a. MAUCHARTIA DC. 2. c. Involue rum mono-triphyl. $1 \mathrm{um}$, rarius nullum, involucella penta-hexaphylla. Herbae europeac, aquaticas, repentes p. procum. bentes, folits pinnatisectis.

Manchartia Necker Elem. $n$. 286, 5 ii sp. Linn. Jaeq. Flor, Austr, $t$, 260. E. B. $t, 639$. Flor, dan. $t, 514$. Reícbenb. Ieonogr, \&. 218.

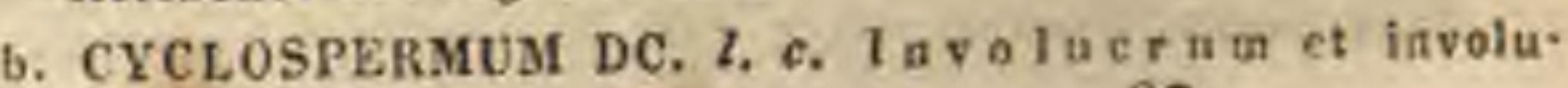


cella nulla. Fructas gluterrimus. - Herbae americanae et indicae, erectae.

Cyclos perm o m Lagasea Amen, nat, II, 101, S s o n A m m i Linn. Jacq. Hort. Vindob. $t .200$.

c. TRACHISCIADIUM DC. $l$. $c$. Invol u crum et involucella nulla. Fructus pilis brevibus, rigidis scaber. Herbae nepalenses et capenses, erectae.

4398. Discoplears $D C$. Calycis $\mathrm{lim}$ bus quinquedentatus, dentibus subulatis, persistentibus. Petala ovata, integra, apieule infracto. Fruetus ovatus, subdidy uns; meriearpia quinquejuga, jogis dorsalibus tribus filiformihus, exsertis, subacutis, duobus lateralibus cum margine aceessorio crasso subconcretis, discum fructum ambientem formantibus, valleculis univittatis, commissura bivittata. Carpophorum bifidum. Semen teretinseulum. - Herba borealia mericana, glabra; caule tereti, erecto v. procumbente, foliis multisectis, laciniis lineari-setaceis, aliis trifidis, aliis indivisis, involucri pleiophylli foliolis indivisis trifidisque, involucellis subpentaphyllis, foliolis lineari-setaceis.

Diseoplenia DC. Mem. $V$. 38, t. 8. 9. Prodr. $I D$ 106. Meisner Gen, 142, (t02,) Ptilimnium Ratin, in $S_{e}$ ringe Bullet, bot. 217. A m m e os s p. Michx. Elliot.

4393. Teptoeantis NUTT, C a lycis limbus obsoletus. Pet a l a elliptica, integra. F r a $c$. tus stylis coronatus, a latere compressus, ovatus; mericarpia quinquejuga, jugis vix prominentibus, lateralibus marginantibus, valleculis univittatis, commissura bivittata. Carpophorum apice brevissime bifidum. Semen durso convexum, facie planinsculum. - Herbae bor eali-americanae, erectae, tenuissimae, glabrae; caule tereti, foliis multifidis, laciniis linearibus, umbellis pedunculatis, oppositifoliis et terminalibus, pauciradiatis, involucro nullo, umbellularum radiis paucis, inaequalibus, involucello brevi, oligophyllo, floribus albis, parvis.

Leptocaulis Nuttall ex DC. Mem. V. 39. t. 10. Prodr. IV. 167. Meisner Gen. 142. (102.) S permole$\mathrm{p}$ is Rafin, in Seringe Bullet. 218. S is o nis sp. Mielix. Eillot.

44DS. FPtyelinotis KOCH. Calyeis limbus quinquedentatus. P et a l a ovata, emarginato-bifida, cum lacinula inflexa, carinae adnata. Fruetns a latere compressus, ovatus v, oblongus; merie a rpia quinquejuga, jugis filiformibus, aequalibus, lateralibus marginantibus, valleculis univittatis, commissnra bivittata. Ca r p ophorum bipartitum. Semen tereti v. gibboeonvexum, facie planiusculum. - Herbae annuae v. biennes, in regione mediterranea, Oriente, India et Capite bonae spe $i$ abservatae; foliis multifido-capillaceis, umbellis compositis, involucro vario, involucellis pleiophyllis, floribus albis.

Ptychot1s Koch Umbellif. 124. DC. Mrem, $V$. 39. Prodr. IV. 107. Wight et Aruott Prodr. 368, Meisner Gen. 148. (104.) B u $\mathrm{i}$ i um Lagasea Amen, nat. II. 10\%. A utmoides Adanson Fam, $I T$, 96 . Sesele os sp. Auct.

a. EUPTхснотIS DC, l.c. I avol и crum nullum, Fruc$t u s$ costntus, laevis nee muricatus. - Herbae Euro. pae australisetregionis meditorraneae oceidentalis. - C a r $\mathrm{n}$ m B un ias L, Jaeq. Hort. Vindob. 11. t. 198.

b. TRACHYSPERMUM DC, $l, c$, Involuernm oligophy. lum, foliolis Jinearibus integris v. trifidls. Fruetus muriculatus. - Herbae regionis mediterraneae orientalis, indicae et capentes. - Trachysperm u link Enumerat. hort, berolin. 1, 267. Am mios Mobeh Method. 99. A m me os $\mathrm{sp}$. Linn. Jacq. Hort. Vindob. II. t. 196. c. HETEROPTYCHA DC. $l$. c. Involaeram nallam. Calyels dentes subbosoleti. Petala parum enargi. uata, nervo medio superue lamellato. Fructus setulis echiaatus. Styli lougi, parau divergentes, Herbae orientales.

4401. Crottameng BESS. F lores polygami, Calyeis tubus in floribus masenlis nullus, in hermaphroditis cylindricus, limbus quinquedentatus. P e t a l a obovata, corvata, sinuato emarginata, cum lacinula inflexa. Fructus oblongus, a latere compressus; mericarpia quinquejuga, jugis filiformibns, aequalibus, lateralihus marginantibus, valleculis univittatis, commissura bivittata, vittis filiformibus $C$ arpoph orn m liberum, bifidum. S emen tereti-convexum, facie planiusculum - Herbae perennes, glabrae, in Europa et $A$ sia media indigenae; foliis pinnatisectis, lobis late linearibus, decurrentibus, cartilagineo-serratis, umbellis oppositifoliis et terminalibus compositis, multiradiatis, involucro polyphyllo, involucelli subdimidiati foliolis interioribus minimis, floribus albis, hermaphroditis masculisque in eadem umbella mixtis.

Critaus Beseer Volkyn, 93. Falearia Rivin. Pentapet. n. 48, Host Flar. austr. I. 381. DC. Prodr. ID. 109. Meisner Gen. 142. (104.) non Cav, nec Zoolog. Drepanophy $11 \mathrm{~nm}$ Hoffuans Umbellif. 110. excl. sp Koch Umbellif. 123. non Richard Prio a it is Delabr. Flor. Auvergn. Hladnickia Reichenb Flor. Germ. 476. Ico nogr. $f$. 1114. S i am F a l c a ria Linn. Jaeq. Flor. austr. t. $85 \%$.

440\%. Sison LAGASC C aly e is limbus obsoletus. P e t a I a ovata, curvata, profunde emarginata, cum lacinula inflexa. St y li brevissimi. Fruetus ovatus, a latere compressus; m eriearpia quinqnejuga, jugis filiformibus, aequalibus, lateralibus marginantibus, valleeulis univittatis, commissura bivittata, vittis abbreviatis, clavatis. Carpophorum hipartitum. Semen gibbo-convexum, facie planinsenlum. Herba biennis, in rupibus calcareis Europa e australis vegretans, caule erecto, tereti, paniculato, foliis pinnatisectis, inferiorum segmentis sublobatis, dentatis, subincisis, superiorum lineari multifidis, involucro involucellisque oligophyllis, radiis um bellae quaternis, inaequalibus, elongatis, umbellularum quaternis $v$. quinis, abbreviatis.

S is on Lagasea Amen, nat. IT. 103. Koch Umbellif. 123. DC. Prodr. IV. 110. Meisner Gen, 142. (104.) S is o n A m a m u m Linn. Jacq. Hort. Vindob. IIT, t. 18, Schkuhr Handb. $t, 65$.

4403. Sellumtzia SPRENG. Caly e is limbus obsoletus. P e $t$ a 1 a elliptica, acnmine terminali brevi, inflexo. Styli erecti, subcapitati, stylopodio conico, demum divergentes. F ruet $\mathbf{u} s$ cylindraceo-prismaticus, a latere snbcompressus; meric a rpia quinquejuga, jugis filifurmibus, exsertis, lateralibus marginantibus, valleculis univittatis, commissura bivittata. Carpophorum indivisum. Semen teretiuscnlam. - Herba $a b$ taica, perennis, glabra; foliis radicalibus et in inferiore caulis parte confertis, bipinnatisectis, seg. mentis multipartitis, ad rhachin decussatis, laciniis linearibus, acutis, umbella caulem superne nudum terminante multiradiata, involucro involucellisque polyphyllis, foliolis multifidis, lobis linearibus, acutis, floribus albis, omnibus fertilibus.

Schnltx ia Sprengel Spec. Umbellif. 102. Schultes Syst. VI. 44. Lagasca Amen. nat, II, 99. DC. Prodr. IV 112. Meisner Gen. 148, (103.) Se hulz i a Sprengel Prodi. Umbellif. 30. Sison eriuitum Pallas in Comment. Pe. tropalit, XIK. $250, t, 7$. 
4494. Ammi TOURNEF, Calyeis limbus obsoletus. Petala obovata, cum lacinula inflexa, emarginato-biloba, lobis inacqualibus, exteriora umbellae saepe majora. Fr n ctus a latere compressus, ovato-oblongus; meric arpia quinquejuga, jugis filiformibus, aequalibus, lateralibus marginantibus, valleculis univittatis, commissura bivittata. Carpoph or um liberum, bipartitum. S e m en tereti-convexum, facie planiusenInm. - Herbae in Europa media et in regione mediterranea indigenae, dauciformes; radice fusiformi, foliis pinnatisectis $v$, multipartitis, umbellis compositis, multiradiatis, involucris polyphyllis, foliolis trifidis $v$. pinnatifidis, involucellorum foliolis pluribus, indivisis.

A $\mathrm{m} \mathrm{m}$ i Tournefort inst. 304. Liun. gen, n.334. Schkuhr t. 129. Sibthorp Flor. graec, t. 273. Gussone Plant, rar. t. 25. Sprengel Prodr. Umbellif. 4t. Lagasea Amen, nat, $I I$. 104. Koch Umbellif. 122. DC. Prodr. IV. 11:. Meisuer Gen. 143. (104.) Vis in a a Girtuer 1. 92. $t$. $2 t$. Gohoria Necker Elem. n, 287. Da u ci s p. Lius. Jaeq. Hort. Vindob. III. t. 26.

4405. Aegopoalium LINN. Caly cis limbus obsoletus. Petala ovata, emarginata, cum lacinula inflexa. Fructus a latere compressus, ovatus, stylopodiis conicis, distinctis, stylis longis, deflexis terminatis; mericarpia quinquejuga, jugis filiformibus, lateralibus marginantibus, vallecelis evittatis. Carpophorum setaceum, apice bifurcum. Semen tereti-convexum, facie planiusculum. - Herbae in Europa et Asia media indigenae; foliis tripinnatifidis $v$. biternatitriternalisectis, laciniis serratis v. integerrimis, umbellis compositis, multiradiatis, involucro involucellisque nullis, floribus albis.

A e g op odil um Linn. Gen, $n$, 368. Gärtner Ir. 274. t. 140. Selhuhir $t$. 79. Flor. dan. $t$. 79. Heffmann Qen. Um. bellif. $82, t, 1, f .6$. Koch Umbellif. 122. DC. Prodr. $I V$. 114. Ledebour Ic. $t$. 7. Meisner Gen. 142. (103.) $\mathrm{P}$ o d agraria Rivia. Pentapet. 47. Münch Method, 89.

408. Carume KOCH. Caly eis limbus obsoletus. Petala obovata, emarginata, cum lacinala inflexa. Fruetus a latere compressus, ovatus v. oblongus, stylopodio depresso, stylis deflexis; mericarpia quinquejuga, jugis filifor. milus, lateralibus marginantibus, valleculis univittatis, commissura bivittata. Ca rpophorum liberum, apice bifureum. Semen tereti-convexum, facie planinsculnm. - Herbae perennes, glabrae, in Europa media et australi, in $A m e-$ rica media et australi, in America bo. reali et India superiore indigenae; radice saepius tuberosa, eduli, foliis pinnatisectis, segmentis multifidis, involucro involucellisque nullis $v$. polyphyllis, floribus albis.

C a r u moch Umbellif. 121. DC. Mem. V. 41. Prodr. IV. 114. Meisner Gen, 142. (103.) Carum, Sisouis et B u uli s p. Linn.

a. CARVi DC. 2. c. 1uvoluerum nullam, involucella nulla v. oligophylla.

C a r u m Linu, gen, n. 364. Flor. dan, t, 1091. E. B. t. 1503, Nees Jun. Plant. offic. XIV. t. 17. C a rum Adanson Fam. II. 98. Sell in sp. Viviani Fragm. i. 15.

b. BULBOCASTANUM DC. 2. c. I nval a $\mathrm{rum}$ et involucella ualla.

Bu lbocastanum Adanson Fam, II. 97, Bua i u Butbocastau um Lian. Flor. dan. $t$. 220. et $\mathrm{S}$ is on verticillat n ni Lias. E. B. $t$, 395. (De germiantione cfr. Trevirauus, Perm. Schrifi. IV. 187.)

440\%. Bunitum $\mathrm{KOCH}$. C aly cis margo obsoletus. Pet a la obovata, emarginata, lacinula inflexa. Fructus a latere contractus, lineari-oblongus, stylopodio depresso v, rarius conico stylisque reflexis; mericarpia quinquejuga, jugis filiformilus, obtusis, lateralibus marginantibns, valleculis bi-trivittatis, commissura quadrivittata, vittis omnibus superficialibus. Carpophorum liberum, bifidam. Semen tereti-convexum, facie planum. - Herbae perennes, mediterraneae, caucasicae et fortassis etiam capenses; radice saepius tuberosa, globosa, caule tereti, in speciebus radice tuberosa praeditis basi attenuato, foliis multisectis, segmentis multifidis, lobis linearibus, involucro vario, involucellis oligophyllis, floribus albis, rarius flavis v. virescentibus.

B unium Koeb msc. DC. Mem.., 41, Prodr. $I V, 113$. excl. sp. Meisner Gen. 8q2. (102.) Bulbocas t a u m La. gasea Amen, nat. H. 99. non Adass. B u 11 il s p. Lian.

a. CHRYSEUM DC. $l$.c. Involueram et involueella polypliylla. F I o r es flavi v. virescentes. Sty li divergeates. - Siis p. Spreng.

b. CAROIDES DC. l. c. Involueram saepius polyphyl. Ium, rarius nullum. FIores albi. Styli e stylopodio depresso divergentes. - Wallroth fae s p. Spreng. (Waldst. et Kitaibel Plant, rar, Hung. $t$. 182, Desfont. in Annal. Mus. XT, t, 30,)

c. CONOPODIUM DC. $l$. c. Involuerum nullum v, olli. gophyllum. St yli e stylopodio conico erecti. Co nopo. dil sect. 1. Koch Umbellif. 118. S e and ic is sp. Des. font. $t .74$. (Sibthorp Flor. graeo, $t, 274$, ) $-7 \mathrm{Tra}$ ch у s perm u m Ecklon et Zeyher Enumerat, 341.

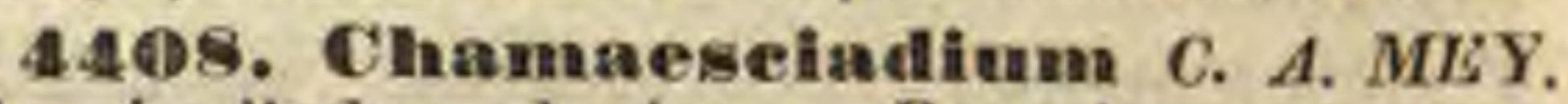
Calycis limbus obsoletus. Petala ovato-lanceolata, integra, apice obliquo v. inflexo, Fructus ovato-oblongus, a latere compressus, stylopodio depresso, marginato stylisque reflexis; m ericarpia solida, quinquejuga, jugis filiformibus, aequalibns, lateralibus marginantibus, valleculis tri-quadrivittatis, commissura quadri-sexvittata. Carpophor nm adnatum, apice bifidum. S emen subsemiteres, facie planum. - Herba caucasica, acaulis; radice fusiformi, elongata, foliis radicalibus bipinnatisectis, segmentis multipartitis, lobis lineari-setaceis, involucro involucellisque polyphyllis, foliolis subulatis, floribus luteis.

Chama es ciadiam C. A. Meyer Verzeicha. Caucas. PRanz. 129. B и а і и а са ule Bleberst. DC,

4809. Cryptotaenia DC, Calycis limbus obsoletus. Petal a obovata, subintegra, in lacinulam inflexam angustata. Fru ctu 8 a latere contractus, lineari-oblongus, stylopodio conico, brevi, stylisque rectis coronatus; me ricarpia solida, quinquejuga, jugis filiforsibus, aequalibus, lateralibus ante marginem positis, valleculis multivittatis, vittis sub cortice adnato absconditis. Carpophorum liberum, apice bifidum. S emen tereti-convexum, facie planinsenlum. - Herbae boreali-americanae et mediterraneae, perennes, erectae, glabrae; radice fibrosa, foliis triseotis, segmentis ovatis, grosse mucronato-dentatis, umbellis plurimis, subpaniculatis, unbellae umbellularumiue radiis paucis, valde inaequalibus, involucro nullo, involucellis oligophyllis, floribus albis.

Cryptotaenia DC. Mem. V. 42. Prodr. IV. 118. Meisner Gen. 143. (104.) Co nopodil seet. 2. Koch $U m$ bellif. 119. Cy $\mathbf{r}$ tospermum Rafinesq. msc. - ? Alacosperm u neeker Elem, n. 276. - Sis on c a naden$\mathrm{se}$ Linn. M yrrhis canadeusis Gärtaer $t, 23$. Sis on Thomasli Tenore.

4410. HPinipinella LINN. C a lycis limbus obsuletus. Pet a la ovata, emarginata, cum lacinula inflexa. Fructus a latere contractus, 
ovatus, stylopodio pulvinato, stylisque reflexis, apice subcapitatis; me ricarpia solida, quin quejuga, jugis filiformibus, aequalibus, laterali bus marginantibus, valleculis multivittatis. C a rpophorum liberum, bifidum. Semen gibboconvexum, facie planiuscnlum. - Herbae in $E u$ ropa media et regione mediterranea obviae, in Oriente et India ruriores; radice simplici, foliis radicalibus pinnalisectis, segmentis subrotundis, dentatis $v$. rarissime indivisis, caulinis tenuissime dissectis, umbellis umbellulisque multiradiatis, exinvolucratis, petalis albis, rarius rubescentibus $v$, luteis.

$\mathrm{Pi}$ i pinella Linn. gen. n. 366. Koch Umbellif. 120. f. 65. 66. DC. Mem. $V$, 42. Prodr. IV, 119. Meisuer Gen, 143. (102.) non Tournef. et Gĩrtuer.

a. TRAGosklinum DC. $l$. c. Fructus glaber. Radices perennes.

Tragoseli u u m Tournef. inst. 163. Mōneh Method. 99. P I m pinell a Spreng. Prodr. Umbellif. 35. Sehul. tes Syst, $V$. 34. Hoffmann Umbellif. 88. (Jarq. Flor. austr. t. 397. Schkulur t, 78. Fior. dan, $t$, 1155. B. B. $t, 407,408$. Desfont. Flor, atlant. $t, 67$ et 67 bis. Nees Plant. offic, $X, t, 19$.

b. TRAGIUM DC. 7. c. Fructus villosus. - Nadices perennes $v$, rarius biennes, folia radicalia uni-bipin. natisecta, segmentis ovatis.

Trag i a m Sprengel Prodr. Umbellif. 91, t, a. f.22. L ed eburia Link Hort. Berolin. 1 . 286 . B u b on is s p. Lagase, (Jacq. Hort. Vindob. II. t, 131. Loisleur t. 3.)

c. ANISUM DC. L, c. F r u ct u s puberulus. - Herbae annuag. A $\mathrm{n}$ is um Adanson Fam. II. 95. Gártner $I$. 109. t. 23. B u bonis sp. Lagasc. (Nees Plant, offic, XII c. 17.

44 1. Tentern BOIS. Caly cis limbus obsoletus. P e t a $\mathrm{l}$ a integra, ovata, apice in curvo convoluta, aequalia. Fruetus a lątere valde contractus, subdidymus, stylopodio pulvinato stylisque breviluus reflexis; mericarpia quinquejuga, jugis filiformibus, aequalibus, lateralibns marginantibus, valleculis interioribus tri. exterioribus quadrivittatis, commissura utrinque bivittata, vitta interiore lata, Carpophorum liberum, indivisum. S e men gibbo-convexum, facie planiusculum, - Herbae hispanicae; foliis radicalibus pinnatisectis bipinnatisectisoe, caulinis tripartitis $v$. ad vaginam linearem redactis, umbellis pauciradiatis, involucro involucelloque nullo, floribus luteis, minimis, fructibus rufis, glaberrimis.

Reuter a Boissier Elench. plant, Hisp. austr. 46 ,

44 12. HEerula KOCH. Calycis limbns quinquedentatus. Petal a obovata, emarginata, cum lacinula inflexa. Fruetns ovatns, a latere contractus, subdidymus, stylopodio breviter conico, marginato, stylis reflexis; meriearpia quinquejuga, jugis filiformibus, aequalibus, lateralibus ante marginem positis, valleculis multivittatis, vittis periearpio crasso, corticoso tectis. Carpophorum bipartitum, eruribus adnatis, fere obsoletum. S e m en undique teres. - Herba perennis, in fossis et aquis lente fluentibus $E$ is 0 pae, Caucasi et Persiae crescens; radice e collo stolonifera, caule vix striato, foliis pinnatisectis, segmentis ovatis, inaequaliter et grosse serratis, umbellis pedunculatis, oppositifoliis et terminalibus, involucri polyphylli foliolis subpinnatifidis.

Berula Koch Deutseht. Flora $I T$. 455. Tauseh $i$ Flora 1834. p. 355. Meisner Gen. 148, (104.) S i i sect. 3 . DC. Prodr. IV. 125. S i um a $\mathrm{g}$ us tif ali um Linu. Jacq. Flor. austr. t, 139, E. B. t. 139.
413. Simme KOCH, Calyeis limbus quinquedentatus, dentibus interdum minimis. $\mathrm{Pe}$ ta la obovata, emarginata, cam lacinula inflexa. Fruetus a latere compressus v. contrartus, suladidymus, stylopodio pulvinato, marginato, stylis reflexis; merica r pia quinquejuga, jogis aequalibus, filiformibus, obtusiusculis, lateralibus marginantibus, valleculis trivittatis, vittis superficia. libus. Carpophorum bipartitum, cruribus ad natis v. liberum. S e m e n dorso convexum, facie planum. - Herbae terrestres v. paludosae, per hemisphaerae borealis regiones temperatas diffusae; foliis pinnatisectis, segmentis ovatis $v$. oblongis, dentalis aut multipartitis, umbellis terminalibas multiradiatis, involucro polyphyllo $v$, interdum submonophyllo, umbellulis multifloris, involucello polyphyllo cinctis, floribus albis.

Slum Koch DeutsoAl, Flora II. 455. Symops, 289. Melsner Gen, 143. (104.) S ii sect. 1. DC. Prodr. IV, 124. S if sp. Linn.

a. EUSIUM Koeh l.c. C a rpoph o ri crura adnata. (Jacq, Flor. gustr. t. 66. E. B. t. 204. Flor. dan. $t$. 296.)

b. SISARUM koch $l$, c. Carpophorum lifierum. Sisa. r u m Adauson Fam. II. 97. (Sehkubr t. 69.)

4414. Buplewruma TOURNEF. Calycis limbus obsoletus. Petala subrotunda, integra, arcte involuta, lacinula lata, retusa. Fruct us a latere compressus v. subdidymus, stylopodio depresso; meriearpia quinquejuga, jugis alatis, acutis, filiformibus v. obsoletis, lateralibus marginalibus, valleculis evittatis v. vittatis, laevibus aut granulatis. Carpophor nm liberum. Semen tereti-convexum, lacie planiusculum. - Herbae v. frutices glaberrimi, in regionibus extratropicis veteris orbis et in Capite bonae spei obviae, in America bo$r$ eali rarae; foliis rarius dissectis, saepissime limbo abortivo petioloque in phyllodium integerrimum mutalo, umbellis compositis, involucris variis, floribus flavis.

B u pleu rum Tonrnef. inst. 309. Linn. gen, n. 328. Jaeq. Elor, aistr. $t$. 356 . Ic. rar. t. 351 . Sibthorp Flor. graec, t. 260-264. Lagasca Amen, nat. II. 100. Koch Um bellif, 44. $f .51 .52$. Reicheab. Ioonogr. t. 164_168. 177179. 183. 521. Eichwald Plant, caucas. t, 10,11. DC. Prodr. IV. 127. Ag ostana Salisbury in Gray Brit. Plant. II. 326. Diaphyllum et 1 s op hyllum Hoffmann Umbellif. 112. Tenoria. Buprestis et Odonites Sprengel Prodr. Umbellif. 27. D i atropa Datuortier Flor. bels. 76. Tra ch y p le urum Reichenb. Consp. 143. - 2 ORiMARIA Raf, in Seringe Bullet, 218, C al y c is limbus integer. Petala basi fovea instructa, apice involuto adnato. $8 \mathrm{ta}$ mina miaima. Stig mata 2, subsessilir. Mericarpia linearia, angulata, nigra. - Herba boreali-americana, feste auctore, penes quem generis fides maneat, Bupleuro aftiais ; caule filiformi, dichotomo, foliis linearibus, integerrizuis, unbella tri-quadríradiata, umbellulis tri-sexfloris involueri triphylli foliolis subulatis, involucellis pentaphyllis, foliolis scariosis, ellipticis, trinerviis, floribus albis, inclusis.

415. Heteromorpha CHAM, et SCHLECHT. Calycis margo quinquedentatus. Petala subrotunda, integra, arcte involuta, lacinula lata, retusa. Fruetus obovato-pyriformis, jugis carinalibus alatis; mericarpia difformia, quinquejuga, exterioris jugis intermediis in alas productis, dorsali lateralibusque filiformibus, obsoletis, interioris jugo dorsali lateralibusque marginantibus alatis, intermediis filiformilsns, vallecnlis univittatis, commissura bivittata. Car p o p h o $\mathrm{rm}$ liberum. Semen teretiuseulum, facie planiusealum. - Frutices capenses, glabri; foliis quatis v. oblongis, integris v. tripartilis aut trisectiv, um- 
bellis multiradiatis, involucro involucellisque brevissimis, polyphyllis, floribus flavis.

He i e r om orph a Cham, et Schlechtend, in Linnaea $x$. 385, t, s. f. 2. DC. Mem. V. 43, Prodr. IV. 134. Meisuer Gen, 143. (103.) Tenoriae s p. Spreng. Bupleurum a 5 b ore a in Thuabg.

T ERUE US У. SESELINEAE Koch Umbellif. 102. Fruetus sectio transversa teres v. teretiuscula. Meric a rpia jugis quinque filiformibus v. alatis, lateralibus marginantibus, aequalibus v, nonnunquam latioribus. S e me n dorso subtereti-convexum, facie planum. - S e selineace eadem fere ratione ac Ammineae per orbem terrarum distributae, in Europa media et Asia boreali nonnihil his sunt frequentiores.

\section{Hielhtensteinia CHAM.} SCHLECHT. Caly cis limbus acute quinquedentatus. P et a l a elliptica, in acumen longum, in flexum producta. Fructus teretiuscuins, stylo podio conico, acuminato, stylisque brevihus, patulis; meriearpia laevia, quinquejuga, jugis filif,rmibus, aequalibus, lateralibus marginantibus, singulis univittatis, valleculis commissuraque evittata. Carpoph or am bifidum. Semen dorso convexum, facie planiusculum. - Herbae c a pen$s e s$, perennes, succo aromalico plenae; foliis radicalibus incisis, caule erecto, fistuloso, ramoso, squamis vaginantibus vestito, umbellis compositis, terminalifertili, lateralibus saepe sterilibus, involucris involucellisque polyphyllis, abbreviatis, marcescentibus, floribus luteis.

Lich tenstein i a Cham, et Schlechtend. in Linnaed I. 394. t. 5. f. 3. DC. Prodr. IV. 135. Ficklon et Zey. her Enumerat, 343. Meisner Gen, 143. (104.) noil allor. Oenanthes sp. Thuab. Spreng.

44\%. Otton H. B. K. Calyeis limbus obsoletus. Petala aequalia, apice acuminatosubulato inflexa. Fructus oblongus, stylis arcuato-divaricatis, capitatis ; mericarpia quinquecostata, ad commissuram snluompressa, costis membranaceis, acntis.... - Herba quitensis, perennis, glabra; caule simplici, parce folioso, foliis (phyllodiis) basi vaginantibus, teretibus, fistulosis, transversim septatis, umbella terminali multiradiata, involucro involucellisque nullis, floribus albis, polygamis, paucis hermaphroditis, reliquis masculis.

Ott o Kunth in $H u m b$, et Bonpl, Nov. gen. et ap. $V$. 20. t. G23. DC. Prodr, IV, 136. Meisner Gen, 143. (104.) 0 en anthes 5 p. Spreng.

4415. Denanthe $L A M$, $\mathrm{C}$ a l y $\mathrm{c}$ is limbus quinquedentatus, in fructu anetus. Petal a obovata, emarginata, cum lacinula inflexa. Fructus cylindraceo-ovatus, stylopodio conico, stylisque erectis, longis; mericarpia quinquejuga, jugis convexinsculis, obtnsis, lateralibus marginantibus, vallecnlis univittatis. Carpophoram indistinctum. Sem en convexum v. teretiuscalum, - Herbae in hemisphaeraboreali veteris orbis indigenae, in A merica rarissimae, plures aquaticae, glabrae; umbellis compositis, involucro vario, saejius nullo, involucellis polyphyllis, floribus in radio umbellulac longe pedicellatis, aborlu masculis, disci sessilibus v. breve pedicellatis, hermaphroditis, petalis ulbis.

0 en ant he Lam, Dict. IV. 596. Lagasea Amen. nat. 11. 96. Koch Umbellif. 112, DC. Prodr. IV. 136. Meisuer Gen, 14i. (104.)

a. OENANTHE Lian, gen, $n, 352$, Species perennes, ra dici- bus tuberoso - fasciculatis. - Jacq. Hort. Vindob. III, t. 55. 62. Flor. dan. t. 846, E. B. t, 348, 2313.

b. PHELLANDRIUM Linn. gen, $n$. 352. Species annuae $v$. biennes, radieibus fibrosis. - Schkuhr $t$. 71. Flor. dan. t. 1154 . Nees Plant, offic, $\bar{X} T \bar{V}, t, 6$.

44\%. Chamarea ECKL, et ZEYH, CaI yeis limbus minute quinquedentatus, fere obsoletus. P e ta la lanceolata, acuminata, acumine inflexo. Fructus ovatus v. subrotundus, a latere compressus, stylopodio conico stylisque divaricatis; merica rpia quinquejuga, jugis aequalibus, filiformibus, obtusis, lateralibns marginantibus, valleculis nnivittatis, commissura plana, bivittata, Carpoph or um liberum, apice bifidum. Semen tereti-convexum, facie planum - Herbae cap enses, biennes; caule tereti, ramosissimo, glabro, foluis omnibus radicalibus, tripinnatisectis, segmentis setaceis, fastigiatis, umbellis quadri-quinqueradiatis, umbellulis novem-duodecimfloris, involucris involucellisque tetra-pentaphyllis, foliolis ovato-acuminatis, striatis, deciduis, floribus albis.

Cha ma rea Ecklon et Zeyher Enumerat. 346. Meisner Gen, 135. (105.) A a e th u m capens e Thanb. (Buraana Afrie. $t$, g2. $f, 1$.

4490. Anesorlhiza CHAM, et SCHLECIIT. C a l y cis limbus quinquedentatus, persistens. P etal a elliptica, acuminata, acumine inflexo marginata. Fructus quinquangulari - prismaticus, stylis reflexis; meric arpia dorso convexa, quinquejuga, disparia, alterum trialatum, jugis carinali lateralibusque alatis, intermediis filiformibus, alcerum quadrialatum, jugo carinali filiformi, intermediis lateralibusque marginantibus alatis, valleculis univittatis, esmmissura plana, bivittata. C a r. po p h or u m bipartitum. Sem en dorso convexum, facie planum. - Herbae ca penses; radicibus fusiformibus, fasciculatis $v$. solitariis, foliis radicalibus petiolatis, bi-tripinnatisectis, caulinis squamaeformibus, umbellis pauci-multiradiatis, involucri involucellorumque foliolis plurimis, margine saepius hyalinis.

A nesorhiza Chamisso et Sehlechtend. in Linnaed $t$. 398. t. 5. f. 4. DC. Prodr. IV. 140. Ecklou et \%egher Enu. merat. 394. Meisuer Gen. 144. (104.)

44:1. Seleroseiadirnm KOCH. Calycis limbus quinquedentatus, dentibus cunicis, persistentibus. Petal a obsordata, in lacinulam truncatam, apice bi-tridenticulatam inflexa. F ract n 8 ovato - globosus, solidus, stylopodio conico stylisque filiformibus, divergentibus; mericarpia quinquejuga, jugis erassis, obtnsissimis, aequalibns, lateralibus marginantibus, valleculis angustissimis, nnivittatis, commissura plana, bivittata, C a r p 0ph or a m liberum, indivisum. Semen tereti-convexum, facie planiusculum. - Herbae Africae boreali-occidentalis et insulae Teneriffa, annua, glabra; foliis in lobos oblongo-lineares multifidos, umbell is axillaribus sessilibus, subexinvolucratis, radiis valde inaequalibus, involucelli penta-heptaphylli foliolis margine membranaceis.

Sclerosciadi n moch msc. DC. Mem, $V$. 43. t. 1. f. J. Prodr. IV, 140. Meisner Gen, 144, (104.) 0 e ua ut he a o difi or a Schousb.

448\%. Dasylema $D C$. Caly cis limbus obsoletus. Petala.... F r uetus ovatas, stylopodio depresso stylisque brevibus; meriearpia connata, quinquejuga, jugis corticoso-cellulosis, tribus dursalibus parvis, duobus lateralibua maximis, obtusis, valleculis angustis, univittatis, commissura plana, ad medium bivittata. Car poph 0 r $\mathrm{nm}$ indistinctum. Semen transyersim sectum 
fere triangulare, nempe dorso subconvexum, ad com missuram angulatum. - Herbae in dic a e, annuae, Oenanthes habitu; caule fistuloso, foliis bipinnatisectis, segmentis cuneatis, apice paucidentatis, umbellis oppositifoliis, quinque-sexradiatis, umbellulis conferlis, multifloris, involucro involucellisque nullis. (104.)

Das $\mathrm{y} 1$ o m a DC. Prodr. IV. 140. Melsuer Gen. 144.

4423. Cynoselativan DC. Calyeis limbes quinquedentatus, dentibus subnlatis, persistentibus. Petala obovata, fere elliptica, integra, enm lacinula inflexa. Fruet us ovali-ublongus v. ovatus, apice attenuatus, stylopodio eonico sty lisque brevissimis, reflexis; mericarpia quinquejuga, jugis erassis, corticosis, lateralibus marginantilius, valleculis angustissimis, univittatis, com missura bivittata, vittis rectinsculis. Ca r po p h or um bipartitum. Sem en subsemiteres. - Herba boreali-americana, glabra; caule angulato, fistuloso, ramoso, parce folioso, foliis pinnati- $v$. palmutisectis, segmentis linearibus, elongatis, integris, basi fere articulatis, foliola mentientibus, infimis et supremis indivisis, linearibus, elongatis, in volucris involucellisque polyphyllis, floribus albis.

C y nosciadium DC. Mem. $V$. 44. $t$, 11, Prodr. IV. 140. Meisner Gen. 144. (105.)

44 8. Aethessa Linn. C a lyeis limbus obsoletus. P'eta la obovata, emarginata, cum lacinula inflexa, exteriora subradiantia. Fructus ovato-globosus; merie arpia quinquejuga, jugis elevatis, crassis, acute carinatis, lateralibus mar ginantibus, paullo latioribus, carina subalata cinctis, valleculis univittatis, commissura bivittata, vittis arcuatis. Carpophorum bipartitum. Seu in a hemisphaerica. Herbae e uro pea e, annuae, erectae, venenosae; foliis multifidis, involucro nullo v. nonophyllo, involucellis oligophyllis, foliolis setaceis, extrorsum lateralibus, patulis v. pendulis, floribus albis.

Aethus a Linn. gen, n. 141. exel. sp. E. B. t. 1198 Hoffanann Umbellif. 95. t. 1. f. 5. Sprengel Prodr. Umbellif. 17. Lagasca Amen. nat. II. 96. Koch Umbellif. 111. DC. Prodr. IV. 141. Meisuer Gen, 145. (105.)

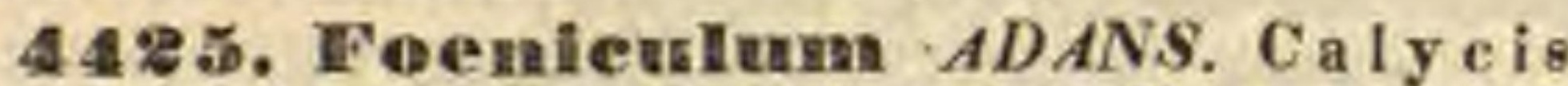
limbus obsoletus, tumidns, integer. Peta 1 a ob"vata, integra, involuta, lacinula subquadrata, retusa. Fructus oblongus, teretinsculus; $m e-$ ric a r ia quinquejuga, jugis prominulis, obtuse carinatis, lateralibus marginantibus, paullo latioribus, valleculis univittatis, commissura plana, bivitiata. Carpophorum adnatum. Semen snbsemiteres. - Herbae in Europa australi spontaneae, passim cultae, biennes $v$. perennes; caule tereti, substriato, ramoso, foliis pinnatisectis, decompositis, laciniis lineari-setaceis, involucro involucellisque subnullis, floribus flavis.

Foeniculum Adanson Fam, II. 101. Gärtner L. 105. t. 23. Hoffmanu Umbellif. 120, $t, 1, f, 13$, Lagasea Amen. nat. II, 99. Koch Umbellif. 112, DC. Prodr. IV. 142, Meís. ner Gen. 145. (105.) A nethu in Foen i eulum Lins. E. B. t. 1208 ,

4426. Fin endmanneta SCOP. Calyeis limbus quinquedentatus, demum nonnibil anctus. l'etal a obovata, integra, involuta, lacinula lata, retusa. Fruetus teres, stylopodio conico stylis que brevibus, reflexis; meri ea r p i quinquejuga, jugis filiformibus, obtusis, aequatibus, lateralibus uarginantibus, valleculis et commissura multivit. tatis. Carp op horum indivisum. Semen subseuiteres. - Herba perennis, glabra, in Europa nedicerranea obvia; radice fusiforni, foliis radicalibus rarius indivisis, saepius uni- v. bipinnatisectis, segmentis ovatis $v$. lanceolatis, serratis, summis ternatisectis, laciniis laviniatis, umbellis terminalibus compositis, multiradiatis, involucris involucellisque polyphyllis, foliolis filiformibus, reftexis, floribus flavis,

$\mathrm{K}$ u $\mathrm{ndm}$ a n $\mathrm{n}$ a Scopoli Introduct, n, 332. DC. Prodr. IV. 143. Meisuer Gen. 145. (105.) B riguolia Bertoloni in Desvaux Journ. Bot, IV. 76, Amen, it. 97. Mauri Plant, Rom. If. $t$. 2. Koch Umbellif, 107. C a m p der i a Lagnses Amen, nat. II. 99. S i um si culum Lian. Jaeq. Hort. Vindob. $t, 133$.

448\%. Beverra DC. Calycis limbus obsoletus. F'etala ovata, acuminata, acumine inflexo. Fructus stylis brevibus, divaricatis coronatus, ovatns v. subritundus, a latere subsompressus, squamis v. pilis patentibus hispidus; in cric a r p a semiteretia, jugis obsoletis, valleculis nnivittatis, commissura bivittata. Ca rpo ph oru m bipartitun. - Suffrutices in Africaboreali et australi extratropica observati, aromatici, subaphylli, glauci, rigidi, scoparii; petiolis vaginantibus, persistentibus, limbo in stirpe juvenili parvo, multipartito, lobis setaceis, in planta adulta nullo v. subnullo, umbellis pauciradiatis, involucro tetrahexaphyllo, parvo, deciduo, involucelli foliolis quatuor v. sex, ovato-lanceolatis, margine membranaceis, deciduis, floribus albis.

Deverra DC. Mem. V. 45. Prodr. IV. 143. Meisuer Gen. 144. (105.)

a. DEVERRARIA DC. 2. c. Fruetus villosi v. hispidi. B abon tortuos as Desfont. Flor, atlant. $t, 73$. B. a ph y II u s Cham. et Schlechtead.

b. PITHYRANTHUS DC. $l$, c, Fructus squauigeri.

Pithyra in th us Viviant Flor, Ljbic. 1s, $t, 7, f .1, \overline{2}$,

4428. Sorenthess LEDEB. C a ly cis limbus obsolete dentatus. P eta la late ovata, acuminata, acumine inflexo, persistentia. Fructus stylis divaricatis coronatus, transversin sectus el lipticus, a dorso subcompressus; mericarpia quinquejuga, jugis vix prominulis, aequalibus, lateralibus marginantibus, valleculis univittatis, commissura quadrivitata. Carpophorum bipartitum. - Herba sibirica, erecta, Seseleos facie; caule tereti, foliis bi-tripinnatisectis, laciniis distantibus, tenuissimis, acutis, involucro subnullo, in. volucellis penta-heptaphyllis, reflexo-patulis, umbellula capitata brevioribus.

Sor a nthus Ledebour Ie. I, 20, t. 82. DC. Prodr. IV 669. Meisuer Gen, 145. (105.)

4 429. Frotoeyela $L I N D L$. C a I y eis limbus obsoletus. Petala elliptica, acuta, integra. Fructns stylis brevibus, erectis coronatus, densissime lanatus, sectione transversali ellipticns, a latere compressus; mericarpia quinquejuga, jugis sub lana abseonditis, acutis, lateralibus mar. ginantibus, valleculis nnivittatis, commissura bivittata. Carpophorum .... S e men teres. Herba himalayens is, foliis tripinnatifidis, umbellis compositis, longeradiatis, umbellulis subcapitatis, involucro involucellisque depauperatis, floribus albis,

Eriocyela Lindley in Royle Himalay. 232, t. $51 . f, 2$ Meisner Gen, 145. (105.)

4430. Seseri LINN. Caly e is limbus quinquedentatus, dentibus brevibus, crassiuscu lis, interdum obsoletis. Peta I a obovata, in lacinulam inflexam coarctata, enarginata $\mathbf{v}$. subinte gra. Fructus stylis reflexis corunatus, ovalis v oblongus, sectione transversali subteres; meri 
f arpia quinquejuga, jugis prominulis filiformibus $v$, elevatis, crassis, corlicosis, lateralibus marginantibus, saepe panto latioribns, valleculis univittatis, exterioribus interdum bivittatis, eommissura bivittata v, interdum quadrivitata. Carpophorum bipartitum. Semen subsemiteres. - Herbae in Europa, Asia media et Americabo. real $i$ indigenae, biennes v. perennes, saepius glaucae; foliis pinnatisectis $v$, ternato-decompositis, involucro subnullo, involucellis polyphyllis, floribus albis $v$, rarius flavis.

Sesel1 Linn, gen. n. 360. Lagasea Amen nat. II. 103. DC, Mem. V. 46, t. 3. f. R. Proulr. IV. 144. Meisner Gen. 144. (105.)

a. HIPPOMARATHRUM DC, l. c. Involucru mullum. I v volucelli foliola fere ad apicem in cupnlam pelviformem, margine dentatam concreta. - Hippomarathrum Rivin, Pentapet. irreg. 67. Flor. Wotteraw I. 413. (Jacq. Flor. Austr. t. 143.)

b. HIPPOMARATHROIDES DC. I. c Invalucrum nulIum v. oligophyllum. In v o l u celli foliola basi tantum concreta. (Smith Exot. Bot, $t, 120$. Waldst, et Kitaibel Plant, rar. Hung, t. 89, 146. Bot. Mtag. t. 2073. 2259.)

c. EUSESELI DC. l. c. I n vol u c r u nullab. Involu celli foliola distincta v. vix basi subconcreta. SeseIi a vera Koch Umbellif. 110. Hippo ararathun Duby Bot, gallie, $t, 234$. M a rath $\mathrm{r}$ m Rafinesq. in Journ. Phys. LXXXIX. 10t. M us ineon Rafinesq. Op. cit. (Gouan Illustr. t. 8. Jacq. Flor. Austr, t, 45. B5. Hort. Vindob. III, $t$. 129. Waldst, et Kitalbel Plant. rar. Hung, t. 117. Ledebour Ic. t. 97, 104, 17\%. Bot. Mag. t. 1749. Hooker Flor. Bor. Amer, t. 93. 94.)

4431. Trolemanania ECKL. et ZEYH Caly cis limbus obsolete quinquedentatus. P $\mathrm{c}$ ta I a elliptica, integra, in acumen longum inflexa. Fruetns stylis reflexis coronatus oblongus, sectione transversali semiteres; me ricarpia quinqnejuga, jugis dorsalibus tribus filiformibus, lateralibns duobus obsoletioribus marginantibus, valle culis univittatis, commissura plana, bivittata. Carpophornm hipartitum. Sem en subsemiteres. Frulex capensis, interdum decempedalis, glaber; ramis purpurascentibus, foliis petiolatis, ternatis, foliolis cuneiformibus, trifidis tripartitisve ant interdum indivisis, lobis oblongo-cuneatis, rotundatis, mucronatis, reticulato venosis, margine diaphanis, unbellis terminulibus, inaequaliter duodecim-sedecimradiatis, umbellulis decem-vigintifloris, involu cro nullo v. oligophyllo, involucelli tetraphylli foliolis subulatis, floribus albis.

Polemannia Ecklon et Zeyher Enumerat, 34n. Mteisner Gen, 145. (105.)

443\%. Hibanotis CRANTZ. Calycis limbns quinquefidus, lobis tenuibus, elongato. subulatis, coloratis, deciduis. P et a l a obovata, in lacinnlam inflexam coarctata, glabra $v$, pubescentia. Fructus stylis reflexis cornnatus, ovalis, sectione transversa subteres; meri c a r pia quinquejuga, jugis erassiusenlis, corticosis, aequalilous, lateralibus marginantibus, valleculis univittatis, commissura bivittata. Carpophorum bipartitum. Semen subsemiteres. - Herbae in Europa et Asia media indigenue; folits pinnatisectis, segmentis ovatis, incisis multifidisve, saepe decussatis, involucro involucellisque saepissime polyphyllis.

L I ba notis Crantz Stirp. austr, 292, Gärtner $I$. 84. t. 21. DC, Mem, $V$, 17. Prodr. IV, 149. Meisner Gen, 144, (105.) non Scop. At ha ma ut tha Scopoll Carniol. $n, 309$. Lagasca Amen, nal. H. 103 . S es ele o s sect. Koch Umbellif. 111 . A t ba ma that $s p$. Linn.

a. ERioTis DC, l. c, Petala pube brevi fasciculata ca- vescentia. - B abon buchtormensis Fisch. (DC. Mem, V. t. $3, f .5$.

b. RELIBANotis De. 2, c. Petala glabra. - Atha. twa a thae $s p$. Linn. E. B. $t, 138$. Fiar. dan, t. 754 . Jecq. Flor, austr, $t$, 399. Hort, Vindob, t, 197. Sibthorp Flor. graec, t. 275. Ledebour 1c. t. 81, 178.

4485. Xutarella MEISN. Caly cis limbus obsuletus. Petal a lanceolata, integra, in lacinulam involutam coarctata. Fruetus stylis reflexis coronatus, oblengus, sectione transversali eliptico-subrotundas; meric arpia quinquejuga, jugis contiguis, crassis, elevatis, apteris, obtosinscule carinatis, Iateralibus vix majoribus, haud marginantibus, valleculis angustis, univittatis, commissura bivittata, Carpophorum bipartitum. Sem en compressum. - Herba pyren a ic a, biennis, laete viridis, glabra; radice elongata, ramosa, crassa, intus spongiosa, septistransversis membranaceis intercepta, caule brevi, subsimplici, crassissimo, fistuloso, basi foliato, superne striato, scabro, foliis ample vaginantibus, tripinnatisectis, lobulis linearibus, marginibus et nervo scabris, apice subcalloso - mucronatis, umbella terminali multiradiata, fructifera coarctata, radiis scaberrimis, valde inaequalibus, centralibus multo brevioribus, involucro nullo $v$. rarius diphyllo, involucell is tetrapolyphyllis, integerrimis, lineari-subulatis, umbella multo brevioribus, deciduis, floribus virentibus, mericarpio altero saepius abortivo.

X at a rdia Meisner Gen, 145. (105.) Petitia Gay in Annal. sc. nat. $X V I$, 217. non Jaeq. A ngelle a se a b $\mathrm{r}$ a Petit in Annal, sc. observ, $T$. 99. $t$. 3. S ellu um $\mathrm{sca}$. b r u m Lapeyr.

4434. Cenollophiven $K O C H$. Caly cis limbus obsoletus. P et a la obovata, emarginata, cum lacinula inflexa. Fructus ovato-oblongus, stylopodio brevi, conico, stylisque obsoletis, sectione transversali subteres; mericarpia quin. quejuga, jugis aequalibus, argutis, subalatis, inflato-cavis, lateralibus marginantibus, valleculiy univittatis, commissura bivittata, Carpophorum obsoletum. S emen semiteres, jnnius adnatum, maturam fere lihernm. - Herba to olgensis, perennis, glabra; foliis bipinnatisectis, segmentis divaricatis, subtrifidis, laciniis lanceolatis, cuspidatis, integerrimis, nervosis, involucro nullo v. monophyllo, involucellis polyphyllis, floribus albis.

C e noloph i um Koch Umbellif, 103. DC. Mem, V. 48. l. 3. f. T. Prodr. IF. 151. Meisner Gen, 145. (105.) A th at. ma n tba denudata Fisch.

4.855. Dethavia. $\mathrm{C}$ a $1 \mathrm{y}$ c is limbus acnte quinquedentatus. Petal a integra, elliptica, utrinque acnta. Fructus sectione transversali subteres; me ricarpia quinquejuga, jugis prominulis, aequalihus, lateralibus marginantibus, valleculis univittatis, commissura bivittata. Carpophornm bipartitum. Semen subsemiteres. Herba pyrenaica, perennis, glabra; foliis radicalibus petialatis, decompositis, lobis linearibus, tenuissimis, involucri foliolis paucis, inaequalibus, involucellis polyphyllis, foliolis lincari-lanceolatis, floribus albis.

Wallrotbia DC. Mom. V. 40. t. 3. f. A. Prodr. IV. 162. Gry in Annal. sc. nat. XXVI. 921. in not. Meisner Gen. 144. (105.) non Roth. Wall rothiae sp. Spreng. LIgusticum ten uifoli a matsond.

4436. Cniflioum CUSS. C a l y a is limbns obsoletus. P etala obovata, emarginata, cnm lacinula inflexa. Frnet us sectione transversali subteres; mericarpia quinquejuga, jngis in alam submembranaceam prodnetis, aequalibus, la. 
teralibus marginantibus, valleculae univittatae, commissura bivittata, Ca r p o h or $\mathbf{n m}$ adnatum. Semen semiteres. - Herbae in Europa australiore, regione ca acasica et India oricnt a li spontaneae, perennes $v$. interdum suffruticosae; foliis ternatisectis $v$. pinnatisectis, segmentis multifidis, lobis linearibus, involucro vario, involucellis polyphyllis, floribus albis $v$, roseis,

C $\mathrm{u}$ id i u m Cnsson Mem. soc, medic. Paris. 1789. p. 280. Hoffuann Umbellif, $I$. 157. Koch Umbellif, 108. $f$. 48. DC Prodr. IV. 152. Ledebour 1c. $t$. 312. Meisner Gen. 14J. (105.) Selin um Lagasc. Amen, nat. IT. 91. Selini sp. Linn. Jacq. Flor. Austr. Append, t. 46. Desfont, Flor, atlant. t. 21

443 \%. Hilymenialiem $L I N D L$, C a ly $\mathrm{c}$ is limbus obsoletus. Petala .... Fructns sectione transversali subteres; $m$ ericarpia quinquejuga, jugis in alam membranaceam productis, subaequalibus, lateralibus marginantibus, valleculis univittatis, commissura quadrivittata. Carpophorum ..... Semen semiteres. - Herbae cachmiranae, perennes; foliis supradecompositis, involucris involucellisque membranaceo-marginatis, flores superantibus.

H y menidi um Lindley in Royle Himalay. 233. Meisner Gen, 145. (105.)

4438. Thaspiumn NUTT. C a l y c is limbus quinquedentatus. Petal a elliptica, in acnmen longum, inflexum attenuata. Fructus subellipticus, a latere hand contractus; mericarpia convexa, quinquejuga, jugis alatis, subaequalibus, valleculis striatis, univittatis, commissura bivittata. Se m e $\mathbf{n}$ teres. Herbae boreali-americ anae; foliis pinnatisectis $v$. triternatisectis, radicalibus interdum indivisis, umbellis terminalibus $v$. oppositifuliis, involucro nullo, involucellis triphyllis, unilateralibus.

T li is s pi um Nuttall Gen,I. 196. exel.sp. DC. Prodr. IV. 153. Meisner Gen, 144. (105.) S m y r nif et Ligustiel s p. Auet.

435. Troelaiseanthes $K O C H$. C a ly$c i s$ limbus quinquedentatus. P e tal a longe un guiculata, spathulato-obovata, subintegra, laci nula triangulari, inflexa. F ructus a latere compressus; merie arpia quinquejuga, jugis argu tis, subalatis, aequalibus, lateralibus marginantibus, vallecolis latis, tri-quadrivittatis, commis sura quadrivittata. Carpoph or u m bipartitum. Semen semiteres. - Herba Europae austra$l i s$, perennis, glabra; folio radicali biternatisecto, segmentis magnis, ovato-lanceolatis, inaequaliter serratis, caule ramosissimo, superne nudo, involucro nullo v. monophyllo, involucellis tri-pentaphyllis, floribus albis, disci sterilibus.

Troohise an thes Koeh Umbellif. 103. f.95. Gaudin Flor. Helvet, II. 401. DC, Prodr. IV. 155. Meisner Gen. 144. (105.) S m y r $\mathrm{i}$ u u n o diflor u m Allioni Pedemont, II, $t, 72$.

44.4. Athamantha $K O C H, C$ a ly c is limbus quinquedentatns. Peta la obovata, emarginata $\mathbf{v}$. integra, cum lacinula brevissima, inflexa, unguiculata. Fructus in collum attenuatus, subteres $v$, a latere parum cumpressns; mericar pia quinquejuga, jngis filiformibus, aequalibus, apteris, lateralibus marginantibus, valleculis bi trivittatis, commissura quadrivitata. Ca r poph orum bipartitum. S emen subsemiteres. - Herbae perennes $v$, biennes, in Europa australio $r$ e et in Oriente indigenae, saepius villoso-velutinae; foliis triternatisectis $v$. pinnatisectis, segmentis incisis mullifidisve, involucro mono-oligophyllo involucellis polyphyllis, floribus albis.

Athamanitha Koch Vmbellif, 100. t. 49: 50. DC. Prodr, IV, 154. excl, sp. Meisuer Gen. 145. (105.) A that ma nthae sp. Linn. Bubouis sp. Linn. Tenore Flor. Neap, $t, 25$

4411. Turbith TAUSCH. Calye is limbus quinquedentatus, deciduus. P e ta 1 a obovata, emarginata, cum lacinula inflexa. F ructus in collnm attennatus, a latere contractus; $m$ e ri. e a rpia quinquejuga, jngis filiformibus, olitusis, aequalibus, lateralibns marginantibus, valleculis univittatis, commissura bivittata. Carpophorum bipartitum. Semen suhsemiteres, - Herba in alpibus Carniae et Pedemontii crescens; foliis tripartito-decompositis, laciniis capillaribus, umbellis terminalibus, involucris deciduis involucellisque polyphyllis.

$\mathrm{T}$ u $\mathrm{rb}$ ith Tausch in Flora 1834. p. 343. Meisner Gen. 146. (105.) Libanotis Scopoli Carn. t.9. At hamantha Matthioli Jacq. Ic. rar. $t$, 57. Sesill Turbith Linn.

44. 4. Wigustieann LINN, Calycis limbus quinquedentatus v. obsoletus. P e t a la bre vissime unguieulata, obovata, emarginata, cam la cinula inflexa. F ruetus subteres $v$, a latere parum compressus; mericar pia quinquejuga, jugis argutis, subalatis, aequalibns, lateralibus marginantibns, valleculis et commissura multivit tatis. Carpo phorum bipartitum. Semen sub. semiteres, - Herbae ut plurimum perennes, in Europa et America boreali, Caucaso et Asia media indigenae; foliis ternatisectis $v$. de compositis, involucro vario, involucellis polyphyllis, floribus albis.

L I gustie u m Linn. gen, n, 346. excl. sp. Allioni Flor. Pedemont. t. 60. f. 1. K. B. t. 1207. Flor, dan. t. 207. Le debour Ic. t, 310. Koeh Umbellif. 104. f. 44-47. DC. Prodr. IV. 157. Meisner Gen. 145. (105.) ? - A c i p h y ll a Forst. Char. gen, 68, Ging idlu m Forst. Char. Gen, 21.

4483. Treachy diume $L I N D L . \mathrm{C}$ a 1 y x ... Petala .... Fructus a latere compressus; mericarpia quinquejuga, jugis inflatis, carnosis, valleculisque verucosis, lateralibus sejunctis, valleculis uni-trivittatis, commissura bivittata. Semen facie depressum, ab epicarpio fere libernm. - Herba Indiae borealis, non satis nota; foliis bipinnatis, foliolis ovato-lanceolatis, inciso-serratis, acutissimis, umbellis simplicibus $v$. compositis, involucris polyphyllis, foliaceis, multifidis, foliolis basi membranaceis, connatis.

Trachydium Lindley in Rogle Himalay, 232. Meis. ner Gen. 144. (105.)

44 4. Sillaws BESS. Calye is limbns obsoletus. Petala unguiculata v. sessilia, obovatooblonga, in lacinulam inflexam coarctata, integra v. subemarginata. Fru et us subteres; mericarpia quinquejuga, jugis argutis, subalatis, aequalibus, Iateralibus marginantibus, valleculis multivittatis, vittis approximatis, unicam simnlantibus, commissura quadri-sexrittata. Ca rpoplo rum bipartitum. S emen subsemiteres. - Herbae perennes, glabrae, in Europa imprimis orienta$l i$ et in Asia finitima crescentes; foliis multisectis, lobis linearibus, involucro nullo v. oligophyllo, involucellis polyphyllis, floribus ochroleucis v. virescentibus

Sila a s Besser in Schultes Syst. VI, XXXVI, in not. Koch Umbellif, 105. DC. Prodr. IV, 161. Meisner Gen, 145. (105.) Peuceda uf sp. Lian. Jacq. Flor. Austr. $t .15$.

4445. Deum TOURNEF. Ca ly $\mathrm{c}$ is limbus obsoletus. P eta I a integra, elliptica, basi et apice acuta, Fruetus subteres; mericarpia quinquejuga, jugis prominulis, acute carinatis, aequalibus, lateralibus marginantibus, valleculia multivittatis, commissura sex-octovittata. Carpophorum bipartitum. Sem c n subsemiteres. - 
Herbae glabrae, in Europae montibus et alpibus editioribus perennantes; caule simpliciusculo, tereti, striato, foliis supradecompositis v. pinnatisectis, segmentis multifidis, laciniis linearibus, acutis, tenuibus, involucro subnullo, involucellis polyphyllis, floribus albis v. purpureis.

M e u m Tournefort inst. 165. Jacq. Flor, austr. $t$. 303. Gärtner 1 . 106, t. 23. Lagasea Amen. nat. II. 100. Koch Umbellif. 103, DC. Men, $V$. 49. Prodr. IV. 162, excl. sp. Meisner Gen, 145. (105.) A that in that sp. Linnt. Ph el. I andri i s p. Linn. Jaeq. Flor. Austr. $t, s 6$.

44406. Dindiressia $G A Y$, C a ly $\mathrm{c}$ is limhus quinquedentatus, demum increscens. P e $t$ a I a sessilia, integra, ovato-lanceolata, acominata, involuta. Fruetus oblongo-ellipticus, a latere compressus; $m$ ericar pia quinquejuga, jugis filiformibus, aequalibns, aequidistantibus, lateralibus marginantibus, valleculis latis, dorsalibn ralibus quadrivittatis, commissura sexvittata, vittis distinctis. Carpophorum bipartitum. S emen undique teres, adnatum. - Herba pyren a ica, perennis, glaberrima; caule simplici, gra. cili, angulato-striato, ad collum nudo, di-triphyllo, foliis pinnatisectis, pinnis decussatis, palmato-tripartitis, segmentis palmato-tri-quinquefidis, lobis linearibus, cuspidatis, umbella terminali, parva, densa, fructifera subglobosa, involucro tri-tetraphyllo, saepius nullo, involucellis mono-pentaphyllis, foliolis lineari-subulatis, umbellulam aequantibus.

Endress i a Gay in Annal. sc, nat. XXVT, 223. Mreis. ner Gen, 145. (105.) M eum pyrenaicum Gay, DC.

444\%. Neogaya MEISN. C a l y c is limbus obsoletus. Petal a obovata, emarginata, cum lacinula inflexa. Fruetus ovalis, subcompressus; meri earpia quinquejuga, jugis elevatis, alaeformibus, basi eontiguis, aequidistantibus, obtusis, lateralibus marginantibus, valleculis obsolete univittatis, commissura quadrivittata. Ca r p o p ho$r \mathbf{n m}$ bipartitum. S emen subsemiteres, fere liberum. - Herbae in alpibus Europae perennes; foliis radicalibus pinnatisectis, segmentis bipinnatifidis, lobis linearibus, caule nudo, simplici, umbella composita, involucri oligophylli foliolis indivisis $v$. subtrifidis, floribus omnibus fertilibus, albis.

Neogay a Meisner Gen. 144. (104.) G a y a Gaudin Flor. Helvet, II. 389. DC. Mem. V. 49. Prodr. IV. 163. Koch Synops. 229. non Kunth. P a ch y p l e u rum Reichenbach Flor. Germ, 471, uon Ledebour. L a s e r p iti a m si mp lex Linn. Jacq. Miscell. $1 I . t$. 2. - - A r piti im Necker Elem, n. 278.

4448. Comioselinum FISCH. Calycis limbus obsoletus. Pet a la obcordata $v$, obovata, cum lacinula inflexa. Fruet ns a dorso compressiusculus v, convexus; mericar pia quinquejuga, jugis alatis, alis membranaceis, lateralibus marginantibus subduplo latioribus, valleculis et commissura multivittatis. Carpophorum bipartitum. Semen facie planum, - Herba bien. nis, glabra, a sudetis in Asiam mediam diffusa; caule ramoso, fistuloso, foliis bipinnatisectis, segmentis pinnatipartitis, lobis oblongo-linearibus, umbellis terminalibus multiradiatis, involucro nullo $v$, oligophyllo, involucelli foliolis lineari-subulatis, umbellulam aequantibus $v$. superantibus.

Conjose! in u m Fiseher ex Hoffmann Umbollif. odit. 2. p. 185, tit. $f, 5$. Wimmer et Grabowsk. in Flora 1828. P. 2is, DC. Prodr. IV. 163. Koch Synops. 299. Meisuer Gen. 145. (105.) Lig us ticu u G melini Cham. et Schlecht. Cszeruaevia Turczaninow msc.
4499. Crithmum TOURNEF. Calyois limbus obsoletus. Petala subrotunda, integra, involuta, lacinula obovata. Fructus sectione transversali subsemiteres; mericarpiis quinquejugis, jugis elevatis, argutis, subalatis, lateralibus paullo latioribus, marginantibus, pericarpio cellulis magnis spongioso. Sem en semiteres, liberum, vittis copiosis undique tectum. - Herbả suffruticosa, in rupibus maritimis $E$ s ropa mediterraneac et atlanticae obvia, glabra, carnosa; petiolis basi vaginantibus, foliis bipinnatisectis, segmentis oblongo-linearibus, umbellis compositis, involucro et involucellis polyphyllis, floribus albis.

Crith m th Tournefort inst. 169. Linn. Gen, n, 340 . Jaeq. Hort. Vindob. t. 187. E. B. t. 819. Koeh Umbollif. 102. DC. Prodr. IV. 164. Meisner Gen, 143. (104.)

TRIBUS VI. PACHYPLEUREAE Ledebour Flor. alt. 1. 295. Fructus a dorso lenticulari-compressus, rhaphe marginali v. submarginali. Meri carpia quinquejuga, jugis erassis, subaequalibus, lateralibus marginantibus. Semen dorso convexum, facie planum. - Tribus a Seselineis vix nisi fructu a dorso compresso diversa, a Silerinis jugis secundariis nullis distincta, stirpes pancissimas Asiae mediae, regionis mediterraneae oceidentalis et Capitis bonae spei colligens.

4450. IKrubera HOFEM. C a ly $\mathrm{c}$ is limbus quinquedentatus. Petal a obovata, emarginata, cum lacinula inflexa. Fructus a dorso lenticulari-compressus; mericarpia quinquejuga, jugis crassis, plicato-connatis, dorsalibus elevatis, obtusis, carinatis, lateralibus marginantibus, rotundatis, juxta rhaphen carinatis, yittis nullis. Carpophorum bifidum. Semen facie planiusculum. - Herbae annuae, una in regione med $i$ terranea imprimis orientali, altera in Capite bona spei indigena; foliis multifidis, lacinulis linearibus, involucro involucellisque oligophyllis, floribus albis, nonnullis interdum masculis.

Krubera Hoffman Umbellif, 1,203 et 202, $t, 61$. f. 14. Koch Umbellif. 86. f. 39. 33. DC. Prodr. IV. 199. Eeklon et Zeyher Enumerat. 353. Meisner Gen, 445. (105.) Ulos perm a m Link Hort. berolin, I. 267, C a p nophyl. Ii s p. Lagase, Tordy li um peregriaum Lina. Couium Desfont, Flor, atlant, $t$. 66 .

4451. Paelnyplearann LEDEB. C a lycis limbus obsoletus $v$. minute dentieulatus. P eta la persistentia, emarginata, cum lacinula inflexa, exteriora radiantia. Fru t $t \mathbf{s}$ a dorso lenticulari-compressus; m eri carpia quinquejuga, jugis elevatis, crassis, corticosis, lateralibns marginantibus, paullo latioribus, vittis nullis. Carpophorum bifidam. Semen facie planiusculum. - Herba in alpibus altaicis perennans; foliis radicalibus longe-petiolatis, bi-tripinnatisectis, segmentis oblongo-linearibus, acuminatis, integris, caulino unico subconformi, saepius abortivo, umbellae multiradiatae radiis inaequalibus, umbellulis radiantibus, involucris involucellisque polyphyllis, foliolis oblongo-linearibus, integris, margine membranaceis.

P a chyple urum Ledebour Flor, alt, $I$, 296. Meisuer Gen. 145. (105.)

4452. Stenocoelimm LEDER. Calycis limbus quinquedentatus. P etal a ovato-orbi- 
culata, subemarginata, cnm lacinula inflexa. Fru c$t \mathbf{u s}$ a dorso compressus; $m$ eri carpia quinquejuga, jugis elevatis, rotundatis, crassis, aequalibus, lateralihus marginantibus, valleculis univittatis, commissura bivittata. Carpophorum bifidum. S e men antice planum. - Herba pubescens, in alpinis Caucasi et Asiae mediae crescens; foliis pinnatis, pinnis bipinnatisectis, segmentis oblongis, aeutis, integris v. bifidis, umbella maltiradiata, umbellulis fructiferis subglobosis, involucris involucellisque polyphyllis, foliolis lanceolato linearibus, margine membranaceis.

Stenocoelium Ledebour Flor. alt. I. 297. Ic. t. 175. Meisuer Gen. 145. (105.)

TIRIBE VIS. ANGELICEAE Koch Umbellif. 98. Fruetus a dorso compressus, margine dilatato-alato, ob rhaphen centralem v. subcentralem duplicato cinctus. Mericarpia quinquejuga, jugis tribus dorsalibus filiformibus v. alatis, duobus lateralibus marginalibus, semper in alam dorsalibus latiorem expansis. S e m e n dorso convexiusculum, facie planiusculum. Tribus parva, borealis, speciebus in Europa media et boreali obviis, paucis in America boreali et Asia arctica indigenis, nonnullis nepalensibus.

4453. Thevistienm KOCH. C a lycis margo obsoletus. P eta la orbiculata, incurva, integra, cum lacinula inflexa, brevi. Fructu's a dorso compressus, mericarpiis margine hiantilus utrinque bialatus; merie arpia quinquejuga, jugis alatis, lateralibus duplo latioribns, valleculis univittatis, commissura bi-quadrivittata. Car p oph or u m bipartitum. Semen facieplaniusculum. - Herba in Europae montibus a Pyrenaeis ad Transylvaniam crescens, perennis, glabra, laevis; caule tereti, foliis ternato-decompositis, segmentis obovato-cuneatis, inciso-dentatis, subcoriaceis, involucro involucellisque polyphyllis, floribus flavis.

Levistienm Koeht Umbellif. 101. f. 41, DC. Prodr. IV. 146. Meisner Gen. 146. (106.) Lig u s ti c u magasca Amen. nat. II. 91. Ligustic in Levisticum Lian. Heyne Arzneigew, VII. $t .6$.

4454 . Selinum HOFFM. C a ly cis limbus obsoletus. P e $t$ a 1 a obovata, emarginata. Fructus a latere compressus, rhaphe centrali utrinque bialatus; mericarpia quinquejuga, jugis membranaceo-alatis, lateralibus duplo latioribus, valleculis univittatis, exterioribus saepe bivittatis, commissura bivittata. Carpoph or u m bipartitum. Sem e n facie planinsculum. - Her bae in Europac mediae et australioris, nec non in Americae borealis sylvis humidis et in Nepaliae montibus crescentes, glabrae, perennes; foliis ternato-decompositis, segmentis pinnatifidis, ambellis compasitis, involucro oligophyllo, involu cellis polyphyllis, fioribus albis.

Selin a m Hotiaann Umbellif: 1. 103. Koch Umbellif. 100. $f$. 29. 23, DC. Prodr. IV. 165. Hooker Flor. Bar Amor. f, 95. Meisuer Gen, 146. (105.) M y lin a ta Gandit Flor. Helvet. $I I$. 346. Thy gelli a um Adanson Fam, II. 100. Car vifolla Vaillant Paris, t. 18. f. 2. Seli u u m Carvifolia Liau. Jaeq. Flor, Austr, t, 16. Flor, dan t. 667 .

4455. Dstereieian HOFFM. Calyeis jimbus quinquedentatas, dentibus Jatis. P e $t$ a $l$ a unguiculata, obovata, emarginata, cum lacinula inflexa. Fructus a dorso compressus, rhaphe centrali utrinque bialatus; $m$ er $\mathbf{i}$ a r p i quinquejuga, jugis tribus dorsalibns filiformibns, elevatis, lateralibus in alam dilatatis, omnibus fistulosis, valleculis univittatis, Carpophoru $\mathbf{m}$ bipartitum. Semen complanatum. - Herba in paludosis Europae mediae et boreali-orienta$l i s$ rara, perennis; caule sulcato, glaberrimo, foliis ternato-decompositis, subtus asperis, segmentis subdivaricatis, cordato-ovatis, inaequaliter dentatis, umbetlis compositis, involucro oligophyllo, involucellis polyphyllis, floribus albis.

Ostericin a Hoffmann Umbellif, 162. Koch Vmbellif. 100 Reichenb. Iconogr. $t .402$. DC. Prodr. $I V$, 167. Meis. ner Gen. 146, (106.) Imperatoria palustris Bess.

4456. Angeliea HOFFM. Caly cis limbus obsoletus. Petala lanceolata, acnminata, integra, acumine recto $v$. incurváto. F ruetus a dorso compressus, rhaphe centrali utrinque bialatus; meric arpia quinquejuga, jugis tribns dorsalibus filiformibns elevatis, lateralibes in alam membranaceam paulo $v$. multn latiorem expansis, valleculis nnivittatis. Carpophorn m bipartitum. S e m en subsemiteres, - Herbae biennes $v$. peren. nes, in Europa et America boreali indigenue; foliis bipinnatiseotis, umbellis terminalibus, involucro nullo $v$. oligophyllo, involucell is polyphyllis, floribus albis.

A ngelica Hoffmann Umbellif, 1, 158. Koeh Umbellif. 99. f. 20. 21. DC. Prodr, IV. 167. exel. sp. Meisuer Gen. 146. (106.) Ang elicae s p. Linn.

a, EUANGELICA DC. $\boldsymbol{l}$. $\boldsymbol{c}$. Petal a longe acuminata v. rarius obeordata. Com miss u ra bivittata. - Caulis foliosus, petioli valde dilatati, umbellae amplae, multiradiatae. Eaeg. Hort. Vindob. IIT. ᄂ. 24. E. B. t. 1128. Heyne Arzneigew. VII. t. 9.)

b. PSeudangeliCa DC. $t$. o. Peta la elliptica, acumina. ta. Co mmiss ura quadrivittata. - Caulis subaphyl. lus, umbellae radii valde inaequales, centrales bre. vissimi, involucrum mozophyllum, setaceum. - S e. seli pyrenacum Lina. Selinum pyrenaeum Gmellin Flor, bad. $t$. 3.

45\%. Anelnangellea HOFFM, Calycis limbus breviter quinquedentatus. Petala elliptica, integra, acuminata, acumine incurvato. Fructus a dorso subcompressus, rhaphe subcentrali utrinque bialatus; mericarpia quinquejuga, jogis erassiusculis, cartilagineis, carinatis, tribus dorsalibus elevatis, lateralibns in alam duplo latiorem productis, nucleo libero, vittis copiosis undique tecto. Carpophoram bipartitum. - Herbae in Europa borealiore et in As ia media et arctica indigenae, perennes; foliis pinnatisectis, segmentis late ovatis, acutis, grosse dentatis, terminalibus lobatis, petiolis amplis, saccato-vaginantibus, involucro subnullo, ininvolucellis dimidiatis, polyphyllis, floribus albis $v$. subvirescentibus.

Archangelic n Hoffmann Umbellif. 1. 166. $f$. fit. 19. 20. Kach Umbellif. 98. t. 17-19. DC. Prodr. IV. 169. Ledebour 1c, t, 168. Meisner Gen. 146. (106.) A ng ellic n A rehangeliea Linn. Flor. dan. 4,206 . E. B, $t, 2561$. Nees Plant. offic, $I X, 1,14$.

TIRIBUS VIII. PEUCEDANEAE DC. Prodr. IV. 170. F ructus a dorso plano v. lenticulari-compressus, margine integro, dilatato, laevigato, alato, complanato v. convexiusculo cinctus. Me ri carpi a jugis quinque, filiformibus v. rarius alatis, lateralibus marginantibus $v$. dilatato - contiguis, nune in margi- 
nem abeuntibus. Rhaphe marginalis, hinc fructus utrinque unialatus. S emen complanatum, v. dorso convexiusculum. - Peucedaneae maxima copia inter $35-50^{\circ} \mathrm{L}$. B. et $30_{-}-12^{\circ}$ L. A. inclusae, in Europa occidentali, insulis Canariis et America boreali rarae, in India orientali et Capite bonae spei paullo frequentiores.

4458. Dpoponax $K O C H$. Ca lycis limbus obsoletus. Petala suborbiculata, integra, cum lacinula acutinscula, involuta. Fruetus stylopodio lato, crasso stylisque brevissimis coronatus, a dorso plano-compressus, margine dilatato, convexo einctus; mericarpia jugis dorsalibus tribus, filiformibus, tenuissimis, lateralibus a nargine haud distinctis, vallerulis trivittatis, commissura sex-decemvittata. S e men complanatum. - Herba Europae australis, perennis; radice crassa, caule aspero, foliis bipinnatisectis, segmentis inaequaliter cordatis, crenatis, obtusis, umbellis compositis, multiradiatis, involucro involu. cellisque oligophyllis, floribus flavis.

0 p op on ax Koeh Umbellif. 96. DC. Prodr. IV. 170. Meisner Gen, 146. (106.). Past i na a 0 po pon ax Linn. Waldst. et Kitaibel Plant, rar. Hung. t.211, Sibthorp. Flor. Graec, t. 288.

4459. Cerala TOURNEF, C a ly cis limbns breviter quinquedentatus, Pet a la ovata, integra, acnminata, acumine adscendente $\mathbf{v}$, incurvo. Fruetus a dorso plano-compressus, margine complanato, dilatato einctus; mericarpia jugis tribus dorsalibus filiformibus, lateralibus in marginem dilatatum abeuntibus, vittis indefinite plurimis, v. vallecnlarum dorsalium tribus, missuralibus quatuor. Carpophorum bipartitum. S e men complanatum. - Herbae medi. terraneae et orientales; radice crassa, caule elato, saepe medulla ampla fibris vagis pereursa farcto, foliis supradecompositis, segmentis saepius in lacinias lineares fissis, umbellis multiradiatis, lateralibus saepe oppositis $v$. verticillatis, involucris variis, floribus luteis.

Fer ul a Tournefort inst, 170, Linn. Gen. n, 343, Sprengei Prodr. Umbellif. 13. exel. sp. DC. Prodr. IP. $17 t$. Meisner Gen. 146. (106.) Ferula et Ferulago Koch Umbellif: 96,97 .

a. FERULAGO DC. l. c. Vitta e dorsales et eommissurales plurimae. - Caulis saepius striatus $v$. angulalus, involucrum tetra-octophyllum.

Verulago Koch Umbellif. 96. Synops. 302. Reichenb. Iconogr. $t$, 371. (Jacq. Flor. austr. Append. t. 5. Desfout. Flor, allant. t. 67. Sibthorp Flor. graec. t. 280.)

b. FERULARIA DC, $l$. $c$. Vit t a e vallecularum dorsalinm tres, commissurales quatuor. - Caulis teres, involuerum nullum.

Ferula Koch Dmbellif. 97. (Sihthorp Flor. graec. t. 279. Bot. Mag, $t$. 2096. - ? Hamb. to Bonpl. Nov. gen, et sp. $t$. 418.) ? L o m a $t$ i u m Rafinesque in Journ. Phys. LXXXIX, 101. Cog 8 w ell i a Schultes Syst, VI, 588.

4460. Derema DON. Calye is limbus breviter quinquedentatus. Petala ovata, acuminata, cum acumine inflexo. For uctus stylopodio a mplo, carnoso, cyathiformi, margine plicatosublobulato stylisque reflexis coronatus, a dorso plano-compressus, margine complanato, dilatato cinctus; mericarpia quinquejuga, jugis tribus interm ediis aequidistantibus, filiformibus, lateralibus in marginem dilatatum abeuntibus, vallecuis uni vittatis, vittis elevatis, commissura quadri- vittata, Carpophorum bipartitum. Semen complanatum. Herbae persicae, glauco-virides, glabrae $v$. viscido-pubescentes, gummi resinosum ammoniacum exsudantes, Opoponacis facie; foliis bi-tripinnatisectis, umbella prolifera, subracemosa, umbellulis nunc subglobosis, floribus sessilibus lanugini immersis albis, nunc pedicellatis, ochroleucis.

Dorem a Don in Edinb, philosoph. Magaz. IX. 46. Linn. Transact. XYT. 599. Meisuer Gen, 146. (106.)

461. Eriosynaphe $D C$. Calycis limbus brevis, obtuse quinquedentatus. Pet a la ovata, integra, acuminata, acumine brevi, incurvo. Fructus a dorso compressus, margine crassíusculo cinetus; mericarpia jugis dorsalibus tribus filiformibns, duobus lateralibus in marginem crassiusculum, intus fungosum abeuntibus, valleculis latis, tenuissime bi-trivittatis, commissura evittata, nervo medio (carpophoro adnato) duebusque lateralibus notata, inter nervos subenncava, tomentosa. S emen complanatum. - Herba wolgensis, perennis, glabra, Ferulae facie; foliis decompositis, laciniis longis, linearibus, involucro involucellisque nullis, floribus flavis.

Rrios ynaphe DC. Mem. $V$. 30. $t$. $t$. f. E. Meisner Gen. 147. (106.) Ferula lo g 1 folia Fisch.

4462. Peucedanum LINN. Cal ye is limbns quinquedentaftus $v$, obsoletus. Petala obovata, in lacinulam inflexam coarctata, emarginata y, subintegra, Fructus a dorso planovel lenticularí-compressus, margine dilatato, complanato cinctns; mericarpia quinquejuga, jugis aequidistantibus, trihus dorsalibus filiformibus, duobus lateraliluss obsoletioribas, margini dilatato contiguis v. in eundem abenntibus, valleculis nni-trivittatis, commissura bi-quadrivittata, vittis superficialibus $\mathbf{v}$, pericarpio tectis. Carp nphornm bipartitum. Semen facie planum. Herbae in Europa, imprimis ausirali, in Asia media et India orientali indigenae, sat pius glabrae, perennes; foliis uni-pluripinnatisretis $v$. trisectis, umbellis terminalibus, involucro vario v. nullo, invotucellis saepius polyphyllis.

Peuceda num et Imperatori a Linn. gen. n. 339 et 359. Palimbia, Peucedauam et limperatoria DC. Prodr, 175-183. Peucedanam, Thys selinum et $1 \mathrm{~m}$ peratoria Koch Synops. 303 _366.

a. RALIMBIA DC. l. c. $\mathrm{C}$ a I y e is limbas obsoletus. Me$r i c a r p i o r u m$ margo angustus, valleculae saepius trivittatae, commissura late bifasciata. - Involucrum nul. lum v. oligophyllum.

Palinbia Besser Volhyn. 94. Pteroselinnm Reichenb. Flor. germ, 453. S eli n u m Gärtner $I_{\text {. }} 88$. t. 21. S e II i i sp. Linn. Jacq. Flor, austr, $t$, 72, P e uced a n i s p. Pallas Act. Petropolit. 1779. p. 258. 4,8 . Ag asillidis s p. Spreng. Prodr. Umbellif. 22.

b. EUPEUCEDANUM DC. $l$, c. C al y e is limbus manifestas. Mericarpiorum margo angustus, valleculae univittatae, commissura bi-quadrivittata. vittis superficialibus, - Involucrum nullum v, oligophyllum.

Peucedanum Gätner $I$ 89. $t .21$. (Waldst. et Kitaibel Plant, rar. Hung. t. 20, 23t. Ledebour Ic, t. 105 . 306. 308.)

c. THYSSELINUM DC. 2. c. Cal y c is limbus manifestus, Merlearpiorum margo angustas, valleculae unir vittatae, eommissura bl-quadrivittata, vittis pericarpio tectis. - Tnvolucrum polyphyllum.

Th y s e li n a m Rivin. Pentapet. irreg, 19, 20. Hotfmann Umbellif. 153. Sprengel Umbellif. 70, Koch $s_{2} n$. ops. 306. Selinum syivestre Lion. Plor. dait. t. 412 .

d. CBRVARIA DC. l. c. Calyeis limbus manifestus. Merlearpior a margo apgustus, valleculae uaivit$98 *$ 
tatae, eommissura bivittata, vittis superficialibus. Involucrum polyphyllum,

Cervaria Gïrtner $r$. 91. $t, 21$. Athamanthae p. Linn. Jacq. Flor. austr. t. 68,69. 0 r cos elini sp. Bieberst. (Jacq. Flor, austr, t, 17. Ledebour Ic, t, 199.)

e. SRLiNoldes $t$. c. Caly eis limbus manifestus. Me $r$ ie a rpior um margo latissimus, subdiaphanas. Valleeulae univittatae, commissura bi-quadrivittata, vittis su. perfieialibus. - Involucrum polyphyllum.

Oreoselin a m Duby Bot. Gallic. 1. 222, Seli$\mathrm{n} \mathrm{m}$ Gaudin Flor. Helv, II, 333. O reos eli n i s p. Bieberst. Hoffm. Selini s p. Linn. Jacq. Flor. austr. t. 71 . Flor, dan. $t, 1330$. (Ledebour Ic. $t .309$.)

f. ANGELICOIDES DC. $l$. c. $\mathrm{C}$ al yeis limbus manifestus. Meri e a r pior u margo latissimus, subdiapbanus. Valleculae univittatae, commissura bivittata, vittis super ficiatibus. - Involucrum nullum.

Angelica vertielllaris Linn. Jacq. Hort, Vin dob. t. 130 .

g. IMPRRATORIA Linn. Caly ci s limbus obsoletus. M e. riearpiorum margo latissimus. Valleculae univittatae, commissura bivittata, vittis superficialibus. - Involucrum nullum.

Im per atoria Linu. gen, n, 359. Lagasea Amen. tat. IT. 90. Koch Umbellif. 95. Synops. 306. DC. Prodr. IV. 183, E. B. $t, 1380$. (Nees jun. Plant, offic. $X I I$, i, 7.).

4463. Seiothammus. CaIye is limbus obsolete quinquedentatus. Petala obovata, emarginata, cum lacinula jnflexa. Fructus a dorso plano-compressus, margine dilatato, complanato cinctus; mericarpia quinquejuga, jugis tenuissimis, tribus dorsalibus, duobus laterafibus, margini dilatato continuis, valleculis univittatis, commissura bivittata, Ca rpophor u m bipartitum. Semen convexiuseulam, facie planum. - Frutices capen ses, glabri; foliis pinnatisectis, segmentis integris v. incisis, umbellis multiradiatis, involucro involucellisque polyphyllis, floribus flavis.

Dregea Rcklon et Zeylier Enumerat. 350. Meisner Gen. 147. (106.) nou K. Mey. Pe ue dani s p. Cham. DC. Laserpitiis p. Thanb.

4464. Cymorringa ECKL, et ZEYH. Cal y $\mathrm{c}$ is limbus breviter quinquedentatus. P e $t$ ala obovata, emarginata, cum lacinula inflexa. Fructus a dorso complanato-compressus, rhaphe centrali utrinque bialatus; me ri carp i quin quejnga, jugis aequidistantibus; tribus dorsalibus filiformibus, dnobus lateralibus in marginem late membranaceum abeuntibus, valleculis bivittatis, commissura bi - v, univittata. Carpophorum libernm, bipartitum. Semen complanatúm. Herbae capenses, perennes, glabrae; radice crassa, foliis omnibus radicalibus, multisectis, lobis lanceolatis, umbellis multiradiat is, involucro involucellisque polyphyllis, floribus albis.

C y n or r hi z a Ecklon et Zeyer Enumerat. 352. Meisner Gen. 142. (106.)

4465. Callisace FISCH. Calyc is limbus subquinquedentatus $v$, fere obsoletus. Pet a Ia ovalia, acuminata, incurvata. Fruet u 8 a dorso compressus, margine alatus, suborbieulatus, basi emarginatus: me ricarpia quinquejuga, jugis dorsalibus tribus obtusis, nerviformibus, duobus lateralibus in alam expansis, per totam superficiem suntuo sibi incumbentibus, valleculis dorsalibus angustis, univittatis, commissura ad margines utrinque univittata. Carpophori apice bifidi crura mericarpiis adnata. S emen complanatum. - Herba dahurica, perennis, Angelicae v. Osterici facie, vaginis amplis, summis aphyllis, umbella pubescente, multiradiata, involucro nullo v. oligophyllo, umbellulis multifforis, densis, involucello polyphyllo, setaceo, floribus albis.

Callis ace Fischer in Hoffmann Umbellif. edit, II. p. 170. exel. sp. DC. Prodr. IV. 184. Meisner Gen, 146. (106.).

446. Evabon LINN. C a ly e is limbus obsoletus. Pet a la obovata, integra, eum lacinula acuta, involuta. Fruetus a dorso lentieulari compressus, margine dilatato, complanato cinctus; meric a rpia quinquejuga, jugis aequidistantibus, tribus intermediis filiformilons, duobus Iateralibus in marginem complanatum abeuntibus, valleculis univitatis, commissura bivittata. Carpophor u m bipartitum. Se m en convexiusculum, facie planum. - Frutices c a p enses, glaberrimi, gum$m i$ resinoso scatentes; caule tereti, foliis biternatisectis, glaucis, rigidulis, segmentis dentatis $v$ pinnatifidis, petiolis vaginantibus, umbellis compositis, multiradiatis, involucro involucellisque polyphyllis, foliolis linearibus, floribus e flavo virentibus.

Bu b o u Linn. gen, n. 330 . exel. sp. Jacq. Hort. Vin. dob. III. t. 36. Koch Umbellif. 9z. DC. Prodr. IV. 184. Meisner Gen, 146, (106.) non Spreng. Galbanophora Necher Elem. n, 228. A g a sillid is sp. Spreng.

448\%. Amethman TOURNEF. Caly $\mathrm{cis}$ limbus obsoletus. Pet a l a suborbiculata, integra, involuta, lacinula subquadrata, retusa. Fruetus a dorso lenticulari-compressus, margine compla nato cinctus; mericarpia quinquejuga, jugis filiformilus, aequidistantibus, tribus intermediis acnte carinatis, duobus lateralibns obsoletioribus, in marginem abenntilus, valleculis latissime univittatis, commissura bivittata. Carpophor am bipartitum. Semen convexiusculum, facie planum. - Herbae annuae, erectae, glabrae, in Europa a ustraliore, Oriente, India et in Capite bona e spei indigenae; foliis composi tis, lobis setaceo-linearibus, involucris et involucellis nullis, floribus luteis.

A neth u m Tournef. inst, 317. Gïrtner I. 91, $t, 21$. Jaeq. Hort. Vindob. $t$. 132. Flor. dan, $t$. 1572. Hoffmana Umbellif. I. 117. t. 1. f. 13. Lagasea Amen, nat. II. 91. Koch Umbelif. 91. DC. Prodr. IV. 185. Nees Plant, offic. Suppl. I. t. S,

4469. Contia $D C$. $\mathrm{C}$ a ly e i s limbus quinquedentatus, dentibus elongatis, acutis. Peta 1 a lanceolata, acuminata, integra. Fructus stylopodiis conicis stylisque divergentibus coronatus, a dorso compressus, ellipticus, utrinque subrectus ; meric a r p ia quinquejuga, jugis alatis, lateralibus latioribus, valleculis univittatis, commissura lata, plana, bivittata. Se m e $\mathbf{n}$ planinseulum. - Herba nepalensis, subacaulis; foliis radicalibus petiolatis, pinnatisectis, segmentis multifidocapillaceis, lobulis abbreviatis, scapis aliis crassis, cauliformibus, umbellam compositam, involucro ditriphyllo, foliolis multifidis munitam gerentibus, aliis elongatis, umbella pauciradiata v. umbellula solitaria, involucellis penta-heptaphyllis, foliolis integris v. bi-trifidis, aculis, floribus albis,

Cortia DC. Prodr. IV. 186, Meisner Gen. 147. (106.) Selutizia Lindleyi Wallieh.

4469. Hagnumatoeaulis TAUSCH. C aI y c is limbus obsolete quinquedentatus. P e ta 1 a ...... Fructus a dorso lenticulari-compressus, margine dilatato, crassiusculo cinctus ; $m$ ex $\mathbf{c}$ a $r-$ pia oblonga, quinquejuga, jugis tribus dorsalibus, elevatis, argutis, corticosis, duobus lateralibus in marginem abeuntibus, valleculis profundis, acutis, univittatis, commissura bivittata. Car- 
pophorum bipartitum. - Herba cretica, perennis; caule ad articulos insigniter nodoso-incrassato, nodis subglobosis, foliis decompositis, lobis $l i$ nearibus.

Ha ma toeanlis Tauseh in Flora 1834. T. p. 3h. Meisoer Gen, 147, (106.)

44. 20. Capmophyllum GÄRTN. Caly eis limbus olssoletus. Pet a la oblonga, subemarginata, in acumen inflexum attenuata. Fruetus lenticulari-compressus, margine dilatato, complanato cinctus; mericar pia quinquejuga, jugis tribus intermediis crassiusculis, carinatis, subflexnosis $v$. tuberculatis, duobus lateralibus in marginem dilatatum abeuntibus, valleculis univittalis, commissura bivittata. Semen convexiusculum, facie planum. - Herbae capenses, annuae; foliis multifido-decompositis, lacinits linearicuneatis fere Fumariae, umbellis oppositifoliis, pseudo-terminalibus, involucris involucellisque tri-hexaphyllis, foliolis margine membranaceis, floribus albis.

C a p n op h y II u m Gärtner II. 39. $t$.85. Koch Umbellif. 95. DC. Prodr. IV, 187. Mleisner Gen, 147, (106.) R u ur i a Link Hort, berolin. 1, 271. non Gärtn. Conit um afr i. c an a m Lian. Jacq. Hort. Vindob. $t$. 164.

448 1. Tiedemanmia $D C$. Calyeis limbus quinquedentatus. Petal a aeuninata, reflexa. Fruetus a dorso plano-compressus, subovatus; mericarpia quinquejuga, jugis filiformibus, subcarinatis, aequidistantibus, approximatis, lateralibus in marginem membranaceum, fructu fere latiorem dilatatis, vittis vallecularum solitariis, easdem implentibus, commissuralibus geminis. Carpophorum bipartitum. Semen complanatum. - Herba boreali-americana, paludosa, glaberrima; caule tereti, foliis lamina abortiva ad phyllodia teretia, acuta, fistulosa, articulata reductis, involucro involucellisque tetra-pentaphyllis, foliolis subulatis, floribus albis.

Tiedemanuia DC. Mrem. $V$. $31, t, 12$. Prodr. IV. 187. Meisuer Gen. 147. (106.) 0 x y polls Rafin. in Seringe Bullet. bot, 1. 217. pro parte. 0 enanthe carolineas is Pers.

44\% Arelnemora $D C$. Calycis limbus quinquedentatus. P e tala obcordata, cum lacinula inflexa. Fructus a dorso compressus, planus, ovalis v, obovatus; mericarpia quinquejuga, jugis filiformibus, subearinatis, aequidistantibus, approximatis, lateralibns in marginem membranaceum, semine fere latiorem dilatatis, vittis vallecularum solitariis, easdem implentibns, commissuralibus geminis, C a r p oph or um bipartitum. S e men complanatum. - Herbae b oreali-americanae, paludosae; foliis pinnatisectis, involucro nullo v. oligophyllo, involucellis pleiophyllis, floribus albis.

A rebe mora DC. Mem. V. 32. Prodr. $I V$. 188. Meis. ner Gen. 147. (106.) $0 \times$ y pollis Rafuesque in Seringe Bullet. bot. 1, 217. pro parte. Sium rigidum Liun. 0 e a a t hes sp. Nutt.

448. Fastimaea TOURNEF. C a lycis limbus ubsoletus v, minute denticulatus. Petala suborbicnlata, integra, involnta, Jacinula lata, retusa. Fructus a dorso plano-compressus, margine dilatato, complanato cinctus; mericarpia quinquejnga, jugis tenuissimis, tribus intermedis aequidistantibus, duobus lateralibus margini dilatato contiguis, vittis linearibus, acntis, jugis vix brevioribus, vallecularum solitariis, commissuralibus geminis v. plurimis. Carpop horum bipartitum. S e m e n complanatum. - Herbae peren- nes, in Europa nuedia, regione mediterranea, Caucaso, Asia media et australi indigenae; radice fusiformi, saepe carnosa, foliis pinnatisectis, segmentis dentatis, incisis $v$. lobatis, umbellis compositis, involucris involucellisque nullis v. oligophyllis, floribus flavis.

P astina ca Tournef. inst. 170. Linn. gen, n. 368 . E. B. t. 556. Flor. dan. t, 1206. Jacq. Hort. Vindob. t, 199. Vent. Cels, t. 78, Lagasca Amen. nat. $I I$, 92 , Koch Um. bellif. 90, f, 26. 27. DC. Prodr. IV, 188, Meisner Gen, 147.

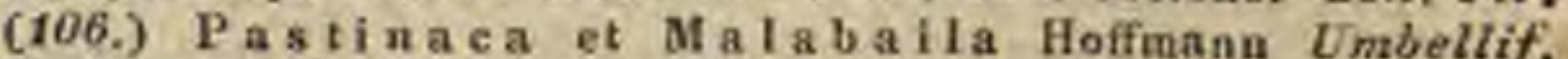
p. 122. t. 1, f. f. 11, p, 125. t. 1. B. f. 6. Peucedaui sp. Sibthorp Flor, graec, t. $27 \%$.

4474. Heiotulus EHRENB. Calye is limbus obsoletns. P et a $I$ a suborbiculata, integra, involuta, lacintla lata, retusa. Fructus a dorso plano compressus, margine dilatato, incrassato, laevi cinctus; mericarpia quinquejuga, jugis tribus intermediis tenuissimis, approximatis, lateralibus remotis, tumidis, marginantibus, valleculis planis, univittatis, vittis filiformibus, commissuralibus geminis, distantibus, omnibns fructu brevioribus. Carp o p h or um setaceum, bipartitrm, - Herba a gyptiaca; foliis bipinnatifulis, involucris nullis, involucellis oligophyllis, tenuissimis, integris $v$, interdum deficientibus, floribus flavis. Leiotulus Elareab, in Linnaea IV. 400, DC. Prodr. 669. Meisner Gen, 140. (102).

445. Astyalamia $D C$. Calyeis limbus quinquedentatus. F e t a la obovata, integra, cum acumine inflexo. Fructus stylopodiis crassis stylisque brevissimis coronatus a dorso compressus, margine dilatato, crasso cinctus; $m e-$ rica rpia fangusa, quinquejuga, jugis dorsalibus tribus, cristatis, approximatis, brevibus, dnobus lateralibus in marginem abeuntibus, vittis vallecularibus paucis, commissuralibus ubsoletis, Carpophorum bipartitum. Sem en complanatum. - Suffrutex canariensis, pedalis; caule tereti, carnoso, glabro, foliis pinnatisectis, segmentis cuneatis, apice inciso-dentatis, extrcmis confluentibus, umbellis compositis, involucris involucellisque poly. phyllis, floribus flavis.

A st y da mia DC. Mem. 53, t. 1, f. DC. Prodr. IV. 190. Webb et Berthel. Elor. Canar. $t$. 76. Crithut u m latifollum Llon. Tenoria canariensis. Spreag. Spec. Umbellif. t. 6. f. 13 .

4486. Symplayoloma $C . A . M E Y . \mathrm{C}$ aIy $\mathrm{c}$ is limbus obsoletus. Petala aequalia, emarginata, cum lacinula inflexa. F r u c t us ellipticus, a dorso compressus, planus, margine rotundatus; mericarpia marginibus arctissime connata, quinquejuga, jugis filffurmibus, tribus internedis approximatis, lateralibus remotis, submar ginantibus, vittis nullis sive obsoletis. Carpo ph or um nullum. S em en complanatum. - Herba caucasica, humilis ; foliorum segmentis tribus v. quinque suborbiculatis, involucris nullis, petalis rubellis.

Sy up yoloma C. A. Meyer Verzeichn. caucas. Pflanz. 127. Meisuer Gen, 141. (103.)

44\%. Bermelemm LINN. Calycis limbus quinquedentatus. P'etala obovata, emarginata, cum lacinula inflexa, exteriora saepe rądiantia, bifida. Fructus a dorso plano-compressus, margine dilatato, complanato einctus; me ric a r ia quinquejuga, jugis tenuissimis, tribns dorsalibus aequidistantibus, duobus lateralibus remotis, margini dilatato contiguis, vittis vallecularum solitariis, commissuraliluns saepins geminis, omnibus fructu frevioribus, saepins clavatis. Car- 
pophorum bipartitum. Semen complanatum. - Herbae in Europa et Asia media obviae, saepe amplae; foliis pinnatisectis, trisectis $v$. lobatis, petiolis late vaginantibus, umbellis multiradiatis, involucris caducis, plerumque oligophyllis, involucellis polyphyllis.

He ra e le u m Linn. gen. $n$. 345. Lagasca Amen. nat, $I T$. 92. Koch Umbellif. 89. DC. Prodr. IV. 191. Meisuer Gen. 147. (106.) Sphond y $1 \mathrm{ta}$ m Tournef. inst. 170.

a. TETRATENIUM DC. l.c. Co m $\mathrm{m}$ is s u $\mathrm{r}$ a quadrivittata. Flores baud radiantes, ochroleuci, - Species nepa. lenses.

b. EUHERACLEUM DC. ?. c. Com $\mathrm{m}$ is $\mathrm{s}$ u a bivittata. $\mathrm{D}$ ub e 11 a c aequales v. radiantes, petala flavo-virescentia.

Heracle um Hoftmann Umbellif. 14t, $t$, $1 . f .6$. (Jacq. Flor. austr. t. 173. Sibthorp Flor. graec. t. 282. Gussone Plant. rar. t. 27.)

c. SPHONDYLIUM DC. $l$. $c$. C o m mis $\mathrm{s}$ a bivitata. U m be 1 la e multiradiatae, radiantes. Petala alba. S phondylium Hoffmann Umbellif. 129. (Jacq. Flor, austr. t. 174. 175. E. B. t. 939. Ledebour IC. t. 303. 304,)

d. CARMELIA DC. $l$. c. Fruetus setis rigidis, adpressis, crassis onustus, vittarum numero ignoto. Pet a fa hispida, exteriora radiantia.

Hera ele a m Carmell LabHlard, Syr. Dec, P.t. 1 .

e. WENDTIA DC. C o m m is $\mathrm{s}$ ra e vittae obsoletae, U mb e 11 a e radiantes. Petala alba $v$. subrosea.

Wendtia Hoffmann $U m b e l l i f, 136, t, 1, B, e t f, 12$, 13. tit. (Crantz Austr. t. 1.)

f. TRiCHOGONIUM DC. l, c. Com mis a ra evittata. $\tilde{U} \mathrm{~m}$ b ll a e haud radiantes. Petala flavescentiu. $\mathrm{C}$ a $\mathbf{u}$ Ies ad genieula lanati v. barbati, - Species nepulensis.

4479. Z Kozimala HOFFM. C a I y e is limbus quinquedentatas. P etala obovata, emarginata, cum lacinula inflexa. Fruct u $\mathbf{s}$ a dorso plano-compressus, medio convexiusculus, hirsutus, margine dilatato, incrassato, Jaevi cinetus; m e ricarpia quinquejuga, jugis tenuissimis, tribus dorsalibns aequidistantibus, duobus lateralibus margini dilatato contignis, remotioribus, vittis vallecularum solitariis, easdem explentibus, totnm semen obtegentibus, commissuralibus geminis, latis. Carpophorum bipartitum. Semen complanatum. - Herbae orientales; foliis decompositis, umbellis compositis, involucro involucellisque polyphyllis, floribus albis, haud radiantibus.

Zozimin Hoffmann Umbellif, 1, 145, t. 1. B. f. 8 . Bieberst. Suppl. 299. Koch Umbellif. 88 . Her a cl e um ab. sinthifolium Venten. Choix $t$, 22. Sibthorp Flor. graec. t. 281 .

4489. Polytaenia DC, Calyeis limbus quinquedentatus. Petal a ovalia, emarginata, cum lacinula inflexa. F,ruetus ovalis, a dorso lenticulari-compressus, glaberrimus, margine tumido, laevi, area dorsali depressa; meric a rpia quinquejuga, jugis tennissimis, vix distinetis, vittis vallecularum geminis, commissuralibus senis, marginis plurimis, epiearpio tectis, C a rp o p h orum indistinctum. S emen complanatum. Herba boreali-americana, glabra; foliis summis oppositis, tripartitis, ramis lateralibus floridis, oppositis, umbellis terminalibus, involucro nullo, involucellis setaceis, floribus flavescentibus.

Poly ta en I a DC, Mem, V. 53, t. 13. Prodr. IV. 196 Meisner Gen, 147, (106.)

480. Johrenia $D C$. C alycis limbus obsolete dentatns. Petala …. F ructus uvalis, a dorso lenticulari-compressus, glaberrimus, subspongiesus, margine tumilo, laevi, area dor- sali plana, subeolorata; mericarpia quinquejuga, jugis tribus dorsalibns filiformibus, demum rufis, vittas includentibus (?), duobns lateralibns in marginem dilatatis, saepe indistinctis, interdum rufis, vittaeformibus, commissura fungosa, evittata, bilineata. Carpophorum bipartitum. Semen complanatam. - Herba libanotica, glaberrima; caule tereti, dichotomo, foliis inferioribus bipinnatisectis, segmentis eum impari bijugis, opposilis, distantibus, in lobos lineares, aculos, basi confluentes partitis, superiorum lobis tribus, linea. ribus, elongatis, integerrimis, umbellis sex-octoradiatis, involucro nullo v. monophyllo, involucelli tetra-pentaphylli foliolis lineari-setaceis.

Johrenia DC. Mem. $V$. 34. t, $1, f$. C. Prodr. IV. 196. Meisner Gen, 1467. (106.)

4481. Trasselquistia LINN, C a ly c is limbus quinquedentatus. P e $t$ a $l$ a obovata, emarginata, cum lacinula inflexa, exteriora radiantia, bifida, Frnctus dimorphi, radii plano compressi, margine accessorio alato, subincrassato, vix rugoso-tuberculato cincti, disei mericarpio altero in urceolum hemisphaericum circa alterum abortiens contracto; meric ar pia quinquejuga, jugis subtilissimis, tribus dorsalibus aequidistantibns, duobus lateralibus margini incrassato contignis v. ab eo tectis, valleculis univittatis, commissura bivittata, vittis filiformibus. Carpophorum bipartitum. S emen complanatum. - Hérbae sy riacae, a Tordylio nonnisi fructu dimorpho diversae; caule hispido $v$. pubescente, foliis pinnatisectis, segmentis pinnatifidis, lobis laciniatis, nunc infimis trisectis, superioribus integris, cordatis, involucro brevi, involucellis umbellulas subsuperan. tibus.

H a s e Iq u is tia Linn. gen, n. 34t. Jacq. Hort. Vind. t. 87. 193. Sprengel Umbellif. 11. Koch Umbellif. 88. DC. Prodr, IV. 197. Meisuer Gen, 146, (107.) Tordy 111 s p. Lam, $t, 193$.

4482. Toredylium TOURNEF, Calycis limbus quinquedentatus. Petal a obovata, emarginata, cum lacinula inflexa, exteriora radiantia, bifida. Fruetus a dorso plano-compressus, margine accessorio incrassato, rugoso-tuberculatocinctus; mericarpia quinquejuga, jugis subtilissimis, tribus dorsalibus at quidistantibus, doobus lateralibus margini incrassato contiguis v. ab eodem tectis, valleculis uni-plurivittatis, vittis comimissuralibus geminis v. pluribus, omnibus filiformilis. Carpophorum bipartitum. Semen complanatum. - Herbae europeae et orientales; folits pinnatisectis, segmentis ovatis, inciso-dentatis, involucro pleiophyllo, floribus albis.

Tor dy II n m Tournefort inst. 170. Linn. gen, $n, 330$. Sprengel Prodr. Umbellif. 11. DC. Prodr. IV. 197. Meisner Gen, 140. (107.)

a. EUTORDYLIUM DC. $\boldsymbol{l}$, c. Vitta e vallecularum sollfariae, commissurales geminae.

To rd y li u m Hoffmann Umbellif. 1, 198. t. 3. $f$. 3 , 4. A. Koch Umbellif. 87. f. 24. 25. (Jacq. Flor. austr. t. 124.)

b. CONDYLOCARPUS DC. $\boldsymbol{l}$. c. Vit a e vallecularum plures, commissurales quaternae, octonae $v$. denae.

Con a y loca rpus Hofimann Umbellif, 1, 809. Koch Umbellif. 86. non Desf. (Jacq. Hort. Nindob, t. 58. Desfont. Flor, atlant. $t$. 38. Sibthorp Flor. graec. $t, 267$. E. B. t. 2440.)

4483. Tordyllopsis $D C$. Calycis limbus quinquedentatus, dentibus acutis, exterioribus majoribns, e basi dilatata cnspidatis. Petala 
umbellae exteriora ampla, obcordato-biloba, reliqua minora, cuspidata, integra v, rarins subbiloba. Stylopodium conicum. Styli duo erecti, elongati. Fru ct us junior hirsutus. - Herba n epalensis, pedalis, tota plus minus hirsuta; caule tereti, striato, erecto, subsimplici, foliis petiolo basi vaginante, pinnatisectis, segmentis uni-bijugis cum impari, ovatis, incisis, dentatis, umbellis terminalibus, sex-ootoradiatis, involucri foliolis quinque v. sex, lanceolato-linearibus, acuminatis, radios subsuperantibus, umbellulis confertis, quindecim-octodecimfloris, involucelli foliolis involucro conformibus, flores excedentibus.

Tordyliopsis DC. Prodr. IV. 199. Meisner Gen. 139. (107.) Tordy lioides Wallieh mse.

TEIEUS RX. SILERINAE Koch Um bellif. 84. Fructus a dorso lenticulari compressus. Mericarpia jugis primariis quinque, secundariis quatuor, minus prominulis. S emen facie planum. - Tribus a paucijugatis ad multijugatas transitum faciens, pauperrima, Europam mediam, regionem mediterraneam, Orientem et Asiam borealem incolens.

4.84. Agasyllis HOFFM. Caly cis lim bus ohsoletus. Pet a I a lanceolata, incurva. Fru ctus ovalis, a dorso compressus; mericarpia jugis primariis quinqne, obtusis, lateralibus paullo minus prominulis, ante marginem accessorium brevissimum positis, secundariis inter exteriora parvis v. plane obsoletis. Nucleus liber, hine convexus, facie planus, vittis plurimis, dorsalibus octonis-denis, commissuralibns quinis-senis tectus. - Herba perennis, c aucasica, Cachrydis facie; caule succulento, foliis pubescentibus, trichotome decompositis, segmentis decursivis, lanceolatis, serratis, sublobatis, umbella multiradiata, involucre nullo, involucellis polyphyllis, foliolis setaceis, floribus albis.

A g a s y 11 is Hoffmann Umbellif. 176, Sprengel Prodr. Umbellif. $f$. 4. excl. reliq. DC. Prodr. IV. 199. Meisner Gon. 141. (106.) Cachrys Iatifolia Bieberst.

4485. Siller $S C O P$. C a lycis limbus quinquedentatus. Pet a la obovata, emarginata, cum Jacinula inflexa. Fruetus a dorso lenticularicompressus; mericarpia jugis filiformibns, elevatis, obtusis, primariis quinque, lateralibns marginantibus, secundariis quatuor minus prominulis, valleculis subjugis secundariis univittatis. Seme $\mathrm{n}$ facie planinsculnm.- Herba perennis, glabra, in Europa et Asia, ab Hispania ad Kamtsehatcam monticola; folitis triternatis, foliolis suborbiculatis, grosse et obtuse crenatis $v$. obsolete trilobis, umbellis multiradiatis, amplis, involucris nullis v. oligophyllis, caducis, floribus albis.

Siler Scopoli Flor. carn. 1. 217. Gärtner 1, 92, $t$. 21. Lagasea Amen, nat, IT. 101. Koch Umbellif, 84. f. 34.35 . DC. Prodr, $I V$. 200. Meisner Gen. 148. (106.) B ra d la e ia Necker Elem. n. 280. L a \& e pitfum tril obum Linn.

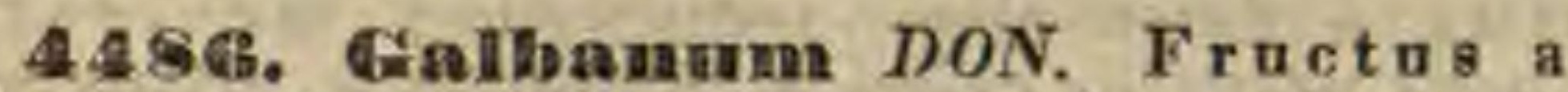
dorso compressus, ellipticns; mericarpia jugis primariis quinque, secundariis duobus, omnibus elevatis, compressis, obtuse carinatis, lateralibus distinctis, marginantibns, valleculis latiusculis, concavis, evittatis, commissura plana. dilatata, bivittata, vittis latis, subarcuatis. - Planta persica, galbanophora, praeter fructum incognita.

Galbavum Don in Linn. Transace, XVI, 603. Meisver Gen. 148. (107.)
448\%. Drmosolemin TAUSCH. Calycis limbus obsoletus. Petala obovata, emarginata, cnm lacinula inflexa, adnata. Fructus a dorso lenticulari-compressus; mericarpia oblonga, quinquejuga, jugis tribus intermediis filiformibus, tenuissime nndalatis, subarticulatis, lateralibus in margines anguste alatos dilatatis, valleculis convexis, jugis secundariis vittam moniliformem intercipientibus, quasi duplicatis, commissura quadri-sexvittata, vittis moniliformibus. Carp op hor um bipartitum. - Herba cretica, perennis, pumila, cauliculis digitalibus supra rhizoma multiceps congestis, basi foliosis, apice scapiformibus, nudis; foliis glaucis, reniformibus, trilobis $v$. trisectis, lobis segmentisque ovato-cuneatis, incisis dentatisque, umbellis tri-septemradiatis inaequalibus, involucris involucellisque nullis, floribus luteis.

Ormosolenfa Tausch in Flora 1834. p. 348. Meisner Gen. 145. 106.) Sison $\mathrm{S}$ ieberianum DC.

TEBIBE $\mathrm{X}$. CUMINEAE Koch Umbellif. 81. Fructus a latere contractus. Meric a r pia jugis primariis quinque, lateralibus marginantibus, secundariis quatuor magis prominulis, omnibus apteris. Sem en rectum, facie planiusculum. - Tribus verisimiliter cum Ammineis conjungenda, genera complectitur duo, alterum mediterraneum, alterum borealiamericanum.

448. Cuminum $L I N N$. C a 1 y $\mathrm{c}$ is limbus quinquedentatus, dentibus lanceolatis, setaceis, inaequalibns, persistentibus. Petal a oblonga, emarginata, cum lacinula inflexa, erectopatula, Fructus a latere contractus; mericarpia jugis apteris, primariis quinque filiformibns, minute muriculatis, lateralibus marginantibus, secundariis quatuor, magis prominentibus, aculeatis, valleculis sub jugis secundariis univittatis. Carpophorum bipartitum. Semen dorso convexum, facie convexiusculum. - Herbae $m e d i$ terraneae; foliis multifidis, laciniis lineari-selaceis, involucri di-tetraphylli foliolis simplicibus $v$. divisis, involucellis oligophyllis, dimidiatis, deтum reflexis, floribus albis $v$, rubentibus.

C nmin am Lian, gen. n. 351. Gürtner I. 107. $t .23$. Sehkuhr t. 80. Lagasea Amen. nat. TI. 95. Sprengel Prodr. Umbellif. 25. Hoffman Umbellif, edic. IT. p. 194. Kach Umbellif. 81 . Nees jus. Plant. offic. XIIt. $t$. 7 , DC. Prodr. IV. 301. Meisner Gen, 150. (102.)

4489, Trepocarpans NUTT. Calycis limbus quinquedentatus, dentibus subulatis, sero deciduis. Petala obcordata, inflexo-emarginata. Fructus pyramidato-angulatus, subteres, a latere contractus; m ericarpia dorso convexa. jugis primaris quinque, filiformibus, vix prosuinulis, utrinque linea fusca vittaeformi marginatis, secundariis quatuor, enstato-elevatis, intus univittatis, commissura crassa, medio suleata, intrs vittata. Semen dorso subcompressum, rectum. Herba boreali-am ericana, Aethusae facic, glabra, ramosa; foliis multifidis, lobis linearibus, umbellis oppositifoliis, quinqueradiatis, involuero mono-triphyllo, foliolis linearibus, umbellulis quinque-octofloris, involucellis tetra-pentaphyllis, dimidiatis, floribus albis.

Trepoca ipu* Nuttall in DC. Mem, D. 56, t, 14 , Prodr. IV. 201. Meisuer Gen, 140. (107.) 
TR IEUS XI. THAPSIAE Koch Umbellif. 73. Fructus a dorso compressus v. sectione transversali subteres. Mericarpia jugis primariis quinque filiformibus, interdum setulosis, lateralibus plano commissurali impositis, secundariis quatuor, filiformibus, exterioribus marginantibus v. omnibus alatis. S em en subcomplanatum v. subtereti-convexum, facie planum. - Europae mediae et australis cives, genus unum boreali-americanum, quoad locum in tribu summe dubium.

4450. Thapsia TOURNEF, C a $1 \mathrm{y} \mathrm{cis}$ limbus quinquedentatus. Petala elliptica, integra, acuminata, acumine inflexo $v$. involuto. Fructus a dorso compressus; mericarpia quinquejuga, jugis primariis filiformibus, tribus dorso, duobus lateralibus plano-commissurali impositis, secundariis quatuor, dorsalibus filiformibus, lateralibus membranaceo-alatis, ala integra, valleculis inter juga secundaria univittatis. C a rpophornm bipartitum. Semen complanatum. - Herbae mediterraneae, perennes; foliis bitripinnatisectis $v$, decompositis, petiolv vaginante, summorum lamina abortiva, umbellis amplis, compositis, multiradiatis, involucro involucellisque nullis v. oligophyllis, deciduis, floribus flavis.

Th apsia Tournefort inst. 17t, Linn. gen, n, 361. Sprengel Prodr. Umbellif, 17. Lagasca Amen, nat, I1, 90. Sibthorp Flor. graec, $t$, 286. 287. Desfont. Flor. atlant. t. 75. Koch Dmbellif, 74. f. 3-5. DC. Proilr. ID, 202. Meisner Gen, 148. (107,)

4491. Cymopterras $R A F I N$. C a ly c is limbus minute quinquedentatus. P e $t$ a $l$ a orbicalato-ovalia, apice inflexo. Fru ct u s subellipticus, compressus, septem-octoalatus, nempe: meric ar$\boldsymbol{p}$ io altero interdum imperfecto trialato, perfectis quadrialatis, alis undulatis, valleculis planis, uninerviis, commissura nuda, tristriata. Carpo phorum adnatum. - Herba boreali-ameri cana, non satis nota, laevis, humilis; radice tuberosa, caule decumbente, subnudo, folitis biternati sectis, lobis brevibus, obtusis, decussatis, petiolo longo, umbellis quadri-sexradiatis, radiis brevibus, involucro nullo, involucellis quinque septempartilis, dimidiatis, floribus polygamis, femineis subsessilibus, albis, centralibus maseulis, pedicellatis.

Cy mopterus Rafiaesque Journ. Phys. LXXXIX, 100. DC. Prodr. IV, 203. Meisner Gen, 148, (107.) non Schult. Tha ps i a Nuttall Gen, 1, 184.

4498. Tasserpitinm TOURNEF, C a lycis limbus quinquedentatus. Petala obovata, emarginata, cum lacinula inflexa. Fructus a dorso compressus $v$. subteres, octoalatus; in eric a rpiorum jugis primariis quinque, filiformibus, secundariis quatuor, omnibus in alam expansis, valleculis sub jogis secundariis univittatis. Carpo. phorum liberum, bipartitum. - Herbae perennes, in Europa imprimis a ustrali et orientali indigenae; foliis bi-tripinnatisectis, segmentis integris, dentatis $v$, incisis, umbellis multiradiatis, involucro involucellisque polyphyllis, floribus albis v. rarius flavis.

L a s e rpit i um Tournefort inst, 324. Line. gen, n. 344 exel. sp. Schkuhir t, 67. Jaeq. Flor. austr. t. 145. 146. 153. Ic, rar t. 55. 350, Desfont, Flor, allant, $t$, 72, Cavanill. Ic. t. 190. Ylor. dan. $t$, 1531. Waldstein et Kitalbel Plant. rar. zung, $t, 199.233$. Sprengel Prodr. Umbellif. 17. Lagase Amen. nat. II, 90. Koch Umbelliff, 74. DC, Prodr. IV. 204. Meisuer Gen. 148. (107.) Siler Mốch Method. 164.
493. Tophoseiadium $D C$. C a ly $\mathrm{cis}$ limbus quinquedentatus. P e $t$ a I a elliptica, integra, acuminata, apice subinvoluta. Fruetu 8 a dorso compressus; mericarpia jugis primariis ...., secundariis quatuor, duobus lateralibus in alam subserratam, dorsalibus in alas interruptas, squamas subretrorsas simulantes expansis. S e m en .... - Herba glabra, maris nigri accola, non satis nota; caule erecto, tereti, foliis inferioribus, (fere Achilleae Millefolium) pinnatisectis, segmentis plurimis, brevibus, multipartitis, lobis lineari-subulatis, summis sessilibus, a basi pinnatisectis, saepius e vaginarum axilla ortis, umbellis compositis, interdum proliferis, involuori foliolis quinis-septenis, ovato-lanceolatis, cuspidatis, involucelli foliolis totidem angustioribus, radios subaequantibus, floribus flavis.

Lophosciadium DC. Mem. V. 57. t. 2, f, P. Prodr. IV. 208. Meisner Gen. 148, (107.) Ferula meoides Linn.

404. DIelamoselinama HOFFM, C alycis limbus quinquedentatus. Pe tala obovata, emarginata, cum lacinula inflexa. Fruetus a dorso plano-compressus; mericarpia jngis dorsalibus duobus plano-commissurali impositis, secundariis quatuor, interioribus tennissime filiformilus, exterioribus membranaceo alatis, ala serrata, jugis omnibus vitta oleifera percursis. Carpophorum bipartitum. Semen complanatum. Frutex incertae originis, in hortis olim $B u b o$ $n$ is Gulbani nomine venditatus; caule simplici, tereti, inferne nudo, foliis tripinnatisectis, segmentis ovatis, acuminatis, serratis, extremis saepe confuentibus, petiolo vaginante, umbellis compositis, multiradiatis, involucris polyphyllis, foliolis incisis, involucellorum integris, floribus albis.

Melanoseli num Hoffmann Umbellif. edit, II. $r$. p. 156. Koch Umbellif. 75. f.6_8. DC. Prodr. $I V$. Meisner Gen. 140. (107.) Selin um de cíplens Schrader in Wendland Sert. Hannov. IIT, t. 13.

TRIBUS XII. DAUCINEAE Koch Umbellif. 76. Fruetus a dorso lenticulari-compressus v. sectione transversali subteres. Mericarpia jugis primariis quinque, filiformibns, setulosis, lateralibus plano commissurali impositis, secundariis quatuor magis prominulis, aculeatis, aculeis liberis v. in alam connatis. Sem en complanatum v. subsemitereticonvexum, antice planiusculum. - Daucineae in Europa australi, Asia et Africa mediterranea obviae, nonnullae Americam borealem et australem extratropicam incolunt, in NovaHollandia rarissimae.

445. Artedia LINN. Caly cis limbus obsoletus. Peta la obovata, emarginata, cum lacinula inflexa, exteriora nmbellae radiantia. Fra :tus a dorso plano-compressus; mericarpia jugis primariis quinque, filiformibus, tribus intermediis dorsalibus, duobus lateralibus plano commissurali impositis, secundariis quatuor, interioribus filiformibus, exterioribus membranaceo-alatis, alis profunde sinnato-lobatis, valfeculis omnibus evittatis, Carpophorum bipartitum. Semen complanatum. - Herba orientalis, annua, glabra; foliis et involucri involucellorumque foliolis in lobos lineares multifidis, umbellis compositis, floribus albis. 
Arte dia Linn, gen, n. 339. Lam. t. 173. Sibthorp Flor. graec. t. 268, Sprengel Prodr. Umbellif. 18. Lagasea Amen nat. IT. 90. Koch Umbellif. 26. $f .9 .10$, DC. Prodr. IV 208. Meisner Gen, 141. (107.) - Figura plantae germinantis apud DC, Kem, $V, t, 19, f, 7$.

4456. Drlaya HOFFM. Cal y eis limbu quinquedentatus. P etala obovata, emarginata, cum lacinula inflexa, exteriora umbellae radiantia, profunde hifida. Fructus a dorso lenticularicompressus; mericarpia jugis primariis quinque, filiformibus, setiferis, tribus intermediis dorsalibus, duobus lateralibns plano commissural impositis, secundariis quatuor, bi-trifariam aculeatis, exterioribus magis prominulis $\mathbf{v}$. subalatis, aculeis apice hamatis v. radiatis, vallecolis sub jugis seeundariis nnivittatis. Carp ophor $\mathbf{p m}$ bifidum. S em e n dorso convexiusculnm, facie com planatum. - Herbae Europae mediae et regionis mediterraneae, annuae; foliis multifidis, lobis linearibus, involucro vario, involucellis polyphyllis, floribus albis, radii hermaphroditis, stylis brevibus, disci maseulis, in alia umbella femineis, stylis longis praeditis.

0 rla y a Hoffmann Umbellif. 1. 58, Koch Umbellif. 78. f. 12. 13. DC. Prodr. IV. 209. Meisuer Gen. 141. (10\%.) Caucalis grandiflora et C. platyearpa Linn. Lam. $t$. 199. $f$. 2 . D a u ci 8 p. Gărtner $t$. 20, $f$. 4 .

449\%. Damens TOURNEF. Calyeis limbus quinquedentatus. Petal a obovata, emarginata, cum lacinula inflexa, exteriora saepe radiantia, profunde bifida. Fruetus a dorso subcompressus, ovatus v. oblongus; mericarpia jugis primariis quinque, filiformibus, setulosis, tribus internediis dorsalibus, duobus lateralibus plano commissurali impositis, secundariis quatuor, aequalibus, magis prominulis, alatis, uniseriato aculeatis, valleculis sub jugis secundariis univittatis. Car poph or um bipartitum. Semen facie planiusculum. - Herbae mediterraneae et a ustro-americanae, saepius biennes; foliis bipinnatisectis, involucri foliolis plurimis, tri-aut bipinnatifidis, involucellorum integris v. trifidis, flo. ribus albis $v$. flavis, centrali saepe sterili, carnoso, atro-purpureo.

D a u c u s Tourrefort inst. 161. Linn. gen. $n, 333$, Gärt ner 1. 79. t. 20. DC. Prodr. IV. 209. Meisner Gen, 141. (107.)

a. PLATYSPERMUM DC. $2, e$ J u g a secundaria aculeis basi latioribus et nauifeste cohaereatibus. - Involucrum nullum v. parvum, foliolis parum divisis.

Plat y s permum Hoffmann Umbellif. 1f6. Koch Umbellif. 68. Laserpitil s p. Desfont. Etor. atlant. t. 70. C a ue alldis s p. Delile Flor. aegypt. $t$. 23. $f$. 2. 3. (Siblhorp Flor, graec, t. 272.)

b. CAROTA DC. $l$. c. Juga secundaria aculeis tenuibus usque basim partitis. Carpophorum ad mediam v. usque ad basim partitum. - Umbellae radii aequales, $v$. centrales regulariter breviores.

Da u cus Hoffmann Umbellif. 1. 64. Koch Umbellif: 78. (Flor. dan. $t$. 723, E. B. $t, 1147,2560$. Desfont. Flor, atlant. t. 59_65. Sibthorp Flor, graec. t. 269 -281.)

e. ANISACTIS DC. $l$ c. Carpophorum indisisum v apice brevissime bifidum. - Umbellae radii valde inaequales. Species austro-americanae et Novae-Hol Iandice.

SUEOTED TI. CAMPYLOSPERMAE DC. Prodr. IV. 215. A lbumen marginibus involntis facie interiori sulco v. canali longitudinali notatum.

TEIBUS XIM.
Koch in DC. Prodr. IV, 215. Fruetus eylindraceus, a dorso subcompressus. M e ric a $\mathrm{r}$ p ia jugis primariis quinque filiformibus, secundariis quatuor, dorsalibus nerviformibus, lateralibus in alam expansis, marginibus nerviv. jugiformibus. S e m e $n$ involutum, semilunare.

4498. Elaeoselinemu $\mathrm{KOCH}$, Calyc is margo obsolete quinquedentatus, P e $t$ a la obovata, emarginata, cum lacinnla inflexa. Fru ctus a dorso subcompressus, teretiusculns, tetrapterus; mericarpia jugis primariis quinque, filiformibus, tribus intermediis dorso impositis, dnobus lateralibus margini approximatis, secundariis quatuor, interioribus obtusis, exterioribus in alam membranaceam expansis, vittis sub omnibus jugis oleiferis, snb primariis tenuioribus, commissuralibus quatuor. C a r p o p hor a m bipartitum v. indivisum (?) S e men involutum. - Herbae perennes, altera mediterrane $a$, sicu $l \bar{a}$ et mauritanica, altera mexicana; caule tereti, glabro, foliis petiolo ramoso decompositis, umbellis umbellulisque multiradiatis, involucris polyphyllis, foliolis linearibus, cuspidatis, floribus flavis.

El a coselinum Koch in DC. Prodr. 1V. 215. Meis. ner Gen. 142. (107.) La s e rpítium meoides Desfont. Flor. atlant, t. 69.

4459. Margotia BOISS. C a ly $\mathrm{c} \mathrm{is}$ limbus longe quinquedentatus. P e t a 1 a lata, biloba, eum lacinula longa, inflexa. Fruetus a dorso subcompressus, teretiusculus, di-tetrapterus; mericarpia jugis primariis quinque, filiformibus, tribus intermediis dorso, duobus lateralibus plano commissurali impositis, seonndariis quatuor, exterioribus in alam membranaceam expansis, interioribus apteris v. rudimentarie alatis, jugis omnibus vittatis. Carpophor $\mathbf{m}$ m bipartitum. Semen marginibus involatum. - Herba his panica, tri-quadripedalis; folitis omnibus radicalibus tripinnatisectis, segmentis ovatis, multifidis, laciniis brevibus, acutis, linearibus, caulibus teretibus, parce ramosis, involucro involucellisque polyphyllis, foliolis lanceolato-linearibus, umbellas multiradiatas, ante anthesim nutantes aequantibus, floribus albis, fructibus magnis, ovatis, mericarpitis dipteris, alis basi et apice emarginatis, obtusis, transversim subplicatis.

Margotla Boissier Elench. plant, Hisp. austr. 52. Meisner Gen, 141, (107.)

TreItidS XIV. CAUCALINEAE Koch Umbellif. 79. Fructus a latere contractus v. subteres. Mericarpia jugis primariis quinque filiformibus, setosis $y$. aculeatis, lateralibus plano commissurali impositis, seeundariis quatuor, magis prominulis, aculeatis v. acnleorum copia valleculam totam tegente obliteratis. Semen involutum v. margine inflexum. Caucalineae Daucineis cohabitant, sed ex America extorres.

45010. Szovitsia FISCH, et MEY. CaIyeis limbus quinquedentatus. Petal a obovatoemarginata, cum lacinula inflexa, subaequalia. F ructus oblongo-ellipticus, a latere subeompressus; meriearpia jugis primariis quinque, filiformibus, subpilosis, duobus lateralibus plano com- 
missurali impositis, secundariis quatnor prominulis, incrasatis, rotundatis, plicis transversis obtectis, univittatis. C a rp oph or um rigidum, apice fissum. S e m en marginibus inflexis sulco notatum. - Herba persica, annua, glabra; foliis decompositis, lacinits elongatis, fliformibus, umbellis lateralibus, involucris nullis, involucellis penta-hexaphyllis, membranaceis, floribus albis.

Szovitsia Fiseher et C. A. Meyer Index Sem. Hort. Petropolit. 1. 835. p. 39

4501. Canealis LINN. C a 1 y $\mathrm{c}$ is limbus quinquedentatus, dentibus ovato-lanceolatis. $\mathbf{P e}$ tala obovato-emarginata, cum lacinula inflexa, exteriora radiantia, profunde bifida. F ructus a latere subcompressus; $m$ eric ar p ia jugis primariis quinque, filiformibus, setosis v. aculeatis, tribus intermediis dorso, duobus lateralibus plano commissurali impositis, secundariis quatuor magis prominulis, simpliei serie acnleatis, vittis in quaque vallecula sub jugis secundariis solitariis, commissuralibus geminis. Carp oph or u m rigidum, apice fissum. S e m e $n$ involutum v. margine infle xum. - Herbae in Europa media et a astra$l i$ indigenae; foliis multifidis, involucro nullo $v$. mono-diphyllo, involucellis tri-octophyllis, foliolis lanceolatis, patulis, floribus albis, disci masculis, sterilibus.

$\mathrm{C}$ a uealis Linn. gen. n. 331. exel. sp. Jacq. Flor. austr. $t$, 157. Hort, Vindob. $t$. 195. Schkuhr $t$. 61. Hoff mann Umbellif. 54. $t, 1, f ., 14$. Koeh Umbellif. 79. $f .14$ DC. Prodr. IV. 216. Meisuer Gen. 140. (107.)

450\%. Turgenia HOFFM. Calycis limbus quinquedentatus, dentibus setaceis. P etaI a obovata, emarginata, cum lacinula inflexa, exteriora radiantia, bifida. Fruct us a latere contractus, subdidymus; mericarpia jugis prima riis quinque, secundariis quatuor, primaris plano commissurali impositis, simplici serie muriculatis v. aculeatis, reliquis omnibus bi-trifariam aculeatis, aculeis aequalibus, valleculis sub jugis secundariis nnivittatis, commissura bivittata. Carp ophor $\mathbf{n}$ m setaceum, bifidum. Sem e $n$ involutum. - Herbae a ustro-europea et orientales, erectae, scabrae; folitis pinnatisectis, segmentis ob. longis, dentatis, umbella pauciradiata, involucro involucellisque tri-pentaphyllis, foliolis ovatis, concavis, aequalibus, margine membranaceis, floribus albis $v$. roseis, disci masculis, sterilibus.

Turgenia Hoffmann Umbellif. 59. Koch Umbellif. 80. f. 16. DC. Prodr. $Y V$. 217. Meisner Gen, 140. (107.) Tordylif $s$. Linn. Caucalid is'sp. Jacq. Hort. Vin dob. $t, 128$

4503. Tophlis $A D A N S, C$ a $l y c$ is limbus quinquedentatus, dentibns triangulari-lanceolatis, acutis, persistentibus. P e $t$ a l a obovata, emarginata, cum lacinula inflexa, exteriora majora, bifida. Eruetus a latere contractus; mericarpia jugis primariis quinque, setulosis, tribus intermediis dorso, duobus lateralibus plano commissurali impositis, secundariis quatuor, copia aculeorum totam valleculam, intus univittatam occupantibus, commissura bivittata. Carpoph or um setaceum, bifidum. S em en margine inflexum. Herbae in Europa et Asia temperata obviae; folit multifidis, pilis brevibus, adpressissimis, in caule retrorsis, in umbellae radiis erectis, umbellis oppositifoliti, involucro mono-pentaphyllo, involucellis penta-octophyllis, foliolis lanceolatis, ciliatis, floribus albis, disci masculis sterilibus, fructum aculeis piliformibus, apice saepius uncinatis.
Torilis Adanson Fam, II. 99. Gärtuer I. 82. Sprengel Prodr. Umbellif. 49. Hoffmann Umbellif. 49. Lagasca Amen, nat, II. 95. DC. Prodr. IV. 218. Meisuer Gen. 140. (107.)

a. EUTORILIS DC. $\boldsymbol{l}$. c. F ruct os aculeolis rigidis, saepius apice uneinatis tecti. - Tordylii sp. Linn. Jacq. Flor, austr, $t$. 261. Append, $t, 24, \mathrm{~S}$ a n d ic is s p. Jacq. ibid. $t$, 46. C a u c alld is s p. Jacq. Hort. Vindob. III. t. 16. (Hoffm. Op, oit, t, 1. f. 18, Koch f. 15. Gärtner $t, 20 . f$. 6.)

b. TRICHOCARPAEA DC, l. $c$. Fructus undique tectas pilis longissimis, setaceis, mollibus, confertis, patulis, colorntis, apice haud uncinatis.

TRLBUS XV. SCANDICINAE Koch Umbellif. 130. Fruetus a latere compressus v. contractus, saepius rostratus. M ericarpia jugis quinque filiformibus, interdum alatis, lateralibus marginantibus, omnibus aequalibus, nonnunquam basi obliteratis, nonuisi apice manifestis. Semen tereti-convexum, facie interiore sulco profundo percursum v. margine subinvolutum. - Europae mediae et australis, nec non regionis taurico-caucasicae potissimum eives, nonnullae mexicanae, quaedam andicolae, nepalenses, australasicae.

4504. Seandix GARTN. Caly c is limbus obsoletus v. subquinquedentatus. P et a I a obovata, truneata v. emarginata, saepius lacinula inflexa. F ru e t as a latere subcompressns, rostro longissimo; m erie a r p i a quinquejuga, jugis obtusis, aequalibus, lateralibus marginantibus, valleculis evittatis v. obsolete univittatis. Carp ophor $\mathbf{u m}$ indivisum v. apice bifnrcum. Semen tereti-convexum, facie profunde sulcatum. - Herbae annuae, in Europa et Oriente obviae; caule tereti, substriato, foliis pinnatisectis, segmentis in lobos lineares multifidis, umbellis pauciradiatis, involucro nullo v. monophyllo, umbellulis pauciradiatis, involucellis tri-heptaphyllis, floribus albis.

S ean d ix Gărtner 1 I. 33. $t$. 85. Lagasca Amen, nat. IT. 37. Koch Umbellif, 132, DC. Prodr. IV. 220. Meisner Gen. 141. (107.)

a. PECTEN DC. l. c. Fructus rnstrum a dorso compressum. Petal a subaequalia. Carpophoram setaceum, indivisum.

S can dix Hoffanan Umbellif, t, 1. f. 22. Flor, dan. t. 844. E. B. t. 1497. Vent. Cels. $t, 14$.

b. WYLIA DC. 2 . c. Fruetus rostrum a latere compressum. Petala radiantia. Carpophorum apice bifidum.

W y li a Hoffanan Umbellif. I, 3.t, 2. (Sibthorp Flor, graec, t. 285.)

4505. Anthrisens HOFFM, C a ly $\mathrm{c}$ is limbus obsoletus. Petala obovata, truncata $v$. emarginata, cum lacinula inflexa, saepe brevissima. Fruetug a latere centractus, costatus, rostro semine breviore; meri car p i a subteretia, ejugata, rostro quinquejugo. Carp ophorum apice bifidum. S emen tereti-convexum, facie profunde sulcatum. - Herbae annuae v. perennes, europea et caucasicae; caule tereti, striato $v$. sulcato, folitis decompositis, laciniis saepius linearibus, umbellulis terminalibus v. oppositifolits, involucro nullo, involucellis polyphyllis, floribus albis, fructu nudo v. ad basim setis verticillatis torquato.

Anthriscus Hoffman Umbellif, 1. 38, $t, 1,1, B$. Koeh Umbellif. 131. $f, 87-60$. Nees Plant. offic. Suppt. t. 8, DC, Prodr. IF. 282. Melisner Gen, 140, (107.) $\mathrm{C}$ ha e- 
rophyllum Lagasea Amen, nat, II. 98, R. B. t, 762. 1268, Hayne Arzneigew. I, t.33. YII. t. 14. Cerefoli a m Haller Helvet, I. 149. S c a nd $\mathrm{i} \in \mathrm{i} s \mathrm{~s} \mathrm{p}$. Linn. K. B. t. 818. Waldstein et Kitaibel Plant, rar, Hung, $2,224$.

4506. Chaerophyllum LINN. C alycis limbus obsoletus. Peta la obovata, emarginata, cum lacinula inflexa. F ructus erostris, a latere compressus v. contractus; mericarpia quinquejuga, jugis obtusis, aequalibus, lateralibus marginantilus, commissura sulco profundo exarata, valleculis univittatis. Ca rpophor um bifidum. S e m en tereti-convexum, seetione transversali semilunare. - Herbae in Luropa, imprimis mediterranea et Asia media obviae, annuae, biennes $v$, perennes; foliis decompositis, segmentis dentatis $v$. multifidis, involucro nullo $v$. oligophyllo, involucellis polyphyllis, floribus albis, interdum roseis v. flavis.

$\mathrm{C}$ b a e r op hy $1 \mathrm{Ium}$ Linn. gen. n. 358, ref. Hoffmanu Umbellif. 1. 33, Koch Umbellif. $130, f .61-63$, DC. Prodr. IV. 224. Meisuer Gen, 142. (104.)

a. PHYSOCACLIS DC. 7 . C. Fruet us subeylindraceus, apice attenuatus, undique tectus setis rigidis, compres sis, angulatis, jugis obtusis, valde depressis. Styli breves, recti. - Species europea, annua, $-\mathrm{S}$ c a $\mathrm{nd} \mathrm{ix}$ nod a s a Linn. Jaeq. Hort. Vindob, III, t. 25. Tor t. lili is macrocarpa Gärtn. $t, 25$.

b. BRACHYSTYLIS DC. l. c. Fruetus elaber, evidenter jugatus. Styli brevissimi, recti. - Species annuae, boreali-americana et nepalensis. - S e andix pro e umbens Linn.

c, EUCHAEROPHYLLUM DC. l. c. Fruetus glaber, evi denter jugatus. St y Ii plus minus divergentes. - Spe. cies biennes $\%$ perennes, gerontogeae. (Jacq. Flor. austr. $t$, 63, 64. 148, 150. Hort. Vindob, $t, 51$. Nees jun. Plant. offic. Sappl. I. t. S, 6.)

450\%. Butinia BOISS. Calycis limbus obsoletus. Petal a oborata, emarginata, cum lacinula inflexa. Fruetus erostris, a latere compressus; mericarpia quinquejuga, jugis filiformibus, intermediis duobus interdum obsoletis, lateratibus marginantibns, valleculis planis, evittatis. Carpophoru mindivisum. S emen antice suleo profundo exaratum. - Herba $h$ ispanica; radice tuberosa, foliis radicalibus teneris, triternatipartitis, segmentis ovatis, bi-trisec. tis, laciniis obtusissimis, caulinis bipinnatis, lobo terminali longiore, caulibus basi flexuosis, parce ramosis, inferne et ad geniculos patule villosis, involucro involucellisque nullis, umbellulisque pauciradiatis, fructu oblongo, rugosulo, lucido, stylis longis patulo-recurvis apiculato.

Butinia Boissier Elench. plant, Hirp. austr. 54.

4508. Dreomyrolnis. Calye is limbus obsoletus. Peta la ovalia, apice integro subinvoluta, extus pilosa. Fructus a latere subcompressus, ovato-oblongus, stylis brevibus, subdivergentibus coronatus; mericarpia quinquejuga, jugis obtusis, prominulis, lateralibus marginantibus, valleculis planis, striatis, univittatis, commissura medio suleata. Carpoph or um hipartitum. Sem en tereti-convexum, ad sutaram suhin volutum. - Herbae peruanae andicolae, puberulae $v$. hirtae, humiles, caespitosae; foliis radicalibus tripinnatisectis, multifidis, lobis lanceolatolinearibus, acutis, scapis erectis, umbella simplici, floribus circiter viginti, involucri foliolis totidem oblongo lanccolatis, floribus albis, polygamis.

Cald a s i a Lagasca Amen. nat. Ir. 98. DC. Mem, $V$. 2. 2. f. 1. Meisner Gen. 144. (107.) non Willd. Myrrhis a ndicola Kunth in Humb. et Bonpl. Nov. gen. et op. $V$. 13. $t .419$.
1509. Splablleroearpus BESS, $\mathrm{Ca}$ Iy cis limbus quinquedentatus, dentibus subulatis. Petal a obovato-cuneata, emarginata, lacinula inflexa, extima umbellae radiantia. Fruetus stylopodio suburceolato, dentato, stylisque brevibus demum deflexis coronatus, elliptico-oblongus, a latere contractus, erostris; me ricarpia quinquejuga, jugis subulatis, lateralibus marginantibus, valleculis convexis, bi-trivittatis, commissura quadri-sexvittata. C a r pop hor um bipartitum. Sem en intus sulco exaratum. - Herba d a hurica; caule tereti petiolisque pilosiusculis, foliis bipinnatisectis, segmentis pinnatifidis, lobis linearibus, acutis, involucro nullo, umbella sex-septemradiata, involucellis pentaphyllis, foliolis lanceolatis, floribus albis, in umbella terminali fere omnibus hermaphroditis, in lateralibus masculis.

$\mathrm{S}$ phalleroearp us Besser in DC. Mem. $V .64 . t .2$. f. N. Prodr. IV. 230. Meisuer Gen. 142. (102.)

4510. Nolopospermum $\mathrm{KOCH}$. C aI y c is limbns quinquedentatus, foliolosus. P e ta la lanceolata, integra, longe acuminata, acumine adscendente. Fructus a latere enntractus; meri $\mathbf{c}$ a $\mathbf{r}$ p a quinquejuga, jugís membranaceo - alatis, dorsalibus argutis, lateralibus marginantibus, doplo brevioribus, vallecnlis univittatis, vittis latis, fuscis, commissura angustissima, evittata, canale inani inter semen et pericarpii commissuram. Carpophorum bipartitum. Semen obtuse tetragonum v. angulatum, angulo commissurae opposito sulco profundo exaratum. - Herba Europae australis, perennis, glabra; foliis ternatisectis, decompositis, segmentis lanceolatis, elongatis, nitidis, decursive pinnatipartitis, laciniis argute pinnatifidis, involucri foliolis plurimis, elongatis, submembranaceis, interdum multifidis, involucellis polyphyllis, floribus albis, breve pedicellatis, umbellis terminalibus amplis, fertilibus, lateralibus minoribus, masculis, fructu saepe deformato, jugis lateralibus, earumque vittis evanidis.

Moloposperm n m Koch Umbellif. 108. DC. Prodr. IV. 230. Meisuer Gen, 142. (107.) L I g a s ticum pelopone s 1 a cu mi Llan. Jacq. Elor, austr, Append. t. 13.

451. Velaea $D C$. Calyeis margo obsoletus, Petala.... Fruetus ovatus, erostris, stylopodio conico depresso stylisque erectis, filiformibus; mericarpia a latere subcompressa, sectione transversali fere teretia, quinquejuga, jugis dorsalibus tribus alatis, duobus lateralibus marginantilns, subfiliformibus, valleculis bi-trivittatis, commissura quadrivittata, Ca r p oph or um a basi bipartitum. Semen margine involutum. Herba m exicana, glabra, ramosa; caule sulcatostriato, foliis ternato-supradecompositis, segmentis subsessilibus, tri-v. pinnatifidis, serratis, basi cuneatis, umbellis multiradiatis, involucro involucellisque nullis.

Velae a DC, Mem, V. 61. t, 2, f. H. Prodr. IV. $23 t$. Meisner Gen, 142. (107.) Ligantieum toluceense Kunth in Humb. et Bonpl. Nov. gen. et sp. t. 482.

451\%. Tamselhia SCHLECHT. C a 1 y $\mathrm{c}$ is limbus obsoletus. P e $t$ a $l$ a integra, apice elongato inflexa. Frnctus a latere contractus, elongatoovoidens; meriearpia quinquejuga, jugis filiformibus, obtusis, lateralibus: marginantibus, valleculis planis, univittatis, commissura sulco profundo exarata. Carpophorum indivisum. Semen..... - Herba mexicana, perennis; foliis radicalibus congestis, pinnatis, tri-septenjugis cum impari, foliolis ovatis $v$. cordatis, trilobis $v$. 99 * 
ternatisectis, scapo, tereti striato, florifero saepe foliis breviore, fructifero elongato, involucro nullo, involucellis oligophyllis, foliolis apice trilobis $v$. trifidis, floribus aureis.

T a us chia Schlechtend, in Linnaea IX, 607. Meisner Gen. 144. (107.)

4513. MIyrelhis SCOP. C a ly $\mathrm{c}$ is limbus obsoletus. P etala obovata, emarginata, cum lacinula inflexa. Fructus a latere compressus; meric arpia quinquejuga, jugis aequalibus, argutis, acutis, carinatis, intus cavis, elevatis, membranac interiori arcte adnatis, vittis nullis. Carpophornm apice fissum. Semen intra pericarpinm liberum. - Herba in Europa media et regione mediterranea crescens, perennis, villosa, Anisum redolens; radice fusiformi, foliis ternatim decompositis, segmentis pinnatifidis, involucro nullo, involucellis polyphyllis, foliolis lanceolatis, ciliatis, umbellulae floribus centralibus masculis, petalis albis.

M yrrh i, Scopoli Flor. carniol. edit. Ir, 1, 247. Hoffmann Umbellif. 1. 27. $t$. 1. $t$. 23. Koch Umbellif. 123. DC. Prodr. IV. 231. Meisuer Gen, 145. (107.) Seand ix o do $r$ at a Lian. E. B. $t, 697$.

4514. Treyera REICHENB. Caly cis limbus obsoletus. Petal a obovata, emarginata cum lacinula inflexa. Fru ctus a latere compressus; mericarpia quinquejuga, jugis aequalibus, argutis, subalatis, lateralibus marginantibus, valleculis planis, univittatis. Carpophorum apice fissum. S e men pericarpio adnatum, facie sulco profundo exaratum. - Herba il $l y r i c a ;$ radice suberosa, caule subsimplici, sulcato, folits bipinnatis, foliolis bi-trilobis, involucro nullo, involucello. rum foliolis ovato-lanceolatis, acuminatis, floribus albis, fructibus atris.

Freyera Reichenb. Pfanzenisst. 291. Meisner Gen. 144. (107.) B i as olettia Koch in Flora 1836. p. 163. Synops. 318. non Presl.

4515. Dsmorrloiza RAFIN, Caly e is limbus obsoletus. Peta I a obovata, vix emarginata, acumine brevissimo, inflexo. Fructus elongatus, basi in caudam attenuatus, solidus, acute angulatus, sectione transversali subteres; mericarp ia quinquejuga, angulis subsulcatis, hispidis, jugis acutis, valleculis planis, evittatis, commissura suleata. Carpophor um semibifidum. S em en teres, anguste involntum, pericarpio multo brevius, - Herbae boreali-americanae, perennes; radice fusiformi, anisata, caulc ramoso, bipedali, foliis biternatisectis, segmentis late ovatolanceolatis, inciso-dentatis, involucro di-triphyllo, involucellique sacpius pentaphylli foliolis lanceolatis, ciliatis, floribus albis, centralibus masculis.

Os morrhiza Rafinesque in Journ, Phys. 89. DC. Prodr. IV. 232, Hooker Flor, Bor. Amer. $t, 96,97$. Meisner Gen, 145. (107.) Uras perm um Nuttall Gen, 1. 192. nen Juss. Spermatura Reichenb. Consp. 141, M y r r hi. dis sp. Auct.

4516. Granmosefadium $D C$. Caly$E$ is limbus rigide quinquedentatus, persistens. Petala obcordata, acnmine inflexo. Fruetns stylis brevibus, conicis, divergentibus, rigilis, cylindracens, erostris; m e ric arpi a quinquejuga, jugis planiusculis, albidis, valleculis planis, univittatis, commissura bivittata. S em e n ...... Herbae orientales, glaberrimae, ramosae; folï pinnatisectis, segmentis multifidis, lobis lineari-setaceis, umbellis compositis, quinque-multiradiatis, involueri foliolis quinis-septenis, multifidis, involu- cellorum lineari-subulatis rariusve incisis, pedicellis post anthesim incrassatis, rigidis.

Grammosciadium DC. Mem, $V$. 62, $t$, 2. f. K, Prodr. IV. 232, Meisner Gen. 145. (107.)

451\%. Dzodia WIGHT et ARN. C a Iyc is limbus obsoletns. Petala suborbiculata, emarginata, lacinula inflexa, retusa. Fructus stylis brevibus, conicis, divergentibus coronatus, oblongus, a latere subcompressus, erostris; $m$ ericarpia quinquejuga, jugis filiformibus, vix prominulis, lateralibus marginantibus, valleculis planis, univittatis, commissura sulco exarata, bivittata. Semen dorso convexnm, facie marginibus involutis suleatam. - Herba indica, glabra, glauca, Foeniculi habitu; caule striato, foliis multifidis, lobis lineari-setaceis, umbellis decem-vigintiradiatis, involucro involucellisque nullis, petalis flavescentibus.

Ozodia Wight et Arnott Prodr. 1, 375. Meisner Gen. 142. $(107$.

TEEIBUS XVI. SMYRINEAE Koch Umbellif. 133. Fructus turgidus, saepius a latere compressus v, contractus. M ericarpia jugis quinque, lateralibns marginantibus v, ante marginem sitis, interdum subobliteratis. S e$m$ e $n$ involutum v. intus sulcatum, semilunare v. complicatum. - Sinyrneae in archipelago graeco et Oriente copiosissimae, in oris mediterraneis, Europa media et India rarae. Capenses sui generis. Paucissimae Americam tropicam et borealem incolunt.

4518. Iagoecia LINN. C a l y c is limbus persistens, quinquefidus, laciniis pectinatis. $\mathbf{P e}$ tala brevissima, obcordato-biloba, cum Iacinula inflexa, lobis aristatis. Fru ctus ovarii loenlo exteriore abortivo postice gibbus, antice planus, stylo extrorsum laterali; mericarpinm quinquejugum, jugis tenuissime capillaribus, valleculis univittatis, commissura bivittata, vittis brevibus, clavulatis. Semen marginibus inaequaliter involutum, facie suleo sublaterali notatum. - Herba mediterranea, erecta, annua; foliis pinnatisectis, segmentis ovatis, uniformibus, alternis grosse tri-quinquedentatis, dentibus aristatis, pedunculis oppositifolits, umbella composita, multiradiata, involucri octo-decaphylli involucellorumque foliolis quatuor pectinatis, umbellulis unifloris, flore pedicellato.

La g a e cia Linn, gen, $n$. 285. Gürtner $I, 103, t .23$. Sclikulir t. 48. Sibthorp Flor. graec, t. 243. Lagasca Amen. nat. II. 106. DC. Prodr, IV. 233. Meisuer Gen, 150, (108.) Cesati in Fricdrichsth. Reise in Griechenl. 275.

4519. Dliverin VENT. $\mathrm{C}$ a 1 y $\mathrm{c}$ is limbus quinquedentatus. P et a I a obcordato-bipartita, Iobis ad basim margine involutis et latere exeavatis, superne undulatis, reflexis. Fructus obovatoovatus, hirsutus; meric ar pia teretiuscula, obtuse quinquejuga, $C$ a $\mathrm{r}$ p o $\mathrm{h}$ or $\mathrm{xm}$ apice bifidnm. Semen facie súlco exaratum. - Herba or ientalis; caule ramoso, erecto $v$, decumbente, albido, foliis Thymum redolentibus, pinnatisectis, segmentis multipartitis, laciniis trifidis, acutis, umbellis triquadriradiatis, umbellulis dense multifloris, involucri tri-tetraphylli foliolis trifidis, lobis saepius tridentatis, involucellorum foliolis plurimis, cuneiformibus, trifidis, floribus omnibus hermapluroditis, aequalibus, albis. 
01 iveria Venten. Hort. Cels, t. 21. Lagasea Amen. nat. IT. 105. DC. Prodr. IV. 234. Meisner Gen. 150. (108.)

4520. Anisosciadium $D C, \mathrm{Caly}$ cis limbus in floribus umbellae extimis lobis maximis, ovatis, foliaceis, interiorum rigidis, mucronatis, uncinatis, centralinm dentiformibus $\mathbf{v}$. nullis. $\mathbf{P} e$ $t$ a l a valde inaequalia, exteriora maxima, obcordato-bifida, interiora minima. Fruetus subpubescens, oblongo-cylindraceus, calyce stylisque duobus rigidis, conicis, erectiusculis coronatus m eri ca rpia semiteretia, altero saepius abortivo, quinquejuga, jugis obtusissimis, valleculis univittatis, vittis fuscis, commissuralibus nullis (?). Sem en margine involutum. - Herba orienta$l i s$; radice simplici, caulibus diffusis, rigidis, ramoso-dichotomis, minutissime puberulis, foliis pinnatisectis, segmentis inciso-pinnatifidis, lobulis brevibus, vix acutis, ramis oppositifolits, involucri tetra-pentaphylli foliolis oblongis, acutis, demum subspinescentibus, inaequalibus, umbellae radiis quatuor v. quinque, involucro longioribus, rigidis, involucellorum foliolis quatuor $v$. quinque ovalibus, patentibus, persistentibus, inaequalibus, floribus albis, septenis $v$. denis, sessilibus, rigidis.

A is os ciadium DC. Mem, V. 63. $t$. 15. DC. Prodr. 1V. 234. Meisuer Gen, 150. (108.)

45:1. Pyenoeyela ROYL. F I ores exteriores mascnli, centralis unicus, hermaphrodi tus, sessilis. Caly $\mathrm{cis}$ limbus quinquedentatus. Petala lanata, emarginata $v$. subbiloba, nunc lanceolata, acumine angusto, inflexo. Fructus oblongus, rostratus, teres, subpubescens; m e ric a r p i a quinquejuga, jugis filiformibus, lateralibus commissuralibus, valleculis bi-trivittatis, commissura bivittata. Sem en marginibus involutum, - Herbae biennes v. perennes, in Arabia, Persia et Himalayae jugis crescentes; foliis trilobatis, lobis dentatis $v$. pinnatisectis, segmentis interdum spinescentibus, supremis abortivis, umbellis longe pedunculatis, multiradiatis, densis, involucri polyphylli foliolis lineari-lanceolatis, erectis, involucellis oligophyllis, umbellularum floribus exterioribus saepe radiantibus, florum masculorum ambientium pedunculis crassis, cylindricis, fructum mentientibus, circa florem centralem conniventibus, petalis albis.

Pyc no y cla Royle Himalay. 232. t. 51, Decaisne in Zouv. Annal, sc, nat. III, 257. Meisuer Gen, 150, (107,)

452\%. Eelhinophora TOURNEF. F Iores exteriores masculi, centralis unicus femineus, sessilis. C a ly $\mathbf{c}$ is limbus quinquedentatus. P e $t$ aI a obovata, emarginata, cum lacinula inflexa, exteriora saepe majora, bifida, Fructus ovatus, subteres, receptaculo cavo inclusus, rostro brevi stylisque elongatis, filiformibus, dnobus v. interdum tribus exsertis; mericarpia quinquejuga jugis depressis, undulato striatis, aequalibus, valleculis suh membrana arachnoidea univittatis. Se$m$ en marginibus profunde involutum. Herbae medit erran eo-orientales, perennes, rigidae, saepe spinescentes; foliis bipinnatipartitis, laciniis incisis, umbellis terminalibus, floribus radii masculis, demum basibus inter se concretis, femineum centralem cingentibus, involucri involucellorumque, foliolis pluribus.

F c l in o p or a Tournefort inst. 423. Linn. gen, n, 329. Lagasca Amen, nat, II, 106. Koch Umbellif. 135. DC. Memt. V. 6\%, Prodr. TV. 234. Meisner Gen. 150. (108.)

a. LEUCOPHORA DC. $l$. $c$. Flore s albi. Petala obcorda ta, glabra, subaequalia. - Foliorum lobi pungentes, teretes $v$, conici, (Cavanill. Ic. $t$. 127. Sibthorp Flor. graec, t. 265. DC. Mem, F. t. 16.)

b. Chrysophora DC. 1 . c. FI to s flavi. Petala ova* ta, barbato-ciliata, exteriora umbellae subradiantia. Foliorum lobí apice dentati. (Sibthorp Flor. graec. t. 266.)

45\%3. Wxomenatha $L A B I L L$. Flores polygami, marginales steriles, centralis unicus fertilis. Caly $\mathrm{cis}$ limbus in floribus sterilibus obsoletus. Petala obcordata, inflexa, Fruetns junior florum sterilinm obovatus, striatus, floris centralis multo major, ovatus, snbpapillosus, setis quindecim rigidis, elongatis coronatus. Semen.... - Herba orientalis; folits pinnatisectis, radicalium segmentis ovatis, dentatis, subincisis, caulinorum lanceolato-linearibus, acutis, umbella terminali composita, umbellulis breve pedunculatis, involucri subdodecaphylli foliolis magnis, canaliculatis, spinosis, radios superantibus, patentibus, involucellorum foliolis septenis-undenis, ad latus exterius sitis, spinosis, umbellulam suparantibus, valde inaequalibus, uno longissimo, nonnullis setiformibus, floribus albis.

E $x$ a e a $t$ h a Labillard. Plant. $\mathcal{S}_{y r}$. Decad. $I, 10, t, 2$. Lagasca Ameñ, nat. II, 106, DC. Prodr. IV. 235. Meisner Gen, 150. (108.)

4524. Aretopus LINN. Fiores polygamo-dioici. Calyeis limbus quinquedentatus. P etala lanceolata, acumine incurro, acuto, integro. Masc. St a mina corolla duplo longiora. Stylopodium planum, stylis brevissimis, deciduis. Ovarinm abortivum. Fem. Stamina nulla. Styli basi inerassati, apice divaricati. Fructus ovato-rostratus, calyce coronatus, a basi ad medium cum involucro conferruminatus, ventre depressinsculus, sulco notatus, haud bipartibilis, loculo altero abortivo adnato. S e men rotundatum, dorso convexum, facie sulco concavum. - Herba capensis, perennis; foliis radicalibus humi adpressis, stellatis, petiolo plano, limbo subrotundo, trifido, lobis dentatis, ciliatospinosis, umbellis masculis compositis, pedunculatis, umbellulis subglobosis, involucello subpentaphyllo, demum increscente, umbellis femineis sessilibus, involucri tetraphylli foliolis concretis, coriaceis, reticulatis, spinoso-dentatis, fructus includentibus, petalis albis.

A retopus Lian. Hort. Cliffort, 495. Gert, n. 1165. Lam. $t .865$, Bot. Reg. $t .705$. Gairtner $f$. III. 14. $t, 189$. DC. Prodr. IV. 236. Meisner Gen. 150. (108.) A p radus Adass. Fam, II, 102.

4525. Caehrys TOURNEF. CaIye is limbus quinquedentatns $v$, rarius obsoletus. Petala ovata, integra, apice involuta v. inflexa. F ruc$t$ u s turgidus, sectione transversa subteres $v$. subdidymns; mericarpia quinquejuga, jugis obtusissimis v, alatis, nudis v. tubereulatis ; commissura plana, mericarpii latitndinem aequans. S em e n nucleus liber, vittis plurimis tectus, margine profunde involutus. E mbry on is cotyledones divergentes. - Herbae mediterraneo-orientales et caucasicae, perennes; folits decompositis, umbellis plurimis, involucro involucellisque polyphyllis, floribus flavis.

C a chry s Tournefort inst, 172. Linn, Ben, $n, 342 . \mathrm{DC}$. Mem. V. 65. Prodr. IV, 236.

a. EUCACHRYS DC. l. c. Calycis limbns obsoletus. Fructus juga lata, crassa, obtasa, interdum obtusissima, vix distincta, setis $v$. tuberculis nullis.

Cachrys Koch Umbellif. 135. $f$. 36. 37. (Pallas It. Append, $t$. 9. Hofftrann Umbellif, $t$. 3. $f$. 2. 4. Ledebour Ic. t. 21. Bichwald Plant, caucas, t. 9.) 
b. ABgOMARATHRUM DC. l. c. Caly cis limbus quinquedentatus. Fruet us juga crassissima, obtusa, valleculas fere obtegentia, plus minus tuberculata v. papillosa, aut rugosa v. tomentosa, rarius laevia.

Aegomarathrum Koch msc. Meisuer Gen, 130. (108.) H i p o ma rath $\mathrm{r}$ m Link Hort, berol, 1. 271 . Koeh Umbellif. 136. (Sibthorp Flor. graec. t, 278.)

c. LOPHOCACHRXS DC. l. c. Caly els limbas quinque dentatus. Fruclus juga arguta, alata, alis in dentes mueroniformes fissis, valleculis latis, apertis.

Cacbrys sicula Aut.

4526. Prangos LINDL. Calyeis limbus quinquedentatus. P e t a 1 a ovata, integra, apice involuta. Fruetus stylopodiis depressis, sectione transversali subteres; mericarpia a dorso compressa, quinquejuga, jugis laevibus, basi crassis, dorso in alas membranaceas verticales desinentibus. S e m en vittis copiosis cinctum, marginibus involutum. - Herbae orientales, perennes; caule tereti, foliis decompositis, laciniis linearibus, umbellis plurimis, floribus flavis.

Pra n go s Lindley in Brandes Journ, of. se. 1835. n. 37. p. 7. Lagasca in Oeios Espagn, emigrad, 1826, p, 15, DC. Prodr. IV. 239. Wallich Plant. As, rar. $t$, 212, P te ro marathrum Koch msc, Cachrydis s p. Auct.

458\%. Colladomia $D C$. C a ly e is limbus integer. Petala ovalia, integra, apice involuta. Fructus stylopodiis depressis, sectione transversali ovalis; mericarpia a lateribus compressa, quinquejuga, jngis dorso in alas membranaceas verticales desinentibus, valleculis latiusculis, univittatis, commissnra angustissima, bivittata. S emen marginibus involutis. - Herba $b y \approx a n-$ t in $a$, perennis, glabra; caule acutissime triquetro, demum subspiraliter torto, foliis decursive pinnatifidis, lobis late oblongis, dentatis, umbellis umbellulisque multiradiatis, involucris involucellisque po lyphyllis, folialis indivisis, floribus aureis.

Colladouia DC, Prodr. IV. 240. Meisaer Gen. 150 (108.) Perlebia DC. Mem, $V$. 67 . uon Mart. La serpi. ti um triquetrum Veat. Cels. $t, 97$.

4589. Teeokia DC, Calyeis limbus brevissime quinquedentatus. P et a la ovata, acumine inflexu. F ructas stylopodiis distinctis, co nicis, stylisque subulatis, divergentibus coronatus, ovatus, didymus, commissura angusta ; m eric arpia semiteretia, quinquejuga, jugis obtusis, fungosis, undique aculeato-muricatis. S e m e $\mathrm{n}$ vittis copiosis cinctum, marginibus valde involutum, area centrali vaena, orbienlari. - Herba perennis, eretica, Angelica facie; radice fasciculato tuberosa, foliis glabris, tripinnatisectis, segmentis ovatis, dentutis, umbellae subseptemradiatae, exinvolucratae radiis inaequalibus, angulatis, umbel lulis decem-quindecimfioris, involucellorum foliolis quinis-octonis, subulatis, floribus albis, sterilibus fertilibusque mixtis.

Lecokía DC. Mem. $V$, 67. t, 2. $f_{t}$ L. Prodr. IV. 240. Meisuer Gen. 130. (108.) C a ch ry s eretica Desfoat. in Annal. Mur.XI. t, 29. S e a ndix $\mathrm{I}$ atifoli a Sibthorp Flor. graec, t. 284.

4529. Magy lareís $K O C H$. Ca lye is $1 \mathrm{im}$ bus obsoletus. Petala obcordata, cum Iacinula inflexa. Fructus ovatós, villoso-tomentosus; merie a rpia quinquejaga, jugis erassis, obtusissimis, valleculis angustis. Sem en vittis pluri. mis, tenuissimis undique tectum, dorso convexum, facie sulco profundo involutum. - Herbae occidentali-mediterran eae, tomento villoso canescentes; foliis pinnatisectis, segmentis lobatis, lobis ovatis, dentatis, decurrentibus, umbellis um bellulisque multifloris, involucratis, floribus albis.
Magydaris Koch mac. DC. Mem. $V$. 68. Prodr. IV. 241. Meisner Gen, 150. (108.) Erioe a chrys DC. mse. Cachrydis s p. Vaht. Desfont.

4530. Hermas $L I N N$. C a ly c is limbus quinquepartitus, foliolosus, persistens. Pe tala ovali-oblonga, acuta, carinata, integra, aequalia. Fruetus ovatus; mericarpia subinflata, a durso compressa, quinquejuga, jugo uno dorsali exserto, duobus mediis majoribus, duobus marginantibus intimis, sub commissura minimis, valleculis latis, multivittatis. Semen liberum, ellipsoideum, facie subconcavum. - Herbae capen$s e s$; folits tomento molli, albo tectis, indivisis, dentatis, umbellis compositis, subglobosis, multiradiatis, involucro polyphyllo, umbellulis involucello triphyllo, radiis exterioribus plurimis, flores masculos, interioribus paucis flores hermaphroditos gerentibus, pedicellis florum sterilium persistentibus, involucellum circa fructum mentientibus, floribus albis v. purpureis.

Hermas Lian. gen. $n, 1332$. Thunberg in Nov, Comment. Petropolit. XIV. 531. t. 11. 12. Gïrtner II, 30, t. 85. Lam. $t, 851$. DC. Prodr. IV. 241. Meisner Gen, 150. (108.)

4531. Fetrocarvi TAUSCH. Calyeis limbus quinquedentatus, deciduns. P etal a obcordata, cum lacinula inflexa. Fructus oblongus, a latere compressus, pube mollissima obductus; meriearpia quinquejuga, jugis filiformibus, tribus intermediis approximatis, duobus lateralibus marginantibus, vallecnlis univittatis. Carpophorum bifidum. Seme $n$ ad commissuram eanali vacuo instructum. - Herba cretic a, perennis; foliis pinnato-decompositis, linearibus, umbellis terminalibus, involucris involucellisque polyphyllis.

Petrocarvi Tausch in Flora 1834. p. 355. Meisner Qen. 150. (105.) Athamantha cretensis Linn. Jacq. Flor, austr. t. se.

4532. Conivan LINN, Ca I y $\mathrm{c}$ is limbus obsoletus. Peta I a obcordata, subemarginata, cum lacinula brevissima, inflexa. Fruetus ovatus, a latere compressus; mericarpia quinquejuga, jugis aequalibus, prominnlis, nndulato-crenulatis, valleculis multistriatis, evittatis. Carpophor $\mathbf{n m}$ apice bifidum. Sem en sulco profundo anguste incisum et complieatum. - Herba virosa, biennis, in Europae et Asiae temperatae ruderatis obvia, in $A m e r i c a m$ transfuga; radice fusiformi, caule tereti, ramoso, maculato, foliis decompositis, involucro involucellisque tri-pentaphyllis, involucellis dimidiatis, floribus albis, omnibus fertilibus.

C o n i um Linn, gen, n. 469. Schkuhr t, 52, E. B. t. 1191. Hoffmaun Umbellif. 99. $t, 1, f .3$, Lagasea Amen, nat. IT. 103. Koch Umbellif. 155, $f$. 40 . Cl c u ta Touruefort inst. 160. Gärtuer $I, 100, t .29$.

4533. Vieatia $D C$. Calyeis limbus obsoletus. Petala ..... Fruetus ovato-oblongus, stylis brevibus, demun divaricatis; $m$ erica r pia fere semiteretia, quinquejuga, jugis filiformilias, vix prominulis, vallecnlis latis, planis, multivittatis, vittis brevibus, commissnra angusta. Carp op hor a m erassum, apice subbifidum. Semen dorso convexum, ad commissuram sulco instructum. - Herba nepalensis, crecta, glabra; foliis petiolatis, bipinnatisectis, segmentis bipinnatifidis, lobis linearibus, acutis, tenuibus, caule basi parce folioso, superne nudo, umbella terminali exinvolucrata, multiradiata, radiis inaequalibus, umbellulis breviorum sterilibus, involucellis nullis $v$. parvis, oligophyllis. 
Vic at i a DC. Prodr, IV.243. Meisner Gen, 151. (108.) Sison coulifollum Wallich.

4534. Arracaelha BANCR. Calyeis limbus obsoletus. P e ta 1 a lanceolata $v$ ovata, integra, acumine inflexo supra nervum medium frerato. Fructus stylopodiis conieis, crassis, stylisque divergentibns, demum deflexis coronatus, ovato-oblengus, a latere subcompressus; mericarpia quinquejuga, jugis aequalibns, haud crenulatis, lateralibus marginantibus, valleculis multivittatis. Sem en subsemiteres, sulco ad commissuram instructum. - Herbae peruanae, perennes; radice tuberosa, crassa, esculenta, foliis unipinnatisectis, segmentis inciso-dentatis, inferioribus tripartitis, umbellis oppositifoliis $v$. terminalibus, involucro nullo $v$. monophyllo, involucellis triphyllis, floribus polygamis, radii hermaphroditis, disci muculis $v$. neutris, petalis albis.

A r r a cacha Bancroft ex Berlin, Gartenb. Verhandl. 1828. p. 382. DC. Prodr. IV. 243, Not, Plant, rar, hort. Genev. 5. t. 1. Bot. Mag. t. 3092 -? Meisner Gen. 151. (108.) C on hi s p. Humb. et Bonpl. Nov, gen. et sp.t. 480 . Hooker Exot. Flor, $t$. 152.

4.535. Pentaery pta LEHM. Calyeis limbus obsoletus. P eta I a lanceolata, acuminata, inflexa, uninervia, carinata. Fruetu s stylopodiis conicis, crassis stylisque divergentibus, demum reflexis coronatus, ovato-oblongus, a latere subcompressus; $m$ eric a rp ia quinquejuga, jugis tribus intermediis approximatis, acntis, duobus lateralibus marginantibus, rotundatis, valleculis coneavis, univittatis, vittis magnis, semilunaribus, commissura plana, bivittata. Ca rpoph or $\mathbf{x}$ m bipartibile. Sem en sectione transversali stellatoquinquangulare, angulis rotundatis. - Herba me. xi cana, basi suffruticosa; foliis pinnatisecto-triternatis, foliolis membranaceis, ovato-oblongis, incisis, duplicato-serratis, subtus glaucescentibus, reticulato-venosis, umbellis lateralibus multiradiatis, umbellulis polygamis, floribus atro-purpureis, inter mediis sessilibus, involucro nullo, involucellis dimidiatis, mono-triphyllis, foliolis lanceolatis, subserratis.

Pentacrypta Lehmana Index Sem. hort. Hamb 1828. p. 16. Linnaea $V, 380, t, 5, f, g$. DC, Prodr, IV, 100 Meisuer Gen. 131. (108.)

4536. Plevirospermana HOFFM. Ca lycis limbus quinquedentatns. Petal a obovata, integra, planav. apice subattenuato-inflexa. Fructus a latere subcompressus, ovatus; mericarpia membrana duplici inclusa, utraque quinquejugi, exterioris inflatae, liberae jugis alatis, eavis, interioris semini arcte adnatae minoribus, elevatis, sub exterioribus sitis, valleculis uni-bivittatis, commissura bivitata, Carpophorum filiforme, bipartitnm. Sem en semilunare. - Herbae in Europa media et in Asiaboreali indigenae, perennes, glabrae; foliis bipinnatisectis, segmentis pinnatifidis, incisis, lobis aeutis, floribus albis.

P I e r osper m u moffmann Umbellif. praef. IX. fig. 16. 22. tit. Kach Umbellif. 134. DC. Prodr. IV, 244, Meisner Gen. 151. (108.) Phy sos permum Vela et Lagase. Amen, nat, II. 75, 97. non Cuss. E ny monos perm um Spreng. mse. Ligusticum a ustriacum Limn. Jacq. Flor austr. $t, 151$.

453\%. Walabaila TAUSCH, Calye is limbus quinquedentatus. P e tal a obcordata, cum lacinula inflexa. Fructus ovatus, a dorso sub. compressus, epicarpio tenui, submembranaceo ; m ericarpia quinquejuga, jugis argutis; snba- latis, aequalibus, lateralibns marginantibus, valleeulis planis, trivittatis, vittis pericarpio innatis, a semine distinctis. Carpophorum bipartitum. S em e n nucleum liberum constituens, dorso obsoletissime striatum, antice sulco oblongo excavatum. - Herba illyrica; foliis triternato-decompositis, umbellis terminalibus, involucris involucellisque polyphyllis, floribus albis.

Malaballa Tausch in Flora 1834, p. 356. Meisner Gen, 150. (108.) $\mathrm{HI}$ a d $\mathrm{n}$ ick i a Koch in Flora 1836, p. 164. Synops. 320. Grafi a Reichenbach Pflanz. Syst, 219. A th amant a gol a k a Hacquet Plant. Carniol. $t .5$.

4538. Wymenolaena $W A L L$, Calyc i limbus obsoletus. P et a I a obovata, integra, plana v. apice attenuato-inflexa. Fructus ovatus v. oblongus; merie arpia quinquejuga, jugis alatis, exsertis, subaeqnalibus, valleculis univittatis, commissura plana, bivittata. Ca rpo p h orum bipartitum. Semen dorso convexum, facie sulco exaratum. - Herbae nepalenses, perennes, glabrae; foliis multisectis, umbellis terminalibus multiradiatis, involucro involucellisque polyphyllis, foliolis membranaceis, saepe dentatis $v$. incisis.

H y m en ol a ena DC. Prodr. IV. 245. Lindtey in Royle Himalay. 233, $t, 52, f, 2$, Meisner Gen, 151, (108.)

4539. Aulacospermum $L E D E B . \mathrm{Ca}_{\text {- }}$ lycis limbus quinquedentatus $\mathbf{v}$. obsoletus. Peta la ovata, integra, acumine inflexo. Fructus a latere subcompressus, ovatus; mericarpia quinquejuga, jugis alatis, subaequalibus, valleculis uni-trivittatis, commissura plana, bivittata. Carpophorum bipartitum. Semen antice sulco profundo involutum. - Herbae altaicae, perennes, glabrae; foliis bipinnatis, pinnis incisis, involucri foliolis integris $v$. bipinnatifidis, involucellorum foliolis integris. 312.

A u lacosper mi am Ledebour Flor. Alt, IV.334,t.311.

45.40. Plizsospermum CUSS, Calyc is limbus quinquedentatus. P e t a I a obovata, subemarginata, enm lacinula inflexa. Fruetus a latere contractus, subdidymus; mericarpia reniformi-globosa, quinquejuga, jugis filiformibus, tenuissimis, aequalibus, lateralibus ante marginem positis, valleculis univittatis, vittis latis. Semen involuto-semilunare. - Herbae perennes, in $E u$ ropa media et australi, nec non in Asia o ccidentali indigenae; folitis inferioribus triternatisectis, summis saepe ad vaginam squamaeformem reductis, involucris involucellisque polyphyllis, floribus albis.

Ph ys o permum Cussone in Mem. soc, medic, Paris. 1782, p. 279. Sprengel in $\mathrm{Mcm}$, soc, h. $\boldsymbol{~ r . ~ M o s q . ~ V . ~}$ p. 1. $f, 1$ 3. Koch Umbellif. 134. DC. Prodr. IV. 246. Meisner Gen. 180. (108.) D a n a Allioni Pedemont. 1392. t. 63. Lagasea Amen. nat. II. 97. He a s l e r a Lagasea Nov. gen. et sp. 13. I ig u s t i e i \& p. Smith 1c. pict, $t$. 11.

4541. Smarnivan LINN. Caly e is limbus obsoletus. Pe $t$ a la lanceolata $v$. elliptica, integra, acuminata, acumine inflexo. Fructus a latere contractus, didymus; meri carpia reniformi-globosa, quinquejuga, jugis tribns dorsalibus prominulis, acutis, lateralibns duobus marginantibus obsoletis, valleculis univittatis, Carp 0phor u m bipartitum. Sem en involutum. - Herbae biennes, in Europa media et a ustrali indigenae, erectae, glabrae; radice carnosa, foliis variis, umbellis terminalibus involucratis, floribus flavis v. flavo-viridibus, saepe polygamis. 
S m y r i u m Lian. gen, $n$, 863. excl. sp. amerie. E. B. t. 230. Waldst, et Kitalbel Plant, rar, Hung. $t$, 23, Sibthorp Flor, graec. 2 . 289, Lagasea Amen. nat, IT. 101. Koch Um. bellif. 133. $f$. 38. 89. DC. Prodr. IV. 247. Meisuer Gen. 151. (108.)

4542. Amosmia BERNH. Caly cis limbus undulatus, edentulus. P e $t$ a l a obcordata, acumine inflexo subradiantia. Fruetus a latere contractus, subdidymus ; meri e arpia ovoidea, quinquejuga, jugis aequidistantibus, medio uninerviis, valleculis depressis, univittatis. C a r p phor um bipartitum. S e men involuto-semilunare. - Herba cretica, biennis, erecta, glabra, radice fusiformi, foliis inferioribus supradecompositis, superioribus compositis, petiolo communi mem branaceo, umbellis oppositifoliis terminalibusque, involucro nullo, involucellis oligophyllis, floribus albis, hermaphroditis.

Ano $8 \mathrm{mia}$ Bernhardi in Linnaea VIT. 608. Meisner Gen, 150.,(108,) $\mathrm{S}$ m y $\mathrm{ru}$ i u ran. Symb, phytolog. I. 5 .

4543. Perid erialia REICHENB. C a I y cis limbus quinquedentatus, deciduns. Petala „.... Fructus a latere contractus, subdidymus; meric arpia ovata, quinquejuga, jugis vix prominulis, valleculis trivittatis, vittis convexis, magis quam juga prominentibus, canale oleifero pereursis, commissura quadrivittata. Carpophoram bipartitum. Sem en semilunare. - Herba boreali-americana, glabra; foliis multifidis, lobis linearibus, elongatis, umbella terminali ampla, decemradiata, fertili, lateralibus oppositis, sterilibus, involucro involucellisque polyphyllis, foliolis linearibus, acutis.

Perideridia Reieheibach P/lanz. Syst, 219. Meisaer Gen, 150. (108.) Eul o p h us Nuttall msc. DC. Mem, $V$. 69. t. 2. f. M. Prodr. IV, 2A8. non Zoolog.

4544. Seallgeria $D C$. C a lycig limbus integer. Petala ohcordata, acnmine brevi, inflexo, obtuso: Fractus subdidymus, stylepodiis erassis, conicis, stylisque filiformibus, refractis coronatus; meriearpia ovata, ad rhaphen contracta, latere vix subcompressa, quinquejuga, jugis filiformibus, valleculis convexu-planis, bi-trivittatis, commissura planiuscula, quadri-sexvittata. Semen intus sulco exaratum. - Herba or $i$ entalis, glabra; foliis radicalibus sive inferioribus petiolo longo, vix basi dilatato, trisectis, segmentis pinnatisectis, lobis divergentibus, lanceolatis, acutis, caule ramoso, subdichotomo, tereti, foliis supremis ad ligulam elongatam, integerrimam $v$ sub unidentatam reductis, umbellis terminalibus exinvolucratis, novem-duodecimradiatis, umbellulis duodecim-quindecimfloris, involucellis oligophyllis, fo. liolis linearibus, parvis, floribus albis.

Scaligeria DC. Mem, V. 70, t. 1. f. B. Prodr. IV. 248. Melsuer Gen. 150. (108.)

SUBDEDO III. COELOSPERMAE. Sem en a basi ad apicem involuto-curvatum.

THRTES XVTI. CORIATDREAE Koch Umbellif. 82. Fructus globosus v. mericarpiis subglobosis didymus. Meriearpia jugis primariis quinque, depressis flexuasisque $v$. sulcum obsoletum formantibus, lateralibus ante marginem accessorium positis, secundariis nullis v. saepius quatuor, magis prominulis, omnibus apteris. - Per Europam australem,
Asiam mediterraneam et Americam borealem sparsae.

4545. Cymboearpum DC. Calycis limbus obsoletus. Petala aequalia, obcordata, cum lacinula inflexa. F r u etus subglobosus, stylopodio depresso, stylisque tandem reflexis coronatus; meriearpia hemisphaerica, solida, quinquejuga, jugis filiformibus, saepe obliteratis, lateralibas marginantibus, secundariis nullis, valleculis evittatis. Ca r poph or a m bipartitum, basi et apice adnatum, medio liberum. S em en facie excavatum. - Herba caucasica, annua, parva, foetida; foliis decompositis, laciniis linearibus, brevibus, umbellis oppositifoliis, involueris involucellisque linearibus, petalis albis.

C y mbocarpum DC. Prodr. IV. 186. n, 4. in not. C. A. Meyer Plant, cauc. 132. Meisner Gen. 152. (108.)

4546. Dhfora HOFFM, C a ly e is limbus obsoletus. Petala obovata, emarginata, cum lacinula inflexa, exteriora aequalia v. subradiantia, bifida. Fructus didymns; merie arpia subgloboso-ventricesa, granulato-rugosa, striis impressis quinque obsoletis notata, lateralibus duobus semicircularibus, ante marginem accessorium positis, vittis nullis, commissura biforata. Ca rp o p horum bipartitum, utrinque adnatum. Semen a basi ad apicem involutum. - Herbae medite rranea e et ta urica e, annuae, foetidae; caule sulcato-angulato, foliis decompositis, umbellis pauciradiatis, involucro involucellisque nullis $v$. monophyllis, floribus albis.

B If ora Hoffmann Umbellif. 19t, $f$, 2, in tit, Koch Umbellif. 83, DC. Prodr. IV. 249. Meisner Gen, 151. (108.) B if o r is Spreng, in Schult. oyst. $V T$. 38, C or io n Link et Hoffuans. Flor portug. IT. 457. A n i d $r$ u Necker Elem. n. 319.

45.47. Astomaea REICHENB. Cal y $\mathrm{cis}$ limbus obsoletns. Petala aequalia, obovata, emarginata, cum lacinnla inflexa. Fructus didymus; mericarpia subglobosa, jugis quinque obsoletis, lateralibus ante marginem accessorium positis, vittis nullis, commissura angusta, imperforata. Carpophorum .... Semen a basi ad apicem involntum. - Herba a gyptiaca, glabra, Seseleos facie; caule tereti, striato, erecto, ramoso, foliis superioribus bipinnatipartitis, laciniis paucis, linearibus, fere subulatis, elongatis, integerrimis, umbellis in apice ramorum ternis, pedunculatis, duobus lateralibus axillaribus oppositis, sex-septemradiatis, centrali decem-duodecimradiata, involucri penta-hexaphylli foliolis lanceolatis, in tegris, acuminatis, umbellulis decem-duodecimfloris, involucellulis tetra-pentaphyllis, floribus albis, omnibus hermapluraditis.

A 5 toma ea Reiclienb. PRanz. Syst.218. As to ma DC. Mem. V. 71. t, 17, Meisner Gen. 151. (108,) non Zoolog.

4548. Atrema $D C . \mathrm{C}$ a $\mathrm{y}$ cis limbus quinquedentatus, dentibus acutis, parvis, persistentibns. Petal a obovata, emarginata, cum lacinula inflexa, subaequalia. Fruetus subdidymus; meri e a r pia subgloboso - ventricosa, costulis quinque prominulis, valleeulis evittatis (?), commissura angnsta, imperforata. Sem en basi ad apicem involutum. - Herba boreali-americana; caule sulcato, angulis sub umbellis acutis dentato-mucronatis, foliis multifidis, laciniis linearibus, umbellis umbellulisque quinque - actoradiatis, involucro involucellisque polyphyllis, foliolis lineari-setaceis, indivisis, fructibus supidis. 
Atrem a DC. Mem, V. 71, $t, 18$. Prodr. IV, 250. Meisner Gen, 151. (108.)

4549. Comiandrum LINN. Calye is limbus quinquedentatus, dentibus inaequalibus, acutis, persistentibus. P eta la obovata, emarginata, cum lacinula inflexa, exteriora radiantia, bifida. Fructus globosus, decemeostatus, vix bipartibilis; mericarpia jugis primariis quinque depressis, flexnosis, secundariis praeter marginalia quatuor, magis prominulis, carinatis, valleculis evittatis, commissura bivittata. Carpophorum semibifidum, basi et apice adnatum, medio solutum. Sem en facie exeavatum, membrana soluta tectum. - Herba mediterranea et orientalis, ob fructus aromaticos passim culta, annua, glabra; caule tereti, foliis multifidis, umbellis tri-quinqueradiatis, exinvolucratis, involucellis subtriphyllis, dimidiatis, floribus albis.

Coriandrum Linn. gen, n, 356. exel. sp. Hoffraon Umbellif. 186. f. 14. 15. tit. Koch Umbellif. 82. f. 72. 73. E. B. $t$. 67. Sibthorp Flor. graec, $t$. 283. DC. Prodr, 12 . 250. Meisner Gen. 151. (108.)

\section{Ordo CLXIII. Araliacene.}

ARALIAE Jussieu Gen. 217. Annal. Mus. XVI. 179. ARALIACEAB Jussieu in Diot, sc, nat. II. 348. A. Richard in Dict. class. T, 505. DC. Prodr. IV. 251. Lindley Intro. duet. edit. 1I. p. 25. Meisner Gen. 152. (109.) ARALIACEAE et HEDERACEAE Bartling Ord. nat. 237, 238.

Arbores, frotices v, rarius herbae perennes, succo aqueo. Caules ramique teretes, in fruticosis saepius scandentes, v. fibrillis radiculiformibus aliis stirpibus pseudoparasitici. Fol i a alterna v. rarissime opposita, nune simplicia v. palmatim aut pinnatim composita, petiolis saepissime elongatis, basi incrassata dilatatis. Stipulae nullae.

Flores hermaphroditi v. polygami, regulares, axillares v. terminales, umbellati v. capitati, umbellis capitulisve in racemum vo paniculam dispositis, nudis v. saepissime involucello instructis.

Calyx tubo cum, ovario connato, limbo supero, saepissime brevi, integerrimo v. dentato.

Corollae petala $5-10$, disci epigyni margini inserta, limbi calycini denticulis alterna, aestivatione valvata, sub anthesi patentia, rarius apice calyptratim cohaerentia, rarissine nulla.

Stamisa cum petalis inserta, iisdem numero aequalia et alterna, rarius dupla, in apetalis simplici loborum calycis numero, cum iisdem alternantia. Fila me $\mathrm{n}$ La brevia, libera, tereti-subulata, rarissime (in Adoxa) bipartita. Antherae introrsae, biloculares, incumbentes, loculi oppositi, longitudinaliter dehiscentes.

Ovarıur calyeis tubo connatum, disco epigyno coronatum, bi-quindecimloculare. Ovula in loculis solitaria, eorundem apici appensa, anatropa. Styli loculorum numero, erecti et conniventes v. interdum connati, nune patentes, quandoque brevissimi, subnulli. St ig mat a simplicia.

Fructus baccatus v. exsuccus, calycis limbo coronatus, bi-quindecimlocularis, loculorum endocarpio saepius soluto, pyrenas chartaceas v. membranaceas monospermas sistente, nonnullis in fructu pluriloculari saepissime efoetis v. obsoletis.

Semina in loculis solitaria, inversa, testa crustacea, interdum marginata. Albumen copiosum, carnosum.

Exвахо in albuminis apice carpico brevis, orthotropus. Cotyle dones breves, germinatione foliaceae. R a dicula cotyledonibus longior, umbilicum attingens, supera.

Araliaceae in regionibus tropicis totius orbis, et in subtropicis temperatisque imprimis Americae borealis magno numero generantur, in Europa et Asia boreali (nec ultra $52^{\circ}$ L. B.) rarissimae, ab Umbelliferis inflorescentia imperfecte umbellata, fructu saepissime plus quam biloculari, in elementa carpica haud secedente, et albuminis consistentia, ab Ampelideis praeter plures notas ovario infero, staminibus ubi simplici petalorum numero cum iisdem alternantibus, et inflorescentia nunquam oppositifolia diversae. Corneae fructu nucamentaceo, Hamamelideae ejusdem dehiscentia et habitu facillime discernuntur. Caprifoliaceae, ad quas tamen Adoxa versimiliter repellenda, corolla gamopetala distant.

4550. Adoxa LINN. Calyx tubo cum ovario connato, limbo semisupero, brevissime bitrifido. Corolla e petala 4 v. 5, calycis limbo inserta, basi cohaerentia, explanata. S $t$ a mina 4 v. 5 , inter corollae lacinias inserta; fil am en ta bipartita, lacinia singula antherae loculum unum peltatum gerente. $O \mathrm{va} r \mathrm{i} m$ inferum, quadri-quinqueloculare. Ovala in loculis solitaria, pendula, anatropa. Styli 4 v. 5, subulati; stigmat a simplicia. B a ce a herbaceo-succosa, dentibus calycinis medie notata, stylis coronata, quadriquinquelocularis v, saepissime abortu paucilocularis, loculis monospermis. Semina inversa, compressa, membranaceo-marginata. $\mathbf{E} \mathbf{m b r} \mathbf{~ o}$ in apice albuminis carnosi brevis, r a di cula supera. - Herba pusilla, tenera, in Europa et As ia media indigena, Moschum redolens; radice tuberosa, alba, ad collum squamata, foliis radicalibus longe petiolalis, ternato-bipinnatis, foliolis crassiusculis, obtuse lobatis, caulino unico, uni-biternato, v. simpliei tripartito-inciso, floribus in capitulo terminali quatuor $v$. sex, viridibus, lateralibus pentameris, terminali tetramero.

A d o $x$ a Lín. gen, $n$, 501. Selhkuhr $t, 109$. Gärtaer $I t$. 14t. $t, 112$, Lam, $t, 320$. Flor, dan, $t, 94$. B. B, t. 453. DC. Prodr. IV. 251. Koeh Synops, 323.

4551. Panax LINN. Flo res polygami. Caly $x$ tubo cum ovario connato, limbo supero, brevissimo, obsolete quinquedentato. Corollae 100 
petala 5, disci epigyni margini inserta, patentia. Stamina 5, cum petalis inserta, iisdem alterna; fil amenta brevia, antherae biloculares, incumbentes. O vari u m infernm, biloculare. $O$ v u$\mathbf{I a}$ in loculis solitaria, pendula, anatropa. Styli 2 divergentes; $s t i g m$ a $t$ a simplicia. Bacca compressa, orbiculata $\mathrm{v}$. didyma, rarius teres obconica, bilocularis, loculis monospermis. S e mina inversa. E $\mathbf{m b}$ ryo in apice albuminis carnosi brevis, r a dic n la supera.-Herbae, frutices v. arbores, in Asia et America tropica et boreali crescentes; foliis ternatis, quinatis $v$. digitatis, rarius supradecompositis v. simplicibus, petiolis basi vaginantibus, umbellulis in racemos, racemis in umbellas dispositis, $v$. in speciebus herbaceis solitariis, in apice caulis longe pedunculatis.

P a n a X Linn. Gen. n, 1166. Lam. t. 860 . Jacq. Ic. rar. z. 643. Aublet Guian. t. 360. Andrews Bot. Reposit. t. 395. Bot. Mag, t. 1333. 1334. Kunth in Humb. et Bonpl. Nov. gen. et sp. V. 10. t. 4t7. f. 2. DC. Prodr. $T$. 939. Wallieh Plant, As, rar. t. 137, Richard Flor. Nov, Zeel, t, 31. Hoo. ker Flor, Bor. Amer. t. 98. Endl. in Annal. Wiener Mus. I. t. 15. Meisuer Gon. 152. (109.) A u reliana Catesby Carolin. App. 16. A rallias trum Vaillant $t$. 43. Plectron i a Loureiro Flor, eochinch, 201.

455. Cussomia THUNB. Cal y $\mathrm{x}$ tubo turbinato, cum ovario connato, limbo supero, bre$\mathbf{v i}$, quinque-septemdentato, dentibus acutis $\mathbf{v}$. interdam obsoletis. Corolla e petala $5-7$, disci epigyni margini inserta, patentia. Stamina 5_7, cum petalis inserta, iisdem alterna; fil amenta brevia, antherae biloculares, incumbentes. Orari $\mathrm{m}$ inferum, bi-triloculare, disco epigyno conico. Ovula in loculis solitaria, pendula, anatropa. Styli $2-3$ divergentes; 8 tig mata simplicia. Fruetus subglobosus, exsucens, bi-trilocularis, loeulis monospermis. Semina inversa. .... - Frutices capenses et Novae$Z$ eelandiae; trunco subsucculento; folits alter$n i s$, glabris, petiolatis, palmatim tri-septemfolialatis, floribus spicatis $v$, racemosis.

Cussonia Thunberg in Nov. Act. Upsat. 1Ir. 212. 1. 12, 13. Lian. f. Suppl. 182, Jussieu Gen, 217. Lam. t. 187. Jacq. f. Eclog. t, 61. Colla Hort. Hiput. t. 26. DC. Prodr. IV. 255. A. Richard Flor. Nov. Zeel. t. 32, Meisner Gen. 159. (109.)

4553. Mavalia THOUAR. Caly $\mathrm{x}$ tubo cylindrico, cum ovario connato, limbo supero, brevissimo, integro. Co roll a e petala 5, disei epigyni margini inserta, patentia. S $t$ a min a 5 , cum petalis inserta, iisdem alterna; fil a m e nta brevia, antherae incumbentes. Ovarium inferum, triloculare. Ovula in loculis solitaria, pendula. Styli 3 , breves; stigmat a simplicia. Bacca cylindriea, trilocularis, loculis monospermis. S emina inversa ..... - Fruticulus in sula e $M a$ dagasear, folits alternis, pinnatis, racemo pendulo, umbellis longe pedunculatis, baceis nigrescentibus.

Maralia Thouars Gen, Madagase, n, 43. DC. Prodr. 1V. 255. Meisner Gen, 158, (109.)

1554. Cillbertia RUIZ et PAV. Calyx tubo obovato, cum ovario connato, limbo sapra ovarium producto, integro. Cor oll a e petala 5 -10, disci epigyni lati margini inserta, patentia. Stamin a 5-10, cum petalis inserta, iisdem alterna; fil amenta brevia, antherae incnmbentes. Ovari u m inferum, quinque v. decemloculare, $O \mathrm{vula}$ in loculis solitaria, pendula, anatropa. Styli brevis, crassi stigmata 5-10, primum erecto - conniventia, demum divergentia. B a c ca calycis margine stylisque coronata, quin- que-decemlocularis, loculis monospermis. S e m in a inversa....-Arbuscula peruviana; foliis alternis, simplicibus, ovali-oblongis, acutis, absolete denticulatis, glabris, umbella terminali composita.

Gilibertia Raiz et Pavon Prodr. 50. t. 8. Flor. Peruv. III, 75. t. 312. DC. Prodr. IF. 255. exel. sp. asiat. Wangeuheiafa Dietr. Gianania Dietr. - Stirpes asiaticae a el. DCandolle ad Gilibertiam relatae, quas inter Gastonia palmata Roxb. Bot. Reg. $t$. 894. versimiliter sunt Hederae species.

4555. Castonia COMMERS. Cal y $\mathrm{x}$ tubo obovato, eum ovario connato, limbo supra ovarium producto, integro. C or o 11 a e petala $5-6$, disci epicyni margini inserta, patentia. S $\mathbf{t}$ a min a 10-12, cum petalis inserta, geminatim iisdem opposita; filamenta brevia, antherae biloculares, incumbentes. Ov a rium inferum, octodnodecimloculare. Ovula in loculis solitaria, pendula, anatropa. Styli $8-12$, breves, ima basi conereti; stig m a t a simplicia. B a c c a exsucea, corticata, costata, calyeis limbo coronata, octoduodecimlocnlaris, Ioculis monnspermis. S e min a inversa .... - Arbor mauritiana, elata, cortice spongioso, foliis alternis, imparipininatis, foliolis bi-trijugis, coriaceis, ovatis, obtusis, integerrimis, racemis sub foliis ortis, umbellas multifloras, exinvolueratas gerentibus.

G a 5 to n ia Commerson ex Jussieu gen, 217. Lam. Dict. IT, 610. DC. Prodr. IV. 256. Meisuer Gen, 159. (109.)

4556. Polyseias FORST. Caly $\mathrm{x}$ tubo cum ovario connato, limbo supero, brevi, denticulato. Co roll a e petala 5-7, saepius 8, disci epigyni margini inserta, lanceolata, patentia. $\mathrm{S}$ t a min a cum petalis inserta, iisdem numero aequalia et alterna; filamenta... O varium inferum... 8 tigmata $3-5$, sessilia, brevissima, erecto-patentia. B a c c a globosa, calycis limbo stigmatibusque coronata, quadrilocularis, loculis monospermis. Semina ...... Frutex oceanicus, an Novae- $Z$ eelandia e incola? valde dubius; foliis pinnatis, umbellis compositis seu verticillato-proliferis, umbellulis multiradiatis, planis.

Poly s ias Forster Char, gen. 32. Lam. $t .320$. DC. Prodr. IV. 257. Meisuer Gen. 132. (109.)

455\%. Toricellin DC. C aly $\mathrm{x}$ tubo cum ovario connato, limbo supero, acute quinquedentato. Corolla e petala 5, disci epigyni margini inserta, oblonga, basi attenuata, apice uncinatoincurva, patentia. Stamin a 5 , cum petalis inserta, iisdem alterna; fil a menta brevissima, antherae ovatae. Ovarium inferum ...... Styli 4, reeti, breves. B a ce a subexsueca, ealycis limbo coronata, quadrilocularis, loculis monospermis. Semina .... - Suffrutex in summis Nepaliae montibus crescens, non satis notus, fortassis ab Hedera non satis diversus; ramis teretibus, eicalricibus annulatis, albidis, glabris, foliis exstipulatis, simplicibus, petiolo basi subdilatato, lamina membranacea, cordato-subrotunda, palmatim quinquenervi, grosse et acute dentata, subquinquelobatu, secus nervos nervulosque pubescente, panicula terminali multiflora, floribus abortu polygamis v. numero partium variabili. (109.)

Toricellia DC. Prodr. IV. 257. Meisner Gen, 159.

4558. Aralia LINN. Calyx tubo cum ovario connato, limbo supero, brevissimo, inte gro v. quinquedentato. Co r o 11 a e petala 5, disci epigyni margini inserta, libera, expansa, S ta m in a 5, cum petalis inserta, ïisdem alterna; filamenta brevia, antherae incumbentes, biloculares. Ova- 
$\boldsymbol{r}$ in $\mathrm{m}$ inferum, quinque-decemloculare. Ovula in loculis solitaria, pendula. Sty Ii 5 , divaricato. patentes; stigmat a simplicia. Drnpa baccata, costata, calycis limbo stylisque coronata, pentadecapyrena, pyrenis chartaceis, monospermis. Se$m$ in a inversa. $\mathbf{E} \mathbf{m}$ b $\mathbf{r} 0$ in apice albuminis dense carnosi brevis, orthotropus, radicula supera. - Arbores, frutices $v$. herbae, in America imprimis boreali, Japonia et Nova-Zeelandia crescentes; foliis alternis, simplicibus, integris $v$. lobatis, digitatis, pinnatis, biternatis, bipinnatis supradecompositisve, foliolis integerrimis v. serratis, petiolis basi vaginantibus, floribus umbellatis, umbellis saepe paniculatis.

A rali a Liaa. gen, $n$. 386. excl. sp. Schkuhr $t, 86$, Cavanill. $I c, t, 313$. Venten. Cels, $t, 41$. Bot. Mag. $t, 1041$. DC. Prodr. IV. 257 . Nees jun. Plant. of fic, Suppl. IV, t. 16. Siebold et Zuceariai Flor. Japon. t. 25. Meisner Gen. 158, (109.) $\mathrm{S} \mathrm{c}$ h e ffler a Forster Char gen. t. 20. Lam. t. 221. Araliae verae Blume Bijdr. 869 .

4559. Seiodaphyllum $P$. BROWNE Cal y x tubo obeonico, eum ovario connato, limbo supero, brevissimo, integro. Co roll a e petala $5-7$, disei epigyni margini inserta, apice calyptratim cohaerentia. Stam in a 5-7, cum petalis inserta, iisdem alterna; filamenta brevia, antherae incumbentes. Ova ri um inferam, quinque-septemlocnlare. $\mathrm{OvnI}$ a in loculis solitaria, pendula, anatropa. Styli $5-7$, breves, conniventes; $s$ tigm a $t$ a simplicia. B a ce a cuneiformis, calyeis limbo sty lisque coronata, penta-heptapyrena, pyrenis osseis, monospermis. S e $\mathrm{m}$ in a inversa. ... - Arbores v. frutices scandentes, in Asia et America tropica indigeni, saepius gummi crystallinum exsudantes; foliis simplicibus, trifoliolatis v. saepissime digitatis, floribus rarius umbellatis, saepissime in capitula globosa congestis, capitulis in racemos dispositis, racemis in apice ramorum solitariis $v$, ag gregatis, floribus bracteolatis.

S ciodaphyllum P. Browne Jam. 190. t. 19. f. 1. Blume Bijdr. 874. DC. Prodr. IV. 259. Meikaer Gen, 158. (109.) A ctinoph y 11 u m Ruiz et Pavon Prodr. 5t, t. 8. Flor. Peruv. IIT. t. 307-311. Kuath in Humb. et Bonpl. Nov, веn. et sp. v. 9.

4560. Tealera LINN. C a Iy x tuho $\mathrm{cmm}$ ovario connato, limbo supero, brevissimo, integro v. guinquedentato. Corolla e petala $5-10$, disci epigyni margini inserta, libera, expansa. Sta mina $5-10$, cum petalis inserta, isdem alterna v. opposita; filamenta brevia, an thera e incumbentes, biloculares. O va rin m inferum, quinquedecemloculare. Ovula in loculis solitaria, pendola. Styli $5-10$, eresti $v$. conniventes, ant in nnicum cohaerenten; $8 \mathrm{t}$ ig un a t a simplieia. Ba c: $\mathrm{c}$ a calyeis limbo stylisque coronata, quinque-decemlocularis, loculis membranaceis, monospermis. Semin a inversa. Embryo in apice albuminis earnosi, endoplenrae processubus rugosi brevis, orthotropus, radicula supera. - Frutices scandentes $v$. erecti, interdum arborescentes, inter $t r o-$ picos totius orbis magno numero, parce in in hemispha erae borealis temperatis crescentes; foliis alternis, nune simplicibus, integris.v. lobatis, nunc compositis, digitatis v. rarissime pinnatis, petiolis basi vaginantibus, floribus capitatis, capitulis racemoso-paniculatis.

He de ra Linn. gen, n. 238. excl, sp. Swartz Flor. Ind. occid, s18. t. 9. Gärtuer 1. 130. t, 26. Smith Ic. rar. t. 4. E. B. t. 1267. Willd, in Berlin. Magas. Mr. t. 5. DC. Prodr. $I V$. 216. Wallich Plant. At, rar. $t$, 190. Wight et Arn, Prodr. I. 376. Meisoer Gen. 152. (109.) A r allia e sect. G y a a te i na Blume Bijar, s71. Arali a e sp. Linn.
Jacq. Amer, t, 61, Hort. Schönbr. t. 51, Kunth in Humb. et Bonpl. Nov. gen, et sp. $t .413-416$.

45G1. Paratropia $D C$. Calyx tubo subconico, tereti v. angulato, eum ovario connato, límbo supero, brevissimo, truncato. Corollae petala 5-9, disci epigyni margini inserta, distineta. Sta min a $5-9$, cum petalis inserta, iisdem alterna; fil am ent a brevia, antherae incumbentes. O va ri u m inferum, quinque-novemloculare. Ovula in loculis solitaria, pendula, anatropa. Stigmata loculorum numero, sessilia, disco erasso, snbconico immersa. B a c c a conica, teres v. angulata, penta-enneapyrena, pyrenis chartaceis, monospermis. Se min a inversa. $\mathbf{E}$ mb $\mathbf{r} \mathbf{y}$ in apice albuminis dense carnosi brevissimus, orthotropus, radicula supera. - Arbores v. frutices saepius scandentes, in Asia tropica indigeni; folits alternis, impari-pinnatis $v$. saepissime digitatis, umbellis in racemos paniculatos $v$. thyrsoideos dispositis.

Paratropia DC. Prodr. IV. 265. Wight et Arn. Prodr, I, 378. Meisner Gen. 152. (109.) Paratropia Araliae sect. Blume Bijdr. IV. 875. Heptapleurum Gärtuer II. $472, t, 178$.

4582. Arthrophyllinm $B L U M$. C a l y x tubo cum ovario connato, limbo snpero, brevi, obsolete quinquedentato. Co roll a e petala 5 , disci epigyni margini inserta. Stamina.cum petalis inserta, iisdem alterna. O v a $\mathbf{r}$ i $\mathbf{~ m}$ inferum, nnileculare. Oval a m unicum, pendulum, anatropum. Styl as brevissimus; st $\mathrm{igma}$ simplex, obtusum. B a c ca calycis limbo coronata, nucleo monospermo, Semen inversum. Embryon is albumine subcorneo inclusi radicula supera. Arbusculae javanicae, inermes; foliis bipinnatis, rarius imparipinnatis ternatisve, foliolis integerrimis, umbellis petiolaribus, compositis.

Arthrophy11um Blume Bijdr, 878. DC. Prodr. IV. 266. Meisner Gen. 152. (109.)

4563. Botryodendrum ENDL. F10res polygamo-dioiei. Mas c. Calyx quadripartitus, laeiniis aestivatione imbricatis. Corolla nulla. Stamina 4 , toro glandulaeformi inserta, calyeis laciniis alterna, exserta; filamenta filiformia, a n t h e $r$ a biloculares, incumbentes. Ovarii rudimentum nullum. Hermaphr. Caly $x$ tubo cum ovario connato, limbo supero, supra ovarium producto, sexpartito, patente. Coroil a nulla. S ta m in a 6, disci epigyni margini inserta, calyeis laciniis alterna, iisdem breviora, patentia. Ov a ri n m inferum, sexloculare. Ov u la in loculis solitaria, pendula, anatropa. Sty $1 \mathbf{i} 6$, intus stigmatosi, stellatim patentes. B a c ca calycis limbo eoronata, sexlocularis, loculis monospermis. Se $\mathbf{m}$ in a inversa, marginata. ..... Arbores in insula Norfolk et in a r chipelagoTaitensi indigenae; trunco elato, simplici, gracili, apice in ramos simplices diviso, foliis in apicibus ramorum alternatim approximatis, penninerviis, capitulis florum involucratis, in paniculam terminalem dispositis.

Botrgode $\mathrm{ad} \mathbf{r}$ a m Endlich. Prodr. Flor, Norfolk, 62. Guillemin in Nouv. Annat. sc, nat. VIT. 349. Meisaer Gen. 158. (109.) - Ovula pendula, olim erecta perperam di. ximus.

4564. Minmelia MEISN. F lores dioici. M a s c. Cal y x quadripartitus, laciniis linearibus, aestivatione valvatis. C or 111 a nulla. S ta m i na 4 , tore glandulaeformi inserta, laciniis alterna; fil ament a brevissima, basi latiora, an $\mathbf{t}$ hera e calyci $100 *$ 
aequilongae, biloculares, dorso supra basim affixae. O v a rii rudimentum nullam. F e m. $\cdots$ - Frutex indicus; scandens; folitis alternis, penninerviis, subcoriaceis, basi dentatis $v$. sublobatis, petiolis volubilibus, pedunculis filiformibus, in apice ramuli brevissimi supraaxillaris aggregatis, singulis umbellam simplicem, multifloram gerentibus, pedicellis basi involucello quadrifido, ciliato cinctis.

Miquelia Meisner Gen. 158, (109.) Araliacea Kleinil Wight et Arnott Prodr, T. 375. in not.

\section{GENUS DUBIAE AFFINITATIS.}

45 65. Touroulia $A U B L$. Caly $\mathrm{x}$ tubo turbinato, basi bibracteolato, cum ovario connato, limbi superi, quinquedentati dentibus ovatis, acutis. Corollae petala 5 , inter calycis dentes inserta, subrotunda, coneava, patentia. Stamina plurima, infra petala calyei inserta, a n th era e biloculares, loculis basi divaricatis. $O$ vari $\mathbf{m}$ inferum ..... S ti r ma sessile, oblongum, striatem. B a ce a carnosa, depresse orbiculata, striata, limbo calycis coronata, septemlocularis, loculis monospermis. S e mina oblonga, angulata, extus convexa, villosa, ferruginea. - Arbor guianensis; trunco excelso, apice ramoso, ramis ramulisque oppositis, tetragonis, foliis oppositis, impari-pinnatis, foliolis oppositis, quadrijugis, sessilibus, oblongis, acutis, dentatis, dentibus setaceo-acuminatis, rhachi alata, stipulis ad basim petioli geminis, brevibus, flavis, racemis terminalibus, opposite ramosis.

Ton roulfa Aublet Guian, I. 492. t, 194. Meisner Gen. 152. (109.) Robia so nia Schreber gen. $n .852$.

\section{Ordo CLXIV. Ampetideae.}

VITES Jussieu Gen, 267. SARMENTACEAR Venten. Tabl. 167. VINIFBRAE Jussieu in Mem. Mus, IIT. 446. A MPELI. DEAE Kunth in Humb. et Bonpl. Nov. gen. et sp. V. 223. DC. Prodr, $I$, 627. Meisner Gen. 51. (36.) SARMENTA. CEAE et LEEACEAE Bartling Ord. nat, 353. VITACEAE Lindley Introduct, edit. II. p. 30 .

Arbores v. frutices, saepissime scandentes, succo aqueo, saepius copioso. Caules ramique teretes $\mathbf{v}$. angulati, ad nodos tumidi. Folia inferiora opposita, petiolata, simplicia, palmata v. impari-pinnata, rarius bipinnata, superiora alterna, pedunculis saepissime in cirrhos ramosos conversis opposita. Stipulae petiolares, interdum nullae.

FLores hermaphroditi v. polygami, regulares, saepissime parvi, inconspicui, virescentes, ut plurimum umbellati, umbellis in racemos, thyrsos v. paniculas dispositis.

Calxx liber, parvus, quadri-quinquedentatus v. interdum integerrimus, intus toro disciformi v. urceolato vestitus.

Corollae petala 4 v. 5 , disei margini extus inserta et dentibus calycinis alterna, libera v. interdum basi inter se cohaerentia, aestivatione valvata, sub anthesi patentia, v. apicibus induplicatis calyptratim cohaerentia, basi soluta.

Stamixa nune cum petalis inserta, iisdem numero aequalia et opposita, fil am en $t$ i s bre- vibus, liberis, an theris bilocularibus, introrsis, longitudinaliter dehiscentibus; nunc urceoli subglobosi, corollae basi adnati, apice emarginato quinquelobi dorso affixa, petalis opposita ; fil amentis introflexis antheras extrorsas biloculares, liberas v. marginibus inter se cohaerentes intra urceolum recondentibus.

Ovariom liberum, nune biloculare, nune trisexloculare. $0 \mathrm{vula}$ in ovarii bilocularis loculis gemina, collateralia, e dissepimenti basi adscendentia, in ovario pluriloculari solitaria, e basi erecta, anatropa. Stylus brevis, simplex; stig ma capitatum v. peltato-subdilatatum.

Bacca bi-tri-sexlocularis, loculis monodispermis.

Seuna erecta, epidermide membranacea, testa ossea, endopleura quandoque rugosa v. induplicata. Alb u me n cartilagineum.

Eивryo in basi albuminis orthotropns, brevis ; radieula infera.

A mpelideae inter tropicos totius orbis, in regionibus subtropicis et in America boreali temperata obviae, ovario libero ovulisque erectis inter Discifloras anomalae, et revera subdubiae affinitatis, per Leeam ad Meliaceas, quibus tamen vix conterminae, accedere videntur.

Genera ad ordinis calcem enumerata fortassis longius aliena.

SUBCIBDA I. VITEAE. Petala et $s$ tam in a libera. Ovarium biloculare, loculis biovulatis. $0 \vee \mathrm{v} I \mathrm{a}$ in loculis gemina, collateralia. - Cirrhi oppositifolii.

4566. Cissus LINN. Calyx liber, brevissimus, obsolete quadri- $v$, rarissime quinquelobus. Co rolla e petala 4 , rarissime 5 , disco hypogyno extus inserta, aequalia, concava, apice cucullata, aestivatione induplicatim valvata, sub anthesi patentia, decidna. Stamina 4 v. rarissime 5 , cum petalis inserta, iisdem opposita; filamenta brevia, a ntherae biloculares, incumbentes, longitudinaliter dehiscentes. Ovarium liberum, disco plus minus immersnm, biloculare. Ovula in loculis gemina, collateralia, e basi dissepimenti adscendentia, anatropa. Stylus brevis; stig ma capitatum. B a c ca uni-bilocularis, aborta mono-disperma. Sem in a erecta, testa ossea, epidermide membranacea. Embryo in axi albuminis dense carnosi minimus, orthotropus; $r$ a dicula infera. - Frutices sarmentosi, scandentes, rarissime arbores, inter tropicos totius orbis, imprimis tamen Asiae crescentes, in subtropic $i$ s multo rariores; foliis alternis, stipulatis, simplicibus $v$. compositis, pedatis $v$, rarius pinnatis bipinnatisve, saepe pellueido-punctatis, petiolatis, petiolo basi articulato, ramis floriferis oppositifoliis $v$. rarissine axillaribus, sterilibus in cirrhos conversis, floribus cymosis, saepissime ad apicem ramulorum umbellatis, umbellis involucratis, pedicellis bas? articulatis.

C is sus Linn. gen, $n, 147$. Jacq. Amer. $t, 189, f, 10$. Hort, Schōnbr, $t, 8 \%$. Ruiz et Pavon Flor. Perue, $t, 100$. 101. Vent. Choix. $t$, 21. Kunth in Humb. ot Bonpl. Nov. 
gen. et sp. V. 228. DC. Prodr. I. 627. Cambessed. in St. Hilaire Flor. Brasil. $I, 342, t, 71$. Royle Himalay $t, 26$. Hooker Bot. Misc. Suppl. t. 6. Meisner Gen, 51. (36.) Sa el an th us Forskoel Descript. 33. C ol umelli a Loureiro Flor, cochinch. 108. C a y $r$ a $t$ i a Jussieu. B o t $\mathrm{r}$ i a Loureiro Flor, cochinch, 191. Irsiala P. Browne Jam, $t$. 4. f. 2. A mpelopsis L. C. Richard in Michaux Flor. Bor. Amer. I. 159. Kunth $l$. $c$. in not. DC. Prodr. I. 633.

456\%. Witis LINN, C a ly x liber, brevissimus, quinquangularis, obsolete quinquedentatus. Corollae petala 5, disco hypogyno extus inserta, aequalia, concava, apice cucullato-induplicato calyptratim cohaerentia, sub antliesi basi solnta, simul secedentia. Stamina 5 , cum petalis inserta, iisdem opposita; fil a m enta brevia, libera, anthera e biloculares, incumbentes, longitudinaliter dehiscentes. O vari $\mathbf{~ m ~ m ~ l i b e r u m , ~}$ disco urceolato, quinquelobo basi cinctum, bilocnlare. Ovu I a in loeulis gemina, collateralia, e basi dissepimenti adscendentia, anatropa. Stigm a sessile, depresso subpeltatum. B a c c a globosa, biloeularis, loculis dispermis v. abortu interdum monospermis. S emina erecta, testa ossea, epidermide membranacea. E $\mathbf{m}$ b r y $\mathbf{o}$ in axi albuminis dense carnosi minimus, orthotropus; radieula infera. - Frutices sarmentosi, in Asia media et America bor a li sponte nascentes, una ab antiquissimis temporibus in singulare mortalium gentis solatium electa, nunc in omnibus regionibus quarum aestiva temperatura media non infra $19^{\circ}$ culta, botros viniferos, pro soli natura et coeli temperie mirum in modum qualitate diversos maturans; folits alternis, simplicibus, cordatis, integris, lobatis v. varie incisis partitisve, paniculis oppositifoliis, sterilibus in cirrhos conversis, floribus subumbellulatis, in spe ciebus gerontogeis hermaphroditis, in americanis dioico-polygamis.

Vitis Linn. gen: $n$, 284. Sehkuhr $t$. 49. Gärtner $I T$, 108. t. 106. Jacq. Hort. Schönbr. $t$. $425-427$, Kunth in Humb. et Bonpl. Nov. gen, et sp. $\boldsymbol{V}$. 226. DC. Prodr. $\boldsymbol{I}$. 633. Meisner Gen, 31. (36.) Jacquem. Voy. 2. 36. Hooker Bot. Mag. Compan, t. 6 .

4568. Pterisantlues BLUM. Involuc r u m foliacenm, lobato-alatum, coriaceum, difforme. F lores polygami, marginales pedicellati masculi, centrales sessiles hermaphroditi. M a sc. Cal yx urceolatus, integer. Coroll a e petala 4 , rhomboidea, erectiuscula. Stamina 4, petalis opposita. Dis cus centralis, tumidus. Herma phr. Calyx brevis, integerrimus. Corolla e petala 4 , patentia. Sta m in a 4, petalis opposita. Ovar i $\mathbf{m}$ m disco immersum. Sti g m a sessile, obtusinsculnm. B a c ca obovata, mono-rarius disperma. S emen erectum, dorso gibbum, sulco longitudinali, intus compressum. Embryo intra albumen cartilagineum bilobum erectus. - Frutex javanicus, scandens; foliis pedato-tri-quinquefoliolatis, foliolis oblongis, acuminatis, repando-dentatis, lateralibus basi obliquis, involucris solitariis, cirrho impositis. (36.)

Pteris anthes Blume Bijdr. 192. Meisner Gen, 51.

SUT (FED II. LEFACEAE. P e ta 1 a basi cobaerentia. Stam in a monadelpha. 0 vari u m tri-sexloculare. Ovula in loculis solitaria. _ Cirrhi nulli.

4569. Teea LINN. C a l y x liber, quinque dentatus, persistens. Corolla toro laminaeformi calyeis basim vestienti inserta, eum urceolo staminifero connata, quinquefida, laciniis revolntis. Urceolus subglobosus, corollae basi adnatus, emarginato-quinquelobus, fauce intus annulo membranaceo semiclausus. S t a m i n a 5 , urceoli dorao inter ejusdem lobos inserta, petalis opposita; fil amenta introflexa, antheras extrorsas, biloenlares, utrinque emarginatas, medio dorso insertas, marginibus plerumque inter se connatas $v$. rarius distinctas intra ureeolum condentia. Ovarium disco semiimmersum, tri-sexloculare, Ovula in loculis solitaria, ex anguli centralis basi adscendentia, anatropa. Stylus brevis, simplex; stigma subcapitatum. Ba e e a tri-sexlocularis, locnlis monospermis. S em in a erecta, testa ossea, endopleura intra albnminis rugas longitudinales profunde immersa. E $m$ br y o parvus, in basi albuminis cartilaginei lobati orthotropus; coty ledonibus ovatis, subfoliaceis, radicula conica, infera. - Suffrutices $v$. frutices, interdum arborescentes, in Asia tropica, insulis borbonicis et Capite bonae spei crescentes; foliis oppositis, uni-bi-tripinnatis, foliolis integerrimis v. serratis, petiolis basi dilatata vaginantibus, pedunculis oppositifoliis, nunquam in cirrhos conversis, cymosodecompositis.

Le a Linne Mantiss, 124. Andrews Bot, Heposit, $t, 353$. Roxburgh Flor. Ind. edit. Wallich II. 467. Blume Bijdr. 195. DC. Prodr. I. 635, Adr. Jussieu in Mem, Mus, XIX. 185. Wight et Arnott Prodr. I, 131. Meisner Gen, 51. (36.) A q uili ci a Liun. Mant, 21t. Lam. $t, 139$. Cavanill. Dissert. VII. t. 218, Gärtner $1,275,0 \mathrm{tti}$ i is Gärtner $t .57$.

\section{GENERA DUBIA}

45\%0. Geruma FORSK, Caly x parvus, planus, quinquedentatus, persistens. Co rollae petala 5, lanceolato-truncata, patentia. Stamin a 5, annulo crasso ovarium cingenti extus inserta; fil ame nta erecta, corolla dimidio breviora, antherae erectae, trigonae. Ovarium globosum, annulo profunde immersum. Stylns filiformis, brevis; stigmat a 3 , patentissima, cuneata, apice emarginata. Capsula ovalis, quadrilocularis (an quinquelocularis?) quadrivalvis. Se$m$ in a in loenlis gemina, ovalia, pulpae trigonae immersa. - Planta a rabica, vix nota; foliis alternis, ovato-oblongis, subserratis.

Ge r u m a Forskael Descript. 62. DC. Prodr. 1. 619.

4581. Hasianthera PALIS. Calyx quinquedentatus, bracteolatus. Co rolla quinquefida. St a m in a 5 , imae corollae inserta, ejusdem lobis alterna; filamenta lata, antherae oblongae, hirsutae. Stylus brevis. - Suffrutex Africae tropicae scandens; foliis alternis, ovato-oblongis, integris, cuspidatis, pedunculis oppositifoliis, apice umbellatim ramosis, floribus capitatis.

La sianthera Palisot Flor. Owar, $I, 85, t, 51$, DC. Prodr, 1 . 636.

45ระ. IBergama FRESEN. Calyx subcampanulatus, quadrifidus, lacinia antica apice bifida. Co ro I lae petala 5 , disco hypogyno annulari extus inserta, lineari-lanceolata, aestivatione imbricata. Stam in a 5, annulo hypogyno intus inserta, petalis alterna; filamenta basi in tubum ovarium cingentem connata, anth era e oblongae, biloculares, incumbentes, loculis oppositis, Iongitudinaliter dehiscentibns. Ovari um liberum, quinqueloculare. .... S ty I ns filiformis; 8 ti $\mathrm{gm}$ a capitatum, quinquelobum, lobis crassis, erectis. Fructus..... - Arbor abyssinica, vix nota, et affinitatis maximopere dubiae; foliis alternis, imparipinnatis, foliolis oblongo-banceola- 
tis, acutis, integerrimis v. obsolete serratis, stipulis intrapetiolaribus geminis, basi connatis, racemo oppositifolio, spicaeformi, simplicissimo.

B ers a m a Fresenius in Mus. Senkenberg. II. 280. t. 17.

\section{Ordo CLXI: Comeat.}

CORNEAE tribus CAPRIFOLIACEARUM Knnth in Humb, et Bonpl. Nov, 8en, et sp. HI, 430. CORNEAE DC. Prodr. $I V .271$. Meisuer Gen. 143, (104,) CORNACEAE Lindley $1 n$ troduct, edit, 11, p. 49.

Arbores v. frotices, ligno duro, rarius trunco subterraneo ramos annuos exserente HeввAв perennes. Folia opposita v. rarissime alterna, simplicia, integerrima v. serrata, penninervia. S tipula e nullae.

Flores hermaphroditi v, abortu polygami, nunc capitati v. umbellati, involucro saepius colorato cincti, nunc rarius corymbosi, exinvolucrati.

Calyx tubo cum ovario connato, limbo supero, quadridentato.

Coroliae petala quatuor, summo calycis tubo inserta, ejusdem dentibus alterna, aestivatione valvata, sub anthesi patentia, decidua.

Stamisa cum petalis inserta, iisdem numero aequalia et alterna. Fil a me nta filiformia, libera. Antherae introrsae, biloculares, dorso insertae, longitudinaliter dehiscentes.

Ovariom inferum, bi- v. interdum triloculare, disco epigyno quandoque obsoleto coronatum. Ovula in loculis solitaria, pendula, anatropa. Stylus simplex, subclavatus; stigma capitatum.

Drupae distinctae v. in syncarpium coalitae, calycis cicatrice notatae, putamine osseo, biv. interdum triloculari, nonnunquam abortu uniloculari.

Semina in loculis solitaria, inversa, testa coriacea.

Emвв io in axi albuminis carnosi, ejusdem fere longitudine. Cotyled ones oblongae, subfoliaceae. Radicula brevis, supera.

Corneae in temperatis et frigidiusculis hemisphaerae borealis, imprimis in America boreali et Nepalia obviae, in Ameriea tropica rarae, a Caprifoliaceis quibuseum olim confusae, petalis liberis imprimis diversae, a reliquis Discifloris habitu et putamine osseo facillime distinguuntur. edule.

Sarcocarpium nonnullarum sapide acidulum,

Genera ad ordinis calcem recensita, quo ad veras necessitudines maximopere dubia.

45ซ 3. Benthamia LINDL. F I a res capitati, involuero petaloideo cineti. Caly $x$ tubo cum ovario connate, limbo supero, eupulaeformi, truncato. Corolla e petala 4 , summo calycis tubo inserta, aestivatione valvata, sub anthesi patentia. Stamina 4, cum petalis inserta, iisdem alterna ; fil amenta brevia, cylindrica, antherae dorso affixae, biloculares, longitudinaliter dehiscentes. $\mathrm{O} v$ a $\mathbf{r} \mathbf{i} \mathbf{~ m}$ inferum, biloculare, diseo epigyno quadrilobo. Ovala in loculis solitaria, pendula, anatropa. Sty lus simplex, clavatus; stigma truncatum. Drupa e carnosae, calyeis limbo coronatae, abortu monopyrenae, inter se et cum receptaculo in syncarpium globosum, torulosum connatae, pyrenis osseis, monospermis. S e men inversum, testa coriacea. Em bryo in axi albuminis carnosi orthotropus; cotyledonibus foliaceis, radicula supera. - Arbores v. frutices mediocres, in Nepalia et Jap on ia crescentes; ramis repetito-diehotomis, folits decussatim oppositis, exstipulatis, petiolatis, integerrimis, costato-nervosis, glabris v. subtus sericeis, capitulis e ramorum dichotomia pedunculatis, involucri tetraphylli colorati foliolis aestivatione valvat is.

Benthamia Lindley in Bot. Reg. t. 1579. Zuccarini et Siebold Flor. Japon, $T, 37, t, 16$. C o r a us c a p it at a Wallich Plant. As, rar, $t, 214$.

458 4. Cornus TOURNEF, F I ores nunc umbellati, involuerati, nunc corymbosi v. paniculati. Cal y $\mathrm{x}$ tubo cum ovario connato, limbo $8 \mathrm{a}-$ pero, brevissimo, quadrideutato. Cor olla e petala 4, summo calycis tubo inserta, aestivatione valvata, sub anthesi patentia. St a m in a 4 , cum petalis inserta, iisdem alterna; fil a m ent a filiformia, a $\mathbf{t h}$ erae dorso affixae, biloculares, longitudinaliter dehiscentes. Ova $\mathbf{r}$ i u $\mathrm{m}$ inferum, bi- $v$. interdum trilnculare, disco epigyno, interdum obsoleto. Stylus subelavatus; $8 \mathrm{ti}$ g ma truncatum. D rupa baccata, calycis cicatrice ambilicata, putamine osseo, bi- $v$. interdum triloeulari, interdum abortn unilocnlari. Se m i $\mathbf{n}$ a in loculis solitaria, inversa, testa coriacea. E mbryo in axi albuminis carnosi orthotropus; cotyled onibus foliaceis, radien la supera. - Arbores v. frutices, rarius trunco subterraneo ramos herbaceos promentes, in temperatis et frigidiusculis hemisphaerae borealis, rarius in America tropica crescentes; foliis oppositis $v$, rarissime alternis, penninerviis, integerrimis, inflorescentia varia, floribus albis $v$. flavis.

C or n u s Toursefort inst. 410. Linn. gen, n, 149. Heritier Monograph, 1788. fol. Gürtaer I, 126. t, 26. DC. Prodr. IV. 271 , excl. sp.

a. ARCTOCRANIA. Flores umbellati, involucrati, rlbi. Trunco subterraneo ramo, floridos simplices promente subherbaceae. - (Heritier t. 1. Bot Mag. t. 880. Flor. dan. $t, 5$, E. B. $t, 319$, )

b. TANYCRANIA. Flores umbellati, involuerati. flavi. - Ar. boreae. - (Schkuhx t. 24. Sibthorp Flor. graec. t. 151. Bot. Mag. $2,586$. )

c. THELYCRANIA. Flores corymbosi v. panieulati, exiavo. lucrati. - Arhoreas $v$. fruticosae. - (Heritier $t .2$-6. E. B. $t, 249$. Pallas Flor, ross, t, 34.)

\section{GENERA CORNEIS AFFINIA.}

45ร5. Ameuba THUNB. Flores dioiei. Masc, Caly x parvus, quadridentatus, Curolla e petala 4 , sub margine disci centro excavati inserta, ovato-Ianceolata, aestivatione valvato-involuta, sub anthesi patentia. Sta m in a 4 , cum petalis inserta, iisdem alterna; fil am e n $t$ a brevia, libera, antherae subrotundo-didymae, dorso supra basim affixae, biloculares, longitudinaliter dehiscentes. O va ri i rudimentum nullum. F em, 
Cal y x tubo cum ovario connato, limbo supero, brevissimo, quadridentato. Cor olla e petala sub disco epigyno inserta, ut in masculis. Stamina nulla. Ova riu m infernm, uniloculare, disco epigyno carnoso. Ovulum unieum, apici cavitatis appensum, anatropum. Stylus brevis, crassus, basi tumidus; sti gma orbiculatum. B a c c a stylo persistente superata, monosperma. S emen inversum. E mbryo in axi albuminis carnosi orthotropus, radicula supera. - Frutex japonicus, glaberrimus, sempervirens; ramis dichotomis, foliis oppositis, petiolatis, coriaceis, remote serratis, pedunculis $e x$ axillis superioribus ortis, paniculas parvas gerentibus, bracteis duabus caducis, flores tres, duos laterales sessiles intermedium pedicellatum cingentibus, petalis atropurpureis.

A u cu ba Thunberg Jap. 4. t. 12. 13. Lam. 2.759. Bot. Mag, t. 1197. DC. Prodr. IV. 274. Don in Edinb. new phiZosoph, Journ, VIII, 167. Blume Flor. Jav, Loranth. 5, in not. A u k u b a Kimpfer Amoen. exot, 775. Ic. $t$. 6 . E u b asis Salisbury Prodr. 68 .

45\% 6. Decostea RUIZ et PAV. F lores dioici. Masc. C a lyx parvus, quinquedentatus. Corolla e petala 5, sub margine disci plani, integri inserta, sessilia, membranacea, plana, aestivatione imbricata, sub anthesi patentissima. $\mathbf{S t a -}$ mina 5. cum petalis inserta, iisdem alterna et subaequilonga; filamenta libera, antherae subrotundo-cordatae, dorso supra basim affixae, biloculares, longitudinaliter dehiscentes. Ovari rudimentum nullum. F em. C a l y $x$ tubo campanulato, cum ovario connato, limbo supero, quin. quedentato. Corolla nulla. Stamina nulla. Ovarium inferum, uniloculare, vertice nudo, exserto, tricuspidato, lobis stigmatosis (?) $\mathrm{O} \mathbf{v}$ u$1 \mathbf{~} \mathbf{m}$ unicum, apici cavitatis sublateraliter appensum. Drupa subcarnosa, calycis limbo coronata, vertice tricnspidata, unilocularis. Semen pendn$\mathbf{l n m}$, ovato-ellipticum, testa membranacea. $\mathbf{E}$. bryo in basi albnminis carnosi parvus, oblongocylindraceus; cotyledonibus brevissimis, radi $\mathbf{c}$ I a umbilico proxima, supera. - Frutex pe$r u a n u s$, volubilis $v$. scandens; trunco super arbores radicante, foliis sparsis, coriaceis, dentatospinosis, glabris, paniculis axillaribus, ramosis, subsessilibus, bracteis involucratis, pedicellis racemosis, floribus atropurpureis.

Decostea Ruiz et Pavon Prodr. 130. Kunth in Annal. sc. nat. II. 146. Adr. Jussieu Ibid, XXV. 6.

\section{GENERA DUBIA.}

45\%. Curtisia $A I T$. Ca ly x tubo turbi nato, basi cum ovario connato, limbo supero, quadridentato. Petala 4 , inter calycis dentes lata basi sessilia. St a mina 4 , cum petalis inserta, iisdem alterna; filamenta subulata, anthe$x$ a e biloculares, globoso-didymae, longitudinaliter dehiscentes. Ovari $\mathbf{n m}$ inferum, quadriloculare, vertice subexserto, lanato. $O \mathbf{v u l a}$ in loculis solitaria, pendula. Drup a baceata, ealycis limbo coronata, putamine quadriloenlari, loculis monospermis. S e m in a inversa. ....-Arbor capen $s$ is; ligno duro, tenaci, folüs oppositis, lanceolatis, petiolatis, coriaceis, penninerviis, dentatis, floribus paniculato-racemosis.

Curtisia Aiton Hort. Kew I. 168. A.-Bichard in Dict. class. V. 203. DC, Prodr. II. 12. Meisner Gen, 153. (110.) Dorati am Solander mic. ex Jaume Expos. Fam. 11. 208. Relli ania et $\mathrm{funghausia} \mathrm{Gmelin} \mathrm{Syst.} \mathrm{247.} \mathrm{ot}$ 259. Si de r oxy 1 o n Burmani Plant, Oap. 235, $t, 89$, H a st s a ga y $B$ a o m Colon.
458 8. Mastixin $B L U M$. Cal y $\mathrm{x}$ tubo cum ovario connato, limbo supero, quadri-quinquedentato. Corolla e petala 4 v. 5 , supera, ovata, basi latiora. St a m i na 4 v. 5 , cum petalis inserta, iisdem alterna; antherae didymae. Ovarium inferum, nniloculare; ovnlo unico, pendulo. StyI u brevis, disco epigyno cinctus; stigma obtusum. Dru pa baccata, umbilicata, nuce rugosa, monosperma. Semen inversum. Embryo intra albumen orthotropus; radienla supera. Arbores javanicae, excelsae; folits alternis, oblongis, acuminatis, floribus terminalibus corymbosis.

M a stixi a Blume Bijdr. 654, DC. Prodr. IV. 275. Meisuer Gen. 155. (110.)

45\%9. Polyosma BLUM. Ca ly x tubo cum ovario connato, limbo supero, quadridentato. Coroll a e petala 4 , supera, basi interdum connata. St a mina 4, cum petalis inserta, iisdem alterna; fil amenta libera, submembranacea, antherae introrsum adnatae, biloculares, longitudinaliter dehiscentes. Ovarium inferum, incomplete biloculare, multiovulatum. St y la s filiformis ; stigma truncatum, simplex. Drupa subbaccata, calyce coronata, nucleo menospermo. Semen..... E mb ryo intra albumen subcartilagineum, radicula supera. - Arbores $v$. frutices javanici; foliis oppositis, exstipulatis, racemis axillaribus terminalibusque, floribus albidis, tribracteolatis, odoratissimis.

Polyos m a Blume Bijdr. 658. DC. Prodr. IV, 275. Meisner Gen. 153. (110.)

4580. Votomita $A U B L$. C a l y x tubo turbinato, cum ovario connato, limbo supero, quadridentato. Corolla e petala 4 , supera, oblonga, acuminata, reflexo-patula. $\mathrm{St}$ am in a 4 ; fil amentis brevissimis, antheris oblongis, in tubuin approximatis, membrana tenni terminatis. Ovarium inferum ..... Stylus filiformis, tubum antherarum perforans; stigmata 4 , oblonga. Drnpa calyeis limbo coronata, unilocularis, monosperma. Sem en striatum. ....... - Frutex guianens $i s$, glaber, vix notus, fortassis ad Rubiaceas repellendus; ramis apice tetragonis, folits oppositis, subsessilibus, ovatis, acuminatis, rigidis, integerrimis, stipulis intra petioli basim duabus deciduis, corymbis axillaribus paucifloris, floribus albis.

Vo to m it a Anblet Guian. I. 90, C. 35. DC. Prodr. IV. 275. Meisner Gen. 153. (110.) G Lo 8 s o co m a Schreber Gen. n. 1728, Gulll emini a Neeker Elem. n. 813.

\section{Drdo CIXI'T. Horanthaceae.}

CAPRIFOLIORUM genera Jussieu gen, 210, LORANTHEAE Jussieu in Annat. Mus. XIT. 292. Mirbel Annal. Mus. XYI. 485. t. 21. Bartling Ord. nat, 231, DC. Prodr. IV. 227. Sixième mémoire sur la famille des Loranthacées. Paris, 1830. 4. Martius in Elora 1830. p.97. Blume Flor. Jav. incompl. LORANTHACEAE Lindley Introduct. edit. II. p. 49. VISCOIDEAE Richard Annal. du Fr. 33.

Frotices sempervirentes, dichotome ramosi, in aliarum stirpium acramphibryarum partibus lignosis implantato-parasitici v. rarius radicibus repentibus, intra corticem sese insinuantibus iisdem adhaerentes, rarissime terrestres, arborescentes. $\mathbf{R}$ ami plerumque no- 
dosi, saepissime ad nodos articulati, teretes, tetragoni v. compressi. F oli a opposita, rarius verticillata v. alterna, subintegerrima, crassiuscule coriacea, penninervia v. palmatinervia, nervis immersis, inconspicuis, interdum ad squamulas stipulaeformes reducta v. plane nulla. Stip u l a e nullae.

Flores nunc unisexuales, parvi, albidi aut flavicanti-viriduli, nune hermaphroditi, speeiosissimi, virescentes, flavi, crocei v. punicei purpureive, in spicas, corymbos v. paniculas, axillares, terminales v. interdum laterales dispositi, rarius umbellati v. capitati, rarissime glomerato-sessiles, uni-pluribracteati v. rarissime ebracteati.

Perigonion in floribus unisexualibus quandoque nullum, saepe simplex calycinum, in floribus masculis partitum, in femineis ovario adnatum, v. ut in floribus hermaphroditis duplex, nempe :

Calyx tubo cum ovario connato, limbo supero, integerrimo v. denticulato aut saepe obsoleto.

Conolsa disco epigyno inserta, petalis quatuor, sex v. octo aut rarissime tribus, liberiş, v. in tubum saepissime hine fissum plus minus cohaerentibus, aestivatione valvatis.

Stamina perigonii simplicis v, corollae laciniis numero aequalia, iisdem opposita et inserta. Filamenta basi adnata, superne libera aut rarissime inter se cohaerentia, rarius nulla. An thera introrsae, biloculares, erectae et adnatae, $\mathbf{v}$. incumbentes et versatiles, longitudinaliter dehiscentes, quandoque multicellulosae, integumento externo maturitate secedente multiporosae, v. uniloculares, transversim dehiscentes.

Ovariem inferum, saepissime disco annulari coronatum, uniloculare. Ovu l um unicum, (an quandoque plura?) ex apice loculi pendulum, anatropum. Stylus terminalis, simplicissimus, interdum nullus. Stig ma terminale, plus minus incrassatum v. interdum obsoletum, indivisum aut rarissime emarginatum v. sublobatum.

Bacca monosperma. S e men inversum, saepissime hinc pericarpii parieti adhaerens, situm erectum mentiens. T es ta membranacea, tenuis. Albumen carnosum, copiosum.

Ensrxo (unicus v. saepe plures) in albuminis cavitate superficiali inversus, periphericus v. interdum lateralis, subelavatus, rectus v. arcuatus. Cotyled on es subcarnosae, obtusae, interdum connatae. $\mathbf{R}$ a di cu l a incrassata, saepissime exserta, supera.

Loranthaceae inter tropicos totius orbis magna specierum copia luxuriantes, in tem- peratis rarae, habitu peculiari et vivendi ratione distinctissimae, multiplici affinitate Corneis, Hamamelideis, Caprifoliaceisque, arctius fortassis Santalaceis Proteaceisque accedunt, ab omnibus embryone in albuminis cavitate superficiali collocato nec incluso diversae. Caeterum ubi lite de integumentorum floralium natura acutiori morpholorum studio, subtilioribus phytotomorum disquisitionibus innixo, olim diremta, hodierna ordines naturales disponendi methodus artificialis repudiata v. certis fuerit legibus stabilita, Loranthaceae etiam sua sede, nisi me omnia fallunt in Thymelearum classe collocabuntur, interim in tanta rerum caligine, ubi ordinum vere naturalium dispositio est fere arbitraria, trita via per hune librum procedere, quam ad generum cognitionem properantes per avia circumagere, consultius putavi.

4581. Misodendron BANKS. F lores dioici. Masc. Flores in axilla foliorum gemini, sessiles. Perigonium nullum. Stamina 3 , circa ovarii rudimentum verticillata; filamenta linearia, antherae hemisphaericae, basi adnatae, rima transversa dehiscentes. Fem. Invol ucrum trimerum, sexflorum, floribus alternis fertilibns ad axim inter se connatis, cum totidem sterilibus setiformibus alternantibus, involucri foliolis inter se et cum ovariorum dorso connatis, ad suturas superne primum hiantibus, setam exserentibus, tandem juxta totam longitudinem dehiscentibus. Perigoni um nullum. Ovaria tria, unilocularia, stig mate conico terminata, in corpus trigonum, angulis cum involucri foliolis connatum coadnnata. $\delta$ vula in loculis solitaria, anguli centralis apici appensa. Fructus ..... - Fruticuli graciles, in Americae antarcticae Fagis $V$ isci more parasitici, aphylli, dichotome ramosi, $v$. foliati, ramulis basi vagina stipulari munitis, foliis alternis, integerrimis, floribus axillaribus, sessilibus, $v$. in spicas basi folio unico stipatas dispositis.

M isodendron Banks msc, ex DC. Mem. VT. 12. t. 11, 12. Prodr. IV. 285. Pöppig et Endlicher Nov. gen. et sp. I. 1. t. 1-3. Delessert Ic. select. III, t. 80. Meisuer Gon. 154. (110.) A n g e Io pog on Pöppig msc.

458\%. Antidaphne PöPP. S i c a e monoicae, strobiliformes, bracteis imbricatis, deciduis. M a s c. geminati. P e ri gon i m simplex, tubo filiformi, limbo brevi, trilobo. Stamina 3 , perigonii fauci inserta, limbi laciniis alterna; filainenta petaloidea, linearia, apice subdilatata, anth er a biloculares, loculis adnatis, acutis, basi discretis, longitudinaliter dehiscentibus. Fem. terni. Periguninm simplex, urceolatum, ovario adnatum, margine integerrimo. O varium uniloculare; stigmate subsessili, capitato-globoso, concavo. Ovalu m unicum, pendulum. B a cea monosperma, endocarpio plicato-costato. S e m e n inversum. ...... - Frutex in arboribus Peruvia e parasiticus; foliis alternis, obovatis, integerrimis, spicis axillaribus brevibus, aggregatis.

A utidaphue Pöppig Nov, gen, et sp. IT. 70, to 199.

4583. Areeuthobium BIEBERST. F $10-$ res dioici. Masc. sessiles. Perigonium simplex, corneo - carnosum, bi-tri- v. rarius quadripartitum, laciniis ovatis, concavis, patentibus. Antherae numero loborum perigonii, singulae 
jisdem medio insertae, sessiles, subglobosae, uniJoculares, rimula transversa dehiscentes, membranaceae. Ovarii rudimentum glandulare, bi-trilobum. Fem. brevissime stipitati. Perigoninm simplex, tubo ovali, compresso, cum ovario connato, limbo bidentato. Staminum rudimenta nulla. Ovarium inferum, uniloculare; ovulo unico, pendulo. Stigma sessile, parvnm, obscure lobatum. B a c ca teretiuscula, pulposa, monosperma. S emen inversum, testa tenui. $\mathbf{E} \mathbf{m}$ b r y o in apice albuminis carnosi rectus; c oty ledonibus brevibus, subdivaricatis, radicula crassa, cylindrica, supera. - Fruticulus parvus, aphyllus, in ramis Coniferarum humiliorum Europae australis, Caucas i et $A$ mericaeborea$l i$ s parasiticus, subcarnosus, repetito-dichotomus, articulatus, articulis vaginantibus, subtetragonis, floribus terminalibus lateralibusque, plerumque ternis, minutissimis.

Arcenthobium Bieberst. Suppl. 629. Hooker Flor. Bor. Amer. I. 278. $t$. 99. Meisner Gen. 154. (111.) R a z ou. mow shia Hoffinann Hort. Hosqu. 1808, n. 1. f. 1. $a_{-} i$. Viscum Oxyeedri DC.

4584. Visemm LINN. F lores unisexuales, monoici v. dioici. M a s c. Perig on i u m simplex, coriaceo - carnosum, quadripartitum, rarins tri-quinquepartitum, laciniis triangularibus, erectis, aestivatione valvatis. An $t$ her a e numero lohorum perigonii, singulae iisilem medio adnatae, multicellulosae, poris plurimis dehiscentes. $0 \mathrm{v}$ ari i rudimentum glandulare v. saepins nullum. Fem. Calyx tubo cum ovario connato, limbo obsoleto. Pet a la 4 , nunc 3 v. 5 , coriaceo-carnosa, summo calyei inserta, valvata. Sta minum radimenta nulla. O v a $\mathrm{r}$ i m inferum, uniloculare; ov n lo unico, pendulo. Stigma sessile, obtusum. B a c ea pulposa, monosperma. Sem en inversum. Embryones intra albumen carnosum saepissime plures; cotyledonibus brevibus, radi cula supera. - Frutices super alias stirpes endogenas per tot um fere orbem parasitici, dichotome ramosi; ramis teretibus, tetragonis $v$. compressis, saepe articulatis, foliis oppositis aut rarissime alternis, nunc nullis $v$. squamaeformibus, floribus spicatis $v$. fasciculatis.

Vis e um Tournef. Inst, 380. Liun. gen. n. 1105. Gärtner $t .131, t .27$. Sehkuhr $t, 320$. L. C. Riehard in $A n n$. Mus. XII, 296. t, 27. DC. Prodr. IV. 277, exel. sp. Meisner Gen. 154. (111.) - Species exoticae numerosae solo ha. bitu cum Visco albo in genus consociatae, quoad integumentorum floralium conformationem et antheirarum strueturam jnquirendae.

4585. Tupein CHAM, et SCHLECHT. Flores dioici. Masc. Perigonium simplex, coriaceum, quadripartitum, laciniis lanceolatis, apice concavis, aestivatione valvatis, sub anthesi patentibus. St a mina 4 , perigonii laciníis opposita et fisdem basi inserta; fil a menta brevia, flliformia, a nthera e late ellipticae, introrsae, biloculares, basifixae, loculis oppositis, longitudinaliter dehiscentibus. Fem. Perigonium simplex, tubo subclavato, cum ovario connato, limbo supero, brevi, quadridentato. Stamin um rudimenta nulla. Ovarium inferum, uniloculare; ovalo unico? pendalo. Stylus brevis, crassus; t $\mathrm{t}$ g m a capitato-subglobosum, bisulcum. Fr a ctus.... - Frutex in. Novae-Zeelandiae Myrtaceis parasiticus; ramis teretibus, ramulis novell is petiolisque furfuraceo-pubescentibus, folitis oppositis, ellipticis, obtusis, immerse penninerviis, margine subpellucidis, integerrimis, racemis termi- nalibus subsessilibus, ebracteatis, pedicellis verticillatis, floribus parvis.

Tupeia Cham. et Schlechtend. in Linnaea III, 203. Meisner Gen, 154. (111.) V is cum antareticum Forst. An $V$ is c um incanum Hooker Ic. $t$. 73. hac refereadam?

458B. Horanthus LINN. Flores hermaphroditi, rarius abortn unisexuales, singuli unitribracteati. Cal y ci s tubus ovatus.v. turbinatus, teres, cum ovario connatus, limbus superus, brevis, truncatus, dentatus v. partitus. C or oll a e petala $4-8$, saepius $5-6$, summo calyci inserta, libera v. plus minus in tubum saepius hine fissum coalita, aestivatione valvata, sub anthesi erecta, patentia $\mathbf{v}$. apicibus reflexa. S $\mathbf{t}$ a $\mathbf{m}$ in a petalis $\mathbf{n u}$ mero aequalia et opposita; filamenta iisdem basi v. ultra medium adnata, apice libera, aequalia $v$. alterna breviora, an $t h$ e rae introrsae, biloculares, basifixae v. adnatae erectae, nune incumbentes versatiles, loculis oppositis, Iongitudinaliter dehiscentibus. O va ri u m infernm, uniloculare; ovul o unico, pendalo. Stylus filiformis; stig ma simplex, capitatum v. turbinatum. B a c c a ovata v. turbinata, vertice nuda v. calycis limbo coronata, unilocnlaris, monosperma. S e$\mathbf{m}$ e $\mathbf{n}$ inversnm. Em bryo intra albuminis cavitatem excentricam rectus $v$. curvatus; co ty le donibus brevibus, distinctis v. cohaerentibus, radicula supera. - Frutices dichotome ramosi, in regionibus tropicis et subtropicis magno numero, in temperatis parcissime viventes, plerumque aliis stirpibus implantati et Visci more parasitioi, rarius radicibus repentibus arborum vetustarum trunco ramisve adhaerentes pseudoparasitici, rarissime terestres, autonomi; foliis oppositis $v$. alternis, integerrimis, saepissime carnoso-coriaceis, floribus in spicas, corymbos v. paniculas axillares aut terminales dispositis, rarius umbellatis v. subcapitatis, rarissime glomerulatis, viridibus, croceis $v$. flavicantibus, saepissime puniceis $v$. purpureis, ob diversam petalorum longitudinem et varium cohaesionis gradum variis.

L or a thus Linn. gen. $n$, 443. Jussien gen. 212. DC. Mem. VI. 15. Prodr, IV. 286. Meisuer Gen. 154. (110.) L o n i c er a Plumier Gen, 33. Gärtner I. 132, 2.27 . H e I ixa $u$ thera Loureiro Flor. cochinch, 176. Lich ten 5 t e fn i a Wendland Collect, II, 4. Mo q u inla Spreng. f. Suppl. 9. Lorauthus et Spirostyles Schultes Syrt. VIT. 17. Loranthus, Strutanthit $s, P h t b i r u s a, P s i t-$ taeanthus, Tristerix et Deudrophthoë Martius in Elora 1830, 97. L or a $\mathrm{thas,} \mathrm{Lepeostegeres,}$ El ytranthe et Lox an ther a Blume Flor. Jav. Loranth. 10. Scurrula, Notanthera et Gaiodendron G. Don Syst, $I I I, 421-431$.

a. EULORANTHUS. F lores interdam dioici, singuli rhacheos foveae inserti, margine bracteolari semicincti. P eta I a linearia, libera, demum reflexa. Filamenta brevia, crassa, subulata, subaequalia v. alterna breviora. Antherae globoso-didymae, basi v. dorso supra

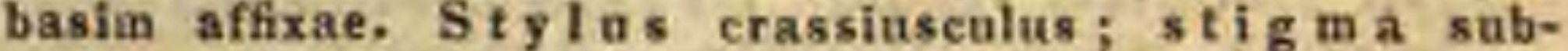
capitatum, interdum obsoletum. - Species a merica. nae, paucae indicae, unica europaea, spicís axillaribus v. terminalibus simplicibus, rhachi carnosa, foveolata, foribus solitarits, albido-flavis v. purpureis.

Lora a thus Martius in Flora 1830. p. 108. Blume Flor. Jav. Loranth. 13. E ul or a $\mathrm{n}$ h i viscoidei, odo. rati et stachyauthi partiu DC, - ? G I u tag o Commers. msc. (Jäeq. Flor. austr, t, 30. Schkuhr t. 34.-De germinatione Loranthi europaei yid. Mirbel is Annal. Mus. XVI, t, 19.)

b. DENDROPEMON BLUM. Flo res siuguli bractea cyathiformi, tridentata stipati. P e $t$ a I a lueari-lanceolata, libera. Fila me nt a brevia, alterna longiora. A $\mathrm{t}$ thera $e$ alteruas efoetae $v$. penifus deficieates. Stylus fillformis; stigma obtusum, - Species antillanae, 101 
racemis aimplicibus, rarius compositis $v$. corymbosis, pedicellis unifloris, floribus parvis, albidis aut pur. purascentibus.

Dendropemon Blume Flor. Jav. Loranth. 13. Enloranthi stachyanthi et protostelides part. DC. (Jacquin Amer, t. 69.)

c. LIPOTACTES BLUM. Flores singuli bractea cupuliformi stipati. P et al a lancéolata, disereta. A u the ra e sessiles, ovatae. Stylus subulatis; stigma obtusum. - Spectes antillanae, spicis tripartilis, flo. ribus parvis, purpureis.

Lipotactes. Blume Flor. Jav, Loranth, 13. L oranthus paucifloras Swartz.

d. PHOENICANTHEMUM BLUM. F lor es singuli bractea capulari obliqua suffulti. Petal a inferne latiuscula, disereta. Filamenta brevia, aequalia. Antherae ovales v. oblongae, basifixae, filamento contínuae. S t y. I us basi crassa, subangulata; $\mathrm{st} \mathbf{l} \mathrm{g} \mathrm{m}$ a capitatam. Species indica e, spicis v. racemis axillaribus, olongatis, simplicibus, floribus parvis, phoenicis, sessili. bus v. pedicellatis.

Phoenicanthem $\mathrm{m}$ Blume Flor, Jav. Loranth. 13. . 14. EnIoranthi et Breviflori allquot DC. (Wallich Plant, As, rar, t. 225.)

E. DENDROPHTHÖ̈ $M A R T$. Flor es singuli bractea Ia. terali v. abbreviata cupulari suffulti. Petala lineari spathulata, in tubum cohaerentia. Fila me $\mathrm{ta}$ aequalia. A $n$ the rate lineares $v$, oblongo-lineares, basifixae, filameatis continuae. Sty I us filiformis; $8 t i \mathrm{gma}$ ob. tusum. - Species asiaticae, australasioae et capenses, pedunculis abbreviato-racemosis $v$. fasciculatis, multi-paucifloris, foribus plerumque longis, fusco-viridulis, flavescentibus, rubentibus v. purpureis.

Dendrophthö̈ Martius in Flora 1830. p. 109.

a. C ieh lanth us. Flores plerumque tetrandri, bractea laterali parva. C a I yx obeonicus, limbo nullo. Pe $t$ al a in tabum tenuem, longum, saepissime curvatum cohaerentia. B a e a e obconicae, stipitatae. - Fami novelli, folia et inforescentia tomento stellato $7 e$ pidota. - Dendrophtoés sect. 1. Blume Flor.

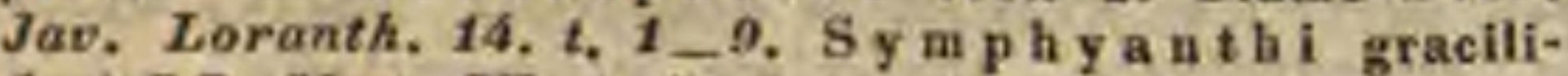
flori DC. Mem. VT, $t$. 5. 6 .

b. Eude ndro phtho ê. Flores plernmque pentandri, rarius hexandri, bractea cupulari abbreviata. Petala in tubum brevem v, elongatam, sacpissime rectum coalita. Baceae sessiles, basi rotundatae. - Tomentum in ramis folitisque nullum, in corollis plerum. que parcum. - Dendrophthoés sect. 2. Blume Flor, Jav. Loranth, 14. $t$. $10-12$.

f. TAPINANTHUS BLUM. Flores singull bracteae cyathiformi, dentatae immersi. Petala linearia, in tubum connata. S $t$ a min $\mathrm{n}$ inclusa, a $n t h$ e $r$ a basifixae, filamentis continure. Stylus filiformis, elongatus; $5 t i g$ ma crassum. - Species africanae, floribus axil. laribus, plerumgue pentameris.

Ta pinanthus Blume Flor. Jav. Loranth. 15. Lora nthi Scurrulae pentamerae DC. Mem, $V I, t, 8,9$. (Palisot Elor. Owar. Ir, 4, t. 39.) L i ch ten s te in ia Wendl. Collect, II. 4. $t$. 39. Grieselich in Linnaea M o. quinia Sprengel fil. Suppl. 9.

5. LOXANTHERA BLUM, Ftores singuli bractea capulari abbreviata suffulti. P eta la lineari-spathulata, inferne in tubun elongatum, proboscideum coadunata. $\mathrm{S}$ ta in u filamenta aequalia, nucinata, an thera auguste lineares, dorso affixae, immobiles. Sty lus fili. formis, elongatus; $8 \mathrm{tig} \mathrm{m}$ a clavatum. - Species $j a$ vanica, inflorescentia subcorymbosa, axillari et terminali, floribus speciosis, laete puniceis.

Lo $x$ a thera Blume Flor. Jav. Loranth, 13.

h. PSITTACANTHUS MART. Fiores singull bractea cuptaliformi suffulti. P e tala lineari-spathulata, inferne in tubum conaiventia, S $\mathbf{t}$ a in $\mathbf{n} \mathrm{m}$ flamenta aequalia. fillformia, a $n$th e ra e liueari-oblongae, dorso affixae, versatiles v, basifixae. St y lus filiformis; $s \mathrm{t} i \mathrm{~m} \mathrm{a}$ capita1um. - Species americanat, floribus in corym. bos terminales $v$, axillares, rarius in racemos aut spicas dispositis, pedunculis uni-pauciforiv, corollis saepius magnis, speciosis.
Psittacanthus Martius in Flora 1830, p. 106. Blume Flor. Jav. Loranth. 15.

c. Eupsittacanthus. Antherate dorsifixae, versatiles. - Os cillat oria e micranthae et calanthae partim DC. Mem, $V_{T}, t, 10$.

B. Trygonanthus. Antherac basifixae.

i. PHTHIRUSA MART. Flores singuli bracteis pluribas gemmaceis cincti. Petala lineari-lanceolata, discreta. St a m in $u$ filanenta brevissima, aequalla, a $\mathrm{the}$ $r$ at ovatae, dorso affixae. Stylus brevis, erassus stigm a capitatum. - Species americanae, fori. bus axillaribus et terminalibus, sessilibus, minutis.

$\mathrm{Phth} \mathrm{i}$ us a Martís in Flora 1830. p, 110. Blume Flor. Jav, Loranth, 16. Lor a $\mathrm{t}$ hi Enloranthi clandestini DC.

k. ELXTHRANTHE BLUM. Flores singuli rhacheos foveolae inserti, bracteis tribus imbricatis involucrati. Petala lineari-lanceolata, inferne in tubum cohaereatia. St a minum filamenta aequalia, a n th erae bas! fixae, lineari-subulatae, - Species indicae, spicis compactis, abbreviatis, arillaribus v. lateralibus, so. litariis $v$. fasciculatis, paucifloris, floribus decussatis, sessilibus, hoxandris, albido-purpureis $v$. croceis.

Fly thrauthe Blume Flor. Jav. Loranth, 16.

1. MACROSOLEN BLUM. Flores singuli bracteis tribus coneretis v. distinetis suffulti. P e $t$ a I a lineari-spathulata, basi in tubum cohaerentia. S $t a m$ in $u m$ filamenta aequalia, antherae anguste lineares v. oblongae, interdum subulatae, basitixae. Stylus filformis; stigm a obtusum v. subcapitatum. - Species indicae, pedunculis multifloris, racemosis $v$, oymosis, rarius paniculatis, rarissime unifloris, floribus ut plurimum speciosis, rubris, puniceis, croceis, flavis v. viridults.

Macrosolen Blume Flor. Jav. Loranih. 16, 2,15, 16. Loranthis y m ph anthi DC. Mem, 6. 2.3 .4 .

m. TRISTERIX MANT. Flo res singuli tribracteati. Pe$\mathrm{ta}$ I a linearia, basi in tubum cohaerentia. S $\mathrm{ta} \mathrm{m}$ in $\mathrm{u} \mathrm{m}$ filamenta subulata, anthera e liaeares, incumbentes. Stylus fitiformis; stigmia capitatum. - Species peruana, inflorescentia racemaso-umbellata, pedicellis unifloris, floribus pollicaribus, tetrandris.

Tristerix Martius in Flora 1830. p. 108, Blume Elor. Jav. Loranth. 17. L. tetrandras Ruiz et Pa. von Flor, Peruv, $t, 285$.

. SPIROSTYLIS PRESL. Flores ebracteati. Petala linearia, vix cohaerentia. Staminum filamenta sub. aequalia, subulata, antherae subhastatze, dorso affixae. Sty I us spiraliter contortus; stig m a isubcapitatum. + Species americanae, inflorescentia racemosa, pedicellis apice trifloris, floribus sessilibus, parvis.

Spir ost ylis Pcesl, in Sckalt. Syst. PIL, 163. Blame Flor. Jav. Loranth. 17.

o. STRUTHANTHUS MART. Flores ternatim congesti, bracteis totidem suffulti. Petala linearia, discreta. Staminum filamenta brevia, subinaequalia, anthe$r$ a e ovatae v. ovato-globosae, dorso infra medium v. prope basim affixae, plerumque connectivi apiculo terminatae. Stylus subulatus v, Interdum subelavatus; stig mi capitatum v. obsoletum. - Species a meri. c anae, inflorescentia simplici $v$, panioulato-ramasa. rhachi subangulata $v$. ancipiti, foribus ternis, sessi libus, bracteis plerumgue tribus discretis, interdum fore obsoletis cinctis, rarius in rhacheos ramificationibus trifidis solitarils, parvulis, albido-v. Ravido. virescentibus, rarius parpurascentibus.

Struthantlits Martius in Flora 1830. p. 103. Blume Flor. Jav. Loranth. 17. L or a nthi oscillantheri pleriqui DC.

p. LEPBOSTEGERES BLUM. Flore 8 plurimi, eongesti , bracteis imbricatis involucrati. Petal a anguste linearia, inferne in tubum coalita. Stamianm filamenta aequalia, antherae subulatae. basifixae. Stylus filifornis; s tig m a subelavatum. B a c c a e stipitatae. Species javanica. floribus sessilibus, gracillimit, longe tubulosits, puniceis, hexandris, in capitula setsitia congestis.

Lepeostegeres Blume Flor. Jav. Loranth, 18. 
q. TOLXPANTHUS BLUM. Flores quatuor v. quinque congesti, beacteis totidem involucrati, P et a la linearia, in tubum connata. Stamin um flamenta aequalia, a $\mathrm{n}$ the rate lineares $v$. ovales, basifixae. Sty 1 us filifor. mis; st i g ma depresso- capitatum v. sublobatum. Species indicae, floribus sessilibus, majuseulis, pentandris $v$. hexandris (?) in capitula pedunculata dispositis.

Toly pan th s Blume Flor. Jav. Loranth, 18, L o$r$ a $\mathrm{n}$ hi symphyanthi involucrati DC.

458\%. Nuytsia $R$. BR. Flores hermaphroditi, ternatim congesti, singuli nnibracteati. C a I y $x$ tubo prismatico-triangulari v. subcompresso-bialato, cum ovario connato, limbo supero, inaequaliter quadri-sexdentato. Coro 11 a e petala $4-6$, linearia, summo ealyei inserta, distincta, aestivatione valvata. S $\mathrm{t}$ a $\mathrm{m}$ in a petalis numero aequalia et opposita; fil a menta iisdem ad medium adnata, superne libera, aequalia, antherae ovatae, basi emarginatae, incumbentes. Ova rin m inferum, nniloculare, uniovulatum. Stylu s filiformis; stigma simplex. Fructus ....... Arbor Novae-Hollandiae austro-occidentalis; foliis alternis, racemis terminalibus, floribus in apice pedicellorum ternatis, sessilibus, bracteis tribus discretis involucratis, flavis.

Nnytsia R. Browa in Journ, geograph, soc. I, 17. Fenzl in Enumerat, plant. Hïgel, 57. Meisner Gen. 154. (110.) Loranthus floribund us Labillard. Nov, Holl. t. 113 .

\section{Ordo CLXVII. Hamamelideae.}

HA MAMELIDEAE R. Brown in Abel Narrat. Journ. Chin. 374. Bartling Ord. nat. 239. DC. Prodr. IV. 267. Meisuter Gen. 153. (109.) HAMAMELACEAE Lindley Introduct. edit. II. p. 48.

Frotices v, arbusenlate, ratius arbores vastae, ramulis teretibus, saepe pube stellata conspersis. Folia alterna, petiolata, simplicia, penninervia, integerrima v. sinuato-dentata. S tipu la e ad basim petiolorum geminae, deciduae, interdum inaequales.

FLores hermaphroditi v, abortu diclines ant polygami, terminales v. axillares, subsessiles, fasciculati, capitati v. spicati, saepius bracteati.

Carxx tubo ovario adhaerente, limbo semisupero, quadrifido v. quinquefido, lobis per aestivationem imbricatis, demum deciduis, nunc truncato, obsolete repando-dentato, dentibus quinis-septenis, callosis.

Corolsa nune nulla, nunc petala calycis fauci inserta, ejusdem lobis alterna, nunc unguiculata, spathulata, nunc exunguiculata, elongato-ligulaeformia, per aestivationem basi valvata, apice saepius singillatim spiraliter convoluta, demum decidua.

Sramiva cum petalis inserta, nunc iisdem numero dupla, alterna petalis opposita semper sterilia, squamulaeformia, nune (in apetalis) subindefinita. Filame n t a libera, nunc brevia, basi dilatata, nunc (in apetalis) elongata, subclavata. Antherae introrsae, biloculares, erectae, nune ovato-quadratae, loculis oppositis, utrinque connectivo, saepius in acumen uncinatum producto adnatis, dorso inter se conferruminatis, medio septo secundario longitudinali bilocellatis, faciei pariete demum tota, vel usque ad dissepimentum secundarium soluta et decidua, rarins rima dehiscentes, nunc (in apetalis) antherae hippocrepicae, rima marginis semicirculari hiantes.

Orartum e carpidiis duobus compositum, calyci adhaerens, semiinferum, vertice denudatum, umbilicato-turbinatum, biloculare. $0 \mathbf{v}$ la in loculis solitaria, ex apice dissepimenti pendula, rarissime plurima, e placenta apici dissepimenti inserta imbricatim pendula, superiora deformia, infimum solum rite evolutum, anatropa v. semianatropa. Styli duo distincti; stigmata simplicia.

Capsura semisupera v. demum supera, coriacea v. sublignosa, bilocularis, carpidiis maturitate apice secedentibus, superne elastice dehiscentibus, epicarpio valvatim soluto.

Semina in loculis solitaria, pendula, nitida, rarius plura deformia, unicum infimum fertile. A I bum en carnosum v. subcartilagineum.

Enвryo in axi albuminis orthotropus, ejusdem fere longitudine. Cotyledones foliaceae, planae v. margine subinvolutae. $\mathbf{R}$ a die ula cylindrica, supera.

Ordo constans speciebus pancis, per Americam borealem, Japoniam, Chinam, Indiam orientalem, Persiam, Madagascariam et Africam capensem sparsis, Corneis, Bruniaceis et Saxifragaceis affinis.

TRETBES I. HAMAMELEAE. Ovarii loculi uniovulati.

\section{SUETRIFUS I. EUHAMAMELEAE.}

Flores corolla donati.

4588. Dieoryphe THOUAR. Calyx thbo eylindrico, longo, basi cum ovario connato, limbo quadrilobo, demum supra ovarium circumseisso. Corollae petala 4, epigyna, lineari-lanceolata, calyce longiora. Stamina 4 , cum petalis inserta, isdem alterna, inclusa; fil am enta subulata, antherae oblongae, adnatae, bilocnlares, locnlis rima laterali dehiscentibus. S q namulae 4, staminibus alternae. Ovarium inferum, biloculare. Ovnla in loculis solitaria, pendula, anatropa. Styli duo distineti; stig mata simplicia. Ca p s ula calycis basi adnata, octocostata, apice breviter exserto bicornis, bilocularis, septicide bivalvis, valvis dorso apice fissis, endocarpio corneo in coces daos bivalves soluto. S e mi$\mathrm{na}$ in loculis solitaria, pendula, testa crustacea, nitida, hilo impresso et rhaphe longitudinali lineari notata. Embryo in axi albuminis subcornei orthotropus; c otyledonibus subfoliaceis; margine sigmoideo recurvatis, radicula cylindrica, supera, - Frutex madagascariensis; ramis debilibus, virgatis, foliis alternis, breve petiolatis, 101 * 
oblongis, penninerviis, integerrimis, stipulis geminis, petiolatis, foliaceis, latis, subcordatis, inaequalibus, corymbo terminali subfasciculato, septemoctofloro, calycibus hirtis.

Dicoryphe Thouars Gen, madagasc, 12. Hist. veg. Afr. austr. edit, 1, p. 31, $t .7$. edit. 2. p. 15. et 31. $t .4$ DC. Prodr. IV. 269. Meisner Gen, 133. (109.) Dic aryph a Sprengel Syst, $I$, s 66 .

4589. Corylopsis SIEBOLD et ZUCC Calyx tubo cum ovarii basi connato, limbi semisuperi, quinquepartiti laciniis subinaequalibus, aestivatione valvatis. Corolla petala 5, perigyna, obovato-spathulata, unguiculata, aestivatione subvalvata. St a m ina 5 , cum petalis inserta, iisdem alterna; fil amenta subulata, libera, antherae basifixae, mucronulatae, quadriloculares, loculis per paria conjunctis, longitudinaliter nnivalvibus. Squamula e 5, truncatae v. emarginatae, staminibus alternae. Ovarinm vertice breviter exserto inferum, biloculare. Ovula in loculis solitaria, pendula, anatropa. Styli 2 , distincti, e bisi incrassata filiformes; st $\mathrm{i} g \mathrm{ma}$ tibus capitatis. Ca psula lignosa, semisupera, calycis limbo cincta, vertice exserto, compressinsculo, subtruncato dorso styligera, biloeularis, apice septicide bivalvis, valvis dorso tandem fissis, endocarpio corneo in coccos bivalves soluto. S emina in loculis solitaria, pendula, testa crusta cea, nitida, umbilico impresso et rhaphe longitudinali lineari notata. E m $\mathbf{b}$ r yo in axi albuminis earnoso-oleosi orthotropus; cotyledonibus fuliaceis, radicula cylindrica, supera. - Frutices japonic $i$; foliis alternis, petiolatis, stipulatis, basi cordata $v$, rotundata subinaequilateris, costatovenosis, apice acutis $v$. cuspidatis, repando-serratis, serraturis setaceo-mucronatis, deciduis, gemmis perulatis folizferis $v$. mixtis, floribus praccocibus, in spicas amentaceas simplices, nutantes dispositis, corollis flavis.

Corylops is Siebold et Zuecarini Flor. japon, I. 45 . t. 19.20.

4590. Trielnoelladus PERS. Caly tubo subcampanulato, inferne cum ovario connato, supra ovarium produeto, limbi quinquelobi lobis aestivatione valvatis. Corolla e petala 5 , epigyna, elongato-linearia, aestivatione valvato - invoInta. Stamina 5, cum petalis inserta, iisdem alterna ; fil am enta brevissima, ant hera e basifixae, mucronatae, oblongo-tetragonae, biloculares, loculis bivalvibus, valvulis inaequalibus, postica latiore reflexa. Ovarium inferum, bilocnlare. Ovula in loculis solitaria, pendula, anatropa. Styli 2 , distincti; $8 \mathrm{t}$ igma ta introrsum lateralia, obliqua. Cap 8 u la bilocularis, quadrivalvis, endocarpio dicoceo ..... - Frutices c a penses, pube molli lepidota villosi; foliis alternis, oppositis, breve petiolatis, integerrimis, capitulis axillaribus terminalibusque pedunculatis, floribus uni-bibracteolatis.

Trichoclad us Persoon Encheirid, IT. 597. DC. Prodr. IV. 269. Meisner Gen. 153. (110.) D a hlita Thun. berg in Act, soc. h, n. Hafn, I, 133, t, 4. nou Cav.

4531. Famamelis $L I N N$. Calyx tubo cum ovario connato, limbo supero v. semisupero, quadripartito, laciniis aestivatione valvatis. $\mathrm{C}_{0}$. ro 11 a e petala 4 , perigyna v. epigyna, elongatoligulaeformia, aestivatione valvato-involuta. S $t$ amin a 4, cum petalis inserta, isdem alterna; fiI amenta brevissima, antherae basifixae, subtetragonae, mueronatae, tiloculares, loculis valvula verticali persistente $\mathbf{v}$. decidua apertis. Squa- mula 4 , staminibus alternae. Ovarinm inferum v. vertice exserto semisuperum, biloculare. 0 vula in loculis solitaria, pendula, anatropa. St y li 2, distincti; stigmata subcapitata. Ca ps $\mathrm{u}$ l a semisupera, calyeis basi stipata, lignoso. coriacea, bilocularis, apice bivalvis, valvis dorso tandem fissis, endocarpio corneo, in coccos duos bivalves soluto. S e min a in localis solitaria, pendula, testa crustacea, nitida, umbilico impresso et rhaphe longitudinali lineari notata. E m br y o in axi albuminis carnoso-oleosi orthotropus; $c 0_{-}$ tyledonibus foliaceis, radicula cylindriea, supera. - Arbusculae in America boreali et in Ch in a indigenae, pube stellata; foliis alternis, breve petiolatis, bistipulatis, ovatis $v$. subcordatis, penninerviis, subcrenato-repandis $v$. integerrimis, floribus capitatis, capitulis axillaribus subsessilibus $v$. pedunculatis, nudis $v$. involucro squamaeformi triphyllo cinctis, floribus singulis bi-tribracteolatis, petalis flavis.

H a m a melis Linn. gen, n. 169. Jussieu gen. 288. R. Brown in Abel China 374. DC. Prodr. IV. 268, excl. sp. Meisner. Gen. 153. (109.)

a. HAMAMELIS $\mathrm{R}, \mathrm{Br}$, l,c. $\mathrm{C}$ a I y $\mathrm{c}$ is limbus semisuperas. A ntherarum valvulae persistentes. - Capitala invo. lucrata. - Tril o p u Mitehell in A.N.C.VIT. H. virgi i i ca Linn. Schkuhr $t, 27$, Duhamel Arbr, $T$. $t, 114$,

b. LOROPETAleiM R. Br. l. c. Caly eis limbus superus. A atherar um valvalae deciduae. - Capitala nuda. - H. chinensis R. Brown l. c. cum ic.

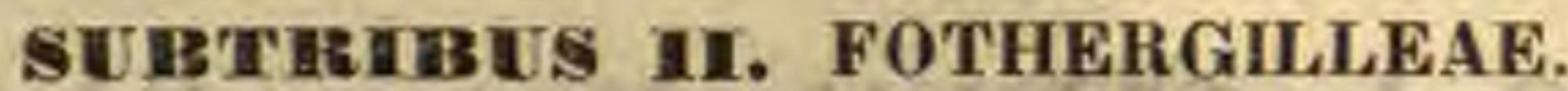
F 10 res apetali.

4598. Prapetia C. A. MEY. Ca ly x tubo campanulate, inferne cum ovarii basi connato, limbo semisupero, truncato quinque-septemlobo. Coro 11 a nulla. Stamina $5-7$, perigyna, calycis lobis opposita et longiora; filam enta filiformia, a n thera e basifixae, oblongo-tetragonae, biloculares, loculis rima longitudinali dehiscentibus. Sq u a mu la e staminibus interjectae nullae? Ovarium semiinferum, biloculare. Ovula in loculis solitaria, pendula, anatropa. Sty $1 \mathrm{i} 2$, stig mat a simplicia. Capsula semisupera, calyce stipata, bilocularis, septicide bivalvis, valvis dorso tandem fissis, endocarpio corneo, in coccos duos bivalves solnto. S e m in a in loculis solitaria, pendula, testa crustacea, nitida, umbilico impresso et rhaphe longitudinali notata. $\mathrm{Em}$ b r yo in axi albuminis carnoso-oleosi orthotropus; cotyledonibus subfoliaceis, radieula cylindrica, supera. - Arbor in Persiaboreali et Ca ucaso indigena, ligno durissimo; foliis alternis, bistipulatis, petiolatis, ovalibus, acuminatis, basi cuneatis, superne dentato-repandis.

Parrotia C. A. Meyer Verseichn. caucas. Pfanz. 46. Melsuer Gen. 153. (110.) Ha ma melis persic a DC.

4593. Fothergilia LINN. FIL. C a l y x tubo campanulato, cum ovarii basi connato, limbo semisupero, subtruncato, calloso, repando quinque-septemdentato. Corolla nulla. Stamina circiter 24, perigyna; fi lamenta longa, clavata, antherae terminales, hippocrepicae, rima semicircnlari ad marginem dehiscentes. Ovar i $\mathbf{u m}$ semiinferum, biloenlare. $0 \mathrm{vula}$ in loculis solitaria, pendala, anatropa. Capsula semisupera, apice biloba, bilocularis, incomplete septicide bivalvis, valvis tandem bifidis, Sem ina in loculis solitaria, pendula, testa ossea, nitida, umbilico impresso et rhaphe longitudinali lineari notata. Embryo in axi albuminis carnoso-oleosi ortho- 
tropus; cotyledonibas subfoliaceis, radi.JS cula cylindrica, supera. - Frutex borealiam er icanus; pube stellata molli, foliis alternis, obovatis, bistipulatis, penninerviis, integerrimis $v$. crenatis, spicis terminalibus, praecocibus, densis, bractea sub quovis flore solitaria, decidua, inferioribus trifidis, superioribus integris, floribus albis, odoratis.

Fothergill a Linn. fil. Suppl. 48. Lam. $t, 480$. Jacq. Yo, rar, t. 100. Duhamel Arbr. edit, nov, IV. $t .26$. Bot. Mag. $t$. 1341. 1342. Turpin Atlas $V$. t. 199, DC. Prodr. IV. 269. Meisner Gen, 153, (110.)

TRIBUS II. BUCKLANDIEAE. O vula in loculis plura, superiora difformia.

4534. Fueluandia $R$. BR. Flores polygamo-dioici, capitati, capitulis octofloris, exinvolucratis. Cal y x subeampannlatus, inferne cum ovarii basi connatus, limbo truncato, carnoso, repando. Corolla e petala perigyna, hermaphroditor um numero varia, lineari-spathulata, carnosa, acstivatione arcuatim incurva, saepe in stamina imperfecta mutata, cito decidua, femin e or u m subquaterna, rudimentaria, caducissima. $S t$ a min a $10-14$, perigyna, dintius persistentia, ferminarum nulla; fil amenta subulata, aequalia, aestivatione flexuosa, antherae oblongae, mucronatae, prope basim affixae, biloculares, longitudinaliter bivalves, valvulis exterioribus latioribus tandem reflexis. O varinm semiinferum, bi loeulare. $0 \mathbf{v}$ ula in loculis sena, placentae dissepimenti partem dimidiam superiorem occupanti inserta, biseriatim pendnla, anatropa, duo suprema intima, minima, intermedia sursum producta et deorsura elongata, infima extima sola fertilia, superne in alam maximam producta. Styli 2 , subulati, re voluti, facie interna stig matosi. Fructus calycum basibus demum connatis multiplex, subglobosus, carnoso-induratus. C a p s u la e semisuperae, demum liberae, s.tylis induratis coronatae, biloculares, loculicide incomplete bivalves, valvis medio septiferis, demum bipartitis. Semina in loculis sena, quatuor superiora efoeta, solida, infimum fertile, convexo-trigonum, testa superne in alam membranaceam auricnlaeformem producta. Embryo in axi albuminis carnosi, parci orthotropus; cotyledonibus planis, earnosis, $r$ adi c u la conico-subulata, nmbilicum ad basim alae situm attingente, sursum centripeta. - Arbor indica, saepius excelsa, Populi facie; ramulis abrupte terminatis, apice gemmiferis, gemmarum squamis binis, oppositis, foliis alternis, estipulatis, petiolatis, late cordato-ovatis, cuspidatis, integris $v$. trilobis, integerrimis, coriaceis, margine cartilagineis, nervosis, reticulato-venosis, pedunculis terminalibus ternis, monocephalis, floribus capitulorum octonis, in verticillos duos alternantes dispositis, interstitiis florum pubescentibus.

Bucklundia R. Brown in Wallich Catalog. 7414. sine charact. Griffith in Asiat. Heseare $h . X I X, 1,94, t, 13.14$.

4555. Sedigwiekin GRIFFITH. Flor e 8 hermaphroditi (?) capitati, capitulis multifloris, exinvolucratis. Caly x tubo cum ovarii basi connato, limbo truncato, lobato, lobis angulatis, medio saepe conicis. Cor olla ...... St a m in a (fertilia?) hine inde persistentia, perigyna; filamenta subnulla, anthera eblongae, adnatae, biloculares, Iongitudinaliter bivalves, valvalis aequalibus. Orarium semiinferum, biloculare. Gvula in loculis indefinite plurima, placentae dissepimenti partem superiorem occupanti inserta.
Sty li 2, subulati, revoluti, facie interiore stigmatosi. Sy ncarpin mubglobosum, induratum, stylis persistentibus echinatum. Ca p s u l a e semisuperae, demum liberae, biloculares, septicide incomplete bivalves, valvis demum bipartitis. S e$m$ in a in loculis efoeta plerima, difformia, ossea, snprema transversa, inferiora pendula, unicum infimum extimnm fertile, pendulum, semianatropum, extus convexiusculum, intus angulatum, testa undique in marginem membranacenm produeta. Fmbryo in axi albuminis carnosi, parci erthotropus; cotyledonibus foliaceis, radic u la eylindraceo-conica, brevi, supera. Arbor assamica, excelsa, Cerasi quodammodo facie, aromatica; gemmis axillaribus terminalibusque imbricatim squamosis, folitis alternis, petiolatis, ovato-oblongis, acuminatis, subcoriaceis, serratis, venosis, serraturis glandulosis, stipulis linearibus, angustis, caducis $v$. petiolo adnatis, induratis, pedunculis axillaribus, solitariis, monocephalis.

$\mathrm{Sedg}$ wick la Grifith in Asiat. Research, $X I X, 1.98$. t. 15.16 .

\section{Ordo ChX VIII. Bmiaceat.}

BRUNIACRAE R. Brown in Abel Narrat, Journ, Chin. 374. DC. Prodr. II. 43. Brongniart in Annal. sc, nat. 373. Lindley Introduct. edit. IT. p. 28. Meisner Gen. 71. (51.)

Fruters v. suffrutices capenses, ericoidei. Fo li a parva, glabra v. pilosiuscula, acerosa, subtrigona, integerrima, apice saepe calloso-ustulata, sessilia $\mathbf{v}$. breviter petiolata, rarius sparsa, plerumque quinquefariam imbricata. Stipulae nullae.

Flones hermaphroditi, parvi, regulares, spicati v. capitati, sessiles, singuli basi bractea bracteolisque geminis lateralibus, raro deficientibus fulti, capitulis nudis, v. foliis majoribus, interdum scariosis, radiantibus involueratis, rarius solitarii terminales, interdum paniculati v. laxe spicati.

Carxx gamophyllus, tubo juxta totam lon gitudinem v. basi cum ovario connato, rarissime libero, limbo quinque- v. rarissime quadrifido aut partito, persistente v, deciduo, laciniis apice saepe callosis, per aestivationem imbricatis. Torus in laminam tenuem, tubum calycis cum ovario connectentem, v. ovarium obducentem expansus, rarissime in discum epigynum effusus.

Corollas petala quinque v. rarissime quatuor, laminae perigynae apici inserta, nonnunquam specie epigyna, laciniis calycinis alterna, unguiculata, ungue lato, basi incrassato, v. callis duobus longitudinalibus interdum cristatis intus notato, libera v. rarissime mediantibus staminibus basi in tubum cohaerentia, per aestivationem imbricata, decidua v. rarius marcescenti-persistentia.

Stamixa 5 v, rarissime 4, cum petalis inserta, iisdem alterna et breviora, raro longiora. Fi lamenta filiformia v. subulata, li- 
bera v. interdum petalorum unguibus basi adglutinata. Antherae introrsae, biloculares, erectae v. incumbentes; loculi oppositi, paralleli, adnati v. basi discreti et saepius divergentes, rima longitudinali dehiscentes.

Orarium tubo calycino adnatum, semiinferum v, inferum, rarissime a calyce liberum, lamina perigyna adnata vestitum, e carpidiis duobus, v. abortu unico, rarius tribus v. quinque, septis tunc evanidis constans, uni-bitriloculare. $0 \mathrm{vula}$ in ovarii bi-trilocularis loculis solitaria v. gemina collateralia, angulo centrali v. dissepimenti apici aut paullo infra apicem appensa, in ovario alterius carpidii abortu uniloculari ex apice placentae parietalis solitaria, in Thamnea e columnae centralis vertice dilatato unica serie dena, pendula, anatropa, funiculi interdum crassi apici excavato semiimmersa. Styli 2 v. 3, terminales, distincti v. basi aut juxta totam longitudinem connati. Stigm a t a minima, papillosa.

Fructus semiinferus v. inferus aut rarissime liber, calyce v, interdum etiam corolla staminibusque persistentibus coronatus, siccus, nucamentaceus, indehiscens, v. capsularis, saepius dicoccus, coccis plerumque ovuli alterius abortu monospermis, rarius dispermis, demum secedentibus, et interne longitudinaliter apertis.

Semra inversa, oblongo - cylindrica v. ovato-compressa; testa crustacea, laevi vi reticulata, umbilico nudo v. cupula carnosa involuto. Alb u men eopiosum, carnosum, album.

EмrR хо in apice albuminis prope umbilicum minimus, orthotropus. Cotyled ones breves, ovatae, crassae. Ra dicula conica, umbilíeum attingens, supera.

Ordo Hamamelideis et Corneis ut videtur proxime affinis, ab his imprimis habitu, corollae aestivatione imbricata et fructu sicco, ab illis insuper stipularum defectu et antherarum structura aliena facile dignoseendus. Rhamneae staminibus petalis oppositis Iongius recedunt. Penaeaceae praeter alias notas vel petalorum defectu et ovulorum situ abunde differunt.

4596. Ferzelia BRONGN. Caly $x$ tubo eum ovario connato, postice plano, antice convexo, limbi quinque- v. rarins quadripartiti laeiniis acutis, saepins apice callosis, duabus posticis paulle brevioribus. Coro 11 a e petala 5 virarins 4 , laminae perigynae inserta, oblonga v. spathulata, ungne vix carnoso. Sta $\mathrm{m}$ in a $5 \mathrm{v} .4$, cum petalis inserta isque alterna et longiora; a ntherae biloculares, loculis parallelis, basi diseretis. Ova ri u m semiinferum, obliquam, uniloculare, ovulo unico, placentae parietali posticae appenso, anatropo. Stylus simplex, suleatus; stigma parvum, subconicum. Nucula e, ovariis plerisque abortivis, placenta spongiosa repletis, pancae, coriaceae, obliquae, monospermae. S e men inversum, ovato-compressum, testa crustacea, laevi. Embryo in apice albuminis carnosi minimns, bilobns, radicn la umbilieum attingente, supera. - Frutices capense 8 ; folitis brevibus, subtrigonis, glabris v. vix pilosis, apice ustulato - callosis, imbricatis $v$. patulis, floribus capitatis, capitulis nudis, terminalibus, solitariis $v$. congestis, floribus tribracteatis, bractea antica clavata, callosa.

Berzeli a Bronguiart Annal. sc, nat. NIIT. 370. 2.35. f. 1. Meisuer Gen, 72. (52.) B run ia e s p. Linn. Wendl. Collect. t. 11. 45 .

459\%. Brumia BRONGN, C a l y $x$ tubo inferne cum ovario connato, superne libero, Jimbi quinquepartiti laciniis subspathnlatis, aequalibus, apice.haud callosis. Co ro Il a e petala 5, laminae perigynae inserta, ovata v. spathulata, ungue glanduloso, saepius bieristato, lamina patente. t a min a 5 , eum petalis inserta, iisdem alterna, longiora $v$. breviora, an therae biloculares, ovatae, loculis parallelis. Ovarium semiinferum, bitoculare; ovulis collateralibus, pendulis, anatropis. Styli 2 , distincti, apice divergentes; stigmata obtusa. Nuculae, ovariis plerisque placenta spongiosa repletis efoetis, paucae, eoriaceae, abortn uniloculares, monospermae. Se m en inversum, ovato - compressum, testa erustacea, laevi. $\mathbf{E m b r y o}$ in apice albuminis carnosi minimus, bilobus; radicul a umbilicum attingente, supera. - Suffrutices capenses, ramosi; ramis subverticillatis, folits nunc parvis, arcte imbricatis floribusque capitatis, nunc folits majoribus, abietinis v. myrtoideis floribusque paniculatis, calycibus uni-v. tribracteatis.

B r u n 1 a Brongniart in Annal. so, nat. VIII. 372. Meisner Gen, 72. (52,)

a. BRUNIA Linn. Calyx pilosus, laciniis spathulatis. Pet a I a subspathulata. Sta $\mathrm{m}$ in a exserta, finaequilonga. Ova rium biloculare, loculis biovalatis. Fructus calyce, petalis staminibasque coronatus.

B runia Linn. gen. edit, 1, 1737. Breyn. Cent, 22. t. 10. Gärtner I. 159. $t$. 30. Weadland Collect, $t$. 35. Nebeli a Necker Elem. $n, 197$. (Bronga, $l . c$, t. 36 . f. 1.)

b. BECKEA Burm. Cal y $x$ lacinlis glabris, scariosis. Petala ovata. Stamina inclusa. 0 vari um biloculare, loculis nui-biovalatis, loculo altero saepissime minore, paeuo. Fruetus, petalis staminíbusque caducis, calyce coronatus.

B e c kea Burmann Prodr. 12. B r uni a e s p. Thunb. Willdenow. P y y li cae sp. Limn. Thanb. (Bronga. Op. cit. .. 35. $f$. ,, )

45영. Raspailla BRONGN, Cal y $x$ tubo campanulato, libero, limbi quinquefidi laciniis acutis, apice callosis. Cor olla e petala 5, laminae perigynae ovario adnatae inserta, obovatooblonga, obtusa, erecta, basi vix carnosa. Sta min a 5, cum petalis inserta, isdemalterna etbreviora, antherae biloculares, ovatae, loculis parallelis. Ovarin m liberum, lamina perigyna adnata ad medinm einctum, biloculare, loeulis uniovulatis; ovulo ex apice dissepimenti pendalo, anatropo. Styli 2, basi approximati, apice divergentes. Fruetns... - Suffrutex ca pen sis; ramis virgatis, fastigiatis, ramulis alternis, oppositis v. subverticillatis, brevibus, folitis parvis, rhomboideis, carinatis, adpressis, spiraliter insertis, glaberrimis, floribus capitatis, capitulis ad apicem ramulorum solitariis, geminatis $v$. ternis, haud involucratis, tomentosis, floribus bibracteatis, parvis, albis.

Ra s pailia Brongniart in Annat. sc, nat VIIT. $3 m$. c. 32. f. 1. Meisner Gen. 72. (58.) B r unia mifor op hylla Thuab. 
4589. Staavia THUNB, C a $1 y \times$ tubo inferne cum ovario connato, superne libero, limbi quinquepartiti laciniis setaceis, apice callosis. $\mathbf{C}_{0}$ foll a e petala 5, laminae perigynae inserta, lanceolata, basi carnosa, incrassata. Stamina 5, cum petalis inserta, iisdem alterna et breviora, a $\mathrm{t}$ h er a e biloculares, ovatae, loculis parallelis. O v a ri u memiinferum, biloculare, loculis uniovulatis, ovulo ex apice dissepimenti pendulo, funiculo cupulaeformi semiimmerso, anatropo. Styli in colnmnam bisulcam connexi; sti gma capitatobilobum. Capsula semiinfera, calyce coronata, vertice libero, conico, bicorni, dicocca, coccis apice bivalvibus, intus juxta totam longitudinem dehiscentibus, monospermis. Sem in a inversa, oblongo-cylindrica, umbilico cupula carnosula cincto. Em b ry o in apice albuminis carnosi minimus, cordiformis; radicula umbilicum attingente, supera. - Suffrutices capenses; foliis linearibus, patentibus, apice callosis, floribus aggregatis, capitulis terminalibus, discoideis, bracteis folitis longioribus, nitentibus, albidis, v. foliis brevioribus, conformibus involucratis.

St a a ria Thunberg Prodr. 41. Wendland Colleot.t.22. Brongulart in Annal. sc. nat, VIIT, 378, $t, 36 . f$. 2. Loddiges Bot. Cab. t. 852. Meisner Gen.72. (52.) L ev i s a u us Sehreber Gen. n. 327. A s troeo ma Necker Elem, n. 196. B r un iae s p. Linn.

4600. Beqardia BRONGN. C a ly $\mathrm{x}$ tubo inferne cum ovario connato, superne libero, limbi quinquepartiti. laciniis angustis, apice callosis. Coroliae petala 5 , laminae perigynae inserta, oblonga v, oblongo-linearia, nnguibus bicarinatis, in tubum cohaerentibus, laminis ereetis. S $\mathbf{t a} \mathrm{mi}$ na 5 , cum petalis inserta, ísdem alterna et basi adhaerentia, exserta, antherae ovatae, biloculares, loculis parallelis, basi discretis. Ovarium semiinfernm, biloculare, loculis uniovulatis, ovu10 medio dissepimento appenso, anatropo. Styli 2 , basi approximati, apice divergentes; stig ma ta simplicia. Cápsula semiinfera, dicocca, coccis interne planis, rima angusta dehiscentibus, monospermis, S e mi na inversa, oblongo-cylindriea, umbilico nudo. Em b ryo in apice albuminis carnosi minimus, bilobus; radicula umbilico proxima, supera. - Suffrutices capenses; ramis gracilibus, erectis, fastigiatis, foliis subulatis, acutis, adpressis, caulem undique tegentibus, floribus capitatis, bracteis foliis longioribus involucratis, floribus tribracteatis, bracteis lateralibus florem aequantibus, antica duplo longiore.

Berardia Brongniart in Annal, so. nat, VIIT. 380. z. 37. f. 2. Meisner Gen, 72. (52.) N e belli a Sweet Hort Brit. 116. Nebeliae sp. Neeker Elem, $n$, 169. B runia pal e a ce a Thunb. Wendland Collect. $t, 21$.

4601. Iinconia LINN. Cal y $x$ tubo cum ovario connato, limbi quinquefidi lacinis brevibus, membranaceis, glabris. C o rolla e petala 5 , laminae perigynae inserta, lanceolata, sessilia, carinato - convoluta, coriacea. St a m in a $5, \mathrm{cnm}$ petalis inserta, iisdem alterna et paullo breviora, antherae biloculares, connectivo apice incras. sato, conico, loenlis basi divergentibus. O va ri u m semiinferum, bilocnlare, loculis biovulatis, ova. lis collateralibus, medio dissepimento appensis, fnniculo cupulaeformi semiimmersis, anatropis. Styli 2 , divergentes; st ig mata obtusa. Caps ul a semiinfera, ealyce coronata, vertice libero, conico, bicorni-dicocea, coceis intus rima dehiscentibus, dispermis v. abortu monospermis. S emin a oblongo - ovoidea, umbilico cupula carnosa cincto. Embryo in apice albuminis carnosi minimus, bilobus; radicula umbilico proxima, supera. - Suffrutices capenses, ericoidei, ramosissimi, ramis erectis, fastigiatis, foliis undique spiraliter insertis, patentibus $v$, laxe imbricatis, brevissime petiolatis, coriaceis, glabris $v$, margine subciliatis, nervo simplici prominente, apice ustulatis, floribus in axillis foliorum superiorum solitariis, sessilibus, in spicam congestis, bracteis quatuor $v$. quinque calycem superantibus involucratis.

L i n e o n i a Linn. Mant. 148. Swartz in Berlin. Magaz. IV. 85. et 284, t. 4. et t, 7. f. 1. Bronguiart in Annal. sc. nat, VIIT, 38\%, t. 37. f. 3. Meisner. Gen, 72. (32.)

4602. Andouinia BRONGN. Calyx tabo brevi, obconico, cum ovario connato, limbi quinquepartiti laciniis maximis, ovate-oblongis, scariesis, nervosis, eoncavis, margine pilosis, imbricatis. Corolla e petala 5 , laminae perigy. nae inserta, longe unguieulata, ungue biearinato, lamina obovata, patente. St a min a 5 , cum petalis inserta, iisdem alterna et breviora; an thera e oblongo-lineares, loenlis parallelis, adnatis. Ovarinm semiinferum, obconicum, vertice exserto, subtrilobo, triloculare, loculis biovulatis, ovulis collateralibus, ex apice anguli centralis pendulis, anatropis. Stylns simplex, trigonus; stigmata 3 , minima, papillaeformia. Fractus .....-Suffrutex ca pensis; ramis ereetis, foliis spiraliter insertis, imbricatis, subcarinatis, floribus in capitulum terminale oblongum, spieaeforme congestis, purpureis.

A u do ui a I a Brongniart in Annat. sc. nat. VIIT. 386. t. 38. $f$. 1. Meisuer Gen. 72. (52.) P a vin da Thunb. msc. Diosma capitata Thuaberg Prodr. 43.

4803. Tittmamia BRONGN. C a I y $x$ tubo sphaerico, ventricoso, cum ovario connato, superne coarctato, limbi quinquepartiti laciniis oblongis, lanceolatis, erectis, subscariosis, apice nstulatis. Co rolla e petala 5 , laminae perigynae inserta, coriacea, unguiculata, ungue bicarinato, lamina obovata, patente. St a m in a 5, cum petalis inserta, iisdem alterna et breviora; a n $t$ h er $r$ a oyatae, biloculares, loculis parallelis, adnatis. O varin m inferum, dissepimento membranaceo, marginibns libero, biloculare, loculis biovulatis; ovuli s collateralibus, ex apice dissepimenti pendalis, anatropis. Stylus simplex; stigma bidentatum. Fr n ctu\&..... - Suffrutex c a pen$s$ is, ramosus; ramulis fastigiatis, subumbellatis, folits linearibus, subcylindricis, incurvis, rugosoasperis, erectis, imbricatis, apice callosis, floribus axillaribus, versus apicem ramulorum approximatis, inflexo subsecundis, squamulis brevibus, scariosis calyculatis.

Tit tma n ni a Brongniart in Annal. se. nat. Vitr. 386. t. 38. f. 2. M 6 s s I e ra Reichenb. Consp. 160, Meisner Gen. 72. (52.)

4804. Thammea SOLAND. C a ly $\mathrm{x}$ tubo brevi, basi cnm ovario eonnato, superne libero, limbi quinquepartiti laciniis lanceolatis, glabris, scariosis, imbrieatis, tubo duplo longioribns. C oroll a e petala 5, infra discum epigynum inserta, unguieulata, ungue Iato, bicarinato, limbo ovato, patente. S t a min a 5 , cum petalis inserta, iisdem alterna et breviora; a $\mathbf{n}$ h e $\mathrm{r}$ a e oblongo-lineares, biloculares, loculis parallelis, adnatis. O v a $r$ i u m inferum, disco epigyno plano coronatum, nniloculare, ovulis subdenis, e colnmnae centralis filiformis apice dilatato unica serie collateraliter pendulis, anatropis. Sty I us simplex, cylindricus; stig ma 
integrum. Fruetus....- Suffrutex capensis; ramis fliformibus, foliis minimis, subrhomboideis, Brevibus, abtusis, carinatis, adpressis, superioribus paulla longioribus, florem subinvolucrantibus, floribus terminalibus, solitariis, albis.

T ha m ne a Solander ex Brongniart in Annal. sc, nat. VJII. 386, t. 38, f. 3. Meisner Gen, 72, (52.)

\section{GENERA DUBIA:}

4605. Heterodon MEISN. Cal y x tabo turbinato, cum ovario connato (?) limbi decemfidi dentibus quinque brevibus, obtusis, quinque alternis elongatis, complanatis, dilatato-truncatis. $\mathbf{P e}$ ta la 5 , perigyna, oblongo - spathulata, distincta. S t am in a 5, cum petalis inserta, iisdem alterna, exserta ; fil amenta filiformia, a n therae uniloculares (?) eucullatae, 0 va rium inferam..... Styli 2 , basi connati, apice divergentes; stigmata obtasa. Fructus ....-Frutex capensis, Berzeliae v. Bruniae facie.

Heterod on Meisner Gen. 72. (52.) B runia superba Don. Reichenb. Hort, bot, t. 100.

4606. Gravenhorstia NEES. CaI y $\mathrm{x}$ ovario semiadhaerens. Petala basi in tubum cohaerentia, corollam infundibuliformem exhibentia. Antherae in fance tubi subessiles, locnlis basi divergentibus. Stylns simplex. Fruetus dicoceus. - Stirps capensis, a Berardia imprimis antheris subsessilibus et stylo singulo, cum fructu basi dehiscente, apice semper continuo, diversa.

Graveahorstia Nees in Lindley Introduct. edit. 2. p. 439. Meisner Gen. 72. (52,)

OBSERVATIO. Erasma genus inter Bruniaceas a cl. R. Brown in Abel Narrat. Journ. Chin, 374, nominatum, verisimiliter uni generum a el. Bronguiart constitutorum erit subscribeadam.

\section{Classis XII. Conmiculatae.}

Herbae, frutices v. Arbores. Folia alterna v. opposita, simplicia v. composita, exstipulata v. rarius stipulata. Ca 1 y $\mathbf{x}$ gamophylJus, liber v. cum ovario plus minus connatus. Coroll a perigyna, petalis distinctis, rarius gamopetala, interdum nulla. Stamina cum petalis inserta, iisdem numero dupla vo rarius aequalia. Ov a ri a plura, verticillata, libera v. plus minus inter se connata, pluriovulata rarinsve uniovulata. F r u c t us loculi pleiospermi aut interdum monospermi. S e m in a albuminosa. Embry o orthotropus.

\section{Ordo CLXIX. Crassulaceat.}

SEMPERVIVAE Jussien Gen, 207, SUCCULENTAE Ventea. Tabl. IIr, 271. CRASSULAE Jussieu in Dict. sc, nat. XI. 369. CRASSULACEAE DC, in Bullet roc, philomat. 1801. n. 49. Prodr. III. 381. Mem. II. 1828, Bartiling Ord. nat. 309. Lindley Introduct. edit. IL. p. 163. Meisner Gen. 134. (98.) Kunth Flor. Berolin, I. 148.

Herbae v, suffrutices, caule ramisque teretibus, plus minus suceulentis. Folia sparsa v. interdum opposita, carnosa, simplieia, in- tegra, rarissime ternata vo impari-pinnata. Stip u la e nullae.

FloRes hermaphroditi $v_{0}$ interdum abortu unisexuales, regulares, in cymas v. racemos secundos aut in cymam dispositos collecti, rarius spicati, quandoque axillares, solitarii.

CALYX liber, saepissime quinquefidus v. quinquepartitus, rarius tri-vigintipartitus, lobis per aestivationem imbricatis, persistens.

Coroldae petala imo calyci inserta, ejusdem lobis numero aequalia et alterna, exunguiculata, libera v. in tubum plus minus longum connata, aestivatione imbricata.

Stamina cum petalis inserta $v$. iisdem in corollam gamopetalam coalitis adnata, nune simpliei eorundem numero et alterna, nune dupla, alterna et opposita. Fil a m en ta inter se distineta, subulato- v. lineari-filiformia. Anthe ra e introrsae, biloculares, basifixae, loculis appositis, longitudinaliter dehiscentibus.

Sqquamular hypogynae ad basim cujusvis ovarii solitariae, planae.

Ovaria tot quot petala, iisdem opposita, verticillata, nunc (in Crassuleis) omnino distincta, nune (in Diamorpheis) ad axim basi v. juxta totam longitudinem coalita, unilocularia. Ovula in placenta suturae ventrali adnata biseriatim plurima, rarius subdefinita, horizontalia $v$. pendula, anatropa. Styli ovariorum dorso continui, liberi, simplices, breves, persistentes. Stigma subterminale, introrsum laterale.

Capsulae folliculares, liberae, sutura ventrali introrsum dehiscentes, rarius in capsulam plurilocularem coalitae, loculis dorso fissis, v. pariete dorsali a marginibus in dissepimenta coalitis et persistentibus soluta apertis.

Semina plurima v, rarissime pauca, minutissima, scobiformia, testa membranacea. A ]b umen tenuissimum, carnosum, quandoque fere obsoletum.

- Ensryo in axi albuminis orthotropus, cylindraceus; cotyledonibus brevissimis, radicula umbilicum contigente.

Crassulaceae florum typo exacte symmetrico insignes, et Saxifragaceis, imminuto ovariorum numero aberrantibus, naturali affinitate proximae, in temperatis calidioribus veteris orbis maximo numero gignuntur, ita ut specierum hactenus cognitarum dimidia pars in Capite bonae spei, una pars sexta in Europa et regione mediterranea, altera in Oriente, Asia media et insulis Canariis habitet, tertia per Americam borealem et tropicam, Asiam calidiorem et Noyan-Hollandiam sit dispersa.

Francoace a e aucto staminum numero et ovariorum symphysi recedunt. 
SUE OAED D. CRASSULEAE DC. Proulr. III. 381. C aps ulae liberae, angulo interiore dehiscentes.

TRIBUS T. CRASSULEAE ISOSTEMONES. S tamin a petalis numero aequalia.

SECTIO I. EUCRASSULEAE, P e $t$ a la omnino libera.

460\%. THLaea MITCH. Caly $x$ tri-quadripartitus. C orolla e petala $3-4$, perigyna, $\mathrm{S}$ t amina $3-4$, perigyna. Squamula hypogynae variae, interdum subnullae. Ovaria $3-4$ libera, unilocularia, ovulis ad suturam ventralem geminis v. pluribus. Caps a I a e folliculares $3-4$ liberae, intns longitudinaliter dehiscentes, di-polyspermae. - Herbae cosmopolitae, aquaticae v. subaquaticae; foliis oppositis, floribus axillaribus parvis, albis.

Till a e a Mieheli Nov, gen, $28, t, 20$. Lina, gen, $n, 177$. Melsner Gen. 134. (89.)

a. TILLAEA DC. Flores tri-tetrameri. P e $t$ al a oblonga, acuminata. $\mathrm{S}$ q a a ula e hypogynae minimae- $v$. nullae. C a p s la e medio subconstrictae, dispermae.

Tilla a DC. in Bullet, soc. philomat, 1801. p. 2. Mem. II. 13. Prodr. III, 381. (E. B. t. 116, DC. Plant. gr. t. 73. Reichenb, Iconogr. t, 191.)

b. BULliarda DC. Flores tetrameri. Petala ovalia v. oblonga, acuta. Squamulae hypogynae lineares. Capsulae polyspermae.

Bulli a r a DC. in Bultet, soc, philomat, 1801,p. 1. Mem. II. 13. Prodr. III. 382. (Schkwhr in Usteri Annat. IT, $t$, 3. Flor. dan, $t, 1510$,

c. HQLOPHYTUM Ecklon et Zeyh. Flores tetrameri. Petala oboyato ssuborbiculata. Squa mula hypo. gyuac cuneatae, truneatae, atropurpureae, ovaria aequan: tes v. subnullae. C a p 8 ula e tetraspermae. - Horbae capenses, floribus axillaribus, solitariis v. cy. mosis.

Hel o phytum Ecklon et Zeyher Enumerat, plant. cap. 288. Crassula natans Thuab. Cr. inermis Thunb.

4BDS. Dasystemon $D C$. C C I y x tri heptaphyllus, foliolis inaequalibus folifformibtis, corolla longioribus. Corolla e petala $3-7$, saepins 5, perigyna, apice revoluto-patula, basi sub. eoalita. St a min a $3-7$, perigyna, flamenta crassa, petalis breviora. Squamulae hypogynae nullae. O v aria $3-5$ libera, uniloeularia. ..... - Herba Novae-Hollandiae, tota papillis squamulosis obsita; radice fibrosa, caule apice ramoso, subdichotomo, foliis oppositis, basi connatis, linearibus, acutis, crassis, planiusculis, subtus sub. convexis, floribus albo-virescentibus.

D as y st e mo n DC. Prodr. IV. 388. Mem. IT. 15. t. 3. Meisner Gen. 134. (98.)

4609. Seztas LINN. Cal y x quinque-novempartitus, corolla brevior. Co rollae petala $5-9$, perigyna, stellatim patentia. St a mina 5-9, perigyna, filamentis tenuibus, acuminatis, Squamulae hypogynae minimae, subrotundae. Ovaria $5-9$, libera, unilocnlaria, ovulis ad suturam ventralem plarimis. Ca p s a lae follicnlares $5-9$, liberae, intns longitudirialiter dehiscentes, polyspermae. - Herbae capenses, tuberibus radicalibus subrotundis perennantes; caule annuo, tereti, simplici, foliorum oppositorum pari unico $v$. duobus petiolatis, saepe verlicillato-approximatis, floribus terminalibus, subumbellatis, albis.

Septas Linn. gen. n. 465. Lam. t. 276. Bot. Mag. t. 1472, Haworih Synops, 61. DC. Prodr, III, 383, excl. sp. Mem, II, 16. Meisuer Gen, 134. (98.)
4610. Crassula $H A W$. Ca ly $\mathrm{x}$ quinquepartitus, corolla brevior. Cor olla e petala 5, perigyna, conniventia v. stellatim patentia. S $\mathrm{tami}$ n a 5, perigyna, filamentis subulatis. S q $\mathbf{u}$ a $\mathbf{m u l}$ a e hypogynae breves. O vari a 5, libera, unilocularía, ovulis ad suturam ventralem pancis v. plarimís. C a ps 1 a e folliculares 5 , intus longitudinaliter dehiscentes, oligo-polyspermae. - Herbae v. frutices, in regionibus mediterraneis parce, copiosissime in Capite bon a e spei provenientes; folits oppositis, integerrimis $v$. subcrenatis, floribus albis $v$, rarius roseis.

Cras s i la Haworth Synops. 51. DC. Prodr, IIT, 383. Mem, 16. Meisaer Gen, 134. (98.) Crassula et Turgos ea Haworth Revis. 8. 9. 14. Crassula, Turgosea, Sarcolípes, Petrogeton et Tetraphy le Ecklon et Zeyher Enumerat. Plant. cap. 290_298. Gom a r a Adanson II. 298.

a. SARCOLIPRS Eekl. et Zeyh, l. e. C a l y el s laciniac planae, mucronatac, corollam subaequantes. Petala patentia. Squamula e lineares. Capsulae subconniyentes, polyspermae. - Herba annua, puboscens; folits oppositis, suboomatis, pedunculis capillaribus unifloris, in dichotomiis solilaritr.

b. PETROgeTON Eckl. et Zejh. $l$. c. C a l y cis Iacinlae planae, corolla breviores. Petal a patentia. $\mathrm{S} q \mathrm{u}$ a mulae parvae, sabspathulato-truacatae. Ca psulae apice divergentes, sex-octospermae. - Herbae c apenses, perennes; folitis oppositis, petiolatis, plerumque late crenatis, floribus arillaribus subumbellatis, v. in dichotomits solitariis. - C rassula Umbella Jacq. Ic. rar, t. 358.

c. TETRAPHYLE Eekl. et Zeyh. , c. C a I y e is laciniae nervo medio incrassato, eorolla dimidio breviores. P etala conniventia. Squamulae minutissimae, apice snbulato-truncatae. C a p s i a e couniventes, polyspermae. - Frutices $p$. herbae, folits carnosis v. subearnosis, quadrifariam imbricatis $p$. interdum subverticillatis, floribus axillaribus iubsolitariis v. terminalibus capitatis.

d. CRASSULA Eckl, et Zeyh. l. c. Caly e is laciniaeplanae, corolla breviores. Petal a patentia. Squa mulae ovatae. Ca ps ula subconniventes, polyspermae. Frutescentes v. fruticosae. - (Jaeq. Hort, Schönbr. z. 430 -432. 471 . Bot. Mag. t. 384. 1765. 177 T. Bot. Reg. t. 1344. DC. Plant. gr. t. 2. 19. 25. 37. 49. 181. Mem. IT. $t .1, f, 2$,

e. PYRGOSEA Sweet. C a Iy cis Iaciniae planae, corolla breviores. Petala patentia, Infra apicem mneronata. Squamula e ovatae, emarginatae. Capsula e subcouniventes, polysperase. - Herbae folits plerisque radicalibus, inflorescentia spicato. thyrsoldea. Pyrgosea Sweet Hort. brit. 283. Turgose a Haworth Heots. 14. (Jacq. Hort. Sohönbr. t. 58, DC. Plant. grt, t, 7. Liak et Otto Ic. select, t. 16. 17.)

4611. Chlohulea $H A W$. Caly $x$ quinquepartitus, corolla brevior. Corolla e petala 5 , perigyna, conniventia, globulo cerino terminata. S $t$ a m in a 5 , perigyna, filamentis subulatie. S quam ula e hypogynae breves, latae, obtusae. Ovaria 5 , libera, nnilocularia, ovulis ad suturam ventralem plurimis. Capsulae folliculares 5 , intus longitudinaliter dehiscentes, polyspermae. Herbae capenses; foliis planis, v. semiteretibus, cultratis, radicalibus saepe spiraliter congestis, caulinis paucis, ftoribus dense corymbosis, subcapitatis, ex albo ochroleucis, parvis.

Glo b u 1 e a Haworth Synops. 60. Revis. 17. Philosoph. Magaz. 1824. Sept. 189. DC. Prodr, III. 390. Mem, IT. 19. Meisuer Gen. 134. (98.) Cras a la e s p. Lina. et Auct. DC. Plant, gr, $2,61,133$. Bot. Mag, t, 1940.

SECTIC n. ROCHEAE. Petala plus minus inter se connata. Ovaria petalis numero aequalia v. pauciora. 
461\%. Thisamtha ECKL. et ZEYH, CaIy e is quinquefidi laciniae erectae. Co roll a perigyna, quinquepartita, laciniis oblongo-lanceolatis, erectis, calyce brevioribus. Stamina 5 , imae corollae inserta, ejusdem laciniis alterna et breviora, Squamulae hypogynae nullae. Ovaria 5 , libera, unilocularia, ovulis ad suturam ventralem geminis. C a p sula e folliculares 5, intus longitudinaliter dehiscentes, mono-dispermae. - Herbae capenses, annuae, subdichotomae; foliis oppositis, floribus parvis, infimis in dichotomiis solitariis, reliquis glomeratis.

This a n tha Eeklon et Zeyher Enumerat. plant. cap. 302. Meisner Gen. 134. (98.) Cras sula s p. Linn. DC.

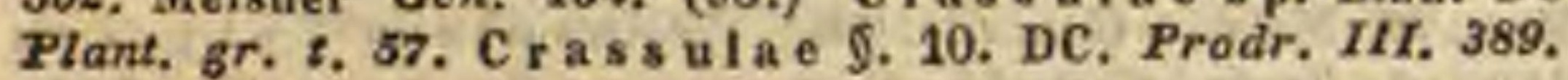

4613 . Grammanthes $D C . \mathrm{Cal}$ y $\mathrm{x}$ campanulatus, quinquefidus, erectus. Cor o 1 la perigyna, tubulosa, tubo calycem aequante, limbi quinque-sexpartiti lobis ovalibus, expansis. Stam in a 5-6, corollae tubo inserta, inclusa, ejusdem lobis alterna. Squamulae hypogynae nnllae. Ovaria 5, libera, unilocularia, ovulis ad suturam ventralem plurimis. Ca p sulae folliculares 5 , liberae, intus longitudinaliter dehiscentes, polyspermae. - Herbae capenses, annuae, oppositifoliae; foliis remotis, sessilibus, planis, ovato-oblongis, floribus cymoso-corymbosis.

Gra min an the s DC. Prodr. III. 392. Mem, II. t. 1. f. 6. Meisner Gen, 134. (98.) V a u a the $^{2}$ Haworth $R e$. vis. 18. Crassula dichotoma L. C. gentianoides Lam.

4614. Cyrtogyne $H A W$. Caly x quinquepartitus, brevissimus. Co ro 11 a perigyna, quinquepartita, tubo brevi, lobis calyce multo longioribus, patentibus. St a m in a 5 , imae corollae inserta, ejusdem laciniis alterna. S qua mula e hypogynae breves. Ovaria 5 , libera, unilocularia, tereti-oblonga, apice gibbosa, in stylos longos sublaterales desinentia, ovulis ad suturam ventralem plurimis. Cap 8 ula e .... - Suffrutices capenses; foliis oppositis, planis, subcarnosis, cartilagineo-ciliatis, ovatis, inflorescentia umbellato-cymosa, floribus albis.

C y r to gy ne Haworth Revis. 8. DC. Prodr. MIT. 392. Mem, II. 19. $t, 1, f$. 6 . Meisner Gen. 134. (98.) C $r$ a s s u1 a deject a Jacq. Hort. Schönbr. 2 . 433, C. albiflor a Bot. Mag. t. 2391.

4615. Hoelnea $D C$. Ca 1 yx quinquepartitus, brevissimus. Corolla perigyna, subhypocraterimorpha, tubo e petalorum unguibus haud penitus coalitis, limbo quinquepartito, patente. St amina 5 , corollae tubo inserta, exserta v. inclusa. Glandula e hypogynae 5. Ovaria 5 , libera, unilocularia, ovulis ad suturam ventralem plurimis. Capsula folliculares 5 , liberae, intus longitudinaliter dehiscentes, polyspermae. - Suffrutices ca penses, carnosi; foliis oppositis, subconnatis, integerrimis, margine interdum cartilagineo ciliatis, floribus umbellato-cymosis, rubris, flavis aut rarius albis.

Ro che n DC. Plant. gr, n. 103. Prodr. nT. 393, Mem. II. 21. t. 1. f. 3. Meisner Gen. 134. (98) $\mathrm{L}$ a r o c he a Per. soon Encheir. I, 337. Romer et Selunites Syst, VI, 707. Haworth Synops. 5o. Crassula Adanson Fam. II. 248.

a. DANIELLA DC. Prodr. IIT. 393. Corolla tubus limbi longltudiue v. brevior, calycem vix superans. Sta. m in a breviter exserta. - Folia basi connata, crassa, albida, oorymbi cymosi, bracteis subnullis.

La rochea Haworth Revis. 8 . Trattin. Thesaur. t. 20. Crassulae sp. Linu. Bot. Mag. $t$. 2035. 2391 . Andrews Bot. Reposit. $t$, 414. DC, Plant, gr, $t, 13$. (DC. Op. cit. t, 103.)

b, FRANCISCARIA DC. Prodr. IIT. 486. C or oll a e tubus cylindraceus, limbo duplo v. triplo longior, ealycem multo superans. A n the rae intra corollae fancem. - Fotia ovalia v. oblonga, connata, plana, cartilagineociliata. Flores ogmoso-umbellati v. capitati, numerosi, bracteati.

Dietrí hia Trattin. Tabular, $t$, 449. Thesaur, $t, 19$. Kalosanthes Haworth Revis. 6. Franciscaea DC. Prodr. IIT. 393. Cras sula a sp. Lian. Jacq. Hort, Schönbr. t, 434. Andr. Bot. Reposit, t. 20. Bot. Reg. t. 320. Bot. Mag. t. 495. 2178. DC. Plant. gr.t.1.

TIF IIS IL. CRASSULEAE DIPLOSTEMONES. Stamina duplo petalorum numero.

SEC'TIC I. UMBULICEAE. Co rolla gamopetala.

4616. Thalamelho ¿ $A D A N S, C$ aly $\mathbf{x}$ quadripartitus, laciniis angustis, acutis, subdistantibus. Corolla perigyna, hypocraterimorpha, tubo cylindraceo, limbo quadripartito, patente. St a min a 8, imo corollae tubo inserta, inclusa. Squamulae hypogynae lineares. Ovaria 4 , libera, nuilocularia, ovulis ad suturam ventralem plurimis. C a ps u la e folliculares 4, liberae, intus longitudinaliter dehiscentes, polyspermae. - Suffrutices carnosi, in Africa boreali-orientali et capensi, in Asia tropica et Brasilia indigeni; foliis oppositis, irregulariter impari-pinnatisectis $v$. ovatis, dentatis, crassis, floribus cymosopaniculatis, laxis, flavis v. rarius rubescentibus aut albidis.

K a Ia n ch o है Adanson Fam. II. 248. DC, Plant. gr. t. 64. 65. 100. Prodr. III. 394. Mem. II, 29. Wallich Plant. As, rar, $t, 166,167$. Meisner Gen, 135. (98.) C a la n $\mathrm{cho}$ h Persoon Encheir. I. 445. K al e n e h o ë Haworth Synops. 109. Vereia Andrews Bot, Reposit, $t$. 2t. $\mathrm{V}$ erea Willdenow Spec, II. 471. Cotyled on is s p. Forsk. Vahl, Venten. Malm. t. 49. Bot. Mag, $t, 1436$.

461\%. Brypplayliam SALISB. Caly x inflato-vesiculosus, hreviter quadrifidus, lobis aestivatione valvatis. Cor olla perigyna, subhypocraterimorpha, tubo longo, cylindraceo, basi obtuse tetragono, limbi lobis quatuor ovato-triangularibus, acutis. St amina 8 , imo corollae tubo inserta, inclusa. Gl and u la e hypogynae oblongae. Ovaria 4, libera, unilocularia, ovulis ad suturam ventralem plurimis. Capsula e folliculares 4, liberae, intus longitudinaliter dehiscentes, polyspermae. - Suffrutices carnosi, in Asia et Af $r i$ c a tropica indigeni, erecti, ramosi, glabri; foliis oppositis, crassis, petiolatis, aliis imparipinnatis, segmentis uni-bijugis, interdum abortivis, lobo terminali maximo, quandoque solitario, omnibus crenatis, crenaturis saepissime gemmiferis, cymis terminalibus paniculatis, floribus e flavo-rubentibus.

B r y op hy 11 u m Salisbury Parad.t.3. Bot, Mag. L. 1409. DC. Prodr. IIT. 295. Mem, 33. Organogr. $t$. 22, f. 2. Wight in Hooker Bot. Miscell. Append, t, 31. Meisner Gen. 135. (98.) Crassouvia Commers. msc. Physocalycium Vest in Flora 1820. p. h09. Cotyle don pinnata Lam.

4618. Cotyledor $D C$. C a I y quinquepartitus, hrevissimus. Co roll a perigyna, tuho ovato-cylindraceo, limbi quinquelobi patentim reflexi y. revoluti lobis obtusis. Stamina 10 , imo corollae tubo inserta, exserta v. subinclusa. S quamula hypogynae ovales. Ovaria 5 , libera, unilocularia, ovulis ad suturam ventralem plurimis. Capsulae folliculares 5 , stylis subulatis acuminatae, liberae, intus longitudinaliter dehiscentes, polyspermae. - Frutices c a penses, carnosi; foliis saepius sparsis, floribus laxe paniculatis, purpurascentibus $v$. aurantiaceis, 
Cotyle do n DC. in Bullet. soc, phitomat. 1801. p. 1. Plant. gr. t. 76, 87, Prodr. III. 396. Mem. I1. 23, t. 1. f. ?. Meisner Gen, 135. (98.) Cotyledonis $s$ p. capenses Auet. Bot, Mag. t. 321. 2045. 2518. 2601. Bot. Reg, t, 91s.

4519. Fistorimia $D C$. Caly $x$ quinquepartitus, brevissimus. Co roll a perigyna, bypocraterimorpha, tubo elongato, tereti, limbo quinquepartito, patente. Sta m in a 10 , summo corollae tubo inserta, breviter exserta. Squamulae hypogynae oblongae, obtusae. Oy a r a 5 , libera, unilocularia, ovulis ad suturam ventralem plurimis. C a p u 1 a e folliculares 5 , in stylos Iongos, filiformes desinentes, liberae, intus longitudinaliter dehiscentes, polyspermae. - Herba $h i s p a-$ $n$ ic $a$, annua v. biennis, erecta; foliis sparsis, subteretibus, oblongis, sessilibus, floribus cymosis, rubellis.

Pistorinia DC. Prodr. IIT. 399. Mom. IT. 25. t. 1. f. 5. Meisner Gen. 135. (98.) Cotyledon hispaniea Löffling It, t. 1. DC, Plant, gr, t. 122. C. Pistorinia Ortega Monogr. 1772, c. ic.

4620. Unabiliens $D C$. Caly $\mathbf{x}$ quinquepartitus, corollae tubo brevior v. aequalis. Corolla perigyna, campanulata, quinquefida, lobis ovatis, acutis, erectis, tubo subaequilongis. S t a mina 10 , imae corollae inserta, exserta. Sq a a m alae hypogynae obtusae. Ovaria 5, libera, unilocularia, ovulis ad suturam ventralem plurimis. Ca $\mathbf{p}$ s u la e follienlares 5 , in stylos subulatos attenuatae, liberae, intus longitudinaliter dehiscentes, polyspermae. - Herbae annuae v. perennes, in Europa australi et Asia media indigenae; foliis rosulatis $v$. alternis, integerrimis aut subdentatis, floribus albidis aut flavis, racemosis $v$. rarissime cymosis.

$\mathrm{U} \mathrm{mbi}$ i i cus DC. in Bullet. soc. philomat. 1801, n. 49. Prodr. IIT. 399. Mem, IT. 25. Meisuer Gen. 135. (98.)

a. ORostachYS DC. l. c. Radiees fihrosae. Folin haud peltata, nec cucullata. Co roll a e quinquepartitae. Orostachys Fiseher Catalog. hort. gorenk. 1808. p. 99. Mem. soc. h, n. Mosq. II. 27i. Cras s ula e sp. Linn. Cot y 1 ed o n is s p. Linn. Pallas $I t, t, O, f .1$. Ledebour Ic. $t .57 .395$.

b. COTYLE DC. $t$. c. Radices tuberosae. Caules sae pe ramosi. Folifa radicalia petiolata, cucullata, plus minas peltata. Co roll a e vix ad medium quinquefidae. U m bilic u s Cam. epit, 858. C ot y le phyl I u m Link Handb. IT. 23. Cotyle don is s p. Lín. E. B. t. 325. Sibthorp Flor. graec. t. 445.

c. MUCIZONIA DC. $t$. c. Herbae annuae, sediformes, foliis alternis. Co rolla e tubus ealycem haud superans. - Cotyledon Muoizonia Ortega Monogr. 1272. c. ic. Jacq. Collect. $\nu, t, 13 . f$. . U $\mathrm{m}$ be li i u s Webb. et Berthel. Flor. canar, $t$. 26. (DC, Mems, $I I$, $t$. 4. f. 6.)

d. RoSULARIA DC, l, c. Herbae perennes, Sempervivi facie, folils radicalibus rosulatis, scapo subpaniculato, annuo. Co roll a e tubus calycem haud superans. - $\mathrm{Co}$. ty ledo als s p. Bieberst. Labillard. Syr. Dec. MII, $t, 1$.

4621. Felueveria $D C$, C a I y $x$ quinquepartitus, Iaciniis foliiformibus, erectis, Coroll a perigyna, quinquepartita, laciniis erectis, erassis, rigidulis, nervo medio incrassato, basi subtrigonis, acatis. Stamina 10, imae corollae inserta, inclusa. Squamae hypogynae breves, obtusae. Ov a ri a 5, libera, unilocularia, ovulis ad suturam ventralem plurimis. Ca p 8 u l a e folliculares 5 , in stylos subulatos attenuatae, liberae, intus longitudinaliter dehiscenteg, polyspermae. - Frutices mexicani, carnosi; foliis alternis caulinis v. rosulatis suboppositis, integerrimis, enerviis, floribus secus rhachin v. secus cymae ramos sessilibus, coccineis v. flavis.
Eetreveria DC. Prodr, III, 401. Mem. II, 28, t. 5. 6. f. a. Haworth in philosoph, Magaz. 1828, $\mathrm{W}, 261$. Bot. Reg. $t, 1247$. Bot. Mag. $t, 3570$. Reichenb. Ic, exot, $t$. 321 . Meisner Gen, 134. (98.) Cotyle donis sp. a merie a pae Auct. Cavanill. Ic. t. 170. S e d i s p. Jacq. f. Eolog. t. 17. libera.

SECTID II. SEDEAE. Petal a omnino

4682. Sedum LINN, C alyx pentaphylIus, foliolis ovatis, saepins turgidis. Corollae petala 5, perigyna, plerumque patentia. Sta mina 10, perigyna. Squamula e hypogynae integrae v. brevissime emarginatae. Ov a ria 5, libera, uniIocularia, ovulis ad suturam ventralem plurimis. Ca psula e folliculares 5, liberae, intus longitudinaliter dehiscentes, polyspermae. - Herbae $v$. suffrutices, in temperat is totius orbis, imprimis tamen Europae et Asiae mediae crescentes; foliis alternis rariusve oppositis, carnosis, teretibus $v$. planis, integerrimis aut rarius dentatis, floribus cymosis, albis, purpureis v. caeruleis aut flavis, interdum tetra-heptapetalis, octo-tetradecandris, squamulis hypogynis integris tunc a Sempervivis distinguendis.

S e du m Linn, gen, n. 616. Gärtner 1, 313, t, 65. E. B. t. 170. 394. 695. 2977. Flor. dan. t, 24. 59. 66. Waldst. et Kitaibel Plant, rar, Hung. $t, 104,181$. Tenore Flor, Neap. t. 40. Bot. Mag. t, 118, 211, 1607, 1927. 2224. 2370, 3474. DC. in Bullet, soc, philomat, 1801, n, 94. Plant. gr, t. 22. 33. 59, 70, 92, 93, 101, 110, 115-120, 143. Prodr. IIT. 401. Mem, IT. 29, t. 1. f. 1. t, 4. f, 1, t, 6. f. 2, t. 7-9, Ledebour Ic, $t$. 58 . 418. Liak et Otto Io. select. $t, 57$, Reicheab. Iconogr. t. 726. 727, 841_845. Royle, Himalay, t. 48. Meisner Gen. 134. (98.) Rhodiola Linn. gen. n, 1124. Lam. t, 819. A n acampseros Tournefort inst. 111. Haworth Synops. 264.

4B83. Sempervivam LINN. Calyx sex-vigintipartitus. Corolla e petala 6 - 20 , perigyna, oblonga, acuta. St a mina $12 \_40$, perigyna. Squamulae hypogynae apice dentatae $\mathbf{v}$. fimbriato-lacerae. Ov a ri a 6_20, libera, unilocularia, ovulis ad snturam ventralem plurimis. C a p sula e folliculares $6 \_20$, liberae, intus longitudinaliter dehiscentes, polyspermae. - Herbae nunc acaules, ex axillis propagines apice foliosas proferentes, nunc caulescentes, propaginibus destitutae, interdum suffrutices carnosuli, in Europ a media et a ustrali, copiosissime in insulis Can a riis crescentes; foliis saepissime revolutis, cymae ramis in corymbum v. paniculam dispositis, petalis flavis, albidis aut purpurascentibus.

Sem pervivnm Lina. gen. n. 612. Lam, $t$. 413. Gärtaer 1 . 341. $t$, 65. DC, in Bullet, soc, philomat, 1801, n. 49. Prodr. III. 4It. Mfem, II. 37, t, 1, f. 4. Meisuer Gen, 134. (98.)

a. CHRoNoBIUM DC. l.c. Propagines nullae. Flores saepius flavi, rarius albi. - Species omnes, unica meditertanea excepta canarienzes et madeirenses. - (Jaeq. Hort. Schönbr, t, 464. DC. Plant. gr. t. 4. 125. 14t. 156. Plant. rar, hort. Genev. $t$. 21. Mem. II. t. 10_12. Bot. Mag. t. 296. 1809. 1963. 1978. 1980. Bot. Reg.t. 278. 892, 1533, 1741. Webb. et Berthel. Elor. Canar, t, 28_30.3

b. JOVIBARBA DC. $l$. c. Propagines ex axillis infimis ortae. Flores purpurascentes aut pallide flavescentes. - Species europeae et boreali-aziaticae. (Jacq. Flor. austr. append. t. 41. E. B. t. 1320. DC. Plant. gr. t. 104-107. Bot. Mag. 2, 68, 57. 1457, 2115.)

c. MONANTHES DC. l. c. Propagines verae nullae, folia clavato-conferta. Flores purpurei. $S q u a m u-$ I ae hypogynae amplae, orbiculato-coehleatae, serrula. tae, petalis duplo breviores, quadruplo latiores, rufae. Species oanarienzis. - Monathes Haworth Revis. 68. (Bot. Mag, t, 93. DC. Plant. gr, t, 157). $102^{*}$ 
SUR QRTD II. DIAMORPHEAE. C a rp i d ia basi v. juxta totam longitudinem in capsulam plurilocularem connata.

4624. Diamorpha $N U T T$. C a $\mathrm{y}$ x quadripartitus. Corolla e petala 4 , perigyna. Stamina 8 , perigyna. O va ri u m e carpidiis 4 , basi connatis, apice divergentibus quadriloculare, loculis angulo centrali panciovulatis. Cap s a la quadrilocularis, vertice plano quadriloba, Iobis divarieatis, acutis, loculicide dehiscens, loculis subtetraspermis. - Herba boreali-americana, pusilla, biennis; ramis verticillatis, foliis alternis, subteretibus, floribus parvis, albis, cymosis.

D i a mor ph a Nuttall Gen. I. 293. DC. Prodr. 1IT, 414. Mem, IT, 48. $t .1$. f. 9. Melsner Gen, 135. (99.)

4625. Penthorum LINN. $\mathrm{C}$ a $1 \mathrm{y} \times$ quinquepartitus. Coroll a e petala 5 , perigyna. Stamina 10 , perigyna, Ovarium e carpidiis 5, basi connatis, apice divergentibns, loculis angulo centrali multiovulatis. C a p s n l a quinquelocularis. pentagona, verticis plani ambitu quinquerostris, rostris cum loculornm dorso secedentibus, dissepimentis cam vertice plano persistentibus. S e mina plurima, minima, lineari-acuminata v. ovata, scabra, placentis latiusculis, loculorum angulo centrali partimque septis adnatis inserta. E mb ryo in axi albuminis tenuissimi, carnosi orthotropus, teretiusculus, gracilis. - Herbae perennes, in America boreali et China indigenae; erectae; foliis sparsis, membranaceis, oblongo-linearibus, inaequaliter serratis, cymis unilateralibus, apice subscorpioideis.

Penthor um Linu, gen, $n$. 580, Lam, $t$, 390. Gärtier I. 312. t. 65. DC. Prodr, IIT. 414, Mem, II. 43. t. 1. f. 8. t. 13. Melsner Gen. 135. (99.)

\section{* Francoaceae.}

4626. Francoa $C A V A N I L L, C$ a ly $x$ quadripartitus, aequalis, Corolla e petala 4 , imo calyci inserta, unguiculata, pinnatim venosa. Stam in a cum petalis inserta, 8 fertilia, cum totidem sterilibus obtusis v. retusis alternantia; fertilium fil amenta subulata, anthera e biloculares, dorso insertae, subcordatae, longitudinaliter dehiscentes. Ovarin m liberum, oblongo - tetragonum, apice quadrilobum, quadriloculare. $O$ v u $L$ a plurima, loculorum angulo centrali biseriatim inserta, horizentalia, anatropa. Stigma sessile, quadrilobum, lobis obtusis, cnm septis alternantibus. Ca p s u la quadrilocularis, quadriloba, loculicide dehiscens, valvulis medlio septiferis, inter se cohaerentibus. S emin a plurima, oblonga, curvata, tubercnlato-rugosa, striata. E mbryo in axi albuminis subfarinacei orthotropus, brevis, teres; ra di cula umbilico proxima, centripeta. Herbae chil enses, perennes, subvillosae; foliis ad basim caulis congestis, subradicalibus, lyratopinnatifidis, reticulato-venosis, glanduloso-dentatis, floribus in scapo simplici $v$, apice diviso-racemosis v. spicatis, pedicellis unifloris, basi braetea persistente suffultis.

Franco a Cavanilles in Anal. cienc. nat. IV. 237. Ic. FI. 77. t. 596. Adr. Jussien in Annal. rC. nat. IIT, 198. t. 12. Dou in Edinb. new philosoph. Journ. VI, st, Kunze in Elora 1831. p. 369. Lindley in Bot. Reg.t, 1645. Hooker in Bat. Mag. t. 3178. 3309. Don in Sweet FI. Gard. YI. 2. 151. Meisner Gen. 13\%. (99.) Llaupanke Feuillé Journ, IT, 248. t, 31 .
462\%. Tetilla DC. Calyx quadrifidus, lacinia postica majore. Coroll a e petala 4 , imo calyci inserta, duo postica multo majora. S t a m in a cum petalis inserta, octo fertilia cum totidem sterilibns, capitellatis alternantia ; fil am en ta filiformi-subulata, a nth e rae biloculares, dorso insertae, subcordatae, longitudinaliter dehiscentes. Ovarium liberum, oblongo-tetragonum, apice brevissime quadrilobum, quadriloculare. Ó vula plurima, loculoram angulo centrali biseriatim in. serta, anatropa, pendala. Stig ma sessile, quadripartitum, lobis obtusis, cum septis alternantibus. C a $\mathrm{p}$ s $\mathrm{I}$ । a quadrilocularis, apice loculicide quadrivalvis. Semina plurima, ovato-oblonga, striata. E mb ryo in axi albuminis celluloso-carnosi brevis, teres, radicula umbilico proxima, centripeta. - Herba chilensis annua, tenera, glabriuscula; foliis radicalibus longe petiolatis, orbiculato-subcordatis, palmatim trinerviis, sinuatodentatis, petiolis planis, basim versus dilatatis, amplexicaulibus, scapo erecto, nudo, simplici, racemo elongato, pedicellis brevibus, unifloris, bracteam linearem superantibus, corollae petalis majoribus orbiculatis, unguiculatis, pinnatim venosis, ochroleucis, basirubris, minoribus anguste lanceolatis, rigidiusculis, rubris, quandoque nanis $v$. omnino obliteratis.

Tetilla DC. Prodr. IV. 667. Adr. Jussieu in Annal. sc, nat. $X X Y, 7$. Pöppig et Eudlicher Nov, gen. et sp. I. 12. t. 19. Galllemin in Delessert Ic. select. UII. 43. $t$. 77. Meisner Gen. 135. (99.) D im orphopetalum Bertero in Mercurio chilen. 1829. $n, 12-16$. A a a $\mathrm{rmos}$ a Miers msc. ex Hooker, Bof. Miscell. TIT, 338. T etrapla s i um Kunze in Flora 1831. p. 378.

\section{* Cephaloteae.}

4628. Ceplanlotas LABILL. Calyx coloratus, profunde sexfidus, aequalis, extus pubescens, laciniis ovato-lanceolatis, aestivatione valvatis, sub anthesi patulis, intus apice denticulo auctis, basi incrassata pilis capitatis hispidulis. Co rolla nulla. S ta min a 12 , tubi calyeini margini inserta, ejusdem laciniis breviora, sex iisdem alterna paullo longiora, praecociora; fi lamenta subulata, erecto-conniventia, antherae subrotundo-didymae, loculis appositis, connectivo snbgloboso, fungoso-celluloso adnatis, Iongitudinaliter dehiscentibus. O v a ría 6, approximata, in receptaculo communi plano circa fasciculnm villorum centralem verticillata, calycis laciniis alterna, sessilia, ovata, subeompressa, dorso rotundata, ventre truncata, unilocularia. O vulum unicum (v. rarissime dao) e basi erectum, anatropum. Sty Ii terminales, teretinseuli; stig mata simplicia. A c h en i a membranacea, calyce aucto staminibusque persistentibus cincta, prope basim circumscissa, basi persistente e membrana simplici, crassinscula, imberbi, nitente, parte superiore decidua e membrana duplici, exteriore pilis deflexis dense barbata, stylo rostrata, et interiore tenui, quandoque intus dehiscente conflata. S emen unicum (rarissime duo), basi cavitatis membranae interioris insertum, oblongo-ovale, teres, funiculo brevi juxta basim insertum, te s ta membranacea, laxiuseula, rhaphe Iaterali tenui et chalaza apieali insignita, endopleura tenui, separabili. Embryo in basi albuminis carnoso-oleosi, subfriabilis axilis, brevissimus, orthotropus; cotyledonibus plano-convexis, radicula tereti, basim seminis attingente, infera, - Herbae $\mathrm{No}$ vae-Hollandiae austro-ocoidentatis; 
caule abbreviato hypogaeo, folits in apice caulis confertis, pseudo-radicalibus, petiolatis, exstipulatis, ellipticis, integerrimis, enervits, planiusculis, glabris, $v$, parce pilosis, petiolo semitereti, basi parum dilatato, ascidiis foliis intermixtis, petiolatis, dependentibus, ore annulato, operculato instructis, pedunculo scapiformi, simplicissimo, villoso, braeteis paucis, alternis, remotis instructo, spica terminali composita, spiculis pedunculatis, quadri-quinquefloris, bracteis spicularum pedunculos subtendentibus subulato-linearibus, floribus subcorymbosis, parvis, albis, ebracteatis.

C e p balot o s Lahillardiére Nov. Holland. II.7. 1. 145 . R. Brown in Flinders Voy, II, 601, t. 4. Edinb. philosoph. Magas. 1832. 314. Hooker in Bot, Mag. t, 3118. 3119. Meis. ner Gen. 105. (74.)

\section{Drdo CEXX. Saxöfragaceae.}

SAXIFragaE Jussieu Gen. 308. SAXIFrageaE Venteno. Tabl. III. 2a7. excl. gen. Jussieu Diet, sc. nat. XXVIT. S60. SAXIFRAGEAE, CUNONIACEAE et ESCALLONIEAE R. Brown in Flinders Voy. $I T$, ot in Franklin Nar. rat. 765. Bartling Ord. nat. 311. 312. et 425. BAUERACEAE, CUNONIACEAE, SAXIFRAGACEAE et ESCALONIACEAE Lindley Introduct, edit, $I T, p, 161-163$ et 27 . SAXIFRAGACEAE DC. Prodr, $1 V .1$.

Herbae, suffrutees v. interdum arboREs, habitu admodum vario. Folia sparsa v. opposita, aut verticillata, simplicia v. ternata aut imparipinnata, integerrima, serrata v. lobata. Stipula e nullae, in fructicosis interpetiolares, deciduae.

Fuores hermaphroditi, regulares, varie dispositi.

Calyx pentamerus, rarius tri-decamerus, foliolis distinctis v. plus minus inter se connatis, tubo libero v. cum ovario plus minus connato, limbo libero, quinquefido v. quinquedentato.

Conolrae petala 5 , rarius pauciora, tori laminae plus minus manifestae, calycis tubum vestienti inserta, ejusdem laciniis alterna, integra v. divisa, aequalia v. interdum inaequalia, rarissime nulla.

Stamina cum petalis inserta, iisdem numero aequalia et alterna, rarius dupla, per vices alterna et opposita, rarissime indefinita. Filamenta libera, subulato-filiformia. Anther a e introrsae, biloculares, ovatae, connectivo interdum effigurato, longitudinaliter dehiscentes v. rarissime poris apertae.

Ovarium libermm v. calycis tubo plus minns connatum, e carpidiis ut plurimum duobus, rarius tribus v. quinque, distinetis v. magis minusve cohaerentibus aut omnino connatis compositum, carpidiorum marginibus introflexis dissepimenta, interdum incomplefa constituentibus. $\mathrm{Ovula}$ in placentis valvularum marginibus introflexis, nunc juxta totam longitudinem, nunc basi v. apice adnatis plerumque plurima, rarissime subdefinita $\mathrm{v}$, solitaria, ho- rizontalia, adscendentia v. pendula, anatropa. St yli carpidiorum numero, ifsdem terminales, nunc omnino distincti, nune plus minus cohaerentes. Stigmat a simplicia.

Froctus capsularis v. rarissime nucamentaceus, maturitate in elementa carpica secedens, carpidiis intus v. juxta totam longitudinem dehiscentibus.

SEMINa rarissime solitaria v. definita, saepissime plurima, minuta, testa lacvi v. scrobiculata, glabra v. interdum pilosa, interdum in alam producta. A l b u m e n copiosum, carnosum.

Embryo in axi albuminis orthotropus, ejusdem fere longitudine, rarius multo brevior. Cotyle d o nes breves, semieylindricaev. ovatae. $\mathbf{R}$ a di cula cylindrica, umbilico proxima, directione carpica varia.

Saxifragaceae vastum plantarum ordinem constituunt, in plures subordines habitn characteribusque satis distinctos secedentem, vix tamen nostro sensu, ubi cum Crassulaceis Ribesiaceisque in classem colligitur, dividendum.

Saxifrageae herbaceae exstipulatae, Crassulaceis proximae, maximo numero in hemisphaerae borealis montibus et alpibus generantur, in America boreali majori formarum diversitate ludentes, in alpibus Americae tropicae et in regionibus antarcticis multo rariores.

Cunonieae frutescentes $\mathbf{v}$. arboreae, stipulis interpetiolaribus et foliis saepius eompositis insignes, aretissime Saxifrageis affines, et vix ab iisdem segregandae, maxima copia in hemisphaerae australis regionibus extratropicis generantur, in Asia et America tropica rarae, cis Cancrum nondum repertae.

A Cunonieis avelli nequeunt Hydrangeae fruticosae, oppositifoliae, simplicifoliae, exstipulatae, Caprifoliaceis Viburneis habitu et inflorescentia quodammodo similes, in India boreali, Japonia et America boreali obviae, in Peruvia et Java rarae.

Ab Hydrangeis facilis est transitus ad Eseallonieas pariter frutieosas, simplicifolias, alternifolias, exstipnlatas, omnes trans aequatorem, plurimas etiam trans Capricornum relegatas, quae facie quamdam cum nonnullis Ericinearum generibus similitudinem mentientes, propius hine ad Ribesiaceas accedunt, illine ad Bruniaceas vergentes, a Myrtaceis certe longius alienae:

SEIBQIET) I. SAXIFRAGRAE DC. Prodr. IV, 17. H e r b a e foliis alternis v. oppositis, exstipulatis v. petioloruin bas? dilatata stipulaeformi. Flores racemosi, paniculati $v$. rarius solitarii.

4690. Eremosyne ENDL. Calycis tubus lurevissimus, hemiaphaericus, cum graxii basi 
connatus, limbi quinquepartiti laciniis linearibus. Corolla e petala 5 , perigyna, linearia. Ovarium ima basi adnatum, biloculare, ovulis intra Joculos solitariis, e placenta basilari glandulaeformi erectis, anatropis. Styli 2 , e basi connata divaricati; stigmata capitata. Fructus $\ldots \ldots$ Herba digitalis, in Nova-Hollandia austrooccidentali indigena; foliis radicalibus rosuTatis, obovato-spathulatis, integerrimis, caulinis alternis, sessilibus, basi profundissime pectinato-pinnatifidis, laciniis linearibus, infimis deflexis, reliquis adscendentibus, lobo terminali latiore, floribus minimis, albis, in cymulis repetito-dichotomis, contractis.

E rem o s y ne Endlicher in Enumerat. plant. Hügel, $\mathbf{5 3 .}$

4630. Dovatin FORST. C a Iy $x$ tubo turbinato, cum ovario connato, bracteola lineari adnata, limbi superi, subtruncati dentibus quatuor v. quinque subulatis, remotis. Corolla e petala 8 v. 10 , epigyna, calycis dentibus conserialia. Stamina 3, epigyna, petalis alterna; fil amenta brevia, antherac ovatae, biloculares, longitudinaliter dehiscentes. Ova ri um inferum, bitriloculare, placentis apici loculorum adnatis, multiovulatis. Styli $3-5$, subulato-filiformes; $\mathrm{stig}$ mata simplicia. Ca ps ula .... - Herba magellanica, rupicola, subacaulis, Saxifragae grönZandicae facie; cauliculis caespitosis, folits alternis, lineari-lanceolatis, obtusis, crassiusculis, glabris, axillis lanigeris, floribus terminalibus, sessilibus, albis.

Donatla Forster Char. gen, t. 5. Jussieu Gen. 300. Lam. to 51. St. Hilaire in Mem. Mus. It. 119. DC. Prodr IV. 33, Hooker Ic. $t, 16$. Meisuer Gen, 136, (100,)

4681. Valhia THUNB. Caly $\mathrm{x}$ tubo cum ovario conato, limbi superi, quinquepartiti laciniis aestivatione valvatis, Co rolla e petala 5, epigyna, patentia, indivisa. Stamina 5 , cum petalis inserta, isdem alterna; fil a m e n ta subulata, anthera biloculares, versatiles, longitudinaliter dehiscentes. Ovari $\mathbf{n} \mathbf{m}$ inferum, uniloculare, placentis geminis, ex apice cavitatis pendulis, multiovulatis. St y li 2, patentes; st i g ma tapitata. C a p su 1 a nnilocularis, inter stylos dehiscens, placentis pendulis. S e m in a plurima, dorso convexa, facie plana. E m bryo .... - Herbae africana et a siaticae, subdichotomae, glabriusculae $v$. subvillosae; foliis oppositis, exstipulatis, linearibus v. lanceolatis, pedicellis axillaribus, geminis, unifloris, floribus albis.

V a hila Thunberg Nov. Gen. II, 36. Jussieu Gen. 318. Lam. $t, 183$, R. Brown in Franklin Journ, 766. Reichnnb. Ie. erot. t, 91. DC. Prodr. IV. 33. Meisner Gen. 136. (100.) Russelia Lina. f. Supplem, 175. B istella Delille in Cailliaud Voy. Meroe $97, t, 63 . f, 2$. 01 d e 1 a a d $i$ a e s p. Auct.

4832. Nimmola WIGHT. C a ly x tubo libero, limbo quadrifido. Cor o 11 a e petala 5 , inter dentes caly cinos inserta, breviter unguiculata, obovata, integra, persistentia. Sta m ina 5 , ealycis tubo demissius inserta, petalis alterna; fila menta decurrentia, a n th er a e biloculares, Iongitadinaliter dehiscentes. Ov a rium liberum, subpedieellatum, incomplete biloculare, placenta septante basi valvarum marginibus inflexis adnata, apice libera, utrinqne multiovulata. Sty I u s filiformis, simplex; stig ma magnum, bilobum. Cap sula calyce inclusa, incomplete bilocularis, styli basi demum fissa apice transversin hians. Semina plurima, ovalia, testa pellucida. $\mathbf{E} \mathbf{m b} \mathbf{r} \mathbf{0}$ in axi albuminis carnosi orthotropus, ejusdem longitu- dine, cylindricus, - Herba indica, glabra, ramasissima; foliis alternis, coriaceis, sessilibus, e basi cordata lanceolatis, acutis, exstipulatis, floribus parvis, rubris, bibracteolatis, ad apices ramorum in fasciculos plurimos congestis.

Nimmoia Wight in Madras Journ, 1837. n. 15. p. 309. t. 20.

4633. Zhalloreknera REICHENB. Ca ly x tubo cum ovario basi connato, limbi semisuperi, decempartiti laciniis radiato-patentibus, intus subeoloratis, alternis paullo minoribus. Corolla nulla. Stamina 10 , perigyna; fil am ent a e basi incrassata subulata, anther a biloculares, longitudinaliter dehiscentes. $O$ va ri $\mathbf{~ m ~ i m a ~}$ basi adnatam, biloculare, placentis dissepimento utrinque adnatis, multiovulatis. Sty $1 \mathbf{i} 2$, divaricati; stigmat a subcapitata. C aps u la bilocularis, birostris, apice loculicide bivalvis. Se $\mathrm{m}$ in a plurima, horizentalia, rugosa. E m b r y o .... Herba in rupibus schistosis alpium Carinthiae et $S$ ty $r$ ia e vegetans, tenella, diffuse ramosa; foliis oppositis, longe petiolatis, cordato-reniformibus, quinque-septemlobis, peduncul is axillaribus subcapillaribus uniftoris, subcorymbosis, calyce intus viridi-flavo.

Za b 1 brueknera Reichenb. Flor. Germ. 55t. 0 reo. splenium Zahlbruckn. msc. Saxifraga paradoxa Sterab. t.14. - Qui in Z. ru pest ri calycis lacioias minores petala credunt, ii flores haud attentius consideraverunt.

4634. Saxifraya $L I N N$, C a ly $x$ liber $v$. inferne cum ovarii basi connatus, quinquefidus $v$. quinquepartitus. Corolla petala 5, perigyna, unguiculata, aequalia $\mathbf{v}$. interdum inaequalia. Stamina 10 , perigyna; fil a menta subulata, a nthera e biloculares, longitudinaliter dehiscentes. Ovarium liberum v. seminfernm, biloculare, placentis dissepimento adnatis, multiovalatis. S tyli 2 , distineti $v$, rarius basi connati; stig mat a subtruncata v. capitata. C a p $\mathbf{u}$ la semisupera v. tandem libera, bilocularis, birostris, inter rostra loculicide dehiscens, septo utrinque placentifero. S e min a plurima, ovoidea, testa laevi v. rugosa, adnata. E m b r yo in axi albuminis carnosi brevis, subcylindricus, orthotropus. - Herbae perennes, habitu multiformi, in hemis $\bar{p}$ a erae borealis temperatis et frigidis, imprimis alpinis, magno specierum numero luxuriantes, in summis America e tropicae jugis rarae, in America australi extratropica rarissimae; foliis radicalibus saepissime rosulatis, caulinis alternis $v$. interdum opposilis, petiolorum basi plerumque dilatata, floribus paniculatis $v$, corymbosis aut abortu solitariis. $\mathrm{S}$ a $x$ if r a g a Limn. gen, n, 764. Jussieu Gen, 309. Gärtner $I$. 177. Stemberg, Revisio Saxifrag. Ratisb. 1810. fol. Haworth Enumer. Sarifrag. Lond. 182t. Don in Linn. Transact, XIII, 341. Moretti, in Bibliotheca italiana. 1829. Gaudin, Flor, Helvet. III. 83. DC. Prodr. IV. 17. Meisner Gen. 136. (100.)

a. PORPHYRION Tauseh Hort. canal. 1. Caly $\times$ longe gamophyllus, erectus, persistens, liber v. cum ovario coalites. S e m i n a angulosa, lacria r. rugosa. - Folia opposita, coriacea v. carnosula, perennantia, flores rubri. violacei v. rarius flavi. - Seringe in DC. Prodr. IV. 17. Antiphylla Haworth Sarifr. 43. excl. sp. Cali pby 11 u m Gaudin Flor. Helvet. IIT, 94. (E. B. t. 9. Allioni Pedemont. $t$. 21. Lapeyr. Pyren. $t .16 .18$. Sternberg Supplem: t. 10. f. 2.)

b. AIZ00NLA Tauseh Hort. canal. $t, \mathrm{C}$ al $\mathrm{y} \times$ longe gamophyllus, erectus, persistens, ovario aduatus. $\mathrm{S} e \mathrm{mi}$ n a ovato triquetra, rugosa. - Folia alterna, sessilia, crasso-coriacea, perennantia, cartilagineo.marginata, margine saepe porosa, Flores albi, lutei v. rubri. Seringe in DC. Prodr. IV. 18. - Chondrosea Haworth Sarifr. 10, cotyledon, Trigonophyllum 
et Poroph y $11 \mathrm{~nm}$ Gandin Flor. Helvet. III. 86, 89. 91. (Jaeq. Flor, aurtr, t. 374. 438, Ic, mar, t. 466. Collect. III. t, 17. Miscetl. I. t. 7. f. 3. Flor, dan, t. 241. Willdenow Hort. berolin, t. 75, Lapeyr. Pyren, t. 11. 13. 15, Bot. Mag, $t, 351$. Sternberg Bevis, $t, 1-3,9$. 10. Suppl. t. 11.)

c. DACTYLOIDES Tauseh Hort. canat, 1. C a lyx longe gamophyllus, erectus, persistens, ovario adhaerens. S e m I n a ragosa. - Folia alterna, herbacea, viri. dia, plana, integra v. lobata, nervosa, margine nec cartilaginea nec porosa, rarissime perennantia. Flo. res albi, luteoli v, rarius purpurei. Seringe in $D C$. Prodr. IV. 23. - Saxif $\mathrm{rag}$ a et $\mathrm{M}$ u s carja Haworth Saxifr. 22_29. Triplinervi um Gaudin Flor. Helvet. III. 116. (Jacq. Flor, austr. t. 389. To, rar. t.81. Flor. dan. $t, 22,118,348.390$. E. B. $t, 454,455,500$. 301, 664. 2275_2978, 2291, 2314. Lapeyr. Pyren. $t$. 19. 27, 28, 30, 32, 34-36, 40-43. Waldst, et Kitaibel Plant: rar. Hung. t, s8, Sternberg Revis. t. 7. 9. 11, 12, 15 19. 23. Suppl. t, 1, f. 3, t. 6, 8.9. Desfont. Flor. atlant. t. 96. Bot. Mag. 1, 1651, 2207. Humb. et Bonpt. Nov. gen. et sp. t. 519. Pöpp. et Eudl. Nov, gen,et sp. t, 18. Brongniart in Nouv. Annal. sc, nat. III. t. 1. Hooker Flor. Bor. Amer. 1. 83. 84. Hooker ad Beechy t, 29.)

d. BERGENIA Monch Method. 664. C a Iy $x$ basi gamophyllus, liber, lobis obtusis, adscendentibus. S em in a angulosa, laevia. - Truneus basi suffrutescens, saepius crassus, folia coriacea perennantia, petiolo basi di. latato. Seringe in DC. Prodr. $I V .37$. M eg a s e a Ha. worth Sarifr. 6. Ge r youia Schrank. - Erophe. ro a Tausch Hort, canal. 1. (Bot. Mag. t,196. Wallich in Asiat. Research, XIIT, $t, 1$.)

e. MICRANTHES Tauseh Hort, canal. $1, \mathrm{C}_{\text {a }}$ y $\mathrm{x}$ basi gamophyllus, liber, Capsula subvesiculosa, nervosa, $s t y l i s$ plerumque usque ad apicem coalitis, $s t i \mathrm{gma}$. tIbus subliberis. Semina oblonga, laevia. - $O a u$. lis subnudus. F'o lia radicalia oblonga, stolones nulli. Flores sacpe parvi, plerumque glomerati, capitati v. paniculati. Seringe in DC. Prodr. IV. 38. - De r m a s e a Haworth Saxifr. 8. (R. B. t. 440. Waldst. et Kitaibel Plant, rar. Hung. t. 18. Sternberg Revis, t. 4. Hooker Flor. Bor. Amer, t. 85, 86.)

f. ARA BIDIA Tausch Hort. canal. 1. Cal y $x$ basi brevissime gamophyllus, liber, patens v, reflexus. Pe tal a lon. ge unguiculata, interdum inaequalia. Semina tongitudinaliter striata. - Foli a alterna, cuneiformia $v$. obovata, rosulata, perennantia. Seringe in DC. Prodr. IV. 40, - S path u Iaria Haworth Saxifr. 47. (Flor. dan. $t, 23$. E, B. $t, 167$. Lapeyr, Pyren, t. 25.)

g. HYDATICA Necker Elem, n. 1205. C a l y $x$ basi vix gamophyllus, ab ovario liber. Filam en ta clavata, apice aeuta. Peta I a nune subaequalia, nune duo elongata, palmatinervia. Cap u I a ovata, subveatricosa, stylis brevissimis. S e m in a subsphaerica, aspera. - $C$ a u $l i$, subnudus, saepe stoloniferus, Folia coriacea, rarius faccida, suborbiculatav. cuneala, in surculis sterilibus rosulata. Seringe in DC, Prodr. IV. 41. - R o. bertsonia Haworth Synops. 321. Saxifr. 52. $\overline{\mathrm{u}} 1 \mathrm{u}$ $\mathrm{x}$ is Haworth Saxifr. 46. Diptera Borkhaus. in Hömer Magaz. T. 29. Li gul a ria Duval Plant. succul.11. (Waldst. et Kitaibel Plant, rar. Hung. t, 44. E. B. t, 2322. Lapeyr. Pyren, $t, 22$-24. Sternberg Suppt, t. 4_6. Jacq. Ic. rar, t. 80, Bot. Mag, t, 22. Hooker Flor. Bor. Amer. t. 88. 3.)

h. MiCROPETALUM Tausch Hort. canal. 1. Calyeis foliola basi vix coalita, ovaria haud adhaerentia. Fila. menta filiformia. S emina oblonga, tubereulosa. Ca ules foliosi, stolonibus mullis, Folia alterna suborbiculata, crassiuscula, marcescentia. Flares paniculati. Seringe in DO. Prodr. IV 43, Cotylea Haworth Saxifr. 10. L o baria Haworth Op. cil, 18. (Jacq. Observ. IT. t. 34. Sternberg Revis, t. 3. 13. Lapeyr. Pyren, 2. 24. Bivona Sitirp. mar, 2. 3.)

i. HIRCULUS Tauseh Hort, canal, $1, \mathrm{C}$ a 1 y $\mathrm{c}$ is follola basi vix coalita, ab ovario libera. $S$ e $m$ in a oblonga, rugoso-punctata. - Caulis foliosus, stoloniferus, folia alterna, angusta, nervosa, integra, saepissime rigide ciliata, marcescentia, Seringe in DC. Prodr.IV. 44. - Kingstonia Gray Brit, plant. II, 331 . Hir. culus, Ciliacia et Leptase a Haworth Saxifr, 40 . 41. (E., B. t, 39. Flor. dan, t, 976. Sternberg Hevis. t. 6. 8. 10. Hooker Flor, Bor, Amer, 1. 87.)
4635. Teptarrinema $R$. BR. C a I y x basi ime ovario adnatus, quinquepartitus. CorolI a e petala 5 , perigyna, breviter unguiculata, ae. qualia, integra. Stamina 10 , perigyna; filamenta subulata, libera, antherae uniloculares, septo parallelo, incompleto. O v a ri a 2 , imo calyei adnata, inferne cohaerentia, milocularia, placentis suturalibus, multiovalatis. Styli breves; stigmata obtusa, Cap 8 ulae 2 , uniloculares, intus longitndinaliter dehiscentes. S e $\mathrm{m}$ in a plurima, adscendentia, scobiformia ; testa ntrinque relaxata, elongato-subulata, nuclenm oralem includens. $\mathrm{E}$ m br y o ..... - Herbae $A$ mericae arctica $e$, Pyrolae facie; foliis ad basim scapi congestis, petiolatis, ovatis $v$. obovatis, coriaceis, grosse serratis, petiolis basi dilatata vaginantibus, scapo nudo, floribus racemoso-paniculatis.

Le p tarr he n a R. Brown in Parry's 1 . Noy. Supplem. 273. DC. Prodr, IV. 48. Hooker Flor. Bor, Amer. I. 256. t. 89. Meisuer Gen, 136. (100.) S a x if rag a p y rol a e fo. li a Dou. S, a mplexifolla Sternberg Revis. Supplom. II, $t, 2$.

4636. Tühtkea BONG. Calyx tubo turbinato, libero, limbo quinquefido, C o roll a e petala 5 , perigyna, subsessilia, aequalia, integra. St am in a 20 , perigyna; fil a m en t a basi monadelpha, apice subulata, anther a subglobosae, biloculares, longitudinaliter dehiscentes. O va ri a 4-6, libera, lana densissima cohaerentia, unilocularia, placenta sutnrali apice pauciovalata. StyIi filiformes, clongati; stigmata obtasa. Ca ps u la e 4-6, uniloculares, intus longitudinaliter dehiscentes. Se mina pauca, pendala, scobiformia; testa ntrinque relaxata, elongato-snbulata, nucleum ovalem inclndens. $E$ m bry o exalbuminosus (?), orthotropus. - Herba Americae arcticae, perennis, stolonifera, dubiae affinitatis, fortassis Rosaceis Spiraeaceis inserenda; foliis al ternis, coriaceis, trifidis, laciniis tri-quadrifidis, radicalibus rosulatis, caulinis alternis, glaberrimis, racemo terminali, bracteato, floribus albis.

L ü the a Bongard in Mom. Academ, St. Petersb. VT. Ser. IT, 130, z, 2. Meisner Gon, 136, (100) Eriogy nia Hooker Flor, Bor. Amer. I. 255. 4. 88, Saxifrag a pecin at a Pursh.

483\%. Tepurepetalum ELLIOT. Caly $x$ tubo turbinato, cum ovarii basi comnato, limbi semisuperi, quinquepartiti lobis ovatis, obtusis, Corolla e petala 5 , perigyna, minuta, spathnIata, persistentia. Sta min a 5 , cum petalis inserta, iisdem alterna, inclusa; fil a menta filiformia, anth era e subglobosae, biloculares, longitudinaliter dehiscentes. 0 v a ri um semiinferum, uniloculare, placentis parietalibus tribus, bilamellatis, multiovulatis. Styli 3 , breves, basi subcoaliti; stigmata capitata. Capsula unilocalaris, apice trivalvis, valvis margine seminiferis. Se min a plurima, ovalia, pnnetata. Bmbryo in axi albuminis carnosi subeylindricus, orthotropus.

Herbae boreali-americanae et chilenses, pusillae, glabrae, caespitosae, ramosae; foliis alternis, sessilibus, spathulato-lanceolatis, obtusis, integerrimis, floribus terminalibus.

Le puropetal u m Elliott Carolin, I. 370, DC. Prodr. IV. 53. Meisuer Gen, 130. (100.) Cryptopetal u in Hooker et Arnott Bot. Miscell. III. 314.

4638. Chrysospleninm TOURNEF. Caly $x$ tubo cum ovario connato, limbi superi, quadri-quinquefidi lobis obtusis, intus coloratis. 
Coro11a nulla. Stamina 8 v. 10 , disci epigyni margini inserta; fil amenta brevia, subulata; ant $h$ e $r$ a reniformes, biloculares, longitudinaliter dehiscentes. O va rin m inferum, uniloculare, placentis duabus ad basim suturalibus, multiovalatis. St jli 2, distineti; 8 tig mata simplieia. Ca p s a I a infera, obeordata, compressa, unilocularis, apice bivalvis. S e m in a parietalia plurima, testa crustacea nitida, funiculo capillari adnato. E m b ryo in basi albuminis carnoso-oleosi minimus, orthotropus. - Herbae in Europa, Americaboreali, Asia media et Nepaliae mon tibus indigenae, ut videtur annuae, succulentae, erectae v. procumbentes, apice corymboso-ramosae, subdichotomae; foliis alternis v. oppositis, sub. rotundis $v$. reniformibus, repando-v. inciso-crenat is, floribus terminalibus et alaribus, subsessilibus, foliis floralibus -sessilibus, luteis cinctis.

Chry s os p f e i u m Tournefort inst. 60. Linn. gen, $n$. 558. Sehkuhr t, 108. Gärtner 1 , 208, t. 44. DC. Prodr. IV: 48. Ledebour Ic. t. 404. 405, Meisner Gen. 137. (100.) Kunth Flor. Berolin. I. 157.

4639. Femelnera $L I N N$, Cal y x tubo Iibero $v$, inferne cum ovario connato, limbi quinquepartiti laciniis aestivatione imbricatis. Cor ol la e petala 5, summo calycis tubo inserta, linearia, indivisa, subinaequalia. Stamina 5 , cum petalis inserta, iisdem alterna, exserta; fil am enta filiformia, antherae biloculares, subglobosae $v$. reniformi bilobae, longitudinaliter dehiscentes. O vari um liberum v. ima basi adnatum, uniloculare, placentis duabus ad suturas parietalibus, maltiovulatis. Styli 2 , elongati, divergentes; $8 \mathrm{ti} \mathrm{gmata}$ subsimplicia. C a p sula nnilocularis, birostris, inter stylos dehiscens. Semina plurima, horizontalia, ovata, testa rugosa, punetatoaspera. Embr y o in axi albuminis carnosi orthotropus. - Herbae perennes, in America bor eali et Asia aretica indigenae; foliis radicalibus confertis, caulinis paucis, alternis v. nullis, omnibus petiolatis, palmatinerviis, lobato-dentatis, petiolis basi auriculato-dilatatis, floribus paniculatis v. racemosis.

H e u chera Linn. gen. $n$. 320, Gärtner $I$. 177. $t$. 362. Schkuhr t. 58. Lam. $t ., 184$. R. Brown in Franklin Narrat. 765. t. 29. DC. Prodr. IV. 51. Prest. Reliq. Haenk. Ir. 56. Hooker Flor, Bor. Amer. I. 233, t. 79. 80. Bot. Reg. t. 1924. Meisner Gen. 136. (100.)

4640. Mitellopsis MEISN, Ca ly $x$ tubo campanulato $v$. turbinato, inferne cum ovarii basi connato, limbi quinquefidi Iobis aestivatione valvatis, demum reflexis. Corolla e petala 5, summo calyeis tubo inserta, trifida $v$, pinnatifida. Stamin a.5, cum petalis inserta, iisdem alterna y. opposita, inelusa; fi. la m e nt a brevissima v. subnulla, a nt her a e ovatae, biloenlares, longitudinaliter debiscentes. Ova ri um inferum v. serai. superam, uniloculare, placentis duabus ad suturas parietalibus, multiovulatis. Styli 2 , breves ; stigma ta simplicia, capitata, v. biloba. Ca p s u i a infera v. semisupera, unilocularis, apice bivalvis, valvis reflexis. Sem in a plurima, horizentalia, ovata. Herbae boreali-americanae; foliis radicalibus petiolatis, lobato-dentatis, scapo sub. nudo, floribus racemoso-spicatis.

Miteflopsis Meisuer Gen, 136. (100) -? Oreanth u 8 Rafinesque in Seringe lullet. bot. $T$. 216.

a. MITEllaria Meisn. l. c. P eta $\mathrm{Ia}$ pinaatifida. $\mathrm{S} t \mathrm{a} \mathrm{m}$ ina petalis opposita, filamentis subnullis. Stig mat biloba. Ca p s a la tafera, longe ante naturitatea aperta. - D r u m mo adla DC. Prodr. $I V, 50$, non Hook. Mitella pentandra Hooker Bot, Mag, t, 2933. b. MitelliNa Meisn. 2. c. Petala trifida. Stamina petalis alteraa, flamentis Lrevissimis. $\mathbf{S} t \mathbf{i g}$ at a indivisar Capsula semisupera. - Mitella trifida Hooker EVor. Bor. Amer. L. 82.

4641. Mitella TOURNEF. Caly x tubo laxe campanulato, inferne imo ovario advato, limbi quinquefidi lobis aestivatione valvatis. Coro 1la e petala 5 , summo calycis tubo inserta, laciniato-v, dentate-pinnatifida, reflexa. St am in a 10 , cum petalis inserta, inclusa; fil amenta brevia, anther a biloenlares, ovatae, longitudinaliter dehiscentes. Ovariu in ima basi adnatum, uniloculare, placentis duabus ad suturas parietalibus, multiovulatis. Styli 2, brevissimi, connati; stigmat a vix distineta. Ca p s la unilocularis, apiee bivalvis. Semina plurima, e fundo capsulae adscendentia, testa crustacea, fragili. $\mathrm{Embryo}$ in axi albuminis carnosi orthotropus, cylindrieus.

Herbae perennes, in Asia et America boreali indigenae; foliis petiolatis, cordatis, lobatis, nunc onnibas radicalibus, nune caulinis solitariis $v$, oppositis, floribus breve pedicellatis, in racemum terminalem, laxe spicaeformem dispositis, albis $v$. roseis,

Mit ell a Tournefort inst, 126, Linn. gen, n, 561, Selkuhr t. 120. Gärtner I. 208. t. 44, Lam. t. 373. DC, Prodr. IV. 49. Melsuer Gen. 136. (100.)

4648. Tellima $R$. BR. C a ly $\times$ tubo inferne cum ovarii basi connato, superne saepius inflato, limbi quinquefidi v. quinquedentati lobis aestivatione valvatis. Corolla e petala 5, summo calyeis tubo inserta, pinnatifida $v$. trifida. Stamin a 10, cum petalis inserta, inclusa ; fil a menta brevissima, a n therae biloeulares, ovatae, longitudinaliter dehiscentes. O varium semiinferum, uniloculare, placentis duabus v. tribus ad suturas parietalibus, St y li $2-3$, breves, distincti; sitigmata capitata, Cap sula semisupera, calyce tecta, unilocularis, apice bi-trivalvis. Sem ina plurima, horizontalia, ovata, ...- Herbae boreali-americanae; foliis radicalibus petiolatis, simplicibus $v$. ternatis, caulinisque dum adsunt alternis, lobatis v. Laciniatis, racemis spicaeformibus.

Tellima R. Brown in Franklin Journ, 766. Lindley in Bot. Reg, n. 11z8. DC. Prodr. IV. 49. Hooker Flor. Bor. Amer. I. 239. Meisner Gen. 136. (100.)

a. AMILLETA. Caly cis tubus supra ovarium inflatus, limbus quinquedentatus. Peta 1 a linearia, laciniato pianatifida. $O$ var 1 u m uniloenlare, placentis parietalibus, distylum. - Folia rotundato-cordata, obtuse lobata, dentata. - Telli m a grandiflora Lindley.

b. ALLETIMA. C a l y c is tubus supra ovarium vix inflatus, limbus quinquefidus. Petala cuneata, trifida. $0 v a$ x i a m uniloeulare, placentis parietalibus tribus, tristylum, - Folia ternata, foliolis sessilibus, ineiso-pinnatifidis. - Telli ma parviflor a Hooker Flor. Bor. Amer, z. 78, f. $a$.

4643. Tharella LINN. Cal y $x$ tubo campanulato, basi imo ovario adnato, limbi quinquepartiti lobis obtusis, aestivatione valvatis, Corolla e petala 5 , perigyna, unguieulata, integra. Stamina 10 , perigyna, exserta; filamenta filiformia, antherae bilocnlares, ovatae, longitudinaliter dehiscentes. O va r i $\mathbf{m}$ basi adnatum, biloculare, placentis dissepimenti basi ntrinque adnatis, multiovulatis. Sty Ii 2 , distincti; stig mat a simplicia, Cap 8 u 1 a membranacea, unilocularis, inter stylos bivalvis, valvis valde inaequalibns, basi margine seminiferis. Semina pauca, subglobosa, testa crustacea. E mb r y o $\ldots . .$. Herbae in $A$ sia et $A$ merica boreali indigenae, 
Mitellae facie; caulibus erectis, nudis $v$. oligophyllis, foliis plerisque radicalibus petiolatis, simplicibus v. trifoliolatis, racemo terminali simplici $v$. panicula composita, pedicellis remotis, fructiferis nutantibus.

T l a rell a Linn. gen, n, 765, Jussleu gen. 309. Lam. f. 373. DC. Prodr. $I V$. 30. excl. seet. 2. Hooker Flor. Bor Amer. 1. 838. 2. 77. 81. Meisner Gen. 136. (100.) -? B I o ndi a Necker Elem. $n, 786$,

4644. Hotela MORR. et DECAISN, C a1 y $\times$ tubo brevissimo, subturbinato, libero v. imo ova rio adnato, limbi quinquepartiti lobis aestivatione imbricatis, deciduis. Corollae petala 5, perigyna, spathulata, integra. Sta m in a 10, cum petalis inserta; fil amenta lineari-spathulata, a $n$ therae biloculares, cordatae, longitudinaliter dehiscentes. Ovarium liberum v. ima basi adnatum, biloculare, ovulis plurimis, juxta dissepimentum adscendentibus. Styli 2, erectiusculi; stigmat a simplicia. Capsula birostris, bilocularis, septicide bipartibilis, loculis intus longitudinaliter dehiscentibus, abortn mono-dispermis. Semina adscendentia, scobiformia, testa membranacea, reticnlata, ntrinque longé ultra nuclenm producta. E m b ryo in axi albuminis carnosi orthotropus, clavato-teretiusculus. - Herbae perennes, japonicae et boreali-americanae, Spireae Arunci facie; foliis bi- v. tripinnatisectis, foliolis serratis, petiolo ima basi dilatato-membranaceo, stipulaeformi $v$, nudo, floribus racemosis, bracteatis.

Hote ia Morren et Decaisn, in Nouv. Annal, se, nat. IT. 316. t. 11. Meisner Gen, 138, (101.) T i a rell a biterIrata Vent. Malmais. $t$. 5i. Tiarella e sect. Pseudastilbe DC. Prodr. 1V. 51. Astilbes sp. Don.

4645. Astilbe HAMILT, Caly x coloratus, profunde quadri-quinquepartitus, lobis ovalihns, obtusis, concavis, aestivatione imbricatis. Coroll a nulla. St a min a 8 v. 10 , lobis calycinis (per paria?) opposita; fil a ment a subulata, antherae sphaericae, biloculares, longitudinaliter dehiscentes. Ovarinm....S tyli $2 ;$ stigmat a truncata, pruinosa. Capsula birostris, bilocularis. .... Semin a plurima... - Herba nepalensis, perennis, robusta, non satis nota, Spireae Arunci facie, pilosa; foliis amplis, biternatis, grosse serratis, petiolis basi valde dilatatis, flaribus parvis, ex albo lutescentibus, spicato-racemosis, in paniculam dispositis.

Astilbe Hamilton ex Don Niepal, 210, exel. sp. DC. Prodr. IV. 51, Meisner Gen, 136. (100.)

4646. Oresitrople BUNG. Caly x coloratus, quinque-sex-septempartitus, demum ampliatus, virescens, lobis oblongis, obtusis, planis, patulis. Corolla nulla. St a m in a 10_14, perigyna, ealycis lobis (per paria?) opposita ; filamenta filiformia, brevia, antherae biloculares, didymae, longitudinaliter dehiscentes. O varium..... Styli 2 , truncati; stigmata simplicia, glabra. Ca p sula birostris, unilocularis, bivalvis, valvis basi introflexa connata seminiferis. S e $\mathrm{m}$ in a plurima ....-Herba acaulis, in fissuris rupium China e borealis crescens; radice crassa, squamosa, bulbillosa, foliis serotinis, cordatis, acutis, amplis, solitaritis, supra glabratis, laete viridibus, subtus primum violaceis, demum pallidis, ad nervos glanduloso-hispidis, margine erosodenticulatis, scapo aphyllo, ebracteato, glandulosohispido, racemis dichotome paniculatis, nutantibus, floribus purpureis, demum virescentibus, antheris laete violaceis.

Oresitrophe Bunge Enumerat, plant, Chin, bor. 31. Meisner Gen. 137. (100.)

SUEO IRED II. CUNONIEAE DC. Prodr. IV. 7. Frutices v. arbores, foliis oppositis, simplicibus v. compositis, stipulis interpetiolaribus. C al $\mathbf{y} \times$ liber $v$. plus minus adhaerens. Corolla e petala $4-5$, nunc nulla. Ovarium bi-quadriloculare.

464\%. Codia FORST. Calyx basi calyculo tubuloso, papposo cinctus, tubo cum ovario connato, limbi superi, quadri-quinquepartiti laciniis oblongo-linearibus. Corolla e petala $4-5$, summo caly cis tubo inserta, lineari-lanceolata, integra. St a min a 8_10, cum petalis inserta, iis dem utrinque contigua; filamenta filiformia, anthera e ovato-subglobosae, biloculares, incumbentes. Ovari $\mathrm{nm}$ infernm, quadri-quinqueloculare (?) loculis biovnlatis. Styli 2 , divergentes; stig mat a simplicia. Cap sula indehiscens, abortu monosperma. S e m en pendalum. E m bryo intra albumen pareissimum orthotropus; cotyledonibus foliaceis, radic nla brevissima, supera. - Frutex Novae-Caledoniae; ramulis oppositis, foliis oppositis, coriaceis, breve petiolatis, obovatis, integerrimis, glabris, stipulis interpetiolaribus caducis, pedinculis axillaribus, solitariis, monocephalis, floribus parvis, albis, in capitula globosa dense aggregatis, receptaculo villoso insidentibus, involucro tetra-pentaphyllo, brevi, refle$x o$, involucellis subcampanulatis, sex-octodentatis, apice pilis longis, rufis papposis.

Co d I a Forst. Char. gen. $t$, 30. Labillard Nov, Caledon. 43. . 46. DC. Prodr. IV. 7. Don in Edinb, new philo. soph. Journ, IX. 93. Meisner Gen. 138. (101.)

4648. Callieoma $A N D R$. Calyx tubo ecalyculato, brevissimo, cum ovarii basi connato, limbi quadri-quinquepartiti lobis ovato-oblongis, persistentibus. Coroll a nulla. Sta mina $8-10$, perigyna; filamenta filiformia, calyeis limbum longe superantia, antherae biloculares, incumbentes, ovato subglobosae. Orarium ima basi adnatum, villosissimum, biloculare, loculis plariovulatis. Styli 2 , flliformes, divergentes; $s$ tigm a ta simplicia. Capsula calyce inclusa, bilocularis, septicide bivalvis, valvis ventricosis, loenlis abortu monospermis. S e mina inversa, ovata, testa erustacea, papilloso-scabra. Embryo ..... - Frutex Nova $\mathrm{e}-\mathrm{Holla}$ adiae orienta$l i s$; ramis foliisque oppositis, simplicibus, penninerviis, lanceolatis, grosse serratis, subtus canis, stipulis interpetiolaribus ellipticis, membranaceis, caducis, pedunculis axillaribus petiolo longioribus, geminis, monocephalis, floribus parvis, in capitula globosa dense aggregatis, supra receptaculum villosum sessilibus, involucro communi tetraphyllo, brevi, reflexo, involucellorum loco bracteolis quatuor $v$. sex membranaceis, flores singulos cingentibus.

C allic om a Andrews Bot. Reporit. t. 566. Bot. Mag. t. 1811. DC. Prodr. IV. 7. exel. synon. Don in Edinb. new philocoph. Journ, IX, 93. Meisuer Gen. 138. (101.)

4645. Calyeomis $R, B R$. Calyx quinquepartitus, persistens, C oroll a e petala 5 . Stamina 10. Discus hypogynus minimus. Styli setacei. Ca p sula membranacea, globosa, bilocularis, apice dehiscens, loculis polyspermis. Se- 
mina minuta, laevia. - Frutex Novae-Hollandiae orientalis, vix notus, erectus, ramosus, sempervirens; foliis simplicibus, ternis, subsessilibus, oblongo-cordatis, acutis, grosse serratis, coriaceis, glabris, subtus glaucis, stipulis paleaceis, persistentibus, floribus parvis, albis, copiosis, verticillatis, pedicellatis, capsula apice hiante, fere Heucherae.

Calycomis R. Brown in Flinders Voy. 549. absq. eharaet. Don in Edind, new philosoph, Journ. IX. 93. Meisner Gen. 138. (101.)

4650. A plna nopetalim $E N D L . C$ a I y x tubo subnullo, libero, limbi explanati, quadripartiti lobis membranaceis, venosis, subinaequalibus. Corolla e petala 4 , inter calycis lacinias inserta, lineari-lanceolata, minima, saepissime nulla. Stamina 8 , imo calyci inserta; filamenta filiformi-subulata, antherae biloculares, basifixae, subsagittatae, eeaudatae. Ovarinm liberum, quadriloculare, loculis ovulo unico, ex apice anguli centralis pendulo, uno alterove obsoleto. S tyii 4 , in unieum quadripartibilem cohaerentes; stigmata brevia, acuta, stellatim patentia. Fructus....-Arbores Novae-Hollandiae orientalis; ramulis verruculosis, foliis oppositis, breve petiolatis, simplicibus, ovatis, nitidis, serratis, stipulis interpetiolaribus caducis, paniculis axillaribus lateralibusque, pedicellis medio setaceo bibracteolatis. IT.

A p han opetal $\mathrm{n}$ m Endlicher in Annal. Wiener, Mus,

465 1. Ceratopetalame $S M I T H$. C a I y tubo turbinato, cum ovarii basi connato, limbi semisuperi, quinquepartiti lobis oblongis, submembranaceis, nervosis, frutiferis auctis. C o rolIa e petala 5 , disco perigyno extus inserta, ungniculata, laeiniata, rigida, persistentia v. nulla. Stamina 10 , cum petalis inserta; filamenta filiformi subulata, a n thera biloculares, incumbentes, subcordatae, connectivo in processum rostelliformem producto. Ovarinm semisuperum, biloculare, ovulis paucis, juxta dissepimentum pendulis. Styli 2 , basi connati, apice distincti; stig$m$ a ta simplicia. C a p sula calycis tubo indurato, decemcostato adnata, limbo ancto, stellatim patente coronata, abortu unilocularis, monosperma, apice hians. Sem en inversum, subrotundum, testa crustacea. E m bryo ..... - Arbores $v$. frutices Novae-Hollandiae orientalis; fo. liis oppositis, simplicibus $v$. ternatis, serratis, glabris, stipulis interpetiolaribus, subfoliaceis, caducis, floribus terminalibus, paniculatis.

Ceratopetalum Smith Nov. Holl. I. 9. DC. Prodr. IV. 12. Don in Edinb. new philosoph. Journ, IX. 94. Meisner Gen. 138. (101.)

a. MERIDEMA Don L.c. C o roll a nulla. - Foli a simplicia. C. monopetalum Calcy.

b. EUCERATOPETALUM, C o r o lla pentapetala. - Foli a ternata. C. gu m m if e r u m Suith $O p$, cit, $t, \overline{3}$.

465\%. Selhinomerin $D O N, C$ a 1 y $x$ quinquefidus, persistens, fructifer haud mutatus. C oro 11 a e petala 5 , laciniata, decidua. St a min a 10 , antherae cordatae, muticae. Ovarinm liberam, biloculare, loculis pluriovulatis. St y li brevissimi, recurvati. Capsula baccata (?) apice clausa. Sem in a .... - Arbor Novae-Hollandiae orientalis, vix nota; foliis simplicibus, petiolatis, elliptico-oblongis, acutis, serratis, coriaceis, glabris, reticulato-venosissimis, petiolis basi articulatis, stipulis indivisis, caducis, floribus par- vis, albis, paniculatis, panicula terminali, ramosissima.

Sebizomeria Don in Edinb. new philosoph. Journ. IX. 94. Ceratopetal u m oratum Calcy, msc.

4653. Platylophess $D O N$. C a lyx quadri-quinquefidus, persistens. Corolla e petala 4 v. 5, disco hypogyno suburceolato extus inserta, trifida, persistentia. Stamina $8 v$. 10 , cum petalis inserta; filamenta filiformia, antherae biloculares, incumbentes, ovatae. Ovarinm liberum, biloculare, ovulis in loculis geminis, collateralibus, ex apice dissepimenti pendulis. Styli 2 , patentiusculi; stig $\mathbf{m}$ a $\mathbf{t a}$ simplicia. Ca p8 ula submembranacea, reticulata, basi turgida, bilocularis, apice compresso-alata, obtusa, indehiscens (?), loculis abortu monospermis. Se min a arcuata, testa coriacea, laevi. E m b ry o.... Arbor capensis; folits oppositis, petiolatis, trifoliolatis, foliolis subsessilibus, coriaceis, lanceolatis, acuminatis, argute serratis, reticulato-venosissimis, glabris, floribus terminalibus, paniculatis.

Platylophus Don in Edinb. new philoroph. Journ. IX. 92. Meisner Gen, 138. (101.) Weinmanniatrifo. Ii a t a Lina.

1654. Anoulopetalam $C U N N$, C a lyx liber, quadripartito-explanatus, lobis coriaceis, lanceolatis, nervosis. Corolla e petala 4 , disco perigyno extus inserta, lanceolata, indivisa, brevissima. Stamina 8 , cum petalis inserta; filamenta filiformia, antherae biloculares, incumbentes, cordatae, connectivo in processum filiformem producto. O va ri um liberum, biloculare, ovulis paucis, juxta tlissepimentum pendulis. StyIi 2, filiformes, distineti; stig mata simplicia. Fructus ...... Frutices insulae Diemen; foliis oppositis, simplicibus, petiolatis, crenatis, coriaceis, glaberrimis, stipulis interpetiolaribus, deciduis, floribus terminalibus, paniculatis.

A nodopetal um A. Cunningham mse. 1829, in Herb. Mus, caes.

4655. Weinmanmia LINN. C a ly 8 liber, quadri-quinquepartitus, persistens. Co ro 11 a e petala 4 v. 5, disco hypogyno urceolato extus inserta, sessilia, integra. St a min a 8 v. 10 , cum petalis inserta; filam enta filiformia, antherae biloculares, incumbentes, ovatae, muticae. Ovari nm liberum, biloculare, bilobnm, ovulis paucis, dissepimento utrinque biseriatim insertis. Styli 2 , divergentes; stigm a ta sulscapitata. Ca psula birostris, bilocularis, bipartibilis, loculis interne rimula hiantibus, demum bifidis. S e min a pauca, reniformi-subglobosa, pilis sparsis hirsuta. Embryo in axi albuminis carnosi orthotropus, teres. - Arbores $v$. frutices oppositifolii, in America tropica, in insulis borbonicis et Nova-Zeelandia crescentes; foliis simplicibus, ternatis, quinatis $v$. impari-pinnatis, petiolis articulatis, rhachi saepissime alata; stipulis interpetiolaribus caducis, floribus racemosis, racemis axillaribus, solitarits, oppositis $v$. terminalibus, geminis, pedicellis saepe fasciculatis, basi bracteatis.

We in ma n ni a Lina. gen, n. 493. Jussieu Gen, 309. Cavanill. Ic. 4. B66. Kunth in Humb. ot Bonpl. Nov, gen. et sp. VI. 49. t. 520-524. DC. Prodr. IV. 8. Cambessedes in St. Hilaire Flor. Brasil. II. 201. Don in Edinb. new philosoph, Journ, TX, 85. Meisner Gen, 138. (101.) Wi ndma n n a P. Browne Fam, 212.

4658. Telospermmm DON. Calyx quadrifidns, deciduns. Co r o 11 a e petala 4 , diseo hypogyno brevissimo, plano extus inserta, sessilia, integra. St amina 8 , cum petalis inserta; 
filamenta filiformia, antherae bilocalares, incumbentes, subglobosae. Ovarium liberum, conienm, biloculare, ovulis paucis, dissepimento placentari utrinque biseriatim insertis. Styli 2, divergentes; stigmata subeapitata. Capsula birostris, bilocularis, septicide bivalvis, placenta libera. S emina panca, oblonga, glabra, Emb r y o in axi albuminis carnosi orthotropus, teres. - Arbores v. frutices, in Nova-Z eelandia indigeni; foliis oppositis, simplicibus v, imparipinnatis, foliolis serratis, petiolis articulatis, stipulis interpetiolaribus eaducis, floribus racemosis, pedicellis sparsis.

Leiosperm um Don in Edinb. new philosoph. Journ. 1X. 91. Meisner Gen. 138. (101.) W e in $\mathrm{m}$ a $\mathrm{n}$ n la $\mathrm{f}$ sp. Forst. A. Cunningh. in Jardin. Annal. of nat. hist. II. 338.

465\%. Aekama A. CUNNINGH. Ca ly x quinquepartitus, persistens, laciniis lineari-spathulatis. Corollae petala 5, disco hypogyno pateriformi decemdentato extus inserta, sessilia, integra. S t a mina 10, cum petalis inserta; filament a filiformia, antherae biloculares, incumbentes, subglobosae. Ovarium liberum, ovatum, biloculare, ovulis plurimis, placentis linearibus, dissepimento utrinque adnatis insertis, Styli 2, divergentes; stig mat a subcapitata. Ca psula birostris, bilocularis, apice septicide dehiscens. Semina plurima, ovata, rostrata, laevia. Embryo.... - Arbor Novae-Zeelandiae, trigintapedalis; ramulis dense cinereo-pilosis, foliis oppositis, imparipinnatis, foliolis ellipticis, serratis, stipulis interpetiolaribus, deciduis, paniculis terminalibus ramosis, pube stellata densa vestitis.

A ekama A. Cunningham in Jardin. Annal. of nat. hist. $I I .358$.

4658. Pterophylla $D O N$. Ca $1 \mathrm{yx}$ quadrifidus, deciduus. Corolla e petala 4 . Stamina 8 . Ovari a m dense lanatum, biloculare. Styli brevissimi, incurvati. Capsula .... Arbor molucoana, vix nota; folits imparipinnatis, foliolis lanceolatis, obtuse acuminatis, crenatis, glabris, subtus glaucis, basi obliquis, tripollicaribus, impari longius petiolulato, stipulis foliaceis maximis, reniformibus, integerrimis, deciduis, floribus minutis, polygamis, spicato-racemosis, racemis terminalibus erectis, aggregatis, subpaniculatis.

Pterophylla Don in Edinb. new philozoph. Journ. 1X. 93. Weinmannia fraxine a Herbar. Smith.

4659. Arvoldia BLUM. Ca ly $x$ quadri partitus. Corolla e petala 4 . Stamina 8 , glandulis interposita, Ovarium didymam, biovulatum. Styli 2, incurvi; stigmata simplicia. Capsula e 2, basi connatae, abortu solitariae, stylis rostratae, intus Iongitudinaliter dehiscentes, monospermae. - Frutices javanici, glabri; foliis, imparipinnatis, glabris, stipulis interpetiolari bus orbiculatis, deciduis, racemis axillaribus terminalibusque geminis v. ternis.

Arnoldia Blume Bijdr. 868. DC. Prodr. IV. 12, Meisner Gen, 138: (101.)

48G0. Gumbllea RUIZ et $P A V$. Calyx campanulatus, quinquefidus, laciniis ovatis, acutis. Corolla nulla. Stamina 5 , imo calyei inserta; fil amenta filiformia, exserta, anthe$r$ a e incumbentes, biloculares, subglobosae. 0 vari um liberum, obcordato-semibifidum, hiloculare, ovulis plurimis. S tyli 2 , subulati, reflexi; stigmat a acuta. Capsula ovata, bifida, birostris, rostris reflexis, bilocularis, loculis polyspermis. Semin a minima, subrotanda. - Arbor per u a- $n a$; foliis oppositis, pinnatis, foliolis integerrimis, stipulis reniformibus, reflexis, floribus racemosis, flavescentibus.

G u a ille a Ruiz et Pavon Prodr. 48, t,7, Flor, Peruv. III. 23. t. 245. Meisuer Gen, 138. (101.)

4661. Caldeluvia $D O N$. $C$ a 1 y $x$ quadriquinquepartitus, decidnns. Co roll a e petala 4 v. 5 , disco hypogyno in glandulas $4-5$ emarginato-bilobas soluto extus inserta, unguiculata, integra. S tamin a 8-10, disco hypogyno intus inserta; filamenta filiformia, antherae biloculares, incumbentes, obcordatae. $O$ varium liberum, bi-triloculare, ovulis plurimis, juxta angulum centralem biseriatis, adscendentibus. Sty li $2-3$, primum erecti, demum reflexi. C a psula bi-trirostris, bitrilocularis, septicide bi tripartibilis, loculis intus longitudinaliter dehiscentibus, polyspermis. S emina fusiformia, adscendentia, testa membranacea, laxa, basi elongata. E m bryo in axi albuminis carnosi orthotropus, clavato-teretiusculns. Arbuscula chilensis; foliis oppositis, simplicibus, coriaceis, lanceolatis, glabris, subtus glaucis, grosse serratis, stipulis interpetiolaribus lanceolatis, deciduis, floribus axillaribus, paniculatis.

Cald cluvia Don in Edinb. new philosoph. Journ. IX. 92. Pöppig et Endlicher Nov, gen. ot sp. I, 9. $t$. 16. Meisner Gen. 138. (101.) D lete r i c a Seringe in DC. Prodr. IV.8. Weinmannia panicula ta Cavanill. Ic. $t .565$.

4682. Cumonia LINN. Cal y $x$ quinquepartitus, deciduns. C orolla e petala 5, disco hypogyno brevissimo extus inserta, oblonga, integra. Stamina 10, cum petalis inserta; filamenta lineari-filiformia, an th era e biloculares, incumbentes, subglobosae. Ovarium liberum, conicum, biloculare, ovulis plurimis, dissepimento utrinque biseriatim insertis, pendulis. Styli 2 , divergentes; stigmata simplicia. Ca psula conica, birostris, bilocularis, a basi ad apicem bipartibilis, columna placentari compressa, libera. S e min a plura, oblonga, compressiuscula, margine anguste membranaceo, irregulari cincta. $\mathbf{E}$ mb ryo in axi albuminis parce carnosi orthotropus; cotyledonibus subfoliaceis, radicnla supera. - Frutex capensis, foliis oppositis, imparipinnatis, foliolis oblongis, coriaceis, serratis, stipulis interpetiolaribus ovatis, amplis, caducis, racemis axillaribus oppositis, densis, spicaeformibus, pedicellis fasciculatis.

C a no nia Linn. gen. n. 556. Jussien gen. 310. Gärtner $I I T$. 34t. t. 295. Lam. t, 371. Loddig. Bot. Cab. $t .826$. DC. Prodr. IV. 12. Don in Edinb. new philosoph. Journ. IX. 92. Meisner Gen, 138. (101.) Osterd y k ia Burmann Afric. $259 . t$. 96 .

4663. Geissois LABILLARD. Ca lyx quadripartitus, deciduus. C o roll a nulla. S $t$ ami na 10, hypogyna (?); fil am enta filiformia, antherae biloculares, incumbentes, ovatae. Ovari um liberum, conicum, biloculare, ovulis plurimis, dissepimento utrinque biseriatim insertis, adscendentibns. (?) Stylus terminalis, basi simplex, apice bifidns; sti g m at a simplicia, subnlata. C a s u l a lineari-oblonga, compressa, bilocularis, bivalvis. Se min a plurima, biseriatim imbricata, compressa, sursum (?) in alam membranaceam producta. E m b r yo....- Arbor $\mathrm{N} \mathrm{o}_{\text {- }}$ vae-Caledoniae; foliis oppositis, petiolatis, quinato-digitatis, foliolis ellipticis, obtusis, integerrimis, supra nitidis, subtus pubescentibus, stipulis interpetiolaribus, oblongis, costatis, deciduis, racemis axillaribus multifloris, solitariis v. ternis. 
Ge is sois Labillardiere Nov, Caledon, 50, t. 50. Dun in Edinb. new philosoph. Journ. 1X. 96. Melsuer Gen, 138. (101.)

4664. Felangera CAMBESS. Caly x sexpartitus, deciduus. Coro 11 a nulla. S t a m in a indefinita, disco cum ovarii basi plas minus connato extus inserta; fil am enta filiformia, anthera e biloculares, inenmbentes, subglobosae. Ovarinm liberum, biloculare, ovulis dissepimento utrinque insertis, plurimis, adscendentibus. Sty1i 2, divergentes; stig mat a capitata. Ca psu $\mathrm{l}$ a birostris, bilocularis, septicide bivalvis, valvis demum bifidis. Semina plurima, complanata, apice in alam producta. E m bry o intra albumen carnosum, parcum orthotropus; cotyledonibus subfoliaceis, $\mathrm{radicula}$ infera. - Arbores brasilienses; ramis foliisque oppositis, petiolatis, tri-quinquefoliolatis, foliolis serratis, stipulis interpetiolaribus caducis, florum racemis axillaribus, simplicibus.

Bel in nger a Cambessedes in St. Hilaire Flor. Brasil. II. 203. $t, 115$ - 117. DC. Prodr. IV. 11. Meisuer Gen. 138. (101.) Pol y $5 \mathrm{t}$ u o $\mathrm{D}$ Don in Edinb. new philosoph. Journ. IX. 95. L a man on i a Flor. flumin. V. t. 104.

46E5. IS rueren KENNED. Calyx tubo brevissimo, imo ovario adnato, limbo sex-decempartito, laciniis foliaceis, persistentibus. Corolla e petala $6-10$, perigyna, decidua. St a mina perigyna, biseriatim indefinita, rarius petalis numero aequalia et alterna; fil am enta filiformia, ant herae dorso supra basim affixae, bilocnlares, loculis connatis, longitudinaliter dehiscentibus. Ovari um ima basi adnatum, biloculare; ovnla in placentis medio dissepimento ntrinque adnatis plurima, horizontalia, anatropa. Styli 2 , flliformes, divaricati; $8 \mathrm{ti} \mathrm{gmata}$ simplicia. Capsula subinflata, bilocularis, apice breviter biloba, rima loculicida hians. Semina in loculis pauca, placentae medio dissepimento adnatae inserta, ovatooblonga, testa granuloso-scabra, rhaphe elevata, laevi. Em b r y o in axi albuminis carnosi orthotropus, subcylinilricus, ejusdem.ferme longitudine; cotyledonibus brevibus, radicula obtusa, umbilico basilari proxima, centripeta. - Frutices Novae-Hollandiae extratropicae, humiles, Boroniae facie; foliis oppositis, sessilibus, tri. foliolatis, foliolis oblongis, integerrimis $v$. dentatis, stipulis nullis, floribus purpureis, axillaribus, solitariis, pedicellatis, nutantibus, rarius terminalibus, subsessilibus, capitatis.

B a a ra Kennedy in Andrews Bot. Reposit, $t$. 198. Salisbury in Annal. of Bot. I. 512. $t$. 10. Venten. Malmait. t, 96. Bot, Mag. t.715. Loddig. Bot. Cabin, t, 1197. Reicheub. Ie. oxot. 1. 77 . DC. Prodr. IV. 13. Don in Edinb, new philosoph. Journ. IX, 95. Melsner Gen, 138. (101.)

4666. Adenilleman BLUM. Cal y x campanulatus, quinquefidus, extus glanduloso-pilosus. Corollae petala 5, calyei inserta, perva. Stamina plurima, cum petalis inserta. Ovari um unicum (uniloculare, placenta suturali unica?). St y lus simplex; stig m a subpeltatnm. CapsuIa calyce inclusa, rostrata, unilocularis, latere dehiscens. Semina plura $(8-12)$, suturae dehiscenti biseriatim inserta, testa crustacea, unicostata. E mbryo. intra albumen; e otyle donib ns foliaceis, ra dicula brevi. - Fitex javanicus, sarmentosus, Rubi habilu; foliis alternis, cordatis, acuminatis, trilobis, inciso-serratis, bisti- pulatis, summis passim indivisis, inflorescentia terminali, paniculato-racemosa, floribus unibracteatis. Acienilema Blume Bijdr. 1120.

466\%. Pellacalyx KORTH. C a ly x tubuloso-campanulatus basi cum ovarios connatus, limbi sexfidi laciniis triangularibus, acutis, aestivatione valvatis. Corollae petala 6, laminae carnosae calycis tubum intus vestienti extus inter limbi lobos inserta, ovato-oblonga, apice lacinista, aestivatione valratim induplicata. S $\mathrm{ta}$ m in a 12, laminae calycis tubum intus vestienti continua, exserta; fil amenta dilatato-subulata, alterna petalis opposita majora, an therae parvae, subrotundae, biloculares, longitudinaliter dehiscentes. O varium tubi calycini basi connatum, octo-duodecimloculare. Ovula in placentis ex apice loculorum pendulis plurima, anatropa. Stylu s teretiusculus, simplex; st $\mathrm{i}$ g ma dilatatum, centro depressum, margine crenulato cinctum. Fru ctus … - Arbuscula javanica, Coffeae facie; ligno rubescente, ramulis subtetragonis, stellatin fusco. tomentosis, foliis oppositis, elliptico-oblongis, breviter obtuse acuminatis, basi rotundatis, serrulatis, serraturis callosis, supra glabriusculis, subtus costatis, nervis stellato-pubescentibus, stipulis interpetiolaribus lanceolatis, obtusiusculis, basi barbato-tomentosis, floribus axillaribus binis-octonis confertis, quasi e bractearum calyculo prodeuntibus, odore aromatico debili, calyce extus viridi, pulvere fusco consperso, intus corollino, albo, ad basin dense piloso, petalis albo flavis.

Pell a e al y $x$ Korthals in Hooven et Vriese Tijdschrift IIT. 20. t. 2.

SEEGTED VIII. HYDRANGEAE DC. Prodr. III. 13. Frutices, foliis oppositis, simplicibus, exstipulatis. Ovari um inferum v. rarius liberum. Fruetus capsularis v. rarissime baccatus.

4685. IIy drangea LINN. F lores omnes fertiles v. marginales steriles. Floribus sterilibns: Calyx membranaceus, venosus, explanatus, quadri-quinquepartitus. Corolla et genitalium rudimenta. Floribas fertilibus: C a ly x tubo cum ovario conuato, costato, limbo snpero, quadri-quinquedentato. Corolla e petala 4-5, annuli epigyni margini inserta, sessilia, ovata, aestivatione valvata. S $t$ a m ina $8-10$, cum petalis inserta; filamenta filiformia, anthe$r$ a e biloculares, Iongitudinaliter dehiscentes, $O \mathrm{va-}$ ri um inferum, biloculare, placentis dissepimenti superne interrupti marginibus adnatis, multiovulatis. St y li 2 , distincti; $8 \mathrm{tig} \mathrm{m}$ a $\mathrm{ta}$ subterminalia, introrsum lateralia. $\mathrm{C}$ a p $8 \mathrm{n}$ I a calycis limbo stylisque coronata, basi bi- superne subunilocularis, vertice deplanato inter stylos foramine a perta semiseptis margine placentiferis. $\mathrm{S}$ e m in a plurima, adscendentia, testa membranacea, adnata, reticulata. Embr yo in asi albuminis dense carnosi orthotropus; cotyledonibus brevissimis, obtusis, radicula cylindrica, infera. - Frutices, in America boreali, Nepalia et Japonia indigeni; folits oppositis, petiolatis, ovatis'v. oblongis, integerrimis $v$. caepius dentatis aut serratis, floribus corymbosis, albis v. roseis, marginalibus plerumque sterilibus, radiantibus, coloratis.

H ydrangea Linn. gen. $n$, 357. Jussien gen. 214. Schkuhr $t, 119$. Lam, $t, 307$. Gärtuer $1,150, t, 30$. Smith $I c$. 
piet, I. t, 12. Bot. Mag. t. 437. Duhamel Arbr. edit. Nov. III. t, 24, Wallich Elor. Nepal, t. 49. 50. Curtois in Sylloge plant. II. 38. Siebold in N. A. N. C. XIV, 686. DC, Prodr. IV. 13. Meisner Gen. 137. (100.) Horten s ia Jussieu Gen. 24. Peautia Commers, msc. Primula-Loureiro Flor. cochinch. 127.

4BS5. Platyerater SIEBOLD et ZUCC, Flores steriles fertilibus mixti. Sterilibus: Cal y x explanatus, membranaceus, venosus, triquadrilobus. Corollae et genitalium rudi menta. Fertilibus: $C$ alyx tubo cum ovario connato, limbo supero, quadripartito. Corolla e petala 4 , annuli epigyni margini inserta, sessilia, ovata, aestivatione valvata. S $\mathbf{t} \mathbf{m}$ in a indefinita, annulo epigyno plnriseriatim inserta; fil a m e n ta filiformia, ima besi cohaerentia, antherae biloculares, basifixae, longitudinaliter. dehiscentes. Ovari nm inferum, biloculare, placentis dissepimento utrinque insertis, multiovulatis. Styli 2 , distincti; stigmata subterminalia, introrsum lateralia. Capsula calycis limbo stylisque coronata, bilocularis, vertice inter stylos dehiscens. Semina plurima, adscendentia, oblonga, testa tenui, membranacea, reticulata, adnata, ultra nuclenm producta. Embryo in axi albuminis orthotropus, subeylindricus; coty led onibus brevissimis, radicula infera. - Frutex humilis, in Japoniae septemtrionalis rupibus humidis, ramis decumbentibus $v$. repentibus radicans; foliis annuis, decussatim oppositis, exstipulatis, petiolatis, oblongo-acuminatis, argute serratis, penninerviis, gemmis perulatis, corymbo terminali, ramoso, rarifloro, floribus cujusvis ramuli superioribus fertilibus, terminali praecociore, infimo sterili, calyce ampliato, explanato, reticulatim venoso, colorato. t. 27 .

Platgerater Siebold et Zuccarini Flor. Japon. I. 62 .

46rD. Selnizophragma SIEBOLD et $Z U C C$. F lor es radiantes steriles, in laminam petaloideam integram expansi. Calyx tubo cum ovario connato, decemnervi, limbo supero, quinquedentato. Corolla e petala 5, annuli epigyni marginf inserta, sessilia, ovata, aestivatione valyata. Stamina 10 , cum petalis inserta; fil ament a filiformia, libera, antherae bilocula. res, basifixae, Iongitudinaliter dehiscentes, $O \mathbf{v}$ a$\mathbf{r}$ i $\mathbf{u} \mathbf{m}$ inferum, quadri-quinqueloculare, placentis carnosis, loculorum angulo centrali adnatis, multiovulatis. Ca psula corticata, oblongo-clavata, decemnervis, calycis limbo stylisque persitentibus coronata, quadri-quinqueloeularis, strato interiori in dissepimenta columnae centrali adnata introflexo e fibris transversis, fasciolatis composito. S e min a pluriseriatim imbricato-adscendentia, lineari-oblonga, testa membranacea, reticulata, adnata, utrinque ultra nucleum producta. $\mathbf{E}$ mbry o...... Frutex in Japoniae montibus crescens, Hydrangeae facie; ramis tereibus, saepius prostratis et radicantibus, foliis decussatim oppositis, deciduis, estipulatis, peivolatis, e basi cordata ovatis v. obovatis, acutis, grosse serratis, penninerviis, imprimis subtus pubescentibus, gemmis perulatis, floribus parvulis, in corymbos cymosos, terminales, multifloros dispositis, ramulis inflorescuntiae ultimis radiantibus, lamina petaloidea, nivea terminatis.

Sehizophragma Slebold et Zuecarini Flor. Japon. I. $58, t, 26$.

467 1. Cornidia RUIZ et PAV. Calyx cubo hemisphaerico, eum ovario connato, limbo supero, quadri-quinquedentato. Corolla e peta- la $4-5$, annuli epigyni margini inserta, sessilia, ovata, aestivatione valvata. St a m in a $8-10$, cum petalis inserta; filamenta filiformia, libera, a $n$th e ra e biloculares, basifixae, longitudinaliter dehiscentes. Ovarium infernm, bi-tri-quadriloculare, placentis in loculorum angulo centrali bilobis, adnatis, multiovulatis. Styli $2-4$, distincti; stigma t a subterminalia, introrsum lateralia. C a p sula calycis limbo stylisque persistentibus coronata, subunilocularis, dissepimentis $2-4$ incompletis, margine utrinque placentiferis, foramine inter stylos. Iate triangulari dehiscens. Semina plurima, adscendentim imbricata, oblonga, testa membranacea, reticulata, utrinque ultra nucleum breviter producta. Emb ry o $\ldots . .$. Arbores $v$. frutices interdum scandentes, in Peruvia et Chili crescentes; foliis oppositis, petiolatis, ovatis obovatisve, coriaceis, rigide serratis $v$. rarius integerrimis, corymbo terminali multiradiato, bracteato.

Cornidia Ruiz et Pavon Prodr. 53, t. 35. Flor. Pe. ruv. IV. t. 335. luedit. Hooker et Arn, Bot, Miscell, III. 344. Porppig et Endlicher Nov, gen, et sp. I, 10, t. 7. Delessert Ic. select. III. 46. t. 79, Meisner Gen, 137. (100.) S a rcos tyles Presl in DC. Prodr. IV. 15. Retiq. Haenk, II. s3. $t, 60$.

46\%2. Adramia $W A L L$. C alyx tubo hemisphacrico, cum ovarii basi connato, limbo semisupero, brevissime quinquedentato, sinubus latis, obtusis. Corolla e petala 5, onmmo calyci inserta, sessilia, aestivatione valvata. St a m in a 10, cum petalis inserta; fil am enta filiformia, libera, anthera e biloculares, basifixae, longitudinaliter dehiscentes. Ovarium semiinferum, incomplete tri-quinqueloculare, placentis semiseptorum marginibus adnatis, multiovulatis. Styli 3-5, breves, distincti; 8 ti g matibus clavatis, subbilobis, B a c c a semisupera, calycis limbo cincta, stylisque persistentibus coronata, incomplete tri-quinquelocularis, semiseptis margine placentiferis. S em in a plurima, angulata, testa coriacea, adnata. $\mathbf{E} \mathbf{m b r y o}$ in axi albuminis dense carnosi subcylindricus; coty led o n i b s brevissimis, radicul a umbilico proxima, centrifuga.Frutices nepalenses et javanici, glabri, ramosi; foliis oppositis, petiolatis, estipulatis, oblongo-lanceolqtis, serratis, panicula terminali corymbosa, multiflora, cyanea, fructibus caeruleis.

A d a mi a Wallich Flor. Nepal. 46, t. 36. Plant, As, rar. t. 213. Bot. Mag. t. 3046. DC. Prodr. 1V. 16, Meisuer Gen. 137. (100.) C y a n i ti s Reinwardt in Sylloge plant. $I T .10$. Blume Bijdr. 921. DC, l. c. Meisner l, c.

4B.3. Broussaisia GAUDICH. Calyx hemisphaericus, liber, quinquepartitus, lobis deltoideo.ovatis, obtusiusculis, aequalibus. Corolla e petala 5, hypogyna (?), calyce duplo longiora, oblonga, acuminata, acumine reflexo, aestivatione valvata. S t a m in a 10 , cum petalis inserta; fil amenta subulata, libera, antherae ovatae, biloculares, longitudinaliter dehiscentes. Ovari u m libernm, subglobosum, quinqueloculare, placentis loculorum angulo centrali adnatis, multiovulatis. Sty Iu s brevissimus, simplex; stig$\mathbf{m}$ a truncatum, obsolete quinquelobum. F r u ct $\mathbf{n}$ s ...... - Frutex sandwicensis, non satis notus; folits oppositis, petiolatis, estipulatis, ovalibus, argute serratis, floribus terminalibus, corymbosis.

B rous s a is i a Gaudlehaud ad Fieycinet.479. 1. 69. DC. 
Prodr. IV. 17. Hooker ad Beechey 84. Meisner Gien, 137. (100.)

SUBORDO IV. ESCALLONIEAE DC. Prodr. IV. 2. Frutices v. arbores, foliis alternis, exstipulatis, simplicibus. 0 varium inferum v. liberum. Styli $2 \ldots 5$, in unum connati.

4674. Eseallonia MUT. Calyx tabo hemisphaerico, cum ovario connato, limbo supero, quinquedentato v. quinquefido. C o r oll a e petala 5, disci epigyni margini inserta, oblongo-spathulata, ungue erecto, lamina obtusa, patente. $\mathrm{S}$ tamina 5, cum petalis inserta; filamenta filiformia, anthera e ovato-oblongae, biloculares. Ovarium inferum, disco epigyno pulvinato $v$. cyathiformi, bi - v. rarins trilocnlare, placentis medio dissepimento v. loculorum angulo centrali adnatis, multiovnlatis. Stylus simplex; stigma subpeltato-dilatatum, bi-trisulcum. C a p s u la calycis limbo et disco epigyno coronata, bi-trilocularis, a basi septicide bi-trivalvis, valvis apice cohaerentibus, colnmna placentifera filiformi, libera. Semina plurima, testa scrobiculata. Embryo in axi albuminis carnosi orthotropus, subcylindricus, brevis. - Arbores $v$. frutices, in America tropica trans a equatorem et australi extratropica crescentes, saepissime resinosi; foliis alternis, integerrimis $v$. argute serratis, estipulatis, floribus terminalibus v rarius axillaribus, solitariis, paniculatis $v$. racemosis, albis, roseis aut purpureis.

Es callonia Mutis in Linn. f. Supplem. 21. Smith Ic. inedit. $I I, t, 30,31$. Venten. Choìx $t, 54$. Gärtner f. $I I I$. 16. t. 182. Kunth in Humb. et Bonpl. Nov. gen. ot op. III. 294. DC. Prodr. IV. 2. Reichenb. Ic. exot. $t$. 202. Link et Otto Ic. select, $t$. 23. Bot. Mag. $t$. 2890 . Bot. Reg. $t$. 1467. Reliq. Hänk. II. $t$. 51 - 59 . St. Hilaire Flor. Brasil. II. z. 181. Póppig et Endifeher Nov, gen, et sp. I. 8, t. 13-15. Hooker Ic, t. 114. Meisner Gen. 137. (101.) Ste re ox y lon Ruiz et Pavon Prodr. 38, t. 6. Flor. Peruv. t. 234-238. Mollia Gmelin Syst. 303. Vigier a Flor. Flumin, Ir. 2, 73. $7 / 4$.

4655. Quintinia $A L P H, D C$. Calyx tubo cum ovario conpato, limbo supero, quinquedentato. Coroll a e petala 5 , annulo epigyno inserta, oblonga, obtusa, patentia. Stamina 5 , cum petalis inserta; fil am enta filiformia, a ntherae ovato-oblongae, bilocnlares. Ovarium inferum, annulo epigyno calycis limbo adnato vertice nudum, septis abbreviatis incomplete quin queloculare, placentis semiseptorum margini adnatis, multiovulatis. Stylus simplex; stigma eapitatnm, obsoléte quinquelobum. C aps nl a calycis limbo coronata, incomplete quinquelocularis, apice septicide quinquevalvis, valvarum marginibus introflexis seminiferis. Se m in a oblonga, testa laevi, nitida: $\mathbf{E}$ mbryo.... - Frutices Nova eHollandiae orientalis et Novae-Zeelandiae; foliis alternis, petiolatis, ovalibus, apice acuminatis, basi angustatis, integerrimis v. dentatis, coriaceis, paniculae terminalis ramis patentibus, racemosis, calycibus basi bibracteolatis.

QuIntinia Alph. DC. Campanulac. 92. in not. DC. Prodr. IV. 3. Nadlicher in Flora 1832. p. 389. $t$. 3. Atakta t. 10. Meisner Gen, 137, (101.) A. Cunniagham in Jardine, Annal. of. nat, Hist, II. 356 .

46r6. Forgesia COMMERS. Ca $\mathrm{y} \times \mathrm{x}$ tubo turbinato, eum ovario connato, limbi superi, quinquepartiti lobis lanceolatis. Co roll a e petala 5, summo calycis tubo inserta, lineari-lanceolata, ima basi approximata, aestivatione subvalva- ta, vix calycis limbo longiora. Stamin a 5, cum petalis inserta; fi lamenta filiformia, erecta; an therae ovatae, biloculares. Ovarinm semiinferum, biloculare, ovalis juxta dissepimentum utrinque plurimis. Stylas simplex, demum bipartibilis; stigm a bilobum. Capsula semisupera, stylis disjunctis superata, bilocularis, inter stylos dehiscens. S em in a plurima $. . . .-A r-$ buscula borbonica, glaberrima; folitis alternis, coriaceis, lanceolatis, utrinque attenuatis, breve petiolatis, serratis, racemo terminali, pedicellis basi bracteatis.

Forgesi a Commers, in Jussieu gen. 164. DC. Prodr. IV. 5. Meisuer Gen. 137. (10t,) D off or gla Lant. $t$. 125.

46รซ. Itea LINN. C a ly x liber, campanulatus, quinquefidus, lobis subulatis, sinubus obtusis, Co roll a e petala 5, summo calycis tubo inserta, lanceolato-linearia, per aestivationem valvata. S ta m in a 5 , cum petalis inserta, iisdem alterna et breviora; fil am ent a subulata, anther a e oblongae, basi subbifidae, biloculares. O var inm oblongum, liberum, biloculare, ovulis juxta medium dissepimentum utrinque biseriatis. S t y l u s simplex, demum bipartibilis; stig m a capitatum, bisulenm. Capsula bilocularis, compressa, bisulca, demum bipartibilis, valvarnm marginibus introflexis seminiferis. Sem in a 8-12, compressiuscula, subcordata, testa erassiuscula, reticulata , rhaphe costaeformi, elevata. E m bryo in axi albuminis carnosi orthotropus, subcylindricus. Frutex boreali-americanus; foliis alternis, lanceolatis, acute dentatis, racemis terminalibus, simplicibus.

It e a Linn. gen, n. 275. L. C. Richard in Michaux Flor. Bor. Amer, I. 156. Lam. $t$, 147. Duhamel Arbr. edit, II. 6. t. 9. Gärtner f. III. 149, $t$. 209. DC. Prodr. IV. 6. excl. sp. asiat. Meisner Gen, 137. (101.) Di conan g i a Mitchel gen. s. Adanson. Fam. IT, 165.

468. Anopterus $L A B I L L A R D$. Ca $1 \mathrm{yx}$ tnbo turbinato, basi imo ovario adhaerente, limbi sexpartiti lobis brevibns, acutis, persistentibus. Corolla e petala 6 , perigyna, ovata, aestivatione imbricata. St a min a 6 , cum petalis inserta, iisdem alterna et breviora; fi l a m ent a subulata, an ther a e cordatae, bjloculares. Ovarium ima basi adhaerens, conicum, uniloculare, ovulis ad suturas parietalibus, biseriatis, pendulis. Stylus brevissimus, simplex; s ti g m a bifidum. C a p s u la oblonga, unilocularis, bivalvis, valvis margine seminiferis. Semin a pendula, ovata, compressiuscula, sursum in alam membranaceam, obtusam producta. Kmbryo intra albumen carnosum minimus, subglobosus, radicula supera. - Arbor insulae Diemen, elegans, glaberrima; trunco gracili, foliis sparsis v. oppositis, ovali-oblongis, utrinque attenuatis, subsessilibus, coriaceis, serratis, serraturis glandulosis, racemis terminalibus, simplicibus.

A nopterus Labillard. Nov. Holland. 1. 86. $t .11 \mathrm{e}$. R. Brown Prodr, 457, et in Eranklin Narrat, 736. DC. Prodr. IV. 6. Meisner Gen, 137. (101,)

\section{ESCALLONIEIS AFFINES.}

* ARgOPHYLLEAE.

46r8. Argophyllum FORST, Calyx tubo turbinato, cum ovarii basi connato, limbo semisupero, quinque-sexdentato. Co roll a e petala 5-6, perigyna, ovato-lanceolata, aestivatione valvata, sub anthesi patentia, basi ope coronae quin- 
que-sexpartitae coalita, coronae lobis petalis oppositis, erectis, fimbriato-laceris. St a m in a $5-6$, calyci inserta, cum petalis alterna; fil a menta brevia, subulata, antherae ovatae, biloculares, versatiles. Ovari $\mathbf{m}$ semiinferum, triloculare, placentis in loculorum angulo centrali multiovalatis. Stylus brevis, simplex; stigm a subcapitatum. C a p s ula semisupera, calyce persistente stipata, trilocularis, apice loculicide trivalvis, valvis medio septiferis. Se m in a plurima, angulatoobovata, fulvo-nitida, tuberculata. Em b ry o....

Frutices Novae-Caledoniae, non satis noti et dubiae affinitatis; foliis alternis, petiolatis, ovatis $v$. ellipticis, subtus sericeis v. tomentosis, integerrimis $v$, serratis, floribus terminalibus, panicula tis' $v$. cymoso corymbosis.

Argophyllum Forst. Char. Gen, t, 15. Lian. f. Supplem, 156. Gärtaer f. III. 149, $t, 210$. Labillard. Nov. Caledon. 37, t, 40. 41.

\section{* ROUSSEACEAE.}

48S4. Toussea SMITH. Caly . liber, quadri-quinquepartitus, laciniis coriaceis, planis, aestivatione valvatis, demum reflexis, persistentibus. Cor o 11 a e petala $4-5$, imo calyci inserta, aestivatione valvata et ope strati carnosi cum disco continui - cohaerentia, sub anthesi distincta, basi campanulato - conniventia, apice revoluta, extns villosa, intus glaberrima, lamina carnosa erassius: cula in ligulam obsoletam liberam desinente obducta. Dis c u carnosus, annularis, crassus, basi ovarii arete adnatus, hine in laminam petala vestientem productus, illine ovarii angulos adnato-obducens. St a min a 5 , disci sinubus inserta, petalis alterna; fila menta late linearia, basi subtrigona, an the ra e breviter exsertae, extrorsae, bilocnlares, basifixae, sagittatae, loculis basi discretis, longitudinaliter dehiscentibus. Ovari um liberum, ovato-pyramidatum, quadri-quinqueangulare, basi disco, angulis petalis oppositis ejusdem prolongationibus usque ad apicem adnatis vestitum, quadri-quinqueloculare, loculis cum petalis alternantibus. $0 \mathrm{v} \mathrm{l}$ a in placentis revoluto-bilobis, e loculorum angulo centrali ope laminae carnosae longe porrectis plurima, anatropa. Stylus ovario continuns, crassus, tetra-pentagonns; s tig ma terminale, discoideo-conicum, quadri-quinqueangulare, quadri-quinquefoveolatum. B a ce a ovato-pyramidata, crasse coriacea, quadri-quinquelocularis, dissepimentis laminisque placentiferis carnoso-membranaceis, loculis pulpa mucosa repletis. S e m in a plurima, minima, oblique ovalia, compressiuscula, funiculis brevissimis, papillaeformibus affixa, testa crustacea, laevissima, rhaphe et chalaza obsoletis. E m b ryo intra albumen carnosum centralis, minimus, subcylindricus, orthotropus; cotyl ed o. nibus brevissimis, discretis, radicula crassa, umbilicum spectante. - Frutex borbonicus, scandens; ramis crassis, nodosis, folitis oppositis, petiolatis, obovutis, acutis, dentatis, stipulis interpetiolaribus membranaceis, acutis, pedunculis axillaribus, unifloris.

Rou s se a SmIth Ie, inedit. I. 6. t. 16. Lam. t. 75. Poiret Dict. VI, 318. Gärtuer f. III. 166, $t, 212, \mathrm{R}$ o u s 80 a Rōm. et Sehult. Syat. III. 3.

\section{*** BREXIACEAE.}

4851. IBrexin THOUAR. C aly $\mathrm{x}$ liber, quinquefidus, persistens, laciniis coriaceis, bre- vibus, acutis, aestivatione imbricatis. Corolla e petala 5, annuli perigyni margini extus inserta, coriacea, oblonga, obtusiuscula, aestivatione imbricata, basi subcohaerentia, superne sub anthesi patentiuscula. Sta mina 5 , cum petalis inserta, iisdem alterna; fil am enta subulata, carnosa, antherae oblongae, erectae, basifixae, bilocnlares, longitudinaliter dehiscentes. D i s c n s annularis, crassus, basi ovarii adnatus, in lobos quinque, multifido-laceros, staminibus alternos desinens. Ovari um superum, ovato-pentagonum, quinqueloculare, ovulis plurimis, in loculorum angulo centrali biseriatis, Stylus brevissimus; st ig m a quinquelobnm, lobis ovatis, acntis, erectis. Drupa oblonga, quinquecostata, apice abrupte conico, breviter quinquecorni, epicarpio papilloso, endocarpio osseo, nitido. S emina plurima, horizontalia, funiculis brevibus subtensa, ovato-angulata, nitida, testa membranacea. $\mathbf{E}$ mb ry o exalbuminosus, orthotropus, amygdalinus; cotyledonibus ovatis, obtusis, radicula cylindrica, centripeta. - Arbusculae madagascarienses; foliis alternis, petiolatis, subcoriaceis, integerrimis $v$. spinoso-dentatis, floribus axillaribus terminalibusque umbellatis, pedunculó compressiusculo.

B rex i a Thouars Gen, madagasc, $n$, 69. Lindley in Bot. Aeg. t. 730. 872. V e na a a Lam. $t$, 131. Wallieh in Rox. burgh Flor. Ind, 312.

\section{Ordo CLXXI. Ribesiaceae.}

CActorum genus Jussieu Gen, 310. grossula. RIEAE DC. Flor. franc. edil. 3. IV. 405. Prodr. IIT. 477. Berlandière Memoire sur la famille des Grossulariees in Mem. soc. Genev. III. 43_60. Bartling Ord. nat, 275. Spach Revisio Grossulariearum in Nouv. Annat. sc. nat. IV. 16. Suites a Buffon $N I$. 144. GROSSULACEAE Lindley Intro. duct. edit. II. p. 26.

Frutress inermes v. spinis infraaxillaribus aut irregulariter sparsis armati, ramis terretibus v. angulatis, imperfecte nodosis, gemmis perulatis.

Foura sparsa, saepius fasciculata, annua v. rarius perennia, simplicia, petiolata, palmatinervia, palmatifida v. lobata, erenata, dentata v. incisa, saepius guttulis resinosis conspersa, vernatione rugoso plicata v. convoluta, petiolo canaliculato, basi dilatato, interdum utrinque margine stipulari adnato v. superne libero, saepissime obsoleto aucto.

Frores hermaphroditi v. saepissime abortu unisexuales, regulares, in racemos interdum depauperatos dispositi, rarius subcapitato approximati v. subsolitarii, nunc ex eadem cum foliis gemma nascentes, ramulum brevissimum, foliorum rosula cinctum terminantes, ramulis succedaneis e foliorum axilla demum evolutis sublaterales, nunc rarius e gemma aphylla evoluti, albi, flavi v. rubicundi, pedicellis basi bractea apice v. medio saepissime bracteolis geminis instructi, apice v. infra apicem articulati, plerumque nutantes.

Calxx coloratus, marcescens, tubo basi cum ovario connato, plus minus supra illud 
producto, elongato-cylindraceo, campanulatov. interdum abbreviato-pelviformi, limbo quinquefido v. rarius quadrifido, laciniis aequalibus v. rarissime subinaequalibus, aestivatione imbricatis v. rarissime subvalvatis, sub anthesi patentibus v. saepe reflexis.

Coroliak petala calycis fauci inserta, ejusdem laciniis numero aequalia ( $5 \mathbf{v}$. rarissime 4) et alterna, parva, saepe minima, subunguiculata, aestivatione distantia v. marginibus imbricata, marcescenti-persistentia.

Sramiva cum petalis inserta, iisdem numero aequalia (5 v. rarissime 4 ) inclusa v. rarissime exserta. Fil ament a filiformi-subulata, aequilonga, aestivatione erecta. Anthe rae introrsae, biloculares, ovatae v. oblongae, medio dorso v. supra basim affixae, apice emarginatae v. apiculatae, aut glandula terminatae, loculis juxta totam longitudinem dehiscentibus.

Ovariom inferum v. vertice breviter exserto semisuperum, disco tenui in laminam calycis tubum intus vestientem continuato coronatum, uniloculare. Placentae nerviformes, parietales v. semiseptis adnatae, geminae, rarius per excessum tres v. quatuor. 0 vula rarissime panca, uniseriata, plerumque plurima, pluriseriata, semper horizontalia, in funiculis brevibus anatropa. Sty li 2 , rarissime $3-4$, nune distincti, nunc ad medium v. usque ad apicem connati. Stigmata brevissima, distincta, simplicia, obtusa.

Bacca calycis limbo emarcido coronata, umbilicata, unilocularis, pulposa, polysperma v. abortu oligosperma.

Semiva horizontalia, angulata, testa gelatinosa, in rhaphe libera reclinata, integumento interiore crustaceo, albumini adnato. Al b um en dense carnosum v. subcorneum.

EмBRxo in basi albuminis orthotropus, minimus, subteres. Cotyled ones brevissimae, obtusae. R a dicula umbilicum chalazae e diametro oppositum attingens, centrifuga.

R ibesi ace a e Saxifrageis proxime affines, sed habitu, fructu baccato, seminibus pulposis et rhaphe libera optime distinctae, hemisphaerae borealis regiones frigidiusculas, imprimis Americam borealem et subarcticam incolunt, in America australi rarae. Baceae plurimarum specierum edules.

4BS\%. Fibes LINN. Calyx tubocum ovario connato, limho supero, colorato, pelviformicampanulato v. tubuloso, quinquefido v. rarissime quadrifido, aequali. Co roll a e petala 5 v. 4 , calycis fauci inserta, parva, squamaeformia. $S t a-$ mina cum petalis inserta, iisdem numero aequalia et alterna, inclusa. O va ri $\mathbf{m}$ inferum, unilaculare, placentis duabus parietalibus nerviformi- bus, oppositis. Ovula plurima, pluriseriata, in funiculis brevibns adnato-reclinata. Sty li 2 , distincti $v$. plus minus connati; $s \mathbf{t} \mathbf{g} \mathbf{m}$ a $\mathbf{t}$ a simplicia. B a ce a calyce emarcido coronata, nnilocularis, polysperma v, abortu oligosperma. Sem in a angulata, testa gelatinosa, in rhaphe maturitate libera reclinata, integumento interiori crustaceo, albumini adnato. Embryo in basi albuminis subcornei orthotropus, minimus, radicula centrifuga. - Frutices inermes v. spinosi; foliis sparsis, digitato-lobatis $v$, incisis, petiolo basi dilatato, semiamplexicauli, pedunculis axillaribus v, e gemmis erumpentibus uni-trifloris $v$, racemoso-multifloris, pedicellis basi unibracteatis, medio v. apice bibracteolatis, floribus virescentibas, albidis, flavis v. rubris, rarissime abortu dioicis.

Ri bes Linn. Gen, n. 281. Berlandière in Mem. soc, $h$. n. Gekew. III. 43. DC. Prodr. III. A77. excl. sect. I. G ros: s u la ria Tournefort Inst. 409. Gärtner 1 . 143.

a. GROSSUlaria DC. $l$. e. $\mathrm{C}$ al y $\times$ plus minus campanu. latus. - Caules ut plurimum aeuleati, pedunculi unitriflori. Folia vernatione plicata. - Grossularia A. Riehard Bot. Medic. II. 487. Spach Buffon VI. 172. (Berlandière t. c., t, 1. f. 2-4. Flor- dan, $t, 546$. E. B. $t$. 1292. 2057. Ledebour Ic. $t, 230$. Bot. Reg. $t$, 1359. Bot. Mag, t. 3530.)

b. BIBESIA DC. $l$, c. C a 1 y $x$ eampanulatus v, eylindricus. - Caules inermes, pedunculi ut plurimum multiflori. Folia vernatione plicata. - Ribes et Botrycarpu m. Aichard l. c. Calobotrya, Coreosma et $\mathrm{R}$ e b is Spach in Nouv. Annal.sc, nat, IV.21_31. C e r ophyllum, Coreosma, Botryocarpum et Rib es Spach Buffon VI, 152_172. (Berlandiere 2 . c. $t .2$. $f .7$ 22. Heritier Stirp. $t, 2,4$, B. B. $t, 1290$. Rứiz et Pavon Flor. Peruv. t. 232, 233. Bot. Reg, t. $1237,1263$. 1349.' 1263. 1i71. 1658. Bot. Mag. $t, 1583.3008 .3335$.

e. SIPHOCALYX DC. l, c. C a ly $\mathrm{x}$ longe tubulosus, eitrinus. - Flores racemosi. Folia vernatione convoluta. S y m p ho cal yx (lege Siphocaly $x$ ) Berlandiere $l$. c. $t . \overline{2}$. f. 23. 24. Chry s obotry a Spach in Nouv. Annal.sc. nat. IV. 18. t, 1, Buffon VI. 148. (Bot. Reg. $t, 125$. 1236.)

4683. TEobsomia BERLAND. C a I y $\mathrm{co-}$ loratus, tubo enpuliformi, cum ovario connato, limbi superi, quadri -quinquepartiti lobis erectis, carinatis, tubo multoties longioribus. Corolla e petala $4-5$, calyeis fauci inserta, cuneiformia, inclusa. S ta min a $4-5$, cum petalis inserta, iisdem alterna, longe exserta. Ova rin m infernm, uniloenlare, placentis duabus nerviformibus, oppositis. Ovula in quavis placenta 3 , uniseriata .... St y lus filiformis, simplex, exsertus; stigm a brevissime bifidum. B a c c a .... - Frutices c alifornici; ramis setosis, spinis tripartitis, foliis trilobis, lobis crenato-incisis, racemis axillaribus bi-trifloris, bracteis ad basim pedicellorum coloratis, floribus rubicundis, baccis hispidis.

Robsonis Spach Buffon VI. 180. R o bs on ia sect. $\mathrm{R}$ ib is Berlandière in Mem. soc. Genev. MI. $t, 1$. f. 1 . DC: Prodr. IIT. 477. Ribes speciosum Pursh. Bot, Reg. t. 1557. R. stamineum Smith. R, fuehsioides Berlandièrẹ t. c. $t, 3$.

\section{Classis XL11. Polycarpicae.}

Herbae, frutices v. arbores, succo aqueo v. in nonnullis colorato. Foli a alterna v. rarius opposita, simplicia v. rarissime composita. Flores hermaphroditiv. diclines. Calyx liber, saepissime deciduus. Corollae petala hypogyna, libera, plana v. interdum tubulosa, nune nulla. Stamina hypogyna, in 
hermaphroditis plerumque indefinita, in uni-|unicum, parietale, amphitropum, micropyle supesexualibus saepius monadelpha. Ovaria plura, ra, in Lardizabaleis. Ovula plura v. plurima, verticillata v. spicata, distincta, rarius conna- parieti undique inserta, campylotropa v. anatrota v. solitaria. Ovula solitaria v. plurima, ana- pa. S tyli terminales, simplices v. trifidi aut tropa, rarius amphitropa. Fructus varius, tridentati, in multis ovarii curvatione demum capsularis v. baccatus, rarius drupacens. Se- basilares, nunc nulli, Stigmata simplicia. $\mathrm{m}$ in a interdum strophiolata. Emb r yo in basi albuminis copiosi minimus, rarius albumen parcum aequans, rarissime exalbuminosus.

\section{Ordo CLXXII. II Tenispermaceate.}

MENISPERMA Jussien Gen, 284. MENISPERMOIDEAE Venten. Tabl. IIT. 78. MRNISPERMEAR Jeaume Exposit. Fam. IT. 82. DC. Syst, I. 509. Bartling Ord, nat. 242. MENISPERMACEAE DC. Prodr. $\boldsymbol{T}$. 242. Lindley Introduct. edit. II, $p, 214$.

Frutices sarmentosi, flexiles, tenaces, ligno ezonato v. rarius zonato. Folia alterna, simplicia, peltinervia v. palmatinervia, saepius peltata, integra; rarius (in Lardizabaleis) composita, subternata. St ipul a e nullae.

Fuones rarissime hermaphroditi, saepissime typice v. abortu unisexuales, dioici v. monoici, racemosi v. rarius paniculati, plerumque minimi, inconspicui, integumentis floralibus uni-pluriseriatis, seriebus numero ternario, rarius bi-quaternario, rarissime quinario alternantibus.

Calyx tri-hexa-dodecaphyllus, rarissime tetra-decaphyllus, foliolis uni-triseriatis, articulatis, deciduis, exterioribus saepe minoribus, liberis v. basi coalitis.

Corollae petala hypogyna, calycis foliolis plerumque dimidio minora v. rarius aequalia, saepissime iisdem multo breviora, quandoque minima, libera v. interdum plus minus inter se coalita, saepius imprimis in floribus femineis nulla.

Stamina calycis foliolis numero aequalia et opposita, rarius plura. Filam en ta subfiliformia v. linearia, nunc libera, nunc interiora monadelpha, exterioribus distinctis, nunc omnia simul in columnam centralem apice saepius peltatam coalita. Anth er a extrorsae, uniloculares v. biloculares, interdum quadriloculares, loculis transversim v. longitudinaliter dehiscentibus.

Floribus femineis, nunc Calyx maris, staminibus efoetis v. nullis, nunc monophyllus, anticus, unguiculatus, deciduus, et Coroura monopetala, postica, unguiculata, calyci adpressa.

Ovaria unilocularia, nune plura verticillata, libera v. basi coalita aut connata, nunc ovarium unicum, excentricum, primum rectum, deinde apice suo curvatum et basi applicatum, cum ea concrescens. $0 \mathrm{vul} \mathrm{um}$ in Menispermeis

Fructus baccatus v. drupaceus, rectus v. lunulatus, subcompressus, nucleo rugoso, utraque facie linea hippocrepica notato, intus a basi usque medium dissepimento bilamellato, e pericarpii basi et apice connatis proveniente, instructo.

Semen rẻctum, inversum, v. hippocrepicum, sinu dissepimenti incompleti apici affixum. Tes ta membranacea, tenuis. A l bum en in Lardizabaleis copiosum, dense carnosum, in Menispermeis parcum, quandoque nullum.

EмвRуо intra albumen in Lardizabaleis minimus, in Menispermeis magnus, homotropus. C otyl e d on e lineares, applicitae, v. latae, foliaceae, saepe disjunctae. Radicula brevis, ab umbilico remota, rarissime eidem proxima.

Men ispermace ae hine Anonaceis, illine Berberideis affines, embryonis magnitudine et albuminis quantitate parca inter Polycarpicas anomalae, inter tropicos Asiae et Americae frequentissimae, in utraque Africae ora rarae, rarissime Cancrum transgrediuntur, unica in Siberia reperta, paucae in Japonia, nonnullae in Americae borealis regionibus australibus vigent.

Lardizabaleae ovulorum numero, embryone minimo, et foliis compositis a Menispermeis distinctae, et olim in proprium ordinem Berberideis arctius conterminum segregandae, in archipelago indico, Nepalia, Madagascaria, Peruvia et Americae meridionalis extratropicae ora occidentali observatae fuerunt.

Phytocreneae, quas Menispermeis subjunximus, fructu adhucdum incognito, omnino dubiae affinitatis.

Ranices plurimarum amarae, tonicae, semina noinnullarum narcotica.

SEIBOIRID I. MENISPERMEAE. DC. Prodr. I. 96. Ovaria uniovulata. E mbryo intra albumen parcum maiusculus, rarius exalbuminosus. - Foli a simplicia.

1694. Agdestis MOC. et SESS. F $10 \mathrm{res}$ hermaphroditi. Calyx tetraphyllus. Corolla nulla. Stamina 24 ; fil amenta filiformia, antherae oblongae, utrinque bifidae, medio ingertae. Carpidia 4, monostyla, in ovarium quadrisulcum coalita; styl o brevi, quadrisulcato, stigmatib a s 4, patentibus, apice subreflexis, - Frutex mexicanus, scandens, glaber; foliis alternis, petiolatis, cordiformibus, pedunculis trifidis, corymbosis, inferioribus axillaribus, superioribus in thyrsum approximatis. 
Ag destis. Macino et Sessé Flor. mexic. ex DC.Syst, I. 343. Prodr. I. 103. Meisner Gen. 8. (7.)

4685. I Teni̊spermam TOURNEE. F lores dioici. Masc. C alyx hexa-dodecaphyllus, foliolis ternatim quaternatimve bi-triseriatis. Coroll a e petala $6-8$, hypogyna, biseriata. Stamina $12-24$, hypogyna, bi-quadriseriata; fil a m e nta linearia, anth era e terminales, adnatae, quadrilobae, lobis subglobosis, transversim dehiscentibus. Fem. Cal yx et corolla marium. Ovari a $2-4$, libera, subpedicellata, unilecularia. 0 v u$\mathbf{l u m}$ unieum, parietale, amphitropum. Styli terminales, breves; $8 \mathrm{tigmata}$ bifida. Drnpae baccatae, putamine osseo, subrotundo-reniformi, monospermo. S e me n reniforme. E mb r y o .... - Frutices scandentes, in America bareali et $\bar{A}$ sia media indigeni; foliis alternis, petiolatis, peltatis $v$. cordatis, angulatis, glabriusculis, integerrimis, racemis axillaribus $v$. supraaxillaribus solitariis compositis, $v$. geminis capitellatis.

Me n is permum Tournefort in Mem. Aeadem. Paris. 1705. p. 237. L.um, t. 824. Schkuhr t, 337. Bot, Mag. t, 1910. DC. Syst, I. 539. Prodr. I. 102, Delessert Ic, select. I. t. 100. Meisner Gen, 5. (7.) T ril o phus Fischer moc.

4686. Pseliman LOUR. Flores dioici. I a s e. Caly x hexaphyllus, foliolis acntis, concavis, patentibus. Coroll ae petala 6 , erecta, apice inflexa, calyce duplo longiora. St a mina 6 ; filamenta calycem subaequantia, antherae didymae. F e m. Ca ly x tetraphyllus, foliolis ovatis, minimis, pilosissimis. Coroll a nulla. Ovari um unicum, subrotundum, Stigma sessile, quadrifidum, laciniis acntis, erectis. Drup a compresso-subrotunda, nuce monosperma, orbiculata, pertusa, armillaeformi. Se men .... - Frutex cochinchinensis, volubilis, tenuis, ramosus; foliis alternis, integerrimis, glabris, in stirpibus masculifloris subcordatis, subrotundis, racemis axillaribus, brevibus subdivisis, in feminifloris foliis peltatis, ovatis, aeuminatis, umbellis axillaribus, compositis.

Pselium Loureiro Flor. cochinch: 762, DC. Syst, 11. 531. Prodr, I. 100. Meisner Gen. 5. (7.)

468 . Cocenans $D C$. F lores dioici $v$ rarius monoici. M a s c. C a 1 y x tri-hexaphyllus, foliolis biseriatis, exterioribus minoribns, basi cohaerentibus, interioribus majeribus, saepe deficientibus. Corollae petala $3-6$, hypogyna, calyce multo minora, unguieulata, interdum nulla, $\mathbf{S}$ tamina 6, hypogyna, libera, petalis opposita; $\mathrm{fi}$ $1 \mathrm{am}$ enta teretiuscula, an therae introrsae, biloculares, longitudinaliter dehiscentes. Ovarii rudimentum nullum. F em. Calyx et corolla marium. Stamin a 6 , antheris efoetis, v. nulla. Ovaria 3-6, v, rarius plura, seasilia v. gynophoro brevi imposita, libera, unilocularia, $\mathrm{O}_{\mathrm{v}} \mathrm{I} \mathbf{\mathrm { um }}$ nnicum, parietale, amphitropum, micropyle supera. Sti g mat a sessilia, simplicia v. bifida, Drupa earnosae, rectae v. campylotropae, putamine reniformi v. subhippocrepico. Sem en nuci conforme, plus minus arcuatum. Embry o intra albumen carnosum homotropus; cotyledonibus parallelis $\mathrm{v}$. albumine interposito divarieatis, radie ula supera.- Frutices volubiles, inter tropicos totius orbis obvii; folis alternis, petiolatis, basi insertis peltatisve, cordatis, ovatis $v$. oblongis, integris $v$.rarius lobatis, pedunculis axillaribus v. rarius lateralibus, masculis saepius multifloris, femineis paucifloris, bracteis minimis $v$. nullis.

Coceulus DC. Syst. I. 515. Prodr. I. 96. excl. sp. Delessert Ic. select, $I$. $t, 93_{-}$97, St. Hilaire Plant, us, Bra- sil. t. 42, Flor, Brasil, 1,47 , Gaudichaud ad Freyc, t. 10t A. Richard Flor, seneg. $t$. 4. Hooker in Bot, Mag. $t$. 2970. 9971. Colebrooke in Linn. Transact, XIIT. $t$, 17. Wight et Arnott Prodr. I. 11. - A b u t a Barrer. Er. aeq. 1. Aublet Guian. I. 618. $t, 250$. non Pöpp. Chondode udron Ruiz et Pavon Prodr. 132. Poppig Nov, gen, et sp. $K$. 65. $t, 190$. - Ba umgartia Märeh Method. 650. Androphylax Wendland Observ. 38. Hort. Herrenh. 3. t. 16. W e nd I a n. d f a Willdenow $\mathcal{S}$ pec. $I I$. 275. - B r a un e a Willdenow $S_{p e c}$ IV. 797. Thli a co ra Colebrooke in Litn. Transact, XIII. 67. - E pibaterium Forster Char.gen. 54. - L i ma cia Lonreiro Elor, cochinch. 761 . F ib r a u re a Loureiro $l$. c. 769. Nephrofia Loureiro 2 . $c$. 692. C ebatha Forskaet Aegypt. 171. Le a e b a Forskael l. c. (Delile Flor. aegypt. t. 51. f. 2.3.) Columbra Commerson msc. Bagalatta Roxburgh mse.

4683. Dheniseosta $B L U M$. Flo res polygami. Masc. Caly $\mathbf{x}$ parvus, quadri-quinquefidus. Cor olla e petala 4 v. 5 , biseriata. Sta m in a 5 , lata, petalis opposita iisdemque basi adglntinata. Ova ri u m didymum, sterile, basi margine membranaceo, brevi, quinquedentato cinctum. Hermaphr. Calyx, corolla et stamina marium. Ovari um didymum. Stigmata 2 , ob. tusiuscula. Drupae baceatae, geminae v, abortu solitariae, reniformes, compressae, monospermae. Sem en.... - Frutex javanicus, scandens, glaber; foliis ovali-oblongis, mucronulatis, floribus axillaribus, paniculatis.

Me niscosta Blume Bijdr. 28. Meisner Gen, 5 .

4689. ฮด ales BLUM. F Io res dioici. M a s c. C a l y $x$ quinquepartitus. C o r o ll a quinquepartita. S t a in in a basi monadelpha, corollae laciniis alterna, anther a e apici flamenti insertae, biloculares, latere dehiscentes. F em. Caly $\mathbf{x}$ et $\mathrm{co-}$ roll a maris, saepe sexfida. O varium simplex, ovato-globosum, uniovulatum. Stigma sessile, orbieulatum, radiato-emarginatum. Fructus ....

Frutex javanicus, sarmentosus, alte scandens; foliis suboppositis, ovalibus, mucronatis, ad costam utrinque tomentosis, corymbis axillaribus, subdichotomis.

Jö de s Blume Bijdr. 29. Meisner Ger. 5. (7.)

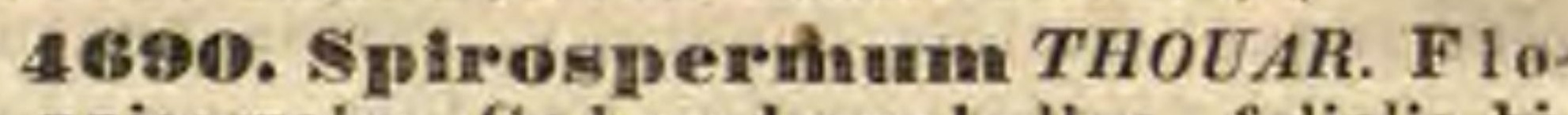
res unisexuales. Calyx hexaphyllus, foliolis biseriatis, interioribus longioribus. Corollae petala 6, concava, ealyee breviora. Stamina 6 , tria interiora basi connata, an therae apici filamentorum insertae, bilobae. F e m. ... Nuces 8 , in orbem dispositae, pedunculatae, monospermae. Semen exalbuminosum. Em b r yo cylindricus, longissimus, spiraliter convolutas. - Frutex madag ascariensis, debilis; foliis alternis, multinerviis, floribus racemosis, dependentibus.

Spirospermum Thouars Gen: Madagasc, $n$. 63, DC. Syst. 1. ata. Prodr. I. 96. Meisuer Gen. 5. (7.)

4698. Thiclaes PERS. F lores dioici. Mas c. C a ly $\mathrm{x}$ hexaphyllus, follolis biseriatis, interioribus majoribus. C orolla e petala 3 , hypogyna, basi eampannlato-conniventia, apice reflexa. St a mina 6, hypogyna; fil amenta inferne monadelpha, alterna breviora, an $\mathbf{t h}$ er a e terminales, subpeltatae, transversim dehiscentes. F e m. Cal y x et cor olla marium. Sta m in a 6 , sterilia, filamentis apice bimaculatis. Ovaria 3 , libera, tinilocularia. Ovul n m unicum, parietale, amphitropum, micropyle supera. St y li terminales, breves, intus stigmatosi. Dru pa e subbaccatae, ternae $v$. abortu solitariae, putamine ovali, osseo. S em en nuci conforme, rugis plicisque longitudinalibus anfractuosum. E mbry o intra albumem tenue reetus; cotyledonibus subfoliaceis, diraricatis, 
planis, radicula brevissima, supera.

Frutices Americae tropicae, scandentes; foliis alternis, simplicibus, petiolatis, floribus axillaribus, racemosis $v$. spicatis.

Tricho a Persoon Encheirid. II. 634. DC. Prodr. I. 103. Meisner Gen. 5, (7.) B a ts ch i a Thunberg in Nov. Aet, Upsal. V. 120, t. 2. A bu ta Pöppig Nov. gen. et sp. II. 64. $t, 188$, non Aubl.

4692. Coseinatumn COLEBR. Flores dioici. M a s c. ..... F e m. C a ly x hexaphyllus, foliolis biseriatis, extus villosis, interioribus majoribus. Corolla nulla. Stam in a sterilia 6 , ovaria basi stipantia. Ovaria 3 , libera, unilocularia. Ov $\mathbf{n} \mathbf{l n m}$ unieum, parietale, amphitropum, micropyle supera. Stylus terminalis, recurvus, intus stighatosus. Drupa e baceatae, ternae v, abortu solitariae, pntamine reniformi, depresso. Seme n nuci conforme, intus endopleurae rugis plicisque anfractuosum. $\mathbf{E} \mathbf{m b r y}$ o intra albumen tenue rectus; cotyledonibus subfoliaceis, divaricatis, flexuosis, foraminibus fenestratis, $\mathrm{ra}$ dicula brevissima, supera. - Frutex ceylanicus, scandens, non satis notus, ligno flavo, amaro; foliis alternis, petiolatis, junioribus saepe peltatis, adultioribus cordatis, quinque-septemnerviti, acuminatis $v$, obtusis, supra glabris, lucidis, subtus pilosissimis, floribus e trunco nascentibus, dense capitatis, capitulis pedunculatis, aggregatis.

Cas cinium Colebrooke in Linn. Transact. XIII. 65. Meisner Gen. 5. (7.) Menispermum fenestratum Gärtner $I, 46$.

4653. Amarnirta COLEBR. Flores dioici. Ma s c. Caly $\mathrm{x}$ tripartitus, brevis. Corol1 a e petala 6 , hypogyna, biseriata, reflexa. Synem a centrale cylindricum, apice capitato-dilatato antheriferum, antherae plurimae, congestae, adnatae, quadriloculares, transversim dehiscentes. F e m. Cal y x triphyllus, cadncissimus. Corolla nulla. Ovaria 3 , in apice gynophori cylindrici sessilia, libera, unilocnlaria. O v n 1 u m unicam, parietale, micropyle supera. Styli brevissimi; stigmat a late capitata. Drupae carnosae, subincurvae, distinctae, putamine sutura introflexa incomplete hilocellato. S e men inversum, putaminis septo semi-bipartitum. Em b r y 0 intra albumen carnosum parcum rectus; c oty ledonibus tenuissimis, testae sulco sejunctis, divaricatis, r adie $\mathbf{n}$ la brevissima, supera. - Frutices indic $i$, volubiles, glabri, cortice suberoso; foliis alternis, petiolatis, simplicibus, integerrimis, late ovatis, basi subcordatis, racemis axillaribus et lateralibus compositis, elongatis, pendulis, pedicellis basi minute tribracteatis, bracteis caducis.

A namirta Colebrooke in Linn. Transact. XIII. 66. Endlicher Atakta t. 39. 40. Wight et Arnott Prodr. T. 446. Arnott in Nouv. Annal.sc, nat. II, 69, t, 3. M en is permum Cocculu s Linn. Gärtner $I ., t, z 0$.

4694. Steplanmia LOUR. F lores dioici. Masc. Cal y x sexpartitus, laciniis biseriatis. Corollae petala 3 , hypogyna, membranacea. Synem a centrale columnaeforme, teres, apicis peltati margine antheriferum, antherae transversim adnatae, uniloculares, in annulum polliniferum confluentes. F e m. C a ly $\mathrm{x}$ triphyllus, foliolis ovato-lanceolatis. Corolla e petala 3 , hypogyna, subrotunda, membranacea. Ova ri um centrale, ovoideum, uniloculare. Ovu 1 u m unicum, parietale, amphitropum, micropyle infera. Stigin at a $3-6$, subulata, inaequilonga. D r u p a carnosa, campylotropa, stylo inverse basilari, putamine compresso, margine transyersim rugoso, sub- costato, cruribus sarcocarpio interposito sejunctis. Sem en nuci conforme, hippocrepicum. E m b r y o intra albumen carnosum, parcum homotropus, subcylindricus, radicula infera. - Frutices Asiae tropicae, volubiles; folits alternis, simplicibus, integerrimis, peltatis, floribus axillaribus, paniculatis, v. masculis dense capitatis, capitulis umbellatis, floribus femineis basi minute unibracteatis.

S teph a nf a Loureiro Flor, eochinch, 747. Endlicher Atakta t. 49. 50. Cly p e a Blume Bijdr. 26. Decaisne in Nouv. Annal, Mrus. III. t. 18. Wight et Arnott Prodr. I. 14. Wa I. T i edde Gärtner II. A88. $t, 180$. Coceuli et $\mathrm{C} i \mathrm{~s}$. s a m pell sp. DC.

4695. Cissnanpelos LINN. Flores monoici v. dioici. Mase. Cal y s quadripartitus, patulus. Corolla hypogyna, gamopetala, cupulaeformis, quadriloba, rarius tetrapetala. Sy n ema centrale columnaeforme, teres, apicis peltati margine antheriferum, an $t h$ er a e $2-4$, adnatae, transversim ovatae, nniloculares, horizontaliter dehiscentes. F em. Caly x monophyllus, foliolo obovato, unguiculato. Co ro 11 a monopetala, petalo foliolo calycino opposito et adpresso. Ovari nm excentricum, obliquum, nniloenlare. Ovalnm unicum, parietale, amphitropum, mieropyle infera. Stylus terminalis, trigonus, apice trifidus v. tridentatns; st igmat a 3 , obtnsa. Drupa carnosa, campylotropa, stylo inverse basilari, putamine compresso, margine tuberculato $v$. rugoso, cruribus in dissepimentum connatis. Se men nuci conforme, hippocrepicum. $\mathrm{E}$ m b r yo intra albamen carnosum, parcum homotropus, subeylindrieus, radicul a infera. - Suffrutices erecti, $v$. frutices aut rarissime herbae volubiles, inter tropicos totius orbis crescentes; foliis alternis, simplicibus, integerrimis, petiolatis, margine $v$, intra marginem insertis aut manifeste peltatis, floribus minutissimis, virescentibus, siccatione saepe atropurpureis, axillaribus et foliorum superiorum abbreviatione terminalibus, masculis composite racemosis $v$. corymbosis, nudis $v$. bracteatis, femine is racemosis, in bractearum alternantium axillis fasciculatis, rarissime ebracteatis.

Ci s s a mp.e I o s Linn. Ben, n, 1138, Lam. t. 830. Swartz Observ. t. 10. f. 5 . Thouars in Journ. Bot. II. 65. t. 3. 4. DC. Syst. I. 352. Prodr. I. 100, Delessert 1c. select, I. t.98. 99. St, Hilaire Plant, us. Brasil, t. 34. 35. Flor. Brasil. I. 40. 2. 11. Meisner Gen. 5. (7.) C a a peb a Plumier Gen. 33. $t, 29$.

\section{GENUS DUBIUM.}

4696. Cymostenuma BLUM. Flores dioici. Mas c, Ca I y $\mathrm{x}$ decaphyllus, foliolis biseriatis, basi coalitis. Corolla nulla. Stamina 5 , monadelpha, antherae extrorsae, biloculares, fere in annulum coalitae. F em. Calyx maris. Cor o I la nulla. Ova ri um simplex, semiinferum, tri-quadriloculare, loculis uniovulatis. St ig mat a 3-4, persistentia. Dru p a baceata, globosa, tritetrapyrena, pyrenis monospermis. Embryo inversus, exalbuminosus. - Stirpes javanicae; foliis nunc integris, ovato-oblongis, acuminat is, mucrónatis, repando-serratis, nunc ternatim-septenatimsectis, segmentis ovato-oblongis, grosse serratis, paniculis axillaribus, v. racemis paniculatis, axillaribus terminalibusque.

5. (7.)

Gy nostemma Blume Bifdr. 23. Meisner Gen.

$10 t$ * 


\section{* PHYTOCRENEAE.}

469\%. Natsiatum HAMILT. Flores dioici. C a ly x quinquepartitus, laciniis lanceolatis, persistentibus. Cor oll a hypogyna, profunde quinquepartita, laciniis eum lobis calyeinis alternantibus ifsdemque longioribus, lanceolatis, acuminatis, recurvis. Discus brevis, cupuliformis, fere liber, quinquelobus, lobis cum petalis alternantibus, bidentatis, dentibus linearibus, apice obtuso incrassatis. Mas c. Stam ina 5 , circa ovarii rudimentum ad basim corollae inserta, ejusdem lobis alter na; fil a m enta brevissima, an thera e erectae, biloculares, ovatae, apiculo brevi terminatae, longitudinaliter dehiscentes. Fem. St a mina 5 , ab ortiva. Ovari am liberum, globosum, hispide pilosum, unilocalare, biovulatum, ovnlis ex apice loculi pendulis. Stylus subnullus; stigmata 2 , elongata, recurva, papillosa. Fru $\mathrm{ct} \mathbf{\mathrm { u }} \mathbf{s} \ldots$. - Frutex Asia e tropicae, volubilis; foliis al. ternis, cordutis, repando-dentatis, scabriusculis, racemis axillaribus, elongatis, hirsutis, pendulis, floribus parvis, virescentibus.

$\mathrm{N}$ a t s f a $\mathrm{t}$ m Hamilton msc. Arnott in Edinb. new phiZosoph. Journ. XVI. 314.

4698. Plnytoerene $W A L L$. Flores dioici. M a s c. in receptaculo earnoso subgloboso aggregati, sessiles. C a ly $\mathrm{x}$ urceolaris, villosus, quadrilobus v. quadripartitus, lobis obtusis. C orolla hypogyna, profunde quadripartita, laciniis cum lobis calycinis alternantibus iisdemque longioribus, lanceolatis, aestivatione valvatis, sub anthesi apice recurvis. S $t$ a $\mathbf{m}$ in a 4 , imae corollae inserta, ejusdem lobis alterna; fil a m en ta carnosa, subulata, basi coalita, superne libera, corollam aequantia, patula, a nthera e versatiles, biloculares, ovatae, acutae, longitudinaliter dehiscentes. Ovarii rudimentum centrale, breve pedicellatum, oblongum, carnosum, setis violaceis hyalinis obsitum. F em, .... - Frutices indici, magni, alte volubiles, ligño mollissimo, pulcherrime poroso, liquore aqueo, limpido, potulento scatente; foliis alternis, petiolatis, magnis, cordatis, $v$. palmatis aut interdum oblongis, floribus parvis, in capitula pisiformia, racemosa, corym bos maximos, oblongos, flaccidos, congestos, e trunci basi $v$. secus ramos inferiores sitos formantia, aggregatis.

Phy toerene Wallieh in philosoph. Magaz. 1823. III. 223. Plant. As, rar. III. t. 216 .

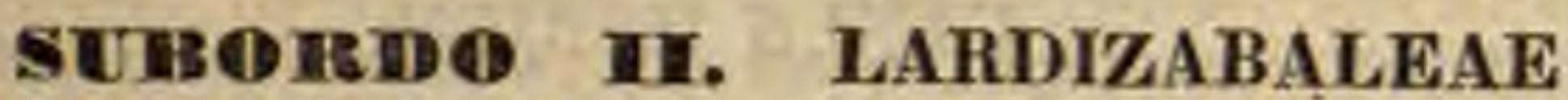
DC. Prodr. I. 95. 0 v a r i a pluriovulata. E mb r yo intra albumen copiosum minimus. - Folia composita.

4695. Burasaia THOUAR, $\mathrm{F}$ lores monoiei. Mas c. Calyx hexaphyllns, foliolis biseriatis, conniventibus, concavis. Coroll a e petala 6 , hypogyna, conniventia. Stamina 6 ; fil am en t a basi coalita, a $\mathbf{n}$ hera e introrsae, adnatae. F e m. Ca 1 yx et corolla maris. Stamina 6 , sterilia. Ovaria $3, \ldots$ Stigm a $\mathbf{t}$ a sessilia. Dr u pa e 3 , subpedunculatae, nucleo falcato, papilloso visco so. Semen anatropum. Embryo in basi albu minis carnosi brevis; cotyled onibus planis, divaricatis, radicula infera, - Frutex madagascariensis, debilis; foliis trifoliatis, floribus axillaribus, racemosis.
B u rasa i a Thouars Gen, madagasc. n, 62. DC. Syut, 1. 314. Prodr. I. 96. Meisner Gen. 3. (7.) Deeaisne in Compt, hebdom. Academ. Paris. 1837, II. 394.

4r.0. Akebia DECAISN. F I ores monoici. Calyx triphyllus. Corolla nulla. Stamin a 6, libera, antheris extrorsis. Ovarinm multiovulatum ....-Stirps as iatica, nondum descripta.

A ke b i a Decaisne in Compt. hebdom, Academ. Paris. 1837, II. 394.

4.11. Stauntonia DC.F lo res monoici. M a sc. C a lyx hexaphyllus, foliolis biseriatis. Co. ro 11 a e petala 6 , glandulaeformia $v$, nulla (?) $S$ ta mina 6 , petalis opposita, distincta $v$. monadelpha (?); anthera extrorsae, adnatae. Ovarii rudimentum. Fem. Calyx maris. Corolla nulla? Sta mina 6 , sterilia, nana. Ovaria 3 , distincta, oblonga, attenuata, moltiovulata. Stigma $t$ a sessilia, simplicia, sulcata, evanida. $\mathbf{B}$ a $\mathbf{c}_{\text {- }}$ ca e saepe tribus pauciores, divaricatae, oblongae, carnosae, sessiles, corticatae, intus longitudinaliter dehiscentes. Semina plurima, nidulantia, oblongo-ovata v, reniformia. Embryo in basi al. buminis carnosi minutus, r a dic u la infera v, centrifuga. - Frutices n e pa lenses et sinici, magni, extense volubiles, gemmiferi, glaberrimi; foliis alternis, petiolatis, peltatim digitatis, foliolis coriaceis, trinerviis, integerrimis, petiolis omnibus utraque extremitate tumidis et articulatis, racemis fasciculatis, subcorymbosis, nudis, laxis, axillaribus v. ad basim ramulorum paucifloris, floribus albis, extus subpurpurascentibus, fragrantibus, baccis magnis, tumidis, purpureis, esculentis.

St ta n ton i a DC. Syst. I. 513. Prodr. T. 96. H o lboelli a Wallich Flor, nepal. 24. $t, 17,16$. teste Wallich Catalog. $n, 4950$, et in Hooker Bot. Misc. II. 145. in not. Sta untonia et Holboelli a Decaisne in Compt. hebdomad. Academ. Paris, 1837. 1I. 394.

a. STAUNTONIA Decaisn. l. c, Petala nulla. Stamina monadelpha.

b. HOLBOELLIA Decaisn. 2 . c. P et a 1 a 6 , glandulaeformia. S tam in a libera.

470\%. Parvatia DECAISN. F lores mon. oici. Caly $\mathrm{x}$ hexaphyllus, foliolis biseriatis. Corolla e petala 6 . St amina 6 , monadelpha, antheris extrorsis. B a c $\mathrm{c}$ a polyeperma. - Stirps asiat ica, nondum descripta.

Parvatia Decaisne in Compt. hebdomad. Academ. Paris. 1837. II. 394.

4\% 103. Chardizabala RUIZ et PAV. F Io. res dioici. Masc. C a lyx hexaphyllus, foliolis biseriatis. Cor o 11 a e petala 6 , hypogyna, coriacea, basi carinata, calyce breviora. $S t$ a $\mathrm{m}$ in a 6 , petalis opposita; fil a m enta monadelpha, antherae biloculares, extrorsae, adnatae, connectivo excurrente superatae, longitudinaliter dehiscentes. Ovarii rudimentum. Fem. Calyx et coro 1 la maris. Stam in a 6 , hypogyna, libera, antheris efoetis. Ovaria 3 , distineta, unilocularia. Ovula nndique inserta, campylotropa. Stigmata sessilia, acuta. B a ccae distinctae, pulposae. Semina plurima, nidulantia, hippocrepica. Em b r y o in basi albnminis dense carnosi minimus, - Frutices per uani, scandentes; folits alternis, bi-triternatis, petiolo ad ramificationes articulato, racemis masculis axillaribus, ramosis $v$. fasciculatis, pedunculis femineis unifloris, basi late bibracteatis, fructu eduli.

L a rdizabala Ruiz et Pavon Prodr. 143, t. 37. Lapeyrouse Voyage IV. 265. $t .6$. 8. DC. Syst. $I$, 311. Prodr, I, 25. excl, sp. Delessert Ic, select. I. $t, 91$. Meis- 
ner Gon. 5. (7.) Decaisne in Compt. hebdomad, Academ, Paris, 1837, III. 394, Bo is siera et Thouinia Dombey mxc. Cog y Ii a Molina Saggio edit. 2. p. 300.

4704. Toquila DECAISN. F lores dioi ci. Cal y x hexaphyllus, foliolis biseriatis. Corolla e petala 6 , membranacea. S $t$ a $m$ in a 6 , monadelpha, an theris extrorsis. B acca oligosperma. Se min a anatropa. - Stirpes a mericana e.

B o quila Decaisne in Compt, hebdomad. Academ. Paris. 1837. II. 394. - Huc ni fallor pertinent $\mathrm{L}$ a r d I z a baI a trifoliolata DC. Delessert $I_{c}$. select. $r$, $t, 92$, et L, dis col or Pöppig Nov. gen. et sp. $t, 189$.

4705. Tremselhelia PRESL. Flores hermaphroditi, Caly x decaphyllus, foliolis biseriatis. Coroll a e petala 10 , squamaeformia, obcordata, calyeis foliolis opposita. Sta min a 5 ; ealycis foliolis exterioribus opposita; fil a m ent a brevia, plano-convexa, an ther a e extrorsae, biloculares, loculis linearibus, adnatis, distantibus, longitudinaliter dehiscentibus. $O$ variu m subglobosum, uniloculare. Ovula 2, parietalia (?) S tyI n terminalis simplex, apice incrassatus; stig. m a $t$ a 5, obovata, stellato-patentia, F r uet u s... - Frutex $l u \approx o$ nensis, volubilis, ramosus, gla. ber; foliis sparsis, exstipulatis, trifoliolatis, foliolis integerrimis, paniculis axillaribus, solitariis, multifloris, pedicellis bibracteolatis, floribus virescentibus.

He n s ch eli a Presl in Reliq. Hänk. II. 81, t. 63.

\section{Ordo CLXXIII. Mymisticeae.}

MYRISTICEAE R. Brown Prodr.399. Bartling Ord. nat. 244. Blume Rumphia $I, 179$. MYRISTICACEAE Lindley Intro duct, edit. II, p. 15.

Aniones interdum excelsae, v. frutices, succo stiptico, in aëre rubescente plerumque scatentes, ramis teretibus v. rarius ancipitibus, cortice saepius reticulato vestitis, novellis ut plurimum furfuraceo-pubescentibus. Folia alterna, subdisticha, breviter petiolata, coriacea, simplicia, integerrima, penninervia, juniora conduplicata, pubescentia v. furfuraceolepidota. Stip ula e nullae.

Flores dioici, in pedunculis axillaribus $v$. lateralibus, aut rarius terminalibus racemosi, glomerati, subcapitati v. paniculati, bractea cucullata suffulti v. rarissime ebracteati, parvi, plerumque inconspicui, albi, luteoli v. tomento aut furfure ferrugineo extus tecti, intus glabri.

Perigonium simplex, crassiuscule coriaceum, tubulosum, urceolatum v. subcampanulatum, trifidum v. rarius bi-quadrifidum, lobis aestivatione valvatis.

M as e. Stamisa $3 \_15$, monadelpha. F ilamenta in columnam solidam, cylindricam v. turbinatam, apice dilatato breviter denticulatam connata. Ant her a e extrorsae, biloculares, columnae v. ejusdem dentibus longitudi- naliter adnatae, rarius ejusdem dentibus insertae, liberae, radiato-divergentes, loculis parallelis, subaequalibus, longitudinaliter dehiscentibus.

F em. Ovarium unicum (rarissime duo, basi connata, altero tunc nano, efoeto), liberum, uniloculare. Ovul um unicum (rarissime duo), e basi erectum, anatropum. Stylus brevissimus v. nullus. Stigma sublobatum v. indivisum.

Bacca capsularis, unilocularis, bivalvis, valvis indivisis v. interdum bifidis, monosperma.

SEMEN erectum, nucamentaceum, arillo carnoso, multifide lacero, saepe aromatico, e funiculi brevissimi, crassi prolongatione orto, partimque hinc cum rhaphe laterali latiuscula plana cohaerente, totum v. maxima e parte obvolutum. Te s $t$ a dura, endopleura membranacea, transversim irregulariter rugosa, rugis intra albumen sese insinuantibus. Albumen copiosum, sebaceo-carnosum, endopleurae rugis transversis ruminatum.

Emвryo in basi albuminis minimus, orthotropus. C o ty le do nes subfoliaceae, divaricatae, planae v. plicato-rugosae. R a dicula brevissima, cylindrica, infera.

Myristiceae inter tropicos Asiae et Americae indigenae, succo rubescente, floris, fruetus et seminis conformatione admodum singulares, ob aliquam cum Anonaceis, mediante imprimis Hyalostemmate affinitatem, praeeuntibus $\mathrm{cl}$. Bartling et Lindley hoc loco collocantur, cum Thymelinis, quas inter ad Aquilarineas proxime adhuc accedere videntur, vix revera affines.

Arillus (macis) nonnullarum specierum ob aromatis illecebras celebris.

4.06. Myristiea LINN: Perigoninm simplex, coloratum, urceolatum v. eylindrico-tubulosum, trifidum, aestivatione valvatum. Masc. Ant herae 6-15, lineares, columnae stamineae, longitudinaliter adnatae. F em. O v a r i m unicum, uniloculare, ovulo solitario $\mathbf{v}$. interdum geminis, e basi erectis, anatropis. Stigma bilobum. B a c e a capsularis, bi- v. interdum quadrivalvis, monosperma. S e m e n nucamentaceum, erectum, arillo carnoso, multipartito inclusum. $\mathbf{E m}$ b r y 0 in basi albuminis carnosi, ruminati parvus; coty led on ibus divaricatis, plicatis, ra di cula brevi, infera, - Arbores $v$. frutices $A s i a$ et $A m e-$ ricae tropicae; foliis alternis, breve petiolatis, integerrimis, floribus axillaribus aut supraaxillaribus, rarissime terminalibus, femineis plerumque solitariis, rarius ut masculi in fasciculos laxos, paucifloros, $v$. capitula densa, interdum in racemos $v$. corymbos aut paniculas dispositis, pedicellis apicem versus bractea semicupulari instructis, fructibus aromaticis $v$. insipidis.

Myristica Linn. gen, n, 1399. Thunberg Act. Holm. 1789. p. 45. Dissert. 1788. Lamark in Mem, Academ. Paris. 1788, $t, 5-7$. Gätner $I, 94, t, 41$, excl, $A_{g}, 3-4$. Humb. et 
Bonpl. Plant, aequinoct, t, 103. Hooker Exot, Flor, t. 13́s. 156. Bot. Mag. 2. 2756, 2757. Blume Rumphia 1. 180, t. 55 59. Vi ro 1 a Aublet Guian. III. 904, $t, 35$. S e b o p h o r a Necker Elem, n. 907 .

480\%. Thema LOUR. Perigoninm simplex, coloratum, tubuloso-v. subrotato-campanulatum, tri-quadrifidum, aestivatione valvatum. Masc. Antherae $8-15$, columnae stamineae apice disciformis dentibus insertae, liberae, radia to-divergentes. Fem. Ovarin $\mathbf{m}$ unicum, uniloculare, ovulo solitario, e basi erecto, anatropo. Stylus brevis; stig $\mathbf{m}$ a depressum, sublobatum. B a c c a capsularis, bivalvis, monosperma. S e m e n nucamentaceum, erectum, arillo carnoso, multipartito inclusum. E mb r y o in basi albuminis carnosi, ruminati minimus; c otyled onibus divaricatis, planis, radicula brevi, infera. - Ar bores Asiae tropicae; foliis alternis, breve petiolatis, integerrimis, floribus et masculis et femineis in capitula axillaria conglomeratis, pedicellis brevissimis, apice bractea instructis, fructibus insipidis.

K n e m a Loureiro Flor. coohinch. 748. Jack in Hooker Bot. Mag. Comp. I. 148. Blume Rumphia I. 187, t. 60. 61 M y $\mathrm{r}$ is ticae s.p. Auct.

4808. Pyrrlaosa $B L U M$. P e rigon in m simplex, coloratum, urceolatum, bi-quadrifidum, aestivatione valvatum. Masc. Antherae 8 , coJumnae stamine turbinatae, apice depressae lobis longitudinaliter adnatae. Ovaria 2 , altero nano effoeto, altero uniloculari, ovulo solitario, e basi erecto, anatropo. St ig m a sessile, obtusum, indivisum. B a e e a capsularis, bivalvis, monosperma. Se men nucamentaceum, erectum, arillo carnoso, multipartito inclusum. Embryo in basi albuminis carnosi, ruminati minimus; cotyledonibus divaricatis, planis, radicula brevissima, infera. - Arbores Asiae tropicae; foliis alternis, breve petiolatis, integerrimis, floribus in paniculis axillaribus conglomeratis, minimis, ebracteatis, fructibus insipidis.

Pyrrhos a Blume Rumphia, I. 190, t. 68, 63. Horsfieldia Willdenow Spec. $I V .872$. M y risticae sp. Gärt. ner t. 4t, $f, 3$. 4. Wallich Plant. As, rar, t, 89. 90.

\section{Ordo CWX $\mathbf{X}$ II: Anonaceae.}

ANONAE Jussieu Gen, 283. Annal. arus, XVI. 338. GLYPTOSPERMAE Venten. Tabl. III. 75. ANONACEAE Dunal Monographie de la famille des Anonacées. Paris. 1817, 4. DC. Syst. I, 463. Prodr, I. 83. Bartling. Ord. nat. 245. Blume Flor. Jav. fase. 7 ot 8. Alph. DC. Mémoire sur Ia famille des Anonacees in Mem. soc, phys. Genev. V, 177. Liadley Intraduct. edit, 2, p. 18, Meisner Gen. 4. (5.)

Arbongs v. Frutices, odore et sapore aromatico, stimulante, interdum acri, ramis ramulisque teretibus, succo acri. Foli a alterna, simplicia, integerrima, penninervia, juniora pubascentia, petiolata, petiolo basi plerumque articulato. Stip u la e nullae.

Flores hermaphroditi, v. rarius abortu unisexuales, in pedunculis plerumque axillaribus, rarius lateralibus v. oppositifoliis, folio brevioribus solitarii v. fasciculati, plerumque virides v. fuscescentes, saepissime rudes.

Calyx triphyllus, foliolis distinctis v. plus minus connatis.
Corollar petala 6 , ad basim tori inserta, biseriata, interiora interdum minora $v$, abortiva, libera v, rarius gamopetala v. subcohaerentia, aestivatione duplici serie valvata, rarissime nulla.

Stamina plurima, rarius definita, libera, tori lateribus multiplici serie articulatim inserta. Filamenta brevissima. Antherae extrorsae, biloculares; loculi connectivo lato, superne producto, truncato adnati, longitudinaliter dehiscentes. Pollin is granula subglobosa, saepe annulatim cohaerentia.

Ovaria plurima, rarius subdefinita, unilocularia, in apice tori sessilia, libera v. subcoalita. O v u lum nunc unicum, e basi erectum, nunc pauca juxta ovarii suturam ventralem adscendentia v. plurima, horizontaliter biseriata, anatropa. Sty li in ovariis terminales, liberi v, inter se cohaerentes. S $\mathrm{\imath igm}$ a $\mathrm{t}$ a simplicia, obtusa $v$, excavata.

Froctus multiplex, carpidiis sessilibus v. stipitatis, capsularibus v. baccatis, unilocularibus $v$. sarcocarpio seminibus interposite transversim plurilocularibus, distinctis v, in syncarpium tessellatum plus minus cohaerentibus, mono-polyspermis.

Semrsa erecta v. horizontalia, ovata v. oblonga, testa chartacea v. crustacea, fragili, umbilic o basilari, rh aphe lineari, interdum eleyata v. subcarnosa, endoplenra testae adriata, membranacea, plicis transversis copiosis, saepius etiam processu juxta rhaphen longitudinali intra albumen penetrans. A I b umen copiosum, dense carnosum, rimis transversis ruminatum, saepe sulco juxta rhaphen semi-bipartitum.

Embryo in basi albuminis minimus, orthotropus. Cotyled ones breves, germinatione foliaceae. Radicula teretiuscula, umbilico proxima, infera v. centrifuga.

Anonaceac inter tropicos totius orbis obviae, nonnullae ob fructus sapidissimos etiam cultae, Schizandraceis et Magnoliaceis proxime affines, stipularum defectu et albumine ruminato distinctissimae. A Myristiceis praeter alias notas arilli defectu differunt.

'TIRIBUS T. BOCAGEAE. Stam in a definita. 0vula pauca, suturae ventrali inserta.

4r.9. Boeagea $S T$, HIL. Calyx tripartitus v. subinteger, cupuliformis, Corollae petala 6, hypogyna, biseriata, late unguieulata, interiora paullo breviora, erecto-patentia. Sta mina 6 , hypogyna, eum petalis inserta omnia fertilia; filam enta brevia, ovato-complanata, anthe ra e biloculares, Iocnlis ovatis, filamento infra apicem extus adnatis, eontiguis, longitndinaliter dehiscentibns. Ovaria 3 , breviter stipitata, libera v. sessilia, basi subcoalita, unilocularia. O vula 
$5-8$, suturae ventrali biseriatim inserta, horizontalia, anatropa. Styli terminales, brevissimi v. nulli; stigmat a obtuse capitata. Baceae abortu interdum solitariae, breviter stipitatae, patentes, tuberculatae, uniloculares, abortu trispermae. S emina horizontalia, elliptica, subcompressa, rhaphe lunulata, subearnosa, testa chartacea, rugosa. Embryo in basi albuminis carnosi, endopleurae rugis transversis ruminati brevissimus, $r$ a dicu1 a nmbilico proxima. - Arbores $v$. frutices bras $i$ lienses; foliis alternis, ovato-lanceolatis, integerrimis, utrinque glabris $v$. subtus pilosis, petiolo brevi, basi articulato, pedunculis extraaxillaribus, solitariis, unifloris, paullo supra basim articulatis, floribus parvis.

B oe a ge a St. Hilaire Flor. Brasil. I. 41, t. 9. Alph. DC. in Mem, soc, $h_{,} n_{*}$ Genev. $V_{\text {. }}$ 215. Meisner Gen, 4. (6.)

4\% 1 10. Fopowia $\mathrm{Ca}$ lyx tripartitus, deciduus. Corollae petala 6 , hypogyna, biseriata, in globum conniventia, exteriora breviora, interiora crassa, apice unguiculo inflexo. S $t$ a $m$ in a 12 , hypogyna, cum petalis inserta, omnia fertilia, cuneiformia; fil amenta subnulla, antherae biloculares, loculis ovatis, connectivo truncato marginibus angulato extus adnatis, longitudinali ter dehiscentibus. Ov a ria 6 , sessilia, conniventia, libera, unilocularia. Ovula 2, suturae ventrali medio inserta, superposita, anatropa. Stig m a $t$ a sessilia, obtusa, verrucuiosa. B a c c a e globosae, aborta solitariae, sessiles, uniloculares, abortu monospermae. S emen subglobosum, rhaphe de pressa zonatum. Embryo in basi albuminis carnosi, endopleurae rugis transversis ruminati minimus, radicnla umbilico proxima. - Arbor $j a$ vanica; ramis patentissimis, subnutantibus, ramulis apice compressis foliisque alternis, elliptico-ob longis, basi inaequaliter rotundatis, integerrimis, sub. tus in venis tomentosis, florum fasciculis oppositifoliis $v$, intrafoliaceis, breviter pedunculatis, solitariis. t. 45 .

Bocagea pisocarpa Blume Flor. Jav. Anon. 90.

1711. Droplhea BLUM. C al y x triparti tus, persistens v. decidnus. Cor o II a e petala 6 , hypogyna, exteriora breviora, patentia, interiora unguibus angustis, laminis dilatatis, snperne in calyptram cohaerentia. St a m in a .6-12, hypogyna, cum petalis inserta, alterna saepe sterilia, squamaeformia; filamenta subnolla, an therae biloculares, loculis ovatis, connectivo lato extus adnatis, longitudinaliter dehiscentibus. O va r i a 3 , in tori convexi apice sessilia, unilocularia, $O \mathbf{v u}$ la $2-3$, snturae ventralis medio inserta, herizontalia, anatropa. Sty li brevissimi, liberi; stig$\mathrm{m}$ a te terminali obtusinsculo. B a c c a e cylindricae, sessiles, abortn monospermae v, dispermae, semine altero erecto, altero inverso. S e m in a oblongo-cylindracea, rhaphe sulciformi, testa chartacea. E mbryo in basi albuminis subeornei, endoplenrae processubus ruminati minimus, radicula umbilico proxima. - Frutices javanici; foliis alternis, integerrimis, pedunculis axillaribus cymosomultifloris, floribus parvis.

Or op lie a Blume Bijdr. 18. Aiph. DC. in Mem. soc.h. $n$, Gonev, $V$, 214, $t$. A. Meisner Gen, 4. $(6$,$) B o c a g e a e 8$ p. Blume Flor. Jav. Anon, t. $40-44$.

48 18. Millusia $A L P H . D C$. Ga ly x tripartitus, lobis subnlatis. Corolla hypogyna, gamopetala, campanulata, tubo basi trisaceato, limbo trifido. S.ta m in a 12 (?) hypogyna, tori ovoidei, pilosi imae basi glabrae inserta; fil a ment a brevissima, subcylindrica, anth era e biloculares, loculis filamenti apici adnatis, rotundatis, distinctis, longitudinaliter dehiscentibus. Ov ar a $15-20$, in apice tori sessilia, libera, unilocularia. $\Theta x$ uI a 2, suturae ventrali inserta, superposita. St i gmat a sessilia, subulata. ..... Planta Asiae tropicae, lignosa; ramis tenuibus, foliis distichis, ellipticis, integerrimis, pilosiusculis, floribus axillaribus solitariis, pedunculis brevissimis, minute uni-bibracteolatis.

Mili us ia Alph. DC. in Mem, soc, h. n. Genev, V.213. c. 3. Wight et Arnott Prodr. I. 10. Meisuer Gen. 4. (6.)

TrEIEUS II. XYLOPIEAE. S $\mathrm{t}$ am in a indefinita. Ovula suturae ventrali inserta, pauca v. plurima.

4813 . Polyalthia BLUM. Caly $\mathrm{x}$ tripartitus v. trifidus, persistens. Corolla e petala 6 , hypogyna, biseriata, inaequalia, nunc interiora longiora, erecta v. patentia, nunc minora, cochleariformi-concava, exterioribus clausis. Stamina plurima, hypogyna, tori convexi v. apice depressi lateribus inserta, claviformia; filament a brevissima, anth erae biloculares, loculis linearibus, connectivo apice truncato-dilatato extus sublateraliter adnatis, longitudinaliter dehiscentibus. Ovarla in apice tori plurima, sessilia, adpressa, libera, unilocularia, Ov a la 2, suturae ventrali prope basim v. medio ingerta, superposita, adscendentia v. horizontalia, anatropa. Styli ovariis continui, saepe coaliti; stigmatibus terminalibus, obtusis v. introrsum breviter decurrentibus. B a $\mathbf{c}$ c a e plurimae $v$. abortu pancae, subsessiles v. pedicellatae, carnosae v. exsuccae, uniloculares, di- $\mathbf{v}$. abortu monospermae. S e $m$ in a transversim $v$, oblique incumbentia, hemisphaerica, subglobosa $\mathbf{v}$. ovalia, rhaphe semicirculari elevata $\mathbf{v}$. sulciformi, testa chartacea, tenaci. Embryo in basi albuminis carnosi v, subcartilaginei, endopleurae rugis transversis ruminati minimus, orthotropus, radicula umbilico proxima. - Frutices v. arbusculae Asiae tropicae; cortice imprimis radicum aromatico, foliis alternis, bifariis, oblongis, integerrimis, plerumque glabris, petiolis brevibus; basi articulatis, pedunculis axillaribus $v$, in eadem specie oppositifoliis aut supraaxillaribus, solitariis v. pluribus aggregatis, supra basim articulatis, unifloris, floribus mediocribus, pallide viridibus, ochroleucis $v$, sordide ochraceis.

Polyalthia Blume Flor. Jav. Anon, 68. Alph. DC. it Mem. soc, $h, n$. Genev. V. 215. Meisner Gen, 4. (6.)

a. EUpolyalthiA Blume t. c. t, 33. 34, 36, f, a, b. C aI y $x$ tripartitus. Petala erecta v. patala, interiora majora. T or us subcylindraceus, superne rotundato-convexus. Stig mata obtusa, conglutinata. 0 v u la suturae ventralis medio inserta, superius adscendens, inferius pendulum. B a c cae intus succidae, mono-disperwae.

b. OXYMiTrA Blume l. c, t. 35, 36. f.d.t.37, C aly $\times$ tripartítus. Pe $t$ a I a basi concava genitalfbus adpressa, subelausa, exteriora multo inajora, elongata, interiora superne supra genitalia in mitram coalita. T orus subcylindraceus, superne rotundato convexus. $\mathrm{Stigmata}$ inerassata, distineta. 0 vula suturae ventrali prope basim inserta, adscendentia. Bac c a e exsuceae, plerumque abortu monospermae.

c. KeNTIA Blnme 2 , $c, t, 38,59, f$, $a$. C alyx breviter trifidus, subcupuliformis. P et a la basi concava genitalibus adpressa, exteriora majora, interiora superue supra genitalia in mitram eoalita. T o rus basisi sublemispliaerica crassiore petalifer, medio subeyliadracens, apice truncato plano-convexo ovariiger. $0 \mathrm{v}$ a $\mathrm{ri}$ a pauca. $0 \mathrm{vu}$ la suturae ventralis medio inserta, horizontalia. Sti $\mathrm{g}^{-}$ 
mata ad internum styloram latus verruculosa, libera. B a c c a e succulentae.

d. GONIOThalamUS Blume $t, c, t, 39,52, f, b, \mathrm{C}$ a 1 y $x$ fere triphyllus. Petal a subclausa, exteriora majora, interiora supra genitalia superne in mitram coalita. T o rus parum elevatus, circa partem superiorem convexiusculam ovaria gerens, depressione orbiculata staminibus obsessa, margine hexagono petalifero. Ovaria pauca. Ovula suturae ventralis medio inserta, horizontalia. Stigmat a ad internum stylorum latus verruculosa, libera. B a c c a e succulentae.

4714. Xylopla $L I N N$. Ca ly x tripartitus v. trifidus, cupulaeformis, deciduns. Co roll a e petala 6, hypogyna, biseriata, interiora minora, omnia oblongo-linearia, basi concava, erecto-patentia. Stamina plurima, torum cyathiformem extus tegentia, claviformia; fil am enta brevissima, a n th er a e biloculares, connectivo truncato antice adnatae, longitudinaliter dehiscentes, $\mathrm{O}$ varia plura, tori fundo inserta, sessilia, libera, unilocularia. Ovula 4 , suturae ventrali inserta, superposita, adscendentia, anatropa. Stigma ta acuta, libera, arcte conniventia. B a c c a e abortu pancae, stipitatae, ovoideae, subcompressae, siccae, saepins tandem ad suturam fatiscentes, uniloculares, v. sarcocarpio tenui seminibus interposito transversim pluriloculares, tetraspermae v. saepins abortn di-monospermae. S e mina obliqua v. suberecta, umbilico basilari arillo spongioso cupuliformi cincto, rhaphe semicirculari, testa chartacea. E m b r y o in basi albuminis carnosi, durins. culi, endopleurae rugis transversis ruminati minimus, radícula umbilico proxima. - Arbores $v$. frutices Americae tropicae; ramulis saepe distichis, foliis alternis, oblongis, acutis, integerrimis, saepe sericẹis, petiolis brevibus, basi articulatis, pedunculis axillaribus, uni-multifloris, folio brevioribus.

Xylo pia Lina. Gen. n, 1027. Jassieu Gen, 284. Aublet Guian, $t$, 292. Gitrtner $I .399$. t. 69. Dunal Anonac. $t .17$ 20. DC. Syst. 1. 499. Prodr. 1. 92. St. Hiltire Plant, us. Brasil, t. 33. Flor. Brasil, I. 31, t. 8. Alph. DC. in, Mem. soc. h. n. Genev. V. 209. Meisuer Gen. 4. (6.) B a $11 \mathrm{i}$ a r d a Necker Elem. n, 1103. X y 1 o picron P. Browne Jam, 250. Embira et Pída iba Piso Brasil. 71. Ib ira Maregrag Brasil. 90 .

4\% 15. Habzelia $A L P H, D C . \mathrm{C}$ aly $\mathrm{x}$ tripartitus. Co rolla e petala 6 , hypogyna, biseriata, interiora minora, erecto-conniventia. S $\mathbf{t a m i n a}$ plurima, lyypogyna, tori convexi lateralibus inserta, claviformia; fil am enta brevissima, anthe. $r$ a e biloculares, loculis linearibus, connectivo truncato antice sublateraliter adnatis, longitudinaliter dehiscentibus. Ovaria plurima, sessilia, unilocularia, libera. Ovula 8 _ 12, juxta suturam ventralem subbiseriata, horizontalia, anatropa. Sty li breves, distineti $\mathrm{v}$. subcoaliti; $s \mathrm{t}$ i g $\mathrm{m}$ at a obtusa. B a c c a e distinctae, elongato-cylindraceae, tornlo sae, polyspermae, periearpii substantia inter se mina penetrante transversim multiloculares. S e mina intra fructus concamerationes solitaria, erecta, nitida, arillo e membranis duabus obcordatis inaequalibus, albis cineta $\ldots . .$. - Frutices in Africa et $A$ merica tropia indigeni; foliis alternis, acutis, integerrimis, subtus pubescentibus, pedunculis axillaribus, solitariis, unifloris, fructibus aromaticis, sapore saepius piperito.

Habzelia Alph. DC. in Mem, soc. h. r. Genev, V, 207. Meisner Gen. 4. (6.). Wa r I a Aublet Guian. II. 605. t. 243. excl. syn. U, ariae et Unonac sp. Auct, Xyl $\mathrm{s}$. Palisot Owar. $t$. 16. H a bzeli et Piper Nigrorum Sera. pioni C. Baubia Fin. 412. P i p e r a et hi o p i cu m Matthioli Comm, 1, 434, c. ic. Lobel, Ic. II, t. 205.
4716. Coeloeline $A L P H . D C$, Calyx trifidus, cupulaeformis, deciduns. Co rolla petala 6, hypogyna, biseriata, interiora minora, omnia oblongo-linearia, supra unguem brevissimum subdilatata, erecto-conniventia. St a mina plura, hypogyna, tori coneavi margini inserta, claviformia; fil amenta hrevissima, antherae biloculares, loculis linearibus, connectivo truncato antice sublateraliter adnatis, longitudinaliter dehiscentibns. Ov a ri a plurima, in tori apice concavo sessilia, libera, unilocularia. Ovula plurima, juxta suturam ventralem subbiseriata, anatropa. Styli acuminati, subcohaerentes; stigm a t a penicilliformia. B ace a e plurimae, stipitatae, ovoideae, polyspermae. S em ina oblonga, exarillata, testa chartacea. E m b r yo in basi albuminis dense carnosi, endoplenrae rugis transversis ruminati minimus, radic ala umbilico proxima. - Frutices Africae et Americae tropicae; folits alternis, acutis, subtus pilosis, pedunculis axillaribus brevibus, solitariis, unifloris, ramis junioribus pubescentibus.

Coel o eline Alph. DC. in Mem, soc, h, n, Genov. V. 208. t. 5. Meisner Gen. 4. (6.) Unona acutiflora Dunal Anonac. $t$. 22. - ? U a na $1 \mathrm{u}$ cida DC. Delessert Ic, se. lect. $T, t$. 89 . Uvaria parviflora A. Richard Flor. Seneg. t. 3. $f .1$

47. 1\%. Uvaria $L I N N$. C a ly x tripartitus v. trifidus, nunc eupuliformis, subinteger. Corolla e petala 6, hypogyna, biseriata, aequalia v. exteriora majora aut rarins minora, patentia v. erecta, interiora apicibus interdum cohaerentia. Stamina plurima, hypogyna, tori crassi, conici v. plano hemisphaerici. lateribus inserta; fil am enta brevissima, anthera biloculares, loculis linearibus, connectivo superne truncato $v$, aristato antice adnatis, longitudinaliter dehiscentibus. Ovaria plurima $v$, rarius subdefinita, in tori apice plano sessilia, adpressa, libera, unilocularia. 0 v 1 a 6 v. plurima, suturae ventrali inserta, remotiuscula et subadscendentia, v. imperfecte biseriata, sibi transversim incumbentia, anatropa. Styli brevissimi v. subnulli, coaliti; stigmat a simplicia v. subcapitata. B a c c a e plurimae, pedicellatae v. subsessiles, carnosae v. siccae, subglobosae v. ovales, nniloculares $\mathbf{v}$. sarcocarpio inter semina penetrante transversim pluriloeulares, nunc oblongae, isthmis inter semina constrictis moniliformes, pleiospermae v. monospermae, seminibus intra loculos transversos solitariis v. geminis. Sem in a elliptica, subcompressa v. globosa, umbilico laterali et rhaphe lineari, testa chartacea v. coriacea. E mbryo in basi albuminis subcartilaginei, endopleurae processubus transversis ruminati minimus, radien la nmbilico proxima. - Arbores $v$. frutices erecti aut sarmentosi, in $\overline{A s} i a$ tropica, nec non in America tropica et boreali calidio$r e$ indigeni; foliis alternis, subdistichis, oblongis, integerrimis, petiolis brevibus, basi articulatis, pedunculis axillaribus, oppositifoliis $v$. lateralibus, solitariis $v$. rarius confertis, interdum fasciculato $v$. corymboso-multifloris, pube saepissime ferruginea, stellata $v$. rarius simplici.

U varia Lian. gen. $n$. 592. Gärtner II. 155, t, 114. U n o n a Linn. f. Supplem. 270. K rokeri a Necker Elem. n. 1097. Uvaria et Uuona Blume Flor. Jav. Anon, 11. Alph. DC, in Mem, soc, h, n, Genev. V. 201. 203. Meisner Gen. 4. (6.)

a. UVARIA Blum. B a c ca e ovatae v. oblongae, plus minus torulosae.

Uvaria Blume Flor. Jav. e. 1. Mitrephora Blume. Asimina Adanson Fam, Ir. 365, Dutal Ano. 
nac. $t .3-11$. DC. Syst. I. 678. Prodr, I. $87.0 \mathrm{rch} \mathrm{i.}$ docarputh L. C. Riehard in Michaux Elor. Bor. Amer. I. 329. (Duhamel Arbr, $t$. 25. Schkuhr $t, 149$. Porcell a Raiz et Pavon Prodr. 84, t. 16. Dunal Op. cit. DC. Syst, I. 480, Prodr. I. 88. - Melodorum Loureiro Flor, cochinch, $\$ 30$. (Wallich Plant. As, rar. t. 122.)

b. UNONA Blum, B a c ca e monillformes.

U n o n a Blume Flor, Jav, 51, $t, 26,27,31, f, a, \mathrm{D}$ es. mos Loureiro Elor. cochinch, $I, 430$. Ma renteria Noronha ex Thouars Gen, madagasc. n. 18. (Vahl Symb. II. t, 36. Wallich Op. cit, t, 121, 265.)

4ว่18. Kexalobus $A L P H . D C$. Calyx tripartitus. C or oll a hypogyna, gamopetala, sexfida, lobis biseriatis, subaequalibus v. interioribus minoribns, omnibus plus minus patentibns. Stamina plurima, hypogyna, tori convexi lateribus inserta, claviformia; fila m enta brevissima, antherae biloculares, loculis connectivo apice dilatato-truncato antice adnatis, Iongitudinaliter dehiscentibus. Ovari a plurima, in apice tori sessilia, libera v. coadunata, unilocularia. Ovula... Stigmata sessilia, subulata. Bacea evales, substipitatae, pleiospermae. Semina in pulpa biseriatim nidulantia, nitida ..... Frutices $s$ enegambici et madagascarienses; foliis alternis, integerrimis, floribus axillaribus, sessilibus v. pedunculatis.

$\mathrm{He} \times \mathrm{al}$ obus Alph. DC. in Mem. soo, $h, n$. Genev. V. 212. t. 5. f. 1. Meisner Gen, 4. (6.) Uvaria monope$\mathrm{t}$ a I \& A. Riehard Elor. senez. $t .2$.

THETES IIE. ANONEAE. St a min a indefinita. Ovula in loculis solitaria, v. gemina collateralia, e basi erecta.

47 1 . Anaxagorea $S T . H I L . C$ al y $x$ tripartitus. Corolla e petala 6 , hypogyna, biseria ta, conniventia, interiora minora. $S$ ta $\mathrm{m}$ in a plurima, hypogyna, tori convexi, superne truncati lateribus inserta, nune aequalia, omnia claviformia, ligulata; filamentis brevissimis, antheris bilocularibus, loculis linearibns, discretis, connectivo apice truneato-dilatato extus adnatis, longitudinaliter dehiscentibns, nune interiora fila mentis elongatis, antherarumque loculis abbreviatis. Ovaria $8-15$, in apice tori breviter pedicellata, unilocularia. Ovula 2 , e basi erecta, anatropa. Styli ovariis continni, brevissimi; $8 \mathrm{tig}$. matibus terminalibns, discoideis, Capsulae corticosae, pedicellatae, subclavatae, nniloculares, superne incomplete bivalves, dispermae. Sem in a erecta, collateralia, hine plana, sulco exarata, inde convexa, umbilico basilari, testa crustacea, fragili. Embryo in basi albuminis dense carnosi, endoplearae rugis transversis ruminati minimus, orthotropns, $\mathrm{r}$ a d i c u I a infera. - Arbusculae guianenses et javanicae, vix aromaticae; ramis subdichotomis, folits alternis, oblongis, submembranaceis, integerrimis, subtus pallide glaucescentibus, petiolis brevibus, haud articulatis, pedunculis axillaribus et oppositifoliis, solitariis, unifloris, floribus mediocribus, pallide viridi-albicantibus.

An axagorea St. Hilaire in Bullet. soc, philomat. 1825 , 91. Plant, us, Brasil, n, 33. p.5. Blume Flor.Jav. Anon. 64. Alph DC. in Mem, soc. h. n. Genev, V.211. Meisner Gen. 4. (6.)

a. ANAXANTHUS. S tamina interiora conformia, paullo longiora. - Species americanae. - Xylopia pri. noides Dunal Anonac. 128, $t, 16$.

b. AgORANTHUS. Stamina intima elongata, apice torta, antheris parvis, efoetis. - Species javanica. - (Blu. me Op. cit. t. 32. et 36. $\bar{f}$. a.)

4890. Artabotrys $R$. BR. Calyx tripartitus. Corolla e petala 6 , hypogyna, biseriata, globoso-conniventia et super genitalia constric$\mathrm{ta}$, interiora aequalia $\mathbf{v}$. minora. St a mina plurima, hypogyna, tori convexi lateribus inserta, claviformia; fil amenta subnulla, antherae biloculares, loculis linearibus, connectivo apice truncato-dilatato extus adnatis, longitudinaliter dehiscentibus. Ovaria $3 \mathrm{v}$. plurima, in apice tori sessilia, libera, unilocularia. Ovula 2 , e basi erecta, anatropa. Styli ovariis continui; stigmatibus obtusis, inter se coalitis. Baccae abortu pancae, discretae, subsessiles, uniloculares, di- v. abortu monospermae. S emina erecta, collateralia, hinc plana, sulco exarata, inde convexa, umbilico basilari, testa ossea. Embryo in basi albuminis cornei, endopleurae rugis transversis ruminati minimus, orthotropus, radicula infera. - Frutices Asiae tropicae, glabriusculi; ramis sarmentosis, apice uncinatis, foliis oblongis, bifariis, integerrimis, nitidulis, pedicellis unifloris, fasciculatim congestis, in ramulorum extremitatibus lateralibus, floribus e flavido-fuscescentibus, odoratissimis.

A rtabotry 8 R. Brown in Bot. Reg. t. 423, Blume Flor. Jav. XIX, 57, t. 28_31. Alph. DC. in Mem. soc. $h, n$. Genev, V. 212: Meisner Gen. 4. (6.) A n o n a o 8 p. Limn. Un ou a e s p. Dunal Anonac. $t$, 12, 12, a, et 27 .

4\%81. Cuattenia RLIZ et $P A V$. C a I y $x$ tripartitus, deciduns. Cor o 11 a e petala 6, hypogyna, biseriata, interiora majora, rarius breviora v. aequalia, erecta v. patentia. Sta min a plurima, hypogyna, tori cupulaeformis v. cylindrici, superne plano-depressi lateribus inserta, claviformia; filamenta brevissima, antherae biloculares, loculis linearibus, connectivo superne truncato antice adnatis, Iongitadinaliter dehiscentibus. Ovaria plurima, in tori apice sessilia, adpressa, libera, unilocularia. Ov $\mathbf{l}$ n m nnicum, e suturae ventralis basi adscendens, anatropnu. Styli breves, cohaerentes; stigmata terminalia, capitato-angulata, coalita. B a c ca e plurimae, stipitatae v. subsessiles, ovatae v. globosae, carnosae v. siccae, uniloculares, monospermae. S e m e n erectum, ovoideum, umbilico prope basim sublaterali, rhaphe lineari v. sulciformi, testa chartacea. Embryo in basi albuminis cartilagineo-carnosi, endoplearae rugis transversis ruminati minimus, radicnla nmbilico proxima, infra. - Arbores $v$. frutices, in Asia et America tropica indigeni; foliis alternis, integerrimis, petiolis brevibus, basi articulatis, pedunculis axillaribius et lateralibus, solitariis $v$. confertis, unipaucifloris, folio saepe brevioribus, inferne articulatis et bracteatis.

Gu atteria Ruiz et Pason Prodr. 85. $t$. 47, Dunal Anonac. 50. t. 30_32. DC. Syst, I. 502. Prodr. I. 93. Delessert Ic. select. I. $t .90$. St. Hilaire Flor. Brasil. . 29. Blume Flor. Jav. Anon. 92, t. 46_53. a. Wallieh Plant. As. rar. t, 266. Alph. DC. in Mem, soc, h, n. Genev, V. 216 . Meisner, Gen. 4. (6.) C a na n g a Aublet Guian. 1. 602. 2. 244. Jussieu Gen, 284. A ber e m or Aublet Guian. I, 610, t. 244. Uvariae sp. Roxburgh Plant. Corom, t. 33. 34.

472. Duguetia $S T$. HIL. Flos ....... Capsula e plurimae, tori magni, transversim bipartiti, inferne cylindrico-globosi, costati et lignosi, staminum cicatricibus notati, apici globosoconico, late favoso, subspongioso-lignoso insertae, liberae, adpressae, ovatae, tri-quinquangulares, stylis' persistentibus acuminatae, in pedicel- 
los vix angustiores, crassos subattenuatae, crassissime lignosae, uniloculares, monospermae. Semen e basi erectum ..... _ Arbor brasiliensis.; ramulis furfuraceis, foliis alternis, lanceolatis, subacuminatis, coriaceis, supra glabris, nitidis, subtus sparsim furfuraceis, petiolis brevibus, basi articulatis, pedunculis extraaxillaribus, solitarits, monocephalis.

D u guetia St. Hilaire Elor. Brasil, I, 35, t, 7. Alph. DC. in Memt, soc, h, n. Genev. V.216.

4.23. Amoma $L I N N$. G a l y $x$ tripartitus v. trifidus, deciduus. Coroll a e petala 6 , hypogyna, biseriata, interiora minora v, rarissime nulJa. S $t$ amina plarima, hypogyna, tori marginibus inserta, elaviformia; f i $\mathrm{l}$ a m enta brevissima, antherae biloculares, loculis linearibus, connectivo superne truncato-dilatato antice adnatis, longitudinaliter dehiscentibus. Ovari a plurima, in apice tori sessilia, libera v. subconnata, unilocularia. Ovulum unicnm, e basi erectum, anatropum. Styli liberi $v$, brevissimi, subnulli; stigmata capituta v. oblonga. Bacea e plurimae, in syncarpinm extus muricatum ant squamosum v. raxius laeve, intus pulposum, polyspermum coalitae. Semen erectum, ovatum v. ellipticum, umbilico prope basim sublaterali, rhaphe lineari, elevata, testa crustaceo-coriacea. E mbryo in basi albuminis dense carnosi, endopleurae processubus transversis ruminati minimus, radicula infera. - Arbores $v$. frutices, in $A f r i c a$ et $A$ merica tro. pica indigenae, in Asiam introductae; folits alternis, integerrimis, penninerviis, nonnunquam peltucido punctatis, petiolis basi articulatis, pedunculis axillaribus aut lateralibus v. oppositifoliis, solitariis $v$. interdum subfasciculatis, uni-paucifloris, bracteolatis, floribus viridulis v. flavescentibus, fructibus edulibus, sapidissimis.

A no na Linn. Gen, n. 693. Jissieu Gen. 283. Anblet Guian, $t$. 246_249. Gärtner $I T$. 193, $t, 138$. Jacq. Observ. $I$. t. 6. f. 1. 2. Forkkael Ic, t, 15. Tussae Flor. Antill, $t$. 28. Dunal Anonac, 28. et 38, t. 2_8. DC, Syst. $X$. 466. Prodr. $I$. 83. Delessert Io, select. $I, t, 86,87$. St. Hilaire Plant, us. Brasil. t.29. 30. Flor. Brasil. T. 24, t, 6. Blume Flor. Jav. Anon. 104. t. 53. b. Bot. Mag. t. 2011. 2911. 2912. 3095. Bot. Reg, t. 1328. Alph. DC. in Mem.soc, h, n, Genev, V. 196. Meisner Gen, 4. (6.) G u a a b a u us Plumier Gen. 43.

47\%4. Fiollimia $S T, H I L, C$ al y $x$ tripartitus, caducus. Corolla hypogyna, subglobosa, apice pervio breviter sexloba, dorso infra Iobos in alas tres. obtusissimas, intuś concavas producta, samaram trialatam mentiens, decidua. Stamina plarima, hypogyna, tori convexi lateribus inserta, lineari-claviformia; fil am en ta brevissima, antherae biloculares, loculis, connectivo apice incrassato-truncato antice adnatis, longitudinaliter dehiscentibus, Ovaria plurima, in apice tori sessilia, unilocularia, coalita. Ovul um unicum, e basi erectnm, anatropum. Styli connati; stigmata coalita. Bac ca e plurimae, in syncarpium squamesum connatae ..... - Arbores $v$. frutices brasilienses; ramulis pilosis, folits alternis, integerrimis, petiolis brevibus, basi articulatis, pedunculis axillaribus, solitartis aut rarissime geminis,
unifloris.

Rolli o i a St, Hillaire Flor, Brasil. I. 28, t. 5. Alph. in Linnaea $\mathrm{KX}$, 315. Meisner Gen, 4. (0.) A. Schlechtend. bripeta $\downarrow$ a Raddi.

\section{GENERA DUBIA.}

4 ช95. Promoalora DUS. Caly x tripartitus, lacinits reflexis. Coro 11 a e petala 6 , hypo- gyna, basi coalita, exteriora patentia, carinata, undulato-crispa, interiora cordiformia, conniventia. St a mina plurima, hypogyna, tori convexi lateribus inserta; fil amenta subnulla, anthera e bilocnlares, loculis oblongis, connectivo extus adnatis, longitudinaliter dehiscentibus. Ovarium unicum, in apice tori sessile, uniloculare. $\mathrm{O} v \mathrm{uI}$ a plurima, párietibus inserta ..... St ig ma sessile, depresso-eapitatum. Bac c a sphaeriea, laevis, pulposa, unilocnlaris, polysperma. Semina ovatooblonga, angulata, testa subcrustacea, rhaphe lineari, elevata. Embryo in basi albuminis carnosi, endopleurae rugis transversis ruminati parvus; cotyledonibus subfoliaceis, radicula umbilico proxima, centrifuga. - Arbor, ut videtur ex Africa tropica a.Nigritis in Antillas introducta; foliis alternis, pedunculis lateralibus, solitariis, unifloris, basi aut supra medium foliaceo-bracteatis, seminibus oleo aromatico scatentibus.

Mon o dor a Dual Anon. 79. DC. Syst. I. 477. Prodr. r. 87 . excl. sp. Bancroft in Bot, Mag. $t$. 3059. Meisser Gen. 4. (6.) A nou a Myristica Gärtner II. 194, 2.125 . - American Nutmeg Long Hist. Jam. IIT. 735. Bancroft in Lunan Hort. Jam. IT. 10. - M. m i e r o c a r p a Dual, quae Ano. na microcarpa Jaeq. Fragm. 40. $t$. 44. $f$. 2 . est Cargilia australis (supr. n. 4248.) teste R. Brown in Tuckey Cong. 475.

4\%8. Carratopetalluma SCHLECHT. Cal yx triphyllus, foliolis furfuraceis, petala aequantibus. Coro 11 a e petala 6 , laminis sagittatocordatis, obtusissimis, unguibus brevibus, latis, basi in annulum connatis. Stamina plurima; fil a mentis subnullis, antheris subtrigonocuneatis, apice glandulosis, obtusis, loculis longitudinalibus, suboppositis. O varia plurima, libera, angulosa, tori pubescentis tuberculis insidentia. - Stirps brasiliensis; foliis alternis, oblongis v. ellipticis, pedunculo ebracteato, basi articulato.

Cardiopetalum Schlechtend. in Linnaea IX. 328. Meisuer Gen. 4. (6.)

4ระซ. Trigymaea SCHLECHT. C a ly x triphyllus, corolla multo minor. Corollae petala 6 , hypogyna, interiora majora, crassiora, dorso convexissima, Stamina plurima; filamenta brevissima, antherae lineares, obtusae, basi attenuatae, Joculis rima laterali dehiscentibus. Ov a ri a 3 , in apice tori conici subsessilia, unilocularia," 0 y ula 6 , suturae ventrali inserta, uniseriata, subadscendentia. St y li breves, distincti; stig mat a lata, pezizaeformia. Fruetus ..... Frutex brasiliensis; ramulis flexuosis, pubescentibus, foliis alternis, brevissime petiolatis, oblongo-ellipticis, integerrimis, pedunculis extraaxillaribus, solitariis, unifloris, flore Pisi magnitudine.

Trig y n a a Schlechtend. in Linnaca IX. 328. Meisuer Gen. 4. (6.)

4\%98. Holboenrpus WIGHT et $A R N$. Ca ly x (?) tubularis, trifidus, coriacens, persistens, fructum includens. .... Carpi dia 5 , unilocularia, in fruetom cartilagineum, oblongum, apice breviter et obtuse quinquelobam, basi quinquelocularem coalita. S e m in a in loculis gemina, lateralia ..... - Stirps ind ica, vix nota; ramis lignosis, foliis breve petiolatis, lanceolatis, acuminatis, glabris, floribus axillaribus, solitariis v. ter- 
nis, subsessilibus, parvis, calyce extus pubescente, basi bracteis 2-3 lanceolatis, glabris cincto.

Lobocarpus Wight et Araott Prodr. I. 7.

4\%8. IIIyalostemana WALL, Flores dioici. Involuerum hexaphyllum, uniflorum, foliolis biseriatis, lineari-lanceolatis. Calyx trilobus, lobis aestivatione valvatis. Corolla nulla. Masc. Stamina plurima, supra torum glomerata. Fe m. O varia plurima, ovulo unico, erecto. Baccae pisiformes, pedicellatae. A 1 b ume $\mathbf{n}$ ruminatum. - Frutex indicus; foliis alternis, distichis, lanceolatis $v$. oblongis, integerrimis, pedunculis lateralibus geminis, unifloris.

H y a I o ste m m a Wallich Catalog, n, 6434. Lindley In. troduct. edit. II. p. 439. Meisner Gon. 4. (6.) U varia dioica Roxb.

\section{ANONACEIS AFFINES.}

\section{* EUPOMATIEAE.}

4830. Xappomatia R.BR. Perigoni m tubo turbinato, cum ovario connato, limbo supero, juxta basim operculo semielliptico, caduco transversim dehiscens. S t a m in a plurima, margini persistenti limbi perigonialis multiseriatim inserta, basibus connata, exteriora fertilia, patula v. reflexa, filamentis e basi lata subulatis, antheris bilocularibus, loculis linearibns adnatis connectivo in mucronem producto superatis, longitudinaliter dehiscentibus, interiora sterilia, petaloidea, sensim minora, arcte imbricatim conniventia. Ovarinm inferum, multiloculare, loculis sparsis, ad angulum centralem multiovulatis. Sti $\mathrm{g}$ ma sessile, planinsculum, areolis subrotundis locnlorum numero notatum. B a c c a turbinato-obovata, limbi perigonialis margine angusto coronata, apice truncato areolata, multilocularis. Sem in a in loculis solitaria v. gemina, angulata, impresso-punctata, umbilico basilari, rhaphe chordaeformi, testa membranacea, endopleura tenuissima. A I b u m e carnosum, testae processubus lobatum, ejusdem prolongatione secundum rhaphen semibipartitum. $\mathbf{E} \mathrm{mb}$ ryo in basi albuminis prope umbilicum minutus; cotyledonibus linearibus, foliaceis, radicula tereti, - Frutex Novae-Hollandiae orientalis extratropieae, erectus, ramosus; trunco gracili, ramis teretibus, subporrectis, foliis alternis, bifariis, petiolatis, exstipulatis, impunctatis, coriaceis, utrinque nitidis, integerrimis, pedunculis axillaribus, unifloris, folio brevioribus, ramuliformibus, foliis alternis, nanis bracteatis.

Eupomatia R. Brown in Elinder's Voyag. II. 49z, t. 2. Meisner Gen, 4. (6.)

\section{Drdo CEXXV. Scleisandracene.}

SCHIZANDREAE Blume Bijdr, 21. Flor. Jav, ic. ANo NACEARUM genus et MENISPERMEAE spuriae DC. $\mathcal{S}$ st I. 465 , et 543 .

Frutices sarmentosi, glabri, succo mucoso scatentes. Folia alterna, simplicia, petiolata, integra, integerrima $\mathrm{v}$, denticulata, crassiuscula, saepe pellucido-punctata. Stipula e nullae.
Flores in pedunculis axillaribus v. lateralibus, solitariis aut confertis, imbricatim bracteolatis solitarii, unisexuales, parvi, saepius odorati.

CALXX tri- v. hexaphyllus; foliola biseriata, exteriora saepe minora, alternatim imbricata, concava, decidua.

Conolla hexa- v. enneapetala; petala imo toro inserta, bi-triseriata, alternatim imbricata, sub anthesi erecto-conniventia, decidua.

Floribus masculis: Stame nunc indefinita, torum conicum obtegentia, rarius definita, torum depressum marginantia. Filamenta brevissima, crassiuscula, libera v. interdum subconnata. Anthera extrorsae, biloculares, loculi discreti, connectivo apice saepius incrassato juxta totam longitudinem adnati, nonnunquam apicibus yicinarum antherarum loculis contiguis adhaerentes, rimula verticali dehiscentes.

Floribus femineis: Ovaria plurima, supra torum plus minus elevatum, saepius demum elongatum sessilia, libera v. interdum cohaerentia, unilocularia. Ovula gemina, parietalia, superposita, pendula. Stigma sessile, ad interius ovárii latus decurrens.

Froctus: Carpidia plurima, baccata, in capitulum conglobata v. juxta torum elongatum laxe spicata, saepius gibboso-curvata, stigmate apiculata, mono-disperma, pericarpio carnoso, intus pulposo, inter semina sese insinuante, dissepimentum spurium constituente.

Skmina in pulpa nidulantia, sublunata, compressiuscula; test a coriacea, umbilico superficiali, verticem fructus spectante notata, endopleura tenuissime membranacea. Albu m en copiosum, carnosum.

Emвrxo in basi albuminis minimus, rectus. Cotyled on es ovatae, plano-compressae. Radicula umbilicum fere attingens, oblonga, teres, supera.

Schizandraceae paucae adhucdum cognitae, a Menispermeis oppido distinctae, a Magnoliaceis habitu sarmentoso, foliis dentatis, exstipulatis, qualitatum aromaticarum defectu, floribus diclinibus, antherisque saepius inter se coalitis vix satis diversae, in Indiae terrae continente et insulis, in Japonia et Americae borealis provinciis australioribus repertae fuerunt.

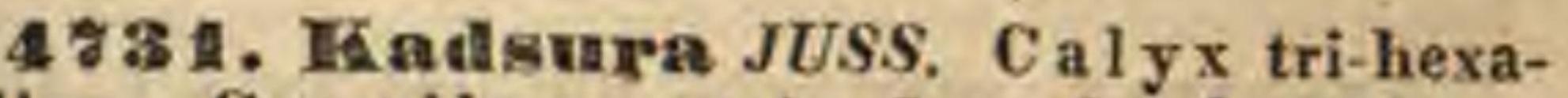
phyllus. Corollae petala 6 v. 9, hypogyna. Mase. Stamina indefinita, torum conicum tegentia; filamenta brevissima, libera v, omnino connata, antherae extrorsae, biloculares, loenlis adnatis, rimula verticali dehiscentibus. Fem. O varia plurima, sessilia, unilocularia, biovulata. Stigmata sessilia. Carpidia baceata, unilocnlaria, disperma, in capitulum connata. Frutices $105 *$ 
javanici et japonici, sarmentosi; foliis alternis, pedunculis axillaribus, unifloris.

$\mathrm{Kadsura}$ Jussieu in Annal. Mus. XVI. 340. Dunal Annonac. 57. Wallieh Flor. Nepal, 1, 7. Blume Flor. Jav. Schizandr. 7. 1. 1. 2. Siebold et Zuccarini Japon, 1, t, 17. Sarcocarpou Blume Bijdr. 21. (Kämpfer Amoen. 470. 185, $t$, 477.)

4ร32. Splarerostemma BLUM. Calyx triphyllus. Corolla e petala 6 , hypogyna. Masc. Stamina indefinita, torum conicum tegentia; fi 1 am en ta brevissima, libera $v$. basi connata, anthera e extrorsae, biloculares, loculis adnatis, rimula verticali dehis centibus. $\mathrm{F}$ e m. $\mathrm{O}$ varia plurima, sessilia, unilocularia, biovulata. Stigm at a sessilia. Ca rpidia baccata, unilocularia, disperma, supra torum demum elongatum laxe spicata. - Frutices scandentes, javanici, bengalenses et nepalenses; foliis alternis, pedunculis axillaribus, unifloris.

$\mathrm{S}$ ph a er os temma Blume Bijdr. 22. Flor. Jav. Schizandr. 13. $t .3-5$. K a d s u ra e sp. Wallich Flor. Nepal. 1. t. $9 \pm 13$.

4\%33. Selbizandra L, C. RICH. Calyx triphyllus. C or o 11 a e petala 9, hypogyna. Mas c. Stamina 6 , torum orbicularem marginantia; fil ament a brevissima, crassa, libera, anther a e extrorsae, biloculares, connatae, loculis adnatis, rimula verticali apertis. Fem. Ovaria plurima, sessilia, nnilocularia, biovulata. Stig ma sessile. C arpidia baccata, unilocularia, monosperma, supra torum demum elongatum laxe spicata. Frutex bor eal $i$-americ anus, sarmentosus; foliis alternis, pedunculis axillaribus, solitariis, unifloris.

Schizandra L. C. Richard in Michaux Flor. Bor. Amer. IT. 18, $t, 47$. Bot. Mag, $t, 1413$.

\section{GENUS DUBIUM.}

4734. MIayma $A U B L$. F 1 ores dioici. M a s c. Calyx triphyllus v. tripartitus. Co rolla e petala $3-9$, calyce breviora. St a $\mathrm{m}$ in a circiter 30 , torum conicum tegentia; fil a m enta brevia, li. bera, antherae tetragonae, apice crassiores. Fem. ..... Frutex guianensis, soli Aubletio notus; foliis alternis, mugnis, breviter petiolatis, oblongis, acuminatis, integris, laevibus, stipulis geminis, parvis, deciduis, floribus axillaribus plurimis, parvis, odoratis, breve pedicellatis, pedicellis unifloris, basi bractea parva munitis, calycibusque velutinis.

M a y n a Aublet Guian. IT. 929. t. 352. Jussieu Gen. 281. Lam. t. 49t. DC. Syst, I. 446. Prodr. I. 79. Meisuer Gen. 3. (3.) non Raddi, St, Hil. et Zuecarin.

\section{Ordo CEXXII. II Iagnotiaceae.}

Magnoliab Jussieu Gen. 280. MAgnoliaceaE DC. Syst. I. 439. Prodr. I. 77. Bartling Ord. nat, 248. St. Hilaire Flor, Brasil. I. 24. Blume Flor. Jav, fasc. XIX. Meisner Gen, 3. (5.) MAgNoliEaE et WINTBREAB R. Browa ex DC. Syst. $\boldsymbol{I}$. 348 , MAGNOLIACEAE et WINTERACEAE Lindley Introduct, edit, $11, p, 16,17$.

Arbores v. fruticks, saepissime elegantes, omnibus partibus, imprimis cortice et fruetibus acri-aromaticis et amaris, ramis teretibus. Fo li a alterna, simplicia, coriacea, penninervia et integerrima, rarissime lobata, reticulatim venosa, saepissime plus minus pellucido-punctata, vernatione plerumque intra gemmam sti- pularem involutiva. Stipula e membranaceae, geminae, laterales, ramulo et petioli inferne incrassati paginae superiori adnatae, apice longe acuminatae, gemmam terminalem foventes, deciduae, cicatricem annularem relinquentes, nune minimae, squamiformes, caducissimae, v. interdum nullae.

FLores hermaphroditi, rarius abortu unisexuales, plerumque magni, speciosi, terminales v. axillares, solitarii, rarius racemosi v. fasciculati, plerumque ante anthesim bractea stipulari spathaeformi, interdum e geminis connatis composita, nunc immediatim infra perigonium sita, nune pedunculo demissius inserta, mox decidua inclusi.

Calyx triphyllus, rarius hexaphyllus, di-v. tetraphyllus, foliolis imbricatis, plerum consistentia et colore a petalis vix v. parum diversis, rarissime subherbaceis, ut plurimum sub anthesi patentibus v. deflexis, caducissimis, rarius aestivatione valvatim connatis, demum dehiscentibus, persistentibus.

Corollae petala sex v. plurima, hypogyna, ad basim tori stipitiformis uni-bi-pluriseriatim inserta, aestivatione imbricata, sub anthesi patentia v. campanulato - conniventia, decidua.

Stamina indefinita, hypogyna, pluriseriata, ad basim tori v. juxta ejus stipitem inserta. Fil am enta libera, saepissime brevia, lata, rarius flliformia, in connectivum plerumque supra loculos productum continua. Antherae biloculares, loculis linearibus rariusve subrotundis, connectivo antice v. lateraliter adnatis, longitudinaliter dehiscentibus.

Ovaria plurima, rarius pauca, rarissime solitaria vel gemina, nunc supra torum conicum conferte imbricatim spicata, sessilia v. brevissime stipitata, libera v. compacta aut inter se connata, rarius in tori apice uniseriatim verticillata, semper unilocularia. Ovula ad suturam ventralem gemina, collateralia v. superposita, aut plura biseriata, sessilia v. funiculis brevibus suspensa, anatropa, rarissime solitaria, e basi loculi erecta. Styli ovariis continui, terminales; stigmata introrsum papillosa.

Fructus varius, carpidiis ovariorum numero v. abortu paucioribus, nunc subpedicellatis, liberis, nunc in syncarpium strobiliforme coalitis, coriaceis v. sublignosis, nunc capsularibus inferne aut superne dehiscentibus, bivalvibus, nune folliculiformibus, carnosis, indehiscentibus, rarissime lignosis, indehiscentibus, stylo indurato alato-samaroideis.

SEmixa in loculis solitaria v. plura, sessilia v. e funiculo e vasis spiralibus conflato, extensili, interdum elongato pendula. Integumentum 
seminis in pluribus supra testam crustaceam carnosum, coloratum, rhaphe funiculo continua inter illud et testam libera, in chalazam in apice seminis sitam desinente, nunc nullum, rhaphe inter testam et endopleuram prorepente.

Eмвryo in basi albuminis carnosi, aequabilis prope umbilicum minimus, rectus. C otyledones brevissimae, saepius vix manifestae. Radicula crassa, chalazae e diametro opposita.

Magnoliaceae in Asia tropica et America boreali calidiore imprimis copiosae, in $\Delta$ merica tropica et australi, Japonia, NovaHollandia et Nova-Zeelandia parcius reperiuntur, Dilleniaceis Anonaceisque proximae, ab illis habitu, partium fructificationis numero ternario, et ovariorum in plerisque dispositione, ab illis stipularum praesentia et albumine aequabili diversae, a Schizandraceis vix satis distinctae.

Illicieae versimiliter etiam ob ligni structuram, ut audio admodum memorabilem, praeeunte ill. R. Brown olim in proprium ordinem segregandae.

Qualitates in omnibus plus minus validae, aromaticae, amaricantes.

SUEDIRID I. MAGNOLIEAE DC. Prodr. I. 77. Ovaria secus torum spicata. Folia epunctata $v$, obsolete pellucide-punctata. Stipulae deciduae.

4ร35. Talauma JUSS. Ca ly x triphylIns', foliolis subherbaceis $v$, coloratis, eaducis. C or o 11 a e petala $6-12$, hypogyna, bi-quadriseriata, campanulato-conniventia, decidua. $\mathrm{S} t$ a $\mathrm{m}$ in a plurima, hypogyna, tori basi incrassatae pluriseriatim inserta; fi l a ment a subnulla, a $n t h e-$ r a e biloculares, loculis linearibus, extrorsum sublateraliter adnatis, longitudinaliter dehiscentibus, connectivo in acumen lignlaeforme, obtusum producto. Ovaria plurima, supra torum compacta, lineari-oblonga, unilocularia, $O$ v ula ad suturam ventralem 2, collateralia, in faniculis brevibus anatropa. Styli in ovariis terminales, crassiuscule conici, intus stigmatosi. Syncarp in m strobiliforme, reticulato - areolatum, stylis persistentibus echinatum, carpidiornm apicibus sublignosis, matnritate irregulariter v. subquaternatim cohaerenti-secedentibus, rhachim subclavatam, alveolis exsculptam nudantibus. S emin a in rhacheos alveolis bina, oblique incumbentia $\mathbf{v}$. abortu solitaria, obovato - trigona, e funiculo extensili, in rhaphen intra integumentum exterius carnosum, coloratum liberam continuo pendula, testa subossea, chalaza apicali, $\mathrm{E} \mathbf{m b} \mathrm{r}$ o in basi albuminis carnoso-oleosi minutus, $\mathrm{r}$ a $\mathrm{d}$ i $\mathrm{cu} \mathrm{l}$ a chalazae e diametro opposita. - Arbores $v$. frutices Magnoliarum habitu, in Asia et, America trapica crescentes; foliis alternis, coriaceis, perennantibus, subreticulato-venosis, integerrimis, stipulis gemmaceis, deciduis, floribus magnis, in ramu. lis solitarie terminalibus, pallide flavicantibus, odoratissimis, bractea spathaeformi, florem ante anthesim includente, mox decidua.

T a t'a u m a Jussieu Gen. 28t. DC. Syst. T. 460. Prodr. r. s1. St HHaire Flor. Brasil. $T$. 20. t. 4. Blume in Batav. Verhandl, IX, 145, Flor. Jav, XIX, 29, $t, 9-12$. Lindley in Bot. Reg. t. 1709. Zuecarini Plant. Nov. fasc, II. 369. $t, 1$. 2. Meisner Gen. 3. (5.) B I u mi a Nees in Flora 1825 . p. 152. Magnolia Plumier Gen. 38, $t$, 7. Magnoliae s. p. Andrews Bot. Heposit. $t$. 226. Veuten. Malmais. $t$. 37. Bot. Mag. t. 977 . Roxburgh Plant, Corom, t, 266. Lirio. de ndri s p. Linn.

4ร38. A romadendrum $B L U M$. C a $1 \mathrm{yx}$ tetraphyllus, foliolis subcoloratis, cadúcis. Corolla e petala $24-32$, hypogyna, sex-octoseriata, patentia, interiora sensim minora, decidua. S $t$ amin a plurima, hypogyna, ad tori stipitiformis basim incrassatam pluriseriata, in conum medio constrictum, ovaria tegentem imbricatim conniventia; filamenta brevissima, libera, anthera biloculares, loculis elongato-linearibus, introrsum adnatis, longitudinaliter dehiscentibus, connectivo in acumen setaceum desinente. $O$ vari a plurjma, supra tori apicem in conum connata, subquadrangula, unilocularia. 0 y.u 1 a ad suturam ventralem 2, collateralia, sessilia, anatropa. Styli in ovariis terminales, subulati, intus stigmatosi. Synearpinm subglobosum, torosoareolatum, lignoso-suberosum, putredine secedens in ca $\mathrm{p} \mathrm{s}$ u 1 a 8 inverse pyramidatas, apicibns lignosis, solutis a basibus membranaceis, rhacheos clavatae alveolis adhaerentibus. Sem in a abortu solitaria, rhacheos alveolis horizontaliter semilmmersa, lenticnlari-depressa, sessilia, integumento externo membranaceo, testa subossea, nigricante. E m b ry o in basi albuminis carnoso-oleosi brevis, radicula infera. - Arbor javana, excelsa, omnibus partibus, imprimis cortice et fructu, aromaticis, amaricantibus; foliis alternis, subdistichis, integerrimis, venosis, stipulis gemmaceis caducis, floribus terminalibus pedunculatis, speciosis, fragrantissimis, albidis, demum stramineis, bracteis ad apicem pedunculi duabus oppositis, connatis in spatham hine fissam, mox basi annulatim secedentem.

A romadendrum Blume Bijdr. 10. Flor. Jav, $X I X$. 25. t. 7. 8. Meisner Gen, 3. (5.)

4\%3\%. Magnolia LINN. Caly $x$ triphyllns, foliolis coriaceo-herbaceis v. subcoloratis, patentibus, caducis. Cor olla e petala 6-12, hypogyna, bi-quadriseriata, patentiuscula v. campanulato-conniventia, decidua. Stamina plurima, hypogyna, juxta tornm stipitiformem multiseriata; fi a menta subnulla, antherae. biloculares, loculis linearibus, introrsum adnatis, connectivo in acnmen breve, simplex $\mathbf{v}$. bifidum producto. Ovaria plurima, libera, supra tori apicem imbricato-spicata, sessilia, libera, unilocularia. O v u l a ad suturam ventralem gemina, superposita, in funicnlis brevissimis anatropa. Styli in ovariis terminales, subulato-conici, intus stigmatosi. C a p8 úl a e ovato-acuminatae, sessiles, imbricato-spicatae, coriaceae, dorso dehiscentes. S e min a 2, v. interdum abortu solitaria, e funiculo extensili, demum elongato, in rhaphen intra integumentum exterius carnosum, rubrum liberam continuo dependentia, testa subossea, chalaza apicali cum acumine impressa. E mbryo in basi albuminis carnoso-oleosi minutus, radic u la chalazae e diametro opposita. - Arbores speciosae, in America borealicalidiare et in Asiatropica indigenae; foliis alternis, integerrimis, venosis, stipulis geminis, vernatione th gemmam elongato- 
acuminatam folium includentem connatis, mox deciduis, floribus ad apices ramorum breviter pedunculatis, solitariis, bructea unica, spathaeformi, $v$. geminis oppositis, caducissimis.

M a g nol 1 a Linné gen, $n$, 690. Jussiée gen, 281, Gärt. ster I. 393. t. 70. DC. Syst. I. 449. Prodr. T. 79. Meisner Gen. 3. (5.) - Duhamel Arbr. edit. nov. II. $t$. 65. 66. Michaux Arbr. forest. III. t. 1-7. Salisb. Parad. t. 43. Andrews Bot. Reposit, t.573. Bot. Mag. t. 1206, 1952. 2164. 2189. 2497. Bot. Reg. 2. 323.407. Zuecarini Plant. nov. fasc. II. 373. t. 3. 4. - Gwilli mia Rottler mse, ex DC. $t$. c. (Species asiaticae. Banks Ic. Kämpfer. t. 42_44. Salisb. Op. cit. t. 5. 38, 87. Bonpl. Op. cit. t. 20. Venten. Malmais. t. 24. Andrews Bot. Reposit. t. 229. 324. Bot. Mag. t. 390. 1008. 1621. Bot. Reg. t. 1164. Wallich Flor. Nepal. t. 23. Plant. As, rar. t. 182.)

4838. Nlanglietia $B L U M$. Calyx triphyllus, foliolis coloratis, patentissimis v. deflexis, caducis. Corolla e petala 6 v. 9 , hypogyna, bitriseriata, campanulato-conniventia, decidua. Stamin a plurima, hypogyna, juxta torum stipitiformem multiseriata, petalis breviora; filamenta libera, an therae biloculares, loculis linearibus, introrsum adnatis, longitudinaliter dehiseentibus, connectivo in acumen subulatum producto. $O$ v aria plurima, supra toram confertim spicata, inter se coalita, nniloeularia. Ovula ad suturam ventralem sex v. plura, biseriata, in funieulis longiusculis anatropa. Styli in ovariis terminales, subulati, intus apice papilloso-stigmatosi. Ca p 8 ula e angulatae, sublignosae, in synearpium oviforme coalitae, demum solutae, semibivalves. Semina sex $v$. interdum plura, aut abortu panciora, e faniculis tenellis pendula, rhaphe intra integumentum exterius carnosum rubrum libera, testa subossea nigricante, chalaza apicali. $\mathbf{E} \mathbf{m b}$ r yo in basi albuminis carnosi minimus, $r$ a dicula chalazae e diametro opposita. - Arbores nepalenses et javanicae, elegantissimae, Magnoliarum facie; foliis alternis, petiolatis, integerrimis, stipulis oppositis, geminis, vernatione in gemmam elongato-acuminatam connatis, folium includentibus, caducissimis, floribus ad apices ramulorum terminalibus, solitariis, breve pedunculatis, unibracteatis, bractea spathaeformi, supra medium pedunculi inserta, flo rem primum includente, demum hinc fissa, a basi circulariter soluta, caduca, pedunculo fructifero infra petalorum et staminum cicatricibus foveolato.

M a $n$ glietia Blume Bijdr. 8. Flor. Jav, XIX. 20, t, 6 . Meisner Gen. 3. (5.) Magnolla Insignis Wallich Flor. Nepal. $t$, 1 .

4 ชิ 39. II ielnelin $L I N N$. C alyx tri-hexaphyllus, foliolis coloratis, patentibus, caducis. Coro 1 la e petala $8-9$, hypogyna, uni-triseriata, patentiuscula, caduca. St amina plurima, hypogyna, ad basim tori stipitiformis pluriseriata; $\mathrm{fi}$ lam ent a libera, brevia, a $\mathrm{n}$ h e rae biloculares, loculis linearibus, adnatis, introrsnm submarginalibus, connectivo in acumen subulatum pro ducto. Ovaria plurima $v$, rarius pauca, supra tori apicem imbricato-spicata, sessilia, libera, unilecularia. Ovula ad suturam ventralem $\&-6$, raro plara, biseriata, subsessilia, anatropa. St y $\mathrm{li}$ in ovariis terminales, flliformes, recurvi; $\mathrm{ti} \mathrm{g}$ I a $\mathbf{t}$ a subterminalia, verruculoso-carnosa. C a $\mathrm{p}$ s u1 a e subglobnsae v. ovatae, sessiles v. brevissime stipitatac, laxe s picatae, coriaceae, juxta totam longitudinem bivalves. S e m in a $3-6$, rarins plura, rarissime abortu solitaria, e funiculo brevissimo, extensili, in rhaphen intra integumentum exterius carnosum, rubrum liberam continuo pendula, testa subosseâ, chalaza apicali impressa.
E m b r y o in basi albuminis carnosi minutus, radien a chalazne e diametro opposita. - Arbores v. frutices indici; ramis divaricatis, foliis alter$n$ is, petiolatis, integerrimis, venosis, vernatione obvolutis stipulis geminis, in gemmam acuminatam connatis, mox deciduis, floribus axillaribus $v$, ad apices ramorum terminalibus, bractea ad apicem pedunculi spathaeformi, interdum e geminis connatis composita, caduca, cicatricem circularem relinquente.

Mie he lí a Linné gen, $n$. 691. Gürtner II. 263, $t, 137$. Jussieu Gen, 280. Lam, t. 493. DC. Syst. 1. A46. Prodr. I. 79. Delessert Ic, seleot, I, $t, 85$. Wallich Flor. Nepal, t, 4, 5. Plant. As, rar, 147. Blume Flor. Jav, XIX. 6. $t .1-5$. Meisuer Gen, 3. (5.) $\mathrm{C} \mathrm{h} \mathrm{am} \mathrm{p} \mathrm{a} \mathrm{c} \mathrm{a} \mathrm{Rheede} \mathrm{Malab.I.31,} \mathrm{t,} \mathrm{19.}$ Adanson Fam, HI. 365. S a mp a ca Rumph Amboin. II. 199. t. 67. 68 .

48 40. TLiviodendrom LINN. C aly x triphyllus, foliolis coloratis, deflexis, caducis. Corolla e petala 6 , hypogyna, biseriata, campannlato-conniventia, decidua, $\mathrm{S}$ t a m in a plurima, hypogyna, tori basi pluriseriatim inserta, petala subaequantia; fil a m enta filiformia, libera, anthera e elongato-lineares, biloculares, introrsae, adnatae. Ovaria plurima, supra torum imbricatospicata, libera, unilocularia. Ov ula ad suturam ventralem gemina, e funiculis brevibus superposite pendula, anatropa. Sty li in ovariis terminales, conici, plano-compressi, apice breviter recurvo intus stigmatoso. Capsula e lignosae, stylis induratis, plano-compressig, lanceolato-alaeformibus superatae, samaroideae, in strobilum collectae, ex axi lignosa persistente deciduae, indehiscentes. Se min a 2 , superposita v. abortu solitaria, ovata, lenticulari-compressa, testa crustacea, sublucida. Embryo..... - Arbor borealiamericana, excelsa; foliis alternis, petiolatis, deciduis, glaberrimis, basi rotundatis, apice truncatis, margine sinuato-quadrilobis, lobis dentatis, stipulis oppositis, latis, deciduis, floribus terminalibus solitariis, magnis, flavo-virentibus, basi bracteis geminis caducis.

Li ri odendron Linn, gen, n. 689. Jussieu gen, 281. Sehkutir t. 147. Gärtner 11, 475. $t$. 178. Michanx Arbr. forest. III. t. 5. Duhamel Arbr. edit, nov, III, t, 18. Bot. Mag. t. 275. DC. Syst. I, 461. Prodr. I. 89. Meisner Gen. 3. (3.) Tuli pifera Hermann Lugd. Batav. 612, ic. Adanson Fam. II. 365 .

SUIBDET III. IILICIEAE DC. Prodr.I. 77. Ovaria simplici serie verticillata. _ Folia pellucide punctata. Stipulae caducae $v$. nullae.

48 41. Thasmamian $R, B R$. Flores dioici v. polygami. Calyx diphyllus, foliolis planis, deciduis. Cor o 11 a é petala $2-5$, hypogyna, patentia, decidna. Stamina plurima, hypogyna; fil a ment a crassinscula, teretia, an therae biloculares, loculis ovatis, extrorsum adnatis, longitudinaliter dehiscentibus. Ovarium unicum, rarissime duo, libera, subsessilia, ovulis ad suturam ventralem plurimis, biseriatis, subhorizontalibus, anatropis. Stig ma subterminale, introrsum decurrens. Fruetns membranaceus, indehiscens. Sem in a plura, pendnla, ovata, subeurvata, testa nitida, fragili. E m b ryo in basi albuminis carnosi minutus, orthotropus, radicula supera. - Frutices glaberrimi, in Nova-Zeelandia, insula Diemen et Nova-Hollandia orientali monticoli; cortice aromatico, foliis sparsis, sempervirentibus, pellucido-punctatis, breve petiolatis, integerrimis, pedicellis ad apices ramorum v, e summo- 
rum foliorum axillis confertis, unifloris, folio brevioribus, gracilibus, teretiusculis, squamis gemmularum convolutis, acuminatis, ramulos novellos terminantibus, deciduis.

T a sm a nnia R. Brown ex DC. Syst. $T$. 445. 348. Prodr. I. 78. Delessert Ie. I. t. 84. A. Riehard Sert. Astrolab. 50. t, 19. Meisner Gen. 3. (5.)

4 4 4. Drimns FORST. Flores hermaphroditi. Cal yx aestivatione clausns, valvatim dehiscens, hi-tripartitus; Iaciniis concavis, persistentibus. C o r o Il a e petala 6-24, hypogyna, unibiseriata, patentia, decidua. Stamina plurima hypogyna, juxta torum brevissime stipitiformem inserta, pluriseriata; fil amenta late linearia, complanata, antherae parvae, biloculares, loculis subrotundis, extrorsum adnatis, longitudinaliter dehiscentibus. Ovaria $2-8$, in summo toro verticillatim sessilia, dorso gibba, libera, unilocularia. Ovula juxta suturam ventralem 6-9, biseriatim pendula, anatropa. Stigmata in ovariis subterminalia, sessilia, mamillaeformia. $\mathbf{B}$ a cca e obovato-gibbae, sessiles. Semina abortu pauca, inversa, obovata, testa crustacea. E mbryo in basi albuminis carnosi minutissimus, orthotropus, radicula supera. - Arbores $v$. frutices, in America a $M e x i c o$ ad fretum $M a-$ gellan, nec non in Nova-Zeelandia crescentes; cortice aromatico, foliis sparsis, petiolatis, estipulatis, integerrimis, subtus incanis v. glaucis, calycibusque et petalis plus minus pellucido-punctatis, floribus axillaribus, solitariis $v$, in apice ramulorum approximatis aut congestis, nunc umbellatis, bracteis involucrantibus caducissimis, squamulis gemmarum terminalium convolutis, acuminatis, caducis.

Drim y s Forster Char. Ben, t, 42, Linn. f. Suppl.270. Jussieu gen. 280, Lam, t. 494. DC. Syst. I. 442, Prodr. I 78. Delessert Ic. select. $I$. $t$. 83. St. Hilaire Plant, us, Bra. sit. t. 26_28, Flor. Brasil. I. 24. Meisner Gen: 3. (5.) Wiuter a Murray Syst, 417. Humb. et Bonpl, Plant, aequinoct, $I, 205, t$. 58 , Winter a n a Soland. Med. obs. $V$. 46. t. 1. Magallan a Commers. msc. C a nell o Dombey muc.

48 43. Intielum LINN. Flores herma phroditi. Calyx tri.hexaphyllus, foliolis inaequalibus, membranaceis. Corollae petala $9-30$, hypogyna, bi-pluriseriata, interiora minora, patentia, decidua. Stamin a $6 \mathrm{v}$. plurima, hypogy na, uni-plurizeriata; fil amenta crassiuscula, compressa, an the rae biloculąres, loculis oblongis, marginalibus, adnatis, longitudinaliter dehiscentibus, 0 varia $6-8$, circa apicem tori verticillatim sessilia, arete contigua, libera, unilocularia. Ov ul n m unicum, e suturae basi adscendens, anatropum. St y li ovariis continui, subulati, recurvi, intus stigmatosi. Cap $\$$ u la coriaceo. sublignosae, liberae, circa columnam brevissimam arcte stellatim contiguae, uniloculares, apice bivalves, monospermae. S e m en erectum, testa crustacea, nitida, hirfe rhaphe perenrsa. E $m$ b r yo in basi albuminis carnosi minimus, orthotropus, $r$ adicula infera. - Frutices sempervirentes, chi nenses, japonici et boreali-americani; cortice aromatico, foliis sparsis, ad ramorum apices subconfertis, petiolatis, oblongis, coriaceis, integerrimis, floribus e gemmis axillaribus, v. ad apices ramuli annotini sitis, tandem ramuli novelli elongatione lateralibus, solitariis $v$, ternis, pedunculatis, capsulis aromaticis, Anisum spirantibus v. insipidis.

Illi cium Linné gen, n. 611. Ellis in Act, Angl, 1770 . p. 524. Loureiro Flor, cochinch. I. 338, t. 69. Lam, t. 493. Duhamel Arbr. edit, nov. III. $t$, 47. Venten. Cels, $t .28$,
Bot. Mag. 1 , 439. DC, Sysf. $I, 440$. Prodr. I. 77. Vriese in Tijdschrift $1,31, t, 2$. Síebold et Zuccariat Flor. japon. $T$. t. 1. Meisner Gen, 3. (5.) $\mathrm{S} k \mathrm{im} \mathrm{m} \mathrm{i} \mathrm{Kämpter} \mathrm{Amoen,} \mathrm{exot.}$ 880. Adanson Fam. II, 364. B a di a n if e ra Lian. Mat. me. dio. 180.

\section{GENUS ILLICINEIS AFFINE.}

4\% 4. Troelhodiendroun SIEB, et ZUCC. FIores hermaphroditi. Perigoninm nullum. Sta min a hypogyna, indefinita, pluriseriata, decidna; fil amenta filiformia, adscendentia, antherae terminales, erectae, biloculares, apice mucronulatae, latere longitudinaliter dehiscentes. ovarinm depresse conicum, quinque-octoloculare. Ovula in locnlis plurima, biseriatim pendula, anatropa. Styli $5-6$, loculornm dorso continui, persistentes, erecti, apice subrecurvi ; stigmatibus juxta internum stylorum latus subdecurrentibus. C a p 8 u l a globosa, stylis coronata, corticata, quinque-octolocularis, a vertice deorsum quinque-octovalvis, valvis coriaceis. Se mina plarima, pendula, linearia, utrinque attenuata, angulata, testa membranacea, glabra, hine rhaphe valide prominente, ab umbilico ad verticem usque percursa, ibique brevissime appendiculata. E m b r y n in albuminis carnosi apice carpico prope nmbilicum minimus, orthotropus; cotyledonibus obtasis, subcarnosis, radi cula crassa, conica, supera. - Frutex v. arbor aromatica, in humidis umbrosis Japoniae meridionalis vegetans; ligno duro, albido, tandem fuscescente, ramis subdichotomis, foliis plerumque per triennium virentibus, coaevis subverticillatim approximatis, internodio satis longo, perulis persistentibus obsito, $a b$ illis anni sequentis remotis, longe petiolatis, ovato-rhombeis, cuspidatis, serratis, coriaceis, glabris, gemmis perulatis, mixtis v. foliiferis, perulis interioribus tandem elongatis, post vernationem persistentibus et longius quam folia a se invicem remotis, floribus coaetaneis, in racemos terminales, simplices dispositis, pedicellis basi bractea lineari suffultis.

Trochodendron Siebold et Zuccariai Flor Japon. $I$. 83. 2.39 .40 .

\section{GENUS VIX NOTUM.}

47.5. Temus MOLIN. Caly $\mathrm{x}$ trifidus. Corolla e petala 18, linearia, longissima. Stam in a 26, petalis breviora, an therae globosae. Ovaria 2 , singula monostyla. B a eca (ovariis demum coalitis?) dicocea. S emina arillata. Arbor chilensis, sempervirens; foliis alternis, petiolatis, ovalibus, laevibus, lucidis, Myristicae odorem spirantibus, floribus terminalibus, pedunculatis, suaveolentibus, calycis lobis obtusis, petalis flavis $v$. albis, bi-tripollicaribus, filamentis setaceis, baccis Coffeae similibus, amarissimis.

Temus Molina Chili 153. Jussieu Gen, 435. DC. Prodr. 1. 77. Meisuer Gen. 3. (5,)

\section{Drdo CLXXVII. Dilleniacene.}

MAGNOLIIS affines Jussien Gen, 281. coll. Annal. Mkr. $x I V$ 129. Mem. Mus, $V$, 233. R. Brown in Flinder, Voy. $I T$. 501. DILLENEAE Salisbury Parad. 73. DILLENIACEAE DC. Syst. I. 395. Prodr. I. 67. St. Hilaire Flor. Brasil. 1. 23. Bartling Ord. nat. 249. Lindley Iutroduct, edit, IT. p. 20. Meisner Gen, 2. (4.)

Arbores, frotices v. supprutices, saepe scandentes, rarissime caudice hypogaeo sub- 
herbacei, ramis teretibus, foliatis, interdum compressis, foliis minute squamiformibus quoad speciem aphyllis. Foli a alterna, rarissime opposita, plerumque coriacea, conspicue penninervia, integerrima v. dentata aut serrata, sessilia v. petiolata, petiolis saepe amplexicauli dilatatis, nonnunquam lamina basi transversim secedente persistentibus. - Stipulae nullae, rarissime ramos acumine conico terminantes, caducae.

Flores hermaphroditi v. abortu unisexuales, saepissime symmetrici, rarius staminibus unilateralibus asymmetrici, terminales, solitarii, racemosi v. paniculati, plerumque flàvi.

CALYX pentaphyllus, rarius pleiophyllus, foliolis coriaceis, saepius inaequalibus, aestivatione imbricatis, persistentibus v, rarius deciduis.

Coroluas petala 5, hypogyna, calycis foliolis alterna, aequalia, ovata v. obovata, integra $\mathbf{v}$. emarginata, aestivatione imbricata, decidua.

Stavina plurima v. rarissime definita, pluriserialia, ovarium ambientia v. unilateralia, libera v. fasciculatim monadelpha aut polyadelpha. Filamenta brevia, basi v. apice dilatata. Anthera introrsae v. extrorsae, biloculares, loculis linearibus v. subglobosis, adnatis, saepe connectivo interposito sejunctis et superatis, secundum longitudinem v. poro apicis dehiseentibus.

Ovaria plura, subdefinita, rarius solitaria, sessilia, unilocularia, libera, v. interdum ad axim plus minus cohaerentia. Ovula nunc solitaria, e basi erecta, nunc suturae ventrali inserta, pauca v. plurima, biseriata, adscendentia, anatropa. Styli in ovariis terminales, simplices, persistentes. Stigmata simplicia v. subcapitata, nune excavato-depressa, emarginata.

Capsurae folliculares v. baccatae, ses'siles, liberae v. connatae, stylis superatae, indehiscentes v. ad suturam apertae, mono-di-polyspermae.

SkMINa erecta v, adscendentia, ovata, testa coriacea v, cartilaginea, umbilico basilari, arillo membranaceo v. pulposo, cupulaeformi, fimbriato - lacero cincta v. interdum nuda. Albumen carnosum, subcartilagineum.

Embryo in basi albuminis minimus, orthotropus, radicula umbilico proxima, infera.

Dilleniaceae Magnoliaceis Ranunculaceisque proximae, habitu, ovariorum numero minori et arilli in plurimis praesentia facile distinguendae, inter tropicos Asiae et Americae pari fere numero obviae, in Africa tropica ut videtur rarae, maxima copia in Nova-Hollandia, imprimis extratropica, generatur.

Qualitates in nonnullis adstringentes, paucissimarum fructus edules, aciduli.

TRIIBUS I. DILLENEAE DC. Syst. I. 411. Antherarum connectivum aequale v. apice angustatum, loculi lineares. - Species asiaticae el australasicae.

4 46. Capellia BLUM. C a l y x pentaphyllus, foliolis subrotundis, persistentibus, CorolI a e petala 5, hypogyna, decidua. S $t$ a $\mathrm{m}$ in a indefinita, hypogyna, intima unica serie multo longiora, omnia fertilia, a $\mathrm{n}$ theris bilocularibus, elongato-linearibus, adnatis, apice rimula duplici longitudinali dehiscentibus. Ovaria $5-8$ v. plurima, unilocularia, basi coalita, ovulis ad suturam ventralem plurimis, biseriatis: S tyli terminales, subulati, divergentes; stigmata acuta. C a p8 ul a e submembranaceae, basi coalitae, intus longitudinaliter dehiscentes, polyspermae. S e m in a ….. Arbor javanica; foliis elliptico-oblongis, repando-serrulatis, glabris, pedunculis terminalibus, multifioris.

Capellia Blume Bijdr. S. Meisner Gen. 2. (5.)

4 ร 4 \%. Colbertia $S A L I S B$. C a l y x pentahexaphyllus, foliolis subrotundis, persistentibus. C or olla e petala 5 , hypogyna, decidua. Sta mi$\mathrm{n}$ a indefinita, hypogyna, intima unica serie multo longiora, antheris effoetis, reliqua fertilia, anthe ris bilocularibus, elongato-linearibus, adnatis, apice poro gemino dehiscentibus. Ovaria 4 v. 12, unilocularia, basi eoalita, ovulis ad suturam ventralem plurimis. Styli terminales, diver. gentes, acuti; s tigmat a subglobosa. Ba c cae pulposae, basi coalitae, polyspermae. Semina reniformia, pulpa pellucida, glutinosa obvoluta. - Arbor Asia e tropicae; foliis alternis, exstipulatis, oblongis $v$. obovatis, amplis, breviter petiolatis, serratis, penninerviti, pedicellis plurimis unifloris, e gemmis squamosis secus ramos annotinos ortis, gemmarum squamulis deciduis, floribus luteis, diametro pollicaribus.

Colbertia Salisbury Parad, n. 73. DC. Syst. I. 435. Prodr. 1. 75. Blume Bijdr. 6. Meisner Gen. 2. (5.) Dill e ui a pentag y n a Roxburgh Plant. Corom. $t, 20$.

4 7 4. IReifferselneidia PRESL, $\mathrm{C}$ al y $\mathrm{x}$ polyphyllus, foliolis pluriseriatim imbricatis, subrotundis, persistentibus. Cor oll a e petala 5, hypogyna, decidua. St a min a indefinita, hypogyna, interiora pluribus seriebus multo longiora, omnia fertilia, an theris bilocularibus, elongatolinearibus, adnatis, apice poro gemino dehiscentibus. Ovaria 15, unilocnlaria, basi, coalita, ovulis ad suturam ventralem plurimis. Styli terminales, filiformes, stellatim patentes; stig $m$ ata obtusa. Fruetus ...... Arbor luzonensis; ramulis velutinis, foliis sparsis, ovatis, amplis, penninerviis, remote sinuato-dentatis, petiolo utrinque alato, ala coriacea infra laminam truncata, pedunculis oppositifoliis, solitariis, unifloris, infra apicem bracteatis, floris expansi diametro sexpollicari.

Relfferscheidia Presl Reliq. Hänk. II. 74. t. 62. Palall Lusonensium.

4ร4. Dillenia LINN. C a y y pentaphyllus, foliolis subrotundis, persistentibus, fruetifer auctus. Coroll a e petala 5, hypogyna, per- 
sistentia. Stamina indefinita, hypogyna, multiscriata, aequilonga, antheris bilocularibus, elongato-linearibus, adnatis, juxta longitudinem dehiscentibus. Ovari a $10-20$, unilocularia, axi coalita, ovulis ad suturam ventralem biseriatis. Sty li radiato-divergentes, intus juxta totam longitudinem stigmatosi. B a c e a plurilocularis, styis radiantibus coronata, polysperma. Semina arillo pulposo induta. - Arbores Asiae tropicae, excelsae; foliis alternis, petiolatis, ovalibus $v$. oblongis, penninerviis, argute dentatis, petiolis basi dilatata semiamplexicaulibus, stipulis nullis, pedunculis e gemma squamosa erumpentibus, solitariis, unimultifloris, floribus flavis v. albis, fructu eduli, acidulo.

Dille $\mathrm{n}$ i a Linn. gen, n. 688. Thunberg in Linn. Trans. act. I. t. 18. 19. Smith Exot. Bot. t.92. 93. Lam. t.492. DC. Syst, I. 435. Prodr. I. 25. Wallich Plant. As. rar, t. 22, 23. Meisner Gen, 2. (5.) S y a lit a Adanson Fam, II. 364 .

ACTINIDIA Lindl. Introduct, edit, II, p. 439. C a I y x pentaphyllus, bractea parra proxime suffultus. Petal a 5 . $S t a m$ in a plurima, a $n$ theris inuatis, extrorsis. C a r p i. d f a 22 , in ovarium solidum, loculis totidem connata, stigmatib us liberis, elavatis, radiantibus, placenta magaa, centrali, fibroso-cellulari, ovulis biseriatis. - Dilleniacea? Wallich Catalog. n. 6634.

4 ร 50. Woxmåx ROTTB. Caly x pentaphyllus, foliolis subrotundis, persistentibus. C orolla e petala 5 , hypogyna, decidua. St a m ina indefinita, hypogyna, mnltiseriata, aequilonga, antheris bilocnlaribus, elongato-linearibus, adnatis, apice rima brevi dehiscentibus. Ovaria $5-10$, unilocularia, libera, ovulis ad suturam ventralem plurimis, biseriatis. Styli terminales, subulato-filiformes; $s \mathbf{t} \mathbf{i g} \mathbf{m}$ a $\mathbf{t}$ a emarginata. $\mathbf{C}$ a $\mathbf{p}-$ sn la e folliculares, sutura ventrali dehiscentes, octo-dodecaspermae. S e min a basi arillo pulposo obvoluta. - Arbores $v$. frutices scandentes, madagascarienses, ceylonenses et Novae-Hollandiae tropicae; foliis alternis, petiolatis, ovalibus, coriaceis, sinuato-dentatis, penninerviis, subtus areolato-venosis, petiolo saepius alato, basi calloso, stipulis magnis, oblongo-acuminatis, junioribus convolatis, ramos acumine conico terminantibus, pedunculis angulatis, juxta ramorum apicem oppositifoliis, racemosis, saepe unilateralibus v. paniculatis, floribus albis v. flavis.

Worm i a Rottboell in Nov, Act. IIafn. 1783. II.p. 329. 2. 3. Salisbury Parad. 73. DC. Syst, I. 433, Prodr. I. 75 . Delessert Io. seleet, I, t. 88. Gaudichaud ad Fregeinet t.99. Meisner Gen. 2. (5.) Clng nia Commers. msc. Le uidla Thouars Gon. Madagasc. n. 37 . D 111 en ine sp. Thunberg in Linn. Transact. I. $t, 20$.

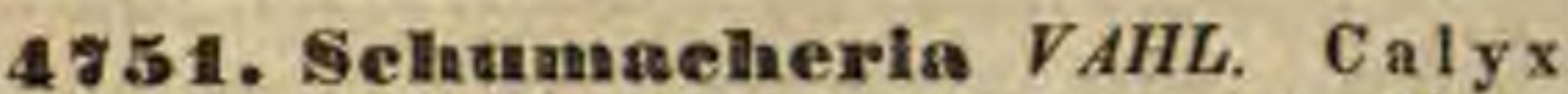
pentaphyllus, foliolis snbrotundis; persistentibus. Corolla e petala 5, hypogyna, calycem subaequantia, duorum margine crispulo. Stamina indefinita, hypogyna, unilateralia, pluriseriata, omnia fertilia; fil amenta brevia, basi coalita, ant herae biloculares, mucronatae, loculis linearibus, adnatis. Ovaria 3 , libera, villosa, unilocularia, ovulé unico, e basi erecto, arillato. Styli terminales, filiformes; $8 \mathrm{t} \mathrm{i} g \mathrm{~m}$ a $\mathrm{t}$ a simplicia. F ructn s.....-Frutices ceylonici, ramosi; ramis glabris, purpurascentibus, teretibus, novellis complanatis, foliis alternis, petiolatis, exstipulatis, coriaceis, lacvibus, glabris, penninerviis, repandoserratis, serraturis mucronatis, petiolo canaliculato, basi dilatato-semiamplexicauli, spicis terminalibus et axillaribus paniculatis, floribus sessilibus, secundis, basi bibracteatis.
Sehum a cheria Vahl in Kiobenhav. Selskab. Skrift. VI. 122. (exel. charact.) Aruott in Edinb. new philosoph. Journ, $X X I, 315$, Pleurodes mia Arnott msc.

4 5\%. A drastea DC. C a ly x pentaphylIns, fotiolis acuminatissimis, persistentibns. Corolla e petala 5, hypogyna, ovalia, calyce breviora. Stamina 10, hypogyna; filam enta linearia, plana, apice emarginata, antherae biloculares, loculis elongatis, lateraliter adnatis. Ovaria 2, libera, subglobosa, unilocularia, ov u lo unico (?), e basi erecto. Styli terminales, e basi conica subulati, recti, approximati; stigmat a simplicia. Capsula e coriaceae, uniloculares, intus longitudinaliter dehiscentes, monospermae. S e m en erectum, arillo membranaceo. Suffrutex Novae-Hollandiae orientalis, paludosus; foliis linearibus, sparsis, subintegris, sericeo-villosis, floribus ramulos terminantibus, solitariis v. binis, inter folia sessilibus,

A drastea DC. Syst. I. 424. Prodr. I. 73, Melsuer Gen. 2. (5.)

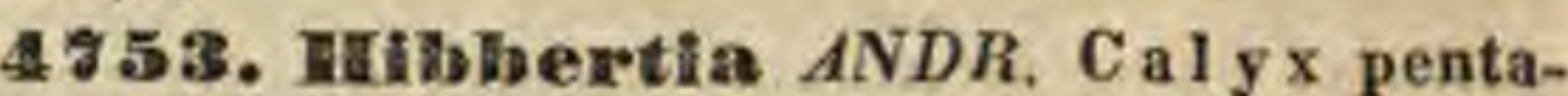
phyllus, foliolis ovatis, persistentibus. Coro 11 a e petala 5, hypogyna, ovalia, ealyce longiora, integra v. emarginato-biloba. Stamina indefinita, hypogyna ; filamenta brevia, filiformia, anthe rae terminales, biloculares, ovatae v. oblongae. Ova ria $1-15$, saepius $2-5$, libera, 8 abglobosa, nnilocularia, ovulis geminis v. pluribns, e sutura ventrali adscendentibus. Sty li terminales, filiformes, divaricati; stigma ta simplicia, subcapitata. Ca p 8 u la e nniloculares, membranaceae, intus longitudinaliter dehiscentes, monopolyspermae. S e min a adseendentia, arillo membranaceo, saepius brevissimo, fere obsoleto.

Suffrutices Novae-Hollandiae, ramosi, erecti $v$. rarius procumbentes, aut interdum volubiles; foliis alternis, plerumque coriaceis, integerrimis $v$. dentatis, brevissime petiolatis, interdum perfoliatis, floribus terminalibus solitariis, breve pedunculatis $v$. sessilibus.

H ib berti a Andrews Bot. Reposit. $t, 126$. 472. Salis. bury Parad, t, 73, Bot. Mag. 4. 1218, 2338, 2672, 3183. Bot. Reg. t. 1001. DC. Syst, J. 428. Prodr. I. 73. Meisner Gen. 2. (5.) Burtouia Salisbary msc. Cistomorpha Caley nse. Dille nia e s p. Labillard. Nov. Holl. $t, 156$. Venten. Chois t. 11. Bot. Mag. t. 449.

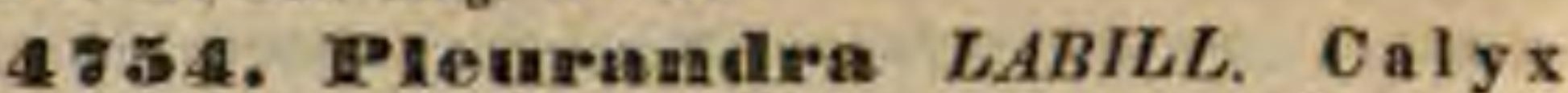
pentaphyllus, foliolis ovalibus v. Ianceolatis. Corolla e petala 5 , hypogyna, obovatav. obcordata. St a m in a $5-20$, hypogyna, unilateralia, omnia fertilia; filam en ta filiformia, brevia, libera v. hasi coalita, antherae biloculares, loculis oblongis, adnatis. Ovaria $2 v$. rarius 1 , snbglobosa, libera v. basi coalita, uniloenlaria, ovn 1 o unico v. paucis, e basi erectis. Styli terminales, subulati, divergentes; st ig mata simplieia. Ca p$\mathrm{s} \mathrm{l}$ a e membranaceae, nniloculares, longitudinaliter dehiscentes, mono-dispermae. S e m in a erecta, arillo membranaceo, lacero. - Suffrutices in Nova-Hollandia extratropica indigeni, ramosissimi; foliis sparsis v. confertis, linearibus, oblongis $v$. obovatis, uninerviis v, enerviis, integerrimis, floribus in apice ramorum solitariis.

Plen ra ndra Labillard, Nov. Holland. II. S. t. 143. 144. DC. Syst. I. 415. Prodri I, 71, Delessert Ic. velect. t. 78-81. Reichenb. Hort. Bot, t. 79. Meisuer Gen, 8. (5.)

4.55. Camallonea LABILLARD. C aly pentaphyllus, foliolis ovalibus, mueronatis, persistentibus. Corolla e petala 5 , hypogyna, obovata v. obcordata. Stamina hypogyna, polya106 
delpha; filament a brevia, filiformia, basibus fas ciculatim connata, apicibus distincta, an $t h e r a e$ bileculares, loculis oblongis, adnatis. Ovaria 3 -6, libera, unilocularia, o vulis 2 , e basi erectis. Styli terminales, subulati; stigmata sim plicia. Cap 8 ulae coriaceae, uniloculares, intus longitudinaliter dehiscentes, mono-dispermae, S emi na erecta, arillo membranaceo, lacero. - $S u f$ frutices Novae-Hollandiae a ustro-occidentalis; foliis alternis, ad apices ramulorum subconfertis, linearibus $v$. cuneatis, integerrimis $v$. apice dentatis, saepius supra basim persistentem transversim secedentibus, floribus ad apices ramorum solitariis $v$. fasciculatim racemosis.

Ca ndolle a Labillard Nov. Holland. II. 33, t. 176. DC. Syst, 1. 424. Prodr. I. 73. Bot. Mag, t. 2711. Endli. cher in Enumerat. Plant. Hï̈gel. 2. Meisner Gèn. 2. (3.)

4 5 6 . Paclaynema $R$. BR. C a lyx pentaphyllus, foliolis subrotundis, concavis, persistentibus. Corolla e petala 5 , hypogyna, ovata. Stamina $7-10$, hypogyna; filamenta crassissima, apice attenuata, erecta, anthera e terminales, biloculares, ovatae. Ova ria $2-3$, libera, unilocularia, o v a l o unico, e basi erecto. S tyli terminales, subulati; stigmata simplicia. Ca p s u l a e 2-3, uniloculares, longitudinaliter dehiscentes, monospermae. $\mathbf{S}$ e $\mathbf{m}$ e $\mathbf{n}$ erectum, arillo membranaceo, cupulaeformi. - Suffrutex Novae-Hollandiae tropicac, ramosissimus, ramulis compressis, phyllodineis; foliis minimis, squamaeformibus, pedunculis supraaxillaribus, solitariis, unifloris.

$\mathrm{Pa}$ a hy uem a R. Brown ex DC, Syst. $T$. 411. Prodr. I. 70. Delessert Ic, select, 1. t, 75. Meisner Gen. 2. (5.)

4 รั. II Iemistemana COMMERS. C a1 y $x$ pentaphyllus, foliolis ovatis, concavis, extus velutinis. Corolla e petala 5, hypogyna, obtusa v. emarginata, duobus paullo remotioribus. Sta mina indefinita, hypogyna, serie lineari-unilateralia, exteriora sterilia, linearia v. spathnlata; fil a m enta brevia, filiformia, libera, anthe$r$ a e biloculares, loculis linearibus, adnatis, $O \mathrm{va}$ ria 2 , distincta $\mathbf{v}$. ima basi coalita, unilocularia; o v u lo unico (?) e basi erecto. Sty li terminales, subnlati, divergentes; stigm at a simplicia. $\mathbf{C}$ a $\mathrm{p}$ $8 \mathbf{1}$ a e 2, uniloculares, Iongitudinaliter dehiscentes, monospermae. Semen erectum, arillo membranaceo, cupulaeformi. - Suffrutices cistiformes, in Madagascaria et Nova-Hol landia tropica indigeni; foliis oppositis v. alternis, oblongis, ovalibus $v$. linearibus, integerrimis, coriaceis, superne glabris, nitidis, subtus al. bido-tomentosis, pedunculis axillaribus $v$. alaribus multifloris, floribus unilateralibus, sessilibus, bitribracteatis.

H e m is te mma Jussieu ex Thouars Gen, madagasc, $n$. 18. DC. Syst. I. 412, Prodr. I. 71. Delessert Ic. select. t. 74_76. Meisuer Gen, 2. (5.) A g Iaja Noronh. msc. ex Thouars l, $c$.

4759. Aerotaema $J A C K$. C a I y pentaphyllus, foliolis ovatis, villosis: Coro ll a e peta la 5 , hypogyna, ovalia. Stamina 5-15, hypogyna; filamenta brevia, erecta, antherae oblongo-subclavatae, biloculares, introrsae, loculis adnatis, apice poro dehiscentibus. Ovaria 3 unilocularia, libera v, ad axim connata, ovulis juxta suturam ventralem paueis $v$. plurimis. St yli terminales, recurvi; $8 \mathrm{t} \mathbf{i} \mathrm{gm}$ a $\mathrm{t}$ a simplicia. C a 8 ulae folliculares, sutura ventrali dehiscentes, di-polyspermae. S e min a reniformia, scrobiculata. - Herbae suffruticosae, in As ia tropica indigenae; caudice hypogaeo, foliis subradicalibus, oblongo-obovatis, penninervits, serratis, rigidule pilosis, petiolis margine dilatato membranaceis, pedunculis axillaribus, subradicalibus, scapiformibus, solitariis $v$. pluribus, uni-multifloris.

A erotrema Jack Malay. Miscell. ex Hooker Bot. Mincell. II. 82. Wight et Arnott Prodr. I. O. Hooker IC. t. 157. Meisner Gen, 2. (5.)

THEIIES HI. DELIMEAE DC. Syst. I. 397. Antherarum connectivum apice dilatatum, loculi subrotundi. _ Species americanae, pauca asialicae et africanae tropicae.

4ร5. Curratella LINN. Caly $x$ tetrapentaphyllus, foliolis inaequalibns, subrotundis, persistentibus, patulis. Corolla e petala 4-5, hypogyna, decidua. St a m in a indefinita, hypogyna, persistentia; fil am enta filiformia, apice subinerassata, antherae introrsae, biloculares, loculis connectivo subaequali adnatis, longitudinaliter dehiscentibns. Ovaria 2 , subglobosa, basi coalita, unilocularia, ovulis geminis, e basi adscendentibus. Styli sublaterales, filiformes; s ti gmat a peltata, emarginato-umbilicata. C a p s u la e coriaceae, hispidae, uniloculares, intus Iongitndinaliter dehiscentes, dispermae. Semina adscendentia, arillo membranaceo. - Arbores humiles, in America tropica crescentes; foliis alternis, ovatis, asperis, integerrimis $v$. dentatis, petiolo saepius alato, floribus racemosis, albis.

C u rat ell a Linn, gen, n. 679. Jussieu gen, 282. Anblet Guian, I. 579. t. 232. Lam. t. 479. DC. Syst, I, 409. Prodr. I, 70. St. Hilaire Plant. us, Brasil, t, 2f. Flor. Brasil. $I$. 22. Meisner Gen. 2. (4.)

4 \% 60. Finzona MART, et ZŨCC. C a l y x triphyllus, persistens. Corolla ......S t am ina indefinita, hypogyna; fil amenta apicem versus difatata, a $\mathrm{n}$ th era e extrorsae, biloculares, loculis oblique adnatis, longitudinaliter de hiscentibus. Ovaria 2, breviter stipitata, ad medium inter se connata, unilocularia, uni-biovalata. Styli breves, cylindrici, persistentes; stigma t a peltato-orbiculata. B a ce a didyma, bilocularis, loculis monospermis. Semina erecta, arillo carnoso, integro, apice pervio. - Frutex brasiliensis; foliis alternis, obovato-ellipticis, integerrimis, costato-venosis, coriaceis, utrinque glabris, florum paniculis axillaribus, bracteatis.

Pinzona Mart., et Zuecarini in Flora 1832. Append. p. 77. Zucearini Novar. stirp. fasc. 1. p. 371. Meisuer Gen. 2. (4.)

4\%61. Dblolioentpas ROLAND. Calyx pentaphyllus, foliolis valde inaequalibus, subrotundis, concavis, persistentibús. C or o 11 a e petala 3-5, hypogyna, decidua. Stam ina indefinita, hypogyna, persistentia; fil amenta filiformia, apice incrassata, an the r a extrorsae, biloculares, loculis oblique adnatis, longitudinaliter dehiscentibus. Ovarinm 1, uniloculare, ovulis geminis, e basi parietis adscendentibus. St ylus subterminalis, incurvus; $s t \mathrm{i}$ m a peltatuin, umbilicatum. B a ce a unilocularis, mono-disperma. Sem in a adscendentia, arillata. - Frutices $A m e-$ ricae tropicae, saepius sarmentosi; foliis alternis, integerrimis $v$, dentutis, pedunculis lateralibus terminalibusve, unifloris v. corymbosis.

Do 1 fo o a rp u \& Rolander in Aot. Academ. Holm. 1765. p. 249, t. 9. Sehrelser Gen, n, 874. Jussieu Gen, 433. DC. 
Syst. I. 405. Prodr. I. 69. Meisner Gen, 2. (4.) Cali nea Aublet Guian. I. 556. t. 221. Jussieu Gen, 434, - S o $\mathrm{r}$ a m i Aublet Guian. $I$. 552, $t, 219$. Lam. $t .463$. M a p pi a Sehreber Gen, n, 1755. Utblis Schott in Spreng. Cur. post. 607.

4 62. Empedoclea $S T$. HIL. C a lyx pentaphyllus, ovatus, foliolis obtusissimis, arcte imbricatis. Corolla e petala 3 , hypogyna, unguiculata; filamenta filiformia, apice subincrassata, anthera e extrorsae, biloculares, lo. culis adnatis, longitudinaliter dehiscentibus. $O \mathrm{va}$ ri u m 1, oblongo-pyramidatum, trigonum, angulo suturali barbatum, nniloculare, ovulis pluribus, juxta suturam biseriatim adscendentibus. Stylu s terminalis, subulatus; s tig ma subcapitatum, sublaterale. Fructus baccatus? ..... Frutex brasiliensis; foliis alternis, ellipticis, obtusis, grosse serratis, utrinque scabris, subtus ferrugineo-pilosis, racemis axillaribus terminalibusque, bracteolatis, floribus albis.

E m pedoclea St. Hilaire Flor. Brasil. I. 19. t. 3. Meisner Gen. 9. (4.)

4ร3. Davilla VELLOZ, C a lyx penta phyllus, foliolis valde inaequalibus, duobus inti mis oppositis maximis, coneavis, valvaeformibus post anthesim clansis. Corolla e petala 1-6, hypogyna, decidua. Stamina indefinita, hypogyna, persistentia; fil a m e $\mathbf{n}$ a filiformi-complanata, apice subdilatata, antherae extrorsae, biloculares, loculis discretis, adnatis, longitudinaliter dehiscentibus. Ovaria $2-3$, subglobosa, libera, unilocularia, ovalis geminis, e basi ad scendentibus. St yli sublaterales, apice incrassati; stigmata peltata, umbilicata. Ca psula e 1-3, nniloculares, calycis foliolis valvaeformibns inclnsae, indehiscentes, tandem irregulariter ruptae, mono-dispermae. S e m in a erecta, arillo meubranaceo, apice tantum pervio inclusa. - Frutices brasilienses, sarmentosi, volubiles; foliis alter nis, saepe scabris, integerrimis $v$. dentatis, breve petiolatis, in petiolum decurrentibus, racemis terminalibus axillaribusque saepius compositis, breviter pedunculatis $v$. sessilibus, floribus luteis, suaveolentibus.

Davilla Vellozo in Vandell. Prodr. 115. t. 2. f. 14 Kunth in Humb. ot Bonpt. Nov. gen. et sp. DC. Syst, $I$. 404. Prodr. I, 69. Delessert Ic, zelect. I, t. 71. St. Hilaire Plant. us, Brasil. t. 22. 23. Flor. Brasil, 1. 15. Meisuer Gen, 2. (4.) Hieron la Flor. fumin. $V, t, 116$. Tetracerae $₫$ p. DC. Delessert Ic. select. I. 69.

4\% 6.4. Heliman LINN. C a I y $x$ pentaphylIns, foliolis aequalibus, persistentibns, reflexis. Coro 11 a e petala $4-5$, hypogyna, decidua. S $t$ a$m$ in a indefinita, hypogyna; filamenta filiformia, apice incrassato-dilatata, an therae extrorsae, biloculares, loculis oblique adnatis, longitudinaliter dehiscentibus. Ovari um 1, ovatum, uniloculare, o v u li a geminis, e basi erectis. Sty. lus terminalis, subulatas; $8 \mathrm{tigma}$ capitatum, subemarginatum. Capsula membranacea, unilocularis, bivalvis, mono-disperma. S e mina erecta, arillo subcarnoso, lacero. - Frutices $A$ sia tropicae, scandentes; foliis alternis, crenulatis $v$. serratis, scabris, floribus terminalibus, paniculatis.

Deli ma Linn. Amoen. I. A03. Sehreber Gen, n. 005 Jussieu Gen. 339. Gïrtner IT. 112. t. 106. Lam. 2. 475. DC. Syst, I, 406. Prodr. I, 69. Delessert Ic. select, I, t. 72. Bot. Mag. 2. 3058. Meisuer Gen, 2. (4.) Tetracerae sp. Vahl.

4\%65. Tetracera LINN. F loreg hermaphroditi v. polygamo-dioici. C a l y $x$ pentaphyllus, rarius tetra-hexaphyllus; foliolis subaequali- bus, persistentibus, patulis. Corolla e petala 3 v. rarius 4 , hypogyna, decidna. Sta m ina indefinita, hypogyna; filamenta complanato-filiformia, apice dilatata, antherae extrorsae, biloculares, loculis oblique adnatis, longitudinaliter dehiscentibus. O varia $3-4$, basi coalita, unilocularia, ovuli s ternis v. quinis, e suturae basi adscendentibus. Styli terminales, sursum incrassati; stigmat a capitata v, concava, dentienlata. C a $\mathrm{P}^{\mathrm{s}} \mathrm{u} \mathrm{I}$ a e $3-4$, coriaceae, uniloculares, intus longitudinaliter dehiscentes, mono-dispermae. $\mathrm{S}$ emin a adscendentia, arillata. - Arbusculae $v$, frutices, saepius scandentes, inter tropicos totius or $b$ is crescentes; foliis alternis, integerrimis v. denticulatis, saepe scabris, floribus racemosis v. paniculatis.

T e tra e e ra Lian. Gen. n. 683. Jussieu gen, 339. Gärtner I. 336. $t$. 69. Lam. $t$. 485. DC. Syst. $I, 397$. Prodr. $I$. 67. Delessert Ic. select, I. t, 67. 68, 70. Labillard, Nov. Caled. $t$. S5. St. Hilaire Flor. Brasil. I, 11, Guillemin et Perrot. Flor. Seneg. I, 2. t. 1. Meisner Gen, 2. (5.) TIg a rea Aublet Guian. II. 920, 2. 350, 351. Jussieu Gen. 339. Lam. t. 485. R hi ni um Sehreber Gen, n. 1545. Eury andra Forst. Char. gen. 41. Jussieu Gen. 280. A s 8 a Houttuyn Pflanz. Syst. I. IV. 2O. W ahlb omia Thunberg in Act. Holm. 1790. p. 215. t. 9. Lam. 485 ,

\section{GENERA DUBIA.}

4868. Trenelintella $D C$. Cal y x persistens, tetra-pentaphyllus. Co rolla e petala $4-5$. $S t a m$ in a indefinita. O va ria $1-2$, singula monostyla. B a ccae 1-2, polyspermae. - Frutices sinenses, scandentes, vix noti; foliis alternis, asperis, floribus racemosis, albis.

Trachytella DC. Syst. I. 410. Prodr. I. 70. Meisner Gen. 2. (4.) A ctae a et Calli g o u u Loureiro Elor. cochinch. I. 405, et 418 .

4\%ร. Treechia SESSÉ et MOC. Caly x pentaphyllus, foliolis aequalibus, ovatis, patentibns. Corolla e petala 5, oblonga, ealycem snperantia, basi angustata, apice subdenticulata. Stamina 10. Ovaria 2 , globosa, glabra. Styli filiformes, breves; stigmata capitata, transverse dilatata. Fru ctu s ...... Frutex mexicanus, ramosus, Curatellae affinis; ramis tortuosis, junioribus angulatis, foliis alternis, ovalibus v. oblongis, floribus secus ramos superiores subracemosis, breviter pedicellatis, subebracteatis, petalis flavis.

Recehia Sessé et Moe. Flor, mexic. inedit, ex DC. Syst. I. 411. Prodr. 1. 70. Melsner Gen, 8. (4.)

\section{Drato CHXYVII. Ranuculaceae.}

RANUNCUla CEAE Jussieu Gen, 231. DC. Syst, 1, 127. Prodr. I. 2. Lindley Introduct. edit. II, p. S. Meisner Gen, 1. (1.) PAEONIACEAE et RANUNCULACEAE Bartling Ord. nat. 351. 253. exel, sp.

Herbat acres, rarius suffrutices v. frutices plerumque sarmentosi, succo aqueo, caule et ramis teretibus v. irregulariter angulatis, pube simplici v. nulla. Foli a alterna, rarius opposita, petiolata, petiolo cauli continuo, basi in vaginae speciem dilatato, plus minus amplexicauli, lamina varie dissecta, rarius simplici, rarissime petiolo ramoso composita, interdum $106 *$ 
abortiva, petiolo in phyllodium mutato. S $\mathrm{ti}$ pula e nullae.

Flokes hermaphroditi v. abortu interdum diclines, regulares v. irregulares, solitarii, racemosi v, paniculati, nudi v. involucro calyciformi, calyci corollino admoto stipati.

Calxx liber, tri-hexaphyllus, foliolis herbaceis v. petaloideis, omnino distinctis, aestivatione saepissime imbricatis, rarius valvatis v. induplicatis.

Corollas petala hypogyna, libera, calycis foliolis numero aequalia et alterna, nune dupla v. tripla, unguiculata, aestivatione imbricata, decidua, aequalia v. inaequalia, forma varia, plana, basi tubulosa, cucullata, saccata v. bilabiata, nunc nulla.

Stamsa plurima, hypogyna, saepissime multiseriata, libera, dẽcidua. Fil a menta filiformia, interdum elongata. Antherae terminales, biloculares, loculis adnatis, extrorsis v. lateralibus, saepius connectivo interposito sejunctis et producto superatis, longitudinaliter dehiscentibus.

Oraria nune definita, verticillata, calycis foliolis numero aequalia v. pauciora, rarjus plura, rarissime solitaria, unilocularia, Jibera, sessilia v. substipitata aut basi plus minus cohaerentia, ovulis juxta suturan ventralem plurimis, biseriatis, anatropis, nune ovar1a indefinita, toro hemisphaerico v. cylindrico spiraliter inserta, libera, unilocularia, plerumque ovulo unico erecto $v$. pendulo, anatropo foeta. Styli ovariis continui, liberi, setacei v. subnlati, persistentes v. rarius decidui; $\mathrm{s} \mathrm{tig} \mathrm{ma-}$ $\mathrm{t}$ a simplicia.

Fructus nunc a chenia monosperma, epicarpio cum semine concreto, supra torum congesta v. spicata, mutica v. saepissime stylo persistente, interdum barbato-plumoso superata, nunc baccae mono-oligospermae v. capsulae unilocnlares, verticillatae, liberae v. angulo centrali inter se connatae, juxta suturam seminiferam apice v. secundum totam longitudinem dehiscentes.

Semina nune solitaria, erecta v. inversa, nune plura, juxta suturam ventralem biseriata, horizontalia, testa in monospermis cum endocarpio connata, in polyspermis saepius spongioso-membranacea, interdum in marginem expansa, rhaphe saepe valida.

Емввхо in basi albuminis cornei minimus, orthotropus; radicula umbilico proxima, $\mathrm{co}^{-}$ tyledonib us germinatione foliaceis.

Ranunculaceae hinc Dilleniaceis et Berberideis, mediante Podophyllo arcte conterminae, illine quibusdam notis ultra polycarpioarum limites ad Rhoeadeas, Papaveraceas et ad Nymphaeaceas accedentes, imo quandam cum Alismaceis affinitatem mentientes, in hemisphaerae borealis regionibus temperatis et frigidis maximo numero generantur, in hemisphaerae australis temperatis multo rariores, in regionibus tropicis Asiae et Americae imprimis monticolae, ex Africa tropica ut videtur exules.

Herba plurimarum acris, radices perennium drasticae v. emeticae, semina saepius aromatica.

TEREUS I. CLEMATIDEAE DC. Syst.I. 131. Calyx coloratus, aestivatione valvatus v. induplicatus. Cor oll a nulla, v. petala calyce breviora, plana. A chenia monosperma, stylis barbato-plumosis caudata. Semen inversum. - Herbae v. saepius frutices sarmentosi, scandentes, foliis omnibus caulinis, opposilis.

4869. Clematis LINN. Caly $\mathrm{x}$ corollinus, tetraphyllus, foliolis aestivatione valvatis $v$. subinduplicatis. Stamina indefinita, hypogyna. Ovaria plurima, libera, uuilocularia, ov n lo unico, pendulo. A $c$ heni a plurima, sessilia, stylo nudo $\mathbf{v}$. barhato candata. $\mathbf{S}$ e $\mathrm{m}$ e $\mathbf{n}$ inversum. - Herbae erectae $v$. suffrutices sarmentosi scandentes, in zonat temperat a e regionibus calidioribus ubique majori copia obvii; foliis oppositis, integris $v$. pinnatisectis, petiolis quandoque cirrhosis, inflorescentia composita, floribus saepius bibracteolatis, bracteolis interdum flori approximatis, involucrum bilobum constituentibus.

C I em a t is Linn. gen. n, 696. Juss. gen. 232. Gürtuer I. 356. DC. Syst. I. 131. Prodr. $T$. 2. excl. sp. Meisner Gen. 1. (1.) $\mathrm{Clem}$ a tit is Tournef. inst. 130.

a. VITICELLA DC. l.e. Involn er um nullam. Calyeis aestivatio valvata. A ehe ni orum caudae breves, im. berbes. - Viti cella Dillen. Giess. 165. (Jacq. Hort. schönbr. $t$, 357. Bot. Mag. t, 834. 1892, DC. Plant, rar. jard. Genev. t. 12. Bot. Reg. t, 1955. II. t, 25.)

b. FLAMMULA DC. $\boldsymbol{l}$. c. In of u erum nullum. Calye is aestivatio valvata. A chen for um caudae barbatoplamosae. - Clem at it is Mönch Method. 196. StyIurus Rafin. Flor. ludov, 27. Trigula Noronh. msc. Clematops is Bojer msc. (Gärtner t. 74. Jacq. Flor. austr. t. 291. 308. 336. Ic. rar. t. 104. Jaeq, f. Eclog. I. t. 32. Bot. Mag. t. 1816. Bot. Reg, $t$, 238. 599. 1234 . Delessert Ic. select. $I$. $1-5$. Hooker Flor. Bor. Amerr. t. 1. Ic. t, 10, 77 -80. Wallich Plant. As, rar, t. 20.98.)

c. CHEIROPSIS DC. $t$. c. I n v o I u c r a m sub flore diphylIum. Caly cis aestivatio induplicata. A chenforum cadadae barbatae. - Vi or na Persoon Encheir. Ir. 98. M n ralt a Adanson Fam. I1. 460. (Sibthorp Flor. graoc. t. 517. Bot. Mag. t. 995. Wallich Plant. As, rar.t. 217.)

4\%क5. Atragene DC. C a lyx corollinus, tetraphyllns, foliolis aestivatione subinduplicatis. Corollae petala plurima, hypogyna, plana, unguiculata, calyce breviora. St a mina indefinita, hypogyna. Ovaria plurima, libera, unilocularia, ovulo unico, pendulo. A ch e ni a plurima, sessilia, stylo barbato caudata. Semen inversum. - Suffrutices scandentes, a $l p i u m$ hemisphaerae bo realis utriusque continentis incolae; foliis oppositis, trisectis, pedunculis unifloris, involucro nullo.

A tragene Linn. gen. n. 695. Jussien gen. 232. Gärtner I. 356, t. 74. Jacq. Flor, austr. $t$. 241, Sehkuhr $t$. 150. Bot, Mag. t. 887. 1951. Meisner Gen, 1. (1.) Cl e matitis sect. A trage a e DC. Syat. I. 165. Prodr. I. 9. 
4 ร 70. Nargovelia $D C$. C a lyx coroltinus, tetra-pentaphyllus, foliolis aestivatione valvatis. Coroll a e petala 6-12, hypogyna, linearia, erassiuscula, calyce longiora. Stam in a indefinita, hypogyna, antheris extrorsis. Ova ri a plurima, libera, unilocularia, ovulo unico, pendulo. A chenia plurima, oblonga, compressa, stipitulo crasso, cavo, apice papposo insidentia, stylo barbatoplumoso caudata, demum spiraliter torta. S em e n inversum. - Suffrutices Asia e tropicae scandentes; folits oppositis, trisectis, segmento intermedio in cirrhum ramosum mutato, lateralibus multinerviis, subintegerrimis, floribus paniculatis.

Na ravelia DC. Syst. 1,167 . Prodr. I, 10. Wight et Arn. Prodr. Flor. Ind. or. I, 2, Meisner Gen. 1. (1.) N a$\mathrm{r}$ a w a el Hermanu Zeylan. 26. Adanson Fam. 1T. 460. A tragene zey 1 anica Lina. Roxburgh Plant. corom. $t$. 188.

TerIEUS II. ANEMONEAE DC. Syst.I. 168. Caly x saepissime coloratus, aestivatione imbricatus. Cor olla nulla v. planipetala, rarissime petalorum ungue tubuloso. A chenia monosperma, saepe stylis barbatis caudata. $\mathbf{S e}$ men inversum. - Herbae erectae, foliis omnibus radicalibus $v$. caulinis allernis, floribus saepius involucratis.

48ร 1. Cyrtorlnynelng NUTT. Invo1 u c rum nullum. Cal yx corollinus, pentaphyllus, foliolis angustis, patentibus. C or olla e petala 5, hypogyna, angusta, unguiculata, ungue laninam aequante, apice processu callosa instructo. St a m in a indefinita, hypogyna. Ovari a plura, libera, unilocularia, ov ulo unico, pendulo. A c hen i a $10-15$, eapitato - congesta, oblongo - cylindrica, suleata, stigmate brevi subulato, introflexo. Se m en inversum. - Herba in A merica e borealis montibus scopulosis indigena, perennis, glabra; caudice petiolorum vaginis squamoso, foliis radicalibus longe petiolatis, subcoriaceis, nitidis, ternati- et bipinnatim divisis, panicula terminali la$x a$, cymosa, floribus luteis.

Cyrtorhy ncha Nuttall ex Torrey et A. Gray Flora of North America I. 26.

4ร ซ. Thallietrum TOURNEF. Invol u crum nullum. Calyx corollinus, tetra-pentaphyllus, foliolis aestivatione imbricatis, caducissimis. Cor olla nulla. Stamina indefinita, hypogyna, Ovaria plura, libera, unilocularia, ov ule unico, pendulo. A $\mathrm{c}$ h e n i a $4-15$, sessilia v. stipitata, stylis brevibus superata, nunc longitndinaliter costata, nunc triptera v, vesiculoso-inflata. S e m e n inversum. - Herbae perennes, per hem is pha erae borealis regiones temperatas diffusae; caulibus annuis, saepe fistulosis, foliis alternis, saepissime petiolo basi dilatato, inflorescentia composita, varia, floribus saepissimé dioicis $v$. polygamis.

Thalictrum Tournefort inst, 270. Linn. gen, $\pi, 697$. Jussien Gen. 232. Gărtner I. 355. DC. Synt. I, 168. Prodr, $I$. 11. Melsier Gen. 1. (1.)

a. TRIPTERIUM DC. 2 . c. A e henia triquetra, angulis alata, snbstipitata. - Radices fibrosae. Folia petiolo ramoso mulcisccta, auriculis membranaceis ad basim ramoso multisecta, auriculis memifionum petioli. - (Jacq. Hort. Vindob. III. t. 81. Bot. Mig. $t, 1818.2025$. )

b. PHYSocarpuM DC. $l$. c. A e h e n f a infiato.vesiculosa, stipitata. - Radices fibrosae. Folia bi-triternatisecta. Species americanae. $\mathrm{P}$ h y s oca r p id i u meichenb. Consp. 192. (Delessert Ie, select. I, t. 9. 7.)

c. EUTHALICTRUM DC. l. c. A chenja ovato-oblonga, costato-striata, sessilia, - Radices fibrorae v, grumo. sae. Folia varia. c. Thalictroides. Radices fibrosae. CGärtn. t.7t. Jacq. Plor, autr. t. 419. 490, Hort. Vindob. t. 95. 96. Waldst, et Kitaibel Plant, rar, Hung. $t$. 174. Flor. dan. $t$. 244. Delessert Io. select. I. t, 8 - 12. Hooker Flor. Bor. Amer. $t$. 2. Ledebour Ic. $t, 138.164 .397$. Wallich Plant, As, rar. t. 129. 264.)

ค. Sy ndes mon. Radices grumosae. Calye is foliola stauia superantia. - S y ndes mo n Hoffmansegg. ex Flora 1832. Intelligbl. 34. A n emo ne thalietroides Limn. Juss, in Annal. Mus, IIr. $t, 21$. $f$. 2. Th. $t$ u b е ros u m Lian. Milier $10, t, 265, f, 2$.

4ร ร. Amemine $H A L L$. Involucrum triphyllum, a flore remotum, foliolis varie incisis. Ca 1 y x corollinus, penta-pendecaphyllus, foliolis aestivatione imbricatis. Corolla nulla. Sta min a indefinita, hypogyna, omnia fertilia v. extima sterilia, glandulaeformia. Ovaria plurima, libera, unilocularia, ovulo unico, pendulo. Achenia plurima, mutica v. stylis barbato-plumosis caudata. Semen inversum. - Herbae perennes, extratropicae, versus polum arcticum et in al. pibus paullo frequentiores, paucissimis in Capite bonae spei et in America australi vigentibus exceptis boreales; radice tuberosa 'v. horizontali, repente, rarius mere fibrosa perennantes; caule annuo, subscapiformi, apice uni-multifloro, foliis radicalibus integris $v$. plus minus divisis, caulinis ternis, iuvolucrantibus, saepius minoribus v. heteromorphis.

$$
\text { A ne mo ne Haller Helv. IT, 60. DC. Syst, T. 188. Prodr. }
$$

I. 17.

a. PUlSatilla. A e he $\mathrm{n} f$ a stylis barbato-plumosis eaudata.

c. Campanaria. Calyels foliola 5 -6. Stamina extima abortiva, glandalaeformia, pedicellata. I $\mathrm{n} \vee 0-$ Iucri foliola sessilia, basidilatata, apice in lobos li. neares palmatisecta. - Folia radicalia saepins pin. natisecta, segmentis multifdis, lobis linearibus $v$. cuneatis, floribus saepius purpureis. - $\mathrm{P}$ uls a tll. 1a Tournef. inst. 148. (Schkuhr t.50. Flor, dan. t. 29. 153, 611. E, B. t, 51. Ledebour Ic, t, 109, 110.)

B. Preonanthus DC. $t$. c. Calyeis foliola 5-6. St a m ina omnia fertilia. Invol u e i foliola triseeta, segmentis petiolatis, pinnatisectis, lobis inciso-serratis. - Folia radicalia petiolo ramoso biternatim secta, segmentis pinnatim inciso.serratis. - Preona nth us Ehrbart Sice. 95. A. al pla a Linn. Jaeq. Flor. austr. $t .85$.

b. ANEmantrus. A chenia ecaudata. - Anemone Tournef, inst. 147.

$\gamma$. Pulsatilloides DC. $l$. c. Calye is foliola $7-20$, oblonga. A chen i a hirsutissima. Invol ueri di-triphylli foliola basl sabvaginantia, apice inciso-dentata. - Fotia radicalia petiotn basi ramoso biternatirecta. Spectes capenses et indicae. - Asternnem ia Reichenb. Consp. 191. (Bot. Mag. t, 716. Royle Hi. malay. $t, 2, f, 1$, )

8. A nemona nthe a DC. $2, c$. Cal y cis foliola 5-15. A chen i a basi hirsutissima v. subglabra, ovoidea, stylo uncinata, In $\nabla$ o I u er i foliola sessilla v. petiolata. - Pedicelli intra involuerum solitarii $v$. rarissime bini, umbellati, uniflori, nudi. - Oriba Adanson Eam. 1I, 459. (Flor. dan. t, 140. 859. Sibthorp Flor. graee. t. 514. Bot. Mag. t. 54, 123, 841. Bot. Reg. $t$. 200, Jussieu in Annal. Mus. IIT. t. 20. 21. $f$. 1 . Delessert Ic, select. I, t. 12-14. Hooker Flor. Bor. Amer. c. 3. f. a. Ledebour Ye. t. 118. 388. Hooker ad Becchey t. 1. Cambessed. ad Jacquem, t. 2.)

e. Anemonospermos DC. 2 . c, Calyeis foliola 5 , rarissime 10. A ch en la subeompressa, villosa, stylo uneinata. U m bella spurie composita, peduneulis ex involucro pluribus, unifloris, uno nado, daobas v. tribus iavolucellum bifolium gerentibus, - (Gairtner 6. 74. Delessert Ic. select. t, 10. 17. Hooker Flor. Bor. Amer. t. 3. f. 6. t. 4. Io. t, 176, Bot. Mag. t. 3376.$)$

5. Homalocarpus DC. 2 . c. Calycis foliola 5 v. 6. 
A thenia compresso-plana, ovali-orbieulata, glaberrima; plane mutica. Pedicelli plurimi, usiflori, intra involuerum umbellati, rarissime solitarii. (Jaeq. Flor, austr. $t$. 159. Hooker Ic. t. 1.)

4ร ร. Thematiea $D I L L E N$. Involucrum calyciforme, flori proximum, triphyllum, integrifolium. C a 1 y $x$ corollinus, hexa-enneaphyllus, foliolis aestivatione imbricatis. Corolla nulla. Sta. $m$ in a indefinita, hypogyna, omnia fertilia. Ovaria plurima, libera, nnilocularia, ovulo nnico, pendulo. A chenia indefinita, stylo brevi apicalata. S e men inversum. - Herbae perennes, in montanis Europae et Americaeborealis, primo vere e gemmis radicalibus squamosis scapos unifloros, tandem folia simplicia, coriacea, tri-septemloba promentes.

He patica Dillen. Nov. gen. 108. DC. Syst. I. 215. Prodr. 1. 22. Bot. Reg. $t$. 387. Meisner Gen. 1. (1.) Is opy ru in Adanson Fam. Ir. 460 . non Linn. A nem one hepatie a Linu. Flor. dan, t. 612. Sibthorp Flor. graec. i. 513 .

4ซร. herbaceus, pentaphyllus, foliolis aestivatione imbricatis. Corolla e petala 5-15, hypogyna, plana. Stamina plurima, hypogyna. Ovaria plurima, libera, unilocularia, ov ul o unico, pendulo. A ch enia plurima, baccata, in receptaculo hemisphaerico spicata, stylo deciduo mutiea. S e m e n inversum. - Herbae capenses, perennes, Umbelliferarum habitu; folīis radicalibus bi-triternatisectis, ramis floriferis saepius umbellatis, floribus irregulariter involucralis.

Kn ow 1t on ia Salisb. Prodr. 372. DC. Syat. I. 218. Prodr. I. 23. Delessert 1c. select, I, t, 19. Bot. Mag. t, 775. Bot. Reg. $t$. 936. Meisner Gen, 1. (1.) A u a ne a i a Venten. Malmais. 12. $t$. 22. A donidis sp. capenses Linn. et Auct. - ? T h e bes i a Necker Elem. n, 1089.

4. 6 . Illamadryas COMMERS. F lo r es abortu dioici. Calyx herhaceus, penta-hexaphylIns, foliolis aestivatione imbricatis. Corolla e petala 10-12, hypogyna, linearia, elongata. S tamina plurima, hypogyna. Ovaria plurima, li. bera, unilocularia, ov u lo unico, pendulo. A chenia plurima, in capitulum congesta, stylo brevi acuminata. S e men inversum. - Herbae magellanicae et chilenses, tomentosae, scapigerae; foliis palmatipartitis integerrimisve, floribus ad apicem scapi congestis $v$. solitariis, exinvolucratis, luteis, abortu dioicis.

Hamadryas Commerson ex Jussieu gen. 232. DC. Syst, I, 226. Prodr. I. 25. Delessert Ic. select. I. t, 22. Hooker IC. t. 137. Meisner Gen. 1. (1.)

4\%รซ. II ydrastis LINN. C a lyx herbaeeus, triphyllus, foliolis aestivatione imbricatis. Corolla nulla. Stamina plurima, hypogyna. O vari a libera, unilocularia, or ulo unicov. duobus pendulis. A chen i a plurima, baceata, dense congesta, stylo brevi apiculata. S e m en inversom. - Herba bor eali-americana, tuberibus radicalibus congestis, intense luteis; caule unifloro, apice di-triphyllo, foliis petiolatis, tri-quinquepartitis, lobis grosse dentatis, acutis, flore terminalialbo, subpurpurascente, fructu rubro, rubiformi.

Hydras tis Linn. Gen, n, 704. DC. Syst, 1.218. Prodr. 2. 23. Hooker in Bot, Mag. t. 3019. 3232. Warneria MilJer IC, $I T .190, t .285$.

4ร8. Adlonis DILLEN, Calyx herba cens, pentaphyllus, foliolis basi interdum productis, solutis, aestivatione imbricatis, deciduis, $\mathrm{C}_{0}$ ro 1 l a e petala $5-15$, hypogyna, ovata. S $t$ a mina plnrima, hypogyna. Ovaria plurima, libera, unilocularia, ov u lo unico, pendulo. A é henia plurima, supra receptaculum ovato-cylindracenm spicata, stylo recto $v$. uncinatim recurvo mueronata. Semen inversum. - Herbae mediterraneae, caulescentes; foliis caulinis pinnatipartitis, multifidis, floribus in apice ramorum solitariis, luteis $v$. sanguineis.

A d on is Dillen Nov. gen, 109. Linn. gen, n, 698. Jussieu Gen, 232. Gärtner I. 353. DC. Syst, I. 220. Prodr. I. 32. Meisner Gen. 1. (1.)

A. ADONIA DC. $t, c$. Petala 5_10. A cheniorum stylus rectus, conicas. - Annuae, arvenses. - S a rped on ia Adanson Fam, IT. 460. (Jacq. Flor, austr, $t$.344. 345. E. B. $t, 708$. Delile Flor, aegypt. t, s3. Reichenb. Iconogr. $t, 317-319$.

b. consiligo DC. $t$. e. Petala 8-15. A chenioram stylus uneinatim recurvas. - Perennes, collinae. (Jacq. Flor, austr. $t$. 4t. Gärtner $t, 74$. Delessert Ic. select, $I, t, 1$, Reichenb. Iconogr. $t$. 321, 822. Ledebour Io. $t$. 119.)

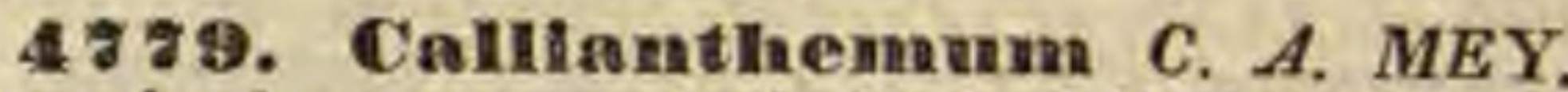
Caly x herbaceus, pentaphyllns, foliolis aestivatione imbricatis, deciduis. Coroll a e petala 515, hypogyna, basi tubulosa. St a min a plurima, hypogyna. Ova ria plurima, libera, unilocnlaria, ovulo unico, pendulo. A chenia plurima, supra receptaculum hemisphaericum spieata, stylo apiculata. Semen inversum. - Herbae alpestres, gerontogeae; foliis radicalibus integris, caulinis multipartitis.

Callianthem um C. A. Meyer in Ledebour Flor. alt. II. 336. Meisner Gen. 1. (1.) Cambessed. ad Jacquem. t. 3. Ranunculas rutaefollus L. Jacq. Collect. $I$. t. 6. 7. Reichenb. Iconogr.f.1048, P. poly petal us Royle Himalay, $t, 2, f$. 2 .

48 80. DIyosmras DILLEN. C al y x subcoloratus, pentaphyllus, foliolis basi productis" aestivatione imbricatis, decidais. Corollae petala 5, hypogyna, calyce breviora, angnste spathulata, ungue tubulesa. St a m in a 5-20, hypogyna. Ovaria plurima, spieata, unilocularia, ovulo unico, pendulo. A chenia plurima, triquetra, supra receptacnlum elongatum spicata, stylo brevissimo acuminata. S e men inversum. Herbae annuae, minimae, inter segetes Europae et Americae borealis habitantes; foliis radicalibus linearibus, integerrimis, scapis nudis, unifloris, receptaculis fructiferis tandem longissimis.

M yonurus Dillen Nov. gen, 106. Linn, gen, n. 394. Jussieu Gen, 233. Gairtner $1.354, t$, 74. Sehkuhr $t, 88$. Flor. dan. $t$. 406. Curtis Flor, lond, IV. t. 26. DC. Syst. $I$. 299. Prodr. I. 25. Meisner Gen. 1. (1.) Kunth Flor. Berolin. I. 13.

4881. Apliamostemma ST. HILAIR. Ca ly $x$ corullinus, pentaphyllus, foliolis aestivatione imbricatis, deciduis. C oroll a e petala 5 , hypogyna, minima, glandulaeformia, orbiculata, bilabiato-foveata. S ta m i na -indefinita, hypogyna, antheris extrorsis. Ovaria plurima, libera, nnilocularia, ovulo unico, pendulo. A chenia plurima, supra receptaculum conicum spicata, stigmate sessili terminata. S e men inversum. - Herbae paludosae, in America a ustrali indigenae, glabrae; foliis lobato-multipartitis, floribus parvis, albo-rubris.

A phanostem ma St. Hilaire Flor. Brasil. T.9. Meisner Gen, 1. (1.) Ranuneulas apiffollus Linn. Delessert Ie. select. I. t. 26. excl. flor.

TIRIBIS III. RANUNCULEAE DC. Syst. I. 228. Calyx aestivatione imbricatus. Corolla petala ungue tubuloso bilabiata, la- 
bio interiore squamaeformi v. nullo. Achen ia sicca. S em e n erectum. - Herbae, foliis radicalibus $v$. alternis, foribus in apice caulis auc ramorum solitariis, involucris nullis.

4782. Casalea ST. HILAIR. C a yx coloratus, triphyllus, foliolis aestivatione imbricatis, deciduis. Corollae petala 3 , hypogyna, ungue basi intus squamula aucto. S tam in a 6 v, plurimá, hypogyna. Ovaria plurima, libera, uni locularia, ovnlo unico, erecto. A chenia pluri ma, compressiuscula, laevia, stylo apiculata. S e men erectum. - Herbae paludosae, glaberrimae, in America boreali, tropica et extratro$p i c a$ indigenae; foliis alternis, integris $v$. partitis, pedunculis oppositifoliis, unifloris, floribus parvis $\boldsymbol{v}$. interdum minimis, albis $v$. luteis.

Cas a le a St. Hilaire Flor. Brasil. . , 6. t. 1. Meisner Gen, 1. (1.) R a n u n culi s p. tripetalae Auet.

4793. Ranumeuluss $H A L L$. C a 1 y $\mathrm{x}$ pen. taphyllus, herbaceus, foliolis aestivatione imbricatis, deciduis. Corolla e petala 5 v. 10, hypogy$n a$, basi intus squamula instructa. $S t a m$ in a plu rima, hypogyna. Ovaria plurima, libera, uni locularia, ovulo unico, erecto. A chenia pln rima, supra receptaculum globosum v. cylindri cum spicata, subcompressa, apice in mucronem v. cornu desinentia, laevia, striata v. tuberculata. Semen erectum. - Herbae annuae v. perennes, per totum orbem dispersae, paucae inter tropicos in summis montibus repertae, in temperatis et frigidis imprimis hemisphaerae borealis copiosae; foliis integerrimis $v$. multifidis, plerisque radicalibus, caulinis ramos $v$, pedunculos subtendentibus, floribus albis $v$. luteis, rarissime purpureis.

R a n u ne a I u s Haller Helv. $I$. 68, Gärtner $I$. 353. DC. Syst. I. 231. Prodr. I. 26. excl. sp. Meisner Gen. 1. (1.) Ra nuneall sp. Linn.

a. BAtrachium DC. Prodr. I. 26. A th enia transversim rugoso-striata. - Petula alba, ungue flavo. foveola neetarifera instrueto. (Fior. dan, $t, 376$, E. B. $t, 2003$. DC, Ic, plant, Gall, rar, $t$, 49.)

b. RANUnCulastrum DC. Prodr. $T, 27$, Actienia laevia, compressa, in kpicam digesta. - Radix grumosa. - Kra pfia DC. Syst. I. 228. (Jacq. Flor, auter, t, 222. Waldstein et Kitaibel Plant, rar. Hung. $t, 108$, Sibthorp Ftor. graec, $t, 518$. Delessert Te. select. $I, t, 31,34-36$. Ledebour Ie. t. 115.)

e. THORA DC. Prodr. 1,30 . A e he nia laeria, subglobosa. - Radix grumosa. (Jicq. Flor. austr. t. 442. Waldst. et Kitaibel Op. cit, $t$, 187.)

d. hecatonia dC. Prodr. $T$. 30. A e he ni a laevia, ova to-subrotuada, in eapitulum subglobosus disposita. Radix fibrosa. - Heeatonia Loureiro Flor, cochinch. I, 370. DC. Syst. r, 227. (Flor. dan. t, 371.397. 551. 665. 795, E. B. $t .387$. 652. Delessert Ie. select. $I$. t. 24. 25. 27. 28. 37. 39. Hooker Flor. Bor. Amer. t.5. f. a. t. 6-9. Hooker ad Beechey t. 2. 3. Ledebour Ic. t. 111. 114. 116. 117, Bot. Mag. $t$. 299s. Cambessed, ad Jacquem. t. 1. f. 2. Hooker Ic. $t$. 173.)

e. ECHINELLA DC. Prodr. I. 41. A chen i a tuberculis v. aculeis seabra. - $\mathrm{P}$ hil o notis Reicheab. consp. 191. (Flor. daa. $t, 219$, E. B. $t, 120$ Desfont. Flor, atlant. t. 113. Waldst, et Kitaibel $O_{p}$. cit, $t$. 176. Delessert $1 c$. select. I, t, 30 )

4r84. Ceratoceplasias MöNCH. Ca1 yx herbaceus, pentaphyllus, foliolis aestivatione imbricatis, subpersistentibus. C oro 11 a e petala 5 , hypogyna, ungue intus foreato. S t a m in a $5-15$, hypogyna. Ova ria plurima, libera, unilocularia, ovulo unico, erecto. Achenia plurima, supra receptaculum longiusculum spicata, basi utrin-1 que gibba, apice longe cornuta, cornu intus stigmatoso. S emen erectnm. - Herbae annuae, pusillae, tomento molli vestitae, in aridis sterilibus et inter segetes per Europam mediam crescentes; foliis radicalibus multipartitis, scapo unifloro.

Ceratoeephalus Mbach Method. 218. DC. Syst. $\boldsymbol{r}$. 230. Prodr. $I$. 26. Delessert Ic, select. $I$. $t$. 23. R in $\mathrm{n}$ ue u l u s $\mathrm{f}$ al catus Jaeq. Flor, austr. $t$. 48. St. Hilaire in Annat. Mus, X. 403 .

4835. Fierela DILLEN. Calyx herbacens, triphyllus, foliolis astivatione imbricatis, caducissimis. Co rolla e petala 6-9, hypogyna, ungue intus foveato. St amin a plurima, hypogyna. Ova ri a plurima, libera, uniloeularia, ov uIo unico, erecto. A che nia plnrima, supra receptaculnm hemisphaericum congesta, obtusa. S emen erectum - Herba perennis, glabra, in pratis Europae totius et Asia e mediae obvia; radice gramosa, tuberibus obovatis, obtusis, foliis petiolatis, pedunculis unifloris, axillaribus terminalibusve, bulbillis in axillis foliorum radicalium saepe glomeratis, floribus luteis.

Fi c a ría Dilleu. Nov, gen. 108. Jussieu gen. 233. DC. Syst. I. 304. Prodr. I. 4. Meisuer Gen, 1. (1.) S e otan u a Adanson Fam, $I I$, 459. Ra a a a u l u s Fi e a ri a Lina. Flor. daa. t. 479 , E. B. $t, 584$.

TIETEES IV. HELLEBOREAE DC. Syst. I. 306. Caly x corollinus, foliolis aestivatione imbricatis. Corolla nulla ve petalis irregularibus, saepius bilabiatis constans. C a ps u la e folliculares, polyspermae, liberae v. plus minus inter se cohaerentes, sutura longitudinali intus dehiscentes. - Herbae, foliis omnibus radicalibus, $v$. caulinis alternis.

4r S6. Callua LINN. Ca ly $x$ corollinus, tetra-pentaphyllus, rarius hexa-oetophyllus, foliolis aestiratione imbricatis, persistentibus v. decidais. Corolla nalla. Stamina plurima, hypogyna. Ovaria $4-10$ v. plurima, libera, uniloealaria, ov ulis ad suturam ventralem plurimis, biseriatis. C a p s ula e foliculares, membranaceae, sessiles, intus longitudinaliter dehiscentes, polyspermae. Semina ovata, rhaphe prominula, chalaza fungosa. - Herbae perennes, in humidis umbrosis Europae et Americae borealis, regianis magellanicae, nec non alpium Asiae medial vigentes; caule tereti, foliis petiolatis, integris v. lobatis, petiolis basi vaginantibus, floribus terminalibus, luteis, exinvolucratis.

Calth a Linn. gen, n, 703. Jnssieu Gen, 234. Gärtner II. I76. DC. Syat, I. 307. Prodr. I. 4. Meisner Gen, 1. (i.)

a. NIRBISIA Don, Cal y $x$ tetraphyllus, rarius hexa-octophyllus. Ca paula e 4 v. 5, stylis superatae. - Herbae nepalenoes; folits cordatis peltatisve, lobatis. Nirbisin G. Don Syst. $I$. 63 . Calthae sp. nepalen ses Hadilton in Edinb. Journ, of. so. 1824. 1,249. (Cambessed, ad Jacquem, t, 4.)

b. PSYCHROPHILA DC, l. c. Caly $\times$ pentaphyllus, persistens. Capsul a 5 r. plurimae, stignatibus sessilihus. - Herbae magellanicae; scapis unifloris, folits radicalibus sagittatis, lobis sursum productit. - (Cavanill, Ic. t, 414.)

c. POPULAGO DC. $t$. c. Cal y $\times$ pentaphylfas, decidaus: C a p s ula e 5-15, stigmatibus sessilibus. - Herbae bore ales; caule folioso, folits cordatis orbiculatisve. (Flor. dan. t. 668. Forster in Linn. Transact. VIIT. 2. 17. Pursls Flor. Bor, Amer, t. 17. Hooker Flor, Bor. Amer, t. 10.) 
478\%. Trollius LINN. C a lyx corollinus, penta-pendeeaphyllus, foliolis aestivatione imbricatis, deciduis. Corolla e petala 5-20, hypogyna, minima, tubulosa, unilabiata. S $\mathrm{t}$ a in in a indefinita, hypogyna. Ovaria plurima, libera, unilocularia, ov ulis ad suturam ventralem pluribus, biseriatis. Capsula e folliculares, coriaceae, cylindricae, sessiles, stylo dorsali acuminatae, transversim nervosae, intus longitudinaliter dehiscentes, polyspermae. S e mina angulata. Herbae in pratis montanis, frigidiusculis he $\mathrm{m} i$ $s p h a e r a e$ borealis vigentes, Ranunculi facie; foliis palmatim-multifidis, floribus terminalibus, luteis, exinvolucratis.

Trollfus Linn gen, n. 700. Jussieu gen, 233. Gürtner II. 176, t. 118. Lam. t. 449. Salisbury in Linn. Transact. VIIT. 302. Flor, dan. $t$. 133. Bot. Mag, $t$, 225, Loddig. Bot. Cab. t. 56. DC. Syst, I, 311. Prodr. I, 45. Delessert Io. select. $I$. t. 44. Meisner Gen, 1. (2.) Geisenia Rafinesq. in New-York Medic. Reposit, II, Hex, V. 450.

48 88. Framthis $S A L I S B$. Invo I $\mathrm{crum}$ sub flore multifidum. Caly $\mathrm{x}$ corollinus, penta-octophyllus, foliolis aestivatione imbricatis, deciduis. Coroll a e petala $5-8$, hypogyna, brevissima, tubulosa, inaequaliter bilabiata. S t a m in a plurima, hypogyna. O vari a 5-6, libera, unilocularia, ov ulis ad suturam ventralem pluribus, uniseriatis. Capsulae folliculares, submembranaceae, stipitibus basi subcoalitis sustentae, stylis brevibus, stigmate obtuso terminatis superatae, sutura ventrali dehiscentes, pleiospermae. S e m in a globosa, uniseriata. - Herbae vernales, Europam et Sibiriam incolentes; foliis radicali bus longe petiolatis, subpeltatis, multisectis, glaberrimis, scapo praecoei, unifloro, flore luteo, in tra involucrum diphyllum, multifidum sessili.

E a n th is Salisbury in Linn. Transact. VITI. 303. DC. Syst, I. 314. Prodr. I. 46. Meisner Gen, 1. (2.) Ko elle a Biria Ranunc, p. 21. Ro be rtia Merat Flor. Paris, 211. Hell eborus Monch Method, 312. Helleboroides Adanson $F a m$. $I T$, 458, Helleborus hiemalis Lina. Jaeq. Flor, austr, t. 202, Bot. Mag, t. 3.

4789. Helleborus ADANS. Ca l y $\mathrm{x}$ subcorollinus, pentaphyllus, foliolis aestivatione imbricatis, persistentibus. Corolla e petala $8-10$, hypogyna, brevissima, tubulosa, bilabiata. Stamin a indefinita, hypogyna, Ovaria $3-10$, basi subeohaerentia, unilocularia, ovulis plurimis, juxta suturam ventralem biseriatis. Capsula folliculares, coriaceae, basi breviter cohaerentes, stylis brevibus stigmatibusque suberbiculatis superatae, intus longitudinaliter dehiscentes, placentis tandem solutis, pleiospermis. S e min a elliptica, umbilico fungoso. - Herbae boreales, gerontogeae; foliis coriaceis, radicalibus palmati. v. pedatisectis, caulibus nunc aphyllis, unifforis, nunc ramosis, foliosis, floribus exinvolucratis, nutantibus, magnis, calyce herbaceo-viridi, albo v. purpurascente.

Helleboras Adanson Fam, II, 458. Gïrtner I, 310. 2. 65. Salisbury in Linn. Transact. VIIT. 304. Biria Ranun. cul. 21. DC. Syet. $I$. 315. Prodr, $r$. 46. Meisner Gen. 1 (2.) Helleboraster Mönch Method, 236. Hellebori s. Lina. Jaeq. Flor, auttr. t, 106, 201. Waldst, et Kitaibel Plant. rar. Hung. t. 101, 271. Sibthorp Flor. graec. $t$. 383 . Desfont, Corollar, t, 45. E. B. t, 613. Bot. Mag. t, 72 . Bot.
Reg. $t, 1643$.

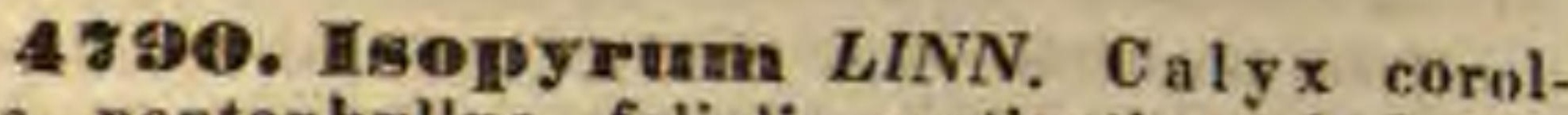
linus, pentaphyllus, foliolis aestivatioue imbricatis, deciduis. Co rol la e petala 5 , hypogyna, brevissima, tubulosa, uni-bilabiata. S tam in a $10 \mathrm{v}$. plurima, hypogyna. Ovaria 3 v. plurima, unilo- cularia, libera, ovuli s ad suturam ventralem biseriatis, paucis v. plurimis. C a p s u la e follieulares, membranaceae, $3-40$, sessiles, basi vix cohaerentes, intus longitudinaliter dehiscentes, oligo-polyspermae, Semina laevia v. granulata, umbilico basilari v, laterali. - Herbae gerontogeae, boreales, graciles, tenerae; foliis membranaceis, trisectis, segmentis trilobatis, floribus pedunculatis, parvulis, exinvolucratis, albis.

I s a p y rum Linn. gen, n. 701. Jussieu Gen. 232. Gärt. ner 1. 312. Salisbury in Linn. Transact, VIIT, 306. DC. Syst. I. 323. Prodr. I. 48. Meisner Gen, 1. (2.)

a. OLFA Adans. Petal a unilabiata, conchiformia. S tamina $30-40$. Capsulace complanatae, breviter stipitatae, abortu mono-trispermae. Semina pyriforuila, laevia, umbilico excavato. - $01 \mathrm{f}$ a Adauson Fam. $\boldsymbol{I r}$. 458. Thalietrella A. Richard in Dict, class, h. $n$. IX. 34. I s o p y $\mathrm{rum}$ Reichenb. Flor. germ, 747. Is opy rum thalletroides Linu. Jacq. Flor. austr. t. 105. (Royle Himalay. $t, 11$ )

b. LEPTOPYRUM neichenb. P etal a tubulosa, bilabiata. Stamina $10-15$. C a p s u lae $3-20$, teretes, basi elbbae, sessiles, polyspermae. Semina subglobosa, grasulata, umbilico lineari. - Leptopyrum Reichenb. $l$. c. Isopyrum A, Richard $7, c$, Is o pyrum fum a rioides Lian. Schkuhr $t$, 153. Gärtner $t$, 63 .

4 9 1 . Ememiom $R A F$, C a ly $x$ corollinus, pentaphyllus, foliolis aestivatione imbricatis, deciduis. Corolla nulla. Stam ina $20-30$, hypogyna. Ovaria $3-6$, saepius 4 , ovulis ad suturam ventralem geminis, pendulis. Capsula e folliculares $2-6$, sessiles, ovatae, compressae, stylo acuminatae, sutura ventrali dehiscentes, dispermae. Semina late ovata, compressa, rhaphe prominente, valida. - Herba boreali-americana, glabra; radice fibroso-grumosa, foliis petiolatis, biternatis, foliolis rotundatis, trilobis, lobis membranaceis, obtusis, petiolis basi auriculatis, pedunculis axillaribus et terminalibus demum elongatis, floribus albis.

Rn e mion Rafinesque in Journ. Phy, XCr. p. 70. DC. Prodr. I. 48. Torrey et A. Gray Flora of North America I. 29.

489. Coptis $S A L I S B$. C a ly x corollinus, penta-hexaphyllus, foliolis imbricatis, decidnis. Corolla e petala $5-6$, hypogyna, cucullata v. linearia. Stamina 20-25, hypogyna. Ovaria $6-10$, libera, unilocularia, ovnlis ad suturam ventralem paucis, biseriatis. Cap s n la e membranaceae, longe stipitatae, ovato-oblongae, stylo acuminatae, substellato - patentes, intus apice dehiscentes, demum explanatae, oligospermae. Semina ovata. - Herbae boreales, subarcticae, amphigeae, parvulae, rigidulae, glabrae; rhizomate horizontali fibrilloso, foliis omnibus radicalibus, longe petiolatis, trisectis, segmentis dentatis, trisectis multijidisve, dentibus lobulisve mucronatis, scapis erectis, uni-trifloris, minute unibracteolatis.

Copti s Sallsbury in Linn. Transact. NIIT. 30S. DC. Syst, I. 321, Prodr. I. 74. Meisner Gen, 1. (2.) Torrey et A. Gray Flora of North America T.28.

a. CHRYSA Torr. et Gr. Petal a angustissima, cucullato-obconiea.

Ch r ys a Rafinesque in Desvaur Journ. Bot, Ir, 170. et in New-York Medic, Reporit, II. Hexad. V. 350. Helleborus irifoliu sinn. Amoen. $I T$. 355. Anemone grönlandl c a Flor, dau. t. 566 .

b. CHRYSOCOPTIS Torr. et Gr. P e tala linearia, follolis calyeiuis conformia, haud cueullata.

Chrysoeoptis Nuttall in Journ, Academ. Philadelph, VIT. $0, t$. 1.

c. PTEROPHYLLUM Torr. et Gr. Petal a medio dilatata, cucullata, toliolis calycinis longiora. 
Pterophyllum Nuttall msc. Coptis aspleni. follia Saliab. Hooker Flor. Bor. Americ. $t, 11$.

4893. Graridella TOURNEF. C a ly subcorollinus, pentaphyllus, foliolis aestivatione imbrieatis, deciduis. Corolla e petala 5, hypogyna, bilabiata, bifida. Sta min a $10-40$, hypo. gyna. Ovarin triloculare, trilobum, ovulis in angulo centrali biseriatis. Capsula e 3 , follieulares, basi connatae, apieibns distinctis introrsum dehiscentes, polyspermae. Semina ovata, testa fungosa, rugosa. - Herbae mediterraneae, annuae, erectae, graciles; foliis tenuissime multifielis, laciniis linearibus, floribus parvis, albidis, ad pedunculorum apices solitariis.

Ġ a ridella Tournefort 1nst. 655. Linn, gen, $\pi, 541$ Jnssieu Gen. 233. Lam. t. 379. Giirtuer IT, 124, t. 118. Bot. Mag. t. 1266. DC. Syst. I. 325. Prodr. I. 48, Meisner Gen. 1. $(8$,

4\% 4. Nigella TOURNEF. Ca ly x corollinus, pentaphyllus, foliolis aestivatione imbricatis, sub anthesi patentibus, deciduis. Coroll a e petala 5-10, hypogyna, parva, bilabiata. Stamina plurina, hypogyna. Ovaria 5 , unilocularia, basi plus minus inter se cohaerentia, ovulis plurimis, ad snturam ventralem biseriatis. Ca p sula e membranaceae, plus minns connatae, stylis elongatis rostratae, apice intus dehiscentes. S em in a ovata, compresso-plana, testa fungosa, rugosa. - Herbae mediterraneae et orientales. annuae, glabriusculae, erectae; foliis capillaceomultifidis, floribus in apice caulis et ramorum soli tariis, nudis $v$. involucratis, capsulis saepe callosoglandulosis, seminibus nigricantibus, acriter aromaticis.

Nigella Tournefort Inst, 134. Linn. Gen, n. 685. Jnssieu Gen. 233. Gärtner II. 174. DC. Syst. I. 326. Prodr, I. 48. Spenner, generis Nigellae monographia. Friburgi, 1829. 4. Meisner Gen, 1. (2.)

a. Nigellastrum DC. Prodr. $1.48 . \quad \mathrm{C}$ a 1 yx flavidus. Sta ni na uniseriata. Cap sulae basibus connexae, compressae. S e m i в a plano-enmpressa, orbienlaria, mar gine membranaceo cincta. - N igell as trum Mönch Method. 313. (Gärtner t, 118. f. 3. Bot. Mag, t, 1264. Delessert IC. select. I. t, 45.)

b, Nigellaria DC. Prodr. I. 49. C a 1 y $x$ eaerulescens. St a m in a multipliel serie. iu phalanges $8-10$ disposita. Capsula e ultra mediam inter se connatae, vix compressie. S e m in a ovata iv, angulata. (Sebkubr $t$. 146. Gärtner t. 118. f. 2. Sibtharp Flor. graee. t. $510-512$. Bot. Mag. t. 1265, Delessert Ic. select. I. L. 46. Nees Plant. offic. Suppl. II, t. 2t.)

c. ERobatos DC. Prodr. $I, 49$. C a Iy $x$ albus v. caeruleus. Stamina multiseriata. Capsulae usque ad apicem coalltae, e membrana dnplici distincta, exteriore infiata foculum sparium constituente. Involuerum sub tlore pentaphyllum, foliis cauliais simile. - Nigella Mönch Method. 311. (Gärtner $t$. 118. f. 2. Bot. Mag. t. 22. Silthorp Flor. graec. th 509.)

4ร95. Aquillegia TOURNEF. Calyx coloratus, pentaphyllus, aequalis, foliolis aestivatione imbricatis, deciduis. Coroll a e petala 5, hypogyna, bilabiata, hiantia, labio exteriore maximo, plano, interiore minimo, deorsum in calcar cavum, apice callosum, inter ealycis foliola exsertum producta. Stam in a plurima, hypogyna, in phalanges 5-10 disposita, intima abortiva, membranaceo-squamaeformia. Ovaria 5 , libera, nniIocularia, o $\mathrm{v} n \mathrm{lis}$ ad suturam ventralem plurimis, biseriatis. Capsula e membranaceae, conniventes, stylis rostratae, intus longitudinaliter dehiscentes, polyspermae. Semin a oblique ovata, nitida. - Herbae in montibus Europae et Asiae obviae, in Americaboreali rarae, ereclae, ut- plurimum ramosae; foliis biternatis, radicalibus $v$, caulinis inferioribus longe petiolatis, floribus terminalibus, solitariis, caeruleis, roseis, purpureis, albis $v$. interdum sordide flavis.

A quilegi a Tournefort inst, 488. Linn, gen, n. 684. Jussieu Gen, 234. Gürther II. 175, t, 118. Jacq. Ic, rar. t. 102. E. B. t. 297. Bot. Mag, t. 246. 1221. Bot. Reg, t, 922. Sweet Fl, Gard. II. t. 55, 103. DC. Syst. I. 333, Prodr. I. 50. Delessert Ic. select. I, t. 47. 48. Meisuer Gen, 1. (2.)

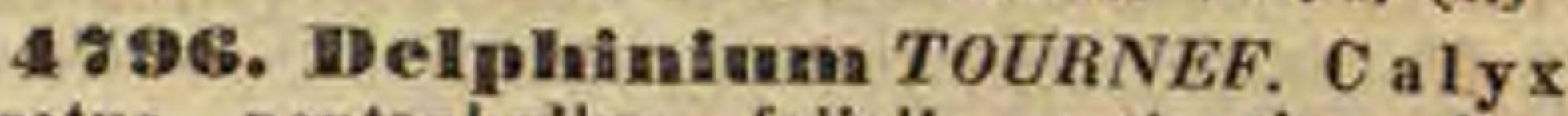
coloratus, pentaphyllus, foliolis aestivatione imbricatis, inaequalibus, extimo basi in calcar cavum producto, omnibus deciduis. Coroll a e petala 4 , hypogyna, libera v. in nnicum sursum apertum coalita, quintum superius nullum, duo inferiora basi in appendicem (calcar internum) intra calcar calycinum receptum producta. Stamin a plurima, hypogyna. Ova ria ut plurimum 3 , rarius 1 v. 5, libera, unilocularia, ov u 1 is ad suturam ventralem plurimis, biseriatis, C a p su l a e folliculares, membranaceae, stylo rostratae, intus Iongi-. tudinaliter dehiscentes. S em in a angulata, testa spongioso - membranacea. - Herbae in temperatis hemisphaerae borealis obviae, plurimae mediterraneae et orientales, paucae borealia me ric ana e, annuae $v$, radice subfasciculata perennes; caulibus erectis, ramosis, foliis sparsis, bitriternatisectis, laciniis linearibus v. palmatim quinquefidis aut quinquepartitis, floribus laxe racemos is v. paniculatis, caeruleis, purpureis, roseis v. albis, rarissime flavis.

Delph in $\mathrm{i}$ m Tournefort inst. 241. Linn. gen. n, 681 . Jussieu Gen. 234. Gärtwen $I, 310$. DC. Syst, $T, 340$. Prodr. I. B1. Meisuer Gen. 1. (2.)

a. CONSOLIDA DC. $l$. c. 0 varium unicum. Petala 4, coalita, ealeare simplici. - Species annuae. (Flor, dan. t. 683. Sibthorp Elor. graec, $t$. 504. 505, Delessert Ic, select. $I$. $t$. 50 _54. Kichwald Plant. caucas. $t .16$.)

b. DELPHINELLUM DC. $l, c, 0$ vari a trio, Petal a lithera, glabra, calcare simplici. - Species annuae. (Sibthorp Op. cit. t. 506. 807. Delessert Op. cit, t, 55, 57.)

c. DELPhINASTRUM DC. 1 . c. 0varia 3-5. Petala libera, inferiora disco barbata, futegra v. bifida, calcare elongato duplici. - Species perennes. - (Jaeq. Ic. rar. t. 101. Gärtner 2. 65. Desfout. Flor, atlant, t. 111. Waldst, et Kitaibel Plant. Hung, rar. t. 81, 2s6. Bot. Mag. E. 1686. Bot. Reg. t. 473. 1193. 1503, 1936. 1999. IT. t. 30. 38. Delessert Op. oit. t. 58 _62. Wallich Plant. As. rar. $t, 128$. Royle Himalay, $t, 12$. Cambessed. ad Jaequem. t. 6. 7.)

d. STAPHXSAGRIA DC. $t$, $c$, Ovaria 3_5. Pétala IIbera, calcare brevi, duplici. C ap s u I a e ventricosae, seminibus paucis, magals. - Species perennes. (Sib. thorp Op. cit. t. 508. Delessert Op. cit. $t$. 63. Sweet Fl, Gard, II, $t, 23$, )

4ร9\%. Acomitum TOURNEF. C a Iyx coloratus, pentaphyllus, foliolis aestivatione imbricatis, valde inaequalibus, postico (galea) maximo, coneavo, cassidaeformi, duobus lateralibus (alis) orbiculatis, duobus anticis oblongis. Corollae petala $5 \mathrm{v}$. interdum pauciora, tria antica minima, unguiformia, saepius in stamina conversa, duo postica (cuculli) sub galea incumbentia, Ionge unguiculata, apice cucullata, cucullo -superne calloso ineurvo, basi in limbum oblengum, emarginatum producto. Stamina plurima, hypogyna. Ovaria $3-5$, libera, unilocularia, ovulis ad suturam ventralem plurimis, biseriatis. Ca ps ula e folliculares, membranaceae, stylis rostratae, intus longitudinaliter dehiscentes. S emina rugosa, testa crassiuscola, spongiosa, rhaphe valida. Herbae perennes, venenatae, in homisphaerae borcalis temperatis et frigidis, montanis etalpinis 
obviae; radicibus tuberosis, tuberibus nunc fibrilliferis, nune napiformibus, foliis petiolatis, palmatim tri-quinquepartitis, lobis ineiso-dentatis v. multifidis, racemis terminalibus, pedicellis e bractearum axillis solitariis, unifloris, bibracteolatis, floribus ochroleucis, caeruleis, purpureis $v$, albis.

A con it um Tournefort inst. 239. 260. Linn. gen. $n$. 682. Gärtner I. 311. $t$. 65. Koelle Monographia Aeoniti. Erlangae, 1788. 4. Reichenbach Illustratio generis Aconiti. Lipsiae 1827. Seringe MIus. Helvet, $I, 115$. ss. DC. Syst. I. 364. Prodr. I. 56. Melsner Gen. 1. (2.)

a. ANTHORA DC. l. c. Caly cis foliola persistentia. Galea conica v. semieircularls. O varla 5. Radix na. piformis, folia in lobos lineares palmatiseota, flores ochroleuci, quandoque caeruleo-variegati. (Jacq. Flor austr. t. 38i.)

b. LXCoctonum DC. $\boldsymbol{l}$. c. Ca 1 y $\mathrm{c}$ is follola decidua. Galea conieo-eylindracea. Ovaria 3. - Radis fibrosa, lobi foliolorum cuneiformes, pinnati raro bipinnatisecti, flores ochroleuci, albi, rarius purpurei aut variegati. (Flor. dan. $t$. 123. Delessert Ic. select. $I$. t. 64. Ledebour Ic, t. 406. Bot. Mag. t. 2570,)

c. CAMMAREM DC. $\boldsymbol{l}$. $c, \mathrm{C}$ a $\mathrm{ly}$ e is foliola decidua. Galea confca, coupressa. Ovaria 3_5. - Radix tuberosa, lobi foliorum trapeziformes, pinnatisecti, flores caerulei, albo-variegati, rarius carnei. (Jaeq. Flor, austr. t. 284. Bot. Mag. t. 119.)

d. NAPELLUS DC. l, $c$. C a I y e is foliola decidua. Galea semicircularis, rarissime navicularis. Ovaria 3 - 5, interdum 7, - Radix tuberosa, lobi foliorum cuneati, bipinnatisecti, flores caerulet v. albi, albo-caerulei v. caeruleo-Ravi. (Jacq. Ic. rar, III. $t, 49$. Wallich Plant. As, rar, t. 4t. Royle Himalay, $t$. 13. Nees jun. Plant, offic, Supplem, IV, $t, 21-24$.)

TERIBES V. PAEONIEAE DC. Prodr.I. 64. Caly $x$ corollinus, foliolis aestivatione imbricatis. Corolla nulla v. planipetala, rarissime petalis nectariferis. Ovari a multiovulata, rarissime uniovulata. Capsulae dehiscentes v. baccatae, saepius abortu monospermae. Herbae v. suffrutices. Tribus parum naturalis.

4998. Trautvetteria FISCH. et MEX. Caly x corollinus, tetra-pentaphyllus, foliolis aequalibus, orbiculatis, aestivatione imbricatis. Corolla nulla. Stamina indefinita, hypogyna, omnia fertilia. Ovaria plurima, libera, unilocularia, ovulo unico, erecto; stigmate sessili. Achenia plurima, sessilia, mutiea, sicca. Semen erectum. - Herba caroliniana, glaberrima; caule erecto, simplici, fistuloso, foliis duobus alternis, inferiore petiolato, petiolo latiusculo, superiore subsessili, lamina basi cuneata, latissima, palmatim tri-quinquefida, lobis ovalibus, basi integris, apice inciso-serratis, subacutis, floribus terminalibus corymbosis, pedunculis dichotomis, extre. mis ebracteatis, inferioribus bractea lineari, minima stipatis.

Trautvetteria Fischer et Meyer Index Sem. hort. Petropolit, I. 1835. p, 29. Meisner Gen, 1. (2.) A c t a e a palmata DC. Cimicifuga palas ata Miehx. Bot. Mag.
t. 1636 .

4ซפอ. A etrea LINN. Ca ly x corollinus, tetra pentaphyllus, foliolis aequalibus, aestivatione imbricatis. Corolla nulla. Stamina indefinita, hypogyna, exteriora sterilia dilatata. O va rinm unicum, uniloculare, ovulis ad snturam ventralem pluribus, biseriatis; sti $\mathrm{g}$ m at e sessili. Ca psula laecata, substipitata, polysperma. S emin a horizontalia, compresso-angulata, laevia. - Herbae perennes, in Europa et America bo- reali indigenae; foliis bi-triternatisectis, segmentis incisis, serratis, floribus racemosis, albis.

A c ta e a Linn. gen, n. 644. excl. sp. Gärtner II. 154. t. 114. Flor, dan. t, s89. Fischer et Meyer Indes. sem. hort. Petropolit, 1833. I. p. 20. Meisner Gen. 1. (2.) Chris to. p hor i a a Tournefort inst. 134 .

4840. IBotsophis $R A F I N$. C a I y x corollinus, tetra-pentaphyllus, foliolis aequalibus, aestivatione imbricatis. Corolla nulla. Sta $\mathrm{m}$ in a indefinita, hypogyna, exteriora sterilia, dilatata, an therae rudimento terminata. Ovarium nnicum, uniloculare, ovulis ad suturam ventralem pluribus, biseriatis; stigmate sessili. Capsula follicularis, substipitata, intus longitudinaliter dehiscens, polysperma. Semina horizontalia, compresso-angulata, la evia. - Herba bor e $l_{i}$-a mericana, perennis; foliis biternatisectis, segmentis incisis, serratis, floribus racemosis, albis.

Botrophis Rafinesque ex Fischer of Meyer Ind. sem. hort. Petropolit. 1835. 1, p. 20. Meisner Gen. 1. (2.) M a or ot y s Rafinesque in N. York Medio. Roposit. II. Hex. V. 350. Desvaux Journ. Bot. 1808. II. 170. Hoffmansegge Verzeichn. IIT. 48. A, t a e a r cem o s a Linn.

4811. Aetinosporen TURCZ. Flóres abortu dioici. Caly $\mathbf{x}$ corollinus, tetra-pentaphylIns, foliolis aequalibus, aestivatione imbricatis. Co roll a nulla. St a m in a indefinita, hypogyna, sterilia pauca fertilibus mixta, per paria connata, dilatata, antheris geminis efoetis. Ov a ria $3-8$, libera, unilocularia, ov u lis ad suturam ventralem pruribus, biseriatis; stylo superata. Ca p sulae follienlares $3-8$, liherae, pedicellatae, intus longitudinaliter deliscentes, polyspermae. Semina verticalia, bracteata, membranaceo-marginata, margine lacero. - Herbae perennes, in Asia media indigenae, foliis bi-triternatisectis, segmentis incisis serratisque, floribus racemosis, albis.

Actinospora Turczaninow ex Ficher Ind. sem. hort. Petropolit. 1835. I. p. II. 26. Meisner Gen. 1. (2.) Cimicifuga frig id a Royle Himalay. $t, 14$.

4802. Cimneifuga LINN. C a ly x corollinus, pentaphyllus, foliolis aequalibns, aestivatione imbricatis. Co rolla petala $4-5$, interdum pauciora, hypogyna, urceolata, fundo nectarifera. St am in a indefinita, hypogyna, omnia fertilia. Ovaria $3-8$, libera, unilocularia, ov $\mathbf{l}$ is ad suturam ventralem pluribus, biseriatis; stylo brevi, terminali. Cap $\&$ u la e follieulares $3-8$, liberae, sessiles v. pedicellatae, stylis mueronatae, intus longitudinaliter dehiscentes. Se m in a verticalia, compressa, squamulis membranaceis obtecta. - Herbae perennes, in Europa, Asia et $A m e r i c a$ borea $l i$ indigenae; foliis bi-triternatisectis, segmentis incisis, serratis, floribus racemosis, albis.

Cim lelf ug a Lina. gen, n, 1282. Amoen, academ, VII. 193. t. 4. Gartner II. 275. t. 140. Lam. t. 487 . Bot. Mag. t. 2069. Meisnet Gen, 1. (2.) A e ta e a e s p. Linn. Amoen. $I$. 364. Schkuhr t. 139. DC. Delessert Ic. select. $I$. $t$. 66.

4803. Xanthoriniza MARSH. Calyx corollinus, pentaphylius, foliolis aequalibus, aestivatione imbricatis. Cor o 11 a e petala 5 , hypogyna, glandnlaeformia, stipitata, truncato-biloba. Stam in a 5-10, hypogyna. Ovaria $5-10$, libera, oblonga, unilocularia, ovalis ad suturam ventralem $2-3$; s ty $1 \mathrm{i}$ s brevibus superata. Ca psulae folliculares $5-10$, sessiles, stylis mueronatae, compressae, intus semibivalves, aborta monospermae. S e m en pendulum. - Suffrutex boreali-americanus, radicis, intus flavae, subodoratae corlice amarissimo, subacri; caule tereti, 
parce ramoso, libro flavo, foliis petialatis, irregulariter pinnatisectis, segmentis ovalibus, acuminatis, inciso-serratis, racemis ramosis, cum foliis e gemmis squamosis ortis, pendulis, floribus atro-purpureis, parvis, abortu saepe unisexualibus.

X a nthorhiza Marshall Arbr. 167. Sehreb. Gen, n. 1581. Lam. t. 854. Meisuer Gen, 1. (2.) $\mathrm{Z}$ anthorhiza Heritier Stirp. 79, $t, 38$, Jussieu Gen, 234. Duhamel Arbr. edit. Nov, III. $t$. 37. Barton Etem. bot, t, 12, DC. Syst. I. 386. Prodr. I. 65.

4804. Faedia TOURNEF, Calyx coriaceo-foliaceus, pentaphyllus, foliolis inaequalibus, persistentibus. Co ro 11 a e petala 5 , rarins 6-10, hypogyna, orbiculata, subaequalia, exunguieulata. St a mina plurima, hypogyna. Ovaria $2-5$, disco carnoso imposita, libera, unilo. cularla, ovulis plurimis, ad suturam ventralem nniseriatis; 8 tigm a ta sessilia, crassa, recurva, papillosa. C a p 8 u l a e $2-5$, folliculares, coriaceae, intus longitudinaliter dehiscentes, polyspermae. S e mina subglobosa, nitida, rhaphe prominula. Herbae perennes $v$, suffrulices, interdum subarborescentes, in temperatis hemis phaerae borealis veteris orbis crescentes; rhizomale horizontali, fibrillas fasciculatas, interdum in tubera incrassatas proferente, caule basi squamis vaginato, gemmis radicalibus, foliis alternis, petiolatis, biternatisectis, floribus terminalibus amplis, purpureis, roseis $v$. albis.

Pa e on la Tournefort inst, 145. Linn. gen, n, 678, Jussieu gen. 234. Gärtner 1 . 309. t. 65. Andrews in Linn. Transact. XIT. 148. DC, Syst. I, 386. Prodr, 1. 65, Mteisnęr Gen. 1. (2.)

a. PAEON DC. Prodr, I, 65, $\mathrm{C}$ a $\mathrm{u} \mathrm{t}$ is herbaceus. Di s $\mathrm{c}$ u s vix expansus 7 , imam ovariorum partem circumdans. EPallas Flor. ross. t, 86. E, B. t. 1513. Andrews Bot. Reposit. $t$. 486, Bot. Mag. t. 474. 926, 1030.1441. 1784. 2964. 2648. Bot. Rep. t. 474.819.1208, 1456. Sweet Brit. Fl. Gard, t. 19, 70. 113. II, $t, 122$. Rochel Plant. Banat. 2. 12.,

b. Moutan DC. Prodr. I. 65. Caulis fruticosus. Dis. c u $s$ ia urceolum ovaria plus minus involventem expansus. (Bonpl. Navarr. t. 1. 9, 23. 47. Andrews Bot. Reposit. t. 64. 373, 448, 663. Bot. Mag. 2, 1154, 1756, 1768, Bot. Reg, t. 42. 379. 485.630.$)$

\section{Ordo CLXXIX. Herberilecte.}

BERBRRIDES Jussieu gen, 286. BERBERIDEAE Venten. Tabl. III. 83. DC. Syst. II. 1. Prodr. I, 105. R. Brown in Tutkey Congo 411. Bartling Ord, nat, 241. Meisner Gen. G. (7.) BERBERACEAB Lindley Introduce, edit. $I T, p .7$. PODOPIIYLLACEAE tribus I. DC. Syst, II. 31, Prodr. I. 111,

Herbar v. frutices, caule ramisque teretibus, sncco aqueo. Foli a alterna, petiolata, impari-pinnata, supradecomposita, pinnati-ternative secta, saepissime mucronato v. spinososerrata, primaria exstipulata, saepius abortiva, in spinam simplicem, trifidam v. impari-penniramosam mutata, ex axilla proferentia ramulum brevissimum, basi squamis imbricatis (hybernaculo gemmae terminalis) obtectum, apice foliis secundariis onustum; folia secundaria simplicia, stipulata, confertissime alterna, integerrima v. spinoso-serrata, rarissime pinnata. Stipulae petiolares, geminae, minimae, caducae.

Flores hermapliroditi, regulares (rarissi- me perigonio destituti), in pedunculis axillaribus, uni-multifloris, racemosis v. paniculatis.

Calyx liber, tri-tetra-enneaphyllus, foliolis simplici v, triplici serie dispositis, saepe coloratis, omnino distinctis, per aestivationem alternatim imbricatis.

Corollae petala hypogyna, decidua, in calyce pluriseriato ejusdem foliolis numero aequalia et opposita, in uniseriato dupla, basi saepe biglandulosa, v. ungue poro instructo aut interdum calcarato.

Stamisa hypogyna, petalis numero aequalia et opposita, raro plara. Fila me n ta brevia, complanata, saepe irritabilia, rarissime filiformia. Anthera biloculares, extrorsae, loculis oppositis, adnatis, membrana exteriore a connectivo elastice soluta, sursum revoluta, v. hine soluta, reflexa, rarissime rima longitudinali dehiscentibus.

Orariom uniloculare, saepius subobliquum. Ovula nunc juxta placentam parietalem indefinita, bi-pluriseriatim adscendentia, nunc e basi v. lateraliter prope basim erecta, subdefinita, anatropa. Stylus terminalis, brevissimus, quandoque subnullus. $\mathbf{S t i} \mathbf{g} \mathbf{m}$ a saepins crassum, peltatum, umbilicatum.

Bacca v. rarius Capsula evalvis, unilocularis, mono-v. oligosperma, vesicaria v. operculo dimidiato aperta, nune siliquaeformis, bivalvis, valvula altera sterili, altera medio seminifera.

Semiva ovata v. globosa, erecta v. horizontalia, testa crustacea v. membranacea, umbilico prope basim sublaterali, rhaphe saepissime manifesta. Albume n carnosum v. subcorneum.

Embryo orthotropus, axilis, albumine multo brevior v. ejusdem fere longitudine. C ot yle đones planae, ellipticae, germinatione foliaceae. Ra di $c$ u la cotyledonibus longior, umbilico parallele contigua.

Berberideae habitu quodammodo peculiari, petalis staminibusque calycis foliolis oppositis, et antherarum dehiscentia insignes, hinc mediante Podophyllo et Diphylleia, nequaquam a reliquis generibus avellenda, arcta affinitate Ranunculaceis accedunt, inde ad Papaveraceas vergunt, etiam Annonaceis per Berberim et Bocageam affines, cum Monochlamydeis Laurineis et Atherospermeis, v. cum Hamamelideis, simili antherarum dehiscentia donatis, nentiquam tamen comparandae.

In temperatis hemisphaerae borealis, imprimis Americae, et in America australi extratropica obviae, parce in Asiae et Americae tropicae montibus excelsis generantur, ex Africa, Australasia et Oceania exules. 
Berberidum baccae acido oxalico scatentes grate acidulae, adstringentes. Nonnullarum radices flavo trigentes.

4805. Aehlys $D C$. Caly $\mathrm{x}$ et corolla nulla. S t a m in a plurima, hypogyna, pluriseria$t_{a}$; fil a m e nt a filiformia, flexnosa, extima apice dilatata; a ntherae globoso-didymae, biloculares, loculis dorso connectivo distinctis, antice valvula communi a basi sursum reflexa dehiscentibus. Ovari um subglobosum, unilocnlare. Ovu 1 a m nnieum, e basi erectum. S ty lus terminalis, subconicus, hinc excavatus, stigmatosus. Fructus ..... - Herba perennis, Americae boreali. occidentalis incola; rhizomate repente, squamis scariosis absesso, foliis omnibus radicalibus, longe petiolatis, petiolo gracili, striato, lamina tri. secta, segmentis basi cuneatis, apice dilatato pro. funde et obtuse inciso-dentatis, nervosis, scapo folia superante simplicissimo, nudo, nitido, spica terminali densissima, floribus parvis, albidis, bracteis et perigonio destitutis,

A c h 1 y s DC. Syst. II. 35. Prodr. I. 112. Hooker Flor. Bor. Amer. I, 30. t. 12. Meisaer Gen, 6. (8.) Le ontice triphylla Smith.

4806. Poilopliyllam LINN. Calyx triphyllus, foliolis subherbaceis, deciduis. Corol1 a e petala $6-9$, hypogyna, uniseriata, obovata, patentia. S $t$ a m in a hypogyna, nunc 6, petalis opposita, nunc $12-18$; fil amenta brevia, antherae extrorsae, biloculares, loeulis adnatis, valvula hinc soluta, reflesa dehiscentibus. Ovar i n in ovatum, uniloculare. O vul a plurima, juxta placentam parietalem nnilateralem adscendentim pluriseriata, anatropa. Stig m a subsessile, peltatum, margine erispatum. Ba c c a ovata, subearnosa, nnilocularis. S e min a plurima, juxta parietem adscendentia, subellipsoidea, testa membranacea, umbilico basilari, rhaphe lineari. Embryo in basi albuminis dense carnosi brevissimus; cotyled on ibus semicylindrieis, radicula crassa, infera. Herbae in America boreali et Asiae mediae montibus indigenae, rhizomate horizontali perennantes; caule erecto, tereti, foliis ad apicem caulis duobus, oppositis v. al ternis, longe petiolatis, peltatis, circumscriptione reniformibus, irregulariter partitis, lobis dentatis, subincisis, floribus intra petiolorum dichotomian $v$. supraaxillaribus, breve pedunculatis, albis, baccis carnoso-fibrosis, flavescentibus.

Po d o p h y 11 u m Linn. gen. $n, 643$, exel. sp. Lam, $t .449$. L. C. Richard in Michaux Flor. Bor. Amer. T. 309. Bot. Mag. t. 1819. Nuttall Gen. II. 265. Bigelow Mat. medic. $I I$. t. 23, DC. Syst. II. 33. Prodr. I. 111. Meisner Ger, 6. (8.) Royle Himalay. 64. Jacquemont $V_{0 y}$. 10, $t .9$. A n a pado. p hy 11 u m Tournefort inst. 128.

480\%. Jefrersonia BART. Calyx tetraphyllus, rarius tri-pentaphyllus, foliolis coloratis, deciduis. Corolla e petala 8, hypogyna, uniseriata, oblongo-linearia, incurvato-patentia. St a min a 8, hypogyna, petalis opposita; filamenta brevissima, antherae extrorsae, biloculares, localis adnatis, valvula a basi sursum revoluta dehiscentibus. Ova rinm obovatum, nniloculare. Ovula plurima, juxta placentam parietalem nnilateralem adscendentim biseriata, anatropa. Stig ma terminale, subsessile, peltatum, suberistatum. Capsula obovata, substipitata, unilocularis, sub apice opereulo dimidiato circumscissa, foramine semilunari hians. S e mina plurima, obovato-oblonga, subarcuata, strophiola umbilicali laxiuscale membranacea, demum lacera. Embryo in basi albuminis dense carnosi brevissimus, reetus. - Herba boreali-americana, acaulis; foliis radicalibus petiolatis, lamina peltata, basi profunde cordata, apice bifida, lobis ovatis, apice exserte uni-bidentatis, nervosis, subtus glaucescentibus, scapo ebraeteato, folia aequante, uniftoro, flore albo.

Jeffers onia Barton in Act. soc. Americ, III. 334. c. ic. L. C. Richard in Michaux Flor. Bor. Amer, I. 236. Sims in Bot.Mag. t. 1513, Nettall Gen. $I$, 253. DC. Syst. II. 34. Prodr. I. 111. Meisuer Gen. 6. (8.) Pod o p hy $11 \mathrm{um}$ d I p h y 11 um Linn.

480s. Diplnylleia $L, C . R I C H$. Calyx triphyllus, foliolis subcoloratis, deciduis. Cor ol. la e petala 6 , hypogyna, uniseriata, ovalia, coneava, patentia. Stamina 6 , hypogyna, petalis opposita; fil ament brevissima, antherae extrorsae, biloculares, Joculis adnatis, valvula a basi sursum revolnta dehiscentibns. O va rinm ovatum, nnilocnlare. Ovula pauea, e placenta prope basim parietali adscendentia, anatropa, S tyIus brevissimus; stigma capitatum, subcristatum. B acca subglobosa, unilocularis, Semina $2-3$, ovato-oblonga, erecta. $\mathbf{E} \mathrm{m}$ b r y o......

Herba boreali-americana, rhizomate repente perennans; caule basisquamato, erecto, tereti, glabro, foliis geminis, alternis, petiolatis, peltatorsubreniformibus, apice bilobis, lobis triangularibus, sublobatis, serratis, nervosis, pedicellis ex apice caulis corymbosis, aliis simplicibus unifloris, aliis ramosis, plurifloris, floribus albis, baccis caeruleo-nigris.

Diphylleia L. C. Richard ex Michaus Flor. Bor. Amer. I: 203. $t$. 19. 20. Bot. Mag. 1666. Nuttall Gon. Amer. I. 209. DC. Syrt. I. 39. Prodr. I. 110. Meisner Gen, 6. (8.)

4809. Bomgrallia $C, A, M E Y$. C a lyx tri-hexaphyllus, foliolis coloratis, deciduis. Corolla e pétála 6 , hypogyna, calycis foliolis opposita et breviora, unguicnlata, ungue exappendiculato, poro nectarifero instructo. St a mi na 6 , hypogyna, petalis opposita; fil amenta brevissima, complanata, a nt herae extrorsae, bilocalares, locnlis adnatis, valvula a basi sursum revolnta dehiscentibus. Ovarium ovato-oblongum, nniloculare. Ovula 4, e basi erecta, anatropa. Stylus terminalis, brevis, disco foliaceo reniformi, plicato, margine stigmatoso terminatus. Capsula vesicaria, membranacea, indehiscens. S e min a $2-4$, e basi erecta, subglobosa .... Herbae orientali-mediterraneae et persicae, acaules, glaberrimae; rhizomate tuberoso, folitis omnibus radicalibus pinnatisectis, scapis apice racemosis, ad ramorum basim squamosis, ftoribus racemosis, aureis.

Bongardi a C. A. MeyerVerzeiehn, Cauc, Pfanz, 174. Chrysogon am Baáhín Hist. III. 876. f. 2. L e a tiec Chrysog on un Liun. DC.

4810. Heontice LINN. Calyx hexaphyllus, foliolis coloratis, deciduis. Corollae petala 6, hypogyna, calyeis foliolis opposita et breviora, unguiculata, ungue squamula aucto. Stamina 6, hypogyna, petalis opposita; filam enta brevissima, complanata, a nt h erae extrorsae, biloculares, locnlis adnatis, valvula a bási sursum revoluta dehiscentibus. O va ri u m ovatooblongum, uniloculare. 0 rula 4, e basi erecta, anatropa. Stylus terminalis, brevis; stigua simplex, obtusum. Ca psula vesicaria, membranacea, unilocularis, indehiscens v. seminum grossificatione longe ante maturitatem rupta. S e m in a $3-4$, e basi erecta, subglobosa, testa membrana- 
cea $\nabla$. subcarnosa, basi excavata umbilicata. E mbryo in albuminis dense carnosi basi endopleurae duplicatura vaginata minimus; cotyledon ibus obtusissimis, brevissimis, subdivaricatis, radi cula crassa, umbilicnm attingente, infera, Herbae glaberrimae, in Europ a mediterranea, Asia media et America boreali indigenae, rhizomate tuberoso perennantes; caule annuo, tereti, foliis radicalibus petiolatis, pinnati- $v$, ternatisectis, caulinis nullis $v$. unico, petiolo trisecto compositis, floribus laxe racemosis v. paniculatis, pedicello basi bractea foliacea, ovata, integerrima stipato.

Le ontice Linn. gen, $n$, 423. Jussieu gen, 287. DC. Syst. IT, 23. Prodir. I. 109, excl. sp.

a. LEONTOPETALUM DC. 2 , c. C a p sula valde inflata, per maturitatem haud rupta. Se min a inclusa, loculi cavitatem haud implentia. - Fol ía omnia radicalia, petiolo simplici $v$, apice partilo-pinnatim- $v$, ternatisecta.

L e on to peot a I um Tournefort Corollar. 484. (Lam. t. 254. fig. 1. Pallas Yoy, t, $7 ., f .3$. Act. Petropolit. 1779. $t .9 . f .4$.

b. CAULOPHYLLUM DC. $\boldsymbol{l}$. c. Capsula ente maturitatem disrupta. S emina nuda. Folium caulinum unicum, sub florum racemo, petiolo a basi tripartito, ramulis laminae segmenta $3-5$ gerentibus.

Ca aI ophyllum L. C. Richard in Brichaux Flor. Bor, Amer. I. 205. t, 21. Nuttall Gen. 1. 210. (Pallas Act. Petropolit. 1 . c. $t$, 8. f. 1 -3. Lam. t. 254. $f .2$. R. Brown in Linn. Transact. XII. 143. t. 7. Bot. Mag. t. 3245. Decaisne in Nouv, Annal. se, nat. $I I, t$. 12, f. c.)

4811. Epimealianm LINN. C a 1 y $\mathrm{x}$ basi bibracteolatus, tetraphyllus, foliolis coloratis, deciduis. Corollae petala 8 , hypogyna, calyeis foliolis biseriatim opposita, exteriora plana, interiora cucullata $v$. in calcar producta. S $\mathbf{t a m i -}$ n a 4 , hypogyna, petalis opposita; filamenta complanata, antherae introrsae, biloculares, apiculatae, loculis adnatis, valvula a basi sursum revoluta, decidua dehiscentibus. 0 vari $\mathbf{m}$ ovoideum v. oblongnm, uniloculare. Ovula plurima, juxta placentam unilateralem adscendentim bi-triseriata, anatropa. Stylus lateralis, eylindricus; stigm a subcapitatum, indivisum v, emarginatobilobum. Capsu I a siliquaeformis, uniloeularis, valvula altera sterili, altera medio seminifera. Semin a abortu pauca, adscendentia, testa subcrustacea, nmbilico supra basim laterali, rhaphe incrassato-inflata, arillaeformi. $\mathrm{Kmbryo}$ in basi albuminis dense carnosi minimus; cotyled on $\mathrm{i}$ b us brevissimis, obtusis, $\mathbf{r}$ a di c al a crassinscula, umbilico parallele contigua, infera. - Herbae in a $t$ pibus Europae, Asia media et Japonia indigenae, rhizomate repente perennantes; foliis ternatis triternatisve, longe petiolatis, foliolis cordatis, argute dentatis, dentibus aristatis, floribus oppositifoliis, racemosis v. paniculatis.

E p ime d i u m Lina. Gen, n, 148. DC. Syst. Ir. 28. Prodr. I. 110. Deeaisue in Nouv. Annal, sc. nat. II, 352.

a. MiCROCERAS Decaisin. l, o. Petal a interiora euenllata. (Lam. t, 83. Sebkuhr t. 24. Sihthorp Flor. grcee. t. 150. Decaisne Op, cit. 12. f.6. Jacquemont $Y_{0}$. $t, 8$ ),

b. MACROCERAS Decaisn. $l$. c. Petala interiora longe calcarata, (Deeaisue $O p$, cit, $t, 12, f, a, t, 13$, )

4813. Vancomveria DECAISN. Cal y x basi bibracteolatus, hexaphyHus, foliolis coloratis, deciduis. Coro 11 a e petala 6 , hypogyna, ealycis foliolis opposita, reflexa, oblonga, obovata, apice cucullata, basi intus appendice spathulata, concava, discolori, adnata. St a mina 6 , hypogyna, petalis opposita, erecto-conniventia; filamenta complanata, antherae introrsae, biloculares, apiculatae, loculis adnatis, valvula a basi sursum revoluta dehiscentibus. Ova ri um oblongum, piloso-glandulosnm, uniloculare. Ov u I a plura, juxta placentam parietalem unilateralem adscendentim biseriata, anatropa. Stylus terminalis, eylindricus; st igma-suboblique capitatum, perforatum. Fru etus follicularis.... - Herba $A m e-$ ricaeboreali-occidentalis, perennis; foliis radicalibus triternatis, foliolis subobliquis, obtuse tri-quinquelobis, glanduloso-pilosis, scapo simplici, laxe racemoso.

Van co u veria Decaisue in Nouv. Annal. so. nat. $\boldsymbol{H}$. 351. T p Im ed fum he xa n d rum Hooker Flor, Bor, Amer. t. 13.

4813. A cemanthers MORR. et DECAISN. Caly x tetraphyllus, foliolis subcoloratis, caducis. Coro 11 a e petala 8 , hypogyna, calycis foliolis biseriatim opposita, omnia plana, interiora paullo majora. Stamina 4, hypogyna, petalis opposita; fil amenta brevissima, antherae conniventes, extrorsae, biloculares, epiculatae, loculis adnatis, valvula a basi sursum revoluta, decidua dehiscentibus. Ovarium oblongum, uniloculare. Ovula plura, juxta placentam parietalem nnilateralem adscendentim biseriata, anatropa. Stylus terminalis, cylindricus; stigma obtusum. Fructus.... - Herba japonica, gracilis; caule tenello, flexuoso, foliis alternis, geminatis, foliolis oblique cordatis, integerrimis, floribus racemosis, lacteis, delicatulis.

A ceranthus Morren et Decaisne in Nouv. Annal, sc. nat. II, 349. $t$. 14. B pime di um dip hy 11 am Loddiges Bot. Oab. t. 1358.

4814. Berberis LINN. Ca lyx heptaenneaphyllus, foliolis coloratis, bi-triseriatis, deciduis. Corolla e petala 6 , hypogyna, calyeis foliolis interioribus opposita, unguiculata, basi intus biglandulosa. Stamina 6 , hypogyna, petalis opposita; fil amenta complanata, antherae extrorsae, biloculares, loculis adnatis, a basi ad apicem valvula decidua dehiscentes. Ovari n m ovatum, uniloculare. Ovula $2-8$, e basi erecta, anatropa. Stylus terminalis, brevissimus; stigma peltatum, umbilicatum. B a e e a unilocularis, mono-octosperma. S e m in a erecta, oblónga, testa crustacea, umbilico prope basim sublaterali, E mb ryo in axi albuminis carnosi orthotropus, ejusdem fere longitudine; cotyledonibus ellipticis, radicula elongata, umbilico parallele contigua, infera. - Frutices, in temperatis Europae, Asiae et Americae obvii, in Americatropica rari; nunc foliis primariis abortivis, saepe in spinam simplicem $v$. partitam mutatis, secundariis in apice ramulorum axillarium brevissimorum fàsciculatis, breve petiolatis. simplicibus, integerrimis v. margine ciliatis aut spinulosis, nunc foliis primariis rite evolutis, impari-pinnatis, bi-septemjugis, stipulis petiolaribus geminis, minimis, caducis, pedunculis axillaribus, uni-multifloris, racenosis, floribus flavis.

B er ber Is Linn. gen, $n, 442$, Gărtner $r$. 200. $t$, 42. St. Hilaire Flon. Brasil. I. 44. Sclirader in Linnaea XIT, 460.

a. BERBERIS Nutlall. Foli a primeria abortiva, ia spinas conversa, secuadaria fasciculata, simplieia, G I a nda Ia ad basim nnguium petalorum manifesta. S t a m i n it flamenta edentula.

Ber beris Nuttall Gen. Amer,, 210 . DC. Syst. II. 4. Prodr. I. 105. Meisaer Gen, 6, (7.) (Flor, daa, $t, 904$. Watsot Jendrolog. $t$, 26. Sibthorp Flor. graec. $t$. 324. Pallas Flor. Rorn, t. 67. Ruiz et Pavon Flor. Perav. 
t. 280_28z. Humb, et Bonpl. Nov, gen, et sp. $t, 430$ 433. Hooker Exot. Flor. $t$. 14. 98. Delessert Ic. select. II. t, 1. 2. St, Hilaire Flor. Brasil, t. 10. Wallich Plant. As, rar. t. 243. Päppig. Nov. gen. et sp. t. 187. Bot. Reg. t. 487. 729. 1750. Bot. Mag, t. 2549.

b. MAHONLA Nutt. Foli a primaria Imparipinnata. Gland $u l$ a $e$ ad basim anguium petalorum fere obsoletae. Staminum filamenta saepius apice bidentata.

Ma hou ia Nuttall Gen. Amer. II. 211. DC. Syst. I. 18. Prodr. I. 108. Delessert Ic, select. II, 2. 34. Meisner Gen, 6. (8.) 0 dos te m o n Rafinesque in Americ. Monthl. Magas. 1819. p. 192. (Parkh Flor. Bor. Amer. I. t. 4. Humb. et Bonpl. Nov, gen. et ep, t. 434. Bot. Reg. $t$. 702. 1176.)

481 . Namedina THUNB, C a ly x polyphyllus, foliolis sexfariam imbricatis, deciduis. Coroli a e petala 6 , hypogyna, oblonga, concava, basi erenata, calyce longiora, cadnca. S $\mathbf{t a} \mathbf{m}$ ina 6, hypogyna, petalis opposita; filamenta brevissima, anth erae erectae, biloculares, acntae, loculis adnatis, longitudinaliter dehiscentibus. Ovari um oblongum, uniloculare. Ovula 2 , e basi erecta, anatropa. Stylus terminalis, brevis, obsolete trigonus, persistens; 8 ti gma obtusum. B a c ca unilocularis, disperma $v$. abortn monosperma. Se min a e basi erecta, hinc convexa, inde concava, testa membranacea, umbilico basilari, rhaphe laterali erassa, chalaza apicali terminata. Embryo in basi albuminis carnosi minimus; cotyledonibus brevissimis, obtusis, radieula crassa, umbilico proxima, infera. - Frutex chinensis, in Japonia et India passim cultus, orgyalis, glaber; foliis alternis, ternatim decompositis, petiolo basi vaginante, ad ramificationes tumido, articulato, foliolis ovato-lanceolatis, integris, glabris, paniculis terminalibus, decompositis, erectis, floribus albis, bracteis lineari-acuminatis, subaristatis, alpressis, baccis rubris.

$\mathrm{N}$ a nd In n Thunberg Nov, gen, T, 14. Flor. Japon. 9. Jussieu Gen. 329. Lam, . 261. Gírtner $T I$. 69. $t$. 92. (mali) Banks Ic. Kämpf. t, 13, 14, Bot. Mag. t. 1109. DC. Syst. II. 22. Prodr. I. 109. Decaisne in Nouv. Annal. sc. nat. II. t, 12. $f . d$. Meisuer Gen, 6 . (8.) $\mathrm{N}$ a n d in Kämpfer Amoen. exot. 76 .

\section{Classis XIII. Rhweades.}

Herbae, rarius frutices v. arbores, succo aqueo v. colorato. Folia alterna, rarissime opposita, simplicia v. interdum composita. Fl ores hermaphroditi v. rarissime diclines. Caly x liber, deciduus. C orolla e petala hypogyna, libera, aequalia v. interdum asymetrica, rarissime nulla. Stamina hypogyna, indefinita $\mathbf{v}$, definita, libera $v$. rarissime diadelpha. Ovari um unicum, e carpidiis duobus v. pluribus compositum, uni-biloculare. Ovula solitaria v. plurima, anatropa, amphitropa v. campylotropa. F r u c t u s varius, capsularis, siliquosus, nucamentaceus v. baccatus. E mbry o nunc in basi albuminis copiosi minimus, rectus v. subarcuatus, nunc exalbuminosus varie curvatus.

\section{Dralo CLXXX. Papaveracene.}

PAPAVERACEAE Jussieu Gen, 236. Bernhardi in Linnaea $V I I I, 401, \quad s s, X I I, 651,58$. Lindley Introduct, edit. $I I$. p. 7. PAPAVERACEAE et FUMARLACEAE DC, $\mathcal{S}$ ye. $I T$. 67. et 105. Prodr. I. 117. et 125. Bartling Ord, nat, 259, 260.

Herbar annuae, biennes $v$. perennes, rarius suffrutescentes, radice simplici v. caudice interdum tuberoso, succo aqueo v. Jacteo, saepissime croceo foetae, canlibus teretibus, interdum epigaeo nullo, candicis hypogaei gemmis folia scaposque exserentibus. Folia sessilia v. saepius petiolata, alterna v, superiora interdum opposita, simplicia v. composita, decomposita v. supradecomposita aut rarissime integerrima.

FLores hermaphroditi, regulares v. irregulares, nune solitarii pedunculati, nune in racemum simplicem, abbreviatum v. compositum dispositi, aut interdum subcymosi ; peduneuli terminales v. rami lateralis elongatione oppositifolii, aut e ramorum dichotomia exserti, ra-

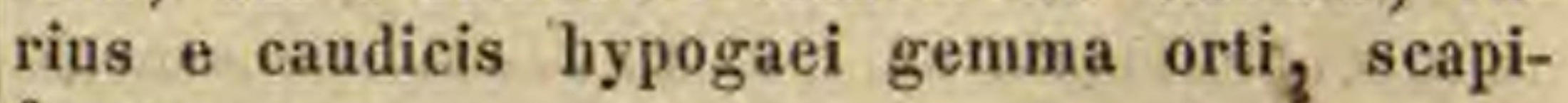
formes.

CaLyx di - v. rarissime triphyllus, foliolis duobus, dextrum et sinistrum ab axi floris latus occupantibus, valvatis v. imbricatis, herbaceis v. interdum subcoloratis, liberis, caducis v. rarissime gamophyllis.

Corowhis petala hypogyna, in Papavereis nunc calycis foliolis numero dupla, quatuor v. sex, aestivatione irregulariter v. longitudinaliter plicata, exteriora interiora equitantia, nunc dupla v. tripla, octo v. duodecim, aestivatione planiuscula, nunc interdum nulla, in Fumarieis quatuor, libera v. varie cohaerentia, lateralia calycis foliolis opposita saepissime cum staminis rudimento connata, posticum basi saccatum v. ealcaratum, anticum postico conforme v. planiusculum, basi aequale.

Stamina hypogyna, in Papavereis numero indefinita, multiseriata, filamentis filiformibus antherisque liberis, bilocularibus, latere v. extus longitudinaliter dehiscentibus, in Fumarieis sex, diadelpha, phalangibus petalis antico et postico oppositis, synemate membranaceo trifido, nune utroque nunc postico basi extus processu brevi glanduloso, nectarifero instructo, lobi medii anthera bi- lateralium uniloculari, loculis longitudinaliter dehiscentibus.

Ovarium liberum, e carpidiis duobus v. plurimis compositum, placentis intervalvularibus multiovulatis v. rarissime uniovulatis, uniloculare. Ovula amphitropa v, anatropa. Stylus terminalis, simplex, interdum nullus. Stigmata connata, placentis numero aequalia et alterna, rarius dupla, iisdem alterna et opposita, interdum collectoribus stipata.

Fructus siccus, v. rarissime baccatus, unilocularis v. interdum septulis transversis plurilocularis, indehiscens $\mathbf{v}$. valvis plus minus completis dehiscens, valvis a placentis persis- 
tentibus, filiformibus $\mathbf{v}$. rarius lamelliformibus, septa incompleta constituentibus solutis, v. easdem bipartientibus, margine auferentibus.

Semrna plurima ve rarissime solitaria, sessilia v. interdum funiculo brevi affixa, subreniformia, umbilico nudo v. caruncula cristaeformi strophiolato. Albumen copiosum, carnosooleosum.

Emвryo in basi albuminis minimus; cotyledonibus duabus v. rarissime unica, interdum tribus v. quatuor bifidis, germinatione filiformibus v. foliaceis, sessilibus ve petiolatis. R a di cula ab umbilico remota, centrifuga.

Ordinis, hinc Berberideis et Ranunculaceis, illine Cruciferis affinis, stirpes maximo numero in hemisphaerae borealis regionibus temperatis generantur, pancae Asiam tropicám, Australasiam, Caput bonae spei et Americam aequinoctialem inhabitant.

Papavereae plures narcoticae, Fumariaceae amaricantes.

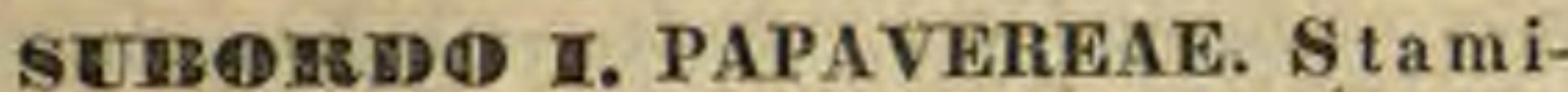
n a libera. Petala regularia, rarius nulla. Suce us lacteus, rarius aqueus.

THEDEUS I. ARGEMONEAE. Succus saepissime croceus.

SUBB'TEITES I. BOCCONIEAE. P e t ala nulla v, aestivatione haud corrugata.

4816. IBeceonia PLUM. Caly $\mathrm{x}$ diphylIns, foliolis coloratis, ovatis, caducis. Co rolla nnlla. Stam in a 8-24, hypogyna; fil a m e nt a brevissima, antherae biloculares, elongato-lineares, latere longitudinaliter dehiscentes. O $\mathrm{va}$ ri u m substipitatum, ovatum, compressum. $O$ y a$1 \mathrm{um}$ unicum, e basi erectum, anatropum, nervis placentariis intervalvularibus sterilibus. Stylns terminalis, bifidus, lobis intus stigmatosis. Caps u la compressa, unilocularis; bivalvis, monosperma, valvis a basi solutis, deciduis, replo annulari persistente. S em en erectum, substipitatum, testa crustaeea, rhaphe lineari, cupula subpulposa seminis stipitem et umbilieum obvolvente. $E \mathrm{mb}$ y o in basi albuminis carnosi brevissimus, ortliotropus; cotyled onibus germinatione ovato-lanceolatis, aequalibns, ra dicu la umbilico proxima, infera. - Suffrutices glaucescentes, succo croceo turgidi, in America boreali subtropica et tropica cis a equat orem indigeni, foliis ob. longis, basi angustatis, breve petiolatis, integris v. pinnatifidis, floribus terminalibus paniculatis, paniculae multiflorae ramis ramulisque unibracteatis.

B o c e a nia Plumler Gen, 35, t. 25. Lina. Gen, n, 591. Jussieu Gen, 236. Giirtner I. 204. $t$. 46. Labi, t. 394. Kunth in Humb. et Bonpl. Nov. gen, ot sp. I. 119, t, 35, DC. Syst. II. 89. Prodr. I, 121. exel. sect, 2. Berahardi in Linnaea VIIT. 460. Meisuer Gen. 7. (9.)

4817. NIaeleza $R$. BR. C a $1 \mathrm{y} x$ diphyllus, foliolis coloratis, ovatis, cadncis. C o r olla nulla. Stamina 24-28, hypogyna; filamenta filiformia, anthera e biloculares, elongato-lineares, latere longitudinaliter dehiseentes, 0 varium sessile, ovatum, compressum. Ovula justa pla- centas intervalvulares oppositas utrinque $2-3$, horizontalia, anatropa. Stigma subsessile, bilobum, lobis oblongis. Capsula subcempressa, unilocularis, bivalvis, tetra-hexasperma, valvis a basi solutis, deciduis, replo annulari seminifero persistente. Semin a horizontalia, ovata, testa erustacea, basi snperne strophiolata. E m b r yo in basi albuminis carnosi minimus; cotyled onib a s nunc tribus aequalibns, nunc duabus $\mathbf{v}$. quatuor inaequalibus, germinatione petiolatis, ovato-subrotundis, radi c n la umbilico proxima, centrifuga, - Herba sinica, perennis; radice repente, foliis alternis, petiolatis, subrotundis, basi cordatis, obsolete lobatis, grasse et obtuse dentatis, venosis, membranaceis, subtus glauco-albidis, paniculae terminalis, elongatae, laxae ramis erectis, paucis, ramulisque unibracteatis.

Macleya R. Brown in Denh, et Clappert. Narrat. 218. Bernhardi in Linnaea DIIT. 460. Meisner Gen. 7. (9.) B a e co n ia cordat a Willd. Jaeq. Fragm. $4.93, f$. 1 . Bot. Mag. $t .1905$.

4818. Samguinaria LINN. C a $1 \mathrm{yx} \mathrm{di}$. phyllus, foliolis ovatis, caducis. Corolla e petala $8-12$, hypogyna, bi-triseriata, interiora angustiora, calyce longiora, decidua. Sta min a 24, hypogyna; fil amenta brevissime filiformia, anthera e terminales, lineares, latere longitudinaliter dehiscentes. Ova ri um compressnm, uniloculare. Ovula juxta placentas intervalvulares ntrinque plura, horizontalia, anatropa. Sti g ma terminale, sessile, crassiusculum, bisulcum. Ca ps u l a oblonga, subeompressa, nnilocularis, bivalvis, polysperma, valvis deciduis, replo annulari seminifero, persistente. Semin a horizontalia, globosa, testa crustacea, nitida, rhaphe cristaeformi, seminis lateri adpressa. E mbryo in basi albuminis earnosi minimus, radicula nmbilico proxima, centrifuga. - Herba boreali-americana, acaulis, succo fulvo, acri scatens; caudice subterraneo, repente, nodoso, fibrillas radicales tenues deorsum, e gemma bivalvi folium petiolatum, scapumque uniflorum exserente, folio reniformi, palmatim quinque - septemlobo, lobis sinuatis, crenatis $v$, repandis, scapo tereti esquamato, flore albo, majusculo.

S a ug u In $\mathrm{n}$ i a Linn. Gen. n, 645, Lam. 6. 440. Bot. Mag. t, 162. Bigelow Med, Bot. t, 7, DC, Syst, I1, 88, Prodr. I. 131. Sweet Fl. Gard. II. t, 147. Berahardi in Linnaea VIIT. A59. Meisaer Gen, 7. (9,)

SURTERIIESS II. PAPAVEREAE VERAE. Pet a la aestivatione corrugato-plicata.

4819. Chelidonium TOURNEF, $\mathrm{Ca}$ lyx diphyllus, foliolis snlicoloratis, aestivatione imbricatis, caducis. Corollae petala 4, hypogyna, integerrima $v$. incisa, decidua. Stam ina plurima, hypogyna; filamenta filiformia, antherae terminales, extrorsae, biloculares, longitudinaliter dehiscentes. O varium subcylindricum, uniloculare. Ovula juxta placentas intervalvalares oppositas plurima, anatropa. Stig ma sessile, bilobum. C a ps ala siliquaeformis, torulosa, bivalvis, valvis a basi solntis, decidnis, replo seminifero persistente. S e min a plurima, ovatoreniformia, nitida, strophiola umbilicali cristaeformi, alba. E mbryo in basi albuminis carnosi brevissimus; e otyledonibus obtusissimis, rad i eula umbilico proxima. - Herbae perennes, in temperatis hemisphaerae borealis obviae, sempervirentes, tenerae, succo croceo, acri fuetae; caule tereti, ramoso, foliis alternis, petiolatis, 
pinnatisectis, segmentis dentatis v. lobatis, pedunculis axillaribus, apice pedicellos plurimos, uniflores, umbellatos, basi bracteolatos gerentibus, floribus flavis, mediocribus.

C hellid on $1 \mathrm{am}$ Tournefort inst. 116. Gärtner II. 164. t. 115. Jussieu Gen, 236. Flor. dan, t. 676. E. B. t, 1531. DC. Syst. II. 98. Prodr. I. 122. Bernhardi in Linnaea VIIT. 461. Meisner Gen. 7. (9.)

4820. Styloplaonerman NUTT. Calyx diphyllus, foliolis pilosis, aestivatione valvatis, eaducis. Co r o 11 a e petala 4, hypogyna, obovata, decidna. Stamina plurima, hypogyna; filament a filiformia, antherae terminales, extrorsae, biloculeres, loculis longitudinaliter dehiscentibus. O va r i $\mathbf{m}$ oblongum, nniloculare, O vu 1 a juxta placentas intervalvulares $5-4$ plurima, anatropa. Stylus terminalis, columnaris; stigma capitatum, tri-quadrilobum. Cap s n la elliptica, setosa, unilocularis, apice valvis $3-4$, incompletis, revolutis, inter placentas filiformes, persistentes dehiscens. S e mina plurima, scrobiculato-punctata, strophiola umbilicali eristaeformi. Embryo ..... - Herbae boreali-america$n a e$, perennes, succo flavo repletae, folits paucis $v$. geminis, summis oppositis, pinnatifidis, floribus terminalibus, subcorymbosis, luteis.

St yl oph or um Nuttall Gen. II. 7. Bernhardi in Lin. naea VIII. 461. Melsner Gen. 7. (9.) Chelid on i um diphyll um Michx. Meconopseos sp. DC.

4821. Argemome TOURNEF. Calyx di-triphyllus, foliolis murieatis, caducis. Corollae petala 4-6, hypogyna, obovata, decidua. Stamina plurima, hypogyna; fil amenta filiformia, antherae terminales, extrorsae, bilocúlares, longitudinaliter dehiscentes. Ovarium ovatum, uniloculare. O vula juxta placentas intervalvulares $4-7$ plurima, anatropa. Stylus subnullus; 8 tigmata $4-7$, radiantia, concava, libera. Ca p s u la ovata, unilocularis, apice valvis $5-7$ incompletis, inter placentas filiformes, persistentes, intus hand productas dehiscens. S e m in a plurima, subglobosa, serobiculata. E m b r y o in basi albuminis carnosi linearis; cotyledonibus brevissimis, obtusis, radienla nmbilico proxima. Herba biennis $v$; perennis, inter trop $i$ cos totius orbis, et in America boreali calidiore obvia, versimiliter in novo orbe indigena, per veterem a mortalibus disseminata, glauca, pilis rigidis subaculeata, succo flavo foeta; foliis sessilibus, penninerviis, repando-sinuatis, sinubus dentato-spinulosis, saepe albo-maculat is $v$. pictis, pedunculis axillaribus, alabastris erectis, floribus flavis $v$, albis.

A r gem o re Tournef, inst, 121, Linn. gen, n. 649 . Gärtuer $1.287 . t$. 60, Jussien Gen. 236. Lam. $t$. 452. Bot. Mag. $t .243 .2342$, Bot. Reg. $t .1264 .1343$. Sweet Flor. Gard. t, 226, 242. Vignier Papav, 49. f. 2. 6. et f. 4. DC. Syst. II. 85. Prodr. I. 120. Beruhardi in Linmaea VIIT. 468. Meisner Gen, 7. (9.) Eeth rus Loureiro Flor. cochinch, I. 421 .

48\%2. MTeconopsis VIGIER. Caly $\mathrm{x}$ di phyllus, foliolis pilosis, aestivatione valvatis, ea dueis, Corollae petala 4, hypogyna, obovata, decidua. St amina plurima, hypogyna; filamenta filiformia, anthera e terminales, biloculares, latere longitudinaliter dehiscentes. O vari um obovatum, uniloculare. Ovula juxta placentas intervalvalares $5-6$ plurima, anatropa Sty Ius terminalis, brevis, demum tortilis, pergistens. Stig m a ta 5-6, radiantia, concava, libera. Ca p s i a obovata, unilocularis, apice valvis 5-6, incompletis, revolutis, inter placentas filifor- mes persistentes, intus vix productas dehiscens. S e m in a plurima, ovata, elevate reticulata, estrophiolata. Embryo .... Herbae perennes, in Pyrenaeis, Anglia, Sibiria, Nepalia et America boreali-occidental $i$ observatae, glaucescentes, succo flavo foetae; foliis alternis, pinnatisectis, pedunculis elongatis, alabastris nutantibus, floribus erectis, fulvis v. rubris.

Meco a ops is Viguier Papav. 20. ot 48, f. 3. DC. Syst. II, 86. excl. sect. 2. Mem. soc. genev, I, t, 2. f. 11. Bern. hardi in Linnaea VIII. 462. Royle Himalay. $t$. 15. Melsuer Gen, 7. (9.) Cerastites Gray Brit, plant, II. 704. Papava ca mbricam Linn. R. B, t. 66.

4833. Papaver TOURNEF. Caly x ditriphyllus, foliolis hispidis v. glabris, caducis. Coro 11 a e petala 4 v. 6 , hypogyna, obovata, decidua. Stamina plurima, hypogyna; filamenta filiformia, antherae terminales, biloculares, loculis latere longitndinaliter dehiscentibus. $\mathrm{O} v \mathrm{a}-$ rin m ovatum, uniloculare. Ovula juxta placentas intervalvulares $4-20$ semiseptiformes plurima, anatropa. Stigmat a $4-20$, radiantia, super ovarii apicem disciformem adnato sessilia, persistentia. Capsula obovata, oblonga v. subglobosa, placentis semiseptiformibus incomplete quadri-vigintilocularis, sub disco stigmatifero persistente valvulis totidem brevibus dehiseens. S e m in a plurima, subreniformia, elevate reticulata, umbilico estrophiolato. E m b r y o in basi albuminis carnosooleosi brevissimus; cotyled onibus obtusis. Herbae annuae v. perennes, in temperatis $\mathbf{E u}$ ropae et Asiae obviate, in Capite bonae spei et Nova-Hollandia rarae, succo lacteo, albo foetae, saepius setoso pilosae; radicibus fibrosis, foliis pinnatim lobatis v, sectis, lobis saepius incisis, dentibus plerumque pilo terminatis, pedunculis axillaribus, solitariis, unifloris, nudis, alabastris cernuis, laevibus v. setoso-pilosis, floribus rubris, flavis v, variegatis.

Papaver Tournefort inst. 119. Linn. gen. n. 648 . Gärtnee 1 , 289. t, 60. Jussien Gen. 236. Jacq. Flor. auslr. t. 83. Flor. dan. $t$. 41. E. B. $t, 603$ - 645. Sibthorp Flor. graec. t. 419. 492. Lindley Colleot. t. 23. Bot. Mag. t. 57. 1633. 16r5. 2344. 3033. Bot. Reg. t. 134. 658, 1570. Viguier Papav. 35. f. $5_{-7}$. DC. Syst. IT. 69. Prodr. I. 117. Delessert Ic. select. II. $t$. $\boldsymbol{7}$. Reichenb. Iconogr. t, 352, 742..746. Sweet Fl. Gard. t. 172. 173. 271. Bernhardi in Limnaea VIII. 462. Meisner Gen. 7. (9,)

48\%4. Closterandira BELANG. Cal y x diphyllus (?), foliolis hispidis, caducis. Coroll a e petala 4, hypogyna, obovata, decidua. St a mina plurima (?) hypogyna; fil amenta basi filiformia, supra medium abrupte dilatata, apice angustata, antherae terminales, biloculares, late ovatae, latere longitudinaliter dehiscentes. O varium obovatum, uniloculare. Ovula juxta placentas 5 (?) intervalvulares. Stig mata 5 , radiantia, super ovarii apicem disciformem, deciduum (?) adnato-sessilia. Ca p s ala oblonga, placentis semiseptiformibus incomplete quinquelocularis (?) disco stigmatifero deciduo apice aperta. S emina … - Herbula persica (?) Papaveris facie, pilosa, humilis; folits bipinnatifidis, pedunculis axillaribus terminalibusque solitariis, unifloris, alabastris erectis. icone.

Closterandra Belanger Vozag. Ic. - Character ex

4895. KToemeria MEDIK, Calyx diphyllus, foliolis aestivatione imbricatis, caducis. Corollae petala 4 , hypogyna, late ohovata, decidua. Stam ina 16-20, hypogyna; filamenta 
filiormia, antherae terminales, extrorsae, oblongae, biloculares, longitudinaliter dehiscentes. 0 vari um longe cylindricum, uniloculare. 0 vnla juxta placentas intervalvulares 2, 3,v. 4 plurima, anatropa. Stigma sessile, bi-quadripartitum. C a p 8 u l a siliquaeformis, teretiuscula, unilocularis, ab apice ad basim bi-quadrivalvis, placentis filiformibus, demum liberis. S emina plurima, reniformia, serobiculata, estrophiolata. Em b r y o ...... - Herbae annuae, graciles, succo croceo foetae, in Europa et Asia mediterranea, nec non in Ta uria indigenae; foliis petiolatis, in lobos lobulosque lineares, saepe mucrone filiformi terminatos sectis, pedunculis solitariis, unifloris, infe. rioribus oppositifoliis, floribus majusculis, violaceis.

Ro e meri a Medikus in Usteri Annal. 1792. III. 13. DC. Syst. II. 92. Prodr, I. 122. Mom, soc. Genev. I. 224, $t, 2$. f. 13. Delessert Ic, select. IT. t. 8. Belanger Voy. Ic. Bernhardi in Linnaea VIII. 463. Meisner Gen. 7. (9.) G 1 a u e 1 s p. Touraef. Sibthorp Flor. graec. $t$. 490 . Chelid on 1 s p. Linn. E. B. $t .201$.

4826. Claucium TOURNEF. C aly x diphyllus, foliolis aestivatione valvatis, caducis. Corolla e petala 4, hypogyna, late obovata, decidua. Stam in a plurima, hypogyna; filamenta filiformia, an therae terminales, extrorsae, oblongo-lineares, biloculares, longitudinaliter dehiscentes. $O$ vari um longe cylindricum, uniloculare. Ovula juxta placentas intervalvalares oppositas plurima, anatropa. S tig ma sessile, incrassato-bilamellatum, persistens. C a psula elongato-siliquaeformis, tetragono anceps, placentis demum in dissepimentum spongiosum concrescentibus spurie bilocularis, bivalvis, valvis ab apice dehiscentibus, replo dissepimento repleto persistente seminifero. S em in a plurima, ovata, serobiculata, estrophiolata, dissepimenti foveolis immersa. Embryo in basi albuminis carnosi brevissimus, rectus; cotyledonibus ovato-lanceolatis, radi cula nmbilico proxima. - Herbae annuae, biennes $v$, subperennes, in $E$ u rop a media et a ustrali, nec non in Asia et Africa mediterranea indigenae, glaucae, succo acri scatentes; radice perpendiculari, foliis radicalibus petiolatis, caulinis sessilibus v. amplexicaulibus, plus minus inciso-pinnatifidis, lobis latis, obtusis, muticis $v$, mucronatis, pedunculis axillaribus $v$, ramis demum elongatis oppositifoliis, solitariis, unifloris, floribus majusculis, luteis, flavis v. puniceis, saepe basi maculatis.

G I a ucium Tournefort Inst. 130. Gärtaer IT. 165. 2. 115. Jussien Gen. 238. Smith Exot. Bot. II, t, 7. B. B. t. 1433. Sihthorp Flor. graec. t. 488. 489. DC. Syst. II. 94. Prodr, I. 122. Hooker Flor, lond, t. 56. Reicheub. Iconogr. t. 297. Fresenius in Mus. Senkenberg. I. $t, 10$. Meisner Gen. 7. (9.) Bernhardi in Linnaea VTI. 463. Chelid on ii s p. E. B. $t$. 8. Flor, dan. $t .585$.

TRE IRES RI. HUNNEMANNIEAE. Bernh" in Linnaea XII. 659. Su c cus aqueus. C a p$\mathrm{sula}$ bivalvis, valvis margine seminiferis.

482\%. Esselnselholtzia CHAM. C a $1 \mathrm{yx}$ pedunculi apici dilatato-tubuloso in marginem annnlarem expanso intns insertus, gamophyllo-dimerus, calyptratim secedens. Co roll a e petala 4, tubuli peduncularis fauci inserta, late obovata idecidua. St amina plurima, com petalis inserta, iisdem basi adhaerentia; fil am e n t a brevissima, subulato-filiformia, antherae terminales, extrorsae, lineares, biloeulares, longitudinaliter dehiscentes. Ovarinm sessile, liberum, longe cy- lindricum, uniloculare. O v u l a juxta placentas intervalvulares oppositas plurima, anatropa. Stigm at a 4 , terminalia, filiformia, duo placentis opposita saepe minora v. nana. C a p s u la siliquaeformis, cylindrica, sulcato - decemstriata, unilocularis, bivalvis, valvis a basi dehiscentibus, margine utrinque seminiferis, Semin a plurima, subglobosa, reticulato-areolata, estrophiolata. E m b r y o intra albumen carnosum rectus; cotyled on ib ns longe linearibus, bifidis, radicula brevi, umbilico proxima. - Herbae perennes, glabrae, glaucae, in America boreali-occidentalí indigenae; radice carnosa, multicipiti, succo croceo turgida, caulibus erectis $v$. procumbentibus, succo aqueo foetis, foliis alternis, petiolatis, decompositis, lobis subcuneatis, trifidis, pedunculis axillaribus, solitariis, unifloris, strictis, folio longioribus, floribus luteis v. croceis, magnis, coelo pluvio clausis.

Eschscholtzia Chamisso in Hor. phys, Berol. 73. t. 15. DC, Prodr. III. 344. Lindley in Bot. Reg. $t, 1168$. 1677. Hooker in Bot. Mag. t. 2887. 3495. Berulardi in Linna6a VIIT, 466. Meisner Gen. 7. (9.) C h r y 8 e is Liadley in Bot. Reg. t. 19.48.

4829. Hunmemanmia SWEET. Caly x diphyllus, foliolis lateralibns, caducis, Coroll a e petala 4 , hypogyna, late obovata, decidua. Stamina plurima, hypogyna; fi lamenta brevia, filiformia, anth er a e terminales, extrorsae, lineares, biloculares, longitudinaliter dehiscentes, 0 v ariu m sessile, longe cylindricum, nniloculare. 0 vula juxta placentas intervalvnlares oppositas plurima, anatropa. Stigma subsessile, peltatum, obsolete quadrilobum. Ca p s u la siliquaeformis, cylindrica, suleato-decemstriata, unilocularis; bivalvis, valvis a basi dehiscentibus, margine utrinque seminiferis. S em ina plurima, subglobosa, reticulato-areolata, estrophiolata. E m br yo intra albumen carnosnm rectus; cotyled on ib t 8 oblongis, basi angustatis, apice-emarginatis, "radic u la brevi, nmbilico proxima. - Herba mexic ana, perennis, glauca, glabra, succo etiam ra. dicis aqueo; caule tereti, erecto, foliis alternis, triternatisectis, laciniis linearibus, obtusis, pedunculo terminali, solitario, unifloro, stricto, floribus magnis, luteis.

Hunnemannia Sweet Brit. Fl. Gard. IIr. $t, 276$. Hooker Bot. Mag. $t$. 3061 . Bernhardi in Linnaea VIII. 464. Meisner Gen. 7. (9.)

4829. Dendromeeon BENTH. Caly x diphyllus, foliolis lateralibus, cadueissimis. Corollae petala 4, hypogyna, obovata, decidua. Stamina plurima, hypogyna; filamenta tereti-subulata, anthera e terminales, biloculares, oblongae, loculis latere longitudinaliter dehiscentibus. O va ri u m eylindricnm, apice attenuatum, uniloculare. Ovala juxta placentas intervalvulares oppositas plnrima, biseriata, horizontalia. Stig ma sessile, bilobum, lobis lamelliformibns, suborbiculatis. Cap sula siliquaeformis, subulata, suleata, unilocularis, bivalvis, valvis margine utrinque seminiferis. Semina plurima, pyriformia, . . - Frutex californicus, glaber; foliis alternis, sempervirentibus, rigidis, lanceolatis $v$. ovato-lanceolatis, acutis, subpungentibus, margine subtilissime serrulatis, penninerviis, subtus reticulato-venosis, subsessilibus, supra caulem articulatis, pedunculis terminalibus, solitariis, unifloris, strictis.

Dendromecon Bentham in Horticult. Trantact, N. ser. I. 407. Hooker Ic. $t, 37$. Bernhardi in Linnaea XII. 660. Meisner Gen, 7. (9.) 
TISTEUS MI. PLATYSTEMONEAE Bernh. in Linnaea XII. 660. S u c cus aqueus. C a p u la trivalvis, valvis margine seminiferis, v. capsulae plures, liberae, in articulos monospermos secedentes.

4530. Platystigma BENTH. Calyx tri-tetraphyllus, caducissimus. Co roll ae petala 6 v. 8 , hypogyna, ovata, biseriatim imbricata, decidua. Stamina plurima, hypogyna; filamenta basi late linearia, apice abruptim filiformia, an ther a e terminales, biloenfares, oblongolineares, loculis latere longitudinaliter dehiscentibus. O vari u m ovato-trigonum, uniloculare, $O$ v ula juxta placentas tres intervalvulares latas indefinita, pluriseriata. Stigmat a 3 , ovata, acuta, patentia. C a psula oblonga, triangulato-sulcata, unilocnlaris, per suleos trivalvis, placentis linearibus, juxta valvularum margines ntrinque decurrentibus. Semin a plurima, minima, ovoidea, atro-nitida, laevissima, E m bry o..... - Herba californica, annua; succo aqueo, caulibus caespitosis, subsimplicibus, abbreviatis, teretibus, fragilibus, patentim pilosis, foliis oppositis $v$. ternatim verticillatis, linearibus, acutis, sessilibus, integerrimis, pedunculis axillaribus et terminalibus solitariis, unifloris, caule multo longioribus, gracilibus, strictis, patentim pilosis, corollae ranunculaceae petalis biseriatis, exterioribus luteis, interioribus pallide flavis $v$, albis.

Platystigm a Benth. in Horticulf. Transact. N. Ser.I. 407. Hooker $r c, t$. 38. Bot. Mag. t. 3575. Lindley in Bot. Reg. t. 1954. Bernhardi in Linnaca XIT. 661. Meisner Gen. 7. (9.)

4831. Meeonella NUTT. Caly x triphyllus, caducus. Cor olla e petala $5-6$, hypogyna. S tamina 4-6, hypogyna; fil a menta membranacea, soperne dilatata, an therae biloculares, brevissimáe, loculis disjunctis. 0 varin m

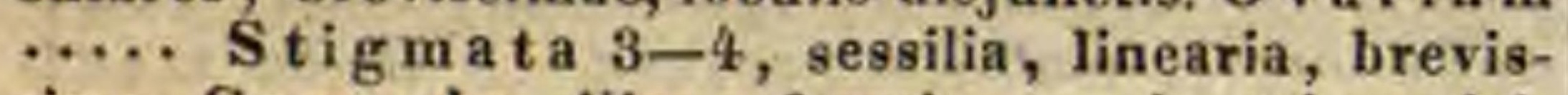
sima. C a p s u la siliquaeformis, tenuis, tri-quadrivalvis, valvis ab apice ad basim dehiscentibus, planis, uninerviis, margine seminiferis. S e mina plurima, subglobosa, nitida, laevia ....-Herba boreali-americana, humilis, glabra, sub. glauca, eaule tenello, dichotome ramoso, foliis radicalibus rosulato - congestis, spalhulatis, caulinis oppositis, linearibus v. lineari-spathulatis, summis ternatis, integris, pedunculis axillaribus, filiformibus, uniftoris, floribus minutis, ochroleucis.

Meoonella Nuttall in Torre, et A. Gray Flora of North Americ. I. 64.

4832. Platystemon BENTH. C alyx triphyllus, cadncissimus. Corolla e petala 6, hypogyna, ovata, biseriatim imbricata, decidua. S tam ina plurima, hypogyna; filament a subpetaloideo-dilatata, oblonga, an th e ra e terminales, biloculares, lineares, loculis latere longitudinaliter dehiscentibus. O vari a $10-12$, linearia, verticillata, marginibus cohaerentia, ad suturam ventralem hiantia. $O \mathrm{v} u$ la juxta ovariorum margines plurima, utrinque alternatim uniseriata, adscendentia, anatropa, in cavitatem centralem apice perviam, ovariorum verticillo formatam prominentia. Stigmat a in ovariis terminalia, linearia, hispidula, erecto-conniventia. $C$ a r p id i a 10-12, siliquaeformia, stigmate persistente superata, marginibus breviter cohaerentia, sutura ventrali elausa, torulosa, subeartilaginea, intus transversium plurilocularia, demnm in articulos monospermos secedentia. S e min a adscendentia, laevia, rhaphe carnosula, cristaeformi. $\mathbf{E} \mathbf{m}$ b $\mathrm{r}$ y o intra albumen carnoso - oleosum orthotropus, subarcuatus, $\mathrm{ra}$ dicula infera. - Herba californica, annua, tenera, spursim pilosa, succo aqueo; caule erecto, subramoso, foliis phyllodineis late linearibus, parallelinerviis, integerrimis, alternis verticillatisque, saepe unilateralibus, pedunculis axillaribus et terminalibus, folia superantibus, solitariis, unifloris, floribus ranunculaceis, luteis.

Platystem on Bentham in Horticutt: Transact. $N$. Ser, $I$, 405. Lindley in Bot. Heg. t. 1679. Hooker in Bot. Mag. t. 3579 . Bernhardi in Linnaea XII. 661. Meisner Gen. 7. (9.)

SUBOTED IT. FUMARIACEAE. S $t$ amin a libera $v$, in phalanges connata. Petala disparia. Succus aqueus.

TRETEUS $v$. HYPECOEAE. S $\mathrm{t}$ a $\mathrm{m}$ in a libera.

4833. Hypecoum TOURNEF. Calyx diphyllus, folivlis lateralibus, deciduis. Corollae petala 4, hypogyna, exteriora anticum et posticum obtusa, triloba, subunguiculata, basi gibba, interiora lateralia trifida, lobo medio cochleariformi, lateralibus patentibus. Stamina 4, hypogyna, petalis opposita; filam en ta libera, linearia, planiuscula, basi utrinque glandula lineari stipata, antherae terminales, biloculares, loculis linearibus, longitudinaliter dehiscentibus. Ovarium teretiusculnm, uniloculare, ovulis juxta placentas intervalvulares pluribus, amphitropis, isthmis transversis interceptis. Ca p s u la siliquaeformis, indehiscens, extus articulatim nodosa, intus septis transversis multikocnlaris, articulis vix sponte secedentibus, monospermis. S em in a subrotunda, lenticulari compressa, hine truncata, umbilico ventrali lineari. E mbr yo in basi albuminis carnosi linearis, subarcuatus, r a di cula eentrifnga. Herbae mediterraneae, annuae, parvulae, succo aqueo; radice perpendiculari, simplici, foliis glabris, glaucis, radicalibus petiolatis, pinnatisectis, segmentis pinnatim in lobulos plurimos divisis, scapis caulibusque saepius pluribus, bifidis v. dichotomis, foliis caulinis $v$. floralibus sessilibus, caeterum radicalibus conformibus, floribus terminalibus, flavis.

H y pecoum. Tournefort inst. 115. Linn. gen. n. 171. Miller Ic. $t, 250, f, 1$, Gärtner $I T$. 164. $t, 115$. Schkuhr $t, 27$. Lam. t. 88. Jacq. Ic. rar. t. 309. Sibthorp Flor. graec. t. 155. 156. DC. Syst, II. 101. Prodr. I. 123. Bernhardi in Linnaea VIIT. 465. Meisner Gen. (7. (9.) Mnemos \$ll at Forskael Aegrpt, 122 .

4984. Clniazosperrunum BERNH. C aly $\mathrm{x}$ diphyllus, foliolis lateralibus, deciduis. $\mathrm{Co}$ rolla e petala 4, hypogyna, exteriora anticum et posticum obtusa, subtriloba, subunguiculata, dorso obtuse carinata, intus subcanaliculata, interiora lateralia trifida, lobo medio postice canaliculato, apicis oblongi lateribus reflexis. S $\mathrm{ta}$ mina 4, hypogyna, petalis opposita; filam enta libera, linearia, planinseula, basi utrinque glandula lineari stipata, anther a e terminales, biloeulares, loenlis linearibus, longitudinaliter dehiscentibus. O varium teretinsculum, uniloculare, ovnlis juxta placentas intervalvulares pluribus, amphitropis, isthmis transversis sejunctis. StyIn s terminalis, brevissimus; - $\mathrm{t}$ ig $\mathrm{m}$ at a 2 , filiformia, revoluta. Cap 8 ula siliquosa, haud articulata, hivalvis, intus septis transversis ineompletis in loculos monospermos divisa. Semina 
subquadrangula, utrinque elevatione cruciata, octaëdron basi quadratum simulantia. - Herba annua, in Asia media indigena, suceo aqueo; foliis radicalibus petiolatis, multifidis, labis linearibus, acutis, caulinis parvis, sessilibus, lobis distantibus, angustissimis, caule erecto, dichotomo, pedicellis aliis in dichotomia solitariis, aliis terminalibus, floribus flavis, purpureo-maculatis.

Chiazos perm um Bernhardi in Linnaea VIIT. 465 . XII. 663. Meisuer Gen, 7, (9.) Hypecoum erectum Linn.

TRIBSUS T. FUMARIEAE Bernhardi in Linnaea VIII. 466. Stam in a in phalanges duas connata.

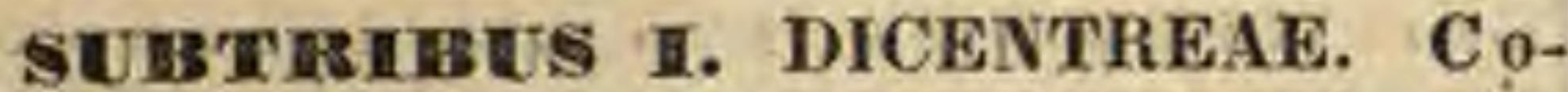
rolla é petalum anticum et posticum conformia, basi saccata v. calcarata.

4835. Daetylieapros $W A L L$. C a I y $\mathrm{x}$ diphyllus, foliolis lateralibus, decidais. Corolla e petala 4, hypogyna, inter se connata, decidua, lateralia interiora ungue filiformi, lamina obcordata, anticum et posticum basi saccata. $\mathrm{S}$ t a m ina 6 , hypogyna, diadelpha, phalanges petalo antico et postico oppositae; s ynemate membranaceo, trifido, utroque basi extus processu brevi glanduloso aucto, lobi medii anthera bi-lateralium nnifoculari. Ov a rium uniloculare, ovu $l i$ s juxta placentas intervalvulares plurimis, amphitropis. Stylns terminalis, deciduus; stig ma bilobum. B a c e a sueculenta, unilocularis, placentis duabus parietalibus oppositis. Semina plurima, lenticulari-compressa, rostellata, umbilico nudo. Embryo .... - Herba n epalens is, annua, cirrhosa, scandens; caule tereti, ramoso, purpureo maculato, foliis alternis, petiolo ramoso triternatis, foliolis membranaceis, ovatis, acutis, subtrinerviis, integerrimis, subtus glaucis, lateralium petiolulis in cirrhos spirales conversis, racemis oppositifoliis, nutantibus, floribus luteis.

Dactyll ca p nos Wallich Flor. Nepal. 51, $t, 39$, Don in Sweot Brit, Fl, Gard. IK, t. 127. Berahardi in Linnaea VIIT, 467. Meisner Gen. 8. (10.)

4836. Dieentar BORKH. Calyx di phyllus, foliolis lateralibus, deeiduis. Cor o lla e petala 4 , libera, decidua, lateralia interiora plana, anticum et posticun basi gibba $v$. in calear producta. St a mina 6 , hypogyna, in phalanges duas petalis antico et postico oppositas approximata; fil a m enta libera, v. basi distincta, superne coalita, intermedia inferne extus processu calcariformi v, obsoleto aucta, anthera biloculari, lateralium antheris unilocularibus. Ovari u m uniloculare, ov ulis juxta placentas intervalvulares pluribus, amphitropis. Stylus terminalis, persistens; st igma bilobnu. Capsula siliquosa, compressa, stylo persistente superata, unilocularis, bivalvis, valvis a replo placentifero persistente solutis. S em in a plura, lenticulari compressa, rostellata, umbilico strophiolato. Embryo intra albuminis rostellum brevis, linearis, - Herbae boreali-americanae et sibiricae; radicibus tuberosis $v$. fibrosis, folits omnibus radicalibus v. caulinis, petiolatis, nultifidis, floribus majusculis, racemosis, albis v. purpurascentibus.

Diclytra DC. Syst. II. 107. Prodr. I. 125. Wight nllustr. $t, 11, f$. $c$.

a. EUCAPNOS Bernh. Corollae petala exteriora basi gibba. St a m i n a basi libera, medio in phalanges coliaegeatia, flamenti medil processu basilari postico obsoleto.
Seminum strophicola carunculaeformis. - Scapigerae, caudice gemmifero, racemis compositis.

E u capios Bernhardi in Linnaea VIII. 468. Meis. ner Gen. 8. (10.) $\mathrm{C}$ a p nor $\mathrm{ch}$ is Borkhausen in Bömer Arehiv T. 2. 46. Pumariae s p. Linn. Ande. Bot, Rieposit. $t$. 395. Bot. Mag. t. 1335. Bot Reg. t, 80. (De. lessert Ic. select. II, t. 9, f. 6. Bot. Mag. t. 303t.)

b. CUCULLARIA Raf. Coroll a e petala exteriora basi in ealear longum produeta. Stam in a libera, in phalanges approximata, frlamenti medii processu basilari postieo caloariformi, longo. S emin a m strophiola brevis, laciniato-tuberculata. - Caulescentes, caudice hypogaeo, squamis carnosis tecto, racemis simplicibus.

C u c ull a ri a Rafinesque in Now.York Medic. Neposiery II, Hex, V, 350, et in Desvaux Journ. Bot. 1809. II. p. 159. D i cl y tra Borkhausen 1. c. (manifesto spahlm. pro Dicentra nee Dielytra.) Dicentra Bernhardi l. c. Meisner $t$. c. B I c u c u 11 a t a Marchant in Ace. Academ. Paris. 1733. p. 280, t. 20. Pumaria CuculI a ri a Linn. Bot. Mag, $t$. 1127.

c. MaCrocapNos Royle in Lindley introduct, edit. $I T$. p. 439. Herba efrrhosa, scandens, habitu praeter eaulem quinqueangularem et racemos pleruaque bi-triflocos a Dactyloeapno vix diversa, et saepins cum illo confusa, flore et fructu a Dicentra hand diversa. Cfr. Bogle Himalay. p. 68 .

483 \%. Adlumia $R A F$. Cal y $\dot{x}$ diphyllus, foliolis lateralibus, deciduis. Cor olla e petala 4, hypogyna, lateralia basi aequalia, eum antico et postico inferne in calear productis in corollam apice quadrilobam, persistentem, demum fungosam connata. Stamina 6 , diadelpha, phalanges petalo antico et postico oppositae; sy nemat e membranaceo, trifido, utroque basi extus processa brevi calcariformi aucto, lobi medii anthera bi- lateralium uniloculari. $O$ v a ri $\mathbf{u}$ m uniloculare, ovuli s juxta placentas intervalvulares pluribus, amphitropis, Stylas terminalis, persistens ; s ti gma bilobum. Capsula siliquosa, compressa, stylo persistente superata, corolla fungosa tunicata, unilocularis, bivalvis, valvis a replo placentifero, persistente solutis. S em in a plura, lenticulari-compressa, rostellata, umbilico nudo. Embryo … - Herba boreali-americana, biennis, glabra, delicatula, caule purpurascente subtortili petiolisque cirrhosis scandens; foliis glaucescentibus, remote alternis, primariis biternatim, reliquis bipinnatisectis, segmentis obovatis, basi cuneatis, petiolatis, apice trilobis v. tridentatis, raccmis axillaribus, compositis, laxis, reflexis, florious albidis $v$. rufescentibus.

Ad 1 um a Bafinesque in New-York Medic, Reposit. IT. Hexad. $V$. 350. et in Desvaux Journ. Bot. 1809. IT. 169. DC. Syst. II. 111. Prodr. I. 126. Berahardi in Linnaea VITI. 568. Meisner Gen. 8. (10.) Bicuculla Borkhausen in Hömer Archiv I. 2. p. 46. Corydalis fungos a Venten. Choix t. 19.

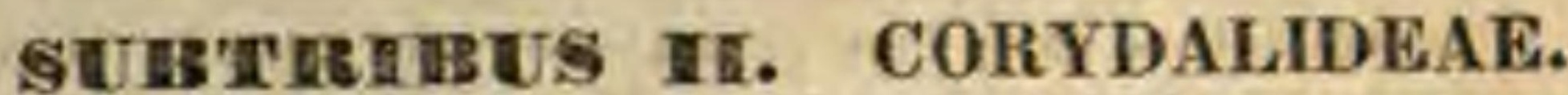
Corollae petalum posticum basi saccatum v. calcaratum, anticum planum.

4838. TPlameoeapmos $B E R N H$. C a l y x diphyllus, foliolis lateralibus, deciduis. Corolla ringentis petala 4 , hypogyna, anticum planum, posticum basi calcaratum, dus Iateralia interiora distincta, antico conformia. Stamina 6, hypogyna, diadelpha, phalanges petalis antico et postico oppositae; s ynemate membranaceo, apice trifido, postico hasi extus processu calcarifurmi aucto, lobi medii a n thera bi-lateralium uniloculari. Ovarium uniloculare, ov ulis justa placentas intervalvulares plurimis, amphitropis. StyI $\mathbf{s}$ terminalis, persistens; $s$ ti g ma bilobum. C a p108* 
s u l a siliquosa, compressa, stylo mneronata, nnilocularis, bivalvis, valvis a replo placentifero persistente solutis. Semina plurima, lenticnlaricompressa, rostellata, umbilieo nudo. E m b r y o... Herba capensis; caule scandente, folits radicalibus caespilosis, ecirrhosis, caulinis alternis, bipinnatisectis, segmentis obovatis et oblongo-cuneatis, integris $v$. incisis, racemis oppositifoliis, densis.

Phacoeap a s Bernhardi in Linnaea XIr. 664. C o$r y d a l i s$ C racea Chamisso et Schlechtend. Ibid. I. B67.

4839. Corydalis DC. Calyx diphyllus, foliolis lateralibus, deciduis. Cor ol 1 a e ringentis petala 4, hypogyna, anticum planum, posticum basi ealcaratum, duo lateralia interiora distincta, antico conformia. Stamina 6 , diadelpha, phalanges petalis antico et postico oppositae; sy nemate membranaceo, apice trifido, postico extus basi processu calcariformi aucto, lobi medii a $\mathbf{n}$ th era bi- lateralium uniloculari. O vari n m uniloculare, ovulis juxta placentas intervalvulares pluribus, amphitropis. Stylus terminalis, persistens v. deciduus; stigma bilobum. Capsula siliquosa, compressa, stylo v. styli basi persistente superata, uniloeularis, biyalvis, valvis a replo placentifero persistente solutis. Sem in a plurima, lenticulari-compressa, rostellata, umbilico strophiolato. E m b ry o in basi albuminis intra rostelInm hinearis, brevis. - Herbae glabrae, saepe glaucae, annuae $v$. perennes, in Europa et in Asia media obviae, in America boreali ra. rae; radice fibrosa $v$. fusiformi, in aliis tuberosa, solida $v$. cava, caule simplici $v$. ramoso, erecto aut decumbente, foliis alternis aut rarius oppositis, petiolo ramoso ternatim pinnatimve sectis, bisectisve, racemis oppositifoliis $v$. termintulibus, pedicellis unifloris, bracteatis, ebracteolatis.

Corydalis Venten. ex DC. Flor. franc. IV. 636. excl. sp. Syst. II. 113. Prodr. I. 126. Wight Ilustr. 11. f. B. C a p nof es Boerhave Lugd. Bat. 391. Tournefort Inst, 237. Ne cke ri a Scopoli Introduct, n, 1436.

a. CAPNOIDES Gärtn. S y n e matis postici calcar breve, obtusum. St yl us deciduus; $s \mathrm{tig}$ m at is prolongationes 4, primariae duae collectoribus adnatae, secundariae fisdem breviores. Ca r u cula umbilicalis coneava, lata, seminis sinum basimque tegens. E.mbryo germinans plumulam inter cotyledones duas ovatas petiolatas evolvens.-Herbae perennes; radice elongata, subsimplici, caulibus plurimis, ramosis, racemis terminalibus; so. litariis, ramorum prolongatione tandem oppositifolitis.

Ca pnoides Gartaer $I I .163,1,113$. Bernhardl in Linnaea VIT. 605. VIIT. 470. Meisner Gen, 8. (10.) Pse udofumaria Borkhausen in Römer Archiv. I. 2. p. 44. B orkliats en ia Elor. Wetteraw. III. 19. Corydalis eapnoldes DC. Fumariac s p. Jacq. Ic. rar. t. 354 . E. B. $t .588$.

b. CAPNITES. Synematis postici ealcar plus minus prodactum. St y 1 us persistens; $s \mathrm{tig}$ mat a collectores vix superantia. Ca r a cu la umbilicalis concava, semi. nis sinum tegens. Embryo germinans plumulam inter cotyledoues duas lanceolatas petiolatas evolvens. - Herbae annuae $v$. perennes; radice subsimplici, caulibus ramosis, racemis terminalibus, ramorum elongatione tandem oppositifolits.

Cory dalis Bernhardi in Limaea PII. 604, VIIT. 469. Meisner Gien, $8,(10$,$) C o r y d alis sect. Capnoi.$ des DC. $Z$, e. excl. sp. E. B. $t .103$. Bot. Mag. $t$. 179. Bot. Reg. t, 66. (Ledelour Ic. 2, 49. 56,)

c. BULBOCAPNoS Bernh. Sy uematis postici calcar elongatum. St ylus persistens; $8 \mathrm{tig}$ mat a collectores vix superantia. C a r un c u I a umbilicalis digitiformis, e processu pellucido curvato, siccitate torto formatis. E mbry o monocotyledoneus, cotyledone germinante ovata, infra radicem tuber perenue gignens, altero aumo follum primordiale, sequentibus caules anouos, simplices, racemis terminalibus solitarlis producens.
B u lbo e a n os Berahardi in Linnaea VII. 604. $t, 14$. f. 6. VIII. 469. Meisner Gen. 8. (10.) Corydalis sectio Capnites DC. $l$. c. Fumariaesp. Jacq. Hort, Vindob, t, 116. Pallas Act, Petropolit. 1779. II. t, 14. (Flor. dan. $t$. 1394. Nees jun. Plant. offic. Suppl. IV. $t$, 18. 19. Bot. Mag. $t$. 3230, 3242, Delessert I0. ze. lect. 1T. t. 9. 10. Hooker Flor. Bor. Amer. t. 13. De tuberis structura cfe. Bischoff in Tiedemann et Treviranus Zeitschr. f. Physiolog. IV. 2.)

d. ? LEONTICOIDES $D C$. $\mathrm{R}$ ad ix fusiformis. Ca ull $\mathrm{s}$ simplex, foliis duobus oppositis.

Corydalls sectio Leonticoides DC. l. c. (Sibthorp Flor. graec, $t$, 667. Wallich Flor. Nepal. $t .41$. 42. Royle Himalay, $2,16$.

4840. Wiscocapnos $C H A M$, et SCHL. C a lyx diphyllus, foliolis lateralibus, deciduis. Corolla e petala 4, hypogyna, anticum planum, posticum basi calcaratum, cum duobns lateralibus interioribus coalitum. S ta m in a 6, diadelpha, phalanges petalis antico et postico oppositae; 8 y n emate membranaceo, apice trifido, postico basi extus glandula aucto, lobi medis a n th er a bi-lateralium uniloculari. Ovari um miloculare, ovulo parictali unico, amphitropo. Stylus terminalis, supra basim deciduus; stigm a bipartitum. Fructus orbicalaris, membranaceus, complanatus, styli basi mucronatus, ntrinque uninervis, ala lata loculum centralem parvam ambennte. Sem e n unicum, lenticulari-compressum, nitidnm, nmbilico nudo. Embryo..... - Herba capensis, annua, ramosa; foliis petiolatis, bipinnatisectis, segmentis cuneiformibus, subtus glaucis, obtuse incisolobatis, petiolis cirrhosis, racemis oppositifoliis, pedunculatis.

Discocap no 8 Chamisso et Schlechtendahl in Linnaea I. 569. Bernhardi Ibid. VIII. 470. Meisner Gen. 8. (10.)

4841. Sarecoerpinos DC. Caly $\mathrm{x}$ diphylIus, foliolis lateralibus, deciduis. Corolla e ringentis petala 4, hypogyna, anticnm planum, posticum basi breviter calcaratum, duo lateralia interiora distineta, antico conformia. Stamina 6 , diadelpha, phalanges petalis antico et postico oppositae; sy $\mathbf{n}$ em a t e membranaceo, apice trifido, postico basi extus glandula aucto, lobi medii anth era bi- lateralinm uniloculari. Ovarium uniloculare, ovalis juxta placentas intervalvulares utrinque solitariis, amphitropis. Sty lus brevis, supra basim deciduns; stigma bilobum. Fructu 8 ovatus, compressus, indehiscens, valvis trinerviis, suturis marginantibus. S em in a $2, \mathbf{c o m -}$ pressa, nitida, umbilico nudo. Em b r yo $\ldots$. Herbae occidentali-mediterraneae, perennes, ramosae, caespitoso-diffusae, basi interdum suffruticulosae, glabrae $v$. pilosae; foliis alternis, longe petiolatis, integris $v$. tripartitis $v$. petiolo dissecto triternatis, crassiusculis, racemis brevibus.

S a rc o c a p u os DC. Syst. II. 129.Prodr. I. 129. Berahardi in Linnaea VIIT. 470. Meisner Gen, 8. (10.) F uma $r$ a e 8 p. Linn. Lam. $t$. 397. $f$. 4. Desfont. Flor. atlant. t. 173 .

4842. Cystleapnes BOERH. Cal y x diphyllus, foliolis lateralibus, deciduis. Corollae ringentis petala 4 , hypogyna, anticum planum, posticum basi calcaratum, duo lateralia interiora distincta, antico conformia, $\mathrm{St}$ a $\mathrm{m}$ in a 6 , diadelpha, phalanges petalis antico et postico oppositae; s y nemate membranaceo, apice trifido, postico basi extus glandula aucto. Iobi medii anthera bi- lateralium uniloculari. $\mathbf{0} \dot{\mathbf{v}}$ a ri $\mathbf{r}$ m niloculare, ovulis juxta placentas intervalvulares, pluribus, amphitropis. Stylus terminalis, supra basim deciduus; stigma bilobum. Capsula vesicaria, 
styli basi mucronata, epicarpio inflato, cum endocarpio membranaceo, subbivalvi, marginibus placentas suberosas gerente reticulo-fibroso cohaerente. Semina plura, lenticulari-compressa, rostellata, nitida, umbilico nudo. Embryo in basi albuminis intra rostellum linearis, brevis, subincurvus. - Herba capensis, scandens, dichotoma, glabra; foliis petiolatis, bipinnatisectis, segmentis trilobis, petiolis apice cirrhosis, floribus parvis; al6is, racemosis.

C y st i a p n os Boerlave Lugd. Batav.391. Gairtner II. 161. t. 115. Borkbausen in Römer Archiv. 1. 2. p. 45. DC. Syst, II. 112. Prodr. $I$ : 126. Bernhardi in Linnaea VIII. 420. Meisuer Gen. 8. (10.) Corydalis Necker Elem, n, 1380. Capnocystis Jussieumsc. Fumaria vesicaria Linn.

4843. Fumaria TOURNEF. Calyx diphyllus, foliolis lateralibus, decidnis, Cor oll a e petala 4, hypogyna, ringentia, anticum carinatum, posticum basi obtuse calcaratum, cum duobus lateralibus interioribus inferne coalitum. Stamin a 6 , diadelpha, phalanges petalis antico et postico oppositae, synemate membranaceo, apice trifido, basi eglanduloso, lobi medii anthera bi- lateralium uniloculari. $O$ v a rium uniloculare, ovulo parietali unico, amphitropo. Stylus terminalis, decidnus; $s t$ igm a bipartitum. Frnctus carnoso-drupaceus, demum siccus, subglobosus, epicarpio ab endocarpio haud solubili, sutura obtusangula, bipartibili. S em en unicum, reniforme, opacum, nmbilico nudo. Embryo in basi albuminis minimus, rectus. - Herbae annuae, in Europa media, regione mediterranea et Asia finitima, nec non in Capite bonae spei indigenae, tenerae, ramosae; foliis alternis, in lobos lineares multifido-decompositis, petiolis saepe cirrhosis, floribus racemosis.

F u m a ri a Tournefort inst, 422. Gärtner II. 162. $t .115$. E. B. $t .589 .590 .943$. DC. Ic. plant. Gall, rar. I. $t .34$. Bernhardi in Linnaea VIIT. 471. Meisner Gen. 8. (10.) Wight nlustr. $t, 11, f . A$. Fum a riae sect. S p hate ro apnos DC. Syst. IT. 133.'Prodr. I. 130.

4844. Platyeapmos DC. C a l y x diphyllns, foliolis lateralibus, deciduis. Coroll a e ringentis petala 4, hypogyna, anticum carinatum, posticum basi obtuse calcaratum, cum duobus lateralibus interioribus inferne coalitum. S $t$ a $\mathbf{m}$ in a 6 , diadelpha, phalanges petalis antieo et postico oppositae; s yn em a te membranaceo, apice trifido, postico basi extus glandula aucto, lobi medii a nthera bi- lateralium uniloculari. Ovarium uni loenlare, ovulo parietali unico, amphitropo. Stylus terminalis, deciduus; stigma bipartitum. Fructus ovalis, compressus, bivalvis, valvulis marginatis, contignis, ima basi connexis, epicarpio ab endocarpio meinbranaceo placentifero soluto. Semen unicum, reniforme, compressum, nitidum, umbilico nudo. E $\mathbf{m}$ b ryo in basi albuminis minimus, rectus. - Herbae mediterraneae et orientales, annuae, ramosae; foliis in lobos lineares multipartitis, racemis subspicatis.

Platycap no Bernhardi in Linnaea VIIT. 471. Meisner Gen, 8. (10.) Fumariae sectio Platy eapnos DC. Syt, II, 131. Prodr, 130. F a mari a 8 p i cat a Liuk.

\section{Drdo CHXXXI. Craceiferce.}

TETRAPETALAE uniformes Rai Hist, XVI, 727. CRU. CIFORMES Tournef, Inst. 210. TETRADYNAMAE Lizi. Gen. 329. Smelowski in Act. Petropotit. 1805. XIV. 470. Schrader N, Journ, III, 159. R. Brown in Aiton Hori, Kew, edil.
2. IV. 71. C. A. Meyer in Ledebour Flor. Llt, III, 3. SILIQUOSAE Linn. Praelect. edit. Giesek. 481. ANTISCORBUTICAE Crantz Flor. Austr, 1. CRUCIATAE Haller Helo. 1. 192. CRUCIFERAE Adanson Fam. IT. 409. Jussien Gen, 237. Desvaux Journ. Bot. ITI. 145. DC. in Mem. Mur. VIT. 169. Syst. II. 139. Prodr. I, 131. R. Brown in Denh. et Clappert. Narrat, 210. ss. Bartling Ord, nat, 261, Liadley Intro. duct edit. 2. p. 58. Meisner Gen. 9. (10.) Kunth in Verhandl. Berlin, Acadom. 1832. p. 33. Flor, berolin. I. 35.

Нвввав annuae v. biennes, rarius perennes, interdum suffrutices, succo in omnibus aqueo. $\mathbf{R}$ a dices in perennibus crassae, saepe napiformes, in annuis graciles, plerumque perpendiculares, subsimplices. Caules teretes v. subangulati, ramosi, etiam in stirpibus annuis sub maturitate fructus saepe fruticosoindurati; rami e foliorum axillis orti, superiores in annuis saepissime abortivi, interdum spinescentes. Folia simplicia, nunc omnia radicalia, nunc caulina, plerumque alterna, rarius inferiora opposita, pinnatinervia, dentata, pinnatifida, lyrata v. varie dissecta, inferiora plerumque petiolata, superiora v. summa sessilia, saepissime auriculato-amplexicaulia. $\mathbf{P}$ ili simplices, furcato-ramosi v. stellati.

Flores hermaphroditi, regulares, in racemis oppositifoliis, ramuli axillaris elongatione manifeste lateralibus, v. ejusdem abortu spurie terminalibus, primum subcorymbosis, demum saepissime elongatis, pedicellis filiformibus, nonnunquam tandem incrassato obconicis, nudis v. rarius foliaceo-bracteatis, mediocres, albi, flavi v. purpurei, rarius caerulei, interdum sordidi, odorati.

Caryx tetraphyllus, foliolis erectis, conniventibus v. patulis, deciduis, aestivatione imbricatis v. rarissime valvatis, duobus lateralibus, fructus valvis oppositis, paullo demissius insertis, saepissime nonnihil latioribus, basi aequalibus v. deorsum gibbis v. concavis, aut interdum calcaratis, foliolis antico et postico placentis oppositis planis, saepe angustioribus.

Corollar petala 4 , hypogyna, calycis foliolis alterna, plerumque unguiculata, lamina integra v. emarginata, rarius bifida v. rarissime pinnatifida, inter-se aequalia, rarius duo antica majora, interdum abortu nulla.

Sтamiva 6, hypogyna, tetradynama, biseriata, seriei inferioris calycis foliolis oppositae duo, ante foliola lateralia sita (nempe duobus ante foliola anticum et posticum semper supressis), breviora (interdum abortu nulla), seriei interioris petalis oppositae quatuor, longioribus (rarissime abortu deficientibus). Filamen ta subulata v. filiformia, simplicia v. longiora dente ancta $v$. interdum bifurca, libera v. nonnunquam per paria connata. Antherae terminales, introrsae, biloculares, loculis longitudinaliter dehiscentibus. Glandula e hypo- 
gynae inter petala et ad basim foliorum calycis numero definitae.

Ovarium liberum, sessile v. breviter stipitatum, abbreviatum v. elongatum, e carpidiis duobus, dextrum et sinistrum ab axi floris latus respiciéntibus, ideo calycis foliolis lateralibus oppositis compositum, carpidiorum marginibus, placentas nerviformes, anticum et posticum floris latus spectantes, ideo calycis foliolis antico et postico oppositas, et mediante textu celluloso in septum coeuntes contingentibus, biloculare, nunc septo incompleto v. obliterato uniloculare, quandoque septis secundariis transversim plúriloculare. Ovul a ovarii bilocularis in utroque loculo juxta placentas intravalvulares nunc ambas, nunc juxta unicam saepissime plura, rarius solitaria v. subdefinita, pendula v. horizontalia, campylotropa v. amphitropa, micropyle supera v. rarius infera, in ovario uniloculari saepius ovulum unicum, ex apice loculi pendulum, v. e funiculo e basi loculi adscendente nutans. Stylus terminalis, simplicissimus, in ovario elongato brevis, in abbreviato longus. Stigmata 2 , patentia v. in unicum connata, placentis opposita.

Fructus siliquosus (elongatus), v. siliculosus (abbreyiatus), bilocularis v. septo obliterato unilocularis, nunc bivalvis, valvis a septo (replo) angusto v. lato, margine placentifero, apice styligero secedentibus, nunc evalvis, valvis nempe cum placentis pertinaciter connatis, indehiscentibus, nunc transversim plurilocularis, in articulos discedeus (lomentum.)

Semrxa in loculis plura v. interdum solitaria, horizontalia v. pendula, compressa v. subglobosa, funiculis liberis v. partim septo adnatis, testa crassiuscula, epidermide membranacea, saepius in marginem $\mathrm{v}$, alam expansa.

Eмввхо exalbuminosus, oleosus, curvatus. Cotyledones 2, integrae v. interdum partitae, supra radiculam adscendentem vorarius descendentem pronae, nune rima commissurali eidem accumbentes (colyledones accumbentes $\mathrm{O} \Rightarrow$ ) et tunc semper planae, nunc dorso eidem incumbentes (cotyledones incumbentes), et tunc v. planae (OII) v. juxta Iongitudinem plicatae, radiculam amplectentes (cotyledones conduplicatae $\bigcirc>>$, aut spiraliter convolutae (colyledones spirales OIIII) v. bis transversim plicatae (cotyledones biplicatae $v$. bicrures OIIIIIIII).

Crueiferae inter Papaveraceas et Capparideas mediae, habitu et eharaeteribus facillime ab iisdem distinguendae, maximo numero in hemisphaerae borealis regionibus temperatis generantur, nec in frigidis rarae, in hemisphaerae australis regionibus extratropicis multo rariores, intra zonam torridam admodum ra- rae, maximam partem in summos montes secedentes. Nonuullae late per terrarum orbem, quaedam mortalium commercio disseminatae.

Qualitates in omnibus antisepticae, acres, plures ob herbam et radices esculentas, aliae ob semina oleosa v. radicem tinctoriam passim cultae.

Generum minis fortassis multiplicatorưm discriminatio in ordine vasto et summe naturali dificillima, dispositio mere artificialis, nec tamen in hoc libro retractanda.

SUEB DRTD T. PLEURORHIZEAE DC. Syst. I. 161. Cotyle dones planae, radiculae adscendenti rimali accumbentes $(\mathrm{O}=$ ).

'TIBIBUS I. ARABIDEAE DC. Syst. I. 161. Siliqua elongata, rarius abbreviata, teres v. compressa, bilocularis, bivalvis, rarissime indehiscens, valvis planis v. subeonvexis aut carinatis. Semina plurima, uni-biseriata. Cotyle don es septo paralellae, marginibus placentas spectantes, radiculae adscendenti, placentam oppositam spectanti, accumbentes. - Herbae cosmopolitae, interdum suffrutescentes.

4845. Mratthiolla $R$. BR. Calyx tetraphyllus, foliotis erectis, duobus lateralibus basi saceatis. Corolla e petala 4, hypogyna, unguiculata, limbo patente, obovato v. oblongo. St a m in a 6, hypogyna, tetradynama, edentula, longiora basi dilatata. Stig ma inerassato-bilobum. Sili qu a bivalvis, teres v, compressa, elongata, valvis planis, placentis dorso obtusis, stigmatis lobis conniventibus dorso ineressatis $\mathbf{v}$. cornigeris, septo enervi. S e.min a plurima, compressa, uniseriata, pendula, saepius marginata, funiculis filiformibns, liberis. Embryonis exalhuminosi cotyledones planee, radiculae adscendenti accumbentes. Herbae mediterranea e, interdum suffrutescentes, erectae $v$. diffusae, ramosae, tomento stellato molli albidae, interdum glandulis pedicellatis scabrae; foliis alternis, oblongis, integris $v$. dentatosinuatis, racemis terminalibus, pedicellis ebracteatis, floribus albis, sordide purpurascentibus v. purpureis, saepe odoratis.

Matthola R. Brown in Aiton Hort, Kes, edit. 2. IV. p. 119. DC. Syst. IT. 162. Prodr. I. 132. Meisner Gen. 10. (10.) Lencoium Mönch Method. 257. Cheiranthi s p. Linn. et Auct.

a. PACHYNOTUM DC, $l, c, \mathrm{~S} t \mathrm{igmat}$ a dorso. incrassata, baud cornigera. Petala obovata, obtasa v. emarginata, plana, pure purpureav. alba. - Cheiranthi s p. Lina. f. Decad. 3t, t. 16. Sehkuhr $t$. 184. Jacq. Hort. Vindol, t. 179. E. B. t. 462. Slbthorp Flor. graec. t. 640 .

b. LUPERIA DC. l. c. Stig mat a dorso erassa v. gibba. haud cornigera. Petala oblonga, undulata v. obliqua, sordide e flavo purparascentia. - Cheiranthi sp. Linn. Sibthorp Flor. graec. t. 636. Bot, Mag. t. 729. Hesperidis s p. Pallas Ic, t. 6 . (Bot. Mag. $t$, 1711.)

c. PINARIA DC, $l, c, \mathrm{St} \mathrm{ig}$ at a dorso in cornua valvis alterna producta, siliqua hine tricuspidata, cuspide lntermedio e stigmatlbus conniventibus orto. P et a la oblooga, undulata v. obliqua, sordide e flavo purpurascentia. - Cheir a th i s p. Sibthorp Flor. graec, $t .637$. Veat, Celt, 2, 93, (Delessert IC. select, II, t, 11, 12.) 
d. ACHNOTUM DC. l. c. Sitg $\mathrm{m}$ at a dorso in cornua val. vis alterna producta, siliqua hine tricuspidata, cuspide intermedio e stiguatibus conniventibus orto. Petala obovata, obtusa v. emarginata, purpurea v. alba. Semin a immarginata. - Triceras Andrzeiowsky msc. Cheiranthi 5 p. Sibthorp Flor graec, $t, 638.639$. (Webb et Berthel. Flor, canar. $t$, 7.)

4846. Notoceras $R$. BR. Calyx tetraphyllus, foliolis erectinsculis, basi aequalibus. C orolla e petala 4, hypogyna, oblonga. Stam in a 6, hypogyna," tetradynama, edentula. Stigma capitatum. Siliq u bivalvis, tetragono-anceps, valvis carinatis, nervosis, apice in mncronem corniformem productis, stylo filiformi brevissimo, placentis dorso obtusis, septo enervi. Semina in loculis subquaterna, pendala, ovalia, compressa, immarginata, funiculis filiformibus, liberis. Embryonis exalbuminosi cotyledones planae, radicula e adscendenti incumbentes. Herbae annuae, sibiricae, erectae $v$. procumbentes, ramosae, pilis bipartitis v., ramosis subcanescentes; foliis oblongis, integerrimis v. sinuatis, racemis oppositifoliis, floribus luteis.

Notoceras R. Browa in Aiton Hort. Hew. edit. 2. IV. 117. DC. Syst. II. 202. Prodr. T. 140. exel. sect. 2 et 3. Meisner Gen, 10. (10.) Di c e rati u m bi corn e Aiton. (Jacq. f. Eclog. $t, 3$, Delessert Ie, select, $t, 17$.)

$484 \%$. A mollmejowsth da REICHENB. Calyx tetraphyllus, foliolis erectiusculis, duobus lateralibus basi subsaceatis. Corollae petala 4 , hypogyna, oblonga, obtusa. Stam in a 6, hypogyna, tetradynama, edentula. S ti g ma obtusum. Sili qu indehiscens, subtetragona, valvis acute carinatis, apice in cornua subconica, compressa, stylum aequantia desinentibus, placentis dorso obtusis, septo enervi. Semina in loculis subquaterna, ovato - oblonga, immarginata, funiculis filiformibus, liberis. Em b r y onis exalbuminosi cotyledones ellipticae, planae, septo contrariae, radicnlae adscendenti accumbentes. - Herba p ont ica, annua, glabra, Cardamines habitu; caule subsimplici, foliis alternis, pinnatisectis, petiolo basi auriculato-dilatato, racemis oppositifolio-terminalibus, floribus albis.

A adrzejowskia Relchenbach Iconogr. $I$. 15, t, 13. Meisuer Gen, 10. (10.) Notocerntis sect. 3. Macroceratfum De, Syst. II. 204. Lepidiam eorautum Sibthiorp Flor. graec, $t, 617$.

4845. Claelirantlius $R$. BR. C a l'y $y$ tetraphyllns, foliolis conniventibus, dnobus lateralibrs basi saccatis. Coroll a e petala 4 , bypogyna, nnguiculata, limbo patente, obovato v, emarginato. St amina 6, hypogyna, tetradynama, edentula. Stigma profunde bilobum, lobis recurvis, Siliqu a bivalvis, tetragona v. aneeps, valvis uninerviis, placentis dorso ohtusis, septo enervi. Se m ina plurima, uniserialia, pendula, ovata, compressa, immarginata $v$. marginata, funienlis filiformibus, liberis. Em br y on is exalbnminosi cotyledones planae, radiculae adscendeati accumbentes. - Herbae biennes $v$. perennes, interdum suffrutescentes, in regione mediterranea, Europa media, Canaris, et Amcricabo. real $i$ spontaneae, pube bipartita, adpressa, rarius nulla; folíis oblongis lanceolatisve, integerrimis $v$. dentatis, racemis elongatis, pedicellis filiformibus, ebracteatis, floribus saepe suaveolentibus, colore vario.

CheIranthus R. Brown in Ailon Hort. Kow. edit. IV. 118. De. Syst. II. 178, Prodr. I. 135. exel. sp. Meisner Gen, 10. (10.) Torrey et A. Gray Flora of North America $I$. 21. S chel hammeria Heist. Helmst. 36. Cheirl Adanson Fam. II, 409. Ch eir a nt hi sp. Linn. a. CHEIRI DC, l.c. SIII qu a anceps, S ty I a s subnullus. S e m i n a immarginata. (Schkuhr $t$. 184.)

b. CHEIROIDES DC, $\boldsymbol{l}$, c. Siliqua tetragana. S t y 1 us filiformis. Semin a marginata. - Psliostylis Andrzeiowsky msc. D i c hro a $\mathrm{n} t \mathrm{~h}$ u $\mathrm{s}$ Webb et Berthel. Flor. Canar. 65, t. 5. 6. (Vent. Malm, t. 83. Bot. Mag, $t .195$. 219.)

e. ? JODANTHUS Torrey et A Gray $l, c$, SHiqua fere teres, subtorulosa, valvis apice abruptis $\nabla$. truncatis. Stylus erassus, stigmate eapitato. S emina margi. nata. - Calycis foliola unguibus petalorum violaceo. purpureorum breviora. - Hes peris pinatifida Michaux.

4849. Dudneya R. BR. C aly x tetraphyllus, foliolis conniventibus, duobus lateralibus basi saccatis. C o r o lla e petata 4 , hypogyna, unguiculata, limbo patente, obovato. St a m in a 6, hypogyna, tetradynama, edentula. Stigmata connata, apicibus distinctis. Siliqua bivalvis, linearis, rostrata, valvis planis, uninerviis, placentis dorso obtusis, septo enervi. Semin a plurima, uniseriata, pendula, compressa, immarginata, funiculis septo adnatis. Em b ry o n is exalbuminosi cotyledones planae, radieulae adscendenti accumbentes. - Suffrutex boreali-africanus, glaberrimus, ramosus; foliis sessilibus, integerrimis, aveniis, inferioribus obovatis, superioribus sublinearibus, racemis terminalibus, ebracteatis, floribus mediocribus, petalis venosis.

o ud ney s R. Brown in Denh, et Clapperton Narrat. 220. Meisner Gen. 10. (10.) Hesperis nitens Viviani Flor. libje. 38. t. 5. f. 3 .

4850. Nasterretivama $R$. BR. Calyxtetraphyllus, foliolis patulis, basi aequalibus, Corolla petala 4 , hypogyna, indivisa. Stami na 6 , hypogyna, tetradynama, edentula. Stigma capitatum, subbilobum. Siliqua bivalvis, saepe abbreviata, siliculaeformis, teretiuscula $\mathbf{v}$. subcompressa, valvis subenervit, concavis, eca rinatis, septo tenui, subenervi, placentis dorso obtusis, inclusis. S emin a plurima, pendula, irregulariter subquadriseriata, immarginata , punctulata, funiculis capillaribus, liberis. E mbryon is exalbuminosi cotyledones crassiusculae, radiculae adscendenti accumbentes. - Herbae ut plurimum aquaticae, annuae, biennes v. perennes, cosmop ol itae, glabrae v, setulis simplicibus, raris, adpressis conspersae, ramosae, saepe radicantes; foliis alternis, variis, saepissime pinnatisectis, petiolo plus minus auriculato-dilatato, floribus racemosis, ebracteatis, flavis v. albis.

$\mathrm{N}$ asturtinm R. Brown in Aiton Hort. Hew. edit. 2. IV. 109. DC, Syst, IT. 187, Prodr. I. 137, C. A. Meyer in Ledebour Flor. Alt. IIT. 5. Meisuer Gen. 10. (10.) S is y mof u m Boerhave Lugd. Bai, 430. S is y m b ril s p. Linn.

a. CARDAMINUM DC. 7 . c, Silf qu a abbreviata, teretiuscala, subdecliaata. Petala alba. Glandula e hypo. gynae 4.

Sis y mbrium Maznol Nov, Carat, 251. C a rdam in u mönch Method, 262, B a e u mert a Flor. Wetteraw. II. 419. Sisymbrium Nastartium Lina. E. B. $t, 855$. Schkuhr $t, 187$.

b. BRACHXLOBOS DC. t. c. Siliqua abbreviata, teretiuscula, plerunique oblouga, declinata. P e ta la dlara. GIand u I a e hypogyuae 6 .

Radicu la Dillen. Nov. gen. 121, $t$. 6. Haller Helv. 1. 211. Mbach Method. 268. excl. sp. Roripa Seopoli Carn. ed, I. p. 520. Adanson Fam, II. 417. B rachyotobos Allioni Pedemont. I. 278. t. 18. Desvaux Journ. Bot. IIT. 170, exel. sp. C a roli.Gmelina Flor. Wetteraw. Ir. 419. exel. sp. Sis ymbrii sp. Lina. E. B, t, 1747, 2324. Flor. dall. $t, 931$. Jaeq. To. rar, $t$. 122, sos. Desfont. Flor. Allant, t, 15t, 155 , excl. 
Sisymbrio amphibio L. (Delessert Ic. oelect, II, t, 14. 15. Ledebour Ic, $t$, 291. Wight Illustr. t. 13.)

c. CLANDESTINARIA DC. $\boldsymbol{l}$. c. Siliqua elongata, cylindrica, erecta. Petala brevissima v, nulla, GI a ndu la e hypogynae nullae.

4851. Farbarea $R . B R$. Calyx tetraphyllns, foliolis erectis, basi subaequalibus. Coroll a e petala 4, hypogyna, unguiculata, indivisa. St a m in a 6, hypogyna, tetradynama, edentula. Stigma capitatum. Siliqua bivalvis, elongata, compresso-tetragona, valvis carinatis, septo enervi, placentis dorso obtusis, vix prominulis. Semina plurima, pendula, uniserialia, immarginata, punctata et lepidota, funiculis filiformibus, liberis. Embryonis exalbuminosi cotyledones crassiusculae, radiculae adscendenti accumbentes. Herbae in Europa et Asia temperata indigenae, biennes $v$, perennes, glaberrimae $v$. setu lis raris, simplicibus conspersae; radice fibrosa, caulibus erectis, ramosis, foliis sparsis, lyrato-pinnati fidis $v$, rarius indivisis, petiolo auriculato-amplexicaulibus, racemis terminalibus aphyllis $v$. fortuito interdum foliosis, floribus luteis v, aureis.

B a rbarea R. Brown in Aiton Hort. Hew. edit. 2. ID. 109. DC. Syst. IT. 205. Prodr. 1. 140. Delessert Ic, select. II. t. 19. C. A. Meyer in Ledebour Elor. alt, 1IT, 9. Meisner Gen, 10. (10.) E r y $8 \mathrm{imi}$ et $\mathrm{S}$ i s ymbrii s p. Lian. Flor. dan. $t, 985$, B. B. $t, 1129$

4852. Streptanthus NUTT. Calyx tetraphyllus, foliolis coloratis, erectis, basi aequalibus. C o r o 11 a e petala 4 , hypogyna, ungue canalieulato saepe torto, lamina lata v. angusta. St a mina 4, hypogyna, tetradynama, subulata, edéntula, majora saepius inter se connata. StyIn 8 brevis v. nullus. Siliqua bivalvis, elongata, compressa v. subtetragona, valvis planinsculis, nninervils, septo enervi, placentis dorso obtusis, vix prominulis, S e min a plurima, pendula, compressa, marginata, funiculis filiformibus, liberis. Embryonis exalbuminosi cotyledones planae, radiculae adscendenti accumbentes. - Herbae in America boreali-occidentali indigenae, biennes $v$. rarius perennes; foliis integris, sinuatodentatis $v$, rarius pinnatifidis, basi sagittato $v$, auriculato-amplexicaulibus, racemis tèrminalibus, aphyllis, floribus purpureis, rarius flavis $v$, albis.

Streptanthus Nuttall in Journ. Academ. Philadelph. $V$. 134. Torrey et A. Gray Flora of North Americ. I. 75.

a. EUSTREPTANTHUS. C a l y $x$ patentiusculus. Petal a limbo lato. - (Nuttall Op. cit. $t$. ?. Hooker in Bot. Mag. $t .3317, \overline{3}$

b. EUCLISIA Nutt. Caly $x$ elausus. P etala limbo angusto. (Bot. Mag. t. 3516. Hooker Ic. $t$. 40. 44.)

4853. Terroitis DILLEN. C a ly x tetraphyllus, foliolis patulis, basi aequalibus. Co rol1 a e petala 4, hypogyna, subúnguiculata, indivisa. S t a m in a 6, hypogyna, tetradynama, edentula. Stigma capitatum. Siliqua bivalvis, elongata, compresso-tetragona, valvis carinatis, septo subchartaceo, enervi, placentis dorso obtusis. S emina plurima, pendula, biserialia, immarginata, laevia, funiculis filiformibus, liberis. Embryo$\mathrm{n}$ is exalbuminosi cotyledones crassiuscnlae, radiculae adscendenti accumbentes. - Herba biennis, in Europa et Asia media indigena, junior pilis furcatis consita, adulta glabra v. pube multi. fida subfloccosa; foliis alternis, amplexicaulibus, integris, racemis terminalibus, elongatis, aphyllis, floribus parvis, albis.
Turrit is Dillen. Nov, gen, 120, $t$, 6. Gärtner $I I, 297$. t. 143. Mönch Method, 256. DC. Syst, II, 211. Prodr. I, 141, excl. sp. C. A, Meyer in Ledebour Flor, alt. III. 13. Meisner Gen. 10. (10.) T u rritis g 1 a b r a Linn. E. B. $t, 777$. Flor, dan, t, 609. Schkuhr 2.185.

4854. Arrabis LINN. Ca ly x tetraphyllus, foliolis ereetis, basi aequalibus v. duobus lateralibus saccatis. Co ro 11 a e petala 4 , hypogyna, unguiculata v. subsessilia, indivisa. Sta $\mathrm{m}$ in a 6 , hypogyna, tetradynama, edentala. Stigma indivisum. Sili qu a bivalvis, elongata, linearis, compressa, valvis planiusculis, nervo prominulo carinatis, rarissime subenerviis, septo enervi v, subenervi, placentis dorso obtusis. S e mina plurima, uniserialia, pendula, compressa, marginata v. immarginata, funieulis filiformibus, liberis v. rarius septo adnatis. E m bry on is exalbuminosi cotyledones planae, radiculae adscendenti incumbentes.

Herbae annuae $v$. perennes, rarissime fruticuli, in temperatis hemisphaerae borealis obviae, trans a equatorem rarae, plerumque setulis rigidis furcatis $v$. simplicibus obsitae, nunc pube molli simplici $v$, ramosa vestitae, rarius glabrae, plus minus ramosae; foliis sparsis, integris $v$. rarius lyratis, radicalibus saepissime petiolatis, caulinis plerumque sessilibus, saepius auriculis dilatatis amplexicaulibus, ${ }^{*}$ racemis terminalibus, aphyllis, floribus albis $v$, roseis.

A rab is Linn. Gen, n. 818. R. Brown in Aiton Hort. Ifew. edit. 2, IP. p. 104. DC. Syat, II. 213. Prodr. I. 142. C. A. Meyer in Ledebour Flor.alt. IIT. 15. Meisner Gen. 10. (10.) Arabis, $A$ bazlearpus et $N$ asturtiks p. Andrzelowsky.

a. PSEUd0ARABIS C. A. Mey. l. c. Glandula hypogyase placentariae et valvariae utrinque geminae. $\mathrm{C}$ a$1 \mathrm{y} x$ basi subaequalis. Pet a la lamina dilatata, patentia. Sillqu a stylo brevissimo apiculata, valvis nerrosis. S e min a immarginata, funiculis liberis. - Herbae perennes, stolonibus repentibus caspitosac, setis bipartitis scabriusculae v. subglabrae; foltis subintegerrimis, petiolatis, supremis sessilibus. - (Waldst. et Kitaibel Plani, rar, Hung. t. 144.)

b. TURritella C. A. Mey. l. c. G 1 and u la e hypogynae placentariae utriaque solitariae, valvariae utriaque geminae. C a l y $x$ basi aequalis. Petal a lamina angusta, saepissime erecta. Siliqua stylo brevissimo apiculata, valvis nervosis. S emina saepissime immarginata, rarlus marginata, funiculis liberis. - Horbae annuae, biennes $v$. perennes, pilis furcatis plerumque hispidae, interdum glabras; caulibus ut plurimum simpli. cibus, folits radicalibus rosulatis, petiolatis, dentatis v. rarius integerrimis, caulinis sessilibus $v$, amplexicaulibus. - T u r ritidis s p. Linn. Jaeq. Ic. rar. t. 126. Waldst, et Kitaibel Plant, răr. Hung. t, 59. (Scbkuhr t, 185. E. B. t, 901. Flor. dan. $t$, 1106. Schknhr 8. c.)

c. EUARABIS C. A. Mey. 2. c. Gland ula e hypogynae placentariae et valvariae ntrinque solitariac, deflexae. Caty $x$ basi bisaceatus. Siliquae stylo brevissimo apiculatae, valvis nervosis. S emin a marginata, funiculis liberis. - Herbae perennes, ramis diffusis radicantibus caespitosae, pube molli, saepe multifiala vestiae; folits dentatis, surculorum sterilium petiolatis, caulium floriferorum amplexicaulibus. - (Flọ. dan. t. 69. Bot. Mag. t, 226. 3021. 3246, 3331. Delessert Ie. select. 11 . $t .23-25$.

d. DENDRoARABIS C. A. Mey. t. c. Glandula hypogynae placentariae et valvariae utrinque solitariae, val. variae aunulares. Cal y $x$ basi bigibbus. Pe tal a lamina dilatata, patula. Siliqua e stigmate sessili apicalatae, valvis nervosis. Se mi na immarginata, funiculis liberis. - Fruticuli erecti, ramosi, pube stellata, minuta vestiti; folits integerrimis, inferioribut petiolatis, caulinis sessilibus. - (Ledebour Ic, $t, 336$.

c. CAmpylocarpus c. A. Mey. t. c. Glandulae hypogynae placentariae et valvariae utrinque solitariae, valvariae semicirculares. C a I y $\mathrm{x}$ basi subaequalis. $\mathrm{P}$ e- 
I la erecta, oblonga. Siliqua pendula, placentis in. crassatis, stylo brevissimo, crasso apiculata, valvis enerviis. S e mi na emargiuata, funiculis septo aduatis. - Herbae biennes, subsimplices, pube ramosa. molli canescentes folitis dentatis, radicalibus petiolatis, caulinit amplexicaulibus. (Jacq. Flor. anotr. 4. 11.)

f. CARDAMiNopsis c. A. Mey. $t$. c. GIa n d u la e hypogyaae placentariae et valvariae utrinque solitariae, valvariae renifortues. Caly $x$ basi subaequalis. Petala lauina dilatata, pateutia. Siliqu a stylo brevi apicula. ta, valvis nervosis, incerdum suheoervis. Semina immarginata, funiculis liberis. - Herbae annuac, bionnes $v$. perennes, erectue $v$. difusae, pilis furcatis saepiut hispidae, interdum glabrae, folits ut plurimum petiolati, saepissime lyratis. (Flor. đan. 2.386 .1382$. 1462. R. B. t. 409.)

g. LEPtostruis C. A. Mey, l. c. Gla udula hypogynae placenfariae nullae, valvariae utriuque geminae. Cal y $x$ basi subaequalis. Petal a lamina dilatata, pa. tula. Sili q a a stylo distiucto, filiforas apiculata, val. vis subeuerviis. Sem in a vix mareinata, funieulis libe. ris. - Herbae perennes, basi suffruticulosal, erectae, pube molli, stellari incanas, foliis sassilibus, inte. gerrimis, radicalibus rosulatis. _ Stevenia cheir a $\mathbf{t}$ ho ides DC. Delessert Ic. select. MI. $\mathbf{t}, \mathbf{2 1 .}$

h. Catalobes C. A. Mey. , c. G G a d ula e hypogynae placentarlae vullae, valvariae utrinque genisae. Ca Jy $x$ basi aequalis. Petala oblonga, erecta. Siliquae pendulae, stigmate subsessili apiculatae, valvis nervosis. S em i na alato marginata, funiculis ima basi septo adnatis. - Herbse biennes, erectae, ramosae, saepe setis simplicibus et pube furcata $v$. stellata hispidae, rarius glabrae. folih dentatis, inferioribus petiolatis, superioribus auriculato-amplexicaulibuz $v$, basi aequalibus, sessilibus. (Delessert Ie, select, II. t. 27. 28.)

4855 . Steverain $F / S C H$, et $A D A M$. C a1y $x$ tetraphyllus, foliolis subpatentibus, duobus lateralibus basi saccatis. Co rolla e petala 4 , hypogyna, brevissime unguiculata, indivisa. Stam in a 6, hypogyna, tetradynama. Stigma simplex, Siliqua bivalvis, oblonga, compressa, inter semina sinuato-angustata, valvis planis, velatinis; ad semina subtorosis, placentis dorso obtusis, septo enervi. Sem in a $2-4$, ovatopressa, immarginata, funiculis filiformibus, liberis. Embry on is exalbuminosi cotyledones planae, radiculae adscendenti accumbentes. - Herba 8 ib ir ic a, annua, pilis stellatis cinereo-velutina; caule e basi adscendente ramosissimo, foliis oblongo-linearibus, basi subangustatis, obtusiusculis, integerrimis, racemis corymbosis, demum elongatis, floribus albis.

Stevenia Adams et Fischer in Mem, soc, nat. Mosc. D. 84, DC. Syst, II, 209. Prodr. I, 14t, excl. sp. Meisuer Gen, 10. (10)

4856. Horraza $R$. BR. C a ly x tetraphylIns, foliolis suberectis, basi subaequalibus. Corolla e petala 4, hypogyna, unguieulata, indivisa. Stamina 6, hypogyna, tetradynama, edentula, Stigma bifidam, lobis conniventibus. Siliqua bivalvis, elengata, sublanceolata, compressa, valvis planis, nervoso-venosis, placentis filiformiluus, inclusis, septo hyalino, subbinervi. Semina plurima, biserialia, pendula, marginata v. immarginata, testa laxa, saepe corrugata, funiculis subu. Jatis, liberis v. septo adnatis. Em bryonis exalhnminosi cotyledones planae, radiculae adscendenti accumbentes. - Herbae in $A$ merica $\operatorname{cl} A$ s $i$ a aretica, néc non in alpibus altaicis indige nae, humiles, perennes, acaules v. subacanles, glab. rae, glandulosae v. pilis simplicibus aut bifurcis raris conspersae; radice crassa, descendente, sublig. nosa, multicipiti, foliis omnibus radicalibus, v. paucissimis juxla caulem interdum sparsis, crassis, saepe dentalis, petiolatis, basi dilatala, scariosa persis. tentibus, scapis radicalibus aphyllis, racemo terminatis, $v$. pedunculis radicalibus, unifloris, floribus majuseulis, purpureis.

Parrya R. Brown in Parry's Voy. App. 268. Hooker Flor Bor. Amer, I. 46. C. A. Meyer in Ledebour Flor. All. III. 27. Meisner Gen. 10. (11.) Neurolo al a Andrzeiowsky in DC, Prodr. 1, 180.

a. NBUROLOMA Andr. I. c. S e mi a a late marginata, testa eorrugata. funiculis basi septo adaatis. - Scapi race. mo terminati, - (R. Brown Op. cit. $t, \bar{B}$. Hooker $O_{p}$. cit. $t, 15:)$

b. LEIOSPORA C. A. Mey. l. c. Semina fmmargianta, laevia, fuuiculis liberis. - Pedunouli radicales uni. flori. - (Ledebour Ic. $1,86$.$) - An hue Er ara n n ia Cha-$ misso in Linnaea YT. 533 . geass obiter isdicatum?

$485 \%$. IP traphyllus, foliolis coloratis, basi subaequalibns. Corolla e petala 4 , hypogyna, unguieulata, integra. Stamina 6, hypogyna, tetradynama, edentula. Stig ma subsessile, subcapitatum. S iliqua bivalvis, ensiformis, acuminata, valvis uninerviis, basi obtusis, apice cuspidatis, septo opaco distincte nni-binervi. S e m in a in loculis subterna, magna, immarginata, testa laevi, funiculis brevibus, latis, basi septo subadnatis. E mbryonis exalbuminosi cotyledones planae, radiculae adscendenti oblique accumbentes." - Herba boreali-american $a$; caudice subterraneo, foliis radicalibus, oblongo-lanceolatis, integris, dense stellato-tomentosis, in petiolum basi dilatata vaginantem angustatis, caulinis paucis, minutis, subamplexicálibus, racemis corymbosis, floribus purpureis, pedicellis fruetiferis horizontaliter patentibus.

Phoeniexulis Nuttall in Torrey et A. Gray Ftora of North America I, 89. Hesper is Menzies il Hooker ad Beecheg. t. 75.

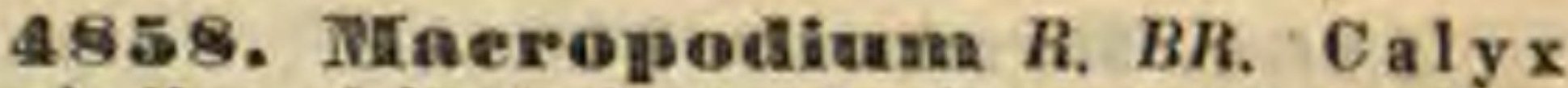
tetraphyllus, foliotis laxis, basi aequalibus. Corolla e petala 4 , hypogyna, linearia v. linearispathulata. St am in a 6, hypogyna, tetradynama. Stigma punctiforme. Sili qua supra torum pedicellata, bivalvis, sublinearis, compressa, valvis planis, nervosis, placentis dorso obtusis, dissepimento hyalino, binervi. Semina plurima, pendula, uniseriata, submarginata, plana, laevia, funiculis subulatis, liheris, Embryonis exalbaminosi cotyledones planae, radicalae adscendenti accumbentes. - Herba perennis, in alpibus altaicis indigena; folitis alternis, petiolatis, superioribus sessilibus, serrulatis, racemo terminali aphyllo, pedicellis brevissimis, sub calyce incrassatis, floribus albis.

$M$ a e $\mathrm{r}$ o podi a $\mathrm{m}$ R. Browa in Aiton Hort, Hew. edit, 2. IV. 108, DC. Syst, II, 244, Prodr. I. 149. C. A. Meyer in Ledebour Flor. Alt, III. 30. Hooker Bot. Miscell. I. 340. t. 67. (excl, t, 68.) Melsaer Gen, 10. (11.) Cardam in e niva is Pallas $I t, t$. $U$.

4555. Creallamaine LINN. Cal y x tetraphyllus, foliolis erectis v. subpatentibns, basi aequalibas. Corollae petala 4, hypogyna, lamina dilatata patente, v. angusta erecta, interdum unlla. St a mina 6, hypogyna, tetradynama, edentula, Stig ma capitatum. Siliqua bivalvis, saepe elongata, linearis, compressa, valvis planis, enerviis, saepe elastice desilientibus, placentis dorso obtusis, prominulis, septo tenui, enervi v, subnninervi. S em in a plurima, pendula, nniserialia, immarginata, laevia, funiculis filiformibus, liberis. - Herbae gosmopolitae, in orbe ve teri et in universwin, hemisphaeraboreali frequentius obviae, annuae, biennes v. perennes, sacpe basi sarmenlosae, glabrae v. rarius setulis sim109 
plicibus v. pube furcata vestitae; radice fibrosa $v$. granulata, foliis alternis, petiolatis, supremis interdum sessilibus, indivisis, lobatis $v$. pinnatisectis, petiolis basi plerumque vix dilatatis, rarissime auriculatis, racemis terminalibus aphyllis, rarissime pedunculis radicalibus unifloris.

C a r a mine Tournefort inst. 109. Linn. gen. n. 812. excI. sp. DC. Syst. II. 245. Prodr, I, 149. C. A. Meyer in Ledebour Flor. Alt. III. 32. Meisner Gen, 10. (10.) Scbkuhr t. 187. Jacq. Flor. austr, $t, 37$. Flor. dan. $t, 20$. 148. 735. E. B, t. 80, 492. 776, 1000. Waidst. et Kitalihel Plant, rar. Hung. $t$. 140. Bot. Mag. t. 1235. Delessert Ic. select. II. t. 29-32. Fxot. Flor 5i. Flor. Bor. Amer. I. 44. Bot. Miscell. $t, 69.111,112$. Ic. $t$. 38. St, Hilaire Flor Brasil. $t$. 106. Ledebour Ic. $t$, 268.

4860. TPteromennon $D C$. Calyx tetra phyllus, foliolis patentibus $v$, suberectis, basi aequalibns. Corollae petala 4, hypogyna, nnguiculata, indivisa, Stamina 6 , hypogyna, tetradynama, edentula. Stigma capitatum. Siliqua bivalsis, lanceolata, valvis planis, enerviis, septo angustiorihns, a basi elastice dissilientibus $\mathbf{v}$, revolutis, placentis dorso alatis, nervo acuto secus stylum ancipitem producto, septo subenervi. S e mina plura, unserialia, pendula, immarginata, funicnlis dilatatis, liberis. Embryonis exalbuminosi cotyledones crassinsculae, planae, radicuiae adscendenti accumbentes. - Herbae mediterraneae, habitu Cardamines; radicibus fibrosis, foliis pinnatisectis, segmentis petiolutatis, racemis terminalibus, pedicellis filiformibus, ebracteatis, floribus albis.

Pteroneuron DC. Syst. IT. 269. Prodr. I. 154. Meisner Gen.10. (10.) Cardamine graeca Linn. Gärtn. t. 143. Sibthorp Flor. graec, t. 631. C. c a r i o s a Waldst. et Kitaibel Plant. rar. Hung. t, 129.

4861. Dentaria TOURNEF. Calyx tetraphyllus, clansus, folielis basi aequalibus. Coroll a e petala 4 , hypogyna, unguiculata, indivisa. S ta m in a 6, hypogyna, tetradynama, edentula. Stigma capitatum. Siliqua bivalvis, elongata, Ianceolata, compressa, valvis planis, enerviis, saepe elastice dissilientibus, placentis dorso obtusis, septo subenervi. S e mi in a plura, uniserialia, pendula, immarginata, funiculis alato-dilatatis, liberis. Embry on is exalbuminosi cotyledones petiolatae, marginibus involutae, radiculae adscendenti accumbentes. - Herbae in te mperatis hemisphaerae borealis obviae, perennes, glabrae $v$, pubescentes; rhizomate horizontali, carnoso, irregulariter dentato, parce fibrilloso, caulibus simplicissimis, erectis, foliis radicalibus saepius nullis, caulinis alternis $v$, verticillatis, palmati- $v$. pinnatisectis, petiolatis, petiolo basi haud auriculato, racemo terminali aphyllo, floribus albis, ochroleucis $v$, purpurascentibus.

Dentaria Tournefort Inst. 111. Línn. gen. n. 81t. Lam. t, 562. Jacq. Flor. Austr, t. 316. Schkuhr t, 183. Flor. dan. $t .361$. E. B. $t, 309$, Bot. Mag, t, 1465. Waldst et Kitaibel Plant, rar, IIung, t, 139, 160. 272. DC. Syst, II. 271. Prodr. I. 154. Barton Flor, Bor. Amer, $t$. 22. Delessert Ic. select. II. $t, 33$. Spener Flor. Eriburg. t, 3. f. 5-7. Meisuer Gen. 10. (10.)

4883. Leavenworthia TORREY. Caly $\times$ tetraphyllus, foliolis suberectis, basi aequalibus. Co roll a e petala 4 , hypogyna, cuneiformia, truncata v. emarginata. S ta mina 6 , hypogyna, tetradynama, edentula. Stylu s distinetns v. subnullus; stigma minute bidentatum. Siliqua oblongo-linearis, cumpressa, subinflata et inter semina contracta, valvis indistincte nervosis, septo uninervi. S e min a uniseriata, margine late akata, funiculis liberis $\mathbf{E} \mathbf{m}$ bryonis exalbuminosi cotyledones orbiculatae, radicula brevissima conica, juxta cotyledonum margines oblique subadseendens. - Herbae bore a li-americanae, annuae, humiles; foliis lyrato-pinnatifidis, scapis laxe racemosis v. pedunculis radicalibus unifloris, floribus luteis.

Leaven worthia Torrey in Annal. Lye. New-York. IIT. 87, t. 5. Torrey et A. Gray Flora of North-America. I. 89, Cardamine uniflora Auct.

TUE IIB US II. ALYSSINEAE DC. Sysl. II. 280. Silicula bivalvis, rarius indehiscens, septo lato, valvis septo parallelis, planis v. concavis. Coty le d o n e s planae, septo parallelae, rarissime contrariae, radiculae accumbentes. Tribus hujus stirpes late per omnem hemisphaeram borealem sunt dispersae, in regione mediterranea, Oriente et florae rossicae territorio copiosae, in Europa media imprimis occidentali rarescunt, $v$. summas petunt alpes et nivis alternae terminos, sed in immensum crescil versus polum arcticum Drabarum imprimis nitidissima calerva, oceani glacialis ef alpium utriusque orbis parvula custos.

4863. Lumaria LINN. Ca l y x tetraphylIns, clansus, foliolis lateralibus basi saceatis. Coro lla e petala 4, hypogyna, unguiculata, limbo obovato. St amina 6, liypogyna, tetradynama, edentula. Silic u la bivalvis, supra torum pedicellata, late elliptica v, oblonga, valvis planis, placentis nerviformibus, marginantibus, septo membranaceo persistente, stylo filiformi coronato. S emi n a plura distantia, alato-marginata, funiculis longis, septo adnatis. Embryonis exalbuminosi cotyledones foliaceae, planae, radicalae acenmbentes. - Herbae in Europa media et australi indigenae, biennes v. perennes, magnae, subpilosae; caulibus teretibus, erectis, ramosis, foliis alternis v. oppositis, petiolatis, cordatis, acuminatis, grosse dentatis, racemo terminali, pedicellis filiformibus, ebracteatis, floribus lilacinis majusculis, septis persistentibus argenteo-nitentibus.

L u n a ri a Linn. gen, n, 809. Medik. Nov. gen. 1, 89. t. 2. $f$. 27. Batsch Analys. $I$. $f$. 20, Gartner $Y I$. 288, $t, 148$. excl. sem. Sehhulur t. 182, Lam. $t$. 561 . R. Brown in Aiton Hort. Kew. edit. 2. IV. 98. DC. Syat, II. 280. Prodr. I. 156. Meisner Gen. 11. (11.)

4884. Rieotia LINN. Caly x tetraphyllus, foliolis lateralibus basi saccatis. Corollae petala 4, hypogyna, nnguiculata, limbo obcordato. S ta m in a 6, hypogyna, tetradynama, edentula. Silicula bivalvis, sessilis, oblonga, valvis planis, placentis nerviformibus, marginantibus, septo mox evanido. S emen ovulorum plurium abortn unicum, immarginatum, compressum, faniculo longo. Embry on is exalbuminosi cotyledones planae, radiculae accumbentes. - Herbae annuae, in Asia mediterranea indigenae, glabrae, debiles, ramosae; foliis alternis, subbipinnatisectis $v$. subbipinnatifidis, petiolatis, racemo terminali elongato, pedicellis jiliformibus ebracteatis, floribus pallide lilacinis.

R le ot ia Linu. gen. $n, 810$. Medikus Nov. gen. $T$. 45. $t$, 2. $f$. 24. Lam. $t$, 56t. Sibtborp Flor. graec, $t$. 630. 1.. Browa in Aiton Hort. Kew. edit, 2, IV. 98, DC. Syst. IT. 284. Prodr. I. 157. Meisuer Gen. 11. (f1.) Scopolia Astanson Fam, $I K$, 419. L u u aria e s p. Gärtn. Miller $I c$. IT. 169. Is a tidis sp. Crantz. 
4865. Farsetia TURRA. Cal y $\mathrm{x}$ tetraphyllus, clausus, foliolis lateralibus basi saccatis Co rolla e petala 4, hyp"gyna, unguiculata, limbo integerrimo $v$, emarginato. S $\mathrm{ta}$ in in a 6 , hypogyna, tetradynama, edentula v. minora intus dentata. Silicula bivalvis, ovalis v. oblonga, valvis planis, septo uninervi venoso, integro v. basi fenestrato. Semina plura, rarius abortn subsolitaria, marginata, funiculis liberis. Em bry on is exalbuminesi cotyledones planae, radiculae accumbentes. - Herbae mediterraneo-arientales, interdum suffruticosae, erectae, ramosae, pube bipartita, adpressa incanae; foliis alternis, oblongis, integerrimis, racemis terminalibus, saepius subspicatis, pedicellis filiformibus, ut plurimum ebracteatis, interdum foliaceo-bracteatis, floribus luteis $v$, sordide ex albo purpurascentibus,

Farsetia Turra Farsetia Denet, 1765. 4. c. ic. Desvaux Journ. Bot. III. 173. DC. Syut, II. 286. Prodr. I. 157. R. Brown in Clappert. Narrat, 216. Meisner Gen 1t, (11.) A ly s s u as Adanoon Fam. IT, 419. Cheiranthi et Alyssi s p. Linn.

a. FARSETIANA DC. l. c. Petal or u m laminae oblongolineares, integerrimae, ex albo purpurascentes. S $t a \mathrm{~m}$ ina omnia edentula. Silicula elliptica, septo basi fenestrato. - Cheiranthas Parsetia Lian. Des. font. Flor. atlant, $t, 160$.

b. CyclocarpaeA DC. 1. c. Petalor a m laminae oblongae, subemarginatae, purpurascestes. S tamina minora intus dente aucta. Silie a I a orbicularis, glabra, septo integro. - Lunaria suffruticosa Venten. Cels, t, 19.

c. FIBIGIA DC. $t$. c. Petal o $\mathrm{r}$ u $\mathrm{m}$ laminae ovatae $\mathrm{y}$, ovaJes, integerrimae, planae. Stam In a minora intus dente aucta. Silicula elliptica, septo integro. - Fibigi a Medikus Gen. 1. 90. t. 2. f. 23. Sibthorp Flor. graec. t. 694. A 1 y s 8 i $\&$ p. Linn. Sehkuhr $t$. 181. (Porten schlag Plant. dalmat. $t$. 10. Delessert Ic. select. II t, 34.)

48EB. DIeniocas DESV. Calyx tetra phyllus, foliolis erectis, basi aequalibus. Coroll a petala 4, hypogyna, unguiculata, limbo integerrimo. Sta min a 6, hypogyna, tetradynama, omnia intus squamula aucta. Silicula bivalvis, ellip. tica, valvis planissimis, septo enervi, avenio, integro. Semina plura, biseriata, immarginata, funiculis setaceis, liberis. Embryonis exalbuminosi cotyledones planae, radicalae accumbentes.

Herba annua, in Hispania et regione taurico-caucasica obvia, erecta, ramosa, pube stellata incana; foliis alternis, linearibus, integerrimis, rucemis terminalibus, pedicellis filiformibus, ebracteatis, floribus minutis, flavis.

M en ioen s Desvaux Journ. Bot, IIT. 173. DC. Syst. II. 325. Prodr. 1. 165, Delessert Io. select, $\boldsymbol{I}$, $t$. 42. C. A. Meyer in Ledebour Flor, alt. III. 44. Meisuer Gen. 11. (11.) A Iyssum Iinifollum Steph.

496\%. Berteroa $D C$. Calyx tetraphyllus, foliolis erectis, basi aequalibus. Corolla e petala 4 , hypogyna, vngniculata, limbo bipartito. St a min a 6, hypogyna, tetradynama, omnia basi intus callo instructa. Silic $\mathbf{n} 1$ a bivalvis, elliptica v. orbiculata, compressa, valvis planis v.. convexinsculis, septo enervi. Sem in a plura, biseriata, marginata, laevia, funiculis subulatis, liberis. Embryonis exalbaminosi cotyledones planae, radiculae accumbentes. - Herbae in Europa m,edia et a ustrali, nec non in Asia $t$ emperata indigenae, biennes, perennes $v$. basi fruticulosae, pube stellata incanae; folits alternis, sessilibus, in tegerrimis, racemis terminalibus, demum elongatis, pedicellis filiformibus, ebracteatis, floribus albis.
Berteroa DC. Syst, II. 290, Prodr. I. 158. Reichenb. Iconogr. t. 231. C. A. Meyer in Ledebour Elor. AIt. III. 46. Meisner Gen. 11. (11.) Al y 8 son Medikus Gen. pl. . 75. t. 1. f. 15. Möneh Method. 267. M ó u eltia Roth Flor. Germ. I. 273. excl. sp. S teven a Audrzeiowst. mac. Far8 etia e sect. 1. R. Brown in Ailon Hort. Kew. edit, 2. ID. 97. A I y 8 \& i s p. Lins. Sthkuhr $t$. 181. Veaten. Celt. $t$. 85 . Sibthorp Flor, graec, $t$. 623. Delessert Ie. select, IT, $t, 37$.

4858. Aubrietia ADANS. C a ly x tetraphyllus, clausus, foliolis lateralibns basi saceatis. Corolla e petala 4 , hypogyna, nnguiculata, limbo integro. Stam in a 6 , hypogyna, tetradynama, minora basi intus dente aucta. Sili e u la bivalvis, oblonga, compressa, stylo acaminata, valvis concavo-planis, septo enervi. Semina plurima, immarginata, funiculis filiformibus, liberis. E m b r y onis exalbuminosi cotyledones planae, radiculae accumbentes. - Herbae mediterraneo-orientales, basi suffrutescentes, tenues, ramosae; foliis ovatis $v$. oblongis, integris $v$. angulato-dentatis, pilis simplicibus v. subramosis puberulis, racemis oppositifoliis et terminalibus, laxis, paucifloris, pedicellis filiformibus, ebracteatis, floribus purpurascentibus $v$ albis.

A u brietia Mdanson Fam. IT. 420. DC. Syst, IT. 293. Prodr. 1. 158. Meisner Gen, 11. (11.) Parsetiae sect. 3. R. Browa in Aiton Hort. Kew. edit. 2, IV. 92 . A 1 y s s u m del t o id e u minn. Sibthorp Flor. graec. t. 628. A ra bis purpurea Sibthorp Op. cit. t. 643.

4869. Vesiearia $L A M$, Cal y $x$ tetraphylIns, clausus, foliolis basi aequalibus. Coro il a e petala 4, hypogyna, unguiculata, limbo integro, obtuso $v$. subemarginato. S t a m in a 6 , hypogyna, tetradynama, edentula. Silieula bivalvis, globosa v. inflata, valvis hemisphaericis v, convexis, membranaceis v. rigidis, septo membranaceo. Sem in a plura, marginata v, immarginata, funiculis basi septo adnatis. Embryon is exalbuminosi cotyledones planae, radiculae aceumbentes. - Herbae mediterraneae et boreali.americanae, basi interdum suffrutescentes; foliis oblongis $v$. linearibus, integris $v$. repandis, racemis terminalibus, pedicellis filiformibus, ebracteatis, floribus flavis.

Vesicaria Lam. Mllustr. 2.559 . R. Brown in Aiton Hort. Hew. edit. 2. IV. 97. Desvaux Journ. Bot. MIT. 171. DC. Syst, II. 295, Prodr. I. 159. Meisuer Gen. 11. (11.) Nuttall in Torrey et Gray Flora of North.America I. 100. A lysanides Medikas Nov, gen, $t, 1, f, 17$. Mönch Me. thod. 264. Alyssoides et Vesicaria Tournefort Inst. 104.

a. VESICARIANA DC. $t$. c, S ie al a globosa, valvis membranaceis. hentisphaericís. - A I y s \& i s p. Lion. Schkabr t. 181. Bot Mag. 120. Waldst. et Kitaibel Plant, rar. Hung t, 196. Sibthorp Flor. graec. t, 697. Flor. dan. t. 1590. (Bot. Mag. t, 2882, 3464.)

b. ALYSSOIDES DC. 2. c. Sili euta ovata, valvis rigidis, concavis. (Delessert Ic. select. II. t. 35.)

c. ? PUYSARIA Nutrall $l$.c. Silicula didyma, valvis nembranaceis, valde Inflatis. (Hooker Flor. Bor. Amer. t. 16.)

48\% 0 . Koniga $A D A N S$. C aly $\mathrm{x}$ tetraphylIns, patens, foliolis basi subaequalibus. Corolla e petala 4 , hypogyna, unguiculata, limbo dilatato, integro. Stam in a 6 , hypogyna, tetradynama, edentula. Silicula bivalvis, subovata, valvis planinsenlis, septo membranaceo uninervi, venoso. Se m in a plura v, abortu solitaria, marginata v. rarius immarginata, funienlis basi septo adratis. Embryonis exalbuminosi cotyledones radiculae accumbentes. - Herbae in regione mediterranea et Asia boreali indigenae, annuae $v$. perennes, pube bipartita, adpressa incanae; foliis sublinearibus, integerrimis, racemis terminalibus, basi interdum foliatis, floribus albis.

$109 *$ 
Koniga R. Brown in Clapperton Narrat. 214. Sieb. thorp Flor graec. 2. 685. L o bu I a ria Desvaux Journ. Bot. III 172. Meisuer Gen, (11 11) Wetib. et Berchel. Flor, Canar. 89, Konig Adansou Fam. $I$. 420. Cl y peol a Necker Elem, n, 1420. O ctade nia R. Brown msc, Alys A i sect. Lo hularia DC. Syst. 11 . 318. Prodr. $X, 164$ Alyssi sp. Linn. Bot. Mag. t. 101. Teuore Flor, neap t. 60. Delessert Ic. select $I I . t \cdot 41 . C_{1}$ y pe ol a e 8 p. Lian

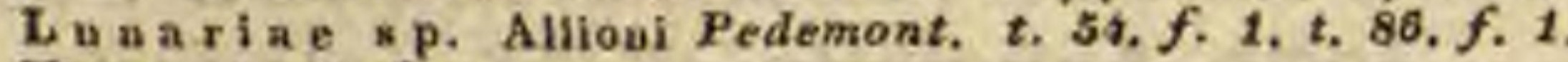
Vivian t. $16 \mathrm{f}$. 1 .

48\%1. Selhivereeluia ANDRZ. Caly $\mathrm{x}$ tetraphyllus, laxiuseulus, foliolis basi aequalibus Corolla e petala 4 , hypogyna, obovato-oblonga. St a mina 6, hypogyna, tetradynama, breviora filiformia, longiora membranaceo - dilatata dente aucta. Silicula bivalvis, ovata, valvis convexis, medio longitudinaliter depressis, solidinsculis, obtusis, septo membranaceo Se mina plura, biseriata, compressa, immarginata, funiculis filiformibns, liberis. $\mathbf{E}$ m b y onis exalbnminosi cotyledones planae, radiculae accumbentes. - Herba a Pod olia usque in Sibiriam diffusa, perennis, pubo stellata velutino canescens; foliis radicalibus rosulatis, ovali-oblongis, dentatis, caulinis paueis, sessilibus, subamplexicaulibus, racemis terminalibus, pedicellis filiformibus, ebracteat is, flo ribus albis, siliculis cano-velutinis.

S ehiwereek a Andrzeiowsky ex DO. Syst. II. 300 Prodr. 1. 160. Delessert $2 c$. select. IT, $t, 36$. Meisner Gon. 11. (11.) Alyssum podalicum Besser.

48\%?. Aumimia DESV. C a ly x tetraphyl Ins, foliolis patentiusculis, hasi aequalibus. $\mathrm{C}$ orolla e petala 4, hypogyna, obovato-oblonga, apice emarginata, St a m in a 6 , hypogyna, tetradynama, omnia basi intus dente ealloso aucta. Silic u la bivalvis, snborbicularis, compressa, valvis planis, septo enervi. Se m i n a in loculis 2-4 rarius abortn solitaria, marginata, funiculis subula tis, liberis. Em bryonis exalbuminosi cotyledonis planae, radienlae accumbentes. - Herbae basi suffruticosae, in Europa orientali et $A s i a$ finitima saxicolae, pube stellata tomentosae; fo liis lanceolatis $v$. oblongis, integerrimis, racemis terminalibus subcorymbosis, floribus luteis.

A u rin i a Desvaux Journ. Bot. IIT. 162. Aly s si sp. Linn. Bot Mag. t. 159. Jacq. 10. rar, t, 503. Waldst, et Kitaibet Plant rar. Hung. $t$. $s 9$.

4583. Feilonema $C, A, M E Y$, C a ly tetraphyllus, foliolis erectis, basi aequalibus. Co rolla e petala 4, hypogyna, lineari-cuneiformia, apice emarginata. Stam ina 6 , hypegyna, tetradynama, eimplicia. Silicula bivalvis, elliptica, compresso-subglohosa, valvis convexis, rigidulis, septo hyalino, enervi. Semina in loculis gemina, opposita, subcompressa, immarginata, funiculis filiformibus, liberis. Embryonis exalbuminosi cotyledones planae, suborbienlatae, radicnlae ac. cumbentes. - Herba Asia e mediae, annua, pube stellata densa canescens; caulibus apice ramosis, fo liis obovatis, integerrimis, racemis subspicatis, fruc tiferis elongatis, ebracteatis, siliculis cano-pubes centibus.

Psilone na C. A. Meyer in Ledebour Flor, att. III. 50. Ledebaur Ic. $t, 209$. A I y es u m d a s y e a r p u m Stepli. A. sibiricum Treviranus in Berlin. Magaz. VIT. $t, 2$. f. 10. 15.

4584. Alysseman $L I N N$. Calyx tetraphyllus, foliolis erectis, basi aequalibes. Cornl la petala 4, hypogyna, subunguienlata, lamina parva, integerrima v, emarginata $\mathrm{Sta}$ m in a 6 hypogyna, tetradynama, nonnulla v, omnia mem branaceo appendieulata. Silic ula bivalvis, subor- biculata, compressa, apice retusa, valvis disco convexis, margine planis, septo tenni, enervi. S e mi$\mathrm{n}$ a in loculis gemina, opposita, pendula, submarginata, laevia, funiculis basi membranaceo-dilatatis, septo adnatis. E m b ry onis exalbuminosi cotyledones planae, radiculae acenmbentes, - Herbae in Europa, regione mediterranea et $A s i a$ media indigenae, annuae, biennes $v$, basi suffruticulosae, pube stellata incano-lepidotae; foliis sparsis, ramarum sterilium interdum rosulatis, sessilibus $v$. petiotalis, integerrimis, racemis terminalibus, aphyllis, simplicibus.

A 1 y $5.5 \mathrm{~m} \mathrm{~m}$ Linn. gen, $n$, 805, exe!, sp. pl, Gärtner $I T$. 282. $t$. 141. Jaeq. Flor austr, t. 338, Sibtharp Flor, graec. t. 626. Bot. Mag. t. 419. Trattinick Thesaur. t. 35. Detessert Ic. select, $t, 38$ - 40 . R. Brown in Clappert. Narrat. 214. C. A. Meyer in Ledebour Flor. alt. III S3. Ledebour Ic. . 255. A d y s eto n Scopoli Carn. IT, 13. Medikus Gon. I. 73 t. 1. $f$. 16. A I y \& s i sect. A d y s e to n exel, sp. plur. DC. Syst. II, 302 .

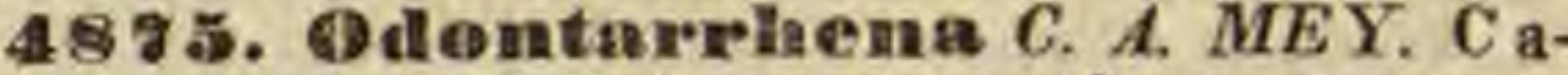
lyx tetraphylins, foliolis eretiusculis, basi aequalibus. Corolla e petala 4 , hypogyna, subunguiculata, limbe obovato v. orbiculato, subintegerrimo. S t a m in a 6 , hypogyna, tetradynama, omnia membranaceo appendiculata. Silicula bivalvis, subelliptica, compressa, valvis planis, septo hyalino, enervi, integro $v$. rarissime fenestrato. Semina in loculis solitaria, pendula, immarginata v. marginata, laevia, funiculis setaceis, liberis. Embryon is exalbuminosi cotyledenes planaé, radiculae accumbentes. - Fruticuli in Europa et As ia media indigeni, saepe ramosissimi, diffusi, pube stellata lepidota incani, $v$. rarius pilis elongatis, fasciculatis hirti; foliis sparsis, subsessilibus, parvis, integerrimis, racemis terminalibus, aphyllis, suepissime corymboso-fasciculatis, floribus parvis, flavis.

Od ontarrhena C. A. Meyer in Ledebour Flor, alt. IIT. 58. Ledebour $2 e, t$. 143, 297. A 1 y 8 s i s p. Auct. Waldst. et Kitaibel Plant, rar. Mung. t. 6. 91. Reichenb. Iconogr. t, 90. et Delessert Ic. select. IT. $t$. 38. (excl. sem.)

48\% F. Ftilotrielnam C. A, MEY. C a ly $x$ tetraphyllus, foliolis erectiusculis, basi aequalibus. Co rolla e petala 4 , hypogyna, unguieulata, limbo suborbiculato, integerrimo. St a m ina 6 , hypegyna, tetradynama, simplicia. Silicu la bivalvis, subelliptica, compressiuscula, valvis subconvexis, septı enervi v. subnninervi. S a. mina in loculis solitaria, pendula, immarginata, laevia, funiculis setaceis, liberis, Embry onis exalbuminosi cotyledones planae, radiculae accumbentes. - Fruticuli $A$ sia e mediae, humiles, apice saepissime corymboso-ramosi, pube plumosoramosa incani; foliis sparsis, sessilibus, sublinearibus, angustis, integerrimis, racemis terminalibus, subcorymbosis, aphyllis, floribus parvis, albis.

$\mathrm{Ptilotrichum} \mathrm{C.} \mathrm{A.} \mathrm{Meyer} \mathrm{in} \mathrm{Ledebour} \mathrm{Flor,} \mathrm{alt.}$ IIT. 64. Ledebonr Ie, $t$. 273. 275. Meisuer Gen, 11.-(11.) AIyssi sp. Bielerst. DC.

48\%ร. Clyneola LINN. Ca lyx tetraphyllus, foliolis erectiusculis, basi aequalibus. Cor o lla e petala 4 , hypogyna, subunguiculata, limbo integro. St a m in a 6 , hypogsna, tetradynama, membranaceo appendiculata. Silien la indehiscens, unilocnlaris, orbienlaris, plana, marginata. S emen unicum, centrale, funiculo laterali, immarginatum. Em hry on is exalbuminosi eotyledunes planae, rarliculae accumbentes. Herbae in Europa australi, et Asia submediterranea indigenae, annuae, pusillae, pube 
stellata brevi canae, erectae $v$. diffusae; foliis oblongo-linearibus, integris, racemis terminalibus, erectis, pedicellis filiformibus, brevibus, ebracteatis, floribus parvis, flavis v. albidis.

C I y peol a Linn. Ben, $n, 806$ excl. sp. pl. Gärtner II, 283. DC. Syst. IT, 326. Prodr. I. 165. Meisner Gen. 11. (11.) Jon t h la s p i Tournef. Intt, 99. Fosselini a Scopoli In. troduct, n, 1458.

a. JONTHLASPI DC., ,, , S il i cula margine cillata, disco glabra v. subpubescens. - Jon th I as pi Touraef. $l$. e. CIy peola Desvaux Journ, Bot. III. 161. $t$. 25, $f, 7$. Cl y pe ol a Jouth Ia s pi Liun. Gärtner t. 14t. Cavanill. Ic, $t, 32$.

b. ORIUM DC. 2, o. Silicula margine dentata, villis mollibus. Tongis lanuginosa. - Oríum Desvaux op. cit. t. $25 . f .10$.

c. BERgERETIA DC. $\boldsymbol{t}$. c. Silleula margine deatata, disco setis rigidis echinata. - Bergeretia Desvaux Op. cit. t. 25. f. 9.

48 \%. Peltaria LINN. Calyx tetraphyl lus, patens, foliolis basi aequalibus. Coroll a e petala 4, hypogyna, unguiculata, limbo obovato, integro. Stamina 6, hypogyna, tetradynama. edentula. Silicula indehiscens, orbiculata $\mathbf{v}$. obovata, compressissima, septo evanido unilocalaris, placentis nerviformibus. Semina $2-4$, abortu interdum solitaria, pendula, immarginata. Embryonis exalbuminosi cotyledones radiculae accombentes. - Herbae in Europa orientali et $A$ sia sub mediterranea indigenae, perennes, erectae, glabrae; foliis integris, radicalibus petiolatis, ovatis, caulinis sessilibus, saepius sagittato-amplexicaulibus, racemis terminalibus, subcorymbosis, pedicellis filiformibus, ebracteatis, floriferis erectis, fructiferis patentibus $v$. subrecurvis, floribus albis.

Pelta ría Linn. Gen, n. 1083. Jacq. Flor, austr, t, 123. Gïrtner 11. 283, t. 141. R. Brown in Aiton Hort. Hew. 8. IV. 77. Desvaux Journ. Bot. IIT, 161, t. 24, f. 8. DC. Syst. II, 328. Prodr. I, 166. Melsner Gen, 11. (11.) B o h nt s $\mathrm{e} \mathrm{h} \mathrm{i} \mathrm{a}$ Crantz Austr. J. t. 1. f. 1. Medikus Gen. I. 22. t. 1. f. 3.

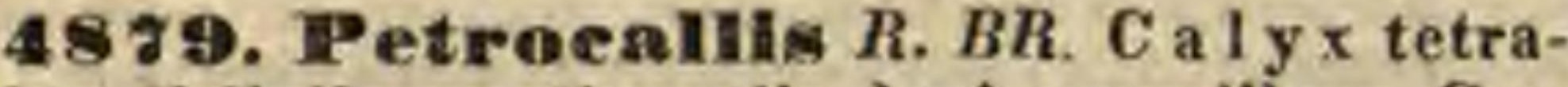
phyllus, foliolis erectinseulis, basi aequalibus. C oro 11 a e petala 4 , hypogyna, unguiculata, limbo integro. Sta mina 6, hypogyna, tetradynama, edentula. Silicula bivalvis, ovalis, compressa valvis planiusculis, medio nervigeris, septo ellip tico, membranaceo, integro. S e in ina in loculis 2 , immarginata, funiculis ex apice loculi parallelis, juxta totam longitudinem septo adnatis, Embry onis exalbuminosi cotyledones planae, radienlae. oblique accumbentes. Herba in alpibus Euro$p a$ a indigena, caespilosa, ramosissima; folits sessilibus, confertis, basi cuneatis, apice tri-quinquefidis, racemis brevibus, subcorymbosis, paucifloris, ebracteatis, floribus roseis.

Petrocallis R. Brown in Aiton Hort, Kew, 2, IV, 93. Desvaux Journ. Bot, IIT. 172. DC. Syst. II 330 . Prodr. $I$. 166. Meisner Gen. 11. (11.) Z i 2 i a Roth Man. bot, II, 896. D raba p y re a ic a Liun. Jaeq. Flor. austr, $t$. 228.

4880. Hraba $L I N N$. Cal y $x$ tetraphyllus, foliolis ereetis, basi aequalibus, Corollae petala 4 , hypogyna, subnnguiculata, limbo integerri mo v. emarginato. Stamina 6, hypogyna, tetradynama, filamenta edentula. Silicula bival vis, subelliptica, compressa, valvis margine convexis, disco planis, nninerviis, septo hyalino, uni binervi $v$. rarius enervi Semina plura, biseriata pendula, immarginata, laevia, funiculis setaceis, liberis. Embryon is exalbuminosi cotyledones planae, radieulae accumbentes. _ Herbae ut plurimum alpestres, in summis montium jugis in. tertropicis rarae, versus polum arcticum copiosiores, trans cancrum haud visae, perennes, biennes iv. annuae, humiles; pube furcata, stellata v. simplici vestitae, rarius glabrae; foliis integerrimis $v$, dentatis, infimis saepissime rosulatis, petiolatis, caulinis'dum adsunt sessilibus, alternis, racemis terminalibus, simplicibus, aphyllis, floribus aureis, ochroleucis, flavis $v$, albis.

D raba Linn. gen. n. 800 , excl. sp. R. Brown in Aiton Hort. Kew, 2. IV. 91. Desvaux Journ. bot. IIT. 17t. DC. Syst, II. 331. Prodr. I. 166. C. A. Meyer in Ledebour Flor. alt, III, 67. Meisner Gen, 11. (11,)

a. DRABELLA DC. l. c. Siliculae elliptico-oblongae, stignate sessili. - Herbae annuae v. biennes; caulibus foliosis, ramosis, Roribus minimis, flavis v, albis. (Lam. e, 556. f. 2. E. B. t. 912.)

b. HOLARGES DC. $t$. c, Sille ala e elongatae, stylo distincto, brevi apiculatae. - Herbae annuae v, biennes; caulibus folionts, saepius ramosis, floribus albis $v$. rarissime favis. - Holarges Blirhart msc (B. B. $t$. 388. Flor. dan. $t$. 130. 1460. Bot, Mag. $t$. 2934. Reichenb. Iconogr. $t .769 .770$.

c. LEUCODRABA DC. $l, c, \mathrm{~S}$ ili ie u l a ovali-oblonga, stylo brevissimo. - Herbae perennes; folits mollibus, pilis ramosis, scapis nudis $v$, parce foliatis, floribus al. bis, petalis obtusis $v$, subemarginatis. (Jaeq. Flor. austr. 2. 432, Miscell. I. t. 17. f. 1. Plor. dan. t, 142. Wahleub. Flor. Lappon, t. 11. f. 1. 3. 5. Delessert Ic. select, II. t, 46. Reichenb. Iconogr, t, 764-766, 768, 773. 774 . Hooker Bot. Miscell. $t$. 32. Ledebour Ic. $t, 200$. 260. 264. 263. 267,)

d. CHRYSODRABA DC.l.c.Silieula ováli-oblonga, stylo brevissimn. stigmate capitato $\mathrm{v}$, bilobo. - Herbae perennes; folits mollibus, planis, pilis plus minus ramosir, rarius simplieibus, scapis peduneulive elon. gatis, foribus flavis, potalir reluso emarginatis. Floc. dan, $t 56$. Wahlenb. Flor Lappon. $t$. 11. $f$. 2. 4. De. lessert Ic, select. II. $t$. 44 . 45. Reiehenb. Leonogr, t, 076. 77t. 772, Ledebour Ie. $t .145$.)

e. AIZOPSIS DC. $t$, o. Sille ula ovali-elliptica, stylo fillformi. - Herbae perenner v. suffrutescenter; fotiis ri. gidis, nervo medio carinatis, ciliatis, pilis rigidis, simplicibus. Mön ehi a e s p. Roth. (Jacq. Flor.austr. t. 192. Bot. Mag. t. 170,)

4884. Wrophila DC. Caly $x$ tetraphyllus, laxiusenlus, foliolis basi aequalibus. C orolla e petala 4, hypogyna, bipartita. Stamina 6 , hypogyna, tetradynama, edentula. Silicula bivalvis, ovalis v. oblonga, compressa; valvis margine convexis, disco planis, uninervis, septo hyalino, subenervi. Sem in a plura, biseriata, pendala, immarginata, laevia, funicolis setaceis, liberis. Embryon is exalbuminosi cotyledones planae, radiculae aceumbentes. - Herbae annuae, pusillae, in hemisphaerae borealis temperatis et frigidiusculis primo vere obviae; foliis radicalibus ovalibus $v$, oblongis, rosulatis, pilis paucis, simplicibus $v$, ramosis, scapis nudis, erectis, pedicellis ebracteatis, saepius elongatis, floribus albis, parvis. Erophila DC. Syst. II. 356. Prodr. I. 172. Meisner Gen, 11. (11.) Ga n s bl u a Adauson Fam. II. 420 . D raba ve rna Lian. Flor. dan. $t, 983$. E, B, $t, 586$. Șehkuhr $t, 179$.

4882. Coelliearia LINN. Cal y $x$ tetraphyllus, laxus, foliolis basi aequalibus. Corolla e petala $\$$, hypogyna, breviter nnguiculata, limbo dilatato, integrerrimo. St a mina 6 , hypogyna, tetradynama, edentula, recta v. geniculata Silicala sessilis v. brevissime supra toram stipitata, bivalvis, globosa, ovalis v, oblonga, valvis ventricosis subcarinatisve, septo integro v fenestrato, uninervi v, enervi S emina piara, biseriata, pendula, immarginata, laevia, punetulata v. scabra. Embryonis exalbuminosi cotyledones planac, radiculae accumbentes. - Herbae in temperatis et 
frigidis hemisphaeraeborealis, annuae, biennes $v$. perennes, saepissime glabrae, rarius pube simplici v. ramosa puberulae; caulibus plerumque ramosis, foliosis, foliis variis, radicalibus saepius petiolatis, caulinis sessilibus $v$, auriculatis, saepissime indivisis, rarius in speciebus aquaticis pectinato-pinnatipartitis, racemis terminalibus aphyllis, floribus albis $v$, rarissime flavis.

Cochlearia Tournefort inst. 101. Linn. gen. n, 803 R. Brown in Aiton Hort. Kew. 2. IV. 89. DC. Syst. II. 358 Prodr. I. 122. C. A. Meyer in Ledebour Flor, alt. 111. 85 Meisner Gen. 11. (11.)

a. ? RHIZOBOTRYA Tausch. Fila menta longiora filiformia, sigmoideofflexuosa. SHlle ula ovata, tamida, valvis concavis. S e nin a in localis $2-3$, tuberculata. Folia radicalia rosulata, subspathulata, corymbum multiforum sessilem aeguantia.

Kh fzobotry a Tausch in Flora 1836. p. 33. Planta Incertae originis, summopere dubia.

b. KERNERA Medik. Fila me nta longiora subdilatata, apice arcuato flexuosa. Silicula globoso-turgida, val. vis convexissimis. Semin a laevia.

K erner a Medikos in Usteri n. Annal, IT. 24. Rei. ehenb. Iconogr. $t$. 648 . M y a g r u 8 axatile Linn. Jaeq. Flor, austr. $t .128$.

c. ARMORACIA Rupp. Filame nt a recta. Sili cu la suhglobosa v. parallele subcompressa, valvis coneavis, haud carinatis. S emina punctulata.

Armoracia Rupp Flor. Jenen, 87. Flor. Welter. II. 426. R a p h a uis Mōnelt Method. 267. Nasturtî $s$ p. DC. Delessert Ic. select, II, $t$, 16. (Sehkuhe $t, 181$. E. B. t. 2283. Waldst. et Kitaibel Plant. rar. Hung. t. 184.)

d. CochILARIA Koch. Filamenta recta. Siticula dissepimento contrarie compressa, valvis plus miaus carinatis. S e min a verruculosa.

Coe hlearia Koch Flor. germ. 65. Coef Ieariae 8 p. Linn. B. B. $t$. 551, 552. 696. Flor, dan, $t$, 100. 329, Delessert Ic. select. $t ., 47.48$.

4883. Tetrapoma TURCZANIN. C a lyx tetraphyllus, patulus, foliolis basi aequalibus. Cor oll a e petala 4 , hypogyna, indivisa. $\mathrm{Sta}$. mina 6, hypogyna, tetradynama, edentula, minora utrinque glandula stipata. $\mathbf{S}$ tig ma truncatum, subquadrilobum. Silicula substipitata, ovato - ellipsoidea, turgida, quadrivalvis, valvis subenerviis, concavis, placentis dorso obtusis, inclusis, septis completis v, incompletis. S e mina pendula, cumulatim subquadriseriata, immarginata, punctulata, funiculis capillaribus, liberis. Herbae sibiricae, annuque $v$. biennes, pube simplici adspersae; foliis runcinato-pinnatifidis, caulinis aurioulato-amplexicaulibus, racemis aphyllis, floribus flavis.

Tetrapoma Turczaninow in Fischer et Meyer Index sem. hort. Petropolit. 1835. I. p, 39. Tetracellion Tarczalnow mec. Camelia a bar ba riaefolla DC.

\section{\&ELENIEAE NUTT.}

4854. Selemia NUTT. Cal y x tetraphyllus, patens, foliolis coloratis, basi subaequalibus. Coroil a e petala 4 , hypogyna, spathulata, crecta, integra. St a m in a 6 , hypogyna, tetradynama, edentula. Glandulae hypogynae 10. O varium lineari-oblongum, compressum; styles ensiformis, stig m a capitatum. Silic a la bivalvis, late ovalis, basi acuta, marginata, valvis reticulatis, subinflatis, septo integro $\mathrm{v}$. incompleto, areolis transversis. S e min a $4-6$ in quovis loculo, orbicnlata, margine cartilagineo, tenui cincta, funiculis liberis. Embry onis exalbuminosi cotyledones planae, septo parallelae, radicula brevissima, placentae proxima, oblique accumbentim adscendens. Herbae bor eal $i$ a merican a e, annuae; folitis pinnatipartitis, racenis terminalibus foliosis, floribus. luteis.

Solenia Nuttall in Journ. Academ. Philadelph. $V_{\text {. }}$ 132. t. 6. Torrey et A. Gray Flora of North-America I. 99.

TEREUS III. THLASPIDEAE DC. Syst. II. 373. Silicula bivalvis, septo contrarie compressa, valvis navicularibus. Cotyle d ones planae, septo contrariae, radiculae adscendenti v. interdum descendenti, septum v. valvarum carinam spectanti accumbentes.

Hemisphaerae borealis et Americae australis extratropicae incolae.

4885. Thaspi DHLLEN. Calyx tetraphyllus, foliolis basi aequalibus, erectiusculis. Corolla e petala 4, hypogyna, integra. Stamina 6 , hypogyna, tetradynama, edentula. Silic ul a a latere compressa, obcordata, bivalvis, valvis navicularibus, carina alatis. Semina in loculis 2-8, pendula, immarginata. Emb r y onis exalbuminosi cotyledones radiculae adscendenti, valvarum dorso parallelae accumbentes. - Herbae annuae v. perennes, in Europa et Asia media indigenae, etiam in America antarctica observatae, glabrae, saepe glaucescentes; folïis integerrimis v. denticulatis, radicalibus petiolatis, caulinis sessilibus, amplexicaulibus, racemis terminalibus, simplicibus, ebraoteatis, floribus albis.

Th la s pi Dillen Giess, 123, t. 6. Desvanx Journ, Bot. IIT. 167. DC. Syst. IT. 373. Prodr. I. 175. C. A. Meyer in Ledebour Flor. alt, III. 92. Meisner Gen, 12. (11.) Th la speos s p. Linn.

a. PACHYPHRAGMA DC. $t$. c. Silienala brevis, apice lata, brevissime emsrginata, stylo nullo. Septum ellipticum, bilamellatum, plicis tribus longitwdinalibus. Se m in a in loculis gemina, haud steiata. - Herba pe. rennis. - Pterolo bi in Aadrzeiowsky msc. C. A. Meyer Caucas. 185. Th I. 1 at ifolin m Bieberst. Delessert Ic, select. II. t. St.

b. CARPOCERAS DC. l. c. Silicu Ia basi ovata, apice Innulatim emarginata, valvis dorso ad apicem in alas corniformes expansis, stylo subnullo, septo membranaceo, oblongo. Sem in a in loculis gemina, longitudinaliter striata. - Herba annua. - Carpoceras Link Hand6. HI. 289. Thlas p I cerat o ca rpon Murray in Nov. Comment. Gölting. $r . t .1$.

c. NOMISMA DC. $l$. o. Silieula plana, suborbieulata, sinu angusto apice enuarginata, valvís compressissimis, toto dorso late alatis, ala nervo marginata, stylo subnullo, $\mathrm{Semina}$ in quovis loculo 6_8, longitudinaliter striatosuleâta. - Herbae annuae v. biennes. - (E. B. t. 1659.)

d. NBUROTROPIS DC. 2 . c. Silicula orbiculata, sinu augusto apice emarginata, valvis compressiusculis, toto dorso late alatis, ala nervo marginata, stylo brevi. S e. mina in quovis loculo 6_8, haud striata. - Herbae annuae v. biennes. - (Jacq. Elor, austr. t, $337, \mathrm{~B}$. B. t. 2354.)

e. PTEROTROPIS DC. l. c. Silieula obovata, apice emarginata v. truneata, valvis eompressiusculis, toto dorso in alam latam immarginatam expansis, stylo filiformi, exserto. S e mina in quovis loeulo $4-8$, haud striata. - Herbae perennes. - (Jacq. Flor. austr. t. 237, 238. Ic, rar, $t, 121$.

4886. Teesulalia $R . B R$. C a lyx quadripartitus, deciduus. Corolla e petala 4 , hypogy$n a$, integra, aequalia $v$. inaequalia. St a $m$ in a 6 , hypogyna, tetradynama, filamenta intus squamula aucta. Sili cula a latere compressa, ovalis, apice emarginata; bivalvis, valvis navicularibus, carina subalatis, septo auguste oblongo, stylo 
nullo. Semina in quovis loculo gemina, suborbi culata, compressa, immarginata. Embry on is exalbuminosi cotyledones planae, radiculae adscendenti, valvarum dorso parallelae accumbentes.

Herbae annuae, in Europa media et a ustra$l i$ indigenae, parvae, glabrae; foliis radicalibus rosulatis, patentibus, petiolatis, pinnatilobatis, scapis e collo plurimis, fere aphyllis, simplicibus, racemis terminalibus, florentibus corymbosis, demum elongatis, pedicellis filiformibus, patentibus, ebracteatis, floribus minimis, albis.

T ees dalla R. Brown in Aiton Hort. Hew. edit. 2. IV. 83. Smith in Linn. Transact. XI. 283. DC. Syst. IT. 391. Prodr. I. 178. Meisuer Gen. 12. (11.) Gu e p in i a Bastard Suppl. 35. Desvaux Journ. Bot. III. 167. Ib e r is Dillen. Nov. gen, 123. I beris a ud ica u lis Linn. Schkuhr t. 179 Flor. dan. $t, 323$, E. B. $t, 111$. Lepidi a m nudicaule Linn.

488\%. Theris LINN. Cal y x tetraphyllus, foliolis basi aequalibus, erectiusculis. Coroll a e petala 4, hypogyna, duo exteriora majora. Stain ina 6, hypogyna, tetradynama, edentula. Silicu la plano-compressa, basi ovata, apice emar. ginata, bivalvis, valis marginutis $\mathbf{v}$. alatis, septo angustissimo, bipartibili, stylo persistente filiformi. S emina in loculis solitaria, ovata, pendula. $\mathbf{E} \mathbf{m b} \mathbf{r} \cdot \mathbf{o}$ is exalbuminosi cotyledones planae, radiculae adscendenti, valvarum dorso parallelae accumbentes. - Herbae v. suffrutices, in Europa imprimis medit er ran ea indigenae; caulibus teretibus, saepius glabris, interdum subcarnosis, folits alternis, linearibus $v$. obovatis, integris, dentatis $v$. pinnatifidis, interdum crassiusculis, racemis terminalibus nunc elongatis, nunc corymbosis $v$, subumbellatis, demum plerumque elongatis, floribus albis $v$. purpurascentibus, exterioribus corymbi subradiantibus, interioribus fere regularibus.

1 beris Linn. gen, n, 804, excl. sp. Gärtner $I T, 279$. t, 141. R. Brown in Aiton Hort, Kew, edit, 2, IV, 83. Desvaux Journ, Bot. III, 166, DC. Syst. II. 393. Prodr. I. 178. Meisner Gen, 12. (12.) A r a b is Adanson Fam. IT. 422. non Linn. Ps eudo-Thlas pi Magnol. Nov, car. 245. Iberis et Thlaspidinm Andrzeiowsky mtc.

a. IBERIDIUM DC. Prodr. r, 179. S e pt u m simplex. Radicula supera. (E. B. t. 52. Bo1. Mag. t. 106. 124. 1642. 2783. 2788. Guernset in Bullet. soc. philomat. $n$. 82. t. 21. Sibthorp Flor. grace, t, 620. Delessert Ic, select. II, t, 5i,)

b. IBERIDASTRUM DC. Prodr, $T$, 181. Septum fere duplex. Semen submarginatum. Radicuia horizon. talis. - Iberis semperflorens Liun.

4888. Cynoearillananum WEBB. et $B E R$. THEL, Caly $\mathrm{x}$ tetraphyllus, foliolis basi aequalibus, erectinsculis. Corolla e petala 4, hypogyna, aequalia, obovata, integra. St a min a $2-4$ hypogyna, edentula. Silicula plano-compressa, orbiculato-ovata, emarginata, bivalvis, valvis planis, nunc carinatis, apice subalatis, septo angustissimo, subenervi, stigmate subsessili, ca pitato. Semin a in loculis solitaria, compressa, pendula, marginata, reticulato-punctulata. $\mathbf{E}$ mb ry on is exalbuminosi cotyledones planae, radicnlae adscendenti, valvarum dorso parallelae accumbentes. - Herba annua, in insulis Canariis, America boreali et Antillis obvia, glabra, ramosa; foliis lineari-lanceolatis, infimis pinnatilobatis, superioribus angustis, incisis, summis li. nearibus, integris, racemis oppositifoliis et termi nalibus, aphyllis, floribus minimis, albis.

C y n be ard a m a m Webb et Berthel. Flor, canar. 96 Lepidfum virginfenim Lian. L. Iberis Selikular t. 180 .
4889. IBfseutella $L I N N$. Caly $x$ tetraphyllus, foliolis erectinsculis, basi aequalibus, $v$. erectis, duobus lateralibus basi gibboso-calcaratis. Cor oll a e petala 4 , hypogyna, unguiculata, limbo obovato, integro. St a m in a 6, hypogyna, tetradynama, edentula. Sili c u la a latere planocompressa, basi et apice emarginata, v. apice in stylum acuminata, bivalvis, valvis orbiculatis; planis, tandem ab axi solntis, semen retinentibus. Semin a in loeulis solitaria, horizontalia, compressa, immarginata. E m b r y o n is exalbuminosi cotyledones planae, radiculae descendenti, septum spectanti accumbentes. - Herbae mediterraneae, annuae $v$. perennes, plerumque hispidae, interdum tomentosae v. glabratae; foliis subradicalibus v. caulinis alternis, oblongis, integris, dentatis $v$, pinnatifidis, caulibus teretibus, erectis, apice saepius ramosis, subcorymbosis, racemis florentibus brevibus, fructiferis elongatis, pedicellis filiformibus, ebracteatis, floribus flavis, inodoris.

B I s cuttell a Linn gen. n, 608. Gïrtner $T$. 278, t. 141. R. Brown in Aiton Hort. Kew. edit. 2, IV. 67. DC. Syst. II. 406. Prodr. I. 181. Meisner Gen. 12. (12.)

a. JONDRABA DC. $t$, $c, \mathrm{C}$ al y $\mathrm{c}$ is foliola lateralia basi in saccum v. calear producta, ombia erecto-conniventia, subapproximata. Gland n la e hypogynae 2 extra stamina gemiuata obtusae, 2 intra stamina lateralia in cornua productae.

Jondeaba Medikus in Usteri Neu-Annal, II. 37. t. 1. $f$. W. Webb et Berthel. Flor. Canar. 92. B is e utell a e calearatae DC. in Annal. Mus. XVIIT, 300, $t, 1$. 2. (Sehkuhr $t$, 182. Delessert Ic, select. II. $t$. S5. Reichenb. Iconogr. t. 602 _603. Bot. Mag. $t$, 2444.)

b. THLASPIDIUM DC, $l, c, \mathrm{Ca} I \mathrm{y}$ e is foliola basi aequalia. GIandulae hypogynae vix proniaulae.

Thlaspidinm Medikas l. c. $t$. 1 . $f$. 8 , B is eutella genuiare DC. Op. cit. $t$. 7-10. (Jacq. Flor. austr. t. 339. Cavanill. Ic, t. 177. Waldst. et Kitaibel Plant, rar, Hung, t. 288. DC. Ic. plant. Gall. rar, $I$. t. 39. Tenore Flor. neap. $t, 01$, Reichenb. Iconogr. t. $606-619$.

4590. Diastroplais FISCH. et MEY. C a 1 y $x$ tetraphyllus, foliolis erectis, lateralibus basi gibbis. Corolla petala 4 , hypogyna, indivisa. St a m in a 6, hypogyna, tetradynama. Iibera, edentula. Sili eul a plano-compressa, bivalvis, valvis navicularibus, earinatis, alatis. Semina in loculis solitaria, immarginata, pendnla, resupinata, funiculis subulatis, basi septo adnatis. Embryonis exalbuminosi cotyledones planae, indivisae, radiculae adscendenti, septum speetanti accumbentes - Fructiculus $A r m$ eniae rossica $e$, humilis, distortus; foliis sparsis, oblongis, parvis, glaucescentibus, racemis terminalibus aphyllis, densis, floribus dilute roseis.

Diastrophis Fisch. et Meyer Index sem. hort. Pe. tropolit. II. $1835 . \mathrm{p} .35$.

4891. Niegaenrpaea $D C$. C a ly $\times$ tetraphyllus, foliolis erectis, basi aequalibus. C oro lI a e petala 4 , hypogyna, sessilia, calycem vix aequantia, integra. Sta m in a 6, hypogyna, tetradynama, edentula. Silicula subsessilis, a latere plano-compressa, basi et apice emarginata, stigmate subsessili, bivalvis, valvis orbienlatis, planis, dorso late alatis, facie tota longitudine axi adnatis, tandem secedentibus, clausis. S e mina in Ioculis solitaria, horizontalia, compressa, immarginata. Embry on is exalbuminosi cotyledones planae, radiculae oblique adscendenti, valvarum dorso parallelae accumbentes. - Herba perennis, in Asia media indigena; radice fusiformi ad collum squamosa, caule tereti, glabro, foliis glau- 
cescentibus, pilis albis mollibus vestitis, radicalibus et caulinis infimis petiolatis, superioribus sessilibus, amplexicaulibus, omnibus plus minus pinnatipartitis, lobis incisis, racemis ramos ramulosque terminantibus, laxis, aphyllis, floribus minutis, violaceis, infimis et summis plerumque abortivis, fructibus magnis.

Megacarpaea DC. Syst, II. 417, Prodr. I, 183, C. A. Meyer in Ledobour Flor, alt. IIT, 99. Ledebour Ie, t. 372 Meisner Gen, 12. (12.) B is cutella megalocarpa Fiseher DC, in Annal. Mus, XVIIT. $t, 3$.

\section{* cremolobeae $R$. bR.}

4852. Cremolobas DC. C a Iy $x$ tetraphyllus, foliolis basi aequalibus. Corolla petala 4, hypogyna, integra. S $t$ a mina 6 , hypo gyna, tedradynama, edentula. Silicula pedicellata, a latere compressa, biscutata, stylo hasi cras. so, subpyramidato, persistente, valvis e styli apice pendulis, orbiculatis, dorso alatis, facie elansis Semina in loculis solitaria, pendula, compressa, immarginata. E mbry o n is exalbuminosi cotyledones planae, radiculae adscendenti, axim fructus spectanti accumbentes. - Herbae v, suffruti ces peruani et chilenses, glabriv. pubescentes, foliis ovatis $v$. oblongis, subintegerrimis, serratis v. pinnatifidis, racemis terminalibus elongatis, multifloris, pedicellis filiformibus, ebracteatis, floribus flavis.

Cremolob us DC. Syst, II. 418. Prodr. I. 184. Нзоker Ic, $t, 32,48.81,99.100$. Meisuer Gen. 12. (12.) B i scutelis a s p. Lam. De. in Annal. Mas. XYIII, $t$, s_6.

4893. Niremonvillea $D C$. C a l y $x$ tetraphyllus, foliolis erectis, duobus lateralibus basi subsaceatis. Corolla e petala 4, hypogyna, linearia, integra. St a mina 6 , hypogyna, subaequalia, edentula. Silicula substipitata, stylo sulcato et stigmate subcapitato terminata, valvis dorso convexis, margine in alam expansis biscntata. S e m in a in loculis solitaria, pendula, compressa, immarginata. E mbry o $n$ is exalbuminosi cotyledones planae, radiculae adscendenti, axim fructus spectanti accumbentes. - Herba peruana; caudicibuss suffruticosis, foliis glabris, radicalibus confertis, linearibus, apice inciso-serratis, caulinis sparsis, inlegris, racemo terminali ebracteato, floribus sordide rufis.

Men onvillea DC. Syst, II. 419. Prodr. I. 184. Delessert Ic, select, II, $t, \sigma \delta$. Meisuer Gen, 12. (12.)

THERES TV. ANASTATICEAE DC. Syst. II. 424. Silicula oblonga v. ovalis, valvis longitudinaliter dehiscentibus, intus in septula, loculos monospermos constituentia productis. Semina pauca, compressa. C otyledones planae, accumbentes $(O \Rightarrow$ ). In Asia et Africa mediterranea indigenae, Alyssineis arcle affines.

4594. IVorettia $D C$. Caly $\mathrm{x}$ tetraphylIns, foliolis linearibus, basi aequalibus, erectiusenlis. Corroll a e petala 4, hypogyna, linearia, integra. St a m in a 6 , hypogyna, libera, edentala. Silicula oblonga, subcompressa, septo oblongo, stylo brevi, subeonico, valvis concavis, in tus in septula semina separantia productis, dehis sentibus, S e min a orbieulata, plana. Embry onis exalbuminosi cotyledones planae, radieulae adscendenti accumbentes. - Herba aegyptiaca. ramosa, pilis fasciculato - stellatis cinereo-hispida; foliis obovatis, basi cuneatis, apice grosse dentatis, racemis ramiformibus, erectis, pedicellis ad axillas braetearum brevibus, bracteis foliaceis, flores superantibus.

Morettia DC. Syst. IT. 426. Prodr. T. 185. Meisuer Gen, 12. (12.) Sinapis. P hil can a Delite Flor, aeggpe. 99. t. 33. $f .3$.

4895. Anastatiea G traphyllus, foliolis basi 'aequalibus, ereetiusculis. C or olla e petala 4 , hypogyna, obovata. Stamina 6 , hypogyna, tetradynama, edentula. Silicula ventricosa, bivalvis, stylo filiformi, apice subuneinato superata, valvis concavis, dorso paulo infra apiccm appendice coriacea, transversa auriculatis, intus medio diaphragmate horizontali imcomplete instructis, a septo latiusculo solutis. S e min a in quovis loculo 2, superposita, pendula, semisepto sejuncta, suborbiculata, planiuscula. Embryonis exalbuminosi cotyledones planae, radiculae adscendenti incumbentes. - Herba annua, humilis, in A egypto, Arabia, Palaestinae et $s_{y}$ ria obvia, superstionibus celebris, $e$ collo ramosa, junior herbacea, villosa, expansa, fruetifera lignoso-indurata, glabrata, ramis in globum cancellatim contractis, humiditate expansis, foliis oblongis, integerrimis $v$. incisis, racemis brevibus oppositifoliis, floribus sessilibus, parvis, albis.

A n astatie a Linn. Hort. Cliffort. 328. Gen. n. 798. exel. sp. Gärtner IT. 286, t, 141. Medikus in Usteri Neu, Annal. I. 50, t. 2. f. 26. Jacq. Hort. Vindob, t. 58. Schkubr t. 179. Lam. t. 355 . R. Brown in Aiton Hort. Kew, edil. 8. IV. 79. Desvanx Journ. Bot. IIT. 169. DC. Sjst. II. 428. Prodr. I. 185. Meisner Gen, 12. (12.) Hie roeontis Adanson Fam. II. 421. Ros a h he rle huntica Camerar. Hort. 147. t. 41. Sturn, Rosa hierichuntica. Lovanii, 1608. 8. Dav. Hess, die Hose von Jericho. Zulrich, 1819. 8.

THRIRUS 区. EUCLIDIEAE DC. Syst.I1. 420. Silicula indehiscens, valvis concavis, indistinctis v. pertinaciter connatis, septo elliptico, interdum evanido. S e min a in loculis solitaria, pendula. C ot y le d on es planae, radiculae adscendenti accumbentes $(\mathrm{O} \Rightarrow$ ), septo dum adest parallelae. - Herbae orienlales.

4896. Euelidium $R . B R$. C a 1 y $x$ tetraphyllus, foliolis erectis, basi aequalibus. Co roli a e petala 4, hypogyna, unguieulata, erecta. Sta$m$ in a 6 , hypogyna, tetradynama, edentula. Ovarin m biloculare, biovulatum, st y lo elongato, subalato, stigmate simplici v, bilobo. Silic ula indehiscens, bilocularis, subglobosa, laevis, valvis hernisphaericis, septo eompleto, chartaceo. Se mina in loculis solitaria, pendula, immarginata, laevia, funiculis setaceis, liberis. Embryon is exalbuminosi cotyledones planae, radienlae adscendenti accombentes, - Herbae in Asia occideniali et mediterranea indigenae, annuae, erectae, ramosae, setulis ramosis simplicibusque plus minus hispidae; foliis radicalibus petiolatis, runcinatis, caulinis sparsis, dentatis v. subintegerrimis, racemis lateralibus, subspicatis, aphyllis, floribus minutis, albis.

Buclidium R. Brown in Ailon Hort, Rew. 2, TD. 74, DC. Syst. II. 421. Prodr. I. 184. C. A. Meyer in Lealebour Flor. alt, III. 102. Meisner Gen, 12. (12,) $\mathrm{S}$ o r i a Adanson Eara. II. 42t. Desvanx Journ. Bot. III. 168, t. 25, f. 3 . Hierochontis Medikus in Usteri n. Annal. Ir. 40, non Adans. A n a statica s y riaca Linn. Jacq. Flor. atutr. t. 6, B unias s y riaca Gärtner $t$, 14t. Vella tea uis$s$ i m a Pallas $I t, t, U, f, z$. 
489. Delathoulan $D C$. C aly $\times$ tetraphyllus, foliolis patentibus, basi aequalibus. Corolla e petala 4 , hypogyna, obovata, basi attenuata. S t a min a 6 , hypogyna, tetradynama, edentula, Ovarium biloculare, biovulatum, stigmate sessili. Silic ula indehiscens, bilocularis, subglobosa, verrucosa, valvis coneavis, septo completo, erasso. Semin a in loculis solitaria, pendula, immarginata, laevia, funiculiss setaceis, liberis. Embryonis exalbuminosi cotyledones planaè, radiculae adscendenti ohlique accumbentes. - Herba annua, in $A$ eg ypto et $\mathcal{S}_{y} r i a$ indigena, erecta, ramosa, basi pilosa; folits inferioribus lyrato pinnatifidis, superioribus subintegris, racemis elongatis, pedicellis brevibus, ebracteatis, flo ribus flavis.

0 eht bod in m DC. Syst. II. 423. Prodr. T. 184. Meisner Gen. 12. (12.) B uns a s Desvaux Journ. Bot, III, 163. B. a eg ypti a ca Lina, Jacq. Hort. Vindob, $t, 145$.

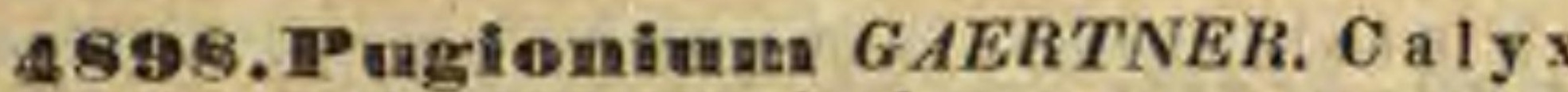
..... Corolla e petala 4, hypogyna, angusta, integra. St a m in a 6, hypogyra, edentula. Ovarinm hispidulum, biloculare, stylo brevi. Si. licula indehiscens, coriacea, transverse ovalis, utrinque in processum puginniformem producta, aculeis paueis echinata, adulta unilocularis, septi rudimento. Semen tunica chartacea inclusum. Embryonis exalbuminosi cotyledones lineari-oblongae, radiculae longae accumbentes. Herba a patribus in oriente et ad mare caspicum ob servata, glabra; foliis linearibus integris, semiamplexicaulibus, racemis laxis, floribus parvis, albis.

P n gion iu m Gïrtner 1T. 291. t, 142. Desvaux Journ, Bot. 160. DC. Syst. IT. 424. Prodr. I. 185. Meisuer Gen. 12. (12.) Bunias cornut hian.

THE IRES IV. CAKILINEAE DC. Syst. II. 427. Siliqua v. silicula transverse in articulos uni-biloculares, mono-dispermos secedens. Semina immarginata. Cotyledones accumbentes, planae, septo dum adest parallelae. - Herbae in temperatis hemisphaerae borealis, imprimis in Asia media olviae.

4899. Ualkile TOURNEF. Caly x tetra. phyllus, suberectus, foliolis lateralibus basi gibbis. Corolla e petala 4 , hypogyna, unguieulata, limbo obovato. Stam in a 6 , hypogyna, tetradynama, edentula, Si li eu l a lomentacea, biarticulata, compressa, articulo inferiore suberoso, subturbinato, superne bidentato-truncato, superiore ensiformi, stigmate sessili. Se m i na in locnlis solitaria, compressa, loculi in erioris pendulum, superioris erectum. $\mathbf{E} \mathbf{m}$ br yon is exalbuminosi radicula cotyledonibus linearibus oblique accumbens

Herbae in Europa et $A$ merica c is cancrum littorales, annuae, glabrae, carnosae, ramosae; foliis pinnatifidis $v$. dentalis, racemis oppositifoliis et terminalibus, erectis, pedicellis filiformibus ebracteatis, floribus albis v. subpurpurascentibus.

Cakile Tohrnef. inst. 483. Seopoli Carn. II. 35. Gärtner $I T$. 287, $t, 141$. Desvaux Journ. Bot, III, 16t. DC. Syst II. 427. Prodr, I, 185. Delessert Ic, select, II. $t$. 57, Meisue Gen, 12. (12.) B u $\mathrm{a}$ iadis s p. Lins.

4900. Choteispora $D C$. Calyx tetra phyllus, clausus, foliolis lateralibus basi gibbis Corolla e petala 4, hypogyna, ungnienlata, limbo oblongo, integerrimo v. obovato, emarginato. Siliqua cylindrica, Iomentacea, inarticulata, polysperma, valvis singulis convexis, tandem cum septi lamella connatis, transversim in loculos monospermos, clansos secedentilus, placentis dorso planis, continuis, persistentibns. Sem in a pendula, immarginata v. marginata, laevia, funiculis setaceis, liberis. Em bryon is exalbuminosi cotyledones planae, radiculae rimali v. oblique adscendenti accumbentes. - Herbae annuae v., biennes, in Asia media indigrenae, ramosae, glandulis pedicellatis et pilis simplicibus $v$. ramosis, plus minus copiosis conspersae; foliis runcinatis, dentatis $v$. subintegerrimis, caulinis sparsis, in petiolum angustatis, racemis lateralibus et terminalibus, pedicellis filiformibus, ebracteatis, floribus violaccis, albis $v$. flavis.

Choris por a DC. 8yst. IT. 435. Prodr. I. 186. C. A. Meyer in Ledebour Flor. alt. IIT, 105. Meisser Gen, 13. (12.) Chorisperm um R. Brown in Aiton Hort. Few. II. IL . 129.

a. ANEURA. Petala purpurascentia v. alba, oblonga, integerrima, Glandula e hypogynae placentariae minutae. Sf 1 iquae maturae vix torulosic, nervis destitutae. Ra dicula exacte rimalis. $C$. $A$. Mey. $L$. c. Raphanus te ù 11 u's Pallas. Schkuhr $t, 202$.

b. RHOMALIUM. Petala flava, apice emargianta. G Iandu l a e bypogyaae placentaria majusculae. Siliqua e maturae torulosae, nervis venisque clavatis rugosae.

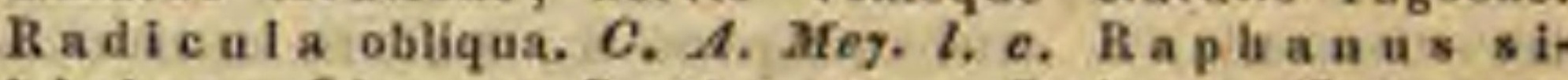
biricus Ling. et R. iberieus Bleberst. (Delessert. Ic. select. $I T, t, 58$. Jacquem. Voy, $t, 14,15$.

490 4. Cordy locarpus DESEONT. CaIy $x$ tetraphyllus, ereetus, foliolis basi aequalibus. Corolla e petala 4 , hypogyna, limbo obovato, integerrimo. Stam in a 6, hypogyna, tetradynama, edentula. Siliqua teres, indehiscens, subtorulosa, transversim bilocnlata, loculo inferiori tri-tetraspermo, superiore globoso, echinato, monospermo, stylo conico, persistente superato. S e$m$ in a losulamenti inferioris pendula, nniseriata, subdistantia, Joculi superioris erectum, omnia elliptiea, compressa. Embryo .... Herba atlantica, annua, dubiae affinitatis, erecta, ramosa, glabra $v$. pilis raris conspersa; folits infimis sublyratis, summis lanceolatis, racemis elangatis, pedicellis ebracteatis, floriferis filiformibus, fructiferis incrassatis, haud elongatis, floribus ochroleucis.

Cordy lo ea rpus Desfont. FVor. atlant, 1L. 79. 2. 159. DC. Syst, II. 434, Prodr. I. 186. Meisner Gen. 12. (12,)

SUIRTIBO II. NOTORHIZEAE DC. Syst. II. 438. Cotyle dones planae, radienlae exacte dorsali incumbentes.(OII).

TIB IIB US WII. SISYMBRIEAE DC. Syst. II. 438. Sili qua elongata v. rarissime abbreviata, bilocularis v. rarissime unilocularis, bivalvis, rarissime indehiscens, valvis planiusculis, concavis v. carinatis. Semin a in quovis loculo plurima, uni-biseriata. Cotyledon es planae, septo parallelae, radiculae dorsali adscendenti, placentam oppositam spectanti incumbentes. - Herbae in temperatis hemisphaerae borealis, imprimis in Europa orientali et mediterranea, et in Asia rossica copiosae.

4907. RIaleolnaia $R$. BR. Caly $\times$ tetraphyllus, foliolis conniventibus, basi aequalibus $\mathbf{v}$. lateralibus gibbis. C orolla e petala 4 , hypogyna, unguiculata, indivisa. St a mina 6, hypogyna, tetradynama, edentula, St ig $\mathbf{m}$ at a 2 ; acuminata, conniventia. Sili qua bivalvis, elongata, teretiuscula, valvis convexis, trinerviis, placentarum 
dorso prominulo, obtuso, septo uninervi. S emin a plurima, pendula, uniseralia, submarginata, laevia, funiculis liberis, filiformibus. E m b ry o$\mathbf{n}$ is exalbuminosi cotyledones planae, radiculae ad. acendenti incumbentes. - Herbae annuae, biennes v. perennes in regionibus meditertaneis et $A s i a$ media indigenac, erectae, ramosae, pube stellata $v$. setulis rigidis, bi-quadrifidis, rarius simplicibus vestitae; foliis caulinis sparsis, oblongis, integerrimis, dentatis, lyratis $v$. sinuato-pinnatifidis, racemis terminalibus et lateralibus laxis, apliyl lis, floribus purpurascentibus $v$. albis.

Matcolmia R. Brown in Aiton Hort. Kew, edit, 2 IV. 121, Prodr. I. 186, Delessert Ic. select. II. $t .89 .60$ C. A. Meyer in Ledebour Flor, alt, MII. 112. Meisuer Gon. 13. (12.) Jaequear. Poy, t. 16. Cheirath i s p. Liun. Bat. Mag. $t$. 166. Sibthorp Elor, graec, $t$. 635. Hes perid is s p. Lam. Desfont. in Annal. Mus. XII, t, 34. Flor. Allant $t, 162$, DC. Ie, plent, Gall, rar, $t, 35$.

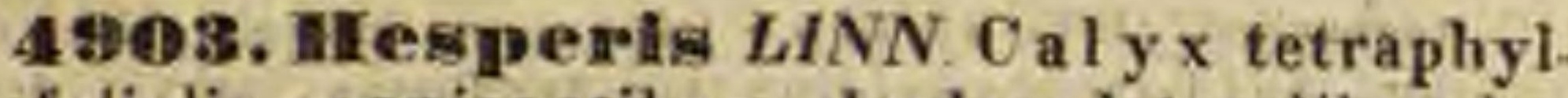
Ins, foliolis eonniventibus, duobus lateralibus basi gibbis. C ir olla e petala 4 , hypogyna, ungui. culata, indivisa. Sta mina 6, hypogyna, tetra dynama, edentula. Stig m a $t$ a 2 , elliptica, erestiuscula. Siliqu a bivalvis, elongata, tetragono teretiuseula v. subcompressa, valvis convexis v planiusenlis, carinatis, subtrinerviis, placentarum dorso prominulo, carinato, septo enervi. S e m i na plurima, pendula, uniserialia, eblonge-subtrigona, immarginata, laeviuseula, rarius compres sa, marginata, Iaevia, funieulis líberis, subulatis v. rarissime filiformibus. E m b r y on is exalbuminosi cotyledones planiusculae, radiculae adscenden ti incumbentes. - Herbae annuue, biennes $v$, rarius perennes, iu Europa media, regionibus me. diterraneis, Oriente etiAsia media indigenae, ramosae, pube cana setulisque furcatis $v$. simplieibus, interdum etiam glandulis pedicellatis vestitae; foliis caulinis sparsis, subsessilibus, ova. to-lanceolatis $v$. oblongis, dentatis $v$. Iyrato-runci natis, racemis terminalibus, laxis, aphyllis, flori. bus purpurascentibus, albis $v$. sordide e flavescenti purpurascentibus, versicoloribus, interdum odoratis.

Hesperis Lian. gen, $n$ 817. Crantz Austr. 3t. R. Brown in Aiton Hert, Kew. 2. IV. 122. DC. Syst. IT. 446. Prodr. I. 188. C. A. Meyer in Ledebour FYor. alt. MI, 112. Meisuer Gen, 13, (12.)

a. HESPBRIDIUM DC. l. c. FIores sordide e flavo pur. puraseentes. Petalor a m lamína angusta. Sili qua compresso-tetragona, septo fangoso. S e m i a a oblonga. eylindraceo trigona, funieulis filiformibus. Radieula exacte dorsalls.

Hesperis Andrzeiowsky in Besser Volhyn, 83. H. tris tix Linn. Jacq. Hort. Vindob t. 118. Bot. Mag t. 230. H. a I s sifolia DC. Delessert. Io. select. If. 2. 61 .

b. DEILOSMA C. A, Meyer l, c. Flores purpuraseentes v, albi, rarissime sordide flavescentes. Pe $b$ a lo rum laimina obovata, dilatata. Sill qua tetrogono-seretiuseula, septo hyalino. Sem i u a oblonga, cylindraceo-trigona, fuaiculis dilatatis. $R$ a dicu I a exacte dorsalis.

Deilos ma Andrzeiowsky in Besser Volhyn 83. (Al lioni Flor, pedemont. $t$, se. $f$ 1. Jaeq. Flor. austr. c. 347. Waldst, et Kitaibel Plant, rar. Hang. 2, 200. Le debour Ic. $t$. 394.)

c. ARABIDIUM C. A. Meyer l. c. Flor es parpurei. Pe ta o r u m laniwa obovata, dilata a. S II i qu a compres sa + veptn subchartaceo. S e in in a cosipressiaseula, fabienlis filiformibus. R a di e u la exacte darsalis. - (H a pric a DC. Delessert Ie. oelect. II. $t$. 62.)

d. PLAGIOLOBA C. A. Meyer l. c. Flores purpurascen. tes. Petal or u m Ismina elliptiea. S III q a a teretius. cula, septo subchartaceo, Semina biuc complanata. Radle ala obfiqua. (Desfont. Flor, allant, $t \cdot 161$, )
4904. Dontogtemom ANDRZ. Caly tetraphyllus, foliolis erectis, basi aequalibus. Coroll a e petala 4, hypogyna, nnguiculata, indivi8a. St a m in a 6, hypogyna, tetradynama, breviora libera, edentula, longiora per paria connata v. intus dente aucta. S $\mathrm{tig}$ ma simplex. Siliqua bivalvis, teretiuscula, valvis convexis, subtrinerviis, placentarum dorso incluso, septo enervi. Semina plurima, pendula, uniseriata, marginata v. imniarginata, laevia, funiculis liberis, filiformibus. E m b y o nis exalbuminosi cotyledones lineares, crassiasculae, radiculae adscendenti incumbentes. - Herbae sibiricae et altaicae, biennes $v$. perennes, erectae, ramosae, pilis simplicibus, saepe etiam glandulis pedicellatis vestitae; foliis caulinis sessilibus, sparsis, angustis, sublinearibus, nunc integerrimis, nunc dentatis v pectinatis, racemis terminulibus et lateralibus aphyllis, floribus albis $v$, dilute purpurascentibus.

Dontosteu on Andrzeiawsky msc. C. A. Meger in Ledebour Flor, alt. III. 118. Ledebour Ic. $t .203 .353$. Meisaer Gen. 13. (12.) A n dreoskia DC. Prodr. I. 190. Sy mbrii seet. Hesperidops is DC. Syst. 1 . 486. S i5 y m bril s p. Lín. Pallas $I t, t$. 96.

4905. Hachypodium WEBB. et BERTHEL, Ca lyx tetraphyllus, foliolis laxiuseulis, basi aequalibus. Coroll a e petala 4 , hypogyna, indivisa. Stamina 6, hypogyna, tetradynama, libera, edentula. Stig ma capitatum, integrum v. bilobum. Siliqua brevissime stipitata, bivalvis, elongata, subtetragona, valvis carinatis, uninerviis, septo enervi, placentis incrassatis, dorso obtusis. Semina plurima, pendula, uniseriata, immarginata, laevia. E m h ry on is exalbaminosi cotyledones planae, radiculae adscendenti incumbentes. - Herbae in Europ a media et regione mediterranea indigenae, annuae, glabrae $v$. pube simplici vestitae; foliis runoinatis v. dissectis, racemis aphyllis, demum elongatis, divaricatis, rigidis, floribus luteis.

Pachypodium Webb et Berthel. Flor. Canar. 75. Sis y mbrinm Columna e L. Jaeq. Flor. austr. $t, 393$. S. pandonic um Jacq. Io, rar. t, 123. S. bursifoliam L. S. er y $8 \mathrm{i}$ mo id es Desfont. Flor, atlant. $t$. 158.

4306. Sisymbriam $L I N N$. Cal yx tetraphyllus, foliolis laxiusenlis, basi aequalibus. Coro 11 a e petala 4, hypogyna, unguiculata, indivisa. Stamina 6, hypogyna, tetradynama, edentula. Stigma simplex. Siliqua bivalvis, plerumque elongata, hexagono-teretiuscula, valvis convexis, saepissime trinerviis, septo eneryi v. binervi, placentis filiformilùs v. incrassatis, dorso obtusis. Semin a plurima, pendula, uniserialia, immarginata, laevia, funiculis filiformibus, liberis. Embryonis exalbuminosi cotyledones lineari-oblongae, planae, radiculae adscendenti incumbentes. - Herbae annuae $v$. perennes, rarissime frutescentes, in Europa et Asia media obviae, in Africa mediterranea, Capite bonae $S_{p e i}$ et $A$ merica boreali rarae, glabrac v. hirsutae, pube simplici, ramesa v. stellata; foliis admodum variis, integerrimis, incisis, compositis decompositisve, caulinis alternis, petiolatis, sessilibus $v$. amplexicaulibus, floribus flavis $v$, albis, ut plurimum in racemos terminales $v$. laterales, aphyllos dispositis, rarius in foliorum axillis subaggregato-sessilibus.

S is y m bri um Linn. gen. n. 813. Allion. Flor. Pedemont. 1. 274. R. Brown in diton Hort. Hes. edia. 2. IV. 111. DC. Syst. II. 45s. Prodr. I. 190 exel. sp. C. A. Meyer in Ledebour Flor, alt. IIT. Meisuer Gen, 13, (12.) E r js i. in u m Touruefort Ins?. 11t, uon Linn. 
a. VELARUM DC. $t$. c. $\mathrm{R}$ a ce mi spicaeformes, aphylli. Flores Jutei. Sili quae subuliformes, pedicello brevissimo, inerassato iusidentes, rhachi adpressae, disse pimento meniliransceo haud inerassato et placentis haud dilatatis. - Herba subvillosa v. glabra.

E r y s i m u un Link Hands. MT. 315. K 1 ne $\mathrm{E}$ I a Andrzeiowaky moe. Cham a epli u m Walteoth Sched, $\boldsymbol{T}$, 377. Webb et Berthol. Flor. Canar, 76. Erysi au um offieinale Líms, Flor. dan. t. 360. Sehkuhr $t .183$. Hayne Arsneigew. $11 . t .13$.

b. NORTA DC, t. c. R a eemi aphylli. Flores flavi v. ochroleuci. Calyx patufus. GI andula annularis fila menta breviora eingen*, et dentes saepe inter filanenta longiora. Siliquat subeyliadricae, stylo brevissimo, septa enervi. - Herbae glabrae $p$. pilis setulis. que simplicibus vestitae.

Norta Adanson Fam, IT. A17. Beass feae $8 p$. Murray. Waldst, et Kitaibel Plant, rar. Hung. $t .90$. Cheiranthis p. Waldat. et Kitaibel Op. cit. $t, 236$. (Jacq. Flor, austr, t. 194. Ledebour Ic, t, 204.)

c. ? PSILOSTYLUM DC. $l$, $\boldsymbol{c}, \mathrm{R}$ a c e $\mathrm{m} \mathrm{i}$ terminales, bi-qua driflori, interdum unifiori. Florea flavi, Caly $x$ clau sus, basi subbisaceatus. Sill q a a teretiuscula, siylo longo, gracili terntiuata. Se mill a oblonga. - Herba libanotica, minima; foliis ovali oblongis, subintegris, glabris, glaucis. - Sis y mbrium exacoides DC. Delessert Ic. select. II. $t$. 63. f. 1.

d. IRIO DC. l. c. Ra cemi aphylli. Flores flavi Calyx clausus. Gla od ula minuta, utrinque ad basim filamentorum breviorum. Sili qua teretiuscula, subeylin. driea, stylo brevi, septo enervi. - Herbae pilis setuliogue simplicibus adspersae, rarius glabrae.

Leptocarpaea DC. Syst. IT. 204. Prodr. T. 140. Descurain i a Weblet Berthel. Flor. Canar, z2, part. (Jacq. Flor. austr. $t$. 322, Ledebour Ic, t, 263.)

e. DESCUREA C. A. Mey. l, e. Ra ce mi aphylli. F I ores flavi. Gal y $x$ laxus, Glandulg in utroque filamento. rum breviorum Jatere. Silliqua cylindracea, stylo bre vissimo, septo binervi. - Herbae glabrae v. pube floccosa incanae.

Descurea Guettard Observ. II. 164. S oplita Haller Hotv. n. 484. Descu ra in i a Webb et Berthel. t. c, part. (Flor, dan- t. se8. E. B. t. $963 .-\mathrm{H} n-$ guenin i a Reichenb. Flor, Germ, 691. Iconograph, t. 299. S. $t$ as a a cetifoli a m Linn.

f. KIBERA DC, $l$, c. R a cem i bracteati, pedicellis in axillis solitariis v. plurinsis, brevissimis. Flares parvi, Hlavi v. albi. Cal y $x$ elausus. Sill q a a e teretiusculae, stylo brevi, erasso, retuso, septo meabraakeeo, enervi. - Herba slabra v. parce puberula.

Kibera Adhasou Fam. II. 417. S. supinam Lisa.

g. ALLIARIA Adans. $R$ a ce mi corymbosi, aphylli, demum elongati. Flores albi. G Jand ula e hypogyae staminum lateralium basim cingentes, et inter stamiaa uajora et ovarium. Silliqua obxoletissime tetragona, stylo bre vi, septo enervi. - Herbae foliis cordatis v. orbicu. latis.

Alliaria Adans, Fam, IT. 418. Scopoli Carn. edit. 1. p. 515. DC. Syat, $I$. 488. Prodr. $1,196 . \mathrm{Er}$ y $8 \mathrm{Im} \mathrm{a} \mathrm{m}$ Alllaria Linn. Flor, dan. $t$. 935. E. B. $t$. 796.

h. ARABIDOPSIS DC. l. c. Racemi aphylli. Flares albi. Caly $x$ laxus. Gland $u$ I a e hypogynae variae. S iliqua teretiuscula, stylo brevi, rarissioie elosgata, septo enervi. - Herbae glaberrimae v. saepius pube ramosa vestifae.

Arabidis sp. Linu. DC. (Desfont. Flor. atlant. t. 157, 159. Delessert Ic. seleot. II. $t$. 63. Ledebour Io. t. 147. 201, 268. 270.) - ? H a limolobos Tausch in Flora 1836. p, $\$ 10$.

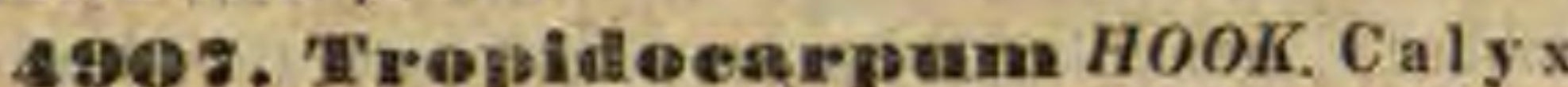
tetraphyllus, foliolis basi aequalibus. Coroll a e petala 4, hypogyna, angniculata, indivisa. S $t$ am in a 6, hypogyna, tetradynama, edentula. Sti g ma emarginato-bilobum. Siliqua bivalvis, linearis v. Janceulato-inearis, a latere compressa, valvis earisatis, septo angustissisno, saepe incompleto. Semina plurima, pendula, uni serialia, oblenga, compressa, immarginata, lae- via, funiculis filiformibus, liberis. $\operatorname{mb}$ by onis exalbuminosi cotyledones breves, angustae, septe contrariae, radiculae adseendenti aceumbentes. Herbae annuae, in Americaboreali-oceidentali indigenat; foliis pinnatifidis, racemis foliosis, flaribus parvis, flavis.

Tropidoearpum Hnoker Ie. $t$. 43. s2. Torrey of A. Gray Flora of North America $I, 96$.

4508. Erysinaman $L I N N, C$ aly $x$ tetraphyllus, foliolis erectis, basi aequalibus $\mathbf{v}$ duobus lateralibus giblis. Corolla e petala 4 , hypogy$\mathrm{na}$, unguiculata ; indivisa. Sta $\mathrm{m}$ ina 6 , hypogyna, tetradynama, edentula. Stigma simplex v. bilobum. Siliqu a bivalvis, elongata, tetrago$n a$, rarius teretiuscala $v$ anceps, valvis acute carinatis v. interdum rotundatis, uninervis, septo enervi, placentis dorso prominente tarinatis v. rarius rotundatis. Se mina plurima, pendula, nniserialia, immarginata, laevia, funiculis setaceis, liberis. Embryonis exalbuminosi cotyledones, oblungae, planae, radiculae adscendenti incumbentes. - Herbae in Europa et Asia media obviae, ut plurimum biennes, rarius annuae $v$ perennes, interdum frutices, setulis parvis adpressis, $b i$ pluripartitis plus minusve dense vestitae, foliis angustis, petiolatis $v$. basi attenuatis, nunquam amplexicaulibus, integerrimis, dentatis $v$. subruncinatis, racemis terminalibus aphyllis, floribus flavis $v$. rarissime albidis.

E r y 8 i m u m Linn. gent. n. 814, exel. sp. Gärtner $r T$. 297. t. 143. R Browa in Aiton Hort. Kew, 2. IY. 115. DC. Syst. II, 490. Prodr. I, 169. exel. seet. 1. C. A. Meyer in Ledebour Flor, alt. III 147. Meisner Gen, 13. (12.)

a. AGONOLOBUS C. A. Meyer l.c. S flí q a a teretiusenla, valvis placentisque dorso rotiondatis. Dissepimen$t$ u $m$ tenne. (Ledebour 1c, $t, 266$, )

b. CUSPIDARIA DC. l. c. Siliqu a aneeps, valrulis cari. nato compressis. Diss e pimentum tenue. - C us pidaria Link Handb. MIT, 315. (C he ira nthas cuspidat us Bieberst. - ? Sibthorp Flor. graec. t, 633.)

e. CHeiRopsis C. A. Meyer l. c. Siliq a a compressotetragoisa, valvis planíaseulis placentisque prominalis dorso carinatis. Dis seplmentum tenue, $\rightarrow$ E. ChefIn $n$th oi des Lias. Jacq. Flor, austr. 2. 23. Sehathr t. 183, Ledebour 1c, t, 3.7. Cheiriniae s.p. Link Handb. III, 314.

d. ERYSIMASTRUM C. A. Meyer 2 , $\boldsymbol{c}$, Siliqua exaete fetragona, valvis placentisque acute carinatis. Disse. pimentura tepue. - Cheiriniae sp. Link 2 . c. Cheiraw thi sp. Jaeq. Flor, austr. $t$. 74. 75. Hort. Vindob. t. 9. Bot. Mag. t.835. (Flor. dan. t, 923. Jaeq. Flor, austr, t. 22, 73. DC. Ic. plant, Gall, rar, 2, 36. Reichenb. Iconogr, $t, 149$. Delessert Ic, select, II, t. 66. 67.)

c. CONRINGIA DC, l. c. Siliqua tetragona, valvis placentisque carinatis. D iss e pimeut $\mathrm{um}$ spongiosum. - Couriugiab sp. Heister Pers. Reichenb. Gorinkia Presl - Crantzia Lagasea mso. Bras. s lea e 5 p. Linn. Schkuhr $t, 186$. Jacq. Flor. austr. t. 282.283.

4DO5. 'Tetroeme BUNGE Caly x tetraphyllns, patens, foliolis basi aequalibus. CorolI a e petala 4, hypogyna, spathulato-linearia, calyce breviora. S ta m in a 6 , hypogyna, subaequalia, edentula. Stigma sessile, brevissime bilobum. Siliq a a bivalvis, abbreviata, subarcuata, subtetragona, quadricornis, valvis convexis, trinerviis, nervo medio tenuissimo, lateralibus marginantibus crassis, sub apice in cornua productis, septo hyalino, enervi, placentis obtusis, basi dilatato-saccatis. S e $\mathrm{m}$ in a plurima, uniserialia, pendala, immarginata, laevia, funiculis filiformibus, liberis. Em b ry on is exalbuminosi cotyledones septo oblique contrariae, radiculae ad110 * 
scendenti incumbentes. - Herba cas $p$ ica, annua, pusilla, pilis furcatis, ramosis canescens; foliis $l i$. neari-oblongis, radicalibus saepe grosse dentatis, floribus minimis, sessilibus, albis, siliquis spicatis, basi adpressis, apice arcuato-deflexis.

Tetrac m e Bunge Catalog. semin, hort. Dorpat, 1836. ex Linnaea Literaturber. 1838. p. 20. Erys im a a q u dricorne Steph. Notoceratis sect. Tetracerati um DC. Syst. II. 204. Prodr. . 140. Delessert Ic. select, II, z. 16 .

49 10. Smelowslkia $C, A, M E Y$. C al y x tetraphyllus, laxus, foliolis basi aequalibus. Coro 11 a e petala 4 , hypogyna, unguiculata, indi visa. St a min a 6 , hypogyna, tetradynama, eden tula. Stigma simplex. Sili qua bivalvis, ab breviata, utrinque angustata, subtetragona, valvis subnavicularibns, subtrinerviis, septo hyalino, enervi v. valide uninervi, placentis filiformibus, inelusis Sem in a in quovis loculo $2-4$, pendula, uniserialia, immarginata, Jaevia, funiculis setaceis, liberis v. ima basi adnatis. E mbryo$\mathbf{n}$ is exalbuminosi cotyledones subellipticae, planae, radiculae adscendenti incumbentes. - Herbae perennes, in Asia media indigenae, plerumque pube ramosa v. simplici vestitae; foliis sparsis, petiolatis $v$, subsessilibus, pinnati- v. bipinnatipartitis $v$, rarius simplicibus, racemis terminalibus aphyllis, floribus albis v. flavis, mediocribus $v$, parvis.

Smetowskia C. A. Meyer in Ledebour Flor, alt III. 165. Ledebour Ic. t. 15t. 283. Meisner Ger, 13. (12,) Cochleariae, H ntehinsiae et Sis y mori s p. DC.

4911. Traplorosperenuma $C . A . M E Y$. Caly x tetraphyllus, foliolis patulis, basi aequalibns. C orolia petala 4 , hypogyna, unguieulata, indivisa. St a mina 6 , hypogyna, tetradynama, edentula. Stig ma simplex. Siliqua bivalvis, abbreviata, subulato-subtetragona, basi subcordata, valvis pellucidis, subnavicnlaribus, triterviis, septo hyalino, enervi, placentis dorso obnusis, inclusis. S em ina panca, uniserialia, pendula, immarginata, serobiculata, funicnlis setaceis, liberis. - Herba altaica, perennis, glaberrima, Cochleariae danicae facie; cauliculis pro. cumbentibus, filiformibus, dense foliosis, foliis subcarnosis, sparsis, petiolatis, ellipticis v. suborbiculatis, subintegerrimis, floribus axillaribus solitariis, pedicellatis, parvis, ochrolencis, pedicellis filiformibus, petiolo brevioribus, demum secundis, nutantibus.

Taplirosperm um C. A. Meyer in Ledebour Flor. alt. III, 172. Ledebour Ic, t, 320. Meisner Gen, 13. (12.)

4912. Iraya STERNB, et HOPP. C a l y $\mathrm{x}$ tetraphyllus, foliolis clausis, basi aequalibus. Corolla e petala 4 ; hypogyna, unguiculata, indivisa. St a mina 6, hypogyna, tetradynama, edentula. St i gma obtusum. Sil i qua bivalvis, linearis, teres v. subcompressa, valvis convexis, uninerviis, sepio enervi. S e min a plnrima, biserialia, pendula, immarginata, laevia, funicnlis filiformibus, liberis. Emb ry onis exalbuminosi cotyledones planae, radiculae oblique adscendent incumbentes. Herbae perennes, humiles, in $E u-$ ropae mediae alpibus et in America arc tica indigenae; folits sparsis, integerrimis v. sinuato aut lyrato - pinnatifidis, racemo terminali denso $v$. elongato.

B ra y a Sternberg et Hoppe in Regensb. Denkschrift.I. 1. 65. $t$, 1. Reichenb. in Sturm. Flor. Germ. 43. Hooker Exot. Flor. t. 121. DC. Syst. IT. 210. Prodr. 1. 141. Hooker Flor. Bor. Amer. $\boldsymbol{I}$. 43. Koch Flor. Germ. 49. Meisuer Gen. 13. (18.) Sis y m bis if sp. Liun. DC.
4913. Heptaleamn $D C$. Caly $x$ tetraphyllus, foliolis linearibus, basi aequalibus, clansis. Co roll a e petala 4 , hypogyna, linearia, calyce duplo tongiora. Stamina 4 v. 6 , hypogyna, edentala. Stig mat a 2 , acuta, conniventia. Siliqua teretiuscula, duriuscula, indehiscens (?) valvis convexis, septo angusto. Se m in a plurima, uniserialia ..... - Herbae annuae, s ibiric a e et persicae, pusillae, glabrae; folitis glaucescentibus, filiformibus, integris $v$, pinnatipartitis, lobis jiliformibus, racemis terminalibus, paucifloris, pedicellis axillaribus, brevissimis, floribus parvis, albidq $=$ purpurascentibus.

Leptale um DC. Syst. IT. 510 . Prodr. $I$ 200. Delessert Ic. select. IT. $t, 68$. Meisuer Gen, 13, (12.) S is y mbrium fillfollu m Willa.

4214. Christolea CAMBESS. Caly tetraphylins, foliolis ereetiusculis, Iateralibus basi subsaceatis. Corolla e petala 4 , hypogyna, indivisa. Stamina 6, hypogyna, tetradynama, edentula. Stig m a conicum, transverse bisuleum. Siliqua sessilis, bivalvis, lanceolato - linearis, complanata, valvis planis, uninerviis, septo tenuissimo, enervi. Sem in a plura, biseriata, compressa, immarginata, funiculis filiformibus, liberis. Embryo n is exalbuminosi cotyledones lineares, obtusae, radiculae adscendenti incumbentes. - Herba Asiae mediae, ramosa, pube brevi simplici conspersa; foliis alternis, sessilibus, obovato-cuneatis, crassis, apice dentato - incisis, racemo terminali, laxiusculo, floribus luteis.

Christolea Cambessedes ad Jacquemont 17, $t, 17$.

4915. Thelypoilinm. Caly $x$ tetraphyllus, foliolis erectis, basi aequalibus. Corolla e petala 4, bypogyna, oblongo - linearia. Stamina 6, hypogyna, tetradynama, edentula. Siliqua supra torum breviter stipitata, bivalvis, teretiuscula, elongata, torulosa. S emin a uniseriata, oblonga, vix marginata. Embryonis exalbuminosi cotyledones planae, radiculae oblique incumbentes. - Herbae boreali-americanae, robustae, annuae $v$. biennes; foliis alternis, integris v.laciniatis, racemis corymbosis, fructiferis vix elongatis, floribus pallide violaceis $v$, roseis, siliquae stipite brevi crasso.

Pach y podium Nuttall in Torrey of A. Gray Flora of North.America 1,96 . Hook. ad Beech. $t$. 74. non Webb et Berthel. Ma e ropodii sp. Hooker Bot, Miscell. $t$. 68 .

4916. Stamileya NUTT. Calyx tetraphyllus, foliolis coloratis, patentibus, basi aequalibus. Corolla e petala 4 , hypogyna, erecta v. spathulata, unguibus laminas superantibus in tubum tetraedrum conniventibus. St a m in a $6, \mathrm{hy}$ pogyna, subaequalia, antheris linearibus, Siliqua supra torum longe stipitata, bivalvis, teretiuscula, gracilis. S e min a oblonga, teretiuscula, E mbryonis exalbuminosi cotyledones oblongae, lineares, radiculae incumbentes. - Herbae b ore $a$. li-americanae, perennes, erectae, glabrae, glaucae; foliis indivisis $v$. lyrato-pinnatifidis, racemis terminalibus, elongatis, uphyllis, floribus luteis.

Stan le y a Nuttall gen, II. 71. De. Syst. II. 510.

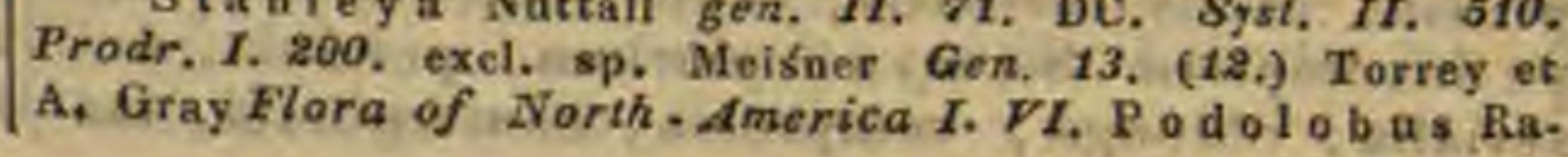


finesq. in Americ. Monthl. Nagas. IV. 194. Cl e o m es sp. Pursh.

4917. Warea NUTT, Cal y $\times$ tetraphyllus, foliolis coloratis, lignlatis v. spathulatis. Corolla e petala 4 , hypogyna, patentia v. reflexa, anguibus angustissimis, laminas superantibus, $\mathrm{S}$ tamina 6 , hypogyna, subaequalia, exserta, antheris linearibus. Siliqua longe stipitata, bivalvis, compressa, elongata, gracilis, septo opaco, uninervi. S e mina plura, uniseriata, lineari-oblonga, immarginata, funiculis filiformibus, liberis. $\mathbf{E} \mathbf{~ m -}$ bry o nis exalhuminosi cotyledones oblongae, pla. nae, radicnlae adscendenti incumbentes. - Herbae boreali-americanae, glabrae; foliis integris, racemis umbelliformibus, fructiferis haud elongatis, floribus albis v. purpureis, siliquis pendulis, curvatis.

Wa rea Nuttall in Journ. Academ. Philadelph, VII. Torrey et A. Gray Elora of North-America-1.98. S tanleya gracilis DC. et St. amplexifolia Nutt.

TRER EUS VITI. CAMELINEAE DC. Syst. II. 513. Silicula ovata v. oblonga, dissepimento parallele compressa v. turgida, bilocularis, bivalvis, valvis planis v. convexis. Se$\mathrm{min}$ a in quovis loculo plurima, biseriata, pendula. Cotyle dones septo contrariae, radiculae dorsali, placentae oppositae parallelae incumbentes. - Europae mediae, alpium Asiae mediae et antarcticae, Americae borealis, An. dium peruanorum el chilensium, nec non Novae-Hollandiae austro-occidentalis eives.

4918. Syrenia ANDRZ. Calyx tetraphyllus, foliolis conniventibus, duobus lateralibus basi gibbis. C o roll a e petala 4 , hypogyna, integra. S $t$ a $m$ in a 6, hypogyna, tetradynama, edentula. Sili cula bivalvis, stylo elongato tetragono, stignate bipartito superata, tetragono - anceps, valvis navicularibus, acute carinatis, uninerviis. Semina plurima, biserialia, pendula, immarginata, laevia, funieulis subulatis, liberis. E m b r y oniz exalbuminosi cotyledones planae, radiculae adscendenti incumbentes. - Herbae biennes, in Europa orientali et $A$ sia media indigenae, erectae, ramosae, setulis arcte adpressis bi. partitis vestitae; foliis sparsis, elongatis, angustis, sublinearibus, subintegerrimis, in petiolum angustatis, racemis lerminalibus aphyllis $v$, basi subfoliosis, interdum subspicatis, fioribus flavis, majusculis.

S y renia Andrzeiowsky ex C. A. Meyer in Ledebour Flor, alt. III. 160. Meisner Gen, 13. (12.) B r y s i m i sect. Sty 1 o ue ma DC. Syst. II. 491. Prodr. T. 196. Rrysimi sp. R. Brown, Waldst. et Kitaibel Plant, rar. Hung. t. 98. Delessert Io, select. II. $t$, 65 . C heirat a i sp. Heritier Stirp, $t$. 44 .

4919. Camelina CRANTZ. Calyx tetraphyllus, foliolis erectis v. patulis, basi aequalibus. Co rolla e petala \&, hypogyna, indivisa. Stamina 6 , hypogyna, tetradynama, edentula. Sil ieul a bivalvis, ovato-subglobosa, dissepimento parallele subcompressa, valvis convexis. S em in a plurima, biserialia, pendula, immarginata, punctato seabra v. laevia, funiculis setaceis, ima basi septo adnatis. $\mathbf{E}$ m bry on is exalbuminosi cotyledones planae, radiculae adscendenti incumbentes. Herbae annuae $v$. perennes, in Europa et $A_{s i a}$ media indigenae, erectae, ramosae, pube v. setulis bi-trifurcatisve obtectae; foliis sparsis, sublanceolatis, sagiltatis $v$. cordatis, basi amplexicaulibus, integerrimis, dentatis v. pinnatifidis, racemis terminalibus aphyllis, fructiferis elongatis, floribus parvis, flavis.

Camelina Crantz Austr. t, 17. Medihus in Usteri Neu. Annal. I, 67. t. 1. f, 11. R. Brown in Aiton Hort. Kew. edic. 2, IV. 83. Desvaux Journ, Bot, $I I T$, 270. DC. Syrt, $I T$. 514. Prodr. I. 201, C. A. Meyer in Ledebour Flor. alt. IIT. 175. Meisuer Gen, 13. (12.) - M y a $2 \mathrm{ram}$ DC. Flor. fr. edit. 3. IV. 817. M 8 n c bia e p. Roth. M yagri sp. Linu.

a, CHAMARLINUM DC. $\boldsymbol{l}$. c. Silicula e obovatae, marginatae, valvis apice mucronatis, stigmate punctiformi. Semin a panctato scabra. - Species annuas; folits acuto sagituatis. - M y a g i a p. Linn. Sehkubr t. 178. Cavanill. Ic. $t$. 66. (Delessert Ic. select. II. . 69.)

b. PSEUDOLINUM DC. , c. Silicula e globosae, immarginatae, valvis mutieis, stylo fliformi, stigmate capitato. - Species perennes; folitis amplexicaulibur, obturiusculis, auriculatis. - Lefol ob i a m Reichenb. Consp. 184. - M yagrum a us riac u un Jaeq. Flor. Austr. t. $11 \overline{1}$.

4920. Stenopetalum $R, B R$. Calyx tetraphyllus, folielis obovatis, conniventibus, lateralibus basi productioribus, Coro 11 a e petala 4, lyypogyna, unguiculata, lamina patente, oblonga, elongato-aeuminata, spiraliter torta. S tamina 6 , hypogyna, tetradynama, edentula. S ili eula bivalvis, obovatav. elliptica, septo parallele compressiuscula, valvis concaviusculis. S emin a plura, biseriata, pendula, subovata, immarginata, funiculis brevissimis, ima basi septo adnatis. Embryonis exalbuminosi cotyledones ovatae, planiusculae, radiculae adscendenti incumbentes. - Herbae Nova c Hollandiae austrooccidentalis; foliis linearibus, integerrimis v. inferioribus lyrato-pinnatifidis, racemis terminalibus, demum elongatis, pedicellis filiformibus, erectis v. nutantibus.

Sten o petalum R. Brown msc. ex DC. Syst. IT. 513. Prodr. I. 201. Badlicher in Enumerat. Plant. Hügel. 4. Meisner Gen. 13. (13.)

49: 1. Fudema HUMB, et BONPL. CaIy $x$ tetraphyllus, foliolis basi aequalibus. Corolla e petala 4 , hypogyna, oblonga, integra. Sta-
mina 6 , hypogyna, tetradynama, edentula. Silicu la bivalvis, ovato-oblonga, obtusa, stylo persistente superata, septo membranaceo apice fenestrato parallele compressa, valvis concavis. Se$m$ in a in loculis $3-12$, ovalia. Embryon is exalbuminosi cotyledones incumbentes (?). Herbae andicolae, caespitosae, perennes; foliis confertis, linearibus v. spathulatis, parvis, sessilibus, obtusis, ciliatis, floribus axillaribus solitariis, pedicellatis, albis.

K u d e m a Humb. et Bonpl. Plant. aequinoct. II. 133. t. 123. Kusth in Humb, ot Bonpl. Nov, gen. et. sp. V. 79. DC. Sjst. II, 518, Prodr, I, 201. Meisner Gen. 13. (13.)

492\%. NIatthewsia HOOK. C a ly x tetraphyllus, foliolis conniventibus, carinatis, basi aequalibus. C or olla e petala 4, hypogyna, unguienlata, lanceolata, siccitate torta. Stamina 6, hypogyna, tetradynama, edentula. Silicula bivalvis, elliptica v. lanceolata, stigmate sessili superata, dissepimento parallele compressa, valvis planis, reticulatis, medio nninerviis. Semina plurima, pendula, immarginata, funiculis liberis. Embryonis exalbuminosi cotyledunes planae, radiculae adscendenti incumbentes. - Suffrutex chilensis, ramosus, dense foliosus; folitis subfasciculatis, lineari-lanceolatis, pinnatijidis, pilis stellatis minute pubescentibus, subtus pallidioribus, racemis terminalibus elongatis, floribus majusculis, siccitate fulvis, 
Matthewsia Hooker Bot, Miscell, IrI. 140. t, 96. Meisner Gen. 13. 13.)

4923. Platypetalum $R$. BR. Calyx tetraphyllus, foliolis patentiusculis, carinatis, basi aequalibus. Coro 1 l a e petala 4 , hypogyna, unguiculata, lamina obovata, integra. St a m in a 6 , hypogyna, tetradynama, edentula. Silicula bivalvis, ovalis, stylo brevissimo apiculata, dissepimento parallele compressa, valvis planiusculis, medio nninerviis. Se m in a plurima, pendula, immarginata, funiculis liberis. E mb ryo $\mathbf{n}$ i s exalbuminosi cotyledones planae, radieulae adscendenti incumbentes. - Herbae perennes, in America
ar ot ica indigenae; caulibus abbreviatis, indivisis, basi denudatis, superne dense foliatis, foliis lanceolatis, obtusiusculis, integerrimis $v$. dente uno alterove instructis, crassis, aveniis, laete viridibus, scapis terminalibus saepius aphyllis, corymbo pauci. floro, ebracteato, fructifero elongato, petalis albis, purpura diluta tinctis.

Platypetalu m R. Brown in Parny's Fogage CCLXVI. Hooker Flor. Bor. Amer. I. t. 33. Meisner Gen. 13. (13.)

4D:4. Eutrema $R, B R, C$ a 1 y $x$ tetra phyilus, foliolis patentiusculis, carinatis, basi aequalibus. Corollae petala 4 , hypogyna, breviter unguiculata, obovata, integra. S tam in a 6 , hy. pogyna, tetradynama, edentula. Silicula bivalvis, lineari-lanceolata, tetragono - anceps, stylo brevissimo apiculata, valvis acute carinatis, sub. trinerviis, dissepimento basi et apice completo, medio deliquescente. Se mina plarima, pendula, immarginata, funicalis brevissimis, papillaeformibus, dissepimenti vestigio aduatis. $\mathbf{E}$ m bry on is exalbuminosi cotyledones lineari-oblongae, radiculae adscendenti incumbentes. - Herba perennis, in $A m e r i c a$ aretica et in summis $A$ siae mediae alpibus indigenae, glabraev. minutissime setulosae; caulibus simplicissimis, erectis, paucioris, foliis radicalibus elongato-petiolatis, ovatolanceolatis, integerrimis $v$. paucidentatis, crassiusculis, planis, uninervïs, cau inis conformibus, inferioribus breve petiolatis, superioribus subsessilibus, corymbis densis, folio florali unico suffultis, caeterum ebracteatis, floribus albis.

I a tre ma R. Browa in Parry's Voyage CCLXVII, t. A. C. A. Meyer in Ledebour Flor, alt, 1II. 163, Ledebour Ic. t. 258. Meisner Gen. 13. (13.) - F. a renicola Hooker Flor, Bor. Amer, t. 24. vix congener.

4585. Aplaresasmess ANDRZ, Caly x te traphyllus, foliolis patentiusculis, earinatis, basi aequalibus. Cor olla e petala 4 , hypogyna, unguiculata, obovata. Sta m in a 6 , hypogyna, subaequalia, edentula. Silicula bivalvis, lanceolata, compressa, stigmate subsessili, valvis planis, medio uninerviis, septo nullo. S e m in a $4-6$, ex apice septi pendula, immarginata, funienlis filiformibus, elongatis. Embryon is exalbuminosi cotyledones plano-convexae, radiculae adscendenti incumbentes. - Herba parva, perennis, in $A m e-$ riea aretica alpic ola, Cardamines bellidifo. liae facie, caulibus hypogaeis caespitosis, squamosis, apice foliosis, foliis longe petiolatis, spathulatis, subearnosis, integerrimis, uninerviis, scapis aphyllis, floribus corymbosis, bracteis foliaceis, subinvolucrantibus, petalis albis v. atropurpureis.

A phragmus Andrreiowsky in De. Prodr. I. 209. Orobinm Reicheab. Consp. 185, 0 reas Chamisso et Sehlechtend, in Linnaea I. 29. t. 1. Hooker Flar. Bor Amer,, , 67, non Brid, nee Zoolog.

4926. Platyspermanm $H O O K, \mathrm{C}$ a I yx tetraphyllus, foliolis patentiusculis, basi aequali- bns. Corolla e petala 4 , hypogyna, subsessilia, obovata. Stam in a 6, hypogyna, tetradynama, edentula. Silicula bivalvis, ovalis, dissepimento parallele compressa, stigmate sessili, valvis planis, septo integro. Semina pauca, compressa, suborbieulata, late membranaceo-marginata, funievlis longiusculis, gracilibus, Embryon is exalbuminosi cotyledones plano - convexae, incumbentes. - Herba boreali-amerieana, humilis, glabra, foliis omnibus radicalibus, patentibus, sub. runcinato-pinnatifidis, in petiolum angustatis, scapis ex eadem radice plarimis, simplicissimis, unifloris, flore erecto, albo.

Platyspermum llonker Flor. Bor. Amor. T. 68. t. 18. f. b. Meisuer Gen, 13. (13.)

THERES IX. LEPIDINEAE DC. Syst. II. 521. Silicula septo angustissimo, valvis carinatis v. valde concavis. Sem in a in loculis solitaria v. pauca, immarginata, ovata, cotyledones planae, incumbentes, septo parallelae (OII). - Lepidineae quamvis per totum terrarum orbem, si florae indicae diliones exci. pias, e quibus nullam haclenus hujus tribus stirpem advexit botanicorum solertia, sint dispersae, attamen ob majorem numerum, quo in Syria, Armenia, Persia elc. gignuntur, florae orientalis eives per eminentiam dici merenlur. Pauciores species regionem mediterraneam et Europam mediam et borealem inhabitant, quarum nonnullae etiam per omnem Americam sunc diffusae. America australis sua sibi genera, ut plurimum frulescentia vindicat. Quae in regione capensi, oceani australis insulis et Nova-Hollanilia hucdum fuerunt repertae, ab europaeis genere non recedunt. Notatu digna regionis taurico - caucasicae, Cruciferarum alias feracissimae, Lepidinearum pauperlas. Caelerum pleraeque species endemicae, paucissimae polydemae, per Europam et Americam borealem vagae. Capsellam per orbem terrarum disseminavic inguietum mortalium commercium.

48: Capsella VENT. C al y $\mathrm{x}$ tetraphyllus, foliolis planis, basi aequalibus. C orollae petala 4 , hypogyna, integra. Sta mina 6 , hypogýna, tetradynama, edentula, Silic ala a latere compressa, inverse triangularis, sinu levi emarginata, dehiscens, valvis carinatis, derso apteris, septo angustissimo elliptico, stylo brevi. S e m in a in loculis plurima, funiculis liberis. Embry onis exalbuminosi cotyledones planae, incnmbentes. Herbae annuae, europa ea e, nunc per orbem terrarum diffusae; radice perpendiculari, caule tereti, ramoso, foliis radicalibus rosulatis, patulis, basi angustata integris, superne dentatis, incisis v. varie lobatis, caulinis alternis, basi sagitattis, oblongis, erectis, racemis terminalibus, elongatis, pedicellis filiformibus, ebracteatis, silicula multo longioribus, floribus parvis, albis, saepe petalis in stamina conversis monstrosis.

C a p sell a Venten. Tabl. III. 110. Desvaux Journ. Bot. III. 168. DC. Syst. II, 382. Prodr. I. 177, Gay in Annal. sc. nat. III. 112. C. A. Meyer in Ledebour Flor, alt. III. 196. Meisner Gen, 11. (13.) Webb et Berthel. Flor. Canar. 98. Marsypocarpus Necker Elem, $n, 1416$. Rod seh fedia 
Gärtaer Flor. Wetteraw. IL. 413. B urs a Guettard Observ. II. 158. B ars a pastoris Tournef. Inst, 103. T h las p i Bu rs a pas to ris Lino. Flor. dan. $t$, 799. Schkuhr $t, 180$. E. B. $t, 3485$, Gärtner $t, 141$. $-\#$ y $\mathrm{m}$ e $\mathrm{n}$ o $\mathrm{I}$ o b a $\mathrm{s}$ Nuttall ex Torrey et A. Gray Flora of North America I. 117.

4928. Jonopsidium REICHENB, $\mathrm{Ca}$ ly $x$ tetraphyllus, foliolis coneavis, basi aequalibus. Corollae petala 4 , hypogyna, integra. Stamina 6 , hypogyna, tetradynama, edentula. Silicula a latere compressa, subrotunda, brevissime emarginata, dehiscens, valvis carinatis, torgidulis, dorso apteris, septo anguste oblonge, stylo brevi. Semina in loculis plurima, funiculis liberis. Embrynnis exalbuminosi cotyledones planae, incumbentes. - Herbalusitanica, annua, pusilla, glabra, radice fibrosa, caule subterraneo v. brevissimo seapigera; foliis radicalibus longe petiolatis, orbiculatis $v$. subcordatis, integris $v$, interdum subtrilobis, minutis, pedunculis radicalibus seapiformibus $v$. rarius axillaribus, filiformibus, flaccidis, unifloris, flore parvo, purpurascente, rarius albo $v$. caeruleo.

Jonopsidi am Reichenb. Iconogr, VII. 26. $t$. 649. Meisner Gen, 14. (13.) Jonopsidiam Cochleariac seet, DC. Prodr. . 124. Jon ops is Cochlea riace sect. DC. Syst. II. 37t. Coeble aria pusilla Brotero Phy. togr. lusit. t. 21, f. 2. 3. Jacq. f. Eclog. t. 132.

4929. IB ivonaen $D C$. C al y $x$ tetraphylIns, foliolis subaequalibus. Coroll a e petala 4 , hypogyna, unguiculata, calyce paullo longiora, lamina parva, subemarginata. Sta mina 6, hypogyna, tetradynama, libera, edentula. Silicnla a latere compressa, ovalis, apice emarginata, dehiscens, valvis earinatis, dorso alatis, septo oblonge, stylo brevissimo, stigmate capitulato. Se$\mathrm{m}$ in a in loculis $4-6$, ovata, pendula, funiculis fili. formibus, basi septo adnatis. Embryonis exalbuminosi cotyledones planae, crassiusculae, incumbentes. - Herba sicula, annua, glabra, glauca, tenella, quadri-sexpollicaris; caule filiformi, parce ramoso, foliis alternis, inferioribus petiolatis, superioribus sessilibus, basi cordato-amplexicaulibus, ovatis, grosse hinc inde dentatis, obtusiusculis, racemis terminalibus, demum elongatis, pedicellis filiformibus, ebracteatis, siliculis brevio. ribus, floribus parvis, luteis.

B i on a e a DC. Syst. II. S54. Prodr. X. 208. Meisner Gen. 14. (13.) $\mathrm{T}$ blas pi luteum Bivona.

4530. Eumomia DC. Calyx tetraphyllus, foliolis aequalibus. Co rolla e petala 4 , hypogyna, aequalia, limbo oblongo, integro. Stamin a 6 , hypogyna, tetradynama, libera, edentala. Silicula a latere plano-compressa, ovalis, subemarginata, dehiscens, valvis carinatis, apice obtusis, dorso apteris, epto oblongo, stylo brevi. Semina in loculis gemina $\mathbf{v}$ abortu solitaria, ex apice dissepimenti pendula, oblongo-triquetra, funiculis basi in unum coalitis. $\mathbf{E} \mathbf{m}$ b y o n is exalbuminosi cotyledones oblongae, incumbentes. - Herbae orientales, suffruticosae, ramosae v. caespitosae; folitis oppositis, superioribus interdum alternis, sessilibus, amplexicaulibus, orbieulatis $v$. cordatis, integris, crassiusculis, racemis terminalibus brevibus, floribus albidis.

E u n om i a DC. Syst. II. 555. Prodr. I. 208, Meisner Gen. 14. (13.) Lepidinm op o it if oll um Labillard. Syr. Deead. $V$. 2. 9.f. 2. Thla pa i cordat u m Desfont. in Annal. Mus. IL. t. 39 .

493 1. Hiatelhinsis $R$. BR. Calyx tetraphylfus, foliolis aequalibus. Curo 11 a e petala 4, hypogsna, integra. Stamina 6, hypogyna, tetradynama, libera, edentula. Silic u la a latere compressa, oblenga $v$. subrotunda, apice integra v. subemarginata, dehiscens, valvis carinatis, dorso apteris, stylo brevissimo. Semina in loculis 2, funieulis distinctis, liberis. E m br y o$\mathrm{n}$ is exalbuminosi cotyledones planae, incumbentes. - Herbae e urope ae, alpicolae; foliis radicalibus pinnatifidis, caule simplici nudo, v. ramoso folioso, racemis terminalibus, erectis, pedicellis filiformibus, ebracteatis, floribus parvis, albis.

Hutchinsia R. Brown in Aiton Hort. Kew. edil, 2. IV. p. 82, excl. sp. DC. Syst, 1I. 384, Prodr. I, 177, excl. sp. Koch Synops. 73. Meisner-Gon. 14. (13.) Noc ca a Reiclienb. Flor. Germ 633. exel. sp. non Monech. N as tu r tioI um Gray Brit Plant. II. 692, L e pid if sp. Lína. Jacq. Flor. Austr. t. 131. 137.

4932. Fepialium $R . B R$. Calyx tetraphyllus, foliolis aequalibus. Corvilae petala 4 , hypogyna, iategra. Stam ina 6 , hypugyna, tetradynama, libera, edentula. Silícula a latere compressa, ovalis, apice integra $v$. plus minus emarginata, dehiscens, valvis carinatis, nunc Iorso apteris, nanc ad apicem rarius per totam longitudinem breviter alatis, septo angusto, val. vis aequilongo $v$, breviere, stylo subnullo v. fili formi. Semina in loculis solitaria, rarissime gemina, ex apice septi pendula, subtriquetra v. compressa, funiculis liberis, dis tinetis. E m br y o$n i s$ exalbuminosi cotyledones oblongae $v$. lineares, incumbentes. - Herbae v. suffrutices minores, latissime per terrarum orbem dispersae, in Europa mediterraneo orientali et Asia finitima imprimis copiose habitantes; caulibus teretibus, ramosis, foliis variis, racemis terminalibus erectis, demum elongatis, pedicellis filiformibus, ebracteatis, floribus albis, parvis.

Le p id ium R. Brown in Aiton Hort. Hew. edit. 2. IV. 85. DC. Syat. II. 527. Prodr. I. 203. C. A. Meyer in Ledebour Flor. alt. III. 198. Meisner Gen. 14. (13,) $\mathrm{N}$ a s t u ri $\mathrm{um}$ et Lepidiug Medikus gen. , 80, 84. Monch $\mathbf{X}$. thod. 269. 220. Venten. Tabt. IIt 110, 111. Cardarin, Lepia et Le pidiom Desvaux Journ, Bot. IIT. 163_165. Iberis, Kandis et $\mathrm{N}$ as $\mathrm{s}$ u $\mathrm{rti}$ isp. Adauson Fam. IL. 163. Lepidil, cochleariae et Thlaspoos sp. Lian.

a. CARDARIA DC. $l$. e. Silieula ovato-cordata, acuta, subdepressa, valvin subturgidis, apteris, stylo filiforai, exserto. - Cardaría Desyaux 2,c. Cardiolepia Wallroth Sched. cril. 3\$0. Jundzillia Andrzeiowsky mic. Coehlearia Draba Lina. Jacq. Flor. Aurtr. t. 315

b. ELLIPSARIA DC. $l$. e. Sili i u l a elliptica, haud emarginata, valvis carinatis, apteris, stylo filiformi. - L. chalepense Linn. L. gl a stifolít m Desfont. F'lor. atlent, $t$. 147. Le piae p. Desv.

e. BRADYPIPTUM DC, $t$, $c$, Silicula elliptica, integra v. subemargioata, valvis carisatis, apteris, stylo brevi exserto, calyce persiatente v. sero deciduo stipata. Folia caulina basi nec amplexicaulia nec auriculata. - $\mathbf{L}$ epidium eoronopifolium Fischer. Lepiace sp. Desv. (Ledebour Ic, $t, 162$. )

d. CARDAMON DC. 1 . e. Silfeula suborbiculata, apice emarginata, valvis carinato-navieularibus, dorso subalatis, stylo brevissimo intra emarginaturam incluso. Cotyledones tripartitae. - Nasturtium Bnerhave Hist, 415. Medikus in Usteri Neu. Annal. II. 44. non R. Brown. Le pid i u a s a tiv a m Linn. Sehkuhr t. 180. Sibthorp Flor. graec, t. G16. Wight Illustr. t. 12. Lepiae sp. Desv.

e. LEPLA DC. l. o. Silicula suborbiculata, aplee emarginata, valvis navicularibus apice alatis, alis ssepins stylo brevissimo intra sinum inclusn aduatis. Cotyledo nes integrae. - Lepiae sp. Desr Lasioptera Andrzeiowsky mac. T h 1 a s peos s p. Linn. E. B, $t, 1385$. (E B $t$. 1803.)

f. DILEPTIUM DC. l. c. Silieula sabellipties, apice brevissime emargiasta, valvis caribatis, omaino apte. 
ris, stylo subuollo. - Flores minimi, interdum abortu di-tetraudri $v$. rarius apetali. - Nast u $r$ tioides Medik. Gen, 1. 81. Mönch Method, 270. Dile ptium Ra finesq. Flor. ludov. 85. (excl. L. virginico) S e uekenbergia Flor. Fetteraw. IT, 413. L e pidils p. Linn. Desv, Jacq. Flor, Austr. $t$, 346. Flor. dan. $t$. 18t. E, B. t. 1595, Ledebour Ic. $t, 98$.

g. LEPIDIASTRUM DC. 2 . c. Sili e ula ovata v: elliptica, integerriua, nequaquam emarginata, stigmate subsessili apiculata, valvis carinatis, epteris. - Schkuhr 2.180. (B. B. t. 182. Cavanill. Ic. $t$. 161. Waldst, et Kitaibel Plant. rar. Hung. 6. 4. A. Rieliard Flor. Nov. Zeel. $t$, 35, Delessert Ic, seleet, II, $t, 73$. Ledebour Ic. t, 154.)

4933 . Ir graenophysa C. A. MEY. Calyx tetraphyllus, foliolis aequalibns. Corollae petala 4 , hypogyna, integra. S t a m in a 6 , hypogyna, tetradynama, libera, edentula. Silicula inflato - subglobosa, indehiscens, valvis hemisphaericis, apteris, septo elliptico, stylo brevi. S e mi$\mathbf{n}$ a in loculis solitaria, ex apice septi pendula, immarginata, funiculo libero, setaceo. Embryon is exalbuminosi cotyledones lineares, incumbentes. - Herba altaica, perennis, pube brevi molli subglaucescens; foliis allernis, membranaceis, oblongis, argute inaequaliter dentatis, infimis in petiolum angustatis, superioribus amplexicauli-sessilibus, racemis terminalibus subcorymbosis, aphyllis, fructiferis elongatis, pedicellis jiliformibus, patentibus.

H $y \mathrm{men}$ op hys a C. A. Meyer in Ledebour Flor. alt. III. 180. Ledebour Ic. $t, 163$, Meisner Gen. 14. (13.)

4D33 \&. Aethionerana R. BR. Calyx tetraphyllus, foliolis insertione inaequalibus. Coro Il a e petala 4 , hypogyna, integra. $\mathrm{St}$ a $\mathrm{m}$ i na 6 , hypogyna, tetradynama, majora inter se connata v. intus dente notata. Silic u la elliptica, a latere plano-compressa, apice saepius emarginata, dehiscens, v. abortu unilocularis, indehiscens, valvis navicularibns, dorso in alam membranaceam, integram v. interdum dentatam expansis, septo angusto, stylo brevi. Semina in loculis plura v. rarius solitaria, funiculis liberis. Embry on is exalbuminosi cotyledones ovales, incumbentes.

Herbae annuae, perennes v. suffrutescentes, a basi ramosae, erectac, diffusae, in Eur opa austra$l i$, imprimis orientali et Asia finitima indigenae; foliis glaucescentibus, sessilibus, integris, ovato-oblongis $v$. interdum linearibus, saepe inferioribus oppositis, caule tereti, tenui, racemis subterminalibus, confertis, pedicellis filiformibus, ebracteatis, floribus minimis, carneis v. purpurascentibus.

A ethionema R. Brown in Aiton Hort. Hew, edit. 2. IV. 80. DC. Syst.Ir, 557. Prodr. Y, 280. Delessert Ic, select, II, t. 74_76. Sweet Fl. Gard. II. t. 69. Meisner Gon. 14, (13.) Th las peos 8 p. Linn. Jacq. Flor. Austr, $t, 236$.

4335. Illexaptera HOOK. Calyx tetraphyllus, foliolis basi aequalibus. Corollae petala 4, hypogyna, obovata, integra. Sta min a 6 , hypogyna, tetradynama, libera v. longiora per paria connata. Silicula substipitata, hexaptera, valvis ad suturas contractis, margine utrinque et dorso in alam membranaceam expansis, demum e septi angustissimi, stylo brevi superati apice pendnlis, indehiscentibus. S e min a in loculis solitaria, immarginata. E m bry on is exalbuminosi cotyledones ovales, planae, incumbentes. - Herbae peruanae et chilenses, andicolae, suffruticosae, simplices $v$. dense caespitosae; folits nunc subradicalibus, pinnatifidis, nunc caulinis confertis, cuneatis, apice trilobis, racemis terminalibus corymbosis, densis, fructiferis vix elongatis, floribus albis.
Hexaptera Hooker Bot, Miscell, $, 350,2,82,74$, Meisner Gen, 14. (13.)

DISPELTOPHORUS Lehm. Index sem. Hamb, 1836, n, 2 Calyx clausus, basi saecatus. Corolla e petala fitegra. Silicula bivalvis, valvis ovalibus, convexo-scutatis, apice basique emarginatis, margine, membranaceo axi stylifero opposite adnatis, basi dehiscentibus..- Herba chilensis, perennis, ramosa, laevis; folits sessilibus, carnosis, li: nearibus, obtusis, supra planiusculis, subtus convexis, floribus racemosis, albidls.

THEE EUS X. ISATIDEAE DC. Sysi. $\boldsymbol{I}$. 563. Sili cula forma varia, indehiscens, monosperma v. rarissime disperma. Semina pendula, rarissime horizontalia. Cotyledones marginibus placentas, rarissime valvularum dorsum spectantes, radiculae adscendenti v. rarissime horizontali, valvarum carinae v. rarissime placentis parallelae incumbentes.

Herbae in temperatis hemisphaerae borealis indigenae, in regione mediterranea et Asia media copiosiores.

4936. BD iptereygoinun DECAISN. C a I y x tetraphyllus, foliolis aequalibus. Corolla e petala 4, hypogyna, ovato-lanceolata, breviter unguiculata, integra. Sta m in a 6, hypogyna, subtetradynama, edentula. $O$ r a ri u m quadrangulum, angulis dentato - cristatis, nniloculare, ovulis prope basim parietalibùs geminis, collateralibus, adscendentibus. Sty lus teres; $8 \mathrm{t}$ ig ma eapitatum. Silicala indehiscens, a latere compressa, sub. rhomboidea, crustacea, dorso utrinque in alam membranaceam expansa, disci utraque facie ala fere obsoleta mnnita, nnilocularis, abortu monosperma. Semen e basiadscendens. Embryonis exalbuminosi cotyledones lineari-oblongae, radiculae descenilenti incumbentes. - Herba arabica, glaberrima, glaucescens, ramoso-diffusa; ramis teretibus, subaphyllis, foliis caulinis ovato-lanceolatis, integerrimis, crassiusculis, planis, aveniis, floribus laxe racemosis, ramulos terminantibus, bracteolatis, bracteolis pedicellis dimidio brevioribus. lineari-lanceolatis, inferne auriculis bifidis, minimis instructis.

Diptery g i um Deealsne in Nouv. Annal. sc. nat. IV. 66. $t$. 3. Pte rolom a Steudel et Hochstett, in Schimper Herb. Arab. n. 85t.

493 \%. Tetraptery gicuna FISCH, et MEY. Cal y x tetraphyllus, foliolis aequalibus. C o ro Lla e petala 4 , hypogyna, integra, aequalia. Stamin a 6 , hypogyna, tetradynama, edentula. O vari m subquadrangulum, angulis membranaceis, uniloculare, ovulo unico, ex apice loculi pendulo, campylotropo. Stigma sessile, subcapitatum. Sili cula cordata, indehiscens, a latere compressa, dorso utrinque in alam membranaceam prodncta, disco utraque facie ala angusta aucto quadrialata, nnilocularis, monosperma. S emen pendaInm. Embry on is exalbuminosi cotyledones radiculae adscendenti ineumbentes. - Herba arme$n a$, annua, glaberrima, glauca; foliis integerrimis, oblongis, superioribus cordato-amplexicaulibus, racemis aphyllis, floribus flavis, fructibus peadulis.

Tetrapterygi m Fischer et Meyer Indes sem. hort. Petropolit. I. 1835, p. 39. Meisner Gen. 14. (13.)

4983. Isatis LINN. Cal y x tetraphyllus, foliolis aequalibus. Cor o 11 a e petala 4 , hypogyna, integra. S $\mathbf{t a m i n a} 6$, hypogyna, tetradyna- 
ma, edentula. Ovarium compressum, uniloenlare, ovulo unico v. rarissime geminis, ex apice loculi pendulis, campylotropis. Stigma sessile, subcapitatum. Silicula indehiscens, a latere plano-compressa, oblonga v. ovata, rarius cordata, valvulis navicularibus, ala foliacea v. incrassata fungosa plana cinctis, nnilocularis, mono-v, rarissime disperma. S e m en pendulum, immarginatum. Embryonis exalbuminosi cotyledones crassiusculae, planae, radiculae adscendenti incumbentes. - Herbae annuae v. biennes, in Europa australi et orientali, nec non in Asia media indigenae, fecula caeruleo tingente plus minus scatentes, erectue, ramosae, spectabiles, pubescentes v. saepius subglabrae, glaucescentes; foliis subinte. gerrimis, caulinis sparsis, sagittato-v. cordatoamplexicaulibus, summis saepe basi aequalibus, racemis terminalibus, elongatis, laxis, aphyllis, pedicellis fliformibus, fructiferis deflexis, floribus parvis, flavis.

Is at is Tournefort inst, 100. Linn. Gen, n. 824. DC. Syst. II. 364. Prodr. I. 210. C. A. Meyer in Ledebour Flor. Alt. III. 202, Meisner Gen. 14. (13.)

a. GLASTUM DC, $b$. c, SiljeuJ a ala fungosa, angusta. - Is a tis Desvaux Journ. Bot. III, 16t. (Schkuhr t, 188. Gärtner $t, 142$. Lam. t. 557. E. B. $t$. 97. Allioni Flor. Pedemont, t, 86. Tratt. Arehiv, t. 68, Delessert Ic. select. II. t, 78. 79. Ledebour Ic. t. 339.)

b. SAMERARIA DC. t. c. Silieula e ala foliaceo-membranacea, lata. - S a meraria Desraux t. c. t. 24. f. o. (Tratt. Archiv. $t$, 70. Delessert Ic, select. II. t. 77.)

4\$35. Trauselnerin FISCH. CaIy x tètraphyllus, foliolis aequalibus. Coroll a e petala 4 , hypogyna, integra. St a m in a 6, hypogyna, tetradynama, edentula. Ovarinm compressum, utroque margine infra apicem angulo prominulo, uniloculare, ovthl o unico ex apice locnli pendulo, campylotropo. Stylus subulatus, membranacens; stigma subcapitatum. Sili c ula indehiscens, cymbaeformis, subtus convexa, superne concava, ala coriacea inflexa cincta, unilocularis, monosperma. Sem en pendulum, immarginatum. Embry on is exalbuminosi cotyledones oblongae, planae, radiculae adscendenti incumbentes. - Herbae annuae, in Asia media indigenae, erectae, ramosae, glabrae, glaucae; foliis integerrimis, radicalibus subpetiolatis, caulinis sparsis, cordatis, amplexicaulibus, racemis terminalibus et lateratibus aphyllis, floribus parvis, flavis.

Taus e heria Fischer in DC. Syst. II. 562. Prodr, $I$. 210. C. A. Meyer in Ledebour Flor. Alt. III, 200. Lede. bour Ic. $t$, 139. Boyle Himalay, t, 17. Meisuer Gen, 14. (13.)

45 40. Thysamoenrpus HOOK. Ca ly tetraphyllus, aequalis. Cor o11 ae petala 4 , hy. pogyna, integra, calyce breviora. Stamina 6 , hypogyna, tetradynama, edentula. Ova ri u m ovatum, compressum, uniloculare. .... St y I u 8 filiformis, deciduns v, persistens, $s \mathrm{ti} \mathrm{gm}$ a obtusum. Silicula indehiscens, ovata, convexo-plana, ala membranacea apice emarginata, integra $v$. foraminibus pertusa, unilocalaris, monosperma. Sem en pendulum, immarginatum. Embry on is exalbuminosi cotyledones ovatae, planae, $r$ adi cula e adscendenti incumbentes. - Herbae annuae, in Anierica boreali-occidentali in. digenae; foliis radicalibus dum adsunt pinnatifidis, caulinis paucis, remotis, basi sagittato-amplexicaulibus, racemis terminalibus aphyllis, pedicellis fructiferis nutantibus.
Thysanocarpus Hooker Flor. Bor. Amer. I. 69. t. 18. A. Ic. $t$, 29. 42. Fischer et Meyer Index Sem. hort. Petropolit. II. 50. Meisner Gen. 14. (13.)

494. Sobolewskia BIEBERST. Calyx tetraphyllus, foliolis aequalibus. Cor ollae petala 4, hypogyna, integra. Sta mina 6 , hypogyna, tetradynama, majora basi latiora, lateralia brevissima. Ova ri $\mathbf{u m}$ ovatum, compressum, uniloculare, ovulo unico, ex apice loculi pendulo, eampylotropo. S t i $\mathrm{g} \mathrm{m}$ a sessile, subeapitatum. Sili c u la indehiscens, oblonga, a Jatere compressa, submembranacea, unilocularis, monosperma. S e m e n pendulum, immarginatum. Em b r y on is exalbuminosi cotyledones lineares, incurvae, radiculae adscendenti incumbentes. - Herba $t a u r i$ ca, erecta, ramosa, fere paniculata; caule tereti, basi suffrutescente, foliis caulinis petiolatis, cordato-reniformibus, dentatis, racemis elongatis, pedicellis filiformibus, ebracteatis, floribus albis.

Sobolewskia Bleberst. Suppl. 421. Cent. plant. ross. II. t. 59. DC. Syst. II, 575. Prodr. $I$, 212. Delessert Ic. select. II. t. 80. Meisuer Gen, 14, (13.) M a c rosporum DC. mso. Crambe ma,crocarpa Bieberst.

4942. Nesllía DESV. Caly $\mathrm{x}$ tetraphyllus, foliolis aequalibus. Co ro Il a e petala 4 , hypogyna, integra. Stamina 6 , hypogyna, tetradynama, edentula. Ovari nm subglobosnm, biloculare, loculis bi-quadriovulatis. St y l u s filiformis, deciduus, stigma punetiforme. Silienla indehiscens, fere ossea, subglobosa, septo obliterata uni-v, incomplete bilocularis, mono-disperma. S e m en horizontale. E $\mathbf{m}$ bry on is exalbuminosi radicula cotyledonibus crassinsculis incumbens. - Herba per Europam et Asiam mediam obvia, annua; erecta, ramosa, diffusa, foliosa, setulis bi-trifidis hispidula; foliis subintegerrimis, caulinis sparsis, oblongo lanceolatis, basi sagittato-amplexicaulibus, rucemis terminalibus elongatis, pedicellis filiformibus, ebracteatis, floribus parvis, flavis.

Neslla Desvaux Journ, Bot, IIT. 162, 163. DC, Syst. IT. St9. Prodr. T. 202. C. A. Meyer in Ledebour Flor. AIt. III. 205. Meisner Gen. 13. (13.) Vogellia Dledik.

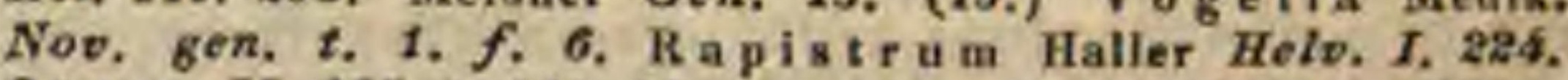
Gärtuer $I T$. 285, $t$, 141. M y a g rum panie ulat u m Lian. Flor dan. $t, 204$. Selkahr $t, 178$.

4543. II yagrem TOURNEF. C a 1 y x tetraphyllus, foliolis aequalibus. Corolla petala 4 , hypogyna, integra, vix calycem superantia, Sta m in a 6, by pogyna, tetradynama, edentula, majora basi per paria subconnata. Ovarin m oblongo - turbinatum, uniloculare, ovulis duobus v. unico, ex apice loculi pendulis. Stylus brevis, conicus, tig ma simplex. Silicula indehiscens, coriacea, suberosa, apice compressa, intus utrinque lacunosa, inferne attenuata, unilocularis, monosperma. S e m e n pendulum, immarginatum. Embry onis exalbuminosi cotyledones crassinsculae, planae, radiculae adscendenti incumbentes. - Herba annua, in agris arenosis Europa e australis et orientalis obvia, erecta, glabra; foliis inferioribus in petiolum longum attenuatis, oblongis, superioribus sessilibus, auriculis auctis sagitlato - amplexicaulibus, omnibus integerrimis v. subdentatis, racemis elongatis, terminali-oppositifoliis, strictis, pedicellis brevibus, filiformibus, erectis, demum obconicis, apice intus cavis, floribus parvis, pallide flavis.

Myagrum Tonruefort Inst. 99. Medik. Gen. plant. I. 39 . t. 1. f. 1. R. Brown in Aiton Hort. Hew, edit. 2. IV. 74. Desvaux Journ. Bot. IIT. 160. $2.25 . f$. 5. DC. Syit. II. 573. Prodr. I. 212. Meisner Gen, 14. (13.) B ricour 
Adanson Fam. IT. 423. Deltocarpus Heritier msc. S Inistrophoram Schrank mec. Myagrum perfoliat a m Linn. Sehkuhr $t$. 178.

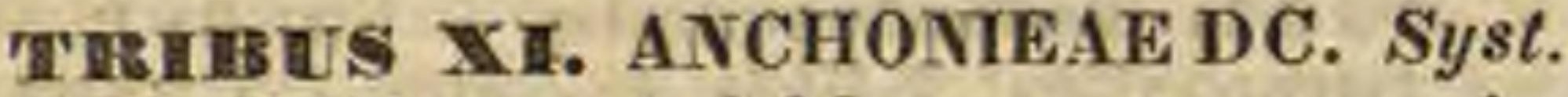
II. 576. Siliqua indehiscens, transversim in loculos clausos, saepissime monospermos secedens. Semina pendula. Cotyledones planae, marginibus valvulas spectantes, radiculae adscendenti, placentae oppositae parallelae incumbentes. - Herbae in Oriente et Asia media indigenae.

4944. THolldbachia $D C$. C a l y $\mathrm{x}$ tetraphyllus, foliolis erectis, basi aequalibus. Co rolIa e petala 4, hypogyna, indivisa. Stamina 6 , hypogyna, tetradynama, libera, edentula. Stigma simplex. Siliqua *abbreviata, inarticnlata, demum in loculos duos clansos, monospermos secedens, valvis carinatis v, ecarinatis, $\mathrm{S}$ e min a pendula, immarginata, laevia, funiculis brevissimis, papillaeformihys. Em br yo nis exalbuminoai cotyledones elipticae, apice subtruneatae, subconcavae, radiculae adscendenti incumbentes, _ Herbae Asia mediae, glaucescentes, glabrae v. versus apicem setis paucis, simplicibus conspersae, foliis subintegris, canlinis sparsis, inferioribus in petiolum attenuatis, superioribus auriculato-subamplexicaulibus, racemis terminalibus et lateralibus, elongatis, laxis, aphyllis, pedicellis filiformibus, fructiferis reflexis, floribus parvis, violaceis.

Goldbachia DC. Syst. IT. sz6. Prodr. I. 212. Delessert Ic, select. $1 T, t, 81$. C. A. Meyer in Ledebour Flor. Alt. IIr. 207. Meisner Gen, 14. (13.) R a phan us lae v ig a t u s Bielierst.

4945. Anelnonifum $D C$. Caly x tetra phyllus, foliolis erectis, duobus lateralibns basi subsaccatis. Cor olla e petala 4 , hypogyna, indivisa. St a min a 6, hypogyna, tetradynama, breviora libera, edentula, longiora per paria connata. Stylas compresso-conicus; stigma subbilobum. Sili u a abbreviata, stylo restrata, isthmo in articulos duos septo crasso biloculares, dispermos, haud separabiles distineta. S e $m$ in a pendula oblonga, immarginata, laevia, funiculis brevissimis, papillaeformibus. $\mathbf{E} \mathbf{m}$ br $\mathbf{y}$ o $\mathbf{n}$ is exalbuminosi cotyledtones oblengae, subenrvae, radieulae adscendenti incumbentes. - Herba lib anotica; caudice duro, foliis radicalibus oblongis, basi angustatis, pube stellata, molli velutinis, integris, racemis terminalibus, foliosis, demum elongatis, floribus purpureis.

Anch ouinm DC. Syst. II. 518. Prodr. 1. 212. Delessert Ic, select. II. 4. 82. Meisuer Gen. 14. (13.)

4946. Stentigana DC. Calyx tetraphyllus, foliolis erectinseulis, basi aequalibus. Co r ol Ia e petala 4, hypogyna, indivisa. 'Stamina 6, hypogyna, tetradynama, breviora libera, edentula, longiora per paria connata. Stig mata 2 , divaricata. Siliqua elongata, inarticulata, teretiuseala, in loculos plurimos, monospermos secedens, valvis subnervasis. Semina pendala, sub. marginata, laevia, funiculis setaceis, liberis, E mbryonis exalbuminosi cotyledones sublineares, crassinsculae, planae, radienlae adscendenti incumbentes. - Herbae in Asia media et Oriente indigenae, biennes $v$. interdum basi fruticulosae, erectae, ramosae, pube stellata subplumosae, et setulis rigidis, glandula terminatis interdum adspersae; foliis oblongis, plerumque sinuatis, crulinis sparsis, subsessilibus, racemis terminalibus et lateralibus, elongatis, aphyllis, floribus flavis, majusculis.

Sterig w a DC. Syst. Ir. 579. Prodr. I, 212. Delessert Ic. seloct. II, t. 83. 84. C. A. Meyer in Ledebour Flor. Alt, IIT. 209. Meisner Gen. 14. (13.) Sterig mos temon Bieberstein Supplem. 4t4. A r throl ob us Steven moc, non Andrz. Cheir a nthi sp. Pallas $n$. $t, k$. $f$. 2. Bieberst.

494\%. Norisia $G A Y$, C a ly x tetraphyllus, foliolis erectis, basi subaequalibus.C oroll a e petala 4, hypogyna, unguiculata, truneata v. emarginata. St a m in a 6, hypogyna, tetradynama, 1ibera, edentula. Stylus crassinsculus, teres; s $\mathrm{t}$ ig m a capitatum, indivisum. Siliqua biartieulata, coriacea, sero dehiscens, articulis suloglobosis, superiore stylo, conico apiculato bi -v. abortu uniloculari, loculis monospermis, inferioris saepissime bilocularis loculis polyspermis. Se min a globosa, articuli superioris pendula $v$, erecta, inferioris horizontalia v. pendula. Embryon is exalbuminosi cotyledones radiculae incumbentes, altera interiore utrinque plana, altera exteriore doroo convexa. - Herba sardoa; acaulis v. interdum caulescens; foliis radicalibus rosulatis, pinnatipartitis, adpresse hispidis $v$. rarius glabris, pedunculis radicalibus unifloris, floriferis adscendentibus, fructiferis deflexis, contortis, fructum subter folia sub terra abscondentibus.

Moris i a Gay in Colla Hort. Ripul. Append. IV. 50 . Moris Flor. Sard. $I$. 105, $t$. 7. Erucaría hypogaea Viviani Flor. cors. Append. $t$. t. 2.

SUBDIRDO III. ORTHOPLOCEAE DC. Syst. II. 581. Cotyledones incumbentes longitudinaliter plicatae, radiculam dorsalem in plicatura foventes $\mathrm{O}>>$.

TIRIRUS XII. BRASSICEAE DC.Syst. II. 581. Sili qua elongata, teretiuscula, bivalvis, septo lineari, valvis plerumque concavis. S emin a plurima, uni-biseriata. Cotyledon es dorso placentas spectantes, longitudinaliter medio plicatae, radiculam adscendentem, placentae oppositae parallelam in plicatura recipientes.

4948. Simappidenatrom LOWE. $\mathrm{C}$ a $1 \mathrm{yx}$ tetraphyllus, foliolis erecto-patentibus, lateralibus basi saccatis. Coroll ae petala 4, hypogyna, indivisa. S $t$ a $\mathrm{m}$ in a 6 , hypogyna, tetradynama, libera, edentula. Siliqua stipitata, bivalvis, elongata, snbtorulesa, rostro compresso sterili, valvis planiusculis, septo spongioso. Semina plarima, oblonga, pendula, submarginata, laevia. $\mathbf{E}$ mbryonis exalluminosi cotyledones conduplicatae, radiculam adscendentem includentes. - Suffrutices maderenses; foliis subcarnosis, rigidis, subintegerrimis, racemis terminalibus, floribus flavis.

Sin a pidendron Lowe Madeir. 36. Sin a peos sect. Dis a e cium DC. Syst. II. 623. Prodr. I. 220. Sina pis frutescens Ait. Hooker Bot, Miscell, $t, 28$. B ras sica fruteseens Soland.

4949. IB Fuśsiea LINN. C a Iy $\mathrm{x}$ tetraphyllns, clausus v, patens, foliolis basi a equalibus. Corolla e petala 4, hypogyna, indivisa. St amina 6, hypogyna, tetradynama, libera, edentula. Siliqua bivalvis, elongata, teretiuscula, valvis convexis, subtrinerviis, venosis, nervo medio recto, lateralibus subsbsoletis v. Alexuosis. S e min a plarima, subglohosa, pendala, uniseriata, immarginata, laevia. Embryonis ex- 
albuminosi cotyledones conduplisatae, radiculam adscendentem includentes. - Herbae in regione mediterranea, India orientali et America a ustrali extratropica indigenae, biennes, rarius annuae v. perennes, interdum basi suffrutescentes; foliis radicalibus petiolatis, lyratis v. pinnatifidis, caulinis sessilibus v. amplexicaulibus, integris, racemis elongatis, aphyllis, jloribus flavis.

B ra usica Linn. gon, n, 820. excl. sp. Gä́rtner $I I .29$. 2. 143. DC. Syst. II. 582. Prodr. I. 213. exel. sect. 2. C. A. Meyer in Ledebour Flor. alt. III. 211. Meisaer Gen. 15. (13,) B rass i a, $\mathrm{R}$ a p a et $\mathrm{Nap}$ a Touruefort inst. 100.

a. BRASSICA. C aly $x$ clausus. (B. B. t. 637. 2924. Sibthorp Flor. Braec. $t$. 645. Desfont. Flor, atlant., 165. 166. Tenore Flor. Neap. $t$, 62 . Delessert Ic, select. II. t. 85. 86.) - Nees juu. Plant. offic. Suppl. IIT, t, 22. 23. Sina pis aigra Lian, B. B. t. 969. Flor. daa. t. 1582 .

b. BRASSICASTRUM. C a $l$ y $x$ patens. B ras $\mathrm{s} i \mathrm{c}$ a $4 \mathrm{t} \mathrm{r}$ u Liak Handb. III, 318, Br. fruti e u los a Cyrillo Plant. rar. II. t. 1.

4950. Simapls TOURNEF. C a I y $\mathrm{x}$ tetraphyllus, patens, foliolis basi aequalibus. Corolla e petala 4 , hypogyna, indivisa. Stamina 6 , hypogyna, tetradynama, libera, edentula. Siliq u a bivalvis, elongata, teretinscula, rostro brevi conico, tereti v. compresso, sterili v. monospermo superata, valvis convexis, tri-quinquenerviis, nervis rectis, aequalibus. Se min a plurima, subglobosa, pendula, uniseriata, immarginata, laevia. Embryonis exalbuminosi cotyledones conduplicatae, radiculam adscendentem includentes.

Herbae cosmopolitae, imprimis mediterra. nea e, biennes, ramosae, glabrae $v$. pilosae; foliis variis, lyratis $v$. inciso - dentatis, racemis terminalibus, aphyllis, floribus flavis.

S in a p is Tournefort Inst, 297. Linn. gen, n.821, excl. sp. Gärtner II. 299. R. Brown in Ailon Hort. Kew, edil, 2, IV. 125. DC. Sytt. II. 607. Prodr. 1. 217. excl. sp. Meisner Q den. 15. (13.)

a. MELANOSINAPIS DC. $\boldsymbol{l}$. c. Siliqua teres v. subtetragona, valvis nempe coneavis, nervo medio subearioatis, stylo brevi, tenui apiculata. - Sin apis Rei. ehenb. Flor. germ. 693. S is y m b r 11 s p. Desfont. Flor. atlant. t. 153. (Delessert Ic. select. IT. t. 87.)

b. Ceratosinapis DC. $\boldsymbol{l}$. $c$, Siliqua rostro conteo, aspermo superata, - S in a pis trum Reiçhenb, $\boldsymbol{l}$, $c$. (Flor. dan. t. 783, E. B. t. 1748. Sehkuhe t. 186. Ar duin. Specim. t. 0. 10. Jaeq. Hort. Vindób, t, 168,171. Willdeiow Hort, berolin, $t, 14$.)

e. ? LEUCOSINAPIS. DC. $t$. c. Siliq u a rostro ensiformi, aspermo superata, valris torosis. - R a mphospermu u Andrzeiowsky msc. Reiehenb. 7 . c. Meisuer Gen. 15. (14.) (Gärtner $t, 143 . \mathrm{E}, \mathrm{B}, t, 1677$.)

d. ? HIRSCHFELDIA DC. $t$. c. Sili qua teres, bilocularis, loeulo utroque subtetraspermo, rostro ovato, monosper. mo, laevi, indehiscente. - Hirschfeldia Mönch Method. 264. Webb et Berthel. Flor. Canar. 85. S. i n ea a Linn. Jacq. Hort. Vindob. 1, 169.

4255 1. Deanepea CAMBESS. Calyx tetraphyllus, foliolis erectis, apiee glanduliferis, lateralibus basi saceatis. Co roll a e petala k, hy pogyna, indivisa. Stamin a 6 , hypogyna, tetra dynama, libera, edentula. Sili qu a bivalvis, elon gata, teres, striata, rostro brevi, conico, tereti, aspermo. S e min a plurima, uniseriata, compressa, pendula, ala membranacea cincta. E m b r y oni s exalbuminosi cotyledones complicatae, radi culam adscendentem incladentes. - Suffrutex. In diae borealis; caule tortuoso, foliis alternis obovatis, integrerrimis, crassis, racemis terminali bus et lateratibus elongatis, floribus roseis.

D o u e pe a Cambessedes ad Jaequemont 18. $t, 18$.
4952. Epreastruma PRESL. C a ly $\mathrm{x}$ te traphyllus, patens, foliolis basi aequalibus. C orolla petala 4 , hypogyna, indivisa. Stamin a 6, hypogyna, tetradynama, libera, edentula. Siliqu a bivalvis, elongata, linearis, rostro brevi, mono-dispermo superata, valvis convexis, uninerviis, Semina plurima, ovata v. oblonga, compressa, pendula, uniseriata, immarginata, laevia. Embryonis exalbuminosi cotyledones canaliculato-complicatae, radiculam adscendentem includentes. - Herbae annuae $v$. perennes, in Europa media et mediterranea indigenae, $S_{i-}$ symbrii facie; foliis radicalibus petiolatis, lyratov. runeinato-pinnatifidis, caulinis sessilibus, integris, racemis elongatis, aphyllis, floribus flavis v. albis.

Erucastrum Presl Flor. sicul, I. 92. Schimper ex Spenner Flor. Friburg. TIT. 946. Meisuer Gen, 15. (14.)

a. ERUCASTRUM. S111qu a supra torum sessilis. B ras. s i cae sect. Eruc a strum DC. Syst. II. 598 , Prodr. I. 216. Sisymbrll sp. Lian. Webb et Berth. Flor. canar. t. 8.

b. MICROPODIUM. Siliq u a supra torum brevissime stipitata. Brassieae sect. Micropodium DC. Syst. II. 604. Prodr. I. 217. Gäntheria Andrzeiowski msc. Bc. el ong a ta Waldst, et Kitaibel Plant, rar. Hung. $t .28$.

4953. Dryelhoplaragrang BUNG. Ca1 yx tetraphyllus, clausus, foliolis lateralibus basi saccatis. Corodla e petala 4, hypogyna, unguiculata. St a mina 6, hypogyna, tetradynama, libera, edentula. Siliqua bivalvis, exacte tetragona, valvis earinatis, septo membranaceo, foveolato, stylo basi tetragono, apice compresso, elongato, aspermo. S e m in a plurima, oblongatosubtriquetra, pendula, uniserialia. Embryonis exalbuminosi cotyledones canaliculato-complicatae, ràdiculam adscendentem includentes. '- Herba in China boreali indigena, ut videtur biennis, glabra, glauca; foliis radicalibus lyrato-pinnatis, lobis varie sectis, caulinis amplexicaulibus, auriculatis, dentatis, floribus majusculis, laete violaceis, siliquis styloque longissimis.

Orychophrag m a Bunge Enumerat. Plant. Chin. bor: 7. Meisner Gen. 15. (14.)

4554. NIorieandia $D C$. Calyx tetraphyllus, clausus, foliolis lateralibus basi saceatis. Corolla petala 4, hypogyna, indivisa. Stamina 6, hypogyna, tetradynama, libera, edentula. Siliqua bivalvis, elongato-linearis, compressa v. compresso-tetragona, valvis planis $\mathbf{v}$ subcarinatis, septo membranaceo, stylo compresso, aspermo v. rarius monospermo. S em in a plurima, ovata, pendala, biseriata, immarginata, laevia. Embryonis exalbuminosi cotyledones canaliculato-complicatae, radiculam adscendentem includentes. - Herbae in Europa et Africa mediterranea indigenae, annuae $v$. biennes, aut basi suffruticosa perennes, glabrae, plerumque subglaucae, caulibus erectis, teretibus, ramosis, albicantibus; folits crassiusculis, integerrimis, sinuato-dentatis $v$, multifidis, racemis terminalibus, laxis, aphyllis, pedicellis filiformibus, fructiferis strictis, floribus majusculis, purpurascentibus.

Morieandia DC. Syst. IT. 626. Prodr. I. 22t. Bot. Mag. $t, 3007$. Meisner Gen. 15, (14.) B ra s s i c a e s p. Lina. Sibthorp Flor. graec, t. 64t. Desfont. Flor. atlant, to 164.

4955. Diplotaxis DC. Calyx tetraphyllus, laxus, foliolis basi aequalibus. Corolla e petala 4, hypogyna, indivisa. Stamina 6, hypogyna, tetradynama, libera, edentula. Siliqua bivalvis, elongato-linearis, compressa, val111 * 
vis uninerviis, septo membranaceo, stylo conico, saepius brevissimo, rarissime mono-dispermo. S emina plurima; ovata, pendula, biseriata v, rarissime abortu uniseriata, immarginata, laevia. Embryonis exalbuminosi cotyledones canaliculato-complicatae, radiculam adscendentem incladentes. - Herbae in Europa media et regione mediterranea indigenae, annuae $v$. biennes aut rarissime perennes, erectae, ramosae, glabrae $v$. hispidae; foliis variis, saepius subcarnosis, racemis elongatis, aphyllis, pedicellis filiformibus, floribus flavis, calycibus plerumque molliter puberulis.

Dip̉lotaxis DC. Syst. IT. 628. Prodr. T. 221. Meisner Gen, 15, (14.)

a. CATOCARPUM DC, 3 , c. Sty 1 a $s$ subnullus; $s t$ igma sessile, subbilobum, Sillqua pendulae, sessiles v. saepius pedicellatae. - Sis y mbrii sp. Vahl, Desfont. Flor, atlant, t. 150 . (Delessert Ic. solect, II. t. 89.)

b. ANOCARPUM DC. $t$. c. Stylus eompresso-conicus, aspermus, v. mono-dispermus; stigmate bilobo. Siliqua e erectae, sessiles v. rarius pedicellatae. - Sin a. peos s p. Linn. Jaeq. Hort. Vindob, $t, 170$. S is y mb ril sp. Linn. E. B. t. 525. 1090. (Delessert Ic. se. lect. II. 2.90.$)$

A958. Eruen TOURNEF. Caly x tetraphyllus, foliolis erectis, basi aequalibus. Corol1 a e petala 4, hypogyna, indivisa. S t a m in a 6 , hypogyna, libera, edentula. Sili qua bivalvis, ovali-oblonga, teretiuscula, valvis concavis, trinerviis, septo membranaceo, stylo valvas subaequante, aspermo, ampliato, foliaceo-compresso, ensiformi-ligulato, acutiusculo. Sem in a plurima, pendula, biseriata, globosa, laevia. Em b ry on is exalbuminosi cotyledones canaliculato complicatae, radiculam adscendentem inclndentes. - Herbac mediterraneae, annuae, erectae, ramosae; foliis pinnatilobis, racemis terminalibus, aphyllis, pedicellis filiformibus, petalis albis $v$. Ravis, venis fuscis reticulatis.

E r u c a Tournefort inst. t. 111, Adanson Fam. 11, 418 , Mönch Method, 256. DC, Syst. III. 636. Prodr. I. 223. Meisner Gen. 15. (14.) $\mathrm{B}$ a z o m u m Link Enumerat, II, 174 . Bras of ea Eruca Lian. Schkuhr t, 186. Sibthorp Flor. graec, t. 646. 647 .

THE TIBES X耳I. VELLEAE DC. Syst. II. 639. Silicula bivalvis, septo lato, elliptico, valvis concavis. Semina in loculis 2 v. 1, rarissime plurima, subglobosa, immarginata. Cotyledones medio longitudinaliter plicatae, radiculam adscendentem in plicatura recipientes. - Regionis mediterraneae incolae.

495\%. Wella DC. Cal y $x$ tetraphyllus, foliolis ereetis, basi aequalibus. Coroll a e petala 4 , hypogyna, unguiculata, limbo integro v, emarginato. St a mina 6 , hypogyna, tetradynama, majora per paria connata. Silienla bivalvis, ovata, a dorso compressa, valvis concavis, dissepimento tenui, elliptico, placentis in stylum ovatum, plannm, foliacerm, apice bistigmatosum coenntibus. Semina in localis 1 v, 2 , pendula, globosa. E mbry on is exalbuminosi cotyledones foliaceae, complicatae, radiculam adscendentem includentes. - Frutex hispani.cus, erectus, ramosus, pilosiusculus; foliis alternis, obovatis, integris, plus minus piloso-scabris, racemis subterminalibus erectis, elongatis, pedicellis brevissimis, inferioribus subbracteatis, superioribus nudis, floribus flavis fructibusque erectis.
Vella DC. Syst. II. 640. Prodr. I. 223; Meisner Gen. 13. (14.) Vella Pseudo eytis u a Lian. Lam. $t$. 555. f. 2. Cavanill, Ic. $t$. 42. Carr i ch te rae s p. Adans.

4958. Holleamn DESV. C aly x tetraphylIns, foliolis erectis, basi aequalibus. Co ro I la e petala 4 , hypogyna, limbo integro. St a in in a 6 , hypogyna, tetradynama, longiora per paria connata. Silicula ovata, valvis indehiscentibus, concavis, septo elliptico, tenui, stylo anguste linguaeformi, acutiusculo, subsubulato. Se m in a in loculis 1 v. 2. E mb r y o.... - Suffrutex $h$ ispanicus, erectus, xamosus, pilis rigidis hispidus; foliis alternis, oblongo-linearibus, inferioribus subdivisis, racemis erectis, elongatis, pedicellis brevissimis, inferioribus subbracteatis, floribus flavis fructibusque erectis.

B ol e um Desvaux Journ. Bot, IIT, 163 et 175. t. 6. DC. Syst. II, 640. Prodr. I. 223. Meisner Gen. 13. (14.) Vella a spera Pers.

4959. Carrielatera $D C$. C al y $x$ tetraphyllus, foliolis erectis, basi subaequalibus. C orolla e petala 4, hypogyna, unguiculata, limbo integro. St a m in a 6, hypogyna, tetradynama, libera, edentula. Silicu i a bivalvis, ovata, valvis concavis, septo membranaceo, stylo ovato, foliaceo. Se $m$ in a in loculis quaterna, pendula, globosa. Embry on is exalbuminosi cotyledones complicatae, radiculam adscendentem includentes. Herba mediterranea, annua, erecta, ramosa, glabra v. pilosiuscula; radice exili, caule tereti, foliis pinnatipartitis, lobis linearibus, dentatis $v$. inciso-pinnatifidis, racemis oppositifoliis, erectis, elongatis, ebracteatis, pedicellis filiformibus, floribus parvis, ochroleucis, siliculis pedicello inflexo nutantibus.

Carrichtera DC. Syst. II. 642. Prodr. 1. 294, Meisner Gen. 13. (14.) Carrichterae sp. Adans. Vella a n $\mathrm{n}$ a Linn. Gärtner $t$, 141 . Schkuhr $t$. 178.

49BO. Suceowia MEDIK. C al y x tetraphyllus, foliolis erectis, basi subaequalihus. Coro 11 a e petala 4 , hypogyna, unguiculata, limbo integro. St am ina 6, liypogyna, tetradynama, libera, edentula. Siliqu a bivalvis, ovato globosa, valvis concavis, echinatis, septo membranaceo, stylo tetragono-subulato. S e m in a in localis solitaria, globosa, pendula. Embryonis exalbnminosi cotyledones complicatae, radienlam adscendentem includentes. - Herba annua, in $\boldsymbol{S i}$ cilia, insulis Balearibus et Teneriffa observata, erecta, ramosa, glabra; radice exili, caule tereti, foliis pinnatipartitis, lobis linearibus, dentatis $v$ incisis, racemis oppositifoliis, erectis, elongatis, aphyllis, pedicellis filiformibus, siliculis erectis.

Succowi a Medikus in Usteri Annat. T. 64. t. 1. f.9. Mỏnch Method, 265. R. Brown in Aiton Hort, Kew. edit. 2. IV. 79. DC. Syst, II, 642. Prodr, I. 224. Meisner Gon. 13. (14.) Bunias baleariea Linn. Jaeq. Hort. Vindob. t. 144. Gouan Illustr. $t$. 20 . Sehkuhr $t, 189$.

4561. Savignya DC. Caly x tetraphylIns, foliolis erectis, basi aequalibus. Coroll a e petala 4, hypogyna, unguiculata, limbo obovato, integro. Stamina 6, hypogyna, tetradynama, libera, edentula. Silicula brevissiue stipitata, bivalvis, oblongra v, oblongo-elliptiea, valvis eonvexiusculig, reticulato-venosis, septo bilamellato, stylo brevi, subtetragono, stigmate eapitato, subintegro. S emin a plurima, liseriatim imbricata, marginata, funiculis horizontalibus, basi septo 
adnatis. Embryon is exalbuminosi cotyledones complicatae, radiculam adscendentem includentes. - Herba a gyptiaca, annua, glabrav. pube simplici conspersa; foliis crassiusculis, inferioribus obovatis, in petiolum angustatis, grosse dentatis, mediis saepe incisis, superioribus linearibus, racemis oppositifoliis, ebracteatis, floribus, parvis, erectis, petatis violaceis, venis saturatioribus, siliculis racemosis, divaricatis, inferioribus saepe deflexis.

Savigny a DC. Syst, II. 283. Prodr. $T$. 157."R. Brown in Clappert. Narrat. 213. Meisuer Gen. 13. (14.) Lunaria parvifl ora Delile Aegipt. $t .35 . f .3$.

THEHES XIE. PSYCHINEAE "DC. Syst. II. 643. Silicula bivalvis, a latere compressa, septo angustissimo, valvis carinatis v. navicularibus, aut in alam dorsalem expansis. Se min a plurima, compressa. E m bry on is exalbuminosi cotyledones complicatae, radiculam includentes. - Africae borealis cives.

4962. Selhouwia DC. C a I y x tetraphyllus, foliolis erectis, basi aequalibus. Corollae petala 4, hypogyna, unguiculata, limbo obovato, integro. S $t$ a mina 6 , hypogyna, tetradynama, libera, edentula, antheris acuminatis. Sili eula bivalvis, compresso-plana, ovalis, utrinque obtusa, stylo subnlato superata, valvis navicularibus, compressissimis, dorso alatis, septo angustissimo. Semin a plurima, compressa, horizontalia, laevia. Embry onis exalbuminosi cotyledones com plicatae, radiculam includentes. - Herba ara bica, annua, ramosa, glabra, Brassicae arvensis facie; foliis inferioribus basi angustatis, sessilibus, superioribus oblongis, basi cordata amplexicaulibus, integerrimis $v$. remote denticulatis, racemis oppositifoliis, primum corymbosis, demum elongatis, ebracteatis, pedicellis filiformibus, petalis roseo-pur purascentibus.

$\mathrm{Sch}$ ouwia DC. Syst. IT. 644. Prodr. I. 224. Meisner Gen. 13. (14.) $\mathrm{T}$ hlas pi a r abicum Vahl.

4983. Eigyelline DESFONT. C a l y $x$ te traphyllus, foliolis erectis, basi aequalibus, $C_{0}$ rolla e petala 4, hypogyna, unguicnlata, limbo obovato. Sta mina 6, hypogyna, tetradynama, libera, edentula; antheris aeutis. Silicula bivalvis, compressa, subtriangularis, stylo e basi tetragona filiformi superata, valvis compresso-ca rinatis, dorso imprimis apiee alatis; septo angustissimo. Semina plurima, ovato-subroupressa, laevia. Embryonis exalbuminosi cotyledones complicatae, radiculam includentes. - Herba $m a u$. ritanica, annua, ramosa, hispida; foliis oblongis $v$, obovatis, dentatis, radicalibus in petiolum angustatis, caulinis alternis, auriculato-amplexicaulibus, racemis oppositifolitis, elongatis, bracteis foliaceis, petalis albis, venis nigricantibus.

$\mathrm{P} s \mathrm{y}$ ch in e Desfont. Flor. atlant. Ir. 69, t. 148. Des. vaux Journ. bot. III, 167. DC. Syot. II. 645. Prodr. I, 224. Meisuer Gen. 13. (14.)

TIEIIBUS XV. ZILLEAE DC. Syst. $\boldsymbol{I}$ 646. Silicula indehiscens, subglobosa, unibilocularis, valvis indistinctis. Semina globosa, in loculis solitaria. Cotyled ones carinato-complicatae, radiculam includentes. Herbae medilerraneae.

4964. Zilla FORSK. Ca ly $\mathrm{x}$ tetraphyllus, foliolis erectis, basi aequalibus. Coro 11 a e petala 4, hypogyna, nnguienlata, limbo integro. Sta min a 6 , hypogyna, tetradynama, libera, edentula. Silic ul a indehiscens, bilocularis, ovato-globosa, suberoso - fungosa, stylo crasso, conico superata. S emina in loculis solitaria, pendula, ovato-rotunda. Embryonis exalbuminosi cotyledones foliaceae, complicatae, radiculam adscendentem includentes. - Herba a e gyptiaca, suffrutescens, glabra, subglauca, ramosissima; ramis teretibus, albidis, junioribus subfoliosis, aetate aphyllis, rigidis, divaricatis, spinescentibus, foliis oblongis, dentatis, racemis paucifloris, apice spinescentibus, pedicellis filiformibus, brevibus, ebracteatis, floribus distantibus, violaceis.

Z. ill a Forskael Aegypt. 121, Ic, t, 17. A. DC. Sytt. IT. 666. Prodr. I. 224. Meisuer Gen, 13: (14.) Bunias s p inos a Lisu. Gärtner $t$. 149, Venten. Malm. $t$. 16.

4\$65. Dilumierria DESV. C a l y x tetraphyllus, foliolis ereetiusculis, basi aequalibus. Corollae petala 4, hypogyna, integra, aequalia. Stam in a 6, hypogyna, tetradynama, libera, edentula. Sili enla indehiscens, unilocularis, globosa, coriacea, muricato-echinata, stylo brevi, stigmatibus duobus in acumen bbtusum, conicum conniventibus. Sen en unieum, lateraliter insertum, globosum. Emb ryo $\ldots .$. - Herba mauritanic a, arenicola, procumbens, multicaulis ; foliis alternis, pinnatilobatis, racemis opposilifaliis aut terminalibus, primum conferte corymbosis, demum elongatis, floribus albis.

M u riea ri a Dekvaux Journ. bot. $I I I, 159 . t$. 25. $f$. 2. DC. Syst, IT. 647. Prodr. I. 225. Meisner Gen, 13. (14,) Bunias prostrata Desfont. Flor. atlant. t. 150. L a eli a 8 p. Per'soon Encheir. IT. 185.

49BS. Calepina $A D A N S$. C al y $x$ tetraphyllus, foliolis subpatentibus, basi aequalibns. Corollae petala 4, hypogyna, obovata, exteriora paullo majora, Stam in a 6 , hypogyna, tetradynama, libera, edentula. Silic ula indehiscens, upilocularis, subglobosa, coriacea, stylo brevissimo, crasso, conico subapiculata. Semen unicum, ex apice pendulum, globosum, superne truncatum. Embry on is exalbuminosi cotyledo. nes,truncatae, curvatae, radiculam adscendentem incumbentem marginibus introflexis amplexantes. - Herba annua, in Europa australi et Tauria indigena, erecta, glabra; foliis radicalibus rosulatis, breve petiolatis, pinnatipartitis, lobis inferioribus utrinque duobus v. tribus parvis, terminali magno, oblongo v. orbiculato, obtuso, caulinis sessilibus, auriculis acutis, sagittatis, oblongis, integris, racemis oppositifoliis, elongatis, aphyllis, pedicellis filiformibus, floribus albis.

Calepina Adanson Fam. II, 423. Desvanx Journ. bot. III. 138. DC. Syst, II. 648, Prodr. I. 255. Meisner Gen. 13. (14.) Rapist rum Berger. Phyt, III. 165. B unias e c chleariolides Murray in Nov. Comment. Gölting. 1777. VIIT. 42, 1 . 3. Waldst. et Kitaibel Plant, rar. Hung. t. 107. L a e I ia e sp. Persoon Encheir. II. 185.

TIRIIBU XVI. RAPHANEAE DC. Syst. II. 649. Silicula v. siliqua articulata v. Iomentacea, rarius subcontinua, plerumque in articulos mono-polyspermos, clausos secedens. Semina immarginata, saepius globosa, in eodem fructu situ varia, erecta v. pendula. Coty le don es canaliculato-complicatae, dorso placentas respicientes, radiculam includentes. Plantae cosmopolitae. 
4ఏ8ร. Crambe TOURNEF. Caly $\mathrm{x}$ tetrapliyllus, foliolis patentibus, basi aequalibus. Corolla e petala 4, hypogyna, indivisa. St am ina 6 , hypogyna, tetradynama, libera, longiora ad apicem dente lateraliter aucta. Siliqua abbreviata, coriacea, indehiscens, biarticulata, articulis unilocularibus, inferiore pedicelliformi, inani, superiore snbgloboso, monospermo. Semen e funiculo e basi erecto, apice incurvo pendulum, globosum, E mbryon is exalbuminosi cotyledo. nes crassae, emarginatae, conduplicatàe, radiculam adscendentem includentes. - Herbae v. suffrutices, in regione mediterranea obviae, in Europae borealis littoribus, Asia media et Patagonia rarae, erectae, ramosae, saepe glaucescentes, glaberrimae $v$. setis simplicibus hirtae; foliis variis, integris'v. dissectis, caulinis sparsis, petiolatis, pinnatim dentatis $v$. incisis, aut pinnatifidis sive lyratis, racemis elongatis, multifloris, in paniculam laxam dispositis, pedicellis filiformibus, ebracteatis, erectis, floribus albis.

Cra m be Tournefort inst. 100. Linn. gen, n. 825. Gärtper II. 292. Jussieu Gen. 242. R. Brown in Aiton Hort. Hew. edit. 2. IV. 72. Desvaux Journ. bot. III. 159. DC. Syst, IL. 650. Prodr. I, 225. C. A, Meyer in Ledebour Flor: Mle. $M I$. 212. Meisner Gen. 15. (14.) Webb et Berthel. Flor. Canar, 87 .

a, SARCOCRAMBE DC. l. c. Sill qua e articulus inferior brevis, depressus, superior globosus. Stig in a sessile. $\mathrm{Staminum} \mathrm{majorum} \mathrm{filamenta} \mathrm{ad} \mathrm{apicem} \mathrm{deate} \mathrm{longo}$ bifurea. - Radix perennix, ad collum multiceps, folia magna, saeps crassa. (Flor. dan. t. 316. E. B. t. 912. Jacq. Ic, rair. t. 128, 129. Delessert Ic. select. II. $t, 91$.

b. LEPTOCRAMBE DC. l.c. Stliq u a e articulus inferior eylindriens, superior globosus. Stig ma sessile. Stam in a majorum filamenta edentula v. apice dente aucta. - Radir annua, caule solitario. - R a pis t rum Medikus in Usteri N. Annal. T. 19. t. 1. f. 2. Mönch Mechod. 211. non alior. M y ag ri \& p. Jaeq. Observ. II. 2. d1. (Gärtaer t. 142. Schkuhr t. 189. Desfont. Flor. atlant. $t$. 15t. Jacq. Ie, rar. t, 804.)

c. DENDROCRAMBE DC. l. c. SIliq a a e articulus inferior cylindrieus, brevis, superior ovato-globosus, stylo maerouatus. St a min u m majorum filamenta edentula v. apice dente aucta. - Caulis fruticosus. - $\mathrm{M} \mathrm{y} \mathrm{ag} \mathrm{ru} \mathrm{m}$ arb or ese ens Jacq. Io, rar, t. 120 . (Heritier Stirp.
t. 72, ,

4DB8. Thapistruma BOERH. Cal yx tetraphyllus, laxus, foliolis basi aequalibus. Cor o1 I a e petala 4 , hypogyna, indivisa. Sta mina 6 , hypogyna, tetradynama, libera, edentula. Siliq a a abbreviata, coriacea, indehiscens, biarticulata, articulis unilocularibus, vix secedentibus, inferiore obeonico monospermo v. sterili, superiore sulgloboso, rugoso, stylo filiformi superato, monospermo. Semen loculi inferioris pendulum, superioris erectum. Embryon is exalbominosi cotyledones complicatae, radiculam includentes. - Herbae in Earopa media et australi indigrenae, annuae $v$. perennes, ramosae, pubescentes $v$. villosae; foliis inferioribus petiolatis, pinnatifidis, sublyratis, superioribus oblongis, dentatis, racemis terminalibus elongatis, subpaniculatis, pedicellis filiformibus, strictis, floribus flavis.

Ra pistrum Boephave Lugd. Batav, 406. Desvaux Journ. bot, IIT. 160. DC, Syst, II. 430. Prodr. I, 227. Meis. ner Gen. 15. (14.) Webb et Berthel. Flor. canar. 86. non alior. S chran k i a Medikus in Dsteri N. Annal. I. 42. t.1. f. 10. Mönch Method. 263 . Co a d y $10 \mathrm{c}$ a $\mathrm{r}$ a Besser msc. Arthrolobus Audrz. mre. Crambes s p. Adans. Cakiles sp. Herit. R. Br. M y agri sp. Llan. Jacq. Elor. austr. $t$.

4963. Hiflesmass DESV. C aly $x$ tetraphyllus, foliolis erectiusculis, basi aequatibus.
Corolla e petala 4, hypogyna, indivisa. 'Stamina 6, hypogyna, tetradynama, libera, eden. tula. Siliqua oblonga, coriacea, angulata, in articulos duos evalves, mono-dispermos separabilis, articulo inferiore apice truncato, superiore in rostrum breve et stylum filiformem abeunte. Se $m$ in a utriusque loculi pendula, alternatim uni et alteri placentae affixa, compresso.globosa. Embry on is exalbuminosi cotyledones complicatae, radiculam adscendentem includentes. - Herbae in Africa boreali et archipelago graec $q$ indigenae, annuae, erectae, ramosae, glabrae; folitis injimis petiolatis, pinnatifidis $v$. lyratis, racemis elongatis, aphyllis, pedicellis filiformibus, demum subincrassatis, floribus albis v. flavis.

Did es m u s Desvaux Journ. bot. IIT. 160, t, 25. f, 11 . DC. Syst. II. 657. Prodr. I. 227. Delessert Ic, select, Ir. t. 92. Meisuer. Gen, 15. (14.) Kakiles s p. Tournef. M y agr i s p. Linn. B a $u$ iad is sp. Sibthorp Flor, graec.
t. 613 .

4970. Evarthroearpus LABILL. CaIy 8 tetraphyllus, foliolis erectis, basi aequalibus. Corollae petala 4, hypogyna, unguiculata, indivisa. Stamina 6, hypogyna, tetradynama, libera, edentula. Siliqu'a biarticulata, teres v. subcompressa, artienlo inferiore obconico, brevi, mono-trispermo, persistente, superiore longo, isthmis pluribus monospermis strangulato, lacunis totidem cellulosis inter semina tumentibus nodoso. Semin a ovata, subcompressa, articnli inferioris pendala, superioris erecta. Embryon is exalbuminosi eotyledones complicatae, radiculam incladentes. - Herbae annuae, in $A$ egypto, $S y$ $r$ ia et Cypro indigenae, erectae, ramosue, subscabrae, Raphani facie; foliis inferioribus petiolatis, lyratis, superioribus sessilibus, grosse dentatis, racemis elongat is, pedicellis filiformibus, erectis, demum incrassatis, omnibus v. saltim inferioribus bracteatis, floribus flavis v. purpurascentibus.

Enarthrocarpus Labillard. Syr. Decad. $V$. 4. $t, 2$. DC. Syst, II, 660. Prodr. I, 228. Delessert Io. select, II. t. 93. Ra phani s p. Dorsk. Delile Aegypt, t. 36. f. 1 .

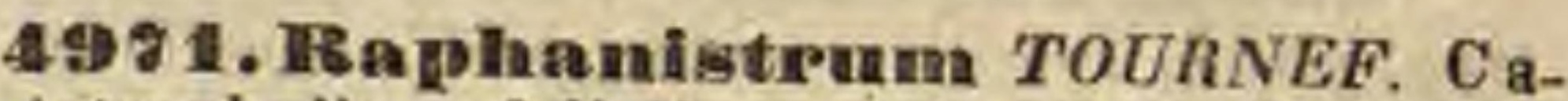
l yx tetraphyllus, foliolis erectis, lateralibus basi subsaceatis. Corolla e petala 4 , hypogyna, indivisa. St a m in a 6 , hypogyna; tetradynąma, libera, edentula. Siliqua evalvis, teres, coriacea, biarticulata, artienlo inferiore inani, superiore isthmis monos permis constricto, moniliformi, stylo conico acuminato. Semin a pendula, subglobosa. Em bryon is exalbuminosi cotyledones crassiusculae, conduplicatae, radieulam adscendentem inelndentes. - Herbae annuae $v_{*}$-biennes, inter segetes Europae mediae et australis obviae, glabrae $v$. subhispidae; radice fusiformi, succulenta, caulibus ramisquc divaricatis, teretibus, foliis inferioribus petiolatis, lyratis, racemis oppositifoliis et terminalibus, elongatis, aphyllis; floribus albis v. flavis.

Raphanlstrum Tournefort Inst. 113. Gürtner IT. 300. t. 143. Medikus in Usteri N. Annal. II, 39. Webb et Berthel. Flor. canar. t. 8. Dandisia et $0 \mathrm{rmyear}$ pus Necker Elem, n. 1407 ot 1409. D a rand e a Delarbre Flor. Auvergn, edit. $2 . t$. 365 , R a p it a a i seet. R a pha. n f strum DC. Syst. II. 666. Prodr. I, 229. Delessert IC. select. $M$. $t$. 94. R a phani sp. Liun. Flor. dan. $t, 678$. Sehkulir t. 188 . B. B. 856.1643 .

$498 \%$ FE tetraphyllns, foliolis erectis, lateralibus basi sub-saceatis. Cor olla e petala 4, hypogyna, indivi-
sa. Stamina 6 , hypogyna, tetradynama, libera, 
edentula, Siliqua indehiscens, bilocularis, fungoso-suberosa, teres, acuminata, septis transversis intercepta. Semina plurima, uniseriata, pendala, globosa. Embryon is exalbuminosi cotyledones crassiusculae, complicatae, radiculam adseendentem includentes. - Herbae in Asia orientali tropica et subtropica spontaneae, nunc ob radicem napiformem, sapidissime acrem, in Eu ro$p a$ et $A$ merica cultae; foliis inferioribus petiolatis, lyratis, racemis oppositifoliis terminalibus, elongatis, aphyllis, floribus albis, venosis.

R a p in a n s s Tournef. Inst. 114. Gärtuer 11.299 , t. 143. Medikus in Usteri N. Annal. I1. 39. Lam. 2. S66. Webb et Berthel. Flor. canar. $t .8$. R a phanf sect. Raphanís DC. Syst, II. Prodr. I, 229.

SUEDIBI IT. SPIROLOBEAE DC. Syst. II. 670. Cotyle don es lineares, incumbentes, circinnatim convolutae.

TRE FUS XIT. BUNIADEAE DC. Syst. II. 670 . Sili cula nueamentacea, indehiscens, bilocularis, loculis septo transverso bipartitis, locellis monospermis. Cotyledones circinnatim convolutae.

4583. Tumias $R . B R$. C a lyx tetraphyl. lus, laxus, foliolis basi aequalibns. Corolla e petala 4, hypogyna, unguiculata, indivisa. Stamina 6, hypogyna, tetradynama, libera, edentula, Silicula nucamentacea, evalvis, subtetragona, bilocularis, loculis dispermis, septo inter semina saepissime bipartitis quadrilocellata. S emin a subglobosa, coehleata, pendula. E mbry unis exalbuminosi cotyledones lineares, incumlientes, circinnatim convolntae, radicula conica, subrostriformis, snpera. - Herbae in Europa et A sia media indigenae, annuae $v$, perennes, erectae, ramosae; radice perpendiculari, simplici, caule tereti, setulis bifidis, interdum etiam glandulis sessilibus, fuscis consperso, foliis integris, pinnatifidis $v$, runcinatis, racemis elongatis, aphyllis, pedicellis filiformibus, patentibus, floribus flavis.

Bunias R. Brown in Aiton Hort. Hew. edit. 2. IV. 75. DC. Syst, IT. 670. Prodr. IT. 299. C. A. Meyer in Le. debour Flor. Alt, III, 21s. Meisner Gen. 15. (14.)

a. ERUCAGO DC. b. c. Calyx erectus. Petala limbo obcordato, obtuse emarginato. Silicula tetragona, angalis cristato-alatis, subdentatis, stylo filformi, qua. drilocellata.

Fru e a g o Tournefort inst. 163, Mronch Methad. 828. Desvaax Journ. Bot, III, 168. B unias. Haller Helv. I. 226. Bunias Erueago Linn. Jaeq. Flor. austr. t. 340. Schkuhr $t$. 189. Gïrtner $t, 142, f, 1$,

b. LAELIA DC. $l$, c. Cal y $\times$ patens. Pet a la limbo obovato, integro. Silicula ovata, bilocularis, loculis mono-dispermis.

La ella Adanson Fam. IT, 693. Desvaux Journ, Bot. III. 160. Bunias-Mönch Method. 277. Bunlas orientalis Lian. Schkuhr $t$. 189. Gärtner $\ell$. 148, $f .4$.

TTEIEUS XVIIII. ERUCARIEAE DC. Syst. II. 673. Siliqua lomentaceo articulata, artieulo inferiore bi-, superiore uniloculari, ensiformi. Cotyledones replicatae, subcircinnatae.

49g. Erucaria G.ZRTN. Calyx tetraphyllas, foliolis erectis, basi aequalibus, Corolla e petala 4 , hypogyna, longe unguiculata, limbo obovato. Stamina 6 , hypogyna, tetradynama, libera, edentula. Siliqua teres, biarticu- lata, articnlo inferiore bivalvi, biloculari, septo membranaceo, superiore evalvi, ensiformi, oligospermo. Semina articuli inferiorjs pendala. superioris erecta. Em bry on is exalbuminosi cotyledones oblongo-lineares, replicatac, apice circinnatae, radiculae incumbentes. - Herbae orientales, eremicolae, annuae, erectae, ramosae, glabrae; caulibus teretibus, albidis, aetate basi induratis, foliis caulinis pinnalipartilis $v$. rarius inciso-dentatis, interdum subcarnosis, racemis oppositifoliis et terminalibus, tandem elongatis, pedicellis brevibus, strictis, ebracteatis, floribus ex albo purpurascentibus.

Ernearia Glirfner IT. 298. Delile Flor. aegypt. 30. R. Brown in Aiton Hort. Kew, edit, 2. $1 Y$. 122. DC. Syst, IT. 673. Prodr. I. 230. Meisner Gen. 15. (14.)

a. AgRIOGONGYLE. Siliculae articulus superior in stylum filiformem prodactus. Bunias my a groidex Lint. (Gärta. t. 143. Venten. Cols, t. 64. Delessert IC. select. II. t. 95.)

b. EREMOGONGYLE. Silicula e artieulas superior stigmate sessili apiculatus. (Dellle Aeggpt. $t$. 34. f. 1.)

SUE (1) W. DIPLECOLOBEAE DC. Syst. II. 676. Cotyledones lineares, incumbentes, bis transversim plicatae. S è mi na contrarie compressa, plana v. globosa.

THEHES XIX. SENEBIEREAE Meisner Gen. 15. Silieula e didymáe, valvis ventricosis, elausis, loculis monospermis. C $0_{-}$ tyle don es biplicilae.

4D5. Semelbiera POIR. Calyx tetra phyllus, patens, foliolis basi aequalibus, Corolla e petala 4, hypogyna, indivisa. Stamina 6 , hypogyna, tetradynama, libera, edentula, minora interdum abortiva. Silic n la didyma, subcompressa, evalvis, bilocularis, stigmate sessili, valvis subglobosis, rugosis v. cristatis, loculis monospermis. S em in a pendula, sulgloboso-triquetra. Em bryonis exalbuminosi cotyledones liplieitae, radicula supera. - Herbae in $E$ uropa media et inter tropicos totius orbis obviae, annuae v. biennes, multicaules, saepius humifusae, ramosae, glabrae v, villosae; foliis alternis, nunc linearibus, integris, nune inciso-serratis v. pinnatilobatis, lobis integris $v$, incisis, racemis opposilifoliis, brevibus, pedicellis ebracteatis, floribus albis, minimis.

Sen ebiera Polret Diet, VIr. 75. Persoon Encheir. II. 185. DC. Syst. II, 521. Prodr. I. 202. Meisner Gen. 16. (15.) Cor o no pus Swith Flor. brit. IT. 591. R. Brown in Aiton Hort. Kew. edit. 2. $I K$, 76, non Tournef. Se ne bie ra et Coronop us DC. in Mem, soc. h, n. Paris. an VIT, p, 142. Elor, franc. $Y V$. 703. Lepldii et Coclaleariae sp. Linn.

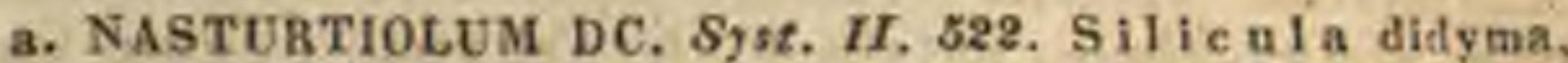
apice emarginata, septo nempe valvis globosis breviore. - Nasturtiolum Medikus Gen. plant, 82, $x, 2, f .21$. Usteri N. Annal. II. 45. Mänch Suppl. 71. Sen e biera DC, in Mem, eit, $t$, 89. Desvaux Journ, bot, III. 163. Webb et Berthel. Flor. canar. 94 . Lep i i i m didy. m a misu. (E. B, $t, 248$.

b. CARARA DC. Syst, II. s24. S Ilieula aplce band emar ginata, septo nempe,valvis panllo longiore, valvis com. pressis, dorso cristato-rugosis. - C is r a r a Caesalpin. Pl. 370. Medikus Gen, plant, $I .33, t, 1, f, 4$. Cor onopus Hall, Helv. 1. 217. Gármer II, 293. $t, 242$. Lam. $t$. 558. Mónch Method, 920. Desvaux Journ, bot. III. 163. Webb et Berthel. Op. eit. 95. Coeblearia Cor no pu Lino. Flor. dan, t, 202. Schkuhr $2,181$. (Delessert Ic. select. II. $t, 71$.) 
e. COTYLISCUS DC, Syst. IT. 526. Silicula apice haud emarginata, bine subconeava, fere cymbaeformis, valvis dorso nec eristatis nec rugosis. - Cotylis cus Des. vaux Journ. bot. III. 164. et 175. t, 25. $f .13$. Coch. learia in otica Delile Aeggpt. $t$. 34. f. 2.

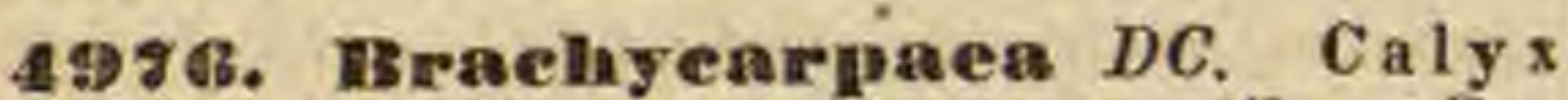
tetraphyllus, foliolis ereetis, basi aequalibus. Corolla e petala 4 , hypogyna, ovato-oblonga, indivisa. Stamina 6, hypogyna, tetradynama, libera, edentula. Silicula didyma, subcompressa, evalvis, hilocularis, stylo brevi, valvis ventricosis, tuberealatis, suberistato - marginatis, loculis monospermis. Semina pendula, subgloboga. $\mathbf{E m b r y o n i s ~ e x a l b u m i n o s i ~ c o t y l e d o n e s ~ b i - ~}$ plicitae, radicala'supera. - Suffrutex capens is, virgatus, glaber; foliis oblong is v. linearibus, integerrimis, mucronatis, racemis elongatis aphyllis, pedicellis filiformibus, floribus magnis, flavis $v$. purpurascentibus.

B ra chyearpaea DC. Syst. II. 698. Prodr. I. 236. Delessert Ic. select. II. $t$, 200. Meisuer Gen, 16. (15.) H eliophila flava Lisn. f.

TIR IIBUS XX. SUBÜLARIEAE DC. Syst. II. 697. Siliculae ovales, bivalves, septo elliptico, valvis convexis, loculis polyspermis. Cotyle dones biplicitae.

49 ร. Subularia LINN. C a y $x$ tetraphyllus, foliolis erectiusenlis, basi aequalibus. Corolia e petala 4, hypogyna, indivisa. Sta mina 6 , hypogyna, tetradynama, libera, edentula. Silicu la bivalvis, elliptica, turgida, valvis convexis, subtrinerviis, septo hyalino, enervi. S em in a plurima, biseriata, pendula, inmarginata, laevia, funiculis setaceis, liberis. Embryonis exalbuminosi cotyledones lineares, biplicitae, radicula brevis, supera. - Herba annua, parvula, in aquis Europae borealis et Asiae mediae vegetans; foliis omnibus radicalibus, elongato-subulatis, scapis lateralibus, racemo laxo, paucifloro, aphyllo terminatis, floribus minutis, albis.

S u b u la ria. Lisn. Gen, n. 799. Flor, dav. $t, 35$. E. B. t. 732. Schkuhr $t, 180$, R. Brown in Aiton Hort. Kew, edit. 8. IV. 91. DC. Syst. IT. 697. Prodr. I. 235. C. A. Meyer in Ledebour Flor, alt. IIT, 218. Co ns a a Adanson Fam. II. excl. sp. Meisner Gen. 16. (15.)

TRERTS XXI. HELIOPHILEAE DC. Syst. II. 676. Siliqua elongata, oblonga v. ovalis, bivalvis, septo lineari v. ovali, valvis planis v. compressiusculis. S e mina plurima, pendula, uniseriata, compressa. Cotyle dones biplicitae. — Omnes capenses.

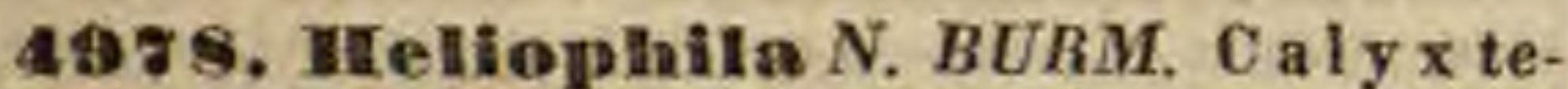
traphyllus, foliolis erectiuseulis, basi subaequalibus. Corollae petala 4, hypogyna, ungue euneato, limbo patente, late obovato. St a min a 6 , hypogyna, tetradynama, lateralia simplicia v. dente aucta. Siliqua septo membranaceo bilocularis, bivalvis, plerumque dehiscens, sessilis et compressa, rarins indehiscens, teres ant pedicellata, marginibus nunc rectis linearis, nane sinuatis, inter semina contractis moniliformis. Semin a plarima, pendula, uniseriata, compressa, saepe ala membranacea cincta. E mbry on is exalbuminosi cotyledones radicula supera plus duplo langiores, lineares, integerrimae, incumbentes, medis transversim biplicitae. - Herbae annuae v, suffrutices ca penses; radice exili, caule tereti, ramoso, fo- liis variis, racemis elongatis, aphyllis, pedicellis filiformibus, floribus flavis, albis, roseis v. laete caerúleis.

Heli ophila N. Burmasn es Linn, gen, 8t6. R. Brown in Aiton Hort. Hew, edit. 2. IV. 99. DC. 'Syst. II. 677. Prodr. I. 231. Meisner Gen, 15. (16.) Trentepohlia Rosh. Nov. sp. 325.

a. CARPONEMA DC. l. c. Siliqua "sessilis, teres, vix Inter semina coarctata, utrinque acuminata, indehiscens v. vix dehiscens. - Herba annua. (Lam. $t, 563, f$. 3.)

b. LEPTORMUS DC. $\boldsymbol{l}$. $\boldsymbol{c}$. S ili q a sessllis, subcompres. sa, gracillima, submoniliformis, monilibus ovato-oblnngis. - Herbae annuae: (Delessert Ic. select, II. t. 96.)

e. ORMISCUS DC. $t$. $c$. Siliqua sessilis, compressissina, moniliformis, monilibus orbiculatis. Se $\mathbf{m}$ i a orbiculata, compressissima. St am in a edentula. - Herbae annuae. (Lam. t. 362. f. 2. Venten. Malm. 113. Jaeq. fragm. $t .69, f$. 2.)

d. SELENOCARPAEA DC. l. c. SHli qua ovalis, fere orbiculata, oligosperma, stylo brevi apleulata. S e miи a compréssissima, orbiculata. - Herbae annuae.

c. ORTHOSELIS DC. $\boldsymbol{l}$. c. Siliqua sessilis, compressa, fere linearis, marginibus rectis aut vix sinuatis, stylo apiculata. St a mina dentata $\mathbf{r}$, edentula. - Herbae annuae v. frutescences. - Helio phil a Beklon et-Zeyher Enumerat. 10. (Burmann in Nov. Act. Upisal, 1773. t. 7. Lam. t. 863. f. 1, Jacq. Ic. rar, t, 506. Bot. Mag. t. 256. 496. Bot. Reg. t. 838. Delessert Ic. select. $\boldsymbol{I}$, t. 97.98.$)$

f. PACHXSTXLUM DC. b. $c$, Siliqu a sessilis, linearis, compressa, velutina, stylo crasso, conico, glabro superata. - Suffrutex pubescens, integrifolius.

g. LANCEOLARIA DC. l. $c$. Sili qua sessilis, compressa, lanceolaris. in styltum brevem desinens. S e min a grandia, - Suffruter glaber, integrifolius.

h. CARPOPODIUM DC. l. c. Siliq ua supra torum longe pedicellata. compressa. elongato-linearis, stylo brevis. simo acuminata. - Suffruter strictus, glaber. - (Delessert Ic. select. II. t, 99.)

4989. Chamirea THUNB. C aly x tetraphyllus, foliolis erectis, duobus lateralibus basi in calcar productis. Cor oll a e petala 4, hypogyna, nnguiculata, limbo oblongo. S $t$ am in a 6 , hypogyna, tetradynama, libera, edentula. Siliq u a supra torum brevissime pedicellata, bivalvis, ovato-oblenga, compressa, valvis planiusenlis, septo membranaceo, elliptico-oblongo, stylo elongato-subulato, corniformi. S e min a pauca, compressa, immarginata. Embryo..... - Herba capensis, debilis, glabra; foliis petiolatis, cordatis, grosse dentatis, racemis laxis, pedicellis filiformibus, ebracleatis, floribus albis.

Ch a mira Thubberg Nov, Gen. IT. 48, DC. Syst. $I$. 677. Prodr. 1. 131. Meisuer Gon, 16. (15.) Heliophlla cir ca e o ldes Linn. fil.

\section{* SchizopetaleaE.}

4980. Sehizopetalon HOOK. Calyx tetraphyllus, clausus, foliolis basi subaequalibus. Corollae petala 4 , hypogyna, nngue calycem superante, lamina ovata, pinnatifida, laciniis linearibus, aestivatione involntis. Stam in a 6 , hypogyna, subaequalia, filamentis liberis, edentulis, antheris sagittato-linearibus. GI andulae hypogynae 4, lineares, erectae, petalis suboppositae, basibus dilatatis geminatim confluentes. O vari $\mathbf{n}$ sessile, biloculare. Stylus brevissimus; stigma lobis connato approximatis, decurrentibus et basi solutis subextintorifforme. Siliqua hivalvis, anguste linearis, torosa, valvis venosis, pube ramosa conspersis, septo membranaceo. S emina plara, uniseriata, sphaerico-lenticularia, E m b ry o$\mathrm{n}$ is exalbuminosi, viridis cotyledones quatuor, 
verticillatae, elongatae, aequales, semiteretes, singillatim subspiraliter involutae, radicula albicans, arcuata, semine paullo longior. - Herba chilensis, annua, pube tenui, ramosa conspersa; foliis alternis, sinuato-pinnatifidis, racemis foliaceobracteatis, floribus albis.

S.chlzopetalon Hooker in Bot, Mag. t. 2379. Exot. Flor. t. 74. DC. Prodr. I. 236. R. Brown in Bot. Reg. t. 752. Meisner Gen, 16. (14.)

\section{GENERA DUBIA.}

4581. Fedlowskia $C H A M$, et SCHLECHT. C a lyx tetraphyllus, laxus, foliolis basi aequalibus. Corolla e petala 4, hypogyna, unguieulata, limbo obovato, integro. S t amin a 6 , hypogyna, tetradyuama, libera, edentula. Siliqua compresso-subglobosa, bivalvis, nnilocularis, stylo et stigmate bilobo superata, valvis hand carinatis, uninerviis. Se mina $8-12 \ldots \ldots$ - Herba sibirica, perennis, pube furcata tomentosa; foliis radicalibus petialatis, bipinnatifidis, caulinis pinnatifidis, racemis terminalibus et oppositifoliis, subcorymbosis, demum elongatis, floribus albis.

Red ow $\mathrm{k}$ i a Cham. et Schlecht: in Linnaea I, 32, t, 2 .

4DS2. Selhimpera STEUD. et HOCHST. Ca ly x tetraphyllus, patens, foliolis basi aequalibus: Coroll a e petala 4, hypogyna, indivisa. Stamina 6, hypogyna, tetradynama, libera, edentula. Silic ula indehiscens, unilocularis, styIo ohliquo, foliaceo-dilatato coronata. S em en pendulum. Emb r yo..... - Herba arabica; foliis runcinatis, Carrichterae Vellae facie.

Schimpera Steud. et Hochist. in Schimper Herb. Arab. petr. $n, 224$.

\section{*}

DIScoviuM Rafin. in Journ, Phys, LXXXIX, 96, C a l y X clausus. Silicula lenticularis, septo integro, valvis ca. riuatis, loculis polyspermis, stylo persistente, stigmate obtuso. - Herba ohiensis, puberula, annua, erecta, gracilis, simplex; folitis distantibus, sessilibus, oblongolinearibus, obtusis, integris, petalis flavis, cuneiformibus, integris, calycem aequantibus.

\section{Ordo CHXXXIE. Capparidene.}

CAPPARIDES Jussieu Gen, 249. Annal. Mus, XVIIT. 474. CAPRARIDEAF, Venten. Tableau IIT. 118. DC. Prodr. r. 237. R. Brown in Denham et Clapperton Narrat. 220. Bartliug Ord, nat, 265. Meisner Gen, 17. (15.) CAPPARIDACEAE Lindley Introduct. edit. $I T, p .61$.

Нвrвав annuae v. rarius perennes, saepe Frotrés, interdum arbores, succo aqueo, caule ramisque ut plurimum teretibus. Foli a alterna v. rarissime opposita, petiolata, simplicia v. palmatim composita, foliolis integerrimis v. dentatis. Stipulae nunc nullae, nunc spinescentes, interdum herbaceae et cauli adnatae, inconspicuae.

Fuores hermaphroditi v. abortu interdum diclines, regulares v. rarius subirregulares, solitarii v, racemosi.

Caryx saepissime tetraphyllus, foliolis distinctis v. plus minus inter se connatis, aestivatione imbricatis, rarius valvatis, interdum diphyllus v. bifidus, quandoque clausus, cir- cumscisse dehiscens, rarissime octophyllus, nonnunquam intus lacinulis $\mathbf{v}$. corona petaloidea auctus.

Torus varius, nunc carnosus, hemisphaericus v. subglobosus, nunc stipitiformis plus minus longus, saepe basi in glandulam nectariferam varie effiguratam tumens, v. ex stipite appendicem tubulosam exserens, quasi bipartitus, nempe crure altero sterili, altero genitalia gerente.

Corollae petala 4 , rarissime 8 , saepius nulla, dum adsunt imo tori marginí inserta, calycis foliolis alterna, saepissime unguiculata, non raro inaequalia, aestivatione imbricatoconvoluta v. aperta, id est. marginibus nec se invicem, nec stamina unquam tegentiá.

Stamiva numero varia, saepissime cum calyce et corolla tetramera sex, rarius octo, saepe numero senario v. octonario multipla v. indefinite plurima, toro hemisphaerico v. globoso margine $v$, undique inserta, $v$. tori stipitiformis apici aequali v. interdum dilatato imposita. Fil ameuta filiformia v. interdum apice clavata, aequalia v. inaequalia, saepissime libera, nonnunquam basi plus minus connata, aestivatione plerumque inflexa, omnia fertilia v, nonnulla interdum ananthera. Antherae introrsae, biloculares, oblongae v. ovatae, basi v. dorso supra basim insertae, erectae v. incumbentes, loculis appositis, longitudinaliter dehiscentibus.

Ovarivm liberum, sessile v. saepius supra torum pedicellatum, pedicello brevi v. longissimo, ovatum v. oblongo-cylindricum aut subglobosum, uniloculare, placentis intervalvularibus nune geminis oppositis, nune pluribus, plerumque quatuor, quinque v. octo, vix tribus, septo nullo v. rarissime placentis productioribus ad axim confluentibus pseudobiloculare. Ovula juxta placentas uni-multiseriata, multa v. plurima, amphitropa v, campylotropa. Stylus terminalis, subulatus v. filiformis, plus minus longus, saepe subnullus. Stigma indivisum, obtusum v, acutum, plerumque sessile, orbiculatum.

Fnderes unilocularis, nune capsularis, cylindricus v. linearis, bivalvis, valvis a replo seminifero, persistente, apice stylo v. stigmate juncto solutis, deciduis, nunc ba c catus, carnosus v. siccus, coriaceus aut crustaceus, indehiscens, cylindricus, ovatus v. globosus.

Semiva plurima v. pauca, rarissime abortu solitaria, replo in capsularibus appensa, in baccatis plerumque in pulpa nidulantia, plus minus reniformia; tes ta membranacea, coriacea v. saepissime crustacea, plerumque aspera, endopleura saepe tumida, umbilico nune intra sinum sito, nune seminis crus cotyledonare terminante. A lbum e n nullum. 
EsвRYo homotropus, arcuatus v. conduplicatus. Cotyledones incumbentes, planae v. convolutae. Radicula teres, cylindrica, brevis v. longa, in fructu capsulari supera, in baccato vaga v. centrifuga.

C apparideae in regionibus tropicis subtropicisque imprimis Africae et Americae obviae, in America temperata et regione mediterranea rarae, plantarum ordinem distinctissimum, et cum nullo alio facile confundendum constituunt, Cruciferis et Resedaceis arcte affinem, illinc ad Bixaceas, jam semínibus albuminosis satis diversas, proxime accedentem.

Herba plurimarum recens qualitatibus stimulantibus antiscorbuticis pollet, Capparidis alabastra plurimorum gustui grata, nonnullarum americanarum baccas viro deleterio scatere dicunt.

R oydsia a solo Roxburghio descripta, pluribus notis anomala, ad ordinis caleem collocatur.

Genus admodum singulare a Cookio ex arehipelago Macquarie $\left(54 \_55^{\circ}\right.$ L. A) relatum, indescriptum in Britanorum Museo delitescere, audio.

TuEIBUS I. ClEOMEAE DC. Prodr. $I$. 237. Fruetus capsularis.

4983. CIeomella $D C$. C a 1 y $x$ tetraphylIns, foliolis brevibus, lanceolatis, patentiusculis. Corolla e petala 4, imo toro inserta, subspathulata, vix unguicalata. S ta min'a 6 , toro brevissime stipitiformi inserta; fi l a m e n t a filiformia, libera, aestivatione inflexa, subaequalia, exserta, a $n$th e ra e oblongae, biloculares, incumbentes, longitudinaliter dehiscentes. Ovari um longe stipitatum, lagenaeforme, uniloeulare, ovulis juxta placentas intervalvulares geminas paucis, amphítropis. Stigma subsessile, obtusum. Capsn la siliculaefornis, obovato-rhomboidea, unilocularis, valvis a replo persistente solutis navicularibus, reticnlatis. S emina 4_6, reniformi-conduplicata, testa serobiculata. Embryonis exalbuminosi, condaplicati cotyledones incumbentes, radicula lon. giuscula, supera. - Herba mexicana et boreali americana, annua, pedalis, glabra, superne ramosa; foliis alternis, trifoliolatis, foliolis petiolo longioribus, anguste lineari-lanceolatis, integerrimis, racemo terminali folioso, floribus flavis.

Cleomella DC. Prodr. T. 237. Torrey in Annal. Lyo. New York. II. 15\%. Don in Edinb. new philosoph. Journ. $X, 113$. Meisner Gen. 15. (15.), Hooker Ic, $t, 28$, Torrey et A, Gray Flora of North-Amer. I. 120.

498. Gymandropsis DC. Calyx tetraphyllns, foliolis brevibus, patentiuseulis. Coroil a e petala 4 , imo toro inserta, unguiculata, aestivatione imbricata v. aperta. Stamina 6 , tori stipitiformis longi apiei inserta; fil a menta filiformia, subaequalia, anth er a e biloculares, longitudinaliter dehiscentes. O varin m stipitatum, uniloculare, ovnlis juxta placentas intervalvulares geminas plurimis, amphitropis, Stigma sessile, suborbiculatum. C a p \& $\mathrm{l}$ a siliquaeformis, subcylindrica, subtorulosa, unilocularis, bi- valvis, valvis a replo seminifero persistente solntis, deciduis. S e min a plurima, reniformia, rugosa. E m b r yon is exalbutainosi, arcuato-conduplicati cotyledones incumbentes, radieula conica. - Herbae annuae v. perennes, in Africa, Asia et America tropica et subtropica indigenae; folitis alternis, tri-septemfoliolatis, foliolis integerrimis $v$. dentatis, floribus terminalibus, racemosis.

Gynandropsis DC. Prodr. $I$, 237, excl. sp. Wight et Arnott Prodr. 1. 21. Meisner Gon. 15. (17.) Torrey et A. Gray Flora of North-Amer. 1. 121. Cle o m es s p. Lian. Cleomes sectio Gynandropsis et Gymaggonia R. Brown in Clappert, Narrat, 222.

a. GYMNOGONIA R. Brown t. c. Corolla a aestivatio aperta: - Species in Africa et Asia tropica indigenae, in Americam transfugae. - Pod og y ne Hoffalansegge Verzeichn. 186. Cleo me pent a phy yll a Linn. Jaeq. Hort. Yindo 8. t. 24. Bot, Mag. $t$. 1681.2656.

b. EUGYNANDROPSIS. C o rolla e restivatio imbrieata. Species americanae. - C leomes s p. Kunth in Humb. et Bonpl. Nov, gen. et up. t. 436.

1985. Cleome DC. Caly $\mathrm{x}$ quadripartitus, persistens $v$. deciduns. Coroll a e petala 4 , imo toro inserta, sessilia v. unguiculata, subąequalia, aestivatione imbricata. S $\mathrm{tamin}$ a 4 v. 6 , toro parvo hemisphaerico $v$, subgloboso inserta; fil a m e $\mathbf{n}$ a filiformia, saepissime inaequalia, declinata, a ntherae biloculares, lengitudinaliter dehiscentes. O va rium sessile v, stipitatum, uniloculare, ov uli s juxta placentas intervalvulares geminas plurimis, amphitropis. S ty 1 u 8 brevissimus v. nullus; $8 t i \mathrm{gma}$ obtusum v. suborbieulatum. C a p s u l a siliquaeformis, sessilis v. stipitata, compressiuscula, unilocularis, bivalvis, valvis a replo seminifero persistente solutis, deciduis. Se mina pauca v. plurima, reniformia, aspera. Em b ry onis exalbuminosi, arcuato-conduplicati cotyledones incumbentes, radicula conica. - Herbae ut plurimum annuae, rarissime suffrutescentes, in regionibus tropicis temperatisque calidioribus totius orbis obviae; foltis simplicibus v. saepius tri-septemfoliolatis, foliolis serrulatis, foribus solitariis $v$. in racemum terminalem dispositis.

Cl e o we Linn. Gen, n, 826, excl. sp. Gärtner I, 368.t, 76 . DC. Prodr. 1. 238, excl. sp. Wight et Arnott Prodr. $I$. 21 . Torrey et A. Gray Flora of North-America $I, 121$. Sin a. pis trui in Móneh Method, 250.

a. PEDICELLARIA DC. 2 . c. Ovarin m suprá torum subglobosum carnosum longe stipitatum. - Species americanae. (Sehreber in N.A. N. C. IV. 2.3. Jacq. Observ. IV. $t$, 76. Willd, Hort, Berolin, t. 18. Bot. Mag. 2.1640. 1857. 3137.) - At a l a n ta Nuttall Gen. Amer. II, 73. Peritoma DC. Prodr. 1. 237. Nuttall in Journ. Academ. Philadelph, VII. 14. (Hooker Flor. Bor, Amer. t. 25.)

b. SILIQUARIA DC, $l$. c, 0 variu m supra torum parvam, hemisphaericum sessile v. breviter stipitatum. - $S p e$. otes gerontogeae. - Cleomes sect. S lliquaria R. Brown in Denham Narrat. 228. Siliqu a r i Forskael Aegrpt. 78. (Schkuhr t. 189. Sibthorp FIor, graec. t. 650,) - Rorida Ia Forskael Aegypt. 35. Rori da Römer et Sehultes Syst. III, 13. (Delile Flor. Aegypt. t. 36. $f .2$.

4986. Daetylaena SCHRAD. Calyx tetraphyllus, foliolis lanceolatis, antico longiore. Cor olla e petala 4 , imo toro inserta, linearilanceolata, dno antica erecta, duo postica paullo longiora, adscendentia. St a min a 6 , toro hemisphaerico parvo, basi postice in glandulam producto inserta, quatuor (lateralia et postiea) ananthera, filamentis subulatis, brevibus, liberis, antica in 
nnicum connata, filamento cylindrico, anthe $r$ is bilecularibus, in unicam erassam longitudinaliter rimis quatuor dehiseentem coalitis. O var i m m sessile, uniloculare, ov nlis juxta placentas intervalvulares geminas plurimis, amphitropis. Sty I n s filiformis, brevis;'s tig ma acutum. Cap s u la siliquaeformis, sessilis, cylindrica, unilo cularis, bivalvis, valvis a replo seminifero persistente solutis, deciduis. S e mina plurima, reniformia, compressinscula, aspera. E mb ry o n is exalbuminosi, arcuato-conduplicatí cotyledones incumbentes, radicula cylindrica. - Herba suffruticosa, incertae originis; foliis alternis, exstipulatis, trifoliolatis, foliolis integerrimis, lateralibus minoribus, racemo terminali paucifloro, floribus parvis, siliquis glanduloso'puberulis.

D a c ty laen a Schrader Hort. Gorting. inedit. Sehultes Syst. VII. p. IX. Cleome monandra DC. Plant, rar. Hort. Genev, $t, 15$.

4988. Playsostemom MART, et ZUCC. Calyx tetraphyllus, decidnns. Corolla e petala 4, hypogyna, adscendentia, unguiculata, obovata. Stamina 6 v. rarius 8 , hypogyna; filamenta filiformiá, declinata, plerumque inaequalia, superiora 2 v. 4 breviora, infra antheram inflato-incrassata, reliqua inferiora longiora, apice aequalia, an therae lineares, erectae, biloculares, longitndinaliter dehiscentes. Ov a riu m sub sessile, declinatum, ovatum v. Ianceolatum, compressum, uniloculare, ovulis juxta placentas geminas intervalvulares oppositas plurimis, horizon talibus, campylotropis. S ty 1 u s terminalis, subulatus, adscendens; $8 \mathrm{tig} \mathrm{m}$ a acutum v. subcapitatum. Capsnla siliquaeformis, ovata v. linearis, unilocularis, bivalvis, valvis a replo seminifero persistente decidais. S' m in a plura, horizontalia, reniformia, transversim rugosa et aculeolata. E mbryonis exalbuminosi, arcuato-conduplicati cotyledones incumbentes, radicula conica. - Herbae annuae, parvae, erectae $v$. prostratae, in $B$ ras $i$ $l i a$ indigenae; foliis sparsis, simplicibus, integerrimis, floribus terminalibus, racemosis, flavis.

P h y s o s te mon Martius et Zuccarini Nov. gen. et sp. 1. 72. $t$. 45-47. Sehultes Syst. VIT. 51. Meisner Gen. 17. (15.)

4989. Polamigia RAFIN. Caly $\mathrm{x}$ tetraphyllus, foliolis lanceolatis. Corolla e petala 4 , imo toro inserta, sessilia v. unguiculata, saepe inaequalia. St am in a octo v. plurima, toro parvo, hemisphaerico, interdum basi postice in glandulam producto inserta; fil amenta filiformia $v$. apice clavata; saepissime inaequalia, declinatá, nonnulla interdum ananthera, an ther a biloculares, longitudinaliter dehiscentes, Ovari u m sessile v. stipitatum, uniloculare, ovulis juxta placentas intervalvulares geminas plurimis, campylotropis. Stylus filiformis, ovario longior v. brevissimus; st igma obtusum. Ca p sula siliquaeformis, sessilis v. stipitata, cylindrica v. compressa, unilecularis, bivalvis, valvis a replo seminifero persistente solutis, decidnis. Semina plarima, reniformia, transversim rugosa. E mbry onis exal buminosi, arcuato-conduplicati cotyledones incumbentes, radicula conica. - Herbae in America boreali et tropica, nec non in Asia calidio. $r e$ indigenae, annuae, subglaueescentes, saepe glanduloso-viscidae, graveolentes; foliis alternis, trinovemfoliolatis, foliolis integerrimis $v$. serrulatis, floribus terminalibus, raccmosis.

P olan is ia Rafinesque in Journ. Phys, LXXXIX. 98, DC. Prodr. I, 249. Wight et Arnott Prodr.I. 22. Meisner Gen.
17. (15.) Torrey et A. Gray Blora of North-Americ. I. 128. $\mathrm{J}$ a cks on i a Rafinesque in Now. York. medic. Fieposit II. Hez. V. 350 .

a. CORYNANDRA. Tor eglandulosus. R e $t a l a$ subsessilia, aequalia. Fil a me a t a apice clavata. - Species indicae. Cory nandra Schrader in Reichenb. Fc. exot. t. 147. Cleome Chelid onit Lian.

b. RANMANISSA. Tor us basi postice in glandulam productus. Petala subsessilia, aequalia. Filamenta filiformia. - Species indicae. (Burmann Zejl. $t$, 99.)

c. EUPOLANISIA. To r us basi postice in glandulam pro. ductus. Pet a I a longe ungaiculata, inaequalia. Filam e n t a filiformia, inaequalia. - Species americanae. Cleomes seet. Polanisia R. Brown in Denham Narrat. 221. Ci. graveolens Barton Flor. Bor. Amer. t. 29. C. unigl a nd u los a Cavanill. Io, t. 300 .

4989. Cyribasiam. C a ly $x$ tetraphyllus, foliolis brevibus, oblongo-lanceolatis, subaequalibus. Co roll a e petala 4 , imo toro inserta, longe unguieulata, postica late cuneiformia, apice parce lacero-dentata, antica cuneata, ad basim laminae laciniata, laciniis linearibus, apice subdilatato incisis $v$. denticulatis. Sta $\mathrm{m}$ in a 6_14, toro minuto, postice appendicem tubulosam, ore truncato denticulatam exserenti inserta; fil a m enta filiformia, declinata, subaequalia, an therae biloculares. O varium stipitatum, declinatum... Stylus filiformis .... Capsu la siliquaeformis, linearis, subtorulosa. S e m in a plurima, reniformia, aspera. ....-Herbae b orea $l i$-am $e_{-}$ ricanae, annuae, pube minuta glanduloso-viscidae; foliis alternis, trifoliolatis, foliolis anguste linearibus, petiolo longioribus, racemo folioso, paucifloro, pedicellis filiformibus, floribus parvis, albis $v$. pallide flavis.

Crist a tell a Nuttall in Journ. Academ. Philadelph. VII. 85. t. 11. Torrey et A. Gray Flora of North.Americ. t. 123, non Zoolog.

4990: Isomeris NUTT. C a lyx cam. panulatus, quadripartitus, marcescens, laciniis ovatis, acuminatis, patentiusculis. Corolla e pctala 4, oblonga, sessilia, aequalia, patentinscula. Stamina 6, toro carnoso, subhemisphaerico, postice in appendicem angustam producto inserta; fil a m enta aequalia, aestivatione inflexa, demum longe exserta. Ova ri $\mathbf{n}$ m stipitatum ..... Stylus brevis; stigma minutum. Capsula magna, coriacea, obovato-elliptiea, inflata, stylo superata. Semina plura, magna, laevia...... - Arbuscula californica, graveolens; radice palari longa, trunco apice patentim ramoso, ligno duro, flavo, ramulis puberulis, foliis confertis, trifoliolatis, foliolis lanceolatis, miucronulatis, glabris, floribus magnis, flavis, in racemos terminales dispositis.

Is o mer is Nuttall in Torreyet A. Gray Flor. of North.Amer. I. 124.

TrRIBUS II. CAPPAREAE DC. Prodr. I. 242. Fructus baccatus.

4951. Selheppexia NECK. C al y x coloratus, tetraphyllus, foliolis duobus exterioribus carinatis, antico majore. Corolla nulla. Stamina 8 , in apice tori in columnam filiformem ineurvam producti, basi postice processn cymbiformi operculato aucti; fil am enta filiformia, a $n$ the ra e ovoideae, biloculares, longitudinaliter dehiscentes. Ovarium stipitatum, ovatum v. oblongum, unilocnlare, ovulis juxta placentas quatuor intervalvulares plurimis, amphitropis. S ti g m a sessile, papillaeforme. B a c ca siliquae$112 *$ 
formis, cylindrica. S e m in a plurima .... Frutices capenses, aphylli; ramis divaricatis, apice spinescentibus, floribus in racemos subcorymbosos $v_{\text {, }}$ umbellas dispositis, pedicellis basi unibracteatis.

S chepperla Necker Elem, n, 1392. DC. Prodr. $I$. 244. Schlechtend. in Linnaea 1 . 235. $t$. 3. Meisner Gen. 17. (15.) Macromerum Burchell Travels I. 388, Cleome j,u n c e a Linn.

4992. Atamisquea MIERS. Ca 1 y $x$ tetraphyllus, foliolis duobus exterioribus (antico et postico) ovatis, obtusis, concavis, intus villosis, duobus interioribus lateralibus multo minoribus, oblongis, obtusis, villosis. Torus carnosus, calycis fundum tegens, triangularis, angulis in dentes, posticum ligulaeformem et duos laterales minutissimos productis. C o roll a e petala 4, linearilanceolata, concava, intus villosa, duo in margine tori ad latera dentis postici, doo ad dorsum dentinm lateralium inserta. S tamina ima basi monadelpha, androphoro villoso, globoso, stipitis ovarii basim cingente, ad latus superius valde gibbo; filamentis 6 , glaberrimis, sursum curvatis, septimo inter duo postica abortivo, brevissimo, spinulaeformi, Ovarium stipiti elongato, lepidoto impositum, clavatum, acuminatum, sursum curvatum ...... Stylhs brevis; stigima acutum, simplex. B a c ca globosa, crustacea, dense lepidota, stylo apiculata. Semen unicum. Embry on is exalbuminosi cotyledones magnae, crassae, invicem longitudinaliter plicato-convolutae, radicula lateralis, teres, supera. - Frutex chilensis, durus, ramosus; ramis teretibus, griseis, sublepidotis, ultimis angulo recto divergentibus, sensim attenuatis, verisimiliter spinescentibus, foliis oppositis, versus ramulorum apices alternantibus, brevissime petiolatis, lineari-oblongis, basi et apice emarginatis, supra canaliculatis, viridibus, subtus lepidotis, nervo carinatis, pedunculis axillaribus, solitariis, unifloris, calyce petalisque externe lepidotis.

A tamis q u a Miers Travels in Chili II. 599. Hooker et Arnott Bot. Miscell. III. 143. Meisuer Gen, 17. (15.) Specimina vidl plurima, nullum floribus perfectls.

4993. Cadaba FORSK. C al y $\mathrm{x}$ tetraphyllus, foliolis inaequalibus, duobns exterioribus concavis, aestivatione valvatis, interiora tegentibas, omnibus deciduis. Coroll a e petala 4 , imo toro inserta, nnguiculata, rarius nulla. S $t$ a$\mathrm{m}$ in a $4-6$, tori stipitiformis, cylindrici, basi hine appendicem tubulosam, ore truncato denticulatam exserentis apici inserta; filamenta subulata, libera, antherae oblongae, acutae, biloculares, longitudinaliter dehiscentes. $O \mathrm{v}$ ari u m longe stipitatum, niloculare, orulis juxta placentas intervalvulares geminas oppositas plurimis, hiseriatis, amphitropis. Stig m a sessile, orbiculatum, subumbilicatum. B a c c a siliquaeformis, subtornlosa. Semina plnra, globoso reniformia, testa cartilaginea. $\mathbf{E}$ m br y o n is exalluminosi cotyledones incumbentim convolntae, radicula conica. - Frutices inermes, in Asia et Africa tropica indigeni, glabri v; pube glandulosa consiti; foliis alternis, simplicibus $v$, trifoliolntis, floribus axillaribus, , solitariis.

$\mathrm{C}$ a d a ba Forskael Aegypt, 67. DC. Prodr. , 244. A. Richard Flor. Seneg. I, 21. Wight et Arnott Prodr, 1. 24. Meisner Gen, 17. (15,) St r ö i a Vahl. Symb; 1 . 20.

a. EUCADABA. Corolla nulla v. tetrapetala, St a mina 4-6. Folia simplicia. (Delessert Ic. select, III. t. 8. 9.) b. DESMoe arPuS. Corolla dipetala, Sta mina 6. Fruetus siccus, a basi ineomplete bivalvis, seminibus replo adhaerentibus, - Folia trifoliolata. - De s mocarpus Wallich Catalog, n, 6928. C a d a ba triphyl1 a Wight in Hooker Bot. Miscell. Append. 2 , 37 .

4994. Thylaelhium LOUREIR. C a lyx folliculiformis, transversim operculo dehiscens. Corolla nulla. Stamina plurima, torí brevis, stipitiformis apici inserta; fil a m e nt a filiformia, libera, antherae biloculares, oblongae, longitudinaliter dehiscentes. O va ri u m stipitatum, uniloculare, ovulis juxta placentas parietales sex v. decem plurimis. Stig ma sessile, orbiculatum. Bacea oblonga, nnilocularis. Semina plarima .... - Frutices inermes, in Africae a ustro-orientalis insulis et continente indigeni; foliis alternis, simplicibus trifoliolatisque, integris $v$. panduraeformibus.

Thy I achium Loureiro Flor. cochinch, 417. Jussien in Annal. Mus. XIT. 71. DC. Prodr. I. 254. Meisner'Gen. 17. (15.) C a p a r is panduraeformis Lam. Thouar.

4995. Niebuhria $D C$. C a I $\mathrm{x}$ infundibuliformis, tubo cylindrico, persistente, limbi campanulati, quadrifidi, decidui laciniis aequalibus, aestivatione valvatis. Co rolla nnlla. Stamin a plurima, tori elongato-stipitiformis apici dilatato - hemisphaerico inserta; fil lamenta filiformia, libera, antherae ovatae, biloculares, longitudinaliter dehiscentes. Ovari u m longe stipitatum, ovoideum, uniloculare, ovulis juxta placentas intervalvulares geminas, oppositas plurimis, amphitropis. Stigma sessile, subeapitatum. Ba c ca ovoidea, unilocnlaris. Semina pauca v. abortu solitaria, in pulpa nidulantia, reniformia. Embryonis exalbuminosi cotyledenes carnosae, incumbentim convolutae, radicula brevis, subconica. - Arbusculae $v$. frutices, in Afric a et Asia tropica et subtropica crescentes; folits alternis, trifoliolatis, stipulis setaceis, minutis, floribus axillaribus solitariis, $v$. terminalibus racemosis.

Niebuhria DC. Prodr. I. 243. excl. sect. II. Wight et Arnott Prodr. $T$, 23, excl. sp. 2. Hooker $Y c, t, 124$. Meisner Gen. 17. (15.) Capparidis $\mathrm{sp}$. Roxb. Roth. Crater a e sp. Burchell.

4DS6. BBeseia $L A M$. C a I y $\mathrm{x}$ tetraphyllus, foliolis concavis, aestivatione valvatis, deciduis, margine fundi glanduloso-subtuberculato. Corolla nulla. Stamina 12 -20, toro vix elevato inserta; fil am en $t$ a subulata, ima basi snbmonadelpha, antherae ovoideae, bilocúlares, longitudinaliter dehiscentes. Ovarinm stipitatum, ovoidenm, nniloculare, ovalis juxta placentam parietalem nnicam 4-5, amphitropis. St ylu s terminalic, brevis; stigma minimum, depressum. B a c c a crnstacea, subglobosa, punctato-tuberculata, unilocularis. S e min a 1-4, in pulpa nidulantia, nucamentacea, reniformia. Embry on is exalbuminosi cotyledones erassae, incumbentim convolutae, radicula longa, subconiea. - Frutices Africae tropicae, inermes, glabriusculi; foliis alternis, simplicibus, coriaceis, integerrimis, petiolo cum rami denticulo articulato, stipulis setaceis, minimis, floribus terminalibus, corymbosis, parvis.

B o s eira Lam. t. 395. DC, Prodr, T. 244. A. Richard Flor. Seneg, I. 23. $t$. 6. Meisuer Gen. 17. (15.) non Thuab. Podoria Persoon Encheir. II. 5 .

499\%. Streblocarpus ARNOTT. C aIy $x$ infundibuliformis, tubo cylindrico, persistente, limbi quadripartiti laciniis aequalibus, aesti- 
vatione valvatis, deciduis, corona faucis nulla. Co roll a è petala 4, caly cis fauci inserta, unguiculata, aestivatione imbrieata. Stam in a plurima, tori elongato-stipitiformis apici dilatato-hemisphaerico inserta; filamenta filiformia, libera, antherae ovatae, biloculares, Iongitudinaliter dehiscentes. Ovari um longe stipitatum, ovato-oblongum, uniloculare, ovulis juxta placentas intervalvulares $\& \mathrm{v}, 8$ plurimis, horizontalibus, amphitropis. Stigma sessile, depresso-capitatum. B ace a siliquaeformis, torulosa, isthmis transversis plurilocularis, loculis juxta axim complanato - dilatatum alternatim tumentibus, monospermis, abortu numero variis. S em in a obsolete reniformia, testa membranacea. Embryon is exalluminosi cotyledones carnosae, incumbentim convolutae, radieulam brevem, conicam obtegentes. - Frutices Africae et Asiae tropicae; foliis alternis, simplicibus, coriaceis, integerrimis, petiolo cum rami denticulo articulato, stipulis setaceis, minimis, floribus axillaribus, solitariis $v$. corymbosis.

Streblocà us Arnott Nouv. Annal. se. nat. II. 235. (absq. charact.) Maerva angustif olla A. Richard Flor. Seneg. $t$. 8. Nieb uhria ob Iong ifolla DC. Hoo. ker Ic. t. 127. Maervae \& p. Cambesed, ad Jacquem. t. 23. 24. - Genus jani inde ab anuo 1832, in herbario et manuscriptis nostris sub alio nomine desigeatum.

4998. Maerva FORSK. Caly $\mathrm{x}$ infundibuliformis, tubo cylindrico, persistente, limbi quadripartiti laciniis aequalibus, aestivatione valyatis, deciduis, corona faucis membranacea, lacero-multipartita, brevi. Coro Ila nulla. S ta min a plurima, tori elongato-stipitiformis apiei dila tato-hemisphaerico inserta; fi l a me nt a filiformia, libera, antherae ovoideae, biloculares, longitudinaliter dehiscentes, O vari um longe stipitatum, oblengum, uniloculare, ovulis juxta placentas geminas intervalvulares oppositas plurimis, horizontalibus, amphitropis. Stig ma sessile, depresso-capitatum. B a e c a siliquaeformis, torulosa. Semina plura, globoso-reniformia, testa crustacea. Embryonis exalbuminosi cotyledones incumbentim convoluta, radiculam obtegens. - $A r$ busculae Africae tropicae, inermes, pube dum adest. simplici; foliis alternis, simplicibus, coriaceis, integerrimis, petiolo cum rami denticulo articulato, stipulis setaceis, minimis, floribus axillaribus solitariis, $v$, terminalibus corymbosis.

Matera Forskael Aegjpt. 104. Vahl. Symbol, x. 36. DC. Prodr. I. 25i. R. Brown in Denh, et Clappert, Narrat, \$26. A. Richard Flor. Seneg, I, 27, t. 7. (exel. t, 8.) Delessert Ic. select, IIT. t. 13. Meisner Gen. 17. (15.)

4DS5. Coricoulendron MART. Ca ly x urceolaris, quadri-quinquefidus, laciniis aestivatione valvatis, ima basi intus ligula petaloidea, opposita anctis. Corolla e petala 4 -5, imo calyei inserta, unguienlata, erecto-patentia. St amina 8 -20, tori stipitiformis, brevis apici inserta; $\mathrm{fi}$ 1 amenta filiformia, basi in urceolum connata, antherae anguste oblongae, biloculares, longitudinaliter dehiscentes. $\mathbf{O}$ va ri $\mathbf{n}$ m longe stipitatum, uniloculare, ov ulis juxta placentas intervalvulares geminas oppositas plurimis, biseriatis, amphitropis. Stigm a sessile, orbirulatum. B a cca subglobosa $v$. elongato-cylindrica, torulosa. Semina plurima, nidplantia, reniformia. Embryonis exalbuminosi cotyledones convolutae. Arbores $v$. frutices $A m$ ericae tropica e, pi$\overline{l i s}$ stellatis tomentoso-pulverulenti; foliis alternis, integerrimis v. repandis, stipulis parvis, deciduis, racemis terminalibus paucifloris.

Colicodendron Martins Herb. Brasil. 201. - ?C a pparis sect. 4. C a Ianthea DC. Prodr. L 250. Cappa. ridis s p. Jaeq. Amer, t. 106. 156. $-\mathrm{Q}$ a adrella Meisner Gen. 17. (15.) Ca p paridis sect. 6. Quadrella DC. l. c. (Jacq. Amer, t, 101. 103. Edit. pict. t, 151. Kunth in Humb. et Bonpl. Nov, gen. et sp, t, 437.)

5000. Capparis LINN. Calyx quadripartitus v. tetraphyllus, foliolis aestivatione imbricatis. Corolla e petala 4 ,-imo toro inserta, aestivatione imbricata. St a $\mathrm{m}$ in a plurima, rarissime definita, toro parvo, hemisphaerico inserta; fil amenta filiformia, antherae ovatae v. oblongae, biloculares, longitudinaliter.dehiseentes. Ovarium longe stipitatum, uniloculare, ovulis juxta placentas parietales duas oppositas"v. quinque plurimis, amphitropis. Stigma sessile, orbiculatum. B a c c a globosa v. siliquaeformis, eoriacea, uniloenlaris. S emin a plurima, in pulpa nidulantia, reniformi - subglobosa, testa crnstacea v. coriacea. Em b ryo exalbuminosus, convolutus. - Arbores v. frutices, saepe scandentes, ut plurimum spinosi, in regionibus tropicis, subtropictsque totius orbis, nec non in regione mediterranea indigeni; foliis alternis, integris 0 . integerrimis, plerumque coriaceis, stipulis spinosis, setaceis $v$. membranaceis et cauli adnatis, floribus solitariis, racemosis, paniculatis $v$. corymbosis, terminalibus, rarius axillaribus v. alaribus, bracteatis, saepissime albidis.

C a p p a r is Linn. gen, n.643. DC. Prodr, 1 . 245. Meisaer Gen. 17. (15.)

a. SODADA Forsk, Caly e is foliola concava. Sta $m$ in a subdefinita. B a c e a ovata. - Frutes a egyptiacus, ramis spinescentibus, subaphillis. - S o d a d a Forskael Aegypt, 81. Delile Flor, aegypt. 24. t. 26. DC. Prodr. 245. H o m b a ck Adanson Fam, $I$. 408. L i ndaćker a Sieber msc.

b. EUCAPPARIS DC. l, c, Cal y e is foliola ovata, coneava, Stam ina plurima v. definita, 0 varii stlpes lougus. B a c c a oyata v. globosa. - Species Berontogeae et australasicae. C a p p ris Plumler Gen. 39. Vol. k a mería Burmann Prodr. 17. (Sibthorp Flor. graec. t. 486. 487. Jaequin Hort. Schönbr. t. 109. Delite Flor. aegypt, t. 31: f. 3. A. Richard Flor: Seneg. t, 5. Bot. Reg. $t, 1320$. Reicheab. Iconogr. $t$. 281 . Delessert Ic. select, t. 10-12. Hook. Ic, t. 123. 126. 128. 181. Wight Itlustr. t. 14, Ie, $t, 71$.

c. CAPPARIDASTRUM DC, l. c. C al y e is foliola parra, subrotunda. Stamia a indefinita. Ovarif stipes mediocris. B a cc a subglobosa. - Species americanae, inermes. (Jaeq. Mmer, t. 104.)

d. CYNOPHALLA DC. $l$. o. Cal y $\mathrm{c}$ is foliola subrotunda, basi intus glandula v. foveola instructa. Stamina indefinita. B a c c aे siliquaeformis, teres. - Species a $m$ e. ricanae, inermes. (Jacq. Amer, t, 98, 99, 74. Edit. pict. t, 145, 147, 151, Reichenb. Ic. exot. $t, 233$.

e. BREYNIASTRUM DC. $l$. c. Caly cis foliola parva, triangularia. St a in a plurima v. definita. B a cea oblonga. - Species a mericanae, inermes, - B reyn i a Plum. Gen, t, 6. (Jacq. Amer. t. 100, 105. 160. Hort. Schōnorr. t. 100. Kuuth in Humb. et Bonpl. Nov. gen, et $s p, t, 438$.

5001. IBasbeckea ENDL. Calyx diphyllus, foliolis aestivatione valvatis, decidnis. Co rolla e petala 7 , imo toro inserta, inaequalia, aestivatione imbricata. St a mina plurima, toro hemisphaerico, parvo inserta; fila menta filiformia, antherae anguste oblongae, biloculares; hongitudinaliter dehiscentes. Ovarin m longe stipitatum, uniloculare, ovulis juxta placentas parietales duas v. plures plurimis, amphitropis. Stigm a sessile, orbievlatum. B a c e a globosa, coriacea, verrucosa. Semin a plurima, in pulpa 
nidulantia, reniformit-subglobosa, testa coriacea, E mbryo exalbuminosus, convolutns. - Frutex insula e Norfolk, scandens; foliis alternis, breve petiolatis, ovato-oblongis, integerrimis, glaberrimis, supra lucidis, stipulis spinosis, validis, uncinatis, pedunculis axillaribus, solitariis, uniftoris, foliis terminalibus mature delapsis racemum terminalem praebentibus, floribus majusculis speciosis, baccis Citri Aurantii majoris mole.

B u sbeckea Endlicher Flor. Norfolk. 64.

5002. Morisomia PLUM. Calyx ventricosús, bifido ruptus. C orol la e petala 4 , obtusa, oblonginscula. S ta m in a plurima, corolla breviora; filam enta subulata, basi in tubulum connata, antherae oblongae, erectae. Ovarinm longe stipitatum, ovatum .... Stigma sessile, eonvexum, umbilicatum. B a c c a globosa, cortica a, unilocularis. S e m in a plurima, in pulpa nidulantia, reniformia, testa crustacea, fragili. Embryonis exalbuminosi, curvati cotyledones ineumbentes, foliaceo - carnosae, convolutae, radicula fusiformis. - Arbor antillana; foliis alternis, petiolatis, ovatis v. oblongis, coriaceis, nitidis, floribus axillaribus subcorymbosis, petiolo brevioribus, albicantibus.

Mo ris on i a Plumier Gen. 63. t. 23, Linn. Cen, n. 642 . Jacq. Amor. $t, 97$. Gärtner $I, 378, t, 78$, Cavanill. Dissert. VI. 308. t, 163. DC. Prodr. I. 254. Meisner Gen. 17. (15.) Capparis Morisonia Swartz Observ. 278.

5003. Crataeva LINN. Calyx quadripartitns, laciniis aestivatiene subimbricatim conniventibus, deciduis. Co $\mathrm{r}$ o 11 a e petala 4 , tori carnosi, hemisphaeriei margini inserta, unguiculata, aestivatione aperta. S t a m in a 8 -28, cum petalis inserta; fil a ment a filiformia, libera, antherae ovatae, bilocnlares, longitudinaliter dehiscentes. Ovarium longe stipitatum, ovojdeum, uniloeulare, v. placentis intervalvularibus ad axim eonjunctis biloculare, ov ulis plurimis, multiseriatis, amphitropis. Stigma sessile, subbilobnm. B a c c a globosa, corticata, uni-bilocularis. Se mina plurima, in pulpa nidulantia, reniformia, testa membranacea. E m br y onis exábuminosi cotyledones incumbentim convolutae, radicula conica. - Frutices $v$. arbores inermes, inter tropicos Asiae, Africae et Americae crescentes; foliis alternis, petiolatis, trifoliolatis, foliolis integerrimis, floribus axillaribus v. terminalibus, corymbosis.

Crata ev a Linn. gen, n. 599. Lam. 2. 395. DC, Prodr. T. 242. exel. sp. B. Brown in Denham et Clappert. Narrat. 223. Wight et Arnott Prodr. I. 23. Meisner Gen. 17. (15.) Hooker Ic. t. 128. Delessert IC. select. IIT. 2 . 7. Othrys Noronh. ex Thouars Gen. Madagasc, $n$, 44.

5004. Fiteliea $R, B R$. C aly x tetraphyllus, foliolis concavis, aestivatione valvatis. Corolla petala 4, tori carnosi, hemisphaerici margini inserta, longe unguiculata, oblenga, nnguibus sub aestivatione indoplicato - valvatis, laminis imbricatis, undulatis. St a mina 12_16, cum petalis inserta; fil ament a filiformia, libera, antherae ovatae, biloculares, longitndinaliter dehiscentes. Ova rium longe stipitatum, ovatum. .... S tig ma sessile, orbiculatum, Ba ce a .... iiis alternis, trifoliolatio picae, scandentes; fo. tiis alternis, trifoliolatis, foliolis integerrimis, stipulis obsoletis, floribus terminalibus, racemosis.

Ritchiea R. Browa in Clappert. Narral, 223. Meis. ner Gen. 17. (15.) Crataeva fragrans Sims in Bot. Mag. $t .596$. C. c a p paroides Andrews Bot. Reposit.
t. 176.
5005. Steriphoma SPRENG, Calyx campanulatus, bilobus, lobis'(antico et postico) subaequalibus. Corallae petala 4, toro brevissime annulari intus inserta, sessilia, duo antica paullo majora. S $t$ a min a 6 , cum petalis inserta, longe exserta; fi l a m ent a filiformia, adscententia, duo postica breviora, anthera e oblongae, biloculares, longitudinaliter dehiscentes, 0 v a ri u m longe stipitatum, ovato-oblongum, placentis intervalvularibus in septum coeuntibus biloculare, o vuli s ad dissepimenti margines utrinque plurimis, biseriatis, amphitropis. Stig ma sessile, depressocapitatum. B a cea globesa, corticata, pulposa. S e m in a plurima, in pulpa nidulantia, irregulariter angulata. Embry onis exalbuminosi cotyledones spiraliter convolutae, radicula conica. Frutex o aracas anus, inermis; ramis pube stellata fuscescentibus, foliis alternis, longe petiolatis, oblongo-lanceolatis, acuminatis, supra nitidis, petiolo apice tumido, pedunculis axillaribus solitariis, unifloris, apice incrassato infractis, calycibus pilis stellatis luteo-rufis, petalis sordide flavescentibus.

Steriphoma Sprengel Cur. post, 130, Gen, plant. n. 1311. Sehult. $f$. Syt. VIT. 82 . Eudlicher in Flora 1832. II. $t .5$. Ro m e r i a Trattinick Gen. plant. 88 . S t e p han i a Willdenow Sp. II. 239. DC. Prodr, I. 253. Meisner Gen, 17. (15.) non Loureiro. Capparis paradoxa Jaeg. Hort. Schönbr. I, 58, t, 111.

500s. Tovaria RUIZ et PAV. Calyx octophyllus, foliolis imbricatis. Córoll a e petala 8 , tori convexi, tuberculati margini inserta, obovata, unguibus dense papilloso-barbatis. S tamin a 8 , cum petalis inserta, iisdem alterna; fil a me n t a subulata, libera, basi pilosa, a nther a e ovatae, biloeulares, longitudinaliter dehiseentes. Ovarium supra torum sessile, subglobosum, ov d I is juxta plácentas 8 intervalvulares plurimis. Stylus terminalis, brevissimus; stigm a peltatum, radiato-octolobum, Jobis subtus sulcatis. B a c c a erustacea, subglobosa, unílocularis. Semin a plurima, intra pulpam nidulantia, hippocrepica, testa crustacea. Embry on is exalbuminosi, arcuato-conduplicati cotyledones incumbentes, radicula conica. - Herba p eruana, annua, glabra; caule erecto, ramoso; folits alternis, petiolatis, trifoliolatis, foliolis integerrimis, intermedio longus petiolulato, lateralibus basi obliquis, racemo terminali multifloro, cernuo, floribus Pyrolae uniflorae floribus similibus.

Tovaria Ruiz et Pavon Prodr. 49. 2.8. Flor. Perud. III. 73. $t$, 309. Pavon in Act. Medio. Matrit, I. 192. Don in Edinb, new philosoph, Journ, PI. 50. Meisner Gen, 17. (16.)

\section{GENERA DUBIA.}

5007. Singana $A U B L$. Calyx tri-quinquepartitus. Corolla petala $3-5$, hypogyna, unguiculata, limbo serrulato. S $\mathbf{t}$ a $\mathrm{m}$ in a plurima, hypogyna; fil amenta filifórmia, antherae subrotundae, biloculares. O va ri um sessile, ovatum, placentis parietalibus 3 , multiovalatis. StyI a terminalis, simplex, incurvus; stig ma capitato-concavnrí. B a c c a crustacea, longe cylindrica, fragilis, unilocnlaris. Semina plurima, magna, sibi mutuo incumbentia, pulpa involuta. Embryo.... Frutex.guianensis, sarmentosus, nodosus; foliis ad nodos binis, approximatim alternis, ovatis, acutis, integerrimis, floribus axillaribus, subcorymbosis. 
Sing a n a Aublet Guian, 574. 0. 230. Jussieu Gen.257. Sterebeekia Schreber Gen, n, 909 .

5008. IItermupoa LÖFFL. Calyx duplex, exterior coloratus, gamophyllus, tubulosus, longus, integer, apice dentibus tribus ruptus, in ferins longins dehiscens, decidnus, interior minimus, tetraphyllus, foilolis subquadrangularibus, truncatis, decidnis. Co roll a e petala 4 , cum calycis interioris foliolis alternantia, erecta, linearia, convexa, obtuse acuminata, ealycem exteriorem paullo superantia. S $t$ a $m$ in a 6 ; fil a ment a longissima, subulata, antherae oblongae, planae, curvae. Ovarinm subulatum, parvum. St y l us filiformis, staminibus paullo brevior; stigma parvum, globosum. B a c ea maxima, teres, oblongo - cylindracea, cortice hine inde incrassato. Sem in a plurima, subrotunda, nidulantia. - Stirps Americae tropicae, soli Löfflingio nota, Breyniae ex eodem affinis.

H e r m u p a Löfling It. 307. DC. Prodr. I. 25t. Meísner Gen, 15, (17.)

\section{GENUS CAPPARIDEIS AFFINE.}

5019. Foy titus, coloratus, laciniis aestivatione imbrieatis. Corolla nulla. Sta $\mathrm{m}$ in a plurima, tori brevis, stipitiformis apiei inserta; filamenta filiformia, libera, an $t$ hera e biloculares, ovatae, loculis longitudinaliter dehiscentibus. O v a ri u m stipitatum, placentis parietalibus tribus biseriatim multiorulatis, in axi coalitis triloculare. Stylus brevissimus; 8 tig ma bifidum. Lobis acutis. Drup a baccata, monopyrena, epicarpio scabro, tenui, sarcocarpio pulposo, putamine lignoso trivalvi. S e men unicum, putamini conforme, testa membranacea. E m b ry o n is exalbuminosi, erecti co. tyledones carnosae, inaequales, major concava minorem induplicatam includens, radicula brevis, retracta, infera. - Frutex indicus; ramis scandentibus, setulosis; foliis alternis, breve petiolatis, oblongis, integerrimis, coriaceis, utrinque glabris. stipulis nullis, floribus terminalibus paniculatis et axillaribus racemosis, pedicellis basi unibracteatis, floribus flavis, fragrantibus, fructu olivaeformi, aurantiaco.

Ro y d s i a Roxburgh Plant, of Corom, III. 86. $t$. 289,

\section{Dralo CLXXXIII. Resedacene.}

RESEDACEAE DC. Theorie etem, edit. 1. p. 214. Jules Tristan in Annal. Mtut. XVIIT. 392. Liadley Collect. n. 22. R. Brown in Denham et Clappert. Narrat, 234. Bartling Ord, nat. 258. Agardh in Flora 1833. p. 113. St. Hilaire in Annal, soc, rogal, doOrleans XIIT, Deuxième Mémoire sur les Résédacees. Montpellier, 1837. 4. Lindley Introduct. edit. II. p. 62. Meisner Gen, 18. (16.) Kunth Flor. Berolin. $I, 64$.

Herbair annuae v. perennes, interdum suffrutescentes, rarius frutices, caule ramisque teretiusculis, succo aqueo. Folia sparsa, simplicia, integra, trifida v. pinnatipartita. Stipulae minutae, glandulaeformes.

Frones hermaphroditi v. abortu unişexuales, plus minus irregulares, racemosi v. spicati, unibracteati.

CaLYx quadri-septempartitus, inaequalis v. subaequalis, herbaceus, laciniis aestivatione subimbricatis, persistens.

Corollar petala $4-7$, rarissime 2 v. nulla, hypogyna, calycis laciniis àlterna, tri-multifida, plus minus inaequalia, postica majora, nune omnia, nune nonnisi majora supra basim dilatatam concavam sinuato-constricta, laminam dorsalem exserentia, aestivatione aperta, decidua.

Drscos hypogynus, inter petala et stamina carnoşus, urceolaris, limbo postice producto integro v. lobato, rarissime nullus.

Stamiva $3-40$, disco intus inserta, aestivatione a petalis haud tecta. Fil amenta filiformia v. subulata, libera v. basi monadelpha. Antherae introrsae, biloculares, terminaIes, longitudinaliter dehiscentes.

Ovaruvm-sessile, v. stipiti plus minus longo, apice aequali v. pulvinato - dilatato impositum, uniloculare, apice hians. Carpi di a 3-6, cum placentis totidem intervalvularibus utroque margine multiovulatis, valvatim v. basi induplicatím connata, nune supra placentas, in massam centralem, liberam, multiovulatam coeuntes, conniventia, rarissime apice cucullata, basi hiantia, uni-biovulata. Ovula amphitropa v. campylotropa. Styli in apicibus carpidiorum breves, cuspidiformes, apice brevissime bilobo stigmatosi, cum placentarum apicibus, nónnunquam in lobulos breves, supra ovarii verticem apertum conniventes productis, alternantes.

Fructus capsularis, membranaceus, apice origetenus.hians, indehiscens, rarissime baccatus, clausus, placentis intervalvularibus, nunc apocarpus, carpidiis vacuis circa placentam centralem conniventibus, v. cucullatis, monospermis, inferne rima apertis.

Semina reniformia v. hippocrepica, epidermide membranacea, hyalina, solubili v. testae crustaceae arcte adnata, endopleura carnosa. A 1 b umen nullum.

Eмвв уо homotrope arcuatus v. complicatus, cotyledonibus incumbentibus, radicula teretiuscula brevioribus v. longioribus.

Resedaceae ob floris et fructus structuram admodum singularem distinctissimae, proxima affinitate Capparideis accedere nunc ab omnibus censentur, illine ad Papaveraceas, praeter alias notas seminibus imprimis diversas, vergentes.

Specierum maxima copia in regionibus mediterraneis, imprimis in Africae ora gignitur, paucae in Europa media et boreali crescunt, nonnullae latissime per regiones extratropicas diffusae, in India boreali, insulis Canariis, Capite bonae spei et California observatae fuerunt. 
Resedae Luteolae radix flavum largitur colorem, Rieseda odorata ob suavem florum fragrantiam cuivis grata, vix ulla tamen morbos resedat.

5010. Dehradenus DELILE. Calyx quinquefidus, laciniis subaequalibus. Oorolla nulla, D is cus hypogynus urceolatus, limbo postice in laminam expanso, antice truncato. S $t$ amina 10-20, disco intus inserta; fil amenta filiformia, libera, deflexa, anth erae ovatae, biloculares, longitudinaliter dehiscentes. O v a r i um sessile, ovatum, tricuspidatum, uniloculare, carpidia tria cum placentis totidem nerviformibus valvatim connata, dorso in stylos breves, apice brevissime bilobo stigmatosos continua, vertice clausa. O v u la juxta placentarum margines utrinque plurima, amphitropa. B a c c a ovato-trigona, unilocularis, elausa, placentis intervalvularibus 3 , nerviformibus. Semina plurima, reniformia, epidermide tenuissime membranacea, testae crustaceae adnata, endopleara carnosa. E mb ryon is exalbuminosi, homotrope arcnati cotyledones incumbentes, radicula breviores. - Frutex a eg y ptiacus, ramosissimus; ramis virgatis, strictis, glabris, floriferis apice demum spinescentibus, foliis linearibus obtusiusculis, subfasciculatis, floribus spicatis, flavescentibus.

$0 \mathrm{chradenus}$ Delfle Flor, aegypt, 15. $t, 31$. Meisner Gen. 18. (16.) Res eda e s p. R. Brown.

501 1. Fesedia LINN. Calyx quadriseptempartitus, laciniis saepe inaequalibus. Coroll a e petala $4-7$, hypogyna, calyeis laeiniis alterna, inaequalia, tri-multifida, postica majora et lateralia intus squama ancta, antica simplicia. $D$ iscus hypogynus urceolaris, limbo postice in laminam expanso. Stamina $10-40$, disco intus inserta; fil amenta filiformia, libera v. basi breviter monadelpha, deflexa, an th erae ovatae, subsagittatae, biloculares, longitudinaliter dehiscentes. O va rium sessile v. substipitatum, obliquum, oblongum v. ovatum, apice tricuspidatum v. trilobum, uhiloculare, carpidia 3 v. $6, \mathrm{cum}$ placentis totidem alternis, nerviformibns valvatim connata v. apice induplicata, dorso in stylos breves, apice brevissime bilobo stigmatosos continua, placentis saepissime in cuspides minntos, inter stylos ereetiusculos v, conniventes productis, vertice hiante, sub anthesi conniventim clauso, O vala juxta placentarum margines utrinque plurima, amphitropa. Capsula ovata v. oblonga, angulata, tricuspidata v, triloba, nnilocularis, apice hians, placentis intervalvularibus 3 v. 6 , nerviformibus. S emin a plurima, reniformia, epidermide tenuis. sime membranacea, adnata v. soluta, testa erustacea, endopleura carnosa, Em b ryonis exalbuminosi, homotrope arcuati cotyledones incumbentes, radicula breviores. - Herbae annuae $v$. biennes, rarius suffrutices, in Europa media et boreali, copiosius in regione mediterranea et Africa extratropica crescentes; foliis sparsis, integris trifidis $v$. pinnatipartitis, stipulis minimis glandulaeformibus, floribus terminalibus, racemosis, pedicellis basi bracteatis.

Rese d a Linn. Gen. n. 608. excl. sp. Gärtner 1 . 369. Reichenbach Flor, germ. 696. Meisner Gen, 18. (16.) Kunth Flor, Berolin, $I, 64$.

a. LUTEOLA Tournef. C a I y x quadripartitus. Petal a 4 , posticum msjus, elongatum, basi lotus appendiculatum, apice multipartitum, duo lateralia et anticum simplicia, basi angustata, apice tripartito-lacera. $\mathrm{S} t \mathrm{a} \mathrm{m}$ i n a 30-40. Ovari um sessile, ovato-depressum, carpldiorum marginibus basi valvatim counatis, superhe indaplieatis, apice hians, placentarum ramis inferne coadunatis, superne bifidis, Juxta carpldiorum contiguorum margines induplicatos procurrentibus.

L a te ola Tournefort, inst. 238. Webb et Berthelot Flor. Canar. 104. R eseda Lute ola Linn. Sehkiuhr t. 129. Flor, dap. t. 864 . E. B. $t .320$.

b. RESEDA Tournef. C al y $x$ quinque-septempartitus. P etal a $5-7$, postica majora tri-maltipartita et lateralia tripartíta intus appendiculata, antica simplieia, bifida $\mathrm{k}$. tripartita. S t a m in a $10-24$. O v a ri u m substipitatum, oblongum, carpidiorun marginibus valvatim connatls, apice hisntibus tricuspe, placentis indivisis.

Reseda Tournefort inst. 238. Webb et Berthel. Op. eit. 101. t. 9. 10. Res e da e sp. Linn. Gärtner $t$. 75. Jaeq. Flor, austr, $t, 132.353$. Ic, rar, $t$. 475. E. B. t. 321. Bot. Mag. $t$. 29. Síbthorp Flor. graec. t. 459. Lindley Collect. $t, 22$.

5017. DIigomeris CAMBESS. C a $1 \mathrm{yx}$ quadripartitus, laciniis duabus posticis panllo majoribus, approximatis, duabus lateralibus a se invicem remotis, cum bractea hypocalycina antica alternantibus. Corolla e petala 2, hypogyna, inter calycis lacinias posticas inserta, scariosa, inappendiculata, distineta $v$, in unicum profunde bilobum connata. Discus nullus. Stamina 3 , hypogyna, duo lateralia petalis opposita, intermedium iisdem alternum; fil a'ment a subulata, basi breviter monadelpha, apice divergentia, a nthérae ovatae, biloculares, longitudinaliter dehiscentes. Ovarium sessile, ovato-depressum, quadrangulare, apice quadricuspidatum, uniloculare, carpidia quatuor cum placentis totidem alternis, late linearibus valvatim connata, dorso in stylos breves, apice brevissime bilobo stigmatosos continua, placentae superne in lobulos breves, supra verticem apertum inter stylos conniventes productae. $O$ a 1 a juxta placentarum margines utringue plurima, amphitropa. Capsula ovatodepressa, angulata, unilocularis, placentis intervalvularibus 4 inerassatis, vertice hians. S e m in a plurima, reniformia, testa coriacea, Incida. E mbryonis exalbuminosi, conduplicati cotyledones angustae, ineumbentes, radicula tereti paullo longiores. - Herbae annuae, erectae, in In dia orientali, Africa boreali, insulis Canariis, Capite bonae spei et California observatae; foliis linearibus, sparsis $v$. fasciculatis, spicis terminalibus, laxis, floribus parvis, inconspicuis.

Nligomeris Cambessedes in Jaequemont Vayage Bot. 23, $t$. 25. R e s e déll a. Webb et Berthel. Flor. Canar. 106. t. 11. Ellim ia Nuttall ex Torrey et $A$. Gray Flora of Nor/h-Americ. X.125. Reseda 5 u b u lata Delile, et R. dipet al a Aiton.

5013. Astrocarpus NECK, C a $1 \mathrm{y} x$ quadri-sexpartitus, laciniis aequalibus. C or olla e petala $4-6$, hypogyna, inaequalia, tri-multifida, intus squamula aucta. D is c us hypogynus urceolaris, limbo postice expanso. Stamina $12-18$, disco intus inserta; filam enta filiformia, libera, a nth era e biloculares, longitudinaliter dehiscentes. Ovari um stipitatum, stipite apice pulvinato, carpidiis 4-6, verticillatis, distinetis, cucullatis, basi hiantibus, intus infra apicem stigmatiferis. Ovnla 1 -2 amphitropa. Capsula e 4 v. 6 , liberae, steilatim patentes, apice cucullato clausae, basi ciliato-lacera hiantes. S e mina intra carpidia solitaria, hippocrepica, epidermide testae crustaceae adnata, endoplenra tumida. E mb r y on is exalbuminosi, homotrope arcuati cotyledones 
accumbentes, radicula longiores. - Herbae meditexraneae, humiles, multicaules; foliis alternis, lanceolato-linearibus, integerrimis, floribus spicatis, unibracteatis, albis $v$. purpurascentibus.

Astrocarpuz Necker Elem, n, 992. Reichenb. Flor. Gorm. 695. DC. Bot. Gall. 1 . 167. Meisuer Gen, 18. (16.) Ses a mgides Tournef. Instit. 238. Tristan in Annal. Mus. XVIII, t. 21. f. 1-4. Se s a mell a Reichenb. Consp. 186. Reseda ses a moldes Linn. Lam. $t$. 400 . DC. Ic. plant. Gall. rar, $t, 40$.

5014. Caylusen $S T$. HIL. C a ly $\mathrm{x}$ quinquepartitus, lacinitis subaequalibns. Corolla e petala 5 , hypogyna, inaequalia, tri-multifida, intus squama aucta. Discus hypogynus urceolaris, limbo quinquelobo, postice expanso. St a m i$n$ a 10-14, disco intus inserta; filament a filiformia, libera, a n therae biloculares, longitudinaliter dehiscentes. Ovari a m longe stipitatum, ovatum, carpidiis 6, circa receptaculum centrale subhemisphaericum verticillatis, basi coalitis, margine interiore apertis, vacnis, apice brevissime bilobo stigmatosis. Ovula plurima, receptaculo centrali inserta, campylotropa (?), C a p \& u I a aperta, sexloba, valvis laxis, super placentam centralem liberam conniventibus. S e mina plurima, hippocrepica, epidermide testae crustaceae adnata, endopleura tumida. $\mathbf{E} \mathbf{m}$ bryo ..... Herba a egyptiaca; foliis lineari-lanceolatis, undulatis, pilosis, ramis hirtis, floribus racemosis, pedicellis basi bracteatis.

C a ylu s e a St. Hilaire Deuzième Mémoire sur les Résedacies. Montpell. 1837. p. 29. R es e d a canescens Linn.

\section{Drdo CLIXXIV. Datisceae.}

DATISCEAE J. S. Presl Rosttin I. 217. R. Brown in Denham Narrat. 25. Bartling Ord, nat, 419. Bennett in Horsfield Plant. Jav. 80. DATISCACEAE Lindley Introduct. edit. $I I$. p. 82.

Herbae annuae, foliis alternis, imparipinnatis v. trisectis, foliolis v. laciniis serratis, glabris, rarius Aввовеs procerae, ramis nudis, foliis serotinis, alternis, quandoque lobatis, gresse et inaequaliter dentatis, subtus tomentosis. Stipulae nullae.

Flores paniculati v. spicato-racemosi, virescentes, inconspicui, dioici v. rarissime hermaphroditi.

Floribus mas culis: Calyx quadrifidus v. quinquepartitus, patens. Corolda nulla. StaMINA in flore tetramero quatuor, calycibus laciniis opposita iisdemque basi adnata; filamentis crassiusculis, demum elongatis, antherarum bilocularium loculis subrotundis, distinctis, introrsum lóngitudinaliter dehiscentibus; in flore pentamero circiter quindecim, in centro tori depressi congesta; filamentis subnullis, an therarum bilocularium loculis linearibus, connectivo nullo contiguis, longitudinaliter introrsum dehiscentibus. Ovari i rudimentum nullum v. discus obsoletus, subtetragonus.

Floribus hermaphroditis et femineis: Calyx tubo tri-tetra-pentagono, cum ovario connato, limbo supero, minute tri- quinquedentato. Corolla nulla. Stamisa in hermaphroditis summo calycis limbo inserta, ét ejusdem dentibus alterna; filamentis brevissimis, an therarum extrorsarum loculis linearibus, longitudinaliter dehiscentibus.

Ovariem inferum, uniloculare, apice hians v. rarissime clausum, compositum e carpidiis tot quot foliola calycis, iisdem alternis, marginibus valvatim commissis, nervo medio placentiferis. Placentae in nervo medio foliorum carpicorum sitae, lineares, prominulae, calycis lobis itaque alternae, prope apicem bifurcatae, cruribus divaricatis, sterilibus. Ovula plurima, bi-pluriseriata, horizontalia v. adscendentia. St yli suturales, in quovis carpidio gemini, placentarum eruribus continui, contigui vicinorum carpidiorum basi approximati v. connati, unicum indivisum v. bipartitum, calycis dentibus oppositum, placentis alternum referentes.

Capsula membranacea, calycis limbo stylisque coronata, unilocularis, apice origetenus hians v. breviter trivalvis.

Semina in placentis parietalibus prominulis plurima, horizontalia v. adscendentia, oblongoteretiuscula ; testa membranacea, longitudinaliter striata, impresso-punctata, umbilico strophiola membranacea, cupuliformi. Albumen carnosum.

Eмввуо orthotropus, axilis, cylindricus, albumine paullo brevior; cotyledonibus brevissimis, radicula longa, umbilico proxima, centrifuga.

Ordo parvus, speciebus perpaucis, per Asiam mediterraneam, Nepaliam, Javam et Californiam huedum observatis constans, nulli cognitorum affinis, placentis carpidiorum nervo medio insertis, isdemque margine styliferis distinctissimus.

5015. Tetrameles $R$. BR. FIores dioici. Masc. Caly x quadrifidns, lobis patentibus, obtusis. Corolla nulla. Stamina 4 , calycis lobiş, opposita et bási iisdem adnata; fil ain en t a crassiuscula, demum exserta, elongata, antherae introrsae, biloculares, subrotundae, loenlis distinctis, longitudinaliter dehiseentibus. Ovarii rudimentum discus, obsoletns subtetragonus. $\mathrm{Fem}$. Caly $\mathrm{x}$ tubo, subtetragono superne subdilatato, basi glanduloso-bispidulo, cum ovario connato, limbo semisupero quadridentato, dentibas brevibus, late ovatis, angulos terminantibus. Corolla nulla, Ovarium inferum, uniloculare, vertice breviter exserto hians, placentis parietalibus quatuor, cum dentibus calycinis alternantibus, apice sterili bifurcatis. Ovula plurima, biseriatim adscendentia, anatropa, funiculo brevi, crasso. Styli 4, placentarum cruribus contiguis eontinui, dentibus calycinis oppositi, indivisi, erassinseuli, intus suleati; stigmata inerassata, oblique truncata, subreflexa. Fruetus .... Arbor javanica, procera; ramis nudis, flexuosis, foliis post anthesim evolutis, acutis v, acuminatis, 
quandoque lobatis, grosse et inaequaliter dentatis, supra laevigatis, subtus petiolisque albo tomentosis, spicis in maribus paniculatis erectis, in femineis elongatis subsimplicibus, pendulis, fasciculatis, floribus parvis, numerosissimis, solitariis, binis, ternis $v$. interdum subverticillatis, ebracteatis.

Tetrameles R. Brown in Derham Narrat. 230. Bennett in Horsfield Plant, Jav, rar. 79. t, 17.

5016. Datisea LINN. Flores dioici. Masc. Calyx quinquepartitus, laciniis patentibus, acutis. Corolla nulla. Stamina $5-15$, in centro floris congesta; fil am enta subnulla, antherae biloculares, exsertae, elongato-lineares, decidnae, loculis contiguis, longitudinaliter dehiscentibus. $O$ varii rudimentum nullum. Fem. Caly x tubo oblongo - tri - pentagono, enm ovario connato, limbo snpero, minuto, tri-quinquedentato, dente uno alterove obsoleto. Ovarium inferum, uniloculare, vertice subexserto hians, pla. centis parietalibus tribus v. quinque, cum dentibus calyeinis alternantibus, apice sterili bifureatis. Ovula plurima, biseriatim adscendentia, anatropa. Styli $3-5$, placentarum cruribus contiguis continui, dentihus ealyeinis oppositi, ad basim bipartiti, lobis filiformibus, stigmatosis. Ca p s u la unilocularis, apice foramine rotundo hians. S e m ina in placentis parietalibus prominulis plarima, horizontalia, oblonga, testa membranacea, Iongitudinaliter striata, impresso-punctulata, umbilico strophiola membranacea cupuliformi. Embryo in axi albuminis carnosi orthotropus, cylindricus ; cotyledonibus brevissimis, radicula elongata, umbilico proxima, eentrifuga. - Herbae annuae, in Asia mediterranea et Nepalia indigenae; foliis alternis, impari-pinnatis, foliolis serratis, floralibus integerrimis, spicis axillaribus terminalibusque racemosis, floribus pedicellatis, bibracteolatis, viridibus.

D a ti s c a Linn. Gen, n, 1132. Jussien Gen, 445. Gärtner I. 147, t. 30. Schikulir $t, 336 .-\mathrm{D}$. hirta Linn, est Rhois sp. teste Bennet in Horsfield Plant. Jav, rar, p. 80.

501\%. Tricerastes PRESL. Flores hermaphroditi. Caly $\mathrm{x}$ tubo oblongo-trigono, $\mathrm{cam}$ ovario connato, limbo supero, minnto, tridentato. Corolla nulla. Sta $\mathrm{m}$ in a $\mathbf{3}, 8 \mathrm{ummo}$ calycis $\mathrm{lim}$ bo inserta, ejusdem dentibus alterna; filamenta brevissima, persietentia, an therae extrorsae, biloculares, lineares, longitudinaliter dehiscentes, deciduae. 0 v a ri n m infernm, uniloculare, vertice clausum, placentis parietalibus tribus. $O \mathbf{v u l a}$ plurima, horizontalia, anatropa. Styli 3 , denti bus calyeinis oppositi, bipartiti, lobis filiformisetaceis, stigmatosis. C a p s u la unilocularis, apice breviter trivalvis. Se mi na in placentis parietalibns plurima, horizontalia, oblonga, testa membranacea, longitudinaliter striata, impresso-pnnetulata, umbilieo strophiola minuta. E mbryo in axi afbuminis carnosi orthotropus, eylindrieus; cotyledonibus brevissimis, radicula elongata, nmbilico proxima, centrifuga. - Herba californ $i$ $c a, u t$ videtur annua, erecta, ramosa; folits alternis, trisectis, argute serratis, segmento intermedio majore inciso pinnatifido, floribus axillaribus, sessilibus, glomeratis, ebracteatis, viridibus.

Tricerastes Presl in Beliq. Hänk, H. 88, t. 64 .

\section{Classis XILI. Welumbia.}

Herbae aquaticae, rhizomate crasso, repente perennantes, succo in nonnullis lacteo.
F olia alterna v. opposita, emersa v. natantia, cordata v. peltata. Flores hermaphroditi, regulares. Calyx liber v. tubo cum ovariis mediante toro connatus. Corolla hypogyna, v. toro ovaria includenti, et cum iisdem plus minus connato, diversa altitudine inserta, rarissime gamopetala. St a m in a plurima, rarissime definita, cum petalis inserta, libera. Ovaria plura, inter se distincta v. verticillatim connata, a toro libera v. eodem inclusa. Ovula in ovarii e carpidiorum plurium coalitione multilocularis loculis plurima, dissepimentorum parietibus inserta; in ovariis distinctis unilocularibus solitaria v. gemina, pendulą, anatropa. Fruet u s baceatus v. nucamentaceus, indehiscens. S emina nunc albuminosa, e mbryo ne minimo, fungilliformi, in albuminis foveola superficiali intra sacculum amnioticum incluso; nunc exalbuninosa, embryon e maximo, plumula valde evoluta intra cotyledones vagina membranacea recondita.

\section{Ordo CLXXXV. Nympleaedeeae.}

HYDROCHARIDEM gencra Jussieu Gen. 68. NYMPHAEACEAE Salisbury in Konig Annal. of Bot. 1I. 69. DC. Syat. II, 39. Prodr. T. 113. Meisner Gen, 6. (8.) exclus. Nelumboneis. Bartling Ord. nat.28. Lindley Introduct, edit. II. p. 10.

Нвrвa aquaticae, trunco repente, crasso, rhizomatoideo vado affixae, folitis floribusque emersis natantibus.

Foris longe petiolata, petiolo crasso, tereti, lamina subrotunda, cordata v. peltata, integerrima v. denticulata.

Flores hermaphroditi, regulares, speciosi, saepe ampli, haud raro suaveolentes, eaerulei, albi, rubri v. flavi, in pedunculis simplicibus, ebracteatis solitarie terminales.

Calyx tetra-pentaphyllus, rarissime hexaphyllus, foliolis herbaceis v. intus coloratis, imo toro insertis, Jiberis v. basi in tubum cum ovariis mediante toro connatum coalitis, limbo supero, persistentibus v. deciduis.

Tonus carnosus, urceolaris, ovaria includens, nunc a ealyce liber, basi v. diversa altitudine petala et stamina gerens, nunc cum calycis foliolis in Lubum coalitis connatus, apice corollam et genitalia gerens.

Corollas petala plurima, imo toro v. illius superficiei diversa altitudine, nunc ejusdem cum calycis tubo connati apici inserta, multiseriata, exunguiculata, libera, interiora saepe sensim in stamina transeuntia, rarissime in corollam gamopetalam, limbn pluriseriatim lobato, summo tori a calyce liberi margini impositam, coalita. 
Sramiva plurima, multiserialia, cum petalis inserta, libera, rarissime corollae gamopetalae tubo intus pluribus seriebus imposita, inclusa, libera, exteriora saepissime ananthera, v, antheras rudimentarias gerentia, sensim in petala abeuntia, rarissime intima sterilia. FiI amenta plus minus petaloidea, lata, saepissime supra antherae loculos producta. Anth e r a e introrsae, biloculares, loculi paralleli, adnati, juxta totam longitudinem dehiscentes.

Carpinia plura, verticillatim inter se et cum toro, intra quem contenta, in ovarium multiloculare connata. Ovula plurima, dissepimentorum parietibus inserta, anatropa, rhaphe adnata, a puncto insertionis ad chalazam apicalem producta, nacleo intra integumenta exteriora e chalaza longe stipitato. S ty li carpidiorum sulco ventrali continui, in $\mathrm{sti} \mathrm{gma}$ peltatum, radiato-striatum, extra torum exsertum, sessile v. stipitatum, persistens, centro plus minus depressum, interdum glandula umbilicatum, coaliti.

Fructus baccatus, e toro carnoso, ancto, stigmate coronato, et e pericarpio membranaceo, pluriloculari, evalvi, intus pulposo, compositus, demum putredine irregulariter fatiscens, rarissime in elementa carpica delabens.

Semra plurima, intra periearpii pulpam nidulantia, ovata v. subglobosa, epidermide plus minus carnosa, secedente, testa dura, saepissime aspera, endople ura membranacea, rhaphe longitudinali et chalaza terminali notata. A 1 bumen farinaceum v. plus minus carnoso-grumosum, friabile, basi ad umbilicum fovea superficiali exsculptum, axi plerumque, ob nuclei stipitem consumptum, canale percursum.

Evввxo orthotropus, intra sacculum nuclei inclusus, albuminis cavitati superficiali semiimmersus; cotyled on ibus brevissimis, crassis, radicula obtusissima, umbilico proxima, chalazae e diametro opposita, sitn carpico vario.

Nymphae aceae aquas puras guietas v. lente fluentes hemisphaerae borealis laeto foliorum aulaeo, et mystico florum decore ornantes, in hemisphaera australi multo rariores, in Americae tropicae fluviis giganteae, tori fabrica et seminum struetura diştinctissimae, $\mathrm{Ne}$ lumboneis, quibus facie admodum similes, et Cabombeis proxime affines, ab his, quibuscum ovariorum numero et dispositione, et embryone in albuminis superficie intra sacculum amnioticum incluso conveniunt, tori praesentia, ovulorum et seminum numero, ab illis ovariis coalitis multiovulatis, et seminibus albuminosis differunt.
Sarracenieae ad Nymphaeacearum calcem a nobis collocatae, ordinem proprium sistunt, iisdem utut proxima necessitudine junctum, habitu tamen, tori defectu, et embryone intra albumen incluso distinctissimum. Remotior est Nymphaeacearum cum Papaveraceis, Ranunculaceis et Hydrocharideis analogia.

Semina plurium edulia. Trunei qualitates amaricantes, adstringentes, adhuc nimis obscurae.

TRIBU I. EURYALEAE. C a l y x tubo cum ovario connato. Corolla e petala libera.

5018. Euryale SALISB. Calyx tubo urceolato, cum ovario connato, limbi superi, quadripartiti lobis intus coloratis, persistentibus. Corolla petala $16-28$, summo calycis tubo pluriseriatim inserta, libera, limbo breviora, interiora sensim minora. Stamina plurima, cum petalis inserta, multiseriata, libera ; fil a m en ta subpetaloidea, a n therae introrsae, biloculares, loculis ovatis, adnatis, longitndinaliter dehiscentibns. O vari u m inferum, subglobosum, sex-novemloculare. Ov u 1 a in loculis 6_. 10 , dissepimentorum parietibus inserta, anatropa. Stigma peltatum, radiatum, centro umbilicatum, liberum. B a c ca ovata, calycis limbo stigmateque coronata, sexnovemlocularis intus pulposa, irregulariter rumpens. S e mina abortu ovulis multo panciora, intra pulpam nidalantia, subglobosa, epidermide carnosa, testa nucamentacea, aspera, endopleura membranacea. Albumen copiosum, carnosum. Em bryo .... - Herba aquatica, aculeis horrida, in Indiae bore at is lacubus vegetans; foliis magnis, natantibus, orbiculatis, peltatis, subtus valide nervoso-reticulatis, inter nervos elevatos purpurascentibus, floribus caeruleó-purpurascentibus, pro magniludine plantae parvis, fructibus demersis.

Euryale Salisbury in Konig Annal, of Bot. Ir. 13. Aiton Hort, Kew, edit. 2. III, 295, Bot. Mag. t, 14\$7, DC. Syst. II. 48. Prodr, I. 114. Meisner Gen. 6. (9.) A nneslea Andrews Bot, Reposit, 4 , 618. Roxburgh Plant. Corom, t. 244. Flor, ind. II. 573. Lie a, Kien sive Kit e o u Mem. Miss, chin. III, 457.

5019. Vietoria LINDL. Calyx tubo campanulato, cum ovario connato, limbi superi, quadripartiti Jobis intus coloralis, decidnis. Coroll ae petala indefinite plurima, summo calycis tnbo multiseriatim inserta, limbo longiora, exteriora patentissima, interiora incurva, multo minora. Stamina plurima, cum petalis inserta, multiseriata, exteriora fertilia, libera; filam entis petaloideis, a ntheris introrsis, bilotularibus, loculis linearibus, adnatis, longitudinaliter dehiscentibus, interiora sterilia, cornuta, stigmatum dorso adnata. Ovarium inferam, subglobosum, multiloenlare. Ovula plurima, dissepimentorum parietibus inserta. .... S $\mathrm{tig}$ m a campanủlatum, radiato sulcatum, tubo adnatum, centro nmbilico conico elevato, limbi liberi lobis reniformibus, dorso staminibus sterilibus cohaerentibus. B a ce a eyathiformis, hasi multiloculata, limbo elevato, truncato, intus radiatim sulcato, centro rostrata. S e m in a plurima, globosa, nueamentacea ..... - Herba ingens, in fluviis Brasiliae borealis et Guianae luxurians; foliis giganteis, diametro sex-octopedalibus, peltatis, orbiculatis, hine emarginatis, supra atro-viridibus, $113 *$ 
planis, margine elevato, subtus nervosis, inter nervos elevatos venosis, sanguineis, pedunculis, petiol is, calycibus foliorumque nervis aculeatis, flo. ribus maximis, quindecim unciarum diametrum saepe aequantibus, speciosissimis, primum candidis, mox sanguineis, fragrantissimis, fructibus demersis, seminibus edulibus.

V iet or ia Lindley Monograph. Lond, 1837. c. ic. fol. max. Bot. Reg. 1838. App. 13. Euryale amaxonica Pöppig in Fror ep. Notiz. $X \times X X$. 9. Heise II. 432. M a r uru Brasil. Egensium.

TIRIBUS II. NUPHARINAE. C a I y liber. Cor oll a e petala libera.

5020. Nymphaea NECK. Caly $x$ tetrapentaphyllns, foliolis imo toro insertis, liberis, intus coloratis, deciduis. Torus urceolaris, ovario adnatus. Corolla e petala $16-28$, toro extus pluriseriatim inserta, libera, plana, superiora sensim minora. Stamina plurima, toro supra petala multiseriatim inserta, libera; filamenta petaloidea, extima saepe sterilia, anthera e introrsae, bilwulares, locnlis oblongis v. linearibus, adnatis, longitudinaliter dehiscentibus. Ova riu m calyci superum, toro petala et stamina gerente inclusum, multiloculare. Ovula plurima, dissepimentorum parietibus inserta, anatropa. Stig ma sessile, peltato-radiatum, centro glandula ovatu-globosa umbilicatum. B a c ca ovata, petalorum staminumque cicatricibus exsculpta; stigmate coronata, multilocularis, intus pulposa, putredine aperta. Sem in a plurima, intra pulpam nidnlantia, ovato - oblonga, epidermide membranacea, solnbili, testa erustacea, endopleura tenuis. sima, rhaphe longitudinali et chalaza apicali notata. A l bu m e n copiosum, farinacenm. E m b r yo intra umbilicum basilarem sacculo amniotico in clusus, albuminis cavitati applieitus, minimus, lenticulari subglobosus. - Herbae in aquis stagnantibus et lente fluentibus regionum temperatarum et subiropicarum, imprimis hemisphaerae borealis obviae, inter tropicos rariores; rhizo. mate carnoso, radicante vado affixae, petiolis pedunculisque teretibus, laevibus, intus lacunoso-cellulosis, ad aquae superficiem pertigentibus $v$. paullo emersis, folits cordatis v. petiatis, integerrimis aut sinuato-dentatis, natantibus $v$. exsertis, glabris $v$ interdum subtus pubescentibus, floribus amplis, speciosis, albis, roseis, rubicundis v. caeruleis, nunquam flavis, saepe suaveolentibus.

N y m p ha e a Neeker Elem, $n, 1828$. Smitb Prodr. Flon graec. 1. 361. Richard Anal. fr. 69. DC. Syst, II. 49, Prodr. I. 114. Meisner Gen, 6. (9.) C a stalia Salisbury in Konig Annal. of Bot. IT. 71 . Le u cony m p ha a Boechage Lugd. Batav. 364 . N y m p ha a 8 p. Tournef. Ling.

a. CYANEA DC. $\boldsymbol{t}$. $\boldsymbol{c}$. An the ra e apice productae. F10. $r$ es caerulei v. caerulescentes. Folli a peltata, integerrima v. obtuse sinuata. - Species africanae, ina asia tica tropica. (Andrews Bot, Reposit, t. 179. 330. Bot. Mag. $t .552$, Annal, Mus. I. t. 25. Venten. Malmais

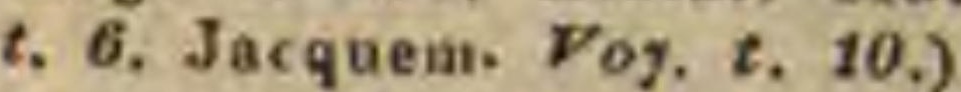

b. Lotos DC. t. e. An ther a aplee haud productae. Flares albi, rosei v. rubri, Folla peltata, rarius integerrima, saepius argute dentata v. subtus pubescen. tia. - Species indicae ot africanae, una in Europa orientali, allera in Antillis indigena. (Salisbury Pa rad. $t$. 14. Delile Flor. Aegypt. t. 60, f. 1. Palisot Flor Owar. t. 83. Waldst. et Kilailiel Plant. rar. Hung. t. 15. Bot. Mlag, t, 797, 1189. 1280, 1369. Wight Fllustr t. 10.)

c. CASTALIA DC. l. e, Antherae apica hand productae. Flores albi. Folia cordata, haud peliata, iategerif. ma, glabra. - Speciez in temperatis hemisphaerae borealis obviae. (Gärtner t, 19. f. 1. Sehkuhr t. 142. Flor. dan. $t$, 602. Willd, Hort. berolin, t, 39. Bot. Mag. 2. 819. 1359. 1525. 1658. De semiue efr. Richard Anal. fr. 41-47. ot Annal. Mus, XVII. 477. Tittmann Keim. ung. $t$, 3.)

5021. Nuplaar SMITH. Calyx pentahexaphyllus, foliolis imo toro insertis, liberis, coloratis, persistentibus. Torus urceolaris, ovario adnatus. Coro 11 a e petala $10-18$, imo toro plariseriatim inserta, libera, calyce breviora, dorso melliflua. Stamina plurima, imo toro pluriseriatim inserta, libera, primum adpressa, deinde elastice patentia; fil a menta brevissima, anthe$r$ a e introrsae, biloculares, loculis oblongo-linearibus, adnatis, longitudinaliter dehiscentibus. Ovarium calyei superum, toro inclusum, multiloculare. Ovula plurima, dissepimentorum parietibus inserta, anatropa. Stig m a stipitatum, peltatum, radiato-striatum, centro depresse umbilicatum. B a c c a subglobosa, basi angustata, petalorum staminumque cicatricibus exsculpta, stigmate coronata, multiloeularis, intus pulposa, putredine aperta. Semina plurima, intra pulpam nidulantia, ovato-acuminata, epidermide carnosa, solubili, testa crustacea, endopleura tenuissima, rhaphe longitudinali et chalaza apicali notata. Alb u m e copiosum, farinaceum. $\mathbf{n}$ m bryo intra umbilicum basilarem saceulo amniotico inclusus, albuminis eavitati applicitus, minimus, lenticularisubglobosus. - Herbae in aquis stagnantibus et lente fluentibus Europae, Asiae et Americae borealis rhisomatis crassi horizontalis radiculis vado affixae, petiolis pedunculisque laevibus, teretibus v. subtriquetris, paullo enersis, foliis cordatis v. sagitlatis, floribus luteis.

Nuphar Smith Prodr. Flor. graec, 2 . 361. Aiton Hort. Few, edit, 2. III. 895. DC. Syst, II. 59, Prodr. I. 116. Delessert Ic. select, II. t. 6. Meisner Gen, 6. (9.) N y m phae a Boerhave Lugd. Batav, 363. Salisbury in Fo. nig Annal. of Bot. IT. 71 . N y mptos anthus Richard Anal. fr. 08. non Lour. Nenu phar Hayne mse. Ny mphac a e s p. Tournef. Linn. Gärtaer $I . t$. 19. $f$. 2. Schkuhr t. 142. Flor. dan. $t$. 603, E. B. t. 159. 2292. Willd. Hort. Berolin. t. 38. Bot. Mag. 2. 864. 1243. - De semine efr. Mirbel in Buffon edit. Deterv. VII. 157. Annal. Dus. XVI. 453. t. 20. Turpin Ibid. VIT. 210. $t, 11, f$. 27. Richard Anal. fr. 41_77, et Annal. Mus. XVII, 230, t. 9. f. 31.52. Brongn. in Annal. so, nat. XIT, t. 39. Tittmann Keim, $t .2$.

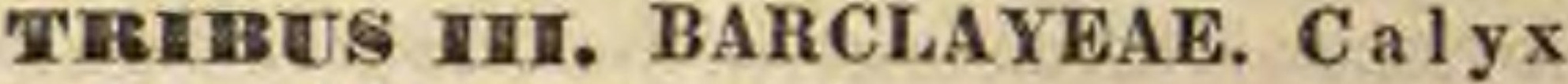
liber. Coroll a gamopetala.

502. Iinarelaya WALL. Calyx pentaphyllus, foliolis imo toro insertis, liberis, subherbaceis, sub apice cuspidatis, deciduis. Torus globosus, ovaria includens. Corolla gamopetala, turi apici inserta, tubo cylindrico, limbi brevis, octo-decemlobi lobis bi-triseriatis, inaequalihus. S tam in a plurima, tubo corollae pluriseriatim inserta, libera, inclusa, seriebus alternis, remotis, duahus supremis sterilibus, subulatis, hamatim incurvis, quatuor v. quinque inferioribus fertilibus; filamentis brevissimis, subulatis, a $\mathrm{t}$ heris basifixis, bilocularibns, longitudinaliter dehiscentibns, Ovarium calyci superùm, toro corollifero inferum, multiloculare, vertice fovea infundibuliformi, radiato striata, ad centrum nsque exsculptum. Ovnla plurima, dissepimentorum parietibus inserta $\ldots .$. Styli foveae ovarii radiis continni, breves, basi in annnlum imae corollae adnatum connati, apicibus subulatis, liberis, convergentibus; stigmata simplicia, obtusa. Fructus calyce, corolla et stylorum annulo 
cum membrana foveam centralem vestiente seorsim deciduis; in elementa carpica subearnoso-grnmosa, intus gelatinosa, indehiscentia delabens. Semina plurima, globosa, testa membranacea, simplici, setis hyalinis, succulentis, patentibus, juxta verticem obsolete umbilicatum densins confertis echinata. Albumen carnosum, friabile. $\mathbf{E} \mathbf{m}$ b ry o extra albumen minimus, ovatus ...... - Herba in aquis stagnantibus regn $i P_{e} g u$ reperta, Potamogetonis, facie, gracilis; foliis perquam tenuibus, elongatis, oblongis, basi paullo angustata cordato-subhastatis, haud peltalis, penninerviis, fluitantibus $v$. natantibus, supra lucidis, subtus ferrugineis, leviter tomentosis, scapis unifloris, elongatis, gracilibus, unifloris, floribus erectis, glabris, ex viridi livescentibus, inodoris, sesquipollicaribus.

B a $\mathrm{rcl}$ a y a Wallich in Linn, Transact. $X V$. 442. t. 18 Meisner Gen, 6. (9.)

\section{* SarRaCeniaceae.}

5023. Sarracemia LINN. Calyx in. voluero minuto triphyllo einctus, pentapliyllus, foliolis aestivatione imbricatis, persistentibus. C oroll a e petala 5, hypogyna, unguiculata, concava, conniventia. Stamina indefinita, hypogyna; fil amenta brevissima, antherae introrsae, biloculares, oblongae, adnatae, loculis longitudinaliter dehiscentibus. Ca ps ul a libera, quinquelocularis. Ovula in placentis e loculornm angulo exsertis plurima, anatropa. Stylus terminalis, brevis; stigma maximum, petaloidenm, peltato quinquangulare, persistens. C a psula quinquelocularis, loculicide-quinquevalvis. S e min a plnrima, minima. E m bry o'in basi albnminis copiosi carnosi prope umbilicum minimus, eylindricus.

Herbae boreali-americana e, paludosae, perennes; radice fibrosa, folitis omnibus radicalibus longe petiolatis, purpureo $v$. flavo-virentibus, petiolis tu. bulosis $v$, infundibuliformibus, lamina parva, rotunda, pedunculi ori plerumque applicila, scapis unifloris, floribus magnis, nutantibus, flavis $v$. purpureis.

Sarracen i a Linn. gen, n. 885. Miller Ic. $\ell$. 241. Smith Exot, Bot, I. t, 53. Michaux Flor. Bor. Amer. T, 310. Dela Pylaie in Annal. soc. Linn. Paris, VI. 388. $2,13$. Hookir Exot. Flor. t. 13. Bot. Mag. t, $780.849,1710,3515$. Nuttall Gen. II. 1O. Americ. philosoph. Transact. 2, ser. 1V. 49. $t .1$. Croome in Annal, Lyc. New-York. IV. 98, t. 6 . Torrey et A. Gray Flora of North.Americ. I. 58. S a r rae a a Tournefort Inst. 476. C o il o p h y $11 \mathrm{u}$ m Morris. Hist. III. 333. B u c a a a phy 11 um Pluckaet Amalth. 2. 370. f. 5.6 .

\section{Drdo CLXXXU'T. Cabonobeae.}

CABOMBEAE Riehard Anal. fr. 68. Bartliug Ord. nat. 87. HYDROPELTIDEAE, Podophyllacearum tribus DC. Syst. II. 36. Prodr. $I$. 112. HYDROPRL TIDEAB, Nymphaeacearum subordo Lindl. Introduct. edit, II, p. 13. HYDRO. PELTIDEAE Meismer Gen, 6. (8) CAMBOMBACEAE A. Gray in Annal. Lyo. New-York, IV. 46.

Нвавав perennes, aquaticae, radicibus fibrosis vado affixae, caulibus natantibus, fistulosis, teretibus. Folia in inferiore caulis parte opposita, submersa, capillaceo-multifida, superiora alterna, longius petiolata, lamina natante, ovali v. orbiculata, centro peltatim inserla, peltinervia, integerrima.
Flores mediocres, hermaphroditi, regulares, lutescentes v. sordide purpurei, pedunculos axillares solitarios, unifloros, ebracteatos terminantes, paullo emersi.

Calyx tri-tetraphyllus, liber, foliolis petaloideis v. intus coloratis, aestivatione imbricatis, persistentibus.

Corollar petala hypogyna, calycis foliolis numero aequalia et alterna, aestivatione imbricata, persistentia.

Stamina hypogyna, calycis foliolis numero dupla v. multipla, iisdem per vices opposita et alterna. Fil am enta libera, subulata v. filiformia. An ther a e terminales, introrsae, biloculares, oblongo-tetragonae. v. oblongae-lineares, loculis parallelis, contiguis, juxta totam longitudinem dehiscentibus.

Ovaria duo v. plurima, libera, verticillata, unilocularia, teretiuscula v. lateribus subcompressa. Ovula juxta suturam ventralem gemina v. terna, superposita, pendula, anatropa, micropyle supera, chalazae basim loculi spectanti e diametro opposita, nucleo intra integumenta exteriora longiuscule stipitato. Styli singuli ovaria singula terminantes, crassiusculi v, filiformes, recti v. incurvi; stigmata simplicia.

Carrinia calyce et corolla persistentibus stipata, abortu ovariis plerumque numero pauciora, interdum solitaria, libera, folliculiformia, stylis superata, unilocularia v. saepissime endocarpio inter semina superposita sese insinuante transversim pseudolocellata, indehiscentia.

Semina nunc abortu solitaria, nune gemina v. rarissime terna, superposita, inversa, globosa. Tes t a coriacea, longitudinaliter striata, rhaphe obsoleta, micropyle mamillaeformi apicem loculi respiciente. Alb u m e n +carnosum, copiosum, in axi, ob nuclei pedicellum obliteratum, canale percursum, apice cavitate superficiali exsculptum.

Еивахо intra nucleum membranaceum, albuminis cavitati superficiali, chalazae oppositae, semiimmersum inclusus, minute fungilliformis. Cotyled ones brevissimae. Radicula crassa, obtusa, apicem fructus spectans.

Cab o m b e a e paucissimis speciebus, in America tropica et boreali calidiore indigenis, quarum una etiam in Nova-Hollandia viget, comprehensae, Nymphaeaceis proximae, sed antheris terminalibus, ovariis liberis, nec toro inclusis, et ovulis pancis distinctissimae, a Nelumboneis, quibuscum ovulorum numero subdefinito conveniunt, tori defectu, seminibus albuminosis et embryone multo minus elabo- 
rato, intra sacculum incluso differunt, a $\mathbf{P}_{0}$ dophyllo, Berberideis a nobis adjecto, certe longius alienae.

5024. Cabomba $A U B L$. C a ly $x$ triphylIns, foliolis petaloideis, persistentibus. Corolla e petala 3, hypogyna, calycis foliolis alterna, persistentia. Stamina 6 , hypogyna; fila men. ta subulata, antherae terminales, introrsae, biloculares, ovato-tetragonae, loculis longitudinaliter dehiscentibus. Ovaria 2_4, libera, unilocularia, Ovn la juxta suturam ventralem 2_3, pendula, anatropa. Styli terminales, breves; stigmatibus obtusis, indivisis. Carpidia $2-4$ v, abortn solitaria, subcarnosa, unilocularia, indehiscentia, stylis superata. Semina 1_3, inverse superposita, globosa. Embryo in albuminis carnosi foveola superficiali intra sacculum amniotienm fungilliformis, radicula chalazae basilari e diametro opposita, supera. - Herbae in aquistagnantibus A mericae tropicae et borealis calidioris vegetantes; caule natante, fistuloso, folits inferioribus oppositis, submersis, peltatisectis, lobis in lacinias capillaceas multipartitis, superioribus alternis, longius petiolatis, lamina natante, peltata, orbiculari, peltinervia, integerrima, pedunculis axillaribus solitariis, unifloris, ebracteatis, floribus parvis, lutescentibus.

Ca bom ba Anblet Guian, 1. 321. t. 124, L. C. Richard in Annal. Mus, XVIr. 230, t, 5, f. 23, Anal. fr. 46. 61, 62. 64. Jussien Gen. 46. Dict, sc, nat: VI, 23. Turpin II, t, 80. DC. Syst. II. 36. Prodr. I. Meisner Gen, 6. (8.) Torrey et A. Gray Flora of North-Amer. I, 54. Schlelden in Wiegm. Archiv. V. 230. t. 7. f. 7. 8. Ne ctris Sehreber Gen, n, 610. Nuttall Gen, Amer, I. 230.

5025. IBrasenia SCHREB. Caly x tritetraphyllus, foliolis intus coloratis, aestivatione imbricatis, persistentibus, Co roll a e petala 3 - 4 , hypogyna, calyeis foliolis alterna, persistentia. Stamina $18-86$, hypogyna; filamenta filiformia, antherae terminales, introrsae, bilocnlares, lineares, loculis longitudinaliter dehiscentibus. Ov aria 6_18, libera, verticillata, unilocularia. Ovu la juxta suturam ventralem 2 , super posite pendula, anatropa. Styli terminales, filiformes, incurvi; stigmatibus simplicibus. Carpidia 6_18, libera, subcarnosa, unilocularia, indehiscentia, stylis superata. Semina abortu soli taria v. gemina inverse superposita, globosa. $\mathbf{E}$ mbryo in albuminis carnosi foveola superficiali, intra sacculum amnioticum fungilliformis, radicula chalazae basilari e diametro opposita, supera. - Herba in lacubus Americae borealis et Novae-Hollandiae orientalis extratropica e vegetans; radicibus fibrosis solo af. fixa, partibus submersisi gelatina viscida obductis, caule tereti, fluitante, foliis alternis, longe petiolatis, ovalibus, centro peltatis, peltinerviis, integerrimis, glaberrimis, natantibus, pedunculis axillaribus solitariis unifloris, ebracteatis, floribus sordide purpureis.

B ras en ia Schreber Gen, n, 938. Nuttall Gen, Ir. 23. Torrey et A. Gray Flora of North-Amer, I. 55, 1 xodia Solander msc. H y dropelitis L. C. Richard in Michaux Flor. Bor. Amer. I. 324. t. 29. Annal. Mus, XVIT. 230 . t. 5. f. 22. Bot. Mag. t. 1147. DC. Syst. II, 37, Prodr. 1 112. Turpin Atlas, II. t. 8t. Meisner Gen, 6. (8.) Rondachine Bose. - Specimina e Nova-Hollandia a Bauero aliisque relata, a boreali-americanis distinquere nequeo.

\section{Ordo CLXXXVII. Velumboneae.}

NELUMBONEAE Nymphaeacearumi tribus DC. Syst, II. 43. Prodr. I. 113. Meisuer Gen, 6. (8.) NELUMBONEAE Bartling Ord. nat. 89 . Martius Conspect, 38. NELUMBIA. CEAE Lindley Introduct, edit. $\boldsymbol{I I}, p, 13$.

Herвas aquaticae, rhizomate horizontali, crasso, ramoso, radicibus fibrosis vado affixo. Foli a longe petiolata, petiolo crasso, tereti, tuberculato, lamina natante orbiculata, centro peltatim inserta, peltinervi, integerrima, vernatione marginibus involuta.

Flores hermaphroditi, regulares, ampli, speciosi, in pedunculis simplicibus, ebracteatis solitarie terminales.

CALYx tetra-pentaphyllus, foliolis imo toro insertis, liberis, aestivatione imbricatis, deciduis. Torus carnosus, obconieus, basi angustata corollam et stamina grerens, apice lato, truncato foveolis discretis pro receptione ovariorum exsculptus.

Conollae petala plurima, imo toro multiseriatim inserta, libera, aestivatione imbricata, sub anthesi patentia, decidua.

Stamina plurima, cum petalis imo toro multiplici serie inserta, isdem breviora, erectiuscula, libera. Fil a m e n t a filiformia, superne subdilatata, supra antheras in appendicem planam v. clavatam producta. An th e ra e introrsae, biloculares, loculis linearibus adnatis, parallelis, longitudinaliter dehiscentibus.

Ovaria plurima, tori foveolis singillatim immersa, libera, nnilocularia. Ovulum unicum, v. interdum gemina collateralia, ex apice funiculi filiformis, e basi loculi juxta parietem adscendentís pendulum, anatropum. Styli breves, simplices, in ovariis singulis terminales; stigmatibus minute capitatis, subpeltatis, indivisis.

Noces plurimae, subglobosae, stylo superatae, coriaceo-corneae, monospermae, e tori carnosi alveolis semiemersae, liberae.

Semen pericarpii cavitatem implens, inversum, testa spongiosa, umbilico apicem, chalaza foveolaeformi, margine obtuse elevato cincta, basim loculi respiciente.

Embryo exalbuminosus, orthotropus. Cotyle don es crassae, carnosae, dorso convexae, faciebus planae, p I umulam diphyllam valde evolutam, petiolis refractis intra vaginam membranaceam clausam reconditam, includentes. I a dicula brevissima, crassa, obtusissima, chalazae e diametro opposita, supera.

Ordo perparvus, e genere unico, speciebusque nonnisi duabus, quarum una Asiam me- 
diam et calidiorem, altera Americam borealem inhabitat, huedum compositus, a Nymphaeaceis, quibuscum facie et plurimis characteribus convenit, ovariis intra tori alveolos liberis, unibiovulatis, et embryonis exalbuminosi maximi plumula valde evoluta distinctissimus, ovulorum numero propius ad Cabombeas accedit, a quibus tori praesentia, et albuminis absentia abunde differt.

5026. Nellumbivim JUSS, C a ly x tetrapentaphyllus, foliolis imo toro insertis, liberis deciduis. Torus carnosus, obconiens, ovaria includens. Corollae petala plurima, imo toro multiseriatim inserta, oblonga, patentia. $\mathbf{S t}$ a min a plurima, ino toro pluriseriatim inserta, libe $r a$; filamen ta filiformia, supra antheras in appendiculam producta, antherae introrsae, bi. loculares, loeulis linearibus, adnatis, longitudinaliter dehiscentibus. Ovari,a plurima, libera, unilocularia, tori alveolis immersa. Ovula solitaria v. gemina, ex apice funiculi a basi loculi ad apicem adscendentis pendala. Styli breves, simplices; stigmate peltato. Nuces plurimae, monospermae, e tori aucti alveolis emergentes, liberae. $\mathrm{S}$ em e $\mathrm{n}$ inversum, exalbuminosum. $\mathrm{Emb}$ r y o crassus, intra pericarpium germinans. - Herbae in aquis $A$ siae calidioris et $A m e r i \delta a$ borea$l i s$ vegetantes, Nymphaearum facie; 'rhizomate crasso, repente, petiolis pedunculisque emersis teretibus, tuberculato-asperis, foliorum lamina centro peltata, orbiculata, penninervi, integerrima, glabra, floribus amplis, albis, roseis v. flavis, seminibus edulibus.

Ne1 u mbium. Jussien Gen, 68. Lam, $t$. 463, Aiton Hort. Kew, edit, 2, III. 332. Bot. Mag. $t$. 903. Turpin in Annal. Mus, VII. 210, t. 11. f. 27. Poiteau Ibid. XIII. 359. t. 29. f. 42_46. Correa lbid. XIV. 74. t. 8. Riehard Ibid. XVII, 349, t, 9. f. 49, 50. 57. DC, Syst. II.43, Prodr. I. 113. Meisuer Geh. o. (8.) Wight Ilustr. t. 9, Ne$1 \mathrm{umbo}$ Touruefort Inst. 261. Adanson Fam. II, 76, Gärt. ner I. 73. t. 19. Mirbel in Annal. Mus. XIIT. 465. t. 34. XVI. 448. ¿. 19. Konig Annal. of Bot. II. 75. Smith Erot. Bot. r. 59. $t .31 .32 . \mathrm{N}$ w $\mathrm{p}$ h a e a e s p. Linn. Delile Flor. Aegrpt. t. 61 .

\section{Classis XII: Parietales.}

Herbae, frutices v. arbores, suceo rarissime lacteo. Folia alterna, opposita v. verticillata, simplicia, stipulata v. exstipulata. Calyx liber v. eum ovario connatus, foliolis distinctis v. gamophyllus. Corollae petala hypogyna v. perigyna, saepissime regularia, interdum nulla. St a $\mathrm{m}$ in a definita $\mathrm{v}$. indefinita, hypogyna v. subperigyna. O v a riu m saepissime-uniloculare, placentis parietalibus. $O \mathrm{vula}$ indefinita, rarius definita, anatropa v. rarissime orthotropa. Fru ctus superus, capsularis, valvis saepissime medio seminiferis, aut baccatus, placentis parielalibus, rarissime inferus, capsularis, placentis cum valvis alternantibus. S e mina albuminosa. E $\mathrm{mbryo}$ in axi albuminis rectus, rarius subexcentricus, arcuatus v. spiralis.

\section{Drdo CWXXXVIII. Cistineae.}

CISTI Jussieu Gon. 294. excl. pl. CISTOIDEAE Venten. Tabl. IIT. 219. CISTINEAE DC. Prodr. I. 263. Bartling Ord. nat. 282. Meisner Gen.: 8. (9) CISTACEAE Lindley Introduct. edit. $I I, p .91$. Spach Suiles de Buffon $V I$. 1-14t. Nouv. Anral. sc. nat, VI. 357.

Herbae, suffrutices v. Frutices, caule ramisque teretibus v. subtetragonis, saepe viscidis, pube v. tomento simplici aut in nonnulis stellato. Folia simplicia, integra, saepius integerrima, primaria opposita, reliqua rarius alterna, plerumque opposita, interdum verticillata, sessilia v. petiolata, petiolis cauli v. ramo continuis, haud raro semiamplexicaulibus. Stipulae cum petiolo semiamplexicauli nullae, petioli basi angustata liberae, foliaceae.

Fuores hermaphroditi, regulares, solitarii terminales, v. in racemos secundos dispositi, saepe speciosi, flavi, albi v. rosei, nunquam caerulei.

CaLxx pentaphyllus, persistens, foliolis biseriatis, duobus exterioribus plerumque minoribus, interdam nullis, rarissime aequalibus $v$ : 'majoribus, tribus interioribus inter se aequalibus, rarissime inaequalibus, per aestivationem marginibus dextrorsum incumbentibus ef simul sinistrorsum tortis.

Corollas petala quinque, rarissime in calyce pentaphyllo tria, hypogyna, eálycis foliolis alterna, ovata v. suborbiculata, brevissime unguiculata, aestivatione dextrorsum contorta, sub anthesi patentia, tenerrima, fugacissima.

Stamiva plurima, hypogyna, saepissime multiseriata, omnia fertilia, v. exteriora quandoque sterilia, rarissime definita. Fil am enta filiformia, libera. Antherae introrsae, bilocnlares, immobiles, ovatae v. laneeolatae, loculis appositis v. suboppositis, longitudinaliter dehiscentibus.

Ovarium liberum, sessile, uniloculare, v. semiseptis tribus v. quinque, interdum sex v. decem ima basi inter se coalitis, superne ad axim distinctis incomplete tri-decemloculare. Placentae nune exacte parietales, nunc semiseptorum marginibus utrinque adnatae, nerviformes v. interdum lamelliformes, marginibus revolutae. 0 vula in quavis placenta pauea $v$. plurima, e funiculis longiusculis porrecta, adscendentia v. rarius pendula, orthotropa v. rarissime semianatropa. Stylu $s$ terminalis, simplex, basi saepissime articulatus, deciduns. Stigmata placentarum numero, conduplicata, in capitulum connata. 
Capsula membranacea v. cartilaginea, interdum fere lignosa, unilocularis, v. septis ad axim distinctis incomplete tri- v. quinque-rarissime sex- v. decemlocularis, apice v. juxta totam longitudinem tri-decemvalvis, valvis medio placentas nerviformes v. semisepta margine placentifera gerentibus.

Semisa plurima v. rarius definita, funiculis longis primum subtensa, $\operatorname{mox}$ ex is decidua, ovata v. subglobosa, testa saepe mucilaginosa, umbilico cum chalaza basilari saepe incrassata coincidente, micropyle huic e diametro opposita, rarissime umbilico prope mediam seminis longitudinem laterali, ope rhapheos brevissimae cum chalaza micropyli e diametro opposita conjuncta: A lbumen farinaceum, rarius subcartilagineum.

Eмввхо rarissime suborthotropus, vix non semper antitropus, intra albumen excentricus v. subcentralis, rectiusculus, conduplicatus v. sigmoideo-biplicatus v. spiraliter convolutus; cotyledonibus planiusculis, ellipticis, linearibus v. ovatis, radicula tereti, longa, chalazae e diametro opposita.

Cistac eat in siccis apricis regionum temperatarum hemisphaerae borealis indigenae, in terris mare mediterraneum ambientibus imprimis copiosae, in America boreali nonnihil rariores, ip Americae tropicae littoribus rarissimae, affinitate proxima ad Violarieas et Droseraceas, seminis structura et embryonis situ et directione imprimis diversas, sed et plurimis notis facillime distinguendas, accedunt.

502ร. Fumana $S P A C H$. C alyx triphyllus, minute bibracteolatus. Corollae petala 5, hypogyna, aequalia. Stamina plurima, hypogyna, extima sterilia, tenerrima, celluloso-moniliformia ; fertilinm filamenta filiformia, libera, a nt hera e biloculares, longitudinaliter dehiscentes. O va rium incomplete triloculare, placentis nerviformibus, semisepta marginantibus. O vula pauca, pendula, anatropa v. semianatropa. Stylus terminalis, cum ovario artículatus, subclavatus; stigma capitato-trigonum. C a p sula chartacea, incomplete trilocularis, loculicide trivalvis, valvis medio semisepta margine seminifera gerentibus. Semina pauea, rhaphe adnata, ad micropylem chalazae e diametro oppositam procurrente, v. prope mediam seminis longitudinem solnta. E mbry o intra albumen uncinatus v. biplicitus, cotyledonibus, radicnlae superae, chalazae e diametro oppositae, albumine interposito incumbentes. - Suffruticuli, in Europa media et regione mediterranea obvii; foliis alternis $v$. oppositis, stipulatis $v$. exstipulatis, sessilibus $v$. brevissime petiolatis, linearibus, pedicellis infraaxillaribus v. oppositifoliis, racemosis, unilateralibus, floribus croceis $v$. citrinis.

F n a n a Spach in Nouv. Annal. sc. nat. VI. 359. t. 16. $f, 1$ 17. Helianthemi sect. Fumana Duaal in DC. Prodr. I. 274. Cisti s p. Lins. Cavanill. Io, t, 165. f. 1,172 . Desfont. Flor, atlant. $t .105$,
5028. Cistus TOURNEF. C a ly x triphyllus, bibracteolatus, bracteolis nanis, rarius calycis foliola aequantibus v. nullis. Coroll a e petala 5 , rarissime 3 , hypogyna, aequalia. S $t$ a mina plurima, hypogyna, omnia fertilia; fil amen$t$ a filiformia, antherae biloculares, longitudinaliter dehiscentes. O v a ri $\mathbf{n m}$ sessile, incomplete tri-quinqueloculare, rarius sex-decemloculare, placentis nerviformibus $\mathbf{v}$. lamellatis, semisepta marginantibus. Ovula pauca $v$. plurima, orthotropa, e funiculis plus minus longis adscendentia v. pendula. St ylu s terminalis, cum ovario artienlatus, filiformis v. clavatus, interdum subnullus; $8 \mathrm{tig-}$ ma capitato-dilatatum. C a p s a la cartilaginea, coriacea v. lignosa, quinque-decemlocularis, rarius tri-sexlocularis, loculieide complete v, apice tri-decemvalvis, valvis endocarpio rarissime soluto, medio semisepta margine seminifera gerentibus. $S$ e $m$ in a plurima v. panca, funiculo ad ehalazam micropyle e diametro oppositam inserta. E mbryo intra albumen antitropus, spiralis, spirae circulis albumine interposito discretis, radicula chalazae e diametro opposita. - Suffrutices v. fruticuli, in regione mediterranea obvii, parcius in $A m e-$ rica boreali, rarissime in tropica crescentes; foliis oppositis, exstipulatis, integerrimis v. subdenticulatis, pedunculis axillaribus v. terminalibus, unimultifloris.

C $18 \mathrm{t}$ u s Tournefort. Inst, 136. Gïrtner 370. $t$. 76. Danal in DC. Prodr. 1. 263. Heli anthe m i sect. 1, et 2 . Dunal b. c. Half mi um, Lad an am, Rhodoeistus, Cistus, Stephanocarpus et Ledonia Spach in Nouv. Annal. sc. nat. YT. 365_370.

a. HALIMIUM Dunal. C a 1 y $\mathrm{c}$ is foliola interiora conformia, bracteolae minimae v. nullae. Orariu u incomplete tri-rarissime quinqueloeulare, placentis filiformibus, semisepta marginantibus. S t y I u $s$ brevis, clavatus. C a ps u la coriaces, complete trivalvis v. quinquevalvis, valvis semisepta medio gerentibus. - Flores albi $v$. citrini. - H ali m i um Spach Op. cit.365. H a $1 \mathrm{im} \mathrm{i} \mathrm{u} \mathrm{m}$ Helianthemi sect. Dunal in DC. Prodr. I. 267. (Cav. Ie. $t$, 9o. Vent. Chois t. 20. Bot. Mag. $t$. 2q4. 687.)

b. LADANIUM Spach, Calye is foliola conformia, braeteolae nullae. 0 va ri $u$ m incomplete quinque-deeenloenlare, placentis cristaeformibus, semisepta marginantibus. S : y l us brevissimus r. subnollus. Caps u 1 a co. riacea v. subliguosa, complete quinque-decemvalvis, valvis medio semiseptiferis, - Flores albi. - $\mathrm{L}$ a d $\mathrm{s}$. n i u m Spach Op. cit. pag. 366. C ist i sect. Ledonia . 2. Dunal $O p$. cit. 266. C. Iada n iferus L. et c. I a u rifoli a s Linn.

c. RHODOCISTÚs Spach, Caly c is foliola decidur, conformia, bracteolae nanae. 0 vari $\mathrm{um}$ incomplete quinqueloculare, placentis nerviformibus, semisepta marginantibus. St ylus gracilis, stamina superans. C a p s uI a ligoosa, ab apice admedium loculieide quinquevalvis, valvis medio semiseptiferis. - Flores purpurei v. rosei. - Rhodoeis tas Spach Op, cit. 367. Webb et Berthel. Elor. Canar. 124, $t, 12$. C. vaginatus Ait. Jacq. Hort. Schin r. $t$. 282. C. candidiss $\mathrm{im} u s$ Danal.

d. BRYTHROCISTUS Dunal, C a 1 y c is foliola persistentia, conformia, bracteolae subaequilongae $\mathbf{v}$, minorex, $0 \mathrm{v}$ ari u incomplete quinqueloculare, placentis nerviformibus, semisepta marginantibus. Sty in s gracilis v. crassus. C a psula liguosa, plus minus complete loculieide quinquevalvis. valris medio semisepta gerentibus. Flores purpurei $v$, roset. - Cistus Spach Op. oit. 367. Erythrocistus, Cist i sect. Dunal in $D C$. Prodr. I. 264. excl. sp. (Jacq. Ic. rar. $t$. 95. Duhamel Arbr. I. 64. Desfont. Flor. Atlant, t. 104. Bot. Reg. t. 408.)

e. LEDONIA Spach. Calycis foliola persistentia, duo minora conformia, tertium majus dissimile, bracteolis aequale. O variu nu ficomplete quinqueloculare, placentis nerviformibus, septa marginantibas. Capsula chartacea v. subcoriacea, ab apice ad basim loculicide 
quinquevalvis, valvis medio semisepta gerentibus. Ledonia Spach Op. eit. 369. Le dou i a Cisti sect. 6, 1. Duual in DC. Prodr, I. 265, exel, sp. (Cav, 10 . t. 215.)

f. ? STEPHANOCARPUS $s$ pach, Calyeis foliola persis. teutia, duo minora conformia, tertium majus dissimile, bracteolis aequale. 0 × ari um quinqueloculare, placentis nerviformilus, septa ad axim contizua marginantibus. Cap s u la cartllagiaea, quinquelocularis, apice septifrage quinquevalvis. - Stephanoe a r pus Spach Op. cit. 365. Webb et Berthel. Flor. Canar. 123. C. mo aspeli e asts Liun. Cav, Ic, $t, 173$. Jacq. Col. lect. II. $t .8$.

5029. Gelianthemuna TOURNEF. $\mathrm{Cal}$ y x triphyllus, bibracteolatus, bracteolis $\mathrm{mi}$ nutis, rarissime calycis foliola aequantibas v, nullis. Eorolla e petala 5, hypogyna, aequalia Stamina plurima, hypogyna, omnia fervília; filamenta filiformia, libera, an $t$ herae bilocolares, Iongitudinaliter dehiscentes. Ovarium uniloculare $v$. incomplete triloculare, placentis nerviformibus, parietalibas v. semisepta marginantibus. Ovala pauca v. plurima, orthotropa, e funiculis plus minus longis adscendentia $v$. pendula. Stylus terminalis, cum ovario articulatus, filiformis v. subelavatus; $s t i g m$ a capitato-trigonum. C a p s la ehartacea v, subcartilaginea, unilocnlaris $v$, incomplete trilocularis, loculicide trivalvis, valvarum endocarpio membranaceo; medio placentas $v$. semisepta margine seminifera gerente. Semina plurima v. pauea, funiculo libero, ad chalazam micropyle e diametro oppositam, inserta. Embryo intra albumen antitropas, uncinatus v. sigmoideus, cotyledonibus radiculae snperae, chalazae e diametro oppositae, interposito albumine accumbentibus $v$. incumbentibus. Herbae, suffrutices $v$. fruticuli, in Europa media et regione mediterranea crescentes; foliis alternis $v$. oppositis, stipulatis $v$. exstipulatis, tri-v. penninerviis, floribus solitariis, umbellatis, racemosis, corymbosis $v$. paniculatis.

Helianthe m a m Tournefort Inst, 128, exel. sp. Gârtn. I. 371, $t, 76$. Dunal in DC. Prodr. 1 . 266. exel, sect, 1, 2. et 7. Helianthem $\mathrm{a}$ a, Rhodax et Tuberaria Spach in Nouv. Annal, so, nat. VI. 360_364. C is if s p. Dian.

a. BRACHYPRTALUM Dunal $l$. c. Petala saepius ealyce minora. S ta $\mathrm{mina}$ pauea. St y i us rectus. Em or yo orthoploceus, cotyledouibus elliptiois v. subrotundis. - Herbae annuae. - Apha s a n the mu ur Helianthemi seet. Spach Op. cit. NT. 360. (Cavasill. Ic. t. 144. Jacq, Observ. III, $t$. 68.)

b. ERICOCARPUM Dunal l. c. Pet a la calyce paullo Ion. giora. Sta a in a plarima. stylus subrectus, basi flexus. Embryo orthoplnceus, cotyledonibus ellipricis v. subrotundis. - Suffrutices. - E rico carp u m He Ilantheni sect. Spach Op. cil.36t. (Delile Aegzpt, $t, 31$. f. 2, Desfont, Elor, atlant. 106, t, 107. Presl Symb, t, 21.)

c. EUHELIANThemum Daual $l, c$, Petala calyce plas duplo longiora. Sta mina plurima. St y I us adsceudeas. apice inflexus. E m b r y o ortboploceus, cotyledonibus ellipticis v. subrotandis. - Suffrutices. - Eu helf a nthe m n m, Helianthemi sect. Spach Op. cit. $36 t, t, 16$. f. 19-29, (Flor. dar. t. 101. E, B. t. 2208. Jacr. Ic rar. $t$, 96. 99. Cavanill, Ic. $t, 140.147 .216 .261$. 263. f. 2. Desfont. Flor, atlant. $t, 109,110$.

d. PSEUdocistus Dunal $\boldsymbol{l}, \boldsymbol{c}$. Petala calyce vix Auplo Jongiora. S s a mina plurima v. interdum pauca. S ty. I u s basi contoria retroflexuk, upice inflexas. E in b r y a circumflexus, eotyledonibus oblougo-linearibus. - Her. bae perennes $v$. suffrutices. - $\mathrm{kbod}$ a $\mathrm{x}$ et $\mathrm{Heli} \mathrm{a}^{-}$ the a i sect. Arg y role p is Spach Op cit. 363. (Jacq. Flor, austr. t. 399. Cavanill. Ie. 2.139 .161 .262 .263$. f. t. Desfont. Flor, atlant. $t$, 108.)

ee TUberaria Dunal $l$, $c$. C a 1 y $x$ saepe ebracteatus. Pe ta la ealyce majora. S tamina plurima. Stylus rec. tus, brevissimus v. subnullas. Embry o diplecolobeus, cotyledonibus oblongo-linearibus. - Herbae annaae $v$. perennes. - Tuberaria Spach Op. cit. 364. $t .16$. f. 24. Webb et Berthel. Flor. Canar, 120. (Cav, Ic. t. 57. f. 1. t. 67 .

f. LECHEOIDES Duaal $l, c$. Flores pentapetali polyandri, cum apetalis triaadris saepe ia eadem stirpe mixif. Species americanae. - Croeanthemum et Heteromeris. Spach Op. eit, 370. et in Bot. Mag. Comp. $I$. 290.

5030. Leehea LINN. C al yx triphyllas, minute bibracteolatus. Corollae petala 3 , hypogyna, parva, lanceolata, subpersistentia. Stamina $3-12$, hypogyna; filamenta filiformia, libera, antherae biloculares, longitudirialiter dehiscentes. Ovarium incomplete triloculare, placentae tres late lamelliformes, semiseptis linea longitudinali adnatae, iisdem contrariae, rectae $\mathbf{v}$. margine utroque revolntae, prope basim facie exteriore uniovalatae. Oval a adscendentia, orthotropa. Stylus brevissimus; $8 \mathrm{tigmata} 3$, fimbriato-lacera, Capsula cartilaginea, incomplete trilocularis, loculicide trivalvis, valvae a semiseptis solutae, placentae semiseptis contrariae, nunc margineque planae iisdem medio adhaerentes, nunc utrinque revolutae ab iisdem separatae. S e$m$ in a 6 , juxta utrumque placentarum marginem singula, erecta, ovato-trigona, eapsalae longitudine, alterna saepius abortiva. E mbr y o antitropus, intra albumen corneum subeentralis, ejusdem Fere longitudine; cotyledonibus ellipticis, planis, radicula eylindriea, supera. - Herbae perennes, basi suffruticulosae, multiramosae, in $A m e$ rica boreali indigenae; foliis exstipulatis, alternis, oppositis verticillatisque, sessilibus $v$, brevissime petiolatis, minutis $v$. angustis, integerrimis, floribus plurimis, racemosis v. paniculatis, minutis, petalis sordide purpureis.

Le che a Linn. Gen, $n, 142$. Girtaer $I 1$. 222, $t$, 129. DC. Prodr. I. 258. Melsner Gen, 8. (9.) Torrey et A. Gray Flora of North-America $I .152$. Le che a et Le chidinm Spach in Bot. Mag. Comp. II, 282 et 286, et in Nouv. An. nat. se. nal. VI. 371, 372.

a. LECHEA Spach 2 . c. La mella e plaeentares membranaceae, fragiles, margiaibus revolatis semina iavoiventes, a semiseplis solutae. Le obeat sp. Linn. et Anct. G a u r a Lam, $t, 28 t, f$. 3 .

b. LECHEOIDES Spací $t$. $c$. La mella e placentares cartilagineae, firmae, margioibus haud revolntae, a semiseptis haud solutae. L. D rummondi Torrey et A. Gray.

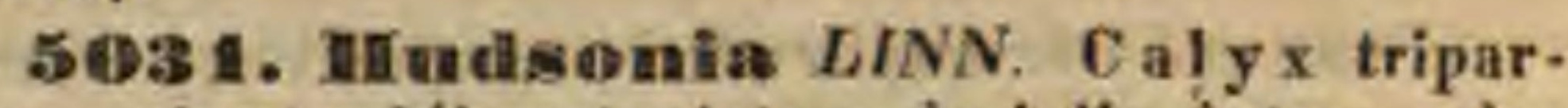
titns, minute bibracteolatas, laciniis intus coloratis, sob anthesi patentibus, fructiferis in tubum conniventibus. Corolla e petala 5, hypogyna, oblongo ubovata, fugacia. Stam ina $9-30$, hypogyna; filamenta filiformia, antherae biIoculares, longitudinaliter dehiscentes. O v a r i $\mathbf{~ m}$ obovatum, uniloeulare, placentis parietalibus tribns, nerviformibus, basi linvulatis. Ovnla e funiculis brevibus adscendentia, orthotropa. Stylus filiformis, rectss; $8 \mathrm{tigma}$ minute=tridentatum. Ca p s u I a obovato-oblonga, obsolete trigona, unilocularis, trivalvis, valvis medio prope basim div. abortu monospermis. Se mina adscendentia, ovata, minute granulata. E mb ry o intra albamen tenue antitropus, spiraliter convolutus, radicula supera. - Fruticuli boreali-americani, dense caespitosi; foliis alternis, exstipulatis, parvis, subulatis, acerosis, imbricatis, tomentosis, persistentibus, floribus sessilibus $v$. pedunculatis, ramulos breves terminantibus, luteis.

H a d s o n i a Linné Mantiss, 1t. Lam. $t$. 407. Willdenow Hort, Berolin. $t$. 15, Gärtner $f, M I T$, 152, $t$, 2to. Nattall 
Gen, II. 4. DC. Prodr. I, 284. Meisner Gen, 9. (8,) Spreh in Nouv, Annal. so. nat, VI. 372. Torrey et A. Gray Flor. of North-Americ, I. 154.

503:. Taeniostema SPACH. Calyx tripartitus, minnte bibracteolatus, laeiniis demum conniventibus. Corolla nulla. Stamina-3, hypogyna, calycis laciniis opposita; filamenta complanata, lineari-spathulata, an $\mathrm{t}$ h er a e minimae, suborbienlares. O va ri um subgloboso - trigonum, uniloculare, placentis parietalibus tribns, prope basim biovulatis. Ovula e funiculis brevibus adscendentia, orthotropa. Sty I us filiformis, rectus; stigm a tripartitum, cristatum. C a ps a 1a ovato-trigona, unilocularis, trivalvis, valvarum endocarpio soluto, medio prope hasim aborta monospermo. S em in a ovato-trigona, adscendentia, testa crustacea. $\mathbf{E}$ mb r yo intra albumen corneum antitropus, subspiralis; cotyledonum apice deorsum spectante, radicula supera. - Herba mexi. cana, pube stellata subtomentusa; folits alternis, exstipulatis, breve petiolatis, integerrimis, pedunculis axillaribus terminalibusque brevissimis, pedicellis fasciculatis, floribus minimis, saepissime , basi unibracteatis.

Ta niostem a Spach in Bot. Mag. Comp. II. 289. Nouv. Annal. sc, nat, VI. 371. Lec bea mexica na Bort. Berolin.

\section{Dedo CLNXXIX.} Droseracene.

DROSEREAE Salisbury Parad. 95. DROSERACEAE DC. Theorie elem, 1. 214. Pradr. I, 317. St. Hilaire in Mem. Mus, XI. 335. Bartling Ord, nat, 285, Lindley Introduct, edit. II. p. 66. Meisuer Gen. 22, (19.)

Herbas, interdum suffrutescentes, acaules v. caulescentes, pilis glanduliferis conspersae et eleganter ciliatae. Folia alterna, saepissime ad basim scapi congesta, simplicia, integra v. rarius bifida aut pedatifida, basi in petiolum angustata, nunc supra petiolum dilatatum articulata, vernatione ab apice ad basim involuta, ciliata, ciliis v. interdum lamina ad nervum medium tactu irritabilibus. Stipu lae nullae, earum loco cilia ad petiolorum bases dilatatas.

Flores hermaphroditi, regulares, terminales v. axillares, solitarii $\mathbf{v}$. in racemos secundos, ante anthesim circinatim involutos dispositi, rarius corymbosi, bracteis nullis $v$. parvis, interdum tamen foliaceis.

Cauxx pentaphyllus, liber, foliolis aequalibus v. subaequalibus, aestivatione imbricatis, omnino distinctis v. basi nonnihil cohaerentibus.

Corouras petala 5 , hypogyna, calycis foliolis alterna et iisdem basi subadhaerentia, brevissime unguiculata, aestivatione imbricata, marcescenti persistentia.

Stamiva hypogyna, nune calycis foliolis numero aequalia et alterna, nunc dupla, per vices alterna et opposita, rarissime tripla v. quadrupla, iisdem solitarie, petalis geminatim v. ternatim opposita. Fil a m en ta filiformia v. linearia, libura. Anth era e extrorsae, biloculares, erectae et immobiles, $\mathbf{v}$, incumbentes et versatiles, demum introflexae, loculis rima longitudinali, rarius poro apicis ant baseos dehiscentibus.

Ovarivм liberum, sessile, nune uniloculare, placentis parietalibus tribus v. quinque, aut rarissime decem, nerviformibus, interdum vasis ovuliferis abbreviatis, in placentam basilar rem liberam conjunctis, nunc rarissime bi- v. triloculare, placentatione ex medio dissepimento incrassato, v. ex loculorum angulo scentrali. Ovila nune in placentis parietalibus y. basilaribus plurima, rarius subdefinita, in medio ovarii bilocularis dissepimento pauca, horizontalia v. adscendentia, nunc in ovario triloculari ex apice anguli centralis loculorum gemina, collateraliter pendula, anatropa. Styli placentarum numero, indivisi v. bifidi v. laciniatopenicillati, rarissime stylus unicus. Stig mata capitata.

Capsola perigonio genitalibusque emarcidis stipata, nunc unilocularis, juxta totam longitudinem tri-quinquevalvis, valvis medio seminiferis, v. apice valvata, placenta basilari libera, nunc bilocularis, loculicide bivalvis, valvis semisepta medio in placentas incrassata gerentibus, rarissime trilocularis, loculicide trivalvis, valvis medio septa a columna seminifera trigona soluta auferentibus.

Sremina plurima v pauca, horizontalia, adscendentia v. rarius pendula; testa crustacea, scrobiculata v. costata, rhaphe Iongitudinali tenuissime filiformi, umbilicum basilarem cum chalaza apicali conjungente, rarius testa relaxata cellulosa, nucleum multo minorem includente. Albumen carnosum.

Embryo orthotropus, nune axilis, albumine parum brevior, cylindricus, nune in basi albuminis brevissimus, eidem semiimmersus, subconicus; cotyledonibus truncatis, radi cula brevissima, infera v. supera.

Droseracea prata aprica turfosa omnium fere elimatum, arctico excepto, inhabitant, in Nova-Hollandia temperata, America tropica, deinde in Capite bonae Spei imprimis copiosae. Panciores in hemisphaera boreali generantur, Europam mediam et mediterraneam, frequentius Americam borealem inhabitantes. Unica undicola, in Gallia et Italia superiore reperta, nec similis alibi visa.

Affinitate Violarieis proximae, facie, stipularum defectu, foliorum vernatione cireinnata, antheris extrorsis, stylo saepius multipliei, placentatione multiformi, et embryone in plurimis minimo, albuninis basi immerso diversae, a Cistaceis definito staminum numero, 
antherarum directione, stylo multiplici, ovulis culatis, pedunculis nudis, folio longioribus, fructisemper anatropis, et embryone recto, a Tur-feris cernuis.

neraceis, quibuscum stipularum defecta, et stylorum numero magis conveniunt, calycis aestivatione imbricata, petalis hypogynis, antheris extrorsis, et seminibus albuminosis distinctae.

Parnassia ad ordinis calcem recensita, Dioneae facie, ovulis parietalibus, seminibus denique scobiformibus cum Droseris nonnullis conveniens, staminibus sterilibus in phalanges connatis, et embryone exalbuminoso ad Hypericineas tendit.

5033. Drosera LINN. Caly $x$ quinquefidus v. quinquepartitns, aequalis, Corolla a petala 5, hypogyna, obovata. Stam in a 5, hypogyna, petalis alterna; filamenta lineari-subalata, antherae extrorsae, bilnculares, immobiles, loculis longitudinaliter dehiscentibus. O vari um uniloculare, placentis parietalibus tribus v. quinque, semicylindricis. O v n la plurima, anatropa. Stylus terminalis, tri-quinquepartitus, crnribus simplicibus, bifidis v. penicillato-multipartitis; sti guata simplicia, subcapitata, v. multipartita. Capsula membranacea, unilocularis, tri-quinquevalvis, valvis medio seminiferis. Semina plurima, oblonga, testa nunc crustacea, nucleum arcte vestiente, nunc laxa, cellulosa, nucleum sulto minorem includente. Embryo in hasi albuminis carnosi plas minus immersus, or thotropus, minimús, subeonicus; radicula umbilico proxima. - Herbae acaules, scapigerae $v$. caulescentes, paludosae, cosmopolita e, elegantes, in hemisphaera australi copiosissimae, in henisphaera boreali multo rariores; foliis alternis, glanduloso-pilosis, juniaribus circinatis, integris $v$. dichotome partitis, in acaulibus saepe rosulatis, scapis junioribus in spiram involutis, floribus rarius solitariis $v$, geminis, saepius pluribus, racemosis, subsecundis, albis, roseis v. purpureis.

Dro s e r a Linn. gen. n, 391. Gärtner I. 291, t.61. Dre. ves et Hayne Flor, europ, t. 47, 75. Hooker Flor, Lond t. 188. 189. Labillard. Nov. Holl, t. 105, 106. Kunth in Kumb. et Bonpl. Nov. gen. et. sp. t. 490. DC. Prodr. 1. 317. St. Hilaire Plant, us. Brasil. t, 15. Ilant, remary. Brasil. 254. t. 25. Flor, Brasil. Hooker Flor. Bor. Amer, t. 27, ad Beechey t. 31. Ic, t, 33. 54. 56. Bot. Mag. t, 3058. Meisner Gen, 28. (19.) Wight Illustr. $t, 20$. Ko rella Rupp. Flor. Jenen. I, 102. Ros.S ol i s Touruefort Inst. 127.

5\$34. Alderevandia MONTI. Ca $1 \mathrm{yx}$ quinquepartitus, aequalis. Cor oll a e petala 5 , hypogyna, ovato-lanceolata calycem aequantia, conniventia. St a min a 5 , hypogyna, petalis alterna ; fil ame nt a subulata, antherae incuintientes. bilnenlares, dińymae, loculis longitudinaliter de hiscentibus. Ovarium sessile ….. Styli 5 , fliformes; stigmata obtusa. Capsula glabosa, uniloenlaris, apice quinquevalvis, valvis medio semina gemina gerentibus. S e m in a parva. … Herbu pusilla, in lacubus et fossis ltaliae et $G$ a $\bar{l}$. lia e vegetans, glabra, pallide v. luride virens, dia phana; caule natante, simplici v, ramo taterali breviore bifido, multiarticulato, pollicari $v$ palmari, ad articulos folioso, foliis verticillatis, senis-novenis, celluloso turgidis, petiolo cuneiformi apice fimbriato, fimbriis setaceis laminam cochleariformem superantibus, floribus paucis, axillaribus, solitariis, pedun-

Aldrovanda Monti in Act. Bonon, Ir. 3. p.5404. t. 12. Linn. gen. n. 390. Lam. 4. 220. DC. Prodr, $T, 390$. Bertoloni Flor. Ital. III, 559. Meisner Gen, 29. (19.)

5อ3 5. Eyblis $S A L I S B$. Cal yx quinquepartitus, aequalis. Corotla e petala 5, hypogyna, obovata, crenata, Stam ina 5 , hypogyna, petalis alterna; fila menta subulata, antherae biloculares, extrorsae, versatiles, introflexae, loculis basi sursum spectante poris geminis in nnum confluentibus apertis. Ovarium sessile, biloculare, dissepimento contrarie compressiusculum. $O \dot{v}$ ula in placentis parvis, subglobosis, medio dissepimento utrinque adnatis plura, anatropa, Stylus simplex; stigma capitato-bilobnm. C apsula obcordata, ventricosa, bilocularis, loculicide bivalvis, valvis septa medio in placentas incrassata gerentibus, stylo bipartibili snperatis. Semin a panea, ovata. .... - Herba Nova Hollandiae, Droserae facie; caule abbreviato, foliis confertis, lineari-filiformibus, margine involutis, vernatione circinatis, pedunculisque axillaribus simplicibus unifloris scapiformibus glandulosopilosis, floribus caeruleis.

B y b i is Salisbury Parad, t. 25. DC. Prodr. I. 319. Meisuer Gen. 22. (19)

5๑28. IDrosoplayllum $L I N K, C$ a 1 yx quinquepartitus, aequalis, Cor olla petala 5, hypogyna, oborato-oblonga. S $t$ a m in a 10 , hypogyna, petalis alterna et opposita; filamenta filiformi-subulata, an the $r$ a e extrorsae, biloculares, versatiles, loeulis longitudinaliter debiscentibns. Ovarin m sessile, uniloculare. Ovula in placenta basilari brevissime eylindrica plurima, erecta, anatropa. Styli 5 , filiformes; $8 \mathrm{ti} \mathrm{gma-}$ ta capitata, Ca psula chartacea, conica, unilocularis, ad medium quinquevalvis, placenta basilari minuta, depressa. Sem in a plurina, e funiculis longiusculis adscendentia, obovata, sompressiuscula, testa crustacea. E m bryo in basi albaminis carnosi semiimmersus, orthotropus, minimus, conicus; radicula umbilicum attingente. Suffrutex lusitanicus, pedalis, pilis glandulosis viscidus; foliis confertim alternis, linearibus, acuminatis, glanduloso-ciliatis, vernatione circinatis, floribus terminalibus, corymbosis.

Drosophyllum Link in Schrader n. Jotsrn. 1806. I. 2. p. 13. St. Hilaire in Mem, Mus, II. 124. $t$, 4. f. 13. DC. Prodr, I, 320. Meisner Gen. 29. (19.) Drose ra 1 usitauiea Lina. Spergula d roserofdes Brotero.

5038. Thonaea ELLIS. Calyx quinquepartitus, aequalis. Corolla e petala 5, hypogyna, oblongo-obcordata, patentia, demum involuta. Stam ina 10_20, hypogyna, calyeis foliolis solitarie, petalis saepius geminatim v, ternatim opposita; filam enta filiformia, antherae extrorsae, biloculares, immobiles, loculis latere longitudinaliter dehiscentibus. Ovarium sessile, uniloculare. Ovala in placenta basilari subglobosa plurima, anatropa. Stylus simplex, crassinsculus; stigmata 5 , fimbriata, arcte conniventia. Capsula membranacea, unilocularis, irregulariter rupta, placenta basilari subglobosa, Se in in a plurima, placentae semiimmersa, ovoideo-pyriformia, testa crustacea, nitida. $\mathrm{S} \mathrm{mbryo}$ in basi albuminis farinacei semiimmersus, orthotropus, minimus, conicus, radienla umbilieum attingente. - Herba boreali-americana, perennis, glaberrima; foliis omnibus radicalibus, rosu- 
lato-patentibus, petiolo dilatuto, spathulato-obcordato, penninervio, lamina breviter stipitata, suborbiculata, utrinque emarginata, valide uninervi, vernatione complicata, et supra petiolum inflexa, margine spinuloso ciliata, irritabili, tactu cum impetu complicata, scapo simplici, apice corymboso multifloro, floribus majusculis, albis.

Di ou a a Ellis in Nov. Act. Upsal. I. 98. . 8. Linn. Mantiss. 15t. Ventea. Malmais, t. 29. Bot. Mag. t, 285. DC. Prodr. I, 390 . Reichenb. Ic. exot, t. 340. St. Hilaire in Mem. Mus, XI, 61. Mreisner Gen. 22. (19.) Torrey et A. Gray Flor, of North-America I. 1ar.

5038. Ro noidenla LINN. Cal y $\mathrm{x}$ quinquepartitus, aequalis. Corolla e petala 5, hypogyna, obovata v. oblonga. Stamina 5, hypogyna, petalis alterna; fil am enta filiformia, antherae biloculares, extrorsae, connectivo dorso in cupulam producto insertae, immobiles, loculis apice poris geminis dehiscentibus, Ovarium sessile, oblongo-trigonum, triloculare. Ovula in loculis solitaria v. gemina, collateraliter ex apice anguli centralis peudula, anatropa. Stylus simplex; stigma capitatum. C a p sula oblongo-trigona, trilocularis, loculicide trivalvis, valvis me dio septa ab axi trigona persistente, apice semini fera soluta gerentibus. S emina in loculis solitaria, inversa, oblongo-cylindrica, testa erustacea, granulata. Emb ryo in axi albuminis carnosi orthotropus, ejusdem dimidio brevior, filiformis, $r$ adicula nmbilico proxima, supera. - Suffrutex capensis, Droserae more glanduloso-pilosus, viscidus; foliis lanceolato-linearibus, pinnatifido-dentatis, confertis, vernatione circinatis, pedunculis axillaribus, racemoso-paucifloris.

Roridula Liun. Syst, 294. Gärtner I. 298, t, 69. (quond situm seminnm mal.) Lam. t, 141. DC. Prodr. I. 320. St. Hilaire in Mem, Mus, XI, 63. Meisuer Gen, 22, (19.) - Irldio n Burmana Prodr. 6.

\section{* Parnassieae.}

5039. IParnassia TOURNEF. Calyx quinquepartitus, liber v. basi imo ovario adhaerens, laciniis aestivatione imbricatis, persistenti bus. Coroll a e petala 5 , imo calyci inserta, ejus dem laciniis alterna, aestivatione imbricata, deci dua. Stamina cum petalis inserta, 5 fertilia iisdem alterna, sterilia rarissime solitaria glandulaeformia, plerumque subindefinita, in phatanges fimbriatas petalis oppositas connata, fertilium fi 1 a m en $t$ a subulata, an therae extrorsae, bilo culares, ovatae $\mathbf{v}$. subglobosae, loenlis longitudi naliter dehiscentibns. O variu m uniloculare, pla centis parietalibus tribus v. quatnor. $O v \mathbf{v} \mathrm{I}$ plurima, anatropa. Stig ma sessile, tri-quadripartitum. Capsula unilocularis, tri-quadrivalvis, val vis medio seminiferis. Semina plurima, scobiformia, testa membranacea, reticulata, taxa, nucleum multo minorem includente. E mbryo ex albuminosus, orthotropus, oblongo-cylindraceus, radicula umbilicum spectante. - Herbae peren nes, glabrae, in temperatis et frigidis $h \mathrm{em}$ is $p h a \mathrm{e}$ rae borealis, imprimis Americae, pratahumida incolentes, in Asiae tropicae montibu. celsioribus rarae; foliis radicalibus longe petiolatis, cordatis $v$. reniformibus, caulinis sessilibus, caulibus scapiformibus simplicissimis, unifloris, monooligophyllis, floribus majusculis, albis $v$. flavescentibus.

Parn as s i a Tnurnef. Inst, 127. Lian, Gen. n, 384. Gärtaer I. 287. t. 60. Schkuhr t. 86. E. B. $t$. 82. Flor. dan. t, 58i, Vent. Malmais. $t, 39$. Bot. Mag, $t, 1459$. DC, Prodr.
1.320. Hooker Flor. Bor. Amer. t.27. 28, Bot. Mtiscell. t. 23. Zenker Plant. Ind, $t$, 5. Meisner Gen. 22. (19.) Kunth Flor. Berolin. I. 99. Arnott in Bot. Mag. Comp. II. 315. Wight. Illustr. 4. 21.

\section{Drdo CXC. Violariene.}

Genera CISTIS aftinia Jussieu Gen, 19t, JONIDIA Ven. ten. Malmais. 27, VIOLARIEAE DC. Flor. fr. 1 V, 801 , Prodr. I. 287. Gingias in Mem, soc, h, n. Genev. II. I. St. Hilaire in Mem. Mus. XI, 66. el 1144. et Plant. remarq. Brasit. 27t. Bartling Ord. nat, 283. MeistieriGen, 20. (18.) VIOLACEAE Jussieu in Annal. Mus. XVIIT. Lindley Introduct, 146. VIOLEAR R. Brown in Tuckey Congo. 440.

Herbae, suffritices v. frutices. Folia alterna v. rarius opposita, simplicia, petiolata, integra v. interdum laciniata, marginibus vernatione saepissime involuta. Stipulae liberae, foliaceae v. marcescentes, in fruticosis non raro deciduae.

Flores hermaphroditi, irregulares, rarius regulares, axillares, solitarii v. varie dispositi, pedicellis bibracte olatis, saepe articulatis.

Calyx liber, persistens v. rarissime deciduus, pentaphyllus, foliolis inaequalibus v. rarius aequalibus, margine saepissime membranaceis, distinctis v. basi inter se coalitis, saepius basi producta solutis, per aestivationem imbricatis, anticum et duo postica exteriora, duo lateralia interiora.

Corollae petala 5, hypogyna v. obscure perigyna, calycis foliolis alterna, marcescentipersistentia v. rarius decidua, nune inter se aequalia, breviter unguiculata, rárius subinaequalia, longe unguiculata, basi oblique in tubum conniventia, plerumque valde inaequalia, antica duo minora exteriora, lateralia altius inserta interiora exunguiculata, posticum (floris resupinatione saepissime anticum) intimum, maximum, unguiculatum, lamina labelliformi v. cucullata, per aestivationem convoluta, ungue saccato v. saepissime in calcar cavum producto.

Stamina 5, hypogyna v. rarius obscure perigyna, petalis alterna. Fil a m enta brevissima, saepe dilatata, complanata, basi non raro in annulum connata. Antherae introrsae, biloculares, circa ovarium conniventes v. interdum inter se conglutinatae, loculi oblique appositi, paralleli, contigui v. parumper discreti, connectivi faciei interiori toto dorso adnati, rima longitudinali antica v. sublaterali dehiscentes, connectivum filamento continuum, semper ultra loculos productum, et apice cum eorundem membrana dorsali in appendicem aridam confluens, staminum posticorum in floribus irregularibus basi v. medio postice in glandulam tumens, $\mathbf{v}$. in appendicem filiformem, petali postici calcar intrantem, productum.

Ovariom sessile, liberum, annulo hypogyno, saepissime obsoleto basi cinctum, e car- 
pidiis tribus, calycis foliolis exterioribus oppositis, valvatim connatis uniloculare. 0 vu 1 a in placentis parietalibus tribus, nerviformibus, cum carpidiorum suturis alternantibus plurima, rarius pauca, anatropa. S t y l u s simplex, persistens, saepius apice incrassatus, declinatus perforatusque; stigmate sublaterali v. terminali, variis formis ludente, rarius breviter trilobo, lobis intus stigınatosis.

Capsula chartacea, coriacea v. sublignosa, interdum membranacea et vesiculoso inflata, unilocularis, ab apice ad basim trivalvis, valvis navicularibus, dorso saepissime incrassatis, medio seminiferis.

Semina saepissime indefinita, ad quamvis placentam biseriata, rarius abortu pauca, rarissime solitaria, funiculis brevissimis affixa, horizontalia v. oblique pendula, ovata v. subglobosa, interdum plano-compressa. T e s t a crustacea, fragilis, interdum membranacea, in alam ambientem, basi emarginatam expansa. Umbilicus prope basim sublateralis, nudus v. caruncula parva vestitus, ope rhapheos linearis, parum elevatae, cum chalaza apicali orbiculari, plus minus incrassata conjunctus. Endopleura membranacea, tenuis. Albumen carnosum, cop̄iosum.

Embryo in axi albuminis orthotropus, ejusdem fere longitudine. Cotyledones saepissime planiusculae, ellipticae v. orbiculares, germinatione foliåceae. R a dicula teres, umbilicum directe attingens, v. eidem parallele contigua.

Violeae herbaceae hemisphaeram borealem copiose incolunt, in temperatis hemisphaerae australis et inter tropicos rariores, fruticosae nonnisi in America aequínoctiali reperiuntur. A I s odine ae flore regulari distinetae, inter tropicos totius orbis observatae, in America frequentius gignuntur.

Affinitate Sauvagesieis, Droseraceis, Cistaceisque conterminae, e longinquo ad Balsamineas, et mediante imprimis genere capsula lignosa donato, propius ad Passifloreas accedere videntur. Hymenanthera genus australasicum, corolla et staminibus Alsodeiae, fructus bilocularis baccati loculis monospermis, inter Violarieas et Polygaleas omnino medium.

Plurimarum, imprimis tropicarum, radices vi vehementer emetica pollent.

TERBSUS I. VIOLEAE DC. Prodr. I. 288. F lores irregulares, petalo postico maximo, dissimili, rarius petalis longe unguiculatis subregulares.

5040. Viola LINN. Calyx quinquepartitus, laciniis subaequalibus, basi producta solutis.
Co roll a e petala 5, hypogyna, inaequalia, antica lateralibus saepe breviora, posticum reliquis majus, basi saceatum v, calcaratum. S t a m in a 5 , hypogyna v. perigyna, petalis alterna, aequalia; filamenta subnulla, antherae introrsae, bilocalares, complanatae, adnatae, apice in appendicem membranaceam productae, loculis longitudinaliter dehiscentibus, duorum anticorum connectivis dorso in appendices intra calcar reconditas productis, rarissime nudis. O vari u ovato-trigonum, nniloculare, placentis parietalihns tribns, $O$ v u 1 a plurima, anatropa. S t y i u s terminalis, clavatus v, subulatus; $s \mathrm{tigma}$ sublaterale v, terminale, varium. Ca p s ula subovato-trigona, calyce stipata, unilocularis, trivalvis, valvis dorso crassiorilus, demuin explanatis, medio seminiferis. S emina plurima, ovato-glubosa, testa crustacea, rhaphe elevata, ab umbilico prope basim sublaterali carunenlato ad chalazam apicalem excavatain producta. E $\mathbf{m}$ bryo in axi albuminis, carnosi orthotropus, ejustem longitudine, radicula nubilico proxima. Herbae in temperatis hemisphaerae borealis copiosae, inter tropicos et in hemisphaera australi multo rariores, nunc cau. lescentes, nunc caule brevissimo v, subterraneo acaules, rarissime suffrulescentes; foliis alternis, peliolatis, nervo medio persistente marcescentibus, admodum variis, stipulis persistentibus, pedunculis axillaribus, solitariis, unifloris, bibracteolatis, haud articulatis, apice incurvis, cernuis, interdum resupinatis, colore vario, nonnunquam suaveolentibus, abortu quandoque apetalis $v$. unisexualibus.

Viala Tournefort Inst, 419. Lina, gen, n, 1007, exel. sp. Gärtner $I I, 139$. t. 112. DC. Prodr, 1.291. Ging i a in Jem. sc. h, n. Genev, II. $t, 1$. St. Hilaire Plant. remarq. Brasil. 275. t, 26. Flor. Brasil. II. 135. Wight et Arnott Prodr. I. 31. Meisner Gen. 20, (18) (Jacq. Flor. austr. t. 19. Collect. IV. t. 11. E. B. t. 620. 621. 894. 1287. Flor. dau, t, 623. Willd. Hort, Berolin, t, 24, 72, Waldst. et Ki. taibel Plant, rar. Hung. t. 223. Cavauill. Ic. t. 589.531. Kuuth in Humb. et Bonpl. Nov, gen, et sp. t. 492.493. Bot. Mag. t. 89. 833.791. 1276. 1795. Bot. Reg. t. 1254. Ledebour Flor alt. $t$. 219. 220. 232, 238. Hooker Bot, Miscell. t. 97 -99. Flor. Hor. Amer. t. 26. Ic. t. 63. 217. Royle Himalay, t, 18. Poppig Nov. gen. et sp. t. 165, 166. Wight Illustr. t. 18. - Er petion DC. mso. ex Sweet F7, Gard, I. 170. (V. hederacea Labillard, Nov. Holland,

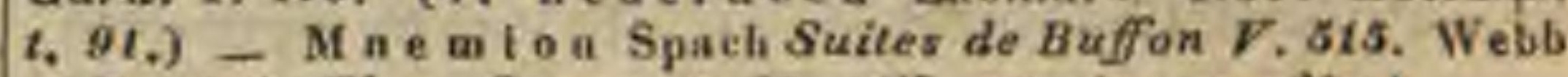
et Berthel. Flor. Canar, \&, 37. (V, tricotor et affia.)

5941. Io andeliama VENTEN. C a ly $x$ profonde quinquepartitus, laciniis inaequalibus, tribus anticis majoribus, basi haud productis. Corolla e petala 5, imo ealyei inserta $v$, rarius hypogyna, valde inaequalia, antica lateralibus breviora, posticum maximum, unģuiculatum, ungue basi saepe latiore et concavo, infra laminam dilatatam plerumque angustato. Stamina 5 , cum petalis inserta, iisdem alterna; fil amenta brevissima, quandoque nulla, libera v. connata, antherae introrsae, biloculares, complanatae, adnatae, apice in appendicem membranaceam productae, loculis longitudinaliter dehiscentibus, duorum anticorum connectivis v. filamentis saepissime plus minus appendienlatis v. gibbosis. O va ri u m subglobosum, uniloculare, placentis parietalibus tribus. Ovula plurima, anatropa. St y I u s terminalis, subclavatus, incurvus; stigma sublaterale. Capsula subovata, perigonio et genitalibus emarcidis stipata, unilocularis, trivalvis, valvis dorso crassioribus, demum explanatis, medio seminiferis. Semina plurimav. pauca, ovato-globesa, testa crustacea, rhaphe elevata, ab umbilico basilari carnnculato ad chalazam apicalem producta. E m b r yo 
in axi albuminis carnosi orthotropns, ejusdem longitudine, radicula umbilico proxima, eentrifuga. - Herbae v. suffrutices, rarius frutices, inter tropicos utriusque orbis, imprimis Americae, parcius in regionibus subtropic is crescentes; foliis alternis $v$. oppositis, serratis $v$, integerrimis, stipulis lateralibus gominis, integris $v$. interdum multipartitis, floribus axillaribus v. racemoso-terminalibus, saepissime nutantibus, pedunculis solitariis $v$. congestis, ut plurimum bibracteatis, saepius infra apicem curvatum articu latis.

Jonidium Venten. Malmais. t. 27. DC. Prodr. 307. Kunth in Humb. et Bonpl. Nov. gent. et sp. V., 373, t, 495500. St. Hilaire Plant, us, Brasil. t.9.11.20. Plant, remarq. Brasil. 292. $t$, 27, Flor, Brasil. I1. 141. Nees Plant. offic. suppl. V. t. 21. 22, Bot. Mag. t. 2453. Wight Illustr. t. 19, Po m b alla Vandelli Fasc. VIT. $t$. 1. DC. Prodr. T. 306. Ca l ce o lar Löfling Ie, t. 184. H y b a $t$ th us Jacq. Amer. 77. Kunth $O p$, cit. $\mathscr{V}$. 385. $t$. 494. S o 1 e a Spreng, in Schra. ders Journ. 1800. II. 190. Viola e s p. Linn. Aublet Guian. t. 318. - H y ban th us Necker Elem, n. 1386. Solea Gingins in DC. Prodr, I, 306. Mem, soc, h, n. Genev. II. t. 2.f. G. Viola concolor Forsier in Linn. Transact, VI, 309. t. 28. - Pige a DC. Rrodr. I. 307, Gingins Op. cit. $t, 2 . f, 4$.

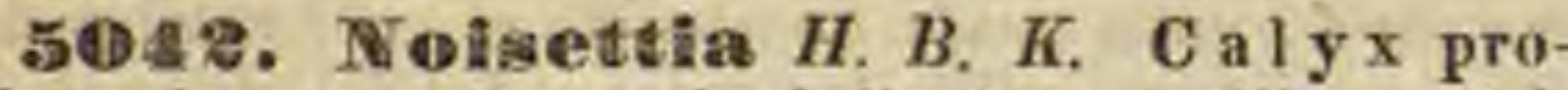
funde quinquepartitus, laciniis inaequalibus, tribus anticis majoribus, basi haud solutis. Corolla e petala 5, imo calyci inserta, valde inaequalia, persistentia, antica lateralibus breviora, posticum maximum, basi longe calcaratum. Sta mina 5 , perigyna, petalis alterna, inaequalia; $\mathrm{fi}$ lamenta brevia, discreta, antherae extrorsae, biloculares, complanatae, adnatae, apice in appendirem membranaceam productae, localis longitudinaliter dehiscentibus, duarnm anticarum connectivis in appendices fililormes liberas, intra calear reconditas productis, $\mathrm{O}$ va rium súbglobo. sum, uniloculare, placentis parietalibus iribus. O v u l a plurima, anatropa. Sty I us terminalis, subclavatus, incurvus; $s \mathrm{t} i \mathrm{~g} \mathbf{m}$ a infra apicem laterale, excavatum. Ca p 8 u la subovata, perigonio et genitalibus emarcidis vestita, nnilocularis, trivalvis, valvis medio seminiferis. Semina pluri. ma, ovato-globosa, testa crnstacea, rhaphe eleva. ta, ab umbilico basilari ad chalazam apicalem, orbiculari-coneavam producta. E in b ryo in axi albuminis carnosi orthotropus, ejnsdem longitudine, radicula umbilico proxima, centrifuga. Suffrutices erecti, $v$. frutices scandentes, in $A m e-$ rica tropica et boreali calidiore indi geni; foliis alternis, denticulatis $v$. serratis, stipulis lateralibus, geminis, floribus breviter racemosis v. fascieulatis, rarissime solitariis, saepe nutantibus, quandoque resupinatis, pedicellis solitariis, bibracteatis v ebracteatis, supra medium arliculatis, articulo inferiore persistente.

Nois ettia Kunth in Humb, et Bonpl. Nov. gen, et sp. . 383. $t$. 499. b. DC. Prodr, $I$ 290. St. Hilaire Plant, re. mary. Brasil. I. 284, t. 26. f. C. Flor. Brasil. IT. 138. Meisaer Gen, 20. (18.) non Mart. et Zuec. B I gelovía DC. msc. Vintaeoides Michaux mse, Violae sp. Rutige
Plant, Guian, 2,10 .

5043. Antalleter ST. HIL. C alyx quinquepartitus, inaequalis, persistens, laciniis basi haud produetis. Coro 11 a e petala 4 , hypogyna, valde irraequalia, decidua, antica lateralitus breviora, posticum maximum, unguiculatum, basi calcaratum. Stamina 5, hypogyna, petalis alterna, inaequalia; fil a m enta subnnlla, an $t h e-$ rae introrsae, biloculares, complanatae, adnatae, apice membranaceae, loculis longitudinaliter de- hiscentibus, duarnm anticarum connectivis basi in appendices filiformes, intra calcar reconditas iproductis. Ovarium ovatuin, uniloculare, placentis parietalibus tribus. Ovula plurima, horizuntalia, anatropa. Stylus terminalis; stigma símplex. Capsula maxima, membranacea, vesienloso-inflata, obtusa, unilocularis, trivalvis, valvis venosis, explanatis, medio seminiferis. Semina plurima, plano-compressa, testa membranacea, in alam latam, ad umbilicum prope basim sub. lateralem excisam expansa. Embryo in lasi albuminis carnosi minutus; cotyledonibus ovatis, radicula brevi, umbilico proxima, centrifuga. - Frutex brasiliensis; foliis alternis, petiolatis, subintegerrimis, stipulis lateralibus, geminis, caducis, floribus axillaribus racemoso-fasciculatis, parvis, fructibus maximis.

An ch i e te a St. Hilaire Plant, us, Brasil, t, 19. Plant. remarq. Brasil, I, 290. Flor. Brasil, 2I. 101, Meisuer Gen. 20. (18.) Nois ettia Martius et Zuccarini Nov. gen et sp. I. 23. t. 19. aon Kuath, Vio I a su m a à Flor. Flu. min. VIIT. $t .161$.

504 4. Selarreiggeria SPRENG. C a l y x profunde quinquepartitus, laciniis valde inaequalibus, tribus postieis multo majoribus, hastatocordatis, in pedunculum subdecurrentibus, daobus anticis minimis, angustis. Corolla e petalá 5 , imo calyei inserta, valde inaequalia, persistentia, antica lateralibus breviora, posticum maximum, hasi ealcaratum. Sta m in a 5 , snbperigyna, petalis alterna, inaequalia; filamenta brevissima, antherae introrsae, biloculares, complanatae, adnatae, apice in appendicem membranaeeam productae, loculis longitudinaliter dehiscentibus, duarum anticarnm connectivis in appendices subulatas, liberas, intra calear reconditas productis. Ovarium subglobosum, uniloculare, placentis parietalibus tribus. O v u l a plurima, anatropa. Stylus terminalis, clavato-dilatatus, incurvus, apice trilobus, lobis intus stigmatosis. Cap s u fa ovata, perigonio et genitalibus emarcidis tecta, unilocnlaris, trivalvis, valvis medio seminiferis, S e min a plurima, ovato-subglobosa, testa crustacea, rhaphe lineari elevata, ab umbilico prope basim sublaterali, minute caruncnlato ad chalazam terminalem producta. E mbryo in axi albuminis carnosi orthotropus, ejusdem longitudine, radicula umbilico proxima, centrifuga. - Frutices brasilienses; foliis alternis, ovatis v. lanceolatis, denticulatis, stipulis lateralibus, geminis, minutis, pedunculis axillaribus, solitariis, unifloris, superne bibracteatis, supra bracteas articulatis.

Sohweiggeria Sprengel N. E. $I I$. 167. St. Hilaire Plant, remarg. Brasil. I. 281. t. 126. f. 6. Flor, Brasil. II. 183. Meisner Gen. 20. (18.) Glos sa r r he a Martius et Zuecariai Nov. gen. et sp. I. 21, t. 15. Giugias in $D C$. Prodr. I. 290.

5Q45. Corymostylifs MART. et ZUCC. C a 1 y $x$ profunde quinquepartitus, laciniis subaequalibus, basi haud prodnetis. Corolla petala 5, ino calyci inserta, valde inaequalia, decidua, antica minima conniventia, lateralia erectiuseula, posticum maximum, basi longe calcaratum. Stam ina 5, perigyna, petalis alterna, subaequalia; filamenta brevissima, anticornm et iateralinm per paria connata, basi in appendiculam brevissimam, villosam producta, antherae introrsae, biloculares, complanatae, adnatae, apice in appendicem membranaceam productae, loculis longitudinaliter dehiscentibus. Ovarin m globoso-trigonum, uniloculare, placentis parietalibus tribus. 
Ovula plúrima, anatropa. Stylus terminalis, clavatus, fadscendens; stigma infra apicem laterale, excavatum, ciliatum. Capsula magna, ovato-subtrigona, lignusa, corticata, unilocularis, trivalvis, valvis medio seminiferis. S e m in a plurima, compre8so-subquadrata, angulata, imbricata, te $s$ ta erustacea, fragili, rhaphe ab umbilico basilari ad chalazam apicalem linearem producta perenrsa. Embryo in axi albuminis carnosi orthotropns, ejusdem longitudine, radicula nmbilico proxima, centrifuga. - Frutices Americae tropicae, scandentes; foliis alternis, petiolatis, ovalis, argute serrulatis, glaberrimis, nitidis, stipulis deciduis, racemis axillaribus foliosis, pedicellis filiformibus, medio bibracteatis, supra bracleolas articulatis, floribus magnis, speciosis.

Corynostylis Martins et Zuecarini Nov. gen. et sp. 1. 25. t. 17. 18. St. Hilaire Plant. remary. Brasil. 291. in not. Caly ptrion Gingins in DC. Prodr. 1 . 28s, et in Mem. soc. $h$. n. Genev, $I$, , t. 2. f. 1. Meisuer Gen. 20. (18.) _. ? Via la Hybauthus Aablet Guian. t. 319.

50 S6. Amg Tha drehox SPRENG. C al y x parvus, quinquepartitus, inaequalis, deciduus. Corolla e petala 5, imo ealyci inserta, longe unguicnlata, spathulata, subinaequalia, decidua, unguibus in tulum sobobliquum conniventibus, Iaminis ellipticis: Stamina 5 , cum petalis inserta, iisdem alterna, decidua; fil a m en ta complanato filiformia, a $\mathrm{n}$ therae introrsae, biloeulares, basifixae, immobiles, apice in mucronem membranaceum prodnctae, laterae Iongitudinaliter dehiscentes. Ovarium ovatum, nniloculare, placentis parietalibus tribus. Ovula plurima, anatropa. Sty 1 u s terminalis, subclavatus; $s t \mathrm{igma}$ truncatum, olssoletedenticulatum, F ru ct $\mathbf{s}$.....

Frutex brasiliensis; foliis alternis oppositisque, oblongo-tanceolatis, remote obsolete serrulatis, stipulis membranaceis, parvis, caducissimis, peduncul is terminalibus solitariis v. ternis, basi bracteolatis, uni-trifloris, pedicellis umbellatis, erectis, supra basim articulatis.

A mphirrhox Spreagel Syst. IV. Cur. post. JI. Meis. ner Gen. 20. (18.) S pathn Iarfia St. Hilaire Plant, re. marq. Bras, 318, t, 28. Flor. Brasil. IT. 10\%. znn Fries nec Zoolog. B r a d l e i a Flor. Flumin, . $, t, 140$.

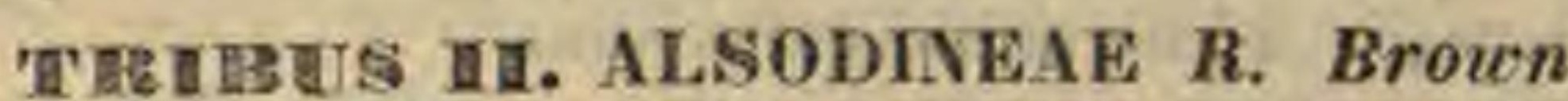
in Tuckey Cong. 440. Flores regulares, petalis brevissime unguieulatis, basi oblique imbricatis, apice patentibus.

504\%. Alsodeia THOUAR. C a ly x quinquepartitus, subaequalis, persistens. Corollae petala 5 , hypogyna, sessilia, aequalia, campanalato corniventia v, patentiuscula. Dise a s hypogynus urceolaris inter petala et stamina, saepissime obsoletus. Stamina 5, hypogyna, petalis al terna, aequalia; fil a menta brevissima, lata, libera $v$, in urceolum eonnata, anth e rae intror sae, biloeulares, loeulis appositis, connectivo in apicem membranaceun producto adnatis, apice bisetis v. membranacen appendiculatis, longitudinaliter dehiscentibns. O va ri um sessile, unilocu2 lare, placentis parietalibus tribus, nerviformibus. Ovula in quavis placenta solitaria, v. terna superposita, anatropa. Stylus terminalis, simplex, subelavatns; stigma obtusum. Capsula menloranacea v. eoriacea, perigonio et genitalibus persistentibus cincta, ovata v. subglobosa, saepe pla- centae unius $\mathbf{v}$. alterins abortu inaequilatera, nnilocularis, trivalvis, valvis medio seminiferis. S emina pauca, subglobosa, testa coriacea, $r$ hap he filiformi clavata, ab umbilico basilari v. supra basim laterali ad chalazam apicalem orbiculatam producta. E mbryo in axi albuminis carnosi orthotropus; cotyled on ib a s planis, subfoliaceis, radicula conica, umbilico proxima, centrifuga. - Frutices $v$, arbores, inter tropicos totius orbis crescentes; foliis alternis oppositisque, breve petiolatis, integerrimis v. serratis, stipulis lateralibus geminis, deciduis $v$, rarius persistentibus, foribus axillaribus $v$, terminalibus, solituriis $v$. saepius racemosis aut paniculatis.

A I sod e i a Thouars Hist. Veg. Afr. austr. II. 55, t, 19 21. R. Brown in Tuckey Congo 4a0. Deeaisne in Nouv. Annal. Mus. IIL. $t$, 19. A I s od e a Martius et Zuecarint Nov. gen. ot sp. I. 27. $t$. 19_21. C o n o horia Kunth in Humb. et Bonpl. Nov. gen. et sp. $\mathcal{V}, 387, t, 491, \mathrm{St}$. Hilaire Plant. us. Brasil. 1, 10. Plant, remarq. Brasil, 319. Flor. Brasil, IX. 148. Hooker Ic, $t$. 63. - D ri p a x Noronh. msc. Physiphora Solander msc. ex $R$. Brown $l$. $c$. Conohoria Aublet. Guian. 1. 239. $t$, 95. Ri a na Aublet Op. cit, I, 237, t, 94. P a s s o r a Aubl. Op, cit. Suppl. 21. t. 380. et Rinorea Aubl. Op. cit. I.235, t.93. - Ceranthe ra Palisot Flor. Owar. II, 11, $t, 65$. Pa s a Iia Solauder msc, ex R. Brown $l$, $c$. - ? P ros thes i Blume Bijdr, 866.

\section{GENUS DUBIUM.}

5048. Fentalolba LOUREIR. Calyx pentaphyllus, foliolis ereetis, lanceolatis, pilosis. Coroll a e petala 5 , lanceolata, campanulato - conniventia, apice subreflexa. Stamina 5 , nrceoli quinquedentati sinubus inserta; filamenta filiformia, corollam subaequantia, antherae ovatae, erectae, Ovarinm pilosum. Stylus brevis, crassus; stigma simplex. Bacea subrotunda, quinqueloba, unilocularis, pentasperma. S e mina ovata, - Arbor cochinchinensis, melliocris, monticola, vix nisi fructus revera baccatus sit, $a b$ Alsodeis diversa; foliis alternis, lanceolatis, obiter serratis, floribus sessilibus, congestis, pallidis.

Pentaloba Loureiro Flor. Cochinch, 199, - ? V a. reca Roxburgh Flor. Ind, edit. Wall, II, 445. non Girtn.

\section{GENUS ALSODINEIS AFFINE.}

5045. IIIymenanthern $R, B R$, Calyx pentaphyllns, imbricatus. Co rolla e petala 5, hypogysa, basi oblique imbricata, apice patentia. Stamina 5, hypogyna, petalis alterna; filam enta bresissima, extus squamula membranacea truncata, libera v. adnata stipata, a $n$ therae introrsae, biloculares, complanatae, marginilous connatae, loculis connectivo lato, membranaceo, supra eosdem longe producto adnatis, longitudinaliter dehiscentibus. Ova ri u m sessile, biloculare, $O$ v uIa in loculis solitaria v. gemina, coltateralia, ex apice cavitatis pendula, anatropa. Sty lu s simplex; st igma emarginato bilobum. B ac c a globosa, basi perigonio et genitalibas persistentibus stipata, stylo superata, bilocularis v. alterius loculi abortu, ant septo obliterato saepins unilocularis, mono-disperma. Semina inversa, Embryo in axi albuminis carnosi orthotropus; cotyledonibus orbiculatis, subfoliaceis, radicula umbilico proxima, supera. - Frutices v. arbusculae, in Nova-Hollandia orientali extratropica insulisque vicinis crescentes; folits alternis, interdum fasciculatis, simplicibus, integerrimis v. serratis, stipulis nullis, floribus axillaribus, parvulis, aborlu interdum polygamis, pedun. 
culis solitariis $v$, fasciculatis, basi bracteolatis, unifloris.

H ymenanthera $R$. Brown in Tuckey Congo 442. Gingius in Mem. soc, h. n. Genev. IT. $t, 2, f .9$. DC. Prodr. I, 316. Hooker in Bot. Mag, t. 3163. Endl. Prodr. Flor. Norfolk. 70. Meisner Gen. 21. (18.)

\section{Drdo CXCI. Sauvagesiene.}

SAUVAGRSIEAE Bartling Ord. nat. 289. SAUVAGEAE, Violariearum tribus Gingins in DC. Prodr. I. 315. Lindley Introduct, edit, $I$, p. 64. Meisner Gen, 2t. (19.) FRAN. KENIACEARUM genera St. Hilaire.

Supfrutices glaberrimi v. rarius herbae anuuae, caule tereti, haud articulato, simplici v. ramoso. F o li a altérna, sparsa $v$. approximata, interdum conferta v. imbricata, simplicia, integra, integerrima v. dentato-serrata, saepissime margine calloso cincta, lanceolata v. linearia, penninervia, in petiolum brevem attenuata, subsessilia v. rarissime sessilia. Stipulae laterales geminae, saepissime pectinato-ciliatae, persistentes.

Flones hermaphroditi, regulares, nunc axillares, solitarii v. gemini, nune terminales, racemosi v, rarius paniculati, albi, rosei aut violacei, v. (in Luxemburgia) flavi, pedunculis plerumque filiformibus, bracteatis.

Calyx liber, profunde quinquepartitus $\mathbf{v}$. pentaphyllus, foliolis aequalibus, v. interdum duobus exterioribus latéralibus ninoribus, concavis, margine saepe membranaceis, interdum coloratis, per aestivationem imbricatis, sub anthesi patentissimis, fructiferis persistentibus, conniventibus, v. (in Luxemburgia) deciduis.

Corollae petala quinque hypogyna, caly cis foliolis alterna, ovata, obovata v. lanceolata, brevissime unguiculata, aestivatione dextrorsum contorta, sub anthesi patentissima, decidua.

Stamina hypogyna, nunc (in Iuxemburgia) omnia fertilia, definita v. indefinita, subuniseriata, antheris caducis, nunc pluriseriata persistentia, seriebus exterioribus (in Sauvagesia et Lavradia) sterilibus, intina fertili; series extima (in Lavradia deficiens) sistit fila colorata, clavata v. spathulata aut apice reniformi dilatata, nunc indefinita, nunc petalis numero aequalia et alterna, series interior petalis opposita, e squamis petaloideis erectis, basi cohaerentibus, apice conniventibus marginibusque invicem incumbentibus, in alabastro sinistrorsum contortis, v. (in Lavradia) in tubum conicum, apice constricto quinque $v$. decemcrenulatum, stamina fertilia et ovarinm includentem, connatis, series in tim a sola fertilis, simplici petalorum numero et iisdem alterna; filamentis brevissi- mis, scariosis, subulatis v. teretibus, squamularum petaloideorum basi adhaerentibus. Anthera extrorsae, basifixae, immobiles, biloculares, loculis suboppositis, parallelis, lateribus apice v. juxta totam longitudinem dehiscentibus. Pollin is granula elliptica, minima.

Ovarium liberum, sessile, erectum, v. breviter stipitatum et declinatum, e carpidiis tribus compositum, nune carpidiorum marginibus valvatim appositis (in Sauvagesia), aut (in Luxemburgia) marginibus minus introflexis nec axim attingentibus uniloculare, nunc (in Lavradia) marginibus basi introflexis ad axim pertingentibus, apice appositis inferne triloculare, superne uniloculare. $0 \mathrm{vula}$ in placentis parietalibus ad carpidiorum sutnras, vel juxta dissepimenti incompleti margines superiores liberos plurima; biseriata, anatropa. St ylus terminalis, simplex, teres v. subclavatus, persistens. Stigma terminale, obtusum, integerrimum v. obsolete tridenticulatum.

Capsula calyce staminibusque emarcidis stipata, v. (in Luxemburgia) nuda, oblonga, ovato-oblonga, triquetra v. triloba, unilocularis v. basi trilocularis, nunc apice sterili trivalvis, valvis basi cohaerentibus, ad suturas v. ad dissepimenti incompleti marginem superiorem liberum, lunulato-truncatum biseriatim seminiferis, nune (in Luxemburgia) juxta totam longitudinem dehiscentibus, valvarum marginibus introflexis semina uniseriata gerentibus.

Semina parva, nunc ovato-elliptica, testa crustacea, scrobiculata, nunc (in Luxemburgia) oblonga, compressiuscula, testa laevi, margine membranaceo angusto, apice latiore cincta, umbilico in omnibus basilari, per rhaphen tenuissime filiformem chalazae apicali juncto. A I bumen carnosum.

Emввуо orthotropus, axilis, albuminis longitudine. Cotyledones breves, planae, sibi invicem incumbentes. Ra dicu la teretiuscula, cotyledonibus longior, umbilicum attingens.

Sauvagesie a e Americae regiones tropicas imprimis orientales incolunt, species plerumque endemicae, sola Sauvagesia erecta per novum continentem late diffusa, in Africae tropicae littore occidentali, et in insulis Madagascaria et Java reperta fuit.

Ordo hinc Violarieis Alsodineis, illine Frankeniaceis arcte affinis, ab illis ovulorum ad margines nec ad axim carpidiorum situ, ab his calyce partito, antheris extrorsis et stipulorum praesentia, ab utrisque insolita staminum sterilium anamorphosi distinctus.

Luxemburgia genus anomalum, nequaquam tamen removendum, a typo ordinis recedit sta- 
minibus omnibus fertilibus, et testa laevi, marginata.

5050. Sauvaresia $L I N N$. C a I $\mathrm{x}$ quinquepartitus, patentissimus, fructifer clausus, Corolla e petala 5, hypogyna, obovalia, aequalia, aestivatione convoluta, sub anthesi patentissima, decidua. S tamina hypogyna, staminodia extima filiformia, apice clavata $v$, reniformi dilatata, definita et petalis alterna $v$. indefinita, interiora petaloidea quinque, petalis opposita, in tubum conniventia, marginibus imbricata, totidem intima fertilia iisdem alterna; fila mentis brevissimis, staminodiis petaloideis basi adhaerentibus, anth $\mathrm{e}$ ris extrorsis, linearibus, basifixis, bilocularibus, loculis apice lateraliter dehiscentibus, Ovari $\mathbf{u m}$ liberum, uniloculare, placentis parietalibus suturalibus tribus. Ovula plurima, anatropa.Stylus simplex; stig ma terminale, obtasum. C a p 8 u la calyce et androecio persistente stipata, ovata v, obIonga, triloba, unilocularis, apice trivalvis. S emina plurima, ad valvarum suturas biseriata, tes ta crustacea, scrobiculata. Embryonis in axi albuminis carnosi urthotropi cotyled on es breves, radicula teretiuscula, nmbilico proxima, centrifuga. - Herbae $v$. suffrutices glaberrimi, in America et Africa tropica crescentes; foliis approximatis alternis, brevissime petiolatis $v$. inlerdum sessilibus, stipulis lateralibus geminis, ciliatis, persistentibus, floribus axillaribus, v, racemosis, terminalibus et bracteatis, albis, roseis v. subviolaceis.

$\mathrm{S}$ a u va ge si a Linn. gen. $n$, 286. Jaeq. Amer, 77, $1,51$. f. 3. Aublet Guian, t. 100. DC. Prodr, I, 315. St. Hilalre Plant, remarq. Brasil. 38. t, 1-4. Flor. Brasil, 1I. 109. Martius Nov. gen. ot sp. I. 34. t. 24, 25. Melsuer Gen. 21. (19.) S a $u$ va ge a Necker Elem, n. 1188. I r o и P. Browue Jam. 179, t. 12. f. 3.

5๑5 1. Lavraeltia $V E L L O Z$. Caly x quinquepartitus, patentissimus, fructifer clausus. Corolla e petala 5 , hypogyna, ovata v. ovato-lanceolata, aequalia, aestivatione convoluta, sub anthesi patentissima. S $t$ a $m$ in a hypogyna, extima staminodia petaloidea, in tuhum ovato-conicum. apice angustato quinquedentatum connata, fertilia quinque inclusa; fi $\mathrm{I}$ a $\mathrm{m}$ e $\mathrm{n} t$ is brevissimis, basi tubo staminoideo adhaerentibus, antheris extrorsis, ellipticis, hasifixis, bilocularihus, loculis latere juxta totam longitudinem dehiscentibus. Ovarium liberum, basi triloculare, dissepimen. tis superne lunulato excisis apice uniloculare. $\mathrm{O} v \mathrm{u}-$ la juxta dissepimentorum margines superiores liberos plurima, anatropa. Stylus simplex; stigma obtusum. Capsula ealyce et androeeio persistente stipata, basi trilocularis, apice uniloculari trivalvis. Semina ad dissepimentorum marginem superiorem liberum biseriata, $t$ e s t a crustacea, scrobienlata. Embryonis in axi albuminis carnosi orthotropi cotyledones obtasae, radicula teretiuscula, umbilico proxima. - Suffrutices brasilienses, glaberrimi; foliis confertim alternis, saepius subimbricatis, brevissime petiolatis, stipulis lateralibus geminis, persistentibus, floribus axillaribus v, terminalibus, racemosis aut interdum paniculatis, bracteatis, albis $v$. roseis.

L a vradia Vellozo ex Vandelli in Römer Script, 88. t. 6. f. 6. DC. Prodr. I. 314. St. Hilaire Plant. remary. Brasil, 69, t. 4. f. 6. t. 5_8. Flor, Brasil, II. 111. Mar. tius Nov. Gen. et sp. I, 31, t. 22. 23. Meisaer Gen. 21. (19.)

5052. Guxemburgia $S T$. HIL. C aly x pentaphyllus, inaequalis, deciduas. Co roll a e pe- tala 5, hypogyna, obovalia, subaequalia, aestivatione imbricato-convoluta, $s u b$ anthesi patentissima, decidua. Stamin a hypogyna, indefinita v. subdefinita, petalis plura, omnia fertilia; filament a brevissima, filiformia, persistentia, a ntherae extrorsae, magnae, lineari-tetragonae, biloculares, liberae $\mathbf{v}$, in massam secnndam conglutinatae, decíduae, locnlis apice poro apertis. Ovarin m brevissime stipitatum, uniloculare, placentis ad valvularum margines plue minus introflexes parietalibus, tribus, Stylus brevis, subulatus; stig m a simplex v. brevissime bidentatum. C a psu la unilocularis, trivalvis, valvarum marginibus introflexis seminiferis. Se m in a plurima, margine membranaceo, apice latiore cincta. $\mathbf{E}$ mbryonis in axi albuminis parci carnosi orthotropi cotyledones breves, radicula umbilico proxima. - Frutices brasilienses, speciosi, ramosi, glaberrimi; foliis alternis, oblongis, dentatis, mucronatis, lineato-nervosis, stipulis lateralibus geminis, ciliatis, caducis v. persistentibus, floribus terminalibus, racemosis $v$, corymbosis, luteis, pedunculis paullo supra basim articulatis, ad articulum bibracteolatis.

L uxemburgia St. Hilaire in Mem. Mus. IX, 35t. Plant. remarq. Brasil. 331. $t$. 29. 30. Flor. Brasil. II. 113. DC. Prodr. I. 350. Meisuer Gen. 21, (19.) PIect. a thera Martius et Zuecaria. Nov, gen, et sp. I. 39, I.36.

\section{Drdo CXCD. Frankeniaceat.}

FrankeniaCEAE St. Hilnire in Mem. Mus, II. 122 XI. 61. Plant, remarq. Brasil. 33. et 325. excl. Sauvagesieis DC. Prodr, I. 349. Bartling Ord, nat, 290. Lindley Introduet. edit. II, p, 67. Meisner Gen, 28, (20,) Webb et Berthel. Flor. Canar, 128.

Herbaf perennes v. suffrutices littorales, ramosissimi, caule ramisque teretibus, nodoso articulatis. Folia opposita, alterna, v. quaternata, juniora saepissime in axillis fasciculata, parva, subsessilia v, petiolata, basi in marginem brevissimum amplexicaulem coalita, integerrima, margine saepissime revoluta. Stipulae nullae.

Ftores hermaphroditi, regulares, in dichotomiis caulium et ramorum, nec non in eorum apice subsessiles, solitarii, cymam dichotomam foliatam, saepe depauperatam et contractam formantes, rosei, carnei v. violacei.

Calxx gamophyllus, liber, longe tubulosus, quadri-quinquefidus, costatus, persistens, laciniis aequalibus, aestivatione subimbricatis.

Corollae petala 4 v. 5 , hypogyna, calyeis laciniis alterna, longe unguiculata, libera, aestivatione imbricatim subcontorta, unguibus tubum aequantibus, intus lamella adnata solubili auctis, laminis sub anthesi patentibus.

Stamina in calyce et corolla tetra-v. penlamera saepissime sex, rarius quinque, hypogyna, petalis alterna; filame nta late subulata, dorso convexa, faciebus plana, apice teretiuscula, aestivatione erecta, sub anthesi calycis tubum aequantia, circa ovarium conniventia, libera v. interdum basi cohaerentia, per- 
sistentia. Antherae extrorsae, biloculares, versatiles, ovatae v. subgloboso-didymae, loculis longitudinaliter dehiscentibus, deciduae.

Ovarivm liberum, sessile, tri-tetraquetrum, uniloculare, placentis parietalibus tribus v. quatuor nerviformibus, prope medium deliquescentibus. Ovula biseriata, e funiculis longiusenlis adscendentia, anatropa. Stylus terminalis, simplex, filiformis; stigmata $3-4$, linearia, intus stigmatosa.

Capsula calycis tubo inclusa, unilocularis, tri-quadrivalvis, valvis medio inferne placentas nerviformes, mono-polyspermas gerentibus.

Semra adscendentia, ovata, testa coriacea, scabra, umbili co basilari, per rhaphen filiformem cum chalaza apicali, incrassata, mamillaeformi conjuncto. A $1 \mathrm{bum}$ en farinaceum.

Еиввуо in axi albuminis orthotropus, ejusdem fere longitudine. Cotyledones ovatooblongae. R a dicula brevissima, obtusa, umbilico proxima.

Frankeniacea littora maris extratropica, imprimis mediterranea et atlantica incolentes, inter ordines parietales, calyce gamophyllo cum corolla staminibusque hypogynis distinetissimae, sed Sauvagesieis Turneraceisque proxime adhuc affines, pluribus characteribus ad Sileneas, placentatione et seminum fabrica caeterum diversissimas accedunt, fortassis, etiam non obstantibus seminibus albuminosis, Tamariscineis aliquatenus comparandae.

Fouquieraceas, habitu, corolla gamopetala, et embryone ut videtur antitropo admodum singulares, ad Frankeniacearum calcem interim collocamus, ita ut inter has et Turneraceas recensitae, nibil certi tamen de earum affinitate adhucdum statuatur.

5053. Wrankenia LINN. Calyx tubulesus, quadri-quinquefidus. Cor o I la e petala $4-5$, hypogyna, longe unguiculata, libera. Stam ina hypogyna, 6 v. rarius 5 ; fil a m e $\mathrm{n}$ a lata, subulata, antherae biloculares. Ovarium sessile, uniloculare, placentis parietalibus tribus v. quinque panciovulatis, ovulis adscendentibus, anatropis. Stylas filiformis; stig ma tripartitum. Caps ni a unilocularis, tri-quinquevalvis, valvis basi medio seminiferis. Sem in a pauca v. plurima, adscendentia. E $m$ bryo in axi albuminis farinacei orthotropns. - Herbae perennes $v$, suffrutices littorates; foliis oppositis, alternis $v$. quaternatis, junioribus saepe faseiculatis, floribus cymosis.

Frankenia Lina. Gen, n, 445. Gärtner f, III, $t, 184$. DC. Prodr. I. 349. Meisuer Gen. 22. (20.) F r n ena Micheli Nov. Gen, t. 28. Nothria Berg. Cap. 171. t. 1. $f .2$.

a. FRANCA. Stylus trifidus, lobis intus stigmatosis. Ca psula tri.quadrivalvis. - (E. B. t. 20s. Lam. t. 268. Sibthorp Et. graec. $t, 313$, Cavanill. Io, $t, 597$. Desfont. Flor, atlant, , 93. Labillard. Nov, Holl, t. 114. Bot. Mag. t, 2896. Webb et Berthol. Flor. Canar. $t$, 18 -17$. b. ? BEATSONIA. Stylus bifidus, stigmatibus globosis. Capsùla blvalvis. - Frutex insulae St. Helenae. Beatsonia Roxburgh f. in Beatson 1t. 300.

\section{* FOUQUiERACEAE DC.}

5054. Fouguiera $H, B, K, C$ al $y \times$ pentaphyllus, coloratus, foliolis biseriatis, ovatis, mueronatis, imbricatis, C orofla liypogyna, gamopetala, tubo cylindraceo, subarcuato, calycein longe superante, limbi quinquepartiti patentis lobis ovato-subrotundis, acute inueronatis, subaequalibus, tubo multo brevioribas. Sta $\mathrm{m}$ in a 12 , hypogyna, exserta, subarenata, alterna parum breviora; filamen ta filiformia, compressa, inferne villoso ciliata et colsaerentia, a n the rae biloculares, ovato - cordatae, submueronatae, erectae, demum inflexo pendulae, longitudinaliter dehiscentes. Ovarium liberum, sessile, uniluculare, placentis parietalibns tribus. $\mathrm{O} v \mathrm{u} \mathrm{la}$ in quavis placenta 6 , liseriata, adscendentia, supra basim inserta. StyIus terminalis, apice trifidus; stigmata obtusa. Fructus ..... Frutex mexicanus, subspinosus; pube simplici, spinis sparsis, brevissimis, persistentibus, foliis in axillis spinarum solitariis, petiolatis, oblongis, integerrimis, subcarnosis, floribus in apice ramorum arcte spicatis, sessilibus, an bracteatis?, corollis coccineis, pollicaribus.

Fo u quiera Kunth in Humb. et Bonpl. Nov. gen. ot sp. VI, 81,t, 527, DC. Prodr, III, 349. Meisner Gen, 124. (94.) Eehereria spicata Flor. mexic, inedit.

5055. Eremuta $H$. B. $K$. C a Iyx pentaphyllns, foliolis biseriatis, suborbienlatis, imbricatis. Corolla hypogyna, gamopetala, tubo cylindraceo, recto, limbo quinquelobo, erecto. Stamina $10 \ldots$ filamenta filiformia, exserta, antherae ovatae.... 0 varium libernm.... Sty Ins filiformis, stamina superans, apice trifilus. Capsula calyce stipata, styli basi mueronata, oblongo-trigona, laevis, trilsenlaris, loculicide trivalvis, valvis coriaceis, concavis, a columna seminifera triangulari demum libera solutis, medio linea longitudinali, colamnae angulo respondente notatis. S e m in a loculis solitaria, inversa, apice interiore affixa, oblonga, compressa, dorso convexa, faeie plana, testa tennissime membranacea, in alam ambientem, basi et apice emarginatam expansa. $\mathrm{Embryo}$ intra albumen parcum, carnosum antitropus, magnus; cotyledonibus foliaceis, subcarnosis, ovatis, obtusis, basi cordatis, radicula cylindracea, acuta, cotyledenibus triplo breviore, umbilico contraria, infera. Arbar mexicana, glabra; ligno albido, fragili, ramis spinosis, spinis sparsis, solitariis, foliis in axillis spinarum fasciculato - congestis, obovato-oblongis, integerrimis, membranaceis, floribus cocejneis, in paniculas terminales, ramosissimas, subcorymbosas, bracteatas dispositis.

B ronnia Kunth in Humb. et Bonpl. Nov. gen. et sp. VI. 83. t. 528. DC. Prodr. III. 351. Melsuer Gen. 129. (94.) Cantua spinosa Willd. Eeheveria paniculata Flor. mex. inedit.

\section{Ordo CXCIIH. Tumeraceae.}

LOASEARUM sect. 1I. TURNBRACEAE Kunth in Fumb. et Bonpl. Nov. gen, et $s p$. VI. 123. TURNERACEAE DC. Prodr. 1II. 345. Bartling Ord, nat, 271. Lindley Tntroduet. edit. 11. p. 180.

Herrab, suffrutices v. Frutices, pube simplici v. rarius stellulata, inermi. Fo lia al- 
terna, simplicia, petiolata, integerrima v. saepius serrata, rarissime pinnatifida, basi saepissime glandulis duabus lateralibus instructa. Stipulae nullae.

Flores hermaphroditi, regulares, axillares, sessiles v. pedunculati, pedunculi liberi, v. cum petiolo connati, simplices, bibracteolati, v. infra medium articulati, ebracteolati, rarissime ramosi, multiflori.

Calyx coloratus, liber, deciduus, basi tubulosus, plus minus profunde quinquefidus, lobis aequalibus, per aestivationem imbricatis.

Corollas petala 5 , mediante toro in laminam tenuissimam, calycis tubum vestientem expanso, eidem supra basim v. fauci inserta, et lobis alterna, brevissime unguiculata, aequalia, per aestivationem contorta, decidua.

Stanisa 5, imo calycis tubo inserta, ejusdem laciniis opposita, inclusa. Fil amenta libera, aequalia, complanato-subulata. Antherae introrsae, biloculares, medio dorso v. supra basim insertae, erectae, vix mobiles, loculi appositi, longitudinaliter dehiscentes, connectivo manifesto nullo.

Ovaruum libernm, e carpidiis tribus valvalim connatis uniloculare, placentis parietalibus tribus, nerviformibus, cum suturis alternantibus. Ovula plurima, biseriata, adscendentim anatropa. Styli tres, terminales, indivisi v. bifidi bipartitive, placentis oppositi; sti gmatibus tribus v. sex, flabellatim multifidis.

Capsora unilocularis, apice v. juxta totam longitudinem trivalvis, valvis medio placentas lineares gerentibus.

Semisa plnrima, biseriata, adscendentia, cylindrica, subeurvata, testa erustacea, saepissime impresso-punctata, umbilico basilari, mediante $r h a p h e$ filiformi cum $c h a l a-$ $\mathrm{za}$ apicali, mamillaeformi juncto, $\mathrm{str}$ op h i o la membranacea tenuissima, seminis basi e latere rhapheos applicita, inde in seminis latus a rhaphe aversum in marginem brevissimum replicata. End op l e ur a tenuissime membranacea. Albumen carnosum.

Embryo magnus, orthotropus, axilis. $\mathbf{C}$ otyledones subellipticae, plano-convexae, germinatione foliaceae. Radicula umbilicum attingens, infera.

Turneraceae in America et Africa tropica indigenae, Malesherbiaceis proxime affines videntur, a quibus stylis terminalibus, seminibus strophiolatis, staminibus perigynis, et coronae membranaceae, petalis subjectae defectu sunt diversae. A Loaseis staminibus definitis, ovario libero, placentis nerviformibus uniloculari, differunt.

5056. Turnera PLUM. Calyx coloratus, tubuloso-infundibuliformis, limbo quinquepar- tito. Corolla e petala 5, calycis fanci inserta, breviter unguiculata, aequalia, limbo longiora. Stamina 5, imo calyci inserta, inclusa; filamenta libera, antherae erectae, biloculares. Ovariu m liberum, uniloculare, placentis parietalibus tribus, nerviformibus. Ovu la plurima, adscendentia, anatrepa. Styli 3 , terminales, indivisi ; stigmat a 3 , flabellato-multifida. Caps nI a nilocularis, apice $v$. juxta totam longitudinem trivalvis, valvis medio seminiferis. Sem in a plarima, subcylindrica, incurva, testa crustacea, umbilico basilari, strophiola membranacea, subunilaterali, rhaphe filiformi ad chalazam apicalem mamillaeformem producta. Embryo in axi albnminis carnosi magnus, orthotropus; cotyledonibus plano-convexis, radi cula umbilienm attingente, infera. - Herbae, frutices $v$. suffrutices, in $\Delta m e-$ rica tropica crescentes; pube simplici, foliis sparsis, plerumque serratis, rarissime pinnatifidis, basi saepissime biglandulosis, stipulis nullis, floribus axillaribus, solitariis, sessilibus v. pedunculatis, pedunculo libero $v$. cum petiolo connato, rarius terminalibus, racemosis, bibracteolatis, flavis.

Turnex a Plumier Gen, 15, t, 12. Lina. gen. n. 736. Jussieu Gen. 313. Aublet Guian. 1. 298. 2. 113, 114. Jacq. Hort, Vindob. IIT, t. 94, Gärtner I, 366, t, 76. Kunth in Humb. el Bonpl. Nov. gen, etsp. VI, 193. DC. Prodr, IHI.396. Canbessedes in St, Hilaire Flor. Brasil, H. 15i. t. 119 -124. Bot. Mag. t. 281. 210b. Meisuer Gen, 193. (89.) P umile a P. Browne Jam, 188, - Bohadschia Presl Reİq. Hänk. II. 98, $t, 68$.

505\%. Piriqgueta $A U B L$. C a ly x coloratus, campanulatus, limbo quinquefido. Corolla e petala 5, ealyeis fausi inserta, breviter unguieulata, aequalia, limbum aequantia v. superantia. St a mina 5, imo ealyei inserta, inclusa; filamenta libera, antherae erectae, bilocalares. Ovariu m liberum, placentis parietalibus tribus, nerviformibus. Ovula plurima, adscendentia, anatropa. Styli 3, terminales, bifidi v. bipartiti; $s t i g m$ a $t$ a 6, flabellato-multifida. Ca psula unilocularis, Iongitudinaliter trivalvis, valvis medio seminiferis. Semina subeylindracea, leviter incurva, testa crnstacea, umbilico basilari, strophiola membranacea, subunilaterali, rhaphe filiformi ad chalazam terminalem mamillaeformem producta. Embryo in axi albuminis carnosi magnus, orthotropus; cotyledenibus plano-convexis, radicula umbilicum attingente, inferaHerbae in America tropica indigenae, stellulato-pilosae; foliis alternis, serratis, glandulosis, stipulis nullis, floribus axillaribus, solitariis, peduneulatis, pedunculo infra apicem articulato, ebracteato, corollis flavis.

Piriqueta Aublet Guian, 1. 298. t. 117. Jussieu Gen. 295, Kunth in Humb. et Bonpl. Nov, gen. et sp, VI. 127. DC. Prodr. IIT. 348, Meisner Gen, 123. (89.) B a r ghartia Necker Elem. n, II86, Burkardia Scopoll In. troduct. n. 1027. Schreber Gen, n, 530. Turnerae sp. Lam. Willd.

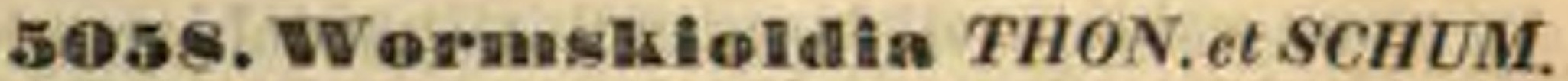
C a 1 y $\times$ subcoloratus, tubulosus, gracilis, limbo quinquedentato. Coroll a e petala 5 , calycis tubo supra hasim inserta, linearia, obtusa, aequalia, limbo paullo longiora. Stamina 5 , imo calycís tulo inserta, hreviter exserta; fil a ment a subulata, libera, antherae erectae, biloculares. Ovari n m liberum, oblongo-cylindrienm, placentis parietalibus tribus. Ovula plurima, anatropa. Styli 3 , terminales, filiformes, indivisi; stigmata subfimbriata. C a p a la siliquaeformis, teres, snbtorulesa, unilocularis, longitudinaliter $115 \%$ 
trivalvis, valvis linearibus, medio seminiferis. S emina obovoidea, testa crustacea, scrobiculata, umbilico basilari, strophiola membranacea, sub. unilaterali, rhaphe filiformi, ad chalazam terminalem mamillaeformem producta. $\mathbf{E} \mathrm{mb} \mathbf{r} \mathbf{0}$ in axi albuminis carnosi magnus, orthotropus; cotyledonibus plano convexis, radienla umbilicum attingente, - Herba Africae tropicae, an nua, Rhaphani cujusdam facie, pilis rigidulis co loratis conspersa; foliis alternis, pinnatifido-v. si nuato-dentatis, eglandulosis, stipulis nullis, floribus versus apicem pedunculi axillaris paucis, racemosis, pedicellis brevissimis, basi minute unibracteatis, floribus flavis.

Wormskioldia Thoning et Sehumacher Plant. Guin. I. 165. A. Richard Flor. Seneg. $T$. 36. t. 11. T rieliceras DC. Plant. rar. hort. Cienev, p. 56 . S $\mathrm{chum}$ acheria Sprengel Gen, plant. $n, 1220$. R a phan us pilosus Willd. Cleome "raphanoides DC.

\section{Ordo CXCIV. Sannydeae.}

SAMYDEAE Gairtmer f. III. 238_242. Ventenant in Mem. Instit, 1807. 143, exel. gen. Kunth in Humb. et Bonpl. Nov, gen. et sp. V. 360. Synops. IIT. 29t. DC. Prodr. II. 47. Bartling Ord, nat, 268, SAMYDACEAE, Liadley Intro. duet. edit. II. p. 64 .

Frutices, arbusculab v. arbores, ramis ramulisque teretiusculis. Folia alterna, saepe disticha, subcoriacea, simplicia, integra, integerrima v. serrata, penninervia, saepissime punctis lineolisque pellucidis notata, breviter petiolata. Stip u la e petiolares, geminae, liberae, deciduae.

Flores hermaphroditi, regulares, axillares, umbellati v. glomerati, rarius solitarii $v$. corymbosi, albido-virescentes, albi, rosei $v$. purpurei. Pedicelli articulati, basi bibracteolati.

Calyx persistens, tubulosus, quadri-quinquefidus v. fere ad basim quadri-quinquepartitus, lobis subaequalibus, per aestivationem anguste imbricatis $\mathbf{v}$. rarissime valvatis, intus saepe coloratis, fundo v. tubo tori lamina tenu vestito.

\section{Corolea nulla.}

Stamina calycis fundo v. summo tubo inserta, ejusdem lobis numęro dupla, tripla v. quadripla. F il ame n ta basi monadelpha, nune omnia fertilia, nunc alterna sterilia, squamaeformia, pilosa, fertilibus subulatis breviora. A $n$ the rae introrsae, biloculares, dorso paullo supra basim affixae, erectae, loculi suboppositi, rima sublaterali longitudinaliter dehiscentes, connectivo nullo manifesto.

Ovarium liberum, e carpidiis 3-5, calycis laciniis alternantibus, marginibus valvatim appositis connatis uniloculare, placentis e carpidiorum nerve medio prominulis parietalibus. O v u la plurima, bi - pluriseriata, adscendentia, semianatropa, acuminata, acumine micropyle terminato saepius contorto, supero. Sty lus terminalis, simplex v. interdum apice breviter trifidus. Stigmata 3, capitata, distincta v. saepissime coalita.

Capsula coriaceo-carnosa, unilocularis, triquinquevalvis, valvis medio seminiferis.

Semiva indefinita, ovulis panciora, angulata, adscendentia. Umbili c us paullo supra seminis basim ventralis, $r$ ha $p$ he brevi crassa, intra integumentum exterius carnoso-pulposum, integrum et totum semen obvestiens, v. in arillum multifido-lacerum fatiscens, prorepente, cum chalaza basilari umbilicato-excavata junctus. Testa crustacea, foveolata, fragilis, endopleura membranacea, tenuis. Albumen copiosum, carnoso-oleosum.

Eив вхо in apice albuminis rectus, vix quartam partem longitudinis seminis aequans. $C_{0}$ tyledones foliaceae, ovatae, planae. $\mathbf{R}$ adi cula obtusa, ab umbilicb remota, chalazae e diametro opposita.

S a mydeae Bixaceis proxime affines, magno numero Americam tropicam incolunt, species Asiae tropicae paucae et vix notae.

5๑59. Samada $L I N N$. C a l y x persistens, tubulaso-campannlatus, coloratus, limbo quinquefido v. rarissime quadrifido aut partito, inaequali. Corolla nulla. Stamina 8-18, summo calyeís tubo inserta, snbexserta ; fil a m ent a basi membranacea dilatata, in tubum connata, apicibus cnspidata, distincta, omnia fertilia, ant hera e oblongae, erectae, biloculares. Ova ri $\mathrm{n}$ m liberum, uniloenlare, placentis parietalibus 3 v. 5, ovulis plurimis, pluriseriatis, semianatropis. Stylus terminalis, simplex; stigma capitatum. Ca p8 u la ovali-globosa, coriaceo-earnusa, unilocularis, apice tri-quinquevalvis, valvis demum explanatis, medio seminiferis. Sem in a angulata, umbilico ventrali, rhaphe brevi erassiuscula, intra integumentum exterins bactatum prorepente, cum chalaza basilari excavata juncto, testa fragili, crustacea, endopleura membranacea. E mb r yo in apice albuminis carnośi parvos, foliaceus, rectus, radicnla chalazae e diametro opposita. - Arbusculae $v$. frutices Amcrica e tropicae; ramis interdum spinescentibus, foliis alternis, integerrimis $v$. serratis, pellucido-punctatis, stipulis petiolaribus geminis, pedunculis axillaribus, unifloris, solitariis v. fasciculatis, floribus albis $v$, rarissime purpureis.

S a m y da Linné Gen, n. 543. Gärtner f, $I I I, 239$. Kunth Synops. III. 298. DC. Prodr. II. 47. Meisner Gen, 72. (59.) Gufdonia Plamier Gen. 2 , 24. excl.sp. Mo n gezia Plor. Flumin. $V$. $t$. 105. 106.

a. EUSAMYDA DC, $l$, c. C a 1 y $x$ basi tubulosus, ad medium fissus. Stam in a 10-12. - Flores majusculi. (Jaeg Collect, II, t, 17. f. 1. Vent. Choix t. 43. Andr. Bot. Reposit. t, 202. Bot. Mag, t.550. Gáliter f, $t, 224$.

b. GUIDONIA DC, $t$. c. $\mathrm{C}$ aly $\mathrm{x}$ ad basin fere partitua. $S$ t a min a 8 v. rarius 10 . Flores minuscuti. Spooies omnes dubiae, (Cavanll1. Ic. $t, 67$, Lam. $t, 353$. f. 8.)

5080. Caseania JACQ. C a ly x persistens, coloratus, quadri-sexfidus, laciniis subaequalibus. C oroll a nulla. Stamina $12-30$, summo ealycis tubo inserta, exserta; filamenta basi inter se coalita, alterna subulata antherifera, al- 
terna squamaeformia, sterilia, pilosa, an thera e ovatae, erectae, biloculares. Ova rium liberam, uniloculare, placentis parietalibus 3 v. 4 , ovulis plurimis, pluriseriatis, semianatropis. Stylus terminalis, indivisus v, breviter trifidus; s t $\mathrm{i} g \mathbf{m a -}$ ta 3 , distincta v. coalita. C a p s u la subglobosa, coriaceo carnosa, unilocularis, tri-quadrivalvis, valvis medio seminiferis. S e m in a paca, ovato-angulata, umbilice ventrali, rhaphe brevi, crassiuscula, intra integumentum exterius baccatum, integrum v, in arillum multifidum fatiscens prorepente, cum chalaza basilari excavata juncto, testa crustacea, fragili, endopleura membranacea. Embryo in apice albuminis carnosi parvus, foliaceas, orthotropus, radic u la chalazae e diametro opposita. - Arbores $v$. frutices, in regionibus tropicis, imprimis Americae crescentes; foliis alternis, distichis, integerrimis $v$. serratis, pellucido-punctatis, stipulis petiolaribus geminis, floribus in axillis foliorum umbellatis $v$. glomeratis, rarius solitariis $v$. corymbosis, albo-virescentibus v. rarius roseis. pedicellis articulatis, basi bracteatis.

C a s e ari a Jacq. Amer. 132, Kunth in Humb. et Bonpt. Nov. gen. et sp, $V, 366$. Cambessed. in St. Hilaire Flor. Brasil. II, 166. A ntig on a Flor. Flumin, IV. t. 148.

a. CASEARIA Stylus iudivisus v. apice breviter trifidus. S tamina 6 - 20.

c. Hexanthera. Stylus indivisus. Stamina ferti. lia 6. - C. ilicifolia Vent. Choix, $t, 44$.

B. Anaviaga. Stylus indivisus. Stamina fertilia 8 . - Anaving a Rheede Malab, IV. $t$, 29 . Lam. Dict. I. 147. t. 355 . I ro и е а а а Aublet Guian. I. 329. t. 127. L a ngle i a Secpoli Introduct. n. 1046. A thena a Sehreber gen, $n, 661$. C a s e a ria Gärtuer f. III. 238. t. 224 - (Jaeq. Act. Helv. VIIT. 38, c.ic. Vent. Choix. $t$, 45.)

$\gamma$. P it u mba. S ty I u s fudivisus. St am in a fertilia 10. Pit um ba Anblet Guian, II. Append. 29. $t$. 385. A uavinga Gärtner f. IIT, 240. $t, 224$. Mells ta ur u m Forst. Char, gen, t. 22. (Jacq. Amer, t. 85. Lam. t. 355. f. 1. Vent. Choix t. 46. Humb, et Bonpl. Nov. gen, et sp. t. 480 . Cambessed. Op, cit. t. 126. 127.)

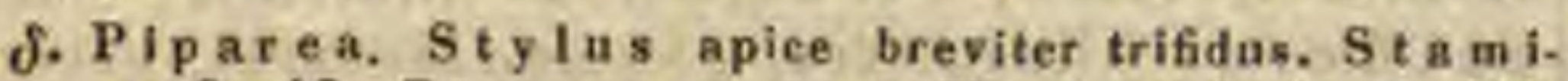
na 9-12. Piparea Aublet II. Append. 31. $t .386$. Gärtn. f. III, 231, t, 294. DC. Prodr. I. 316. A. Richard in Diet. hist, nat. XIII. Gio.

6. CHAETOCRATER. Stylus indivisus v- apice breviter trifidus. Sta $m$ in a $24-30$.

Chaetoicrater Ruiz et Pav, Prodr. 6t, $t, 36$. DC. Prodr. II. 52, Crateria Persodn Eneheir. I. 695. Lindley a Kunth Malv. 10. (Vent. Choix t. 47. Kuath in Humb, et Bonpl. Nov, gen. etsp, t.479. Cambessed. op. cit. t. 125.)

\section{Drdo CXCI. Bixaceae.}

BIXINEAE Kunth Diss. Malvac, 17. Humb. ot Bonpl. Nov, gen, et sp. $\nu, 331$. DC. Prodr. $T$. 259. Bartling Ord. nat. 281. BIXACEAB Lindley Introduct. edit. II. p. 72 . FLACourtianeAE L. C. Riehard in Mem. Mus. 1, 366. DC. Prodr. I, 255. FLACOURTIACEAE Lindley Introduct, edit. II. $p, 70$.

Arbores v. fruticks, saepissime glabri, pube dum adest stellulata, ramis teretibus. Foli a alterna, simplicia, integra, integerrima v. dentata, saepissime pellucido punctata. Stipulae petiolares geminae, caducissimae, saepius nullae.

Flores hermaphroditi v. abortu saepius unisexuales, axillares, solitarii $\mathbf{v}$, congesti, rarius terminales, paniculati.
Calyx liber, tri-tetra-pentaphyllus, v. quadri-septem-duodecim-partitus, persistens v. deciduus, herbaceus v. coloratus, aestivatione imbricatus v. interdum subvalvatus.

Cororla nune nulla, nunc petala tot quot foliola v. laciniae calycis, iisdem alterna, et saepe similia, insertione hypogyna, libera, aestivatione imbricata.

Stamiva indefinita, immediatim hypogyna, v. disco annulari aut hemisphaerico, interdum inferne calyeis basi adhaerenti pluriseriatim inserta, omnia fertilia v, rarissime extima ananthera. Filamenta filiformia, libera. Anthera e introrsae, biloculares, loculis longitudinaliter v. interdum apice dehiscentibus.

Ovarıu liberum, sessile, uniloculare, placentis parietalibus duabus v. pluribus, simplicissimis v. subramosis. Ovula plurima, anatropa. Stylus terminalis, simplex v. ad basim partitus. Stig mata obtusa v. capitata.

Fructos unilocularis, nune baccatus indehiscens, nunc capsularis, valvatim dehiscens, valvis medio seminiferis.

Semina plurima, epidermide saepissime carnosa, arillaeformi, colorata, te sta crustacea, rhaphe longitudinali et chalaza apicali saepissime in endopleura membranacea manifestis.

Enвryo in axi albuminis plus minus copiosi orthotropus; cotyledonibus saepissime foliaceis, radicala umbilico proxima.

B ix aceae in regionibus tropicis subtropicisque totius orbis crescentes, plantarum ordinem constituunt cum nullo alio in Parietalium classe facile confundendum, sed nondum certis limitibus eircumseriptum, et genera plurima quoad veram integumentorum floralium naturam et seminum fabricam ninis imperfecte cognita colligentem, hinc Homalineis, Samydeis, Passifloreisque multa necessitudine affinem, illinc per nonnulla genera Tiliaceis conterminum, olim notis pluribus accuratius expensis, expulsis generibus fortassis pluribus repurgandum, et dividendum.

TuRIBUS I. BIXINEAE. Stylus simplex. Fructus dehiscens.

5061. Bixa LINN, Flores hermaphroditi. Calyx pentaphyllus, basi quinquetuberculatus, deciduus, foliolis coloratis, orbiculatis, aestivatione imbricatis. Corolla e petala 5, hypogyna, calycis foliolis alterna et aequilonga, aestivatione imbricata. Stamina plurima, fundo calycis pluriseriatim inserta; fil a m enta filiformia, libera, aequalia, antherae introrsae, biloculares, elongato-tetragonae, basi affixae, apice uncinatim inflexae, locnlis in curvatura terminali rimula dehiscentibus. Ova rinm sessile, liberum, dense setosum, uniloculare. Ovula in placentis 
parietalibus duabus plurina, pendula, anatropa. Stylus terminalis, cylindricus, apice compressus; stigma brevissime bilobum. Ca psula cordata, compressinscula, aculeis setaceis hispida, unilocularis, bivalvis, valvis medio placentam nerviformem gerentibus, endocarpio membranaceo, solato, Semina plara, biseriatim e funiculis brevibus pendula, turbinata, epidermide pulposo rubra, testa cornea, rhaphe filiformi ab umbilico basilari ad chalazam latam, verticem deplanatum occupantem producta, endopleura membranacea, ad chalazam testae arcte adnata. $\mathbf{E} \mathbf{m b} \mathbf{r y o}$ in axi albuminis carnoso-oleosi orthotropus; coty le don ibus foliaceis, ovato-cordatis, medio transverse plicatis, radicula tereti, umbilico proxima, supera. - Arbuscula America e tropica e incola, inter tropicos utriusque orbis, ob epidermidis seminum pulpam rubro tingentem culta; foliis alternis, petiolatis, cordato-oblongis, integerrimis, nitidis, stipulis petiolaribus geminis, deciduis, floribus terminalibus paniculatis, bracteatis.

B ix a Linn, Gen. 654. Gïrtner $I, 292, t, 61$, Kunth in Humb. et Bonpl. Nov. Gen. et sp. V. 353. Bot. Mag.t. 1356. DC. Prodr. I, 259. Meisuer Gen, 19. (17.) Wight Illustr. t. 17 .

5062. Telhimecarpus $B L U M$. F lo res hermaphrediti. C a $1 \mathbf{y} \times$ quinquepartitus, deciduus. Cerolla petala $4-5$, incisa. Stamina plurima, disco inserta, a $n$ theris cuspidatis. O varium unum ..... Sty lus subulatus; stigma simplex. CapsuIa lignosa, quadrivalvis, valvis extus echinatis, intus pulpa farinacea repletis, medio seminiferis. Se mina in quavis valvula 1 v. 2, basi arillata....-Arbor javana, excelsa; foliis alternis, petiolatis, ovalibus, acutis $v$. acuminatis, pedunculis lateralibus, unifloris.

Echinocar pus Blume Bijar, 56. Meismer Gen, 19. (17.)

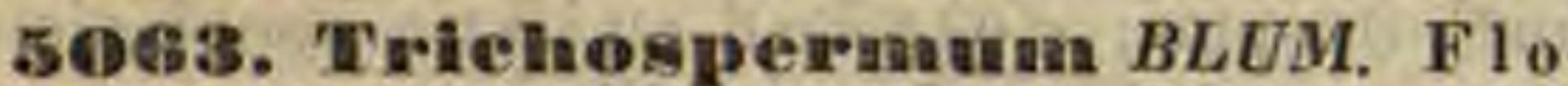
res hermaphroditi. Caly $x$ pentaphyllus, deciduus, foliolis ovalibus, aestivatione imbricatis. Co rol 1 ae petala 5 , ovalia, calyce paullo minora. Stamina plurima, disco hypogyno inserta; filam enta libera, antherae didymae. Ovari u m subbiloculare..... Stylus nullus; s $t$ ig mata 2, emarginata. Cap 8 ula reniformis, bi valvis, valvis extus hirtis, medio placentam linearem gerentibus. Semina plura, lenticularia, aril lata, ambitu ciliata. E m bry o intra albumen car nosum; cotyledonibus foliaceis, orbieulatis, radicula centripeta. - Arbor javana; foliis alternis, ovato-oblongis, serrulatis, basi cordatis et subtus biglandulosis, stipulis ovatis, cymis axilla ribus, solitariis.

Triehospermum Blume Bijdr. 56. Meisner Gen. 19. (17.)

5Q64. Hindackenia PRESL. Flores …. C aly x pentaphyllus, sero deciduus; foliolis ovalibus, laevibus, reflexis. Co rolla...... Sta mina.... Dis cus nullus. Ovarin m... Stylus terminalis, persistens, erectus, longus, subtriqueter; stigmat a 3 , lanceolata, acuta reflexo-patentia. Capsula stylo indurato supera ta, subglobosa, lignosa, aculeis rigidis, e basi lata acutatis, patentibus echinata, unilocnlaris, bival vis, valvis medio seminiferis. Se m i na nunc uni eum, subglobosum, nunc quatuor angulata, tes $t$ a membranacea, sicca. E $m$ b r $\mathbf{y} 0$ in axi albuminis carnosi orthotropus; cotyledonibus cordatis, planis, radicula tereti, umbilico proxima. Arbor $v$. frutex mexicanus, non satis notus; ramis angulatis, foliis alternis, petiolatis, oblongo-lanceolatis, integerrimis, supra nitidis, penninerviis, reticulato-venosis, stipulis ...., racemis axillaribus, multifloris, fructibus pedicellatis, Aesculi Hippocastani capsulas juniores referentibus.

L i udackeria Presl in Reliq. Hänk. [II. 89, t. 65 . Meisuer Gen. 19. (17.)

50B5. Demlanmia MEISN, $\ldots \ldots$ C a $\mathrm{p}-$ sula basi calyce cupuliformi, minuto stipata, ovoídea, subearnosa, laevis, incomplete triloeularis, ab apice trivalvis, valvis crassis, basi coalitis, medie semisepta seminifera gerentibus. Scmina juxta utrumque semiseptorum marginem gemina, superposita, pendula, ovoidea v. mutua pressione angulata, umbilico et rhaphe filiformi, longitudinali manifestis, epidermide carnosa, testa crasse coriacea. $\mathbf{E} \mathbf{m}$ b ry 0 in axi albuminis carnosi magnus, orthotropus; cotyledonibus ovalibus, obtasissimis, submembranaceis, radicula brevi, obtusa, umbilico proxima, supera. - $A r$ bor v. arbuscula Novae-Hollandiae orientalis sublropicae; foliis alternis, petiolatis, elliptico - v. lineari-oblongis, acutis, integerrimis v. obsolete dentato-serratis, coriaceis, supra glaberrimis, subtus albo-farinosis, stipulis nullis, fructibus albis.

Denham ia Meisner Gen. 18. (16.) nou Sehott Le ucoearpon A. Richard Sert. Astrolab. 46. $t$, 18, non Brid:

TREIBUS II. PROCKIEAE. S $t y l u s$ simplex. Fructus indehiscens.

506s. Carpotroche. Flores abortu polygami. Cal yx triphyllus, deciduns, foliolis concavis, patentibus, sericeis. Corolla e petala 9, hypogyna, sericea, ovalia, aestivatione imbricata, patentia. Stamina plurima, annulo hypogyno dentato, demum aucto extus inserta, multiseriata, corolla breviora; fil am enta filiformia, libera, a $\mathrm{t}$ h er a e biloculares, oblongo-lineares, erectae, muticae, loculis oppositis, adnatis, longitudinaliter dehiscentibus. Ovari u m (in floribus masculis nullum) intra discum sessile, liberum, globosum, alis longitudinaliter $12-14$, cristis totidem inter alas brevioribus, disci hypogyni dentibus oppositis, uniloculare. Ovula in placentis parietalibns sex v, septem plurima, nultiseriata, pilosa, pendula, anatropa. Styli $6-7$, breves, basi plus minus connati, apice distincti; $8 \mathrm{tigm}$ at a subcapitata. B a c e a globosa, lignosa, sericea, alis 12_14 latioribus transversim venosis, cristisque totidem angustioribus, undulatis, unilocnlaris, pulposa. Semina plurima, parietalia, angulata, epidermide carnosa, pulposa, testa crustacea, rhaphe filiformi ab umbilico basilari umhonato ad chalazam apicalem suborbicularem, ampląm producta. E mb ry o in axi altuminis carnosi orthotropns; cotyledonibus foliaceis, subcordatis, radicula tereti, nmbilico proxima, centrifuga. - Arbores brasilienses; foliis alternis, petiolatis, serrulatis, stipulis petiolaribus subulatis, deciduis, floribus in racemos simplices, erectos dispositis, odoratis, albis, fragrantibus, sericeis, maseulis minoribus, paucioribus, in diversis arboribus ab hermaphroditis segregatis, pedicellis bractea, bracteolisque duabus alternis munitis, supra bracteolam superiorem articulatis, fructibus pugni mole. M a y it a Raddi Plane, nuon, Brasil. 23, f. 1. Zuecarini Nov, stirp. pug. II, 363. t.5. 6, non Aubl. (v. supr.n. 473t.) 
5068. Dneolba FORSK. FIores hermaphroditi. C al y $\mathrm{x}$ ad basim quinquepartitus, deciduus, laciniis obtusis, concavis, aestivatione imbricatis. Corollae petala 5, hypogyna, calycis foliolis alterna et longiora, ovalia, obtusa, patentia. Stamina plurima, annulo hypogyno earnoso, lato, prominenti pluriseriatim inserta, petalis breviora; fil amenta filifurmia, libera, ant herae biloculares, oblungo-lineares, Joeúlis oppesitis, connectiso filiformi ultra eosdem in apiculum producto adnatis, tongitudinaliter dehiscentibus. O variu m in disco sessile, liberum, globoso-depressum, sulcatum, uniloculare. Ovula in placentis parietalibus prominulis quinque $\mathrm{v}$. decem plurima, biseriata, anatropa. Stylu s terminalis, simplex, cylindrieus; stig ma terminale, orbiculato-disciforme, radiato-sulcatum. B a c c a coriacea, globosa, sulcata, unilocularis, intus pulposa. S emina plurima, parietalia, in pulpa nidulantia, ovoideooblonga, testa crassiuscule coriacea, rhaphe filiformi, solnbili. E m b r yo in axi albuminis carnosi orthotropus; cotyledonibus planis, obtasis, radie al a brevissima, tereti, umbilico prosima, centrifuga. - Arbor Africam tropicam, a Nubia, ad promontorium viride inhabitans, biorgyalis, ramosissima, spinis extraaxillaribus simplicibus, foliis alternis, petiolatis, ovalioblongis, acuminatis, serratis, stipulis nullis, floribus ramulos terminantibus, magnis, albis.

O n c o b a Forskael Aegrpt. 103. Jassien Gen. 292. Lam. t. 471. A. Richard Flor. Seneg. I. 32. t, 10. Meisuer Gen. 18. (17.) L u ud i Thonning et Schumacher Plant. Guin. II, 5,

5oss. Plagberos LOUREIR. Flores unisexuales. Cal y $\mathrm{x}$ decem-duodecimpartitas, persistens, laciniis biseriatis, rotundatis, interioribus inaequalibus, aliis exteriores aequantibus, aliis minoribus. Co rolla nulla. Stam in a plurima, toro expanso inserta; filamenta filiformia, libera, a ntherae biloculares, versatiles, Joculis basi rimulis duabus apertis, connectivo in aenmen attenuatum, obtusum longe ultra loculos producto, Ovarinm ...... Stylus terminalis, crassus, acutns; st ig ma capitatum, angulatum, snpra triquadrisulcum. B a c c a tri-tetrasperma. Semina arillata?... - Frutices Asiae tropicae, non satis noti, inermes $v$, spinosi; faliis alternis, crenato-serratis, serraturis glanduliferis.

P boberos Loureiro Flor. Cochinch. 389. Wight et Arnott Prodr. 1,29 . Meisner Gen, 18. (17.) Fla co urtiae sp. Wallich.

5QB9. IShinanthere BLUM. Flores hermaphroditi (?) C a ly $\mathrm{x}$ uctopartitus, persistens, laciniis biseriatis, interioribus majoribus, basi biglandulosis. Corolla nulla. Stamin a plurima, inaequalia, a $\mathrm{n}$ h h ra e rostratae, biloculares. 0 varium ..... Stylus brevis; stigma obtusum, tri-tetragonum. B a ce a globosa, stylo persistente rostrata, tri-quadrilocularis. S e $\mathrm{m} \mathrm{ina} \mathrm{in} \mathrm{loculis}$ 2_4. E mbryo....-Frutex javanicus, ramosus, spinosus; foliis alternis, ovato-oblongis, serrulatis, basi biglandulosis, coriaceis, glabris, racemis axillaribus et terminalibus, brevibus, tomentosis, floribus parvis, odoratissimis.

Rhina nthera Blume Bijdr. 1121.

5080. Fualia $L A M$, Flore sermaphroditi. C a lyx quinque - septempartitus, persistens, laciniis coloratis, ovalibus, aestivatione imbricatis. Corolla nulla. Sta mina plurima, diseo glanduloso calycis fondum vestienti inserta; fil a menta capillaria, libera, anth erae introrsae, bilo- cnlares, subgloboso-didymae, loculis longitudinaliter dehiscentibus. Ova rinm sessile, liberum, ovatum, uniloculare. Ovula in placentis parietalibus tribus v, quatuor plurima biseriata, v. gemina collateralia, Stylus terminalis, filiformis; stig ma tri-quadrifidum. B a oc a globosa, coriacea, stylo superata, unilocularis. Se m in a pauca .... - Frutices mauritiani; foliis alternis, exstipulatis, scape in eadem stirpe variis, floribus in axillis foliorum v. secus ramos sessilibus, albidis.

Ludla Lamark Dict. IIT. 612, $t$. 466. Jacq. Hort. Schönbr. 2. 119. DC. Prodr. I. 261. Meisaer Gen, 19. (17.)

50ร1. Ihaetia LUFFL. Flores hermaphroditi. Calyx pentaphyllus, foliolis coloratis, aestivatione imbricatis, ovatis, marcescentibus. $\mathrm{C}_{0}-$ roll a e petala 5, hypogyna, calyeis foliolis alterna, aestivatione imbricata, saepissime nulla. St a min a plurima, toro glanduloso inserta; $\mathrm{fi}_{-}$ Iamenta filiformia, libera, aequalia; antherae introrsae, biloculares, ovatae, dorso affixae, loculis subdistinetis, longitudinaliter dehiscentibus. Ovari u m sessile, libernm, ovatum, uniloculare. Ovula in placentis parietalibns tribus plurima, pendula, anatropa. Stylus terminalis, brevis; stigma parvum, obsolete lobatum. B a c ca ovata v. trigona, coriacea, stylo mucronata, unilocularis. Semina in placentis parietalibus tribus plurima, subbiseriata, epidermide membranaceo gelatinosa, testa roriacea, endoplenrae arcte adhaerente, E $\mathbf{m}$ bryo in axi albuminis carnosi orthotropus; cotyledonibus suberbiculatis, foliaceis, radicula umbilico proxima, centrifuga. - Arbusculae Americae tropicae, ramosissimae; foliis alternis, petiolatis, crenatis $v$. serratis, pellucido-punctatis, stipulis petiolaribus geminis, deciduis, floribus in racemulos axillares $v$. terminales dispositis, bracteolatis, albis $v$. flavidis.

L a e tia Lüfliug Th, 232. Lins. gen, $n$, 651. Jaeq. Amer. 167., 108. 183. f. 60. Swartz Flor. Ind. occid. IT, 950. Kunth in Humb. et Bonpl. Nov, gen. et sp. V. 355. DC. Prodr. I. 260. Martius Nov. gen. el sp. II, 27. t. 165. Meisner Gen. 19. (17.) T h a m $n$ i a P. Browae Jam. 2ss, $t, 25, f .2$. H e 11 . wing in Adanson Fam. IT, 167.

5ดระ. IProekia $P$. BROWNE. Fiores hermaphroditi v. abortu unisexuales. Calyx tripentaphyllus, foliolis coloratis, aestivatione imbricatis, inaequalibus, oratis, inarcescentibus. Corolla nulla. Stamina plurima, toro glanduloso inserta; fil am enta eapillaria, libera, aequalia, a $n$th er a e introrsae, biloculares, subglohoso. didymae, loculis longitudinaliter dehiscentibus. O varium sessile, liberum, nniloculare. $\mathrm{Ovula}$ in placentis parietalibus tribus plurima, anatropa $S$ ty 1 as terminalis, filiformis; st igmate olstuso, v. stylus subnallus, stigmate late suborbiculato, planinseulo. B a e ca globosa, sobexsucea, uniloendaris. Se $m$ in a $6 \_8$, in placentis parietalibus biseriata v. gemina collateralia, angulata $\ldots \ldots \mathbf{E} \mathbf{m}$ b ryo ineurvns.... - Frutices a mericani et mauritiani, vix congeneres, sed mihi quoad fructum incogniti; foliis alternis, integerrimis $v$. dentatis, glabris, stipulis petiolaribus, deciduis, floribus axillaribus, pedunculatis.

Prock ia P. Browne in Linn. gen. n. 667, Lam. Dict. V. 625. DC. Prodr. I. 260. Meisuer Ger. 19. (17.)

a, PROCKIARIA.DC, $l$, e. Sty 1 us filiformis; $s t i g$ th te obtuso. T i ue a Spreng. N. E, II. 165. (Lam. t. 465,f.1.3.)

b. APHLOIA DC. $l$. $c$. Stig un sessile, late orbiculatam; planiuseulum. Light foo fia. Swartz Prodr. 83, non Herit. L u di a e s p. Bory Voyage $I Y, t, 24$. (Lam, $t .465$. f. 8.) 
5083. Tamara $A U B L E T$. Flores hermaphroditi. Caly $x$ sexpartitus, persistens, laciniis aestivatione imbricatis. Corolla e petala 6 , sub disco hypogyno inserta, calycis foliolis alterna, subrotunda. Stamina plurima, cum petalis inserta; filamenta filiformia, anthera e introrsae, biloculares, loculis longitudinaliter dehiscentibus. $O$ v a ri $\mathbf{m}$ liberum, diseo orbiculato, plano insidens, uniloculare. $O \mathrm{v}_{\mathrm{u}} 1 \mathrm{a}$ in placentis parietalibus tribus plurima, anatropa. Stylus simplex; stigma capitatum. Ba c ca globosa, fere sicea, stylo mucronata, uniloeularis. ..... S e min a plurima, striata. ....-Arbuscula g uianen$s i s$; ramis vimineis, foliis alternis, ovato-oblongis, acutis, denticutatis, subtus subtomentosis, stipulatis, floribus axillaribus et terminalibus, racemosis, flavis, pedicellis unibracteatis.

B a nar a Aublet Guian, 1, 547, t, 217. Jussien Gon. 293. DC. Prodr. I. 259. Meisner Gen. 19. (17) A s er a Sehott in Sprengel Cur. post. 407. B o e a Flor. Flumin. $V . t, 113$. ? Prockiae $8 \mathrm{p}$. Hooker Ic. $t, 74$.

XYLADENIUS Desvaux in Hamilt. Prodr. Flor. Ind. occid, 41 . C a I y $x$ profunde tripartitus. P et a 1 a 3 , tomentosa, marcescentia. Stamina plurima, inclusa. Stylus unicus; 8 tigma peltato-umbilicatum. Capsula nnilocalaris, polysperma. - Arbor guianensis; ramis rugoso. glandulosis, junioribus pubescentibus, folits alternis, subcordato-lanceolatis, aouminatis, remote serrato.dentatis, subglabris, dentibus uniglandulosis, glandula unilaterali ampliore, cuculliformi ad basim. - ? В а и аг a fag ifoti a Vahl Symb, HT. 65.

50\% 4. Hâlalía $H, B, K$. F lore s hermaphroditi, Calyx sex-octofidus, persistens, laciniis biseriatis, obtusis, conniventibus, interioribus majoribus, aestivatione imbricatis. Sta m in plurima, hypogyna, exserta, omnia fertilia; fila ment a tiliformia, libera, a $\mathbf{t}$ herae bilocula res, ellipticae, loculis contiguis, longitudinaliter dehiscentibus. Ovarium sessile, liberum, subglobosum, uniloculare. OvuIa in placentis parietalibus tribus plurima, horizontalia, anatropa. St yI us terminalis, brevis; tigma indivisum, obtusum. B a ce a globosa, stylo mucronata, unilocularis. Sem in a in placentis parietalibus tribos plurima, obovato-pyriformia, testa crustacea, undulato-striata, rhaphe filiformi ab umbilico basilari attenuato ad chalazam apicalem nmbonatam producta. Embryo in axi albuminis carnosi orthotropus; cotyledonibus erassis, plano-convexis, obtusis, radicula tereti, umbilico proxima, centrifuga, - Arbores Novo-Granaden $s e s$, inermes; ramis sparsis, foliis alternis, serra tis, stipulis petiolaribus geminis, paniculis terminalibus, fructiferis lateralibus, solitariis, subsessi libus, bracteolatis, floribus pedicellatis, subfasciculato-congestis, albidis.

$\mathrm{K}$ a bli a Kunth in Humb. el Bonpl. Nov. gen, et sp. VIII. 234. $t$. 652. 653. Meisner Gen. 18, (17.) non Reunw.

50\%5. Azara RUIZ et PAV. Flores her maphroditi. CaI y $\mathbf{x}$ quadri septempartitus, persis tens, laciniis aestivatione valvatis $v$. subimbrica tis. Corolla nulla. Stamina plurima, disco carnoso calycis fundum vestienti inserta; filamenta capillaria, libera, omnia fertilia v, plurima ananthera, antherae introrsae, biloculares, subglobosae, loculis rima longitndinali dehiseentibus. O va ri um sessile, liberum, suliglobosum, uniloculare. Ovula in placentis parietalibus tribus plurima; horizontalia, anatropa. Stylus terminalis, simplex; stig ma obsoletissime trilobum. B a c a globosa, stylo superata, sicca, uniloeularis, apice in styli basi fissura dehiscens. S e mi- $\mathrm{na}$ in placentis parietalibus tribus abortu panea, adscendentia, angulata, epidermide spongiosa, testa crustacea, rhaphe lata, ab umbilico basilari ad chalazam dilatatam apicalem producta. Emb ryo in axi albuminis carnosi orthotropus; cotyledonibus foliaceis, reniformibus, radicula umbilico proxima, infera. - Frutices $v$. arbores chilenses, frondosae, denuo scrutandae; foliis amarissimis, alternis, petiolatis, integerrimis $v$. serratis, glabris $v$. subtus tomentosis, stipulis petiolaribus geminis, foliaceis, plerumque valde inaequalibus, altera nana, saepe obsoleta, floribus corymbosis $v$. spicatis, fragrantibus.

A z a ra Ruiz et Pavon Prodr, I, 79, 1. 36. Syst, 137. DC. Prodr, I, 262. Dou in Edinb. new philosoph. Journ. X, 117. Meisner Gen, 19. (17.) LilenI a Bertero in Bullet. sc. nat. $\mathrm{XX}, 108$.

a. EUAZARA. Calyx quínque-septempartitus, patens, Iacinils aestivatione subimbricatis, basi liappendiculatis. Sta mina indefinita, plurima ananthera. - Folia dentata. Stipulae foliaceae, inaequales, allera maxima, diutius persistens. - Don l. c. (Hooker ad Beechey t. 4. Pöppig Nov. gen, et sp. t. 167.)

b. ALMEJA. Caly $\mathrm{x}$ quadrifidus, connivens, lobis aestivatione valvatis, basi interiore squamula auetis. S $t$ a$\mathrm{m}$ in a in fasciculis perigonii laciniis alteruis, definite numerosa, onaia fertilia. - Folia plerumque integer. rima, Stipulae foliaceas subaequales, persistentes. Flores spicati. Dou l. c. - Azara integrifolla Ruiz et Pav.

5086. Fineda RUIZ et PAV. Flores hermaphroditi. Caly $\mathrm{x}$ octo-decempartitus, persistens, laciniis biseriatis, exterioribus majoribus valvatis, interiores imbricantihus. Corolla nulla. St a m in a plurima, disco carnoso, piloso, calycis fundum vestienti inserta; filam enta capillaria, libera, omnia fertilia, antherae introrsae, biloculares, subglobosac, Ioculis longitudinaliter dehiscentibus. $O$ va ri $\mathbf{m}$ sessile, liberum, subglobosum, nniloculare. Ovula in placentis parietalibus tribus v. quinque plurima, adscendentia, anatropa. Stylu s terminalis, simplex; stigm a obsolete tri-quinquelobnm. B a c ca globosa, stylo superata, sicca, unilocularis, apice in styli basi fissura dehiscens. Semina in placentis parietalibus tribus v. quinque abortu pauea, adscendentia, subrotundo obovata, epidermide crassiuscula, cellulosa, testa crustacea, rhaphe dilatata, ab umbilico basilari fistuloso ad chalazam apicalen areolaeformem producta. Em hryo in axi albuminis carnosi orthotropus; cotyled onibus reniformibns, radicula brevi, obtusa, nmbilico proxima, infera. - Frutex peruanus, erectus, ramosissimus; foliis sparsis, petiolatis, elliptico-oblongis, basi integerrimis, apice serratis, mucronatis $v$ retusis, utrinque ramulisque pube brevissima, simplici incano-tomentosis, stipulis ad basim petiolorum geninis, parvis, subulatis, deciduis, floribus terminalibus paucis, corymbosis, pedunculis filiformibus, unifloris, calycibusque undique tomentosis.

Pineda Roiz et Payon Prodr. 76. t. 14. Syst. I, 133. DC. Prodr. II. 54. Don in Edinb, new philosoph, Journ. X. 116. Meisner Gen, 73. (59.) Hom alli s p. Pers.

5อรร. Christanmia PRESL, Flores hermaphroditi. C a lyx sexpartitus, persistens, laciniis lanceolatis, acntis. Corolla e petala 5, perigyna, persistentia, calycis foliolis alterna et subconformia, paullo majora. St a min a plurima, perigyna, omnia fertilia; fil amenta filiformia, patentia, antherae biloculares, subglobosae, dorso affixae, longitudinaliter extus dehiseentes. Ovarin m sessile, liberum, subglobosum, uni- 
loculare. Ovala in placentis parietalibus tribus plurima, subtriseriata ..... Stylus terminalis, teretiuseulus; $s \mathrm{tig} \mathrm{ma}$ indivisum, obtusum. Ba cc a subglobosa, stylo mucronata, unilocularis, Sem in a plnrima. .... - Frutex peruanus; ramis ramulisque sparsis, foliis alternis, petiolatis, denticulatis, stipulis petiolaribus geminis, setaceis, deciduis, pedunculis terminalibus bifloris, pedicellis bractea suffultis.

Chr is t annia Presl in Helig, Hänk. II, 91. $t$. 67.

5079. Dasyantherra PRESL. F lores hermaphroditi. Caly $\mathrm{y}$ tetraphyllus, persistens, foliolis oblongis, aestivatione valvatis. Coroll a e petala 4, hypogyna, calycis foliolis alterna et conformia, paullo majora, aestivatione valvata, persistentia. Stamina plurima, hypogyna, exserta, omnia fertilia; filamenta filifurmia, li bera, a $n$ therae biloculares, subglobosae, piloso-hispidae, extus (?) longitudinaliter dehiscen tes, deciduae. Ovarin m sessile, liberum, globosum, uniloculare. Ovila ..... Stylus ter minalis, crassus; $s \mathrm{tig}$ a quadrilobum. B a cc a globosa, stylo mucronata, unilocularis. S e mina $3-8$, per placentas parietales duas $v$. tres irregula. riter sparsa, semilunaria, compressa, inaeqnaliter rngosa, fusca...-Arbor v. frutex $l u z$ on ensis; foliis alternis, coriaceis, repandis $v$. serratis, racemis axillaribus $v$. terminalibus, multifloris, bracteatis.

Dasianthera Presl in Heliq. Hän, II. 90, $t, 66$. Meisner Gen, 19. (17.)

TIE IB UIS I II. FLACOURTIANEAE. S t ylus simplex. Fruetus indehiscens.

5อร9. Whacourtia COMMERS. Flores hermaphroditi, polygami v.dioici. Caly x quadriquinquepartitus, persistens v. deciduus, laciniis aequalibus, aestivatione imbricatis. Co ro il a nulla. Stamina plurima, hypogyna, pluriseriata; fil a$m$ enta filiformia, libera, an therae biloculares, reniformes, loculis connectivum latiusculum mar ginantibus, longitudinaliter dehiscentibus. G la ndula e hypogynae stamina cingentes, liherae $v$ in annulum connatae, saepius nullae. Ovari um sessile, liberum, placentis parietalibus sex ad decem, lamelliformibus, nunc abbreviatis unilocu lare, nune centrum attingentibus sex-decemloculare. Ovula in placentis alternis jnxta utrumque parietem gemina, superposita, anatropa, superios horizontale, inferius pendulum, placentis alternis sterilibus. Stig m a sessile, radiato tri-decemparti. tum, laciniis linearibus, superne sulco exaratis, apice dilatato bilobis. $\mathrm{B}$ a $\mathrm{c} \boldsymbol{c}$ a glohosa, 8 tigmate $\mathrm{co-}$ ronata, unilocularis, polysperma. S e m in a $6-20$, circa axim biseriatim superposita, lentienlari-com pressa, testa coriaceo-ossea. E mb r y o in axi albuminis carnosi ortbotropus; cotyledonibus planis, foliaceis, radic ula teretiuscula, umbili. co proxima, supera v. vaga. - Arbores $v$. frutices, in Madagascaria, Asiatropica et America aequinoctiali indigeni, saepissime spinosi, spinis axillaribus $v$, stipularibus, solitariis; foliis alternis, petiolatis, integerrimis $v$. denticulatis, stipulis nullis, floribus axillaribus, solitariis v. fasciculato-congestis, rarius racemulosis, pedicellis basi bracteatis.

F la c o u ti a Commers. ex Heritior Stirp. 95. Jussieu Gen. 219. DC. Prodr. I. 256. Kunth in Humb. et Bonpl. Nov. gen. et sp. VII, 238: Wight et Arnott Prodr. 1, 29. Meisner Gen. 18. (16.)

a. RAMONTCHI. CaI yx deciduus. Glandulae hypogy nae ad basin staminum nullae.

Species gerontogeae.
Stig u a rota Loureiro Flor, Cochinch, 778. DC. Prodr. I. 257. Rh a m nopsis Reichenb. Consp. 188. (Heritier t. 30. Lam, t. 826, Roxburgh Plant, Corom, $t .68 .69$. 222.)

b. CRAEPAlOPRUMNON. Cal y $x$ persistens. GIand aI a e hypogynae stamina eingentes, calycis lacinils gemibatim v. ternatim oppositae, saepius in anuulua connatae. - Species americanae. (Kuath in Humb, elBonpl. Nov. gen, et sp. t, 65d.)

5080. Thoumea POIT, Flores dioici. Caly x quadri-quinqnepartitus, membranacens, persistens, laciniis ovatis, obtusissimis, aestivatione imbricatis. Corolla nulla. Masc. Sta mina plarima, centrum floris occupantia, exserta; fila menta filiformia, libera, anthera evatosubrotundae, biloculares, loeulis contiguis. Ann ul a s erenatus basim staminum cingens. O vari i rudimentum nullum. Fe m. Sta min a m rudimenta nulla. O va ri um sessile, liberum, annulo erenato basi cinctum, calyce longius, uniloculare. $O \mathrm{v}$ u $\mathrm{ka}$ in placentis parietalibns quinque v. sex linearibus circiter viginti, adscendentia, anatropa. Styli 5_6, terminales, placentis alterni, breves, teretes, divaricato-snbreflexi ; stigmatibas suborbiculato-truneatis. Baeca pisiformis, stylis superata, unilocularis. Sem ina $6 \_8$, parieti reticutatae affixa, ovato - angulata, testa cartilaginea. Embryo in axi albuminis earnosi orthotropus; cotyledonibus ovatis, plano-convexis, $r$ adicula brevi, obtusa, umbilico proxima, infera. - Frutex do mingensis; ramis fastigiatis, primariis inferne spinosis, spinis ramosis, ramulis inermibus, foliis alternis, petiolatis, coriaceis, crenato-serratis, stipulis nullis (?), floribus axillaribus fasciculatim congestis, baccis croceis, pisiformibus.

$\mathrm{R}$ o u me a Poltean in Mem. Mrus, r. 62, t, 4. DC. Prodr. 1.256. excl, sp. asiat. Kunth in Humb. et Bonpl. Nov. gen, et sp. VII. 238. in not. Meisner Gen. 18. (16.) Ko el e ra Willd. Sp. IV. 750. excl. descript. B e s s e r a Sprengel Pugill. II. 90. exel. sp. asiat. Li m a ei a Dietrich.

508 1. Vuelieytug FORST. F Iores dioici. Caly x brevissimns, quinquedentatus, persistens. Corollae petala 5, hypogyna, calycis dentibus alterna, oblonga, aestivatione imbricata, calyce longiora. M a $8 \mathrm{c}$. S $t$ a $\mathrm{m}$ in a 5 , infra discum orlicularem, centrum floris occupantem, medio obsolete umbonatum inserta, petalis alterna; filamenta brevissima, anthe rae subsessiles, conniventes, introrsae, biloculares, cordato-tetragonae, loculis contiguis, juxta totam longitndinem dehiscentilus, connectivo filiformi, dorso medie lobulum brevissimum inter Ioculos exserente. Ovarii rudimentum nullam. Fem. Stamina 5 sterilia, hypogyna, petalis alterna, squamuliformia, ovarii basi adpressa. Ova ri $\mathbf{m}$ m sessile, liberum, ovatosubglobosum, uniloculare. Ovala in placentis parietalibus subramosis (?) plnrima, anatropa. Stigma sessile, radiato quadri-quinquelobum, lobis ovatis, patentibus. B a c c a coriacea, globosa, unilocularis, intus pulposa. S e min a pauea, intra pulpam nidulantia, angulata, epidermide, carnosula, testa crassiuscule coriacea, endopleura membranacea, chalaza apicali notata. E m b ry o in axi albuminis carnoso-oleosi orthotropus; c otyledonibus ovatis, subfoliaceis, radicula tereti, umbilice proxima, centrifuga. - Arbores Novae-Zeelandiae; folits alternis, petiolatis, serratis, stipulis nullis, pedicellis uniftoris, in axillis foliorum fasciculatis, foliis floralibus, saepius ante anthesim dejectis, ramis innascentibus. 
Melley tus Forster Char. gen, t. Ge. Gürtaer I. 206 , t. 44. f. 3. Lam. $t$, 812. DC. Prodr, I. 257. Meisner Gen, 18. (16.)

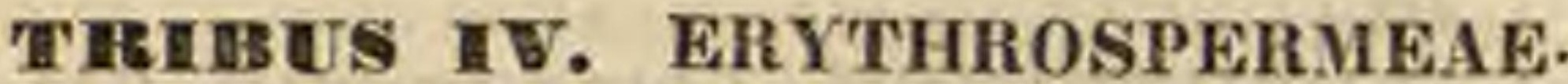
Stylus multiplex. Fructus dehiscens.

5082. Kágellaria $L I N N$. F lo r es dioici. Cal yx pentaphyllus, deciduas, foliolis ovatis, acutis, aestivatione imbricatis. Corolla e petala 5 , hypogyna, calycis foliolis alterna et majora, aestivatione imbricata, basi intus glandulis tribus, in floribns femineis defieientibus aucta. Diseus hypogynus nullns. Masc. Sta mina 10_20, in centro floris congesta; fil a m enta subnulla, antherae oblongae, biloculares, loculis oppositis, connatis, apice rimulis duabus sublateraliter de. hiscentes. Ovarii rudimentum nullum. Fem. Staminnm rudimenta nulla. O va rium sessile, liberum, nniloculare. $O \mathbf{v u l a}$ in placentis parietalibus plurima, anatropa. Styli $2-5$, terminales, breves, patentiusculi; $s t i g m$ a $t$ a simplicia, obtusa. Ca p s ul a globosa, coriacea, pubescenti granulosa, unilocularis, pulposa, incomplete tri-quinquevalvis, valvis medioseminiferis. Se mina plura, angulata, epidermide carnosa, testa coriacea. Embryo.... - Frutices capenses, inermes; foliis alternis, petiolatis, integerrimis $v$. serratis, velutinis, stipulis nullis, racemis axillaribus pacifloris, folio brevioribus.

Kigellaria Linn. Gen. n. 1128. Gärtuer I, 206. t. 44. Lam. t. 821 . Jacq. Collect. 296. Ic. rar. t. 628. DC. Prodr. I. 257, Meisner Gen, 18. (16.)

5083. Erytlanos perranum LAM. F Io $\boldsymbol{r}$ es hermaphroditi. Calyx penta-hexaphyllus, deciduus, foliolis membranaceis, coloratis, concavis, interioribus majoribus, aestivatione imbrieatis Corolla e petala $6-7$, hypogyna, calycis folio lis alterna et conformia, panllo minora. Di se us hypogynus nullus. Stamina $6 \_7$, hypogyna, petalis alterna, circa ovarium conniventia; fila menta brevia, libera, plana, cuneata, anthera e biloculares, loculis linearibus, connectivum adnatim marginantibus, longitudinaliter dehiscentibus. Ovari n liberum, uniloculare. Ovnla in placentis parietalibus tribus $v$. quatuor plurima, anatropa. Styli $3-4$, brevissimi, patentes; stig. m a $\mathrm{t}$ a simplicia, obtusa. Ca p s $\mathrm{n}$ l a coriacea, gra. nulata, globosa vel ovoidea, nnilocularis, ad mediom tri-quadrivalvis, valvis medio seminiferis. Semina pauca, oblonga, angulata, epidermide pulposa, ruberrima, testa coriacea. Embryo in axi albaminis carnosi orthotropus; cotyle doni. bus foliaceis, subcordatis, radicula umbilico proxima, centrifuga. - Arbores $v$. frutices ma ur $i$ tian $i$; foliis allernis $v$, ternatim verticillatis, breve petiolatis, integerrimis, nitidis, stipulis nullis, floribus terminalibus $v$. axillaribus, in racemos, paniculas v. corymbos dispositis.

E, r throspermum Lam, $t, 274$. Poiret Dict. Suppl. 1I. S94. Thouars Hist, Veg. Afr. austr, 65, t, 21. DC. Prodr. 1. 257. Meisuer Gen, 18. (16.)

\section{GENUS DUBIUM.}

3084. Taelnibota $A U B L$. Caly $\times$ quinquepartitus, laciniis oblongis, acntis, persistentibus, Coro 11 a e petala 5, hypogyna, oblonga, acuta. Sta mi na 6, hypogyna, petalis alterna; filamenta filiformia, antherae biloculares, sub. rotondae, $O$ varinm sessile, trigonum ...... Stigmata $3 \ldots$. Capsula trigona, trilocnla- ris, loculicide trivalvis, valvis medio dissepimenta margine seminifera gerentibus. Semina plurima, minuta, nigra..... - Frutex guianensis; ramis sparsis, rufescenti hirtis, foliis alternis, brevissime petiolatis, ovatis, integerrimis, glabris, stipulis ad basim petioli geminis, anguste acuminatis, deciduis, floribus axillaribus racemosis, parvis, albis, capsula nigra.

Tach ibot a Aublet Guian. I. 287, t. 112. Jussieu Gen, 295. S a Imas i a Sehreber. Gen. n. 513.

\section{PANGIACEAE Blum.}

5085. III dingecerpus $G A R T N$. F lo res dioici. Cal y $x$ pentaphyllus, deciduus, foliolis biseriatis, duobus exterioribus planis, tribus interioribus majoribus, concavis, subpetaloideis, aestivatione convolutis. Corolla e petala 5, hypogyna, exunguiculata, ciliato-fimbriata. Squa mula e 5, hypogynae, petalis oppositae et dimidio breviores, subearnosae, pilosae. Ma s c. St a m in a 5 , centrum floris oecnpantia, petalis alterna; filam enta subulata, libera, conniventia, basi pilosa, antherae biloculares, subreniformes, loeulis connectivum latiusculum marginantibus, Inngitudinaliter dehiscentibus. Ovarii rudimentam nullum. F e m. Stamina 5, petalis alterna, antherarum loculis efoetis. Ovarium sessile, liberum, uniloculare. Ovula in placentis parietalibns tribus v. quatuor plurima, pluriseriata, horizontalia, anatropa. Stigma peltatim sessile, latum, quinquepartitum, lobis planis, cuneatis, bifidis. B a cca globosa, stigmatis reliquiis incrassatis coronata; nnilocularis, pulposa. S e mi n a plurima, placentis parietalibus affixa, obovato-pyriformia, testa crustacea, Iongitudinaliter striata. E m b ry o in axi albuminis carnoso-oleosi orthotropus; cot y le do. nibus foliaceis, ovato-cordatis, radicula tereti, umbilico proxima, centrifuga. - Arbores Asiae tropicae; foliis alternis, petiolatis, ovatis, acuminatis, serrulatis, venosis, glabris, stipulis petiolaribus geminis, acutis, persistentibus, pedunculis axillaribus corymbosis, paucifloris, petiolum vix superantibus, baccis inebriantibus.

H y d no ear p s Gartner 1.288, t. 60. Vahl Symb. IrT. 100. DC. Prodr. I. 257. Wight et Arnott Prodr. I, 30. Meis. ner Gen. 18. (16.) Wight Iilustr. $t, 16$. G y noca rd ta Roxburgh Plant. Corom. IIT. 95. Meisner Gen, 73. (33.) Chaulmoogra Roxhargh Flor. Ind. III, 835. Chil. moria Hamilt. in Linn. Transact, XIII, 500. Marotti Rheede Malab. I. $t, 36, \mathrm{M}$ unnieksia Denstedt Mort. Malab, 1. $n, 36$. P a n g i i m Rumph Amboin. Ir. $t$. 59. Reluw. in Syllog. plant, II. 12.

\section{Drdo CXCVI. HIonculineae.}

HOMALINEAE R. Brown in Tuckey Congo 438. DC, Prodr. IT, 53, Barlling Ord. nat. 269. Meisner Gen, 73, (52.) HOMALIACEAE Lindley Introduct, edit. II, p. 55.

Arbusculae v. frutices, ramis alternis, teretibus. Foli a alterna, breve petiolata, simplicia, integra, integrerrima v. denticulata, penninervia. Stip ula e deciduae v, nullae.

Flores hermaphroditi, regulares, spicato racemosi v. panieulati, pedicellis ebracteatis.

Perigonium tubo brevi, turbinato v. subcampauulato, libero v. saepissime cum ovarii basi connato, limbo decem-trigintapartito, la- 
ciniis patentibus, biseriatis, interioribus angustioribus, tenerioribus, subpetaloideis.

Stamina summo calycis tubo inserta, numero subdefinito varia, plura ante limbi lacinias interiores subfasciculata, ante lacinias exteriores semper pauciora, v. saepissime nulla, et eorum loco glandulae liberae v. adnatae. Fil am en ta subulato-filiformia, libera. Antherae introrsae, biloculares, longitudinaliter dehiscentes.

Ovarivm semiinferum v. rarissime liberum, uniloculare, Ovula in placentis parietalibus duabus, tribus v. quinque, versus basim saepissime deliquescentibus, plurima, rarius pauca, subdefinita, pendula, anatropa. Styli placentarum numero, liberi v. basi connati, apice distincti. Stigmata simplicia v. capitata.

Fructes unilocularis, baccatus va saepius capsularis, apice in valvas medio seminiferas dehiscens, oligospermus v. abortu monospermus.

Senina inversa, ovata v. angulata.

EnвRxo in axi albuminis carnosi orthotropus; cotyledonibus foliaceis, radicula crassa, umbilico proxima, supera.

Hom aline a e nullibi copiosae, in America tropica cis jequatorem, Africae continente intratropico, Capite bonae spei, Madagascaria, insulis Borbonicis et Asia calidiore huedum observatae fuerunt. Affinitate inter Bixaceas, Samydeas et Passifloreas a natura locatae, ovario adhaerente, staminumque ante perigonii lobos interiores situ, optime distinctae.

508B. Fiomaliam $J A C Q, P$ er ig o $\mathrm{n}$ i u m tubo turbinato, enm ovarii basi connato, limbi semisnperi, dnodecim-quatunrdecimpartiti Johis biseriatis, patentibus, exterioribus panllo latioribus. Stamina summo ealycis tubo inserta, nmmero varia, ejusdem laciniis interiuribus ternatim quaternatimve opposita, cum glandulis carnosis, rarissime deficientibus, ante lacinias exteriores solitarie sitis alternantia; filamenta filiformia, libera, a n therae biloculares, dilymae, longitndinaliter dehiscentes. Ovarium semiinferum. uniloculare. Ovula in placentis parietalibus tribus plurima, pendula, anatropa. Styli 3 , filifor. mes, liberi v. liasi connati; st igmat a rapitata. Capsnla unilocularis, apice lreviter trivalvis, valvis medio semina pauca gerentibus. Semina parva, ovata. ...-Arbusculae Americae tropicae; foliis alternis, breve petiolatis, membranaceis $v$, coriuceis, dentatis $v$, rarius integerrimis, stipulis deciduis, floribus in spicas axillares v. terminales, simplices $v$. paniculatas dispositis,

H o m a li u macquin Amer. 170. $t$. 183. $f$. 78. Swartz Flor, 1nd, occid, 989, t. 17. Lam, $t$. 483. DC. Prodr, II. 53. Meisuer Gen. 73. (53.) A c o m a Adanson Fam, 11,510 .

a. NAPIMOGA Aabl. Glandulae ante calyeis Iacinias exteriores uullae. - Na p Imog a Aublet Guian, $\boldsymbol{I}_{.}, 592$. t. 237. DC. l. c. Meisner l. c. T a t i a Seopoli Intro. duct. $\pi .269$.

b. RACOUBEA Aubt. Q I a nd ula e calycis lacinis exterioribus oppositae, - $\mathrm{R}$ a co u be a Aublet Op. cit. $I .590$. t. 236. Lag u u z i a Seopoli Intraduct. $n$. 949.
5๑8ร. PHackweHia COMMERS, Perigon in tubo turbinato, cum ovarii basi connato, limbi semisuperi, coriacei, decem-trigintapartiti lobis biseriatis, patentibus, subaequalibus v, interiorilus latioribus. Stamina summo calycis tubo inserta, numero varia, nempe ejnsdem laciniis interioribus solitarie, geminatim ternatimve opposita, cum glandulis ante lacinias exteriores solitarie sitis v. iisdem adnatis alternantia; $\mathbf{f i} \mathbf{l}$ a $\mathbf{m}$ e $\mathbf{n}$ a filiformia, libera, an th erae introrsae, biloculares, didymae, longitudinaliter dehiscentes. Ovari n m semiinferum, uniloculare. Ovula in placentarum parietalium trium v. quinque, hasi deliquescentium apicibus subquaternatim pendula, anatropa. Styli $3 \_5$, subulati, basibus in conum connati; stigmata simplicia, acuta. Capsula unilocularis, ahortu mono-oligosperma. S emina inversa, angulata. $\mathrm{E} \mathbf{m b} \mathbf{r y o}$ in axi albuminis carnosi, parei orthotropus; cotyledon ib as foliaceis, radic u l a supera. - Arbusculae $v$. frutices, in Madagascaria, insulis Borbonicis, Asia tropica et Nepalia indigeni; foliis alternis, breve petiolatis exstipulatis, coriaceis, dentatis $v$. rarius integerrimis, glabris v. subtus pubescentibus aut tomentosis, spicis terminalibus et axillaribus, simplicibus $v$. paniculatis.

B La ok wellia Commerson ex Jussieu Gen. 343. Lam. t. 412. Venten. Choir t. 55-57. DC. Prodr, 11. 54. Lindley in Bot. Reg, t. 1308. Wallich Plant As, rar, t. 179. Meisner Gen. 73. (53.) Delessert To. select, III. t. 53. Vermontea Commers. ex Steudel Nomencl. 11t. Asteran. thi us Loureiro Flor, cochinch, 1, 273. DC. Prodr. II. 55. Hooker in Bot. Mag. 2. 2659. Meisner Gen, 73. (53.) P y. th a gor e a Loureiro Flor. cochineh.

5088. Anetia. Perigoninm tubo obconico, cum ovario connato, limbi superi, coriacei, decem-duodecimpartiti lobis biseriatis, exteriorilus angustioribus reflexis, interioribus erectis, conniventibus, margine induplicatis. St amina 15_-18, summo calyeis tubo inserta, biseriata, ejusdem laciniis ternatim opposita, duobus lateralibus exterioribus, tertio intermedio interiori, cum glandulis carnosis, 5 v, 6 interioribus extus, 10 v. 12 exterioribns intus oppositis, alternantia; filamenta filiformia, libera, antherae introrsae, bilocnlares, didymae, loculis longitudinaliter dehiscentilus. Ovarium inferum, uniloculare. Ovula in placentis parietalibus quinque, basi deliquescentibus plurima, pendula, anatropa. StyIu s fusiformis, erassas, (ovarium superum mentiens), apice quinquefidns, laciniis filiformibus; sti $\mathrm{m}$ a ta capitata. C a 8 u Ia unilocularis, abortn monosperma. S emen inversum, ovatum. E mbryo in axi albuminis carnosi orthotropus; cotyledonibus subreniformibas, foliaceis, radic n la crassa, supera. - Frutex Africae tropicae; ramis patentibus, foliis alternis, brevissime petiolatis, coriaceis, margine undulatis, floribus spicatoracemosis, parvis, cinereis.

B y rs a n thus Guillemin in Delessert Io. select. III. 30. $t$, 52. non Presl.

5089. Erivallaplaus NEES. Perigoni m tubo brevissimo, turbinato, libero, limbi decempartiti, coriacei lobis biseriatis, exterioribus basi glandulosn-incrassatis, interioribus angustioriluss. St am in a plurima, calycis tubo lana densa pulvinata vestito inserta, biseriatim fasciculata, fascieulis lobis interioribns oppositis subhexandris, alternis interioribas ante lobos exteriores sitis bitriandris; fil a menta filiformia, libera, anthera e introrsae, biloculares, didymae, loculis lon- 
gitudinaliter dehiscentibus. Ovarinm liberum, sessile, calycis lana velatum, uniloculare, Ovu1 a 4 , in placentis parietalibus duabus geminatim pendula.... Stylus crasses, cylindricus; stigma brevissime bilobum, lobis lunulato excavatis, Ba'eca subglobosa, stylo rostrata, tetrasperma. Sem in a angulata, nitida. ..... Arbores capenses; foliis alternis, exstipulatis, brevissime petiolatis, coriaceis, glabris, repando-denticulatis, racemis axillaribus, paucifloris. 271.

Eriudaphus Nees in Eicklon et Zegher Enumerat.

5096. IIIyoianthein THOUAR. Perigonium campanulatum, tubo cum ovarii basi connato, limbi decempartiti lobis exterioribns calycinis, oblongis, conniventibus, interioribns petaloideis brevioribus, unguiculatis. St amina pentadelpha, calyci inserta, fasciculis tetra-pentandris; filamentis tenuibus. Squama e 5 , staminum fasciculis alternae. Ovarium semiinferum, apice conicum, uniloculare. Ovula quatuor .... Styli 4. .... Fruetus abortn monospermns.... - Arbusculae $v$. frutices $m$ a $d a g$ as. carienses, elegantes; foliis alternis, breve petiolatis, crassis, floribus numerosis, in racemos axillares dispositis.

Myriantbeia Thouars Gen, Madagasc. $n, 7 t, \mathrm{DC}$, Prodr. II. 55. Meisuer Gen, 73. (52.)

5DD i . Nisa NORONH. Perigon i m turbinatum, tubo cum ovarii basi connato, limbi decem-duodecimpartiti lobis interioribus petaloideis, erectis. Stamina 5 v. 6 , calycis laciniis interioribus opposita. G $\mathrm{I}$ a nd $\mathrm{u}$ la $\mathrm{e} 5$ v, 6 , staminibus alternae. Ovarium semiinferum .... Styli 2 -3.... Fruetus... - Frutices $v$. arbusculae madagascarienses; foliis alternis, sinuato-dentatis, floribus spicatis, nudis, $v$. in involucris magnis, coloralis, compressis reconditis.

$\mathrm{Nis}$ a Noronba ex Thouars Con. Madagasc, $n, 81$. DC. Prodr, M. 55, Meisner Gen, 73. (52.)

5092. Asterepein THOUAR. Calyx magnus, quinquefidus, persistens, lobis oblongis, patentibus. Corollae petala 5, calyei inserta, ejusdem laciniis alterna, patentia, decidua. $\mathbf{S} t$ am in a 10, alterna breviora; fil amenta filiformia, basi in urceolum calyci adnatum coalita, a nther a e ovatae, obtusae, bilocuiares, dorso insertae, intus longitudinaliter dehiscentes. O $\mathrm{va}$ ri um liberum, sessile, triloculare. Ovala in loculorum angulo centrali pauca, superposita, amphitropa? Stylus brevis, trifidus; stigmata capitate. C a psu la calyce ancto stipata, trilocularis ...... s em in a reniformia ....... - Arbor madagascariensis, mediocris, Blackwelliae ex auctore affinis; foliis alternis, breve petiolatis, integerrimis, floribus in panicula terminali divaricata plurimis.

Asteropela Thouars Gen. Madagasc. n, 73, Hist. Veg. Afr. austr. $3 t, t, 15$. DC. Prodr. I. 55, Meisner Gen,
73. (53.)

\section{Drdo CXCEPII. Passifioreae.}

CUCURBITACEIS AFFINRS Jussieu Gen, 536. PASSI. FLOREAE Jussieu in Annal. Mus. VI. 102. Dict. sc. nat. XXXVIIT. 48. St. Hilaire in Mem. Mus, $V, 304, I X, 190, \mathrm{DC}$, Prodr. IIT. 321, excl. trib. 3. Bartling Ord. nat, 270. Meis. ner Gen, 124, (89.)
Herbae v. saepius suffrutices, plerumque scandentes, rarissime arborescentes, caule ramisque teretibus. Folia alterna, nune simplicia, integra v. lobata aut palmatim divisa, petiolo laminae continuo, nudo v. saepius utrinque glanduloso, nunc rarius composita, imparipinnata. Stipula e ad basim petioloram geminae, persistentes v. deciduae, interdum nullae. Cirrhi dum adsunt axillares, ex pedicellis sterilibus, nunc ex eadem cum fertilibus axilla nascentes, nune in axillis sterilibus orti, rarius pedunculi multiflori pedicello uno v. altero cirrhoso.

Flones hermaphroditi v. abortu unisexuales, regulares, speciosissimi. Pe dunculi saepissime uniflori, sub flore plerumque articulati, et ad articulum involucello triphyllo, v. gamophyllo tripartito instructi.

Penigonium corollinum, gamophyllum, tubo urceolato v. tubuloso, interdnm brevissimo subnullo, limbi quadri-quinque- rarissime tri-, saepius octo-decempartiti laciniis biseriatis, saepissime patentibus, exterioribus interdum herbaceis, interioribus magis corollinis, quandoque minoribus $v$, interdum deficientibus, fauce rarissime nuda, plerumque corona filamentorum uni-pluriserialium, distinctorum v. in tubum coalescentium munita. Tor us in laminam perigonii fundum vestientem, saepissime annullo plus minus manifesto definitam expansus, stipitem liberum, cylindricum, plus minus elongatum, rarissime abbreviatum, genitalia elevantem exserens.

Stamina rarissime subindefinita, plerumque perigonii laciniis exterioribus numero aequalia et opposita, (in nonnullis Modecceis iisdem alterna!) interdum dupla, nunc imo perigonio inserta, nune stipitis ovarii apici v. saepius basi hypogyne inserta; filam enta subulata v. filiformia, libera v. saepissime in tubum stipitem arcte vaginantem connata, apicibus distincta, anther a e introrsae, biloculares, dorso insertae, rarius erectae, saepissime versatiles, sub anthesi extrorsae, loculis parallelis, longitudinaliter dehiscentibus.

Ovarıu plus minus longe stipitatum, rarissime subsessile, uniloculare. Ovula plurima, in placentis parictalibus, saepissime tribus, rarissime quinque, uni-biseriata, funiculis plus minus longis, apice incrassato in cupulam expansis sustenta, anatropa. Styli placentarum numero, basi connati, apice distincti, patentes. Stig mata clavato-incrassata v, peltatim dilatata, interdum subbiloba.

Fructos unilocularis, nunc baceatus, carnosus, indehiscens, nune capsularis, crustaceus v. coriaceo-subvesiculosus, tri-quinquevalvis, valvis medio placentiferis. 
Semisa in placentis linearibus plurima, funiculis crassiusculis, plus minus longis sustenta, iisdem apice in arillum carnosum, saepe coloratum, cupulaeformem v.saccatum expansis excepta v. fere omnino inclusa, testa crustacea, impresso-scrobiculata, ab endopleura membranacea, rhaphe filiformi, nmbilicum basilarem cum chalaza apicali jugente percursa, solubili. A l b umen carnosum, testae scrobiculis punctatum.

Euвrxo in axi albuminis orthotropus, ejusdem fere longitudine. Cotyledones foliaceae, planae. R a dic ula teres, umbilico proxima, centrifuga.

Pas s ifl ora e miro florum decore insignes, in regionibus tropicis Novi continentis maximo numero generantur, in Asia et Australasia tropica multo rariores. Africa tam aequinoctialis quam australis extratropica, in minore specierum numero, formarum a typo primario deviantium feracissima.

Affinitate hinc inter ordines Parietalium Homalineis, Samydeis, Malesherbiaceis, Papayaceisque proximae, ab omnibus facillime distinguuntur, inde ad Capparideas, seminis structura et habitu longe alienas, et mediantibus Modecceis, ad Cucurbitaceas, ovario infero et embryone exalbuminoso diversissimas, accedunt.

TIR I BUS I. PAROPSIEAE. F 1 o $\mathrm{r}$ e $\mathrm{s}$ hermaphroditi. 0 va ri u $\mathrm{m}$ sessile v. stipitatum. Fructus capsularis. - Caules non scandentes, ecirrhosi.

5053. IRyania VAHL. Perigoninm quinquepartitum, persistens, laciniis biseriatis, lanceolatis, subaequalilus, aestivatione imbricatis, Corona nulla. Stamina plurima, hypogyna, subbiseriata; f il a $m$ e $n t$ a filiformia, libera, a $n t h e-$ $r$ a e introrsae, biloculares, longe lineares, dorso supra basim affixae, longitudinaliter dehiscentes. Discus urceolaris, petaloidens, laxus, ovarii basim cingens, interdum obsoletus. O va ri um ses. sile, uniloculare. $\mathrm{O} \times \mathrm{ala}$ in placentis parietalibus quatuor $\mathbf{v}$, quinque plarima, subuniseriata, horizontalia, anatropa. S ty I us terminalis, apice quadri-quinquefidus, st $\mathrm{g} \mathrm{gm}$ a ta capitellata, $\mathrm{C}$ a p s ula ovato-acuminata, suberoso-lignosa, unilocularis, tri-quinquevalvis, valvis medio placentam linearem gerentibus. S e min a plurima, subglobosa, arillo subcarnoso, juxta rhaphen longitudinalem adnato cineta. E $\mathbf{m b} \mathbf{r y} 0$ in axi albuminis se. baceo-carnosi orthotropus; cotyled on ibus pla. nis, foliaceis, subcordatis, ra di c nla tereti,-umbilico proxima, centrifuga. - Arbores Americae tropicae, pube stellata conspersae; foliis alternis, subintegerrimis, stipulis petiolaribus, geminis, deciduis, pedunculis axillaribus, solitariis v. geminis, basi bracteolatis.

R y a $\mathrm{i}$ a Vahl Eclog. I. 51, t,9. Meisner Gen, 124, (98.) $\mathrm{P}$ at risia L. C. Bichard in Act, soc. h. n. Paris. 111. Kunth in Humb. et Bonpl. Nov, gen. et sp. $\boldsymbol{V}$. 356. Delessert Io, select, III, 2, 14, R y a nea et Patris i a DC. Prodr. I. 255.

5994. Smeathmannia SOL. Perigon i um decempartitum, laciniis biseriatis, exterio- ribus semicalycinis, persistentibus, interioribus petaloideis, marcescentibus. Co r o n a urceolaris membranacea, imo perigonio inserta, simplex, abbreviata, ore denticulato. St a m in a circiter 20 , apici gynophori brevis inserta, nniseriata ; filamenta libera, anthera e biloculares, lineares, incumbentes, longitudinaliter dehiscentes. $0 \mathrm{v}$ ari um breviter stipitatum, nniloculare. Ov ula in placentis parietalibus quinque plurima, horizontalia, anatropa. Styli terminales $5 ; \mathrm{stigmata}$ peltata. Cap sula chartacea, inflata, unilocularis, quinquevalvis, valvis medio placentam filiformem gerentibus. S e min a plura, uniseriata, funiculi longi apice in arillum expanso excepta, testa crustacea, scrobiculata. E mbryo in axi albuminis carnosi orthotropus; cotyledonibus foliaceis, radicula umbilico proxima, centrifuga. - Frutices Africae tropicae, fortassis decumbentes; foliis alternis, oblongis $v$. ovatis, subdentatis, stipulis lateralibus, utrinque solitariis $v$. geminis, distinctis, callosis, floribus axillaribus, subsolitariis, pedunculis quandoque brevissimis, basi bracteolatis.

Smeathmannia Solasder msc. ex, $n$. Brown in Tuckey Congo 439. Linn. Transact. XIII. 220. DC. Prodr. IIT. 322. Meisner Gen, 124. (89.) B ül o w i a Schumacher in Danske Selskabs naturvidenskab. Afhandl. IV. 20.

5095. Paropsia NORONH. Perigoni u m desempartitum, laciniis biseriatis, interioribus subpetaloideis, minoribus. Corona filamentosa, imo perigonio inserta, filis capillaribus, uniseriatis, in phalanges quinque perigonii laciniis interioribus oppositas approximatis. S $\mathrm{ta}$ in a 5, perigonii laeiniis exterioribus opposita, basi cum gynophoro brevi connata; fil a menta apice libera, antherae biloculares, cordatae, dorso affixae, longitudinaliter dehiscentes. Ovarin m breviter stipitatum, uniloculare. $O \mathrm{v} \mathbf{u} 1 \mathrm{a}$ in placentis parietalibus tribns plurima, horizontalia, anatropa. Stylas terminalís, apice trifidus; 8 tigmata capitata. C a psu la subgloboso-trigona, vesiculosa, tomentosa, unilocularis, trivalvis, valvis medio placentam nerviformem gerentibus. S em in a plurima, ovato-compressa, funiculo longo, apice in arillum capnliformem expanso excepta, testa crustacea, scrobiculata. E m bryo in axi albuminis carnosi orthotropus; cotyledonibus planis, tenuissime foliaceis, ovatis, radicula brevi, umbilico proxima, centrifnga, - Frutex mada gascariensis, quinque-sexpedalis; folies alternis, ovato-oblongis, obiter serratis, stipulis nullis, floribus axillaribus fasciculatis, pedicellatis, arillo eduli suavissimo.

Paropsia Noronha ex Thouars Hist. Deg. Afr.austr. 59. $t, 19$. DC. Prodr. III, 328. Meisser Gen, 124. (89.)

TIEIBUS II. PASSIFLOREAE VERAE. F lor es hermaphroditi. Ovarium stipitatum. F ru ctus baccatus v. interdum capsularis. Caulis scandens, pedicellis axillaribus cirrhosis.

5096. Thompsono ía $R$. BR. C alyx octopartitus, laciniis biseriatis, interioribus paullo minoribus, coloratis: Corona filamentosa, imo perigonio inserta, filis uniseriatis. Stam in a 8 , basi cum gynophoro brevi connata; filamenta superne libera, alterna perigonii lobis exterioribus opposita paullo longiora, anthera e biloculares, ovato-oblongae, incumbentes, longitudina- 
liter dehiscentes, Ovarium breviter pedicellatum, uniloculare. Ovula in placentis parietalibus quatuor plurima, horizontalia, anatropa. S ty. lus terminalis, quadripartitus; stigmat a eapitata. Fruetus..... - Frutex madagas cariensis, cirrhis axillaribus scandens; foliis alternis, imparipinnatis, foliolis petiolulatis, ellipticis, coriaceis, pedunculis axillaribus, subquinquefloris.

Thompsonia R. Browu in Linn. Transact. XIIT. 220. Deid a minT hompsontana DC.

509\%. Deidamia THOUAR, Perigoniu m quinquepartitum, laciniis aniseriatis, intus coloratis. Coron a flamentosa imo perigonio inserta, filis uniseriatis. Stamina 5 , perigonii laciniis opposita, basi cum gynophoro brevi connata; filam enta apice libera, a $t h$ erac bilocalares, ovato-oblongae, incumbentes, longitudinaliter dehiscentes. Orarium breviter stipatum, uniloculare. Ovala in placentis parietalibus tribus v, quatuor plurima, horizontalia, anatropa. St y I us terminalis, tri-quadripartitus; $s \mathrm{tigma-}$ ta capitata. Capsula ovoidea, suberustacea, nnilocularis, tri-quadrivalvis, valvis medio placentam semicylindricam gerentibus. Semina plurima, ovata, compressa, funiculi longi apice in arillum expanso semiinclusa, testa crustacea, scrobiculata. Embryo in axi albuminis carnosi orthotropus; cotyledonibus foliaceis, radicula umbilico proxima, centrifuga. - Frutices madagascarienses, scandentes; foliis alternis, impari-pinnatis, foliolis bijugis cum impari, petiolulatis, obovatis $v$. ellipticis, integerrimis, apice nucronatis v. emarginatis, petiolulis basi glandulosis, cirrhis axillaribus, pedunculis axillaribus bi-septemfloris.

Deidam ia Thouars Hist, Veg. Afr, austr, 61, t. 20. DC. Prodr, III, 337. excl, sp. 3. Meisner Gen, 124. (90.)

50D8. Passifiorn JUSS. Perig on iu m tubo brevi, urceolato, limbi quadri-qninquepartiti laciniis nniseriatis, v. decempartiti biseriatis, coloratis. Coron a faucis filamentosa, filis bi-pluriseriatis. Urceolus subcarnosus, gynophori basim laxe cingens. St a $\mathrm{m}$ in a $4 \mathrm{v}$. 5 , perigonii laciniis exterioribus opposita, cum gynophoro longo connata; filamenta apice libera, antherae biloculares, oblongae v. lineares, incumbentes, longitudinaliter dehiscentes. Ovarium longe stipitatum, uniloeulare. $\mathrm{O} \mathbf{v} \mathrm{l}$ a in placentis parietalibus tribus plurima, pluriseriata, horizontalia, anatropa. Styli 3 , cylindrici; stigmat a capitata, Bacea subglobosa, pulposa v. interdum membranacea, subvalvata, nnilocularis, placentis parietalibus tribns. S e mina plurima, ovata, subcompressa, funicali apice in arillum carnosum expanso inclusa. $\mathbf{E} \mathbf{m}$ br y 0 in axi albuminis carnosi orthotropus; cotyledonibus foliaceis, radicula unbilico proxima, centrifuga. - Herbae $v$. frutices cirrhosi, scandentes, rarius arbores ecirrhosae, in America tropica copiose, parcius in Asia crescentes; foliis alternis, integris, lobatis $v$. divisis, stipulis ad basim petiolorum geminis, interdum nullis, psdunculis axillaribus, solituriis, geminis v. pluribus, uni-v, rarius plurifloris, superne articulatis, saepissime tribracteatis, bracteis interdum involucrantibus, perigonio admotis.

Pass iflora. Jussieu Gen, 397. Kunth in Humb. et Bonpl. Nov, gen, et sp. $I 1,126$. DC. in Mem, soe, $h, n, G e$ nev. I. 435, Prodr. III. 322, Meisner Gen. 124. (90,) G r an a diII a Tournefort Inst, 123, 124. Gärtuer I, 289. P a s. siflorae sp. Lian.

a. TETRAPATHEA De. $l$. c. Perigoni um quadripartitum. Stamiua 4. - Pedunculi triflori, ex alite axillis eirrhi, bracteae minimae v, obsoletae. - Species Novae.Zeelandiae.

b. CIECA $D C$. l. c. Perig o $\mathrm{n}$ i $\mathrm{m}$ quinquepartitum. S tamia a 5. - Pedunculi unifori, saepe ex eadem cum cirrhis axilla orti, bracteae minimae $v$, nullae. Cieca Medikus Malv. 97. A $k$ tephananthex et Monactineirma Bory in Annal. gen. sc. phys. Ir. 138. B a I d u in a Rafia. (Lian. Amoen. Academ, I.t, 10, f. 2. 3. 7. 13. 14. 16. Jacq. Hort, Schünbr, t, 181, Hort, Vindob. t. 20. Ic, rar, $t$, 606. Cavanill. Dissert. $\boldsymbol{X}$. t. 279_274. Jussiea in Annal. Mus, VI, $t, 38 . f$. 2 . t. 39, f. 2. Smith E.rot. Bot. I. t. 28. Bot. Reg. t. 79. 144. 188, 507. 600, 870. Pöppig Nov, gen, et sp. $t, 177$ -179.)

c. DECALOBA. Perigonium slecempartitum. Stami. na 5. Fruetus pulposus. - Pedunculi uni-multifori cum cirrhis nati, Bracteae obsoletae $v$. involucrantes, integrae $v$, integerrimae.

1. E udecaloba. Involucrum nullum $v$. minimum et a flore distans. Peduncali uniflori et eirrhi simpliçes ex eadeo axilla. - Folia lobata. De calo b a DC. $l, c$. Pass iftora Bory $l$. c. $t$. 24. (Linil. $t$. $c, t, 10$. f. 8. 9. 12. Jасq. Hort, Schönbr. t. 498. Smith Ic. pict, I, t, 1, Cavabill. Ic, $t, 269,290$. Tussac Flor. Antill, t. 4. Bot, Mag. t. 2868. Bot. Reg. t, 78, 95. 432. 577. 897 . Wight IC. $t, 39$.

2. Gr a n a di1la DC. $t$. c. Involucrum sub flore triphylIum, foliolis integerrimis v, dentatis, haud lacinistis. Pedunculi uniflori et cirrhi-simplices ex eadem axilla. - Folia integra, lobata v. dissecta. - A n thact ni a Bory t. c. (Lisu. Op. cit. $t, 10, f, 1,2,4-6$. 19_29. Aublet Guian. $t$. 324. 325. Jassieu Op, cit. t. 33, f. t. t. 39. 40, 41. $f, 2, t$. 65. Cavanill. Dis. sert. $t .280$ 282. 292. 294. '296. Bot. Mag. $t, 28.66$. 651. 1989. 2023. 2967. Bot, Reg. t. 13. 14. 88. 94.285. 332. 488, 584. 677. 848, 1339.)

3. Tacsonioides DC. 2. c. Tubus perigonil quam in eneteris longior, limbo tamen brevior. Infloreseeutia, cirrhi et involucrua Granadillae. - (Cavanill. IC. t. 425. Bot. Reg. $t$. 668.)

4. Pol y a the a D. l. c. Pedunculi wultiflor, cirrbiferi. Involuerum nullum v. minimum. P o I y a thea DC, l. c. (Linn. Op. cit. t. 37. f. 1, t. 41, f. t. Bot. Reg. 2. 59. Bot. Mug. t, 2015. Wallich Flor. Nepal. t. 1t. Blume Rumphia $t, 51$. 52. )

? d. DysosmiA DC. l. c. Perigo niam decempartitam. Stamiua 5. Fructus supeapsularis. - Pedunculi solitarii, unifmri, ex eadem cum cirrhis axilla orti. Involucrum su flore triphyllum, foliolis in lobos setaceos, apice glandulosos multipartitis, - (Linn. Op. cit. t, 10. f. 17. Cavanill. Dissert. X. t. 289. Bot. Mag. t. 288. 2619.)

e. ASTROPHEA DC. l. c. Perigoni um decempartitum. Stamina 5. Fruetus pulposus? - Arbores, cirrhis nullis, foribus exinvolucratis. (Humb. et Bonpl, Plant. aequinoct, $t$, 22, 23.)

5695. WImracula TOURNEF. P erigon i n m tubo brevi, subtns suleato, limbi quinquepartiti laciniis uniseriatis, v. decemportiti biseriatis, coloratis. Corona faucis simplex, uembranacea, tubuloso-conica, ore truncato v. denticulato. Ureeolus carnosns, gynophori basim laxe cingens, quinque-decemlobus. S ta m in a 5 , perigonii laciniis exterioribus opposita, cum gynophoro longo comnata; fil ament a apice libera, antherae biloculares, oblongae v. lineares, incumbentes, longitudinaliter dehiscentes. Ovari um longe stipitatum, uniloenlare. $O v \mathbf{v} \mathrm{Ia}$ in plarentis parietalibus tribus plurima, pluriseriata, horizontalia, anatropa. Styli 3 , eylindrici; stigmata capitata. B a c c a subglobosa, unilocularis, intus pulposa, placentis parietalibus tribns. S e m in a plurima, ovato-compressa, funiculi apice in arillum carnosum expanso inclusa, testa crustacea, scrobiculata. E mbryo in axi albuminis carnosi orthotropas; cotyledonibus foliaceis, radicuI a umbilico proxima, centrifuga. - Frutices a n- 
tillani, scandentes, cirrhiferi; foliis alternis, sub. orbiculatis, bi-trilobis, petiolis eglandulosis, stipulis setaceis, pedunculis axillaribus solitariis $v$. geminis, subunifloris, mediv tribracteatis, bracteis angustis, acuminatis.

M uruenia Tournefort Inst. 215. Jussieu Cen. 398. DC, Prodr. III, 333. Meisner Gen, 124. (90.)

a. PENTARIA DC. l. c. Perigo n ii limbus quinquepartitus. - Passiflora or bieulata Cavanill. Dissert. 10. t. 286.

b. DRCARIA $D C$. l, c. P e r Ig o n 1 lt limbus decempartitus. - Passiflora Murueuja Lina. Amoen, $1, t$. 10 . f. 10. Cavanill. Dissert. 10. $t$. 287. Bot. Reg. $t$. 574 .

5100. Disemna LABILL. Perigon i m tubo brevi, subtas suleato, limbi decempartitilobis biseriatis, interioribus minoribus, corollinis. C 0 ron a faucis duplex, exterior filamentosa, filis nniseriatis, interior tubuloso-conica, longitudinaliter plicata, ore truncato $v$. denticulato. Urceolus carnosus, gynophori basim laxe cingens, guinquelobus. Sta mina 5 , perigonii laciniis exterioribus opposita, eum gynophoro longo connata; fila $\mathrm{m}$ e $\mathrm{t}$ a apice libera, an $\mathrm{the}$ a biloculares, oblongae, incumbentes, longitudinaliter dehiscentes. O va ri n m longe stipitatum, uniloculare. Ovula in placentis parietalibus tribus plurima, pluriseriata, horizontalia, anatropa. Styli tres, cylindrico-subelavati; stigmata subcapitata. B a e a suhglobosa, uniloenlaris, intus pulposa, placentis parietalibus tribus, Semina plurima, ovata, compressa, funiculi apice in arillnm carnosnm expanso inclusa, testa ernstacea, scrobiculata. Embryo in axi albuminis carnesi orthotropus; cotyledonibus foliaceis, radicnla umbilico proxima, centrifuga. - Frutices Novae-Hollandiae tropicae et subtropicae, insularum$q u$ e adjacentium, Passiflorae facie; foliis alternis, tri-quinquelobis, stipulis setaceis, pedicellis axillaribus, solitariis v. geminis, unifloris, bracteis a flore remotis.

Dise m m a Labillard. Nov. Caled, 78, 1.79. DC. Prodr. IIT. 332. Meisner Gen, 124. (90.) P a s s Ifl o r a e s p. Forst. Andrews Bot. Beposit, $t$. 295. Bot. Reg. t. 233. 237. Wend-

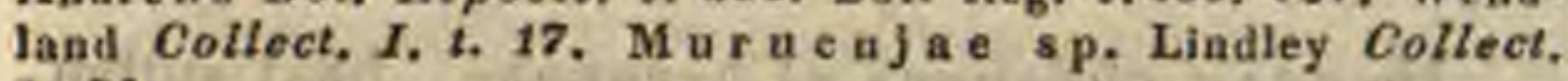
t. 36 .

5401. Tracsonaia JUSS. P e rigon in tubo longo, cylindraceo, limbi decempartiti laciniis biseriatis, interioribus paullo minoribus, petaloideis. Corona duplex, faucis annularis v. filamentosa, filis nni-biseriatis, medii tubi membranacea, integra $\mathbf{v}$. filamentosa, rarissime biseriata. Stamina 5, perigonii laciniis exterioribus opposita, cum gynophoro longo connata; fila menta apice libera, antherae biloculares, oblongae, incumbentes, longitudinaliter dehiscentes. Ovari um longe stipitatum, nniloculare. Ovala in placentis parietalibus tribus plnrima, pluriscriata, horizontalia, anatropa. Styli tres, cylindriei; stigmata capitata. Ba ec a subglobosa, unilocularis, intus pulposa, placentis parietalibus tribus. Semin a plurima, ovato-compressa, funieuli apice in arillum carnosum expanso inclusa, festa crustacea, scrobiculata. Embryo in axi albuminis carnosi orthotropns; cotyledonibus foliaceis, $r$ adi $\mathrm{e}$ la nmbilien proxima, centrifnga. - Frutices Americae tropica e, scandentes, cirrhosi, Passiflorae facie; folits alternis, stipulatis, integris $v$. trilobis, pedunculis axillaribus unifloris, solitariis $v$. geminis, braeteis liberis $v$. in involucrum connatis.
Ta csani a Jussieu Gen. 398. Annat. Mus, VX. 388. Kunth in Humb. et Bonpl. Nav. gen. et sp. II. 140. DC. Prodr. III. Meisner Gen. 124. (90.)

a. EUTACSON1A. Corona fancis et tubi simplex, meabranacea. Pas sifl or a e $s p$. Linn. Smith $I c$, inedit. $2,24$. 25. Cavanill, Ic. t, 426. 428, Dissert. X. t, 275. 276. (Jussieu in Annal. Mus. VI, t, 89.60.)

b. DISTRPHANA Juss, $l$. $c$. Coron a faacis doplex, tubi simplex vo duplex. - Distephia Salisbury msc. Passiflo ra e s p. Cavanill. Dissert. X.t. 281. (Püppig Nov. Gon. et sp. t. 180. 181.)

\section{GENUS DUBIUM.}

5102. Vareca GXRTN. B a cea supera, ovata, hexagona, disco parvo, obsolete sexcrenato insidens, brevi mucrone terminata, uniloenlaris, cortice coríaceo, tenui, carne per aetatem spongioso-membranacea, in cellulas partiales pro seminum receptione discreta, $S$ e $\mathrm{m}$ i na plura, alia placentis tribus parietalibus nerviformibus affixa, alia in centro nidulantia, omnia cellulis propriis carnosis inclnsa, majuscula, subovata, angulata, testa coriavea, crassa, endopleura membranacea, Embryo in axi albuminis carnosi orthotropus, ejusdem fere longitudine; cotyledonibus tenuissime foliaceis, ovatis v. rotundatis, $r$ a dícula teretiuscula, longa, centrifuga $v$. vaga. Stirps z eylanica, praeter fructum incognita.

Varec a Gärtner 1. 290. t. 60. Wa lwareka Cíngal.

THE IIS III. MODECCEAE. Flores unisexuales. Ovarium stipitatum, fructus capsularis. - Caulis scandens, pedicellis cirrhosis.

5103. Nollecea $L I N N$. F 1 or e s unisexnales. Involucellum nullum. Perigoninm campanulato- v. conico-tubulosum, limbi octo-decempartiti laciniis biseriatis, contignis v. exterioribus altius connatis, interiorilus minoribus profundins distinctis, tubo demissius insertis. M a sc. S q a a mu la e 5, petaloideae, imo tubo insertae, staminibus oppositae, interdmm nullae. St a mina 4-5, imo perigonio inserta, ejusdem laciniis exterioribus opposita, inelusa; fil a m ent a subulata, basi in annulum nembranaceum connata, anthe rae introrsae, biloculares, oblengo-lineares, erectae, loculis longitudinaliter dehiscentibns. 0 varii rudimentum fusiforme. Fem. S $t$ a m in a stelia 4 v. 5, imo perigonii tubo inserta, subulata, basi in annulum gynophorum eingentem eonnata. Ovarium stipitatum, uniloculare. 0 vala in placentis parietalibus tribus plurima, biseriata, horizontalia, anatropa. Stylus brevissimus v. subnullus; stigmata tria, dilatata, eltusa, subpetaloidea. Ca psula globosa suberustacea, v. elliptico-angulata, membranaceo-vesieularis, unilocnlaris, trivalvis, valvis medis placentam nerviformem gerentibus. S e min a plurima v. interdum ahortu pauéa, ovata, compressiuscula, funienli apice in arilium eyathiformem, carnosum expanso inclusa, testa crustacea, serobiculata, $\mathbf{E}$ m b r yo in axi albuminis carnosi, scrobienlati orthotropus; cotyledonibus foliaceis, radic ala nmbilico proxima, entrifnga. - Nerbue $v$ frutices, in Asia et Afriea tropiea indigeni; foliis alternis, indivisis v. palmatilobis, petiolis apice biglandulosis, stipulis obsoletis, pedunculis dxillaribus ramosis, ramis lateralibus pauci-multifloris, medio eirrhoso circinato, floribus viridulis, parvis. 
Modecea Lamark Dict, $I V$. 208. R. Beown in Bot. Reg. n. 433. DC. Prodr. III. 336. Wight et Arnott Prodr. I. 333. Meisner Gen, 124. (90.) Blume Rumphia I. 166.

a. MICROBLBPHARIS Wight et Arn. t. c. Perigonii conico-tubulosi tubus basi aequalis, limbi laciniae interiores exterioribus contiguae v. subcontiguae. - (Blume $O p$. cit. $t$. 48 -50.)

b. Blepharantuus Wight et Arn. l. c. Perigonil tubuloso-eampanulati tubus busi gibis $5-10$, limbi lacinlae interiores tubo demissius insertae, lineares, ciliatae. - B lepharan th us Smith Gramm, of Bot. 158. (Rheede Malab. VIIT, $t, 20$ 23. Jacq. Fragm, $t .131$. Bot. Reg. t. 433.)

5104. Paselnanthus BURCH. Flores polygami. In vol a c e $11 \mathrm{um}$ nullum (?) $\mathrm{Pe-}$ rig on i um persistens, tubulosum, decemfidum, lobis exterioribus ovatis, interioribus oblongolinearibus, petaloideis. S tamin a 5 , inter se libera; antherae lineares, basi insertae. Ovari um stipitatum; stig mata 3 , brevissima, C a psu la subbaccata, trivalvis, hexasperma. S e m in a arillo carnoso munita. - Frutex capens is, scandens; foliis glabris, glaucis, oblongo-linearibus, repandis, uninerviis, subtus triglandulosis, petiolis brevissimis, eglandulosis, pedunculis trifidis, ramis lateralibus unifloris, intermedio cirrhoso.

Paschanthus Burchell Travel. T. 843. DC. Prodr. IIT. 336. Meisner Gon. 124. (90.) - An Mo dece a e speeies?

5105. Kolbia PALIS. Flores dioiei. M a sc. Invol uce I I n m calyciforme, breve cam panulatum, obtuse quinquefidum. Perigonin m tubuloso-campanulatum, limbi decempartiti laciniis exterioribus acutis, patentiusculis, margine glandeloso-serrulatis, interioribus oblongo-spathulatis, plumoso-ciliatis, snbaequilongis. St am in a 5 ; $\mathrm{fi}$ 1 am e nta brevia, basi in annulum connata, a ntherae longe lanceolatae, conniventes. F em. ..... - Planta Africae tropicae occidentalis, sarmentosa; foliis alternis, petiolatis, cordatis, integerrimis, pedunculis axillaribus racemosis, quadrifloris, perigonii tubo et limbi laciniis exteriobus purpureis, interioribus caeruleis.

K ol b i a Palisot Flor. Owar. IT, 91. $t$, 120. DC, Prodr. IIT. 230. Meisner Gen. 127. (92.) - An Modece a e species ?

5106. Cerntiosieyos NEES. F I ores unisexuales. Mas c. Involuc ell u m tetra-pentaphyllum, foliolis linearibus, patentibns. P erigon i u m inflato-campanulatum, quadri-quinquefidum. Sta mina 4_5, imo perigonio inserta, ejusdem laciniis alterna (?), inclusa; $f \mathrm{i} l$ a menta subclavata, ima basi connata, a n thera e introrsae, biloculares, loculis linearibus, eonneetivi dilatati retusi margini adnatis, longitudinaliter dehiscentibus. Sq u a mula e 4_5, subulatae, perigonii lobis oppositae cum staminibus alternae, iisdem basi extus contiguae, O varii rudimentum centrale, stigmatibus 5_8, brevibus, subulatis, coloratis. F e m. Involucell um nullum (!). Perigonium an guste campanulatum, quinquefidum. Sta $\mathrm{m}$ in a sterilia 5, subulata, imo perigonio inserta. $0 \mathrm{va}$ rium longe stipitatum, uniloculare, Ovula in placentis parietalibus quatuor plurima, horizontalia, anatropa. Stigmata 4 , bifida. Ca p sula siliquaeformis, tetragona, quadrivalvis, valvis chartaceis, basi et apice cohaerentibus, medio placentam linearem gerentibus. S emin a plurima, fnniculis longis inserta, brevi-eylindrica, utrinque truncata, integumenta carnoso tuberculato, nucleum e chalaza suspensum, cetera libernm includente. E mbryo in axi albuminis carnosi ortho- tropus; cotyledonibus foliaceis, radicula chalazae opposita. - Herba capensis, perennis, scandens; foliis alternis, petiolutis, palmato-triseptemfidis, laciniis acuminatis, serratis, racemis axillaribus cirrhiferis, floribus femineis in racemorum masculorum alis solitariis, parvis, virescentibus.

Ceratiosicyos Nees in Eeklon et Zeyher Enumerat. plant. cap. 281. Meisuer Gen. 124. (90.) Harvey in Annal. of nat. hist, III. 421, t, 10.

510\%. Acharia THUNB. Flores unisexuales. In voluce 11 um triphyllum. Perigon i um campanulatum, trifidum. M a $8 \mathrm{c}$. St a min a 3 , imo perigonio inserta, ejusdem laciniis alterna, singula diantherifera; fi l a m e $\mathrm{t}$ a linearisubulata, perigonii faucem aequantia, apicis dilatati margine ntrinque antheram bilocularem, adnatam, longitudinaliter dehiscentem gerentia. Sq u amula e 3 , ovatae, pilosae, staminibus alternaé, perigonii laciniis oppositae. F e m. S q u a m u la e 3, hypogynae, ovatae, pilosae. Ova ri a m brevissime stipitatum, uniloculare, placentis parietalibus tribus, subbiovulatis. St ylus apice trifidus; st igmat a oblique truncata, biloba. Ca 8 u la subsessilis, unilocularis, valvis medio submonospermis, apice styli segmento rostratis, margine involutis. Semina ovoidea, compressiuscula, basi arillo parvo, unilaterali instructa. $\mathbf{E} \mathbf{m}$ b r y o in axi albuminis carnosi cylindricus, ejusdem dimidio brevior.

Herba capensis, erecta, gracilis, glauca, sparsim pilosa; foliis alternis, petiolatis, profunde trifidis, lobis oblongo-lanceolatis, acutis, cuneatis, incisis, stipulis nullis, floribus axillaribus subgeminis, breve pedunculatis, nutantibus.

A charia Thubberg Prodr. 14, c, ic. Harwey et Arnott in Journ. of nat. sc. III. 120. i. 9.

\section{Drdo CXCVIII, MIalesherbiacene.}

MALESHERBIACEAE Don in Edinb. new philosoph. Journ. 1826, 321. Lindley Introduct. edit. II, p. 71. Meisner Gen. 123. (89.) PASSIFLOREARUM tribus 3. DC. Prodr. IIT. 337.

Herbae chilenses et peruanae, basi suffrutescentes, puberulae v. subtomentosae, ramis alternis, erectis, teretibus. Folia alterna, sessilia, sinuato- v. dentato-pinnatifida, superiora interdum subintegerrima. S $t$ i p u 1 a e nullae.

Flores hermaphroditi, regulares, nunc in axillis foliorum solitarii, racemum elongatum formantes, nune terminales, paniculati v. fasciculati.

CALYx submembranaceus, obsolete coloratus, tubo campanulato v. elongato-eylindrico, nervoso, limbo quinquefido, regulari, laciniis aestivatione imbricatis. Corona membranacea, abbreviata, annularis v. profunde decemloba, tori laminae tenuissimae, calycis tubum intus vestienti continua, faucem cingens.

Corólua petala 5, summae calycis fauci, contigue supra coronam inserta, ejusdem laciniis alterna et aequilonga v. paullo longiora, aestivatione convolutiva. 
Sramisa quinque, hypogyna, gynophori basi v. apici incrassato inserta, calycis laciniis opposita, breviter exserta. Filamenta filiformia, libera v. basi cum gynophoro connata. Antherare introrsae, biloculares, ovales, longitudinaliter dehiscentes.

Ovавио breviter stipitatum, oblongum v. subglobosum, uniloculare. Ovula in placentis parietalibus tribus, versus cavitatis apicem abruptim desinentibus plurima, multiseriata, pendula, anatropa. Styli tres, dorsales v. subverticales, nunquam centrales, cum placentis alternantes, filiformes. Sti $g$ m t a indivisa, clavata v. capitata.

Capsuca globosa v. oblonga, stipitata, calyce inclusa v, breviter ultra eundem exserta, unilocularis, apice breviter trivalvis, valvis cum stylis persistentibus alternantibus, intus medio linea longitudinali, infrá apicem abrupta seminiferis.

Semina plurima, ovalia. T esta crustacea, longitudinaliter costatá, transvêrsim rugosa, umbilico basilari, eum chalaza apicali tumida, ope rhapheos longitudinalis fungosae conjuncto. Endopleura membranacea. A Ib um en carnosum, copiosum.

Еиввуо in axi albuminis orthotropus, ejusdem longitudine. Cotyledones orbiculatae, dorso convexiusculae, faciebus planae. $\mathbf{R}$ a dicu la crassiuscula, teres, umbilicum attingens, centrifuga.

M al es herbiace a Turneraceis proximae, ab iisdem gravissimis characteribus, annulo calycis faucem coronante, staminibus ovarii stipitulo insertis, stylis dorsalibus cum placentis alternantibus, et seminum umbilico estrophiolato diversissimae. A Passifloreis, quibus artificiali charactere accedunt, habitu, perigonii natura, et stylorum positione distinguuntur,

5108. VIalesherbia $R U I Z$ et $P A V, C$ aIy $x$ longe tubulusus, cylindraceus, limbo quinquefido, corona faucis profunde decemloba, lobis truneatis, denticulatis. Corolla e petala 5 , sum mae calycis fanci supra coronam inserta, lancewlata, limbi lohis alterna et breviora. Sta min a 5 , gynophori stipitiformis brevis apici calloso-inerassato villoso inserta, exserta; fil am enta filiformia, a n thera e biloevlares, oblongae, incumbente 8 , loculis longitndinaliter dehiscentibus. $O$ va ri u m stipitatum, oblongum, uniloculare, placen tis parietalibus tribus, nerviformibus, ap ce deliquescentibus. Ovula plurima, anatropa, Styli tres, dorsales, filiformes, cum placentis alternan tes; stigmata clavata, indivisa. C a ps ula stipitata, ohlongo trigona, calycem persistentem superans, unilocularis, apice trivalvis, valvis medio seminiferis, stylis cum valvis alternantibus. S emina plurima, ovalia, testa crustacea, costata, rhaphe et chalaza fungosa, $\mathbf{E} \mathbf{m}$ bryo in axi albuminis carnosi orthotropus, radicula umbilico proxima. - Suffrutex peruanus, pilis simplicibus densis pubescens; ramis alternis, erectis, foliis alternis, lineari lanceolatis, acutis, profunde sinuatodentatis v. pinnatijtdis, dentibus laciniisque glanduloso-ciliatis, floribus axillaribus, sessilibus, solitarits, lucis, in racemum elongatum, cylindraceum dispositis.

Ma lesherbia Presl in Retiq. Hänk. Ir. 45. Malesherbia thyrsiflora Kuiz et Pavou Prodr. 45. Flor. Peruv. t. 254. Gynopleura tubulosa Cavanill. Ic. t. 375.

5105. Cymoplewra $C A V$. Caly campanulatas, limbo quinquefido, coruna fancis annulari, membranaeea, dentieulata. Corollae petala 5, summae calyeis fanci supra coronam inserta, ovata, limbi lobis alterna et paullo longiora. Stamina 5, basi cynophori brevis stipitiformis inserta, eidem inferne adnata, exserta; filam en$t$ a complanato-filiformia, a $n t h$ e ra e biloculares, ellipticae v, oblongae, incumbentes, loculis longitadinaliter dehiscentibus. Ovariam stipitatum, subglobusum, nniloeulare, placentis parietalihus tribus $v$, quatuor nerviformibus, infra apicem deliquescentibus. Ovula plarima, anatropa. Styli tres v. quatuor, dorsales v. subverticales, filiformes, cnm placentis alternantes; $8 \mathrm{tig} \mathrm{mat}$ a capitata, indivisa. Capsula intra ealyeem persistentem stipitata, obovato-trigona, unilosularis, apice trivalvis, valvis medis seminiferis, stylis cum valvis alternantibus. Sem ina plurima, ovalia, testa crustacea, costata, rhaphe et chalaza fungusa. Embryo in axi albuminis carnosi orthotropus; radie ula nubilico proxima. - Herbae chilen$s$ es, basi suffrutescentes; ramis alternis, erectis, foliis alternis, sessilibus, oblongis pinnatifidis, v. linearibus integerrimis, floribus terminalibus paniculatis v. fasciculatis, flavescentibus v caeruleis.

Gy nopleura Presl in Reliq. Hänk. H. A5. G y a opleura linearifolia Cavabill. IG. $t, 376$. Mules lierb iae sp. Poir. Don in Sweet Fl. Gard. $t, 167$, Bot. Mag. t. 3362, Endlicher, Atakta t, 9. (wal.)

\section{Ordo CXCIX. Lomseae.}

LOASEAE Jussien in Annal. Mrus, $V$. 18, Dict. sc, nat, XXVIT. 93. DC, Prodr, IIT. 339. Bartling Ord. nat. 272. Meisuer Gen. 125. (90,) LOASEAE VERA E Kuath in Humb. et Bonpl. Nov, gen, et. sp. VI, 113̆, LOASACEAE Liadley Introduct. edit. II. 53 .

Herbae amerieanae, erectae v. scandentes, saepius dichotome ramosae, plerumque setulis rigidiusculis, interdum tuberculatis $\mathbf{v}$. glochidatis, urentibus obsitae, succo aqueo. C a u les ramique teretiusculi v. tetragoni. Folia opposita v. alterna, simplicia, saepissime palmatiloba, incisa. Stipula e et cirrhi nulli.

Flores hermaphroditi, regulares, solitarii v. aggregati, peduneulati, pedunenlis bibracteolatis, axillaribus v. terminalibus, saepius rami axillaris elongatione oppositifoliis, majusculi, elegantes, albi, lutei v. rarius rubri.

Cacreis tubus subglobosus $v$. hemisphaericus, rarius cylindricus, cum ovario connatus, saepissime costatus, costis nonnunquam spiralibus, limbus superus, qnadri-quinquepartitus, persistens v. rarius deciduus, lobis/saepissime. 
trinerviis, per aestivationem imbricatis v. contortis.

Corollas petala decidua, calycis fauci inserta, rarissime ejusdem lobis numero aequalia et alterna, vix non semper dupla, quatuor v. quìnque iisdem alterna majora, breviter unguiculata, fornicato-concava, aestivatione induplicatim valvata, rarius plana, sessilia, per aestivationem contorta, totidem interiora calycis lobis opposita minora, rarius exterioribus planis conformia, apice interdum antherifera, plerumque squamaeformia, dorso nuda v. saepissime infra apicem aristata.

Stamina cum petalis inserta, nunc iisdem simplici loborum calycis numero praesentibus dupla, alterna et opposita, nunc plura, rarissime omnia fertilia, plerumque exteriora fertilia numero varia in phalanges ante petala majora sitas approximata, interiora sterilia varie transformata, petalis minoribus geminatim, ternatim y. quateruatim opposita. Fil a menta filiformia v. subulata, libera v. basi per phalanges connata. Antherae introrsae, biloculares, supra basim v. medio dorso insertae, loculis appositis, parallelis v. basi divergentibus, juxta totam longitudinem dehiscentibus. Pollin is granula subglubosa, laevia.

Ovarivm inferum, vertice breviter exsertum, uniloculare, placentis parietalibus tribus v. quinque, rarius quatuor, carpidiorum totidem margines combinantibus, nerviformibus v. Iatiusculis porrectisque. Ovula plurima, rarissime pauca, pendula, anatropa. Stylus simplex, filiformis v. trigonus; $s t i g m a$ indivisum v. tri-quadrifidum.

Capsola calycis tubo omnino adnato, interdum tamen nonnisi ad nervos adhaerente tunicata, ejusdem limbo persistente coronata, v. rarius limbo deciduo vertice nuda, unilocularis, rarissime baccata, indehiscens, saepissime apice exserto, rarius juxta totam longitudinem $\mathrm{tri}_{\mathrm{i}}$ quinquevalvis, valvis alternantibus cum placentis totidem, eorundem margini adhaerentibus v. tandem liberis, nerviformibus aut nonnunquam latis, valvulas alternas angustiores medio seminiferas mentientibus.

Srmina plurima, rarissime pauca, subdefinita, e funiculis brevissimis pendula, ovata v. compressa, testa saepissime laxa, reticulata, interdum echinata. Endopl eura membranacea, tenuissima, ad chalazam apicalem testae adhaerens. Albumen carnosum.

Eмввxо in axi albuminis carnosi orthotropus, ejusdem fere longitudine. Cotyled on es planae, parvae, germinatione foliaceae. R adicula teres, cotyledonibus longior, umbilico proxima, supera.
L, o a sace a emnes americanae, majori numero hujus continentis regiones subtropicas, imprimis occidentales incolentes, Turneraceis, Malesherbiaceis Cucurbitaceisque affines creduntur, placentis cum valvulis alternantibus a cunctis Parietalibus tamen distinctissimae, et in hac classe revera anomalae, fortassis Papaveraceis propius affines, et olim Rhoeadeis associandae.

5110. Acrolasia PRESL. Caly $\mathrm{x}$ tubo cylindrico, cum ovario connato, limbi superi, quinquepartiti Iobis aequalibus. C o roll a e petala 5, summo calyeis tubo inserta, ejusdem lobis alterna, plana. St a min a 10 , summo calycis tubo inserta, quinque alterna petalis opposita paullo breviora; fila menta filiformia, a ntherae bilaculares, longitudinaliter dehiscentes. Ovarin m inferum, uniloculare, placentis parietalibus tribus, nervifurmibus. Ovula .... Stylus simplex, trigonus; st igma bbtusum. Ca p s n la cylindriea, calycis limbõ coronata, unilocularis, vertice breviter exserto trivalvis, valvis cum placentis nerviformibus alternantibus. S e $m$ in a pauca, angulata, rugosa..... Herba ohilensis, annua, pilis patentibus; hyalinis scabra; folitis inferioribus oppositis, superioribus alternis, sinuato-pinnatijidis, floribus axillaribus terminalibusque, solitariis, parvis, petalis albis, apice pilorum fasciculo ornatis.

Acrolasia Presl in Relig. Hänk. IT, 39. t. 54.

5112. Mentzelia LINN. Caly x tubo cylindrico, cum ovario connato, limbi superi, quinquepartiti lobis aequalibus. Co rolla e petala 5, summo calycis tubo inserta, ejusdem iobis alterna, aequalia, plana. St a m in a plurima, cam petalis inserta, subaequalia v. exteriora longiora, interiora saepius in phalanges petalis oppositas approximata ; filamenta filiformia, basi interdum latiora, a nth era e biloculares, longitudinaliter dehiscentes. Ovarin m inferum, unilocnlare, placentis parietalibus trihus, v. quinque nerviformibus. 0 vaI a panca v, plurima, pendula, anatropa. Stylus simplex, trigonns; st ig ma trifidum, laciniis acutis, conniventibus. C a 8 s l a cylindrica, calycis limbo coronata, nnilocularis, vertice breviter exserto tri-quinquevalvis, valvis cum placentis nerviformibus alternantibus. S e $m$ in a pauca v. plarima, ovata $v$. oblonga, angulata, rugosa v: taberculata. E mbryo in axi albuminis carnosi orthotropus, rectus $\mathrm{s}$ subinenrvus, radicala umbilico proxima. - Herbae in America tropica cis a equatorem et boreali calidiore indigenae, hispido-scabrae, pilis glochilatis v. barbatis; foliis alternis, grosse dentatis, floralibus saepe oppositis, floribus alaribus v. terminalibus, solitariis, geminis $v$ ternis, rarissime in racemo terminali subsecundis, aureis.

Mentzelia Linn. Gen, n, 6ro. Jussieu in Annal. Mus. V. 24. Kunth in Humh. et Bonpl. Nov. gen, et sp. VI. 119. DC. Prodr. III. 343 .

a. OLIGOSPRRMA. Ca p s la vertice trivalvis, placentis parietalibus tribus. Se mina $3-9$. - Flores in dichotomils sessiles, rami abortu saepius oppositifolit, $v$. in apice ramorum solitarit, gemini v. terni; folitis foralibus oppositis. ILan. $t, 425$. Cavanill. Ic. $t, 70$. Bot. Mag. $t, 1760.3204$ )

b. MACROSPERMA. C a ps ula vertice trivalvis, placentis parietalibus tribus. Sem i na pluriana, majuscula. Flores axillares $v$. terminales solitaril, sessiles, for lits floralibus oppositis. - Bartonia a urea Lindl. in Bot. Reg. t. 1831. Bot. Mag, t. 3649 . 
c. MICROSPERMA. C a ps u 1 a vertice quinquevalvis, placentis parietalibus quinque. $\mathrm{S}$ e $\mathrm{m}$ in a laumera, minias. - Flores in racemo terminali subsecundi, pedicellis basi unibracteatis. - Mierosperma Hooker Ic. t. 234,

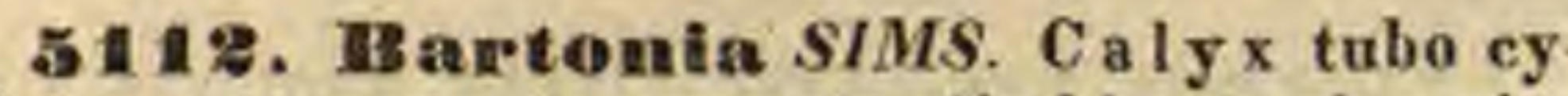
lindrico, cum ovario connato, limbi superi, quinquepartiti lobis aequalibus. Cor olla e petala 10 summo ealyeis tubo inserta, plana, aequalia $v$. alterna limbi lobis opposita angustiora, apice an therifera. Sta min a plurima, cum petalis inserta fil a menta filiformia, libera, antherae bilo culares, longitudinaliter dehiscentes. Ova rium inferum, uniloculare, placentis parietalibus tribns v. septem nerviformibus. Ovula plurima, anatropa. Stylus simplex; stig ma obtusum. C a psula cylindrica, calycis limbo coronata, uniloca laris, vertice breviter exserto tri-septemvalvis valvis cum plaventis nerviformibus alternantibus. S e mina plurima, complanata, alata ..... Herbae boreali-americanae, pilis rigidis barbatis conspersae, erectae; foliis alternis, sessilibus, sinuato-v. inciso-pinnatifidis, floribus terminalibus solitariis, amplis, albis.

B a rto n i a Simis in Bot. Mag, $t$. 1487. Nuttall Gen. 1. 297. DC, Prodr. III. 339. Hooker Flor. Bor. Amer. t. 69. Meisaer Gen. 125. (90.)

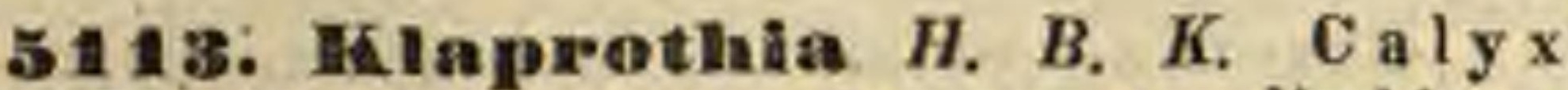
tubo subtarbinato, cum ovario connato, limbi saperi, quadripartiti lobis a equalibus. Co ro I/ a e petala 4, summo calycis tubo inserta, ejusdem laciniis alterna, aequalia, subrotunda, concava. Stamina plurima, eum petalis inserta, esteriora sterilia 20 , quinatim in phalanges isdem alternos collerta, filamentis capillaceis, apice in membranam irregulariter laceram dilatatis, interiora fertilia 16 , quaternatim in fasciculos petalis oppositos approximata; filamentis filiformibns, glabris, antheris bilocularibus, longitudinaliter dehiscentibus. Ovariu m inferum, uniloculare, placentis parietalibus quatuor, nerviformibas, ealyeis laciniis oppositis, uniovulatis, cum totidem nervis sterilibus alternantilus. Ovula in placentis singulis solitaria, alternatim eorundem medio v. supra medium affixa, pendula ......St y lus simplex; stig m a quadrifidum, lobis acutis, conniventibus. B a cea unilocularis, tri-tetrasperma. .... - Herba volubilis, ex Andibus quinduensibus ab Humboldtio relata; ramis retrorsum strigosis, foliis oppositis, argule dentatis, hispido hirtis, pedunculis terminalibus, demum caulis elongatione axillaribus, subdichotomis, paucifloris, brac teat is, floribus albis.

Klaprothia Kunth in Humb. et Bonpl. Nov. gen et sp, VI. 121. t. 537. DC. Pródr. MII. 343. Meisner Gen, 125. (90.)

5114. Selerodlunix PRESL. Calyx tubo cylindrico, spiraliter striato, limbo supero, quadridentato. Corollae petala 4 , summo calycis tubo inserta, ejusdem dentibus alterna, aequalia, obovata, apice conrava. St a m in a 12 , cum petalis inserta, iisdem ternatim opposita, omnia fertilia; filamenta filiformia, anthera e biloculares, longitudinaliter dehiscentes. Ovariu m inferum, uniloculare, placentis parietalibus quatuor, nerviformibus. Ovala plurima $\ldots . . \mathrm{S}$ t $\mathbf{y}$ lus filiformis; stigma emarginatum. Capsula spiraliter torta, unilornlaris, apice quadrivalvis. Sem in a plurima, minima, scrobiculata ..... Herba mexicana, volubilis, pilis retrorsum his pidis scaberrima; foliis superioribus oppositis, lon- ge petiolatis, serratis, racemis axillaribus|terminalibusque paniculatis, floribus parvis.

Selerothrix Presl Symb. IT. 3. t. 53, Meisner Gen. 125. (90.)

51 15 . Creammatoeanpons PRESL. CaI y $x$ tubo lineari, cum ovario connato, limbi su peri, quinquepartiti laciniis aequalibus. Co rolla e petala 10 , summo calyeis tubo inserta, quinque ejusdem laciniis alterna, cucullata, hasi subsaceata, majora, quinque jisdem opposita multo minora, apice bieallosu triaristata. Sta $\mathrm{m}$ in a plurima, eum petalis inserta, exteriora sterilia acuminato-eonica granulata, petalis minoribus per paria opposita, interiora fertilia, in fasciculos 5 , iisdem majoribus oppositus approximata; filamenta filiformia, a $n$ the ra e biloculares, longitudinaliter dehiscentes. Ova ri u m inferum, uniloculare, placentis parietalibus tribus, nerviformibus. Ovula plurima, pendula, anatropa. Stylus simplex; stigma acutum. Capsu Ia linearis, torta, limbi caIycini reliquiis coronata, uniloeularis, juxta totam longitudinem trivalvis, valvis margine seminiferis. Sem in a plurima, sabglubesa, iesta fibrosa, reticulata. $\mathbf{E}$ m b ry o in axi albuminis carnosi orthotropus, radicula umbilico prosima. - Herba chilensis, volubilis, pubescens; foliis oppositis, pinnatisectis, floribus axillaribus terminalibusque solitariis, subsessilibus, flavis.

Grammatotheca Presi Symb. T. 59. t, 38. S e y pha $\mathrm{tus}$ Don in Sweet Fl. Gard, $t, 238$.

51 1 . Hoasn $A D A N S$. C a ly $\mathrm{x}$ tubo ovato v. cylindrico, longitudinaliter costato $v$, spiraliter striato, limbi superi, quinquepartiti lobis aequalibus. Co ro 11 a e petala 10 , summo calyeis tubo inserta, quinque ejusdem lobis alterna majora, cuenllata, quinque iisdem opposita multo minora, dorso triseta. Stamina plurima, cum petalis inserta, exteriora sterilia filiformia, petalis minoribus geminatim opposita, interiora fertilia, in fasciculos 5 iisdem majoribus oppositos approximata; filam e n ta filiformia, antherae biloculares, longitudinaliter dehiscentes. 0 v a ri n m inferum, uniloculare, placentis parietalibus tribus, lamelliformibus. Ovula plurima, pendula, anatropa. StyI u simplex; tigma trifidum, lobis acutis, conniventibus, Capsula ovata v. glohosa, laevis v. costata, calycis limbo coronata, unilocularis, vertice breviter exaerto trivalvis, valvis cum nervis placentiferis, tandem liheris alternantibus. Semin a plurima, testa laxe fibroso - reticulata, endopleura membranacea. Embryo in axi albuminis carnosi orthotropus, r a di $c u$ la umbilico proxima. - Herbae peruana et chilenses, ramosde, pilis prurientibus armatae; folins alternis $v$, oppositis, exstipulatis, dentatis $v$. lobatis, floribus axillaribus, extraaxillaribus v. oppositifoliis, solitariis $v$, racemosis.

L o a sa Adansou Fam, IT. 50. Jacq. Observ. IT. 15. t. 33. Jussien Gen. 328. Annal. Mus. V. 24. $t, 1$-5. (exel. t. 3. $f$. 1.) Humb. et Bonpl. Plant. aequinact. t. 14. 15. Kunth in Humb, et Bonpl. Nov. gen. et sp. V. DC. Prodr. III. 340. excl. sect. 1. Hooker Exot. Flor, t, 83, Bot. Mag. t. 2372, 3218 3632, Bot. Reg. t. 285. 1599. N. s. 1839. t, 22. Presl Symbol, t. 61. Cambessedes in St. Hilaire Flor Brasil. II. 210. Meisner Gen. 125, (90.) L o a s a Lisa. Praelect. edit. Giesecke 334. Ortig a Feuillé Peruv, IK. 737. t. 43.

511 7. Cajoplaora PRESL. C a ly x tubo ovato, spiraliter decemcostato, limbi superi, quinquepartiti lobis aequalibus.C C roll a e petala 10 , summo calycis tubo inserta, cucullata, quinque 
ejusdem lobis alterna majora, quinque isdem op posita multo minora, apice emarginata $v$. tridentata Stamina plurima, cum petalis inserta, exteriora steriia filiformia, petalis minoribus quater natim opposita, interioră fertilia, in fascieulos 5 isdem majoribus oppositos approximata; filam enta filiformia, a $n$ therae introrsae, biloculares, loculis longitudinaliter dehiscentibus. Ova. ri u m inferum, uniloculare, placentis parietalibns tribns, lamelliformibus. Ov u l a plurima, pendula, anatropa. Stylus simplex; st ig m a bifidum, lo bis acutis, conniventibus $\mathrm{C}$ ap $8 \mathrm{u}$ a ealycis limbo reflexo coronata, s piraliter costata, unilocularis, trivalvis, valvis basi et apice cohaerentibus, cuu nervis placentiferis liberis alternantihus. S em in a plurima, testa laxe fibroso-reticulata, endopleura membranacea. E mb ry o in axi albuminis carnosi orthotropus, radic u I a umbilico proxima. - Herbae peruanae et chilenses, ramosae, scandentes, piloso-prurientes; foliis oppositis, exstipulatis, lobatis $v$. pinnatifidis, pedunculis axillaribus $v$. terminalibus, solitariis, unifloris.

C a jo phor a Pres! in Reliq Hänh, IT. 41. t. 56. Méisner Gn. 125. (90.) Loasae sect. Helicteroides DC. Prodr. III. 340 Lo as a contorta Lam. Jussieu in Annat. Mus. $V$, 25. t. 3. f. 1 .

5118. Hitumenbachia $S C H R A D$. Calyx tubo turbinato v. subgloboso, cum ovario connato, spiraliter decencostato, limbi superi, quinquepartiti lobis aequalibus. Corollae petala 10 , snmmo calycis tnbo inserta, cucullata, quinque ejusdem lobis alterna majora, quinque iisden. opposita multo minora, dorso biseta. S tamina plurima, cum petalis inserta, exteriora sterilia filiformia, petalis minoribus per paria upposita, interiora fertilia in fascienlos istem majoribus oppesitos approximata; filamenta filiformia, antherae intrursàe, biluenlares, longitodinaliter dehiscentes Ovarium inferum, uniluculare, placentis parietalihus quinque, lamelliformibus. O vula plurima, pendula anatropa. Stylus simplex; st igma aentum Capsula apice nuda spiraliter costata, unilorularis, desemvalvis, valvis alternis latioribns sterilibns, alternis angustioribus, medio placentiferis Semina plurima, testa laxe fibroso. reticulata, endoplenra membranacea. E mbryo in axi albuminis carnosi orthotropus, radicula nmbilieo proxima. - Herbae Americae tropicae, ramosae, scandentes, pilis prurientibus armatae; foliis oppositis, lobatis, exstipulatis, floribus axil laribus, solitariis, bracteatis.

B l u me n b a c hi a Sthrader in Comment. Gotting. VI. 92 . t, 1, Reishenbach $\mathrm{Te}$ exot, t, 12t. DC. Prodr, I, 340 . Cambesse des in St Hilaire Flor. Brasil. H. 207. t. 118. Bot. Mlag.
t. 2865. 2599.

\section{Drdo CC. Papayaceare.}

PAPAYAE Agardh Class, Plant, p, 20. CARICEAR Tur. pili Atal, Dict, sc, nat. II, 2, 212. PAPAYACEAE Martits Conspeet, 169. Lindley Introduct, edit. II, p, 69. Meísuer
Gen, 123. (89.)

Arbores lactescentes, trunco cylindrico, basí incrassato simplici, apice comoso v. rarins ramoso, rapide crescente. Folia in apice trunci v. ramorum confertim alterna, longe petiolata, digitato-palmatifida, laciniis integris v. sinuato aut inciso-pinnatifidis. Stipulae nullae.
Flores unisexuales, dioici v. rarius monoiei, axillares, masculi in racemos compositos v. corymbos, feminei in racemos simplices dispositi.

Floribus masculis: Calyx minimus, quinquedentatus.

Corolia hypogyna, infundibuliformis, tubo tereti, limbi quinquepartiti lobis tubo brevioribus, aestivatione valvatis, sub anthesi patentibus.

Sramina 10 , corollae fauci inserta, inclusa, alterna limbi lobis opposita longiora. Fil amen $t$ a lineari-complanata, in staminibus corollae lobis oppositis subnulla. An therae introrsae, biloculares, loculis linearibus, contigue parallelis, filamento in connectivum nonnihil supra eosdem obtuse producto adnatis, longitudinaliter dehiscentibus.

Ovari rudimentum centrale liberum, cylindricum, in cuspidem subulatum desinens.

Floribus feuneis: Calyy liber, minimus, quinquedentatus.

Совоцlak petala 5 , hypogyna, libera, linearia, aestivatione valvata, sub anthesi basibus conniventia, apice patentia.

Staminem rudimenta nulla, v. ad basim petalorum minima.

Ovarivm liberum, sessilé, ovato-subglobosum, uniloculare, v. quinqueloculare, septis completis. 0 v u $\mathrm{l}$ a in placentis parietalibus quinque longitudinalibus, cum septis dum adsunt alternantibus plurima, subhorizontalia, anatropa. Stylus terminalis, brevissimus. Stigma depressum, magnum, radiato-quinquelobum, iobis planis, patentibus, cuneatis, apice fimbriato laceris.

BAcca ovata v. subclavata, quinqueangulata, unilocularis, carne firma, intus pulposa.

Semisa plurima, placentis parietalibus quinque pluriseriatim affixa, v. in pulpa nidulantia, ovata, compressiuscula, testa intra epidermidem laxam, carnosam, mucilaginosam, exsiccatione corrugatam erustacea, atra, umbilico basilari. A I bumen carnosum.

Enвкуо in axi albuminis orthotropus, ejusdem fere longitudine. Cotyled on es ellipticae, foliaceae. Radicula brevis, teres, umbilico proxima, centrifuga.

Papayaceae in America tropica indigenae, cultura per Asiam et Africam nune dispersae, habitu Artocarpeas quasdam referentes, affinitate proxima ad Cucurbitaceas et Passifloreas accedere censentur, tranco arboreo, suceo lacteo, et corolla marium gamopetala staminifera revera distinetissimae.

Fructus edulis, immaturus et semina inter pharmaca anthelminthica efficacissima laudantur, 
Mira sucei fibrina scatentis in emolliendis animalium carnibus crudis qualitas, nonnullarum tamen venenatus.

5119. Cariea LINN. Flores unisexuales, saepissime dioici. Calyx liber, minimus, quinquedentatus. Mas c. Corolla hypogyna, infundibuliformis, limbo quinquepartito. S $t$ a m i. n a 10 , eoroliae fauci inserta, alterna limbi laciniis opposita longiora; fil a me nt a complanatolinearia, a $\mathbf{n}$ h era e introrsae, biloculares, loculis contigue adnatis, Iongitudinaliter dehiscentibus Ovarii rudimentum. Fem. Co roll a e petala 5, hypogyna, libera. Stamin um rudimenta nulla, v. minima ad basim petalorum. Ovari um sessile, liberum, unilocalare, placentis parietalibus quinque, multiovulatis. Styl a s brevissimus; st i g ma radiato-quinquelohum, lobis fimbriatis. B a e a ovata, quinquangalata, unilocularis, pulposa. S em ina plurima, parietalia, baceata. Embryo in axi albuminis carnosi orthotropus, mugnas; $\cot$ yledonibus ellipticis, foliaceis, sadicula brevissima, centrifuga. - Arbores Americae tropicae, lactescentes, trunco simplici $v$. rarius ramo so; foliis terminalibus, confertim alternis, longe petiolatis, digitato palmatis, pedunculis axillaribus, masculis multifloris, racemosis $v$. corymbosis, femineis paucifloris.

C a ric a Limn. Gen, n. 1t27. Aublet Guian, t, 356. Jacq Hort. Sehënbr, t, 309-311. Jaeq. 1. Ectog. t. 68.69. Bot. Reg. t. 459, Bnt. Maz. t. 2898.2899. 3633. Poppig Nov. gen, et sp. $t, 182$. Flor. Fltumin, $X$. $t \quad 130-133$. Р a p a a Touruef. Inst, 441. Jussieu Gen. 399. Gírtuer II. 191, t, 112. ? Jaracatia Margí. Brasil. 128. De sucei lactei natura ef. Vauquelin in Annales de Chemie XLIII 267. Holder in Mem. Werner soc, III. 245_249. De specie veueuata vid. Pöppig Op. cil, 11.60 .

5120. Vasconcella $S T$. HIL. Flores unisexuales, monoiei (?). Calyx liber, minimns, quinquedentatus. Mase. Co roll a hypogyna, infundibuliformis, limbo quinquepartito. S $\mathrm{t}$ a $\mathrm{m} \mathrm{i}$ na 10 , corollae fanei inserta, alterna limbi laci. niis opposita longiora; fil a me nta complanatolinearia, ant herae introrsae, bilorulares, loca lis contigue adnatis, longitudinaliter dehiscentibus. Ovarii rudimentum. Fem. Coroll ae pe tala 5 , hypogyna, libera. St a $\mathrm{m}$ i $\mathrm{n} \mathrm{u} \mathrm{m}$ rudimenta nulla, Ovari um sessile, liberam, quinqueloculare, septis completis, sterilibus, cum plarentis parietalibus, biseriatim multiovulatis alternantibus. Stylus brevis, quinquefidus, laciniis subulatis, antice stigmatosis, Fruetus....-Arbor Bra siliae meridionalis, comosa; ramis brevibus, 'foliis Quercus Roboris, fructu eduli.

Vaseoncella St. Hilaire Mem. Resed. II, 12, innat. Umbuzeiro Lusitan. Jacamatchih a Guaran.

\section{Classis XIVII. Peponiferae.}

Herbae v. frutices scandentes. Folia alterna, simplicia, saepe palmatiloba. Cirrhi laterales v, rarius axillares. Flores saepissime unisexuales. Cal y $\mathbf{x}$ et corolla pentamera. St amina 5 v. pauciora, libera v. inter se connata. Ovarium inferum, rarissime uniloculare uniovulatum, saepissime tri-quinqueloeulare, nunc ovulis paucis e basi ereetis, nunc plurimis placentis parietalibus insertis. B a c c a (pepo) saepissime polysperma, rarissime monosperma. Embryonis exalbuminosi orthotropi cotyledones foliaceae.

\section{Ordo CC1. NHandirobeae.}

NHANDIROBEAE $\mathrm{St}$. Hilaire in Mem. Mus, XT. 215 CUCURBITACEARUM Tribus 1. DC. Prodr. III. 297.

Herbae v. suffrntices scandentes. Folia alterna, petiolata, simplicia, cordata, palmatinervia, integra. Stipulae nullae. Cirrhi axillares, cum petiolis nascentes.

Frores in foliorum axillis solitarii v, racemosi, regulares, unisexuales, dioici.

Masc. Caryx tri-quinquepartitus, lobis patentibus.

Corollar petala 5 , imo calyci v. Jaminae carnosae tubum vestienti inserta, ejusdem lobis alterna, distincta v. inter se connata, patentia.

Stamina 5, imae corollae inserta, ejusdem lobis alterna, rarissime decem, quorum quinque petalis opposita sterilia. Fil amenta brevia, crassa. Anthera extrorsae, uni-bilocutares, loculis adnatis, distinctis, longitudinaliter dehiscentibus.

FEv. Caly x tubo hemisphaerico v. turbinato, cum ovario usque ad mediam circiter ejusdem longitudinem v. fere ad apicem connato, limbo semisupero v. fere supero, quinquepartito.

Corollar petala 5, summo calycis tubo inter ejusdem lacinias inserta, libera $v$. inter se connata.

Oraniem inferum v. semiinferum, triloculare. Ovula in loculis pauca, subdefinita, rarius plurima, e basi adscendentia, anatropa. Styli tres, distincti, patentes, simplices v. apice bifidi; stigmata simplicia v. reniformi biloba.

Bacca carnosa, nunc subglobosa, medio calycini limbi reliquiis zonata, nune hemispliaerica v. turbinata, prope apicem zonata, trilocularis, loculis propter axim centralem crassissimam trigonam, angulis septa praebentem parvis, parieti admotis.

Semisa in Joculis pauca, subgemina, rarius plura, e basi erecta, imbricata, ovalia v. oblonga, plus minus compressa, submarginata v. superne in alam membranaceam producta.

Eмвryonis exalbuminosi, orthotropi cotyle don es crassae, carnosae, oleosae, radic u la brevissima, infera.

Nhandirobeae inter tropicos Asiae et Americae creseentes, Cucurbitaceis proxime affines, ab iisdem ovarii struetura, ovulorum numero et situ, stylis distinctis et cirrhis axil- 
laribus diversae, pluribus notis adPassifloreas, ovaria libero el placentatione parietali distinctissimas, accedunt.

5121. Fevillea LINN. Flores dioici. II asc. Calyx tubo brevi campanulato, limbo quinquepartito, patente. Co roll a e petala 5, imo calyci inserta, ejusdem lobis alterna, basi subcoalita, rotato-patentia. S ta min a 5 , imae corollae inserta, ejnsdem lobis alterna, interdum 10, alterna sterilia; fil am enta brevia, superne incrassata, antherae extrorsae, biloculares, didymae, loculis adnatis, longitudinaliter dehiscentibus. F em. C al y $x$ tubo hemisphaerioo, limbo semisupero, quinquepartito. Corolla e petala 5, summo calycis tubo inserta, ejusdem lobis alterna, patentia. Stamina sterilia 5 , petalis alterna, saepissime nulla. Ovari um vertice breviter exserto semiinferum, triloculare. Ovala in loculis pauca, e basi erecta, anatropa. Styli 3 , filiformes; stig mata lata, reniformi-biloba. B a cea globosa, carnosa, medio limbi calycini cicatrice zonata, trilocularis, loculis axi centrali trigona crassissima parieti admotis. Semina in loculis pauca, erecta, imbricata, ovalia v. suborbiculata, compressa, submarginata. E m b r y on i s exalbuminosi cotyledones carnosae, radicula brevissima, infera. - Herbae America e tropicae, frutescentes, scandentes; foliis alternis, petiolatis, exstipulatis, cordatis, palmatinerviis, glabris, cirrhis axillaribus, pedunculis axillaribus uni-multiflo. ris, floribus parvis, seminibus oleosis, amaris.

Feville a Linn. Gen. n, 1118. Jussien Gen. 397. Lam. t. 815. Kunth in Humb. et, Banpl. Nov, gen. et sp. II. 12d. VII. t. 640. DC. Prodr. III. 297. Meisner Gen. 126. (91.) Feuille a Persoon $\mathcal{S} y s t$, veg. 15. p. 929. Nhandiroba Plumier Gen, 20, $t$. 27.

5122. Zanonia LINN. Flores dioici. Ma 8 c. C a ly x trilobus. Co roll a subrotata, quin. quepartita, patens. Stamina 5; filamenta plana, basi connata, antherae uniloculares, apicilsus filamentorum adnatae. Fem. Caly x tubo oblongo, turbinato $v$. hemisphaerico, cum ovario connato, limbo supero, quinquelobo. Co rolla

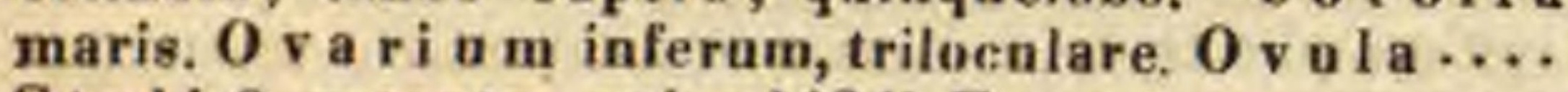
St y li 3, patentes, apice bifidi. F r a et us carnosus, elongato turbinatus $\mathbf{v}$, hemisphaerieus, superne limbi ealyei cicatrice zonatus, trilocularis, loculis axi centrali trigona, crassissima parieti admotis, apiee breviter trivalvis. S e $\mathbf{m}$ in a in loculis $2 \mathrm{v}$. plurima, ovata, ala foliacea, magna cincta. E mbryo exalbuminosus, inversus? - Plantae indicae, scandentes, glabrae; foliis alternis, petio. latis, exstipulatis, glabris, basi cordatis, integerrimis, cirrhis axillaribus, pedunculis axillaribus racemosis.

Z a n o n i Lian, Gen, a. 1117. Jussien Gen, 397. Blume Bijdr. 937. DC. Prodr. III. 398. Wight et Arnott Prodr. I. 340. Meisner Gen, 126, (91.)

a. ZANONIA Blum. l. $c$. Fruetus elongati, subtrieoni loculi dispermi. - Penarvalli Rheede Malab. VIII. t. 47. 48. (Lam, $t$, 816, Wallich Plant. As, rar. t. 133.)

b. ALSOMITRA Blum. l. c. Fruetus hemisphaericl, superae truacati loculi polyspermi.

\section{Ordo CCII. Cucurbitaceae.}

CUCURBITACEAE Jassieu Gen, 393, St. Halite in Mem, Mus: V, 304. IX, 190. Hamilt. in Transact, of the Trish, Academ. XI. 229. DC. Prodr, IIT. 297, excl, geil. Seringe in
Mem. soc. phys. Genev. III. 2. 1, Bartling Ord. nat. 273. Lindley Introduct. edic. $I I .51$. Schrader in Linnaea XII. 401. excl. gen.

Herbae annuae v, suffruticosae, rarius rrvTICEs, radicibus fibrosis v. saepe tuberosis. C a u le s teretiusculi v. angulati, succosi, scandentes, ramis lateralibus. Foli a alterna, petiolata, simplicia, palmatinervia, saepissime palmatim divisa v. integra, aut angulata, lobata, basi saepissime cordata, plus minusve aspera. Cirrhi e stipula laterali abortiva, solitarii, simplices v. ramosi, spiraliter torti.

Flores monoici v. rarius dioici, rarissime polygamo-monoici v. hermaphroditi, in pedunculis axillaribus solitarii, fasciculati, paniculati v. racemosi, albi, flavi v. interdum rubri.

Calyx tubo cum ovario connato, plus minus elongato, interdum supra ovarium producto, in maributs abbreviato, ut plurimum campanulato, limbi plus minus manifeste quinquedentati v. quinquelobi lobis aestivatione imbricatis.

Corollar petala 5, calycis limbo inserta, ejusdem dentibus v. lobis alterna, libera v. saepissime gamopetala, et simul calyci adnata, ejusdem limbo quasi continua, rotata v. campanulata, quinqueloba, lobis integris v. interdum fimbriatis.

Stamina imae corollae v. basi calycis inserta, petalis alterna, plerumque quinque, rarius tria v. duo, nunc libera, nune monadelpha vel saepius per paria connata, ita ut in floribưs pentandris quatuor per paria cohaereant, tertium maneat liberum. F il a m ent a brevia, crassa, apice continuo in connectivum rectum v. sinuato-flexuosum transeuntia. Antherae extrorsae, uni-biloculares, loculo lineari, connectivi margini adnato, recto v. juxta ejusdem gyros flexo, saepe longissimo, interdum in annulum polliniferum confluentes, longitudinaliter dehiscentes.

Ovarium inferum, rarissime uniloculare, ovulo unico ex apice loculi pendulo, plerumque e carpidiis tribus v. quinque compositum, carpidiis usque ad axim idealem involutis, iterumque revolutim porrectis, marginibus ovuliferis parietem attingentibus sex - v. decemloculare, septis alternis sterilibus, alternis angulo parietali utrinque ovuliferis, saepissime septis primariis e carpidiorum marginibus introflexis obsoletis triquinqueloculare, v. secundariis e earpidiorum marginibus revolutis pariter obliteratis uniloculare, placentis parietalibus tribus v. quinque geminatis. Ovul a plurima, pluriseriata, horizontalia, anatropa. Stylus terminalis, brevis, trifidus v. tripartitus. St i g m a ta incrassata, lobata v. fimbriata.

Bacca (pepo) carnosa v. sicca, tri-quinquelocularis, v. saepissime septis in pulpam solutịs 
unilocularis, placentis paríetalibus polyspermis, indehiscens v. rarius subvalvatim elastice dehiscens, aut operculo aperta, rarissime typice unilocularis, sicca, monosperma.

Semina rarissime unicum, pendulum, alias plurima, horizontalia, plerumque compressiuscula, funiculis brevibus sustenta, epidermide aquosa, distenta, demum exsiccata, membranacea, testa membranacea v. subcornea, saepe margine incrassato cincta. A 1 b u m e n nullum.

Embryo orthotropus; cotyledonibus foliaceis, venosis, radic u la brevi, umbilicum attingente, centrifuga, pl umula diphylla.

Cucurbitaceae in regionibus tropicis subtropicisque totius orbis magno numero obviae, in temperatis multo rariores, e climate frigido exulant.

Fructus nonnullarum edules, magni in gentium sub fervido coelo degentium oeconomia momenti, aliae principio resinoso amarissimo scatent, multae apud medicos laudis. Complurium semina oleosa.

Generum discriminatio perquam difficilis et adhucdum problematica.

SUEORED I. TELFAIRIEAE. Carpidiorum margines seminiferi intra loculum porrecti, parietem haud attingentes. S e mina plurima, nucamentacea.

5123. Telfaireda HOOK, Flores dioici. Masc. Caly $\mathrm{x}$ tubo brevi, turbinato, persistente, limbi quinquepartiti laciniis lanceolatis, argute serratis, deciduis. Corolla e petala 5, summo calyeis tubo inserta, obovato - cuneata, apice fimbriato-laciniata, aestivatione imbricata, sub anthesi patentia, cum calycis limbo decidua. S t am in a 5, cum petalis inserta, iisdem alterna; fil am enta crassinseula, filiformia, basi triadelpha, a ntherae distinctae, biloculares, Joculis linearibns, rectinsculis, connectivi erassi, plani; subcordati margini utrinque adnatis. Fem. Calyx tubo eum ovario connato, oblongo, decemsulcato, hasi toroso, superne attennato, limbo supero, minuto, decidno. Corolla maris, summo calycis tabo inserta. Ova rium inferum, tri-quinqueloculare, locnlis longitudinaliter incomplete bilocellatis, ovnlis plurimis, juxta semiseptarum margines bifidos involutos utrinque uniseriatis, horizontalibus. Stylus brevis, subtrigonus, exsertus; st ig ma capitatotrilobnm, crassnm, pruinosum. B a ce a carnosa, elongata, sulcata, pulposa, tri-quinquelocularis, polysperma. Se m in a compressa, orliculata, basi retusa, testa membranacea, fibroso-reticulata. Embryonis exalbuminosi e otyled on es carnosae, oleosae, radic al a brevissima. - Frutex, in Africae austro-orientalis litto ribus spontaneus, Kouemé Nigritis dictus; eaule lignoso, extus suberaso, scandente, ramis elongatis, centumpedalibus, dependentibus, inferne teretibus, superne angulatis, foliis-alternis, longe petiolatis, quinatodigitatis, foliolis oblongo-ovatis, subsessilibus, acuminatis, dentato - repandis v. laciniatis, tres $v$. quatuor pollices longis, duos pollices latis, laterali- bus minoribus, basi extus auriculatis, omnibus nervosis, supra glabris, lucidis, subtus pallidioribus, albo-punctatis, ad nervos scabriusculis, cirrhis e basi petiolorum lateralibus, bipedalibus, bipartitis, stipula axillari cirrho opposita, concava, petiolulata, pubescente, floribus axillaribus, masculis racemosis, pedunculo tereti, pedicellis brevibus, unifloris, basi bractea suborbiculari breve petiolata, profunde serrata, puberula instructis, femineis solitariis, calycibus pulverulentis, pubescentibus, verruculosis, peta. lis crassiusculis purpureis, basi lineis virescentibus distinctis, extus pubescentibus, intus papillosis, fructibus maximis, duos $v$. tres pedes longis, octo circiter pollices crassis, sexaginta libras pendentibus, pulpa amara, seminibus pollicem latitudine metientibus, cotyledonibus carnosis, edulibus, oleo copioso scatentibus.

Telf a iria Hooker Bot. Mag. t. 2751. 2758, Bot. Mrscell. II. 154. t. 81. 82. Meisner Gen. 172. (92.) Joliffia Bojer ex Delile in Mem. soc. h. n. Paris, III, 314, t, 6. DC. Prodr. III. 316. A m pelosi cy os Thouars Hist. veg. Afr. austr. 68, t. 22. Feville s pedata Smith in Bot. Mag. t. 2681 .

SUBDIBD II. CUCURBITEAE. Carpidiorum margines revoluti parietem attingentes. S e min a plurima.

§. 1. CONIANDREAE. Stamin a 5 , exserta. A nther a e uniloculares, loculo lineari, recto, antice adnato.

5124. Coniandra SCHRAD. Flores monoici. Masc. Cal y x campanulatus, quinquefidus. Corolla calyei adnatim inserta, limbo quinquepartito, patentissimo. St a m in a 5 , corollae fauci inserta, saepe triadelpha, conniventia, antherae uniloculares, loculo lineari, recto, connectivo oblongo-conieo antice adnato. Fem. Calyx tubo ovato, superne abruptim attenuato, cum ovario connato, limbo supero, campanulato, quinquefido. Coroli a calycis limbo inserta, quinquefida. Ovari um inferum, trileculare, placentis juxta septa utrinque parietalibus, multiovalatis. Sty lu s brevis; stigma depresso-capitatum, subtrilobum. B a c c a ovata, rostrata, trilocularis, oligosperma. Semin a obovata ..... - Herbae capenses, rhizomate tuberoso perennantes; foliis alternis, petiolatis, membranaceis, palmatipartitis, mucronato-dentatis, papilloso-scabris, cirrhis simplicibus, floribus parvis, virescentibus, masculis ra: cemosis, femineis solitariti, fructibus flavis.

Coni andra Schrader in Ecklon et Zeyher Enumerat. plant. Cap. 275. Meísner Gen, 126. (91.) Bry on ia dis. secta Thuab.

5125. Cyrtonema SCHRAD. Flores monoici. Ma $8 \mathrm{c}$. Cal y $x$ campanulatus, quinquefidus. Co ro 11 a calyci adnatim inserta, limbe quinquepartito, patente. Stamin a 5 , corollae fauci inserta; filamenta incurvata, apieibus crassioribus conniventibus triadelpha, antherae uniloculares, loculo lineari, recto, connectivo incrassato infra apjeem antice sublateraliter adnato. F em. Calyx tubo fusiformi, cum ovario connato, limbo supero, campanulato, quinquefido. Cor olla calyeis limbo adnatim inserta, quinquefida. Ovari um inferum, triloculare, placentis juxta septa utrinque parietalibus, multiovulatis. Sty lus brevis; stigmat a 3 , obtusa. B a cea fusiformis, rostrata, trilocularis, oligosperma, Semina obovata ...... - Herbae capenses, 
rhizomate tuberoso perennantes, scabrae; foliis al ternis, peliolatis, integris $v$. digitato-partitis, sca. bris, cirrhis simplicibus, floribus flavo-viridibus, masculis racemosis, femineis solitariis.

C yrtonema Schrader in Eeklon et Zegher Enumerat Plant, Cap. 275. Meisuer Gen, 127. (10.) B ry o Io b a Thunb.

§. 2. MELOTHRIEAE. S $\mathrm{t}$ a $\mathrm{m}$ i n a $2-5$. Antherae biloculares, loculis connectivum integrum marginantibus, rectis $\mathrm{v}$. inflexis.

5126. Melothria LINN. Flores monoici. M a 8 c. $\mathrm{C}$ a ly $\mathrm{x}$ campanulatus, quinquedentatns. Cor ofla calyei adnatim inserta, subrotata, quinquefida, Iobis patentibus eiliatis v. denticnlatis. Stamina 3 , corsllae fauci inserta; fila menta brevia, antherae bilocnlares, loculi lineares, connectivi dilatati basi et apice emarginati marginibus adnati, recti v. sigmoidei. Fe m. Cal y x tubo ovato v. suloglobeso, eum ovario connato, limbo supero, campanulato, quinquedentato. Corolla maris. Ovari um inferum, triloculare, placentis justa septa utrinque parietali. bus, multiovulatis. Stylus brevis; stigma tripartitum, fimbriatum. B a c ca ovata v. globosa, oligosperma. Semina subtrigona, basi oblique truneata. Embryonis exalbaminosi cotyledo. nes foliaceae, plano-convexae, radicula bre vissima, centrifuga. - Herbae Americae $t r o-$ picae, pubescenti scabrae; folits alternis, petiola tis, cordatis, angulatis v. lubatis, cirrhis simplicibus $v$. bijidis, pedunculis axillaribus, unifloris, femineis elongatis.

Melothria Limn. Gen. n. 68. Law, t, 28, DC. Prodr. HIT. 313, excl. sp. Meisner Gen. 127. (91.) Pôppig Nov. gen, et sp. II, 55, t, 124.

SICYDIUM Sehlechteud. in Linn, VII.38s. Flo res diol. ci. Masc, Cályx quinquelobus. Corolla peotapetala. Stamina 3 , libera, antherae blloculares, regulares. haud flexuosae. Fe ny...... Herba mexicana; caule angulato, folits allernis, petiolatis, subreniformi-corda tis, obtusissimis, pedatinervits, Erumosa-scabris, panicu. lae axillaris multiflorae, folia superantis ramis inferio. ribus foliaceo-bracteatis, floribus parvis.

512\%. Thelnmeria ENDL. Flores mon oici v. dioici. Mase, Ca ly $x$ campanulatus, quinquedentatus. Corolla calyei adnatim inserta, limbo quinquepartito patente, intus pilosa. S $\mathrm{ta}$ m ina 3 , rarins 5 , basi corollae inserta, libera; filamenta brevia, antherae biloculares, loculis linearibus, connectivi orbiculati $\mathbf{v}$. subcordati marginibus adnatis, apice demum confluentibus. G I andu l a basilaris, trilnba. Fe $m$. Ca ly $x$ tubo subgloboso v. fusiformi, cum ovario connato, limbo supero, campanolato, quinquedentato. Coroll a maris. Stamina sterilia, saepius nulla. Ovarium inferum, triloculare, placentis juxta septa hine parietalibus, multiovblatis. St ylus cylindricus; s tigma tri-quadrifidum, lobis capitatis, conniventibus, v. flabelliformibus, patulis. G tandula styli hasim cingens trifida y. tripartita. B a cea coriacea, exsucca, oblengo-fusifurmišs, ovata $\mathbf{v}$. subglobosa, polysperma. Semina ovata, basi truncata, margine incrassato cineta. Embry on is exalbuminosi, cotyledones foliaceae, plano-convexae, $r$ a dic nl a brevissima, centrifuga. - Her. bae perennes, in Asia et Africa subiropica et tropica crescentes, papilloso v. piloso scabrae; foliis alternis, petiolatis, angulato dentatis $v$. $l_{0}$. batis, cirrhis simplicibus, floribus axillaribus, maseu- lis racemosis, pedunculis femineis unifloris v. aggregatis.

Z e h neria Endlicher Flor. Norfolk, 69. Meisner Gen. 126. (91.) Pil og y ne Selirader Index Sem, hort, Göting. 1835. Ecklon et Zeyher Enumerat, 277. Linnaea XII. 408. Meisuer Gen: 126. (91.) B ryonia e sp. Aut.

51 28. Ammuria LINN. F Lores dioici. Ma s c. Ca l y x tubo campanulato, ventricoso, limbe quinquepartito.C oroll a imo calyciadnatim inserta, limbi liberi, quinquepartiti laciniis angustis, patentíbus. S $t$ a $m$ i n a 2 , imae corollae inserta, libera; fil a ment a brevissima, a $n t$ he $r$ a e biloeulares, loculis linearibus, connectivi lati mutici, v. angnsti in acumen producti marginibus adnatis, rectis v. flexuosis, F em, Caly x tubo cum ovario connato, limbo supero, eampanulato, quinquefido. C o rolla maris. St a $m$ in a 2 , sterilia. $O v$ arium inferum. Sty I as bifidus; st $\mathrm{igmata}$ bipartita. Bace a wblongo-subtetragona, bi-quadrilocularis, polysperma Semina .... - Herbae Americae tro $p$ icae; radice crassa, verrucosa, foliis alternis, petiolatis, cordatis, integris v. pedatisectis, cirrhis simplicibus, pedunculis axillaribus, maseulis elongatis, racemosis, femineis unifloris.

Anguria Linn. Gen. n. 399. Jyssieu Gen. 395. Jaeq. Aner. edit pict. $t, 155$ Lam. $\ell .747$. Kunth in Humb. et Banpl. Nov gen.et sp. IT 12t. DC. Prodr. IIT. 318. Meisner Gen, 126. (91.) Poppig Nov. gen, el sp, I1. 51. t, 169, 170. Ps igu'ria Necker Elem, n. 384.

5129. Ehymeloceurpa SCHRAD. Flores monoici. Ma s c Caly $x$ tubo urceolato subgloboso, limbo quinquedentato. Corulla calyei adnation inserta, campanulata, limbo quinquepartito, patente, dentienlato. S $t a m$ in a 3 , basi corollae inserta, libera; fil ame n ta brevia, anthe rae biloculares, loculis linearibns, connectivi dilatati bilobi marginihus infra apicem adnatis. Fem Caly $x$ tubo basi ventricoso cum ovario connato, apice anguste tubuloso. longe supra ova. rium producto, limbo campanulato, quinqueden. tato. Corolla maris. Ovarium inferum, triloculare, placentis juxta septa multiovulatis. StyI us brevis; stigma tripartitum. Bacea ovata, sulcata, longe rostrata, polysperma. Semina obovata, basi truncata, margine incrassata. $\mathbf{E} \mathbf{m}$ bryonis exalbuminosi cotyledones foliaceae, radicula umbilico proxima, centrifuga. - Herba Africae tropicae, pilosa; radice napiformi, foliis alternis, breve petiolatis, cordatis, subdentatis, cirrhis simplicibus, racemis masculis paucifloris; floribus femineis in eadem saepius axilla solitariis, sessilibus, corollis luteis.

R hy neboe a r p a Schrader in Linnaea XII. A03. absq. charact. Triebosanthes foetidissima Jaeq. Col. lect. Ir. 341. Ic. rar. t. 624. Melo thriae sp. DC.

§. 3. BRYONIEAE. Stam in a 5 , saepissime triadelpha. Antherae uniloculares, loculo lineari, connectivum lobatum gyrose marginante.

5130. Bryomia $L I N N$, Flores monoiei v. dioici. M a s c. Cal y x, campannlatns, quinquefidus. Corolla imo calyei adnatim inserta, quinquepartita. Sta mina 5, imae corollae inserta, triadelpha; fil amenta brevia, antherae uniloculares, loculo lineari, secus connectivi incisndentati marginem dorsalem gyrose adnato. G I a nd a la basilaris triloba. Fem. Cal y $x$ tubo subglohoso, cum ovarie connato, supra ovarium constrieto, limbo supero, campanulato, quinquefido, 
Corolla maris. Ovari um inferum, triloculare, placentis juxta septa utrinque parietalibus, multio vulatis. Stylus trifidus v. tripartitus; stigm a$t$ a capitata v. reniformi-biloha. Glan d u la annularis, styli basim eingens, integra v. lobata. B a cea globosa v, ovata, oligosperma. S e min a obovata, basi truncata, margine tumido cincta. $\mathbf{E} \mathbf{m}$ bryonis exalbuminosi cotyledones foliaceae, plano convexae, radi cu la brevissima, centrifuga. - Herbae in regionibus temperatis et calidioribus totius orbis obviae, radice tuberosa perennantes, pilosae v. piloso-asperae; foliis alternis, petiolatis, cordatis, angulatis $v$. trifidis, floribus axillaribus, racemosis v. fasciculatis, femineis saepe solitariis.

B r y o a ia Lina. Gen, n. 1480 . exel. sp. Lam. $t, 796$. Jaeq. Flor. dustr. t. 199. Sehkuhr t. 316. E. B. $t, 439$. Gärtner 1. 46, t, 88. Desfont. Corollar. t, 70. DC. Prodr. IIT. 304. excl. sp. Meisner Gen, 127. (91.) ? S ole a a Loureiro Flor, cochinch, $699,-$ ? C u c u me r o id es Gärtner II. 485. t. 180.

5131. Citrullus NECK. F lore s monoici, Ca 1 y $x$ profunde quinquefidus, planiusculus, laciniis lanceolato-linearibus, Cor olla imo ealyci adnatim inserta, quinquepartita, plana, subrotata. St a m in a 5, imae corollae inserta, triadelpha; fil am enta brevia, antherae uniloculares, loculo lineari, eecus connectivi inciso-trilobi marginem dorsalem gyrose adnato. F e m, C a I y $x$ tabo globoso, cum ovario connato, limbo supero, profunde quinquefido. Corolla maris. Stamina sterilia rudimentaria. $O$ v a r i u $m$ inferum, tri-sexloculare, placentis juxta septa utrinque parietalibus, multiovulatis. Sty I us cylindraceus, trifidus; $s \mathrm{tig}$ at a convexa, reniformi-cordata. $B$ a cca globosa, carne solida, polysperma. S e min a obovata v, oblongo-obovata, compressa, basi truncata, margine obtusa. Em b r y on is exalbuminosi cotyled un es foliaceae, plano-convexae, radicul a brevissima, centrifuga. - Herbae annuae, humifusae, ex As i a calidiore ortae, aliae ob fructus mole saepius ingèntis carnem sapidissimam, albam v. amoene rubram, Germanorum principibus olim saepe exitiosam, sed sub sidere fervido agricolas miro refrigerio recreantem, nunc passim per regiones tropicas et temperatas calidiores cultae, aliae ob baccam principio peculiari amarissimo scatentem inter medicos celebres; foliis alternis, cordatis, lobatis, lobis integris pinnatisectisve, cirrhis bi-trifidis, pedunculis axillaribus, solitariis, unifloris.

Citrullus Necker Elem. $\pi, 389$. Schrader in Eoklon, et Zeyher Enumerat. plant. Cap. 279. Linnaea X11. 418, Meisner Gen, 126. (9t.) Coloc y u this Tournef. Inst. 107. Rigocarpus Necker Elem. n. 386. Cucurbita Citrallus L. et C. Colocy athis Linn. Nees Plant. offic. XII. t. 10. 11. C u cumeris sp. Seringe.

513\%. Eebalium L. C. RICH. Flores monoici. Mas c. C a ly $\mathrm{x}$ brevissime campanulatas, bi-quinquepartitus, laciniis acutis. Corolla calyei inserta, quinquepartita, laciniis aentis, patens. St a mina 5, imo calyci inserta, triadelpha; $f$. lamenta brevia, a ntherae uniloculares, lo. eulo lineari, connectivi crassi, sigmoidei dorso intra marginem adnato. F e m. C a l y x tubo ovato, enm ovario connato, supra ovarium constricto, limbo campanulato, quinquepartito. Cor oll a ma ris. Sta $m$ in a sterilia nulla. Ovariu $m$ inferum. triloculare, placentis juxta septa ntrinque parietalibus, multiovulatis. Stylus cylindraceus, trifidus; stig un a hippocrepica. Ba ec a ovalis, muricata, basi maturitate a pedunculo solnta perforata, lympham mucilaginosam seminibus foetam explodens. S e m in a ovalia, vix compressa, laevia. Embryonis exalbuminosi cotyledones plano-convexae, ra di $\mathrm{e}$ u la brevissima, centrifuga. Herba, in ruderatis Europae australis obvia, annua, glauca, erecta $v$. prostrata, ramosa, hispida; foliis alternis, petiolatis, cordato-oblongis, $a b$ tusis, grosse crenatis, cirrhis nullis, pedunculis axillaribus, mascul is cymoso-multifloris, femineis in eadem axilla unifloris, floribus flavis.

Eebali a m L. C. Richard mic. Reichenb. Flor, Germ. 294. Momord i ea E 1 a te r i a m Lina. Sehkuhr $t$, 313 . Bot. Mag. $t, 191 \%$. Nees Plant, offic. XVI. $t$. 11.

5133. NI 1 mandiea LINN. F lores monoici. Masc. Calyx brevissime campanulatus, quinquepartitus, patens. Corolla calyci inserta, quinquepartita, laciniis patentibus, obtusis, subundulatis. Stam in a 5, imo ealyci inserta, triadelpha; filam enta brevia, crassa, antherae conniventes, uniloculares, locnlo lineari, connertivi erassi, undulati margini extus adnato. F e m. C a$1 \mathrm{y} \times$ tabo obovato $\mathrm{v}$. subcylindrico, cum ovario connato, limbo supero, quinquepartito, patulo. Corolla maris annulo epigyno inserta. S $t$ a m in a 3 , rudimentaria, styli basim cingentia. Ovari $\mathbf{m}$ infernm, triloculare, placentis juxta septa hinc parietalibus, multiovulatis. Stylas eylindricus, trifidus v. tripartitus. B a eca pulposa, muricata v. tuberculata, maturitate elastice irregulariter rupta, polysperma. Sem in a compressa, marginata, integumento baceato colorato, exsiceatione rugoso. Embry o nis exalbuminosi e otyledone 8 foliaceae, plano-convexae, radicala brevissima, centrifoga. - Herbae in Asia et America tropica indigenae, glabriusculae $v$. hirtae; foliis alternis, cordatis, palmato-tri-quinquelobis, cirrhis* simplicibus, elongatis, pedunculis axillaribus, filiformibus, unifloris, medio v. supra basim bractea foliacea instructis.

M o m or di c a Linn. Gen, n. 1477, exel. sp. Gärtaer II. 48. t. 88, Lam, t. 794, Bot. Mag. t. 2445, DC, Prodr, III. 311. excl. sp. Meisner Gen. 127. (91.) El a tór i u m Tournef. A mordica et Poppya Necker Elem, $n, 391,399$. M u rie i a Loureiro Flor. coehinch. 733. DC. Prodr. IIT. 318. Ne u rosper a a Rafinesque in Journ. Phys, LXXXIX. 108. Spreagel NV. E. I. 144. DC. Prodr. TII, 3IS.

5134. Tufra TOURNEF. Flores monoici v. dioici. Mas e. Ca ly x eampanulatus, quinquedentatus. Corolla calyei inserta, profunde quinquepartita, patens. St a m in a 5, imo calyci inserta, distincta v. mona-triadelpha; fil am enta brevia, anth erae uniloenlares, loculo lineari, connectivi crassi margini sinuato extus adnato. F em. C aly x tubo clavato, eum ovario connato, limbo supero, quinquefido. Corolla e petala 5 , annulo epigyno inserta, basi vix coalita. St a m in a abortiva. Ovarium inferum, triloculare, placentis juxta septa hinc parietalibus, multiovolatis. Stylus trifidus; $8 \mathrm{tigmata}$ crassa, reniformibiloba v. bipartita. B a ce a obovata v. oblonga, demum exsucca, intus fibrosa, indehiscens $v$. disco epigyno deciduo apice operculo aperta, polysperma Semin a compressa, reticulata v. scrobiculata. Ilerbae in Asia et Africa tropica indigenae; foliis alternis, petiolatis, lobatis, dentatis, scabris, cirrhis simplicibus, floribus masculis racemosis, femineis solilariis.

L u f f a Tournef, Act, R, \&, 107. Caranill. Ie, I. 7, f, 9. Blume Bijdr. 929. DC. Prodr. III. 302. Wight et Arnott Prodr. I. 343. Meisner Gen. 126. (91.) T u ria Porskael Aegypt. 165. Lam. Diet. VIIT, 139. exel. sp. DC. Prodr. 1II. 303. Meisner l. c. Trevouxia Seopoli Introduet. 585. 
5135. Bemineasa $S A V I$. F lores poly gamo-monoici. Mase. Calyx quinquefidus, laciniis brevibus, latis, margine undalato-dentatis. Corolla ealyei inserta, quinquefida, lobis obovatis, obtusis, undulatis. St a m in a 5 , imo calyei inserta, triadelpha; filamenta brevia, lata, divaricata, a $\mathrm{n}$ h erae uniloculares, loculo lineari, connectivi dilatati, anfractuoso-sinnati margini dorsali adnato. F em. C a I y x tubo cylindrico, cum ovario connato, limbo supero, quinquepartito. C orolla maris, disco epigyno inserta. S tamina sterilia, interdum aeque fertilia. Ovarium inferum, triloculare, placentis juxta septa parietalibus, multiovulatis. Styln 8 brevis; stigma crassissimum, irregulariter trilobum. B a c e a obovatocylindriea, lanata, glauco-pruinosa, polysperma. S emin a ovata, margine incrassato-cincta. E mbryo .....-Herba indica, moschata, pilosissima; foliis alternis, petiolatis, cordatis, subquinquelobis, lobis acutiusculis, crenatis, cirrhis simplicibus, pedunculis axillaribus unifloris, floribus magnis, luteis.

Benincas a Savi Mem. 1818. p. 6. c. ic. Delile in Mem, Mcadem, Paris. 1826. VII. 395. -Seringe in Mem. soc. h, n. Genev. III. 1. 32, t. 4. DC. Prodr, III. 303. Meisuer Gen, 127. (91.) Cucurbita cerifera Fisch.

5 1136. Hagenaria $S E R$. F lor es monoici. Masc. Calyx tubo campanulato, limbo brevi, quinquepartito. Cor ollae petala 5, summo calycis tubo inserta, ovata, acuta, patentia. S t amin a 5, imo calyei inserta, triadelpha; filamenta brevia, conniventia, an thera e uniloculares, loculo lineari, connectivi erassi, anfractuososinnati, papillosi margini dorsali adnato. F e m. C a ly x tabo cylindrico v. ventricoso, superne attenuato, cum ovario connato, limbo supero, brevi, quinquepartito. Corolla maris. Ovari u m inferum, triloculare, placentís juxta septa parietalibus, multiovalatis. St ylus subnullus; stigin a ta 3 , erassa, biloba, granulosa. B a c e a carnosa, maturitate lignescens, polysperma. S e mina olovato - oblonga, compressa, margine tumido, apice truncato-bilobo eincta. Embryonis exalbuminosi cotyledones foliaceae, radicula brevissima, centrifoga. - Herba annua, molliter pubcscens, moschata, in Asia et Africa calidiore ut videtur indigena, nunc per tropicos totius orbis diffusa; fuliis alternis, petiolatis, cordatis, subintegris $v$. lobatis, basi biglandulosis, cirrhis tri-quadrifidis, pedunculis axillaribus unifloris, fasciculatis, floribus albis.

L age n a ria Seringe in Mem. soc, h. n. Genev, III. 29. t. 2. DC. Prodr. III. 299. Meisuer Gon. 127. (91.) C u curbita Lagenaria Linn. Lam. $t$. 795. Gärtuer $t, 88$.

\$. 4. CUCUMERINAE, $\mathrm{s}$ ta min a 5 , saepissime triadelpha. Antherae plus minus connatae, loculis linearibus extus adnatis, sursum et deorsum flexis.

513\%. Cueumis LINN. F lores monoici v. polygami. Ma s c. C a ly x campanulatus, quinquedentatus. Corolla e petala 5 , calyci inserta, ovata, acuta, patentia. Stamina 5, calyei inserta, triadelpha; fil a me nta conniventia, anthera e lineares, loculi linearcs, connectivi erassinsculi, recti dorso infra apicem integrum v. bipartitum anfractu simpliei adnati. $\mathrm{F}$ em. C aly $\mathrm{x}$ tubo subgloboso v. cylindrico, eum ovario connato, lim. bo supero, quinquedentato. Co rolla maris. Ora- rium inferum, triloculare, placentis juxta septa utrinque parietalibus, multiovulatis. St ylus brevis; stigmata $\mathbf{3}$, crassa, bipartita. Ba ce a carnosa, sulcata, verrucosa v. laevis, indehiscens v. irregulariter rupta, polysperma. Semina uvata, compressa, margine acuta. Embryon is exalbuminosi cotyledones foliaceae, radicula brevissima, centrifuga. - Herbae annuae, humifusae, cirrhiferae, in Asia tropica indigenae, ob fructus edules nunc passim in hortis cultae; foliis alternis, petiolatis, integris $b$. lobatis, pedunculis axillaribus, unifloris, masculis saepissime aggregatis, femineis solitariis.

Cu c um is Lian. Gen, n, 1479. Schkuhr t. 315. Jacq. Hort. Vindob. t.9. Gärtner t. 88. f.1. Seriuge in Mem, soe. h. n. Genev, III, t. 3. DC. Prodr. IIT, 299 exel, sp. Nees Plant. offic. Suppl, V. t, 12-14. Meisuer Gen, 127. (91.) Cucu in is et Melo Tournef, Inst. 104. excl. sp.

5138. Cueurbita LINN. Flores monoici. Ma s c. Cal y x tubo brevi, eampanulato, quinquefido. Coroll a imo calyei adnatim inserta, campanulata, limbi quinqnefidi lobis aestivatione induplicatis. S t a m in a 5 , imae corollae inserta, triadelpha, in columnam conniventia, a n therae uniloculares, loculo lineari, connectivi vix incrassati, mutici dorsó pluribus anfractibus longitudinalibus adnato. F e m. C a l y x tubo ovato v. obovato, cum ovario connato, limbo superô, quínquefido. Corolla maris. St amina sterilia. Ovari u m inferum, tri-quinqueloculare, placentis juxta septa utrinque parietalibus, mnltiovulatis. Stylus trifides; st i $\mathrm{gm}$ a $t$ a inerassata, biloba. B a cc a obovato-elavata, globosa v, depresso-sphaerica, polysperma. S e mina ovata, compressa, margine tumido cineta. E mb r y o n is exalbuminesi c o tyledone 8 foliaceae, radicula brevissima, centrifuga. - Herbae annuae, cirrhosae, in Asia tropica et temperata indigenae, nunc passim per terrarum orbem cultae; foliis alternis, petiolatis, cordatis, integris v. tri-quinquelobis, pedunculis axillaribus, solitariis, unifloris, floribus luteis.

C u c u rbit a Lian. Gen, n. 1478. Gärtaer II. 94. t.88. exel. Lagenaria et Citrullo. Seringe in Mem.soc. h. n. Genev. III. 29. t. 1. DC. Prodr. III. 316. Meisner Gen. 127, (91.) P e po et Melopepo Touruef. Inst, $t_{\mathrm{t}} 33.34$.

5132. Coceinfa WIGHT et ARN. Flores dioiei. Mas c. Calyx quinquefidus, Jaeiniis subulatis. Corolla imo ealyei adnatim inserta, campanulata, limbi quinquefidi lobis acuminatis, integerrimis. Stam in a 5, imae corollae inserta; fil a m e nt a monadelpha, ant h e ra e triadelphae, extrorsae, muticae, loculis longitudinalibus anfractuosis. F e m. Cal y x tubo oblongo, superne attenuato, cum ovario connato, limbo supero, quinquefido, C orolla maris. St a min a sterilia triadelpha, Ovarium inferum, triloculare, placentís juxta septa parietalibus, multiovulatis. Stylus brevis, trifidus; $s$ tig ma ta bifida. B a c ca oblonga, maturitate irregulariter rupta, polysperma. S e m in a ovata, compressa, integumento gelatinoso. Em irryo.... - Frutex indicus, scandens, glaber; fuliis altornis, longe petiolatis, cordatis, integris, quinquangularibus quinquelobisque, minute dentatis, supra punctatis, subtus basi glanduliferis, cirrltis simplicibus, pedunculis axillaribus, solitariis, unifloris, bracteatis, corollis majusculis, albis, fructu immaturo lineis decem longitudinulibus albis distincto, maturo coccineo.

Co cel a ia Wight et Arnott Prodr. I. 347. Hooker Ic. t. 138. Meisuer Gen, 127. (92.) B r y on i a grand is Liau. Momordica monadel pha Roxb. 
5140. Treiclesenthes LINN. Flores monoici v. interdum dioici. Mas c. Calyx subelavato-rampanulatus, quinquefidus, C orol I a calyei inserta, quinquepartita, laciniis integris v. bifidis, fimbriato-ciliatis. Stam in a 5 , imae corollae inserta; filamenta triadelpha, an therae coalitae, extrorzae, muticae, loculis longitudinalibus, gyroso-flexuosis. Fem. C a l y $x$ tubo oblongo $v$. ovato, cum ovario connato, limbo supero, quinquedentato, Corolla maris. Ovari um inferum, triloculare, placentis joxta septa parietalibus, mul. tiovulatis. St y I 8 s trifidus; stig mata oblongosubulata. B a ce a oblonga v. suliglobosa, pulposa, polysperma. Semina ovata, compressa, marginibus. acuta. Em hryo ..... - Herbae annuae $v$. perennes, cirrhosae, in Asia et America tropica crescentes; foliis alternis, integris v. palmatilobis, floribus masculis racemosis $v$, rarius solitariis, femineis plerumque solitariis, interdum racemosis.

Triebosanthes Linn. Gen, a. 1476. DC. Prodr III. 313. Wight et Arnntt Prodr, I. 349. Meisner Gen. 127. (91.) Ceratosanthes Jussieu Gen, 39t. Anguina Micheli Gen. 12.

a. CERATOSANTHES $s$ chrad, Coro 11 a e laciniae bifidae. Ceratosanthes Schrader in Linnaea XII. 403. excl. sect. 2. T r. t u b e ros a Willd. Bot. Mag. $t .2703$.

b. EUTRICHOSANTHES Wight et Arn.l. c. Corollae laciniae iutegrae. B ractéae racemorum masculorum parvae, pedicellis multo breviores. - Trichosanthes Schrader $O_{p}$. cit. p. 40s. (Micheli Op. cit. $t .9$. Lam. , 749. Jaeq. f. Eclog. t. 128.)

c. INVOLUCRARIA Wight et Arn. l. c. Corolla lacinlae integrae. B ra ct te a e racemorum maseulorum magnae, foliaceae, pedicellis multo Inngiores, flores ante anthesim involucrantes. - Invola cra ria Seringe in Mem. soc. $h, n$, Genev, III. $t$. 4. DC. Prodr. III. 318. Meisner Gen, 12z. (91.) Trichos an thes palmata Roxb. Modec a bracteata Lam.

5114. Flaterivan $J A C Q$. Flores monoici. Mas c. Caly x longe tubulosns, eylindricns, limbo brevissime quinquedentato. Corolla e petala 5, snmmo calyei inserta, vix coalita, linearia v. lanceolata, patentia. Stam in a $5,+c a l y c i s ~ t u b o$ inserta, monadelpha, a $n$th e ra e extrorsae, muticae, longitudinaliter flexuosae. F e m. C a l y x tuho basi ventricoso, cum ovario connato, supra ovarium producto, cylindrico, quinquedentato. Corolla maris. Stamin a sterilia glandulaeformia. Ovarium inferum, triloculare, placentis juxta septa parietalibus, multiovulatis. Stylng eylindricus; stigma capitatum. B a e ca compressa, murieato-echinata, hine contracta, reniformis, elastice bi-trivalvis, polysperma. S em in a compressa, margine membranaceo cineta. $\mathbf{E} \mathbf{m}$ b r y $0 \ldots .$.

Herbae scandentes, cirrhosae, in America tropica et subtropica cis aequatorem. indigenae; foliis alternis, petiolatis, angulato-lobatis, pedunculis axillaribus, masculis multifloris, femineis unifloris.

Elaterinm Jacquin Amer, 241, $t$, 15t. Edit. pict. 118 t, 232, Linn, sp, n, 1398. Jussieu Gen. 394. Lam, t, 743. Kunth in Humb. et Bonpl. Nov, gen. et sp. H. 120, DC Prodr. III. 310. Meisner Gen. 127. (91.) Momor dica Necker Elom, n. 390.

51 $\triangle 2$. Cephalandar SCHRAD. F lores dioici. M a s c. Caly x breve eampanulatus, quinquedentatus. Corolla calyci inserta, quinquepartita, planiuscula, laciniis apice recurvis. Stamin a 5, imae corollae inserta. triadelpha, inferne cohaerentia, apice in capitulum subglobosum antherifernm connata, a $n t h$ er a e nniloculares, extrorsae, distinctae, longitudinaliter flexuosae. F e m. C a I y $x$ tubo cum ovario connato, limbo supero, quinquedentato. Corolla maris. Ovarium inferum, triloculare? Sti $\mathrm{g}$ m a lobatum. Ba c $\mathrm{e}$ a trilocularis?, polysperma. S e m in a compressa, basi oblique rostellata, intra marginem utringue linea depressa notata.... - Herba capens is, scandens; radice ramosa, ramis tuberascentibus, foliis alternis, breve petiolatis, quinquelobis, glaucescentibus, cirrhis simplicibus, pedunculis axillaribus, solitariis, unifloris, floribus magnis, aurantiaceo-luteis, fructibus puniceis, ovi columbini forma et mole, seminibus albidis.

Cephalandra Schrader in Ecklon et Zegher Enumerat, plant. Cap, 280. Meisner Gen, 126. (91.) B r y o uia qu in qu el o ba Thunb. Bot. Mag. t. 1820.

§. 5. CYCLANTHEREAE. Stamina monadelpha, colnmnae apice in discum orbiculatum, margine antheriferum dilatato.

51 43. Cyellamthera SCHRAD. F lores monoiei. C a ly x brevissimus, planus, laciniisquinque subulatis, distantibus. Corolla hemisphaerica, calyci adnatim inserta, quinquefida, lobis triangularibns, acutis. St a m in u m colnmna brevissima, in diseum peltatum, orbicularem, margine antheriferum desinens, an therae transversim adnatae, in annulum polliniferum confluentes. F e m. Caly $\mathrm{x}$ tubo oblongo, cum ovario connato, in collum rostriformen attenuato, limbo quinquepartito. Corolla maris. Ova ri um inferum.... Stigm a sessile, convexum. Fructus carnosus, nnilocularis, demum cavus, placenta propendente, margine vtrinque seminifera. Semina plurima, horizontalia .... - Herba mexicana, annua, scandens, glabra; foliis alternis, petiolatis, cirrhis bifidis, floribus parvis, virescèntibus, axillaribus, masculis corymbosis, pedunculo elongato, femineis in eadem axilla sessilibus.

Cy cla nthera Schvader Index Sem. hort. Göting. 1831. ex Linnaea Litterat. Berioht VIIT. 23. Linnaea XII. 408. Meisuer Gen. 127. (92.)

\section{GENERA MINUS NOTA.}

5144. Selhizoearpum SCHRAD. F10res monoiei. Masc. Calyx quinquedentatus. Co roll a infundibuliformis, limbo quinquefido, patente. Stamina 3 ; filamentis liberis, antheis cohaerentibus. GlanduIa in centro floris. Fem. Cal y maris. Corollae tubus basi squamis clausus. Glandula styli basim cingens. B a e e a basi sexlocularis, polysperma, a basi in valvulas plures, apice cohaerentes dehiscens, Herba mexicana, annua, nondum descripta.

$\mathrm{S}$ chizo earpum Schrader Index Sem. hort, Götling. ex Linnaea Litlerat. Bericht VI. p. 73. Meisner Gen, 126. (91.)

51 45. Gplenamtias $S C H R A D$. Flores hermaphroditi. Calyx tubo elongato-cuneato, cum ovario connảto, limbo supero, quinquefido. Corolla annulo epigyno calycis limbum vestienti inserta, campanulata, quinquefida, patens. S $t$ amin a 5, sub corollae limbo inserta, distincta v. triadelpha; filamenta hrevia, antherae introrsae, basifixae, gyrosae. Ovariu m inferum... Sty lus cylindraceus; stigmata 3 , subpeltata. B a c e a elliptico-subglobosa, rostrata, costata, trilocularis, spongiosa, polysperma. S e m i n a ovato-elliptiea, compressa, margine obtusa.

Herba mexican $a_{;}$radicefibrosa, caule angulato, 118 * 
scabro, foliis alternis, longe petiolatis, cordutis, quinquelobis, angulato-dentatis, scabris, cirrhis inaequaliter bi-quinquefidis, floribus axillaribus, semipollicaribus, in racemum brevem, pedunculatum dispositis.

$\mathrm{S} p$ he nantha Schrader in Linnaea $\mathrm{X} I I .416$.

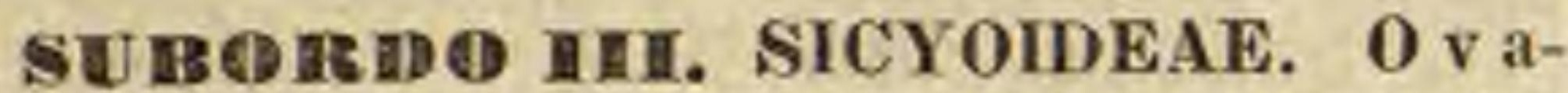
rium uniloculare. Ovulum unicum, ex apice Toculi pendulum.

5146. Sieyos LINN. Flores monoici M a sc, Cal y $\mathrm{x}$ campanulatus, subulato - quinquedentatus. Coroll a calyei adnatim inserta, limbo quinquefido. St am in a 5 , in columnam apice capitatu-antheriferam connata, a $\mathbf{n}$ the rae oblongae v. subglobosae, nniloculares, adnatae, demum confluentes. F em. C a ly $x$ tubo cum ovario connato, supra ovarinm constricto, limbo supero, campanulato, quinquedentato. Ovari $\mathbf{m}$ inferum, uniloculare. Ovil um unicum, ex apice loculi pendalum, anatropum. Stylus apice bi-trifidus; stigm a ta indivisa. Nu cula coriacea, ovata, echinata, monusperma. S emen fanieulo brevi appensum. Embryon is exalbuminosi, orthotropi cotyledones foliaceae, radicula brevissima, supera. - Herbae in regionibus tropicis subtropicisque totius orbis obviae, scandentes, cirrhosae; foliis alternis, petiolatis, angulato-lobatis, asperis, pedunculis axillaribus, floribus masculis elongato-racemosis, femineis umbellato-glomeratis rariusve solitariis.

Sf e y o s Linn. Gen. n. 1481. Gärner II. 45. t. 88. Lam. t. 796, DC, Prodr. IIT. 309. Póppig Nov.gen. et sp. t. 172. Dleisner Gen. 127. (91.) Sicyolides Tournef. Inst, 28. B a d a ro a Bertero msc.

514. Sechium $P, B R$. FIores monoici. I a s c. Caly x tubo clavato - campanulato, limbo quinquefido. Co roll a calyci adnatim inserta, limbo quinquepartito. Sta $\mathrm{m}$ in a 5 , imae corollae inserta, in columnam apice trifidam coalita, a $\mathrm{n} t \mathrm{~h} \mathrm{e}-$ $r$ a e cohaerentes, unilocnlares, extrorsae, loculis flexuosis, adnatis. Fe m. C a l y $x$ tubo cum ovario connato, supra ovarium constricto, limbo supero, campanulato, quinquefido. Co roll a maris. Ovari u $\mathrm{m}$ inferum, uniloculare. $O \mathrm{v} u \mathrm{~L}$ u $\mathrm{m}$ nicum, ex apice locali pendulnm, anatropum. Sty l a 8 apice trifidus; stigmata incrassato-biloba, Bacea globosa v. obovata, unilocularis, monosperma. Semen inversum, subglobosum, marginibus acutum, testa lignosa, laevigata. E mbryo..... Herbae Americ a e tropicae; foliis alternis, petiolatis, cordatis, angulatis $v$. lubatis, cirrhis lateralibus, bi-quinquefidis, floribus masculis racemosis, femineis in eadem axilla solitariis.

Sechium P. Browne Jam. 355. Linn, Gen. n, 148\%. Jussieu Gen, 391, Swartz Flor. Ind. occid. Ir. 1150. DC. Prodr. HI. 313. Poppig Nov. Gen. ot sp. II, 56, t. 176. Meisuer Gen, 127. (92.) C ha y o ta Jacq. Amer, edit.piot. t. 245. SI c yli sp. Jaeq. Amer. L. 163.

\section{genera penitus DuBia.}

51 48. Frythropalum $B L U M$. F lores (abortu?) monoici. C al y e is margo superus, obsolete quinquedentatus. Corollae petala 5, ovata, dentibus calycinis alterna, basi intus bicallosa. Stam ina 5, petalis opposita, ad marginem disci epigyni inserta; filamenta brevia, antherat erectae, latere dehiscentes, Ovarium .... StyI a s brevis. Fractus clavatus, unilocularis, trivalvis, valvis carnosis, subbipartibilibus, S e men unicum, tunicatum. - Frutex javanicus, scandens; foliis petiolatis, subpeltatis, oblongis, acuminatis, integerrimis, glabris, pedunculis axillaribus ramosis, pedicellis subumbellatis.

E rythropalum Blume. Bijdr. 921. DC. Prodr. III. 303. Meisuer Gen. 126: (91.)

5149. Zureea COMMERS. F Iores masculi axillares, solitarii, bractea ampla concava involuti. Caly $x$ maximas, eampanulatus, quinquefidus, extus basi quinqueappendiculatus, quasi calyculatus." Sta mina 5. - Planta herbarii Commersoniani, habitu cucurbitaceo, cirrho laterali.

$\mathrm{Z}$ u c c a Commers. ex Jussiou Gen, 398. Poiret Supplem. V. 586. St, HHaire in Mem. Mus, IX, 190. DC. Prodr. IIT. 319. Meisuer Gen. 126. (91.)

5150. Allasia LOUR, Calyx inferus, tubo brevi, limbi quinquefidi laciniis subacutis, pilosis. Co ro 11 a e-supera e petala quatuor (!), parva, subrotunda, concava, pilosissima, Stamina 4 ; fil ament a subulata, crassa, calyei subaequalia, antherae bilobae, inversae, lobis bilocularibns. Ov a r i u m subrotnndum, inter calycem et corollam. Stylus subulatus, staminibus aequalis; st i $\mathrm{m}$ a acutum. B ac ca carnosa, magna, oblonga, obtusa, ğlabra, pendula, unilocularis. S e m ina plurima, nidulantia, compresso-ovata, tumida. - Arbor magna, in Africae ora o rientali indigena; ramis patentibus, inermibus, foliis oppositis, petiolatis, quinato-digitatis, foliolis ovalibus, integerrimis, pilosis, pedunculis subterminalibus multifloris, floribus pallidis, baccis rubro-fuscis.

A Il a s i a Loureiro Flor, cochinch, 107. DC. Prodr, III, 319. Meisuer Gon, 186. (91.)

5151. Thaladianthan BUNGE. F 1 ores abortn polygami, monuici? M a s c. C a lyx campanulatus, limbi quinquepartiti lacinils lanceolatis, elongatís. Co rolla subeampanulata, petalis basi inter se et cum ealyce connatis, inaequalibus, tribus adscendentibus conniventibus, majoribus, duobus minoribus deflexis, subbilabiata, fauce ventricosa, tubo brevi. Stamina 5 ; fil a menta omnia libera, a nthera e biloculares, ovali-oblongae, intus dehiscentes. S q a a ma ad basim petali superioris medii majoris lata, inflexa, ovarii rudimentam obliteratum tegens. Ne u tr. Caly $x$ rotatas, quinquepartitus. Co rolla rotata, quinquefida, ealyce dimidio brevior. An the rae 5, effuetae, corneae, lunatae, sessiles, conniventes. Ovar ii vestigiam nullum. - Herba annua, scandens, tenera, in ruderatis circa $\mathrm{Pe}-k$ ing lecta; foliis alternis, petiolatis, profunde cordatis, denticulatis, cirrh is stipularibus simplicibus, capitulis florum abortivorum in axillis infimis sessilibus, in sequentibus breve pedunculatis, in axillis superioribus ramis foliatis, floribus masculis axillaribus, longius pedicellatis, flavis, magnitudine Campanulae rotundifoliae.

Thla di a nt li a Buage Enumerat. Plant, Chin. bor. 29. - Genus magnopere dubium, ex naico specimine constitutum, et a el- auctore ob stirpis similis, fructibus ellipticís quinquesulcatis aurantiacis onustae iconem, in herbario picto sinieo visam, ad Cacurbitaceas relata. An monstri aliquid?

\section{CUCURBITACEIS AFFINES.}

* Gronovieae.

5 15:. Troonovia LINN. Flores hermaphroditi. Caly x tubo sulogloboso, qninquenervi, 
cum ovario connato, limbo supero, infundibuliformi-campanulato, quinquefido. Corolla e petala 5, lineari-lanceolata, calyeis fauci inserta, ejusdem laciniis alterna et breviora. Sta $\mathrm{m}$ in a 5 , eum petalis inserta, iisdem alterna, inclusa; filamen $\mathbf{c}$ a subulata, libera, anthera e terminales, biluculares, subgloboso-didymae, longitudinaliter dehiscentes. 0 va ri r'm infernm, uniloculare. $O$ v u$1 \mathrm{um}$ unicam, ex apice loculi pendulum, anatropum. Sty Ius terminalis, simplex; stig ma subcapitatum, indivisum. IUrceolus epigynus, carnosus, truncatus, styli basim cingens. Nucula subglobosa, ad angulos calycis laciniis continuos costata v. obsolete alata, monosperma. S eme $n$ inversum, testa membranacea, longitudinaliter suleato-striata, E mbryonis exalbuminosi cotyle don es carnosae, marginibus inaequaliter lobnlatis induplicatis, radicula brevissima, supera. - Herba c a mpechiana, scandens, cirrhosa, pilosa; foliis alternis, petiolatis, cordato-quinquelobis, pedunculis oppositifoliis, subcorymbosis, floribus bractealis parvis, flavo-virentibus.

Gro novia Liss. Gen. n. 391. Jussieu Gen. 394. Jaeq. Collect. III. 197. Ic, rar. t. 338. Lam, t, 144. Kunth in Humb. et Bonpl. Nov, gen, et sp. II, 119. DC. Prodr, III, 320. Meisner Gen. 125. (90.)

\section{Ardo CCIET. Begoniaceae.}

BEGONIACEAE- R. Brown in Tuckey Congo 164. Bartling Ord, nat, 420. Lindley_Introduct, edit. II. p. 56.

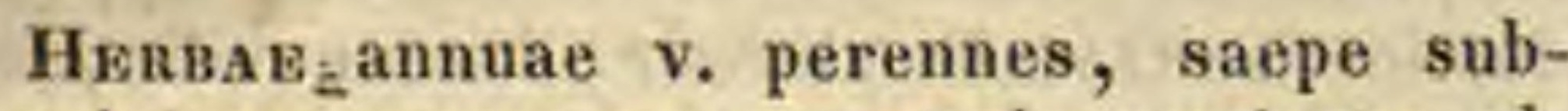
suceulentae, succo aqueo, caule ramisque alternis teretibus, nodoso-articulatis. Folia alterna, petiolata, simplicia, palmatinervia, integra v. interdum palmatilobata, basi saepissime cordata, plerumque plus minus inaequilatera, interdum dinidiata, dentata v. serrata, serraturis saepe mucronatis, rarissime integerrima, vernatione marginibus involuta, petiolo supra caulem articulato. Stipulae laterales membranaceae, liberae, deciduae, basi lata subintrapetiolares.

Frores unisexuales, monoici, in cymis axillaribus, pedunculatis, dichotomis, masculi centrales, feminei in ambitu, bracteis sub inflorescentiae ramificationibus membranaceis.

Masc. Perig on i um petaloideum, tetraphyllum, foliolis duobus exterioribus majoribus, subrotundis, aestivatione planis, sibi invicem applicitis, duo interiora alterna minora, complicata includentibus. *

Stamina plurima, in centro floris congesta. Filamenta brevissima, libera $\mathbf{v}$. basi inter se connata, in connectivum obtusum continuo desinentia. An the rae extrorsae, biloculares, loculi lineares, connectivi marginibus adnati, paralleli, discreti, apice sese hand contingentes, longitudinaliter dehiscentes. Poll in is granula oblonga, laevissima, sulco longitudinali notata. 0 va ri i rudimentum nullum.

FEM. Perigonium corollinum, tubo subelavato, triptero, cum ovario connato, limbo supero, profunde quadri - novempartito, laciniis aestivatione imbricatis, sub anthesi erectis v. patentibus.

Ovarivm inferum, triloeulare, septis cum alis tubi perigonialis alternantibus. $0 \mathrm{vula}$ in placentis e Joculorum angulo centrali prominulis, geminatis, longitudinalibus plurima, anatropa. Styli tres, breves, crassi, bifidi. Stig$m$ a t a incrassata, basi continua, tortuoso-flexuosa v. capitata.

Capsula membranacea, perigonio emarcido coronata, membranaceo trialata, trilocularis, toculicide per medias alas trivalvis, valvis medio septa tenuissime membranacea, ab axi placentifero soluta gerentibus, basi et apice cohaerentibus.

Semiva plurima, minima, oblonga, exarillata, testa tenuissime membranacea, longitudinaliter striata, umbilico basilari.

Eмвву0 in axi albuminis carnosi orthotropus, teretiusculus, ejusdem longitudine; cotyledonibus brevissimis, radicula longa, umbilicum contingente, centripeta.

Be g o n i a ce a e in Asia et America tropica indigenae, nulli cognitorum ordinum aretius affines v. similes, olim Polygoneis consociatae, hic, quin aliquid de vera earum affinitate, quae nobis omnino problematica est, statuatur, ad calcem Peponiferarum, ad quas notis aliquibus, fortassis tamen nimis levibus accedunt, collocantur.

5153. Eegonia LINN. Flores monoiei. Mas c. Perigonium tetraphyllum, foliolis subrotundis, duobns exterioribus majoribus. St a mina plurima; filamenta brevissima, libera v. basi connata, a ntherae extrorsae, bilocolares, locoli lineares, discreti, connectivi continui obtusi margini adnatae, longitudinaliter dehiscentes. Fem. Perigoninm tubo triptero, cum ovario connato, limbi superi, quadri-novempartiti, persistentis lobis pluriseriatim inbricatis. Ovarium inferum, triloculare. Ovnla in placentis e loculorum angulo eentrali bilamellatis plurima, anatropa, Styli 3 , bifidi; stigmata erassa, flexuosa v. capitata. Capsula membranaceo-trialata, trilocularis, loculieide trivalvis. S e min a plurima, minima, striata. Embryo in axi albnminis carnosi orthotropus. - Herbae in Asia et America tropica indigenae; foliis alternis, petiolatis, integris v. palmatilobis, basi saepe cordatis, inaequilateris, integerrimis, dentatis $v$. mucronato-serratis, stipulis lateralibus membranaceis deciduis, cymis axillaribus pedunculatis, dichotomis, floribus albis, roseis $v$, rubicundis.

Begonia Lian. Gen, n. 1156. Anblet Guian, $t .348$. 349. Jussieu Gen, 436. Dryander in Linn. Transaot, I, 155. t. 14._16. Gärtaer $I, 156, t$. 31. Jacq. Ic. rar. t. 619. Salisbury Parad. 2. 72. Smith Exot. Bot. t. 101. Hooker Exat. Flor, t, 17, 18, 57. Kunth in Humb, et Bonpl. Nov. gen, et sp, VIT, 176, $t, 64 t$-6at. Link et Orto Ic. $t, 10,38$. Bot. Mag. $t, 1473,2723.2846 .2869 .2900,2966.3166,3367.3580 .3559$. 3564. 3591. 3720, Bat. Reg.11. 364. 471. 666, 1352, 1665, 1995. Popplg Nov, gen. et sp. $t, 11,12$. Flor. Fiumin. $X, t, 33-54$. - Eupet a I u m Liadley Introduct. edic. $I$, p. 57 . B. petalodes Bot. Reg. $t, 1757$. perigoaii coliolis interiokituas albis, exteriora rubra subaequantibus, vix satis a reliquis differt. 


\section{Classis XEVIJ, Opuntiae.}

Frutices v. arbores succulentae, saepissime aphyllae, succo lacteo v. aqueo. Folia dum adsunt alterna, simplicia. Stipula e nullae. Ca lyx tubo cum ovario connato, limbo multiplici, sensim in petala pluri-multiseriata transeunte. S $\mathbf{\text { a }} \mathrm{m}$ in a indefinita, libera. Ovarium uniloculare, placentis ad suturas parietalibus tribus v. plurimis, multiovulatis, ovulis anatropis. E m b r y o exalbuminosus v. albumine parco inclusus, reclus $\mathbf{v}$. arcuatus.

\section{Drdo CCII: Cacteae.}

CACTUS Linn. Gen, n. 613. $S p$. pl. CACTI Jassieu Gen. 310. excl. 6. 1. CAC TOIDEAK Venten. Tabl. III. 289. NOPALEAE DC. Theorie elem. 216. OPUNTIACEAE Jussien in Dict. sc. nat. $X X X V$. 144. exel. Grossul. Kunth in Humb. et Bonpl. Nov, gen, et sp. VI. 65. Bartling Ord, nat, 276. CaCtenE DC. Prodr. IIT. 457. Hevue des Cactées. Paris, 1829. Mem, Mus, XVII. Liuk et Otto in Verhandl. Preuss. Gartenb. Ver. IIT. 4t2. Martius in N. A. N. C. XVT. Pfeiffer, Enumeratio diagnostica Cactearum Berolin, 1837. 8. Zuccarini Novar. Stirp. fasc, III. Scheidweiler in Bullet. Aoa. dem. Bruxell, 1838. Aoùt. Lemaire, Cact. Hort, Monvill. Paris, 1838. Cactearum genera nova. Paris, 1838. Miquel in Bullet. sf. phys. et nat, en Néerlande 1839. p. 87-118. CACTACEAE Lindley Introduct. edit. II, 53.

Plantan fruticosae v. arborescentes, habitu peculiari, succo aqueo v. lacteo scatentes. R a dix lignosa, simplex v. ramosa, longa v. abbreviata, fibris sparsis, cortice laevi. C a uli s ramosus v. suppressa gemmarum evolutione simplicissimus, teres, angulatus, costatus, alatus v. planus, ramis abortivis tuberculatomamillatus, elongatus v. globoso-contractus, carnosus, cortice crasso, plerumque viridi, tela cellalosa laxa, fibris ligneis raris tenuibus, rarius pluribus et duris, lignum verum formantibus, canaie medullari farcto. Foli a plerumque nulla, pulvino sub gemma posito indicata, nunc rudimentaria, decidua, rarius perfecta, plana, petiolata. Gemmae e folii latentis, rudimentarii v. perfecti axilla simplicis v. duplicis ordinis, una inferior vix explicanda, perulis spinescentibus munita, nuda v. tomentosa, altera superior contigua, in florem v. ramnlum evoluta. Stipulae nullae. Spin a e perulis abortivis ortae, cujusvis fasculi numero definitae $v$. indefinitae, novis quovis anno accedentibus, nunc annotinis conformibus (spinae homoeacanthae), v. crassioribus et paucioribus (heteracanthae), raro omnino nullae.

Flores hermaphroditi, solitarii, e ramo abortivo, ant in axilla rami abortivi axillaris, ebracteati.

Perigonion multiplex, calyce a corolla vix distineto.

C a lyx petaloideus v. rarius foliaceus, nunc gamophyllus, tubo cum ovario cohaerente, in- tefium supra illud producto, laciniis nnmero indefinitis, limbum superum, marcescenti decidunm formantibus, nunc foliolis secundum lineas spirales multiplas ovarium vestientibus, in fructu persistentibus. Corolla e petala tenera, a calycis foliolis certo limite haud separata, bi-pluriserialia, seriebus aliquando spiralibus, exteriora intimis calycis foliolis similia, interiora majora, nunc distincta, tubo calycino rotatim inserta, v. erecta, inferne in tubum longum coalita, apice libera, saepissime marcescentia v. decidua.

Stamna indefinita, multiseriata, tubo v. petalorum basi inserta, interiora plerumque minora. Filamenta filiformia, basi saepissime latiora, petalis plerumque breviora. Antherae introrsae, biloculares, connectivo tenui, vix manifesto, loculos aequante $v$. rarius breviore, erectae, oblongae v, rèniformes, latere longitudinaliter dehiscentes: Poll e n simplex, globosum, laeve, zonis diaphanis duabus v. tribus.

Ovarium inferum, e carpidiis tribus v. pluribus, margine placentiferis, valvatim contiguis compositum, uniloculare, placentis parietalibus carpidiorum numero, e marginibus appositis duplicatis. Ovula plurima, horizontalia, anatropa. Stylus terminalis, simplex, elongatus, cylindricus $v$. pyramidatus, pervius v. farctus, longitudinaliter plus minus distincté striatus, deciduus v. cum petalis marcescens. Sti gmat a placentarum numero, Jinearia, expansa $v$. in fasciculum aut spiram collecta aut subulata, facie papillosa.

Bacca laevis v. calycis foliolis adnatis spinosa et setosa, apice umbilicata, unilocularis, pulposa, sero maturescens, placentis parietalibus nerviformibus, rectis v. flexuosis, pulpiferis.

Semina plurima, nidulantia, globulosa $v$. ampullaceo-digitaliformia, testa subossea, nigra, nitida, scrobiculata, umbilicó maguo, circulari, pallido. Endopleura tenuis. Albumen nullum $v$. parcissimum.

Eмввто rectus, clavatus v. subglobosus, aut curvatus, hemicyclicus. Cotyledones liberae, $\mathbf{v}$. in corpus ovoideum, emarginatum connatae. R a di c ula umbilicum spectans.

Cacte a e Americam tropicam et subtropicam magno numero inhabitant, unde in Europam mediterraneam, Asiam et Africam calidiorem a mortalibus propagatae; in America boreali usque ad $49^{\circ}$ L. 13 . observatae fuerunt, nonnullae, sedillae admodum dubiae, in Madagascaria, Ceylone et imperio Sinensi nasci dicuntur.

Ordinis habitu admodum insignis affinitas subobscura, Ribesiaceae quibus olim consociatus, et revera multis numeris conterminus, facil- 
lime distinguuntur tum habitu, tum partium perigonii, genitalium et placentarum numero definito, Mesembryanthemeae ad quas aliis characteribus accedunt, placentarum situ et fructus indole diversae.

Fruetus nonnularum sapide acidali. Plurimae in hortis cultae, hodie Adonistis magnae curae sunt.

Ordines descriptionem et generum characteres e praeclaro cl. Miquel tractatu mutuati sumus.

\$. 1. CaCteae tubulos ae. Miq. C orolla tubo supra ovarium producto.

51 1 4. Caetus LINN. P e rig on ium multiplex, tubuloso-subeampaniforme, basi ovario connatum, segmentis inferioribus paucis, parvis, coloratis, tubo adhaerentibus, petali is $6 \ldots 25$, bitriseriatis, tubo brevioribus, intimis latioribus. St a in in a medio tubo adnata, pluriseriata, inclusa; filamenta filiformia, antherae ovales, oblongae, erectae, $\mathrm{Ov}$ ari um inferum, unilocula$r e$, placentis parietalibus multiovulatis. Stylas filiformis, stamina superans; $8 \mathrm{tig} \mathrm{m}$ a tri-septemlobum, lobis linearibus, elongatis v. lobulatis. B a $c$ c a perigonio mareido coronata, laevis, oblonga v. elavata, unilocularis, pulposa, placentis parietalibus nerviformibus. S e m i n a plurima, in pulpa nidulantia, subglobosa $\mathbf{v}$. digitaliformia. Embryonis exalbuminosi, orthotrepi, elavati v. ovati cotyledones brevissimae, radieula crassa, obtasa. - Frutices carnosi, in America tropica et subtropica indigeni, simplices $v$. pauciramosi, succo lacteo $v$, aqueo foeti; ramis abortivis tuberculiformibus, nunc liberis, spiraliter dispositis, nunc in costas longitudinales coalitis, apice psrulas spinescentes, circulariter in areolis locatas, homoeacanthas $v$, heteracanthas, primum plerumque tomiento velatas gerentibus, floribus in axillis tuberculorum trunci spiraliter dispositorum, v. in apice trunci simplicis dense aggregatorum, solitariis, sessilibus, basi tomento cinctis, parvis, roseis, albicantibus $v$, virescentibus, per unum $v$, plures dies florentibus.

Cactus Lina. Gent, $n, 613$, exel. sp. pl. Miquel $i n$ Bullet. N6́ert. 1839. p. 108, Melo e a tus Tournefort Inst. 653, exel. sp. C a ctus et $\mathrm{M}$ a millaria Hawerth Synops. 172. et 177. Mam illaria et Melocactus DC. Revue Caet. 26, et 32.Prodr. III. 459. 460. A r i o carpus Seheidweiler in Bullet. Academ. Bruxell, 1838. Aoút. A nh a I o n i m Lemaire Cact. Nov, gen, ot sp. 1.

a. MAMILLARIA Haw. Trunei subglobosi v. eylindracei, simplices v. ramosi, tuberculis spinigeris spiraliter dispositis, ex axillis saepe lanatis floriferi. Spinae homoeacanthae v. Geteracanthae, extimae saepe setiformes. Flores saepe zonae ad instar truneum circumdantes, per plures dies florentes, durante florescentia adhuc cresceutes et vividius colorati. Stig m a $t$ a liaearia v. brevia, rotundata, lobiformia, verrueulosa. Miquel. $l$. $c$.

Hamlliaria Haworth $l$. $c$. Melocacti \$. 1. Pfeiffer Enumerat. 40, E c hi a o c a cti Willdenow Enumerat, Suppl. 30, A rioc arpus Scheidweiller $l$. $c$. A uhalo n ium Lemaire l. c. (DC, Ficvue t. 2. $f$. 1 . Martius $N . A . N, C, X V I, t, 19.20,23$. Otto et Pfelffer Abbild, $t, 3, f .5$.

b. MELOCACTUS Tournef. Tranci simplices, globosi, ovoidei v. pyramidales, validi, tuberculis in series longitadiuales coneretis costati et profuade sulcati. Spinae homoeacanthae v. heteracanthae, plerumque fortes, in areolis ovalibus $\vee$. circularibus, areolae sursum non elongatae, nascentes plerumque tomeato circumdatae.
Flores ex axillis mamillaram exiguarum, in vertice truaci spiraliter dense aggregatarum, et tomento deaso obvolatarum exorti, rosei, ephemeri. St $\mathrm{g}_{\mathrm{g}} \mathrm{a} t \mathrm{t}$ linearia. B a cea e rubrae, pleramque clavatae, subcostatae, perigonio sicco coronatae. S e mi a a digitaliformia. Mi. quel l. $c$.

Melocactus Tournef. $l$. c. DC. $l$. c. Pfeifter $t$. c. 9. 2. Ca ctus Haworth 2. c. (DC. Pl. gr. 112. Revue t. 6. Link et Otto Bert, Gartenb. Nerhandl. III. $t, 11$. 12. 13. 15. 25. Bot. Mag, $t, 3090$.

5155. Cehindeactus LINK et OTTO. Perigonium multiplex, tubuloso-subcampaniforme, basi ovario connatum, foliolis eal y einis plurimis, squamatis, tubo spiraliter aflixis, petalis plurimis, multiseriatis, expansis. Stamin a tubo indiscriminatim inserta, multiseriata, corolla breviora; fil a m enta filiformia, inaequalia, superiora longiora, antherae. oblongae. Ovari n m inferum, uniloculare, placentis parietalibus multiovalatis. Sty lus cylindracens, fistulosus, stamina superans; stigma multipartitum, lobis linearibus. B a c ca perigonio marcido coronata, calycis foliolis adnatis squamata, unilocularis, pulposa, placentis parietalibus nerviformibus. Semina plurima, in pulpa nidulantia, subglobosa. Em bryo nis exalbuminosi, ovati cotyedones connatae, radicula obtusissima. Frutices americani, melocactiformes, simplicissimi, raro tuberculis in ramos evolutis ramosi, carnosi, globosi, ovoidei v. placentiformes, costati $v$. tuberculati, costis paucis v. plurimis, latis v. angustis, rectis $v$. undulato-crispis, aetate numero auctis, nempe vetustis sursum fissis, spinis ex areola sursum plerumque anguste elongata, versus trunci apicem plerumque copiosioribus, juventute basi lana circumdatis, floribus e tuberculis spiniferis ad apicem costarum ortis, subinde tuberculis ultimis dense la. natis, tanquam e cephalio prodeuntibus, magnis, per plures dies florentibus.

E chinocactus Liak et 0tto in Berl. Gartenb. Ver. handl. III, 480. c. ic. DC. Revue t. $7-10$. Mem, $t$. 10. 11. Prodr. IIT. 461. Martius int N. A. N. C. XVI. t. 13-15. Pteiffer Enumerat. 47. Miquel in Bullet Néerl. 1839. p. 105. Melocacti s p. Auet. - Dis eocactus Pfeiffer in Otto Gartenseit. 1837. p. 24t. - ? As t r o phy t u m Lemaire Cact. Nov, gen, ot sp. 3, et 103.

515B. Eelhimopois ZUCC. Perigon i $\mathbf{u}$ multiplex, tubo basi cum orario connato, elongato-subcampannlatum, foliolis calycinis plurimis, tubo spiraliter adnatis, petalis numerosis, multiseriatis. Stamina plurima, fundo tubi confertim inserta, et versus corollae limbum anticum convergentia, alia tubo longitudinaliter connata, faucem circulatim eingentia; fil a ment a filiformia, corolla breviora, anth era eblongae. Ovari um inferum, uniloculare, placentis parietalibus multiovalatis. Sty la s stanina superans; stigma multipartitum, lobis linearibus. B a c c perigonium dejiciens ovoidea, calycis foliolis adnatis squamesa, hirta, unilocularis, placentis parietalibus nerviformibus. Semin a plari$m a$, in pulpa nidulantia, $E$ in b r y o $n$ is exalbuminosi, ovoidef cotyled on es connatae, radicuI a obtusissima. - Frutices brasilienses et chilcns es, carnosi; truncosphaeroideo v. depresse globoso, costuto-angulato, floribus e tuberculis spiniferis in summis costis ortis, rubentibus $v$. albicantibus, anthesi nocturna, vix per biduum, nec ultra triduum durante, baccis piloso-lirsutis, virescentiluteis.

Ee hinopsis Zucearinf in Abhandl, Mrünch. Academ. VII. 675, Otto et Pfeiffer Abbild. Cact, t. 4. Miquel in Bal- 
let. Néerl. 1839. p. 109. E chinonyet a a thus Lemaire Cact, Nov. gen, et sp. 10. C e rei globosi exel. sp. Pfeiffer Enumerat. 70. Eehino eacti sp. Auet. Link et Otto Ic. t. 9. Bot, Mag, $t, 3411$. Bot. Reg, $t, 1707,1717$. Turpin-Ob. serv. $t$, 2 ,

515\%. Cereus $H A W$. Perigonium multiplex, tubo basi eum ovario connato elongatocampanulatum, foliolis calycinis nunc numerosis, tubo spiraliter adnatis, ex axillis setiferis, nunc paucis, tubo inferne nudo, petalis plurimis, multiseriatis. St a min a tabo indiseriminatim inserta, corolla breviora; fil am enta filiformia, a $\mathbf{n}$ herae oblongae. Orarium inferum, uniloculare, placentis parietalibus multiovulatis. Stylus filiformis, stamina superans; $s t i g m a$ multipartitnm, lobis linearibus, B a c ca ovoidea, areolata, calycis foliolis persistentibus squamata v. tuberculata, unilocularis, pulposa, placentis parietalibus nerviformibus. Semina plurima, in pulpa nidulantia. E m br y onis exalbuminosi c otyledones foliaceae, liberae, radicula teres, obtusa. - Frutices Americae tropicae, carnosi, demum indurescentes, axi ligneo medullifero percursi, elongati, stricti $v$. flexiles, simplices, continui, $v$. lateraliter ramosi, longitudinaliter costati $v$, angulati, costis paucis v. pluribus, e costis spiniferis coalitis ortis, rarissime ad tubercula spinifera foliorum rudimentis ornati, spinis homoeacanthis $v$. he teracanthis, in quovis fasciculo annue numero auctis; floribus e tuberculis spinigeris in summis costis ortis, interdum e vertice lanato tanquam cephalio nascentibus, ephemeris, gracilibus, tubo longo, baccis plerumque sequenti demum anno maturescentibus.

Cereus Haworth Synops. 173. DC, Revue 39. Memoir. 21. Prodr. III. 463. exel. sp. Pfeiffer Enumerat, 69. exel. \$. 1. 4. et 7. Miquel in Bullet. Néerl. 1839, p. 111 . Cirinos um Necker Elem n, ruo.

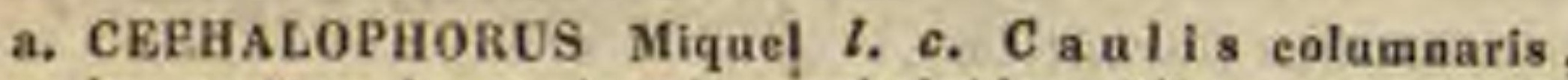
in vertice dense lanato cephaloideo obliquo ex areolis floreas. Se a i a reniformia.

Cephalophorus Lemaire Cact, Hort. Monvill. p. 33. Cephalacereas Pfeiffer ex Outo Gartenzoit. 1838. p. 142. Pilocere us Lewaire Cact. nov. gen. et sp. 6. Melocacti S. 3. Pfeiffer Enumerat, 46. C. 8 enilis Dyck. C. bradypus Lelom. in N.A.N. C. XVI. $t$. 12, C. Columa a Trajani Karw.

b. EUCEREUS Miquel l. c. Caules angulati $v$, costati, columsaros aut flexiles, e costarum tabereullis undique florentes.

Ceref \$. 2. Pfeiffer Enumerat. 75. (DC. Plant. gr. t. 59. 58. 127, 143. Hevue t. 12. Bot. Reg. t. 336, 486. 1565. 1596. 1807. Bot. Mag. t. $3125,3381$.

5158. Playllocaetug LINK, Perigoniu m multiplex, infundibuliforme, tubo basi cum ovario connato, longe cylindrico, glabro, inermi, foliolis calycinis sparsis, remotis obsito, p e talis limbum formantibus pluriseriatis, campanulatim conniventibus. Stamina plarima, tubi parti su periori et fauci inserta, cornlla breviora; f i la menta filifermia, antherae oblongae. Ovarium inferum, uniloeulare, placentis parietalibus multiovulatis. Sty lus longus, stamina aequans; s t ig. m a multipartitum, lobis linearibns. B a c ca ovoidea, umbilicata, costatu-angulata, foliorum calycis reliquiis sparsim squamulata, unilocularis, pulposa, placentis parietalibus nerviformibns. Sem ina plurima, reniformia. Embry on is exalbuminosi cotyledones connatae, radicula obtusissima. - Frutices Americae calidioris, ramosi; caule demum tereti ramisque carnosis, dilatatis, compressissimis, nervo medio valido dipteris, marginibus remote grosse crenatis, omnino aphyllis $v$, in axillis setulas tenues gerentibus, floribus e ramorum crenis lente increscentibus, rubris, albicantibus $v$. virentibus, ut plurimum per aliquot dies florentibus, perigonii foliolis viridibus sensim in colorata abeuntibus, baccis rubris.

Phylloe act a s Link Handb, III, 11, E p ip byllum Hermann Parad. Lugd. Batav. Addend. Hawsth Synops. 197. exel. sp. Phylarthus Necker Elem, n, 742. $\mathrm{P}$ hyll. a thus Miquel Bullet. Néerl, 1839. p. 112. Cere i alati DC. Prodr. IIT. 469. exel. sp. Pfeiffer Enumerat. 123. (Bonpl. Navarr. $t$, 3. DC. Plant, gr. t, 145. Revue, t, 14. Bot. Reg. t, 304. 1331. Bot, Mag. t, 2092, 2692.)

5159. Epiplnyllume PFEIFE. C a ly s tubo nudo, cum ovario connats, limbo supero octopartito. Corolla supera, petalis pluriseriatis, exterioribus liberis reflexis, interioribus inferne in tubum fauce obliqua connatis. Stamina plurima, alia summo calycis tubo inserta, breviora, alia corollae tubo inserta, longiora, limbum |superantia; filamenta filiformia, anthera eblongae. Ovari um inferum, uniloculare, placentis parietalibus multiovulatis. Stylus filiformis, stamina subsuperans; stigma tripartitum, laciniis linearibus, vix expansis. B a c ca pyriformis, calycis limbo coronata, unilocularis, pulposa, placentis parietalibus nerviformibus, S émina ..... Frutices brasilienses, carnosi, articulati, articulis alatis, truncatis, subinermibus, apice tomentoso interdum spinuloso ramosis et floriferis, floribus speciosis.

E piphyllum Pfeiffer Enumerat. 127. Miquel Bullet. Neerl. 1839. p, 113. E pip bylli s p. Haworth. Cactus truncatus Liak. Bot. Reg. $t$. 696. Bot. Mag. $t$. 2526. Hooker Exot, Flor, $t .20$.

\section{\$. 2. CaCteae Rotatae. Miq. Corol-} Ia rotata, tubo supra ovarium haud productó.

5160. IE hipsalis G GRTN. Cal y $\mathrm{x}$ tubo cum ovario connato, limbo supero, brevi, tri-sex partito. Coro 11 a e petala $6-8,8$ mmo calycis. tubo inserta, ejusdem limbo longiora, patula. Stam in a 12_ 30 , basi petalorum inserta, iisdem subaequilonga; filam enta filiformia, stricta, anthe rae oblongae $v$, reniformes. Ova rinm inferum, uniloculare, placentis parietalibus multiovulatis. Stylus filiformis, exsertus; stigma tri-octopartitum, laciniis filiformibus. B a ec a subglobosa, calyeis limbo emarcido coronata, unilocularis, pulposa, placentis parietalibus nerviformibus. Se mina plurima, subpyriformia, E mbryonis exalbuminosi cotyledones crassae, subfoliaceae, breves, acutae, radieula conica. Frutices carnosi, axi lignoso praediti, in America tropica, in arborum vetustarum truncis pseudo-parasitici $v$. terrestres, subradicantes, elongati, ramoso-articulati $v$. foliaceo-dilatati, subaphylli, squamulosi, folioli marcidi rudimento ad crenas instructi, floribus lateraliter e setarum fasciculis $v$. caulium crenis ortis, $v$. in ramulorum apicibus terminalibus, exiguis.

R hipsalis Gärtner $T$. 136. 't. 28. Haworth $S$ ynops. 186. DC. Hevue 77. Prodr. IIT. 475. H a rio ta Adanson Fam. II. 243. Mliquel in Bullet, Néerl, 1839, p. 114. R hips alis et Hariota DC. Memoire 23. Rhipsalis, Lepisminm et Hariota Pfeiffer Enumerat. 129-19i.

a. RHIPSALIS Pfoiff. Flores laterales, parvi, albidi, ealyeis limbo tri-sexpartito. B a c ca pellueida. - Cas. les articulati, ramosi, teretes, costali $v$. alati. (DC. Pl. gr. t. 59. Hook. Erot. Flor. t. 2. Link et Otto IC. t. 39. Bot. Mag: $t$. 2740, 3078.)

b. LBPISMIUM Pfeiff. Flores laterales, e pilorum faseiculis enati, tubo calyeis immerso, limbi foliolis $4-5$, 
subimbricatis, petalis $5-7$, lanceolatis, recurvato.patu. lis, altis v, raseis. - Caules articulati, angulati, angulis tribus $v$. quinque repando-erenatis, erenis squamulis $v$. folii rudimento instructis.

c. BARIOTA $D C$. Flores in ramulis terminales, llavi, plerunque clausi, calycis foliolis $4-5$, petalis $7-10$; stigmatibus 5. B a c e a alhida. - Caules ramosi, articulati. subteretes. (Link et Otto Ic. t. 21. Bot. Mag. t. 2461.)

518f. Denutin TOURNEF. Calycis foliola plurima, foliacea, ovario adnata, summa plana, brevia. Corolla e superae petala plurima, obovata, basi connata, rotato expansa. Stamina plurima, basi petalorum inserta, istem breviora; fil a menta libera $v$. nonnihil inter se connata, antherae oblongae. Orarium inferum, uniloculare, placentis parietalibus multiovnlatis. Stylus cylindraceus, hasi constrictus; stigma tri octopartitum, laciniis crassis, erectis. B a e c a ovoidea, apice umbilicato tuberculata, saepe spinigera, uniloenlaris, pulposa, placentis parietalibus nerviformibns. Semina plurima, reniformia. $\mathrm{E} m$ bryonis subspiralis, albumen tenue cingentis cotyledones semicylindricae, germinatione fo liaceae, radicuta longa, cylindrica. - Frutices carnosi, articulati, in America calidiore tropica et extratropica indigeni, nonnulli inter tropicos veteris orbis et in regionem mediterraneam olim advecti, nune quasi spontanei, trunco axi lignoso percurso ramisque cylindricis aut compressis, articulis oblongis $v$, ovatis, spinis heteracanthis, validis et setiformibus, in foliorum rudimentis subulatis mox caducis axillaribus, quincunciatim $v$. spiraliter dispositis, cujusvis fasciculi annue numero auctis, floribus e fasciculis spiniferis $v$. articulorum marginibus ortis, albis, rubris v. flavis, magnis, speciosis, staminibus saepe irritabilibus, baccis exiguis v, mag$n i s$, viridibus, purpureis $v$. flavis, saepe ficiformibus, edulibus, secundo $v$. tertio anno demum maturescentibus.

Opuntia Tournefort Inst, 239. t. 129. Gürtner 11.265. t. 138. Haworth Synops. 187. DC. Prodr. III. 421. Pfeiffer Enumerat. 143. Miquel in Bullet. Néerl. 1839. p. 116. T u n a Dilles. Eltham, f. $397 \_383$, (DC, $P l, g r . t, 137.138$ Revue 2. 15, 16. Bot, Mag. t, 1557, 2241. 3293. 3301. Bot. Reg. $t$. 255. 1906. 1726.)

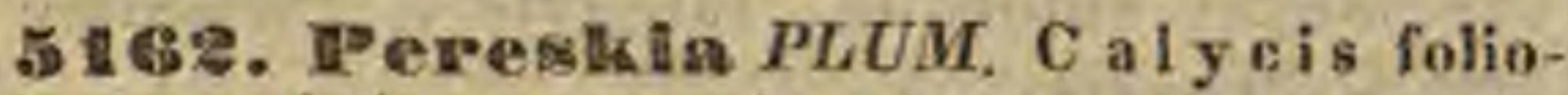
la plurima, foliacea, ovario adnata, saepe persistentia. Corolla e superae petala plurima, pluriseriata, fere libera, magna, expansa. Stamina plurima, petalornm basi affixa, iisdem breviora; filamenta filiformia, libera, antherae oblongae. Ovarium inferum, uniloculare, placentis parietalibus multiorulatis. St y I a s filiformis, crassiusculus; stigmatis multipartiti laciniae fasciculatae v. spiraliter aggregatae. B a c ca globosa v. ovata, calycis foliolis vestita v. setoso-areolata aut longe spinosa, unilocularis, pulposa, placentis parietalibus, nerviformibus. Se m in a plarima. Embryonis cotyledones magnae, foliaceae. Frutices lignosi $v$, interdum arborescentes, in $A m e-$ ric a tropica indigeni; ramis terelibus, foliis legitimis, petiolatis, latis, oblongis $v$. rotundatis, magnis, hyeme deciduis, in axillis gemmas glabras $v$. tomentosas, spinis validis armatas gerentibus, floribus plerumque ramulos terminantibus, solitariis, sublateralibus $v$. subpaniculatis, albis, flavescentibus aut roseis, petalis ovatis aut rotundatis, interdum fimbriato-fissis, baccis globosis v. ovatis, magnis, flavescentibus, virescentibus v. rubicundis.

Pereskfa Plamier Gen, 35, $t, 26$. Liun. Gen, edit. 1. n. 402. Haworth Synops, 197, DC, Revie t. 17-20, Prodr,
1II. 474. Pfeiffer Enumerat, 175. Miquel in Bullet. Neerl. 1839. p. 117. Peirescia Spreng. Syst. 1 . 498. (Bot. Mag. t. 3478, Bot. Reg. t, 1473 . Reicliznb. Ic. exot. $t .398$. 324.)

\section{Classis XHX. Caryophyllinae.}

Herbae v. suffrutices, succo aqueo. Fo lia alterna v. opposita, simplicia, integra et saepe integerrima, exstipulata v. stipulata. Flores hermaphroditi, regulares. Calyx liber v, rarissime cum ovario connatus. Corolla e petala definita, rarissime plurima. Sta$\mathrm{m}$ in a hypogyna v. perigyna, definita, rarissime indefinita. Ova ria rarissime plura, plerumque unicum, uniloculare, placentis basilaribus v. e loculorum angulo centrali, rarissime e nervo medio carpidiorum. 0 v u la saepissime amphitropa. Fructus capsularis v, utricularis, mono-polyspermus. Sem ina saepissime reniformia. E m b r y o periphericus, curvatus v. annularis, albumen farinaceun cingens.

\section{Drdo CCV'. MEesenhoryanthemere.}

Mesembryanthemeay Feazl in Annal. Wien, arus. 1. 367. 349. FICOIDEARUM genera Jussieu et Auct.

Suffrotices v, rarius herbae succulentae. Folia opposita v. alterna, carnosa, forma varia, plana, teretia v. trigona. Stipulae unllae.

FLones hermaphroditi, regulares, axillares, alares v. terminales, solitarii, ternati, cymoso-corymbosi v. rarissime paniculati, plerumque speciosi, sole fervente, interdum sub vesperam expansi, aurei, crocei, purpurei, violacei, rosei v. albi.

Calyx tubo carnoso, cum ovario connato, limbi superi, quinquepartiti, rarius bi-octopartiti laciniis herbaceis, foliiformibus v. semiscariosis, plerumque inaequalibus, aestivatione imbricatis.

Corollas petala plurima, summo calycis tubo inserta, multiseriata v. rarius uniseriata, linearia, post anthesim marcescentia v. gelatinose confluentia.

Strama indefinita, cum petalis inserta, multiseriata. Filamenta longitudine varia, subulata v. setacea, libera v. basi inter se connata. Antherae introrsae, biloculares, ovales, versatiles, loculis appositis, parallelis, rima fongitudinali lateraliter dehiscentibus. Pollin is granula ovalia, trisulcata, sulcis medio foratis.

Ovariem cum calycis tubo connatum, e carpidiis quatuor ad viginti conflatum, carpidiis circa axim centralem crassam subhorizontaliter verticillatis quadri-vigintiloculare, carpidiorum marginibus suturam ventralem liberam superam constituentibus, valvatim connatis v. in septum 
spurium plus minns distincte introflexis. Placentae lineares, carpidiorum nervo medio adnatae, fundum loculi occupantes. Ovula plurima, pluriseriata, funiculis longis, filiformibus inserta, amphitropa. Stig m a ta axim centralem terminantia, loculorum numero, cristaeformia, crassa, filiformia v. setacea, rarissime multipartita, filiformia, minima, distincta v. basi coalita.

Capsola primum carnosa, demum sublignosa, exsucca, apice truncato, depresso, cristis v. costis quatuor ad viginti exarata, ad costas (suturas ventrales) longitudinaliter dehiscens, carpidiorum a se invicem haud secedentium epicarpio suberoso-incrassato, ab apice centrali ad basim periphericam ab endocarpio chartaceo $\mathbf{v}$. pergameneo in lacinias triangulares, temperie humida erectiusculas, siccitate conniventes, soluto.

Semina plurima, placentae basilari-parietali, lineari, extremitate peripherica plerumque in tuberculum cartilagineum incrassatae, funiculis incurvatis inserta, globuloso-pyriformia, testa crustacea, opaca, laevi, granulata v. tuberculata, umbilico ventrali. A Ib umen farinaceum, plus minus copiosum.

Enвryo periphericus, dorsalis, curvatus v. uneinatus, magnus. Cotyledones ovales v. oblongae, obtusissimae. Radicula teres, umbilico adversa, prominula.

Me sembryanthemeae florm decore insignes, maximo numero in Capite benae spei generantur, paucae in Nova-Hollandia, paucissimae injregione mediterranea vivunt.

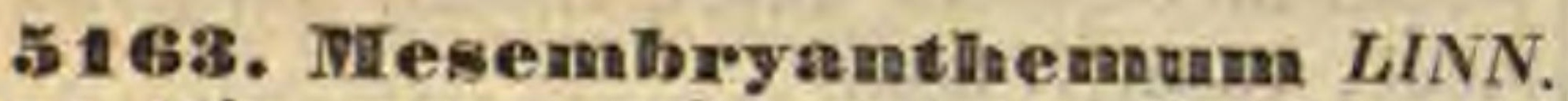
Caly $x$ tubo cum ovario connato, limbi superi quinquepartiti v. rarius bi-octopartiti laciniis inaequalibus, foliiformibus v. scariusis. Coroll a e petala plurima, summo calyeis tubo inserta, linearia, uni pluriseriata. Stamin a plurima, cum petalis inserta, multiseriata, anth era biloculares, longitudinaliter dehiscentes. Ovarium inferum, quadri-vigintiloculare, carpidiis circa axim centralem horizontaliter verticillatis, sutura ventrali supera libera, placentis linearibus parietalibus, fundum locoli oceupantibus, multiovulatis. Ovnla amphitropa. Stigmata $4 \ldots 20$, in axi terminalia. C a p sula exsucea, apice truncato-depresso multiradiata, quadri-vigintilocularis, loculis ad suturas ventrales liberas hiantibus, epicarpio ab endocarpio soluto hygroseopica. Semin a plurima, globuloso.pyriformia, testa crustacea. E mbry o curvatus v. uncinatus, albumen favinacenm cingens. - Suffrutices $v$. herbae succulentae; folïs oppositis alternisque carnosis, exstipulatis, floribus axillaribus, alaribus terminalibusque, solitariis, cymoso-eorymbosis $v$, rarius paniculatis.

Mese m br y a n the m a m Línn Gen, n.628, Gärtuer $I I$. 201. t. 126. Jaeq. Hort. Schönbr. t. 108. 278, 279. 442. Hort. Vindob, t. 476, 477, III, t, 6. 7, Ie, rar. t, 457-489. Fragm. t. 11. 50 52. Bot. Mag. t. 32. 70. 262. 326, 396. 448. 510. 1220. 1513, 1647. 1663. 1824, 2144. Bor, Reg. t. 980, 494. 58\%, 863. Audrews Bot. Reposit. $t, 384.508$ 5io. Link et Otta Abbild. $t$. 43. 44. DC. Plant. $8^{r}, t, 5,6$.
10. 11, 17, $24,29,35,41,47,53,54,66,71,72,78,89.63$. 84. 88. 89, 96, 95. 108, 128, 134, 135. 146. 147. 153.158. 159. Prode, III. 415. Meisner Gen, 129. (93.) Mesem. bry a them am et H ymenogyne Hawarth Revis. 74. et 192. Mesembryanthus Necker Elem. n, 735. Mesembryon Adanson Fam. IT, S63.

\section{Ordo CCVI. Portotaceae.}

PORTULACEAE Jnssieu Gen. 513, exel, gen. St. Hilaire in Mem. Mus. IT, 195. DC, in Mem, soo, h, n. Paris IV. 174 . Prodr. III. 351. Bartling Ord, nat. 303. Meisner Gen, 130. (94.) Fenzl in Annal, Wiener Mlus, I. 348, 351, II, 285. PORTULACACEAE Lialley Introduct, edit. II. p. 123. AL. SINEARUM, PARONYCHIEARUM et FICOIDEARUM pars. Auct. plur.

Herbas anuuae v. perennes, saepe suftraticosae v. frutescentes, rarins frutices, caule ramisque plerumque diffusis, teretibus v. rarius angulatis, pube nulla, nuuc simplici, rarius stellata v. compressa, biacuminata. Folia alterna v. subopposita et basi connata, forma admodum varia, semper integra et integerrima, plus minus carnosa, uninervia, v. nervo tenui parenchymate copioso tecto enervia, avenia, sessilia v. breviter petiolata. Stipulae nullae v. laterales, subulatae, setaceae, interdum fimbriatae, rarissime axillares, in pilorum v. setarum fasciculos solutae, nunc scarioso-foliaceae, integrae, folia velantes.

Flores hermaphroditi, regulares, in cymas terminales v. axillares, simplicissimas v. divisas, interdum racemiformes v. fasciculatim aut umbellatim contractas dispositi, rarius solitarii, terminales v. axillares, sparsi.

Car $\mathrm{xx}$ basi nudus v. interdum bracteolatus, liber v. tubo cum ovario connatus, persistens v. deciduus, diphyllus, v. bi-quinquefidus aut partitus, foliolis v, laciniis aestivatione imbricatis, planis v. apice interdum cucullatis, intus saepissime coloratis, integris v. rarissime fimbriato-laceris.

Corolla saepissime nulla, nunc petala quatuor v. sex, rarissime plura, imo calyci inserta, distincta v. basibus plus minus coalita, tenerrima, admodum fluxa, mox apicibus contorta, gelatinoso confluentia.

Stamiva hypogyna v. calycis basi aut tubo inserta, nune numero definita, calycis laciniis numero aequalia, et tunc semper iisdem alterna, v. dupla aut tripla, rarissime numero pauciora, nunc indefinita, pluriseriata, extima semper petalis dum adsunt opposita, et earum unguibus adhaerentia, calycis laciniis autem alterna, v. in phalanges eodem situ aggregata. F iI a m en ta filiformia v. subulata, libera v. basibus interdum in eupulam aut irregulariter subconnata, apicibus semper distincta, aequalia v. inaequilonga. Antherae introrsae, biloculares, dorso v. infra apicem affixae, loculis discretis v. contiguis, longitudinaliter dehiscentibus. 
Drscus hypogynus ovarii basim cingens, sae. pissime obsoletus.

Ovariom sessile, liberum v. rarius cum calycis tubo connatum, uni-octoloculare. $0 \mathrm{v}$ u $1 \mathrm{a}$ in ovario uniloculari rarissime solitaria, plerumque plurima, placentae centrali liberae funiculis distinctis inserta, v. e funiculis discretis liberis, e basi loculi adscendentibus pendula, in ovarii plurilocularis loculis nune solitaria, nune pauca v. indefinita, angulo centrali tota longitudine, nunc ejus medio v. apici per funiculos longos v. brevissimos affixa, semper amphitropa, micropyle supera v. infera. Stylus terminalis, in lacinias loculorum numero, intus stigmatosas fissus v. partitus, rarissime simplex, stigmate capitato terminatus.

Fruetus uni-octolocularis, mono-polyspermus, forma varius, ovoideus v. Ienticularis, aut inverse pyramidatus, membranaceus, chartaceus, coriaceus v. sublignosus, rarissime indehiscens, saepius operculo circumseissus, plerumque loculicide valvis dehiscens, valvis medio septiferis, indivisis, nonnunquam calyce aduato drupaceus, indehiscens, ad angulos cornutus v. alatus.

Semra globoso-lenticularia, reniformia $\mathbf{v}$. pyriformia, tes ta saepissime crustacea, interdum membranacea, laevi v. sulcata aut granulata v. tuberculata, umbilico nudo v. strophiola subcarnosa munito. Albumen farinaceum v. plus minus carnosum.

Eмввуо periphericus, cyclicus v. arcuatus, albumen cingens, rarissime rectiusculus, ejusdem lateri applicitus. Cotyled ones incumbentes, crassitie variae. R a dicula umbilicum spectans.

Portul a ce a e nullo climate omnino exules, in temperatis Europae èt Asiae mediae multo quam in America boreali, frigida etiam atque arctica, rariores, in regionibus tropicis subtropicisque hemisphaerae australis maximo numero proveniunt, in Capite bonae spei imprimis copiosae. Affinitate inter Mesembryanthemeas, Paronychias et Alsineas mediae, praeter alias notas, quibus singulae tribus a proxime affinium ordinum generibus analogis facili negotio discriminantur, staminum serie extima inter calycis lacinias sita, in sua classe distinctae sunt.

TIRIIBUS I. TETRAGONIEAE Fenzl in Annal. Wiener Mus. II. 287. Caly cis triquinquefidi tubus eum ovario connatus. Corol1a nulla. Ovarium tri-novemloculare, loculis uniovulatis. Fructus drupaceus v. nucamentaceus, ad angulos cornutus v. alatus, uni-novemlocularis. S o min a in loculis solitaria, pendula.
5194. Tetragouia LINN. C a y $x$ tubo cum ovario connato, demum increscenté, limbi superi, tri-quinquefidi laciniis carnosulis, intus coloratis, demum conniventilus, Co rolla nulla. $S t$ a $m$ in a $1-5, v$. indelinita, inter calycis lacinias solitaria v. aggregata; fil a m enta filiformi sabulata, antherae biloculares, didymae, loculis oblongis, basi et apise discretis, longitudinaliter dehiscentibus. O v a $\mathrm{ri} \mathrm{u}$ inferum, tri-quinqueloculare, interdum octo-novemloculare v. abortn uni biloculare. $O$ vula in loculis solitaria, in apice anguli centralis funiculo brevi appensa, amphitropa, micropyle supera. Stigmat a loculorum numero, brevia, intus stigmatosa. Drnpa v.nux ossea, calyeis tubo angulis in cornua v. alas longitudinales expanso vestita, vertice nudo radiatim suleata, uni-novemlocularis. S e m ina in loculis solitaria, pendula, pyriformi-reniformia, testa crustacea, nitida, fusca, longitudinaliter striata, umbilico nudo. E m bryo cyclicns, albumen farinacenm cingens. - Herbae annuae v. suffruticosae, in hemisphaerii a ustralis insulis et promontoriis obviae, diffusae, succulentae, glabrae v, villosae; folits alternis $v$, suboppositis, planis, carnosis, plerumque integerrimis, floribus alaribus $v$. axillaribus, solitariis v. glomeratis, aut interdum in spicam $v$, racemum dispositis.

Tetragon i a Linn. Gen, n. 672. Scopoli Delic. I. $t, 14$. Murray in Comment, Gótting, 1783, t. 5. Gartner IT, 204. 483. t. 127. et 179. Lam. $t$, 437. Heritier Stirp. $t, 39$. DC. Plant. gr. 23. 24. 113. 114. Prodr. III. 451. Bot. Mag. t. 2362. Meisner Gen, 129, (93.) Feuzl in Annal. Wien. Mus. II. 287. D e midovia Pallas Hort. Demidov. $t$. 1. Te trag ono e a p u 8 Commelyn Hort. Amst. II. $t .102 .103$.

Tretreds II. AIZOIDEAE Fenzl in Annal. Wiener Mus. II. 288. C aly x liber, quadri-quinquefidus v. partitus. Corolla nulla. Styli 2-5. Capsula lignosa, bi-quinquelocularis, abortu interdum unilocularis, ad angulos loculicide dehiscens. S e m in a in loculis 1_10, ex apice columellae centralis pendala.

51 1 B.5. A izoon LINN. Calyx profunde quinquefidus $v$, quinquepartitus, intus plerumque coloratus. Coroll a nulla, St amin a calycis sinubus inserta, solitaria, v. 2_9 in phalanges colleeta; filamenta filiformia, antherae biloeulares, loculis basi et apice discretis, longitudinaliter dehiscentibus. O varium inferum, quinqueloculare. Ovulá in loculis dno v. plurima, ex anguli centralis apice incrassato pendula, amphitropa. Stigmat a 5, subelavata. Ca p sula suberosa, obpyramidato-pentagena, vertice depresso quinquesulea, quinquelocularis, loculo uno alterove vacuo, ad angulos et sulcos loculicide dehiscens. Semin a in loculis $2-10$, pendula, pyriformi-reniformia, estrophiolata, nitida. E mbryo hemicyclicus, albumen farinaceum cingens, radi c nI a supera. - Herbae saepius suffruticosae, prostratae, copiosius in Capite bonae spei, paucissimae in Europa australi, Africa boreali et Arabia petra ea crescentes, pube simplici $v$. biacuminata hirsutaev villosae; foliis alternis $v$, rarius oppositis, integerrimis, floribus alaribus et axillaribus, plerumque confertis, saepe secundis, sessilibus.

A 1 z 0 о а Linn. Gen, n. 629. Gărtner , 370. t, 76. Lam. t. 437. DC. Plant, gr. t. 30, 136. Prodr. III, 453. Meisner Gen, 129, (93.) Fenzl in Annal. Wien. Afus, 11. 288, V es$1 \mathrm{ing}$ ia Fabricins Felmst. 363. Fi co ide a Dillenius Eltham. i. f. 143. G 1 ini s. p. Porsk. 
5166. Gallenta LINN. Caly $\mathrm{x}$ profunde quadri-'quinquefidus, intus coloratus. Co rolla nulla. S ta min a 8 v. 10 , ealyeis sinubus binatim inserta; filamenta filiformia, antherae biloculares, loculis basi et apice diseretis, longitudinaliter dehiscentibus. O vari $\mathbf{m}$ bi-quinquelocnlare. Ovula in loculis solitaria, ex apice anguli centralis incrassato pendula, amphitropa. S $t$ ig m ata 2-5, crassiuseule filiformia. C a $p$ s u l a sublignosa v, suberosa, nunc obpyramidato-tri-pentagona, vertice depresso tri-quinquesulea, tri-quinquelocularis, nunc anceps, vertice emarginato $\mathbf{v}$, retuso obcordata, bilocularis, juxta angulos et sulcos loculicide dehiscens, v, denique loculo uno v. altero abortivo farcto unilocnlaris, et saepissime tune in dehiscens. Semina in loculis solitaria, pendula, pyriformi-reniformia, nitida. E m b r yo hemicyclicus, albumen farinaceum cingens, radicula supera. - Herbae $v$. frutices c a penses, plerumque diffusi, ramosissimi, villosi, pube biacuminata hispiduli aut papillosi; foliis alternis $v$. oppositis, car nosulis, inlegerrimis, floribus sessilibus, axillaribus $v$. alaribus, sparsis $v$. cymoso-confertis, subse cundis, interdum per cymas dichotomas, iteratas, corymbosas v. paniculaeformes dispositis.

G al e ni a Linn. Gen. $n$. 499. Feazl in Annal. Wiener Mus, 1I, 288.

a. KOLLERIA Fenzl $l$. c, O va ri u m quadri quiaqueloeulare. $\mathrm{C}$ a $\mathrm{p}$ s u la tri quinquelocularis, tri.pentagoua, ver. tice depresso tri-quinquesulca, ad angulos et sulcos de hiscens. - Flores conferti, cymoso-spicati, subseoun$d i$, foliis interstincti, minores digjni, interdum cum tetra pentagynis mixti.

Kolleria Presl Symb. T. 23. t. 14, Aizoi sp. Auct. Eckl. et Zeyh.

b. EUGALENIA Fenzl l. c. Ovarin m biloculare v. abortu usiloculare. C a ps u I a aplee emarginato v. retuso obcordata, aneeps $\vee$. inaequaliter tetragona inferius ad angulos dehiscens. - Flores plerumque cymoso-pani. culati, confertissimi, foliis longioribus vix inter. stincti, rarius axillares. cymoso-spicati, minores tritetragyni, interdum cum digynis mixti.

Ga lenia Linn. Gen, n. 492. Lam, t. 314. Sialodes Ecklon et Zeyher Enumerat. plant, cap. 329. A i. zoi s p. EekI. et Zeyh.

S16\%. HPIntlaus FENZL. Caly x tubnlosus, semiquinquefidus, laciniis erectis, subinaequalibus, intus coloratis. Corolla nulla. Stamin a 5 , imo calyci inserta, ejusdem laciniis alterna, subexserta; filamenta capillaria, antherae bilocnlares, loculis basi et apiee discretis, longitudinaliter dehiscentibus. $O$ v a ri u liberum, trilo culare, Ovula in loculis solitaria, ex apice anguli centralis pendula, amphitropa. Stylus tripartitus, cruribus teretibus, stigmatosis. Ca p s n. la intra calycem inclusa, ovoidea, basi membranacea, apice rotundata, sublignosa, dense papillosa, triloenlaris, loculicide trivalvis. S e mina in loculis solitaria, pendula, pyriformia, nitida. Embr yo uneinatus, albumini farinaceo applicitus, radic nl a supera. - Fruticulus c a pensis, humifusus, squarroso-ramosus, pube biacuminata, alpressa sericeus; foliis minimis, imbricatis, allernis oppositisque, ovato-triquetris, floribus minimis, uni-bibracteolatis, in axillis foliorum sessilibus, al. ternis.

Plint lus Fenzl in Nov, Stirp, arus. Nindob. Dec. VT. n. 60. Annal. Wiener Mus. II, 288.

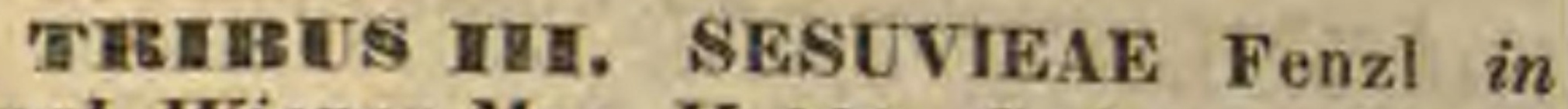
Annal. Wiener Mus. II. 289. C al y x quinquefidus, rarius bifidus v. bipartitus, liber v. tubo ovario semiadnato. Corolla nulla, rarius petala 4_6. Ov a riu m uni-quinqueloculare, loculis multiovulatis. C a p u la circumscisse dehiscens.

5168. Trianthema $S A U V A G$. C a l y x tubo brevi, inferne cum ovarii basi connato, limbi quinquepartiti laciniis intus coloratis, apice saepe fornicatis et dorso mucronatis, Co rolla nulla. S $t$ a m in a 5 v. 10 , rarius plura, solitarie, geminatim v. per phalanges inter ealycis sinus inserta; fil amenta filiformia, antherae biloculares, didymae, co-datae v, reniformes, longitudinaliter dehiscentes. Ovarium ima basi adnatum, apice truncatum, biloeulare, v, abortu uniloenlare. $O$ v uI a in loculis pauca $\mathbf{v}$. solitaria, dissepimento $\mathbf{v}$. parieti a basi ad medinm funiculis inaequilongis inserta, adscendentia v. pendula, amphitropa. S $t$ igmat a 2 , teretia, v. abortu unicum, excentricum. Ca p sula subeylindrica $v$, turbinata, apice truncata, bi-v. nnilocularis, parte superiore suberoso- incrassata a basi membranacea circumscisse dissiliente. Se mina in loculis solitaria v. gemina, horizontaliter snperposita, septo demum obliterato saepissime pseudoparietalia, subreniformia, rugosa. Embryo annularis, albumen farinaceam cingens. - Herbae inter tropicos totius or$b$ is, et in subtropicis Africae obviae, basi interdum suffruticosae, prostratae, v. squarroso-diffusae, carnosulae, saepissime purpurascentes, glabrae $v$. pubescentes; foliis oppositis, basi membrana stipulari combinatis, floribus axillaribus $v$. alaribus, sessilibus, solitariis, glomeratis v. cymoso-subspicatis, membranaceo-bibracteolatis.

Trian the ma Sauvages Method, 127. Linn. Gen, $n$. 537. Gärtaer II. 213. DC. Prodr. III. 331. Wight et Aruott Prodr. I. 354. Meisner Gen. 130. (94.) Fenzl in Annal. Wien. Mus. II. 289.

a. ROCAMA DC. $l$. c. Stamina 5. - Rocama ot Pap u la ri a Forskael Aegypt, 69, 71. (Gärtwer t. 128. Lam. t. 375. DC. Plant. gr. t, 109.)

b. ZALEYA, DC, $l$ c. Stam ina 10 v. plura. $-\mathrm{Za}$ I e y a Burmann Flor. indic. 110, t, 31. f. 3.

s 11 6. Diploehoniun FENZL Calyx tubo brevi, infundibuliformi, libero, limbi qninquepartiti laciniis petaloideo-membranaceis, apice fornicato-mucronatis, sinnbus acute prominentibus, deflexis, C or olla nulla. $\mathrm{S} t$ a $\mathrm{m}$ in a plurima, caIycis fanci tumidulae circulariter inserta, inter ejusdem lacinias subeongesta; fi l amenta filiformia, inaequilonga, antherae biloculares, ellipsoideae, didymae, versatiles, longitudinaliter dehiscentes. Ovari $\mathbf{n}$ libern $\mathrm{m}$, bilor nlare. Ov n la plurima, septi medie inerassato tota longitudine funiculis distinctis affixa, amphitropa. S $\mathrm{tig} \mathrm{ma-}$ ta 2 , elongato-filiformia, e basi horizontali infracto-adscendentia. C a p 8 i la ellipsoideo-oblonga, bilocularis, transversim dehiscens, operculo conico, chartaceo, baseos persistentis epicarpio ab endocarpio tenerrimo, marginibus introflexis axim placentariam retinente distincto. Semina in loculis plurima, snbreniformia, laevia, nitida. Embryo fere cyclicus, albnmen farinaceum parcum cingens. Herba capensis, succulenta, papulosa, dichotome ramosa, foliis oppositis, integerrimis, planis, obovatis $v$. ellipticis, margine revolutis v. reduplicatis, floribus in ramorum dichotomiis sessilibus, alaribus, supremis axillaribus.

D iploch on fum Peazl in Nov. Stirp. Mus. Vindob. Dec. VII, n. 65. Annal. Wiener Mus, IX, 298. 
5H g0. Sesuvitum LINN. Calyx tubo brevi, infundibuliformi, libero, limbi quinquepartiti laciniis intus coloratis. Corolla nulla. S tam in a $10 \mathrm{v}$. plurima, rarissime 5 , calycis fanci circulariter inserta, in phalanges ejusdem laciniis alternas approximata; fil a menta filiformia, inaequilonga, a $\mathrm{n}$ therae biloculares, ellipsoideodidymae, longitudinaliter dehiscentes. O va ri um libernm, tri-quinqueloculare. Ovala in loculis plnrima, angulo centrali funiculis distinctis inserta. Styli $3-5$, crassiusculi, teretes. Capsula ellipsoidea, membranacea, tri-quinquelocularis, medio circumscisse dehiscens, baseos persistentis epicarpio ab endocarpio haud soluto, S emin a plurima, globuloso-compressinscula, epidermide tenuissime membranacea, a testa crustacea nitida solubili. E mb r y o cyclicus, albumen farinacenm includens. - Herbae prostratae, succulentae, in littoribus tropicis et subtropicis totius orbis obviae; foliis oppositis, integerrimis, sub. aveniis, glabris, floribus alaribus v. axillaribus, solitariis, rarius glomeratis $v$. subcymoso-spicatis, sessilibus $v$. breve pedunculatis, saepissime intus purpurascentibus.

S e s u vi u m Linn. Gen. $n$, 624. Jaeq. Amer. $t$, 25. Lam. t. 434. Bot. Mag. 't. 1701. DC. Plant, gr. t. 9. Prodr. III, 453. Hooker Bot, Mag. Comp. t. 33. Meisner Gen, 130. (94.) Fenzl in Annal. Wiener Mus. Ir, 292. A I z o o n Audrews Bot. Repasit, $t$. 201. non Linn. H a If $\mathrm{m}$ us Loffling Ic. 191.

51 1 1. Pyxiporaa FENZ $L$. C aly x liber, quinquepartitus, laciniis aequalibus, acułninatis. Corolla nulla. Stamina plurima, imo calyci hypogyne inserta; filame nta subulata, inaequilonga, basi in tubum ovarium cingentem coalita, antherae biloculares, cordato-subrotundae, longitudinaliter dehiscientes. O va ri u m liberum, bi-triloculare. $O \mathrm{vul}$ a in loculis plurima, angulo centrali funiculis bi-triseriatis inserta. S $\mathrm{ti} g \mathrm{ma}$ ta 2_3, filiformia. Capsula ovoidea, membranacea, bi-trilocularis, circumscisse dehiscens. S emina in loculis pauca, subreniformia, laevia, atra. Embryo ..... Herba moluccana, prostrata, carnosa, glabra; foliis oppositis, linearibus, floribus axillaribus solitariis, pedicellatis, $b i$ bracteolatis.

P y $x$ ipom a Penal in Annal. Wiener Mas. II. 293. Trianthema pol yandrum Blume, Decaisne in Mem. Itus. IIT. 448 .

51 ว 2. Aneistrostigma FENZL. Ca1 y $x$ tubo campanulato, libero, limbi quinquepartiti laciniis obtusis, duabus interioribus latioribus semiscariosis, concaviusculis. C o r o 11 a nulla. S $t$ a mina $7-9$, inter calycis sinus et ante ejus. dem lacinias interiores inserta; fil am en $t$ a subulata, subaequilonga, antherae biloculares, Io culis oblongo-linearibus, divergentibus, longitn dinaliter dehiscentibus. Ovarium liberum, uni locnlare, Ovula plurima, columellae basilari liberae funiculis distinetis inserta, amphitropa. S t y I 8 terminalis, filiformis, sigmoidens, apicis nn cinati, recurvi facie exteriore stigmatosa. Capsu la subglobosa, membranacea, unilocnlaris, me dio cireumseisse dehiscens, placenta basilari. Sem ina $4-8$, reniformia, lucida, atra, - Herba Novae-Hollandiae orientalis extratro. picae, Cypseleae v. Herniariae facie, glabra; cáudiculis perennantibus, humifusis, ramosis, foliis parvis, ovalibus, alternis et oppositis, ramulorum confertis, petiolis basi stipulatis, vaginuntibus, floribus axillaribus, solitariis, breve pedicellatis, minimis.
Ancistros tig m a Fenzl in Nov, Stirp, Mus, Vindob. Decad. X, n, g2, Annal. Wiener Mus. II. 293.

51\%3. Cypselea TURPIN. Calyx tubo brevissime cyathiformi, libero, limbi quinquepartiti laciniis obtusis, duabus interioribus latioribus, semimembranaceis, Corolla nulla. Sta $\mathrm{m}$ in a 1_3, calycis sinubus inserta, ejnsdem laciniis breviora; filamenta subulata, antherae biloculares, didymae, loculis ovalibus, longitudinaliter dehiscentibus. Ovarinm liberum, uniloculare. Ovu I a plarima, placentae basilari liberae funiculis distinctis inserta, amphitropa. St igma bipartitum, laciniis teretibus, abbreviatis. Eaps u la globosa, membranacea, unilocularis, medio transversim dehiscens, placenta basilari. S emin a plurima, minima, pyriformia, lueida, ferruginea. $\mathbf{E} \mathrm{m}$ b r yo arcuatus, albumen farinaceum cingens. - Herba domingensis, parvula, annua, carnosula, prostrata, Centunculi v. Montiae facie; foliis alternis et oppositis, parvis, ovalibus et obovatis, petiolatis, petiolo in membranam stipularem, fimbriato-laceram ampliato, floribus alaribus et axillaribus, solitariis, parvis, breve pedunculatis, virescentibus.

C y poele a Turpia in Annat. Mus. VII, 219. t, 12, f.5. DC. Prodr, IIT. 353. Meisner Gen, 130. (94.) Penzl in An. nal, Wiener Mus. Ir. 293. R a di a n s Rafinesque Speceh. I. 88. Milleg ra a Surian, in Herb. Juss.

51\%4. Portalnea TOURNEF, Caly x tubo cum ovario inferne connato, limbo semisupero v. supero, bifido v. bipartito, eireumscisse deciduo. C o r o 11 a e petala 4 -6, summo calycis tnbo inserta, libera v. ima basi coalita, integerrima, duo saepius majora, fugacissima, colliquescentia. St a min a $8 \mathrm{v}$. plurima, petalorum imae basi aggregatim inserta; fil a menta subulata, antherae biloculares, didymae, locnlis ovalibus, longitudinaliter dehiscentibus. Ovarium semisuperum v. inferum, uniloculare. Ovula plurima, columellae basilari liberae, simpliei v, ramosae funieulis distinctis inserta, amphitropa. S ty. I $\mathrm{s}$ tri-octofidus v. purtitus, lobis intus stigmatosis. Ca psula ovata v. subglobosa, membranacea, uniloeularis, medio v. infra apicem circumscisse dehiscens, placenta basilari. S e mina plurima, reniformia, laevia v. striata et granulosa. E mbryo annularis, albumen farinaceum incladens. - Herbae carnosae, humiles, inter tropicos Americae copiosae, in veteris orbis regionibus calidis et temperatis rarae; folits alternis v oppositis, integerrimis, teretiuscu. lis $v$. planis, pilis stipularibus in axillis congestis, rarius nullis, floribus alaribus v, axillaribus, solita. riis, remolis v. ad ramorum apices congestis, sessilibus $v$. pedicellatis, involucro foliorum subverticillatim congestorum universali $v$. partiali, rarius proprio tetraphyllo, calycem mentiente cinctis, petalis flavis, purpureis $v$. roseis, tenerrimis, sole matutino expansis, meridiano in gelatinam colliquescentibus.

Portulaca Tournef. Inst. 118. Jussleu Gen. 318. Gätuer II, 2t2, I. 128. Jacq. Collect. II, t, I7. f. I. DC. Pl. gr. t. 123. Prodr. III. 353. Bot. Reg. t. 792. 793. 1672, 2885. Bot. Mag. t. 3065. Badl. Atakt, t. 6. Meisner Gen. 130. (94.) Penzl in Amal. Wiener Mus. II. 294. M e ridia na Lion. ex Limn. f. Suppl. 248. Merida Ne. cker Elem. n. 1195. L a mi a Vandelfi in Römer Seript, 116. t. 7. $f$. 15. Portula ca s p. Linn.

Trengers IV. PORTULACARIEAE Fenzl in Annal. Wiener Mus, II. 294. Cal y x diphyllus, liber, persistens. Corolla persis- 
tens. Ovarium liberum, uniloculare. Ov uI $\mathrm{m}$ unicum, basifixum. Stigmata 3 . Capsula triptera, indehiscens, monosperma.

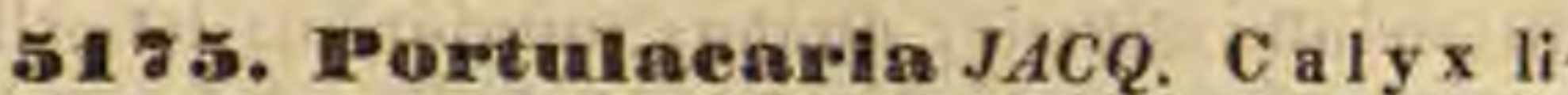
ber, diphyllus, persistens, foliolis membranaceis, subrotundis. Corolla e petala 4-5, hypogyna, aequalia, calyee longiora, persistentia. S ta mina 5 -7, petalorum basi solitarie v. binatim inserta; fil a menta subulata, an therae biloculares, loculis oblongis, coadunatis, longitudinaliter dehiscentibus. Ovarinm liberum, ovatum, acute triquetrum, uniloculare. $\mathrm{O}$ v $\mathrm{l}$ um unicum, basilare, amphitropum, micropyle infera. Stylus brevissimus; stigmata 3 , patentia, intus papillosa. Ca p sula exsucca, triptera, indehiscens. S emen....- Frutex capensis, glaberrimus, squarroso-ramosus, Crassularum frutescentium facie; foliis oppositis, obovato-subrotundis, carnosis, planis, deciduis, floribus ante anthesim glomerutis, sessilibus, squamulis minutissimis interjectis involucratis, glomerulis in ramis aphyllis, angulatis, brachiato-paniculatis confertim alternis, succedanea efflorescentia pedicellatis, umbellas axillares formantibus, parvis, roseis.

Portulacaria Jaequin Collect. I. 160, t, 22. DC. Plant. gr. t. 132. Prodr. 1IL. 360. Meisner Gen, 131. (95.) Fenzl in Annal. Wien, Mus. II, 294. H ã u ke a Salisbury Prodr. 174. Claytonia Portulacaria Linn. Lam. t, 144, f. 2. Crassula Portulacaria Lina. Portu. laea fruticos a Thunb.

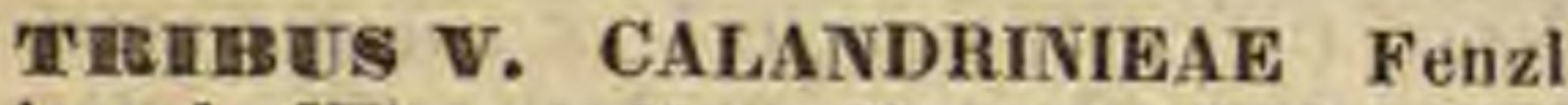
in Annal. Wiener Mus. II. 295. C aly x liber, diphyllus, bipartitus v. bifidus, rarissime trifidus. C o r oll a e petala libera v. basi in tubum coalita, rarissime nulla. Ovarium uniloculare. Capsula valvata.

51ร6. Anaeampserros LINN. C a ly x diphyllus, demum deciduus, foliolis subinaequilongis, aestivatione equitantibus. Corollae petala 5, hypogyna, tenerrima, discreta, aestivatione contorta, mox gelatinoso confluentia, unguibus solutis ovarium calyptratim tegentia. $\mathrm{S}$ ta mina $12 \_30$, hypogyna, petalorum basibus subaggregatim adhaerentia; filamenta filiformia, a $\mathrm{th}$ er a e biloculares, ovates, versatiles, longitndinaliter dehiscentes. Ovariu m liberum, uniloculare. $O \mathbf{v}$ u la plurima, placentae basilari liberae funiculis distinctis inserta, amphitropa. Stylus filiformis, apice trifidus, lobis revolntis, intus stigmatosie. Ca p s u la unilocularis, epicarpio carnoso, basi soluto, dissiliente, endocarpio membranaceo ad basim tri-sexvalvi, valvis reticulato venosis, enm nervis totidem liberis alternantibus, placenta basilari. Semin a plurima, acntangula, dorso subtrialata, testa tenuissime membranacea, endopleuram flavescentem laxe tegente. Embryo enrvatus, albumen parcum, farinaceum eingens. Herbae c a pensis, suffruticosae, humiles; caudicibus crassis, foliis sessilibus, confertissimis, succulentis, ovato-trigonis, teretiusculis, semiorbicularibus $v$. globosis, stipulis intrafoliaceis in pilos fas. ciculatos solutis $v$. liguliformibus, basi barbatis, arcte imbricatis, floribus nunc in caudiculis distinctis, vel in pedunculis elongatis, solitariis v. racemosis, stipulaceo braeteatis, albis, roseis, purpureis v.
flavis.

A n a ca mpseros Sims in Bot. Mag.n, 1357. DC. Ca. talog. hort. Monspel. 77. Prodr. III. 355. Meisner Gen. 130.
(94.) Fenzl in Annal. Wiener Mus, Ir, 295. Te I e phiastrum Dillen. Elth. 376. Ru Iingi a Ebrliart Beitr. III. 133. exel, sp. Haworth Synops, 124, non $A$. Br.

a. AVONIA $E$. Meyer msc. Flores terminales sessiles, cauliculis floriteris distinctis nullis, stipulis eongestis involuerati. Cal y $x$ diutine persistens. Capsula plerumque trivalvis. Se ui u a augulata. - Folia hemi. sphaerica, dorso convexa, facte concava. Stipulae iguliformes, basi barbatae.

b. TELEPHIASTRUM Dillen, $l, c, t, 281$, Flores in caudiculis distinetis solitarii, v. longe pedunculati, ra. cemosi. C a l y $x$ mox deeiduas. C a p s i la tri-sexvalvis. Semin a trialata. - Stipulae in pilos $v$, lanam solutae. - Portalacae sp. Lina. (Bot. Mag. t. 1357. 1367. 1368, DC. Pl, gr, ₹, 3.)

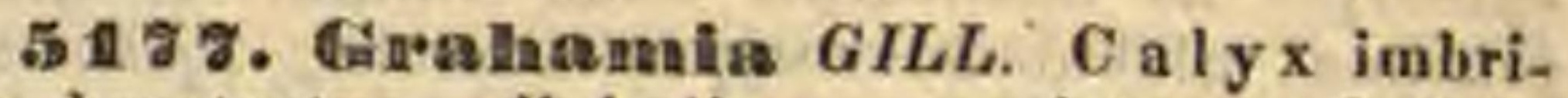
cato-bracteatus, diphyllus, persistens, foliolis oblongo-lanceolatis, concavis, mueronatis, dorso nervosis, margine seariosis. Corolla e petala 5, hypogyna, obovata, obtusa, mueronata, eito marcescentia. Stamina plurima, hypogyna; filauenta filiformia, basi coalita, antherae biloculares, erectae, longitudinaliter dehiscentes. Ovarium liberum, oblongnm, uniloculare. Ovula plurima, placentae basilaris liberae funiculis distinctis inserta. Stylus filiformis, superne incrassatus, apice quadri-quinquefiđus, lobis linearibus, margine revolutis, intus stigmatosis. C a psula nnilocularis, quadri-quinquevalvis. Semina plurima, compressa, late memhranaceo-alata. $\mathbf{K} \mathbf{m}$ b rуo $\because . .-$ - Fruticulus chilensis, divaricatoramosus, glaber; foliis alternis, carnosis, teretioblongis, obtusis, stipulis intrafoliaceis, in pilos solutis, floribus solitariis, ramos breves v, elongatos terminantibus, bracteis calycem involucrantibus octo $v$. novem arcte imbricatis, scariosis, uninerviis, apiculatis, interioribus lanceolatis, exteriores oblongas superantibus, corolla alba, calyce longiore.

Grah a mia Gillies ox Hooker Bot. Miscell. IIr. 331. Meisner Gen, 130. (94.) Feuzl in Annal. Wiener Mus. II. 296. X e r a it h u s Miers Travels in Chili $I I .329$.

5118. Tralinama $A D A N S$. C a ly $\mathrm{x}$ diphyllus, deciduns, foliolis ovatis, oppositis. Corolla e petala 5, hypogyna, libera v. basibus coalita, tenerrima, fugacia. S $t$ a min a $10 \_30$, petalorum unguibus aggregatim inserta; fil a m ent a filiformia, anthera e biloculares, ovatae, longitudinaliter dehiscentes. O va riu m liberum, uniloculare. Ovu la plurima, placentae basilari liberae funiculis distinetis inserta, amphitropa. StyI s s filiformis, apice trifidus, lobis patulis, intus stigmatosis, v, st igmata 3 , sessilia, arete conniventia, Ca p 8 ula chartacea, nitida, unilocularis, trivalvis, epicarpio ab endocarpio haud soluto, placenta basilari. S e m in a plurima, lenticulari v. gleboso-reniformia, testa crustacea, nitida, laevissima, striata, umbilico strophiolata. Embryo annularis, albumen farinaceum cingeńs. - Herbae interdum suffrutescentes, carnosae, glaberrimae, in America tropica et subtropica copiosae, parcius in Capite bonae spei, Arabia felici et Oceania intertropica crescentes; foliis alternis $v$, suboppositis, integerrimis, exstipulatis, foribus cymosis, racemosis v. solitariis, axillaribus, purpureis, flavis $v$. albis, fugacibus.

T a Iin u m Adanson Eam. $I T$. 145. excl, sp. Gärtuer $I T$. 219. Sims in Bot. Mag. n. 1357. Haworth Synops. 123. DC. Prodr. III. 366. Melsuer Gen. 130. (94.) Fenzl in Annal. Wiener Mrus. II, 296.

a. PHEMERANTHUS Haf. Stig mata 3 , sessilia, arete conaiventia, stigma simplex mentieatia. - Herbao bo. reali-americanae, perennes. - P he me ranthus Ra- 
finesque Speceh. I.86. T, t e r et if ol i u u Parsh. Lod. dig. Bot. Cab. t, 819 .

b. TALINASTRUM DC. $l, c, S$ ty $\ln s$ filiformis; $s \mathrm{tigma}$. tibus 3 , distinetis. - Suffrutices. - Portulacae s p. Linn. Jacq. Observ. 1. t. 23. Hort. Vindob. II. 15t. IIT. $t$. 52. R uli aglae sp. Ehrh, Oryglae s p. Forsk. (Cavanill. Ic. $t$. 1. Gärtner $t, 128$. Bot. Mag. t. 1357. 1543.)

c. 2 TALINELLUM DC. l. c. St $\mathrm{y} I \mathrm{n} s$ erassus. Stigmata 3, ersssa, planiuscula. - Merbae annuae. - T a. Iini s p. Ruiz et Pav. Kunth.

d.? EUTMON Rafinesq. in Allant. Journ, 1832, VI. 23. Stamfía 5, petalis alterna. T. napiforme DC.

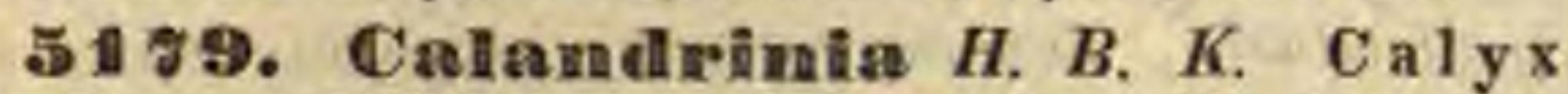
bipartitus v. bifidus, persistens, laciniis integerrimis, inaequaliter bi-tridentatis v. sublobatis, glabris v, hirsntis. Corolla e petala $8 \ldots 5$, rarissime $8-10$, subhypogyna, libera $v$, ima basi subeonnata, subrotunda, ovalia v. oblonga, integra, mox gelatinoso confluentia, ovarium tegentia. S $t$ a m ina $3 \_15$, rarius indefinita, subhypogyna, petalis aggregatim opposita et basi subcohaerentia; filam en $t$ a filiformia, libera $v$. inferne subcoalita, a $n$ the ra e biloculares, ovatae, longitudinaliter dehlscentes. Ovari u m libernm, uniloculare. O v uIa plurima, columellae centrali liberae funiculis distinctis inserta, amphitropa. Stylus filiformis, trifidus v. tripartitus, lobis intus stignatosis, in clavam arete conniventibus. C a p $8 \mathrm{al}$ a oblongoelliptica, membranacea v. chartacea, trivalvis, solumella hasilari seminifera. Sem ina plurima, lentienlaria, testa crustacea, nitida, laevi v. opaea, granulata aut pubernla, nmbilico estrophiolato. E m b ryo annularis, albumen farinaceum incladens. - Herbae $v$, suffrutices succulenti, glabri $v$. hirsuti, in America imprimis australi extratropica, rarissime in Nova-Hollandia meridionali indigeni, foliis alternis, integerrimis, estipulatis, foribus axillaribus aut oppositifoliis, solitariis $v$. racemosis, corollis purpureis $v$. dilute roseis, speciosissimis $v$. interdum inconspicuis.

C a landrinia Kunth in Humb. et Bonpl. Nov. Ben. et sp. VI. 77. t. 526. DC. Prodr. IIT. 358. Bot, Mag, t, 3357. 3369. 3379. Bot. Reg, t. 1598, 1605. N. s. 1839. t. 4. Hooker Exot. Flor. t, 82. Flor. Bor. Amer, $t$, 70. Meisner Gen. 130. (94.) Fenzl in Annal. Tiener Mus, II. 296. Cos mi a Dombey mse, ex Jussieu Gen, 312. P la cosper$\mathrm{m}$ a Haworth in Philosoph. Magaz. 1827. $p$. 124. G e u n s i a Flor. Dexle, inedit.

5180. Claytonia LINN. C a ly x diphylIns v. bipartitus, laciniis integerrimis, ovatis. Corolla e petala 5, hypogyna, aequalia, lihera v. unguibus coalita, integra, emarginata v. bifida, mox contorta, gelatinoso confluentia. Sta m in a $\mathbf{5}$, petalorum imis nnguilus ingerta; fil am en ta filiformia, antherae biloculares, ovatae, longitudinaliter dehiscentes. $O$ v a $r$ i $m$ uniloculare. $O \mathbf{v} u$ la 3-6, funiculis totidem basilaribns liberis inser ta, amphitropa. Stylns distinctus, trifidus, lobis intus stigmatosis, patentibus v, erectis, Ca p s u la ovata, unilocularis, trivalvis, valvis ima basi medio seminiferis. Semina 3-6, glohulosa v. len ticularia, testa crustacea, laevissima v. granulata, nitida, umbilieo eatrophiolato. Embryo hemicycliens, albumen farinaceum eingens, $r$ adicula infera. - Herbae in Asia el America subarcticae et arcticae, annuae $v$. perennes, glabrae, succulentae, rarlice fibrosa v. rhizomate tuberoso sustentae; foliis integrerrimis, radicalibus petiolatis, caulinis sessilibus, alternis et oppositis, interdum connatis, racemis terminalibus v. axillaribus, solitariis $v$. in cymam bifurcatam dispositis, saepissime secundis, vernatione subscorpioideo-involutis, floribus albis $v$. roseis, magnitudine variis.

Cla yton ia Linn. Gen, $n, 287$. Lam. 2,144 . Gärtner 11. 220. t. 129. Bonpland in Annal, Mus. VIT. t. 6. Plant. aequinoct. t. 26. Salisbury Parad, t, 71. Pursh Flor. Bor Amer. t. 3. St. Hilaire in Mem. Mus. II. 197. $t, 4 . f$. 15. DC. Pl. gr. t. 131. Prodr. III. 360. Hooker Flor. Bor. Amer, t. 71_74. Bot. Mag. t. 941, 1309. 1336, 2243. Sweet Fl. Gard. $t, 216, I I, t, 163$. Meisner Gon, 130, (94.) Fenzl in Annal. Wiener Mus. IT. 297. L i mn i a Linné in Act. Upsal. 1746. p. 130. t. S. Claytonia et Limnia Ha. worth Synops, 11.

5181. THonecosmia $F E N Z L$. C a ly x diphyllus, persistens, foliolis ovali-subrotundis, obtnsissimis v. retusis, dorso in alam sacciformem, verticaliter compressam 'protrusis, herbaceis. Coroll a e petala 3 v, rarissime 4 , hypogyna, oblonga, libera, demum gelatinoso-confluentia, apice contorta, oyarinm coronantia. Stamen 1, petalo oppositum; fil ament um filiforme, an thera bilocularis, longitudinaliter dehiscens. Orari u m liberum, uniloculare. Ovula $2 \_4$, basilaria. Sty Ius brevissimns, bifidus; $8 \mathrm{tigm}$ atib ns abbreviatis, patentibus. C a p 8 u la membranaces, unilocnlaris, bivalvis, basi seminifera. Semina 1 v. 2, lentieulari-compressa, obtase granulata, lueida, estrophiolata.... - Herba chilensis, annua, multicaulis, sucoulenta, glabra; foliis radicalibus rosulatis, lamina deltoideo - rhombea, ob, tusa, in petiolum late linearem, longissimum angustata, caulinis alternis, exstipulatis, floribus minutissimis, brevissime pedicellatis, per racemos axillares et terminales, basi foliatos, superne aphyllos dispositis, subsecundis, confertis.

Monocosmia Fenzl in Nov. Stirp. Mus. Pindob. Decad. X, n, 93, Annal. Wien, Mus, II. 297. T all пu m мо и. a ndrum Ruizet Pav. Corrigiola del toide a Pöppig.

5182. NIontîa MICHEL. C a I y x di-rarissime triphyllus, persistens, foliolis ovatis, obtusis. Corolla e petala 5 , hypogyna, duobus interioribus paullo majoribus inaequalia, ad medium in tubum antive sd hasim fissum cratita. Sta min a $3 \_5$, snmmo corollae tubo inserta, ejusdem lobis omnibus, v, minoribus exterioribus opposita; filam enta filiformia, antherae ovátae, biloculares, longitudinaliter dehiscentes. Ovari um liberum, turbinato-trigonum, nniloculare. O vuIa 3 , basilaria, amphitropa. Stylus brevis, tripartitus, cruribns subplumoso-stigmatosis, patulis. Ca p s la membranacea, unilocalaris, trivalvis, basi seminifera. Semina 2_3, lénticularia, testa erustacea, tuberenlata, nitida, umbilico estrophiolato. Embryo annularis, albumen farinacenm cingens, radi c u la infera. - Herba pusilla, procumbens, repens, in uliginosis Europae mediae et borealis, nec non in $A$ sia et $A$ merica sub. aretica et arctica obvia; foliis oppositis, spathulato-oblongis $v$. linearibus, integerrimis, carno. sulis, racemis paucifloris, subterminalibus, demum lateralibus, floribus subsecundis, corolla alba, calycem subsuperante.

Mont ia Micheli Nov, gen. 17, t, 13, Lum. Gen. n. 101. Sehkuhr t, 20. Ghrtner If, 220, t. 129. Flor, dan. $t, 131$. E, B. $t, 120 f$. DC.Prod , III.362. Mertens et Koch Deutscht. Flor, T. 402. Sturm D. Flor. fase. 11. Meisper Gen, 130. (94.) Fenal in Annal. Wiener Mus. II. 298. Cu mera ria Dillen. Nov, gen. 114. $t$. 6. Alsi uol des Vaillant Bot. Paris, t. 3. f. 4 .

5183. Calyptriallimsm NUTT. Calyx diphyllus, persistens, foliolis ovatis, subinaegualibus, margine scariosis. Cor olla e petala 3 , hypogyna, juxta totam longitudinem in tubum coni- 
enm, apice subtridentatum, subdiaphanum, eapsalae apicem demum calyptratim tegentem coalita. Stamen 1, corollae tubo insertum. Ovarium .... Styli 2, minuti. Cap s u la oblongo-linearis, siliquaeformis, compressa, unilocularis, bivalvis. Se mina $6-10$, funiculis discretis, e basi capsulae adscendentibns, inaequilongis inserta, atra, nitida..... - Herba californica, annua, succulenta, depressa, ramosa, Calandriniae habitu; foliis alternis, radicalibus spathulato-oblongis, spicis axillaribus confertis, floribus minutis, interdum secundis, corolla pallide rosea.

Calyptridium Nuttall in Torrey et A. Gray Flor. of North.Americ. I. 198. Fenzl in Annal. Wiener Mus. II. 298.

\section{GENERA PENITUS DUBIA.}

ULLUCUS LOZAN. CaI y $\mathrm{x}$ diphyllas, deciduus, foliolis oppositis, subrotundis, concavis, pellucidis, coloratis. Corolla e petala 5, calyce lougiora, eordata, apice attenuata, basi in tubum brevissimum subconuexa. S t a m ina 5 ; filamenta brevissima, erecta, a $\mathrm{n}$ therae bilo. eulares, ereetae. Ovarium subglobosum. Stylus filiformis, longitudine staminum; stig ma simplex. Capsula unilocularis. Semen unicum, oblangam. - Herba peren. nis, glabra, in hortis $Q$ uitensium, ob radicem mucilaginosam, edulem, sub nomine Ulluco ot Melloeo culta; caule ramoso, angulato, folits alternis, petiolatis, cordatis, integerrimis, erassis florum racemis axillaribus, simplicibus, nutantibus, pedicellis bracteis brevissimis stipatis.

Ullu cus Lozano in Seman. Nouv. Gran, 1809. p.185. ex DO. Prodr. ITI. 360. Meisuer Gen, 130. (94.) Fenzl in Annal. Wiener Mut, II. 298, - Anue potius Boussingaultiae species?

LEPTRINA $n . A F$. Caly $\mathrm{x}$ tripartitus, laciniis ellipticis, obtusis. Corolla nulla. Stamina 3 , hypogyna, calyeis lacinifs alterina. 0 vari a m ovale. Styli 3 , breves, acutí. Ca ps u J a unilocularis, trivalvis, trisperma. Se mi a a centro aftixa. - Herba boreali.americana, annua, glabra; foliis radicalibus tribus, lineari-lanceolatis, acutis, integrit, scapo unifloro, folia aequante.

Leptrina Rafinesque in Journ. Phys. LXXXIX.p.96. DC. Prodr. MIT. 368. Meisner Gen, 130. (94.) Feazl in Annal. Wienier Mus. 11. 299.

THERES MU. MOLLUGINEAE Fenzl in Annal. Wiener Mus. II. 299. Cal y x quinquepartitus, rarius quinquefidus, rarissime quadripartitus, persistens. 0 v a $\mathbf{r}$ i a $\mathrm{m}$ nunc uniloculare, multiovulatum, nune tri-quinqueloculare, loculis uni-multiovulatis; ovula basilaria v. anguli centralis medio, aut omni ejusdem longitudini funiculis distinctis inserta. Capsula loculicide valvata.

5184. Orygia FORSK. Cal yx quinquepartitus, persistens, laciniis inaequilongis, ovatis, cuspidatis, margine membranaceis, patulis, Corolla e petala plurima, spathulato-linearia v. ovalioblonga, integerrima, tenerrima, calyce breviora, demum in cupulam carnosulam, capsnlae basim arete cingentem confluentia. S ta m in a plurima, imo calyci inserta, partim in phalanges cohaerentia; $\mathrm{fi}$ i a m enta subulato-triquetra, antherae bilocnlares, versatiles, loculis lineari-oblongis, parallelis, longitudinaliter deliscentibus, $O \mathrm{va}$ arinm liberum, snbgloboso-pentagonum, quinqueloculare. Ovula plurima, loculorum angulo centrali funiculis distinctis inserta, amphitropa. S tig. mata 5, linearia, demum recurva, Capsula chartacea, rotnndato - pentagona, quinquesulca, quinquelocularis, loculicide quinquevalvis, valvis medio semisepta a columnae centralis persistentis angulis refracta gerentibns. S e m in a plurima, funiculis adscendentibus diseretis inserta, reniformia, testa crustacea, atra, concentrice rugosa, umbilici strophiola parva, biauriculata. E m b r y o annularis, albumen farinaceum cingens. - Herba suffruticosa, glabra, in Arabia felici, India orientali et Capite bonae spei observata; caulibus ramosissimis, diffusis, ramisque angulatis, foliis alternis, petiolatis, orbicularibus et ellipticis, carnosis, cymis axillaribus et subterminali-oppositifoliis, elongatis, dichotome racemiformibus, floribus pedicellatis, demum reflexis, calycibus apice margineque purpurascentibus, petalis albis v. purpurascentibus, stigmatibus flavis.

0 rygla Forskael Aegypt. 103. Jussieu Gen, 316. Diet. sc. nat. XXXVI. 512. DC. Prodr. XII, 455. Meisuer Gen. 131. (95.) Fenzl in Annal. Wiener Mus, If. 299. c o rb i. ch o a i Scopoli Introduct, 1196. A xonotech ium Fenzl in Annal. Wiener Mus.1. 354. Portula ca de cambens Vahi. Giinus trianthemoides Heyae.

5185. C개느us $L O ̈ F F L$. Caly $\mathrm{x}$ quinquepartitus, persistens, laciniis planis, muticis, v. dorso infra apicem subcucullatum mucronatis. C orolla nulla, v. petala indefinita, subperisyna, angustissime ligulaeformia, bi-trifurea v. setiformia, calyce breviora. Stamina $3 \_20$, imo calyci inserta, distincta y. in phalanges aggregata; fil amenta subulata, a ntherae biloculares, versatiles, loculis linearibus, parallelis, longitudinaliter dehiscentibus. Ovarium liberum, ovatum, tri pentagonum, tri-quinqueloculare. $O$ v a la plurima, loculorum angulo centrali funieulis distinctis, elongatis inserta, amphitropa. Stigmata 3_5, linearia, patentia. Ca p sul a chartacea, rotundato tri-pentagona, tri-quinquesulca, tri-quinquelocularis, loculicide tri-quinquevalvis, valvis medio septa a columna centrali persistente solnta gerentibus. S emina plurima, funieulis adscendentibus cireumflexis inserta, reniformia, testa crustacea, laevi v. tuberculata, strophiola umbilicali integra. Embryo annularis, albumen parcum, farinosum cingens. - Herbae annuae, interdum suffrutescentes, in regionibus subtropicis tropicisque totius orbis obviae, ramosae, prostratae, glabrae v. pube stellata tomentosae, foliis alternis $v$. pseudo verticillatis, integerrimis $v$. denticulatis, floribus in glomerulos v. umbellulas oppositifolias, sessiles confertis, v. ad singulos ramorum nodos subsolitariis, longius pedicellatis.

G I i n u s Lóffling $X t$. 145, Lian. gen, $n$, 610 , Gïrtner $I T$. 236. DC. Prodr. III. 455. Meisner Gen. 131. (95.) Fenzl in Annal. Wiener Mus. $T$. 356.

a. EUGLINUS. $\mathrm{C}$ a $1 \mathrm{y} \mathrm{cl}$ s lacialae mueronatae. - Pubes stel. lata. - G II n a s Loffl. $t$. c. Lam. t. 483, Gärtn. t. 130. Sibthorp Flor, graec. $t$. 472 . Rolo fa Adanson Fam. IT. 256. P h y s a Thouars Gen. Madagasc. 20. Ple nekia Rafinesque $S_{p e c c h .}$. 194. Do o siera Roxburgh msc.

b. PSEUDOGLINUS. C a l y c is laciniae planae, muticae. Pubes nulla. - Molluginis s p. Linn. Ruiz et Pav. Cambessed, in St. Hilaire Flor. Brasil. t. 109. P h a rnacel sp. Auet.

5186. Mollugo LINN, Calyx quinquepartitus, persistens, laciniis mnticis, herbaceis v. albo-marginatis, aestivatione imbricatis. Corolla nulla. St am ina $3 \_5$, rarissime $6 \_10$, hypogyna, exteriora ealycis laciniis alterna; filam e nt a brevia, subulata, an therae biloculares, globosae, minimae, longitudinaliter dehiscentes. D is cus hypogynus nullus. Ovari a m liberum, ovato-trigonum, trilocalare. O v ul a plurima, lo- 
eulorum angulo centrali funiculis brevihus inserta, amphitropa. Stigmata 3 , lineari-teretinscula $\mathbf{v}$. subcuneata. Capsula tenue membranacea, seminibus torosa, rotundato trigona, trisulca, trilocularis, loculicide trivalvis, valvis medio septife ris. S emina plura v. plurima, globulosa, testa crustacea, granulata v, costata, umbilico estrophiolato. E mbryo annularis, albumen farinaceum includens. - Herbae annuae, humiles, plerumque humifusae, dichotome ramosae, in regio. nibus tropicis veteris orbis, rarius in $A m e-$ rica aequinoctiali et boreali temperata, locis potissimum cultis obviae; foliis planis, linearibus, lanceolatis $v$, obovato - spathulatis, integerrimis, ad nodos pseudoverticillalis, stipulis obsoletis, fugacissimis, floribus per cymas axillares dichotomas, racemiformes dispositis, $v$, in umbellulas ad nodos sessiles aut pedunculatas agghegatis.

Mo11 u g o Ltan. Gen. n, 139. Gärtner II, 235, t, 130. Lam. t. 52. Seringe in DC. Prodr. $I, 391$, excl. sect, 2. Penzl in Annal. Wiener Mus. I. 375. (excl. subgen.) II. 246. C e r vi a n a Minuart Monogr. 1. T rieh 1 is Haller Hort. Göt. ting. 26. part. - ? Gali a s $t$ f u $\mathrm{m}$ Heister ex Fabric. Hort. Helmst. edit, 1. p. 108.

518\%. Rharearaceram LINN. Calyx quinquepartitus, persistens, laciniis obtnsissimis, intus et margine membranaceo saepe coloratis, aestivatione imbricatis. Corolla nulla. Stamin a 5, rarissime $6 \_7$, imo calyei inserta, calycis laciniis alterna; filamenta filiformia, antherae biloculares, lineari-oblongae v. subglobosae, longitudinaliter dehiscentes. D is cus hypogynus cyathiformis, tri-quinquefidus $\mathbf{v}$. partitus, rarissime obsoletus. Ovarium liberum, ovato-trigonum, triloculare. Ovula plura, loculorum angulo centrali funiculis lrevissimis inserta, amphitropa. Stigmata 3 , obovata, carnosa, subtus carinata, faciebus reflexis demnm cristaeformia, rarius teretinseula, cuneiformia. Ca p su la chartacea, basi rotundato-trigona, apice triquetro-trisulea, trilocularis, loculieide trivalvis, valvis medio septiferis. S em in a in loculis 4-8, globoso-lenticularia, acute marginata, v. globosa, dorso zona prominula eineta, testa erustacea, laevissima v. subtilissime granulata aut reticulata, umbilico estrophiolato. E mb ry o annularis, albumen farinaceum includens. - Herbae v. suffrutices capenses, squarroso-diffusi; foliis teretiusculis, acicularibus, setaceis v. jiliformibus, rarius planis, lanceolatis, ellipticis $v$. obovatis, plerumque seta terminatis, caudiculorum et ramorum perennantium alternis, confertis $v$. rarius remotis, superne in comam approximatis, caudiculorum annuorum ad nodos remotissimos pseudoverticillatis, stipulis geminis, capillaceofimbriatis, cymis di-trichotomis, racemiformibus, $v$. prolificatione compositis, terminalibus et alaribus longe pedunculatis, axillaribus saepe sessilibus, ramulis peduncularibus interdum minimis umbelliformibus, rarissime ad flores solitarios redactis.

Pharnaceum Linn Gen. n. 106. excl. sp. Gärtner $I T$. 235. t. 130. Lam. t. 214. Bot. Mag. $t$. 1883. Fenzl in Annal. Wiener Mus. II. 2a6. M oll u g o sect. II. Seringe in DC. Prodr. 1. 391. excl. sp. Ginginsia DC. in Mem, soc. $h$. n. Paris: ID. 177. et 185, $t$. 16. 17. Prodr. IIT, 362.

5183. Ir ypertelis E.MEY. C a 1 y quinquepartitus, laciniis obtusissimis, coloratis, membranaceo-marginatis, aestivatione imbricatis. $\mathrm{C}_{0}$ rolla nulla. Stamin a $12 \_80$, hypogyna, biseriata, exteriora calycis laciniss solitarie alterna, interiora longiora, basi in cupulam obsoletam cohaerentia v. in phalanges connata; filamenta filiformia, antherae biloculares, oblongae, longitudinaliter dehiscentes. Dis cus hypogynus nullus. Ovari u m liberum, quinqueloculare. Ovula plurima, loculorum angulo centrali funiculis brevissimis inserta, amphitropa. Stigmat a $3-5$, carnosa, teretia, uncinato-recurra. C a p su la chartacea, ellipsoidea, suleata, tri-quinquelocularis, loenlieide tri-quinquevalvis, valvis medio septiferis. Semina plurima, lenticularia v. pyriformia, testa crustacea, laevissima, nitida, umbilico estrophiolato. Embryo....-Suffrutices capenses, humiles; caule decumbente, squarroso-ramoso, foliis alternis, confertis $\boldsymbol{v}$ remote verticillatis, teretiusculis, carnosis, glaucis, muticis, basi in vaginam stipularem amplexicaulem, truncatam, utrinque unidentatam dilatatis, umbellis axillaribus, alaribus $v$. terminalibus, simplicissimis, longe pedunculatis.

H ypertelis R. Meyermsc. ex Fenel in Annat. We. nor Mus. IT. 261. Pharnaceum verrueosum Ecklon et Zeyh.

518D. Isammetroplan ECKL. et ZEYH. C al y $\times$ quinquepartitus, laciniis ovalibus, margine petaloideis, aestivatione imbricatis. Corolla nulla. Stamina 5, hypogyna, ealycis laciniis alterna; fil amenta basi in cupulam membranaceam connata, a ntherae biloculares, globosae, minimae, longitudinaliter dehiscentes. Di\&cns hypogynus nullos. Ovarium liberum, tri-quinqueloculare. $O \mathrm{vala}$ in loculis solitaria, medio anguli centralis funiculo brevissimo inserta, amphitropa. Stylus distinctus, tri-quinquefidus, lobis filiformibus, revolutis, intus stigmatosis. Ca psula chartacea, globose tri-pentagona, tri-pentasperma, tri-quinquelocularis, loculicide tri quinquevalvis, valvis medio septiferis, interdum abortu nnilocularis, monosperma. Semina in lecnlis solitaria, globulosa, testa crustacea, granulata, umbilico estrophiolato, E m b ryo .....-Herbae capen ses, perennes, saepissime suffrutescentes, $\mathrm{rat}$ mosissimae, stipulalae v. exstipulatae; ramis nune distincle nodoso-geniculatis, verticillato-foliatis, nunc inordinate ramulosis, foliis rigidis, tota longitudine arctissime quadrifariam imbricatis, facie acute tetragonis, floribus minimis, in cauliculis distinctis, alaribus $v$. terminalibus, articulatis, in umbellas simplicissimas, ad nodos sessiles dispositis, $v$. ad genicula glomeratis.

Ps a m motroph a Eeklon et Zeyler Enumerat. plant. Cap. 286. Meisuer Gen. 131. (95.) Fenzl in Annal. Wiener Mus. II. 264. M a Il og o n a Fenzl Op. cit, I, 353. P h a rnacei sp. Linn. Thanb.

saso. Coelanthum $E$. MEY. Calyx persistens, infundíbuliformis v. campanulatus, semiquinquefidus, laciniis aequalibus, petaloideis, apice rotundatis. Corolla nulla. Stamina 5, inter calycis lacinias inserta ; fil a menta brevissima, a ntherae biloculares, sagittatae, basifixae, filamenta subsuperantes, longitudinaliter dehiseentes. Dis c us hypogynus nuilus. O variu m liberum, triloculare. Ovula in loculis plurima, angulo centrali funiculis brevissimis inserta, amphitropa. Stigmata 3 , teretinsenla, carnosa. Ca psula chartacea, oblonga, prismatico-trigona, trilocularis, loculicide trivalvis, valvis medio septiferis. S e m i na plurima, globosa, compressiusenla, testa reticulata, umbilico estrophiolato. Herbae capenses, annuae, laevissimae; foliis radicalibus rosulato-congestis, obovatis $v$, lanceolatis, in petiolum longum angustatis, enerviis, muticis $v$. aristato-mucronatis, cauliculis scapiformibus, 
apice di-tricholomis, foliis filiformibus, congestoverticillatis, stipulis fimbriato-laceris, floribus subracemosis, breve pedicellatis.

Co el a $\mathrm{n} t \mathrm{~h} \mathrm{~m}$ E. Meyer msc. Fenzl in Annal. Wiener Mus. II. 267.

5191. A erosanthes ECKL, et ZEYH. Ca ly $x$ quinquefidus, persistens, tubo brevi, in fundibuliformi, laciniis carnosulis, carinatis, acu minatis, intus coloratis, erectis. Corolla nulla. S ta m in a $10 \_40,8 u m m o$ calyeis tubo biseriatim inserta, in phalanges approximata, exteriora longiora, ejnsdem laciniis alterna; iil a m e $n$ ta filiformia, a nt h'erae biloculares, lineares, longitndinaliter dehiscentes. D is cus hypogynus nullus. Ova rinm liberum, uniloculare. Ovula in loculis solitaria, placentae basilari brevissimae inserta, amphitropa. St igmat a 2, filiformia. C a psula globosa, compressiuscula, saepius basi attenuata, bilocularis, disperma, v. abortu unilocularis, mono-disperma, loculicide bivalvis, valvis medio septiferis. S e min a 1 _2, basifixa, globosoreniformia, testa crustacea, lacunoso-tuberculata, granulata, umbilico estrophiolato. Embryo annularis, albumen farinaceum includens; $\mathbf{r a d i} \mathbf{c} \mathbf{u}$ la infera. - Suffrutices capenses, decumbentes, plerumque diffusi, glaberrimi; foliis oppositis, carnosulis, lineari-lanceolatis $v$, oblongis, basi connatis, ramulorum abortu interdum quaternatim pseudo-verticillatis, stipulis nullis, floribus axillaribus $v$. ala ribus, solitariis, peduriculatis.

Acrosanthes Eeklon et Zeyher Enumerat. plant. Cap. 328. Fenzl in Annal. Wiener Mrus. IT. 268.

¿nsts. Sellatedea $C H A M$, et $S C H L$. Calyx quinquepartitns, laciniis obtusis, carnosulis. Corolla nulla. S qu a m $\mathrm{l}$ a e petaloideae 5 , caIycis laeiniis oppositae et breviores, ligulatae, apice bifidae. Stamina 10 , imo calyci inserta, alterna calycis laciniis squamulisque oppesita longiora; filamenta filiformia, a $\mathrm{th}$ erae ovatae, bilocnlares, longitudinaliter dehiscentes. Dis e us hypogynus nullus. Ovari um liberum, unileculare, Ovula plurima, colamellae basilari liberae inserta, amphitropa. Sty $1 \mathrm{i} \mathbf{3}_{-} 4$, apice stigmatosi, calyeis laciniis oppositi. Cap 8 u la chartacea, ovoidea, unilocularis, tri-quadrivalvis. Se mina colnmellae basilari inserta, plurima, globosa, testa crustacea, tuberculata, atra, umbilico estrophiolato. Embry o ....- Frutex tripedalis, glaber, in insulis sandwicensibus et littoris sinici australis observatus; ramis nodosis, bifurcatis, junioribus tetragonis, foliis oppositis, ses. silibus, basi subconnatis, lanceolatis, membranaceo. carnosulis, exstipulatis, floribus plurimis, minulis, pedicellatis, in cymas in paniculam brachiatam dis. positas confertis.

$\mathrm{S}$ eh ie de a Chamisso et Schlechtend. in Linnaea $I_{\text {. }}$ 46. Fenxl in Endlicher Atakt, t. 14. Annal. Wiener Mus. II. 272. Portulacea Hooker et Araott ad Beechey 188 .

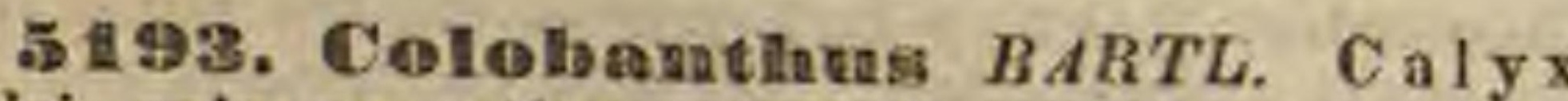
quadri-quinquepartitus, Iaciniis acutis, enerviis, carnosulis, interdum rigidis. Corolla nulla. Sta$m$ in a $4-5$, calyeis laciniis alterna, annulo perigyno membranaceo, obsoleto inserta; fila m enta filiformia, antherae biloculares, ovatie, longitudinaliter dehiscentes. D is e 8 hypogynus nullns. Ovari n m liberum, uniloculare. Ovula plurima, columellae filiformi liberae funienlis longis inserta, amphitropa. Styli $4-5$, apice stigma. tosi, calycis laciniis oppositi. Capsnla merbbranacea, ovoidea, unilocularis, usque ad basim qua- dri-quinquevalvis, valvis cum calycis laciniis alternantibus. Semin a columellae centrali inserta, plurima, globosa, testa crustacea, nitida, subtilissime granulata, umbilico estrophiolato. E mb ryo annularis, albumen farinaceum cingens. Herbae perennes, caespitosae, humiles, in Amer $i$ cae australis tropicae et antareticae jugis, nec non in Nova-Hollandia méridionali crescentes, cauliculorum inlernodiis plurimis, brevissimis, foliorum vaginis longis sese excipientibus inclusis; foliis oppositis, exstipulatis, carnosulis, linearibus, planis, marcescentibus, v. rigidis, ovato-lanceolatis, triquetris, arcte imbricatis, perennantibus, floribus axillaribus, solitariis v. geminis, minutis.

Co loba $n t h$ as Bartling in Neliq. Hänk, $I T$ 13. t. 49. Fenzl in Endlich. Atakt. t. 49. Annal. Wener Mus, I. 48. II. 273. Saginat et Spergulae s p. Kunth. Durv. Labillard. Nov. Holl, $t, 142$.

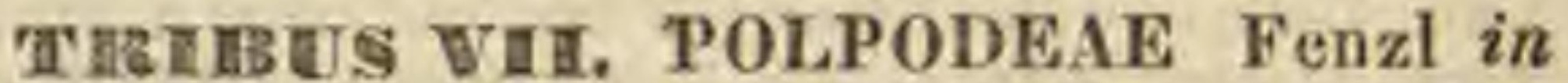
Annal. Wiener Mus. II. 300. Caly x quadripartitus, laciniis petaloideis, fimbriato-laceris. Corolla nulla. Stamina 4 , hypogyna. Capsula obcordata, bilocularis, bivalvis, disperma, seminibus medio columnae centralis insertis.

5194. PoIpodila PRESL. C a l y x quadripartitus, laciniis petaloideis, fimbriato-laceris, basi bracteolis 3-4 imbricatis, cartilagineo-marginatis, utrinque inferne fimbriatis. Corolla nulla. Sta mina 4, hypogyna, calycis laciniis alterna; fil amenta filiformia, exserta, an the rae biloculares, loeulis linearibus, basi discretis, longitudinaliter dehiscentibns, $O$ va ri u m liberum, lenticulari-compressum, biloculare. Ovula in loenlis solitaria, septi medio funieulo brevissimo inserta, amphitropa, micropyle infera. $\mathrm{Sty} \mathbf{l} \mathbf{4} 8$ bipartitus, cruribus elongato-filiformibns, stigmatosis, ereetis. Caps u 1 a ehartacea, bilocularis, late obcordata, dissepimento contrarie compressa, loculicide bivalvis, valvis medio septiferis. Semin a in loculis solitaria, globoso-reniformia, testa crustacea, atra, granulata, umbilico estrophiolato. Emb ryo leviter arcuatus, albuminis farinacei lateri dorsali applicitus. - Suffrutex, capensis, humilis, diffuse ramosus; ramis foliis sessilibus, densissime imbricatis obtectis, amentum cylindricum ramosum referentibus, foliis alternis, minutis, carnosulis, subcartilagineo-marginatis, canaliculatis, adpressis, apice recurvis, basi utrinque lamina stipulari, semiadnata, fimbriata auctis, floribus solitariis, binis $v$. ternis, axillaribus, sessilibus, bractearum stipularumque fimbriis velatis, confertissime spicatis

PoIpoda Presl Symb. 1. 1. t. 1. Meisner Gen. 132. (96.) Fenzl in Annal. Wiener Mus. I1, 300. B lepharole p is Nees in Lindley Introduct. edit. II. p. 442.

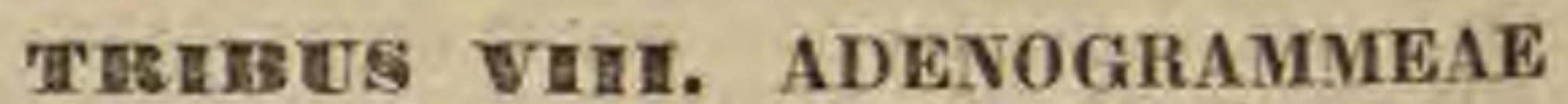
Fenzl in Annal. Wiener Mus. II. 274. C aly x quinquepartitus. Cor olla nulla. Stamina 5. Ovarium uniloculare, ovulo unico. Stylus filiformis; stigmate capitato. Capsula indehiscens, monosperma.

5195. Ademogramena REICHENB. Caly $x$ persistens v. deciduus, globosus v. ovoideus, quinquepartitus, laciniis margine et intus 
coloratis, Corolla nulla. Stamina 5 , basi in annulum membranaceum hypogynum cohacrentia, calycis laciniis alterna; fil amenta filiformi-subulata, a $\mathrm{n}$ h e ra e biloculares, ovales, versatiles, longitudinaliter dehiscentes. Ovari n m liberum, subglobosum v. conicum, uniloculare. Ovulu m unicum, funiculo e basi loculi adscendenti, libero appensum, amphitropum. St ylns filiformis, sub. obliquus; stigma rapitatum. Capsula charta. cea, unilocularis, indehiseens, conica, recta et anceps, v. lenticularis, oblique acuminata, laevis v. marginibus papillosa, faciebus interdum impres 80-punctata. Semen unieum, ovoideum, testa membranacea. Embryo uncinatos v, annularis, albumen farinaceum cingens, $r$ a dic u la supera. - Suffrutices $v$. herbae annuae, in Capite bo. nae spei indigenae, graciles, dichotome ramosae, diffusae, glabrae; foliis verticillatis, obovatis, lanceolatis, linearibus $v$. filiformibus, muticis $v$. aristato-mucronatis, obsoletissime stipulatis, floribus parvis, sessilibus $v$. breve pedicellatis, in umbellas axillares sessiles dispositis.

Adenogram mia Reichenbaeh Ic, exot. IT. 3. $t .109$. Meisner Gen, 131. (95.) Fenzl in Annal. Wiener Mus. II. 254. S teudelia Presl Symb. I. 3. t. 2. Eiklon et Zeyher Enumerat, plant. Cap. 183. Ph a r a a cei sp. Auet.

\section{GENUS PORTULACEIS AFFINE.}

51DS. Hewista PURSH. C a ly x bracteolis subulatis involucratus, hepta enneaphyllus, foliolis spiraliter pluriseriatis, aestivatione convoln tis, ovatis, concavis, submembranaceis, coloratis, interioribus angustioribus. Co roll a e petala plarima, calycis foliolis subeonformia, teneriora, interiora minora. Stamina $12 \_20$, hypogyna; filamenta calyce breviora, erecta, antherae biloculares, lineares, breviter apiculatae. Ovarin m liberum, globoso-trigonum, hisulenm, nniloculare (?). O v u la plurima, columellae centrali liberae inserta. Stylus sexpartitus, cruribus longe filiformibus, erectis, stigmatosis, Capsula .... - Herba boreali-a mericana, non satis nota; radice perenni, subfusiformi, ramosa, alba $v$. sanguinea, eduli, siccitate fragili, foliis radicalibus plurimis, stellatim patentibus, subtereti linearibus, oblusissimis, glabris, carnosulis, fasciculo vasorum centrali percursis, scapis radicalibus plurimis, folia superantibus, erectis, teretibus, glaberrimis, nudis, uni-bifioris, sub flore articulatis.

Lewis i a Pursh Flor. Bor. Amer. II. 368. Hooker Bot. Miscell. I. 344, t. 70 . Flor. Bor. Amer, ic, inedit. Fenzl in Annal. Wiener Mus. II. 301.

\section{Ordo CCLPII. Caryopleylleae.}

CARYOPHYLLEAE et AMARANTACEARUM sect. III. Jussieu Gen, 299. et 98, CARYOPHYLLEAE DC. Prodr. III. 365. SCLERANTHEAE, PARONYCHIEAE, ALSINEAE et SILENEAE Bartling Beitr. IT. 153-160. Ord. nat. 300305. SILRNACEAE, $\triangle L S I N A C E A B$ et ILLECEBRACEAE Lindley Introduch, II, p.124-127, CARYOPHXLLEAE FenzI. Dissert, inedit.

Herbae v. suffrutices, rarissime frutices humiles, caule ramisque saepissine dichotomis, teretiusculis v. angulatis, nudis v. pube simplici, rarissime stellata sive ramosa, plus minusve copiosa consitis, villosis $\mathrm{v}$. tomentosis. Foli a opposita et saepissime basi connata, rarissime alterna, simplicia, integra, sae- pissime integerrima, rarissime denticulata, forma inter setaceam et orbicularem admodum varia, sessilia v. petiolata, plerumque uni-trinervia, rarius plurinervia, avenia v. venulosa. Stipulae nunc nullae, nunc scariosae, interpetiolares, rarius petiolares, rarissime semiintraaxillares.

Flores hermaphroditi, v. interdum alterius sexus organis imperfectis subunisexuales, regulares, in inflorescentiam centrifugam, cymosam, simplicem, regulariter dichotomam v. rarius racemiformem aut compositam, thyrsoideam v. paniculatam dispositi, rarissime per ramos sparsi, cymis nunc multifloris, paniculam, corymbum, fasciculum, glomerulum v. umbellam referentibus, nunc paucifloris, simpliciter bifureatis, v. ad florem solitarium, ad basim pedicelli bibracteatum redactis.

Calyx liber, herbaceus, semiscariosus v. scariosus, rarissime demum baccatus, tetrapentamero-gamophyllus, foliolis plus minus connatis, quadri-quinquedentatus v. partitus, laciniis aestivatione imbricatis.

Conolua nune nulla, nune petala ealycis laciniis numero aequalia, rarius abortu panciora, iisdem alterna, libera, plana, aequalia, integra, bifida v. bipartita, nonnunquam fimbriato-lacera, nuda v. ungue intus appendiculato, interdum minima, sujuamulaeformia v. setacea, nune sinubus laciniarum calyeis, nune disci v. annuli membranacei aut glandulosi ejusdem basim vestientis margini extimo, v, retro discum distinctissime $\mathbf{v}$. obsolete perigyne v. subhypogyne inserta, nune simul eum staminibus carpophori stipitiformis, plus minus distincti apici hypogyne imposita.

Stamina nune calycis laciniis numero aequalia et opposita, rarius pauciora, nunc dupla, interiora breviora, aeque fertilia v, rarissime castrata, petalis dum adsunt v. calycis sinubus opposita, ejusdem summo tubo v. basi perigyne v. subhypogyne inserta, v. cum petalis in apice carpophori hypogyna. Filamenta filiformia v, subulata, libera v. basi in cupulam membranaceam obsoletam coalita. Antherae introrsae, biloculares, medio dorso insertae, saepe versatiles, loculis oppositis, parallelis, latere longitudinaliter dehiscentibus. Pollin is granula ovalia v. globosa, trisulcata v. dodecaëdrico-pentagona, sulcis v. faciebus medio foratis.

Ovarivm liberum, sessile v. stipiti plus minus distincto, apice petala et stamina gerenti impositum, uniloculare v. rarius plus minus complete tri-quinqueloculare. $0 \mathrm{vu} \mathrm{lum}$ nnicum v. plurima, funiculis e fundo ovarii ortis, liberis, v. inferne in columellam centralem coalitis inserta, amphitropa. Stylus unicus, bi-quinquefidus v, partitus, v. styli duo aut quinque, 
aut $\mathrm{stigmata}$ totidem a basi discreta, intus longitudinaliter papilloso-stigmatosa, filis conductoriis stigmatum numero, discretis $v$. in unum coalitis, centralibus aut rarissime parietalibus, cum placenta centrali junctis.

Frocrus: utriculus membranaceus, monospermus, indehiscens v. basi in lacinias plures, apice cohaerentes fatiscens, rarissime nucamentaceus, v. capsula membranacea, pergamenea v. subeartilaginea, uni-quinquelocularis, apice in valvas v. dentes stylorum numero aequali v. duplo dehiscens, rarissime baceata, indehiscens, mono-polysperma.

Semisa globosa, reniformia, lenticularia v. pyriformia, cylindrica v. oblonga, compressa, rarissime carinato-concavo-convexa, erecta $v$. subhorizontalia. Test a membranacea v. crustacea, laevissima, rugulosa, reticulata, granulata, tuberculata v. muricata, rarissime glochidata, a $\mathrm{mbili}$ c 0 apicali v. marginali, rarius ventrali, micropyle proximo, v. interdum ab ab illa remoto, nudo v. strophiolato. En d opleura tenerrima, testae plus minus adhaerens. Albumen centrale, raro laterale, farinaceum v. rarissime subearnosum.

Емввуо periphericus, subspiralis v. cyclicus, rarius rectus v. curvatus, albumini adplicitus, rarissime in axi albuminis rectus. Cotyledones plano-convexae, incumbentes, rarius accumbentes. R a dicula teres, basim v. rarius apicem fructus respiciens.

Stirpes cosmopolitae, in hemisphaerae borealis regionibus extratropicis, imprimis inter $30-60^{\circ}$ L. B., maximo numero generantur, in hemisphaera australi multo rariores, inter tropicos rarissimae, potissimum alpicolae.

Virtutes paucae, refrigerantes, leniter solventes, nonnullae principio peculiari saponaceo scatent.

Ordo cum reliquis in hac classe recensitis, rejecto olim charactere e petalorum praesentia petito, cum Chenopodeis Amarantaceisque collocandus, Portulaceis per Adenogrammeas et Mollugineas arete accedit, a quibus nonnisi staminum serie extima calyeis laciniis opposita, nec alterna, diseriminatur.

Genera ovario uniloculari fructuque utriculari indehiscente donata, a Chenopodeis Camphorosmeis, et Polyenemeis Aerveisque Amarantaceis foliis stipulatis oppositis, staminibus manifeste perigynis, et embryone rectiusculo v. leviter incurvo, facillime distinguuntur. Reliqua fructu capsulari pleiospermo donata, partim isdem characteribus, partim petalorum praesentia typica, et fructus dehiscentia valvari, nec ut in illis circumscissa, nullo negotio dignoscuntur.

In exponendis ordinis difficillimi et injucundissimi generibus egregii usus mihi fuisse dis- sertationes ineditas cl. Fenzl, quas ille occulatissimus botanicus jam nonum in annum parturit, grate memoro.

SUIBOIE II. PARONYCHIEAE St. Hilaire in Mem. Mus. II. 276. He r b a e v. suffrutices, foliis oppositis v. rarius alternis, scarioso-stipulatis. Ovarium saepe, uniovulatum. Fructus nucamentaceus v. utricularis, monospermus, indehiscens v. a basi in lacinias apice coalitas fatiscens, nunc capsularis, polyspermus, apice tri-quinquevalvis. $\mathbf{E} \mathbf{m}$ b $\mathbf{r}$ y o periphericus, rectinsculus, curvatus v. interdum subspiralis, rarissime axilis, rectus. Species inter $25-40^{\circ}$ L. B. copiosissimae.

THABES I. ILLECEBREAE R. Brown Prodr. 413. Flores appendicibus lateralibus nullis. Cal yx herbaceus v. demum cartilagineo-induratus, tri-quinquefidus v. partitus, laciniis plerumque rigide mucronatis $v$. spinescentibus, rarins muticis. O.varium uniovulatum. S $\mathrm{tylus}$ bifidus v, bipartitus, rarissime indivisus; interdum distincte duplex. Fructus utricularis, indehiscens, rarius a basi in lacinias apice cohaerentes dehiscens, rarissime nucamentaceus. S emin is chalaza cum umbilico confluens. Embryo teretiusculus, annularis, curvatus v, rarissime rectiusculus.

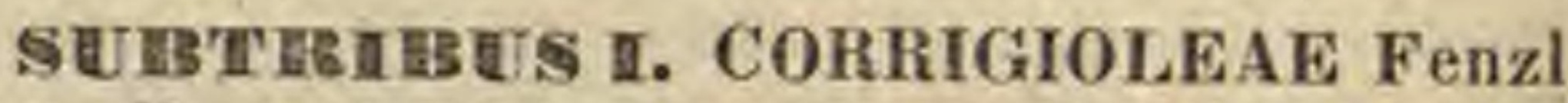
msc. Fructus nucamentaceus, calyce membranaceo inclusus. - Folia allerna, stipulata.

5ำ. Corroigiola LINN, Caly $\mathrm{x}$ herbaceus, persistens, quinquepartitus, laciniis obtnsissimis, petaloideo-marginatis. Cor olla e petala 5 , perigyna, ealycem aequantia, rotundata, integerrima. Stamina 5, disci perigyni obsoleti margini inserta, petalis alterna; fil a in enta filiformia, a $\mathbf{t}$ herae biloculares, longitudinaliter dehiscentes. Ovarium uniloculare, Ovulum unicum, apici funiculi bàsilaris liberi appensum, anatropum Stylus brevissimus, tripartitus; stigmat a minima, teretiuscula, recurva. N nx crustacea, ovoideo-trigona, calyce tecta. Semen ovoideo-globosum, testa membranacea. E m b ry o cyclicus, albumen copiosum includens, rad i cula supera, - Herbae annuae v, perennes, in Eu ropa et in Capite bonae spei crescentes, rarius suffrutices, in America australi extratropica indigeni, cauliculis filiformibus, simpliciusculis, procumbentibus, specierum suffrutescentium e caudice crasso, polycephalo, scariose squamato emergentibus, foliis oblongis linearibusque, carnosulis, glaucis, stipulis scariosis, nuno bipartitis, semiintrafoliaceis, basi uniauriculatis, nunc indivisis, axillaribus, biauriculatis, floribus parvis, confertissime $v$, remote glomerato spicutis aut racemosis, spicis $v$. racemis terminalibus oligophyllis v. aphyllis, laxius v. confertius corymbosis.

Corrigiola Lina. Gen, n, 378. Gärtaer I, 358. t. 75. Lam, t. 213. Flor, dan. t. 334. E. B. t. 668. Jassieu in Mem. Mus. I. 389. St. Hilaire in Mem. Mus. II. z. 4. $f$, g2. DC. Prodr. ITI. 366. Meisner Gen, 132. (96.) Polyg on ffolia 


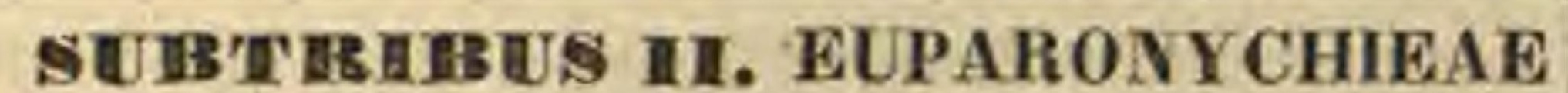
Fenzl msc. Utriculus membranaceus indehiscens, $\mathbf{v}$ : a basi in lacinias plures apice cohaerentes apertus, calyce membranaceo v. indurato-cartilagineo inclusus. - Folia caulina et ramorum primariorum opposita, summa saepius alterna, rarissime pseudoverticillata, stipulata.

5198. II Terniaria TOURNEF. C a ly $\mathrm{x}$ herbaceus, immutate persistens, profunde-quinquefidus, tubo infundibuliformi $v$. cupuliformi, laciniis ovatis. Co rolla e petala 5 , setacea, laciniarum sinnbus inserta. S t a $\mathrm{m}$ in a 5 , rarius abortu pauciora, disco carnoso calycis faucem marginanti inserta, petalis alterna; fil amenta brevissime filiformia, a n therae biloculares, longitudinaliter dehiscentes. Ovarium calycis tubo immersum, liberum, uniloculare. Ov a $\mathrm{l}$ am nni cum, e basi erectum, amphitropum, micropyle infera. Stylu s brevissimus, bifidus v. bipartitus. Utriculus indehiscens, ealyce tectus. S emen globoso-lenticulare, verticale, testa crustacea, nitida. E m br y o eyclicvs, albumen farinaceum includens; radi $\boldsymbol{c}$ ula infers. - Herbae v. suffruticuli, in temperatis sterilibus veteris orbis obvii, villosi $v$. rarius glabri, humifusi, caespites deplanatos efformantes; foliis ovalibus, oblongis $v$. linearibus, sessilibus, caulinis et ramorum primariorum oppositis, ramulorum plerumque alternis, stipulis lateralibus scariosis, minimis, ovatis, integerrimis $v$. ciliatis, floribus minutissimis, glomeruis axillaribus $v$. oppositifoliis, plurimis, plerumque spicatim confertis, foliolis interstinctis, spicis abbreviatis, longitudine ramulorum, alternis.

H e rniaria Tournefort Inst. 288, Linn. Gen, n. 308. Sehkubr t, 56. Lam. $t$. 180. B. B, $t, 206$. Sibthorp Flor. graec, $t$, 258. Jussieu in Mem. Mus, I, 389. DC. Prodr, III. 367. exel. 9. 2. Mem. IV. ᄂ, 3, Meisuer Gen, 132. (96.)

5195. Hilecellorum GÄRTN. FIL. C aly $\mathrm{x}$ ad basim quinquepartitus, ebracteatus, laciniis demum suberose incrassatis, niveis, cuneatis, a latere compressis, carinatis, facie plano-coneaviusculis, dorso ad apicem subencnllatum aristatocornutis. Corolla e petala 5 , inter calycis laci: nias inserta, minutissime setacea. Stamina 5 , subhypogyna, petalis alterna; filamenta setacea, antherae biloculares, longitudinaliter dehiscentes, Ovarinm unilocalare. $O v \mathrm{u} / \mathrm{um}$ nnicum, e basi erectum, amphitropum, micropyle infera. Stylus brevissimus; stigmata 2 , minutissime capitata. Utriculus uembranaceus, calyce inclusus, basi in lacinias quinque $\mathbf{v}$, decem apice cohaerentes dehiscens. Sem en basifixnm, cuneato-oblongam, compressiusculam. Embry o rectinsculus, albuminis farinacei lateri applicitus, radicula infera. - Herba in Furopa et Asia media indigena, multicaulis, glaberrima; caulibus filiformibus, prostratis, simplicibus v. ramosis; folits oppositis, brev'ssime petiolatis, ovatis v. ova libus, subrotundis, stipulis scariosis minitis, floribus per cauliculorum totam longitudinem ad nodos verticillatis, congestis, sessilibus.

IIlecebrum Gärtner fil. HIT. 36. 1. 184. Jussieu in Mem. Mus. Ir. 386. R. Browa Prodr. IIT, A16, in not. DC. Prodr. III. 369. Meisuer Gen. 132. (96.) 11 le ce brum verticill at um Lian. Sebkuhr L. So. Sehrader Journal 1801. t. 4 .

5\%96. Cardionenas $D C, \mathrm{C}$ a $\mathrm{ly} \mathrm{x}$ ad basim quinquepartitns, scarioso - involueratus, brac- teolis stipulaeformibus, quatuor linearibus integerrimis, quinta majore serrulata, laciniis intus subcoloratis concaviusculis, dorso apice in cornu rectum, conicum produetis. Co rolla nulla. Stam in a 5, subhypogyna, calycis laciniis opposita, obcordato-petaloidea, tria fertilia ex emarginaturae sinn in filamentum subulatum producta, duo sterilia mutica, a ntherae subrotundae, bilocnlares, longitudinaliter dehiscentes. O variu m unilocnlare. Ovulu m unicum ...... Styli 2, distincti, setacei, revoluti; stigmata simplicia. Utriculus ovoideo-oblongus, monospermus. S emen.... - Herba mexicana, perennis, pusilla, multicaulis; foliis appositis, confertis, sub. distichis, linearibus, acutis, floribus axillaribus, sessilibus, parvis, albo-viridibus.

Cardionema DC. Prodr. IIT, 372. Mem. IV. 8 . t. 1. Meisner Gen. 132. (97.) Bivonaca Moc. et Sessé Flor. mexic. inedit.

5201. Fentreaena BARTL, Calyx quinquepartitis, scarioso-involucratus, bracteolis duabus v. tríbus stipulaceis, subaeqnalibus, ovatis, concavis, margine fimbriatis, tubo brevissime infundibulari, demum indurato, laciniis cuneato-linearibus, subcartilagineo-marginatis, tribus aestivatione exterioribus apice subcucullato in spinam patentem longissimam productis, dnabus interioribus spinoso-mucrónatis v, muticis. Corollae petala 5 , calycis fauei inter lacinias inserta, minima, late ovata, integerrima, $\mathbf{v}$, cuneato-linearia, bidentata. St a m i n a 5, v. abortu panciora, disco calycis tubum vestienti inter petala inserta; filam e nt a brevissima, antherae globulosae, biloculares, longitudinaliter dehiscentes. Ovarinm substipitatum, uniloculare. Ovulum unicum, basifixum, amphitropnm, micropyle infera. StyI us brevissimus, subcapitatus; stigmata 2 , punctiformia. Utriculus oblongus, calyce inclusus, indehiscens. Semen erectnm, cuneatooblongum, umbilico basilari apiculato. Embryo parum curvatus, albuminis farinacei lateri applicitus, radicula infera. - Herbae in America australi extratropica indigenae, perennes, ramosissimae; cuulibus stipulato-vaginatis, folits alternis, confertis, subulato-setaceis, spinuloso-mucronatis, stipulis scariosis, argenteo-nitentibus, triangularibus, longe attenuatis, integerrimis v. fimbriolatis, floribus juxta totam ramorum longitudinem confertis, in axillis foliarum sessilibus.

Pentaca ena Bartling in Relfo. Mank. II. 5, t. 49. f. 1. Paranyehiae sect. Acanthon ychia DC. Prodr. III. 372. Mem. IV. t. 4. St. Hilaire Flor. Brasil, II, $t, 113$.

5*0\%. IPanonyehia JUSS, C a I yx quinquepartitus, exinvolucratus, tubo brevissime in fundibulari v. enpuliformi, laeiniis herbaceis v. semiscariosis, ad apicem cucnllatum v. rarins convolutum aequaliter mucronatis $v$. aristatis, rarius muticis, fructiferis clausis. Cor o 11 ae petala 5 , calycis sinnluus inserta, minutissìme setiformia, interdum nulla. Stamina 5, v, abortu pauciora, disci calycis fundum vestientis margini insprta, petalis alterna; fil amenta brevissima, antherae subglobosac, bilocnlares, longitudinaliter dehiscentes. Ovarium sessile, uniloculare. Ovu$1 \mathrm{n} \mathrm{m}$ unicum, funiculi basilaris liberi apiei affixum, amphitropum, micropyle infera, mox supera. $S t y$ I $\mathrm{s}$ bifidus v. partitus, ramis stigmatosis, distinetis, erectis v. recurvo-patulis. Utriculus indehiscens, v. basi laciniis quinque $\mathbf{v}$, pluribus apice cohaerentibus dehiscens. Semen e funiculo basilari libero suspensum, oblongum, compres- 
sinsculum v. globoso-lenticulare. Em b rye annularis, albumen farinaceum includens, radicula supera. Herbae in regionibus temperatis et calidioribus extratropicis totius or$b i$ is crescentes, perennes $v$. rarius annuae, saepe caespitosae; foliis oppositis $v$. interdum ternatim aut quinatim pseudo-verticillalis, variis, integerrimis, stipulis interfoliaceis, scariosis, argenteis, integerrimis, fissis v. bipartitis, hinc ad nodos quasi quaternatis, floribus cymoso-glomeratis $v$. fasciculatis, bracteis scariosis, latissimis occultatis, v. semiverticillatim glomeratis, bracteolis minutissimis interstinctis, nunc in cymulas corymboso-paniculatas confertis.

$\mathrm{Par}$ o n y hi a Jussien in Mem, Mus. I, 388. DC. Prodr. III. 370. exel. sect. 3. et sp. pl. Fenzl Dissert. inedit. $\mathrm{P}$ aron y chiae sp. Tournef. Illecebri s p. Liun.

a. ANOPLONYCHIA Fenzl msc. Calye is laciniae herbaceae, margine vix scariosae, ovato-oblongae v. laaceo. latae, acutae, concavae, muticae, pubescentes. Corol1 a e petala 5 . Stylns brevissiaus, bifidus. Ut ri culus calyce inclusus, basi indehiscens. - Flores densissime cymoso glomerati $v$, capitati, bracteis stipula. ribus lalissimis, scariosis ocullati, - Herbae geron. togeae, caespilosae. - $\mathrm{P}$ a ron y chi a e spec. sect. 2 . DC, l. c. Illecebri s p. Lian. Schrader Journ. 1801 . t. 4. (Spec, prototyp: P. capitata; P. serpyllifolia; P. nivea; P. incana.)

b. ACONYChIA Fenzl msc. Calycis laciniae semiscario. sae, rarissime herbaceae, ovali-oblongae, marginibus inflexne, ad apicem cucullatum brevissime aristato-macronatae, sinubus extus incrassato-marginatis. Corolla e petala 5 . Stylus brevis, bifidus v. bipartitus. Utriculas calyee inclusus, basi dehiscens. - Flores densissime cymoso-glomerati, late scarioso-bracteati, blomerulis sive fasciculis axillaribus $v$. terminalibus, confertis vel remotis. Folia opposita v. rarias pseado-verticillata. - Herbae amphigeae, annuae v. perennes, - Paron y chiae sp. sect. 2, DC. $l$. c. Illecebri sp. Linn. Schrad. l. $c$. (Species prototypate sunt: P. polygonifolia; P. argentea; P. arabica; P. chilensis; P. brasiliana; P. çommunis.)

c. EUNYCHIA Fenzl msc. Caly cis basi urceolato-constricti laciolae ovali-oblongae, semiscariosae, marginibus inflexre, ad apicem cucullatum aristis subspinescentibus, patentissiais terminatae. Corollae petala 5. Stylns bipartitus. Utrleulus indehiseens (?) calyce inclusus. - Flores ad nodos glomerato-congesti, quasi semiverticillati, bracteolis minutissimis, seta. ceis interstincti. Folia plerumque pseudo-verticillata. - Herba medicerranea, annua, nudiuscula. - $\mathrm{P}$ aronyehia echinata Linn. Schrad. 2 . c. Sibthorp Flor. graec, $t$. $24 \overline{\text {. }}$.

d. CHAETONYCHIA DC. $2, c$. C a Iy eis laciniae ovali-oblougae, cuneatae v. lanceolatae, semiscariosac, plerumque rigidae, marginibus Inflexae, ad agicem cucullatum v. rarius couvolutum arista erecta v. patentissima terminatae. Corolla e petala 5. Sty I u s bifidus v. bipartitus. Utriculus indehiscens (?), calyce inclusus. - Flores in cymulas iterato-dichotomas, corymbose $v$, paniculatim per ramos dispositas congesti, bracteolis scariosis, anguste linicaribus, rarissime latis suffulti. Folia opposita. - Herbae amphigeae, plerumque suffrutescentes, rarius annuae, ereotae v. procumbentes. Paronyeliae sect. Chaetonyebia et sect. Eunyehia $\mathrm{sp}$, plur. DC. 2 . $c$. Webb et Berthel. Flor. Canar. t. 20. P I ottzla Araott in Lindley Introduct. edic. II. P. 441. II e r n i a ria sect. 2. DC. Prodr, IIT. Gavanill. Io, $t, 137$.

e. SIPHONYChL Torr. et A. Gray. Caly cis laciniae Iineares, semiscariosae, apice concaviasculae, muticae. Co ro Ila e petala 5 . St y las filiformis, calyeis longi. tudine, apice minute bifidus. Utrical as ealyce inclu. sus. - Flores in cymulas terminales, laxe glomeraricana, annua, procumbens, diffuse ramosa. - $\mathrm{Siph}$ o u y chi a Torrey et Gray Flora of North-Amerio. I. 173. Herniaria a merieana Nuttall.

f. ANYCHIA L. C. Rich, C a I y c is laciniae ovati-oblongae, herlaceae, margine vix scariosae, ad apicem subcucul- latem obsoletissime mucronatae. Co rolla nulla. S tami na 3 v. rarius 5 . Ut rie u I us indehiscens, calycem aequans v. superans. - Flores in ramorum dichoto. mits foliatis alares, in cymam paniculaeformem effu. sam vel corymbosam aut fasciculiformi contrartam dispositi, stipulis angustis, bracteolaribus suffulti. Folia opposita, ovalia v, lanceolata. - Herbae boreali. americanae, annuae, Iini catharctici facie, caule erecto $v$, adscendente, dichotome ramosissimo. - A n y. chia L. C. Richard in Michaux Flor. Bor. Aner. $\boldsymbol{I}$. 113. Jussieu Mem. Mus. 11. 389. 'DC. Prodr. III, 369. Queriae sp. Lina. Ortega Decad, $t$, 15. $f$. 2. Gärtner II. t. 128.

5298. Cymanecarpos FORSK. C a ly x quinquefidus, tubo urceolari, fance annulo glanduloso incrassato coarctata, laciniis linearibus, margine membranaceis, intus subcoloratis, ad apicem cucnllatum breve mucronato-aristatis, demum supra medium hypocrateriformi patentibns. Corolla e petala 5 , calycis sinubus inserta, setacea. St a min a 5 , annuli perigyni processubus triangnlaribus basi laciniarum calyeis adnatis' inserta, petalis alterna et insertione altiora; filamenta setacea, antherae biloculares, longitudinaliter dehiscentes. $O$ va ri u m sessile, nniloculare. $O \mathrm{vu} \mathrm{Inm}$ unicum, funiculi basilaris liberi apiei affixum, amphitropum, micropyle infera, mox supera. Stylus elongatus, filiformis, apice trisuleatus v, obsoletissime stigmatoso-tridentatus. Utriculus subehartacens, calyce indurato inclusus, indehiscens. S e $m$ e $n$ inversum, oblongum, testa membranacea, laevi. E m bryo annularis, albumen farinaceum includens, radieula supera. - Fruticulus squarroso-diffusus, in Africa bor eali et Arabia petrae a indigenus, cortice fissili, albido; foliis oppositis, teretiusculis, crassis, filiformibus $v$. cuneato-lanceolatis, mucronatis, facile defluentibus, stipulis ovato-triangularibus, parvis, scariosis, integerrimis, floribus glomeratofasciculatis, bracteolis minutissimis, stipularibus interstinetis, glomerulis axillaribus et terminalibus, sessilibus.

G y m n o a r pos Forskael Descript. 65. Ic. $t, 10$. Desfont Flor. atlant. I. 203 . Jussied in Mem. Mus. H. 388. St. Hilaire in Mem. Mus. II. 388. Viviani Flor. Libyc, t, 10. f. 1. DC. Prodr. III. 369. Meisner Gen. 132, (97.)

\section{GENERA NON SATTS NOTA.}

5\%04. Whinterlia SPRLNG, C a l y $\mathrm{x}$ membranaceus, quinquefidus, tubo urceolato, decemcostato, fauce annulo constricto, laciniis brevibns, lanceolatis. Corolla e petala 5 , inter calycis lacinias inserta, iisdem panllo longiora, ovalia, obtusa, erecto patentia, persistentia. S $t$ amina 5 , mediis calycis laciniis inserta; filamenta brevissima, crassinscula, antherae didymae. Ovarium sessile..... Stylus setaceus; stigma simplex, obtusum. Ca psula subglobosa, stylo superata, unilocularis, trivalvis, monosperma .... Herba in dica, uliginosa; caulibus filiformibus, ramosis, foliis oppositis, breviter petiolatis, integerrimis, floribus in omnium foliorum axillis solitariis $v$. rarius geminis, brevissime pedunculatis, parvis, albis, capsulis atro-purpureis.

Winterlia Sprengel Syst. I. 788. Meisner Gen, 132. (97.) S ellow a Roth Nov. sp. 162. DC. Prodr. III. 380 .

5205. Hithopluila $S W A R T Z$, Calyx tripartitus, laciniis acutis. Corollae petala 3 , ovato-lanceolata. S qu a ma e 2 , calycis laciniis oppositae. Stamina 2 , ad latera ovarii. Stylus crassus, apice obtuse emarginatus. Fructus.... 
Herba in rupibus insulae desertae Navaza Antillarum lecta, ninutissima, glabra; foliis amplexicaulibus, linearibus', obtusis, floribus albidis, congestis.

Lith oplifla Swartz Flor. Ind. occid, X. 47, t. I. DC. Prodr. IIT. 380. - Planta maxime dubia, ob folia amplexicaulia rectíns, partibus floris aliter denominatis, ad Amarantaceas ablegenda.

T'TEISUS III. PTERANTHEAE R. Brown in Wallich Plant. As, rar. I, 17. Flores axillares, ternati, appendiculis lateralibus pinnatipartitis, simplicibus v. ramosis stipati. C alyx herbaceus, demum subcartilagineo induratus, quadri-quinquepartitus, laciniis rigide mucronatis v. subulatis. 0 va r i u m uniloculare, uniovulatum. Stylus bi-tripartitus. Utricplus calyce inclusus, membranaceus, indehiscens. S e m in um chalaza lateralis, ab umbilico distineta. Em b ry o planus, rectus, albuminis farinacei lateri adplicitus.

5\%O8. Peterantinus FORSK, Flores ternati, pedunculo communi membranaceo, cavo, turbinato - inflato, compresso insidentes, medius sessilis, perfectus, laterales brevissime stipitati, plerumque abortivi, appendiculis duabus subulatis pinnatipartitis rigidis utringue stipati, v. in appendienlas ejusmodi solitarias mutati. $C$ aly $x$ quadripartitus, demum slausus, compressus, laciniis oblongo-linearibus, concavis, exteriorihus duabus apice cucullatis , dorso carinatis, superne in alam verticalem, scarioso-marginatam, rigidam, spinuloso-mucronatam productis, interioribus carinatis, inaequilongis, spinuloso-mucronatis. Corolla nulla. S t a min a 4, calycis laciniis opposita; filam e n ta subulata, basi in cupulam subhypogynam, edentulam connata, a $n$ therae biloculares, versatiles, longitudinaliter dehiscentes, Ovarin m sessile, uniloculare. $\mathrm{O}$ vulum nnicum, e basi erectum, semianatropum. Sty Ins brevis, bifidus, ramis stigmatosis, recurvis, Utriculus membranaceus, ealyce inclusus, indehiscens. S e m e $n$ erectum, oblongum, compressum, testa tenui, laevissima, chalaza infra medium laterali. $\mathbf{E} \mathbf{m}$. bryo semini conformis, rectus, albuminis lateri hinc applicitus, radicula tereti, prominula, infera. - Herba mediterranea, annua, di-trichotome ramosa; foliis oppositis v. pseudo-verticilla. tis, carnosulis, linearibus, obtusis, stipulis minutis, floribus in paniculam, superius fasciculatam, foliosam dispositis, singulis bracteolis duabus scariosis, ciliatis suffultis, appendicularum flores aequantium laciniis imbricatis, subulato-setaceis, unvinulato-recurvis, intus membranaceis.

Pteranthus Forskael A6gypt. 36. Gärtner f. III, 178. t. 213. Lo ui che a Heritier Stirp. I. 135. t. 65. C a m p ho. ros ma Pteranthus Sibthorp Flor. graec. t. 153.

520\%. Connetes BURM. F I o res ternati, pedunculo communi filiformi insidentes, medius sessilis, laterales brevissime pedicellati, appendicibus duabus axillaribus, setaceis, simplicibus v. ramosis, plumoso-multipartitis, demum exerescentibus, squarroso-divaricatis involuerati. Calyx quinquepartitus, demum elansus, laciniis oblengolinearibns, coneavis, ad apicen subeucullatum spinuloso-mucronatis, C o roll a e petala 5, linearia, basi cupulae staminiferae extus adnata. Stami na petalis alterna; fil a m enta subulata, basi in cupulam subhypogynam, edentulam connata, anthera e biloculares, versatiles, longitudinaliter dehiscentes, Ova ri nm sessile, uniloculare. $O$ vuI $\mathrm{nm}$ unicum, e basi erectum, semianatropum. St y lu s elongatus, filiformis, apice trifidus. Utric u lus membranaceas, calyce indurato inclusns, indehiscens. S emen erectum, oblongum, cрmpressum, testa tennissima, chalaza infra medium laterali. $\mathrm{E}$ m b ry o semini conformis, rectus, albuninis farinacei laterali hinc applieitns, radicula tereti, prominula, infera. - Herbae annuae, As ia e et Africae tropicae planities incolentes, diffuse ramosae; foliis oppositis $v$. pseudo-verticillatis, obovatis, lanceolatis $v$. linearibus, stipulis minutissimis, setaceis, quaternis $v$. senis, florum fasciculis trifloris, pedunculatis, plurimis, in ramis alternis, cymose paniculatim dispositis, appendiculis plumoso-multipartitis, ferrugineis, in fructu longissimis involucratis, basi bracteolis binis, linearisetaceis, reflexis stipatis.

Com etes Burman Flor. Ind. 39. t. 15, f. 3. R. Browa in Wallich Plant. As, rar, $1,17, t$, 17, S a It i a R. Brown in Salt. Abysin. B. 376. - Notandum el. R. Brown, postquam intellexisset plantam a se in catalogo stirpium abyssinicarum Saltiae nomine desiguatam, esse Cometem Burmanni, aliud genus ex Amarantacearum ordiue, cujus typus Aohyranthes papposa Forsk., Saltiam dixisse; quod ideo obverso, quia a nonaullis Achyranthem papposam pertinaci errore ad Cometem trahi video.

THEIIBUS IIII. POLLICHIEAE DC. Prodr. III. 377. Caly x quinquedentatus, tubo urceolato, fructifero baccato. Ovarium uniloculare, biovulatum, ovulis basilaribus amphitropis, filo conductorio centrali. Utriculus indehiscens, monospermus, ovulo altero efoeto.

5209. Pelitielnia SOLAND, C a 1 y $x$ tubo urceolato, limbi quinquedentati dentibus minutis, conniventibus, muticis, fauce disci perigyni adnati glandulis quinque squamaeformibus cum dentibns alternantibus clansa. Corolla e petala $5 \mathrm{v}$. abortu paucíora, interdum nulla, minima, squamulaeformia, carnosula, disei glandulis basi extus inserta. S $t$ am in a 1 v. 2, limbi dentibus basi inserta et breviora, a nt herae versatiles, biloculares, longitudinaliter dehiscentes. Ovarium nniIoculare. Ovnla 2, basilaria, eirca filum conductorium simplicissimum inserta, amphitropa. Stylus filiformis, elongatus, apice stigmatoso bitidus. Utriculas intra calycembaceatum liber, membranacens, indehiscens, ovulo altero sterili superstite monospermus. S eme n verticale, oblengum, chalaza umbilico contigua, prope basim marginali. Embryo teretiusculus, rectiusculus, albuminis farinacei laterali applicitus; coty ledones accumbentes, radicula infera. - Herba c apensis, suffruticosa, diffuse ramosa; foliis pseudo-verticillatis, lineari-lanceolatis, stipulis subulatis, ad nodos congestis, interioribus fimbriatis, floribus minutissimis, ad nodos glomerato-verticillatis, bracteolis stipularibus membranaceis, in fructu parum incrassatis, minutissimis interstinetis.

Pollichia Solander in Aiton Hort. Hew. I. 5. Smith Spicileg. I. $t$, 1. Jusslen in Mern. Mus. IT, 388, DC. Prodr. III. 377. Meisner Gen. 132. (97.) non alior. Neckeria Gmelin Syst. $I$. 16. non alior. Me e r b a rg i a Möuch Supp. lom. 116.

THERE TS T. TELEPHIEAE DC.Prodr. III. 366. Caly $\mathrm{x}$ quinquepartitus, O varium 
incomplete tri-quadriloculare, pluriovulatum. Folia alterna, stipulata.

5209. Teleplaiman TOURNEF. Ca Iyx ad basim quinquepartitus, laciniis carnosulis, haud mutatis. Corolla e petala 5 , imo calyei inserta, obovato-oblonga $\mathbf{v}$. oblongo-linearia, integerrima. Stamina 5, ealycis laciniis opposita; filamenta subulato-filiformia basi obsoletissime in annulum membranaceum, snbhypogynum connata, anth er a e biloculares, longitudinaliter dehiscen tes. O vari u m dissepimentis, basi columellam centralem liberam attingentibus, superne deliquescentibus incomplete tri-quadriloculare. $O$ vula plurima, funiculis distinctis colnmellae centrali inserta, amphitropa. Styli 3_4, patentim recurvi, apice stigmatosi. C a psula chartacea, ovoidea, pyramidato-trigona, basi incomplete tri-quadrilocularis, tri-quadrivalvis, valvis medio septiferis. S e $\mathbf{m}$ in a plurima, columellae centrali liberae affixa, globuloso-reniformia. $\mathbf{E} \mathbf{m}$ bryo fere annularis, albumen farinacenm eingens. Herbae mediterraneae et capenses, suffruticulosae, multicaules, glabrae, glaucae; foliis alternis, bi. natis $v$. interdum oppositis, ovalibus et oblongis, facie enerviis, stipulis minimis, scariosis, semiintrafoliaceis, floribus cymoso-fasciculatis v. conferte racemosis, racemis terminalibus congestis.

Telep h i и Tournefort Inst, 128. Linn. Gen, n, 377. Sehkuhr $t, 85$, Gärtuer $I I .221, t$. 129. Lam. t. 213. Shaw Specim, 572 c. ic. Jussieu in Mem. Mus. I. 389 . St. Hi laire Ibid. II. 390. DC. Prodr. IIT, 366. Meisner Gen, 132 (96.)

TIEIIES v. POLYCARPEAE DC. Prodr. III. 373. Ov a ri um uniloculare, pluri-multiovulatum, columella centrali distincta v. obsoleta. Capsula apice in valvas stylorum numero dehiscens, oligo-polysperma. - Folia opposita v. pseudo-verticillata.

SUD'TEIBSUS I. LOEFLINGIEAE Fenzl $m s c$. Calycis laciniae margine supra basim setoso-appendiculatae.

ธ2 11. Hoeflingia LINN. Calyx quin quepartitus, laciniis tribns exterioribus longioribus, margine utrinque in setam productis, dnabus interioribus brevioribus carinato-compressis, marginibus membranaceis, ciliolatis, infra apicem productam teretem mucronatum, in setulas minutis simas desinentibus. C orolla e petala $3-5$, imo calyci inserta, minima, conniventia. Stamina ¿ 5, perigyna, ealycis laciniis opposita; filam ent a brevissima, antherae biloculares, longitudinaliter dehiscentes. Ova ri u m uniloculare. Ovula plurima, columellae basilari liberae inserta, amphitropa. Stylns brevis, tridentatus, trifidus v. tripartitus. Capsula membranacea, conica, uniloeularis, trivalvis. S e min a plurima, columellae centrali liberae inserta, oblonga, teretiuscula, prope umbilicum basilarem rostellata. Embryo dorsalis, rectinsculus, albumini farinaceo applicitus; cotyled ones accumbentes, $\boldsymbol{r}$ ad icula exserta. - Herbae annuae, glandulosopuberulae, in regione mediterranea et in America boreali a ustraliore indigenas; foliis oppositis, subulato-setaceis, stipulis foliorum marginibus semiadnatis, in setas liberas demum productis, floribus in ramorum dichotomiis et foliorum axillis solitariis, geminis $v$. ternis, sessilibus.
Loeflingia Linu, in Aot. Holm, 1758, p, 15, $t, 1$. f. 1. Loefling It, $t, 1, f$. 1. Cavanill, Ic, $t, 94,148, f, 2$, Lam. t. 19. Jussieu in Mem. Mus. IJ. 386. St. Hilaire Ibid. II. 386. DC. Prodr. IIT. 380. Meisner Gen, 133. (97.)

\section{SUETEETES III. SPERGULEAE Bart-} ling Beitr. 158. Caly $\mathrm{c}$ is laciniae margine haud appendiculatae.

5211. Cerullis MOS. et SESS. Calyx quinquepartitus, laciniis apice in mucronem setaceum productis. Corolla nulla. Stamen unicum, subhypogynum, calycis laciniae oppositum; fil am ent um breve, subulatum, an thera bilocularis. Ova ri $\mathbf{n}$ m uniloculare, multiovulatum. Stylus filiformis, brevis, apice bifidus. Capsula polysperma. S e mina reniformia ...... Herba mexican a, humilis, diffusa, Herniariae $\bar{v}$. Pollichiae facie; foliis oppositis v. pseudo-verticillatis, linearibus, cuspidatis, stipulis membranaceis, interfoliaceis, solitariis, floribus axillaribus, parvis, solitariis, breve pedicellatis, uni-bibracteolatis.

C erd ta Moẹino et Sesse Flor. Mex. inedit. ex DC. Prodr. III. 377, Mem, IV, 9. t. 2. Meisner Gen, 132. (97,)

521\%. Pollyearpon LÖFFL, Calyx quinquepartitus, laciniis herbaceis, margine anguste membranaceis, compressis, dorso carinatis v. subalatis, apice cucullatis, mueronatis sive muticis. Corolla e petala 5, imo calyci inserta, lineari v. obovato-oblonga, integerrima, erosa v. bidentata. S $t$ a mina $3-5$, cum petalis inserta, iisdemalterna; fil am en ta filiformia, anth er ae biloculares, longitudinaliter dehiscentes. O v arium uniloculare. Ovula plurima, placentae basilari inserta, amphitropa. Sty lus brevis, tripartitus v. trifidus, lobis stigmatosis. Capsula membranacea, unilocularis, trivalvis, valvis tnbuloso-convolutis ore obliquo hiantibus. Semina plurima, dorso acute convexa, facie rectiuscula, umbilico prope basitn sublaterali. Embryo albuminis farinacei dorso applicitus, leviter arcuatus; cotyledonibus incumbentibus, radicula umbilico parallele contigua. - Herbae annuae v. perennes, in temperatis calidioribus totius orbis obviae, tenellae, multicaules, glaberrimae; foliis oppositis $v$. verticillatis, oblongis, ovalibus $v$. obovatis, floribus numerosissimis, in cymas multoties iteratas, scarioso-bracteolatas, in corymbos v. fasciculos contractas dispositis, confertissimis.

Pol y ca rpo a Lofrling in Linn. Gen. n. 105. Gärtner IT. 294. t. 129. E. B. 2 . 103t. Cavanill. Ic. t, 151, f. 2. Lam. 2 . 51. Jussieu in Mem. Mus, IT, 390. DC. Prodr. III. 376. Meisner Gen. 133. (97.) Trichlis Haller Hort, GöLting. 26. part. A nt li y II is Adanson Fam. 1I. 281. H agea Bivona Manip. II. 2. Molli a e $\mathrm{L}$ a hay a $\mathrm{s}$. Sehult.

5213. Aversia CAMBESSED. Cal yx quinquepartitus, laciniis herbaceis, margine hyalino-membranaceis, subaequalibus v. exterioribus duabus aut tribus longioribus, omnibus navicularicompressis, dorso carinatis, apice subcucullatis, muticis. Coroll a e petala $5 \mathrm{v}$, rarius 3 , imo calyei inserta, linearia, integerrima $v$. apice bidentata. St a mina 3 v, rarius 5 , cum petalis inserta, iisdem alterna; fil amenta filiformia, a n therae biloculares, longitudinaliter dehiscentes. O v ari n m uniloculare. Ovul a plurima, placentae basilari inserta, amphitropa. Stylus tripartitus; stigmatibus recurvis. Capsula membranacea, unilocularis, trivalvis, valvis conceavis, haud convolntis. S emina plurima, tereti-fusiformia, umbilico supra medium laterali, Embryo in asi 
albnminis carnosuli rectus, radicula ab nmbilico remota. - Herbae annuae, in Asia, Africa et America tropica observatae, pubescentes sive villosae, multicaules; foliis oppositis et pseudo-verticillatis, linearibus, lanceolatis v. elliptico-oblongis, scarioso-stipulatis, floribus plurimis in ramulorum dichotomiis cymisque axillaribus, multoties iteratis, inferius plerumque foliaceo- superne mere scarioso-bracteatis, in corymbos $v$. fasciculos contractis, confertis, sessilibus.

Arversia Cambessedes in St. Hilaire Elor. Brasil. II. 184. t. 112. Ha palosia Wight et Arnott Prodr. $I$. 358. Polycarpon apurense Kunth. Polycarpaea memphitie a Delile Aepypt, 67. $t$, 24. $f$. 2. Loeflingia indica Retz. P haruaceum dep ressum Linn.

52 14. Drtegia LÖFFL. Caly x quinquepartitus, laciniis herbaceis, margine scariosis, oblongis, integerrimis, carinatis, tribus exterioribus brevibns basi margine glandulis coloratis tribus v. quinque adhaerentibus stipatis. CorolIa e petala $2-3$, imo calyci inserta, ovalia v. late linearia, snbtruncata, minima, saepissime nulla. St a mina 3 v. 2, subhypogyna, calycis laciniis opposita; fil am ent a filiformia, an therae biloeulares, longitudinaliter dehiscentes. O va r i mi uniloculare. Ovula plurima, placentae basilari inserta, amphitropa. Stylus tridentatus v, trifidus, Iobis stigmatosis, tertio saepe breviore $v$ abortivo, Caps n la membranacea, calyce inclnsa, unilocularis, trivalvis, valvis concavis, haud convolntis. Semina plurima, minima, teretiuscule cuneiformia, umbilico prope basim laterali, Embryo rectiusculus, albuminis farinacei lateri applicitus; cotyledonibus incumbentibus, ra dicula umbilico parallele contigna. - Herbae in regione mediterranea occidentali indigenae, erectae, ramosissimae, annuae $v$. perennes; caule ramisque quadrangulis, foliis oppositis, linearibus, stipulis lateralibus quatuor, setaceis, basi in glandulas nigricantes incrassatis, floribus minutissimis, in cymulis corymbiformibus $v$. fascicu. latis, in paniculam brachiato-ramosam dispositis, spicatim congestis, bracteolis scariosis suffultis.

O rteg i a Löffling $I t .112$. Limn. Gen, $n .51$, Gärtner II. 224. $t$, 29. Allioni in Act, Taurin. III, $t$, A. f. 1. Cavanill. Ie, $t, 47$. DC, Pradr, I 388, et III, 375. Meisner Gen. 133. (97.) Ortega Lina. Spec. edic, I. p.560. Ju u ca ria Cluslus Hist. II. 147. f. 2.

52 quinquepartitus, laciniis medio subcartilagineo. incrassatis, ecarinatis, duabns extimis subbrevio ribus, oblongis, integerrimis, obtusis, muticis, interioribus semiscariosis, longioribns, obovatooblongis, apice membranacen sinu acnto emarginatis. Corolla e petala 5, subhypogyna, spathulata. Stamina 3, snbhypogyna, petalis alterna; filamenta filiformia, antherae biloculares, longitudinaliter dehiscentes. Ova ri um unilocn lare. $O \times$ u la plurima, placentae basilari inserta, amphitropa. Sty I us ad basim tripartitus; stig matibus brevissimis, papillosis. Capsula globosa, subchartacea, uniloculąris, trivalvis, valvis concavis, haud convolntis. S emina plurima, pyriformia. Embryo annularis?... _ Herba bo reali a niericana, perennis, dichotome ramosa; foliis radicalibus rosulatis, obovatis, spathulatis $v$. late ellipticis, in petiolum longe angustatis, basi stipulis setaceo-multifidis, congestis stipatis, cau linis subulato-setaceis, minimis, ramis adpressis, bracteaeformibus, floribus in apiçe ramorum paucis, glomerato-sessilibus.
Stipulicida L. C. Rich. in Michaux Flor. Bor. Amer. I, 26. 2. 6. Nuttall Gen. I. 29. DC. Prodr. III. 375. Meisner Gen, 133. (97.) Torrey et A. Gray Flora of North. Amer. I. 173. Polyearpum stipulieidum Pursh.

5216. Polycarpaea $L A M$. C a l y $\mathrm{x}$ quinquepartitus, laciniis semiscariosis v, scariosis, concavis, enerviis, ecarinatis, apice rectis, integerrimis, muticis. Coroll a petala 5, subhypogy$\mathrm{na}$, integerrima $\mathbf{v}$, rarius apice bidentata, rarissime margine inaequaliter dentata. Stamin a 5 , hypogyna v. subperigyna, petalis alterna; filamenta filiformia, antherae biloculares, longitudinaliter dehiscentes. Ovariu un uniloculare. O ч I a plurima, placentae basilari inserta, amphitropa. Sty lus plus minus elongatus, trifidus, tridentatus v. capitato-trisuleatns. Ca p su la chartacea, saepissime colorata v. lineis variegata, nniloenlaris, trivalvis. S e m in a plurima v, abortu pauca, cuneiformia v, oblonga, teretiuscula, dorso convexiuscula, facie recta, nmbilico supra basim laterali, E m br yo dorsalis, incurvus, albominis farinacei lateri applicitus; cot yled on i bus acumbentibus, rarius oblique incumbentibus, $r$ a dicula nmbilico parallela. - Herbae in regionibus tropicis et extratropicis calidioribus totius orbis obviae, annuae v, perennes, interdum suffruticulosae; foliis oppositis v, pseudoverticillatis, plerumque linearibus, rarius ovalibus, ellipticis $v$. obovato-spathulatis, stipulis plerumque distinctis, scariosis, nitidis, ad nodos congestis, floribus plurimis, in cymas fasciculatim v corymbose contractas, rarius paniculatim effusas dispositis, plerumque sessilibus.

Poly earpa e a Lamark Journ. Hist, nat, $I T, 8, \mathrm{DC}$. Prodr. III. 373. Meisuer Gen. 133. (97.) H a ge a Venten. Tabl. II. 240. Mollia Wiltd. Hort. Berot. I, 11, La ha y a Rön. et Schult. Syst. $V$. 402. H y ala Heritier msc. A uthyllis Adauson Fam. II. 27t. part. A chyra athis. Ce,losiae, A t ternantherae, IIIecebri sp. Auet.

a. HEMIXERA. Calycis laciniae semiscariosae, duae exteriores breviores. Petala linearia, interdum apice bidentata. St y I us trifidus, tridentatus v. capitato-trlsulcatus. - Herbae annuas $v$, perenhes. oanarion. ses,bareali. afric ana et arabica e; caulibus foliosis, rarisime scapiformibus, e foliorum rosula emergentibus, apice floriferis, folitis plerumpue pseudo-verticillatis, obovato-spathulatis, ovalibus, ellip. ticis $v$. oblongis, rarissime linearibus, floribus sessilibus, cymoso fasciculatis $v$. corgmbosis. - P. Te ner iff a e Lam. Op. cit. $t$. 25. Webb et Berthel. Flor. Canar. 2. 21-23. P. staticaeformis Steud. et Hochst, Herb, un. it, $1837, n, 940$, Mollia latifolia Willd. Schrauk Hort. Monae. t. 29.

b. ANAPRRA, Calyeis laciniae subcarinatae, ovatae, semiscariosae, exteriores duae subbreviores. Petala acuta, margine inaequaliter dentata. Sty I us elongatis,

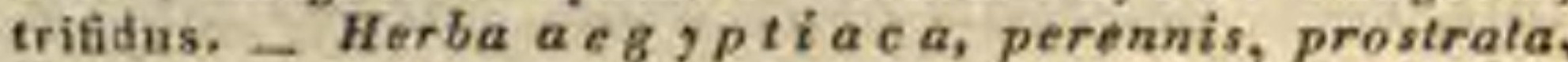
fragilis; folits oppositis $v$. pseudoverticillatis. $t i$ nearibus, subtus marginibus incrassatis quasi canaliculatis, rigidis, floribus in cymulas laterales et ter. minales, corymbiformes $v$. fasciculiformes congestis, secsitibus. - P. Ir a gills Delile Flor. Aegypt. 2.24. f. 1 .

c. KATAXERA. Calyeis laeiniae aequilongae, omnino scariosae, nitidae, ecarinatae, erectae, planiusculae. Petala obtusa v, rotundata. Stig in a capitatutn, trisulcatum v. trifidum, cruribus stignatosis conglutinatis clavatum. - Herbae in Africa tropiea et a ustrali etratropica, India arientali et Brasilia indigenae, erectae, ramosissimae, Amarantacearum fa. cie; folits saepissime fasciculato-verticillatis. lanceola. tis, linearibus v. subulato.setaceis . saepe fasciculato. verticillatis, stipulis splendentibus, aggregati, Rori. bus in cymis corymbose v. fasciculatim contractis, rarius paniculatim offusis confertissimis, sessilibus $v$. pedicellatir. - Celosiae sp. Roxb. Achyranthis sp. Willd. Hllecebris p. Pers, Atternantherae sp. 
Reichenb, in Sieb. Herb. Seneg. n. 60. (DC. Mem. IV. t. 5. 6. Hook. Bot. Mrg. Comp. I, t, 6.)

5\% $1 \%$. Aylmeria MART, C aly x quinquepartitus, scariosus, coloratus, laciniis aequalibus, subcarinatis, muticis. Co rolla e petala 5 , imo calyci inserta, oblonga, integerrima. Stamina 10 , imo calyei inserta, quinque petalis alterna fertilia, totidem sterilia minutissime squamaeformia, petalis opposita ; fertilium filamenta filiformi-subulata, an thera e biloculares, longitudirialiter dehiscentes. Ovari $\mathbf{n} \mathbf{m}$ uniloculare. Ovn l'a plura, foniculis discretis e basi erectis affixa, amphitropa. Stylus elongatus, filiformis; stig ma capitato-trisuleum. C a p 8 u la ealyce inclusa, chartacea, colorata; unilocularis, trivalvis. S e mina abortu pauca, reniformia, laevia. Em br yo anunlaris, albumen farinaceum cingens; cotyledonib ns late linearibus, incumbentibus. - Herbae Novae-Hollandiae tropicae, annuae, erectae $v$ diffusae, dichotome ramosae; foliis oppositis v. pseudoverticillatis, linearibus, stipulis scariosis, elongatis, floribus roseis $v$. violaceis, nitidis, pedi cellatis, in cymas corymboso-fasciculatas, terminales, longe pedunculatas congestis.

A y Imeria Martius in N. A. N. C, XIII. 276. Fenzl in Annal, Wiener Mus. I. 340. Meisner Gen, 133. (97.)

52 18. Sperralaria PERS. C a I y x quinquepartitus, laciniis nune herbaceis, carnosulis, enerviis v. obtuse carinatis, aequalibus, muticis. Coro 11 a e petala 5 , rarius pauciora v. nulla, imo calyci inserta, brevissime unguiculata. Stamin a 10 , nune 5 v. 3 , florum superiorum 1_9, annulo perigyno ohsoletius glanduloso inserta, dum quinque v. pauciora omnia $\mathbf{v}$. pleraque petalis alterna ; filamenta subulato-filiformia, an the$r$ a e biloculares, longitudinaliter dehiscentes. 0 varium nniloculare. Ovnda plurima, colnmellae centrali distinctae inserta, amphitropa. Stylus tri-v, quinquepartitus, rarissime bifidus, lobis stigmatosis recurvo-patentibus. C a p $s$ a chartacea, globoso-v, ovoideo-tri-pentagona, unilocularis, tri-quinquevalvis, valvis concavis, dum calycis laciniis numero aequales isdem alternis. S emina plarima, pyriformia, lenticulari-compressa, saepissime margine scariaso cincta, laevia, granulata v. muricata. E m bryo uncinatus v, annularis, albumen farinacenm cingens; cotyledonibus incumbentibus. - Herbae amphigeae, potissimum salinae et littorales, annuae, perennes $v$. interdum suffrutescentes; foliis oppositis $v$. fasciculato-verticillatis, plerumque carnosulis, setaceis, filiformibus $v$. rarissime linearibus, stipulis scariosis, integris $v$, interdum apice fissis, floribus albis $v$, ro$s e i s$, in ramorum dichotomiis alaribus, $v$. in cymis demum racemiformibus remotis $v$. confertis, pedicellat is, post anthesim plerumque refractis, demum erectis.

S pergulari a Persoon Encheir. I. 504. (Arenariae sect.) Cambessed. in Si, Hilaire Flor. Brasil. II, 175. $t, 110$. Le pigo na m Fries Addend. Flor. Holland. 259. Waliber Flor. Gothoburg. 45. Stipnlaria Haworth Synops. 104. B u da et Tis: a Adanson Fam. II. S07. D elil a Dnmor180, $t$, 111. Aelg. 110. B a lard I a Cambessed. Op, cit. II. 180. $t$. 111. A renariae species stipulatae Lima. et Auet.

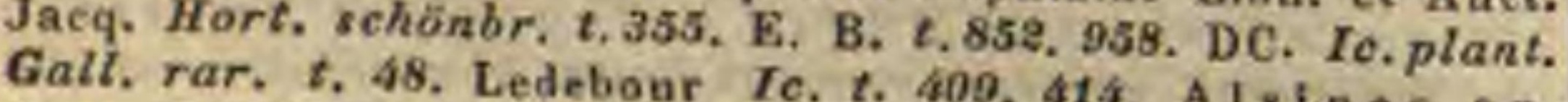
Auet. Delite Flor. Ledebour Tc. t. 409, 414. A 1 si a es s p.

52 19. Spergula LINN, C a I y quinquepartitus, laciniis ovalibus, herbaceis, margine membranaceis, carnosulis. Ooroll a e petala 5 , imo calyci inserta, ovata, brevissime unguiculata, Stamina 5 v. 10 , annulo perigyno glanduloso inserta, quinque longiora calycis laciniis opposita ; fil amenta subulato-filiformia, antherae biloculares, longitudinaliter dehiscentes. Ovarium uniloculare. Ov al a plurima, columellae centrali crassae inserta, amphitropa. St y li 5 , distincti, calyeis Iaciniis alterni. Capsula membranacea, ovoidea, quinquelocularis, quinquevalvis, valvis ealyeis laciniis "ppositis. Semina plurima, globoso-lenticularia, acnte marginata $v$. alata, laevissima v. elevato-papillosa, funiculis fungoso-incras. satis inserta. E m bryo annularis, albumen fari. naceum cingens; cotyledonibus incumbentibus, apice spiraliter involutis. - Herbae in regionibus temperatis totius orbis crescentes, arvenses, annuae, dichotome $v$, verticillato-ramosae, in cymas racemiformes, divaricato flexuosas solutae; foliis anguste lineari subulatis $v$. filiformibus, carnosis, ad nodos tumidos verticillatim fasciculatis, stipulis ovatis, scariosis, floribus pedicellatis, ante et post anthesim refractis, demum erectis.

Spergula Linn. Gen, n. 798. excl. sp. exstip. Gärt. ner II. 230 . $t .130$, E, B. $t, 1535,1536$. Sturm Deutschl. Flor. fasc. 12. Reichenb. 1conogr. $t, 703$-706. A re u ariae, Stellariae et Alsines sp. Auet. quorund.

5290. Drymaria WILLD. C a ly $\mathrm{x}$ quinquepartitus, laciniis herbaceis v. semiscariosis. Co rolla e petala 5 , imo calyci inserta, rarissime pauciora v. nulla, profunde bi-quadrifida v. partita, unguibus latis, margine integerrimis, dentatis v. fimbriatis. St a m in a 5 v, abortu pauciora, annulo membranaceo subhypogyno inserta, petalis alterna; fil a m en ta subulato.filiformia, an thera e biloculares, longitudinaliter dehiscentes. 0 vari u m uniloculare. Ov a Ia plura v. plarima, coIumellae centrali distinctae inserta, amphitropa. Stylns plus minus longus, apice trifidus, lobis stigmatosis. Capsula membranacea, ovoidea v. oblonga, nnilocularis, trivalvis. Sem in a pauca v. plurima, lenticulari-reniformia, rugulosa v. tuberculata, estrophiolata. E m bryo hippocrepiens v. annularis, albumen farinaceum cingens; cotyledonibus incumbentibus. - Herbae americanae el asiaticae, tropicae et subtrapicae, annuae v. perennes, graciles, plerumque dif. fusae, ramosissimae, ad nodos saepe radicantes, Stellariae facie; foliis oppositis, cordato-subrotundis, ovatis, ellipticis, lanceolatis $v$. linearibus, integerrimis, stipulis petiolaribus geminis v. pluribus setaceis, interpetiolaribus saepe fugacibus, cymis terminalibus et axillaribus foliatis $v$. bracteolatis, plerumque effusis paniculaeformibus v. corymbosis, rarius depauperatis, floribus pedicellatis, albis.

Drymarla Willdenow ex Róm. et Schult. Syst. $V$. 406. Kunth in Humb. et Bonpl. Nov. gen. et sp. VI. 21. t. 515. 516. DC. Prodr. I. 395. Meisner Gen, 133. (97.) Holos te un co rdat u u Lina. Lam. $t$. $51 . f$. 2. Swartz Prodr. t. 7 .

SUBG IEID II. SCLERANTHEAE Link Hort. Berol. 417. Her ba e oppositifoliae, exstipulatae. Stamin a tubi calycini fanci inserta. Ovarium upi-biovulatum. Utriculus monospermus, calycis tubo indurato, fauce constricto inclusus. E m b ry o peripherieus, annularis. - Herbae cosmopolitae, e regionibus arcticis exules.

5291. Miniarum FORST. FI ores gemini v. terni, in apise pedunculi axillaris sessiles, basi quadribracteolati. Cal y $\mathrm{x}$ quadrifidns, tubo ureeolato, limbi laciniis ovato triangularibus, aesti- 
vatione imbricatis, sub anthesi conniventibns, fructifer cartilagineo-induratus. Coroll a nulla. Stamen 1, calycis fauci insertum, laciniarum exteriorum uni oppositum; fila m e n t a m subulatum, breve, a nthera bilocularis, ovalis, minima, longitudinaliter dehiscens. $O$ v a $r$ i u m liberum, uniloculare. OvuJam unicum, v. rarissime gemina, columellae tennissime filiformis apici appensa, alterum minus, amphitropa, micropyle sn. pera. Stylus bipartitus, lobis intns stigmatosis. Utriculus membranaceus, indehiscens, calyeis tubo inclusus, monospermus. Semen inversum, globoso-pyriforme, laeve, apiculatum. E mb ryo annularis, albumen farinaceum cingens; cotyledonibus incumbentibus, radicula exserta, supera. - Herbae humiles, caespitosae, in NovaIIollandia extratropica, Nova-Zeelandia et ad fretum magellanicum crescentes, Scleranthi facie; foliis oppositis, connato-subvaginantibus, confertissimis, exstipulatis, pedunculis axillaribus solitariis, apice bi-trifloris, fructiferis elongatis, post florum lapsum bracteolis qualuor persistentibus coronatis.

M niarum Forster Char, 1. t. 1. Comment, Gótting. 1789. t. 1. Lina. f. Supplem. 18. Labillard. Nov, Holl. t. 2. R. Brown Prodr. 412. St. Hilaire in Mem, Mus, II, 262. Jussieu Ibid, II. 387. DC. Prodr, III. 378. Meisuer Gen, 133. (97.) Dito c a Banks et Soland, ex Gärtner II. 196. t. 126.

5232. Seleranthus $L I N N$. Flores cymoso-paniculati $\mathrm{v}$, faseiculati. C aly $\mathrm{x}$ quinquefidus $v$. rarius quadrifidus, tubo infundibulari $v$, urceolato, laciniis ovatis, obtusis v, acotis, herbaceis v. semiscariosis, aestivatione imliricatis, sub anthesi patentibus, demum conniventibus, cum tubo fructifero induratis. Corolla nulla. Stamina 10 , calycis fanci inserta, quinque fertilia ejusdem laciniis opposita, cum totidem sterilibus setaceis v. squamiformibus, nonnullis interdum penitus obliteratis, alternantia; fertilium fila menta subulata, a nth era e bilocnlares, loculis ovalibus, basi divergentibus, longitudinaliter dehiscentibus. Ovarium libernm, uniloculare. $O v \mathrm{ulum}$ unicum, apici columellae tenuissime filformis, liberae appensum; amphitropum, micropyle supera. Styli 2, distincti, apise intus stigmatosi. Utritulus membranaceus, indehiscens, ealycis tubo inclusus, monospermus. S emen inversum, lenticulare, laeve. Embryo annularis, albumen farinaceum cingens; cotyled on ibus linearibus, incumbentibns. - Herbae in temperatis he misphaeraeborealis, et in Nova.Hollandia indigenae, ut plurimum annuae, multicaules, dichotome ramosae $v$. rarius subsimplices; foliis oppositis, basi connatis, linearibus v. subulato-setaceis, exstipulatis, interdum confertissimis et subsecunde falcatis, floribus in ramulorum dichotomiis sessilibus, cymas axillares et terminales, foliatas v. sub. scarioso-bracteolatas, paniculaeformes, corymbosas v. glomerato-faseiculiformes constituentibus.

Selerauthus Linu. Gen. n. 562. Gärtner IT. 196. t. 126, Sehkuhr t. 120. Flor. dan. $t$. 504. 563. R. Brown Prodr. 412. St. Hilaire in Mem, Mus, II, 387. Jnssien Ibid.
II. 387. DC, Prodr. IIT. 378. Nees Gen, plant. III, 77 . (mal.) Meisner Gen, 133. (97.)

5293. Guilleminea $H, B . K$. Flores in axillis foliorum capitato glomerati, singuli tribracteati. C a lyx quinquefidus, tubo infundibulari, limbi laciniis ovatis, acntis, herbaceis, sub anthesi patentibus, cum tubo persistentibus. C orolla nnlla. Stamina 5 , ealycis fanci inserta, ejusdem laciniis opposita et breviora, sterilia nulla; fil amenta basibus dilatatis subconnata, antherae introrsae, uniloculares, longitudinaliter dehiscentes. Ovarium liberum, uniloculare. Ovulum unicum, e columella tenuissime filiformi, libera pendolum, amphitropum. Sty Ins simplex; st igma emarginatum. Utriculus membranaceus, indehiscens, stylo mucronatus, calyce irrelusus, monospermus. S emen inversum, lenticulare, verraculosum. Em b r y o annularis, albumen farinacenm cingens, radienla supera. - . Herba quitensis; caulibus humifusis, opposite ramosissimis, foliosis, lanatis, foliis oppositis, oblongis, basi angustata connatis, exstipulatis, capitulis in axillis foliorum sessilibus, solitariis, octo-duodecimfloris.

Guillem In e Kunth iñ Humb. ot Bonpl. Nov. gen. et sp. VI. 40. t. 518. DC. Prodr. III. 378. Meisner Gen. 133. (97.) 11] ecebrum deas um Willd.

SUBOHED III. ALSINEAE Bartling Beitr. I. 159. Herb a e v. suffrutices, foliis oppositis, exstipulatis. St a min a perigyna v. subhypogyna. Ovarium sessile, pluriovulatum, rarius uniovulatum. Styli v. stigmat a basi distincta. Capsula simpliei v. duplici stylorum numero in dentes v. valvas dehiscens. E $m$ b r y o periphericus, curvatus v. annularis. Species boreales, arcticae et antarcticae, plurimae subalpinae el alpinae.

TRETBUS I. SABULINEAE Fenzl msc. Ova rium uniloculare. Capsula in valvas tot quot styli dehiseens, valvis integerrimis.

SUIBTIEIIBUS I. SAGIVEAE Fenzl msc. Styli tot quot laciniae calycis, iisdem alterni. Capsula valvulae calycis foliolis oppositae.

5224. Sagina LINN. Calyx quadri-quinquepartitus, laciniis carnosulis, subenerviis, apice conniventibus v. inflexis. Coroll a e petala $4-5$, hypogyna, integra v. emarginata, saepe obsoleta v. nulla. St a min a hypogyna, nune 4 v. 5, calycis foliolis opposita, nune 10, isdem opposita et alterna, omnia fertilia; fil amenta libera, anthera biloculares, longitudinaliter dehiscentes. Ova ri am liberum, sessile, uniloculare. Ovula in placenta basilari libera plurima, amphitropa. Stigmata $4-5$, filiformia, brevia, calycis laciniis alterna. Caps al a membranacea, unilocularis, ad basim quadri-quinquevalvis, valvis apice integerrimis, calycis laciniis oppositis. Semina placentae basilari inserta, plurima, minima, subreniformia v. pyriformia, laevia v. subtilissime granulata, estrophiolata, Emb ryo cyclieus, albumen farinaceum cingens; ootyled on ibus incumbentibus. - Herbae in temperatis he misphaerae borealis obviae, parvulae, annuae v. perennes, glaberrimae v. glanduloso-puberulae; foliis oppositis, filiformibus v. subulatis, enerviis v. uninerviis, exstipulatis, floribus minutis, plerumque longe pedicellatis, axillaribus v. terminalibus, solitariis $v$, in cymam simplicem aut iterato dichotomam dispositis, post anthesim increscentibus, saepe ex apice pedicelli stricti uncinato-cernuis.

Sagina Lion. Gen, n, 176. Fenzl in Annal. Wiener Mus. I, 43. S a gina e s. Auct, E. B. t. 880. 2195. Cartis Elor. Lond. t. 158, 291. Hooker Flor. Lond, $2,115 . \mathrm{S}$ p e r- 
5ulae $s$ p. exstipulatac Linn. et Auet. R. B. $t$, 210s. Flor. dan. t. 1577. Curtis Flor. Lond. t, 139, 261. Reichenb. Iconogr. $f$. 263. 264. S perg ell a Reichenb. Flor. Germ. 110. Phaloè Dumortier Flor. Belg. 110. A Isinella Dillea. Gen. 6 .

SUBTEIRUS II. EUALSINEAE Fenzl msc. Calyx quadri-quinquepartitus. Styli 2_3, interdum 4 5 , calycis laciniis in aestivatione exterioribus v. omnibus oppositi. C a psulae valvulae calycis laciniis alternae, v. dum iisdem numero pauciores interioribus oppositae.

ร225. BufTonia $S A U V A G$. C al yx qua dripartitus, exsucco-glnmaceus, compressus, laciniis exterioribus conduplicatis, brevioribus. C orolla e petala 4 , perigyna, minuta, integerrima v. apice bidentata. S ta in in disco perigyno mem branaceo inserta, nunc 4 , calycis laciniis opposita, nunc 8 , iisdem opposita et alterna; filamenta libera, an th erae biloculares, longitudinaliter dehiscentes. Ova rium liberum, sessile, uniloculare. Ovula 4 , immediatim basilaria, amphitropa. Stig mat a 2, filiformia, brevia, calycis laciniis exterioribus opposita. Ca ps ula membranacea, lenticulari-compressa, unilucularis, jnxta angulos usque ad basim bivalvis, valvis planis, integerrimis v. retusis, calycis laciniis interioribus oppositis. S em in a 2, basilaria, erecta, hippocrepiformia, concentrice seriato-granulata, estrophiolata. E mbryo annularis, albumen farinacenm cingens; cotyledonibus semiteretibus, accumbentibus v. oblique incumbentibus, radicula infera. - Herbae $v$, suffrutices, in regione mediterranea et taurica, in Persia boreali et Arabia petraea crescentes, Junci bufonii lu. xuriantis facie; caulibus nudiusculis, virgatis, pa. niculato ramosis, folits oppositis, subulatis, superioribus adpressis, exstipulatis, floribus cymoso-spicatis, racemosis $v$. paniculatis.

B uff on i a Sauvages Meth, nat. 14t, Gärtner $\pi .220$. t. 129. Lam. t. 87. R. B. t, 1313.-DC. Prodr. III. 332. Fenxl in Annal. Wiener Mus, I. 51, t. 6. f. 1-g. Meisuer Gen. 25. (29.) B u foula Lion. Amoen. Academ, I. 386. Gen, n. 186. Mobringiae s p. Sibthorp Flor, graec, t. 368.

ธ2:8. Dueria LÖFFL. Flores glomerato-capitati, bracteis retrorsum uncinatis, seariosis involuerati, extimi in capitulo bini $v$, terni steriles (intermedio nempe mascalo $v$, neutro, lateralibus bibracteolatis, rudimentariis), interiores hermaphroditi. Calyx quinquepartitus, laeiniis inaequalibus, una v. altera uneinatim recurva, omnibes demum rigescentibus. Corolla nulla. Disc u s perigynus ligulas 5 truncatas, calycis laciniis oppositas exserens. St a m in a 10, disci glandulis inserta, omnia fertilia; fila menta libera, an th era e biloculares, longitudinaliter dehiscentes. Ovarium liberum, sessile, unilnculare. OvuI $\mathbf{m}$ maicum, in apice funiruli e basi loculi adscendentis, liberi snspensum, micropyle supera. Styli 3 , filiformes, breves. Capsula tenerrime membranacea, uniloenlaris, nsque ad medium in valvas tres, integerrimas, calycis laciniis interioribus oppositas dehiscens. Se men unicum, oblongum, compressum, estrophiolatum. E mbryo annuiaris, albumen farinaceum includens, $r$ adic $\mathrm{l}$ la e apice rustellato, super umbilicum et cotyledonum filiforminm incambentinm apicem producto, supero, descendente. - Herba annua, humilis, regionis mediterranéae et taurico-cau- casica e incola; foliis oppositis, subulatis, confertis, exstipulatis, florum glomerulis rigide bracteolatis terminalibus, sessilibus, solitariis v. fastigiato-fasciculatis.

Q ue r i a Loffling $1 t$. 48. Linn. Gen, n, 108. Lam. . 52 , Quer Flor, espan, VI. $t$, 15. f. 2. Ortega Cent. $t$. 15. f.1. DC. Prodr. III. 279. Meisuer Gen, 25. (22.) Fenzl Mo. nogr. Alsin. inedit.

529\%. Alsine $W A H L E N B$. C aly $\mathrm{x}$ quinque-rarissime quadripartitus, laciniis tri-plurinerviis, rarius uninerviis v. enerviis, fructiferis haud mutatis. Corollae petala $4 v$, 5, subhypogyna v. perigyna, late ovata, angustissime linearia v. setacea, integerrima $v$, rarius retusa ant emarginata, rarissime obsoleta v. nulla. D is ci subhypogyni v. distincte perigyni glandulae membranaceae $\mathbf{v}$. carnosulae, truncatae, emarginatae v. bilobae. Stam in a 10 v. 8 , rarius 5 , rarissime panciora, disci glandulis inserta, omnia fertilia; fil amenta libera, a nt herae biloculares, longitudinaliter dehiscentes. Ovarinm liberum, sessile, uniloculare. Ovala plurima, columellae centrali liberae inserta, amphitropa. Stig mat a 3 , calycis laciniis exterioribus opposita, interdum 4 v. 5 , rarissime 2, filiformia, brevia. Caps u la ovoidea v. conica, membranacea, chartacea v, pergamenea, avenia, usque ad basim in valvas stigmatum numero, calycis laciniis interioribus oppositas v. omnibus alternas dehiscens. S e mina plurima, coInmnae centrali inserta, globoso-reniformia, lenticularia $\mathbf{v}$. pyriformia, rostellata, laevia, granulata v, muricata, estrophiolata, E m b ry o annularis, albnuen farinaceum cingens; cot yl ed on ibu $s$ angustissime linearibus, incumbentibus. Herbae v. suffrutices, plerumque caespitosi, in regionibus temperatis et frigidis hemisphaerae borealis crescentes; foliis oppositis, exstipulatis, filiformibus, setaceis v. lineari-subulatis, rarius lanceolatis, rarissime oblongis $v$. ovalibus, tri-quinquenerviis, rarius plurinerviis, interdum uni- $v$. enervils, floribus albis $v$, rarissime roseis, nunc solitariis terminalibus, nune in cymas jasciculatas, paniculatas $v$. corymbosas, bracteolatas aut rarius foliosas dispositis.

Alsine Wahlenberg Flor. lappon. 129. excl. op. stipulat. et A. peploide. Feazl Monogr. Alsin, iaedit. Areuariae sp. Lisu, et Auet.

1. SABUlineaR Fenzl msc. He rbae amphigeae, extra. tropicae, boreales, anuae, fugaces, caulfculis a basi v, ultra medium dichotomis iteratis in eymam paniculaeformem . effusam, rarius fastigiato-contractan, multifloram solutis. Folía triuervia, subulata v, seta. cea. Flores minuti, interdum apetadi, bi-triandri v. peuta-decandri, distiacte pedieellati. C a I y x fruetifer basi haud iuduratus, laciniis subaequilongis, trinerviis, concoloribus, corollam superantibus, raro subaequantlbus. - Arenariae sp. Lian. et Auct. Vaillant Bot. Pa. ris. t. 3. f. 1 . Seguier Veron. t. 6. f, \&. Fior. dall. t. 389. E. B. t. 219. Schrank Hort, Monac, t. 30. A I s I. ues s p. Lien. Sibthorp Flor, grace, t. 293. S a bu liua sp. Reichenb. Alsinellae sp. Harta. Minuartiae $s$ p. Mart. (Species prototypa: A. tenuifolia Wahlenb.)

2. MINUARTIRAR Fenzl mse. Herbae europeae, mediterraneae. canarienses, taurico-caucasicae, persieae, syriacae et arabieae, annuae, biennes v. perenues, ea aliculis specterum annarum ia cymas fasciculiformes foliosas seusim transeuntibus, perennantium cymis corymbiformlbus v. paniculiformibus pedunculatis terminatis. Foll a tri-septemnervia, nervis primarils crassitie aequalibus, lineari-subulata $v$, setacea. F 1 o r e s saepe sub. sessiles v. sessiles, tri-peata-decandri. Caly ois clausi. conici, basi demum iadurati laciaiae plerumque inaequilongaé, acutissimae, rigidae, albidae, striis duabus dorsalibus parallelis pictae, rarissime concolores, virides. Co rol. 
I a inconspieua, minima v. nulla, specierum perennantium interdum ealycem aequans v. superans. - Mi n u artia Löffling It. 48. Linn. gen, $n, 107$. Cavanill. Ic. $t$. 277. $f, I$. $t, 568, f$. 2. A re narlate sp. Liun. Vaillant. Bot. Paris. t. 2, f. 3. Jacq. Flor. austr. t. 182. Vahl Symb. t. 12. Sibthorp Flor. graec. t. 442, Labillard, Plant, Syr. Decad, IV. t. 3, f. 1. (Spee, prototyp.: A. (Minuartia) diehotoma et M. montana. Alsine fasciculata et setacea.)

3. TRYPHANE Fenzl msc. Herbae amphigeae, extratro. picae, boreales et arcticae, collinae et alpinae, humiles, perenues, caespitantes, haud proserpeates. Foli a subulato-linearia v. setacea, trinervia, infima et turio num confertissima, saepe imbrieata. Flores solitarii, pauci v. plurimi, in cymam terminalem bracteolatim dispositi, Caly cis elausl, ovoidei, basi haud indurati laeiniae concolores, tri-septemuerviae, aequilongae. P e. tala e basi latiore in unguiculum brevissimum con tracta, ovato-subrotunda, ovata v. ovato-oblonga, unuquam obovata v. euneata, apice integerrima, obtusa, $\mathrm{S} t \mathrm{a}$. mina 10. - Aren a ría e 8 p. Lisu. et A act. Jacq. Collect. I, t. 16. f.1. Flor, austr, t. 404. 4h5, E. B. t.512. 2638. Flor. dan. t. 1518. Hooker Flor. Lond. 203. Ledebour Io, $t, 417$. S ag in a e s p. Reichenb, Iconogr. $f$. 875. Sabuliaae sp. Reichenb. Alsinellae sp. Swartz. (Spee. prototyp.: Als. recarva, verna.)

4. ARETIOIDEAE Fenzl msc, He r b a e europeae, alpicolae, pulvinatim eaespitosae, deusissime imbricato-foliatae Flores terminales, solitarii, subsessiles. Calyx quadripartitus. S tamina 2_10, rarissime pauciora, Alsine aretioldes Mert, et Koch. Siebera Sehra. der in Herb. Sieb. Alp. Sommerauera Hoppe in Flora 1819. 1 . 26. C herleriate $8 \mathrm{p}$. Sering.

5. LANCEOLATAE Feuzl msc. He rbae europeae, alpinae et subalpiaae, caespitosae, saepe proserpentes. Folla quadri-decemnervia, nervis marginalibus apice areuatim confluentibus, obovatis, oblongis v. lanceolatis, planis. Petala ovata, oralia v. oblonga, nunquam obovata, integerrima, calycem superantia. - Arenarlae s p. Linn. et Auet. Arduin. Specim. t. 10. Allioni Flor. Pedemont. t. 26. f. 5 . Villars Delphin, VI. t. '17. Visiani plant. Dalm. $t$. 3. f. 2. D u foure a cerastifolia Grenier in Aot, soc. Linn, Burdig. IX. 25. S a bulina s p. Reichenb. (Spec. prototyp. : Als. lanceolata, Arduini.)

6. ACUTIFLORAE Fenzl msc. Herbae v, s uffrutices gerontogei, alpini et subalpini, laxe caespitosi, rigidi v. flaceidi. Fo lia lanceolato-linearia, subulata v. fili formia, in sicco distincte trinervia, interdum venulosa v, obsolete trinervia, nervo medio validissinto. Caly $\mathrm{cis}$ laciniae auctissimate, longe acominatae, rigidulae v. pungeates, P e ta la obovato-oblonga, cuueata v. lisearilanceolata, integerrima, retusa v. obsolete emargiaata. A renarlate sp. Linn. et Auet. Jacq. Collect.I. t.18, Flor, austr. t. 2zo. Villars Delph, $t, 47$. Smith $Y c$, in. edit. t. 35. Sturm Deutschl. Flor. t. 24. S a butin मе s p. Reichenb. Stellariae s p. Wulfen. (Spec. proto typ,: Als. austriaca, juniperina.)

7. SPECTABILES Feazl msc. S affruticult amphigei, boreales et arctici, alpini et subalpini, basi decumbentes, densius v. Jaxius caespitosi. Foli a subulato-filifor mia v. subulato-linearia, recta v. faicata, uni- v. obsolete pluriuervia, caadiculorum saepissimc aggregatofasciculata, Flo res plerumque speciosi, interdum hermaphrodito - mono.diolel. Cal y cis clansi, plerumque eylindricl, rarissime ovoldel laciniae late ovales v. oblongo-lineares, omnes v. saltim interiores obtusae, apice membranaceo-marginatae. Petal a late obovata, cuneata v. rarissime linearia, emarginata v. retusa. - A re$\mathrm{n} \boldsymbol{n}$ ri a e s p. Linn. et Auet. Jaeq. Flor, austr, t. 278. Villars Delph. IIT, t, 47. Labillard, Syr. Decad, IV t. 4. f. 1. Ledebour Ic. t. 415. Hooker Flor. Bar. Amer. t. 34. S perg ula e sp. Linn. Saith Ie. inedit, t, 18. Stellariae sp. Linn. et Auct. Alsinellae sp. Swartz in 1et. Holm. 1789. t. 1.f. 1. Sa bulinae $s$ p. Reichenb. (Spee. prototyp.: A. squarrosa, Iarieifolla, arctica, biflora.)

8. Cherleriae Fenzl mse. S a $\mathrm{f} \times \mathrm{r}$ ti culi europei, alpicoli, pulvinatim caespitosi, confertissime imbricatofoliati, uniflori. Folla canalienlato-triquetra. Flor es minuti, hermapluroditi v. mono.dioiei, apetali v. rarissime petalis setaceis v. linearibus angustissimis, calyce bre vioribus v. subaequilongis. D is ci perigyni glandulae distinctae, emarginatae. - Cherleria Haller, $I t$. Helv II. n, 79. t, 1. Hitt. I. $t$, 21. Linn, Gen. n, 227, Jacq. Flor, austr. t. 284. E. B. t. 1212.

9. SAGINELLA Fenzl mse. Herba annua, chilensis, tenella, dichotome ramosa, multiflora. Folia lineari-triquetra, carnosula, Peta la in calyce quinquepartito $3-4$, rarius pauciora $\vee$. nulla, integerrima, minima. Stamia a $2-3$, rarius $1 .-A$ acutillora Fenzl msc. (Cumming plant. Chil, n. 294. Bertero plant, Chil. $n$. 86. 57.)

10. SPERgella Fenzl mso. Herbae annuae, in regione mediterranea et Arabia indigenae, simplicissimae v. fastigiato-ramo:ae. Folia setaceo-filiformia, uninervia. C y ma scarioso-bracteolata, longissime pedunculata. Fiores rosei, pedicellis post anthesim deflexis. Ca 1 y. cis laeiniae ovales, obtusissimae, chartaceo-scariosac, viridi-carinatae. Stamina 10. - Arenariae sp. Labillard. Plant, Syr. Dec. IV. t. 3. $f$ 2. Sibthorp Flor. graee, $t$. 490, Als. pieta Penzl (Herb. un. it, 1835. n, 220. Chesney plant, Euphrat, n, 126.)

11. ALSINANTHE Fenzl msc. Her ba amphigeae, boreales, perennes : graciles, humiles v. elongatae, plerum. que laxe caespitosae. Folia triquetro-subulata v, fill. formia, carnosa, uninervia v. lineari-subulata ant setacea, carinato bisuleata, caudicularum sacpissime faseiculata. C a l y e is herbacei, ovoidei laciniae acatiusculae v, acuminatae. Petala obovata, cuneata v, angustis. sime linearia, rarissime nulla. $\mathrm{S}$ em i a daedaleo-rugulosa. - Arenaria e s p. Auct. DC, Tc. plant. Gall. rar. t. 46. S pergula e s p. Swartz Act. Holm. 1799, t. 3. (Spee, prototyp.: A. Rossii, stricta, Michauxii.)

12. UNINERVIAE Fenzl msc: Herbae boreali-americanae, aunuae, pauci-multiflorat. Foli a lineari-subulata, fillformia v. rarissime laneeolata, uninervia, carnosula, haud fasciculata. Cal y cis ovoidei laciniae enerves v. tri-quinquenerves, acutae $\mathrm{v}$. obtusae. Petala obovata v. cuneata, retusa v. emarginata, rarissime ovalia, integerrima, calyce longiora. S o mia a concentrice rugalosa. - Arenariae sp. Auet. Stellariae sp. Auct. (Sp. prototyp.: A. patula, glabra.)

13. PSAMMOPHILAR Feuzl msc. Herbase regionis medi. tersaneae, anuae v. perennes, diffasae, ia cymas pa. niculaeformes, herbaceo* v. foliaceo-bracieatas solutae. Polia oblonga, lanceolata, llneari-subspathulata v. If. neari-subteretia, patentia, enervia v. uninervia, carnosula. F l o res parvi, albi v. rosei. Petala ovata, brevissime unguiculata, calycem aequantia v. subsuperan. tia. - A renariace 8 p. Auct. Vahl $S$ mb. 2. 33. Sibthorp Flor. graec.' $t$. $49 t$. Che rleriae $\$$ p. Forsh. (Sp. prototyp. : A. thymifolia, procumbens.)

5283. 'Thiplatein $B A R T L$. C aly $x$ florum inferiornm quinquepartitus, superiorum quadripartitus, laciniis oblongis v. obovato-oblongis, obtusis, patentibus, demum reflexis, marcescentibns. Co rolla e petala 4 v. 5 , perigyna, obovato-oblonga, integra, in unguem euneato angustata, calycis laciniis angustiora, subaequilonga, D i $8 \mathrm{e}$ i subhypogyni, membranacei glandnlae subquadratae, emarginatae, interdum fere biauricolatae. St a min a 4 v. 5, glandularum disci sinubus inserta; filamenta libera, antherae biloculares, longitudinaliter dehiscentes. O v a ri u m sessile, uniloculare, $0 \mathrm{v}$ u l a 3 , funicalis basilaribus distinctis, erectis inserta, amphitropa. Stig mata 3 , capillaria, brevia. Ca p s ul a membranacea, ovoideo-triquetra, unilocularis, usque ad basim trivalvis, valvis planis, stellatim patentibus. Semina 3 v. abortu saepissime 2, globulosa, compressiuscula, dorso lato depressa, seriato-tuberculata, opaca, estrophiolata. Embry o cotyledonibus linearibus, incumbentibus involutus, cyclicospiralis, albumen parcum includens. - Herba mexicana, debilis, glaberrima, laxe ramosa, Möhringiae muscosae facie; foliis oppositis, exsti. pulatis, anguste linearibus, uninerviis, flaccillissimis, floribus minutis, albis, per ramos sparsis, solitariis, laxe pedicellatis, alaribus axillaribusque. 
Triplateia Bartling in reliq. Hänk, Ir. 11, t. 50. H y menella Moęino et Sessé Flor, mex. ex DC. Prodr. I. 390 .

5229. IItonkeneja EHRH. F lo res hermaphrodito-dioici. M a s c. C a I y $\times$ quinquepartitus, laciniis late ellipticis v. oblongis, obtusiusculis, carnosis, enervits, apice demum conniventibus. Corolla e petala 5 , perigyna, obovata, integerrima, breviter unguiculata, calycem aequantia. D is ci perigyni glandulae crassae, profunde emarginatae, lobis subglobosis. Stamina 10, disci glandulis inserta, omnia fertilia, calycem aequantia; filamenta libera, anthera biloculares, longitudinaliter dehiscentes. 0 v a r i u m stylis ovnlisque imperfectis sterile. $\mathrm{F}$ e $\mathrm{m}$. Caly $\mathrm{x}$ marium, laciniis fructiferis patentissimis, Co roll a e petala obovato-subrotunda, brevissime unguiculata, calyce multó breviora. $\mathrm{S} t$ a $\mathrm{m}$ in a 10 , minutissima, antheris efoetis. Ovarium sessile, uniloculare. Ovula plura, columellae basilari obsoletae inserta, amphitropa, Stig mat a 3 , saepe 4 v. 5 , filiformia, brevia, demum reflexa. C a p s ula carnosa, subglobosa, unilocularis, stigmatum numero in valvas latissime ovatas, coriaceas, venulosas dehiscens. S e min a pauca, maxima, pyriformia, apice radienlari rostellata, facie umbilicali cochleariformi-exsculpta, subtilissime granulata, Incida, atro-purpurea, umbilico estrophiolato. E m bry o annularis, strato tenui albuminis spongioso-farinacei tectus, majorem ejusdem portionem includens, cotyledonibus linearibus, incumbentibns. - Herba succulentá, inter $30^{\circ}$ et $80^{\circ}$ $\boldsymbol{L}$. B. omnium marium littora incolens; rhizomate repente, caulibus adscendentibus, tetragonis, dichotome ramosis, foliis oppositis, sessilibus, subconnatis, exstipulatis, ellipticis, floribus axillaribus et alaribus solitariis, pedicellatis.

Honkeneja Ehrhart Beitr. IT, 281. Reichenb. Flor, Germ. 568. A de a a ri u m Rafinesq. in Journ. Phys. LXXXIX. 259. Halianthus Fries Hall, 75. Hallia Dumortier Am in on lia Desvaux Arenaria peploides Linn. Flor. dan. t. 684 . B. B. t. 189.

5230. Hepyrodielis FENZL. Caly quinque-interdum sex-septempartitus, laciniis usque ad basim distinctis, linearibus, herbaceis, fructiferis patulis. Co ro Il a e petala $5-7$, hypogyna, obovato - cuneata, retnsa, calyce longiora. Di s ci subhypogyni glandulae lineares, truncatae, postice poro nectarifero sacciformi. Stam in a 10 , v. 12_14, omnia fertilia, longiora disci glandulis inserta; filamentis e basi late lineari plana apice setaceo-subulatis, breviorum petalis oppositorum filiformibas, anthera biloculares, Iongitudinaliter dehiscentes. Ovarium sessile, uniloculare. Ovula 4_6, circa columellam-filiformem, liberam verticillatim basilaria, amphitropa. Stigm a t a 2 v. 3 , elongato-filiformia, apice subclavata, patentia. Capsula membranacea, globoso-inflata, usque ad basim bi-trivalvis, valvis obtusis, conchiformibus, indivisis. Semina 1 v. 2, rarissime 3 , globosa, tuberculato-echinata, fulva, opaca, funiculis carnosis, subglobosis, umbilico estrophiolato. Emb ry o annularis, albumen farinaceum includens; cot y led onibus late linearibus, planis, incumbentibus, radienla inflexa. fuse ramosa, Stellariae holosteae facie; caulibus tetragonis, ad angulos hispidis, foliis oppositis, basi connatis, exstipulatis, latissime linearibus lanceolatisque, acutis v. acuminatis, clongatis, flaccidis, scabris, floribus albis, in cyma multoties iterata, paniculaeformi, diffusa, pedicellis fructiferis deflexis.

Lep yrodic lis Fenzl Monogr. Alsin. inedit. Go uffeia holosteoides C. A. Meyer Verzeichn. Caucas. planz. 217, Cambessed, in Jacquemont Voy. Bot. $t$. 30.

TPEF IBUS H. MERCKIEAE Fenzl msc. Ova rium incomplete v. complete tri-quinqueloculare. Capsula in valvas tot quot styli dehiscens, valvis integerrimis.

5231. II erekia FISCH. Caly x quinquepartitus, laciniis herbaceis, capsulae adpressis, Corollae petala 5, perigyna, spathulata, anguste unguiculata, integerrima. Disci subhypogyni glandulae carnosulae, minutae. Sta m ina 10, disci glandalis inserta, omnia fertilia; filament a subulata, libera, a nt he ra biloculares, longitudinaliter dehiscentes. Ovarinm sessile, triquinqueloculare, loculis semisepto secundario incompleto bilocellatis. O v u l a plurima, columellae centrali brevi, distinetae, apice in fila tria v. quinque discreta, persistentia solutue inserta, amphitropa. Stigmat a $3-5$, capillaria, calycis foliolis alterna. Capsula membranacea, vesiculoso inflata, vertice medio depresso subglobosa, sulcis latis tri-quinqueloba, septis supra colnmnam centralem retractis discretis incomplete tri quinquelocularis, loculis semisepto secundario basi et apice productiore bilocellatis, septicide tri-quinquevalvis, valvis cocciformibus, dorso profunde sulcatis, apice uncinatim inflexo integerrimis. Se m in a plurima, laevia, nitida, fusco-rubra, funiculis abbreviatis, clavatis, fungosis, nmbilico estrophiolato. E mbr yo annularis, albumen farinaceum includens; cot y I ed on ib n s anguste linearibus, incumbentibus. - Herba in Asia et America arctica indigena, debilis, effuse caespitosa, Honkenejae peploidis fere facie; foliis oppositis, subsessilibus, ellipticis, exstipulatis, floribus axillaribus et terminalibus solitariis, paucis, longe pedicellatis, albj.

Merck i a Fischer msc. Chamisso et Schlechtend. in Lin. naea 1 . 59. W $11 \mathrm{~h}$ el m s i a Reichenb. Consp. 206. A r en aria physodes Fischer, DC. Stellaria ovalifolla Hook.

5232. Dolopluragma FENZL. C a ly x quinquepartitus, laciniis herbaceis, rotundatis $v$, acuminatis, capsulae adpressis. Corollae petala 5 , perigyna, obovata v. lineari-oblonga, integerrima. Dis ci hypogyni glandulae carnosae, bigibbosae. St a min a 10, disci glandulis inserta, omnia fertilia; filamenta subulata, an therae biloculares, longitudinaliter dehiscentes. Ovar i u m sessile, uniloculare, carpidiorom marginibus introflexis, columnam centralem hand attingentibus incomplete triloculare. Ovula plara, colnmellae basilari liberae inserta, amphitropa. Stigm a $\mathbf{t}$ a 3 , brevia, subelavata. Ca p 8 u la globosotrigona, incomplete trilocularis, foculicide trivalvis, valvis medio semiseptiferis. Semina pauca, estrophiolata ..... - Herbae nepalenses, humiles, suffrutescentes, caespitosae, rigidae; foliis perennantibus, densissime confertis, sexfariam stellatim expansis $v$. deflexis, late subulatis, pungentibus, nitidis, floribus axillaribus et terminalibus solitariis, brevissime pedicellatis, albis $v$. roseis.

Do loph ragm a Fenzl in Annal. Wien, Mus, I. 63. t. 7. Cherleriae sp. Don. Arenarlae sp. Wallich.

TIRIES III. STELLARINEAE Fenzl msc. 0 varium uniloculare. Styli $2 \ldots 5$, ca- 
lycis laciniis alterni v. oppositi. Capsula duplo numero stylorum in valvas integerrimas dehiscens, v. valvis tot quot styli, apice bidentatis bifidisve.

SUIBTIREUS I. ARENARIEAE Fenzl msc. Styli $2-3$, rarissime 4 v. 5, calycis laciniis oppositi. Capsula globosa, ovoidea v. oblonga, rarissime conica.

5233. Thylacospermum FENZL. C al yx tubo distincto, infundibuliformi, limbi quadripartiti laciniis oblongis, acutiusculis, apice incrassato-carinatis. Corolla e petala 4, calyeis fauci inter lacinias inserta, oblonga, obtusa, integerrima. Disci calycis tubum vestientis glandulae ejusdem laciniis oppositae carnosae, elongatae, bilobae. Stamina 8 , summo calycis tubo inserta, omnia fertilia; filamenta setacea, libera, anther a e biloculares, longitudinaliter dehiscentes. O v a r i u m stipitatum, uniloculare. Ovula 4, placentae basilari globosae, minimae, funiculis brevissimis inserta, amphitropa. Styli2, filiformes, calyce longiores, intus longitudinaliter stigmatosi. C a p s u la chartacea, nitida, sphaerica, basi subattenuata, únilocularis, quadrivalvis. Se m in a quatuor, basilaria, tri-tetragona, testa cellulosa, laxa, solnbili, umbilico estrophiolato. Embryo annuläris, crassinsculus, albumen parcissimum, farinaceum includens; cotyledonibu s linearibus, accumbentibus v, oblique incumbentibus. - Herba n epalensis, alpicola, suffruticulosa, pulvinatim caespitosa, Alsines aretioidis $v$, Arenariae bryoidis facie, glaberrima; foliis perennantibus, rigidis, quinquefariam imbricalis, confertissimis, minutissimis, lanceolatis, subcartilagineomarginatis, mucronulatis, floribus in apice ramulorum solitariis, sessilibus, foliis stellatim patentibus involucratis.

Th y I a cos permum Fenzl Monograph. Alsin, inedil. Periandra Cambessed. in Jacquemont Voy. Bot. p. 27. non Mart. Flourensia Cambessed. Op. cit, t. 29, non DC.

5234. Aremaria $L I N N$. C a ly $x$ quinquepartitus, laciniis herbaceis, erectis, fructiferis adpressis. Corollae petala 5 , perigyna, circumscriptione varia, ex ovato-subrotunda et obovata v. linearia, integerrima $\mathbf{v}$. denticulata, retusa $\mathbf{v}$. breviter emarginata, rarissime nulla. Disei subhypogyni v. perigyni glandulae membranaceae v, carnosae, obsoletae v. distinctae, plerumque bigibbosae v. retuso-truncatae. Stam in a 10 , disco inserta, omnia fertilia; fil amenta subulata v. setacea, libera, antherae biloculares, longitudinaliter dehiscentes. Ovari u m sessile, uniloculare. Ovula pauca v. plurima, columellae centrali liberae, distinctae inserta, amphitropa. Stig$\mathrm{m}$ a $\mathrm{t}$ a $2-3$, rarins 4 , rarissime 5 , filiformia. $\mathrm{C}$ a $\mathrm{p}$ $8 \mathrm{u}$ la membranacea, chartacea v. erustacea, globulosa v. ovoidea, unilocularis, primum dentibus duplo stylorum numero dehiscens, demum in valvas duas vel tres, bidentatas, interdnm longitudinaliter fissas secedens. Se m in a plurima, globulosa, lenticularia v. pyriformia, saepe compressa, scabra v. rugulosa, epaca, rarissime laevia, nitida, umbilico estrophislato. E m b ry o annularis, albumen farinaceum cingens; cotyledonibus incumbentibus v. rarius oblique accumbentibus, radic $\mathbf{c}$ a saepe exserta. - Herbae v. suffruticuli, ut plurimum parvuli, humifasi, per totum fere terrarum orbem diffusi, maximo numero in hemis phae- rae borealis temperatis et frigidis cres centes, in Nova-Hollandia et Oceánia nondum reperti; foliis variis, floribus nunc solitariis, alaribus, axillaribus v. terminalibus, nune pluribus $v$. plurimis, in cymam foliosam v. bracteatam, corymbiformem v. paniculatam dispositis, albis aut rarissime purpureis.

A renaria Linn. Gen, n. za4. Mertens et Koch Deutschl. Flor. IIT. 268. Fenal Monograpk. Mtsin. inedit.

a, EREMOGONE Fenzl. C al yx basi demum induratus. Styli 3, in nonuallis floribus saepe 4. Capsula pergameneo-erustacea, nitida, in dentes sero bifidos v. valvulas bideotatas dehiscens. Semin a compressa, pyriformla v. oblonga. Cotyled on es oblique aecambeates v. Incumbentes. - Herbac suffruticosae, regionis taurico-caucasicae, Sibiriae et Americae borealis arcticae incolae, erectae, rigidae, caudicibus lignosis, incrassatis, polycephalis, caulibus floriferis elongatis, strictis, sim. plicissimis, turionibus apice foliorum setaceorum $v$. lineari filiformium coma densa vestitis.

E remogone Fenzl Verbreit, der Alsin. 13. Arenariae sp. graminifoliae Auct. Stuith $I c$, inedit. $t$. 16. 17. Schrader Hort. Götting. 1, $t$. 5 . Ledebour Io, $t, 6,403$. Hooker Flor. Bor. Amer, $t, 53$, Royle Himalay, $t, 21$.

b. EUTHALIA Fensl, Caly $\mathrm{x}$ basi haud indtrascess, Peta la interdum nulla. Styli 3 , in nonaullis floribus interdum 4 v, 5. Capsula ovoidea, calyce inclusa v. illa paullo longior, oligo-v. polysperma, in deates v. valvulas debiscens. Sem ín a globulosa v. lenticula. ria, scabra, raro laevissima, Jncida. - Herbae annuae v. biennes, amphigeae; folits planis, lativ v. an. gurtis, caule in cymam paniculaeformem, foliosam, rarius depauperatam soluto, $v$. suffrutescentes, caes. pitasae, caulibus fliformibus, floribus nune terminalibus axillaribusque solitariis, nune per cymas de. pauperatas, terminales dispositis.

Euthalia Fenal msc. Arenaria Mertens et Koch 1. c. A renariae sp. Lỉnn. et Auct, Jacquin Collect, 1. t. 16. f. 1. t, 17, f. 1. Heritier Stirp, t, 15. Cavanill. Io. $t, 299$. f. 2. E. B. $t, 923.1745$. Brotero Phytogr. Iusit. t. 73. Sibthorp Flor. graec, t. 437. 438. Veaten. Cels. t. 34. Waldst, et Kitaibel Plant. rar, Hung. t. 276. DC. Ic. plant, Gall, rar, $t$, 45. Kunth in Humb. et Bonpl. Nov. Gen. et sp. t. St7. Gay in Annat. se. nat. IV. t.3. A. A Is ina at lias Desvaux Stellariae sp: Linn. Spergulastri sp. Michaux, Mierope. tall sp. Pers. Cherlerlae sp. Bartl.

c. PORPHYRANTHA, Ca $l y x$ basi haud induraseens. $S t y$. ii 3-4. Ca ps ul a conica, recta, longe demum e calyce exserta, polysperma, dentibus dehiscens. - Herba $p y$. renaica, caespitosa, pasciflora; folits ovato-laneeolatis, nitidis, rigidulis, petalis roseis, integerrimis.

Dufonres purpurascens Grenier in Aot. se. Linn, Burdigal. $1 X$. 25. Areuaria purpurascens Ramond. DC. Ie, platt. Gall, rar. $t, 46$.

d. GOUfFeta Robill. et Cast. C a 1 y e Is herbacei lacinfae subulato-lanceolatae $\mathrm{v}$, mucronatae $\mathrm{v}$, aristatac. St y 11 , rarissime 3. Capsula chartacea, nitida, oblonga v, sabglobosa, ealyce laclusa, primua dentibus conaiveatibus dehlscens, tandem in valvas duas, apice firsas secedens, mouo-trisperma. Sem í a scabra, opaca. Herbae circa Masolitiam et in Syria mesopo. tamica hucusque solum observatae, annuae, glaberrimae, multiflorae; folits linearibus $v$, setaceis, floribus minutis, albis, cymoso-paniculatis.

Qouffeia Robill, et Cast. ex DC. Fl. fr. V. 609 . Reictent. Iconogr. $f$. 585, nou C. A. Meyer et Cambess. Arenaria spinuliflora Seringe in DC. Prodr. $I$. 406.

e. DiCRANilla Fenzl. Calyeis laciniae apicibus margi nibusque parum inflexis conniventes. Styli 2 , interdum 3. Ca p s nI a membranacea, ovoidea, ultra medím valvulis dehiscens, oligosperma. S e mi na laevissima. lucida, atra. - Herbae mexieanae et quitenses, alpicolac, pulvinatim caespitosae; folits confertissime quadrifariam v. quinquefariam imbrica- 
tis, minutis, ovatis $v$. ovato-lanceolatis, carinatis foribus terminalibus, solitarits, sessilibus, minimis, folits occultatis, gemmis axillaribus increscentibus tandem alaribus.

Dieranilla Fenzl mse. Arenaria bryoides et A. dieranoides Kuntl.

5235. II Hiningis LINN. C'aly $\mathrm{x}$ quadri-quinquepartitus, laciniis herbaceis, erectis, fructiferis adpressis. Co r o 11 a e petala 4 v. 5, perigyna, obovata, ovalia v. oblonga, integerrima v. retusa. Dis ci subbypogyni glandulae obsoletae v. distinctae, retuso-truncatae v, bigibbosae. St a mina 8 v. 10 , diseo inserta, omnia fertilia; fil amenta subulata, antherae biloculares, longitudinaliter dehiscentes. Ovarium sessile, uniloculare. Ovala plura, columellae centrali liberae, distinctae inserta, amphitropa. Stigmata 2 v. 3 , interdum 4 , filiformia, brevia. Ca s $n$ I a membranacea, ovoidea v. globosa, nnilocularis, duplo stigmatum numero in valvas recurvatas dehiscens. Semina plura, globoso-lenticularia, reniformia, laevissima, lueida, umbilico distincte strophiolato. Em bryo annularis, albumen farinaceum cingens; cotyledonibus linearifiliformibus, incumbentibus. - Herbae annuae $v$. perennes, in regionibus temperatis et frigidis hemisphaerae borealis obviae, flaccidae, caespitosae; caulibus plerumque elongatis, ramosis, foliis variis, filiformibus, linearibus, ovatolanceolatis $v$, rarissime obovatis, patulis $v$. flaccide reflexis, floribus alaribus aut axillaribus, rarius terminalibus, solitariis $v$, in cymas paucifloras, aphyllas dispositis.

M 6 h r i g 1 a Linn. Gen, $n$, 264. Schkuhr $t$. 108. Jacq Flor. ausir. t. 449. Mertens et Koch Deutschl. Flora IIT. 271. Penzl Monograph. Alsin, inedit. A re n a r i a e $8 . p$. Linn. et Anet.. Jacq. Collect. $I$. $t, 15$. Sehkuhr $t$. 128. E. B. $t, 1485$. Curtis FLor. Lond. IV. t. 31. Reichenb. Iconogr. $f .260$. Ledehotur Ic, $t$, 482. Hooker Flor. Bor. Amer. $t, 36.37$. Alsinantbi sp. Desvaux Sabulinaie sp. Reichenb.

5236. Wrascheninikg oira TURCZAN. C a Iy $\mathrm{x}$ quinquepartitus, laciniis herbaceis, lanceolatis, acuminatis, fructiferis adpressis. C o rolla e petala 5, subhypogyna, cuneato-oblonga, emarginata. Stamina 10 , subhypogyna, omnia fertilia; fil a menta setacea, an therae biloculares, longitudinaliter dehiscentes. Ovariu m sessile, uniloculare. Ovula plura, columellae centrali liberae, distinctae inserta, amphitropa. Stig mata 3 , capillaria, elongata, erecta. Ca p sula tenuissime membranacea ovoideo-globosa, unilocularis, duplo stylorum numero in valvas paten. tissimas dehiscens. Semina plurima, globulosa, tuberculis diglochidatis hispidissima, umbilico estrophiolato. Emb ryo annularis, albumen farinaceum cingens; cotyledonibus linearibus, incumbentibus. - Herba baicalensis, Stella riae holosteae facie; caulibus subterraneis gracilli mis, repentibus, ad genicula radiculas et tubera globulosa agentibus, floriferis flaccidis, tetragonis, fo liis oppositis, exstipulatis, lanceolatis et lanceolato linearibus, laxe patentibus, floribus alaribus et axillaribus solitariis, sparsis, longe pedicellatis.

Krascheainfkowi a Turezaninow in Flora 1834. $r$. Beibl. p. 9.

$5 \% 3 \%$. IBrachystemma $D O N$. quinquepartitus, laciniis coloratis, seariosis, elliptico-lanceolatis. C or o 11 a e petala 5 , perigyna, minuta, lineari-lanceolata, integerrima. D i s c subhypogyni glandulae trigonae, truncatae. S $t$ amina 10, disco inserta, quinque ealycis foliolis alterna breviora, ananthera; filamenta subnlata, libera, fertilium antherae biloculares, longitudinaliter dehiscentes. Ovarinm sessile, uniloculare, columella centrali nulla. Or.ula 4 , basilaria, amphitropa. Stigmat a 2 , filiformia, calycis laciniis exterioribns opposita. Capsula membranacea, sphaerica, duplo stylorum numero in valvas dehiseens. Sem en abortu nnicum, magnum, rugosum, rufum, umbilico estrophiolato. Embryo annularis, albumen farinaceum cingens; cotyledonibns semicylindricis, incumbentibus. - Herba nepalensis, diffuse ramosa, glabriuscula; caulibus tetragonis, nitidis, foliis oppositis, petiolatis, exstipulatis, flaccide patentibus, lanceolatis, trinerviis, floribus numerosissimis, in paniculas axillares, brachiatim ramosas, cymiferas dispositis.

B r a chystem m a Don Nepal, 216. Fenzl in Endlich, Atakt, t. 16 .

5239. Dalontostemuna BENTH. Caly $x$ quinquepartitus, laciniis herbaceis, elliptieis, pube moniliformi, articulata hirsutis, fructiferis patulis. Corolla e petala 5 , perigyna, obovata, cuneato-unguiculata, apice fimbriato-serrulata. Disci subhypogyni glandulae carnosulae, late lineares, truncatae. Stam in a 10 , dísco inserta, omnia fertilia; filamenta subulata, libera, antherae biloculares, longitudinaliter dehiscentes. Ova rium sessile, uniloculare, columella centrali nulla. O v 1 a 4 , basilaria, amphitropa. S t i g mat a 2, filiformia. Ca psula membranacea, globosa, nnilocularis, dupio stylorum numero in valvas patentes, revolntas dehiscens. S e mina 2_3, funiculis basi bulbose tunentibus inserta, globnlosa, compressiuscula, daedaleo-rugulosa, castanea, umbilico estrophiolato. Em b ry o annularis, albumen farinaceum cingens; cotyledonibus linearibus, planis, incumbentibuis. - Herba nepalensis, Cerastii sylvatici facie, dichotome ramosissima, diffusa; folius oppositis, exstipulatis, patentissimis, ellipticis, floribus in cymam terminalem, foliatam, multoties dichotomam, paniculaeformem dispositis.

0 dontostemma Bentham msc. Fenzl in Endlicher Atakt, t. 34.

5239. Holostemun LINN. C a l y x quinquepartitus, laciniis herbaceis, subenerviis, fructiferis adpressis. Cor oll a e petala $\overline{5}$, perigyna, obovata, emarginata v. eroso-denticulatta. D i sci subhypogyni glandnlae obsoletae v. distinctae, carnosulae, lineares, truncatae. St a min a subhypogyna 3 v. 5 , rarins 10 ; fila menta setacea, libera, anthera e biloculares, longitudinaliter dehiscentes. Ovarium sessile, nniloculare. Ovula plurima, columellae liberae inserta, amphitropa, $S t i g m$ at a filiformia 3 , rarias 4,5 , calycis laciniis opposita. Ca $\mathbf{8} 8$ ula membranacea, ovoideocylindrica, calyce paullo longior, apice duplo stigmatum numero, dentibus apice spiraliter revolntis dehiscens. Semina plurima, scabra, oblonga, concavo-convexa, facie cava longitudinaliter elevato-carinata, umbilico apicali estrophiolato. E mb r yo hippocrepiformis, albumen parcum farinacenm includens; cotyledonibus linearibus, planis, incumbentibus, seminis faciei dorsali convexae, radicula elongata tereti angulo faciei ventralis adplicitis. - Herbae annuae, in Europa et Asia temperata indigenae; caulibus simplicissimis, superne plerumque glutinosis, foliis oppositis, connato-sterilibus, exstipulatis, ovalibus et oblongo-lan- 
ceolatis, glaberrimis, floribus in cymam terminalem contractam, umbelliformem dispositis, pedicellis post anthesim refractis, demum erectis.

H o l o s t e um Linn. Gen. n. 136. excl. sp. stipulat. Schkuhr t, 20. Gärtner II, 231. t, 130. K. B. t, 27. Flor. dan. t. 1204. Cerastiu m Huds, in Dicks. Hort, sicc. 2. n. 5 . Stellaria Debray Alsines sp. Lam. Arenariae sp. Bleberst. Sibthorp Flor. graec. $t$. 439.

5\%40. Stellaria LINN, Calyx quadriquinquepartitus, laciniis herbaceis, fructiferis adpressis, inermibus v, rarissime spinescentibus, C oroll a e petala $\%$, 5 , perigyna, abortu interdum pauciora v. nulla, bifida v. bipartita, rarissime laciniata. Dis ei subhypogyni v. perigyni glandulae obsoletae v. distinctae, "truncatae, bigibs bosae $v$. emarginatae. Sta $\mathrm{m}$ in a 8 v. 10, rarius pauciora, subhypogyna v. perigyna, omnia fertilia ; fil am e n ta subnlata v. setacea, libera, antherae biloculares, longitudinaliter dehiscentes. Ovari um sessile, uniloenlare. Ovula panea v. plurima, columellae centrali liberae parvae v. fere obsoletae inserta, amphitropa. St igma ta $\mathbf{3}$, rarius 2, interdum 4 v, 5, filiformia. Ca p 8 u la membranacea, globosa, ovoidea v. oblonga, unilocularis, dnplo stigmatum numero ultramedium in valvas erectas, recurvas v. revolutas dehiscens. S emin a plurima v. pauca, rarissime solitaria, reniformia, rugnlosa, granulata v. mnricata, opaca, umbilico estrophiolato. E m b r yo annnlaris, albumen farinaceum cingens; cotyledonibus lineari-filiformibus, incumbentibns, - Herbae cosmopolitae, plerumque diffusae, interdum scandentes, rarissime suffrutescentes et dense caespitosae; caulibus frequentissime angulatis, laevissimis, rarius scabris, saepe linea decurrente pubescentibus $v$, villosulis, ad nodos infimos plerumque fragilibus, foliis oppositis, exstipulatis, petiolatis v. sessilibus, plerumque patentibus $v$, reflexis, rarissime imbricatis, floribus pedicellatis, rarissime sessilibus, nunc in ramorum dichotomiis alaribus, axillaribus aut terminalibus, solitariis, paucis $v$, plurimis, nunc in cymas depauperatas $v$. multoties iteratas, diffusas, saepissime axillares, longe pedunculatas dispositis,

Stellaria Linn. Gen. n. 368. exel. sp. Feazl Mo. nograph. Alsin, inedit.

a. SCHizotechiU Menzl. C a 1 y $x$ quinquepartitus. S $t$ amin a 10 , sublypogyna. 0 v a $\mathrm{r} f \mathrm{u}$ in bi-triovulatum, co. Inmella centrali subualla. St y 113 , rarius 2 . Cap s ula monosperma v. rarissime disperma. - Herba nepa. lensis, diffusissima, elongata; caulibus tetragonis, follis glabriusculis, sessilibus, lanceolatis, inferio. ribus interdum somipede longioribus, margine crispatis, cynulis per paniculas brachiato-ramosas, laxas, valde elongatas dispositis.

Schizotechium Fenzl Verbreil. der Mlsin. 13. Stellaria erispata Wall.

b. EUSTELLARIA Fensl. C a I y $x$ quiaque-rarissime quadri. partitus. S $\mathrm{ta}$ m in a 10 , interdum pauciora (3_5), plerumque disco perigyno inserta. 0 va $\mathrm{rium}$ plariovulatum, Sty $1 \mathrm{i} 3$, interdum 4 v. 5 , rarius 2 . Capsula oligo - v. polysperma. - Herbae humiles, caespitosae, amphigeae, polymorphae, foribus alaribus, axil. laribus, sparsis, rarius solitariis, terminalibus, sae. pissime per eymas dichotomas multoties iteratas, fo. liaceo $v$. scarioso bracteatas dispositis.

ce. Petiolares Penzl mse. Folia omnia v. saltim inferiora in petiolum distinctum angustata, Iamina cordata, ovata v. elliptica. C a ly $x$ interdum quadripar. titus. - Stellariae sp. Linn. et Auet. Flor. dan. t, 271. 438.525. E. B. t. 92, 537. Gussone Plant, rar. t. 37. $f$. 1. A I sines sp. Linn. et Auct. Holnstei sp. Swartz, A Is i a ella Benthan in Wallieh Catalog. n. 630. (Species prototypae: St. nemorum, media, saxifraga, flaccida.)

B. Insignes Fenzl msc. C a u les teretlusculi v. sub. angulati. Folia ounla sessilia $\%$. tantue infima in petiolum latum obsoletum angustata, cordata, ovalia v. oblonga, numquam e basi latiore rectilineo-lanceolata, nec ad margines aculeolato seabra. Flores magni, solitarii, axillares v. alares, sparsi v. in ramorum dichotomiis foliosis, multoties fteratis plurimi. - Stellaria e s p. Linn. et Auet. Jacq. Ic, rar. t. 468. Smith Ic. inedit. t. 14. Ledebour Ic. $t .167$. (Species prototypae: St. bulbosa, dichotoma, ruscifolia, radians.)

$\gamma$. Holost ea e. Fenzl msc. Ca u les acutanguli, fraglles. Folla connato-sessilia, e basi latiore rectilineolanceolata, longe attenuata, margine aculeolato-scabra, rigida, infima confertiora, superioribus malto breviora, reflexa. Flores speciosi, in cymam panieuliformi-effusam, inferius foliosam, superne herbaceobracteatam dispositi. Capsula sphaerica, inflata. Stellaria holostea Linn. Flor. dan. $t$. 698. Cartis Flor, lond. II, t. 30 .

8. Larbreae Fenzl. msc. Caules angulati, basi plerumque diffasi, flaceide adscendentes $v$. erecti, rarissime repentes, caespitosi. Folia varia, sessilla. Flores mediocres v. minimi, specierum pauciflorarum axillares et terminales, plerumque longe, rarissime breve pedicellati, in speeiebus multifloris in ramorum dichotomilis iteratis foliosis, v. In cymas pedunculatas, alares axillaresque, scarioso.bracteatas, effasas dispositi. S tam ina plerumque distincte perigyna. Ca ps ula ovoidea, oblonga v. turbinata, polysperma. - L arbrea St. Hilaire in Mem. Mus. II. 261. S tell arfae sp. Linn. et Anet. R. B. $t .803$. Flor. dan. t, 1047. Curtis Elor, Lond. VI. t. 28. Ledebour Ic. t. 410. 419. 42t. Hooker Flor. Bor. Amer. $t$. 3i. Jaequemont Voy, Bot, $t, 31$. S perg ulastri sp. Mielix. Micropetali s p. Pers. (Species pro. totypae: St. saxatilis, longissina, graminea, uliginosa, borealis, longipes, humifusa.)

E. Spincscentes Fenzl moc. Caules nitidi, dense foliosi. Foli a ovato-v. lineari - subulata, recarva, canalieulata, triquetra, rigida, pungentia, juniorum fasciculis axillaribus plerumque pseudo-vertielllata. Flores alares v. axillares, interdum cymoso - corymbosi, ealycis Iaciniis spinescentibus. - Species ausira. lasicae. Stellaria squarrosa Hook. St, pungeus Brongn. ad Duperrey t. 78.

c. LEUCOSTEMMA Benth, Calyx quadripartitus. Sta. mi n a 8, subhypogyna. O va rium multiovulatum, eo. lomella centrali distincta. Styli 2. Capsula ovoideooblonga, polysperma. - Herbae nepalenses, niti. dae, faccídae, folits lineari-lanceolatis $v$. ovatis, acuminatis. - Leucostem a Beutham in noyle Himalay. $\ell, 2 \overline{1}, f .1 .2$.

d. ADENONEMA Bunge, $\mathrm{C}$ a l y $x$ quinquepartitus. P etala ealyce multa breviora, minutissima, bifida $\mathrm{v}$. bipartita. Stamina 10 , perigyai. O variam pluriovolatum. Styli 3. Capsula mono.disperma. - Suffruticuli dense v. pulvinatim caespitosi, in $A=i a$ arctioa, alpibus altaleis el peruanis crescentes; fo. liis confertissime imbricatis, late subulato-triquetris, oblongis v. Linearibus, rarius remotis, floribus ses. silibus $v$. breve pedicollatis, plerumque solitariis, rarius pluribur congestis, in cymas terminales brac. teolatas dispositis.

Adenouema Bunge Verzeichn, Altai, Pflanz. 36. Stellaria petraea Bang. Ledebour Ic. $t$, 401 . Area aria Cherleriae Piseh. Ch. dieranoides Cham. et Schl. Ch. I a e vis Bartling.

SUITTEIETS I T. CERASTIEAE Fenzl $m s c$. Styli 5 , rarissime 4 v. 3 , calycis laciniis oppositi. Capsula cylindrica v. cylindrico-conica, recta v. incurva, duplo stylorum numero dentibus dehiscens.

5241. Cerastium LINN. Caly $\mathrm{x}$ quinque- rarissime quadripartitus, laciniis herbaceis, fruetiferis adpressis. Corollae petala 5 v. 4 , subhypogyna, obeordata, obovato-eaneata v. oblonga, profunde emarginata $\mathbf{v}$. rarius retusa, rarissime integerrima v. laciniata. $\mathrm{S}$ ta $\mathrm{m}$ in a $10_{-} 8$, 
rarins $5-4$, subbypogyna; fil a menta subulata v. setacea, libera, antherae biloculares, Iongitudinaliter dehiscentes. Ovari um sessile, uniloculare. Ovu I a plurima, columellae centrali liberae, elongatae inserta, amphitropa. Stig ma$t$ a 5 , rarins $4 \mathbf{v}, 3$, filiformia, calycis lacinits opposita. Capsula membranacea, eylindrica v. eylindrico-conica, recta $v$, incurva, calyce longior ant rarissime brevior, duplo stigmatum numero in dentes apice circinnatim v. margine revolutos, erectos, v. planos in conum conniventes dehiscens. Semina plurima, globulosa, reniformia v. angulato-compressa, granulata, tuberculata v. papilloso-muricata, nmbilico estrophiolato. E mb r.yo annularis, albumen farinaceum includens; coty. ledonibus incumbentibus. - Herbae amphi geae, annuae $v$. perennes, densius $v$, laxius caespitosae, plerumque hirsutae v. villosae; caulibus saepissime teretiusculis, dichotomiis iteratis in inflores. centiam cymoso-paniculaeformem, foliatam solutis, v. cyma distincta, saepissime scarioso-bracteata, corymbiformi, paniculaeformi v. rarissime subumbellata terminatis, foliis variis, sessilibus v. interdum sensim in petiolum angustatis, remotis $v$. rarissime imbricatis.

Cerastium Lina. Gen. n. 585. Fenzl Monograph. Alsin, inedit.

a. DiCHODON Bartl. Peta la profunde emarginata. StyIi 3 , interdum 4 v. 5 . C a p s u 1 a rectiuscula v. ineurva, calyce longior, dentibus margine subrevolutis, erectis v. patulis dehiscens. - Herbae planitierum et alpium Europae ot Asiae media e atque aretioae in. colae, annuae $v$. perennes, glabriusculae $v$. glanduloso-puberulae, pauci-muliflorae.

Dic hod on, Stellariae sect. Bartlling in Koch Synops. 118. Cerastit et Stellariae sp. Linn. et Auct. Jacq. Collect. I. t. 19. Swith Ic, rar, t, 15. E. B, t,911. Walcist. et Kitaibel Plant, rar. Hung. t. 22.

b. SCHIZODON Fenzl. Petala calyce treviora, apice incisa. Stig mata 5, Cap $s$ ula anguste eylindrico-conica, calyce multo longior, dentibus plasis, serius valvulis linearibus, in conum conniventibus debiscens. Herbae annuae, in regione mediterranea Syria et Persia indigenae, dichotome ramosae, multiflorae, glanduloso.viscidae.

Sehizodon Fenzl msc. C. dichotomum L. et C. inflatum Link. Myosotidls sp. Móneh Method. 225. A Is ine cornicula ta Clusius Hist. II, 148, $c$, ic.

c. STREPHODON Sering. Petala incisa v. emargiuata. St y 1 i 5. Ca p s u lae dentes apice circinnato-revoluti. Herbae annuae $v$. perennes, paucissimae in regione mediterranea et taurico-caucasica, plarimae in Asia media et boreali indigenae, di. chotome ramosae, multiforae, rarius simplices, co. rymbosó v. umbellatim cymosae.

Strephodon Cerastil sect. Seringe in DC. Prodr. I. 414. Cerastil s p. Linn. et Auct. Schrank Hort, monac. t. 75. Bot. Mlag, $t$. 1789. Ledebaur Ic. t. 251 ; 102, 424, 433. Bngell. et Parrot Reise Krim, $t$, 3. Wight Illustr. $t .26$.

d. ORTHODON Sering. Potal a incisa, euarginata v. lacluiata. St a m in a 10 , rarissime 5 v. 4 . Styli 5 v. rarissime 4. Capsula plerumque calyce longior, rarissime brevior, incurva v, interdum erecta, dentibus erectis v. patalis, margine subrevolutis. Herbas amphigeae, annuae $v$, perennes, habilu et inflorescentia variae.

Orthodon Cerastil sect. Seringe in DC. Prodr. $T$. 415. Cerastii sp. Linn. et Auct, Jacq. Collect. $I$. t. 20. E. B. $4.93,472,473$. Sibthorp Flor. graec. $t$. 454 . 445. Lapeyr. Pyren, $t$. 10. Waldst. et Kitaibel Plant. rar. Hung, t. 97, 168. DC. Ic, plant, Gall, rar, t. 44. Reichenb. 1conogr. t, 315. 316. 379, 380_382. 387.388. 399. 400 - 103. Sturm Deutschl. Flor. f. 93. Rochel Plant. Banat. t. 2. f. 6. 6. Ledebonr Ic. t. 149. E s. warchia Reichenb. Flor. germ, 293. Saginae sp.
Smith E. B. $t$, 66. Alsines sp. Flor. Flum. $I I T$, t. 105.

e. MöNChIA Ehrh. Cal y x quadri-quinquepartitus. Pe$t a l$ a integerrima v, retusa. St a m in a 4,8 v. 10. Styli 4-5. Capsula eylindrica, recta, ealyce brevior v. subaequilonga, dentibus matgiue subrevolutis. Horbae annuae, europeae et boreali-americanae, glaberrimae, Stellarias herbaceas habitu aemulantes, folits lineari-lanceolatis, foribus longissime pedicellatis, terminalibus, solitariis $v$. in cymam depanperatam aut effusam dispositis.

Möuchia Ehrhart Beitr. IT. 277. Saginae $8 \mathrm{p}$. Linn, E. B. t. 609. Curtis Flor, lond, II. $t, 12$, Flor. dan. t. 834. Alsinella e sp. Mònch, Cerastium mantfe um Linn. Waldst, et Kitaibel Plant, rar. Hung. t. 96. Stellariae sp. DC, Arenaria calyeía Poir. Malachil sp. Reichent. Koch.

SUDTPIBIS IIR. MALACHIEAE Fenzl msc. Petala bipartita. Styli 5, calycis laciniis alterni. Capsula ovoideo-pentagona, simplici stylorum numero in valvas apice bidentatas, calycis laciniis opposilas dehiscens.

5\%4\%. NIallaelhimn FRIES, C al yx quinquepartitus, laciniis herbaceis, muticis. Corollae petala 5 , subhypogyna, ultra medium v. usque ad basim bipartita, laciniis linearibus, patentibus. S tamina 10 , subhypogyna, omnia fertilia, longiora disci glandulis carnosis inserta; fil a menta subulata, libera, anthera e biloculares, longitudinaliter dehiscentes. Ovarium sessile, uniloculare. Ovula plurima, colnmellae centrali liberae, fungosae inserta, amphitropa. Sty li 5 , rarissime 4 v. 6, ealycis laciniis alterni. Capsula membranacea, ovoideo-pentagona, calyce longior, unilocularis, simplici stylorum numero in valvas calycis laciniis oppositas, bidentatas, apice recurvatas y. revolutas dehiscens. Semina plurima, subglobosa, tubercnlata, opaca, umbílico estrophiolato. E m b r yo annularis, albumen farinaceum includens; cotyledonibus incumbentibus. Herba in Europa et Asia media indigena, perennis, Stellariae nemorum facie, mollis, flaccida, interdum scandens; caule di-trichotome ramoso, tetrağono, ad nodos tumido, foliis ovato-cordatis, inferioribus in petiolum attenuatis, superioribus sessilibus, floribus in cymam terminalem foliatam, multoties iteratam, flaccide $v$. squarrose effusam dispositis, pedicellis post anthesim reflexis, apice cum fructu cernuis.

Malachiou Fries Flor. Hall. 27. Larbrea Seringe in DC. Prodr. 1. 395. nou St. Hil. M y o s o to n Mónch Method. 295. Cerastil s p. Linn. et Auct. B, B. t. 838. Curtis Flor. Lond. . $t, 96$. Flor. dan. $t .1337$.

SUIB GIEID IV. SILENEAE DC.Prodr, I. 351 . H e rb a e v. suffrutices, foliis oppositis, exstipulatis. Calyx gamophyllus. Petala cum staminibus gynophori plus minus distincti apici hypogyne inserta. - Species in temperatis calidioribus hemisphaerae borealis maximo numero crescentes.

TEIIBUS I. DIANTHEAE Kunth Flor. berol. I. 106. Cap s u la apice dentibus v. valvulis dehiscens, polysperma. Se min a oblonga v. ovalia, compressa, dorso convexa, facie plana v. convexiuscula, medio Iongitudinaliter carinata v, marginibus involutis canaliculata, 
placentae centrali columellari peltatim affixa. Embryo excentricus, rectus.

5243. Velezia LINN. C a l y $x$ ebracteolatus, tubo cylindrico, gracili, quinque-sexdentato. Corolla e petala 5 v. 6 , earpophori distincti, stipitiformis apici hypogyne inserta, unguibus tnbum aequantibus, apice barbatis, laminis angustis, emarginatis v. quadridentatis. Stam in a 5 v. 6 , rarissime 10 , cum petalis inserta; fi la m en ta filiformia, an therae biloculares, longitudinaliter dehiscentes. Ovarin m uniloculare, ov ulis plurimis, colnmellae centrali filiformi peltatim insertis, amphitropis. Styli 2 v. 3, filiformes, intus stigmatosi. Ca p su i a membranacea, elongato-cylindrica, nnilocularis, apice dentibns quatuor v. sex dehiscens. S e m i na plurima, columellae filiformi flexunsae inserta, oblongo-linearia, dorso convexa, marginibus involutis profunde canaliculata, in sulco medio umbilicata. $\mathbf{E} \mathbf{m}$ b r yo intra albumen farinaceum excentricus, umbilico parallelns, dorso admotus, rectus; cotyledonibus planiusculis, incumbentibus, radi enla tereti, producta, supera. - Herbae mediterraneae, annuae, squarroso-dichotome ramosae; foliis oppositis, lineari-subulatis, floribus per totam ramorum longitudinem axillaribus, solitariis, breve pedunculatis, pedunculis rigidissimis, nudis.

Velezi a Lina. Gen. n, 647. Gärtner IT. 226. t. 129. Lam, $t$. 186, Sibthorp Flor. graee. $t .391$. DC. Prodr, $I$. 387. Meisner Gen, 24. (21.)

52 44. Tianthus LINN. C a ly $\mathrm{x}$ basi bracteolis duabus v. pluribus imbricatis cinctus, rarissime ebracteolatus, tubo cylindrico v, interdum clavato ant turbinato, quinquedentato. Corolla e petala 5, carpophori distincti, stipitiformis v. enpuliformis apici hypogyne inserta, ungnibus linearibus elongatis, laminis crenatis, dentatis v. Iaciniatis, rarissime integerrimis, basi nudis v. barbatis. Stamina 10 , cum petalis inserta; filamenta filiformia, anthera e biloculares, longitudinaliter dehiscentes. Ovarium unilocnlare, ovulis plurimis, columellae centrali crassae peltatim insertis, amphitropis. Styli 2, filiformes, intus stigmatosi. Capsula chartacea, cylindrica v, oblonga, unilocularis, apice dentibus v, valvulis quatuor usque ad medium dehiscens. S e mina plurima, in columella centrali erassiusenla horizontalia v. oblique imbricata, ovalia v. oblonga, depressa, dorso convexiuscula, facie margine incrassata, plus minus distincte earinata, umbilico centrali. E mbr yo intra albumen farinaceum excentricus, umbilico parallelus, dorso admotus; c otyled on ibus plano-convexis, radicula tereti, producta, vaga. - Herbae $v$. suffrutices, in Europa et in $A$ sia boreali, rarius in $A$ merica septemtrionali et in Capite bonae spei crescentes; caulibus nodoso articulatis, folitis oppositis, basi plerumque connatis, saepe gramineis, $l i$ nearibus, rarius lanceolatis $v$. oblongis, floribus terminalibus, solitariis v. cymoso-paniculatis, corymbosis, fasciculatis $v$. glomerato-congestis.

Di a nt h s Lina. Gen, n. 770. DC. Prodr. I. 355.

a. CARYOPHYLLUM, Plores solitarii v, plares, per eymam simplicem v. eompositau varie dispositi, subinde faseieulato-aggregati, involucro uviversali polyphyllo herbaceo v. nulio. Cal yx cylindrieus, herbaceus, cbarta. ceus v. pergameneus, striato-multinervis, basi bracteolis duabus v. pluribus, herbaceis v. pergameneis, Imbricatis cinctas, fructifer fnteger $v$. rarissime hithe fissus. C o o oll a hypocraterimorpha, petalorum unguibus linea- ribus in laminam dilatatis, - Herbae $v$. suffrutices amphigei. - Di a n thus Linn. et Auct. Flor, dan. $t .230$. 578, 1694. F. B. $t, 62$. 214. Jaeq. Flor, austr. $t .68$. To. rar. 2 , 82, 467. Hort. Schönbr. t, 271. Thunberg Flor. japon, t. 23. Vent. Cols, t. 39. Labillard. Plant. syr. Dec. I. I. t. S. Waldst. et Kitaibel Plant, rar. Hung. t. 38, 172. 181. 191. 292. DC. Ic. plant. Gall. rar t. 41. Bieberst. Cent. pl. ross, t. 39. Hooker Flor. Lond, t. 134. Sibthorp Flor. graec. t. 392 405. Sturm Deutschl. Flor, 23. 28, 34, 51. Ledebour Ic, $t, 197.420$. Reichenb, Hort, bot, t. 25. 35. 56. Iconogr. f, 259. 347. 713_715. 792. 75t. 732. 735_737. 739_744. 748. Bot. Mag. t. 25. 39. 297. 295, 1162. 1204, 1205. 1629. 1739. 1740. 1775, 2038, 2039. 2067. 2288.

b. KOHLRAUSCHIA Kunth. F1 ore s eapitato-eongesti, rarissime solitarif, sessiles, involuero universali hexaoetophyllo, searioso cineti. O a l y $x$ floris centralis ebrac. teolatus, lateralinm bibracteolatus, bracteolis scariosis, tubum aequantibus v. subsuperantibus, convolutis, tubo tenerrime membranaceo, obsolete qoinquedentato, tongitudinaliter quinquezonato, zonis cum simbus aternantibus, lineolatis, albis, opacis, fruetifer hine longitudinaliter usque ad basim fissus. Coroll a petalorum unguibas longis, laminis suberectis elavato-tubuliformis. KohIra us ohia Kunth Flor. berolin, I, 108, exel. sp. D. prolifer et di minutus Lipn. Flor. dan. t. 221. E. B. t. 956, D. velutinus Guss. Tanicae sp. Scopoli. Ca ryophylli sp. Möneh.

c. TUNICA Scop, Flores solitarif v, faseiculato-congesti, involuero universall tetraphyllo, scarioso císcti, fascieuli centrales pedicellati, ebracteolati, laterates ses. siles, basi bracteolis duabus scariosis stipati. C a l y $x$ turbinatus v, tubuloso-elavatas, submembranaceus, herbaceo-quiuquangulatus, profande quinquedeatatus. C o. ro II a hypocraterimorpha $v$. infundibuliformis, petalorum ungaibus sensim in laminam dilatatis. - T u n fea Scopoli Carniol. 1.300. excl. sp. Mertens et Koch Deuschl. Flor. IIT. 182. Fisch. et Mey. Index. sem. hort. Petropolit. 1837. p. 48, exel. sect. 2. Im p e ratia. Mónch Method, 225. Diant hus Saxifraga Linn. Gynsophilla Saxifraga et rigida Linn. Sibthorp Flor. graec, $t$. 382, Smith Exot, Bot, $t$. 90. G. d i a nt ho ides Sibthorp 2,383 . Ko h Iraus ehiae sp. Kunth.

d. PSEUDOTUNICA Fenal. F1 o res solitaril, pedicellati, cymosi. Caly $\times$ ebracteolatus, elavatus v. turbiantas, herbaceo-membranaceus, augulatus. Corolla infandibuliformis v. eampanalata, petalorum unguibus sensim in. lamioas dilatatis. - G ypsophil a.e sp. Desfont. Flor, atlant, $t, 97$. Sibthorp Flor, graec, $t, 381-386$. Ledebour Ic. 1.5. Tunica e sect. 2, Fisclier et Mey.l. c.

TiRIBUS Ir. LYCHNIDEAE Fenzl msc. C ap sula apice in dentes $v$, valynlas dehiscens, v. baccata, indehiscens, polysperma. Semina globulosa, reniformia v. lenticularia, umbilico marginali funiculis distinctis affixa. E $\mathrm{mbryo}$ periphericus, annularis v. hemicyelicus.

5245. Aypsophila LINN. Calyx ebractenlatus, turbinatus v. campanulatus, semimembranaceus v. rarissime herbaceus, angulatus, quinquefidus. Corollae campaniformis petala 5 , carpophori obsoleti cyathiformis apici hypogyne inserta, laminis exappendiculatis, integris, emarginatis v. bidentatis, in ungues coneato-attenuatis. St a min a 10, cum petalis inserta, rarissime alterna petalis opposita sterilia v, abortiva; filamenta filiformia, antherae biloculares, longitudinaliter dehiscentes. Ovari n m uniloculare ovulis plurimis, placentae centralis funiculis distinctis inserta, amphitropa. Styli 2 v. rarissime 3 , filiformes, intus stigmatosi. C a p s u la chartacea, globulosa v, ovoidea, unilocularis, ab apice nltra medium valvulis quatuor $v$, rarissime sex dehiscens. S emina plurima, reniformia, emarginaturae sinu umbilicata, rugulosa v. granulata. 
Embryonis annularis v. semiannularis albumen farinaceum cingentis cotyledones incumbentes. $\$$ Suffruticuli caespitosi $v$. herbae perennes, aut rarius annuae, in temperatis calidioribus hemisphaerac borealis veteris orbis crescentes, plerumque ramosissimae, multiflorae, glabrae v. glanduloso-puberulae; foliis oppositis, sessilibus, variis, saepe carnosulis, glabris, rarius pubescentibus, floribus plerumque parvis, roseis $v$. albis, venulis purpureis variegatis.

G y p 80 phil a Linn. Gen, $n, 768$. DC. Prodr. $I, 351$. excl. sp.

a. DICHOGLOTTIS Fisch. et Mey. Herba e aunuae, a basi dichotome ramosae, usque ad apices foliosae. Fio. res plurimi, ab infimis dichotomiis per totam herbam sparsi, pedicellis capillaribus elangatis, post anthesim patentissimis v. reeurvis, apice sursum aduneis. Corolla e petala linearia v, latius aut angustius cuneata, integerrima, bidentata, retusa v. bifida. - D i choglottis Fischer et Meyer Index sem. hort. Petropolit. 1835. $I$. p. 25. G. m u rallis Linn. Flor. dan, t. 1268. Schkuhr t. 120. Sibthorp Flor. graec. t. 381. S a p on aria porrigens Linn. Jacq. Hort. Vindob. $t$, 109.

b. HETEROCHROA Bunge. Her ba sibiricae, perennes, caespitosae, decumbeates v. adscendentes. Flores ia ramis pauciores, axillares, solitaril $\vec{v}$. per cymam teiminalem, foliaceo-bracteatam, corymbiformem dispositi. Calyx semiquinquefidus, herbaceus. Corollae petala oboyato-cuneata, discoloria, mutabilia. Cap sula ultra medium in valvulas dehiscens. - Heterochroa Bunge in Ledebour Flor. Alt. IT. 131. Ledebour Ic. t. 155. Jacquem. Doy, $t$. 28. Arenaria purparea Willd, A. sericea Ser. violacea Ledeb.

c. STRUTHIUM Ser. Suffrutices $v$. herbae perennes, rarissime anuuae. Flores plerumque uumerosissimi per cymas multoties iteratas, paniculaeformes, corymbosas, rarius faseleuliformes ant capituliformes, scarioso-bracteatas, dispositi. - Struthi um Gypso. phillae seet. Seringe in DC. Prodr. $I$. 352 , exci. sp. Gypsophilae sp. Lina, et Auct. Jacquia Flor. Austr. $t, 407$. et Append. $t$. 1. Hort. Vindob. t. 138. Waldst. et Kitaibel Plant, rar. Hung. t. $4 t$. Setirank Hort, Monae, t. 31. 32. Delile Flor. aegypt. t. 29. $f .1$. Ledebour Io, $t, 176.402$. Bot. Mag, $t, 1281$, 1449. R 0 kejek a Forskael Aegypt, 90 . B a n f $\mathrm{fy}$ a Baumgarten Flor, transylv, 1. 385. Reichenb. Ieonogr. $f .586$.

5246. Saponaria $L I N N$, $\mathrm{C}$ a I y $\mathrm{x}$ ebracteolatus, cylindricus, eilipsoideo-oblongus, ovoideo inflatus v. rarius clavato-campanulatus, quinquedentatus. Corolla e hypoeraterimorphae petala carpophori obsoleti cyathiformis, v. rarins distincti stipitiformis apici hypogyne inserta, unguibus linearibus, calyeem aequantibus v. superantibns, laminis basi nudis $v$. appendiculatis. St a m in a 10 , cam petalis inserta; fila menta filiformia, antherae biloculares, Iongitudinaliter dehiscentes. Ovari um uniloculare, ov ulis plurimis, placentae centrali elongatae funiculis distinctis insertis, amphitropis. S tyli 2, 3 v. 5, filiformes, intus stigmatosi. Ca p sula membranacea, chartacea v. pergamenea, cylindrica, oblonga v. ovoidea, apice duplo stylorum numero in dentes recurvatos dehiscens. S e m in a pauca v. plurima, globulosa v. reniformia, dorso saepe planiuscula, facie depressa, rugulosa v. granulata, rarissime lenticulari-compressa, ambitu papillis paleaceis cristata. Embry o annularis, albumen farinaceum cingens; cotyled on ibus incumbentibus. - Herbae $v$. suffruticuli caespitosi, ger ontogei boreales; foliis oppositis, variis, floribus solitariis, terminalibus $v$. in ramorum bifurcationi. bus alaribus et axillaribus, v. per cymas terminales varie contractas dispositis, minutis $v$. magnis spec. tabilibus, purpureis, albis v, rarissime flavis.

Saponaria Fenal Dissert. inedit. Sapouariae, Lyelualdis et Silenes sp. Linu. et Auct. a. SMEGMANTHE Fenzl. Caly x cylindricus v. ellipsol. deo-oblongus, haud angulatus. Styli 2 . Capsula quadridentata.

c. Bolanthus. Cauliculi floriferi polyphylli, simplices v. ramosi. Folia linearia v, subspathulata, interdum pseudo-verticillata. C y m a e terminales, fascícnliformes, capitato-congestae. Flores minuti. Saponariae seet. Bolauthus Seringe in $D \bar{C}$. Prodr. I. 366. excl, sp. 12-15. S a po n a riae sp. Labillard, Syr. Dec. IV. $t$. 4. f. 2, Penzl Sert, Cabul. t. 2. G y psophilae s p. Sibthorp. Flor, graec. t. 387,388 .

P. Cymanthus. Herbae perennes. Cymulae co. rymbiformes v. faseiculiformes, solitariae, termina. les, v. plures thyrsoideo-confertae. - B o otia $\mathrm{S}$ a. po a a ria e sect. Seringel, c. exel. S. officinali. (Jaeq. Flor. Austr. Append. t, 23. Cavanill. Ic, t, 134. Bie. berst. Cent, plant, ross. II. $t, 66$.)

$\gamma$. P roteinia. Herbae annuae, a basi dichotome ramosae, v. ultra medium dichotome paniculatae, dichotomiix foliosis. Flo res alares, superiores axillares, plerumque minuti. - Saponaria oriegtalis Linn. Sweet Fl. Gard. I. Proteini a sect. S a pon a ria e Seriage 2, e, excl. sp. G_8.

8. Smegmatham $\mathrm{s} i \mathbf{u m}$. Herbae suffrutescentes, eaudicibus ligaescentibus, caespitosis, eauliculis floriferis simplicissimis, oligophyllis. Foli a radicalia congesta. Flores sessiles v, subsessiles, pauei v. plu. rimi, terminales, eapitato - congesti, plerumque ma. jusculi, speciosi. - Saponariae sect. Bolan. thus Seringe l. c. exel, sp. 10-11. (Alioni Flor. pedemont. t. 23. f. 1. Portenschlag Plant. Dalmat. t. 7. f. 2.)

b. SILENANTHE Fenzl. Ca Iy x-cyliadricus, clavato-eampannlatus v. ellipsoideo-oblongus, fructifer inflatus, te. res v. decemcostatus. S tyli tres. Capsula sexdentata.

c. Helio sperma. Herbae laxe caespitosae, eauliculis unifluris v. superne in cymam pauei-analtifloram, corymbiformem, patulam solutis. Flores longe pedicellati, C a I y $x$ clavato-tampanulatus. C a p $s$ I a mem. branacea, stipitata, S emin a lenticulari-compressa, ambitu papillis scariosis cristata. - S $f 1$ ene qua. drifid a et S. A Ip e 8 tris Liau. Jacq. Flor, austr. t. 96. 120. Waldst. et Kitaibel Plant. Hung, rar. t. 212. Reichenb. Iconogr. $f .1176,1177$, L y $\mathrm{ch}$ id is s p. Linn. et Auct.

$\beta$. Nanosilene. Herbae alpicolae, dense eaespitosae, cauliculis erectis, oligophyllis, uni-rarissime bis floris. C a I y x cylindricus, amplus v. inflatus, ecosta. tus. Pet a lor u m lamina basi appendiculata. S e u in a ambitu haud eristata. - Sileues sect. Na nasile ne Oth in DC. Prodr. $\bar{I}$. 367 , S II e nes s p. Lian. Jacq. Collect, II. $t, 10$. Flor. dan, $t, 21$, E, B, $t, 1081$.

$\gamma$. E11santhe. Herbae annuse v. perennes, erectae, simplicissimae $v$. superne in cymam foliatam elonga. tau, simpliciter v, repetito dichotomam solutae. C a. 1 y $x$ oblongus, herbaceo.decemcostatus, profunde quiaquedentatus, demam vesiculoso-inflatus. S e a i n a haud eristata. - Sit e ne no etlfl or a Linn. Schkuhr $t$, 122. Gärtn. $t .130, f$. 8. S, Eli s a bet ha Lian. Reichenb. lconogr. $f .1221$.

c. MRLANDRIUM Röhl. Fi o res plerumque alterius sexus abortu dioiei. Caly $\times$ fruetifer ovoideo inflatus, decem. deatatus. Styli 5. Capsula decemdentata. - MeIandrinm Rohling Deutschl, Flor. edit. 1. 254. Lychnis diuraa et L. vespertian Sibthorp. Selikuhr t. 124. E. B. t. 1559.1580 . Flor. dan. t. 792 , Reichenb. Iconogr, f. 476 .

ธ24\%. Waecaria $M E D I K, \mathrm{C}$ a 1 y x ebracteolatus, ovoideo-pyramidatủs, pentagonus, quinquedentatus, fructifer maximus, faciebus intrusis prismatico-quinquealatus. Coroll a e petala 5, carpophoro brevi, crasso hypogyne inserta, unguibus linearibus, laminis obovatis, denticulatis, basi nudis. Stamina 10, cum petalis inserta; fil a menta filiformia, antherae biloculares, longitudinaliter dehiscentes. Ovarium basi birarissime triloculare, septis infra columellae cen- 
tralis apicem abrupte desinentibus superne uniloculare, loculis semisepto parietali incomplete bilocellatis. Ov u la plurima, columellae centrali basi cum septis connatae, apice liberae funiculis distinctis inserta, amphitropa. St y li 2 v, rarissime 3 , filiformes, intus stigmatosi. C a p s u la crnstacea, ovoidea, basi septis 2_3 completis membranaceis, totidemque alternis carinaeformibus incomplete quadri-sexlocularis, apice dentibus quatuor v. sex, endocarpio membranaceo irregnlariter secedente fissis, dehiscens. Sem in a plurima, globosa, majuscula, dense grannlata, umbilico ventrali, E mb ry o annularis, albumen farinacenm cingens; cotyledonibus incumbentibus. - Herba annua, segetalis, nunc per terrarum orbem diffusa, glaberrima; foliis oppositis, oblongis v. lanceolatis, basi connatis, caule erecto, in cymam corymbiformem, amplam soluto, floribus rubris.

Vacearia Medikus Philosoph. bot, 1. 96.'Möneh Jlethod, 63. S a ponaria Va ce a ria Linn. et Anet. Gärtner t. 130. Bot. Mag. $t$. 5990 . G y ps o phila V a cea ria Sibthorp Flor, graec. $t$. 380 , L y e h a is Vacearia Seop.

5248. Silleme LINN. C al y x ebracteolatus, cylindricus, clavatus, subeampanulatns, oblongus v. ovoideus, teres $v$. angulatus, quinquedentatus v. quinquefidus. Corolla e petala 5 , rarissime abortu nulla, carpophori stipitiformis elongati v. brevissime cyathiformis apici hypogyne in. serta, unguibus linearibus, laminis integris, bi$v$, multifidis, basi nudis v, appendieulatis. S $t$ a min a 10 , cum petalis inserta, rarissime alterna petalis opposita abortiva; filamenta filiformia, a $n$th er a biloculares, longitudinaliter dehiscentes. O v a rin m basi tri-rarissime bi-quinqueloculare, septis snpra columellae apicem, rarius eirca medium, rarissime prope basim deliquescentibus $\mathbf{v}$. abrupte desinentibus superne uniloculare. Ovu Ia plurima, columellae centrali cum septis connatae v. superne liberae funiculis distinctis inserta, amphitropa. Styli 3 , rarissime 2 v. 5 , filiformes, intus stigmatosi, C a p sula membranacea, chartacea $\mathbf{v}$. crustacea, cylindrica, oblonge, ovata v, subglobosa, basi plus minus distincte tri- v, bi - quinquelocularis, apice in dentes duplo stylorum numero dehiscens. Semina plurima, reniformia, globulosa v. Ienticularia, laevia, rugulosa v. granulata v, echinata, emarginaturae sinu umbilicata. E $\mathrm{mb}$ ryo annularis v. hemicyclicus, albumen farinaceum cingens; cotyledonibus incumbentibus. - Herbae a mphigeae, in regione mediterranea imprimis copiosae, annuae $v$. perennes, rarissime suffrutices; folits oppositis v. rarissime verticillat is, inflorescentia cymosa, varia, interdum ad flores solitarios terminales redacta.

Silene Linn. Gen. n. 778. Otth in DC, Prodr. I. 36r. excl. sect. 1. et sp. plur. Silenes, S a ponariae, Cucubali, Lycbnidis et Viscagin is s p. Linn. et Auct.

a. BEHENANTHA Oth l. c. "Flores solitarif v. paniculati. Calyx vesiculoso-inflatus." -Sile nes s p. Llin. et Auct. Tournef. Corollar. t. 35. Murray Comment. Gotting 1784. $t$. 2. E. B. $t, 164$. Sibthorp Flor. graec. $t .415$, Tenore Flor. Neap. $t$. 37. Bot. Mag. t, 280. 1102. 2255. Reichenb. Ic. $t, 27$, Ledebour Ic. $t, 163$. Bory et Chaub. Morea $i, 13$.

b. OTITES 0tth 1 . o. „Flores verticillato-spicati." - Sile. nes et C a c u b a li s p. Linn. et Auct, E. B, t. 85. Waldst. et Kitalbel Plant, rar. Ilung. t. 56. Sibthorp Flor.graec. $t$. 432, 435. Ledebour Ic. $t$. 163. Reicheab. Iconogr. $f$. 504. Bot. Mag. t. 1997. - B o o ti a Necker Delic. Gal. lobelg, I, 193. Saponaria officinalis Linn, E. B. t. 1060 .

c. CONIOMORPHA Otth $l$, c. s Flores solitarii v, paniculati.
Caly $x$ fundo umbllicato, dentibus longissimis." (Jacq. Flor, austr, t. 223. Wight Illustr, t. 27.)

d. STACHYMORPHA 0 th l. c. ${ }_{n}$ Flores spicati axillares, non oppositi. Calyx decemstriatus," (Jacq. Hort, Vindob. III. t. 81. E. B. t. 86. 1178 . Waldst. et Kitaibel $O_{p .}$ cit. t. 29. Desfont, Flor, atlant. t, 98, 100. Bot. Mag. t. 114. Sehrank Hort, Monac, $t$. 39. St. Hilaire Elor. Brasil. t. 108.)

e. RUPIFRAGA Oth $l$ : 1 . „Caules stricti. Pedunculi filiformes. Calyces campanulati v. cylindriej." (Jaeq. Collect. Suppl. t. 14. f. 1. Waldst, et Kitalbel Op. cit. t, 163. 162. Sibthorp Flor, graec, t. 425.)

f. SIPHONOMORPHA Otth l. c. "Flores paniculati, raro solitarii, pedicelli oppositi, breves. C a 1 y $\times$ tubulatus." (Jacq. Hort. Vindob. $t$. 84, K. B. t, 465. Flor, dan. $t, 248$, Smith Ic. inedit, $t, 13$. Waldst, et Kitaibel Op. cit, t. 8. 213, 208. 249. Cavanill. Ic, $t$, 564. Sibthorp Flor, graeo. t. 418. 419. 425. 428. 499. Desfont. Flor. allant, t. 99. Delile Flor. aegypt, t. 29. $f$. 2. Venten. Cels. $t$. 83. Bot. Reg. $t$. 247, 1444. Bot. Mag. t, 382. 689. 807. Ledebour Ic, t. 138, 160, 396. Reichenb. Iconogr, $f, 416$-418, 425. 427. 465.)

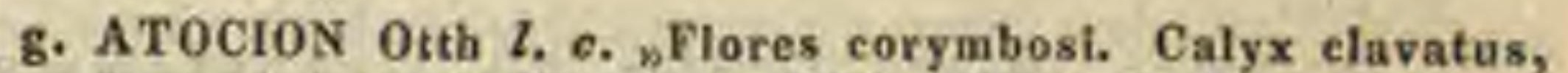
decemstriatus," (E. B. $t$. 1398. Allioni Pedemont, $t$, 23 . $f$. 3. Sibthorp Flor. Braec. $t$. 417.)

52 49. Viseneia RöHL. Calyx ebracteolatus, oblongus, clavatus v. turbinato-campanulatus, teres v. quinquedentatus. Corolla e petala 5, carpophori brevis v. elongati apici hypogyne inserta, unguibus linearibus, laminis bifidis, excisis v. subintegris, basi nudis. S ta min a 10 , com petalis inserta; fil am ent a filiformia, anthera e biloculares, longitudinaliter dehiscentes. 0 varium basi quinque-rarissime triquadriloculare, septis circa medium v. apicem columellae centralis sensim deliquescentibus superne uniloculare. Ovula plurims, columellae centrali cum septis connatae v. superne liberae funiculis distinctis inserta, amphitropa. St y li 5 , rarissime 3 v. 4 , filiformes, intus stigmatosi, $\mathrm{Ca}$ a $\mathrm{s} \mathbf{\mathrm { la }}$ basi quinque, rarius tri-quadrilocularis, apice inter stylos simplici eorundem numero in dentes dehiscens. Semina plurima, minuta, reniformia, granulata v. tuberculata. E m b r yo annularis, albumen farinaceum cingens; cotyledonibns incumbentibas. - Herbae europeae et arcticae, $a m p h i g e a e$, annuae $v$. perennes, erectae; foliis oppositis, linearibus $v$. lanceolatis, floribus in dichotomiis ramorum alaribus $v$, in cymulas thyrsoideo$v$. subumbellatim confertas congestis, roseis v. purpureis.

Vis e a ria Röhling Deutschl. Flor. II. 37. Fenźl Dis. sert. inedit.

a. HYMENANTHE Fenzl msc, C a ly $x$ fruetifer membranaceus, longitudinaliter striatus, nee inter strias transversim rugosus, dentibus v. lacinifis brevibus. - Vis caria Röhling l. c. Ly chn id is s p. Linit. et Auct, Flor.dan. t. 65. 1032, E. B. t. 788, 2254. Sturm Deutschl, Fl. fase. 51. Sileues sp. Baumg. Viseaginis sp. Rohling edit, 1. (L. vis e a ri a et a lpina L, L. laeta Ait. L. corsicn Lois.)

b. EUDIANTHE Reickenb. Cal y cis fruetiferi tubus an. gulatus, transversim rugosus, lacioíae elongatae. L y chnidis sect. Endianthe Reichenb. Flor, ex. ours. 824. A grostemma Coeli-Rosa Lian. Bot. Mag. $t .295$.

52 50. Hyelnais TOURNEF. C a ly $\mathrm{x}$ ebracteolatus, subcylindricus, clavatus, turbinatus, campanulatus v, ovoideus, membranaceus v. coriaceus, angulatus $v$. teretiusculns, quinquefidus v. quinquedentatus. Corolla e hypocraterimorphae petala 5, earpophori elongati v, brevissime cyathiformis apici hypogyne inserta, unguibus linearibus, laminis indivisis, bifidis v. laciniatis, 
basi appendiculatis $v$, rarius nudis. St a min a 10, eum petalis inserta; fiIamenta filiformia, anth ora e biloculares, longitudinaliter dehiseentes. Ovarinm uniloculare. Ovala plurima, placentae centrali columellari funieulis distinctis inserta, amphitropa. Sty Ii 5, filiformes, intus stigmatosi. Capsula chartacea v. crustacea, unilocularis, apice dentibus quinque, stylorum basibus persistentibus superatis dehiscens. Semina plurima, reniformia v. lenticulari-compressa, discoidea, laevia v. granulata aut tuberculata. E m b r yo annalaris, albumen farinaceum includens; c ot y ledo$\mathrm{nibus}$ incumbentibus. - Herbae in extratropicis hemisphaerae borealis amphigeae, perennes $v$, rarissime annuae; foliis oppositis, inflorescentia varia.

Ly e hnis et A grostem m a Linn. Gen. n. 583. 584 .

a. GITHAgo Desfont. C a I y e is fructiferi coriacei laciniae longissimae. P e t a lor u m laminae exappendiculatae, integrae.

Githago Desfont. Catalog. 159. Agrostemma Git h a go Lina. E. B, $t, 741$, Flor, dan, $t, 575$. Schkulir t. 124.

b. Agrostemma Lina. C a ly c is fructiferi coriacei, angustatl laciniae tortae. Pet al o rum laminae integrae, basi purgenti.appendiculatae,

Agrostemma coronaria Lina. Gärtner $t$. 130. Bot. Mag. $t$. 24.

c. EULXCHNIS Fenzl. Cal y x membranaceus, cylindricus, clavatus y, turbinatus. C or olla hypoeraterimorpha.

Lyehnidis sect. 2. et 3 . Eulychia is et Agros. te $\mathrm{mma}$ DC, Prodr. $r$, 385, exel, sp. Jacq, Ic, rar, $t, 84$. E. B. $t$. 573. Flor. dan. $t$. 590 . Bot, Mag. $t$. 223. 257. 2104. Bot. Reg. $t$. 478. Reichenb. Hort. $t, 5$, Siebold et Zuecar. Flor. japon, $t$, 48. 49. A grostem matis sp. Linn. He d e o m a Loureiro Flor. cochinch. 351. (L. Flos Jovis L. L. falgens Fisch. L. chalcedoniea L. L. grandiflora Jacq. L. Flos Cuculi L. L. pyrenalea Berg. L. sibirica L.)

d. GASTRoLychNis Fenzl. Cal y $x$ membranaceus, fructifer vesiculoso.inflatus, ellipsoideus $v$, ovatus. C orol. I a tubulifonmis v. Infundibuliformis, ealyce brevior v. paullo longior. Lychnidis sp. Linn. Flor. dan. $t .806$, Wahlenb. Flor. Lappon, t. 7. Ledebour Ic. $t, 3$, (L, apetala L. L. brachypetala Fisch. L. tristis Bung.)

5251. Cuenloalus TOURNEF. C a ly ebracteolatus, campanulatus, fratifer inflatus, teres, membranaceus, semiquinquefidus. Corolla e petala 5, carpophori stipitiformis apici hypogyne inserta, unguibus longis, angustis, lamina bifida, hasi appendiculata. S $t$ a mina 10 , cum petalis inserta; fil am enta filiformia, antherae biloculares, longitudinaliter dehiscentes. $O$ v ariu m uniloculare. Ovula plurima, placentae centrali liberae funiculis distinetis inserta, amphitropa. Styli 3, filiformes, intus stigmatosi. Capsula globosa, baccata, atro-nitens, unilocularis, indehiscens, Semin a plarima, reniformia, scrobiculata. Embryo annularis, albumen farinaceum cingens, cotyledonibus incumbentibus. Herba perennis, in Europa media obvia, brachiato-diffusa, subscandens; foliis oppositis, ovatis, acuminatis, floribus alaribus et axillaribus pendulis.

C а с д bal is Toarnefort Tnst. 197. Gätaer II. 376.t.77. E. B. $\ell .1577$. DC. Prodr. I, 367. S e ribatea Flor. Wetter. II. 96. Ey chn anthus Grelin Flor. Baden. II. 269. C acuball sp. Lin. L yehnidis sp. Scop. Sileues sp.
Willd.

THEIBDS IUL. DRYPIDEAE Fenzl in Annal. Wiener Mus. II. 309. C a psula inferne membranacea, superne chartacea v. crustacea, medio irregulariter transversim rumpens, mono-oligosperma. Semina oblonga, compressiuscula, umbilico apicali. Embryo periphericus, annularis, v. extremitate cotyledonari involuta subspiralis.

52.ั. Drypis MICHEL. Ca ly x tubulosus, compressiusculus, limbo quinquedentato, spinuloso-mucronato, basi ad angulos demum calloso-induratus. Coroll a e petala 5 , ad basim cupulae stamineae carpophoro obsoleto inserta, longe unguiculata, laminae basi denticulis duobus coronatae, semibifidae v. bipartitae, laciniis linearibus, obtusis. Stamina 5, petalis alterna, cupulae membranaceae hypogynae infra marginem liberum obsolete sinuatum extus inserta; fil a menta filiformia, calyce longiora, ant he rae biloculares, longitudinaliter dehiscentes. O var i um obovatum, uniloculare, ovelis basilaribus tribns, amphitropis. St y 1 i 3 , filiformes, intus stigmatosi. Utric nI us subcylindricus, calyce inclusus, inferne tenue membranaceus, superne chartacens, nitidus, demum supra medium irregulariter transversim rumpens, abortu monospermus. Semen erectum, oblongum, compressiusculum, extremitate radiculari rostriformi supra umbilicum prodncta. E mbryo albumen farinaceum includens; cotyledonibus incumbentibns involutis spiralis, radicula extraria, - Herba mediterranea, perennis, rigidissima, nitida, subcaespitosa; caule ramisque quadrangulis, fragilibus, foliis oppositis, subulatis, spinescentibus, floralibus ovatis; spinoso-dentatis, floribus minutis, dilute carneis $v$. roseis, in cymas corymbiformes, densas dispositis, subsessilibus.

D r y $\mathrm{p}$ is Mieheli Gen, 24, t, 23. Linn. Gen, $n, 381$. Gärtner $I T, 218, t, 128$. Schkuhr $t, 86$. Jaeq. Hort. Vindob. $t, 49$. DC. Prodr. I.388. Meisuer Gen. 24. (22.) Fenzl in Annal. Wiener Mus. II. 309.

5:53. Aeanthoplayllesm C. A. MEY. Cal y x tubulosus, quinquedentatus, basi haud induratus. Corolla e petala 5, cupulae hypogy nae membranaceae summo margini cum staminibus inserta, longe unguiculata, lamina basi nuda, integerrima, retusa v. emarginata. Sta m in a 10, cum petalis inserta, quinque iislem opposita breviora; fil a m enta filiformia, longissime exserta, an thera biloculares, Iongitudinaliter dehiscentes. Ovari um oblongum, uniloculare, ovulis basilaribus quatuor, amphitropis. Styli 2 , filiformes, longissimi, intus stigmatosi. Ut riculns oblongo-cylindricus v. obovato-oblongns, calycem aequans $v$. superans, inferne tenuissime membranaceus, superne pergameneus, nitidus, supra medium irregulariter transversim rumpens, abortu di-monospermus. S e mina erecta, oblonga, compressiuscula, extremitate radiculari oblique porrecta. E mbryo annularis, albumen farinaceum includens; cotyledonibus incumbentibus, radic u la extraria. - Suffrutices regionis caucasicae et Asiae media e, squarroso-ramosi, puberuli; foliis oppositis, rigidis, acerosis, teretiusculis, triquetris $v$. planiusculis, carnosis, interdum fasciculis axillaribus pseudoverticillatis, floribus in cymas corymbiformi-paniculatas $v$. glomerato-fasciculatas, capiluliformes dispositis, sessilibus, centralibus basi nudis, lateralibus bi-sexbracteolatis, albis, roseis $v$, ochroleucis.

A eanthophyllum C, A. Meyer Verzeichn. cauc. Pfanz. 210. Fenzl in Annal. Wiencr Mus, I, 37, t, 5. II. 309. Saponaria pungens Ledebour Ic. $t$. 4. Dianthis spinos us Desfont. in Mem, Mus, t. 16. $f .1$. 


\section{Drato CCVIII. Pleytolaceaceate.}

PHYTOLACCEAE R. Browa in Tuekey Congo 454. Bartling Beitr. $I I$. 142. Ord. nat. 299. RIVINEAE et PBTIVEREAE Agardh Class. 218. 221. PHXTOLACCACEAE et PETIVERIACEAE Líndley Introduct, edit. $I$, p. 210. et 212.

Herbae v. fruticks, caule ramisque teretibus v. irregulariter angulatis, nodis imperfectis. Folia alterna, rarissime subopposita, simplicia, integra, saepissime integerrima, rarius obsolete denticulata, quandoque pellucide punctata, penninervia $v$. interdum uninervia et avenia, membranacea v. carnosula, sessilia v. in petiolum nonnunquam decurrentem angustata. Stipulae nullae, v. ad basim petiolorum geminae, liberae, subulatae, deciduae v, in aculeos uncinatos mutatae.

Fuones hermaphroditi, regulares v. subirregulares, spicati, racemosi v. cymoso-glomerati, axillares, terminales et oppositifolii, pedicellis nudis v. uni-tribracteatis.

CAwyx quadri-quinquepartitus, laciniis herbaceis, margine saepe membranaceis, intus non raro coloratis, aequalibus, v. interdum inaequalibus, aestivatione imbricatis.

Corolla saepissime nulla, rarius petala calycis laciniis numero aequalia et alterna v. panciora, imae ejusdem basi perigyne inserta, lamina basi in unguem abruptim angustata.

Stamisa disci perigyni, imum calycis fundum vestientis margini sublyypogyne, v. carpophori obsoleti aut rarius distincti basi hypogyne inserta, nunc calycis foliolis numero aequalia et alterna, nunc plura, exteriora alterna, interiora opposita, $\mathbf{v}$. in phalanges iisdem alternas collecta, nunc indefinita, subirregulariter congesta. Filamenta filiformi-setacea v, e basi lata ovata aut subulata, libera v. baseos dilatatae fimbriis in cupulae speciem. subcohaerentia. An thera e introrsae, biloculares, basi v. dorso affixae, erectae v. incumbentes, locnlis oppositis, connatis v, basi aut rarius etiam apice discretis, longitudinaliter dehiscentibus.

Ovariux e carpidiis pluribus, rarissime unico subexcentrico compositum, carpidia inter se distincta v. plus minus connata, carpophoro obsoletissime papillaeformi, rarius distincte stipitiformi, in axim haud producto insidentia, unilocularia. O v a l u m unicum, basifixum, campylotropum v. rarius amphitropum. Styli introrsum laterales, carpidiorum singulorum anguli centralis apice inserti, distincti v, rarius ima basi coaliti, uncinato recurvi, intus stigmatosi.

Fructus utricularis, baceatus, cocciformis, nucamentaceus v. samaroideus, carpidiis liberis v. connatis, demum secedentibus, indehiscentibus, monospermis.
Semen erectum, testa membranacea v. crustacea, nitida, fragili.

Euвryo nune periphericus, annularis, albumen copiosum farinosum includens, cotyledonibus angustis planis, v. latis inaequalibus, altera exteriore interiorem marginibus amplexante; nunc rectus, cotyled onibus foliaceis, convolutis, albumine parco discretis v. plane exalbuminosus. Ra di cul a infera.

Phytolaccaceae in regionibus tropicis et subtropicis totius orbis obviae, inter $50^{\circ} \mathbf{L}$. B. et $40^{\circ}$ L. A. inclusae, inter Oleraceas, $\mathbf{C a -}$ ryophyllinas et Columniferas Malvaceas affinitatem mediantes, carpidiis uniovulatis, indehiscentibus, embryone peripherico, foliis alternis, habitu et inflorescentia Chenopodeis proximae, sed staminum situ cum calycis laciniis alternante, eorundum numero saepe aucto, et carpidiorum pluralitate diversissimae, inter $\mathbf{C a}$ ryophyllinas staminibus cum calycis laciniis alternantibus, inflorescentia et foliis alternis arctissime ad Portulaceas accedunt. Genera embryone recto subexalbuminoso v. exalbuminoso donata a reliquis haud segreganda, cotyledonum forma Malvaceis nonnihil approximantur. Gyrostemeae columnae centralis praesentia a reliquis distinctae, inter Phytolaccam et Malvaceas omnino mediae.

SUIB (DIRED I. PETIVERIEAE, E mbryou is cotyledones convolutae. - Folia stipulata.

TiRIIISUS I. PETIVERIEAE VERAE. E $m$ bry o $n$ is recti v. curvati cotyledones convolutae, albumine pareo v. nullo.

525 quepartitus, Iaciniis oblongis v. ovalibus, petaloideis, saepe inaequalibus, fructiferis reflexis. C orolla nulla. Stamina plurima, dísco carnoso perigyno assymetrice inserta; filamenta filiformia, inaequilonga, calycem panllo superantia, antherae biloculares, sagittatae, loenlis linearibus, basi discretis, longitadinaliter dehiscentibus. O va ri um simplex, uniloculare, oblongum, a latere compressum. O vulum unicum, basifixum, amphitropum. Stig ma lineare v. cristaeforme, juxta angulnm ovarii internum ab apice altra medium decurrens, demum inerassatum. A ehenium samaroideum, oblongum, maximum, a latere compressum, angulo interiore rectiore incrassato, apice cristaeformi recurvo, dorsali convexo in alam suberispatam magnam expanso, facielons supra basim utrinque alis duabus v. tribus brevissimis, rigidulis, inaequalibus appendiculatis. Semen erectum, oblongum, laeve, Kmbryonis exalbuminosi, curvati e otyledones foliaceae, convolutae, rad i enla infera. - Suffrutices $v_{2} a r-$ busculae humiles, in America tropica erescentes; foliis alternis, petiolatis, ovalibus v. elliplicis, penninerviis, integerrimis, peliolis basi utrinque stipulis in aculeos uncinato recurvatos mutalis stipatis, floribus racemosis, racemis alternis, in paniculas apleyllas, inter aculeorum par inserlas dispositis. 
S e zu i er ia Löffling It, 191. Linn, Gen, n. 676. Jussieu Gen. 440. Flor. Flum. V. t. 101.

5255. Petiveria PLUM. C a ly $\times$ quadripartitus, lacinilis linearibus, obtusis, aequalibus, fructiferis adpressis, herbaceis. Corolla nulla. Sta $\mathrm{m}$ in a disco carnosulo calycis fundum vestienti inserta, nunc 4 , ejusdem laciniis alterna, nune 8 , alterna et opposita, plerumque inaequilonga; filam enta filiformia, anthera biloculares, didymae, loculis basi et apice distinctis, longitudinaliter dehiscentibus. Ovarinm nnicum, uniloculare, rarissime dno, altero rudimentario, obovatum, a latere-compressiusculum, apice rotundato uncinulis quatuor adpressis auctum. $O$ v ulum unicum, basifixum, amphitropnm. Stỳlus juxta ovarii angulum interiorem decurrens; stigmate infra apicem penicillato-multipartito. $A \mathbf{c h}$ enin m lineari-cuneatum, a dorso compressum, facie ventrali stylo decurrente carinatum, apice emarginatum, sinu styli rudimento mucronatum, lobis utrinque in setas geminas, rigidissimas, adpresso-reflexas productis. Se m en erectum, linearicompressinsculum, t est a membranacea, endo carpio subadhaerenti. E m b r y o rectus, compressiusculus; cotyledonibus foliaceis, inaequilongis, breviore ovali-subrotundo, apice integerrimo, basi ad medium bifido, radicnlae tereti elongatae, inferne peltatim inserto, alterum longiorem, oblongum, basifixum, utrinque integerrimum, retrorsum convolutum, apice ultra medium in semetipsum replicatum involvente, a l bu$m$ ine ad embryonis latera congesto, in stratum tenne inter cotyledonis longioris apicem replicatum producto. - Herbae Americae tropicae, suffruticosae, erectae, elongato-ramosae, odore allia ceo; foliis alternis, petiolatis, ellipticis v. lanceolatis, pellucide punctatis, integerrimis, basi utrinque stipulis herbaceis, subulatis stipatis, floribus in spicas elongatas, solitarias v. geminas, laterales, oppositifolias, aphyllas dispositis, remotis, parvulis.

Petiveria Plumier Gen. 93. t. 219. Linn. Gen. n. 659. Act. Holm, 1744. $t$, 7. Trew. Ehret. $t, 67$. Gätner $I$. 363. $t, 75$.

TIRITBUS IE. RIVINEAE. Embry 0$\mathrm{n}$ is annularis albumen farinaceum cingentis cotyledon exterior major, interiorem minorem involutam amplectens.

5256. Molnama MARTIUS, Ca ly x quadrifidus, laciniis inaequalibus, antica ovata fere ad basim distineta, tribus in nnam inaequaliter trilobam, lobo medio majore cohaerentibus, fructiferis erectis, herbaceis. Corolla nulla. Stamin a 4, hypogyna, calycis laciniis alterna; filamenta filiformia, brevia, antherae biloculares, longitudinaliter dehiscentes. Ov a ri u m simplex, nniloculare, ovato-globosum, a latere compressiusculum. Ovul am unieum, basifixum, amphitropum. Stylns brevissimus, crassus, subla teralis; s tig ma truncato-snbcapitatum. A cheninm lenticulare, crustaceum, styli rudimento apiculatum. S e men achenio conforme, verticale, testa memhranacea, endocarpio adhaerente. E mbryo annularis, albumen farinaceum cingens; cotyledonibus membranaceis, altera exteriore majore, interiorem minorem involutam amplectente, radicula conica, infera. - Herba brasi liensis; caulibus ramosis, angulatis, foliis alternis, petiolatis, integerrimis $v$. obsolete crenatis, sti pulis ad basim petiolorum geminis, ovato-subulatis, racemis oppositifolio-terminalibus, simplicibus, pedicellis basi bracteatis, apice minutissime bibracteolatis.

Mo h la n a Martius Nov, Gen. et sp. III, 170, t. 290. Hille ria Flor. Flumin. I. t. 122. Rivinae $\mathbf{s}$. Rulz et Pavon Flor. Peruv, t. 102, f. a. Hooker Ic. $t .130$.

525\%. IRivina LINN. Ca ly x quadripartitus, laciniis herbaceis, aequalibus, fructiferis reftexis. Corolla nulla. S $t$ a $\mathrm{m}$ in a 4 v. 8 , imae calycis basi subhypogyne inserta, quatuor exteriora cum ejusdem laciniis alternantia; fil a me $n t a$ filiformi-subulata, a $n$th er a e biloculares, Iongitudinaliter dehiscentes. Ova ri um simplex, uniloculare. $O \nabla \mathbf{n}$ l u m unicum, basifixum, amphitropum. Stylus brevissimus, sublateralis; s tig ma simplex v. capitatum, B a e c a demum exsucca, subglobosa. Semen ereetum, ovoideum v́. subglobosum, testa crustacea, scabra. Em bryo annularis, albumen farinaceum cingens; cot y ledonibus membranaceis, altera exteriore majore interiorem minorem marginibus involutam amplectente, radicula infera. - Herbae $v$, suffrulices, in America tropica crescentes, erectae; foliis alternis, petiolatis, penninerviis, integerrimis, stipulis minimis, deciduis, spicis v. racemis terminalibus, demum alaribus $v$. lateralibus, oppositifoliis, floribus pedicellatis.

Rivina Plumier Gen. t. 39. Linh, Gen, n, 164. Jacq, Observ, $I, t, 2$, Gärtuer $I, 375, t$. 77. Lam, $t, 81$. Sehrader Non, Gen. t. B. Kunth in Humb, et Bonpl. Nov. Gen, et sp. II. 183. Solano ides Tournef.

SUBDITID II. PHYTOLACCEAE. E mbryonis annularis cotyledones planae v. plano-convexae, haud convolutae. - Stipulae nullae.

TRERES membranacea.

5859. Himean LINN. C a I y $x$ quinquepartitns, laciniis herbaceis v. semimembranaceis, intus coloratis, late ovatis. Cor olla e petala 5, imo calyci inter lacinias inserta, ovato-subrotunda, unguieulata, saepissime nulla. Stam in a plerumque 7 , rarius 6 v. 5 , rarissime 8 v. 10 , quinque exteriora calycis laciniis alterna, disci hypọgyni membranacei margini inserta; filame nta e basi lata subulata, margine laevia v. inferne barbato-fimbriata, a n h era e biloculares, versatiles, longitudinaliter dehiscentes. O v a ri u m subglobosum, carpidiis duobus hemisphaerieis, facie commissurali plana connatis biloculare, 0 v u 1 a in loculis solitaria, funieulo basilari oblique adscendenti et carpidii parieti dorsali semiadnato inserta, campylotropa. Styli 2, terminales, distineti v. basi connati, carpidiorum commissurae paralleli, (eorundem dorso contrarii), clavato-filiformes, intus stigmatosi. Fruetu s subglobosus, dicoecus v. abortu monococcus, cocci secedentes, indehiscentes, cartilaginei, hemisphaerici, margine saepe incrassato obtusi, dorso reticulatim v. echinatim scrobiculati, epicarpio faciei commissuralis inflato, loculum interiorem minorem, sterilem, apertum v. elausum mentiente. S e m e n unicum, verticale, cavitati conforme, reniforme, compressum, test a membranacea, tenui. Em b r y o anularis, albnmen farinacenm cingens; cotyledonibus linearibus, incumbentibus, radicula infera. Herbae annuae $v$, suffrutices, in Africa tropica et capensi indigeni, diffuse ramosi, procumben- 
tes, glabri v. glanduloso-viscidi; foliis alternis, carnosulis, planis, uninerviis, integerrimis, stipulis nullis, floribus in cymas terminales, alares $v$. laterales oppositifolias corymboso-conferlis $v$. glomerato-congestis.

L i m e u m Lian. Gen. n. 463. Gärtn. I. 367. t. 76. Fenzl in Annal. Wiener Mus. r. 34t, D i earpae a Presl Symb. I. 37. $t, 26$, Ga udiula Gay in Bullet. sc, nat. XVIII. 412. Li inseotia Adanson Fam. IT. 269.

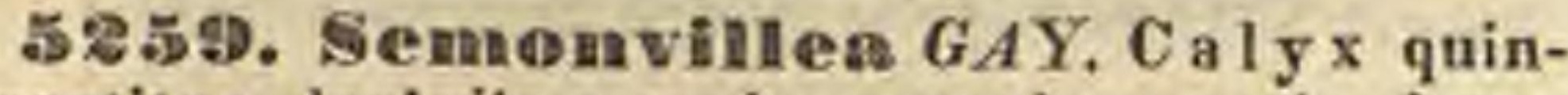
quepartitus, laciniis margine membranaceis, intus subcoloratis, ovalibus v. oblongis. Cor olla e petala 5, imo calyci inter lacinias inserta, subrotunda, unguiculata, saepissime nulla. Stamina 7 , hypogyna, quinque cum calycis laciniis alterna, duo iisdem opposita ; fil a m enta e basi lata, margine fimbriato-barbata subulata, an therae biloculares, versatiles, longitudinaliter dehiscentes. O varinm compressuin, carpidiis daobus lenticularibus, facie commissurali plana connatis biloculare. Ovula in loculis solitaria, placentae basilari brevi, carpidii parieti dorsali semiadnatae in. serta, campylotropa. Styli 2 , terminales, distincti, carpidiorum dorso paralleli (eorundem commissurae contrarii), filiformes, intus stigmatosi. Fruet us orbicularis, dicoccus, cocci secedentes, indehiscentes, crustacei, margine obtusi $v$. in alam ambientem producti, dorso convexi, rugoso-tubereulati, medio in cuspidem brevem horizontalem producti, facie commissurali plani v, coneaviusculi. S emen unicum, verticale, cavitati conforme, reniforme, plano-convexnm, testa membranacea, tenui. $\mathbf{E} \mathbf{m}$ b r yo annularis, albumen farinaceum cingens; cotyledonibus semiteretibus, incumbentibus, $\mathbf{r}$ ad icula infera. - Herbae annuae, in Africa tropica et capensi indigenae, subsimplices $v$. ramosae, erectae $v$, diffusue; foliis alternis, linearibus, carnosulis, integerrimis, stipulis nullis, floribus in racemis solitariis $v$. geminis cymosis, subsessilibus, remotis.

Semonvillea Gay in Bullet, sc. nat, XVIII. 412. Fenzl in Decad, Mut. Vindob, n. 48.

TEUIBUS 1\%. GIESEKIEAE. S e $\mathrm{m}$ in u $\mathrm{m}$ testa crustacea.

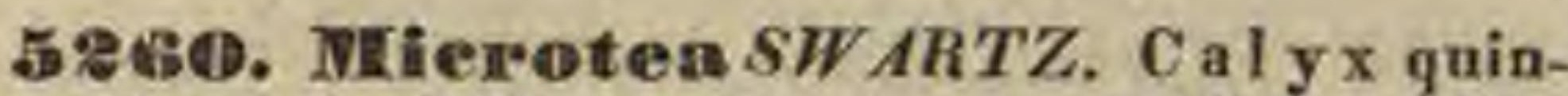
quepartitus, laciniis herbaceis, aequalibus. Corolla nulla. Stamina 5 v. 8 , imae calycis basi subhypogyne inserta, quinque exteriora ejnsdem laciniis alterna; filamenta filiformia, anthe$\mathbf{r}$ a e biloculares, longitudinaliter dehiscentes. $0 \mathrm{v}$ ari um simplex, oniloculare, ovulo unieo, basifixo, campylotropo. Styli 2_5, unilaterales, basi coaliti, penicilliformes. A $\mathrm{e}$ h en i m subglobosum, chartaceum, scrobiculato-echinatum v. glochida tum. S emen erectum, uncinatum, testa crustacea. Embryo semiannularis, albumen farinaceum eingens; cotyled onibus incumbentibus, radicula infera. - Herbae Americae tropicae, annuae, debiles, ramosae; foliis alternis, petiolatis, integerrimis, stipulis nullis, racemis oppositifoliis, elongatis, floribus minutissimis, pedicellatis.

Microtea Swartz Flor. Ind, occid, I. 543 . S c b o lle ra Swartz in Aot. soc, h, $n$. Havn. H. 210. A n c is tra. carpus Kunth in Humb. et Bonpl. Nov. gen. et sp. II. 186. $t$. 129. A p han a $n$ the Link. Enum. 1, 383.

52B1. Cỉesekia LINN. C a l y x quinquepartitus, laciniis margine membranaceis, ovaIibus, obtusis. Coroll a nulla. Stamina 5_15, solitarie v. geminatim ant ternatim imo calyci inter ejusdem lacinias subhypogyne inserta; filamenta e basi late ovata subulata, antherae biloculares, versatiles, longitudinaliter dehiscentes. Ova rii carpidia 5, abortu 3 v. 4, supra torum papillaeformem sessilia, verticillata, adpressa, Iibera, unilocularia, ovulo unico, basifixo, campylotropo. Styli breves, carpidiorum angulo centrali adnati, apice libero recurvi, intus stigmatosi, demum uncinati. Utriculi $3_{-} 5$, liberi, verrucosi v, cristato - murieati. S e men erectum, ovatum, testa crustacea, nitida, fragili. $\mathbf{E} \mathbf{m b r y} \mathbf{0}$ semiannularis, albumen farinaceum cingens; $\mathbf{c o -}$ tyledonibus linearibus, incumbentibus, $\mathbf{r}$ a dicula infera. - Herbae in Asia et Africa tropica et subtropica crescentes, annuae, prostratae, dichotome ramosae; foliis alternis $v$. suboppositis, linearibus, oblongis $v$. subspathulatis, integerrimis, carnosulis, subtus glandulis subcutaneis dense verruculosis, stipulis nullis, floribus minutis, virescentibus, demum saepissime purpurascentibus, in cymulis oppositifoliis umbellatim v. glomeratocongestis.

Giese kia Linne Mant, II. App. 183, Lam. $t$. 221. Roxburgh Plant. Corom. t. 183. Ko elreutera Marray Nov. Comment. Götting. III, t, 2. $f, 1, \mathrm{M} 11 \mathrm{t}$ u s Lour eiro Flor, cochinch, I. 369.

5262. IPlaytollacea TOURNEF. F lores hermaphroditi $\mathbf{v}$. rarissime diviei. Calyx quinquepartitus, laciniis rotundatis, herbaceis $v$, margine membranaceis, saepe petaloideis. Corolla nulla. Stam ina 7_30, interdum 5 v. 6 , disco carnosulo subhypogyne inserta, extima cum calycis laciniis alternantia, reliqua in phalanges $\mathbf{v}$. inordinatim congesta; filamenta subulata, antherae biloculares, incumbentes, Ingitudinaliter dehiscentes. Ovarii carpidia $5 \ldots 10$, rarissime 12 , toro convexiusculo insidentia, unilocularia, ima basi vel juxta totam longitudinem connata, ovulo unico, basifixo, campylotropo. Styli carpidiorum angulo centrali continni, discreti, apice recurvo stigmat $6 s i$. F ru et u 8 earpidia indehiscentia, discreta, exsucca, v. carnosa, in baccam globoso-depressam, plurilocularem, longitudinaliter sulcatam connata. Semina in loculis solitaria, subglobosa v. reniformia, testa crustacea, fragili, nitida. E m bry o annularis, albumen farinaceum copiosum eingens; cotyled onibus linearibus, planis, incumbentibus, radicula infera. - Herbae amphigeae, tropicae et subtropicat, saepe elatae, erectae v. rarius volubiles; radice fusiformi v, napiformi, crassa, nonnullarum vehementer drastica, foliis al ternis, petiolatis, penninerviis, integerrimis, stipulis nullis, floribus spicatis $v$. racemosis, racemis $v$. spicis subterminalibus, ramuli axillaris ipcremento demum oppositifoliis, aphyllis, primum erectis, tandem cernuis, pedicellis bibracteolatis.

P h y tola ce a Tournef. Inst. 154. Linn. Gen, n, 800. Gärtuer $I$. 137. Kunth in Humb. et Bonpl. Nov, gen. et sp. 11. 182. Póppig et Endlicher Nov. gen, et sp. I, 26.

a. KERMESIA. Carpidia sueculenta, in baceam plurilo. cularem, врісе depressam, longitudinaliter suleatam coa. lita. - Dillen. Hort, Elth. t, 339. f. 308, 309. Miller Ic. $t, 207$. Heritier Stirp. $t$. 70. Schkuhr t, 126. Gärtuer t. 87.)

b. PIRCunia, Carpidia carnosula, demum exsueca, omnino distineta. - Pircun ía Bertero msc. A a iso$m$ e $r$ a Don in Edinb, new philosoph. Journ. XrII. 238. (Heritier Stirp, $t$. 69. Hoffmann in Comment, Götting. XII. t. 2. 3. Pöppig et Endlich. Op. cit. $t .43$. -45.)

5265. Wreilia ADR. JUSS. Flores hermaphroditi. Caly $x$ quinquepartitus, laciniis mem- 
branaceis, obovatis. Corolla nulla. Stamina 8_ 10, carpophoro hypogyne inserta, extima quinque calycis laciniis alterna; fil am e n t a subulata, anth erae biloculares, incumbentes, longitudinaliter debiscentes. Ova ri i carpidia 7 v. 8, aborta interdum panciora, carpophoro distincto stipitiformi insidentia, libera, unilocularia, ovulo unico, basifixo, campylotropo. Styli carpidiorum angulo centrali continui, filiformes, apice recurvi, intus stigmatosi. Fru et a s carpidia discreta, baccata, demum exsncea, indehiscentia. Semina solitaria, erecta, reniformia, testa crustacea. E mb ry o annularis, albumen farinaceum cingens; cotyledonibus linearibus, planis, incumben. tibus, radicula infera. - Herbaperuana, suffruticosa, volubilis; folits alternis, petiolatis, integerrimis, stipulis nullis, spicis axillaribus, floribus tribracteolatis.

Ercllia Adr. Jussieu in Annal. sc, nat. $X X V, 11, t, 3$. f. 1. Don in Edinb, new philosoph. Journ. XIIT. 237. B ridges i a Hooker et Aruott in Bot. Miscell, III, 168, t. 102. Suriaua volubilis Doubey mse.

\section{* GYROSTEMONEAE.}

5264. Gyrostenan on DESONT. F lores dioici. Calyx sex-septemlobus, lobis ovatis, obtusis. Corolla nulla. Masc. Sta mina plurima, concentrice multiseriata, a $\mathrm{n} t \mathrm{~h}$ er a e sessiles, erectae, cuneato-trigonae, apice obtuso incrassatae, biloculares, loculis appositis, connatis, latere longitudinaliter dehiscentilus. F e m. C a r p id ia plurima, cirea colnmnam centralem crassam, apice vix dilatatam in ovarium multiloeulare connata. Ovula in loculis solitaria, columnae centralis medio inserta, adscendentia, eampylotropa. St yli carpidiorum angulo centrali continui, breves, recurvi, intus stigmatosi, liberi, cirea columnae apicem depressum, saepissime proliferam radiati. Fructus obovatus, vertice depressiusculus, polycoccus, coceis monospermis, membranaceis, compressis, secedentibus, dorso inerassatis, profunde sulcatis, anguli centralis rectiusculi medio dehiscentibus. Semen uncinato-conduplicatum, testa membranacea, transversim rugosa, umbilico strophiolato. E mbryo homotrope arcuatus, albumen farinaceum cingens; cotyledonibus linearibus, incumbentibus, radicula tereti, infera. Fruticuli Novae-Hollandiae austro-occidentalis ramosissimi; foliis allernis, lineari semiteretibus, mucronatis, floribus in axillis foliorum solitariis, pedunculatis.

\section{Gyrastemon Desfont, in Mem, Mus. DY, 16, $t, 6$.}

52Gs. Cod ondearpus $A$. CUNNINGH. Flor es dioici. Masc. $\cdots$ F em. Caly x cyathifor$\mathrm{mis}$, sinuato quinque-sexdentatus, $\mathrm{O}$ va $\mathbf{r i u m} \ldots$. Fruetus campanulatus, polycoceus, coceis monospermis, membranaceis, compressis, a columna centrali, apice dilatato depresso concentrice stigmatosa secedentibus, durso incrassatis, transversim costatis, anguli centralis apice lunulatim exciso dehiscentibus, plurimis sterilibus. Semin a uncinatim conduplicata, colnmnae centralis apiei, carpidiorum contiguorum alternatim altius et demissius inserta, testa membranacea, transversim rugosa, nmbilico strophiolato. Embryo homotrope arcuatus, albumen farinaceum cingens; cotyledonibus linearibus, incumbentibus, $r$ adie ula tereti, infera. - Arbores v. arbusculae, in Nova-Hollandia orientali et occidentali indigenae; foliis alternis, obovatis $v$. ellipticis, in petiolum angustatis, penninerviis, integerrimis, sti pulis nullis, pedunculis axillaribus solitariis, unifloris, racemos terminales foliosos formantibus.

Codonocarpus A. Cunainglian mse, ex Hook. Bot. Miscell. $I$. 244. Gyrosteman is s p. Desfoat. in Mem. Mas, VIII. $t$, 10, Hooker Bot, Miscell. t. 53 .

\section{Classis L. Colameniferae.}

Arbores v. frutices, rarius herbae, succo aqueo v. mucilaginoso, pube saepissime stellata. Folia alterna, plerumque simplicia, penninervia v. palmatinervia, integra, pinnatifida v. palmatiloba, rarissime palmatim composita. Stipulae ad basin petiulorum liberae. $\mathbf{C}$ a ly $\mathbf{x}$ liber, aestivatione valvatus. $\mathbf{C}_{0-}$ rolla e petala hypogyna, calycis foliolis numero aequalia, aestivatione convolutiva, saepe nulla. Stam ina indefinita, saepissime monadelpha, v. definita, sterilia saepius calycis lobis opposita. Carpidia uni-multiovulata, libera v. cum axi centrali in ovarium pluriloculare connata. Ovula axi inserta, amphitropa v. anatropa. Fructus capsularis, rarius baccatus v. nucamentaceus. E $\mathrm{mb}$ ry o albumine parco mucilaginoso $\mathrm{v}$. carnoso solido inclusus, rarius exalbuminosus. Cotyledones foliaceae v. carnosae, saepissime corrugatae v. complicatae.

\section{Dralo CCIX. Mrabucene.}

MALVACEAE Jussien Gen, 271, part. R. Brown in Tuckey Congo 498. Kunth Malvas. 1. Bartling Ord. nat. 344. excl. sect. 2. Lindley Introduct. edit, II. p. 59.

Нвrbae, suffrutices v. Fretices, rarius Arbores, pube saepissime stellata, caule ramisque teretibus. Folia alterna, petiolata v. rarissime subsessilia, simplicia, plerumque palmatinervia, integra v. palmatiloba aut partita, saepissime crenata v. dentata. Stipulae laterales geminae, persistentes v. deciduae.

Foores hermaphroditi, regulares, in pedunculis axillaribus, solitariis v. rarius congestis, continuis v. articulatis, interdum foliorum floralium abortu, v. ramorum evolutione succedanea racemosi, paniculati v. corymbosi.

CALyx saepissime bracteolis verticillatim approximatis, distinctis v. plus minus coalitis involucellatus, rarius ebracteolatus nudus, pentaphyllus v. foliolis longius breviusve connatis quinquefidus v. partitus, rarissime triquadrifidus, foliolis v. laciniis aestivatione valvatis, persistens $v$, interdum deciduus.

Corolda petala quinque, lypogyna, calycis foliolis alterna, unguiculata, unguibus saepissime basi inter se et cum imo tubo stamineo coalita, lamina saepissime inaequilatera, integra v. emarginata, aestivatione convolutiva, decidua. 
Stтамих in tubum cylindricum v. filiformem, basi saepe latiore ovaria tegentem coalita, apice v. infra apicem nudum, truncatum v, quinquedentatum in filamenta plurima, monantherifera solutum, coalita. Filamenta inter se distineta, rarius subfasciculatim cohaerentia. A $n$th e rae terminales, reniformes, sinu insertae, versatiles, simplices, receptaculo pollinifero unico, rima semicirculari in valvas duas dehiscentes, saepissime demum explanatae. Pollinis granula globosa, hispida.

Ovariom sessile, e carpidiis quinque v. pluribus, rarius tribus v. quatuor compositum, nunc circa axim centralem styliferam, plus minus evolutam, interdum apice expansam, quandoque tenue columniformem verticillata, marginibus introflexis clausa, libera v. inter se coalita, nunc rarius supra axim pluribus seriebus congesta. Ovula intra carpidia solitaria v. plurima, eorundem angulo centrali inserta, pendula, adscendentia v. horizontalia, amphitropa v. semianatropa. Styli in axi terminales, carpidiorum numero, inferne coaliti, superne distincti. Stigmata simplicia v. capitata, rarius coalita.

Fruetus nunc carpidiis distinctis v. plus minus ad margines introflexos coalitis pentapolycoccus, coceis liberis v. e septicida dehiscentia provenientibus, demum angulo centrali apertis, saepe simul dorso fissis, mono-oligospermis, nunc carpidiorum marginibus penitus connatis capsularis, quinque-plurilocularis, rarissime trilocularis, loculicide dehiscens, valvis medio septiferis, rarius indehiscens, siccus v. interdnm baccatus, loculis nt plurimum polyspermis.

Srmrva solitaria v. plurima, angulo centrali loculorum inserta, suspensa, adscendentia v. horizontalia, plus miuus reniformia, medio sinu v. prope extremitatem inferiorem inserta, rhaphe a puncto insertionis ad seminis extremitatem superiorem producta v. infra illam desinente, interdum nulla. T esta crustacea, aspera v. rarius laevis, interdum pilis v. lana copiosa vestita, quandoque subpulposa. Albume n parcissimum, mucilaginosum v. subcarnosum.

Enвrxo intra albumen semini homotrope arcuatus. Cotyledones foliaceae, saepissime cordatae, sese plicato involventes. $\mathrm{R}$ adicula rectiuscula, umbilicum spectans.

Malvaceae in regionibus tropicis utriusque orbis ingenti copia nascuntur, versus polos sensim numero imminuuntur, e zona frigida omnino exules, in universum trans Capricornum quam cis Cancrum rariores.

Omnes mucilagine copiosa, varii in medicina usus, scatent, paucissimae subacidae. Lana gossypina, nonnullarum semina tegens, maximi in generis humani oeconomia momenti.

Bombacearum genera nonnulla arctius ad Malvaceas accedentia, facillime foliis compositis, et lana fructus ex endocarpio, nece seminum epidermide nata, distinguuntur.

THERES I. MALOPEAE. Calyx involucello cinctus v. rarius nudus. C a r pidia plurima, unilocularia, monosperma, in capitulum congesta.

5\%66. Palava CAVAN. Involucellum nullum. Cal y x quinquefidus, laciniis aestivatione valvatig, Corollae petala 5, hypogyna, obovatoinaequifatera, unguibus imo tubo stamineo adnata, aestivatione convolutiva. Tubus stamineus basi dilatata, fornicata ovaria obtegens, superne angustatus, columnaeformis, apice in filamenta plurima filiformia divisus, a ntherae reniformes, bivalves. Ovari a plurima, unilocularia, supra receptaculum conicum capitato-eongesta. O v u I n m unicum, suturae ventrali insertum, adscendens. St y I ns in receptaculo terminalis, apice multifidus; $s t i g m$ at a capitellata. Carpidi a plurima, congesta, indehiscentia, monusperma, calyce inclusa. Semen ..... - Herbae peruanae, glabriusculae $v$, tomentosae; folits alternis, petiolalis, ovatis, sublobato sinuatis, stipulis lateralibus geminis, pedunculis axillaribus, solitariis, unifloris, supra medium articulatis, floribus parvis, purpureis.

P a la va Cavanill. Dissert. I. 40, $t, 11, f$. 4. 5. Lam. t. 577. Palavia Möneh Mothod. 609. DC, Prodr. I. 458. Bot. Mag. t, 3100. Meisner Gen, 26. (22.) Malo pe par$v$ iflor a Heritier Stirp. $t .50$.

5ะดร. Vhalope $L I N N$. Involucelli triphylli foliola cordata. Cal y x quinquefidns, laciniis aestivatione valvatis. Corolla e petala 5 , hypogyna, obovato-oblonga, subtruncata, nnguibus imo tubo stamineo adnata, aestivatione convolutiva. T a b a s stamineus basi fornicata, dilatata ovaria obtegens, superne fil a m e n t a pluriima filiformia exserens, an $t$ herae reniformes, bivalves. Ovaria plurima, unilocnlaria, snpra receptaculum subglobusum capitato-congesta. $\mathrm{O}$ va$1 \mathrm{um}$ unieum, suturae ventrali insertum, adscendens. Stylus in receptaculo terminalis, apice multifidns; stigmata minutissime capitellata. Carpidia plurima, congesta, indehiscentia, monosperma, calyce inclusa. Semen ..... Herbae mediterraneae, annuae; foliis alternis, petiolatis, ovatis, integris $v$. trifidis, stipulis lateralibus geminis, pedunculis axillaribus solitariis, unifloris, petiolo longioribus, floribus purpurascentibus v. albis.

Mal ope Linn. Gen, n, 843, Lam, t. 883. Cav. Diss, IT. t. 27. f. 1. 2. DC. Prodr. I. 429. Meisuer Gen, 26. (22.)

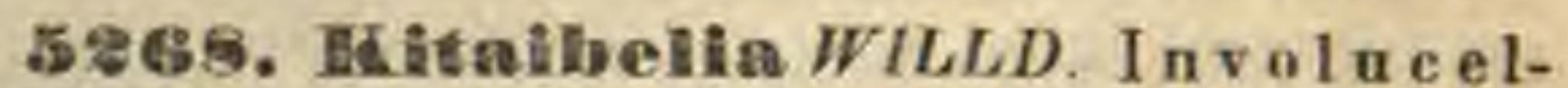
I n m laxum, sex-novemfidum, calycem superans. Cal y $x$ quinquedentatus, dentibus aestivatione valvatis. Corolla e petala 5 , hypogyna, obovata, unguibus imo tubo stamineo adnata, aestivatione convolutiva. Tubus stamineus basi dilatata ovaria obtegens, superne columnaeformis, filame ta plurima filiformia exserens, antherae reniformes, bivalves. Ovaria plurima, uniloenlaria, supra receptacnlum subglobosum congesta. O vnIn unicum, suturae ventrali insertum, adscendens. St y 1 u 8 in receptaculo terminalis, apice 
multifidus; stigmata obtusa. Carpidia plurima, reniformia, in eapitulum quinquelobum congesta, indehiscentia, monosperma. S e m e n .... -. Herba perennis, orgyalis, ramosissima, juxta $\bar{D}$ a nubium a $\mathrm{i}$ stralem crescens; foliis alternis, petiolatis, cordatis, tri-septemangulatis, lobis acuminatis, duplicato-serratis, stipulis lateralibus geminis, pedunculis axillaribus unifloris, solitariis $v$. pluribus, involucello calycem superante, corollam albam $v$. pallide roseam aequante.

Ki taibeli a Willdenow in Berlin. Neu. Schrift. II. 107, t. 4. f. 4. Waldst. et Kitaibel Plant, rar. Hung. I. 29. t. 3. DC. Prodr. I. 436. Meisner Gen. 26. (29.)

THEIISUS HI. MALVEAE. Cal y $x$ involucello cinctus. C a rpida quinque v. plurima verticillata, libera $v$. in capsulam polycoccam coalita.

5289. Iavatera LINN. Involuce $11 \mathrm{u} \mathrm{m}$ tri-sexfidum, persistens v. decidunm. Cal y x quinquefidus, laciniis aestivatione valvatis. Coro il a e petala 5, hypogyna, ovata, unguibus imo tubo stamineo adnata, aestivatione convolutiva. T u b u s stamineus basi dilatata ovaria obtegens, superne angustatus, columnaeformis; fil am en ta plurima, filiformia, a ntherae reniformes, bivalves. O varia plurima, unilocularia, ad basim receptaculi conici v. superne in discum orbicnlarem expansi verticillata. Ovula in locnlis solitaria, adscen dentia. Stylus reeptaculo continuue; $8 \mathrm{tig-}$ mata plurima, filiformia. Carpidia plurima, reniformia, receptaculi in conum producti $v$. in discum depressum expansi basim cingentia, indehiscentia, monosperma. S e $\mathrm{m}$ i na reniformia, testa crustacea, sinu umbilicata. E m b'ryo intra albumen parcum, mucilaginosum homotrope areua tus; cotyledonibus foliaceis, sese plicato involventibus, radic ula infera. - Herbae, frutices v, arbores, in Europa media et regione mediterranea, imprimis occidentali crescentes; foliis alternis, petiolatis, tri-septemlobis $v$, angulatis, stipulis petiolaribus geminis, floribus axil laribus, solitariis $v$. in racemos aut corymbos termina. les dispositis.

L a vatera Linn. Gen, n, 842. DC. Prodr. I. 438, Meísuer Gen, 26. (22.)

a. AXOLOPHA DC. 2. c. R e cep f c u lum truncatam, radiato cristatum. - Gouan. Illustr. $t$. 11, f. \&. Cav. Diss. It. t. 31. f. 1. t, 32. f. 3. Bot. Mag. t, 2226.)

b. OLBIA DC. l, c. Re ceptacula m couicum, ultra car. pidia produetum. - 01 bi a Medik. Malv. 41. Jacq. Flor. Allant, $t, 17 \overline{1}$. 172. Gairtn. $t .136).-\mathrm{S}$ a vin i o i a Webb et Berthel. Flor, Canar. 30.t. 13, L. ace. rifolia Cav. - Navae a Webb et Berthel. Op. cit. 32. t. 1. C. L. pho enicea Vent. Malm. t. 120.)

c. STEGIA DC. 1. c. Recepta eulum eolumnare, in discum latum, depressum, ovaria obtegentem expansum. - St egi a Mōnch Method. 609. (Jacq. Hort. Vindob. t.72. Cav, Diss. II. t. 31. f, 1. Gärta. $t, 136$.

52 ร0. Althaea $C A V$. Involucellum sex-novemfidmm. Cal yx quinquefidus, laciniis aestivatione valvatis. Corollae petala 5, hypo gyna, obovata, emarginata, unguibus imo tubo stamineo adnata, aestivatione convolutiva. T n b a 8 stamineus basi dilatata ovaria obtegens, superne angustatus, colomnaeformis, fil am enta pluri. ma filiformia exserens, antherae reniformes, bivalves, Ovaria plurima, nnilocularia, circa receptaculam centrale columeliaeforme verticillata. Ovulu m unicam, suturae ventrali insertum, adscendens. $\mathrm{St}$ I $\mathrm{I} s$ in receptaculo terminalis; $8 \mathrm{ti} \mathrm{g}$ mat a plurima, setacea. Carpidia plurima, re- niformia, circa axim brevem in orbem depressum verticillata, indehiscentia, monosperma. S e mina reniformia, testa crustacea, sinu umbilicata. Embryo intra albumen parcissimum mucilaginosum homotrope arcuatus; cot y led o nibus foliaceis, sese plicato - involventibus, radicula infera, Herbae annuae v, perennes, tomentosae, in temperatis hemisphaerae borealis, nec non in Asia calidiore indigenae, foliis alternis, petiolatis, lobatis v. partitis, stipulis floralibus geminis, pedunculis axillaribus solitariis, $v$, in racemum aut corymbum terminalem dispositis.

A Ithaea Cavauill. Diss. IT. 21. DC. Prodr. I. 436. Meisner Gen. 26. (28.)

a. AlThAEASTRUM $D C$. C a r pidi a immarginata. - Involucellum saepius octo-novemfidum. - A I that a Linn. Gen, n. 839. Lam. t. 581. Gärtn. $t$, 136. Cav. Diss. II. t. 29. f. 1. 2. t. 30. f. 1-3. Ic. t. 420 . Forb e r i a Scopoli Introduct. n, 1274.

b. ALCAEA DC, l. c. Carpidia márgine membranaceo suleato circuadata. - Involucellum sex-septemfidum. Alce a Linn. Gen, n. 840. Lan. t. S81. Cav, Diss, $\overline{I T}$. t. 27. f. 3. t. 28. f. 2, t. 29. $f$. 3. Waldst, et Kitaibel Plant, rar, Hung, $t$, 47. Bot. Mag. $\iota, 892,1916$. (Gärtu. t. 136.)

52ช1. MIñva LINN. Involucellum bractea bistipulata, basi calyci adnata v, rarius pedunculo inserta. $\mathbf{C}$ a I $\mathbf{y} \mathbf{x}$ quinquefidus, laciníis aestivatione valratis. Corolla e petala 5, hypogyna, obovata, saepius inaequilatere emarginata, unguibus imo tubo stamineo adnata, aestivatione convolutiva. T u b a stamineus brevis, columnaeformis, apice in fil amenta plurima filiformia divisus, a ntherae reniformes, bivalves. Ovarium sessile, multiloculare. Ovula in toculis solitaria, adscendentia. Styli loculorum numero, filiformes, axi centrali inserti, basi coaliti; stigmata obtusa. Capsula depressa, polycocea, coccis monospermis, ab axi centrali vix dilatata solubilibus, apice interdum bicuspidatis, nune dorso v. angulo centrali bivalvibus, nunc indehiscentibus. Semen reniforme, testa crustacea, emarginaturae sinu nmbilicata. Embryo intra albumen parcissimum, mucilaginosum homotrope arcuatus; cotyled on ibus foliaceis, sese plicato involventibns, ra dicula infera. - Herbae, suffrutices $v$. frutices, rarius arbusculae, per totum or be $m$ dispersae, in regione mediterranea et $C a p i t e$ bo nae $S$ pei frequentius tamen crescentes; foliis alternis, petiolatis, integris $v$. saepius angulatis, plus minus lobatis, rarissime digitato-partitis, stipulis petiolaribus geminis, floribus axillaribus, nunc in apice ramulorum subsessilibus; et foliis bracteaeformibus stipatis, nunc racemosis, spicatis v. glomeratis, corollis coloris omnis.

M a I v a Linn. Gon. n.841. Lam, $t$, s92. Gärtner $I T .245$. t. 136. Heritier Stirp, $t, 27$. Jacq. Hort, Schönbr, $t .139$. 294. Hort. Vindob, $t$, 35. 141, 156. Ic. rar. t. 139. Cav. Diss. II. et $V$. ic. Bot. Mag. t. 1998, 2179. 2298, 3698, Bot. Reg. t. 1306. Adr. Jussien in St, Hilaire Flor. Brasil. I. 213. Torrey et $\Lambda$. Gray Flora of North.Amer. I. 225, M a lva e seet. Malvastrum DC. Prodr. $I$. 430. Nuttallia Dieks. et Barton Flor. Bor. Amer, IT, 74. t. 62. Hooker Exot. Elor, t. 171. 172. Bot. Mag. t. 2612, 3287. Bot. Reg. t. 1938. Lavaterate sect. 1V. DC. Prodr. J. 439. C a 1Iir th o e Nuttall in Journ. Academ. philadelph. II. 181. An the un Medik. Malv. 42.

ธะจุร. Splhaeralcea $S T$. HIL. InvoIuc ellum triphyllum. Cal y x quinquefidus, laciniis aestivatione valvatis. Corullae petala 5 , hypogyna, obovata, inaequilatere emarginata, ungribus imo tubo stamineo adnata, aestivatione convolutiva. Tabus stamineus brevis, columnae- 
formis, apice in filamenta plurima, filiformia divisus, a ntherae reniformes, sinn insertae, versatiles, rima semicirculari apertae, bivalves, septo manifesto. Ovarium sessile, multiloculare, Ovula in loculis 3 , angulo centrali inserta, superius adscendens, inferiora pendula. Styli loculorum numero, filiformes, basi plus minus coaliti; stigmat a capitellata. Capsula globosa, umbilicata, multilocularis, polycocea, coccis tri - v. abortu monospermis, dorso primum locnlicide fissis, tandem secedentibus. Sem in a reniformia, testa crustacea, emarginaturae. sinu umbilicata. E mbryo ..... - Arbores, frutices $v$. suffrutices, in America tropica et boreali calidiore crescentes; foliis alternis, petiolatis, dentatis $v$. saepius tri-quinquelobis, stipulis petiolaribus geminis, pedunculis ad ramorum apicem axillaribus, interdum geminatis, unifloris $v$. umbellatim aut racemose bi-paucifloris, corollis violaceis, rubescentibus $v$ : carneis.

Sph a e ralicea St. Hilaire et Adr. Jussieu Plant, us. Brasil. t. 82. Flor. Brasil. t. 209. P h y mosi a Desvaux in Hamilt. Prodr. Flor. Ind. occid, 43. M a I va e seet. $\mathrm{Sp}$ ba eroma DC. Prodr. I. 435. M a I vae s p. Jacq. Hort. Schōnbr, t. 293, Cav, Diss, II, t. 16. f. 1. t. 20. f. 1. Ic t. 95. Bot. Mag. t. 2534. 2787. 2893. - ? M elip h I e a Zuecarini Plant. Nov. fasc. IT. 389. $t, 9$.

ธะระ. ㄱำ lum triphyllum. Calyx quinquefidus, laciniis aestivatione valvatis. Corollae petala 5 , hypogyna, obovata, nnguibus imo tubo stamineo adnata, aestivatione convolntiva. T n b us stamineus brevis, conicus, apice in filamenta $10-20$ quinquefasciculata, filiformia divisus, a $n t h \mathrm{e}$ $\boldsymbol{r}$ a e reniformes, sinu insertae, versatiles, rima semicirculari apertae, bivalves, septo manifesto. Ovari um sessile, multiloculare. Ovula in loculis gemina, angulo centrali superposite inserta, appendice parietali transversa sejuncta. Styli loculorum numero, filiformes, basi plus minus coaliti; st igmat a capitellata. Cap s u l a depressa, multilocularis, polyeocea, coceis di - v. abortu monospermis, solubilibus, bienspidatis, apice et angulo interno dehiscentibus, bivalvibus, margine dorsali medio in appendicem septiformem transversam introflexis. S e $\mathrm{m} \mathrm{i} \mathrm{n}$ a compresso-reniformia, testa crustacea, emarginaturae sinu umbilicata. E m bryo intra albumen parcissimum, mueilaginosum semicirculariter complicatus; cotyledon ibus foliaceis, sese plicato involventibus. Herbae repentes $v$. humifusae, in Am erica $t$ ro pica australiore et boreali extratropica calidiore hucdum observatae; folis alternis, petiolatis, tri-novemlobis, serrato-incisis, stipulis petiolaribus geminis, pedunculis axillaribus, solitariis v. rarius geminis, unifloris, gracilibus, floribus violaceis $v$, rubris.

M od I o l a Mönch Method, 620. Adr. Jussien in St, Hilaire Flor. Brasil. I, 210, t. 43. H a y ne a Reichenb. Consp. 202. non alior. Malvae seet. Modiola DC. Prodr, $I$. 435. M a 1 va $\mathrm{s}$ p. Lian. Cav, Diss, II, $t, 16, f, 3$. Bot. Mag. $t, 2515$.

5284. Urema LINN. Involucellum calyciforme, quinquefidum. C a ly $x$ quinquefidus, lacinis cum involucelli lobis alternantibus, aestivatione valvatis. Corollae petala 5, hypogyna, oblique inaequilatera, unguibns imo tubo stamineo adnata, aestivatione convolutiva. Tubus stamineus brevis, columnaeformis, infra apicem truneatum, nudum antherifer, an $t$ he ra e pacae, reniformes, sinu filamentis brevissimis insertae, linea semicirculari dehiscentes, bivalves, septo manifesto. Ovariam sessile, quinquelobum, tuberculatum, quinqueloculare. $O \mathbf{v} \mathbf{n}$ a in loculis solitaria, e basi anguli centralis adscendentia. StyIus apice exserto decemfidus; $s t i g m a t a$ capitellata. Ca p s u la aculeis apice stellulatim glochidatis echinata, pentacocea, coccis monospermis, indehiscentibus. S em en trigono-reniforme, testa crustacea, emarginaturae sinu umbilicata. Emb ry o intra albumen parcissimum, mucilaginosnm homotrope arcuatus; cotyledonibus foliaceis, sese plicato - involventibus, radicula infera. Frutices inter tropicos totius orbis, imprimis Asiae crescentes; foliis alternis, petiolatis, integris $v$. saepius in eadem stirpe lobatis, subtus ad basim nervi medii, interdum etiam lateralium proximorum glandula sessili, longitrorsum rimosa notatis, stipulis petiolaribus geminis, floribus axillaribus solitariis, inferioribus nonnunquam ramuli axillaris floriferi abbreviatione glomerulum, superioribus fo. liorum floralium abortu racemum terminalem mentien. tibus, corollis luteis $v$. roseis.

U re a Lion. Gen, n. 84\%. Girtner $M$, 259, $t, 135$. Cav. Diss, VI. 2. 183_185. Colla Hort. Hipul, t.26, Schrank Hort. Monac, t, 79. DC. Prodr, I. 441. Adr. Jussien in St, Hilaire Plant, us. Brasil, t. 26. Flor. Brasil. 1.219, Wallich Plant. As. rar, $t .26$.

5285. Pavomia $C A V$. Involncellum penta - polyphyllum, foliolis distinctis v. connatis, uni -v. rarissime biseriatis. Ca Iy $\mathbf{x}$ quinquefidus, laciniis aestivatione valvatis. Corollae petala 5, hypogyna, plus minus inaequilatera, unguibus imo tubo stamineo adnata, patentia, erecta $v$, in tubum conniventia, aestivatione convolutiva. $T \mathbf{u}-$ bus stamineus colnmnaeformis, petalis brevior, subaequalis $v$. interdum longior, infra apicem nudum, quinquedentatum fi lam enta plus minus copiosa, filiformia exserens, antherae reniformes. O v a ri u m sessile, plus minus quinquelobum, quinqueloculare. Ovula in loculis solitaria, e basi anguli centralis adscendentia. Stylus apice exserto decemfidus; $s t i g m$ at a capitellata. Capsul a pentacocea, coceis monospermis, nunc angulatis, latere coalitis, nune obovatis, nonnisi ad axim cohaerentibus, muticis $\mathbf{v}$. apice tricuspidatis, solubilibus, bivatvibus $v$. indehiscentibus, siccis v. vissidis. S e m e n triguetro-reniforme, testa crustacea, emarginaturae sinu umbilieata, E mbryo intra albumen parcissimnm, mueilaginosum homotrope arcuatus; cotyledonibus foliaceis, sese plicato - involventihus, $r$ a di cula infera. - Frutices $v$, suffrutices, rarissime herbae, in $A$ merica rarissime in As ia tropica crescentes; foliis alternis, petiolatis, integris, dentatis, lobatis v. partitis, glabris $v$. scabris aut varie pubescentibus, interdum pellucido-punctatis, stipulis petiolaribus gemi. nis, pedunculis axillaribus, solitariis v. rarius pluribus, uni-v, rarissime bifloris, foliis supremis rudimentariis bracteaeformibus saepe in apice ramorum glomeratis, eorymbosis, racemosis $v$. paniculatis, corollis colore vario.

Pavon ia Cavanill. Diss. IIT. 132. Adr. Jussieu in St, Hilaire Flor, Brasil, I. 220, Meisner Gen, 26. (22.)

a. PAVOONIA Nees ot Mart, Involucelli foliola libera v. ima basi connata, calycem aequantia v. superantia. C orolla plana v, petalis in tabuen coavolatis. Co cei sicei, mutici ₹. apice aristati, bivalves.

Pa vonia Nees et Mart. in N. A. N. C. XI. D6. DC. Prodr. I. 442.

c. Ty pha lea DC. l. c. Coeci apice teiaristati, aris tis retrorsum hittis, Corolla plana. - Uacq. Fc. 
rar. t. 522. Cav. Diss. III. t, 45. f. 2. 3. t. 49. f. 1. VI. t. 197.)

B. Malache Trew. Coce i mutici. Cor oll a plana.Malache Trew Ehret, 50. Malache et Cancel. laria DC.'l.c. Hibisei sect. Pentaspermum spec. DC. Thornthonia Reichenb. Consp. 202. eoll. Hands. 287. Col u mell' a Commers, msc. (Jaeq. Ic. rar, t. 14t. Cav. Diss. IIT. t. 45. f. 1. 46. f. 1 . 2. $t, 47, f .1$. 2. $t$. 48. f. 3. t. 49, f. 2. Kunth in Humb. et Bonpl. Nov. gen, et sp. $t$. 477. St. Hilaire Flor, Brasil. t, 45-46.j

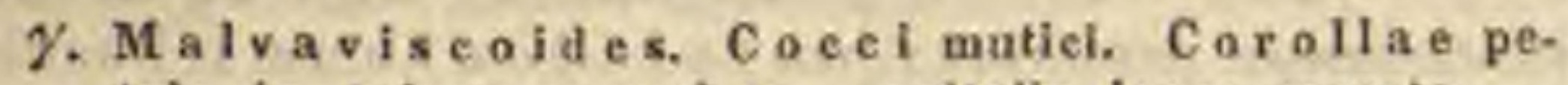
tala in tubum consoluta, genitalia longe exserta, Acbaniae sp. Nees et Mart. Malvavis ci seet. A note a DC. Prodr. I. 445. (St. Hilaire Flor. Brasil. $t$. 47.)

b. LOPimila Nees et Mart. Invol u celli foliola libera, setacea, calycem superantia. Corolla plana. Coc ci mueilagine viseida illiniti, indehiscentes. L o p im i a
Nees et Mart. Op. cic. Xr. 96. DC. Prodr. 1. 457. S i. da mal a cophylla Link et Otto Io. sel. 4. 30.

c. LEBRETONIA Schrank, Invol u cell u m quinquepartitum. Corolla e petala in tubum convoluta. Coeci sicci, muliei, indehiscentes. - Le bre to a ia Selirank Hort, Monas. $t$. 90, Nees et Mart. in $N, A . N, C, X I$. 98. DC. Prodr. I. 446. Wight et Arnott Prodr. I. 47. Wight Ic. . 4. (Bot. Mag. t. 3692.)

?. d. GOETHEA Nees et Mart. In volucellam inflsto ve. siearlum, calyce longius, quadri-sexpartitum. CorolI a e petala basi subconnata, erecta, apice libero contorta. C o c ci sicci, mutici, indehiscentes. G o eth e a Nees et Mart. in N. A. N. C. XI. 9t, t. 7. 8. DC. Prodr. 1. 501. S $\mathrm{chouwia}$ Schrader in Götting. gel. Anzeig. 1821. p. 717 .

TRIIEUS HII. HIBISCEAE. Calyx involucello cinctus. Carpidia tria v. quinque, rarissime decem, in capsulam loculicide dehiscentem v. rarius indehiscentem coalita.

5รร6. Kosteletzkya PRESL. I n voI uce $11 \mathrm{u} \mathrm{m}$ hepta-decaphyllum, persistens. Corolla e petala 5, hypogyna, obovata, unguibus imo tubo stamineo adnata, aestivatione convolutiva. Tubus stamineus columnaeformis, superne filamenta plura exserens, a ntherae reniformes, bivalves, Ovarium sesaile, simplex, quinquelo. culare. $O \mathbf{v u l a}$ in loculis solitaria, angulo centrali inserta, adscendentia. Styli 5 , filiformes, basi coaliti. C ap sula depresso-orbieulata, quinquelocularis, loculicide quinquevalvis, valvis medio septiferis, columella centrali persistente. Semina in loculis solitaria, adscendentia, subreniformia, testa erustacea, sinu umbilicata. Embryo ...... Herbae $v$. suffrutices, in America tropica et subtropica crescentes, saepius hispidi v, tomentoso-villosi; foliis alternis, petiolatis, hastatis, sagittatis $v$. cordato ovatis, stipulis lateralibus geminis, pedicellis axillaribus, solitariis, unifloris, infra apicem arliculatis.

Kosteletzk y a Presl in Reliq. Mänl. II, 130, t, 70. Meisner Gen. 27. (23.) Hibisci sect. Pentaspermum sp. DC. Prodr. I, 447. Cav. Diss. III. $t$. 80 .

52 ร. polyphyllum, foliolis simplicibus $\mathrm{v}$. bifureatis. $\mathrm{C}$ a1 y $x$ quinquefidus, persistens, foliolis aestivatione valvatis. Corolla petala 5 , hypogyna, obova to-inaequilatera, unguibus imo tubo stamineo adnata, aestivatione convolutiva. T $\mathbf{u}$ b $\mathbf{n}$ \& staminens columinaeformis, infra apicem nudum, truneatim v. quinquedentatum fil a menta plus minus copiosa exserens, a $n$ the rae reniformes, bivalves. O va ri um sessile, simplex, quinqueloculare. Ovula in loculis plurima v. pauca, angulo cen- trali inserta. Stylus terminalis, apice exserto quinquefidus; sigmat a capitellata, rarissime cohaerentia. Ca p s u la quinquelocularis, loculicide quinquevalvis, valvis medio septa margine seminifera gerentibus, columella centrali nulla. Sem in a plurima v, interdum abortu panca, adscendentia, reniformia, testa crustacea, nuda ant squamulosa v. interdam lanata. Embryo intra albumen parcissimnm, mueilaginosum homotrope arcuatus; cot y l ed onibus foliaceis, sese plicatoinvolventibus, radisu la infera. - Arbores, frutices $v$. herbae, in regionibus tropicis subtropicisque, parce in temperatis calidioribus crescentes; foliis alternis, petiolatis, integris $v$. lobatis, glabris, varie pubescentibus $v$, scabris', stipulis lateralibus geminis, floribus axillaribus, solitariis v. foliorum abortu terminalibus, paniculatis, corymbosis, racemosis $v$, rarius spicatis, stipulaceobracteatis, corollis amplis, petalis coloris varii, saepissime basi macula discolori distinctis.

H 3 b is e a s Linn. Gen, n, 846, exel. sp. Gîrtner II. 250. t. 134. Kunth in Humb. et Bonpl. Nov. gen, et sp. $V$. 288. DC. Prodr. I. 446, excl. seet. 2. 3. 10. et 11. Adr. Jussieu in St. Hilaire Flor. Brasil. I. 242, Meisner Gen. 27. (23.) Ke tm i a Tournef. Inst. 26.

a. FURCARIA DC, $\boldsymbol{l}$, c. Calyx nervis glandula lineari instructis. Semina glabra. Involucelli foliola sae. pissime bifurca. - (Cav. Diss. III. t. $51, f .1, t .53$, f. 1. t. 54. f. 2. Wallich Plant, As, rar, t. 4. St, Hilalre Flor. Brasil. t. 48. Bot. Mag. t. 1356.)

b. KETMIA. Caly $x$ eglandulosus, haud inflatus. S e mina glabra v. pabescentia, v. dorso líaea pilosa. In volu. celli foliola simplicia v. rarissime bifurca, distinetat v. basi connata.

c. Cremontia DC. $l$. c. Involucelli foliola distincta. Corolla convoluta. - Cremoutia Commers. msc. (Cav. Diss. IIT. t. 56, f. 2., t, 57, f. 1, 2, t. 66. f. 2. t. 67, f. 1. t. 68, f. 1. 2. Bot. Reg. t. 168. Bot. Mag, t. 3144. Wight Ic, t, $5,6$.

ק. Ketui a DC. l. e. Involueelli foliola distincta. Corolla patens, - (Cav. Diss. III. t, 59.f, 2, t,60. f. 2. t. 69. f. 1. 2. Bot. Mag. t, 83, 165.)

$\gamma \cdot \mathrm{Sabdariffa}$ DC. $l$ c. Involucelli foliola hasi connata. - (Cav. Diss. IIT, $t .70$, f. 2. $t, 198 . f .1$. Bonpl. Nav, $t$, 29. Bot. Reg. $t$, 608.)

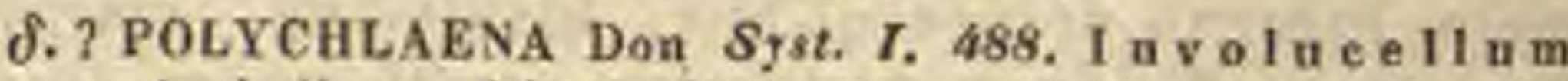
polyphylfum, foliolis linearibus, ciliatis, calyce longio. ribus. Capsula quiequelocularis, pilosa, loculis monospermis. Se mina angulata. - Herbae $g^{u} i$. neenses: annuae; folits serratis, lanceolatis $v$. ovatis, stipulis subulatis, floribus terminalibus, cymosis, albis.

c. TRIONUM DC. $l$. c. CaI y $\times$ eglandulosus, demum vesiculoso-inflatus, membranaceus. Se min a glabra. $1 \mathrm{n}$. valn c ell um polyphyllum. - T riou um Medik. Malv. 46. (Cav, Diss. III. t. 64. Bot. Mag. t. 209. Bot. Reg. $t$ 806. 875.)

d. BOMBICELLA DC. l. $c$. Ca 1 y $\mathrm{x}$ eglandulosus, haud in. flatus. Stamina lana gossypina involuta. Involuce $11 \mathrm{um}$ penta-decaphyllinm. (Cav. Diss. IIIT. t. 66.

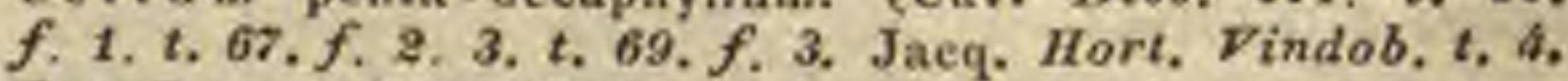
Bot. Reg. t. 230. 337.)

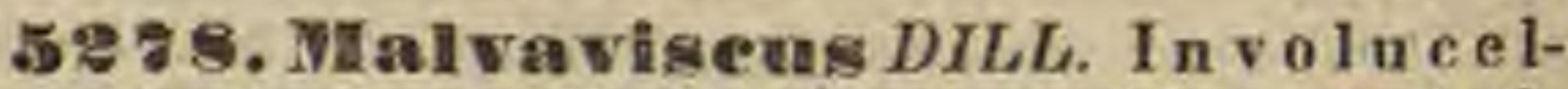
l $\mathbf{n}$ m polyphyllum. Cal y $\times$ quinquefidus, laciniis aestivatione valvatis. Corollae petala 5 , hyppgyna, dimidiato - inaequilatera, basi lobnlo aucta, unguibus imo tubo stamineo adnata, aestivatione et sub anthesi convolutiva. T $\mathbf{n}$ b u s stamineus filiformis, longe exsertus, tortus, infra apicem nudum, quinquedentatom fil a menta plurima, brevia exserens, antherae reniformes. Ovarium sessile, quinquelobum, quinqueloculare. Ovnla in loculis solitaria, e basi anguli centralis adscendentia. Ba c ca subglobosa, quinquesulcata, quin- 
quelocularis, Se min a in loculis solitaria, reniformia. $\mathbf{E} \mathbf{m}$ b r y 0 intra albumen parcissimum, mueilaginosum homotrope arcuatus; cotyledonibus foliaceis, sese plicato-invulventibus, radicula infera, - Frutices $v$, arbusculae $A$ merica $t$ ropicae; foliis alternis, petiolatis, integris $v$. obsolete lobatis, stipulis petiolaribus geminis, pedunculis unifloris, axillaribus v. terminalibus, solitariis, geminis $v$. ternis, corollis.sanguineis.

Ma I va vis cus Dillen. Elth, 210, t, 170, f. 208. Cava. nill. Diss, TII. 131. t. 48. f. 1. Kunth in Humb, et Bonpl. Nov. gen. et sp. V., 283. DC. Prodr. 1, 445. exel, sect. 2. Meisner Gen, 27. (23.) $\Lambda$ e han i a Swartz Flor. Ind. oc. cid. II. 1292. Bot. Reg. $t, 11$. Bot. Mag. $t .2305$.

ธะร๖. Tugesila JUSS. Involucell $\mathbf{m}$ hexa polyphyllum. Caly x quinquefidus, laciniis aestivatione valvatis. Corolla e petala 5 , hy pogyna, obovato-inaequilatera, unguibus imo tulon stamineo adnata, aestivatione convolutiva. Tubus stamineus colnmnaeformis, infra apicem nudum, quinquedentatum fila menta plus minus copiosa, brevia exserens, antherae reniformes, Ovari u m sessile, simplex, tri-quadriloculare. Ovula in loculis 4-8, angulo centrali inserta, adscendentia. Stylus terminalis, apice exserto breviter tri-quadrifidus $v$. indivisus; $8 \mathrm{tig} \mathbf{m}$ a $\mathrm{t}$ a distincta v. conglutinata. C a p s u a tri-quadrilocularis, loculicide tri-quadrivalvis, valvis medio septiferis. Se min a in loculis pauca $v$. abortu interdum subsolitaria, reniformia, testa erustacea, sinu umbilicata, pilis gossypinis plus minus lanuginosa. Embryo intra albumen parcissimum, mucilaginosum homotrope arcuatus; cotyledonibus foliaceis, sese plicato-involventibus, radicula infera. - Frutices $v$. suffrutices, in America et Africa tropica indigeni, foliis allernis, petinlatis, integris $v$. palmatim lobatis, stipulis petiolaribus geminis, linearibus, pedunculis axillaribus, solitariis, unifloris, corollis luleis, calycibus granulis nigris punctatis.

Fugosia Jussieu Gen, 274. Adr. Jussieu in St. Hilaire Flor. Bratil. 1, 195, t. 49. 50. Guillen, et Perrot. Flor. Seneg. I. 69. Meisner Gen, 27. (23.) Ci enfu s i a Cavauill. Diss. III, t74. t, 22. $f$.2. Lam, $t, 577$, Clenfu eg ia Willd. Spec, IIT. 723 . Re do u te a Venten. Cels. $t$. 11. Kunth in Humb. et Bonpl. Nov, gen. et sp. $V .293$.

5380. Serrraea $C A V$. Involucellum triphyllum, foliolis subuembranaceis, cordatis, latis, integerrimis, ealyeem includentibus. Ca $1 \mathrm{y} x$ quinquefidus, laciniis aestivatione valvatis. Corolla petala 5, hypogyna, obovata, inaequilatera, unguibus imo tubo stamineo adnata, aestiva tione convolutiva. T и bus stamineus colnmnaeformis, a basi ad apieem nudum, quinquedentatum fil amenta plurima, hrevia exserens, an the rae reniformes. Ovarium sessile, simplex, quinqueloculare. $O \mathrm{vala}$ in loculis gemina, colla teralia, medio angulo centrali inserta. Stylus terminalis, apice exserto quinquefidus; $s \mathrm{t} i \mathrm{gm}$ a $\mathrm{a}$ oblique truncata. Caps nla quinquelocnlaris, loculieide quinquevalvis, valvis medio septiferis la ciniis calycinis oppositis. Semin a in loculis gemina v. abortu solitaria, reniformia, compressa, testa crustacea, sinu unbilicata, villosa. E m b r y o intra albumen parcissimnm, mucilaginosam homotrope arcuatus; coty ledon ib us foliaceis, sese plieato-involventibus, radi cu la infera. - Suffrutex arabicus, ramosus, pube brevi, mollissima incanus; foliis alternis, petiolatis, cordatis, trilobatis, denticulatis, stipulis petiolaribus geminis, setaceis, deciduis, pedunculis axillaribus, solitariis, unifloris, petalis flavis, basi macula purpurea distinctis.

Serra e a Cavanill, Diss, 1T. 83, t. 53. f. 3. Deeaisue in Nouv. Annal. sc. nat, IV. 20 . t. 4 Senraea Willd. Spec. III. 695. Se a ra DC. Prodr. I. 457. D u m r eichera Steudel et Hochst. in Schimp. Herb. Arab. 1837.

528 1. Abellanoselams MEDIK. Invo. I u r. ell um penta-decaphyllum, caducum. C a I yx tubulosus, quinquefidus v. quinquedentatus, sub anthesi hine fissus et basi circumseisse deciduus, limbi laciniis aestivatione valvatis. Corollae petala 5, hypogyna, obovata, patentia, nnguibus imo tubo stamineo adnata, aestivatione convolutiva. Tubus stamineus columnaeformis, superne filamenta plurima filifurmia exserens, anthera e reniformes, bivalves. O va rin m sessile, simplex, quinqueloculare. Ovula in loculis plurima, angulo centrali biseriatim inserta, adscendentia. Stylus terminalis, apice exserto quinquefidus; stigmat a capitellata. Capsula pyramidatoquinqueangularis, quinquelecularis, loculicide juxta totam longitudinem quinquevalvis, valvis medio septiferis. S e m i n a plurima, subreniformia, testa crustacea, glabra, $\operatorname{sinu}$ umbilicata. E mb ry 0 intra albumen parcissimum, mucilaginosum homotrope arcuatus; cotyledunibus foliaceis, sese plicato-involventibus, rad ic nl a infera. - Herbae $v$, suffrutices, saepius aculeati, in Asia, rarius in America tropica crescentes; folits alternis, petiolatis, palmatilobis, stipulis petiolaribus geminis, pedunculis axillaribus, solitariis, unifloris, corollis magnis, flavis.

A beImos e hus Medikus Malvac. 45. Wallich Plant. As. rar, I. 39. PresI Reliq. Hänk, IT, 133, Wight et Arnott Prodr. I. 53. B a mi a R. Browa mse. Wallich $O p$. eit. t. 44. If y me a oc aly $\mathrm{x}$ Zenker Plant. Ind. 8, t, 10. $\mathrm{H}$;bis ci seet. Manihot et sect. Abelmosehi spec. DC. Prodr. T. 4i8. 469. H i b is ei 8 p. Limn. Cav, Diss. HI. t. s2. f. 2. t, 61, f. 2, $t, 62, f, 2, t, 63, f, 1,2$.

ธะ82. Ihagumaria DON. InvoIncelI $\mathbf{m}$ oliguphyllum, minimum, rarissime obsoletum. C a l y x tubnlosns, quinquedentatas, persistens, dentibus aestivatione valvatis. Corollae petala 5, hypogyna, obovato-oblonga, unguibus imo tuho stamineo adnata, aestivatione convolutiva. Tubus stamineus basi dilatata ovarium obtegens, superne columnaeformis; fil a me nta plurima, filiformia exserens, antherae reniformes, bivalves. O v a ri u m sessile, quinqueloculare, simplex. Ovula in loculis subquaterna, angulo centrali inserta, adscendentia. Sty ln s simplex, apice infundibuliformi-clavatus; $8 \mathrm{t} i \mathrm{~g}$ a radiatim quinquelobum, Iobis obtusis, Ca $p \&$ u I a quinquelocularis, epicarpio coriaceo, solubili, endocarpio cartilagineo, intns setoso-lanato, loculicide quinquevalvis, valvis medie septa bipartibilia, margine seminifera gerentibus. S e m in a in Joculis bina $v$. abortu interdum solitaria, reniformia, testa crustacea, nuda, sinu umbilicata. Embryo .... Arbor insulae Norfolk; foliis allernis, breve petiolatis, coriaceis, oblongo-lanceolatis, integerrimis, subtus albido-lepidotis, stipulis deciduis, pedunculis axillaribus, solitariis, unifloris, brevibus, crassiusculis, paullo infra apicem articulatis, floribus speciosis, albo-roseis.

Lag u a ria Don Syst. I. 485. Eadlich. Flor. Norf. 75. H i bisci sect. Lagunarla DC. Prodr. $I$. 45at. Lagu $a$ ta $\mathrm{s}$ p. Sims. Bot. Mag, t. 769. Vent, Malm, 2. 42. H ibisci s p. Aadrews Bot. Heposit. $t .286$.

3\%8B. Paritiumen ADR. JUSS. Involac e 11 am decem-duodecimfidam v. dentatum, Caly $\mathbf{y}$ quinquefidus, laciniis aestivatione valvatis. 
Coro 11 a e petala 5 , hypogyna, expansa, unguibus imo tubo stamineo adnata, aestivatione convolutiva. Tubus stamineus colunnaeformis, infra apicem quinquedentatum, nudum fil am ent a plurima, brevia exserens, antherae reniformes. Ovarium sessile, simplex, quinqueloculare, loculis septo secundario parietali verticalinincomplete bilocellatis. Ovula in loculis plura, angulo cen trali inserta, adscendentia. Stylus terminalis, apice exserto quinquefidus; $s \mathrm{t} \mathrm{i} \mathrm{g}$ a $\mathrm{ta}$ eapitellata. Ca p s u la quinquelocularis, loculis incomplete bilocellatis, loculicide per septa incompleta bilamellata quinquevalvis, valvis margine introflexis, medio septa completa gerentibus. Semin a abortu panca, testa crustacea, sinu umbilicata, nuda. Embryo intra albumen parcissimum, mucilaginosum homotrope arcnatus; cotyledonibus foliaceis, plicato-convolutis, radicula infera. Arbores $v$. frutices, inter tropicos totius or$b i s$ crescentes; foliis alternis, petiolatis, integris, subtus ad basim nervi primarii glandulosis, stipulis lateralibus geminis, latis, deciduis, pedunculis unifloris, axillaribus $v$. terminalibus et tunc stipulatobibracteatis, corollis lutescentibus v. purpurascentibus.

Partitium Adr. Jussieu in St, Hizaire Flor. Brasil, I. 198. Guillem. et Perrot. Flor, Seneg. I. F9. t. 13. Meisner Gen. 27. (23.) Wight Ic, t, 7. P a r i ta Seopoli Introduct, $n$. 1276. Pariti Rheede Malab, I, t,30, Adanson Fam. II. 40t. $\mathrm{A} z$ a n $\mathrm{z}$ a Moc. et Sesse Flor, mex. inedit. ex DC. Prodr. III. 453. H ibisci sect. Azanza DC. 2. c, H ib iscus tiliace us Linn, et H. tricuspis Cav. Diss. III. $t$. 55. f. 1. 2.

5284. Thespesîn CORR. Involuc elI um triphyllum, caducam. Caly $x$ eupuliformis, repando-truncatus. Coroll a e petala 5, hypogyna, ovata, unguibus imo tubo stamineo adnata, aestivatione convolutiva, T $\mathbf{x}$ b $\mathbf{~} 8$ stamineus coInmnaeformis, superne filamenta plurima, filiformia exserens, an therae reniformes, bivalves, O v a $\mathbf{r}$ i u sessile, simplex, quinqueloculare, loculis semisepto parietali verticaliter incomplete bilocellatis. Ovn Ia in loculorum angulo centrali pauca, adscendentia. Stylus terminalis, simplex, superne incrassstus, quinquesulcus; $s \mathrm{tigmata}$ quincque, brevia, acuta. Ca psula coriacea, subglobosa, mucronata, indehiscens, quinquelocularis, loculis semisepto parietali membranaceo incompleto verticaliter bilocellatis, placentis centralibus fungosis. Semina in loculis sulqquaterna, adseendentia, obovato-triquetra, tomentosa. Embryo intra albumen parcissimum, mucilaginosum leviter arcuatus; $\cot$ yledonib as foliaceis, sese plieatoinvolventibus, $\mathrm{r}$ a $\mathrm{d}$ i $\mathrm{c} \mathrm{u}$ I a infera, - Arbores in Asia et Oceania tropica crescentes; foliis alternis, petiolatis, cordato-subrotundis, integerrimis, quinque-septemnerviis, subtus lepidotis, nervis basi glandula instructis, stipulis petiolaribus geminis, pedunculis axillaribus, solitariis, umifloris, petalis flavis, basi macula purpurea distinctis.

Th es pesia Correa in Annal. Mus. IX. 290, t. 8.f.2. DC. Prodr. I. 455. Meisner Gen, 23. (22.) Wight Ic, t. 8 . M a I s a vis c us Gartaer $I T, 253, t, 135$, non Dill. H i b is. cus populaeus Lian. Cav. Diss. IIT, $t$. $56, f, 1$.

5285. Deeaselisistin WIGHT. et $A R N$. Involucellum decaphyllum, foliolis basi plus minus inaequaliter coalitis. Calyx quinquefidus, laciniis aestivatione valvatis, trinerviis, nervis lateralibus juxta suturam combinatis, decurrentibus. Corolla e petala 5, hypogyna, obovato-inaequilatera, unguibus imo tubo stamineo adnata, aesti. vatione convolutiva. $T \mathbf{u b u}$ s staminens colnmnae- formis, infra apicem nudum fil am enta plurima, brevia exserens, antherae reniformes. $0 \mathrm{va}$ ri n m sessile, simplex, decemloculare. Ovala .... Stylus terminalis, apice exserto decemfidus; $8 \mathrm{tig}$ m a $\mathrm{t}$ a capitellata. C a p s n la decemloenlaris, loenlieide decemvalvis, valvis medio septa, columnae centralis brevis decangularis basi adhaerentia gerentibus. S e mina in loculis solitaria, reniformia, nuda .... - Frutex indicus; foliis alternis, petiolatis, coriaceis, ovatis, integris $v$. obsolete lobatis, utringue dense tomentosis, subtus albidis, nervo medio basi poro glanduloso.

Decas chisti a Wight et Arnott Prodr. I. 52. Meisner Gen, 23. (27.) Hibis eus crotonifolius Wall.

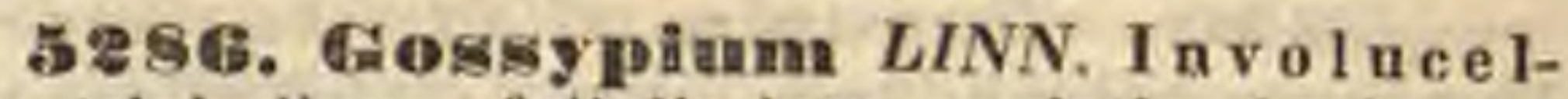
$1 \mathrm{um}$ triphyllum, foliolis late cordatis, basi coalitis, dentato-incisis. C a ly x cupulaeformis, subinteger v, obtuse quinquedentatus. Corollae petala 5, hypogyna, obovato-inaequilatera, unguibus imo tubo stamineo adnata, aestivatione convolutiva. Tubus stamineus basi dilatata, fornicata ovarium obtegens, superne angustatus, columnaeformis, filamenta plurima, fiformia, simplicia v. bifurca exserens, a $\mathrm{n}$ the rae reniformes, bivalves. Ovarium sessile, simplex, tri-quinqueloculare. $O$ v $\mathrm{u} l \mathrm{a}$ in loculorum angulo centrali plurima, biseriata, adscendentia. Stylus terminalis, simplex; $8 \mathrm{tigma}$ clavatum, tri-quinquesulcum. Ca p s u l a crassiuscule coriacea, tri-quinquelocularis, apice loculicide tri-quinquevalvis, valvis medio septiferis. Semina plura, ovata, angulata, epidermide spongiosa, dense lanata. E m b ryo intra albumen mucilaginosum subarcuatus; cotyledonibus foliaceis, plicato sese involventibus, radie u la infera. - Herbae annuae $v$. perennes, saepe suffruticosae, in Asia et Africa tropica indigenae, nunc in regionibus calidioribus totius orbis vastis agris cultae, seminum lanugine denticulis minimis aspera, facile in fila ducenda, telam praebente sacerdotibus Aegyptiorum olim gratam, aevo medio in chartam, cui plurima graeci imprimis ingenii monumenta ad nos usqus transmissa debemus compactam, nunc majorem mortalium partem molli veste tegentem, et ingentibus mercalorum curis agitatam; foliis alternis, petiolatis, cordatis, palmatinerviis, tri-quinquelobis, lubis acutis ramulisque junioribus cum involucellis saepissime punctis nigricantibus conspersis, glabris, subtus ad basim nervorum saepe glandulosis, stipulis petiolaribus geminis, lanceolatis, pedunculis terminalibus $v$. oppositifoliis solitariis, unifloris, floribus majusculis.

Gos s y p i u m Linn. Gen, $n, 845$, Gärtner $I I$. 246, $t, 134$. Cav. Diss. DI, t, 164. 166 169. 193. DC, Prodr. $I$. 456. Royle Himalay, t. 23. Wight Illustr, t. 27. 28, a-e. Ic. t. 9-11, X y to n Touraef. Inst. 27.

TERIIBUS IJ. SIDEAE. C a ly x involucello nullo nudus. C a r pi $\mathbf{i}$ a quinque v. plura verticillata, in capsulam loculicide dehiscentem connata, v. in fructum polycoccum obiter coalita.

528\%. Amodia CAV. Involucellum nullum. Cal y x quinquefidus, laciniis aestivatione valvatis. Corolla e petala 5, hypogyna, obovata, unguibns imo tubo stamineo adnata, aestivatione convolutiva. Tu bus stamineus basi fornicata, dilatata ovarium obtegens, superne angustatus, coInmnaeformis, apice in fil amenta plurima, filiformia solutus, antherae reniformes, bivalves. 
Ovarium sessile, multiloculare. Ovula in loculis solitaria, angulo centrali appensa. Styli loculoram numero, filiformes, hasi coaliti; stigmat a capitellata. C a p 8 I a orbiculata, depressa, polycocea, coeci monospermi, apiribus cuspidatis v. muticis radiantes, indehiscentes, parietibus demum obliteratis aperti. S emen suspensum, subreniforme, testa crustacea, sinu umbilicata. Embryo intra albumen parcissimum, mncilaginosum homotrope arcuatus; cotyledonibus foliaceis, sese plicato-involventibus, radicula supera. Herbae in America tropica cis a equatorem indigenae; folizs alternis, petiolatis, integris, angulatis, hastatis et trilobis, stipulis lateralibus geminis, pedunculis axillaribus, solitariis, unifloris, floribus violaceis $v$. flavis.

A no d a Cavauill. Diss. I.38, t. 10. f. 3. t. 11. 1. 2. Ic. t. 431. Kunth in Humb, et Bonpl. Nov. Gen. et sp. V. 265. Reichenb. Ic. exot. t, 34. 44. DC. Prodr. T. 458. Sehlechtend. in Linnaea, XI. 205. Meisner Gen. 27. (24.) S I da e sp. Willd. Bot. Mag. t. 336, 1541.

5288. Cristaria $C A V$. Involuce 11 um nullum. C a ly $x$ quinquefidus, laciniis aestivatione valvatis. Coro Ila e petala 5 , hypogyna, obovata, unguibus imo tubo stamineo ádnata, aestivatione convolutiva. T $\mathbf{T}$ bus stamineus basi dilatata fornicata ovarium obtegens, superne angustatus, columnaeformis, in filamenta plurima, filiformia solutus, a n therae reniformes, bivatves. Ovariu m sessile, multiloculare. Ovula in loculis solitaria, angulo centrali appensa. Sty Ii loculorum numero, filiformes, basi coaliti; st $\mathrm{i} g$ m a t a capitellata. C a p s a la orbicularis, depressa, polycocea, lamina discoidea membranacea sinnato dentata tecta, coceis monuspermis, angulo centrali cohaerentibus, dorso fissis, apice in alam membranaceam duplicem, erectam, obtusam productis. S em en suspensum, reniforme, testa crustacea, sinu umbilicata. Embrye intra albumen parcissimum, mucilaginosnm homotrope arcuatus; cotyledonibus foliaceis, sese plicato-involventibus, radieula sopera. - Herbae peruanae et chilenses, annuae $v$, perennes, saepius prostratae, glabrae v. tomentosae, ramosae; foliis alternis, petiolatis, cordatis $v$, incisis pinnatifidisque, pedicellis axillaribus, solitariis, unifloris, medio $v$. infra apicem articulatis, corollis violaceis.

Cristaria Cavanill. Io, D. 10, t. 418, DC, Prodr. $I$. 458. Presl Meliq. Hänk. II. 119. Meisner Gen. 27. (24.) Sidae s p. Heritier Stirp: t. 57. Cav. Diss. 1, t. 4. f. 2.

D\&SD. Sida KUNTH. Invo I ce 11 u m nullum. C al y x quinquefidus, saepius cupulaeformis, laciniis aestivatione valvatis. Corolla e petala 5 , hypogyna, obovata, saepius inaequilatera, unguibus interdum in tubum convolntis, imo tubo stamineo adnatis, aestivatione convolutiva. Tubus stamineus basi dilatata fornicata ovarium obte gens, superne angustatus, columnaeformis, apice in filamenta piurima, filiformia divisus, an therae reniformes, bivalves. Ovari um sessile, quinque-mnitiloculare. Ovula in loculis solitaria, angulo centrali snspensa. Styli loculornm nnmero filiformes, basi plus minuseoaliti; stigma ta capitellata. C a psula quinque-moltilocularis, penta-polycocea, coceis monospermis, anguli centralis medio ad insertionem seminis excisis, inde. hiscentibus $v$, apice intus apertis, colnmna centrali persistente, basi in memhranam expansa. Semen suspensum, snborbiculari-complanatum, testa crustacea, baseos inaequilatere emarginatae sinu umbilicata. Embryo intra albumen parcum, subcarnosum v. mucilaginosum semicircula- riter complicatus; e otyledonibus foliaceís, plicato sese involventibus, radicula supera. Herbae, suffrutices $v$. frutices, in regionibus tropicis et $s u b t r o p i c i s$ talius orbis crescentes; foliis alternis, petiolatis, integris $v$, rarius lobutis, stipulis lateralibus geminis, pedunculis infra apicem articulatis, axillaribus, solitariis v. pluribus, uni-multifloris, rarius floribus spicatis $v$. corymbeso-racemosis.

Sid a Kunth in Humb. et Bonpl. Nov. gen, et sp. $\boldsymbol{V}$. 256. t. 173. Adr. Jussieu in St. Hilaire Flor. Brasil. $\boldsymbol{I}$. 173. t. 33 -36. Plant. us. $t .49-50 . \mathrm{S}$ id a et $\mathrm{N}$ a p a e a Linn. Gen, n. 837. 838, exel. sp. Stevartia Forskael Aegypt. 126. Malviada Medikus Malv. 23. Sidae sect. 1. DC. Prodr. I. 459. excl. sp. Periptera DC. $l$. c. (Bot, Mag. t. 1644.) Dict y o carpus Wight in Madras Journ, of sc. $V$. call. Arnott in Nouv. Annal. sc, nat, XI. 169. Sidae s p. Cavanill. et Auet.

5290. Gaya H. B. K. Involucellnm nullum. C a ly $x$ quinquefidus, laciniis aestivatione valvatis. Corollae petala 5 , hypogyna, obovata, unguibus imo tubo stamineo adnatis, aestivatione convolntiva. T u b n s staminens basi dilatata fornicata ovarium tegens, soperne angustatus, columnaeformis, apice in filamenta plurima, filiformia divisus, antherae reniformes, bivalves. Ovarium sessile, multiloenlare, loculis basi intus appendice ligulaeformi anctis. 0 v uIa in loenlis solitaria, ex apice anguli centralis pendula, Styli loculorum numero, filiformes, inferne plus minus connati; stigmat a capitata. Cap sula sulovesiculosa, polycocea, coccis monospermis, anguli centralis medio ad insertionem seminis excisis, dorso bivalvibus, ligulan interiorem valvuliformem exserentibus, columna centrali stylifera persistente, multisulcata. Sem en suspensum, suborbiculare, complanatum, testa crustacea, baseos emarginatae sinu umbilicata. E m br y o intra albumen parcum, mucilaginosum semicircalariter complicatns; coty 1 ed o nibns foliaceis, suborbiculatis, semet plicato-involventibus, radicula supera. - Herbae perennes, suffrutices $v$. frutices, in America tropica indigeni; folïs alternis, integris $v$. obsolete trilobis, stipulis lateralibus geminis, pedunculis axillaribus solitariis unifloris, infra apicem articulatis, corollis flavis $v$. aureis.

G a y a Kunth in Humb. et Bonpl. Nov. gen. et sp. $V$. 268. t. 475, 476. Adr. Jnssien in St, Hilaire Flor. Brasil. I. 150, t. 38. Meisner Gen. 27. (24.) S ida e s p. Auet.

5291. IIalachra $L I N N$, Involueel$1 \mathrm{um}$ nullum. Caly $\times$ quinquefidas, laciniis trinerviis, aestivatione valvatis. Corolla e petala 5 , hypogyna, inaeguilatera, unguibus imo tubo stamineo adnata, aestivatione convolutiva. Tubus staminens brevis, columnaeformis, infra apicem nudum exserens filam en a 20 , fertilia, filiformia, antherae reniformes, sinu insertae, versatiles, rima semicirculari apertae, bivalves, septo manifesto. O va r i n m sessile, quinquelobnm, quinquelocvlare, $O$ v u la in loculis solitaria, e basi anguli centralis adscendentia. Stylus apice exserto decemfidus; stig mata capitellata. C a ps u I a pentacocca, coceis solubilibus, monospermis, angulo centrali dehiscentibus. S em en reniforme, testa crustacea, emarginatnrae sinu umbilicata. Embryo intra albumen parcissimum, mucilaginosum homotrope areuatus; cotyle d onibus foliaceis, sese plicato-involventibns, $\boldsymbol{r a -}$ di c u l a infera, - Herbaev. suffrutices, ut plurimum palustres, in America tropica crescentes, nonnulli simul in Africa et Asia observati; caule 124 
lineis decurrentibus tomentoso, foliisque pilis pungen. tibus hispido, foliis alternis, plus minus longe petiolatis, integris v. labatis, serratis, stipulis ad basim petiolorum utrinque solitariis $v$. geminis, floribus in capitula pedunculata, quinque-multiflora, invo lucro tri pleiophyllo cincta dispositis, corollis luteis, albidis $v$. lutescentibus.

$\mathrm{M}$ a 1 a c h r a Linn. Gen, n. 1266. Jacq. Io, rar, t, 578, 549. Cav, Diss. II. t. 33. f. 2. exel, reliq. Schrank Hort. Mo. nac, t. 56. DC. Prodr. I. 441. exel. sp. 3. 5.10. et 14. Adr. Jussieu in St. Hilaire Flor. Brasil. I. 216.

529?. Abratilom G ln m nullum. Cal y x quinquefidus, saepias enpu. laeformis, laciniis aestivatione valvatis, Corolla e petala $\delta$, hypogyna, obovata, saepius inaequilatera, ungribus imo tubo stamineo adnata, aestivatione convolutiva. Tubus staminens basi dilatata fornicata ovarium obtegens, superne angustatus, columnaeformis, apice in filamenta plurima, filiformia divisus, rarios simul infra apicem antherifer, a $n t h$ e $r$ a reniformes, sinu affixae, versatiles, rima semicirculari apertae, bi valves, septo manifesto. O va ri u m sessile, quinque-multiloculare. $\mathrm{O} v \mathrm{u} / \mathrm{a}$ in loculis 4 , 9 , angulo centrali inserta, adscendentia et pendula. Sty I i loculorum numero, filiformes, basi plus minus coaliti; stig mata capitata. Capsala penta-polycocca, coccis hand secedentibus, apice introrsum rima apertis. Semina in loculis pauca vabortu solitaria, reniformia v. subhippocrepica, testa crustacea, emarginaturae sinu umbilicata. E in b r y o intra albumen parcnm, subearnosum homotrope arcuatus; cotyledonibus foliaceis, petiolulatis, basi auriculatis, sese plicato-involventibus.

Herbae, suffrutices $v$. frutices, nonnullae arbores, in regionibus tropicis et subtropicis to. tius orbis crescentes; foliis alternis, petiolatis, cordatis, dentatis $v$, rarissime obsolete lobatis, stipulis lateralibus geminis, pedunculis axillaribus, solitariis $v$, pluribus, uni-multifloris, infra apicem articulatis, interdum floribus spicatis v. racemosis, rarissime corymbosis.

A b utilon Gärtner $I T .251, t, 135$. Kunth in Humb. et Bonpl. Nov. gen. et sp. V. 270. t. 424. Adr. Jussieu in St. Hilaire Flor. Brasil. I. 154. t. 40_42. Plant, us, t. 51 . Guillemin et Perrot. Elor. Seneg. $t$. 14். Booker Bot. .Mag. Compan. $t$. 2. Wight Ic, $t, 12$. Si d a e $\mathbf{s}$. Lian. Jacq. Hort. Sohönbr. t. 113. Ic, rar. t. 137. Cav. Diss. I. t. 5. 4. t. 7. f. o. V. t. 128. f. 1. 2. VI. t. 1 -7. VII. t. $1-10$, IX. t. 2. XIIT. t. 4. Heritier Stirp, t. 59 -63. Bot. Mag. t. 2753. 2759, 2821, A b utili s p. Tournef. Dillen.

5\%马3. Bastaredia KUNTH. Involucellum nullum. Caly $\mathrm{m}$ quinquefidas, laciniis aestivatione valvatis. Corolla e petala 5, hypogyna, ovato-inaequilatera, unguibns imo tubo stamineo adnata, aestivatione convolutiva. Tu b us stamineus columnaeformis, apice in fil a m e $\mathbf{n t a}$ plurima, filiformia divisus, an $t$ herae reniformes, bivalves, septo manifesto. O v a r i u m sessile, quinque-multiloculare. Ovula in loculis solitaria, angulo centrali inserta, adscendentia $v$. pendula. Styli loculorum numero, filiformes, basi coaliti; stigma ta capitata. Caps n la penta-polygona, quinque-multilocularis, loculicide quinque-multivalvis, valvis medio septiferis, columalla centrali persistente. Semina in loculis solitaria, adscen. Jentia v. suspensa, subreniformia, testa crustacea, sinu emarginatarae nmbilicata. Ein bryo intra alhumen parenm, mncilaginogum homotrope com. plicatus; cotyledonibus subfoliaceis, petiolulatis, basi auriculatis, sese plicato-involventibus.
Frutices, in America tropica et boreali calidiore indigeni; foliis alternis, cordatis, integerrimis $v$. dentatis, stipulis lateralibus geminis, peduniculis axillaribus solitariis, geminatis ternatisve, unifloris, interdum foliorum abortu racemosis.

B a stardia Kunth in Humb. et Bonpl. Nov. gen, et sp. V. 235. Adr. Jussieu in St, Hilaire Flor. Brasil. I. 153.

a. ABUTIL0IDES. Caps ula haud inflata. Semen sus. pensum. - Sid a bivalvis Cav. Diss. $t .11$. f.2. (Kunth Op. cit. t. 472.)

b. GAYOIDES. Capsula vesicularis. Semen adscen. deas. - Sida c ris pa Lian. Cav, Diss, I. t. 7. f. 1. V. t. 135. f. 2. (St. Hilaire Op. oit. t. 39,)

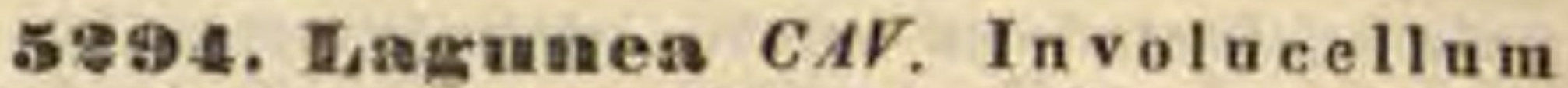
nullum. C al y $x$ quinquefidus, laeiniis aestivatione valvatis. Corollae petala 5, hypogyna, obovato oblonga, unguibus imo tubo stamineo adnata, aestivatione convolutiva. Tubus stamineus coInmnaeformis, apice in $\mathrm{f} i \mathrm{I}$ a $\mathrm{m}$ e $\mathrm{t}$ a plurima, filiformia solutus, anthera e reniformes, sinu insertae, versatiles, rima semicirculari apertae, bivalves, septo manifesto. O v a r i u m sessile, quinqueloeulare. Ovula in loculis 5_6, angulo centrali inserta. Sty 1 i 5 , filiformes, basi coaliti; stig mat a capitellata, stellatim pilosa. Capsula ovata, quinquelocularis, Ioculicide quinquevalvis, valvis margine planis, medio septa seminifera gerentibus, basi $\mathrm{cmm}$ columna centrali filiformi, caeterum libera coalitis. Sem in a in loculis $3-6$, reniformia, testa erustacea, pilosa, sinu emarginaturae nmbilicata, Embry o .... Herbae annuae, in $A$ sia et Africa tropica crescentes; foliis alternis, petiolatis, cordatis, trilobis tripartitisve, summis saepe integris, stipulis lateralibus geminis, pedunculis axillaribus solitariis, unifloris, infra apicem articulatis, foliorum superiorum abortu saepe racemum terminalem formantibus.

La gu ue a Caranill, Diss. V. 279, t. 136. (non III. 173. t. 71.). DC. Prodr. I. 474. (exel, sp. 4.) Guillemiu et Perrot. Flor. Seneg. I. 76. Wight et Aruott Prodr. I. 55. Meis nee Gen, 27. (24.) Sola n d r a Murray in Comment. Göt. ting. 1784, p. 21. t. 1. Lam, $t, 580$, non Swartz. T r ig a e ra Cavanill. Diss. I, 4t, t. 11. (non II. App, 1. supr. p, 3847,) H i biscus Sola a d ra Heritier Stirp, $t$, 49.

52ญร. ญำ I $\mathrm{m}$ nullum. Cal y $\mathrm{x}$ quinquefidus, laciniis aesti, vatione valvatis. Corolla e petala 5 , hypogynaungribus imo tubo stamineo adnata, aestivatione convolutiva. Tubns stamineus columnaeformis, apice in $\mathrm{fil}$ am e $\mathrm{n} t$ a plurima, filiformia divisus, anthe rae reniformes, bivalves. Ovari um sessile, quinqueloculare, loculis septo parietali transversim bilocellatis. Ovula locelli superioris gemina, collateralia, inferioris unieum, pendulum. St yli quinque, filiformes, basi coaliti; st ig mata capitellata. Ca p 8 ul a pentacocca, coceis basi columnae centrali adhaerentibus, apice solutis, septo transverso bilamellato biarticulatis, articulis haud secedentibus, inferiore monospermo v. sterili, indehiscente, superiore dispermo, bivalvi. Semina reniformia, testa crustacea, sinu nmbilicata. Embryo..... Frutices in $A$ si a et $A m$ erica tropica indigeni; foliis alternis, petiolatis, cordatis, integris, stipulis lateralibus geminis, pedunculis axillaribus solitariis v. pluribus, unifloris, interdum foliorum abortu spicatis, infra apicem articulatis, corollis flavis.

Wi s s a u u la Medikus Malv, 25. PresI in Beliq. Hänk. II. 117. t. 69. S ida periplocifolla Linn. Cav. Diss.

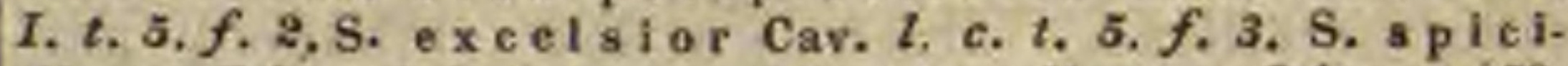
flora DC. - ? S. hernand loi des Heritier Stirp. $t, 58$. 


\section{GENUS DUBIUM.}

5296. Ingenlhouzia MOC. et SESS, Calyx nudus, tripartitus, lobis ovato-lanceolatis, acuminatis. Corolla e petala 5. Urceolus campanulatus interstamina. $\mathrm{Stam}$ in a plurima, monadelpha. Stylus unus. ....- Herba mexicana, Gossypii facie; foliis petiolatis, trilobis, lobis ovato-lanceolatis, acutis, integris, pedicellis oppositifolis, unifloris, floribus ex flavo rubescentibus.

Ingentouzi a Moẹ. et Sessé Elor. mexic, inedit. ex DC, Prodr. I. 474.

\section{Ordo CCX. Sterculiaceae.}

STERCUliaceaE Vent. Malmais. Ir. 91. excl. Byttneriaceis. Schott et Bndl. Melet. 30. Lindley Introduct. edit. II. p. 92. BOMBACEAE et STERCULIACEAE Kunth Malv. 6. BOMBACEAF et BYTTNERIACEARUM tribus I. DC. Prodr. $\boldsymbol{I}$. $48 t$. STERCULIACEAE et MALVACEARUM tribus Il. Bartling Ord. nat. 340, et 346.

Arвores saepius vastae, ligno molli, levissimo, rarius frutices, pube stellata. Folia alterna, petiolata, nunc simplicia, integra $\mathbf{v}$. palmatiloba, nune palmatim composita, foliolis supra apicem petioli, etiam in simplicifoliis saepissime incrassatum, articulatis, v. ejusdem apici complanato continuis, integerrimis v. serratis. Stipulae ad basim petiolorum utrinque liberae, caducae, rarissime nullae.

Flores hermaphroditi v. alterius sexus organis imperfectis diclines, regulares $v$, interdum subirregulares, quandoque maximi, in aliis mediocres v. parvi, nune in pedunculis axillaribus solitariis v. pluribus, interdum foliorum abortu racemum formantibus, rarius oppositifoliis, solitarii vel interdum plures, nune in paniculam rảmosam dispositi. $\mathrm{Ped} u \mathrm{ncu}$ li v. pedicelli continui aut articulati, nudi v. stipulaceo bracteati, bracteis plerumque mature defluentibus, nunquam in involucrum coeuntibus.

CaLxx gamophyllus, pentamerus, foliolis varie coalitis, aequalibus v. interdum inaequalibus, parte libera aestivatione valvatis $\mathbf{v}$. rarissime (in Ochromate et Cheirostemone) imbricatis, nune (in Bombaceis) inaequaliter ruptus, foliolis interdum geminatim coalescentibus, v. truncatus, obsulete quinquedentatus, semper plus minus coriaceus, extus tomento denso stellato, saepius, imprimis in generibus apetalis, laete colorato indutus.

Corowa nune nulla, nunc pentapetala, petalis imo toro insertis, cum calycis lobis alternantibus, unguiculatis, unguibus saepe tubo stamineo adglutinatis, aequalibus $v$. interdum inaequalibus, nonnunquam inaequilateris, aestivatione convolutiva v. longitudinaliter imbricata.

Stamina hypogyna, indefinita, in tubum nunc supra ovarium sessile longe productum, nunc ovarii stipitati carpophoro adnatum, infra ova- rium definitum $\mathbf{v}$, in cupulam liberam illud ambientem expansum, in filamenta plurima solutum v. in lobos definitos desinentem, connata. Filamenta distincta $v$. in fasciculos collecta, simplicia v. interdum bifurca. An therae extrorsae, subbiloculares, nunc in filamentorum apicibus terminales, loculis connectivo lato circumplicitis, rectis v. anfractuosis, saepissime confluentibus, nunc tubi staminei lobis latis adnatae v. stipitulo brevi insertae, loculis divaricatis, septo transverso distinctis, v. oblique juxta positis, plus minus discretis, bivalvibus. Pollinis granula laevia, subtrigona.

Ovariom sessile, nonnunquam fundo calycis subimmersum, $v$. in stipite cum tubo stamineo vaginatim connato, rarius intra tubum libero elevatum, e carpidiis quinque, rarius tribus v. duobus, follicularibus, verticillatis, connatis, obiter coalitis v. omnino liberis compositum, axi centrali saepissime obsoleto v. saltim sub maturitate obliterato. Ovula ad suturam ventralem saepe plurima, rarius pauca v. solitaria, horizontalia, adscendentia, semianatropa v. anatropa, rarius amphitropa v. orthotropa. S tyli terminales, simplices, plus minus inter se coaliti, nunquam distincti; stig ma ta loculorum numero, libera v. connata.

Froctus nunc capsularis, quinquelocularis, rarius indehiscens, saepissime loculicide quinquevalvis, valvis medio septa ab axi centrali soluta v. eandem auferentia gerentibus, nunc drupaceus $v$. interdum baccatus, quinque- aut bi-trilocularis v, abortu unilocularis, nune e carpidis liberis follicularibus, lignosis v. crustaceis, sutura ventrali dehiscentibus rariusve indehiscentibus, saepe membranaceis, longe ante maturitatem apertis et explanatis compositus, endocarpio intus saepissime dense lanato v. pilis prurientibus consito.

Semina plurima, pauca v. solitaria, ovata v. angulata, rarissime compressa et superne in alam membranaceam producta, testa crustacea v. membranacea, epidermide interdum succulenta arillaeformi, rhaphe et chalaza obsoletis v. plus minus distinctis. A l bumen nune carnosum sat copiosum, nunc parcum mucilaginosum, siecitate friabile, nunc omnino nullum, v. saltim sub maturitate omnino consumptum.

Enвryo nune in axi albuminis rectus, nunc albuminis strato tenui inter ejusdem plicas sese insinuante tectus, homotrope arcuatus, cotyledonibus foliaceis sese plicato-involventibus; nune exalbuminosus, cotyledonibus carnosis plus minus crassis, planis v. rugosoplicatis, rarius spiraliter circa plumulam convolutis, radicula recta v. incurva, umbilicum spectante v. ab eodem remota.

S t e r c li a e a e, paucissimis isque quoad veram affinitatem adhuedum subdubiis ex- 
ceptis, quae in Nova-Zeelandia et Nova-Hollandia extratropica generantur, omnes tropicae, in Africa et Asia frequentius quam in America obviae.

Bombaceae proxima affinitate Malvaceis accedunt, a quibus earum pars foliis palmatim compositis, simplieifoliae fruetus fabrica v. antheris facillime distinguuntur. Helictereae inter Bombaceas et Stereuliaceas mediae, hae ad Byttneriaceas genuinas et Lasiopetaleas, habitu et antherarum fabrica facile dignoscendas, accedunt.

Genera ad normam subdivisionum a cl. Sehottio nostro meeum propositarum, olim verosimiliter dividenda, sed fructibus et seminibus plurimarum specierum nondum satis notis, characteres acutius circumseribere, hoc loco non licet.

Semina plurium edulia, oleosa; lana fructus gossypina vilior, vix magni usus.

THEIS I. BOMBACEAE Schott et Endl. Melet. 36. Flores hermaphroditi. Calyx quinquefidus, saepe irregulariter divisus, aestivatione tunc obscura. Corolla regularis, rarissime nulla. Filamenta in tubum ovaria superantem coalita. Antherae solitariae, v. plures coadunatae, loculis distinctis v. confluentibus, saepe anfractuosis. $0 \mathrm{v}$ arium sessile. Fructus e carpidiis coalitis saepissime capsularis. S e mina saepissime lana earpica v. pulpa involuta.

\section{§. 1. Folia palmatim composita.}

529\%. Adansonia $L I N N$. C alyx subcampanulatus, quinquefidus, deciduus, laciniis aestivatione valvatis. Corolla e petala 5 , hypogyna, calyce longiora, late obovata, basi inter se et cum imo tnbo stamineo coalita, patentissima, aestivatione convolutiva. T a bus stamineus cylindricus, apice in fil a menta plurima, filiformia, patentissima, monantherifera solutus, an therae reniformes, bivalves, Ovarium sessile, liberum, quinque - decemloculare. $0 \mathrm{vula}$ in loculorum angulo centrali plurima, snbuniseriata, amphitropa. St y Ins filiformis, longe exsertus, deflexus; s ti g mat a 5-10, acuta, stellatim patentia. C a p. s ila lignosa, obovato subclavata, suleata, quinquedecemlocularis, indehiscens, scptis tenuissime membranaceis, loculis pulpa farinosa, fibris filiformibus pertexta, tandem compacta, in portiones irregula. res, transversas secedente farctis. S e min a plnrima, in pulpa nidulantia, subgloboso - reniformia, testa crustacea, atra, nitida, sinu umbilieata. $\mathbf{E}$ m. b ryo intra albumen tenuissime carnosum homotrope arenatns; cotyled onibus foliaceis, involuto-conduplicatis, radieula crassa, incurva. Arbor Africae tropicae, nun in America et Asia passim culta; trunco humili, diametri gigantei, apice dense comoso, ligno laxo, levissimo, ramis patentibus $v$. interdum deflexis, truncum velantibus, foliis alternis, petiolatis, palmatim quinquefoliolatis, foliolis brevissime petiolulatis, ellipticis, acutis, integerrimis, stipulis deciduis, pedunculis axillaribus, solitariis, unifloris, bibracteatis, nu- tantibus, floribus magnis, albis, fructus tomentosi pulpa grate acidula.

A da n s o n a Línu. Gen, n, 836. Gürtner IL. 253. t. 135. Cavanill. Dissert. V. 298, ใ. 157, Lam. †. 588. Tussac Flor. Antill. III, $t, 33.34$. DC. Prodr. I. 4t8. Huoker in Bot. Mag. t. 2791. 2792. Schott et Endl. Melet, 36. Meisuer Gen, 28, (25.) В o a b a b P. Alpin. Aegypt. 66. Adanson in Act. Paris. 1261. p. 218, t. 16, 17. 0 phelus Loureiro Elor. cochinch, 50 .

5298. IPaelhira $A U B L$. Caly x cupulaeformis, truncatus v. obsolete quinquedentatus. Corollae petala 5, hypogyna v. subperigyna, linearia, calyce multo longiora, erecto-patentia, aestivatione imbricata. Tub as stamineus brevis, in fil amenta plurima filiformia, elongata, basi plernmque geminatim cohaerentia, in fasciculos quinque collecta, apice monantherifera solutus, an therae incumbentes, lineares, arcuatae v, reniformi replicatae, bivalves Ovarium sessile, liberum v. basi calycis fundo incrassato subimmersum, quinqueloculare, Ovala plurima, loculorum angulo centrali inerassato multiseriatim inserta, horizontalia, anatropa. Stylus filiformis; $8 \mathrm{t}$ ig $\mathrm{m}$ a breviter quinquelobum. Ca $\mathrm{p} s \mathrm{ul}$ a lignosa, septis maturitate obliteratis subnnilocularis, loculicide quinquevalvis, valvis medio septorum rudimenta gerentibus. Semin a plurima, maxima, subquadratata, angulata, testa crustacea, nuda, umbilico basilari lato. E mbryo albumine pareissimo mucilaginoso indutus; cotyled onibus crassis, transversim oblungis, exteriore triplicata interiorem quadruplo minorem involvente, radicula tereti, subincurva v. replicata, umbilicum spectante. - Arbores America e tropica e, coma densa conspicuae; foliis alternis, longe petiolatis, palmatim tri-novemfoliolatis, foliolis cum apice petioli incrassato articulatis, $v$. eidem in discum complanato continuis, stipulis deciduis, pedunculis $e$ supremorum foliorum, saepe mature delabentium axillis solitariis, unifforis, bi-tribracteatis', crassis, floribus maximis, calycibus basi impresso-glandulosis, petalis tomentosis, extus plerumque rufo virentibus, intus albicantibus $v$, rubentibus.

P a chir a Aublet Guian. 11. 725. t. 291. 298. Jussieu Gen, 279. Cavanill, Diss, IIT, 176, t, 72, f. 1. Lam. t. 589. Kunth in Humb, et Bonpl. Nov. gen. et sp. V. 302. Adr. Jussieu in St, Hilaire Elor. Brasil. 1. 252. t. 51 . C a r oIInea Lian. f. Supplem. 314. Swartz Flor. Ind, occid. IT. 1209. Bot. Mag. t. 1412. Hooker Exot. Flor. t. 100. DC. Prodr. I. 478. Martius et Zuecariui Nov, gen, et sp, I, 83. t. 56. Schott et Eiadl. Melet, 35. Meisner Gen, 28. (25.)

5299. Chorista $H . B . K$. Cal yx campanulatus, bi tri-qainquelabus, lobis aestivatione valvatis. Corolla e petala 5 , subperigyna, calyce multo longiora, linearia v. oblongo-spathulata, patentia v. reflexa, aestivatione convolutiva. Tub u s stamineus dnplex, exterior brevior, apice quinquelobus, lobis bilobulatis, vaginans interiorem longiorem, basi adnatum, apice quinquelobum, lobis diantheriferis, antherae extrorsae, lineares, adnatae, subflexuosae, bivalves. Ova ri u m basi calycis fundo incrassato immersum, incomplete quinquelocalare. $O \mathbf{v}$ a l a plurima, placentis semisepta marginantibus pluriseriatim inserta, horizontalia, anatropa. Stylus filiformis, e tubo stamineo breviter exsertus; s tig ma capitato-quinquelobum, hirtellum. Capsnla lignosa, pyrifor$\mathrm{mis}$, incomplete quinqueloenlaris, loculicide quinqnevalvis, valvis medio septiferis. S e mina plurima, lanata. .... - Arbores brasilienses, aculeatae; foliis alternis, longe petiolatis, palmatim quinque-septemfoliolatis, foliolis cum petiolo 
articulatis, lanceolato-acuminatis, serratis, stipulis deciduis, pedunculis in supremorum foliorum axillis solitariis, geminis $v$. ternis, foliorum lapsu quasi racemosis, unifloris, sub flore bi-tribracteolatis, corollis magnis, rubescentibus.

C horisia Kunth in Humb. et Bonpl. Nov. gen. et sp. $\mathcal{V}$. 295, ל. 485 . Nees et Martius in N. A. N. C. XI. 101. t. 9. DC, Prodr. $I$. 480. St. Hilaire Plant, us, Brasil, t. 63. Flor. Brasil. I. 266. Sehott et Endi. Melet. 35. Meisner Gen. 25. (28.)

5300. Bombax LINN. C a I y x cupulaeformis, truncatus. Corollae petala 5 , hypogyna, calyce multo longiora, oblongo-lanceolata, patentia $v$. reflexa, aestivatione convolutiva. $T \mathbf{~ u b} \mathbf{b} \mathbf{s}$ stamineus brevis, eylindricus, in fi lamenta plarima, filiformia, elongata, apice bieruria, in fasciculos quinque v. plares collecta divisus, cruribus monantheriferis, an thera e oblongae, connectivo lineari circnmplexae, bicrures, bivalves. 0 varium sessile, liberum, quinqueloculare. Ovula plurima, loculorum angulo centrali multiseriatim inserta, horizontalia, anatropa. Stylus filiformis; sti $\mathrm{g}$ a peltatum, sulcato-pentagonum. Ca $\mathrm{p}$ uI a lignosa, elliptiea, quinquelocularis, loculieide quinquevalvis, valvis ab axi pentagono septifero, densissime lanato solutis, S em i na plurima, lana pericarpica involuta, obovato-globosa, basi acuta, testa crustacea, umbilico basilari. Embryonis albumine parcissimo friabili inclusi cotyledones foliaceae, cordatae, replicato envolutae, radi c u la eylindrica, reeta, umbilicum attingens. Arbores Americae tropicae, excelsae, apice comosae; foliis alternis, longe petiolatis, palmatim quinque-octofoliolatis, foliolis petioli apici in discum complanatum expanso continuis, subintegrerrimis, stipulis deciduis, pedunculis in supremorum foliorum axillis solitariis, unifloris, florum lapsu subterminalibus, floribus magnis, albis, pubescentibus.

B o m b a x Linn. Gen. n. 835. exel. sp. plar. Schott et Eadi. Melet, 35. C e ib a Mart. et Zuec. Nov. gen, et sp. I. 95. in not. B. C e ib a Linn. Jacq. Amer, $t, 176, f, 1$. B. M u g u ba Mart. et Zuce, Op. cit. t, 99.

5301. Eriotheea SCHOTT et ENDL. C al y $x$ campanulatus, obsolete tri-quinquedentatus. Corella e petala 5 , hypogyna, obovato-oblonga, ealyce longiora, erecto-patentia, aestivatione convoluta. Tubus stamineus cylindricus, apice in filam enta plurima, filiformia, multiseriata, simplicia, monantherifera solutus, a $n$ the$r$ a e reniformes, bivalves, valvis mox reflexis pileoliformes. O v r i u m sessile, liberum, quinqueloculare. Ovula plurima, loculorum angulo centrali pluriseriatim inserta, horizontalia, anatropa. Stylus filiformis; stigma simplex. Ca p8 u la lignosa, pyriformis, quinquetocularis, loenlicide quinquevalvis, valvis ab axi pentagono septifero, densissime lanato solutis. Semin a plurima, lana pericarpica involuta, ovata, testa crustacea, seabra, umbilieo basilari. Embryon is albumine pareissimo friabili inclusi cotyledones foliaceae, cordatae, replicato-convolntae, ra dicula cylindriea, refracta, umbilico proxima. Arbores brasilienses; foliis alternis, longe petiolatis, palmatim tri-quinquefolialatis, foliolis cum apice petioli articulatis, pedunculis axillaribus, solitariis, geminis $v$, ternis, unifloris, floribus albis.

Erlotheca Schott et Eadl. Melet. 35. Meisuer Gen. 28. (25.) Bombax parviftorum et B. pubeseens Martlus et Zuec. Nov. gen. et sp, $t, 57,58$.

5392. Ereiodemellan DC. Calyx campanslatus, tri-quinquelobus, lobis aestivatione valvatis. Corolla petala 5, hypogyna, calyce longiora, oblonga, erecto-patentia v. reflexa, aestivatione convolutiva. Tubus stamineus cylindrieus $v$, ventricosus, apice solutus in filam ent a 5, filiformia, simplicia, di-triantheriferâ, antherae extrorsae, lineares, adnatae, rectae $v$. anfractuosae, bivalves. O vari um sessile, liberum, quinqueloculare. Ovnla in loculis plurima, angulo centrali pluriseriatim inserta, horizontalia, semianatropa. Stylus filiformis; stigma capitatum v. breviter quinquelobum. Ca p sula lignosa, quinquelocularis, loculicide quinquevalvis, valvis ab axi pentagono septifero, quinquepartibili, densissime lanato solutis. Semina plurima, lana earpica involnta, ovata, testa crustacea, umbilico basilari, chalaza infra apicem laterali. E m bry onis albumine parcissimo friabili inclusi coty ledon es foliaceae, cordatae, replicato-convelutae, radieula basi recurva, umbilico proxima. Arbores Americae et Asiae tropicae, inermes v. aculeatae; foliis alternis, longe petiolatis, palmatim tri-septemfoliolatis, foliolis cum apice petioli incrassato articulatis, stipulis deciduis, pedunculis unifloris, solitariis $v$. fasciculatis, ad apicem ramorum axillaribus $v$. foliorum lapsu subterminalibus, corollis mediocribus v. magnis, extus pubescentibus $v$, lanatis, roseis, albidis $v$, sordide ochroleucis.

Eriodendron DC. Prodr. $T$, 479. Martius et Zuecarini Nov. gen. et sp. I, 86. Adr. Jussieu in St. Hilaire Flor. Brasil. I. 264. Celb a Plumier Gen, 42. Gärtuer II, 244. B o ub acis s p. pestandrae Auct.

a. CEIBA Plum. Gen, t, 32. T u b u s stamineus medio ventricosus, filamentis diantheriferis, antheris longitudinaliter adnatis, rectis. - Erlode adra n Sehott et Eudl. Melet. 35. B o m b ax erianthos Cav, Diss, V. $t, 152$. (Mart. et Zucc. Op. cit. . 96, 97.)

b. CAMPYLANThBRA Schott et Endi, Melet. 35. T u bus stamineus basi ventricosus, filameatis diautheriferis, antheris horizontalibus, anfraetuosis. Stigma quin. quepartitum, - E. S a m a u a Mart. et Zuce. Op. eit. t. 98 .

c. Gossampinus Schott et Epril. Melet. 35. T u b u s sta mineus basi ventricosus, filamentis bi-triautheriferis, autheris lunatis, flexuesis. S $t_{\mathrm{g}} \mathrm{m}$ a eapitatua. - C e ib a Gärtner t. 133. Gos s a minus Rumph Amboin. $x$. $t$. 80. Gos s a m pía a a $\mathrm{b}$ a Hamilt. in Linn. Trans. act. $x V y$. 126. B ombax pentand rum Liag. Cav. Diss. t. 132.

? d. ERIONE Schott et Endl. Melet. 35. Tu bu s staminens apice pulvinato locrassatus, filamentis diantheriferis, antheris longitudinaliter aduatis, apice recurvatis. S ty. 1 us anfractu spirali exsertus. Fructus ..... E. ja s mintodorum St. Hilaire Elor, Brasil, $t .52$,

5303. Salmalla SCHOTT et ENDL.

C a ly x eampanulatus, inaequaliter tri-quinquelobus, lobis obtusis, aestivatione valvatis. Co rollae petala 5, hypogyna, ealyce longiora, ovata, erecto patentia, aestivatione cenvolutiva. Tubus stamineus ventricosus, in filamenta plurima, pluriseriata, filiformia, simplicia v. apice bifurca, exteriora monantherifera, interiora passim diantherifera solutus, an $t h$ e $r$ a extrorsae, horizontales, reniformes $\mathbf{v}$, anfractuosae, bivalves. Ova ri $\mathbf{m}$ sessile, liberum, quinquefoculare. Ovula in loculis plurima, multiseriata, horizontalia, anatropa. Stylus filiformis; stigma quinquefidum, lobis acutis, patentibus. Cap 8 ula lignosa, quinquelocularis, loculicide quinquevalvis, valvis ale axi septifero densissime lanato solntis. Scmina plurima, ovata, lana copiosa obvoluta. ...... Arbores Asiae tropieae; foliis alternis, longe petiolatis, palmatin quinque-septemfoliolatis, stipulis 
deciduis, pedunculis axillaribus solitariis v. pluribus, floribus magnis, rubicundis.

$\mathrm{S}$ a $1 \mathrm{mali}$ a Sehott et EndI. Melet, 35 . B om b ax ma$1 \mathrm{ab} a x$ ie um DC. Wight Illustr.t.29. B. heptaph y $11 \mathrm{um}$ Roxburgh Plant. Corom, t. 2n, B. in s ign e Wallich Plant. As. rar. t. 79. 80. Gos a mpinus $\mathrm{rab} \mathrm{ra}$ Hamilt. in Linn. Transact. $X V ., 128$.

\section{§. 2. Folia simplicia.}

5304. Cavanillesia $R U I Z$ et $P A V$. C alyx ebracteolatus, campanulatus, quinquefidus, persistens. Corolla e petala 5 , calyce duplo longiora, aequalia. Tubus stamineus cylindricus, ima basi petalis adnâtus, apice in fil amenta plurima, filiformia, inferne pentadelpha, singula monantherifera solutus, an the rae reniformes, bivalves. O vari um sessile, pentagonum, quinqueloculare, loculis biovulatis. Stylus simplex; stigma capitatum. Capsula pentaptera, axi lignoso, abortu uniloculari, monospermo, indehiscente, alis coriaceo-membranaceis maximis, rotundatis, venosis. Semen oblongum, utrinque acutum, substantia gummosa involutum. E m b r y onis exalbnminosi cotyledones crassae, chrysaloideo contortuplicatae. - Arbores Americae tropicae, excelsae, pube stellulata; foliis alternis, petiolatis, cordatis $v$, subpeltatis, quinque-septemlobis, membranaceis, deciduis, floribus umbellatis, ante folia erumpentibus, roseis.

- Cavanillesia Ruiz et Pavon Prodr. 97, $t$, 20. Kunth in Humb. et Bonpl. Nov, gen, et sp. V. 305. P o u r retia Willdenow Spec. III. 844. Humb. et Bonpl. Plant. aequizinoct, II. 162, t, 133. Correa in Annal. Mus. 1X. 293, t, 26. DC. Prodr. I. 47z. Sehott et EndI. Melet, 36.

5305. Durlo RUMPH. Ca ly $\mathrm{x}$ basi involucello bilobo, patente cinctus, urceolatus, medio ventricosns, obsolete quinquedentatus. Corollae petala 5, hypogyna, unguiculata, ovato-lanceolata, calyce multo longiora, patentia. T'a bus stamineus brevissimus, in fil am enta plurima, filiformia, inferne in phalanges quinqne coalita solutus, singula pluriantherifera, antherae in capitula terminalia globosa coacervatae, loculis anfractuose confluentibus. Ova rium ovato-oblongum ...... Stylus filiformis; stigma capitatum. Capsula ovato-subglobosa, tuberculis suberosis pyramidatis dense muricata, fibroso-corticosa, carnosa, quinquelocularis, loculicide dehiscens. Semin a in loculis $2 \_5$, ovato-oblonga, horizentalia, uno latere arillo carnoso-submucoso, lobato tecta, testa dura, endoplenra suberoso cellulosa, mucilaginosa. E mbry on is exalbuminosi, recti cotyle i on es carnosae, apice conferruminatae, basi distinctae, radicnla retracta, inverse pyramidalis, subtetragona. - Arbor moluccana; foliis alternis, petiolatis, obovato-oblongis, penninerviis, integerrimis, supra lucidis, subtus floribusque lepidoto-fusco-cinereis, petiolis apice incrassatis, corymbis lateralibus multifloris, fructibus maximis, foetidissimis.

D u rio Rumph Amboin, I. 99, t. 29. Linn. Gen, n.698. Lam. 2. 641. Konig in Linn, Transact. VII, 266, t. 14-16. DC. Prodr. 1, 480. Sehott et Eadl. Melet, 34. Meisuer Gen.
28. (24.)

5306. Dellaroma SWARTZ. riacens, tubuloso-infundibulifor qrefidi , tabuloso - infundibuliformis, limbi qninquefidi lobis tribus rotundatis, aestivatione induplicatis, duobus acutis, subimbricatis. Coroll ae petala 5, hypogyna, calyce longiora, revoluta, aestivatione contorta. Tub us stamineus subinfun- dibuliformis, quinquelobus, apice hine fissus, lobis pluriantheriferis, an the rae extrorsae, adnatae, loculis linearibus anfractuose confluentibns. $0 \mathrm{v}$ arium sessile, oblongum, quinqueloculare. Ov nIa in loculorum anguio centrali plurima, biseriata ..... Stylu s cylindricus, erassus; stigmata 5, spiratim contorta. Ca p su la elongata, decagona, quinquelocularis, loculicide quinquevalvis, valvis medio septiferis, densissime sericeo lanatis. S e mina plurima, oblonga, lana carpica involuta.... - Arbor antillana, ligno levissimo; foliis alternis, petiolatis, cordatis, angulatosublobatis, subtus pubescentibus, stipulis ovato-lanceolatis, deciduis, floribus in apice ramulorum pedunculatis, magnis, albis.

0 chroma Swartz in Act. Holm. 1792, p. 148. $t$. 6. Flor. Ind. occid. 1I. 1144. t. 23. DC. Prodr. I. 480. Schott et Endl. Melet. 34. Meisuer Gen, 28. (24.) B o m b a x $\mathrm{p}$ $\mathrm{r}$ a $\mathrm{m}$ i d a le Cavanill. Diss. $V, t .153$.

$530 \%$. Cheirostement HUMB. et BONPL. C a I y x basi tribracteatus, subcampanulatus, quinquepartitus, laciniis deciduis, erassis, intus coloratis, basi foveolatis, aestivatione quincuncialibus. Co rolla nulla. Tubus stamineus cylindricns, exsertus, apice quinquefidus, laciniis secundis, apice mucronatis, diantheriferis; an $t h$ era e extrorsae, adnatae, lineares, rectae, parallelae, bivalves. Ovarium liberum, sessile, quinquelocnlare. Ovula in loculis plurima, angulo centrali biseriatim inserta, adscendentia, anatropa. StyIn s filiformis, apice incurvus; stig ma acutum. C apsula oblonga, quinquangularis, quinquelocularis, loculicide quinquevalvis, valvis medio septa villosa, margine utrinque seminifera gerentibus. Sem in a plarima, ovoidea, testa crustacea, nitida, atra, chalaza rosea terminata. Embryo in axi albuminis carnosi orthotropus, ejusdem fere longitudine; cotyledonibus foliaceis, ovatis, planis, $r$ a dicula brevi, obtusa, umbilico proxima. - Arbor mexicana; trunco gracili, elato, coma densa, globosa terminato, ligno albo, levissimo, foliis alternis, petiolatis, subrotundo ovaiis, acute quinque-septemlobis, basi cordatis, supra glauco-virentibus, subtus albido-tomentosis, stipulis ovatis, acuminatis, deciduis, pedunculis in ramulis suboppositifoliis, solitariis, unifloris, calyce extus cano-tomentoso, intus purpureo.

Chefros tem on Hnmb. et Bonpl. Plant. aequinoct. 1 . 82, t. 24. Nov, gen. et sp. V. 302. Tilesius in let. Petro. polit. V. 321. t. 9. Fischer Ibid, 581, DC. Prodr. I. 480. Schott et Endl. Melet, 34. Meisner Gen, 28. (24.) C he i r anthodeudron Larraga Dissert. c. ic. M a cpal o- $^{-}$ ch iquah u itl Hernandez Mesic. 382. $f$. 1. 459. $f$. 2. Arbol de Manitas Hispan.

\section{GENUS BOMBACEIS AFFINE.}

53๑5. Neesia BLUM. Caly $\mathrm{x}$ involucello tripartito caduco cinctus, aestivatione inflato turbinatus, clausus, vertice ruptus, in eupulam amplam, planam, marginibus involntam patens, intus coloratus, deciduns. Coroll ae petala 5, hypogyna, oblonga, inaequilatera, aestivatione contorta, decidua. Sta mina plurima, hypogyna, corolla breviora, ima basi coalita, omnia fertilia; fil a m enta complanato-filiformia, superne latiora, interiora longiora, antherae extrorsae, biloculares, didymae, loculis parallelis, discretis, longitudinaliter dehiscentibus. Ovar i $\mathrm{m}$ sessile, ovoideo-conicum, quinqueloculare, septis ad axim 
hiantibns. Ovula in placentis septa marginantibus plurima, utrinque horizontaliter uniseriata, anatropa. St ylus conicus, erassus; stigma capitato-pentagonum. Cap s a la lignosa, globosoovoidea, quinquangularis, muricato-tessellata, incomplete quinquelocularis, locnlicide quinquevalvis, valvis medio septa crassissima, pilis stellatis prurientibus hirta, margine seminifera gerentibus. Seminta ovulis pauciora, subhorizontalia, septorum foveolis impressa, ellipsoidea, testa coriacea, atra, lucida, umbilico basilari semicirculari, per | rhaphen filiformem introrsam cum chalaza apicali juncto. Embryo in axi albuminis carnosi orthotropus; cotyledonibus magnis, foliaceis, planis, ovatis, basi emarginatis, penninerviis, radi cula brevi, conica, recta, umbilicum attiǹgente, centripeta. - Arbor javanica, procera, pube stellata; foliis alternis, petiolatis, obovatoellipticis, coriaceis, penninerviis, integerrimis, stipulis lateralibus geminis, lineari-lanceolatis, deciduis, floribus in corymbos laterales breves, bracteatos dispositis, mediocribus, roseis, capsulis magnis, fusco-nigris.

Neesia Blume Flor. Jav. Praef. VII. N. A. N. C. XVII. 75. . 6. E s e a be cki a Blume Bijdr. 119. non Kunth Cotylephora Meisuer Gen. 36, (28.)

\section{GENERAËDUIA.}

5309. TI. Tontezuma MOC, et SESS. C aI y nudus, hemisphaericns, truncatus, sinuato dentatus. Corolla e petala 5 , subsinuata, maxima. Sta $m$ in a plurima, spiraliter circa stylum longe monadelpha, suleis quinque distincta. O va rium ..... Stylus in stigma elavato-ligulatum desinens. B a c e a globosa, quadri quinqnelocularis, polysperma. - Arbor mexicana; foliis petiolatis, cordiformibus, acutis, integris, glabris, pedunculis unifloris, infra folia e ramis ortis, floribus purpureo-phoeniceis, amplis.

Mo ntezum a Moçino et Sessé Flor. mex, inedil. ex DC. Prodr, $I, 47 \%$.

5310. 1Hamanea SCHLECHTEND. F 10 res polygami. Caly $\mathbf{x}$ basi tribracteatus, campanulatus, truncatus. Corolla e petala 5, calyce longiora, oblique obovata, basi inter se et cum tubo stamineo coalita, aestivatione convolutiva. Tubus stamineus brevis, in fil amenta plurima, elongato-filiformia, monanthera solutus, a nthera e reniformes, bivalves. Ovari um sessile, triloculare, loculis pluriovulatis, intus pilosis. Stylus simplex; stigmata $1-3$, crassinscula, apice revoluta. Fructus ....- Arbuscula mexicana; foliis alternis, longe petiolatis, ovatis, basi sucordatis, acuminatis v. acutis, subtus glaucescentibus, integerrimis, stipulis anguste linearibus, acuminatis, deciduis, pedunculis e foliorum supremorum axillis cymosis, floribus exlus ferrugineotomentosis.

- H a m p e a Schlechtend. in Linnaea XI. 371 .

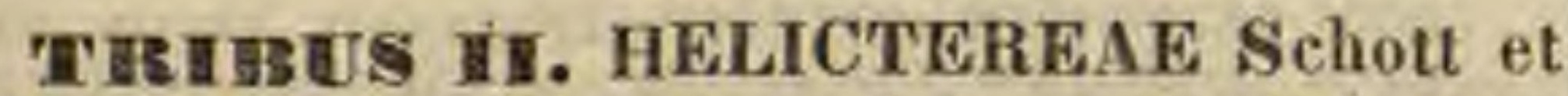
Fndl. Melet. 30. F lo r es hermaphroditi. C alyx et corolla saepissime irregularis. Stamin a in tubum ovaria superantem, v. carpophorum ambientem coalita, apicibus distincta. Ovarium sessile v. stipitatum. Fruetus e carpidiis distinctis v. coalitis, mono-polyspermis. - Folia simplieia.
§. 1. MYRODIEAE Schott et Endl. $l$. $c$. T ub u s stamineus ultra ovarium sessile longe productus. An thera e sessiles v. subsessiles.

531 1. Pllagiantlaus FORST, Calyx urceolato-subcampannlatus, quinquefidus v. quinquedentatus, persistens, dentibus aestivatione valvatis. Corolla e petala 5 , imo tubo stamineo insèrta, ovalia v, oblonga, patentia, aestivatione convolutiva. T u bus stamineus brevis, cylindricus, apice quinquefidus, laciniis singulis bi-triantheriferis, antherae extrorsae, biloculares, adnatae, loculis parallelis v. divaricatis, bivalvibus. O vari um sessile, biloculare. Ovula in loculis solitaria, medio dissepimento inserta, pendula. Styln s terminalis, crassiusculus; $s \mathrm{ti} \mathrm{gma}$ bilobum, obtusum. C a p $8 \mathrm{l}$ a indehiscens, chartacea, fragilis, bilocularis, didyma, v. abortn unilocularis, inaequilatera, styli rudimento apiculata, mono-disperma. S e m en inversum, subglobosum, testa crus tacea, umbilico ventrali, E m bry o intra albumen carnosum arcuato conduplicatus; cotyledonib us foliaceis, latis, undulatis, radicu I a e adscendenti, subclavatae, albumine interposito incumbentibus. - Arbores $v$ frutices ramosi, in Nova-Z e elandia et insula Diemen indigeni; foliis alternis, ovato-lanceolatis, serratis, $v$. fasciculatis, linearibus, integerrimis, stipulatis, floribus parvis, inter foliorum fasciculos solitariis, $v$, in racemos paniculatim ramosissimos, terminali-oppositifolios dispositis.

Plagianthus Forster Char, gen, $t$. 43. DC. Prodr. I. 477. Hooker Bot. Mag. t. 3271, 3396. Meisner Gen, 29. (25.) A. Cunaingham in Annal. of Nat. Hist. IV. 24.

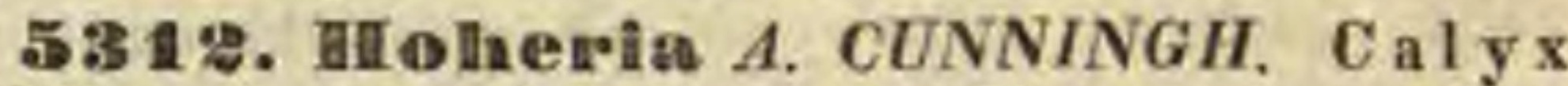
cyathiformis, persistens, aequaliter quinquedentatus, dentibus triangularibus, acutis, aestivatione valvatis. Corolla e petala 5 , hypogyna, obovatoacuminata, concava, suhintegra, basi inter se et cum tubo stamineo coalita, aestivatione imbricata. $\mathrm{S} t$ a $\mathrm{m}$ in a $20-2 t$; fil am ent a ima basi in tabum coalita, anthera e extrorsae, peltatae, nnilornlares, longitudinaliter bivalves, Ovari $\mathbf{m}$ sessile, quinquelobum, quinqueloculare .... S tyI a s quinquepartitus; $8 \mathrm{tigmat}$ a 5 , dilatata, depressa, lobata. Fruetus.... - Arbuscula Novae-Zeelandiae, biorgyalis, spectabilis, sempervirens; foliis alternis, petiolatis, ovatis, acuminatis, membranaceis, penninerviis, venosis, duplicato-serratis, stipulis caducis (?), floribus facie florum Philadelphi, in axillis foliorum pedunculatis, pedunculis fasciculatis $v$, umbellatis, plerumque unifloris, medio articulatis, petalis albis, calyce duplo longioribus, extus pube stellata cinerea sericeis.

$\mathrm{H}$ o heria A. Cunningham in Annal. of Nat, Hist. III. 319. - H oheri Nov. Zeel.

5313. Myroelia $S C H R E B$. C aly $x$ tubuloso-obeonicus, tri-quinquedentatus, demum hinc fissus, dentibus aestivatione valvatis. Corollae petala 5, unguibus imo tubo stamineo inserta, oblongo-inaequilatera, calycem multo snperantia, patentia v. reflexa, aestivatione convolutiva. $T \mathbf{u}$ b u s stamineus eylindricus v. filiformis, superne dilatatus, quinquedentatus, v. aequalis, truncatns; anthera e $20 \_30$, tubum terminantes v. eidem infra apicem biseriatim adnatae, extrorsae, geminatim approximatae, bivalves. Ov a ri u m vonicum, basi calycis fundo incrassato immersum, biloculare $\mathrm{v}$. interdum triloculare. Ov u Ia in loculis gemina, collateraliter adscendentia. $S t y / n$ s filiformis, 
tubi staminei longitudine; stig ma obtuse bilobum. Ca p sula snbgloboso-didyma, bilecularis, indehiscens, bipartibilis. Sem ina in loculis solitaria, erecta, dorso-convexa, facie plana, dissepimento adhaerentia, testa tennissima, pelliculaeformi, superne incrassata. $\mathbf{E} \mathbf{m b}$ r yon is exalbumi. nosi cotyl edones crassissimae, farinaceae, conferruminatae, altera exterior multo major interiorem minorem includens, radicula brevissima, retracta, infera. - Arbores $v$. frutices A merica e tropicae, odore aromatico gravi, tenaci; foliis alternis, petiolatis, coriaceis, ovatis $v$, oblongis, integerrimis $v$. obsolete dentatis, glabris, stipulis lateralibus geminis, deciduis, pedunculis solitariis, unifloris, oppositifoliis, ramuli abortu interdum axillaribus v. folii lapsu lateralibus, bracteis tribus alternis, brevibus, stipulaeformibus, floribus albis.

Myrodia Schreber Gen, n. 1147. Swartz Flor. Ind, occid. II. 1227, DC. Prodr, $I$, A77.

a. EUMYRODIA DC. $l$. $c$. T u bus stamineus eylindrieus, apice ampliato quinquedentatus. Antherae 30 , decem den. tibus gemination interpositae, reliquae eosdem marginan. tes. Ovarium biloculare. - Myrodia St. Hilaire Flor. Brasil. I. 268, t. 33. - ? L e $x$ a r 2 a Llave Nov. Stirp. II, 7.

b. QUARARIBEA DC. $l$, c. T u bus staminens filiformis, apiee aeqaali subtruncatus. Antherae 20 , infra apicem

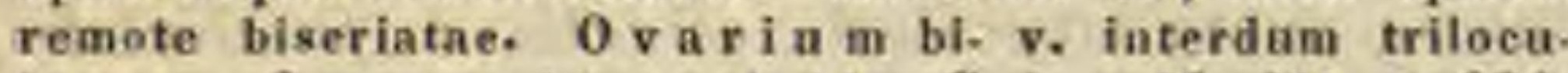
lare. - Quararibea Aublet Guian. II, 691. t. 278. Cavanill, Diss. III, 175, $t, 71, f .2$. Gerberia Sco. poll Introduct, n. 1297.

5314 . Matisia $H U M B$. et BONPL, C a1 y $x$ urceolato-campanulatus, bi quinquelobus, hine demum fissus, lebis aestivatione valvatis. Corol1 a e petala 5 , hypogyna, obovato-oblonga, subinaequalia, calyce lengiora, aestivatione convolu tiva. Tubus stamineus cylindricus, quinquefidus, lobis linearibus, obtusis, singulis extus antheras $6 \_12$, biseriatas gerentibus, antherae adnatae, longitndinaliter bivalves. $O$ va ri $\mathbf{m}$ ses. sile, quinqueloculare. Ovula in loculis gemina v. terna, anguli centralis apici collateraliter appensa (?). Stylus cylindricus, tubi staminei longitudine; stigma subcapitatum, sulcato-quinquelobum. Drup a ovata, quinquelocularis. Semina in loculis solitaria, dorso eonvexa, facie angulata, testa membranacea, fragili. Embry onis exalbuminosi cotyledones crassae, cor. rugatae, radicula....-Arbores peruanae; foliis alternis, petiolatis, ovatis, cordatis $v$, oblongis, integerrimis, membranaceis, glabris, junioribus subtus pube stellata tomentosis, stipulis laterali. bus geminis, deciduis, pedunculis unifloris, lateralibus, subaggregatis, bi-tribracteatis, tandem nudis, floribus albis $v$. roseis, extus glabris $v$. sericeis.

M a tisi a Humb. et Bonpl. Plant, aequinoct, I. 10. t.2. 3. Kunth in Humb. et Bonpl. Nov. gen, et sp. V. 306. DC. Prodr. I. 477. Póppig Nov, gen. et sp. II, 35, $t$. 150. Meis. ner Gen, 29. (25.)

§. 2. EUHELICTEREAE Schott et Endl. l. c. Tubus stamineus elongatus, ovarium stipitatum ambiens. An the rae in singulorum filamentorum apicibus liberis singulae.

5i315. Methoriam SCHOTT et ENDL. Calyx tubulosus, limbi bilabiatim quinquefidi laciniis aestivatione valvatis. Corolla e petala 5 , hypogyna, unguibus tubum ealycis aequantibus, apice utrinque aurieulatis, laminis subbilabiatim patentibus, aestivatione convolutiva. Tubus stamineus elongatus, cylindricas, liber, apice infracto ampliato decemfidus, laciniis monantheriferis; a ntherae extrorsae, biloculares, loculis adnatis, apice contiguis, basi discretis, bivalvibus. Ovarium longe stipitatum, e tubo stamineo exsertum, carpophoro libero, quinqueloculare. Ovula in Inculis gemina, angulo centrali inserta, superposita. (?) Stylns simplex, arlscendens; st igma capitatum. Capsula globosa, tomentosa, quinquelocularis.... - Frutices Novae-Hollandiae tropicae, tomento stellato dense canescentes; foliis alternis, brevissime petiolatis, oblongis, integerrimis v. serratis, stipulis lateralibus geminis, cymulis axillaribus abbreviatis, pauciftoris, floribus roseis.

Methorin m Sehott et Endlicher Melet, bot. 29. t. 5 . Meisuer Gen, 29. (25.)

53 16. II I lieteres LINN. C aly $x$ tubulosus, limbi subaequaliter $\mathbf{v}$. bilabiatim quinquefidi laciniis aestivatione valvatis. Corolla e petala 5, hypogyna, unguibus tubum ealyeis aequantibus, apice utrinque $v$, hinc anriculato appenticulatis, superioribus interdum nudis, laminis aequalibus v. bilabiato-patentibus, aestivatione convolutiva. Tubas staminens elongatus, eum carpophoro connatus, apice infracto libere quinque-decemmultipartito, laciniis exterioribus monantheriferis, interioribus quinque sterilibns, distinctis v. connatis; a n thera e extrorsae, biloculares, adnatae, Inenlis horizontaliter,divaricatis, bivalvibus. Ovari u m stipitatum, carpophoro $\mathrm{cam}$ tubo stamineo connato intra ejusdem apicem liberum sessile, e carpidiis quinque, nnilocularibus, cum staminibus sterilibus alternantibus, angulo centrali subcohaerentibus compositum, rectum $\mathbf{v}$, spiraliter contortum. Ovula plurima, suturae ventrali biseriatim inserta, adscendentia. Styli 5 , coaliti, recti $\mathbf{v}$. spiratim contorti; st ig m a ta acuta $v$. capitellata. Ca p s la e 5, leguminiformes, coriaceae v. lignosae, rectae v. spiraliter inter se contortae, uniloculares, sutura ventrali dehiscentes. Semina plurima, biseriata, horizontalia, ovata v. angulata, testa crustacea, verruculosa, rhaphe filiformi longitudinali, umbilienm basilarem eum shalaza apicali calyptraeformi incrassata jungente. E m b ry o intra albumen parcum, carnesum orthotropus; cotyledonibus foliaceis, circa radiculam teretem, umbilico proximam replicato-convolutis. - Arbores $v$. frutices, in America, rarius in Asia tro$p$ ic a crescentes, pube $v$. tomento stellato $v$, ramoso instructi; foliis distiche alternis, petiolatis, basi saepe inaequilateris, integerrimis $v$. serratis, rarius lobatis, stipulis lateralibus geminis, cymulis paucifloris, axillaribus $v$. foliorum abortu in racemos terminales dispositis, pedicellis stipulaceo bracteatis, floribus flavescentibus $v$. rubris.

Helícteres Liun. Gen, $n, 1024$. Gärtner 1.308 . Kunth in Humb. et Bonpl. Nov, gen. et sp. $V$. 303. DC. Prodr. I. 475. St. Hilaire Flor, Brasil, I, 271.

a. EUHELICTERES. Cal y $x$ bibracteatus. Corolla e bilabiatae petala uaguibus apice utriuque aurienlatis. Tubi staminei lobi $10-15$, quorum 5 v. 10 steriles, lobis interioribas sterilibus petaloideis liberis solitarie v. geminatim suboppositi. - Spccies americanae. - Helicteres Schott et Endl. Melet. bot. 31 .

ce. Orthocarpaea $D C$. Filameuta fertilla 5 . Ca p s u la recta. - H. proniflor a Rich. H. pentand $\mathrm{ra}$ L.

B. Spirocarpaea DC. Filamenta fertilia 10. Cap8 u I a spiraliter contorta. - (Jaeq. Amer. t.149. 179. Mickan Delect. IV, t. 1. St. Hilaire Plant, us. Brasil. t. 64, Flor. Brasil. t. 64.)

b. ISORA Schott et Endl. Caly x bilabiatus. Co rollae bilabiatae petala inferiora unguibus inappendicalatis, duo 
superiora appendicula unilaterali maxima. $\mathbf{T} \mathbf{u}$ b i staminei Iobi steriles 6 , ligulaeformes, minnti. C a ss ula in spiram contorta. - Species indicae. - isor a Schott et Endl. Melet, 31. H. Isora H. greviaefolia DC.

c. ALICTERES Neck. Caly $x$ vix bilabiatus. Coroll a e subaequalis petala unguibus inappendiculatis. T $\mathbf{T}$ bi staminei $15 \mathrm{v}$, naltifidi lacinlae interiores steriles in urceolam quinquefidum connatae. Capsula recta. Species americanae. - Alicteres Necker Elem, $n$, 1801. Sehott et Endl. Melet. 31. H. carthagenensis Jacq.

d. ORTHOTHECIUM Sehott et Endl. C a I y $\mathrm{x}$ vix bilabiatus. C o r o ll a e subaequalis petala unguibus apice utrin. que obsolete appendiealatis. T u b i staninei laciniae ex. teriores 10 fertiles, in ureeolum, quilaque steriles brevissimas includentem, coalitae. C a p s ui a recta. - Species americanae, - $0 \mathrm{rth}$ otheclum Schott et Endl, Melet...31.

\$. 3. REEVESIEAE Schott et Endl. $l$. $c$. T u b u s stamineus elongatus, ovarium stipitatum ambiens. Antherae plures, supra tubi apicem sessiles.

531ซ. Ungeria SCHOTT et ENDL. Ca$1 \mathrm{y} \times$ clavato-campanulatus, limbi subbilabiatim quinquefidi laciniis aestivatione valvatis. Co rolla e petala 5, hypogyna, unguibus tuhnm ealycis aequantibus, inappendiculatis, laminis patentibus, aestivatione convolutiva. T $\mathbf{n}$ b $\mathbf{n} 8$ stamineus elongatus, cum carpophoro connatus, apice urceolatim ampliato, libero, quinquefido, laciniis infra apicem nudum utroque margine superposite triantheriferis, a n th er a e extrorsae, biloculares, adnatae, loculis divaricatis, transversim bivalvibus. Ovarium stipitatum, carpophoro cum tubo stamineo connato, intra ejusdem apicem ampliatum incluso-ressile, qninquelobum, quinqueloculare. Ov 1 a in loculis solitaria, angulo centrali inserta, adscendentia (?) S ty li 5 , breves, coaliti; stig$\mathrm{m}$ a ta simplicia. $\mathrm{C}$ a $\mathrm{p}$ s $\mathrm{l}$ a coriacea, quinquangularis, quinquelocularis, loculicide quinquevalvis, valvis medio septiferis, tandem bipartibilibus, a columna centrali quinquangulari solutis. Semina in loculis solitaria, ovato globosa, testa coriacea, laevi, umbilico ventrali. E m b ryo intra albumen copiosam ...... - Arbor insulae Norfolk, pube stellata; foliis alternis, petiolatis, abovatis $v$. avato-ellipticis, crasse coriaceis, integerrimis, supra glabratis nitidis, subtus glauco-tomentosis, stipulis fugacibus, cymis terminalibus dense paniculatis, floribus roseis.

Ungeria Schott et Endlieher Melet, bot. 27, $t, 4$. Meisner Gen, 29. (25.)

53 18. Feevesia $L I N D L . C$ al y $\mathrm{x}$ clavatocampanulatus, limbi inaequaliter tri-quinquefidi laciniis aestivatione valvatis. Corolla e petala 5, hypogyna, nnguibus tubum calycis aequantibus, apice calloso-incrassatis, laminis patulis, inaequilateris. T u bus stamineus elongatus, cum carpophoro connatus, apice urceolatim ampliato libero, quinquefido, laciniis singulis triantheriferis, an thera e extrorsae, bilocnlares, adnatae, loculis divaricatis, transversim bivalvibus. O va ri u $\mathrm{m}$ stipitatum, carpophoro cum tubo stamineo connato, intra ejusdem apicem ampliatum incluso-sessile, quinquangulare. Ovula in loculis gemina, angulo centrali superposite inserta. Stigma sessile, quinquelobum. Capsu la lignosa, obovata, quinguangularis, quinquelocularis, loculieide quinquevalvis, valvis medin septa margine seminifera gerentibus, axi centrali nullo. S emina in loculis gemina, superposita, deorsum in alam producta.
..... - Arbor chinensis, foliis alternis, petiolatis, lanceolatis, acuminatis, integerrimis, glaberrimis, stipulis nullis (?), petiolis apice tumidis, $r a-$ cemis terminalibus compositis, floribus albis, calycibus stellato-tomentosis.

R e vesi a Lindley in Brandes Quaterl. Journ, 1827. III. 109. Bot, Reg. $t$, 1236. Schott Melet, 31. Meisner Gen. 29. (25.)

TIIB US III. STERCULIEAE Schott et Endl. Melet. 33. Flores abortu nnisexuales. Ca lyx regularis. Corulla nulla, Filam enta in tubum carpophoro connatum coalita. Antherae plus minus perfecte biloculares, curvato-oblongae, ad ovarii perfecti v. efoeti basim. Fructus e carpidiis follicularibus verticillatis, sutura ventrali dehiscentibus v. indehiscentibus. - Arbores, foliis simplicibus v. palmatim compositis, petioli apice tumido.

53 19. Feritiera $A I T$. F I o res nnisexnales. Cal y $x$ campanulatus, quinquedentatus, dentibus aestivatione valvatis. C oroll a nulla. M a se. T u bus staminens cylindricus, inclasus, apice antherifer, an the rae 5-10, extrorsae, bilocnlares, capitato-congestae, loculis bivalvibns. F e m. Anthera e 10 efoetae, in apice carpophori brevissimi sessiles, inter carpidia geminatae. $0 \mathrm{va-}$ ria 5, unilocnlaria, verticillatim arete contigna. Ov u la ad suturam ventralem 2-4, horizentalia, anatropa. Styli breves, apice recurvi; stig mata simplicia. Carpidia 5, vel aborta paneiora, distineta, lignoso-coriacea, dorso carinato-alata, indehiscentia, unilocularia, abortu monosperma. S e m e n unienm, suturae ventrali insertnm, horizontale, subglobosum v. ovatum, testa chartacea, rugosa, nmbilico basilari lato. Embryonis exalbuminosi orthotropi cotyled on es crassissimae, carnosae, inaequales, lobato-rngosae, radienla brevissima, obtusa, umbilieum attingens, centripeta, plnmula diphylla. - Arbores Asiae tropica e; foliis alternis, petiolatis, oblongis v. late lanceolatis, integerrimis, subtus albo-lepidotis, foribus paniculatis, parvis, calycibus tomento stellato rubro indutis.

Heritiera Aiton Hort. Rew. IT, 5.6. Hamilt. in Symes Ava t. 28. DC. Prodr. . . 484. Schott et Endl, JAelet. 32. Wight et Arnott Prodr. I, 63. Meisner Gen, 30. (25.)

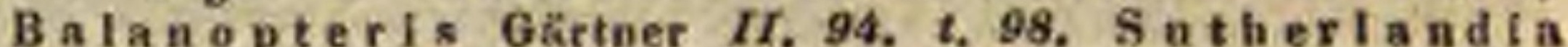
Gmelin Syst. 1027. S a m a n d r a Lian. Flor. Zeglan, 433. A ta n 8 Rumph Amboin, III. $t .63$.

5320. Stereulia LINN, F Iores abortu unisexnales. C a lyx coloratus, eampanulatus v. rarius tubulosus, quinquefidus v. quinquepartitus, laeiniis subeoriaceis, aestivatione valvatis $\mathbf{v}$, induplicatis, snb anthesi patentibus, reflexis v. interdum a pice cohaerentibus. M a s $\mathrm{c}$. Tubus staminens inclusus v. demum exsertus, solidus, apice in urceolum quinque-decemlobum ampliatus, lobis conniventibus, extus antheriferis, an $\mathrm{t} h$ erae adnatae, biloculares, congestae, loculis distinctis, bivalvibus. Ovari rudimentum intra stamineum urceolum sessile. F em. Tubus stamineus cum earpophoro brevi v. plus minus longo connatus, antheris efoetis, ovarii basim cingentibus terminatus. Ovari a 5 , unilocularia, in apice earpophori ultra tobnm stamineum hand producti sessilia, v. singillatim stipitellata, unilocularia, conniventia v. ad axim coalita. Ovula plurima, ad suturam ventralem biseriata, horizontalia v. adscendentia, 125 
orthotropa v. amphitropa. Styli simplices, plus minus inter se coaliti; stigm at a simplicia $v$. connata. C a r pidia follienlaria 5 v. abortu panciora, distineta, nnilocularia, sessilia v. stipitellata, patentia v. deflexa, nunc coriacea v. sublignosa, maturitate ad suturam ventralem hiantia, nunc membranacea, sub grossificatione aperta, cymbiformia $\mathbf{v}$. explanato-foliacea, semina exserta maturantia. Se min a juxta suturam ventralem biseriatim plurima, abortu pauca $v$. interdum solitaria, horizontalia $\mathbf{v}$. adscendentia, ovato-subglobosa, testa coriacea, ad umbilicum basilarem intra epidermidem carnosam stipitata. Embry on is antitropi v, umbilico paralleli cotyledones crassae, carnosae, dorso convexae, facie planae, aequales, interdum connatae, ra d i c u la brevissima, umbilico e diametro opposita, centrifuga, v. ab eodem remota, infera, plumula diphylla - Arbores inter tropicos totius orbis, imprimis tamen $A s i a e$ et $A f r i c a$ crescentes, pube stellata; foliis alternis, petiolatis, nunc simplicibus, integris v. lobatis, petioli apice tumido, nune digitatim compositis, stipulis lateralibus geminis, deciduis, paniculis ramosis, axillaribus $v$. infra gemmam terminalem sitis, floribus flavis, rubris $v$, interdum variegatis, extus plus minus tomentosis, forma variis, pericarpiis intus saepe retis urentibus consitis.

Sterenlia Linn. Gen. n. 1086. Cav. Dissert. V. 284. DC. Prodr. I. 481. St. Hilaire Flor. Bras. I. 277.

a. STERCulia Schott et Endi. Molet.32. C a 1 y x profunde quinquepartitus, patens. T $\mathrm{u}$ b u s stamineus elongatus, cylindricus, apice in urceolum quinquelobum expansus, lobis tridentatis, triantheriferis. Styli connexi, ab. rupte reeurvi; stigmat a obtusa ..... Folliculi subsessiles, polyspermi.

c. Eust o r e uli a Sehott et Endl. l.c. Arbores indicae, folits palmatim compositis, floribus laxe racemosis, rubris, footidissimis. St. foeti a Linn. Cav. Diss. $V$. t. 141. Sonnerat Voy, $t, 132$. C $10 \mathrm{mpan}$ us maJor Rumph Amboin. III. t. 107.

B. Ivira Schott et Endl. l. c. Arbores americanae; fotiis simplicibus, integris v. trilobis, floribus pani. culatis. Ivira Aublet Guian. 11. 694. t. 279. Cav. Diss. $V . t, 162$. Theo doria Necker Elem, n. 1048. Chich a e Presl in Reliq. Hänk. II. 140. M a te a ti a Flor. Flum. $I X, t, 05$. (S t. $\mathrm{C}$ h i $\mathrm{ch}$ a St. Hilaire Plant. us, Brasil. t. 46.)

b. SOUTHWellia Salisb. Parad, t, 69. C a I y x campanulatus, quinquefidus, laciniis apice connexis. Tubus stamineus cylindricus, inelusus, marium filamentis apice liberis, antheras in capitulum inordinate coacervatas gerentibus, feminarnm antherae $15-30$, sessiles, seric simplici, siuuata ovarii basim eingentes. Ovaria coa dunata. Styli coaliti; stig ma subpeltatua, obtuse quinquelobam. Follic u If sessiles, oligospermi. S e mi. n a nuda. Arbores inter tropicos veleris orbis cres. centes; folits simplicibus $v$, compositis. floribus plerumque flavercentibus. - Schott et Eadl. Melet, 38. B a1 a ng has Burmann Flor. Zejlan. 84. C a va I am Rumph Amboin. r. 4, 49. - ? T ri p b a ca Loureir. Flor. co chineh. 708. As tro de nd ro n Dennst, z. Hort, malab. 1V. 69. St. B a I ang has Linn. Cav, Diss, $V . t, 144$. Wight Illustr.t, 30. St. m o no s p e rm a Venten. Malm. t. 21. St. Tragaca n tha Lindi. in Bot, Reg. t. 1353. St. versicolor Wallich Plant. As. rar. t. 39.

c. PORCILOdermis Sehott et Endi. Melet, 33. Calyx inflato-campaniformis, quinque-sexfidus, laciniis revolutis. Tubus staníneus masculoram cylindricas, inclu. sus, basi ovaril sessilis rudimento tumidas, filamentis apice liberis, antheras in capitulum inordinate coacer vatas gerentibus, ferninarum subnultus, antheris sessi. libus inordioatis obsessus. $0 \mathrm{v}$ a $\mathrm{r}$ i a conaexa. S $\mathrm{t}$ y $\mathrm{I}_{\mathrm{i}}$ coadnnati; s tigmata ligularia, recurva. Follienti stipltellati, gummosi. Indehiscentes (?) - Arbor Novae-Hollandiae; folits fere populneis, cuspidatis, ob. solete crenulatis, lucidis, floribus terminalibus mag. nis, in racemum terminalom ramosum dispositis, pen. dulis, pulchre striato-maculosis.

d. BRACHYCHITON Schott et Endl. Melet. 34. Calyx cyathiformis, quinquefidus, laciniis dilatatis, patentibus, aestivatione induplicatis, tubo intus basi annulo uncinatim inflexo, lobato. Tu b u 8 stamineus inclusus, marium antheris in capitulum eoacervatis terminatus, feminarum antheris effoetis, ovarii basim pluriseriatim cingentibus. 0 varia coadunata. Sty'li eoaliti; stig. ma ta liguliformia, radiata. Folliculi distincti, sti. pitellati, polyspermi. S e m in a nuda. - Arbor Novae. Hollandiae tropicae; foliis alternis, petiolatis, rotundatis, latissimis, sublobatis, repandis, floribus in arillis foliorum mature delabentium subsolita. riis, magnis, utrinque punctis saturatioribus conspersis.

e. TRICHOSIPHON Sehott et Endl. Melet. 34. C a l y x in. fundibuliformis, quiaquefidus, laciniis patentibus. $T$ nbus stamineus masculorum inclusus, medio inernssatas, villoso barbatus, filamentis apice liberis, antheras in capituluu inordinate concervatas gerentibus, feminarum .... Folliculi sessiles, oligospermi. Se mina nuda. - Arbor Novae-Hollandiae, forescentiae tempore aphylla, racemis terminali-axillaribus, brevibus, floribus erectis.

f. COLA Schott et EndI. Melet. 33. C a I y x urceolatis, quinque-sexfidus, laciniis erectis. T u bus stamiacus brevissimus, demum saepe elongatus, antherae 10-15, sessiles, loculis superpositis, ovarium v. ovarii rudimentum bi-triseriatim eiugentes. O varia subdistincta, sessilia; stigmata sessilia, simplicia, reflexa. Folli culi sessiles, oligospermi. Se m in a magna, arillata (2) - Arbores Africae tropicae; foliis ovatis $v$. oblongis, acuminatis, intordum trilobis, subglabris, Roribus axillaribus terminalibusque paniculatis, parvis, seminibus magnis, edulibus. - C n l a Bauhin Pin. 507. St. a cuminata Palisot Flor. Owar, $t$. 24. St. heterophylla Palis. Op. cit. $t$. 40 . St, graudiflora Vent. St. nitida Vent. St. marerocarpa Don. St. eor difolia Guillem. et Perrot. Flor. Seneg. t. 15. S t. tomentos a Guillem. et Perrot. Op. cil. t. 16. L unan a e DC. Prodr. II. 92, Edwardia Rafist. Spech. 1 158, B i e h y Lunan Jamaic, I. 86. ? Culh amia Forskael Aegrpt. 96.

g. CAVAllium Schott et Endl. Melet. 33. C a 1 y $x$ campanulatus. quinquefidus, erectus. $T$ a $b$ a $s$ stamiaeus bre$v$ is, medio constrictus, apice in filamenta 10 , monanthera, alterna breviora solutus. Sty $1 \mathrm{i}$ connexi, bre. ves; stigmat a coadunata in noicum quinquelobum. Follie uii eoriacei sessiles, oligospermil. - Arbores indicae; foliis cordatis, lobatis, floribus paniculatis, copiosis, minutis. - S t. u rens Roxburgh Coroms. $t$. 24. S t, c o m o s a Wallich Plant. As. rar, $t, 127$.

h. HICDEGARDIA Sehott et Endl, Molet.33. C al y x quinquepartitus, reflexus. Tub us stamineus elongatus, fusiformi-clavatus, antheris decem biseriatis, inferioribus ovarii angulis oppositis. Styll counexi; st ig ma. ta coadunata, planiuscula, minuta. Follic uli membranacei, longi stipitati, ventricosi, venosi, apice in alam latam", cultriformem desinentes, oligospermi (3) $-A r$. bores indicae; folitis cordatis, acutis, membranaceis, glabris, floribus odoratis. - St. populifolia Roxburgh Wallich Plant. As, rar. $t, 3$.

i. SCAPHIUM Schott et Endl. Melet, 33. Caly $x \ldots .$. Follicull stipitati, venosi, longe ante maturitatem aperti, deran cymbiformes, basi monospermi. - Species indica. - S t. $s$ ca p ti gera Wallieh.

k. FIRMIANA Marsigl, in Act. Patav, I. t, 1.2. $\mathrm{C}$ a $1 \mathrm{y} \times \mathrm{x}$ ad basim quiaquepartitus. T u bus stamineus elongatus, cyliadricus, autheris plurimis. Follic uli membranacei, longe ante maturitatem aperti, foliorum ad instar expansi. - Lrbor chinensis; folits palmato-quinquelobis, glabris. - Sehott et Endl. Melet. 33. S t. p I a tanifoli a Linn. Cav. Diss. V, t. 145.

1. ERYTHROPSiS Lindl. in Bot, Reg. n. 1236. C a 1 y $x$ iufundibuliformis, quinquedentatus. Tubus stamineus exsertus, antheris 30 , sessilibas, congestis. Folliculi membranacei, stipitati, longe ante maturitatem aperti, explanati, folifformes, dependentes, dispermi. Arbor indica; folitis palmato-quinquelobis, foribus fructibusque coccineis. - Schott et Endl. Melet. 33. 
St. colorat a Roxburgh Plant. Corom. $t$, 25. Hooker I.. $t$. 143 .

5321. Pterygota SCHOTT et ENDL. Flores abortu unisexuales. Caly x coloratus, campanulatus, quinquepartitus, laciniis lanceolatis, carnosis, apice reflexis, aestivatione valvatis. Corolla nulla. Mas c. Tabus stamineus cylindricus, inclusus, apice in urceolnm quinquelobum expansus, lobis singulis extus superposite pentantheriferis, antherae biloculares, loculis subparallelis, bivalvibus, Ova rii rudimentum in api ce tubi staminei intra ejusdem arceolum sessile. Fem. Tubus staminens cum carpophoro hrevis. simo vaginatim connatus, in lobos quinque cum earpidiis alternantes solutus, lobis extus antheras effoetas, coacervatim superpositas gerentibus. Ovaria 5, unilocalaria, inter lobos antheriferos sessilia, verticillatim arcte contigua. Ovula ad suturam ventralem plurima, horizontalia, biseriata. Styli breves, apite recurvi; $8 \mathrm{tigmata} 8 \mathrm{sb}$ emarginata. Folliculi 5, v. abortu panciores, longe stipitati, sublignosi, subrotundi, uniloculares, sutura ventrali dehiscentes. S emina pluri ma, biseriata, horizontalia, compressa, testa fibroso-spongiosa, apice in alam longam cultriformem expansa, umbilico basilari. Embryonis exalbuminosi, orthotropi cotyled on es carnosae, planae, trinerves, radi $\mathrm{cula}$ larevissima, obtnsa, umbilicnm attingens, centripeta, plumnla diphylla. - Arbor bengalensis, ramosa; foliis alternis, petiolatis, cordatis, acutis, integerrimis, glabris, florescentiae tempore deciduis, stipulis lateralibus geminis, subulatis, caducis, racemis axillaribus v. subterminalibus paniculatis, tomento ferrugineo stellato dense tectis, floribus brevissime pedicellatis, extus ferrugineo-lomentosis, intus rubro et flavo variegatis.

Pterygota Sehott et Endl. Melet. 32. Meisner Gen. 30. (25.) Sterculia a lat a Roxburgh Plant. of Corom. III. 84. 4. 287 .

\section{Drdo CCXI. Büttneriaceae.}

BÜTTNERLACEAE R. Brown in Flinders Voy. II. 540 . Kunth Malvac, 6, DC. Pradr, $I$, 481. exel, sect. 1. BÜTT NERIACEAR, HERMANNIACEAE et DOMBEYACEAE Bartling Ord. nat. 341 -3y3.

Arbores, frutices v. suffrutices, ereeti v. interdum scandentes, rarius HеRвAE annuae v. perennes, pube stellata v. bifurca, rarissime lepidota. Folia alterna, petiolata, simplicia, penninervia v. palmatinervia, integra, pinnatifida v. saepius palmatiloba, dentata v. serrata, rarissime integerrima. Stipulae ad basim petiolorum liberae, deciduae, interdum persistentes, foliaceae, rarissime nullae.

Flores hermaphroditi, regulares, in pedunculis axillaribus v. oppositifoliis, rarius subterminalibus varie dispositi, cymosi, paniculati, spicati v, glomerati, nudi v. involucello unilaterali aut ambiente, rarius involucro communi stipati.

Calxx herbaceus, membranaceus v. coriaceus, interdum coloratus, quadri-quinquefidus v. partitus, laciniis aestivatione valvatis.

Conoula nunc nulla, nnne petala calycis laciniis numero aequalia et alterna, hypogyna, libera, plus minus distincte unguicnlata, nunc plana, aestivatione convolutiva v. spiratim contorta, nunc concavo-fornicata, superne in laminam lignlaeformem, indivisam v. partitam, saepe tubi staminei lobis cohaerentem producta, aestivatione valvatim induplicata, decidua v. persistentia.

Stamina hypogyna, nune petalis numero aequalia et opposita, nunc dupla, alterna fertilia petalis opposita, nunc multipla, uniseriata, sterilia calycis lobis numero aequalia et subopposita, cum fertilibus pluribus alternantia, v. rarissime omnia fertilia, nunc plurima pluriseriata, interiora sensim longiora, omnia fertilia et coalita. Filam en ta rarissime libera, plerumque in cupulam, tubum v. columnam plus minus coalita. A n the ra e extrorsae v. rarius subintrorsae, in singulis tubi staminei lobis singulae, v. rarissime plures transversim superpositae, erectae v. incumbentes, biloculares, loculis appositis v. oppositis, parallelis, contiguis v. basi discretis, longitudinaliter v. rarius prope apicem poro v. rimula dehiscentibus.

Ovarium liberum, sessile v. interdum breviter stipitatum, e carpidiis quatuor aut quinque, rarius pluribus, rarissime abortu paucioribus v. solitariis compositum, carpidiorum marginibus in dissepimenta introflexis, columnam centralem attingentibus quadri-quinque $v$. interdum decemloculare. $0 \mathrm{vala}$ in loculis gemina collateralia, v. plurima biseriata, saepissime adscendentia v. subhorizontalia, rarissime pendula, anatropa. Styli terminales, in unicum coaliti; stigmata loculorum numero, erecta v. patentia.

Froctus rarissime indehiscens, plerumque capsularis, membranaceus, coriaceus v. lignosus, quadri-quinque-decemlocularis, nune loculicide dehiscens, vaivis medio septa saepius demum bipartita gerentibus, nunc septicide in elementa carpica solutus, coccis demum bivalvibus.

Semra in loculis nunc gemina $v$. abortu solitaria, nunc multa v. plurima, plerumque adscendentia, rotundata, $v$. interdum compressa et superne in alam membranaceam producta, testa crustacea v. membranacea, umbilico basilari v. prope basim laterali, nudo v. strophiolato, cum chalaza opposita per rhaphen longitudinalem plus minus manifestam conjuncto. Alb um en carnosum $v$. mucilaginosum, interdum nullum.

Embryo nunc albumine inclusus, nunc exalbuminosus, rectus v. homotrope arcuatus; c otyledonibus carnosis v. saepius foliaceis, integris v. bipartitis, planis v. plicatis aut involutis, aut rarius spiraliter convolutis, radicula recta v. incurva, umbilico proxima, saepissime infera. 
Büttneriace a e cum Sterculiaceis et Malvaceis haud facile confundendae, regiones tropicas totius orbis, Caput bonae spei et NovamHollandiam incolunt, juxta naturales tribus per regiones segregatae.

TRERUS I. LASIOPETALEAE Gay in Mem. Mus. VII. 431. C a ly $\mathrm{x}$ corollinus. P eta la minute squamulaeformia v. nulla. S t a min a libera v. basi coalita, fertilia 5 petalis opposita, sterilia nulla v. fertilibus solitarie alterna, a $\mathrm{n} t \mathrm{~h}$ e $\mathrm{r}$ a e extrorsae, incumbentes. 0 vari um tri-quinqueloculare, loculis 2 -8 ovulatis, ovulis adscendentibus. Carpidia libera v. in capsulam loculicide dehiscentem coalita. Semina strophiolata. Embryo in axi albuminis carnosi orthotropus, rectus, cotyledonibus foliaceis, planis. - Frutices Novae-Hollandiae.

5322. Seringia $G A Y$. Inflorescentia cymosa, oppositifolia. Bracteola e vagae. Caly $x$ petaloideus, marcescens, quinquepartitus, laciniis introflexis, aestivatione valvatis. Corolla nulla. St amina 10, hypogyna; fil amenta subulata, basi connata, alterna calyeis laciniis opposita ananthera, antherae extrursae, biloeulares, lineares, medio dorso insertae, loculis extns juxta totam Iongitudinem dehiscentibus, 0 y a. ria 5, verticillatim approximata, unilocularia. Ovula 3 , suturae ventrali superposite inserta, adscendentia, extrorsum anatropa. S ty l u s terminalis, simplex; stigmate acuto. Carpidia 5, compressa, superne in alam brevem, truncatam producta, unilocularia, primum ventre hiantia, mox dorso fissa, bivalvia. S e mina 2_ 3 , juxta suturam ventralem adscendentia, ovata, testa subcrustacea, aspera, rhaphe introrsa, filiformi, 80lnbili, ab umbilico basilari, strophiola carnosa crenata cincto, ad chalazam terminalem incrassatam producta. E $\mathbf{m}$ b ryo in axi albuminis carnosi orthotropus, ejusdem longitudine; cotyl e do n ibus foliaceis, orbiculatis, planis, dorso rhaphen respicientibus, radicula teretí longa, umbilicum attingente, infera. - Frutex Novae-Hollandiae orientalis, pube stellata; folïs alternis, breve petiolatis, inaequaliter dentato-angulatis, stipulis parvis, deciduis, inflorescentia oppositifolia, cymosa, bracteis subherbaceis, deciduis, calycibus dorso fructibusque pubescentibus.

Seriugla Gay in Mem. Mus. PIT. 448. $t$. 16. 17. DC. Prodr. I. 488, Meisuer Gen, 32, (26.) G a y a Sprengel Syst. II, 971, Lasiopetalum arborescens Aiton.

5323. Tuiehenotia GAY. Inflorescentia axillaris, racemosa. Bracteola hypocalycina persistens, tripartita. Calyx petaloideus, persistens, campanulatus, quinquepartitus, laciniis aestivatione valvatis, dorso demum tricostatis. Coroll a e petala 5, hypogyna, calycis laciniis alterna, minima, squamaeformia. $\mathrm{S} t$ a $\mathrm{m}$ in a 5, hypogyna, petalis opposita; fil a m enta subnlata, antherae extrorsae, biloculares, lineari-lanceolatae, dorso insertae, loculis latere utrinque rima longitudinali dehiscentibus, Ovar i um sessile, quinqueloculare, loculis intns densissime tomentosis. Ovula in loculis 5 , angulo centrali subbiseriatim inserta, adscendentia..... Stylus filiformis, brevis; stigma simplex.
Frnetus .....

Frutex canescens, in NovaHollandia oc $\overline{i d}$ entali indigenus, foliis brevissime petiolatis, ternato - verticillatis, lineari-lanceolatis, penninerviis, integerrimis, margine revolutis, supra pubescentibus, subtus dense griseo-tomentosis, stipulis nullis, racemis axillaribus folio brevioribus, bracteolae hypocalycinae tripartitae-laciniis ovato-ellipticis, calycibus utrinque tomentosis. $\mathrm{G}$ uichenotia Gay in Mem, Mus. VIT. 448. $t$. 20. Meisner Gen, 33. (25.)

5324. 'Thomasia $G A Y$. Inflorescenti a ramosa, oppositifolia. Bracte ol a hypocalycina persistens, tripartita. Caly $\mathbf{x}$ petaloideus, persistens, campanulatus, quinquepartitus, laciniis venosis, aestivatione valvatis. Corolla e petala 5, hypogyna, calycis laciniis alteraa, minima, squamaeformia, saepius nulla. Stamina hypogyna, quinque fertilia petalis opposita, totidem sterilia alterna, saepius defieientia; filam e n a brevia, subulata, distincta v, basi connata, anthera extrorsac, bilocnlares, ovoideo-oblongae, medio dorso insertae, loculis latere utrinque rima longitudinali dehiscentibus. Ovarinm sessile v. substipitatum, trilbeulare. O v u I a in loculis 2_8, angulo centrali subbiseriatim inserta, adscendentia, extrorsum anatropa. Stylus subulato-filiformis, glaber; $s \mathrm{tig} \mathrm{m}$ a acutum. $\mathrm{C}$ a p $8 \mathrm{u}$ la calyce persistente inclusa, trilocularis, loculicide trivalvis, valvis medio septiferis, S emina in loculis pauca v. solitaria, adscendentia, ellipsoidea, testa suberustacea, pubernla, $r$ ha $p$ he introrsa adnata, umbilieam basilarem, strophiola crenata cinctum, cum chalaza apicalijungente. $\mathbf{E}$ mb r yo in axi albuminis carnosi orthotropus, ejusdem longitudine; cotyledonibus foliaceis, orbiculato-cordatis, planis, dorso rhaphen respicien tibus, radienla tereti, longa, umbilieum attingente, infera. - Frutices rigidiusculi, in NovaHollandia austro - occidentali indigeni, pilis stellatis hispidi $v$. tomentosi; ramis abbreviatis, foliis alternis, breve petiolatis, ovatis, lobatis, rarius oblongo-ellipticis, subintegris, utrinque hispidis $v$. tomentosis, stipulis foliaceis, persistentibus, plerumque petiolatis, racemis oppositifoliis, paucifloris, bracteolae hypocalycinae, tripartitae laciniis subulatis, intermedia majore.

Thom a sia Gay in Mem. Mus. VIT. 650, t. 21, 22. DC. Prodr. I. 489. Meisner Gen. 33. (26.) L a 8 i o pet alli s. Labill. Nov. Holl, t. 88. Audrews Bot. Reposit, , 459. Sims Bot. Mag. t. 1485, 1486, 1755.

5325. Lasiopetalum SMITH. In florescentia cymosa, oppositifolia. Bracteola hypocalyeina persistens, tripartita. Calyx petaloideus, indurato-persistens, campanulatus, quinquepartitus, laciniis aveniis, aestivatione valvatis. Corollae petala 5, hypogyna, calycis laciniis alterna, minima, squamaeformia. S $t$ a mina 5 , hypogyna, petalis opposita; filamenta brevia, subulata, libera, an therae extrorsae, biloculares, ovato-lanceolatae, medio dorso insertae, loculis apice intus poro dehiscentibus. Ovarium sessile, triloculare. $O \mathrm{v}$ u l a in loculis $2-3$, angulo centrali superposite inserta, adscendentia, extrorsum anatropa. Stylus subulatus, brevis, glaber v. basi pubescens; stigm a simplex. C a p8 u la calyce indurato inclusa, trilocularis, loenlieide trivalvis, valvis medio septiferis, intus glabris. Sem in a in loculis solitaria, adscendentia, ovata, testa curiacea, puberula, rhaphe introrsa, adnata, umbilicum basilarem, strophiola digitato-laciniata cinctum, cum chalaza apicali jungente. E m b ryo 
in axi albuminis carnosi orthotropus, ejusdem longitudine; $c$ ot $y$ ledonibus foliaceis, cordato-orbiculatis, planis, dorso rhaphen respicientibus, radicula tereti, longa, umbilieum attingente, infera, - Frutices Novae-Hollandiae occidentalis, tomento stellato; ramis virgatis, vimineis, foliis alternis, brevissime petiolatis, linearilanceolatis, integerrimis, penninerviis, subtus to mento denso discolori tectis, stipulis nullis, bracteis hypocalycinis tripartitis herbaceis, laciniis subulatis, intermedia longiore, calycibus intus glabris v, utrinque tomentosis.

Las i opeta I u m Smith in Linn. Transact, IV. 216 Rudge Ibld. $X$. t. 12. Andrews Bot. Reposit. t, 208. Bot Mag. t. 1766. Venten. Malmais. t. 59. Gay in Mem, Mus. VII. 445. t. 18, 19. DC, Prodr. I. 489. Meisner Gen. 32 (26.)

5326. Corethrostylls ENDL. Inflorescentia cymosa, oppositifolia. Bract e ola e a calyce remotae, coloratae. C al y $x$ petaloideus, marcescens, ad basim quinquepartitus, laciniis lanceolato-acuminatis, stellato-patentibus, aestivatione valvatis. Corolla nulla. Sta $m$ in a 5 , hypogyna, calycis laciniis alterna; filamentabrevissima, subulata, libera, a n therae extrorsae, biloculares, ovoideo-oblongae, medio dorso insertae, loculis apice intus poro dehiscentibus. Ovari um sessile, triloculare. Ovula in loculis gemina, collateralia, ex anguli centralis basi adseendentia, extrorsum anatropa. St y Ius elongatus, pilorum fascieulis retrorsis hispidus, pyramidatoscopaeformis. St ig m a simplex. Ca p s u la calyce emarcido, connivente tecta, trilocularis, loculicide trivalvis, valvis medio septiferis, intus glabris. Se $m$ in a in loculis solitaria, erecta, ovato-oblonga, testa durissima, rhaphe introrsa filiformi ad. nata, umbilieum basilarem, strophiola cupulaeformi multipartita cinctum, cum chalaza apicali, mamillari jugente. $\mathbf{E} \mathbf{m} \mathbf{b} \mathbf{r} \mathbf{~ o}$ in axi albuminis carnosi orthotropus, ejusdem fere longitudine; cotyledonibus foliaceis, ovatis, planis, dorso rhaphen respicientibus, r adicula tereti, longa, umbilicum attingente, infera. - Frutices $\mathrm{Nov}$ a e- $\mathrm{Hol}_{\mathrm{l}}$ landiae a ustro-occidentalis, pilis stellatis consiti; foliis alternis, petiolatis, cordatis, integerrimis $v$, repando subsinuatis, inflorescentia oppositifolia cymoso-racemosa, bracteis foliaceis, bracteolis sparsis, coloratis, alabastris acuminatis.

Corethrostylis Endlicher Nov. Stirp. Mus. Vindob. Decad. $n, 1$.

$53 \%$ \% . Keravalrenia $G A Y$. Inflorescentia corymbosa, oppositifolia. Bracteola hypocalycina nulla. Calyx petaluideus, persis. tens, quinquefidus, laciniis rotato-patentibus, acutis, aestivatione valvatis. Corolla nulla. Sta min a 5, hypogyna, calyeis laciniis alterna; fil ame nta subulata, basi dilatata, supra ovarium con. niventia, libera, a n th er a extrorsae, hilueulares, ovato-oblongae, durso supra basim insertae, localis latere utrinque rima longitudinali dehiseentibus. Ovarium sessile, trilubum, triloculare. Ovula in loculis 3-6, angulo centrali subbiseriatim inserta, adscendentia ..... Styli 3 , filiformes, basi distincti, superne connati; $8 \mathrm{tig} \mathrm{m}$ a acutum. Ca p sula calyce persistente, molli involucrata, abortu unilocularis, bivalvis. S e m in a abortu gemina v, unicum, reniformia, umbilico basilari strophiola carnosa, subrotunda, integra cineto. E mbryo.... - Frutices Novae-Hollandiae austro-occidentalis, pilis stellatis hispiduli; foliis alternis, breve petiolatis, ovatis, sinuoso-un- dulatis, stipulis petiolaribus minutis, persistentibus, inflorescentia corymbosa, oppositifolia, pedicellis supra medium articulatis, bracteis ad basim pedicellorum obsoletis, bracteolis nullis.

Keraudrenia Gay in Mem. Mus, VIT. 461, t. 23. DC. Prodr. I. 489. Meisuer Gen. 33, (26.)

TTEIBUS III. BÜTPNERIEAE DC. Prodr. I. 484. P e ta la sessilia v. unguiculata, concava v. fornicata, superne saepissime in ligulam producta. Tubus stamineus apice in lacinias plures fissus, laciniis sterilibus cum petalis alternantibus, fertilibus iisdem oppositis, mono-triantheriferis. Ovariu m quinqueloculare, loculis bi-pluriovulatis. Fruetus capsularis, loculicide v. septicide dehiscens. S e $\mathrm{m}$ i $\mathbf{n}$ a nuda v. strophiolata. E m b r y o exalbuminosus, cotyledonibus plieatis v. convolutis, $v$ : in axi albuminis carnosi rectus, co tyled o nibus foliaceis, planis. - Herbae, frutices $v$. arbores, in Asia, et frequentius in America tropica crescentes.

5328. Talingia $\boldsymbol{R} . \boldsymbol{B R}$. C a l y $x$ quinquefidns, persistens, laciniis aestivatione valvatis. Corolla e petala 5 , hypogyna, e basi lata marginibus inflexis concava in ligulam producta, aestivatione valvata. T u b u 8 stamineus urceolatus, decempartitus, laciniis quinque sterilibns enm petalis alternantibus, petaloideis, integerrimis, patentibus, totidem alternis fertilibus petalis oppositis, filiformibus, monantheriferis, ant herae extrorsae, biloculares, didymae, locnlis longitudinaliter bivalvibus. Ovari u m sessile, quinquelobum, quinqueloculare. Ovn $\mathrm{la}$ in loculis gemina, angulo centrali inserta, adscendentia, anatropa. StyIn s simplex; st igm at a quinque, simplieia, cohaerentia v. subdistincta. Capsula laevis v, ehinata, quinqueloculariß, pentacocea, coccis monospermis, dorso bivalvibus. S e m e n adacendens, ovatum, testa crustacea, nmbilico basilari, strophiolato. Embryo in axi albuminis carnosi orthotropus; cotyled onibus foliaceis, planis, radicn I a tereti, nmbilico proxima, infera. Frutices Novae-Hollandia e; pube stellata tomentosi, foliis alternis, petiolatis, inferioribus saepe lobatis, superioribus integris, dentatis $v$. serratis, stipulis lateralibus geminis, cymis oppositifoliis $v$. axillaribus, paucis, floribus sacpissime candidis.

Ruflng i a R. Brown in Bot, Mag. t, 2191, 3182. St. Hilaire Flor. Brasil. I. 140, in not. Meisuer Gen. 32. (26.) B ü tneriae sp. Gay in Mem. Mus. X, $t, 12,13$.

5329. Commersonia FORST. C a ly $\mathrm{x}$ quinquefidus v. quinquepartitus, persistens, laciniis aestivatione valvatis. Corolla e petala 5 , hypogyna, e basi lata marginibus inflexis cencava, superne in ligulam producta, aestivatione valvata. T u b u s stamineus urceolatus, vigintipartitus, laciniis quindecim sterilibus $\mathrm{cum}$ petalis ternatim alternantibns, elongatis, ligulatis, basi inter se v. lateralibus hine cum fertili contigua cohaerentibus, fertilibus quinque petalis oppositis, brevissimis, monantheriferis, a ntherae extrorsae, biloculares, globosae v. didymae, loculis contigais v. divaricatis, transversim bivalvibus. Ova rium sessile, quinqueloculare. 0 v u 1 a in loculis 3.6, angulo centrali subbiseriatim inserta, adscendentia, anatropa, Sty li 5, distincti v. plns minus coaliti; s tig in a t a simplicia v, capitellata. C a p sula glo- 
bosa, setis flaccidis, pilosis echinata, quinquelocuIaris, loculicide quinquevalvis, valvis medio septiferis. Se m in a in loculis $2-3$, obovata, adscendentia, testa crustacea, umbilici basilaris strophiola laciniata. $\mathbf{E} \mathbf{m}$ br y o in axi albuminis carnosi orthotropus, ejusdem longitudine, cotyledonibus foliaceis, planis, radicnla tereti, umbilico proxima, infera. - Arbores $v$. frutices, pube stellata tomentosi, in Asia et Oceania tropica, frequentius in Nova-Hollandia crescentes; foliis alternis, petiolatis, ovatis, basi saepe inaequilateris, dentatis $v$. incisis, stipulis parvis, deciduis, cymis oppositifoliis $v$. axillaribus, folio brevioribus, bracteis parvis, deciduis.

Commerson i F Forster Char, gen, t. 43. Linn. f. Supplem. 56. Gärtner II. 79. t. 94. Lam. t. 218. Andrews Bot. Reposit, t. 519. Bot. Mag. t. 1813, Kunth in Humb, ot Bonpl. Nov. gen, et sp. V. 311. in not. Gay in Mem. Mus. X. 205. 2. 3. 4. DC. Prodr. I, 486. St. Hilaire Flor. Brasil. I. 140. in not. Meisuer Gen. 32. (26.) [R est i a ria a I b a Rumph Amboin, III, $t, 119$, - ? M e d u s a Loureiro Flor. cochinch. 49t. J ü $\mathrm{rg}$ ens i a Sprengel $S y s t$. IIT. 50.

5330. Abroma $J A C Q$. C a $1 \mathrm{y} \mathrm{x}$ membranaceus, quinquepartitus, persistens, laciniis aequalibus, aestivatione valvatis. Corolla e petala 5, hypogyna, ovata, ungue imo tubo stamineo inserto, basi dilatata concavo, lamina plana, aestivatione valvata. T a b a s staminens' brevis, urceolatus, quinquefidus, lariniis obcordatis, petalis alternantibus, sinubus petalis oppositis triantheriferis, anthera e extrorsae, biloculares, didymae, loculis transversis, discretis, bivalvibus, 0 vari u m sessile, quinqueloculare. Ovnla in loculis plurima, angulo centrali vix incrassato biseriatim inserta, horizontalia, anatropa. Styli 5 , conniventes; stigmata simplicia. Ca p s u la membranacea, quinquealata, apice truncato quinquerostris, quinquelocularis, juxta alas suturales incomplete loculicide quinquevalvis, valvis medio septa margine seminifera gerentibus. S e m in a plurima, ovato-subglobosa, testa coriacea, umbilico basilari, strophiola cupulaeformi carnosa cincto $\mathrm{E} m \mathrm{~b}$ ry o in axi albuminis carnosi orthotropus, ejusdem longitudine; cotyledonibus foliaceis, suborbiculatis, planis, radicula tereti, umbilico proxima, centripeta. - Arbusculae multicaules, subsimplices, in Asia tropica crescentes; pube stellata, foliis alternis, petiolatis, integris palmatilobisque, stipulis petiolaribus geminis, pedunculis extraaxillaribus, oppositifoliis v. subterminalibus, paucifloris, bracteatis, corollis sordide purpureis.

A brom a Jacq. Hort. Vindob. IIT. t. 1. Gärtner $t$. 306. t. 64. Salisbury Parad. t. 102. Kunth in Humb. et Bonpl. Nov. gen, et sp. V. 318. DC. Prodr. I. 485. Meisner Gen, 32. (26.) A ka br o ma Linn. f. Supplem. 341. Lam. t. 636. 637. Hastingi a Konig.

5331. Büttneria LÖFFL. C al y $\mathrm{x}$ coloratus, profunde quinquefidus, persistens $v$. deciduns, laciniis aequalisus, aestivatione valvatis. Coroll a e petala 5 , hypogyna, erecta, longe unguiculata, apice concavo cucullata, cuculli apice infexo superne in ligulam simplicem v. triplicem producto, inferne varie diviso, tnbo stamineo adhaerente, aestivatione valvata. $T$ u b u s stamineus urceolatus, apice decem-quindecimfidus, lacinits quinque v. decem sterilibus, cum petalis alternantibus, quinque fertilibus petalis oppositis, brevissimis, singulis monantheriferis, a n ther a e petalorum cucullo obtectae, extrorsae, biloculares, subglobosae v. didymae, loculis contiguis v. discretis, longitudinaliter v. transversim bivalvibus. 0 variu $m_{\text {ses- }}$ sile, quinquelobum, quinqueloculare. $0 \mathrm{v} u \mathrm{la}$ in loculis gemina, angulo centrali superposite inserta, anatropa, superius adscendens, inferius pendulum. Styln s simplex; stigma quinquefidum. Ca psul a subglobosa, echinata, quinquelocularis, pentacocca, coceis monospermis, a columna centrali filiformi persistente solutis, angulo interiore dehiscentibns. S emen inversum v. adscendens, ovato-trigonum, testa crustacea, scabra, rhaphe lineari, longitudinali, umbilicum basilarem cum chalaza apicali crassa mamillari jungente. Embryo exalbuminosus, orthotropus; cotyledonibus foliaceis, suborbiculatis, bilobis, circa radiculam superam $\mathbf{v}$. inferam spiraliter convolntis. Suffrutices erecti, $v$. frutices saepius scandentes, volubiles, in America, rarissime in Asia tropic a crescentes, inermes $v$. aculeati; foliis alternis, petiolatis, variis, petiolis interdum incrassato-triquetris, stipulis lateralibus geminis, floribus umbellatis $v$. rarius corymbosis, umbellis simplicibus, involucratis, plerumque in racemos $v$. paniculam dispositis, parvis, saepe atropurpureis.

B ủ tin e ria Löflling It. 313. Linn. Gon. n, 268. Aublet Guian. t, 96. Jacq. Hort. Schönbr. t, 46. Cavanill. Diss. V. 290, t. 148 -156. Roxburgh Corom. $t$. 29 . Kunth in Humb. et Bonpl. Nov, gen. et sp. V. 314. t. 481. DC. Prodr. I. 486. exel. sp. australas. St. Hilaire Flor. Brasill. $I, 138$. t. 27_29. Pohl Plant. Brasil. t. 145_154. Meisner Gen. 32. (26.) Chaet ae a Jacq. Enumerat. 17. - Heterophy 11 u mojer msc. Telf a ir ia Newmann msc. ex Hooker Bot. Miscell. 1. 291, t. 61.

5332. Ayemia LINN. C a ly $x$ membranacens, quinquepartitus, persistens, laciniis aequalibus, aestivatione valvatis. C o r o 1 l a e petala 5 , hypogyna, longe unguiculata, conniventia, lamina subfornicato - dilatata, dorso infra apicem glandula pedicellata superata. Tu b u s stamineus subinfundibuliformis, decem - quindecimdentatus, dentibus quinque v. decem obtasis, sterilibns, quinque petalis oppositis monantheriferis, a $\mathrm{t}$ h er a e extrorsae, biloculares, didymae, loculis subdiscretis, bivalvibus. Ovarium intra tubum staminenm breviter stipitatum, subglobosum, quinqueloculare, O v u 1 a in loculis solitaria (?), angulo centrali infra apicem appensa, anatropa. Stylus simplex; stig ma inçrassato-pentagonum; obsolete quinquelobum. Ca p sula globosa, muricata, quinquelocularis, pentacocca, coccis monospermis, a columna centrali filiformi, persistente solutis, dorso bivalvibus. S emen inversum, ovato-trigonum, testa erustacea, scabra, rhaphe sulciformi longitudinali, umbilicum basilarem cum chalaza apieali, orbiculari, depressa, margine elevato cincta jungente. Em bryo exalbuminosus, orthotropus; $\boldsymbol{c}$ otyledonibus foliaceis, suborbicnlatis, bilobis, circa radiculam fnsiformem spiraliter convolutis. - Herbae antillanae et mexicanae, annuae et perennes, glaberrimae, pubescentes $v$. tomentosae, erectae $v$. prostratae; foliis alternis, petiolatis, ovatis, serratis, stipulis lateralibus geminis, setaceis, pedunculis axillaribus, uni-pauciforis, folio brevioribus, pedicellis filiformibus aggregatis, basi stipulaceo bracteatis.

A y en ia Limn. Gen. n. 1020. Gürtner $I$. 302. t, 79. Cavanill. Diss. $V$. 289. $t$. 147. DC. Prodr, $I$, 487. Meisner Gen. 32. (26.) D a y e n i Miller Ic. t. 118. - Geaus, nisi ovula revera in omnibus solitaria, vix satis a Büttueria diversum.

5333. Theobroma LINN, C a l y x quinquepartitus, coloratus, deciduns, laciniis aequalibus, aestivatione valvatis. Corollae petala 5, hypogyna, cucullato-concava, cucalli apice inflexo superne in ligulam spathulatam producto, aesti- 
vatione fvalvata. Tubus staminens brevis, urceolatus, decemfidus, laciniis quinque sterilibns $\mathrm{cum}$ petalis alternantibus, lineari-subulatis, totidem fertilibus petalis oppositis, brevioribus, singulis diantheriferis; a ntherae extrorsae, biloculares, didymae, intra petalorum cucullum reconditae, 10culis transversis, discretis, bivalvibus. Ova rium sessile, quinqueloculare. 0 vula in loculorum angulo centrali 8_10, biseriata, horizontalia. S tyI $\mathrm{s}$ apice quinquefidus; $s \mathrm{tig} \mathrm{m}$ a $\mathrm{ta}$ simplicia. Fructus coriacen-lignosus, ovato-oblongus, apice attenuatus, quinquangularis, ad angulos rugosotuberculatus, quinquelocularis, indehiscens. S emin a in pulpa nidulantia, ovata, angulata, testa crustacea, fragili, endopleura membranaceo-pulposa. Embryonis exalbuminosi cotyled ones crassae, Iobuloso-corrugatae, radicul a brevissima. - Arbusculae in America tropica indigenae, ob fructus pulpam amaram, sed coctionis artificio mitigatam plurimis gratam et utilem cultae; foliis alternis, petiolatis, magnis, ovatis $v$. oblongis, indivisis, stipulis petiolaribus geminis, pedunculis axillaribus, foliorum lapsu lateralibus, nunc simplicibus unifloris, fasciculato-congestis, nunc ramosis multifloris.

Th t o br o m a Linn. Gen, n.900. exel, sp. Jussicu Gen. 276. Humb. et Bonpl. Plant, aequinot, $t, 30$. Kunth Nov. gen, el sp. V. 315. Tussac Flor. Antill, t. 13. DC, Prodr, 1. 484. Meisner Gen, 32. (26.) C a c a o Tournef. Inst, 444. Aublet Guian, $t, 274$, Gärtner $I T, 190, t .122$.

5334. Guazuma PLUM. C a ly $\mathrm{x}$ profunde bi-tripartitus, laciniis inaequilateris, aesti . vatione valvatis. Corollae petala 5 , hypogyna, unguiculata, obovata, apice cucullata, cuculli apice inflexo superne in ligulam linearem bifidam produeto, inferne bifido tubo stamineo adhaerente, aestivatione valvata. $T$ ubus stamineus campanulatus, apice decemfidus, laciniis quinque sterilibus cum petalis alternantibus, ovatis, acuminatis, integerrimis, totidem fertilibns petalis oppositis, linearibùs, apice in lacinias tres breves, singulas monantheriferas divisis, an therae extrorsae, biloculares, didymae, loculis transversis, diseretis, bivalvibus. O v a ri u m sessile, quinquelobum, quinqueloculare. Ovnla in loculis plurima, angulo centrali incrassato biseriatim inserta, subhorizontalia, anatropa. Styli 5 , coaliti; stigmat a simplicia. Ca ps u la subglobosa, lignosa, tessellato-tuberculata, quinquelocularis, apice incomplete loculicide quinquevalvis. S e min a plurima, angulata, testa coriacea, crassa, basi umbilicata. Embryo in axi albuminis carnosi orthotropus, ejusdem longitudine, cotyledon i b a foliaceis, transversim elliptieis, planiusculis, radi cula tereti, umbilicum attingente, centripeta. - Arbores Americae tropicae, pube stellata plus minus tomentosae; foliis alternis, ovato-oblongis, inaequaliter dentatis, stipulis lateralibus geminis, deciduis, corymbis axillaribus.

G u a z $\mathrm{m}$ a Plumier Gen, 36, t, 18. Jussien Gen, 276. Cavanill. Ic. $t$. 299. Kunth in Humb. et Bonpl. Nov, gen, et sp. V. 302. DC. Prodr. L. 485. St. Hilaire Plant. us. Brasil. t. 47. 48. Flor. Brasil. I, 147. Meisner Gen, 32. (26.) Wight Illustr. $t$. 31. B u b $\mathrm{r}$ m a Schreber Gen. $n$. 1216. The obromatis sp. Linn,

\section{* KLEINHOVIEAE.}

5335. IK leinhovia $L I N N$. C a ly $\mathrm{x}$ quinquepartitus, laciniis planis, trilus anticis oblongolanceolatis, duabus posticis ovato-oblongis, basi oblique connatis, aestivatione valvatis. Cgroll a e petala 5, hypogyna, calycis longitudine, imo tubo stamineo adnata, inaequalia, posticum complicatotubulosum, truncatum, antica planínscula, lateralibus sabcucullatis angustiora, aestivatione valvata. T u b u s stamineus elongato-cylindrieus, incurvas, apice ampliato quinquefidus, laciniis linearibus, petalis oppositis, singulis triantheriferis; antherae extrorsae, biloculares, subgloboso-didymae, peltatim stipitatae, loculis divarieatis, bivalvibus. Ov a ri u $\mathrm{m}$ longe stipitatum, breviter ultra tubum stamineum exsertum, quinquelóbum, quinqueloculare. $0 \mathrm{vula}$ in loculis quaterna, angulo centrali biseriatim inserta, horizontalia, anatropa. Stylns simplex; stigma crenulatum. Capsula membranacea, inflata, turbinata, quinquangularis, quinquelocularis, loculicide quinquevalvis, valvis medio septiferis, axi centrali nullo. Semin a in loculis solitaria, medio anguli centralis inserta, subglobosa, testa crustacea, tuberculata, rhaphe longitudinali percursa, endopleura membranacea, carnosa. Embry on is exalbuminosi cotyledones spiraliter eirca plumulam convolutae, radicula umbilico proxima, centripeta. - Arbor Asiae tropicae; folits alternis, petiolatis, cordatis, acuminatis, integerrimis, glabris, tri-septemnerviis, stipulis lateralibus ensiformibus, paniculae terminalis ramosae ramis stipulaceo-bracteatis, floribus glabris, roseis.

Kleinhovia Linn. Gen, n. 1024. Gïrtner $I T, 261$, t. 137. Cavanill. Diss. V. 288, t, 146. Lam, t. 734. Kunth in Humb. ot Bonpl. Nov. gen, et sp. V. 313. DC. Prodr. . 488. Roxburgh Flor. Ind. III. 1\%0. Wight et Arubtt Prodr. I. 64. Melsner Gen. 33. (26.)

OBSBRVATIO. Genera Actino p hor a Wallich Catalog, $n$. 1163. et $\mathrm{P}$ e $\mathrm{n}$ tag lot $\mathrm{t}$ s Wallich Catalog. $n_{+} 1166$, inter Büttnerisceas recensita, nobis ignota.

TRIBUS III. HERMANNIEAE DC. Prodr. I. 490. Corolla e petala plana. Sta$\mathrm{m}$ in a basi monadelpha, petalis numero aequalia et opposita, omnia fertilia, O vari u m unipluriloculare, loculis bi-multiovulatis. C ap sula loculicide dehiscens. S e min a pauca v. plurima. Embryo in axi albuminis carnosi rectus v. homotrope arcuatus, cotyledonibus foliaceis, planis. - Herbae v. frutices, inter tropicos lotius orbis, et copiosissime in Capite bonae Spei crescentes.

5336. Waltheria LINN, Cal y $\mathrm{x}$ turbinato-campanulatus, persistens, quinguefidus, decemnervis, basi nudus v. bracteolatus, laciniis aestivatione valvatis, C orolla e petala 5 , hypogyna, spathulato - v. ovato - oblonga, calyce breviora v. longiora, unguibus imo tubo stamineo adnata, aestivatione convolutiva. St a min a 5 , hypogyna, petalis opposita; filamenta inferne in tubum connata, superne plus minus distineta, a nthera e extrorsae, biloculares, longitudinaliter dehiscentes. O varin m sessile, obovato-inaequilaterum, uniloculare. $O$ vula 2, placentae parietali superposite inserta, adscendentia, anairopa. Stylus simplex, in ovarii latere placentifero rectinsculo subterminalis; st i $\mathrm{gma}$ acutum, penicillatum v, tuberculatum. C a ps u I a obovata, stylo laterali superata, unilocularis, dorso longitudinaliter fissa, bivalvis. Sem en abortn unicum, adscendens, obovatum, testa crustacea, umbilico basilari. E mb ry o in axi albuminis carnogi orthotropus, ejusdem longitudine; cotyled on ibus 
foliaceis, radicula tereti, umbilico proxima, infera, - Herbae, suffrutices v. arbusculae, inter tropicos totius orbis crescentes, pube stellata cum bifurca et simplici mixta; foliis alternis, petiolatis, inaequaliter serratis, nervis subtus prominentibus reticulatis, stipulis lateralibus geminis, angustis, floribus in capitula axillaria v. terminalia aggregatis, rarissime glomerulis paniculatis, corollis luteis $v$, aureis.

Wa the ria Linn. Gen. n. 827. Cav Diss. VI. 315. t. 170. 171. Jaeq. Ie, rar, $t, 130$. Kunth in Humb, et Bonpl. Nov, gen et sp. V. 332. Sehrank Hort. Monac, t. 55. St. Hilaire Plant, us. Brasil. t. 36. Flor, Brasil, II. 149. Meisner Gen, 33. (26.) Delessert Ic. select. IIT. $t, 24$. Lo p han th us Forster Char. gen. 14. Ast ropus Sprengel $N$. E. IIT. 64. Rle dle ia e s p. DC. Delessert Op. eit, III, t, 23.

$533 \%$. Meloelhia LINN. Calyx quinquefidus, persistens, laciniis aestivatione valvatis. Corollae petala 5, hypogyna, spathulato-oblonga, unguibus imo tubo stamineo adnata, aestivatione convolutiva. St a mina 5 , hypogyna, pétalis opposita et breviora; filamenta basi in tubum connata, a nthe ra extrorsae, biloculares, longitudinatiter dehiscentes. Ova ri um brevissime stipitatum, quinqueloculare. $\mathrm{O}$ val a in loculis gemina, angulo centrali superposite inserta, adscendentia, anatropa. St yli 5 , basi connati; stig. ma $t$ a clavulata. C a 8 ul a membranacea, pyramidato-pentagona, angulis suturalibus compressis, acutis $v$, acuminatis, quinquelosularis, loculicide quinquevalvis, valvis medio septiferis, a coInmna centrali seminifera filiformi, quinquepartibili solutis. Semina in leculis gemina, superposita v. abortn solitaria, adscendentia, obovata, testa crustacea, umbilico hasilari. Embryo in axi albuminis carnosi orthotropus, ejusdem longitudine; cotyledonibus foliaceis, planis, $r a-$ dic ula tereti, umbilico proxima, infera. - $A r$ busculae $v$. frutices, in America tropica crescentes, pube stellulata; foliis alternis, petiolatis, ovatis v. oblongis, serratis, stipulis petiolaribus geminis, pedunculis terminalibus, axillaribus v. oppositifolius, multifloris, floribus pedicellatis, umbellatis, violaceis v. albis, pedunculis basi bracteatis.

Melo ch ia Linn. Gon. n. 829. excl, sp. pl. Jacq. Hort. Vindob. $t$, 30, Gärtner II, 153, t, 113. Cav, Diss. VI, t, 172. f. 1. Kunth in Humb. et Bonpl. Nov. gen. et sp. V. 322. DC. Prodr. I, 490. Meisner Gen, 33. (26.)

5338. Thilleia VENTEN, Caly quinquefidus, nudus v, basi tribracteatus, laciniis aestivatione valvatis, Corollae petala 5, hypogyna, spathulato-oblonga, unguibus ino tubo stamineo adnata, aestivatione convolutiva. Stamina 5 , hypogyna, petalis opposita et breviora; filam e n t juxta totam longitudinem in tubum connata $v$, apice distincta, an $t h$ e $r$ a e extrorsae, biloculares, Iongitudinaliter dehiscentes. Ov a ri $\mathbf{m}$ sessile v. brevissime stipitatum, quinqueloculare. Ovula in loculis gemina, angulo centrali superposite inserta, adscendentia. Styli 5 , liberi v. basi connati; stigmata clavulata. C apsula globosa, subcrustacea, quinquelocularis, loculicide v. septicide quinquevalvis, valvis demum bifidis v. partitis, a columella centrali seminifera, solida v. quinquepartibili solutis. S e $\mathbf{m}$ i $\mathbf{n}$ a in loenlis gemina superposita, v. abortu solitaria, adscendentia, obovata, testa crustacea, umbilico basilari. Embryo in axi albuminis carnosi orthotropns, ejugdem longitudine; cot y ledonibus foliaceis, planis, radienla tereti, umbilieum attingente, infera. Herbaev. frutices, inter tropicos totius orbis crescentes, pube stellulata; foliis alternis, petiolatis, serratis, stipulis petiolaribus geminis, floribus terminalibus, axillaribus v. oppositifoliis, eapitatis, umbellatis, verticillatis, glomerato spicatis v. racemoso-paniculatis, albis v. favis, pedunculis basi bracteatis.

Ried le a Venten. Choir, $t$. 37. R iedle la DC. Prodr. I. 490, exel. sp. Mougeotia Kunth in Humb. et Bonpl. Nov. gen. et sp. $V$. 326. t. 483. 484. Alt he ria Thouar. Gen, Madagase, $n, 64$. Lo $\mathrm{ch}$ e $\mathrm{m}$ i a Arnott in Nouv. Annal. sc, nat, XI. 172, M elo chla e sp. Linn. Swartz. Jaeq. Ic. rar. t. 507. Cavanill, Diss. VI. t, 173. f. 1. t. 174. f. 1. t. 175. f. 2. St. Hilaire Flor, Brasil, I, 31. 32.

5339. Playsodium PRESL. C a 1 y $x$ quinquedentatus, persistens, demum vesiculosoinflatus, dentibus aestivatione valvatis. Corolla e petala 5, hypogyna, lineari-spathulata, calyce breviora, unguibus imo tobo stamineo adnata, aestivatione convolutiva, $\mathrm{S}$ t a $\mathrm{m}$ in a 5 , hypogyna, petalis opposita; filamenta in tubum connata, apice libera, a ntherae extrorsae, biloculares, longitudinaliter dehiscentes. Ova ri $\mathbf{n}$ m stipitatum, stipite ultra tubum stamineum exserto, quinqueloculare. Ovula in loculis gemina, angulo centrali superposite inserta, adscendentia, anatropa. Styli 5 , terminales, filiformes; $s \mathrm{tigmata}$ obtusa. Caps u la intra calycem conniventem Ionge stipitata, depresse globosa, coriacea, tomentosa, quinquelocularis, loculicide quinquevalvis, valvis medio septa a columella seminifera tereti tandem a basi sursum solnta gerentibus. Se m in a in loculis gemina, superposita, adscendentia, obovata, testa subcornea, umbilico basilari. Em b r y o in axi albuminis carnosi orthotropus, ejusdem longitudine; cotyledonibus foliaceis, planis, radi c: u la tereti, umbilico proxima, infera. - Arbor v. frutex mexicanus, pube stellata tomentosus; folits allernis, petiolatis, subcordato-ovatis, dentatis, stipulis petiolaribus geminis, deciduis, pedunculo terminali-oppositifolio, corymboso-multifloro, bracteis deciduis.

Physodium Presl in Reliq. Hank, II. 150. t. 72. Meisner Gen. 33. (26.)

5340. Hermammia $L I N N$. C a I y x campanulatas, quinquefidus, persistens, saepe deruum vesiculoso-inflatus, laciniis aestivatione valvatis. Corolla e petala $\tilde{\kappa}$, hypogyna, petalis opposita et breviora; filamenta ima basi monadelpha, membranacea, plana, superne latiora, a ntherae extrorsae, biloculares, ovatae, acnminatae, longitudinaliter dehiscentes. Ovarin m breviter stipitatum, quinqueloculare. $O \mathrm{vula}$ in loculis plurima, angulo centrali biseriatim inserta, adscendentia, anatropa. Sty li 5 , coaliti; stig mat a acuta. Ca p s ula coriacea, quinquelocularis, loculicide quinquevalvis, valvis medio septiferis. Semina plurima, reniformia, testa coriacea, sinu umbilicata. Embryo intra albumen carnosum homotrope arcnatus; cotyledonibus foliaceis, planis, radicula tereti, infera, - Frutices c apenses, pube stellata tomentosi v. hirsuti; foliis alternis, palmati- v. pinnatipartitis, v. saepius integris, incisis $v$. sinuatis, stipulis petiolaribus geminis, foliaceis, pedunculis axillaribus terminalibusque uni-multifloris, bracteis stipularibus, floribus saepissime flavis.

H e rm a n $\mathrm{n}$ a Linn. Gen, n. 628. Cavanill. Diss. VT. 327. t. 177, 182. Jacq. Hort, Schänbr, t, 117-129. 213213. 291. 292. Wendt, Sert. Hannov. t. 4. 5. 10. Bot. Mag. t. 299. 304. 307. 1348. 1349. Andrews Bot, Heposit. $t$. 164. DC. Prodr. I. 493. Meisner Gen, 33. (26.)

5341. MIalnernia LINN. C al yx campanulatus, quinquefidus, persistens, laciniis aesti- 
vatione valvatis. Corolla e petala 5, hypogyna, obovato- v. obcordato-oblonga, aestivatione spiraliter convolutiva. Sta m in a 5 , hypogyna, petalis opposita et breviora; fil am enta basi brevissime monadelpha, medio abruptim dilatata, a n therae extrorsae, biloculares, ovatae, acuminatae, longitudinaliter dehiscentes. O v a ri $\mathbf{m}$ breviter stipitatum, quinqueloculare. $O \mathbf{v u l a}$ in loculis plarima, angulo centrali biseriatim inserta, adscendentia, semianatropa. Styli 5 , distincti v. coaliti; stigmat a acuta. Capsula coriacea, quinquelocularis, loculicide quinquevalvis, valvis medio septiferis. Semina plurima, reniformia, testa coriacea, sinu umbilicata. Embryo intra albumen carnosum homotrope arcuatus; cotyledonibus foliaceis, planis, radieula tereti, infera. Herbae v. suffrutices c a penses, glabriv. saepius pube stellata plus minus tomentosi; foliis alternis, trifidis $v$. pinnalipartitis, lobis saepissime incisis, stipulis petiolaribus geminis, foliaceis, pedunculis axillaribus, terminalibus $v$. oppositifoliis, paucifloris, pedicellis filiformibus, nutantibus, floribus saepissime rubris.

Mahernia Linné Mant, 59. Cavan. Diss, VI. t, 176. f. 1. 2. t. 177. f. 3. $t$, $178 . f, 1, t, 181, f .2, t, 200, f .1 .2$. Jacq. Hort. Schönbr. t. 54 201. Andrews Bot. Neposit. t. 85. Bot. Mag. t. 277. 353 . Bot. Reg. t. 224, DC. Prodr. I. A96. Meisner Gen. 33. (26.)

TEIIBUS I\%. DOMBEYACEAE Kunth Malvac. 12. Corolla e petala plana. Stamin a $15-40$, basi monadelpha, rarissime omnia fertilia, plerumque 5 sterilia ligulaeformia, petalis subopposita. Ovari u m quinquepluriloculare. Ovula in locutis $2 \mathrm{v}$. plura, adscendentia. Fructus capsularis, loculicide v. septicide dehiscens, E mbryo intra albumen carnosum, parcum, cotyledonibus foliaceis, saepe bifidis, contortuplicatis, rarius planis. - Arbores $v$. frutices, in regionibus tropicis veteris orbis crescentes.

5342. Reuizia $C A V$. Involucellam tri phyllum, cadneum. C a I y x quinquepartitus, persistens, laciniis aestivatione valvatis. Corollae petala 5, hypogyna, oblongo-inaequilatera, aestivatione convolutiva, sub anthesi patentia, deci dua. St a min a $30-40$, hypogyna, basi in cupalam connata, omnia fertilia; f i la menta filiformi subulata, a n therae introrsae, biloculares, erectae, locnlis longitudinaliter dehiscentibus. O varium sessile, decemloculare. Ovula in locnlis gemina, angulo centrali superposite inserta, adscendentia, anatropa. Styli 10, brevissimi, erectiusculi; stigmata simplicia. Capsula depresse subglobosa, decemlocularis, septicide decacocea, coccis membranaceis, angulo centrali apertis, dispermis $v$, abortu monospermis. Semina subtriquetra ..... - Frutices borbonici; foliis alternis, petiolatis, cordatis, integris $v$. lobatis, crenatis, subtus farinaceo-tomentosis; ramorum sterilium interdum palmatipartitis, lobis laciniatis, stipulis subulatis, deciduis, pedunculis axillaribus folio longioribus, bifidis, corymboso-multifloris.

Ru iz i a Cavanill. Dissert. III. 117 t. 36. f, 1.2.t.39. f. 1. Jussieu Gen, 275. Jaequin Hort. Schönbr. t. 295. DC. Prodr. I. 497. Meisuer Gen, 34. (27.)

5343. Pentapetes LINN. Invo Ince Il a m triphyllum, unilaterale. Cal y $x$ quinquepartitus, deciduus, laciniis aestivatione valvatis. C o- rolla e petala 5 , hypogyna, obovata, aestivatione convolutiva, sub anthesi patentia, decidna, Stam in a 20, hypogyna, basi in eupulam connata, quinque sterilia ligulaeformi-subclavata cum tribus fertilibus alternantia; fi lamenta filiformisubulata, brevia, a nth.erae introrsae, biloculares, erectae, loculis longitudinaliter dehiscentibus. Ovarium sessile, quinqueloculare. $O$ vula in loculorum angulo centrali plura, geminatim superposita, anatropa. Stylus terminalis, simplex; stigm a quinquefidum, laciniis setaceis, patentibus. C a p \& $\mathbf{l}$ la quinquelocularis, loculieide quinquevalvis, valvis medio septiferis. S e min a in loculis plura, adscendentia, angulata, rhaphe et chalaza incrassatis. E m b r yo ..... Herbae annuae, in Asia tropica indigenae, pube stellata; foliis alternis, longe petiolatis, hastatolanceolatis, stipulis deciduis, pedunculis axillaribus unifloris, solitariis $v$. geminis, floribus cernuis, magnis, rubris.

Pentapetes Linn. Gen, n, 834. Miller Ic, t, 200. Ker in Bot. Reg. t. 575. DC. Prodr. I. 498, exel. sp. et synon. Meisuer Gen, 34. (27.) Moranda Scopoli Intro. dact. n. 1312. D o m be y a pho e $\mathrm{a}$ ce a Cavanill. Diss. IIT. t. 43, f. 1 .

5344. IBrotera CAV. Involícelln m triphyllum, nunc unilaterale, foliolis linearibus, nune ambiens, foliolis latis, cordatis. C a I y x quinquepartitns, persistens, laciniis aestivatione valvatis. C orollae petala 5, hypogyna, calycem aequantia, inaequilatera, apice spiraliter convoluta, nec. unquam expansa, simul decidna. S t a m in a 10 - 15, basi in arceolum petalorum ungnibus adhaerentem connata, quinque sterilia ligulaeformia, longiora, fertilia inter sterilia solitaria v. geminata, ifsdem breviora, fil amenta lineari-complanata, anthera e introrsae, biloculares, erectae, longitadinaliter dehiscentes. O v a $\mathrm{r}$ i a m sessile, quinqueloculare. $O$ vala in loculorum angulo centrali plura, geminatim superposita, adscendentia. StyIn s simplex; stigma radiato-quinquepartitnm. C a p s u la quinquelocularis, valvis medio septa ad axim connexa gerentibus, Semina in loculis plura, adscendentia. Embryo in axi albuminis carnosi rectus; cotyledonibus foliaceis, divaricato-bifidis, radicula umbilico proxima, infera. Fruticuli pube molli velutini, in Afriea tropica crescentes; foliis alternis, breve petiolatis, ovatis, crenato-serratis, stipulis subulatis, pedunculis axillaribus unifloris, solitariis v. geminis.

Broter a Cavanill, in Anal. scienc. nat. I, 33. excl. synon. et patria. Ic, $V ., 19, t, 433$, Gaillenis et Perrot. Elor. Seneg., . 85. $t, 17$. Spreageli a Schultes Observ. bot. 134.

5345. Assonia CAV. Involncellum monophyllom, unilaterale, tricrenatum. C a I y x quinquepartitus, persistens, lacinits aestivatione valvatis. Corolla e petala 5, hypogyna, oblongosubfalcata, inaequilatera, subscariosa, aestivatione convolutiva, persistentia. St a m in a 20 , hypogyna, basi in cupulam connata, quinque sterilia, ligulaeformi-subelavata, cum tribus fertilibus alternantia; filamenta filiformia, ligulas superantia, antherae introrsae, bilorulares, erectae, loculis longitudinaliter dehiscentibus. O varinm sessile, quinqueloculare. $O$ v ula in loculis gemina, collateralia, e basi anguli centralis adscendentia, anatropa. Styli 5, brevissimi; stigmata subclavata. C a p s u l a quinquelocularis, septicide quinquepartibilis. S e m ina in loculis gemina, collateralia, triquetra …. - Arbusculae borb o $n$ i126 
ca e, Thespesiae populneae facie; foliis alternis, petiotatis, cordatis, acuminatis, subserratis v. crena tis, glabris $v$.junioribus subtus adpresse tomentosis, pedunculis axillaribus et terminalibus, corymboso multifloris.

As s o n i a Cavanill. Dissert. III. 120, $t$. 42. $f$. 1. Jus. sien Gen, 287. DC. Prodr. I. 498. Meisner Gen, 34. (27.) Ko n igia Commersonmsc, Vahli a Dahl Observ. bot. 40.

5346. Hombeya $C A V$. Involucellnm triphyllum, unilaterale, deciduum. Calyx quinquepartitus, persistens, laciniis aestivatione valvatis. Corolla e petala 5 , imo calyci inserta, obovato-inaequilatera, aestivatione convoluta, marcescenti persistentia. Sta mina $15 \_20$, imo calyci inserta, basi in cupulam brevem connata, quinque sterilia filiformia v. ligulaeformia, cum duobus v, tribus fertilibus paullo brevioribus alternantia; filamenta filiformia v. subulata, an. the rae introrsae, biloculares, erectae, loculis longitudinaliter dehiscentibus. Ovarium sessile, quinqueloculare. Ovula in loculis $2-4$, angulo centrali biseriatim inserta, adscendentia. Sty lus terminalis, simplex; $8 \mathrm{tigma}$ quinquefidum, lobis acutis, revolutis. Ca p s u a coriacea, quinquelocularis, septicide pentacocea, coceis tandem bivalvibus, abortu monospermis. S e mina adscendentia, rhaphe adnata, e haIaz a incrassata. E mbryo in axi albuminis parei, subcarnosi orthotropus; cotyledonib ns foliaceis, bipartitis, convolntis, radicula umbilico proxima, infera. Arbusculae v. frutices, in insulis borbonicis, Madagascaria et parcius in Asia tropica crescentes, pube stellata; foliis alternis, petiolatis, cordatis, integris v. lobatis, crenatis, stipulis deciduis, floribus axillaribus umbellatis $v$. corymbosis, involucelli foliolis ovatis $v$, cordatis, v. anguste lanceolatis linearibusve.

D o m be y a Cavanill. Dissert. IIT, 121, t. 38_42. Gärt. ner IT. 259. $t$. 137. Lam. t. 137. DC. Prodr. I. 498. Wal lich Plant, As, rar. t. 235. Bot. Mag, t. 2905. Meisuer Gen, 34. (27.)

534\%. Xeropetalum DELILE. InvoIucellum nullum. Calyx quinquepartitus, persistens, laciniis aestivatione valvatis. Corolla e petala 5, imo ealyci inserta, obovato-inaequilatera, aestivatione convoluta, tandem scariosa, persistentia. St a m in a 20 , imo calyci inserta, basi in cupulam brevem connata, quinque sterilia ligulaeformi-subclavata, cum tribus fertilibus paullo brevioribus alternantia; fil amenta filiformia, anther a e introrsae, biloculares, erectae, loculis longitudinaliter dehiscentibus. Ovarium sessile, tri-quinqueloculare. Ov ul a in loculis 2_-3, ex anguli centralis basi collateraliter adscententia, anatropa. St y I us terminalis, tri-quinquefidus $v$. partitus, lobis acutis, intus stigmatosis, revolutis. C a p 8 ula coriacea, tri-quinquelocularis, loculicide quinquevalvis, valvis medio septa ab axi fili formi, basí seminifera soluta gerentibus. S e mina in loculis solitaria, adscendentia, rhaphe solubili, chalaza incrassata. E m bryo in axi albuminis carnoso-mucilaginosi orthotropus; c ot y l ed on ibus foliaceis, bipartitis, radienla brevi, umbilico proxima, infera. - Arbores in Africa tro. pica et australi subtropica indigenae, florescentiae tempore suepe aphyllae; folits alternis, petiolatis, basi cordatis, dentatis $v$. crenatis, stipulis deciduis, florum paniculis lateralibus, pedicellis corymbosis $v$, umbellatis, bracteolatis, bracteolis deciduis, interdum calyci admotis, nec tamen involu. cellum constituentibus, floribus roseis.
Xeropetalu m Delile in Cent. plant. Voy. Catlilaud, Meroé p. 84. Eadlicher in Decad, Nov. Stirp. Mus. Vindob. p. 35. Le a we a hoeckia E. Meyer msc.

5348. Vhelleamia FORSK. Invol ueelI n m triphyllom, unilaterale. C a l y $x$ quinquepartitus, persistens, laciniis aestivatione valvatis. Corollae petala 5 , hypogyna, obovato-inaequilatera, aestivatione convolutiva, sub anthesi patentia, decidua. Sta mina 10, hypogyna, basi in cupnlam connata, alterna sterilia ligulaeformia, alterna fertilia brevissima; fil a menta subulata, a $\mathbf{t}$ h e rae introrsae, biluculares, erectae, loculis longitudinaliter dehiscentibus. $O$ v a ri $\mathbf{u}$ m sessile, quinqueloculare. $O \times$ a 1 a in loculorum angulo centrali plura, gemination superposita, adscendentia, anatropa. St y lus terminalis, simplex; st igma quinquefidum, laciniis acutis, cohaerentibus v. patentibus, Capsula quinqueloenlaris, loculicide quinquevalvis, valvis medio septiferis. Semina in loculis plura, adscendentia, angulata, rhaphe et ehalaza incrassatis. $\mathbf{E} \mathbf{m}$ b $\mathbf{r} \mathbf{y}$ o in axi albuminis earnoso-mucilaginosi sigmoidens; cotyled onibus foliaceis, latis, plicato-flexuosis, radicula umbilico proxima, infera. - Arbores $v$. frutices, in Asia et Africa tropica crescentes, pube stellata; foliis alternis, petiolatis, ovatis, basi cordatis, integerrimis $v$. serratis, stipulis deciduis, pedunculis axillaribus solitariis, unifloris v. umbellatim triquinquefloris.

M e I ha n i a Forskael Aegypt, 64. Aiton Hort. Hew. edit. 2. IV. 146. DC. Prodr. I. 499. exel, sp. Wallieh Plant. As. rar. t. 77. Wight Illustr. t. 23. Meisner Gen. 34. (27.) Do mbe y a e 8 p. Audrews Bot. Heposit. t, 389. Bot. Mag. t. 1000.

5349. Astrapaea $L I N D L$. F lores dense corymbosi, exinvoluerati, singuli involucello triphyllo cineti, y. eapitate-nubellati involucrati, involucricommunis polyphylli foliolis magnis, snbrotundo-ovatis, duobus exterioribus oppositis, singuli unibracteati, Caly $\mathrm{x}$ pentaphyllus, foliolis lineari-lanceolatis, aestivatione valvatis. C orolI a e petala 5, hypogyna, ealyce longiora, obovatooblonga, in tubum convoluta. Stamina corollam aequantia v. superantia, in tubum cylindricum, quinquenervium, apice in filamenta vigintiquinque brevia solutum coalita; filam enta quinque intima sterilia, cuspidato-ligulaeformia, exteriora fertilia subbiseriata, filiformia, anthera e introrsae, biloculares, erectae, oblongae, loculis longitudinaliter dehiscentibus. O varium sessile, quinqueloculare. $\mathrm{O}$ v $\mathrm{I}$ a in loculoram angulo centrali gemina, superpusita, adscendentia, anatropa. Stylus terminalis, filiformis, exsertus; stigmata 5, brevia, acuta, patentia. F ruetus ...... Arbores indicae et madagas carienses; ramis crassis, teretibus, fistulasis, stellato-tomentosis, foliis alternis, longre petiolatis, magnis, cordatis, acuminatis, integris v. sublobatis, late crenatis, supra pubescentibus, subtus tomentosis, stipulis magnis, foliaceis, ovato-acuminatis, persistentibus, pedunculis axillaribus solitariis, longis, hirtis, folium subaequantibus, corymbo denso v. umbella capitata, pugni mole, floribus coccineis $v$. albidis.

Astrapaea Ltadley Collect, $t$. 14. Martius Amoen. bot. Monac. $t$, 4. DC. Prodr. I. 500. Meisner Gen, 43. (27,) Hilsenbergia. Bojermsc. Dombe ya can a a i a a Hoo. ker in Bot. Mag. 2 . 3619 .

5350. Cllossostemon DESFONT $\mathrm{C}$ a1 y x quinquepartitus, membranaceus, extus stellato-tomentosus, laciniis oblongis, acutis, tri-qua- 
drinerviis, aestivatione valvatis. Corollae petala 5, hypogyna, lanceolato oblonga, aeuminato. cuspidata, maltinervia, membranacea, glabra, calyee duplo v. triplo longiora, aequalia, patentia. Stamina. 35 , hypogyna; filamenta 5 laciniis calyeis opposita ananthera, Iongiora, membranacea, lanceolato-linearia, acuta, trinervia, subreticulato-cellulosa, petalis triplo breviora, 30 fertilia dianthera, filiformia, glabra, ima basi annulatim connata, decem filamentis sterilibus contigna iisdem usque ad medinm adnata, an therae biloculares (geminae connatae?). Ovarium sessile, ovatum, quinquesuleatum, stellulato-tomentosum, quinqueloculare. Ov ula in loculis 10 , angulo centrali biseriatim inserta. Stylus brevis; stig m a quinquefidum, lobis subulatis, conniventibus. Fructas.... _ Frutex (?) persicus, ramosus; foliis alternis, petiolatis, ovato-subrotundis, sublobalis, dentatis, pube stellata hispidis, stibulis lateralibus geminis, subulato acuminatis, flori pus terminalibus corymbosis, roseis.

G1 o s 8 os te mo n Desfont, in Mem, Mus. MIT. 238. t.2. Kunth in Humb. et Bonpl. Nov. gen, et sp. V. 311, in not, DC. Prodr. I. 485, Meisner Gen, 32, (26,)

5351. Troelaetia DC. Invol u cell u m nullum. Cal y $x$ quinquepartitus, foliolis lanceolatis, aestivatione valvatis. C o r ol la e petala 5 , hypogyna, obovato-subrotunda, aestivatione convolutiva, decidua. Stamina $15 \_30$, hypogyna, basi in urceolum connata, quinque v. septem sterilia, ligulae formia, integra v. irregulariter bifida, cum duo bus v. tribus fertilibus brevissimis alternantia; filamenta subnulla, antherae introrsae, biloculares, erectae, locnlis longitudinaliter dehiscenti bus. $O$ vari u $m$ sessile, quinqueloculare. $O$ vula in loculorum angulo centrali plura, biseriatim ad scendentia, anatropa. Sty Ius terminalis, filiformis; stig ma obtuse quinquelobum. C a psula quinqueloeularis, loculicide quinquevalvis, valvis medio septa margine seminifera gerentibns. S e mina plurima, subrotunda, aptera, $\mathbf{E} \mathbf{m}$ bryo $\mathbf{y}$... - Arbusculae borbonicae et madagasea rienses, ferrugineo-lepidotae; folitis alternis, petiolatis, ovatis $v$. ovato-lanceolatis, coriaceis, penninerviis, integerrimis, pedunculis axillaribus uni trifloris.

Trochetia DC, in Mem. Mus, X, 106, t, 7,8 , Prodr. I. 499. Meisuer Gen. 34. (27.)

535\%. Pterospermam $S C H R E B$. Involucell u m nullum v. triphyllum. Cal y $x$ quinquepartitus, basi tubulosus, laciniis linearibus, extus tomentosis, aestivatione valvatis. Corolla e petala 5 , hypogyna, oblique obovata v. oblonga, calyce breviora, aestivatione convolutiva, decidua. St a mina 20, basi in columnam cum ovarii stipite brevi connatam coalita, quinque sterilia subclavata, cum tribus fertilibus brevioribus alternantia; filamenta filiformia, antherae introrsae, bilnea lares, erectae, lineares, acutae, longitudinaliter dehiscentes. $O$ varium stipite brevi elevatum, quinqueloculare. $\mathrm{O} \mathrm{v} \mathrm{Ia}$ in Joeulis plura, angulo centrali biseriatim inserta, anatropa. Stylus terminalis, simplex; stigma clavatum. C a p sula clavata, lignosa, quinquelocularis, loculicide quinquevalvis, valvis medio septa crassa, cuneiformia gerentibus. Semina in loculis abortu pauca $v$. solitaria, adscendentia, compressa, superne in alam membranaceam, latam, obtusam producta. Embryonis exalbuminosi v. albuminis lamina tenuissima inclusi, orthotropi coty led o nes sabfoliaceae, contortuplicatae, radicula brevis, umbilico proxima, infera. - Arbores $v$. frutices, in Asia tropica crescentes, pube stellata squamulosae; foliis alternis, sessilibus v. breve petiolatis, cordatis, oblique $v$, cuneato - oblongis, coriaceis, penninerviis, integerrimis, subtus reticulatis, stipulis deciduis, pedunculis axillaribus uni-paucifloris.

Pteros per m u in Sehreber Gen, n, 1124, DC. in Mem. Mus. X. 111. Prodr. I, 500, Wight et Aruott Prodr. I. 68. Meisner Gen. 34. (22.)

a. VELAGA Adans. Involuce $11 \mathrm{um}$ nullum. - Velag a Adanson Fam, II, 389. V el a go Gärtner $I T .245$. P e n t a. pteridls sp. Linn. Cavanill, Diss. MIT. t. 43. 44. (Bot. Mag. $t$. 620. 1596. Wight in Hooker Bot. Miscell. Ap. pend. t. 26. Hooker Ic. t. 125.)

b. PTEROLAENA DC. Invol u cell u m triphyllum, foliolis maximis, cordato-subrotundis, fimbriato-laceris. $P$ terospermum semis agittatum Roxb. DC. in Mem. Mus. X, $t, 9$.

5353. IKydin ROXB. Involucell n m tetra-hexaphyllum, calycem ambiens et ejusdem basi adnatum. C a l y x campanulatus, quinquefidus, lobis aestivatione valvatis. Corolla e petala 5, hypogyna, obcordato-inaequilatera, imo tabo. stamineo inserta, aestivatione convolutiva. Tub as stamineus e basi ventricosa cylindricus, in filam enta 5 , filiformia, patentia, singula tetrantherifera soIntus, an the r a geminatim superpositae, contignae, adnatae, biloculares, Iongitudinaliter dehiscentes, Ovari $\mathbf{m}$ sessile, triloculare. Ov ala in loculis gemina, ex anguli centralis basi collateraliter adscendentia, anatropa. Sty lus tripartitus; stigmata peltatim dilatata, carnosa. Ca psula trilocularis, trivalvis, rarius abortu uni-bilocularis. Semina in loculis solitaria, adscendentia, aptera ..... - Arbores indicae; foliis alternis, petiolatis, subcordatis, quinquenerviis, subquinquelobis, stipulis deciduis, floribus paniculatis, albis.

K y dia Roxburgh Plant. of Corom, IIT, 11, t, 245. 216. DC. Prodr. I, 300. Wight et Araott Prodr, I, 69. Meisner Gen. 34. (27.)

TIEISUS \%. ERIOLAENEAE Arnott Prodr. 1. 70. Petala plana. Stamina plurima, multiseriata, in colunnam connata, omnia fertilia. Ant hera e biloculares, erectae. Arbores indicae.

5354. Erifolaema $D C$. Involneellnm flori proximum, tri-pentaphyllam, foliolis pectinato mnltifidis, calyce brevioribus. Cal y $x$ quinquepartitus, Iaciniis aeuminato-linearibus, basi intus biglandulosis. Corolla e petala 5 , hypogyna, calyce breviora, onguibus coriaceis, tomentosis, aestivatione convolutiva. St amin a plurima, multiseriata, interiora sensim longiora, umnia fertilia, in columnam stylo perviam coalita, antherae extrorsae, biloculares, erectae, loculis longitudinaliter dehiscentibus. Ovarium sessile, decemloculare. Ovu I a in loculis plurima, angulo centrali biseriatim inserta, adscendentia. Stylus filiformis; stig ma stellato-decemlobum. Caps a I a lignosa, decemlocularis, Ioculicide decemvalvis, valvis medio septiferis. S em in a plurima, adscendentim hiseriata, imbricata, compressinscula, superne in alam obtusam producta. $E \mathrm{mb}$ r yo in axi albuminis carnosi rectus; cotyled onibus orbiculatis, bilobis, snbplicatis, ra dicula recta, nm. $126 *$ 
bilico proxima, infera.

Arbores indicae; foliis alternis, longe petiolatis, cordato-obovatis, serratis, subtus stellato-pubescentibus v. tomentosis, stipulis deciduis, pedunculis axillaribus unifloris $v$. tri pluriftoris.

Eriol a e a DC. in Mem. Mus. X, 102, t. 5. Prodr. I. 501. Wallich Plant, As. rar. $t$. 64. Wight et Araott Prodr. I. 70. Meisner Gen, 35. (27.)

5355. NI $1 \mathrm{~nm}$ flori proximum, tri-tetraphyllum, foliolis an guste lanceolatis, integris, minutis, ovatis, lobatis, caducis. Ca I y x quadri.quinquepartitus, laciniis oblongo-linearibus, basi intus biglandulosis, aestivatione valvatis. Co roll a e petala 4 _5, hypogyna, calycem aequantia, unguibus coriaceis, tomento. sis, aestivatione convolutiva. $\mathbf{S}$ ta $\mathrm{m}$ in a circiter 20 , ploriseriata, omnia fertilia, in tubum conieum stylo pervium coalita, a nthera extrorsae, biloculares, erectae, loculis longitudinaliter dehiscentibus, Ovarin m sessile, quinque-decemloculare. Ovala in loculis plurima, angulo centrali biseriatim inserta, adscendentia, superne in alam producta. Sty Ins filiformis; stigma stellato quinque - decemlobum, C a p 8 ul a lignosa, quinque-decemlocularis, loculicide quinque-decemvalvis, vảlvis medio septiferis. Semina ..... Arbores in dicae; folits alternis, longe petiolatis, late ovatis, cordatis, serratis, pubescentibus v. subtus tomentosis, stipulis deciduis, pedunculis axillaribus paniculatis, folio longioribus.

Mierol aen a Wallich Catalog. n. 1173. Wight ef Arnott Prodr. I. 70. Meisner Gen. 35. (gz.) Wallichia DC. in Mem. Mus. X. 104. t. 6. Prodr. I. 501. J a e k i a Sprengel Syst, III, 85. S chille ra Reichenb. Consp. 204.

\section{GENERA DUBIA.}

5356. Visenia HOUTT. C a $1 \mathrm{y} \times$ quinquefidus, Corollae petala 5. St a min a 5, basi monadelpha, sterilia nulla. O varia 5 monostyla, connata. Capsulae 5, connatae, bivalves, monospermae. Semina in fundo capsulae affixa, superne in alam producta. A I bum en amygdalaceum. Embry on is cotyledones foliaceae, radicula infera. - Arbores indica e; foliis cordatis, acuminatis, obtuse serratis, albido-canescentibus, corymbis axillaribus pedunculatis, floribus subumbellatis.

Vis enia Houttuyn Syst. VT. 287. t. 46. f. 3. Blume Bijdr. 88. Meisner Gen. 33. (26.) W is e ni a Gmel. Syst. 515. A le urodendron Reinwardt in Syllog. Plant. Ir. 12. G108sosperm am Wallich Catalog. $n$. 1153.

535\%. Exitelia BLUM, Cal y $\mathrm{x}$ quinquepartitus, persistens. Corolla e petala 5, calyce vix longiora. Stamina plurima; filamentis basi leviter connatis, omnibus fertilibus, marcescentibus, antheris bilocularibus. Ovarinm didymum, villosnm. Stylus unus, lateralis, peraistens; st $\mathrm{g}$ ma simplex. Drupa (?) ovalis, villosa, bilocularis. Se min a in loculis solitaria, basi affixa.- Arbor javana; foliis alternis, oblongis, integerrimis, basi subtus biglandulosis, stipulis nul. lis, floribus corymbosis, axillaribus terminalibusque.

Exite lla Blame Flor. Jav.Praef. VII, Maranthes Blume Bijdr. 89.

\section{* PHILIPPODENDREAE.}

5358. Philippodendron POIT, F 10 res dioiei. M a s c. … F e m. C a l y $x$ eampanu- latas, limbi quinquefidi laciniis ovato-lanceolatis, aequalibus, patulis. St a mina sterilia 10, hypogyna; f i a m e $\mathrm{n}$ a inferne in tubam superne coaretato conicum, extus medio squamis petaloideis 5, spathulato-lanceolatis, calycis laciniis alternis anetum connata, apice libera, a nther is reniformibus, efoetis, rima transversa bivalvibus. Ova rium liberum, sessile, uniloculare. OvaI $\mathrm{m}$ unicum, ex apice loculi pendulum. Stylus terminalis, rectus, brevis; $s \mathrm{tig}$ m a clavatum, maximum, subineurvum, papilloso-rugosum. F r a et $\mathbf{n} 8$.... Planta e seminibus n epalensibus in tepidariis Noisetit educata, primo sistens fruticem gracilem, diffusum, foliis parvis instructum, dein in arborem pyramidalem excrescens; foliis allernis, petiolatis, lobatis, serratis, stipulatis, floribus parvis, virescentibus, in paniculas laterales terminalesque dispositis, pube stellata, in ramulis folïsque novellis sparsa, in ovariis densissima.

Phillppode adro a Poiteau in Nouv. Annal, sc, nat. VIII. 183. t. 3 .

535. Hiassollettia PRESL. F lores monoiei, fasciculati, masculi laterales, pedicellati, basi nudi, femineus centralis, sessilis, basi involucello urceolato, integerrimo instructus. Calyx pentaphyllus, foliolis nninerviis, duobus exterioribus paullo angustioribus. Corolla nulla. M a se. T a bus stamineus obconicus, triqueter, brevis, tridentatus, dentibus calloso-marginatis, a n therae 3 , sessiles, cum tubi staminei dentibus alternantes, ovales, biloculares. F e m. T u bus staminens obconicus, quadrangulus, brevis, quadridentatus, dentilsus petaloideis, ovatis, pubescentibus, $A$ nt herae 4, steriles, sessiles, tabi staminei dentibus oppositae, ovato-subglobosae, inaequales. Ovarinm tubi staminei calyeisque basi globosa inclusum, sessile, obovatam, nniloculare. Ovulum unieum, pendulum Stylus tubo stamineo longior, tetragonus, velutinns, ereetus; stigmata 2, semipeltata, pfana, colorata. Fruetus earnosus, globosus, apice eicatrieula orbiealari notatus, monospermus. - Stirps in insulis Mariannae ab Haenkeo lecta; ramis lignosis, foliis petiolatis, excentrice peltatis, ovatis, membranaceis, ooto-decemnerviis, integerrimis, immerse reticulatovenosis, panioulis axillaribus multifloris, floribus parvis, virescentibus.

Biassolettia Presi in Reliq. Hänk, 141.

\section{Dralo CCXII. Tiliacene.}

TILIACEAE Jussieu Gen. 290. excl, gen. Venten. Tabl. IIT. 204. Kunth Malvac. 14. DC. Prodr. I. 803. Bartling Ord. nat. 338. Lindley Introduct, edit. II. p. 99. Meisner Gen, 36. (28.) ELAEOCARPEAE Jussieu in Annal, Mus. XI. 31. DC. Prodr. I. 519. Wight et Arnott Prodr. I. 81. Meisner Gen. 39. (29.) ELAEOCARPACEAE Lindley Op. cit. 97.

Arbores v. frutices, ligno saepe levi, rarissime невваE, pube simplici, ramosa v. stellata. Folia alterna v, rarissime opposita, petiolata v. interdum sessilia, simplicia, penninervia v. palmatinervia, integra v. palmatiloba, crenata, serrata v. dentata, saepissime coriacea, subtus reticulato-venosa. S tipula e ad basim petiolorum geminae, liberae, deciduae v. rarius persistentes. 
Flores hermaphroditi, v. rarissime sexus alterius organis minus perfectis unisexuales, axillares $\mathrm{v}$. rarissime terminales, solitarii, racemosi v. corymbosi, nudi v. bracteati, rarius involucello libero v. gamophyllo, valvato cincti.

CaLXX saepissime tetra-pentamerus, foliolis liberis v. plus minus connatis, tetra-pentaphyllus v. quadri-quinquefidus aut partitus, aestivatione valvatus, deciduus.

Conollae petala calycis foliolis numero aequalia et alterna, in basi tori plani v. in stipitem brevem elevati (in Elaeocarpeis) hypogyna, unguiculata, basi saepe squamula v. foveola aucta, integra v. apice incisa aut fimbriato lacera, aestivatione imbricata, sub anthesi patentia, decidua, rarissime nulla.

Stamixa rarissime definita, duplo foliolorum calycis numero, saepissime indefinita, hypogyna, tori saepe in stipitem brevem elevati apici pluriseriatim inserta, et basi margine discoideo ejusdem integro $v$. lobato cincta, omnia fertilia, v. extima nonnunquam sterilia, filamentosa, rarius intima petaloideo-dilatata. Fi iamenta filiformia v. subulata, libera v. basi in annulum brevem $v$. in phalanges subcoalita. Antherae introrsae, biloculares, ovales, subrotundae v. lineares, erectae v. incumbentes et versatiles, loculis appositis v. rarius oppositis, parallelis v. interdum basi divergentibus, juxta totam longitudinem dehiscentibus, rarius (in Elaeocarpeis) apice valvulis transversis, in unicam confluentibus apertis. Pollin is granula laevia.

Ovarium liberum, sessile, v. toro stipitiformi, apice staminifero sustentum, e carpidiis pluribus $(2-10)$ verticillatim connatis, v. basi connexis et apice discretis compositum,bi-decemloculare, loculis interdum septo secundario verticali incomplete bilocellatis, rarius septulis horizontalibus transversim plurilocellatis. $O \mathrm{vu}$ la loculorum angulo centrali inserta, nunc pauca, subdefinita, nunc plurima, biseriata, pendula, horizontalia, adscendentia, anatropa. Styli loculorum numero, in unicum coaliti; stig mat a distincta v. cohaerentia.

Fructus saepe setosus v. echinatus, nunc laevis, costatus v. alatus, nunc capsularis, loculicide v. rarius septicide dehiscens, nunc indehiscens, coriaceus, lignosus v. drupaceus, rarissime baccatus, plurilocularis, v. abortu pauci-quandoque unilocularis.

Skmisa in loculis solitaria v. plurima, erecta, inversa v. horizontalia, ovata v. angulata, testa membranacea $v$. crustacea, aptera aut rarissime superne in alam membranaceam producta, rhaphe et chalaza saepissime manifestis. Albumen carnosum, rarissime nullum.

Emвryo in axi albuminis orthotropus; c otyledonibus foliaceis, planis, rarissime in semine exalbuminoso amygdalinis, $\mathrm{r}$ adicu la umbilico proxima, infera, supera v. centripeta.

Tiliacea e proxima affinitate ad Büttneriaceas Dombeyaceas, mediantibus Pterospermo et Lühea accedentes, et a Ternströmiaceis calycis aestivatione facillime distinguendae, in regionibus tropicis maximo numero generantur, pauciores, nec ultimi decoris, hemisphaerae borealis regiones temperatas fixa sede inhabitant, nonnullae in hemisphaerae australis regionibus subtropicis vigent.

Fructus nonnullarum edulis, lignum multiplieis usus. Infusi florum Tiliae vires antispasmodicae non satis celebrandae.

SUEOTID I. TILIACEAE VERAE. Corolla nulla v. petala integra. Antherae longitudinaliter dehiscentes.

TTEIBUS I. SLOANEAE. C o roll a nulla. - Americanae.

5360. 而rasseltia $H . B . K$. Caly x membranaceus, octopartitus, persistens, laciniis biseriatis, quatuor exterioribus ovatis, acutis, concavis, totidem interioribus alternis paullo longioribus, subspathulatis, obtusis. Corolla nulla. Stam in a plurima, fundo orbiculato inordinatim inserta; fil a m e nta capillaria, calyce longiora, persistentia, a thera e biloculares. Ovarium sessile, basi glandulis octo cinctum, subglobosum, obliquum, bi-triloculare. Ovula plurima, loculorum angulo centrali inserta. St y I u s terminalis, subulatus; stigma perforatum. Fruct as sub globosus, laevis, indehiscens, loculis mono-dispermis. Semina subrotunda, dorso convexa, facie plana, infra extremitatem acutiorem (superiorem?) inserta, testa subcrustacea. E mbryo intra albumen carnosum virens; cotyledonib u s magnis, orbiculato-cordatis, foliaceis, concavis, margine corrugatis (?), radicul a umbilico proxima, - Arbor ad fluvium Magdalenae Americae tropicae ab Humboldtio reperta; ramulis alternis, teretibus, foliis alternis, petiolatis, dentatis, quinquenerviis, basi supra biglandulosis, stipulis nullis (?), umbellis terminalibus sessilibus, cymosis, bractealis, floribus pedicellatis, fructibus rubris.

Ha s seltia Kunth in Humb. et Bonpl. Nov, gen, et sp. VII. 231. t. 601. Meisner Gen. 38. (29.)

5361. Ablamia $A U B L$. Calyx quadriquinquepartitus, laciniis ovatis, acutis, aestivatione ..... C orolla nnlla. St a mina plurima, hypogyna; filamenta filiformia, libera, antherae minutae, subrotundae, biloculares, longitudinaliter dehiscentes, O v a ri um sessile, ovatum, villosum. Styli 2, filiformes, apice breviter bifidi; stigmata obtusa. Ca ps ula ovata, pilosa, pilis longis rigidis, deciduis, unilocularis, quadrivalvis. Se mina plurima, minuta, columnae centrali oblongae, liberae inserta, membrana viscosa, rubra involuta.... - Arbor guianensis, trunco elato, apice ramoso; folits alternis, petiolatis, ovato-oblongis, acutis, rigidis, glabris, integerrimis, margine undulatis, stipulis nullis (?), corymbis axillaribus paucifloris, folio brevioribus. 
A b la n i a Aublet Guian. I. 585. t, 234. Lam. $t$. 479. DC. Prodr. I. 516. Meisner Gen. 38, (29.) Trichoca rpus Sehreber Gen. n, 923.

5362. Dasymema SCHOTT. Ca lyx quadri-octopartitus, laciniis ovato-lanceolatis, aestivatione valvatis. Corolla nulla. Sta mina plurima, disco hemisphaerico foveolato pluriseriatim inserta; filamenta brevissima, antherae introrsae, adnatae, biloculares, oblongo-lanceolatae, acutae, muticae, pubescentes, loculis ultra medium longitudinaliter dehiscentibus. 0 v a $\mathbf{r}$ i u m supra discum sessile, quadriloculare. Ovala in loculis quaterna, in angulo centrali geminatim superposite pendula, anatropa. Styli 4 , subulati, erecti, apice patentes; stigm at a acuta. Caps $\mathrm{u}$ l a lignosa, dense echinato-setosa, abortu unilocularis, monosperma, quadrivalvis, valvis medio septorum vestigia gerentibus. S emen inversum, ovatum, integumento carnoso, ad chalazam fructus basim spectantem incrassato. - Arbores $v$. arbusculae $A$ mericae tropica e; folits alternis, saepe approximatis, integerrimis $v$, serratis, subtus pubescentibus v. villosis, stipulis setaceis, deciduis, floribus axillaribus, fasciculato-subracemosis.

D a s y n e m a Sehott in Sprengel Cur. post, 408. A denobas ium Presi $s y m b$. bot. 39. $t, 27$. Foveolaria Meisner Gen. 36. (28.) Sloanea e seet. Myriochaeta et $\mathrm{F}$ oveodaria DC. Prodr. $I$. S15. Slo a ne a e s p. Aublet Guian. $t$. 242. Lam. $t$, 469. Slo a ne a mon o s perma Flor. Flum. V. 2. 100.

5363. Sloanea LINN. Caly x quadrisex-septemfidus $\mathbf{v}$, partitus, Iaciniis ovato-lanceolatis, aestivatione valvatis. St a m in a plurima, disco hemisphaerico foveolato pluriseriatim inserta; fil amenta brevissima, an-therae introrsae, adnatae, biloculares, Ianceolatae, acuminatae, loculis coriaceis, pubescentibns, longitudinaliter bivalvibus. O va rium supra discum sessile, quadriloculare. Ovala in loculis plura, angulo centrali inserta, pendola, anatropa. Stylus subulatus; stigma simplex. Capsula lignosa, dense echinato-setosa, quadrilocularis, loculicide quadrivalvis, valvis medio septa a columna centrali persistente avulsa gerentibus. Semina in loculis 1_3, ovata, inversa, integumento carnoso, ad chalazam fructus basim spectantem incrassato.... Arbores Americae tropicae; foliis alternis, petiolatis, ovatis $v$, cordatis, integerrimis vel dentatis, stipulis cordatis v. linearibus, persistentibus, floribus axillaribus, racemoso-fasciculatis.

S1oa ne a Linn. Gen, n. 655. Swartz Flor, Ind, occid. 11. 938. DC. Prodr. T. 515 . exel. sect. 3. et 5. Meisuer Gen. 36. (28.) Sl o a n a Plumier Gen, $t, 15$.

a. SLOANA DC. $l$. c. C.al y x sex-septemfidus. C a p $\leqslant \mathrm{u} 1 \mathrm{a}$ ab apice ad basim dehiscens. - Stipulae cordato-trian. gulares, serratae. - S. d e n ta $\mathrm{t}$ a L. (Plum. Ic. edit. Burm. $t, 24 \%$.

b. GYNostoma DC. l. c. Cal y $x$ quinquepartitus. C ap. s u I a a basi ad apiceu dehiscens. - Stipulae lineares. - S. Massoni Swartz.

z c, OXYANDRA $z$. c, C a 1 y $x$ quinquepartitus. Tor u 8 obsoletus. Caps a la fortassis setis destituta. - S. co ry mbiflara DC.

THERES 1I. GREWIEAE. Corolla e petala integra. _- Amphigeae.

5364 . Apeiba $A U B L, C$ a ly x pentaphyllus, rarins tetraphyllus, foliolis coloratis, lanceolatis, aestivatione valvatis, Co rolla e petala 5 v. 4, hy pogyna, obovata v. lanceolata, calycem aequantia v. longiora, aestivatione convolutiva. Stam ina plurima, hypogyna; filamenta filiformia, libera, anthera e lanceolato-tetragonae, basi insertae, apice in acumen membranacenm productae, biloculares, longitudinaliter dehiscentes. O vari $\mathbf{m}$ sessile, oeto-multiloculare. Ovula in loculorum angulo centrali plurima, multiseriata, ana. tropa. St y l us simplex, snperne incrassatus; stigma infundibuliformi-depressum, dentieulatum. Ca p sula orbiculata, umbilicata, coriacea, echinata v. tuberculato-aspera, octo - multilocularis, loculis intus pulposis, basi v. rarius apice angulo centrali demum fatiscentibus. Sem in a plurima, circa placentas e loculorum angulo centrali incrassato nidulantia, minuta, ovata, testa crustacea, chalaza apicali crassa, rhaphe obsoleta. $\mathbf{E}$ m. bryo in axi albuminis carnosi orthotropus; $c 0$ tyledonibus foliaceis, planis, radicula tereti, umbilico proxima, centripeta, - Arbores $v$, arbusculae, in $A$ merica tropica indigenae; foliis alternis, breve petiolatis, integerrimis $v$, serratis, utrinque stellato-pubescentibus, supra viridibus, pube subtus conferta discoloribus, stipulis lateralibus geminis, deciduis, pedunculis terminalibus et oppositifoliis, di-trichotome ramosis, multifloris, bracteatis, floribus flavis v. virescentibus.

A p e I b a Aublet Guian, I. 538, $t, 213-216$. Gärtner II. 188. t. 121. Lam, t, 470. Kunth in Humb. et Bonpl. Nov. gen. et sp. V. 347. DC. Prodr. I. 564. Meisuer Gen. 37. (28.) S I n a nea Loffling It. 311, non Linn. A u b letia Schreber Gen, n, 889. Swartz Flor. Ind, occid, t. 16. f. 1.

5365. Tithen WILLD. C a l y $\mathrm{x}$ involucratus, pentaphyllus, foliolis lanceolatis, aestivatione valvatis, involueri hexa-dodecaphylli foliolis lanceolatis v. linearibus, valvatis, patentibus v. tandem revolutis. Corollae petala 5, hypogyna, obovata v, oblonga, aestivatione apice convoluta, unguibus diseretis, trasi intus glandula adnata anctis. Stamina plurima, hypogyna, in phalanges quinque petalis alternas collecta; filament a basibus connata, exteriora cujusvis phalangis sterilia, penicillata v, fimbriato-ligulata, interiora fertilia, subulata, anthera ovatae v. oblongae, incumbentes, bilosulares, longitudinaliter dehiscentes. Ova ri u m sessile, quinquelocnlare, loculis nervo carpidiorum intus prominulo interdum incomplete bilocellatis. Ovala in localorum angulo centrali sex v, plurima, biseriata, adscendentia, anatrops. Stylus simplex, sursum incrassatus; stig ma capitato-pentagonnm v. obsolete quinquelobum. C a p sula ovata, obsolete pentagona, lignosa, quinquelocularis, ab apice ad medium loculicide quinquevalvis, valvis medio septiferis. Se min a plurima, juxta dissepimentorum margines ntrinque oblique adscendentia, imbricata, compresso-ovata, testa crustacea, margine superiori in alam membranaceam obtosam producta, umbilico ad basim alae sublaterali. Em b ry 0 in axi albuminis carnosi orthotropus; coty ledonibus foliaceis, planis, ovatis v. cordatis, radic u la brevi, tereti, umbilicum attingente, infera. Arbores Americae tropicae orientalis; foliis distiche alternis, petiolatis, duriusculis, supra viridibus, subtus tomento stellato denso discoloribus, nervis anastomosantibus prominentibus reticulatis, serratis, stipulis lateralibus geminis, deciduis, floribus nunc terminalibus solitariis, nunc saepius pedunculis axillaribus terminalibusve dichotome ramosis cymosis, paniculae - v. racemiformibus, bracteis sub dichotomiis verticillatis, deciduis, petalis albis v. rarius roseis. 
L ä he a Willdenow in Verhandl. Berlin, nat. Freund. ITI. 409. t.5. DC. Prodr. T, 517, Martius et Zuecariul Nov, gen. et sp. $I, 98$, t. 61 _63. St. Hilaire Plant. us, Brasil, t. 66. Flor, Brasil. I, 289, t. 57. 58. Pohl Plant, Brasil. t. 186. 187. Meisner Gen. 37. (28.) Brotera Flor. Flum. VIT. t. 163. 164. A llegri a Moçino et Sesse Flor. Mexic. ex Do. Prodr, $\boldsymbol{I} .517$.

5385. NIollia MART, et ZUCC. C a l yx pentaphyllus, foliolis linearibus, aestivatione valvatis. Corolla e petala 5, hypogyna, cuneata, apice truncato nervo excurrente mucronata, aestivatione convolutiva. Stamina plurima, hypogyna, in phalanges quinque petalis alternas collecta; filamenta basibus connata, omnia fertilia, interiora breviora, an therae longe lineares, incumbentes, biloculares, longitadinaliter dehiscentes. Ovarinm sessile, biloculare. Ovula medio dissepimento utrinque biseriatim inserta, plurima, anatropa. Stylus filiformis, apice incurvas; stigma obtusum. Capsula obcordata bilocularis, dissepimento contrarie compressa, alato-subanceps, lignosa, ab apice ad medium localicide bivalvis, valvis medio septiferis, inter se mina transversim septuliferis. S e $m$ in a plurima, dissepimentorum marginibas atrinque inserta, septulis transversis geminatim segregata, horizontalia, subdeltoidea, compressa, testa duriuscula, marginata ......-Arbor brasiliens is, me diocris; foliis alternis, petiolatis, ovato-oblongis, apice serratis, supra virentibus, subtus pube lepidota discoloribus, nervisque anastomosantibus prominulis reticulatis, stipulis lateralibus geminis, deciduis, pedunculis axillaribus solitariis v. subcoryntbo sis, floribus albis, speciosis.

Mol11a Martius et Zuccarinl Nov, gen, et sp. $T .96$. 2. 60. Meisner Gen, 37. (28,) S chlechtendalia Sprengel Cur, post. 295.

538\%. Hellocarpus LINN. C al y $\mathrm{te}$ traphyllus, foliolis linearilanceolatis, aestivatione valvatis. Corolla e petala 4 , hypogyna, spathulata, obtusa, calyce breviora, aestivatione convolutiva. S $\mathrm{ta} \mathbf{m}$ in a plurima, stipitis brevis, tetragoni, basi e regione petalorum quadriglandulosi apiei aequali inserta; filame nta filiformia, libera, a ntherae oblongae, dorso insertue, erec. tae, biloculares, fongitudinaliter dehiscentes. $O \mathbf{y}$ arium in stipite staminifero sessile, compressiusculum, quadrilocnlare. $0 \mathrm{v} \mathrm{a} \mathrm{la}$ in loculorum angulo centrali solitaria, infra apicem appensa, anatropa. Styln s filiformis; sti $g$ ma bifidum, laciniis revolutis. C a p s u la stipitata, subelavata, abortu bilocularis, septo parallele lenticulari compressa, ambitu radiis filiformibus, plumosis ciliata, locnlicide bivalvis, valvis concavis, medio septiferis, hine monospermis, inde vacuis. Semina in localis solitaria, ovata, eompressa, laevia. E m b ryo in axi albuminis carnosi orthotropus, ejusdem fere longitudine; cotyledonibus foliaceis, planis, radicula umbilice proxima, supera. - Arbores v. frutices Americae tropicae, pube stellata tomentosi; foliis alternis, petiolatis, trilobis, inaequaliter serratis, subtus tomento denso discoloribus, stipulis lateralibus geminis, deciduis, floribus terminalibus, paniculatis $v$. cymosis.

H eli o c ar p us Lian. Hort, ctiffort. 211, t. 16. Gen. n. 606. Trew Ehret, Piet. t. 45. Kunth in Humb. et Bonpl. Nov, gen, et sp. V. 341. DC. Prodr, I, s03. Meisuer Gen. 38. (29.) M o ntia Houston.

5is68. Entellea $R$. BR. C aly $\mathrm{x}$ tetrapentaphyllus, foliolis lanceolatis, aristatis, aestivatione valvatis. Corollae petala 5 , hypogyna, obovalia, basi angustata, apice undulato sublacera, calycem aequantia, aestivatione convolutiva. $\mathbf{S}$ t am in a plurima, hypogyna, petalis breviora, omnia fertilia; fil amenta filiformia, libera, subtorulosa, a $t h$ erae didymae, incumbentes, biloculares, longitudinaliter dehiscentes. Ov a ri u m sessile, quinque-sexloculare. $0 \mathrm{vuI}$ a in loculorum angulo centrali plnrima, biseriatim pendala, anatropa. Stylus simplex; stigma denticulatum. Caps a la globosa, setis longis, rigidis, plumoso pubescentibus echinata, quinque-sexlocularis, apice breviter loculicide quinque-sexvalvis. Sem in a in loculorum angulo centrali plurima, biseriata, parva, obovata. Embryo in axi albuminis carnosi orthotropus, ejusdem fere longitudine; cotyledonibus foliaceis, planis, cordatis, radicula umbilico proxima, supera, - Arbor Nova e-Zeelandiae, Sparmanniae facie, parva, ligno levissimo, spongioso, pube stellata tomentosa; foliis alternis, petiolatis, cordatis, angulatis, duplicato crenatis, quinquenerviis, stipulis parvis, foliaceis, persistentibus, umbellis terminalibus, pedunculatis, simplicibus, involucro polyphyllo brevi, pedicellis ebracteatis, floribus albis.

Entel e a R. Brown in Bot. Mag. t, 2480. Melsner Gen. 36. (28.) A peiba a ustralis A. Richard Ftor. Nov. Zeel, $t, 34$.

5369, Sparmannia THUNB. Calyx tetraphyllus, foliolis lanceolatis, muticis, aestivatione valvatis. Corolla e petala 4 , hypogyna, obovalia, basi angustata, calycem aequantia, aestivatione convolutiva. Stamina plurima, hypogyna, petalis breviora, exteriora sterilia, moniliformia, flaceida, fertilium fil a m e n t a tornlosa, libera, an therae didymae, incumbentes, biloculares, longitudinaliter dehiscentes, O vari um sessile, quinqueloculare. Ovnla in loculorum angulu centrali plurima, biseriatim pendulá, anatropa. Sty lus simplex; stigm a denticulatum. C a psula globosa, setis longis, rigidis echinata, quinquelocularis, loculicide ad basim quinquevalvis, valvis medio septiferis. Semina in loculis gemina, pendola, ovalia. Em bryo in axi albuminis carnosi orthotropus, ejusdem fere longitudine; cotyled onibus foliaceis, planis, cordatis, radicula umbilico proxima, supera. - Frutex capensis, pube stellata molli; foliis alternis, longe petiolatis, petiolis strictis, lamina cordata dependente, angulata, duplicato-crenata, stipulis lateralibus geminis, foliaceis, parvis, persistentibus, umbellis terminalibus, simplicibus, pedunculatis, involucro polyphyllo brevi, pedicellis ebracteatis, floribus albis, staminibus purpureis luteisque.

S parma a $\mathrm{i}$ a Thunberg Nov, gen, 88. Lina. f. Sup. plem, 41. Retz Observ. V. t. 3. Venten. Malmais. t. 78. Bot, Mag. $t$. 516. DC. Prod?. I. 503. Melsuer Gen, 37. (28.)

53 ร๑. Clappentonia MEISN. C a lyx pentaphyllus, foliolis coriaceis, extus hirsutis, intus coloratis. Corolla e petala 5, oblonga. Stam in a 8 , filis plurimis capillaceis cincta, a ntherae oblongae. Ovarium oblongum....S tylns simplex; stigma sexdentatum. Capsula echinata, quinquelocularis, loculicide quinquevalvis, valvis medio septiferis. S emin a plurima, arillata (?) ..... - Arbor guineensis; folïs subtus tomento fulvo tectis, inferioribus obtuse tri-quinquelobis, summis spathulato-oblongis, dentatis, floribus terminalibus, ternis, caeruleo-violaceis.

Clappertonia Meisner Gen. 36. (28.) Honkeny a Willdenow in Usteri Delect. Opusc. bot. II. 20t. $t$. 4. DC. Prodr, I. s06. - ? Nov, gea. a, 1. R. Browa in Tuckey Cong. 498. 
$53 \%$ 1. Corehorus LINN, C al y x pentaphyllus v. rarissime tetraphyllus, foliolis lanceolatis, estivatione valvatis. Coroll a e petala 5 hypogyna, obovata, in unguem angustata, calyei aequalia v. breviora, aesticatione convolutiva. $\mathbf{S} t$ a$\mathrm{m}$ in a rarissime calycis foliolis numero dupla, saepissime indefinite multipla, imo toro $v$, interdum stipiti brevi intra marginem urceolarem inserta; filamenta filiformia, flexuosa, libera, anthera e ovatae, incumbentes, biloculares, longitudinaliter dehiscentes, Ovari nm supra torum v, in stipite staminifero sessile, septis primum incompletis, mox ad axim coalescentibus bi-quinqueloenlare. Ovula plurima, primum semiseptorum marginibus utrinque, mox loculorum angulo centrali biseriatim inserta, pendula, anatropa, $\mathbf{S t y}$ las simplex, superne crassior; stig ma infundibuliformi-excavatum, margine crenulatum. C a p$\mathrm{sula}$ elongato-siliquaeformis, apice interdum triquadricornis, nunc ovoidea v. globosa, bi-quinquevalvis, valvis medio septa margine utrinque seminifera gerentilus, rarissime septulis inter semina transversis munita, axi centrali nullo. Semina plạrima, angulata v. meniscoidea, testa crustacea, rhaphe et chalaza apicali manifestis Embryo in axi albuminis carnosi varie replicatus; cotyledonibus foliaceis, suborbiculatis, planis v. flexuosis; radicula tereti, umbilico proxima, supera. - Herbae, suffrutices $v$. frutices, inter tropicos totius orbis crescentes, pilis simplicibus $v$. interdum stellatis; foliis alternis, petiolatis, serratis, serraturis interdum mucronatis, inferioribus in caule et ramis saepe minoribus hete romorphis, stipulis lateralibus geminis, pedunculis brevissimis, oppositifotiis v. juxta axillam lateralibus, uni-paucifloris, bracteatis, floribus flavis.

Corehorus Lins. Gen. n. 675. Gietuer T, 307. II. 482. Kunth in Humb. et Banpl. Nov. Gen. et sp. . $^{3} 35$. DC. Pradr. I. 504. St. Hilaire Flor. Brasil, I, 279. Wight et Aruott Prodr, r. 72. Meisuer Gen, 36. (28.)

a. ANTICHORUS Linn. $f$. C a I y x tetraphyllus. Cor o Il a e petala 4. Stamina 8, imo toro laserta. Capsula siliquneformis, subulata, quadrilocularis. - Herba arabica, annua.

A titich or us Linu. fil. Easc. 3, t, 2. DC. Prodr, I. 504. Meisner Gen, 36. (28.) Cari eter fa Scopoli Introduct. 255. Jassiaen Forskael degypt. 210.

b. CoRETA $P$. Browne, C a 1 y $x$ pentaphyllas. Corolla petalk 5. St a m ina indefinita, imo toro inserta. Ca ps ula siliquaeformis, bl-tri-sexlacularis. - Coreta P. Browne Jam, 1/7.

c. Eucoreta. Caps u Ia apice haud cornuta, bi-raris. sime trilocularis, septulis transversis nullis v. obsoletis.-Corchorus sect. C aret a DC. Prodr. I. 504. (Jacq, Hort. Vindob, t. 58. Kuath Op, cil. $t$. 487 . St. Hi-

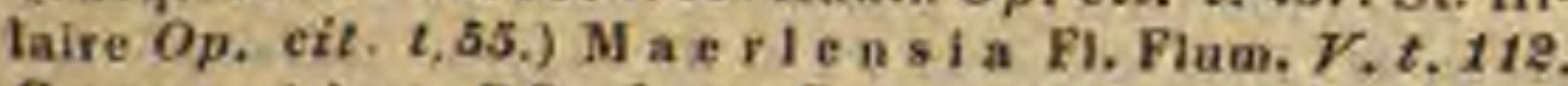

P. Coretoides DC. 2 . c. Capsalu apice baud coruta, tri sexlocularis, septulis transversis plus minus completis. - (Lam. t. A78. f. 1, Jaeq. Hort. Pindob. c. 85, 173. Gatrtuer t. 64. f. 2.)

$\gamma$. Ceratocoreta DC. 2 . c. Ca p s u 1 a apice patentim tri-quisquecornix, tri-quinquelocularis, septulis transversis nullis. (Burouan. Flor. Ind. $t$. $37 . f$. 2 . Gartaer $t$, 64. $f$. 2 .

c. GUAzUMoIDES DC. $l$. c. Caly $\mathrm{x}$ pentaphyllus. Coro Il a e petala 5. Stam i a iadefinfta, stipiti brevi intra niarginem urceolarem inserta. Ca p s u I a ovata, setoso

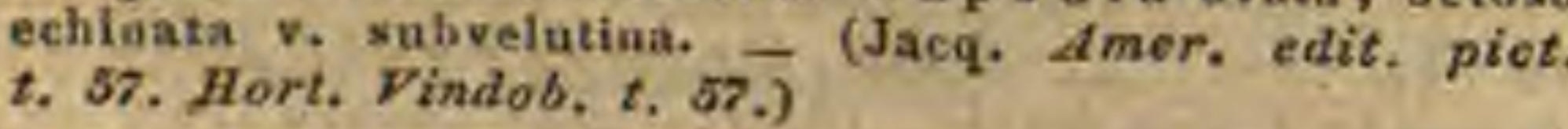

2 d. GANJA DC. l. c. C a p 8 a 1 a subglobosa, apice truncato depressa, rugoso. maricata. - Ganja Rumpl amboin, $V, t$. 78, $f$. 1 . Corchoras capsularis Lina. Gärtn. t. 179. Jacq. f. Eelog. t. 120.

53 z. Triumfetta PLUM. Cal y x pen

taphyllus, foliolis linearibus, planis, muticis v. apice fornicatis, dorso infra apicem mueronatis, aestivatione valvatis. Corollae petala 5 , hypogyna, oblonga, unguiculata, calyce breviora, aestivatione convolutiva, interaum nulla. Sta mina 10-30, apiei stipitis hrevis, basi e regione petalorum quinqueglandulosi, intra marginem urceolatum, petaloideum inserta ; $\mathrm{fil}$ a m ent a filiformia, libera, a ntherae didymae, incumbentes, bilnculares, longitudinaliter dehiscentes. Ovarium in stipite staminifero sessile, bi - quinqueloculare, loculis semisepto parietali longitudinali bilocellatis. Ovula in loculorum angulo centrali gemina, collateraliter pendula, anatropa. Stylus filiformis; st ig ma brevissime quinquefidum, lobis acutis, conniventibus. Ca ps n la subglobosa, aculeis uncinatis echinata, bi-quinquelocularis, loculis saepius septo secundario bipartitis, indehiscens $\mathbf{v}$. septicide di-pentacocca, coecis dorso convexis, ventre acutangulis, mono-dispermis. Semina in loculis solitaria, $\mathbf{v}$. gemina collateralia, septo secundario discreta, pendula, testa crustacea. E m b r y o in axi albuminis carnosi orthotropus, ejusdem fere longitudine; cotyledonibus foliaceis, planis, radicula tereti, nmbilico proxima, supera.

Frutices, suffrutices $v$. rarissime herbae, inter tropicos totius orbis crescentes, pube stellata; foliis alternis, petiolatis, integris $v$. lobatis, serratis, serraturis saepius argutis, interdum setigeris, stipulis lateralibus geminis, persistentibus v. deciduis, pedunculis oppositifoliis v. ad axillas lateralibus, solitariis v, fasciculatis, unifloris v. subum bellatim paucifloris, bracteatis, fructiferis reflexis, floribus flavis.

Triumfetta Plamier Gen, t, 8. Linn. Gen. n, 600. Kunth in Humb. et Bonpl. Nov. gen. et sp. $V, 341$. DC. Prodr. I, s06. St. Hilaire Flor. Brasil. I, 283. Wight et A nuott Prodr, $I .73$.

a. LAPPULA DC. $t$. c. Fruetus indehiscens, loculis monospermis. - Tri a m fett a Gärtner II. 137. $t, 11 t$. (A. Rieliard Flor. Seneg. $t, 19$. Plumier edit. Burm. t. 255 )

b. BARTRAMEA DC.l.c. Pruetus di-pentacocens. coecis mono-dispermix. - B a rt ra m e a Gärtn. II, 137, 2.111. Lam, t, 400. Jacq. Amer, t. 90. Miller Ic. t. 298. Kunth Op. cit. t. 488 . Lindley Collect, t. 29. Bot. Mag. t.2296. Bot. Reg. t. 1058, DC. Plant, rar, hort. Genev, t. 17. Gaudich. ad Fregc. $t$. 102. A. Richard Op. cit. t. 18. St. Hilaire Op. cit, $t, 56 . b$. - ? P o r p a Blume Bijdr. 117.

53 38. Tilia LINN, C a l y x pentaphyllus, foliolis lanceolatis, aestivatione valvatis, Co ro 1 la e petala 5, hypogyna, subspathulata, calyce longiora. Sq u a ma petaloideae 5 , petalis oppositae, subconformes sed breviores, interdum nullae.S $\mathrm{t}$ a $\mathbf{m}$ in a plurima, hypogyna; fil a ment a filiformia, libera v. hasi irregulariter polyadelpha, $8 q u$ amis petaloideis dom adsunt inferne saepe adhaerentia, simplicia v, apice bifurca, anthera e didymae, biloculares, longitudinaliter dehiscentes. O y a rium sessile, guingueloculare. $\mathrm{O}$ v $\mathrm{ula}$ in loculorum angulo centrali gemina, subcollateralia, semianatropa. Stylus simplex; stig ma quinquedentatum. N ux chartacea $v$. lignosa, quinquecostata, septis obliteratis nnilocnlaris, mono-disperma. S e mina obovoidea, parieti adplicita, adscendentia, testa cartilaginea, $\mathbf{E} \mathbf{m}$ b ryo in axi albuminis dense carnosi orthotropus; cotyledonibus foliaceis, subcordatis, transversim flexuosis, inaequaliter quinquelobis, lobis subconvolntis, radicula elongata, umbilico subventrali parallele enntigua, infera. - Arbores in Europa et Asia finitima, copiosius in America boreali crescentes, ob co- 
mae densae decorem, ligni levis in sculpendis deorum imaginibus facilem usum, et florum suave aroma, mortalibus japetigenis familiares; pube simplici $v$. stellata, foliis alternis, distichis, petiolatis, basi oblique cordatis $v$, truncatis, apice acuminatis, serratis, nervosis, subtus saepe discoloribus, stipulis lateralibus geminis deciduis, pedunculis axillaribus et subterminalibus, basi unibracteatis, apice tri-multifloris, bractea chartacea, ligulata, reticulato-costata pedunculo usque ad mediam longitudinem adnata, bracteolis nullis, floribus lutescentibus v. albidis, mellifluis.

Tili a Linn. Gen, $n, 606$, Gärtner $I I, 150, t, 113$. Ventenat Monograph. Paris, 1802, 4. DC. Prodr. I. 512. Spach in Nouv. Annal, sc, nat, II. 331. Meisner Gen. 36. (28.)

a. TILIA Reichenb. Consp. 209. S quamae petaloideae nullae. - Species europeae. (Vent. Op. cit. $t .1$. f. 1. 2. Schkuhr t. 141. Duham, Arbr, t. 50. Hayne Arzneigew. t, 46-48. Guimpel Deutschl. Holsart. $t$, 100 108. Flor. dan. $t, 553$, E. B. $t .601,1705,2590$. Hooker Flor. Lond, $t, 190$.

b. LINDNERA Refchenb. Consp. 209. $\mathrm{S} q \mathrm{u}$ a m a petaloideae staminibus oppositae. - Species $\delta$ oreali america nae, unica Europae austro-orientalis incola. (Waldst. et Kitaibel Plant, rar, Hung. $t$. 3, Vent. Op. cit. t. 2_5. Duham. Arbr, I. 51 -52. Michx. Flor. Sylv, $t, 131-133$. Gulnpel fremd, Holzart, $t, 45$. Spach Op. cit. $t, 15$.

5884. Wrownlowia $R O X B$. Calyx pentaphyllus, foliolis aestivatione valvatim connatis, subaequaliter tri-quinquefido ruptus. Corolla e petala 5 , hypogyna, oblonga, calyce longiora, aestivatione convolntiva. Stam in a plurima, stipitis brevis, tnrbinati apici aequali inserta, intima quinque sterilia petaloidea, ovarium cingentia, exteriora fertilia; fil a m enta filiformia, antherae biloculares, didymae, longitudinaliter dehiscentes. O v a $\mathbf{r i u m}$ in stipite staminifero sessile, quinqueloculare. OvuIa in Ioculis gemina, superposita, adscendentia, semianatropa. Stylus subulatus; stigma simplex. Ca p 8 u la e $1-5$, monospermae, basi tantum connexae, bivalves. Semina erecta, testa friabili. Embryonis exalbuminosi, recti cotyled one s planae, carnosae, radic nla brevis, oblonga, infera, plumula diphylla. - Arbor indica, gigantea, pube stellata; ramis patentibus, foliis alternis, petiolatis, cordatis, angulatis, integerrimis, tri-septemnerviis, basi inaequilateris, subtus densius pubescentibus, stipulis nullis, paniculis terminalibus ramosis, amplis, floribus flavis, inodoris.

B row ulowia Roxburgh Plant. of Corom. III. 61. t. 265. Wallich in Bot. Reg. t. 1472. Meisner Gen. 37. (28.) H u m a Roxburgh Flor. ind. $I I$. 640. - Geus habitu Berryae, staminibus interioribus sterilibus petaloideis Tiliae, fructu apocarpo Christianae, sed seminibus exalbuninosis et plumula valde evoluta fortassis Heritierae propius ac. cedens.

53ร5. Christiana $D C$. $\mathrm{C}$ a l y $\times$ trilobus, persistens, Corolla e petala 5 , persistentia. Stam in a indefinita, persistentia, Cap 8 u la e 5 , monospermae, basi tantum connexae. - Stirps Africa e tropicae, nondum descripta.

Chrlstiana DC. Prodr. 1. 516. Nov. gen. n. 3. R. Brown in Tuckey Congo 428.

53 g G. Grewin JUSS. C a lyx pentaphyllus, foliolis linearibns v. lanceolatis, intus colora tis, aestivatione valvatis. Coroll a e petala 5 , hypogyna, calyce breviora, apice integra v. emarginata, basi intus glandula adnata $v$, foveola nectarifera instructa, aestivatione convolutiva, rarissime nulla. Stam ina plurima, stipitis brevis, crassi, basi nudi $v$, e regione petalorum quinqueglandulosi apici aequali inserta; fil a m e $\mathbf{t}$ a filiformia, libera, antherae didymae, biloculares, longitudinaliter dehiscentes. Ovari um in apice stipitis staminiferi sessile, bi-quadriloculare, loculis indivisis $\mathbf{v}$. septo parietali Iongitudinali bilocellatis. Ovula in loculis solitaria vemina collateralia, e basi erecta, rarius tria $v$, quatuor angulo centrali superposita, horizontalia, anatropa. Stylus simplex; stigma brevissime bi-quadrilobum. Drupa quadriloba, mono-tetrapyrena, pyrenis osseis, laevibus v. fibrosis, nunc bilocularibus dispermis, nune septis transversis tri-quadrilocellatis, tritetraspermis. S e min a erecta $v$, horizontalia, testa membranacea. Embryo in axi albuminis parci v. copiosi, carnosi orthotropus, ejusdem fere longitudine; cotyledonibus planjs, foliaceis, radicula tereti, umbilico proxima, infera v. centripeta. - Arbores $v$. frutices, in Asia et Africa tropica et subtropica crescentes, pube stellata; foliis alternis, petiolatis, integerrimis v, serratis, subtus discoloribus, tri-septemnerviis, stipulis lateralibus geminis, pedunculis axillaribus $v$. terminalibus geminis, pedicellis umbellatis, bracteolatis, nudis $v$. involucratis.

Grew in Jussieu in Annal. Mus. II, 89. DC. Prodr. I. 508. Wight et Arnott Prodr. I. 75. Meisner Gen, 38. (28.)

a. MALLOCOCCA. Drupa mono-tetrapyrena, pyrenis unilocularibus, monospermis. S e m in a erecta. A I bume plus minus copiosum. - Grewia et Microcos Liвn. Gen, $n, 896,897$.

ce. Nehemia. Inflorescentla axillaris v. psendo. terminalis, pedanculis solitariis v. pluribus, pedicel. lis umbellatis. Petala basi glandula nectarifera. Ovariun quadriloculare, octoovulatum. - Grewia e 8 p. Linn. et Auet. Gürtner $t, 106$. Jussieu $O p$. eit. $t$, 47-3t. Palisot Flor. Owar, t, 102, 108, Royle Himalay, t. 22. Hooker Bot. Mag. Comp. $t$, 10. Presenius in Mrus. Senkenb. $t$. 10. Wight Itlustr, t. 33. M a I. loc o c e a Forst. Char.gen.t. 39. C h a d a r a Forskael Aegypt. 105. Siphomeris Bojer ex Hook, Bot. Miscell. III, 213.

B. M i crocos. I florescentia terminalis, paniculata, floribus ternatis, involueratis. Petala basi foveola nectarifera. $O$ va $r$ i u $m$ blloculare, triovulatum. Microcos Linu, $t$. c. Gñrtner $t$. 57. Jack in Hook. Bot. Miscell. I. 281, t. 60. A r sI \& Loureir. Flor. cochinch. 409.

b. DAMINE. Drupa di-tetrapyrena, pyrenis transversim tri-quadrilocellatis, tri-tetraspermis. S e m ina borizontalia. A I b a men subuullnm. - Vincentia Bojer in Hook. Bot. Miscell. $I, 293, t, 62, G$ rewia $D$ amine Gärtuer $I T, 113, t, 106 . f .3$.

538\%. Diploplaraetam DESFONT. Cal yx pentaphyllus, foliolis oblongis, obtusis, aestivatione valvatis. Corollae petala 5 , hypogyna, spathulata, aestivatione convolutiva, ungue basi intus squamula adnata aucto. Sta mina plurima, stipitis brevis, teretis, basi e regione petalorum quinqueglandulosi apici intra discum orbiculatum quinquelobum inserta; fi la menta filiformia, libera, antherae subglobosae, biloculares, longitudinaliter dehiscentes. Ovarium in stipite staminifero sessile, ovato-pentagonum .... Sty I n s simplex, brevis; stig m a quinquedentatum. C a p sul a globosa, tomentosa, quinquealata, indehiscens, decemlocularis, septis alternis alis oppositis seminiferis, alternis stecilibus, loculis septulis inter semina transversim plurilocellatis. S e mina in locellis transversis solitaria, horizontalia, angulo parietali inserta, testa crasse fungosa, scrobiculata. Em bryo in basi albuminis carnosi orthotropus, parvus; cotyledonibus 127 
subfoliaceis, orbiculatis, radieula brevi, crassa, centrifuga. - Frutex v, arbor, ins ulae Java incola; foliis alternis, sessilibus, oblongis, apice serratis, basi inaequalibus, subtus tomentosis, stipulis lateralibus geminis, foliaceis, altera biloba medio, altera dimidiata margine setam subulatam exserente, floribus in apice ramulorum solitariis $v$. paucis, subcorymbosis.

Diplophract um Desfontaines in Mem. Mus, $V, 34$. t. 1. DC. Prodr. I. 514. Meisner Gen. 37. (28.)

5:3 8 . Columbia PERS. Calyx penta phyllus, foliolis oblongis, acutis, aestivatione valvatis. Corolla petala 5, hypogyna, spathulata, calyce breviora, aestivatione convolutiva, ungue basi intus glandula adnata aucto. St a mina plurima, stipitis brevis, teretis apici in discum nndulatum expanso inserta; fil a menta filiformia, libera, inaequilonga, antherae subrotundo-didymae, biloculares, langitudinaliter dehiscentes. Ovarium in stipite staminifero sessile, subrotundo-quadrangulare, quadriloeulare. Ovala in loculis pauea, angulo centrali inserta, adscendentia, anatropa. Stylus simplex, subulatus; stigm a acutum. Capsula subrotunda, tetraptera, basi cuneata, coriacea, quadrilocularis, alis bilamellatim partitis septicide tetracocca, coceis dorso convexis, ventre acutangulis, apice emarginatis, margine utrinque membranaceo alatis, indehiscentibus, monospermis, axi centrali nullo. S e m in a adscendentia, oblique obovato-oblonga, coriacea, chaleza apicali notata. $\mathbf{E} \mathbf{m}$ bryo in axi albuminis earnosi orthotropus, ejusdem dimidio brevior; cotyledonibus foliaceis, planis, radicula brevi, tereti, nmbilico proxima, infera. - Arbor manillana, excelsa; ramulis hirsutis, foliis alternis, basi obliquis, ovato-lanceolatis, serratis, subtus glaucis, trinerviis, floribus terminalibus, racemosis, bracteatis, rubris.

Colum bia Persoon Encheir. II, 66. DC. Prodr, I. 512. Co I o n a Cavanill. Ic. IV. 47, t, 370. Kanth in Humb. et Bonpl. Nov, gen, et sp. $V$. 335. in not. Meisuer Gen, 37. (28.)

53\%5. Terrog ROXB. Calyx pentaphyllus, foliolis aestivatione valvatim connatis inaequaliter tri-quinquefido ruptus, subpersistens. C orolla e petala 5 , hypogyna, oblonga, calyce longiora, aestivatione convolntiva. Sta min a plurima, hypogyna; fil am enta filiformia, basi subconnexa, antherae didymae, biloculares, longitudinaliter dehiscentes. Ovarinm sessile, trilobum, triloculare. $\mathrm{O} v \mathrm{u}$ la in loculorum angulo centrali 6 - 8 , biseriatim pendula, anatropa. Styli 3 , filiformes; stig mat a capitata, Capsui a subglobosa, sexalata, trilocnlaris, loculicide trivalvis, valvis medio septiferis, dorso sursum in alas geminas longitudinales, basi deliquescentes, membranaceas, obtusas expansis. Semin a in loculis $1-4$, pendula, dense rigide pilosa. $\mathbf{E} \mathbf{m}$ b r y 0 in axi albuminis carnosi orthotropus, ejusdem fere longitudine; cotyledonibus foliaceis, planis, radicula umbilico proxima, supera. - $\mathrm{Ar}$ bor indica; foliis alternis, petiolatis, cordatoovatis, acuminatis, integerrimis, glabris, basi quinque-scptemnervitis, subtus discoloribus, slipulis lateralibus geminis, ensiformibus, deciduis, paniculis axillaribus et terminalibus diffusis, floribus plurimis, albis, parvis.

Berry a Roxburgh Plant. of Corom. IIT. 59, t. 264. DC. Prodr. I, 517. Wight et Arnott Prodr. I, 81. Wight Illustr. t. 34. Meisner Gon, 37. (28.) E spera Willdenow in Berlin, n. Schrifh, IIT, 449. DC. Prodr, 1, 517. Meisner
Gen, 37. (28.) A mmonilla Cingal. Trincomalee. Wood Angl.

5380. Mruntingia LINN. C a l y x pentaphyllus, rarius heptaphyllas, foliolis lanceolatis, aestivatione valvatis. Co rollae petala 5 v. 7 , hypogyna, obovalia, calyce longiora, aestivatione convolutiva. Stam in a plurima, hypogyna; filam ent a filiformia, libera, an $t h$ era e ellipticae, dorso insertae, biloculares, loculis basi et apice discretis, longitudinaliter dehiscentibus. Ovar i u m sessile, basi pilis glandulosis cinctum, sexseptemloculare. Oval a plurima, loculorum angulo centrali partimque septorum parietibus inserta, anatropa. Stig ma sessile, pyramidato-capitatum, obsolete angulatum. B a c c a globosa; st igmat e umbilicata, irregulariter multilocularis. Semin a plurima, minima, in pulpa nidulantia, te $8 \mathrm{ta}$ membranacea, mucilaginosa. F m b ryo in axi albuminis carnosi orthotropus, dimidio albumine brevior; cotyledonibus brevissimis, obtasis, ra die u la crassiuscula, umbilico proxima. Arbuscula in collibus calcareis insularum Cariba e ar um crescens, pube stellulata subtomentosa; foliis alternis, breve petiolatis, oblongis, acuminatis, dentatis, basi obliquis, subtus discoloribus, stipulis lateralibus geminis, deciduis, pedunculis axillaribus geminis $v$, ternis, unifloris, basi bracteatis, floribus albis.

M unt ing i a Plumier Gen, 6, t.14, Linn, Gen, n, 651. Jacq Amer. t. 107. Gärtaer r. 285. $t .59$. Kunth in Humb, et Bonpl. Nov. gen. et sp. V. 348. DC. Prodr. I. 514. Meisaer Gen. 37. (28.) $\mathrm{C}$ a 1 a b u r a Plucknet Mant. t, $158, f .4$.

5381. Trilix LINN. C a I y x triphyllus, foliolis ovatis, acutis, planis, patentibus, persistentibus. Corolla e petala 3 , lanceolata, acuta, ealyce minora. Stamina plurima; filamenta eapillaria, corollae longitudine, antherae subrotundae, didymae, minutae. Ov a rium pentaconum. Styius cylindrieus; stigma simplex. B a c c a subpentagona, quinquelocularis, calyce tecta. Semina plurima, subrotunda, minuta. Frutex carthagenensis, biorgyalis, ramosissimus; ramis teretibus, scabriusculis, foliis alternis, petiolatis, subpeltatis, cordato-ovatis, serratis, acuminatis, venosis, pubescentibus, petiolis terelibus, glabris, pedunculis plerumque terminalibus, pedicellis alternis, unifloris, teretibus, pubescentibus, floribus luteis.

Trillx Linne Mantiss, Ir. 153, ot 247. Meisner Gen. 38. (28.) Jacquinia Mutis mso.

\section{GENERA DUBIA.}

5382. IBameroftia MACFAD. CaIyx octophyllus, foliolis anguste lanceolatis, persistentibus. Corolla e petala 8 , calyce longiora, late lanceolata. Stamina 8 , hypogyna; filamenta subulata, antherae parvae. Ovarium globosum. Stylus brevis; stigma sexfidum, patens, persistens. B a c c a globosa, sexlocularis. S e min a plurima, in pulpa nidulantia, rotundata, compressa, nigra. - Herba $j$ amaicensis, basi suffruticosa; ramis teretibus, glabris, foliis alternis, petiolatis, trifoliolatis, foliolis breve petiolatis, lanceolatis, acuminatis, subintegerrimis, glabris, intermedio longiore, racemis terminalibus simplici. bus, floribus breve pedicellatis, virescenti-albis, pedicellis basi bractea lineari stipatis, baccis viridibus.

B a r of i a Maefadayen Flora of Jamaica $1,112$. 


\section{*}

5383. Vantamea $A U B L$. C a ly x brevis, quinquefidus. Coroll a e petala 5 , disco hypogyno cyathiformi, brevissimo inserta, longe linearia, patentia. Stam ina plurima, cum petalis inserta; filamenta capillaria, antherae subrotundae, parvae. Ova rium disco basi einctum, subrotundum. Stylus filiformis; stigma obtusum. Fruetns..... - Arbor guianensis; foliis alternis, breve petiolatis, ellipticis, integerri. mis, floribus terminalibus, corymbosis.

V a t a ne a Aublet Guian, Ir. 572. t, 229. Jussieu Gen. 434. Le m n is cli a Selireber Gen, n, 902.

SURORIDOII. ELAEOCARPEAE. C 0 rolla e petala incisa v. fimbriato-lacera. A nthe ra e apice valvula transversa apertae.

TTRUBUS III. ELAEOCARPEAE VERAE. Fructus drupaceus. - Asiaticae el australasicae.

5384. Elaeocarpus LINN. Calyx tetra-pentaphyllus, foliolis lanceolatis, aestivatione valvatis. Co roll a e petala 4 -5, hypogyna, aestivatione imbricata, cuneata, tri-quinqueloba, lobis laciniatis. Stamina 15-50, disco hypogyno glanduloso inserta; fil amenta brevia, subulata, an $t$ h erae erectae, longe lineares, loculis introrsum adnatis, appositis biloculares, apice rima transversa bivalves, valvis aequalibns, obtusis, saepe barbato setosis. Ovarinm sessile, basi disco cinctum, tri-quinqueloculare. $O v a l$ a in loculis 2 v. 4 , pendula, anatropa. S $t$ y I u s subnlatus; stigma simplex. Drupa monopyrena, nuce tuberculata, tri-quinqueloculari, rarius abortu uniloculari. S e m in a in loculis solitaria, inversa. $\mathbf{E m}$ b ryo in axi albuminis carnosi orthotropus, ejnsdem longitudine; cotyledonibus planis, oblongis, radienla cotyledonibus breviore, supera. Arbores Asiae tropicae; foliis alternis, lanceolatis, subintegerrimis v. serratis, petiolis basi et apice saepissime tumidis, stipulis deciduis, floribus axillaribus, racemosis, petalis extus glabris.

E 1 a e o carp us Linn. Gen, n, 553 .

a. ELAEOCARPUS Gärtn. Ovari um triloculare, loculis biovulatis. Drupa nucleo tri-uailoculari.

E1 a e ocarp us Gärtner $I$. 202. . 43. (ual. quoad situm seminis), Wight et Arnott Prodr. I. 83. Hook. Ic, t. 134. 155. A cer atinm DC. Prodr. I, 519. E I a e 0carpi sp. DC. l. c. exel. eharact, - ? A denodas Loureiro Flor. chochinch. 361. Loehneria Scopoli Introduct. 1232.

b. GANITRUS Gärtn, Ovarium quinqueloculare, loculis quadriovulatis. D r u p a nueleo quinqueloculuri.

Ganitrus Gärtner II, 271. t. 139. (mal. quond si. tum semivis) Wight et Arnott 2. c. in not. - ? C r a s. ped u m Loureiro Flor. cochinch. 410.

5385. Mionocera $J A C K$, C a ly x pentaphyllus, foliolis laneeolatis, aestivatione valvatis. Coroll a e petala 5, hypogyna, aestivatione imbricata, cuneata, tri-quinqueloba, lobis laciniatis v. subintegerrimis. St a m in a $25-80$, diseo hypogyno glandnloso inserta; fil am enta brevia, subulata, antherae erectae, longe lineares, loculis introrsum adnatis, appositis biloculares, apice rima transversa bivalves, valvala antica mutica, postica connectivo dorsali excurrente cuspidata. Orari um sessile, basi disco cinctum, bi - quinqueloculare. $O$ vnla in loculis 2 v. plura, pendula, anatropa. S t y I u s subulatus; s $t$ i $g \mathrm{~m}$ a simplex. Drup a monopyrena, nuce laevi $v$, tuberculata, uni-bi- rarius quinqueloculari. Se $\mathrm{m}$ in a in loculis solitaria, inversa. Embryo in axi albnminis carnosi orthotropus, ejusdem fere longitudine; cotyledonibus planis, oblongis, radicula cotyledonibus breviore, supera. - Arbores Asiae tropicae et Novae-Hollandiae; foliis alternis, approximatis; lanceolato- $v$. cuneatooblongis, integerrimis $v$. serratis, petiolis basi et apice tumidis, stipulis deciduis, racemis axillaribus folio brevioribus, petalis saepissime extus sericeis.

M o nocera Jack Malay, Miscell, ex Hooker Bot. Miscell. II. 85. Wight et Arnott Prodr. I, 83. Meisner Gen. 39. (29.) Bl a e carpus DC. Prodr. I, 519. quoad charact. exel. sp.

a. EUMONOCBRAS. Petalor um lobi laciniati. Anthe $r$ a e valvula postica longe cuspidata, snticam acutam longe superans. $0 \mathrm{v}$ a $\mathrm{r}$ i u biloculare, loculis multiovulatis. - Elaco carpi sp. Cavanill. Ic, t, 501 . (Wight IItustr, $t$, 35.)

b. GANITRoceras. Petal orum lobi laciaiati. An therace valvula postica cuspidata anticam acutam longe superans. O variu m tri-quiaqueloculare, loculis pauclovulatis. - Ela e o a r pi s p. australasicae Bot. Mag. t. 1737. Bot. Reg, t, 657. Bonpl. Malmais, $t$, 50. Turpin Atlas Diet. sc, nat. t. 148. Eriostemi s p. Colla Hort. Nipul. $t$. 30 .

c. DiCERAS. Petalorum lobi subintegerrimi. Anthe$r$ a e valvula postica cuspidata, antican aeuminatam paul. lo superans. Ovari u m biloculare, loculis pluriovula. tis. - Dicera de $\mathrm{t}$ a ta Forst. Char. gen, $t .40$.

5386. IBeythea. Calyx pentaphyllus, foliolis lanceolatis, aestivatione valvatis. Co rolla petala 5, hypogyna, aestivatione imbricata, oblongo-linearia, apice breviter biloba, lobis obtusis, integerrimis. Stamina 15 , disco hypogyno glanduloso inserta; fil a m ent a brevia, subulata, an th era e ectae, oblongo-tetragonae, bilocnlares, loculi oppositi, ab apice ad medium loculieide bivalves, valvis aequalibns, obtusissimis. O v a r i u m sessile, basi disco cinctum, biloculare. Ovula plurima, pendula, anatropa. StyIu s snbulatus; stigma simplex. Drupa monosperma ...... Arbor sandwicensis; folits alternis, petiolatis, ovato-acuminatis, serratis, glaberrimis, stipulis deciduis, racemis axillaribus paucifloris, petalis extus pubescentibus.

Elaeocarpas bifidus Hook. et Arnott ad Beechey 110. 2., 24.

\section{GENERA DUBIA.}

538\%. Frotesia DC. Flo res hermaphroditi v. abortu unisexuales. Cal y x quadripartitus, foliolis aequalibus, ovatis. Corolla e petala 4, hypogyna, aestivatione imbricata, cuneiformia, apice breviter triloba, lobis obtusis, integerrimis. St a $\mathrm{m}$ in a circiter 12 , disco glanduloso inserta; fil am ent a brevissima, an the ra e erectae, cordato-tetragonae, acutae, biloculares, poris sub apice dehiscentes, Ovarium sessile, tri-quinqueloculare. Ovula ..... Stylus subulatus; stigm a bi-quadrifidum. B a c c a sicea, membranacea, ovata v. subglobosa, tri-quinquelocularis, indehis. cens. S em in a in loculis gemina, angulo centrali inserta, superposita, angulata. Embry o.... Arbores insulae Diemen et Novac-Zeelandiae; foliis alternis oppositisque, breve petiolatis, serratis, pedunculis axillaribus unifloris, solitariis v. fasciculatis, v, racemis lateralibus multifloris. 
Friesia DC. Prodr. T, 590. Mrisuer Gen, 39, (29.) A. Cumningh. in Annal. of nat, Hist. IV. 24, D i e e r a 8 e rrata Forst. - ? Ela eocarpus peduncularis Labillard. Nov, Holl, $t, 158$.

5388. A cromodia $B L U M$. F 1 ore $s$ dioici. I a sc. Calyx tetraphyllus. C o rolla e petala 4 , parva, apice erosa. A nt h e ra e 8_12, lineares, puberulae, muticae. Fem, $\cdots \cdots$ - Arbor $j a v a-$ $n$ ic $a$; foliis sparsis, lanceolatis, serratis, subtus punctatis, racemis axillaribus, simplicibus.

A er o nodia Blume Bijdr, 123. Meisner Gen, 39. (29.) A erozus Spreng. Cur. post. 145.

TTE TEUS IV. TRICUSPIDARIEAE. Fructus capsularis v. baccatus (?) - Peruanae et chilenses.

5389. Vallea MUTIS. Calyx pentaphyl Ins, foliolis oblongo-lanceolatis, subcoloratis, aestivatione valvatis. Corolla e petala 5 , hypogyna, aestivatione imbricata, obovata, apice triloba, lobis integerrimis, obtusis. Sta min a circiter 30 , diseo hypogyno biseriatim inserta; fil am e n ta basibus subulatis arete conniventia, apicibus filiformibus adscendentia, an $t h$ era e erectae, lon ge lineares, biloculares, loculis oppositis, apice matico utrinque poro dehiscentibus. Ovarium sessile, basi disco einctum, tri-quinqueloculare. Ovala in loculorum angulo centrali 2, superposita, amphitropa (?) Sty l n s subulatus, simplex; stigma breviter tri-quinquefidum. C apsula mnricata, tri-quinquelocularis, loculicide tri-quinquevalvis, valvis patentibus, medio septiferis. S e m ina in quovis loculo $2 \ldots \ldots$ - Arbores peruana e; foliis alternis, petiolatis, cordatis, integerrimis, stipulis foliaceis reniformibus, sessilibus $v$. petiolatis, persistentibus, pedunculis axillaribus et terminalibus bi-trifloris, bracteatis.

V alle a Mutis in Linn. $f$. Supplem. 226. Ruiz et Pavon Prodr. t. 14. Kunth in Humb. et Bonpl. Nov. gen, et sp. V. 350. t. 489. DC. Prodr. I. 520. Meisuer Gen, 39. (29.)

5390. Trienspialaria $R U I Z$ et $P A V$. Caly x campanulatus, brevis, obsolete quinquedentatus, sub anthesi deciduus. Coroll ae petala 5 , hypogyna, aestivatione induplicatim valvata, late linearia, apice trifida, lobis acutis, integerrimis. Stamina 20, annulo hypogyno, glandulosodecagono intus inserta; fil amenta filiformia, subadscendentia, antherae erectae, oblongotetragonae, biloculares, loculi oppositi, apice breviter loculicide bivalves, valvulis aequalibus, retusis. Ovarium disco hypogyno impositum, tri-quinqueloculare. $\mathrm{O}$ v $\mathrm{n}$ la in loculis plurima, biseriatim pendula, anatropa. Stylus subulatus; stigma simplex. Ca psula coriacea, triquinquelocularis, loculieide tri-quinquevalvis, valvis medio septa margine seminifera, a columna centrali tenui persistente soluta gerentibus. S e mina pauca ......-Arbor chilensis; foliis alternis oppositisque, breviter petiolatis, ovatooblongis, serratis, stipulis petiolaribus subulatis, persistentibus, peduneulis axillaribus solitarits, unifloris, folio brevioribus.

Trícuspidaria Ruiz et Pavon Prodr. 64. t. 36. Syst. 119. DC. Prodr. I. 590. Meisner Gen, 29. (39.) Tric us p is
Persoon Encheir. II. 9.

5391. Crimodendilera MOLIN, C a ly x pentapbyllus, foliolis erectis, lanceolato-pyramidatis, acutis, integerrimis, subcarnosis, basi sub. saccatis. Cor ol ia nulla, Stamina 12, e margine tori crassi orta; fil amenta subulata, li- bera, antherae filamentis aequilongae, lineares, ntrinque sulcatae, bivalves, valvis emarginatis, muticis. Ovari um ovato-globosum, pilosum,

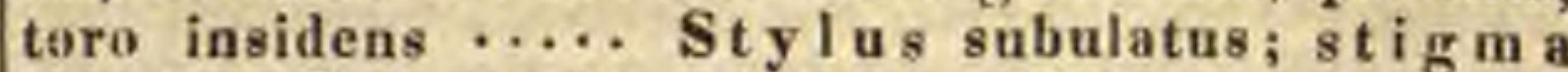
simplex. B a c ca (?) globosa, pilosa, stylo rigido superata ..... Semina $3 \ldots$ - Arbor chilen$s i s$; foliis alternis et oppositis, brevissime petiolatis, oblongo-lanceolatis, coriaceo-membranaceis, aculeato-serratis $\hat{v}$. integerrimis, penninerviis, $j u$ nioribus subpubescentibus, pedunculis axillaribus solitariis, unifloris, strictissimis, apice incrassatis.

Crinode ndron Molina Chili 314. Cavanill. Dissert. V. 300. t. 159. Hooker Bot. Miscell. III. 156. t. 100.

\section{Classis II. Guttiferae.}

Arbores v. frutices, rarissime her$\mathrm{b}$ a e, succo in plerisque resinoso, limpido $\mathrm{v}$. colorato. Foli a alterna v. opposita, simplicia, rarissime composita, saepissime integra th integerrima. Stip ulae deciduae v. persistentes, saepius nullae. Caly $x$ liber v. rarissime ovario adnatus, aestivatione imbricatus. Corol1 a e petala saepissime hypogyna, calycis foliolis numero aequalia v. plura, aestivatione convolutiva, rarius nulla. S ta $\mathrm{min}$ a indefinita $\mathbf{v}$. rarius subdefinita, saepissime polyadelpha. Carpidia plura, in ovarium uni-pluriloculare coalita. Ovula in loculis solitaria v. indefinita, saepe anatropa, rarius orthotropa, campylotropa v. amphitropa. Embryo rectus, saepissime exalbuminosus, rarissime albumine carnoso inclusus. Cotyle don es foliaceae v. saepius carnosae et conferruminatae.

\section{Ordo CCXIII. Dipterocarpeae.}

DIPTEROCARPEAE Blume Bijdr. 222. Flor. Jav. faso. 7. 8. Wiglit et Aruott Pradr, 1, 83, Meisner Gen. 35. (27.) DIPTERACEAE Lindley Introduct. edit, II. p. 98. SHO. REACEAE Roxburgh msc, ex Wallich Catalog $n$, 4905.

Arbores asiaticae, ingentes, succis resinosis turgidae. Foli a alterna v. ad basim ramulorum opposita, petiolata, integerrima, penninervia, venosa, vernatione involuta, petiolo articulatim inserto. Stipula e convolutae, deciduae, ramos acumine conico terminantes, post lapsum cicatricem semicircularem relinquentes.

Flores hermaphroditi, regulares, juxta ramorum apicem e foliorum axillis racemosi, rarius paniculati, axillares v. terminales, pedicellis ebracteatis, articulatis.

Cauxx pentamerus, foliolis liberis, imbricatis, v. basi in tubum connatis, limbi laciniis aestivatione subvalvatis, nune omnibus aequalibus demum aequaliter auetis, nune duabus oppositis $v$. interdum tribus majoribus, in fructu masimis, alaeformibus.

Corolrar petala quinque, hypogyna, calycis foliolis alterna, exunguiculata, libera v. basi 
in tubum brevissimum coalita, aestivatione convolutiva, sub anthesi patentia, decidua.

Stamisa hypogyna, indefinita, rarissime subdefinita, uni-biseriata. Fil am enta brevia, subulata, distincta v. basibus interdum per paria connata. Anthera e introrsae, biloculares, loculi oblungo- v. elongato-lineares, oppositi, connectivo in cuspidem setaceam producto utrinque juxta totam longitudinem adnati $v$. interdum basi distincti, latere longitudinaliter dehiscentes. P ollen globosum, laeve.

Discos nullus. Ovariom liberum, triloculare. Ovula in loculis gemina, collateralia, ex anguli centralis apice pendula, anatropa. Stylus terminalis, simplex; stigma acutum v. obtusum, integerrimum v. obsolete tridenticulatum.

Frectus calyce inclusus, styli basi persistente rostratus, abortu unilocularis, monospermus, nunc nucamentaceus, indehiscens, nunc capsularis, trivalvis.

Semen inversum, nunc chalaza cum pericarpii fundo concrescente situm erectum mentiens, nune hinc sulco longitudinali dissepimenti, demum saepe e pariete soluti, reliquiis commissum, illine rhaphe percursum. Test a membranacea, tenuis.

Emrryo exalbuminosus, orthotropus. C otyled on es maximae, saepe inaequales, oblique sibi incumbentes, nunc subfoliaceae, chrysaloideo - contortuplicatae, nunc crassissimae, marginibus rugosae, basi bilobae, saepe longiuscule petiolatae, per germinationem bypogaeae. R a di cula brevis, cylindrica, immersa, supera. Plum ula conica, diphylla.

Dipterocarpea e in nemoribus arehipelagi indici et in terra continenti usque ad Himalayae radices habitantes, Tiliaceis Elaeocarpeis, Malvaceisque affines habentur, ab illis petalis integris, disci et albuminis defectu et cotyledonum conformatione distinetae, ab his staminibus liberis v. basi tantum subconnatis, corollae aestivatione, antherarum structura et ovulorum situ diversae, et ob calycis aestivationem in pluribus generibus manifeste imbricatam e Columniferarum classe exeludendae, et Guttiferis, quibuscum praeter qualitatem resinosam etiam pluribus aliis notis conveniunt, potius accensendae, Chlaenaceis Ternstrōmiaceisque proxime affines.

Pleraeque resinam largiuntur balsameam, thus Brahmae naribus gratum. Camphora quae e Dryobalanope elicitur, prae laurina celebris.

Lophira ordinem distinctissimum, ex Africae tropicae regionibus inexploratis olim ditandum, sistere videtur.

5392. Hipteroearpus $G \ddot{A R T N}$. C a lyx liber, tubo campanulato, demum ancto, limbi quinquefidi laciniis tribus dentiformibus, duabus oppositis elongatis, maximis, increscentibus, reticulato-venosis, aestivatione valvatis. Corollae hypogynae petala 5, aequalia, aestivatione convolutiva, basibus latiora, imbricata, subcohaerentia, superne inaequilatera, patentia. St amina hypogyna, indefinita, subbiseriata; fil amenta basibus membranaceo-dilatatis distincta $v$, subconnata, an th er a e biloculares, elongato-lineares, loculis adnatis, connectivo in cuspidem setaceam producto. Ovari u liberum, calyeis tubo inelusum, triloculare, loculis bievulatis. Ovula ex apice anguli centralis collateraliter pendula, anatropa. Stylus filiformis, simplex; stigma obtusum. N nx lignosa, calycis tubo aucto inclusa, ejusque laciniis tribus brevibus, duabus foliaceo anctis coronata, stylo mueronata, abortu nnilocularis, monosperma. Semen inversum, chalaza cum fundo nucis concrescente situm erectum mentiens, hine sulco longitudinali dissepimenti a pariete soluti reliquiis commissum, inde $r \mathbf{h}$ a phe simplici, crassiusenla percursum. Embryo exalbuminosus, orthotropus; cotyledonibus maximis, carnosis, aequalibus, contortuplicatis, radi cula brevi, crassa, supera. - Arbores Asiae tropicae, excelsae, resinifluae; foliis oppositis, integerrimis, coriaceis, stipulis caducis, floribus racemosis, magnis, speciosis, albis, rubro tinctis.

D i p ter o c a r p us Gärtner $f .1 M T .50, t .187,188 . f . t$. Roxburgh Plant. Corom. 2, 213. Blume Flor. Jav, Dipterocarp, 8.t. 1_6. Wight et Arnott Prodr. Flor. Ind. or. $I$. 84. Melsner Gon. 35. (27.) P te r y g i u $\mathrm{m}$ Correa in Annal. Mus. VIII, 397. t. 6. - ? C a r y o 1 o b is Gärtner 1 , 215. t. 48.

5393. Inyoballanogs $G A R T N, \mathrm{C}$ a I y $\mathrm{x}$ fructifer liber, tubo cupulari, limbo in alas quinque foliaceas, erectas, rigidas, aequales, sinu lato sejunctas expanso ..... C a p s u la cupulae calycinae semiimmersa, lignoso-fibrosa, unilocularis, trivalvis, monosperma. Sem en inversum, hinc sulco longitudinali dissepimenti parietalis reliquiis commissum, illinc rhaphe crassiuscula percursum. Embryonis exalbuminosi, orthotropi cotyledo nes maximae, carnosae, valde inaequales, contortuplicatae, radi c n la brevis, crassa, supera. - Arbor insula e Sumatra, incolis Capúra dic$\overline{t a}$, camphorifera; foliis alternis, ramulorum inferioribus oppositis, integerrimis, coriaceis, stipulis caducis, floribus ignotis, calycis laciniis aequalibus, capsula valvata, et cotyledonibus inaequalibus a Dipterocarpis satis ut videtur distincta.

D r y obala nops Gärtner f. III. 49. $t, 186, f .2$. Colebr. in Asiat. Hesearch, XII. 536. c. ic. Heyne Arzneigew. XII. t. 18. P terygi s p. Correa in Annal. Mus. X. 159. t. 8. f. 8 .

5384. Eateria LINN. Caly x quinquepartitus, laciniis aequalibus, oblongis, obtusis, fructiferis immutatis v. anetis. Corollae petala 5, hypogyna, aequalia, aestivatione convolutiva, basi subimbricata, superne patentia. S t a m in a hypogyna 15 _ 50 , uni-biseriata; fil am enta brevissima, crassiuscula, antherae biloculares, oblongo-lineares, loculis adnatis, connectivo in cuspidem setaceam producto. Ovarin m liberum, triloculare, Ioculis biovnlatis; ovula ex apice anguli centralis collateraliter pendula, anatropa. Stylus filiformis, simplex; stigna acutum, integerrimum v,tri-sexdentatum. C ap s a la calyce reflexo stipata, coriaceo - fungosa, pyramidata, rotundato-trigona, abortu unilocularis, mono-disperma, trivalvis. Semen inversum, testa membranacea, dura, E mbr y on is exalbuminosi, orthotro- 
pi cotyledones maximae, crassissimae, valde inaequales, basi bilobae, petiolatae, marginibus, rugosae, radicula brevis, immersa, supera. Arbores in dic a e, copalliferae, folits alternis, oblongis, integerrimis, rigidis, venosis, floribus terminalibus v, axillaribus, paniculatis, albis.

Vat eria Linn. Gen, n. 668. Jussieu Gen. 158. Lam. t. 475, Gärtner f. III. 53. Wight et Arnott Prodr. I. 83. Meisner Gen. 35. (27.) Arnott in Annal. of nat. Hist. III. 155.

a, EUVATERIA Arnott 2 . c, C a ly e is laciniae obtusae, fruetiferae haud mutatae. Petal a ovalia, ealycem vix superantia. S $t$ a m in a $40 \_50$, antherarum loculis linearibus. Stylus elongatus; stig wa acutum. - Panicula terminalis, magna. - (Roxburgh Plant. Corom. t. 288. Gärtner f. $t$. 189. Wight Illnstr. $t .36$. E I a e o. carpus copalliferus Retz Observ. IV. 27. Vabl Symb. III, 67,j P a e n a Rheede Malab. IV . 33. t. 15 .

b. ISAUXIS Arnott $l$. c, Caly c is laciniae ovatae, fructiferae auctae, elongatae. Petal a faleata, calyce triplo longiora. St a min a 15, antherarum loculis oblongis. Stylus trevis; stig ma clavatum, tri-sexdentatum. Paniculae axillares, folio breviores. - S eidlia Kosteletzky Medic. pharm. Bot. p. 1945, (Wight Ic. t. 26.)

5395. Vatiea LINN. Ca ly x pentaphyllus, foliolis imbricatis, demum in alas foliaceas, erectas, rigidas, subaequales expansis. Corolla e petala 5, hypogyna, aequalia, aestivatione convolutiva, sub anthesi patentia, marginilıus subrevoluta. St a min a hypogyna $15-100$, uni-biseriata; fila menta brevia, filiformia, basi abruptim dilatata, a $n t h$ e $r$ a e oblongo-lineares, connectivo in cuspidem setaceam producto. Ovarium triloculare, loculis biovulatis. $0 \mathrm{vnla}$ ex apice anguli centralis collateraliter pendula, anatropa. S tyIus filiformis, simplex; stigm a acntum. C a p8 ula coriacea $v$. lignosa, inclusa, ovata, mucronata, aborta unilocularis, monosperma, subbivalvis. Semen inversum, hinc sulco longitudinali dissepimenti parietalis reliquiis commissum, inde rhaphe percursum. Em bryonis exalbuminosi, orthotropi cotyled ones maximae, crassissimae, inaequales, basi bilobae, petiolatae, marginibus rugosae, ra dic ula immersa, supera. - Arbores indicae, resiniferae; foliis alternis, coriaceis, integerrimis, venosis, stipulis caducis, paniculis $e$ foliorum deciduorum axillis $v$. terminalibus, floribus flavis.

Vatic a Linn. Mant, II. 152. Smith Ic. inedit, t. 36. Lam. ${ }^{2}$ 397. DC. Prodr. I. 517. Wight et Arnott Prodr. I. 84. Meisuer Gen, 35. (27.) S ho r e a Roxburgh Plant. Co. rom. IIT. 9. t. 212, Gärtner f, III. 47. $t, 186 . f$. 1 .

5396. IIoppea $R O X B$. C a l y $\mathrm{x}$ pentaphyllus, foliolis imbricatis, inaequalibus, duobus oppositis v. tribus demum increscentibus, alaeformibus. Corolla e petala 5 , hypogyna, aestivatione convolutiva, basibus in tubum brevem connata, lineari-oblonga, obliqua, patentia. St a m in a 15, hypogyna, corollae basi adhaerentia, decem calycis foliolis per paria opposita inferne connata, quinque isdem alterna, libera; fil amenta brevia, basi incrassato-dilatata, an $t$ hera e biloculares, loculis brevibus, obtusis, connectivo in cuspidem setaceam producto. Ovarin m liberam, triloculare, loculis biovulatis. Ovula ex apice anguli centralis collateraliter pendula, anatropa. Stylus filiformis, simplex; stigma acutum. C a ps u a coriacea (?) evalvis, abortu uniloen. laris, monosperma. S emen inversum. Em bry onis exalbuminosi, orthotropi cotyledones... radie ula supera. - Arbores in dicae; foliis al- ternis, integerrimis, saepe in nervorum axillis glandulosis, stipulis subulatis, caducis, paniculis axillaribus et terminalibus, ramulis alternis bifariis, floribus parvis, flavis, juxta paniculae ramos subsessilibus, secundis.

H op pe a Roxburgh Plant, Corom. IIT. 9. t. 210. Flor. ind. II. 609. Wight et Arnott Prodr. I. 85. Wight Illustr. t. 37. Meisner Gen, 35. (92.) D a m m a r a s el a n i ca Rumph Amboin, II. 168. $t .56$.

\section{* Lophiraceae.}

539\%, Loplnirea BANKS, Calyx pentaphyllns, foliolis tribus interioribus minoribus, concavis, duobns exterioribus oppositis majoribns, inaequalibus, demum in alas elongatas expansis. Corolla e petala 5, hypogyna, exunguicalata, per aestivationem apicibus convoluta, tandem patentia. Stamina hypogyna, indefinita, subbiseriata; fil amenta filiformia, brevia, an $\mathbf{t h}$ erae biloculares, loculis linearibus, oppositis, parallelis, adnatis, apice rimula laterali dehiscentibus. D is cus nullus. Ovarin m conicum, nniloculare, ov ulis plurimis placentae basilari crassae liberae adnatis, elongatis, recurvis, nnciformibus, in capitulum dispositis. Sti g $\mathbf{m}$ a $\mathbf{t}$ a 2 , minima, tortilia, reflexa. Nux coriacea, fusiformis, basi,coarctata et cum calyce ampliato conferruminata, nnilocularis, abortn monosperma. S e men erectum, testa membranacea, tenui. Em b r y on is exalbuminosi cotyled on es amygdalinae, plano-convexae, radicula brevissima, immersa, infera. Arbores Africae tropicae, pyramidales, ramosae; cortice sicco, foliis alternis, petiolatis, integerrimis, costato-venosis, petiolo articulato, stipulis minimis, utrinque ad petioli basim solitariis, deciduis, floribus axillaribus et terminalibus paniculatis, luteis, pedicellis divaricatis, supra basim articulatis, ad articulum minutissime bibracteolatis.

L o p hi r a Banks apud Gärtner $f$. III. $52 . t, 188$, Guillemin et Perrot. Elor. Seneg. 1. 109. t. 24.

\section{Drdo CCIV. Chlaenacene.}

CHLAENACEAR Thouars Hist, Neget, Afr. austr. A6. DC. Prodr. I. 521. Bartling Ord. nat. 336. Lindley Introduct. edit, II. p. 90. Meisner Gen. 35. (27.)

Arbores mediocres v. arbusculak, rarius Frutress scandentes, partibus omnibus glaberrimis $\mathbf{v}$. junioribus pilis simplicibus scabris, ant pube stellata conspersis. Folia alterna, simplicia, integerrima, coriacea, penninervia, glaberrima, saepius vernatione longitudinaliter plicata. Stipulae gemmaceae, ramos acumine conico terminantes, folii explicatione dejectae, nunc ad basim petiolorum persistentes, interdum, ut videtur, nullae.

Flores hermaphroditi, regulares, axillares et terminales, corymbosi, racemosi v. paniculati, pedunculis basi nudis v. decidue bracteatis. Involu cram nunc biflorum, membranaceum, demum auctum, flores sessiles fovens, nunc ejus loco bracteolae geminae, florum in apice pedunculi geminatim sessilium basi adpressae, saepissime involucrum nullum, floribus singulis involucello proprio urceolato v. 
cylindrico, persistente, indurato $\mathrm{v}$. baccato $\mathrm{mu}$ nitis.

CaLxx involucello brevior v. longior, triphyllus, foliolis concavis, membranaceis v. coriaceis, imbricatis, persistentibus.

Corollae petala quinque v. rarissime sex, hypogyna, oblonga v. obovata, aestivatione convolutiva, sub anthesi unguibus in tubum conniventibus apice patentia.

Staniva saepissime indefinita, rarius duplo petalorum numero definita, urceolo hypogyno, crenato intus inserta. Fil a menta libera, filiformia v, rarissime sursum latiora. An the rae biloculares, incumbentes, rarissime loculis diseretis, filamenti apici dilatato utrinque adnatis, longitudinaliter dehiscentes.

Ovarium liberum, sessile, triloculare. 0 v ula in loculis gemina, ex apice anguli centralis collateraliter pendula, rarius plura, angulo centrali biseriatim inserta, anatropa. Stylus terminalis, cylindricus, simplex; st igma capitato-trilobum.

Capsula involucro v. involucello inclusa, calyce et saepius etiam petalorum unguibus persistentibus stipata, triloba, trilocularis v. abortu unilocularis, loculicide trivalvis, valvis medio septiferis, a columella centrali, apice seminifera solutis.

Semiva in loculis gemina, collateraliter pendula v. saepe abortu solitaria, ovata v. compressiuscula, test a coriacea, rugosa.

Емввуо in axi albuminis carnosi v. cornei orthotropus, ejusdem longitudine. Co ty led ones cordatae, tenerrime foliaceae, longitudinaliter undulato-plicatae v. apice inflexae. $\mathbf{R}$ adicula cylindrica, umbilico proxima, supera.

Chlae nace a e omnes in Madagascaria indigenae, calyce triphyllo cum corolla penta- v. hexamera et floribns saepissime involucratis $\mathbf{v}$. involucellatis inter Guttiferas facile distinguun tur. Ventenatia genus africanum tropicum, non satis notum, floribus exinvolucratis et petalorum numero majore diversum, interim dubie ordini approximatur.

Hugonia distincti ordinis pignus, in classe fructu drupaceo cum embryone foliaceo albuminoso singularis.

E u c r y p hi a inter Chlaenaceas, Ternströmiaceas et Hypericineas media, ab illis foliis oppositis, ab his semine albuminoso praeter alias notas diversa.

5398. Sareolaema THOUARS. Involacell um carnosum, urceolatum, quinquedentatum, ferragineo-tomentosum, persistens. C al yx involucello inclusus, triphyllus, foliolis membranaceis, concavis, imbricatis. Corolla e petala 5 , hypogyna, oblonga, obtusa, aestivatione convolntiva, sub anthesi, ungnibus inferne in tubum conniventibus, patentia: $\mathrm{S}$ tamina plnrima, urceolo hypogyno crenato intus inserta; fil am en ta filiformia, libera, a n th e r a e biloculares, incumbentes, quadrangulares, lateribus longitudinaliter dehiscentes. O v a r i u m liberum, triloculare. Ovula in loculis gemina, ex apice anguli centralis collateraliter pendula, anatropa. StyI u cylindricus, simplex; stigma capitato-trilobum. C a p 8 u I a involncello baceato, intus pilis prurientibus vestito inclusa, calyce et petalorum unguibus persistentibas stipata, ovato-acuminata, triloba, trilocularis, loculicide trivalvis, valvis medio septa a columella seminifera persistente soIuta gerentibus. Semina in loculis gemina, ex apice columellae centralis collateraliter pendula, abortu saepe solitaria, ovata, compressiuscula, testa coriacea, rugosa. E $\mathbf{m}$ br yo in axi albuminis carnosi orthotropus, ejusdem longitudine; cotyl e d on ibus foliaceis, cordatis, tenerrimis, longitudinaliter undulato-plicatis, radi c u l a cylindrica, nmbilico proxima, supera. - Arbores madagascarienses, mediocres; ramis dichotomis, junioribus pilis scabris ferrugineis, stipula conica, decidua, folium longitudinaliter plicatum includente terminatis, foliis alternis, petiolatis, coriaceis, ovatis, penninerviis, integerrimis, paniculis axillaribus terminalibusque paucifloris, pedunculis basi decidue bracteatis, floribus majusculis, speciosis.

Sarcol a $\mathrm{n}$ a Thouars Hist, veg. Afr. austr. 37. ¿. 9. 10. DC. Prodr. 1. 581. Meisner Gen, 35.

5395. Teptollaema THOUAR. Involucel Inm subcarnosum, cylindricum, sexdentatum, persistens, Caly $\mathrm{x}$ involucello longior, triphyllus, foliolis ovatis, villosis, imbricatis. Corolla e petala 5, hypogyna, oblonga, obtusa, aestivatione convolutiva, sub anthesi unguibus exsertis in tubum conniventibus apice patentia. Stamin a 10 , urceolo hypogyno integerrimo intus inserta; f i I a m e n t a filiformia, libera, antherae biloculares, incumbentes, ovatae, utrinque emarginatae, longitudinaliter dehiscentes. Ovarium liberum, trilocnlare. Ovula in locnlis gemina, ex apice anguli centralis collateraliter pendula, anatropa. Stylus cylindricus, simplex; st ig ma capitato-trilobum. Caps ula involucello baccato inclusa, ealyce persistente stipata, abortu unilocularis, monosperma. S e m e $\mathbf{n}$ inversum, obovato - oblongum, eompressiosevlum, testa coriacea, rugosa. $\mathbf{E} \mathbf{m}$ b ry o in axi albuminis cornei orthotropus, ejusdem dimidio longior; cotyle do nibus cordatis, foliaceis, tenuibus, apice in flexis, rad i cula cylindrica, umbilico proxima, supera. - Arbuscula madagascariensis; trunco tri-quadripedali, coma densa, pyramidali, foliis al ternis, petiolatis, coriaceis, ovalibus, penninerviis, integerrimis, glaberrimis; undulatis, stipulis gemmaceis, sub vernatione caducis, corymbo terminali, denso.

Le ptola e a Thouars Hist, veg. Afr. austr. 4t, $t, 11$, DC. Prodr, I. 522. Meisner Gen, 35.

5400. Selhizolnema THOUARS, Invo I ceru m biflorum, parvum, membranaceum, fimbriatum, demum ampliatum, laciniatum, viscosum, connivens. Caly $x$ triphyllus, foliolis membranaceis, concavis, imbricatis. Corolla e petala 5, hypogyna, obovata, aestivatione convoluta, sub anthesi conniventia. Stamina plurima, urceolo hypogyno integerrimo intus inserta; filamenta libera, snrsum latiora, antherae biloculares, loculis discretis filamenti apici dilatato utrinque adnatis, longitudinaliter dehiscentibus. O va r i $\mathbf{~ m}$ liberum, triloculare Ovula in loculis gemina, 
ex apice anguli centralis collateraliter pendula, anatropa. S ty lns cylindriens, simplex; stig ma obtuse trilobum. Cap sula intra involnerum sessilis, ovata, triloba, trilocularis, loculicide trivalvis, valvis medio septa a columella seminifera persistente soluta gerentibus. Se mina in loculis gemina, ex apice columellae centralis collateraliter pendula, abortu saepe solitaria, ovata, acuminata, testa coriacea, rugosa. $\mathrm{E} m$ bryo in axi albuminis cornei orthotropus, ejusdem longitudine; cotyledonibus foliaceis, cordatis, undulatis, apice incorvis, radicula cylindrica, umbilico proxima, supera. - Arbusculae madagascarienses, ramosae; ramulis foliisque junioribus pube stellata conspersis, adultis glabratis, folits alternis, petiolatis, coriaceis, penninerviis, integerrimis, sti. pulis ad basim petiolorum geminis, ovatis, acutis, floribus paniculatis $v$, racemosis. t. 12.

$\mathrm{S} \mathrm{chizola} e \mathrm{n}$ a Thouars Hist. veget. Afr. austr. 43.

5401. Th Hodolaema THOUAR. Invo1 u cr um v. involucellum nallum. Ca l y x minute bibracteolatus, triphyllus, foliolis ovatis, concavis, carnosis, imbricatis. Corolla e petala 6, hypogyna, obovate-inaequilatera, aestivatione spiraliter contorta, sub anthesi unguibus convolutis apice patentia. Stamin a plurima, urceolo hypogyno integerrimo intus inserta; $f i l a m e n t a$ filiformia, libera, an therae biloculares, incnm. bentes, quadrangulares, lateribus longitudinaliter dehiscentes. $O$ v a $\mathbf{r} \mathbf{i}$ m liberum, triloculare. Ovula in loculis plura, angulo centrali inserta... Stylus cylindricus; stigma capitatnm, trilobum. Fructus ..... - Frutex madagascariensis, scandens; foliis alternis, petiolatis, coriaceis, mucronatis, penninerviis, integerrimis, glabris, pedunculis axillaribus solitariis, nudis, apice bifloris, floribus maximis, purpureis, Camelliae flores aemulantibus.

$\mathrm{R}$ hodol a e n a Thouars Hist, veg. Afr. austr. 47, t. 13 . Gen. Madagasc. n. 56. DC. Prodr. I. 225. Meisuer Gen. 35. - ? $\mathrm{P}$ a a d or a Noronh. msc. Mena-hisara Madegas.

540\%. Wentenatia PALIS. InvoIucr $\mathbf{n} \mathbf{m}$, involucellum nullum. Calyx ebracteolatus, triphyllus, foliolis rotundatis, concavis, imbricatis, deciduis. Corollae petala 11 -12, hypogyna, oblonga, obtusa, basi angustata, subaequalia, patentia. Stam in a plurima, hypogyna; filamenta filiformia, libera, antherae biloculares, snblineares, basi insertae, loculis latere longitudinaliter dehiscentibus. $O$ v a r i $\mathbf{m}$ liberum, oblongum, quinquelocufare. Ov u la plurima, loculorum angulo centrali inserta, adscendentia, imbricata, oblonga, complanata. St y lus simplex; stigma subquinquelobum. Fructus ovoideus, apice styli reliquiis rostratus, sulcatus, earnosus, quinquelocularis. Se mina..... - Arbuscula beninensis; foliis alternis, petiolatis, ovatis, acuminatis, penninerviis, integerrimis, glaucis, stipulis nullis, floribus terminalibus, speciosis.

Ventenatia Palisot Flor. Owar. I. 29, t. 17. DC. Prodr. I, 587. Cambessed, in Mem, MUs, XVI, 409. Meisner Gen. 35. (27.)

\section{* EUCRYPHIEAE.}

5403. Eneryplnia $C A V A N$. C a 1 y $x$ ebracteolatus, tetraphyllus, foliolis subscariosis, im- bricatis, apice calyptratim conglutinatis, basi circumscisse deciduis. Coroll a e petala 4 , hypogyna, ealycis laciniis alterna, inaequilatera, aestivatione convolutiva, decidua. Stam in a pluri. ma, receptaculo carnoso, piloso inserta, pluriseriata, libera; fil amenta petalis breviora, antherae versatiles, orbiculatae, biloculares, lo. culis basi et apice distinetis, longitudinaliter dehiscentibus. Ovarin m liberum, sessile, quinque. duodecimloculare. Ovula in loculis circiter sex, angulo centrali uniseriatim inserta, pendula. St y li $5-12$, filiformes; $s \mathrm{tig} \mathrm{mat}$ a truneata. Ca p $8 \mathrm{ula}$ oblonga v. ellipsoidea, costata, quinque-duodecimlocularis, penta-dodecacocea, coceis cymbiformibus, osseis, apice bifidis, ex axi centrali in fila soluta pendulis, oligospermis. Semina in loculis pauca, inversa, oblonga, compressa, imbricata, in alam membranaceam producta. $\mathbf{E} \mathbf{m}$ b $\mathbf{r} \mathbf{y}$ in axi albuminis parei, carnosi rectus ; coty le donibus foliaceis, ellipticis, radicula brevissima, supera. - Arbores in insula Diemen et Chilo $\ddot{e}$ indigenae, resinosae, gemmis terminalibus et axillaribus perulatis, perulis oppositis, ramis ramulisque oppositis, subcylindricis, articulatis; foliis oppositis, petiolatis, coriaceis, integerrimis $v$. crenulatis, penninerviis, subtus reticulatis, stipulis nullis, pedunculis axillaribus solitariis, unifloris, basi bracteis duabus scariosis connatis, deciduis stipatis.

Eucryph ia Spach Suites d Buffon, $V$. 344, in not,

a. CARPODONTOS Labill. Ovarium et eapsula vil. losa, quinque-decemlocularis. - Folia integerrima, supra viscosa, subtus discolora.

Carpodontos Labillardiere Voyage II, 16. $t .18$. Nov. Holl. II. 122. DC. Prodr. 1. 556.

b. EUCRYPHIA Cav. Ovariam et eapsula glabra, duodecimlocularis. - Folia irregulariter crenulata, utrinque concolora, subtus retioulata.

E u er y ph i a Cavanill. $I c . I V, 49$, t. 372, DC. Prodr. I. 556 .

\section{* HugoniacEaE.}

5404. Firugonaia LINN. Caly $x$ pentaphyllus, foliolis quincunciatim imbricatis, persistentibus. Coroll a e petala 5, hypogyna, oblongo-inaequilatera, aestivatione contorta, sub anthesi patentia. Stamina 10, hypogyna; filam en t a basi in urceolum connata, superne libera, filiformia, alterna breviora, antherae introrsae, biloculares, cordato-ovatae, longitudinaliter dehiscentes. Ovarin subglobosnm, quinquelo. culare. Ovala in loculis gemina, ex apiee anguli centralis collateraliter pendula, anatropa. Sty 1 i 5 , filiformes, distincti; stigmat a reniformi-dilatata. D ru p a baceata, carnosa, pentapyrena, pyrenis osseis, uni-bilocularibus, mono-dispermis. S e$m$ in a inversa. E m b ry o in axi albuminis carnosi orthotropus, ejusdem longitudine; cotyledonib u s foliaceis, planis, radicula tereti, umbilico proxima, supera. - Frutices indic $i$; foliis alternis, floralibus suboppositis, breve petiolatis, ovalibus, integerrimis v. subserratis, coriaceis, supra nitidis, subtus tomentosis, stipulis lateralibus geminis, subulatis, deciduis, pedunculis axillaribus, solitariis, unifloris, folio brevioribus, saepe in spinam circinnato-uncinatam mutatis.

H u g o n i a Linn. Gen, n. 831. Gastner $r$. 281, $t$. 58 . Cavanill. Dissert, III. 177. $t, 73$. DC. Prodr. X, 522, Wight et Arnott Prodr. I, 72. Wight Itlustr, t. 32, 


\section{Drdo CCXV. Ternstrimiacene.}

TERNSTRÖMIEAE Mirbel in Bullet, soc, philomat, 1813. p. 381. TERNSTRŌMIACEAE DC. in Mem. soc. phys. Genev. I. 393, Prodr. 1. 593, Bartling Ord. nat. 335 , Cam. bessed. in Mem. Mus, XVI. 401. Lindley Introduct, edit. II. $p$. 79, - TBEACEAE Mirbel $l$. $c$. CAMEllikaE DC. Theorie elem. ed. 1. Prodr. 1. 589. CAMELLIACEAE Bartling Ord. nat. 335.

Arbores v. frutices, succo aqueo, ramis ramulisque teretibus. Folia alterna, saepe ad apices ramorum fasciculatim approximata, rarissime opposita, simplicia, integra, rarissime palmatifida, plerumque perennia, coriacea, rarissime membranacea, pellucide punctata, penninervia, integerrima v. dentata, subtus saepe sericeo nitentia. Petioli basi cum ramulo articulati. Stip u la e plerumque nullae, rarissime inter folia opposita interpetiolares, v. ad basim petiolorum alternantium laterales, geminae.

Flores hermaphrodití v. interdum abortu polygami, regulares, nunc axillares, solitarii v. fasciculati, nunc terminales, ramosi v. paniculati, saepissime albi, rarius rosei v. rubri, rarissime flavi. Pedunculi basi articulati, nudi $\mathbf{v}$, bracteati.

Calxx plerumque liber, rarissime inferne cum ovarii basi connatus, persistens v. rarius deciduus, saepissime basi bibracteolatus, tritetra-pentaphyllus, rarius pleiophyllus, foliolis omnino distinctis v. interdum plus minus coalitis, coriaceis, concavis, subinaequalibus, imbricatis.

Corollak petala hypogyna v. rarius perigyna, calycis foliolis numero aequalia, iisdem alterna v. opposita, rarius plura, libera v. inferne distinctius v. obsoletius connata, saepe inaequilatera, per aestivationem imbricata v. subcontorta.

Stamrna indefinita, pluriseriata, hypogyna v. perigyna, saepissime petalorum basi adhaerentia. Filamenta saepissime brevia, filiformia v. subulata, libera v. ima basi coalita, rarius in phalanges distinctas collecta. Antherae introrsae, biloculares, basi v. dorso insertae, mobiles v. adnatae, loculi arcte appositi v. basi discreti, antice longitudinaiiter, ra rius apice v. basi poro dehiscentes, connectivum postice protuberans, interdum apice incrassatum $\mathbf{v}$. in glandulam excavatam productum. Poll in is granula triloba v. trigona.

Ovarium liberum v. rarissime inferne calyci adnatum, e carpidiis duobus, tribus v. quinque, rarius pluribus compositum, prima juventute saepissime uniloculare, carpidiorum marginibus introflexis placentiferis, serius in axim centralem coalescentibus bi-tri-quinqueloculare. Ovula in placentis e loculorum angulo centrali exsertis nunc pauca, definita, nunc inde- finite plurima, pendula v. rarius adscendentia, campylotropa v. anatropa. S tyli loculorum numero, saepissime in unicum coaliti; stig mata cohaerentia v. distincta, acuta v. obtusa.

Froceus bi-quinquelocularis, nune indehiscens, coriaceus v. carnosus, uunc capsularis, loculicide dehiscens, valvis medio septa margine seminifera, v. nuda, a columna centrali seminifera persistente soluta, gerentibus.

Semra in loculis indefinita, pauca v. solitaria, hippocrepiformi-conduplicata, subrotunda v. angulata, sive compressa et alata, adscendentia, pendula v. horizontalia, nuda v. interdum arillo carnoso inclusa. T es ta crustacea, laevis v. impresso-punctata, rarissime dense lanata, v. membranacea, a basi sursum v. utrinque, rarius undique in alam membranaceam expansa. Alb um en carnosum v. subcartilagineum, saepe parcum v. nullum.

Емвкхо albumine, dum adest, inclusus, homotropus, rectus v. arcuatus aut conduplicatus. Cotyledon es in albuminósis planae, oblongae, lineares v. reniformes, interdum longitudinaliter plicatae, in exalbuminosis saepissime crassae, carnoso-oleosae, distinctae. $\mathrm{K}$ adicula brevissima v. longa, umbilico proxima. Plumula inconspicua vix manifesta.

Ternströmiaceae potissimum in America tropica et Asia orientali gignuntur, paucissimae Americam borealem, unica insulas Canarias, inhabitant. Genera vix non omnia endemica. Sauraujae species americanae ab asiaticis fortassis separandae. Cochlospermi, generis in ordine subanomali, species diversae ad Orinocum, Nigrum et Gangem repertae.

Ordinis, nisi omnes tribus in familias distinetas velis erigere, vix dividendi, summa cum Clusiaceis, imprimis per Camellieas arctissime conterminas affinitas, quae tamen foliis constanter oppositis, majori integumentorum floralium numero, calycis natura, radiculae directione et embryonis conformatione egregie distinguuntur, nec ideo tamen genera Ternströmiacearum oppositifolia, nec stipulata, floris et seminis fabrica apprime reliquis conformia, eliminanda. Aristoteliaceae ad ordinis calcem recensitae, ad Elaeocarpeas plurimis notis accedunt.

TIRIBUS I. COCHLOSPERMEAE. C aIyx pentaphyllus. Corollae petala 5. Anthe ra e basifixae, apice poro unico dehiscentes. Ovarium septis incompletis placentiferis uniloculare. O v u l a amphitropa. F r u e t u s capsularis. S e min a reniformia, dense lanata. Embryo in axi albuminis homotrope arcuatus; cotyledonibus planis. _Folia allerna, palmatiloba, petiolo bistipulato. Tropicae amphigeae. 
5405. Coehlospermum $K U N T H, \mathrm{C}$ a1yx persistens, ebracteolatus, pentaphyllus, foliolis imbricatis, dnobus exterioribns minoribus. Corollae petala 5, hypogyna, calycis foliolis alterna, inaequilatera, aestivatione contorta, persistentia. Stamina plurima, hypogyna, pluriseriata, persistentia; fi lamenta filiformia, antherae basifixae, longae, lineari-tetragonae, quadriloculares, apice poro unico apertae. Ovarium liberum, semiseptis tribus $v$, quinque incomplete tri-quinqueloculare. Ov u la plurima, semiseptorum marginibus utrinque pluriseriatim inserta, amphitropa. Stylus filiformis, apice hamatus; stig ma truncatum, minute denticulatum. Ca psula coriacea, incomplete tri-quinquelocularis, locnlis medio semisepta margine seminifera gerentibus, endocarpio chartaceo a mesocarpio transversim fibroso pone dissepimenta in valvulas interiores, cum exterioribus alternantes soluto. $\mathrm{S} \mathrm{e}$ mina in placentis linearibus, semiseptorum margini utrinque adnatis, basi et apice deliquescentibus plurima, reniformia v. cochleata, emarginaturae sinu umbilicata, testa intra epidermidem crustaceam, lana gossypina alba dense vestitam crustacea, endopleura membranacea. E mb ryo in axi albuminis carnosi homotrope arcuatus; cotyI ed on ibus planis, integerrimis, sibi incumbentibus, radicula tereti, seminis partem acutiorem umbilico propiorem spectans. - Arbusculae $v$. frutices, in regionibus tropicis totius orbis crescentes; foliis alternis, petiolatis, palmatifidis, lobis integerrimis v. serratis, glabris, stipulis lateralibus geminis, petiolis cum ramo articulatis, floribus terminalibus, paniculatis, magnis, luteis, pedunculis basi articulatis.

Coch L o s per mu m Kunth Malvac, 6. St. Hilaire Plant. us. Brasil, t. 57. Flor. Brasil. 1, 296. Cambessed, in Mem, Mus. XVI. 408. A. Richard Flor. Seneg. 98, t, 21. Wight in Hook. Bot. Miscell. Suppl. t, 18. Wight et Arnott Prodr. I. 87. Meisiner Gon. 40. (30.) Wittels bachia Mart. et Zuecarini Nov. gen, et sp. I. 80, $t, 5 \overline{5}$. M ax imiliauia Schrank et Mart. in Flora 1819. p. 458. B o mbax Gos 8 y. p i u minn. Sonnerat Voy. t. 133. Cavanill. Dissert. t. 137.

TREDES IT. TERNSTRÖMIEAE. C aly $\mathrm{x}$ pentamerus, liber v. cum ovarii basi coalitus. C or o 11 a e petala 5 , rarissime 6 , distincta v. connata. Antherae basi insertae, longitudinaliter dehiscentes. $\mathrm{O}$ v a $\mathrm{r}$ i u m biquinqueloculare. Ovula plurima, campylotropa. B a c c a sicca, v. capsula irregulariter dehiscens. E mbry o cylindricus, homotrope bicruris, exalbuminosus v. albumine carnoso inclusus. - Folia alterna, integra, exstipulata. Tropicae et subtropicae, ampligeae.

5406. Anmeslea $W A L L$. Cal y x bibracteolatus, tubo brevissimo, cum ovarii basi connato, limbi quinquepartiti laciniis inaequalibns, imbricatis. Corolla gamopetala, hypogyna, limbi quinquefidi lobis acutis, calycis laciniis oppositis, imbricatis, conniventibus. S tamin a plurima, disco perigyno biseriatim inserta, inclusa; fil a me nta brevissima, antherae introrsae, biloculares, lineares, cuspidatae, adnatae, longitudinaliter dehiscentes. Ovarium semiinferum, triloculare. O vula plarima, ex anguli centralis apice pendula, campylotropa. Stylus simplex; stigmata 3 , subulata. B a e ca sicea, snbglobosa, ealycis limbo coronata, trilocularis. Semina in loealis abortu solitaria v. gemina, pendula, arillo carnoso inclnsa, hippocrepiformi-conduplicata, testa chartacea, nitida. E m b r y o exalbuminosus, eylindricus, homotrope bicruris; cotyledonibus et radicula superis. - Arbor martabanica; foliis alternis, breve petiolatis, lanceolatis, subcoriaceis, integerrimis, stipulis nullis, floribus axillaribus, solitariis , longissime pedunculatis.

A nne s le a Wallieh Plant, As, rar. I. 5. t, 5, Meisner Gen. 40. (30.)

540\%. Diealyx LOUR. Ca ly x tubo basi bi-tribracteolato, cum ovario connato limbo supero, quinquepartito. Corolla supera, profunde quinquepartita. Stamina plurima, basi eorollae inserta. Ovarium inferum, triloculare. Ovnla in loculis plurima, pendula. Stylus simplex; stigma obtusum, trigonum. Drupa baceata, nucleo triloculari v. abortu uniloculari, locnlis monospermis. Semen inversum. Embryonis albaminosi, linearis, subincurvi radicula supera. Arbores Asiae tropicae, foliis alternis, petiolatis, serrulatis, floribus axillaribus et terminalibus, spicatis, racemosis $v$. paniculatis.

Dicaly x Lonreiro Flor. cochinch. 816 Blume Bijdr. 1116. Sariava Reinwardt.

5408. Visnea LINN. F. C a I y x ebracteolatus, inferne cum ovarii basi connatus, quinquefidus, laciniis subaequalibns, imbricatis. Corolla e petala 5, perigyna, calycis laciniis alterna, ovata, acuta, imbricata. Stamina 12 , cum petalis inserta, inclusa; filamenta brevissima, antherae introrsae, biloculares, lineares, mncronatae, adnatae, longitudinaliter dehiscentes. Ovarium semiinferum, triloculare. $O$ vula.... Stylus trifidus; stigmata acuta. Bac ca sicca calyeis limbo coronata, bi-trilocularis. Semina in loculis 1_2.... - Frutex canariensis; foliis alternis, breve petiolatis, ellipticis, coriaceis, serratis, stipulis nullis, pedunculis axillaribus solitariis, brevibus, unifloris.

V is nea Linn. f. Suppt. 36. 251. Moca nera Jussieu Gen, 318. Bory Ins. Fort, t. 7 .

5409. Ternströmia MUT. C a $1 \mathrm{y} \times$ bibracteolatus, pentaphyllus, persistens, foliolis imbricatis, exterioribus minoribus. Co rolla gamopetala, quinquefida, lobis aestivatione imbricatis, ealycis foliolis suboppositis. Stam in a plurima, corollae basi adhaerentia, pluriseriata; fil a menta brevissima, an therae introrsae, biloculares, lineares, mucronatae, basi insertae, erectae, longitudinaliter dehiscentes. O va ri n m libernm, biquinqueloculare. OvuIa in loculis $2 \_4$, ex angulo centrali pendula, campylotropa. Stylns filiformis; stigma simplex. C a psula coriacea v. subcarnosa, subglobosa, styli basi rostrata, biquinquelocularis, irregulariter bi-quinquevalvis, valvis seminiferis. S e m in a 2_4 v. abortn solitaria, pendula, hippocrepiformi-conduplicata, testa crustacea, nitida, punctata. E m b ry o cylindricus, in axi albuminis carnosi homotrope bieruris; cotyledonibus et radicula superis. - Arbores v. frutices, in America tropica crescentes; foliis alternis, petiolatis, coriaceis, integerrimis $v$. serratis, stipulis nullis, pedunculis axillaribus solitariis, uniftoris.

Ternstr $8 \mathrm{~m} \mathrm{I}$ a Mutis ex Linn. f. Supplem. 39. Swartz Flor. Ind, occid. II. 929. Ruiz et Pavon Prodr, $t, 2 t$, Kunth in Humb. et Bonpl. Nov. gen. et sp. V. 207. $t$. 463. f. 1. DC. in Hem. soc. phys. Genev. I. 408. t. 1. Prodr. I. 523 . Cambessed. in Mem. Mus. XVI. 403 . St. Hilaire Flor. Brasit. I. 231. Moricand Plant. Americ. $t, 3$. To a n a bo Aublet 
Guian, I. 569. t, 297. 228, T on a be a Jussien Qen, 268. Du pinia Necker Elem, n. 1042. A mp ha a ia Banks msc.

5410. Eurya THUNB. F lores polygami v. dioici. C a ly $\mathbf{x}$ bibracteolatus, quinquepartitus, persistens, lobis imbricatis, subaequalibus. Coro LIa gamopetala, quinquepartita, laciniis lobis calycinis oppositis, aestivatione imbricatis. Sta m in a 12_-15, imae corollae inserta, uniseriata; fila menta brevia, antherae introrsae, biloculares, oblongae v, lineares, muticae v. mucronatae, basi insertae, erectae, longitudinaliter dehiseentes. O v a $\mathbf{r}$ i $\mathbf{m}$ liberum, bi-quinqueloculare. Ovula in loculis plura, ex angulo centrali biseriatim pendula, campylotropa. St y lu s bi-quinquefidas v. partitus; stigmata acuta. B a cea sicca, bi-quinquelocularis. Semina in loculis plara, biseriatim pendula, hippocrepiformi conduplicata, testa crustacea, nitida, punctata. $\mathrm{E}$ mbry o exalbuminosus, cylindrieas, homotrope bicruris; cotyledonibus et radicula superis. - Arbores v. frutices sempervirentes, in Asia tropica et subtropica crescentes; foliis alternis, coriaceis, sllipticis $v$. cuneato-obovatis, integerrimis v. serratis, pedunculis axillaribus unifloris, subfasciculatis, floribus parvis, albis.

Eury a Thusberg Flor. japon. 11. $t$. 25. R. Brown Appond. to Abel Clarke Chin. 379. o. ic. DC. in Mem,soe. phys. Genev. I. 416. Prodr. I. 585. Cambessed, in Mem. Mus, XVI, 405. Loddig. Bot. Cap. t. 1213. Wight et Arnott Prodr. I. 86. Meisuer Gen. 4t. (31.) Wight Illustr, $t, 38$. Goeria Blume Bijdr. 124.

5411. Cleyera THUNB. Caly $\mathrm{x}$ bibracteolatus, pentaphyllus, persistens, foliolis imbricatis, subaequalibus. Corolla e petala 5, hypogyna, calycis foliolis alterna, basi latiora, aestivatione imbricata. Stamina plnrima, petalornm basibos adhaerentia, pluriseriata; filamenta brevissima, antherae introrsae, biloculares, lineares, mucronatae, basi insertae, erectae, longitudinaliter dehiscentes. O va ri u m liberum, bitriloculare. $O \vee v$ la in loculis 2_4, ex anguli centralis apice pendula, campylotropa. Stylus filiformis, simplex; $s$ tig ma bi-tripartitum. B a cea sicca, bi-trilocularis. Sem in a in leculis 2 , pendula, hippocrepiformi-complicata, testa crustacea. L mb ry o eylisdriens, in axi albuminis carnosi bomotrope bicruris; cotyledonibus et radicnia superis. - Frutices sempervirentes, in Asia tropica, Nepalia et Japonia indigeni, Ternströmiae facie; foliis alternis, petiolatis, coriaceis, integerrimis $v$. serrulatis, stipulis nullis, pedunculis axillaribus solitariis, unifloris, floribus parvis, albis $v$. flavescentibus.

Cle y e ra Thuberg Flor. japon, 12. DC. in Mem, soc. phys. Genev. 1. 412. Prodr. I. 525. Cambessed, in Mom. Mus, XVI. 405. Hooker ad Beechey t. 33. Wighiz et Arnott Prodr. I. 86. Meisner Gen, 41. (30.) H ofe ría Scopoli Introduct. n. 846. M u k o p f Kaimpi. Amoen. 374. io. S u ka k i Kümpf. Op. cit, z77. Banks Ic. Kämpf. $\iota .33$.

5418. Frezierse $S W A R T Z$. C alyx bibracteolatus, pentaphyllus, persistens, foliolis imbricatis, exterioribus minoribus. Corolla petala 5, hypogyna, calycis foliolis alterna, subaequalia, orbiculata, aestivatione imbricata. S $\mathrm{ta} \mathrm{m}$ in a plurima, hypogyna, pluriseriata ; filamenta brevissima, an $t h$ e $r$ a introrsae, biloculares, oblongae v. lineares, basi insertae, erectae, longitudinaliter dehiscentes. Ovari n m liberum, tri-quinqueloculare. Ovula plurima, loculorum angulo centrali biseriatim inserta, pendula, campylotropa. Stylus brevis, simplex; stigma triquinquelobum. B a c e a sicca, styli basi rostrata, tri-quinquelocularis. Sem in a in loculis plurima, rarius pauca, pendula, arcuata, testa erustacea, nitida. $\mathbf{E} \mathbf{m b}$ r y o cylindricus, in axi albuminis carnosi homotrope areuatus; cotyledonibus et radicula supera. - Arbores americanae, pleraeque peruanae andicolae, paueae in Antillis monticolae; foliis alternis, petiolatis, coriaceis, serrato-dentatis, stipulis nullis, pedunculis axillaribus unifloris, solitariis v. fasciculatis, basi bracteolatis, floribus parvis, albis.

Frexiera Swartz Flor. Ind. occid. II. 971. Humb. et Bo npl. Plant, aequinoct. I. $_{23}, t . \delta_{\text {_ }}$ 9. Kuath in Humb. et Bonpl, Nov. gen. et sp. $\nu$, 209. DC, in Mem. soc. phys, Genev. I. 414. Prodr. I. 524. Cambessed, in Mem. Mfus, XVI. 40\%. Meisner Gen. 41. (30,) E roti um Solander ox Swarts Prodr. 85.

5413. Hettsomia $R U I Z$ et $P A V$, Caly $\mathrm{x}$ bibracteolatus, pentaphyllus, persistens, foliolis imbricatis, exterioribus minoribus. Cor ollae petala 5_6, hypogyna, calycis foliolis alterna, lanceolata, interiora angustiora, imbricata. Stam ina plurima, hypogyna, pluriseriata; filamenta brevissima, incnrva, anth er a e introrsae, biloculares, lanceolatae, basi insertae, erectae, longitudinaliter dehiscentes. Ovari n m liberum, triquinqueloculare. Ovula in placentis e loculorum angulo centrali prominulis plurima, multiseriata ..... Stylus brevissimus, simplex; stigma tri-quinquelobum. B a ce a globosa, styli basi rostrata, tri-quinquelocularis. Se mina plurima, minima, trigona, ossea. Em br y o...... Frutices peruani, vix a Fresieris satis diversi; foliis alternis, petiolatis, lanceolatis, coriaceis, integerrimis $v$. obsolete serrulatis, subtus tomentosis $v$. lanatis, stipulis nullis.

Le t ts o m i a Ruiz et Pavon Prodr. 77, t, 14. Syst, 134. DC. in Mem. Mus, soe, phys, Genev. I. 418. Prodr. I. 525. Cambessed, in Mem. Mus. XVI. 404. Meisner Gen, 41. (30.)

TIRIEUS III. SAURAUJEAE. C a I y $x$ pentamerus, liber. Coroll a e petala 5, distineta. Antherae incumbentes, loculi basibus discretis sursum spectantibus poro aperti. Ovarium quinqueloculare. Ovula plurima, anatropa. Capsula apice loculicide dehiscens. Semina aptera. Embryo in axi albuminis carnosi orthotropus, subeylindriens. - Folia alterna, integra, exslipulata. Tropicae amphigeae.

54 14. Saurauja WILLD. C a ly x bi-tribracteolatus, quinquepartitus, persistens, lobis ovatis, obtusis, imbricatis. Corolla petala 5 , hypogyna, ealycis lobis alterna, libera v. ima basi cohaerentia, obtusa, imbricata. Stam ina plurima, hypogyna, pluriseriata, petalorum basibus sacpe adhaerentia; fil a menta filiformi-subulata, brevia, a $\mathbf{n} t \mathbf{h}$ e ra e extrorsae, biloculares, dorso insertae, versatiles, loculi basibus discretis, tubnlosis, reclinatione demum sursum spectantilus poro aperti. O v a ri u m liberum, disco saepissime obsoleto basi cinctum, quinqueloculare. O v ula in placentis e loculorum angulo centrali prominalis plurima, anatropa. Styli 5 , fliformes; stigm a t a subeapitata. C a p s u la coriacea v. lignosa, stylis coronata, quinquelocularis, apice loculicide quinquevalvis, valvis medio septa ab axi centrali seminifero superne solnta, inferne eidem adhaerentia gerentibus. S e mina plurima, in placentis nidulantia, ovata, testa crustacea, impresso sero$128 *$ 
biculata, rhaphe longitudinali et chalaza apieali manifestis. E mbryo in axi albuminis carnosi, testae impressionibus plus minus scrobiculati orthotropus, ejusdem dimidio brevior, subcylindricus, cotyled onibus semiteretibus, obtusis, radic u la umbilico proxima. - Arbores $v$. frutices, in Asia et America tropica indigeni; ramis saepe hirtis, foliis alternis, petiolatis, coriaceis, integerrimis v. serratis, stipulis nullis, racemis axillaribus ramosis $v$. corymbosis, bracteatis, floribus albis $v$, flavis.

$\mathrm{S}$ a u ra u j a Willdenow in Berlin. n. Schrifl. IIT. 406. t. 4. Cambessedes in Mem. Mus. XVI. 405. P a l a v a Ruiz et Pavon Prodr. 88, t, 22. Kunth in Humb, et Bonpl. Nov. gen. et sp. t. 648_650. Synops. III. 212. A pateli a DC. in Mem, soc, phys. Genev, I. 426, 2. 8. Prodr, I. 326. Dylessert Io, seleet. IIT. $t$. 26. et $\mathrm{S}$ a u ra nja DC. Op. cit. I. 419, t. 2-7. Prodr. I. 595. Delessert Op. cit. HI, $t .25$. Wallich Plant. As, rar, $t, 148,178$. S c a p ha Noronh, msc, Vanalphimia Leschenault. msc. Marumia Reinwardt in Syllog. plant. II, 10. Re i $\mathrm{n}$ a $\mathrm{rd} t \mathrm{i}$ a Nees Ibid. I, 96. B I u m i a Sprengel Syst. III. 126. D a v y a et Le ucothe a Moẹ, et Sessé Flor. Mexic. inedit.

5415. Mrierosemma $L A B I L L$. C a l yx persistens, ebracteolatus, penta-hexaphyllus, foliolis imbricatis, aequalibus. Co roll a e petala 10 v. 12, brevissima, distineta, integra v. fissa, basi latinsenla, calycis foliolis solitarie v. per paria opposita. S $\mathrm{ta}$ m in a circiter 30 , hypogyna ; filam en t a calyce subduplo longiora, filiformia, basi in phalanges subcohaerentia, antherae introrsae, biloculares, loculis filamenti apici orbiculato dilatato adnatis, basi discretis, rima confluente apertis, tandem reniformes. Ovarin m libernm, globosum ..... Stylus simplex, brevis; stigm a quinque-sexfidum. C a p 8 ula perigonio et staminibus persistentibns stipata, ovata, pilosa, decem duodecimlocularis, loculieide dehiscens, valvis medio septiferis. Sem in a in loculis solitaria, invera, ovata, compressiuscula. Embryo intra albumen carnosum orthotropus; cotyled onibus foliaceis, planis, radicula brevi, supera. - Frutex Nova e-Caledoniae, erectus, ramo. sus; ramulis teretiusculis, pubescentibus, foliis al. ternis, breve petiolatis, coriaceis, elliptico-oblongis, penninerviis, integerrimis v. crenato-subundulatis, stipulis nullis, pedunculis in apice ramulorum congestis, unifloris, basi bractea oblonga, fulvo pilosa, decidua stipatis.

Mi cros e m m a Labillardiere Nov. Caledon, 58, t. 57 .

TRIBUS IV. LAPLACEAE. C a ly $x$ tetra-pentaphyllus. Corollae petala 4 _, saepissime calycis foliolis numero aequalia. A ntherae incumbentes $v$. erectae, longitudinaliter dehiscentes. 0 v a r i $m$ tri-quinque-rarius pluriloculare. Ovula plurima, rarius solitaria, anatropa. Capsul a loculicide v. septicide dehiscens, axi seminifera persistente. S e min a alata. $\mathbf{E} \mathrm{mb}$ ry o $\mathrm{n}$ is exalbuminosi cotyledones planae. - Folia integra, alterna v. rarissime opposita, rarissime stipulata. Omnes Americanae tropicae.

54 16. Laplacea H. B. K. Caly $\mathrm{x}$ ebracteolatus, tetra-pentaphyllus, foliolis inaequalibus, concavis, imbricatis, deciduis. Corollae petala 5 -9, hypogyna, subaequalia, inaeqnilatera, aesti- vatione contorta. Stamina plurima, hypogyna, pluriseriata, interdum petalorum basi adhaerentia; fil a m enta filiformia, a $n$th erae extrorsae, bilocalares, oblongae, dorso supra basim emarginatam insertae, versatiles, longitudinaliter dehiscentes. O va ri u $m$ liberam, quinque-septem $v$, interdum decemloculare, 0 vula in loculis $3-6$, angulo centrali biseriatim inserta, pendula, anatropa. Styli 5, 7 v. 10, breves, patentes; stigm a t a simplicia, obtusa. Ca p s u la quinque-septem v. decemlocularis, loculicide ab apice ad medinm dehiscens, valvis erassis, lignosis, medio septa superne a columna seminifera crassa soluta, inferne eidem cohaerentia gerentibus. S e m in a in loculis 3_6, pendula, oblonga, compressiuseula, testa crustacea, superne in alam nucleo longiorem producta, umbilico ad basim alae lineari. $\mathrm{E}$ mbryonis exalbuminosi, orthotropi cotyled ones ovatae, plano-convexae, radicula brevis, cylindriea, umbilico proxima, snpera. - Arbores $v$. frutices, in America tropica crescentes; foliis alternis, petiolatis, coriaceis, elliptico-lanceolatis v. cuneato-inaequilateris, integerrimis - serratis, petiolis basi articulatis, stipulis nullis, pedunculis axillaribus solitariis, unifloris, ebracteatis, basi articulatis, floribus extus sericeo-pubescentibus, albis v. rubris.

L a pla ce a Kunth in Humb. et Bonpl. Nov. gen, et sp. V. 207. t, 461. DC. Prodr. I. 587. Cambessed. in Mem. Mus, XVI, 407, t. 1, f. a. St, Hilaire Flor. Brasil. I, 299. Moricand Plant. Americ. t. 2. Meisner Gen. 40. (30.) $\mathrm{H}$ a emo ch a r is Salisbury msc. Martius Nov. gen. et sp. $I$. 106. t. 66. 67. non Zoolog. Wi kst r $6 \mathrm{~m}$ i a Schrader in Gotting. Anzeig. 1821. p.710. Lin d le y a Nees in Flora 1821, p. 299. Gordoniae s p. Swartz. DC.

541\%. Bonmetia MART. et ZUCC. CaIyx persistens, ebracteolatus, pentaphyllus, foliolis imbricatis, exterioribus minoribus. Corolla e petala 5, hypogyna, calycis foliolis alterna, aequalia, inaequilatera, aestivatione contorta. S $\mathrm{ta}$ min a plurima, hypogyna, pluriseriata; f i l a$m$ e $n t$ a filiformia, persistentia, a nthera e introrsae, biloculares, incumbentes, ovatae, loculis basi subdiscretis, poro dehiscentibus. O va rium liberum, triloculare. $O \mathbf{~ v ~} 1 \mathrm{a}$ in loculorum angulo centrali plurima, multiseriata, adscendentia.... Stylus filiformis, apice trifidns; stig mata snbcapitata. C a p su la trilocularis, septicide trivalvis, valvis coriaceis, apice stylo, inferne marginibus introflexis eum columna seminifera subulata, superne libera cohaerentibus. S e mina plurima, adscendentia, lineari-scobiformia, testa membranacea, utraque extremitate producta. $\mathbf{E} \mathbf{m} \mathbf{b} \mathbf{r}$ y o... - Arbores v. frutices, in Brasilia tro pica crescentes; foliis alternis, in ramulorum apicibus confertis, basi in petiolum cum ramo articulatum angustatis, coriaceis, integerrimis, uninerviis, pinnatim venosis, stipulis nullis, pedunculis axillaribus basi articulatis, uni-paucifloris, in racemum terminalem foliosum approximatis, pedicellis bracteatis, floribus magnis, speciosis, albis.

B o n etia Martius et Zuccariol Nov, gen, et sp. $I$. 115. $t$, 110, exel. synon, Nees et Martius in $N . A, N$. $C$. XII. t. 6. Cambessed. in Mem. Mus, XVI, 409. St. Hilaire Flor. Brasil. I, 301. Meisner Gen. 40. (30,) Kiese$r$ ia Nees in Neupied Reise I. 104.

5418. Arellytaea MART, et ZUCC. Caly $\mathrm{x}$ persistens, ebracteolatus, pentaphyllus, foliolis imbricatis, subaequalibus. Co roll a e petala 5 , hypogyna..... Stamina plurima, hypogyna, in phalanges quinque, calycis foliolis oppo- 
sitas collecta; fil am enta filiformia, basi coalita, antherae introrsae, biloculares, erectae, subreniformi-didymae, biloculares, longitudinaliter dehiscentes. O va ri um liberum, quinqueloealare. 0 vula in loculis plurima, angulo centrali biseriatim inserta, adscendentia. St y lus simplex; stigma obsolete quinquelobum. C a ps a la quinquelocularis, incomplete septicide quinquevalvis, valvis coriaceis, margine introflexis, inferne a columna seminifera conico - pentagona solutis, superne cohaerentibus. Se mina plurima, linearia, biseria. tim imbricato-adscendentia ...... - Arbuscula brasiliensis, non satis nota; foliis alternis, ad ramorum innovationes fasciculatim congestis, obovato-lanceolatis, in petiolum brevem cum ramulo articulatum angustatis, coriaceis, uninerviis, costato venosis, integerrimis, stipulis nullis, pedunculis terminalibus trifloris, pedicellis basi bractea suffultis.

A rehytae a Martius et Zucearini Nov. gen. et sp. $\boldsymbol{I}$. 116. 2. 73. Cambessed, in Mem. Mus, XVI. 410. Meisner Gen. A1. $(30$.

5419. Kielmeyera MART. el ZUCC. C a 1 y x persistens, ebracteolatus, pentaphyllus, foliolis imbricatis, exterioribus minoribus. Cor o1. la e petala 5, hypogyna, ealycis foliolis alterna, aequalia, inaequilatera, aestivatione contorta. $\mathbf{S t a}$ m in a plurima, hypogyna, pluriseriata, interdum petalorum basi adhaerentia; fil amenta filiformia, persistentia, antherae introrsae, biloculares, incumbentes, oblongae, longitudinaliter dehiscentes, connectivo erassiuseulo, interdum apice in glandalam producto. Ovarin m liberum, semiseptis tribus margine placentiferis demum coalitis triloculare. $\mathrm{O}_{\mathrm{v}} \mathrm{al}$ a plurima, angulo centrali biseriatim inserta, adscendentia, anatropa. S tyIu s simplex; stig mata 3 , coalita v. distincta, interdum emarginata. Capsula trilocularis, septicide trivalvis, valvis lignosis, navicularibus, marginibus introflexis a columna centrali seminifera angulata solutis, deciduis. S e min a transversim oblonga,compressa, biseriatim imbricato-adscendentia, testa in alam membranaceam, utrinque protensam, basi ad umbilicum deliquescentem expansa. $\mathbf{m}$ bryo $n$ is exalbnminosi, orthotropi cotyledones reniformes, planae, carnosae, radicula brevissima, umbilico proxima, infera. Arbores, frutices $v$. suffrutices, in Brasilia tropica indigeni, succis resinosis turgentes; foliis alternis, saepe ad ramulorum apices confertis, in petiolum cum ramo articulatum angustatis, coriaceis, integerrimis, uninerviis, pinnatim venosis, stipulis nullis, floribus terminalibus et axillaribus in corymbos $v$. racemos dispositis, rarius paniculatis, magnis, speciosis, albis $v$. roseis, pedunculis bracteatis, basi articulatis.

Kielmeyera Martius et Zucearini Nov, gen, et sp. I. 109. t. 68_72. Cambessed. in Mem. Mus. XVI. 412. St. Hilaire Plant, us. t. 58, Flor, Brasil, I, 303, t, 60, 61, 63. Pobl Plant. Brasil. t. 129-132. Meisner Gen, 41. (30.) Martineria Flor. Flumin, $V$. $t, 114$.

5420. Carraípa $A U B L . C$ a 1 y x persistens, ebracteolatus, pentaphyllus, foliolis imbricatis, subaequalibus. Corollae petala 5 , hypogyna, calycis foliolis alterna, dimidiato-inaequilatera, aestivatione convolutiva. S ta min a plurima, hypogyna; fil amenta filiformia, libera v. ima basi inter se coalita, persistentia, antherae introrsae, biloculares, incumbentes, ovatae, connectivo apice in glandulam excavatam insrassato adnatae, longitudinaliter dehiscentes. Ovari n m liberum, triloculare. Ovula in loculis $1 \_3$, ex apice anguli centralis pendnla. Stylus simplex; stig in a obsolete trilobum. C a p s a la trigona, triloenlaris, uno v. altero loenlo abortiente saepe inaequilatera, septicide dehiscens, valvis lignosis, margine angustissimo introflexis, a columnae centralis crassae, trigonae, faciebus seminiferae angulis solutis. S e m in a in loculis solitaria, inversa, oblonga, compressa, testa membranacea, aptera. Embry onis exalbuminosi, recti c otyled on e 8 crassae, plano - convexae, intra basim emarginatam radiculam brevissimam superam foventes. - Arbores v. frutices, in America tropica crescentes; foliis alternis $v$, rarissime oppositis, breve petiolatis, penninerviis, integerrimis, stipulis nullis, floribus axillaribus et terminalibus, corymbosis, rucemosis $v$. paniculatis.

Caraipa Aablet Guian. I, 561. 2. 293. 224. Jussieu Gen, 434. Martius et Zuecarini Nov. gen, et sp. I, 103. t. 64. 65. Cambessedes in Mem, Mus, XPI, 413, t. 18. Meisner Gen. 40. (30.)

ร421. Marilla $S W A R T Z$. Cal yx persistens, ebracteolatus, tetra-pentaphyllus, foliolis imbricatis, subaequalibus. Co roll a e petala $4 \ldots 5$, hypogyna, calycis foliolis alterna, aequalia, obovato-oblonga, aequilatera, aestivatione convolnta. S t a m in a plurima, hypogyna, pluriseriata ; $\mathrm{f} \mathrm{i} \mathrm{la-}$ menta filiformia, antherae introrsae, biloculares, oblongae, erectae, connectivo apice in glandulam excavatam producto adnatae, longitndinaliter dehiscentes. Ovari um liberum, oblongo-lineare, tri-quadriloculare. O vula plurima, loculorum angulo centrali inserta, biseriata, pendnla. Stylus brevissimus, simplex; stigma capitatotri-quadrilobum. C a p s u la linearis, incurva, triquadrilocularis, septicide tri-quadrivalvis, valvis coriaceis, margine introflexis, a columna seminifera solutis. Sem in a plurima, pendula, imbricata, compressa, oblonga, ala membranacea fimbriata cincta. Emb ryo .... - Arbor a n tilla $n a$; foliis oppositis, petiolatis, membranaceis, uninerviis, costato venosis, integerrimis, pellucidopunctatis, stipulis nullis, racemis axillaribus, folio brevioribus, pedicellis inferioribus oppositis, superiaribus sparsis, basi articulatis.

Marila Swartz Prodr. 84. DC. Prodr. T. 558, Cambes. sed. in Mem. Mus, XVI, 411. t, 17. f. d. Meisner Gen, 40. (30.) Monoporina J. S. Presl Rostin, II. 2. p, 278. t. 41. $f .2$, S с y phat a C. B. Prest Symb. $I, 7$, $t$. 14. An is os tict e Bartling Ord, nat. 294, in not. Cap paris commutata Sieb.

5422. NIahurea $A U B L$. C a $\mathrm{y} \times$ persistens, ebracteolatus, pentaphyllus, foliolis imbricatis, exterioribus minoribus. Coroll a e petala 5, hypogyna, calycis foliolis alterna, aequalia, obovato-aequilatera, aestivatione convolutiva. St amina plurima, hypogyna, pluriseriata; filamenta filiformia, antherae introrsae, bilocalares, oblongae, erectae, connectivo apice glan. duloso excavato adnatae, longitudinaliter dehiscentes. Ov a ri um liberum, oblongum, tri-quinqueloculare. 0 v u I a plurima, loculorum angulo centrali inserta, pluriseriata, pendula. St yl us simplex, longus; stigma tri-quadrilobum. C a psuIa oblonga, tri-quadrilocularis, septieide tri-quadrivalvis, valvis eoriaceis, margine introflexis, a columna seminifera angulata solutis. S e m in a plurima, pendula, imbricata, compressa, linearia, utrinque in alam membranaceam produeta. $\mathbf{E} \mathbf{m}$ bryo ..... - Arbor guianensis; foliis alternis, petiolatis, coriaceis, pellucido-punctatis, costatis, integerrimis, stipulis ad basim petiolorum 
geminis, lanceolatis, persistentibus, floribus racemosis.

M a h a re a Aublet Guian, I. 558, t. 122. Jussien Gen, 434. DC. Prodr, I. 357. Cambessed, in Mem, Mus. XVI. 411. t. 16. f. $C$. Meisner Gen, 40. (30.) Bonnetía Selireber Gen, n, 915. non Mart. et Zuce.

THRIBEUS v. GORDONIEAE. Calyx pentaphyllus. Cor o 11 a gamopetala. Anthe$r$ a e erectae v. versatiles, longitudinaliter dehiscentes. Ovariu m quinqueloculare. 0 vula pauca. C apsu I a loculicide dehiscens. S emin a pendula, alata. Embry on is exalbuminosi cotyledones longitudinaliter plicatae. _ Folia alterna, integra, exstipulata. Species borealiamericanae et asiaticae.

5423. Stuartia CATESBY. Calyx persistens, uni-bibracteolatus, pentaphyllus v. quinquepartitns, foliolis imbricatis, lanceolutis v. obtusis, subaequalibus. Corolla e petala 5, hypogyna, calycis foliolis alterna, ima basi cohaerentia, obovata, erenulata, aestivatione imbricata. Stamin a plurima, hypogyna, pluriseriata, petalorum basibus adhaerentia; filament a filiformia, inter se libera, anthera e introrsae, biloculares, ovatae, longitudinaliter dehiscentes. 0 v arium liberum, quinqueloculare. $O$ ₹ula in loculis gemina, angulo centrali prope basim superposite inserta ..... Styli 5 , distincti $v$, in unum connati ; stigmata obtusa v. capitellata. C a psula ovoidea, quinquangularis v. sulgglobosa, quinquelocularis, loculicide quinquevalvis, valvis lignosis, medio septiferis. $\mathbf{S}$ e m in a in loculis gemina, superposita, orbiculata, plano-convexa, testa crustacea, in marginem membranaceum angustum expansa. Em bryo ...... - Frutices borealiamericani; foliis alternis, petiolatis, membranaceis, serrulatis, subtus pubescentibus, stipulis nullis, pedunculis axillaribus unifloris, solitariis v. geminis, floribus magnis, albidis.

$\mathrm{S} t$ uartia Catesby Carolin. ITI. 13. Linn. Gen. 847. He. ritier Stirp. n. 73. Torrey et A. Gray Elor. of. North.Amer. I. 293.

a. MALACHODENDRON Cavan. Caly eis pentaphylli foliola laneeolata. Corolla e petala profunde crenata. St y I i 5, distineti. Caps u 1 a quinquangularis. - Ma1 a chodendro a Cavanill. Dissert. $V$. 302, $t, 158$. DC, Prodr. I. 528. Bot, Reg. $t$. 1t04. Cambessed, in Mem. Mus. XVI, 406. Stewartia pentagyna Heritier Stirp. t. 74. Smith Exot. Bot. t. $10 t$.

b. STEWARTIA Cavan, Cal y cis quinquepartiti laciniae obtusac. Coroflae petala obiter crenata. Styli in unum coanati. Caps'ula globosa. - Stewartia Ca. vauill. Dissert. $\nu$. 303. $t$. 159. DC. 1 . c. Cambessed. l. c. St. Mala eltodend 0 a Ling. Act. Upsal. 1741. t. 2. Heritier Stirp. $t$. 23. Lam. $t$. 593. St. marylandica Andrews Bot, Reposit. $t, 73$.

54:4. Cordonia ELLIS. C a I y $\mathrm{x}$ persistens, nudus v. decidue bracteolatus, pentaphyllus, foliolis imbricatis, rotundatis, concavis, subaequalibus. Corollae petala 5 , hypogyna, calycis foliolis alterna, basi subcoalita, obovata v, obcordata, aestivatione imbricata. St a min a plurima, hypogyna, pluriseriata, petalorum basibns adhaerentia; fil am enta filiformia, libera v. inferne in fasciculos quinque subcoalita, anth erae introrsae, biloculares, oblongae, basi v. supra basim affixae, erectae v. versatiles, longitudinaliter dehiscentes. O v a r i u m liberum, quadri-quinqueloculare. Ovula in loculis $3 \ldots 5$, angulo cen- trali biseriatim inserta, pendula. Sty I us simplex; stigma quinquefidum. Capsula ovoidea v. subglobosa, quadri-quinquelocularis, loculicide quadriquinquevalvis, valvis lignosis, medio septa inferne columnae seminiferae abbreviatae cohaerentia gerentibus. S e $\mathrm{m}$ in a in loculis $2-4$, compressa, biseriatim pendula, imbricata, superne in alam membranaceam, oblongam, obtusam producta. E mbryo exalbuminosus, rectus; cotyledonibus ovatis, longitudinaliter plicatis, radicula brevi, supera. - Frutices in America boreali et Asiae tropicae et subtropicae alpibus indigeni; foliis alternis, breve petiolatis, coriaceis, integerrimis $v$. crenatis, pedunculis axillaribus sulitariis, unifloris.

Gord oni a Ellis Philosoph. Transact. LX, t, 11. Linn, Mant. Cavanill. Dissert. V. 307. DC, Prodr. T. 528, excl. sect. 2. Cambessed. in Mem, Mus. XVI. 408. Wight et Ar. nott Prodr. I. 87. Torrey et A. Gray Flora of North-Amer. I. 223.

a. LASIANTHUS $D C, \boldsymbol{l}$, c. S $\mathrm{tam}$ in u m filamenta petalo. rum basi adhaerentia, in tubum brevent pentadelphum coalita. S ty l u s staminum longitudine. C a p s u 1 a ovoidea. - Folia perennia. Flores axillares, peduneulati. - Hyperienu Lnsianthas Linn. Gordonia I. a s i a th $^{\mathrm{s}} \mathrm{s}$ Catesby Carolin, $t$. 44. Cavanill. $t$. 16t, Bot. Mag, t, 668. Cambessed. Op. cit. t, 16. f.B. $\mathrm{S} \mathrm{ch}$ i$\mathrm{ma}$ Reinwardt ex Blume Bijdr. 129. Polyspora Sweet Hort, brit. 61. Don Syst. I. 57k. C amellia a xill a ris Roxb. Bot. Reg. $t, 349$. Bot. Mag. t. 2047.

b. FRANKLINIA Marshall $A r b$. 48. S $\mathrm{ta} \mathrm{m} i \mathrm{a} u \mathrm{~m}$ filamenta petalorum basi adhaerentia, inter se libera. Stylus staminibus brevior. Capsula globosa. - Folla decidua. Flores axillares, subsessiles. $-\mathrm{L}$ ac at he a Salisbury Parad, t. 56. (Ventea. Malmais, t. 1. Cayanill. Op. cit. t, 162.)

THIBUS VI. CAMELLIEAE. C al $\mathrm{y} x$ penta-enneaphyllus. Corolla e petala 5 - 9 . A n thera incumbentes, longitudinaliter dehiscentes. $0 \mathrm{v}$ a $\mathrm{r}$ i u m tri-quinqueloculare. $0 \mathrm{va-}$ la pauca. Ca psula loculicide dehiscens. Semina nucamentacea. En bryo nis exalbuminosi cotyledones crassae, carnoso-oleosae, cum radicula brevissima articulatae. - Folia alterna, integra, exstipulata. Asiaticae.

5485. Camellia $L I N N$, C a 1 y $x$ ebracteolatus, penta-enneaphyllus, foliolis bi-triseriatim imbricatis, interioribus sensim majoribus, deciduis. Corolla e petala $5-7$, hypogyna, imbricata, interiora majora. Stamina plurima, hypogyna, pluriseriata, saepe imis petalis adhaerentia, basi plus minus inter se cohaerentia; fil a m en $t$ a subulata, anther a e incumbentes, biloculares, oblongae, connectivo crassiusculo, loculis longitndinaliter dehiscentibns. O va ri nm libernm, triquinqueloculare. $\mathrm{Ovula}$ in loculis 4 -5, angnlo centrali alternatim inserta, pendula. Stylus triquinquefidus; stigmata capitellata. Capsula tri-quinquelocularis, indehiscens, loculicide triquinquevalvis, valvis medio septiferis, axi centrali persistente, faciebus seminifero. Semina in loculis abortu solitaria, rarius gemina, inversa, testa nucamentacea, umbilico apicali impresso. E mbryonis exalbuminosi cotyled on s crassae, carnosae, inaequales, rad ic u la brevissima, supera. - Frutices sempervirentes, Asiae aus tralis pla gam orientalem incolentes, ob laetissimum florum decorem magnis Adonistarum studiis merito celebratae; foliis alternis, petiolatis, coriaceis, nitidis, integerrimis, gemmis magnis, perulis distiche 
imbricatis tectis, floribus axillaribus et terminalibus speciosissimis, albis, roseis v. purpureis.

C a melli a Linu. Gen, n, 848. Cavanill. Dissert, VI. 305. Cambessed, in Mem, Mus. XVI, 415.

a, SASANGUA Nees. Capsula indehiscens, septis tenuissime membranaceis. - $\mathrm{S}$ a s a $\mathrm{n}$ g u a Nees in Siebold Nippon. II. p. 13. Camelli a Sasangua Thunb. Flor. Japon, t, 30. Bot. Mag. t. 2080. Bot. Reg. t. 667. C. d ruplf era Lour. C. ole ifera Staunt. Chin. $\boldsymbol{I}$. 466. ic. Bot. Reg. $t$. 942.

b. KISSI. C a p \& a I a loeulicide tri-quinquevalvis. $-\mathrm{C}_{\mathrm{a}}$ me lli a Nees $l$. $c$. (Cavanill. Diss, $t$. 160. Jacq. $\overline{\text { Ic. }}$ rar. t. 553. Duhamel Arbr, edit, nov. t. 71. Andrews Bot, Reposit. t. 25. Bot. Reg. t. 1078. Bot. Mag. t, 2784. Wallich in Asiat. Rescarch. XIII. C.ic. Plant. As. rar. t. 256.)

5486. Thea $L I N N, \mathrm{C}$ aly $\mathrm{x}$ persistens, ebracteolatus, pentaphyllus, foliolis imbricatis, exterioribus minoribus, Corollae petala 6_9, hypogyna, imbricata, exteriora minora, omnia basi inter se cohaerentia. Sta m in a plurima, hypogyna, pluriseriata, imis petalis adhaerentia; fi l a m enta filiformia, a nt her a e incumbentes, biloculares, oblongae, connectivo crassiuscnlo, loculis longitudinaliter dehiscentibus, Ovarium liberum, trilocalare. Ov ula in loculis quaterna, angulo centrali alternatim inserta, superiora adscendentia, inferiora pendula. Stylus trifidus; stigmata 3 , acuta. Capsula subsphaeroidea, bi-triloba, tri-v, abortu bilocularis, loculicide dehiscens, valvis medio septa ad axim coalita gerentibus. Sem in a in loculis solitaria v. rarius gemina, testa nueamentacea, umbilico ventrali impresso. Embryonis exalbuminosi cotyledones crassae, carnoso-oleosae, radic u la brevissima, umbilico proxima, centripeta. - Frutices $v$. arbusculae, in imperii sinensis montibus sponte crescentes, et ob folia infusum mortalibus omnigenis jam gratum largientia cultae, ramulis gemma acuminata, inter perulas convolutas, deciduas folium includentibus terminatis; foliis alternis, petiolatis, tenerrime coriaceis, penninerviis, serrulatis $v$. subintegerrimis, stipulis nullis, pedunculis axillaribus, solitariis, unifloris, floribus albis.

Th ea Linné Gen. $n$. 668. Blackwell Herb. $t$. 351. Lett. som Monograph. Lond. 1772. 4. Gärtner $I T, 83, t, 95$. Bot. Mag. t. 998. 3148. Cambessed, in Mem, Mus, XVI. 415. Nees jun. in Siebold Nippon fasc. II. 12. Meisner IGen. 41. (31.)

\section{GENERA DUBIA, TERNSTRÖMIACEIS} AFFINIA.

542\%. Codloya RUIZ et PAV. Calyx polyphyllus, deciduus, foliolis coloratis, rotundatis, imbricatim pluriseriatis, interioribus sensim longioribus. Corolla e petala 5 , hypogyna, obovato-oblonga, obtusa, aestivatione convoluta, sub anthesi patentia. St amina plurima, hypogyna, pluriseriata, extima ananthera, libera $\mathrm{v}$. in phalanges quinque distinctas, cum petalis alternantes coalita, interiora fertilia 10 - 40 libera; f i la menta brevia, subulata, an therae extrorsae, biloculares, basifixae, longe lineares, apice poro daplici dehiscentes. Ovari u m liberum, substipitatum, tri-pentagonum, utrinque attenuatum, triquinqueloculare, dissepimentis ad axim distinctis, margine placentas faciebus applicitas gerentibus. Ovula plurima, angulo loculorum centrali biseriatim inserta, imbricata. S tyl n s brevis, attenuatus; stigma simplex. Capsula lignosa, triquinquelocnlaris, septicide dehiscens, valvarum marginibus introflexis, placentas lineares, solubi- les gerentibus. S e min a plurima, oblonga, alata. Arbores Americae tropicae; folitis alternis, petiolatis, coriaceis, nitidis, transversim striato-costatis, integerrimis $v$. subserrulatis, stipulis nullis, floribus racemosis, flavis.

Godoya Ruiz et Pavon Prodr. 58. t. 11. Syst. 101. DC. Prodr. I, 558. Martius et Zuecariai Nov. gen, et sp. $\boldsymbol{I}$. 118. t. 74. Meisner Gen. 40. (30.) Go dovi a Persoon Encheir. $I, 467$.

5488. Adlinandra $J A C K$, $\mathrm{C}$ al $\mathrm{y} \mathrm{x}$ bibracteolatus, persistens, quinquepartitus, laciniis subrotundis, crassiusculis, imbricatis. Corolla e petala 5 , basi lata, erecta v. conniventia. Stamina plurima, plariseriata, subpolyadelpha, a n thera e biloculares, adnatae, glabrae, filamento producto apice mucronatae. $\mathbf{O}$ ari u m Iiberum .... Styl u s persistens, subnlatus; stig ma simplex. B a $c$ c a quinquelocularis, placentis angnlo centrali exsertis, loculos fere bipartientibns. Sem in a plurima .... - Arbor sumatrana, dumosa; foliis alternis, subintegerrimis, exstipulatis, pedunculis axillaribus unifloris, subsolitariis,

153. Adinandra Jack ex Hooker Bot. Mag. Compan, I.

5429. Pyremaria $B L U M$. $\mathrm{C}$ a 1 y x bibracteolatus, pentaphyllus, foliolis imbrieatis. Corolla e petala 5, hypogyna, calycis foliolis alterna, basi imbricatim conniventia. St a mina plurima, hypogyna, basi petalorum subadhaerentia, a n $t$ hera e didymae, extrorsae. O va ri u liberum, quinqueloculare. Ovula in loculis gemina, superposita. Sty li quinque, approximati, emarginati. B a c e a subglobosa, depressa, carnosa, locnlorum endocarpio chartaceo. Semina in loculis gemina, superposita, ossea. Em bryonis exalbuminosi, erecti cotyledones foliaceae, contortuplicatae. - Arbor javanica; foliis alternis, petiolatis, oblongis, coriaceis, serratis, stipulis nullis, pedunculis axillaribus, solitariis, unifloris, floribus albis.

P y renarla Blume Bijdr. 1110. Meisuer Gen, 40. (30.)

5430. Teueoxylon BLUM. Flores abortu polygami. Ca ly x liber, quadripartitus, laciniis obtnsis, imbricatis. Corolla subcampannlata, quadripartita. Mas c. S tamina 12_14, partim hypogyna, partim corollae basi subadnata, inclusa, a ntherae biloculares. Ovarii rudimentum. F e m. O va ri um quadriloculare, loculis multiovulatis. Stylus bipartitus; st igmat a emarginata. Drup a corticata, mono-dipyrena, pyrenis subosseis, monospermis. Embryo in albumine carnoso inversus. - Arbor javanica, procera; ramis patentibus, ramulis folitisque distichis, folits parvis, alternis, approximatis, elliptico-lanceolatis, coriaceis, aveniis, supra lucidis, subtus ramulisque. sericeo-pubescentibus, floribus axillaribus, masculis confertis, femineis solitariis.

Le ue ox y 1 on Blme Bijdr. 1169.

5431. Euryanthe SCHLECHTEND. C a . ly $x$ quinquepartitns, laciniis subaequalibus, aestivatione imbricatis. Corolla e petala 5 , hypogyna, calycis laciniis alterna, oblonga, aestivatione spiraliter convoluta, Stam in a plurima, hypogyna; fi l a menta ima basi cohaerentia, inaequalia, alterius lateris duplo fere longiora et validiora, an- 
th erae introrsae, biloculares, lineares, basifixae, loculis oppositis, apice rima brevi dehiscentibus. Ova ri um liberum, ovoideum, trilocalare. $O$ v ula plurima, loculorum angulo centrali inserta. StyIus simplex, deciduus; stigma indivisum. Ca psula coriacea, trilocularis, loculicide trivalvis, valvis medio seminiferis. S e min a plurima, reniformia....$-H e r b a$ m exicana, ramosa, partibus junioribus pube tenuissima, subfasciculata canescentibus; foliis alternis, longe petiolatis, circumscriptione cordato-orbicularibus, digitato-partitis, laciniis subspathulatis, sinu rotundato sejunctis, inaequaliter subduplicato-serratis, uninerviis, pinnato-venosis, stipulis lateralibus geminis, lineari-acuminatis, persistentibus, racemis terminalibus bracteatis, subsecundis, ramuli axillaris evolutione oppositifoliis.

Eury an the Sehlechtendahl in Linnaea $V$. 294.

\section{* ARISTOTELIACEAE.}

5432. Aristotelia HERIT. Calyx turbinatus, quinque-sexfidus, laciniis lanceolatis, acutis, aestivatione imbricatis, Coroll a e petala 5 _6, disco hypogyno extus inserta, obcordata, aestivatione imbricata. St a min a $15 \_18$, cum petalis inserta, ternatim calycis laciniis opposita; filamenta brevia, antherae erectae, oblongae, acutae, biloculares, loculis apice rima brevi dehiscentibus. Ovarium supra torum sessile, triloculare. Orula in loculis gemina, superposita, pendula, semianatropa. B a c c a rotundato-triquetra, pulposa, trilocularis, septis tenuissime membranaceis. S e mina in loculis gemina, superposita, angulata, testa ossea, umbilico ventrali appendiculato, endoplenra membranacea, chalaza orbiculari terminata. $\mathbf{E} \mathbf{m}$ bryo in axi albuminis carnosi rectus, ejusdem fere longitudine, umbilico parallelas; cotyledonibus ellipticis, foliaceis, longitudinaliter undulato-plicatis, radicu la teretinscula, ab umbilico remota, supera. - Frutex chilensis, ramis diffusis, foliis suboppositis, petiolatis, oblongis, acutis, dentato-serratis, glabris, sempervirentibus, stipulis deciduis, racemis axillaribus, brevibus, floribus virentibus.

Aristotelia Heritier Stirp. II, 21, t, 16. Ruiz et Pavon Prodr. t. 12. Lam. t. 399. Gürtaer f. III. 160. t. 211. DC. Prodr. II, 56. Meisuer Gen, 73, (53.) B e a u a ri a Herb. Deless.

\section{Drdo CСХ}

GUTTIFerae Jussieu Gen. 243, partim. Choisy in Mem. soc. h, n. Paris, I, 210. DC. Prodr. I. 557. Cambessed, in Mem, Mrs. XVI, 417. Meisuer Gen. 31. (41.) GARCINIEAE excl. Carpodontels Bartling Ord. nat, 298, CLUSIACEAE Lindley Introduct. edit, II, $p_{t}, 24$.

AввоRes v. rarius frutices, interdum parasitice scandentes, succo resinoso, flavo scatentes. Ram i ramulique opposili, plerumque tetragoni, articulati. Foli a decussatim opposita, petiolata, simplicia, integerrima, coriacea, plerumque nitida, penninervia, nervis secundariis saepe transversis, impressis, confertis, rarissime pellucido punctata, petiolis basi cum ramo articulatis.

Frores regulares, saepissime terminales, rarius axillares, solitarii v. conferti, interdum racemosi v. paniculati, hermaphroditi v. abortu polygami sive dioici, albi, rosei v. rubri, rarissime flavi, pedunculis nudis v. bracteatis, articulatis.

CAExx nudus v. interdum bracteolatus, ditetra-hexaphyllus, rarius polyphyllus, interdum quinque - sexpartitus, foliolis saepissime membranaceis, coloratis, imbricatis, plerumque decussantibus, exterioribus minoribus.

Corollae petala toro carnoso, interdum angulato, rarissime in discum lobatum expanso inserta, calycis foliolis numero aequalia v. rarius plura, iisdem alterna v. opposita, libera, aestivatione imbricato-convoluta $v$. interdum contorta, decidua.

Stamina plurima, rarissime subdefinita, libera v. basi in annulum aut in phalanges petalis alternas v. oppositas, rarius in tubum coalita. Fil a m e nt a filiformia v. crassa, carnosa. Anthera e introrsae v. extrorsae, biloculares v. rarissime uniloculares, loculi saepissime lineares, adnati, paralleli, contigue appositi v. a connectivo discreti sublaterales, rima longitudinali, rarius poro apicis aperti. P ollin is granula triloba v. obsolete trigona.

Ovarium liberum, sessile, uni-bi-quinquev. interdum pluriloculare. Ovula in loculis nune solitaria, v. gemina, in ovario uniloculari interdum subquaterna, e basi erecta, orthotropa v. anatropa, nunc plurima, loculorum angulo centrali uni-pluriseriatim inserta, horizontalia v, adscendentia, anatropa. S tylus simplex, saepissime subnullus vo nullus. Stig ma conicum v. peltatum, lobatum.

Froctus nune capsularis, loculis polyspermis v. rarissime monospermis, valvatim dehiscens, columna seminifera angulis septante persistente, nunc drupaceus v. baccatus, bi-multilocularis, rarius unilocularis, loculis monospermis $\mathbf{v}$. interdum di-pleiospermis.

Srmina ovata v. angulata, testa chartacea v. membranacea, nunquam in alam expansi, saepe arillo carnoso involuta, $v$. arillo laxe cupuliformi, membranaceo basi cincta. Albu me n nullum.

Емввуо rectus, orthotropus v. antitropus. Cotyled on es magnae, crassae, saepe inaequales $v$. in corpus solidum conferruminatae. Radicula minima.

Clusiacea in Asia et America tropica indigenae, in Africa ut videtur rarissimae, succo flavo resinoso insignes, Ternströmiaceis, Maregraviaceis et Hypercineis proxime affines, foliis oppositis basi articulatis, cum embryone exalbuminoso combinatis, facillime distinguuntur. Genera plurima, non satis cognita, ex analogia ad tribus suas relata.

Canellaceae nimis imperfecte cognitae, Moronobeis ut videtur arcte affines, ob embryo- 
nem albuminosum a reliquis omnino separandae sunt.

TERIE pluriloculare, loculis uni-pluriovulatis. Capsula valvata, columnae centralis demum liberae angulis septantibus.

\$433. Tovomita $A U B L$. Flores polygami. Caly $\mathrm{x}$ ebracteolatus, di-v, tetraphyllus, foliolis duobns exterioribus minoribns, interioribus deeussantilus. C o r o 11 a e petala 4, rarius 6 v. 10, hypogyna, calycis foliolis opposita, libera, subaequilatera, aestivatione convolutiva. $S \mathrm{ta}$ mina plurima, toro crasso inserta, pluriseriata; fil amenta incrassata, brevia, libera, antherae introrsae, biloculares, minimae, loculis filamentorum apici oblique adnatis, divergentibus, longitudinaliter dehiscentibns. $O$ v a $r$ i $\mathrm{m}$ liberum, sessile, quadri-quinqueloculare. $0 \mathrm{vula}$ in loculis solitaria, angulo centrali prope medium v. paullo supra basim inserta, adscendentia, anatropa. S ty1 i 4 -5, terminales, brevissimi, interdum subnulli, subcohaerentes; 8 tig $\mathrm{m}$ a $\mathrm{t} \mathrm{ibu} \mathrm{s}$ incrassatis. C a p su l a coriaceo - carnosa, stylis persistentibus superata, quadri-quinquelocularis, valvis a columna centrali tetra-pentagona, angulis septante solutis. Semina in loculis solitaria, columnae centralis faciebus prope basim inserta, adscendentia, arillo carnoso insolnta, testa chartacea, nitida, rhaphe longitudinali, ramosa. Embryonis exalbuminosi, orthotropi cotyled ones crassae, connatae, radicula brevissima, umbilico proxima, infera. Arbores $v$. frutices, in America tropica et in Madagascaria crescentes, succis resinosis scatentes; foliis oppositis, petiolatis, integerrimis, glabris, petiolis cum ramo articulatis, stipulis nullis, floribus racemosis $v$, rarius cymosis, axillaribus terminalibusve, hermaphroditis v. abortu polygamis, pedunculis basi articulatis.

To vo m it a Aublet Guian, II, 956, t, 364. Jussieu Gen, 256. Cambessed, in Mlem. Mus, XVI. 419. St. Hilnire Flor. Brasil. I. 243, t, 64, Ma rialva Vandelli in Mömer Script. 118. DC. Prodr. 1. 560. Marialve a Martius Nov, gen. et sp. II. 82. 2. 166. 167. Be a uharno is ia Ruiz et Pavon in Annal. Mus. 7t. t. 9, Mier a n thera Choisy in Mem, soc. h, n. Paris, I. 242. t, 11, 12. DC. 1. c. Bertolouin Sprengel N. E. IT, 110. Oehroe a rp 4 \& Tliouars Nov, gen, Madagase, $n, b 0$, DC. $t, c$.

5434. Vert ieillaria RUIZ et PAV. F I ores hermaphroditi (?). C a l y x ebracteolatus, diphyllus, foliolis coloratis. Corolla e petala 4, hypogyna, libera, aestivatione convolntiva. Stamina plurima, hypogyna, pluriseriata; filamenta filiformia, libera, antherae introrsae, biloculares, ovatae, longitudinaliter dehiscentes. Ovarinm liberum, sessile, oblongum, subtrilo bum, triloculare. $O \mathrm{vula}$..... S ti gma sessile, concavum, trilobnm. Ca p sula oblonga, subtrigona, triloeularis, trivalvis, valvis crassis, corticosis. S e min a in loculis solitaria, oblonga ..... - Arbor peru a na, excelsa, e trunco ramisque incisis balsamum virens stillans; foliis oppositis, oblongis, acuminatis, integerrimis.

Verticillaria Ruiz et Pavon Prodr. 8t, $t .15$. Cambessedes in Mem, Mut. XVI. 420. Meisner Gen. he. (31.) Chtoromyron Persoon Encheir. I. 73, DC. Prodr. I, s64.

5435. IIavetia $H$. B. K. F 1 ores dioici. Caly x bibracteolatus, tetraphyllus, foliolis decussatis, orbicularibus, exterioribus minoribus, basi connatis, interioribns imbricatis. Corollae petala 4, hypogyna, decussata, erassa, orbicularia, aestivatione convoluto-imbricata. Masc. Stamin a 4, receptaculo carnoso inserta, petalis opposita; fila menta clavata, basi in columnam solidam connata, apice in connectivum cordatum constricta, antherae introrsae, biloculares, loculis linearibus, connectivi margini adnatis, longitudinaliter bilocellatis, bivalvibus. F e m. S t a m in a 4, sterilia, filamentis dilatatis, eirca ovarium confluentibus, persistentibus, antheris efoetis. Ovari um liberum, sessile, ovatum, quadriloculare. Ovula in loculis plurima, angulo centrali biseriatim inserta, horizontalia, anatropa. Stigma sobsessile, peltatnm, quadrilobum. C a p 8 u l a quadrilocularis, quadrivalvis. .... S e min a plurima, ovata, basi arillo subcarnoso, laxe capulaeformi cincta...-Arbor Americae tropicae, succo glutinoso, flavo scatens; ramis ramulisque oppositis, foliis decussatim oppositis, crassiusculis, aveniis, integerrimis, glaberrimis, floribus parvulis, albidis, in paniculas terminales, pyramidatas, bracteatas dispositis.

Havetila Kunth in Humb. et Bonpl. Nov. gen, et sp. V. 204. t. 468. Cambessedes in Mem. Mus. XVI. 421. Martius Nov. gen, et sp. III. 166, t. 197. f. 3.

5436. Remgreria MEISN. F lores dioici. C a l y x bracteolis pluribus, decussantibus, connatis stipatus, pentaphyllus, foliolis ovatis, aestivatione convolutivis. Corollae petala 5, hypogyna, oblonga, basi angustata, patentia. M a s c. S ta min a 10, receptaculo biseriatim inserta, in discum compacta; filamenta crassa, brevia, connectivo extus convexo, intus angulato, a ntherae extrorsae, biloculares, loculis linearibus, subverticaliter divergentibus, adnatis, bilocellatis, vertice poro dupliei, brevissime lineari apertis. F em. Stamina 5, sterilia, carnosa, oblongoangulata, ovarium arcte cingentia. Ova ri $\mathbf{m}$ liberum, sessile, pentagonnm, quinqueloculare. Ovula in loculornm angulo centrali plurima, pluriseriata, horizontalia, anatropa. S tigma maximum, peltato-conicum, quinquepartibile. C a ps l a ovato-acuminata, quinquelocularis, quinquevalvis, valvis a columna centrali pentagena, angulis septante solutis. Semina plurima, columnae centralis faciebus pluriseriatim inserta, horizontalia, ovata, basi arillo subcarnoso, laxe cupulaeformi cincta..... - Arbor Americae tropicae, aliarum stirpium truncos parasitice obducens; foliis decussatim oppositis, breve petiolatis, obovato-spathulatis, coriaceis, nitidis, integerrimis, stipulis nullis, paniculis terminalibus parvis, trichotomis.

Reng geria Meisner Gen. 42. $(31$,$) Schweiggera Mar-$ tius Nov. gen. et sp. III, 166, t. 197. f. 2 .

543\%. Quapeya $A U B L$. Flores dioici. C a lyx bibracteatus, bi-triseriatim bracteolatus, bracteolis deeussantibus, basi connatis, hexaphyllus, foliolis suborbiculatis, membranaceis, convoluto-imbricatis. Corollae petala 5, hypogyna, subcoriacea, oblonga, aestivatione valvata. Ma se. S t a mina plurima, receptaculo inserta, pluriseriata; filamenta brevia, basi in corpns carnosum, pentagonum, intus concaviusculum connata, apice subulato - attenuata, antherae extroraae, bilocnlares, loculis linearibus, parallelis, discretis, adnatis, longitudinaliter dehiscentibus. F e m. St am i n a sterilia 5 , oblonga, carnosa, eirca ovarium conniventia. Ovariu m liberum, sessile, penta- 
gonum, quinqueloeulare. 0 vnla in loculorum angulo centrali plurima, pluriseriata, horizontalia, anatropa. Stigma magnum, peltato-conieum, quinquepartibile. Ca ps u la ovato-acuminata, quinquelocularis, quinquevalvis, valvis a columna centrali pentagona, angulis septante solutis. S e m in a plurima, columnae centralis faciebus pluriseriatim inserta, horizontalia, ovata, basi arillo carnoso, laxe cupnlaeformi cincta ..... Arbores g $u$ i $a$ nenses, interdum scandentes; folits decussatim oppositis, obovatis $v$. ovato-oblongis, basi in petiolum attenuatis, coriaceis, nitidis, integerrimis, stipulis nullis, paniculis terminalibus brachiatis.

Q u a p o y a Aublet Guian. IT. 898, $t$. 343, 344. Martíus Nov, gen, et sp. III. 167. t, 296.f. 2. Meisner Gen, 42. (31.) $\mathrm{X}$ a in the Schreber Gen, $n, 1561$.

5438. Clusia LINN. Flores hermaphrodito-polygami. Ca ly x bibracteolatus, bracteolis basi connatis, hexaphyllus, foliolis imbrieatis, subcoloratis. Corolla e petala $4-9$, hypogyna, aestivatione convolntiva, sub anthesi patentia. Stamina plurima, hypogyna, multiseriata; fil am enta basi in tubum crasse carnosum, angulatum coalita, superne distincta, linearia v. spathulata, anthera extrorsae, biloculares, loculis linearibus, parallelis, discretis, adnatis, longitndinaliter dehiscentibus. O vari $\mathbf{m}$ m liberum, sessile, angulato-subglobosum, quinque-quindecimloculare. 0 v $\mathbf{~ I ~ a ~ i n ~ l o c u l o r u m ~ a n g u l o ~ c e n t r a l i ~}$ plurima, pluriseriata, horizontalia v. pendula, anatropa. Stigma maximum, peltato-conicum v. radiatum, partibile. C apsula coriacea, globosoangulata, quinque-quindecimlocularis, valvis a columnae centralis angulis septantibus solutis. Semina plurima, columnae centralis faciebus bipluriseriatim inserta, pendula $\mathbf{v}$. horizontalia, ovata, testa chartacea, rhaphe longitudinali, ehalaza terminali lata, arillaeformi. Emb ry onis exalbuminosi e otyledones carnosae, plano-convexae, $r$ adicula brevissima, umbilico proxima, supera v. centripeta. - Arbores guttiferae, in America tropica et boreali-subtropica indigenae, parasiticae, aliarum stirpium truncos obducentes et saepe enecantes; foliis decussatim oppositis, petiolatis, crassis, integerrimis, uninerviis, aveniis, nitidis, stipulis nullis, floribus cymosis, pedunculis pedicellisque bibracteatis, floribus amplis, speciosis, albis, roseis, purpureis, fusco purpurejs v. flavis, plerumque nutantibus, e toro saepissime resinam exsudantibus, capsulis albis, caepaceo micantibus.

Cl u si a Linu. Gen, n, 1154. Jussieu Gen, 2s6. Jacq. Amer. t. 166. 167. Edit, pict. t. 250. 251. Lam. t, 852. Cambessed, in Mem. Mus, XVI. 420. St. Hilaire Flor. Bra. sil. I. 315, t. 65. Martius Nov, gen, et sp. III. 164. t. 288. Sehlechtend, in Linnaea VIII. 180. t. 4. Meisner Gen. 42. (31.)

5439. Arrualea ST, HILAIRE. Flores hermaphroditi (?). Caly $x$ polyphyllus, foliolis imbricatis, inaequalibus, exterioribus minoribus. Corolla petala $9-10$, hypogyna, aestivatione eonvolutiva, sub anthesi patentia. Stamina plurima, receptaculo conico multiseriatim inserta, in massam compaetain, foveolatam arete coalita, antherae biloculares, lineares, adnatae, apice poro dupliei dehiscentes, Ovarin m receptacnlo earnoso immersum, oetoloculare. 0 v u 1 a in loculis 1 v. 2 ? .... Sty I u s terminalis, brevis; s tig m a peltatum, octolobum. Fructas.... - Arbuscula brasiliensis, non satis nota, succum visco. sum stillans; foliis decussatim oppositis, petiolatis, obovatis, coriaceis, glaberrimis, integerrimis, sti- pulis nullis, floribus in apice ramulorum solitariis, magnis, albido-roseis.

A rrudea St. Hilaire et Cambessed. Flor, Brasil, $\boldsymbol{I}$. 318. t, 66. Mem. Mus, XVI, 42t. Meisuer Gen. 42, (31.)

TEI IBUS II. MORONOBEAE. $0 \mathrm{va-}$ ri u m pluriloculare, loculis pluriovulatis. F ructus baccatus, indehiscens, plurilocularis, loculis pleiospermis.

5440. Chrysopia NORONH. Calyx persistens, ebracteolatus, pentaphyllus, foliolis imbrieatis. Corolla e petala 5, diseo hypogyno extus inserta, calycis foliolis alterna, contortoglobosa. Dis e as annularis, integerrimus v, quinquelobus. S t a m in a disco intus inserta, in tubum conieum, nervosum, tri-quinquelohum coalita, lobis linearibus, planis, patentibus, apice truncato inciso tri-quinquedentatis, singulis extus infra apicem tri-pentantheriferis, a n $t$ h era e lineares, parallelae, adnatae, longitudinaliter bivalves, $O \mathrm{va-}$ r i u m liberum, tubo stamineo inclusum, quinqueloculare. Ovala in loculorum angulo centrali 5_10, biseriata, adscendentia. Sty Ins cylindricus; s t igma quinqueradiatum, lobis exsertis, obtusis, suleo longitudinali stigmatosis, cum tubi staminei laciniis alternantibus. B a e c a quinquelocularis. Semina ovato-oblonga, adscendentia, testa membranacea. E mbryonis exalbutninosi cotyledones in massam oleosam conferrnminatae. - Arbores madagascarienses, succo flavo scatentes; folitis oppositis, petiolatis, ovatis $v$. spathulatis, coriaceis, uninervits, transversim venosis, integerrimis, stipulis nullis, floribus terminalibus corymbosis v. umbellulatis, ebracteatis, intense purpureis.

Chrysopia Noronh. ex Thouar. Gen. Madagaso. $n$, 48. DC. Prodr. I. 563. Cambessed. in Mem. Mus, XVI. 422. t. 19. Meisuer Gen. 42. (32.)

5441. Iroronobea $A U B L$. $\dot{C}$ al y x persistens, bibracteolatus, pentaphyllus, foliolis imbricatis. Corolla e petala 5 , disco hypogyno extus inserta, calycis foliolis alterna, contorto-globosa. $\mathrm{D}$ is c u s annularis, carnosus, integerrimus v. sinuatus. St a m in a disco intus inserta, in tabum basi ventrieosum, enervem, apice tri-quinquefidum coalita, laciniis linearibus, planis, contorto-patentibus, apice integerrimis, singulis extus infra apicem tri-tetrantheriferis, a $n t h$ e $r$ a lineares, adnatae, parallelae, longitudinaliter bivalves. Ovarium liberum, tubo stamineo inclusum, quinqueloculare. Ovala in loculorum angulo centrali pauca, biseriata, adscendentia. Sty In s eylindricus; stigma quinqueradiatum, lobis exsertis, acntis, cum tubi staminei laciniis alternantibus. B a c c a quinquelocularis, oligosperma ...... Arbor Am ericae tropicae, succo viscido, flavo scatens; ramis oppositis, saepe scandentibus, folits oppositis, petiolatis, coriaceis, nitidis, parallele confertim venosis, integerrimis, stipulis nullis, floribus terminalibus confertis, decidue bracteatis bibracteolatisque, pulcherrime coccineis.

Mor on obe a Aublet Guian, Ir, 79. t, 313. Jnssieu Gen. 257. DC. Prodr. I. 563. Cambessed. in Mrem. Mlus. XVI. Martius Nov, gen. et sp. III, 162, t, 188. Meisner Gen, 43. (32.) S y mpho n ia Linn. f. Suppl. 302. B I a ekstonia Seopoli Introduct, n, 1250. A a e u ris cus Preal Symb. I. 71, t. 48 .

THEIBUS HII. GARCINIEAF. $0 \mathrm{v}$ arium pluriloculare, loculis uniovulatis. Fruc- 
I u s drupaceus v. baccatus, loculis monospermis.

544.2. TIIammea LINN. F10 res abortu polygami. C alyx deciduus, ebracteolatus, diphylIus, foliolis aequalibus. C orolla e petala $4-6$, hypogyna, subaequilatera, aestivatione imbrieatoconvolnta. St am in a plurima, hypogyna, libera v. ima basi coalita; fil am enta filiformia, brevia, antherae introrsae, biloculares, adnatae, loculis longitudinaliter dehiscentibus. Ovarin m liberum, quadriloculare. Ov ula in loculis solitaria, e basi erecta, anatropa. Stylns brevis; stigma quadrilobum, lobis emarginatis. Drupa tetragono-subglobosa, stylo mamillata, sarcocarpio carnoso, putamine cartilagineo, quadri- v. abortu bi-triloculari. Semina in loculis solitaria, erecta, magna, crassa, testa tenui. Em b ryo exalbuminosus, orthotropus; cotyled onibus crassis, carnosis, radic u la brevissima, umbilico proxima, infera. - Arbores Americae tropicae; foliis oppositis, petiolatis, obovatis $v$, acutis, coria. ceis, pellucide punctatis, transverse striato venosis, integerrimis, stipulis nullis, pedunculis axillaribus, solitariis $v$. geminis, unifloris.

M a m m a Libn. Gen, n. 1156. Jaeq. Amer, $t, 181$. Edit. pict. t. 248. Jussleu Gen. 257. DC. Prodr. I. 561. Kunth in Humb. et Bonpl. Nov. gen, et sp. Y. 201. Cam. bessed. in Mem. Mus, XVI. 424. Meisaer Gen, 43. (32.)

5443. Garcinia LINN. F 1 ore 8 monoici v. dioici. Calyx persistens, ebracteolatus, tetraphyllus, foliolis subaequalibus, imbricatis. Corol1 a e petala 4, hypogyna, calycis foliolis alterna, aestivatione imbricato-convolnta. Ma s c. S t a m ina plurima, receptaculo carnoso, quadrangulari inserta, libera $v$. ima basi coalita; filam enta filiformia, brevia, a n th er a e introrsae, biloculares, erectae, loculis longitudinaliter dehiscen. tibus. $O v$ ar $i \mathrm{i}$ rudimentum. F e $\mathrm{m}$. St a $\mathrm{m}$ in a sterilia $8 \ldots 30$; fi la m e n ta distincta, $v$. monadelpha ant tetradelpha, fasciculis cum petalis alternantibus, glandnlis nullis interjectis. Ovarium liberum, quadri-decemloculare. $O$ vula in loculis solitaria, e basi erecta, anatropa. Sty I us terminalis, brevis; stigma late peltatum, sublobatum D rup a carnosa, balsamiflna, stylo superata, pntamine chartaceo, quadri - decemloenlari. Semina in loculis solitaria, erecta, pulpa carnosa involuta, testa coriacea. Enbryo exalbuminosus, ortho. tropas; cotyledonibus crassis, carnosis, conferruminatis, radieula brevissima, infera. Arbores indicae; foliis oppositis, petiolatis, coriaceis, integerrimis, nitidis, stipulis nullis, floribus terminalibus $v$, axillaribus.

G a r ci ni a Linn. Gen, n. 594. Roxhurgh Plant, of Corom. III. t. 298, DC. Prodr. I. 560, Wallich Plant. As, rar, t. 258. Cambessed, in Mem. Mus, XVI. 425. Wight et Arnott Prodr. I. 100. Meisner Gen. 43. (32.) C a m b og fa Linn. Gen. n. 650. Ma a g os t ana Rumph Amboin $I$. 132. $t$. 43, 44. IIT. 55, $t, 30$. Gärner $I I, 105, t, 105,0 \times \mathrm{y}-$ ca r p us Loureiro Flor. cochinch. 746. B r I n d o a i a Thouars in Dict, sc. nat, $V .339$.

54.4. Stalagmites MURR. Flores hermaphroditi v. abortu polygami. C aly $\mathbf{x}$ persis. tens, ebracteolatus, tetra-pentaphyllus, foliolis subaequalibns, imbrieatis. Co rolla e petala 4 v. 5 , hypogyna, calycis foliolis alterna, aestivatione imbrieato-convoluta. Stamina hypogyna, tetrapentadelpha, phalanges petalis oppositae, glandulis magnis truncatis alternae, elongatae, planae, apice in fil amenta brevia solutae, antherae introrsae, biloculares, erectae, loculis longitudi- naliter dehiscentibus. Ovarinm liberum, triquinqueloculare. Ovn la in loculis solitaria, e basi erecta, anatropa. Stylus brevissimus; stig ma peltato tri-quinquelobum, lobis truncatis, cuneatis. B a ce a globosa, carnosa, tri-quinquelocnlaris, Semina in loculis solitaria, erecta, pulpa carnosa involnta, testa coriacea. Embry o exalbuminosus, orthotropns; cotyledonibus crassis, carnosis, conferruminatis, radicula brevissima, infera. - Arbores indicae; foliis oppositis, breve petiolatis, subcoriaceis, integerrimis, nitidis, stipulis nullis, floribus axillaribus, fasciculatis.

$\mathrm{Stal}$ a $\mathrm{m}$ ites Murray in Comment, Gotting. IX. 175. DC. Prodr, I. 569. Cambessed, in Mem, Mus. XVI. 425. $\mathrm{X}$ a $\mathrm{nth}$ och y m u s Roxburgh Plant. of Corom. IT. $31, t, 196$. 270. DC. Prodr. 1.561. Hooker in Bot, Mag. $t$. 3088, Wight et Arnott Prodr. I. 101. Meisner Gen, 43. (32.)

5445. Pentadesma $D O N$. Ca lyx persistens, tetra-pentaphyllus. Corolla e petala decidua. Stamina plurima, pentadelpha, Stylus simplex. Ba ec a magna, carnosa, styli basi superata. Se mina $3_{-} 5$, magna, angulata, - Frutex Africae tropicae, succo scatens; folits longe lanceolatis, coriaceis, nitidis, integerrimis.

Pentades ma G. Don in Hortic. Transact. $V$. 457. Syst. I. 619. Meisner Gen, 43. (32,) The Buter or Tallow Tree of Sierra Leone R. Brown in Tuckey Congo 474 .

54 46. II eloradendrom GR $A H A M$. F I ores diclines. Calyx persistens, membranacens, tetraphyllus, foliolis subrotundis, imbricatis. Corolla e petala 4 , hypogyna, calycis foliolis alterna, oblonga, concava. Mase. Stamina plurima, inferne in columnam tetragonam coalita, superne distincta, antherae terminales, operculo umbilicato circumscisse dehiscentes. F e m. Stamina sterilia plura, filiformia, libera. Ovari um liberum, quadriloculare $\ldots . . S \mathrm{~s}$ ig ma sessile, qua drilobum, lobis patentibns, euneatis, apice truncato serratis, basi intus biglandulosis (?) B a c e a glo. bosa, carnosa, quadrilocularis. S e m in a in loculis solitaria, anguli centralis medio inserta, oblonga, umbilico ventrali. Emb ry on is exalbuminosi coty ledones crassae, coadunatae, radicula filiformis, centripeta (?) - Arbor ceylanica; foliis oppositis, petiolatis, obovato-ellipticis, coriaceis, nitidis, subtus pallidioribus, integerrimis, stipulís nullis, pedicellis axillaribus brevissimis, confertis, unifloris,

Hebradendron Graham in Bot. Mag. Compan. $\boldsymbol{I I}$. 199. $t, 27$. Wight Illustr. $t, 44$. Cambogia Gutta Liun. M a ngostana Morella Gärtner $t$. 105.

TRIBUS IV. CALOPHYLLEAE, Ovari m biloculare, loculis biovulatis, v. uniloculare, uni-triovulatum. F ructu s capsularis v. drupaceus, unilocularis, mono-tetraspermus.

5447. Tresua LINN. F lores hermaphro diti. C a ly x persistens, ebracteolatus, tetraphyl. Ins, foliolis imbricatis, duobns exterioribus minoribus. Corolla e petala 4 , hypogyna, calycis foliolis alterna, aestivatione imbricato-convoluta. St amina plurima, hypogyna, basi in annulum carnosum imis petalis adhaerentem coalita; $\mathrm{fila}$ menta filiformia, brevia, antherae introrsae, biloculares, erectae, loculis longitudinaliter dehiscentibus. Ov a ri $\mathbf{n}$ m liberum, biloculare, 0 v nI a in loculis gemina, e basi erecta, collateralia, anatropa. Sty Ins terminalis, longiuscnlas; stigm a peltatum, indivisum. Ca p su Ia globoso-ovoidea, dissepimenti obliteratione unilocularis, bivalvis. Semina 1 - $k$, erecta, ovoidea, hine plana 
inde convexa, testa chartacea. E mbryo exalbuminosns, orthotropus; cotyledon ibus erassissimis, distinctis, ra di c n la brevissima, umbilico proxima, infera. - Frutex Asiae tropicae; trunco gracili, stricto, foliis oppositis, petiolatis, oblongo-lanceolatis, acuminatis, integerrimis, supra nitis, subtus glaucis, nervo medio marginibusque coloratis, nervis secundariis transversis, parallelis, confertis, fere obsoletis, stipulis nullis, floribus axillaribus v. terminalibus, solitariis, albis, magnis.

Mesua Linn. Gen. n, 665, Jussien Gen. 258. DC. Prodr. I. 562, Cambessed. in Mem. Mus. XVI. 426. t. 17. f. 6. Wight et Arnott Prodr, I. 102. Meisner Gen. 42, (31.) Rhyma Scop. Introduct. n, 1185. Nagas sa ri u m Rumph Amboin. Auct. t. \&. Rheede Malab. IKr. $t, 35$.

5448. Calopla yllume $L I N N$. F l or es hermaphroditi v. abortu polygami. C al y $\mathrm{x}$ ebracteolatus, di-tetraphyllus, foliolis duobus exterioribus minoribus. Corolla e petala 4 , rarissime 2 , hypogyna, decussata, calycis foliolis opposita v. alterna, aestivatione imbricato-convolata. St a mina plurima v. rarius subdefinita, hypogyna, libera v. basi subpolyadelpha; fil am enta filiformia, brevia, antherae introrsae, biloculares, erectae, loculis longitudinaliter dehiscentibus. 0 vari um liberum, uniloenlare. O v $\mathbf{n}$ I $\mathbf{m}$ nnienm, e basi erectum, orthotropum. Stylus terminalis, longiusculus; stig ma late peltatum, integrum v. sublobatum. Drupa globosa v, ovoidea, monosperma. Semen erectum, tes ta submembranacea. Embryo exalbuminosus, antitropus; cotyledonibus crassissimis, coalitis, radicnla brevissima, supera. - Arbores inter tropicos totius orbis crescentes; foliis oppositis, petiolatis, coriaceis, integerrimis, nitidis, nervis transversis parallelis confertissime striatis, stipulis nullis, cymis racemosis $v$, paniculatis, saepissime multifloris.

CaIophyllum Linn. Gen. n, 658. Jassieu Gen, 258. Jacq. Amer. t. 165. DC. Prodr. 1. 562. Cambessed, in Mem. Mus. XVI, 427. $t, 17 . f$, $c$. St. Hilaire Flor, Brasil. $T .320$. t. 67. Wight in Hooker Bot. Miscell, Suppl.t. 17. Wight et Arnott Prodr. 1. 102. Meisuer Gen, 43. (32.) Wight Illustr. 2 , 45, B i a $\mathrm{t}$ g o r Rumph Amboin. $I I, t, 71,72$.

5445. Fayea $W A L L$. Flores hermaphroditi, Calyx tetraphyllus, foliolis decussantibns, aequalibus, duobus exterioribus ima basi subconnatis, aestivatione valvatis. Corolla e petala 4, hypogyna, calycis foliolis alterna et vix majora. Stam in a plurima, hypogyna, multiseriata, ima basi subcoalita; filamenta filiformia, antherae introrsae, biloculares, loculis connectivum subreniforme, apice in glandulam excavatam productum marginantibus, lougitudinaliter dehiscentibus. Ova rium liberum, uniloculare. Ovu$1 \mathrm{a}$ in loculis 4 , e basi erecta, anatropa. Stylus filiformis; stig m a obsolete quadrifidum, lobis subulatis. Fruetus ..... Arbor indica, procera, frondosa; foliis oppositis, breve petiolatis, in apice ramorum approximatis, oblongis, acuminatis, coriaceis, subenervïs, integerrimis, stipulis nullis, floribus terminalibus paniculatis, dilute roseis.

$\mathrm{K}$ a y e a Wallich Plant. 1s. rar, IIT. 4. t, 210. Meis. ner Gen. 43. (32.)

\section{GENERA DUBIA.}

5450. Wetheestia $L I N N$. Cal yx nullus. Corollae petala 4 , obovata, coneava, patentia. Stamina plurima; fil amenta filiformia, corolla longiora, anthe $x$ ae oblongae. Ovarinm globosum ...... Stylus eylindrieus, staminum longitudine; stigma infundibuliforme. B a c $c$ a ovata, succulenta, unilacularis. Sem ina 3 , ovato-oblonga, maxima. - Arbor martinicensis, vix nota; ramis articulatis, compressis, laevibus, pabescentibus, foliis oppositis, petiolatis, lanceolatis, integerrimis, glabris, petiolis brevibus, pubescentibus, pedunculis axillaribus, subternis, trifidis v. trifloris.

Bh e e dia Lian. Gen, n. 84t. Jussieu Gen. 258. Tussae Flor. Antill, III, t. 32, DC, Prodr, I. S64. Cambessed, in Mom, Mus. XVI, 424. Meisner Gen, 43. (32.) V a u, R h e edi a Plumier Gen. 45, Burm, 1e. Amer. 2.257.

5451. Apoterian BLUM. C a I y x nullus. Corolla e petala 4 . Stam in a plarima, basi submonadelpha, a nt hera e oblongae, longitudinaliter dehiscentes. Ovari um uniovalatum. Styl us filiformis, inflexns; $8 \mathrm{tig} \mathrm{m}$ a peltatum, depressum. Dru p a baceata, nueleo monospermo. Arbor javana, Calophylli facie; ramulis tetragonis, foliis elliptico-oblongis, obtusis, basi acutis $v$. rotundatis, pedunculis axillaribus confertis, brevibus, pedicellis unifloris, subumbellatis.

A p oterium Blume Bijdr. 218. Meisner Gen. 43. (32.) Sula tri Javan.

545ร. Gtelleclaospermatata $B L U M . \mathrm{Ca}-$ ly $x$ quinquefidus, persistens, laciniis acutis, Corolla e petala 5 , oblonga, concava, conniventia. $\mathrm{St}$ a $\mathrm{m}$ i n a circiter 40 , receptaculo insidentia ; $\mathrm{fl}$ amenta filiformia, a ntherae subrotundae. Ovarium trigonnm. Stylus subulatus: stigmata 3 , oblonga, reflexa. C a psula unilocularis, triloba, trivalvis. S e me n unieum, subrotundum, pedicellatum, aristatum. - Arbor co chinchinensis, magna; ligno rubro, gravi, duro, ramis expansis, flexuosis, foliis alternis, lanceolatis, integerrimis, glabris, racemis terminalibus laxis, floribus parvis, albis, capsula rubra.

Stele ehosperm u m Blume Flor. Jav. Dipterocarp. p. 7 . in not. Vateria flex a os a Loareiro Flor, oochinch. 409. - Geans e el. Biume sententia Calophyllo affine, sed ob folia alterna, calycis quinquefidi Jacinias acntas, et flores racemosos vix liujus loci.

5453. Cymotroelhes BLUM. Calyx quadripartitus, persistens. Corolla petala 4 , fimbriata. Stamina 8 , disci hypogyni margini inserta. O va ri u m quadri-sexloculare, locnlis triovulatis. Stylus filiformis; stigma peltato-radiatum. B a c c a globosa, pulposa, quadri-sexlocalaris. S emina abortu solitaria, compressa, axi affixa. - Arbor javana, procera; foliis oppositis, elliptico-oblongis, utrinque acutis, coriaceis, pedunculis axillaribus unifloris, confertis.

G y not r oeh es Blume Bijdr. 218. Meisner Gen, 42. (32.)

5454. Niacanea JUSS, F lo res ...... B ac e a magna, pyriformis, extus gibba, inaequalis, cortice coriaceo, unilocularis, intus pulposa, tetra-hexasperma. S e m in a receptaculis lateralibus affixa, ovata, coriacea, in pulpa nidulantia. Frutex guineensis, sarmentosus; foliis oppositis, petiolatis, ovatis, acutis, penninerviis, serratis, floribus axillaribus, solitariis.

Macanea Jussien Gen. 257. Macahanea Aublet Guian, Suppl. 6. t. 371 .

545 . IVreoubea $A U B L$. F lores . ... Fructus aurantiformis, subcompressus, cortice tenui, punctato, subseabro, unilocularis, polyspermus. Sem in a parietalia, oblonga, subeurva, hine sulcata, arillata. - Arbor guianensis, lactescens; ramis oppositis, petiolatis, ovatis, integerrimis, nervis secundariis transversis, fructibus racemosis. M a coubea Anblet Guian, Suppl. 17, t, 378. Jussieu Gen. 257. 
OBSERVATIO. So a I a Manuel Blanco Flora de Filip. 437, genus e el. Lindley Bot.Reg. 1839. App. p. 76. ad Clusiaceas referendam, mihi omnino iguotum.

\section{* CANELlaceaE.}

5456. Pllatonia MART. Calyx persistens, ebracteolatus, pentaphyllus, foliolis imbricatis, duobus exterioribus minoribus. Coroll a e petala 5, hypogyna, calycis foliolis alterna, aestivatione contorta, campanulato - conniventia. Stamina plurima, diseo hypogyno quinquelobo extus inserta, saepe geminatim connata, in phalanges quinque cum petalis alternas, basi planas, apice in filamenta brevia solutas, collecta, antherae introrsae, bilvenlares, loculis longe linearibns, immerso adnatis, longitudinaliter dehiscentibus. Ovari u m liberum, quinqueloculare. Ovula in loculorum angulo centrali plura, superposita, uniseriata, horizontalia, anatropa (?). S t y 1 u s cylindricus; stig ma quinqueradiatum, laciniis subnlatis. Ba e ca globosa, spisse carnosa, quinquelocularis, $v$, abortu tri-quadrilocularis. $\mathrm{S} \mathbf{e} \mathrm{m} \mathbf{i}$ a in loculis solitaria, inversa, dorso convexa, ventre planiuscula, testa membranacea, umbilico ventrali lineari. Embryo intra albumen copiosum, carnosum, cryptis plurimis, flexuosis, oleiferis exsculptum inclusus, teretiusculus, curvatus, obliquus; cotyledonibus connatis, radicula supera. - Arbor brasilien$s i s$, vasta, cortice crasso; ramis validis, ramulis suboppositis, foliis oppositis, decussatis, petiolatis, in apicibus ramulorum, confertis, coriaceis, supra nitidis, subtus pallidioribus, penninerviis, integerrimis, stipulis nullis, floribus terminalibus, solitariis, magnis, nutantibus, roseis, pedunculo basi bracteolato, baccae carne acidulo-dulci et nucleis amygdalinis edulibus.

P1 a to n i a Martius Nov. gen. et sp. ITT. 108, t, 288. f. 2. $t$. 289. Meisner Gen. 43. (32.) Mo ro nobea e s c u. lenta Arruda de Camara Discorso p. 32. P a coury Abbeville Hist. Miss, Capuc, 229.

545\%. Canella P. BROWN. C a Iyx per. sistens, ebracteolatus, triphyllus, foliolis imbricatis, subrotundis, concavis. Co ro 11 a e petala 5, hypogyna, oblonga, concava, aestivatione convolutiva. Stamina in tubum urceolato-cylindricum, truncatum coalita, antherae 21, tubo infra apicem extus longitudinaliter adnatae, lineares, parallelae, discretae, juxta longitudinem bivalves. Ova ri um liberum, tubo stamineo inclusum, triloculare. Ovu I a in loculis plura, angulo centrali inserta. Stylus cylindricus; $8 \mathrm{tig}$ a exsertum, bilobnm, lobis brevibus, obtusis. B a c c a globosa, carnosa, abortu uni-bilocularis. S e mina in Joculis 2_3, superposita, subglobosa, reniformia, rostellata, testa crustacea, atra, nitida. Embry o in seminis rostello intra albumen carnosum, dnriusculum parvus, curvatus, teretinseulus; co tyled onibus linearibus, radicula sursum centripeta. - Arbor antillana; trunco stricto, apice ramoso, foliis petiolatis, approximatim alternis, obovatis, junioribus pellucido-punctatis, adultioribus corianeis, enerviis, integerrimis, stipulis nullis, floribus terminalibus corymbosis, violaceis.

C a nella P. Browne Jam, 275, t. 27. f. 3. Marray Syst, 443. Girtuer $1.373, t, 77$. Swartz in Linn. Transact. I, 96. t. 8. DC. Prodr. I. 563. Meisner Gen, 42, (32.). W i ateran ia Linn. Gen, n. 598.

5458. Cimmanodendron. C a 1 y x ebracteolatus, triphyllus, foliolis imbricatis, sub- rotundis, Coroll a e petala 5 , hypogyna, orbicalato-ovata, cum totidem squamulis obovatis, ciliatis, duplo brevioribus alterna. $T$ a b u s stamineus brevis, ovarium cingens, a $\mathrm{t}$ h e $r$ is decem sessilibus, erectis, contiguis, ovatis, bilocellatis. $\mathrm{O} v \mathrm{a}-$ rium ovatum ..... Stylns crassns, angnlatus; stigma truncatum. Fructus..... - Arbor brasiliensis, mediocris; cortice glabro, albicante, transversim rimoso, calloso, ramis folitisque alternis, petiolatis, ellipticis, coriaceis, crassis, glaberrimis, integerrimis, subtilissime venosis, subtus pallidioribus, stipulis nullis, pedunculis axillaribus trifloris, e gemmis squamosis prodeuntibus.

Canella axillaris Nees et Martius in N. A. N. C. $x I T .\{t, 3$. Hierba Moeira do Sertan Brasil.

\section{Ordo CCX DIE. DIarcgraviacede.}

MarCgravia CEaE Jussieu in Annal. Mus, XIV. 397. Kunth in Humb. et Bonpl. Nov. gen, et sp. VII. 2z7. DC. Prodr. I. B65. Bartling Ord. nat, 280. Lindley Introduct, edit. II. p. 76. Meisuer Gen, 44. (32.)

Arborgs v. prutices inermes, erecti v. scandentes et radicantes. Folia alterna, simplicia, petiolata v. sessilia, penninervia, integerrima v interdum subserrata, glaberrima, nitida, cum ramis articulata. S ti pu 1 a e nullae.

Flores hermaphroditi, umbellati v. in racemos, aut rarius in spicas terminales dispositi. Pedunculi basi articulati, saepius bracteati, bracteis interdum sacciformibus v. cucullatis, petiolatis. Bract e o la e ad calycis basim minimae, laterales, foliola calycina extima mentientes, nunc nullae.

Cabxx liber, di-tetra-hexa-pentaphyllus, foliolis subaequalibus, distinctis v. basi subcohaerentibus, per aestivationem imbricatis, coriaceis, plerumque coloratis, deciduis.

Conolbar petala hypogyna, subcoriacea, nunc calycis foliolis numero aequalia et alterna, libera v. basi subcoalita, aestivatione imbricata, sub anthesi patentia, nunc saepius, ut videtur, plura, in calyptram clausam v. apice laceram, basi circumscisse solutam, et staminum incremento sub anthesi dejectam connata.

Srauiva nunc toro hypogyne inserta, nunc ejusdem prolongationis discoideae basim ovarii cingentis, liberae $v$. inferne adnatae margini imposita, rarissime calycis foliolis numero aequalia et opposita, saepissime subindefinite plura, uniseriata, rarissime plurima, pluriseriata, aestivatione stricta. Fil a m e $\mathrm{t}$ a libera, v. ima basi inter se, et quandoque etiam petalorum basibus cohaerentia, inferne latiora, plerumque complanata, superne angustata, erecta v. patentia. Antherae introrsae, biloculares, ovatae, lineares y. oblongae, dorso supra basim affixae, erectae v. demum patentes, loculi appositi, parallele contigui, juxta totam longitudinem, rarius apice rimula brevi dehiscentes.

Ovarium sessile, liberum, interdum disco staminifero adnato basi cinctum, tri-quinque 
multiloculare, carpidiorum marginibus introflexis inter placentae centralis lobos immissis, rarissime axim haud attingentibus, dissepimenta constituentibus. Ovula plurima, placentae centralis lobis carnosis $\mathbf{v}$. interdum geminatis, e loculorum angulo centrali exsertis affixa, adscendentia, (anatropa?), micropyle prope punctum insertionis infera, nucleo prominulo. S ti g$\mathbf{m}$ a sessile, radiatum, indivisum v. sublobatum, rarius stylum brevem terminans.

Fructus in pluribus fortassis b a c catus,

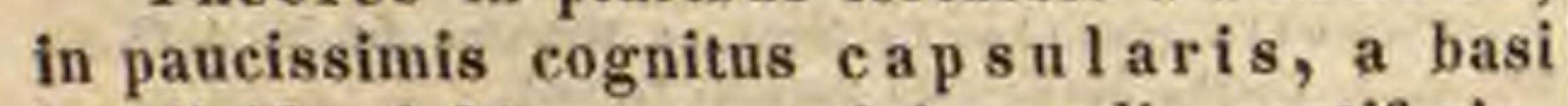
loculicide dehiscens, valvis medio septiferis, a placenta persistente, carnosa, substipitata, lobata solutis.

Semixa ovulorum plurimorum abortu pauca, in placenta nidulantia, adscendentia, oblonga, utrinque obtusa, recta $v$, incurva, te sta duriuscula, areolata, umbilico marginato impresso supra basim laterali, endopleura membranacea. Albumen nullum.

Eмввуо homotrope incurvus, clavato subcylindricus; cotyledonibus brevissimis, obtusis, radicula longa, conica, acuta, umbilico parallele contigua, infera.

Maregraviaceae Americam tropicam orientalem potissimum inhabitant.

Ordo vix satis a Clusiaceis distinctus, ob fructus et semina pancissimarum specierum adhuedum cognita subdubius.

5459. IRuyselnia $J A C Q$. C a ly $\mathrm{x}$ bibracteolatus, pentaphylius, foliolis imbricatis, subaequalibus, coloratis. Coroll a e petala 5, hypogyna, ima basi cohaerentia, aestivatione imbricata, demum reflexa, decidua. S t a mina 5, hypogyna, petalis alterna et ima basi adhaerentia; fil a m e n$t$ a complanata, subulata, a $n$ thera e introrsae, hilocnlares, ovales, dorso supra basim affixae, erectae, loculis Iongitudinaliter dehiscentibus, $O \mathrm{v}$ ari u m liberum, conico tetra-hexagonum, quadriquinqueloculare. O vula plurima, placentae centralis carnosae lobis, e loculorum angulo centrali prominulis inserta, adscendentia. Stigma sessile, radiato quadri-quinquesulcatum. C a p s u la coriacea, subglobosa, quadri-sexlocularis, a basi dehiscens, loeulicide quadri-sexvalvis, valvis medio septiferis, placenta carnosa, stipitata, quadrisexloba persistente. Se min a in loculis $3-6$, in placenta nidulantia, curvato-oblonga, adscendentia, testa dnriuscula, areolata, umbilico supra basim laterali. E mbry on is exalbuminosi cotyledones brevissimae, obtusae, radicula longe conica, umbilico parallele contigua, infera.

busculae v. frutices, Americam tropicam orien$t$ ale $m$ incolentes; ramis sarmentosis, foliis simplicibus, alternis, breviter petiolatis, articulatis, coriaceis, nitidis, integerrimis, saepe inaequilateris, racemis terminalibus, densis, bractea colorata pedicelli apici inserta, colorata, simplici $v$. postice bicruri, antice in calcar cavum desinente.

R u y s ch i a Jacq. Amer, 75, t, 51, f. 2, DC. Prodr. I, 556. Martius Nov. gen, et sp. III, 174. t. 292 294. Meisner Gen. 44. (32,) So u ro u be a Aublet Guian. I. 244 . t. 97. Jussieu Gen, 428, Kunth in Humb, et Bonpl. Nov. gen. et sp. VIT. 218. S u rubea Meyer Fissequeb. 119. Log ha ni a Seopoli Introduct, $n, 1026$.

5460. Norantea $A U B L$, Ca l y x bibracteolatus, pentaphyllus, foliolis imbricatis, subaequalibus, coloratis. Corollae petala 5, hypogyna, concava, aestivatione imbricata, decidna. St a mina definita, rarius pauca, uni-biseriata, hypogyna, ima basi petalis adhaerentia; filam e nta brevissima, complanata, antherae introrsae, biloculares, lineares, dorso supra basim affixae, erectae, loculis longitudinaliter dehiseentibns. Ovarium liberum, conicum, septis tribns v. quinque, receptaculi placentiferi lobos haud attingentibus v. inter ejusdem lobos immissis, incomplete tri-quinqueloculare. Ovula plurima, placentae centrali carnosae, tri-quinquelobae inserta, adscendentia. St ig m a sessile, obtusum, tri-quinqueradiatum. B a c c a globosa (?), stigmate persistente umbilicata, tri-quinquelocularis, loculis dispermis. S e min a teretia, utrinque obtusa, nitida, placentae pulposae immersa ...... - Arbores $v$. frutices, in Guiana et Brasilia crescentes, interdum scandentes, radicantes; foliis simplicibus, alternis, articulatis, crassiusculis, nitidis, aveniis, integerrimis, exstipulatis, floribus in racemos terminales, saepe strictos, longissimos dispositis, pedicellis basi articulatis, bractea asciformi, petiolata, colorata, oblique patente $v$, rarius pendula.

Nor a nte a Aublet Guian, I. 554, $t$. 220. Jussien Gen. 245. Kuath in Humb. et Bonpl, Nov. gen. ot sp. VII, 218. t. 647. DC, Prodr. I, s66. Cambessedes in St, Hilaire Flor. Brasit. I, 241, t. 69. Martius Nov, gen, et sp. III. 179. t. 295. 296. A s c i u $\mathrm{m}$ Schreber Gen, n, 903. Vahl Eclog. $41, \mathrm{~S} \mathrm{eh}$ w a r $\mathrm{z}$ a Flor. Flumin. $\boldsymbol{V}, t, 8 i$.

5461. IIraregravia PLCM. Caly x bibracteolatus, tetra-hexaphyllns, foliolis imbricatis, subaequalibus, subcoloratis. Co roll a e petala hypogyna, in calyptram conicam deciduam connata. Stam in a $12-40$, disco membranaceo angusto, imam ovarii basim eingenti inserta, uniseriata; fil a men $t$ a libera, e basi latiore subulata, a $n$ ther a e introrsae, biloculares, lineares, dorso supra hasim insertae, patentes, loculis longitudinaliter dehiscentibus, Ova ri um liberum, conico-multiangulare, octo-duodecimloenlare, Ovula plurima, placentae centralis Iobis bilamellatis, e loculorum angulo centrali prominnlis utrinque inserta, adscendentia. Stig ma sessile, radiato-suleatum. C a p sula corticata, octo-duodecimlocularis, irregulariter e basi dehiscens, valvis placentam carnosam persistentem nudantibus. S e $m$ in a plurima, in placenta nidulantia, minima, oblonga, testa reticulata... - Frutices $A m$ erica e tropicae parasitici, sarmentosi; foliis alternis, distichis, integerrimis, coriaceis, ramulorum sterilium heteromorphis, stipulis nullis, ramulis floriferis saepe dependentibus, pedunculis ebracteatis, racemosis $v$. in apice ramorum umbellatis, apice crassioribus, exterioribus floriferis, interioribus sterilibus, apice cucullum elongatum, obtusum, coriaceum gerentibus.

M a regravi a Plumier Gen, 7, t, 29. Linn. Gen, n.640. Jussieu Gen. 244. Jacq. Amer. 2. 96. Lam. t. 447. Jussieu in Annal. Mus. XIV. 409. $t$, 25. DC. Prodr. $I$, 565. Hooker Exot. Flor. t, 160. Kunth sjnops. IV. 234, Meisner Gen. 44. (32.)

\section{GENUS DUBIUM.}

5462. Antholoma LABILLARD. Caly $\times$ tetraphyllus $\vee$. rarins diphyllus, ovatus, caducus. Corolla gamopetala, ovato-cylindracea, margine erenata, subdentata. S t a m in a plurima, 
diseo fungroso, alveolato inserta; fil a me nta brevissima, antherae oblongae, apice introrsum dehiscentes. O varium obtuse tetragonum, quadriloculare ..... S ty lus longus; $8 \mathrm{tigma}$ acutum. Fruet us .....-Arbor Novae-Caledoniae; foliis ad apices ramulorum sparsis, petiolatis, elliptico-oblongis, coriaceis, racemis axillaribus subumbellatis, reflexis, pedunculis nudis.

A ntboloma Labillardiere Nov. Holland. IT. 121. Vojage t. 41. DC. Prodr. 1 . 365 . Meisner Gen. 44. (32.)

\section{Ordo CCXVIII. HIypericineae.}

HYPERICA Jussieu Gen. 254. HYPERICINEAE DC. Flor. fr. ed. 3. IV. 860. Choisy, Prodromus d'une Mono. Graphie de la famille des Hyperieinces Geneve, 1821. 4. DC. Prodr. I. S41. Bartling Ord, nat, 291. Meisner Gen, 44. (33.) HYPERICACEAE Lindley Introduot. edit, $I I, p .7$. Spach Suites a Buffon $V$. 335. Nouv. Annal. sc, nat. 349.

Arbores, frutices, SUFFrutices v. HERBas perennes aut rarissime annuae, succis resinosis, coloratis v. limpidis foetae, ramis oppositis v. rarius verticillatis, nodoso-articulatis, tetragonis, rarius compressis bifacialibus v. teretibus. Foli a opposita v. interdum verticillata, simplicia, sessilia v. petiolata, integra, penninervia, integerrima v. glanduloso denticulata aut crenulata, saepissime glandulis resinosis, pellucidis, immersis punctata, et punctis vesiculosis nigris margine conspersa. Stipulae nullae.

Flores hermaphroditi, regulares, terminales et axillares, paniculati v. in cymas dichotomas, nudas v. bracteatas dispositi, lutei, Tarius rubri v, albi.

CaLyx liber, persistens, pentamerus v. rarius tetramerus, foliolis plus minus connatis, biseriatis, duobus exterioribus saepe minoribus, quadri-quinquefidus v. partitus, rarius tetraphyllus, foliolis decussatis, duobus exteriorihus majoribus, aestivatione valvatis, interiora multo minora tegentibus.

Coroldae petala hypogyna, calycis foliolis numero aequalia et alterna, sessilia v. plus minus distincte unguiculata, ungue nudo, v. supra basim intus foveola, v. squamula carnosa aut petaloidea aucta, aequalia, plus minus inaequilatera, flabellato venosa, aestivatione spiraliter contorta, decidua $v$, involuto aut contorto persistentia.

Stamina hypogyna, rarissime definita, plerumque indefinite plurima. Filamenta filiformia, interdum libera v. monadelpha, saepissime in phalanges tres $\mathbf{v}$. quinque plus minus connata, phalangibus interdum cum glandulis v. squamulis hypogynis alternantibus. An $\mathbf{t}$ h er a e introrsae, biloculares, subdidymae, dorso insertae, mobiles, saepe glandula terminatae, loculis longitudinaliter dehiscentibus.

Ovariem e carpidiis tribus v. quinque, rarissime pluribus compositum, carpidiorum marginibus introflexis, nunc abbreviatis uniloculare, $v$. iisdem axim haud attingentibus, aut superne saltim distinctis incomplete tri-quinqueloculare, nune marginibus inter se ad axim coalitis triquinqueloculare, place ntis ex angulo central plus minus porrectis.

Ovoua in loculis plurima, biseriata, rarius definita, rarissime solitaria, plerumque horizontalia, rarius adscendentia, interdum pendula, anatropa v. nonnunquam amphitropa. Styli terminales, tres v. quinque, rarissime plures, filiformes v. clavati, omnino liberi v. basi aut ultra medium connati; stigmata distincta, capitata v. truncata, rarissime biloba.

Capsula unilocularis, placentis parietalibus, juxta suturas dehiscens, replo placentifero persistente, v. tri-quinquelocularis, septicide v. rarius loculicide tri-quinquevalvis, valvarum marginibus introflexis, ab axi placentifero solutis, persistentibus v. deciduis.

Semiva in loculis plurima v. rarius subdefinita, rarissime solitaria, horizontalia, adscendentia v. interdum pendula, recta v. curvata, cylindrica v. compressa, umbilico basilari v. rarius sublaterali funiculo brevi inserta, exarillata. Testa crustacea v. membranacea, scrobiculata v, rarius laevis, interdum relaxata, laxe cellulosa, arillaeformis, nucleum multo minorem includens, saepius ad chalazam umbilico e diametro oppositam in alam membranaceam producta. A I b u me n nullum.

Eмввуо orthotropus, rectus v. homotrope arcuatus; cotyled onibus foliaceis v. rarius carnosis, plerumque brevibus, radicula tereti, obtusa, cotyledonibus plerumque longiore, umbilico proxima.

Hypericea Clusiaceis affinitate proximae, ab iisdem ramis pedunculisque inarticalatis, numero partium in plerisque (praeter Ascyrum) quinario, antheris incumbentibus nec adnatis, stylis distinctis filiformibus, seminum in plurimis numero indefinito, arilli defectu et embryonis structura diversae, per regiones temperatas et calidiores totius orbis diffusae, maximo numero sub hemisphaerae borealis coelo temperato gignuntur, in America tropica haud infrequentes, in Africa et Asia aequinoctiali rariores.

TIRIBUS T. HYPERICEAE. Gla n du1 a e inter stamina nullae.

5463. Aseyrum LINN, C a 1 y x tetraphylIus, foliolis decussantibus, exterioribus plerumque multo majoribus, rarissime subaequalibus. CorolI a e petala 4, hypogyna, calycis foliolis alterna, aestivatione imbricato-convoluta. Stamina plurima, hypogyna, basi breviter subpolyadelpha ; filamenta filiformia, antherae introrsae, bilocalares, didymae, longitudinaliter dehiscentes. O varium sessile, uniloculare, placentis parietalibus snturalibus 2 v, 3 , rarissime 4 . Ov a I a plurima, horizontalia, anatropa. Styli placentarum nu- 
mero, liberi v. ima basi cohaerentes; stig mat a obtusa, C a p su la compressiuscula, unilocularis. juxta placentas bi-tri-quadrivalvis, placentis nerviformibus, tandem solutis. Se $m$ in a plurima.... - Frutices $v$. suffrutices, in $A m$ erica cis a equatorem indigeni; foliis oppositis, saepe amplexicaulibus, coriaceis, nigro-punctatis, integerrimis, stipulis nullis, floribus axillaribus terminalibusque, cymosis $v$. paniculatis, pedicellis infra apicem bibracteolatis.

Asc y ru u Linn. Gen. n. 903. Nuttall Gen. II. 15. Choisy Hyperic. 60. DC. Prodr. I. 35. Meisuer Gen. 44. (33.) Torrey et A. Gray Flor. of North Amer. I. 156.

a. ASCXRUM Spach. Calyeis foliola exteriora multo majora. - A scy r um Spach Suites a Buffon $V .346$. Nouv. Annal. so. nat. V., 368.

b. ISOPHXLLUM $S$ pach, C al y c is folinla subaequalia. Is o ph y II u m Spach Suites a Buffon $\nu$. 346. Nouv. Annal. sc. nat, $V$. 367 . - ? A. microsepalum Torr. et Gr.

5464. IIyperieum $L I N N$. C a ly x pentaphyllus v. quinquepartitus, laciniis imbricatis, aequalibus v. duabus exterioribus majoribus. C orolla e petala 5, hypogyna, calycis foliolis aequalia, aequilatera v. plus minus inaequilatera, aestivatione imbricato-convoluta. Stam in a plnrima, hypogyna, in phalanges tres v. quinque collecta ant irregulariter polyadelpha, rarins libera, rarissime definita; filamenta filiformia, anthera introrsae, biloculares, didymae, longitudinaliter dehiscentes. Ovari u m sessile, nunc uniloculare, placentis ad suturas tribus v. quinque parietalibus, v. in introflexis carpidiornm marginibus porrectis, nunc tri-quinqueloculare, marginibus introflexis ad axim revolutis plus v. minus coalitis. Ovula plurima, rarissime subdefinita, bipluriseriata, horizontalia, anatropa. Styli 3 v. 5 , filiformes, liberi v. basi plus minus coaliti; st igmata capitata. C a psula uni-tri-quinquelocnlaris, rarissime indehiscens, subbaccata, alias septicide tri-quinquevalvis, placentis suturalibus valvarum marginibus adhaerentibus v. solutis, v. centralibus in columnam indivisam $v$, partibilem coalitis. S e m in a in loculis plurima, rarissime pauca v. abortn solitaria, cylindrico-oblonga, recta v. incurva ; testa crustacea, scrobiculata, nucleum arcte vestiens, v. laxa, reticulato-cellulosa, nuclenm multo minorem includens, endopleurae membranaceae strato interiore subearnoso. E mb ry o exalbuminosus, orthotropus, cylindricus; cotyledonibus brevibus, obtusis, radicula umbilico proxima, - Herbae v. suffrutices, in regionibus te mperatis et calidioribus totius orbis, maximo numero in temperatis calidioribus hemisphaerae borealis crescentes; foliis oppositis, petiolatis, sessilibus v. amplexicaulibus, integerrimis $v$, interdum subserrulatis, saepissime pellucido-punctatis, stipulis nullis, floribus solitariis, cymosis, corymbosis, paniculatis $v$. rarius umbellatis, flavis.

H y perieum et Androsa e m u Tournef. Inst. 128. Hy peri cum et Sa rot hra Linn. Gen, n, 383, et 902. - Gienera a cl. Spach auper ex Hyperiei dismembratione extructa, et infra eunmerata, utrum geueris sectionis vere naturales praebeant, partimve typos in genera propria erigeados contineant, cautius est inquirendom.

a. DROS ANTHINAE Spach. C al y x quinquefidus v, quinquepartitus. Stamina triadelpha, persistentia. Ovari u m triloculare, tristylum. $0 \mathrm{vu}$ ia in loculis $6-12$, horizontalia v, adscendentia. Cap s u l a tricocea, coccís mono-trispermis, demum placentaque centrali deciduis. Persiae et Asia minoris incolae. - D ros a n hina Hypericearum sectio 1 . S pach Suites d Buffon $V .342$.
Nouv. Annal. sc. nat. V. 354. - Generum distinctorum typi?

?a. ERBMOSPORUS Spach, Caly $\times$ quinquepartitus, lacinils secrato-ciliatis. S $t a m$ i $\mathbf{n}$ m phalanges breves, sub. octandrae. 0 va $\mathrm{r} 1 \mathrm{um}$ triloculare, loculis 6-8ovulatis, Ca ps ula tricocca, coecis subcoriaceis, eymbiformibus, evalvibus, facie foramiue circulari apertis, aborta mo. nospermis, placenta fungosa, subglobosa. S e me n crassum, arcuatum, medio affixum, minute reticulatum. $\mathrm{Em}$. b $\mathbf{y}$ o viridis, radicula infera. - Herba persica. basi suffruticosa, Hyperici linearifolii facie; folits linearibus, punctatis, subcarnosis, margine revolutis, ramulis axillaribus et terminalibus brevibus, aphyllis, panioulam multifloram constituentibus.

Eremosporus Spach in Suites d Buffon $\boldsymbol{V} .378$. Nouv. Annal, sc. nat. $Y, 356$.

b. DROSANTHE Spach. C al y x quinquefidus, laciniis denticulatis v. pectinatis. $O \mathrm{v}$ a $\mathrm{r}$ i $\mathrm{um}$ triloculare, Iaculis 8-12ovulatis, ovulis adscendentibus $v$, horizontalibus. Ca ps u la tricocca, coccis membranacels, subeymbiformibus, demun facle bivalvibus, aborta oligospermis, placeata ossea, ovoidea, trícuspidata. S e m in n majuseula, arcuata, velutina, ninute serobiculata, radicala infera v. centripeta. - Herbae basi suffruticosae, in Persia et $A s i a$ minori indigenae; folits sessili. bus v. amplexicaulibus, glaucescentibus, foribus terminalibus racemosis $v$, paniculatis.

Drosanthe Spach Suites a Buffon $V$. 376. Nouv. Annal, sc, nat. $\boldsymbol{V}$. 333 .

A. HYPERINEAE Spach. C a I y $\times$ quinquepartitus v. quinquefidus, rarissiane pentaphyllus, foliolis distinete biseriatis. Sta $\mathrm{m}$ n a triadelpha, persistentia v. rarissime decidua. Ova ri u triloculare, tristylum, multiovulatum. Capsuta septicide trivalvis, valvis et placenta centrall indivisa persistentibus. - H y per In ea e Hypericearum seet. 2. Spach Suites d Buffon $V$. 342. Nouv. Annat. so. nat. V. 355.

a. WEBBlA Spach, Calyx profande quinquefidus. Pet a la distisete unguieulata, concava. S ta m I u m phalanges 12-25andrae. Capsula coriacea, placenta crassa, pyramidali, trigona. Seminum testa spon- giosa, laxa, nucleum multo miuorem includens. - $\mathcal{S} p \sigma-$ cies canarienses.

We b b i a Spach Suites d Buffon $V$. 408. Nouv, An. nal. so. nat, $\nu$. 356. Webb et Berthel. Flor. Canar. 46. t. 4. 5. H. canariense L. H. floribundum Ait. Reichenb. Ic. exot, $t$. 95.

b. HYPERICUM $S$ pach. C a ly x quinquepartitus, lacinlis aequalibus $v$. inaequalibus. Petala vix unguiculata, plava. CapsuIa cartilaginea v- chartacea, rarissime coriacea, placeuta nerviformi v. pyramidall trigona. S eminum testa memhranacea, nucleum arcte vestiens, minutisxime reticulata. - Species in temperatis veteris orbis indigenae, paucissimae americanae.

H y perie u m Spach Suiles a Buffon V. 383, Nouv. Annal. sc. nat. $V, 356$. Webb et Berthel. Flor, Canar. 43. $t$. 3. 4 .

c. Holosepalum Spach 1. c. Calyeis laciniae integerrimae. Caps ula chartacea, vitis copiosis, tenerrimis, membranaceis striata. - Folia opposita, integerrima. - (Spec. h. sect, H, humifasum L. H. nanam Poir. H. cuneatum Poir. H. heteroplyllam Vent. H. erispum 1. H. tetrapterum Fries, H. undulatum Schousb. H. pusctatum Lam.)

B. Milleporum spach l. o. Caly e i s laciniae integerrimae. Capsula cartllaginea, valvis dorso bivittatis, lateribus vesteulis ovoideis v. elavatis subbiseriatis, arcte superpositis transversim rugosis. Folia opposita, integerrima. - H. perforatum $L$.

$\gamma$. Adenosepalum $S_{\text {pach }} \boldsymbol{l}$. $c$, Calycis laciniae ciliato-denticulatae v. pectinatae, denticulis glasdula nigra terminatis. Ca ps u I a ehartacea, vittis plurimis tenuibus, longitudinalibas striata. - Folia opposila, integerrima. (Spec. h. sect. H. reflexum L. f. H. glandulosam Ait. H, elegans Steph. H. linearifolium Vahl. H. hyssopifolium ViI. H. serpyllifollum Lam. H. aethiopleum Thunb. H. pulehrnm L. H. numaulariam L. H. formosum Kunth. H. triplinerve Veat. H. mostanum L. H. tomentosum L. H. suberosum Salzm. H. lanuginosum Poir. H. Iusitanicum Poir.) 
8. Drosocarpium Spach $l$ c. Calycis Iaciniae serrulatae $\vee$. fimbriatae, lacinulis saepissime glandula opaca terminatis. Cap s u I a eartilaginea v. subcoríacea, vesiculis resiniferis verruculosa v. transversio rugosa. - Folia opposita, superiora amplexicaulia, nonnunquam serrulato-ciliata. (H. 1. H. barbatum L. H. gupharbinefolium Sp. H. Moubretil Sp. H. Richeri Vili. H. Burseri Bauh. H. dentatum Lois!. H. cilintum Desr.)

E. Coridium Spach $t$. c. Calycis laciniae serrulatae v. subserrulatae. Capsula coriacea, vittis longitudiualibus striata, v. vesiculis seriatis transversim rugulosa. - Folia verticillata, integerrima. (H. I. H. empetrifolium W. H, Coris L. H, ericoides L.)

5. CrossophylInm Spach $l$. $c$. CaIycis laciniae serrolato-ciliatae, eiliis glanduliferis. C a p s u I a subeartilaginea, yittis eopiosis striata. - Folia opposila, sessilia, basi biauriculata, serrulato-ciliata. H. orlentale Desr.

c. OLYMPIA Spach. Caly cis pentaphylli foliola biseriata, duo exteriora lateralia wulto majora. Petal a valde inaequilatera, subdolabrlforsia. C a p 8 u I a subcoriaces, placeata crassa, pyramidali, tríquetra. Seminum testa punctato-scrobiculata, lueida. - Species mediterranea. - $01 \mathrm{y} \mathrm{mpi} \mathrm{a} \mathrm{Spach} \mathrm{in} \mathrm{Suites} \mathrm{a} \mathrm{Buffon} V$. 406 . Nouv. Annal, se. nat, $V .359$. H. olympicum L.

B. ANDROS $A$ EMINAE. Spach, C a I y x pentaphyllas, foliolis saepissime biseriatis, inaequalibus. $\mathrm{S} t \mathrm{a}$ m in a saepissiwe pentadelpha, rarissime tetra-hexa-octadelpha, marcesceatia v. decidua. O va r fum tri-quinqueluculare, rarissime sex octoloculare, placentis ad axim appositis, haad conaatis. S tyll loculorum numero, liberi, aut basi v. fere ad apicem connati. Capsula septicide dehiscens. A ndros a e m i a a Hypericearum sect. 3. Spach in Sut tes a Buffon $V$. 411. Nouv, Annal. se, nat. $V .359$.

d. CAMPYLOPUS $S_{p a c h}$. C a ly e is folibla membranacea, subaequalia. St a m in a marcescentia, inia basi submonadelpha. Ovarium triloculare, stylis diseretis. Cap s u la trilocularis, trivalvis. placenta tripartibili. - $s p e$ cies mediterraneo-orientalis. - C a m p y I o p u $x$ Spach Suites à Buffon $\mathcal{V}$. 411. Nouv. Annal. so. nat. $\mathcal{V}, 360$. H. origanifolium D,Urv.

PSOROPHYTUM Spach. C a ly eis bibracteolati foljola coriacea, finaequalia. St a a $\mathrm{f}$ u $\mathrm{m}$ phalanges $4-5$, brevissimate, deciduae. 0 v a ri $\mathbf{n}$ m quadri-quinqueloculare, stylis diseretis. Capsula subeoriaeea, quadri-quinquevalvis, placenta pyramidali indivisa. - Species medi. terraneo-occidentalis. - Psorophyt $\mathrm{nm}$ Spach Suites d Buffon $V$. 413. Nouv. Annal. se, nat. $V, 360$, H. balearicum L.

f. ANDROSAEMUM Allion. Caly eis foliola coriacea, in aequalia. St aminu phalanges 5 , decidoae. Ova $\mathrm{r}$ lu m incomplete triloeulare, stylis distinctis. Ca p \& u 1 a unilocularis, immatura baceata, maturitate sieca, iadehiscens v, apice breviter trivalsis. - Species mediter raneace, A nd ros a e m u m Allioni Pedemont n, 1440. Spach Suites d Buffon $\nu$. 414. Nouv. Annal. se, nat. , 360. H. Androsaemum L. H. elatum Desr, Juss. in Annal. Mus, III. $t, 17$. H. hircinum L. H. inodorum Willd. H. foliosum Ait.

g. EREMANTHE Spach, Calye is foliola subcoriacea inacqualia. S $\mathrm{ta}$ m $\mathrm{f}$ a $\mathrm{m}$ phalanges 5 , Lreves, deciduae Ovari um quinqueloculare, apicem versus uniloculare, stylis dlstinctis. C a p \& u I a subcoriacea, quiaquesalvis, placenta centrall pyramidali pentaédra, breve stipitata, in laminas quinque lineari-lanceolatas. marginibus seminiferas secedente. - Species orientalis. - Eremant the Spach in Suites d Buffon $V$. 42t. Nouv. Annal. so. nat, V. 363. H. calyeinum L. Bot. Mag. $t$. 146.

h. CAMPYLOSPORUS Spach. Calye is foliola coriacea subaequalia. S ta min $u$ m phalanges 5 , breves, marcescentes. 0 varium quinqueloculare, stylis basí $v$. fere ad apicem connatis. C a psula quinquevalvis, placenta eentrali persistente, pyramidali, quinquecristata. Semina subulata, areuata. - Species borbonicae et madagarcarienses. - Campylos por a s Spach Suites ¿ Buffon $V$. 423. Nouv, Annal. so, nat. $\nu$. 363. H. Ianceolatum Desr. H. angustifolium Desr.

i. NORYSCA $s$ pach. C a lycis foliola coriacea, subae qualia. St a m i n u m phalanges 5 , brevissimae, deciduae. ovarinm quinqueloculare, stylis saepissime fere ad apicem coalitis. Caps ula coriacea, quínquevalvis, placenta centrali persistente pyramidali, pentagoua, guin. quecristata, eristis dorso seminiferis. Sem in a minuta, rectiuscula. - Species indicae. - Norys ca Spach in Suites d Buffon $\nu$. 42r. Nouv, Annal. sc. nat, $\nu$. 363. H. chinense L.

k. ROSCYNA Spach. Caly cis follola herbaeea, inaequalia v. rarissime subaequalia. Sta $\mathrm{min} \mathrm{um}$ phalanges 5 , breves, marcescentes. O v a ri um quinqueloenlare, sty. lis inferne connatis. Capsula chnrtacea, quinquevalvis, placenta centrali persistente pyramidali, pentagona, quinquecristata, eristis dorso seminiferis. S e mina minuta, subrecta. - Species sibiriece et boreali. americanae. - $R$ os e y a a Spach in Suites a Buffon $V$. 429. Nouv. Annal, sc. nat. V. 346. H. Ascyron L. H. Gebleri Ledeb. H. pyramidatum Ait.

C. BRATHYDINEAE. Spach. C a ly $\mathrm{x}$ pentaphyllus, rarissime tetraphyllos. Stamin a omuino libera et decidua, v. basi irregulariter polyadelpha et mareescentia. $0 \mathrm{v}$. rlu m unj-triloenlare, stylis tribus distiactis $v$, interdum coalitis. Capsula bi-trivalvis. - Brathy dineae Hypericearum sect. 4. Spach Suites d Buffon $\nu .432$. Nouv. Annat. sc. nat. $V .364$.

I. MYRIANDRA Spaoh. Caly cis foliola herbacea, inaequalia. Sta a i a a plurima, decidua. Ovariam nniloculare v. plas minus complete trilocalare, stylis 3 distinctis. Cap 5 u I a trivalvis, placentis centralibus v, suturalibus, filfformíbus v. Iineari-lanceolatis. - Species boreali.americanae. - M y ria a d ra Spaeh Suites d Buffon V. 434. Nouv. Annal. sc. nat. V. 364. H. prolificum L. H, adpressum Bart. H, rosmarinifolium Lam. H. galioides Lam. H. fasciculatum Lam.

m. BRATHYDIUM $s p a c h, C$ al y $\mathrm{c}$ is foliola herbacea, inaequalia. Sta mina plurima, persistentia. Ovariun uniloculare, stylis 3 , basi connatis. C a p 8 u la chartacea, trivalvis, placentis suturalibus, lineari-lanceolatis. species boreali.americanae. - B rathydium Spach Suites a Buffon $V$, 448. Nouv. Annal, sc. nat. V. 365 , H. procumbens Miehx. H. dolabriforme Vent. H. sphaeroearpum Michx. H. eistifolinm Desr.

n. BRATHYS Mut. Caly eis foliola inaequalla v. subaequalia. St a m in a sobdefiuita $(5 \ldots 30)$ v. indetiaite plnrima, persistentia. Ovari um uniloculare, stylis $\mathbf{3}$, rarius 4-6, distinetis. C a ps u la chartacea 8 . subeoriacea, unilocularis, tri- rarius 4-6valvis, placentis snturalibus nervi- v. filiformibus. - Species in America boreali et australi, Capite bonae apei et Nova-HoLlandia crescentes. - B rathys Spach Suites d Buffon V. 443. Nout, Annal. so, nat. $V .366$, B r a th y $8 \mathrm{Mu}-$ tis in Linn. $f$. Suppl. 43. R e ce v e u a Flor. Flumin. V. t. 119. 120. H y perie i s p. Saith Ic. inedit. $t .4 t$. Jussien in Annal. Mut, IIT. t. 16. f. 1. 2. Labillard. Nov, Caled, t. 53. Kunth in Humb. et Bonpl. Nov. gen. et sp, t. 456, 457. St. Hilaire Flor. Brasil. t. 69. A s e y r I s p. Lablllard. Nov. Holl. t. 174. 175. S a r oth ra Linn. Gen, n, 383. Gärtner $I T, 168, t, 144$. Barton Flor. Bor. Amer. t. 92. Greville in Hooker Bot. Miscell. III. 23s, t. 107.

TREREUS IT. ELODEAE. Glandula e v. squamula e hypogynae cum staminumphalangibus alternae.

54S5. Elodea ADANS. Cal y $\mathrm{x}$ quinquepartitus, laciniis subaequalibus, aestivatione imbricatis. Corollae petala 5 , hypogyna, ealycis laciniis alterna, ungue nudo v. basi glandula nectarifera ancto, aestivatione imbricato snbconvolnta. S $t$ a m i na $9-45$, in phalanges tres, cum glandulis v, squamnlis totidem hypogynis alternantes coalita; filamenta snperne discreta, filiformia, antherae introrsae, biloculares, didymae, longitudinaliter dehiscentes. O va rium sessile, septis tribus placentiferis plus minus completis, unitriloculare. $\mathrm{Ov}$ ula plurima, subhorizontalia, anatropa. Styli 3 , distincti, filiformes; stigmata capitata. C a p sula unilocularis v. trilocularis, juxta suturas trivalvis, placentis suturalibus v, ad axim coalitis, tandem solutis. Semina plurima, 
subcylindriea, testa membranaeea, scrobiculata. Eu b r yo exalbuminosus, orthotropus, oblongocylindracens, r a d i c u l a umbilico proxima. Herbae perennes $v$, suffrutices, in America boreali et regione mediterranea, rarissime in Europa media crescentes; foliis oppositis, planis v. margine revolutis, integerrimis, stipulis nullis, floribus axillaribus terminalibusque, solitariis $v$. subcymosis, pedicellis saepissime bibracteolatis.

Ela dea Adansou Fam. II. 443. Pursh Flor. Bor. Amer, II. 379. Nuttall Gen. II, 17, T ri a den i um Rafinesque in Nes-York Medic. Reposit. II. Hexad. $V, 350$. M a rti a Sprengel Syst. III. 333. H y periei s p. Lina.

a. ELODEA Spach. Caly eis laciniae subeoriaceae, integerrimac. Petala decidua, ungue audo. Sta m i a 9 , in phalanges rriandras collecta. Squamulae hypogy. nae stamiuum phalangibus alternae, subcoriaceae, integerrimae. C a ps u l a membranacea, trilocularis. - Herbae borcall-americanae, glaberrimae; folits subsessilibus v. amplexicaulibus, planis, obtusis. - Elode a Spach Suites a Buffon V. 363. Nouv. Annal. sc. nat. V. 165. et 353. H. virgin i cum Linn. Aadrews Bot. Reposit. t. 558 .

b. ELODES $S_{p a c h}$. Caly cis laciniae submembranaceae, glandulis stipitatis ciliatae. Petal a persistentia, ungue appendice fimbriolata aucto. Sta m in a 15 , iu phalanges pentandras collecta. S q u a u u la e hypogynae sta. minum phalaugibus alternae, petaloideae. blfidae. C a ps ula chartacen, unllocularis. - Herba Europae mediac, paludosa, lomentoso-villosa; folits sessi. libus, planis, - Elodes Spach Suites d Buffon $V$. 369. Nouv. Annal. sc. nat. V. 171, 353. H y peric u m e lodes Linn. Schkuhr $t .213$.

c. TRIADENIA Spach. Calyeis Jaciniae subcoriaceae, integerrimae. P eta la persistentia, ungue glaudula carnosa aucto. Sta m і а $27-45$, in phalanges enaeandras. peutdecandras eollecta. G I a n d u I a e hypogyuae stamiaua phalangibus alternae, crassac, carnosae, obtusae. $\mathrm{C}$ a psula chartacen, trilocularis. - Suffrutices medi. terraneit folitis oppositis, subcarnosis, parvis, mar. gine revolutis. - Triade $\mathrm{n}$ i a Spach Suites d Buffon V. 37o. Nouv. Annal. sc. nat. $V$. 175 et $354 . t, 4.5$.

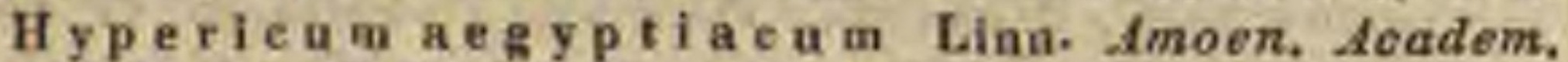
VIII. $t, 8, f .3$. Bot. Reg. t. 196.

5486. Vismia VELLOZ. Ca 1 y $x$ quinquepartitus, persistens, laciniis aestivatione imbrieatis. Corollae petala 5, hypogyna, calyeis laciniis alterna, aestivatione imbricata, saepins pagina superiere villosa. Stam in a plarima, hypogyna, in phalanges quinque petalis oppositas, apice in filamenta filiformia solutas coalita, antherae introrsae, biloculares, subrutundae, longitu dinaliter dehiscentes. Squamula e 5, hypogy. nae, petalis alternae. $O \mathrm{v}$ a $\mathrm{ri}$ i m sessite, quinquelo. culare, $O$ v u la plarima, loculorum angulo centrali bi-pluriseriatim inserta, anatropa. Styli 5 , apice obtuso intus stigmatosi. Ba e ca globosa, quinque locularis, v. septis ad axim deliquescentibus, margine placentiferis subunilocularis. S e m in a pluri ma, testa erustacea, verrucolosa, endopleura membranacea, Em b r y o exalbuminosus, orthotropus, oblonge cylindracens, radicula umbilico proxi. ma, - Arbores v, frutices, in America et Africa tropica indigeni; ramis oppositis, foliis oppositis, petiolatis, integerrimis, saepius glandulosopunctatis, stipulis nullis, floribus terminalibus, paniculatis $v$. cymosis.

$\mathrm{V}$ ismi a Velloza ex Vandelli in Römer Script. 138 1. 7, f. 4, Ruiz et Pavon Syst. 183. Kunth in Humb, et Bonpl. Nov. gen, et sp. IV, 181, $t$. 450, Choisy Hyperic. 3. t. 1 . 2 . DC. Prodr, 1.542 . St. Hilaire Flor, Brasil. $I, 325, t, 68$. Co a pia Piso Brasil., 126. Seopoli Introduet. n. 1236. H y perfel s p. Aublet Guian, t, 311. 312.

54B8. Psorespermana SPACH. Ca I yx quinquepartitus, persistens, laciniis aestiva- tione imbricatis. Corolla e petala 5, hypogyna, calycis laciniis alterna, aestivatione imbricata, ungue nudo $v$. appendice minima instructo, pagina superiore saepe villosa. Stam in a plurima, hypogyna, in phalanges quinque petalis oppositas, apice in filamenta filiformia solutas coalita, an thera e introrsae, biloculares, subrotundo-didymae, longitudinaliter dehiscentes, Squamula e 5, hypogynae, petalis alternae, O vari nm sessile, quinqueloculare. Ov ula in loculis solitaria v. gemina, angulo centrali inserta, adscendentia. Styli 5 , ima basi coaliti; $8 \mathrm{tigmata}$ clavato capitata. B a cea globosa, coriacea, quinquelocularis, septis membranaecis. Semina in loculis solitaria, ovalia, compressa, testa erustacea, verruculosa, endopleura membranacea, umbilico lineari supra basim laterali. E in b r y o exalbuminosus; cotyledonibus magnis, ovalibus, subcarnosis, radicula brevi, clavata, sursum flexa, umbilice proxima. - Frutices $v$. arbores $A \mathrm{fr} i$ cae tropicae; ramis oppositis, saepe dichotomis, foliis oppositis, petiolatis, integerrimis $v$. obsolete crenulatis, nigro-punctulatis, floribus terminalibus cymosis, v. cymoso-paniculatis aut corymbosis, luteis.

Psorospermum Spach Suites d Buffon $V$. 351. Nouv. Annal. sc. nat. $V$. 157. et 350. Ha rouga s p. Persoon, Choisy. Vismia guineensis Chois. Guillemin et Perrot. Flor. Seneg. t. 23. (excl, fig. ovar,) B y peri. е um guineense Linn. Amoen. Academ. VIXi. 32. t. $8 . f^{\circ} t$.

5468. III quepartitus, persistens, laciniis aestivatione imbricatis, Corolla e petala 5, hypogyna, ealycis laciniis alterna, aestivatione imbricata, punctulata. St a m in a 15 , hypogyna, in phalanges quinque triandras, petalis oppositas, apice in fila menta filiformia sulutas coalita, antherae intrursae, biloenlares, subgloboso-didymae, Iongitudinaliter dehiscentes. Ovarium sessile, quinqueloculare. Orula in loculis $2-3$, angulo centrali inserta, pendula, anatropa. Styli 5, basi coaliti; stig. in a t a capitata. Drupa globosa, pentapyrena, pyrenis chartaceis, mono-dispermis. Se min a $n b-$ longa, inversa, cylindracea, testa minute scrohicolata. E mbryo exalbuminosus, rectus, radicula umbilico proxima, supera. - Frutices $m a$ dagascarienses, succo luteo foeti; foliis oppositis, petialatis, integerrimis, glanduloso-punctatis, flaribus terminalibus, paniculatis.

H a rong a Thouars Gen. Madagase, n, 49. Spach Suites a Buffon $V$. 455. Nouv, Annal. se, nat. $V$. 350. H aro II g a n a Lam. $t$, 645. A rong a a Persoon Encheir. II. 91. exel. sp. Haemocarpus Noronh. msc.

5469. Elliaea CAMBESS. C a l y x quinquepartitus, persistens, imbricatus. Corolla e petala 5, hypogyna, calyeis laciniis alterna, basi intus appendice lineari cucullata aucta, aestivatione imbricata. Stam in a plurima, hypogyna, in phalanges tres coalita; fil am enta filiformia, villo8a, inferiora breviora, a ntherae introrsae, biloculares, subgloboso-didymae, longitudinaliter dehiscentes. Glandula e 3, hypogynae, oblongae, emarginatae, staminum fasciculis alternae. Ovarium sessile, triquetrum, triloeulare, loculis septo parietali incomplete bilocellatis. Ovula in loenlis gemina, anguli centralis basi inserta, semisepto interposito discreta, adscendentia. S tyli 3 , filiformes; stigmata capitata. Caps nia oblonga, acuta, hexaëdra, trisulea, trilocularis, epicarpio ernstaceo, secedente, endocarpio carti- 
lagineo, tricoceo, coccis dispermis, bilocellatis, demum bipartitis. Semina adscendentia, com. pressa, testa membranacea, superne in alam latam, obtusam producta, umbilico prope basim sublaterali, endopleura membranacea. Embryo exalbuminosns, rectus, compressus; cotyledonibus brevibus, obtusis, radi $\mathrm{e} u$ la longa, umbilico pa. rallele contigua, infera. - Frutex ma dagascariensis, succum flavidum stillans; ramulis tetragonis, decussantibus, articulatis, foliis oppositis, petiolatis, penninerviis, pellucido-punctatis, integerrimis, petiolis cum ramulo articulatis, stipulis nullis, floribus terminalibus cymosis, luteis.

Eli ge a Cawbessed, in Annal. se. nat, $X X, 400, t, 13$. Spach in Nouv. Annal. se, nat, $V$. 351, C uss on ia Com. merson msc. Lauig erostemma Chapelier msc. H y pe. ricum articulatum Desr.

$54 \%$. Ancistrolobus SPACH. C a $1 \mathrm{y} \mathrm{x}$ quinquepartitus, persistens, laciniis imbricatis. Corolla petala 5, hypogyna, ealyeis laciniis alterna, basi intus nuda (?), aestivatione imbricata. Stamina plnrima, hypogyna, basi in phalanges tres coalita; fil a m ent a filiformia, inaequilonga, glabra, anth era e introrsae, bilocnlares, subgloboso-didymae, longitudinaliter dehiscentes. Squa mulae 3 , hypogynae, convolutae, staminum phalangibus alternae, Ovarium sessile, triloculare. Ovula in loculis $5-6$, anguli centralis basi inserta, adscendentia. Styli 3 , superne incrassati; $8 \mathrm{tigmat}$ a capitata, papillosa. Cap$8 \mathrm{ul}$ a coriacea, oblonga, teretinscula, trilocularis, loculieide trivalvis, valvis medio dissepimenta cartilaginea, basi seminifera gerentibus. S emina in loculis 5 v. 6 , oblonga, compressa, superne in alam membranaceam reticulatam, obtusam, nervo marginatam producta. E m b r yo rectus, cylindricus; cotyled onibus apice uncinatim inflexis, radicula aequilonga, infera. - Frutex $v$, arbor in Macao Sinarum crescens; ramis cylindricis, ramulis angulatis $v$. ancipitibus, foliis oppositis, breve petiolatis, coriaceis, integerrimis, margine revolutis, nigro-punctatis, stipulis nullis, pedunculis axillaribus et terminalibus brevibus, uniquinquefloris, pedicellis cymosis, floribus aurantiaceis.

Ancistralobus Spaeh Suites d Buffon $P, 360$. Nouv. Annal, sc. nat. V. 3se, t, 6. f.6. - ? H y pericu a cochiachinense Lour. H, ehinense Retz. H. biflorum Desr. Elodea s u atrana Jack.

5481. Treidesmis SPACH. C a Iy $\mathrm{x}$ quinquepartitus, persistens, laciniis imbricatis. Corolla e petala 5, hypogyna, calycis laciniis alterna, basi intus appendice lineari, triloba aucta, aestivatione imbricata. Stamina 5 , hypogyna, in phalanges tres coalita; filament a filiformia, glabra, inferiora breviora, antherae introrsae, biloculares, subgloboso-didymae, longitudinaliter dehiscentes. Squamula e 3, hypogynae, subulatae, staminum phalangibus alternae. Ovarium sessile, triloculare. Ovala in loculis plurima, angulo centrali juxta totam longitudinem biseriatim inserta, adscendentia, superne in alam longam, obtusam producta. Styli 3 , filiformes; 8 tig mata obtusa, emarginato-biloba, ciliolata. Capsula lignosa, trilocularis, loculieide trivalvis, val vis apice bifidis, medio septum crassum, juxta totam longitudinem placentiferum gerentibus. S em in a plurima, imbricata ...- Arbores $v$. frutices in Moluccis crescentes; ramis subdichotomis, cylindricis, florescentiae tempore aphyllis, ramulis angulatis, e gemma terminali folia membranacea, si- nuato-denticulata, penninervia, pellucido punctata explicantibus, pedunculis e foliorum annotinorum, delapsorum axillis solitariis, geminis v. fasciculatis, unifloris, nudis.

Trides mis Spach Suites di Buffon $V$. 358. Nouv. Annal. se, nat, $V$. 352. t. 6. f. a. - ? Н y perfenm biflor u Choisy. Elodea formosa Jack.

54 2. Cratoxylom BLUM. Calyx quinquepartitus, persistens, C orolla e petala 5 . Stamina plurima, basi diadelpha. Ovarinm ..... Styli et 8 tigmata 3 . Capsula submembranacea, trilocularis, trivalvis, valvis medio septiferis. S emina plurima, compressa, superne in alam foliaceam desinentia. Emb ry on is exalbuminosi, reeti radi cula infera. - Arbor javana, excelsa; folits oppositis, breve petiolatis, oblongolanceolatis, floribus terminalibus, paniculatis.

Cratoxylon Blume Bïjr. 143. Meisner Gen, 14. (23.). Spach in Nouv, Annal. sc. nat. $V$. 352. H o r a s e h uch ha Blume Catalog. Hort. Buitenz.

\section{GENUS DUBIAE AFFINITATIS.}

54 ร 3. Iancretia DELILE. C al y $\mathrm{x}$ pentaphyllus, foliolis lanceolatis, margine membranaceo glandnloso-ciliatis, aestivatione imbricatis. Corolla e petala 5, hypogyna, calycis foliolis alterna et vix longiora, oblonga, obtusa, aestivatione convolutiva. S $t$ a mina 10 , hypogyna; filamenta e basi membranacea complanata apice subulata, an therae introrsae, cordato-oblongae, biloculares, longitudinaliter dehiscentes. Ovari $\mathbf{~ m}$ liberum, sessile, quinquelobum, quinqueloculare. O v 1 a in loculorum angulo centrali plurima. Styli 5 , distineti; $8 \mathrm{tig} \mathbf{m}$ a ta eapitata. C a p s u la quinqueloba, quinquelocularis, septicide dehiseens, placenta centrali libera. Semina plurima, minima, oblonga, alveolata. E mbryo .... - Suffrutices in $A$ egypto et Africa tropica indigeni, non satis noti, procumbentes, ramosissimi; ramis oppositis, adscendentibus, villosis, apice compressis, foliis oppositis, junioribus in axillis faseiculatis, brevissime petiolatis, ovato-ellipticis, serrulatis, resinoso-punctatis, stipulis ad basim petiolorum geminis, lanceolatis, ciliatis, floribus axillaribus solitariis $v$. aggregatis, sessilibus $v$. pedunculatis, basi bibracteatis, parvis, albo-roseis.

L a neretia Dellie Flor. Aegypt. 69, t.25. DC. Prodr. 1. 555. Gulllemin et Perrott. Flor. Seneg. I. 108. Meisner Gen. 14. (33.)

\section{* OCHRANTHACEAE Lindl.}

5484. Delnraintlie LINDL. C al yx pentaphyllus, coloratus, foliolis concavis, obtusis, biseriatis, duobus exterioribas brevioribus. Corollae petala 5, hypogyna, calycis foliolis alterna et conformia, paullo majora, unguiculata, subconvoluta. Stamina 5, hypogyna, petalis alterna, erecta, rigida, an $\mathbf{t h}$ era e introrsae, biloculares, medio affixae, erectae, longitudinaliter dehiscentes. Discus cyathiformis, pentagonus, carnosus, angulis complanatis, Ovarium liberum, ovatum, obtuse trigonum, triloculare. 0 vula circiter sex, placentae versus apicem axeos appensa. Styli 3, subulati, ereeti..... Frutex ch in ens is, glaber; ramis junioribus cinereo-maculatis, adultis cinereis, foliis oppositis, petiolatis, bbovato-lanceolatis, acuminatis, serratis, basi integerrimis, stipulis interpetiolaribus ovatis, serrulatis, pallidis, thyrso terminali congesto, paucifloro, 
pedicellis basi bractea squamulaeformi, medio bibracteolatis, floribus albidis, demum flavescentibus, inodoris.

0 ehra nt he Lindley in Bot. Reg. $t, 1819$.

\section{Dralo CCXIX. Flatineae.}

ELATINEAE Cambessed, in Mem, Mus. XVIIT. 225. et in St. Hilaire Flor. Brasil. 1I. Arnott in Edinb. Journ. of nat, and geograph. sc. 1830. p. 426. Fiseher et Meyer in Linnaea X. 69. Meisner Gen. 131. (95.) ELATINACEAE Lindley Introduct. edit. $I I, p, 88$.

Herbar annuae, paludosae, saepissime parvulae, caulibus plerumque prostratis, e nodis radicantibus. Folia opposita, sessilia v. brevissime petiolata, integerrima v. denticulata, juniora saepe ramuli axillaris abbreviatione in vetustiorum axillis fasciculata, interdum verticillum mentientia. Stipulae interpetiolares membranaceae, saepissime incisae.

Fronss hermaphroditi v. rarius abortu unisexuales, regulares, axillares, solitarii v. fasciculati, pedunculati v. sessiles, interdum glomerati.

Calyx tri-quadri-quinquepartitus, laciniis aequalibus, acutis, aestivatione imbricatis.

Corollas petala $3-5$, hypogyna, calyeis laciniis alterna, aestivatione imbricata.

Stamiva hypogyna, saepissime duplo petalorum numero, iisdem per vices alterna et opposita, rarius, nee nisi in calyce trimero, simplici petalorum numero iisdemque alterna. Filamen ta filiformi-subulata, libera, An therae introrsae, biloculares, dorso affixae, loculis appositis, parallelis, antice longitudinaliter dehiscentibus.

Ovarien liberum, sessile, tri-quadri-quinqueloculare, carpidiorum marginibus valvatis, v. plus minus introflexis, cum columnae centralis placentiferae angulis magis minusve prominulis connatis. $0 \mathrm{v}$ u la in loculis plurima, angulo centrali inserta, anatropa. Styli loculorum numero, breves; stigmat a capitata.

Capsuca stylis persistentibus superata, triquadri-quinquelocularis, ad suturas dehiscens, tri-quinquevalvis, valvis margine planis, v. juxta totam longitudinem, aut superne tantum introflexis, cum columnae liberae, juxta totam Iongitudinem v. inferne septiferae, inter septa seminiferae angulis alternantibus.

Srmixa plurima, eylindracea, recta v. incurva, longitudinaliter costata, transversim rugosa, rarius ellipsoideo-oblonga, laevia, rhaphe filiformi, ventrali v. laterali, umbilicum basilarem eum chalaza apicali parum manifesta jungenté. Al bum en nullum.

Emaryosis exalbuminosi, orthotropi v. homotrope incurvi, cylindracei cotyledones breves, obtusae, ra di c u la cotyledonibus multo longior, umbilicum attingens.
Elat in e a per totum fere terrarum orbem dispersae, fossas, oryzeta et lacus incolentes, a Caryophylleis Alsineis, quibuscum olim consociatae, differunt stigmatibus capitatis, et embryone rectiusculo, exalbuminoso, ab Hypericineis columnae centralis praesentia diversae, a Lythrarieis petalorum et staminum insertione hypogyna longius distant.

54\%5. Elatime LINN. Caly $\mathrm{x}$ tri-quadripartitus. Corollae petala 3 v. 4 , hypogyna. Stamin a 6 v. 8 , rarissime 3 et petalis alterna, hypogyna; filamenta libera, antherae introrsae, biloculares, longitudinaliter dehiscentes, $O \mathrm{va-}$ rium tri-quadriloculare. $O v \mathbf{v} l a$ in loculis plurima, angulo centrali inserta, anatropa. Styli $3-4$, breves; stigmata eapitata. Capsula tri-quadrilocularis, tri-quadrivalvis, valvis margine planis, cain columnae liberae septiferae, inter septa seminiferae angulis alternantibus. Semina plarima, cylindracea, recta v. plas minus incurva, longitudinaliter costata, transversim rugosa, $\mathrm{nm}$ bilico basilari. Embry on is exalbuminesi, orthotropi v. homotrope inenrvi radicula nmbilico proxima, - Herbae in temperatis subtropicisque totius orbis obviae, radicantes; foliis oppositis, junioribus interdum in axillis fasciculatis, stipulis membranaceis, floribus axillaribus, pedunculatis $v$. sessilibus, solitariis $v$. fasciculatis.

El a t in e Lion. Gen, n. 685. Gärtner Ir, 142. DC. Prodr. I. 390. Cambessed, in Mem. Mus, XVIIT. 229.

a. Crypta Nuttall, Flores trimeri. Stamina 3 v. 6. - Folia integerrima, axillaria fasciculata nulla.

C rypta Nuttall in Journ. Academ, n. sc. Phila. delph. $1.117, t, 6, f .1$. Cry ptin a Rafinesq. E, triandra Sehkubr $t$, 109. b. f. 2, E. a m bigu a Wight in Hook. Bot. Miscell. App. t. 5. Illustr. t. 25. E. hex. a $\mathrm{d}$ ra DC. Ie, plant. Gall, rar, $t, 43 ., f .1$.

b. HYDROPIPER. Flares tetrameri. Stamina 8. - Fo. lia integerrima, axillaria fasciculata nulla.

B irolia Bellardl in Mem.. Academ. Turin. XVIT. 64. E. H y dropipe r Linn. Sehkuhr $t$. 1096. DC. Ic. plant. Gall. rar. t. 43. f. 2.

c. Alsinastrum. Flores tetrameri. Stamina 8. Folia subdentata, junioribus arillaribus pseudo-ver. ticillata. - Potamopitys Buxbaum E. A Isinastrum L. Gärta, t, 112,

5486. IBergia $L I N N$, C al y $x$ tri-quinquepartitus. Corulla e petala 3 v. 5 , hypogyna. Stam in a 10 , rarius 3 et petalis alterna, liypogyna; fil a m enta libera, an therae introrsae, biloeulares, longitudinaliter dehiscentes. Ovarium quinqueloculare. Ovula in loculis plurima, an gulo centrali inserta, anatropa. Styli 5 , breves; st igma ta capitata. C a p 8 ula quinquelocularis, quinquevalvis, valvis margine introflexis, cum colomnae liberae, juxta totam longitudinem septiferae, inter septa seminiferae angulis alternantibus. S emina plurima, cylindracea, leviter incnrva, Iongitudinaliter costata, transversim rugosa, umbilico basilari. Em bry on is exalbuminosi, homotrope incurvi radicula umbilico proxima. Herbae in Asia et Africa tropica et subtropica crescentes, erectae; foliis oppositis, junioribus saepe ranulorum axillarium abbreviatione fasciculatis, stipulis membranaceis, floribus axillaribus, pedunculatis $v$. sessilibus, glomeratis.

Bergia Linn. Gen, n, 791. Roxbargh Plant, Corom. t. 142, DC. Prodr. I. 390. Guillem. et Perrot. Flor. Seneg. I. 42, t. 12. Wight in Hooker Bot, Miscell. App. t. 28. 
Cambessed. in Mem. Mus. XVIII, 299. Elatines s p, Delile Flor, aegypt. $t$. 26, f. 1 .

$548 \%$. Nilerimea $C A M B$. Caly x quinquepartitus. Corolla e petala 5 , hypogyna. Stamina 10 , hypogyna; fil amenta libera, antherae introrsae, biloculares, longitudinaliter dehiscentes. Ovarium quinqueloculare. OvuIa in loenlis plurima, angulo centrali inserta, anatropa. Sty Ii 5, breves; stigmat a capitata. Ca psula quinquelocularis, septicide quinquevalvis, valvis margine introflexis, septa constitnentibus, columna centrali libera, seminifera, basi septa brevia valvis alterna exserente. S e mina plurima, ellipsoideo-oblonga, laevia, umbilico basilari. E mbryonis exalbuminosi, orthotropi radicula nmbilico proxima. - Herba brasiliensis, radicans, Bergiae facie; foliis oppositis, junioribus interdum in axillis fasciculatis, stipulis membranaceis, floribus axillaribus, pedunculatis.

Merim a Cambessed. in Mem. Mus. XVIIT. 230, et in St. Hilaire Elor. Brasil. II. 160, t. 107.

\section{GENUS DUBIUM.}

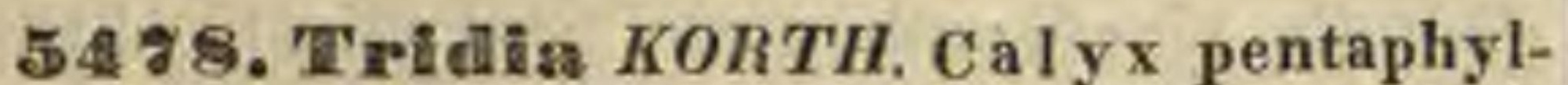
Ins, foliolis ovatis, aentis, imbricatis, exterioribus paullo majoribus. Cor o 11 a e petala 5, hypogyna, calycis foliolis alterna, ovata, obtusa, aestivatione apice subcontorta. Stam in a 10 , hypogyna, petalis paullo breviora; fil a m enta filiformia, libera, a ntherae introrsae, biloculares, subgloboso-didymae, longitudinaliter dehiscentes. Ovarium liberum, sessile, subtrigonnm, uniloculare. Ovula in placentis tribus suturalibus plurima, biseriata. Styli 3 , teretes; $s \mathrm{tigmata}$ subcapitata. Capsula calyce eincta, ovato-subtrigona, membranacea, unilocularis, trivalvis, valvis apice styliferis, margine seminiferis. Se mina plurima, oblonga, teretiuseula, transversim costata. Embryo in axi albuminis; cotyledonibus ovato-oblongis, basi subtruncatis, ra dicula tereti, minima. - Herba sumatrana, semipedalis; caule erecto, tetragono, saepe partito, foliis oppositis, basi membranulae ope subcoalitis, sessilibus, cordatis, ovatis, acutiusculis, quinquenerviis, margine reflexis, floribus axillaribus $v$, alaribus $s 0$. litariis, bracteis oblongis.

Tridi a Korthals in Hoeven et Vriese Tijdschrift. III 17. $t, 1$.

\section{Ordo CCXX, Reaumeuriaceas.}

REAUMURIEAE Ehrenberg in Linnaea $I$. 274. Annal. scienc, nat, XII, 78. REAUMURIACEAE Lindley Introduct. edic. II. p. 91 .

Frotices v. suffrotices divaricato-ramosi, ramis ramulisque teretibus, plus minus glauci, glabri. Folia alterna, saepe conferta, sessilia, integerrima, plus minus carnosa, glandulis immersis, resinoso-alcalinis conspersa. Stipulae nullae.

Flores hermaphroditi, regulares, in axillis foliorum $v$, in apice ramulorum solitarii, sessiles.

Canyx nune campanulatus, plus minusve profunde quinquefidus, bracteolis imbricatis stipatus, nune polyphyllus, foliolis orbiculatis pluriseriatim imbricatis, interioribus sensim majoribus.

Corollae petala 5, hypogyna, sessilia v. unguiculata, nuda v. basi squamulis dnabus, margine hinc nervo medio adnatis, illinc liberis, ambitu fimbriato-ciliatis, interdum petala collateralia connectentibus aucta, aestivatione convolutiva, plus minus inaequilatera, oblique venosa, sub anthesi patentiuscula, din persistentia, tandem decidua.

Stauina hypogyna, nune indefinita, libera v. irregulariter polyadelpha, interdum etiam petalorum basibus adglutinata, nunc definita 8 v. 10 , ima basi in annulum brevissimum hypogynum coalita; filam enta filiformi-subulata, a ntherae introrsae, biloculares, ovatoellipticae, incumbentes, versatiles, longitudinaliter dehiscentes.

Ovarium sessile, liberum, e carpidiis duobus, quatuor v. quinque, marginibus valvatim connatis conflatum, placenta basilari brevi, biquinqueloba, inter lobos septa tenuissime membranacea, parietem attingentia exserente, biquinqueloculare, septis apicem versus oblique deliquescentibus superne uniloculare. Ovula in placentae lobis, ad loculorum anguli centralis basim sitis, solitaria (?) gemina v. quaterna, adscendentia, anatropa. Styli loculorum numero, distincti, filiformes v. subulati; stigm at a simplicia.

Capsura membranacea, bi - quinquelocularis, interdum septis seminum incremento inaequali ad parietem repressis unilocularis, biquinquevalvis, valvis dissepimentis tenuissimis oppositis, et ab iisdem solutis.

Semina pauca, ovulis saepe pauciora, erecta, majuscula, compressa, dense ferrugineo-pilosa, pilis sursum spectantibus. A I b u men parcum, farinosum, ad seminis latera incrassatum.

Eмввуо intra albumen orthotropus, ejusdem longitudine, radicula exserta, infera.

Ordo parvus, e speciebus paucis, regionem mediterraneam et Asiam mediam inhabitantibus constans, hinc Hypericineis arete affinis, illine per Hololachnam ad Tamariscineas accedens, ab Aizoideis et Mesembryanthemeis, quibus Reaumuria olim consociata, longiss distans.

54\%9. Halolaellua EHRENB. Calyx campanulatus, quinquefidus, bracteolis tribus cinctus. Corolla e petala 5, hypogyna, calyeis laciniis alterna, oblongo-inaequilatera, unguieulata, ungne nudo, aestivatione convolutiva. Stam ina 8 _ 10, ansulo brevissimo hypogyno inserta; filamenta filiformi subulata, libera, an therae biloculares, ovato-ellipticae, incumbentes, longitadinaliter dehiscentes. O vari n m sessile, bi-quadriloculare, OvuIa in loculis solitaria (?), placentae brevi ad angulum centralem hasilari inserta, adscendentia, anatropa. Sty 1 i $2-4$, breves, subulati; $8 \mathrm{tig} \mathbf{m}$ a $t$ simplicia. Cap 8 ula bi-quadrilocularis, Toculicide bi-quadrivalvis, valvis a 
dissepimentis tenuissimis solutis. Semina in locnlis solitaria (?), erecta, undique sursum pilosa. Embryo..... - Suffrutex Asiae mediae; foliis allernis, confertis, obtuse trigonis, carnosis, patentibus, minutissime punctatis, floribus axillaribus solitariis, sessilibus.

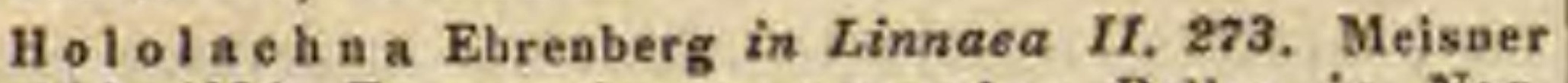
Gen, 129. (93.) T в marix songarica Pallas in Nov. Act. Petrop. X. 324, t. 10, f. 4.

5480. Thenmmania HASSELQ. C aly x campanulatus, quinquefidus, bracteolis subimbricatis cinctus. C oro 11 a e petala 5 , hypogyna, calycis laciniis alterna, ovata, basi squamulis geminis submarginalibus fimbriato-ciliatis aucta, aestivatione convolutiva. Sta m i n a plurima, hypogyna; fil a menta subulato-filiformia, basi irregulariter polyadelpha, a n the ra e biloculares, ovato-ellipticae, incumbentes, longitudinaliter dehiscentes. Orarin m sessile, basi quinqueloculare, septis apice deliquescentibus superne uniloculare. O v u 1 a in loculis 4, placentae brevi ad angulum centralem basilari inserta, adscendentia, anatropa. Styli 5, filiformes, elongati; stigmata simplicia. C a p \& $\mathrm{I}$ a quinquelocnlaris, loculicide quinquevalvis, valvis a dissepimentis tenuissimis soIntis. $\mathrm{S}$ e $\mathrm{m}$ i $\mathrm{n}$ a in loculis gemina $\mathbf{v}$. abortu solitaria, erecta, oblonga, compresso-triquetra, undique sursum pilosa. E mbry o orthotropus, albumine parco, farinaceo, ad latera seminis incrassato cinctus, $\boldsymbol{r}$ ad i $\mathbf{e}$ la exserta, infera. - Suffrutices diffusi, in regione mediterranea et Asia media indigeni; folïis alternis, subcarnosis, glaucis, glandulis immersis notatis, floribus axillaribus et in apice ramulorum terminalibus, solitariis.

Re a m u ria Hasselquist ex Linn. Gen, $n$, 686. Lam. t. 489. Salisbury Parad. Lond, t. 18. Jacq. fil, Eclog t. 18. Bot. Reg. t, 845. Bot, Mag, t, 2057. DC. Prodr. $1 I I$. 456. Ehrenberg in Linnaea II. 273. Meisner Gen, 129. (93). H y perici sp. Labillard $S y r$, Decad. $I T, t, 10$.

5481. Eiellawalliar $L E D E B$. C a $I y \times p a-$ lyphyllus, foliolis pluriseriatim imbricatis, orbiculatis, interioribus sensim majoribus. Corollae petala 5, hypogyna, calycis laciniis alterna, unguiculata, oblique truncata, basi squamulis gemi. nis, submarginalibus, fimbriato - ciliatis aueta, aestivatione convolntiva. Sta $m$ in a plurima, hypogyna; filamenta libera, antherae biloculares, longitudinaliter dehiscentes, Ovarin m sessile, basi quinqueloculare, septis apice deliquescentibus superne uniloculare. Ovala in loculis 2 , placentae brevi ad angulum eentralem basilari inserta, adscendentia, anatropa. St yli 5, filiformes; stigm at a simplicia. Cap sula dissepimentis membranaceis ad parietem repressis unilocularis, quinquevalvis, pentasperma v, abortu monosperma. Semina erecta, compressa, undique sursum pilosa. Embryo orthotropus, albumine parco, farinaceo, ad latera incrassato cinctus, radicula exserta, infera. - Frutex caspicus, divaricato-ramosus; foliis alternis, lineari-teretibus, carnosiusculis, glaucis, glandulis immersis notatis, pedunculis axillaribus solitariis, unifloris.

Richwaldia Ledebour in Eichwald Plant. Casp. cauc. p. $38, t, 34$.

\section{Ordo CСХХ1. Tamaniscineae.}

PORTUlacearuM gen. Jassieu Gen, 313. TAMARIS. CINEAR Desvaux Dissert, 1815. ex Annal, se. nat. IV. 344. St. Hilaire in Mem, Mus. IT, 205. DC. Prodr. III, 95, Es. renberg in Linnaea $I I .241$. 282. Annal. sc, nat. XII, 68. TAMARIC ACEAE Lindley Introduct, edit, II, p. 126. TAMA. RISCUS Tournefort Inst. 661. TAMARIX Linn. Gen, 375. Willdenow in N. Schrif. Berlin, nat. Fr. IV. 78.

Herbae suffuticosae, frutices v. Arbusculas. Folia alterna, sessilia, minula, subimbricata, carnosiuscula, interdum amplexicaulia, integerrima, saepe impresso-punctata, plerumque glaucescentia. Stipulae nullae.

Flones hermaphroditi, regulares, in racemos spicatos ramulos terminantes dispositi, pedicellis bractea suffultis, albi v. rosei.

Calyx liber, persistens, pentaphyllus v. rarius tetraphyllus, foliolis imbricatis, biseriatis, duobus exterioribus, interdum foliolis basi cohaerentibus quinquepartitus.

Corollas petala 5, hypogyma, calycis laciniis alterna, aestivatione imbricata, marcescentia.

Stamina petalis numero aequalia et alterna v. dupla, nunc disci hypogyni margini inserta, geminis ejusdem dentibus basi stipata et libera, nunc immediatim hypogyna; fil a mentis inferne in tubum membranaceum coalitis, superne liberis. A $\mathrm{n} t \mathrm{~h}$ e $\mathrm{r}$ a e introrsae, biloculares, dorso paullo supra basim insertae, loculis appositis, longitudinaliter dehiscentibus.

Ovarium liberum, sessile, saepissime trigonum, e carpidiis tribus, rarius duobus v. quatuor valvatim connatis conflatum, placentis parietalibus longitudinalibus v. supra basim deliquescentibus, cum suturis alternis. Ovula plurima, adscendentia, anatropa. Styli placentarum numero, liberi v. rarissime in unum coaliti. Stigmata obtusa v. truncato-dilatata.

Capsula unilocularis, v. placentis hasi productioribus inferne interdum pseudo-trilocularis, saepissime tri- rarius bi-quadrivalvis, valvis medio placentiferis, placentis e basi crassiore sursum deliquescentibus, v. paullo supra basim desinentibus.

Semina plurima, adscendentia, $t$ e $s t a$ membranacea, ad chalazam apicalem pilis confertis erectis longe papposa, v. in rostrum rectum, pilis patentibus plumosum producta. Albu m e n nullum.

Eивахо orthotropus, semini conformis. Cotyledones oblongae, obtusae, plano-convexae. Ra dicula brevis, conica, umbilicum basilarem attingens.

Ta maris cine ae in hemisphaerae borealis regionibus temperatis calidioribus obviae, a Lythrarieis, quibus arctius quam ordinibus parietalibus affines creduntur, corollae et staminum insertione hypogyna, disco nempe staminifero a calyce libero, facillime distinguuntur.

5482. Myriearia DESV. Caly x quinquepartitns, laciniis aestivatione imbricatis. $\mathrm{Co}$ roll a e petala 5, hypogyna, ealycis laciniis alterna, aequalia. Stamin a 10, hypogyna; fila- 
men ta inferne in tubulum membranaceum coalita, superne libera complanato-subulata, alterna, petalis opposita breviora, a ntherae introrsae, biloculares, longitudinaliter dehiscentes. $0 \mathrm{v}$ ari $\mathbf{u m}$ sessile, uniloculare. Ovula in placentis tribus, prope basim parietalibus, cum suturis alternańtibns plurima, adscendentia, anatropa. St y1i 3 , in unum coaliti; stigmat a subeapitata. Cap s u la unilocularis, valvis baseos medio placentam brevem sursum deliquescentem gerentibns. S emina adscendentia, testa membranacea, ad chalazam apicalem in restrum rectum, pilis patentibus plumosum producta. E in bry on is exalbuminosi, orthotropi radi cula umbilico proxima, - Herbaev, suffrutices, in Europa et Asia media crescentes; foliis alternis, sessilibus, linearilanceolatis, parvis, confertis, racemis spicaeformibus terminalibus simplicibus $v$. compositis, pedicellis bracteatis.

M y rlearia Desvaux in Annal. sc. nat. IV. 348. DC. Prodr. III. 27. Ehreuberg in Linnaea II, 252, Royle Himalay, $t$, 45. T a maric is 8 p. Linn. Miller Ic. $t .262 . f .2$. Selakuhr t. 35. Pallas Flor, ross. $t .80$.

5483. Troielnamrous ARNOTT. C a ly x pentaphyllus, foliolis imbricatis. Corolla e petala 5, hypogyna, calycis foliolis alterna, subinaequalia. St a min a 10 , disci hypogyni urceolati, decemdentati margini inter dentes inserta; fi l a m e n $t$ a libera, alterna petalis opposita breviora, anth erae introrsae, biloculares, longitudinaliter dehiscentes. O vari um sessile, uniJoculare. Ovula in placentis parietalibus duabns v. tribus, cum suturis alternantibus plurima, adscendentia, anatropa. Styli $2 \_3$, breves; stigmat a obtusa. Ca p o u I unilocularis, bi-trivalvis, valvis medio placentam inferne crassiorem, sursum deliquescentem gerentibus. Semina adscendentia, testa membranacea, ad chalazam apicalem in rostrum rectum, pilis patentibus plumosum prodécta. Embryon is exalbuminosi, orthotropi radicul a umbilieo proxima, - Frutex indicus; foliis alternis, oblongis, amplexicaulibus, adpressis, racemis terminalibus spicaeformibus, floribus majusculis.

Trichaurus Arnott in Wight Prodr. I. 40. Wight Ic. $t$. 22, Illustr. $t$. 24. $f$. B. T a marix ericoides Willd. in N. Sohrift. Berlin, nat. Fr. IV. $t, 4$. M y r lea. ria vaginata Desv.

5484. Tamagrix LINN. C a l y x tetrapentaphyllus, foliolis imbricatis. Cor oll a e petala 4 v. 5, hypogyna, calycis foliolis alterna, aequalia. Stamina 4 -10, disei hypogyni, seutelliformis margini inserta, hasi utrinque dense glanduloso stipata; fila m ent a libera, aequalia, antherae introrsae, biloculares, longitudinaliter dehiscentes. Ovarinm sessile, uniloculare. Ovula in placentis parietalibus tribns, rarius duabns v. quatuor plurima, adscendentia, anatropa. Sty$1 \mathrm{i} 3$, rarius 2 v. 4 ; $8 \mathrm{ti} \mathrm{g} \mathbf{m}$ a t a truncata, dilatata. Capsula unilocularis, tri-rarius bi-quadrivalvis, valvis medio placentam inferne incrassatam, sursum deliquescentem gerentibns. Se m in a adseendentia, testa membranacea, ad ehalazam apicalem dense papposa. Km bry on is exalluminosi radicula umbilico basilari proxima. - Frutices $v$, arbores, in regione mediterranea, insulis Canariis et India orientali crescentes; folitis alternis, squamaformibus, imbricatis, floribus parvis, in foliorum axillis solitariis, in racemos spi catos, saepissime paniculatos dispositis.
T a marix Desvaux in Annal. sc. nat. 1V. 348. DC. Prodr. III. 95. exel. sp. Ehrenberg in Linnaea II. 258. Wight et Arnott Prodr. I. 40.

a. OLIGADBNIA Blirenb, l. c. Stamina 4, disci dentibus octo interposita. - T. $\mathrm{F} a \times a$ Will. T. $t$ e $t a n d r a$ Pall. b. DECADENIA Elurenb. 2 . c. Stami n a 5 , discl dentibus decem interposita. - (Miller Ic. $t, 262, f .1$. Pallas Fl. ross, I. t. 77. 79. St. Hilaire Mem, Mus. II. 6. 4. f. 17. Wight Illustr.t. 24. Webb et Berthel. Flor, Canar. t. 25.)

c. POLYADENIA Ehreab. $l$, c. Sta mina 10 , disci dentibus viginti interposita. - T. passerinoides Delll. excl. reliq.

\section{Classis III. II IISperides.}

Arbores v. frutices, succo in paucis balsameo, in pluribus aqueo. Folia alterna, composita v. rarissime simplicia, saepissime integerrima. Stipula e nullae. Calyx liber, aestivatione imbricata. Corolla e petala hypogyna, ealycis laciniis numero aequalia, aestivatione valvata v. convolutiva. Stamina petalorum numero duplo v. quadriplo, rarius multiplo v. simplici, libera, monadelpha v. polyadelpha. C a r p i dia plura, in ovarium uni-pluriloculare coalita. Ovula in loculis solitaria v. plura, anatropa, rarius orthotropa v. amphitropa. E m b r y o saepissime exalbuminosus, rarius albumine carnoso inclusus. Cotyle don es plerumque carnosae, saepe conferruminatae.

\section{Drdo CCXXII. Heanimiaceae.}

HUMIRIACEAE Martius Nov, gen. et $s p$, II. 147. Adr. Jnssieu in St. Hilaire Flor, Brasil. IT, 87, Lindley Intro. duet. edit, II, p. 104. Meisuer Gen, 17. (34.)

Arbores, arbuscular v. Frotices, in America tropica indigenae, succo balsameo. Folia alterna, simplicia, coriacea, nitida, penninervia, integerrima v. interdum obiter crenulata, saepe punctis glandulosis marginata, breviter petiolata, v. limbo in petiolum aut interdum in caulem decurrente sessilia. Stipula e nullae.

Fuores hermaphroditi, regulares, axillares v. terminales, irregulariter cymosi v. corymbosi, pedunculis basi articulatis, bracteatis.

$\mathbf{C}_{\Delta L \mathbf{X}}$ quinquefidus v. quinquepartitus, persistens, lobis aequalibus, aestivatione imbricatis, apice interdum callosis, v. dorso poro impresso notatis.

Corollar petala 5, hypogyna, calycis lobis alterna, oblonga v. lineari-lanceolata, coriaceo - carnosula, dorso medio saepe incrassata, aestivatione imbricata v. contorto convolutiva, sub anthesi patentia v. reflexa, decidua.

Stamiva hypogyna, duplo v. quadruplo petalorum numero, rarius indefinita, bi-quadrimultiseriata. Filamenta basi in tubum connata, superne libera, filiformia, alterna breviora, rarius in phalanges petalis alternas congesta, phalangibus basi in tubum coalitis. 
Antherae introrsae, biloculares; loculi appositi, ad basim connectivi in ligulam crassam obtusam producti adnati, discreti, paralleli v. divergentes, longitudinaliter dehiscentes. P ol$1 \mathrm{in}$ is granula globoso-trigona, angulis papillas diaphanas exserentia. Ovarium liberum, sessile, disco annulari carnoso, costato, dentato basi arete cinctum, quadri-quinque-sexloculare, loculis apice ob septa prima juventute incompleta perviis, demum clausis, continuis v. septo secundario transverso bilocellatis. Ovula loculorum angulo centrali inserta, pendula, anatropa, nunc solitaria, nune gemina superposita, interdum septo transverso segregata. Stylus terminalis, cylindricus; stigma quinquelobum, lobis obtusis, patentibus.

Drupa parce carnosa, putamine osseo, quadri-quinqueloculari, v. abortu uni-triloculari, loculis continuis v. septo transverso bilocellatis.

Semrna in loculis locellisve solitaria, inversa, testa membranacea, nitida. A l b u m e n carnosum, copiosum.

Embryo in axi albuminis orthotropus, ejusdem longitudine, cylindricus. Cotyledones brevissimae, obtusae. Radicula elongata, umbilico proxima, supera.

Ordinis distincti a cl. Martius primum indieati, Meliaceis et Aurantiaceis, illine fortassis Symploceis affinis, rudimenta. Differt a Meliaceis, in quarum catervam e Jussiei incertae sedis generibus Humirium a Candolleo est evocatum, habitu, staminibus interdum indefinitis, insigni connectivi dilatatione, albuminis carnosi copia, et embryonis gracillimi elongata radicula. Aurantiaceae, ovulorum insertione et situ apprime convenientes, facie, connectivo haud incrassato, et seminibus exalbuminosis facillime distinguuntur. Symploceae et Styraceae qualitatibus, ovulorum insertione, et embryonis forma similes, corolla gamopetala et ovarii cum calyce cohaesione diversae.

Humirii species nonnullae e trunco inciso resinam fundunt balsameam (Balsamo de Umiri), balsamo Copaivae succedaneam, peruani aemulam.

5485. Saceoglotis MART. Cal yx quinquefidus, lobis ovatis, apice eallosis, aestivatione imbricatis. Coroll a e petala 5 , hypogyna, lineari-lanceolata, aestivatione imbrieata, sub anthesi revolnta, deeidna. St a in in a 10 , hypogyna; filamenta basi in tubuin eoalita, superne libera, filiformia, alterna breviora, antherae introrsae, biloculares, loculis ad basim connectivi in ligulam carnosam, triangularem, obtusam produeti adnatis, discretis, longitudinaliter dehiscentibus. Ovarium libernm, sessile, hasi diseo annulari vigintidentato cinctum, quadri-sexloculare, $O$ v $\mathbf{u}-$ 1 a in loculis solitaria, angulo centrali prope apicem inserta, pendula, anatropa. Stylu s terminalis, filiformis; stigma depresso-capitatum, ob. solete lobatum. .... - Arbor brasiliensis; foliis alternis, simplicibus, obsolete crenulatis, subcoriaceis, nitidis, petiolatis, stipulis nullis, corymbis axillaribus bipartitis, folio brevioribus, pedicellis basi decidue bracteatis.

Saccoglottis Martius Nov.gen.et sp. 1r.146. Meis. ner Gen, 17. (34.)

5486. Humirium $M A R T$. Cal yx quinquefidns, lobis ovatis, aestivatione imbricatis. $C_{0}-$ rolla e petala 5 , hypogyna, lanceolata, aestivatione imbricata, sub anthesi erecto-patentia, decidua. Stamina 20, hypogyna; fil amenta inferne in tubum coalita, superne libera, filiformia, ciliata, alterna breviora, antherae introrsae, biloculares, loculis ad basim connectivi in ligulam carnosam obtusam producti adnatis, discretis, longitudinaliter dehiscentibus. Ovarium liberum, sessile, basi disco adnato, vigintidentato cinctum, quinqueloculare, loculis septo trans. verso bilocellatis. $O$ v u la in loculis gemina, superposita, septo transverso sejuncta, hine in locellis solitaria, angulo centrali inserta, pendula, anatropa. Stylus terminalis, filfformis; stigma quinquelobum, lobis obtusis. D rup a sulucarnosa, putamine osseo, quinqueloculari, loculis septo transverso bipartitis, superposite decemlocellato, locellis monospermis, nonnullis interdum efnetis v. obliteratis. S em in a inversa, testa membranacea, nitida. Embryo in axi albuminis carnosi subcylindriens; cotyled onibus brevissimis, obtusis, rad i cula elongata, umbilico proxima, supera. - Arbores $v$. arbusculae, balsamifluae, in America tropica crescentes; foliis alternis, sinplicibus, integerrimis, coriaceis, nitidis, plerumque punctis glandulosis marginatis, sessilibus $v$, petiolatis, limbo in petiolum v. caulem decurrente, stipulis nullis, floribus axillaribus terminalibusque dense corymbosis, bracteatis, albis, parvulis.

H u mirium Martius Nov. Gen, et sp. IT. 142, t. 198. 199. Adr. Jussieu in St. Hilaire Flor. Brasil. IT. 88. Meis: ner Gen. 17. (34.) H u miria Jussieu Gen, 435. DC. Prodr. I. 619. Hu uir i Aublet Guian, I. 564, 2. 225. M y r o de ndron Sehreber Gen. n. 901. Werniseckia Scopoli Inttroduct. $n$. 764 .

548\%. Felleria NEES et MART. C a lyx quinquepartitus, lobis ovatis, dorso poro glanduloso impressis, aestivatione imbricatis. Co rolla e petala 5, hypogyna, oblonga, aestivatione contorta, sub anthesi patentia v. reflexa, decídua. Stam in a plnrima, hypogyna; fil a menta in fasciculos quinque cum petalis alternantes digesta, basi in annulum brevem coalita, superne libera, filiformia, a n the rae introrsae, bilocnlares, loculis ad basim conneetivi in glandulam conicam producti adnatis, parallelis, apice discretis, longitudinaliter dehiscentibus. Ovari um liherum, sessile, basi disco annulari dentato einctum, quinqueloculare. Ovula in loculis gemina, superposita, angulo centrali inserta, pendula, anatropa, inferioris funienlo longiore. Sty I u s terminalis, filiformis; s $t$ i $\mathrm{g} \mathrm{m}$ a quinquelobum, lobis obtusis. Drupa subcarnosa, putamine usseo, abortu unitriloculari, loculis monospermis. S e m in a inversa, test a membranacea, nitida. Embryo in axi albuminis earnosi parci subcylindrieus; cotyledonibus brevissimis, obtnsis, radicula elongata, nmbilico proxima, supera. - Arbusculae $v$. frutices brasilienses; foliis alternis, simplicibus, integerrimis, coriaceis, nitidis, petiolatis, exstipulatis, floribus in ramulis terminalibus iterato dichotomis cymosis, dichotomiis articulatis, superioribus bibracteatis, ovariis interdum loculo sexto auctis. 
Helleria Nees et Martius in N. A. N. C. XII. 39. t. 7. Martius Nov. Gen. et sp. II. 167. Adr. Jussieu in St. Hilaire Flor. Brasil. II. 90. Meisuer Gen. 47. (34.)

\section{Drdo CCXXIII. Dincinear.}

OLACINEAE Mirbel in Bullot. soc, philomat. 1813. n. 75. p. 377. Jussieu in Mem, Mus, II, 438, R. Brown in Elinders Voy. II. 570. Tuckey Congo 558. DC. Prodr. . 531. Bartling Ord, nat. 423. Meisner Gen. 65. (33.) OLACACEAE Lindl. Introduct. edit. II. p. 32.

Arborgs v. frutices, erecti v. interdum scandentes, inermes v. ramis axillaribus spinescentibus armati, glabri v. parce pubescentes. Foli a alterna, interdum disticha, simplicia, integerrima, petiolata, nonnunquam squamaeformia, saepissime coriacea, petiolo cum ramulo articulato. Stipula e nullae.

Flores regulares, hermaphroditi v. abortu polygami, axillares, corymbosi, racemosi v. spicati, distincte v, obsolete bracteati, rarissime terminales, paniculati, pedunculis basi articulatis.

Calyx liber, parvus, gamophyllus, truncatus v, denticulatus, persistens, fructifer immutatus v. auctus.

Corollak petala quatuor-quinque v. sex, hypogyna, subcoriacea, intus saepe villosa, aestivatione valvata, libera v. omnia aut quaedam mediantibus staminibus per paria connexa, decidua.

Stamina hypogyna, libera v. filamentorum ope cum petalis cohaerentia, rarius petalis numero aequalia et alterna, saepissime dupla, iisdem per vices alterna et opposita, omnia fertilia, v. alterna petalis opposita fertilia, cum totidem sterilibus alternantia, rarius petalis alterna omnia v. nonnulla solum fertilia, et sterilia indivisa v. bifida petalis opposita. Fil amenta filiformia v. complanato-subulata. Anther ae introrsae, biloculares, cordato-oblongae, erectae, longitudinaliter dehiscentes.

Ovarium liberum, nune uniloculare, columella centrali libera $v$, rarius nulla, nunc tri-quadriloculare. Ovula in ovario uniloculari nunc gemina, cavitatis apici collateraliter appensa, nunc unicum v. terna, ex apice columellae liberae collateraliter pendula, in ovarii plurilocularis loculis solitaria, ex apice anguli centralis pendula, semper anatropa. St ylus terminalis, filiformis, interdum subnullus. S tigma truncatum, capitatum v. obsolete trilobum.

Drupa calyce minimo stipata va ampliato ciucta, succulenta v. exsucca, putamine crustaceo v. osseo, uniloculari; monospermo.

Srmen inversum, testa membranacea, umbilico basilari apicem fructus respiciente, ope rhapheos filiformis, interdum ubsoletae, cum chalaza apicali, basim carpicam spectante, conjuncto. Albumen carnosum; copiosum.
Embryo in axi albuminis carnosi orthotropus, ejusdem dimidio brevior, rarius longior, cylindricus; cotyledonibus semiteretibus, radicula umbilico proxima, supera.

Olacinea e inter tropicos totius orbis et in Nova-Hollandia extratropica parvo numero crescentes, dubiae affinitatis, a Brownio Santalaceis adjectae, a Jussieuo prope Sapoteas coliocatae, proxime ad Aurantiaceas, ut ut ovarii et seminis structura distinctissimas, accedere videntur.

Genera plura non satis nota, olim accuratius explorata, ordinis affinitatem illustrabunt.

5488. Teneina ADR. JUSS, Calyx brevis, quinquefidus, persistens. Co roll a e petala 5 , disco hypogyno inserta, basi intus villosa, aestivatione valvata, sub anthesi patentia. Stamin a 5, cum petalis inserta, iisdem alterna; filamenta crassiuscule filiformia, a $n$ ther a e introrshe, biloculares, cordatae, medio dorso insertae, longitudinaliter dehiseentes. Ov a r i n m libernm, vilhosum. Ovula 2 , ex apice cavitatis collateraliter pendula. Stylus brevis, ineurvus; stig ma truncatum. Caps u la coriacea, ovato-oblonga, mucronata, villosissima, unilocularis, abortu monosperma, indehiscens. Semen inversum, subglobosum, testa nembranacea, albumine carno8o. Embryo.... _ Frutex senegalensis, ramosus; ramis subcompressis, villosis, foliis alternis, approximatis, cauli appressis, breve petiolatis, ovatis, integerrimis, coriaceis, supra lucidis, subtus reticulatis, utrinque glabris, stipulis nullis, floribus terminalibus, laxe paniculatis, bracteolatis, pedunculis dense pubescentibus, bracteolis minimis, ciliatis, villosis, caducis, alabastris oblongis, rufescenti-villosis.

I c a eina Adr. Jussieu in Mem. soo. h. n. Paris. $I$.

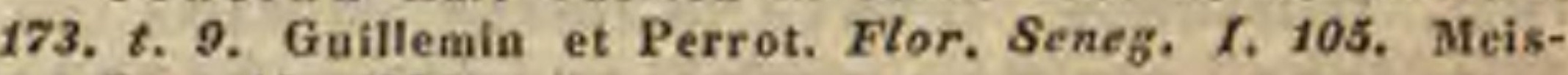
ner Gen. 45. (33.)

5485. Bpilia $R O X B$. C a 1 y $x$ minimus, quinquedentatus. Co roll a e petala 5 , hypogyna, libera, oblongo-lanceolata, aestivatione valvata, sub anthesi patentissima. St a m in a 5, hypogyna, petalis opposita, cum squamulis quinque carnosis, truncatis, cuneatis alterna; fil a m enta subulatocomplanata, a ntherae introrsae, biloculares, ovatae, Iongitudinaliter dehiscentes. Ova ri u m libernm, conicum, velutinum, uniloculare. OvuI n m unicum, ex apice columellae centralis liberae, conoideae pendulum, anatropum. St ig m a sessile, obtusum, tripunctatum. D r p p a baccata, putamine monospermo, S e m e $\mathbf{n}$ inversum. E mbr yo in axi albuminis carnosi orthotropus, teretiusculus, radicula supera, - Frutices in $A$ sia et Africa tropica crescentes, ramosissimi, subscandentes; foliis alternis, subdistichis, petiolatis, coriaceis, supra nitidis, integerrimis v. obsolete serrulatis, cum ramulo articulatis, deciduis, stipulis nullis, floribus axillaribus minimis, pedunculi bracteis squamaeformibus, pellato-orbiculatis, singulis subtrifloris, in amentum dense imbricatis, sub anthesi deciduis.

Opilla Roxburgh Plant. of Coromand. II. 31. t. 158. Meisner Gen. 45. (33,) Wieht Illustr. $t$, 40, Groutia Guillemin et Perrot. Flor. Seneg. I, 100. t. 22.

* Lepionurus Blume. Bijar. 1143. Flores aborta monoici. C al y $\times$ liber, parvus, integerrimus, coloratus. Corolla profunde quadripartita, lacinils pateatibus. Sta- 
n Ina 4 , corollae laciniis opposita; fila menta brevissi. ma, basi corollae inserta, a thera e.... Ovarium margine brevi, carnoso cinctum..... Stig m at a 4 , acuta, sessilia. Dr a pa baceata, putamine monospermo. S e m e n alhuminosum. E mb ryo iuversus. - Frntex $j a v a n i c u s$; folits alternis, oblongis, integerrimis, glabris, spicis axillaribus, pendulis, ante anthosim bracteis imbricatis trifloris oblectis.

54D0. Ximenia PLUM. C a ly $\mathrm{x}$ minimus, quadrifidus, fructifer haud mutatus. Corollae petala 4 , hypogyna, inferne intus villosa, aestivatione valvata, apicibus nudis sub anthesi revoInta. Stam ina hypogyna; filamenta capillaria, antherae introrsae, biloculares, lineares, erectae, longitudinaliter dehiscentes, Ova ri u m liberum, triloculare. O v u 1 a in loculis solitaria, ex anguli, centralis apice pendula, anatropa. St yI us simplex; stigma capitatum. Drupa baccata, calyce minimo stipata, putamine osseo, monospermo. Semen inversum, tes t a membranacea. Embryo in apice albuminis carnosi orthotropus; cotyledonibus ellipticis, radicula tereti, supera. - Arbores v. frutices, inter tropicos totius or bis crescentes; ramulis axillaribus spinescentibus saepe armati, foliis alternis, petiolatis, coriaceis, ovatis $v$, lanceolatis, integerrimis, petiolis basi articulatis, stipulis nullis, pedunculis axil laribus, unifloris v. corymbose plurifloris.

$\mathrm{Xim}$ en i a Plumier Gen. 6. t. 21. Linn. Gen. n. 470. Jussieu Gen, 259. Jacq. Amer, t. 277. Law, t. 297. DC. Prodr. I. 533. Labillard. Nov. Caled. 2. 39. Cambessed. in St. Hilaire Flor, Brasil, I, 341. Gnillem. et Perrat. Flor. Seneg. I. 202. Meisner Gen, 45. (33.) He y ma 88 oli Aab. let Guian, I. 324, $t, 125$, Lau, $t, 297$. R o tt b o elli a Scopoli Introduet, $n, 1060$. Tet a no sia Richard msc.

5491. Helsteria $L I N N$, Caly $\mathrm{x}$ minimus, quinqnefidus, fructifer maximus, cupulaeformis. Corolla e petala 5 , hypogyna, aestivatione valvata. Stamina 10, hypogyna; filamenta plana, an therae subrotundae, biloculares, longitudinaliter dehiscentes. 0 variu $m$ libe rum, triloculare. Ovula in loculis solitaria, ex apice anguli centralis pendula, anatropa. Stylus brevis; st ig ma obsolete trilobum. D rupa haccata, calyce ampliato-cincta, putamine monospermo. Seme n inversum, t e s ta membranacea. E mbryo in apice albuminis carnosi minimus, orthotropus, radicula supera. - Arbores America e tropicae, inermes; folits alternis, petiolatis, co. riaceis, integerrimis, petiolo cum ramo articulato stipulis nullis, floribus axillaribus, parvis, peduncu. lis basi articulatis.

He is te ri a Linn. Gen. n. 535. Jacq. Amer, t. 81. Jussleu Gen, 260. Lam. $t$. 354. DC. Prodr. I. 332. Cambessed. in St, Hilaire Flor. Brasil, I. 340. Meisner Gen, 45. (33.)

5492. DIax LINN. C a I y x cupulaeformis, truncatus, minimus, fructifer auctus. Coroll a e petala hypogyna, nunc sex, mediantibus filamentis per paria eonnexa, nune quinque, quorum quatuor geminatim connexa, unum liberum, omnia aestivatione valvata. $\mathrm{S} t$ a $\mathrm{m}$ in a fertilia $\mathbf{3}$, rarins 4 v. 5 , petalis alterna, sterilia 5 v. 6 , iisdem opposita, indivisa $v$. bifida; fila me $n$ ta petalis adhaerentia, ant herae introrsae, biloculares, erectae, longitudinaliter dehiscentes. Ovari um liberam, uniloculare, $\mathrm{O}$ v $\mathrm{I}$ a 3 , ex apice columellae centralis, filiformis, liberae pendula, anatropa. Sty I Is terminalis, simplex; stigma subtrilobum. D r u p a exsucea, intra calycem auctum siccum libera, putamine crustaceo, monospermo. S emen inversum, test a membranacea, Embryo in axi albuminis carnosi orthotropus, teretiusculns, radi cula supera. - Arbores $v$, frutices glabri, in Asia et Africa tropica, et Nova-Hollandia extratropica crescentes, inermes $v$, aculeati, erecti $v$. interdum scandentes; foliis alternis, saepe distichis, petiolatis, integerrimis, cum ramulo articulatis, deciduis, interdum squamulaeformibus, stipulis nullis, floribus axillaribus, solitariis v. spicatis, parvis, albicantibus, saepe polygamis.

0 la x Lian. Amoen. Academ, I, 387, Vahl Symb. III, 7. Enum. II. 33. Roxburgh Plant, Corom, II. L, 102 Gartner f. IIT. 119. t. 201. R. Brown Prodr. T, 337, in Tuokey Congo 552. Wight et Arnott Prodr. I. 88. Fis s il i a Commers. in Jussieu Gen. 260. Lam. $t$. 28. S p e $\mathrm{rm}$ a $x$ y $r \mathrm{um}$ Labillard. Nov, Holl, II, 84. t. 233, R o x burg hi a König.

\section{GENERA PENITUS DUBIA.}

5493. Pseudalein THOUAR, Calyx minimus, urceolaris, sabinteger. Corollae petala 3 , in tubum conniventia. S ta mina 6 , petalis arcte applicita, specie epipetala, et capillamenta apice bifurca ex utroqne petalorum latere. $0 \mathrm{va}$ riu m conicum. St y i a s longitudine corollae; s tigma trilobum. D r u p sphaerica, monosperma. Em b ry o exalbuminosus, carnesus; cotyledonibus indiscretis, oleosis. - Arbuscula madagascariensis, ramosa; foliis alternis, laevibus, floribus axillaribus, pedunculis paucifloris.

P se udaleia Thouars Gen, madagasc. n. 51 . DC. Prodr. 1. 533. Meisner Gen. 45. (33.) - Videtur Olax, albumine pro embryone descripto.

5494. Pseudaleoides THOU $A R, \mathrm{C}$ aIy minimus, ureeslaris, integer. Corollae petala 4 , inaequalia, basi lata, conniventia. Stam in a 6 ; fi l a m en ta petalis dispariter applicita et ad speciem inserta, lata, an th era e basifixae. Ovarium uniovulatum. Stylas corollae longitndine; stigmata 3 , globosa. Fructus ..... - Frutex madagascariensis, debilis; foliis alternis, racemis unilateralibus, paucifloris, a Pseudaleia partium numero diversus.

Pseudaleoides Thouars Nov, Gen. madagasc. n, 58 . DC. Prodr. I. 533. Meisner Gen. 45. (33.)

5495. Hilatea BLUM. Flores dioici. I a s c. Ca Iy $x$ parvus, pentaphyllus, foliolis imbricatis. Corolla e petala 5 , basi coalita; filamenta brevia, antherae didymae. Fem. C aly $\mathrm{x}$ maris. Corolla nulla. Ovarium aniovulatum. Stigma sessile, magnum, discoideum, obtusum. Dru p a baceata, putamine oblongo, rugis angulato, monospermo. Sem en albumine carno80. E mb r y o inversus. - Arbores javanicae; foliis alternis, integris, coriaceis, junioribus, ramulis et pedunculis axillaribus lepidotis, floribus masculis in spicas ramosas, femineis in racemos simplices dispositis.

P late a Blume Bijdr. 646. Meisner Gen. 48. (33.)

54DG. Stemonureas BLUM. Flores hermaphroditi v. abortu dioici. Corolla petala $5 \mathrm{v}$, rarius 6 , inferne coalita. St a $\mathrm{m}$ in a $5 \mathrm{v}$, rarius 6 , hypogyna, petaliz alterna; fil amenta compressa, singula apice fasciculo villorum munita, antherae introrsae, biloculares. Ovar i um liberum, oblongum, uniloculare. Ovnla 2, pendula. Stig ma sessile, obtusum. Dru pa baceata, umbilicata, nucleo monospermo. E m bryo parvas, apici albuminis earnosi immersus, $r$ a dicula supera. - Arbores $v$. frutices, in insula Ja va crescentes; foliis alternis, integerrimis, floribus axillaribus spicatis, parvis.

Stem on a r u s Blume Bijdr. 648, Meisner Gen, 45. (33.) 
a. EUSTEMONURUS Blum. l,o, Filam e $\mathrm{ata}$ aestivatione incurva, demum exserta, patentia.

b. ANACOLOSA Blua, $t$. c. Filamenta aestivatione erecta, haud exserta.

549\%. Aomplinamelira WALL. F I ores abortu unisexuales. C a 1 y $x$ quadri-quinquedentatus. Corolla e petala 4 v. 5 , inappendieulata, apice inflexa $v$. pilis clavatis obsita. St am ina 4 v. 5, subclavata; fila m enta compressa, lihera v. leviter unita, tubum eirca ovarinm formantia. Mase. Antherae biloculares, loculis parallelis, contignis, partim filamenti apici immersis, dorso et sub loculis pilis clavatis inaequalibus eristatae. $O$ vari i rudimentum. Fem. Sta $\mathrm{m}$ in a ut in mare, antheris efoetis. Ovarinm petala aequans, oblongum, uniloculare. Ovula 2, oblonga, ex apice loculi pendula. Stig m a sessile, magnum, ovarii verticem tegens. Drup a coriacea, umbilieata, mono-disperma. - Frutices $v$ arbusculae indicae; foliis alternis, simplicibus, integerrimis, cymis axillaribus, dichotomis, multifloris, floribus parvis, flavo-virescentibus, masculis numerosis, femineis paucis.

G o m pha ndra Wallich Oatalog. n, 3718, 7204. Lindle y Introduct, odit. II. p. 439. Wight Illustr. 102.

OBSERVATIO, Quil esia Manuel Blaneo Flor. de $F i$ lipin. 176, genus e cl. Lindley Bot, Reg. 1839, App. p. 76. ad Olaeineas referendum, milii iguotum.

\section{GENUS OLACINEIS AFFINE.}

5498. Ballanites DELIL. C a l y $\mathrm{x}$ pentaphyllus, foliolis aestivatione valvatis, deciduis. Co roll a e petala 5, ad basim disci glandulosi angulati, ovarii basim cingentis inserta, lanceolata, basi angustata, aestivatione valvata, sub anthesi patentia. Stam in a 10 , cum petalis inserta; filamenta subulata, antherae introrsae, biloenlares, ovatae, dorso insertae, longitudinaliter dehiscentes. Ovari u m liberum, oblongum, villosissimum, quinqueloculare. Ovula in loculis solitaria, ex apice anguli centralis pendula, anatropa, Stylus filiformis, simplex; stigma capitatum. Drupa baccata, ovoidea, acuta, putamine lignoso, pentagono, abortu uniloculari, monospermo. S em en inversam, te sta fibrosa, endoplenra membranacea, circa radicnlam incrassata. E mbryo in axi albuminis carnosi orthotropus; cotyledonibus ovatis, radicula tereti, 8 npera, plumula diphylla. - Arbor Africae tropicae, in Aegypto et Antillis culta, spinis axillaribus validis; foliis alternis, bifoliolatis, foliolis oblongis $v$. ovalibus, coriaceis, integerrimis, stipulis nullis, floribus axillaribus, cymosis, virescentibus, suaveolentibus.

B al anites Delile Flor. Aegypt. 72, t. 28. f. I. DC. Prodr, I, 708. Guillem. et Perrot. Flor. seneg. I, 103. Meis. ner Gen. 45. (33.) Xinénfá a egyptiaca Limn. Ag Ihalid Prosp. Alpin. Aegypt, 20, t. 11, L 6 b a k h Abdollatif.

\section{Drdo CCXXIV: Aurantiacene.}

AURANTIORUM seet. 2, Jussieu Gen, 260. HESPBRIDEARUM sect. 2. Venten. Tabl. ITI. 154. AURANTIACEAE Correa in Annal. Mus. VI. 376. Mirbel in Bullet. soc, philomat. 1813. p. 379. DC. Prodr. 1. 535. Bartling Ord. not. 392, Wight et Arnott Prodr. I. 90. Liadfey Introduot.edit. II, p. 105, Meisner Gen. 46. (34.)

Arbores v. frutrebs, glandulis immersis, oleo essentiali foetis undique conspersi, sae- pissime glabri, ramis axillaribus haud raro in spinas rectas v. uncinatas mutatis armati, erecti, rarissime seandentes. Foli a alterna, impari et simpliciter pinnata, plurijuga v. unijuga trifoliolata, v. foliolo terminali solum superstite unifoliolata, foliola cum petiolo saepe alato-dilatato articulata, integerrima v. crenata aut serrata, penninervia, coriacea, punctis glandulosis, versus margines plerumque confertioribus, pellucidis notata. S tipulae nullae.

Flores hermaphroditi v, rarissime abortu unisexuales, regulares, axillares $v$. terminales, solitarii, corymbosi v, racemosi, albi, rubicundi v. flavi.

Caryx liber, brevis, urceolatus v. campanulatus, quadri-quinquefidus v. dentatus, interdum subintegerrimus, rarissime trifidus, laciniis aestivatione imbricatis, marcescens.

Corollae petala calycis laciniis numero aequalia et alterna 4 v. 5 , rarissime 3 , ad basim tori brevissime stipitiformis, rariusve in discum expansi hypogyne inserta, libera v. interdum inferne cohaerentia, aestivatione leviter imbricata, plana v. carinata, sub anthesi erecta v. patentia, decidua.

Stamina hypogyna, nunc petalis numero dupla, iisdem alterna et opposita, nunc multipla. Filamenta libera, v. basi aut ad medium in tubum connata, in polyandris saepe polyadelpha, lineari-subulata, basi plerumque dilatata, plana, rarissime subfornicato-concava, superne altenuata, aequalia v. alterna breviora. An thera e introrsae, biloculares, imo v. medio dorso insertae, erectae v. incumbentes, loculis appositis, contiguis, longitudinaliter dehiscentibus.

Ovariva liberum, toro saepe substipitiformi insidens; interdum ejnsdem margine discoideo cinctum, loculis calycis laciniis numero aequalibns v. paucioribus, rarius pluribus, quinque-multiloculare. Ovula loculorum angulo centrali inserta, nune solitaria, nune gemina, collateralia v. superposita, nune plurima, biseriata, saepissime pendula, rarius horizontalia, anatropa. Stylus terminalis, crassiusculus, cylindricus v. conicus, distinctus v, ovario continuus. Stig ma plus minus eapitatum, indivisum v. obsolete lobatum.

Bacca sicca v. carnosa, cortice crasso, evalvi, bi-plurilocularis, saepe abortu unilocnlaris, loculis plerumque monospermis, rarius polyspermis, mucilagine v. cellulis vesiculosis farctis.

Srmina inversa v. subhorizontalia, testa membranacea, sicca v. mucosa, interdum lanata, umbilico prope seminis apicem carpicum sito, per rhaphen saepe vasculoso-ramosam, cum chalaza late orbiculata, extremitatem umbilico e diametro oppositam occupante, conjuncto. 
Eubryo exalbuminosus, orthotropus. C otyl edon es nunc amygdalino-carnosae, planoconvexae, saepe inaequales, basi plus minus distincte auriculatae, nunc crassae, virides, sublobato-rugosae. R a di cula retracta, brevissima, umbilico proxima, supera. Plumula manifesta.

A urantiaceae Asiam tropicam sponte sua incolentes, cultura nunc per regiones calidiores totins orbis dispersae, ob fructuum cum forma decora saporem, florum odorem et omnes partes oleo volatili aromatico scatentes inter humani generis delicias ab antiquissimis temporibus celebratae, et fabulis consecratae, affinitate proxima Meliaceas et Humiriaceas contingunt, inde ad Rutaceas Xanthoxyleas, et Terebinthaceas Amyrideas accedunt.

§. 1. LimoneaE Wight et Arnott Prodr. I. 90. S t a m in a duplo petalorum numero. Ovula in loculis solitaria ve gemina collateralia.

5499. Atalantia CORR, C aly $\mathrm{x}$ quadriquinquedentatus, C oroll a e petala 4-5, hypogyna. Stamina 8 v. 10; filamenta basi in tubum coalita, superne libera, subulata, anth erate cordato-ovatae, biloculares, longitudinaliter dehiscentes. Ovarin m tri-quadriloculare. Ovula in loculis 2, angulo centrali prope basim collateraliter inserta ..... S ty I a s tubi staminei longitudine; stif m a tri-quadrilobum. B a ec a globosa, triquadriloenlaris. S e m in a in loculis abortn solitaria. Embryonis exalbuminosi cotyledones amygdalinae, radicula brevissima. - Frutices in dici, spinosi; foliis alternis, simplicibus, cum petiolo articulatis, apice emarginatis, floribus axil. laribus et terminalibus racemosis.

Atal a tía Correa in Annal. Mus. VI. 383. DC. Prodr. I. 335. Wight et Arnott Prodr. I. 90. Meisner Gen, 46. (34.) Li monla monoph y 11 a Lina. Roxburgh Plant, corom. t. 82, T u rraca virens König in Aet. Holm. 178s, t. 10 .

5J00. Triplhasia LOUR. C a l y $\mathrm{x}$ trifidns. Corolla e petala 3 , hypogyna, basi subcoalita. St am in a 6 ; fil a me n ta libera, subalata, basi latiore complanata, anthe ra e cordato-oblongae, biloculares, longitudinaliter dehiscentes. $O_{\mathrm{v}} \mathrm{a}-$ ri u m toro brevissime stipitiformi impositum, obovatum, glabrum, triloculare. Ovula in loculis solitaria, ex apiee anguli centralis pendula, anatropa. Sty las longiusculus, erassus; stigma obtusum. B a c ca trilocularis v, abortu unilocularis. Sem in a in loculis solitaria, inversa, mucilagine involuta. E mbry onis exalbuminosi cotyledones crassae, lobatae, radieula brevissima, sopera. - Frutex sinensis, spinosus; foliis alternis, trifoliolatis, foliolis ovatis, retusis, supro medium crenulatis, lateralibus minoribus, saepe abortivis, racemis axillaribus, brevibus.

Triphas i a Loureiro Flor. cochineh. 189. DC. Prodr. I. 333. Wiglit et Arnote Prodr. I. 91. Meisuer Gen, 46. (34.) Li un on trifoliolata Lian. Jacq. Ic. rar. $t, 463$. Andrews Bot, Feposit, $t, 143$.

5501. Limeonia LINN. Caly $x$ quadriquinquefidus. Co roll a e petala $4-5$, hypogyna, libera, St amina 8_10, fil amenta libera, subulata, basi latiore complanata, an thera e cor- dato-oblongae, biloculares, longitudinaliter dehiscentes. 0 va ri u m toro brevissime stipitiformi impositnm, obovatum, glabrum, quadri-quinquelnculare. Ovula in loculis solitaria ve gemina collateralia, ex apice anguli centralis pendula, anatropa. Stylas longus; stigma obtusum. Bacea quariri - quinquelocularis $\mathrm{v}$, abortu nni-trilocularis. Semina in loculis solitaria, inversa. Embryo. nis exalbuminosi cotyled ones amygdalinae, radicula brevissima, supera. - Arbores vi.frutices in Asia tropica sponte crescentes, spinosi v. rarissime inermes; foliis alternis $v$, impari pinnatis, paucijugis, foliolis integerrimis $v$. interdum crenatis, petiolo saepius dilatato, floribus axillaribus racemosis, v. terminalibus paniculatis.

L i m a a i a Linn. Gen. n. 524. Lam, $t .353$, DC, Prodr. I. 535. Roxburgh Plant, Corom. t. 86. Bot. Mag. t. 2416. Wallich Plant, As. rar. t. 24s. Wight in Hooker Bot. Mis. cell. Suppl, t. 33. Wight et Arnott Prodr. I, 9t. Wight Ittustr. 2. 41. Wi a terlia Dennst, z. Hort. Malab. II. 9.

5502. Glyeosmis CORR. Caly $\mathrm{x}$ quadriquinquefidus. Cor o 11 a e petala 4 v. 5 , hypogyna. St amina 8-10, libera; fil amenta alterna breviora, e basi latiore complanata, sursum attenuata, an the rae cordato-oblongae, biluculares, longitudinaliter dehiscentes. O vari um ovatum, tori discoidei centro breviter stipitiformi impositam, quadri-quinqueloculare. Ovula in loculis solitaria, ex apice anguli centralis pendula, anatropa. Stylu s conicus, ovario continuus, brevis, crassus; stig ma obsolete lobatum. B a c $c$ a globosa, abortu uni-bilocularis. Semina in loculis solitaria, inversa, testa membranacea $\mathbf{v}$, rarius mucilaginosa. Embryonis exalbuminosi c otyledon es amygdalinae, basi minute anriculatae, $\mathrm{ra-}$ dicula brevissima, supera. - Arbores $v$, frutices Asia e tropicae, inermes; foliis imparipinnatis, foliolis alternis, integerrimis v. serrulatis, floribus racemosis $v$, paniculatis.

GI y eos mis Correa in Annal. Mus, DI. 384. DC. Prodr. I. 538. Wight et Arnott Prodr. I, 92. Wight in Hook. Bot. Miscell. Suppl. t. 39 Meisner Gen. 46. (34.) L i monia $s$ p. Roxburgh Plant. Corom, $t$, 84, 85 .

5503. Selerostylis BLUM. Caly $\mathrm{x}$ brevis, quadri-quinquefidus. C o ro 11 a e petala 4 v. 5 , hypogyna. Stamina 8 v. 10 , libera; filament a alterna breviora, e basi latiore complanata, sursum attenuata, an th era e cordatae, biloculares, longitudinaliter dehiscentes. Ovariu m ovatum, tori discoidei centra impositum, bi-triloculare. Ovnla in loculis solitaria v. gemina collateralia, ex apice anguli centralis pendula, anatropa. StyI us brevis, crassus, vix ab ovario distinctus; st ig ma obtusum. B a c e a sicea v. carnosa, bilocularis v. abortu nnilocularis. Semina in loculis solitaria, inversa, testa nembranacea, venosa. Embryonis exalbuminosi cotyled ones amygdalinae, radicula brevissima, supera. Arbores $v$. frutices Asiae tropicae, spinosi v. inermes; foliis simplicibus $v$. imparipinnatis, integerrimis $v$, crenulatis, racemis axillaribus rariusve terminalibus, brevibus, interdum pedunculis axillaribus unifloris.

Sclerostylis Blume Bijdr. 133. Wight et Arnott Prodr. I. 93. Meisner Gen, 46. (34.) L imoni a billocularis Roxb.

5504. Itissea $A R N O T T$. C a I y x cupulatus, brevissime et obtuse quadrifidus. Corollae petala 4 , perigyna. Stamina 8 , hypogyna, libera; fil amenta plana, linearia, apice abruptim acuminata, alterna breviora et latiora, a $n$th $\mathrm{e}$ - 
ra e cordato-ovatae, breviter mucronatae, biloculares, Iongitudinaliter dehiscentes. Ova ri um toro carnoso cupulaeformi insidens, ovali-lineare, biloculare. 0 vula in Iocalis gemina, angulo centrali collateraliter inserta,..... Stylus ovario continuus, crassiusculus, subelongatus; stigma capitatum, obtusum. B a ce a subglobosa, bilocularis. Se min a in loculis solitaria..... - Frutex c eylanicus, spinosus; foliis simplicibus, glabris, oblongo-lanceolatis, floribus in corymbos subsessi$l e s, v$, racemos breves axillares dispositis.

$\mathrm{R}$ is s o a Arnott in N. A.N. C. XVIIT. 324. L imonia citrifolia Moon.

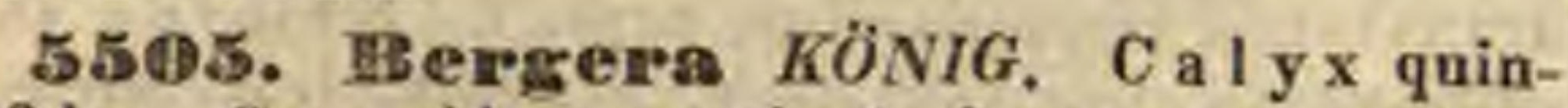
quefidus. Corolla e petala 5, hypogyna, patentia. Stam in a 10, hypogyna, libera; filamenta subulata, basi compressa, antherae ovatae, biloculares, longitudinaliter dehiscentes. Ova. ri $\mathbf{m}$ toro elevato impositum, biloculare. Ovula in loculis solitaria, anguli centralis medio inserta, semianatropa. Stylus longus, crassus; st ig ma obtusum. B a c c a abortu unilocularis, monosperma. Semen inversum, testa membranacea, mucilagine involuta. Embryon is exalbuminosi coty l ed on es carnosae, basi distincte auriculatae, radicula supera, villosa. - Arbuscula indica; foliis imparipinnatis, foliolis alternis, acuminatis, pubescentibus, serratis, paniculis terminalibus, corymbiformibus.

Berger a König in Linn, Mantiss. S65. Selireber Gen. n. 718. Roxburgh Plant, Corom. t, 112, DC. Prodr. 1.94. Wight Ic, t. 13. Meisuer Gen. 46. (34.)

\$.2. ClaUSEneAE Wight et Arnott Prodr. I. 90. S $\mathrm{t}$ a $\mathrm{m}$ i $\mathrm{n}$ a duplo petalorum numero. Ovula in loculis gemina, superposita.

5506. MTurraya KöNıG. C a l y x quinquepartitus. Corollae petala 5, hypogyna, inferne in tubum conniventia. $S t$ a min a 10 , hypogyna, libera; filamenta alterna breviora, lineari-subulata, an ther ae ovatae, biloculares, longitudinaliter dehiscentes. Ovarium toro subhernisphaerico impositum, biloculare. Ovula in loculis gemina, angulo centrali superposite inserta, pendula. Stylus longus; stigma obtusum, obsolete bilobum. Ba c ca carnosa, bi - v. abortu unilocularis, loculis liquore foetido plenis. Semina in loculis solitaria, inversa, testa crassa, lanata, Embryonis axalbuminosi cotyledones amygdalinae, basi minutissime auriculatae, radicula supera. - Frutices Asiae tropicae, inermes; foliis alternis, impari-pinnatis, foliolis integerrimis, apice acuminato retusis $v$. emarginatis, pedunculis axillaribus v. terminalibus unifloris, v. corymboso pauci-multifloris.

M u r r y a König in Linn. Mantiss. 563. Sebreber Gen. n. 712. Murray in Comment. Götting. $I X, 186, t, 1$, Lam. t. 332. Bot. Reg. t. 434. DC. Prodr. I. 537, Hooker Exot. Flor. t. 134. Wight et Aruott Prodr. I. 94. Meisner Gen. 46. (34,) Chale as Loureiro Flor. cochinch, 270. M a r$\checkmark$ a n a Sonnerat Voy, $t, 139$.

550\%. Cookfa SONNER, Cal y $x$ quadriquinquefidus. Co rolla e petala $4-5$, hypogyna, ovalia, naviculari-concava v. carinata, alabastrum carinato-angulatum. Stam in a 8 v. 10, hypogyna, libera; fil amenta subulata, a ntherae subrotundae, biloculares, longitudinaliter dehiscentes. $O$ varium toro brevissime stipitiformi insidens, glandulosum, fasciculato-pilosum, quadriquinqueloculare. $0 \mathrm{v} u \mathrm{la}$ in loculis gemina, angulo centrali superposite inserta, pendula, anatropa. Stylus brevis, crassus; stigma quadri-quinquedentatum. B a c c a globosa, cortice tenui, quinquelocularis v. abortu uni-bilocularis, loculis liquore balsameo fuetis. Semin a in loculis solitaria, inversa. .....-Arbusculae Asia e tropicae, inermes; folitis imparipinnatis, foliolis alternis $v$. oppositis, basi obliquis, floribus terminalibus paniculatis.

Cookia Sonnerat Voy, IT, 130. t. 131. Lam. t. 354. Jacq. Hort. schönbr. $t$, 101. DC. Prodr, I, 537. Wight et Arnott Prodr. I. 95. Meisner Gen. 46. (34.) Quinaria Loureiro Flor. cochinch, I. 334, - ? A a 1 a c i a Loureiro Op. cit. 335 .

5508. Clausena BURM. Caly x quadridentatus. Corollae petala 4, hypogyna, ovalia, concava, patentia, alabastrum globosum. Stamina 8 , hypogyna, libera, snbaequalia; filamenta basi concavo-subfornicata, conniventia, superne subulata, antherae ovatae v. oblongae, biloculares, longitudinaliter dehiscentes. Ovari u m toro in stipitem elevato insidens, quadriloculare. Orula in loculis gemina, angulo centrali superposite inserta, pendula, anatropa. Sty lus cylindricus; 8 t $\mathrm{g} \mathbf{m}$ a integrum, quadrilobum. $\mathrm{B}$ a cca sicca, abortu unilocularis, monosperma. S emen inversum, testa membranacea, E mbry on is exalbuminosi c otyledones carnosae, basi distincte auriculatae, radicula supera. - Arbores $v$. frutices Asia e tropicae; foliis imparipinnatis, foliolis integerrimis $v$. serratis, pubescentibus, floribus parvis, terminalibus et axillaribus, panicula. tis v. racemosis.

Cla us e n a Burmann Flor, ind. 89. Lam. $2,310$. DC. Prodr. I. 338. Wight et Arnott Prodr. I. 95. Wight Ic, t, 14. Meisuer Gen. 46. (36.) A m y ridis s p. Roxb.

5509. II feronelum BLUM. C a lyx urceolatus, integerrimus. Corolla e petala 5, hypogyna, lineari-lanceolata, patentia. St a min a 10, hypogyna, libera, alterna breviora; fil amenta subulata, an therae subrotundo-didymae, biloculares, longitudinaliter dehiscentes. O varium toro brevi stipitiformi insidens, quinquelosulare. O vala in locnlis gemina, angulo centrali superposite inserta, pendula. Stylus crassus; 8 tigm a obtusum. B a ce a exsucea, intns septis quinque chartaceis intortis lamellata, mono-disperma. Semin $\mathbf{n}$ testa membranacea. Embry onis exalbuminosi cotyled on e s foliaceae, contortuplicatae. - Arbor javana; foliis imparipinnatis, foliolis alternis, obliquis, corymbis terminalibus.

Micromelum Blume Bijdr, 137. Wight et Arnott Prodr. 1,90 , in not. Meisner Gen, 46. (34.)

5510. Paramignya WIGHT. C a $1 \mathrm{yx}$ nrceolatus, obtuse quinquelobus. Coroll a e petala 5, hypogyna, lanceolata, patentia. Sta min a 10, hypogyna, libera, aequalia; fi l a m enta compressa, apice subulata, a n the rae oblongae, obtusae, biloculares, longitudinaliter dehiscentes. Ovarium toro brevi stipitiformi insidens, basi ejusdem margine carnoso lobato cinctum, quinqueloculare. $O \mathbf{v} \mathrm{u} I \mathrm{a}$ in loculis gemina, angulo centrali prope medium superposite inserta, pendula. St y la s cylindricus; s ti g ma capitatum, obsolete quinquelobum. Bace a pomiformis, corticata, pulposa, endocarpio subcoriaceo, quinqueangulari, abortu monosperma, S e min a .... Frutex indicus, scandens; spinis axillaribus, uncinatis, foliis alternis, simplicibus, ovatis, lanceolatis, acuminatis, glabris, floribus axillaribus, solitariis $v$. 
rarius ternis v. quaternis, albis, odoratissimis, fructibus ovatis, obtuse quinquangulatis, inter angulos sulcatis, obsolete pubescentibus.

Paramignya Wight nlustr. 108. Micromelum monophylla m Wight $O p$. cit. $t$. 42.

5511. Luvumga HAMILT. Caly x tubulosus, quadridentatus. Co roll a e petala 4 , hypogyna, reflexa. Stamina 8 ; filamenta ad medinm in tubum coalita, antherae lineares, incumbentes, bilocnlares, longitudinaliter dehiscentes. Ovari u m toro brevi stipitiformi insidens, bi-triloculare. Ovula in loculis gemina, angulo centrali superposite inserta, pendula, anatropa. Stylus cylindricus; stig ma subglobosum. B a $\mathrm{c}$ c a sicea, oblonga, bi-trisulca, bi-trilocularis. S e. mina in loculis solitaria, inversa, testa membranacea, venosa. Embryonis exalbuminosi cotyledones foliaceae, carnosae, radicula obtusa, supera. - Frutices ind $i c i$, multicaules, scandentes, spinosi, foliis alternis, trifoliolatis, foliolis lanceolatis, integerrimis, racemis axillaribus multifloris.

Luv ung a Hamilt. ex Wallich Catalog. n. 6388. Wight et Arnott Prodr. I. 90, in not. L a vang a Meisuer Gen. 46. (34.) Limonia $8 \mathrm{c}$ andens Roxb.

§. 3. CITREAE Meisner Gen, 46. St a$m$ in a petalis numero dupla v. multipla. Ov'u1 a in loculis plurima, biseriata.

5512. Feromia CORR. Flores abortn polygami. Calyx planus, quinquedentatus. Corolla e petala 5 , interdum 4 v, 6 , hypogyna, patentia. St a m in a 10 , interdum 11, hypogyna; filament a dilatata, basibus coalita, a n $\mathbf{t}$ h e ra e lineari-oblongae, tetragonae, biloculares, longitudinaliter dehiscentes. 0 varin toro elevato impositum, quinque - v. interdum sexloculare. $0 \mathrm{v}$ u 1 a in loculis plurima, angulo centrali biseriatim inserta, pendula, anatropa. Stylus subnullus; stig ma oblongum. B a c c a cortice duro, quinquelocularis. S e min a plurima, pulpae carnosae immersa, $\mathbf{E}$ mbryonis exalbuminosi cotyledones crassae, carnosae, radicula vaga. - Arbores indicae; foliis impari-pinnatis, bi-trijugis, foliolis subsessilibus, obovatis, obsolete crenatis, juxta marginem pel. lucide punctatis, petiolo subulato, racemis axillaribus et terminalibus laxis, paucifloris.

Fe ro ni a Correa in Linn. Transaot. $\nu$. 222. Roxburgh Plant. Corom, t, 141. DC. Prodr. 1. 538. Wight et Arnott Prodr. $I$, 96. Wight Ic, $t$, 15. Meisner Gen. 46. (34.)

5513. Aegle CORR. Flores hermaphroditi. Ca 1 y $x$ quadri-quinquedentatus. Corollae petala $4 \ldots 5$, hypogyna, patentia. $\mathrm{Sta}$ m in a $30 \_40$, hypogyna; fil a m e n t a filiformi-snbulata, libera, an th era e lineari-oblongae, bilocnlares, longitudinaliter dehiscentes. Ovarium octo-quindecimloculare. Ovala in loculis plurima, angulo centrali hiseriatim inserta, subhorizontalia, anatropa. St y 1 u s brevis, crassus; stigma eapitatum. $\mathrm{B}$ a c $\mathrm{c}$ a cortice duro, octo-quindecimlocularis. $\mathrm{S}$ em in a in loculis 6_10, testa lanata, mucilagine obducta. Embryonis exalbuminosi cotyledo. nes amygdalinae, basi minutissime auriculatae, ra di cula brevissima, centripeta v. supera. - Arbor indic a, spinis simplieibus; folits imparipinnatis, uni-v, rarissime bijugis, foliolis oblongis $v$, late lanceolatis, crenulatis, inconspicue punctatis, terminali majore, pedunculis axillaribus paucifloris, floribus majusculis, longe pedicellatis.
A e gle Correa in Linn. Transaot. $\nu$. 222. Roxburgh Plant. Corom. $t, 143$. DC. Prodr. 1. 538. Wight et Arnott Prodr. I. 96. Wight Ic. t. 16. Meisner Gen. 46. (34.) B e$10 u$ Adanson Fam. $I T, 408$. C $x$ a t a ev a e s p. Linn.

5514. Citrus LINN. C a I y x urceolatus, tri-quinquefidus. Co r o I l a e petala 5-8, hypogyna.S $t$ a $m$ in a $20-60$; f i l a $m$ e $n t$ a basi compressa, plus minus coalita, polyadelpha, a $n t h$ e ra e oblongae, biloculares, longitudinaliter dehiscentes. 0 vari um multiloculare. Ovula in loculis 4_8, angulo centrali biseriatim inserta, pendula, anatropa. Stylus teres; stigma hemisphaericum. B a c ea carnosa, plurilocularis, loculi vesiculis pulposis transversis irregularibns repleti. Sem in a in loculis pauca, horizontalia v. pendula, testa membranacea. Embryonis exalbuminosi cotyledone s carnosae, saepe inaequales, basi minutissime auriculatae, radicula supera. - Arbores $v$. frutices, spinis axillaribus armati, in Asia tropica indigeni, nunc propter poma, quae ferunt aurea, miram florum fragrantiam et comae decorem in regionibus calidioribus totius orbis sub div, in frigidis intra hibernacula culti; foliis abortu unifoliolatis, foliolo cum apice pedicelli saepe alati articulato.

Citrus Linn, Gen, n. 1218. Lam. t. 639. DC. Prodr. r. 539. Wight et Arnott Prodr. I. 97. Meisner Gen. 46. (34.) Siebold et Zuccariui Flor. japon. $t$. 15. - De speeierum varietatibus eultura ortis cfr. J. B. Ferrarlus, Hesperides s. de malorum aureorum cultura et usu libri IV. Romae, 1646. fol, G. Gallesio, Traité du Citrus, Paris, 1811. 4. Risso in Annal. Mus. XX, 199. ss. Risso et Poiteau, Histoiro des Orangers, Paris, 1820. fol. Sickler, dor Orangerie. Gärtner. Weimar, 1806. 4.

\section{GENUS DUBIUM.}

5515. Chiomotria JACK. C aly $\mathrm{y}$ nutus, quinquepartitus. Co ro 11 a e petala 5 , calyce paullo longiora. Sta mina 10 , erecta; antherae incumbentes. O $\mathrm{v}$ a $\mathbf{r} \mathbf{n} \mathrm{m}$ biloculare. Ovula in loculis gemina, pendula. Stylus crassus, stamina aequans; $8 \mathrm{t} \mathrm{ig} \mathrm{ma} \mathrm{capitatum.} \mathrm{B} \mathrm{a} \mathrm{ce} \mathrm{a}$ subdepresso-globosa, pulpa farinacea, spongiosa farcta, monosperma. S e m en globosum, apice nmbilicatum. Embryon is exalbuminosi coty led on e s maximae, convexo-planae, rad i cu la minima, supera, pl u m n l a brevis, conica, - Frutex Asiae tropicae; foliis oppositis, pellucide punctatis, sti. pulis subulato-acutis, racemis axillaribus ramosis, erectis, pedicellis multifloris, floribus parvis, virescentibus.

C. hionotria Jack Malay. Miscell. ex Hooker Bot. Mag. Compan, I. 155.

\section{Ordo CCXXV. Mleliaceae.}

MELTAE Jussien Gen, 263. MELIACEAE Jussien in Mem. Mus, 11I. 436. DC. Prodr. I. 819. excl. trib. III. Bartling Ord. nat. 355. Adr. Jussieu in Mrem. Mus, XIX, 153. Lindley' Introduct, edit. II. p. 101.

Arbores v. Frutices. Folia alterna, rarissime subopposita, paucis simplicia et tune integerrima v. pinnatiloba, nonnullis bipinnata, plerisque pinnata, foliolis alternis v. oppositis, integerrimis v. denticulatis. S ti pula e nullae.

Flores hermaphroditi v. abortu polygami, regulares, paniculati, corymbosi, racemosi v. spicati, terminales v. frequentius axillares, inflorescentia saepius definite cymulosa. 
Calyx liber, tetra-pentaphyllus v. quadriquinquefidus, foliolis v. laciniis aequalibus, aestivationel imbricatis.

Corollae petala quatuor v. quinque, rarissime tria, disco hypogyno inserta, ealycis foliolis alterna, iisdem duplo longiora, distincta, v. rarius basi inter se aut cum tubo stamineo coalita, aestivatione valvata v. imbricata.

Stauina cum petalis inserta, duplo eorundem numero, alterna petalis opposita paullo breviora. Filamenta lata, complanata, apice bidentata v. bifida, marginibus in tubum plus minus longum, diversiformem connata. An th e$r$ a e introrsae, biloculares, medio v, imo dorso inter filamentorum dentes singillatim affixae, iisdem breviores et tubo inclusae, v. longiores exsertae, longitudinaliter dehiscentes. Pollinis granula subglobosa, laevia, zonis pellueidis, tribus v. quinque cincta.

Discus hypogynus nunc obsoletus, nunc stipitiformis, ovarium elevans, v. annularis, interdum in tubulum carnosum v. membranaceum, ovarii basim vaginantem productus.

Ovarium liberum, pluriloculare, loculis petalis numero aequalibus, raro paucioribus $v$. pluribus, apice saepissime perviis. Ovala in loculis saepissime gemina, collateralia v. superposita, rarius solitaria, rarissime quatuor, biseriata, anatropa, semianatropa, amphitropa v. orthotropa. Stylus simplex, rectus, plerumque ovario continuus, tubo stamineo brevior v. subaequalis. Stig m a capitatum, pyramidatum v. saepius peltato-discoideum, lobulis v. angulis loculorum numero notatum.

Fructus varius, baccatus, drupaeformis v. saepius capsularis, loculicide dehiscens, valvis medio septiferis.

Semrina in loculis abortu saepissime solitaria, arillo carnoso vestita v. exarillata, erecta, inversa v. horizontalia, forma varia, semper aptera. Albumen carnosum v. nullum.

Erisryo nunc albumine inclusus, cotyledonibus foliaceis, radicula exserta, nunc exalbuminosus, cotyled onibus crassis, interdum conferruminatis, ra dic ula brevi, plerumque inter cotyledones retracta, nunc iisdem verticaliter collateralibus supera, nunc horizontaliter superpositis centripeta, umbilicum spectante v. centrifuga, umbilico ventrali e diametro opposita.

Meliace a e inter tropicos Asiae et Americae pari fere copia obviae, parcius in Africa provenientes, in regionibus subtropicis rarae, Aurantiaceis et Cedrelaceis affinitate proximae, pluribus notis tum ad Rutaceas, tum ad Sapindaceas accedunt.

Omnes viribus amaris, adstringentibus, tonicis pollent.
TRIBES 1. MELIEAE Adr. Jussieu in Mem. Mus. XIX. 216. Embryo in axi albuminis tenuis carnosi, cotyledonibus foliaceis, radicula exserta, - Species gerontogeae, folitis simplicibus v. bipinnalis, rarius simpliciter pinnatis, foliolis plerumque dentatis.

5516. Quivisia COMMERS. Cal yx cupulaeformis, quadri-quinquedentatus, persistens. Coroll a e petala 4 v. 5, hypogyna, linearia, aestivatione subvalvata v. imbricata. Tubas stamineus subeampanulatus, octo - decemdentatus, dentibus antheriferis. Antherae 8-10 terminales, erectae. Ovari n m sessile, quadri-quinqueloculare. $O v \mathbf{v l a}$ in loculis gemina, anguli centratis medio collateraliter inserta, semianatropa, micropyle supera. Stylus filiformis; stigma capitatum, quadri-quinquesulcum, Ca p s u l a quadriquinquelocularis, loculicide quadri-quinquevalvis, valvis medio septa, a columella seminifera quinque. loba soluta, gerentibus. S e m in a in loculis gemina, collateralia v, abortn solitaria, inversa, umbilico laterali. E mbryo in axi albuminis carnosi rectns, cotyledonibus foliaceis, planis, $r$ adic n la tereti, supera. - Arbores $v$. frutices borbonici et madagascarienses; folitis alternis $v$. suboppositis, simplicibus, integerrimis $v$. in eodem ramo pinnato-lobatis, floribus axillaribus $v$, in racemum v. corymbum brevem, pauciflorum dispositis.

Quivisia Commers. In Jussieu Gen. 264. Cavanill. Dissert. VIII. 367. t. 211_214. DC. Prodr. I. 620. Adr. Jussien in Mem. Mus. XIX, 216. $t$. 12. f. 1. Meisner Gen, 50. (36.) Gilibertia Gaelin Syst. 682 .

$551 \%$. Calodryum DESV. Calyx campanulatus, profunde quinquefidos, laciniis aestivatione imbricatis. Cor olla e petala 5, hypogyna, elongato-linearia, aestivatione subvalvata, saepissime marginibus medio irregulariter inter se coalita. T u b a s stamineus cylindricus, petala superans, apice breviter decemfidus, laciniis antheriferis, an $\mathbf{t h e r}$ a $\mathbf{1 0}$ terminales, erectae, apice mucronato-appendiculatae. 0 vari $\mathbf{m}$ m sessile, quinquelocalare. O v 1 a in loculis gemina, anguli centralis medio collateraliter inserta, semianatropa, micropyle supera. Sty l u f fliformis, st ig ma capitatum, apice quinquelobo-apienlatum. Fruct ns..... Frulex v. arbor madagascarien$s$ is; foliis alternis, petiolatis, simplicibus, integerrimis $v$. subsinuatis, pedunculis axillaribus abbreviatis, bracteatis, uni-bifloris.

Calo dr y u Desvaux in Annal. se, nat. IX. 401, t.51. Adr. Jussfeu in Mem, Mus. XIX, 217. t. 12. f. 2. Meisner Gen. 50. (36.) T u r raea I a n e olata Cavanill. Dissert. t. 20s. $f .1$.

5548. Naregamin WIGHT et $A R N$, C aI y x cupulaeformis, quinquefidus. Corolla e petala 5, hypogyna, elongato-ligulaeformia, distincta. Tubus staminevs cylindricus, elongatus, apice globoso-inflato quinquecrenatus, crenaturis antheriferis, antherae terminales, patentes, apice mucronato - appendiculatae. Ovari u m sessile, triloculare. Ovu Ia in loculis gemina, anguli centralis medio collateraliter inserta, semianatropa, micropyle supera. Stylus filiformis; stigma minute capitato - discoidenm, apice apiculato - trilobum. Ca p s n la submembranacea, triangularis, trilocularis, trivalvis, valvis orbicularibus. Semina in loculis gemina, collateralia, pendula, compressiuscula, Iatere ventrali angustissime bialata, umbilico excavato. Em bryo .... _ Frutex ind icus, 
glaber; foliis trifoliolatis, foliolis cuneato-obovatis, integerrimis, sessilibus, petiolo marginalo, floribus magnis, in pedunculis axillaribus solitariis, longis.

Naregania Wight et Arnott Prodr. I. 116. Meisner Gen, 50. (36.)

5519. Turreaca LINN. C a l y x cupnlaeformis, quinquedentatus. Coroll a e petala 5, hypogyna, elongato-ligulaeformia, aestivatione convolutiva. Tubns stamineus elongato-cylindricus, petala subaequans, apice decemfidus, laciniis simplicibus v. bifidis, fance intus antherifer. Anthera e 10 inclusae, erectae, laciniis tubi alternae, apice in ligulam simplicem v. duplicem productae. Ovari $\mathbf{~ m}$ sessile, quinque-decem-vigintiloculare. 0 v 1 a in loculis gemina, anguli centralis medio superposite inserta, anatropa, superius adscendens, inferius pendulum. Stylus filiformis; stig ma clavatum v, eapitatum. Fruetus .... Arbores v. frutices, in Capitis bonae spei interioribus, Madagascaria et Asia tropica crescentes; foliis alternis, petiolatis, integerrimis $v$. obtuse lobatis, floribus in axill is foliorum mature defluentium, in ramulis brevibus imbricatim multibracteatis confertis, pedicellatis.

Tu rra e a Linn. Mantiss. 1306 . Smith $T c$, inedic, $t, 10$ 12. Cavanill. Dissert, t. 204. 205. f. 2. DC. Prodr. I, 620. Adr. Jussieu in Mem. Mus. XIX, 217. t, 12. f. 3. Meisner Gen. 50. (36.)

5520. IVelia LINN, C al y x quinquepartitus, laciniis aestivatione imbricatis, Co ro 11 a e petala 5 , hypogyna, lineari-spathulata, aestivatione convolutiva, sub anthesi patentia. T u b us stamineus subcylindricus, laxus, apice decemfidus, laciniis bi-tripartitis, fauce intus antherifer, a $n t h$ e ra e 10 inclnsae, erectae, laciniis tubi oppositae, subapiculatae. $O$ v ar in $\mathbf{m}$ disco brevi insidens, quinqueloenlare. Ov u Ia in loculis gemina, angulo centrali supra medium superposite inserta, anatropa, superius adscendens, inferius pendulum. Stylus columnaeformis, st ig mat e subcapitato-quinquefido, basi articulata decidnus. D ru p a suhearnosa, putamine osseo, quinqueloculari. Se min a in localis aborta solitaria, inversa. Em b r yo in axi albuminis carnosi orthotropus, cotyledonibus foliaceis, radicul a umbilico proxima, supera. Arbores, in regionibus tropicis veteris or. $b i s$ passim obviae, una cultura etiam per regionem mediterraneam et Americam divulgata; ramis foliorum delapsorum cicatricibus late trilobis notatis, glabratis, novellis et inflorescentiis saepissime tomento stellato farinosis, foliis alternis, bipinnatis, foliolis cum impari jugatis, dentatis, plerumque acu minatis, interdum basi confluentibus, pedunculis axil. laribus inferne simplicibus, superne paniculatim ramosis, multifloris, floribus et imprimis ovariis non nunquam parte sexta auctis.

Me 11 a Liun. Gen. n. 526. exel, sp. Gärtner $I T$. 474. exel. synon. Cavanill. Dissert. $t$. 207. Bot. Reg. $t$. 643. DC. Prodr. I, 621. Air. Jussien in Mem. Mus, XIX, 219, $t, 13$ f. 4. Meisner Gen. 50. (36.) $\Delta \mathrm{zed}$ erach Tournef. Inst. 387. Adauson Fam. IT, 349 .

5521. Azadirrachta ADR. JUSS. C a lyx quinquepartitus, laciniis aestivatione imbricatis. Corolla e petala 5 , hypogyna, subspathulata, aestivatione convolutiva, sub anthesi patentia, Tubus stamineus subeylindricus, apice decemfidus, lobis biseriatis, obtusis, patentihus, fauce in tus antherifer, a $\mathbf{n}$ h e ra e 10 , subexsertae, erectae, tubi laciniis oppositae, muticae. Ovari um disco brevi insidens, triloculare. Ovula in locu- lis gemina, angulo centrali prope apicem collateraliter inserta, pendula, anatropa. Stylu s crasse filiformis; stigm a trifidum, lobis conoideis, erectis. Drupa ovalis, putamine osseo, abortu unilo. culari, monospermo. Semen inversum. $\mathbf{E}$ bryo in axi albuminis carnosi orthotropus, e otyíd onibus foliaceis, radicula umbilico proxima, supera. - Arbor indica; ramis novellis glabris, foliis alternis, simpliciter abruptim imparipinnatis, foliolis valde inaequilateris, serratis, glabris, infimis basi interdum lobatis, terminali dum adest plerumque citius deciduo, paniculis axillaribus, mul tifloris, floribus interdum quinta parte imminutis.

A $\mathrm{z}$ adi $\mathrm{r}$ a clt $\mathrm{ta}$ Adr. Jussieu in Mem. Mus, XIX, 220. t. 13. f. S. Meisner Gen. 50. (36.) Wight Ic. t. 18. Melia A $z$ a d l $\mathrm{r}$ a e h t a Linn. Cavanill. Dissert. $t$. 208, non Gärtu.

558\%. Mlallea ADR. JUSS, Calyx cnpulaeformis, quinquedentatus. C o roll a e petata 5 , hypogyna, lanceolata, aestivatione valvatim induplicata, sub anthesi patentia. Tubus staminens decempartitus, basi integra cupulaeformi, incrassata, laciniis linearibns, apice bifidis, inter lobos an. therifer, anthera e 10, erectae, cordatae, subapiculatae. Ovarium sessile, quinqueloculare. Ovula in loculis gemina, anguli centralis medio collateraliter inserta, semianatropa, micropyle supera. Stylus brevis, clavatus; stigma hemisphaericum, quinque apiculatum. D rup a carnosa, pentapyrena, pyrenis osseis, abortn monospermis. Se $\mathrm{m}$ in a inversa, umbilico ventrali. $\mathrm{E} m$ br yo in axi albuminis carnosi orthotropus, cotyle donibu 8 foliaceis, radicula supera. - Frutex in. dicus ; foliis alternis, imparipinnatis, foliolis oppositis, inaequilateris, integerrimis, v. supra medium remote dentatis, pedunculis axillaribus, basi inferne simplicibus, superne corymbose v. paniculatim multifloris.

Malle a Adr. Jnssieu in Mem, Mrus, XIX, 221, $t, 13$. f. 6. Wight et Arnott Prodr. $r$. 118. Melia baceifera Roth. E ckebergia indica Roxb.

5523. Cípratessa $B L U M$, Caly $\mathrm{x}$ obsolete quinquedentatus. Cor oll a e petala 5 , patentia. Tubus stamineus decempartitus, parte integra brevi, laciniis petala subaequantibus emarginatis, antherae 10, intus adnatre. Ovarium annulo cinctum, quinqueloculare. $0 \times \mathrm{va}$ in $10-$ culis gemina. Stylus brevis; stigma capitatum, apice quinquedentatum. C a psula (?) globosa, quinquesulea, pentacocca, coccis monospermis .... - Frutex javanicus; foliis imparipinnatis, foliolis oppositis, integerrimis.

Cirade ss a Blume Bijdr. 162. Adr. Jussien in Mem. Mus. XIX. 222.

THEIBUS 1I. TRICHILIEAE Adr. Jussieu in Mem. Mus. XIX.223. Em b r y on is exalbuminosi cotyledones crassae, radicula brevis, plerumque retracta. - Species amphigeae, foliis alternis, simpliciter pinnatis, foliolis integerrimis.

5524. A glisola LOUR. Ca l y x quinquedentatus v. quinquepartitus. C or o 11 a e petala 5 , hypogyna, libera v. basi coalita, aestivatione imbricata, sub anthesi conniventia. Tubus stamineus brevis, apice urceolato dilatato, integerrimo v. dentato, intus antherifero, an the r a 5 inclusae, erectae, mntieae. Ovarium nniloculare, saepe abortivum. Ovula $2 \ldots . .$. Stylus brevissimus; s t i g m a latum, integrum v. subbilobum. B a cea 
corticata, exsucea, mono-disperma. S e min a exarillata ..... E mbryonis exalbuminosi coty ledon e $s$ crassissimae. - Arbores $v$. frutices, $A$ s $i$ a e tropica $e_{;}$foliis alternis, imparipinnatis, foliolis oppositis, integerrimis, paniculis axillaribus, diversiformibus, interdum cum ramulis foliisque lepidotis, floribus abortu polygamis.

A g la ja Loureiro Flor. chochineb. I, 216. Jack. Malay. Miso. 1.n. 2. 33. DC. Prodr. I. 537. Blume Bijdr. 169. Adr. Jussieu in Mem. Mus, XIX, 245, t. 14.f. 7. Hook. et Arn, ad Beechey t. 34. Meisner Gen, 48. (35.) C a mu $u$ i um Rumph Amboin, $V$, 28. $t$, 18. C a m ba $\mathrm{a}$ i a Commers, msc.

5.5\%5. DIIInea ROXB. Calyx quinquefidus, laciniis aestivatione imbricatis. Corolla e petala 5, hypogyna, concava, aestivatione convoIntiva, sub anthesi erecta. Tubus stamineus abbreviatus, apice subgloboso-dilatato intus antherifero; antherae 5, inclusae, erectae, muticae. Ovarium disco semiimmersum, bi - triloculare. Ovula in loculis solitaria v. gemina, anguli centralis medio inserta, horizontalia, anatropa. St yl u s brevis, crassus; $8 \mathrm{tigma}$ truncato-dilatatum, obsolete emarginato bi-trilobum. B a c c a corticata, exsucca, abortu unilocularis, monosperma. Se m e n arillo carnoso, completo inclusum. Em b r y o n is exalbnminosi cotyled on es crassae, transverse sibi incumbentes, radicula brevissima, retracta, centripeta. - Arbores $v$. frutices Asiae tropicae; ramis foliisque novellis lepidotis, foliis alternis, imparipinnatis, foliolis oppositis v. suboppositis, integerrimis, paniculis axillaribus multifloris, seminum arillo eduli.

Mil ne a Roxburgh Flor, ind, I. 637. Edit. Wall. IT. 430. Jack, in Linn, Transact, XIV. 114, Wight et Arnott Prodr. I. 118. $\mathrm{N}$ y a le li a Deast. z. Hort. Malab, IV, 16.

5.526. Lansions $R U M P H$. $\mathrm{C}$ a ly $\mathrm{x}$ pentaphyllus, foliolis aestivatione imbricatis. Corol1 a e petala 5 , hypogyna, subrotunda. Tubus staminens urceolato-subglobosus, intus antherifer ; a ntherae 10, inclusae, erectae, muticae. Ovari um annulo exiguo cinctum, quinqueloculare. Ov u la in loculis gemina ..... Sty $\mathbf{l}$ us brevis, crassus; stigma irnneato - radiatum. B a c ca corticata, quinquelocularis, loculis nonnulis abortivis. Semina in loculis solitaria, ovulorum coalitione interdum diembrya, arillo baccato inclusa. Embryonis exalbuminosi cotyledonescrassissimae, transversim sibi incumbentes.

Arboresindicae; foliis alternis, imparipinnatis, paucijugis, foliolis alternis, integerrimis, paniculis axillaribus, fructu eduli.

L a n s i a m Rumph Amboin I. 151.t. 54. Blume Bijdr, 164. Jaek in Linn. Transact, XtV. 115, t. 4, f. 1 . Adr. Jussieu in Mem, Mus, XIX. 233. S p ha ex o s a cme Wallich in Roxb. Flor. ind, II, 429.

5ระซ. Nemedra JUSS. Caly x breviter et obtuse quinquelobus. Co r oll a e petala 5 , by pogyna, concava, aestivatione imbricata, 8 bb anthesi conniventia. Tubus staminevs urceolatosubglobosus, intus elevato octo-decemcostatus, costis a pice inerassato antheriferis; a $\mathrm{n}$ th e rae $8 \mathrm{v} .10$, inclusae, erectae, pyramidatae, muticae. Ova. ri $\mathbf{m}$ sessile, triloculare. 0 vula in loculorum angulo centrali solitaria, adscendentia .... Stigma sessile, ovoidenm, apice trilobatum. Fructa $8 . . .$. Frutex Novae-Hollandiae tropicae; foliis alternis, imparipinnatis, foliolis paucijugis, lanceolatis, subintegerrimis, subtus lepidotis, paniculis axillaribus et terminalibus confertis, pube furfuracea conspersis, corollis interdum sexta $v$. septima parte auctis.
Nem ed ra Jussien in Mem. Mus. XIX. 293, t. 14, f, 8 , Meisuer Gen. 48. (35.)

5583. Amoora $R O X B$. Calyx triphyllus, nudus $v$. bibracteolatus, foliolis aestivatione imbricatis. Coroll a e petala 3 , hypogyna, lata, concava, patentia. T ubus stamineus subglobosus v. campanulatus, obsolete sexlobus, intus antherifer; a n thera e 6, inclusae, tubi lobis oppositae, dorso insertae, oblongae, trigonae. Ovarin m sessile, depressum, triloculare. $O$ v 1 a in loculis gemina, angulo centrali superposite inserta, semianatropa, micropyle supera. Sti $\mathbf{m}$ a subsessile, pyramidato - triquetrum. C a p 8 u la coriacea, trilocularis, loculicide trivalvis, valvis medio septiferis. Semina in loculis solitaria, arillo carnoso, plus minus completo involuta, umbilico ventrali. Embryonis exalbuminosi cotyled ones crassae, saepissime coalitae, radicula brevissima, supera. - Arbores procerae, in Asia tropica crescentes; foliis alternis, imparipinnatis, foliolis multijugis, inaequilateris, floribus obortu polygamis, masculis in paniculas, hermaphroditis in racemos $v$. spicas axillares dispositis.

A moo r a Roxburgh Plant, of Corom. III. t. 258. Wight et Arnott Prodr. $\boldsymbol{I}$. 119. A a u r a Schultes f. Syst. VII. XII. 1621. A nders on i a Roxburgh Flor. ind. IT. 212. non Alior. A phanami $\mathrm{x}$ is Blume Bijdr, 165. Adr. Jussieu in Mem, Mtus. XIX. 223, $t, 14 . f .9$.

5529. Dysoxylon BLUM, C alyx parvus, quadri-quinquefidus, Corolla e petala 5 , hypogyna, ovali-oblonga, rotato-patentia. T u b u s stamineus brevis, octo-decemdentatus, fauce in-

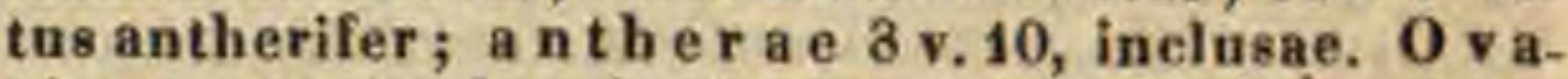
rium annulo brevi cinctum, tri-quadriloculare. Ovala in loculis gemina......Sty Ins filiformis; stigma subpeltatum. Capsula coriacea, trilocularis, loculicide trivalvis, interdum abortu uni-bilocularis, bivalvis, valvis medio septiferis. Semina in loculis solitaria, exarillata, umbilico ventrali lato, Embryonis exalbuminosi cotyledone 8 maximae, plerumque sibi oblique incumbentes, radicula .... - Arbores $j a v a-$ nicae, vastae, cortice et ligno saepe foetido; foliis alternis, abrupte pinnatis, foliolis basi obliquis, pedunculis axillaribus solitariis, paniculatim multifloris.

D y s ox ylo n Blame Bijdr. 172, excl. sect, 2. Adr. Jussieu in Mem. Mus. XIX, 224. Meisner Gen. 48. (32.)

5539. Sellatzochiton SPRENG. C a I y $\mathrm{x}$ urceolatus, snbintegerrimas. Cor olla e petala 5, hypogyna, linearia. Tu b s staminens coniens, apice sex-octofidus, fance intus antherifer; a ntherae 6 , rarius 7 v. 8 , inclusae ..... 0 va. rium annulo brevissimo cinctum, trilocnlare. Ovula in loeulis solitaria ...... Stylus clavatus; 8 tig ma obtusum. Cap 8 nla trilocularis, v. abortu bi-unilocularis, loculicide bi-trivalvis, valvis medio septiferis. S e mina in loculis solitaria, arillo carnoso, incompleto cineta. E m b ry onis exalbuminosi c ot y le do n es maximae, peltatae, ra die ula... Arbores javanicae; foliis abrupte pinnatis, foliolis suboppositis, oblongis, basi obliquis, floribus supraaxillaribus, laxe panicutatis.

Schizochit on Sprengel Cur. post. 251. Meisuer Gen. 48. (35.) Chin o c het o a Blume Bijdr. 163. Adr. Juss. in Mem. Mus. XIX. 226.

5531. Symowm ADR. JUSS. C alyx quadripartitus, laciniis aestivatione imbricatis. C orolla e petala 4, hypogyna, ovata, aestivatione convoluta, sub anthesi patentia. $T$ u b u s stamineus 
expulaeformis, subiategerrimus, fance intus antherifer; a $t$ he rae 8 , subinclnsae, ereetae, ovatae. 0 va ri $\mathbf{m}$ diseo aequali insidens, trilocolare. Ovula in loculis gemina, laminaè ex apice loculi pendulae utrinque adnata, unicum mentientia. Stylus brevis, crassus; stigma discoideum. Ca $\mathbf{s}$ u la trilocularis, leculicide trivalvis, valvis medio septiferis. Se mina in loculis gemina, laminae carnosae ex apice anguli centralis pendulae intus adnata, ab eadem involuta. Embryonis exalbuminosi c ot yledones erassae, radicula brevissima, supera. - Arbor Novae-Hollandiae subtropicae; foliis alternis, imparipinnatis, foliolis quinque-septemjugis, elliptico-lanceolatis, integerrimis, subtus ad nervorum axillas barbatis, racemis axillaribus, paucifloris.

S y n o m Adr. Jussieu in Mem. Mus. XIX. 226. $t, 15$. f. 10. Meisner Gen. 48. (35.) S ch outensi a Endl. Flor. Norf. 79. in not. excl. synou. Trichilia glandulosa Smith.

5532. Hinrtiglnsea $A D R$, JUSS. C aly $x$ quadri-quinquepartitus $v$. dentatus, nune subinteger. Corolla e petala $4-5$, basi cum tubo stamineo connata, rarius libera. T u b n s stamineus cylindricus, apice octo-decemdentatus, dentibus simplisibus $v$, bifidis, fance intus antherifer; anth e r a e 8_10, inclusae, tubi crenaturis alternae, erectae. Ova rium sessile, tubulo erenulato vaginatum, tri-quadriloculare. Ovula in loculis nune solitaria, anatrope horizontalia, nune gemina collateralia semianatrope pendala. Stylus filiformis, interdum subnullus; stig ma discoideum. C a p s u la tri - quadrilocularis, loculicide tri-quadrivalvis. Semina in loenlis solitaria horizontalia, v. gemina collateralia, pendula, exarillata v. arillata. Emb ryon is exalbuminosi cotyled ones carnosae, verticales; $r$ a di e u la supera, v. horizontaliter superposita, centripeta. - $\mathrm{Ar}$ bores in Nova-Hollandia orientali et insulis vicinis, nec non in Moluceis crescentes, non satis notae, et in plura genera olim separandae; lig. no interdum graveolenti, foliis abrupte $v$, rarius imparipinnatis, foliolis oppositis, paniculis axillaribus, saepe laxifloris $v$, racemiformibus.

Hartighsea Adr. Jussieu in Mem, Mus. XIX, 207, t. 15. $f$. 11. A. Richard Sert. Astrolab. t. 11. Meisner Gen, 49. (35.) Trichilia o s p. Forster. Labillard. Nov. Caled, t. 54. Macrochiton sect. D y sox y 1 i Blume Bijdr. 172.

5533. Wgielenares $B L U M$, C a ly x cupulaeformis, quadrifidus, lobis aestivatione valvatis. Coroll ae petala 4, hypogyna, lihera, aestisatione imbricata, sub anthesi medio reflexo-patentia. Tubus stamineus cylindricus, apice octofidns, lobis emarginatis, fauce intus antherifer; anthe$r$ a e octo inclusae, tubi lobis alternae, erectae. Ovarinm sessile, tubo urceolato, crenulato vaginatum, quadriloculare. $O \mathrm{vula}$ in loculis gemi. na, anguli centralis medio superposite inserta, horizontalia, anatropa. Sty Ins filiformis; $s \mathrm{ti} g \mathrm{ma}$ discoideum. Capsula quadrilocularis v. abortu bilocularis, loculicide bi-quadrivalvis, valvis medio septiferis. Sem in a in loenlis solitaria, arillo carnoso, incompleto tecta; cotyledonibus crassissimis, sibi invieem superpositis, ra dicula brevissima, centripeta. - Arbores moluc cana $e$; foliis imparipinnatis, foliolis oppositis, integerri. mis, inflorescentia axillari, racemiformi, floribus interdum parte quinta auctis.

Epicharis Blume Bijdr. 166. Jussien in Mem, Mus. $X I X$, 228. t. 15, f, 12. Meisner Gen. 49. (35.)

5534. Cabrallea ADR. JUSS. brevis, pentaphyllus, foliolis aestivatione imbricatis. Coroll a e petala 5, hypogyna, libera, aestivatione imbricata, sub anthesi medio reflexo patentia. Tubus staminens cylindricus, apice decemfidus, lobis emarginatis, fance intas antherifer; antherae 10, inclusae, tubi lobis alternae, erectae, subarcuatae. Ova ri am sessile, tubulo obsolete pentagono, quinquecrenato vaginatum, quinqueloculare. Ovula in loculis gemina, anguli centralis medio superposite inserta, pendula. S t y I n s filiformis; st $\mathrm{ig}$ ma discoideum. F ructus .... - Arbores v. frutices brasilienses; foliis alternis, imparipinnatis, foliolis oppositis, inaequilateris, terminali longe petiolulato, diffor$m i$, paniculis axillaribus, interdum in ramis abbreviatis aphyllis pluribus subfasciculatis, floribus nonnunquam quinta parte imminutis.

Cabrale a Adr. Jussieu in Mom. Mus, XIX, 299. t, 16. f. 13. Meisner Gen, 49. (35.)

5535. Didymoelhitom $B L U M$. Calyx brevis, pentaphyllus, foliolis aestivatione imbricatis. Corolla e petala 5, linearia, tubo stamineo inferne arcte adnata, superne libera, reflexa, T ubus stamineus cylindriens, apice decemfidus, lobis emarginatis, fauce intus antherifer; antherae 10 , inclusae, tubi lobis alternae, erectae. Ovarium sessile, tubulo membranaceo, lageniformi, quinquecrenato eum styli parte inferiore inclusum, quinqueloculare. Ovula in loculis gemina, anguli centralis medio subeollateraliter inserta, semianatropa, micropyle supera. Sty lus filiformis; st igm a discoideum. B a c ca corticata, ovata, obortu bi-trilocularis. Semina in loculis solitaria, angulo centrali inserta, exarillata. Embryonis exalbuminosi cotyledones crassae, radicula supera. - Arbores $v$, frutices mollucani; folits imparipinnatis, foliolis alternis oppositisve, mollibus, floribus in spicis axillaribus simplicibus $v$. compositis glomerulatis, glomerulis bracteatis.

Didymoebiton Blume Bijdr. 17\%. Adr. Jassieu in Mem. Mus. XIX, 230. t. 16. f. 14. Meisner Gen, 49. (35.)

5536. Cronatoelintom $B L U M$. C a 1 y x minimus, obsolete quinquedentatus. Corolla e petala 5, hypogyna, oblonga, patentia. Tubus staminens brevis, conicus, angulatus, decemdentatus, fauce antherifer, anthera e $10 \ldots \ldots$. Ovari u m sessile, tubulo membranaceo cinctum, quinqueloculare. Ovala in loculis gemina ...... Sty lus filiformis; $s t i g m$ a peltato angulatum. Capsula globosa, coriacea, tri-quadrilocularis, tri-quadrivalvis. Semina in loculis solitaria, angnlo interiori affixa, exarillata, Embryonis exalbuminosi cotyledones maximae, plano-convexae, radicula supera. - Arbor javana; foliis imparipinnatis, foliolis suboppositis, basi saepe inaequilateris, racemis axillaribus, compositis.

Gon i o ehit on Blume Bifdr. 176. Adr. Jussieu in Mem, Mus, XIX, 231. Meisner Gen, 48. (35.)

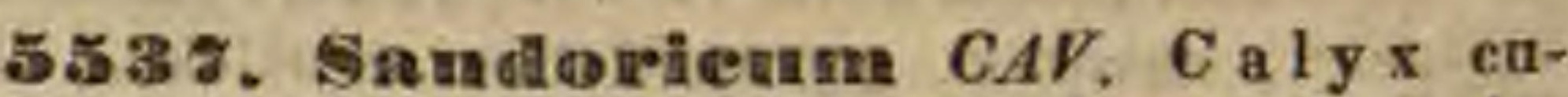
pulaeformis, breviter et obtuse quinquelobus, lobis aestivatione imbricatis. Corollae petala 5, oblonga, libera, aestivatione imbricata, sab anthesi patentia. T u b us stamineus cylindricus apice quinquedentatus, dentibus intus basi antheriferis; an ther a e 10, inclusae, ereetae, introrsae, cordatae. Ovarinm calycis fundo semiimmersnm, superne cum styli basi tubulo membranaceo, lacero, quinquedentato vaginatum, quinquelocu- 
lare. Ovula fin loculis gemina, ex angulo centrali prope apicem collateraliter pendula, subcoalita, anatropa. S t y l n s columnaeformis; $s t \mathrm{i} g \mathrm{ma}$ longum, basi globosum integrum, superne quinquefidum, lobis crassiusealis, emarginatis, subpatentibus. B a c ca pomiformis, quinquelocularis $v$, ahortu tri-quadrilocnlaris. Semina in loculis solitaria, inversa, axillo chartaceo, extus pulposo inclusa. Limbryon is exalbuminosi cotyledones crassissimae, $\mathrm{r}$ a di $\mathrm{e}$ u l a supera.-Arbor in dic n; foliis alternis, pinnatim trifoliolatis, foliolis ovatis, integerrimis, subtus pubescentibus, paniculae axillaris peduneulis brevibus, floribus inde subglomerato-confertis, bracteis longiusculis stipatis, fructibus sapide acidulis.

Sa ndor i e m Rumph Amboin. 1, 167, t. 64. Cavanill. Dissert. VII. 359, $t$, 202. 203. Lam, t. 350. Roxburgh Plant. of Corom. $t, 261$. Flor. Ind, IT, 292, DC. Prodr, I. 621. Adr. Jussieu in Mem. Mus. XIX, 232, $t, 16, f, 15$. Wight et Arnott Prodr. I. 119. Meisuer Gen. 49. (35.)

5539. Whelbergia SPARM. C aly x hrevis, quinquefidus, laciniis aestivatione imbricatis. Corolla e petala 5 , hypogyna, oblonga, libera, aestivatione imbricata, snb anthesi erecta. Tub ns stamineus campanulatus, apice decemdentatus, dentibus antheriferis; ant her ae 10 , erectae, apiculatae. Orari um sessile, disco annulari libero v. adnato basi einctum, quadri-quinqueloculare. Ovula in loculis gemina, angulo centrali superposite inserta, pendula, anatropa. Sty I us bre vis, crassns; stigma discoideum, absolete quadri-quinquelobum. B a c c a coriacea, exsucea, quadri-quinquelocularis, loculis nonnullis interdum effoetis. S e $\mathbf{m}$ in a in loculis solitaria, inversa, exarillata. Em bry onis exalbumingsicot y ledones carnosae, radic ula supera. - Arbores in Africa tropica et in Capite bonae Spei crescentes; foliis imparipinnatis, foliolis oppositis, integerrimis, floribus axillaribus paniculatis, pube brevi albicantibus, fertilibus cum sterilibus, saepe monstrosis mixtis.

Ekeberg ia Sparmann in Act, Holm, 1779, p. 282, t.9. Lam. $t$, 358. DC. Prodr. $I$. 623. Adr. Jussieu in Mems. Mus. XIX. 233. t. 17. Guiltemin et Perrot. Flor. Seneg, $1,31$. Meisner Gen, 49. (36.)

5539. Walsuma $R O X B$. CaIy x brevis, quinquefidus, laciniis aestivatione imbricatis. Corollae petala 5 , hypogyna, oblonga, libera, aestivatione imbricata, sub anthesi patentia. T ubus staminens profunde decemfidus, laciniis linearibus, apice bifidis, infra apicem inter lobos antheriferis; a $t$ herae 10, erectae, apiculatae. Ovari u m sessile, disco annulari carnoso immersum, liberum, bi - triloculare. Ov ula in loenlis gemina, ex angulo centrali prope apicem collateraliter pendula, anatropa. S t y 1 u a brevis, clavatus; st igma globosum, bi - triapiculatum. B a c $c$ a carnosa, indehiscens, abortu unilocularis, monosperma, Se men inversum, arillatum. E mb r y o... Arbores in dic a e; folits alternis, trifoliolatis, rarius foliolo terminali abortiente bifoliolatis, v. abrupte pinnatis, bijugis, paniculis axillaribus v. terminalibus, pedunculatis.

W a I s u ra Roxburgh Flor. ind. IT, 388. Wight et Arnott Prodr, I. 120. Meisner Gen. 49. (36.) Wight Illustr. t. 55. He ynea trifoliata Adr. Jussiea.

5540. Fleymea ROXB. Calyx brevis, quinquefidus, laciniis aestivatione imbricatis. Corollae petala 5 , hypogyna. oblonga, aestivatione imbricata, sub anthesi erecta. Tubus stamineus profunde quinquefidus, laciniis late linearibus, apice bifidis, inter lobos antheriferis; anther a e 10 , terminales, erectae, apiculatae. Orarin m diseo carnoso immersum et adnatum, biloculare. O v u Ia in loculis gemina, ex angulo centrali prope apicem collateraliter pendula, anatropa. Styl o s brevis, clavatus; stig ma glohosum, bi-triapieulatum. Capsula carnosa; abortu unilocularis, bivalvis, monosperma. Sem en inversum, arillatum. Embryonis exalbuminosi cotyledones carnosae, erassae, radicula supera. Arbores indicae, foliis imparipinnatis, multijugis, foliolis oppositis, integerrimis, paniculis axillaribus, pedunculatis, floribus interdum quinta parte imminutis.

He y n e a Roxburah in Bot. Mag. t, 1738. Plant. of Co. rom, III. t, 260, Flor. Ind. II. 390. DC. Prodr. I 624. Adr. Jussieu in Mem. Mus. XIX, 234, t. 18. f. 17. exel. sp. Wight et Arnott Prodr. I. 120. Melsner Gen' 49. (36.)

5541. Trielnilia LINN. C a ly $\mathrm{x}$ brevis, quadrifidus $v$. dentatus, lobis aestivatione imbricatis. Corolla e petala 4 v. 5, hypogyna, oblonga, libera, aestivatione imbricata, sub anthesi erecta $v$. patentia. Tubus stamineus irteger $v$. decemfidus aut partitus, laciniis linearibus, integris, apice antheriferis; a $n$th era e 10 , terminales, erectae, muticae, Ovari um disco libero v. snbadnato, ant tubo stamineo inferne cohaerente insidens, bi-triloculare. Ovula in loculis gemina, angulo centrali collateraliter $v$. superposite inserta, anatropa. Sty lu s brevis, ovario continuus; $8 \mathrm{tig} \mathrm{ma}$ capitatum, bi - trilobum. C a p s u I a bi-trilocularis v. abortu unilocularis, loeulicide bi-trivalvis. S e m in a in loculis gemina v. saepius abortu solitaria, inversa, arillo carnoso tecta v. inclusa. $\mathbf{E} \mathbf{m}$ bryonis exalbuminosi cotyledones crassae, ra dic u la supera. - Arbores $v$, frutices inter $t r$ opicos Americae, rarius in Africa crescentes; foliis alternis, imparipinnatis, foliolis alternis v. oppositis, multijugis $v$. interdum terminali solum superstite unijugis, paniculis axillaribus multifloris, interdum subfasciculatis.

Trichill a Linn. Gen, n, 528. Kunth in Humb. et Bonpl. LVov. gen. et sp. V. 214, VII. 226. DC. Prodr. I. 629, exel. sp. Adr. Jussieu in Mem, Mus, XIX, 235. Meisner Gen, 49. (36.)

a. EUTRICHiLia. Flores pentameri. Antherae gla. brae. Ovula collateralla. - Trichilla Jass. Gen. 265. E I e aj a Forskael Aegypt, 127. (Jacq. Amer. t. 82. 175. Edit. pict. t. 123. 260. Hort, schönbr. Ł. 102. Gnillew, et Perrot. Flor, seneg. t, 30. Adr. Jussieu Op. cit. t. 18. f. 18, a. St, Hilaire Flor, Brasil, $t, 99$.

b. PORTESIA. Flores tetrameri. An therae villosae. O vula superposita. - Portes ia Cavanill. Dissert. 7. t. 215. excl. reliq. Jussieu Gen, 265. (Adr. Juss. op. oit. $t, 18 . f .18, b$.

?c. TORPESIA. FI ores tetrameri. T a b us stamineus quadridentatos, dentibus bicrenatis, inter dentes antherifer. - Portesia mueronata Cavanill. $t, 216$. - An A zadirachtae sp.? suspieante id cl. Jussieu.

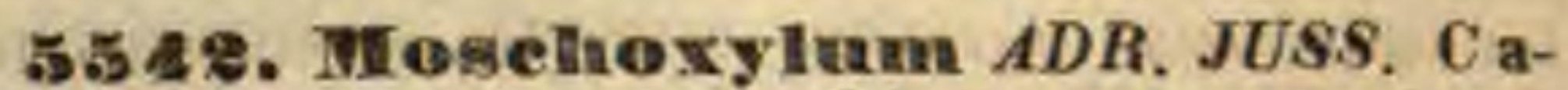
Iy $x$ brevis, quadri-quinquefidns v. dentatus, rarius subinteger. Co rolla e petala $4-5$, libera $\mathbf{v}$. in corollam gamopetalam, quadri - quinquefidam coalita. T u b us stamineus brevis, octo-decemdentatus, inter dentes subulatos antherifer; anth era e 8_10, terminales, erectae. Ovari u m disco insidens v. semiimmersum, triloeulare. Ovula in loculis gemina, angulo centrali inserta, collateraliter pendula, anatropa. Sty lus brevis; stig ma eapitatum, indivisum v. trilobum. Ca p s n la trilocularis, loculieide trivalvis. Semina in loculis $182 *$ 
solitaria, arillo succoso vestita. K m b r yo..... Arbores v. frutices Americae tropicae, ligno aliurum Moschum redolente, aliorum amaro; foliis pinnatis, foliolis alternis v. cum impari-oppo. sitis, paniculis nunc terminalibus amplis, nunc axillaribus brevibus, gemma interposita interdum subfasciculatis, floribus parvis, globulosis, ovario interdum loculo quarto aucto.

Moseh oxy I u m Adr. Jussien in Mem, Mur. XIX, 238. t, 19. $f$. 19. Meisner Gen, 49. (36.) Triehiliac sp. Swartz. Andrews Bot, Reposit. t. 637. Hooker Exot. Flor. t. 128. Adr. Jassieu in St. Hilaire Flor. Brasil. t. 98.

5343. Gunarea LINN. C a l y $x$ brevis, quadridentatus, quadrifidus v. partitus, laciniis aestivatione imbrieatis. Corolla e petala 4, hypogyna, libera, oblonga, aestivatione imbricata, $s \mathrm{nb}$ anthesi erecta. Tubus stamineus cylindricus v. prismati co-tetra-octogonus, sub apice integerrimo v. octosinuato intus antherifer; an the rae inclusae, imo v. medio dorso insertae. Ovarin m disco interdum stipitiformi insidens, quadriloculare. $0 \mathrm{v}$ u la in loculis nune solitaria, angulo centrali inserta, adscendentia, nunc gemina, superposita. Stylu s brevis; s'tig ma discoideum. C a p $8 \mathrm{n}$ la laevis v. costata aut tuberculata, quadrivalvis. Semina in loculis solitaria v. gemina, umbilico ventrali. E mbryonis exalbuminosi, antitropi coty led ones crassae, superpositae, ra dic n la dorsalis.

bores $v$. frutices, in $A m e r i c a$ tropica crescentes; foliis imparipinnatis, foliolis oppositis, integerrimis, paniculis axillaribus, interdum spicifor. mibus $v$, racemiformibus.

G a a re a Lina. Mant, $n$ 130s. Venten. Choix. $t$, 41. DC. Prodr, I 623. Adr. Jussieu in St, Hilaire Flor. Brasil.|II. t. 100. Plant. us, t. 71, Mem, Mlus. XIX. 239. t. 19. f. 20. Meisner Gen. 49. (35.) Hooker Ic. t. 129 ? - E I u th e ria P. Browne Jam, 369. Mella e s p. Jacq. Amer. $t, 176 . f .37$.

5544. Carrapa $A U B L$. C aly x tetra-pentaphyllus, foliolis squamaeformibus, aestivatione imbricatis. Corollae petala $4-5$, hypogyna, libera, aestivatione imbricata, sob anthesi reflexa. Tub u s stamineus urceolatus, octo-decemcrenatus, intus antherifer; an therae $8-10$, inclnsae, erectae, tubi crenaturis alternae, crassae. $O \mathrm{va}$ ri um disco latiori, concavo insidens, quadri-quinquecostatum, quadri-quinqueloculare. $\mathrm{O} v \mathrm{ula}$ in loculis quaterna, angulo centrali biseriatim superposite inserta. Sty lus brevis, erassus; stigma pileiforme, convexum. Ca psula lignosa, dissepimentis obliteratis unilocularis, quadri-quinquelocularis, polysperma. S e $m$ i n a maxima, circa axeos centralis reliquias in globum compacta, irregulariter angulata, umbilico ventrali. E mbryonis exalbuminosi, antitropi cotyledones superpositae, crassae, inaequales, radie ula dersalis, - Arbores in Africae et Americae tropicae littore atlantico crescentes; foliis imparipinnatis, mul. tijugis $v$. abruptis petiolo in apiculum desinente, paniculis ex axillis bractearum summos ramos aphyl. los imbricatim tegentium confertis, multifloris, quasi terminalibus, bructeis coriaceis, longis, basi utrimque glandula scutelliformi, impressa.

C a r a p a Aublet Guian. Suppl, 33, t, 387. Adr. Jussieu in Mem. Mus, XIX. 248. t, 20, $f, 21$. Meisner Gen. 48. (35.) Xy lacarpus Schreber Gen. n. 646. Persoonia Willd. Spec. III. 331 .

5545. Xyloearpas ADR. JUSS, C a 1 y x urceolatus, quadrifidus, laciniis aestivatione imbricatis. Corolla e petala 4 , hypogyna, libera, aestivatione imbrieata, sub anthesi réflexa. T u b us stamineus urceolatus, apice octofidus, laciniis acn- tis, bipartitis, intus inter lacinulas antherifer; antherae 8, inclusae, erectae. Ovarium disco latiori, concavo insidens, quadrisulenm, quadriloculare. 0 v u la in loculis 2_5, angulo centrali inserta. Stylus brevis; stigmate lato, supra convexo pileatus. Ca psula sphaerica, carnosa, dissepimentis tenuissime membranaceis obliteratis subunilocularis, quadrivalvis, polysperma. S e mina maxima, cirea axeos centralis reliquias in globum compacta, subadscendentia, dorso convexa, angulato-difformia, integumento crasso, spongioso. Embryonis exalbuminosi, antitropi coty ledones crassae, superpositae, inaequales, conferruminatae, radicula dorsali, brevi. - Arbores moluccanae, littorales; foliis abrupte pinnatis, paucijugis, paniculis axillaribus laxe paucifloris, seminibus intra capsulam germinantibus.

Xyloe arpus Adr. Jussieu in Mem, Mus. XIX, 243. t. 20. f. 22. Wight et Arnott Prodr. I. 121. X y lo c arpus G ra na tu m König in Naturforscher $X X$, 2. Ca r a pae sp. Blume.

\section{GENERA DUBIA.}

5546. Calpandria $B L U M$, Calyx tetraphyllus, persistens, foliolis inaequalibus, imbricatis, Corolla e petala 4 , patentiuseula. S t a min a 25 - 40 , intima libera, exteriora in tnoum cylindricum, intus fance antheriferum coalita, Ovari u m tri-quadriloculare, localis quinqueovulatis. Stig ma semitrifidum. Ca p s u la lignosa, subglobosa, trilocularis, loculicide trivalvis, valvis medio septiferis. S e m in a in loculis 1-2, difformia, nucamentacea (?) exarillata. E m b ry on is exalbuminosi, inversi cotyled on es maximae. - Frutex javanicus; foliis simplicibus, lanceolatis, serratis, floribus axillaribus $v$. lateralibus, solitariis $v$. geminis.

C a I pandri a Blume Bijdr. 178. Adr. Jussieu in Mem. Mus, $X I X$. 244, t. 20. f. 22. Meisner Gen. 49. (36.)

554\%. Dalontandira H. B. K. Cal yx hemisphaeriens, quinquedentatus. Cor ollae petala 5 , ovato-acuta, aequalia, aestivatione valvata. St a m in a 10, hypogyna (?), brevia, inferne connata, quinque ananthera petalis opposita cum totidem fertilibus alternantia; antherae ovatae, cordatae, biloculares, intus longitudinaliter dehiscentes. Dis c u s nullus. O r a ri u m sessile. Styl a $s$ brevissimus; stigma obtusum. Fructus... - Arbor novo-granadensis; inermis, ramulis alternis, foliis alternis, simplicibus, membranaceis, integerrimis, petiolo infra apicem articulato, stipulis nullis, paniculae axillaris simplicissimae ramis brevissimis, multifloris, floribus conglomeratis.

Odont a ndra Kunth in Humb, et. Bonpl. Nov. Gen. et sp. VII. 298. Adr. Jussieu in Mem. Mus. XIX. 255.

\section{GENUS MELIACEIS AFFINE.}

5548. Aitomia LINN. $F$. Ca I yx quadriquinquepartitus, laciniis aestivatione imbricatis. Co rolla e petala 4 v. 5, hypogyna, ovata, calyce longiora, aestivatione convolutiva, sub anthesi patentia. Sta mina 8 v. 10 , hypogyna, petalis longiora; fil am enta planiuscula, basi dilatata in tubum membranaceum coalita, superne distincta; anthera e filamentis multo latiores, ovatae, dorso supra basim affixae, introrsae, biloculares, loculis latere longitudinaliter dehiscentibus. Ovarin m sessile, liberum, disco brevi annulari membranaceo cinctum, hirsutum, quadri - quinqueloculare. 
Ovula in loculis gemina, angalo centrali prope basim collateraliter inserta, adscendentia, amphitropa, micropyle infera. C a p sula vesicaria, profunde quadri-quinqueloba, quadri-quinquevalvis, loculicide dehiscens, valvis medio septiferis. Semina in loculis gemina $v$. abortu solitaria, reniformia, sinu umbilicata testa subcarnosa, crassiuscula. E m b r y o nis exalbnminosi, pellicula tenui adhaerente involnti, incurvi cotyledones planiusculae, elliptico-lanceolatae, radie ala brevissima, infera. - Frutex capensis; foliis alternis, simplicibus, lineari-lanceolatis, integerrimis, in ramulis abbreviatis congestis, fasciculatis, floribus axil. laribus, solitariis.

A it on i a Linn. f. Suppl. 303. Adr. Jussieu in Mem. Mus, XIX, 186. Den in Edinb, new. philosoph, Journ, XIIT. 242.

\section{Drdo CCXXVI. Cedrelaceae.}

CRDRElaA R. Brown in Flinders Voy, II, 595. Bartling Ord. nat. 355, MELLACEARUM Tribus III. DC. Prodr. I. 624, CEDRBLACEAB Adr, Jassieu in Mem. Mus. XIX, 258. Lindley Introduct, edit. II. p. 103.

Arвorss saepe excelsae, ligno plerumque denso, odorato, colorato. Foli a alterna, pinnata, foliolis alternis v. saepius oppositis, integerrimis v. serratis. Sti p u la e nullae.

Flores hermaphroditi v. saepius alterius sexus organis efoetis polygami, regulares, in paniculas terminales, amplas, rarius axillares, cymuloso definitas dispositis.

Calyx liber, tetra-pentaphyllus v. quadriquinquefidus aut partitus, foliolis v. Jaciniis aestivatione imbricatis.

Corollar petala hypogyna, calycis foliolis numero aequalia et alterna, iisdem duplo v. plus duplo longiora, distincta, interdum unguiculata, aestivatione contorta v. contortoconvolutiva.

Stamina disco hypogyno cum petalis inserta, iisdem numero duplo et breviora, alterna petalis opposita alternis semper antheriferis breviora, interdum sterilia v. plane deficientía. Fil a m enta nune lata, plana, apice bidentata, marginibus in tubum octo-decantheriferum coalita, nune subulata, distincta, apice monantherifera. An th e r a e introrsae, biloculares, imo v. medio dorso insertae, saepe versatiles, biloculares, loculis longitudinaliter dehiscentibus.

Discos hypogynus glandulosus, ovarium stipitans v. annulatim ejusdem hasi circumpositus et subcohaerens, interdum longior, tubuliformis, ovarii basim vaginans.

Ovarion liberum, loculis petalorum numero aequalibus v. interdum paucioribus. $O \mathrm{vula}$ in singulis loculis quatuor, octo, duodecim v. plura, placentis septa marginantibus, cum axi centrali coalitis biseriatim inserta, adscendentia v. pendula, anatropa. Stylus terminalis, simplex. Stig $\mathrm{m}$ a apici styli nune aequale, nune latius, peltato-discoideum, angulis v. lobis loculorum numero notatum.

Capsula lignosa, tri-quinquelocularis, sep- tifrage tri-quinquevalvis, valvis ab axeos centralis crassae, tri-pentagonae v, alatae, angulis septantibus solutis.

Semina juxta loculorum angulum centralem columnae persistenti biseriatim inserta, plana, ímbricata, exarillata, pendula v. adscendentia, testa fungoso-membraniformi, basi v. apice aut undique in alam expansa, endopleura membranacea, umbilico basilari v. laterali. A lbum en carnosum parcum, v. nullum.

Емввуо nunc albumine inclusus, partimque cum illo confusus, nunc exalbuminosus, orthotropus, rectus, subobliquus v. transversus; c otyled on ibus carnosis v. planiusculis, radicula brevissima, umbilicum respiciente, supera, infera v. centripeta.

Cedrelaceac ob ligni praestantis pulchritudinem, et corticis in pluribus vim febrifugam celebres, a Meliaceis seminum numero et testa in alam expansa diversae, in Asia et Australasia tropica majori numero generantur, in America aequinoctiali paullo rariores, in Africa rarissimae.

TERIBUS I. SWIETENIEAE Adr. Jussieu in Mem. Mus. XIX, 248. Co roll a e aestivatio contorta. Stamin a in tubum coalita. Umbilicus in apice alae rhaphe percursae situs.

5549. Swietenia LINN. Calyx obtuse quinquefidus, brevis. Corolla e petala 5 , hypogyna, patentia. T ub u s stamineus subcampanulatus, decemdentatus; a n th er a e 10, inclusae, cum dentibus alternantes, medio dorso affixae, apiculatae. 0 va ri um basi disco annulari einetum, quinqueloculare. 0 v $\mathrm{I}$ a in loculorum angulo centrali plurima, pendula, semianatropa. Sty In s brevis; s $\mathrm{t}$ g m a discoideum, supra quinqueradiatum. C a p s a a lignosa, quinquelocularis, a basi septifrage quinquevalvis, valvis bilamellatis, axim septifernm superne pentagonum, inferne quinquealatum nudantibus. Semina plnrima, e summo axi pendula, biseriatim imbricata, compressa, snperne in alam membranaceam producta, rhaphe intra alam ab umbilico in ejusdem vertice sito ad chalazam supra seminis basim lateralem prorepente. E mbryo intra albumen carnosum respectu seminis transversus; cotyledonibus inter se et cum albumine conferruminatis, ra di $\mathrm{c}$ u la brevissima, papillaeformi, chalazae e diametro opposita, centrifuga. - Arbor Americae tropicae, procera; ligno durissimo, rubro-fusco, foliis abrupte pinnatis, foliolis oppositis, inaequilateris, integerrimis, paniculis axillaribus $v$. subterminalibus, laxifloris.

S wie te a i Linn. Gen, $n$, 575. Gärtner 11. 89. $t .96$, (ic. mal.) Cavanill. Dissert. VIT, 365, $t, 209$. DC. Prodr. I. 685. Hnoker Bot. Miscell, I, 21. s\$. t. 16, 17. Adr, Jussieu in Mem. Mus. XIX. 248 $t$, 22. $f$. 25. Zueearini Nov. Stirp. fase. Ir. 355. t, 7. a. b. Meisner Gen. 47. (35.) М a ago u i Adanson Fam, II, 343. Ro i a Seopoli Introduct. n, 1014, Cedra siller pict. 2.

5550. Khaya ADR. JUSS. Calyx tetraphyllus, foliolis imbricatis. Coroll ae petala 4, hypogyna, patentia. T u b u s stamineus basi ventricoso-inflatus, apice octodentatus, dentibus la- 
tis latere contortim imbricatis; antherae 8 , inclusae, cum dentibus alternantes, summo dorso filo brevi affixae. Ovarium disco annulari impogitum, et basi cinetum, quadriloculare. Ovula in Ioculorum angulo centrali plurima, biseriatim pendula, semianatropa. Sty lus brevis, pentagonus; stigma peltatum, pentagonum. Capsula lignosa, ab apice septifrage quinquevalvis, valvis bilamellatis, axim septiferum, pentagonum nudantibus. Se min a plurima, axeos faciebus biseriatim inserta, uniseriatim imbricata, pendula, compressa, membranaceo-marginata, rhaphe intra marginem, ab umbilico in vertice seminis sito ad chalazam supra basim lateralem prorepente, E mbry o intra albumen carnosum respectu seminis transversus; cotyledonibus inter se et cum albumine conferruminatis, radic u la brevissima, papillaeformi, vaga. - Arbor senegambica, excelsa, ligno Swieteniae; foliis abrupte pinnatis, foliolis paucijugis integerrimis, paniculis in apice ramorum confertis.

K ha y a Adr. Jussieu in Mem. Mus. XIX. 249. It. 21 . Gnillem. et Perrot. Flor. Seneg. I. 129. t, 32. Meisner Gen. 47. (35.) Swietenia senegatensis DC.

కธธนใ. Soymidla $A D R$. JUSS. Cal y x pentaphyllus, foliolis imbricatis. Corolla e petala 5, hypogyna, breviter unguiculata, patentia. Tub a stamineus brevis, cupulaeformis, apice decemlobus, lobis basi imbricatim coadunatis, apice distinctis, bidentatis; a n t h e ra e 10 , subinclusae, inter loborum dentes summo dorso filo brevi affixae. Ovari $\mathrm{nm}$ disco lato, tubi fundum vestienti impositum, quinqueloculare. O v ula plurima, in loculorum angulo centrali biseriata, anatropa. Stylns brevis; stigma peltatum, pentagonum. Ca ps ul a lignosa, quinquelocularis, ab apice septifrage quinquevalvis, valvis bilamellatis, axim septiferum, pentagonum nudantibus. S e m ina plurima, e summo axi pendula, biscriatim imbricata, compressa, nucleo marginato, utrinque in alam, supra longiorem producta, rbaphe ab umbilico in apice alae sito ad chalazam in basi nuclei diametraliter umbilico oppositam prorepente. Embryo orthotropus, exalbuminosus; cotyledonibus foliaceis, basi bianricalatis, radicula brevissima, supera. - Arbor indica, procera, ligno Swieteniae, cortice amarissimo, adstringente; fotiis abrupte pinnatis, in summis rumulis confertis, foliolis oppositis, tri-sexjugis, ovali-oblongis, obtusis, integerrimis, paniculis axillaribus termina libusque amplis.

So y mid a Adr. Jussieu in Mem. Mus. XIX, 250. t. 29. f. 26. Wight et Arn. Prodr. I. 122. Meisner Gen, 47, (33.) Swietenia febrifuga Roxburgh Plant, Corom, $t, 17$. De corticis virlbus febrifugis efr. Will. Roxburgh, Description of a new species of Swietenia London, 1793, 4. Andr. Dunean, Tentamen inaugurale de Swietenia Soymida. Edinb. 179\%. 8, et Breton, on the efficacy of the bark of Swietenic febrifuga, as a substitute for that of Cinchona, in Medico. chirurs. Transact, Val. XI. part. I. p. 300.

$555 \%$. Clilekrassia $A D R$. JUSS, C a ly $\mathrm{x}$ brevis, quadri-quinquedentatus. Coroll a e petala $4 \ldots 5$, hypogyna, erecta. Tubus staminens cylindrico-oblongus, apice decemerenatus, a ntherae 10 , exsertae, crenaturis impositae, erectae. Ov arium diseo lato impositum, triloculare. Ovula plarima, in loculorum angalo centrali biseriata, pendula, anatropa. Sty lns brevis, crassus, ovario continuus; stigm a eapitatum, subtrilobum. Ca p s a l a lignosa, trilocularis, ab apice septifrage trivalvis, valkis bilamellatis, axim septiferum, tripterum nudantibus. Semin a pln- rima, axeos faciebus biseriatim inserta, imbricata, pendula, compressa, deorsum in alam membranaceam producta. $\mathrm{E}$ mb r y o orthotropus, exalbuminosus; cotyled on ibus orbicularibus, inaequilateris, radicula snpera, cylindrieo-oblonga, obliqua, exserta, cotyledonum margini latiori applieita. - Arbores indicae, procerae; foliis $a b$ rupte pinnatis $v$, interdum bipinnatis, foliolis subopposilis, inaequilateris, integerrimis, paniculis terminalibus, floribus majusculis.

Chi ckrassia Adr. Jussieu in Mem. Mus, XIX, t, 22. f. 27. (Chukrasia sphalns.) Wight et Arnott Prodr. $\boldsymbol{I}$. 122. Meisner Gen. 47. (35.) Wight Illutr. t. 56, Plag i otax is Wallich Catalog. $n .1269,1270$, excl, 1271. S wi e. tenla tabularis Roxb.

TrE IIJUS II. CEDRELEAE Adr. Jussieu in Mem. Mus. XIX. 252. Cor olla e aestivatio convolutiva $v$, contorto-convolutiva. $\mathbf{S}$ tami na libera. Umbilicus si semen superne in alam productum, ad ejusdem basim situs.

5553. Chllorexylorn $D C$. Calyx quinquepartitus, brevis, Corolla e petala 5 , hypogyna, breviter unguiculata, patentia. Stamina 10, disci hypogyni, decemsinuati sinubus extas inserta, omnia fertilia; fil a m enta libera, subulata, patentia, alterna longiora, anthera e cordatae, apienlatae, versatiles. Ova rium basi disco cinctum et connatum, triloculare. Ovala in loculis 8 , angulo centrali inserta, adscendentia, anatropa. IStylus brevis, trisulcus; stigma obsolete trilobum. Ca ps u la oblonga, trilocularis, ab apice septifrage trivalvis. Se min a in loculis quaterna, adscendentia, compressa, superne in alam producta. E mbryo.... - Arbor indica, ligno denso, flavescente; foliis abrupte pinnatis, foliolis plurimis, alternis suboppositisve, parvis, valde inaequilateris, minutissime pellucido-punctatis, paniculis terminalibus, amplis, ramosis.

Chlorox y 1 on DC. Prodr. I. 625 Adr. Jussien in Mem. Mus. $X I X$. 252. t. 23. $f$. 28. Wight et Arnott Prodr. 123. Meisner Gen. 47. (35.) Wight Illustr. t.36. b. S w ie te n i a Chlor oxylo n Roxburgh Plant. Corom, $t$. 64 .

5554. FIindersia $R$. BR. C a I y $x$ quinquefidus, brevis. C o r o 1 I a e petala 5 , hypogyna, sessilia, patentia. St a mina 10 , disei hypogyni cyathiformis, decemplieati, suberenati dorso inserta, alterna petalis opposita, sterilia; filamenta libera, compresso-filiformia, antherae cordatae, apiculatae, juxta basim affixae, conniventes. Ovarium disco laxe einctum, quinqueloculare. Ovula in placentis e loculorim angulo centrali exsertis, semiseptiformibus, juxta utrumque latus bina, superposita, adscendentia, semianatropa. Stylus simplex, obtuse pentagonus; stig m a peltatum, profunde quinquelobum. Cap8 ula lignosa, echinata, tuberculata, quinqueloenlaris, apice septieide quinquevalvis, valvis cymbiformibus, solutis ab axi quinquealata placentifero, demum quinquepartibili, segmentis spongioso lignosis, valvis oppositis septiformibus, utrinque dispermis. Se min a adscendentia, compressa, imbricata, umbilico ad basim sublaterali, superne in alam membranaceam prodncta. E m b y yo exalbuminosus, transversus; cotyled onibus crassofoliaceis, radi cula brevissima, ab umbilico remota, centripeta. - Arbores, in Nova-Hollan. dia tropica et in Moluceis indigenae, gemmis ramulorumque apicibus gummiferis; foliis alternis, imparipinnatis, uni-trijugis, foliolis integerrimis, 
pellucido-punctatis, paniculis terminalibus, confertis, floribus parvis, albis, odore debili, haud ingrato.

Filindersia R. Brown in Flinders Vog, Ir, 595. t. 1. DC. Prodr. I. 695. Adr. Jussieu in Mem. Mus. XIX, 253. Meisner Gen. 47. (35.) A rbor radulifer a Rumph. AmBoin, III. 201, t. 129.

5ร5. Dxleya A. CUNNINGH. Flores .... C a p s u la lignosa, echinato-tuberculata, quinquelocularis, ab apice ad basim septicide quinquevalvis, valvis cymbiformibus, secedentibus ab axi quinquealato placentifero, quinquepartibili, segmentis suberosis, valvis oppositis, septiformibus, utrinque trispermis. Sem in a horizontalia, compressa, imbricata, undique, imprimis basi et apice in alam membranaceam producta, umbilico laterali. Embryo exalbuminosus, orthotropas, respectu seminis transversus; cotyledonibus crasso-carnosis, glanduloso punctatio, radicula brevissima, umbilico proxima, centripeta. - $A r$ bor Novae-Hollandiac orientalis subtropicae, excelsa; foliis imparipinnatis, floribus ignotis.

$0 \times 1$ e y a A. Cunninghaw in Hooker Bot. Miscell. $X$. 246. $t$. S4. Meisner Gen, 47. (35.) - Yellow - Wood Colon.

5556. Cedrelia LINN. C a Iy x quinquefidus, brevis. Co roll ae petala 4 , hypogyna, intus a basi ad medium plica longitudinali, G e n i talia stipitata. St a mina 10 , apici disci eum stipite concreti, quinquelobati, quinquecostati, inter costas plicis petaloram adnati inserta, alterna petalis opposita ananthera, brevissima v. obsoleta, fertilium fila in enta abulata, antherae biloculares, cordatae, dorso insertae, versatiles. 0 variu m stipiti discoque insidens, quinqueloculare. Ovnla in loculis 8 v. 12 , angulo centrali inserta, pendula, anatropa. Stylus brevis, pentagonus; stigma peltatum, obsolete pentagonum, supra quinqueradiatum. C a p su I a quinquelocularis, ab apice septifrage quinquevalvis, valvis columnam septiferam pentagonam nudantibus. Semina ex axi pendula, compressa, imbrieata, deorsum v. ntrinque in alam membranaceam producta, umbilico in apice nuclei terminali $\mathbf{v}$, ad basim alae superioris sito. E mbry o intra albumen earnosum, parcum orthotropus; cotyledonibus subfoliaceis, radi cula brevi, exserta, nmbilico proxima, supera. - Arbores in Asia et America tropica crescentes, ligno odorato, colorato; foliis alternis, abrupte $v$, imparipinnatis, foliolis oppositis suboppositisve, multijugis, saepe inaequilateris, integerrimis $v$. remote et obsolete serratis, paniculis terminalibus, amplis.

Cedrela P. Browne Jam. 158. Linn. Gen, n, 277, Jus. sieu Gen. 266. Gärther II, 84. Adr. Jussleu in Mem. Mus. XIX. 2Si. St. Hilaire Flor, Brasil. II. 60. Forsten, Cedrela fobrifug. L, B, 1836, p, 15. Meisner Gen, 47. (35.) Jo nsonia Adanson Fam, II. 343. Cedrus Miller Diet. 2.

a. CEDRUS. Stipes genitalium longas. $0 \mathrm{vala}$ in loculis subduodena. Semina deorsum in alam producta, umbilleo terminali. - Species americanae. (Gärtaer 2.95. Ruiz et Pavon Flor. Peruv. IIT, 9. Adr, Jussieu in Mem. Mrus, XIX, 255. t, 23, f. 29. St. Hilaire Flor. Brasill, t, 101 . Flor. Flumin, $11, t, 67,68$.

b. TOONA. Stipes genitalium brevissimas. $0 \mathrm{vula}$ in loculis suboctona. $\mathrm{Se}$ a $\mathrm{f}$ a atrinque in alam producta, unbilico ad basim alae superioris in apice uuclei. Speoies asiaticae. - (Roxburgh Plant, Corom. Q, 238. Royle Himalay, t. 25, Forsten $O p$. cit. ic. C a vera ce a Jones in Asiat. Research. IV. 281. Surenus Rumph Amboin, III, 126, - De Cedrelae febrifugae cortice efr. Horsfield in Transact, of the Patavian Society VIIT. 43. 44. Blnme Bijdr. 202. Kirckhoff in Journal complem. Dict, sc, med, $t$, 28. p, 109. Waits, Warnemingen over eenige Javaansche geneesmiddelen, Amst, 1829. p. 27. 55. Nees in Brandls, Archiv. XII. 33. Forsten Op. cit. p. $23-34$.

\section{GENUS DUBIUM.}

$555 \%$. Ixiomantlees $J A C K$, Caly x quinque-sexpartitus, lobis subrotundis. Corolla e petala 5_6, subrotanda, glatinosa. St a m in a 10 v. 20 , a nthera e biloculares. Nectarium ova. rium cingens margine ob filamenta circumposita saepe crenulatum. Ovarium ..... St y lus sim. plex, erectus; stigma capitatum. Capsula supera, calyce et corolla persistentibus cincta, ovato-acuminata, quinquelocularis, quinquevalvis, valvis margine introflexis. Semina in loculis 2, margini interiori dissepimentorum affixa, compressa, in alam membranaceam producta. Embryo in axi albuminis centralis inversus, foliaceus, planus, radicula supera. - Arbores Asiae tropica e; foliis alternis, simplicibus, integerrimis $v$. crenatis, stipulis minutis, deciduis, corymbis axillaribus, dichotomis.

Ixionanthes Jack Malay. Mincoll. ex Hooker Bot. Mag. Comp. I. 154.

\section{Classis IIII. Acena.}

Arbores v. frutices, saepe scandentes, rarissime herbae, interdum cirrhosae. Foli a opposita v. alterna, simplicia v. pinnatim aut palmatim composita. Stipula e persistentes v. deciduae, saepius nullae. C al y x liber, aestivatione imbricatus v. subvalvatus. Corolla e petala saepissime disco hypogyno inserta, calycis foliolis numero aequalia et alterna, $\mathbf{v}$. uno deficiente pauciora, interdum nulla. S $\mathbf{t a -}$ min a cum petalis inserta, iisdem numero aequalia v. saepius dupla, rarissime multipla. C arpidia 3 , rarius 2 , rarissime $4-5$, in ovarium unicum coalita, plus minusve distincta nec tamen libera, saepissime alata. Ovula in loculis solitaria v. gemina, rarissime indefinita, saepissime anatropa. Em bry o curvatus, convolutus v. rarius rectus exalbuminosus v, rarius albumine carnoso inclusus. Cotyle dones foliaceae v. carnosae, interdum conferruminalae.

\section{Ordo CCXXIII. Acerineas.}

ACBRA Jussieu Gen. 50. Annal. Mus. XVIIT. 477. ACERINKAB DC. Theorie elem, ed. II. p. 244 . Prodr. I. 593. Bartling Ord. nat, 360. Meisuer Gen, 56. (40.) ACRRACEAE Lindley Introduct. edit. II. p. 81 .

Arbores, succo in nonnullis lacteo, in plurimis limpido, saccharato. Folia e gemmis squamosis nascentia, opposita, petiolata, saepissime simplicia, palmatinervia et palmatiloba, rarius imparipinnata, tri-quinquefoliolata, foliolis petiolulatis, dentatis v. incisis. Stipulae nullae.

Flones hermaphroditi v. abortu polygami, monoici v. dioici, regulares, in racemos $v$. corymbos simplices v. compositos, axillares et 
terminales dispositis, pedicellis sparsis, exarticulatis, bractea mox caduca suffultis.

Canyx liber, glandulosus, quadri-quinquepartitus, rarius sex-novempartitus, laciniis saepe coloratis, aestivatione imbricatis, deciduis.

Conolta nulla, ve petala calycis laciniis numero aequalia, iisdem alterna et saepe similia, disei hypogyni carnosi, liberi margini inserta, breviter unguiculata, aestivatione imbricata.

Stramina medio disci inserta, calycis laciniis numero aequalia v. plura $4-12$, saepius 8 . Fil a menta filiformia, libera, interdum brevissima, subnulla. An therae introrsae, biloculares, oblongae, versatiles, loculis appositis, longitudinaliter dehiscentibus.

Ovarium liberum, sessile, e carpidiis duobus, columnae centrali e toro exsertae inferne adnatis compositum, biloculare, bilobum, dissepimento contrarie compressum. Ovula in loculis gemina, angulo centrali superposite inserta, amphitrope pendula. Sty lus inter ovarii lobos columellae centrali continuus; stigm a bifidum.

Fructus e coccis duobus samaroideis compositus, coccis dorso in alam horizontalem $\mathbf{v}$. verticalem, margine inferiore incrassatam productis, a columella centrali persistente, indivisa v. bifida solutis, indehiscentibus, monospermis v. rarissime dispermis.

Semina angulo centrali afixa, adscendentia, testa membranacea, endopleura carnosa. A I b umen nullum.

Eмввуо conduplicatus v. convolutus; c otyledonibus foliaceis, accumbentibus, irregulariter complicatis, radicula descendente, umbilicum spectante.

Acerineae a Malpighiaceis calyce deciduo semper eglanduloso, ovario constanter dimero, loculis saepius biovulatis, ovuli structura, embryonis radicula infera, foliis palmatinerviis v. compositis facillime distinguendae, in hemisphaerae borealis regionibus temperatis habitant, in America boreali numerosiores.

5558. Acer $M O ̈ N C H$. F lore s polygami. Cal y $\mathrm{x}$ quinque -interdum quadri-novempartitus, laciniis aestivatione imbricatis. Corolla e petala calycis laciniis numero aequalia et alterna, disei hypogyni lobati margini inserta. Stamina 8 , rarius 5-12, cum petalis inserta; fila menta libera, filiformi-subulata, a nt herac introrsae, biloculares, versatiles, longitudinaliter dehiscentes. O vari um sessile, biloculare, bilobum, dissepimento contrarie compressum. Ovala in loculis gemina, angulo centrali superposite inserta, amphitrope pendala. Stylus inter ovarii lobos centralis; stigma bifidum. Fructus dicoeeus, bipartibilis, coceis dorso in alam margine inferiore inerassatam productis, indehiscentibus, mono-v. rarius dispermis, columella centrali persistente, integra v. bifida. S e m e n adscendens, testa membranacea, endopleura carnosa. E mbryon is exalbuminosi, conduplicati c oty led on es irregulariter plicatae, radieula descendens. - Arbores in temperatis hemisphaeraeborealis obviae, plurimae liquore limpido, saccharato, rarius sublacteo scatentes; foliis oppositis, simplicibus, palmatinerviis, lobatis, exstipulatis, floribus racemosis $v$. corymbosis axillaribus terminalibusque.

Acer Linn. Gen, n. 1155, excl. sp. Mönch Method. 334. Gărtner II. 166, t, 116. Sehkuhr t, 35t, 352, 353. Heritier Stirp, t, 98. Pallas Flor, ross, t. 3. Duham. Arbr. t. 2. 10, 36, Sibthorp Flor. graes, t, 361, Michaux Arbr. for. 1T, t, 14-17. Desfont. in Annal. Mus. VII. $t$. 25. Trattinick Archiv, $r$. c. ic. DC. Prodr. I. 393 . Wallieh Plant. As. rar. t. 104. 105, 139. Hooker Flor, Bor. Amer, $t, 38,39$. Spach in Nouv. Annal. sc. nat. II. 160. Meisuer Gen, 56. (40.) Torrey et A. Gray Flora of North-Amer. I. 246.

555\%. Negando $M O ̈ N C H$. F lo res dioiei. C a l y $x$ minimus, quadri-quinquedentatus. Corolla nulla. Ma se. Sta mina $4-5$, ealycis dentibus opposita; filamenta subnulla, antherae introrsae, biloculares, versatiles, longitudinaliter dehiscentes. F em. O va ri um sessile, biloculare, bilobum, dissepimento contrarie cumpressum. 0 vula in loculis gemina, angulo centrali superposite inserta, amphitrope pendula. Stylus inter ovarii lohos centralis; stigma bifidum. Fruetus dicocens, bipartibilis, coceis dorso in alam margine inferiore incrassatam productis, indehiscentibus, monospermis, columella centrali persistente, bifida. S e m e n adscendens, t e s t a meubranacea, endopleura carnosa. E m b r y o n i exalbuminosi, conduplicati cotyled ones irregulariter plicatae, radicnla descendens. - Arbores borealia mericana e; folits oppositis, imparipinnatis, triquinquefoliolatis, dentatis $v$, incisis, exstipulatis, floribus masculis fasciculatis, pedicellis capillaribus, femineis racemosis.

Neg u a do Möuch Method. 334. Nuttall Gen, Amer. $I$. 253. Hooker ad Beeche, t, 77. Torrey et A. Gray Flora of North-Amer. I, 249. Ne g u ndi u m Rafin. A e er Neguado Linn. Michaux Arbr. for. I. L. 46.

5560. Dobinea HAMILT. F 1 o res monoici. Masc. pedicelli ebracteati. Calyx campanulatus, quadridentatus. Co ro 11 a e petsla 4 , calycis dentihus alterna, disci perigyni margini inserta, oblonga, unguiculata. S ta m in a 8 , cirea ovarii rudimentum inserta; filamenta filiformia, ima basi connata, alterna longiora, an the$r$ a e introrsae, biloeulares, snbgloboso-didymae, longitndinaliter dehiscentes. F e m. pedicelli bracteae coloratae adnati. Caly $x$ et e o rolla nulla. Ovariu in sessile, unilocalare. Ovul nm unicum ..... Stylus terminalis, filiformis, apice revolutus; stigma obtusum. Fructus compressus, margine angusto membranaceo cinetus, indehiscens, monospermus. S e m en erectum, compressiuscnlum, testa tenuissime membranacea. E mbryonis exalbuminosi cotyledones planae, subfoliaceae, radicula brevis, crassa, descendens. - Frutex nepalensis; ramis teretibus, foliis oppositis, simplicibus, petiolatis, penninerviis, elliptico-oblongis, argute serratis, apice acuminato integerrimis, exstipulatis, floribus terminalibus, laxe paniculatis, pedunculis pilosis, feminearum pedicellis cum bractea colorata, demum scariosa, obcordata, reticulato-venosa connatis, fructibus bracteae medio insidentibus.

Dob ine a Hamilton ex Don Nepal. 249. Meisner Gen. D. $(40$. 


\section{Drdo CCXXVIII. MIalpighiaceae.}

MALPIGHIAE Jussieu Gen, 2s.. MALPIGHIACEARUM Sect. II. Venten. Tabl, $I I I$, 131. MALPIGHIACEAE Jussieu in Annal. Mus, XVIIT, 679. DC, Prodr. I, 577. St. Hilaire Mem. Mus, X, 162, et 368. Bartling Ord. nat. 385. Adr. Jussiea in St. Hilaire Flor. Brasil. III. 3. Lindley Introduct. edit. II. p, 121. Griesebach in Linnaea XIII.

Adr. Jussieu Synops. Gener. Malpigh, in litt, 19. Sept, 1839.

Arbores v. frotices, ramis interdum scandentibus, rarius sufreuticuli erecti. Folia opposita, rarissime ternata, quandoque alterna, petiolata, simplicia, penninervia, integerrima, rarius dentata v. lobata, petiolo cum caule articulato, apice saepius glanduloso. Stip ula e ad basim petioli saepissime geminae, infra articulum, rarius supra eundem laterales, plerumque rudimentariae v. omnino obsoletae, rarius majusculae, in unicam interpetiolarem coalitae v. interdum intraaxillares. Pu bes varia, nunc e setis medio affixis, margine utroque liberis, urentibus, nunc e pilis sericeis ferrugineis v. metallico nitentibus, adpressis, innocuis.

FLorfs hermaphroditi v. abortu unisexuales, interdum in eadem stirpe dimorphi, alii superiores normales, inferiores solitarii abnormes, corolla, staminibus et stylis rudimentariis praediti, fructum perfectum maturantes. Inflorescentia corymbosa v, racemosa, foliorum supremorum abortu saepe terminalis et composita, pedicellis basi bracteatis, medio articulatis, infra articulum bibracteolatis.

Calyx liber, profunde quinquefidus v. quinquepartitus, aequalis, persistens, laciniis aestivatione valvatis v. subimbricatis, sub anthesi plerumque conniventibus, omnibus v. saepius quatuor ima basi biglandulosis $\mathrm{v}$, rarins medio uniglandulosis, saepe in eodem genere naturali etiam eglandulosis.

Corollas petala 5 , immediatim hypogyna v. disco hypogyno a calyce libero, v. eidem ima basi demum subadhaerenti inserta, calyeis laciniis alterna, distincte unguiculata v. rarissime exunguiculata, aequalia v. subinaequalia, aestivatione imbricata, sub anthesi plerumque patentissima, lamina saepissime concava, margine denticulata, fimbriata $\mathbf{v}$. integerrima.

Stamina cum petalis inserta, duplo eorundem numero, nunc omnia fertilia, alterna petalis opposita saepe breviora, nunc petalis opposita omnia v. plurima sterilia aut plane abortiva, petalis alterna vel omnia perfecta vel nonnulla sterilia, varie deformata. Fil a m enta filiformia v. subulata, basi inter se connata, rarissime libera. Antherae introrsae, biloculares, erectae v. incumbentes, intus longitudinaliter dehiscentes, loculis appositis v. suboppositis, connectivo tenerrimo vix manifesto v. crasso, interdum apice in glandulam pro- ducto, dorso saepe villoso. Pollin is granula globosa, ovoidea, tetraëdrica v. dodecaëdrica, costata, poris nullis v. definitis aut indefinitis.

Ovarivm liberum, e carpidiis tribus v. rarius duobus, in axi coalitis v, apice discretis compositum, tri- v. interdum biloculare. $0 \mathrm{vu}$ la in loculis solitaria, funiculo brevi, ex apice anguli centralis vo e medio dissepimento pendulo, inserta, adscendentia v. semianatrope reclinata (lycotropa Grieseb.), funiculo sub fructificatione libero, demum adnato. Styli inter ovarii lobos exserti 3 , distincti v, in unum connati. Stig mata indivisa, truncata v. dilatata.

Carpidia 3 v, abortu pauciora, plus minus inter se coalita v. discreta, saepe dorso v, etiam marginibus in alas producta, rarius aptera, drupacea, demum secedentia, indehiscentia, monosperma.

Semina in loculis solitaria, inversa, testa membranacea, endopleura tenui. Alb a men nullum.

Eмввуо rarissime rectus, saepissime conduplicatus; cotyledonibus carnosis v. rarissime foliaceis, apice inflexis, exteriore majore interiorem minorem amplectente, interdum circinnatim involutis, radicula brevissima, supra umbilicum sita, supera.

Malpighiaceae Acerineis Erythroxyleisque proxime affines, ab illis praeter calycem in plerisque glandulosum, petala longe unguiculata, stamina monadelpha et fructum plerumque trimerum, ovulis intra loculos solitariis pendulis, et embryonis radicula supera distinctae, ab his imprimis petalis exappendiculatis et seminibus exalbuminosis diversae, maximo numero Americae tropicae campos et sylvas primaevas, imprimis trans aequatorem sitas, parcins regiones trans Capricornum subtropicas incolunt, in Asia aequinoctiali multo rariores, in Senegambia et Capite bonae Spei rarissimae.

Generum characteres e manuscripta ordinis perdifficilis synopsi, a cl. Adr. de Jussieu rara humanitate mecum ultro communicata, hoc loeo exponi potuisse, gratus glorior.

Coriariam ovario pentamero in Acerum classe anomalam, sed vix a Malpighiaceis removendam, ad calcem ordinis posui.

DIVISIO I. MEIOSTEMONES Adr.Juss. msc. S $\mathrm{t}$ a $\mathrm{min}$ a petalis numero aequalia et alterna, nonnulla saepissime sterilia, nune plura, nunquam tamen dupla. Stylus simplex, trium coalitione v. duorum abortu, rarius triplex, duobus tune semper minoribus. Carpidia aut varie alata aut aptera, nunquam tamen carnosa, saepe filo rhapheformi subtensa, et ex eodem solubili pendula. - Flores saepe dimorphi, superiores normales, inferiores 
abnormes, calyce corolla et staminibus rudi. mentariis $v$. abortivis, fructu et seminibus perfectis.

55e1. Camarea $S T, H I L$. Flo res dimorphi, normalibu s: C a I y x profunde quinquefidus, Jaciniis quatuor basi biglandulosis. Corollae petala 5, hypogyna, calyce Iongiora, unguicnlata, vix denticulata. Stam in a 6 , hypogyna, horum quinque ealycis laciniis opposita; filamentis tribus juxta totum fere longitudinem, duobus basi tantum coalitis, antheris quatuor fertilibns, subrotundis, bilocularibas, longitudinaliter dehiscentibus, duobus staminum subliberorum sterilibus, in massam petaloideam, contortuplieatam transformatis. Ovaria $3-4$, libera, receptaculo conoideo, stylifero affixa, unilocularia, ovulo unico, pendulo, reclinato. Stylus simplex; stigma indivisum. Carpidia $3-4 \mathrm{v}$. abortu pauciora, dorso seriatim muricato-cristata v. echinata et lappulacea, indehiseentia, monosperma. S e men inversum. E m b r y o n is exalbuminosi cotyledones inflexae, radicula brevis supera. FI o ribus abnormibus: $\mathrm{C}$ al yx quinquepartitus, eglandulosus. Coroll a nulla. Anthera e uniege rndimentum sessile. $O$ va ria $2 . S$ t y lns nullos v. rudimentarius. Carpidia 1 v. 2 , monosperma. Semen perfectum. - Suffrutices bras $i$. lienses; foliis oppositis $v$, ternatim verticillatis, saepe subalternis, integerrimis, stipulis inconspicuis, floribus normalibus solitariis, ad folia superiora axillaribus, aut foliorum supremorum abortu umbellatis $v$, subcorymbosis, pedunculis interdum pluribracteatis, flavis, abnormibus in inferiorum axillis subsessilibus, occultatis, minimis, decoloribus.

$\mathrm{C}$ a $\mathrm{m}$ a r e a St. Hilaire Hist. plant, remarq. Brasil. $I$. 155. t. 18, Adr. Jussien in St. Hilaire Flor. Brasil. III. 66. t. 175, 176. Synops. Malpigh, mse. Meisuer Gen, 34. (39.) Griesebach in Linnaea XIII. 187.

55G2. Janusia $A D R$. JUSS, F lo res di morphi, normalibus: Cal y x quinquefidus, laeiniis quatuor hasi biglandulesis. Coroll a e peta la 5 , hypogyna, calyce longiora, unguiculata. St a m in a 5, hypogyna, calycis laciniis opposita omnia fertilia, $v$, rarius duo connectivi dilatatione et loculorum abortu sterilia; fi la m enta ima basi coalita, an therae fertilium introrsae, biloculares, longitudinaliter dehiscentes. Ova ria 3 , hasi inter se et eum reeeptaculo conico, stylifero connata, unilocularia, ov ulo unico, pendulo, recli nato. Sty Ins simplex, trigonus; stigma capi tatum, indivisum. S am a ra e $\mathbf{3}$. abortu paucio res, axi cohaerentes, dorso superne in alam, margine antico crassiorem compressae, inferne crista breviore marginatae, subtus filo rhapheformi, de mum solubili subtensae, indehiscentes, monospermae. Sem en inversum. $\mathbf{E} \mathbf{m}$ bryon is exalbuni nosi cotyledones apice inflexae, radicula brevissima, supera. Floribus abnormibns: $\mathrm{Ca}$ lyx quinquepartitas, eglandulosus. Corolla nulla, v. petala $1-2$, radimentaria. Antherae unius subsessilis rudimentum. Ovari a 2 . S t y $1 \mathrm{i}$ nulli v. rudimentarii. Fructus normalis. - Frutices $v$. suffrutices brasilien ses, saepe scandentes; foliis oppositis, petiolatis, integerrimis, stipu lis inconspicuis, pedunculis axillaribus v, terminalibus, umbellatim tri-quadrifloris, scmel $v$. iterum bibracteolatis et supra supremum bracteolarum par cum pedicello breviori articulatis, floribus normalibus flavis, abnormibus decoloribus, minimis, in axillis diversis, ejusdem $v$, alius rami simililer sed brevius umbellatis.

Jau usia Adr. Jussien Synops. Malpigh, msc. G a u. diehaudia guaranftiea St. Hilaire Hist, plant. re. marq. Brasil. t. 19, b. Elor, Brasil, t. 174. a,

5563. Selhwannas. Calyx profunde quinquefidus, laciniis quatuor basi biglandulosis. Corollae petala 5, hypogyna, ealyce longiora, unguienlata, fimbriata. Stamina 6, hypogyna, hornm quinque ealycis laciniis opposita, omnia fertilia; filam en t a ima basi coalita, anthe ra e introrsae, biloculares, orbiculares, dorso villosae, longitudinaliter dehiscentes. O vari a 3 , receptaenlo communi stylifero imposita, unilocalaria, ov u Io unico, pendulo, reclinato. St y I u 8 simplex; stigma capitatum, indivisum. S a m arae 3 , apice in alam margine antico erassiorem expansae, filo rhapheformi sulubili subtensae, indehiscentes, monospermae. $\mathrm{S}$ e $\mathrm{m}$ e $\mathrm{n}$ inversum. Eimbryonis exalbuminosi cotyledones apice inflexae, radicula brevis, supera. - Frutices bras ilienses, scandentes; foliis oppositis, petiolatis, integerrimis, minutissime stipulatis, umbellis quadrifloris, ad apices ramulorum in paniculas congestis, pedunculis floriferis apice bibracteolato cum pedicellis subaequalibus articualtis, basi bracteatis, floribus rubris.

Fimbriaria Adr. Jussien in St, Hilaire Flor, Bra. il. III. 63. t. 173. Synops. Malpigh, msc. Meisner Gen. S4. (39.) Griesebach in Limnaea XIII. 188,

5564. Crandielnaudia $H, B . K$. F lores dimorphi, normalibus: Caly x quinquefidus, laciniis omnibus $\mathbf{v}$, quatuor basi biglandulosis. C orolla e petala 5, hypogyna, calyce longiora, unguiculata, plas minus dentieulata. St a mina 5 , hypogyna, calycis lacinits opposita, omnia fertilia v, saepius duo ananthera; f i l a m e $\mathrm{n}$ t a ima basi coalita, anthera e introrsae, biloculares, longitudinaliter dehiscentes. Ovaria 3 , angulo centrali coalita, uniloeularia, o v u 10 unico, pendulo, reclinato. Stylus unieus, duobns rudimentariis v. abortivis; stigma obtusum. Samarae 2 v. 1, ala suborbiculari, nunc breviore, nunc latiore, integra v. lobata marginatae, dorso medio cristatae, filo rhapheformi ab insertione ad basim alae extenso, demum solnbili pedicellatae, indehiscentes, monospermae. S e m e $n$ inversum. E m b ry o$n$ is exalbuminosi cotyled ones apice inflexae, radicula brevissima, supera. Floribus obnormibus: C a 1 y $x$ quinquepartitus, eglandulosus. Corolla nulla, v. petala $1-2$, saepe rudimentaria. Antherae unicae rudimentum minimum, subsessile. Ovaria 2 . Styli nulli v, rudimentarii. Fruetus normalis. - Frutices mexicani, saepius volubiles; foliis oppositis, integerrimis, basi plerumque setaceo-biauriculatis, stipulis inconspicuis, floribus normalibus flavis $v$. croceis, in ramis lateralibus abbreviatisque terminalibus, racemosis, umbellatis rariusve solitariis, pedunculis apice bibraeteolatis, cum pedicello articulatis, abnormibus, dum adsunt, inferioribus, ad axillas foliorum rami $v$. bractearum ramuli, plerumque solitariis, rarius geminis v. ternis, subsessilibus, decoloribus, minimis.

Gandichandia Kunth in Humb. et Bonpl. Nov. gen, et sp. V. 166. Adr. Jassiea Synops. Malpigh. mso. - A s p 1e a $\mathrm{r}$ a $\mathrm{L}$. C. Richard in Mem. Mus. II. 399. t. 12. Lagasca Nov. gen. et sp. n. $z$. A cosmus Desvaux msc. (Status abnorais.)

a. TRIT0MOPTERYS Adr. Juss, $l$, c. Samara quasi trialatae, alae trilobae labis duobus supernis, tertio inferno. 
b. GAUDICHAUDIA Adr. Juss. L, c. Sa m a rac ala latiore integra marginatae. (Kunth Op. cit, t. 445.)

556.5. Dinemanatha ADR. JUSS. CaIy profunde quinquefidus, laciniis quatuor basi uni-biglandulosis. Corolla e petala 5, hypogyna, calyce longiora, unguieulata. Stamina 10, hypo. gyna; filamenta basi inter se coalita, alterna petalis opposita longiora, duo antherifera, octo sterilia abbreviata. Ovaria 3 , in unieum trilocnlare coalita, singnla dorso longitudinaliter tricristata, verrucusa. Ovula .... Styli 3 , apice truncato stigmatesi. S a m a r a 3 , parvae, dorso medio cristatae, margine utrinque alatae, alis distinctis. Semina..... Fruticulus peruanus, ericoideus; foliis oppositis, stipulis inconspicuis, floribus in racemos terminales paucifloros dispositis, pedicellis cum pedunculo proprio, apice bibracteolato articulatis.

Dinemandra Adr. Jussieu Synops. Malpigh. mso.

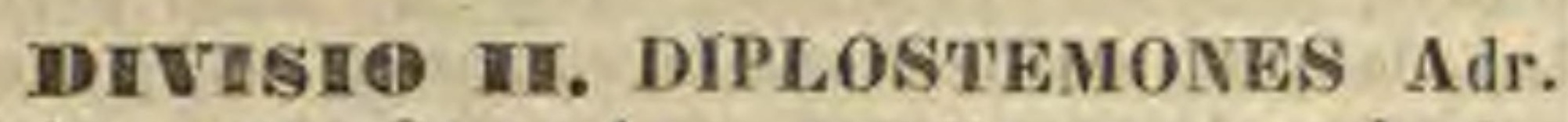
Jussieu msc. Stamina petalis numero dupla. Styli 2-3, plerumque distincti, rarissime partim v. omnino connati, v, unius aut duorum abortu solitarii. Carpidia nunc alata, ala marginante (pleuropterygiae), v. dorsali (notopterygiae), nunc aptera (apterygiae), lignosa, coriacea v. carnosa. - Flores monomorphi.

SUE IDIVHSIO I. PLEUROPTERYGLAE. Carpidia alata, ala marginante.

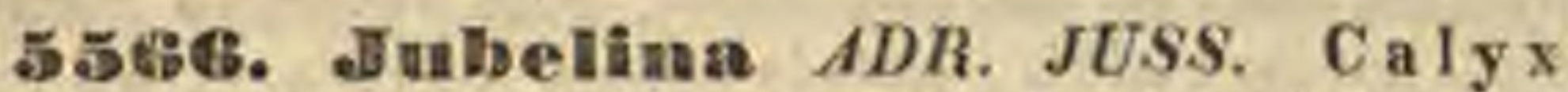
quinquepartitus, laciniis quatuor basi uniglandulesis. Corollae petala 5, hypogyna, calyce paullo longiora, unguiculata, denticnlata. Stam in a 10, hypogyna, omnia fertilia; fil am e n ta basi coalita, antherae introrsae, biloculares, glabrae, longitudinaliter dehiscentes. Ovaria 3 , in unicum trilobum coalita, singula dorso trieristata, unilocularia, ovulo uniei, pendulo. Styli 3, breves, apice truncato-bilobo stigmatosi. S a m arae 3 , in axi coalitae, singulae dorso longitudinaliter quinquealatae, alis angustis, undulatis sinuatisque, epicarpio inflato spuriae triloculares, loculis lateralibus vacuis, intermedio fertili. monospermo. S e men inversum. Embryonis exal bnminosi radicula supera. - Frutex guianensis, scandens; foliis oppositis, breve petiolatis, magnis, integerrimis, petiolis minutissime bistipulatis, umbellis quadrifioris, foliorum supremorum aborlu paniculam terminalem componentibus, vulgo ternatis, pedunculis brevissimis, bracteatis bibracteolatisque, bracteis bracteolisque umbellam primum includentibus, dein involucrantibus.

$\mathrm{J} u \mathrm{~b} \in I \mathrm{i}$ a Adr. Jussieu in Delessert. Ic. select. III. 19. t. 32. Synops, Malpigh. msc.

556\%. Diplopterys ADR. JUSS. C a I y quinquepartitus, laciniis quatuor biglandulosis. Corollae petala 5, hypogyna, calyce longiora, nnguiculata, fimbriata. Stamin a 10 , hypogyna, omnia fertilia; fil ane nta inferne coalita, antherae introrsae, biloculares, villosae, longitndinaliter dehiscentes. Ovaria 3 , in unicum trilobum coalita, singula dorso obsolete quinquecristata, unilocularia, ovnlo unico, pendnlo, reclinato. Styli 3 , rigidi, apice truneato stigmatosi. Carpidia 3 , in axi coalita, dorso longitudinaliter quinquealata, alis lignosis, parum prominen- tibus, media simplici cristaeformi, lateralibus parallelis, geminatim basi et apice conflnentibus, indehiscentia, monesperms. $\mathbf{S}$ e m e $\mathrm{n}$ inversum .... - Frutex guianensis scandens; foliis oppositis, breve petiolatis, integerrimis, inftarescentris axillaribus, umbelliformibus, umbellis plerumque ternis, quadriftoris, pedunculis subnullis, pedicellis basi articulatis, sub articulo bracteatis bibracteolatisque, bracteis bracteolisque umbellam biseriatim subinvoluerantibus, floribus luteis, diversis plantae partibus siccatione nigrescentibus.

Diplopterys Adr. Jussieu in Delessert. Ic. select. III. 20 . t. 33. Synops. Malpigh. msc.

55BS. Miraea $J A C Q$. Calyx profunde qninquefidus, laciniis eglandulosis v. quatuor biglandalosis. Corolla e petala 5 , hypogyna, calyce longiora, unguiculata, reflexa, denticulata v. subintegerrima, Stam in a 10 , hypogyna, omnia fertilia; fil amenta basi coalita, antherae introrsae, bilocnlares, plerumque glabrae, longitadinaliter dehíscentes, Ova ria 3 , angulo centrali inter se coalita, singula dorso cristato-trigona, uniloevlaria, ovulo unico, pendulo, reclinato. Styli 3, rigidi, apice uncinato-compresso hine stigmatiferi; stigmate discolori. Samarae 3 v. abortu pauciores, dorso membranaceo-cristatae, margine utroque alatae, alis semiorbienlaribus, cristatae subaequalibus v. saepius majoribus, distinctis $v$, in unicam confluentibus, indehiscentes, monospermae. Semen inversum. Embryonis exalbuminosi cotyled ones apice inflexae, radienla brevissima, supera. - Frutices Americae tropicae, plerumque seandentes; foliis oppositis, breve petiolatis $v$, subsessilibus, integerrimis, glabris $v$. varie pubescentibus, bistipulatis, stipalis subnullis, $v$. magis conspicuis et cum petiolo partim connatis, umbellis axillaribus quadrifloris, simplicibus $v$. saepius ternis, $v$, racemis terminalibus, numc simplicibus, nunc paniculatim ramosis, pedunculis floriferis in umbellis axillaribus subnullis, in racemis terminalibus brevibus, cum pedicellis articulatis, apice opposile bibracteolatis, floribus parvis v. me. diocribus, luteis, roseis aut lilacinis, nonnunquam pubescentibus.

Hiraea Jacquia Amer, 137. Kunth in Humb, et Bonpl. Nov, gen. et sp. $V$. 167. DC. Prodr. I. 586 . excl. sp. Bsiat. Adr. Jussieu in St. Hilaire Flor. Brasil. ITI, 13. Synops. Malpigh. msc. Meisner Gen. 55. (39,) Griesebach in Linnaea XIII. 239.

a. HIRABA Jacg. Amer. $t$. 176. $f$, 42. Umbellae axillares, pedicellis sessilibus.

b. MASCAGNiA Bertero msc. Racemi terminales et axillares, saeplus paniculati, interdum cocymbose contracti, rarissime umbellae, pedicellis baud sessilibus. (St. Hi. laire Flor. Brasil. 6. 163_165.)

5569. Trisispis BURCH. Caly x brevis, quinquepartitus, eglandulosus. Coroll a e petala 5, hypogyna, ealyce longiora, Innge nnguiculata, fimbrista, inaequalia. Sta m in a 10, hypogyna, omnia fertilia; fi l a m en $t$ a inaequalia, basi inter se et cum ovarii stipite coalita, a n thera introrsae, bileculares, glabrae, longitudinaliter dehiscentes. Ovaria 3 , utroque margine in alam expansa, in unicum hexapterum, trisinuatum, pilosum, breviter stipitatum, trilocnlare coalita, loculis uniovulatis, ovulo pendulo. Styli 3 , glabri, longi, graciles, flexuoso-patentes, apice acuto complanati et in ligulam subtus stigmatosam snbdilatati. S a mar a e 3 v, abortu paciores, axi coalitae, margine alatae, ala sentiformi, apice interdum interrupta, medio dorso saepe cristatae, indehiscen$193 *$ 
tes, monospermae. S em en inversum. Em bry o$\mathbf{n}$ is exalbuminosi $\mathrm{r}$ a dicula supera. - Frutices inderdum scandentes?, an arbores?, in $\bar{A}$ sia tropica et in $C$ apite bona e $S$ pei crescentes; foliis oppositis $v$. rarius subalternis, petiolatis, integerrimis, glabris $v$, pilosis, exstipulatis, racemis $v$, corymbis axillaribus paucifloris, aut terminalibus et supremorum foliorum abortu paniculam plurifloram componentibus, pedunculis floriferis brevibus, basi breviter bracteatis, apice cum pedicello longiore articulatis, infra v. supra medium bibracteolatis, bracteolis alternis $v$. oppositis, floribus roseis.

Triaspis Burchell Travel. II. 280. f. 290. Adr. Jus. sieu in Delessert Ic, select. III. 21, t. 36. Synops. Mal. pigh. msc. Fl a b e 11 a r i a Cavanill. Dissert, IX. 436. t.264. exel. folio. Hirae a e sp. Willd. DC.

5580. Aspidopterys ADR. JUSS. C alyx brevis, quinquepartitus, eglandulosus. Corolla e petala 5, hypogyna, ealyce longiora, exunguieulata integerrima. St a m in a 10, hypogyna, omnia fertilia; fil a m e n t a filiformia, distincta $v$. ima basi coalita, a $n$ the ra e introrsae, biloculares, ovatae, glabrae, longitudinaliter dehis. centes. 0 varia 3 , utroque margine in alam ovatam expansa, in unicum hexapterum, trisinuatum, pilosum v, glabrum, triloculare coalita, loculis uniovelatis, ovulo pendulo. Styli 3 , subaequales, stamina superantes, glabri; stigmata capitellata, plerumque virentia. Samarae 3 , in axi coalitae, margine alatae, ala scutiformi, ovata $\mathbf{v}$. orbiculata, interdum medio dorso breviter crista. ta, indehiscentes, monospermae. S e m e $n$ inversum. Embryonis exalbuminosi, recti radie ula supera. - Frutices Asiae tropicae, scandentes; foliis oppositis, petiolatis, integerrimis, glabris $v$. pilosis, eglandulosis, exstipulatis, paniculis axillaribus $v$. supremorum foliorum abortu terminalibus, e racemulis $v$. saepius ex umbellul is compositis, pedunculis floriferis basi breviter bracteatis, basi v. supra basim brevius bibracteolatis, apice cum pedicello plerumque longiore et gracili articulatis, floribus parvis, albis $v$. flavescentibus, inodoris.

Aspidopterys Adr. Jussieu Synops. Malpigh, msc. Hiraea Roxburgh Hort. Calc. 90. Flor. Ind. II. 447. Blume Bijdr. 225. Wallich Plant. As, rar. I. 13. t. 13. Triopteris Roxburgh Plant. Corom. II. 32. $t, 160$.

E5\%1. Tristellatein THOUAR. Calyx quinquepartitus, eglandulosus. Corollae petala 5, hypogyna, calyce longiora, unguiculata, sagittato-ovata, integerrima, extrorsum carinatoangulata. St a mina 10 , hypogyna, omnia fertilia; fil a menta ima basi coalita, rigida, introflexa, apice truncato articulata, quinque petalis opposita longiora, crassiora, antherae introrsae, biloculares, oblongo-lineares, acutae, glab rae, longitudinaliter dehiscentes. Ovari a $\mathcal{B}$, in nnicum trilobum coalita, singula dorso multiappendieulata, unilocularia, o v u lo nnico, pendulo, reclinato. Stylus unus, eum staminibus declinatus; $8 \mathrm{tigma}$ t e truncato minuto terminatus, duo minimi, papillaeformes. S a mara e 3 , solubiles, singulae dorso multialatae, alis angustis, aliis secundum lineam dorsalem mediam cristatam uniseriatis, aliis longioribus marginalibus, in stellam quadri - septemradiatam, cristae circumpositam verticillatis. Semen .... Frutices madagas. earienses et oce anici, scandentes; foliis oppositis $v$. quaternatim verticillatis, integerrimis, petiolo apice biglanduloso, racemis terminalibus et lateralibus, supremorum foliorum abortu saepe compositis, pedunculis floriferis erectis, basi bracteatis, apice v. infra apicem bibracteolatis, bracteolis setaceis, oppositis v. alternis, floribus luteis.

Tristellatela Thouars Gen. madagase. 47. A. RIchard Sert. Astrolab. II. 38. $t$. 15. Adr. Jussieu Synops. Malpigh, msc. Meisner Gen. 84. (39.) DC. Prodr. I. 583. $\mathrm{Z} \mathrm{y} \mathrm{mu} \mathrm{m}$ Noronh. msc. Thouars Hist, veget, Afr. austr. 6. $t .23$.

ธร82. Hifiptage GARTN. Caly x quinquepartitus, uniglandulosus, glandula magna, laciniis duabus interposita, partimque pedicello adnata. Corolla e petala 5, hypogyna, calyce longiora, unguienlata, fimbriata, inaequalia, reflexa. Stamina 10 , hypogyna, omnia fertilia, decimum reliquis multo longius crassiusque; fil am ent a ima basi coalita, antherae introrsae, biloculares, longitudinaliter dehiscentes. $0 \mathrm{v}$ aria 3 , in unieum trilobum coalita, singula dorso tri-quadriappendiculata, appendiculis una $\mathbf{v}$. duabns mediis, duabus lateralibus, unilocularia, ov u lo unico, pendulo, reclinato. St y I us unus perfectus, longus, aestivatione circinnatus; $s \mathrm{ti} \mathrm{g} \mathrm{mate}$ capitato, demum acuto, dno rudimentarii, rostriformes. S a mara e $3 \mathrm{v}$, abortu pauciores, singulae trialatae, alis marginalibus duabus lateralibus, tertia superiore media, dorso crista brevi longitudinali, interdum nulla, indehiscentes, monospermae. Sem en inversum. Embryon is exalbuminosi cotyledones inflexae, radicula brevissima, supera. - Frutices Asiae tropicae, scandentes; foliis oppositis, petiolatis, integerrimis, racemis terminalibus et axillaribus, summorum foliorum abortu nonnunquam compositis, pedunculis erectis, basi bracteatis, apice opposite, $v$. paullo infra apicem alterne bibracteolatis, cum pedicello articulatis, floribus albis, petalo quinto discolori, ad basim flavescente, vulgo fragrantibus.

Hiptage Gärtner II. 169. t. 116. DC. Prodr. I. 583. Meisuer Gen. 54. (39.) Adr. Jussieu Synops, Malpigh, msc. Wight Illustr. t. 50. G ä rtuera Sehreber Gen, n, 735 . Roxburgh Plant, Corom, t. 18. M oli n a Cavanill. Dissert. IX. 435. t. 263. M a da b lot a Sonnerat Voy. IT. 135. S u cco wi a Dennst. Comm, z. Hort, Malab. VI. 59.

5573. Troiopterys LINN. Calyx quinquepartitus, laciniis quatuor basi biglandulosis. Corolla e petala 5 , hypogyna, calyce longiora, unguiculata, subintegerrima. $\mathrm{S} t$ a m in a 10 , hypogyna, omnia fertilia, alterna longiora; f il a m eni a ima basi coalita, a ntherae introrsae, bilocnlares, glabrae, longitudinaliter dehiscentes. 0 varia 3 , in nnicum trilobum coalita, singula dorso longitudinaliter trieristata, lobuloque infra cristam mediam appendiculata, nnilocularia, ovulo unico pendulo, reclinato. Sty 1 i 3 , breves, rigidi, apice oblique truncato stigmatosi. Sa ma rae 3 , singulae dorso trialatae, alis dnabus lateralibns erectis, cum tertia inferiore descendente in unam marginalem alte trilobam confluentibus, medio praeterea brevius cristatis, indehiscentes, monospermae. Sem en inversum. Embryonis exalbuminosi cotyle done $s$ apice inflexae, radicula brevissima, supera. - Frutices scandentes, in America tropica indigeni; foliis oppositis, brevissime petiolatis, eglandulosis, glaberrinis, venosis, lucidis, racemis axillaribus et terminalibus, interdum inferne ramosis, pedunculis floriferis basi bracteatis, supra basim bibracteolatis, apice cum pedicello longiore articulatis, floribus caeruleis $v$. violaceis.

Trioptery 8 Lian. Gen. n. 547. Cavanill. Dissert. 1X. 431. $t$. 259. Kunth in Humb. et Bonpl. Nov, Gen. et sp. $V, 167, t, 45 t$. DC. Prodr. I. 586, Meisuer Gen, 55, (39.) Adr. Jussieu Synops. Malpigh, msc. 
55\% 4. Tetrapterys CAV. Caly x quinquepartitus, laciniis omnibus v. saepius quatuor basi biglandulosis, rarissime subeglandulosus. $\mathrm{C}$ orolla e petala 5 , hypogyna, calyce longiora, unguiculata, subintegerrima v. dentata. $\mathrm{St}$ a m in a 10 , hypogyna, omnia fertilia, alterna longiora; filamenta basi coalita, antherae introrsae, biloculares, glabrae v, rarius hirsutae, longitudinaliter dehiscentes. Ovaria 3 , angulo centrali inter se coalita, singula dorso medio eristata, latere utroque biappendiculata, nnilocularia, o v ulo unico, pendulo, reclinato. Styli 3 , rigidi, breves, apice truncati, hinc stigmatiferi; stigmate discolori. S a mar a e 3, v. abortu pauciores, margine quadrialatae, alis cruciatim divergentibus, duabus superioribns totidemque inferioribus aequalibus $\mathbf{v}$. inaequalibus, dorso cristatae, non raro inter alas et cristam processubus membranaceis alaeformibus, brevissimis muricatae, indehiscentes, monospermae. S e men inversum. E mbryon is exalbuminosi coty led on es apice inflexae, radicula brevissima, supera. -Frutices $A$ m ericae tro pica e, scandentes; foliis opposit is, integrerrimis, glabris v. pubescentibus, saepe lucidis, breviter petiolatis, bistipulatis, stipulis saepius minimis, rarius petiolaribus, nonnunquam majoribus, in unam interpetiolarem connatis, inflorescentiae racemosae $v$. saepius umbellatae racemis et umbellis pautifloris, ramos v. ramulos laterales terminantibus, saepe foliolis supremis abortivis $v$. imminutis paniculam terminalem componentibus, rarius ramulo florifero contracto subsessilibus fasciculiformibus, et tunc praecocibus, pedunculis brevibus, cum pedicellis plerumque brevioribus articulatis, basi bracteatis, apice $v$, rarius infra apicem bibracteolatis, bracteis bracteolisque interdum majusculis aut etiam foliiformibus panieulae, inde foliosae, intermixtis, floribus parvis $v$, mediocribus, flavis, interdum rubro suffusis.

Tetra ptery s Cavanill. Dissert. IX. 433. $t, 260,-262$. Kunth in Humb. et Bonpl. Nov, gen. et op. V. 168. DC. Prodr. I. 587. Adr. Jussien in St. Hilaire Flor, Brasil. III. 5. t. 161, 162. Synops, Malpigh. msc. Meisuer Gen. 58. (39.) Griesebach in Linnaea XIII. 531. Triopterys sp. Gärta. II. 168, t. 116. Willd. Swartz.

SUIBIIVISID II. NOTOPTERYGIAE Adr. Juss. msc. Ca rpidia alata, ala dorsali.

55ร5. 埴eteropterys $H, B, K$. Calyx quinquepartitus, laciniis quatuor basi biglandulosis, rarius eglandulosus. C oroll a e petala 5 , hypogyna, calyce paullo longiora, unguieulata, vix dentata, saepe carinata. Stamina 10 , hypogyna, omnia fertilia, alterna calycis laciniis opposita longiora, postica saepe breviora; f il a me n ta basibus coalita, a n the ra e introrsae, biloculares, glabrae, longitudinaliter dehiscentes. Ovaria 3 , angulo centrali coalita, dorso compresso gibba, unilocalaria, ovalo unico, pendulo, reclinato. St yli 3 , rigidi, apice uneinato compresso hinc stigmatosi. Samarae 3, v. abortu pauciores, angulo centrali coalitae, apice in alam margine postico, inferiore crassiorem expansae, latere ntroque convexae, laeves, indehiscentes, monospermae. Sem en inversum. Embry onis exalbuminosi cotyledones apice inflexae, radicula brevissima, supera. - Frutices Americae tropicae, interdum scan. dentes; foliis oppositis, breve petiolatis, integerrimis, glabris v. pubescentibus, pube interdum nitore metallico, subtus saepe glanduliferis, stipulis inconspicuis, inflorescentiae aspectu vario, paniculis v, corymbis terminalibus aut ad suprema folia axillaribus, ex umbellulis racemulisve partialibus conflatis, foliorum supremorum bracteaeformium abbreviatione vulgo compositis, pedunculis brevibus, cum pedunculis vix longioribus articulatis, basi bracteatis, infra articulum opposite bibracteolatis, floribus parvis, luteis, rarius roseis, rarissime caerulescentibus.

He te ropterys Kunth in Humb. et Bonpl. Nov. gen. et sp. V. 163. DC. Prodr, I. B91, exel. sect. 2. Adr. Jussieu in St, Hilaire Flor. Bras, IIT, 23, Synops. Malpigh, msc. Griesebach in Linnaea $X I I T$, 217. B a n is teria e $\mathrm{s}$. Linn. et Auet.

a. PEIXOTOPTERYS Grieseb. $t$. c, Samara e praeter alam dorsaleu crista brevi laterali utrinque auetae.

b. EUHETEROPTERXS. S a mara e praeter alam dorsalem exappendiculatac. - B a a is te ri a e $8 \mathrm{p}$. Linn. Jacq. Hort. Schönbr, t. 105. Cavanill, Dissert. t. 243 _246. Venten. Choix. t. S1. (Adr. Jussieu in St. Hilaire Flor. Brasil, t. 166, 167.)

55ร6. Aeridocarpus GUILLEM. et PERROT. C a l y $\mathrm{x}$ quinquepartitus, lacinia una v. altera basi impresse biglandulosa, rarins eglandulosus. C o r o 11 a e petala 5, hypogyna, calyce longiora, unguieulata, subintegerrima, inaequalia. St am in a 10 , hypogyna, omnia fertilia, subaequalia; fi1 a me nt a libera, brevia, rigida, a $n t h$ erae introrsae, biloculares, longe cordato-lanceolatae, glabrae, longitudinaliter dehiscentes, Ovaria 3, in unum trilobo-carinatum, lobo uno minore coalita, a latere compressa, dorso rursum alata, hirsuta, unilocularia, o vulo unico, in funiculo ex apice loculi pendulo reclinatim adscendente. St y li 2 , plano-filiformes, elongati, patentes, acuti, aestivatione introrsum circinati, cum tertii rudimento minimo. S a mara e 1 v, 2 , in axi coalitae, apice in alam rectam $v$, obliquam, margine antico superiore incrassatam productae, indehiseentes, monospermae. Se m e n inversum. E mbryon is exalbuminosi cotyled ones rectae, radicnla brevis, supera. - Arbores $v$. frutices Africae tropicae, interdum scandentes; foliis alternis $v$. rarius suboppositis, integerrimis, obovatis, glabris v. rarius pilosis, subtus glandulis impressis, exstipulatis, racemis terminalibus et lateralibus, foliorum supremorum abortu saepe compositis, pedicellis plus minus gracilibus, apice reflexis, basi extus bractea, intus bracteola laterali duplicistipatis, floribus luteis.

A erido e a p us Guillemin. et Perrot. Flor. Seneg. $\boldsymbol{I}$. 123. t. 26. Meisuer Gen. S5. (39.) Adr. Jussieu Synops. Malpigh, msc.

Б5ร\%, Hophopterys ADR. JUSS, C alyx quinquefidus, laciniis quatuor medio extus

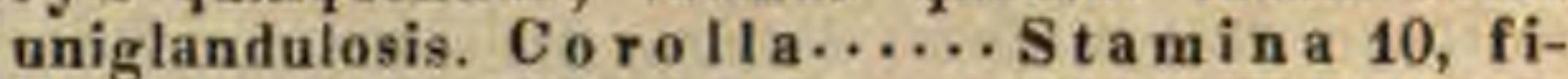
I am entis basi dilatata inaequaliter coalitis; anthe ris...... 0 varia 3 , subdistincta, dorso tricostata, sub apice introrsum stylifera, unilocularia, ova lo unico, pendulo, Stigmata.... Carpidia 3 , abortu interdum 2 v. 1 , crista lineam mediam marginante superata, latere costata, indehiscentia, monosperma. S e me $\mathbf{n}$ inversum. $\mathbf{E}$ mbryonis exalbuminosi radic ula snpera. Arbor $v$. frutex guianensis; folits oppositis, petiolatis, magnis, integerrimis, eglandulosis, stipulis nullis? racemis axillaribus et terminalibus, supremorum foliorum abortu compositis, pedicellis basi cum pedunculo communi articulatis, sub articulo extus bracteatis, bracteolis duabus introrsum lateralibus.

Lo phopterys Adr. Jussieu in Delessert. Ic, select, IIT. 18. 29. Synops, Malpigh, mse.

55\%8. Peixoton ADR. JUSS, C a 1 y $\mathrm{x}$ quinquepartitus, laciniis quatuor basi extus biglan- 
dulosis. Corollae petala 5 , hypogyna, calyce longiora, unguiculata, lacero-ciliata. S t a m in a 10 hypogyna, alterna calycis laciníis opposita, loculorum abortu et connectivis in massam glanduliformem ampliatis sterilia; fil a me nt a basi coalita, fertilinm antherae introrsae biloculares, longitudinaliter dehiscentes, O varia 3 , angulo centrali inter se coalita, derso tricristata, unilocularia, ovulo nnico, pendulo, reclinato. Styli 8 ; stig $\mathbf{m}$ a $\mathbf{t a}$ capitellato-terminalia. $\mathrm{S}$ a $\mathrm{m}$ a $\mathrm{r}$ a e $3, \mathbf{v}$. abortu panciores, in axi coalitae, dorso trialatae, alis lateralibus brevibus, intermedia longiore, margine antico crassiore, indehiscentes, monosper mae. S e m en inversum. E mb ry on i s exalbuminosi cotyledones apice inflexae, radicula brevissima, supera. - Frutices volubiles, in America a ustrali tropica et subtropica indigeni; foliis oppositis, integerrimis, latis, subtus basi biglandulosis, stipulis interpetiolaribus magnis, e geminis connatis, umbellis quadrifloris, foliorum supremorum abortu in pariculas magnas terminales $v$, laterales dispositis, junioribus foliorum abortivorum stipulis valvatim conniventibus inclusis, pedicellis basi cum pedunculo brevissimo articulatis, infra articulum bracteatis bibracteolatisque, floribus flavis.

Peixotoa Adr. Jussieu in St. Hilaire Flor. Brasil. III. 59. t. 172. Sjnops Malpigh, mso. Meisner Gen. 55. (39.) Griesebach in Linnaea XIII. 212.

55ร9. EBanisteria LINN. Calyx quinquefidus, laeiniis quatuor basi extus biglandulosis, rarius eglandulosus. Co ro 11 a e petala 5 , hypogyna, calyce longiora, unguiculata, fimbriato-dentata, inaequalia. S $\mathrm{ta} \mathrm{m}$ in a 10, hypogyna, omnia fertilia, alterna calycis laciniis opposita longiora, postica saepe breviora; filame nt a basibus coalita, antherae introrsae, biloculares, connectivo crasso, glandulaeformi, interdum excrescente, 1oculis glabris v. pilosis, longitudinaliter dehiscentibus. Ovaria 3 , angulo centrali coalita, a latere compresso-gibba, unilocularia, ov al o unico, pendulo, reclinato. Styli 3 , rigidi, apice uncinatocompresso truncati et hine stigmatosi. S a m a rae 3 , v, abortu pauciores, angulo centralí coalitae, apice in alam, margine antico superiore crassiorem expansae, latere interdum muricatae v. cristatae, indehiscentes, monospermae. S e m e n inversum. Embry on is exalbuminosi cotyle dones apice inflexae, radical a hrevissima, supera. Arbores $v$, frutices Americae tropicae, interdum scandentes; foliis oppositis v. ternatim verticillatis, integerrimis, breviter petiolatis v. subses silibus, subtus ad basim glanduliferis, stipulis geminis, minutis, deciduis, inflorescentia umbelliformi in apice ramorum ramulorumve terminalium, um bellis plerumque quadriforis, foliorum supremorum bracleaeformium abbreviatione in paniculas plus mi nus amplas, terminales lateralesve dispositis, pedun culis floriferis subnullis, pedicellis basi articulatis, infra articulum extus bractea, bracteolisque gemi nis lateratibus stipatis, bracteis bracteolisque um bellam biseriatim quasi involucrantibus, floribus ro seis $v$, luteis.

B a nisteria Linn. Gen, $n$, s73. exel, sp. pl. Kunth in Humb, et Bonpl. Nov, gen, et sp. V. 161, exel. sp. DC Prodr. I. 587. excl, sp. Adr, Jussien in St, Hilaire Flor. Brasil. III. 35. 2. 168, 169. Synops. Malpigh, mse. Meisner Gen. 55. (33.) Griesebach in Linnaea XIII. 90, Ban ist e$r$ Ia s p. Aublet Guian, $t$. 185, 186. Jaeq. Observ. III. t. 56. Cavanill. Dissert, $t, 246.267$. 248. 249. 250. 231, 252, 253, 256. 237. Venten. Choix t. 50. 51. d. Bot. Reg. t. 937,

5580. Eyssopterys BLUM, C a $1 \mathrm{y} x$ quinquepartitus, eglandulosus, C o roll a e petala 5 , hypogyna, ealyce longiora, vix unguiculata, snbintegerrima. Stamin a 10, hypogyna, omnia fertilia, subaequalia; fil am enta filiformia, gracilia, basibus incrassatis in urceolum sinuato - pentagonum connata, antherae introrsae, biluculares, ovatae, glabrae v. saepius pilosae, longitudinaliter dehiscentes. Ovaria 8 , angulo centrali inter se coalita, dorso compresso-gibbosa, unilocularia, o vulo unico, in funiculo ex apice loculi pendulo adscendente. Styli 3 , graciles, incurvi; stigmat a capitellata. S a mara e $3, \mathbf{v}$, abortu panciores, in axi coalitae, apice in alam margine antico superiore crassiorem expansae, latere tuberculatae, indehiscentes, monospermae. Sem en inversum. Embryonis exalbuminosi, gracilis, vix incurvi cotyledones collaterales, radicula supera. Frutices mol $u \in c a n i, u t$ videtur scandentes; folits oppositis $v$. suboppositis, integerrimis, margine subtus glanduliferis, petiolo longo, ad apicem biglanduloso, basi bistipulato, stipulis saepe excrescentibus, inflorescentiis in apice ramorum terminalibus, saepe ramulis axillaribus pedunculos communes mentientibus quasi axillaribus, et isdem apice dichotomis quasi ternatis, racemosis, racemis brevibus, densiftoris, in umbellas interdum contractis, pedicellis brevibus cum pedunculis vix longioribus, basi bracteatis, apice bibracteolatis arliculatis, bracteis squamuloideis, imbricatis, floribus plerumque abortu masculis, ovario ad tubercula villosa redacto, in. terdum enneandris.

R ys so pterys Blumemsc. Adr. Jnssieu in Delessert. Ic. select. MII. 21, t. 35, Synops. Malpigh. msc, H i r a a ovata et H. obscura Blume Bijdr. 226, B anisteria timorensis DC.

5581. Stigmapluyllon ADR. JUSS. Ca. I y $\times$ quinquepartitus, laciniis quatuor hasi extus biglandulosis. Corolla e petala 5, hypogyna, ealyce longiora, unguiculata, saepissime denticnlatociliata, inaequalia. Stamina 10 , hypogyna, dissimilia et inaeqnalia, quatuor subinteriora calycis laciniis glanduliferis opposita minora v. sterilia, sex subexteriora semper fertilia, alterna crassiora et majora stylis opposita, filamenta basibus connata, a n therae introrsae, biloculares, connectivo crasso, glandulaeformi, loculis longitudinaliter dehiscentibus, staminum quatnor interiorum nullis v, efoetis, Ovaria 3 , angulo centrali coalita, dorso gibba, unilocularia, ovulo unico, pendulo, reclinato. Styli $\mathbf{8}$, divaricati, apice introrsum in cucullum foliaceum expansi, v, rarius tantum compresso dilatati, intus mamilla stigmatica instrueti. $S$ a $m$ a ra e $\mathbf{8} v$, abortu pauciores, in axi coalitae, apice in alam, margine antico superiore crassiorem expansae, latere saepe cristatae, indehiscentes, monospermae. Sem en inversum. Embryonis exalbuminosi coty led on es apice inflexae, radicula brevissima, supera. - Frutices A meric a e tropicac, plerumque scandentes, radice in multis tuberosa; foliis oppositis $v$. ternatim verticillatis, in summis ramis remotioribus $v$, in terdum alternis, petiolatis, integerrimis, dentatis $v$. varie lobatis, interdum eiliatis, petiolo plus minus elongato, apice biglanduloso, basi bistipulato, stipulis minutis, deciduis, inflorescentiis umbelliformibus, in apice ramulorum terminalibus, v. saepius in ramulis axillaribus, plerumque dichotomis, pedunculos communes mentientibus quasi axillaribus, pedicellis cum pedunculis subaequalibus, basi braeteatis et apice bibracleolatis, articulatis, apice saepissime incrassatis, ante anthesim recurvis, floribus luteis. 
Stigm a p hy 110 n Adr. Jussieu in St. Hilaire Flor. Brasil, III. 48, t. 170. 171, exel. sp. Synops. Malpigh, msc, Meisner Gen. 55. (39.) Griesebach in Linnaea XIIT. 201. Ban i steriae $8 \mathrm{p}$. Auet. Cavan, Diss, 2,254 . 256. Vellozo Flor. Elum. t. 149. 150 . 160.

5ธ.8\%. IBraelhypterys ADR. JUSS, C a Iy $x$ quinquepartitus, laciniis quatuor basi extus biglandulosis. Corollae petala 5, hypogyna, calyce longiora, unguiculata, denticulato-ciliata, inaequalia. S $t$ a $m$ i na 10, hypogyna, omnia fertilia et subaequalia, $\mathbf{v}$. interiora minora, sterilia; fi la menta basibus coalita, antherae introrsae, biloculares, connectivo glandulaeformi plus minus ampliato, loculis longitudinaliter dehiscentibus, Ovaria 3 , angulo centrali coalita, dorso gibba, unilocularia, ovulo unico, pendulo. Styii 3 , divaricati, apice extrorsum in appendiculam majusculam, foliaceo - dilatatam v. unciformi - compressam producti, introrsum papilla stigmatica discolori instrueti. $\mathrm{S}$ a $\mathrm{ma}$ a e $3 \mathrm{v}$, abortu pauciores, apice in cristam brevem compressae, indehiscentes, monospermae. S e m en inversum. $\mathbf{E} \mathbf{m}$ bryo...... - Frutices Americae tropicae, littorales; ramulis planis, ancipitibus, sarmentosis, volubilibus, foliis oppositis, petiolatis, integerrimis, minutissime bistipulatis, inflorescentiae umbelliformis umbellulis tri-octofloris, ramos v. ramulos laterales, foliis duobus parvis, involucrantibus instructos terminantibus, pedunculis floriferis sub nullis, pedicellis longiusculis, basi articulatis, sub articulo extus bractea, latere utroque bracteola instructis, floribus luteis, interdum croceo maculatis.

B rachyptery \& Adr. Jussieu in Delessert Io. select. III. 20. 4. 34. S)nops. Malpigh. mse. Stig ma p h y 11 on Paralias Adr. Juss.

5593. Thangallis $M A R T$. C al y x quinquepartitus, eglandulosns, magnus. Coroll a e petala 5 , hypogyna, calycem aequantia v. breviora, unguiculata. Stamina 10, hypogyna, omnia fertilia; filamenta brevia, basi coalita, antherae introrsae, biloculares, oblongo-subquadratae, longitudinaliter dehiscentes. Ovaria 3 , in unicum trigonum, triloculare coalita, loculis uniovulatis, o v u lo pendulo, reclinato. Styli 3 , distincti v. basi coaliti; st igmat ibus capitato-carnosis ter minati. Drup a trigona, tricorca, calyce ampliato involnta, coceis dorso cristae costaeformi instruetis, lignosis, secedentibus, indehiscentibns, monospermis, Semen inversum. Embryonis exalbuminosi cotyledones apice inflexae, radicula brevissina, snpera. - Frutices brasilienses, scandentes; foliis oppositis, breve petiolatis, integerrimis, subtus discoloribus, novellis inflorescentiisque pilosis, pilis in squamam radiantibus, floribus racemosis, terminalibus et e foliorum supremorum interdum abortivorum axillis, inde quasi paniculatis, pedunculis floriferis brevibus, bracteatis, cum pedicello longiore cernuo articulatis, infra articulum bibracteolatis, corollis flavis.

Thryallis Martius Nov, gen. et, sp. III. 77, t, 830 231. non Linn. Meisuer Gon, 54. (39.) Adr, Jussieu Synopz. Malpigh, msc.

5594. Tretcomaria HOOK, et $A R N$. Ca1 y $x$ quinquepartitus, laciniis quatuor basi extus biglandulosis. Corolla e petala 5, hypogyna, ealyce longiora, unguiculata, crenulata, dorso sericea. St a min a 10 , hypogyna, omnia fertilia; $\mathrm{fi}$. lamenta basi coalita, ant herae introrsae, biloculares, subrotundae, longitndinaliter dehiscentes. Ovaria 3 , sericen-pilosa, in nnicum trilobum, triloculare coalita, locnlis nniovulatis, o v ul o pendulo. Styli 3 , distineti, clavati, apice truncato - tubulosi. D ru p a triloba, trilocularis, lobis pilorum fasciculo dorsali, penicilliformi, denso longoque instructis, haud secedentibus, indehiscentibus, monospermis. S e m e $\mathbf{n}$ inversum, $\mathbf{E}$ m bryo ....... Frutex chilensis; foliis oppositis, brevibus, subsessilibus et semiamplexicaulibus, deciduis, ramis apice spinescentibus $v$. uni-paucifloris, floribus aurantiaceis.

Tricomari a Hooker et Arnott Bot. Miscell, IIT, 158. t. 100. Meisner Gen. 55. (39.) Adr. Jussleu Synops. Malpigh, msc.

SUEDI IISID III. AP'TERYGIAE Adr. Juss. msc. Carpidia aptera.

5585. MI alpiglhia LINN, Ca 1 y $x$ quinquepartitus, laciniis omnibus $v$, rarius tribns aut quatuor basi biglandulosis. Corolla e petala 5 , hypogyna, calyce longiora, unguienlata, lamina dentieulata, interdum carinata. St a $\mathbf{m}$ in a 10 , hypogyna, omnia fertilia, aequalia $v$. alterna breviora; filamenta glabra, basi in tubum coalita, anther a e introrsae, biloculares, longitudinali. ter dehiscentes. Ovari u m triloculare, loculis uniovulatis, o val o pendulo. S t y li 3 , distineti, apice truncato intus stigmatosi. Drup a earnosa, tripy rena, pyrenis osseis, angulo centrali subeohaerentibus, dorso tri-quinquealatis v. eristatis, monospermis. S e m e $n$ inversam. Emb r y on is exalbuminosi cotyledones planae, radieula brevissima, supera. - Arbusculae v. frutices, in $A m e-$ rica tropica cis a equatorem crescentes; foliis oppositis, integerrimis $v$. spinoso-dentatis, glabris $v$. tomentosis, aut in quibusdam setis urentibus adpressis, utroque fine pungentibus, medio incrassatis et incudis instar affixis, stipulis geminis, minutis, deciduis, floribus rubris, roseis v. albidis, rarius solitariis, plerumque fasciculis terminalibus v. plerisque axillaribus, umbellatim v. corymbose bi-mullifloris, pedunculis floriferis bracteatis, cum pedicello articulatis, ad articulum bibracteolatis.

Malpighia Linn. Gen; $n$, 579 , excl. sp. L. C. Richard ex Jussieu in Annat, Mus, XVIII. 480. Kunth in Humb. et Bonpl. Nov, gen. et sp, V. 145. DC, Prodr, I, 577. Meisner Gen. 57. (39.) Adr. Jussieu Synops. Malpigh, moc. Mal. p ig hi a e s p. Lam, t, 581. Cavan. Diss. 2. 234_236. Colla Hort. ripul. t. 11. Bot. Mag. t. 813. Bot. Reg. t, 96. 189. 568.

5586. Fumelhosia L. C. Rich. Cal yx quinquepartitus, laciniis omnibus v, quatuor basi biglandulosis. Corollae petala 5 , hypogyna, ealyce longiora, subnnguiculata, inter se inaequalia et saepe dissimilia, Sta min a 10, hypogyna, omnia fertilia; filam en ta basi in tubum coalita, anth erae introrsae, biloculares, glabrae $v$. pilosae, longitudinaliter dehiscentes. O va $\mathbf{r}$ i $\mathbf{~ m}$ bi-triloeulare, loenlis nniovalatis, ovalo pendulo, reclinato. Sty 1 i $2_{-} 3$, in unum partim v. omnino v. cum stigmatibus coaliti. Drapa lignosa, ditripyrena, pyrenis osseis, monospermis. Semen inversum. Embryonis exalbuminosi cotyledones planae $v$, apice incurvae, radicula brevissima, supera. - Arbores $v$. frutices, in Am erica tropic a crescentes; ramis lenticellarum copia saepe scabris, foliis oppositis, integerrimis, in axilla saepe gemmas plures ferentibus, stipulis ad basim pefioli geminis, subintraaxillaribus, saepe quasi in unam conniventibus, floribus racemosis, racemis axillaribus, rarius ramulos axillares brevissimos terminantibus, flavis v. rarius albidis, pedunculis bractealis cum pedicello articulatis, infra pedicellum bibracteo- 
latis, bracteola utraque $v$. saepius altera basi et latere uniglandulosa.

B u n ch o s f a L. C. Richard ex Jussieu in Annal. Mus. $\mathrm{XVIIT}$, 481, Kunth in Humb, et Bonpl, Nov, gen, et sp. $\nu$. 183. DC. Prodr. I. 581. Synops. Adr. Jussieu Malpigh. msc. Meisner Gen. 54. (39.) Griesebach in Linnaea XIII. 182. MaI a cmae a Griesebach $O p$. cit. 284. Malpighiae s p. Jacq. Amer. t, 177. Ic. rar. t, 469. Hort. Schönbr.t. 104. Fragm, t, 83. Andrews Bot. Reposit, t. 604. Cavanill. Diss. t. 238.239.

558\%. Dicella GRIESEB. Calyx quinquepartitus, laciniis quatuor basi biglandulosis. C or oll a e petala 5, hypogyna, calyce longiora, unguiculata, extus sericea, inaequalia. Stamin a 10 , hypogyna, omnia fertilia; fi l a m ent a inferne in tubum coalita, a $n$ therae introrsae, biloculares, basi pilosae, longitudinaliter dehiscentes. O va r i u m biloculare, loculis uniovulatis, ovul o pendulo, reclinato. Styli 2, distincti, breves, apice uncinato hine stigmatosi. Drupa lignosa, putamine tenui, abortu uniloculari, monospermo. Sem en inversum. Embryo...... Frutices brasilienses, scandentes; foliis oppositis, petiolatis, integerrimis, minutissime bistipulatis, floribus in corymbos aut racemos, terminales $v$, axillares, breves dispositis, pedunculis oppositis, basi bracteatis, apice bibracteolatis, cum pedicello articulatis, junioribus bracteolis oppositis, valvatim conniventibus inclusis.

Dicella Griesebach in Linnaea XIII. 249. Adr. Jussieu Malpigh. Synops. msc. B u n ch o 5 i a Adr. Jussieu in St. Hilaire Flor, Brasil, III, 69, 177.

5588. Frardachin ADR. JUSS. C a ly x quinquepartitus, laciniis omnibus basi biglandulosis. C o rolla e petala 5 , hypogyna, calyce longiora, unguienlata, inaequalia et dissimilia. Stamina 10, hypogyna, omnia fertilia; fil a menta brevia, basi in annulum glabrum coalita, an therae introrsae, biloculares, oblongae, glabrae, Iongitudinaliter dehiscentes. $0 \mathrm{v}$ a $\mathbf{r}$ i $\mathbf{m}$ triloculare, loculis uniovulatis, ovulo pendulo, reclinato. Styli 3, apice attenuato hinc stigmatosi. D rupa lignosa, putamine tenni, abortu uniloculari, monospermo. Semen inversum. Embryonis exalbuminosi cotyledones apice inflexae, radic n la brevissima, supera. - Frutices brasilienses; foliis oppositis, petiolatis, magnis, coriaceis, marginatis, stipulis in unicam intraaxillarem connatis, floribus racemosis, racemis terminalibus tripartitis, pedunculis floriferis brevibus, bracteatis bibracteolatisque, bracteola altera glandulifera, cum pedicellis longioribus articulatis.

B u rdac hia Adr. Jussieu Snops, Malpigh. msc.

a. BURDACHIA Mart. msc. D r u pa trigono-pyramidata.

b. CARUSIA Mart. msc. D r u p a sphaeroidea.

558. Pterrandra ADR. JUSS. Caly quinquepartitus, laciniis basi extus biglandulosis v. eglandulosis. Cor oll a e petala 5, hypogyna, calyce longiora, nnguiculata, limbo subintegerri. mo. Stamina 10, hypogyna, omnia fertilia; fil amenta libera, a ntherae introrsae, biloculares, connectivo glanduloso-incrassato, loculis longitudinaliter bivalvibus, valvula exteriore v. rarius ntraque in appendicem cristaeformem, longitudinalem expansa. Ovaria 3 , subdistineta $v$. basi ad angulum centralem cohaerentia, unilocularia, uniovulata, ovulo pendolo, reclinato. Styli filiformes, introrsum sublaterales; $8 \mathrm{t} i \mathrm{~g}$ in a $\mathrm{t}$ a acuta. Fructus ...... - Frutices Americae tropicae; folits oppositis, petiolatis, integerrimis, stipulis magnis, in unicam intraaxillarem coalitis, flo- ribus ad apicem ramorum v. in supremorum foliorum axillis spicatis $v$. racemosis, racemis inferne interdum subramosis $v$. axi contracta umbellato-fasciculatis, roseis, pedicellis basi articulatis, infra articulum bibracteolatis, extus bractea (semper?) stipatis. Ptexandra Adr. Jussieu in St. Hilaire Elor. Brasil. III. 72. Synops, Malpigh, msc. Meisner Gen, 54, (39.) Griesebach in Linnaea XIII. 288.

a. PTERANDRA Adr. Juss, msc. FI o r es umbellato-fascicu. lati, 0 v a r i a villosa. - (St. Hilaire Flor, Brasil.t, 179. a. b.) - Ec phy macal y x Pohl in Flora, 1825. p. 183.

b. ANDROPTERA Adr. Juss, msc. Flores spicati v. racemosi. Fructus tricoceus, coceis bivalvibus, Gal. p himia e sp. Kunth (Delessert Ic, seleot. III. t.30.).

5590. Galphimia $C A V$. Calyx quinquepartitus, laciniis pleramque eglandulosis. C orolla e petala 5 , hypogyna, unguiculata, limbo saepius extrorsum carinato-costato, ciliolato. S tamin a 10, hypogyna, omnia fertilia; fil am enta distincta v. ima basi coalita, ant herae introrsae, biloculares, loculis longitudinaliter dehiscentibns. Ov a riu m trilobum, triloeulare, loculis uniovnlatis; ovalo pendulo, reclinato. Styli 3 , filiformes; stigmat a acuta. Fructus tricocens, coecis juxta suturam dorsalem bivalvatim dehiscentibus, monospermis. S e $m$ en inversum. E m b r y o$n$ i s exalbuminosi c ot y ledon e s complicatae, radi en la brevis, supera. - Frutices Americae tropicae, imprimis mexicani; foliis oppositis, petiolatis, integerrimis, saepe glaucescentibus, in margine, juxta basim et in petiolo glanduliferis, bistipulatis, stipulis plerumque basi inter se in unicam bipartitam axillarem, et cum oppositis in vaginulam interpetiolarem coalescentibus, racemis terminulibus, pedisnculis brevibus, cum pedicellis articulatis, basi bracteatis, infra articulum bibracteolatis, interdum subnullis, bracteis bracteolisque tunc in caule contiguis, floribus luteis $v$. aurantiaceis, saepe rubro maculatis.

$\mathrm{G}$ a $1 \mathrm{p}$ h i w i Cavanill.Ic. V, 61, t, 489, 563. Kunth in Humb. et Bonpl, Nov. gen. et sp. V. 172. DC. Prodr. $I$, 382, Adr. Jussieu in St. Hilaire Flor. Brasil. III. 70, t. 178. Synops. Malpigh. msc. Meisner Gen. 54. (39.) Griesebach in Linnaea XIIT, 259. Thry allis Lim. Gen, n, 333, non Mart.

5591. Spachea ADR. JUSS. C a ly $\mathrm{x}$ quinquepartitus, laciniis omnibus basi biglandnlosis. Co ro 11 a e petala 5, hypogyna, calyce duplo longiora, anguicnlata, reflexa. Sta $\mathrm{m}$ in a 10 , e quibus $1-3$ nonnunquam partim v. omnino abortiva, fil a m e nt a basi cum calyce in annulum pilis longiusculis hispidum connata, a n the ra e introrsae, biloeulares, longitudinaliter dehiscentes. 0 varin m didymum, biloculare, loculis uniovulatis, ovulo pendulo, reclinato. Styli $2 ; 8 \mathrm{tigmata}$ truncato-biloba. D r u p a lignosa, pntamine osseo, biloculari, loculis monospermis. Sem en inversum .... Arbores v. frutices America e tropic a e; foliis oppositis petiolatis, integerrimis, saepe variegatis, stipulis in unicam intraaxillarem, imo petiolo adnatam connatis, racemis terminalibus simplicibus, pedunculis brevissimis, bracteatis, infra apicem bibracteolatis, cum pedicello articulatis, bracteola inferiore longiore, in glandulam desinente.

$\mathrm{S}$ p a che a Adr. Jussieu in Delessert Ic. select. III. 19. $t, 31$. Synops. Malpigh. msc. Mal pigh ia elegans c. W, F. Meyer Essequeb.

5592. IBy.sonima L.C.RICH. Calyx quinquepartitus, laciniis omnibus basi biglandulosis, rarissime eglandulosis. Coro 11 a e petala 5 , hypogyna, calyce longiora, unguiculata, limbo 
integerrimo v. denticulato. St am ina 10, hypogyna, omnia fertilia; filamenta brevia, basi coalita in annulum pilis longis hispidum, antherae introrsae, biloculares, oblongae, glabrae v, pilosae, longitndinaliter dehiscentes. Ovari um triloculare, loculis uniovulatis. Ovula pendula. Styli 3 ; stigmat a aenta. Dr upa globosa, putamine osseo, trilocnlari, loculis monospermis. S emen inversum. Embryonis exalbuminosi cotyle dones planae, radicula brevissima, supera. - Arbores v. frutices Americae tropicae; foliis oppositis, petiolatis, integerrimis, stipulis in unicam intraaxillarem, saepe imo petiolo adhaerentem coalitis, racemis terminalibus simplicibus v, rarius inferne compositis, pedunculis bracteatis, cum pedicellis articulatis, ad articulum bibracteolatis, fluribus flavis, croceis $v$. rarius albis.

B y rs on $1 \mathrm{ma}$ L. C. Richard ex Jussieu in Annal. Mus. XVIII, 481. Kunth in Humb. et Bonpl. Nov, gen, et sp. V. 147. t. 446_449. DC. Prodr. I. 579. Adr. Jussiea in St. Hilaire Flor, Brasil. III. 7. t. 180, Synops. Malpigh, mse. Griesebach in Linnaea XIIT. 250 . M a I pig h fa $\mathrm{s}$ p. Aublet Guian, t. 181_184. Cavan. Diss. $t$, 237. 240, 241. Bot. Mag. ใ. 809.2462 .

\section{GENERA DUBIA.}

5593. IPlatyuenan WIGHT et ARN. Ca1 yx quinquepartitus, eglandulosus. Corolla e petala 5, subaequalia, plana, unguiculata, integerrima. Stamina 10 , fertilia, alterna longiora; filamenta hasi dilatata complanata, persistentia, a $n$ the rae lineari-oblongae, deciduae. $0 \mathrm{va-}$ rium apice breviter tricarinato-alatum ..... Styli in unum filiformem, staminibus longiorem coaliti.... Fruetus...-Arbores Asiae tropic a e; foliis oppositis, ellipticis, obtusis, glabris, integerrimis, floribus terminalibus racemosis.

Platy nema Wight et Arnott in Edinb. new. philo. soph. Journ. XV. 179. Prodr, I, 107. Meisuer Gen, 5ै4. (39.) Adr. Jussieu Synops. Malpigh, msc.

5594. Crucantlaus FORSK. Calyx parvus, campanulatus, quinquepartitus, eglandulosus. Corolla e petala 5, calyce multo longiora, unguiculata, ovata, concava, patentia. Stami$n$ a 10 ; fil a m e $t$ a filiformia, recta, antherae ovatae, didymae, incumbentes. Ovarium ovale, villosum, e al y c e longius, S ty li3, subulati; stigmat a truncata. Drupa ..... - Frutex v, arbor mediocris, in Arabia crescens; racemis farinosocinereis, foliis oppositis, confertis, mediocribus, pe tiolatis, glabris, corymbis terminalibus, pedicellis subumbellatis, compositis, floribus albis, drupis ovi columbini magnitudine.

Ca ue an th as Forstael Descript. 91 . DC, Prodr. $I$. 583. Meisner Gen, 54. (59.) Adr, Jussien Synops. Malpigh. msc.

5595. Tembix LOUREIR. C aly x tripartitus, laciniis ovatis, concavis, erectis. Corol1 a e petala 5 , ovata, concava, calyce paullo longiora. Stamina 10 ; filamenta filiformia, alterna longiora, an therae bilocnlares, erectae. Ovarium ovatum. Styli 3 , oblengo-turbinati, bisulcati, erecti; $8 \mathrm{tig} \mathbf{m}$ a $\mathrm{t}$ a verticaliter compressa, emarginata. B a c e a parva, ovata, trilocularis ..... - Frutex cochinchinensis, scandens; folits oppositis, magnis, cuneiformibus, petiolatis, integerrimis, racemis subterminalibus parvis, floribus pallidis.

B e m b ix Loureiro Flor. cochinch, 346, Adr. Jussieu Synops. Malpigh, msc.

\section{* CORIARIEAE.}

5596. Conineia NISS. Flores hermaphroditi v, abortu polygami, monoici v. dioici. C a l y x quinquepartitus, persistens, laciniis aequalibus, aestivatione imbrieatis, sub anthesi patentibns. Corolla e petala 5, hypogyna, calyeis laciniis alterna et breviora, aequalia, exnnguiculata, intus carina prominente aucta, crassiuscula, in fructu persistentia, increscentia, succosa. $\mathbf{S t a -}$ m in a 10, hypogyna, petalis alterna et opposita ; filamenta capillaria, libera, antherae introrsae, biloculares, basi bifida insertae, longitudinaliter dehiscentes, in floribns femineis efvetae. Ovarinm sessile, libernm, quinquelobum, quinqueloculare, loculis cum petalis alternantibus, in floribus masculis efoetum v, rudimentarium, $O$ v $u$ Ia in loculis solitaria, ex apice anguli centralis pendula, anatropa. $\mathbf{S t i g m a t a ~} 5$, e centro ovarii lenge exserta, filliformia, papilloso-villosa. F r n c$t$ us pentacoceus, calyce membranaceo petalisque carnosis tectus, coccis erustaceis, indehiscentibus, monospermis. Semina e coccorum angulo centrali pendula, testa membranacea. $\mathrm{Embry}$ on is exalbuminosi, orthotropi cotyledones planoconvexae, ra di c ula brevi, obtusa, supera. Arbores inermes, $v$. frutices interdum sarmentosi, in regione mediterranea, Peruvia, Chili, Nova Zeelandia et Nepalia hucdum observati; ramis tetragonis, inferioribus ternis, superioribus oppositis, foliis oppositis, rameis saepe ternatis, simplicibus, sessilibus v. breviter petiolatis, ovatis $v$. cordatis, quinquenerviis, integerrimis, gemmis squamosis, racemis ramos ramulosve terminantibus, simplicissimis, pedicellis oppositis v. superioribus alternis, basi bracteatis, medio saepius bibracteolatis,

Coria ría Nissol. in Act, Academ, Paris. 1711. $t$. 12. Linn. Gen. n. 458, Lam. t. 822. Duhamel Arbr, I, t, 73. Schkuhr t, 334. DC. Prodr. I. 739. Kunth in Humb. et Bonpl. Nov. gen, et sp, VIT. 168. $t$. 636, Wallich Plant, At. rar. t. 289. Nees Plant, offic. Suppl, I. t. 1. Mvisner Gen. 56. (40.)

\section{Drdo CCXXIX. Enythroxyleae.}

ERYTHROXYLEAE Kunth in Humb. et Bonpl. Nov. gen. et sp. V. 175. DC. Prodr. $\boldsymbol{X}$. 573. Bartling Ord. nat. 361. Lindley Introduct, edit, II, p. 422, Meisner Gen,40. (56.)

Suffrotices, frutiebs v. Arbores, ramulis saepius complanatis, apice compressis. FoI i a alterna v. rarissime opposita, simplicia, penninervia v. triplinervia, integerrima, plerumque glabra. Stip ula e intraaxillares, concavae, scarioso-squamiformes, in pedunculis aphyllis bracteoliformes.

Fuones hermaphroditi, regulares, in axillis foliorum v. stipularum solitarii, gemini v. fasciculati, albidi v. flavo-virentes, pedunculati, pedunculi stipulis bracteolati, quinquangulares, apice gradatim incrassati.

Calyx liber, persistens, quinquepartitus v. rarius quinquefidus.

Cororaa petala quinque, hypogyna, calycis laciniis alterna, aequalia, basi lata, singula intus squamis duabus sibi invicem impositis, inter se et cum ungue conferruminatis aucta, per aestivationem imbricata. 
Stauna decem, hypogyna. Filamenta basi complanata, et in urceolum connata, apice teretiuscula, filiformia, libera. A $\mathrm{n} t \mathrm{~h}$ e ra e introrsae, biloculares, ovato-subglobosae, dorso supra basim affixae, mobiles, loculi suboppositi, paralleli, lateraliter juxta totam longitudinem dehiscentes.

Ovariom liberum, e earpidiis duobus v. tribus compositum, valvarum marginibus introflexis dissepimenta praebentibus bi-triloculare. Ovula nune in singulis loculis solitaria, nunc uno v. duobus efoetis in unico unicum, ex apice anguli centralis pendulum, anatropum. S tyli tres, nunc distincti, nunc basi v. ad medium, rarissime usque ad apicem connati. Stig m ata 3 , subcapitata.

Drupa ovata, angulata, abortu unilocularis, monosperma.

Semen inversum, testa coriacea, rhaphe obsoleta, chalaza parum inerassata. Album en cartilagineum, parcum.

Enв ryo orthotropus, axilis, seminis fere longitudine. Cotyledones ellipticae v. lineares, planae, foliaceae. R adicula brevis, teres, umbilicum fere attingens, supera. Plu$\mathrm{mula}$ inconspicua.

Erythroxyleae unico genere comprehendendae, pleraeque Americam tropicam incolunt, pancae Africae australis insulas et Indiam orientalem inhabitant.

Lignum plurimarum specierum materie rubro tingente scatet. Erythroxyli Coca folia stimulans opiatum Peruanis praebent.

Erythroxyleae Malpighiaceis arete affines, et in earum caterva olim a Jussievo recensitae, ob habitum peculiarem, petalorum appendices, fructum drupaceum abortu monospermum, et semina albuminosa a Kunthio merito in proprium ordinem segregatae fuerunt.

5ร9ซ. Erythroxylum LINN, Calyx quinquepartitus $v$, quinquefidus. Corollae petala 5, hypogyna, intus squamis duabus sibi invicem impositis, et cum nngue connatis aucta, Stamin a 10 , hypogyna; filamenta basi in ureeoInm connata, a $n$th erae biloculares. Ovarium bi-triloculare, loculo unico fertili uniovulato, o v a1 o ex apice anguli centralis pendulo, anatropo. Styli 3 , distincti v. connati; st ig mata capitata. D rupa abortu unilocularis, monosperma. E mb ryo in axi albuminis cartilaginei, parei orthotropas; cotyledonibns foliaceis, radieula supera. - Arbores v. frutices regionum tropica$r u m$; foliis alternis, integrerrimis, stipulis axillari. bus, fioribus solilariis, geminis v. fasciculatis.

Frythroxy 1 am Liun. Gen, n. 595. Juss. Gen, 253. Cav. Dissert, VIIT. 399. St. Hilaire Plant, us, Bras, $n, 69$ Flor, Brasil. II. 66 .

a. ERYTHROXYLON Kunth. C a I y $x$ quinquepartitus v. quinquefidus. St yli distincti v. basi ant ultra medium connati.

Erythroxylon Kunth in Humb. et Bonpl. Nov. gen. et sp, $V$. 175. $t$, 453. De. Prodr, I. 573, Meisner Gen. 56. (40.) Ve nellia et R a e la na Commers. mse.
Ste u deli a Spreng. Syst, II. 391. (Jaeq. Amer, t, 187. Cavanill. Dissert. VIII. t. 229. Vahl. Symb. t. 63. St. Hilaire Plant. us. Brasil. t. 69. Flor. Brasil. t. 102. 103. Hooker in Bot, Mag. Comp. t. 21. Delessert Ic. select. IIT. t. 28.)

b. SETHIA Kunth. CaIyx quinquefidus. Styll fere ad apicen conuati.

Sethia Kunth $O p$, cit. $V$. 175. DC. Prodr. $I$. 576. Wight et Aruott Prodr. 1. 106. Meisuer Gen. 56: (40.) Wight Illustr. $t$. 48 . E r y throxy lon moaog y um Roxburgh Plant. Corom, $t .88$.

\section{Ordo CCXXX. Sapindacene.}

SAPINDI Jussieu Gen, 246. SAPINDACRAE Jussieu in Annal. Mus. XVITI. 376. DC. Prodr. T. 601. Bariling Ord. nat. 362. Cambessed. in Mem. Mus. XVIIT. 1. Lindley Introduct, edit, II, p. 193. Meisuer Gen, 52. (37.)

Arbores, frutices v. suffrutices, erecti v. scandentes, saepe cirrhosi, rarius herвas, succo acqueo, caule ramisque teretibus v. angulatis. Foli a alterna, aut rarissime opposita, plerumque composita, ternata v. imparipinnata, rarius abruptim pinnata, interdum bitriternata v. bipinnata, nonnunquam foliolis lateralibus rudimentariis v. abortivis, et terminali solo evoluto folia simplicia mentientia, rarius vere simplicia, foliolis alternis v. oppositis, integerrimis, serratis $v$. incisis, saepe punctis v. lineolis pellucidis notatis, petiolo interdum alato. Stipula e caducae v. saepissime nullae.

Flores hermaphroditi v. staminum aut ovarii abortu polygami, racemosi v. racemosopaniculati, albi, rosei v. rarissime lutei, saepe parvi, inconspicui, pedicellis inferioribus saepius abortivis, in cirrhos mutatis, bracteolis ad basim pedicellorum minutis, lateralibus.

$C_{A L Y X}$ e foliolis quinque compositus, foliola rarius aequalia, saepe inaequalia, duo postica haud raro adscendentia et omnino inter se in unicum connata, lateralia exteriora plerumque minora, quintum anticum saepe deflexum, omnia nunc inter se distincta, nunc plus minus coalita, aestivatione imbricata.

Discus carnosus hypogynus v. subperigynus, nunc calycis fundum occupans, regularis, annulum integrum, lobatum v. crenatum inter stamina exserens, nunc unilateralis, in postica floris parte brevior v. omnino deliquescens, in antica in laminam, interdum duplicem productus, v. glandulas petalis oppositas exserens.

Conolla nulla, v. petala disco aut annulo extus inserta, calycis foliolis alterna, posticum inter calycis foliola postica, imprimis dum haec inter se connata deficiens, reliqua 4 inter se aequalia $v$. inaequalia, aestivatione imbricata v. rarissime subvalvata, ungue intus medio villoso aut glanduloso, nune omnium, nune anticorum tantum squama cucullata v, cristata, saepe in appendicem inflexam desinente aucto.

Stamiva disco intus (rarissime extus) in- 
serta, duplo foliorum calycis numero uniseriata 8-10, aut abortu pauciora, rarissime quadrupla, biseriata, ovarium cingentia, saepissime excentrica, in floribus masculis a disco in antica calycis parte luxuriante saepe in posticam retrusa. Filamenta filiformi-subulata, libera $\mathbf{v}$, basi inter se coalita, saepe villosa, aequalia v. inaequilonga. Antherae introrsae, biloculares, dorso insertae, connectivo cum filamento articulato mobiles, loculis suboblique appositis v. suboppositis, intus v. latere longitudinaliter dehiscentibus.

Ovarrom in floribus masculis rudimentarium v. nullum, in hermaphroditis liberum, sessile v. brevissime stipitatum, nunc centrale, nunc disci inaequali evolutione retrusum, excentricum, subobliquum, triloculare, rarius biv. quadriloculare. Ovula loculorum angulo centrali inserta, saepissime solitaria, adscendentia, rarissime suspensa, rarius gemina v. interdum terna, superposita, inversa et adscendentia, nonnunquam plurima, horizontalia. Stylus terminalis, simplex; stigmata loculorum numero.

Froctus bi-tri-quadrilocularis, v. abortu unilocularis, nune capsularis, lignosus, coriaceus v. membranaceus, loculicide v. septicide dehiscens, valvis septiferis $v$. ab axi angulis septante solutis, nunc samaroideus, samaris dorso, basi v. apice membranaceo-alatis, axi adnatis, saepissime indehiscentibus.

Srmina globosa v. compressa, in loculis solitaria v. gemina, rarissime plura, erecta v. adscendentia aut rarissime pendula, testa crustacea $v$. membranacea, interdum in alam expansa, saepe arillata v. umbilico lato instructa. Albumen nullum.

Embryo rarissime rectus, saepe curvatus v. spiraliter convolutus. Cotyledones incumbentes, interdum transversim plicatae, nonnunquam in massam carnosam coalitae. R a dicula in convolutis extraria, saepe brevissima, umbilicum spectans, infera v. rarissime supera.

S a pindace a e ab ordinibus proximis nonnisi plurium notarum combinatione distinguendae, in regionibus intertropicis totius orbis, copiosius tamen in America reperiuntur, in regionibus subtropicis et temperatis hemisphaerae australis multo rariores, cis Cancrum nisi in China boreali vix obviae.

Hippocastaneas olim imprimis propter folia opposita palmatim composita in proprium ordinem segregatas, vix a Sapindaceis reliquis, quarum loco cis Cancrum vigent, separandas putaverim, foliis in Ungnadia, genere Aesculo arctissime affini, oppositis et imparipinnatis, iisdem neque in Valenzuelia, genuino Sapindacearum genere, alternis. Caeterum propriam inter Sapindaceas sibi tribum vindicant, a Sapindeis ovarii loculis biovulatis, a Dodonaeeis embryone haud spiraliter convoluto diversae, quibus notis ad Meliosma, et ad genera Sapindacearum anomala, quodammodo accedunt.

TIRIBUS I. SAPINDEAE Cambessed, in Mem. Mus. X VIII. 18. Ov u la in loculis plerumque solitaria. E m b r y o curvatus v. rarius rectus.

5598. Cardiospermum LINN. C alyx tetraphyllus, foliolis concavis, duobus exterioribus multo minoribus. Co r o 11 a e petala 4, receptaculo inserta, calycis foliolis alterna et ima basi subcohaerentia, intus supra basim squamula aucta, doo interiora a staminibus remota, squamis aequilateris, inflexo-cucullatis, dorso infra apicem cristato-appendiculatis, superiora squamis in. aequilateris, latere emarginatis, inappendiculatis. D i s c u s in glandulas duas, rotundatas v. linearielongatas, petalis inferioribus oppositas tumens. Stamina 8, receptacnlo excentrice inserta, ovarium cingentia; fi l a m en t a antica saepe breviora, libera v. ima basi coalita, subulato-filiformia, a nthe ra e introrsae, biloculares, dor 60 insertae, mobiles, longitudinaliter dehiscentes. Ovarium sessile, excentricum, triloculare. Ovala in loculis solitaria, anguli centralis medio inserta, adscendentia. Sty I us brevis, trifidus, lobis intus stigmatosis. C a p sula trigona, membranaceo-vesisulosa, trilocularis, loculicide trivalvis, septa valvis opposita, axi centrali trigono, gracili adhaerentia, tenuissima, bilamellata, tandem deeidua. S em in a in luculis solitaria, globosa, adscendentia, funiculo crasso, saepe in arillum brevem, bilobum expanso, te sta crustacea. Em bryonis exalbuminosi cotyledon es magnae, incumbentes, medio transversim conduplicatae, ra dic u la brevis, nmbilieo proxima, infera. - Herbae volubiles, rarius suffrutices erecti, in Am erica tropica obviae, paucae a fric anae, una per regiones tropicas totius orbis diffusa; foliis alternis, biternatis v. rarius supradecompositis, petiolatis, foliolis dentatis $v$. incisis, saepe punctis $v$. lineolis pellucidis notatis, stipulis nullis, floribus masculis et hermaphroditis in eadem stirpe $v$. dioicis, in racemos $v$, paniculas axillares dispositis, pedunculo communi in plurimis apice bicirrhoso.

C a r dios perm um Linn. Gen, $n$, 498. Gärtner 1.381. t. 79. Lam. t. 317. Kunth in Humb, et Bonpl. Nov. gen, et sp, V. 104, t. 439. DC. Prodr. I. 106. Walliels Plant. As. rar. $t$, 14. Cambessed, in St. Hilaire Flor. Brasil. T. 348. t. 73, Mem. Mus. XVIII, 18, $t, 1, f . a . b$. Meisner Gen. 52. (37,) C or i u d u m Touruef. Inst. 296.

ธร95. Urvillea $H . B . K, C a l y x$ pentaphyllus, foliolis coneavis, duobus exterioribus minoribus. Co roll a e petala 4, receptaculo inserta, ealycis foliolis alterna, quinti superioris sede vacua, intus supra basim squamula ancta, duo inferiora a staminibus remota, squamis infra apicem in appendicem inflexam productis, superiora squamis inappendiculatis. D i s c u $s$ in glandulas quatuor, petalis oppositas tamens, glandulis duabus inferioribus paullo majoribus. S ta m in a 8 , receptaculo excentrice inserta, ovarium cingentia; filam en ta libera $v$. ima basi coalita, subulato-filiformia, antherae introrsae, biloenlares, forso insertae, mobiles, longitudinaliter dehiscentes. 0 ₹ ari u m sessile, excentricum, trilocalare. O v n 1 a in loculis solitaria, angulo centrali paullo supra 134 * 
medium inserta, adscendentia. Stylus brevis, trifidus, lobis intus stigmatosis. Capsula membranacea, trilobo-triptera, samaris tribus dorso alatis, medio subinflatis, ab axi centrali filiformi tandem solutis, indehiscentibus, monospermis. S e m ina adscendentia, subglobosa, basi arillo carnoso, bilobo cincta, te s t a crustacea. E mbryo .... Frutices Americae tropicae, scandentes, volubiles; foliis alternis, ternatis, petiolatis, foliolis integerrimis $v$, dentatis, interdum pellucido-punetatis, stipulis nullis, floribus in eadem stirpe masculis et hermaphroditis, axillaribus, racemosis, in racemi ramulis brevissimis, bracteolatis, subfasciculatis, racemis basi bicirrhosis.

U r ville a Kunth in Humb. et Bonpl. Nov. gen, et sp. 105. $t$. 400. DC. Prodr, 1, 608. Cambessed. in St, Hilatre Flor. Brasill. I, 358. $t$, 74. Mom. Mus, XVIII, 19. Bot, Reg. t. 1077. Meisner Gen. 58. (37.)

5BOD. Serjania PLUM. Calyx pentaphyllus $v$. foliorum superiorum coalitione tetraphyllus, foliolis concavis, duobus exterioribus minoribus. Co rolla e petala 4 , receptaculo inserta, calycis foliolis alterna, quinti superioris sede vacaa, intus supra basim squamula aucta, duo inferiora a staminibus remota, squamis infra apicem in appendicem inflexam productis, superiora squamis inappendiculatis. Dis e us in glandulas quatuor, petalis oppositas tumens, glandulis duabus

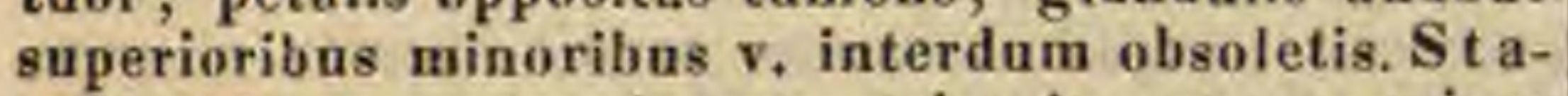
$m$ in a 8 , receptaculo excentrice inserta, ovarium cingentia; fil a m enta basi coalita, subulato-filiformia, a ntherae introrsae, biloculares, dorso insertae, mobiles, longitudinaliter dehiscentes. Ova rium sessile, excentricum,triloculare. $O$ v u l a in loculis solitaria, angulo centrali paullo infra apicem inserta, adscendentia. Stylus brevis, trifidus, lobis intus stigmatosis. Fruetus trialatus, samaris tribus axi centrali adnatis, membranaceis, basi in alam produetis, apice monospermis, indehiscentibus. S e m in a adscendentia, funiculo crasso, saepe in arillum brevem, bilobum expanso excepta, testa crustacea. Embryonis exalbuminosi, curvati cotyledones incumbentes, exterior incurva, ab interiore biplicata apice subamplexa, radic ula brevis, umbilico proxima, infera. - Frutices scandentes, volubiles, in $A$ m e rica tropica crescentes; foliis alternis, petiolatis, ternatis, bi-triternatis $v$, imparipinnatis, foliolis den. tatis $v$, subintegerrimis, saepe pellucido-punetatis, stipulis ad basim petiolorum minutis, floribus in eadem $v$. in diversis stirpibus masculis et hermaphroditis, racemosis, racemis axillaribus, saepe basi bicirrhosis.

Serja n I a Plumier Gen, 34. t. 35. Kunth in Humb. et Borpl. Nov. gen, et sp, V. 108. $t, 441$. DC. Prodr. I. 608. Cambessed, in Mem. Mus. XVIIT, 20. St. Hilaire Flar. Brasil. I. 355. t. 75. 76. Meisner Gen. 59. (37.) Seri a n a Schumacher in 1 ct. soc. h, $n$, hafn, III. 2, p. 126. t. 11. 1I. Paulliaiae sp. Linn. Jacq. Hort. Schünbr. t. 99.

5601. Tovilieia $A U B L$. Caly $x$ quinque. partitus, laciniis subaequalibus, duabus exterioribus. Corolla e petala 5 , receptaculo inserta, calycis laciniis alterna, intus ad basim appendice latiuseula, bipartita, pilosa aucta. D is c us ealyeis fandum ocenpans, apice breviter quinquelobus, lobis duobus inferioribus majoribus. Stam in a 8 , disco inserta; fil amenta libera, snbulato-filiformia, a $n t$ h era e introrsae, biloculares, dorso insertae, longitudinaliter dehiscentes. Ovarin m sessile, centrale, triloculare. Ov a Ia in loculis solitaria, angulo centrali paullo infra apicem in serta, adscendentia, Stylus brevis, trifidas, lobis intus stigmatosis. Fruetus trialatns, samaris tribus, axi centrali adnatis, membranaceis, basi in alam, demum lamellato-bipartibilem productis, apice monospermis, indehiscentibus. S e m in a adscendentia, te 8 t a erustacea. $\mathbf{E} \mathbf{m}$ b r yon is exalbuminosi, curvati cotyled o n es incumbentes, exterior interiorem transversim plicatam amplectens, radicula brevis, umbilico proxima, infera. Arbor guianensis; foliis alternis, abrupte pinnatis, foliolis suboppositis, lanceolatis, integerrimis, an. tice ad basim latioribus, stipulis nullis?, racemis in apice ramorum paniculam, densam formantibus.

Toul i ei a Aublet Guian. 1. 359. t, 140. Lam. t. 317. Jussieu Gen, 248, DC. Prodr. I. 612. Cambessed. in Mem. Mus, XVIII. 29. Meisuer Gen, 59. (37,) Ponate a Selireber Gen, n, 682 .

5802. IBridgesia $B E R T$. C a ly x basi aequalis, profunde quinquepartitus, laciniis subinaequalibus. Corolla e petala 4 , receptaculo inserta, calycis laciniis alterna, quinti superioris sede vacua, intus supra basim squamula cuenllata, apice cristata ancta. Dis e a s incompletus, quinquelobus. Sta m in a 8 , receptaculo excentrice inserta, ovarium cingentia; filam enta libera, subulato-filiformia, antherae introrsae, bilocnlares, dorso insertae, mobiles, longitudinaliter dehiscentes. Ovarium excentricum, brevissime stipitatum, triloculare. Ovula in loculis solitaria, ex anguli centralis basi adscendentia. Sty Ins filiformis, apice breviter trifidus, lobis intus stigmatosis. Cap s n la membranacea, trilobo-triptera, samaris tribus ad axim connatis, a basi ad medium inflatis, apice in alam productis, indehiscentibus, monospermis. Semina ereeta, subglobosa, exarillata, testa membranacea. E m b r y o n $i$ s exalbuminosi, curvati cotyle don es magnae, incumbentes, transversim biplicitae, se invicem amplectentes, radicula brevissima; infera. - Frutex chilensis, erectus, ecirrhosus; foliis alternis, simplicibus, exstipulatis, inciso-lobatis, serratis, peduncul is axillaribus, solitariis, unifloris.

Bridgesia Bertero msc. ox Cambessed, in Nouv. Annal. Mus. III. 234. $t$. 13, non Hook. Triptero carpus Meisner Gen. 52 (37.)

5403. Favilimia LINN. Caly $x$ pentapbyllus, v. foliolorum duorum superiorum coalitione tetraphyllus, foliolis concavis, duobus exterioribus minoribus. Corollae petala 4 , receptaculo inserta, caly cis foliolis alterna, quinti superioris sede vacua, intus supra basim squamula aucta, duo inferiora a staminibus subremota, squamis infra apicem in appendicem inflexam productis, superiora squamis inappendiculatis. Di se $\mathbf{c} s$ in glandulas 4, petalis oppositas tumens, glandulis duabus superioribus minoribus $v$, obsoletis. $S t$ a $m$ i a 8 , receptaculo excentrice inserta, ovarium eingentia; filamenta libera v. basi coalita, subulato-filiformia, an th e rae introrsae, biloculares, dorso insertae, mobiles, longitudinaliter dehiscentes. Ovarin m suhstipitatum, excentricum, triloculare. O vala in loculis solitaria, angulo centrali medio v. supra medium inserta, adscendentia. Sty I u \& brevis, trifidus v, tripartitus, lobis intus stigmatosis. C a p 8 a la pyriformi-trigona, membranacea v. coriacea, apice saepe trialata, trilocularis, v. abortn uni-biloenlaris, trivalvis, valvis cum dissepimentis membranaceis, persistentibus, ex axi centrali enatis alternantibus. Semina in loculis solitaria, adscendentia, funiculi brevissimi apice in arillum bilobum expanso 
seminclusa, test a crustacea. E mbryonis exalbuminosi, curvati $v$, rarissime recti cotyle dones incumbentes, radicula brevis, nmbilico proxima, infera. - Frutices scandenles, volubiles, in America tropica magno numero ob. vii, in Africa tropica rari; foliis alternis, petiolatis, stipulatis, ternatis, bi-triternatisve, v. pinnatis, bipinnatis aut decompositis, foliolis dentatis, serratis $v$, rarius integerrimis, saepe punctis $v$. lineolis pellucidis notatis, floribus masculis et hermaphroditis in eadem $v$. in diversis stirpibus, in racemos axillares, basi bicirrhosos dispositis.

Pa ullinia Linn. Gen, n, 331. exel, sp. plar. Jacq. Observ. t. 61. 62. Hort. Schönbr, t, 268. Ic. rar. t. 430 . Schumach. in Aet. soo, h. n. Hafri. III. 2. p. 129. t, 11. Jussieu in Annal. Mus. IV. 340. t. 66. Kunth in Humb. et Bonpl. Nov. gen, et sp, V. 114. DC. Prodr. I. 604. Hooker Exot. Flor. t. 110. St. Hilaire Plant. remarq. Brasil. 236. t. 23. f. 6. Cambessed, in St, Hilaire Elor. Brasil, I. 369. t. 77. 78. Mem. Mus. XVIII. 29. Delessert Ic, select. III. t. 37. Meisner Gen, 52. (37.) Se m a rill a ri a Ruiz et $\mathrm{Pa}_{\mathrm{a}}$ von Syst. 92, C u rur u Plum. Gen. 36. $t, 35$.

5804. Enourea $A U B L . \quad \mathrm{C}$ al y $\mathrm{x}$ tetraphyllus, foliolis duobus oppositis majoribus. Coro Il a e petala 4 , calyei inserta (?), inaequalia, intus ad ungres squamula aucta. Dis e i glandulae 2 , ad basim petalorum majorum. St a $\mathbf{m}$ in a 13, receptaculo inserta, inaequalia, basi connata. Ova rinm excentricum. Stigmata 3 , sessilia. Capsula sphaerica, unilocularis, trivalvis, monosperma. S e m e n erectum, pulpa farinosa vestitum. - Frutex guianensis, scandens, cirrhosus; foliis imparipinnatis, foliolis bijugis, coriaceis, subtus ferrugineo-puberulis, racemis paniculatis.

En o ure a Aublet Guian. I, 588, $t, 235$, DC. Prodr. I. 618. Cambessed, in Mem. Mus. XVIII. 36.

5BO5. Sellamidellia LINN, C a ly x foliolorum dnorum superiorum coalitione quadripartitus, laciniis duabus exterioribus minoribns. C o rolla e petala 4 , receptaculo inserta, calycis laciniis alterna, quinti superioris sede vacua, intus nuda, v. squamula aucta. Di s eus incompletus, glandulas 4, petalis oppositas, exserens. Stamina 8, receptaculo excentrice inserta, ovarium cingentia; fil am enta libera vasi coalita, saepe inaequilonga, subulato-filiformia, antherae introrsae, biloculares, dorso insertae, mobiles, longitudinaliter dehiseentes Ovarium sessile, excentricum, plus minus profonde bi-trilobum, bi-triloenlare, lobis obtusis. Ovula in loculis solitaria, e basi anguli centralis adscendentia. Sty I u s axi centrali insertus, inter ovarii lobos immersus, bi-trifidns, lobis filiformibus, patentibus, intus longitudinaliter stigmatosis. Fructus indehiscens, uni-bitrilobus, nni-trilocularis, siceus v, carnosus, putamine crustaceo. Semina in loculis solitaria, e basi erecta, funiculo brevissime in arillum carnosum expanso excepta, t es t a membranacea. E mbryonis exalbuminosi, curvati cotyled on es incumbentes, transversim biplicitae, radicuIa brevis, nmbilico proxima, infera. - Arbores v. frutices ecirrhosi, in regionibus tropicis subtropicisque totius orbis crescentes; foliis al ternis, petiolalis, exstipulatis $v$. rarius foliolorum lateralium abortu simplicibus, foliolis dentatis, serratis, subintegerrimisve, saepe punctis $v$. lineolis pel lucidis notatis, floribus polygamis, in racemos axillares dispositis.

S e bmidelia Linn. Mant. 67. Juss. Gon. 247, Knnth in Humb. et Bonpl. Nov, gen, et sp. V. 129. DC, Prodr. 1. 610. St, Hilaire in Mem. Sus. XII, $t, 13$, Plant, remarq.
Brasil. 159. t. 19. Plant, us, Brasil. \&, 67, Cambessed, in St. Hilaire Flor. Brasil. I. 329. t. 82. Mem. Mus. XVIII. 23. Wight et Arnott Prodr. I. 109. Meisner Gen. 62. (37.) Alloph y 11 u s Linn. Gen. n. 476. Loureiro Flor, cochineh. I, 286. Palisot Flor, owar, t. 107. O r n it r o p he Jussieu Gen. 247. Lam. t. 309, Roxburgh Plant. Corom. t, 61. Labillard. Nov. Caled, t. B2. Toxicodendron Gärtner 1, 207. t. 44. - A por eti ca Forst. Char. gen. 66. Jussieu Gen. 247. Gemella Loureiro Flor. cochinch, 796. U s u bls Burmann Flor. ind. $t$. 32. $f$. 1 . N a s $\mathrm{x}$ a $\mathrm{vi}$ a Flor. Flumin. III. $t, 155,156$.

5606. Walenzuelia BERT, C a l y x basi inaequalis, profunde quinquefidas, laciniis snbinaequalibns. Corolla e petala 4 , receptaculo inserta, calycis laciniis alterna, quinti superioris (rarissime praesentis) sede vacna, intus supra basim aucta squamula profunde bifida, cucullata, apice cristata. D i s c n s incompletus, quadrilobus. $\mathrm{S} t$ a$m$ in a 8 , rarins 7 v. 6 , excentrica, basi ovarii circumposita ; filamenta libera, subulato-filiformia, a nt her a e introrsae, biloculares, dorso insertae, mobiles, longitudinaliter dehiscentes. $0 \mathrm{v}$ ari um sessile, trilobum, triloculare. Ovala in loculis solitaria, ex angnli centralis basi erecta. Stylus filiformis, inter ovarii lobos insertus; st igma tridentatum. Cap $8 \mathrm{n}$ la membranacea, inflata, triloba, v. abortu bi-uniloba, tri-nnilocularis, loculicide tri-univalvis. Semina in loculis solitaria, ereeta, exarillata, te st a membranacea. Embryonis exalbuminosi, curvati cotyle dones magnae, incumbentes, exterior interio. rem transversim biplicatam amplectens, r a di $\mathbf{c u -}$ la brevissima, umbilico proxima, infera. - Arbus. cula chilensis, ecirrhosa ; foliis oppositis! decussantibus, simplicibus, oblongo-lanceolatis, trinerviis, integerrimis, brevissime petiolatis, exstipulatis, pedunculis axillaribus solitariis, uni-bifloris.

Vale nzuelia Bertero msc. ex Cambessed, in Nouv. Annal, Mus. 1II, 236. t. 14. Meisner Gen. 53. (38.)

56O8. Irina $B L U M$. Calyx quinquepartitus, persistens. Corollae petala 5 , calycis laciniis alterna et aeqnilonga, intus nuda. D is e u s emarginatus, genitalia cingens. Sta min a 5 , ovario approximata, flornm masculorum longissima. Ova rinm didymum, biloculare. Ovn I a in Joeulis solitaria. Stylns simplex; stigma obtnsum. Fruetus abortu unilobus, coriaceus, indehiscens, monospermus. Semen exarillatum. $\mathbf{E} \mathbf{m}$ bryonis cotyledones crassae, in radiculam descendentem angustatae, - Arbores javanica $e$, non satis notae; foliis abruple pinnatis, spicis terminalibus, paniculatis.

Irin a Blume Bijdr. 299. Cambessed, in Mem, Mus. XVIII, 24. Meisuer Gen. 53. (38.)

5808. Prosten CAMBESS. Caly $\mathrm{x}$ quinquepartitus, Jaciniis subaequalibus, duabus exterioribus, Corolla petala 5 , sub disco hypogyno inserta, ealyeis laciniis alterna, basi intus squamula parva aucta. D is cus annularis integerrimus. Sta m in a 20, disco intus biseriatim inserta; fil amenta filiformia, libera, antherae introrsae, biloculares, oblongae, dorso insertae, mobiles, longitndinaliter dehiscentes. Ovarium sessile, trilobum, triloculare. Ovula in loculis solitaria, e basi erecta. Stylus simplex, inter ovarii lobos insertus; stigma minute tridentatam. Fruetas abortu unilobus, indehiscens, carnosus (?) monospermus. Sem en ....-Arbor v. frutex guia$n$ ens is, ecirrhosus; foliis alternis, imparipinnatis, foliolis ovato-lanceolatis, glabris, racemis compositis, floribus subfasciculatis. 
Prostea Cambessed. in Mem. Mus, XVIII. 23, $t, 1$. f. $C$. Ornitrophe pinnata Poir.

5609. Hepisanthes $B L U M$. C a I y $x$ tetraphyllus, foliolis inaequalibns, imbricatis. Coro 1 la e petala 4 v. 5 , calyce parum longiora, intus squama aucta. Stam in a 8 , brevissima, ovario approximata. Ovarium trigonum, triloculare. Ovula in loculis solitaria. Stylus subnullus; st ig m a obtusum. Drupa (?) tetragona, nueleo triloculari. Semin a in loculis solitaria. - Arbor javanica; foliis abrupte pinnatis, foliolis suboppositis, racemis simplicibus, axillaribus lateralibusque.

L e pis a nthes Blame Bijdr, 237. Cambessed, in Mem, Mus. XVIII, 25. Meisner Gen. 53. (38.)

5610. Sapindas $L I N N$. Caly x quinquepartitus, aequalis. Corolla e petala 5 , receptaculo inserta, calycis laciniis alterna, basi intus nuda v. supra unguem squamula aucta. Discus calycis fundum occupans, regularis, integer v. crenulatus. Stam in a 8 v. 10, disco intus inserta; fil amenta subulato-filiformia, libera, an $t h e$ $r$ a e introrsae, biloculares, dorso insertae, mobiles, longitudinaliter dehiscentes. 0 varinm centrale, sessile, triloculare $v$, rarius uniloculare. Ovula in loculis solitaria, e basi erecta. StyI us simplex; $8 \mathrm{t}$ ig m a breviter bi - trilobum Fructus carnosus, uni-bilobus, rarissime trilobus, lobis globulosis, indehiscentibns, monospermis, endocarpio crustaceo. S e m i $n$ a erecta, exarillata, te 8 ta membranacea. E mbry on is exalbuminosi, curvati v. rarius recti, cotyledone 8 incumbentes, crassae, radicula brevis, umbilico proxima, infera. - Arbores inter tropicos totius orbis crescentes; foliis alternis, petiolatis, exstipulatis, abrupte pinnatis, foliolis al. ternis $v$. oppositis, integerrimis, saepe pellucidopunctatis, floribus polygamis, racemosis, racemis axillaribus, saepe foliorum superiorum abortu in apice ramorum paniculam formantibus.

S a pi nd a s Linn. Gen, n, 449. Jussieu Gen, 247, Gärtner $I .342, t$, 70. Lam, $t$, 370. DC. Prodr, $I$, 607. St. Hi. laire Plant, us, Brasit, $t$. 68. Cambessed. in Mem. Mus. XVIII. 56. et in St. Hilaire Flor. Brasit. 1. $389.2,81$. Wight et Arnott Prodr. 1. 110. Meisner Gen, 53, (32.) Delessert Ic, select, III, t. 37. Wight Illustr. $t, 51$.

5611. Ereioglossume $B L U M, C$ a 1 y $\mathrm{x}$ pentaphyllus, foliolis duobus interioribus minoribus. Co rolla e petala 4 , basi intus aucta ligula bifida, villosa. Stam in a 8 , inaequalia, villosa. Ovaria 3 , stylo connata, uniovulata. Stylus simplex; stigma obtusum. Baceae ellipticae, basi eonnatae, abortu saepe solitariae. - Frutex javanicus, Sapindi facie; foliis pinnatis, triquadrijugis, saepe cum impari, foliolis elliptico - oblongis, obtusis, basi obliquis, subtus ramulis paniculisque rufo-tomentosis.

Erioglossum Blume Bljdr. 229. Sapindas edu1 is Blnme Catalog. hort. Buitenporg. 62.

5612. Nilatayloa $A U B L$. Ca! y $\times$ profunde quinquefidus. Corolla e petala 5 , intas ad basim breviter appendienlata. Diseus calyeis fundum oceupans, octocrenatus. St a m in a 8 , disco intus inserta. Ovarium centrale, biloculare. OvuIa in loculis solitaria, medio dissepimento inserta, adscendentia; stig ma subsessile, tridentatum. Fract ns..... Arbor guianen$s i s$; foliis alternis, exstipulatis, abrupte pinnatis. tri-quadrijugis, floribus racemoso-paniculatis.

M a t a y b a Aublet Guian. I, 331, t, 128. Lam, t, 298. Cambessed, in Mem. Mus, XVIIT, 36. Meisner Gen. 52. (38.)
Ephielis Sehreber Gen, n, Gir. Ernstingla Necker Elem, n. 974 .

5613. Moulinsia CAMBESS. C a l y $\mathrm{x}$ quinquepartitus, laciniis duabus exterioribus minoribus, C o rol I a e petala 4, receptaculo inserta, calycis laciniis alterna, quinti superioris sede vacua, intus supra basim squamula cucullata, apice cristata, infra apicem inflexum desinente aucta. Disens incompletus, quadrilobus, lobis petalis oppositis. Stamina 8 , receptaculo excentrice inserta, ovarium cingentia; fila men ta filiformia, libera, inaequalia, a n th e ra introrsae, biloenlares, dorso insertae, mobiles, longitudinaliter dehiscentes. Ovari n m excentricum, sessile, trilobum, triloculare. Ovula in loculis solitaria, e basi erecta. Stylus inter ovarii lobos simplex; stig ma subtrilobum. Cap 8 u la tri- v. aborta biloba, tri- v. bilocularis, loculieide bi-trivalvis, valvis medio septiferis. S em in a in loculis solitaria, erecta...-Arbor timorensis; foliis oppositis, petiolatis, exstipulatis, abrupte pinnatis, foliolis oppositis, integerrimis, floribus terminalibus, racemosis .

Moulins ia Cambessed. in Mem. Mus, XVIIT. 27.t. 2. Meisner Gen, 52. (37.) - ? Sap indus rubiginosus Roxb. Corom, $t, 62$.

5B14. Cupamia PLUM. Caly $x$ quinquepartitus, aequalis, Co rolla petala 5, receptaculo inserta, calycis laciniis alterna, aequalia, supra nnguem squamula aucta, interdnm nulla. Disc us calyeis fundum occupans regularis, integerrimus $\mathbf{v}$, crennlatus. Stam in a $8 \mathrm{v}, 10$, diseo intus inserta; filamenta filiformia, libera, an the$r$ a e introrsae, biloculares, dorso insertae, mobiles, longitudinaliter dehiscentes. Ov a ri u m centrale, sessile, triloculare. Ovula in loculis solitaria, angulo centrali paullo snpra basim inserta, adscendentia. St ylus simplex, apice trifidus, lobis intus stigmatosis. Capsula coriacea v. sublignosa, pyriformis, di-trigona, bi-triloeularis, loculicide bi-trivalvis, valvis medio septiferis. Se$\mathrm{min}$ a in loculis solitaria, subglobosa, erecta, arillo cupulaeformi, earnoso inclusa, test a crustacea. Embr yo nis exalbnminosi, plus minus curvati cotyledones crassissimae, incumbentes, radieula brevis, umbilico proxima, infera. - $A r-$ bores $v$. frutices erecti, intèr tropicos totius orbis crescentes; foliis alternis, petiolatis, exstipulatis, abrupte pinnatis, foliolis oppositis $v$. alternis, integerrimis $v$. serratis, interdum pellucide punctatis, floribus polygamis, in racemos axillares dispositis.

Cupania Plumier Gen, 49. t. 19. Linn. Gen. n, 279. Labillard. Nov, Caled. $t$. 14. Cambessed, in Mom. Mus. $X V I I T .28$, t. 3. St. Hilaire Flor. Brasil, I, 385, $t, 79,80$. Trigou is Jacq. Amer, 102, Vo u a ra na Anblet Guian. IT. Suppl. 12. t. 374. M n I i n a e a Jussien Ger, 245. Lam. t. 305. Roxburgh Plant, of Corom, $t, 60$. Gelo $\mathrm{n}$ i u m Gärt. ner II. 221. $t$. 139. Thouars Gen. Madagase. $n$. 45. non Willd. et Roxb. Ti n a Römer et Sehult. Syst. $V$. n. 984, St a dmannia Lamarek, $t, 312$. Mis e ho e arpus Blume Bijdr. 238. G u i a a Cavanill. Ic. IV. 49. t. 373.-B Iigh i a König Annal. of Bot, $I I, 571, t, 16,17$. A k ees i a Tussac Flor. Antill. I. 66. t. 3. H a r p uli a Roxburgh Flor. Ind. edit. Wall, $I T$. 44t. B on $\mathrm{nani}$ a Rafinesque Specch, $\mathrm{XV}$. 115. D i me rez a Labillard. Nov, Caled, 51. t. 51. D i plo. pet a 1 on Sprengel Syst. o.p. 146. Ra to n i a DC. Prodr. I. 618, S a pind i s p. Aublet Guian, t, 138, 139. E rioglos$\mathrm{s}$ u $\mathrm{m}$ Gaillewia et Perrot. Flor. seneg. $t$. 28. non Blum. coll. Arnott in Nouv, Annal. sc, nat, II, 23. D igo nocarpus Flor. Flum. IV. $t, 14$. Trigonocarpus Flor. Flum. IV, t, 15.

5615. Aplaninis BLUM. Calyx quadripartitus, inaequalis. Corolla e petala 4, ciliata, basi intus bisquamata, $\mathrm{D}$ is cus hypogynus geni- 
talia cingens. St a mina 5 , ovario approximata. O v a r i m ovatum, compressum, biloculare. Ovula in loculis solitaria. Stylus subnullus; stigmate emarginato. Fruetus ..... Arbor javana; foliis abrupte pinnatis, foliolis suboppositis, racemis terminalibus, compositis.

A p ha nia Blume Bijdr. 236. Cambessed, in Mem, Mus. XVIIT. 37.

5616. Talisia $A U B L$. Caly $\times$ profunde quinquefidus, aequalis. Corolla e petala 5 , receptaculo inserta, calyeis laciniis alterna, intus supra basim squama limbum aequante, densissime pilosa, aucta. Di s c u s carnosissimus, calycis fundum occupans, regularis, crenatus. S $t$ a $m$ in a 8 , disco intus inserta; fil a m enta filiformia, libe$r a$, antherae introrsae, biloculares, dorso insertae, mobiles, longitudinaliter déhiscentes. 0 vari um centrale, sessile, triloculare. Ovala in loculis solitaria, e basi anguli centralis adscendentia, Stigma subsessile, obsolete tridentatum. Fructus ..... - Arbores v. frutices, eirrhis destituti, in America tropica crescentes; foliis alternis, exstipulatis, abrupte pinnatis, foliolis alternis, integerrimis, floribus polygamis, racemosopaniculatis.

T a I is i a Aublet Guian, I. 349. t. 136. Vabl Eclog. II. 29. 30. Lam, t, 310. DC. Prodr. I. 609. Cambessed, in Mem. Mus. XVIII, 29. Meisaer Gen, 52. (38.) -? A c I a do de a Ruiz et Pavou Prodr. 133, t. 29.

581\%. Nephelium LINN. Calyx plus minus profunde quadri-sexfidus v. partitus, inaequalis v. subaequalis. Corolla nulla v. petala 4_6, receptaculo inserta, calyeis foliolis alterna, glabra v. dense pilosa, basi squamula ancta v. esquamulata. D isens annularis, calycis fundum occupans, regularis. St a $\mathrm{m}$ in a $8 \mathrm{v}$. 10, rarius 6 , disco intus inserta; filamenta filiformia, basi coalita, a ntherae introrsae, biloculares, dorso insertae, longitudinaliter dehiscentes. Ovari u m centrale, substipitatum, obcordato-bilobum, biloculare. Ovula in loculis solitaria, e basi erecta. Stylus inter lobos simplex; stigma bifidum $v$. bilobum. Fructus indehiscens, lobo altero saepissime efoeto, minuto unilobus, tuberculatus v. mnricatus, rarius laevis, monospermus. S e men ovato-snbglobosum, erectum, arillo carnoso inclusum, te 8 t a crustacea. Em b r y a $n$ is exalbuminosi, recti cotyledones crassissimae, radicula hrevissima, infera. - Arbores Asiae tropicae; foliis alternis, exstipulatis, abrupte pinnatis, foliolis alternis $v$. oppositis, rarissime simplicibus, floribus racemoso panieulatis.

Nephe 11 u m Linn. Gen, n. 1425. Lam. t. 746. Cambessed. in Mom. Mus. XVIII, 30. Wight et Arnott Prodr. $I$. 113. Meisner Gen, 53. (38.) Wight To. t. 24. 25. E a phoria Commers. ex Jussieu Gen. 247. Lam, t. 306. DC. Prodr. I. 611. Bot. Reg. t. 1059, 1729. S c y tali a Girtner I. 179. t. 42. Dim o car pus Loureiro Flor. cochinch. I. 268. Pometía Porster Prodr. 392. Li-tehi Sonuerat Voy. t. 129 .

5819. Thouinia POIT. Caly $\mathrm{x}$ quadriquinquepartitus, aequalis. Co roll a e petala 4 v. 5, receptaculo inserta, ealyeis foliolis alterna, aequalia, esquamata. Discus calycis fundum oecupans regularis. $\mathrm{St}$ a min a 8 v. 10 , disco intus inserta; filamenta libera, filiformia, antherae introrsae, biloculares, dorso insertae, mobiles, longitudinaliter dehiscentes, 0 va ri u m centrale, sessile, trilobum, triloculare. Ovala in loculis solitaria, angulo centrali prope basim inserta, adscendentia. Stylus axi centrali inter ovarii lobos insertus, breviter trifidus, lobis intus stigmatosis. Fruetus trilobus, tripterus, samaris tribus membranaceis, axi centrali adnatis, dorso et apice in alam productis, basi monospermis, indehiscentibas. S e m in a erecta, compressinscula, exarillata, $t$ e st a membranacea. Embryoais exalbuminosi, eurvati cotyledones lineares, incumbentes, radicula conica, nmbilico proxima, infera, $-A r$ bores v. frutices, saepe scandentes, in $A m e r i c a$ et Nova-Hollandia tropica crescentes; foliisalternis, petiolatis, exstipulatis, abrupte pinnatis $v$. trifoliolatis, interdum foliolorum lateralium abortu simplicibus, foribus polygamis, racemosis, racemis axillaribus, rarissime sterilibus et in cirrhos conversis.

Thoufuia Poiteau in Annal. Mus. IIT. 70. t. 6. 7. Turpin Ibid, $\nu, t$, 26. Humb. et Boapl. Plant. aequinoct. t. 56. Kunth in Humb. et Bonpl. Nov. gen et sp. V. 123. DC. Prodr. I, 612. Cambessed. in St. Hilare Flor. Brasil.I. 384. Mem. Mus. XVIII. 30. t. 1. f. D. A. Richard Sert. Mstrolab. t. 12. Melsner Gen, 52 . (37.) Th y a a Hamilton Prodr. Flor. Ind. occid, 36. - ? V a rgasia Bertero ex Sprengel Syst. II. 285, et 888. Gen. n. 1789.

5619. Hypelate $P$. BROWN. Calyx quinquepartitus, aequalis. C o r o 11 a e petala 5, receptaculo inserta, calycis laciniis alterna, esquamulata, rarins nulla. D iscu s calycis fundum oecupans, subinteger v. lobatns. S t a min a 8 v. 10, disco intas inserta; fit am ent a filiformia, libera, a ntherae introrsae, biloculares, dorso insertae, mobiles, longitudinaliter dehiscentes. Ova riu m centrale, sessile, bi-triloculare. Ovala in loculis $2-3$, angulo centrali inserta, pendula. Stylus terminalis, simplex; stigma brevissime bi-trilobum. Fructus globosas, siceus, indehiscens, abortu uni-bilocularis. Se mina in loculis solitaria, inversa, exarillata, t es ta coriacea. E m br y onis exalbuminosi, erecti cotyled on es crassae, incumbentes; radicula brevis, supera. - Arbores antillanae et ma uritianae; folitis alternis, petiolatis, exstipulatis, trifoliolatis $v$, abrupte pinnatis, foliolis oppositis $v$. alternis, subintegerrinis, floribus glomeratis $v$, in paniculas breves dispositis.

H y pela te P. Browne Jam, 280. Swarti Prodr. Flor. Ind, occid. II. 653, t. 14. DC. Prodr. I, 614. Cambessed. in Mem. Mas, XVIIT, 31. Delessert To. select, II, t. 39. Melleoceae sect. Sphaeroeocea DC, Prodr. 1. 61s.

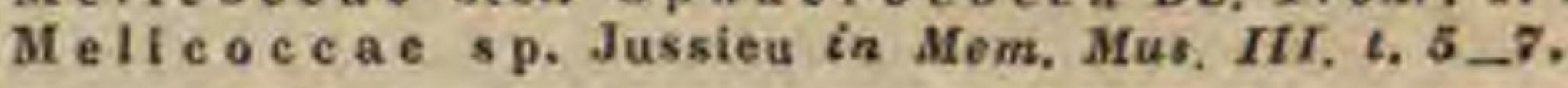

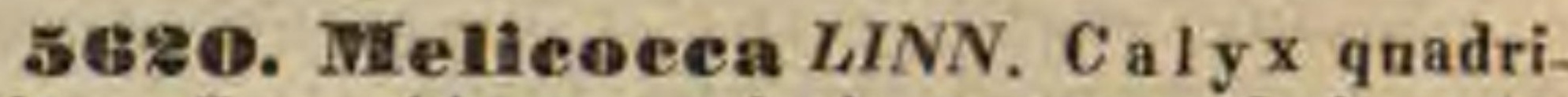
partitus. Corolla e petala 4, receptaculo inserta, ealycis laciniis alterna, esquamulata. Discus calycis fundum occupans, subintegerrimus. Stamin a 8 , diseo intus inserta; fil a ment a filiformia, libera, antherae introrsae, biloculares, dorso insertae, mobiles, longitudinaliter dehiscentes. Ovari um centrale, sessile v. substipitatum, bitriloculare. O v u Ia in loculis solitaria, e basi ereeta. Sty l as terminalis, simplex; stigma tripartitnm, lobis oltusis. D rn pa subearnosa, putamine crustaceo, abortu uni-biloculari. Semina in loculis solitaria, erecta, arillo pulposo involuta, t e st a coriacea. E mbryon is exalbuminosi, recti cotyled ones crassae, coalitae, radicula brerissima, infera. - Arbores Americae tropicae; foliis alternis, exstipulatis, abrupte pinnatis, foliolis suboppositis, racemis spicaeformibus.

Melie oce a Linn. Gen, n. 47. Jaeq. Amer, 6 , 72. Kunth in Humb. et Bonpl. Nov. gen, et sp. V. 180. Cambessed. in Mem, Mus, XVIII. 32, excl, sp. Asiat, Melic ocea e sect. Oocoeca DC. Prodr. 1. 615. Melicoceae sp. Jassieu in Mem. Mus. III, $t$, 4. C as imira Seopoli Intro. duct, n, 1026 . 
56921. Selhleidelnera WILLD. Caly $x$ quinquedentatus. Corolla nulla. Discus calycis fundum occupans regularis, lobatus. Stam in a 6_10, disco intus inserta; fil a m e $\mathrm{nta}$ filiformia, libera, antherae introrsae, biloculares, dorso insertae, mobiles, longitudinaliter dehiscentes. O varium centrale, sessile, triloculare. Ovula in loculis solitaria, e basi erecta. Stylus terminalis, simplex; stig m a tripartitum, lobis obtusis. Orup a sicca, putamine crustaceo, triloculari v. abortu nni-bileculari. S e m i na in loculis solitaria, erecta, arillo pulposo involuta; $t$ e $s t$ a coriacea. E m bry onis exalbuminosi, curvati cotyledones incumbentes, radicula brevis, nm. bilico proxima, infera. - Arbor indica; foliis alternis, exstipulatis, trijugis, foliolis oppositis, integerrimis, floribus in racemos axillares, spicaeformes dispositis.

Schlefehera Willdenow Spec. IV. 106. Wight et Arnott Prodr. 1. 114. Meisner Gen. 35. (38.) C u 8 a m. b $1 \mathrm{a} \mathrm{m}$ Rumph Amboin I, $t$. 57. Hamilton in Werner. Transact. $\boldsymbol{F}$. 357. K o o n Gärtner II. 486, t. 180. M e li co e c a trijug a Jussieu in Mem. Mus. III, $t, 8$.

TRIIBUS IE. DODONAEACEAE Cambessed. in Mem. Mus, XVIII, 33. $0 \mathrm{vul} \mathrm{a} \mathrm{in} \mathrm{lo-}$ culis $2-3$. E mbry o spiraliter convolutus.

562\%. Inelleuteria $L A M$. C a I y x quinquepartitus, aequalis. Co roll a e petala abortu 3 v. 4 , receptaculo inserta, calycis laciniis alterna, oblonga, intus ad unguem appendice parva, bipartita aucta. D i s c u 8 carnosissimus, totum calycis fundum occupans, regularis, octocrenatus, Stam ina 8 , rarius $5-7$, diseo intus inserta; $\mathrm{fi}$ lamenta libera, subulato-filiformia, an $t h$ er a e introrsae, biloculares, dorso insertae, longitudinaliter dehiscentes. Ovarium sessile, triloculare. Ovula in loculis gemina, anguli centralis medio superposite inserta, superius adscendens, inferius pendulum. Sty lus simplex; stig ma indivisum, acntum. C a p $s$ u la vesiculoso-inflata, basi tri-, apice subnnilocularis, loculicide trivalvis, valvis medio septa seminifera gerentibus. S em in a globosa, exarillata; $t$ es $t$ a crustacea. $E$ m br y o $n$ i s exalbuminosi, spiraliter convolnti radicnla extraria, umbilicum spectans. - Arbor sinensis, parva; foliis alternis, exstipulatis, imparipinnatis, foliolis alternis v. oppositis, ovatis, grosse et inaequaliter dentatis, floribus racemoso-paniculatis, luteis.

Koelreuteria Laxmana in Nov. Comment. Petropolit. $X V I$. E61. $t$. 18. Heritier Sert. $t$. 19. Dubamel Arbr. edit, nov, $t$, 36. DC. Prodr. I. 166. Cambessed. in Mem. Mus. XPIII. 33. t. 1. F. C. Meisner Gen, 53. (38.) $\mathrm{s}$ a piadus chinensis Lian. fil.

5623. Cossignia COMMERS. Caly $\mathrm{x}$ quinquepartitus, subaequalis. C o roll a e petala 4 , receptaculo inserta, esquamulata. D i s c u s calycis fundum occupans, irregularis, hinc productior, inde fere obsoletus. Stamina 6 v. 5 , disco inserta, excentrica; fil amenta libera, subulato. filiformia, antherae introrsae, biloculares, longitudinaliter dehiscentes. Ovarium excentricum, sessile, triloculare. O vula in loculis terna, angulo centrali supra medium superposite inserta, intermedium horizontale, superius adscendens, inferius pendulum. S ty In s longiusculus, simplex; stigin a subcapitatum. Ca p s n la stylo snperata, trilocularis, loculicide trivalvis, valvis ab axi central persistente, trigono, seminifero solutis. Se mina in loculis $3 \mathrm{v}$. abortu 2 , exarillata; t e $8 t$ a crustacea. Embryonis exalbuminosi, spiraliter convoluti radic a la extraria, umbilicum spectans. - Frutex borbonicus, ecirrhosus; foliis alternis, exstipulatis, imparipinnatis, bi-trijugis, foliolis integerrimis, floribus paniculatis.

Cossignia Commerson ex Jussieu Gen. 248. Lam. t. 256. DC. Prodr. I. 614. Cambessed, in Mem, Mus. $X V I I I, 33$,

5684. Hog res monoici. C al y $x$ quinquefidus, antice fissus. Corolla nulla. Discus in femineis nullus, in masculis suborbicularis, calyeis fundo adnatus, crenatrs, subdimidiatus. S $\mathrm{tam}$ in a 8 , in femineis rudimentaria, in masculis circa ovarium efoetum inserta; filamenta filiformia, libera, e ralyeis incisura propendentia, antherae introrsae, biloculares, ellipticae, supra basim emarginatam insertae, longitudinaliter dehiscentes. O va r iu m sessile, trigonum, triloculare. Ov u Ia in loculis gemina, anguli centralis medio superposite inserta, inferius adscendens, superius pendulnm. St yl us centralis, subulatus, trisuleatus; stigm a obtusum. Cap s a la subgloboso-trigona, trilocularis, loculicide trivalvis, valvis medio septa, margine hinc seminifera gerentibus. Se min a in loculis solitaria, adscendentia, subglobosa; test a ossea, nitida, umbilico basilari, orbiculari. Embryonis exalbuminosi, spiraliter convoluti $r$ a dicula extraria, umbilicum spectans, infera. - Arbores peruan a e; foliis alternis, exstipulatis, trifoliatis, saepius foliolorum lateralium abortu simplicibus, foliolis membranaceis, dentato-serratis, floribus in racemos axillares, breves, paucifloros disposilis.

Llagu noa Ruix et Pavon Prodr. 126, t. 28. Kunth in Humb. et Bonpl. Nov, gen, ot sp. V. 130, t. 462, f. 2. Cambessed, in Mem. Mus. XVIII. 34. Meisner Gen, 53 (38.) A mirola Persoon Encheir. II. 565. DC. Prodr, I, 616, Hooker Ic, t. 132.

5625. Diplopeltis ENDL. Flores polygamo-dioici. Calyx pentaphyllus, foliolis aequalibus, aestivatione imbricatis, Corolla e petala 4 , receptaculo inserta, calycis laciniis alterna, quinti sede vacua, orbiculata, unguiculata, ungue esquamulato, patentia. Discus postice in squamam erectam, carnosam, bilamellatam, inferne genitalium basim amplectentem, soperne sinuatodentatam productus. Stam in a 8 , inter discum et ovarimu inserta, subexcentrica; filamenta filiformia, in masculis longe exserta, in femineis brevissima, a n thera e introrsae, bilnculares, ovatae, medio dorso insertae, longitndinaliter dehiscentes. Ovarium (in masculis efoetmm) sessile, subglobosum, pilis glandulosis hirtum, triloculare. Ovula in loculis gemina, anguli centralis medio superposite inserta, superius pendulum, inferius e funiculo longiori adscendens. Stylus centralis, filiformis, longe exsertus, apice incurvus; stigma simplex. Cap a la depressa, triloba, verruculosa, trilocularis, septicide tripartibilis, coceis demum angulo centrali dehiscentibus. Semina in loculis solitaria, e funiculo longinsculo adscendentia, erecta, testa crustacea, umbilico basilari, funieuli expansione minuta, arillaeformi stipato. E m b r y o n i s exalbuminosi, spiraliter convoluti radicula extraria, umbilicum spectans, infera. - Suffrutex Novae-Hollandiae austro-occidentalis; ramis subtetragonis, pube candicante conspersis, foliis alternis, sessilibus, in stirpibus masculis oblongo-cuneatis, apice obtuso incisis, basi integerrimis, glabris, margine obsolete ciliatis, summis intgerrimis, in stirpibus femineis latioribus, acutis, usque ad basim 
inciso-pinnatifidis, laciniis lanceolatis, infimis stipulaeformibus, setis adpressis utrinque hispidis, panicula utriusque sexus simplici, e racemis scorpioideis, paucifloris, pedunculis nigro-tomentosis, bracteis in masculis integerrimis, feminarum pinnatifidis, floribus albis, caeruleis $v$, roseis, staminibus in masculis, stylo in femineis, paullo minoribus, longe exsertis.

Dipl o pel t is Endlicher in Enumerat, plant. Hilgel. 13. Lindl. Bot. Heg. 1839. t. 69 .

5626. Dodomaen $L I N N$, F lo res polygami. Ca l y x tri-quadri-quinquepartitus. (Vo r oll a nulla. D is c us obsoletus. Stamina 5 v. plura, receptaculo inserta; fil a $m$ ent a brevissima, filiformia, antherae biloculares, crassae, tetragonae, basi insertae, longitudinaliter dehiscentes. Ovari um centrale, sessile, tri-tetraquetrum, tri-quadriloculare. $0 \times \mathrm{ula}$ in loculis gemina, anguli centralis medio superposite inserta, superius adscendens, inferius pendulum. Stylus centralis, tri-tetragonus, apice tri-quadrifidns, lobis intus stigmatosis. Capsula membranacea, di-tritetraquetra, bi-quadrilocularis, septicide bi-quadrivalvis, valvis navicularibus, dorso alatis, a columna centrali alata, persistente, medio seminifera solutis. Semina in loculis gemina v. abortu solitaria, tumide lenticularia, testa crustacea, interdum marginata. Em bryon is exalbuminosi, spiraliter convolnti radicula extraria, umbilicum spectans, infera. - Arbusculae $v$. frutices saepissi. me viscosi, per regiones tropicas et tropi cis circulis vicinas totius orbis spar sim, copiosissime in Nova-Hollandia extra. tropic a provenientes; foliis alternis, exstipulatis, nunc simplicibus integerrimis, nunc imparipinnatis, foliolis saepissime incisis, floribus axillaribus et terminalibus, saepissime racemosis, hermaphroditis $v$. unisexualibus, monoicis $v$. dioicis.

D o do n a e a Lian. Gen, n. 855. Cavanill. Ic. $t$. 397. Lam. t. 304. Audrews in Bot. Reposit. t. 230. Rudge in tinn. Transact, XI, t, 19. 20. Bot. Mag, t, 2860 . Bot. Reg. t. 10s1. Kunth in Humb. et Bonpl. Nov, gen. et sp. V. 132 . t. 449. Cambessed, in Mem, Mus, XVIII. 35. Endlicher Atakt, t. 30. 31, Meisner Gen. 33. (38.) Wight Illustr. t, se,

5B3\%. Aleetryon GARTN. Caly x pentaphyllus, aestivatione imbricatus. Corolla nulla. St amina 8, hypogyna, a $n$ the rae biloculares, incorvatae, filamentorum longitudine, Ovarium triloculare. Ovula .... Stylus simplex; 8 tigm a trifidum. B a c c a sicea, aborta unilocularis, monosperma, margine v. apice in alam cristatam compressa. S e m e n basi erectnm, arillo carnoso cupulari stipatum. Embryon is exalbuminnsi cotyledones spiraliter convolutae, radicula extraria, infera. - Arbores in Nova-Zeelan. dia et Nova-Hollandia orientali crescentes; foliis imparipinnatis, paucijugis, foliolis alternis, integerrimis, racemis axillaribus terminalibusve.

A l e ctr y o n Gärtner I. 216. c. 46. DC. Prodr. I. 617. Cambessed, in Mem. Mur. XVIII. 35. A led r y o a A. Cun ningh. in Annal. of Nat, hist. III, 318. R v o n y moides Soland. msc.

\section{GENERA ANOMALA.}

5628. Hlösslea $E N D L$. C a ly x quinquefidus, aequalis. Discus adnatus. Co roll a e petala 5 , disei basi extus inserta, aequalia, ungue nudo. St a mina 10 , cum petalis inserta; filamenta libera, subulata, antherae introrsae, hiloculares, loasi emarginata insertae, longitudina. liter dehiscentes, Ovariu m sessile, triloculare.
Ovula in loculis gemina, anguli centralis medio inserta, oblique contigua, peltatim amphitropa, micropyle supera. Stylns terminalis, crassus; 8 tigma depresse subcapitatum, obsolete trilobum. C a p s a I a clavata, trilocularis, trivalvis, valvis cum septis alternantibus, colnmnam tripteram, alis septantem, faciebus seminiferam nudantibus. Sem i a in loculis abortu solitaria, triangularia, basi et apice in euspidem producta, testa ossea, dorso membrana lacerula tecta, umbilico ventrali, nucleum multoties minorem, integumen. to tenuissimo includente. Embryonis exalbuminosi, leviter arcuati cotyledones foliaceae, trilobae, convolutae, radi cula supera. - Arbor Africae trapicae; florescentiae tempore aphylla, paniculis in apice ramorum confertis, multifloris.

Plöss le a Eadlicher in Nov, stirp. Mus. Vindob.Dec, n. 47.

5B2.. Xanthoceras $B U N G$, Flores abortu polygamo-monoici. C a 1 y e is foliola 5 , subaequalia, obtusa. C o r o 11 a e petala 5 , bypogyna, basi villosa. G I a nd u la e 5 , petalis alternae, ligulatae, reflexae. St a min a 8 , hypogyna, anther a e apice glandala auctae, biloculares, intus dehiscentes. Ov a ri $\mathbf{m}$ globosum, triloculare, Ioculis octoovulatis. Stylug simplex, crassus; stigma capitatum, trilobum. Capsula eorticata, trilocularis, trivalvis, valvis medio septiferis. Semina plurima, magna, obovato-subglobosa, compressa. - Arbor in montibus $\mathrm{Ch} i$ nae borealis obvia, decem ad quindecim pedes alta; foliis imparipinnatis, foliolis serratis, floribus terminalibus, gemmaceis, racemosis, albis, capsula trigona-subglobosa, seminibus magnis, nitidis, nigris.

$\mathrm{X}$ a $\mathrm{nthocer}$ as Bunge Enum, plant, Chin. bor. 11 . Meisuer Gen. 53. (38.)

5630. IVIasonia $S T$. HIL. F lores polygami. Caly $\mathrm{x}$ quinquepartitus, subobliquus, laciniis lineari-ellipticis, inaequalibus, reflexis. Coro 11 a e petala 5, subperigyna, calycis laciniis alterna, multoties longiora, linearia, patentia, subinaequalia. Dis e us calycis fundum occupans, irregularis, antice abbreviatus, postice productior, bilamellatus. Stamina 8 , in femineis brevissima, disco intus inserta; fil ament a libera, subulata, declinata, antherae introrsae, biloculares, ellipticae, dorso supra basim bifidam insertae, mobiles, longitudinaliter dehiscentes. Ovarin m in floribus maseulis minimum, sessile, triloenlare. Ovnla in loculis plurima, angulo centrali biseriatim inserta, horizontalia. Stylus terminalis, curvatus; $8 \mathrm{ti} \mathrm{g}$ a obsolete trilobum. Capsula lignosa, globoso-trigona, trilocularis, loculicide trivalvis, valvis a colnmna centrali lignoso-suberosa, basi et apice in dissepimenta producta solntis. Se mina in quovis loculo 6 - 8 , basi columnae inserta, compressa, adscendentim imbricata, transversim oblonga, testa chartacea, margine in alam membranaceam prodncta, nmbilico marginali. E mbryonis exalbuminosi, recti coty le dones magnae, suborbiculatae, radicula brevis, umbilicum attingens, centripeta. - Arbores brasilienses, campestres; cortice suberoso, foliis alternis, exstipulatis, abrupte pinnatis, foliolis emarginatis, integerrimis, glabriusculis v. pubescentibus, floribus paniculatis $v$, racemoso panieulatis, in eadem panicula polygamis. 
Magonia St. Hilaire Mem, Mus. XIT. 336, t. 12. et 13. a. Plant, remarq. Brasil. 238. t. 23. 24. a. Cambessed.
in Mem. Mus, XVIII, 35. St. Hilaire Flor. Brasil. I. 394. Meisner Gen, 53. (38,) P ha e c arpus Martius et Zucearini Nov. gen. et sp. 1. 61, $t, 37.38$.

\section{GENERA PENITUS DUBIA.}

5631. Valentinnia SWARTZ. C a Iy quinquepartitus, coloratus, patens, persistens. Corolla nulla. Stamina 8 , calyce paullo breviora; filamenta subulata, antherae subrotundae. Ovarinm liberum, subrotundam. Stylus cras. sus; $s \mathrm{tig} \mathrm{m}$ a capitatum. Capsula baceata, intus pulposa, tri-quadrivalvis, valvis revolutis. S e m in a $3 \_4$, erecta, oblonga, pulpa lutea obvoluta. - Frutex antillanus, bi tripedalis; caule rigido, ramoso, inermi, ramis subdivisis, glabris, foliis alternis, petiolatis, ovato-lanceolatis, sesquipollicaribus, margine ut in Ilice aquifolio undulato. spinosis, glabris, rigidissimis, floribus terminalibus, subumbellatis, in apicibus ramulorum pedicellatis, coccineis, fructu primum niveo, demum coccineo.

Valeutinia Swariz Flor. Ind. occid. 687. $t$. 14. Schreber Gen, n. 1748. DC. Prodr. 1. 618. Meisner Gen, 53. (38.) - Malpighia Plumier Ic. $t, 167$. $f$. 2. 11 ex Plucknet Alm, 197. t. 196. f. 3. - Genus a Swarzio ad Dumosas a Jussieo ad Saaydeas, a Caudolleo ad Sapindaceas relatum.

5632. IBacaria $A U B L$. „D rnp a ovata, glabra, sublutea, unilocularis. Nuces tres, oblongae, angulatae, extus convexae, simul junctae. quandoque binae, ex una parte planae, ex altera convexae, saepius unica nux ovata, aeuta. $\mathbf{N}$ ucleus viridis, testa fragilis." $-{ }_{n}$ Frutex guia$n$ e $n s i s$, caules simplices, decempedales e radice emittens. Folia alterna, pinnata, trijugata, foliolis ovatis, acutis, glabris, integerrimis, costae triangulari adnexis, superne in acumen desinenti, ad basim crassiori, paullo supra hanc basim prominet tuberculum, aculeis quinque, plus minus rigidis instructum. Fructus racemosi, terminales. Drupa succulenta, acida. Nucleus viridis, saporis Pisi immaturi."

Ra caria Aublet Guian. Supplem. 24, t. 382. DC. Prodr. X. 618, Meisner Gen, 53. (38.)

5\$33. Eustathes LOUR. C al y x pentaphyllus, foliolis ovatis, concavis. Corolla e petala 5 , ovata, patentia, calycem aequantia. S $t$ amin a 8 , receptaculo inserta; fil a m e $n t a$ subnlata, erecta, an the rae biloculares, ovatae, erectae. Ovarium subrotundum, pilosum. Stylus fitiformis, staminibus subaequalis; $8 \mathrm{tig} \mathrm{ma} \mathrm{obtu-}$ sum, emarginatum. B a ce a globosa, carnosa, unilocularis, tetrasperma. - Arbor cochinchinen$s i s$, magna, ligno firmo, subrubro; ramis patentibus, folitis alternis, ovato-oblongis, acuminatis, integerrimis, glabris, venosis, racemis subterminalibus, subsimplicibus, oblongis, floribus albis, baccis mediocribus, corticosis, glabris.

Eus t at hes Loureiro Flor, chochinch. 289. DC. Prodr. 618. Meisner Gen. 53. (38.)

5B34. Pedicellia LOUR. Fi or es polygamo-dioici. C a l yx yuinquepartitus, brevis, laeiniis acutis, reflexis. Corolla nulla. Discus carnosus, quinquecrenatus. Stamina 8 ; filament a filiformia, reflexa, calyee triplo longiora, ant her a e biloculares, erectae. Ovarin m subrotundum, stipitatum. Stylus subnullus; stig. ma ta 3 , acuta, reflexa. C a p s u la subrotunda, pedicellata, trivalsis, monosperma. S em en pedicellatum, arillatum. - Arbor cochinchinen$s i s$, parva; ramis patentibus, foliis oppositis, pe- tiolatis, lanceolatis, integerrimis, glabris, racemis terminalibus longis, floribus pallidis.

Pedicelli a Lonreiro Flor, cochinch. 805. DC. Prodr. 1. 618. Meisner Gen, 33. (38.)

5435. Pappea ECKL. et ZEYH. CaI $\mathrm{yx}$ inaequaliter quinquepartitus. Coro $\mathrm{Hl}$ a e petala $4-6$, intns barbata. $S$ t a m in a $8-10$, diseo annulari hypogyno inserta; fil a m en tis villosis. Ova ri n m triloculare, loculis nniovulatis. StyI us simplex; stigma subtrifidum. Carpidia 3 , capsulari-drupacea, basi connata, globosa, abortu saepe gemina r. solitaria. - Arbor capensis; foliis alternis, obovato-oblongis, obtusis, margine revolutis, integerrimis, coriaceis, glaberrimis, racemis congestis.

P a p pe a Ecklon et Zeyher Enumerat. plant. Cap. 53. Meisner Gen, 58. (37.)

5836. Ptaeroxylom ECKL. et ZEYH. Caly $\mathrm{x}$ tetraphyllus. C o roll a e petala 4 , nuda. D i s cus hypogynus glandulosus. Stamina 4 , libera; fil a ment is glabris, Ovarinm biloculare, compressum. Styli 2, distincti v. fere ad apicem coaliti; stigmata capitata. Capsula bilocularis, eompressa, apice subbiloba, basi cordata, disperma, intus dehiscens. S emina alata. Cotyled ones erectae, planae. - Arbor capensis; folits imparipinnatis v. folioli terminalis abortu abrupte pinnatis, foliolis coriaceis, inaequilateris, integerrimis, quinque-septemjugis, sensim decrescentibus, racemis paniculatis, axillaribus, ad ramulorum apicem confertis.

P taeroxy 1 on Ecklon et Zeyher Enum, plant, Cap. 54. Meisner Gen. 52. (38.) Nieshout Colon.

563ร. Hippobromus ECKL. et ZEYH. F lores diclines. Cal y $x$ pentaphyllus, persistens, inaequalis. Corolla e petala 5, hypogyna, aestivatione imbricata. Ma s c. Stam in a 8 , intra diseum urceolatum inserta. O va ri u m abortivum. F e m. O varium triloculare, disco insidens. Stylus brevis, crassus. Stig ma capitatum, trifidam. Stamina 8, abortiva. Fractus drupaceus, subearnosus, pyrenis $1-3$. S e m e n pendulum. E mbryon is exalbuminosi coty led on es carnosae, conduplicatae, radic ula supera, umbilicum spectans. - Arbor ca pensis, resinifera; foliis abrupte pinnatis, foliolis oppositis, paniculis axillaribus, floribus rufescenti-velutinis, calycis foliolis rotundato-concavis, cum petalis ciliato-laciniatis.

H ippobromus Eeklon et Zeyher Enum. 15t, R b us a 1 a tu m Thunb. Pardepis Colon,

5838. Tarrietia BLUM. Caly $\mathrm{x} . .$. Corolla .... Stamina ..... Carpidia.... 3_4, monosperma, pedicellata, deorsum in alam simplicem, membranaceam desinentia. E m b r y o. n is radicnla supera, ad umbilicum versa. - Arbor javanica, altissima; folits quinquefoliolatis, foliolis petiolulatis, oblongis, acutis, coriaceis, glabris, racemis axillaribus, compositis.

Turrietia Blume Bijdr. 297. - Genus a el. auctore Malpighiaceis adaumeratum, sed ob folia composita potius Sapindaceum, v. fortassis Acerineis adscribendum.

OBSERVATIO. Genera Do ra $\mathrm{n} \times \mathrm{y} 1 \mathrm{um}$ Nerand et C a 1 lidry nos Nerand a $\mathrm{cl}$. Gaudichaud ad Fregcinet 99 , nec non Cardiopteris Wall. sive Si oja Hamilt. a el. Liodley Introduct. edit. IT. P. 82, et Royle Himalay, 136. commemorata, nullibl deseripta, nobis iguota sunt.

\section{* MELIOS MiEAE,}

5639. Neliosma $B L U M$. Cal yx persistens, nudus $v$, uni-tribracteatus, pentaphyllus 
foliolis duobus exterioribus aequalibus, tribus interioribus saepe inaequalibns, aestivatione imbricatis. Corolia e petala 5 , receptaculi margini inserta, decidua, tria exteriora calycis foliolis interioribus alternantia orbicularia, integra, aestivatione imbricata, dno interiora calycis foliolisiste rioribus alterna, minora, bifida, acnta. St am i n a 5 , petalis opposita, iisdem ima basi subcoalita, tria sterilia ante petala majora, duo fertilia ante minora; fi l a m e $n t a p l a n a$, a $n t h e r a e$ biloculares, loculis oppositis, globosis, connectivo terminali, transversim elliptico, antrorsum patelliformi, carnoso, margine membranaceo intus insertis, transversim dehiscentibns. Di sc us hypogynus, planus, liber, triangularis, angulis bidentatis, cum petalis majoribus alternantibus. Ovarium sessile, triloculare. Ovula in loculis gemina, angulo centrali inserta, superposita. St yIns simplex, brevis, crassus; st igma subbilobum. Drupa abortu nnilocularis, monosperma, dissepimenti superne evanidi basi persistente indurata. Semen subrotundum, semisepto basilari circumpositum et intrusum. Embryonis exalbuminosi, conduplicati e o t y 1 e do n e s oblongae, radi $c \mathbf{l}$ a incurva, infera. - Arbores As iae tropicae; foliis alternis, exstipulatis, simplicibus, integerrimis, $v$, rarius abrupte pinnatis, foliolis denticulato-serratis, paniculis terminalibus et versus ramorum apices axillaribus, floribus saepius minutis, subspicatis, in ramulos breves juxta paniculae ramos horisontales dispositis.

Meliosma Blume Flor. Jav.Praef. $P N$. Millington I a Roxburgh Plant. Corom, III, t. 284. Flor. Ind, $I$, 109. non Lino. Arnott in Edinb, new philosoph. Journ, XV. 178. Wight et Arnott Prodr. 1 . 115.

\section{* HIPPOCASTANEAE.}

5640. Umginadia ENDL. F lores polygami, CaI y $x$ quinquepartitus. Coroll a e petala 3 , hypogyna, inaequalia, unguibus apice cristatis, erectis, laminis patentibus. To rus postice laminam genitalium basim amplectentem exserens. St a m in a 9, basi cum tori lamina et ovarii stipite connata; fila ment a filiformia, exserta, adscendentia, antherae bilocnlares, Iongitudinaliter dehiscentes. Ovarinm stipitatam, triloculare. Ovnla in loculis gemina, anguli centralis medio collateraliter inserta, adscendentia. Sty I u s brevissimus, conicus; 8 ti $\mathrm{gma}$ simplex. Fructus ......-Arbor boreali-americana; foliis alternis, exstipulatis, imparipinnatis, trijugis, foliolis oppositis, obsolete crenulatis, racemis lateralibus corymbosis.

Ung n a di a Endlieher Atakt. t. 36. Nov. stirp. Decad, $n, 86$.

5641. Aesculats LINN. F lores polygami. C a lyx campanulatus $v$. tubulosus, quinquefidus v. quinquedentatus, plus minns inaequalis. Coroll a e petala 5 , v, antici abortu 4 , hypogyna, pins minus inaequalia et saepe dissimilia, unguibus erectis, laminis patentibus, D is c us annularis, integerrimns v. lobatus saepe unilateralis. St a mina $6-8$, saepissime 7 , hypogyna, libera; filamenta filiformia, adscendentia, a $n$ therae biloculares, Iongitudinaliter dehiscentes. 0 v a ri u m sessile, triloculare. $O \vee \mathrm{u} 1 \mathrm{a}$ in loeulis gemina, anguln centrali superposite inserta, inferius adscen. dens, superins appensum. S t y lus filiformis; stigma auctum. Capsula coriacea, luevis v. echinata, trilocularis v. abortu bi-uniloeularis, loculicide dehiscens, valvis medio septiferis. Se$\mathrm{m}$ i $\mathrm{n}$ a in loculis abortu solitaria $v$, rarissime gemina, testa coriacea, nitida, umbilico basilari lato, deraso, exarillato. Embryonis exalbuminosi curvati cotyled on e 8 maximae, carnosae, conferruminatae, radic a la brevis, umbilieo proxima, plumula diphylla. - Arbores $v$. frutices, in Indiaboreali et in America borealicalidiore sponte crescentes; foliis oppositis, petiolatis, exstipulatis, palmatim quinque - novemfoliolatis, foliolis sessilibus v, petiolatis, penninerviis, serratis, floribus in racemos $v$. paniculas terminales, thyrsoideas dispositis.

A e s c u l us Linn. Gen. n. 462. Jussieu Gen, 2st, H i p. poc as t a n u m Tournefort Inst. 612. Gärtner II, 135, t. 111. Pavia Boerhave Lugd.Batav, 260.

a. HIPPOCASTANUM. Capsula echinata. Aesenlus DC. Prodr. I. 59\%. (Schkulir t, 104.) A esculns et P a vi в e seet. I. Spach in Nouv. Annal. sc, nat. II. 39 . (Bot. Reg. t. 993. Watson Dendrolog, t. 121. Guimpel et Hayne fremd. Holzart. $t$. 22. 24.)

b. PAVia. Caps nla inermis. Pavia Boerh. l. o. DC. Prodr. I. 399. P avia e sect. II. Spach Op. cit. p. 55. (Duham. Arbr. edit. nov, IIT, t, 19. Watson Deadrolog. $t, 120,163$, Guimpel et Hayne $O p$, cit, $t, 21,23$. Bot. Reg. t. 310. 993. 1009. 1018.) - M a croth y rsus Spach Op, oit. t, 61. (Jacq. f. Eclog, t, 9. Guimpel et Hayne Op, cit. t, 26. Bot. Mag. t. 2118.) C a o th y r. s us Spach Op. cit. p. 62.

\section{Drdo CCXXXI. Rhizobolece.}

RHIZOBOLEAE DC. Prodr. . 599. Bartling Ord. nat, 365. Caubessed. in St. Hilaire Elor. Brasil, I, 322.

Arbores vastae, in America tropica indigenae. Folia opposita (an interdum alterna?) petiolata, palmatim tri-quinquefoliolata, foliola brevissime petiolulata, coriacea, crenato-serrata, rugoso-venosa, petiolo articulato. Stipula e nullae.

Flones hermaphroditi, regulares, magni, spectabiles, racemosi, pedicellis basi et infra apicem articulatis, bracteatis. $\mathbf{S}$ i $\mathbf{p}$ u 1 a e nullae.

Calxx liber, persistens, quinque-v. sexpartitus, laciniis aequalibus, obtasis, aestivatione imbricatis.

Corolla petala 5-8, hypogyna, cum calycis laciniis numero aequalia iisdem alterna, crassiuscula, aequilatera, subconcava, aestivatione convoluta, sub anthesi erecta v. patentia, decidna.

Staursa plurima, disco carnoso ovarii basim cingenti inserta. Filamenta filiformia, ima basi inter se et cum petalis cohaerentia, decidua. A n therae introrsae, biloculares, ovatae v. oblongae, dorso affixae, mobiles, loculis appositis, longitudinaliter dehiscentibus.

Ovarum liberum, sessile, quadri-quinqueloculare. Ovula in loculis solitaria, medio angulo centrali inserta, semianatropa, micropyle supera. Styli centrales, loculorum numero, distineti. Stigma la minute capitata.

Noces quatuor v. sex, saepe abortu pauciores, a latere compressae, distinctae, angulo centrali cohaerentes, indehiscentes, mo- 
nospermae, epicarpio membranaceo, laxiusculo, secedente, endocarpio lignoso-subosseo, extus setis rigidis clavatis, cum carne oleosa mixtis, stupposo v. tuberculato, intus laevi.

Sвmen reniformi-trigonum, dorso convexo carinatum, utrinque angustatum, ventre supra medium funiculo brevi in carunculam bilobam dilatato affixum, te st a tenui, fungosa, derasili, endopleura membranacea. Albumen nullum.

Embryo curvatus. R a d i c u la maxima, crassa, totum semen explens, apice supero brevissime apiculata. Cauliculus intermedius anceps, elongatus, adscendens, intra radiculae sulcum superficialem collocatus, apice c otyle dones duas, minutas, sibi invicem applicitas gerens.

$\mathbf{R}$ hizob ol ea e embryonis radicula portentosa distinctissimae, Sapindaceis et Hippocastaneis affinitate proximae, mediante Mangifera Anacardieis accedentes, a Clusiaceis foliis compositis longius distant.

Embryo amygdalinus (valgo Pequi, Souari, v. Suvarrow) deliciosus, oleosus.

5642. Caryocar LINN. Caly $\mathrm{x}$ persistens, quinque-sexpartitus, laciniis aequalibus, imbricatis. Cor olla e petala 5 - 8 , calycis laciniis alterna et multo majora, subaequalia, aestivatione convolutiva. St a mina plurima, disco hypogyno prominulo inserta; fil amenta filiformia, basi inter se coalita et petalis subadhaerentia, anthera e introrsae, biloculares, dorso insertae, longitudinaliter dehiscentes. O v a ri n m liberum, sessile, quadri - quinque - sexloculare. Ovala in loculis solitaria, angulo centrali inserta, semianatropa, micropyle supera. Styli $4-6$, terminales, filiformes; stig m a t a minute capitata. $N$ u ces $4-6$, v. abortu pauciores, compressae, ad axim conglutinatae, indehiscentes, epicarpio membranaceo, endocarpio lignoso, setis elavatis, rigidis stupposo $\mathbf{v}$. tnbercuiato. Semina in loculis solitaria, reniformia, tes ta tenui, subfungosa, dorso profunde carinata, umbilico ventrali carunculato, E m b r y on is exalbuminosi, curvati, radicula maxina, snpera, caudicnlus adscendens, intra radiculae sulcum ventralem receptus, apice cotyledones duas, minimas, sibi invicem applicitas gerens. - Arbores Americae tropicae; ramis oppositis, articulatis, foliï oppositis, petiolatis, palmatim trifoliolatis, foliolis brevissime petiolulatis, coriaceis, rugoso-venosis, serratis, petiolis basi arliculatis, exstipulatis, floribus terminalibus racemosis, basi et infra apicem articulatis, embryone amygdalino, eduli.

C a r y n c a r Linne Bant, 247. DC. Prodr. $T$. 599. Cambessed, in St. Hilaire Flar. Brasil. I. 522. Meisner Gen. 43. (32.) Rhizobolu 8 Gärtner IT. 93. Correa in Annal. Muss. V. 394. A canthocary x Arrado do Camara Dis. corso.

a. PEKEA Aublet Guian. IT, 594. t, 238. 239. Foli a quiaquefoliolata. Lam. $t$. 486. (Gärtner t. 98.)

b. SOUARL Aublet Guian. Ir. $399 ., t, 260$. Foll ia trifolioJata. (Cavanill. Ic. t. 361. 362. Hooker in Bot, Mag. t, 2727. 2728. St. Hilaire Flor. Brasil, $t, 67$, bis, Cor rea $O p$. eit. $t . \quad s, f .2$.

5643. Anthodiseus $G, F, W$. MEYER. Calyx planus, obsoletissime quinquelobus. Co- rollae petala 5, hypogyna, oblonga, concava. S t a mina plurima, annulo calycino ovarium cingenti inserta; fil am en t a capillaria, tortuosa, libera, antherae didymae, minutae, erectae. O vari um liberum, subrotundum, depressum, striatum ...... St y li 14-20, subulati, apicibus incervi; stigmata acnta. Ba c c a (?) corticata, subrotunda, depresso-plana, umbilicata, radiatim suleata......-Arbor es sequeboensis, vix nota; ramulis teretibus, glabris, foliis sparsis, ternatis, petiolatis, foliolis oblongis, acuminatis, basi in petiolum brevissimum angustatis, serrato-crenatis, venosis, utrinque glabris, supra lucidis, racemo terminali, simplicissimo, pedicellis medio bibracteolatis,

Anthodiscus C. F. W. Meyer Flor, Essequeb, 193.

\section{Classis III: Polygalinae.}

Herbae v. frutices, succo in nonnullis lacteo. Foli a alterna v. rarius verticillata, simplicia, exstipulata. F l o r e s regulares, calycis aestivatione valvata, petalorum induplicata, staminibus hypogynis liberis; v. irregulares, aestivatione imbricata, staminibus cum petalis connatis. An the rae uni-biloculares, poro apicali dehiscentes, rarissime longitudinaliter dehiscentes. Ovarium biloculare, loculis unibiovulatis, rarissime pluriovulatis. Fructus capsularis v. rarissime drupaceus. Semina carunculata. E mb ryo intra albumen orthotropus v. rarius exalbuminosus.

\section{Ordo CCXXXII. Tremandreae.}

TREMANDREAE R. Brown in Flindors Voy. $1 T$. 544. DC. Prodr. $I, 343$. Bartling Ord, nat. 253. TREMANDRACRAE Lindley Introduet. edit. II. p. 109.

Fruticuli Novae-Hollandiae, graciles, saepissime pilis glandulosis consiti, v. pube stellata tomentosi. Folia alterna v. verticillata, sessilia v. brevissime petiolata, simplicia, integerrima v. dentata, interdum ramis foliaceocompressis minutissima, squamaeformia. Stipula e nullae.

Flores hermaphroditi, regulares, axillares, solitarii, pedunculati.

Calyx liber, tetra-pentaphyllus v. quadriquinquepartitus, foliolis v. laciniis per aestivationem valvatis.

Coroluae petala $4-5$, hypogyna, ealycis laciniis alterna, aequalia, brevissime unguiculata, per aestivationem involuta, stamina geminatim segregantia, sub anthesi patentia, decidua.

Staviva 8-10, hypogyna, petalis geminatim opposita, libera. Filam en ta brevissima, crassiuscula. Anth er a e conniventes, extrorsae, biloculares, loculis filamento continuis, saepe septo longitudinali biloculatis, connectivo dorsali nerviformi, apice cum loculis in tubulum, poro apicali pollen emittentem confluente.

Ovariux sessile v. breviter stipitatum ova- 
tum, biloculare. Ovala in loculis solitaria, v. gemina collateralia, ex apice dissepimenti pendula, anatropa. St ylus terminalis, simplex; stig m a acutum.

Capsula ovata, dissepimento contrarie compressa, bilocularis, loculicide bivalvis, valvis medio septiferis.

Semina in loculis solitaria, inversa, umbilico nudo, chalaza infra apicem laterali, rhaphe supra eandem in carunculam uncinatam incrassata. A l b u m en carnosum.

Enвryo in axi albuminis orthotropus, ejusdem dimidio longior, cylindricus; c otyledonibus semiteretibus, obtusis, radicula umbilico proxima, supera.

584 . Tetrathees SMITH. C a ly x quadri-quinquepartitus, C o r o 11 a e petala $4-5$. St a mina $8-10$, antherae biloculares, loculis saepe biloculatis, tubulo apicis dehiscentes. O vari u m biloculare, loculis biovulatis. St y I u s et stigma simplex. C a p 8 ul a bilocularis, compressa, loculicide bivalvis. S e m in a in loculis solitaria, inversa. - Fratices ericoidei, interdum juncei; foliis parvis alternis, verticillatisve, saepe pilis glandulosis conspersis $v$. setosis.

Tetratheca Smith Nov. Holl. I. t. 2. Erot. Bot. t. 20_29. Labillard. Nov. Holl, $1,25 . t, 22.123$. Rudge in Linn. Transact. VIII. $t$, 11. Reichenb. Ic, exot, $t, 78$. DC. Meisner Gen. 22. (20.) Prodr. I. 343.

5645. Tremamdlera $R, B R$. C a I y x quinquepartitus. Corolla e petala 5 . Stamina 10, antherae biloculares, poro apicis dehiscentes. Ovari u m biloculare, loculis nniovalatis. St y I u 8 et $\mathrm{s}$ tig ma simplex. Cap $\mathbf{s} \mathbf{1}$ a bilocularis, compressa, loculicide bivalvis. $\mathrm{Se} \mathrm{m}$ in a in loculis solitaria, inversa. - Frutices ramosi, tomento stellato tecti; foliis alternis, ovatis, integerrimis $v$, grosse dentatis.

Tremand ra R. Brown ex DC.Prodr. I. 344. Meisner Gen, 22. (20.)

\section{Ordo CCXXXIII. Polygateae.}

POLYGaleas Jussien in Annal, Mus. XIV. 386. Mem. Mus, I, 385, R. Brown in Flinders Voy, IT, 5j9. DC. Prodr. $I$. 321. Bartling Ord, nat. 256. St, Hilaire et Moquin Tandon Mem. Mus. XVIT. 313, XIX, Meisner Gen, 23, (20.) POLYGALACEAE et KRAMERIACBAE Liadley Introduct. edit. $I$. p. $84-87$.

Herbae, sufrevetices interdum volubiles v. Frotices, succo in nonnullis lacteo, caule ramisque teretibus v. angulatis. Folia sparsa, simplicia, integra, saepe integerrima, sessilia v. basi petiolata. Stipulae nullae.

Flores hermaphroditi, irregulares, axillares, solitarii, spicati v. racemosi, rarius paniculati, pedicellis basi saepe artieulatis, bractea antica bracteolisque lateralibus geminis stipati.

Casyx pentaphyllus, rarius tetraphyllus $\mathbf{v}$. interdum trifidus, plus minus irregularis, foliolis tribus, postico et duobus anticis approximatis exterioribus, aequalibus v. subaequalibus, duobus lateralibus interioribus (alis) plerumque multo majoribus et petaloideis.

Corolla petala tria v. quinque hypogyna, calycis foliolis alterna, mediante tubo stamineo basi coalita v, rarius distincta, inaequalia, duo postica approximata, anticum (carina) majusculum, concavum, genitalia includens, unilobum et cristatum v. trilobum nudum, lateralia minora, saepe brevissima, squamaeformia v. omnino abortiva.

Stamina octo, rarissime quatuor, hypogyna. Filamenta in tubum antice fissum coalita, rarius libera. Antherae erectae, basi affixae, uniloculares v. rarius biloculares, apice poro unico v. geminis dehiscentes.

Discus hypogynus completus v. unilateralis, saepius nullus.

Ovarium liberum, compressum, biloculare, loculo altero petalum anticum, altero calycis foliolum posticum respiciente, interdum minore effoeto, dissepimento angustissimo, faciebus ovarii contrario. Ovula in loculis solitaria, dissepimento paullo infra apicem appensa, rarissime gemina, superposita, anatropa. Stylus terminalis, simplex, apice saepe incurvus et incrassatus, indivisus v. bidentatus aut bilubus. Stigma superficies loborum, aut inter lobos simplex.

Capsula compressa, bilocularis, margine Ioculicide dehiscens, rarius Drupa abortu saepius unilocularis, rarissime hinc in alam expansa, samaroidea.

Serro inversum, testa crustacea v. membranacea, umbilico rarius nudo, saepissime caruncula carnosa, interdum appendice simplici v. duplici, v. coma totum semen involvente aucto. Albumen carnosum v. mucilaginosum, parcum, interdum parcissimum v. nullum.

Емввхо orthotropus, axilis, albuminis longitudine. Cotyledones plano-convexae. Radicula brevis, umbilico proxima, supera.

Polygaleae floris et fructus oeconomia distinctissimae, in regionibus temperatis et calidis totius orbis generantur, ob qualitates amaras a medicis landatae.

5646. Sallomonia LOUREIR. Calyx pentaphyllus, foliolis subsecundis, postien dunbins anticis approximatis, dnobusque lateralibus interio. ribus subaequalibus. Corollate petala 5, hypogyna, mediante tubo stamineo basi coalita, antieum majus, coneavo-galeatum, genitalia includens, subtrilobum, nudum, postica conniventia. Stamin a 4, hypogyna, adscendentia, aequalia; fil amenta in tubum antice fissum coalita, superne libera, an therae terminales, erectae, uniloculares, poro apieis dehiscentes. D is c n s hypogynus nullus, O varium a latere compressum, margine denticulatum, biloculare. 0 v $\mathrm{a} 1$ a in loculis solitaria, ex apice dissepimenti pendula, anatropa. Styins ovario contrarie compressus, apice ins:urvus, brevissime bilobus, lobis acutis, stigmatosis. C a p s u l a membranacea, compressa, obeordatobiloba, margine saepius laeiniato - ciliato loenlicide dehiscens. S e min a in loculis solitaria, inversa, testa crustacea, nmbilico nudo. Embryo intra albumen parcissimum rectus; cotyledonibns 
suborbiculatis, radicula supera. Herbae pusil. lae, in Asia et Nova-Hollandia tropica indigenae; foliis alternis, cordatis, floribus terminalibus, spicatis.

Sal o w o n a Loureiro Flor, cochinch, 18. DC. Prodr. I. 333. St. Hilaire et Moquí in Mem. Mus, XVIII, $t, 29$. f. 3. XIX, 330. Delessert Ic. select. III, $t, 19$. Meisner Gen. 23. (20.) Wight Illustr. $t$. 22. $f$. B. et $C$.

564\%. Polygalla LINN. Calyx pentaphyllus, persistens, foliolis postico et duobus anticis approximatis parvis, duobus lateralibus (alis) interioribus maximis, petaloideis. Corollae petala 3 v. 5, hypogyna, mediante tubo staminen basi coalita, anticum (carina) majus, concavo-galeatum, genitalia includens, trilobum $v$. unilobum et apice cristatum, cristae laciniis biseriatis, lateralia minima, saepissime nulla, postica antico minora, conniventia, S t a m in a 8 , hypogyna, adscendentia, subaequalia; filamenta in tubum antice fissum coalita, superne libera, anth erate terminales, erectae, uniloculares, poro apicis dehiscentes. D is c u s hypogynus unilateralis v. nullus. $O$ vari um a latere compressum, biloculare. $O$ v ula in loculis solitaria, ex apice dissepimenti pendula, anatropa. St y I u 8 terminalis, ovario contrarie compressus, saepissime apice dilatatus, nune simplex; stig mat e prope apicem laterali, v, biquadrilobus, lobis stigmatosis. Ca psula membranacea, compressa, orbicularis, elliptica v. obovata, apice saepe emarginata, bilocularis, margine localicide dehiscens. Se mina in loculis solitaria, inversa, testa crustacea, caruncula umbilicali saepe pilosa, simplici v. appendiculata. Em b ryo in axi albuminis carnosi rectus v. leviter arcuatus, cotyle d on i b u s plano-convexis, $r$ a d i c u l a supera. Herbae, suffrutices, $v$. frutices, in temperatis $h e$ misphaerae borealis, inter tropicos Asiae et Americae, et in Capite bonae Spei crescentes; foliis alternis, $v$. sparsis, rarius oppositis $v$. verticillat is, integerrimis v. subintegerrimis, interdum glanduloso-punctatis, racemis terminalibus, quandoque lateralibus et alaribus, simplicibus, spicaeformibus $v$, capitatis, interdum dispositione corymbum v. paniculam mentientibus, pedicellis sparsis, rarissime subnullis, basi tribracteatis.

Polygala Linn. Gen. n, 851. Jassieu Gen. 99. DC. Prodr. $I$. 321. St. Hilaire et Moquin in Mem, Mus. XVII. t. 27. 28, XIX, 326. St, Hilaire Flor. Brasil. 1T, 8. Meisner Gen. 23. (20.)

a. PSXCHANTHUS DC. t. c. Carina ample eristata. Capsula glabra, marginata. Bracteae ad basim pedicellorum persistentes. - Frutices capenses et arabici. Ps yehanthus Rafinesq. Specch, I. 116. (Andrews Bat. Reposit. t, 370, Bot, Mag. t, 345, 1780. 2438. Bot. Reg. t. 150. 637. 645. 669, 1146. Loddiges Bot. Cab. t. 1000, 1927.)

b. POLYGal.oN DC. 2. c. Carina eristata. Capsula glabra. Bracteae ad basim pedicellorum mox deciduae. - Frutices v. herbae, in Europa et Asia temperata crescentes, - (Jacq. Flor, austr. t. 412. 413. Desfont. Flor. Allant. t. 174 -176. Flor. dan. t, st6. Link et Hoffransegge Flor. Portug. $t$, 55. Reichenb. Iconogr. t. 21. 28.1

c. BLEPHARIDIUM DC, l,c. Carina cristata. Ca ps u la apice emarginata, margine ciliata. - Herbae indicae, senegambicae ot aegyptiacae, parvae, saepius ramosissimar, racemis brevibus, lateralibus, bracteis ad basim pedicellorum parvis. - (Walliet Plant. As, rar. t. 184 185. Delessert Ic. select. III. $t$. 15.)

d. CLINCLINIA DC. Z. c. Carín a cristata, alae oblongae. Capsula glabra, marglnata, apiee emargisata, utrinque ad apicem subdentata. - Herbae americanae, suffruticulosae. - C Ii n elli a Feuillé Observ. II, t, 13.

e. TIMUTUA DC. 7. c. C arin a cristata, crista interdum minutissima. Capsula glabra, ovali-oblonga, vix emarginata. - Herbae americanae; folits alternis $v$. verti. cillatis, racemis elongatis $v$. confertis, spicaeformibus aut capituliformibus. (Anbiet Guian, $t$, 22z. Kunth in Humb. et Bonpl. Nov. gen, et sp, $t$, s06_509. Martius Mat. Medic. $t$. 28. et t. 8. f. 6. St. Hilaire Plant, us. t. 71. Flor. Brasil, IT, t. 83-87, )

f. SENEGA DC. $l$. c. Carina Imberbis. C a ly eis foliola anticum et postica subaequalia. - Herbae americanae, folits alternis. (Kuuth:Op. oit, $t, 510-512$. St. Hilaire Flor, Brasil. II. t, 88, 89. Bot. Mag. t, 105t.)

g. CHAMAEBUXUS DC. $l$. c. Carin a suberistata $v$-apice callosa, C a I y cis foliolum posticua concavo-cucullatua, basi intus glandula auctum. - Herbae $v$. suffrutices, folits paucis, magnis. - Ch a ma e buxus Dilteu gen. t. 9. Triclis perm a Rafuesque Speceh. I. 117. (Jacq. Flor, austr. t. 233. Bol, Mag. t. 2825. Wallich Plant. as. rar, t. 100. Delessert Ic, select. III. t. 16_18. Hooker Bot. Mag. Comp. t. z,)

h. ?. BRACHXTROPIS DC. l. c. Carina imberbis, petalis reliquis et alis ealyeinis multo brevior. - Fruticulus lusitanicus, vix congener, - Polyg a la microphylIa Lins.

5648. Eadiera DC. Calyx pentaphylIns, deciduus, foliolis postieo et duobus anticis approximatis paullo minoribus, duobus lateralibus (alis) interioribus, subpetaloideis. Corollae petala 5, hypogyna, mediante tubo stamineo basi coalita, anticum (carina) majus, concavo-galeatum, genitalia includens, subtrilobum, ecristatum, postica conniventia. Sta m in a 8 , hypogyna, adscendentia, subaequalia; fil amenta in tubum antice fissum coalita, superne libera, antherae terminales, erectae, uniloculares, poro apicis dehiscentes. Di s cus hypogynus unilateralis. Ovarium a latere compressum, bilocolare. Ovula in loculis solitaria, ex apice dissepimenti pendula, anatropa. Stylus terminalis, ovario contrarie compressus, apice subbilobus, lobis stigmatosis. Cap su la compressa, obeordata, bilocularis, lobo altero interdum abortivo, utroque margine suleata, loculicide dehiscens. Se mi na in loculis solitaria, inversa, testa crustacea, caruncula nmbilicali maxima, oleosa, $\mathbf{E} \mathbf{m b} \mathbf{r y o}$ in axi albuminis gelatinosi rectus; cotyledonibus plano-convexis, radicula supera, - Suffrutices a ntilla$n i$; foliis alternis, integerrimis, floribus axillaribus, racemosis.

B a di era, DC. Prodr, 1. 336. St. Hilaire et Moquin in Mem. Mus. XVII. 351, t. 29. f. 1. XIX, Delessert Io. select. III. t. 21. Meisner Gen, 23. (20.) P e na a Plumier Gen. 28. t. 25, non Liun.

5645. Comesperma LABILL. Calyx pentaphyllus, deciduns, foliolis postico duobusque anticis approximatis parvis, duobus lateralibus (alis) interioribus maximis, petaloideis. Corolla petala 5, hypogyna, mediante tubo stamineo inferne coalita, decidua, anticum (carina) maximum, concavo - galeatum, trilobum, genitalia includens, lateralia et postieum minutissima. St a m in a 8 , hypogyna, adscendentia, subaequalia; fil am e n ta in tubum antice fissum connata, superne libera, an th er a terminales, erectae, nniloculares, poro apicis dehiscentes. Di 8 e $\mathbf{u}$ s hyogynus carnosus. $O$ va ri $\mathbf{m}$ a latere compressam, biluculare. $O$ v $\mathbf{n}$ I a in loculis solitaria, e dissepimenti apice pendala, anatropa. Stylus terminalis, compressiusculus, curvatus, deciduns; stig ma terminale, subbilobum. C a p s u I a coriacea, compressa, cnneatospathulata, bilocularis, margine loculieide dehiscens. S e mina in loculis solitaria, inversa, caruncula nmbilicali pilis longissimis semen totum involventibus comosa. Embryo in axi albuminis mucila- 
ginosi orthotropus, radicula supera. - Herbae erectae $v$. scandentes, aut frutices arborescentes, in Nova Hollandia et Brasilia crescentes; foliis alternis, integerrimis, floribus paniculatis v, racemosis, sessilibus $v$. saepius pedicellatis, pedicellis basi articulatis, tribracteatis.

C o m e s per m a Labillard. Nov. Holland. II. 21, $t, 159$. 162. DC. Prodr. I. 334. St. Hilaire et Moq. in Mem. Mus. $X V I I, 351, \ell$. 29. $f$. 2. XIX. 329. St. Hilaire Flor, Brasil, II. 36. $t$. 90, 91, Delessert Ic. select, III. $t$, 20. Meisuer Gen, 23. (20.)

56ธด. Muraltia NECK, Calyx pentaphyllus, persistens, foliolis glumaceis, subaequalibns, duobus lateralibus interioribus paullo majoribus. C o r o 11 a e petala 3 , hypogyna, mediante tubo stamineo inferne coalita, decidua, anticum (carina) majus, concavo-galeatum, genitalia includens, unilobum, crista ampla, diphylla, duo postica conniventia. S tamina 8 , hypogyna, adscendentia, subaequalia; filamenta in tubum antice fissum coalita, superne libera, antherae terminales, erectae, uniloculares, longitudinaliter dehiscentes. D is cus nullus. Ovarium a latere compressum, uniloculare, apice tuberculis quatuor coronatum. Ovula in loculis solitaria, e dissepimenti a pice pendula, anatropa. Styl u s termina lis, ovario contrarie compressus, eurvatus, apice clavato-incrassatus, truncato-bilobus, lobis stigmatosis. C a p \& u I a membranacea, compressa, apice quadricornis, bilocularis, margine loculicide dehiscens. Stamina in loculis solitaria, inversa, caruncula umbilicali carnosa, E mb ry o...... Frutices v. suffrutices capenses, ramosissimi; foliis sparsis v. fasciculatis, crassis, rigidis, integerrimis, saepe acicularibus, pungentibus, floribus axillaribus, subsessilibus, solitariis, basi tribracteatis.

M u ra Itia Necker Elem, n, 1382. DC. Prodr, I, 335. St. Hilaire et Moq. in Mem. Mus, XVII, 352, t. 29. f. 4. $X I X, 331$. Meisner Gen, 23. (20.) H els te r I a Bergius Flor. Cap. 185. Pol y g a la e 8 p. Linn. Andr. Bot. Reposit, t, 263. 324, 455. Bot, Mag, t. 340. 1006. 1714.

5851. II undila KUNTH. Caly $\mathrm{x}$ pentaphyllus, persistens, foliolis postico duolusque anticis parvis, duobus lateralibus (alis) interioribus maximis, petaloideis. Coroll a e petala 8 , hypo. gyna, mediante tubo stamineo inferne coalita, decidaa, anticum (earina) majus, concavo galeatum, genitalia includens, nune unilobum, opice cristatum, nune trilobum, nudum, duo postica conniventia. Stamina 8, liypogyna, adscendentia, subae. qualia; filamenta in tubum antice fissum coalita, superne libera, antherae terminales, ereetae, unilocalares, poro apicis dehiscentes. Dis. cus hypogynus, nrceolaris. Ovarium a latere compressum, biloculare. $O_{\mathrm{v}} \mathrm{Ia}$ in loculis solitaria, e dissepimenti apice pendula, anatropa. Stylus terminalis, apire clavato-incrassatus, bilobus v. bidentatus, lobis stigmatosis. D rupa bilocularis v. abortu unilocularis. Se min a in loculis solitaria, inversa, testa membranacea, umbilico estrophiolato. E m bry o in axi albuminis carnosi orthotropus, radicula supera. - Frutices capenses et brasilienses, ramosissimi, ramis apice spinescentibus; foliis sparsis v. alternis, integerrimis, floribus axillaribus solitariis, pedicellatis, pedicello tribracteato.

M u ndl a Kunth in Humb, et Rompl. Nov, gen, at sp. V. 399. in not. DC. Prodr. 1. 337. St. Hilaire et Moquin in Mem. Mus. XVII. 352, XIX. 332. St. Hilaire Flor, Brasil. IT. 39. Meisner Gen. 23. (20.) Ny landita Dumertier Famill. 23, Vascon DC. mse. Polyga la e sp. Linn.

a. ECMUND1A, Carla a uniloba, apiee cristata. Stylus apice bilobus, lobo altero erecto, altero incurvo. Dru. pa bi. v, abortu uniloeularis. - Species capenses, fo. liis sparsis. (St. Hilaire et Moquin in Mem, Mus, XVII. t. 30. f. 1 -8.)

b. TRIMUNDIA. Carina triloba, nuda. Stylus apice bidentatus, dente inferiore breviore. Dru pa abortu unilocularis. (St. Hilaire l. c. t. 30. f. 9-11. Flor. Brasil. c. 92.)

565. Nommina RUIZ, et $P A V$. Caly $\mathrm{x}$ pentaphylhus, deciduns, foliolis postico et duobus anticis approximatis parvis, duobns lateralibus (alis) interioribus maximis, petaloideis. Cor o 11 a e petala 3 , hypogyna, mediante tubo stamineo basi coalita, decidua, anticum maximum, concavo - galeatum, genitalia includens, trilobum, nadum, duo postica contigue approximsta, hine margine tubi staminei basi adnata, medio intus sacculo obliquo aucta. Sta m in a 8, hypogyna, adscendentia, subaequalia; filamenta in tubum antice fissum coalita, superne libera, villosa, an therae terminales, erectae, uniloculares, rima obliqua apice subintrorsum dehiscentes, demum bilabiatae. Dise us hypogynus protuberans. Ovarium a latere compressum, biloculare, loculo postico saepe minore, effoeto. Ovula in loculis solitaria, e dissepimenti apice pendala, anatropa. Stylus terminalis, deciduus, ovario contrarie compressus, curvatus; $\mathbf{s t} \mathrm{ig}$ ma terminale, bilobnm, lobo inferiore glandulaeformi. Drupa carnosa v, sicea, suborbicularis v. obovata, margine membranacea cincta v. aptera, uni-bilocularis. Semina in loculis solitaria, inversa, testa membranacea, umbilico estrophiolato, interdum piloso. E m b r y o in axi albuminis gelatinosi, parci orthotropus; cot yledonib a s plano-convexis, radicala brevi, supera. Herbae, frutices $v$. arbusculat, in $A$ mer $i$ ca tropica et a strali extratropica crescentes; foliis alternis v. sparsis, subintegerrimis integerrimisque, apice saepius emarginatis, petiolo basi articulalo, racemis terminalibus v. lateralibus aut interdum axillaribus, simplicibus, spicaeformibus, interdum longe pedunculatis, pedicellis sparsis, incurvis, basi articulatis, tribracteatis.

MonnIna Ruiz et Payon Syst, I, 160. Kunth in Humb. et Bonpl. Nov. gen. et sp. V. 409. t. 501_505. DC. Prodr. I. 338. St. Hilaire et Moq. in Mem. Mus, XVIT, 352. c. 30. f. 2. XIX. 333. St. Hilaire Flor. Brasil. I1. 59. $2,93-95$. Hooker ad Beechey t. 6. Bot, Mag. $t, 3122$. Meisner Gen. 23. (20.) - H e be a nd r a Bospl. in Berl. Jiagaz. 1802. 40.

5853 . Securidaea LINN, Caly $\mathrm{x}$ pentaphyllus, deciduus, foliolis postico et duobus anticis approximatis parvis, duobus lateralibus (alis) interioribus maximis, petaloideis. Corolla e petala 5 , hypogyna, mediante tubo stamineo basi coalita, decidua, anticum (carina) majus, concavogaleatum, genitalia includens, trilobum, lobo medio minore, crispato - plicato, interdum reflexo, lateralia minima, postica antico minora, conniventia, Stam in a 8, hypogyna, adscendentia, subaequalia; filamenta in tubum antice fissum coalita, superne libera, an therae terminales, erectae, biluculares, apice poris geminis dehiscentes. Discus hypogynas prutuberans. O varium a latere compressum, antice apice gibbosum, unilonulare. O v $1 \mathrm{n} \mathrm{m}$ unicum, ex apice loculi postico pendalnm, anatropum. Stylus postice lateralis, compressus, subfalcatus, supra basim deciduus; stigma terminale, subbilobum. Ca p 8 u la nnilocularis, indehiscens, apice postico eristato, marginato, antico in alam longam, erectam, cultriformem proilucto. Semen inversnm, testa membranacea, umbilico nudo. Embryo in axi albuminis gelatinosi ortho- 
tropus; cotyledonibus plano-ronvexis, radicula hrevi, supera. - Arbusculae v. frutices scandenles, in America tropica obvii; folits alternis, integerrimis, petiolo basi articulato, biglanduloso, racemis terminalibus et axillaribus simplicibus, laxis, pedicellis sparsis, basi articulatis, tribracteatis.

Se euridaca Linn. Gen, n. 825. Jaeq. Amer. $t .183$. Lam. t. 599. DC. Prodr, I. 340. St. Hilaire et Moq. in Mem. Jtus, XVIL. 354, t. 31. f. I, XIX. 335. St. Hilaire Flor. Brasil. II. 67. t. 96. Delessert Ic, select. IIT. $t, 22$. Meisuer Gen. 23. (20.)

\section{GENERA VIX NOTA.}

5654. IBredemeyera WILLD. C alyx pentaphyllus, coloratus, foliolis duobus interioribus. Corollae petala 3 , irregularia, medium carinaeforme. Stamina 8 ; filam entismonadelphis, antheris oblongis, erectis. Drupa ovata, minima, foeta nuce conformi, biloculari. - Frutex America tropicae, vix notus, nec fortassis a Monnina diversus; foliis alternis, floribus terminalibus paniculatis, paniculae ramosissimae, multiflorue, divisuris bracteolatis.

Bredeme yera Willdenow in Berliner Verhandl, IIT. 411, t. 6. DC. Prodr. 1. 340. St. Hilaire et Moq. in Mem. Mus, XIX. 337. Meisner Gen. 23. (20.)

5655. Carpolobia G. DON. Cal y x pentaphyllus, subbilabiatus. Corolla e petala $8-5$, carinali lato, reliquis aequalibus, omnibus unguiculatis. St a m in a 8, monadelpha. D rupa monosperma, semine villoso, sericeo, v. legumen seriseum inonospermum. - Frutices Africae tropicae, ramosi; foliis alternis, ovatis v. cordatis, acumina$t$ is, integris, racemis axillaribus, paucifloris

C a r polobia Don Syst. I. 370. Meisner Gen, 23. (20.)

\section{GENERA ANOMALA.}

5456. Kerameria LÖFFL. Calyx tripentaphyllus, foliolo postico duobusque lateralibus subaequalibus, duobus anticis dum adsunt inaequalibus, approximatis, altero interiore minore, quandoque ubsoleto. Corollae petala 5, hypogyna, inaequalia, tria antica approximata, unguiculata, unguibus basi connata, lamina parva, saepe abortiva, duo postica remota, sessilia, crassiuscula, oblique conniventia. St a m in a 4 , v, abortu $1-3$, hypogyna, calycis foliolis anticis lateralibusque uppusita, inaequala, lateralia Iongiora, adscen. dentia, antica ereeto conniventia; fila menta libera, crassiuscule filifurmia, a $\mathrm{n} h$ e ra e teruninales, erectae, biloculares, apice poro duplici dehiscentes. Disens hypogynus nullus. Ovarinm subglobosum, uniloculare. O vala 2 , collateralia, ex apice parietis antici pendula, anatropa. StyI us terminalis, adscendens; $8 \mathrm{t} \mathbf{i} \mathrm{g} \mathrm{m}$ a simplex. C a p 8 u ! a lignoso - coriacea, indehiscens, subglobosa, echinato - glochidata, unilocularis, aborta monosperma. S emen inversum, testa membranacea, umbilico nudo. E m b r y o exalbuminosus, coty ledunibus plano-convexis, infra basim bianriculatis, radieulam superam amplectentibus.

Suffrutices in America tropica et subtropica obvii, multicaules, diffusi, sericeo-villosi, inermes v. spinis axillaribus armati; foliis alternis, integerrimis, simplicibus vel interdum trifoliatis, exstipulatis, racemis spicaeformibus simplicibus, foliatis, floribus pedicellatis, tribracteatis.

$\mathrm{K}$ r a un eri a Löfting $\mathrm{It}, 195$. Ruiz et Pavon Prodr, t.3. Flor, Peruv, t, 93. Jussieu in Mem, Mus, I, 390. DC. Prodr.
I. 34t. St, Hilaire et Moquin in Mem, Mus. XVIX. t, 31 . f. 2. XIX 336. St, Hilaire Flor, Brasil, II. 73. t. 97. Hooker ad Beechey 8. $t$. 5. Meisuer Gen. 23. (20.)

$565 \%$. Xamthoplnylluam $R O X B, \mathrm{C}$ a1 y $x$ pentaphyllus, deciduus, foliolo postico duobusque anticis subaequalibus, duobus lateralibus inte. rioribus majoribus, subpetaloideis. Corolla petala 5, hypogyna, distincta, anticum eymbaeforme, lateralia et postica aequalia. Sta mina 8, hypogyna; filam enta filifurmia, duo antica carinae busi adhaerentia, lateralia ante calycis foliola interiora distineta, reliqua petalorum lateralium et posticorum unguilus singillatim cohaerentia, anthe rac terminales, erestae, poro apieis dehiscentes. Diseus hypogynus eupuliformis. Ovariu in brevissime stipitatum, subgiobosum, unilocalare. Ovula in plarentis duabus oppositis parietalibus brevibus utrinque $2-6$, adscendentia $v$. pendula, anatropa. Sty I us terminalis, apice incurvus; stigm a brevissime bilobum. D r u pa coriacea, suhearnosa, globosa, unilocularis, abortu monosperma. Sem en subglobosum, testa memhranacea, endupleura carnosa, umbilico ventrali. Embryo exalbuminosus, orthotropus; cotyledonibus hemisphaericis, carnosis, radicula brevissima, umbilico proxima, centrifuga. - Arbores Asiae tropicae; foliis alternis, breve petiolat is, coriaceis, lucidis, estipulatis, racemis axillaribus, supraaxillaribus $v$. terminalibus, multifloris.

Xanthophyll a m Roxburgh Plant. Corom. III, 82 . t, 284. Flor. Ind. II. 221. Nees in Flora I825. P. 120. Wight et Arnott Prodr. I. 39. Meisner Gen, 23, (20.) Wight Illustr. $t .23$. J ach i a Blume Bijdr. II. 60 .

5659. Seulamea $L A M$. C a ly $x$ tripartitus. Corolla e petala 3 , sub diseo hypogyno inserta, linearia, reflexa. S t a m in a 6 , disco hypogyno extus inserta, aequalia, tria petalis opposita praecocia; filamenta brevissima, antherae terminales, biloculares, subgloboso-didymae, longitudinaliter dehiscentes. 0 v a r i $\mathbf{m}$ compressum, apice truncatum, subemarginatum, biloculare. Ovula in loculis solitaria, ex apice dissepimenti pendula, anatropa; $8 \mathrm{tigmata2,8ublateralia,}$ sessilia, obtusa. Ca p s u la compressa, obeordata, marginata, snbsuberosa, bilocnlaris, indehiscens. $\mathrm{Sem}$ in a in loculis sulitaria, inversa, testa membranacea, umbilico strophiolato. Embry o exalbuminusus; cotyled on ib ns foliaceis, snbearnosis, radienla brevissima, conica, snpera. - Arbuscula moluccana et oc e anica; folits alternis, petiolatis, in apice ramorum confertis, ovali-oblongis, costatis, glabris, racemis axillaribus, folio brevioribus, floribus parvis.

So a la me a Lam. Dict, $I$. 449. DC. Prodr. I. 335. St. Hilaire et Moq. Mem. Mus. XIX. 334. Endlicher in Annal. Wiener Mus, I. 188, t. 16. Meisner Gen, 23. (20.) C a rd Ioe a r u s Reinwardt. in Sylloge Plant, $I I .14 . \mathrm{Rex} \mathrm{A} \mathrm{ma-}$ ror is Rumph Amboin. II. 129. $t .40$.

\section{* TRIGONIACEAE.}

5659. Trigonia $A U B L . C$ a 1 y $\mathrm{x}$ liber, plus minus profunde quinquepartitus, laciniis per aestivationem imbricatis, duabus posticis et una antica exterioribus, paullo minoribus, duabus lateralibus interioribus majoribus. Corollae petala 5, hypogyna, calycis laciniis alterna, inaequalia, posticum maximum, concavum, basi gib- 
bum, adscendens, duo antica adscendentia, carinata, inaequilatera, lateralia duo interiora minora, plana, patentia, apice oblique truncata. Stamina hypogyna, 5, 6, 10, 12, exeentrica, petalis anticis opposita, in alabastro erecta; fil am enta complanata, in tubum hine fissum connata, lateralia minora, castrata, a n the $r$ a e introrsae, biloculares, dorse affixae, loculi appositi, longitudinaliter dehiscentes. G I a n I u l a e $2-4$, (stamina abortiva?), hy pogynae, ad basim ovarii sitae, petalo postico oppositae. O v a ri u m liberum, e carpidiis tribus, marginibus in dissepimenta columnae centralis trigonae angulos attingentia introflexis, triloculare. $O \mathrm{vula}$ in loculis plura, columnae centralis angulo affixa, amphitrope pendala. Stylus terminalis, simplex; s tig m a trilobum. C a p o u l a trigona, trilocularis, septicido-trivalvis, valvis coriaceis, carinatis, apice emarginatis, columna centrali triptera, libera. Se m in a columnae centrali affixa, rotundata, testa chartacea, nubilico ventrali, lana densa laxa involuta. E mbryo in axi albuminis dense carnosi rectus, transversus; cotyledonibus magnis, rutundatis, complanato-foliaceis, ra di cula brevi, obtusa, ab umbilico remota. - Frutices Americae tropicae, scandentes, sarmentosi; foliis oppositis, brevissime petiolatis, penninerviis, integerrimis, stipulis petiolaribus, caducis, floribus in racemos axil. lares $v$. in paniculas terminales dispositis.

Trigonia Aublet Guian. I, 390. t. 149. 150. Lam. t. 347. Kunth in Humb. et Bonpl. Nov. gen, et sp. $V$. 14t. DC. Prodr. I. 571. St. Hilaire et Moquia in Mem. Mtus. XVIII. 2. 31. $f$. 3. Cambessedes in St. Hilaire Flor, Brasil. II, 80 , t. 105. Meisner Gen, 40. (23.) Ml a ine a Flor. Flumin. VII, $t, 8$.

\section{Classis It: Frangulaceae.}

Arbores, frutices v. rarissime herbae, succo aqueo. Folia alterna v. rarius opposita, simplicia, integra, rarissime ternanatim v. pinnatim composita. Flor es saepissime hermaphroditi. Ca Iy $\mathrm{x}$ liber v. cum ovario connatus. Cor olla e petala calycis laciniis numero aequalia, perigyna $v$. hypogyna, libera v. inter se subcoalita, rarius nulla. S $t$ a m in a petalorum numero, rarissime plura, petalis alterna v. opposita. Ovarium bi-tri-pluriloculare, interdum septis margine ovuliferis incompletis uniloculare. Ovula in loculis solitaria v. gemina, rarius plurima, anatropa. Fruc$\mathbf{t} \mathbf{u}$ s capsularis, baceatus v. drupaceus. S e mi$\mathbf{n} \mathbf{a}$ in loculis solitaria $\mathbf{v}$. plurima, saepe arillata. E m b r $y_{0}$ intra albumen orthotropus.

\section{Ordo CCXXXIE. Pittosporeae.}

PITTOSPOREAE R. Brown in Flinders $V_{0 y}$. IT. 542. DC. Prodr. I. 345. Bartliag Ord. nat. 377, Lindley Introduct. edit. II. p. 31. Meisner Gen. 66. (47.) Putterlick, Sjnopsis Pitlosporearum. Vindobonae, 1839. 8.

Arbones v. Frutices erecti aut interdum scandentes. Folia alterna, petiolata, simplicia, integra v. interdum pinnatisecta, margine integerrima, crenata v. dentata, subcoriacea. Stipula e nullae.

Flores hermaphroditi, regulares, axillares v. terminales, interdum gemmae axillaris evo- lutione oppositifolii, solitarii v. in racemos, corymbos aut cymas dispositi.

Calyx liber, pentaphyllus, v. foliolis phis minus connatis, aestivatione imbricatis quinquefidus, deciduus.

Corollae petala 5, hypogyna, calycis foliolis alterna, distincta, erecta aut rarius patentia, unguibus saepissime conniventibus, interdum coalita, laminis aestivatione imbricatis sub anthesi patulis, decidua.

Staniva 5, hypogyna, petalis alterna, erecto-conniventia, rarius patentia, interdum subsecunda. Fil a menta libera, filiformia v. subulata. Anthera e introrsae, biloculares, baseos plerumque emarginatae dorso insertae, loculis appositis, rima longitudinali, interdum apice breviter hiante, inferius connivente et ideo poriformi, dehiscentibus.

Ovarivm liberum, sessile v. brevissime stipitatum, e carpidiis duobus ad quinque, medio semiseptiferis, valvatim appositis compositum, nune septis in axi contiguis biloculare, nune iisdem axim haud attingentibus incomplete biquinqueloculare. Ovula plura v. plurima, semiseptortm marginibus discretis v. in axi contiguis, vix incrassatis utrinque biseriatim inserta, horizontalia v. subadscendentia, anatropa. Stylus terminalis, simplex. Stigma obtusum v. subcapitatum, brevissime emarginato-bilobum, obsolete quadrilobum v. rarius bifidum.

Froctus bilocularis, v. septis axim hand attingentibus incomplete bi-quinquelocularis, nunc capsularis, membranaceus, coriaceus v. sublignosus, bi-quinquevalvis, valvis medio semisepta, plus minusve producta, margine utrinque seminifera gerentibus, nunc baccatus, carnosus v. exsuccus, indehiscens.

Semiva plurima v. abortu pauea, globosa v. angulata aut fere reniformia, plerumque liquore resinoso, aromatico obvoluta, interdum illo inter se compacta; tes t a laevi nitida, rhaphe brevi, adnata v. interdum soluta, chalaz a m umbilico approximatam, nucleum suspendentem intrante. Album en copiosún, dense carnosum, durum, aequabile.

Eмвнуо in basi albuminis, in regione umbilici minimus, orthotropus, subglobosus v. cordiformis; radicula plus minus attenuata, e otyledonibus obsoletis.

Pittosporeace in Nova-Hollandia extratropica copiosissime erescentes, in insulis Oceani pacifici, Japonia, Asiae continente inter tropico, Nepalia, insulis Mauritianis, Capite bonae spei et Canariis rarae, in America nondum observatae fuerunt.

Affinitate Celastrineis capsularibus proximae, ab iisdem corollae et staminum insertione hypogyna, disci defectu, ovulorum numero et embryone minimo facillime distinguuntur. 
Genera ad ordinis calcem recensita, novorum ordinum pignora.

5969. Citriolotus $A$. CUNNINGH. CaIyx pentaphyllus, subaequalis, bracteulis imbricatis cinctus. Coro 1 I a e petala 5 , hypogyna, ealyeis foliolis alterna, unguibus erectis, in tubum conniventibus v. cohaerentibus, apice patentia. Stamina 5, hypogyna, petalis alterna, inclusa; fil a ment a complanato-subulata, stricta, anth er a e introrsae, biloculares, subsagittatae, dorso affixae, longitudinaliter dehiscentes. Ovar i u m sessile, incomplete biloculare. 0 vala $2-4$, semiseptorum marginibus utrinque inserta, anatropa. Stylus filiformis, brevis; 8 ti $\mathrm{gma}$ depresso-capitatum, obsolete bilobum. Bacca coriarea, 8 bbglobosa, stylo superata, mono-tetrasperma, pulpa resinosa fareta. S em in a subglobosa, irregulariter angulata. E mb r yo in basi albuminis duri, prope nmbilicum minimus, orthotropus. - Frutex NovaeHollandiae orientalis extratropicae; ramis procumbentibus, pube stellata consitis, ramulis axillaribus spinescentibus, foliis alternis, breve petiolatis, ovatis v. obovato-cuneutis, apice acutis $v$. subtruncatis, sinuato subspinoso-dentatis, floribus axillaribus solitariis, sessilibus, minimis, baccis aurantiacis.

Citriobatus A. Cunningh, ex London Hort. Brit. Supplem, 1832. I, 585. absq. charact. Putterlick Synops. Pittospor, 4. Orang e. Thor a Coloa.

5GB1. Pittospontum SOL $A N D$. C a I y $\mathrm{x}$ quinquefidus v, quinquepartites. Corolla e peta. la 5 , hypogyna, calycis foliolis alterna, unguibus erentis, in tubum conniventibus v. cohaerentibus, apice patentia v. reflexa. St a $\mathrm{m}$ i $\mathbf{n}$ a 5 , hypogyna, petalis alterna, inclnsa; filame nta subulata, stricta, anthera e introrsae, biloculares, subsagittatae, erectae, longitudinaliter dehiscentes. Ovarium sessile, incomplete bi-tri-quinqueloculare. Ovula plurima, semiseptorum uarginibus utrinque inserta, anatropa. Stylus filiformis, brevis; stigma subcapitatum, obsulete emargisato - bi-tri-quinquelobum. C a p 8 u la subglobosa, ovata, ovato - conica v, obovata, angulata v. compressiuscula, incomplete bi-quinquelocularis, bi-quinquevalvis, valvis coriaceis, crassis, medio semiseptum margine seminiferum gerentibus. S emina plurima, resinoso-viscida, valvis apertis saepe in globum compacta, subglobosa, angulata v. plus minus complanata. $\mathbf{E}$ bryo in basi albuminis duri, prope umbilicum minimus, orthotropus. - Arbusculae v. frutices, in insulis Canariis, Capite bonae spei, in insulis Borbonicis, Japonia et archipelago sandwicensi rarae, in Indiae continente paullo frequentiores, copiosissime in Nova-Hollandia ex. tratropica et Nova Zeelandia crescentes; foliis alternis, integerrimis v. interdum paucidenta. tis, floribus terminalibus $v$. axillaribus, solitariis $v$. corymbese aggregatis, bracteatis.

Pit tnsp o r n m Solander apud Gärtn. T, 286, t. 59. Lam. t. 143. Andrews Bot. Reposit. t. 151. 383. Veateu. Cets, $t, 76$. Bonpl. Malm, $t, 21$. Bot. Reg, $t, 186$. Bot. Mag. t. 1306. 1684. 2075. 3161. DC. Prodr. I. 346. Sweet El. austr. t. 25. Hooker ad Beeckey t. 32. Wight ot Aruott Prodr. I. 153. Meisuer Gen, 66. (48.) Putterliek Synops. Pittosp. 5. Senaciae, Celastri et Evanymisp. Auet.

5668. Fursaria $C A V$. C a ly x pentaphyllus, patens. Corolla e petala 5, hypogyna, ealyeis foliolis alterna, oblonga v. lanceolata, pa- tentia. Stamina 5, hypogyna, petalis alterna, patentia; filamenta subulata, antherae inirorsae, biloculares, ovoideae, rectae, dorso afiixae, tandeu reelinatae, longitudinaliter dahiscen. tes. Ovari u m subsessile, incomplete biloculare. Ovula pauca, semiseptorum marginibus utrinque inserta, semianatropa. Stylus filiformis, brevis; stigma obsolete bilobum. Capsula obcordata v. reniformis, compressinscula, incomplete bilocn laris, apice loculicide bivalvis, valvis medio septiferis. S e min a in loculis $1 \ldots 2$, reniformia, umbilico ventrali. E m b ry o in basi albuminis duri, prope umbilicum minimus, orthotropus. - Frutices Novae-Hollandiae orientalis, inermes $v$. ramulis spinescentibus armati; foliis altérnis, subsessilibus, obovato-cuneatis, retusis, integerrimis v. oblongo-linearibus, acutis, argute serratis, pedunculis terminalibus ternatis $v$. paniculam multifloram constituentibus, floribus albis $v$, extus roseo-tinctis.

Bursaria Cavanill. Ic. IV. 30. t. 350. Bot. Mag. t. 1767, DC, Prodr. 1.347. Meisner Gen. 66. (48.) Patterlick Synops. Pittospor. 19. It e a $8 \mathrm{p}$ inos a Aadrews Bot. Reposic. t. 314 .

5063, Dncosporvm PUTTERL. Calyx pentaphyllus, minimus, subaequalis. Coroll a e petala 5, hypogyna, calycis foliolis alterna, subspathulata, subaequalia, adscendentia. Stamina 5, hypogyna, petalis alterna, subsecunda; filament a filiformia, apice flexunsa, an $t$ herae introrsae, bilaculares, ovoideae, reetae, durso aflixae, tandem reclinatae, longitudinaliter dehiscentes. Ovarium brevissime stipitatum, biloculare. Ovu Ia in loculis plarima, dissepimenti axi utrinque biseriatim inserta, horizontalia, anatropa. StyIus filiformis, brevis; stigma simplex, convexiusculum. C a p $\&$ I a membranacea, ovoidea, compressiuscula, bilocularis, apice loculicide bivalvis, valvis medio septa duplicata margine seminifera, demum superne sejuncta, basi coalita gerentibus. Sem in a in loculis 6_10, globosa, nitida, rhaphe brevi, strophiolaeformi. $\mathbf{E} \mathbf{m}$ b r y o in basi albuminis duri, prope umbilienm minimus. - Suffrutex No va e-Hollandiae austro-occidenta$l i s$; ramis volubilibus, folitis alternis, integris, sinualo-dentatis et pectinatim ciliato.dentatis, pedunculis oppositifoliis, simplicibus v, ramosis, pedicellis unifloris, floribus candidis, purpureo-striatis.

0 n cospor u m Putterlick in Nov, Stirp. Mus. Vindob. Dec, II. 21, Synops, I'illospor. 21.

5G6.4. PRarianthus $H \ddot{U} G E L$. C a I y x pentaphyllus, subaequalis. Co roll a e petala 5 , hypogyna, calyeis foliolis alterna, spathnlata, unguibus conniventibus, laminis patulis. St a m ina 5 , hypogyna, petalis alterna, erecta; fi lamenta e basi plana latiore filiformia, a $n t h$ e rae introrsae, biloculares, ovoideae, rectae, dorso affixae, tandem reclinatae, longitudinaliter dehiscentes. $O$ v a ri u m brevissime stipitatum, biloculare. 0 val a in loculis plurima, dissepimenti axi utrinque biseriatim inserta, horizontalia, anatropa. Sty I a filiformis; 8 tig ma subeapitatum, ohsolete emarginatobilobum. Ca p su la membranacea, oblongo-ovalis, compressiuscula, bilocularis, loculicide bivalvis, valvis medio septa margine utrinque seminifera gerentibus. S e min a plurima, subglobosa v. angulata, nitida. Embryo in basi albuminis duri, prope nmbilicam minimus, orthotropus. - Suffrutices Novae-Hollandiae austro-ocoidenta$l i s$; ramis volubilibus, folits alternis, ellipticis $v$. oblongo-ellipticis, integerrimis v. inferioribus argute serratis aut pinnatifido-incisis, pedunculis termina- 
libus ramosis, ramis simplicibus $v$. di-trichotomis, floribus speciosis candidis, flavis, purpureis $v$. caerulescentibus.

Marla n th us Hingel mse, Bndlicher Enumerat, plant. Hügel. 8. Putterlick Synops, Piltospor, 22, B ill ard i e a rarififolia DC.

5665. Clneiramt hera $A$. CUNNINGH. C aIy x pentaphyllus, subaequalis. Cor olla e petala 5 , hypogyna, calycis foliolis alterna, ovata, breviter unguiculata, rotato - patentia. Stam ina 5 , hypogyna, petalis alterna, subsecunda; fil a me nta subulata, antherate introrsae, biloculares, oblongo-lineares, basens èmarginatae dorso insertae, loculis prope apicem intus rimula brevi dehiscentibus. Ovarium ellipticum, compressinsculum, subdeclinatum, hilocalare. Ovnla in locelis plurima, dissepimenti axi utrinque biseriatim inserta, horizontalia, anatropa. Stylus brevis, adscendens; 8 tigma obtusum, bifoveolatum. Bac ca chartacea, sicea, ventricosa, bilocnlaris. S e min a plurima, subglobosa. $\mathbf{E} \mathrm{m}$ bry $\mathbf{0}$ in basi albuminis duri minimus, orthotropus. - Suffrutex in NovaHollandia orientali et austro-oceiden tali indigenus, erectus; ramis erecto-patentibus, strictis, foliis alternis, linearibus, acutiusculis, integerrimis $v$, apice subincisis, junioribus in axillis fas ciculatis, pedunculis ramos terminantibus corymbo sis, pedicellis strictis, ftoribus cyaneis.

Cheirantluera All. Cunningh. ex Bot. Reg. n. 1719 Brongniart ad Duperrey t.77. Hooker Ic, t. 47. Meisner Gen. 66. (48,) Putterlick Synops. Pittospor. 24.

5668. Sollya LINDL. Cal y x pentaphyl Ins, minimus, subaequalis, Corolla e petala 5 , hypogyna, calycis foliolis alterna, ovata, sulıses silia, stellatim patula. Stamina 5, hypogyna, petalis alterna, conniventia; filam enta subula ta, a $n$ the $r$ a e introrsae, biloculares, oblongae, subsagittatae, baseos emarginatae dorso aflixae, in conum approximatae, loculis intus rima longitudinali, apice hiante dehiscentibns. Ov a ri a m ellipsoideo-cylindricum, bileenlare. Ovula in localis plurima, dissepimenti axi utrinque biseriatim inserta, horizontalia, anatropa. Stylus brevis, rectus; $8 \mathrm{tigma}$ absolete emarginatum. B acea exsuceo-chartacea, fusiformis, stylo mueronata, bilocularis. Se min a plurima, snbglobosa v. ovoidea, angulata. Em bryo in basi albuminis duri, prope nmbilieum minimus, orthotropus. - Suffrutex in Nova-Hollandia austro-oceidentali et in insula Diemen indigenus; ramulis volubilibus, foliis alternis, oblongo-ellipticis, primariis serrato-dentatis, adultioribus integerrimis, pedunculis in ramulis minoribus terminalibus $v$. oppositifoliis, in cymam divisis, flaribus nutantibus, caeruleis.

$\mathrm{S}$ oll y a Lindley in Bot. Reg. t. 1460, $1840, n$. 3. Don in Sweet Fl, Gard. t. 232. Hooker in Bot. Mag, $t$ 3532. Meisner Gon. 66. (47.) Putterlick Synops. Piltospor. 25. B il I a rdiera fusiformis Labillard. Nov, Holl. c. 90 .

5468. Promaya $H \ddot{U} G E L$. Cal y x pentaphyllus, foliolis subulatis, aeaualibas. Corolla e petala 5 , hypogyna, calycis foliolis alterna, ovata v. obovata subsessilia $\mathbf{v}$. breviter unguienlata, inferne conniventia, apice subrotato-patula. Sta mina 5 , hypogyna, petalis alterna, ereeto-patentia; fila menta subulato-filiformia, antherae introrsae, biloenlares, oblongae, baseos emarginatae dorso aflixae, apice revolutae, longitudinaliter dehiscentes. O v a $\mathbf{r}$ i $\mathbf{m}$ ellipsoideo-cylindricnm, biloculare. Ovala in toenlis plurima, juxta disese. pimenti axim utrinque liseriata, horizontalia, anatropa. Stylus breris, rectus; stigma ubsolete emarginatum. B a ec a coriaceo-carnisa, cylindriea, mutica, bilocularis. Se $\mathrm{m}$ in a in loculis plurima, intra pulpam resinosam nidulantia, subglobosa v. angulata. Embry o in basialbuminis dnri, prope umbilicum minimns, orthotropns, - Suffrutices Novae-Hallandiae austro-oceidentalis; ramis volubilibus, foliis alternis, oblongis $v$, linearibus, integerrimis, pedunculis in apice ramulorum brevibus, solitariis, di-trichotome cymosis, floribus caeruleis.

Pron a y a Hügel msc. Fedlicher in Enumerat. plant. Aügel, 9. Bot, Archiv. $t$, 6. Putterlick Synops, Piltospor, 26. S piranthera Hooker in Bot. Mag. n. 2523. C a mp ylanhera Hooker Ic, $t$. 82. Billardiera ros mariuifoIía DC.

5668. Eillardiera SMITH. C a $1 \mathrm{y} x$ pentaphyllus, foliolis subulatis, aequalibus. Corollae petala 5, hypogyna, calyeis foliolis alterna, ovato-oblonga, inferne in tubum conniventia, apice patentia. Stamina 5, hypogyna, petalis alterna, supra ovarium conniventia; filamenta complanato-subulata $\mathrm{v}$. filiformia, a $n t h e r a e$ introrsac, biloculares, oblongae, dorso affixae, erectae, Iongitudinaliter dehiscentes. Ovarium ellipsoideo-cylindrieum, biloculare. $O \mathrm{val}$ a in locnlis plurima, dissepimenti axi ntrinque biseriatim inserta, horizontalia, anatropa. Sty lus filiformis, rectus; st ig m a subcapitatum, obsolete bilobum v. bifidum. Ba e e a sueculenta, glahra v. hirsuta, ellipsoideo - cylindrica v. ovoidea, stylo mucronata, bilocularis. Semina in loculis plurima, intra pulpam resinosam nidalantia, angulato subglobosa v, reniformia. $\mathbf{E} m \mathbf{b} \mathbf{r} \mathbf{y} n$ in hasi albuminis duri, prope nmbilieum minimus, orthotropus. - Frutices in Nova-Hollandia extratropica orientali et in insula Diemen indigeni; ramis volubilibus, foliis alternis, integerrimis, crenatis $v$. sinuato-dentatis, pedunculis ex apice ramulorum solitariis, simplicibus, pendulis, unifloris, floribus flavis.

Billardier a Suith Nov. Holl. 1, 1, Labillard. Nov. Holl, t. 89. Weadl, Hort. Herren, 1II, 2, 15. Salisbary Pa. rad. t. 48, Bot. Mag. t. 80t, 1313, 1507. Sweet Fl, austr. t. 54. DC. Prodr. I, 345. exel. sp. Meisner Gen, 66, (48,) Putterlick Synops. Pittospor. 27. L a bill a r d fer a Rōmer et Schultes Syst. $\nu, X X V I$.

\section{GENERA PITTOSPOREIS AFFINIA.}

5BGD. Staelnyurus SIEB. et ZUCC. CaI y x bibraeteolatus, tetraphyllus, foliolis carinatis, duobus exterioribus coriaceis, interioribus paullo majoribns, tenerioribes, bracteolis oppositis. Cor o I I a e petala 4, hypogyna, calycis foliolis alterna et multo inajora, olovata, breviter unguiculata, aestivatione imbricata, sub anthesi erecta, decidua. S $t$ a $m$ i n a 8 , hypogyna, inclusa, alterna petalis opposita breviora; fila m en ta libera, complanato-subulata, antherae introrsae, biloculares, ovatae, dorso insertae, Ingitudinaliter dehiseentes. Ovari n m sessile, ovato-oblongam, obsolete tetragonnm, quadriloenlare. Ovula plurima, placentis e loculorum angulo centrali prominulis pluriseriatim inserta, horizontalia, anatropa. Stylus ovario continuns, cylindricns; $8 \mathrm{tig}$ m a capitato-peltatum, papillosum. B a c e a coriacea, exsncea, quadrilocularis, dissepimentis membranaceis, axi centrali nulla. Semina in loculis plurima, placentis in angulo centrali sitis tri-quadriseriatim affixa, horizontalia, angulata, pulpa celatinosa tunicata, testa crustacea, fragili, laevi. $\mathbf{E} \mathbf{m}$ br y 0 in axi albuminis carnosi orthotropus, ejusdem fere longitudine, 
cotyledonibus ellipticis, planis, incumbentibus, rad icula cylindrica, umbilico proxima, centripeta. - Frutex japonicus, sex-quindecimpedalis; ramis alternis, floriferis deflexis, foliis annuis, alternis, petiolatis, subcordatis, acuminatis, argute serratis, glabris, stipulis nullis, floribus in racemos simplices, multifloros, sub amentorum forma autumno e foliorum axilla provenientes, dispositis, unibracteatis bibracteolatisque, alabastris per hyemem bracteis inclusis, primo vere ante folia explicatis, petalis virescenti-albis, baccis olivaceo - virentibus, in racemi rhachi lignoso-incrassata subsessilibus.

Stachyurus Siebold et Zucearini Flor. japon. $X$. 42. $t, 18$

56ร0. ERe Herlimia ZUCCARIN. $\mathrm{C}$ alyx tetraphyllus, foliolis ovato-lanceolatis, acntiusculis, aequalibus, aestivatione imbricatis. Corolla petala 4, hypogyna, calycis foliolis alterna et triplo longiora, ubovato-oblonga, obtusa, brevissime unguiculata, aestivatione imbricata, sub anthesi patentia, decidua. S $t$ a $m$ in a 8 , hypogyna, petalis paullo breviora; fil a m e n ta libera, aequilonga, e basi incrassata subulata, anther a e introrsae, biloculares, ovatae, dorso supra basim insertae, longitudinaliter dehiscentes. O v a ri u m brevissime stipitatum, ellipticum, utrinque attenuatum, compressiusculum, biloculare. Ovula plarima, in placentis crassis, medio dissepimento utrinque adnatis multiseriata, horizontalia, anatropa. St ylus terminalis, simplex, cylindricus, incurvus; $8 \mathrm{tigma}$ simplex, truncatum. Fru ctns.... - Frutex mexicanus, ramosissimus; ramulis teretibus, nudis, divaricalis, in spinas vali. das desinentibus, foliis alternis, sessilibus, minutis, subulatis, caducis, stipulis nullis, floribus axillaribus, in racemos simplices, multifloros, erectos, strictos dispositis.

Ko e berlin ia Zuceariai Münchner Denkschrift, 1832. p 358. Meisuer Gen. 66. (47.)

\section{Ordo CCXXXI. Staphyzleaceae.}

STAPHXLEACEAE Bartling Ord, nat. 381. Liadley In. troduct. edit, II, p. 121. CELASTRINRARUM tribus I. DC. Prodr. II, 2.

Arbores v. frutees erecti. Folia opposita v, rarissime alterna, trifoliolata v. imparipinnata, foliolis oppositis, petiolulatis, serratis, interdum stipellatis et vernatione involutis. Stipula e ad basim petiolorum geminae, deciduae.

Flores hermaphroditi v. abortu polygami, regulares, axillares v. terminales, racemosi v. paniculati, pedicellis basi decidue bracteatis.

Catrx liber, coloratus, quinquepartitus, deciduus v. persistens, laciniis aestivatione imbricatis.

Corollae petala 5, disco hypogyno libero, margine crenulato imposita, v. sub disci margine iuserta, calycis laciniis alterna et paullo majora, aestivatione imbricata, decidua.

Sramiva cum petalis inserta, iisdem alterna et breviora v. vix longiora. Filamenta subulata, libera, aequalia. Antherae introrsae, biloculares, longitudinaliter dehiscentes.

Ovaria 2 v. 3 , basi v. juxta totam longitudinem in unicum bi-triloculare, bi-trilobum coalita, Ovula juxta suturam ventralem in 10culorum angulo centrali plura, uni-biseriata, horizontalia v. adscendentia, anatropa. Styli ovariorum numero, distincti v. subcoaliti, demum sejuncti; stigma ta indivisa.

Fructus nune capsularis, membranaceus, inflatus, bi-trilocularis, bi-trilobus, Iobis apice sutura ventrali apertis, nunc baccatus, tri-v, abortu bilocularis, indehiscens.

Semina in loculis pauca $\mathbf{v}$. abortu interdum solitaria, adscendentia v. subhorizontalia, globosa, basi truncata, testa ossea, nitida. Alb u me n carnosum, parcum v. subnullum, ad laminam tenuem redactum.

Embryo intra albumen orthotropus; cotyledonibus plus minus crasse carnosis, plano-convexis, radicula brevi, umbilico proxima, infera v. centripeta.

Staphyleacea in temperatis Europae et Americae borealis, in Japonia, in Antillis, Mexico et Asia tropica indigenae, a Celastrineis, quibuscum a plerisque conjunguntur, foliis pinnatis et seminum structura optime distinctae, et in Frangulacearum classi anomalae, observante cl. Bartling pluribus notis ad Sapindaceas accedere videntur.

587 1. Turpinia VENT. Flores polygamo-dioici. C a ly $\mathrm{x}$ subcoloratus, persistens, quinquepartitus, laciniis aestivatione imbricatis. Corolla petala 5, sub disci hypogyni, orbicularis margine decemerenato inserta, ealycis laciniis alterna et longiora, obovata, aestivatione imbrieata, sub anthesi patentiuscula. S ta $\mathrm{m}$ in a 5 , disco inserta, petalis alterna et subaequilonga; filamenta complanato - subulata, antherae introrsae, biloculares, curdatae, longitudinaliter dehiscentcs. Ovariu m sessile, trilobum, triloculare. Ovula in loculorum angulo eentrali pauca, uniseriata, horizontalia $\mathbf{v}$. adscendentia, anatrupa. Styli 3 , subcoaliti; stigm a ta patentia, subeaneata. B a cea trigona, trilocularis. S emina in toculis $1-3$, subhorizontalia, subglobosa, basi truncata, testa ossea, nitida. E m br y o in axi albuminis carnosi orthotropus, eotyled on ibus planiusculis, carnosis, radic n la umbilico proxima, infera. - Arbores v. frutices, in Antillis et in Asia tropica crescentes; foliis oppositis, imparipinnatis, bistipulatis, foliolis oppositis, petiolulatis, exstipellatis, coriaceis, serratis, paniculae terminalis ramis oppositis v. alternis, floribus albis, fructu eduli.

T arpinsa Venten, Choix, t, 31. DC, Prodr. 1I. 3. Wight et Arnott Prodr. $I, 156$. Meisuer Gen, 67. (48.) D a Irу ш pele a Roxburgh Plant. Corom. 1IT. 876. $t, 279$.

56ร.. Euseaplis SIEB. et ZUCCAR. Flores hermaphroditi. Caly $x$ persistens, quinquefidus, laciniis aestivatione imbricatis. Corolla e petala 5, sub disco hypogyno annulari crenato inserta, calycis laciniis alterna et longiora, obovata, aestivatione imbricata, sub anthesi patula. 
Ovaria 3 , libera, sessilia, unilueularia, Ov ula juxta suturam ventralem solitaria, v, gemina superposita. Styli 3 , distineti, erecto-conniventes; $8 \mathrm{t}$ igmata subeapitata. Cap $8 \mathrm{ula}$ a tres $v$, abortu pauciores, basi calyce persistente cinctae, divaricato - patentes, pergamenae, uniloculares, bivalves, monospermae. S e m e $n$ arillatum, testa ossea. Embry o intra albumen carnosum ortho. tropus; cotyledonibus orbicularibus, planis, radicula brevi, cylindrica. - Frutex japonicus; foliis oppositis, imparipinnatis, trijugis, foliolis petiolulatis, stipellulatis, ovato-lanceolatis, acuminatis, serrulatis, glabris, paniculis terminalibus, dichotomis.

Eusca phis Siebold et Zuccarini Flor, japon, $t, 67$.

5683. Staplinglea LINN. F lores hermaphroditi. Calyx coloratus, quinquepartitus. deciduss, laciniis aestivatione imbricatis. Corollae petala 5, disco libero, complanato inserta, calycis laciniis alterna et subaequilonga, aestivatione imbricata, sub anthesi erecta. St am ina 5, cum petalis inserta, iisdem alterna; fil amenta filiformi-subulata, an the ra e introrsae, biloculares, longitudinaliter dehiscentes. Ovaria $2-3$, sessilia, lineari-oblonga, ima basi v. rarius juxta totam longitudinem coalita. Ovu I a juxta suturam ventralem plura, biseriata, adscendentia, anatropa. Styli 2_3, filiformes, distincti v, coaliti; stig. mat a subeapitata. Ca ps u la membranacea, vesiculoso - inflata, bi-trilocularis, bi-triloba, lobis apice sutura ventrali dehiscentibus. S e mina in loculis pauca $v$. abortu solitaria, adscendentia, subglobosa, basi trnneata, testa ossea. $\mathbf{E} \mathrm{mb}$ ry 0 intra albuminis laminam tenuem orthotropus; co ty le donibus carnosis, plano convexis, radicula brevissima, umbilico proxima, infera. - Frutices in temperatis hemisphaerae borealis obvii; foliis oppositis $v$, interdum alternis, trifoliolatis $v$. imparipinnatis, bistipulatis, foliolis oppositis, stipellatis, serratis, vernatione involutis, racemis axillaribus paniculatis, floribus albidis.

Staphylea Linu. Gen, n, 324. Lam, $t$. 210. Sehkuhr t. 84. Gartuer I. 334. t. 69. Duham. Arbr. IT, 72. DC. Prodr. II. 2. Delessert Ic, select. III. t. 51. Meisner Gen, 67. (48.) Staphylodendron Tournef. Inst. t. 386. B umald a Thuub. Flor. japon. 8 .

\section{Ordo CCXXXVI. Celastmineae.}

RHAMNORUM sect. II. Jussieu Gen. 377, exel, pl. CE. LASTRINEAE R. Brown in Flinders Voy. Ir. 5.54. exel. gen. Brongniart in Annal. sc, nat, $\boldsymbol{X}$. 328. Bartiling Ord. nat. 378, CEL ASTRINEARUM tribus 1I. ERONYMEAE DC. Prodr, II. 3. CELASTRACEAE Liadley Introduct, edit, $I$. p. 119.

Arbisculae v. prutices, interdum scandentes, ramulis sparsis v. uppositis, teretibus aut tetragonis, nonnunquam spinescentibus. Folia alterna, rarius opposita, breve petiotata, simplicia, integra, penninervia, integerrima v. dentata, saepissime coriacea, et glaucescentia. Stipula e parvae, caducissimae.

Flokes hermaphroditi v. abortu unisexuales, regulares, axillares, cymosi, parvi v. mediocres, albidi, virescentes v. purpurei.

Calyx quadri-quinquefidus v. partitus, laciniis aequalibus, aestivatione imbricatis, persistentibus.
Drscus carnosus, annularis v. orbiculatus, calycis fundum vestiens, liber $\mathrm{v}$, interdum ovario adhaerens.

Conollae petala $4-5$, calycis laciniis alterna, sub disci margine inserta, basi latiora, sessilia, plana, aestivatione imbricata, sub anthesi patentia, decidua.

Staura petalis numero aequalia et alterna, nunc cum iisdem sub disci margine inserta, nune ipso margini continua, nonnunquam disco intra marginem imposita. Filamenta tereti-v. compresso-subulata, brevia. Antherae introrsae, biloculares, erectae, basi vel dorso insertae, loculis connectivo saepe postice dilatato adnatis, longitudinaliter dehiscentibus.

Ovarium sessile, disco plus minus immersum, liberum v. interdum basi eiden adnatum, bi-tri-quinqueloculare. Ovula in loculis solitaria v. saepissime gemina, collateralia, e basi erecta v. adscendentia, rarius plura, in angulo centrali biseriatim adscendentia, anatropa. StyI u brevis, crassus. Stigma minute bi-triquinquelobum.

Froctus bi-quinquelocularis, nune indehiscens, drupaceus v. interdum samaroideus, loculis monospermis, nunc capsularis, loculicide dehiscens, valvis medio septa margine seminifera gerentibus, loculis abortu monospermis v. rarius bi- rarissime polyspermis.

Semina erecta v. adscendentia, arillo carnoso v. pulposo, colorato, laterali v. saepius cupulari, plus minus producto, interdum nonnisi foramine exiguo apice pervio excepta v. inclusa, rarissime exarillata, testa crustacea v. membranacea, rhaphe longitudiuali percursa. Alb am en carnosum, copiosum.

Eмввуо in axi albuminis orthotropns, ejusdem longitudine v. saltim dimidio longior; c otyledonibus foliaceis, planis, radicula cylindrica, umbilico proxima, infera.

Celastrinea eadem fere cum Rhamneis ratione per orbem terrarum distributae, in Capite bonae spei copiosissime habitant. Affinitate Rhamneis, Aquifoliaceis, Hippocrateaceis et Pittosporeis proximae, ab his disci praesentia, genitalium insertione perigyna, seminum in plurimis numero definito, et embryone multo perfectiori distinguuntur, ab Hippocraticeis staminum numero, et albuminis praesentia, ab Aquifoliaceis ovulis erectis et embryone perfectiore, a Rhamneis staminum ante calycis lacinias situ, et fructus et embryonis indole diversae.

Ordo, si quis alius, monographo diligenti commendandus. Genera fructu drupaceo donata, quoad disci et endocarpii indolem, et albuminis naturam accuratius exploranda.

TRImES I. EVONYMEAE. Fructus capsularis, loculicide dehiscens. 
568 4. Putterliekia. C a I y x planus, quinquepartitus, lobis obtusis, patentibus. Cor olla e petala 5 , sub disci perigini, hemisphaerici, costati margine inserta, calycis laciniis alterna et majora, oblonga, patentissima. St a mina $\mathbf{5}$, cum petalis sub disci margine inserta, iisdem alterna et snbaequilenga; fila in en t a subulata, patentissima, anthera introrsae, biloculares, subgloboso didymae, longitudinaliter dehiscentes. Ovar i u m disco semiimmersum, triloculare. Ovula in loeu lis plurima, angulo centrali biseriatim inserta, ad scendentia, anatropa. Stylus simplex, trigonns s t ig m a obsolete trilobum. Capsula trigona, trilocularis, loculicide trivalvis, valvis coriaceis, crassis, medio septum margine utrinque seminiferum gerentibns. Se $\mathrm{m}$ in a in loculis $2-6$, adscen dentia, arillo carnoso, colorato, apice pervio inclu sa. E $m$ bryo in axi albuminis carnosi urthotropus cotyledonibus foliaceis, ovatis, radicula cy lindrica, nmbilico proxima, infera. - Frutex ca. pensis, sempervirens, inermis $v$, ramis axillaribus spinescentibus armalus; foliis alternis, breve petiolatis, obovatis $v$. ellipticis, coriaceis, penninerviis, in tegerrimis $v$, argute remote serratis, pedunculis axillaribus paucifloris, divaricato-ramosis, folio longioribus.

Celastrus pyracanthus Lina. Miller Ie, $t .87$ Gärtner $t$, 95. Bot. Mag. $t$. 1167.

56ชร. Toplaopetalum WIGHT. C aly $\mathrm{x}$ scutelliformis, quadri-quinquelobus, lobis ro. tondatis, brevibus. Corolla e petala $4 \mathrm{r}$. 5, sul disci crassi, tetra-pentagoni, ealycis tubum replen tis margine inserta, sessilia, orbiculata, patentia, circa basim cristis lobulisque carnosis instructa, margine laevia. Stam in a 4 v. 5 , supra discum inserta, petalis alterna; filamenta subulata, persistentia, a n herae introrsae, biloculares, ovatae, longitudinaliter dehiscentes. Ovari u liberum, diseo semiimmersum, tri-quadrilucnlare. Ovila in loenlis $8-12$, biseriata, adscendentia. Styl n s brevis, persistens; stigma obtusum. Capsula tri-quadriangularis, tri-quadrilocula. ris, loculicide dehiscens. Semina in loculis abortu subgemina, arillata......-Frutices ma $l a$ barici et nepalenses, glabri; foliis oppositis. petiolatis, integerrimis $v$. serratis, floribus axillaribus magnis, corymbosis.

Lop ho petalum Wight mse. ex Arnott in Annat. of Nat, hist. III. 150. Evou y mus grandifloras Wall. E. 1 a cidus Don.

5686. Wvonymas TOURNEF. C a I y planus, quadri-quinquefidns, lobis obtusis, patentibus. Corolla e petala $4-5,8$ b diseo perigy. no, carnoso, orbiculari, integro inserta, calycis laeiniis alterna et majora, patentia. $\mathbf{S t a m}$ in a 4 v. 5 , glandulis supra discum prominulis inserta, petalis alterna; filamenta subulata, brevissima, an therae introrsae, biloculares, connectivo dorsali lato, loculis transversim v. longitudinaliter dehiscentibns. O v a ri o m disco seinimmersum, triquinquelesulare. Ovula in loevlis gemina, ex angulo centrali adscendentia, anatropa. Capsula tri-quinqueloba, tri-quinquelocularis, Ioculicide dehiscens, valvis coriaceis, medio septiferis. Se$m$ in a in loeulis gemina v, abortu solitaria, adscendentia, pulpa v. arillo carnoso colorato, apice pervio inclusa, testa chartacea. $\mathbf{E} \mathbf{m b} \mathbf{r y} 0$ in axi abominis carnosi orthotropns; cotyled nnibus foliaceis, suborbicolatis, radi $\mathrm{e}$ u a tereti, umbilico proxima, infera. - Frutices in temperatis $h e$ - mis phaerae borealis indigeni, erectiv. interdum scandentes, ramulis tetragonis; foliis oppositis, petiolatis, ovatis, serratis $v$. denticulatis, pedunculis axillaribus, cymosis.

Es o n y m us Tournefort Inst. 388. Linn. Gen, n. 2zt. Lam, t, 131. Schkuhs $t$. 47. Gärtner If. 149. 2,113 . Jaeq. Flor, austr, t. 49. 289. Hort. Vindob. t. 120. Duham. Arbr. edit. Nov, III, $t, 7$-9, DC. Prodr. II. 3. Wallich Plant, As. rar. t. 250. Hooker ad Beechey t.54, Bot, Mag. t, 2384. Royle Himalay. $t$. 31 . Wight et Aruott Prodr, I, 160. Meiswer Gen. 68. (48.)

$56 \%$ \%. Polyearulia JUSS, C a 1 y x minimns, quinquelobus. Co ro Il a e petala 5, perigyna(?), caIyvis Ioliolis alterna et multo majora, ovata, patentia. Stamina 5, cum pelalis inserta, iisdem alterna; fil amenta brevia, an ther a e subrotundae, biloculares. Ovariu $m$ sessile, depressinscule subglobosum, tri-quinqueloculare. Ovula ...... Stylus simplex; stigma lobatum. Caps u la coriacea, tri-quinquevalvis, valvis medio septa basi utrinque seminifera gerentibus. S e mina pauca, oblonga, arillo laciniato calyculata.... Frulex madagascariensis; foliis allernis, ovato-oblongis, coriaceis, penninerviis, integerrimis, pedunculis terminalibus $v$. cum foliis alternan. tibus, foliaceo-dilatatis, abcordatis, sinu tri-quadrifloris.

Pol y e a rd i a Jussieu Gen, 377. Lam. t. 132. DC. Prodr. II. 10. Meisner Gon. 68. (48,) Florind a Norouh. C 0 m. mers onia Commers.

5688. Catlia FORSK. Flores hermaphroditi? Caly x planus, quinquelobus. CorolIa e petala 5 , sub disco perigyno orbieulari inserta, calycis laciniis alterna et majora, ovata, patentissima. St amin a $5,8 u b$ disei margine inserta, petalis alterna et breviora; fil am en ta subulata, antherae introrsae, biloenlares, longitudinaliter dehiscentes. Ovari am diseo semiimmersum, triloculare. Ovula in loculis gemina, angulo centrali inserta, adscendentia, anatropa, cupula carnosa nulla. Stylus brevissimus; stigma tripartitum. C a p \& u l a coriacea, triquetra, trisulea, trilocnlaris, loculicide trivalvis, valvis medio septiferis. Semina in loculis gemina $v$. abortu solitaria, juxta septi marginem adscendentia, arillo membranaceo, molli, colorato tecta, testa membranacea. Embryo intra albunen carnosum orthotropus, ejusdein fere longitudine; coty led on ib us foliaceis, $\mathbf{r}$ a di cula infera. - Arbusculae $v$. frutices, in Asia et Africa tropica crescentes, plerumque spinosi; foliis sparsis, suepe in ramulis brevibus fasciculatd-congestis, coriaceis, integerrimis $v$. crenato-serratis, ciliis stipularibus, corymbis axillaribus, subdichotomis, floribus pedicellatis, subfosciculatis, albis.

Catha Forskael Aegypt, 63. Don Syst. II. 9. exel. sp. Sonueratia Commers. msc. C elastri sect. G y muosporia Wight et Arnott Prodr, I. 159. N ov. G e n us Kuntil in Humb. et Bonpl. Nov, gen, et sp. VII. 64. in nor. excl. sp. Cela stri s p. Linn. Lam. Bot. Mag, t. $20 z 2$.

\$๕ ci. Calyx urceolatus, quinquefidus, Corollae petala 5 , sub disco perigyno orbiculari inserta, caIyeis laciniis alterna et multo majora, ovato_oblonga, apice patentia. Stam in a 5 , disci sinubus inserta, petalis alterna et hreviora; filamenta subulata, antherae introrsae, biloculares, Inngitudinaliter dehiscentes. O v a $r$ in m diseo insidens, bitri-quadriloculare. Ovnla in localis 2 , e basi erecta, collateralia, anatropa, cupula carnosa excepta. Stylus brevis, crassns; stigma 
5B8 4. Putterliekia. C a I y $\mathrm{x}$ planus, quinquepartitus, lobis obtusis, patentibus. Cor ol la e petala 5 , sub disci perigini, hemisphaerici, costati margine inserta, calycis laciniis alterna et majora, wblonga, patentissima. Sta mina 5 , cum petalis sub disci margine inserta, iisdem alterna et snbaequilonga ; fil am en t a subulata, patentissi ma, ant herae introrsae, biloculares, subgloboso didymae, longitudinaliter dehiseentes. O va ri u m disco semiimmersum, triloculare. $\mathrm{O}$ vala in loculis plurima, angulo centrali biseriatim inserta, ad scendentia, anatropa. Stylus simplex, trigonns; s t ig m a obsolete trilobum. Capsula trigona, trilocularis, loculicide trivalvis, valvis coriaceis, crassis, medio septum margine utrinque seminiferum gerentibus. Se $m$ in a in loculis $2-6$, adscen dentia, arillo carnoso, colorato, apice pervio inclu sa. E $\mathbf{m}$ bryo in axi albuminis carnosi orthotropus; cotyledonibus foliaceis, ovatis, radicula cy lindrica, umbilico proxima, infera. Frutex ca. pensis, sempervirens, inermis $v$. ramis axillaribus spinescentibus armatus; foliis alternis, breve petiolatis, obovatis $v$. ellipticis, coriaceis, penninerviis, in tegerrimis $v$, argute remote serratis, pedunculis axillaribus paucifloris, divaricato-ramosis, folio longioribus.

Celastrus pyracanthus Linn. Miller Ic, $t, 87$. Gärtner $\imath$, 95. Bot. Mag. . 1167.

56รร. Toplaopetalum WIGHT. C aly $\mathrm{x}$ scutelliformis, quadri-quinquelobus, lobis rotundatis, brevibus. Corolla e petala 4 v. 5 , sub disci crassi, tetra-pentagoni, calycis tobum replen tis margine inserta, sessilia, orbiculata, patentia, circa basim cristis lobulisque carnosis instructa, margine laevia. Stam in a 4 v.5, supra discum in serta, petalis alterna; filame nta subulata, persistentia, a n therae introrsae, biloculares, ovatae, longitudinaliter dehiscentes. Ova $\mathbf{r}$ i m liberum, diseo semiimmersum, tri-quadrilecnlare. Ovnla in loculis $8-12$, biseriata, adscendentia. S t y I u s brevis, persistens; stigma obtusum. Capsula tri-quadriangularis, tri-quadrilocularis, loculicide dehiscens. Semina in loculis abortu subgemina, arillata......-Frutices malabarici et nepalenses, glabri; foliis oppositis, petiolatis, integerrimis $v$. serratis, floribus axillaribus magnis, corymbosis.

Lo phopetalum Wight msc, ex Arnott in Annal. of Nat, hist, III, 150. Evou y mus grandiflorus Wall, E. 1 ucidus Doll.

5Bre. Dvomymas TOURNEF, $\mathrm{C}$ a I $\mathrm{x}$ planus, quadri-quinquefidus, lobis obtusis, patentibus. Corolla e petala $4-5,8$ b disco perigy. no, carnoso, orbiculari, integro inserta, ealyeis laciniis alterna et majora, patentia. Sta m in a 4 v. 5, glandulis supra discum prominulis inserta, petalis alterna; filamenta subulata, brevissima, an. the rae introrsae, bilocnlares, connectivo dorsali lato, Ioculis transversim v. longitudinaliter dehiseentibns. O va ri u m disco semiimmersnm, triquinqueieculare. Orula in loenlis gemina, ex angulo centrali adscendentia, anatropa. Ca psula tri-quinqueloba, tri-quinquelocularis, locnliside dehiscens, valvis coriaceis, medio septiferis. Se$\mathrm{m}$ ina in loculis gemina v. abortu solitaria, adscendentia, pulpa $v$. arillo carnoso colorato, apiee pervio inclusa, testa chartacea. Emb ryo in axi alouminis earnosi orthotropus; cotylednnibus foliaceis, suborbiculatis, radi $e$ u la tereti, umbilico proxima, infera. - Frutices in temperatis he- mis phaerae borealis indigeni, erecti $v$. interdum scandentes, ramulis tetragonis; foliis oppositis, petiolatis, ovatis, serratis $v$. denticulatis, pedunculis axillaribus, cymosis.

$\mathrm{E}$ v o n y m u s Tournefort Inst. 388, Linn. Gen, n. 27t, Lam. t, 131. Schkuhr t. 47. Gärtner It. 149. $t, 113$. Jaeq. Flor, austr, t, 49, 289, Hort, Vindob, t, 120. Duham. Arbr. edit. Nov, IIT, $t, 7$-9. DC, Prodr. II. 3. Wallich Plant. As, rar, t. 250. Hooker ad Beechey t.54. Bot. Mag. t. 2384. Rayle Ilimalay, $t$. 31. Wight et Aruott Prodr, I, 160. Meisuer Gen. 68. (48.)

56 \%. Polyearedia JUSS, C a 1 y $x$ mininus, quinquelobus. Co roll a e petala 5, perigyna(?), calycis fuliolis alterna et multo majora, ovata, patentia. Stamina 5 , cnm pelalis inserta, iisdem alterna; fil amenta brevia, antherae subrotundae, biloculares. Ovariu m sessile, depressiuscule subglobosun, tri-quinqumeloculare. Ovula ...... Stylus simplex; stig ma lobatum. Ca ps u la coriacea, tri-quinquevalvis, valvis medio septa basi utrinque seminifera gerentibus. S e min a pauca, oblonga, arillo laciniato calyculata .... - Frulex madagascariensis; foliis allernis, ovato-oblongis, coriaceis, penninerviis, integerrinis, pedunculis terminalibus $v$. cum foliis alternantibus, foliaceo-dilatatis, obcordatis, sinu tri-quadriftoris.

Pol y cardi a Jussieu Gen, 377. Lam, t. 132. DC. Prodr. II. 10. Meisner Gen, 68. (48,) Florind a Norouh, $\mathrm{C}$ ommers onla Commers.

5698. Catlua FORSK. Flores hermaphroditi? Caly $\mathrm{x}$ planus, quinquelobus. Corolla e petala 5 , sub disco perigyno orbiculari inserta, calycis laciniis alterna et majora, ovata, patentissima. Stamin a 5 , sub disei margine inserta, petalis alterna et breviora; fil am en ta subulata, antherae introrsae, biloculares, longitudinaliter dehiscentes. Ovarium disco semitimmersum, triloculare. Ovala in loculis gemina, angulo centrali inserta, adscendentia, anatropa, cupula carnosa nulla. Stylus brevissimns; $s t i g m$ a tripartitum. C a p s u l a coriacea, triquetra, trisulea, trilocularis, locnlicide trivalvis, valvis medio septiferis. S emina in loculis gemina $\mathbf{v}$. abortn solitaria, juxta septi marginem adscendentia, arillo membranaceo, molli, colorato tecta, testa membranacea. E m b r yo intra albumen carnosum orthotropus, ejusdem fere longitudine; coty ledonib n s foliaceis, radicula infera. - Arbusculae $v$. frutices, in $A$ sia et Africa tropica crescentes, plerumque spinosi; foliis sparsis, suepe in ramulis brevibus fasciculato-congestis, coriaceis, integerrimis $v$. crenato-serratis, ciliis stipularibus, corymbis axillaribus, subdichotomis, floribus pedicellatis, subfosciculatis, albis.

Catha Forskael Aegypt. 63. Don Syst. II. 9. exel. sp. Sonueratia Commers. msc. Celastri sect. Gymu o sporia Wight et Arnott Prodr. I, 159. N ov. G o n u s Kunth in Humb. et Bonpl. Nov. gen, et sp. VII. 64. in not. exel, sp. C e la stri s p. Lina. Lam. Bot. Mag. $t .2022$.

ธุดร. Celastrus KUNTH. Flo res dioici. Cal yx urceolatus, quinquefidus. Corollae petala 5 , sub disco perigyno orhiculari inserta, ealyeis laciniis alterna et multo majora, ovato-oblonga, apice patentia. St am in a 5 , disci sinubus inserta, petalis alterna et breviora; filamenta subulata, a ntherae introrsae, hiloculares, longitudinaliter dehiseentes. O va rium diseo insidens, bi tri-quadriloeulare. ONn 1 a in loculis 2, e basi ereeta, collateralia, anatropa, eupula carnosa excepta. Stylus lirevis, crassus; stigma 
Fructus samaroidens, tripterus, indehiseens, epicarpio tenuiter membranaceo, reticulato-venoso, endocarpio chartaceo, in alas producto, abortu unilocularis, monospermus. Semen erectum, teres, apice attenuatum, testa granulata. $\mathbf{E}$ b b r y o in axi albeminis carnosi orthotropus, magnus; cotyledonibus lanceolatis, planis, venosis, radien la exserta, infera. - Arbusculae mex $i$. canae, Celastri facie; folüs allernis, petiolatis, exstipulatis, coriaceis integerrimis, glabris, utrinque concoloribus $v$, subtus pallidis, pedunculis axillaribus, cymosis.

WI m merl a Schlechtend, in Linnaea VI. 427. Meisner Gen. 68. (49.)

5885. Fraunleofera $M A R T$. Cal y x quinquefidus. Corolla e petala 5, inter calycem et discum perigynum staminiferum inserta, laciniis alterna et majora, patentia. Stam ina 5 , disri tenuis, cum basi calycis connati, ovarium exeipientis angulis continua, petalis alterna et breviora; fil a menta subulata, a ntherae introrsae, biloeulares, subgloboso-didymae, longitudinaliter dehiscentes. Ovarium depresso-globosam, uniloculare. Ovnl um nnicum, e basi erectum. Sty Ins cylindricus, brevis; $s$ tigma depresso-capitatum. Capsula (?) subsiliquaeformis, cylindriea, coriacea, fibrosa, indehiseens, monusperma. S em en erectum. - Frutex brasiliensis, ramosissimus; foliis sparsis, petiolatis, serratis, no vellis pubentibus, floribus minutis, in racemos spiciformes, axillares et terminales irregulariter dispositis, solitariis v. subaggregatis, bracteis minimis interstinctis.

F r a u a h of er a Martius Nov. gen, et sp. IIT, 85, $t .235$. Meisuer Gen. 69. (49.)

5688. Fieurestylia WIGHT et ARN. Caly $x$ profunde quinquefidus. Coroll a petala 5 , sub disco perigyno crasso, crenulato inserta, ovata. Stamina 5 ; cum petalis inserta, iisdem alterna et breviora; fila m en ta subulato-complanata, a ntherae introrsae, biloculares, loculis longitudinaliter dehiscentibus, connectivo dorsali, lato. Ova $\mathrm{r}$ i $\mathrm{m}$ disco semiimmersum, biloculare, Inenlo altero minori abortivo, altero perfecto. Ovula 2, collateralia, adscendentia, anatropa. Stylus brevis, crassus; stigma latum, subpeltatum. Drup a inaequilatera, stylo sublaterali, earne tenui, putamine crustaceo, basi irregulariter perforato, abortu nniloculari, monospermo. Se m e n ereetum, putamine arilliformi obtectum. Embryo in axi albuminis copiosi, carnosi orthotropus; cotyledonibus latis, orbiculatis, planis, radicula infera. - Frutices indici; foliis oppositis, breve petiolatis, integerrimis, albidis, pedunculis axillaribus et terminalibus, vix petiolo longioribus, paucifloris.

Pleurostylia Wight et Arnott Prodr. T. 157. Meisner Gen, 69. (49.) Celastri sp. Wallieb.

$588 \%$. IIratogia THUNB. F lores polygami? C a ly $x$ quadri-quinquepartitus, persistens. Curolla e petala $4-5$, sub dises perigyno brevissime annulari inserta, calycis laciniis alterna et multo majora, obovato-oblonga, ereeta $r$. patentia. Stamina 4 v. 5, disci margini inserta, petalis alterna et breviora; fil a menta subulata, antherae introrsae, biloeglares, ovato-subglobosae, longitudinaliter dehiscentes. Ovarium sessile, biloculare. Ovula in loculis solitaria, e basi erecta, sessilia, Stylus brevis, crassus; stigma bilobum, lobis emarginatis. D rupa sicea, glo. bosa, fragilis, bilocularis v. abortu unilocularis. Sem in a in loculis solitaria, erecta, ovata, dorso convexa, facie excavata, testa coriacea, rugosa. Embryonis exalbuminosi, orthotropi cotyledones foliaceae, orbiculatae, radicula brevissima, infera. - Frutices capenses; foliis oppo. sitis, breve petiolatis, coriaceis, glaucescentibus, margine subrevoluto crenato-serratis, pedunculis uxillaribus paucifloris v. cymoso-multifloris, floribus minutis.

Hartogia Thunberg Nov. gen. 5, 35. c, ic. Linn. f. Suppl, 128, DC. Prodr. II. 12. Meisuer Gen, 69. (49,) S e h re. be r \& Thubberg Prodr. $t .2$.

5839. Elaeodendion $J A C Q$. F lores polygami. Caly x quadri quinquepartitus. Corolla e petala 4 v. 5 , sub disci perigyni crassi, integerrimi v. sinuati margine inserta, calycis laciniis alterna et majora, patentia. S $t$ a m in a 4 v. 5 , disci margini inserta, petalis alterna et breviora; fila menta subulata, an therae introrsae, biloculares, ovato-subglobosae, longitudinaliter dehiscentes. Ovari um disco immersum, bi-triloculare, rarius quadri-quinqueloculare. $O_{\mathbf{v}} \mathrm{ala}$ in loeulis solitaria v. gemina collateralia, e basi erecta, anatropa Stylus brevis, crassus; stigma obsolete bi-quinquelobum. Drup a sicea $\mathbf{v}$. pulposa, putamine lignoso, bi-quinqueloculari, interdum abortu uniloculari. Se min a in loculis solitaria v. interdum gemina collateralia, ereeta, testa membranacea v. sponginsa, rugosa. Embryo intra albumen parenm orthotropus; cotyledonibus carnosis, subfoliaceis, radicula infera. - Frutices $v$. arbusculae, in insulis Mauritianis, Asia trapica, Nova-Hollandia extratropica et Capite bonae spei crescentes; fuliis alternis oppositisque, coriaceis, crenatis $v$. serratis, pedunculis axillaribus, cymosis v. fasciculatis,

El a e o de a dro a Jacq. f. in Lct, helv. I. 36. Girtner I. 224. $t$. 57. Lam. $t$, 132. DC. Prodr. $I T$. 10. exel. sp. R a. beutia Commers. in Jussieu Gen. 378. S chrebera Retz Observ. bot. VI. 23. $t$. 3. Portens ch I a gi a Trattinick Archiv. 250. L a ma r c ki a Hortulan. N e r ij a Roxburgh Flor. Ind. edit. Wall. II. 444. S c y to p h y 11 u m, L a u ri dia, M y straxylon et Crocoxylon Ecklon et Zeyher Enumerat. Plant. Cap. 124_-128.

5 B85. VIyginala $J A C Q$. C a lyx parvus, nrceolatus, quadrifidus v. quadripartitus. CorolI a e petala 4, sub disco perigyno urceolato, quadrilobo inserta, calyeis laciniis alterna et majora, patentissime reflexa. S $t$ a $m$ in a 4 , inter disci $10-$ bos inserta, petalis alterna et breviora; fi l a men$t$ a subulata, a $n t h$ erae introrsae, bilocnlares, subgloboso didymae, longitudinaliter dehiscentes. 0 vari a m sessile, tri-quadriloculare. $O v n L a$ in luculis solitaria, e basi erecta, anatropa. Sty I n s brevissimus; stigma tri-quadrilobum. Drupa subglubosa, putamine osseo, aborta nniloculari, monospermo. S e m e $\mathbf{n}$ erectum ...... - Frutices America e tropicae, inermes; foliis sparsis, in ramulis oppositis $v$. ternatis, simplicibus, integris, parvis, stipulis petiolaribus geminis, pedunculis axillaribus dichotome bi-sexfloris, bracteatis, floribus minutis, rubellis v. albis, fructibus coccineis,

M y ginda Jacquin Amer. 24. t. 16. Ic. rar. $t, 311$. Swartz Flor. Ind, occid. I. 340. Kunth in Humb. ot Bonpl Nov, gen, et sp, VII, 66. exel. sp. DC. Prodr. II, 12, excl. sp. Meisner Gen. 49. (69) $\mathrm{R}$ h a e o m a Linn. Gen. n, 144. Crossopetalu u P. Browa Jam. 145, t. 17. $f$. 1 .

5BDQ0. Breoplnila NUTT. Calyx tubo brevi, urceolato, limbo quadripartito, patente, Corollae petala 4, sub disci plani, calycis faucem 
et ovarium obtegentis margine inserta, subrotunda, concava. Sta mina 4, disci margini inserta, petalis alterna et subaequilonga ; f l a ment a complanato-subulata, patentia, an therae introrsae, biloculares, loculis longitndinaliter dehiscentibus, connectivo dorsali lato. O vari um liberum, calycis tubo inclusum, disco apice adnato tectum, bilnculare. Ovula in loculis gemina, collateralia, e basi erecta, funiculis longiusculis crassiusculis stipitata, anatropa. Stylus brevis; stigma capitatum, obsolete trilobum. Capsula coriacea, ovalis, compressa, bilocnlaris, bivalvis, disperma, v abortu monosperma. S emin a erecta, lata, basi arillo membranaceo lacero stipata. E m b r y o …. - Frutex boreali-americanus, humilis, sempervirens, ramosissimus; foliis opposilis, approximatis, integerrimis $v$, remote serratis, floribus axillaribus, subsolitariis, minutis.

Oreophila Nuttall ex Torrey et A. Gray Flora of North.Amer. I. 258. P a $\mathrm{c}$ h y $s i \mathrm{im} \mathrm{a}$ Rafinesq. in Monthl. Magaz. 1818. ilex myrsinites Pursh. My ginda integrifolia DC. Hooker Flor. Bor, Amer, t. $4 t$.

\section{GENERA DUBIA.}

5691. Carpodetus FORST. Cal y x tobo turbinato, com ovario connato, limbi semisuperi, quinquepartiti laciniis linearibus, deciduis. Corollae petala 5, ealycis laciniis alterna et duplo longiora, aestivatione valvata. Stamina 5 , petalis alterna; fil am enta brevissima, sululata, an therae introrsae, biloculares, ovatae, longitadinaliter dehiscentes. Ovarinm semiinferum, quinqueloculare, $\mathrm{O} \mathbf{v}$ u a in loculis solitaria, erecta. Stylus simplex, staminibus longior; stigma depresso - capitatum. B a ec a coriacea, exsucea, calycis limbo coronata, quinquelocularis. S e mi na in loculis solitaria, erecta, angulata, rugosa. $\mathbf{E}$ mbryo $\because \cdots$ - Arbuscula Novae-Zeelandiae, decem-vigintipedalis; ramis foliosis, sparsis, divaricatis, foliorum delapsorum cicatricibus tuberculatis, foliis alternis, petiolatis, ovali-oblongis, acutis, glanduloso-serratis, superne puberulis, subtus glabris, discoloribus, reticulatis, racemis axillaribus terminalibusque, corymbosis.

Carpodetus Forster Char. gen. 17. Sprengel Pugill. I. 20. DC. Prodr. II. 29. Meisuer Gen, 71. (Ët) A. Cunningh, in Annal. of nat, hist, III, 247.

5692. Bhesa HAMILT. Calyx quinquefidns, laciniis recnrvis. Corolla e petala 5 , sub disci perigyni, carnesi, quinquelobi margine inserta, recurva. S tamina 5 , inter disei lobos inserta, petalis alterna. Ovarium disco subimmersnm, glohosum, basi glabrum, apice lanuginosum, uniloculare. Orula in loculis solitaria, e hasi erecta. Styli 2, filiformes, distantes; stig mata parva, capitata ..... - Frutices $v$. arbores, in India o rient ali crescentes; foliis alternis, exstipulatis, petiolatis, glabris, elliptico-oblongis, integerrimis, penninerviis, venis transversis conferte striatis, floribus parvis, spicatis, spicis axillaribus, simplicibus v. ramosis paniculam terminalem formantibus.

B hes a Hamilt. ex Arnott in Edinb. new philosoph. Journ. XVI. 315. - ? K a r rím i a Wallich Catalog. $n, 4334$. -36 et 7200. Meisner Gen. 67. (48.)

5693. Actemiton $B L U M$. F lores abortu dioici. C al y x liber, urcenlatus, quadridentatus. Corollae petala 4. Stamina 4, basi subeoalita, petalis slterna; a thera e subincumbentes. $O$ vari um uniloculare, quadriovulatum. Stig mat a 2 , sessilia. B a c ca globosa, mono-trisperma. S emi- n a basi hilo prominulo notata. E m b ry o exalbuminosus, erectus. - Frutex javanicus, sarmentosus; foliis oppositis, ovato-ellipticis, cuspidatis, integerrinis, glabris, aculeis axillaribus geminatis, patentibus, floribus racemosis, axillaribus et terminalibus, parvis.

A ete git o n Blume Bijdr. 1143. Meisner Gen. 69. (49.)

5694. Tralliana LOUR. C a $1 \mathrm{y} \times$ persistens, pentaphyllus, foliolis brevibus, rotundatis. C oro 11 a e petala 5 , oblonga, patentia, reflexa, calyce longiora. Discus magnus, erectus, decemcrenatus. Stam in a 5, receptaculo inserta; filamenta brevia, antherae biloculares, subrotundae. Ovarium liberum, subrotundum. StyI 8 staminibus aequalis; stig ma ..... Bacea subrotunda, bilocularis, disperma. S em in a dorso convexa, facie angulata. - Frutex cochinchinensis, scandens; foliis alternis, cordatis, acuminatis, crenatis, glabris, floribus lateralibus albovirescentibus, pedunculis dichotomis.

Tralli an a Loureiro Flor. cochinch, 194. DC. Prodr. 11. 11. Meisner Gen, (69, 49.)

5695. Lepta LOUR. Caly $\mathrm{x}$ minimus, quadripartitus, laciniis ovatis, patentibns. Corolla e petala 4, subtriangularia, snleata, inflexa, calyce duplo longiora. S tam in a 4 , receptaculi angulis inserta, petalis alterna; fil a m ent a subulata, a nthera e ovatae, biloculares. Ovarinm liberum, subrotundum, quadrisulcum. Stylus subnullus; stig ma obtusum. B a ce a quadriloba, lobis ovatis, monospermis, versus centrum leviter coalitis. S emin a subrotunda. - Arbuscula co. chinchinensis, ramosissima; folïs ternatis, lanceolatis, integerrimis, undulatis, glabris, racemis axillaribus compositis, parvis, floribus albie, minimis.

Le pta Loureiro Flor. cochinch, 103, DC. Prodr. II. 18. Meisuer Gen, 258.

5696. Croupla $A U B L$. C a l y x minimus, quinquedentatns. Corolla e petala 5 , diseo calycino extus inserta, lanceolata, apice intus in appendicem lamelliformem, propendentem producta. Stamin a 5, disco inserta, cum petalis alternantia; fil amenta brevissima, antherae tetragonae. Ovarium subrotundum. Stigmat a 5 , acnta. Bacea pisiformis, calyeis basi persistenti adnata, quinquestriata, unilocularis, di-pentasperma. Se min a subrotanda, dorso - convexa, facie plana, laevia ..... Arbores guianenses; foliis alternis, petiolatis, ovato-lanceolatis, acutis, integerrimis, subtriplinerviis, venosis, stipulis petiolaribus minimis, deciduis, pedunculis axillaribus, solitariis, umbellatim v. capitatim multifloris.

Gou p i a Aublet Guian. I.295. 2, 116. Jussieu Gen, 378. Lam, t. 217. DC. Prodr, II, 29. Meisner Gen, 71. (51.) G u pi a Jauae $S t$. Hit. Exposit. fam, $I I$. 267. G lo s s o p et a I u schreber Gen. n. 526.

569y. Perrottetia H.B.K. Cal y x quinquelobus, persistens. Coroll a e petala 5 , snb disco perigyno, orbiculari inserta, calycis laciniis alterna et multo majora, osata, acnta, aestivatione valvata, patentia, persistentia. S t a m in a 5, cum petalis inserta, iisdem alterna et breviora; filamenta subulata, persistentia, antherae introrsae, cordato-reniformes, biloculares, longitudinaliter dehiscentes. Ovarium liberum, depresse subglobosum, biloculare. 0 vula in laculis 2, e basi erecta, collateralia. Stigma sessile, bilobum. Drup a baccata, subglobosa, dipyrena v. abortu monopyrena, pyrenis erustaceis, tumide 137 
Ienticularibns, costatis, membrana reticulata tectis, monospermis. Sem en .... - Frutex (?) peruanus, inermis; foliis alternis, simplicibus, integerrimis, membranaceis, epunctatis, stipulis petiolaribus geminis, subfalcatis, paniculis axillaribus bracteatis, floribus minutissimis, sessilibus, fasciculato-congestis, atropurpureis.

Perrottetia Kunth in Humb. et Bonpl, Nov. gen.et sp. FI1. 73. t. 629. Meisner Gen. 67. (48.)

5B98. Aluatea $R U I Z$ et PAV. Calyx coloratus, coriacens, campanulatus, pentagonus, quinquefidus, laciniis ovatis, acntis. Corolla nulla. Stamina 5 , receptaculo inserta, calycis laciniis alterna; filamenta brevissima, anthera e cordatae, erectae. Ovarium sessile, obcordatum, biloculare. Stylus hrevis, simplex; stigma obtusum. Cap s u la obcordata, bilocularis, loculicide bivalvis, valvis medio septiferis. Se mina plnrima, dissepimento ntrinque perpendiculariter inserta, biseriatim superposita, margine membranaceo cincta, - Arbor peruana; ramis quaternatim verticillatis, erectis, purpurascentibus, foliis oppositis, breve petiolatis, integerrimis, obovatis $v$. oblongis, coriaceis, supra nitidis; parum venosis, corynibo terminali multifloro, floribus lutescenitibus.

A lzatea Ruiz et Pavon Prodr. 40, t. 7 . Flor. peruv. III. 20. t. 241. DC. Prodr. II. 10. Meisner Gen, 68. (49.) (A|ziniana Dietrich Gart. Lexic.)

\section{GENUS CELASTRINEIS AFFINE.}

5699. Dulongha H. B. K. C al y $\mathrm{x}$ tubo cum ovario connato, limbo supero, quinquedentato. C orolla petala 5, sub margine disci epigyni, orbiculati inserta, calycis dentibus alterna, ovata, aestivatione valvata, patentissima, persistentia. Stamina 5 , cum petalis inserta, iistem alterna et breviora; filam enta subulata, antherae introrsae, biloculares, subgloboso-didymae, longitudinaliter dehiscentes. Ovari um infernm, incomplete biluculare. O v u la $10-12$, semiseptorum marginibus utrinque inserta, reniformia. .... Stigma ta 2, sessilia, acutiuscula, recurvatopatula, cum septis alterna. B a c $\mathrm{c}$ a globosa, calycis limbo petalisque coronata, incomplete bilocularis, tetra-hexasperma. Se m in a subreniformielliptica, tuberculata, - Arbor $v$. frutex, in Peru$v i a$ crescens; folitis alternis, petiolatis, lanceolatooblongis, acuminatis, basi angustatis, apicem versus serratis, penninerviis, reticulato-venosis, membranaceis, glabris, supra versus apicem floriferis, racemo e nervo medio enato, sessili, abbreviato, bi. partito v. dichotome quadrifido, floribus pedicellatis, minutis, albis.

Dulongia Kunth in Humb. ot Bonpl. Nov. gen, et sp. NII, 76, t, 683. Meisner Gen, 67. (48.) P h y 11 o in o m a Willd. Msc. ex Römer et Schult. Syst. DI, 210.

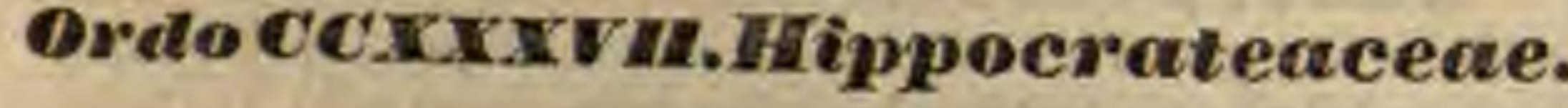

HIPPOCRA TICEAE Jussien in Annal. Mrus. XVIII. 483. R. Brown in Tuekey Congo, 187. HIPPOCRATEACEAE Kunth in Humb. et Bonpl. Nov. gen. ot sp. V, 136. DC. Prodr. 1 . 567. Bartling Ord. nat. 380 , Liudley Introduct. edit. II. p. 120. Meisuer Gen, 56. (40.)

Arbesculae v. protices, interdum ramis cirrhorum more contortis scandentes. Folia opposita, petiolata, simplicia, integra, integerrima v. serrulata, coriacea, petiolis basi articulatis. Stipulae petiolares, parvae, caducae.

Flores hermaphroditi, regulares, parvi, indecori, saepius virescenti-albidi, in racemos, corymbos v. paniculas dichotomas, axillares dispositi, interdum rhachi florali contracta umbellati v. subfasciculati, pedunculis pedicellisque basi bibracleatis.

Calyx liber, persistens, parvús, quinquepartitus, laciniis per aestivationem imbricatis. Torus a calyce liber, disciformis, subintegerrimus, inter petala et ovarium expansus.

Conollae petala 5, calycis laciniis alterna et majora, inter eadem et disci basim inserta, lata basi sessilia, aequalia, aestivatione imbricata, sub anthesi patentia.

Stamiva 3, disco intus, inter ejusdem marginem et ovarium v. prope apicem inserta, in alabastro erecta. Fil a m e n ta complanata, basi dilatata, apice saepe extrorsum flexa. An therae loculis nunc apici filamenti impositis, transversim contiguis, septo demum obliterato pseudo-uniloculares, apice transversim dehiscentes, nunc loeulis filamento parum super eosdem prominulo utrinque appositis et adnatis, longitudinaliter dehiscentibus, perfecte biloculares.

Ovanom disco plus minus immersum, liberum, triloculare. $O \mathrm{vula}$ in loculis definita $\mathrm{v}$. indefinita, angulo centrali uni-bi-triseriatim paullo supra basim v. medio peltatim inserta, anatropa v. semianatropa, micropyle infera. Styli breves, in unicum coaliti. Stigma terminale, simplex v, obsolete trilobum.

Fructes nunc capsularis, e carpidiis tribus v. abortu paucioribus, basi tantum cohaerentibus, a latere compressis, bivalvibus, nunc baccatus, indehiscens, abortu saepe unilocularis, monospermus.

Semra in loculis pauca v. abortu solitaria, in capsularibus oblonga, compressa, basi in alam producta, in baccatis ovoidea v. globosa, aptera, saepe pulpa mucilaginosa obvoluta, tes ta

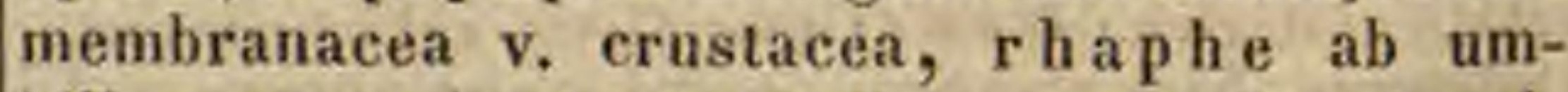
bilico, prope basim laterali v. ventrali, ad apicem seminis producta, endopleura tenuissima, rarius spongioso-incrassata. A I b u men nullum.

Euвryo rectus, subglobosus v. compressus. Cotyledones magnae, carnosae, saepe coalitae. R a dicula brevissima, infera.

Hippocrateace a emnes tropicae, plurimae in Novo continente gignuntur, pauciores gerontogeae, per Asiam et Africam pari fere numero distributae.

Ordo olim Acerineis conjunctus, Celastrineis proxime affinis, mediantibus Elaeodendro et Ptelidio, generibus albumine parcissimo dona- 
tis, staminibus tribus in calyce et corolla pentamera distinctissimus.

Lacepedeam calycis segmentis inaequalibus, petalis unguiculatis, staminibus quinque et stylo tripartito a reliquis generibus diversam, ad calcem ordinis posuimus.

Specierum nonnullarum pericarpium, testa, ipsae imo colyledones, filis copiosissimis spiralibus, nt in Casuarina et Collomia scatent.

Tontelearum plurium baccae edules, sapidae. Hippocrateae comosae semina oleosa.

ธว๑0. Hippocratea LINN. C a 1 y $x$ quinquepartitus. Curolla e petala 5 , ad basim disci inter calycem et ovarinm expansi extus inserta, hasi lata, aequalia, patentia. St amina 3 , disco intus prope basim $v$. marginem inserta; $f i$ la men ta complanata, basi dilatata, libera, apice extrorsum flexa, a $i$ h erae terminales, uniloculares, apice transversim dehiscentes. Ovarium disco plas minus imtuersum, triloculare. O v 1 a in loculis 2-6, angulo centrali biseriatim inserta, adscendentia. Stylus brevis; stig mat a 8 , coalita, Ca p 8 u 1 a e 8 v, abortu panciores, basi cohaerentes, coriaceae, compressae, uniloculares, angulo centrali dehiscentes, bivalves, valvis carinatis. $\mathrm{Se}$ min a in loculis pauca, basi affixa, inferne alata, oblonga, conpressa, testa membranacea, rhaphe ab umbilico ad a picem seminis prodacta. E $\mathrm{m}$ b r yo exalbuminosus, in apice seminis situs, compressus; cotyledonibus magnis, complanatis, coadunatis, radicula brevissima, infera. - Arbores $v$. frutices, ramis contortis scandentes, in $A s i a, A f r i$ ca et America tropica crescentes; foliis oppositis, petiolatis, integerrimis $v$. serratis, stipulis caducissimis, petiolis basi articulatis, floribus in paniculas axillares, dichotomas dispositis, parvis, indecoris, ramulis pedicellisque basi bracteis geminis suffultis.

H ip poeratea Linn. Gen, $n$. 54, Lam, $t$, 28. Ruiz et Pavon Flor, peruv, t. 47. $f$. a. Rudge Guian, t. 8. 9. Roxburgh Plant. Corom, t. 130, 205. DC. Prodr. 1. 567. Tur. pin Atlas IV. t..162. Cambessed, in St. Hilaire Flor. Brasil. $I I$, 102. Guillemin et Perrot. Flor. seneg. $I$, 111, $t, 25$. 26. Wight et Arsott Prodr. I. 103. Co a Plumier Gen, 8, t. 35. B ejuco Läilling 1t. 404. Daphnikon PohI in Flora 1825. p. 183, Per e $8 \mathrm{k}$ i a Flor. Flumin. $I$. t. 81.

5 ร01. Tontelea $A U B L$. Caly $x$ quinquepartitus, Coroll a e petala 5, ad basim disci inter calycem et ovarium expansi extus inserta, basi lata, aequalia, patentia. Sta $\mathrm{m}$ in a 3 , disco intus prope basim inserta; fil a m ent a complanata, lihera, apice extrorsum deflexa, a $n t h$ er a e terminales, uniloculares, apice transversim dehiscentes. Ovarin $m$ disco plus minns immersum, triluculare. 0 v $u l a$ in loculis 2_ 10, angulo centrali inserta, bitriseriata, adscendentia? Styl us brevis v. subnul lus; stig ma terminale, obsolete trilobum. Fruct us carnosus, globnsus, bi-trilncularis. S e mina in loculis abortn solitaria, ovoidea, mucilagine in voluta ..... - Arbores parvae, $v$. frutices interdum scandentes, in America tropica indigeni; foliis oppositis, breve petiolatis, integerrimis v, serratis, petiolis basi articulatis, deciduis, floribus axillaribus dichotome paniculatis, v. panicularum rhachi abortiva umbellatis, ramulis pedicellisque basi bracteis geminis suffultis.

Tontel e a Aublet Guian. I. 31. t, 10. Lam. t. 26. Tousella Sehreber Gen. n, 74. Meisner Gen. 36. (40.) Sicelfum P. Brown ex Poiret Supplem, $V, 146$. A n tho. don Ruiz et Pavon Flor, peruv, I. 45, t. 74. f. 2. Kunth in Humb. et Bonpl. Nov. gen, et sp, $V, 140, t$. 443. A nthodis cus Martius in Schulles Mant. I. 253, $\mathrm{S}$ a I a ei a Cambessedin St, Hilaire Flor. Brasil. II, 104. non Linn. $R$ addis i a Leaudro de Sacrament, in Münchner Denk. schrift. VIT, 249. t. 15. Meisner Gen. 56. (40.) Cle ci a Flor. Flum. $1, \ell, 73,74$. S a pura.Brasil.

ธซ๑ะ. Salacia LINN. Calyx quinquepartitas. Co rolla e petala 5, ad basim disci inter calycem et ovarium expansi extus inserta, basi lata, aequalia, patentia. Stamina 3 , disco intus prope basim inserta; fil am e nta complanata, libera, a n t h e r a e extrorsae, biloculares, bilobae, loculis adnatis, longitudinaliter dehiscentibns. Ova $r$ in $m$ disco plus minns immersum, triloculare. $O_{v} u l a$ in loculis $2 \mathrm{v}$. plura, angulo centrali inserta, uniseriata, peltatim aflixa. Styl us brevis; stigma terminale, obsolete trilobum. Fructus carnosus, indehiscens, abortu sacpe unilocalaris, monospermus. S em en subglobosum, pulpa mucilaginosa involutum, testa crustacea. E m. bryonis exalbuminusi cotyledones crassae, coalitae; radic a la brevissima, infera. - Arbusculae $v$, frutices, in Asia et Africa tropica, rarissime in $B$ rasilia crescentes; foliis oppositis, petiolatis, integerrimis $v$. serrulatis, petiolis basi articulatis, stipulis deciduis, floribus axillaribus corymbosis $v$. dichotome paniculatis, interdum rhacheos primariae contractione subumbellatis, ramulis pedicellisque basi bibracteatis.

Sal a ela Linn. Mant. 293, Guillemin et Perrott. Flor. seneg. T. 113, t. 27. Wallich Plant. As, $t, 278$. Wight in Hooker Bot. Miscell. Suppl. t. 36. Arnott Prodr. I. 104. uon Cambessed. C al y pso Thonars Hist. Veg. Afr. austr. I. 29. $t, 6$ Cambessed, in St, Hilaire Flor. Brasil. II. 110 . t. 104. (quond situm radiculae errouta) Johni a Roxburgh Flor, ind, edit, Wallich I. 172

\section{GENUS HIPPOCRATEACEIS AFFINE.}

5รD3. Hacepedlea H.B.K. C a ly $\mathrm{x}$ quinquepartitus, laciniis cllipticis, concavis, duabus exterioribus paullo brevioribus. Co ro 1 a e petala 5 , inter calycem et diseum hypogynum annularem, undulato-decemlolum inserta, brevissime ungniculata, obovato-oblonga, vix calyce longiora. Stamin a 5 , ad basim disci extus inserta; filam enta lineari-subulata, libera, a $\mathbf{n}$ th erae introrsae, biIoculares, ovato-ellipticae, obtusae, basi bifidae, dorso affixae, erectae, longitudinaliter dehiseentes. Ovari um sessile, ovato-conicum, decemsuleatum, triloculare. Ovula in loculis 8 , angulo centrali biseriatim inserta. St ylu s erectus, trisuleatus, demum a basi ad apicem tripartibilis, lobis apice cohaerentibus; stigma obsolete trilobnm. B a c c a elliptica, a pice tricuspidata, trilocularis, loculis duobus saepissime efuetis. Se m in a in toculis 2-3, reniformia......-Arbor mexicana; folits oppositis, breve petiolatis, serrulatis, stipulis peliolaribus geminis, paniculae terminalis ramosae ramis ramulisque oppositis, bracteatis, floribus pedicellatis, albis, suaveolentibus.

L a e eped e a Kunth in Humb. et Bonpl. Nov. gen. et

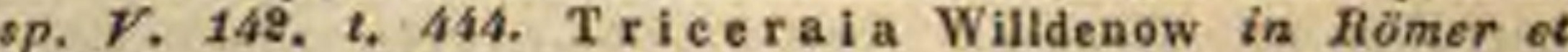
Schult. Syst. IV. 803.

\section{Ordo CCXXXVIII. Micineae.}

RHAMNORUM genera Jussieu Gen, 376. AQUTPOLIACEAE DC, Theorie elem. ed. I. p, 217. Bartling Ord. nat. 376. Lindley Introduct, edit. II. p. 298, exel, gen. pl. Meisner Gen. 252, (160.) CELASTRINEARUM tribus III. DC. Prodr. II. 11. excl. gen. ILICINEAE Brougniart Annal. ac. nat. X. 329. 
Arborgs v. frutices sempervirentes, ra- olim fructu cognito longius fortassis remomulis plerumque tetragonis. Folia alterna v. vendum.

opposita, petiolata, simplicia, saepissime plus minus coriacea, glabra, nitida, penninervia, integerrima v. aculeato-dentata. S $\mathrm{t}$ i p u $\mathrm{I}$ a $\mathrm{e}$ nullae.

Flones hermaphroditi v. abortu unisexuales, regulares, in axillis foliorum solitarii v. fasciculati, pedunculis simplicibus v. interdum dichotome cymosis parvi, albidi v. virescentes.

Calyx parvus, quadri-sexfidus v. partitus, persistens, laciniis obtusis, aestivatione imbricatis.

Corolla hypogyna, saepissime subgamopetala, petalis cum calycis laciniis alternantibus, basi coalitis v. rarius omnino distinctis, aestivatione imbricatis, sub anthesi patentibus v. erecto-patulis, deciduis.

Stamina petalis numero aequalia et alterna, eorundem bases connectentia v. rarius distincte hypogyna. Filamenta erecta, filiformia $\mathbf{v}$. subulata, petalis breviora. Antherae introrsae, biloculares, loculis adnatis, longitudinaliter dehiscentibus.

Ovarium sessile, carnosum, truncato-subglobosum, bi-sex-octo v. interdum pluriloculare. Ovula in loculis solitaria, ex apice anguli centralis pendula, saepissime funiculo in cupulam brevem expanso excepta, anatropa. Stigma subsessile, lobatum, lobis loculorum numero.

Drupa baccata, di-octo-pleiopyrena, pyrenis lignosis v. osseis, saepe fibrosis, indehiscentibus, monospermis.

Skmen inversum, pyrenae cavitati conforme, inversum, testa membranacea, rhaphe dorsali filiformi, umbilico apicem loculi spectante, nudo v. funiculo cupulaeformi tecto. Alb ume'n carnosum, copiosum.

EмвRу0 in albuminis apice carpico orthotropus, minimus v. vix seminis triente longior, subcylindricus, v. globosus, rarius foliaceus; $\mathrm{co-}$ tyled onibus obtusissimis, crassis, v. orbiculatis, planis, $\mathrm{r}$ a $\mathrm{d}$ i c a 1 a umbilico proxima, supera.

Ordo diu cum Celastrineis confusus, a quibus disci perigyni in legitimis generibus defectu constanti, corolla hypogyna, saepius gamopetala, ovulis ex apice loculorum pendulis, nec e basi erectis v, adscendentibus, embryone denique minuto-inverso distinguitur, pluribus notis ad Ebenaceas, quibus fortassis olim erit approximandus, accedere videtur.

Species per regiones temperatas et calidiores hemisphaerae borealis frequentius, quam in hemisphaerae australis regionibus tropieis subtropieisque, obviae.

Genera plurima dubia. Rhaptostylum, genus americanum, staminibus denis anomalum,

5r04. Cassine LINN. Flores hermaphroditi v. polygami. Calyx minimus, quinquepartitus. Corolla e petala 5, annulo hypogyno inserta, calycis laciniis alterna et multo majora, patentia, Stamina 5, cum petalis inserta, iisdem alterna et subaequilonga, patentia; f $\mathrm{il}$ a me n t a subulata, antherae introrsae, biloculares, subgloboso-didymae, longitudinaliter dehiscentes. Ova ri n m sessile, triloculare. Oval a in loculis solitaria, ex apice anguli centralis pendula, anatropa. Stig m a sessile, trilobum, lobis acutis. D r a p a exsucea, putamine erustaceo, triloculari, loculis monospermis, Semina inversa, subtriquetra, testa coriacea. $\mathbf{E} \mathbf{m b} \mathbf{r} \mathbf{y}$ in apice albuminis carnosi minutus; cotyle donibus planis, radicula supera-Frutices capenses, ramulis tetragonis; foliis oppositis, breve petiolatis, coriaceis, nitidis, integerrimis $v$. serratis, pedunculis axillaribus, cymoso-multifloris, folio brevioribus, floribus parvis, albidis.

C a s s ine Linn. Gen. n, 371. Lam. t. 130. Gärtner II, 72. t. 92, DC. Prodr. II, 11. Meisuer Gen, 258. M a u roe ui a Miller Diet.

5รB5. Hex LINN. Flo res hermaphroditi v. rarius polygami. Caly $\mathrm{x}$ parvus, urceolatus, quadridentatus, rarius quinque - sexdentatus, persistens. Corolla hypogyna, rotata, quadripartita, rarius quinque - sexpartita, laciniis ubtusis, aestivatione imbricatis. St amina imae corollae inserta, ejusdem laciniis numero aequalia et alterna; fil a ment a filiformia, a $n$ the $r$ a e introrsae, biluculares, longitudinaliter dehiscentes. O va ri u m sessile, quadriloculare. Ovala in loculis solitaria v. interdum gemina, collateralia, ex apice anguli centralis pendula, anatropa. Stig ma $t$ a 4 , sessilia, distineta v. coalita. Drupa baccata, sulghlobosa, stigmatibus coronata, tetrapyrena, pyrenis osseis, venosis, monospermis. Se m in a inversa, subtriquetra, testa tenuissime membranacea. $\mathrm{E}$ mb r yo in apice albuminis carnosi, sulco longitudinali bipartiti minimus, subglobosus, bilobus; $r$ adicula supera. - Arbusculae $v$. frutices, in America tropica et boreali, in Asia calidiore et in insulis Canariis obviae, una species etiam in Europa media et boreali-occidentali indigena; foliis alternis, coriaceis, crenatis $v$. spinoso-dentatis, pedunculis axillaribus, uni-multijloris, bracteatis, floribus albis.

Hex Linn. Gon, $n, 172$, Schkuhr $t$. 28, E, B. $t .496$. Flor. dan. $t$. s08. Jacq. Ie. rar, $t$. 310 . Collect. $V$. $t .2$. f. 2. Willd. Hort. Berolin. I. t. 31. Bat. Mag, t. 2043, DC. Prodr. II. 13. Kanth in Humb. et Bonpl. Nov. gen. ot sp. VII, 69, St, Hilaire Plant. ws, XLI. Hooker Ic. 2. 139. 199. Webb et Berthel. Flor. Canar. t. 69. Meisner Gen. 258. A q u if o li um Turuefort Inst. 371. Gärtner II. 72. $t$. 92. Palto ria Rulz et Pavon Flor. Peruv. I. 54. $t .84 . f .6$. M a coucou a Aubl. Guian, $I$. 88. $t$. 34. La b a 1 a Seopoli Introduct. $n$, 863. Burglaria Weadl. $\mathrm{Chomelia}$ Flor. Flum. $I, t, 106$.

5706. Prinos LINN. Flores hermaphroditi v. saepius polygami. C a ly $\mathrm{x}$ parvus, urceolatus, quadri-sexdentatus, persistens. CorolI a hypogyna, rotata, quadri-sexfida, laciniis aestivatione imbricatis. S $\mathrm{tam}$ in a imae corollae inserta, ejusdem laciniis numero aequalia et alterna; fil am enta filiformia, antherae introrsae, biloculares, longitudinaliter dehiseentes. $0 \mathrm{v}$ ari um sessile, sex-octoloculare. O v u I a in loculis solitaria, ex angali centralis apice pendula, ana. 
tropa. Stigmata $6-8$, sessilia, distincta v. coalita. D rup a baccata, subglobosa, stigmatibus coronata, hexa-octopyrena, pyrenis osseis, monospermis. S e min a inversa, testa tenui, membranacea, E mbryo in apice albuminis carnosi minimus; radic ala supera. - Frutices in Amer $i$ ca boreali obvii, in Antillis et in Asiacalidio re rari; foliis alternis, petiolatis, serratis $v$. rarius integerrimis, deciduis $v$. persistentibus, pe. dunculis axillaribus, masculis et hermaphroditis saepius multifloris, femineis unifloris.

Príuos Lian. Gen. n. 461. Swartz Flor, Ind, occid. 622. Duhamel Arbr. I. t. 23. DC. Prodr. IT. 16. Hooker ad Beechey t. 36. Wallich Plant. As, rar. t. 261. Meisner Gen, 252. A egería Adanson Fam. II. 166. Winterliz Mouch Method. 74.

5\%0\%. Nemopanthes RAF. FIores dioiei v, polygami. Caly $x$ minimus, annularis, integerrimus. Corolla e petala 5 , hypogyna, oblongu-linearia, reflexa. Sta mina 5 , cum petalis inserta, iisdem alterna et paullo breviora; fil amenta subulata, antherae introrsae, biloculares, subglobosae, Iongitudinaliter dehiscentes. Ovarium sessile, tri-quadrilobum, tri -quadriloculare. $O$ vula in loculis solitaria, ex apice anguli centralis pendula, anatropa. S $\mathrm{t}$ i $\mathrm{g} \mathrm{m}$ a $\mathrm{t}$ a $3-4$, sessilia. Ba ce a subglobosa, tri-quadrilocularis. Semina...... Frutex canadensis, humilis, ramosus; foliis alternis, oblongis, breve petiolatis, coriaceis, penninerviis, integerrimis, glaberrimis, pedunculis axillaribus, solitariis, unifloris, strictis, jiliformibus, folio paullo brevioribus, floribus albidovirescentibus, baccis rubris.

Nemopanthes Rafinesque in Journ. Phys, LXXXIX. 96. DC. Plant. rar. jard. Genev. 8. t. 3, Prodr. II. 17. Meisner Gen, 252. Nultallia DC. Rapp, jard. Genev. IV.27. Il ex ean a dens is Michaux Flor. Bor. Amer, 1.49 .

5\%0S. Byronia $E N D L$. Flores hermaphroditi, Calyx parvas, tri-quadripartitns, persistens. Corolla hypogyna, subcampanulata, sex-ortofida, lobis obtusis, erecto-patentibus. Stam in a imae corollae inserta, ejusdem lobis numero aequalia et alterna, brevissima ; fi la ment a subulata, antherae introrsae, biloculares, subglobosae, didymae, longitudinaliter dehiscentes. O v a ri u m sessile, globesum, suleato-costatum, duodecim-sedecimloculare. $O \mathrm{v}$ ul a in loculis snlitaria, ex apice anguli centralis pendula, anatropa. Stig ma sessile, late discoideum, centro umbilicatum, margine duodecim-sedecimlobum. Fructus...... - Arbuseula sandwicensis; ramis angulatis, foliis alternis, petiolatis, ovalibus, coriaceis, integerrimis, supra lucidis, cymis axillaribus paucifloris, petiolo longioribus, bracteis oppositis, membranaceis, ovalibus, floribus albis.

B y rouia Eudlicher in Annal. Wiener. Mus. I. 184. Meisuer Gen, 49, Polystigma Meisner Gen. 252. Ilex a n o ma a Hooker ad Beechey $111, t, 25$.

5899. Villaresia $R U I Z$. et $P A V$. Flores hermaphroditi. C a I y x quinquepartitus, persistens. Corolla e petala 5 , imo calyci inserta, ejusdem laciniis alterna, oblon ra, nervo medio intus prominulo instrueta, aestivatione imbricato - convolutiva. S $\mathrm{t}$ amina 5 , cam petalis inserta, iisdem alterna et paulto breviora; fil amenta complanato - subnlata, antherae introrsae, biluculares, cordatoreniformes, longitudinaliter dehiscentes. O v ar i u in sessile, conicum, semisepto parietali incomplete biloculare. $O \mathrm{vula} 2$, ex semisepti apice utrinque solitarie pendula, anatropa. St y l u \& bre- vis, crassus, sublateralis; stigma obliquum, ob. tusum. Drup a globosa, parce rarnosa, putamine lignoso, septo parietali superne latiore incomplete biloculato, abortu monospermo. Semen inversum, suleo ventrali semisepto immissum, testa tenuissime membranacea. E in b r y o in apice albuminis earnosi, testae processubus transversim rimulosi minimus, orthotropus; cotyledonibus orbiculatis, planis, radicula cylindrica, umbilico proxima, supera. - Arbor chilensis, sempervirens, procera; ramulis pubescentibus, foliis alter. nis, petiolatis, coriaceis, ellipticis, mucronatis, glaberrimis, supra nitidis, margine calloso integerrimis v. spinuloso denticulatis, floribus albis, parvis, in capitula racemoso - paniculata dispositis.

Villa resia Rulz et Pavon Flor. Peruv. IIT, 9. t, 231. Adr. Jussieu in Annal. sc. nat. XXV. 14. t. 3. f. 2. Meis. ner Gen. 252. (160.) Ci tro u ell a Don in Edinb. new philosoph. Journ, XIII. 243. C it r us chilensis Molina Chili ed. 2. p. 293. Gulllip atagua v. Guilli u Chilea. $\mathrm{Na}$ r a a jilla Hispan.

\section{GENERA DUBIA.}

5710. Jodina HOOK, et ARN. Calyx quinquefidus, aestivatione valvatus. Coroll a e petala 5, disco carnoso, calyeis tubum vestienti inserta, ealyeis laciniis alterna et paullo breviora, oblonga, carnosula. S ta min a 5, mediis calycis laciniis inserta; fil a m enta brevissima, antherae biloculares. Ovarium disco immersum, biloculare. Ovula in loculis solitaria v, interdum gemina, ex apice anguli centralis pendula. Stylus simplex; stigma concavum, bilobum ...... Frutex austro-americanus; folitis alternis, rhombeis, utroque angulo spinoso-mucronatis, apice nervo excurrente spinosis, coriaceis, supra nitidis, floribus axillaribus glomeratis, subsessilibus.

J o di n a Hooker et Arnott Bot, Miscell. III. 171, Meisner Gen, 68 (48.) 11 e $x$ r a s cifolia Lam.

57 11. Monetia HERIT. Caly $\mathrm{x}$ ventricoso-campanulatus, tri-quadrifidas. C orollae petala 4, linearia, calycis laciniis alterna, apice subreflexa. Sta mina 4 , receptaculo inserta, petalis alterna; fil amenta incrassata, an therae subsagittatae, incumbentes. Ovarium liberum ...... Stylus brevis ; stigma acutum. Fruct n s subearnosus, pisiformis, unilocularis, dispermus v. abortu monospermus. S e mina orbieularia, subcompressa. - Frutex capensis; ramis tetragonis, foliis oppositis, coriaceis, integerrimis, nitidis, ad axillas bispinosis, floribus axillaribus, sessilibus, parvis, virescentibus.

Mo net i Heritier Stirp. 1. 1. A z i m a Lam. 1ll. t. 807. Jussieu Gen. 425. Meisner Gen. 252. (260.)

\section{GENERA ILICINEIS AFFINIA.}

5ร12. Skimmia $T H U N B$. F lores polygami. C a l y $x$ quadrifidus, persistens. C o r o 11 a e petala 4, exunguiculata, decidua. Ma s c. S t a m in a 4, hypogyna, petalis alterna; a $\mathrm{n}$ th eris introrsis, dorso insertis. D i s $c$ a s carnosus, quadrilobus, ovarii rudimentum breviter apiculatum cingens. F e m. S t a m in u m rudimenta ovario breviora. Dis c us annularis, ovarii basim eingens. Ovarium liberum, quadriloculare. Ovula in loculis solitaria, pendula. Sty 1 u s cylindricus, simplex; tigma crassnm, quadrilobum. Dr u a carnosa, demum sicca, tetrapyrena, pyrenis cartilagineis, monospermis. S e m en pendulum, testa membranacea, tenui. Embryonis exalbuminosi cotyled on es cras- 
sae, planae, sibi impositae; radicula brevis, infera. - Frulex japonicus; foliis sempervirentibus, alternis, versus apices ramorum confertis, petiolatis, oblongis, coriaceis, integerrimis, pellucide glandu. loso-punctatis, supra viridibus, subtus pallidis, floribus terminalibus, dichotome paniculatis.

$\mathrm{Sk} \mathrm{immia}$ Thuaberg Flor, Japon, 4. 62. Jussieu Gen. 425. DC. Prodr. II. 18. Meisner Gen. 252. Z u се a riu i Not, msc. Dec, 1839. S i n. S a a vulgo Mija ma $\mathrm{Skimmi}$ Kämpfer Awoon, 779. Banks Ic. Kämpf, $t, \delta$.

5ร13. IShaptostyluar $H, B$. C a ly quinquefidus, laciniis ovatis, acutis, aequalibus. Corollae petala 5, hypogyna, calyris laciniis alterna et triplo longiora, sessilia, ovata, acuta, aestivatione valvata. St a mina 10, hypogyna, petalis breviora; fil a m enta complanato-linearia, apice subulata, basi inter se et rum petalis cohaerentia, alterna petalis opposita breviora, antherae introrsae, biluculares, transversim elliptisae, longitudinaliter dehiscentes. Ovarinm sessile, late conicum, triloculare. Ovula in loculis solitaria, ex apice cavitatis pendnla. Stigma sessile, trilobum. Fruetus..... Arbor novo-granatensis, inermis, glabra; ramis alternis, gracilibus, foliis alternis, petiolatis, oblongis, acuminatis, integerrimis, membranaceis, reticulato venosis, supra nitidis, subtus pallidioribus, stipulis nullis, floribus in axillis foliorum fasciculato-congestis, pe dunculatis, minutis, albis,

$\mathrm{R}$ haptost $\mathrm{ylu} \mathrm{m}$ Humb. et Bonpl. Plant, aequinoct. II. 139. t. 125. Nov, gen, et sp. VIT, 78, t, 621. Meisuer Gen. 67. (48.)

\section{* NitrariaceaE.}

5ร14. Nitrearia LINN. Calyx quinque fidns, minimus, subcarnosus, persistens. Corol1 a e petala 5, imo calyei inserta, oblonga, concava, aestivatione induplicatim valvata, apice obtuso cucullata. St a min a 15 , imo calyei inserta; fil a m enta subulata, a $n$ therae introrsae, biloculares, subrotundae, loculis subdiscretis rimula obliqua dehiscentibus. Ovarinm liberum, ses. sile, obovatum v oblongum, tri-v. sexloculare. Ovula in loculis solitaria, ex apice anguli centralis pendula, in funiculis longis, primum liberis, demum saepissime cum integnmento concrescentibus, anatropa. S $\mathbf{t}$ y $\mathbf{l}$ u 8 terminalis brevissimus, crassas; stigmata 3 v. 6, papillaeformia Drnpa baceata, ovato acuminata, pntamine osseo, abortı vnilocnlari, monospermo, extus scrobieulato, fapice valvis sex subulatis, alternis brevioribus dehiscens. S em en ovato-acuminatum, inversum, rhaphe fili: formi, longitudinali, intra epidermidem aridam friabilem libera, testa membranacea, $\mathbf{E}$ mb ryo exalbuminosus, orthotropus; cotyledonibus ellipticis, plano-convexis, radicula brevi, tereti, supera. - Frutices, in arvis salsis Asiae mediae, Africae mediterraneae et tropicae cres. centes, inermes $v$. ramis spinescentibus armati; foliis alternis, crassiusculis, saepe faseiculatis, oblongis $v$. obovatis, integerrimis $v$, apice tridentatis, floribus solitariis v. cymoso fasciculatis, albis, drupis nigris $v$. rubris, salsis.

Nitraria Linn. Gen. n. 609. Pallas Flor. Rose. $I$. t. 50. Lam. t. 403. Gärtaer 1. 279. t. 38, Desfont. Flor. atlant. I. 372. DC. Prodr III. 536.

\section{Ordo CCXXXIX. Rleammeae.}

RHAMNORUM genera Jassieu Gen. 376. RHAMNEAE R. Brown in Flinders Voy. $I T, 554$. DC. Prodr. II, 19.
Adr. Brongniart in Annal. sc. nat. $X, 320$. Bartling Ord. nat. 375. Meisner Gen. 70. (49.) Reisseck Synops. Rhamn, msc. 1860. KHAMNACEAE Lindley Introduct, edit. II. $p, 107$.

Arbongs, arbusculae, Frutegs v. suffruтress, interdum ramulorum apicibus cirrhosis scandentes, inermes, v. saepe ramulis spinescentibus v. stipulis in aculeos transformatis armati, rarissime нвввав. Folia simplicia, alterna v. subopposita, rarius opposita, penninervia v. triplinervia, integerrima v. serrata, petiolata, persistentia v. decidua, interdum minima, abortiva. Stipulae parvae, liberae, deciduae $v$. persistentes, in aculeos transformatae, interdum nullae.

Flores hermaphroditi, rarius abortu unisexuales, monoici, dioici v. polygami, regulares, parvi, saepissime virescentes, axillares, solitarii v. fasciculati, umbellati ant cymosi, rarius spieati, in spicas simplices v. interruptas glomeratim dispositi, rarius terminales, paniculati, v. glomerati aut capitati.

CaLxX gamophyllus, extus saepe villosus, tubo expanso v. sub campanulato, aut rarius tubuloso-cylindrico, libero $\mathbf{v}$. inferne aut rarius per totam fere longitudinem cum ovario v. cum ovarii basi connato, limbi quinquefidi aut partiti, rarissime quadrifidi laciniis ovato-triangularibus v. interdum subulatis, acutis, aestivatione valvatis.

Drscos perigynus, strato simplici aut duplici. Stratum simplex aut laminam continuam tubum laciniasque tegentem, aut saepius carinas versus apices incrassatas effornans. Strati duplicis interius $\mathbf{v}$, discus proprius ad faucem v. circa ovarium limitatum v. extensum, forma varium.

Coroular petala $4-5$, calycis fanci, rarissime tubo paullo demissius, saepissime ad marginem disci inserta, limbi laciniis numero aequalia et alterna, ísdem saepissime breviora, sessilia v. plerumque plus minus longe unguiculata, lamina rarius plana, integra v, emarginata, frequentissime concava, convoluta, aestivatione complicata.

Stamisa cum petalis inserta, iisdem dum adsunt opposita, calycis laciniis alterna et numero aequalia, saepissime petalis inclusa, nune exserta, erecta v. patentia. Filamenta cylindrica, rarius compressa, saepe brevissima, basi petalorum unguibus plerumque cohaerentia, inter se libera. A n th e r a e introrsae, dorso supra basim v. prope medium insertae, versatiles, nunc ovatae, biloculares, loculis oppositis, parallelis, basi subdivergentibus, longitudinaliter dehiscentibus, nunc reniformes v. fere orbiculares, loculis apice confluentibus uniloculares, rima transversa hippocrepica bivalves. Pollinis granula elliptica, sulco longitudinali exarata. 
Ovarium sessile, nunc liberum, disco saepissime immersum, nunc calycis tubo inferne adhaerens, nunc omnino eidem adnatum, e carpidiis tribus, rarius duobus, rarissime quatuor conflatum, carpidiorum marginibus in dissepimenta introflexis tri-, rarius bi- v. quadriloculare. Ov ula in loculis solitaria, rarissime bina, e basi erecta, sessilia $\mathbf{v}$. funiculo stipitiformi, interdum cupulato sustenta, anatropa. Styli loculorum numero, plus minus inter se connati; stigmata simplicia, coalita v. distincta.

Froctus liber, v. calyce adnato tunicatus, bi-trilocularis, rarissime abortu unilocularis, nunc drupaceus, indehiscens, pericarpio carnoso, spongioso v. sicco tenuissimo, in alas membranaceas interdum expanso, endocarpio duro, fibroso v. ligneo, putamen bi-triloculare, rarius pyrenas distinctas efformante, nunc capsularis, di-tricoccus, coccis crustaceis, apice secedentibus, rarissime basi solutis, ex axi persistente pendulis, maturitate angulo interiori inferne dehiscentibus.

Semina in loculis solitaria, rarissime bina, e basi erecta, sessilia, v. funiculo brevi, crasso, cupulaeformi, rarius in arillum crustaceum fragilen dilatato sustenta; tes ta laevissima, fibrosa, crustacea, membranacea v. coruea, umbilico basilari, rhaphe laterali $\mathbf{v}$. dorsali et tunc seminis sulco profundo excepta, ad chala $\mathrm{z}$ a m apicalem incrassatam producta, e $\mathrm{ndo-}$ pl e ura membranacea, libera v. testae adnata. A I b u m e n carnosum, parcum, flavescens, embryonis lateri applicitum, interdum nullum.

Eиввуо magnus, orthotropus, flavescens v. viridis; cotyledonibus planis, applicatis, plus minus carnosis, radicula brevi, infera.

Rhamneae per regiones temperatas et calidas totius orbis diffusae, maximo numero in regionibus subtropicis utriusque hemisphaerae generantur, in regionibus tropicis circulis inclusis rariores, a $40^{\circ} \mathrm{L}$, rarescentes, e climate frigido exules.

Ordinis diagnosis, ad genera staminibus cum calycis laciniis alternantibus, et ovarii loculis uniovulatis ovulisque erectis donata restricti, a proxime affinibus Celastrineis et Ilicineis perquam facilis.

Genera plura staminum situ Rhamneis evidenter affinia, sed ovulorum numero, et directione distinctissima, nec tamen aliis ordinibus accensenda, ad Rhamnearum calcem apte collocari posse videntur.

TRIEUS 1. PALIUREAE Reisseck Rhamn. msc. Fructus semiinferus, siccus, alatus, nuce lignosa foetus. - Frutices; foliis alternis, basi obliquis.
5\%15. Ventilago GARTN. Calyx patens, quinquefidus, laciniis ovatis, acutis, subcarnosis, medio carinatis, Co roll a e petala 5, disci carnosi, plani, tuberculosi, glabri, ealycis tubum vestientis margini inserta, ejusdem laciniis alterna et breviora, obovato - spathulata, unguiculata, convoluta, deflexa, Stam in a 5, cam petalis inserta, iisdem opposita et paullo longiora; filamenta cylindrica, petalorum unguibus basi adnata, anthera e introrsae, biloculares, connectivo exenrrente apieulatae, longitudinaliter dehiscentes. $0 \mathrm{v}$ ari u m disce immersum, liberum, subglobosum, biloculare. O v ula in loculis solitaria, e basi ereeta, anatropa. Stylus brevis, compressus, pilesus, apice bieornis; stigmata 2, conica. Nucula coriacea, sphaerica, ealyce demum adnato basi stipata, stylo in alam membranaceam oblongam transformatis superata, indehiscens, abortu unilocularis, uonosperma, $\mathrm{S}$ e $\mathrm{m}$ e $\mathrm{n}$ erectum, subglobosum, testa nembranacea. $\mathbf{E}$ m b r yo exalbuminosus, orthotropus; eotyledonibus crassis, carnosis, plano-convexis, radieula brevissima, infera. Frutices tropica Asiae incolentes, magni, scandentes; ramis rigidis, glabris, foliis alternis, breve petiolatis, oblongis, acuminatis, basi obliquis, remote serratis subintegerrimisque, floribus in racemos axillares, longissimos, solitarios, geminatos $v$. ternos Alispositis, rhachi pubescente, pedicellis simplicibus, brevibus, fusciculatis.

V entil a go Gärtuer $I$. 223, t. 49. Roxburgh Plant. Co. rom. I, 55. $t, 76$. Flor, indic, edit. Wallich, II, 413. DC. Prodr. II. 38. Brongniart in Annal, sc. nat. X. 358. t. 12. f. 4. Wight et Arnott Prodr. I. 164. Meisner Gen, 71. (51,) Punis vi a i a 1 is Rumph $A m b o i n ~ V . t .12$.

5\% 16. Palineus TOURNEF. Caly x tubo expanso, subplano, limbi quinquefidi laciniis patentibus, ovatis, acutis, intus vix earinatis. C orollae petala 5 , disci calycis tubum vestientis margini inserta, ejusdem laciniis alterna, obovata, subspathulata, unguiculata, convolnta, deflexa. Sta in in a 5, cum petalis inserta et fisdem opposita; fil a m e n ta cylindrica, basi compressa, petalorum unguibus adnata, a n the rae introrsae, biloculares, ovatae, loculis basi disjunetis, longitudinaliter dehiscentibus. Ovari um disco semiimmersum et basi cohaerens, snperne liberum, triloculare. Ovala in loculis solitaria, e basi erecta, anatropa. St y li 3 , conici, vix ab ovario distineti; stigmata oblonga. Fruetus siecus, spongiosocoriacens, hemisphaericus, soperne in discum magnum, orbicularem, submembranaceum expansus, putamine lignoso, triloculari. Se m in a in loculis solitaria, erecta, compressa, obovata ; tes t a crustacea, laevissima. E m b r yo intra albumen carnosum, tenne orthotropus; cotyledonibns maximis, subrotundis, planis, radicula brevi, conica, infera. - Frutices in regione mediterranea, Nepalia et China indigeni; foliis alternis, ovatis $v$. cordatis, trinerviis, crenulatis, aculeis stipularibus geminis, allero recto, allero recurvo.

Pali u r s Tournefort Inst. 387. Laur, $t$. 210. Gärtner I. 203. t. 43. Don in Bot, Mag. t. 2535. DC. Prodr. II. 28, Brongniart in Annal sc, nat. $X$. 353. t. 12. $f$. 1. Meisner Gen, 71. (51,) As pido e a p us Neeker Elem, n. 802. ? Rhamui sp. Linn. A ubletia Loureiro Flor, co. chinch. 348.

TRIBUS 1. FRANGULEAE Reisseck msc. Fructus superus v. seminferus, calycis cupula fultus, drupaceus v. capsularis, coccis indehiscentibus $v$. intus rima apertis. $-A r$ - 


bores $v$. frutices; foliis alternis, rarius op-
positis.

ธะ 1 ร. Zizyplnens TOURNEF, Caly $\mathrm{x}$ tubo expanso, vix concavo, limbi quinquefidi, patentis laciniis subtriangularibus, medio intus carinatis. Co rolI a e rarins defieientis petala 5, disci plani, ealycis tubum vestientis margini pentagono inserta, ejnsde:n laciniis alterna, obovato spathulata, ungniculata, convolnta, deflexa. Stamina 5 , cum petalis inserta, iisdem oprosita et subaequalia v. Iongiora; filamenta cylindrica, antherae introrsae, hiloculares, ovatae, loculis longitudinaliter dehiscentibns. Ovari um disen immersum et adnatum, bi-v. rarius triloculare. $O v \mathbf{v l a}$ in loculis solitaria, e basi erecta, anatropa. Styli $2-3$, conici, divergentes $v$, rarius coaliti; st ig mata parva, papillosa. Fr nctus carnosus, calyce persistente v. ejusdem tubo circumscisso suffultus, putamine lignoso, bi-tri- v. abortu uniloculari Semina in loculis solitaria, hine plana, inde convexa; t e s t a tenni, fragili, laevissima, fulva, esnica. E m b r y o exalbuminosus, v. albumine tenuissimo cinctus, orthotropus; cotyl edonibus magnis, crassis, adpressis, radicula brevi, infera. - Frutices in regionibus subtropicis et mediterraneis copiosius crescentes, inter tropicos America e parcius obvii; ramis virgatis, spinosis, foliis alternis, subdistichis, triplinerviis, stipulis nunc ambobus spinescentibus, altera recta, altera recurva, nunc una in spinam mutata, altera abortiva $v$. caduca, floribus in cymas paucifloras axillares, petiolo bre. viores $v$, vix longiores, saepissime subsessiles dispositis, fructu eduli, Lotophagis et Aethiopis grato.

$\mathrm{Z} \mid \mathrm{z}$ y p hus Tournef. Inst. 403. Gärtuer $r$. 202, $t$. 43. Lam. $t$. 185. Daham. Arbr. Edit, nov. IIT. $t, 16$, DC. Prodr. II. 19. Bronguiart in Annal. sc, nat. X. 35t. t. 13. f. 2. Guillem, et Perrot. Flor. seneg. t, 37. Meisner Gen, 71. (51.) R h a mni sp. Linn. Pallas Flor, ross. $I T$. $t .59$. Desfont. in Aet, Academ, Paris. 1788, t. 21. Cavanill, Ic, t. S0s, f. 1. Palluri s p. Vahi Eelog. III. t, 23.

5ซ18. Condalia $C A V$. C aly $\mathrm{x}$ tubo $\mathrm{ex}$ panso, subplano, limbi quinquefidi laciniis patentibns, ovatis, acutis, membranaceis, glaberrimis. Corolla nulla. Stamina 5 , disci plani, pentagoni angulis emarginatis inserta, calycis laciniis alterna et subaequilonga; fil a m e n t a cylindrica, erecta, antherae introrsae, biloculares, ovatae, loculis longitudinaliter dehiscentihns. O varium disco cinetum, liberum, ovatnm, biloculare. Ovula in loculis solitaria, e basi erecta, anatropa. Sty Ius cylindriens, simplex, elongatus; $8 \mathrm{tig}$ a trunc:atum, indivisum. Drupa ovata, putamine abortu nnilocnlari, monospermo. S e me n erectum, sulco destitutum, - Suffrutex chilensis, ramosissi. mus, glaberrimus; ramulis spinescentibus, foliis al. ternis, subsessilibus, ovato-oblongis, penninerviis, integerrimis, floribus axillaribus.

Co a da li a Cavanill. Anal, ciene. nat, I. 39, t, 4 . Ic. VI, 16, t, 325. DC. Prodr. II. 28. Brongniart in Annal. se. nat, $x, 355, t, 12, f, 3$. Meisner Gen. $71,(31$.

5\%19. Berehemia NECK. C a ly $\mathrm{x}$ tubo brevi, hemisphaerico, limbi quinquefidi laciniis acutis, erectis. Corollae petala 5 , disci annularis, calycis tubum explentis, plani v. margine interiore elevati limbo inserta, laciniis alterna, convoluta v. cucnllata, erecta. Stamina 5, cam petalis inserta, iisdem opposita et inclusa v. exserta ; fil a $m$ e $n t$ a cylindriea, an $t h$ era e introrsae, biloculares, ovatae, Joculis longitudinaliter dehiscentibus, Ovari nm disco semiimmersum, liberum, biloculare. Ovul a in loculis solitaria, e basi longe stipitata, anatropa. Fructus exsuccus v, vix earnosus, lignosus, oblongus, calycis tubo circumscisso suffultus, bilocularis, indehiscens. S em in a in loculis solitaria, e basi erecta, inferne attenuata, testa fibrosa, facie interiore periearpio arete adnata, nucleum minorem, e chalaza apicali suspensum includente. E mbryo exalbuminosus v. albumine tenuissimo einctus, orthotropus; cotyle donibus planis, applicitis, radicula brevissima, infera. - Frutices in America boreali cali diore, nec non in Asia tropica indigeni, ramosissimi. erecti $v$. subscandentes; foliis alternis, multinervïs, integerrimis, nervis obliquis, approximatis, subsimplicibus, floribus in axillis superioribus subumbellatis, et in paniculas terminales dispositis.

Berchemia Necker Elem, n. 800. DC. Prodr. 1I, 22. Brongoiart in Annal, sc, nat. X, 356, $t, 3, f$. 1 . Wight et Arnott Prodr. I. 163. Meisuer Gen. 71, (51.) Hook. ad Beechey t. 37. Wight Ic. t. 19. 0 e no p I e a Hedwig f. Gen. I. 151, 0 e noplia Sehultes $S y s t, V$. 332. R ham a s voI u bilis Lina. Jacq. Ic, rar, t. 336 . R h. flor ibundus Wallicb.

5\% 20. Sageretia BRONGN. Caly $\mathrm{x}$ tubo urceolato $v$, hemisphaerico, limbi quinquepartiti laciniis acutis, erectis, intus carinatis. C orolla e petala 5 , disei urceslaris, calycis tubum vestientis margine interiore elevati margini exteriori inserta, limbi laciniis alterna, obovata, unguiculata, convoluta v, cucullata, erecta. S t a m in a $5, c \mathrm{~cm}$ petalis inserta, iisdem opposita et inclnsa v. longiora; fi la m e nt a cylindrica, a $n t h$ er a e introrsae, biloculares, ovatae, longitudinaliter dehiscentes. Ovarium liberum, disen arete cinctum, triloculare. Ovula in loculis solitaria, e basi erecta, anatropa. Stylus brevis, crassus, trisulcatus; stig ma brevissime trilobum. Fructus.... Frutices in America tropica et bareali calidiore, nec non in India orienzali et $i m$ perio sinarum indigeni; ramis gracilibus, subvirgatis, ramulis saepe spinescentibus, foliis suboppositis, breve petiolatis, lanceolatis $v$. oblongis, penninerviis, serratis, floribus in spicas simplices $v$. ramosas, interruptas, rigidas, patentes, axillares $v$. terminales dispositis, parvis, solitariis v. glomeratis.

$\mathrm{S}$ я ge retia Brongniart in Annal, sc. nat. X. 359. $t .13$. f. 2. Meisner Gen. 71. (51.) R ha m ni 8 p. Micbaux. Kunth in Humb. et Bonpl. Nov. gen. et sp. t. 619. Z iz y phi s p. Wall.

รระ1. Hoventa THUNB. Calyx tubo expanso, planiusculo, limbi quinquepartiti laciniis subpatentibus, ovatis, acutis, trinerviis, intns subcarnosis, carinatis. Corolla e petala 4, disci carnosi tenuis, plani, calyeis tubum vestientis margini elevato, pilosn inserta, limbi laciniis alterna, unguieulata, apice ronvoluta, emarginata. Stam in a 5 , enm petalis inserta, fisdem opposita, breviura et involuta ; fil am ent a subulata, areuata, an therae intrursae, biloculares, ovatae, loeulis longitudinaliter dehiscentibus. O va rium liberum, diseo semiimmersum, pilosum, triloenlare. Ovula in loculis solitaria, e basi ereeta, anatropa. Sty lu s trifidns, lobis conniventibns; st igmata truncata. Fructus pednnculis carnosis, crassis insidens, sphaericus, triloenlaris, tricoceus, cocris crustaceis, monospermis. S e mina ..... Arbor mediocris, in Asia orientali temperata, a Nepalia ad Japoniam obvia; ramis numerosis, palentibus, ramulis subpubescentibus, foliis alternis, subdistichis, ovatis, acuminatis, basi subinaequalibus subcordatisve, trinerviis, serratis, 
glabris, foribus axillaribus terminalibusque cymosis, cymis dichotomis, supraaxillaribus, petiolo longioribus, pedunculis fructiferis esculentis, stpore dulci, Pyro simili, praeditis.

Hovenia Thunberg Flor. Japon, 101. Lam. $t, 131$. DC. Prodr. I. 40. Lindley in Rot. Rog. $t$. 501 . Wallieh in Roxburgh Flor, ind. 11 . 414. Brongniart in Annal. sc. nat. X. 367. $t$. 15. f. 2, Meisner Gon, 70. (50.) Sik u, vuigo Ken et Ken po konas Kimpfer Amoen, 809.

$5 \%$. ceolato, libero, limbi quadri-quinquefidi laciniis erectis v. patentibus, aentis, menlio intus carinatis. Corolla nulla, v, petala $4-5$, margini disci carnosi, calycis tubum vestientis inserta, limbi laciniis alterna et breviora, planiuscula, emarginata. Stamina $4-5$, summo diseo inter calyeis lacinias inserta, petalis dum adsunt opposita; fila$m$ enta brevissima, eylindrica, a $n t h$ er introrsae, biloculares, ovatae, loculis basi discretis, Iongitudinaliter dehiscentibus. Ova ri $\mathbf{m}$ liberum, tubo calycis brevius v. subaequale. Ovula in loenlis solitaria, e basi erecta, anatropa. Styli $3-4$, basi connati, superne plus minus liberi; stigmata obtusa, papillosa. Dru pa baccata, sphaerica, di-tetrapyrena, pyrenis osseis, indehiscentibus, monospermis. S e m in a erecta, testa laevi, nunc sulco dorsali profundo, rhaphen recipiente exsculpta, nnne compressa, rhaphe introrsum laterali. Embryo intra albumen carnosum, parcum orthotropus; cotyledo n ib as carnosis, planis v. margine recurvis, seminis sulcum amplectentibus, radicula brevissima, infera. - Frutices $v$, arbusculae, in temperatis extratropicis hemis phaerae borealis, et in America tropica indigenae; foliis alternis, bistipulatis, breve petiolatis, integerrimis $v$. dentatis, saepissime glabris, nunc perennantibus, coriaceis, penninerviis, nervis vage ramosis, nunc deciduis, nervis approximatis, parallelis, floribus axillaribus, racemosis v. cymosis, cymis in fasciculum contractis.

Rhamn us Jussieu Gen. 380. Lam. Dict, IV. 461. Gärtner II. 110. DC. Prodr. II. 23. Brongniart in Annal sc. nat, $X, 360$. Meisner Gon, 71 . (51.) $\mathrm{R}$ h a $\mathrm{m}$ a $\mathrm{i}$ s p. Linn. et Auet.

a. RHAMNUS. Bronga. l, c. Flores saepius dioici et quadrifidi, rarius quinquefidi. S e m in a dorso sulco profundo, rhaphen recipiente inseulpta. $\mathrm{B}$ mb r y o $\mathrm{n}$ is co. tyledones marginibus reeurvis, sulcum amplectentibus. - Folia in plerisque coriacea, perennantia, vage venosa, in nonnullis membranacea, lineata, nervosa.

a. Alaternus Tournof. Plares racemosi. Alater. n u s Tournef. Inst. 366. M a re ore II a Neeker Elem. n. 299. (Duhamel Arbr. edit. nov, III, $t, 14$, Heritier Sert, t, 5. Venten. Malmais. $t$. 34. Brongniart Op. cit, $t, 13, f, 3$, )

B. Cervispina Dillen. Flores faseiculati. Cer$v$ is p In a Dillen. Nov. gen. $t .8$, Mönch Method. 656. R hamuas Tonrnef. Inst. 366. Cardiole is Ra. finexq. Neogen. 1895. n. 2. (E. B, $t, 1699$. Jacq, Flor. austr, t. 53. Collect. II. t. 11. Herit. Sert, t, 9. Pat las Elor. Ross, II. t, 61, 62. Cavan. Ic, t, 181, 182 Duham. Arbr. edit. nov. III. t, 10. 13. Waldst, et Kitaib. Plant, rar. Hung. $t$, 255, Kunth in Humb. et Bonpl. Nov. gen, et sp. t. 616. 617. Brongn. Op. cit. t. 14. f. 4.)

b. Frangula Brongn. l. c. Flores saepissime hermaphroditi et quinquefidi, rarius quadrifidi, $S e$ m i a a compressa, umbilico denudato exserto, rhaphe laterali. $\mathbf{E}$ mb r y o n is cotyledones planae. - Folia membranacea, caduca, integerrima, lineata, nervis parallelis, ap. prosimatis.

Frangula Tournef. Inst. 383, Monnch Method. Suppl. 271. (Gärtner t. 106. Duham. Arbr. edit. Nov. III. t. 15. Heritier Sert. t. 8. Brobgniart Op. cit. t. 13. f. s. Hook. Fl, bor. Amer. t. 42.43.
5ระ3. Harvinskia ZUCCARIN, $\mathrm{C}$ a I y tubo urceolato, limbi quinquefidi laciniis ovatoacutis v. subulatis, intus earinatis, erectis. Corolla e petala 5, disci urceolati, ealycis tubum vestienlis, apophysibus 5 brevibus, filiformibos, laciniis oppositis et basi adnatis, apice liberis aneti, margini subelevato infra basin laciniaram inserta, iisdem al. terna et breviora, obcordata, complicata, undulatolacera, staminibus breviora. Sta m ina 5 , cum petalis inserta iisque opposita; filamenta filiformia, petalis involuta, a ntherae exsertae, infra dorsi medium affixae, oblongae, biloculares, loealis rima longitudinali latere apertis. Ovarinm liberum, subglobosum, biloculare, dissepimento per totam longitudinem medio interrupto. Ovui a in loculis bina, collateralia, e basi funiculo cupulaeformi erecta, apice oblique acuta $v$, incurva, anatropa. Drupa globusa, carnusa, calyce toto persistente stipata, styloque superata, putamine lignoso biloculari, loeulo altero dispermo, altero abortu monospermo, v. uniloculari, dispermo. Semina erecta, funieulo brevissimo sessilia, obovata, ra phe interna, elevata, carinata, testa membranacea, verrucosa, endoplenra tenuissima, adnata. Embryon is intra albumen carnosum orthotropi cotyled ones ovales, convexae, carnosae, $r$ a d i c a la infera, brevissima, obtusa. - Arbusculae et frutices m exicani; foliis suboppositis, inlegerrimis, parallele penninerviis, glanduloso-punctalis, rarius pictis, stipulis lanceolato-subulatis, membranaceis, floribus axillaribus, pedunculis simplicibus v. cymosis, drupis glandulosis.

Karwins kia Zuccarini in Nov. Stirp. Fascic. 1.349. c. 16. Meisner Gen. 71. (50.) R bamnus $\mathrm{H} \mathrm{umboldtia.}$ a u s Kunth in Humb. ot Bonpl. Nov. gen, et sp, $t, 618$.

5\%24. Seutia COMMERS. Calyx tnbo hemisphaerico $v$. urceolato, limhi quinquepartiti laciniis acutis. Corolla e petala 5, disci carnosi, calycis tubum vestientis margini exteriori inserta, ejusdem laciniis alterna, brevia, snbplana, unguiculata, emarginato - biloba, rarius galeata. S ta m ina 5 , cum petalis inserta, iisdem opposita et snbaequilonga fil am enta cylindrica, crassiuscula, antherae introrsae, biloculares, ovato-oblongae, margine longitudinaliter dehiscentes. O rarium basi ealycis adhaerens, disco cinctum, bitriloculare. Ov u l a in locnlis solitaria, e basi erecta, anatropa. Stylus simplex, subconicos; stigma bi-trilobum. Capsn la calyeis tuho circumscisso libero enpulata, bi-trilocularis, ditricocea, coccis indehiscentibus, monospermis. $\mathrm{Se-}$ men erectum, testa membranacea. Embryo exalbuminosus, orthotropus; coly led onibus planoconvexis, subearnosis, radicula brevissima, in fera. - Frutices borbonici, antillani et ma labarici; foliis alternis, per paria approximatis, suboppositis, integerrimis $v$. vix serrulatis, coriaceis, penninerviis, bistipulatis, stipulis minutis, caducis, spinis nullis $v$. in axillis foliorum inferiorum sterilium e pedunculis transformatis, petiolum subaequantibus, floribus axillaribus, in umbellulas simplices, paucifloras, petiolo vix longiores congestis.

$\mathrm{Sentia}$ Commers. msc. ex Brongniart in Annal. se. nat, $X$. 368. Meisner Gen. 70. (50.) S e ntis Commers, msc. Sar comphalns P. Browne Jam, 179. Rhamnte efr. c u m s e is s us Lion. fil. R h. fe r re us Vahl $S y m b, I I I, t, 38$. C e a n ot hi $\mathrm{s}$. Gärtner $t$, 106. fig. inf. $D C$,

5ร25. Nolten REICHENB, Caly $\mathrm{x}$ urceolatus, tubo basi obconica cum ovario eonnata, 8u138 
perne libero, limbi quinquepartiti laciniis ovatis, acutis, erectis. Corolla e petala 5 , disci carnosi, calycis tubum vestientis margini inserta, limbi laciniis alterna et breviora, sessilia, subrotnnda, cucullata. S ta min a cum petalis inserta, iisdem opposita et inclusa; filamenta brevissima, infle$x a$, a $t$ h er a magnae, introrsae, biloculares, Joculis longitudinaliter dehiscentibus. $O$ va rium inferum, triloculare. Ovnla in loculis solitaria, e basi erecta, anatropa. Stylas simplex, trigonus; st ig ma obsolete trilobum. Fructus sphaericus, inferus, calycis circumscissi cupula adnata basi involutus, siccus, indehiscens, trilocularis, tricoccus, coccis dorso ala tenuissima cristaeformi earinatis, crnstaceis. Se min a fnniculo brevi, stipitiformi snffulta, compressa, orbiculari-ovata, testa coriacea, crassa, laevissima. E mb ry o in albumine carnoso tenui orthotropus; cotyledonibas maximis, suborbiculatis, viridibus, radi $\boldsymbol{c}$ ul a cylindrica, brevi, infera. - Suffrutex glaberrimus, in Africa tropica et australi subtropica indige-

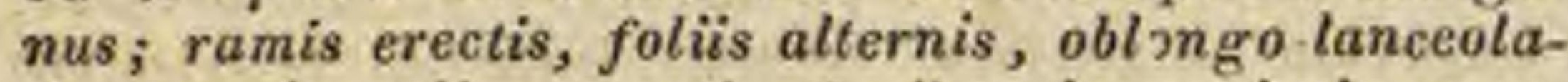
tis, penninerviis, serratis, floribus in paniculas paucifloras, axillares et terminales dispositis.

Nolte a Reichenb. Consp. n, 3800. Meisner Gen, 70. (50,) Vittmannia Wight et Arbott Prodr. I. 106. non slior. Wille metia Brongniart in Annal. so, nat, X, 370. t. 16. f. 1. Ceanothi sect. Sarcomphaloides DC. Prodr. IT. 32. Ceanothus africanus Linn. Pluknet Alw. $t$, 126. $f$. $x$, Seba Thouar, I. $t$. 22, $f$. 6 .

5ร26. Ceanothus LINN, $\mathrm{C}$ a 1 y $\mathrm{x}$ tubo subhemisphaerico, coneavo, limbi inembranacei, eolorati, quinquepartiti laciniis ovatis, acutis, valvatim conniventibus. Co rolla e petala 5, disci annularis, subpentagoni, spongiosi, mamillosi, calysis tabum vestientis margini inserta, limbi laciniis alterna, longe unguiculata, exserta, patentia, limbo cueullata. St a mina 5 , cum petalis inserta, iisdem oppusita et primum inclusa, dein exserta et erecta; filamenta filiformia, antherae introrsae, bilocnlares, ovatae, loculis longitudinali ter dehiscentibus, $O$ varin $m$ disco semiimmersum, globosum, tricostatum, triloculare. $0 \mathrm{vala}$ in Joculis solitaria, e basi erecta, anatropa. Stylus simplex, trifidus; stig mat a minima, papillaeformia. Cap s u la basi tnbo calycis circumscisso ad nato cincta, tricostata, trilocularis, trieocea, coccis crustaceis, bivalvibus, monospermis. S e mi n a erecta, funiculo brevissimo enpulaeformi suffulta, subtrigona, testa ernstacea, rhaphe introrsum laterali. E m b r y o intra albumen carnosum orthotropus; cotyledonibus maximis, planis, radie u la brevissima, infera. - Suffrutices borealia mericani, glabri $v$. pubescentes, rarius spinescentes; ramis erectis, foliis alternis, serratis, subtrinerviis, floribus in paniculas terminales compositis, $v$, in racemos axillares dispositis, laete coloratis, albis, flavis v. caeruleis.

C e an oth a s Linn. Gen. $n$, 267. exel, sp. pl. Miller Ic. t. 57, Gairtner t. $106 \mathrm{fig}$. sup. Bot. Reg, t. 291. Bint, Mag. t. 1479. Bat. Cab. t, to0. Kunth in Humb. et Bonpl. Nov. gen. et sp. VTt, $t$. 615. Brangniart in Amnal, sc, nat. X, 369. $t, 13$. f. 4. Hoaker Flor, Bor. Amer. t, 45 . Meisner Gen, 70. (50.) Torrey et A, Gray Flora of North.Amer, $I, 264$. C e a n th i sect. Eucsanoilous DC. Prodr. II. 3i. Borrestia Rafinesque in New.York Medic, Reposit, II. Hexad, V. 350.

5ร ร ร. Cormenema REISSEK. C a I y $\mathrm{x}$ tubo brevissimo, expanso, limbi quinquefidi laciniis ovatis, acutis, patentibus. Corolla nulla. Sta$m$ in a 5, margini disci subrotundi, ovarium tegentis, eirca basin laeiniarum limitati inserta; filamenta filiformia, antherae ovatae, bilocula- res? Ova rium fundo calyeis immersum, trilocnlare. Ovula in leculis solitaria? ...... Stylns brevis, simplex. Fructus sphaericus, tricostatus, calyce persistente, circumseisso, adnato ultra medium eupulatns, carnosus? trilocularis. S e mina ...... - Frutex brasiliensis; foliis alternis, ovato-lanceolatis, integris, penninerviis, nervis suboppositis, stipulis abortu solitariis, spinescentibus, foribus axillaribus, fasciculatis, pedunculis filiformibus, simplicibus.

Cormonema Reissek msc, Ca esia spinos a Flor. Flumin. III. $t$. 23. Character generis ex fcone citata desumitus.

5ซะ8. Colvobina L. C. RICH. Calyx tubo hemisphaerieo, plus minus expanso, limbi quinquefidi laciniis ovatis, acutis, snbpatentibus, medio intus carinatis. Coroll a e petala 5, disei carnosi, pentagoni, planiuscnli, calycis tubum replentis et ovario adhaerentis margini inserta, limbi laciniis alterna, obovata, unguiculata, convoluta. St amina cum petalis inserta, isdem opposita et longiora; filamenta filiformia, involuta, antherae exsertae, introrsae, biloculares, ovatae, loculis longitudinaliter dehiscentibus. O v в ri a m disco immersum et inferne eidem adhaerens, triloculare. Ovn la in loculis solitaria, e basi erecta, breviter pedieellata, anatropa. Sty I u s trifidus, lobis obtusis, intus stigmatosis. Cap s ula sphaerica, ealyeis tubo circumscisso, adnato semiinvoluta, trilocularis, tricocea, coceis crustaceis, intus dehiscentibus, apice bivalvibus, monospermis. S emina e funieulo brevi erecta, testa coriacea, laevissima, rhaphe introrsum laterali notata. $\mathbf{E} \mathbf{m}$ bryo a lateribus albuminis carnosi strato tenui cinctus, orthotropus; cotyledonibus planis, erassis, $r$ a dicula brevissina, infera. - Frutices, inter tropicos totius or bis, imprimis $A m e r i-$ c ae crescentes; foliis alternis, integerrimis v. crenulatis, penninerviis, nervis distantibus, reticulatis, glaberrimis v. saepius pubescentibus, interdum ferrugineo-villosis, floribus in cymas axillares, paucifloras, breves congestis $v$. fasciculatis, pedunculis simplicibus.

Colubrina L. C. Richard ex Brongniart in Annal. sc. nat. X. 368. t.15. f. 3. Meisner Gen, 7o. (50.) T a b a nthera Commerson msc. Ceanothi sp. Linn. Cam. t. 129. Cavanill. Ic. t. $440 . f .1$. Jacq, Hort. Vindob, t. 49. 50.

5ร29. Alliphitomia REISSEK, F los... Fructus globosns, calyeis circumseissi cupula adnata basi involutus, drupaceus, pericarpio prius carnoso, serius exsucco, farinaceo, abortu binuculatus, nuculis cocciformibus, dorso convexis, ventre subangulatis, angulis approximatis, carinatis, basi foramine ovali interne instructis, apice pungentibus, rima demum longitudinali ab apice ad dorsi medium apertis, superius bivalvibus, usseis, monospermis. S e m in a obovata, dorso ennvexiuseula, ventre leviter sulcata, arillata, arillo tenui, crustaceo, laevi, nitido, superius apcrto, desiliente, raphe interiori, arillo adnata, testa cornea, crassa, nitida, endopleura tenni, soluhili, fusca. E m h r yo intra albumen molle, granulosum orthotropus; cotyledonibus ovalibus, foliaceis, radicula brevi, infera, incerva. - Arbor a ustralasica, $60-80$ pedalis; folitis alternis, oblongis, integerrimis, subtus incanis, coriaceis, stipulis subulatis, villosis, fugacibus, floribus in ramulis subterminalibus paniculato-racemosis.

A Iphitonia Reissek msc. Colubrina exeelsa Feazl in Enum, pl. Hügol, 20 in adn. 
TIRIEUS III. COLLETIEAE Reissek msc. Fructus superus, calycis cupula fultus, siccus, apterus. - Frutices ramis spinescentibus foliisque decussatis, ramulis floriferis v. florum fasciculis infra spinas.

5ร3๑. Colletia COMMERS. $\mathrm{C}$ a $1 \mathrm{y} \mathrm{x}$ membranaceus, campanulatus v. tubulosus, limbi quinquefidi laciniis ovatis, suberectis, disco annulari, supra fundum tubi adnato, margine integro, involuto. Corolla nulla. Stamina 5, inter lacinias calycis, summo tubo, rarius demissius inserta; filamenta filiformia ad tubi fundum decurrentia, antherae reniformes, loculis apice confluentibus uniloculares, hippocrepicae, rima arcuata bivalves. O v a r i $\mathbf{~ m}$ liberum, glohosum, triloculare. Ovnla in loculis solitaria, e basi erecta, anatropa. S tylus filiformis, simplex, calycis tubum aequans; stig m a obsolete trilobum. Fructus siccus, sphaericus, calycis basi circumscissa, libera $v$, inferne vix adhaerente stipatus, trilocularis, tricocens, coccis crustaceis, secedentibus, bivalvibus, monospermis. S em ina erecta, ovata, testa crustacea, laevissima, raphe introrsum laterali. E m b ry o albuminis carnosi, flavi strato tenui tectus, orthotropus; cotyledonibus maximis, carnosis, planis, radicula brevissima, infera. - Suffrutices peruani et chilenses, ramosissimi, subaphylli; ramis decussatim oppositis, divaricatis, ramulis spinescentibus, interdum foliaceo-dilatatis, foliis nullis $v$. minutissimis, oppositis, integerrimis, floribus axillaribus fasciculatis $v$, infra spinarum basin sitis, nutantibus, albidis $v$, albido - roseis.

C olle ti a Commers, ex Jussieu Gen. 380. Lam. Ill. t, 129. Kunth in Humb. et Bonpl. Nov. gen.et sp. Vir. 58. DC. Prodr. II. 28. exel, sect. 2. Brongo. in Annal. so. nat.X.366.t.14. f. 1, Hooker Bot. Miscell, I. 151. t,43. 44. Bot. Mag, t.3644. Meisuer Gen, 70. (50.)

5ร31. Disearia $H O O K, \mathrm{C}$ a 1 y $\mathrm{x}$ tabo membranaceo, colorato, breviter cylindrico - campanulato, limbi quinque - rarius quadrifidi laciniis triangulari ovatis, patentibus, disco tubi fundo adnato, basin ovarii eingente, carnoso, pateriformi, margine libero, elevato vel subinflexo, subundulato. Co rolla e petala numero laciniarum calyeis iisque interposita, parva, squamaeformia, staminibus minora, v, nulla. S t a min a inter lacinias calycis inserta, petalis majora; fil a m e nt a subulata, ad tubi fundum decurrentia, a n the rae ovato-cordatae, biloculares, locnlis parallelis, rima longitudinali antice apertis. Ovarium semisuperum, obsolete trisuléatum, glabrum v. pilosiusculum, triloculare, Ovula in loculis solitaria, subglobosa, erecta, funiculo brevissimo, vix disereto. S ty l a s cylindricus, tubi faucem attingens; stigma obsolete trilobum, Inbis rotundatis. Fruetus...... Frutices in vallibus Andium chilensium et peruvianorum, rarius in Nova-Hollandia obvii; ramulis spinescentibus, decussatis, floriferis foliosis, infra spinas sitis, foliis breviter petiolatis, integris v. crenatis, deciduis, stipulis minutis, subulatis, floribus axillaribus, solitariis fasciculatisve, pedunculis simplicibus.

Dise aria Hooker Bot. Miscell, I. 156. Meisner Gen, 70. (50.)

a. PENTAPASMA. C a 1 y $\mathrm{x}$ quinquefidns. - Species austro. americanae. (Hook. op, cit. t.4t.f.d.) Collet i a e $\mathrm{sp}$. Venten, Choix, t. 15.

b. TETRAPASMA. C a ly $\mathrm{x}$ quadrifidus. - Species ausiral. arica. - Tetrap a s is a Don Syst, $I T, 40$, Meisner Gen.
70. (50.) Discaria a ustralis Hook. op. oit. $t, 45$. f. $a$. Don Syst. II. 35. Coll et i a p a bes c ens Brongn.

5ร32. Adolphia MEISN. Calyx tubo hemisphaerico, inferne cum ovarii basi connato, limbi quinquefidi laciniis ovatis, acutis, erectis. Corolla e petala 5, disci tubum ealycis incrustantis margini, ad faucem inerassato inserta, limbi laciniis alterna et subaequilonga, erecta, cucullata. S $\mathbf{t}$ a m in a 5 , cum petalis inserta, iisdem opposita et paullo breviora; fil amenta erecta, a ntherae introrsae, cordatae, loculis apice conflnentibus uniloculares, rima hippocrepica bivalves. $0 \mathrm{v}$ arin m semiinferum, triloculare. Ovula in loenlis solitaria, e basi erecta, anatropa. Sty Iu s simplex, filiformis, tubo calyeis longior; stigm a simplex. Fruetus..... Frutex mexicanus, ramosissimus, ramis oppositis, cylindricis, extremis spinescentibus, spinis simplicibus, patentibus, axillaribus, rigidis, foliis oppositis, longe linearibus, integerrimis, glabris, subenerviis, floribus axillaribus, solitariis, pedunculo gracili, folits breviore.

Adolphia Meisner Gen. 70, (50.) Colletia fafesta Brongn. Ceanothus infesta Kunth in Kumb. et Bonpl. Nov. gen. et sp. t. 614 .

5833. Delnetophilla PÖPP. Ca 1 y $\times$ tubo membranaceo, colorato, hemisphaerieo, limbi quinquefidi laciniis reflexis, intus carina versus apicem incrassata callosis, diseo pateriformi, fundo adnato, margine libero, subundulato, rugoso, ovarium cingente. Corolla e petala 5, lamina convoluto-cueullata, in unguem angustata, tubo ad marginem disci inserta, patentia. Stamina 5 , petalorum longitudine, iisdem primo inclusa, serius libera; fila m e $\mathrm{n}$ a teretia, filiformia, subulata, antherae ovatae, biloculares, rima longitudinali antice apertae. Ovari um semisuperum, sphaerienm, profunde trisuleatum. Ovula in loculis solitaria, funiculo brevissimo erecta, anatropa. Stylus discretus, brevis, cylindricus, faucem superans; stigma obsolete trilobum. Fruetus sphaeriens, profunde tricostatus, superus, calycis circumscissi cupula adnata, discoque persistente stipatas, siceus, tricocens, coccis periearpio demum membranaceo obvolutis, erustaceis, intus ad axeos medium foramine lato, subovato perfossis, extus linea longitudinali dorso tandem dehiscentibus, monospermis. Semina in coccis solitaria, erecta, funiculo brevissime cupulaeformi basifixa, ovoideoglobosa, dorso convexa, ventre angulata, testa coriacea, nitida, laevi, endopleura tenuissime membranacea, fuscescente. Emb ryo intra albumen tenuissimum orthotropus; cotyledonibus maximis, obtusis, $r$ adi $c$ u la brevissima, cylindrica, infera. - Frutices ad rivos Andium chilensium crescentes; ramulis decussatis, elongatis, divergentibus, spinosis, foliis alternis, parvis, obtusis, integerrimis, trinerviis, glaberrimis, stipulis subrotundis, scariosis, persistentibus, floribus axillaribus $v$. infra spinas sitis, fasciculalis, pedunculis unifloris.

0 che to phila Pöppigmsc. Reissek msc. Sageretia trinervia Gillies msc. ex Hook. Bot. Miscell. IIT. 173. Ceanothus riparius et C. divergens Pöpp. mso.

5834. Fetamilla BRONGN. Calyx urceolatus, extus villosus, limbi quinquefidi laciniis ovatis, acutis, erectis, medio carinatis, intus tuboque disci illimitati strato earnoso vestitis. C o rolla e petala 5 , summo calycis tubo inter ejusdem lacinias inserta, parva, subrotunda, cucullata, brevissime unguiculata, subinclusa. St a m in a 5 , cum petalis inserta, iisdem opposita et inelnsa; filamenta cylindrica, erecta, anthera e introrsae, $138^{*}$ 
nniloculares, rima hippocrepiea bivalves. Ovari n m liberum, conicum, basi lata sessile, pilosum, triloculare. O v ula in loculis solitaria, e basi erecta, anatropa Stylus brevis, conieus; $8 \mathrm{tig}$ ma tridentatum. D rupa calycis tubo adnato cincta, spongioso - subcarnosa, putamine lignoso, dnrissimo, simplici, triloculari. Semina in loculis solitaria, e basi erecta, testa crustacea, rhaphe introrsum laterali percursa. $\mathbf{E} \mathrm{m}$ b ryo intra albuminis carnosi, duri stratum tenue orthotropus; coty ledonibus planis, carnosis, elliptieis, ra dic u la brevissima, infera. - Suffrutices in America australi extratropica indigeni; ramis elongatis, subsimplicibas, apice suepe spinescentibus, nudis v. ad basim vix foliosis, foliis oppositis, parvis, integerrimis, spicis in ramis junioribus brevibus, paucifloris, oppositis, floribus parvis, extus fusco-villusis.

Retanilla Brongniart in Annal. sc. nat, X. 364, $t$, 2. Meisuer Gen. 71. (50,) Molia a a Commerson msc. Col. letiac sect. Retanilla DC. Prodr. II, 28. Colletiac s p. Ventea. Cels, $t, 92$, Choir t. 16.

$5 \% 35$. Talguenea MIERS. C alyx tabo turbinato - obconico, limbi quinquefidi laciniis acntis, reflexis, tubo intus disci indiscreti strato tenui vestito. Corolla e petala 5, inter calycis lacinias inserta, erecto-conniventia, cucullata. Stamina 5 , cum petalis inserta, iisdem opposita et inclusa; filamenta brevia, complanata, an thera e introrsac, orbiculares, uniloculares, transversim bivalves. 0 v a rium liberum, triloculare. $0 \mathrm{vul}$ a in loculis solitaria, e basi erecta, anatropa. Stylus subulatus, longe exsertus, hirsutissimus; $s \mathrm{ti} g \mathrm{ma}$ simplex, acutam. Ca p s 1 a membranacea, stylo superata, aborta unilocularis, monosperma, bivalvis. Se m en erectum, ellipticum, hinc snleo longitudinali exaratum, testa coriacea, nitida. $\mathbf{E}$ m b $x y 0$ intra albumen subcornenm, parcum ortho tropus, subcylindricas; cotyled onibus brevibus, obtusis, radicula tereti, infera. - Frulices chilenses andicoli; fuliis confertis, decussatis, ellipticis, quinquenerviis, integerrimis, subcanescentibus, spinis axillaribus decussatim oppositis, validis, floribus e tuberculo axillari infra spinas egredientibus.

Talguenea Miers Travels in Chili $T I$. 520 . Trewo a Gillies ex Hooker Bot, Miscell. I. 158, t, 45. B. (exel. T. trinervi) Meisner Gen, 71. (50,) Colletia Trathuen Colla Plant, ckil. t. 7 .

THE IIEU IT. PHYLICEAE Reissek $m s c$. Frue tus inferus, capsularis, apterus, ealyce persistente superatus v. deciduo areolatus. Frutices inermes, ericoidei, foliis alternis.

5ช36. Walpersia REISSEK. C a l y x lanatus, tubo brevi, suburceolato v. breviter campanulato, inferne cum ovarii basi connato, superne libero, limbi quinquefidi laciniis angustis, elongato-subnlatis, apice triquetris, erectis, lanuginosis. Corollae petala 5 , disci calyeis tubum strato tenui vestientis summo margini inserta, limbi laciniis alterna, setacea, minima, apice piloso incurva. Stamina 5, eum petalis inserta, isdem opposita ; filamenta brevissima, antherae introrsae, uniloculares, reniformes, rima hippocrepica bivalves. Ovarium inferum, vertice plano glabrum v. villosum, triloculare. $0 \mathrm{vula}$ in loculis solitaria, e basi erecta, anatropa. Stylus brevis, simplex; st i g m a obsolete trilobnm. Capsula basi calyce adnato induta, laevis, ver. tice exserto rugoso villosa, trilocularis, trieucea, coccis lignosis, demum secedentibus, monospermis. Semin a erecta, funiculo brevi cupulaeformi sustenta, oblongo-subtriquetra, testa coriacea, laevissima. E m b y o intra albunen carnosum fla. vescens orthotropus; cotyledonibus magnis, planis, radicula brevissima, infera. - Suffrutices capenses, ericoidei; ramis fastigiatis, tomentosis, foliis alternis, subtus villosis, supra glabris, margine convolutis, breve petiolatis, stipulatis $v$. exstipulatis, floribus capitatis, capitulis tomentosis, elongatis $v$. sphaericis.

Walpersia Reissek mse. Trich ocephalus Brong. niart in Annal. so, nat. X. 374. t. 17. f. 1. Meişaer Gen. 70. (30.) Phyliea stipularis Lina. et Ph. spicatu Linn. Lam. $t, 127, f, 3$.

583\%. Petaloposom REISSEK. C a lyx villesus, tubo subcampanulato, basi eum ovario connato, superne libero, limbi quinquepartiti laciniis basi inflexis, gibbosis, conniventibus, gibbis barbatis, faucem claudentibus, tubo intus disci strato tenui tecto. Coro 11 a e petala 5 , inedio calycis tubo inserta, inclusa, limbi laciniis alterna, conchato - cueullata, ciliato-barbata. St a m in a 5 , cum petalis inserta, iisdem opposita et inclusa; filamenta brevissima, apice incurva, antherae introrsae, reniformes, loculis apice confluentibus uniloculares, rima hippucrepica bivalves. 0 varium inferum, triloculare. Ovula in loculis solitaria, e basi erecta, anatropa. Stylus brevis, simplex; stigma capitatum, obsolete trilobum. Capsula calyce adnato induta, vertice areolata, trilocularis, tricocca, coccis crustaceis, demum secedentibus, intus dehiscentibus, monospermis. Semin a erecta, funiculo brevi cupulaeformi, laciniato sustenta, obovato-trigona, testa coriacea, laevi, E m b ryo intra albumen carnosum, pareum orthotropus; cotyle donibus magnis, planis, radicula brevissima, infera. - Fruticulus capensis, Phylicae facie; ramis fastigiatis, folits alternis, cordato-cuspidatis, margine revolutis, subtus lanatis, exstipulatis, floribus capitatospicatis, villosis, bracteis foliaceis, florem subaequantibus.

Petalopogou Reissek in Decad. Nov. slirp. Mus. Vindob. $\boldsymbol{X}$. n.92. P h y $1 \mathrm{i}$ ca e uspi data Eeklou ei Zeyher.

58 8. Phyliea LINN. Caly x extus lanatus, tubo cylindrico, basi cum ovario connato, superne libero, limbi quinquefidi laciniis subulatis, erectis, apice callosis, trigonis, Cor o 11 a e petala 5 , margine disci ovarium tubumque strato tenui tegentis inter lacinias inserta, oblonga, complicatocueullata, ungue brevissimo discreto. St a m in a 5 , cum petalis inserta iisque inclusa; filamenta subulata, antherae oblongae, biloculared, loculis parallelis, rimis distinetis, longitudinaliter dehiscentibus. $O$ va $\mathrm{rium}$ inferum, triloculare. 0 v ula in loculis solitaria, e basi erecta, anatropa. St y I us simplex, discretus, clavatus $\mathbf{v}$. filiformis, tubo brevior; $8 \mathrm{tig} \mathrm{ma} \mathrm{simplex,} \mathrm{integerrimum.} \mathrm{C} \mathrm{a} \mathrm{p} \mathrm{s} \mathrm{ula}$ ovoidea, apice coaretata v. dilatata, ealycis tubo persistente v. rarius deciduo superata, trilocularis, tricocea, coccis coriaceis, sejunctis, demum intus apertis, monospermis. S em in a crecta, funiculo brevissimo capulaeformi excepta, ovato-oblonga, testa crustacea, laevi, erassa, raphe introrsum laterali. E m bry o intra albumen carnosum orthotropus; cotyledonibua ovatis, carnosis, planis, ra dicula brevissima, infera. - Frutices v. suffrutices ericoidei, in Capite bonae spei crescen- 
tes; ramis erectis, fastigiatis, foliis sparsis, exstipulatis, linearibus, margine revolutis, supra glabris, pubescentibus $v$. longe pilosis, subtus villosis, floribus capitatis v. spicato-capitatis, bracteis foliaceis, ciliatis v. plumoso-pilosis cinctis.

$P$ h y li c a Linn. Gen, n, 266. Jussieu Gen. 381, Gärtner $I$. 114. $t$. 24. Sprengel Berlin. Magaz. VIIL. $t, 8$. f. 5 -7. Wesdland Coll. t, 7, B0. Bot. Reg. t.711. Loddlg. Bot. Cab. t. 36. 849. P h y lic a e sect. Plamos a e DC. Prodr. $I T$. 35. sect. Strig os a e Beongn. in Annal. sc, nat. $X, 376$.

5ร3פ. Tylanthus REISSEK. C a 1 y x tubo obeonico, basi ovario adnato, superne libero, limbi quinquefidi laciniis ovatis, acutis, erectis, extus cristato-villosis, intus apiec callosis. Corolla e petala 5, margine disci concavi, pateriformis, supra tubi medium limitati inserta, subrotunda, coneava, fornicato - eucullata, in unguem angustata. S t a mina 5, cum petalis inserta, isque inclasa; fil amenta brevissima, incurva, an therae reniformes, loculis apice confluentibus aniloculares, rima hippocrepica bivalves. O var i u m ellip soidenm, inferum, triloculare. $O$ v u la in loculis solitaria, e basi ereeta, anatropa. S ty $1 \mathbf{n} s$ indisere tus, simplex, brevissimus, conicus; stigma simplex, obsolete tridentatum. Capsula sphaerica, calyeis tubo persistente superata, trilocnlaris, tricocca, coccis crustaceis sejunctis, demum intus longitudinaliter a basi apertis, monospermis. S e mi n a erecta, funiculo brevi cupnlaeformi fulta, ovata, dorso convexa, ventre subangulata, testa crustacea, laevi, raphe introrsum laterali. E m b r y o intra albumen carnosum orthotropus; cotyled on ibus ovalibus, applicatis, earnosis, radicala brevissima, infera, recta. Suffrutices ericoidei, in Capite bonae spei et insula Madagascar indigeni; ramis erectis, fastigiatis, foliis densis, sparsis, exstipulatis, li nearibus, margine revolutis, supra glabris, verrucosis v, pubescentibus, subtus villosis, floribus terminalibus capitatis $v$. spicatis, bracteis brevibus scariosis, villosis cinctis.

Tyla ut hus Reissek msc, Phyli cae sp. Linn. Gärtner 1 . 14t. t. 24. Sprengel in Berlin, Magaz. VIIT, t, 8. f. 1.2. Bot. Magaz. $t$, 224. P hylica e sect. Bricoideae DC. Prodr. 1I, 34. Bronga. in Annal. sc, nat. X, 376.

5\% 10 . Soullangia BRONGN. C a ly $\mathrm{x}$ extus villosus, tubo obconico, cum ovario connato, limbi quinquepartiti laciniis acutis, apice callosis, patentiusculis. Corolla e petala 5, disei epigyni pentagoni margini elevato inserta, calycis laciniis alterna et breviora, breviter unguicalata, cucullata. Stam in a 5, cum petalis inserta, iisdem opposita et breviora; fil amenta arcuata, anthera e introrsae, uniloculares, reniformes, rima hippocrepica bivalves. O variu in inferum, trilocula. re, disco plane tectum. Ovula in loculis solitaria, e basi erecta, anatropa. S ty l n s brevis, conicos; stigma tridentatum v. trifidum. Capsula ovata, vertice plano areolato, ealycis laciniis cincto, trilocularis, tricocca, coccis crustaceis, secedentibus, demnm intus apertis, monospermis. Semin a erecta, funiculo brevissimo, cupulaeformi excepta, ovato-oblonga, testa crustacea, laevi, crassa, rhaphe introrsum laterali, E m bryo intra albumen carnosum orthotropus; cotyledonibus oblongis, carnosis, planis, ra d i c n la brevissima, infera. - Arbores, frutices v, suffrutices ramosissi$m i$, in Capite bonae spei, nec non in insulis Oceani atlanticitrans aequatorem sitis crescentes; foliis alternis $v$, rarissime oppositis, breve petiolatis, ovatis, cordatis $v$. lanceolatis, rarius linearibus, subtus villosis, supra saepissime glabris, stipulis nullis, floribus in axillis foliorum superiorum $v$. bractearum solitariis, spicatis $v$. paniculatis, pube brevi tectis.

$\mathrm{S}$ o u la $\mathrm{ng}$ i a Brongniart in Annal, sc, nat, $X, 377$, t. 17. Lindley in Bot, Reg. $t, 1498 . f .3$. Meisner Gen, 70, (50.) Pbylieac sp. Venten. Malm. t. 57. Sprengel in Berl. Magaz. VIIT. $t, 8, f$. 4. Wendl. Collect. $t, 26$.

5ร4 1. Spyridium FENZL, C a I y colaratus, extus tomentosus, tubo tubinato, basi cum ovario connato, superne libero, limbi quinquefidi laciniis obtusiuseulis, erectis. Coroll a e petala 5 , calycis fauci inserta, ejusdem laciniis alterna et breviora, subsessilia, cucullata, conniventia. Sta$m$ in a 5, disci carnosi, calycini tubi partem inferiorem vestientis, quinquelobi sinubus superposita, petalis inclusa; filamenta brevissima, a $\mathbf{t h}$ erae introrsae, ovatae, bilocnlares, loculis inferne secedentibus, rima longitudinali latere apertis, quasi bivalves. Ovari $\mathbf{m}$ inferum, vertice complanato villosum, triloculare. Ovula in loculis solitaria, e basi erecta, anatropa. St ylus simplex; stigma trisulcatum, papillosum. Fruetus..... Frutex Novae-Hollandiae orientalis, Phylicae facie, foliis confertis, acerosis, mucronatis, glaberrimis, marginibus conduplicato-convolutis, stipulis squamaeformibus, minimis, adpressis, persistentibus, glabris, florum capitulis terminalibus, pisiformibus, sessilibus, bracteis orbicularibus, spadiceis, glabris, involucratis, floribus minutissimis, albido-tomentosis. in not.

Spyridium Fenzl in Enumerat. plant. Hïgel. 24.

5\% 42. Cryptandira SMITH. Caly $\mathrm{x}$ coloratus, extus saepe villosus, intus disci indiscreti strato incrustatus, tubo campanólato, rarius cylindrico, ovarii basi connato, superne libero, limbi quinquefidi laciniis acutis, erectis v. patentibus, intus carina versus apices incrassata percursis. $\mathrm{Co}$ rolla e petala 5, calyeis fanci inserta, ejusdem laciniis alterna, parva, eueullata, subsessilia, coriacea, persistentia. Stamina 5 , cum petalis inserta, iisdem opposita et inclusa; fi la in enta brevissima, anth erae introrsae, biloculares, longitudinaliter dehiscentes. O va ri u m seminferum, apice libero villosum, triloculare, $0 \mathrm{v}$ u la in loculis solitaria, e basi erecta, anatropa. Sty las simplex; $s t i g ~ m$ a tridentatum v. trilubnm. Ca psu Ia semiinfera, calyce et corolla persistentibus tunicata, trilocularis, tricocea, coccis bivalvibus, monospermis. Se mina erecta, funiculo brevi cupulaeformi subtensa, oblongo-trigona, testa coriacea, laevi. E mb r yo intra albumen carnosum orthotropus; cotyledonibus magnis, carnosis, planis, radicula brevissima, infera. - Suffruti. ces ericoidei, in Nova-Hollandia indigeni, erecti, ramosissimi; ramis fastigiatis $v$. patentibus, interdum spinescentibus, foliis alternis, integerrimis, glabris, floribus ad apices ramulorum aggregatis $v$. solitariis, erectis $v$. nutantibus, basi squamulis quinque parvis imbricato - calyculatis.

Cryptandra Smith in Linn, Transact. IV. 217. Rudge Ibid. X. $t$, 18. DC. Prodr. IL. 38. Brongniart in Annal, sc, nat. X. 372. $t$. 14. f. 3. Meisner Gen. 70. (50.)

TIRE msc. Fruetus capsularis, apterus, coccis intus basi foramine membrana tenui velato apertis. - Erutices inermes, folis alternis. 
57 43. Ponaderris LABILL, C a I y $\mathrm{x}$ coloratus, tubo obconico v. hemisphaerito, cum ovarii basi connato, limbi quinquefidi laciniis ova to-oblongis, acutis, subpatentibus, extus villosis, intus glabris, coriaceis, subplanis. C orolla nulla v. petala 5, apici disci cum calycis tubo et ovario connati, vix manifesti inserta, limbi laciniis alterna et breviora, erecta, breviter nnguiculata, obcordata, ovata vel lanceolata, plana. St a m in a 5 , cum petalis inserta, iisdem opposita et longiora; fil ame nta gracilia, antherae introrsae, bilocnlares, ovato-oblongae, medio dorso affixae, longitudinaliter dehiscentes, demum subtortae. Ovarium semiinferum, apice libero villosum, trilocnlare. Ov u I a in locnlis solitaria, e basi ereeta, anatropa. Stylus trifidus, lobis patentiusculis; stigmata subeapitata. Capsula calycis tubo inferne vestitu, tricocea, coceis apice sejunctis, indehiscentibus, basi foramine lato, primum endocarpio membranaceo velato apertis, mo nospermis. S e m in a erecta, funiculo brevi, cras so, cupnlaeformi sustenta, testa coriacea, laevi. E m bryo intra albumen carnosum flavescens or. thotropus; cotyledonibus carnosis, magnis, adpressis, rad icula brevi, infera. - Frutices in Nova-Hollandia indigeni, erecti, ramosi, pube stellata $v$. simplici plus $v$. minus dense tomeniosi; foliis oppositis, integerrimis v, serratis, penninerviis, utrinque villosis $v$. supra glabratis, floribus corymbosis $v$, in paniculas corymbiformes dispositis, axillaribus terminalibusque, a basi ad apicem florentibus.

Pom x derris Labillardiere Nov, Holl, , 6t, t. 86. 87. Venten. Malmais, $t, 38$. Bot. Mag, t, 1310. 1823. 3212, 3219. Sweet Flor, austr. $t$. 41. Loddig. Bot. Cab, t. 180 DC. Prodr. IT, 33, Brougniart Annal, se, nat. X. 571, t, 16. f. 2. Aiph. DC. in Mem, soe. h. n. Genev. VI. t. 4. Meisner Gen. 70. (50.) Pom at o der is Schultes Syst, $V_{\text {. n. }}$. 685. P omatiderris Kunth in Humb, et Bonpl. Nov, gen, et sp. VII. 60, in not. Ce a noth i s p. Andrews Bot, Reposit. t. 569 .

5\% 4. Trymalium FENZL. C a 1 y $\mathrm{x}$ tubo hemisphaerico v. turbinato, cum ovarii basi connato, limbi quinquefidi laciniis ovatis, acutis, patentiusculis, intus coloratis, carina subflexnosa pereursis. Co rolla e petala 5, disei carnosi annularis, pentagoni $\mathbf{v}$. lobati sinubus exterioribus inserta, limbi laciniis alterna et breviora, breviter unguiculata, convoluta v, eucullata. S t a min a 5 , com petalis inserta, iisdem opposita et longiora; $\mathrm{fila}_{\mathrm{a}}$ menta filiformia, inflexa, antherae introrsae, biloculares, subrotundae, longitudinaliter dehiscentes. O va ri n m semiinfernm, apice libero villosum, bi-quadriloculare, Ovnla in loculis solitaria, e basi erecta, subglobosa, funiculo cupulaeformi. St y la s bi-tri-quadrifidus v. partitus; st $i$ g. mat a obtusa. C a ps u l a calycis tubo circumscisso v. persistente vestita, bi-quadrilocularis, ditetracocea, coecis basi $\mathbf{v}$, apice secedentibus, indehiscentibus, inferne foraminulo exiguo perforatis, monospermis. Se min a erecta, obovata, compressa, faniculo brevissimo snbtensa, testa coriacea, laevi. Embry o intra albumen carnósum orthotropus; cotyledonibus erassis, carnosis, radicula brevissima, infera. - Frutices in NovaHollandia a ustro-occidentali indigeni, Pomaderridum facie; foliis alternis, integerrimis $v$. obsolete dentatis, penninerviis, subtus pube stellata tomentosis, supra saepe glabratis, floribus villosis, racemoso-paniculatis $v$. cymoso-glomeratis.

Try malium Fenzl in Enumerat. plant. Hïgel. 20. Ce a n ot hi s pec. Labillard. Nov. Holl, $t .84$. $8 s$.
TiRIBUS VI. GOUANIEAE Reissek msc. Fructus inferus, capsularis, calyce deciduo areolatus, pyriformis v. trigonus, apterus v. alatus, coccis intus rima apertis. - Frutices inermes cirrhosi, vel herbae.

5\% 45. Hellinus E.MEY. C a I y x tubo urceolato-obconico, cum ovario connato, limbi quinquefidi laciniis ovatis, acutis, patentissimis, carina longitudinali elevata percursis. Co rolla e petala 5, disei epigyni carnosi, obsolete pentagoni margini inserta, calycis laciniis alterna et breviora, breviter unguiculata, convolutu-eucullata. Stam in a 5 , cum petalis inserta, iisdem opposita et breviora; fil a me nta subulata, apiee incurvata, a ntherae introrsae, biloculares, ovatae, longitudinaliter dehiscentes. Ovarium inferum, ovatum, triloculare. Ovula in loeulis solitaria, e basi erecta, anatropa. Fructus ovatus, teres, apice areolatus, tricoccus, coceis crustaceis, demum intus dehiscentibus, monospermis, axi centrali nulla. S e mina erecta, dorso convexiuscula, testa cornea, nitida. E mb ry o intra albumen carnosum, tenue orthotropus, flavescens; cotyledonibus maximis, planis, radicula brevissima, infera. - Frutex in Abyssinia et Capite bonae spei obvius, ramulorum apicibus cirrhosis scandens; folits alternis, petiolatis, ovatis v. subrotundis, basi subcordatis, apice mucronatis, penninerviis, integerrimis, membranaceis, pedunculis versus apicem ramorum axillaribus, cymosis.

Helinus E. Meyer msc. Willemetia scandens Reklon et Zeyh. Rham us mystacinus Ait.

57 46. Gouania $J A C Q$. C a ly $\mathrm{x}$ tubo obconico v. urceolato, cum ovario connato, limbi quinquefidi patentis v. patentiusculi laciniis membranaceis, ovatis, acutis. Corollae petala 5 , disci carnosi, stellati, in lobos liberos, calycis laciniis oppositos expansi sinubus inserta, calycis laciniis alterna et breviora, breviter unguiculata, apice emarginata, convoluta v, cucullata, membranacea v. subcoriacea. St a mina 5, cum petalis inserta, iisdem opposita et breviora; fil am en ta subulata, basi complanata, apice incurva, an therae introrsae, biloculares, ovatae, e connectivi apice pendulae, loculis rima longitudinali latere apertis. Ov a ri u m inferum, elliptico - trigonum, triloculare. $O v \mathbf{v} \mathrm{l}$ a in loenlis solitaria, e basi erecta, anatropa. Sty Ius trifidus $v$, tridentatus; stigmata acuta. Fruet us ovato-trigonus v. trialatus, alis demum bipartitis tricoceus, coccis spongioso-coriaceis, margine bialatis v. incrassatis, indehiscentibus, monospermis, axi persistente, tripartito. S emina erecta, dorso convexa, ventre angulata, testa coriacea, dura, raphe introrsum laterali. $\mathbf{E} \mathrm{m}$ b ry o intra albumen carnosum, tenue orthotropus, flavescens; cotyled on ibus maximis, planis, radicula brevissima, infera. - Frutices inter tropicos totius orbis obvii, in America copiosi, ut plurimum scandentes; ramulis saepe aphyllis cirrhiformibus, foliis alternis, petiolatis, penninerviis, nervis inferioribus validioribus, arcuatis subtriplinerviis, dentatis, glabris, pubescentibus v. tomentosis, stipulatis, floribus abortu saepe polygamis, nonnunquam apetalis et decandris, in ramulis nudis glomerato-spicatis, bracteis subulatis, fugacibus.

Gouania Jaequin Amer, 261. Linn. Gen, $n, 1167$. Gärtuer f. $I I T, 19$. DC.Prodr. II, 38. Brongn, in Annal, sc. nat. X. 378. Wight et Arnott Prodr, I. 166. Meisner Gen. 70. $(50$,$) Retinaria Gättner I I .187$. 
a. AMERICANAE. Flores hermaphroditi. (Jacq. Amer. t. 179. Lam. t. 845. f. 1. Gärtuer f. t. 183.)

b. GRRONTOGRAE. Fl ore $s$ polygami. Retin a ria Gärtner $t$. 120. (Lam, $t$. 845. f. 2. Roxburgh Plant. Corom. t. 98, Bronga. Op. cit. t, 16. f, 3.)

5\%4\%. Feissekia. C a I y x tubo obconico, cum ovario connato, limbi quinquefidi laeiniis patentibus, membranaceis, ovatis, mueronatis, marginatis, aestivatione reduplicata cristas quinque efformantibus, intus carinatis. Corolla e petala 5, mar cini disci subrotundi, pateriformis, tubum vestientis inserta, laciniis calycis alterna et subaequilonga, apice emarginata, convoluto-cucullata, subcoriacea. Stamina 5 , cam petalis inserta, isdem opposita et breviora; fil amenta subulata, compressa, apice incurva, antherae introrsae, biloculares, ovatae, e connectivi apice pendulae, loculis parallelis, rima longitudinali latere dehiscentibus. Ovarium inferum, obtuse tetragonum, quadriloculare. Ovula in loculis solitaria, e basi erecta, oblonga, anatropa. Stylns basi margine disei interno, annulari cinctus, trifidus; stigmata filiformia. Fruetus ovatus, calyce persistente coronatus, quadrialatus, alis rotandatis, demum bipartitis quadricoceus, coecis spongioso - coriaceis, intus secedentibns, inapertis, monospermis, axi persistente multipartito. Se min a sessilia, erecta, dorso convexa, ventre angulata, testa coriacea, crassa, nitida, impresso-punctata, raphe interna. $\mathbf{E} \mathbf{m}$ b ry o intra albumen carnosum, tenue orthotropus; cotyledonibus obovatis, subplanis, radic ula brevi, infers, aenta. - Frutex brasiliensis, ramulis abortu saepe cirrhiformibus seandens; foliis allernis, petiolatis, cordatis, dentatis, penninerviis, nervis inferioribus validioribus, stipulis subulatis, floribus abortu saepe polygamis, in axillis foliorum juniorum pedunculo elongato umbellatis, bracteis setaceis.

Gouania smilacina Smith in nees Cyclop. 16. Brongn, in Annal. sc, nat. $X, 380$. G. co r d i fo il a Raddi.

5848. Cramenaria $M A R T$. C a 1 y x campanulatus, tubo inferne cum ovario connato, superne colorato, libero, limbi qninquefidi laciniis ovatis, acutis, aestivatione, disci simplicis strato per tubum effuso excedente, reduplicata. Corol1 a e petala 5 , inter calycis lacinias inserta, iisdem primum breviora, demum ampliata, elongata, longiora, eucullata. St a m in a 5 , cum petalis inserta, iisdem opposita et inclusa; fil amenta filiformia. antherae introrsae, subglobosae, biloculares, loculis apice approximatis, longitudinaliter dehiscentibus. Ovarium inferum, globoso-subtrigo. num, triloculare. Ovula in loculis solitaria, e basi erecta, anatropa. S ty I us brevis, cylindricus; stig ma tripartitum, lobis obtusis, glandnlosis. Capsula calyce tecta, obovato-trigona, trilocularis, tricocca, coccis chartaceis, dorso eonvexis, obcordatis, ala marginali cinctis, intus bifacialibus, sulco longitudinali apertis, monospermis, axi persistente, tripartita. S e $\mathbf{m}$ i $\mathbf{n}$ a ereeta, obovata, testa cornea, nitida, endopleura farinacea. $\mathbf{E}$ bryonis exalbuminosi cotyledones suborbiculares, carnosae, plano-convexae, radicula brevissima, infera. - Herbae brasilienses, rhizomate lignoso perennes, v. radice fibrosa annuae; ramulis filiformibus, glaberrimis, foliis alternis, sessilibus $v$, breviter petiolatis, integerrimis, bistipulalis, floribus parvis, albis, in pedunculis articulatis, bibracteatis terminalibus, v. axillaribus cymosis.

C r u m e a r a Martius Nov. gen, et sp. IT, 68, $t, 160$. Brongniart in Annal. sc.nat, $X$. 380. Meisuer Gen. 70. (50,)

\section{GENERA DUBIA.}

5749. Solemamtha $G, D O N, \mathrm{C}$ al y $\mathrm{x}$ persistens, quinquefidas. Co r oll a e petala 5 , in tnbum conniventia, decidua. An the rae 5, biloculares, singulae sub squama insertae. Ovarinm bilobum. - Frutex Novae-Hollandiae, ramosus; ramis rigidis, spinosis, foliis oblongo-lanceolatis, serratis, fasciculatis, floribus axillaribus et lateralibus albis.

Sol en an th a G. Don Syst. $1 T_{*} 39$, Cryptandra spinos a Cunningh.

5ร50. Seluafferia $J A C Q$. F I o res abortu dioici. Cal y x quadripartitus, obtusus, persistens. Coroll a e petala $\$$, calyeis foliolis alterna et majora. Sta mina 4, petalis opposita. Ovari um biloculare...... Sty $\mathbf{l}$ us brevis v. nullus; s tig$m$ a $t$ a 2 , indivisa $v$, bifida. B a ce a sicca, bipartibilis, rarius abortu unilocularis, loculis monospermis. Se mina ereeta. Embryo in axi albuminis carnosi, suboleosi rectus, planus. - Frutices antillani, floribus plurimis, axillaribus, pedicellatis, parvis, albis.

$\mathrm{S}$ chäfferin Jacquín Amer, 259. Swartz Flor. Ind, occid 327, t. $7 . f$. a. Lam. $t .809$, DC. Prodr. $I$. 40 . Meisner Gon, 71. (51.) (Sloane Jam. II, t. 209, f. 1.)

\section{GENERA RHAMNEIS AFFINIA.}

5\%51. Corolkia $A$. CUNN. F lo res dioici. Ma sc......F e m. Caly x tubo ovario adhaerente, limbo quinquefido, aestivatione valvato, persistente. Cor ollae petala 5 , disci epigyni, carnosi, glandulosi margini inter ealyeis lacinias inserta, laneeolata, decidua. O v a $\mathbf{~ i ~ u ~} \mathrm{m}$ inferum, biloculare. $O$ v u la in loculis solitaria, pendula. S tyl u s simplex; st igm a capitatum, lobatum. D rup a exsucca, sphaerica, bilocularis, fragilis, nitida, apice nmbilieato villosa. Semina in loculis solitaria, inversa. $\mathrm{E}$ in bryo...... Frutex Novae$Z$ eelandiae; ramis ramulisque strictis, albo-tomenlosis, foliis alternis, petiolatis, lanceolatis, acutis, coriaceis, supra plerumque glabris, lucidis, subtus dense albo-lanatis, floribus parvis, subpaniculatis, paniculis brevibus, axillaribus v. terminalibus, cano-pilosis, petalis albis, calyce triplo longioribus, extus villosis, drupis pisiformibus. 499.

C o rokla A. Canaingham in Annal. of Nat, hist. ITH.

5ซร2. Strombosia $B L U M$, Caly $\mathrm{x}$ inferns, parvus, planus, obsolete crenulatus. CorolI a e petala 5, campanulato-conniventia, ad fancem villosa. Stam in a 5 , brevia, petalis opposita et inserta, antherae introrsae, didymae. Ovarin m disco immersum, quinqueloculare, loculis uniovulatis, v. triloculare, loculis subbiovulatis. Stylus brevis; stigma obtusinsculum, obsolete denticulatum. F r u ctu s baccatus (an drupaceus?) torbinatus, substipitatus, abortu monospermus.Arbor javanica, procera; foliis alternis, oblongis, acuminatis, integerrimis, glaberrimis, lucidis, floribus viridibus, in fasciculos axillares paucifloros dispositis.

St r o m bos i a Blume Bijdr. 1154. Meisuer Gen, 71, (51.)

5853. Samara LINN. C a l y x minimus, quadripartitus, acutus, persistens. Corolla e petala 4 , ovata, sessilia, basi lacuna longitudinali. St a mina 4, petalis opposita, eorundem lacunae immersa; filamenta subulata, longa, anthe- 
rac subcordatae. Ova rium ovatum, corolla dimidio brevius. S t y 1 u s cylindriens, ovario longior; stigma infundibuliforme. Drupa subro. tunda, monosperma. - Arbuscula zeylanica; ramis purpurascentibus, laevibus, foliis alternis, petiolatis, lanceolato-ellipticis, obtusis, integerrimis, utrinque lacvibus, corymbis axillaribus vix petioto longioribus, fioribus copiosis, luteis.

$\mathrm{S}$ a un a $\mathrm{r}$ Linn. Mant, IT. 144. exel. Burmann. synou. Meisner Gon, 71. (51.)

5854 . I ennantia FORST. C a l y x penta phyllus, deciduus, foliolis lanceolatis, aestivatione imbricatis, patentibus. Coroll a nulla. $\mathrm{S}$ tamina 5 , ad basim annuli hypogyni inserta, calyeis foliolis alterna; filam enta tereti-subulata, antherae introrsae, biloculares, ovato - 8 buglobosae, dorso insertae, longitudinaliter dehiscen tes. Ovari $\mathrm{m}$ ovoto-oblongum, triloculare, lo. culis biovnlatis, ovulis ex apice loculi pendulis, superpositis? Sti g m a sessile, discoideum, obsolete trilobum. Drupa sicea, monosperma. Semen inversum. - Arbor quadragintapedalis, in Nova-Zeelandia et insula Norfolk indigena, cortice albo; ramis teretibus, albo punctatis, folvis alternis, petiolatis, elliptico-oblongis $v$. obovatis, integerrimis $v$. supra medium obsolete serrulatis, venosis, glabris, floribus terminalibus corymbosis, hermaphroditis, nonnullis abortu masculis.

Pen a a tia Forster Char. 67. A. Richard Flor. Nov. Zeel. 368. Endlieher Norf. 80. A. Cunningh, in Anzal. of Nat. hist, III. 248, Meisuer Gen. 7t. (51,)

5ช55. Daplningiphyllenen BLUM. F 10 res dioici, Calyx liber, parvus, crenulatus. Coro Ila nulla. Masc. Stam in a 6_10; fil a ment a brevia, basi connata, antherae erectae, tetragonae. $\mathrm{F}$ e m. $\mathrm{O}$ va $\mathrm{rinm}$ biloculare, loculis biovulatis, Stigma sessile, bifidum. Dru pa baceata, ovalis, stigmatibus coronata, putamine fibroso, monospermo. E mb ryo in albumine carnoso inversus, minntus. - Arbor javanica; foliis sparsis, oblongo-lanceolatis, integerrimis, glabris, infra glaucis, exstipulatis, racemis axillaribus, simplicibus.

Daphniphyllum Blume Bijdr. 1153. Deisner Gen. 71. (51.)

5ร56. Crypteronia BLUM, Flores abortu monoici. Cal y x liber, parvus, quinquedentatus. Corolla nulla. Stamina 5 , ealyeis laciniis alterna, brevissima. Ova ri u m biloculare, margine membrànaceo cinctum ..... St y I u s unus; stigma obtısum. Capsu la subglobosa, stylo coronata, bilocularis, hivalvis, dissepimentis valvis contrariis. Semina plurima, albuminosa, superne arillo subulato terminata ..... Arbor javanica, procera; foliis oppositis, oblongis, integerrimis, racemis paniculatis, lateralibus, floribus parvis.

70. (31.)

Crypterania Blume Bijdr. 115t. Meisner Gen.

OBSBrvatio. Galdicia Nerand, Quoia Neraud, et Carolinta Neraud, gesera Rhamuearum a el. Gaudichaud ad Erejcinet 30. commemorata, nemini notata videntar.

\section{Ordo CCXL. Chathetiaceare.}

CHAILLETIEAE R. Brown in Tuckey Congo 448. CHAIL. I.ETIACEAE DC. Prodr. $I T$. 57. Lindley Introduct. edit. II. p. 108 .
Arbusculae v. prutices. Folia alterna, petiolata, penninervia, integerrima, plus mius coriacea. Stipula e petiolares, geminae, deciduae.

Flores hermaphroditi v. polygami, in pedunculis axillaribus, liberis v. saepius petiolo adnatis fasciculati v. dichotome corymbosi.

Calxx pentaphyilus v, quinquedentatus, aequalis v. subaequalis, extus hirtus v. pilosus, intus coloratus.

Corollae petala (stamina abortiva ?) quinque, imo calyci inserta, ejusdem Jaciniis alterna et subaequilonga, integra, emarginata v. bifida, nunc libera, inter se aequalia, nunc mediantibus staminibus connexa, inaequalia, corollam bilabiatam simulantia.

Srauisa 5, cum petalis inserta, iisdem alterna et subaequalia v. longiora. Fi la m e n $t$ a subulato-filiformia, libera v. cum petalis connexa. Antherae introrsae, biloculares, longitudinaliter dehiscentes.

Glandulae perigynae quinque, petalis liberis oppositae, in Tapura nullae?

Ovanivm liberum, sessile, bi-triloculare. Ovula in loculis gemina, collateraliter pendula. Styli $2-3$, fliformes, distincti v. plus minus coaliti. Stigmata simplicia, capitata v. biloba.

Froctus nune capsularis, bilocularis, loculicide bivalvis, loculis abortu monospermis, nunc drupaceus, coriaceus, exsuccus, putaminis bi- v. abortu unilocularis loculis monospermis.

Semex inversum, nudum v. arillo colorato stipatum. A lb umen nullum.

Enвryo rectus; cotyledonibus carnosis, plano-convexis, r a di c ula brevissima, supera.

Chailletiaceae inter tropicos Asiae, Africae et Americae parvo numero hucdum observatae, plurium generum per diversos ordines adhuc vagantium accessione locupletandae et illustrandae, affinitate inter Frangulaceas et Terebinthaceas fluctuantes, ex cl. R. Brown Aquilarineis, stipularum defectu facillime dignoscendis, proximae, e nonnullorum sententia Ulmaceis affines creduntur.

ธรธร. M๓acurra ROXB. F lores polygami. Caly $x$ pentaphyllus, foliolis ovalibus. Corolla e petala 5, calycis foliolis alterna et aequilonga, angustiora. Stamin a 5 , receptaculo inserta, petalis alterna et breviora, a ntherae introrsae, biloculares, cordatae, longitudinaliter dehiscentes. Glandula e 5, ovales, petalis oppositae. Ovarium ovatum, cordatum, compressiusculum, biloculare. $O \times n l a$ in loculis gemina, ex apice cavitatis eollateraliter pendula. Styli 2 , recurvi; stigmata subbiloba. Capsula transverse ovalis, biloba, biloeularis, apice breviter bivalvis. S emina in loculis abortu solitaria, inversa, oblonga, dorso-convexa, arillo colorato tec- 
ta, testa fibrosa, intus spongiosa. Em bry o $\mathrm{n}$ is exalbuminosi cotyledones semini conformes, radicula brevis, supera, plumula bi-quinqueloba. - Arbuscula indica; ranis numerosis, adscendentibus, adultorum cortice aspero, punctis albis consperso, junioribus villosts, flavescentibus, foliis alternis, breve petiolatis, late lanceolatis, ackminatis, integerrimis, tenuibus, glabris, stipulis subulatis, villosis, floribus parvis, plurimis in fasciculos axillares, breviter pedunculatos collectis, masculis et hermaphroditis in diversis stirpibus, calycibus extus villosis.

M o a enrra Roxburgh Flor, ind, $I$. 70 . W a hlenbie rg i a R. Brown in Wallich Catalog. n. 4342. Meisn. Gon. 73. (53.)

5ร58. Claailletia $D C$. Calyx quinquepartitus. Co rolla e petala 5 , imo calyci inserta, ejusdem laciniis alterna et subaequalia, emarginata v. bifida. St a m i n a 5, cum petalis inserta, ifsdem alterna et subaequilonga ; filam enta filiformisubulata, an therae introrsae, biloculares, longitudinaliter dehiscentes. Glandnlae 5, perigynae, petalis oppositae. Ovarium sessile, triloculare. Ovula in loculis gemina, collateraliter pendula. Styli $2-3$, filiformes, distineti v. coaliti; stigmata capitata. Drupa coriacea, exsucea, pntamine bi-v, ahortu uniloculari. Semina in toeulis solitaria, inversa, ovato-oblonga, testa meubranacea. E m b r y o n is exalbuminosi cotyledones crassae, plano-convexae, radicula hrevissima, supera. - Arbusculae $v$. frutices, in Guiana, Madagascaria, Africa tropica oc cidentali, et in insula Timor crescentes; foliis alternis, breve peliolatis, coriaceis, venosis, integerrimis, stipulis petiolaribus geminis, deciduis, pedunculis axillaribus fasciculatis $v$. dichotome corymbosis, liberis $v$. basi cum petiolo connatis, quasi ejusdem apici insertis, calycibus extus villosis $v$. hirtis, intus glabris.

C hailletia DC. in Annal. Mus, XVYr. 158, t. 1.f. 2. excl. sp. Prodr. II. 57. Turpin All. II, t, 247. Meisner Gen. 73. (53.) S y m phyllanth $\mathrm{ns}$ Vahl in Skrivter of Naturhistorie-Selskabet VI, 86. Mestotes Soland, mso. $\mathrm{Pa}$ trisia Rohr msc. Dich apetal u m Thonars Gen, mada gasc, n. 78. Le ucosi a Thousrs Gen, madagase, n. 79. Pla p p ertia Reíchenb. Consp. n, 3824.Meisn. Gen, 73. (53.)

5ร 50. 'Tagpara $A U B L$. Cal $\mathrm{y} \times$ quinquepartitus, lobis inaequalibus, obtusis, ciliatis. Coroll a e petala imo calyci inserta, mediantibus staminibus in corollam bilabiatam, labio superiore tridentato, inferiore bipartito coalita. St a m in a 5 , cum petalis cohaerentia, calycis lobis opposita, duo postica cum antico longe exserta, duo lateralia brevissima, inclusa; filamenta filiformia, a $\mathrm{t}$ h erae biloculares. O var $\mathrm{i}$ m sessile, ovatotrigonum, triloculare. $0 \mathrm{vula}$ in loculis gemina, collateraliter pendula. Stylus filiformis, exsertus, hirtus; stigma trilobum, lobis obtusis, Fructus..... Frutex guianensis, ramosus; foliis alternis, breve petiolatis, ovatis, acutis, subcoriaceis, venosis, integerrimis, stipulis petiolaribus geminis, deciduis, floribus parvis, in apice petioli incrassato sessilibus, tribracteatis.

T a p a r a Aublet Guian. I. 126, t. 48. Rielard Dict. bot. 34. DC. Prodr. II. 58. Meisner Gen, 73. (53.) Ro h. $r$ ia Schreber Gen. $n$. 63. Chailletia sessiliflora DC. Annal. Mus, XVII, t. 1. f. 2. (folium,)

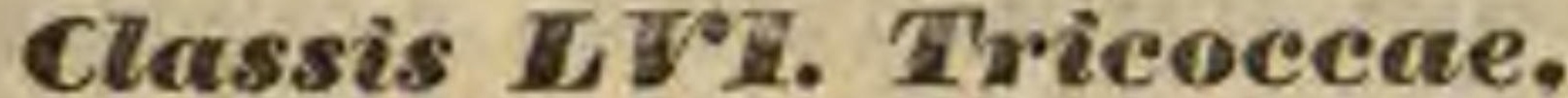

Herbae, frutices v. arbores, succo aqueo v. lacteo. Folia alterna v. opposita, simplicia, rarissime palmatim composita, integra v. palmatiloba, interdum nulla. Flores saepissime unisexnales, saepe incompleti. Calyx liber. Cor olla e petala definita v. nulla. Ovarium bi-tri-multiloculare. Ovula in loculis solitaria, v. gemina collateralia, ex angulo, centrali pendula, rarius e basi adscendentia, anatropa. Fructus capsularis, septicide in cocca delabens, axi centrali superstite, rarius baccatus $v$. drupaceus. Se mina in loculis solitaria, v. gemina collateralia, inversa v. rarius erecta. E mb ryo in axi albuminis carnosi orthotropus, ejusdem longitudine.

\section{Ordo CCXLI. Enaperreas.}

EMPETREAE Nuttall Gen, II, 233. Don in Edinb. new philosoph. Mag, 1828. II, 59, Bartling Ord, nat. 372, Lindley Introdaet, edit, IT. 'p. 117 .

Froticuli ericoidei, aridi, erecti v. procumbentes, ramosissimi, ramis teretiusculis. Folia alterna, interdum subverticillatim aggregata, coriacea, acerosa, simplicia, integerrima. Stipula e nullae.

Flores parvi, regulares, dioici v. polyga$\mathrm{mi}$, in axillis foliorum superiorum sessiles, solitarii v. pauci aggregati, rarius in apice ramorum glomeratim conferti, nudi v. bracteolis squamaeformibus, imbricatis cincti.

$\mathbf{C}_{\text {as Yx }}$ liber, tri- vel rarissime diphyllus, foliolis aestivatione imbricatis, coriaceis v. saepius membranaceis et bracteolis conformibus.

Corollae petala hypogyna, calycis foliolis numero aequalia et alterna, isdem similia v. distinctius corollina, brevissime unguiculata, marcescenti persistentia.

Stamisa (in floribus femineis rudimentaria v. nulla) cum petalis inserta, iisdem numero aequalia et alterna. Fil a m e $t$ a filiformia, exserta, libera, antheris delapsis persistentia. Antherae extrorsae, biloculares, subgloboso-didymae v. oblongae, longitudinaliter dehiscentes.

Ovarium (in floribus masculis rudimentarium) disco insidens, subglobosum, e carpidiis duobus, tribus, sex v. novem compositum, carpidiorum marginibus introflexis, columellae centralis tenuissimae, demum obliteratae costas attingentibus, tri-sex-novemloculare. $0 \mathrm{vula}$ in loculis solitaria, ex anguli centralis basi adscendentia, anatropa. Stylus brevis, angulatus v. subnullus. Stig m a radiato-lobatum, lobis truncatis, laciniatis $\mathbf{v}$. inciso-pinnatifidis.

Drupa baccata, sphaerica, subdepressa, apice umbilicata, di-tri-hexa-enneapyrena, pyrenis in axi cohaerentibus v. distinctis, osseis, monospermis.

Srmiva in loculis solitaria, pyrenae cavitati conformia, triangularia, erecta. Testa mem- 
branacea, tenuis, hinc vasorum reticulo, ab umbilico basilari tuberculiformi ad $\mathrm{ch}$ al az a m punctiformem, in apice seminis sitam procurrente, percursa. Albumen testae conforme, copiosum, dense carnosum, pallidum.

Eиввуо in axi albuminis orthotropus, ejusdem fere longitudiue, teres. Cotyledones semicylindricae, breves, obtusae. Ka di cula cylindrica, umbilico proxima, infera.

Ordo perparvus, speciebus paucis per Enropam mediam alpestrem et borealem, Lusitaniam, Americam borealem et regionem magellanicam dispersis, diu cum Ericineis, quibus nullo modo affinis, consociatus, dein a Nutallio distinctus, sed invita natura Coniferis approximatus, tandem a D. Don circumscriptus, Euphorbiaceis et Celastrineis proximus.

Corematis baccae (Camerinheira) a Lusitanis adhibentur praeparando potui acidulo, quem febricitantibus commendant medici populares. Empetri nigri folia sapore acidulo, haud ingrato pollent.

57 60. Corema DON. F l ores polygami. Calyx ebracteolatus, triphyllus, membranacens, Coroll a e petala 3 , calycis foliolis alterna. S $\mathbf{t a -}$ mina 3, ealycis foliolis opposita, exserta; filamenta filiformia, antherae extrorsae, biloculares, oblongae, longitudinaliter dehiscentes. 0 variu m disco carnoso insidens, triloeulare. Ovala in loculis solitaria, e basi erecta, anatropa. St yIns brevis; stigma radiato-sexfidum, lobis incisis. Drupa baceata, globosa, tripyrena, pyrenis monospermis. Semina erecta, testa membranacea. Embryo in axi albuminis carnosi orthotropus, ejusdem longitudine, teretiusculus; cotyledonibus brevissimis, radieula infera. - Fruticulus erectus, in ora maritima $L u s i$ taniae crescens, ramosissimus, rigidus, punctis resinosis conspersus; foliis sparsis, patentibus, linearibus, obtusis, supra planis, margine revolutis, stipulis nullis, floribus terminalibus, glomeratis, receptaculo piloso, squamis villosis bracteato insidentibus, majusculis, albidis, baceis albis.

Corema Don in Edinb. new philosoph. Journ. IT. 63. Empetrum al b u Linn. Gärtner $I I, 167, t, 106$.

5\%61. Empetroum TOURNEF. Flores polygami. Ca lyx squamis, sex imbrieatis cinctus, triphyllus, coriacens. Coroll a e petala 3 , talycis foliolis alterna. Stamina 3 , calycis foliolis opposita, exserta; filamenta filiformia, anthera extrorsae, bilueulares, subgloboso-didymae, longitudinaliter dehiscentes. Ovari n m disco carnoso insidens, sex. novemloeulare. $0 \mathbf{v u l a}$ in locnlis solitaria, e hasi erecta, anatropa. Stigma subsessile, radiato-sex novemfidum, lobis laeiniatis. D rup a baceata, depressa, hexa-enneapyrena, pyrenis monospermis. S e mina erecta, testa membranacea. E mbryo in axi albuminis carnosi orthotropus, ejusdem longitudine, teretiusculus; cotyledonibus brevissimis, radicula infera. - Fruticuli in Europa et Asia boreali, nec non ad fretum Mag ellanicum crescentes, procumbentes, ramosissimi; foliis alternis, subverticil latim canfertis, linearibus v. oblongo-linearibus, obtusis, supra planis, atro viridibus, nitidis, margine revolutis, subtus convexis, nervo membranaceo, stipulis nullis, floribus parvis, axillaribus, solitariis, sessilibus, dioicis $v$ : interdum hermaphroditis, atro-sanguineis, baccis nigris $v$, rubris.

Empetrum Touraef. Inst. 421. Linn. Gen, n, 1100. exel. sp. Selikuhr $t$. 318, E. B. $t$. 526. Flor. dan. $t .975$. Don in Edinb. new philosoph, Journ. II. 82. Nees Jua, Gen. plant, II, 1. t, 42.

576\%. Ceratiola L, C. RICHARD, C a I y x squamis quatuor imbricatis munitus, diphyllus, foliolis membranaceis, fimbriato-ciliolatis, braeteolis conformibus. Corollac petala 2 , calycis foliolis alterna et conformia, conniventia. Stamina 2, calycis foliolis opposita, exserta; filam enta filiformia, an $t$ hera extrorsae, globoso-didymae, biloculares, longitudinaliter dehiscentes, 0 vari u m disco carnoso insidens, biloculare. Ovula in loculis solitaria, e basi erecta, anatropa. S tyl a s brevis, crassus; stig m a radiato-subsexfidum, lobis inciso-pinnatifidis. Dr up a baceata, globosa, dipyrena, pyrenis monospermis. Semina erecta, testa membranacea. E m b ry $\mathbf{o}$ in axi albuminis carnosi orthotropus, teretiusculus, ejusdem fere longitudine; cotyled onibus brevibus, radicula infera, - Suffrutex boreali-americanus, adscendens, rigidus, ramosissimus; ramis simplicibus, strictis, foliis alternis, verticillatim approximatis, patentibus, acerosis, obtusis, nitidis, supra carinatis, subtus sulco exaratis, stipulis nullis, floribus axillaribus sessilibus, solitarits $v$. paucis aggregatis, baccis aurantiacis.

Ceratiola L. C. Richard in Michaux Flor. Bor. Amer. II. 292. Pursh Flor. Bor. I. 21, t. 13. Don in Edinb. new philosoph. Journ, II, 63. Hooker in Bot, Mag. t. 2738 .

\section{Ordo CCXIII. Stackleonsiaceae.}

STACKHOUSEAE R. Brown in Flinders Voy, II, 555. Bartling ord nat. 368 . STACKHOUSIACEAE Lindley $\mathbf{I n}$. troduct, edic. p. 118.

HsRB, E perennes, interdum suffrutescentes, in Nova-Hollandia extratropica indigenae, succo aqueo. Folia alterna, simplicia, integerrima, interdum minuta. Stipulae ad basim foliorum geminae, minutissimae.

Flores hermaphroditi, regulares, in spicas terminales, simplicissimas dispositi, singuli tribracteati.

CaLyx liber, tubo ventricoso, limbi quinquepartiti laciniis aequalibus v. subinaequalibus.

Corollae petala 5, calycis fauei inserta, ejusdem laciniis alterna, unguibus linearibus in tubum, calyce multoties longiorem, rectum v. apice incurvum cohaerentia, laminis linearibuś, stellatim patulis.

Stamina 5, cum petalis inserta, iisdem alterna, inclusa. Fil a m en t a filiformi-subulata, libera, duo alterna breviora. An $t$ herae introrsae, biloculares, basifixae, loculis longitudinaliter dehiscentibus.

Ovarium sessile, liberum, e carpidiis tribus v. quinque, angulo cum columna centrali cohaerentibus compositum, tri-quinqueloculare, tri-quinquelobum. Ovula in loculis solitaria, 
e basi erecta, anatropa. Styli loborum numero, distincti v. basi aut juxta totam longitudinem coaliti; stigmata indivisa.

Fructus tri-pentacoccus, coccis siccis, apteris v. alatis, a columna centrali persistente solutis, indehiscentibus; nonospermis.

Seиina erecta, testa membranacea, hine rhaphe longitudinali percursa. Alb umen carnosim.

Enвryo in axi albuminis orthotropus, ejusdem fere, longitudine; cotyledonibus brevibus, obtusis, radicula infera.

Ordo perparvus, Celastrineis et Euphorbiaceis arcte affinis, ab his coccis indehiscentibus seminibusque erectis, ab illis stipularum praesentia, petalorum unguibus in tubum coalitis, disci carnosi defectu, et ovarii elementis subdistinctis diversus.

5ร63. Staekhousia SMITH. Calyx tubo ventricoso, limbo quinquepartito. Corollae petala 5, calyeis fanci inserta, nnguibus linearibus in tubum rectum cohaerentihus, laciniis stellatim patentibus. Stamina 5 , cum petalis inserta; filamenta filiformia, libera, duo alterna breviora, a n therae introrsae, biloculares, Iongitudinaliter dehiscentes. Ovarium tri-quinquelobum, Iobis uniovulatis, o v u 10 e basi erecto, anatropo. Styli $3_{-5}$, liberi v. plus minus coaliti; stigmata indivisa. Fructus tripentacoccus, coceis apteris, subcrustaceis, laevibus v, muricatis, a columna centrali persistente solutis, indehiscentibns, monospermis. S e mina erecta, testa membranacea. Embryo in axi albuminis carnosi orthotropus, ra di $\mathrm{cu}$ la infera. Herbae perennes $v$. suffruticosae, in Nova. Hol landia extratropica indigenae; foliis spar sis, integerrimis, oblongo spathulatis v. lineari-lanceolatis, interdum minutis, minute bistipulatis, spicis terminalibus simplicibus, floribus tribracteatis.

$\mathrm{S}$ tackhoux i $\mathrm{Smith}$ in Linn. Transact, IV. 218. Labillard. Nov. Holl. t. 104. Lindley in Bot. Heg, t. 1917. A. Richard Sert. Astrolab. t. 33.

5\%64. Tripterocoecus ENDL. C a lyx tubo ventricoso, limbe quinquepartito. Corolla petala 5 , calyeis fanci inserta, unguibus linearibus, in tubum apice incurvam enhaerentibus, laminis stellatim patentibus. Stamina 5 , cum petalis inserta ; fila m ent a subulato-filiformia, libera, duo alterna paullo breviora, anthera e introrsae, biloculares, longitudinaliter dehiscentes. Ovarinm trilobo-triquetrum, lobis uniovulatis, ovnlo e basi erecto, anatropo. Stylus cylindricus, indivisus; $s t \mathrm{ig} \mathrm{m}$ a brevissime trilobum. Fructus tricocens, coccis trialatis, alis membranaceis, reticulato-venosis, lateralibus dorsali longioribus, a columna centrali persistente solutis, indehiscentibus, monospermis. Semina erecta, testa membranacea. E $m$ bryo in axi albuminis carnosi orthotropus, ra di cula infera, - Herbae in Nova-Hollandia austro-occidentali et in insula Diemen indigenae, Basi suffruticosae, caespitoso-ramosae; ramis tetragonis, basi parce ramosis, superne aphyllis, folitis alternis, angustissime bistipulatis, spicis terminalibus simplicibus, laxiusculis, pedicellis brevibus, basi tribracteatis, floribus suaveolentibus.
Tripteracoccus Eadlicher in Enumerat, plant. Hügel. 17.

\section{Ordo CСХиIII. Euphorbiacene.}

EUPHORBIAE Jussieu Gen. 384. TITHYMALOIDEAE Venten. Tab, 1IT. 483. EUPHORBIACEAE R. Brown in Flinders Voy. II. 555. Adr. Jussieu, de Euphorbiacearum ge. neribus medicisque earundem viribus tentamen. Parisits, 1824. 4. Bartling Ord, nat. 369. Lindley Introduot. edit. $\boldsymbol{X}$. p. 112.

Herbae, froticks v. arbores, succo aqueo v. in pluribus lacteo, caudice in nonnullis carnoso, cactiformi. Folia alterna v. rarius opposita, sessilia v. saepius petiolata, simplicia, rarissime palmatim composita, integra v. nonnunquam palmatiloba. Stipulat parvae, membranaceae, saepissime deciduae, in plurimis nullae.

Flores unisexuales, monoici $v$, dioici, saepissime incompleti, solitarii, fasciculati, spicati v. racemosi, bracteis uni-plurifloris, nunc masculis in eadem cum femineis inflorescentia plerumque superioribıs, nune in diverso ramo v. stirpe segregatis, interdum umbellati, masculis cum femineis involucro communi interdum florem hermaphroditum mentiente cincti.

Calxx liber, quadri-quinque-sexfidus v. partitus, aestivatione valvatus $v$. imbricatus, rarius di-polyphyllus, interdum nullus.

Corolua saepissime nulla, nune petala calycis laciniis numero aequalia et alterna, rarius plura, imo calyci v. sub disco calycis fundum vestiente inserta, aestivatione saepissime convolutiva, plerumque cum squamulis v. glandulis alterna.

Floribus masculis: Stamina nunc definita, calycis laciniis numero pauciora, aequalia v. dupla, nunc indefinita, centro floris v. sub ovarii rudimento inserta; filamenta libera $v$. coalita, interdum in ovarii abortivi stipitem coeuntia, a ntherae introrsae v. extrorsae, biloculares, loculis saepissime distinctis, interdum divaricatis, filamenti apici v. infra apicem glandulosum v. cuspidatum insertis, longitudinaliter dehiscentibus, rarissime poris apertis.

Floribus femineis. Ovarium sessile v. rarissime stipitatum liberum, bi- v. saepius triloculare, rarius pluriloculare, carpidiorum marginibus in dissepimenta introflexis, cum axi centrali stylifera coalitis.

Ovusa in loculis solitaria ant gemina collateralia, angulo centrali infra apicem, saepissime sub columnae protuberantia exstinctoriformi appensa, anatropa. Styli loculorum numero, distincti $v$. in unum simplicem aut divisum coaliti, interdum brevissimi v. nulli; stigmata totidem distincta v. coalita.

Froctus saepissime epicarpio membranaceo v. fibroso capsularis, rarius epicarpio carnoso baccatus, intus di-tri-polycoccus, coceis sae139 * 
pissime a columna persistente secedentibus, unilocularibus, indehiscentibus v. bivalvibus, mono-dispermis, rarissime loculicide dehiscens.

Srmina pendula, testa crustacea, saepissime caruncula umbilicali instructa v. arillata. Albumen carnosum, plus minus copiosum.

Enвryo intra albumen orthotropus, ejusdem longitudine. Cotyledones plano-convexaev. planae, interdum foliaceae, rectae v. nonnunquam varie flexae. Ra dicu la umbilico proxima, supera.

Ordo vastissimus, multiformis, summe naturalis, hine Frangulaceis et Terebinthineis mediantibus Inglandeis et Burseraceis conterminus, illine fructus imprimis fabrica ad Malvaceas accedit.

Euphorbiaceae in America aequinocliali maximo numero provenientes, in regionibus extratropicis novi orbis multo rariores, in Asia et Africa tropica, imprimis cis aequatorem, minus frequenter generantur, in regione mediterranea et Asia temperata paullo quam in regionibus veteris orbis, inter cancrum et aequatorem sitis, frequentius obviae.

Plurimae venenatae, nonnullae aromaticae, v. resiniferae, quorundam semina, ab lato embryone, edulia, Aliquae ob radicem fecula scatentem inter tropicos cultae, magni in oeconomia gentium Americanarum momenti.

TRIBES T. EUPHORBIEAE Bartling Ord. nat. 372. 0 v a ri i loculi uniovulati. Flores monoici, apetali, inter involucrum commune masculi cum femineis.

5765. TPedilianthus NECK. Flores monoici, intra involucrum eommune masculi plures, femineum unicum stipantes. Involucrum eommune calceiforme, superius coarctum, basi ven. tricosum et intus glanduliferum, hinc hians, aucturn lacinia fornicata, fancem claudente. F I o res masculi inaequaliter pedicellati, pedicellis ebracteolatis. Calyx et eorolla nulla. Stamen uni cum; fil a mento cum pedicello articulato, eidem crassitie aequali, antherae bilocularis didymae loculis globosis. F los femineus longius pedicellatus. Cal yx et corolla nulla. O varium sessile, trilueulare, loculis uniovulatis. Stylus simplex, erassus; 8 tigmata 8 , brevia, bifida. Capsuia laevis, tricocea, coccis elastice bivalvibus, monospermis. - Frutices lactescentes, inermes, in America et Asia tropica crescentes; foliis alternis, integerrimis, subcarnosis, breviter petiolatis, petiolo ad basim utrinque glanduloso, pedunculis terminalibus aggregutis, foliis bracteaeformibus stipatis, singulis involicrum unum rubrum ferentibus.

PedHan th us Necker Elem,n, 1150. Paiteau in Annal. Mas. XIX. 38s, t. 19. Kunth in Humb, et Bonpl. Nov. gen. et sp. II 63. Adr. Jussieu Eupharb, 59. Bot. Reg, $t .832$. Crepidaria Haworth Synops. 67. T teh y maloides Tour. nefort Inst. 654. E u pho rbiae sp. Linn. Jacg. Amer. t. 92. Hort, schönbr, $t$, 270 .

5ร66. Euplnorbia LINN. F lores monoici, intra involucrum commane masculi plures femineum unicum stipantes. Invol a $\mathrm{crum}$ commune campanulato - turbinatum, limbo quadri-quinquefido, extus quinque-uniglanduloso, Iaciniis membranaceis, integris v, ciliato-fissis, glandulis magnis, cum laciniis alternantibus, substipitatis, truncato-peltatis, crassis, forma variis. Flores masculi singuli braetea eiliato-lacera stipati, pedicellati. Calyx et corolla nulla. Stamen unicum, fil a m e n to cum pedicello articulato, eidem crassitie aequali, anthera e bifocularis, didymae loculis globosis. F lo s femineus longius pedicellatus. Ca l y $x$ minimus, dentatus v. lobatus, saepissime obsoletus. O $\mathrm{v}$ a r i u m sessile, triloculare, loculis uniovulatis. Styli tres, bifidi, rarius in unum apice bifidnm connati; stigmata 6 v. ra. rius 3 , biloba. C a p s la laevis v. verracosa, glabra v. pilosa, tricocea, coceis elastice bivalvibus, decidnis, monospermis. - Plantae lactescentes, per totum terrarum orbem diffusae, in regionibus temperatis hemisphaerae borealis, ubi majori numero obviae, herbaceae, in regionibus calidioribus imprimis hemisphaerae australis suffrutescentes, fruticosae $v$. arboreae, nonnullae imprimis capenses cactiformes, aphyllae, foliis in reliquis alternis $v$. rarius oppositis, saepissime stipulatis, florulibus saepe verticillatis, integris, integerrimis, serratis $v$. denticulatis, involucris in ramis floriferis dicholomis alaribus v. terminalibus, plerumque in apice caulis umbellato - congestis.

Eupharbia Linn. Gen. n. 609. Jussieu Gen, 386. R. Brown in Elinders Voy. IT. 555 . Kunth in Humb. et Bonpl. Nov. gen. ef sp. II. 5i. Adr. Jussien Euphorb. 57. 4. 17, f. 61. Röper Enumeratio Euphorbiarum Göuing. 1824. 4. T it h y ua I u s Touraef. Inst, $t$. 18. Gärtaer fr. 115, $t, 107$. E uphorbium Isnard in Act. Academ. Paris, 1720. Eu p horbia, Keraselma, Athymalus et Tithymalus Necker Elem, $n, 1153.1155 .1157$. E u phor b I a, Treis i a, Dactylantbus, Medusea, Tithymalus, Galo. rhoeus, Fsula et Anfsophyllum Haworth Synops. succ. 126 - 164 .

ธรดร. Anthostema ADR. JUSS. Flores monoici, intra involucrum commune masculi plures involucellati, femineum unicum lateralem exinvolucellatum comitantes, In vo l u c rum commune profunde bilobum, lobis intus glandala minuta instructis. Masc. Involucrum suboctololum, lobis dissimilibus. F lores plurimi, receptaculo plano impositi, pedicellati, bracteis paleacis interjectis fasciculati, inaequilongi. Calyeulns minimus, tri - quadrifidus. S $t$ a m e $n$ unicum; fi lamento basi articulato, a ntherae bilocularis, didymae loculis subglobosis. F em. InvolucelI u m nullum. F los longius pedicellatus, pedicello apice incrassato. C al y x pedicelli apiei continuus, campanulatus, tri-quadridentatus. 0 va $\mathrm{rin}$ m sessile, triloculare, loculis nniovulatis. Stylus brevis, erassus, trifidus; stigmatibus tribus, subbilobis. Capsu 1 a carnosa, tricocca, coceis monospermis, - Arbor sene gambica, lactescens; foliis alternis, integerrimis, glabris, venosis, peduneulis axillaribus, multifloris, ramosis, ad divisuras articulatis.

A in thostem a Adr. Jussieu Euphort, 56, $2,18, f, 60$.

5\%68. Dalechampia PLUM. Flores monoici, masculi cum femineis intra involucrum commune pedunculatum, diphyllam, foliaceum, basi appendiculis quatnor stipnlaeformibus. Ma 8 c. Invol acellum pednnculatum, di-pentaphyllum, multiflorum, floribns pedicellatis. $\mathrm{C}$ al $\mathbf{y x}$ quadriquinquepartitus, aestivatione valvata. St a mi ina plurima; filamentis inferne in stipitem pedicello continuum connatis, antheris biloculari- 
bus. Squamae nonnullae interdum filamentis interjectae, plures in umbellae latere fascieulatae, apice pluripartitae, resinifluae. F e m. I n vol uc e l. liu m subsessile, diphyllum, triflorum, floribus brevissime pedicellatis, Calyx quinque-sex-interdum decem-duodecimpartitus, laciniis integris, dentatis et eiliatis, demum saepissime increscentibus, rigidis, spinulosis v. papposis. Ovarium sessile, triloculare, loculis nniovulatis. Stylus simplex, oblongo-subislavatus; $8 \mathrm{ti} \mathrm{gma}$ indivisum, capitato-peltatum v. infundibuliforme. Capsula calyce acuto, longe pedicellato cineta, tricocea, coccis monospermis. - Frutices scandentes $v$. volubiles, saepissime hispidi, in America tropica copiosi, in Asia et Africa ruriores; foliis alternis, longe petiolatis, bistipulatis, nunc subintegris, nunc tri-quinquelobis $v$. partitis, tri-quinquenerviis, basi biappendiculatis, pedunculis axillaribus saepius bracteatis, bracteis stipuliformibus, involucri communis foliolis saepissime trilobis, demum membranaceis, reticulato - venosis.

Dale eha m p ia Plumier Gen, 38, Linn. Gen, n. $108 x$. Kunth in Humb. et Bonpl. Nov. gen. et sp. II. 28. Adr. Jussteu Euphorb. 35. t, 17. f. 59. Endlicher Alakta t, 20.21.

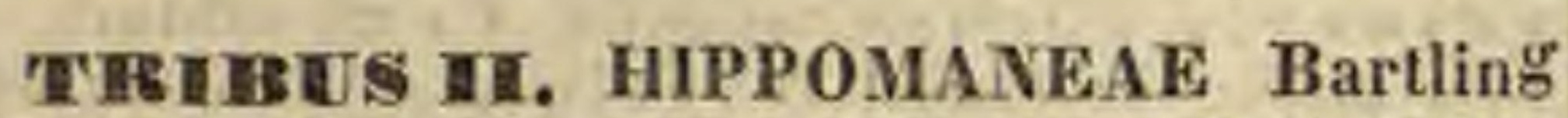
Ord. nat. 372. $0 \mathrm{varii}$ loculi uniovulati. Flores apetali, spicati, bracteis uni-multifloris.

5869. Niaproumet $A U B L$. F lores monoici. M a s c. in eapitula amentiformia, involnero bipartito, brevi, bibracteato cincta, squamis interjectis aggregati, pedicellati. C aly x bi-quadrifidus. Stam en filamento exserto, apice indiviso v, bifido, diantherifero, a n $t$ h e $r$ is extrorsis, bilobis. Flos femineus ad basim capituli masculiflori unicus, brevi pedunculatus, bibracteatus. C a ly $\mathrm{x}$ trilobus. $O \mathrm{v}$ a riu $\mathrm{m}$ triloculare, loculis uniovnlatis. St y1 u s brevis, crassus, trifidus; stigmat a 8 , reilexa. Cap sula tricocea, coccis bivalvibus, monospermis, seminibus osseis, inferne scrobiculatis. - Arbores guian enses el brasilienses, lactescentes; foliis alternis, petialatis, integerrimis, glabris, superne lucidis, venosis, florum capitulis amentiformibus, ovatis, in paniculus parvas, terminales dispositis.

M a p r o une a Aublet Guian. II, 895, t. 342. Adr. Jus. sieu Euphorb. 54. t. 17. St. Hitaire Plant, us. Brasil. t.65. A c y op ie on Lina. f. Suppl. 413. Smith Ic. ineditt. t. 42. Lam. t. 743, Gärtner $I I, 266 . t$. 138.

5ร รด. Adenopeltis $B E R T$. F 1 o r e 8 monoici, amentiformes, feminei $1-2$, ad basim amenti, reliqui masculi, omnes sessiles, solitarii ad axillam squamae introrsum biglandulosae, laciniis duabus filiformibus, lateralibus, persistentibus stipati. Ca 1 y $x$ nullus, Ma $8 \mathrm{c}$. Sta mina 2, filamentis inferne in unienm, basi articulatum coalitis, antheris extrorsis, bilobis. Fem. Ovari um triloculare, loculis uniovnlatis. Stylis, reflexi, simplices, intus stigmatosi. Ca ps u ia tricocca, coceis monospermis. - Frutex chilensis; foliis alternis, obovatis, dentibus minutissimis, basi subtus in glandulam discolorem incrassatis, marginatis.

Ad du opeltis Bertero ex Bullet, sc, nat, XX1. 128. Adr. Jussieu in Annal, sc, nat, $X X V, 24$. Colli g a y mach o Chilen.

5\% 1 1. Colliguaja $M O L I N$. F lo r es mo. noiei, amentiformes, feminei ad basim amenti 80 litarii, reliqui masculi, omnes sessiles, solitarii, squama eglandulosa. Calyx nullus. Masc. St a m in a $10-12$, squamae patentis nervo medio atrinque inserta; fila mentis brevissimis, confluentibus, a $\mathrm{t}$ heris bilocularibus. F em. Bractea lanceolata, bracteolis duabus lateralibus stipata. Ovarium subsessile, bi-triloculare, loculis uniovalatis. St yli $2-3$, patentissimi, simplices, intus stigmatosi. Cap 8 ula di-tricocea, coecis monospermis. - Frutices chilenses, lactescentes, glaberrimi, apice ramosi, foliosi; ramis junioribus rubicundis, foliis oppositis $v$, rarius alternis, brevissime petiolatis, lanceolatis, integerrimis $v$. nigro glanduloso serratis, amentis terminalibus.

Colli g a aja Molina Chili 199. Adr. Jussieu Euphorb. 62. Hooker Bot. Miscell. I. 139, 1. 39. 40. Delessert 1c, se. leet. III. t. 88.

5ร ร 2. Ex Execamia LINN. F lo res dioici v. monoici, floribns femineis ad basim spicae masculae solitariis v. pluribus, sessilibus v. pedicellatis, singuli bractea squamaeformi, basi extus saepissime peltatim biglandnlosa stipati, masculi sessiles. Ma s c. Caly x triphyllus, foliolis distinctis v, coalitis. Stamina 3 , calycis foliolis alterna, rarius 2 v. 4 ; filamen $t$ is basi inter se et enm ovarii abortivi stipitulo coalitis, apice liberis, an $t h$ eris biloòis, ex apice filamenti pendulis. F em. Calyx triphyllus. Ovari n m triloculare, loculis uniovulatis. Stylus tripartitus, lobis patentibus, simplicibus, intus stigmatosis. Capsula trilocularis, tricocea, coccis bivalvibus, monospermis. - Arbores $v$. frutices, saepissime lactescentes, in regionibus tropicis Asiae et Americae crescentes; foliis alternis, crenatis $v$. serratis, rarius integerrimis, glabris, spicis axillaribus.

Excoecarla Linn. Gen. n. 1102. Swartz Flor. Ind. occid. 1119. Adr. Jussieu Euphorb. 32.

a. GYMNANTHES, FIores monoici, feminei ad basim spicae masculae solitaril v. pauci, sessiles aut pedicel. lati. - Species americanae, lacte destitutae? - G y m. nauthes Swartz Prodr. 96. Gussonia Sprengel N. E. $I T, 118, t$. 3. Sebastianta Sprengel Op. cit. IT. 119. t. 2. (Jussieu Op. cit, $t, 16, f$, s5.)

b. EXCORCARIA. Flores dioici, masculi spicati, femi. nei subracemosl. - Species asiaticae et australasicao, lacte copioso scatentes. - Bxcoe carla Eudlicher Flor. Norf. 82. (Wight in Bot. Mag. Comp. t. 30.)

5\%83. Styldeeras ADR. JUSS, Flores nnne monoici, in iisdem spicis maseuli plures inferiores, femineus unieus terminalis, nune dieici, masculi spicati, feminei solitarii. M a $\mathbf{s} \boldsymbol{c}, \mathbf{S}$ q $\mathbf{u}$ a ma antherifera simplex, basi inserta, Antherae circiter 10, introrsae, sessiles, oblongae, inaequales, longitudinaliter dehiscentes. Fem. Cal y $x$ brevis, tri-quinquepartitus, 0 va ri um bi-qnadriloculare, loculis uniovulatis. St y li 2 , oblongi, distantes, incurvati, intus glanduloso-canalieulati. F ructus eapsularis (?) globosus, stylis persistentibus bicornis, bi-quadrilocularis, loculis monospermis, seminum testa fragili. - Arbores $A m e$ ricae tropicae; foliis Laurocerasi, alternis, integerrimis, coriaceis, nitidis, floribus axillaribus, nunc in iisdem spicis solitariis $v$. geminis, masculis pluribus cum terminali fernineo unico, nunc in diversis arboribus masculis spicatis, femineis solitariis, pedunculatis, bracteis ad basim pedunculorum plurimis, imbricatis, fructu eduli.

Styloceras Adr. Jussieu Euphorb. 53. t. 17. Kusth in Humb. et Bonpl. Nov. Ben. et sp. VIT. 172. $t, 637.638$. Trophis laurifolia Willd.

5\% 4. Commia LOUR. Flores dioici. Masc, amentacei, squamis imbricatis, unifloris. Calyx nullas. Filamentum unum, breve, anthe $r$ a multilocularis (antherae plares filamenti 
apici adnatae?) Fem in ei racemosi, Caly $x$ tripartitus, brevis, persistens. 0 va ri u m.....Styli 3 , reflexi, breves; stig ma ta crassiuscula. Ca psula triloba, trilocularis, loculis intus, hiantibus, monospermis. - Arbuscula coch inch in en$s i s$, succo resinoso scatens; foliis alternis, integer. rimis, glabris, amentis masculis axillaribus, brevi bus, racemis femineis subterminalibus, parvis, numerosis.

C o m m i a Loureiro Flor. chochinch. 742. Adr. Jussieu Euphorb. 53.

5ซร5. Symaspisma. Flores monoici. M a s c. amentacei, squamis peltatis, unifloris. $C$ a1 y $x$ pentaphyllus, convolutivus. S $\mathrm{t}$ a $\mathrm{m}$ in a $10_{-} 15$; fil am entis in columnam basi quinqueglandulosam connatis, an theris terminalibus, extrorsis, distinctis. Fem. racemosi. Caly $x$ minimus, quinquedentatus. Ova ri $\mathbf{n}$ m trilobum, triloculare, loculis uniovulatis. Stylus brevissimns, trifidus, lobis acntis, intus sulco longitudinali stigmatosis. C a 8 u l a tricocea, coceis elastice bivalvibus, monospermis. - Frutex Novae-Caledoniae; foliis alternis, petiolatis, subspathulato-acuminatis, integerrimis, glabris, amentis masculis axillaribus et terminulibus cylindricis, demum elongatis, racemis femineis elongatis, laxis, pendulis. t. 75 .

Crozophora peltata Labillard. Nov. Caled, 74.

58\% M a s. Amentum dense multiflorum, squamis imbrieatis, unifloris. Caly $\mathbf{x}$ hrevis, nrceolatus, truncatus. Fil a ment um columnare, crassum, medio tuberculis bi-triseriatim verticillatis, singulis subtus monantheriferis, Fem. solitarii, Calyx urceolatus, integer, ovarium arcte cingens, demum tripartito-lacerus. Ovari um sessile, duodecimoctodecimloculare, Ioculis uniovulatis. Stylns longe exsertus, sursum infundibuliformi-dilatatus; stigma maximum, concavo-peltatum, radiatoduodecim-octodecimlobum. C a p \& u I a lignosa, depressa, orbienlata, torosa, dodeca-netodecacocca, coccis elastice dissilientibus, bivalvibus, monospermis. - Arbores Americae tropicae, lactescentes; foliis alternis, petiolatis, petiolo basi squamaceo bistipulato, apice biglanduloso, cordatis, serratis, junioribus involutis, amentis masculis terminalibus $v$, in ramulis axillaribus longe pedunculatis, flore femineo solitario, juxta pedunculum amenti masculi subsessili.

H u ra Linn. Hort, Oliffort. t. 34. Jussieu Gen. 391. Lam IIt. t. 793. Turpin Atlas II, t. 289. Adr. Jussieu Eu. phorb. $5 t$.

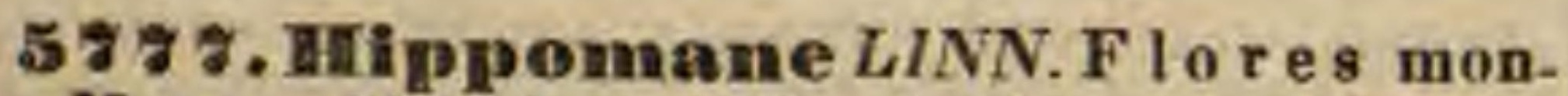
oici. Mas e uli glomerati. Caly $x$ turbinatus, bifidus. Filament $\mathbf{n} \mathbf{m}$ breve, apice diantheriferum, antheris adnatis, extrorsis. F em. solitarii. Calyx tripartitus. Ovari um sessile, subseptemloculare, loculis uninvulatis. Stylus brevis, crassus; stigmata septem, acuta, radiatim patentia. Fructus carnosus, pomiformis, intus polyeoccus, coceis in nucem lignosam, superfieie inaequalem et sinuosam coalitis, indehiscentibus, monospermis, pluribus saepe efoetis. Arbor Americae tropicae, lacte viroso scatens; foliis alternis, petiolatis, petiolo basi bistipulato, apice biglanduloso, ovatis, subserratis, glabris, lucidis, venosis, floribus masculis glomeratis, glomerulis in spicas terminales dispositis, multifforis, alternis, bractea basi utrinque glandulosa stipatis, femineis ad basim spicae masculae solitariis.
H i p pomane Linn. Gen, n. 1088. Jussieu Gen, 391. Turpin Milas. II. t. 278. Adr. Jussieu Euphorb. 51.t, 16.f.si. M a n c a

5ร8 8. Paeliystemon $B L U M$, Flores dioiei. Mas e. aggregati, Cal y $x$ tubulosus, tridentatus. Stamen unicum inclusum; filam ento crasso, anther a terminali, poro dehiscente. F e m. solitarii. Cal y $x$ ureeolatus, subintegerrimus, Ovariu m globosum, quinque - sexsulcum, quinque-sexloculare, loculis uniovulatis. St $\mathrm{ig} \mathrm{m}$ ata 5 -6, subulata, usque ad medium coalita, F r u c t u carnosus, sulcatus, quinque-sexlocnlaris, quinque - sexvalvis, - Arbor japonica, Mappae facie; foliis alternis, longissime petiolatis, peltatis, trilobis, glanduloso-denticulatis, magnis, deciduis, floribus spicatis, spicis axillaribus ramosis, bractea. tis, bracteis in masculis, multifloris, in femineis unifloris.

P a chy stem on Blume Bijdr. 626 .

58 9. Dnallantlaus ADR. JUSS. Flo. res monoiei. Masc. glomerati. Cal y x diphyllus, compressus, foliolis semiorbicularibus, basi emarginata glandulosis. St a min a $6-10$, filamentis brevibus, complanatis, partim conratis, antheris extrorsis, adnatis. Fem, solitarii. $\mathrm{C}$ aly x maris, deciduus. O varium sessile, oblongosubeylindricum, biloenlare, locnlis uniovulatis. St y l a s crassus, bipartitus; $s t i g m$ a $t a 2$, glandolosa, oblonga, basi et apice bifida, stylornm apicibus extus subpeltatim adnata. Capsula biloeularis, bivalvis, loeulis monospermis. - Frutices in Asia et Nova-Hollandia tropica crescentes; foliis alternis, longe petiolatis, integrerrimis, glabris, petiolis apice biglandulosis, floribus terminalibus spicatis, masculis glomeratis, glomerulis subtrifloris, confertis, bractea basi biglandulosa stipatis, femineis bracted simili instructis, longius pedunculatis, in eadem cum masculis spica inferioribus, $v$, in diversam spicam remotis.

$0 \mathrm{mal}$ an thus Adr. Jussieu Euphorb. 50, t. 16. f. 33. Graham in Bot, Mag. $t$. 2780 . C a r u m b i m Reinwardit in Sylloge Plant. I1. 6.

5ร 8D. Stillimgia GARD. Flores monoici, Masc. aggregati. C aly x cupuliformis crenulatus $v$. bifidus. Sta mina 2 , exserta; fila$\mathrm{men} t$ is basi coalitis, a ntheris extrorsis, adnatis. F e m. solitarii. C a I y x tridentatus v, trifidus. Ovari u m sessile, triloculare, loculis uniovulatis. Stylus brevis, erassus; stigmata 8 , simplicia, patentissima. Ca p 8 n la globosa, tricocca, coccis monospermis. - Arbores $v$. frutices lactescentes, in Asia et America tropica, nec non in insulis bourbonicis crescentes, lactescentes, foliolis alternis, petiolatis, petiolis apice biglandulosis, integerrimis $v$. serrulatis, floribus masculis in spicas saepissime terminales glomeratis, bracteolatis, glomerulis bractea basi plerumque biglandulosa stipatis, femineis in eadem spica inferioribus, $v$, in diverso ramg subsolitariis.

Stilling ia Garden apud Linn. Mant. $I$. n, 1279. Kunth in Humb. et Bonpl. Nov. gen, et sp. II, 64. Arir. Jassieu Euphorb. 49. t. 16. S a p i a m Jacq. Amer, 249. t. 158. Kunth in Humb. et Bonpl. Nov, gen, et sp. IT. 64. Adr. Jussieu Op. cit. 49. t. 15. T riad i c a Loureiro $O_{p}$, cit. 50.

5881. Mierostaelhys ADR. JUSS. F 10 res monoici. Cal yx tripartitus. Masc. Stam ina 3 ; fila mentis brevibus, liheris, a $n$ theris bilucularibus, adnatis. F em. Ovarium sessile, triloculare, loculis uniovulatis. Stylus tripartitus, reflexns; stigmata simplicia. Capsula laevis v. regulariter echinata, prismatico tricocca, 
coccis monospermis. Se mina teretia. - Herbae v. suffrutices America e tropicae; foliis alternis, minutissime bistipulatis, argute serrulatis, floribus axillaribus, aut extraaxillaribus bracteatis, bracteis basi saepissime biglandulosis, femineis unifloris, solitariis, masculis multifloris, distiche spicatis, spicis gracillimis.

Microstachys Adr. Jussieu Euphorb. 48, $t, 15$. Cnemidost a chys Martius et Zuecarini Nov, gen. et sp. I, 66. t, 40-44. Tragi a e s p. Linn. Vahl Eclog. II.t.19.

TREIBUS BII. ACALYPHEAE Bartling Ord. nat. 371. O varii loculi uniovulati. Flo$r$ e $s$ apetali giomerato-spicati v. racemosi.

5ร82. Tragia PLUM. FI ores monoici. Masc. Caly x tripartitus. Stamina $2-3$; fil amentis brevibus, an $t$ heris terminalibus. Fem. C a I y x sexpartitus, rarius quinque-octopartitus, laciniis persistentibus, interdum pinnatifidis. Ovarium triloculare, locnlis uniovulatis. St y l us trifidus; stigmatibus tribus. Cap sula hispida, tricocca, coccis subglobo. sis, bivalvibus, monospermis. S e mina subglobosa. - Herbae v. suffruticcs, in America, imprimis boreali calidiore, in Asia et Afri. ca tropica, nec non in Capite bonae spei crescentes, interdum scandentes $v$. volubiles, hispidae; folits alternis, stipulatis, serratis, lobatis $v$. rarius pinnatifidis, floribus axillaribus, racemosis, femineis ad racemi basim solitariis v. paucis, longissime pedicellatis, masculis pluribus, pedicellis brevibus, omnipus bracteatis, bracteis angustis, integris v. bitripartitis.

Tragi a Plamier Gen, 14, Ie.t. 2s8. Linn. Gen, n. 1048. Jaequin Ic. rar. $t$. 190. Paliset Flor, Owar. 54. Kunth in Humb, et Bonpl. Nov. Gen. et sp. II. 92, Adr. Jassieu Kuphorb. 47. $t$. 15. S e horige ram Adanson Fam, II. 335.

5793. Cnesmone BLUM. Fl o res monoici. Masc. Calyx urceolatus, trifidus. Stamina 3 ; fila mentis brevibus, antheris infra apicem adnatis, introrsis, cuspide filamenti inflexo superatis. Fem. Calyx triphyllus, persistens. Ovari nm triloculare, loculis uniovalatis. Stigmata S, sessilia, carnosa, basi coalita, persistentia. Ca p s u la hispida, tricocea, coceis subglobosis, bivalvibus, monospermis, Se min a subglobosa, - Herba javanica, suffruticosa, scandens, hispidula; foliis alternis, stipulatis, ovatooblongis, basi exciso-cordatis, inaequaliter dentatis, spicis oppositifoliis, basi nudis, floribus femineis paucis, masculis pluribus, omnibus subsessilibus, tribracteatis.

Cnesmone Blame Flor. Jav.Praef.VI. C nes mos a Blume Bijdr, 630 .

5.84. PIuknetia PLUM. F lores monoici. M a s e. Calyx quadripartitus. St amina 8_-16; fila mentis coalitis, basi glandulis quatuor barbatis cinctis. $\mathbf{F}$ e $\mathbf{m}$. $\mathbf{C}$ a ly $\mathbf{x}$ quadripartitus. O va rin m quadriloculare, loculis uniovulatis. Stylus simplex, elongatus; stigma peltatum, quadrilobum, lobis medio supra punctatis, C a psu la depressa, tetracocca, coccis anguloso-carinatis, bivalvibus, monospermis. Se m in a globosa, arillata. - Frutices America e et Asiae tropicae; folitis alternis, petiolatis, cordatis, serratis, floribus axillaribus, racemosis, femineo unico, infimo, masculis pluribus, longius pedicellatis.

Pluknetia Plumier Gen. 47, t, 13, Jo, t. 286. Linn. Gen. n, 1080. Jussieu Gen. 399. Adr. Jassieu Euphorb. 47. $\mathrm{S}$ a j o r Rumpb $A m b o i n . ~ I, ~ t .70, f .2$.
5ร85. Anabaena ADR. JUSS. Flores monoici. M asc. Caly $x$ campanulatus, quinquepartitus. St a m in a 10, squamulis quatuor cincta; fil amenta ima basi coalita, antherae terminales, globoso - quadrilobae. Ovarii rudimentum centrale, stipitatum, echinatum. F em. Caly quinquepartitus. Orarium sessile, triloculare, loculis uniovulatis. Stylus crassus, clavatus; stigma trilobum, lobis obtusis, extus medio glandula scutiformi notatis. C a p s n l a tricocea, epicarpio tenui sexpartibili, coccis subearinatis, monospermis. Semin a angulata, ossea. - Frutex brasilien sis, volubilis; foliis alternis, longe petiolatis, cordatis, serratis, floribus axillaribus, racemosis, femineo unico injimo, longe pedicellato, masculis pluribus, cum pedunculis brevibus articulatis, bracteatis.

A n a b a na Adr. Jussieu Euphorb. 47, $t, 15$.

5\% 86. Nereuriallis LINN. F 1 o r e 8 monoici v. dioici. Masc. C al yx tri-quadripartitus. Stam in a $8-12$, v. interdum plura; fil amentis liberis, exsertis, antherarum loculis globosis, discretis. F e m. C a ly x tri-quadripartitus. Fil a menta $2-3$, sterilia, ovario adpressa. Ovari u m didymum, biloculare, rarius trilobum, triloculare, loculis uniovulatis. St y li 2 v. 3, breves, crassiusculi, intus stigmatoso-fimbriolati. Capsu 1 a echinata v. tomentosa, di-v, rarins tricocea, coccis subglobosis, monospermis. S e mina ovata, strophiolata. - Herbae annuae $v$, perennes, inlerdum suffruticosae, in Eur op a, imprimis a ustra$l i$, rarius in Asia et Africa tropica obviae; foliis oppositis $v$, rarius alternis, stipulatis, dentatis $v$. subintegerrimis, floribus axillaribus et terminalibus, masculis glomeratis, glomerulis spicatis, bracteatis, femineis spicatis, fasciculatis v. solitariis. Mer eurlalls Tournef. Inst, 308. Linn. Gen, n, 1125. Gärtner II, 114. t. 107. Jussieu Gen, 385. Adr. Jussieu Euphorb. 46.

a. LiNozostis. Ca psuIa dicocea. Folla opposita. Species europeae. (Linn, f, Decad. I. t, 8, Sehkuhr t. 239. Gärtaer $t$, 107, E, B, $t$. 359 . 1872, Flor. dan. t. 400, Curt, Flor, Lond. II. $t$, 65. Steraberg in Re. gensb. Denkschrift. I. t. 4. Adr. Jussieu Euphorb. $t$. 14.) Nees jun. Gen, plant, II, 1. $t .40$.

b. TRISMEgista. Capsula tricocea. Folia alterna. Species senegalensis et indica.

5\%8\%. A ealyplaa $L I N N$. F lor es monoici v. dioici. Mase. C a l y x quadripartitus. Stamina $8-16$; fil a $m$ en $t$ a basibus incrassatis connata, antherae loculis distinctis, infra apicem filamenti appensis, liheris, oblengis, flexuosis. F em. C a 1 y $x$ tripartitns. O varinm triloculare, loculis uniovulatis. St y li tres, laciniati, laciniis tenuibus, irregularibus, (plerumque rabris). Capsula tricocea, eoceis subglobosis, bivalvibus, monospermis. Semina subglobosa, strephiolata. - Arbores, frutices $v$. herbae, Urticae v. Amaranti facie, in regionibus tropicis et subtropicis, imprimis Americae crescentes, nonnullae amphigeae; foliis alternis, petiolatis, stipulatis, serratis $v$, rarissime subintegerrimis, flo. ribus axillaribus $v$. terminalibus spicatis, masculis in glomerulos bractea minuta stipatos collectis, femineis solitariis, geminis v. ternis, intra bracteam ipsis longiorem, plerumque serratam v. lobatam, persistentem, spicis amentiformibus, nunc androgynis, floribus inferioribus et interdum terminali uno abortivo femineis, reliquis masculis, nunc unisexualibus, in diversa $v$, in eadem stirpe, masculis terminalibus, $v$, rarius femineis superioribus. 
A caly p ha Linb, Gen, n, 1082. Gärtuer II, 115. t. 107. Lam. $t$. 780. Sehkuhr t. 311. Jacq. Hort. schönbr. t. 243246. Ic, rar. t, 620. Cavanill. Ic. $t, 568$-570, Kunth in $H u m b$. et Bonpl. Nov, gen, et sp. II. 92. Adr. Jussieu Euphorb. 45. t. 14. Hooker in Bot. Mag. Comp. $t$, 29. C u p a m e 11 Adauson Fam, II. 356, U s teri a Denst. 2. Hort, Malab. V. 5 . - ? C a t u r u s Lian. Mant. $L$, n. 1280. Adr. Jussien Euphorb. 45, t. 14. Gal u ru s Sprengel $S_{y s t} t, 361$. C a n d a felis Rumph Amboin. IV. $t$. 37. A ealy pha hispida Burmani Flor, ind. t, 61 .

58 89. Drappa ADR. JUSS. Flores mon oici v. dioici. Mas c. Caly $\mathrm{x}$ bi-tripartitus. Sta$m$ ina $2 \_12$; filam enta libera $v$. basi coalita, antherarum loculis globosis, horizontalibus, longitudinaliter dehiscentibus. F e m. Cal y x irregulariter bi-trifidus. Ovari um bi-tri-rarius quadriloculare, echinatum, loculis uniovulatis, Sty1i $2-4$, distincti v. ima basi coaliti, oblongi, intus plumoso-stigmatosi. C a p 8 u la echinis longis raris armata $v$. interdum inermis, di-tri-tetracocea, noceis monospermis. Se mina tunica carnosa arillata. - Arbores $v$. frutices Asiae tropicae; foliis alternis, longissime petiolatis, peltatis, subtus saepissime granulis resinosis conspersis, stipulis ad basim petiolorum geminis, deciduis, spicis axillaribus ramosis, bracteatis, bracteis magnis, sessilibus, femineis plerumque unifloris, masculis multifloris, capsulis saepe granulis resinosis, luteis, gummi ammoniaceum spirantibus conspersis.

M a p pa Adr. Jussien Euphorb. 44 $t, 14$. Blume Bijdr. 693. Ricinus Mappa L, et R. tanarius L.

5\%89. Nacananga THOUAR. Flores dioici. Masc. Calyx quadripartitus. Stamina 8-12; filamentis exsertis, liberis, antheris terminalibus, cruciatimbisulcis. Fem. Caly x minimus, nrceolatus. Ovarium uniloculare, ovulo unico, pendulo. Sty I us terminalis, liguliformis, hine villeso-stigmatosus. Cap s $\mathrm{ul}$ a folliculiformis, saepe tuberculosa, unilocularis, monosperma. Semen ex apice loculipendulum, e mbryone intra alhumen carnosmm minimo, radicula supera. Arbores $v$. frutices resiniflui, madagascarien$s$ es et mauritiani, ovario monomero inter Euphorbiaceas anomali; foliis alternis, peltatis $v$. cordatis, basi biglandulosis, stipulis deciduis, floribus axillaribus, masculorum glomerulis bracteatis, in spicus ramosas dispositis, femineis saepe solitariis, bracteis glandulosis stipatis.

Mnearanga Thouars Gen. Madagasc. n, 88, Adr. Jussíeu Euphorb. 43. P a n o p i a Noronha msc.

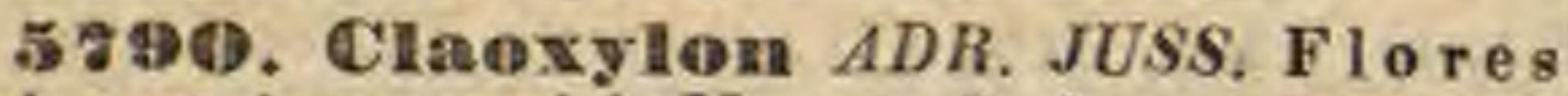
dioici v. rarins monoici. M a 8 c. Calyx tri-quadripartitus. Stamina plarima, receptaculo hemisphaerico inserta, squamnlis mixta; filamentis liberis, antherarnm locolis in apice filamenti distinctis, erectis, rimula brevi longitudinali dehis. centihus. F em. C a ly $\mathrm{x}$ brevis, tripartitns, intus glandulis tribus carnosis, coloratis, cum laciniis alternantihus auctus. Ovarium bi-tri-quadriloculare, loculis uniovulatis. Styli 2_4, reflexi, intus plumoso-stigmatosi. Cap 8 u la di-tetracocea, abortu inferdum monococea, coccis monospermis. Sem in a arillo carnoso tunicata. - Arbusculae $v$. frutices, borbonici, indici et $j a v a n i$; foliis alternis, petiolatis, glanduloso-serratis, scabris, floribus in spicis $v$. racemis axillaribus solitariis, laxe fasciculatis v. glomeratis, fasciculis v. glomernlis bracteatis, singulis bracteolatis, brevissime pedunculatis, plerumque imprimis ante anthesim purpureis.

Cla o xylon. Adr. Jussieu Euphorb. 43. t. 14. Ery. throchilus Reinwardt in Blume Bijdr. 614. A c a Iy h a spleiflor a Burmann Flor. ind, t. 61, f. 2.
5\%91. Comceveliba $A U B L$. F 1 o r es dioici. Mas c...... F e m. Ca ly x quinque-sexpartitus, laciniis rigidis, acutis, basi intus uniglandulosis, extus glandulis tribus bilobis anctus. Ovariu m trigonnm, pilis fasciculatis pulverulentum, triloculare, loculis uniovalatis, ovulis infra apicem insertis. St $y$ In 8 tripartitus; 8 tig m a $t$ a 3 , biloha. C a psula coriacea, sexcostata, tricocca, coccis bivalvibus, monospermis. Se mina arillo carnoso calyptrata. - Arbor guianensis, succo viridi scatens; foliis alternis, petiolatis, ovato-oblongis, acutis, dentatis, subtus cinerascentibus, stipulis minutis, deciduis, floribus masculis ignotis, femineis spicatis, singulis pedicello crasso, trigono, basi multibracteolato insidentibus.

C o n ce veib a Anblet Guian. II. 923. $t$, 353. Adr. Jus. sieu Euphorb. 43, in not, t, 14. f. 42, B.

5รง2. Aparistlomivan. F I o res dioici. M a sc. Calyx tripartitus. Sta mina $\mathbf{3}$ v. 4 , exserta; filamentis inferne coalitis, antheris introrsis, adnatis. F em. C aly $x$ quinquefidus, eglandulosus. O va ri um triloculare, loculis uniovulatis, ovulis apice insertis. Styli 3 , intus plumoso-stigmatosi. C a p sula tricocea, coccis monospermis. S e min a arillata. - Arbor guianensis; foliis alternis, longe petiolatis, subserratis, supra glabris, subtus nervis prominentibus reticulatis, petiolo basi stipulato, floribus in spicas axillares $v$. terminales, simplices aut fasciculatas dispositis, masculis glomerulatis, glomerulis multibractea. tis, femineis solitariis, pedicello incrassato, basi bracteolato insidentibus.

Conceveibum Richard ex Adr. Jussieu Euphorb. 49. t. 14. f. $42, B$.

5รง ร. Ganphalea $L I N N$. F I o res monoici. Calyx qnadripartitns. Fila me n $\mathrm{t}$ m disco glanduloso impositum, snperne dilatatom, pileiforme, ambitu bi-trilobum, lobis monantheris, antherarum loculis distinctis, lobi lateribus subimmersis. Ovarium obtase trigonum, triloculare, loculis uniovulatis. Sty Ins brevis, crassus; stigm a obsolete trilobum. Fructus carnosus, intus tricocens, demnm tripartibilis, coccis monospermis. Semin a magna, subglobosa. - Arbores $v$. frutices scandentes, in Guiana et Antillis crescentes; foliis allernis, bistipulatis, petiolatis, integerrimis, crassis, subtus nervis prominentibus reticulatis, petioli apice biglanduloso, florum paniculis brevibus, stipula longissima, biglandulosa stipatis, flore femineo unico terminali, masculis pluribus inferioribus bracteolatis, in paniculam communem, terminalem, magnam, ramosam dispositis.

0 in $\mathrm{p}$ h ale a Linn. Gen. n. 1093. Aublet Guian, II, 843. 1.328, Adr. Jussieu Euphorb. 54. t. 17. $f .58,1039$. 0 an p haIa ndria P. Browne Jam. 335 . D a c tro la Adanson Fam. II. 357 .

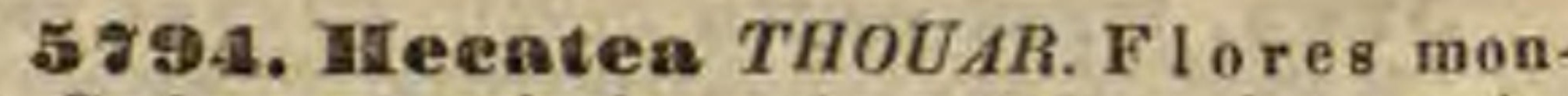
oici. Caly $\mathrm{x}$ urceolaris, quinquelobus, intus coloratus, disco annulari crasso. C o r o 11 a nulla. Masc. Fil amentam superne dilatatum, incrassatum, pileiforme, trilobum, lobis monantheris, antherarum loculis distinctis, lobi lateribus snbtus otrinque adnatis. F e.m. Ovarium ovatum, triloculare, loculis uniovulatis. Stylus brevis; $8 \mathrm{ti} \mathrm{m}$ at a 3 , minima. B a c c a obverse turbinata, trisperma, seminibns e columellae filiformis cruribus pendulis. - Arbores ma dagascarien$s e s$, mediocres; foliis allernis, oppositis v, ternatim approximatis, breve petiolatis, penninerviis, integerrimis, basi biglandulosis, pedunculis axillaribus semel $v$. repetite dichotomis, floribus femineis in di- 
chotomiis solitariis, masculis terminalibus pluribus, bracteis sub dichotomiis oppositis, basi biglandulosis.

He a te a Thouars Hist, Veg. Mfr. austr. 13, et 30, t. 3.

5\%\$5. Cleidion $B L U M$. Flores monoici I a 8 c. Ca Iyx tripartitus, patens. Stamina plurima, receptaculo convexo inserta, a $\mathbf{t}$ h e rarum loculis connexis, introrsum sub apice adnatis, in longum transverse dehiscentibus. Fem. Caly $\mathrm{x}$ parvus, quinquepartitus, persistens. Ovarium didymum, biloculare, loculis uniovulatis. Sty I us longus, bis bipartitus, persistens. C a p sula dicocea, coeris monospermis. Semin a .... $-\mathrm{Ar}$. bor $j a$ va nica, triginta ad quadraginta pedesalla; foliis alternis, longe peliolatis, oblongis, serratis, glabris, floribus masculis glomerulatis, in spicas axillares, simplices dispositis, femineis solitariis, pedunculo demum clavato insidentibus.

Cleidion Blume Bijdr. 612.

5896. Alelhorner SOLAND. F 1 o r e 8 dioici. Mas c. Caly $x$ bi-tri-quinquepartitus. Sta$m$ in a 8 ; filamentis basi in annulum connatis, antheris introrsis, adnatis, longitudinaliter dehiscentibus. Fem. Cal y $\mathrm{x}$ quinquedentatus v. partitus, Ovarin m didymum, biloculare, rarissime trilobum, triloculare, loculis uniovulatis. Stylus longus, profunde bi-tripartitus, lobis linearibus, intus stigmatosis. Ca psul a baceata, di-tricocea, eoccis monospermis. $\mathrm{s} \mathrm{e}$ in a arillata. - Arbores $v$ arbusculae, in $A$ merica, rarius in $A f r i c a t r o$ pica crescentes; foliis alternis, petiolatis, subintegerrimis $v$, serratis, glabris, nervis subtus prominentibus, aridis, fragitibus, floribus axillaribus $v$. terminalibus, masculis in spicis plerumque ramosis glomeratis, glomerulis alternis, bracteatis, femineis solitariis, $v$. in spicas simplices dispositis.

A I c hor ne a Solander ex Swartz Flor. Ind. occid. II. 1153. Adr. Jussien Euphorb. 42. t. 13. H e r me 8 i a Humb. et Bonpl.Plant, aequinoot. 1, 162, t. 46. Nov. gen, et sp, II. 91.

TIBIEUS IV. CROTONEAE Blume Bijdr. 599. O v a ri i loculi uniovulati. Flores saepissime corollati, fasciculati, spicati, racemosi v. paniculati.

5ร9ซ. Fareia ROHR, Flores monoiei. Caly x bipartitns, laciniis aestivatinne valvatis. Corolla e petala circiter 10 , lanceolata, calyce longiora, reflexa, piloso-sericea. Mas c. Stamin a plurima, receptaculo hemisphaerico, villoso, ambitu multiglanduloso inserta; fila mentis liberis, antheris adnatis. Fem. Ovariam disco margine inerassato impositum, trigonum, triloculare, loculis uniovulatis. Stylus brevis; stig ma trilobum, lobis obtusis, coloratis. Capsula subglobosa, tricocea, coecis monospermis. - Arbus. cula antillana; foliis alternis, petiolatis, elliptico-oblongis, acutiusculis, integerrimis, glabris, venosis, pedunculis terminalibus, racemosis, quinquesexfloris, bracteatis, unico infimo femineo, reliquis masculis.

G a re i a Rohr ex Vahl Symb. III, 100, Aot. Hafn., II. 218. $t, 9$. Adr. Jussieu Euphorb. 41, $t, 13$.

5\%98. Mabea $A U B L$. Flores monoici. Ma sc, C a lyx quinquedentatus. Cor olla nulla. Sta min a 9-12, receptaculo subconico inserta; filamentis subnullis, a n theris extrorsis, adnatis. $F$ e in. Cal y $x$ quinquefidus, aequalis, $v$. sexfidus, laciniis tribns exterioribus brevioribus. Ovarium globosum, triloculare, locnlis nniovnlatis. St ylu s trifidus, lobis filiformibus, contor- tis; stigmatosis. Capsula tricocca, coccis monospermis. - Arbusculae guianenses et brasilienses, lactescentes; ramis sarmentosis, pendulis, foliis allernis, petiolatis, integerrimis v. subcrenatis, superne lucidis, subtus venosis, stipulis ad basim petiolorum exiguis, floribus terminalibus dense paniculatis, pedunculis basi v. supra basim bractea. tis, bracteis utrinque glandulosis, femineis inferioribus, paucioribus, longissimis, unifloris, masculis trifidis, triftoris.

Mabe a Aublet Guian, II, 867, t. 334. Adr. Jussien Euphorb. 40, t. 13.

5 ร 99. Siphomia $R I C H$, F 1 o res monoici. Cal yx campanulatus, quinquefidus v. quinquedentatus, laciniis aestivatione valvatis. Corolla nulla. M a s c. Stamina connata in columnam infra apicem antheriferam, a $\mathrm{t}$ he $\mathrm{ris} 5 \mathrm{v} .10$, uni-biseriatim vertisillatis, adnatis, extrorsis. F em. Ovarium basi calyeis circulari, persistenti impositum, sexcostatnm, triloculare, loculis nniovulatis. Stigmat a $\mathbf{3}$, sessilia, subbiloba. C a p$8 \mathrm{u}$ la magna, fibroso-eorticata, tricocea, $v$. abortu interdum di-v. monococca, coceis elastice bivalvibus, monospermis. - Arbores guianenses et brasilienses, succo resinoso, in massam elasticam facile concrescente foetae; ramis apice foliosis, foliis alternis, longe petiolatis, ternatis, foliolis integerrimis, venosis, glabris, floribus axillaribus $v$. terminalibus, racemoso-paniculatis, femineo in quovis racemo unico terminali, reliquis masculis.

Siplionia Richard ex Schreber Gen, n, 1466. Adr. Jussieu Euphorb. 39. t. 12. Hevea Aublet Guian, II. 871. t. 335 .

5800. Elaterios permum BLUM. F 10res monoici. Mas c. Caly x tetraphyllas, foliolis imbricatis. Corolla nulla. Stam in a 10-15, disco interdum villoso, in ambitn glanduloso inserta; filamentis brevibus, antheris introrsis, adnatis. F e m. Calyx tetra-hexaphyllus, foliolis imbricatis, deciduis. Ova rium annulo villoso, setigero cinctum, triloculare, loculis uniovulatis. Stigmata 3 , subsessilia, emarginata. D rup a subglobosa, tri-quadrisulea, putamine tricoceo, coceis monospermis. Se mina pulposoarillata, - Arbores javanicae; foliis alternis, versus apicem ramorum saepe subverticillatis, longe petiolatis, integerrimis, basi biglandulosis, coriaceis, venosis, tenuiter reticulatis, glabris, floribus axillaribus, corymbosis $v$, racemosis.

Elat,erios permu m Blume Bijdr. 620.

5S01. Amala PISO. F I ores monoici. C aI y x campanulates, quinquedentatus. Corollae petala 5 , calyce longiora, unguieulata, aestivatione convolntiva, patentia, cum glandulis quinque alternantia. Stam ina 8 ; filame $n t$ is basi coalitis, superne distinctis, filiformibus, tribus interioribns longioribus, anthe ris incumbentibus. Fe m. Ova ri u m bi-triloeulare, loculis nniovulatis. Stylus brevis, bi trifidus; $8 \mathrm{tigmata}$ integra v. denticulata. D rup a carnosa, pulverulenta, putamine osseo, bi-triangulato, in angulis sub apice fenestrato, bi-triloculari, loculis monospermis. - Arbores brasilienses, lactescentes; foliis alternis, petiolatis, quinatis, foliolis integerrimis, nervosis, nitidis, petiolis apiee biglandulosis, floribus terminalibus, paniculatis, masculis pedunculatis, bibracteatis, biglandulosis, femineis subsessilibus.

A n d a Maregrav. Brasil, 110. Piso Brasil. 148, Adr. Jussieu Euphorb. 39. 1, 12. Martius Anoen. Monac, t, 1 , 
St. Hilaire Plant. us. t, 54. Johannesia Vellozo Atograph, I, 199. c. ic. Gomez in Mem. Ulisipp. III. 6, c. ic. A adis $\mathrm{c}$ us Flor, Flum, II, t, 86.

580R. Aleurites FORST. Flores monoici. Caly $\mathrm{x}$ tubulusus, bi-trifidus, laciniis aestivatione valvatis. Corolla e petala 5 , ealyce parum longiora, aestivatione convolutiva, cum squamis v. glandulis quinque alternantia. M a s c. $S t$ am in a plurima; filamen $t$ is brevihus, in receptaculum conicum, colnmnare connatis, a n the$r$ is introrsis, adnatis. Ovarium tunica distineta, villosa, superne fissa involutam, bi-triluculare, loculis uniovulatis. Styli $2-3$, bipartiti, laciniis acutis. Fructus carnosus, apice dehiscens, div. rarius tricoccus, coecis chartaceis, intus sub apice hiantibus, bivalvibus, monospermis. - $A r$ bores in Asia et Oceania tropica obviae; foliis allernis, longe petiolatis, basi biglandulosis, integris $v$. lobatis, paniculis magnis, composi tis, floribus femineis in paniculis partialibus infe. rioribus, raris, crasse pedunculatis, masculis superioribus, multibracteatis, partibus fere omnibus pilis stellatis, minutissimis farinoso-canescentibus,

Aleurites Forster Char. Gen. 56. Adr. Jussieu Eu. phorb. 39. $t$, 12. Blume Bijdr, 619 A in bi a a x Commers. msc. Telope a Solander msc. C a mirium Rumph. Amboin, II. 181, t, 58. C roto a is et J at ropha e sp. Lian.

58D3. Dstodles $B L U M$. Flores dioici. Masc. Calyx bi-trifidus. Corolla e petala 5. Stamina plarima; filamentis disco glanduluso insertis, an the rarum loculis discretis. Fe m. Cal y x pentaphyllus, foliolis imbricatis, inaequalibus, deciduis. Corollae petala 5 , calyce longiora. 0 v a ri u margine erenulato, earnuso cinetum, trilocnlare, Ioculis uniovulatis. Styla s pro. funde tripartitus, laciniis bipartitis, tortuosis, divaricatis, Fruetus globosus, sexsuleatus, intus tricocens, coccis osseis, monospermis. - Arbor javanica; foliis alternis, ramulorum confertis, longe petiolatis, basi biglanduloso-serratis, coriaceis, subtus in axillis venarum pubescentibus, caeterum glabris, floribus axillaribus, paniculatis.

Ostodes Blame Bijdr. Gis.

5804. Clacoeocea COMMERS. Flores monoici vel? dioici. Caly $\mathrm{x}$ bi-tripartitus, laciniis aestivatione valvatis. Coro 11 a e petala 5 , calyce duplo longiora, aestivatione convolutiva. St a in ina $10 \_12$; fil amentis inferne connatis, quin. que exterioribus brevioribus, an theris introrsis, duabus supremis saepe abortivis. F e m. O vari m tri-quinqueloculare, loculis nniovulatis. Stigma ta 3 _5, subsessilia, simplicia $v$. bifida. Fruet in carnoso-fibrosns, intus tri-pentacocens, coceis monospermis. - Arbores Asiae tropicae; folits alternis, longe petiolatis, basi biglandulosis, integris $v$, inferioribus lobatis, glabris v, junioribus pubescentibus, floribus terminulibus, paniculatis, pedunculis articulatis.

El a e ococe a Commers. ex Adr. Jussieu Euphorb. 38. t. 11. D r y a a d r a Tbunb. Jap, 13, $t, 27$. Correa in Arnal. Mus. VIII. 69, $t, 32$, Vernici a Loureiro Flor, eochinch. 72t. A basia Kämpfer Amoen, exot. 789.

5805. Jatrogha KUNTH. F I o res mon oiei. C a 1 y $\times$ quinquepartitus, laciniis margine glandulesis, aestivatione convolutiva. Coroli a e petala 5, ealyce duplo longiora, aestivatione convolutiva, cain glandnlis quinque alternantia. Stamina 8-10; filamentis inferne sonnatis, snperne filiformibus, liberis, antheris introrsis biloealaribus. F e m. Ora rím glandulis quinque acutis cinctum, triloculare, loculis uniovula- tis. Styli 3 , filiformes, distineti; $s t$ ig m a $t$ a crassa, peltata, subcordata, undulata. Ca p s u la tri. cocca, coceis monospermis. - Arbores $v$. frutices, aut rarius herbae lactescentes, in $A m$ erica $t$ ropica et subtropica copiose, parcius in Arabia et India crescentes, glandulis viscosis conspersi; foliis alternis, integris $v$. saepius palmatilobis, floribus axillaribus aut terminalibus corymbosis, saepe laete coloratis.

J a tropha Linn. Gen, n, 1084. excl. sp. Jaeq. Amer. t. 173. 183. Andrews Bot, Reposil, t. 267. Salisbury Pa. rad. c. 91. Bot. Reg. t. 604. 1464. A de no r h o pi um Poht Plant. Brasil, I. 12, t, 9. J a t r o p h a e s p. Neck. Crotou is $s$ p. Forst.

5SD6. Cureas $A D A N S$. F lore 8 monoici. Caly x brevissimus, quinquepartitus. Ma $8 \mathrm{c}$, C orolla globoso - campanulata, quinquefida. Stam in a 10 , ima basi coalita, quinque exteriora cum glandulis totidem conoideis alternantia; fil a mentis filiformibus, antheris introrsis, bilueularibus. Fem. Corollae petala 5, calyce unalto majora, aestivatione convolntiva. Ovariuon disco brevi quinquelnbo insidens, triloculare, loculis uniovulatis. St yli 3 , filiformes, distincti; stig mata crassa, biluba. Ca psula tricocea, coccis monuspermis. - Frutex Americae tropicae; foliis alternis, petiolatis, angulato-quinquelobis, integerrimis, basi truncatis, reticulato septemnerviis, glaberrimis, corymbis longe pedunculatis, masculis terminalibus, femineis axillaribus.

C a r c as Adanson Fam. II. 356. B r o m f e I d i a Necker Elem, n, 1143. Castiglionia Ruiz et Pavon Prodr. 139. 1. 37. Jatropha Polil Plant. Bras. I, 13. Jatropha C ure as Lian. Jaeq. Hort. Vindob. IIT. t.63. Adr. Jussieu Euph, t. 11. f. 34. A.

580\%. Cuidoseolus POHL. Flores monoici. Mase. Cal y $\mathrm{x}$ corollinus, hypocraterimorphus v. eampanulato-tubulosus, quinquefidus. Corolla nulla. Stam ina $10-15$, exteriora breviora, subdistineta, basi glandulis quinque minutis stipata, interiora longius connata; fila me ntis filiformibus, anthe $r$ is introrsis, bilocularibus. F e m. Ca ly $x$ corollinus, quinquepartitus, aestivatione convolntiva. Corolla nulla. Ovari nm basi glandulis 5 minimis stipatum, triloculare, loculis uniovulatis, Styli 3 , basi cohaerentes, multifidi; st igmata simplieia, Capsula setoso-hispida, tricocea, coccis monospermis. - Frutices $v$. suffrutices, rarius herbae, in America tropica et boreali calidiore crescentes, pilis urentibus hispidae $v$, rarius aculeatae; foliis allernis, petiolatis, integris v. palmatilobis, floribus axillaribus et terminalibus cymosis, albidis.

Cnidoscol as Polıl Plant. Brasil. I. 56. t. 49-52. Bivone a Rafinesq. Flor. ludov. 138. J us s i evi a Houston Relig. $t$. 15. Jatrophae s p. Lian. et Auet. Adr. Jussieu Euph, t. 11. $f, 34 . B$.

5808. Mitunilhot PLUM. Flores monoici. C a ly $x$ corollinus, campanulatus, quinquefidns, aestivatione convolutiva. Corolla nulla. Masc. Sta m in a 10, disei carnosi margini inserta, libera, alterna breviora; fil amen tis filifurmibus, a ntheris introrsis, bilocularibus. Orarium disco carnoso insidens, triloculare, loculis nniovulatis. Stylus brevis; stig at a 3 , pluriloba, lobis in massam conicam, sinuoso-saleatam compaetis. Ca ps n I a tricoeca, coceis bivalvibus, monospermis. Frutices $v$. suffrutices mediocres, dichotomi, inermes, eglandulosi, in America indigeni, nonnulli ob radicem tuberosam, fariniferam culti; foliis alternis, petiolatis v. subsessilibus, integris v. saepius palmatilobis aut partitis, lobis integerrimis v. sinuatis, 
saepissime glauco pruinosis, floribus axillaribus aut terminalibus, racemoso paniculatis, bracteatis, bru. neo-lutescentibus $v$, rarius purpurascentibus, extus valde pruinosis

$\mathrm{M}$ a $\mathrm{u}$ th ot Plumier Cat. 20. excl. sp. Tournef. Inst. 438. Adanson Fam. II. 356. Polil Plant. Brasil, I. 27 t. 10_48 $\mathrm{d}$ a n iptra Kunth in Humb. et Bonpl. Nov. gen. et sp. II. 106. t. 109. Adr. Jussiea Euphorb. 37. t, 10, f. 33. Ma nd f oce a Link Handb. II. 436. J a tropha M a ih o t et J. Jauipha L. Mandihoca Piso Bras. 32. et 55. Mandijh n Maregrav. Bras, 65.et 293. A v pi Casp. Baub. Pin, 91. С в m а g и е Аubl, Guian, 111. Mem. 3. p. 66.

5809. TEieinus TOURNEF. Flores monoiei. Caly x tri quinquepartitus, laciniis aestivatione ralvatis. Corolla nulla, Masc. Stam ina plurima; filamentis moltifariam ramosissimis, a $n$ therarnm loculis distinotis, ex apire filamenti pendulis. O varinm globosum, triloculare, Ioculis uniovalatis. St ylus brevis; stigmat a 5 , profunde bipartita, oblunga, colorata, plamosa. Ca p 8 a la plerumque echinata, tricocca, coccis monospermis. - Arbores, frutices $v$. herbae elatae, arboriformes, in Asia et Africa tropica sponte crescentes, una nunc per regionem mediterraneam divulgata; foliis alternis, petiolatis, peltatis, palmatilobis, lobis serratis, petiolo apice glanduloso, basi stipulato, floribus terminalibus, paniculatis, masculis inferioribus, superioribus femineis, omnibus cum pedicellis articulatis, bracteis interdum biglandulosis stipatis.

R i c in us Tournef. Inst, 307. Linn. Gen. n, 1805, Gãrtner $I T, 116, t, 107$. Sehhuhr $t, 312$. Adr. Jussieu Euphorb. 36. Nees jua. Gen, plant, II. $t, 38$.

58 10. Spathiostemon BLUM. F I ores dioici. Mas e. Caly x tripartitus, patens. Corol1 a nulla. Stamina plurima; filamentis inferne in columnam connatis, verticillatim ramosis, a $\mathrm{nthe}_{\mathrm{r}} \mathrm{s}$ didymis. F em. Caly $\mathrm{x}$ quinquepartitus. Ovarin m triloculare, loculis uniovulatis. Styli 3, longi, intus plumoso-stigmatosi. Capsula muricata, tricoeca, coccis monospermis. - Frutex javanicus; foliis alternis, eltipticis, acuminatis, integerrimis, glabriusculis, spicis axillaribus lateralibusve solitariis aut geminis puberulis, floribus tribracteolatis, femineis pedicellatis, masculis sessilibus.

Spathiostemon Blume Bijdr. 621.

5941. IBalloglaia ENDL. F Iores monoici. Caly x quinquepartitus, laciniis aestivatione imbricatis, Corolla e petala 5 , ad basim disei annularis quinquelobi inserta, calyce longiora, aestivatione convolutiva. Stamina plurima; filamentis basi in columnam brevem, crassam connatis, superne liberis, a n theris extrorsis, adnatis. Fem. Ovariu m triloculare, loculis uniovnlatis. Sty 1 ns brevissimus; $8 \mathrm{tig} \mathrm{m}$ a $\mathrm{ta} 3$, linearia, bipartita, lobis contortis. C a $\mathrm{p} s \mathrm{u}$ la epicarpio carnoso, demum secedente, tricocca, coccis monospermis. - Arbuscula insulae Norfolk; foliis oppositis, petiolatis, ovato-ellipticis, nitidis, stipulis membranaceis, floribus terminalibus, corymbosoracemosis.

B a log hi a Endlicher Prodr. Flor. Norf. 84 .

$581 \%$. Ficino earpus DESFONT. F lores monoici. Caly $x$ quinquepartitus, laciniis aestivatione valvatis. Co roll a e petala 5 , calyce lon. giora, aestivatione convolntiva. M as c. Stam ina plurima; filamentis in colnmnam basi quinqueglandnlosam, a basi ad apicem antheriferam connatis, a $\mathrm{n}$ h e ris extrorsis, adnatis. Fem. Ovarium squamulis quinque hypogynis cinctum, pa- pillosum, triloculare, Ioculis uniovulatis. Stylus brevis; 8 tig in a t a 3 , linearia, bipartita. Ca p 8 ula globosa, echinata, trisulca, tricoeca, coccis monospermis. - Frutices Novae-Hollandiae; foliis alternis, confertis, anguste linearibus, mar. gine revolutis, mucronatis, floribus terminalibus solitariis $v$. corymbosis, pedicellis clavatis, bas $i b i$ bracteatis.

R i clin o e a r p us Desfónt. in Mem, Mus. III. 459, $z 22$, Adr. Jussieu Euphorb. 36. E e h in os ph a e $\mathrm{r}$ a Sieber msc. Ro peria Sprengel $S_{y s t}$. $11 T$. 147.

5813. Amperea $A D R$, JUSS. Flores monoiei v. interdum dioici. H a 8 c. C a l y $x$ campanulatus, quinquefidus, laciniis nestivatione valvatis, sub anthesi patentibus. Co rolla nulla. Stamina 8 ; filam entis filiformibus, ima basi coalitis, quatuor exterioribus brevioribns, antherarum loculis ovatis, distinctis, ex apice connectivi granuliformis pendulis. Fem. Calyx quinquepartitus, laciniis acutis, rigidis, persistentibus. Ovari um glabrum, triloculare, loculis uniovalatis. Stylus brevis; stigmata 3 , erecta, bifida, laciniis acntis. C a p 8 ula ovoidea, membranacea, tricocea, coceis bivalvibns, monospermis, ah axi columellari deciduis. - Suffrutices NovaeHollandiae, spartei; ramis compressis, erectis v. virgatis, foliis alternis, raris, brevibus, linearibus, acutis, floribus axillaribus, solitariis, geminis $v$, fasciculatis, pedunculis multibracteatis, rigidis, acutis, interdum ciliatis, floribus masculis et femineis in eadem stirpe remotis, rarius dioicis.

A mperea Adr. Jussieu Euphorb. 38. 1, 10. Bronguiart ad Duperr, $t$. 49. A. Riehard Sert. Astrolab. $t, 20$.

5814. Mozinma ORTEG. F I ores dioici. $\mathrm{C}$ a ly $\mathrm{x}$ quinquepartitus, patens, laciniis lanceolatis, acutis. Co rolla urceolata. Stam ina $8-13$, ima basi connata, glandulis quinque truneatis eincta ; filamentis subulatis, inclusis, quinque exterioribns brevioribus, an theris incumbentibus. Ovari um glandulis quinque hypogynis cinctum, biloculare, loenlis uniovulatis. Stylus bifides; st ig $\mathbf{m}$ a $t$ a 2 , lata, emarginata, v. quatuor linearia. C a psula calyce persistente cincta, dicocea v. abortu monococea, eoceis monospermis. - Frutices mexicani, suoco gummoso foeti; foliis alternis $v$. fasciculatis, stipulatis, integris v. interdum lobatis, saepe pilis glanduliferis ciliatis, floribus axillaribus aut terminalibus bracteatis, femineis solilariis v. geminis, masculis fasciculatis aut corymbosis.

Moz In na Ortega Decad. 105, $t, 13$. Adr. Jussieu Euphorb. 35. Lo n e e i r a Cavanill. Ie. $V$. 17. t. 429. 430. Willd. Spec, $1 V .866$.

5815. Hisingera HELEN. F I ores dioici. Masc. CaI yx tetraphyllus. C or o ll a nulla. S t a m in a $15-25$; fil a m e n ta distincta, glandulis minutis, difformibus, quaternatis stipata. F em. Ca I y x hexaphyllus. Corolla nulla. Ova ri um biloculare, loculis biovulatis. Styli 2 , breves, crassi; stig mata capitato-depressa, antice bidentata. B a c ca subrotundo-didyma, bilocularis, loculis monospermis. - Frutex antillanus, ramosus; ramis alternis, foliis alternis, apice serratis, coriaceis, nitidis, glabris, floribus axillaribus, confertis, pedunculatis, pedunculis brevibus, unifloris.

His Inger a Helenins in Act. Holm. 1792, p. 32. $t .2$. Willdenow $S p, I V .835$. Adr. Jussieu Euphorb, 34.

5816. Hemieyelia WIGHT, et ARN, F lores dioiei. Cal y x quadripartitas. Corolla nulla. Masc. St a mina 8 , sub margine disci plani, 140 * 
carnosi inserta; filam entis flliformibus, exsertis, antheris subcordatis, localis connectivo sejunctis. Fem. $O$ vari u m disco carnoso insidens, biloculare, locnlis nniovulatis, altero eum stig mate mox abortiente. Stig m a $\mathbf{t}$ a 2 , sessilia, semicircularia, margine dentata, dentibus triangularibus, arcte inflexis. F ru ct tus subdrupaceus, aborta unilorularis, monospermus. S e m e $n$ inversum, arillatum. - Frutex indicus, glaber, ramosus; foliis alternis, breviter petiolatis, ellipticis, obtusis, coriaceis, supra imprimis nitidis, pedunculis e gemma axillari v. laterali imbricata solitariis v. binis, fructu globoso, pisi magnitudine, subgriseo.

He mieyelia Wight et Arnott in Edinb. new philosoph, Journ. XIV. 297.

581 1 . Celonium $R O X B$. F 1 ores dioiei. Ca ly x quinquepartitus, reflexus, aestivatione convolutiva. Coro Il a nulla. Mas e. Stam in a 12 v. plurima, receptaculo hemisphaerico, multiglanduloso inserta; fil amentis exsertis, antheris extrorsis, oblongis, adnatis. Fem. O va rium disco glanduloso, crenulato impositam, bi-trilo culare, loculis uniovulatis. S $\mathrm{t}$ i g $\mathrm{m}$ a $\mathrm{t}$ a $2-3$, sessilia, lata, laciniata. C a p 8 u I a bi-tricocca, coccis monospermis. - Frutices Asiae tropicae; foliis allernis, petiolatis, basi bistipulatis, integerrimis $v$. apice serratis, coriaceis, glaberrimis, lucidis, venosis, junioribus interdum stipula simplici vaginante, mox caduca inclusis, floribus axillaribus fasciculatis, fasciculis multibracteatis.

Gelonium Roxburgh ex Willdenow Spec. IV. 831. Flor. Ind. III, 829. Adr. Jussieu Euphorb, 34 t. 10. Hooker in Bot. Mag. $t$.323t. non Gärtn. et Thouar, E r y th r o. carpus Blume Bijdr. 604.

5848. Codiaevm RUMPH. F lo re s monoici. Masc. Caly $\mathrm{x}$ quinquepartitus, reflexus, aestivatione convolutiva, $\mathbf{C}$ o $\mathbf{r} 011$ a e petala 5 , squamaeformia, calyeis laciniis breviora, cum glandulis totidem alternantia. Stam in a plurima, receptaculo inserta ; $\mathrm{fil}$ a m en $\mathrm{t}$ is aestivatione erectis, liberis. a n ther a r um loculis connectivo snbdilatato utrinque adnatis. Fem. Cal y x quinquefidus. Coroll a nulla. Ovari u m basi squamulis 5, hypogynis cinctum, triloeulare, loculis uniovulatis, Styli 8, filiformes, simplices, reflexi. Capsula sicca v. subbaccata, tricocea, coceis monospermis. - Arbores v. frutices Asiae tropicae; foliis alternis, integris, glaberrimis, lucidis, interdum pulchre variegatis, floribus axillaribus $v$, terminalibus, in racemos unisexuales dispositis, sin. gulis unibracteatis.

Cod ia eu mumph Amboin. IV. 65. $t, 25-27$. Adr. Jussieu Euphorb. 33. 2.9 . Blume Bijdr, 605. P h y 11 a area Loureiro Flor. Cochinch. 705. Croton variega6 u $\mathrm{m}$ Linin.

5819. Tottlera $R O X B$. Flores dioici. $\mathrm{Cal}$ y $\mathrm{x}$ tri-quinquepartitus, Jaeiniis aestivatione valvatis, demum patentibus. Corolla et glandulae nullae. Stamina plurima, receptaculo conrexo, nudov. villoso inserta; filamentis filiformibus, aestivatione erectis, liberis v. basi coalitis, antherarum loculis conneetiva mutico v, in glandulam minimam producto utrinque adnatis. Fem. Ova ri n m bi-tri-quadrilueulare, loenlis naiovalatis. Stylus profunde hi-tri-quadripartitus, laeiniis intus plumoso-stigmatosis, C a p. 8 ula fnermis $v$, molliter echinata, ant grannlosa, bi-tri-tetracocea, coceis monospermis. Se mina tunicata. - Arbores v. frutices Asiae tropicae; foliis alternis, petiolatis, basi interdum biglandulo sis, inlegerrimis $v$. crenatis, venosis, pilis stellatis subtus conspersis $v$, obsitis, rarius utrinque glabris, ploribus in spicas v. racemos, axillares aut termina. les, simplices $v$. ramosos dispositis, solitariis $v$. glomeratis, bracteatis.

Rottlera Roxburgh Plant. Corom. I. 36. t. 168. Flor. Ind. III. 826. Adr. Jussien Euphorb. 32, t. 9. Blume Bijdr. 606. Mallotus Laureiro Flor. cochinch. 781. Crotonis sp. Auet. - Adisca Blume Bijdr. 609, sta. minibus uon reeptaculo insertis, basi tantum eoalitis, aatherarum loculis apici filamentorum graniformi utrinque ad. aatis, et floribas plerumque monoicis ex cl. auctore a Rott. lera diversa.

58\%0. Adriamia $G A D D I C H$. F $10 \mathrm{r}$ e 8 dioici. M a s c. Caly $x$ imbricato tri-quinquebracteatus, quinquepartitus, laciniis inaequalibus, aestivatione valvatis, Corolla nulla. Sta mina plurima, receptaculo convexo inserta; fila mentis brevissimis, aestivatione erectis, liberis, Ineulis linearibus, connectivo, apice in ligulam pilosam producto, utrinque adnatis. F e $\mathrm{m}$. C a $\mathbf{y} \mathbf{x}$ maris, involucro brevi, tri-quinquepartito, aestivatione imbricato cinctus. Corolla nulla. Ovarium sessile, loculis uniovulatis. Styli 3 , distincti, bipartiti, lobis linearibus, pilosis. C a p s u la tricocea, coccis bivalvibus, monospermis. Semina carunculata. - Frutices Novae-Hollandiae, inermes, pilis fasciculatis tomentosi; foliis alternis, petiolatis, petiolo ad basim biglanduloso, integris $v$. tri-quinquelobis, floribis terminalibus, spicatis, masculis sessilibus, femineis paucioribus, breviter pedicellatis.

Adria nia Gaudichaud ad Fregcinet 486, $t, 116$. Croton quadripartitu m Labillard. Nov. Holl, t. 222. 223.

5821 . Cheillosa $B L U M$. F l o r e s dioici. Caly $\mathrm{x}$ inaequaliter quinquepartitus, patens, $\mathrm{C}_{0-}$ rolla nulla. Ma $8 \mathrm{c}$. S $\mathrm{t}$ a m in a $8-10$; $\mathrm{fil}$ a ment is exsertis, liberis, antheris terminalibus. Ovarii rudimentum centrale, annulo brevi, glanduloso inclusum. F em. Ovari um basi urceolo cinctum, triloculare, loculis uniovulatis. Stylus persistens, profunde tripartitus, laciniis reflexis, apiee bifidis, Ca p 8 u I a globosa, tomentosa, sexsulca, tricocea, coccis monospermis. Semin a subbaccata. - Arbor javanica, procera; foliis alternis, cuneato-oblongis, versus apicem remote serrulatis, coriaceis, glabris, racemis axillaribus compositis, ramulisque pubescentibus.

Cheilos a Blume Bijdr. 613 .

5822. Aeidotom SWARTZ. F l o res monoici v. dioici. Masc. Caly $x$ profunde quinquepartitus, reflexns. Corolla nulla. Stamina plurima, receptaculo globoso inserta; fil amentis liberis, antheris erectis. Fem. C a I y x profunde sexpartitus, patens. Stylus brevis, trifidus; $8 \mathrm{tigmata}$ reflexa, tomentosa. Cap $8 \mathrm{ula}$ tricocea, coccis bivalvibus, monospermis. - Arbuscula $v$. frutex jamaicensis; foliis alternis, stipulatis, integris, glabris, nervosis, floribus in diversis ramis masculis et femineis, femineis longioribus, plerumque terminalibus, bracteis ninutis stipatis, ramis, petiolis pedunculisque setis urentibus hispidis, folitis iisdem ciliatis.

A cid ot on Swartz Flor. Ind, occid. 952, t. 18. Adr. Jussieu Euphorb. 32.

5823. Ealiogpermum BLUM. F10res monoici. Ca I y $x$ quinquepartitus, aestivatione convolntiva. Corolla nulla. Masc. Stamin a $16-20$, diseo plano, ad ambitum glanduloso imposita; fi lament is liberis, aestivatione erectis, antherarum loculis apici filamentorum 
adnatis. Fem. Ovarium basi margine brevi, membranaceo cinctum, triloculare, loculis uniovulatis. Stigmata 3 , sessilia, basi cohaerentia, apice latiore emarginata, nuda. C a p $8 \mathrm{u}$ la tricocca, coccis ehartaceis, intus dehiscentibus, monospermis. Sem in a variegata, superne areola nmbilicali carnosa. - Frutex javanicus; foliis alternis, oblongis, grosse repando - serratis, basi biglandulosis, margine et subtus ramulisque cum pedunculis, bracteis et floribus pilis sparsis strigosis, floribus masculis axillaribus, fasciculatis, femineis solitariis intermixtis, pedicellis basi unibracteolatis.

Balios permum Blume Bijdr. 603.

OBSERVATIO. Ha ematospermum Wall. geuns a cl. Liudley Introduct. edit. II. p. 116. inter Baliospermum et Adelikm nominatum, mihi penitus est lincognitum.

5924. Hendecandira ESCH. Flores dioici. Mase. Caly $\mathrm{x}$ quinquefidus, aestivatione imbricata. Corolla nulla. GI and ula e 5, caly. cis laciniis oppositae. Stam ina $6 \_10$, filamen$t i s$ liberis, aestivatione inflexis, a n therarum loculis oppositis, adnatis. F e m. C a l y $x$ quinquefidus. Corolla et glandulae nullae. Ovarium triloculare, loculis uniovulatis. Styli 3 , breves, radiatim quadripartiti; 8 ti $g \mathbf{m}$ a tibus terminalibus inflexis. Cap 8 u l a trieocea, coccis bivalvibus, monospermis. - Herbae v. suffrutices mexica$n i$ et californici, a basi ramosi; ramis, foliis calycibusque pilis stellatis incano lepidotis, foliis alternis, oblongis, obtusis, integerrimis, nervo medio subtus-valido, floribus masculis in racemos spicaeformes, terminales $v$. oppositifolios dispositis, breve pedicellatis, minute bracteatis, femineis solitariis.

Hendec and ra Bscholtz in Mem. Academ. Petersb. $X$. Astrogy ne Benthaw Plant. Hartweg. 14. Croto a g a cilis H. B. Kunth.

5825. Adelia LINN. F I ore s dioiei. Caly $\mathbf{x}$ quinque - sexpartitus, aestivatione valvata. Corolla nulla. Masc Stamina plurima; $f$. I a m entis basi coalitis, aestivatione erectis, antheris globosis. Fem. Ovarinm disco glanduloso insidens, triloculare, loculis uniovulatis. Stigm a ta $\mathbf{3}$, subsessilia, lacera. Cap s u Ia tricocea, coceis monospermis. - Frutices Ameri. ca e tropicae; ramis interdum in spinam desinentibus, foliis alternis, integerrimis v. subserratis, glabris $v$. subtus cum ramulis, pedunculis, bracteis et calycibus tomentosis, floribus axillaribus, spicatis aut fasciculatis, interdum solitariis, bracteatis.

A de li a Linn. Gen. $\pi, 1137$. Adr. Jussieu Euphorb. 31. t. 9. nou Michaux. Be r a a d i a Houstou. msc. ex P. Browne Jam. 361 .

5826. Crotomopsis $L, C, R I C H, F I 0-$ res monoici. Ma $8 \mathrm{c}$. C a I y $\mathrm{x}$ quinquepartitus. Corolla e petala 5 , receptaculo inserta, calycis laciniis alterna, spathulata, patentia. Stamin a 5 ; filamentis liberis, exsertis, antheris introrsis, filamentorum apici dilatato adnatis. F e m. C a ly x quinquepartitus, laciniis duabus exterioribus saepe obsuletis. S quam ula e petaloideae 5 , calyeis laciniis oppositae et breviores. Ovari u m uniloculare, ovulo unico, pendulo. Stigmata 3 , subsessilia, biloba. Fractus sicens, indehiscens, semine unico inverso, embryone intra albumen carnosum orthotropo. - Herba boreali a mericana, squamulis furfuraceis consila; foliis alter nis, linearibus $v$, ellipticis, integerrimis, subtus argenteo-lepidotis, floribus in extremis ramulis axillaribus, foliorum lapsu spicatis, femineis inferioribus, bracteatis, calycibus et fructibus pilis stella. tis obsitis.
Cratonopsis L. C. Richard in Michaux Flor. Bor. Amer. II. 185. t. 46. Adr. Jussieu Euphorb. 31. t. 9. L e pte m on Rafinesque in New-York Medic. Reposit. II. Hex. $V, 350$. F riesia Sprengel Syst. III, 850.

5827. Croton LINN. F lores monoici v. rarissime dioiei. Mas c. Calyx quinquepartitus, aestivatione valvata. Coroll a e petala 5 , aestivatione convolutiva. G 1 a nd $\mathbf{n}$ l a e 5 , petalis alternae. $S t$ a $m$ i n a $10_{-} 20 \mathrm{v}$. interdum indefinita, receptaculo nudo v. villoso inserta; fil a m e nt is liberis, aestivatione inflexis, demum erectis, exsertis, a nthe $\mathbf{r i s}$ introrsis, filamenti apici adnatis. F e m. C a I y x quinquepartitus, persistens. Corolla nulla. $G I$ and $\mathbf{L} I$ a e $v$, appendiculae 5 , ovarii ba. sim stipantes. Ovarium sessile, triloculare, loculis uniovulatis. Styli tres, bifidi v. multipartiti, laciniis intus stigmatosis. Ca p sula tricocea, coccis bivalvibus, monospermis. - Arbores, frutices, v. suffrutices aut herbae, in America tropica copiose, rarius in Asia et $A f r i c a$ calidiore crescentes; foliis alternis, stipulatis, basi saepe biglandulosis, integris, serratis $v$. lobatis, pilis stellatis $v$. squamul is lepidotis consitis, floribus laxius densiusve racemosis aut spicatis, spicis racemisve axillaribus aut terminalibus, nunc abbreviatis, capituliformibus, nunc elongatis, spicis nunc sexu distinctis, nunc bisexualibus, masculis saepissime superioribus, inferioribus femineis.

C r ot a n Linn. Gen, n. 1083, excl. sp. Kunth in Humb. et Bonpl. Nov. gen. ot sp. IT. 66. excl. sp. Geiseler Monographia Hall, 1808. 8. excl. sp. plurim. Jussieu Euphorb. 28 . $t .8$ f. $A$. excl. reliq. St. Hilaire Plant. us. t. 59. 60. Nees jun. Plant. offic. Suppl, $V, t$. 9. Ri ci n o i des Tournef. Inst. 433. C a se a rilla Adanson Fam, Ir. 355. Trides mus Loureiro Flor. coohinch, 706. Cratan. A roton, Lantia et C i nog a \& u necker Elem n, 1122-1125. R i c j no ca r pus Boerhav. Lugd, Bat. I, 254. B r u n s v i a Necker Elem, $n, 1126$.

5828. Juloerotom $M A R T$. F l o res monoici. M a s c, Ca 1 y $x$ rotato-campanulatus, quinquefidus, laciniis tribus nonnihil longioribus, angustioribus. Coro 11 a e petala 5, lineari spathulata. G 1 and u l a e 5, petal! s alternae. St a mina 10, circa ovarii rudimentum centrale inserta, exserta, subinaequalia; fila m entis filiformibus, basi barbatis, lana densa cohaerentibus, superne pubescentibus, liberis, an theris introrsis, filamenti apiei adnatis. Fem. Calyx quinquepartitus, laciniis tribus exterioribus multo latioribus, margine lobatis, duabus interioribus linearibus, integris v. bifidis. Coru I la nulla, Ovari um sessile, triloculare, loculis uniovalatis. Stylus trifidus, laciniis intus stigmatosis. Capsula tricocea, coceis monospermis. - Suffrutex brasiliensis; ramis trigonis v. angulatis, angulis petiolisque fusco-tomentosis; folits alternis, petiolatis, late ovatis, acu. minatis, basi subcordatis, denticulatis, supra asperulis, subtus dense stellato-tomentosis, spicis axillaribus terminalibusque densifloris, tomentosis, floribus inferioribus femineis, superioribus masculis, singulis bractea oblique lanceolata, integra v. triloba, ciliata stipatis.

Juloeroton Martius Herbar, Brasil, p. 119. Cro. ton cordatum Vellozo Flor. Flum, X, $t, 66$.

5829. Crozophora NECK. F I o $r$ es monoici. Mas c. Calyx quinquepartitus, aestivatione valvata. Co rolla e petala 5 , aestivatione convolutiva. $\mathrm{St}$ a $\mathrm{m}$ in a 5 , rarius 8 v. $10 ; \mathrm{fil}$ a $\mathrm{m}$ enti s basi in columellam centralem coalitis, tribns v. quinque exterioribus brevioribus, conniventibus, aestivatione erectis, a ntheris extrorsis, infra apicem filamentorum adnatis, iisdem excurrentibus apieulatis. Fem. C al y $\mathbf{x}$ decenpartitus, laciniis 
Linearihus. Corolla nulla. Ovarium sessile, trilocnlare, loenlis uniorulatis, Styli 3 , bifidi, intus stigmatusi. C a p sul a globosa, tricocea, coccis monospermis. - Frutices $v$. herbae, in Afric a tropica et boreali, rarissime in Europa $m e$ diterranea crescentes; foliis alternis, stipulalis, stipulis deciduis, sinuatis, saepe plicatis, mollibus, cum ramis et floribus pilis stellatis tomentosis $v$. fa. rinosis, floribus in apice $v$, in divisuris ramorum racemosis, bracteis linearibus, longiusculis stipatis, inferioribus femineis, longius pedunculatis, masculis superioribus, densius congestis.

Crozopbora Necker Elem, n, 1127. Adr. Jussieu Euphorb. 27. t. 7. Nees jun. Gen. plant. II. $t .37$. Tour uesolia Seopoli Introduct, n. 1097. Crotonis sp. Linn. et Auct. Delile Flor. aegspt. $t$. 51 .

5930. Chiropetalum $A D R$, JUSS, F 10 res monoici. C a 1 y $x$ quinquepartitus. M as e Corolla e petala 5, calycis laciniis alterna, unguiculata, lamina palmation tri-septempartita. laci niis acutis. Glandula e 5, petalis alternae et interiores. Stamina 5; filamentis inferne in stipitem ovarii abortivi coalitis, superne distinctis, patentibus, antheris introrsis, adnatis. Fem. Corolla nulla GIandula e 5, calycis laciniis oppositae. Ovarium sessile, triloculare, loculis uniovulatis. S t y 1 i 3 , distincti, bifidi, reflexi. Capsu la globosa, tricocca, coccis monuspermis. - Herbae chilenses et peruanae, colore violaceo-rubente imbutae; pilis simplicibus, foliis alternis, serratis, floribus in spicas axillares dispositis, inferioribus femineis, masculis superioribus pluribus.

Chiropetalum Adr. Jussien in Annal, sc, nat. $X X V$. 21. Crotonis sp. Tam. Cavanill. Ic. $t, 6$. Adr. Jussieu Euphorb. t. 8. f. 26. C.

5\$31. Caperomia ST, HIL. F lor es monoici v. dioici. C a 1 y $x$ quinque-sexpartitns. Corolla e petala 5 v. 6 , calyeis laciniis alterna, aestivatione convolutiva. G I a n d a I a e nullae. Masc. Stamina $10 \mathrm{v}, 12$; filamentis inferne in ovarii abortivi stipitem coalitis, superne dis tinctis, biseriatim verticillatis, an theris introrsis, bilobis, versatilibns. F em. Ovarium ses sile, triloculare, loculis uniovulatis. Stylus tri partitus, lobis flabellato - multipartitis, stigmatosis. Ca p s u l a subglobosa, tricocea, coccis monosper mis. - Herbae v. suffrutices aculeati $v$ hispidi, in America tropica indigeni; pilis simplicibus, folits alternis, junioribus colore purpureo imbutis, spicis axillaribus pedunculatis, bracteatis.

Cape ronia St. Hilaire in Mem. Mus. XII, 342. Plant. remarq. Brasil. 204. C a v a illa Flor, Flum. V. $t .102$. Croton eastancaefolium et c. palustre Lina. Kunth. Ade. Jussieu Euphorb. $t .8, f$ B. Bot. Mag. t. 2294. - $2 \mathrm{~S}$ chinz a Denst. Hort. malab. $\nu$. 7 .

5832. Ditaxis VAHL. Flores moneici v. rarissime dioici. C a ly $\mathrm{x}$ quinquepartitus, aestivatione valvata. Co ro Il a e petala 5, calycis laciniis alterna, aestivatione convolutiva. $M$ a 8 e. GIandula e nullae. St amina 10 ; filamen$t$ is inferne in ovarii abortivi stipitem coalitis, superne distinctis, patentiusculis, biseriatim verticillatis, a $n t h e r i s$ introrsis, adnatis. Fem. Glandula e 5, calyeis laciniis oppositae. Ovarin m sessile, triloculare, Inculis uniovulatis. St y$1 \mathrm{us}$ trifidus, laciniis bifidis; $\mathrm{stig} \mathrm{matib} \mathrm{ns} 6$, lobato-erenulatis. Capsula triencea, coccis hival vibus, monospermis. Se min a laevia. - Frutices antillani; foliis alternis, solitariis v. fasciculatis, junioribus imprimis floribusque colore puniceo imbutis, pedunculis axillaribus bracteatis, pauciflo- ris, flore femineo terminali unico majore, masculis duobus v. rarius pluribus inferioribus, cito deciduis, bracteis persistentibus, floribus in specie dioica femineis, axillaribus, solitariis $v$. geminis, pedunculatis, pedunculo medio bibracteolato.

Ditaxis Vahl ex Adr. Jussieu Euphorb, 27, t. 7 . Kunth in Humb. et Bonpl. Nov. gen. et sp. VII. 170 . t. 639 .

5833. IIonotaxis BRONGN. Flores monoici. Caly $x$ quadri-quinquepartitos, aestivatione valvata. Curoll a e petala 4 v. 5 , breviter unguiculata, hastato-triluba, labis baseos convolutis conchiformia. G I a n $\mathrm{d}$ l a e $4-5$, petalis alternae, oblongu-clavatae. M a s c. S ta m in a 8 - 10 . uniseriata; filamentis chpillaribus, ima basi in tubulum coalitis, a $\mathrm{n}$ he $\mathrm{ris}$ bilocularibus, loculis subglobosis, connectivi bipartiti cruribus divaricatis adnatis. F e m. Ova rium sessile, triloeulare, loculis uniovulatis. Stig a ta 3 , bipartita, fimbriato - papillosa. Capsula tricocea, coceis bivalvibus, monospermis. Semin a laevia, caruncula conica. Herbae, in Nova-Hollandia extratropica indigcnae, graciles, a basi ramosae; folits alternis $v$, superioribus oppositis ternatisque, floribus axillaribus terminalibusque, umbellatim fasciculatis, involucratis, masculis pluribus, femineum unicum centralem sessilem $v$. brevius pedicellatum cingentibus.

Monntnxis Brongniart ad Duperrey 223. t. 49, Eadlicher Makt, $t .8$.

5834. Argythammina $P . B R O W N$. F I nres monoici. Masc. Calyx quadripartitus, villosus, aestivatione valvata. Corolla petala 5 , ealyeis laciniis alterna, subunguieulata, villosa, colurata. Stamina 4, petalis opposita; filamentis exsertis, ima basi sub ovarii rudimento centrali minuto coalitis, antheris introrsis, ineumhentibus. G I a nd u la e 4, staminibus alternae. F e m. Ca ly $x$ guinquepartitus, villosus, persistens. Coroll a nulla. S qua mula e 5 , hypogynae, calyeis laciniis oppositae. Ovari um sessile, trisulcum, triloculare, loculis uniovulatis. St y li 8 , his bifidi, breves; stigmat a lacera. Ca psula tricocca, coccis bivalvibus, monospermis. Se mina punctata. - Frutex antillanus; foliis alternis, nervosis, cum floribus colore puniceo imbutis, floribus in ramulis axillaribus brevissime pedunculatis, bracteatis, inferioribus femineis majoribus, superioribus masculis minutis.

A rgy thamnia P. Browne Jam. 338. Swartz Flor. Ind occid 1.335. Adr. Jussien Euphorb. 26.t.7. - ? A ter a a n us P. Browne Jam. 339.

5835. Trigonostemon BLUM. F1ores monoici. Calyx quinguepartitus. Corolla e petala 5 , campannlato - conniventia, glandulis 5 interjecta. Masc. Stamina 3 ; filamentis inferne in unum coalitis, apice liberis, bifidis, a $n$ herarum loculis superne divergentilus, extrorsum infra apicem adnatis. F em. Ovarium triloculare, locnlis uniovulatis. Styli 3 , bifidi. Capsula tricocca. - Frutex $j a v$ anicus; foliis sparsis, in apicibus ramorum ternatim verticillatis, breviter petiolatis, oblongis, acuminatis, basi obtusis, serrulatis, subtus pubescentibus, racemis axillaribus simplicibus, floribus geminatim $v$. ternatim confertis, bracteatis.

Trigonostemon Blume Flor. Jav. praef. VIIT. Trigostemon Blume Bijdr. 600 .

5836. It gparia BLUM. Floreg dinici. Calyx tripartitus. Corolla petala 5 , in femi- 
neis intus squamulis totidem instructa. Mase Sta $\mathrm{m}$ in a 5 , circa ovarii rudimentum inserta, an. therist extrorsum adnatis. Ovari um glandulis 5, pedicellatis, cum petalis alternantibus cinc. tnm, biloculare, loculis biovulatis. S $t \mathbf{i g} \mathbf{m}$ a $\mathbf{t a} 2$, lata, sessilia, emarginata. Fruetus corticatus, exsucens, subtomentosus, ponctatus, monospermus, rarius bilocularis, dispermus. - Frutex javanicus ; foliis alternis, oblongo-lanceolatis, integerrimis, venosis, supra glabris, subtus glaucis et tenuiter strigosis, spicis axillaribus, simplicibus, solitariis, floribus breviler pedicellatis, unibracteatis.

R y paria Blume Flor. Jav. Praef. VIIT. R y parosa Blume Bijdr. 600 .

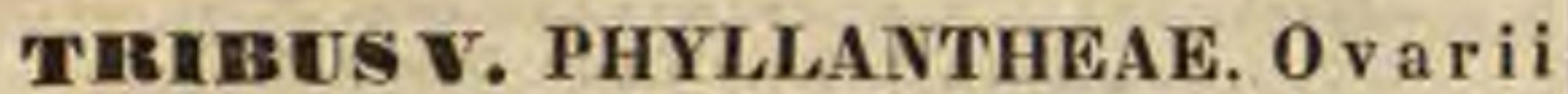
loculi biovulati. $\mathbf{S}$ t a $\mathrm{m}$ in a centro floris inserta.

583\%. Cyclostemom BLUM. Flores dioici. C a I y $x$ quadri rarius quinquepartitus. C orolla nulla Mase. Stamina plurima; filamenta basi annulo inserta, antherae introrsae, oblongae. Fem. Ovarin disco urceolari cinctum, biloculare, Ioculis biovulatis. Stylas brevissimus; $s \mathrm{t} i \mathrm{~g}$ a $\mathrm{t}$ a 2 , lata, emarginata. Fructus earnosus, indehiscens(?), bilocularis, loculis mono-dispermis. - Arbores javanicae; foliis allernis, minute bistipulatis, subintegerrimis $v$. serratis, coriaceis, venosis, basi interdum obliquis, floribus axillaribus fasciculatis, bracteolatis, femineis interdum solitariis.

C y clostem a n Blume Bijdr. 597 .

5838. Enehidiuma $J A C K$. F lore 8 monoici. Cal y $\mathrm{x}$ quinquepartitus. Corollae petala 5, petalis basi biglandulosis. St a m in $\mathbf{m}$ filamenta in columnam centralem connata, a $n t h$ e $r$ is 10 , radiatim patentibus. Fe m. Ovari u m trilobum. Styli 3 ; stigmata 6. Fruetus...... Frutex indicus; foliis subverticillatim confertis, petiolatis, lanceolatis, acuminatis. integerrimis, glabris, subcoriaceis, floribus axillaribus spicatis, inferiori. bus femineis.

Enchidium Jack in Hook. Bot. Mag. Comp. II. 257. -? Arbor spicalarum Ruaph Amboin. IIT. 167, $t$. 160.

5839. I riedelia $W I L L D$. Flores monoici. C al y $x$ quinquefidus. Corollae petala 5 , aestivatione convolutisa. Stamina 5 ; fil a mentis in ovarii abortivi stipitem, diseo plano, orbiculato, sinuato impositum, inferne connatis, snperne liberis, a $\mathbf{t}$ heris introrsis. Fem. Ovarium disco connivente, apiee quinquefido immersum, bi-triloculare, loculis biovulatis. Sty $\backslash$ i 2 v: 3 , apice bifidi. Fruetus baceiformis, bi-trilocularis. lo culis dispermis v. aburtn monospermis. - Arbores $v$. arbusculae interdum scandentes, in $A s i a$ et Africa tropica indigenae; foliis alternis, sti pulatis, integerrimis, floribus glomeratis, glomerulis bracteatis, nunc axillaribus, nunc in ramulis, foliorum lapsu denudat is quasi spicatis, unisexualibus $v$. masculis cum femineis mixtis.

Brindeli a Willdenow Spec. IV.978. Adr. Jussieu Euphorb. 26. t. 7. H e y di a Deast. Hort. Malab. IV. 18. Cluytias sp. Roxburgh Plant. Corom. t. 169-173.

5840. Cluytia $A I T$. Flores dioiei. CaI yx quinquefidus. Masc. Corolla petala 5, cum appendieibus totidem bi-trifidis, glandulosis alterna, aestivatione convolutiva. Stamina $\mathbf{5}, \mathbf{f i -}$ Iam ent $\mathrm{i}_{\mathrm{s}}$ inferne in ovarii abortivi stipitem, basi glandulis quinque integris $\mathbf{v}$, bilobis stipatum con natis, superne liheris, an theris introrsis, demum extrorgum versis. F em. Cor olla e petala 5 , hy- pogyna. Ap pendices glandalosae totidem, integrae v. bilobae, petalis oppositae. Ovari um triloculare, loculis uniovulatis. Styli 3 , bifidi, reflexi. Ca psula globosa, tricocca, coceis monospermis. - Arbusculae $v$. frutices capenses; foliis alternis, stipulatis, saepe angustis, rigidis, floribus axillaribus bracteatis, breviter pedunculatis, solitariis $v$. fasciculatis.

Cluytia Aiton Hort. Kew III,419. Willdenow Hort. be. rol. t. 5i. 52, Jacq. Hort. Schönbr. t. 50. Bot. Reg. t. 779. Bot. Mag. t. 1321. 1945. Adr. Jussien Euphorb. 25. t. 6. C I u tf a Boerh. Lugd, Bat, II, 260. Linn. Gen, n. 1140, Gárt. ner II. 117, t, 107. Altor a Adanson Fam, II, 356. Crat och willa Necker Elem, $n, 1129$.

z941. Andraclane LINN. F lores monoici. Cal yx quinquepartitus. Masc. Corollae petala 5, membranacea, cum squamulis totidem bipartitis, rarissime deficientibus alterna. $\mathrm{Sta} \mathrm{m} \mathrm{i}$ na 5 ; filamentis basi in ovarii abortivi stipitem coalitis, superne liberis, antheris introrsis. Fem. Corulla nalla. Ovarium basi nudum, v. squamulis tribus bifidis, calycis laciniis alternis stipatum, triloculare, loculis biovulatis. Styli 3, breves, divaricati, bifidi, lobis stigmatosis. Ca ps u la trieocea, coccis bivalvilous, dispermis. Sein in a punctata. - Frutices v. herbae, ab Europa mediterranea per Orientem et Indiam sparsim provenientes; foliis alternis, integerrimis, stipulatis, floribus axillaribus, solitariis aut fasciculatis, bracteatis.

A ndrachne Linn. Gen, n. 1059. Adr. Jussleu Eu. phorb. 256.

a. TELEPHIOIDES Tournef. Inst. $485 . \mathrm{S} q \mathrm{a}$ a $\mathrm{m}$ u $\mathrm{l}$ a e calycís laciuiis alternae. - Species mediterraneae et orientales, herbaceae $p$, suffruticosae. - Eraclissa et Lim e u in Forskael Descript. 208, (Adr. Jussieu Op. cit. t. 6. f. 20. Nees jun, Gen. plant, II. t, 39. Eichwald Plant. Cauc, $t, 20.1$

b. ARACHNE Nech. Elem n, 1146. $\mathrm{S} q \mathrm{q}$ a $\mathrm{m}$ a $\mathrm{l}$ a e nullae. Species indicae, fruticosae. - Clatiae sp. Linn.

5942. Savropus BLUM. F lores monoici. Masc. Caly x depresso-orliculatus, coriaceus, coloratus, limbo sexdentato. Corolla et glandalae nullae. Stam ina 3 ; filamentis in colnmnam apice trifidam connatis, a $n t h e r i s$ extrorsis, columnae lobis reflexis ad apicem adnatis. Fem. Caly x sexpartitus, laeiniis biseriatis. Ovariu m triloculare, Ioculis biovulatis. St y I us subnullus; st igmat a 3 , reflexa, bifida. Capsul a carnosa, intus tricoeca, evecis chartaceis, mono-dispermis. Semina cochleata, difformia, angulo interno arillo carnoso obtecta. - Frutices $j a$ vanici, Phyllanthorum facie, interdum scandentes, ramis pinnaeformibus.

S a u rop us Blume Bijdr. 595 .

5943. Agymeia $L I N N$. Flores monoici. Cal yx sexpartitus. Corolla nulla. Masc. Stamina 3 ; filamenta coalita in columnam centralem, disco membraniformi sexlobo, calycis lacinias intus partim vestienti impositam, apice trilobam, lolis extus antheriferis, a n theris adnatis. Fem. Ovaria m triloculare, apice foveolatum, loculis biovulatis. Styli 3 , bifidi, ovarii foveolae immer8i. C a p su la trilocularis, a basi ad apicem sexvalvis, loculis dispermis. Se mina arillata, arillo in tres partes fissili, unam dorsalem caducam, duas laterales persistentes, columnae centrali inde dodecapterae adpositas. - Frutices $v$. herbae Asiae tropicae; foliis alternis suboppositisve, bistipulatis, parvis, floribus axillaribus, fasciculatis, fasciculis pauciforis, bracteatis, femineis unico v. duobus, longius pedunculatis, reliquis masculis. 
A g y ne i a Linu. Gen, n, 1330, Veaten. Cels, t. 23. Adr. Jussieu Euphorb. 24. t. 6. f. 22.

5844. Teicearpus BLUM. F 1 or es dioici. Masc. $\cdots \ldots$ F em. Caly x parvus, quadri - quinque - rarius sexdentatus, Corolla nulla. Ovarinm triloculare, loculis biovnlatis. Stigm a t a 8 , foveae ovarii immersa et subcoalita, persistentia. Capsula apice foveata, corticata, intus tricocea, eoccis chartaceis, dispermis $v$. abortu monospermis. - Arbores $v$, frutices javanici; foliis alternis, integerrimis, venosis, spicis axillaribus, confertis.

\section{L ei ocarpus Blume Bijdr. 581 .}

5845. IIferamthea DESFONT. FIores monoici. M a sc. Caly x coloratus, hexaphyllus, foliolis tribus interioribus majoribus, petaluideis. Corolla nulla. Sta $\mathrm{m}$ in a $\mathbf{3}$, cirea diseum glandulosum, trilobum inserta; filamentis liberis, a $n t h$ eris adnatis. F e $m$ Cal y x sexpartitus, laciniis subulatis. Corolla nulla. Ovari $\mathbf{n}$ m triloculare, loculis biovulatis. Styli 3 , simplices, revoluti, intus stigmatosi. Capsula stylis persistentibus acuminata, tricocea, coccis bivalsibus, dispermis. - Suffrutex Novae-Hollandiae; foliis alternis, ternatim fasciculatis, linearibus, flo. ribus axillaribus solitariis, geminis v. ternis, breviter pedunculatis.

Mlcranthe a Desfontaines in Mem. Mus. IV. 253. t. 14. Adr. Jussieu Euphorb. 24.

5S46. MIenareda COMMERS. F I o r e s monoici. Ca ly x magnus, quinquepartitus, persistens. Corolia nulla. Masc. Glandulae 5, calycis laciniis alternae. S $t$ amina 5 ; fil amen$t i s$ liberis, an theris extrorsis, adnatis. Ova $r$ i $\mathbf{m}$ disco glanduloso latiori insidens, trilocnlare, loeulis biovulatis. St ylus crassus, trifidus, lohis bifidis. Capsula trieocea, coecis bivalvibus, dispermis. - Arbuscula madagascarien$s i s$; ramis oppositis $v$. alternis, foliis alternis $v$. saepius oppositis, bistipulatis, integerrimis, glabris, floribus axillaribus, solitariis $v$. paucis fasciculatis, femineis cum masculis mixtis, longissime et tenuissime pedunculatis, bracteatis.

Menarda Commerson ex Adr. Jussieu Euphorb. 23. $t, 18$.

584\%. Plnyllantlums SWARTZ. F I o res moneici $v$. rarius dioici. C a 1 y x quinque-sexpartitus, laciniis biseriatis. St a m in a 8 , rarius 5 ; filamenta in columnam, glandulis 5 v. 6 ant disco quinque-sexlobo cinctum coalita, antheri s extrorsis, arlnatis. F e m. O va ri $\mathbf{m}$ basi glandulis 5-6 cinctum $v$. disco glandulnso ant membranaceo insidens, triloculare, loculis biovulatis. St yli 3, basi interdum connati, plerumque bifidi; stigmatibus sex. Capsula tricocca, coccis bivalvibus, dispermis. - Arbores, frutices $v$. herbae, in regionibus tropicis et subtropicis totius orbis, frequentius in America crescentes, nunc foliati, floribus axillaribus, nunc aphylli, ramulis foliaceo-dilatatis, margine floriferis.

Pbyllanthus Swartz Flor. Ind, occid, I1, 1101. Kuath in Humb, et Bonpl, Nov. gen. et sp. Ir. 108.

a. XYLOPHYLLA Linn. Frutices aphylli, extremis ramulis bistipulaceis, complanatis, foliacen dilatatis, ereuatis. Flores in ramorum crenulis fasciculati, omnes unisexuales, aut feminei cum masculis mixti, multibrae. teati, bracteis persisteutibus.

X ylophylla Liun. Gen, n, 1299, Gärtner IT. 123. t. $108 \mathrm{Jaeq}$. Ic, rar, $t, 616$. Bot. Reg, $t, 373$. Bot. Mag. t, 1021, 2652. Adr. Jussieu Euphorb. 24, t, 5. f, 17, Genesip hy 11 a Heritier Sert. angl. 29. $t .39$.

b. PHYLlantuUS Linn. A rbores, frutices v. herbae, foliis alternis, stipulatis, nune magnis, venosis, nuuc saepius miuoribus, in ramulis alternis, piusatin dispositis, floribus axillaribus, subsolitariis, aut saepius fasciculatis, foliis delapsis quasi racemosis, multibracteatis, bracteis acutis, persistenlibus, interdum congloba. tis, fasciculatis, nune unisexuatibus, ane femiveis pancis cum masculis plaribus nixtis.

P b y 11 a $n$th a s Liané Gen, $n$ 1050, excl. sp. Gãrtner II. 125. 1. 108, Jacq. Hort, schönbr. IL. t. 193. Adr. Jussieu Euphorb. 21. $t$. $5 . f$. 16. 1, excl. sp. pl. Blume Bijdr. 593. DC. in Mem. soo. phys. Genev. V. t. 4. Nir u ri Adanson Fam, II.356, C o a a i i Aublet Guian. II. 927. $t .354$. N y $\mathrm{p}$ ha a thus Loureiro Flor. co. chinch. 663. ? Cathetus Loureiro Flor, oochinch. 746. ? B re y a i Forster Char, Gen, t, 73.

5848. Trelamilhesa $B L U M$, F 1 o r e s monoici. M a s e. C a I y $\mathrm{x}$ coriaceus, turbinatus, limbi dentibus sex, biseriatis, couniventibus. Corolla nulla. Sta mina 3 , inelusa; fi la menta in colnmnam coalita, antherae extrorsae, infra colamnae apicem tricuspidatum adnatae. F e m. C a I y $x$ brevis, urceolatus, sexlobus, Ovarinm triloculare, loculis biovulatis. St $\mathrm{ig} \mathrm{m}$ a $\mathrm{ta} 3$, brevia, sessilia, interdum semibifida. Ca p su la baccata, intus trieocea, coccis ehartaceis, dispermis. - Frutices indici, Phyllanthi facie; foliis siccitate nigrescentibus.

Melanthesa Blume Bijdr. 590. Phrllanthi sp. Lian. et Auct. Adr. Jussieu Euphorb, t. 5. f. 16. B.

5845. Kinganelia JUSS. F I o res monoici. M a sc. Calyx quinquepartitus. Corulla nulla. St a m i n a 5 ; $\mathrm{f} \mathrm{il} \mathrm{a} \mathrm{m} \mathrm{e} \mathrm{n}$ a inaequalia, in colnmnam medio diantheriferam, apice trilobo triantheriferam, basi quinqueglandulesam coalita, antherae extrorsae, subgloboso-didymae. F e m. Ova ri $\mathbf{~ m}$ disco quinqueglanduloso rinctum, triloculare, loculis biovulatis. St y 1 i 3 , bipartiti, laciniis acutis. B a ce a succulenta, trilocularis, leculis dispermis. - Frutex indicus et mauritianus, Phyllanthi facie; folis pinnatim dispositis, floribus axillaribus fasciculatis.

K irganeli a Jassieu Gen, 382. Euphorb, 21. t. 4. A rdingheila Commers, mse. Phylla athus Kirganelia Willd.

5850. Embliea GÄRT. Flores monoiei. Cal yx sexpartitus. Corolla nulla. Ma $8 \mathrm{c}$. St a mina 8 ; filamenta in columnam gracilem, apice breviter trifidam, basi eglandulosam v, glandnlis 6 stipatam coalita, antherae extrorsae, connectivn excurrente apiculatae. Ovari um disco earnoso insidens $v$. tubo membranaceo, inaequaliter quinquefido inclusum, trileculare, loculis biovulatis. Fructus drupacformis, intus tricoccus, coccis bivalvibus, dispermis. - Arbores v. arbusculae indicae; folits alternis, stipulatis, parvis, in ramulis alternis, pinnatim dispositis, deciduis, floribus axillaribus fasciculatis, post foliorum lapsum spicatis, spicis sexu distinctis v, masculis cum femineis mixtis, bracteatis, bracteis persistentibus.

E mblle a Gärtner $I T$, 122, t. 108. Jussieu Euphorb. 20. t. 5.f. 15. M y robala nus $\mathrm{E} \mathrm{m}$ blic a Rumph Amboin. $\nu I I .1 . t, 1$. Nelli.C a m a r a m Rheede Malab. 1.69. $t .38$. Phyllanthi sp. Lina.

5851. Cieen LINN. Flores monoici v. dioiei. Caly $\mathrm{x}$ quadripartitus, intus glandulis guatuor alternis v, disco glanduloso instructus. Corolla nulla. Masc. S $t$ a mina 2 -4; fil amentis liberis, antheris extrorsis, adnatis. Ovariu m quadri-quinqueloculare, loculis biovulatis. Styli 4_.5, reflexi, bifidi, Fructas bacciformis, 
intus tetra-pentacoceus, coccis di- $v$. abortu monospermis. - Arbores $v$. frutices, in $A$ s $i$ a $t$ rop $i$ ca et in Antillis crescentes, Phyllanthorum facie; foliis alternis, in ramulis alternis, deciduis, subpinnatim dispositis, stipulatis, integerrimis, glabris, floribus axillaribus fasciculatis, foliis abortivis $v$ mature delabentibus racemos mentientibus.

C i с а Linu. Mant. I, n 1275. Jaeq. Hort. schönbr, t, 294. Adr. Jussieu Euphorb 20. \&. 4.f. 13. Bluare Bijdr. 589. Ch e ra uela kumple Amhoin. VIL. $t, 33,-$ ? Triearyum Loureiro Flor. cochinch, 681 .

5852. Heptonema $A D R$. JUSS F lo res dioiei. Caly y qninquepartitus. Corolla nulla. Musc. Stamina 5 v rarius 6 ; filamentis liberis, capillaceis, exsertis, an $t h$ eris erassioribus, loculis distinctis, e connectivo graniformi primum pendulis, demum erectis. Fem. Ovariu m tri-quinqueloculare, loculis biovulatis. Styli 3_5, hipartiti, lobis acutis, stigmatusis. C a p8 ula globoso-depressa, tri-pentacocca, coccis bivalvilus, dispermis. - Frutex madagasca. riensis, ramosus; foliis alternis, stipulatis, longe petiolatis, subintegerrimis, villosis, pedunculis axillaribus, solitariis, femineis longioribus, unifloris, masculis multifloris, floribus subumbellatis, multibracteatis, bracteis longiuscule linearibus.

Le pto nem a Adr. Jussieu Euphorb, 19, t, 4.f, 12, A ca. Iypha venosa Poir.

5853. A ni๊รomema $A D R$. JUSS. Flores monoici. Masc, Calyx quinquepartitus, intus glandulis quinque alternis, Corolla nulla. St amina 5 ; fil a m enta crassa, 2 v. 3 lateralia libera breviora, 2 v. 3 centralia omnino inter se cualita, antherae snbgloboso-didymae, loculis filamenti apici utrinque adnatis. Fem. Calyx quadri-sexpartitus, intus glandulis totidem alternis. Ovarium sex-decemloculare, loculis superposite biovulatis. C a p \& n l a globoso-depressa, umbilicata, sex-decemsulea, sex-decemlocularis, Semina in loculis gemina, superposita, angulata, saepe nonnulla abortiva, - Frutices in dici, ramosi; foliis in ramulis fasciculatis, subpinnatim dispositis, alternis, stipulatis, integerrimis, fuscis, floribus axillaribus, bracteatis, pedunculatis, masculis fasciculatis, femineis subsolitariis, foliorum lapsu quasi racemosis,

A nis a ue ma Adr. Juxsieu Euphorb, 19, t, 4, f, 11, P h y 1 . Iathus reticulatus Poir.

5854. Chochichtomogsis $B L U M$. F lores monoici. Masc. Calyx sexpartitus, laciniis biseriatis. Corolla nulla. Sta mina 3 ; filamenta coalita, antheris extrorsis, sub apice adnatis. F e m, Cal y $x$ tri-rarius bipartitus. O vari un triloculare, loculis biovulatis. St y li 3 , subu lati. C a p \& u I a tricocea, coccis dispermis.

Stirps javanica, arborescens; foliis oblongo-ovalibus, obtusis, basi subcordatis, subtus sericeis, ramulis pinnaeformibus, fructibusqae tomentosis.

Glochidionopsis Blume Bijdr. 888 .

5855. Clochialion FORST. F 1 or e s monoici, Calyx sexpartitus, laciniis biseriatis, eglandulosis. Corolla nulla. Masc. Stam in a 3 -6; f il amentis in columnam inferne coalitis. apice brevissime distinctis, antheris extrorsis, sub filamentornm apice libero adnatis. F e m. O varium sex-duodecimloculare, loculis biovulatis. Stylus crassus, brevis v, subnullus; stig $\mathrm{mat}$ 6_12, brevia, obtusa, erecta v, conniventia. Capsula corticata, ovato globosa v. globoso-depressa, hexa-dodecacocca, cuccis chartaceis, dispermis. Se- min a fenestrata, saepe superposita. - Arbusculae $v$ frutices, in Asia et Oceania tropica crescentes; foliis alternis, integerrimis, subcoriaceis, superne glabris, subtus venosis, fioribus axillaribus pedunculatis, solitariis v. fasciculatis, fasciculis unisexualibus, $v$. floribus masculis cum femineis mixtis.

Glochidion Forster Char. gen, $t, 57$. Adr. Jussieu Euphorb. 18. t.3.f. 10. B ra d l e i a Banks ex Gärtner II.127. t. 109. Lam. t. 772. Cavanill, Ic, t, 371. Labillard. LNov, Caled. $\iota, 76-78$,

5856. Gymoon ADR. JUSS. F 1 o $\mathrm{r}$ e 8 monoiei. Mas e. Caly x guinquepartitus. Cor olla nulla. Stamina $3 \_6$; filamentis brevissimis, inferne in columnam brevissimam coalitis, snperne distinctis, an theris extrorsis, sub filamentorum apice libero adnatis. Fem. Cal y $x$ sexpartitus, Corolla nulla. Ovarium sexsulcum, tri-sexloculare, loculis biovulatis. Stig mata 3 , hine convera, inde angulata, in massam ovoideam, ovario duplo majorem, tripartibilem coalita. Fruct u s....... Frutices in dici; foliis alternis, bistipulatis, integerrimis, coriaceis, glabris, floribus axillaribus fasciculatis, femineis cum masculis pluribus mixtis, fasciculis multibracteatis.

G y noon Adr. Jussieu Euphorb. 17. t, 3. f. 9. Wight et Arnott in Edinb. new philosoph. Journ. XIV. 299.

5\$ร์. Seepasma BLUM. Flores mon. oici. Mas c. C a lyx quadripartitus, laciniis biseriatis, conniventibus, duabus exterioribus majoribus, intus glandulis quatuor alternis, C,o rolla nulla. Filamentum unicum, crassum, clavatum, antheris duabus, divaricatis, loculis distinctis, summo filamento utrinque adnatis, longitodinaliter dehiscentibus. F e m. Cal y $x$ quinquepartitus, persistens. Corolla nulla. Ovarium disco glanduloso cinclam, quinque octolnculare, loculis biovalatis. Sti rm a ta $5-8$, scssilia, brevia, subemarginata, Cap sula suleata, quinqueoctolocularis, loculis dispermis, semine uno quandoque efoeto. - Frutex javanicus, ramosus; foliis in ramulis fasciculatis, subpinnatim dispositis, alternis, stipulatis, integerrimis, inaequilateris, glabris, floribus axillaribus bracteolatis, pedunculais, masculis subgeminatis, femineis solituriis, foliis delabentibus quasi racemosis.

Scepasma Blume Bijdr. 533.

5858. Epistyliam $S W A R T Z$. F lo res monvici. Masc. Calyx quadripartitus, laciniis biseriatis, duabus exterioribus majoribus, intus glandolis quatnor alternis. Corolla nulla. Fila mentum unieum, apice incrassatum, antheris duabus, divaricatis, loculis distinctis, summo filamento ntrinque adnatis, transversim dehiscentibus. Fem. Caly $x$ quinquepartitus, intus glandulis quinque alternis. Ovariom carnosum, triloculare, loculis biovulatis. Stylns brevis v. nullus; st ig mat a 3 , snbbiloba. C a psula oblonga, obtuse trigona, trilocularis, trivalvis, loculis di-v. abortu monospermis, - Arbores v. frutices jama $i$ censes; foliis alternis, bistipulatis, integerrimis, glabris, nitidis, venosis, floribus fasciculatis, femineis cum masculis pluribus mixtis, fasciculis supra axem communem axillarem racemosim dispositis.

Epistyli a m Swartz Flor. Ind, oocid, 1095, t, 22. Adr. Jussieu Euphorb. 17. t. 3. f. 8.

585. Toranthera RUDG. F 1 o r e 8 monoici. Caly x coloratus, quinquepartitus, laci- 
niis aestivatione imbricatis. Co rolla e petala 5 , calyce multu breviora. Mas c. Glandalae 5, petalorum basi insertae, tarnosae, bilobae. St a m ina 5 , circa ovarii rudimentum squamulosum inserta; fil a menta filiformia, libera, ant herae terminales, subtetragonae, quadriloculares, apice poris quatuor distinctis apertae. Fem. GIandula e breviores in annulum decemlobum subconnatae. Ovari a m sexcostatum, triloculare, loculis biovulatis. St yli 3 , bifidi, lobis patentibus, subulatis, stigmate subfusiformi, minimo terminatis. Capsula depresse globosa, verrucosa, sexcostata, tricocea, coccis bivalvibus, dispermis. Semin n m testa carnosa, foveolata, alba. - Fruticuli Novae-Hollandiae orientalis extratropicae, ramosissimi, glabri; foliis alternis, stipulatis, plerumque linearibus, integerrimis, floribus, ad upices ramulorum confertis, subracemoso-corymbosis, pedicellatis, pedicellis bracteatis, bracteis inferioribus longioribus, foliaceis, subinvolucrantibus.

Por a dhe ra Rudge in Lisn, Transact. X. 302, t. 29. f. 2. Bronguiart in Annal. se, nat, XXIX, 384. Voyage Du. perr. 218, t. 50. Hügel Bot, Archiv, $t, 8$,

TIRIEUS V. BUXEAE Bartling Ord. nat. 370. Ovarii loculi biovulati. Stamina sub ovarii rudimento sessili inserta.

5861. Flügsea WILLD. Flores divici. Cal y $x$ profunde qquinquepartitus. Co rolla nulla. Ma $8 \mathrm{e}$. Stamina 5 ; filamentis sub ovarii rodimento bis bifido insertis, exsertis, an theris extrursis. Glandala e 5, staminibus interpositae. Fem. Ovarium disco membranaceo insidens, bi-triloculare, loenlis biovalatis. Stylns subnallus; $8 \mathrm{tigmata} 2$ ig, reflexa, bifida v. bipartita. Fruetus capsularis v. subbaccatus, bitrilocalaris, loculis dispermis, semine altero saepins efoeto. - Frutices ind $i c i$, ramosi; ramis alternis, saepe in spinam desinentibus, foliis alternis, parvis, glabris, floribus axillaribus fasciculatis, fasciculis multibracteatis.

Flügge a Willdenow Spec, IV. 757. Adr. Jussieu Euphorb. 16. 6. 2. Blume Bijdr, sso.

5861. IR fletheria $V A H L$. Flores dioici. Calyx quadri-quinquepartitus. Corollae petala 4 v. 5. Stamina 4 v. 5; filamentis sub ovarii rudimento simplici, conico insertis, exsertis, an the $x i s$ oblongis, erectis. Fem. Ovarium disco carnoso impositam ...... Stylus brevissimus; stigmat a 3 , revoluta, supra canalicnlata. Fruetus suberosus, sexsuleus, intus subcartilaginens, trilucularis, loculis a basi bivalvibus, monospermis, - Arbor antillana, ingens, Mammeae facie; folits alternis, subcoriaceis, integerrimis, glabris, subtus venosis, floribus in spicis axillaribus, bracteatis.

Richeria Vaht Eclog. I. 30. t. 4. Adr. Jussien Eu. phorb. 16.

5862. Aanareo $A U B L E T$. Flores mon. oici. Caly x quinquepartitus, laciniis concavis. $\mathrm{C}_{0}$ rolla nulla. Stamina 5; filamentis brevi. bus, sub ovarii rudimento trilobo $\mathrm{v}$. trifido, disco glanduloso quinquelobo impositis, v, glandulis quinque interpositis, antheris introrsis, filamentorum apicibus dilatatis adnatis. F em. Ovarimm disco glanduloso insilens, triloculare, loculis biovulatis. Stigm at a 3 , sessilia, crassa, subbilo. ba. C a p 8 u a drupaeformis, obtuse trigona, intus tricocea, roccis bivalvibus, abortu monospermis. -
Arbores v. frutices guianenses; foliis alternis, bistipulatis, integerrimis, glabris, lucidis, nervosis, floribus glomerulatis, glomerulis in spicas axillares $v$. terminales dispositis, bractea squamosa $v$. foliacea stipatis, masculifloris, $v$, femineum unicum, cum pluribus masculis mixtum, bracteis multis, inaequalibus interjectis continentibus.

A m a n o A Aublet Guian. I. 256. t. 101. Adr. Jussieu Euphorb, 15, t. 2.

5863. Hithoxylom. Flores monoici. Ca ly $x$ quinquefidus, laciniis planis, venosis. Corolla nulla. Stam in a 5 ; fil amentis calycem aequantibus, sub ovarii rudimento glandulaeformi, indiviso, disci glandulosi orbiealati centro insertis, an theris extrorsis, subglöboso-didymis, transversim dehiscentibns. F e m. O vari u m disco glanduloso orbiculari, extus saepe staminum rudimenta gerenti impositum, triloeulare, loculis biovulatis. Stylus brevis, ovario continuas; stigmata 3 , patentia, apice bifida. Fruetus .....-Arbor taitensis; foliis alternis, breve petiolatis, oblongo lanceolatis, coriaceis, glaberrimis, supra nitidis, stipulis parvis, subrotundis, pedunculis axillaribus, unifloris, nutantibus, ebracteatis, solitariis v. paucis, masculis cum femineis mixtis.

Soeurinega nitida Lindley Colleot.t.9. non Willd.

5864. Seeuninega COMMERS. Flores disici. Masc. Cal y x quinquepartitus, laciniis planis. Corolla nulla. Stamina 5 ; filame nt is exsertis, sub ovarii radimento tripartito lineari, disci integri v. profunde quinquelobi centro insertis, ima basi connatis, a $n$ the $r i s$ introrsis, oblongis, longitudinaliter dehiscentibns. F e m. Ca l y x quadri-sexpartitus, reflexus. Ovari um disco glandnloso impositum, triloculare, loculis biovulatis. St i g m a $\mathrm{t}$ a 3 , subsessilia, reflexa, subbiloba. Capsula trieocea, coecis bivalvibus, dispermis, seminum testa crustacea, atra. - $A r$ bores mauritianae; ligno durissimo, foliis alternis, integerrimis, coriaceis, glabris, nitidis, venosis, floribus axillaribus, masculis glomeratis, multibracteatis, bracteis ciliatis, conglobatis, femineis longe pedunculatis, pedunculis fasciculatis, hasi bracteatis.

Securinega Commers. ex Jussieu Gen. 38s. Adr. Jus. sieu Euphorb. 14. $t$. 2.

5865. Geblera FISCH. et MEY. Flores dioiei. Caly $\mathrm{x}$ quinquepartitus. Corolla nulla. Masc. Stamina 5 ; filamentis exsertis, liberis, sub ovarii rudimento lineari tripartito, disco glanduluso, sinuato insertis, enm glandulis quinque alternantibus, an the ris introrsis, elliptieis, longitudinaliter dehiscentibus. F e m. O vari um triloculare, loculis biovulatis. Stigmat a 3 , sessilia, reflexa, biloba. C a p 8 u I a tricocca, coccis bivalvibus, dispermis, seminum testa membranacea. - Suffrutex dahuricus; foliis alternis, integerrimis, membranaceis, venosis, glabris, floribus axillaribus pedunculatis, peduncalis basi bracteolatis.

G e b I e r a Pischer et Meyer Index, Sem, hort. petropolit. 1835. I. 28, X ylophylla ramiflora Ait, $\mathrm{Phar}$ n a ceum suffruticosum Pallas It, Ir , 716, $t$, E. f. .

5866. Savia WILLD. F I o res dioici. Caly $x$ quinquepartitus. Co roll a e petala 3 _5, cirea discum glandulosum inserta, calycis laciniis alterna et breviora, interdum nulla. M a s c. Stam ina 5 ; filamentis brevibus, sub ovarii rudimento simpliei v. tripartito disco insertis, liberis, a $n t h$ eris introrsis, adnatis. Fem. Ovari a m disco impositum, triloculare, loculis biova- 
latis. Ca psula tricocea, coccis bivalvibus, abortu monospermis. - Frutex antillanus; foliis alternis, integerrimis, glabris, venosis, stipulis ad basim petiolorum geminis, minutis, caducis, floribus masculis glomerulatis, glomerulis subspicatis, pluribracteatis, femineis axillaribus, solitariis, bracteatis, subsessilibus.

S av ia Willdenow $S p e c, 1 V .971$. Adr, Jussieu Euphorb. 15. $t$. 2. Croton sessiliflor u $\mathrm{m}$ Swartz.

586\%. Aetephilla BLUM. F lores monoici. C a ly $\mathrm{x}$ profunde sexpartitus, laciniis hiseriatis. Corolla e petala 6 , eirea discum emarginatum inserta, calycis laciniis alterna et breviora. Masc. Stamina 6; filamentis subulatis, sub ovarii rudimento tripartito disco insertis, a $\mathrm{n} t \mathrm{~h} e-$ rarum loculis extrorsis, subrotundis. Fem. Ovari u m triloculare, loculis biovulatis. S t y 1 i 3 , breves, divaricati, seminifidi. Cap su la tricocca, coccis dispermis v. abortn monospermis. - Frutex javanicus; foliis alternis, bistipulatis, ellipticooblongis, integerrimis, coriaceis, glabris, venosis, floribus axillaribus glomerulatis, glomerulis pluribracteolatis, masculis subsessilibus, femineis longe pedunculatis.

A te tephil a Blame Bijdr. $\boldsymbol{s 8 1}$.

5848. Trieera $S W A R T Z$, Flores mon oiei. Mas c. Caly x quadripartitus, laciniis lan ceolatis, acutis, Corolla nulla, Stamina 4 fil amentis sub ovarii rudimento centrali inser tis, oblungis, crassis, antheris lanceolatis, acutis, demuin recurvis. F em. Ca $/$ y $x$ pentaphyllus, apqualis. Corolla nulla. Ovarinm triloculare, foculis biovulatis. Styli 3 , persistentes, teretes, demum bipartibiles; stig matibus recurvis, acn tis, Cap sula trigona, tricornis, trifariam de hiscens, intus tricocca, coccis dispermis, semini bus laevibus, lucidis, atris. - Frutices antillan $i$; foliis alternis, coriaceis, integerrimis, glaberrimis, nitidis, floribus racemosis, femineo unico terminali, inferioribus masculis, longius pedicellatis, pedunculo pedicellisque basi bracteatis.

Tricer a Swartz Flor, Ind, occid. I. 333, t. 7. Sehreber Gen, n. 1416. Crantzi ia Swartz Prodr. 38. Vahl Symb. IL. 99. B a x i s p. Adr. Juss.

5849. Buxus TOURNEF. F lo res monvici. Calyx tetraphyllus, foliolis decussantibus, inaequalibus, marinm uni-, feminarum tribracteolatis, bracteolis conformibus, adpressis. Corolla nuila. Masc. Stamina 4; filamentis sub ovarii rudimento insertis, crassinsculis, breviter exsertis, antheris erectis, ovatis. Fem. Ovari um apice inter stylos torulosum, triloculare, loculis biovulatis. Styli 3, persistentes, crassi, intus glandnloso-canaliculati, demum bipartibiles; stigmatibus recurvis, acutis. Capsula globosa, trirostris, extns coriacea, trivalvis, valvis e stylis hipartitis bicornibus, intus tricocea, eoccis dispermis, seminibus laevibus, lucidis, atris.

Arbores v. frutices, in Europa australi sponte crescentes; foliis oppositis, sempervirentibus, inte gerrimis, e laminis duabus solo margine cohaerentibus, superiore coriacea, venosa, inferiore membranacea, petiolis brevibus, in ramulos exinde tetragonos decurrentibus, stipulis minutis, e gemmarum perulis persistentibus, floribus axillaribus glomerulatis, bracteis imbricatis, glomerulum involucrantibus, mascu. lis pluribus, unum femineum cingentibus, v. omnibus masculis.

B u $x$ u \& Tournef. Inst. 345. Linn. Gen, $n$, 105. Gärtner 1I. 123. t, 108. Schkuhr t. 287. Adr. Jussieu Euphorb. 13. t. 1. f. 3. Nees jua. Gen. plant. 41.
5890. Paelhysandra $M I C A X$. Flores monoiei, C al y x quadripartitus, laeiniis decussantibus, marium uni-, feminarum tribracteolatus, braeteolis conformibus, adpressis. C o roll a nulla. Ma s $\mathrm{c}$. S t a m in a 4 , sub ovarii rudimento inserta; filame ntis exsertis, latis, complanatis, an theris terminalibus, introrsis, demum recurvatis. F e m. 0 vari um breve, triloculare, loculis biovulatis. Styli 3, crassi, recurvi, intus glandulosi et suleati; stigmatibus oblique truncatis. Cap sula subglobosa, stylis persistentilus tricurnis, tricocca, coccis dispermis. - Herba boreali-a meric a na, procumbens; foliis allernis, petiolatis, ovatis, repando-crenatis, glabris, spica ex imo caule pedunoulata, basi squamis imbricatis cincla, floribus inferioribus paucis femineis, superioribus masculis.

Pachysandra Michaux Flor. Bor. Amer, $I T, 177$. t. 45. Bot. Reg. t. 33. Adr. Jussieu Euphorb. 13. t. 1.

58 \%. Theencoris $A D R$. JUSS. F I o res dioici (?). Masc. Cal y $x$ quinque-sexpartitns. Corolla nulla. Stamin a 5 , sub ovarii rudimento obconico inserta, calyeis laciniis opposita; fil am entis aestivatione erectis, flexuosis, antheraru in loculis distinctis, ovatis, ex connectivi apice glaudulaeformi pendulis. G 1 a n d a la e 5, staminibus alternae. F e m. C aly x quinquepartitas. Ova riu m disco glanduloso impositum, trilo. culare, loculis biovulatis. Styli 3 , terminales, e basi inerassata attenuati, apiei bifidi, lobis divaricatis, stigmatosis. Fruetus ...... Frutex v. arbor madagascariensis; folits alternis, petiolatis, integerrimis, glabris, stipulis ad basim petiolorum geminis, minutis, caducis, racemis basi bracteatis, axillaribus $v$. terminalibus, solitariis aut geminatis, laxis, floribus breviter pedicellatis, bracteolatis.

The cacoris Adr. Jussieu Euphorb. 12,, 1 . - Acalypha glabrata Vabl.

55\%2. Mieroelus $W I G H T$ et $A R N$. F Iores dioici. Mas c. Calyx quinquepartitus, laciniis incurvis, cueullatis, stamina incindentibus. Corolla nulla. Stamina 5, sub ovarii rudimento fangilliformi, apice coneaviusculo inserta, calycis laciniis opposita; filamentis subnallis, antheris introrsis, bilocularibus, cordato-ovatis. Fem. Caly x..... Ovarium triloculare, loculis biovulatis. St y li 3, lineares, elongati, integri, recurvi, flexuosi, intus stigmatosi. F r u ctus drupaeformis, trilocularis, loculis abortn monospermis. - Arbor indica; foliis alternis, petiolatis, trifoliolatis, foliolis late ellipticis, acuminatis, glabris, penninerviis, denticulato-serratis, pellucido-punctatis, lateralibus breviter, terminali longius petiolulatis, paniculis axillaribus petiolum superantibus, floribus masculis minutis, viridescentibus, fructu globoso, Pisi magnitudine, fusco.

Mieroelus. Wight et Arnott in Edinb, new philosoph. Journ. XIV, 298.

5893. Adenoerepis BLUM. Flores dioiei. C a I y x profunde quadripartitus. Corolla nulla. S ta in in a 6 , sub ovarii rudimento cyathi. furmi inserta, glandulis interposita; f ilamentis erectis, a $\mathrm{th}$ e $\mathrm{ris}$ introrsis, didymis. $\mathrm{F} \mathrm{em.} \mathrm{O}$ vari n m snbglobosum, biloculare, loculis hiovuiatis. Stig $m$ a obtusum, hirsutum, sessile. Fruetus .......-Arbor javanica; foliis alternis, oblongis, obsolete crenulatis, glabris, stipulis ad basim petiolorum geminis, minutis, deciduis, floribus in racemis axillaribus lateralibusve breviter pedicellatis, subternis.

Adenoerepis Blume Bijdr. 579.

$141^{*}$ 
5874. Drypetes VAHL. F lores dioici. Cal y $x$ quadri-sexpartitns, inaequalis. Corolla nulla. Mase. St a m in a $4-6$, sub disco centrali, ambitu sinusto inserta, exserta; filamentis erectis, a $n t h e r i s$ introrsis, didymis. F em. Ova rinm diseo glanduloso insidens, biloculare, loculis biovnlatis, v. abortu uniloculare, ovulis parieti appensis. Sty li 2 , breves, teretes, divarieati, rarius uniens, lateralis; $s \mathrm{tig} \mathbf{m}$ a $\mathrm{t}$ a capitata $v$. emarginata. Dr n pa biloha, bilueularis, v, abortu uniloba, hine plana, unilocnlaris, loculis abortu monospermis. - Arbores v. frutices antillani; foliis alternis, brevissime stipulatis, integerrimis $v$. subserratis, subcoriaceis, glabris, lucidis, venosis, floribus axillaribus fasciculatis, fasciculis multibracteatis.

Drypetes Vahl Eclog. fasc, III. 49. Poiteau in Mem. Mus. I. 151. t. 8_10. Adr. Jussieu Euphorb, 12.

58\%5. Sareococea $L I N D L$. Flores monoici. Calyx tetraphyllus, aequalis. Corola nnlla. Stam ina $3-4$, sub ovarii rudimento inserta, exserta: filam entis filiformibns, anthe ris introrsis, ovatis. Fem. Calyx pulyphyllus, imbricatus. Corolla nulla. Ovarium biloenlare, loenlis biovulatis. S $t$ igmat a 2 , sessilia, revoluta. D r u p a exsucca, stigmatibus persistentibus coronata, abortu unilocularis, putamine membranaceo, monospermo. - Frutex nepalensis, sempervirens; foliis alternis, breve petiolatis, inte gerrimis, nitidis, nervis primariis baseos costaeformibus, margini parallelis, reliquis pinnatim patentibus, floribus axillaribus spicatis, masculis superio ribus, femineis ad basim spicae masculae ternatis, sessilibus.

$\mathrm{S}$ areococe a Lindley in Bot, Reg. $t, 1012$. Pachys a odra procumbens Hooker Exot. Flor, $t, 148$, B uxus sallgua Don.

58\%6. Hyaenanche LAMB. Flores dioici, Masc. Cal y x penta-heptaphyllus. Stamina $10-30$; filamentis brevibus, a ntheris oblongo-ovatis. F em. Caly x polyphyllus, foliolis imbricatis, deciduis. O va ri um quadriloenlare, localis biovulatis. Styli 2-4; $8 \mathrm{tigmata} 4$, reflexa, glandulosa, fimbriata. Fru ctus suberosus, extus octesulcus, intus tetracoecus, coccis bivalvibus, dispermis. - Arbor c a pe $n s i s$, foliis ternatim v. quaternatim verticillatis, petiolo brevi, canaliculato, integerrimis, lucidis, crassiusculis, venosis, floribus axillaribus, femineis in pedunculis brevibus, paucifloris, masculis in racemis longioribus, congestis, bracteatis.

H y a na ne he Lambert Cinchon, $58, t, 10$. Adr. Jussieu Euphorb. 40. Toxic ode a d ro n Thunberg in Act. Acad. Hotm, 1796, p. 190, $t, 7 .-\mathrm{Jatropha}$ globosa Gấrtuer $t$. 109.

58 \%. IIfedyearpans $J A C K . \mathrm{C}$ al y x qua dripartitns. Stamina 4 . Ovariam triloculare, loculis biovulatis. Stigmat a 3 , sessilia, carnosa. C a p 8 I a baceata, trilocularis, trivalvis, Se min a arillo sapido tunicata. Embryo intra albumen inversus. - Arbor sumatrana; foliis alternis, simplicibus, subintegerrimis, stipulis ovatis, acutis, deciduis, racemis axillaribus et lateralibus fasciculatis.

Hed y earp u s Jack in Linn, Transact, XIV. 118.

58ร8. Plerandia ROXB. 'C al y qua dripartitus. St amina 8 , brevia. Ovarium triloculare, loculis biovulatis. St ig ma $\mathrm{ta} 3$, sessilia, subbiloba. B a c ca corticata, trilocularis, loculis di $-v$, abortu monosperrais. S e $\mathrm{m}$ in a arillo sapido tunicata. E m b ry o intra albumen carnoso-viseosum inversus. - Arbores Asiae tropicae; foliis alternis, simplicibus, integerrimis $v$. crenatis, bistipu. latis, floribus racemosis.

Pierardia Roxburgh Flor, indic. II. 254. Jaek in Linn. Transact. $X I V$. 119. P i e ra nd i a Blume Bijdr. 578 .

\section{GENERA DUBIA.}

58\%ळ. Nieborea $A U B L$. F lores monoici. Caly $x$ sexpartitus, laciniis lanceolatis, basi intus fovea marginata instruetis. Corolla nulla. Ma s c. St a mina 3 , cum ovarii rudimento in columnam basi crassam, apice trilobam, tripartibilem coalita, antherac 3 , infra columnae lobos adnatae, biloculares, loculis divarieatis, transversis, longitudinaliter dehiscentibus. F em. Ovariu m triloculare, loculis biovulatis. Stylus simplex (?); stigmat a... Cap sula triliba, tricoeca, loculis bivalvibus, dispermis. - Frutex guianensis; foliis alternis, subsessilibus, ovatis, acutis, integrerrimis, glabris, stipulis exiguis, floribus axillaribus et terminalibus corymboso-racemosis, superioribus masculis, inferioribus in eodem ramo femineis.

It e bo rea Aublet Guian. Ir. 825. t. 323. R hopi um Schreber Gen, n, 1382. T e $\mathrm{p}$ h $\mathrm{r}$ a $\mathrm{n}$ th us Necker Elem, $n .980$.

5880. Heren MUTIS, Flores dioici. Involucrum subgloboso vesicaeforme, hinc hians, demum explanatum, basi emarginatum, extus bracteolis duabus oppositis inaequalibus. Ma s c. Stamina plurima, brevissima, receptaculo biseriatim inserta, squamulis membranaceis plicatis, multifidis interstincta, a $\mathrm{n}$ he rae basi fixae, oblongae, tetragonae. 0 va ri a 4, efoeta, in receptaculi latere breviter pedicellata. Fem. Ovaria 4 , supra receptaculum, squamulis plurimis nultifidis stipatnm, pedicellata, singula trilucularia, loculis uniovulatis, monostyla. Stylus brevis, subtrigonus; stigmat a 3 , peltata, umbilieata. Ca p sula pedicellata, tricocca, coccis bivalvibus, monosperınis. Semina inversa, arillata. - Arbores Americae tropicae; foliis alternis, breve petiolatis, oblongis v. lanceolatis, integerrimis, subtus ferrugineo-lepidotis, involucris axillaribus pedunculatis, pedunculis fasciculatis.

Pera Mutis in Act. Academ, Holm. 1784 p. 299. $t .8$, Peridium Schott in Sprengel Cur. post. 410. Spixia Leandro de Sacrameato in Münchner Deakschrift. VII. 231. t. 13.

5881. Aextoxienm RUIZ et PAV. Flores dioiei. Mase. Invol a crum globosum, undique clausum, irregulariter a basi secedens. $C$ alyx hexaphyllus, foliolis biseriatis. Corollae petala 5, calyce majora, oblonga, subfornicata, intus lamella lineari, carinae longitndinaliter adnata. Stamina 5 , petalis alterna et breviora; $f \mathbf{i}$ lamenta crassa, clavata, anthera e introrsae, biloculares, globoso-didymae, loculis rimula brevi, obliqua dehiscentibus. Squamula e 5, carnosae, lnnulatae, staminibus alternae, ovarii abortivi basim cingentes. Fem. Ovariu m..... Stylus unus, bifidus. Drupa monosperma. S emen inversum. E m b r y o intra albumen carnosnm foliaceus, $c$ otyled on ibus tenuissimis, oblongis, basi subcordatis, apice reflexis, ra di cula subulata, supera. - Arbor chilensis, procera; folïis oppositis, breve petiolatis, oblongo-lanceolatis, integerrimis, supro glabris, subtus albo-furfuraceis, squamulis ferrugineis conspersis, stipulis nullis, racemis axillaribus folio multo brevioribus, ebracteatis, furfuraceis.

A extoxicum Ruiz et Pavon Syst. 260, Hooker Io, t.12. 
5882. DIargaritaria LINN, F. Flores dioici. C a Iy x quadridentatus. C o roll a e petala 4 , calyci inserta. Ma $8 \mathrm{c}$. St a min a 8 , receptaculo inserta; filamentis setaceis, calyce longioribus, antheris subrotundis, parvis. Ovarii rudimentum monostylum. Fem. Ovarium..... Styli 4_5, filiformes; stig in a ta simplicia. Fructus globosus, sub integumento baceato cartilagineo tetra-pentacoccus, coceis nitidis, bivalvibus. - Arbor surinamensis, dioeca; stirpis masculae foliis oppositis, ovatis, floribus paniculatis, numerosissimis, stirpis feminue foliis alternis, floribus axillaribus, solituriis.

Margaritaria Linn, f. Suppl. 428. Adr. Jussieu Euphorb. 59 .

5883. Suregada ROXB. F lores dioici. Caly x pentaphyllus. Mas c. Stamin a plurima; filamentis linearibus, a $t$ heris erectis. Fem. Ovari um ovoideum, sexangulare. Stigmata 3 , scssilia, bipartita. Capsula tricocea, coccis saepissime monospermis. - Arbor ind ica; foliis integerrimis, glaberrimis, venosis, floribus brevissime pedunculatis, oppositifoliis.

S u reg a d a Roxburgh ex. Willd, in Berl, neue Schrift. IV. 206. Adr. Jussieu Euphorb, 60.

5984. Hexadiea LOUR. Flores monoici. M a sc. C a ly $\mathrm{x}$ quinquepartitus, patens. Co. rollae petala 5 . Stamina 5 ; filamentis brevibus, a n theris bilobis, ereetis. Fem. Calyx sexpartitus, persistens. Corolla nulfa. Stigmat a 6 , sessilia, concava, conniventia, C a p 8 u la globosa, sexlocularis, sexvalvis, loculis monosper mis. - Arbor cochinchinensis; foliis alternis, integerrimis, glabris, floribus fasciculatis, subterminalibus, masculis et femineis in diversis ramis.

Hex ad ic a Loureiro Flor, cochinch, 683. Adr. Jussieu Euphorb. 60 ,

ร885. Homonoia $L O U R$. F 1 ores dioici. Ma 8 c. Cal y x tripartitus, basi extus trisquamosus. Coroll a nulla. St a min a circiter 200 ; $\mathrm{fi}$ 1 a mentis in fasciculos 20 connexis, antheris subrotundis. F e m. S qua ma simplex, acuta, multifida. Calyx et corolla nulla, Stigmata 3 , villosa, oblonga. C a poula triloba, trilocularis, trivalvis, loculis monospermis. - Arbuscula co chinchinensis; foliis allernis, angustis, integer. rimis, tomentosis, floribus minutis, amentiformibus, amentis subterminalibus, linearibus.

H om o n o i a Loureiro Flor, cochinch, 783. Adr. Jussieu Euphorb. 60.

5886. Cladodes LOUR. Fl ore s monoici, C a 1 y $x$ quadripartitus. C o r o I 1 a nulla. Iasc. Stamina 8 ; filamentis membranaceis, brevibus, a n theris subrotundis. Fem. Stigmat a 3 , oblenga, reflexa. Capaula subglobosa, triloba, trilocularis, trivalvis, valvis monospermis. - Arbuscula cochinchinensis, ramosissima; foliis alternis, serratis, glabris, rugosis, floribus terminalibus, racemoso-spicatis.

C I ad od es Loureiro Flor, cochinch, 204. Adr. Jussieu Euphorb. 61.

598\%. Eehinus LOUR. Flores dioici. M a sc. Ca lyx squamaeformis, apice* inaequaliter multifidus. Corolla nulla. Stamina circiter $\mathbf{3 0}$, ealyce breviora; fil amentis capillaribns, antheris subrotundis, minimis. Fem. Calyx quinque-sexfidus, laciniis inaequalibus, patentibus. Corolla nulla, Ovarium bílobum. Styli 2, pilosi, breves; stigmata simplicia. Capsula villis subulatis, setosis echinata, dicocea, coccis subglobosis, monospermis. - Arbuscula cochinch in ensis, caule declinato; foliis sparsis, integerrimis, ovatis v. tricuspidatis, reticulato-venosis, pedunculis lateralibus, paucifloris.

E e hi a s Loureiro Flor. cochinch. 787. Adr. Jussieu Euphorb. 61. - ? U I a s s i u вu Rupla Amboin. IIT, 42, t. 23.

5888. Laseadium $R A F$. F lore s monoici. Ca y $\mathrm{x}$ limbo integro. Coroll a nulla. Masc. Stamina circiter 12; filamentis brevibus, antheris crassis. Fem. Ovarium trilobum. Styli 3, partiti. Capsula ovata, laevis, trisperma. - Frutex boreali-americanus, totus lanatus, ramosus; foliis alternis, longe petiolatis, floribus terminalibus, masculis pluribus, circa femineum solitarium umbellatis.

Lascadi am Rafinesque Ludov, 114. Adr. Jassieu Euphorb. 62.

Geqera Des fontenaea Flor. Flum, III, t. 146, et M a ine a Elor. Flum, VIT. t. 8., evideuter Euphorbiaceis adscribenda, ex iconibus nimis mancis collocari nequeunt.

L i m a n a a Blanco Flor. Filíp. 821. L u a a a Blanco Op. cit. 783. a el. Liadley Bot, Reg. 1839. App. p. 73. Euphorblacels adaumerata, míhi plaue Incognita sunt.

\section{Classis LVII. Terebinthineae.}

Arbores, frutices v. rarius herbae. Succi in multis balsamei v. resinosi, in nonnullis lacteo-viscosi, caustici, plurimarum partes herbaceae glandulis oleo aromatico foetis. F oli a opposita v. aiterna, saepissime pinnatim composita, in aliis simplicia, integra v. rarius partita. S ti p u l a variae, saepe nullae. Flores hermaphroditi v. abortu unisexuales, rarissime incompleti v. irregulares. Ca ly $\times$ liber, rarissime adnatus. Cor olla e petala calycis laciniis numero aequalia, perigyna v. hypogyna. Stamina duplo petalorum numero, rarius plura. Ovarium unicum v. plura, verticillata, libera v, in unicum plus minus coalita. Ovula in loculis solitaria, gemina v. rarius plura. Fructus elementa libera v. connata, indehiscentia v. varia dehiscentia. E mbryo rectus v, curvatus, exalbuminosus v, albumine plus minusve copioso inclusus.

\section{Drdo CCXLIV. Jaglandeae.}

JUGLANDEAE DC. Theorie elem. 21s. Kunth in Annal. sc, nat. II. 343. Blame Flor. Jav, fasc, VIIT, Bartling Ord. nat. 397. JUGLANDACEAE Liadley Introduct, edit. $I$. p. 180

Arbores, succo aqueo v, in quibusdam resinoso. Folia alterna, impari-v. interdum abrupte pinnata, foliolis integerrimis v. serratis, saepissime epunctatis, trita odorem aromaticum spirantia. Stip ula e nullae.

Flores monoici v, rarius dioici, incompleti, spicis masculis amentiformibus, floribus femineis terminalibus, aggregatis v. racemosis, interdum cum spicis masculis in paniculam collectis.

Flores masculi in spicas amentaceas collecti. Calyx bracteae squamiformi, uniflorae, 
integrae v. rarius trifidae, intus complanatoadnatus, bi-tri-sexpartitus, laciniis membranaceis v. herbaceis, inaequalibus, concaviuscuculis, aestivatione imbricatis.

Staniva 3 v.plurima, receptaculo complanato, cum bracteae hypocalycinae nervo medio confluenti inserta, calycis laciniis opposita et alterna. Fila menta brevissime filiformia, libera. Antherae erectae, biloculares, basi insertae, crassiusculae, oblongae, loculis oppositis, parallelis, connectivo saepe supra eosdem producto et incrassato adnatis, longitudinaliter dehiscentibus. P o 11 e $\mathrm{n}$ globosum. D is c i et $0 \mathrm{varii}$ rudimentum nullum.

Flores feminei nunc terminales pauci, aggregati, bracteis gemmaceis minutis stipati, nunc laxe racemosi, involucro unifioro, basi cupulaeformi, cum basi calycis connato $\mathrm{v}$. demum cum ea concrescente, eincti, involucri limbo expanso, complanato-orbiculari v. quadripartito, laciniis inaequalibus alaeformibus, cum fructu increscentibus.

Calyx tubo cum ovario connato, limbi superi, tri-quinquepartiti laciniis minutis, saepe inaequalibus, deciduis v. rarius marcescentipersistentibus.

Corolla saepissime nulla, rarius petala minuta, summo calyci inserta, ejusdem laciniis alterna et vix longiora, basibus latis cohaerentia, apice patula, decidua.

Ovariom inferum, basi dissepimentis duplicatis, cum columna brevi ovulifera confluentibus, apice truncatis, bi-quadrilcculare, superne uniloculare. Ovulum unicum, in columnae centralis apice sessile, erectum, orthotropum. Styli $1-2$, brevissimi; stigmat a $2-4$, rarius plura et inaequalia, elongata, fimbriatopapillosa, interdum stigma sessile, discoideum, quadrilobum.

Dropa monopyrena, nuda $v$. involucro adnato, aucto alata, epicarpio parce carnoso v. coriaceo, intus saepe fibroso, irregulariter v. subvaivatim secedente, aut pertinaciter adnato, putamine osseo v. lignoso-rugoso, sulcato v. costato, intus basi bi-quadriloculari, superne uniloculari, evalvi v. bivalvi, monospermo.

Senex basi sua receptaculo erasso, cum dissepimentis abbreviatis cohaerenti insertum, erectum, laeve v. sinuato-torulosum, basi biquadrilobum, lobis intra loculos intrantibus. Testa membranacea, tenuis, endopleura tenuissima. Alb um en nullum.

Emвryo semini conformis, antitropus. $\mathbf{C}_{0}$ tyledones crassae, carnosae, oleosae, bilobae, sinuoso-torulosae. R a d icula brevissima, supera. Plumula in pluribus diphylla, pinnata.

Juglandeae in America boreali copiose crescentes, in Asia temperata et calidiore ra- riores, floribus imperfectis a reliquis Terebinthacearum ordinibus distinctae, pluribus notis ad Cupuliferas, foliis simplicibus, et fructus fabrica diversissimas, accedunt.

5889. Carya NUTT. F l o res monoici: Masculi laterales, amentacei. Calyx bracteae unifiorae, integrae interne adnatus, bi-tripartitus, Jaciniis membranaceis, ovatis, tertia inferiore multo minure. St am ina $3-6$, receptaculo bracteae nervo medio adnato inserta; fil am en ta brevissima, libera, a ntherae crassae, pilosae, bilo. culares, loculis oppositis, connectivo supra eosdem producto adnatis, longitudinaliter dehiscentibus. Ovarii rudimentum nullum. Flores feminei terminales, pauci aggregati. C a ly $\mathbf{x}$ tubo ovato, cum ovario connato, limbo supero, quadripartito. Corolla nulla. Sta minum rudimenta nulla. Ovari um inferum, basi quadriloculare, dissepimentis duplicatis, centro in ovuli receptaculam crassum coalitis, superne uniloculare. $O$ vulum unicum, in receptaculi apice sessile, erectum, orthotropum. Stigma sessile, magnum, diseoideum, quadrilobum, papillosum. Drupa mono. pyrena, epicarpio coriaceo-subcarnoso, quadrivalvi, putamine laevi, subtetragono, inferne incomplete quadriloculari, superne uniloculari, interdum bivalvi, monospermo. S emen receptaculo crasso affixum, erectum, inferne quadrilobum, intra loculos immersum, sinuato-torulosum ; testa menbranacea, tenui. Em bry on is exalbuminosi, antitropi cotyledones carnosae, bilobae, lobato sinuatae, radieula brevissima, supera, plumula diphylla, pinnata. - Arbores boreali-americanae; pube stellulata, foliis alternis, imparipinnatis, epunctatis, exstipulatis, pedunculis masculis et femineis ex una cum foliis gemma erumpentibus, femineis terminalibus triftoris, masculis sub foliis, apice bibracteatis, tristachyis, spicis amentaceis, gracilibus, pendulis, arcte bracteatis.

C a ry a Nuttall Gen. II. 220. Kunth in Annal, sc. nat. nat, 11, 344. Meisner Gen. 74. (54.) $\mathrm{S}$ c o r i a s Rafinesq. in New. York Medic, Reposit. II. Hex. V. 350. H ic orius Riatiuesq. Ludov. 109. J a g l a n d ls s p. Linn. Gärth. $t .89$. Miclix. Arbr. $t .3-10$.

5890. ฮuglams LINN. F I o res monoici : Mastuli laterales, amentacei, C al y x bracteae uniflorae, integrae interne adnatus, quinque-sexpartitus, laciniis membranaceis, inaequalibus, concavis, aestivatione imbricatis. St am ina plurima $(14-36)$, receptaculo bracteae nervo medio adnato inserta; fila menta brevissima, libera, anthera e rrassae, biloculares, toculis oppositis, connectivo supra eosdem producto adnatis, longitadinaliter dehiscentibus. Ovarii rudimentum nullum. Flores feminei terminales, solitarii v. pauci glomerati. Caly x tubo ovato, cum ovario connato, limbo supero, quadrifido v. quadridentato. Corolla e petala 4 , summo ealyei inter ejusdem lacinias inserta, minuta, basibus latis subcohaerentia, apice patula. Stamin $\mathbf{m}$ m rudimenta nulla. Ovarium inferum, basi quadriloculare, dissepimentis duplieatis, eentro in ovuli receptaenlum crassum coalitis, superne uniloculare. Ovu$1 \mathbf{~ a ~ m ~ u n i c u m , ~ i n ~ r e c e p t a c u l i ~ a p i c e ~ s e s s i l e , ~ e r e c - ~}$ tum, orthotropum. Styli 2, brevissimi; stigma ta 2 , elongata, recurvata, papilloso-fimbriata. Drapa monopyrena, epicarpio parce carnoso, intus fibroso, irregulariter rumpente, putamine osseo, extus rugoso, irregulariter sulcato, inferne quadriloculari, superne uniloculari, bivalvi, mo- 
nospermo. Semen receptaculo crasso affixnm, erectam, inferne quadrilobum, intra loculos im missum, sinuato-torulosum, testa membranacea tenui. Embryonis exalbuminosi, antitropi $\mathbf{c}$ oty le dones carnosae, bilobae, lobato-sinuatae, radicula brevissima, snpera, p l n m ula diphylla, pinnata. - Arbores inermes, glabrae, in America bor eali, nec non in Persia, unde ob nu. cis oleosae saporem in Europam propagatae, sponte crescentes; foliis alternis, imparipinnatis, epunctatis, aromaticis, exstipulatis, amentis masculis in distinctis gemmis solitariis $v$, rarissime pluribus congestis, sessilibus, dense bracteatis, floribus femineis ramulorum apici insidentibus, solitariis, geminis, ternis $v$, quaternis, ebracteatis $v$, bracteolis subulatis cinclis.

J ug I a a s Linn, Gen, n. 1071. exel. sp. Watson Dendrolog. t. 158. 192. Nuttall Gen, IT. 220. Kunth in Annal. sc. nat. II. 344. Meisuer Gen. 74. (54.)

5891. IPteroenrya KUNTH. Flores monoiei, masculi amentacei. Calyx bracteae nniflorae intus adnatus, quinque-sexpartitns, laciniis uembranaceis, inaequalibus, coneavis, aestiva tione imbricatis. Stamina $10-20$, receptaculo bracteae nervo medio adnato inserta; fil a me $\mathbf{n} \mathbf{t a}$ brevissima, libera, antherae erassae, biloculares, loculis oppositis, connectivo haud supra eosdem producto adnatis, longitndinaliter dehiscentibus. O varii rodimentum nullum. F Iores fem ine i laxe spicati. Invo I n e r n m nniflorum, basi cnpuliformi cum calyce connatum, limbo expla nato orbiculari, horizontaliter patentissimo, obsolete bilobo. Caly $x$ tubn ovato-subgloboso, cum ovario connato, limbi superi, tri-quinquepartiti laciniis minutis, inaequalibus. Corolla nulla. Sta minu un rudimenta nulla. Ovarium inferum basi quadriloculare, dissepimentis centro in ovnl receptaculum erassum coalitis, superne uniloculare. $O$ v u l um unienm, in receptaeuli apice sessile, erectum, orthotropum. Styln s terminalis, brevis; $s t$ iginat a 2, elongata, revoluta, papilloso-lacera, decidua. Drupa parva, invelueri adnati limbo patentissino transversim suboblique bialata, subglobosa, epicarpio coriaceo, hand solubili, putamine osseo, laevi, basi quadriloculari, superne uniloculari, indehiscente, monospermo. S emen receptaculo crasso affixum, erectum, inferne quadrilobum, intra Joculos sese insinuans, laeve, testa membranacea, tenui. E m br y onis exalbuminosi, antitropi cotyledones carnosae, bilobae, radicula brevis, smpera. - Arbor caucas ic a; foliis alternis, imparipinnatis, epunctatis, spicis simplicibus, masculis densis, femineis elongatis, pendulis, remotifloris, floribus parvis.

Pterocary a Kunth in Annal. sc. nat. Ir. 345. Meisuer Gen. 74. (5/.) Juglans pterocarpa Michx.

5892. Wngellamullia LESCHEN. S $\mathrm{p}$ cae monoicae, panienlato-ramosae, ramis lateralibus masculis, rhacheos parte superiore feminea, v. dioicae. Flores masculi: Calyx bracteae uniflorae, trifidae, lobo medio dilatato, interdum dentiformi v. obsoleto intus adnatus, trifidus, subcomplanatus, laciniis subfoliaceis, lateralibus minoribns, intermedia saepins alaeformi, aestivatione obscure imbricatis. Stamina $5-19$, ntrinque juxta calycis complanati nervum medium inserta; filame nt a brevissima, libera, anthera e crassae, subdidymae, biloculares, loculis connectivo supra eosdein producto adnatis, longitudinaliter dehiseentibus. Ovarii rudimentum nullum. Flo. res feminei: Involuerum unifloram, inferne cupnliforme, demum auctum et cum ovario coalescens, limhi liberi, quadripartiti laciniis foliaceis, inaequalibus, postica minima, anxieulaeformi, conduplicata, reliquis elongatis, alaeformibns, intermedia longissima. Caly x tubo ovato-globoso, cum ovario connato, limbi superi, quadri-quinquepartiti laciniis minutis, angustis, inaequalibus, marcescentibus v. partim persistentibus. Corol l a nulla. Staminum rudimenta nulla. Ovarium inferum, basi bi-v. incomplete quadriloculare, dis. sepimentis duplicatis, centro in ovuli receptaculum crassum coalitis, superne uniloculare. Ovalum unicum, in receptaculi apice sessile, erectum, orthotropum. Styl ns terminalis, brevis; stigmat a $2-4$, rarius plura, elongata, inaequalia, papilloso-lacera, persistentia. Drupa parva, cum involueri basi cupuliformi connata, ejusdem limbo elongato apice trialata, ovato-globosa, basi a latere compressiuscula, epiearpio coriacen-subcarnoso, intus fibroso, haud solubili, pntamine tenni, fragili, laevi, antice et postice bicostato, lateribns bisuleo, basi bi-quadriloculari, superne uniloculari, indehiscente, monospermo. Sem en receptacnlo crasso affixum, erectum, inferne bi-quadrilobum, intra loculos immissum, sinuoso-sublobatum, testa membranacea, tenai. E m bryon is exalbuminnsi, antitropi cotyledones subfoliaceae, sinuoso. rugosae, sublobatae, radicula brevis, obtnsa, supera. - Arbores Asiac tropicae, magnae, nonnullae resiniferae; foliis alternis, abrupte pinnatis, foliolis inaequilateris, subtus saepe resinoso. punctatis, spicis masculis gracilibus, densifloris, femineis longioribus, pendulis, laxinsculis

Engelle ardtia Leschenault ex Blume Flor. Jav, fase, VIIT. p. 5. t, $t-5$, Wallich Plant. At. rar. t. 199. 208. Meisner Gen. 74. (54.) Pte ril e ma Reinwardt in Sylloge Plant, II, 13. 31. D a m ma ra Rumph Amboin. II, 168.

\section{NuX rossitis.}

JUGLANDITES Sternb. N u x globosa, sulcata, ragosa, seminis Inbis approximatis, simplicibus.

Juglandites Sternberg. Flor, primig. 2. 83. f. 3. Ja glandis s p. Bennguiart Classific, t. 6. f. 6 .

\section{Ordo CCXI D. Anacardiaceae.}

TEREBINTHACEA RUM genera Jussien Gen, 368. CASSU. VIEAE v. ANACARDIEAE R. Brown in Tuckey Congo 431. Bartling Ord, nat.395. TEREBINTHACEAE Kunth in Annal. sc. nat, II. 333, TEREBINTHACBARUM Tribus I. et II. DC, Prodr. II. 62, 55. ANACARDIAC RAE Lindley Introduct. edit. $I T$. p. 166.

Arbores v. pruticks, snceo balsameo v. gummoso, plures viscoso-lacteo, caustico foetae. Folia alterna, nunc simplicia, integerrima, nunc temata v. imparipinnata, foliolis integerrimis v. serratis, epunctatis. Stipula e nullae.

Fuores saepissime abortu unisexuales, monoici v. dioici, rarius hermaphroditi, regulares, parvi, plerumque minuti, axillares v. terminales, spicati aut paniculati.

Caryx liber v. rarissime tubo cum ovario connato, tri-quinquefidus v. partitus, rarius plurifidus, saepissime persistens, in nonnullis demum auctus.

Corolua petala calycis lacinis numero 
aequalia, iisdem alterna et majora, disco perigyno, orbiculari v. annulari, rarius gynophoro brevi inserta, aestivatione imbricata $\mathbf{v}$. rarius valvata, in nonnullis persistentia, demum increscentia.

Stamina cum petalis inserta, iisdem numero aequalia et alterna, v. dupla, rarius plura, nonnulla interdum efoeta, in floribus femineis sterilia. Fil amenta subulata v. filiformia, libera v. interdum basi in discum coalita. Antherae introrsae, biloculares, longitudinaliter dehiscentes.

Ovarium liberum, v. rarissime calyci adnatum, saepissime unicum, uniloculare, rarius quinque $\mathbf{v}$. sex distincta, quorum quatuor $\mathbf{v}$. quinque efoeta $v$. ad stylum redacta, libera $v$. fertili unico adnata. In floribus masculis saepe ovarii unius v. plurium rudimenta. Ovulum unicum, funiculo filiformi, e basi loculi adscendenti, nune libero, apice inflexo, nunc parieti adnato insertum, adscendens v. pendulum, amphitropum v. semianatropum. Stylus unicus, terminalis v. sublateralis, simplex, interdum plures, ovariis nempe pluribus efoetis, ad molem minimam redactis, cum uno fertili coalescentibus styli plures, saepissime inaequales. S ti $\mathrm{g} \mathrm{m}$ a ta indivisa.

Froctos indehiscens, monospermus, saepissime drupaceus, rarius exsuccus, in plurimis oleo caustico $\mathrm{v}$. terebinthino scatens.

Semen erectum v. inversum, testa membranacea, interdum cum endocarpio confusa, umbilico in plurimis ventrali. Alb umen nullum.

Embryonis carnosi v. rarius subfuliacei cotyledones plano-convexae, radicula plus minus curvata, nunc supera v. lateralis, aut interdum inter colyledones latens, nunc infera, uncinatim adscendens.

Terebinthaceac ob succos resinosos, multiplicis usus, celebres, maximo numero in regionibus tropicis et subtropicis, rarius in temperatis totius orbis crescentes, hinc Burseraceis et Zanthoxyleis, ovariorum fertilium et ovulorum numero facillime distinguendis, proxime affines, illinc ad Rosaceas et Leguminosas tendunt.

Genera denuo sub incudem revocanda, et plures fortassis tribus, habita imprimis gynophori et disci ratione, vix ex embryonis natura instituendae.

Spondiaceae, ad ordinis calcem positae, inter Anacardieas et Burseraceas ambigunt, illis ovulis solitariis et embryone, his carpidiis pluribus fertilibus accedentes.

5853. IPistaeia LINN. F I o res dioici. $M$ ase. Calyx parvus, quinquefidus. Corolla nulla. St a $\mathrm{m}$ in a 5 , ealyci inserta, ejusdem laciniisopposita; fil a me nt a brevissima, basi in discum confluentia, a nt hera e biloculares, magnae, subtetragonae, longitudinaliter dehiscentes. O varii rudimentum. Fem. Calyx parvus, triquadrifidus, laciniis ovario adpressis. Corolla, stamina et diseus nullus. O va ri u m unicum, ses. sile, uniloculare, rarissime triloculare, locnlis duobus radimentaris. Ova/ nm unicum, funiculo e basi loculi adscendenti appensum. St ylus brevissimus; stigm at a 3 , subspathulata, recurva, papilloso-puberala. Dru pa exsucea, putamine osseo, monospermo. S e men adscendens. Em bryon is exalbuminosi cotyledo nes erassae, planoconvexae, radicula supera, lateralis, cotyledonibus accumbens. - Arbores v, arbusculae, in regione mediterranea indigenae, etiam in Mexico observatae, Terbinthumv. Mastichen sudantes; foliis alternis, ternatis $v$, impari- aut abrupte pinnatis, exstipulatis, inflorescentia axillari, paniculata $v$. racemosa, pedicellis basi unibracteatis, seminibus amygdulinis, oleosis.

Pistacia Liun, Gen. n. 1108. Kunth in Annal. sc. nat. II. 329. DC. Prodr. II.64 Meisaer Gen, 75. (54.) T ere b f uth us Jussieu Gen. 371.

a. TEREBINTHUS Tournef. Inst, 345. Folf a ternata v. imparipinoata, deeidna (Duhamel Arbr, I. t, 87. Edit. Nov, IV. t. 17. Nees jun, Plant, offic, t. 352. Hunb. et Boupl. Nov, gen. et sp. t. 608. Webb et Berthel. Flor. Canar. t. 66.)

b. LENTISCUS Tournef. Inst. 380. Fo li a abrupte pinata, perenuatia, (Duham. Arbr. edit. nov, IV, $t, 18$. Bot. Mag. t. 1967. Nees jun. Plant, offic, t, 35t, )

5894. Iupuisia $A$. RICH. F lo res hermaphroditi. Caly $\mathrm{y}$ minimus, cupulaeformis, obsolete quinquedentatus, persistens, Corollae petala 5, calyci inserta et multo longiora, oblonga, acuta, concava, aestivatione valvata. St a m ina 5 , calyci inserta, petalis alterna et breviora; fil amenta subulata, antherae introrsae, biloculares, ublongae, Inngitudinaliter dehiscentes. Ovarium unicum, liberum, sessile, uniloculare. Ovu 1 um unicum, funiculo filiformi, e basi loculi adscendenti appensum. Sty I ns terminalis, simplex; $8 \mathrm{tigma}$ obtusum, indivisum. Fructus... - Arbor sen egambica; foliis alternis, imparipinnatis, bi-quadrijugis, foliolis alternis, coriaceis, elliptico acuminatis, integerrimis, glaberrimis, floribus parvulis, rubescentibus, intus puberulis, in paniculam terminalem dispositis.

D u p u i s i a A. Richard Flor. Seneg. $I$. 148. $t$. 38. Meisner Gen, 75. (54.)

5895. Sorinaleis THOUAR. F $10 \mathrm{r}$ es polygamo-disiei. Caly $\mathrm{x}$ persistens, urceolatas, obsolete quinquedentatus, interdum septemdentatus, dentibus acutis. Co rolla e petala 5-7, medio calycis tubo inserta, oblonga, patentia, aestivatione subimbricata. Mas c. Stamina $10 \_20 \mathrm{v}$. interdum plura, disco tenni, calycis fundum vestienti inordinate inserta; $\mathrm{f}$ il a m e $\mathrm{n} \mathrm{t}$ a brevissima, ant he rae biloculares, oblongae, hasi bifida insertae, longitudinaliter dehiscentes. He r m aphrod. Stam in a 10, disci perigyni margini nniseriatim inserta. Ovarium unicum, liberum, sessile, conicum, uniloeulare. O v u 1 a m nnienm, funiculo e basi loculi adscendenti appensum. StyI s s terminalis, brevis, crassus; st i g ma trilobum. D ru pa compressa, putamine filamentoso, monospermo. Sem en inversum. Embryonis exalbuminosi cotyledones crassae, carnosae, radic ula lateralis, adsecndens. - Arbusculae madagascarienses et africanae tropicae; foiis alternis, imparipinnatis, foliolis alternis, obliquis, integerrimis, paniculis in apice ramorum axil- 
laribus, ramosis, bracteatis, floribus parvis, purpureis.

Sorindei a Thouars Gen, madagase, 23. R. Brown in Tuckey Congo 431. Kunth in Annal. sc. nat. 1I. 342 , DC. Prodr. 1I. 80. Wiglt et Aruott Prodr, I, 170. Meisner Gen, 75. (54.) Mangifera pinuata Lam. non Linn.

5896. Comoeladia $P . B R O W N$. F 10 res dioici. Calyx tri-quadripartitus, aequalis, persistens, Corallae petala $3-4$, sub diseo hy pogyno, tri-quadrilobo inserta, ovata, aequalia, patentissima, aestivatione inbricata. Stamina 3-4, cum petalis inserta, iisdem alterna et breviora; fil amenta libera, antherae introrsae, biloculares, longitudinaliter dehiscentes, in floribus feminis efoetae. Ova ri n m unisum, liberum. sessile, uniloculare, in floribus masculis efoetum Ovulum unicum, funieulo e basi loculi adseendenti, apice incnrvo insertum, pendulum Stigma ta 3 , sessilia. Drupa olivaeformis, sueculenta, superne tripunctata, putamine membranaceo, monospermo. Semen oblongum, funiculo basilari, complanato appensum, testa membranacea. Embryonis exalbuminosi cotyledones carnosae, plano-convexae, radionla supera, curvata, pla mala diphylla. - Arbores A merica tropicae, succo glutinoso, aqueo v. lacteo, ad contactum aëris nigrescente scatentes; foliis alternis, imparipinnatis, foliolis oppositis, coriaceis, rigidis, saepe spinoso-dentatis, racemis axillaribus paniculalis, floribus minutissimis, conglomeratis, bractealis, purpureis.

Co mo c I a d l a P. Browne Jam. 124. Jaequia Amer. 12. t. 173. $f$. 4. Laus. $t$, 27. Kuntls in Annal. sc, nat, II. 341. et in $\mathrm{H} u m b$, et Boopl. Nov, gen, etsp, VII. 15. $t, 607$. DC. Prodr. II. 65. Meisuer Gen. 74. (54). D o d o n a e a Plumier edit. Burm. t. 118.

5897. Cyrtoearpa $H, B, K$. F 10 res polygami? Calyx quinquepartitus, laciniis subrotundis, aequalibus, patentissimis. Co roll a e petala 5, sub disco perigyno orbiculari, margine de cemcrenato inserta, calycis laciniis alterna et duplo Iongiora, ovato-elliptica, aequalia, patentissima. Stamina 10, cum petalis inserta, iisdem dimidio breviora, antherae introrsae, biloculares, longitudinaliter dehiscentes. Ovari um ovatum, in floribus mascnlis ejus Inco tubercula $5 \ldots .$. Stylus nnus; stigma quadrifidum. Fruetus obovato-ellipticus, drnpaceus (?) supra medinm quinquetuberculatus, perigonio et filamentis persistentibus fultus, foetus putamine durissimo..... - Arbar Novae Hispania e incola; ramulis su. perne foliiferis, inferne floriferis, foliis alternis, imparipinnatis, foliolis oppositis, integerrimis, sti. pulis nullis, fioribus subsessilibus, glomerato-spicatis, bracteatis, albis.

Cy rtocarpa Kunth in Humb, et Bonpl. Nov, gen. et sp. VII. 20, t. 609. Meisuer Gen, 75. (54.)

5998. Ddina ROXB. FIores polygamomonoici. Caly x breviter quadrilobus, persistens, laciniis rotundatis. Corollae petala 4 , ad basim disci perigyni, carnosi, octocrenati inserta, oblonga, concava, patentia, aestivatione imbricata, Sta in in a octo, disco perigyno infra marginem inserta, ejusdem crenis alterna; filamenta pa. tentia, petalis breviora, an the rae introrsae, biloculares, ovatae, longitudinaliter dehiscentes. Ovarin m in floribus masculis sterile, quadripartitum, lobis clavatis, compressis, erectis, in floribus femineis nnicum, liberum, sessile, oblongum, uniloculare. $O \mathbf{v} \mathrm{I} / \mathrm{nm}$. nnicam, funiculo brevi prope apicem loculi appensum. Styli 4 , distan- tes, breves, erecti; stigmata simplicia. Drupa baceata, stylis persistentibus superata, putamine haud compresso, durissimo, indehiscente, monospermo. S em en nacleo conforme. Embryonis exalbuminosi, leviter curvati cotyle do n es carnosae, planae, radicula supera. - Arbores, in India orientali et Africa tropica obviae; foliis in apice ramorum alternis, imparipinnatis, triquadrijugis, foliolis oppositis, sessilibus, oblongoovatis, acuminatis, integerrimis, subtus pallidioribus, glabris v, tomentoso velutinis, racemis terminalibus fasciculatis, interruptis, filiformibus, pendulis, floribus parvis, fasciculatis.

Odina Roxburgh Elor. ind. II. 293. Royle Himalay. t. 31. $f$. 2. Wight et Aruott Prodr. I. 171. Meisuer Gen. 24. (54.) Wo dur Auders. ? H a berlia Denust. 2. Hort. Ma. lab. IV. 32, La n nea A. Richard Flor. Seneg. I, 133, $t, 42$.

5899. Regia COLEBR. Flores hermaphroditi. Caly $x$ brevis, quinquepartitus, persistens, laciniis rotundatis. Coroll a e petala 5 , inter calycem et discum integrum, concavnm, ovarii basim cingentem inserta, ovalia, Patentia. Stamin a 10 , disci basi inserta, corollam subaequantia, alterna breviora; fila me nta subulata, ant herae globosae, bilobae, longitudinaliter dehiscentes. Ovarinm unicum, liberum, diseo subimmersum...... Stylus hrevis, ennicns; stigma simplex. Drup a baceata, putamine ovali, compresso, osseo, ruguloso, fragili, monospermo. S e m en inversum, testa membranacea, tenui. $\mathrm{E}$ m bryonis exaltominosi cotyledones ovales, magnae, carnosae, radicula brevissima, supera, crassa, - Frutex indicus, scandens?; folits alternis, imparipinnatis, quinque-septemjugis, foliolis suboppositis, brevissime petiolulatis, cordatis, acuminatis, remote serratis, lobis inaequalibus, superiore angustiore subintegerrimo, junioribus utrinque pubescentibus, petiolo supra canaliculato, villoso, basi incrassato, stipulis nullis, puniculis axillaribus et terminalibus, ramosis, ovatis, pedunculis villosis, bracteis ad basim pedicellorum solitariis, ovatis, floribus plurimis, minutis, pallide virentibus, suaveolentibus.

Pegia Colebrooke in Linn, Transact. XV. 364. Meis: ner Gen. 25, (34.)

5900. Solenoearpus WIGHT et $A R N$.

F lores hermaphroditi. Caly $x$ brevis, quinquefidus, deciduus, laciniis rotundatis, Corolla e petala 5 , inter ealycem et discum integrum, ovarii basim cingentem inserta, ovalia, aequalia, aestivatione imbricata. Sta min a 10 , infra marginem disei inserta; filamenta alterna lireviora, corollam subaequantia, an $t$ h e rae elliptieae, biloculares, longitudinaliter dehiscentes. O varium unicum, liberum, sessile, unilueulare. Ovulam unicum, funiculo brevi prope apicem loculi appensum. Stylus brevis, crassus, stamina aequans, hinc suleo longitudinali; $\mathrm{t} \mathrm{i} \mathrm{g} \mathrm{m}$ a obliquum. Fractus subrenifurmi-obliquas, pericarpio vittis oleiferis percurso, unilocularis, monospermus. S emen ex apice lateris convexioris fructus pendulum ......-Arbor? ind ica; foliis ramorum juniorum alternis, in apice adultorum fasciculatis, longe petiolatis, imparipinnatis, quinque - septemjugis, foliolis elliptico -oblongis, acuminatis, obsolete crenulatis, glabris, subtus pallidioribus, nervis lateralibus pellucidis, intra marginem confluentibus, paniculis in apice ramorum fasciculatis.

Solenocarpus Wight et Arnott Prodr. I, 17t.

5901. Sehimus LINN. Flores dicici. C a ly $x$ quinquepartitus, persistens, laciniis aequa- 
libus, subrotundis. Corolla petala 5 , inter calycem et discum annularem, uadulato-sinuatum inserta, obovato-oblonga, aequalia, aestivatione imbricata. St a m in a 10 , sub disco inserta; f il a ment a subulata, libera, an the $r$ a e introrsae, bi loculares, ellipticae, longitudinaliter dehiscentes, in flurihus femineis efoetae. $0 \mathrm{v}$ a $\mathrm{ri}$ u $\mathrm{m}$ unicum, liberum, sessile, uniloculare, in floribus masculis efoetum. Ovn I $\mathrm{m}$ unieum, e funiculo parietali adscendente pendulum. St yli $3-4$, terminales, brevissimi; stig mata capitellata. Drupa sphaeriea, succulenta, putamine osseo, extus vittis sex longitudinalibus oleiferis exsculpto, uniloculari, monosper mo. Semen compressum, e funiculo parietali ad. scendente pendulum, testa membranacea, endo pleura subcarnosa Embryonis exalbuminosi cotyledones planae, $r$ ad i $s u l$ a infera, adscendens, elongata. - Arbusculae in America tropica trans a equatorem, et in australi extratropica indigenae; foliis alternis, imparipinnatis, multijugis, foliolis alternis $v$. oppositis, sessilibus, lanceolatis, integerrimis v. serratis, epunctatis, terminali longissimo, stipulis nullis, paniculis axillaribus et terminalibus bracteatis, folio brevioribus, floribus parvis, albis, fructibus rubris.

S c bi n us Linn. Gen, n. 1130. Miller Ic. t. 246. Lam. t. 892. Kunth in Annal. se, nat. II. 139. DC. Prodr. II, 74. Hooker in Bol. Mag. 2. 3339. Meisaer Gen, 24. (54,) Molle Clusius Exot. 322. Tournefort Inst. 661. M a III Feuillé Peruv. III. 43, t. 30 .

5902. Duvaua KUNTH. Flores poly. gamo-monoici v. dioici. Caly x quadri-quinquefdus, aequalis, persistens. Co roli a e petala 4 v. 5, sub disco lato, vetusinnato inserta, ovata, coneava, aequalia, patentissima, aestivatione imbrieata. Stamina 8 v. 10 , cum petalis inserta, quatuor iisdem alterna longiora; fila menta subulata. patentia, a $\mathbf{n}$ h e rae introrsae, biluculares, ovatae, utrinque emarginatae, dorso supra basim insertae, longitudinaliter dehiscentes. Ovarium unieum, liberum, sessile, conicum, uniloculare, in floribus masculis efoetum. Ovulum unicum, ,prope apicem cavitatis appensum. Styli $3-z$, brevissimi; otigmata capitata. Drupa pisiformis, parce carnosa, putamine coriaceo, sinuato ruguloso, monosperimo. Se men inversum. E m bry on is exalbuminosi, leviter curvati a oty ledones planae, radicul a lunga, supera. - Arbores $v$. frutices ch in enses et sand wicenses, sempervirentes, graveolentes, inermes $v$.ramis axillaribus spinescentibus armat $i$; foliis alternis, petiolatis, simplicibus, integerrimis $v$. sinuato-dentatis, racemis axillaribus, sessilibus, multifloris, solitariis, geminis v. ternis, floribus pedicellatis, luteo-albicantibus, pedicellis basi unibracteatis, fructibus nigris, Juniperum redolentibus.

D u va ua Kuntir in Annal. sc. nat, II. 340. DC. Prodr II. 74. Lindley in Bot. Heg. $t, 1368,1573,1380$. Meisner Gen, 74. (54.) A m y r is polyg a ma Cavan. Ic, t, 239. S chiai a p. Andrews Bot. Heposit. $t$. 620 . Hui a g ha $\mathrm{n}$ Chilen.

5903. Mauria KUNTH. F lores hermaphroditi, Cal y x parvas, urceolatus, quadri-quinquelobus, aequalis, persistens. Corolla e petala 4 -5, inter calyeem et discom annnlarem, perigynum, sinuatum inserta, aequalia, lata basi sessilia, aestivatione imbricata. St a m i n a $8-10$, sub diseo inserta, corolla multo breviora; fil a ment a subalata, libera, a $n$ therae introrsae, biloculares, uvatae, longitudinaliter dehiseentes. Ovarium libernm, sessile, nniluculare. Ov nl um nnicum, funieulo brevi prope apicem luculi appensum, anatropnu. Stylus brevis, crassus; tigmacras- sissimum, tri-pentagonum, truncatum, angnlis papillosis. D rupa parce carnosa, oblique elliptica, compressa, stigmate umbilicata, putamine chartaceo, monosperno. S em en pendulum, subreniformi-oblongum, compressum, testa membranacea. Embryonis exalbuminosi cotyledones complanatae, radicula supera, uncinato-descendens. - Arbores peruanae, inermes; foliis alternis, simplicibus v. pinnatis, uni-bijugis cum impari, integerrimis, epunctatis, stipulis nullis, paniculis in apice ramulorum axillaribus et terminalibus, bracteatis, floribus albido roseis.

$\mathrm{M}$ a u $\mathrm{ria}$ Kunth in Annal. se, nat. II, 338. Humb. et Bonpl. Nov. gen. et sp. V11. 11, t. 605. 606. DC. Prodr. II. 75. Meisuer Gen. 74. (54,)

5904. Lithraea MIERS. Flores polygamo-dioici. Caly $\mathrm{x}$ snbeampanulatus, quinquefidus, aequalis, persistens. Corolla e petala 5 , inter calycem et discum annularem integerrimam, perigynum inserta, aequalia, sessilia, aestivatione imbricata. Sta m in a 5 v. 10 , sub diseo inserta, corolla breviora; filamenta subulata, libera, anthera introrsae, biloculares, ovatae, basi emarginatae, Iongitudinaliter dehiscentes. Ova rin m liberum, sessile, nniloculare. Ovulnm unicum, e funiculo a basi loculi adscendente suspensum. Stylus brevis; stig ma trilobum, lobis ubtusis. Drupa resinoso-pulposa, globosa, stylo mucronata, putamine orbiculari, compresso, laevi. Sem e n inversum, testa membranacea Embryonis exalbuminosi cotyledones planae, radieula supera, nncinato descendens. - Frutices chilen. ses et californici; foliis alternis, simplicibus, coriaceis, integerrimis, estipulatis, racemis axillaribus et terminalibus paniculatis.

L ithrae a Miers Travels in Chili IT. S29. Hooker Bot. Miscell. III, 175. Meisuer Gen. 74. (54.)

a. LLITHI Stam in a 10. - Species chilensis. - Llithi Feuille Observ. III. t. 23. fig. dext. L a u r is c a ustiea Molina. Rhus caustica Hook, ad Beechey $t, 7$. Litri Chilen.

b. MALOSMA. Stamina 5, - Species californicae. $\mathrm{Rhof}$ sect. Malos ma Nuttall in Torrey et $A$. Gray Flor, of North-Amer. $I, 219$.

5905. Theus $L I N N$. Flores polygami, mono-dioici. Cal y $x$ parvus, quinquepartitns, persistens, laciniis aequalibus, aestivatione imbricatis, Corolla petala 5 , sub disco orbiculari inserta, sessilia, aequalia, patentissima, aestivatione imbricata. S $\mathrm{tam}$ in a 5, cum petalis inserta, iisdem alterna; fil a m e n t a subulata, libera, a n therae introrsae, biloculares, longitudinaliter dehiscentes, in floribus femineis efoetae. Ovarium unicum, liberum, sessile, ovatum v. globosum, uniloculare, in floribus masculis efoetum. Orulum unicum, funiculo e basi loculi adscendenti appensum. Styli 3 , breves; stig mat a obtusa v, capitata. Drupa exsucca, putamine osseo, monospermo. S e m e $n$ inversum, testa membranacea. Embryonis exalbuminosi cotyledones planae, radicula supera, uncinato-descendens. Arbores $v$. frutices, in regionibus temperatis subtropicisque totius orbis crescentes, in Capite bonae spei et America boreali copiosi, inter tropicos rari, inermes v. rarius spinosi, plures verniciflui v. succo lacteo aut caustico turgidi; foliis alternis, ternatis v. rarius imparipinnatis aut simplicibus, stipulis nullis, paniculis axillaribus et terminalibus, bracteatis, interdum contractis, floribus parvis.

$\mathrm{R}$ h us Linn. Gen. n, 369, Gärtner I. 205, 1. 44. $f$. 2. Kunth in Annal. sc, nat, II, 337. DC. Prodr, II, 66. Wight et Araatt 
Prodr. I. 178. Meisuer Gen, 74. (54.) Torrey et A. Gray Flor, of North Amer. I. 216.

a. Cotinus DC. $l$. c. FIores hermaphraditi. Drupa semicordata, venosa. glabra, putaniue triangulari. Folia simplieia, flores laxe paniculati. pedicellis plu rimis abortiris, demum elongatis plumoso-hirtis. - Species mediterraneo-caucasica. Cotin us Tour. nefort. Inst. 380, $\mathrm{R}$ h. Colí a us Lian. Jaeq. Flor. austr. t. 238.

b.? METOPIUM DC. $\boldsymbol{l}$. c. Flores hermaphroditi. Drupa ovato suboblonga, glabra, puramíne membrauacro, umplo. - Folia imparipinnata foliolis bijugis, ovatis, lange petiotulatis, integerrimis. - Species jamaicensis, quoad fructum non satis nota. M $=$ to $\mathrm{p}$ i u $\mathrm{m}$. Brawne Jam. 127, t. 13. f. 3, R h. Metoplum Linn. (Sloane Jam, $t, 199 ., f .5$.

e. SUMAC. DC, $l$. c, Flores polygamo-dioiel v. herma. phroditi. Drupa ovatn rotunda, saepe villosa, nuclen larvi v. striato. - Frutices foliis imparipinnatis $v$. palmatim trifoliolatis, petiolo nitlo $v$. subalato, flo. ribus paniculatis.

$\alpha$, R h u s Tournefort Inst. 38t, F a li a imparipinnata. Species mediterraneae, boreali americanae, capenses. japonicae, pancae in America et Asia tropica indigenae. (Jace. Hort schénbr, t, 341, 342, Murray in Comment, Götting VT, t.13. Sibthorp Flar. graec. t. 290. Duhamel Arbr. edit, nov. II. t. 47. 48. Ruis et Pavon Flor. Peruv, t. 252. Kunth in Humb. et Bonpl. Nov. gen, et sp. t. 603, 604. Bigetow Med. Bot. I. ใ. 10.)

B. Taxieodendron Toaraefort Inst. 38t. F a I i a trifoliolata. - Species boreali-americanae, capenses et boreali-africanae. - Pocophorim Necher Elem, n. 934. (Jecq. Hort, schönbr. t. 343-346. Du. hamel Arbr. edit. nov. II. $t .48$. Cav, Ic, t. 132. Bot. Mag. 2. 1806. Hooker Flor, Bor. Amer, t, 46.)

d. THEzera $D C, t$. $c$, Flo res dioici. S tyli 3 , breves, distiacti. Dru p a subrotunda, apice trifubercnlata, nucleo compressi, - Folia palmatim tri-quinquefoliolata foliolis sessilibus. Flores breviter racenosi. - Spe cies mediterraneae. - $\mathbf{R}$ h a m n i s p. Jacq. CDesfont. Flor, atlant. $t, 27$.

e. LOBADIUM DC. l. c. Flores polygami, Discus quinquelobus, lobis petalis oppositis $S t y \mid i \quad 3$, breves. aistiucti. Drupa subeompressa, villosa, nucleo laevi. - Frutices boreali americani, aromatici, foliis palmatim trifoliolatis foliolis sessiltbus, grosse inciso. serratis. Flores in paniculam densam, amentiformem dispositi. - Labadia m Rafiaesque in Journ. Phys. LXXXIX. 98. Turpia i Rafinesque in New-York Me. die. Reposit, Ir. Hexad, $\mathcal{D}, 350, \mathrm{~S}_{\mathrm{c}}$ h m a l $\mathrm{z}$ i a Desvaus in Journ.Bot. IT, 170. (Turpin in Annal. Mus. V.t.30.)

5908. Styphomia NUTT. Flores po. lygami. Cal yx imbrinato-bracteolatus, hepta-enneaphyllus, foliolis coloratis, concavis, margine seariosis, pluriseriatim imbricatis. Corolla e petala 5, sub disei margine inserta, oblonga, breviter unguiculata, calycis foliolis conformia, intus prope hasim pubestentia. Sta $\mathrm{m}$ in a $5-7$, cum petalis inserta; fil a ment a subulata, libera, a $n$ thera e introrsae, hilornlares, longitudinaliter dehiscentes, in floribus femineis efoetae. Ovariom nnicum, li berum, sessile, ovatum, uniloculare. Ovulu m nnicum, funiculo e basi loeuli adscendenti appensum. Styli 3 , breves; stigmata ubtusa. Drupa exsucea, putamine osseo, $m * n$ ns permo. S e $m$ en inversum, testa membranacea. E m br yo ..... Arbusculae resinosae, $s u b m a$ ritima e, ramosissi. mae; foliis alternis, simplicibus, sempervirentibus, coriaceis, integerrimis, paniculis terminalibus contractis.

Sty phonia Nuttall ex Torrey et A. Gray Flora of North-Amer. 1, 220, - ? Rhus molle H. B. K. Rh. a t $\mathbf{r}$ a Labill.

5อ0\%. Botryceras WILLD. Floreg polygamo-dinici. Ca I y x parvus, quadri-quinque partitus, persistens, laciniis aequalibns, aestiva- tione imbricatis. Corollae petala $4 \ldots 5$, imo caIyci inserta, sessilia, aequalia, reflexo-patentia, aestivatione imbricata. St a m in a 4 v. 5 , cum petalis inserta, iisdem alterna, in floribns hermaphroditis brevissima; filam enta filiformia, libera, antherae introrsae, biloculares, longitudinaliter dehiscentes. Ovarium unicum, liberum, sessile, ovato subrotundum, compressissimom, nnilocolare. Ovulum unicum, prope cavitatis apicem appensum. Stylus unicus, arcuato adscendens; s tig ma capitatum. D ru p a sicea, ovato-subrotunda, compressissima, epicarpio membranaceo, rugosissimo, secedente, putamine subosseo, monospermo. S em en inversam, testa membranacea. Embryonis exalbuminosi eotyledones planu-convexiusculae, radicula snpera, uncinatodsscendens. - Arbuseula capen sis, succo resinaso turgida; foliis alternis, simplicibus, dentato-serratis, glabris, paniculis axillaribus thyrsoideis, bracteatis, masculis gracilibus, folia subaequantibus, ramis primariis alternis, remotis, bracteis lerminalibus partim flores superantibus, incurvatis, paniculis hermaphroditis abbreviatis, condensatis, ramis ramulisque approximatis, cum floribus introrsum versis et valde inerassatis, bracteis latioribus, persistentibus.

Botryceras Willdenow in Berl. Magaz. $V$. 396. La uropliyllas Thuab. Prodr. Flor. Cap. 153. Bern. hardi in Linnaea XII. 129_136. Daphaitis Sprengel Syst. $I$. 491, exel. synon.

5\$08. Loxostylis SPRENG. F. F I o res monoiei. Cal y $x$ parvus, coloratus, quinquepartitus, frutifer maximus, scariosns. Coroll a e petala 5, snb disci hypogyni minuti, quinquelobi Inbis inserta, lanrealata, calyce dnplo Inngiora, in floribus femineis minuta. Stamin a 5 , inter disci lobos inserta, petalis alterna et breviora, valde inaequalia, in floribos femineis efoeta ; fil a ment a libera, subulata, anth era e introrsae, bilocnlares, oblongae, dorso insertae, longitudinaliter dehiscentes. $O$ vari um ovatum, compressiusculum, aniloculare, line gibbum, inde styliferum, $O v u$ I u m...... st y li $3-4$ sublaterales, inaequales; stigmata capitata. Drupa exsueca, subovalis, obliqua, putamine osseo, inonospermo. Semen oblongum, compressu-subreniforme, sinn umbilicatum. Em bryonis exalbuminosi cot y ledones subearnosae, accumbentes, latere interiori snpra basim excisae, radicula subulata, lateralis, adscendens, cotyledunibns brevior. - Frutex capensis; folitis imparipinnatis, bi-sexjugis, foliolis oppositis, subsessilibus, lanceolatis, integerrimis, rhachi alata, floribus terminalibus paniculatis.

L ox os ty If s Spreng. ex Reichenbacb Ic, exot, $t, 205$. Eeklon et Zeyloer Enum, 152. Meisner Qen, 76. (55.) A nasillis E. Meyer msc.

5909. Astronium $J A C Q$. F 1 or e s dioiei. C a ly $x$ parvas, coloratus, quinquepartitus, laciniis aequalibus, subrotundis, in floribus femineis persistentibus, increscentibus, maximis, scariosis, subspathulato-oblongis, patentissimis. Coroll a e petala 5, sub disci perigyni, quinquelobi lobis rotundatis inserta, oblonga, obtusa, in floribus femineis minuta, squamaeformia. S tam ina 5 , inter disei lobos inserta, petalis alterna et breviora, in floribus femineis efoeta; fil a m e $t$ a libera, $s u b u$ lata, a ntherae introrsae, biloculares, oblongae, basi emarginatae, dorso supra basim affixae, longitudinaliter dehiscentes. Ovarinm unicum, liherum, sessile, avatam, uniloculare. O v ulum.... Styli 3, breves, reflexi; stig mata subcapitata, 
obtusa. Caryopsis teretinscula, oblonga, attenuato - rostrata, exsucea, pericarpio tenui, membranaceo. Semen teretiusculo oblongum, hine pla niusculum, medio umbilico lineari-oblongo notatum. Embryonis exalbuminosi, recti cotyled wn es carnosae, plano-convexae, subinaequales, accumbentes, radicala lateralis, adscendens, cotyledonibns brevior - Arbores America tropi. cae, succo terebinthino, decolori scatentes, florescen. tiae tempore aphyllae; foliis post fructuum disseminationem erumpentibus, alternis, imparipinnatis, trijugis, foliolis oppositis, epunctatis, paniculis ramosis, bracteatis, femineis terminalibus, masculis axil laribus, floribus pedicellatis, parvis, purpurascentibus, seminibus oleosis, immaturis lactescentibus.

A s tron i u Jacquin Amer. 261. $t$. 181, $f$. 96. Kunth in Annal. sc. nat. II. 341. DC. Prodr. II. Meisaer Gen, 75. (54.)

5910. NIelamorrlapea $W A L L$. Flores hermaphroditi? Calycis foliola 5 , in calyptram quinquenervem, caducam valvatim cohaerentia. Corollae petala 5 -6, lanceolata, acuminata, aestivatione imbricata, persistentia, frutifera maxima. St a $\mathrm{m}$ in a plurima, toro convexo undique inserta, filamenta capillacea, petalis breviora, libera, a $n$ the rae introrsae, bilocnlares, basi bifida insertae, longitudinaliter dehiscentes. O va ri $\mathbf{~ m}$ unicum, stipitatam, oblique lenticulare, unilocu lare. Ovulum unicum, funiculo e basi loculi ad scendenti appensum. Stylus prope verticem lateralis, simplex; stigma parvam, convexum. Fructus pedicellatus, involuero corollino maximo, stellatim patente suffultas, coriaceas, depresso-reniformis, obliquns, indehiscens, mono. spermus. Semen decumbens, testa chartacea Embryonis exalbuminosi cotyledones carnosae, crassae, radieula lateralis, adscendens, in cotyledonum commissuram replicata. - Arbores magnae, Semecarpi facie, in Indiae continente inter $14^{\circ}-25^{\circ} \mathrm{L}$. A. crescentes, succo viscido, ferrugineo, ad contactum aëris in vernicem atram cito converso scatentes; coma late protensa, foliis alternis, simplicibus, amplis, coriaceis, penninerviis, integerrimis, paniculis axillaribus, florentibus oblongis, frutiferis laxis, amplis, cornllis auctis maximis, rufis, demum ferrugineis onustis.

Melanorrboe a Wallich Plant. As, rar. I. 9, $t, 11$. 12. Meisner Gen. 25. (55.)

591 1. Gleata $L I N N$. Caly $\mathrm{x}$ tubulosus, lacerus, deciduss. Coroll a e petala 5, rarins 4 v. 6, toro longo stipitiformi agglntinata, ealyce longiura, lanceolata, patentia. Sta mina 4-6, aequalia, toro supra medium inserta, an therae subrotundae, versatiles. Ovarium stipitatum, superne depressum, uniovulatum. Stylus simplex, lateralis; stigma obtusum. Drupa stipitata, difformis, corticata, rugosa, monosperma. Embryo exalhuminosus, erectus. - Arbor javanica, Mangiferae facie; folitis alternis, simplicibus, versus apicem ramulorum confertis, oblongis, obtusis, coriaceis, integerrimis, glabris, floribus paniculatis, fere Clematidis flammulae.

G1 at a Linn. Mant. 293. DC. Prodr. 1, 501. Blume in Elora 1825. Bijdr. 1159. Meisner Gen, 75. (55.) $-\mathrm{R}$ h u $\mathrm{n}-$ geis Javan.

591: Stagmaria $J A C K$, C a lyx tubulosus, limbo irregulariter rupto, deciduus. Coro 11 a e petala 5 , toro stipitiformi inserta, calyce longiora, ohlonga, obtusa, patentia, subreflexa.
Stam in a 5, toro supra petala inserta, iisdem al. terna et subaequilonga; filamenta filiformia, a ntherae breves, oblongae, biloculares. Ovarium stipitatnm, trilobum, lobis uniovulatis, duobus v, uno saepe abortivis. Styli 1 - 3 , ovarii lobos terminantes; $8 \mathrm{ti} \mathrm{g} \mathrm{m}$ a $\mathrm{t}$ obtusa. B a c ca resinusa, reniformis, hinc suleata, cortice varicoso, monosperma. S e m e n cavitati conforme, E mbryonis exalbuminosi, erecti cotyledones coalitae, fissura laterali, radicula incurva. Arbor sumatrana, succo resinoso, caustico sea. tens; foliis alternis, petiolatis simplicibus, ellipticolanceolalis, basi angustatis, apice obtusis $v$. retusis, integerrimis, glaberrimis, nitidis, stipulis nullis, paniculis axillaribus pedunculatis, floribus plurimis, pedicellatis, albis, odore narcotico.

Stagmaria Jack Malay. Miscell, ex Hooker Bot. Mag. Compan $I$. 267. Kayo Rangas Malay. Arbor Ver. n i cis Rumph Amboin. $I T, 259, t, 86$. - Gesus vix a Gluta diversum.

54) 13. Symalegnais $W A L L$. Calyx coloratus, spathaceus, hine fissus. Corollae petala 4. 5, Lro stipitiformi basi adnata, calyce duplo longiora, membranacea, lineari-lanceolata, paten. tia, aestivatione imbricata. Stam in a $4 \_5$, toro sub ovario inserta ; fil a me nta cuspidata, patentia, antherae ohlongae, basi bifidae, Iongitndinaliter dehiscentes. Ova ri $\mathbf{~ m}$ pedicellatum, depressinscule subglohosum, hinc stylo apiculatum illine abliquum, uniloentare. Ovulum unieum, erectum. Stylus lateralis adscendens, filiformis; sti $\mathrm{gma}$ aimplex, acutum. Fruetus..... Arbuscula pinangiana; ramis ramulosis, angulatis, foliis alternis, versus apices ramorum approximatis, simplicibus, lanceolatis, coriaceis, integerrimis, nitidis, nervosis, corymbis terminalibus ramosis, pedicellis capillaribus, basi bractea lineari caduca stipatis, calyce coccineo, corolla nulla.

S y ndesmis Wallich in Roxburgh Flor, ind, II. 314. Meisuer Gon. (54.)

5914. Holligarna $R O X B$. Flo res polygamo-dioici. Cal y x quinquedentatus. Coroll a e petala 5, calyci inserta, basibus latis contigua, oblonga, villosa, patentia. Stamina 5, eum petalis inserta, iisdem alterna et breviora; filamenta subulata, an therae introrsae, bilocalares, Iongitudinaliter dehiscentes. Ovarium cum ealycis tubo connatum, uniloculare. O v ulu m unicum, parieti prope apicem loculi appensum. St y li $1 \_3$, terminales; $s t i g m$ a ta lunulata $v$. capitata. Drup a infera, olivaeformis, ovata, subcompressa, carne parca, celluloso resinosa, putamine evalvi, monospermo. S e m e $\mathbf{n}$ inversun. Embry onis exalbuminosi, transversi cotyledon e s crassae, carnosae, radic a la umbilico opposita. - Arbores indica e, excelsae; foliis alternis, petiolatis, simplicibus, oblongis, acutis v. acuminatis, penninerviis, integrerrimis, petiolo supra basim utrinque processu setiformi deciduo aucto, floribus axillaribus et terminalibus, paniculat is $v$. racemosis.

Hollgarna Roxburgh Plant, Corom, IIr. 79, t. 282. Flor. Ind. II. 80. DC. Prodr. II. 63. Wight et Aruott Prodr. I. 96. Meisner Gen. 77. (55.) H a de s t a p h y 11 u m Deanst. z. Hort. Malab, IV. 9.

5915. IIangifera LINN. Flores polygami. Caly x quinquepartitus, laciniis oblongis, patentibus, aestivatione imbricatis, deciduis. C orolla petala 5, disco perigyno quadri-quin- 
quelobo inserta, oblonga, basi squamula glandulosa aucta, patentia, apice reflexs. Stamina 5 , enm petalis inserta, iisdem alterna, basi cwalita, uni cum v. dus fertilia; fil a me nt is subulat s, car nosis, a n theris introrsis, bilocularibus, cordato ovatis, dorso affixis, longitudinaliter dehiscenti bus, reliqua sterilia, filifurmia, glandula minuta terminata. Ovarium unicum, liberum, sessile, obliquum, uniloculare. Ovulum unicum, suturae ventrali panilo supra basim insertum, adscendens. Stylus sublateralis, simplex, curvatus, exsertus; stigma obtusum. Drupa subreniformis, compressinscula, carnosa, putamine lignoso, extus fibroso, uniloculari, bivalvi, monospermo. S em en oblongum, compressiusculum, testa chartacea, tenui. Embryonis exalbuminosi cotyledones crassae, carnosae, plano-convexae, $r$ a dieula infera, adscendens. - Arbores Asiae tropicae, nunc in America cultae; foliis alternis, petiola tis, simplicibus, penninerviis, integerrimis, exstipu latis, paniculis terminalibus ramosissimis, bracteatis, floribus parvis, pedicellatis, albidis $v$. rubescentibus, fructu eduli.

M a n g ife ra Liua. Gen $n, 278$. Gärtuer $I T .96, t, 100$. Lam. t. 138. Jaeq. Io, rar. t, 337. Tussac Flor. Antill. II. $t$. 15. Kunth in Annal. so nat, 11, 335. DC. Prodr, II. 63. exel. sp. Wight et Arwatt Prodr. 1. 169. Ma ng a Ruiuph Amboin. 1, 93. $t, 25$. M a n Rheede Malab, IV. 1, $t, 1,2$, De Mansiterae iadicne semine polyembryo efr. Reinwardt in N. A, N. C, XIT. 34t-346. t. 36 .

5916. Anaenrdium ROTTB. F lores polygamo-dioici. C a ly $x$ quinquepartitus, laciniis erectis, aestivatione imbricatis, deciduis. Corol. Ia e petala 5 , imo calyci inserta, lineari-acuminata, apice patentia. Stam in a $9-10$, perigyna, unicum (rarius plara) reliquis multo longins et crassius, fertile, reliqua inclusa, saepissime sterilia; fil amenta inferne inter se et cum petalo. rum basibus connata, anthera e introrsae, biloculares, ovato - ellipticae, dorso affixae, longitudinaliter dehiscentes. Ovarium unicum, liberum, sessile, uniloculare. $O \mathrm{v}$ a $\ln$ m unicum, lecnli fundo affixum, adscendens. Stylus sublateralis, simplex, curvatus, exsertus; stigma snbeapitatnm. N n x reniformis, sinu laterali umbilicata, pedicello ampliato, pyriformi, carnoso insidens, coriacea, indehiscens, monosperma, pericarpio intus celluloso, oleifero. S emen reniforme, erectum, testa co. riacea, adhaerente. Embryonis exalbuminosi cotyledone's semilunatae, carnosae, plano-con. vexae, radicula brevis, uncinata, e basi cotyledonum adscendens. - Frutices v. arbores $A m e$ ricae tropicae, in Asia calidiore nunceul. tae; foliis alternis, petiolatis, penninerviis, simplicibus, integerrimis, estipulatis, paniculis terminali. bus corymboso-ramosis, diffusis, bracteatis.

A nacardi a m Rottboell Act. Hafn, HI. 252. Jacq. Amer. I. 124, t. 18t, $f$. 35. Kunth in Annal. sc. nat. II. 334. DC. Prodr. II 62. St. Hilaire in Guillem. Archiv. bot, I. 269. Wight et Arablt Prodr. I. 168 . Meisuer Gen, 75. (55.) Cass uviu a Rumph Amboin. I, 177, $t$, 69. Lam. Dict. I. 22. t. 322. A c a j o u Tournefort Inst. 433. A e a $f$ u b a Gärtner 1 . 192. t. 40. R hi no ear $\mathrm{p}$ is Bertero mise. ex Kunth in Annal, se. nat. II. 335. et in Humb. ot Bonpl. Nov. gen. et sp. VII. 6, $t$ 60t. M о во d y $\mathrm{nam}$ us Poht Plant. Brasil, $I T, 67, t, 144$.

Б๑1 \%. Semeenrpus $L I N N$. F I ore s polygamo-dioici, Calyx quinquefidus, laciniis aestivatione imbrieatis, decidais. Corollae petala 5 , sub disco nrceolato, imo ealyci adnato inserta, snbinaequilatere ovata, patentissima. S $\mathbf{t}$ a m in a 5 , cum petalis inserta, iisdem alterna; fil a- menta subulata, aequalia, libera, antherae introrsae, biloeulares, cordatae, dorso affixae, lungitudinaliter dehiscentes. O v a r i u m unicum, íberum, sessile, ovatum, uniloculare. Ovulum unicum, ex apice loculi pendulum, anatropum. Styli 3 , terminales; stigmata subclavata. Nu x cordiformis, compressiuscula, toro incrassato turbinato v. cupulaeformi insidens, pericarpio crasso, duro, resinoso-celluloso, indehiscens, monosperma. S e m en pendulum, testa subcoriacea, endopleura carnosula. E m bryon is exalbuminosi cotyled on es crassae, carnosae, plano-convexae, radi $c$ n a brevissima, inter cotyledones retracta, supera, piumula diphylla. - Arbores indicae; foliis alternis, petiolatis, simplicibus, penninerviis, integerrimis, glaberrimis $v$. subtus tomentosis, stipulis nullis, paniculis terminalibus, ramosis, bractealis.

Semecarpus Linn. f. Supplem, 25. Roxburgh Plant. Corom. t, 12, Kunth in Annal. so, nal. II. 337. DC. Prodr. II. 62. Wight et Aruatt Prodr. 1. 168. Meisner Gen. 75. (55.) A nacardi u m Lam. Diet. I. 139. t. 208. Gártuer I. 192. $t$. 40, Cas uvium s I vestre Rumph Amboint. I. $t, 70$.

5918. Bowea MEISN. Flores hermaphroditi? C a ly x quadri-quinquepartitus, laciniis rotundatis, aestivatione imbricatis, deciduis. Corolla e petala 4-5, imo calyci inserta, oblonga, basi intus carinata. Stamina $4-5$, tum petalis inserta, iisdem alterna, omnia fertilia; fil a menta brevia, snbulata, a n therae introrsae, biloculares, ovatae, obtuse apiculatae, longitudinaliter dehiscentes. Ov a ri um unicum, liberum, sessile, oblique ovatum, uniloculare. O v $\mathbf{l} \mathbf{u}$ m unicum, suturae ventrali paullo supra basim insertum, adscendens. Stylus brevissimus, lateralis; stigmat a 3 , inaequalia, unnm filiforme, duo minuta. D rupa ovata, compressiusenla, earnosa, putamine tenui, extus fibroso, nniloculari, evalvi, monospermo. S e m e n cavitati conforme, testa cum endocarpio confusa. Embryou is exalbuminosi cotyledones oblongae, carnosae, radicula infera, conica, tranversa, plumula biloba. Arbor indica; foliis oppositis, petiolatis, simpli. cibus, penninerviis, integerrimis, stipulis nullis, paniculis terminalibus, densis, bracteatis, floribus parvis, flavescentibus.

B o u e MeisnerGen. 75. (55.) Ca n bessede a Wight et Aruott Prodr. I, 170. in not, non Kunth nec DC. Mangifera oppositifolia Roxburgh. Meriam Burmes.

5919. Euchanamia ROXB. Flores hermaphroditi. Caly $\mathrm{x}$ brevis, obtuse quinquefidus, rarius tri-quadrifidus, persistens, Co rollae petala 5, disco perigyno, orbiculato, quinqueerenato inserta, oblonga, recurvato-patentia. Stami na 10, cum petalis inserta, iisdem breviora, patentia; fil amenta subulata, libera, antherae introrsae, biloculares, ovatae v. oblongae, loculis arnatis, Iongitndinaliter dehiscentibus, 0 varia 5_6, libera, sessilia, disco immersa, unicum fertile, oblique ovatum, uniloculare, reliqua ad stylos simplices reducta. Stylus subterminalis, subulatus; stig ma oblique truncatum. Ovul um unieum, funiculo e basi loculi adseendenti affixum, recurvatum. D ru pa parce carnosa, ovoidea, compressa, putamine osseo, bivalvi, monospermo. Semen hine acutum, inde crassum, carinatum. Embryonis exalbuminosi, transversi cotyledo nes erassae. - Arbores indicae; foliis alternis, petiolatis, simplicibus, coriaceis, penninerviis, integerrimis, nervis transversis parallelis, stipulis 
nullis, paniculis terminalibus et axillaribus ad apices ramorum confertis, floribus parvis, ulbis, fructibus rubris.

B uchanania Roxburgh Plant. Corom. IIr. $t .262$. Flor. ind. II, 385 DC. Prodr, II, 63. Wight et Araott Prodr. I. 169. Meisuer Gen. 75. (53.) Delessert Ic. select. III. t. 54. La $\mathrm{n} 2 \mathrm{z}$ a Buchanan in Asiat. Besearch. V. 123. Buchanauia et Cambersedea Kuath in Annal. so. nat. II. 336, 338. L u a d i a Puerari msc.

CONIOGETON Blum. Bijdr. 1156. "Calyx inferus, quinquepartitus. Petala 5 . Sta $\mathrm{m} I \mathrm{a}$ a 10 , aequalia. 0 vari a 4-5, monostyla, uniovulata, urceolo denticulato cincta. StIg a a ta obtusa. Dru pa solitaria, baceatd, nuclen len. ticulari, monospermo." - ${ }^{A} A r b o r^{\prime \prime}$ ljavanica, $B h u n$. gas dicta) folits alternis, simplicibus, cuneato oblongis, obtusis, integerrimis, coriaceis, glabris, floribus panicu. latis, terminalibus."

\section{* SPONDIACEAE.}

5920. Spondias LINN. Flores polygami. Caly $\mathrm{x}$ parvus, quinquefidus $v$. quinquedentatus, coloratus, deciduus. Corolla e petala 5 , sub disci crenulati margine inserta, sessilia, patentia, aestivatione subvalvata. Sta mina 10 cum petalis inserta; fil a m e $\mathbf{t}$ a filiformia, libe ra, antherae introrsae, biloculares, oblongae, derso snpra basim affixae, longitudinaliter dehiscentes. Ovari n m sessile, quinqueloculare. Ov nla in loculis solitaria, angulo centrali prope apicem appensa, anatropa, St y I i 5 , brevissimi, crassi, distincti, sursum conniventes; st $\mathrm{i} g \mathrm{~m}$ a $\mathrm{ta}$ obtusa. D ru p a carnosa, putamine lignoso, quinqueloenlari, quinquelobo, lobis extus fibrosis v. echinatis, axi inter se coalitis, v. discretis nonnisi basi cohaerentibus, monospermis. Semina inversa, testa membranacea. $\mathbf{E} \mathbf{m}$ bry o $\mathbf{n}$ is exalbuminosi, recti cotyledunes plano-convexinscnlae, radicula supera. - Arbores inter tropicos totius orbis crescentes; foliis alternis, imparipinnatis, foliolis integerrimis v. serratis, paniculis axillaribus et terminalibus bracteatis, floribus albidis v. rubris, fructu eduli.

S pondias Linn. Gen. n. 327, Gärtner 1T. 109. (exel. sem. deseript.) Kuath in Annal, sc. nat. II. 363. DC. Prodr. II. 24. Wight et Arnott Prodr. 1. 172. Meisaer Gen, 76. (55.)

a, MOMBiN DC, l. c, Putamin is laeviuseull loculi contiguo aduati. - Foltola integerrima. - M o m b in Plu. mier Gen. 44. t. 22, (Jacq. Amer. t. 88. Gärtaer t. 104. Guillew. et Perrot, Flor, Seneg. t. 40. 41.)

b. CYTHERAEA DC. l. c. Putamints eshinati lobi dis. tautes, basi tantum connexi. - Foliola serrata. (Soanerat $V_{0}$ g. t. 123. Lam, t. 384, Gărta. $t, 103$. )

5921. Poupartia COMMERS. F lores abortu unisexuales. C a ly $\mathrm{x}$ quinquefidus, laciniis ovatu-eltipticis, subeoneavis, aequalibus. Corolla e petala 5 , suh disco magno, orbieulato, decemcrenato inserta, calyce triplo longiora, sessilia, ovato-elliptica, patentissima, apice subrevoluta, aestivatione imbricata. Stam in a 10 , sub disco inserta, corolla dimidio breviora; fil a in enta subulata, libera, alterna petalis opposita paullo breviora, anthera e introrsae, biloculares, ovato-oblongae, basi emarginatae, dorso supra basim affixae, longitudinaliter dehiscentes, Ovari $\mathbf{m}$ in floribus masculis rudimentarium, in floribus femineis biloculare (?) $\mathrm{O}_{\mathrm{v}} \mathrm{ula}$ in toculis solitaria, dissepimento superne appensa. Sty $1 \mathrm{i} 5$, approximati. D r u a putamine osseo, biloedari, loculis monospermis. Semina inversa, subfaleata, testa membranacea, E m br y on is exalbuminosi, semini conformis cotyledones plano-convexinsculae, subfalcatae, radicula supera, inflexa. - Arbor bor- bonica; foliis alternis, imparipinnatis, nonnullis simplicibus intermixtis, foliolis integerrimis, floribus racemosis, axillaribus et terminalibus, atro-purpureis.

Poupartia Commers. ex Jussieu Gen, 372. Lam. Dict. V. 606. Kunth in Annal. sc. nat. II. 364. DC, Prodr. 1I. 75. Meisuer Gen, 76, (35.)

\section{GENERA DUBIA.}

5922. Exathea $\mathrm{M} A C F A D$. F lores polygamo-dioici. Caly $x$ quinquepartitus, extus puberulus, laciniis rotundato-ovatis, aestivatione imbrieatis. Corolla petala 5, rotundata, breviter unguiculata, calyeis laciniis alterna et panllo angustiora. Stam in a 7 v, 8 , inter disei annularis carnosi, rubri, puberuli lobes irregulariter inserta; filamenta calyce paullo longiura, antherae ovatae, biloculares. Ova riu m conicum, villosum, disco insidens. S t y l u s brevis (?); s ti g m a obtusum. Dru p a cortice glanduloso, putamine ehartaceo. S emen unicum. Em br y on is cotyledones carnosae, r adicula supera, curvata. - Arbor jamaicen$s i s$; ramis erectis, teretibus, glabris, rimoso-punotulatis, foliis alternis, imparipinnatis, foliolis bitrijugis, subsessilibus, integerrimis, oblusis v. emarginatis, membranaceis, epunctatis, obsolete venosis, supra nitidis, subtus nervo medio puberulis, petiolo subtriquetro striato, stipulis nullis, panicula terminali, sessili, ramosissima, aureo-tomentosa, floribus plurimis, albis, fragrantibus.

Exot he a Macfadyen Flora of Jamaica I. 232.

5923. Inerten $R U I Z$ et $P A V$. Caly quinquedentatus, persistens, dentibus ovatis, acutis, erectis. Corollae petala 5, ovata, sessilia, ealyce paullo longiora, patentia, marcescenti-persistentia. Sta m in a 5, petalis alterna et longiora; filamenta subulata, erecta, antherae ovatae. Ovarin m ovatum, liberum. Stylus subnlatus, brevis, erectus; $s \mathrm{t}$ i $\mathrm{g} \mathbf{m}$ a bifidum, laciniis acutis. Drupa (?) obovata, unilocularis, monosperma (?) - Arbor peruana; foliis imparipinnatis, foliolis oppositis, petiolulatis, ovali-lameolatis, serratis, ad venarum axillas subtus villosis, basi biglandulosis, racemis axillaribus et terminalibus.

H u ertea Ruiz et Pavon Prodr. 34, t. 6. Flor. Peruv. III. 5. t, 227. f. a. DC. Prodr. II. 90. Meisuer Gen, 77, (56.)

5924. II eeria MEISN, Fl ores hermaphroditi v. abortu diclines. Cal y x quinque-sexpartitus. Coroll a e petala $5 \ldots$, sab disco ureeolato inserta. Stamina 5 -6. Ovarium sessile, uniloculare.... Stigmata 3 . Fructus,subexsutcus, monospermus. S e m en adscendens. E mbryo exalbuminosus, incurvns; c ot yled on ibus plano-convexis, radic ula elongata, plumula perspicue evoluta. - Arbor capens is; foliis alternis, coriaceis, penninerviis, floribus terminalibus, paniculatis $v$. racemosis.

Heeria Meisner Gen, 25, (55.) R 8 meria Thuab. Fl. Cap. 194. Eikton et Zeyber Enum. 142. A a a p bre. a i u $\mathrm{E}$. Meyer msc.

5925. Fumplaia LINN. C a I y tubnlosus, trifidus. Co roll a e petala 3 , oblonga. Stamina 3 , petalis aequalia, exserta. Ovarium nnom, subtrigonum. Sty $\mathbf{l}$ as nnus, Drapa coriacea, turbinata, trisnlea. putamine trilueulari, trispermo. - Arbor na alabarica; foliis simplicibus, racennis terminalibus.

R u m phia Linn. Gen, n. 47, Lan, t. 25. DC. Prodr. II. 90. Rheede Malab. IV, $t, i t$. 
5926. Augia LOUREIR. Caly $\mathrm{x}$ truncatus, expansus, minimus. Coroll a e petala 5 , receptaculo inserta, oblonga, patentia. Sta mina plurima, receptaeulo inserta; fila menta filiformia, corolla longiora, ant herae subrotundae. Ovarinm liberum, compressum, snbrotundum. Stylus filiformis; stigma obtusum. Drupa sublenticularis, verticaliter compressa, parva, nitida, putamine monospermo .... - Arbor sinica, vernicifera, mediocris, cortice scabro; ramis adscendentibus, foliis imparipinnatis, subquinquejugis, foliolis lato-lanceolatis, acuminatis, integerrimis, glabris, parvis, paniculis laxis, magnis, circa apicem ramorum undique dispositis, drupa fusca, magnitudine quatuor linearum, cortice tenui, laevi.

A a gi a Loureiro Flor. cochineh. 411. Jussieu in Mem. Mus. XIV. 397. "Ex fisso hujus arboris cortice emanat sueeus resinosus, teaacissimus, legitima sineasis Veraix." Lour, l, c.

\section{GENUS ANOMALUM.}

592 \%. Sabia COLEBR. Caly $\mathrm{x}$ minimus, pentaphyllus, foliolis inaequalibus, aestivatione imbricatis. Corolla e petala 5, ad basim disci hypogyni, quinquedentati inserta, calycis foliolis alterna v. subupposita, glanduloso-punctata, aestivatione imbricata, sul anthesi patentissima, plana. S tam in a 5 , cum petalis inserta, iisdem opposita et breviora, disei dentibus alterna, patentissima; filamenta subulata, earnosula, glanduloso-pune. tata, antherae extrorsae? biloculares, subglobosu-didymae, longitudinaliter dehiscentes. 0 varium globoso-didymum, biloculare. Ovula in loculis solitaria, e basi anguli centralis adscendentia. Sty I us brevis, bisuleus; stig ma simplex. Drupa hiloba, lobis reniformibus, styli apice primum cohaerentilos, munospermis, altero saepissime abortivo. S emen erectum, spiraliter canvolutum, testa chartacea. Emb r y o n is exalbuminosi, arcuati cotyled on es carnosae, semini homotrope convolntae, radic ula infera-Frutices indic $i$, scandentes; foliis alternis, breve petiolatis, simplicibus, ovalis $v$, oblongis, coriaceis, integerrimis, penninerviis, venosis, supra lucidis, subtus glaucis, sti pulis nullis, floribus lerminalibus paniculatis, parvis.

$\mathrm{S}$ abia Calebrooke in Linn Transact, XII. 355, $t, 14$. Wallicli in Roxburgh Elor. ind. II. 308. Meisuer Gen, 76. (55.) S abjá. Int Bengul.

\section{Drdo CCXIIT. Barseracene.}

TEREBINTHACEARUM genera Jussiea Gen, 368, BURSERACEAE Kuith in Annal. so. nat. IT. 333 Lindley In troduct edit. II. p. 110. TEREBINTHACKARUM tribus IV. DC. Prodr. II. 75. Meisner Gen 77. (55.) AMYRIDEARUM sect. H. Bartling Ord, nat. 393.

Arbones v. yrutices, succo balsameo v. resinoso scatentes. Folia alterua, imparipinnata v, ternata, interdum foliolorum lateralium abortu unifoliolata, foliolis oppositis v, alternis, integerrimis $\mathbf{v}$. serratis, rarissime pellucidopunctatis. Stipulae petiolares geminae, plerumque deciduae, saepissime nullae.

Flores regulares, hermaphroditi v. saepissime abortu unisexuales, in racemos $v$. paniculas, ax llares aut terminales dispositi, parvi.
Casyx liber, tri-quadri-quinquefidus, persistens.

Coroldae petala calycis laciniis numero aequalia, iisdem alterna et majora, sub disco orbiculari v. annulari, libero v. cum calycis fundo connato inserta, aestivatione saepissime valvata, nonnunquam imbricata, sub anthesi erecta v. patentia, decidua.

Stamina cum petalis inserta, daplo eorundem numero, omnia fertilia, alterna petalis opposita plerumque reliquis, omnia iisdem breviora. Filamenta subulata, libera v, ima basi inter se et cum disco coalita. A $\mathrm{n}$ th e ra e introrsae, biloculares, longitudinaliter dehiscentes.

Ovartom liberum, sessile, bi-quinqueloculare. Ovula in loculis gemina, anguli centralis apici collateraliter appensa, anatropa. Styl us simplex v. interdum nullus. Stig $\mathrm{ma}$ indivisum, vel bi-quinquelobum.

Fructus drupaceus, putamine mono-pentapyreno, pyrenis osseis, abortu monospermis, epicarpio sicco, interdum valvatim secedente, plerumque resinoso, rarius capsularis, septicide dehiscens, loculis abortu monospermis, endocarpio subosseo.

Semsa inversa, teretia v. angulata, rarissime compressa, et margine membranaceo cincla. A l b umen nullum.

Embryonis orthotropi cotyledones corrugato-plicatae, rarissime laeves, plano-convexae, ra dicula brevis, recta, supera.

Burseraceat inter tropicos totius orbis crescentes, ob succos resinosos, multiplicis in medicina et variis artibus usus celebres, a reliquis Terebinthaceis ovarii plurilocularis ovulis geminis pendulis, et cotyledonibus in plerisque plicato-convolutis optime distinctae, ovulorum situ et numero ad Euphorbiaceas accedunt.

A myrideae ad ordinis calcem positae, ovario uniloculari, ovulis geminis, ex apice cavitatis pendulis, diversae.

5928. Boswellin ROXB. Flores hermaphroditi. C a ly $x$ parvns, quinquedentatus, persistens. Corollae petala $5,8 u b$ disco annulari earnoso, crenulato inserta, obovato-oblonga, basi angustata, aestivatione subimbricata, sub anthesi patentissima. Stam ina 10 , hypogyna, alterna petalis opposita breviora ; fila in en ta subulata, persistentia, antherae introrsae, bilecnlares, ovato-nblengae, basi emarginatae, Inngitudinaliter dehiscentes, caducae. Ovarinm sessile, triloculare. Ovu la in loculis gemina, collateralia, pendula. S t y I n s brevis, staminum longitudine; s tig m a capitatum, trilobum. Ca p 8 u la drupacea, trigona, trilocularis, septieide trivalvis, valvarum endocarpio subosseo. Sem in a in loculis abortn solitaria, inversa, compressinscula, margine membranaceo lato cincta. Embry on is exalbuminosi cotyledones contertuplicatae, multifidae, radi cula supera. - Arbores indicae, Elaphrï facie, resiniferae, balsamifluae; foliis deciduis, in 
apicibus ramulorum approximatim alternis, imparipinnatis, foliolis oppositis, sessilibus, serratis, stipulis nullis, racemis axillaribus solitariis, $v$. terminalibus paniculato-congestis, bracteolatis, floribus breviter pedicellatis, albis.

B os wellia Roxburgh Plant. Corom, III. 4. t, 207. Kunth in Annal. sc, nat, II. 348, DC. Frodr. II, 76. Nees juo. Plant. offic. 2.355. Wight et Aroott Prodr. I, 174. Meisner Gen. 77. (55.) L iban us Colebraok, Asiat, Research, IX. 37\%, c. ic.

5929. Frotiuna BURM. Flores diclines. Calyx parvns, quinquefidus, persistens. Coroll a e petala 5, snb discu urcenlato, trun cato, decemcostato inserta, sessilia, oblonga, acu ta, aequalia, aestivatione valvata, sub anthesi patentissima. Sta m in a 10 , sub disco inserta, petalis breviora; fil am ent a libera, alterna caly cis laciniis opposita reliquis paullo Iongiora, a n the rae introrsae, biloculares, dorso supra basim affixae, utroque latere longitudinaliter dehiscentes. Ovarium sessile, ovatum, triloculare (?) Ovala in loculis gemina, axi centrali collateraliter appensa. Stylus simplex; 8 t igma indivisum. Dru a tripyrena, pyrenis duabus saepe abortivis..... - Arbor javanic a, balsamifera, vix nota; foliis allernis, imparipinnatis, foliolis oppositis, inaequilateris, integerrimis, pellucido punctulatis, paniculis axillaribus ramosis, bracteatis, floribus pedicellatis, parvis, interdum parte quinta imminutis.

Protium Burmann Flor. Ind, 88. Kunth in Annal. sc. nat. II, 350. DC. Prodr. II. 78. Meisner Gen. 77. (56.) A my ris Protium Linn. T i ngulong RumphAmboin. VII. t. 23. f. 1 .

5930. IBalsamodendron KUNTH. Flores polygami. Calyx campanulatus v. tubalosus, quadridentatus, coloratus, persistens. Corolla e petala $4, s u b$ disce annulari, octoglan duloso inserta, lineari-oblonga, calyce panllo Iongiora, aequalia, aestivatione valvatim induplicata, sub anthesi erecto: patula. $S t$ a $m$ in a 8 , sub disco inserta, ejusdem glandulis alterna, corolla breviora; filam enta filiformi-subulata, libera, al. terna petalis opposita paullo breviora, an $\mathrm{t}$ e $\mathrm{rae}$ introrsae, biloculares, ovatae v, oblongae, muticae $v$. mucronatae, longitudinaliter dehiscentes. Ovarium sessile, biloculare. Ovula in loenlis gemina, axi centrali collateraliter appensa. Sty Ins brevissimus; 8 tigma obtuse quadrilobum. D rupa globesa v. ovata, putamine dipyreno, pyrenis osseis, unilocularibns, abortu monospermis, altera saepissime effoeta $\mathbf{v}$. obliterata. Embry o .... - Arbusculae balsamifluae, in Africa et Asia tropica indigenae; foliis alternis, trifoliolatis, foliolis inciso-dentatis, floribus terminalibus $v$. axillaribus, solitariis aut fasciculatis.

B a Is a mode nd $\mathrm{r}$ o $\mathrm{B}$ Kunth in Annal. sc, nat, $Y$. 348 . DC. Prodr. 1T. 76. Nees Plant, offic. 2. 356-358. Meisuer Gen. 77. (56,) Arnott in Annal. of nat, hist, III. 85. H e de lotia A. Richard Flor. seneg. 150, t. 39, et in Guillem. Archiv. Bot, I. 480. Ni otout Adanson Voy. 162. B al. s a m a Gleditsch in Berl. Verhandl. III, 127. $2.3 . f$. 8 B a less am Bruce Voy, $t, 25$. Com mi phora Jacq. Hort. schönbr, $t$. 294. A m y ridis s p. Liana. Forsk. Vahl Symb, I. $t, 11$.

ธรง3 1. Wlapharium $J A C Q$. F lo res hermaphroditi (?) Cal y x quadripartitus, persistens, lacinis aequalibus, erectis. Corolla e petala 4 , sub disco orbiculari, integerrimo inserta, ealyce paullo longiora, aequalia, aestivatione valvata, sub anthegi erecto-patula. Sta mina 8 , cum petalis inserta, iisdem breviora; filamenta filifor- mia, libera, a ntherae introrsae, biloculares, oblongae, dorso supra basim insertae, longitudinaliter dehiscentes. Ovarium sessile, ovatum, biloculare. Ovnla in loculis gemina, axi centrali collateraliter appensa, anatropa. Sty I o brevis. simus; st igmata 2 , eapitellata. D rup a pisiformis, cortice crasso, bi-trivalvi, putamine dipyreno, pyrenis osseis, arete adglutinatis, pulpa molli vestitis, unilocularibus, abortu monospermis, pyrena altera saepissime efoeta $v$, obliterata. Sem en inversum, suborbiculatum, dorso-convexum, facie planum, testa membranacea. Emb r y on is exalbuminosi, orthotropi cotyledones suborbicnlatae, carnusae, corrugatae et plicatae, radicula brevissima, a cotyledonibus obtecta, supera. Arbores v. arbusculae, in $A m$ erica tropica crescentes, balsamifluae; foliis in apice ramulorum alternatim confertis, quolannis deciduis, imparipinnatis, foliolis oppositis, coriaceis, rugosis, serratis, epunctatis, rhachi plerumque alala, racemis axillaribus, simplicibus, floribus albo-virescentibus, basi uni-medio bibracteolatis.

Elaphriam Jacquin Amer. $I$. 105. $t$, 71. Kunth in Humb. ot Bonpl. Nov. gen. et sp. VII, 26. t, 611-613. Amal. sc. nat. II. 347, Meisis. Gen. 77. (56,) DC. Prodr. I. 723,

5932. Iefea $A U B L$. C aly x parvus, quadri-quinquedentatus, persistens. Corollae petala 4 v. 5, sub disco orbieulato, ovarii hasim vingente inserta, basi lata, aequalia, aestivatione valvata, sub anthesi patula, apice revoluta. Stam in a 8 v. $10,8 u b$ disco inserta, petalis breviora; fila menta filiformia v. snbulata, antherae introrsae, biloculares, cordatae v, oblengae, supra basim emarginatam insertae, longitudinaliter dehiscentes. Ovarium sessile, ovatum, quadriquinqueloculare. Ovula in loculis gemina, collateralia, pendula. Stylus brevissimus; stig mata $4 \ldots 5$, capitellata. D ru p a exsucea, epicarpio coriaceo, bi-quinquevalvi, putamine mono-pentapyreno, pyrenis pulpa obvolutis, subosseis, unilocularibus, abortu monospermis. S e men inversum, testa membranacea. Embryonis exalbnminosi cotyledones corrugato-plicatae, radicula brevis, supera. - Arbores in America et rarius in $A$ sia tropica crescentes, balsamifluae $v$. resinosue; foliis alternis, imparipinnatis $v$. rarius trifoliolatis, foliolis oppositis, epunctatis, integerrimis $v$. serratis, racemis axillaribus et terminalibus, simplicibus $v$, ramosis, interdum congestis, pedicellis basi uni-medio bibracteolatis, floribus albis.

I e ic a Aublet Guian, I. 337, t, 130 - 135. Jussieu Gen. 37o. Kunth in Annal. sc. nat. II. 349. Humb. et Bonpl. Nov. gen, et sp. VII 26. DC. Prodr. II. 77. Wight et Arnott Prodr. 1. 177. Meisner Gen, 27, (56.) Burserae s p. Colebrook. in Linn. Transact, $X V ., t, 4$.

5\$33. IBurgera $J A C Q$. F lo res polygami. Caly x parvas, tri-quinquepartitus, lobis aequalibus, obtusis, patentibus, Corolla e petala $3_{-} 5$, sub disco annulari integerrimo inserta, ovato-oblonga, calyce multo majora, basi latiora, aestivatione valvata, sub anthesi reflexo-patentia. S $t$ a $\mathrm{mi}$ na $6 \_10$, cum petalis inserta, iisdem subaequalia, alterna calycis foliolis opposita paullo breviora; filamenta subulata, libera, anthera introrsae, biloculares, oblongae, dorso supra basim affixae, longitudinaliter dehiscentes. 0 va $\mathrm{r}$ i $\mathrm{um}$ sessile, ovatum, triloculare. Ovu la in loculis gemina, infra apieem anguli centralis collateraliter suspensa, anatropa. Stylus brevissimus, crassus; stigma obtuse trilobum. Drupa globosa, trisulea, v. obligue oblonga, hine convexa, inde 
obtusangula, cortice coriaceo-carnoso, trivalvi, putamine tripyreno, pyrenis osseis, pellicula pul. posa tectis, unilocularibas, aborta monospermis, dnabus saepissime minimis, efoetis. Semen inversum, ovatum, umbilico infra apicem ventrali, testa membranacea. Embry on is exalbuminosi, orthotropi cotyledones foliaceae, carnosae, contortuplicatae, radi cula brevis, supera. - Arbor antillana, gummifera; foliis alternis, longe petiolutis, impuripinnatis, interdum foliolorum lateralium abortu tri- v. unifoliolatis, foliolis petiolulatis, membranaceis, integerrimis, obsolete punctulatis, racemis axillaribus et terminalibus simplicibus, folio brevioribus, pedicellis unibracteatis, floribus parvis, masculis saepius tetra-pentameris, hermaphroditis ut plurimum trimeris.

Bursera Jacquin Amer, 94. $t$. 65. Swartz Observ. 130. Kunth in Annal. sc, nat, II. 350. DC, Prodr. II. 78. Turpin Allas II. $t$, 264. 265. Meisner Gen. 77, (56.)

5DS4. Trattinaickin WILLD. Flores polygamo-monoici. Cal y x cnpuliformis, trifidus, laciniis aestivatione imbricatis. Coroll a gamopetala, campanulata, trifida, laciniis aestivatione valvatis. Stamina 6 (v. 5.) hypogyna (?) inclusa; fil a m e $t$ a brevissima, basi dilatata, antherae introrsae, biloculares, lineari-oblongae, erectae, basifixae, connectivo dorsali latiusculo, longitudinaliter dehiscentes. O vari u m ovato-globosum. ..... Stylus brevis, teres; stigma capitatum, angulatuı. 1) ru p a monosperma? .... - Arbores brasilienses, balsamifluae; foliis alternis, imparipinnatis, foliolis coriaceis, petiolulatis, integerrimis, petiolis petiolulisque canaliculatis, paniculis terminalibus amplis, multifloris, ramis ad basim bractealis, floribus paucis, glomeratis, singulis bracteolatis, albidis $v$, carneo-rufescentibus.

Trattinickia Willdenow Spec, pl. IV.975. nou aliar. Martins Nov, gen, et sp. III. 92, $\ell$. 239. DC. Prodr. MI. 89. Meisuer Gen. 75. (54.)

5D35. MIareing COMMERS. Flores hermaphroditi. Cal y $\mathrm{x}$ quinquefidus, persistens, laciniis ovatis, acutis, aequalibus. Corolla e petala 5, sub disco annolari, laxo inserta, calyce duplo longiora, basi lata, ovata, acuta, paullo obliqua, aequalia, plana, aestivatione vaivata, sub anthesi apice patention reflexa. Stamina 10 , sub disco inserta, petalis multo breviora; filamenta libera, subulata, subaequalia, a $\mathbf{n}$ h er a e intror. sae, biloculares, ovato-oblongae, basí emarginatae, dorso supra basim affixae, longitudinaliter dehiscentes. Ovari um sessile, subglobosum, disco laxe cinctum, quinqueloculare. $O \mathrm{vula}$ in loculis gemina, angulo centrali collateraliter appensa. Stigm a sessile, orbiculatum, obsolete sinoato-quinquelobum. Drup a stigmate persistente umbilicata, cortice crasso, coriaceo, valvatim secedente, pa. tamine pentapyreno v. abortu tri-monopyreno, pyrenis osseis, extus convexis, intus obtusangalis, pulpa gelatinosa obtectis, unilocularibns, abortu monospermis. Se me n inversum, ovatum, peltatim affixum, testa membranacea. Embryon is exalbuminosi cotyledones plicato - corrugatae radicula supera. - Arbor mauritiana, resinosa; foliis alternis, imparipinnatis, foliolis oppo sitis, coriaceis, integerrimis, epunctatis, paniculis in apice ramorum axillaribus, bracteatis, floribus albidis.

Marignia Commers. ex Kunth in Annal. so. nat. II. 350. DC, Prodr, II, 79. Meisuer Gen. 77. (55.) Delessert Ic. select. $I I I, t$, SG, D a $\mathrm{m} \mathrm{m}$ a ra Gärtner $I I .100 . t, 103$, non alior. Bursera obtasifolia Lam.

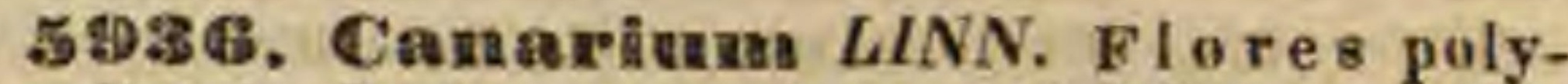
gamo-dioici, Caly $\mathrm{x}$ urceolatus, bi-trilobns, lobis inaequalibus. CoroIla e petala 8 , sub diseo urceolato, ovarii basim cingente inserta, calyce duplo longiora, oblonga v. ovata, cuncava, aequalia, aestivatione imbrieata. St a m in a 6 , sub disco inserta, petalis breviora, aequalia v. inaequalia; fil am enta subulata, a $n t$ he ra e introrsae, bilocnlares, cordato-oblongae, hasi insertae, longitudinaliter dehiscentes. Ovarium sessile, obovatum, triloculare. Ovnla in loculis gemina, axi affixa, collateralia, medis suspensa. Sty I u s brevissimus v. nullus; s ti g m a minute trilobum. Drup a parce carnosa, putamine osseo, crasso, costato-trigono, triloculari, loculis duobus efoetis $\mathbf{v}$, obliteratis, tertio monospermo. S em en inversnm, testa membranacea, Lmbryonis exalbuminosi, recti cotyled ones carnosae, tripartitae, lubis plicatis v. conturtis, radicula snpera. - Arbores Asiae tropicae, balsamifluae; foliis alternis, imparipinnatis, foliolis oppositis, coriaceis, integerrimis, epunctatis, superioribus basi bistipulatis, stipulis magnis, deciduis, paniculis terminalibus, bracteatis.

C a narlum Linne Mant, 127. Giarther II. 98. $t$, 102. Kónig in Annal. of Bot. $I, 306, \ell, 7$. Kunth in Annal, se. nat. 352. DC. Prodr. II. 79. Blume Bijdr, 1161. Sehultes Syst. VI XIII. Meisner Gen, 77. (56.) P i mel e a Loureiro Flor. cochinch, II, 495. Colophou in Commers. msc. ex Kunth in Annal, sc, nat, II, 352. DC. Prodr. II, 79. Meisuer Gen. 77. (58.) Delessert Ic. select. III, $t$. 5 b̈.

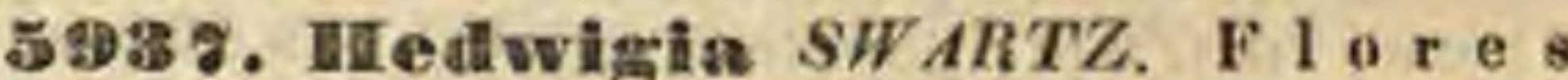
polygami. Cal y $x$ urceolatus, quadrilobus, lobis aequalibus. Corolla e petala 4 , sub disco cupuliformi, ortosinuato, in sloribus maseulis conico inserta, basi lata, connata, aestivatione valvata, aequalia. Stamina $8,8 u b$ disco inserta, subaequalia, petalis dionidio breviora; fil a menta brevia, complanata, libera, an therae introrsae, bilocnlares, oblongae, basi insertae, immobiles, longitudinaliter dehiscentes. O v a ri um sessile, ovatosubglobosum, quadriloculare. Ovula in loeulis gemina, ex a pice anguli centralis collateraliter pendula, anatropa. Sty Ins brevissimus; $8 \mathrm{tig}$ ma obtusum, quadrisulcatum. D r a p a depressinscule globosa, tri-quadrisulea, cortice coriareo, resinoso, putamine tri-tetrapyreno, pyrenis osseis, basi extus gibbis, unilocularibus, abortn monospermis. S e m en inversum, ovato-subglobosum, testa membranacea. Embryonis exalbuminosi, orthotropi cotyledones crassae, carnusae, plano-convexae, radien la brevissima, supera. - Arbor domingensis, succo balsameo; foliis alternis, imparipinnatis, foliolis oppositis, petiolulatis, integerrimis, epunctutis, paniculis in ramulis axillaribus, ramosis, floribus albis, parvis.

Hedwigia Swarts Flor. Ind. oocid, II. 670 t. 13. Kunth in Annal, sc, nat, II. 353. DC. Prodr. IT. 80 . Meisuer Gen, 77. (56.) Tetragastris Gärtner $I I, 130$. t. 109. Sobwagriehenia Reichenb Consp. 147. - ? Kuorrea Moçino et Sessé Flor. Mexic. inedit.

5638. Garougn ROXB. Flores hermaphrosliti. Ca 1 y $\mathrm{x}$ campanulatus, quinquesnleatus, quinquefidus, lasiniis erectis. Corolla petala 5 , inter disci carnosi, quinquelohi, ealycis tubo adnati lobos apice emarginato-biglanduloses inserta, linearia, aestivatione induplieatim valvata, sub anthesi erecto-patula. St a m i n 10 , suhaequalia, alterna cum petalis, alterna ad basim Ioborusn calyeis inserta; fil amenta subulata, basi pilosa, a $\mathrm{n}$ the $\mathrm{r}$ a e introrsae, biloculares, longitudinaliter 143 
dehiscentes. Ovarin m sessile, ovatum, quiaqueloculare. Ovala in loculis gentina, angulo centrali collateraliter appensa. Stylus crassus; stigma quinquelobum. Drapa glubosa, pentapyrena v. abortu mono tripyrena; pyrenis osseis, monospermis. Sem en .... - Arbor indica; foliis alternis, impuripinnatis, foliolis subsessilibus, crenato-serratis, floribus paniculatis.

G a rug a Roxburgh Plant. Corom. IIT. 5. $t, 208$. DC. Prodr. 1I. 80. Wight et Aruott Prodr. 1. 157. Meisuer Gen. 77. (56.) Ku n thi a Deuust. Hort. Malab IV. 3.3. - G. madagascarieasis DC. Delessert Ic. select. III, $t$. 57 . diversis. simi certe generis, sed cujus ?

5939. Heanprielaia $E H R E N B$. F lores hermaphroditi. Ca I y $\mathbf{x}$ quadrifidus, persistens, laciniis aestivatione valvatis. Corollae petala 4, hyporyna, extus hirta, intus nuda, aequalia. Stamina 8 , hypogyna, basi coalita. D iscus nullns Ovarium ovatum, biloculare (?) loculis uniovu latis. Stylus brevissimus, erassus; stigmate parcum latiori, tristriato. Dru pa carnosa, globosa, viridis, epicarpio exteriore coriaceo carnoso, bi-quadrivalvi, deciduo, interiore dimidiato, laetissime rubro-succulento, bilobo, putaminis basim obtegente, persistente, putamine dipyreno, pyrenis osseis, compressis, e colnmella bipartita pendulis, altera abortiva, altera monosperma. S e me n inversam. Embryonis exalbuminosi e otyle. dones magnae, plicatae, radic ula libera, supera, - Arbor in maris rubri insula vulca nic a Ket a mbul observata; succo nullo, ligno fragili, cortice glabro, epidermide ut in Betula alba flaccida, sed flavo-viridi, foliis allernis, magnis, tri-quinquefoliolatis, exstipulatis, paniculis axillari bus brevibus, paucifloris, folio multo brevioribus, floribus inodoris.

$\mathrm{H}$ e m p rich ia Ehrenberg in Linnaea IV, 396. Meisner Gen. 76. (55.)

\section{GENERA VIX NOTA.}

5940. Wagarostrum $D O N$. F I o res hermaphruditi. Caly x tri-quadripartitus, brevis. Coro 1 la e petala 3 _. Sta m in a 6 v. 8 , alterna breviora; filamentis supra basim incrassatis, antheris magnis, Ovarium simplex, inferne attenuatum, in stipitem hasi petaliferum et staminigerum, apice tri-quadrilobum, tri-quadriloculare. Ovula in loculis gemina, ex apice anguli centralis pendula. St y l u s prismatico tri-tetragonus, crassus, osario fere aequalis, glaber, apice bi-trilobus. F ructus ...... Frutices in Africa tropica et $C a$ pite bonae spei indigeni; foliis alternis, imparipinnalis, foliolis alternis, obliquis, pellucido-punctatis, floribus in racemos $v$, paniculas axillares dispositis, pedunculis pedicellisque basi bracteatis.

Fag a r a str u m Dou Syst. II, 87, Meisner Gen, 77. (66.) Geans distinctum Adr. Jussieu in Mems. Mus. XIT, S06. in not. Fagara eapensis Thuob. P. armata Thumb. Amyris anisata Willd. Elaphriug iuaequale DC.

5. 4. EPleramania SWARTZ, F10res dioici. Calyx tri-quinquepartitus, persistens, Corolla e petala 3 - 5 , imo ealyci inserta, ejus. dem laciniis longiora, aestivatione valvata. M a s e. Stamina 3 v. 5 , eum petalis inserta, iisden al terna et longiora; fila me $\mathrm{t}$ a filiformia, anthe rat introrsae, biloculares, didymae, longitudinaliter dehiscentes. F em. Ovarium oblongum, compressiusculum .... Styli 2 , breves, recarvi persistentes; stigmata simplicia, acnta. Drupa ovato-subrotunda, putamine biloculari, loculis monospermis. S em in a ovato-oblonga. - Arbores antillanae; foliis alternis, imparipinnatis, foliolis ellipticis $v$. oblongis, integerrimis, floribus racemosis.

Pieramnia Swartz Prodr. 27. Flor. Ind. occid. I, 218. t. 4. Schreber Gen, n. 1517. Meisuer Gen, 75. (54)

594\%. Niethyseoplayllama ECKL. et ZEYH. Flores hermaphroditi. Calyx quinquelobus, persistens. Corollae petala 5 , aestivatione imbricata. St a mina 5 , sub disco inserta. Ovarium diseo crenato insidens. Stylus brevis, crassus; $s t i g m$ a trilobum. Fruetus capsularis, oblongus, trilocularis, mono-dispermus. -

Frutex c apensis, resinifer; foliis oppositis, lanceolatis, utrinque acutis, margine revolutis, undulatim repando dentatis, glabris, glaucis, ramis subfastigiatis, approximatis, paniculis axillaribus oppositis, dichotomis, paucifloris.

Methyscophy 11 a m Eeklon et Zeyh. Enumerat. II. 152. Meisuer Gen, 76. (55.)

5843. Trapireia JUSS. C a 1 y x pentaphylIas, foliolis subrotandis, deciduis. Corolla petala 5, diseo staminifero inserta, subrotunda, concava, calyeis foliolis alterna et breviora. Sta in $\mathrm{i}$. n a 10, disco inserta, petalis breviora; fil a m e nta filiformia, a $\mathrm{n}$ h era ebovatae, biloculares. $0 \mathrm{va}$ ri u m sabrotandum, disco insidens. .... Stigmata 5. Capsula subrotunda, quinquesulea, unilocularis, quinquevalvis, pentasperma. Se mina ovata, membrana obvoluta, valvis affixa. Arbor guianensis, foliis alternis, imparipinnatis, tri-quinquejugis, foliolis suboppositis, ovato-oblongis, integerrimis, glabris, superioribus sensim minoribus, floribus axillaribus et terminalibus paniculatis.

T a piria Jassiea Gen, 372. DC. Prodr. IT, 90, Ta. pirira Aublet Guian, II. 470. t. 188. S a I a berria Necker Elem, n, 985. J o n e qu etia Sehreber Gen, $n$, zos.

5944. Howreira MEISN, C a l y x brevis, eampanulatus, quinquedentatus. Coroll a e petala 5 , oblonga, conniventia, infimo majore, Stamina 10 , brevia. Ovarium …s tig ma sessile, lentieulare, persistens. B a c ca rotunda, pulpa resinoso suceosa, unilucularis, mono-diaperua. Arbuscula cochinchinens is; foliis alternis subpetiolatis, ovatis, integerrimis, Citrum olentibus, pedunculis axillaribus et terminalibus multifloris.

Lo u reira Meisner Gen. Comm. 53. non alior. To. 1 u ife r a Loureiro Flor. eochinch, 321, nou Linn.

5945. Trieeros LOUR. Calyx pentaphyllus, persistens, foliolis acutis, patentibus. $\mathrm{Co}$ rolla e petala 5, calyce Inngiora, oblonga, patentia. Stamina 5, corollae subaequalia; filain enta capillaria, an thera e biloculares, ovatae. Ovari um subrotundum, inaequale. St y li 3 , breves, basi distantes; $8 \mathrm{tigmat}$ a simplicia. $\mathrm{B}$ a ce a coriacea, inferius rotundata, apice tricornis, trilocularis, loculis munospermis. Semina subrotunda, acuminata. - Arbor eochinchinensis, mediocris; ramis patentibus, foliis impari-bipinnatis, bijugis, foliolis ovatis, acuminatis, serratis, duris, racemis subterminalibus laxis, floribus albis, bacca parva.

Triceros Loureiro Flor. cochinch, 230. DC. Prodr. 1I. 89. Meisuer Gen, 77. (56.)

5946. Harbylus $P . B R O W N$. C a Iy $x$ campanulatus, quadri-quinquefidus. Cor olla e petala $4-5$, e calycis margine orta. Sta min a $8-10$, e fundo calycis. Ovarium liberum. Stylus et 
st ig ma simplex. Capsula trilocularis, loculis dispermis. - Arbor jamaic ensis; folitis alternis, pinnatis, floribus racemosis.

Barl,y I us P. Browne Jam, 116. DC. Prodr. II, 91. Meisner Gen. 77. (56.) B a r o I a Adanson Fam. II. 344.

PACHYLOBUS Don $S y s t, r I .98$. Pructus superus, ovalis, uiger, unllocularis, e a h ry o ne magno, cotyledonibus bi-tripartitis, lobis crassis, angulatis, contortis. - Arbores e memoria Donii indicatae, folits imparipinnatis, foliolis oppositis, ovatis integerrimis, guarum fructus amariet ad. stringentesin insula $S t$. Thomae in sinuGuineae, sub nomine $\mathcal{S}$ af $u$ et $P a s c o$, venditantur.

\section{BURSERACEIS AFFINES.}

\section{* AMYRIDEAE,}

594\%. Amyris LINN. FIores hermaphroditi v. polygaui. Ca I y x parvas, urceolatus. quadridentatus, persistens, Corolla e petala 4 , hypogyna, basi cuneato-subunguiculata, aestiva tione imbrisata, sub anthesi patentissima. S $\mathrm{t}$ a $\mathrm{m}$ ina 8 , hypogyna, petalis breviora; filamenta subulata, libera, antherae introrsae, bilocnlares, longitudinaliter dehiscentes. Ov a ri $\mathrm{u}$ in toro prominenti, incrassato, disciformi insidens, uniloculare. Ovula 2 , ex apice cavitatis pendula, anatropa. Stigm a sessile, capitatum. Drupa subglobosa, putamine chartaceo, monospermo. Semen inversum, subglobesum, testa membranacea. E mbryon is exalbuminosi, orthotropi $\mathrm{co-}$ tyledones plano-convexae, radicula brevissima, supera, - Arbores v. frutices resinosi, in America tropica et boreali calidiore crescentes; foliis oppositis, ternatis $v$. imparipinnatis, foliolis oppositis, pellucido-punctatis, paniculis axillaribus et terminalibus, ramosis, bracteatis, floribus parvis, solitariis $v$. ternis, albis, pedicellis lateralibus medio bibracteolatis, drupis nigris $v$, rubris, oleo aromatico scatentibus.

A my ris Linn. Gen, n. 473, excl. sp. Jaeq. Amer, 107. Kunth in Annal. sc. nat. II. 364. Humb. et Bonpl. Nov. gen. et sp. VII, 37, t, 610, DC, Prodr. II, 8t. exel. sp. asiat. Torrey et A. Gray Flor, of North-Amer. I. 22t. Meisner Gen. 74. (56.) E I e m ife r a Plumier edit, Burm. IP. 87. L u cin i u Pluckn. Almag. $t$. 201 . $f$. 3 .

\section{Drdo CCXIIII. Connaraceace.}

CONNARACEAK R. Brown in Tuckey Congo 431, Kunth in Annal. se, nat. II. 359. Bartling Ord, nat. 394. Lindley Introduct, edit. II. p. 157. TEREBINTHACEARUM tribus 7. DC. Prodr. 1I. 84, tribus VI. Meisuer Gen, 78. (56.)

Arbores v. frutices, interdum sarmentosi. Folia alterna, trifoliolata $v$. imparipinnata, foliolis coriaceis, venosis, epunctatis, integerrimis. S $t$ i p u l a e nullae.

Flores hermaphroditi v. rarius abortu unisexuales, regulares, axillares v. terminales, racemosi sive paniculati, bracteati.

Calyx quinquepartitus, persistens, laciniis imbricatis v. rarius aestivatione valvatis.

Corollar petala 5 , imo calyci inserta, ejusdem laciniis alterna et plerumque longiora, sessilia v. unguiculata, aestivatione imbricata.

Stamina 10, subhypogyna, alterna petalis opposita reliquis, omnia iisdem breviora. Filam e n t a filiformia v. subulata, libera v, ima basi in annulum perbrevem coalita. Antherae introrsae, biloculares, subglobosae v. ovatae, longitudinaliter dehiscentes.

Ovarıa quinque, sessilia v. breviter stipitata, libera, nunc omnia fertilia, nunc saepius plura, v. praeter unum omnia ad stylos redacta, v, efoeta aut tandem abortiva, fertilia unilocu. laria, biovulata. Ovula collateralia, e basi erecta, v. e sutura ventrali paullo supra basim adscendentia, anatropa. Styli in ovariis singulis singuli, terminales, filiformes, longiusculi, simplices, omnino liberi; stigmatibus obtusis, dilatatis, indivisis.

Capsular 5, aut abortu pauciores v. solitariae, sessiles v. breviter stipitatae, coriaceae, leguminiformes, uniloculares, sutura ventrali bivalves v. rarius indehiscentes.

Sвмiva gemina v. saepissime abortu solitaria, e basi loculi erecta, v. e sutura ventrali adscendentia, arillo carnoso cinctá aut rarius exarillata, testa coriacea, endopleura membranacea. A 1 b u m e n nullum, v. carnosum, copiosum.

Емвгуо antitropus, exalbuminosus, cotyledonibus carnosis, plano-convexis, v. in axi albuminis carnosi, ejusdem dimidio longior, cotyledonibus foliaceis, planis, radicula brevi v. brevissima, supera, umbilico basilari e diametro opposita.

Connarace a in Asia, Africa et America tropica crescentes, a reliquis Terebinthinearum ordinibus, inter quos Anacardieis mediante Bachanania, et Zanthoxyleis per Brunelliam propius accedunt, embryone antitropo diversae, hinc per Cnestin, mediante Averrhoa, Oxalideis, illine Leguminosis Detarieis, vix nisi ovariorum numero, embryonis situ et stipularum defectu distinguendis, accedunt.

Genera ad ordinis calcem recensita dubiae in classi affinitatis.

5948. Commaras LINN. Calyx quinquepartitus, persistens, laciniis ovatis, aestivatione imbricatis, fructus basi adpressis. Co roll a e petala 5, imo calyei inserta, ejusdem laeiniis alterna et longiora, sessilia, aestivatione imbricata, sub anthesi apice patenti-reflexa. S t a m in a $10, \mathbf{s u b}$ hypogyna, calycem aequantia, alterna petalis opposita breviora; filam en a filiformi-subulata, ima basi in annulum brevem coalita, antherae introrsae, biloculares, cordato-subrotundae, dorso insertae, longitudinaliter dehiscentes. Ovaria 5 , sessilia, quorum quatuor saepissime abortiva, ad stylos redacta, quintum uniloculare, ovulis geminis basilaribus, collateralibus, erectis, orthotropis; stylo simplici, elongato, stigmate dilatato. Ca psula sessilis, coriacea, unilocularis, indehis. cens, ahortn monosperma. Sem en e basi loculi erectum, arillatum. Embryonis exalbuminosi, antitropi c otyled on es carnosae, plano-convexae, radicula brevissima, supera, umbilico e diametro opposita. - Frutices in $A s i a$ et $A m e-$ rica tropica indigeni; foliis alternis, exstipula148 * 
tis, trifoliolatis v. imparipinnatis, foliolis coriaceis, integerrimis, epunctatis, paniculis axillaribus, mul. tifloris, floribus bracteatis, albis.

Connarus Lian. Gen, n. 944. DC. in Mem. soc. $\pi, n$. Paris. II. 383. t. 15. Prodr. II. 84. Meisner Gen. 78. (56.) Rou rea Aublet Guian, $r .467, t .187$. Kunth in Annal. se. nat. II. 360. $\mathrm{R}$ o be r g i a Schreber Gen, n. 787. M a I b r a n $c$ i a Necker Elem, $n, 1171$. S a in $t$ a I o i d e s Linn. Flor, Zejl, $n, 408$.

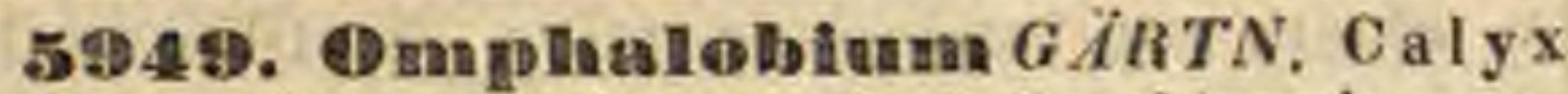
quinquepartitus, persistens, laciniis oblongis, acutis, aestivatione imbricatis, fruetus basim laxe cingentibus. C oro 11 a e petala 5, imo calyci inserta, ejusdem laciniis alterna et longiora, brevissime unguiculata, aestivatione imbricata, sub anthesi apiee patentia. St am ina 10 , calycem aequantia, alterna petalis opposita breviora; filamenta filiformi-subulata, ima basi in annulam brevem coalita, anthera e introrsae, biloculares, subrotundae, dorso insertae, longitndinaliter dehiscentes. Ovaria 5 , sessilia v. brevissime stipitata, nonnulla saepissime sterilia, nnilocularia, ovulis geminis, suturae ventrali supra hasim insertis, collateralibus, adscendentibus, orthotropis; st y lo simplici, elongato; st igmate dilatato. Capsu1 a e 5 v, abortu pauciores, interdum solitariae, hasi attenuatae v. breviter stipitatae, coriareae, leguminiformes, uniloculares, sutura ventrali bivalves, di-v. abortu monospermae. S e m in a e sutura ventrali prope basim adscendentia, arillata. $\mathbf{E} \mathbf{m}$ b $\mathbf{r} \mathbf{~ o -}$ nis exalbnminosi, antitropi cotyledones carnosae, plano-convexae, radic u la brevissima, supera, nmbilico e diametro opposita. - Arbores $v$. frutices, in Asia, Africa et Americatropica crescentes; foliis alternis, exstipulatis, trifoliolatis v. imparipinnatis, foliolis integerrimis, epunctatis, racemis axillaribus, saepius in paniculam terminalem confertis.

$0 \mathrm{mphalobiam} \mathrm{Gärtner} \mathrm{I.} \mathrm{217.} \mathrm{t.} \mathrm{46.} \mathrm{DC.} \mathrm{in} \mathrm{Mem.}$ soc. h, n, Paris, IT, 386. Prodr. MT,85. C a n a it us Kunth in Annal, sc, nat, 1I, 360. Meisuer Gen, 87. (55.) T a pow a i a Adanson Fam. IT. 343 ,

a. CONNAROIDEA DC, l. c. Capsn I a e solitariae. B y rsoearpus Schumaclier in Danske naturwedensk. Selskabs Afhandl. III, 246. C onnari sp. Cav, Diss. t. 221. 222. Lam. t. 572, DC, in Mem, soc. h, n. Paris. II. t. 16. Turpia Allas, II, t. 276. S pondi oid is sp. Smeathman.

b. CNRSTOIDEA DC, $l, c$, Ca p s a la e plures. Conna ri 8 p. Lam. Cav. Diss. $t$. 223, (Delessert Ic. select. III. t. 58.)

5.50. Cunestis JUSS. Caly $\mathrm{x}$ quinquefidus, persistens, laciniis aestivatione valvatis. Corolla e petala 5 , calyci supra basim inserta, ejnsdem laciniis alterna et breviora, brevissime ungui rnlata, spathulata v, suborbiculata, aestivatione imbricata. Stam ina 10 , cum petalis inserta, inclusa, alterna petalis opposita breviora; fil a m e n$t$ a filiformi-snbulata, an $t$ herae introrsae, hilorulares, reniformes, basi insertae, longitudinaliter dehiscentes. Ovaria 5 , sessilia, conniventia, unilocularia, ovulis geminis, suturae ventrali panllo supra basim insertis, collateralihns, adscendentibus, arthotropis; stylis simplicihus, elongatis; stigmatibus obtusis. Capsula 5 v. abortu pauciores, interdum solitariae, brevissime stipitatae, coriaceae, leguminiformes, uniloculares, sntura ventrali bivalves, intus et extus prurienti-pilosae, abortn monospermae. Se men e sutara ventrali prope basim adscendens, ellipticum, compressiuscnlum, exarillatum. En b ryo in axi zlluninis carnosi rectus, antitropus, alliomine paullo bre. vior; cotsledonibus foliaceis, radicula um- bilieo e diametro opposita, snpera. - Frutices in Asia et America tropica crescentes, saepe scandentes; foliis alternis, exstipulatis, imparipin. natis $v$. trifoliolatis, foliolis coriaceis, integerrimis, epunctatis, racemis axillaribus bracteatis, paniculatis.

C nes tis Jussieu Gen, 374. Lam, $t$, 387. Pallsot Flor. Owar. 2. 59, 60, R. Browa in Tuckey Congo 423. Kunth in Annal. sc. nat, II. 359. DC. Mrodr, II. 86. Meisuer Gen, d7. (55.) S p.audioidis s p. Smeathmana.

\section{GENERA DUBIA.}

5Đ51. Thysamus LOUREIRO. C al y pentaphyllus, persistens. Cor o 11 a e petala 5 , whlonga, ealycem aequantia, patentia. S $\mathbf{t a m}$ in a 10 , brevia; filamentis reflexis, antheris sulirotundis, erectis. Ovariu in tetragonum. Styli 4 , filiformes, ovarii angulis a latere inserti; st i i $\mathbf{m}$ ata breviter bifida. Ca p s a la e quatuor, oblungae, gibbosae, apice recurvae, cortice lanuginusu, a latere dehiscente, monuspermae. Sem in a oblongo-ovata, laevia, basi tunica carnosa, fimbriata involuta. - Frutex cochinchinens $i s$, inermis; foliis pinnatis, decemjugis, foliolis integerrimis, glabris, pedunculis lateralibus, multifloris, calyce rubescente, petalis albis.

Th y s a us Loureiro Flor, cochinch, 348. DC. Prodr. II. 91. Adr. Jussien in Mem, MLus, XIT, 520 Meisu, Gen, 76 , (55.)

$595 \%$. Eangeonas $J A C K$. F lores pulygamo-disici. C a l y x brevis, quinquepartitus. C orolla e petala 5, calyce Iongiora, erecta, marginibns inflexa, intus glanduluso pilosa. Sta m in a 5 , petalis breviora, erecta, glandalis decem geminatis, villosis alterna. Ovarium quinquelobum, lobis uniovulatis, Stylus simplex, brevis, incurvus; stigmata 5 , erassa, recurva. Capsilae $3 \_5$, subovatae, glabrae, hine dehiscentes, mo. nospermae. S e m en exarillatum, exalbuminosum. Arbuscula sumatrana; foliis in apice ramorum confertis, pinnatis, multijugis, foliolis oblongis, lanceolatis, ucutis, integerrimis, glaberrimis, paniculis axillaribus longis, floribus purpureis, masculis et hermaphrodit is in diversis stirpibus.

$\mathrm{E}$ uryeoma Jack in Foxburgh Flor. Ind. edit. Wal. lich II. 307. DC. Prodr. II. 86. Meisner Gen. 76. (55.)

\section{* SURIANEAE.}

5פ53. Suriana PLUM. Flores hermaphroditi. C a l y $x$ quinquepartitus, persistens, aestivatione contortim imbricata. Coroll a e petala5, tori carnosi, calycis fundum replentis imo margini inserta, calycis laeiniis alterna et subaequilonga, aestivatione imbricata. St a mina 10 , cum petalis inserta, inclusa, alterna iisdem opposita saepissime sterilia v. abortiva; fila menta e hasi lata pilosa, subulata, libera, persistentia, anth er a introrsae, biloculares, longitudinaliter dehiscentes. Ovaria 5, toro carnoso insidentia, petalis opposita, unilocularia, libera, ovulis geminis collateralibus, erectis, campylotropis. Styli filiformes, ovariorum angulo centrali infra medium ininserti; stigmate simplici. Carpidia 5 , coriacea, libera, evalvia, abortu monosperma. Semin a erecta, uncinata. E m b r y o $\mathbf{n}$ is exalbuminosi, uncinati cotyledones oblongae, carnosae, incumbentes, radic al a umbilico upposita, desendens. - Frutex in littoribus maritimis inter tropicos totius orbis obvius; foliis ad apices ramulorum confertis, simplicibus, oblongo-spa- 
thulatis, integerrimis, crassiusculis, subvelutinis, exstipulatis, floribus subterminalibus braclealis, luteis.

S u ri a u Plumier Gen. 37. Io, edit, Burm, $t$ 249. Linn. Gen. n. 581. Jussieu Gen. 339. Laa, t, 389. DC. Prodr. II. 91. Wight et Arnott Prodr. I. 360.

5954. Cracoruan LINN, Flores herma phroditi. Calyx minutus, tri-quadrifidus, regu laris, persistens, Co rolla e petala 3 v. 4, sub discu inserta, sessilia, aequalia, ealyeis laciniis alterna et multo longiora, aestivatione imbricata, sub anthesi patentiuscula. S tam in a $\mathbf{8}$ v. 4 , gynophoro medio inserta, petalis alterna et breviora; filamenta filiformia, libera, antherac introrsae, biloculares, dorso supra basim affixae, longitudinaliter dehiscentes. Ovarium grnophoro staminifero insidens, tri-quadrilobum, Iri-quadriloculare, loculis petalis oppositis. Ovula in loculis gemina, loculorum angulo centrali inserta, superposita, pendula, campylotropa. St y l u s centralis simplex; stig ma tri-quadrilobum. Fruetus tritetracoecus, v. abortu monococens, coecis drupaceis, parce carnosis, putamine osseo, septo secundario oblique transverso bilocellatis, locellis monospermis. Sem in a wlique pendula, uncinatim condaplicata. E m b r yo n is exalbuminosi, uncinati c ot y led o nes semiteretes, obtusae, incumbentes, radicula cotyledonibus longior, umbilico e diametro opposita, adscendens. - Frutices inermes, in Gallia mediterranea, Hispania èt insulis Canariis crescentes; foliis allernis, simplicibus, angustis, integerrimis, peduncul is axillaribus solitariis, bibractealis, superioribus uni- inferio ribus trifloris $v$. apice glomerulato-multifloris,

C n e orum Linn. Gen, n. 48. Lam. t. 27. Ventev. Cels. t. 77. Jeantme St. Hilaire Plant. franc, t, 5, Kunth in Ansal. sc, nat, 11.357 , DC. Prodr, 11.83 , C h a maele a Tour nef. Inst, 42t. Gärtuer $I .342, t, 20$.

5S55. Heterodendrom DESEONT Flores hermapliroditi, Cal y cupuliformis, subintegerrimus v. obsolete dentatus, persistens. $\mathrm{C}$ nroll a nulfa. Marg " membranaceus in fundo foris, ovarium laxe eingens, integer. Sta in ina $6-12$, inter discum et ovarium inserta, breviter exserta, subaequalia; fil a m e $t$ a brevia, inferne tumidula, libera, an the rae introrsae, biloculares, obovatae, basi bifido sagittata insertae, latere longitudinaliter dehiscentes, aequales. O variu m liberum, sessile, nune obovato-subrotundum, quadriloenlare, subquadrilobnm, sti g matibus 4 , sessilibus, papillosis, patentibus terminatum, nunc ohovatum, compressum, biloculare, stig mat e obtuso, simplici umbilicatum. Ovula in quovis loculo unieum, in ovario quadriloeulari subrotunda-obovatum, tuberculo ex axi enato insidens et erectum, in biloculari obovatum, supra basim affixum. Fruetus 8 . Frutex NovaeHollandiae; foliis oleae, sparsis, simplicibus, coriaceis, integerrimis, exstipulatis, racemis axillaribus geminis, pedicellis brevibus, sparsis, basi articulatis, ebracteatis (?)

Heterodendron Desfont, in Mem. Mus. IV. 8, t. 3. Kunth in Annal. so, nat. II, 365. DC. Prodr. II, 92.

\section{Ordo CCXLEIII. Dehnaceae.}

OCHNACEAB DC, in Annal. Mus. XVIT, 398. Prodr. $I$ 735. St. Hilaire in Mem. Mus. X. 129. ss. Bartling Ord.nat. 383. Liadley Introduct, edil. IL. p.129. Meisn. Gen, 66, (47.)
Arbores, frutices v. sufroutices, glaberrimi v. rarissime puberuli, succo aqueo, satpissime amaro. Foli a alterna, simplicia, breve petiolata, coriacea v. rarius membranacea, saepe venis parallelis, horizontalibus confertim striata, integerrima v. serrata. Stipulae ad basim petiolorum geminae, liberae et deciduae, $v$. in unicam intraaxillarem, persistentem connatae.

Flores hermaphroditi v. rarissime abortu unisexuales, racemosi v. corymbosi, aut rarius solitarii, pedicellis basi v. medio articulatis.

Calyx liber, tetra-pentaphyllus, v. quadriquinquepartitus, foliolis v. laciniis saepe coloratis, corolla tamen multo rudioribus, aestivatione imbricatis.

Conorlae petala hypogyna, ad basim gynophori brevis inserta, ealycis foliolis numero aequalia et alterna, v. rarissime dupla, iisdem majora, aestivatione imbricata, sub anthesi patentia.

Stamina cum petalis hypogyne inserta, calycis laciniis numero dupla, rarius tripla, quadrupla v. subquintupla, omnia fertilia, Fil amenta filiformia v. subulata, libera, antheris longiora v. breviora. An therae introrsae v. extrorsae, biloculares, ovatae, oblongae, lineares v. lineari tetragonae, basi v. rarissime supra basim insertae, erectae, loculis coriaceis, saepissime transversim annulato-rugosis, juxta totam longitudinem v. saepius rimula abbreviata, aut poro apicis dehiscentibus.

Ovarium gynophoro, apice saepissime dilatato, insidens, e carpidis quatuor, quinque aut rarius pluribus, axi centrali stylifera plus minusve depressa, magis minusve quadri-quinquelobum, lobis obliquis v. pronis, unilocularibus, uniovulatis. Ovulu m e basi loculi adscendens, v. ex angulo centrali infra apicem pendulum, anatropum. Stylus centralis, simplex v. in lobos breves, loculorum ovarii numero, divisus. Stig mat a simplieia.

CARPIDIa drupacea v. baccata, in gynobasi demum ampliata sessilia v. brevissime stipitata, patentia, unilocularia, monosperma.

SEMEN erectum v, inversum, te sta membranacea. Albumen nullum v. parcissimum, carnosum.

Euвryo orthotropus, nunc exalbuminosus, cotyledonibus carnosis, plano-convexis, radicula brevissima, infera, nune albumine carnoso, parco inclusus, c otyledonibus foliaceis, radicula brevi, supera.

Ochnaceae inter tropicos tolius orbis, imprimis Americae crescentes, Simarubaceis proximae, ab eorundem generibus simplicifoliis seminibus erectis, v. embryone albuminoso, foliaceo, et antherarum fabrica facillime distinguuntur. 


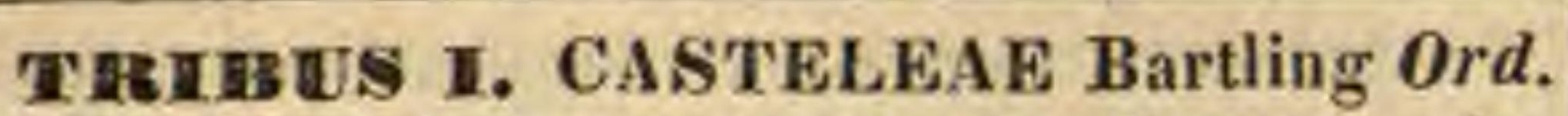
nat. 384. Antherae extrorsae. Semina inversa, albuminosa.

5\$56. Casteln TURPIN. F lores abortu nnisexuales. Caly x parvus, quadripartitus. C orolla e petala 4, hypogyna, calycis laciniis alterna et inulto majora, ovalia, cencava, patentia. S ta m in a 8, sub diseo hypogyno, parvo inserta, petala aequantia; filamenta subulata, an therae extrorsae, ovatae, bilocnlares, Inngitudinaliter dehiscentes. Ora rium gynophoro brevi insidens, profunde quadrilobum, lobis ov u lo unico, ex angolo centrali infra apicem pendulo, anatropo foetis. Stylus centralis, brevis, apice quadrifidus, Jobis acutis, intus stigmatosis. Drupae 4, patentes, basi attenuata substipitatae, putamine compresso, rugoso, bivalvi, monospermo. S emen inversum, compressum, testa membranacea. $\mathbf{L} m$ bryonis intra albumen tenuissime carnosum, or thotropi cotyledones foliaceae, planae, $r$ adicula brevissima, supera. - Frutices antillani, ramosi; ramis apice, ramulisque axillaribus $v$. infra. axillaribus, brevibus, spinescentibus armati, foliis al ternis, subsessilibus, ellipticis v. ovalis, coriaceis, rigidis, mucronatis, margine revolutis, supra nitidis, subtus discoloribus, floribus axillaribus, bre vissime pedicellatis, solitariis $v$. subfasciculatis, cro ceis, fructibus rubris.

C a s te 1 a Turpin in Annal. Mus. VIr. 78, t. 5. DC. Prodr. I. 738. Hooker Bot, Miscell, 1, 271, $t, 56$. Meisner Gen. 66. $(47$.

5\$5ซ. Elvasia DC. Caly $\mathrm{x}$ tetraphyllns, foliolis aestivatione imbricatis. Corollae petala k, hypogyna, calycis foliolis alterna et majora, obovata, patentia. Stam in a 8 , hypogyna; fila$m$ enta filifurmia, an the rae extrursae, bilosulares, ovatae, dorso insertae, transversim rugosae, apice poris duobns dehiscentes. Ovarium gynophoro columnaeformi, brevi insidens, quadrilobum, lobis ovulo unico, ex angulo centrali infra apicem pendulo, anatropo foetis. Sty la s filifor mis, simplex; s $t \mathbf{i} g$ ma capitatum, indivisum Fructus.... - Frutex brasiliensis; foliis alternis, breve petiolatis, oblongis, uninerviis, ve nis plurimis parallelis lineatis, integerrimis $v, m i-$ nutissime denticulatis, stipulis parvis, aristato-acuminatis, racemis terminalibus ramosis, pedicellis basi auriculatis, floribus parvis.

EIv a sia DC. in Annal. Mus. XVIT. 422, t. 20. Prodr, I. 738. St. Hilaire Flor, Brasil, I. 69. in not, Meisuer Gen. 66. (47.)

TISETS II. OCHNEAE Bartling ort. nat. 384. Antherae introrsae. Semina erecta, exalbuminosa.

5558. Gomphia SCHREB. Caly $\mathrm{x}$ entaphyllus, saepissime coloratus, foliolis imbricatis, deciduis. Curollae petala 5, hypogyna, calycis foliolis alterna et paullo majura, saepissime obovata, unguiculata, patentia. St a mina 10 , hypogyna, erecta, conniventia; filamenta brevissima, antherae introrsac, biloculares, basi affixae, subulato-tetragonae, transversim annulatorugosae, apice poris duobus dehiscentes. Ovarium columna centrali stylifera depressissima quinque-sexpartitum, lobis gynophori oloconici apiei oblique insidentibus, obovatis, obtusissimis, ov ulo unico e basi adscendente anatropo foetis; s tylo inter lobos centrali simplicissimo, stig mate minimo. B aceae 5 v. abortu pauciores, gynophoro demnm ampliato insidentes, uniloculares, monospermae. S e m en erectum, testa membranacea. Embryonis exalbuminosi, orthotropi cotyledones carnosae, plano-convexae, radienla brevissima, infera. - Arbores, frutices v. suffrutices, in Asia et Africa, multo frequentius in America tropica crescentes; foliis allernis, persistentibus, simplicibus, breve petiolatis, coriaceis, nitidis, ovalibus $v$. oblongis, subintegerrimis $v$. argute serratis, stipulis axillaribus geminis, nunc distinctis, caducis, nune in unicam, intrafoliaceam, persistentem coalitis, panicul is aut racemis terminalibus v. interdum simul axillaribus, bractea tis, floribus luteis, pedicellis angulatis, basi articulatis.

Gomphia Sehreber Gen, n. 783. DC. in Annal, Mus. XVIT. 414. t. 6_19. Prodr. I. 736. Humb, et Bonpl. Plant, aequinoct. Ir. 2t, t, 7h. Palisal Flor, owar, t, 7t, 72. Kuath in Humb. et Bonpl Nov. gen et sp. VI. 13. St. Hilaire Plant, remarq Brasil. 90. t.9 Plant us, $t 38$. Flor. Brasil. I. 60. t. 12. 13, Poht Plant. Brasit. t. 178_t85. Meisuer Gen. 67. (47) Japotapit a Pluaier Gen. 4t, 32. Ourate a Aublet Guian. $I, 397 . t, 158$. C o r re i a Vellozo in $R \ddot{b}$. mer Seript. 106. t. 6. f. 11. P hilomeda Noronh. ex Thouars Gen. madogaso 17. So ph is te qu es Commers. mse. Cittorhy nehus Wilid. msc. $0 \mathrm{ch}$ na e sp. Lisn. Gärtuer t, 20. f. 2, Flor. Flum. V, t. 89-94.

5959. Dehma SCHREB. C a I y x pentaphyllus, coloratus, foliolis imbrieatis, deciduis. Corolla e petala 5-10, hypogyna, calyce paullo majora, obevata v, oblonga, patentia. Sta im ina plurima, petalis breviora; filamenta filifurmia, a nthera e introrsae, biloculares, filamentis breviores v. longiores, basi affixae, loculis oppositis, ovatis, filamento brevioribus, juxta totam longitudinem, $v$, linearibus filamentum superantibus, rima basim hand attingente, plus minus longa de. hiscentibus. Ovariu u columna centrali stylifera depressissima, ampliata tri-quinque-decempartitum, lobis gynophoro ovato $\mathbf{v}$. hemizphaerico lata basi oblique insidentibus, obtusissimis, ov ulo unico, adscendente foetis; stylo inter lobos centrali, apice quinque-decemfido, $s t \mathrm{ig} m$ a $t \mathrm{ibu} s \mathrm{minimis}$. Baccae 5-10 v. abortu pauciores, interdum solitariae, gynophoro ampliato insidentes, uniloculares, monospermae. Semen .... - Arbores v. frutices, in Asia et Africa tropica crescentes; foliis alternis, deciduis, simplicibus, serratis v, rarius subintegerrimis, stipulis axillaribus geminis, deciduis, racemis pedunculatis, saepissime e gemma squamosa, infra folia annotina orlis, bractealis, floribus luteis, pedicellis medio aut paullo supra basim arliculatis.

0 e h a schreber Gen. n. 354. Lam. $t$. 472. DC. in Annal. Mus. XYIT. 410. t. 1 -15. ot 19. f. 2. Prodr. I. 735. Roxburgh Plant, Corom. t. 89. A. Richard Flor. Seneg. t. 35. Meisner Gen. 66. (47.) Diporid i u Weadlaud f. Beitr. II, 24. (Ochuae sp. capenses.)

\section{GENUS DUBIUM.}

5\$Re. Walk era $S C H R E B$. C a ly $\mathrm{x}$ pentaphyllas, foliolis lanceolatis, persistentibus. C orolla e petala 5, calyce paullo longiora, lanceolata, persistentia. Stamina 5 , petalis dimidio hreviora, antheris ovatis, Ovarinm .... StyI u s unicus, setaceus, staminum lnngitudine. Drap a e 5, reniformes, receptaculo parvo, conico, fungoso insidentes, putamine subosseo, monospermo. S e m en renifurme, sinu nubilicatum, funiculo brevi, e putaminis basi orinndo insertum, testa spongioso-coriacea, rrassiusenta. E mbryonis exalluminosi, inversi cotyled on es semilunatse, carnosae, plano-convexae, radicula teres, acu- 
minata, supera, uncinato-deseendens. - Arbor Asiae tropical; foliis alternis, serrato-crenatis, racemis subcorymbosis.

IV a I kera Seltreber Gen, n, 378. DC. in Annal, Mus. XVII, 42t. Prodr, I. 737. Metsuer Gen. 67. (47.) M ees i a Gärtier $I .344, t, 80, \mathrm{~T} s \mathrm{jo}$ e a t t i Rheede Hort. Malab. $V$. 95. $t .48$.

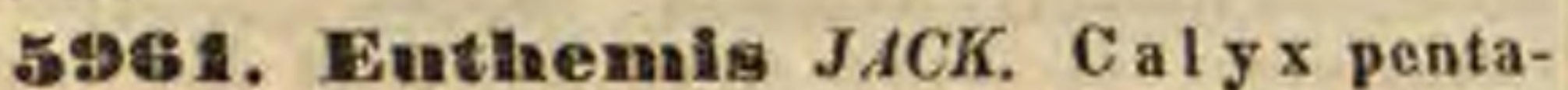
phyllus, foliolis imbricatis. Corolla e petala 5, hypogyna, calyee duplo longiora, ovato-oblonga, obtusa, reflexa. Sta in in a hypogyna, nua: 5 fertilia, nune 10 , alterna sterilia; fi $\mathbf{l}$ a m e $\mathbf{t}$ a brevissime filiformia, a $\mathbf{t}$ her a e longae, erectae, conniventes, biloculares, apice in asumina poris aperta productae. Ovarium oblongam, quinqueloculare .... Styl u s terminalis, filiformis; stikua simplex. Drupa baceata, slylo persistente superata, sarcocarpiu pulposo, putamine pentapyreno, pyrenis fibrosis, monospermis. Semina inversa. $\mathbb{E}$ u b ry 0 in axi albuminis carnosi orthotropus, ejusdem fere longiludine; rotyledoni bus semieylindricis, obtusis, radicula cotyledonibus longiore, supera. - Frutices indici, erecti; foliis alternis, petiolatis, acutis, lamina glaberrima, nitida, nervis parallelis transversis striatu $v$. elegantissime venoso reticulata, spinuloso-serrata, basi angustata $v$. in petiolum decurrente, petioli plani, superne canaliculali, basi semiamplexicaulis sti pulis linearibus, lanceolatis, acuminatis, ciliutis, caducissimis, racemis subsimplicibus, terminalibus, demum caulis elongatione laleralibus oppositifoliis, floribus pedicellatis, geminatis, bracteis ovalis, acutis, petalis albis v purpurascentibus.

Eut hemis Jack Malay. Miscell. ex Wallich in Roxburgh Elor, ind. II. 303.

\section{Drdo CCXIIX. Simarabaceae.}

SIMARUBACEAE Richard Analys. du fr. 21. Lindley Introduct. edit $I I$. p. 120 . St,MARUBEAE DC. in Arnal, Mus. XVIT. 323. Prodr. I. 733. Adr. Jussieu in Mlem. Mas XII. 512. Meisu. Gon, 65. (47.)

Arbores v. Frotices. Foli a alterna, in paucis simplicia, plerumque impari- v. abrupte pinnata, foliolis oppositis v. alternis, integerrimis, epunctatis. Stipulae nullae.

Fuoses hermaphroditi v. abortu unisexuales, axillares v. terminales, in umbellas, racemos v. saepius in paniculas dispositi, albidi, virescentes aut purpurascentes, pedicellis bracteolatis.

Canyx quadri-quinquepartitus, persistens, laciniis aestivatione imbricatis.

Coronlae petala 4 v. 5 , hypogyna, calycis laciniis alterna et longiora, aestivatione contortim imbricala, sub authesi patentia v. in tubum conniventia, decidua.

Stamina hypogyna, petalis numero dupla, iisdem breviora v. Iongiora. Fil a menta singula dorso squamulae inserta, filiformia. Antherae introrsae, biloculares, dorso supra basim insertae, loculis parallelis, adpositis, longitudinaliter dehiscentibus.

Ovaria 4 v. 5, gynophoro brevi, lato, basi staminifero insidentia, libera, unilocularia. 0 v u1a solitaria, sub anguli interioris apice appen- sa, anatropa. S t y l i ex apieibus ovariorum discretis orti, mox in unum, saepissime tortum coaliti. Stigma quadri-quinquelobum.

Drupak 4 v. 5, aut abortu pauciores, in gynophoro verticillatim sessiles, uniloculares, monospermae.

Semiva inversa, cavitati conformia, testa membranacea, rhaphe longitudinali et chalaza apicali notata. A 1 b umen nullum.

Eubryo orthotropus. Cotyledones crassae, carnosae. Radicula brevissima, inter cotyledones retracta, supera.

Simarubaceae ob insignem omnium partium amaritiem inter medicos celebres, paucissimis simplicifoliis asiaticis et africanis exceptis, omnes americanae tropicae, ovariis uniovulatis, fructu drupaceo, seminum testa menbranacea et embryonis exalbuminosi radicula retracta, ab affinibus ordinibus facillime distinguendae, ab Ochnaceis, quibus propius accedere videntur, stylis ex ovariorum apice ortis, ovulis semper pendulis, et antheris longitudinaliter dehiscentibus diversae.

5982. Quassia DC. Flores hermaphroditi. Cal y x brevis, quinquepartitus. Corollae petala 5, hypogyna, calyce multo longiora, aestivatione contortiz imbricata, sub anthesi in tobam conniventia. Stamina 10, hypogyna, petalis longiora ; filamenta squamulae brevis, apice pilosae dorso inserta, filiformia, flexnosa, antherae introrsae, bioculares, ovato-oblongae, dorso supra hasim insertae, longitudinaliter dehiscentes. O va ria 5 , gynophuri brevis, lati centro insidentia, libera, anilucularia; ovulo unico, angulo centrali infra apicem appenso, anatropo. Styli ovariis cuntinni, basi distreti, mox in nnicum staminibus longiorem, contortum coaliti; $8 \mathrm{tigma}$ quinquesuleum. Drupae 5 v. abortu pauciores, sessiles, patentinsculae, vniluculares, monuspermae. Se mina inversa, testa membranacea. $\mathbf{E} \mathbf{m}$ bryonis exalbuminosi, orthotropi cotyledo. nes carnosae, radicula brevissima, inter cotyledones retracta, supera. - Arbor guianensis, nunc in Antillas advecta; foliis alternis, imparipinnatis, petiolis alatis, foliolis oppositis, integerrimis, nitidis, floribus majusculis, coccineis, in racemos terminales, simplices $v$. ramosos dispositis, pedicellis basi bracteatis, sub apice articulatis, ad urticulum bibracleolatis.

Q u assi a DC. in Annal. Mus. XVIr, 323. Prodr. I. 733. Adr. Jussieu in Mem, MLs. XII. 513. 2 , 25. f. 13. Meisuer Gen. 63. (47.) Qu a s s i a a mara Lian. f. Lam. t. 343. f. 1. Lood. Bot, cab. t. 178.

5983. Simaraba $A U B L$. F lores diclines. Caly $x$ bresis, cupulaeformis, quinquedentatus v. partitus. Corolla e petala 5, hypogyna, calyce multo longiora, aestivatione contortim imbrieata, sub anthesi patentia. M a 8 c. $\mathbf{S} \mathbf{t}$ a m in a 10 , hypogyna, petala subaequantia, alterna fisdem opposita paullo breviora; fil amenta squamulae hrevis, apice pilosae dorso inserta, filiforini-subulata, strieta, a ntherae introrsae, biloculares, cordato-ovatae, longitudinaliter debiscentes, 0 vari a rudimentaria, gynophoro brevi insidentia, interdum nulla. F e m. St a m in am rudimenta squamulae 10 . Ovaria 5 , gynophoro brevi, aequilato 
insidentia, libera, nnilocularia, ovnlo unico, angulo interiori infra apicem appenso, anatropo. Sty li ovariis continui, basi discreti, mox in uni. cum brevem, erectum coaliti; stigmate lato, quinquelobo. Drupa e $5 \mathbf{v}$, abortu pauciores, sessiles, patentiusculae, uniloculares, munospermae. Semina inversa, testa membranacea. Embryo. nis exalbuminosi, orthotropi cotyled on es carnosae, radicula brevissima, inter cotyledu. nes retracta, supera. - Arbores Americae tropicae; foliis alternis, abrupte pinnatis, foliolis alternis, integerrimis, superne nitidis, racemulis folio bracteaeformi stipatis, in paniculas axillares v. terminales dispositis, pedicellis bracteolatis, flori bus parvis, canescentibus $v$. virescentibus, margine interdum purpurascentibus.

S I ma r u b a Aublet Guian. IT, 856, 1, 331, 332, DC. in Annal. Mus. XVIL. 423. Prodr. I. 733. Kunth in Humb. ef Bonpl. Nov, gen. et sp. VI, 16 . St. Hilaire Plant. us. Brasil. t. 5 Flor, Brasil. I. 70. Adr. Jussieu in Mem. Mas. XII. 514. t. 27. f. 44. Meisuer Gen, 65. (48.) $Q$ u a s $s$ i a

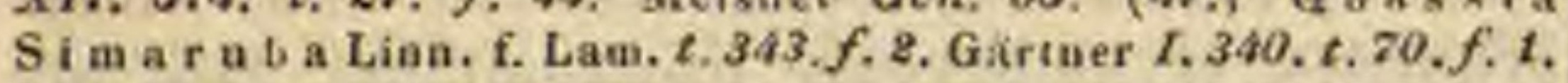

5DG4. Simaba $S T$. HIL. Flores hermaphroditi. Calyx parvus, quadri-quinquedentatus v. partitus. Corolla e petala \& v. 5, hypogyna, calyce multo longiora, aestivatione contortim imbricata, $8 n b$ anthesi patentia. St a min a 8 v. 10 , hypogyna, corollam subaequantia, alterna petalis opposita paullo breviora; fil amenta squamulae brevis v. elongatae, pilosae dorso inserta, filiformia, stricta, antherae introrsae, bilocnlares, cordatae, basi emarginata insertae, Iongitudinaliter dehiscentes. Ovaria 4 v. 5 , gynophorobrevi, latiori v. subaequali insidentia, libera, unilocularia, "v ul unieo, angulo interiori infra apicem appenso, anatrupo. Styli ovariis continui, in unicum brevem, quadri-quinquesuleam, rectum coaliti. Stigma quadri-quinquelobum v. dentatum. Drupae 4 v. 5 , ant ahortu interdum pauciores, sessiles, patentiusculae, saepissime exsuccae, testa membranacea. Embryonis exalbuminosi, orthotropi cotyledones carnosae, radienla brevissima, inter cotyledones retracta, supera. - Arbores $v$. frutices Am erica e tro. picae; folits alternis, in iisdem ramis nonnullis simplicibus, plurimis ternatis $v$. abrupte aut impari. pinnatis, foliolis oppositis, aut rarius subalternis, intege rimis, coriaceo nitidis v. rarius pubescentibus, floribus albidis, virescentibus aut carneo-flavicantibus, saepe melliodoris, axillaribus $v$ terminalibus, in paniculas nunc breves, racemuliformes, nunc magnas et ramosissimas dispositis, pedicellis bracteolatis.

$\mathrm{Sim}$ a b a St. Hilaire in Bullet soc. philomat. 1823,p. 129. Plant remarq. Brasil. t, 10, 11. Flor. Brasil. I.t. 14. Kunth in Humb. et Bonpl. Nov, gen. et sp. VI. 18 t. st4. a b. DC. Prodr, I. 733. Adr. Jussien in Mem, Mus. XII, 515. $t .45$, Meisn. Gen. 65. (67) Sim a b a Aublet Guian. I, 400. $t .153$. et A r u ba Anblet Op. cit. I. 293, t, 115. P h y llo s te nt a Necker Elem. n, 1075. Z wing e r a Schreber Gen, n. 1759.

5๑65. Somaden GARTN, Flo r e s hermaphroditi. Ca ly $\mathbf{x}$ brevis, quadripartitus. Corolla e petala 4 v. 5 , hypogyna, calyce multo longiora, aestivatione contortim imbricata, sub anthesi patentiuscula. S t a min a 8 v. 10 , hypogyna, corolla breviora, snhaequalia; fil a me n $t a$ squamulae brevis, pilosae dorso inserta, subulata, a $\mathrm{th}$ erae introrsae, biloculares, ovatae, dorso supra basim insertae, longitudinaliter dehiscentes. Ovaria 4 v. 5 , gynophoro brevi, stipitiformi, angnstiori insidentia, libera, unilocularia, ov ulo unico, anguli interiori infra apicem appenso, anatropo. Sty li ovaris continui, basi discreti, mox in unicum petala superantem coaliti; s $\mathrm{tig} \mathbf{m a}$ acutum. Drupae 4 v. 5 v. abortu pauciores, saepe solitariae, compressae, exsuccae, rugosae, uniloculares, monospermae. Se min a inversa, testa membranacea. Embryonis exalbuminosi, orthotropi cotyle don es carnosae, radicula brevissima, inter cotyledones retracta, supera. - Arbores $v$. arbusculac, in Asia tropica et in Madagas. caria indigenae; faliis alternis, petiolatis, sim. plicibus, integerrimis, subtus reticulato-venosis, ad nervorum axillas glandulosis, pedunculis axillaribus v. terminalibus pendulis, apice in umbellam quin. que-multifloram, bracteis minutis basi involucratam divisis, fioribus majusculis, petalis extus albidis, intus sanguineis, calycis laciniis saepe basi extus biglandulosis.

Samadera Gärtner $I I .352, t, 139$. Adr. Jussieu in Memi. Mus, IIT. 516. t. 27. f. 46. Presi Symb. $t$. 51. Wight et Arwott Prodr. I. 131. Hooker Ic, C. 7. Meisner Gen, 65. (47.) $\mathrm{S}$ a m and u r Liau, Flor, Zeyl. 433, Lo candI Adurxou Fam, II. 449. Vittm a n вia VahI Symb. III St. $t, 60$. Ni ot a Lam. t. 299. DC. Prodr. T. 592. Wallich Plant as. rar. $t$. 108. Biporeila Thouars Gen, madagase, n. 46. Ma ud y ta Cammers. mso. Manuagala Manuel Blanco Flora de Eilippinas 306.

\section{GENERA SIMARUBACEIS AFFINIA.}

5D68. Nima HAMILT. Flores hermaphroditi. Ca l y x quinquepartitus, persistens. Corollae petala 5, hypogyna, oblonga. Stamin a 5, hypogyna; fila menta basi dilatata, antherae introrsae, bilocnlares, Iongitudinaliter dehiscentes. Ovaria 5, disco crasso insidentia, in unicem coalita, pilosa. Styli 5, coaliti, superne distineti, revoluti, lobis intus stigmatosis, Ca p$8 \mathrm{u}$ la e 5 v. abertu pauciores, subrotundae, monospermae. Se mina inversa. Embryonis exal buminosi cotyled on es crassae, carnosae, $r a-$ dicula brevissima, supera. - Arbuscula nepalensis; foliis alternis, imparipinnatis, quadrijugis, foliolis serratis, floribus corymboso paniculatis.

$\mathrm{Ni}$ a Hamilt. msc. Adr. Jussieu in Mom. Mus. XIT. 516. Meisner Gen, 65. (47.) $\mathrm{S} \mathrm{im} \mathrm{a} \mathrm{b} \mathrm{a} \mathrm{quass} \mathrm{io} \mathrm{ides} \mathrm{Doll.}$

596\%. Harroisonia R. Bh. Flores hermaphroditi. Calyx brevis, quadrifidus. Corolla e petala 4, hypagyna, calyce unulto langiora, aestivatione subvalvata, sub anthesi inflexa, S ta. mina 8 , hypogyna, petala aequantia, alterna iisdem opposita panllo breviora; fil a m en ta squamulae bilobae, eiliatae dorso inserta, subulata, antherae introrsae, biloculares, cordatae, longitudinaliter dehiscentes. Ov a ri u m stipiti hrevi, basi staminifero insidens, simplex, apice quadriloculare. Ovula in loculis solitaria, ex apice anguli centralis pendula. Styli 4 , centrales, basi discreti, mox in unum teretem, stamina aequantem coaliti. Stig m a obtusum, obsolete quadrisulcum. B a c c a globosu-quadriloba, quadrilocularis, loculis monospermis, nonnullis saepe efoetis, Semen snbglobosum, ex apice loculi pendulum, testa crassiuscnla, umbilieo prope apicem orbiculari. Embryonis exalonminusi, viridis cotyledones sibi invisem incumbentes, medis sursum replieatae, interjecta endopleurae induplicatura, radicula supera, - Frutex timorensis; ramis sparsim aculeatis, folits altcrnis, petiolatis, inferioribus tri., supremis unifoliolat is, foliolis basi dentatis, lateralibus minoribus, inaequilateris, aculeis ad basim petiolorum geminis, pedunculis axillaribus, so. 
litariis, basi simplicibus, apice corymbosim ramosis, pedicellis saepius bracteolis geminatim oppositis stipatis.

Harris on ia R. Brown msc. Adr. Jussien in Mem. Mfus. XII 517, t, 28, f. 47. Gaudichaud ad Freycinet t, 103. Meisuer Gen. 65. (74,) E b c l $\mathrm{i}$ u g i a Keichenbach Consp. 199.

\section{Ordo CCL. Zanthoxyleae.}

TEREBINTHACEARUMI genera Jussien Gen, 374. DIOS. MEARUM genera et PTELEACEAE Kunth, DC. Prodr. I. 725. II. 82. ZANTHOXYLEAE Adr. Jussiea in Mem. Mus. XII. 422, 497. Battling Ord nat.385. X ANTHOX XLACEAKL Lindley Introduct, edit. II. p. 135.

Arbores, arbusculae v. Frotices, inermes v, interdum acnleati. Foli a alterna v. opposita, simplicia aut saepius abrupte v. imparipinnata, petiolo in nonnullis marginato $\mathrm{v}$. alato, foliolis alternis sive oppositis, saepissime pellucido-punctatis, rarius epunctatis, integerrimis v. serratis. Stipula e nullae.

Flores polygami, abortu saepissime unisexuales, rarius hermaphroditi, in iisdem v. in diversis inflorescentiis monoici v, dioici, regulares, axillares v. terminales, varie dispositi.

$\mathbf{C}_{\text {alyx }}$ liber, persistens v. deciduus, quadriquinquepartitus, rarius tripartitus, laciniis aestivatione imbricatis aut rarius valvatis.

Corollas petala calycis laciniis numero aequalia, iisdem alterna et longiora, ad basim gynophori inserta, aestivatione convolutim imbricata, decidua, rarissime nulla.

Masc. Stamiva cum petalis inserta, iisdem numero aequalia et alterna, plerumque longiora, rarius dupla. Fil am enta libera, filiformia v. subulata, basi aequalia, rarissime in squamulae dorso inserta. A n thera e biloculares, longitudinaliter dehiscentes.

Ovarur rudimentum, gynophoro stipitiformi insidens, staminibus brevius, rarius nullum.

Fem. Stтамisa nulla v. rudimentaria, ad basim gynophori inserta, ovario breviora.

Ovaria gynophoro insidentia, petalis numero aequalia aut rarius pauciora, nune omnino distincta $v$. basi plus minus cohaerentia, singula unilocularia, nunc in ovarium unicum, pluriloculare penitus coalita. $0 \mathrm{vula}$ in loculis gemina, contigue superposita v. collateralia, rarissime quatuor, saepissine anatropa v. semianatropa. Styli loculorum numero, nune in unum coaliti, nune basi disereti, apice cohaerentes, nunc omnino distincti, rarius brevissimi v. nulli. Stig mata distincta v. coalita.

Fructus nune simplex, bi-quinquelocularis, baccatus v. rarissime samaroideus, indehiscens, v. membranaceus aut coriaceus, in cocca intus dehiscentia delabens, nune multiplex, e drupis v. capsulis pluribus, supra gynophorum sessilibus v. stipitatis, indehiscentibus v. sutura ventrali dehiscentibus compositus, epicarpio in plurimis subcarnoso, endocarpio in nonnullis solubili, vix elastico.
Semra in loculis gemina v. saepius abortu solitaria, pendula, testa crustacea, laevi, nitida, rarissime in alam expansa. Albumen carnosum, plus minus copiosum.

Embryo in axi albuminis rectus v. leviter arcuatus, ejusdem fere longitudine. Cotyled on es ovatae v. oblongae, complanatae. Radicula cotyledonibus brevior, supera.

$Z$ anthoxyleae in regionibus tropicis totius orbis, imprimis Americae obviae, parce in regionibus subtropicis provenientes, a proxime affinibus Diosmeis fructus interiore fabrica et floribus dielinibus, a Simarubaceis ovulorum numero et seminibus albuminosis distinguuntur, ab Anacardieis plerisque, habitu affinibus, albuminis praesentia diversae.

Diversae plurimarum partes amarae v, aromaticae.

5968. Dyetioloma $D C$. F lo r e s abortu diclines. C a l y x quinquepartitus, decidnus, $\mathrm{C}_{0}$ rollae petala 5 , hypogyna, ealyce multo majora, ovato-lanceolata, aestivatione imbricata, in acumen breve introflexum desinentia. $\mathbf{S} \mathbf{t a m}$ in a $\mathbf{5}$, petalis subaequalia et alterna; fil a menta subulata, dorso squamnlae dense lanatae ad basim gynophori inserta, a ntherae introrsae, biloculares, ovatae, erectae, dorso hispidulae, intus longitudinaliter dehiscentes, in floribus femincis rudimentariae v. efoctae. Ovaria 5, gynophoro brevi, sulgloboso insidentia, tomento denso coalita, unilocularia, in floribus masculis efoeta. Ovula 4 , suturae ventrali biseriatim inserta; e funiculis brevibus porrecta, amphitropa, micropyle supera. S t y $1 \mathrm{i} 4$, in unicum brevem, erassum coaliti; st igma capitato.quinquelobum, mox decidum. Ca p s u la e 5, distinctae, compressae, unilocnlares, introrsum dehiscentes, hivalves, tri-tetraspermae. S emina late reniformia, compressa, dorso in alas duas parallelas, radiatim reticulatas, fibra marginali connexas expansa, sinu ventrali umbilicata. Embryo intra albuminis stratum tenne homotrope arcuatus, teretiusculus, radicula supera. - Arbusculae brasilienses; foliis alternis, imparipinnatis, foliolis multijugis, suboppositis $v$. alternis, oblongis, basi inaequilaleris, integerrimis, margine glandulosis, supra glabris, subtus albidis, ramulis terminalibus floriferis, dichotome in corymbos latos divisis, pedicellis bracteolatis, floribus tomentoso-albicantibus, femineis paucis, masculis coprosis intermixtis.

D y etiolo m a DC. Prodr. II. 89. Adr. Jussieu in Mem. Mus. XII. 499, $t$, 24. Meisner Gen. 64. (46.)

5969. Pitavia MOLIN. F1ores abortu diclines. C a I y $x$ quadripartitus, decidnus. Cor olla e petala 4, hypogyna, calyce multo majora, ovato-oblonga, obtusa, aestivatione imbricata. St a $\mathrm{m}$ in a 8 , ad basim gynophori, in floribus mascnlis oblongi inserta, omnia fertilia, alterna petalis opposita breviora; filamenta sululata, petala aequantia, a ntherae introrsae, bilnculares, cordatae, erectae, longitudinaliter dehiscentes. Ovaria 4, gynophore tetragono, carnoso insidentia, libera, nnilocularia, in floribus masculis rudimentaria. Ovula in locnlis gemina, suturae ventrali collateraliter inserta, horizontalia, semianatropa? Styli 4 , terminales, basi distineti, 144 
superse in nnum brevem, crassum coaliti; stigm a minute quadrilobum. Dra pa e 4, v, abortu pauciures, distinctae, rarne densa, putumine tenui, monospermo. Sem en ovoideo-oblongum, testa crustacea, nitida. E m b r y o n i s exalbuminosi (?) recti cotyled ones foliaceae, planae, radi. cula brevis, supera, - Arbor chilensis, sempervirens; foliis petiolalis, simplicibus, oppositis, $v$, ternatim verticillatis, lanceolatis, obtusis, serratis, glaberrimis, pellucido-punctatis, aromaticis, pedunculis axillaribus trichotome paniculatis, ad di visuras opposite bibracteatis, pedicellis bracteolatis, floribus femineis in distinctis ramis (an arboribus?) minus copiosis, fructibus amarissimis.

Pit a vi a Molina Crili edit. 2, p. 287. Don in Edinb. new philosoph, Journ, XrII, 24t, Gal vexi a Ruiz et Pavon Syst. I, 97. Adr, Jussieu in Mem. Mus, XII. 500, t. 25 f. 37. Meisuer Gen, 64. (46.)

5อริอ. ำ hermaphroditi. Cal y $x$ quadripartitus, Corolla e petala 4 , calyrem aequantia v. superantia. Stamin a 4 , ad hasim gynophori brevis, quadritobi inserta, petalis alterna; fil amenta subulata, antherae introrsae, biloculares, Iongitudinali ter dehiscentes. 0 v a ria 4 , gynophoro insidentia libera, unilowularia, glabra. Ovula .... St y li acuti, distincti, reflexi; $s t i g m$ a $t$ a simplicia. D r upae 4 v, abortu pauciores, munospermae. Se m ina inversa. E $\mathrm{mb}$ ryo intra albnmen carnosum rectus, cotyledonibus crassiusculis, radicula supera. - Frutices, in Asia et Africa tropica indigeni, amarissimi, saepissime pube rufescenti, simplici vestiti; foliis alternis, imparipinnatis, quadrisexjugis , foliolis oppositis, integerrimis v. serratis, epunetatis, flnribus minimis, intus purpurascentibus, in spicis axillaribus, oblongis, interrupte glomeratis, glomerulis brevissime pedicellatis, bracteolatis.

B ruce a Miller Fasc. t. 25. Heritier Stirp. 19. t. 10. Guernset in Bullet. soc. philomat. 3. n, 84. p. 189. Rox. burgh Flor. Ind. edit, Wallich, 1. 469. Kunth in Annal. sc. nat. IT. 368. DC. Prodr. IT. 88. Adr. Jussieu in Mem. Mus. XIT. 501. Meisner Gen. 65. (47.) Decalsne in Nouv, Annal. sc. nat, III, t. 20. Gonus Loureiro Flor. cochinok, 809. Wo og i ù o os Brute Abyssin. edit. gall, V. 87, t. 21.

5981. Ervanellin RUIZ et PAV. FIores diclines. Caly x quadri-quinquepartitus. Coro Il a nulla. Masc. Stamina 8 - 10 , disci depressi, hirsuti, ime calyei adnati margini octo-decemlobo inserta, calycem paullo superantia; fil ament a subulata, ant herae introrsae, biloeula. res, ovatae, cordatae, dorso affivae, longitudinaliter dehiscentes. Ovari a sessilia, rudimentaria. Fem. Stamina calyce multo breviora, antheris efoetis sterilia. Ovaria 4 v. 5 , sessilia, distincta, hirsuta, uniloenlaria. 0 v n 1 a gemina, suturae ventrali collateraliter inserta. St y li terminales, breves, recurvi; $s \mathrm{t} i \mathrm{~g} m$ a $t$ a simplieia. C a p sula e 4 v. 5, aut abortu panciores, patentes, nniloculares, bivalves, endorarpio cartilagineo-lignoso, solnto, hine fisso v. bivalvi, monodispermo. Se mina inversa, epidermide membracea, testa erustacea, umbilico longe lineari. I mbryo intra albumen rectus; cotyled o $\mathrm{n}$ bus ovatis, planis, radicula supera. - Arbores inermes $v$. interdum aculeatae, plus minus ferrugineo-tomentosae, in America tropica et in insulis sandwieensibus indigenae; folits oppositis $v$. ternatim verticillatis, simplicibus, trifoliolatis $v$. in eodem ramulo interdum imparipinnatis, foliolis coriaceis, integerrimis aut saepius crenatoserratis, impunctatis, stipulis petiolaribus geninis, parvis, caducis, floribus in paniculas v. corymbos axillares aut terminales dispositis, pedicellis bracteatis, floribus interdum per excessum septempartitis, tetradecandris.

B ru nellia Ruiz et Pavon Prodr, $71, t, 12$. Humb, et Bonpl. Plant. aequinoct. $T, 210, t, 59-62$, Nov. gen. et sp. $V I I$, 42. Kunth in Annal, sc, nat, II. 361. DC. Prodr. II. 87. Adr. Jussieu in Mem. Mus. XIT. 501, Meisuer Gon. 64. $(46$.

ฐ๑ร2. Zantlaoxylon KUNTH. F I ores abortu polygami. C a l y $x$ tri-quadri-quinquefidus v. partitas. Corollae petala hypogyna, calyeis foliolis numero aequalia et alterna, longiora, aestivatione imbrieata, rarissime nulla. M a s c. Stamina hypogyna, petalis numero aequalia et al. terna; fila in en ta filiformia v. subulata, an thera e introrsae, biloculares, longitudinaliter dehiscentes. Ovarii simplicis v. multiplicis rudimen. tum, gynophoro brevi v. stamina subaequanti impositum. Fem. St am ina nulla v, brevissima, ananthera, squamnliformia, rarius antheris efoetis instructa. O varia petalis numero aequalia vauciora $(5-1)$, gynophoro subgloboso v. cylindrico insidentia, plus minus approximata $v$, inferne coalita, unilocularia. Ovula gemina, suturae ventrali medio appensa, anatropa. Styli terminales, distincti $v$. superne coaliti, interdum brevissimi v. subnulli; stig mat a capitata, distineta v. coalita. C a ps u la e 1,5 , in apice gynophori sessiles v. stipitatae, semibivalves, endocarpio cartilaginen, adnato v. solnto, mono-dispermae. S e min a ovata v subglohosa, e funiculo membraniformi v, filiformi propendentia, epidermide sulscarnosa, demam exsiccata, membranacea, testa ussea, atra, nmbilico ventrali, lineari. E m b r yo in axi albuminis rectus v. subarcuatus; cotyledonibus ovatis v. orbieularibus, planis, radi cula supera. - Arbores v. frutices, in America tropica copiose, parcius in America boreali calidiore, in Asia et Africa aequinoctiali crescentes, saepe ramulis, petiolis $v$. nervis foliorum aculea tis armati; foliis alternis $v$. opposilis, rarius simplicibus $v$. trifoliolatis, saepissime abrupte v. imparipinnatis, petiolo communi nonnunquam alato, foliolis plerumque pellueido punctatis, floribus parvis, virescentibus $v$. albidis, axillaribus aut terminalibus, fasciculatis, spicatis, ramosis, cymosis, corymbosis $v$. paniculatis, bracteatis.

Z a n thoxylan Kunth in Huorb. et Banpl. Nov, gen.et sp. VI, 1. DC Prodr. T. 725. St. Hilaire Flor. Brasil. I. 24. Adr. Jussieu in Mem. Mus, XII. 503. Wight et Arnott Prodr. I. 185. Torrey et A. Gray Flora of North-Amer, I. 214. Meisuer Gen. 64. (46.)

a. EUZANThoxyLUM. Caly $\mathrm{x}$ quinquepartitus, petaloi. deas. Corolla nulla. Stamia 5 , Ovaria 5 . $\mathrm{Z}$ a n th ox y $1 \mathrm{um}$ Colden Novebor, 68 Linn. Gen, n, 130. Pag ar a Adanson Fam, Ir. 364. (Daham. Arbr,, , $t, 97$. Adr. Jussien $O_{p}$, cit. $t, 25, f .38, b$, )

b. PTERoTA $P$. Brown. C a 1 y $x$ quadripartitus. Corol1 a e petala 4. Stamina 4 . 0 varia 2 v. interdum 1. - Perota P. Browae Jam 189. Fa g a ra Jacq. dmer. t. 14. Liun. Gen. n, 1109. L a caris Hamilt, ex Waltich Catalog. n. 7119 .

c. FAGARA Lam, Ca Iy $x$ tripartitus. C o roll a e petala 3 . St a min a 3. Ovaria 3. Fag a r a Lam. Dict, 11.626 . IIl. $t .84$. To bi ni a Desvaux in Hamilt. Prodr. Flor. Ind. occid. 56. (Sloane Jam. II. t. 168. f. 4.)

d. OCHROXYLUM Schreb. Caly $\mathrm{x}$ quiaquepartitus. $\mathrm{Co}$ rollae petala 5. Stamina 5 . 0 varia 3 . -0 chro. $x$ y 1 u m Sehreber Gen. $n, 508$. C u r ti s i a Schreb. 1798. $\mathrm{K}$ a m p ma $\mathrm{n}$ i a Rafinesque in New.York Medio. Moposit. II. Herad. $\nu$. 350. P en'tanome Moc. et Sessé Flor. mex. (Adr. Jussiea Op. cit. t. 25. f. 38. a.)

- PoHlana Nees et Mart. Cal y x quinquepartitus. Co. rollac petala 5. Stamina 5. Ovarium 1. - Pa b- 
1 a n a Nees et Martius in N. A. N. C. XI. 185, L a ng s. d o r fi a Leaudro in Act. Monac, 1819. p. 229. M a q u e$r$ i a Commers. (Adr. Jussieu $O_{p}$, cit, $t, 25, f$. 38, c.)

f. RHETSA Wight et Arnott. C al y $\times$ quadripartitus. C orolla e pelala 4. Stamina 4. 0varinm 1. - Z. R hets a DC. T y pallia Deunst, z. Hort, Malab, $\nu .34$.

g. Aubertia Bory. Calyx quadripartitus. Corollae petala 4. S ta mina 4. O varia 4. A ubertia Bory Voy. Afr. 1. 336, t, 18, - ?.A m p a c us Rumph Amboin, II. 186, t. 62. Pi cra s ma Blume Bijdr. 298. Meisner Gen. 64. (46.)

5973. Flackburmia FORST. FInres abortu monoiei. Ca I y $x$ quadrifidus. Corolla petala 4, hypogyna, calycis foliolis alterna et longiora, aestivatione induplicatim valvata. Ma s c. Sta min a 4, hypogyna, petalis alterna et breviora ; filamenta subnulla, antherae introrsae, biloculares, cordato-ovatae, lougitudinaliter dehiscentes. O varii radimentum conicum, sinplex. Fem. Stamina nulla. Ovarium unicum, gynophoro brevissimo insidens, uniloculare. OvnI m m unicum (?) cavitati prope apicem appensum, anatropum. Stylus brevissimus, ovario continues; stigma obtusum. C a p 8 ula subglobosa, sessilis, nnilocularis, semibivalvis, endocarpio cartilagineo adnato. Sem e $n$ globosnm, e funiculo filiformi propendens, epidermide membranacea, testa ossea, atra. E mbryo in axi albuminis carnosi obliquus; cotyledonibus foliaceis, orbicularibus, planis, ra di c u la brevissima, supera. Arbor insulae Norfolk; foliis alternis v. oppositis, imparipinnatis, bi-quadrijugis, foliolis oppositis, breve petiolulatis, ovatis, acuminatis, integerrimis, glabris, paniculis axillaribus terminalibusque confertis, fructiferis cernuis.

B lack bu n ta Forst. Char. Gen. t. 6. DC Prodr. II. 38. Adr. Jnssieu in Mem. Mus. XiI. 510. in not. Endlicher Flor. Norf, 87. Meisu, Gen, 65. (46.) B i a e k b o u r n e a Kunth in Annal. sc. nat, II, 356. P tele a pin nat a Lisu, f.

59\% 4. Hoymia $A D R$, JUSS. Flores dielines. Mase. Calyx brevis, quinquefidus. C orolla e petala 5 , hypogyna, calyce multo longio. ra, ovato-lanceolata, acuta, coriacea, aestivatione valvata, sub anthesi erecta. $\mathrm{S} t$ a $\mathbf{m}$ in $\mathbf{u}$ m rudimenta 5 , calycis laciniio opposita, linearia, ciliata. Ovaria 5, gynophoro brevi discoideo insidentia, angulo centrali coalita, unilocularia, dorsu sulcato subbiluba, glanduloso-punctata, 0 v u I a gemina, suturae ventrali superposite inserta, superius adscendens, inferius pendulum Stylus centralis, crassus, pentagonus; st ig ma dilatato-peltatum, quinquesulcum. Cap 8 u la e 5 , basi subcoalitae, apice divergentes, glandoloso-tuberculatae, dorso bivalves, endocarpio cartilagineo solubili, abortu monospermo. Semina inversa, subglobosa, testa sub epidermide laevi tessellatim foveolata, umbilico ventrali, lineari. Embry o intra albumen earnosun rectus; cotyledonibus ovatis, tenuibns, radicula sapera. - Frutex sinieus, in Japania cultus; trunco erecto, ramis patentibus, decussatis, farctis, ramulorum medulla ampla, foliis oppositis, imparipinnatis, bi-trijugis, foliolis brevissime petiolulatis, obovato-ellipticis, integerrimis, utrinque molliter pubescentibus, fioribus divicis, in cymam dichotomam dispositis, cymae ramis crassis, subtetragonis, cum bracteolis, pedicellis basi articulatis et calycibus tomentoso-villosis, rubro-fuscescentibus.

Boym i a Adr. Jussieu in Mem, Mus, XII. 507, 4, 25. f. 39. Siebold et Zucearini Flor. Japon. . . 50, t. 21. Meisner Gen, 64. (46.) 0u-tehou-y u (Go-sju-ju) Sin.

5\$ร 5. Tod Thlia JUSS, F l ores abortu diclines, Calyx brevis, quinquedentatus, Corollae petala 5, hypogyna, calyce multo majora, "vatu-oblonga, acuta, aestivatione imbricata. M a $8 c$. $\mathbf{S} \mathbf{t}$ a $\mathbf{m}$ in a 5 , ad basin gynophori inserta, petalis alterna et longiora; fil amenta filiformia, antherae introrsae, biloculares, ovatae, dorso supra basim insertae, longitudinaliter dehiscentes. O varii rudimentum prismatico-pentagonum, gy nophoro brevi, conico impositum. F e m. Sta m in a 5 , ananthera. Ovari u m gynophoro brevi, quinquesulco insidens, sinplex, ovoidenm, earnosum, quinqueloculare. 0 v u I a in lacnlis gemina, angulo centrali superposite inserta, superius adscendens, inferius pendulum. S t ig m a subsessile, latum, peltato quinquelobum. Fru ct as carnosus, punctates, quinquesulcus, quinquelocularis, endocarpio cartilagineo, tenui, loculis monospermis. Senina inversa, angulato-reniformia, testa ossea, sinu umbilicata, E mbryo intra albumen carnesum homotrope arcuatus; cotyledonibus ovato oblongis, radicula supera. - Frutices in Asia tropiea, in insulis Borbonicis et Madagas. caria indigeni, nonnunquam ramulis, petiolis, nervis et pedunculis aculeatis Zunthoxylorum more armati; foliis alternis, trifoliolatis, foliolis pellucidopunctatis, basi nonnunquam biglandulosis, floribus paniculatis, paniculis axillaribus, solitariis aut rarius geninatis, pedicellis bracteolatis, masculis et femineis in diversis ramis $v$, arboribus.

Toddalia Jussien Gen, 321. Lam. t, 139. f. 1. (ercl. f. 2.1 Kunth in Annal sc, nat. MI. 356. DC. Prodr. II. 83, exel. sp. Adr. Jussieu in Mem. Bus, XII. 508, $t, 26 . f$. 40. Wallich Plant. As. rar. $t$ 232. Wight et Arnott Prodr. 1.149. Meisner Gen, 64. (46) S co poli a Smith Ic. inedit. II. 34 . non alior. Crantzia Schreber Gen, n. 362. Paulliaia as iatic a L.

5986. Wepris COMMERS. Flore 8 abortu diclines. Caly $\mathrm{x}$ brevis, quadripartitus. Corolla e petala 4, hypogyna, calyne multo majora, ovato-oblonga, acuta, aestivatione imbricata. Ma $8 \mathrm{c}$. St a mina 8 , ad basim gynophori inserta, quatuor petalis opposita breviora; filamenta complanatosubulata, an $t$ herae introrsae, biloculares, ovato-oblongae, dorso supra basim affixae, longitudinaliter dehiscentes. O varii rudimentum quadripartitom, gynophoro brevi insidens. F em. S tamin um rudimenta squamulae 8 , minutissima, ad basim gynophori. Ovari um gynophoro brevissimo, obconico insidens, simplex, subglobosum, carnosum, quadrilocnlare. Ov $\mathrm{nJa}$ in Ioculis gemina, angulo centrali prope apicem collateraliter inserta. S $t$ igm a sessile, latum, convexo-peltatum, in amhitu quadrilobum. Fruet us carnosus, punctatus, quadrisulcus, quadrilocularis, endocarpio lignoso, denso, Ioculis dispermis. Sem ina ovoidea, in unicun biloculare, loculo altero efneto, altero embryonifero coalita, testa ossea. Embryo intra albumen carnosum areuatus; cotyledonibus oblongo-ovatis, radicula supera. - Arbuseula barbonica; foliis alternis, trifoliolatis, foliolis integerrimis, glaberrimis, reticulato venosis, pellucido punctatis, floribus terminalibus paniculatis, masculis et femineis in diversis ramis $v$. fortassis arboribus.

Vepris Comers. ex Adr. Jussieu in Mtem. Mus. XIT. 509. t. 26. f. 41. Meisner Gen. 64. (46.) Toddalia pa. u i c u lat a Lam, t. 139, f. 2. Mirbel Elem, Bot, t, $30, f .3$.

598\%. Fitelea LINN. Flores diclines. C a ly x brevis, quadri.quinquepartitns. Corollae petala 4 5 , hypogyna, calyce multo longiora, aestivatiene imbricata, sub anthesi patentissima. 144 * 
St am ina 4 v. 5 , ad basim gynophori inserta, petalis alterna et longiora; fila in enta subulata, inferne incrassata et hirsnta, a $n$ therae introrsae, bilozulares, cordato-ovatae, durso supra basim insertae, longitudinaliter dehiscentes. Ova rii rudimentum, gynophoro oblongo, sulcato insidens. F em. Stam in a $4-5$, brevissima, antheris efoetis, O varium gynophoro convexo insidens, compressum, biloculare. Ovula in loculis gemina, angulo centraii superposite inserta, superins adscendens, inferins pendulum. Stylus terminalis, brevis; stigma bilobum. Fructus compressus, samaroideus, centro turgidus, bilocularis, indehiscens, ambitu in alam orbicularem membranaceam, reticulato-venosam expansus. S em in a in loculis aburtu solituria, inversa, oblongo-ovoidea, testa tenui, serobiculata. F m b r yo intra albumen carnosum rectus; cotyledonibus oblongo-ovatis, planis, radicula supera... Frutices in America boreali calidiore indigeni; foliis alternis, tri- v. rarius quinquefoliolatis, fuliolis integrerrimis, pellucido-punctatis, lateralibus inaequilateris, floribus albido-virescentibus, corymbosis, corymbis in paniculas axillares $v$, terminales dispositis, pedicellis bracteolatis, masculis interdum staminibus sex $v$. septem inaequalibus, femineis ovario quandoque triloculari, stigmate trilobo.

P tele a Linn. Gen, n, 152. Miller Ic, $t, 211$, Lain, t, 84. Gärtaer I. 223. t. 49, Kunth in Annal, sc, nat. $I T$, 355, DC. Prodr. II. 82. Adr. Jussieu in Mem. Mus, XII. 510. t. 26. f. 42. Meisuer Gen, 63. (64.) Torrey et A. Gray Flora of North.Amer. I. 214. B ell u c e i a Adauson Fam, $I I, 344$.

\section{GENERA ZANTHOXYLEIS AFFINIA.}

598 8. A eronyelnia FORST. C a ly $x$ brevis, quadripartitus, laciniis aestivatione imbricatis. Corolla e petala 4 , ad basim disci hypogyni inserta, calyce majora, aestivatione valvata. Stam in a 8, sub disco inserta, omnia corolla, alterna petalis opposita reliquis breviora. Ovarium ses. sile, basi disco carnoso, truncato, octogono, laevi adnatum, quadriloculare. $0 \mathrm{vula}$ in loculis gemina, angulo centrali infra apicem coliateraliter inserta, amphitropa. Stylus brevissimus v. 8uhnullus, ovario continuus; $s t i g m$ a capitatum, quadrilobum. Fruetus baccaeformis, subglobosus, quadrilocularis, sarcocarpio crasso, subcarnoso, endocarpio tenui, crustaceo, Ioculis aboriu monospermis. Se mina inversa, nucamentacea, atra, durso convexa, facie acuta, unbilico lineari. $\mathbf{E} \mathbf{m}$ bryo intra albumen carnosum rectus; cotyle donibus ellipticis, radicula brevi, supera. Arbores $v$. arbusculae, in $A$ sia et $A$ ustralasia tropica et $s u b t r o p i c a$ indigenae; foliis oppositis, petiolatis, simplicibus, integerrimis, minutissime pellucido-punctatis, aromaticis, petiolo apice interdum tumido et subgeniculato, inflorescentiis axil laribus cymoso paniculatis, pauci-mullifloris, folio brevioribus, petalis et jilamentis glanduloso-punetatis.

A $e$ rou y cli ia Forst. Char. gen, 27. Blume Bíjlr. 244. Sehott Rufac, 3. t.2. 3. Meisuer Gen, Comment. 44. C y min 0 s m a Gärtner I, 280, t. 58. DC. Prodr, I, 729. Adr. Jus. sieu in Mem. Mus, XII, 465, t, 17. f, 11. Meisu. Gen, 60. (44.) J a $\mathrm{m}$ bolifer a Lian. Gen, n, 479. exel. synon. Vahl Symb. III. 52. t. 61. Dryander in Linn. Transaet, Ir. 233. Gel a Loureir. Flor.cochinch. I. 285. A n ke ad a Herm. Mus, 73, La $x$ ma nn fa Suith. Dorle n a Denust. z. Hort, Malab. V. 15. L a wso nía A cron y chia Liun, f. Labillard. Nov, Caled. $t .65$.

$$
\text { * }
$$

59ร9. Spathelia LINN. Flores hermaphroditi, Caly $\mathbf{x}$ coloratus, quinquepartitus, laciniis subaequalibus, membranaceis, oblengis, ob- tusis, aestivatione imbrieatis. Corolla e petala 5 , hypogyna, calyce longiora, aequalia, oblongoelliptiea, subconvexa, aestivatione imbricata. Discus nullus. Stamina 5 , hypogyna, petalis alterna et breviora; fila m e n ta libera, inferne villosa, complanata, tricuspidata, cuspide medio longiore, antherifero, antherae biloculares, lineari-oblongae, basi bifidae, dorso supra basim insertae, incumbentes, longitudinaliter dehiscentes. Ovarium sessile, subeonieum, inferne incrassatum, superne triangulatem, triloculare. 0 v uI a in loculis gemina, collateralia, tuberculo ex axi centrali affixa. Stigm a ta 3 , sessilia, obtusa, patula. Drup a exsucea, triquetro-alata, putamine lapideo, triluculari, rotundato-triguno, angulis atque loculamentis stipatis appendice teretiuscula, superne in moeronem prominente, interne canaliculata, resina fluida scatente. Semina in loculis solitaria, inversa, teretiuscula, utrinque acnminata, testa coriacea, e fibris transversis cuntexta, cum putamine prope canales resiniferos cohaerente. E mb ryo intra albumen carnosum, modice erassum rectus, ejusdem longitadine; cotyledonih u s lineari-eblongis, planis, tenuibus, $r$ a d i eu I a brevissima, supera, - Arbuscula jumaicensis; trunco simplici, inferne foliorum delapsorum cicatricibus toroso, apice comoso, foliis alternis, confertis, impuripinnatis, multijugis, Sorbi aucupariae foliis similibus, foliolis sessilibus, subalternis, lanceolatis, basi rotundatis, crenatis, glabris, nervis rhachique supra villosulis, floribus inter folia racemosopaniculatis, terminalibus, purpurascentibus.

S p athelia Linn. Gen. n. 323. Lam. t, 209. Gärtner 1. 278. t. 58. Ker in Bot. Reg. t. 670. Kunth in Annal. sc, nat, II. 357. DC. Prodr. IT. 84. Meisuer Gen. 77. (56.) S p a the P. Browat Jam, 187.

5980. Ailantlums DESFONT. Flores polygami. Masc. Cal $\mathbf{y} \times$ brevis, quinquefidus, laciniis ovatis, aequalibus, aestivatione imbricatis. Co roll a e petala 5, sub diseo hypogyno inserta, calyee longiora, sessilia, ovata, aestivatione indnplieation valvata, sub anthesi patentia. St a mina 10 , sub disco inserta, corollam aequantia $\mathbf{v}_{+}$ superantia, alterna petalis opposita paullo breviora ; fil a me n t a filiformia, basi hispida v. glabra, apice flexuosa $v$. stricta, a $n t h$ era introrsae, biloculares, oblongae, basi bifidae, dorso insertae, longitudinaliter dehiscentes. Dis e u s centralis, basi petala et stamina gerens, superne productus in annulum sinuato-quinqueplicatum, plicis petalis oppositis. Ovaria rudimentaria, quinque v. pauciora, minuta, compressa, disco immersa. F e m. et Herm. Calyx maris, persistens. Corolla maris. S $t$ a $m$ in a in floribus hermaphroditis abortu saepius $2 v, 3$, in femineis nulla. $\mathrm{D}$ i s e u s maris. Ovaria 2 v. 5 , sessilia, libera, compressa, uni. locularia, ovulo unico, suturae ventrali infra apicem inserto, semianatropo, micropyle supera. Styli ovariis infra apicem intus continui; stigm a t a subeapitata. S a m arae $3 \ldots 5$, v. aborta paueiores, oblongae, compressae, membranaceae, reticulatae, medio tumidae, uniloculares, indehiscentes, monospermae. Sem en oblique ovatum, ex angulo interno sub apice suspensum, testa membranacea, endopleura carnosa, testae arcte adnata. Embryonis exalbuminosi, recti e otyledones foliaeeae, suborbiculatae, planae, radicula brevis, supera. - Arbores Asiae tropicae, excelsae; foliis alternis, imparipinnatis, foliolis oppositis, epunctatis, obliquis, dentatis $v$. 
serratis, paniculis terminalibus, ramosis, bracteatis, floribus albido-virescentibus $v$. flavescentibus, in paniculis terminalibus amplis, ramosis fasciculatis, pedicellis bracteolatis.

A il an thus Desfont, in Aot. Academ. Paris, 1786. p. 263. $t$. 8. Heritier Stirp. t. 84. Roxburgh Plant. Corom. t. 23. Kunth in Annal. sc. nat, II. 358. DC. Prodr. 11. 88, Adr. Jussieu in Mem, Mus. XII, 311. Wight et Arnott Prodr. I. 150. Meisner Gen. 65. (47.)

\section{GENERA DUBIA.}

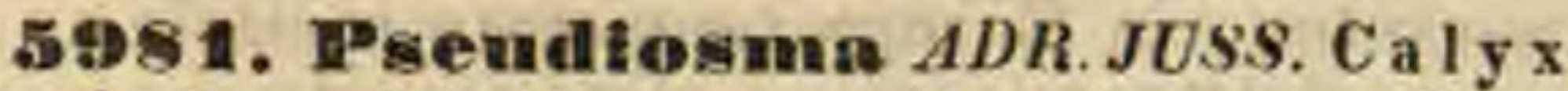
pentaphyllus, foliulis ovatu-vblongis, patentibus. Corolla e petala 5, oblonga, ealyce longiora. Antherae 5, sessiles, lineares, apice conniventes. O vari u m quinquelobum, nectario crasso, coronaeformi cinctum. St y l us staminibus aequalis; stigma simplex. Capsula e 5, pedieella tae, subreniformes, monospermae. Semina exarillata. - Arbor cochinchinensis, parva, ra. mosissima, expansa; foliis alternis, lanceolatis, integerrimis, glabris, racemis subterminalibus compo. sitis, floribus flavis.

Pseudjosma Adr. Jussieu in Mem. Mus, XII. 519 Di os un a Loureiro Flor, cochinch, 200, нон Lius.

59S\%. Tetradiuma LOUR. Cal y $\mathrm{x}$ minimus, tetraphyllus, persistens, foliolis acutis, patentilus. Corolla e petala 4 , ovata, incurva, suberecta, calyce longiora. Stamina 4 ; fila in e n ta crassa, subulata, pilosa, petala aeguantia, antherae biloculares, ovatae, erectae. Ovarium subrotundum, quadrilobum. Stylns nullus; stigmat a 4 , subulata, erecta. C a p 8 u a e 4 , subro tundae, monospermae, apice dehiscentes. Semi n a subrotunda, nitida, arillata. - Arbor cochin chinens is, mediocris; ramis adscendentibus, foliis imparipinnatis, lanceolatis, glabris, integerrimis, racemis subterminalibus, trichotomis, amplis, floribus albicantibus.

Tet radiu a Loureiro Flor. cochinch, 115, DC. Prodr. IT. 88. Adr. Jussieu in Mem. Mus. XIT. 520. Meiswer Gen. 65. (47.) el 76. (55.)

5983. I hallagomia $B L U M$. F 1 o res dioici. Ca I y x parvus, quadrifidus. C o rolla e petala 4 , sub disco annulari brevissimo inserta, calyce triplo longiora, basi lata, aestivatione valvata, sub anthesi patentia. Ma sc. Stamina 4, petalis alterna et breviora, a $n$ the ra e introrsum incumbentes. Ovarii rudimentum; stigmate quadrifido. Fem. Stam in a 4 , ananthera, Ovarium globoso-depressum, quadrisuleatum, quadriloculare, loculis biovulatis. St y 1 us brevis; st $\mathrm{ig}$ ma peltatum, magnum. Ca p s la globosa, sulcato-quadriloba, quadrilocularis, S e m in a in loculis gemina, superposita, angulata. - Arbor javanica, procera; foliis oppositis, imparipinnatis, foliolis oblongis, integerrimis, epunctatis, corymbis axillaribus et terminalibus.

Philagonia Blume Bijdr, 250. Nees in Flora 1825. p. 125. DC. Prodr. II. 90. Adr. Jussieu in Mem. Mus. XII. 521. Meisuer Gen, 64. (46.)

5994. IBischofin $B L U M$. F 1 ores diniei. Caly x pentaphyllus, in femineis parvus. Corolla nutla, $M$ a $8 \mathrm{e}$, S $t$ am in a 5 ; fil amentis brevibus, in urceolum superne peltatum connatis, apice vix liberis, a $\mathbf{n}$ h eris bilocularibus. Fem. Stami. n nm rudimenta squamaeformia, interdum duo. Ovariu ovato-globosum, triloculare. Ovala in loculis gemina, pendula. Stigma ta sessilia 3 , linearia, reflexa, basi approximata. Fructus (an dehiscens) intus tricocens, coccis dispermis. - $\mathrm{Ar}$ bor javanica, valida, ligno durissimo, rubicundo; foliis alternis, trifoliolatis, foliolis serrulatis, fioribus paniculatis, axillaribus v. lateralibus, pedicellis basi tribracteolatis.

B is ch ofl a Blume Bijdr, 1163. Meisuer Gen. 64. (46.) et 77 . (56.)

5985. Asaphes $D C$. C a l y x brevissimus, quadri-quinquedentatus. Coroll a e petala 4-5, linearia. Stamina 4_5, hypogyna, petalis breviora. Ovarium liberum. Styli et stigmata $\mathbf{3}$. Capsula pisiformis, umbilicata, quadrisulca, quadrilocularis, quadrivalvis, tetrasperma. - Frutex c apensis, Rhois facie; foliis allernis, petiolatis, ternatis $v$, rarius binatis, interdum inferioribus simplicibus, foliolis parallelo venosis, floribus terminalibus paniculatis, minutissimis.

As a phes DC. Prodr. II. 90. Meisner Gen. 76. (55.) B o s c i a Thuab. Nov. Gen. 1298. Flor, cap. I. 587, Adr. Jussieu in Mem. Mus. XII. 521. non Lam. Dun e a nia Rei. cheab. Consp. 197. Meisaer Gen. 65, (47.)

5986. Plnellime $L A B I L L$. C a I y brevissimus, quadridentatus. Corolla hypogyna, subrotata, quadripartita, laciniis patentiusculis, apiee inflexis. Sta m in a 4 , imae corsllae inserta, ejasdem laciniis alterna; fil a m enta brevissima, a ntherae ovatae, biloculares, subversatiles. Ovari u m tetragonum, quadriloculare. Ovula .... Stylus brevis; stigma quadridentatum. Cap8 u la corticata, quadrilocularis, loculis suberosis, intus dehiscentibus, monospermis. .... - Frutex Novae-Cal edoniae, non satis notus, vix hujus loci; foliis alternis, versus apices ramorum approximatis, comosis, spathulato-oblongis, acuminatis, glabris, margine crassiusculo, subreflexo subdentalis, subtus glaucis, petiolo brevi incrassato gibbo, racemis axillaribus compositis, folio brevioribus, bracteis exiguis, foliorumque axillis barbatis.

P helli ne Labillard. Nov. Caled, $35, t, 38$.

598\%. Cuindilia GILL, Calyeis foliola oblonga, extus pubescentia. Corolla.... St a. m in a libera. Ovarium toro parvo insidens, trilobum, triloculare, pubescens. Ovula in loculis solitaria, e basi anguli centralis adscendentia. St yI us unieus; stigma trilobum. Fruetus tricarpellaris, trilobus, lobis (duobus saepe abortivis) subglobusis, crasse crustaceis, indehiscentihus, monospermis. S emen globosum, adscendens, testa crustacea, fragili. Embry o nis exalbuminosi cotyled on es inagnae, crassae, cartilagineae, verticaliter hippocrepice curvatae, ra d i $\mathbf{a}$ lam brevem, transversam, apice sursum spectantem fere involventes, - Frutex chilensis andicola, ra mosus, foliosus; ramis oppositis, teretibus, foliorum delapsorum cicatricibus notatis, foliis oppositis, uncialibus, ovatis, vix acutis, ad basim in petiolum brevissimum, semiamplexicaulem abruptim angustatis, integerrimis, trinerviis, glabris, carnoso-coriaceis, pellucido punctatis, stipulis nullis, pedunculis axillaribus, pubescentibus.

G u indilia Gillies ex Hooker et Arnott Bot, Miscell. IIT, 170. Meisuer Gen, 62. (45.)

\section{Ordo CCLI. Diosmeae.}

RUTACEARUM genera Juss. Gen, 297. DIOSMEARUM genera R. Brown in Flinders Voy. II. 545. DIOSMBAB Adr. Jussieu in Mem. Afus, XIT, 466. Bartling Ord, nat, 386 .

Arbusculan v. prutuces, rarissime hbrbae. F olia opposita v. alterna, coriacea, simplicia, ternata v. imparipinnata, subtus saepissime glanduloso-punctata, integerrima, rarius serrulata v. sinuata, punctis glandulosis, sae- 
pissime pellucidis conspersa, aromatica. Stip u la e nullae, earum loco interdum glandulae ad petiolorum basim.

Flores hermaphroditi, aut rarius abortu unisexuales, regulares $\mathbf{v}$. irregulares, axillares v. terminales, conferti, subumbellati v. corymbosi, bracteati, interdum supra receptaculum conferti, involucro cincti, calycibus et corollis tunc abortivis, albi v. rubescentes, rarissime flavescentes.

Calyx quadri-quinquefidus v. partitus, persistens v. deciduus, laciniis aestivatione imbricatis.

Corollas petala calycis laciniis numero aequalia, iisdem alterna et majora, sub disco hypogyno, libero v. rarissime basi calycis adnato inserta, decidua aut interdum persistentia, plerumque libera et unguiculata, per aestivationem convolutim v. contorte imbricata, rarius lata basi in tubum conglutinata, et tune saepissime per aestivationem valvata, rarissime abortu nulla.

Stauina cum petalis inserta, hypogyna v. rarissime perigyna, iisdem numero aequalia et alterna, rarius dupla et tune petalis opposita (interdum etiam alternorum nonnulla) sterilia v. saltim breviora. Fil a me nt a subulata, libera, rarius in tubum coalita v. petalis adglutinata. Antherae introrsae, biloculares, dorso supra basim insertae, loculis appositis, parallelis, contiguis, intus longitudinaliter dehiscentibus, connectivo cum filamento articulato, apice saepins in processum glandulosum, interdum apice excavatum, producto.

Ovaria sessilia v, gynophoro imposita, disco cincta v. plus minus immersa, petalis numero aequalia aut pauciora $\left(5_{-}-3\right)$, unilocularia, libera v. plus minus coalita, apice semper distincta. Ovula in loculis gemina, suturae ventralis medio inserta, collateralia v. oblique superposita, superius adscendens, inferius pendulum, rarissime ovula quatnor. Styli ovariorum numero, ex eorundem margine interiore infra apicem orti, basi distincti, mox in unum coaliti, rarius solis apicibus cohaerentes. Stigmat a stylos terminantia, in capilulum tri-quinquesulcum v. breviter lobatum coalita.

Capsula tri-pentacocca, rarius monococea; cocci distincti v. basi coaliti, saepius dorso infra apicem cornuti, uniloculares, abortu monospermi, rarissime dispermi, epicarpio sicco, rudi, subcoriaceo, saepissime transversim venoso-striato, glanduloso-punctato v. muricato, apice sutura ventrali dehiscente, endocarpio laevissimo, cartilagineo, soluto, elastice bilobo, marginibus v. basi membranacea saepe cum semine secedente.

S guisa oblonga v. subreniformia, testa cartilaginea, laevi. Ál b u m e n carnosum v. nullum.
Emвryo albumine inclusus v. exalbuminosus, rectus v. subincurvus, interdum multiplex. $C_{0}$ tyled o nes oblongae, planae v. corrugatae, sese involventes, germinatione foliaceae. Ra d icula supera, recta v. inflexa.

$D$ ios meace maximo numero in Africa australi extratropica, et in Nova-Hollandia indigenae, parcius aliquantum in America tropica generantur, in Europa temperata rarissimae, ex Asia et Africa tropica omnino exules.

Ordinis, arcta affinitate ad Zanthoxyleas, et mediante Dictamno ad Rutaceas accedentis diagnosim, in endocarpio cartilagineo sub capsulae maturitate penitus soluto et elastice bilobo positam, Zanthoxyli species nonnullae subsimili fructus structura donatae, et Tetradiclis, genus Rutaceis utique accensendum, infringunt.

Tribuum e characteribus botanicis discriminatio, distributioni geographicae pulehre convenit.

Diosmeae plures ob vires aromaticas corroborantes inter medicos celebres.

TREIBES I. CUSPARIEAE DC. Mem. Mus. IX. 141. Flores regulares v. irregulares. Petal a libera, in corollam gamopetalam coalita. Stamina in polypetalis petalis numero aequalia, libera, omnia fertilia, in gamopetalis iisdem saepissime adglutinata, nunc omuia antherifera, nunc $2-5$ ananthera, uno v. duobus tune supra petalorum numerum additis. Ovaria petalis numero aequalia, libera v. magis minusve coalita, unilocularia, biovulata, ovulis superpositis, superiore adscendente, inferiore pendulo. Sty li superne v. juxta totam longitudinem coaliti. S e m in u m testa coriacea. Embry on is exalbuminosi, curvati cotyledones magnae, saepissime biauriculatae, corrugalae, exterior interiorem involvens, radicula inflexa, inclusa. - Arbores v. frutices, rarissime herbae, in America tro pic a crescentes; foliis alternis $v$. rarissime suboppositis, uni-v. saepius trifoliolatis.

5988. Splranthera $S T$. HIL. Calyx brevis, cupulaeformis, profunde quinquedentatus, pentagonus. Cor oll a e petala 5 , suh disco hypogyno inserta, longe linearia, in ungnem angustata, subfaleata, snbinaequalia, aestivatione imbricata, sub anthesi erecto-patula. St a mina 5 , rum petalis inserta, iisdem alterna et paullo breviora; fil amenta filifurmia, tuberculata, antherae intrursae, biloculares, oblongo-lineares, locnlis oppositis, longitudinaliter dehiscentibus, cannectivo erasso, demum spiraliter revolnto adnatis. Ovarium gynophoro stipitiformi, disco cylindraceo-campanulato, decemdentato vaginatio insidens, quinquelobum, quinqueloculare, villosum. Ovnla in loculis gemina, angulo centrali superposite inserta, superius adscendens, inferius pendulnm. Stylas petalis longior, basi hispidus; s ti g ma capitellato-quinquelobum. C a p s nla pentacecea, v. abortu di-tetracocea, coccis bival- 
vibus, endocarpio cartilagineo, soluto, elastice bi lobo, basi membranarea, cum semine secedente, abortu monospermo. Sem en reniforme, sinu umbilicatum, testa coriacea. Embryonis exalbuminosi, homotrope curvati eotyledones magnae, basi biauriculatae, corrugatae, exterior interiorem involvens, radicula teres, inflexa, umbilico proxima. - Erutex brasiliensis; foliis al ternis, petiolatis, trifoliolatis, foliolis ovato-acumi natis, crassiusculis, integerrimis, glaberrimis, subtus glaucis, floribus in apice caulis axillaribus simulque terminalibus, corymbosis, speciosis, albis, suaveolentibus.

$\mathrm{S}$ pira $\mathrm{nthera}$ St. Hilaire in Bullet. philomat. 1823. p. 130. Plant, remarq. Brasil, 147, t. 17. Flor. Brasil, $I$. 43. DC. Prodr. I. 728. Adr. Jussieu in Mem. Mus. XII. 892. ᄂ. 23. $f .3$. Meisuer Gen. 62. (45.) Te rp n a u th us Nees et Mariius N. A. N. C. XI, 159, t. 19, k, t. 31 .

5989. Alancidea ST. HIL. Calyx bre vis, quinquepartitus, deciduns. Corolla e petala 5 , hypogyna, calyce multoties longiora, ungniculata, spathulata, aequalia v. subaequalia, aestivatione inbricata, $8 \mathrm{ub}$ anthesi erecta. S $t$ a min a 5 , hypogyna, petalis alterna et paullo breviora, omnia fertilia; fil amenta libera, inferne complanato-dilatata, intus supra medium dense barbata, antherae introrsae, biloculares, lineares, obtusae, imo dorso affixae, baxi bifidae, mobiles, longitadinaliter dehiscentes. Ovarinm sessile, diseo cupulaeformi, trancato cinetum, obtasum, profunde quinquelobum, quinqueluealare, glabrum. O vula in loculis gemina, angulo centrali snperposite inserta, superins adscendens, inferius pendulum. St y I us staminum longitudine, glaber; stigma late capitatum, obtuse quinquelobum. C a p s u I a abortu mono-dicocca, coccis bivalvibus, endocarpio cartilagineo, soluto, elastice bi lobo, basi membranacea cum semine secedente, abortu monospermo. S e m e n reniforme, sinu um bilicatum, testa coriacea. Embryonis exalbu minosi, homotrope curvati cotyled ones mag nae, corrngatae, basi biaurieulatae, exterior in teriorem contortuplieatam involvens, radicula brevia, obtusa, inflexa, cum cotyledone interior involuta, umbilico proxima. - Arbores, arbusculae $v$, frutices, in Brasilia tropica crescentes, foliis alternis, superioribus nonnunquam oppositis petiolatis, simplicibus, integerrimis, petiolo apice incrassato, ramulis floriferis terminalibus, basi indivisis, nudis, apice in racemos compositos, panicu latos $v$, thyrsoideos divisis, pedunculis partialibus bracteatis, pedicellis medio bibracteolatis, floribus lilacinis, rubris v. caeruleis.

A I m e i de a St. Hilaire in Bullet, philomat, 1823, p, 129 Plant, remarq. Brasil, I. 142, t. 15. Flor. Brasil. I. 85. t. 18. DC. Prodr, I, 729. Adr. Jussieu in Mem. Mus. XIT. 402. 2. 23. $f$. 33. Meisuer Gen. 62. (45.) A $r u b$ a Nees et Mart, in N. A. N. C. XI. 152, et 172. t. 19. f. H. t. 27. et 29. (excl. t. 28.) non Aubl.

5590. Gallpea ST. HIL. Calyx brevis, cupulaeformis, rarins turbinato-campanulatus $\mathbf{v}$. campanulatus, quinquedentatus v. quinquefidus, saepius pentagonns, interdam inaequalis, persis. tens v, deciduus. Corolla e petala 5 v. rarissime 4, hypogyna, linearia, subinaequalia, villosa v. pubescentia, inferne in tubum saepissime pen tagonam eonglutinata v. rarius conniventia, apicibus liberis aequaliter $\mathbf{v}$, subbilabiation patala, deeidna. Stamina 5 , rarius $6,7,8$ v. 4 , petalis plus minus adhaerentia v. adglutinata, rarissime omnia fertilia, saepissime $2-4$ antheris rudimen- tariis v, abortivis castrata; fil a menta brevia, saepissime complanata et barbata, anthera e introrsae, biloculares, oblongo-lineares, basi biloba $v$. subbiloba affixae, subimmubiles, longitudinaliter dehiscentes. Ovaria 5 v. rarissime 4 , disco depresso, obsolete decemdentato insidentia, libera v. angulo centrali cohaerentia, unilocularia. $O$ vu $/ \mathrm{a}$ gemina, suturae ventrali superposite inserta, superius adscendens, inferius pendalum. St yli 5 , rarissime liberi, saepissime basibus distineti, apice coaliti; s tig ma quinquepartitum v. quinquecostatum. Ca p s u la aborta mono-dicocea, coccis bivalvibus, endocarpio cartilagíneo, soluto, elastice bilobo, basi membranacea cum semine secedente, di- v. saepias abortu monospermo. Semen reniforme, sinu umbilicatum, testa coriacea. E m b r y onis exalbuminosi, homotrope curvati e ty led on e s magnae, corrugatae, basi biauriculatae, exterior interiorem conturtuplicatam involvens, $r$ a di $c$ ula brevis, obtusa, inflexa, cum cotyledone interiore involnta, umbilico proxima. - Frutices $v$. rarius arbores, in $A$ merica tropica crescentes; foliis alternis, simplicibus, petiolo apice incrassato, $v$ trifoliolatis aut interdum quadri-quinquefoliolatis, foliolis integerrimis, pellucido punctatis v. interdum punctis glandulosis conspersis, floribus axillaribus v. extraaxillaribus, rarius terminalibus, saepe racemosis, rarissime corymbosis $v$. paniculatis.

Grallpe a St. Hilaire Bullet, soc, philomat. 1893. p, 131. Plant, remarq. Brasil, 129. t. 19_16. Flor, Brasil, I, 87. Adr. Jussieu in Mem. Mus. XII. 493. t. 23. $f$. 34. Meisner Gen. 62. (45.) G a li pea Aublet Guian, II. 662. Ł. 269, et R a p u ti a Aublet Guian. II. 670. $t, 272$. Lam. $t, 10$. DC. Prodr. I. 730. et Pholid and ra Necker Elem, n. 542. Sciuris Schreber Gen. n. 53. - Cusparia Humboldt Tabl. Geograph. B o n p l a ndl a Willdeaow in Act.soc, nat. curios. Berol, 1802. p. 24. Richard in Mem. Mus, Instit. p. 82. Humb. et Bonpl. Plant. aequinoct, 11 . 59, t. 57. A agostura Römee et Schultes Syst. IV. XIX, Galipea, C a sparfa et R a p utia DC.in Mem Mus, $I X, 149.142,138$. t. 10. Con choca r p u s Mikan Delect. I. t. 2. Nees et Martius in N. A. N, C. XI. 150 et 158. t. 18. f. B. et t, 2t. Ravia Nees et Mart, in N. A, N. C. XI. 167. t. 19, f. E. t.23.24. L a slos te $\mathrm{mum}$ Nees et Martius $X I, 152$, et 17t, $t, 19$. f. G. t. 26. A rub a e $8 \mathrm{p}$. Nees et Mart. Op. cit. t. 28. 0 be nto n ta Velloz. Flor. Flum. T. t. 46. (G. macrophylla St. Hil.) Daugervilla Flor. Flum, I, t, 66. (G, penta. gyna St. Hil. (Rossen i a Flor. Flum. I. t. 77 . (G. heterophylla St. Hil.)

5991. Diglottis NEES et MART. Cal y x campannlatus, profunde quinquefidas, laciniis aequalibus, erectis, acutis. Co rollae petala 5, hy pogyna, lanreolata, a basi ad mediom in tubum coalita, apicibus liberis, aequalibus, ereetinsculis. Stamina 5, duo fertilia, tria antherae abortu sterilia, corolla breviora, eidem adglutinata ; fil ame nt a lineari-complanata, superne barbata, antherae introrsae, biloculares, cordiformes, adnatae, longitadinaliter dehiscentes, connectivo in ligulam aeutam, barbatam producto soperatae. Ova ria 5 , disco cupulaeformi cincta, conniventia, unilocularia. Ovula gemina, suturae ventrali superposite inserta, superius adscendens, inferius, pendulum. Sty li 5, ex ovarioram angulo interiori, in unum brevissimum eonnati; $8 \mathrm{tigma}$ obtusum, integrum. Cap \& u l a pentacocea..... Frutex brasiliensis; folitis alternis, petiolatis, simplicibus, lanceolato ovatis, intogerrimis, pellucido-punetatis, petiolis apice tumidis, floribus in paniculu terminali, subracemosa, brevi subsessilibus, bracteatis.

Diglottis Nees et Martias in N. A. N. C. XI. 151. et 170, t. 19, f. F. t, 25. DC. Prodr. I, 732. Adr. Jussieu in Ment. Mus, XrT. 494. Meisner Gen. 68, (45.) 
599:. Erythroehiton NEES et MART. C aly x magnus, coloratus, tubulosus, tubo com. presso, quinquecostato, limbi bilabiati lobis aequalibus, integris v. superiore trifido. Corolla hypogyna, gamopetala, subhypocraterimorpha, tubo ealycem aequante, limbi quinquepartiti laciniis aequalibus, patentibus. Stamina 5 , omnia fertilia, tubo corollae breviora et eidem adglutinata, limbi lobis alterna; filamenta complanata, subulato - triangularia, basi in tabum brevissimum coalita, a $\mathbf{t} \mathrm{h}$ er a e introrsae, bitoculares, lancenlatae, erectae, muticae, longitndinaliter dehiscentes. O v a ri a 5 , disḱo urceolato glanduloso cincta et superata, unilocularia. Ovula gemina, sutu rae ventrali superposite inserta, superins adscendens, inferius pendulum. C a $\mathrm{p}$ sula pentacocea, coccis bivalvibus, endocarpio eartilagineo, soluto, elastice bilobo, basi membranacea cum seminibus secedente, dispermo v, abortu monospermo. S e m ina reniformia, sinu umbilicata, testa curiacea, tuberculate muricata. Embryo ..... Arbuscula brasiliensis; folits alternis, simplicibus, petiolatis, lanceolatis, longissimis, integerrimis, glabris, ramulis axillaribus subaphyllis, floriferis pedunculos longissimos mentientibus, floribus in axilla folii bracteaeformis duobus $v$, pluribus faseiculatis, breviter pedunculatis, pedunculo basi articulato, bibracteolato, calycibus rubris, corollis albis.

Ervthroehiton Nees et Martius in N. A. N. C. XI. 151, et 165, t. 18, f. D. t, 22. DC. Prodr. 1 . 732. Adr. Jus. sieu in Mem. Mus, XIT. 495. Meisner Gen, 62, (45.)

5993. Tieorea $A U B L, C$ aly x parvus, quinquedentatus. Corolla hypogyna, gamopetala, infundibuliformis, tubo elongato, limbi quinquepartiti laciniis aequalibus $\mathrm{v}$. inaequalibus, patentibus. S $t$ a m in a 5-8, quorum $2-6$ antherarum abortu sterilia, cum corollae tubo coalita, filame nta lineari-complanata, exserta v. inclusa, libera $v$. basi inter se coalita, anthe $r$ ae introrsac, biloculares, loculis adnatis, baei in appendicem vacuam productis, longitudinaliter dehiscentibns. 0 varia 5, disco cupulaeformi cincta, libera v, angulo centrali coalita, unilocnlaria. Ovula gemina, suturae ventrali superposite inserta, superius ad scendens, inferius pendulum. Styli 5 , ex ovariorum apice orti, in unicum tnbum corollae aequan tem, glabrum coaliti; stig m a capitato-quinquelobum. Ca psula pentacocca..... - Arbores $v$. frutices, in Brasilia et Guian a crescentes; foliis alternis, nunc simplicibus, cum petiolo articulatis, nunc saepissime trifoliolatis, foliolis lanceolatis, in tegerrimis, pellucido.punetatis, ramulis terminalibus floriferis, aphyllis, basi simplicibus, superne in corymbos, paniculas $v$, racemos compositos divisis, pe dicellis bracteatis, floribus albidis $v$. ochroleucis glandulis pellucidis $v$, tuberculiformibus conspersis.

T i o r e a Aublet Guian, II. 689, t. 277. DC. in Mem. Mus, IX. 144, t 8. 9. Prodr. I. 730. St, Hilaire Plant, re marq Brasil. 1. 139. t. 14.f. D. Flor, Brasil. 1. 91 . Adr. Jussieu in Mem. Mus. XII, 495, $t, 23 . f, 35$, Presl $s y m b$. t. 17. Meisner Gen 62. (45.) 0 zop hyllu m Sehreber Gen n. 1105. S ci uris Nees et Mart. in N. A. N. O. XI, 150. et 15s, $t, 18$. f. A, et $t$, 20. non Schreb. Cost a Fior. Flum. I. 8. 48 .

5994. Momiera LINN. Caly $\mathrm{x}$ quinqnepartitus, laciniis inaequalibus, daabns corollam longe superantibus, duabus multo brevioribus. $\mathrm{Co}$ roll a hypogyna, gamopetala, tubo incurvo, limbi bilabiati labio superiore integro, inferiore quadrilobo. Stamina 5, quorum duo fertilia, tria antherarnm abortu sterilia, corollae tubo breviora et adglutinata; fil ament a complanato-subulata, mediu barbata, an therae introrsae, hilocolares, cordiformes, adnatae, longitudinaliter dehiseentes. Ovaria 5, sqnama hypogyna, crassiuseula, longiore, apice bidentata, staminibus sterililus opposita, persistente stipata, sessilia, approximata, unilocularia. Ovula in loculis gemina, suturae ventrali superposite inserta. Styli 5 ex ovariorum apicibus, in nnieum, glabrum, staminibus breviorem coaliti; s t i g m a capitatı-quinquelobum. Capsula pentacocea $v$, abortu dicocea, coccis bjvalsibus, endocarpio cartilagineo, soluto, elastice bilobo, basi membranacea cum semine secedente, aborta monospermo. S e m en renifurme, sinu umbilicatum, testa coriacea, tuberculata. E m lo ry onis exalbuminosi, homotrope curvati cotyled on es laeves, basi biauriculatae, exterior interiorem involvens, radicula brevis, obtusa, inflexa, cotyleduni interiori incumbens, umbilico proxima. - Herba villosa, in maritimis Americae tropicae orientalis obvia; foliis alternis v. suboppositis, petiolatis, ternatis, subtilissime pellucido. punctatis, pedunculis axillaribus, apice ramosis, floribus brevissime pedirellatis, secundis.

Moniera Llun. Gen. n. 850. Anblet Guian. IT, 730 . t. 293. Kunth in Humb. et Bonpl. Nov. gen. ot sp. VI, 9. Nees et Martius in $N . A, N$. C. XI. 162. t. 18. f. $C$. DC. Prodr. I, f. C. Adr. Jussien in Mem, Mus. VII. $t, 52, f .31$. Meisaer Gen. 62. (45.) $\mathrm{A}$ ublet la Riehard in Persoon Encheir. II. 638.

TIR IBUS II. PLLOCARPEAE Bartl. Ord. nat. 388. Flor es regulares. Petala libera. Stamina hypogyna, petalis numero aequalia v. rarissime dupla, omnia fertilia. Ovari a petalis numero aequalia, libera $v$. in unum coalita. unilocularia, biovulata, ovulis superpositis v. collateralibus, rarissime uniovulata. Semin is testa coriacea, crustacea v. membranacea. Embryonis recti, exalbuminosi cotyled ones magnae, ovalae, radicula brevis. - Arbores $v$. frutices, in America tropica el A uscralasia crescerles; foliis allernis v. opposilis, uni-bi-trifoliolatis, integerrimis.

5995. Mlelieope FORST. C a 1 y $x$ quadripartitus, persistens. Corolla e petala 4, calyce longiora, ovata, patentia. Stam in a 8 , petalis breviora; fil am enta subulata, an therae introrsae, biloculares, subcordiformes, longitudinaliter dehiscentes. O va ria 4 , diseo brevi, oetolobo insidentia, unilocularia, superne coalita, 0 v ula $\ldots$ Styli 4 , in unum roaliti; stigma crassiuseulum, tetragonum, centro umbilicatum. C a p 8 u la tetracocea, coceis coriaceis, bivalvibus, endocarpio cartilagineo, soluto, elastice bilobo, monospermis. S emen ovatum, funiculo filiformi appensum, testa coriacea. E m b r y o intra albumen carnosnm rectus; cotyled onibus oratis, foliaceis, radicula infera (?) - Frutices Novae-Zeelandiae; foliis oppositis, petiolatis, uni-trifoliolatis, foliolis pellucido-punctatis, floribus axilluribus, racemosis $v$. cymoso-paniculatis.

Mellienpe Forster Char. Gen, 28. Lam. t. 294. DC. Prodr. 1, 723. Adr. Jussieu in Mem Mus. XII. A85. Meisuer Gen. 63. (46.) A. Cuaningh, in Annal. of nat hist, IHT. 315. B a tog a a a Banks ex Gärtner I. 331, t. 68.

5996. Evodia FoRST. Cal y x quadripartitus, persistens. Coroll a e petala 4 , ad basim disci hypogyni, urceolaris, quadrisinuati ingerta, ob- 
longo-lanceolata, calyee majora, aestivatione valvata, sub anthesi erecta. St a mina 4 , cum petalis inserta, iisdem alterna et breviora; fil a ment a complanata, apice subulata, antherae introrsae, biloculares, cordato-ovatae, connectivo exeurrente apiculatae, longitudinaliter dehiscentes. $0 \mathrm{v}$ aria 4, sessilia, approximata, disco semiimmersa, nnilocularia, hirsuta. Ovul a juxta suturam ventralem gemina, collateralia, pendula. Styli ex ovariorum apice orti, in unicum, brevissimum, quadrisuleum coaliti; st $\mathrm{igm}$ a obsolete quadrilobuın. Capsula tetracocea, coceis bivalvibus, en docarpio cartilagineo, soluto, elastice bilobo, monospermo. S emen ovatum, testa ossea, umbilico ventrali lineari. E m b ryo intra albumen carnosum, pareum rectus; cotyledonibus ovatis, radie ula mediocri, supera.-Arbusculae v. frutices, in Nova-Hollandia et Oceania tropica et subtropica crescentes; foliis oppositis, petiolatis, uni bi-trifoliolatis, foliolis oblongis $v$. linearibus, pellucide punctatis, integerrimis, inflorescentia axillari, cymoso-paniculata, pauciflora, pedicellis supra medium articulatis, ad articulum bibracteolatis.

Evodi a Forster Char. gen. $t$, 7 . Adr. Jussieu in Mem. Mrus, XIT. 484. t. 22. $f$. 28 . Labillard. Nov. Caled. t, 74. Endlieter Prodr. Flor. Norf. 86. Schott Rutac. $t$. 1, A. Richard Sert. Astrolab. 61. $t$. 22. Meisuer Gen, 62. (45.)

5ร9ร. Fsentbeelsia KUNTH. C a 1 y x quinquepartitus. Corolla e petala 5 , hypogyna, infra discum inserta, ealyce majora, aestivatione imbricata, sub anthesi patentissima. S tamina 5 , ad basim disci inserta, petalis alterna, iisdem breviora v, suhaequalia; fil a m ent a subulata, demum reflexa, a ntherae introrsae, biloculares, cordiformes, durso prope basim affixae, versatiles, longitudinaliter dehiscentes. Ovarium disco nrceo Iato v. orbiculari, subintegerrimo v. sinuato quin quelobo semiimmersum, tuberculatum, quinquelobum, quinqueloculare. Ovula in loculis gemi na, angulo centrali collateraliter appensa, anatro pa. Sty I u s centralis, brevissimus; stigma capitato-inerassatum, quinquesulcum. Ca p $s$ I a sub glohosa, echinata, septicide pentacocca, cuecis bi valvibus, endocarpio cartilagineo soluto, elastice bi lobo, facie interiori membranacea seminifera, monosperma, circumscisse secedente. Sem e n oblon gum, testa cartilaginea, umbilico lineari. $\mathbf{E} \mathbf{m}$ bry onis exalbuminnsi, orthotropi cotyled on es crassae, plano-convexae, inaequales, radicula brevissima, supera. - Arbores $v$. frutices, in $A m e-$ rica tropica, imprimis in $B$ rasilia crescentes; foliis alternis $v$. suboppositis, petiolatis, unifoliolatis $v$. trifoliolatis, foliolis integerrimis, pellucidopunctatis, petiolo complanato v. supra concavo, racemis axillaribus et terminalibus paniculiferis, pedi. cellis bracteatis, floribus parvis, albis, virescentibus v. ochroleucis, glanduloso punctatis.

E se ubeckia Kunth in Humb et Bonpl. Nov.gen.etsp VIT, 206, t. 655 Adr. Jnssieu in Mem. Mus. XIt. 486. Martins Nov. gen, et sp. III. 80 t. 232.233. Pohl Plant. Brasil.II t, 128. Nees Plant, offic. Suppl, t.94. Meisn. Gen, 63. (45.) E s e ube ckia et Coly thrum Schott Rutac. 9 et 13. t. S. et? Evodia St. Hilaire Plant. us. t. 4. Plant. remarq. 149. Flor. Brasil. $T$. $79-2 \mathrm{P}$ ol e m b $\mathrm{r}$ u m Adr. Jussieu in Mem, Mus, XII, 519, t, 28, f, 49. Seliott Rutac, 11, $t, 6$.

5ys8. Netrodorea ST. HIL. Calyx parvus, quinquefidus. Corolla e petala 5, hypogyna, infra disenm inserta, calyre multo majura, aestivatione valrata, snb anthesi patentissima. S ta$m$ in a 5 , inter disci lobos inserta, petalis alterna fil a in enta brevissima, subulata, reflexa, an the rae introrsae, biloculares, cordiformes, dorso affixae, versatiles, longitudinaliter dehiscenteg. Ovarium disco supra illud expanso immersum et velatum, tuberculatam, quinquelobum, quinqueloculare. Ovnla in loculis gemina, angulo centrali collateraliter appensa, anatropa. Stylus brevissimus; $8 \mathrm{tigma}$ obtusum, indivisum. Fructus..... - Frutex brasiliensis; foliis oppositis, simplicibus $v$. bifoliolatis, lanceolato oblongis, integerrrimis, pellucido-punclatis, petiolorum basibus dilatatis, concavis, sursum productis, conniventibus, gemmam terminalem includentibus, post ejus explicationem hiantibus, stipulis nullis, paniculis terminalibus et lateralibus bracteatis, floribus parvis, atro-purpureis, punctato-glandulosis, interdam parte quinta imminutis.

M etrodorea St. Hilaire Flor, Brasil, r, 81, t. 16. Adr. Jussieu in Mem, Mus. XII. 487. Meisner Gen, 63. (45.)

5999. Pilloearpus $V A H L$. Calyx parvus, quinquedentatus. Co rolla e petala 5 , ad basim disci hypogyni inserta, calyce multo majora, lanceolata, basi latiuscula, aestivatione subvalvata, sub anthesi reflexa, apice brevissime uns:inatim inflexa. Sta m in a 5 , disco petalis paull, altius inserta, iisdem alterna et paullo longiora; fil a menta subulata, reflexa, antherae introrsac, biloculares, suborbiculatae, dorso affixae, basi bifidae, mobiles, longitudinaliter dehiscentes. Ova ria 5 , minuta, basi cohaerentia, diseo crasso immersa partimque coalita, unilocularia, glabra: 0 v u la juxta suturam ventralem solitaria, v. gemina saperposita, pendula. Styli ex ovariorum angulo interiore infra apicem orti, brevissimi, vix supra eadem exserti, apice in stigma latum, quinquesulcatum coaliti. C a p su la pentacocca $v$. abortu mono-tetracocea, coccis bivalvibus, endocarpio cartilagineo, soluto, elastice bilobo, basi seminifero, monospermo. Sem en ovatum, testa membranacea, unbilico ventrali. Embryon is exalbuminosi, recti colyledones crassae, basi bianriculatae, radicula in brevissimam, superam occultantes. - Frutices brasilienses; foliis petiolatis, in eadem interdum stirpe alternis oppositisque, simplicibus $v$, bi-trifoliolatis lobatisve, integerrimis, pellucido-punctatis, racemis terminalilus $v$. demum lateralibus, pedicellis patentibus, basi, sub apice medioque bracteolatis, rarius iisdem abbreviatis spiciformibus, floribus viridescentibus v. pupurascentibus, glanduloso-punctatis.

Pilocarpus Vaht Eclog. 1 . 29. t, 10, St. Hilaire in Bullet, philomat, 1823. p. 130, Plant, remarq. Brasil. $I$. 145. t. 16. Flor, Brasil. I. 82. t. 17. De. Prodr, I, 728. Adr. Jussien in MLem. Mus. XII. 488. t. 22. f. 29. Nees et Martius in N, A, N, C. XI, 126. 2. 19. Meisu, Gen, 63. (45)

6006. HIIrtia $V A N D E L L$. Cal y x parvus, cupulaeformis, obsolete quinquedentatus. CorolI a e petala 5, disen hypogyno inserta, calyce multo majora, lineari-lancenlata, intus smpra basim barbata, acstivatione subimbricata, sub anthesi medio reflexa, apice acuminata, uncinatim inflexa. St a min a 5, disco petalis paullo altius inserta, iisdem alterna et vix longiora; filam enta complanata, erecta. glanduloso-tuberculata, an thera e introrsae, biloculares, anguste ovatae, dorso affixae, immobiles, basi bifidae, longitudinaliter dehiscentes. Ovari u m disco lato, depresso, subquinqueiobo insidens, pentagonum, quinqueloculare, glabrum. $0 \mathrm{vula}$ in loculis gemina, angulo centrali superposite inserta, pendula, anatropa. Stylus ex ovarii apice brevis, crassus, conicus; stig ma obtusum, quinquesuleum. C a p 8 u I a quinquelocularis v, abortu bi-quadrilocularis, locu- 
lis mono-dispermis. Semina inversa, testa crustacea, umbilico ventrali, lineari, epidermide tenui, succulenta, arilliformi. E $\mathbf{m}$ b r y o in axi albuminis carnosi rectus; cotyle donib us magnis, ovatis, radicula brevi, supera. - Suffrutex brasiliensis, caudice subsimplici, crasso, glaberrimo; foliis allernis, simplicibus, magnis, pellucido-punctatis, integerrimis, ramulis terminalibus, corymbose multifloris, pedunculis crassis, bracteatis, pedicellis bracteolatis, floribus roseis.

Hortia Vellozo ex Vandelli in Römer Script. 188. DC. Prodr. I, 732. St. Hilaice Plant. us. Brasil. t. 17. Flor. Brasil. I. 80. Adr. Jussien in Alem. Mus, XII. 489, t. 22. f. 30. Meisuer Gen, 63. (45.)

6001. Choisya $K U N T H$. Caly $x$ pentaphyllus, deciduus. Corolla e petala 5, ad basim gynophori brevissimi inserta, calyce duplo longiora, subungniculata, patentia. Stamina 10 , cum petalis inserta, alterna iisdem opposita et breviora; filaw ent a subulata, an thera e introrsae, biloculares, cordifurmes, obtusae, dorso affixae, mobiles, longitudinaliter dehiscentes. O va ria 5, gynophoro brevissimo insidentia, in unicum quinqueloculare, pubescens coalita. Ovula in loculis gemina, angulo centrali superposite appensa, anatropa. Stylus brevis, quinquesulcus, hispidulus; stig ma glabrum, capitatum, obsolete quinquelobnm. Caps u la quinquesnlca, quinquerostrata. Frutex mexiean us; foliis oppositis, petiolatis, trifoliolatis, foliolis integerrimis, pellucido-punctatis, petiolis subtus canaliculatis, pedunculis in apice ramulorum axillaribus, apice trifidis, subumbellatim plurifloris, basi bracteatis, ad divisuras et sub pedicellis bracteolatis, braeteis magnis, deciduis, corollis albis calycibusque glanduloso-punctatis.

$\mathrm{C}$ h o is y a Kunth in Humb. et Bonpl. Nov. gen. et sp. VI. 4 t. 513. Adr. Jussieu in Mem. Mus. XII. 490. Meisner Gen. 63. (46.)

\section{GENUS NON SATIS NOTUM.}

BO02. Ceijera SCHOTT. C a ly $\mathrm{x}$ quinquepartitus, persistens. Coroll a e petala 5, ovata, patentissima $v$. recurva. Sta $\mathrm{m}$ ina 5 , sub disco inserta, petalis alterna et breviora; filamenta subulata, erecta, anthera e introrsae, biloculares, ovatae, muticae, Iongitudinaliter dehiscentes. Ovaria 5, disei orbieularis, carnosi, plani, lae vis, ambitu quinquesinuati centro insidentia, coalita. Sty Ius centralis, brevis; sti g m a capitatam. Ca psula abortu mono-tricocea, coecis basi sohaerentibus, glanduloso-punetatis, monospermis Sem en albuminosam..... Frutex $N$ ovae-Ho $t$ landiac tropicae; foliis alternis, breve petiola. tis, lanceolatis, integerrimis, glabris, inflorescentia terminali, cymoso-paniculata, pauciftora, brevi.

Geijera Schott Rutac. 7. $t$, 4. Meisner Gen. 80. (44.)

TIEIFES III. BORONIEAE Bartling Ord. nat. 388 . Flores regulares. Petala libera v. rarissime basi coalita. Stamina liypogyna, rarissime perigyna, duplo, rarissime simplici petalorum numero. Ovaria petalis numero aequalia, libera, unilocularia, biovulata, ovulis superpositis, superiure adscendente, inferiore pendulo. Sty Ii superne coaliti. Seminis testa crustacea. Embryo in axi albuminis carnosi rectus, gracilis, teres, radicula cotyledonibus linearibus longiore, supera. - Frutices $v$, arbores, in $A u s t r a l a$ si a indigeni; foliis oppositis $v$, alternis, simplicibus, rarius cernatis $v$, imparipinnalis.

BDO3. Tieria SMITH. Calyx quadrifi. das. Corolla e petala 4 , disci perigyni, ovariorum hasim cingentis margini inserta, calyce multo longiora, ovata v. oblonga, subunguieulata, aestivatiune imbrisata $\mathbf{v}$. subvalvata, sub anthesi patentia. Stamina 4 , glandularum disci dorso inserta, petalis alterna et longiora; filamenta subulata, glabra, an the ra e introrsae, biloculares, cordiformes, versatiles, longitudinaliter dehiscentes. Ovaria 4, gynophoro brevi insidentia, ejusdem margine basi cum calyce concreto, extus staminifero eincta, uniluenlaria, glabra. O v u 1 a in Inculis gemina, suturae ventrali superposite inserta, superius adscendens, inferius pendulum. Styli ex ovariornm angulo interiori, in unicum brevem, crassum, glabrum coaliti; stig m a late capitatum, obsolete quadrilobum. C a psu la tetracocea, coceis patentiusculis, bivalvilous, endocarpio cartilagineo, suluto, elastice bivalvi, monospermo. Sem en oblongum, testa crustacea, crassa, umbilico prope basim laterali. Em bry o in axi albuminis carnosi reetus, $\mathrm{eylindrieus;} \mathrm{r}$ a di $\mathrm{e} \mathrm{n} l$ a supera.-Frutices $v$. rarius arbores, in Nova-Hollandia orientali extratropica crescentes, glabri v. pilis stellatis conspersi; foliis oppositis, petiolatis, trifoliolatis, rarius, interdum in eadem stirpe, simplicibus, glanduloso-punctatis, pedunculis axillaribus ant rarius lerminalibus, nunc unifloris, nunc saepius di-trichotomis, bi-multifloris, ad divisuras articulatis el opposite bibracleatis, floribus parvis, albis.

Z i e ri a Smith in Linn. Transact. ID. 216. Rudge Ibid. X. $t, 17, f .2$. Andrews Bot, Neposit, t. 606. Bonpl. Navarr. t. 24. Bot. Mag. t. 1395 DC. in Mem. Mus. XIt. 483, t. 22. f. 27. Meisuer Gen. 60. (40.) Delessert Ic. select. III. i. $48+50$.

BO04. IBoromia SMITH. C a l y x quadrifidus v. quadripartitus. Co ro 11 a e petala 4 , hypogyna, caIyce longiora, ovata, aestivatione imbrieata, sub anthesi patentia, mareescenti-persistentia. $\mathrm{S} t$ a $m$ in a 8 , hypogyna, petalis breviora, alterna calycis laciniis opposita paullo reliquis longiora, interdum antheris efoetis sterilia; fil a me n t a linearia, ciliata v. tubereulata, libera, sub apice interdum dilatato in filum antheriferum attenuata, an $t h$ erae introrsae, biloculares, cordiformes, apice moticae v. Lreviter appendiculatae, longitudinaliter dehiscentes. Ovaria 4, gynophoro disciformi, margine integerrimo v. sinuato insidentia, uniloeularia, glabra. Ovula in loculis remina, suturae ventrali superposite inserta, superius adscendens, inferius pendulum. Styli ex ovariornm apice in unicum brevissimum glabrum coaliti; $s t i g m$ a aequale et subeapitatnm, quadrisuleum. Ca p o n la tetracocea, coceis ovalihus v. oblongis, interdnm leguminiformilus, pluribus saepe efoetis, bivalvibus, endoearpio cartilagineo soluto, elastice bilobo, basi seminifero, abortu monospermo v. rarissime dispermo. Sem en ovatum, testa erustacea, umbilico prope hasim ventrali. Em hryo in axi albuminis carnosi rectus, teres, gracilis; radicula supera. - Frutices in Nova-Hollandia tropica et extratropica indigeni; foliis oppositis, simplicibus $v$. interdum in eadem stirpe imparipinnatis, integerrimis v. serrulatis, pellucide v. glanduloso-punctalis, pedanculis terminalibus $v$, saepe prope apicem ramulorum axillaribus, oppositis, nunc simplicibus, unifloris, nunc ramosis, bi-tri-multiftoris, pedicellis basi v. medio articulatis, ad articulum bibraeteolatis, 
apice saepissime incrassatis, floribus roseis, purpurascentibus $v$. rubris, suaveolentibus.

B or o ni a Suith in Linn. Transact, VIII, 285, t, J_7. Labillard. Nov. Holl. t. 124_126. Vent. Malm. $t, 38$. Gärtner f. III. 156. $t$. 211. (quoad radiculae directionem erronea) Bot. Reg, t. 842. 1000, II. 1838. $t$. 12, Bot. Mag. 1763. DC, Prodr. 1I. 721. Adr. Jussieu in Mem. Mus, XII. 482. t. 29. f. 26. Reichenb. Ic. exot, t. 73. 74. Sweet Flor. Austral, t. 19. 48. Meisner Gen, 60. (44.)

6005. Cyamothamnus LINDL. C al yx tetraphyllus. Corollae petala 4. Stamina 8; fila mentis membranaceis, subulatis, anthe$r$ a e appendice ipsis aequali anctae. $O$ vari u m simplex …. C a p sn la quadripartita, loculis bivalvibns, monospermis ...... Frutices $v$. herbae, ut videtur annuae, in Nova-Hollandia austrooccidentali crescentes; foliis biseriatis $v$. simplicibus, filiformibus, floribus axillaribus solitariis, cyaneis.

C y an ot ha m n as Lindley Swan-River XVIII.

6006. Eriostemon SMITH. C a 1 y $x$ quinquepartitus. Corollae petala 5, hypogyna, calyce multo longiora, ovata $\mathrm{v}$. oblonga, aestivatione imliricata, sub anthesi patentia, marcescenti persistentia. Sta m ina 10, hypogyna, persisten ia, petalis breviora; fila m e $\mathrm{t}$ a lineari-subulata, hispida, libera, alterna petalis opposita breviora, sub apice interdum dilatato in filum antheriferum attennata, antherae introrsae, hiloculares, cordiformes, apice breviter appendiculatae, longitu. dinaliter dehissentes. Ovaria 5, ynophoro disciformi insidentia, nnilocularia, glabra. $O \times n l a$ in loculis gemina, suturae ventrali superposite inserta, superins adscendens, inferius pendulum. Sty li ex ovariornm angulo interiori, in unicum, staminilous breviorem, glabrum v. hispidulum coaliti; sti $\mathrm{g} \mathbf{m}$ a capitellatum, quinquesuleatum. Ca $p$ s u1a pentacorea, coccis livalvibus, endocarpio cartilagineo, suluto, elastice bilobo, basi seminifero, ahortn monospermo $v$. rarius dispermo. Semen oblongo-reniforme, testa crnstacea, umbilico ven trali. E m bryo in axi albuminis carnesi rectus, teres, radicula snpera. - Frutices in NovaHollandia tropica et extratropica indigeni, pilis stellatis hispiduli; foliis alternis, simplicibus, integerrimis, glanduloso punctatis v. tuberculatis, apice interdum calloso-mucronatis, pedunculis axillaribus, nunc simplicibus, unifloris, bracteis imbricatis tectis, $v$, oppositis aut verticillatis medio instructis, nunc umbellatim in pedicellos basi brac. teatos divisis, rarissime in racemos terminales dispositis.

E rioste m o n Saith in Linn, Transact. IV. 221. Rudg. Ibid. XI. t, 26. Labillard. Nov. Holl, t, 14t, Nov. Caled. t. 58, DC. Prodr. I. 720. Adr. Jussieu in Mem. Mus, XII. 481, t. 21. $f$, 25. Loddig. Bot. Cab. $t, 1247$. Bot. Mag. t. 2854 3180. A. Richard Sert. Astrolab. t. 26, Hooker Ic. $t .60$. Delessert Ic, select, IIT. $t, 45-47$, Meisner Gen, 60. (40.)

600\%. Crowea SMITH. Caly x quinquepartitus. Corolla e petala 5, hypogyna, calyce multo longiora, whlongo-lanceolata, aestivatione imbrieata, sub anthesi patula. St a $m$ in a 10 , hypogyna, petalis breviura; fil a me n t a linearia, riliato-hispida, in tulum approximata, alterna petalis opposita hreviora, a $\mathrm{n}$ h erae introrsae, biloculares, corrlato-oblongae, apice in appendicem elongato-subulatam, harbatam productae, longitudinaliter dehiscentes, 0 va ri a 5 , gynophoro dis. ciformi, obtuse quinquelobo insidentia, unilocula. ria, glabra, Ovula in loculis gemina, suturae ventrali superposite inserta, superius adseendens, inferius pendulum. Styli ex ovariorum apice, in unnm, staminibus multo breviorem, glabrum cosliti; st ig m a capitatum, quinquesulcum. Ca psuIa pentacocea, coccis bivalvibus, endocarpio eartilagineo, solnto, elastice bilobo, basi seminifero, a hortu monospermo. Semen ovatum, testa crustacea, umbilico prope basim ventrali, E m b ry o in axi albuminis carnosi rectinsculus, teres, gracilis, radicula supera. - Frutex Novae-Hollandiae orientalis; foliis alternis, simplicibus, lanceolatis, integerrimis, glanduloso-punctatis, in ramos inde angulatos decurrentibus, pedunculis axillaribus unifloris, basi bracteis minutis, squameloideis, imbricatis cinctis, corollis purpureis.

C rowea in Linn. Transact. IV. 280. Venten, Malm. t. 7. Andrews Bot, Repnsit, $t, 79$. Bot. Mag. $t$. 989, DC. Prodr. I, 720. Adr. Jussieu in Mem. Mus. XII, 481, $t, 21$. f. 24. Meisner Gen, 60. (44)

600S. Philotheea $R U D G$. C a ly $\mathrm{x}$ quinquepartitus. Corolla e petala 5, hypogyna, ealyce multo longiora, unguiculata, aestivatione imliricata, sub anthesi erecto-patula. S $\mathrm{t}$ a $\mathrm{m}$ in a 10 , hypogyna, petalis paulo breviora; filamenta inferne in tubum glabrnm coalita, superne distincta, hirsuta, alterna petalis opposita breviora, a ntherae introrsae, biloculares, apiee brevissime glanduloso appendiculatae, cordatae, dorso supra basim insertae, longitudinaliter dehiscentes. $O$ vari a 5, gynophoro brevi, erasso, basi staminifero insidentia, unilocularia, glabra. Ovu la in loculis gemina, sutarae ventrali superposite inserta, superins adscendens, inferius pendulum. Styli ex ovariorum angulo interiori, in unicum centralem, tubo stamineo lireviorem, fusiformem, hispidum coaliti; stigma eapitellatum, quinquesuleum. C a p su l a pentacocea, coccis bivalvibus, endocarpio snbeartilagineo, soluto, elastice bilolo, basi seminifero, abortu monospermo. S em e n oblongoreniforme, testa crnstacea, umbilico ventrali. Embryo in axi albuminis carnosi rectus, teres, grarilis, radi $\boldsymbol{c} \mathrm{n}$ la supera. - Frutices ericoidei, in Nova-Hollandia orientali extratropica indigen $i$; foliis allernis, simplicibus, linearibus, integerrimis, brevibus, glanduloso-punctatis, pedunculis axillaribus et terminalibus solitariis, unifforis, bracteis minutis, squamulaeformibus stipatis.

Phil ot he a Rudge in Linn. Transact. XI, 298, $t .21$, DC. Prodr. I. 721. Reichenb. Ic, select. $t$. 200. Meisuer Gen, 60, (44.)

6009. Phebalium VENT. C a ly $\mathrm{x}$ brevis, snbinteger $v$. quinquedentatus aut partitus. Corollae petala 5, hypogyna, calyce multo longiora, sulnnguienlata, lanceolata, aestivatione imbricata, $8 n b$ anthesi patentia v, reflexa. S tamina 10, hypogyna, petalis longiora, alterna iisdem opposita paullo breviora; filamenta filiformia $v$. subulata, glabra, an the rae introrsae, biloculares, ovatae, muticae, dorso snpra basim emarginatam insertae, longitudinaliter dehiscentes. Ovaria 5, gynophoro lorevi, crasso, lasi staminifero insidentia, unilocularia, glabra, lepidota v. pilis densis velata. Ovula in leculis gemina, suturae ventrali subcollateraliter inserta, superius adscendens, inferius pendulum. Styli 5 , ex ovariorum angulo interiori, in unicum teretem, glalırum, quinquestriatum coaliti; stigma stylo aequale v. capitato-dilatatum, quinquesuleatum. C a p 8 ul a pentacocea, coccis bivalvibus, endoearpio eartilagineo, solnto, elastice bilobo, basi seminifero, abortu monospermo. S e me n ovatum, testa crustacea, umbilico prope hasim ventrali. E $m b$ r yo in axi albuminis carnosi rectus, teres, gracilis, radic ula 145 * 
supera. - Arbusculae et frutices, in Nova-Hollandia extratropica indigeni, pube stellata vestiti $v$. squamulis argenteis aut rufescentibus lepi. doti; foliis alternis, linearibus v. lanceolatis, rarius ovatis, glanduloso-punctatis, pedunculis axillaribus aut terminalibus, umbellatim v. corymbose-ramosis, pedicellis bracteatis, floribus parvis, nonnunquam sexta parte auctis.

Phe ballum Venten. Malm. 102. DC. Prodr. I. 719. Adr. Jussieu in Mem, soc, $h, n$, Paris. II. 130. Mem. Mus, XII. 479. Meisner Gen, 60. (44.)

a. CORREOLDES. Calyx minimus, vix conspicuns. Co roll a e aestivatio valvata. Stig in a stylo latius, verrucosum, quinquelobum, - Species tomentosae, folits subovatis. (Adr. Jussieu in Mem. soc. h, n. Paris, 11 . t. 10. 11. f. 1.)

b. ERIOSTEMoIdes. C a l y $x$ manifestus. Co rolla e aestivatio imbricata. Stigma styli apex angustatus. Species lepidotae, folits angustioribus. - Erioste. mon is s p. Labillard. Nov, Holl, t, 14t. (Adr. Jussieu Op. cit. t. 11. f. 2, t, 12, f. 1, 2, Hooker Ic. t. 57. 59.)

6010. Chorilaena $E N D L$. F lo res exinvolucrati, in cymas axillares aggregati, braeteolati. Caly x pentaphyllus. Corollae petala 5 , hypogyna, ealyce vix longiora, lanceolata, aestivatione imbricata, snb anthesi erecta. $\mathrm{Stami}$. n a 10 , hypogyna, petalis multo longiora, alterna iisdem opposita paulio breviora; filam enta filiformi-subulata, inferne ciliato-hispida, superne glabra, an therae introrsae, biloculares, ovatae, longitudinaliter dehiscentes. O varia 5, gynophoro discoideo, basi staminifero insidentia, unilocularia, glabra. $0 \mathrm{vala}$ is loculis gemina, angulo centrali inserta, contigne superposita, superius adscendens, inferius pendulum. Styli 5 , ex ovariorum angulo interiori, in unicum filiformem, basi hispidulum, stamina aequantem contorti; stigina quinquelohum. Capsula pentacocea, coccis bivalvibus, endocarpio eartilagineo, soluto, elastice bilobo, basi seminifero, abortu monosperme. S emen oblongum, testa crustacea, umbilico ventrali, lineari. $\mathcal{E} m b r y o$ in axi albuminis carnosi restus, filiformis, r a dicula supera. - Frutex Novae-Hollandiac austro-occidentalis, Thomasiae facie; foliis alternis, petiolatis, ovatis, basi truncatis, coriaceis, profunde lobato-sinuatis, supra pube stellata conspersis, subtus aureotomentosis, cymis axillaribus densis, septenis, quatuor brevissime pedicellatis, tribracteolatis, tribus centralibus, sessilibus, bibracteolatis, bracteolis $l i$. nearibus, calycem aequantibus, calycibus cum corollis flavis stellato-tomentosis.

$\mathrm{C}$ horil a e n Endlicher in Enumerat. plant. Hügel 17. Meisner Gen. Suppl.

6011. Diplolaema $R, B R$. Flores intra involucrum multipartitum in receptaculo plano confertim sessiles, involucri laciniis imbricatim triseriatis, exterioribus tomentosis, interioribus petaloideis. Caly $x$ nullus, Coroll a e petala $5, v$. abortu interdum pauciora, hypogyna, squamaefor mia, nuda v. ciliata. St amina 10, hypogyna, petalis multo longiora, exserta, alterna petalis opposita paulle breviora; fil amenta filiformi-subalata, inferne ciliata, superne glabra, antherae introrsae, biloculares, oblongae, incumbentes, longitudinaliter dehiscentes. Ovaria 5, gynophoro depresso insidentia, unilocularia, glabra. Ovula in loculis gemina, angulo centrali inserta, contigue superposita, superius adscendens, inferius pen. dulum. S ty li 5, ex ovariorum angulo interiori, in unicum filiformem, basi hispidulum, stanina aequantem coaliti; stig ma obtuse quinquelobum.
Capsula pentacocca, coceis bivalvibus, endocarpio cartilagineo, soluto, elastice bilobo, basi semi. nifero, abortu monospermo. S em en oblongum, testa crustacea, nmbilico ventrali, lineari. E mbryo in axi albuminis carnosi rectus, teretiusculus, gracilis, ra di c u la supera. - Frutices in $\mathrm{No}$ $v a-H_{0} l l a n d i a$ austro-occidentali indige$n i$; foliis alternis, petiolatis, ovatis $v$. obovatis, ob. tusis $v$, retusis, crassis, ramulisque coriaceis, penninerviis, integerrimis, glanduloso punctatis, supra pube stellata conspersis, subtus dense albo-tomentosis, involucris multifloris, florem unicum simulantibus, terminalibus, solitariis, sub anthesi nutantibus.

Diplo I a en a R. Brown in Flinders Voy. II. 546. Des. fontaines Mem, Mus, III, 450, t. 19, 20. DC. Prodr. I. 719. Adr. Jussleu in Mem. Mus. XII. 479. Meisuer Gen, 60. (44.)

6012. Correa $S M I T H$. Caly $\mathrm{cupulae-}$ formis, subintegerrimus v, quadritobus. Corolla e petala 4, hypogyna, calyce multo longiora, basi valvatim conniventia $v$, in tubum longe coalita. Sta min a 8 , hypogyna, petalis aequilonga $\mathbf{v}$. exserta, quatuor iisdem opposita breviora; filamenta libera, glabra, subulata v. basi dilatata, a $\mathrm{n}$ therae introrsae, biloculares, muticae, dorso supra basim insertae, longitudinaliter dehiscentes. O varia 4, gynophuro brevi, ambitn staminifero, suboctolobo insidentia, unilocularia, pilis stellatis dense congestis velata. Ovula in loculis gemina, suturae ventrali snperposite inserta, superins ad. scendens, inferius pendulum. St y li ex ovariorum angulo interiori, in unicum centralem, stamina aequantem v. superantem coaliti; stig in a aequale, quadrilobum. Cap s u la tetracocea, eoceis nonnullis saepe abortivis, hivalvibus, endocarpio cartilagineo, soluto, elastice bilobo, basi seninifero, abortu monospermo. S e m e n obsolete reniforme, testa ernstacea, umbilico ventrali. Embryo in axi albuminis carnosi rectus, teres, gracilis, $r a-$ dicula supera. - Frutices, in Nova-Hallan. dia orientali et australi indigeni, pube stel. lata, densa tomentosi v. pulverulenti; foliis oppositis, breve petiolatis, simplicibus, subovatis, integerrimis, punctato-pellucidis, floribus ramulos axillares abbreviatos, pedunculiformes terminantibus, 'solitariis, geminatis v, ternis, breviter pedunculatis, speciosis.

Cofrea Smith in Linn. Transact. IP. 219. Exot. Bot. II, t. 72. Venten. Malmais, $t, 13$, Salisbury Parad. $t, 100$. Gärtner f. III. 155, t. 210. Andrews Bot, Reposit, t. 18. 436. 653 Bot. Mag. t. 1766. Bot. Reg. t, 26, 1224. Sweet Flor. Austral. t. 1. DC, Prodr. I. 7I9. Adr. Jussieu in Mem. Mus. XII. 478, t. 21. f, 28, Hook, Ic, t. 2. 3. Meisner Gen, 60. (44.) M a z e $\mathrm{t}$ ox e r on Labillard. Voy. 11. 11. C n r. re a s Hoffuansegg. Verzetchn, 168. A ntoma r chi a Colla Hort. Ripul. App. II. 345. Melsner Gen. 60. (44.)

8013. Hürgelia $R, B R$. C a l y x decendivisus. Coroll a e petala 10 . S tam in a indefinita, perigyna. - Genus a ustralasicum, nondum descriptum.

H üg elf a R. Brown msc. (coll, Flinders Voy, IT, 546.)

TRETSE I IV. EUDIOSMEAE. Flores regulares. P e t a l a libera, rarissime nulla. Stamina perigyna, fertilia petalis numero aequalia et alterna, saepissime cum totidem sterilibus alternantia. Ovaria petalis numero aequalia v. pauciora, plus minus coalita, unilocularia, biovulata, ovulis superpositis v. collateralibus. Semin is testa coriacea, tenuis, rarissime crustacea. E mbry on is exalbuminosi v. rarissime subalbuminosi, recti coty- 
le d on es carnosae, laeves, radicula supe. ra v, interdum centripeta. - Fruticuli ca. penses, rarissime arbores; foliis alternis v. oppositis, simplicibus, saepe imbricatis, planis, v. marginibus revolutis teretibus aut subtriquetris, saepissime imbricatim confertis.

6014. Calodendron THUNB. Calyx brevis, quinquepartitus, laciniis rigide patentibus. Corolla e petala 5 , ad basim disci brevis, tubalosi inserta, calyce multo longiora, angusta, oblonga, reflexa, extus pilis stellatis hispida. Stamin a 10 , basi disci adnata, petala sulaequantia, alterna petalis opposita sterilia, petaloidea, tuberculosa, in glandulam ovatam desinentia, alterna fertilia; filamentis elongato-filiformibus, anther is introrsis, bilocularibus, ovatis, apice glandulosis, longitudinaliter dehiscentibus, decidnis. Ovaria 5, gynophore elongate stipitiformi insidentia, in unum quinquelobum, quinqueloculare coalita, glandulis stipitatis confertim tuberculata. Ovula in loculis gemina, angulo centrali superposite horizontaliter inserta, anatropa. C a p su la breviter pedunculata, subgloboso-quinqueangularis, echinata, quinquelocularis, septicide quinquevalvis, valvarum endocarpio cartilagineo, dorso adnato, marginibus liberis eircumseisso. Semina in loculis gemina, superposita, horizontalia, angulata, testa crustacea, atra, umbilico ventrali. E mbryonis exalbuminosi, orthotropi ontyledone 8 in massam carnosam, oleosam conferrumina. tae, radieula minima, umbilico proxima, centripeta. - Arbor capensis; ramis oppositis v. ternatim verticillatis, foliis oppositis, petiolatis, magnis, glandulis plurimis pellucido-punctatis et iisdem in margine argute crenulatis, pedunculis terminalibus, paniculatim ramosis, pedicellis compressis, sub flore dilatatis.

Calodendron Thunberg Prodr. 44. Dissert. 1. 42. Lam. Journ, h. n, I, 56. t. 3. DC, Prodr. I. 712. Adir, Jus. sieu in Mem. Mus. XII. 469, t. 19. $f$. 15. Meisuer Gen. 61. (44.) Pallasia Houttuyn $P f$. Syst, $X, 319, t$. 22, Dic tamu us cape us is Linn, t. Lam, $t$. 344. $f$. 2 .

G015. Adlemandlra $W I L L D$. Cal y $x$ quin quepartitus, glanduloso-punctatus. Coroll a e petala 5, ad basim disci fundo ealycis adoati inserta, calyce longiora, breviter unguicalata, patnla. S tam in a 10 , disci margini libero inserta, alterna petalis opposita ananthera; filam ent a hispida, sterilia in glandulam coneavam v. globosam desinentia, fertilia sterilibus breviora, a n the ris intrarsis, bilocularibus, magnis, ovoideis, glandnla pedicellata, cochleariformi v. globosa, demum refract $n$ terminatis, longitudinaliter dehiscentibus. O varia 5, sessilia, angulo centrali inter se coalita, glandulis stipitatis, in apice copiosioribus et longioribus conspersa, unilocularia. Ovula in localis gemina, anguln centrali enllateraliter appensa, anatropa. Sty lus centralis, calyce brevior; stig ma depresso-globosum, qninquelobum. Ca p 8 u ta pentacocca, coccis bivalvibus, endocarpio soluto, cartilagineo, elastice bilobo, monospermo. S e in en inversum, testa coriacea, tenni. Embryonis exalbuminosi, orthotropi e otyledones carnosulae, radieula brevissima, supera. - Frutices ca penses; foliis alternis $\hat{v}$. rarius oppositis, breve petiolatis, planis, coriaceis, glandulis erebris punctatis, iisdem margine quasi crenulatis, apice callosis, petiolo basi biglanduloso, floribus albidis, incarnatis v. rubicundis, magnis, in summis ramulis interdum subumbellatim divisis solitariis, bracteatis, bracteis saepe geminis, oppositis.

A de n a ndra Willdenow Enumerat. 256. Bartliug et Wendl. f. Diosm. 69, t. A.f. S. Adr. Jussien in Mem, Mrus. XIT. 470. $t, 19 . f, 6$. Meisuer Gen, 61. (45.) G I a nd u 1 if a I ia Wendland Collect. 1. t. 10. $0 \mathrm{ck}$ la et $0 \mathrm{cken} \mathrm{Ia} \mathrm{Dietrieh}$ H a e $n$ kea Schesidt in Usteri Annal. $x, 115$. Diosmatis s p. Linn. et Auct. Schrader Sert. hanov. T. $t$. 8. Bot. Mag. t. 273. 1271. 1519, Bot. Beg. t. 553. Ha rtog i a $\mathrm{sp}$. Berg.

601 1 . Colleomema $B A R T L$, et WENDL. $F$. Caly $\mathrm{x}$ quinquepartitus. Corollae petala 5, ad basiu disci calyeis fundo adnati, margine quinquelobi inserta, calyce longiora, ungue lato, longitudinaliter canaliculato, lamina patente. Stamina 10 , ad basim disci inserta, petalis breviora, alterna jisdem opposita ananthera, eorundem basi adnata, et unguis canaliculo applicita, breviora, teretia, apice attenuato-glandulosa, alterna disci lobis opposita fertilia, ungues aequantia, anthe$\mathrm{ris}$ introrsis, bilocnlaribus, subrotundis, glandula minnta, sessili terminatis, longitudinaliter dehiscentibus. $O$ va ria 5 , sessilia, angulo centrali inter se coalita, apice in cornu patens producta, glabra, unilocularia. Ovula in loculis gemina, angulo centrali superposite appensa, anatropa. StyI u s centralis, staminum longitudine; stigma eapitatum, papillosum, obsolete quinquesuleum. Ca p sula pentacocea, coccis compressis, punetato-rugosis, apice postico breviter corniculatis, bivalvibns, endocarpio cartilagineo, soluto, elastice bilobo, monospermo. $\mathrm{S}$ e $\mathrm{m}$ e $\mathrm{n}$ inversum, testa coriacea, tenui. Embryo n is exabuminosi, orthotropi cotyledones carnosulae, ra dicu la brevissima, supera. - Frutices capenses; foliis alternis, brevibus, linearibus, acutissimis, glandulosopunctatis, floribus albis, in summis ramulis axil. laribus solitariis, breviter pedunculatis, bracteis pluribus adpressis, calyciformibus stipatis.

C a leon em a Bartling et Wendl. f. Diosm, 55, t. A,f. 3 . Adr. Jnssien in Mem, Mus, XIT, 471, t. 19, f. 17. Bat, Mag. t. 3340. Meisner Gen 61. (45,)

891 1 . Dîsman $B E R G, C$ a $1 \mathrm{y} x$ quinquepartitus. Coroll a e petala 5 , ad basim disci, ealycis fund" adnati, margine liberi, glandulosi, sinuato-quinquelobi inserta, calyce longiora, patentia. St a m in a 5, ad basim disci inserta, ejusdem lobis et petalis alterna; fil a m e $n t$ a filiformi-subulata, glabra, petalis breviora, a ntherac introrsae, biloenlares, subrotundae, glandula sessili terminatae, longitudinaliter dehiscentes. 0 v a r i a 5 , sessilia, in unicum apice quinquelobum coalita, glabra, unilocularia. Ovala in loculis gemina, angulo centrali superposite appensa, anatropa. Sty I us centralis, staminibus brevior, arcuatus, glaber; st i g m a capitatum, quinquesulcatum. Capsula pentacocea, eoceis compressiusculis, transversim rugosis, apice postieo breviter corniculatis, bivalvibus, endocarpio cartilagineo, soluto, elastice bilobo, monospermo. S em en inversum, testa coriacea, laevi v. apiee prope umbilicum cristata. E mbry on is, intra albuminis carnosi stratum tenue orthotropi, cotyledones carnosulae, plano-convexae, $r$ a dicula brevissima, supera. Frutices capenses; foliis alternis $v$, oppositis, lineari-acutis, carealiculatis, argutissime serrulatis v. interdum ciliatis, glanduloso-punctatis, floribus albis $v$. rubescentibus, in apicibus ramulorum nunc solitariis, nunc corymbosim aggregatis, breviter pedicel. latis, pedicellis bracteatis, bracteis interdum oppositis.

D fosma Bergius Flor. Cap. 62. Linn. Gen, n. 272. exel. sp. Gärtner 1 . 82, t. 94 . Bartling et Wendland Collect. 
I, t. 1. 8. 9. Adr. Jussieu in Mem, Mtus, XIt. 472. t, 18. f. 13. Di os matis sect. Eudiosma DC. Prodr. I. 716 .

G1) 1 . Fuelnaetis $B A R T L$, et WENDL. $F$. Ca ly $x$ quinquepartitus. Corolla e petala 5 , ad basim disci calyeis fundo adnati, margine liberi, brevis, sulsquinqnecrenati inserta, calyce pasllo Iongiora, vix unguieulata, medio intus transversim barbata. Sta mina 5 , cum petalis inserta, iisdem alterna et breviora; filamenta subulata, ant k e ra e introrsae, biloculares, subrotundae, glandula sessili, minuta, subglobosa terminatae, longitudinaliter dehiscentes. O varia 5, sessilia, in unicum apice obtuse quinquelobum coalita, glabra, unilocularia. Ovnla in loculis gemina, angulo centrali superposite appensa, anatropa. Styins centralis, staminibus brevior, rectus, glaber, st $\mathrm{ig}$ ma late capitatum, quinquesuleum. C a p s u i pentacocea, coccis compressinsculis, transversim rugosis, apice postico breviter corniculatis, hivalvibus, endocarpio cartilagineo, solnto, clastice biJobu, mono-dispermo. Se mina inversa, testa coriacea. E m b r yo......-Frutex capensis; foliis alternis, lanceolato-carinatis, carina biseriatim punclatis, margine cpunctalis, serrulato-scabris, ciliatis, floribus albis, in apice ramulorum capitatim glomeratis, pedunculis brevissimis, opposite bibracteolatis.

E u c b a e $t$ is Bartling et Wendland Diosm 15. $t$. A.f. 1 . Adr. Jussieu in Mem. Mus. XII. 472. Meisner Gen.61. (45.)

B119. Acmademia BARTL. et WENDL $F$. Caly $x$ quinquepartitus. Corolla e petala 5 , ad basim disci calycis fundo adnati, margine liberi, brevis, integerrimi inserta, late unguiculata, unguibus intus barbata. S t a m i n a 10, inclusa, quinque petalis alterna ad basim disci inserta fertilia, quinque disci margini imposita petalis opposita sterilia, brevissima, interdum nulla; fi. I a m enta subulata, anthera e introrsae, biloculares, ovatae, glandula conica terminatae, longitudinaliter dehiscentes. Ovaria 5, sessilia, in unicum, apice in massam quinquelobam hispidam productum eoalita, unilocularia, glabra. Ovula in loculis gemina, angulo centrali superposite appensa, anatropa. Stylus centralis, staminilus brevior, rectus; stigm a late capitatum, obsolete quinquesulcum. Ca $\mathrm{p}$ n la pentacocca, enceis cum. pressiusculis, transversim rugosis, apice postico corniculatis, bivalvibns, enducarpio cartilagineo solato, elastice bilobo, monuspermo. Semen inversum, testa coriacea. Embryonis exalbuminosi, orthotropi cotyle don es carnosulae, ra dic la brevissima, supera. - Frutices capenses; foliis decussatim oppositis, quadrifariam imbricatis, brevibus, crassiusculis, carinatis, hinc subtrigonis, sublus punctatis, floribus albis $v$. rubris, terminalibus, solitariis, subsessilibus, bracleis calyciformibus, imbricalis stipatis.

A c ma de u i a Bartling et Wendl. f. Diosm. 59. t. A.f. 4 . Adr. Jussieu in Mem. Mus. XII. 4F3, $t, 18, f$. 14. Meisner Gon. 6t. (45.)

BD20. Parosma WILLD. C a ly $\mathrm{x}$ quinquefidus $v$, quinquepartitus. Corolla petala 5 , ad basin disci calycis fundo adnati, margine liberi, brevissimi inserta, ealyce multo majura, brevi. ter unguiculata, patentia. Stam in a 10 , ad basim disci inserta, quinque petalis alterna et subaequilonga fertilia; filamentis filiformi-sululatis, glabris v. hispidis, a n th eris introrsis, biloeularibus, ovoideis, glandula minuta terminatis v. muticis, longitudinaliter dehiscentibus, quinque petalis opposita sterilia, isdem dimidio breviora et adpressa, petaloidea, subulata, apice obsolete glandulosa, eiliata. Ovaria 5 , in unieum apice auriculato-quinquelobum coalita, saepius glandulosotuberenlata, unilocularia. $0 \mathrm{vu} / \mathrm{a}$ in loculis gemina, angulo centrali superposite appensa, anatropa. Siylu s centralis, staminibus longior, arcuatus, glaher $v$, hasi hispidus, apice attenuatus; st i g ma minute quinquelubum. Eapsula pentacocca, coceis coupressiusenlis, apice extrorsum auriculatis, glandulosu-punctatis, bivalvibus, endocarpio cartilagineo, soluto, elastice bilobo, monospermo. Semen inversum, testa coriacea. Embryonis exalhuminosi, orthotropi cotyledones carnosulae, radie u fa brevissima, supera. Frutices capenses; foliis oppositis $v$, alternis, coriaceis, planis, punclatis, margine nune glandulososerrulatis, nunc subintegerrimis $v$, revolutis, floribus albis $v$. rubellis, nune in ramulis axillaribus pedunculiformibus solitariis v. ternatis, breviter pedicellatis, pedicellis sacpe folio bracleaeformi stipatis, bracteis adpressis, imbricatis, calyciformibus munitis, nunc fasciculatis, pedunculis unifloris, e gemma axillari minuta, polyphylla prodeuntibus.

Baros ma Wiltdenow Enum. 257, Bartling et Weudl.f. Diosm, 94. t. B. f. 6. Adr. Jussieu in Mtem, Mius, XIt, a74.

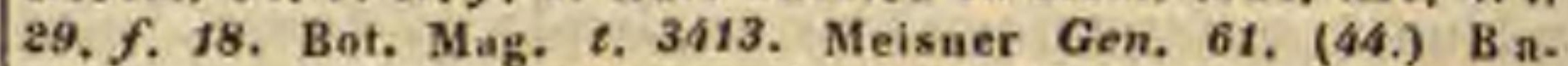
$r$ y o s m a Römer et Schultes syst. $V$. $X X V$. Pa rapetalife r a Wendland Collect. 92, $t, 15$. 34. Dios matis sect. B a ros ma DC. Prodr. I. 7t4. D los ma e s p. Thunb. Bot. Mag. t. 1616. Bot. Reg. $t$. 502, Hartogia e $8 \mathrm{p}$. Berg.

602 1. Agathosma WILLD. C a $1 \mathrm{y} x$ yuinquepartitus. Coroll ae petala 5 , ad basim disei brevis, glandulosi, calycis fnndo adnati et wvariis saepius adpressi inserta, ealyce multo longiora, unguiculata, nnguibus angustis, longis, plerumque hispidalis, lamina latiore integra, patente. St a min a 10 , ad basim disei inserta, quinque petalis alterna fertilia, saepissime inaequalia; $\mathrm{fil}$ ame nt is tereti-filiformilus, antheris introrsis, bilocularibus, subglobosis, glandula minuta, glnbulosa, sessili terminatis, longitudinaliter dehiscentibus, quinque petalis opposita sterilia, petaIoidea, ungue hispido, limbo spathalatim expanso, apice olssolete glanduloso. Ovaria $2-3$, in unicum apice hispido hi-tricorne coalita, unilocularia, glabra. Ovu Ia in locnlis gemina, angulo centrali collateraliter appensa, anatropa. Sty I u s centralis, stamina aequans, glaher, apice attennatus; s tigm a minute bi-trilobum. C a p su la tricocea, coccis apice extrorsum eorniculatis, bivalviluns, endocarpio cartilagineo, soluto, elastice hilobo, monospermo. S e m e n inversum, testa coriacea, laevi v. ad umbilisum eristata. Embryonis exalbuminosi, orthotropi cotyledones carnosulae, radienIa brevissima, supera. - Frutices capenses; foliis alternis, minutis, angustis, saepissime marginibus revolutis subtrigonis, nunc planis, integerrinis $v$. glanduloso denticulatis, plerumque punctatis, floribus rubescentibus, lilacinis $v$, albis, in apicibus ramulorum capitalim, aut saepius subumbellatim aggregatis, pedunculis unifloris, basi bracteis squamulvideis stipatis, et circa medium bibracteolatis, bracteis allernis, minimis, filiformibus.

A gathos ma Willdenow Enumer. 259. Bartling et Wendl. T.Diosm. 121, t. B.f.7. Adr. Jussieu in Mem. Mus. XII. 425, t. 20.f 19. Meisn, Gen. 01. (44.) B и c c o Wendiand Cotlect, I. f. 2. 3. 13. 28. 77. Diosmatis sect. A g a thes uta et Dictinsma DC. Prodr. I. 714. Diasmatis sp. Jacq. Collect, $11 t .278$ t. 20. $f .1$. Venten. Malm, $t, 72.93$. H a rtog la e sp. Lina. Berg.

BO2 2. Ml aerostylis BARTL, et WENDL, $F$. Calyx quinguepartitus. Corolla e petala 5, ad 
basim disci calycis fundo adnati, margine libero incrassati inserta, ealyee longiora, inferne in unguem latum, intus villeso-barbatum saepius angustata, apice patentia. Stam ina 5 , cum petalis inserta, iisdem alterna, exserta; fil a menta filifurmia, a $n$ therae introrsae, biloculares, oblongae v. subglobosae, glandula sessili minuta, globosa terminatae, longitudinaliter dehiscentes. Ov a ria 3, sessilia, disci margine eonnivente velata, apice in massam subaequalem, liberam producta, unilocularia, glabra. Ovula in loculis gemina, angulo centrali collateraliter appensa, anatropa. Sty Ins centralis, longus, exsertus, apice attenuatus; stigna minute trilobum. C a p su l a tri- v. monococca, coceis apice in cornu compressum attenuatis, bivalvibus, endocarpio cartilaginen, solubili, elastice bilobo, monospermo. S em en inversum, testa coriacea, ad umbilicum eristata. E in b r y on is exalbuminosi, orthotropi cot y ledones ear nosulae, radi is l a brevissima, supera. - Fruticuli capenses; foliis allernis v. oppositis, brevibus, juxta margines et nervorum medium subcarinatum punctatis, floribus rubescentibus, in apicibus ramulorum subumbellatim aggregatis, pedunculis brevibus v. subnullis, basi bracteatis.

Macrostylis Bartling et Wendland f. Diosm. 191. t. B.f.8. Adr, Jussien in Memt. Mus. XII, 476, t. 19, f. 20. Meisner Gen. 6t. (4S.) Dios a a e sp. Auet.

6023. Empleurum SOLAND. Calyx basi incrassatus, quadrifidus. Corolla et d is c us nullus. Sta mina 4, hypogyna, calyeis laciniis opposita et multo longiora; fil amenta sulula. ta, antherae introrsae, biloculares, ovatae, crassae, apice glandala immersa notatae, latere longitudinaliter dehiscentes. Ovari um unieum, excentricum, sessile, uniloculare, compressum, apice hine in cornu eavitate longius, compressum desinens, inde st y $1 \mathrm{~nm}$ lateralem, cornu aequantem, teretem, inflexum, glabrum, apice in $8 \mathrm{t} i \mathrm{gm}$ a simplex attenuatum exserens. Ovula gemina, suturae ventrali styliferae collateraliter appensa, anatropa. C a psula monosucca, coreo superne in cornu compressum producto, bivalvi, endocarpio cartilagineo, soluto, elastice bilobo, monospermo. Semen inversum, testa coriacea, ad umbilicum cristata. Emb ry on is exalbuminosi, orthutropi cotyled on es carnosulae, aequales, radien la hrevissima, supera. - Frutex capensis; foliis alternis, lineari-oblongis, glabris, sublus punclis glandulosis notatis et iislem margine crenulatis, floribus axillaribus, solitariis, geminis $v$, ternatis, peduncu. lis brevibus, basi bracteolatis, floribus saepe abortu polygamis, rarissime ovario duplici gaudentibus.

$\mathrm{E} \mathrm{m} \mathrm{pl}$ e u r u Solander ex Aiton Hort. Kew. III. 340. Smith Exot. Bot, II. $t$, 63. Gärtner f. III. $t$. 2t1. (anal.) DC. Prodr, I. 718, Adr. Jussieu in Mem, Mus, XII. 476. t. 19. $f$, 2t. Meisuer Gen,61. (54.) Diosu a u a le a p s u la. ris Liun. f. Suppl. 155.

TRIBUS v. DICTAMNEAE Bartling Ord. nat. 389. Flores irregulares, Pet a la libera. St a m in a duplo petalorum numero, libera. Ovaria petalis numero aequalia, subdistincta, quadriovulata. Syli superne coaliti. S e minum testa tenuis, atra, nitida. E mb ryo intra albumen carnosum rectus. - Herbae europa ea e, graveolentes, foliig allernis, imparipinnatis.

BO24. Dietammus LINN. Calyx brevis, quinquepartitus, inaequalis, laciniis duabus inferioribus longioribus, deciduus. Corolla e petala 5, ad basim gynophori inserta, calyce longiora, unguiculata, lanceolata, inaequalia, quatuor superiora geminatim adscendentia, quintum inferius declinatum. St a m in a 10, eum petalis inserta, declinata, alterna calycis laciniis opposita petala superantia; fil a m e n t a subulato-filiformia, antherae introrsae, biloculares, terminales, sabrotundae, longitudinaliter dehiscentes. O varia 5, gynophoro stipitiformi glabro insidentia, basi coalita, unilocularia, tuberculoso-hispida. Ovala in locnlis $3-4$, sutnrae ventrali inserta, pendula, anatropa. S tyli 5, ex ovariornm angulo interiore infra apicem orti, basi distincti, mox in unum, inferne hispidulum, declinatum, petala superantem coaliti ; st ig ma obtusum, papillosum. C a psu la stipitata, pentacocea, coceis basi inter se coalitis, apice cnspidatis, hivalvibus, endocarpio cartilagineo, soluto, elastice bilobo, margine membranaceo cum seminibus secedente, $\mathrm{S}$ e m in a $2-3$, „vato-subylobosa, testa tenui, atra, nitida. E mbryo in axi albmminis carnosi, basi et apice tenuis, ad latera incrassati orthotropus; coty ledonibus crassis, obovatis, radicula brevi, snpera. - Herba perennis, basi suffruticosa, in Europa a ustraliore obvia, speciosa, graveolens; foliis alternis, imparipinnatis, qualri-sexjugis, foliolis serrulatis, pellucido-punctatis, petiolis inter juga saepius subalatis, floribus in apicibus ramorum racemosis, albis aut purpurascentibus, racemis inferne compositis, superne simplicibus, pedunculis bracteatis, pedicellis basi medioque bracteolatis, inflorescentia glandulis substipitatis, in diversis flor is partibus plus minus confertis, quasi hispida.

Dieta a n s Linn. Gen. $n$. 522. Lam. $t$. 344. $f$. 1 . Schkubr t. 114. DC. Prodr. I. 712. Adr. Jussieu in Mem. Mus. XIT. 467, t, 18, f. 12, Meisner Gen, 61. (44.) F ra$x$ in ell a Tournefort Inst. 243. Gartner $I, 337 . t$. 69. (De atmosphaerae combustihilis phaenomeao efe. Biot in Nouv. Annal. Mus, I. 273-281.)

\section{Drdo CCLII. Ratacear.}

RUTACEARUM pars Jnssieu Gen, 297. DC. Prodr. $\boldsymbol{T}$. 709. RUTBAE Adr. Jussieu in Mem. Mus. XIL. 46t. RUTACBAF Bartlling Ord, nat, 389. Lindley Introduct, edit, II. p. 130.

Нвrbas perennes v. suprouticks. Folia alterna, simplicia, varie lobata aut decomposita, rarius integra, saepissime glanduloso-punctata v. tuberculata. Stipula nullae, v, earum loco (in Pegano) dentes setiformes ad foliorum basim.

Fuores hermaphroditi, regulares, in apicibus ramorum corymbosi v. racemosi, lutei v. rarius albi.

Cazx liber, persistens, quadri-quinquepartitus, laciniis integris v. (in Pegano) pinnatifidis, aestivatione imbricatis.

Conollas petala hypogyna, decidua, gynophori brevissime stipitiformis imae basi inserta, calycis laciniis numero aequalia, iisdem alterna et longiora, basi in unguem brevem coarctata, lamina plana $\mathbf{v}$. interdum apice fornicata, et margine undulato-sinuata, aestivatione contortim v. convolutive imbricata, sub anthesi patentia v. patentissima. 
Sramina cum petalis inserta, duplo v. rarius triplo eorundem numero, alterna petalis opposita saepe breviora. Filamenta filiformia, libera v. interdum breviter monadelpha, basi saepe dilatata. An therae introrsae, biluculares, muticae v. interdum connectivo inter loculos oppositos, in glandulam minutam producto superatze, loculis longitudinaliter dehiscentibus.

Ovarıux gynophoro brevi, rarius longiusculo, basi saepissime in discum carnosum, glandulosum expanso insidens, profunde tri-quadri-quinquelobum, tri-quadri-quinqueloculare. Ovula in singulis toculis $2-4 \mathrm{v}$. plurima, placentae ex angulo centrali prominulae biseriatim inserta, anatropa v. amphitropa. Styli ex imo loborum angulo, basi saepe discreti, superne in unicum coaliti. Stigma tri-pentagonum, sulcatum.

Capsula nune (in Pegano) trilocularis, loculicide trivalvis, valvis medio dissepimenta in axi centrali cohaerentia gerentibus, nunc quadri-quinqueloba, lobis apice introrsum dehiscentibus, endocarpio cartilagineo, adnato v. rarissime demum soluto.

Semisa in loculis plerumque abortu pauca, pendula $v$, adnata, reniformi-arcuata, Testa crustacea v. subspongiosa, scrobiculata v. punctata. A l b um e n carnosum.

Embryo in axi albuminis concolor v. viridis, homotrope arcuatus v. rectus, seminis longitudine. Cotyledoues lineares v. oblongae, complanatae, interdum bipartitae. Ra dicula cylindrica, cotyledonibus saepissime paullo longior, supera.

Rutaceae Zygophylleis proxime affines, ab iisdem foliis alternis, exstipulatis, stylo basi saepius multiplici, ovulorum situ, et albumine carnoso differunt.

Peganum pluribus notis inter utrumque ordinem ambigit, foliis stipulatis, epunetatis, et eapsulae dehiscentia Zygophylleis, aliis characteribus, imprimis alterno foliorum situ, albuminis consistentia, et habita Rutaceis propinquius.

Speeies ommes gerontogeae, in hemisphaerae borealis regionibus temperatis habitant, in regionibus mediterraneis et Sibiria australi frequentissimae, versus polum et aequatorem numero valde imminutae.

BQะร. Peganum LINN, $\mathrm{C}$ a $1 \mathrm{y} x$ quinque partitus, persistens, laciniis foliaceis, oblongolinearibus, integerrimis v. pinnatifidis. Corolla e petala 5, ad basim gynophori inserta, subaequalia, integra, trinervia, aestivatione contortim imbrieata, sub anthesi patentia. Stamina 15 , cum petalis inserta, iisdem breviora, nonnalla abortiva; fil amenta glabra, basi membranaceo-dilatata, a $n$ therae introrsae, biloculares, linearioblongae, longitudinaliter dehiscentes. Qvarin m gynophoro brevi, in diseum erassum, eupulaeformem, abbreviatum expanso insidens, globoso - tri. Iobum, triloculare. Ovula in loculis plnrima, placentae ex angulo centrali prominulae funiculis brevibus appensa, anatropa. Stylus simplex, apice clavato-trigonns, demum spiraliter tortus. Ca ps n la subgloboso-triloba, triloenlaris, loculicide trivalvis, polysperma. S e $\mathbf{m}$ i $\mathrm{n}$ a angulatoreniformia, testa spongioso-scrobienlata. Embryo in axi albuminis corneo-carnosi leviter arcuatus; cotyledonibus ovatis, tennibus, radieula tereti, supera. - Herba graveolens, eglandulosa, in Europa a ustrali et Oriente indigena, annua v. perennis, ramosa; foliis alternis, sessilibus, integris $v$ irregulariter multifidis, basi dentibus duobus setiformibus stipulatis, pedunculis in apice ramorum oppositifoliis, folio brevioribus, unifloris, floribus albis, nervis virescentibus.

Peganum Linn. Gen, n. 601. Gärtner II. 87, t. 95. Kam. $t$. 401. Sibthorp Flor. graec, $t$. 455. DC. Prodr. $I$. 712. Adr. Jussieu in Mem. Mus. XII. 461, t, 16. $f$. 8. Meis. ner Gen, 60. (44.) H a r u a I a Môuch Method. 239.

BO26. BBoenatinglhausenia REICHENB. C a ly $\mathbf{x}$ brevis, quadripartitus, sero deciduus, $C_{0-}$ rolla e petala 4, ad basim disci laxe urceolati, gynophori stipitiformis basim cingentis, apice glanduloso-tnberculati inserta, calyce Inngiora, subsessilia, obovata, erecto-patentia. S $t$ a $m$ in a 6-8, cum petalis inserta, hreviter exserta, inaequalia; fil amenta subulata, a ntherae introrsae, biloculares, longitudinaliter dehiscentes. 0 varia 4, gynophoro stipitiformi, longo insidentia, in unicam quadrilobum basi approximata, unilocularia. O vula 6 _, placentae juxta suturae ventralis basim prominulae inserta, amphitropa. Styli ex ovariorum angulo interiori infra apicem exserti, in unicum brevem, demum quadripartibilem coaliti; st $\mathrm{ig}$ a aequale, quadrisulcum. Cap $8 \mathrm{u}$ la 4 , basi coalitae, superne patentes, subclavatae, intus infra apicem styliferae, uniloculares, sutura ventrali dehiscentes, pleiospermae. Semina reniformia, striata, punetata, E m b r yo intra albumen carnosum homotrope arcuatus, subcylindricus, radicula supera. - Herba nepalensis, perennis, Rutarum more glandulis oleosis punctata; foliis alternis, bipinnatis, foliolis obcordatis, pellucido-punctalis subglaucescentibus, panicula terminali composita, gracili, subpilosa, ramis pedicellisque foliaceobracteatis, pedicellis jiliformibus, floribus candidis.

Boenuinghause ai a Reichenbach Consp. 187. Meisner Gen. 60. (44.) Ruta ulbiflora Hooker Exot. Flor. t. 79 .

G02\%. Huta TOURNEF. Caly x brevis, quadripartitus, sero deciduns, laciniis aestivatione imbricatis Corolla e petala 4 , ad basim gynopheri inserta, calyce multo longiora, aestivatinne conturtim imbricata, suh anthesi patentissima, limbo fornicato, plernmque laciniato v, sinuato. S ta mina 8 , cnm petalis inserta, iisdem longiora, alterna illis opposita panllo breviora, omnia patentissima; filamenta subulato-filiformia, glabra, antherae introrsae, biloculares, ovatae, obtusae, longitudinaliter dehiscentes. Ovarium $\mathrm{sy}^{-}$ nophero lmevi, erasso, discoiden, ambitu poris nectariferis octo inseulpto insidens, subglolioso-quadrilobum. O vula in loculis 6_12, placentae ex angulo centrali prominulae funiculis brevissimis appensa, anatropa. Stylus centralis, brevis, sursum attenuatus ; st ig ma aequale, quadrisulcum. Ca psula quadritotia, quadrilocularis, tobis 
apice introrsum dehiscentibus, v. snbearnosis, indehiscentibus, polyspermis. Sem in a angulato-reniformia, testa subirustacea, punctata. Embry o in axi albuminis carnosi leviter arcuatus; cotyledonibns lineari-ovatis, planis, altera saepius v. interdum ambobus bipartitis, radic ula tereti, supera. - Herbae perennes v. suffrutices, in regionibus temperatis et calidioribus exiratropicis hemisphaerae borealis veteris or bis indigenae, graveolentes, glanduloso-punctatae; foliis alternis, exstipulatis, pinnatis $v$. saepissime decompositis, pellucido-punctatis, pluribus viridi luteis, in corymbos $v$, ravemos terminales dispositis.

R u ta Tournefort Inst. 133, Linn. Gen, n. S23. excl. sp. DC. Prodr. $I$. 709, exel. sect. 3 et 4 . Adr. Jussieu in Mem. Mus. XII. 462. Meisuer Gen, 60. (44.)

a. RUTERIA DC. l. c. F r u c t u s carnosus, indehis. ceas. - Folia pinnata, foliolis supra petiolum articulatis. Ruteria Webb et Berth. Flor. Canar. 14. R. pinnata Linn. Bot, Reg. $t, 307$.

b. RUTA DC. l, c. Fruetus dehiseens, - Folia pinnatisecta v. decomposita. (Jacq. Ic. rar. 1. 76. Duham. Arbr. 11. t. 61. Sibthorp Flor. graec, t. 368. 369. Bot. Mag, t, 2018, 2311. Tenore Flor. neap. t. 36. Adr. Jus. sieu Op. cit.t. 17. f.9. Reichenb. Iconogr. t, 786-790)

6028. 필 aploghyllenm $A D R, J U S S$. CaI $\mathbf{y} \mathbf{x}$ brevis, quinque-sexpartitus, sero deciduus, laciniis aestivatione imbrieatis. Corollae petala 5 v. 6, ad basim gynophori inserta, calyce multo longiora, unguienlata, aestivatione contortim imbricata, sub anthesi patentia, limbo plano, inte gerrimo. Stamina 10 v. 12 , cum petalis inserta, iisdem breviora v. subaequalia, alterna illis opposita reliquis breviora, patentia; fil a m en ta basi dilatata, intus pilosa, anthe rae introrsae, biloculares, uvatae, glandula minuta termiaatae, longitadinaliter dehiscentes. Ovari u m gynoplıoro brevi, obconico, lato insidens, subgloboso-quinque-sexlobum, quinque-sexloculare, rarissime triquadriloculare. 0 v 1 a in loculis $2-4$, placentae ex angulo centrali prominulae inserta, amphitropa (?). St y I us centralis, staminum longitndine, sursum incrassatus; stig ma capitatum, quinquesexsuleatum. Capsula sabglobosa, quinyue-sexloba, lobis apice intrarsum dehiscentibus, loculis di-tetraspermis. Se mi na reniformia, testa scrohiculata v. tubereulata, sinu umbilicata. Embryo intra albumen carnosum homotrope arcuatus; cotyledonibus oblongis, incumbentibus, $r$ ad icula supera. - Herbae perennes $v$. suffruticuli, in Europa australi el $A$ sia temperata crescentes; foliis alternis, exstipulatis, simplicibus, integerrimis, interdum gemmae axillaris foliis primariis evolutis spurie trifoliolatis, glanduloso-punctatis, floribus terminalibus corymbosis, luteis v. rarissime albis.

H a p lophy $11 \mathrm{~nm}$ Adr. Jussien in Mem. Mus.h XIH 464. $t$. 17. f. 10. Meisner Gen. 60. (44.) Delessert Ic. select. IIT. t. 43. 4i. R u tae $\mathbf{s}$ p. simplieifoline et trifoliolatae Linu. et Auct. Sibttiorp Flor. graec. $t$. 370 . Labillard. Syr. Decad, I. $t$. 14. Bot, Mag. $t$. 2254.

60\%5. Tetradielis STEVEN, Calyx quadripartitus, persistens, laciniis aestivatione imbricatis. Corollae petala 4 , sub disco hypogyno inserta, ovalia v. obovata, brevissime unguiculata, aestivatione imbrieata, diu persistentia. Stamin a 4 , cnm petalis inserta, iisdem alterna; fila. menta compressinscula, an therae introrsae, biloculares, subglobosae, dorso insertae, longitudinaliter dehiscentes. Ovari $\mathbf{m}$ disco insidens, obtuse quadrangulum, medio depressum, quadri- loculare. Ovula in loculis $4-6$, placentae ex angulo adscendentis apici funicalis brevibus affixa, pendula, anatropa. Stylus centralis simplex, persistens; stigma clavatum, quadrisuleum. Caps u la snbgloboso-tetragona, depressa, medio nubilicata, faciebus quadrisulea, quadrilocularis, ad angulos loculieide dehiseens, endocarpio soluto, bivalvi, valvulis crustaceis, margine membranaceis, involutis, sulco angusto introrsum biantibus, singulis semen singulum includentibns, placenta inter valvularum facies filiformi libera, di tetrasperma, epicarpii valvis basi et apice inflexis, medio septum obliteratum gerentibns, singulis tocnlorum contiguorum endocarpii valvalam retinentilus. Semina oblonga, testa tenui, laevi, dilute flavo-fusca. Embryo in axi albuminis carnosi, parei rectus; cotyledonibus crassis, radicula supera, - Herba tenella, succulenta, glaberrima, glauca, multicaulis, fugax, in planitierum Tauriae, maris Caspici, Mesopotamiae et Aegypti inferioris obvia; foliis primaräs ramisque oppositis, caulinis alternis, inferioribus pinnatisectis, laciniis linearibus, inaequalibus, superioribus tripartitis, summis indivisis, floribus in spicam terminalem, foliaceo-bracteatam dispositis, spica ut in Heliotropio primum revoluta.

Tetradielis Steven in Bieberstein Flor. Taur. cauc. III. 277. et 648, C. A. Meyer Verzeichn, cauc, casp. Pflanz, 226. Lindley ad Chesn. inedit. A n a trop a Ehreuberg in Linnaea IV. 402 .

\section{Ordo CCLIIL. Zygophylleae.}

RUtAcearum sect. I. Jussiea Gen, 296. ZYGophyL. LEAE R. Brown in Flinders Voyage $I T, 545$, DC. Prodr. 1 . 703. Adr. Jussieu in Mem. Mus. XII. 450. Bartliug Ord. nat. 390. ZYGOPHYLLACEAE Lindley Introduct, edit. II. p. 133.

Herbae, frotés v. arbones, ligno durissimo, ramis saepissime nodoso-articulatis, ramulis teretiusculis $v$, rarissime semiteretibus. Folia opposita, interdum alternatim aborliva, composita, nune imparipinnata, tuneque foliolorum lateralium abortu interdum simplicia, nunc abrupte pinnata, saepe unijuga, petiolo apice tune in mucronem brevem v. Jacinulam producto, interdum complanato v. margine foliaceo cincto, foliolis sessilibus, oppositis $v$. rarius alternis, integerrimis, epunctatis, satpissime inaequilateris, planis v. subearnosis et interdum teretibus. Si i pulae ad basim petiolorum geminae, persistentes, interdum spinescentes v. rarius deciduae.

Flores hermaphroditi, regulares, albi, caerulei, rubescentes v. saepius lutei, in pedunculis unifloris, saepissime solitariis, axillaribus $v$. inter binas foliorum oppositorum stipulas nascentibus, ebracteatis.

Calxx liber, persistens v. rarius deciduus, quadri-quinquepartitus, laciniis aestivatione imbricatis v. rarissime valvatis.

Corollar petala hypogyna, calycis laciniis numero aequalia, iisdem alterna et longiora, aestivatione convolutim imbricata, decidua.

Stamisa petalorum numero dupla, hypogyna, decidua, biseriata, exteriora calycis laci146 
niis opposita plerumque longiora, rarissime breviora. Fil a m e $n$ ta filiformia, rarissime basi nuda, aequalia v. dilatata, plerumque squamae integrae v. emarginatae aut lacerae dorso inserta. A n th e r a e introrsae, biloculares, erectae v. dorso supra basim affixae, loculis appositis, connectivo ubsoleto contiguis, longitudinaliter dehiscentibus.

Ovariux toro convexo, rarius depresso insidens, basi interdum glandulis distinctis v. in discum sinuatum coalitis stipatum, simplex, plus minus profunde sulcatum, quadri-quinqueloculare v, rarissime decemloculare. $0 \mathrm{vul}$ a in loculis nune duo superposita, nunc plura biseriata, rarissime (in Kallströmia) solitaria, ex apice loculi pendula, anatropa v. (in Fagonia) gemina, in funiculis brevibus e basi loculi adscendentibus uutantia, mox erecta, orthotropa. Styli loculorum numero in unicum coaliti, interdum nulli. Stigma simplex, v. quadriquinquelobum.

Froctus capsularis v. rarius subcarnosus, angulatus v. alatus, interdum tuberculatus v. spinosus, quadri-quinque-v. rarissime decemlocularis, loculicide dehiscens v. septicide in cocca bivalvia $v$, rarius indehiscentia delabens, axi centrali persistente v. obsoleto, rarius indehiscens, loculis septis inter semina transversis plurilocellatis.

Semina saepissime abortu ovulis pauciora, interdum solitaria, pendula, ovoidea, laevia, umbilico infra apicem acutum inserta, rhaphe lineari, longitudinali, ad chalazam basilarem producta, rarissime (in Fagonia) in loculis solitaria, e basi erecta, compressa, seabra, umbilico cum chalaza confluente, rhaphe obsoleta. Tes ta membranacea. Albume n corneo-cartilaginum, albicans, (in Guaiaco transverse rimosum) rarissime (in Tribulo) nullum.

Eмввуо viridis, in axi albuminis orthotropus, rectus v. leviter arcuatus, rarissime (in Fagonia) antitropus. Cotyled ones foliaceat. Hadicula umbilico parallela v. e diametro opposita, supera.

Zy gophylleae fructus et seminis structura, albuminis consistentia, et characteribus vegetativis ab aliis Rutacearum ordinibus facile distinguendae, illine Oxalideis proxime affines, utriusque hemisphaerii regiones extratropicas calidiores frequentissime incolunt, ab Africae ora boreali occidentali, per regionem mediterraneam, ad Sibiriae australem et Indiae borealem limitem imprimis copiosae, inter tropicos, in Capite bonae spei, Nova-Hollandia et America trans Capricornum multo rariores. Americanae pleraeque fruticosae $\mathbf{v}$. arboreae, albumine copiosiore donatae.

Seetzeniae affinitas subdubia, Melianthi, etiam Geraniaceis et Sapindaceis aliquantisper accedentis, perquam obscura. Bibersteinia inter Geraniaceas et Zygophylleas media.

Nonnullae principio peculari resinoso, amaro foetae.

TRIBUS I. TRIBULEAE. S e mina exalbuminosa.

G030. Tributins TOURNEF. C a l y $x$ quinquepartitus, deciduus. Corolla e petala 5, hypogyna, calyce majora, patentia. Sta in in a 10, hypogyna, petalorum longitudine; f i l a m e $n t a$ subulato-filiformia, alterna calycis laciniis opposita basi extus glandula stipata, alterna petalis opposita eglandulosa, paullo breviora, antherae introrsae, biloculares, cordatae, Iongitudinaliter dehiscentes. Ovari a m sessile, hasi urceolo brevi, decemlobo einctum, adpresse pilosum, quinqueloculare. 0 v u la in loculis $3 \_4$, angulo centrali superposite inserta, oblique pendula, anatropa, rhaphe introrsa. Sty I us brevissimus v. nullus; s tigma magnum, pyramidato-quinqueangulare, angulis papillosis. Fru c tus depresso-pentagonus, pentacoccus, cocci axi centrali nullo demum sejuncti, indehiscentes, dorso irregulariter tuberculosi v, spinosi, intus septis inter semina horizontalibus oblique transversim bi-quadrilocellati, locellis monospermis. Se $\mathrm{m}$ in a ovato-acuta, ex angulo centrali oblique suspensa, testa membranacea. $\mathbf{E}$ mbryonis exalbuminosi, orthotropi cotyledones ovatae, axi parallelae, radicula conica, sursum centripeta. - Herbae, in Europa australiore et in regionibus tropicis subtropicisque totius orbis obviae, saepissime procumbentes, diffusae; foliis oppositis, altero saepe minore, bistipulatis, abrupte pinnatis, foliolis oppositis, integerrimis, pedunculis in axilla folii minoris alternatim solilariis, unifloris, floribus luteis v. albis. Tribulas Tournefort Inst, 141. Lian. Gen, n. 532. Schkuhr t. 115. Gärtu. I. 335, t. 69. Sibthorp Elor. graec. t. 372. Kunth in Humb. et Bonpl. Nov. gen, et sp. VI.11. Bot. Reg. t. 791. DC. Prodr, 1. 703. exel, sp. Adr. Jussieu in Mem. Mas, XII. 451. t. 14. f. 1. Meisuer Gen. 59. (43.)

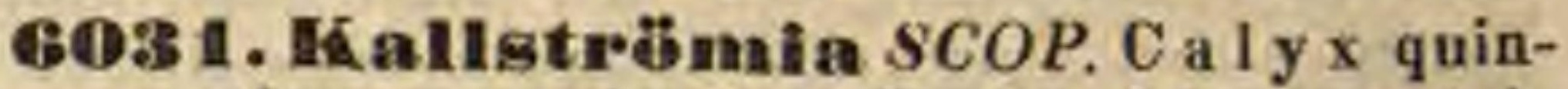
que-se partitus, persistens. Co roll a e petala 5 -6, hypogyna, calyce majora, patentia. Stamina 10 v. 12 , hypogyna, petalis breviora; filame nta subulato-filiformia, eglandolosa, alterna petalis opposita paullo breviora, eorundem unguibus subadglntinata, an the $r$ ae introrsae, biloculares, ovato-oblongae, incumbentes, longitudinaliter dehiscentes. Ovari u m sessile, basi disco earnosulo, tenui cinetum, decem-duodecimloenlare. Ovula in loculis solitaria, ex apice angali centralis pendula, anatropa. Stylus e basi conica attenuatus; $s t \mathrm{igma}$ clavatum, subemarginatum, verticaliter striatulum. Fruct a s angulato-pyramidalis, deca-dodecacoceus, cocei ab axi superne in stylum dilatato-nmbraculiformi soluti, indehiscentes, dorso cristati, ventre sulcati, uniloculares, monospermi. Sem ina ovata, ex anguli centralis apice pendula, testa membranacea. Embryonis exalbuminosi, orthotropi cotyled on es ovatae, axi contrariae, radic ula conica, supera. - Herbae in America tropica indigenae, erectae, diffuse ramosae; folits oppositis et alternis, abruptepinnatis, bistipulatis, foliolis oppositis, integerrimis, pedunculis axillaribus, solitariis, unifloris, floribus miniatis.

Kallströmia Scopoli Introduct. 937. Meisner Gen. 59. (43.) E hre ubergi a Martius Nov. gen. et sp. II. 78. 
t. 163. Heter ozy g is Bunge Verzeichn, Altaischer P/anz. 82. ia uot. Tribulus a k $\mathrm{ximus}$ Lian. Jacq. Ic. rar. t. 462 .

TRE IBUS II. ZYGOPHYLLEAE VERAE. Semina exalbuminosa.

B032. Chitonia MOC. et SESS. C alyx quadripartitus, deciduss, laciniis inaequalibus. $\mathrm{Co-}$ rolla petala 4, liypogyna, obovata, emarginata, breviter unguiculata, calyce multo majora. Stamina 8 , hypogyna, aequalia, petaliz breviora; filamenta tereti filifurmia, erecta, antherae introrsae, biloculares, ovatae, dorso insertae, loculis longitudinaliter bivalvibus, harbatis. Ovarium sessile, oblongum, acute quadrangulnm, quadriloculare. Ovula in loeulis gemina, angulo centrali superposite appensa, anatropa. Stylus ovario continuus, eylindricus; stig ma latum, capitato-quadrilobum. C a p s ula quadrilocularis, septicide quadrival vis, valvis compressinsculis, dorso et apice in alam coriaceam, latam productis, axi centrali pentagono seminifero. Sem in a in loculis gemina, superposita, pendula, ovato-compressa, superne truneata, testa coriacea, rhaplie longitudinali, ad chalazam umbilico apicali e diametro oppositam in eristam membranaceam brevem expansa. Emb ryo in axi albuminis carnosi orthotro. pns, viridis; cotyledonibus oblongis, radio a la rylindrica, brevi, obtusa, supera, - Frutex mexicanus, sericeo hirtus; foliis inferioribus alternis, superioribus oppositis, alternalim abortivis, imparipinnatis, bi-sexjugis $v$. interdum trifoliolatis, foliolis oppositis petiolulatis, integerrimis, mucronulatis, stipulis brevissimis, lineari-lanceolatis, pedunculis oppositifoli-terminalibus, solitariis, unifloris, floribus magnis, purpureo roseis.

Cbitonia Mocino et Sessé ex DC. Prodr. I. 707. Zutcearini Nov. Stirp. faso. $I .355 . t$, 17. Meisuer Gen. 59. (43.)

6033. Juliania $L L A V$, et $L E X$. C a $\mathrm{y} x$ pentaphyllus, foliolis oblongis, deciduis. Corolla e petala 5 , calyce majora, ovalia, apice dente obliquo notata, patentia. S ta m in a 10 , alterna breviora; fil a menta subulata, crassiusenla, a ntherae tetragonae, quadrisuleatae. Ovarium globoso pyramidatum, ad medinm quinqueangulatum, quinquelos:nlare, loculis biovulatis (?). Sty1 us brevissimus, teres, villosus; $8 t \mathrm{~g}$ ma capitato pentagonum, villosum. C a p s u la quinquelocularis, quinquevalvis. - Frutex mexicanus, aromaticus, ramosissimus ; ramisjunioribus compressiusculis, pubescentibus, foliis alternis oppositisque, alternatim abortivis, trifoliolatis, rarissime digitatis, foliolis obovatis, subspathulatis $v$. oblongis, intermediis longioribus, omnibus integerrimis, glabris, parum ciliatis, glandulis plurimis, translucidis conspersis, pednnculis cymosis, longissimis, paniculat is, quadri-sexfloris, pub-scentibus, bracteis oblongis, acutis, ciliatis, villosis, calycibus et petalis glandulosis. II. 4.

Juliania Llave et Lekarza Nov, Veget. Deseript.

8034. Fagonia TOURNEF. $\mathrm{C}$ a $1 \mathrm{y} \mathrm{x}$ quinquepartitus, deciduns. Corolla e petala 5, hypoEyna, unguiculata, ealyce longiora. $\mathrm{S} t$ a $\mathrm{m}$ i na 10 , hypogyna, subaequalia; fil a menta tereti-fitiformia, basi nuda, erecta, a ntherae introrsae, biloculares, cordatae, longitudinaliter dehiscentes. 0 va ri u m sessile, acute quinqueloculare. $O$ vula in loenlis gemina, e basi anguli centralis in funi- culis brevibus collateralibns primun reclinata, mox erecta, orthotropa. Stylus ovario continnus, quinquangulatus, persistens; s $\mathrm{t} i \mathrm{~g}$ a acutum, quinquesnlcum. Capsula pyramidato-pentagona, pentacocea, coccis compressis, ab axi centrali persistente demum solutis, endocarpio adnato $v$. secedente, bivalvibus, abortu monospermis. S em ina ex axeos persistentis basi erecta, ovata, compressa, testa scabra, mueilaginosa. E m bryo intra albnmen carnoso-corneum antitropus; cotyledonibus ovatis, planis, radicula supera. Herbae mediterraneac et orientales, basi lig. nosae, saepissime pilis brevibus, apice interdum tuberculatis hispidae; ramis patentibus, alternatim axillaribus, foliis oppositis, stipulis geminis saepe spinescentibus munitis, trifoliolatis $v$, in eodem interdum ramulo unifoliolatis, foliolis integerrimis, mucronatis, pedunculis inter foliorum oppositorum stipulas solitariis, unifloris, floribus purpureis aut violaceis, rarius lutescentibus.

Fagonia Tournefort Inst. 141. Linn. Gon. n, 531. Gärtner 11 . 153. $t$. 113. Bot. Mag. $t$. 24t. Delile Flor. aegzpt. t. 27. f. 2. t. 28. f. 2. 3. DC. Prodr. I, 704. Adr. Jussien in Mem. Mus, XII. 453. t. 14. f. 2. Meisuer Gen. 59. (43,)

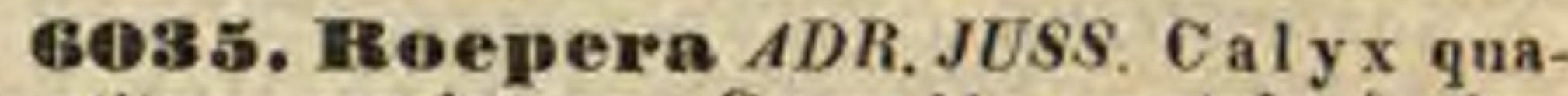
dripartitus, persistens. Corolla e petala 4 , hypogyna, unguiculata, ealyce longiora. S ta mina 8 , hypegyna, petalis breviora; filamenta sululata, basi nuda, a ntherae introrsae, liloculares, ovatae, longitudinaliter dehiscentes, O varin m sessile, basi squamulis quatuor, calycis laciniis oppositis, extus tomentosis stipatum, quadricostatum, quadriloculare. Ovula in loculis gemina, angulo centrali superposite appensa, anatropa. Stylus ovario continuns, quadrisuleus; st ig ma minute quadrilobum. Fructus capsularis, indehiscens, quadrilocularis, quadriangulatus, angulis in alam membranaceam, reticulato - veno. sam expansis, loculis tribus saepissime efoetis, quarto aborta monospermo. S e m en inversum, ovato-acutum, testa scabra. E mbry o intra albumen tenue orthotropus; cotyledonibus ovatooblongis, plano-convexis, radicula brevi, conica, supera. - Frutices Novae-Hollandiae, Zygophylli facie; ramis patentibus, foliis oppositis, stipulis binis interjectis bifoliolatis, foliolis integerrimis, petiolis complanatis, pedunculis in stipulae axilla solitariis $v$, geminis, unifloris, floribus flavis.

Roepera Adr. Jassien in Mem, Mas. XIT, 454. t. 15. f. 3. Meisuer Gen. 59. (43.) Delessert Ic. select. III. t, 48. Zy gophyllum Billardierif DC. et Z. frutienlo8 u $\mathrm{m}$ DC.

6036. Zygophyllum LINN. Calyx quinqnepartitus, deciduns, laciniis subinaequalibus. Corolla e petala 5, hypogyna, unguiculata, ealyeem aequantia v. superantia. S $t$ am in a 10 , hypogyna, inaequalia, petalis longiora; filamenta squamulae integrae, rarins ciliato lacere v. bipartitae basi intus adnata, filiformia, flexuosa, a ntberae introrsae, biloculares, ovatae v. obInngae, versatiles, longitudinaliter dehiscentes. Ovarium gynophoro brevi, nunc convexo brevissimo, nune concavo, disciformi insidens, oblongo-pentagonuin, quinqueloculare. Ovala in loculis gemina, v. plura angnlo centrali superposite appensa, anatropa, rhaphe partim v, omnino libera v. demum adnata. Sty Ins ovario continuus, quinquesuleatus; st ig ma minute quinquelobum. Fructus capsularis, pentagonus v. pentapterus, quinquelocularis, nune septicide pentacoccus, axi seminifera persistente, nunc loculicide quinqueval146 * 
vis, valvis medio septa seminifera gerentibus. S emina in loculis abortu solitaria, panca v. plurima, pendula, compressa, subreniformia, testa crustacea, rhaphe libera v. adnata. $\mathbf{E} \mathrm{mb}$ r y o intra albnmen parcum rectus; cotyled onibus ovatooblongis, radicula obtusa, supera. - Frutices v. suffrutices, per om $n$ em Africam obvii, in insulis mediterraneo-orientalibus, syria et $A$ sia media rariores; foliis oppositis, membranaceis, bistipulatis, bi- v. rarissime unifoliolatis, foliolis saepe carnosulis, planis $v$. interdum teretibus, petiolo complanato $v$, subnullo, pedunculis inter foliorum oppositorum stipulas solitariis $v$. geminis, uniftoris, pelalis rubris, albis aut saepius favis, ple rumque mascula basilari et nervis flabellatis, rubescentibus aut violaceis, distinctis, floribus quandoque parte quarta imminutis.

Z, y g o h y 11 u m Lioo. Gen. n. 530. Gärtner II. 146. DC. Prodr. I. 705. exel. sp. Adr. Jussieu in Mem. Mus.XIT. 455. $t, 15 . f, 4$. Meisn. Gen 39 , (43.) F a b a g o Tuurnef. Inst. $t .230$.

a. FABAG0, Capsula loculicide dehiscens. Semin um rhaphe omnino v. partim adnata. - Foliola plana. (Gärtner t. 112 . Adr. Jussieu Op, cit. $t$, 15. $f$. 4. Ledebour Ic. $t, 109,140,218,373,382,383$.

b. AGROPHYLLUM, C a p s u la septicida. S e m in u m rhaphe libera. - Folia teretia. Agrophyllum Necker Elem. n. 967. Forshael Ic. t. 11. 12. Delile Flor. aegspt, $t, 27, f, 3$. DC, $F l . g r ., 256$. Bot. Mag. $t .372$. 2184. Webb et Berth. Elor. Canar. t, 1.)

GQ38\%. 'Thel clasentherea ERRENB. C a l y x campanulatus, quinquefidus, persistens. CorolI a e petala 5, hypogyna, ealyce longiora, anguste linearia, obtusa. Stamina 5, hypogyna, calycis laciniis opposita; fil a m enta membranaceo-dilatata, antheris latiora, antherae filamentis longiores, filiformes, erectae, didymae, apice fissae, losulis parallelis, longitudinaliter dehiscentibus. O vari u m breviter stipitatum, ovatum, quinqueloeulare. Ovula in loculis plurima, angulo centrali biseriatim appensa, anatropa. Styl us ovario continuus et Iongior, quinquesulcatus; stigma capitatum. Caps a la ovata, obtuse pentagona, quinquelocularis, quinquevalvis, loculis polyspermis, superne dehiscentibus, suturis intus setosis. Sem in a reniformia, ovato-acuta, rugulosa. E mhryo in axi albuminis orthotrupus; cotyled onibus subfoliaceis, radicula supera. - Herba arabica, tenerrima, bi-tripollicaris; foliis alter nis, stipulatis, setaceo-linearibus, apice dentatis, floribus longe pedunculatis, nutantibus, pedunculis greniculatis.

Trichanther a Khrenberg in Linnaea $I V .401$.

6035. Larrea CAVANILL. C a ly $\mathrm{x}$ quinquepartitus, deciduns, laciniis subinaequalibus. Corolla e petala 5 , hypogyna, unguiculata, calyce longiora. Stamin a io, hypogyna, subaequalia, petalis longiora; fila me nta squamae bi fidae basi intus inserta, filiformia, stricta, a $\mathbf{n}$ the rae introrsae, biloculares, cordatae, longitu. dinaliter dehiscentes. Ovarium breviter stipitatum, globosum, profunde quinquesulesm, quinqueloculare. Ovula in loculis 5 - 6 , angulo centrali biseriatim appensa, anatropa. Stylus ovario continuus, quinquesulcus, sursun attennetus, demum quinquepartibilis; stig ma minute quinquelobuin. Fructus profunde quinquelobus, in nures quinque evalves, abortu monosperas sece dens. Semina inversa, ovoideo-oblonga, testa laevi. Embryo in axi alhuminis carnosi, densi orthotropus; cotyledonibus ovatis, radie u la conica, supera. - Frutices peruani andicoli, humiles; ramulis distiche alternis, singulis basi bistipulatis, nodo gemmiformi interdum foliffero oppositis, foliis oppositis, stipulis duabus brevibus acutis munitis, pinnatisectis v. bifidis aut bipartitis, pedunculis inter binas foliorum oppositorum stipulas solituriis, unifloris, floribus luteis.

La r re a Cavanill. Annal. cienc, nat. 11. 119, t. 18, 19. Ic. VI, 39. t. 559. 360. DC. Prodr. I. 708. Adr. Jussieu in Mem. Mus. X1I, 456. $t$. 15. $f$. Meisner Gen, 39. (43.)

80B3. Poglieria $R U I Z$ et $P A V$. C a l y quadripartitus, deciduns. Corolla petala 4 , hypogyna, subunguiculata, calyee paullo longiora. Stamina 8, hypogyna, petalis breviora; filam enta squamulae truncatae dorso infra apicem inserta, filiformia, a n thera e introrsae, biloculares, cordatae, longitudinaliter dehiseentes. Ovarium gynophoro brevi insidens, quadrisuleum, quadriloculare. Ovula in locnlis quatuor, angulo centrali biseriatim appensa, anatropa. Sty li 4 , snrsum attenuati, inferne coaliti, apiee breviter distincti; stigmata simplicia. Fruetus carnosus, globoso quadrilobus, loculis abortu monospermis. Semina inversa, ovuidea, pendula, testa laevi. Embry o intra albumen carnosnm leviter areuatus; cotyledonibus uvatis, radieula supera. - Frutex peruanus et chilensis; ramis patentibus, rigidis, foliis oppositis, stipulis geminis spinacformibus munitis, abrupte-pinnatis, foliolis suboppositis, integerrimis, coelo sereno expansis, instante pluvia contractis, ramulis axillaribus, saepe abbreviatis $v$. subnullis, foliorum pari onustis, pedunculis unifloris, fasciculatis, fasciculis paucifloris.

Po rlieria Ruiz et Pavon Prodr. 55, $t .9$. DC. Prodr. I. 707. Adr. Jussieu in Mem. Mus, XII, 457. t. 16. f. 6 . Meisuer Gen. 59, (43.)

6040. Plectroearpa GILL, C a 1 y $x$ profunde quinquepartitus, laciniis subaequalibus. Corollae petala 5, hypogyna, obovata, in un. guem attenuata, calyce panilo longiora. Sta min a 9 , aequalia, summum squamae bifidae, recurvae, magnae, carnosae, duplicato-laminatae intus adnatum, filamento vix squamam superante, seeunduin et octavnm squamis bipartitis, latere superiore majore filamentis paullo Iongioribns, caetera squamulis aequaliter bipartitis, minutis, anther a biloculares. Ovarium gynophoro tenui impositum, ovatum, quinqnesulcatum, dense villosum, quinqueloculare. Ovula in localis gemi. na, ex apice anguli centralis suspensa. Stylus pentagonus, apice acutus. Fructus villosus, subnlato-pentagonus, in naces quinque villosas, dorso infra medium in calcar subulatum, longum, deflexum productas, indehiscentes, aborta monospermas solubilis. S e m e n pendulum, compressum. Embryo in axi albuminis carnosi, tennis rectus; cotyledonibus ovalibus, foliaceis, planis, radicula supera. - Frutex bonariens is a ndicola, ut videtur procumbens, ramosus; ra. mis nodosis, striatis, griseis, spinosis, spinis e nodis solitariis, fere ad basin quadripartitis, lobis subulatis, rectis, validis, subaequalibus, horizontaliter circa mucronem brevem centralem patentibus, folïs e gemmis infra spinas fasciculatis, imparipinnatis, foliolis quadri-quinquejugis, oblongis, basi hinc lobatis, sericeo pubescentibus, terminali minore, floribus inter folia pedunculo brevi, simplici, villoso.

Plectrocarpa Gillies ex Hooker et Arnott Bot. Miscell. 1 III. 166.

6041. Gualacum PLUM. Caly $\mathrm{x}$ quin. 
quepartitus, deciduus, laciniis inaequalibus. Coro 11 a e petala 5 , hypogyna, unguiculata, calyce longiora. Stam ina 10 , hypogyna, subaequalia, petalis breviora; filam enta subulata, esquamata, antherae introrsae, biloculares, ovato-ob. longae, incumbentes, longitudinaliter dehiscentes. Ova ri um basi in stipitem brevem attenuatam, bi v. quinqueloculare. $O \mathbf{v} u I$ a in loculis 8 , angulo centrali biseriatim appensa, anatropa. S t y i n 8 ovario continuus, brevis, acutus; stigma simplex. Fruetus brevissime pedieellatus, subcarnosus, profunde bi-quinqueangulatus, angulis compressis, bi-quinquelocularis, loculis =ortu monospermis. Semina in apice anguli centralis funiculo brevi appensa, ovoidea, testa laevi, Em liryo in axi albuminis cartilaginei, transversim rimosi orthotropus; cotyledonibus foliaceis, radicula supera: - Arbores antillanae, ligno durissimo, principio peculiari resinoso scatente; ramulis nunc ramo breviori nunc folio oppositis, ad nodos articulatis, foliis oppositis, stipulis duabus caducis munitis, abrupte pinnatis, bi-septemjugis, foliolis ceriaceis, integerrimis, reticulato-venosis, pedunculis inter binas foliorum oppositorum stipulas enalis, opposite geminatis, unifloris, floribus caeruleis.

Guaiacum Plumier Gen. $t, 17$, Linn. Gen, n. 518 , Lam. $t$, 342. Gärtaer $I T, 148 . t$, 113. DC. Prodr. I. 706. excl. sp. Adr. Jussieu in Mem. Mus. XII. 456. t. 16. $f .8$. Meisner Gen. 59. (43.) Lindley in Bot. Reg. 1839. t. 9.

\section{GENERA ZYGOPHYLLEIS AFFINIA.}

BO4\%. Seetzenia $R . B R$. Calyx quinquepartitus, aestivatione valvatus. Co rolla nulla. Stam in a 5, hypogyna, calycis laeiniis opposita et paullo longiora; filam enta subulata, nuda, an therae introrsae, biloculares, subgloboso-didymae, longitudinaliter dehiscentes. Ovariu m sessile, ublongum, earnosum, quinqueloculare. Ovula in loculis solitaria, ex apice anguli centralis pendula, anatropa. Sty Ii 5 , teretes, liberi, reflexi; $8 \mathrm{tig} \mathbf{m}$ a $t$ a capitata, papillosa. Fructus capsularis, ovoideus, pentacuccus, coccis ab axi centrali pentarona solutis, dorso sareocarpio anguste lineari vestitis, endocarpio crustaceo, caeterum nudo, apice intus exciso, monospermis. Semin a inversa, ovalia, compressa, testa intra integumentum mucosum crustacea. Embryo intra albumen caraosum tenue orthotropus; cotyledonibu s crassiusculis, radie ula brevi, supera. Suffrutices, in Afrioa tropica et in deserto sinaic o observati, lanati $v$. glabri, ramosi, ramulis articulatis; foliis oppositis, trifoliolatis, foliolis planis, apiculatis, terminali majore, obovato, stipulis interpetiolaribus, membranaceis, pedunculis axil. laribus, unifloris, fructiferis pendulis.

S e etze n i a R. Brown in Denham, Oudn. et Olappert. Narrat. 231. Decaisne in Nouv. Annal, sc. nat. III. 280. t. 7. Meisaer Gen. 59. (43.) Z ygophy $1 \mathrm{I}$ u m I a n $\mathrm{t}$ u m Willd.

\section{* MELIANTHEAE.}

BO43. Irelianthus TOURNEF. Calyx coloratus, magnus, quinquepartitas, laciniis inaequalibus, infima brevissima remota, deorsum gibba, apice snbeucullata, intus eava, glandulam mellifluam, membrana propria, conduplicata cinctam fovente, reliquis laneeolatis, planis, duabus superioribus majoribus, laterales margine tegentibus. Coroll a e petala 5, ealyce breviora, liga- laeformia, subperigyna, quatuor inferiora declinata, medio tomentosa et inter se conglutinata, basi et apice distineta, quinto reliquis admoto, nune inter calycis lacinias superiores remoto, minimo, saepissime nullo. Stamina 4, hypogyna, duo superiora libera, duo inferiora breviora, basi connata, inter ovarium et glandulam media; $f$ I am e nt a linearia, apice interdum dilatata, antherae introrsae, biloculares, ovato-oblongae, longitudinaliter dehiscentes. Ovarium sessile, subquadrilobum, basi quadriloculare, apice septis axim haud attingentibns uniloculare. $O$ vu I a juxta septorum marginem superiorem liberum inserta, utrinque $2-4$, horizontalia $\mathbf{v}$. adscendentia, anatropa, S ty Ius centralis, simplex, intus fistulosus, extus quadrisulcus, apice attennato-subincurvas; stigma subquadrifidum. Fructus calyce et corolla marcescente stipatns, membranaceus, vesi. carius, quadrilocularis, loculis dorso in alam reticalatain compressis, saperne distinctis, intus satura dehiscentibus, infra inter se coalitis, medio turgidis, monospermis. Se min a inversa, subglobosa, testa crustacea, nitida, ambilico conico, foveolato, rhaphe longitudinali costaeformi. $\mathbf{E}$ mb $\mathbf{r} \mathbf{~} \mathrm{o}$ in axi alhuminis cartilagineo-carnosi, densi orthotropus, viridescens; cotyledonibus lineari-ovatis, $r$ adi $c$ ula tereti, apice truncato incrassata, supera. - Frutices capenses et nepalenses, glaberrimi; foliis alternis, imparipinnatis, foliolis dentatis, inaequilateris, latere inferiore decurrentibus in peliolum inde inter juga alatum, inferius nudum, basi stipulatum, stipulis nunc distinctis, nunc in unam intrapetiolarem maximam, adnatam coalilis, floribus in racemos uxillares terminalesve dispositis, breviter pedicellatis, bracteatis, inferioribus interdum apetalis, diantheris, filamentis reliquis sterilibus.

Melia $\mathrm{u}_{\mathrm{t}} \mathrm{s}$ Toarnefort Inst. 245. Linn, Gen, n, 795, Jussieu Gen, 795. Lam. t. 859. Vahl Symb. IIL. 85. Bot. Reg. t. 45. Bot. Mag. t. 301. Gärtner f. IIT. I58. t. 2t1. DC. Prodr. I, 708, Adr. Jassieu in Mem. Mus, XII, 459, t, 28. f. 48. Meisuer Gen. 59. (43.)

\section{** BIEBERSTEINIEAE,}

6944. Fiebersteinin STEPH. Caly x quinquepartitus, persistens, laciniis duabus exterioribus latioribus. Co rolla e petala 5, disco hypogyno imo calyci adnato inserta, scrobienlata, breviter unguiculata, patentissima. S ta m in a 10 , cnun petalis inserta, alterna iisdem opposita breviora, eglandulosa, alterna longiora, basi extus glandula stipata; fil a m enta libera, longiora hasi dilatata, antherae introrsae, biloculares, ovatae, incumbentes, longitudinaliter dehiscentes. Ov a r a 5, gynophoro brevi insidentia, libera, unilocularia, ovulo unico, e funiculo adscendente inverso, anatropo. Styli 5 , ovariornm angulo interiori supra basim inserti, filiformes, liberi; stigmatibus obtusis cohaerentes, Cap $8 \mathrm{nl}$ a e 5 , ovatae, acutae, dorso convexo carinatae, lateribus nervoso-rngosae, angulo interiori compressae, indehiscentes, monospermae. S em en inversum, leviter arcuatum, testa membranacea, umbílico infra apicem introrsum laterali, punetiformi, rhaphe lineari, chalaza supra basim late orbicnlari, venosa, micropyle apicali. Embryonis exalbaminosi, homotrope arcuati, viridis cotyled ones oblongae, carnosiusculae, planae, rhaphe parallelae, ra di eula crassa, supera. - Herbae perennes, in As ia media indigenae, glandulis stipitatis hispi- 
dulae; foliis alternis, petiolatis, imparipinnatisectis, segmentis incisis, stipulis petiolo adnatis, floribus in racemum terminalem simplicem, bracteatum dispositis, luteis.

Biebersteinia Stephan in Mrom. soc, nat, Mors. $I$. 126. t. 9. DC. Prodr. I. 707. Adr. Jussieu in Mem. Mus. XII. 458. Ledebour Flor, Alt. III. 225. Ic. 2 . 4G7, Royle Himalay. t. 30. Bunge Verzeichn, Alt. Pflanz. 80. Meisner Gen. 59. (43.)

\section{Classis LEIII. Gruinales.}

Herbae v, suffrutices, rarissime frutices $v$, a rbores, sueco aqueo, in nonnullis acidulo. Foli a alterna v. opposita, nunc simplicia, saepe lobata, nunc digitatim v. pinnatim composita, interdum laminae abortu phyllodinea, stipulata v. exstipulata. Calyx liber. aestivatione imbricatus. Corolla e petala definita, hypogyna, rarissime nulla. Stamina hypogyna, petalis numero aequalia et alterna, $v$. dupla, rarissime tripla, saepissime monadelpha, alterna non raro ananthera; a n the ra e biloculares, longitudinaliter dehiscentes. Ovarium e carpidiis immediatim coalitis v. axi centrali adnatis compositum. $0 \mathrm{vula}$ in loculis solitaria, gemina v. rarius plura, situ vario. Fr u c t u s capsularis v. rarissime baccatus. E mbry o exalbuminosus, v. albumine carnoso inclusus, rectus v. curvatus; cotyled on ib u s germinatione foliaceis.

\section{Drdo CCLIV: Geramiacene.}

GRRANIA Jussieu Gen. 268. GERANIOIDEAB Venten. Tabl. III. 170, GKRANIACEAE DC. Flor. fr. ed. $\boldsymbol{z}$. $I V$. 838. Prodr, I, 673, Bartling Ord. nat. 348. Lindley Intro. duct, edit. $I I$. p. 137.

Нввва в acaules, quandoque tuberosae, rarius sufprotices, interdum carnosi, nodis ut plurimum perfectis, solubilibus, internodiis teretibus v. tetragonis. Foli a inferiora opposita, altero tunc plerumque minore, superiora alterna v. opposita, petiolata, simplicia, saepissime palmatinervia, palmatimque divisa, rarius uni-bipinnatisecta, interdum integra, crenata. Stipulae ad basim petiolorum geminae, foliaceae v. scariosae.

Flores hermaphroditi, regulares v. irregulares. Pedunculi foliis alternis oppositi, v. ex axilla unius oppositorum, plerumque minoris enati, quandoque in dichotomiis alares $\mathbf{v}$. radicales, rarissime uniflori, saepius biflori, saepissime umbelliferi, umbella simplici, involucrata.

Calyx liber, persistens, pentaphyllus, v. foliolis basi connatis quinquepartitus, foliolis aequalibus v. postico basi in calcar, longitudinaliter cum pedunculo connatum producto inaequalibus, per aestivationem imbricatis, duobns lateralibus exterioribus, anticorum uno semiexteriore, altero et postico interioribus.
Corollae petala ad basim gynophori, imo margine in laminam expansi, centro in columnam longe producti inserta, calycis laciniis a\}terna, nunc iisdem numero aequalia, nunc antici v. rarius plurium abortu pauciora, unguiculata, aequalia v. inaequalia, aestivatione convolutiva, caduca.

Stamiva cum petalis inserta, duplo eorundem numero, biseriata, alterna exteriora petalis opposita breviora, interdum omnia v. partim sterilia, interiora fertilia, rarius tripla, ternatim coalita. Filamenta membranacea, complanata, inferne plus minus monadelpha, e basi latiore subulata, exteriora basi interdum glandula adnata aucta. Anther a introrsae, biloculares, oblongae, dorso-affixae, versatiles, loculis oppositis, parallelis, connectivo nullo manifesto, longitudinaliter dehiscentibus.

Ovaria 5, circa gynophori columnaeformis, stylis paullo brevioris basim dilatatam vertichlata, unilocularia, inter ejusdem angulos sutura ventrali adnata, inter se distincta, oblonga. Ovula 2, suturae ventrali inserta, superposita, alterum adscendens, alterum pendulum, utrumque semianatropum. Sty li carpellares, columna longiores, basi inter se distincti, columnae adglutinati, supra columnam inter se conferruminati, summo apice breviter distincti, intus longitudinaliter stigmatosi.

Capsulae 5, membranaceae, maturitate cum stylis elastice a columna solutae, stylis spiraliter tortis caudatae, iisdem apice inter se coalitis e calyce extractae, e columna suspensae, v. serius sejunctis deciduae, uniloculares, abortu monospermae, sutura ventrali, post seminis emissionem arcte connivente, dehiscentes.

Srmen capsulam replens, trigonum, t es t a crustacea, umbilico paullo supra basim ventrali, cum chalaza basilari ope rhapheos brevis, filiformis juncto. A I b u me n nullum.

Cmaryo curvato-conduplicatus. Cotyle dones magnae, foliaceae, flexuoso-convolutae, interdum pinnatifidae. R a di cula conica, dorso convexa, facie plana, cotyledoni interiori applicita, intra endopleurae membranaceae processum vaginalem recondita, umbilicum attingens, cum cotyledonum apice fruetus basim spectans.

Geraniaceae in temperatis extratropicis totius orbis obviae, magno numero in Capite bonae spei crescunt, boreales symmetrico florum decore amoene rusticae, svavissimae pratorum et collium nostrorum deliciae, australes incompto splendidae inconstantiae fnco male elegantes, Adonistarum prostibula, viridariorum pestis.

6045. Trodimm HERIT. Calyx profunde quinquepartitus, laciniis subinaequalibus, basi haud-preduetis. Corollae petala 5, imo gyno- 
phoro inserta, calyciis laciniis alterna, unguiculata, obtusa, caduea. St amina 10 , cam petalis inserta, brevissime monadelpha, biseriata; filamenta membranacea, complanata, persistentia, e basi dilatata subulata, quinque exteriora breviora petalis opposita, ananthera, alterna interiora fertilia, longiora, basi extus glandula adnata aueta, antheris introrsis, bilocularibus, incumbentibus, obtusis, longitudinaliter dehiscentibus, caducis. Ovaria 5 , oblonga, gynophoro columnaeformi stylis paullo breviori basi latiori hine adnata, unilocularia, biovulata, ovulis adscendentibus v. suspensis. Styli filiformes, basi distincti, gynophoro longitudinaliter adglutinati, supra gynophorum arcte connati, summo apice liberi; stigmatibus introrsum lateralibus. Caps aIa e 5, oblongae, stylis basi ad apicem elastice a gynophoro solutis, complanatis, intus villosis, ant rarius glabris, inferne spiraliter tortis eaudatae, iisdem apice cum gynophoro coalitis suspensae, uniloculares, abortu monospermae, sutura ventrali dehiscentes. S e m e n trigonum, testa erustacea, uubilico paullo supra basim ventrali, rhaphe brevi, filiformi eum chalaza basilari juneto. Emb ryonis exalbuminosi, conduplicati coty ledones magnae, foliaceae, flexuoso-convolutae, interdum pinnatifidae, ra d i u la conica, descen. dens, unbilicum attingens. - Herbae acaules $v$. saepius caulescentes, rarissime suffruticosae, in $t \mathrm{em}$ peratis totius orbis crescentes, in calidioribus rarae; foliis oppositis, altero saepius minore, $v$, alternis oppositisque, bipinnatifidis $v$. pinnatis, rarius tripartitis, lobatis $v$. crenatis, stipulis lateralibus geminis, plerumque scariosis, pedunculis folio alterno appositis $v$. ex axilla folii oppositi minoris ortis, aut in dichotomiis alaribus, interdum radicalibus, rarissime unifloris, saepissime umbelliferis, umbella simplici, involucrata.

Erodfum Heritier Geran. $t$. 2-6, moc, Willd, $\mathcal{S}_{\text {pec }}$ III. 625. Jacq. f. Eelog. t. 58. Sibthorp Flor. graec. t.651658. DC. Flor. fr. IV. 838. Prodr. I 644, Kuwth in Humb. et Bonpl. Nov. gen, et sp. $V .228$ St. Hilaire Flor. Brasil. $I$. 96. $t$. 19. Meisn. Gen, 57. (4t.) Ge ra a i i sp. Linn. Cav. Diss. $t$, 8s. $f$, 2. $90,96,113 . f$ 2, 125. 126. Desfout. Flor. atlant, t. 168. 169. Gärtser t. 79. f. dextr. S c o lo p a c i u m Eekion et Zevber Enum. 59. B. I a c r as s a tu m Herit. Bot. Mag. t. 261. Cav. Diss, t. 9t. f. 2.

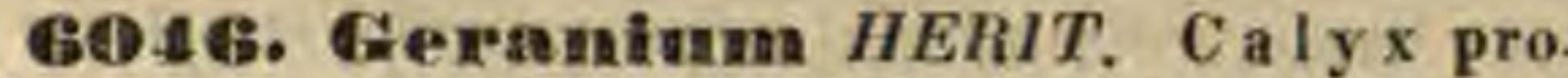
funde quinquepartitus, laciniis subinaequalibus, basi haud productis. Corolla e petala 5, imo gy. nophoro inserta, ealycis laciniis alterna, unguieulata, obtusa, eaduca. Stam in a 10 , eum petalis inserta, brevissime monadelpha, biseriata; filam en ta membranacea, eomplanata, e basi dilatata subulata, quinque exteriora petalis opposita aeque fertilia, eglandulosa, an therae introrsae, biloculares, incumbentes, obtusae, longitudinaliter dehiscentes, caducae. Ovaria 5 , oblonga, gynophori columnaeformis elongati, stylis paulio brevioris basi latiori hine adnata, uniloenlaria, biovulata, ovulis adscendentibus v, suspensis. Styti filiformes, basi distincti, gynophoro longitadina. liter adglutinati, supra gynophorum arete connati, summo apice liberi; stig matibus introrsum lateralibus. Capsulae 5 , obovatae $v$. oblongae, stylis a basi ad apicem elastice a gynophoro solutis, revolutis, complanatis, intus glabris v. rarius villosis sive puberulis caudatae, iisdem apice cum gynophoro coalitis primum suspensae, demnm ruptis deciduae, uniloculares, aburtu monospermae, sutura ventrali dehiscentes. Semen trigo- num, testa erustacea, umbilico paullo supra ba sim ventrali, rhaphe brevi, filiformi cum chalaza basilari juncto. Emb ryonis exalbuminosi, conduplicati cotyled ones magnae, foliaceae, flexuoso-convolutae, radic ala conica, descendens, umbilicum attingens. - Herbae, rarissime suffrutices, in temperatis totius orbis crescentes; caulibus articulato-nodosis, foliis oppositis, altero saepe minore, $v$. alternis oppositisquef, petiolatis, saepe plus minus orbiculatis, palmati- v. digitatopartitis, stipulis lateralibus geminis, plerumque scariosis, pedunculis folio alterno oppositis, $v$, ex axilla folii oppositi minoris ort is aut in dichotomiis alaribus, rarius radicalibus, uni-bifloris, infra pedicellum $v$. pedicellos quadribracteatis.

Ge r a n u m Heritier Geran, $t, 36-40$. DC, Prodr, Fl, franc. IV. 844. I. 639. St. Hilaire Flor. Brasll. I. 100. t. 20. Kunth in Humb. et Bonpl. Nov. gen. et sp. V. 229. Meisuer Gen. 57. (41.) Geran it s p. Liun. Cav. Diss.

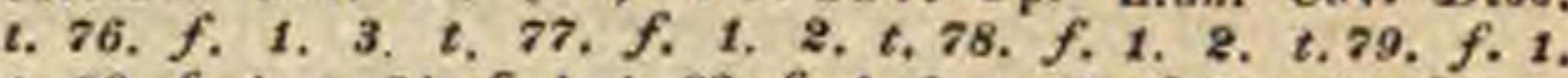
t. 80. f. t. t. 81. f. 1. t. 82, f. 1. 2. t. 83. f. 2, t. 84. f. 1,2 . t. 88. f. t. t. 86. f. 2, t. 87 f. 1, t, 89. f. 1. 2. t. 93. f. \&. t. 99. f. 2. t. $12 /$ Garta. t. 79. sinistr. Jaeq. 1c. rar. $t, 134$. Hort. schönor. t. 140. E. B. t. 121, 157, 405. 424. F1. dau. t, 596. 689. 936, 1107, 1122. Sibthorp Flor. graeo. 659_661. Waldst. et Kitaibel Plant, rar. Hung. 1, 123, 124. Bot. Mag. t. 55. 203. 2377, 2420. 3732. Bot, Reg, 1839, t. 10. Hooker Flor. Bor. Amer, t. 40. Wallich Plant, As, rar. t. 209. Royle Himalay. t. 27. Jaequea. Voy, t. 37. 38.

604\%. Nomsonia LINN. F. Cal y x profunde quinquepartitus, laciniis aequalibus, aristatis, basi hand produetis. Corolla e petala 5, imo gynophoro inserta, ealycis laviniis alterna, obtusa, eaduea. St a mina 15 , cnm petalis inserta, biseriata, exteriora 10 breviora, interiora 5 longiora, calycis laciniis opposita, omnia fertilia, monadelpha v. pentadelpha; fil amenta membranacea, complanata, e basi latiore subulata, antherae introrsae, biluculares, incumbentes, obtusae, longitndinaliter dehiscentes. Ovaria 5 , oblonga, gynophori columnaeformis elongati, stylis paullo brevioris basi latiori hine adnata, unilocularia, biovulata, ovulo altero adscendente, altero pendolo. Styli filiformes, basi distincti, gynophoro longitudinaliter adglatinati, supra gynophornm connati, apice liberi; $s t i g m$ at $i b u s$ introrsum lateralibus. Ca psula e 5, oblongae, stylis a basi ad a picem elastice a gynophoro solntis eavdatae, iisdem revolutis, et apice cum gynophoro coalitis sus. pensae, uniluenlares, abortu monospermae, sutura ventrali dehiscentes. S e m e $n$ trigonum, testa :rustacea, nmbilico paullo supra basion ventrali, rhaphe brevi, filiformi $\mathrm{cnm}$ chalaza basilari juncto. $\mathbf{E}$ in b r y .... - Herbae inermes $v$. suffrutices spinosi, in Capite bon ae ${ }^{s} p$ e $i$ crescentes; foliis alternis $v$. oppositis, integris, lobatis v. multifidis, stipulis ad basim petiolorum geminis, pedunculis unipluribracteatis.

M o n s on f a Linn. f. Supplem, 342. DC, Prodr. I. 608. Meisner Gen. 87. (41.)

a. ODONTOPETALUM DC. $l$. c. Herbae foliis alternis. lobatis v. multifidis. Pedunculus vniflorus, medio bracteis $6 \_8$ versicillatis cinetus. P e ta I a oblonga, apice grosse dentata. S $\mathrm{tam}$ in a pentadelpha. - Mo nsou i a Lina, 2, $c$. Klotsch in Linnaea $X$. 429. (Cav, Diss. t. 74. f. 1. 2. Bot. Mag, 2. 73. 385.)

b. HOLOPETALUM DC. $l$, c. He r b a e, follis alternis, ova. libus, deotatis. Peduneul us unifloras, bibraeteola. tus, v. biflorus, quadribracteolatus. Petal a obovata, crenulata. Stamina pentadelpha. - O I opeta I um Klotseh l. c. (Cav, Diss. t. 113, f, 1, Heritier t, 4t.)

c. SARCOCAULON DC. $l$, $c$, C a u lis fruticosus, earnosus, spiuis horridus. Folia alterna, integerriaa v. deatata, Pedu aculus ualfloras, medio bibracteolatus. Petala integerrima. Sta mina monadelpha. - 
Sarcocaulon Klotseh $l$. $c$. Geranium spino. s и аи Burmauk. Cav. Diss. 1. 7s. f. 2. (Heritier t. 42.)

64) 48. Pellargonium HERIT. C a ly x quinquepartitus, laciniis subinaequalibus, postica basi in calcar cavum, plus minus longum, pedicello adnatum producta, Cor oll a e petala 5 , rarius aborta $4 \mathrm{v}$. interdum 2 , imo gynophoro inser ta, calyeis laciniis alterna, unguiculata, aequalia v. inaequalia, obtusa, caduca. St a m in a 10 , cum petalis inserta, inferne in tubum coalita, inaequalia, alterna petalis opposita breviora umnia, v. partim ananthera; filamenta complanata, membranaeea, e basi lata subulata, postica saepe productiora, a ntherae introrsae, biloculares, ineumbentes, obtusae, longitudinaliter dehiscentes, cadueae. Ovaria 5, oblonga, gynophori columnaeformis, elongati, stylis paullo brevioris basi latiori hine adnata, unilocularia, biovelata, ovuI i s adscend entibns v. suspensis. Sty Ii filiformes, basi distineti, gynophoro longitudinaliter adglutinati, supra gynophorum arcte connati, summo apice liberi; $8 \mathrm{ti} \mathrm{gm}$ a t $\mathrm{i}$ b $\mathbf{s}$ introrsum lateralibus. Capsu 3 ae 5 , oblongae, stylis a basi ad apicem elastice a gynophoro solutis, complanatis, intus villosis, inferne spiraliter tortis caudatae, iisdem apice cum gynophoro coalitis suspensae v. demum sulutis deciduae, uniloculares, aborta monospermae, sutura ventrali dehiscentes. Semen trigonum, testa crustacea, ombilico paullo supra basim ventrali, rhaphe filiformi, brevi cum chalaza basilari juncto. Embryonis exalbuminosi, conduplicati cotyledones magnae, foliaceae, flexuoso-convolutae, ra di cula descendens, conica, umbilientn attingens, - Herbae acaules $v$. caulescentes, v. suffrutices interdum carnosi, in Capite bonae Spei magno numero, parcius in Nova-Hol. landia extratropica et in insulis atlan tico-australibus crescentes; foliis oppositis $v$. superioribus alternis, petiolatis, integris $v$, varie disectis, stipulis ad basim petiolorum geminis, foliaceis $v$. scariosis, pedunculis oppositifolits $v$, axillaribus, rarius alaribus $v$, radicalibus, floribus saepissime umbellatis, umbella simpliei, involucrata.

Pelargoninm Heritler Geran. inedit. Aiton Hort. Kew. IT, 417. DC. Prodr. I. 649. Meisuer Gen, 57. (41,) Pelargonie a e Sweet Geran. I. p. 8.

a. HOAREA Sweet Geran، n, 18. Petal a 5 , rarias 2 v. 4 , oblongo-linearia, duo superiora parallela, longe unguiculata, medio abruptim reflexa. St a $\mathbf{m}$ i $n$ a longe tubulosa, petalorum isferiorum Jongitudine, quinque. v. ra. rius duo aut quatuor antherifera, caetera sterilia, recta v. apiee incurva, tria inferiora fertilibus breviora. Herbae capenses, acaules. radice tuberoso-rapacea, folitis radicalibus petiolatis. - Geranii sp. Limb. Cav, Dist. $t$ 97. f. 1. t. 101, f. 2. t. $108, f .1 . t .115$. f. 1. 3. t. $118 . f$. . . t. 120. f. 3. Andrews Bot. Reposit. c. 60. 204. 209. 222. 924. 239. 247. 249. 269. 292. 303. 317. 398. 354. 480. (Herit. Geran. 2. 7. 43. 44. Jacq. Ic. $\operatorname{rar}, \mathbf{t}, 510-521$, Vent, Malm, t. 65 Bot. Mag. $t$. 1877 . Sweet Geran. 1, 18, 38, 91, 106, 123, 132, 135, 151, 159 166. 174.)

h. DIMACRIA Lindl, in Sweet Geran. n. 46. Petala 5 , inaequalia, duo superiora conuiventia, apice divarieata. St a a $^{\mathrm{a} a}$ calyce breviora, fertilium duo inferiora reliquis duplo longiora, porrecta, supremum brevissimum, sterilia minima, subaequalia. - Herbae acanlos, ra. dice tuberoso rapacea, folits petiolatis, pinnatisectis. - G e ra nii sp. Linu. Cav. Diss, $t$. 104. $f$. 2. 115. f. 2. Andrews Bot, Feposit. t. 109. 305. 311. (Sweet Geran, t. 46. 103.)

c. CYNosBATA DC. Prodr, $I$, 654. P eta 1 a 5 , subaequaJa, subovalia, calycem duplo fere superantia. Sta mi a a erecta, alterua sterilia antheriferis breviora. (Jaeq. f,
Eclog $t$. 97. ) d. PERISTERA DC. Prodr. $T$. 654. P e $t$ a la 5 , subrequalia, calycem aequantia v. paullo superautia, Stania quinque longiora fertilia v. unum eastratum, alterna lrevissima sterilia, dentiformia. - Herbae caulescen. tes, Geranii v. Erodii facie. - Geran $1 \mathrm{i}$ s p. Linu. Cav, Diss. $t$ 123. f. 2. Andrews Bot, Reposit. $t$. 254. (Heritier Geran. t. 10. Jacq. Hort. schönbr. t. 133. Ic. rar. t. 523. Jacq. f. Eclog. t. 99. 100. Sweet Geran. t. 48.)

e. OTIDIA Lindl. in Sweet Geran. $t, 98$, Petala 5, subaequalia, oblongo linearia, calyce duplo cíciter Inngio ra, duo soperiora biauriculata. St a mi n u erecta, quin. que fertilia. quorum duo superiora spathulata v. subu. lata, tria interiora breviora. - Caules fruticoso-car. nosi, folia alterna, carnosa, pinnatisecta. flores albidi. - G e ranii s p. Cav, Diss, $t, 99 . f .1 . t, 100$. f. 2. Heritier Geran. t. 13. Weadand Hort, Herrenh. $t$. 13. Bot, Mag. t. 313. 3029.)

f. POLYACTIUM DC. Prodr. $r$, 655. Petala 5, subaequalia, obovata, calycis lacinias subaequales revoluras superabtia. Sta mi na 10 , quinque fertilia, quatuor inferiora longiora subulata, superius latius, spathulatum, apice reflexum. - Herba subcaulescens, radice napi. formi, folits pinnatisectis. - P, u u $1 \mathrm{i} i \mathrm{radia}: \mathrm{um}$ Wendl. Sweet Geran. . 145.

g. ISOPETALUM Sweet Geran. $t$, 126, C a ly eis laeinia superior in foveolam nectariferam, nec in tubua desi. nens. Petala aequalia. Sta mina in tubnm brevissisimum coalita, 5-6 fertilla, patentia, apice incurva, sterilia inaequalia, subulata, iucurva. - Frutex insu. lae $s t$. Felenae, caule carnoso, foltis cordatis, sub. pellatis. - Geranium Cotyledonis L. P. coty. le don is Heritier Ger. $t$, 27 .

h. CAdPylia Sweet Geran. p. 8. P e ta 1 a 5, inaequalia, duo superiora majora, ungue auriculato v. verrucoso. $\mathrm{S} t$ a m I и a 10 , pilosa $v$. pubescentia, quinque fertilia, quinque alterna sterifla, quorum duo superiora longiora. - Herbae ramosae, vix basi suffrutescentes. folit. petiolatis, ovatis aul oblongis, dentatis v. subincisis.

c. $\mathrm{C}$ a m pyli in Lindl, in Sweet. Geran. $t$. 75. 88. 114. 157. Pet a I a superiora ad unguem appendiculata. $\mathrm{S}$ t mi a fertilia erecta, sterilium duo suprema recurvo. hamata. G e rau i s p. Cav. Diss, $t$. 79. f. 1, t. 103. f. 2. 3. Andrews Bot. Reposit. t. 115. (Jacq. Hort. schönbr. $t, 131.132$. To. rar $t .594$-326.)

B. Phymatanth us Lindl. in Sweet Geran, $t, 43,96$. Petal a superiora supra unguem verruensa. S $\mathrm{t}$ m in a brevissime monalelpha, fertilia recurvo-patentia, sterilia recta. (Jacq. Ic. rar. $t$, 527. Bot. Mag. t. 240.)

- MYRRHIDIUM DC. Prodr. 1 . 657. Petala 4. v, raris. sine 5, duo superiora maxima, obovato-cuneata, sacpius lineis ramosis striata, duo v. tria iuferiora multo minora, oblongo. linearia. St a m in a 10 , tabo flamentisque reetis, saepius quinque fertilia et quinque alterna sterilia, rarius septem antherifera. - Herbae bien. nes $v$, perennes, rarius suffrutescentes, caultbus te. retibus, foliis pinnatim, rarius ternatimsectis, saepe multifidis. Ge ranii sp. Linn. Cav. Diss, $t, 116 . f$. 1 . (Jacq. Ic, rar, $t, 528-535$. Willd. Hort, Berolin, $t, 17$. )

k. JENKINSONIA Sweet Geran. t. 79. Petala 5, dao superiora reliquis muito majora, spice emarginata, linels picta. Sta mi a a 10 , adscendentia, basi pilosa. apice patentia, septem antherifera, quorum tria superiora breviora, tria sterilia abbreviata. - Suffrutex capensis, folitis palmatim quinquefidis, floribus ochrolezcis. P. q u in a tu no Bot. Mag. $t$. 547 .

1. CHORISMA Lindl. in Sweet Geran, $n$. 79. Pet a 1 a 4 , rafius 5 , duo superiora longe ungoiculata, Inferioribus 2 v. 3 multo majora. St a mina 10 , in tubum loggissimum, declinatum, medio geniculatum coalita, septem fertilla, quorum duo inferiora libera, tria sterilia abbreviata, subulata. - Suffrutex capensis, carnosus, foliis cordatis, obtuse lobatis. - P, tetragon nm Heritier Geran. $t, 23$. Jacq, Ic. rar. $t$. 132. Roth $A b$ handl, t, 11, 12. Bot. Mag. t, 136. DC. Plant, Gr,t.96. Jenkinsonia tetragona Sweet Geran. $t .99$.

m. PELARGIUM DC. Prodr. $T$, 658. Petala 5, inaequalia, duo superiora approximata. Sta $\mathrm{m}$ in a 10, inaequalia, septem astherifera, tria sterilia, subulata. Pelargon i m Lindley in $S$ weet Geran, $n, 41$. 
c. C i c o u ia DC. $t$. c. Petala unicolora, 2 superiora breviora et augustiora. Stamina brevia et erecta, 2 in. fima brevissima, antheris fere sessilibus. - Caules fruticoso-carnosi. - C і со и і и ш Sweet Geran. p.9. et n. 13. Ge ranii s p. Cav. Diss. t.98. f. 2, t. 104. f. 3. $t .105$ f. 2. $t$. 106. $f$. 2. (Heritier Geran, $t .18$ Bot. Mag. t. 103. Sweet Geran, t, 13, 63. 143, 176.)

B. Is opetalofidea DC. l. o. Petala magnitudiue subaequalia. Isopetafum, Cortusina et $\mathrm{Eumor}$. pha Ecklon et Zeyher Enum. 76, 77, C alliops is Sweet Geran. $l$. c. Geranil k p. Linn. Cav. Diss

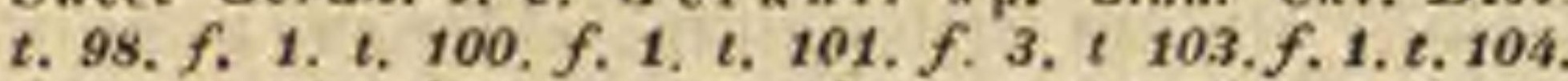
f. 1. t. 107, f. 1. t, 109, f. 1. t. 1t1, f. 1, t, 114. f. 2. t. 117. f. 1. 2, t, $120, f$. 2. t. 121. f. 2, 3.t. 122 , f. 2. Andrews Bot, Reposit, t. 37, 108, 114, 121, 160, Jaeq. Hort. Vindob. IIT, t. 39. Hrritier Geran, t, 9. 11. 12. 24_26. Jacq. Hort. Schönbr. $t, 134.136$. 138. Ic. rur. t. 529, 536. Collect IT. $t$. 22. f. 3. Jacq. f. Eclog. t, 27, 98. Willd. Hort. Berolin, t. 34. 76. 77. Thouar. Flor. Aguan. t. 13. Bot. Mag. t. 20. 201. 309. 477, 493, 394. 1641. Sweet Geran. t, 2. 14. $28,39,45,48,49,51,59,55,56,58,61,65,68,69$. 76. 83. 89. 93, 95. 97. 102, 110, 115, 121, 124. 125. 129. 133, 140, 147, 148, 153, 170, 172.)

$\gamma$. Anisopetala DC. l. c. Petala 2, superiora longiora etlatiora. Geranli sp. Linu. Cav, Diss, t. 100. f. 2. t. 10t. f. t. t. 109. f. 2. t. 105. f. 1. t. 106. f.t. t. 108. $f .1 . t, 109 . f .1, t .110$ f. $1 . t$. 111. $f .2$. t, 112, f. 1. 2. t. 114. f. 1. t, 117. f. 3. t. 118. f. 3. t. 119. f. 1, t. 121. f. 1. t, 123. f. 1. (Heritier Geran, t. 14 17. 20 29, 29, 30.32-35. Jacq. Hort, Schönbr. t. $130-135$. Io, rar. t. 537-545. Roth Abhandl, t. 10 . Sweet Geran, t. 5. 16, 19, 37, 50, 53, 57, 62, 80, 87. 127. 128, 138, 167.)

\section{GERANIACEIS AFFINES.}

\section{* RHYNCHOTHECEAE.}

BO43. Filaynelnotheen $R U I Z$, et $P A V, C$ a1 y $x$ pentaphyllus, regularis, persistens. Corolla nulla. S $t a m$ ina 10, hyporgyna; fil amenta capillaria, libera, calyce paulio longiora, persistentia, a ntherae introrsae, biloculares, incumbentes, longitudinaliter dehiscentes, deciduae. O v ari urm liberum, sessile, sulcato-quinquelobum, quinqueloculare. Ovala in loculis gemina, angulo centrali prope apicem superposite appensa. S tyI u s brevissimus; stigmata 5 , elongata, teretiuscula, carnosa, patentia. Caps u la pentacocea, stylo elongato rostrata, coceis ab axi centrali quinquesulcato demum solubilibus, coriaceo-membranaceis, unilocularibus, monospermis, angulo ventrali apertis. Semen oblongo trigonum, utrinque attenuatum, testa tenui, adnata. $\mathbf{E}$ mb ryo in axi albuminis carnosi rectus, viridis, ejusdem fere longitudine; cotyled on i b us linearibus, planis, radicala teretiuscnla, brevi, surera. Frutices perua $n i$, ramosissimi, ramulis apice spinescentibus horridi; ramis oppositis, tetragonis, foliis oppositis, petiolatis, exstipulatis, integris $v$, trifidis, floribus pedunculatis, in apice ramorum fasciculato congestis.

Rhyuchotheca Ruiz et Pavon Prodr. 142. $t, 15$. Kunth in Humb. et Bonpl. Nov, gen. et sp. V. 232, $t, 466$. 465. DC. Prodr. 1. 637. Meisner Gen. 57. (41.)

\section{* LEDOCARPEAE.}

6050. Ledecarpon DESF. C a I y $\mathrm{x}$ bracteolis linearibus involucellatus, pentephyllins, foliolis subaequalibus, indricatis. Coroll a e petala 5, hypogyna, calycis foliolis alterna et majora, obovata, aestivatione conterta, sub anthesi patentia. Stamina 10, hypogyna, alterna petalis opposita paullo breviora; filamenta filiformi- subulata, libera, a $n$th er a e intrursae, biloculares, oblongae, basi insertae, longritudinaliter dehiscentes. Ovarinm liberum, sessile, snbglobosum, quinqueluculare. $O \mathrm{v}$ u la in luculis plarima, angulo centrali biseriatim inserta, campylotropa. Stigm a sessite, quinqnelobum, lobis ereetis, ohtusis. Ca p su la quinquelocularis, apice loculicide quinquevalvis, valvis medio septa inferne cam columna centrali coalita gerentibus. S e m i na plurima, compressa, margine membranaceo eincta, umbílico supra basim laterali. E m b r y o intra albamen carnosum bicruris; cot yledonib ns linearibus, planis, involutis, $r$ adicula tereti, longa, ab umbilico remota. - Suffrutices peruani et chilenses, graciles, stricti; foliis allernis $v$. rarius oppositis, tripartitis, laciniis linearibus, integerrimis, margine revolutis, pubescentibus, glaucis, stipulis nullis, floribus terminalibus, solitariis, longe pedunculatis, luteis.

L.edocarpon Desfont. in Mem. Mus, IV. 250. DC. Prodr. I, r02. Lindley in Bot. Reg. C. 1392. B a I b is ia Cavanill. Anal, d. cienc, nat. VIT. 62. t. 46. Don in Edinb. new philosoph. Journ. XI, 276. Klotsch in Linnaea $\boldsymbol{X}, 43 t$. Meisuer Gen 58. (49.) Presl Symb. 2.44. Cru ek ha n s i a Hooker in Bot, Miscell. II, 211, $t$. 90. Cistocarpu a Kanth in Mem, soo, h. n, Paris, III, 389, O e not he ra s p. Ruiz et Pav.

G051. Wendtía MEYEN, CaI y x bractenlis linearibns involncellatus, pentaphyllus, foliolis aequalibus, imbricatis. Corollae petala 5, hypogyna, calycis foliolis alterna et paullo breviora, ovata, aeuminata, aestivatione contorta, sub anthesi patentia. Stamina 10 , hypogyna, alterna petalis opposita vix breviora; filamenta filiformi-subulata, libera, ant herae introrsac, biloculares, ovatse, basi insertae, longitudinaliter dehiscentes. Ovari um liberum, sessile, subglobosum, triloculare. Ovula in loculis genina, angulo centrali inserta, subcollateralia, pendula, semianatropa. Stigma sessile, tripartitum, lobis petaloideis, lanceolatis, ereetis. C a p 8 u I a.... - Frutices chilenses, erecti $v$, prostrati, Potentillae facie; foliis oppositis, breve petiolatis, cuneatis, venosis, plus minus profunde tri-plurilobis, sericeovillosis, stipulis nullis, pedunculis in apice ramulorum gracilibus, unifloris, ternatis, floribus luteis.

We udtia Meyen Reise $r$, 307. Klotselt in Linnaea $X$. 432. Meisner Gen. 58. (49.) Martinieria Guillem in De. lessert Ic. select. III. 23, $t$, 60. Ledocar pum Rey aol. d s it Hooker Ic. t. 14 .

\section{**** VIVIANIEAE.}

605\%. Caesarea CAMBESS. C a $1 \mathrm{y} \times$ campanulatus, decemnervis, quinquefidus, persisteus, laciniis aentis, aestivatione valvatis. Corolla e petala 5, hypogyna, calyeis laciniis alterna et majora, oblonga, unguiculata, aestivatione conturta, sub anthesi erectinsenla. S $t$ a $\mathrm{m}$ in a 10 , hypogyna, inclusa, alterna, petalis opposita, breviora, alterna longiora, saepe glandulae hypogynae, peltiformi inserta; fil am enta filiformia, libera, a n the rae biloculares, versatiles, ovatae, longitudinaliter dehiscentes. O va rium libernm, sessile, trilocalare, trilobum. $O \times n 1$ a in locelis gemina, angnlu centrali superposite inserta, superius adscendens, inferius pendulum. Stig mata 3 , sessilia, filiformia, intus papillosa. C a p 8 al a obcordato triloba, loculicide trivalvis, valvis medio septa seminifera gerentihus. Se min a ovuli inferioris abortu solitaria, pendula, rotundata, testa membranacea, seabriuscula, umbilico basilari. 
E mbryo intra albumen copiosum, carnosum curvatus; cotyledonibns linearibus, radienla umbilico proxima, snpera. - Herbae in Brasilia e ustrali indigena, ramosae; foliis oppositis $v$ ad basim ramulorum qualernatim verlicellatis, brevissime petiolatis, ovato- $v$. longe lanceolatis, grosse serratis $v$. sinuatis, supra glabriusculis $v$. velutinis, subtus niveo-tomentosis, floribus in apice ramulorum axillaribus, longe pedicellatis, subpaniculatis, albis, violaceis $v$. rubicundis.

C a es area Cambessed. in Mem. Mus. XVITI. 373. t. 18. Klotseh in Linnaea $X$. 435. Meisner Gen. 58. (42) Viviaulae sp. Auct.

6A53. Viviamía $C A V$. Calyx campanulatus quinquedentatus, decemcostatus, persistens, dentibus acutis, aestivatione valvatis. Coro 11 a e petala 5, hypogyna, ealycis laciniis alterna et longiora, oblonga, nnguieulata, aestivatione contorta, sub anthesi patentiuscula. Stam in a 10 , hypogyna, breviter exserta, alterna petalis "pposita breviora, alterna Iongiora ante glandulas 5 , hypogynus inserta; fil am enta filiformia, libera, antherae biloculares, oblongae, erectae, longi tudinaliter dehiscentes. Ovarium liberum sessile, triloculare, trilobum. Ovala in luculis gemina, angulo centrali superposite inserta, superius adscenden 8 , inferius pendulum. Stig mat a 3 , sessilia, filiformia, intus papillosa. Ca p su la obcorlato-triloba, trilocularis, loculicide trivalvis, val. vis medio septa seminifera gerentibus. Semina in loculis gemina, superposita, subglobosa, superius adscendens, inferius pendulum, testa membranacea, umbilieo basilari. $\mathbf{E} \mathbf{m}$ b ryo intra albumen carnosum, copiosum curvatus; cotyledonibus linearibes, radi cula nmbilico proxima. - Suffrutices chilenses, aridi, opposite ramosi; foliis oppositis, brevissime petiolatis, ovatis, integerrimis $v$. crenatis, supra pubescentibus, subtus niveo tomentosis, paniculis terminalibus brevibus dichotomis, floribus albis, roseis $v$. purpurascentibus.

Viviania Cavanilles in Anal. cienc, nat. VIT. Z10, t. 49. Don in Edinb, new philosoph, Journ, VIII, 170. Book. Bot. Misc. III. 148. Klotseh in Linnaea X, 343. Meisuer Gen. 58. (42) Delessert Ic. select. $t$. 41 . M a c $\mathrm{r}$ a e a Lindlev in Brandes Quaterl. Journ, XXV, 104. Hooker in Bot. Miscell. I. 175. $t$. 50. Xeropetal on Heoker msc.

6054. Cisssaroloryon $P O ̈ P P, C$ a 1 y $x$ campanulatus, quinquefidus, persistens, laciniis trinerviis, acutis, aestivatione valvatis. Co roll a e petala 5, hypogyna, calycis laciniis alterna et longiora oblonga, unguiculata, aestivatione contorta, sub snthesi erectiuscula. St a in in a 10 , hypogyna, inclusa, alterna petalis opposita breviora, alterna lungiora, ante glandulas quinque hypogynas, obcordatas inserta; fil a un enta filiformia, libera, a $n$ therae introrsae, biloculares, subgloboso-didymae, longitadinaliter dehisentes. Ovari um lituerum, sessile, ohovatum, triloculare. Ovula in loculis $2-3$, antrulo centrali inserta. S t y I a filiformis; stigmata 3 , linearia, divarieata. Capsula triangularis, trilocularis, loculieide trivalvis, valvis medio septa seminifera gerentibus. Se mina in loculis solitaria v. gemiaa, pendula, subglolosa, hasi arillo lacero eincta, testa cornea. E mlo ryo in basi albuminis carnosi orthotropns, ejusdem dinidio brevior; cot yled on i b ns whlongis, radicula nmbilieo proxima, supera. - Suffrutex chilensis, andicola, prostratus; caulibus tere. tibus, nitidis, parum ramosis, puberulis, folits oppo- sitis, longe petiolatis, subrotundis, basi truncatis, crenato-quinque-, septemlobis, supra puberulis, subtus cum pedicellis axillaribas filiformibus calycibusquc incano-tomentosis, petalis aeruleis.

C is s a robryou Pöppig Fragm. Synops. 29. Klotscl. in Linnaea X, 438. Meisuer Gen, 58. (12.)

6955. Thinostigma KLOTSCH, Cal yx campanulatus, quadrifidus, persistens, laciniis acnminatis. Cor o 1 l a e petala 4 , hypogyna, calyeis laciniis alterna et longiora, oblonga, unguiculata, aestivatione contorta, sub anthesi erectiuscula. Stamina 8, hypogyna, inclusa, alterna longiora ante squamulas quatuor hypogynas, obcordatas inserta; fil amenta filiformia, libera, ant herae biloculares, sagittatae, erectae, longitudinaliter dehiscentes. O vari um liberum, sessile, subcompressum, liloculare. $\mathrm{O}$ v $\mathrm{Ia}$ in loculis solitaria, dissepimento appensa. Stylus filiformis; stig$\mathrm{m}$ a $\mathrm{t}$ 2, longe linearia. C a $\mathrm{p} \mathbf{\mathrm { u }} \mathrm{l}$ a $\ldots . .-\mathrm{Her}-$ bae in Brasilia meridionali indigenae; foliis oppositis, longe petiolatis, suborbiculari-ovalis, basi in petiolum angustatis, obtusis, crenatis, supra saturate viridibus, pube evanescente hirlellis, subtus tenuissime niveo-tomentosis, pedicellis axillaribus filiformibus, pubescentibus, calycibus villosis, petalis caeruleis.

Linostigma Klotseh in Linnaea $X$, 438. Meisner Gen. 58. (42.)

\section{Dralo CCLD. Einear.}

LINEAE DC. Theorie elem. edit. I. p, 89, Prodr. I. 423. Bartling Ord, nat. 369. LINACEAE Lindley Introduct. edit. IT. p. 89 .

Herbae annuae v. perennes, aut suffrutices, caule ramisque teretibus, $v$. interdum angulatis. Folia alterna v. opposita, rarius verticillata, simplicia, sessilia, linearia, integerrima, avenia, basi interdum biglandulosa. S $t$ i p u 1 a $\mathrm{e}$ nullae.

Flones hermaphroditi v. rarissime abortu unisexuales, regulares, terminales, paniculati, paniculato - corymbosi v. rarius corymbosi, in pedunculis unifloris, lutei, caerulei, carnei v. albi.

Calyx persistens, pentaphyllus, foliolis integris, v. quadripartitus, laciniis trifidis, aestivatione imbricatis.

Corollae petala 5 v. 4 , hypogyna, calycis laciniis alterna et longiora, basi in unguem angustata, aestivatione contorta.

Stamina fertilia petalis numero aequalia et alterna, sterilia totidem petalis opposita, dentiformia v. penitus deficientia. Fil a m enta complanato-subulata, basi plerumque in cupulam brevem coalita, rarius omnino libera, saepissime marcescenti-persistentia. Antherae introrsae, biloculares, lineares, oblongae v. ellipticae, basi v. dorso affixae, loculis appositis, parallele contiguis, longitudinaliter dehiscentibus.

Ovarium quadri-quinqueloculare, rarius in flore pentamero triloculare, loculis collateraliter biovulatis, septo dorsali plus minus com- 
pleto verticaliter incomplete v. complete bilocellatis. 0 vula pendula, anatropa. Styli $3-5$, filiformes, liberi. Stigm a ta simplicia, lineari-elongata v. subcapitata.

Capsura globosa, calyce staminibusque persistentibus indusiata, stylorum reliquis superata, tri-quadri-quinquelocularis, loculis dispermis, septo secundario dorsali verticaliter semibilocellatis v. septo secundario axim attingente complete bilocellatis decemlocularis, loculis monospermis, dehiscentia septicida, in cocos hinc lunulatim excisos v. sutura dorsali bivalves soluta.

Semisa pendula, compressa, testa coriacea, splendente, $\mathrm{umbilico}$ ad seminis extremitatem angustiorem sublaterali, e n dople u r a carnosa, tumida, albumen mentiente. A 1 b nmen nullum.

Enввуо rectus v. subarcuatus, complanatus. Cotyledones planae, ellipticae, germiuatione foliaceae. Ra di c u la umbilico parallele contigua, supera.

L in e a ob librum tenacissimum et semina oleosa humano generi utiles, in regionibus temperatis totius orbis, frequentissime tamen in regione mediterranea crescentes, Geraniaceis et Oxalideis proximae, illine ad Caryophyllaceas Sileneas, quibuscum olim confusae, et ad Elatineas accedunt.

6056. Lumuna LINN. C a l y xentaphyllus, foliolis integris. Corolla e petala 5, hypogyna. Sta min a 10 , hypogyna, ima basi coalita, aiterna calycis foliolis opposita fertilia basi biglandulosa, alterna petalis opposita ananthera, dentiformia; fil amenta complanato-subulata, a ntherae introrsae, biloculares, longitudinaliter dehiscentes. O variu m sessile, tri-quinqneloculare, Ioculis biovulatis, semisepto dorsali verticaliter incomplete bilocellatis, $\mathbf{v}$. septo dorsali completo decemleculare, loculis uniovulatis, $O$ v $\mathrm{a}$ la pendula, anatropa. Styli 3. v. 5, filiforimes, liberi v, basi coaliti; st igmat a eapitellata v. linearia. Caps u la subglobosa, nune tri-quinquelocularis, loculis septo dorsali verticaliter semi-bilocellatis, apice septicide tri-quinquevalvis, valvis semi- bifidis, loculis dispermis, nune decemlocularis, septicide deeacosea, coccis indehiscentjlbus, monospermis. S emin a pendula, testa coriacea, endopleura carnosa, tumida. Embryonis exalbuminosi recti v. subarcuati radicula supera. - Herbae $v$, suffrutices in temperatis tolius orbis crescentes, inter tropicos rari; foliis alternis, oppositis v. verticillatis, integerrimis, floribus panicnlatis v. corymbosis, luleis, caeruleis, carneis v, albis.

L іл и п Dillen. Lina. Gen, $n, 389$. excl, sp. Smbh Flor, Brit. I. 342. Exot. Bot. 2. 17. Gãrtuer II. 146, t, 112. Laa. $t, 219$. Sehkulir $t$, 87. Jacg. Flor. Austr. $t, 31,215$. 321. 418. Cav, Ic, $t, t, 108$. E. B. t. 40. 381. Brotero Phy. togr. lusit, t. 6. Waldst. et Kiraibel Plant, rar. Hung. t. 105. 17\%. Desfont. Flor, allant, $t$. 78-81. Sibttorp Flor, graec. t. 307. Bonpl. Nav. C. 17. Bot, Mag. t. 403, 431. 1048, 1086. 1too, 1163 . Bot. Reg. $t, 1326$. DC. Prodr. I. 423. Schiede in Linnaea $I$. 65. St. Hilaire Flor. Brasil. I. 129. t. 24. Ledebour Ic. 2 , 142. Meisuer Gen, 57, (41.) Rei w ward tia Dumortier Enumerat 19.
605\%. TRadiola DILLEN. Calyx quadripartitus, laciniis trifidis. Corolla e petala 4, hypogyna. St amina 4, ralyeis laciniis opposita, sterilia nulla; fil amenta complanato-subulata, a $\mathbf{n}$ h e $r$ a e introrsae, hiloculares, longitudinaliter dehiscentes. Ovarium sessile, quadriloenlare, loculis biovulatis, semisepto dorsali verticaliter incomplete bilocellatis, Ovnla pendula, anatropa. Styli 4, filiformes; stig mat a capitellata. $C$ aps u l a depressa, quadrilocularis, tetracocea, coceis semibilocularibns, dispermis, bipartibilibus. S em in a pendnla, testa coriacea. E m b ry on is exalbnminosi, recti radicula snpera. - Herba europaea, annua, pusilla, dichotome ramosa, erecta, glabra; foliis oppositis, sessilibus, ovatis, acutis, floribus alaribus et terminalibus, solitariis, pedunculatis erectis, albis.

R a di ol a Dillen. Giess, 161, Gen, App. 127. t, 7. Gaclin Sjst. 289. E. B. t. 895. DC. Prodr. I. 425. Meisner Gen. 57. (41.) Kunth Flor. Berolin. I. 139. Li in u R a d io I a Linn. Flor. dan, t. 178.

\section{Ordo CCLII. Dxalidene.}

OXALIDEAE DC. Prodr. I. 659. Bartling Ord, nat. 351. Meisuer Gen. 57. (42.) OXALIDACEAE Lindley Introduct. edit. II. P. 140.

Herbae acaules v. caulescentes, radice saepius bulbosa v. tuberosa, rarius Suproctcвs, rarissime Aввоnвs, caule ramisque teretibus v. interdum angulatis, succo aqueo acidulo foetae. Folia alterna, saepissime conferta, petiolata, digitata, rarius abruptim v. imparipinnata, interdum foliolorum lateralium abortu spurie simplicia, juniora spiratim involuta, foliolis sessilibus v. rarius petiolulatis, integerrimis, saepissime obeordatis, interdum irritabilibus. Stipulae nullae.

Flores hermaphroditi, regulares, umbellati, racemoso-paniculati $\mathbf{v}$. in pedunculis axillaribus solitarii, albi, rubri v. flavi, colorum intensitate admodum varia.

Cacyx liber, quinquefidus v. quinquepartitus, laciniis subaequalibus, aestivatione imbricatis.

Corollae petala 5 , hypogyna, calycis laciniis alterna et longiora, aequalia, obtusa, breviter unguiculata, libera v. ima basi coalita, aestivatione contorta, sub anthesi erecta v. patentia, decidua.

Stamisa 10, hypogyna, ima basi coalita, alterna petalis opposila breviora, aeque fertilia v. interdum ananthera, plerumque glaberrima, alterna calycis laciniis opposita longiora, saepe hirtella. Filamenta filiformia v. subulata, complanata. Antherae introrsae, biloculares, ovatae v. ellipticae, dorso insertae, demum sacpius extrorsun versae, loculis oppositis, parallelis, basi non raro discrelis, longitudinaliter dehiscentibus.

Ovaruom sessile v. gynophoro brevissimo aequali insidens, e carpidiis quinque, petalis oppositis, angulo centrali per totam longitudinem 147 * 
connatis compositum, quinquelobum, quinqueloculare. Ovula in loculorum angulo centrali solitaria v. plarima, unica serie superposita, pendula, anatropa. Styli 5, filiformes, liberi v. ima basi coaliti, persistentes. Stigmata capitata, interdum biloba v. bifida.

Fructes nunc capsularis, columnaris, ovatus v. subglobosus, herbaceo-membranaceus, quinquelobus, quinquelocularis, loculis medio dorso longitudinaliter fissis, valvis ab axi persistente haud solutis, nunc b a c c a tus, oblongus, quinquesuleus, quinquelocularis, indehiscens.

Semina loculorum angulo centrali inserta, solitaria v. plura, subdefinita, pendula, saepissime ovata, plerumque epidermide carnosa (arillo), apice elastice solubili vestita, testa crustacea, saepissime longitudinaliter costata, inter costas transversim rugosa, umbilico prope basim laterali. A lbumen carnosum, copiosum, interdum coloratum.

Embryo in axi albuminis rectus v. curvatus. Cotyled on es saepissime ellipticae, radicula parum latiores. Radicula saepissime brevis, umbilicum attingens, supera.

$0 \times a l i d e a e$ affinitate Geraniaceis proximae, illinc ad Zygophylleas et Connaraceas accedeutes, e nullo climate, si frigidum exceperis, exules, maximo numero in Capite bonae spei et America tropica et australi subtropica generantur, in Asia tropica rarae, sed arboreat.

6058. Dxalis $L I N N$, C a $1 \mathrm{y} x$ quinquefidus v. quinquepartitus, persistens, Corolla e petala 5, ad basim gynophori brevis inserta, calycis laciniis alterna et longiora, obtusa, breviter unguiculata, libera v, ima basi coalita, aestivatione contorta. St a mina 10 , eum petalis inserta, libera v. hasi coalita, alterna petalis opposita breviora, saepissime glabra, alterna longiora plerumque hirtella; fil a in en ta complanato-subulata, apice acuta, a $\boldsymbol{t}$ herae introrsae, biloculares, dorso insertae, demum reflexae, longitudinaliter dehiscentes. O variu m gynophoro brevi insidens, quinqueloculare, quinqueangulatum, usque ad axim quinquelobnm. Ovula in loculis solitaria v. plnrima, angulo centrali inserta, pendula, anatrupa. Styli 5 , centrales, liberi v, basi coaliti. S $t$ i g $m$ a $t$ a capitata, bifida, laciniata v, penicillata. C a p s u l a herbaceomembranacea, usque ad axim quinqueloba, lobis uniloenlaribns, medio dorso fissis, a columna centrali haud secedentibus. Sem in a in loculis solitaria $v$. pauea, ovata, epidermide carnosa, elastice dissiliente, testa crustacea, costata, umbilico prope basim sublaterali, E m b ryo in axi albuminis carnosi rectus v. subcurvatus; cotyledonibus ovalibas v. ellipticis, radie $\mathbf{n}$ a ambilico paraltele contigua, supera. - Herbae $v$, suffrutices, in America tropica et $\bar{C}$ apite bonae spei magna copia, parcius et sparsim in regionibus temperatis et calidioribus reliqui orbis crescentes, caulescentes sive radice tuberosa aut bulbosa acaules; foliis allernis, saepe confertis, bi-trifoliolatis, interdum foliorum lateralium abortu simplicibus $v$, ab- ruptim pinnatis multijugis, foliolis integerrimis, saepissime obcordatis, pedunculis saepissime cymoso-bifidis, umbelliferis, pedicellis bracteolatis, floribus co. loris omnis.

$0 \times$ alis Lian. Gen, n, 582, Thunberg Dissert Ups, 1781. Gärtaer II. 152. t, 113. Jacyuin Monographía Oxalidum. Viennae 1794. 4. Zuceariui MLonograph. Oralid. Amerie. in Münchner Denkschrift 1825 et 1831. St. Hilaire Flor. Bra sil. I. 104. Meisner Gen, 57. (42.) 0 x y s Tournef. Inst. t. 19. Oxalis et Biophytum DC. Prodr. I, 690. et 689.

a. PALAMOXYS. Aeaules v. stipite brevi, basi nudo, foIils petiolatis, palmatim v. peltatim quinque-multifolio. latis, foliolis eglandulosis, seapis unitloris, $D C$. (Cav. Ic, t. 393. f. 2. t. 411. 412. Jaeq. Oxal. t. 78. 75. 81.)

b. ADENOXYS. Caulescentes, caulibus nune sparse foliosis v. apice tantum foliosis, nuac subacaules, foliis pe. tiolatis, tri-quinquefoliolatis, foliolis linearibus, aplee subtus callos glaudulosos gerentibus, pedunculis uniflaris. $D C,-$ (Jacq. Oxal. t, 36, 38, 39. 76, f, 3, 77 . f. 4. Hort. Schünbr. t. 206, 273. Ic rar. t. 473. Bot. Mag. , 1549, )

c. ACETosetra. Acaules v, subeaulescentes, foliis trifolio. latis, petiolis immarginatis. foliolis subtus hand glandulosis, stapis unifloris, DC, - (Flor. dan. t. 980 . Jacy. Oral. t, 19.28-35. 40-70. Hort. Sohönbr, t.205. 206. 273. 274. Bot. Mag. $t$. 1549. 1683.)

d. PTEROPODOXYS. Acaules, folis glabris, bi-trifoliolatis, petiolulatis, seapis unifloris. DC. - (Jacq. Oxal. t. $23-27$.

e. HAPLOPBYLlOXXS. Acaules v, rarius caulescentes, foliis unifoliolatis, pubesceutibus, petiolis immarginatis, seapis pluri. aut saepius uniflorís. DC. - (Jacq. Oral. t. 21. 22, 79. f. 2.)

f. AEgOPODOXYS. Acaules v. caule basi nudo, apice tantum folioso douatae, peduaculis uni-bi- aut multiflo. ris, foliis radicalibus petiolulatis, pluri-, ant saepius trifoliolatis. DO. - (Cav. IC, t. 237. Jacq. Oxal, t. 6-8. 77. f. 1, t, 78. f. 3, t. 80. f. 2, Hort. Schönbr. t. 356. Bat. Mag. t. 2386. 2881. St. Hilaire Flor. Brasil. t. 25.)

g. PARThENOXYS. Caulescentes, caulibus elongatis, sparse foliosis, foliis saltem supremis petiolatis, tri.quinquefoliolatis, pedunculis axillaribus unifloris, $D C$. (Jacq. Oxal. t, 18. 20. Hort. Sohönbr. t. 275. Hort, Vindob. . 71.)

h. RHODOXYS. Caulescentes, caulibus basi bulbosis, elongatis, sparse foliosis, folils sessilibus, trifoliolatis, vil. losis, eglandulosis, pedunculis axillaribus unifloris. $D C$. - (Jaeq. Oxal. t, g-17. 77. $f$. 3 . Bot. Mag. $t, 1031$. 1698.)

i. Ceratoxys. Caulescentes, caulibus basi haud bulbosis, herbaceis $v$. rarissime suffraticosis, foliolis, pe. dunculis rarius unifloris, saepius bi-multitlaris, foliis palmatim trifoliolatis, foliolis sessilibus, obeordatis. $D C$. - (Jacq. Oral. t. 4. 5. 78. f. 1. Hort. Schönbr, t, 204. Humb. et Bonbl. Nov, gen. et sp. $t$. 469 . St. Hilaire Plant. us, t. 46. Flor, Brasil, t. 24. Bot. Mag. t, 2415. 2830. Bot, Reg. t. 1073. 1123. Wight Ic, $t, 17$.)

k. PHYLlODOXYS. Caulescentes, suffruticosae, caule folioso, petiolis saepissime aphyllis. foliaceo dilatatis. $D C$. - (St. Hilaire Flor. Briasil. $t$. 23.)

1. THamnoXys, Caulescentes suffruticosae, foliosae, fo. lits trifoliolatis, foliolis ovatis v. Ianceolatis, intermedio petiolulato, pedunculis - multifloris, ovarii loealis saepissime uniovulatis. $D C,-$ (Jacq, Oxal. $t, 1-3$. Kuath in Humb. et Bonpl. Nov. gen. et sp. 470, 471. St. Hilaire Flor. Brasil. t. 22. Plant, 4s. t. 45. Bot. Reg. t. 8to. Bot. Mag, t. 3748.]

m. BIOPнXтUM. Caulescentes, foliis ad apieem caulis verticillato-fascieulatis, abrupte pinnatis, foliolis maltijagis, oppositis, pedunculis apice umbellato-multifloris. B i op b y tum DC. Prodr. I, 689. (Jaeq. Oxal, t. 78. f. 4. St, Hilaire Flor. Brasil. $t$. 21.)

6059. Averroma LINN. C a lyx quinquefidus v. quinquepartitas, persistens. Corolla e petala 5, hypogyna, calycis laciniis alterna et longiora, oblonga, obtusa, breviter ungniculata, libera, aestivatione convoluta, sub anthesi patentia. 
St a mina 10 , cum petalis inserta, basi coalita, alterna iisdem opposita breviora, aeque fertilia $v$ ananthera; fil am en ta filiformia v. subulata, an therae introrsae, biloculares, ovatae v. subglobosae, dorso insertae, longitudinaliter dehiscen. 1es. Ovari u m sessile, quinqueangulatum, quin quesulcatam, qguinqueloculare. Ovula in loculis plurima, angnlo centrali uniseriatim inserta, anatropa. Styli 5, filiformes; stig mat a capitellata. $B$ a ec a oblonga, quinqnesulcata $v$, quinquean gulata, quinquelocularis. Se $\mathrm{m}$ in a in loeulis piurima, uniseriata, testa crustacea, nuda v. arillata E mbryo in axi albuminis carnosi orthotropus; cotyledonibus foliaceis, $r$ ad i : a I a brevi, umbilico proxima. - Arbores indicae; folïs al. ternis, imparipinnatis, exstipulatis, foliolis alternis, subsessilibus, multijugis, ovato-lanceolatis, integerrimis, racemis terminalibus paniculatis.

A ver rhoa Linu. Gen. n. 576 . Correa in Annal. Mus. VIII, 71. t. 2, DC. Prodr. I. 689. Meisn, Gen, 57. (42.)

a. BILIMB1. Stamina omaia fertilia. Baeca obtusan. Ealu. Se mi ua exarillata. - B il imbi Rheede Malab. III. t. 45. 46. B $1 \mathrm{I}$ m bi $\mathrm{g}$ b $\mathrm{n}$ I a Ranph Amboin. $I, t 36$. A. B $11 \mathrm{im}$ bi Lian. Cav. Diss. VII, t. 219.

b. CARAMBOLA. Stamina alterna petalis opposita ananthera. B a c e acutangula. $S \in m i$ u arillata. - T a. mara Toug a Rheede Malab. III, t. 43. 44. P r и и ш stellatum Blimbing Rumph Amboin. I. c. 35. A. C ar ambola Lín. Cav. Diss. VII. $t, 220$.

\section{Ordo CCI VII. Balsamineae.}

BALSAMINEAE A. Richard in Dict, hist, nat, $I T, 173$. De. Prodr. I. 685. Kunth in Mem. soe, h. n. Paris. III. 384. (1827.) Bartling Ord, nat. 422. Roeper, de foribus et affinitale Balsaminearum. Basileae, 1830. 8. Aruott in Linnaea IX. (1834.) p, 112_118. Roeper, Ibid. 119-124. t. 1. Agardh in Flora 1833. II. 113-120. Roeper, 1bid. 1834. 1. 89-91. 97-111. Agardh. Ibid. 1836. 1. 193. 205. 208-221. Ropper, Ibid. 1836. I. 241-245, Presl, über den Blüthenbau der Balsamineen, Prag. 1837. 8. Beruhardi, in Linnaea XIT. (1838.) p. 669-680. Kuuth Flor, Lerolin. I. 82. BALSAMINACEAE Liadley Introduct, edit. II, p, 138. - HYDROCEREAF Bijdr, 241.

Неввае ut plurimum annuae, erectae, tenerae, caule ramisque teretiusculis $\mathbf{v}$. angulatis, succo aqueo turgidis, radice fibrosa v. interdum tuberosa. Foli a interdum omnia radicalia, longe petiolata, cordata v. reniformia, plerumque caulina, alterna v. opposita, rarius terna, breviter petiolata, quandoque sessilia, simplicia, penninervia, lanceolata v. linearia, dentata v. mucronato - serrata. Petioli interdum basi pilosi, utroque margine stipularum loco glandulis cupuliformibus, substipitatis instructi. Pedunculi axillares, rarissime foliorum superiorum abbreviatione racemum terminalem formantes, uni-tri-pluriflori, solitarii, gemini v. terni, bracteati, pedicellis unifloris, interdum basi $\mathbf{v}$. supra medium bracteolatis, saepius nudis.

Flores hermaphroditi, irregulares, non resupinati, flavi, albi, rosei, violacei aut elegantissime variegati, in stirpe culta facillime pleni.

CaLyX pentaphyllus, irregularis, coloratus, caducus : foliola duo extima lateralia, opposita, parva v. minima, aestivatione inter se hine valvata, illine anticis incumbentia, p o sti cu m maximum, saccato-concavum, basi in gibber v. in calcar cavum productum, aestivatione corollam complectens, duo a $t$ ic a nunc lateralibus subaequalia, hinc ab iisdem obtecta, illine dextrum sinistro incumbens, nunc minutissima, rudimentaria v. omnino nulla.

Cororla hypogyna, pentamera, elementis cum calycis foliolis alternantibus, nunc liberis pentapetala, nunc coalitis spurie tripetala: pe$\mathrm{t} \mathrm{I} \mathrm{Im}$ anticum (inter calycis foliola antica (dum adsunt), e regione postici calcarati positum), maximum suborbiculato-concavum v. fornicatum, apice saepissime emarginatum, aestivatione reliqua amplectens, duo postica (inter calycis foliola lateralia et posticum sita) minora, inter se distincta, marginibus contiguis involuta, illine duobus lateralibus (inter calycis lacinias laterales et anticas, dum adsunt sitis), omnium minimis connata v. aestivatione incumbentia.

Stanina 5, hypogyna, petalis alterna, ovario aequilonga, superne cohaerentia, marcescentia, demum basi soluta, ovarium calyptratim tegentia, tandem dejecta. Fil am enta tenuia, semiteretia, glabra, superne dilatato-incrassata, apice cohaerentia v. connata. Antherae introrsae, biloculares, ovato-ellipticae, marginibus cohaerentes, apice distinctae, connectivo cum filamento continuo, loculis oppositis, longitudinaliter dehiscentibus, v. interdum infra apicem liberum subtransversim ruptis.

Ovarium liberum, sessile, oblongo-teres, v. prismatico teretiusculum, saepissime tomentosum, quinqueloculare, e carpidiis quinque, cum staminibus alternantibus compositum, carpidiorum marginibus introflexis, cum columnae centralis, quinqueangularis, apice in flla tenuissima, stylum petentia, solutae angulis connatis, dissepimenta constituentibus. Ovula in loculis pauca v. plurima, angulo centrali superposite unica serie inserta, pendula, anatropa. Stigma sessile, conicum, integrum v. quinquepartitum.

Fructus nunc capsularis, oblongo-prismaticus v. teretiusculus, apice' columnae centralis deliquescentia unilocularis, inferne quinquelocularis, epicarpio carnosulo, endocarpio cartilagine 0 , elastice in valvulas 5 , loculicidas dissiliens, valvis nunc apice solutis involutis, v. a basi ad apicem extrorsum revolutis, medio semisepta a columnae persistentis angulis soluta gerentibus, saepissime mox juxta semisepta bipartitis, nune drupaceus, subglobosus, quinquelocularis, epicarpio carnoso, endocarpio osseo, putamen quinquelobum constituente.

Semisa in loculis plurima, v, abortu pauca aut interdum solitaria, columnae immediatim 
affixa, pendula, elliptico-subrotunda, compressiuscula. Testa tenuissime membranacea, tuberculato-punctata, glabra, umbilico basilari parvo. Endopleura inconspicua. A 1bumen nullum.

Enввуолis exalbuminosi, orthotropi cotyledones carnosae, plano-convexae, radicula brevissima, obtusa, umbilicum attingens, supera, plumula brevis, emarginato-biloba.

Balsamineae locis humidis umbrosis nascuntur, copiosissime in Asiae orientalis regionibus temperatis et calidioribus repertae. Paucae Africam australem extratropicam, et Americam borealem incolunt. Europam unica species, etiam per Asiam borealem late diflusa, inhabitat.

Ordo parvus, Oxalideis Lineisque proximus, floris structura ab iisdem facillime distinguendus, a Cruciferis et Fumariaceis, quibuscum a nonnullis comparatur, fruetus fabrica longissime distat.

6060. Innpatiens $L I N N$. C a l y $\mathrm{c}$ i s pentaphylli, colorati foliola inaequalia, posticum maxi. mum, basi calcaratum, lateralia minora, antica minima v, obsoleta. Corolla e petala 5 , hypogyna, ealyeis foliolis alterna, antienm maximom, suborbiculato-concavum, postica cum lateralibus minaribus per paria connata. Stamina 5 , hypogyna, petalis alterna, ovarium arete eingentia; filamenta superne coalita, antherae introrsae, hiloculares, subconnatae, longitudinaliter dehiscentes $v$. infra apicem subtransversim ruptae, Ovariu $\mathbf{m}$ sessile, oblongo pentagonum $v$. teretiusculum, qninqueloculare. $O$ v u la in loculis plurima v. pauca, angulo centrali superposite inserta, uniseriata. Stig $\mathbf{m}$ a sessile, quinquedentatum v, quinquefidum, C a p s u la oblonga, pentagona v. teretiuscula, superne uni-, inferne quinquelocularis, loculicide quinquevalvis, valvis medio semiseptiferis, a columna persistente elastice dissilientibus, saepissime septicide bifidis, ab apice ad basim involutis, v. sursum revolutis, endocarpio cartilagineo. Sem ina in loenlis plurima v. pauca, rarissime abortu solitaria, inversa. Embryonis exalbuminosi, orthotropi cotyledones plano-convexae, radicula obtusa, supera. - Herbae saepissime annuae, in $A s i a$ orientali tropica et subtropica copiosae, in Capite bonaespei, America boreali, Europa et Asia temperat a rarae; foliis alternis, oppositis $v$. ternatis, lineari-v. lato-lanceolatis, serratis $v$. dentatis, rarissime omnibus radicalibus longe petiolatis, exstipulatis, pedunculis axillaribus, solitariis v. aggregatis, uni-plurifloris.

1 mpatiens Linn, Gen, n, 1008. Lam. t. 725. Sehkuhr t. 270. Flor. dan. t. 382 Bot. Mag. t. 1256. 3582. Kunth in Mlem. soc, h. n, Paris, IIT, 387. Hooker Exot. Flor, t. 137. 141. 156. Ledebour Ic, $t, 89$ Wallich Plant, As, rar. $t$ 19. 193. 194. DC. in Mem, soo. phys, Gonev. V. t. 1. Royle Himalay. t. 28. Wight in Hooker Bot. Mag. Comp. I, $t$ 18. Wight et Arnott Prodr. I. 135. Meisa. Gen, 58. (49.) B a Is a. wian Gärtner $1 I, 15 t, t, 113$. Impatiens et BuIsamin s Rivin. Tetrap. irreg. IV. 146. DC. Prodr, I, 685-687.

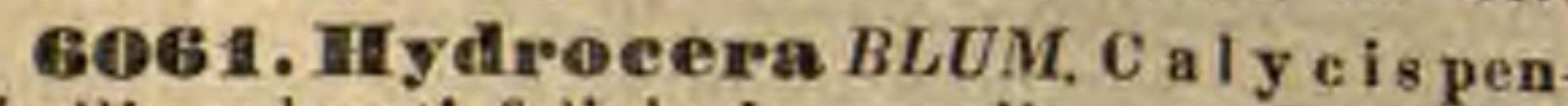
taphylli, colorati foliola iuaequalia, posticum maximnm, basi gibbosum, lateralia anticis minurihns incumbentia. Cor o 11 a e petala 5, hypogyna, caly- cis foliolis alterna, inaequalia, libera, anticum maximum, fornicatum, postica basi cuneata, lateralia minora. St am ina 5, hypogyna, petalis alterna, ovarinm arcte cingentia; fil a m enta apice connata, an the ra e introrsae, biloculares, subeonnatae, apice dehiscentes. Ovarin m sessile, oblongu-pentagonum, quinqueloculare. Ov u $\mathrm{la}$ in loculis $2 \_3$, angulo centrali superposite inserta, pendula, anatropa. Stigm at a $\tilde{5}$, sessilia, acuta. D r p a baceata, snbglubosa, pntamine usseo, quinquelobo, quinqueloculari. Se m in a in loculis abortu solitaria, inversa. E m bry o $\mathrm{n}$ is exalhuminosi, orthotropi cotyledones plano-convexae, radicula teres, supera. - Herbae indicae, natantes; caulibus angulatis, foliis alternis, petiolatis, lineari- v. lalo-lanceolatis, serratis, utrinque glaberrimis, glaucis, stipulis nullis, pedunculis axillaribus solitariis, bi-trifloris, pedicellis filiformibus, pedunculo longioribus.

H y drocer a Blume Bijdr.291. Wight et Arnott Prodr. T. 140. Meisuer Gen. 58. (42.) Ty to nia Don Syst. 1. 749. Impatiens triflora L. I. natans Roxb. Willd.

\section{Ordo CCLVIII. Tropaeoleae.}

TROPAEOLEAE Jussieu in Mem. Mtus. IIT. 447. DC. Prodr. I. 683. Bartling Ord, nat. 366. Meisner Gen. 58, (42.) BALSAMINACEARUM Subordo Lindley Introduct. edit. II. p. 139.

Herba e tenerae, diffusae v. volubiles, glabrae, succo aqueo, acidulo, radice saepius tuberosa, caule ramisque haud articulatis. Folia primordialia opposita, bistipulata, reliqua alterna, exstipulata, petiolata, simplicia, pellata, integra, lobata v. profundissime palmatipartita, lobis integris v. incisis, interdum poris pellucidis notatis.

Flores hermaphroditi, asymetrici, axillares, solitarie pedunculis saepissime elongatis, plerumque ebracteatis insidentes.

CALXX coloratus, persistens, quinquefidobilabiatus, labio superiore bifido, inferiore trifido, basi in calcar cavum, liberum, intra florem hians producto, lobis aestivatione valvatis v. imbricatis.

Corollas petala imo calyci inserta, ejusdem lobis saepissime numero aequalia et alterna, sessilia v. plus minus distincte unguiculata, duo antica calearis fauci inserta, a reliquis remotiuscula, reliqua saepissime minora v. interdum onnia deficientia, in aestivatione singula longitudinaliter plicata, marginibus se invicem tegentia, sub anthesi plana, calycem aequantia v. superantia.

Stavixa 8, hypogyna, ovarium ambientia, inaequilonga v. subaequilonga. Filamenta subulata, libera. Antherae introrsae, biloculares, baseos foveolat insertae, erectae, mobiles, complanatae, a latere longitudinaliter dehiscentes.

Ovariu x sessile, liberum, trilobum, triloculare, rarius didymum, biloculare, lobis teretibus, longitudinaliter costatis v. alatis. Ovula in loculis solitaria, ex apice anguli 
centralis pendula, anatropa. St y 1 u s centralis, triqueter v. filiformis, apice breviter trifidus v. bifidus, lobis cum earpidiornm costa dorsali continuis; stigmate terminali minimo, vix manifesto terminatus.

Froctus nunc baccatus, trilobus v. abortu bi-unilobus, nunc siccus, tricoceus, coccis fungosis v. subcarnosis, costatis, indehiscentibus, nunc samaroideus, samaris duabus facie cohaerentibus, membranaceo-trialatis.

Semina in loculis solitaria, inversa, testa cartilaginea v. saepius cum endocarpio confusa. A 1 b umen nullum.

Enвryo orthotropus. Cotyledones rectae, crassae, juniores semiorbiculatae, distinctae, demum plerumque inter se et cum testa conferruminatae, basi in auriculas approximatas, distinctas, radiculam brevem, umbilico proximam, superam recondentes, productae.

Tropaeoleae in America australi extratropica indigenae, Geraniaceis et Limnantheis, a quibus imprimis carpidiorum numero et radiculae situ differunt, proxime affines, quibusdam characteribus ad Sapindaceas et Malpighiaceis, ut ut omnium notarum summa diversissimas, accedere videntur.

cos\%.Chymocarpus DON. Calyx coloratos quinquefidus, subbilabiatus, labio superiore bifido, inferiore trifido, basi in calcar cavam, intra florem hians producto, lobis subaequalibus, aestivatione valvatis. Corotlae petala 2 , calyei inter labii inferioris lobos laterales et intermedium, ad ealearis faucem inserta, spathulata, aestivatione longitudinaliter complicata, sub anthesi plana, calyce breviora. Stamina 8, hypogyna; filament a subulata, basi dilatata, inaequilonga, a ntherae introrsae, biloculares, globoso-didymae, longitudinaliter dehiscentes. Ovarium sessile, trilobum, triloenlare. O v u I a in loculis solitaria, ex angali centralis apice pendula, anatropa. Styl us terminalis, triqueter; stig ma tridentatum. B a ce a calyce aucto, carnoso eincta, triluba v. abortu bi-uniloba, lohis subglobusis, laevibns, monospermis. S e m in a inversa, testa cartilaginea, alba. Embryonis exalbuminosi, inversi cotyled un es subrotundac, compressae, radicula brevis, supera. - Herba in America austro-orientali extratropica indigena; radice tuberosa, perenni, caulibus filiformibus, scandentibus, glabris, foliis alternis, petiolatis, subpeltatis, quinato-partitis, laciniis elliptico-oblongis, integerrimis, basi angustata substipitatis, stipulis nullis, pedicellis axillaribus unifloris, elongato filiformibus, ebracteatis, calycis limbo virente, tubo rubescente, calcaris infundibuliformis, inferne constricti basi clavata, mellifera, post anthesim circumscisse decidua, petalis puniceis, baccae atro-violaceae pulpa eduli, dulei.

Ch y m o c a p us Don in Linn, Transact. XVIT. 13. et 145. T ropa e $01 \mathrm{um}$ pe $\mathrm{ntap}$ b $11 \mathrm{um}$ Lab. Mlustr, $t, 177$. St. Hilaire Plant. us. Brasil. $t$, $4 t$, COvulum apud Schleideu 2 , A. N. C. XIX, 36, t, 8, f, 126.)

6063. Tropaeolum $L I N N$. C al y x co loratus, quinquefidus, subbilabiatus, labio superiore bifido, inferiore trifido, basi in calcar intra florem hians producto, Iobis aequalibus, aestivatione imbricatis, Corolla e petala 5, imo calyci inserta, ejusdem laciniis alterna, plus minus nnguiculata, inaequalia, integra $\mathbf{v}$, incisa, doo antica ad calearis faucem a reliquis remota, aestivatione imbricata, longitadinaliter plicata, sub anthesi plana, calycem aequantia v. superantia. S $t$ a mina 8 , hypogyna; fil amenta subulata, basi dilatata, inaequilonga, antherae introrsae, biloculares, sub-didymae, longitudinaliter dehiscentes. Ovari um sessile, trilobum, triluculare. Ovnla in loculis solitaria, ex anguli centralis apice pendula, anatropa. Sty lus terminalis, triqueter; otig ma tridentatum. Fructus tricocens, encris fungosis v. subcarnosis, dorso costatis, indehiscentibus, monospermis. S e mina inversa, testa cum endocarpio confusa. Embryonis exalbuminosi, inversi cotyled on e s basi bianricnlatae, in massam carnosam conferruminatae, auriculis approximatis, $\mathrm{ra}$ diculam brevem, superam abscondentibus. Herbae annuae $v$. perennes, diffusae $v$. volubiles, in A merica a ustrali extratropica crescentes, radice saepius tuberosa; folits alternis, petiolatis, peltatis, integris $v$. digitato-partitis, lobis indivisis $v$. incisis, stipulis nullis, pedicellis axillaribus, unifloris, ut plurinum elongatis, plerumque ebracteatis, foribus speciosis.

Tropaeo $1 \mathrm{um}$ Linn. Gen, n, 466. Sehkubr t. 105. Jaeq. Hort. Schönbr, t, 98. Cav. Ic, $t, 395$. Ruiz et Pavon Flor. Peruy. t. 313_314. Andrews Bot. Reposit, t, 617. 335. Bot, Mag, t, 23, 98, 135t. Bot. Reg, t, 718. DC, Prodr. I. 683. exel. sp. St. Hilaire Plant, 25 . Brasil. $t$, 43. Flor. Brasil. I. 98. excl. sp. Päppig et Endl. Nov, gen, et sp. I. t. 35-38. Meisner Gen. 58. (42.) (Historia impraegnationis apud Schlelden $N$. A. $N$. $C, X I X, 54, t, 8, f .120$ -125.)

6064. Magallana CAVAN. Caly $\mathrm{co-}$ loratus, yuinquefido-bilabiatus, labii superioris bipartiti lobis divaricatis, inferiore trifido, in ealcar cavum, intra florem hians producto. Coroll a e petala 5, inter calycis lacinias inserta, tria postica longe ungniculata, ovata, cucullata, duo antica sessilia, linearia. Stamina 8 , hypogyna; filament a subulato-filiformia, basi in annulum coalita, ant herae introrsae, biloculares, subgloboso-didymae longitudinaliter dehiscentes. O v ari u m sessile, didymum, hiloculare, lobis trialatis. Ovala......Stylus filiformis; stigma bifidum, lohis divaricatis, altero brevi, crasso, altero long iore, subulato. S a m a r a e 2 , uniloculares, trialatae, alis membranaceis, monospermae. Semen oblongum ...... - Herba in America antarctic a indigena, annua; caule scandente, foliis alternis, petiolatis, tripartitis, laciniis lanceolatis, acutis integerrimis, poris pellucidis lutescentibus notatis, petiolis cirrhosis, stipulis nullis, floribus axillaribus solitariis, pedunculatis.

M a gallan a Cavauill. IC, IV, so, t. 344. DC, Prodr. I. 684. Meisner Gen. 58. (42.)

\section{Ordo CCLIX. Limnantheae.}

LIMNANTHEAE R. Brown in Land, et Edinb, philo. soph. Mag, et Journ. 1833. Meisn. Gen. 135. (99.) Torrey et A. Gray Flora of North-Amer. $\boldsymbol{I}$. 209. LIMNANTHACEAE. Lindley Introduct. edit. II. p. 142.

Herbae annuae, boreali-americanae, paludosae, flaceidae, glauco-virides, glaberrimae, sapore acidulo. Folia alterna, longe petiolata, pinnatifida v. bipinnatifida, laciniis angustis 
abbreviatis, lanceolatis v. ovalibus. Stipulae nullae.

Flores hermaphroditi, regulares, pedunculos axillares, folio longiores, unifloros, solitarios terminantes, albi, ebracteati, pedunculi apice incrassato, turbinatam calycis basim simulante.

Calyx tri- v. quinquepartitus, persistens, laciniis acutis, aestivatione valvatis, sub anthesi patentiusculis.

Corotras petala calycis laciniis numero aequalia ( 3 v. 5 ) et alterna, iisdem breviora $v$. longiora, annulo perigyno brevissimo, tenuissime carnoso, in alabastro conspicuo, sub anthesi fere obsoleto inserta, oblonga v. cuneata et retusa, longitudinaliter uni-multinervia, aestivatione convolutiva, sub anthesi erectopatentia, tenera, marcescentia.

Sramixa cum petalis inserta, duplo eorundem numero ( 6 v. 10 ), petala aequantia v. iisdem breviora, in alabastro alterna petalis opposita breviora, sub anthesi subaequalia, alterna ante calycis lacinias sita basi extus glandula parva munita. Fil a menta complanatosubulata v. subulato-filiformia, marcescentia. Antherae introrsae, biloculares, ovato-subglobosae v. subgloboso-didymae, dorso juxta basim insertae, loculis longitudinaliter dehiscentibus.

Ovaria calycis laciniis numero aequalia (5 v. 3), interdum pauciora (2), iisdem opposita, verticillatim sessilia, unilocularia, libera, basi cum stylo communi mediante gynobasi connexa, unilocularia, uniovulata. Ovulum e basi erectum, anatropum. Stylus centralis, filiformis, strictus, apice breviter tri-quinquefidus. S $t i g$ m a ta simplicia, acuta v. minute capitata.

Acuenia 3 _- 5, abortu saepius 2, coriaceosubearnosa, laeviav, tuberculata, monosperma.

Semen erectum, cavitati conforme, testa membranacea, umbilico juxta basim ovali, rhaphe dorsali, lineari.

Eмввхоnis exalbuminosi, orthotropi cotyledones carnosae, plano-convexae. Ra dicula brevissima, retracta, infera. Plumula dipbylla.

Ordo hine plurimis notis Tropaeoleis, vix nisi flore irregulari distinctis, propinquus, illine ovarii structura ad Rutaceas accedens.

Boss. Floerluea WILLD. Caly $\mathrm{x}$ tripartitus, persistens, laciniis aestivatione valvatis. Coroll a e petala 3 , annulo perigyno, tenuissime earnoso, brevissimo inserta, calycis latiniis alterna et breviora, oblonga, marcescentia. $\mathrm{Stam}$ in a 6 , cum petalis inserta, a equalia ; fil a me nta complanat..subulata, antherae introrsae, biloculares, subgloboso-didymae, longitudinaliter dehiscentes. Ovaria 3 , sessilia, unilocularia, cum stylo com. muni mediante gynobasi connexa. O vula solita- ria, e basi erecta, anatropa. Stylus centralis, filifurmis, staminum longitudine; $8 \mathrm{tigma}$ trifidum, Iobis acutis. Achen i 8 v, abortu 2, coriacea, tuberculata, monosperina. Se m en erectum. $\mathbf{E}$. bryonis exalbuminosi, orthotropi e otyledon es carnosae, plano-convexae, radicula brevissima, retracta, infera. - Herba bore ali a mericana, paludosa, subsucculenta, pallide viridis; caule tenello, decumbente, foliis alternis, longe petiolatis, pinnatipartitis, laciniis lanceolatis v. ovalibus, obsolete venosis, summis sacpe trilobis $v$. tridentatis, pedunculis axillaribus, solitariis, unifloris, fio. ribus parvis, albis.

Floerkea Willdenow in Neue Berl. Schrif. III. 148 . Nuttall Gen. I. 228. R. Brown in Lond. et Edinb. philosoph, Mag. et Journ. July. 1833, Lindley in Hooker Journ, of Bot. I. t. 1. Torrey el A. Gray Flor. of North - Amer. I. 210, Meisner Gen, 135. (99.)

BDEB. Wimmantheg $R . B R$. C a ly $\mathrm{x}$ quinquepartitus, persistens, laciniis aestivatione valvatis. Corolla e petala 5, imo calyei inserta, ejus. dem laciniis alterna et majora, euneiformia, retusa. St a m in a 10 , cum petalis inserta, subaequalia, alterna calycis laciniis opposita, basi extus glandula munita; fil a m en ta subulato-filiformia, antherae introrsae, bilocnlares, ovato-subglobosae, longitudinaliter dehiscentes. Ovaria 5 , sessilia, unilocnlaria, cum stylo communi mediante gynobasi connexa. Ovu Ia solitaria, e basi erecta, anatropa. Stylus centralis fliformis, stamina superans, apice breviter quinquefidas; $8 \mathrm{tig} \mathrm{mata}$ minuta, eapitellata. A $\mathbf{c}$ h e $\mathbf{n}$ ia 5 , coriaceo-subcarnosa, monosperma. S em en ereetum. E m li y o. n is exalbnuinosi, orthotropi cotyledones carnosae, plano convexac, ra di c u la brevissima, retracta, infera. - Herba california, paludosa, multicaulis ; foliis alternis, longe petiolatis, bipinnatifidis, pinnis subopposilis, laciniis alternis, abbreviatis, obtusis, pedunculis axillaribus, solitariis, unifloris, folio longioribus, floribus majusculis, albis, petalis basi flavescentibus, tenerrimis, intus sparsim setosis.

Li m a a $\mathrm{n}$ thes R. Brown in Lond. et Edinb, philosoph. Mad. et Journ. July. 1833. Bentham in Hortic. Transact. II. Ser. I. 409, Eadlich. Atakt, t, 27. Don in Sweet Fl, Gard. II. t. 378. Lindley in Bot. Reg. t, 1673. Torrey et A. Gray Flor. of North-Amer. I. 209. Meisner Gen, 135. (99.) (Historia impraegnationis apud Schleiden $N, A, N . C, X I X, 86$. t. 8. f. $128-130$.)

\section{Classis LIX. Calyciflorae.}

Herbae, suffrutices, frutices v. a rbores. Folia alterna, opposita v, verticillata, simplicia, penninervia, integerrima v. serrata. C a ly x cum ovario connatus v. liber, rarissime irregularis, lobis per aestivationem valvatis. Corolla e petala calycis fauci inserta, ejusdem laciniis numero aequalia, interdum panciora v. nulla. Stamina cum petalis $v$. infra pelala inserta, plerumque duplo eorundem numero, rarius multiplo v. numero simplici pauciora, antherae longitudinaliter dehiscentes. Ovari n m uniloculare v. loculi tot quot lobi calycis, multiovulati, v. uniovulati. Fructus capsularis, rarius baccatus v. nucamentaceus. E m b ryo exalbuminosus, v, in axi albuminis carnosi orthotropus. 


\section{Drdo CCLX. Vochysiaceae.}

VocuYSIF,AE St. Hilaire in Mem, Mus, VI. 265. IX. 340. E. Mryer in N. A. N. C. XI, 812 DC. Prodr, III. 25. Bartling Ord. nat. 320, VoCHYSIACEAE Martias et Zuec. Nov. gen. et sp, I 123. Meisuer, Gen 119, 185.) VOCHYACBAE Liadley Introduct, edit. $11 . p .87$.

Arbores v. rarius frutichs aut sefrouticrs, cortice saepe suberoso, rimoso v. verruculoso, ramis oppositis, junioribus ut plurimum tetragonis, plerumque succo resinoso turgidis. Folia opposita ve verticillata, in extremis ramulis interdum alterna, saepissime coriacea, penninervia, integerrima. Stipulae ad basim petiolorum membranaceae, persistentes v. caducae, quandoque nullae, sed illarum loco petioli utrinque glandula subumbonata muniti.

Flores hermaphroditi, irregulares, racemosi, paniculati v. eymosi, plerumque terminales. Pedicelli bracteolati, articulati.

Calyx liber v. rarissime cum ovario connatus, pentaphyllus, foliolis liberis $\mathbf{v}$. basi inter se plus minus conuatis, inaequalibus, duobus lateralibus exterioribus minoribus, duobus anticis majoribus, aestivatione imbricatis, quinto postico maximo, concavo, intus colorato, basi plerumque in calcar producto, aestivatione cueullato.

Corolla plerumque mono-, rarius di-trirarissime pentapetala, in monopetalis petalum e toro inter calycis foliola antica exsertum, ejusque basi ungue adnatum, ungue latiusculo, carnoso, lamina obcordata, lata, venosa, aestivatione convoluta, in tri-pentapetalis petala calycis foliolis alterna, ejusdem basi adnata, oblonga, obtusa, aestivatione imbricata.

Stamisa unum v. quinque, ealycis basi adnata, plerumque unieum, rarius duo v, tria fertilia, reliqua abortiva v, rudimentaria, petalis alterna v. opposita, fertile unicum petalo unico saepissime hinc contigue alternum. Filamentum erectum, demum excrescens, apice in connectivum crassum, cordiforme, saepe vertice cucullatum, et marginibus introflexis ante anthesim stylum amplectens, dilatatum. A nthe r a introrsa, bilocularis, loculis appositis, in alabastro bilocellatis, connectivi marginibus utrinque longitudinaliter adnatis, plus minus sejunctis, longitudinaliter dehiscentibus.

Ovarion liberum, triloculare, loculis unibi-multiovulatis, ov ulis loculorum angulo centrali basi v. juxta totam longitudinem insertis, biseriatis, amphitropis, micropyle supera, rarissime Ovarium inferum, uniloculare, ovu1 i s geminis, e basi erectis, anatropis. StyIus terminalis, simplex, subtrigonus; stigma capitato-trigonum v. obsolete trilobum.

Fructus capsularis, coriaceus v. lignosus, ovato-trigonus, trilocularis, loculicide trival- vis, valvis medio septiferis, rarius epicarpio valvatim secedente septicide dehiscens, col um na centrali triquetra v. teretiuscula, aut saepius abbreviata, subnulla; rarissime fructus inferus, indehiscens, unilocularis, monospermus, calycis laciniis excrescentibus, alaeformibus superatus.

Semina in loculis solitaria, bina v. plura, columnae centralis faciebus $v$. imae basi inserta, adscendentia, depresso-bracteata v. compressa, rhombea v. oblonga, umbilico ventrali, testa chartacea, duriuscula, toto ambitu in marginem, v. superne in alam, saepius oblique truncatam expansa, in fructu indehiscente s emen unicum, e basi erectum, cylindricum, testa membranacea, solubili. A 1 b u m e n nullum.

Емвнто in generibus capsularibus homotropus, cotyledonibus magnis, foliaceis, corrugato-convolutis, radicula brevi, supera; in fructu monospermo embryo orthotropus, cotyledo nibus semicylindricis, rectis, radicula brevissima, infera.

Vochysiaceae nulli plantarum ordini arcte aflines, Guianam et Brasiliam inter 10 et $12^{\circ}$ lat. australis magno satis numero incolunt, sylvas primaevas, fluviorum ripas, camposque siccos decorantes.

Bos\%. Callisthene MART. Calyx liber, pentaphyllus, foliolis lateralibns exterioribns duobus anticis brevioribus, postico maximn, calearato. Corolla petalum unicum, calyeis basi inter foliola antica insertum, ubeordatum, unguieulatum. Sta men nvicum, basi calycis insertum, petalo alternum; filamentum cylindricum, incurvum, a nthera bilocularis, loculis adnatis, connectivo canaliculato-cucullato, stylum recipiente sejunetis, longitudinaliter dehiscentibus. Ovari u in liberum, triloeulare. Ovula in loculorum angulo centrali pauca, biseriata, amphitropa. StyI u s terminalis, filiformis; stig ma subeapitatum. C a ps a la ovata, trilocularis, septieide trivalvis, valvis margine semisepta a columnae centralis trigonae, tandem liberae angulis soluta gerentibus. Semina colomnae centralis faciebus biseriatim inserta, depress" bracteata, testa memliranacea, undique in alam membranaceam producta, umbilico ventrali, lineari. Emb r yo exalbuminosus, homotropus, rectus; eotyledonibus foliaceis, subearnosis, corrugato-complicatis, radi $e u l a$ brevis. sima, supera. - Arbores elegantes, succis resinosis foetae, Brasiliae interioris campos apricos incolentes; ramis foliisque oppositis, subdistichis, integerrimis, penninerviis, gemmis axillaribus, perulatis, stipulis minutissimis, deciduis, pedicellis axil. laribus et lateralibus solitariis, unifloris, oppositis, folio brevioribus.

C a lli is thene Martius et Zuec. Nov. gent. et sp. $I$. 123. t. 75. 76. DC. Prodr. III, 25. Meisner Gen, 119. (85.) C alli sthe ni a Sprenget Gen. n. 28.

6088. Amplhiloeluia MART. Calyx liber, pentaphyllos, foliolis lateralibus exterioribus duolus anticis brevioribus, postico maximo, brevissime calcarato. Corolla e petalum unicum, 
calycis basi inter foliola antica insertum, obcordatum, ungnienlatum. St a m in a 2 , basi calycis in serta, petalo alterna, unicum fertile, sterile clavi furme, interdum obsoletum, fertilis fil a m e $\mathrm{t} \mathrm{nm}$ ireve, compressiusculam, an $t$ he ra bilotularis, dorso affixa, loculis connectivo canaliculato, sty. Ium recipiente adnatis et sejunctis, longitudinaliter dehiscentibus. O va riu m liberum, triloculare. Ovula in loculorum angulo centrali pauca, biseriata, amphitropa. Sty lus terminalis, subcylindrieus; stig ma subeapitatum. Ca p s u la trigona, trilocularis, corticata, corticis valvis tribus, cum endocarpii subeartilaginei, loculicide trivalvis valvulis alternantibus, columna centrali nulla. Semi na....- Arbores brasilienses; gemmis perulatis, perularum rudimentis ad ramorum basim persistentibus, foliis oppositis, petiolatis, coriaceis, reticulato-venosis, integerrimis, petialis basi utrinque glandula munitis, floribus terminalibus, subinterrupte racemosis.

A mp hil o elhia Martius et Zuec. Nov. gen, ot sp. L. 127, t. 27. DC. Prodr, III. 26. Mieisner Gen, 119. (85.) A gardhia Sprengel Syst. I. 4.

6989. Qualea AUBLET. Calyx liber, pentaphyllus v, quinquepartitus, foliolis lateralibus exterioribus quam duo antica breviurihus, posties ovato v. orbiculari, basi in calcar patens v.sursum flexum producto. Corollae petalum unicom ealycis basi inter foliola antica insertum, obova tum v. obcordatum, ungaicalatum. Stam in a 5 , basi calycis inserta et ejusdem foliolis opposita unieum petalo alternum fertile, reliqua sterilia, clavaeformia, fertilis filame nt $\mathbf{m}$ m crassinsca. Ium, compressnm, an thera hilocularis, loculis connectivi crassi, cordiformis marginihns introfle $\mathrm{xis}$ adnatis, longitudinaliter dehiscentibus. Ova rinm liberum, triloculare, Ovula in localorum angulo centrali plurima, hiseriatim imbricata, amphitropa. Stylus terminalis, brevis, trigonas, st ig ma subcapitatum. Ca p 8 ula lignosa, conve. xe trigona, obtusa, trilocularis, locnlicide trivalvis, valvis medio septa, columnae centralis subtrigonae, interdum abbreviatae basi adhaerentia, gerentibas. Semina juxta colamnae centralis facies biseriata, adscendentia, imbricata, a latere compressa, testa coriacea, glabra v. pubescente, superne in alam membranaceam, trancatam pro. ducta, umbilico prope basim ventrali, lineari. Embryo exalbuminosus, homotropus, rectus; c. o y l ed o n i b n s foliaceis, suborbiculatis, convolntis, r a d i c u l a brevi, supera. Arbores brasilienses et guianenses, cortice suberoso; ramis resina scatentibus, ramulis subdichoto mis, tetragonis, gemmis axillaribus perulatis, folii: opposilis $v$. interdum verticillatis, petiolatis, coria. ceis, integerrimis, costatis, inter costas reticulato venosis, petiolis ad basim utrinque glandula stipatis, racemis axillaribus, lateralibus $v$. terminalibus, floribus flavis, caeruleis $v$, roseis, fragrantibus.

Qualea Aublet Guian, 1. t. 1. 2. Jussieu Gen. 424. Lam, t. 4. St. Hilaire in Mem. Mus. VI, 265, 269. Martlus et Zuce, Nov. gen, et sp. I. 130, t. $79-81$. exel. sp. DC. Prodr. III. 28. Meisuer Gen, 119. (85.)

6080. Selautielaia. C a y x liber, pentaphyllns, foliolis duobus lateralibus exterioribus brevioribus, duobus anticis et postico ecalcarato subaequalibus. Coro ll a petalum unieum, calycis basi inter foliola antica insertum, orbiculatum unguienlatum. Sta min a 2 , basi calycis inserta, petalo alterna, utramque fertile v. alterum in petalum cenversum; filamenta compresso-tere- tiuscula, adscendentia, antherae biloculares, loculis connectivi cordati marginibus adnatis, longitudinaliter dehiscentibus. $O$ variu m liberum, triloculare. $O \mathrm{rula}$ in loculorum angulo centrali plurima, biseriata, amphitropa. St y l us termina. lis, brevis, subtrigonus; stigma capitatum, obsolete trilobum. Capsnla lignosa, convexo-trigona, obtusa, trilocularis, loculicide trivalvis, valvis medio septa, columnae centralis trigonae basi adhaerentia, gerentibus. Sem in a juxta columnae centralis angulos biseriata, adscendentim imbrieata, a latere compressa, testa chartasea, apice in alam membranaceam truncatam producta, umbilico ventrali, lineari. E w bry o exalbuminosus, homotropus, rectus; cotyledonibus foliaceis, suborbiculatis, convolnto-corrugatis, radi cula brevi, supera. - Arbor brasiliensis, vigintipedalis trunco torto, cortice suberoso, ramulis tetragonis, gemmis axillaribus, perulatis, foliis oppositis, de. cussatis, breviter petiolatis, coriaceis, lineari oblon. gis, integerrimis, petiolis utrinque glandula umbonata stipalis, floribus bracteatis.

Qualea ecalcarata Martius et Zuce. Nov. gen, et sp. I. 131, t, 78 .

60\% 1. Voelaysia JUSS, Caly $\mathrm{x}$ liher, quinquepartitus, coloratus, Jacinis duabns lateralibus exterioribus totidemque antieis brevissimis, postica maxima, earinato-concava, saepe cucullata, basi in calear producta. Corollae petala 3 , imo calyci inserta, linearia v. spathulata, anticum inter calycis lohos anticos insertum, plerumque duobus lateralibus majus. Sta mina $\mathbf{3}$, basi calycis inserta, lateralia petalis alterna sterilia, subspathulata, intermedium petalo antico oppositum ! fertile; filamentum breve, an $t$ hera bilocularis, loculis connectivi elongati, oblongi v. spathulati, stylum ampleatentis, superne dilatati et cocullati marginibus adnatis, longitudinaliter dehiscentilus. Ovari nm liberum, triloculare. Ovula in locnlis solitaria y. rarins bina, ex anguli centralis basi adscendentia......S ty 1 ns terminalis, filiformis; stigma sublaterale, trigonum, Cap 8 nla coriacea v. sublignosa, ovata v. orbienlata, trigona, angulis prominentibus lateribus concava, trilocularis, loculieide trivalvis, valvis medio septiferis, columna centrali obsoleta. Sem ina in loculis solitaria, e basi erecta, superne in alam membranaceam producta. Embryo ....... Frutices $v$. arbores excelsae, saepe succo resinoso turgidae, in Brasilia et Guiana crescentes; ramis angulatis, foliis oppositis, decussantibus, v. verticillatis, stipulatis, plerumque petiolatis, coriaceis $v$. membranaceis, inlegerrimis, penninerviis, racemis terminalibus, compositis, elongatis, saepe paniculatim angregatis, pedicellis uni-biftoris, basi bibracteolatis, floribus flavis, odoratis.

V o ch y s i a Jussieu Gen. 426. St. Hilaire in Mem, Mus. DT. 166. Martius et Zuee. Nov. gen. et ep. I. 139. $t .83-92$. Pohl Plant. Brasil. II, 18, t, 11t-119. DC. Prodr. IIT, 26. Meisner Gen, 119. (85.) V a eh y Aublet Guian. I, 18. t. 6. Vo eh y a Vaadelli in Römer Script. 69. t. 6. Sa Imonia Necker Elem, $n, 808$. Cucullaria Schreber Gen, $n, 1 t$. Struekeria Flor. Flamin. $t, t, 20$.

BD 2 . Salvertia ST. HIL. Caly x liber, e basi sulurceolata quinquepartitus, laciniis oblongis, subaequilongis, duabus lateralibus exterioribus paullo latioribus planis, anticis et postica basi in calear rylindrienm producta coneavis. Cor 011 a e petala 5 , imo calyci inserta, ejusdem laciniis subalterna, subaequalia, oblonga, patentia. St a mina 3 , imo calyci inserta, petalis lateralibus 
et antico opposita, lateralia sterilia, clavaeformia, intermedium fertile; fi l a m e $\mathrm{nt}$ a m breve, rectum, anthera bilocularis, loculis connectivi linearioblongi, canalicalati, stylum recipientis marginibus introflexis adnatis, longitudinaliter dehiscentibus. Ovari a m liberum, triloculare. $O \mathrm{vula}$ in loculis solitaria, angulo centrali prope basim inserta, amphitropa. Stylus terminalis, erassus; $s$ t i gm a prope apicem snblaterale, sentelliformi-ellipticum. Ca p s u la ovato-triquetra, triloenlaris, locnlicide trivalvis, valvis medis septiferis, columna centrali nulla. Sem ina in loculis solitaria, oblonga, compressa, testa coriacea, superne in alam producta, umbilieo ventrali, lineari. E mbry o exalbuminosus, rectus; eotyledonibus subfoliaceis, late ellipticis, spiraliter convolutis, radie ula brevi, supera. - Arbores brasilienses, ramulis crassissimis, resina turgidis, folits verticillatis, plerumque octonis, petiolatis, stipulatis, obovatis, coriaceis, costato-venosis, integerrimis, race mo terminali composito, maximo, floribus speciosis, svaveolentibus, albis $v$. roseis, interdum stylo prolifero florem imperfectum gerente monstrosis.

$\mathrm{S}$ a I ve rtia St. Hilaire in Mem. Mus. $V T, 266 . \mathbf{I X}, 340$. Martius et Zuce. NoD, gen, el sp. I, 152, t.93, DC. Prodr. MII. 28. Pohl Plant, Brasil, 11, 15. t, 110, Meisuer Gen, 119, (85.)

\section{*}

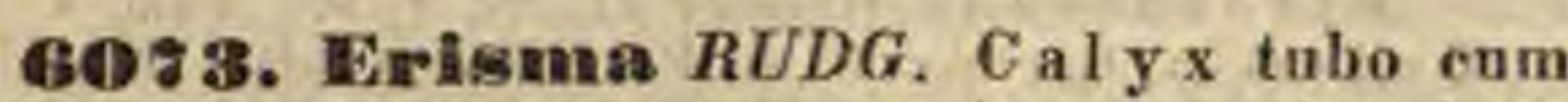
ovario connato, limbo supero, quinquepartito, lacinils duabus anticis, totidemque lateralibus exterioribus paullo minoribus, persistentibus, demum exerescentibus, quinta postica maxima, navienlariconcava, inaequaliter obcordata, intus colorata, basi in calar cylindrieum libernm producta, aestivatione convolnta, decidua. Corolla e petalum unicum, inter limbi calycini lacinias anticas insertnm, unguiculatum, lamina late obeordata, aestivatione convoluta. Stamina inter calycis laci nias inserta, 3 -4 sterilia clavata, fertile nnicum, hine petalo contiguum; fil amento filiformi, anthera biloculari, paullo supra dorsum affi. xa, locnlis connectivo erasso, in aeumen globosum producto adnatis, longitudinaliter dehissentibus. Ovarinm inferum, uniloeslare. 0 vula 2 , e basi

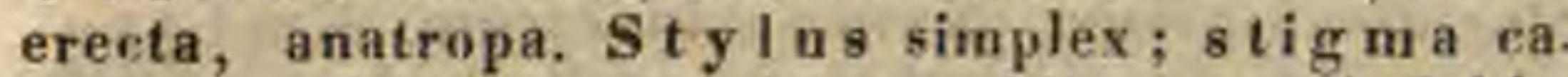
pitatum. Fruetus coriaceo-snblignosus, indehis. cens, cylindricus, ealycis laciniis lateralihus anticis productis alatus, postice laciniae quintae cicatrice excisus, alis coriaceis, venosis, oblongis, ohtusis, antisarum altera inngissima laterali minimae, altera minore laterali majori contigua. Semen abortu unicum, erectum, cylindricum, testa membranacea, solubili. Embryo exalbuminosns, or thotropus; cotyled onibus semieylindricis, $r a$. die ula brevissima, supera. - Arbores vastae, in Guianae et Brasilia e sylvis primaevis humidis degentes, ranulis glabris $v$. farinoso-pulverulentis; folits oppositis, petiolatis, acuminatis $v$. ouspidatis, remote costato-venosis, integerrimis, stipulis ad basim petiolorum geminis, membranaceis, persistenti bus, floribus terminalibus paniculatis, paniculae ramis subverticillatis, fastigiatis, bracteatis.

E ris m a Rudge Guian. T. 7, t, 1. Martius et Zuce. Nov. gon, et sp. I. 136. t. 82. DC. Prodr. III. 29. Reichenb. Ic. exot. t. 116. Pöppig in Froriep. Notiz. XXXV. 120. Meisner Gen. 119. (85.) De bra a a Kömer et Schultes Syst, I. 4. Dittmaria Sprengel Syst, $I$. 4 .

SOF 4. Lozania SEB. MUT. Ca ly $\mathrm{c}$ is tubus subventricosus, limbus quadripartitus, lobis ovato-acutis, persistentibus. Cor olla nulla. Dise. us quadrangnlaris, calycis fundum occupans. St amen 1, oblique sub ovario insertum; fil amentum apice attenuatum, anthera ovata, didyma. Ovariam ovatum. Stigmata 3 , parva, sulscapitata. C a p s n la ovata, tetragona, acuminata, trilocularis, trivalvis. Semina 6 , saepe 3 abortiva, angulosa, fundo capsulae inserta. Arbor Novo.granatensis; foliis allernis, oblongis, serratis, floribus spicatis, pedunculis axillaribus confertis, pedicellis basi bracteolu lineari suffultis.

Lozania Seb. Matis in Soman. iNov. IGran. 1810. p. 20. ex DC. Prodr. III. 30. Meiseer Gen, 119. (85.)

\section{Ordo CCEXI. Combretaceae.}

RLABAGNORUM et ONAGRARUM genera Jussieu. COM. BRETACEAE R. Brown Prodr. I. 351. ot in Flinders Voy, II. 5j8. DC. Prodr. III.9. Mem. soc. phys. Genev, IV, 1 - 42. Bartiug Ord, nat. 322. Lindtey Introduct, edit, 2, p. 38. Meisner Gen. 110. (78.) TERMINALLACEAE Jeaune St. Hilaire Rxpos, fam. nat. I, 178. MYROBALANEAE Jussien in Annal. Mus. V. 293. Diot, se. nat, XXXT. 458.

Arbores v. frutrees, erecti v. interdum scandentes. Foli a alterua v. opposita, simplicia, penninervia, integra, integerrima v. dentata, petiolata, coriacea, petioli apice saepissime biglanduloso. Stipulae nullae.

Fuones regulares, hermaphroditi v. abortu polygami, in spicas, racemos v. capitula, nuda sive involucrata, axillaria v. terminalia dispositi, singuli bractea bracteolisque duabus lateralibus oppositis, interdum cum calycis tubo concrescentibus muniti.

Calyors tubus cum ovario connatus, limbus superus, quadri-quinquefidus, lobis per aestivationem valvatis, post anthesim decidnis r. rarius cum fructu persistentibus.

Corolla nulla, ve petala summo calycis tubo inserta, ejusdem laciniis numero aequalia et alterna, per aestivationem valvata.

Sramina cum petalis inserta, nune iisdem numero aequalia et alterna, saepius dupla, alterna iisdem opposita altius inserta, rarissime tripla. Fil a m e n ta libera, filiformia v. subulata. Anthera e introrsae, biloculares, dorso affixae, erectae v. incumbentes, loculi oppositi, paralleli, basi saepe angustati v. divergentes, rima longitudinali debiscentes. Annulus v. discus epigynus, quandoque radiatus v. crenatus, interdum obsoletus.

Ovariom calyci innatum, in floribus abortu masculis saepe semisuperum, nniloculare. 0 v $u-$ la definita $2-4$, rarius 5 , in apice ovarii efuniculis longis pendula, anatropa. Stylus terminalis, simplex. Stigma indivisum.

Frnctus drupaceus, indehiseens, calyce adnato, saepe demum alis longitudinalibus aucto, membranaceo, coriaceo v. baccato vestitus.

Senen ovalorum plurium abortu plerumque solitarium, pendulum, loculi cavitatem explens. Testa membranacea, tenuis. Endo$148 *$ 
p leur a tumidiuscula, in cotyledonum plicas sese insinuans. A I b u m e n nullum.

Embryo orthotropus. Cotyledon es foliaceat, spiraliter convolutae v. crassiusculae, secundum longitudinem v. irregulariter replicatae. R a dicula umbilicum attingens, supera.

Combretaceae in regionibus tropicis utriusque orbis habitant, in veteri orbe in universum frequentiores, specierum utriusque tribus dnabus tertiis gerontogeis. Terminalieae in Indiae orientalis terra continente et insulis copiosissimae, parcius Africam aequinoctialem incolunt, in America majori quam in Africa numero crescentes. Combretea pari fere numero per Americam et Africam tropicam sedibus suis collocatae, in India orientali minus frequentes reperiuntur. Paucissimae trans Capricornum, in Africae promontorio australi observatae fuerunt. Plures inter Rhizophoras littorales.

Ordo mediantibus generibus corolla ornatis Oenothereis et Rhizophereis conterminus, et Myrtaceis Puniceisque affinis, per genera apetala ad Santalaceas, quibuscum olim confusus, accedit, embryonis structura etiam Gyrocarpeas revorans.

Semina nonnullarum edulia, qualitates in pluribus adstringentes, quaedam vernicifluae.

Tirimes T. TER MiNALIE AE DC. Prodr. III. 9. Caly $\mathrm{x}$ quinquefidus. Corolla saepissime nulla. Stamina 10 . E mbryon is cotyledones foliaceae, spiraliter convolutae.

60ร5. F meida LINN. C a ly x tubo teretiovato, cuin ovario connato, supra ovarium constricto, limbo urceolato campanulato, quinquedentato, deciduo. Coroll a nalla. St a mina 10, biseriata, alterna ad basion limbi, alterna longiora inter dentes calycis inserta; fila menta filiformia, antherae suhgloboso-didymae, longitudinaliter dehiscentes. Ovarin m infernm, uniloculare, ovuli s 3 , ex apice loculi pendulis, anatro. pis. Stylas subulatus, acutus; stigma simplex. Drupa baceata, putamine angulato, monospermo. S e m e $n$ inversum, cylindraceo-oblongum. Embryenis exalbuminosi, orthotropi cotyledones foliaceae, spiraliter cirea radicula m superam convolutae. - Arbores Americae tropicae; foliis alternis, cuneiformibus, integerrimis, glabris v. margine villosis, pedunculis axillaribus, floribus spicatis v, cupitalis, sericeis, ramorum apicibus interdum, verisimiliter insecti cujusdam ictu, in cornua longa, spongiosa excrescentibus.

Bue ida Lino. Gen. n, $54 t$ Lam. t. 356. Vahl Eolog. Z. $t$, 8. Gärtuer f, III. 20S. t. 217. DC, Prodr. III. 9. Bit. Reg. $t$. 907. Meisuer Gen, 110 . (79) B uceras P. Browne Jam $t$. 23. $f$. $t$. H u dsa n i Robias. in Lunan. Hort, iam,
il. 310 .

6076. Termatnalia $L I N N$. F Iores polygami. C a I y x tubo cylindraceo, cum ovario connato, supra ovariom constricto, limbo campanulato, quinquedentato, decidno. Co r o II a nulla. S ta m in a 10, calycis limbo biseriatim, alterna ejusdem dentibus opposita demissius inserta; fil a men ta subulata, antherae biloculares, ovatae v. subglobosae, lon- gitndinaliter dehiscentes. O v a r i u m inferam, uniluenlare, ovulis 2 , ex apice ioculi pendulis, anatropis. Stylus subulatus; stigma acutum. Drup a angulata v. compressa, ad margines saepe bialata, carnosa v. exsucea, putamine lignoso, monospermo. Se men inversum. Embryonis exalbuminosi, orthotropi cotyled on es circa radic u Iam superam spiraliter convolutae. - Arbores v. frutices, inter tropicos totius orbis crescen. tes; folitis ad apices ramorum confertim alternis, integerrimis, exstipulatis, floribus abortu polygamis, bracteatis, spicatis, spicis saepe ante foliorum ortum supra gemmarum squamas provenientibus.

Terminalia Linn. Mant. 2t. Jacq Collect. I, 130. DC. Prodr. III. 10. Cambessed, in St, Hilaire Flor. Bra. sil. II. 239. Wight et Arnott Prodr. I, 312. excl. sect, 2. et 3. Meisuer Gen, 110. (79.)

a. CATAPPA DC. l. c. D r u p a compressa, margine circumalata $v$, attenuata.

Catappa Gártner $I I$. 206. $t$. 127. Terminalla Lam. $t$. 848. $\mathrm{T}$ a $n \mathrm{i}$ bo a $\mathrm{e}$ a A ablet Guian, $I$. 448, $t, 178$. A d a ma r a Adanson Fam. II. 445. (Jaeq. Hort. Vin. dob. III. t. 100. t, Ic. rar. t. 197. Spreugel Antiq. bot. 2. Martius et Zuec, Nov, gen, etsp. 2. 27. St. Hilaire Flor. Brasil. t. 128. Bot. M.12. t. 3004. Tu.pin Atlas, III. t. 8. Guillemin et Perrot. Flor, Seneg, t, 63.)

b. MYROBaLANUS Gärtn. Drupa ovata, laevis v. augulata.

M y robala nus Gärtaer $1 T, 90$, ใ. 97. Lam. $t .849$. B a d a mi a Gitrtuer $l$. c. P a me a Aablet Guian. $I r$. 946. $t$. 359. F a tra e a Thouars Observ, Plant, Afr. 19. Jussieu in Dict. se. nat. XVI, 206. (Roxburgh Plant. Corom. t. 197. 198. 224. Guillem, et Perrot. Flor. Seneg. $t$. 64.)

60\%ซ. Pentaptern $R O X B$. F lores polygami. Cal y x tubo ovato, quinque-septemeostato, cum ovario connato, supra ovarium constricto, limbo campanulato, quinquefido. Co rolla nulla. St a m in a 10 , exserta, alterna ad basim limbi, alterna inter calyeis tacinias inserta; filamenta filiformia, an therate biloculares, subgloboso-didymae, longitudinaliter dehiscentes. Ovarinm inferum, uniloculare, ovnlis $2-3$, ex apice loculi pendulis, anatropis. St ylas filiformis; stigma acutum. Drupa curiacea v. sublignosa, ovata, in alas quinque v. septem verlicales pruducta, putamine monospermo. Seme $\mathbf{n}$ inversum. E m bryonis exalbuminosi, orthotropi cotyledo nes spiraliter circa radiculam superam convolutae. Arbores Asiae tropicae; foliis oppositis suboppositisque, petiolatis, integerrimis, basi subtus biglandulosis, spicis axillaribus et terminalibus, saepe in paniculam approximatis.

Pentapter a Roxburgh Catalog. hort. Calc. 34. Flor. ind. II. 437 . DC, in Mem, soc. phys. Genev. IV. 19, $t, 1,2$. Prodr. IIT, 14.

G078. Cetonia ROXB. Flores polygami. Cal y x tubo quinquecostato, cum ovario connato, supra ovarium cunstricto, limbi persistentis, campanulati lobis lanceolatis, trinerviis. Corolla nulla. Stam in a 10, calyeis laciniis breviora, bi. seriata, alterna imo limbo, alterna ejusdem sinubus inserta; fil a m enta filiformia, ant herae subgleboso-didymae, longitulinaliter dehiscentes. $O$ vari u $m$ inferum, uniloculare, ov u $l i$ s 3_4, ex apice loeuli pendulis, anatropis. St $\mathbf{y} \mid \mathbf{u} s$ filiformis, pubescens; stigma obtusum. Nax crustacea, ovato-oblonga, rotundato-pentagona, calycis limbo coronata, monosperma. Semen inversum. Em bryonis exalbuminosi, orthotropi cotyledones foliaceae, spiraliter circa $r$ adi. culam superam convolutae. - Frutices in $d i c i$ 
scandentes; foliis oppositis, breve petiolatis, ovatis, acuminatis, integerrimis, subtus minutissime resino. so punctatis, junioribus villosis $v$. tomentosis, race mis axillaribus $v$, in paniculam terninalem dis positis.

Qetonia Roxburgh Plant, Coront. I. 61, t. 87. Flor. Ind, II. 428. Gärtwer f. III. 210. t, 217. DC. Prodr. III. 15. Wiglit et Aruott Prodr I. 315. Meisuer Gen, 110. (79.) Caly copteris Lam. $t$. 357 .

6089. Chumeon $P A V$. F lores polygami. Ca l y x tubo cylindrico, cum ovario connato, supra ovarium constricto, limbo campanulato, quin. quedentato, deciduo. Corolla nulla. St ami n a 10 , calycis limbo biseriatim, alterna ejnstem dentihus opposita demissius inserta; fila in e n ta subulata, an therae biloculares, subgloboso-didymae, Iongitudinaliter dehiscentes. Ovarium inferum, uniloculare, $0 \mathrm{vul}$ is 2 , ex apice loculi pendulis, anatropis. Sty I n s subulatns; stigma acutum. F r u e t u s coriaceus, bi-quinquealatus alis membranaceis, inaequalibus, abortu monospermus. Semen inversum. E in b ryo $n$ is exalbuminosi, orthotropi cotyledones circa radicu1 a m superam spiraliter convolutae. - Arbores pe ruanae et brasilienses; foliis ad apicem ramorum confertim alternis, integerrimis, basi subtus biglandulosis, spicis axillaribus, saepe ante folia inter gemmarum squamas provenientibus, bracteatis.

Ch u n co a Pavon in Jussieu Gen. 76. Poiret Supplem. II. 25s. DC. Prodr. III, 15. Caubessed, in St. Hilaire Flor. Brasil. II. 243. Gimberuatía Ruiz et Pavon Prodr. 138. 2.36 .

6080. Itamatorella $H, B, K, \ldots F \mathrm{~F}$ u tus nueamentaceus, coriaceo-lignosus, quinquangularis, angulis superne alatis, apice attenuatus, rostratus, monospermus. S e m en inversum, ovato-subconicum, hine raphe percursum. E mbryonis exalbuminosi, orthotropi cotyledo. nes foliaceae, circa radieulam superam convolutae. - Frutex America e tropicae inermis; ramulis subternis, foliis in apice ramulorum subter. nis quaternisve, coriaceis, integerrimis, pedunculis terminalibus, demum alaribus, brevibus, frutibus in apice pedunculi capilato-congeslis, bracteis interjectis.

Ramatuella Kunth in Humb. et Bonpl. Nov, gen. et sp. VII, 25i, t, 656. DC. Prodr. IIT. 16. Meisaer Gen 110. (79.)

Gos1. Conocarpus GÄRTNER, FIores dense aggregati. Calyx tubo cum ovario connato, compresso, supra ovarium hand prodacto, limbo oblique supero, urcenlatn, quinquefido, de ciduo. Corolla nnlla, S tam in a $5-10$, calycis limbo inserta, biseriata, exserta; fil amenta filiformi-subulata, an therae biloculares, cordatae, longitudinaliter dehiscentes. Ovarium inferum, uniloenlare, ovulis geminis, ex apice locnli pendulis, anatropis. Stylus filiformis; tig ma acutum. Fructus sqnamaeformes, coriaceo-suberosi, reflexi, dorso convexi, facie coneavi, aretissime retrorsum imbricati, monospermi. S emen inversum, inaequilatere oblongum. E m bry on is exalbuminosi, orthotropi cotyledones foliaceae, eirca radieulam superam spiraliter convolutae. - Arbores $v$. frutices, in A merica tropica et borealic alidiore, nec non in $A f r i$ ca occidentali littorales; foliis alternis, crassiuscule coriaceis, integerrimis, versus basim biglandulosis, capitulis in ramulis axillaribus et termina libus racemosis, floribus arctissime confertis, singulis unibracteatis.
Conocarpus Gärtner II. 470. t. 177. Kunth in Humb. et Bonpl. Nov. gen, et sp. VI. 113. Guillemin et Perrot. Flor. Seneg. $I, 228$. Rudbechia Adanson Fam. II, 80 . Conocarpi sect. Eucouocarpus De. Prodr. III. 16. Conocarpi s p. Jacq. Amer. t. st. f. 2. t. 82, f. 1 .

6082. Anogeissus $W A L L$. Flores lare aggregati. Caly $x$ tubo inferne compresso, diptero, cum ovario connato, longe supra ovarium producto, filiformi, persistente, limbo eyathiforni, quinquedentato, deciduo. Corolla nalla. Stami na 10, ealycis limbo inserta, biseriata, exserta; filamenta filiformi-subulata, antherae biloculares, cordatae, longitudinaliter dehiscentes. Ova rium inferum, unilucolare, ovulis 2 , ex apice loculi pendulis, anatropis. Stylus filiforuis; stigma acutum. Fruetus compressi, coriacei, bialati, calyeis tubo filiformi mucronati, sursoin laxe imbrieati, monospermi. Semen invèroum, ovoideam. Embryon is exalbuninosi, orthotropi cotyledones crassiusculae, circa ra d i c u I a m superam spiraliter convolutae. Arbores in Asia et Africa tropica crescentes; foliis alternis, integerrimis, eglandulosis, floribus luteis, in capitula axillaria, pedunculata dispositis, singulis unibracteatis.

Anogeissus Wallich Catalog. n. 4014. Gaillemin et Perrot. Flor. Seneg. I. 279. $t$. 65. A a der s on i a Roxburgh msc. Conocarpl sect. Leiocarpus et $\mathbf{A}$ nogeissus DC. Prodr. III. 16. Mem. soc. h, n. Genev. IV. $t .3$.

8083. Thagueularia GART. F lores polygami. Calyx tubo turbinato, adnato-bibracteolato, cum ovario connato, limbi superi, persistentis, urceolati, quinquelobi lobis obtusis. CorolI a petala 5 , summo calyeis limbo inter ejusdem lacinias inserta, minuta, subrotundo-concava, caduca. Sta m in a 10 , ealyeis limbo biseriatim, alterna petalis opposita altius inserta, inclusa; $f$ il amenta subulata, a nthera e biloculores, cordatoacuminatae, longitndinaliter dehiscentes. Ovari um inferum, unilosulare, ov u 1 is 2 , ex apice loculi pendulis, anatropis. St y I u s filifurmis; 8 tig ma capitatum, emarginato-8ubbilobum, D rupa coriacea, calycis limbo corunata, obovato-cuneata, compressiuseula v. trigona, marginata, monosperma. S e in e $n$ inversum, obovato-oblongum. Embryonis exalbuminusi, orthotropi cotyledones subfoliaceae, circa radicula m superam convolutae. - Arbuscula Americae tropicae littoralis; foliis opposilis, petiolatis, ellipticis, coriaceis, obsolete venosis, versus marginem tuberculis glandulosis, subtus perforatis obsitis, pedunculis terminalibus et axillaribus tristachyis, floribus sessilibus, bracteatis, seminibus intra nucem germinantibus.

L a t u ncularia Gärtner f. IIT. 209, t. 217. DC. Prodr. IIT. 17. Kunth in Humb. et Banpl. Nov, gen, et sp. VIT. 256. Cambessed, in St, Hilaire Elor, Brasil. II. 245. Meisner Gen, 110. (78.) S p h e u o c r p u \& Richard Analys, $d$, fr. 92. Hor a u Adanson Fam. II. 80. Conocarpus race. mos a Lina. Jacq. Amer. $t, 53$.

8084. Lummitzera WILLD. C a l yx tubo oblongo, compresso, adnato-bibracteolato, limbi superi, persistentis, tubuloso-campanulati, quinquelobi lobis obtusis, saepe inaequalibus. Corolla e petala 5 , summo calyeis limbo inter ejusdem lobos inserta, duplo iisdem longiora, oblonga, patentia. Stamin a 10 , calycis limbo biseriatim, alterna petalis opposita altius inserta, exserta, 3 $v$. 5 interdum abortiva; fil amenta filiformi-subulata, an therae biloeulares, ovato subglobosae, longitudinaliter dehiscentes. Orarium inferam, 
uniloculare, ovn lis $3_{-}$, ex apice loculi pendulis, anatropis. Stylus subulatus; stigma acutum. D ru pa coriacea, calycis limbo corónata, ovatooblonga, compressa, angulata, monosperma. S emen inversum. Em bryonis exalbuminosi, orthotropi cotyledones foliaceae, circa ra diculam snperam convolutae. _ Frutices v. arbores, in Asiu tropica inter Rhizophoras liltorales; foliis alternis, cuneato-obovatis, retusis $v$, emarginatis, basi in petiolum brevissimum angustatis, integerrimis $v$. obsolete crenatis, glabris, crassiusculis, sub. aveniis, spicis brevibus, plerumque simplicibus, axillaribus solitariis, v. terminatibus corymbosis, floribus albis $v$, rubris, bractea parva stipatis.

Lum itzera Willdenow in Berl. n. fr. IY. 186. DC. Prodr. III, 22. Presl in Reliq. Haenk. II. 25. Wight et Arnett Prodr I.316. P y r $\mathrm{r}$ h a in th a Jack in Malay. Misc. ex Hooker Bot. Mag. Compan. r. 156. Petal ou a Roxburgh Flor, ind. II, 372. non Swartz. Brugule r a Thouars Dict. sc, nat. V. 375. Gen, madagase, $n$ 70. DC. Prodr, III, 23, non Lam. Funkia Dennst. z. Hort. malab. VI, 37. Kara-Kan. del Rheede Hort. Malab. VI, $\ell$, 37. L a guncula rla e s. Gaudichad ad Frejcinet $t, 104,105$.

6085. Curerien $A D A N S$. $\mathrm{C}$ a ly $\mathrm{x}$ tubo ob longo, gracili, cum ovario connato, supra ovarium constricto, limbo persistente, tubuloso-canpanulato, quinquedentato. Corolla e petala 5 , summo ealycis limbo inter ejusdem dentes inserta, anguste oblongo-linearia, decidua. S t a m in a 10, calycis limbo biseriatim, alterna petalis opposita altius inserta, exserta; fil am enta filiformia, an the rae bilocnlares, subgloboso-didymae, longitudinaliter dehiscentes. Ova ri um inferum, uniloculare, ovulis 4, ex apice loculi pendulis, anatropis. Stylus filiformis; $8 \mathrm{tigma}$ capitatum. Cap. sula coriacea, calycis limbo coronata, anguste cylindraceo-pentagona, incurva, indehiscens, monosperma. S e men inversnm. Embry o nis exalbuminosi, orthotropi cotyledones foliaceae, circa radiculam superam convolutae. - Frutex senegambicus; foliis oppositis, breve petiolatis, ovalibus, integerrimis, supra glabris, subtus cinerascentibus, nigro-punctatis, floribus parvis, favescentibus, in capitulum pedunculatum, involucro tetraphyllo valvato, demum reflexo cinctum dispositis.

Gu i e r a Adanson ex Jussieu Gen, 320, Lam. t. 360. DC. Prodr. III. 17. Guilleuin et Perrot. Flor. Seneg. 1, 281. t. 66. f. 2 .

6986. Poivrea COMM. C a l y x tubo subfusiformi, quinquecostato, supra ovarium eonstricto, limbo infundibuliformi-eampanulato, guinquedentato, deciduo. Corollae petala 5, summo calycis limbo inter ejusdem dentes inserta, oblon. ga, decidua. Stam i n a 10, ealycis limbo biseriatim, alterna petalis opposita altius inserta, exserta; fila in enta filiformia, anthera e biloculares, subgluboso-didymae, longitudinaliter dehiscentes. Ovariu m inferum, uniloculare, ovuli s $2-3$, ex apiee laeuli pendulis, anatropis. Stylus filiformis; stigma acutum. Drupa ovata, subossea, quinquangulata $\mathbf{v}$. in alas quinque verticales, membranaceas produrta, monosperma. Semen inversum. Embryonis exalbuminosi, orthotropi $e 0$ tyledones 2 v. 8 , juxta longitudinem irregulariter convolutae, radicula supera. - Frutices sae. pissime scandentes, inter tropicos totius orbis crescentes, inermes $v$, aculeis ad basim ramulorum uncinatis armati; foliis alternis v. oppositis, integerrimis, spicis axillaribus et terminalibus interdum paniculatis, bracteis sub flore solitariis.
Poivrea Commers. ex Thouars Observ. pl, Afr. 28. DC. in Mem, soc. phys. Genev. IV. 10. t. 4. 3. Prodr. III. 17. Quillemin et Perrot. Flor. Seneg I. 282. t. 66. Wight et Arnott Prodr. I. 317. Meisuer Gen. 110. (78.) Crist a cia Sonuerat $V_{0 y}$. IT. 217. $t, 140$, non Cav. Go noe a r us Hamilt. Prodr. Flor. Ind. occid. 39. non Thunb. C o m b r e ti s p. decandrae Auct. Iucq. Amer. ed pict, $t, 260$. f. 27. Law. $t$ 262. f. 2, Roxb. Plant. Corom. $t$. 59. Bot. Reg. $t, 429,1165$, Bot, Mag. $t, 2944$.

THEIEUS IT. COMBRETEAE, C alyx quadri-quinquefidus. Cor o 11 a e petala $4-5$. Stamina $8-10$. E m bry o n is cotyledones crassae, irregulariter v. longitudinaliter plicatae.

G08\%. Combretum LÖFFL. Flores polygami. Caly tubo eylindraceo v. tetragono, cum ovario connato, supra ovarium constricto, limbo campanulato, quadrifido, deciduo. Corol: 1 a e petala 4, summo calycis limbo inter ejnsdem lobos inserta, cadnca. S t a m in a 8 , calycis limbo biseriatim, alterna petalis opposita altius inserta, exserta; filam enta filiformi-subulata, antherae biloculares; versatiles, longitndinaliter dehiscentes. Ovarium inferum, uniloculare, ov $\mathbf{n}$ Iis 2_6, ex apice loculi pendulis, anatropis. St yI us subulatus; stigma aentum. Frnetns coriacens, quadrialatus, alis membranaceis, aequalibus, indehiscens, aburta monospermus. Semen inversum. Embryonis exalbuminosi, orthotropi cotyled on es plica media longitudinali reflexae, cruciato-divaricata, ra dicula supera. - Arbores $v$. frutices sacpe scandentes, inter tropicos totius or bis crescentes; foliis oppositis v. rarius alternis, integerrimis, exstipulutis, floribus spicatis, spicis axillaribus v. terminalibus, interdum paniculatis,

$\mathrm{C}$ o m bret um Löfling 1c. 308. Ling. Gen, n, 475. Jacq. Amer. $t, 176, f$. 30. Gärtner 1. 176. t. 36. Aublet Guian, I. 137. Humb. et Bonpl Plant. aequinoct. t. 132. Nov. gen. et sp. 538. Palisot Flor. Owar, t. 118. Dou in Edinb. phi. losoph. Journ, 1824. p. 344. et in Linn. Transact. XV. 421. excl. sect. I. DC. in Ment soc. phys, Gencv, IV. $t .5$. f. b. c. Prodr. 1IL. 18. Cambessed. in St. Hilaire Flor. Brasil. II. 246. t. 129. 130. Guillea. et Perrot. Flor. Seneg. t. 67. 68. Bot. Reg. t. 1631. Wigbt et Aruott Prodr. I. 317. Meisuer Gen, $110,(78$.$) A et in Adanson Fam. II. 84. F or s-$ g a rdi a Flor. Flum. IV. $t, 13$.

6088. Cacoucia $A U B L$. Caly $\mathrm{x}$ tubo ovato, quinquecostato, cum ovario connato, supra ovarinm constricto, limbn tubuloso-campanulato, acute quinquedentato, deciduo. Coroll a e petala 5, summo calycis limbo inserta, ejustem dentibus alterna et longiora, acuta. Sta min a 10-14, imo calyeis limbo inserta, longe exserta; fil a menta filiformia, a n the ra e biloculares, cordato-ovatae, longitudinaliter dehiscentes. Ova ri n m inferum, uniloculare, ovulis 3 , ex apice loculi pendulis, anatropis. Stylus filiformis; stigmasaentum. B a ce a pulposa, ovata, ntrinque acuta, quinquangulata, unilocularis, mono-disperua. S e mi$n$ a inversa. Em bry on is exalbuminosi, orthotropi c otyled on es crassae, carnosae, radic a la supera. - Frutices guianenses, scandentes; foliis alternis oppositisque, breve petiolatis, ovatis, acutis, integerrimis, venosis, racemo terminali spicaeformi, simplici, floribus majusculis, coccineis, bracteatis.

C a couci a Aublet Guian. I. 450, t, 179. Jussieu Gen. 300. Lam. $t$. 359. DC. Prodr. IIt. 22. excl. sp. Meisaer Gent. 110. (78.) Schous b o a Willdenow Spec. 378 . H a m b erger a Scopoli Introduct, $n$, 226, H a m bergia Necker Elem, n. 830. 


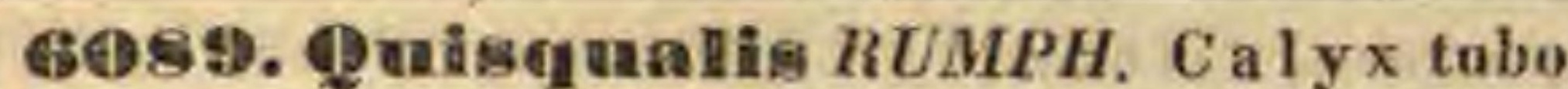
basi quinquecostato, eum ovario connato, longissime supra ovarinm producto, gracili, eum limbo quinquefido decidno. Corolla e petala 5 , summo calyeis limbo inter ejusdem lobos inserta, iisdem longiora, ovali-oblonga, obtusa. St amina 10 , ealycis fauci inserta, exserta, alterna breviora; filamenta filiformi-subulata, a $\mathbf{t}$ h e ra e biloenlares, ovatae, longitudinaliter dehiscentes. Ovarinm inferum, uniloculare, ovalis 4, ex apice loculi pendulis, anatropis. Stylus filiformis, exsertus, inferne ealycis tubo adhaerens; stigma truncatum, obtusum. D rupa sicea, quinquesulcata, acute quinquangulata, monosperma. $\mathbf{S}$ e m e $\mathrm{n}$ inversum. Embryonis exalbuminosi, urthotropi cotyled on es crassae, earnosae, plano convexae, radic u la brevissima, supera-Frutices in As ia et Africa tropica crescentes; ramis saepe scandentibus, foliis oppositis $v$, interdum alternis, ovatis, integerrimis, spicis axillaribus et terminalibus, floribus majusculis, colore mutabili, albo et rubro variantibus.

Quis qualis Rumph Amboin. $V, 71, t, 38$, Linn. Gen. n. 839. Burmaan Flor, ind, t, 28, $f$. 2. Lam. t. 357. Palisot Flor. Owar, t. 34. Bat. Mag. t. 2033. Bot. Reg. t. 492. Blume Bijdr, 641. DC, Prodr. III, 29. Wight et Arsolt Prodr. I. 318. Meisuer Gen, 110. (78,)

GQS0. Spluallanthus $J A C K$. C a $1 \mathrm{y} \times$ tubo inferne cum ovario connato, longe supra ovarium producto, hine gibbo, cum limbo quinquepartito deciduo. Corollae petala 5, summo ealycis limbo inter ejusdem lacinias inserta, ovato oblonga, acuta, Stamina 10, calycis limbo biseriatim in serta, breviora. Ovarinm infernm, uniloculare, ovulis 3 , ex apice loculi pendulis. Stylus filiformis, tubo calycis hinc adnatus; stig in a simplex. Fructus quinquealatus, alis membranaceis, aequalibus, indehiscens, monospermus. Semen inversum, quinquangulatum. Embryon is exal buminosi cotyledones plano-convexae, angulatae, radicula brevissima, snpera. - Frutex malayanus; ramis teretibus, fere glabris, foliis ple rumque alternis, breve petiolatis, ovato-oblongis, acuminatis, basi subcordatis, integerrimis, glaberrimis, petiolis subrecurvis, stipulis nullis, spicis terminalibus solitariis $v$. ternis, pendulis, floribus sessilibus, bracteis lanceolatis, acutis, calyce brevioribus.

$\mathrm{S} p$ h a 1 a n th a s Jack in Malay, Miscell. I. 155. Meisner Gen, 110. (78.)

\section{GENERA DUBIA.}

6091. Chrysostaelnys POHL. Calyz tubo cylindraceo, eum ovario connato, supra ovarium coustricto, limbo campanulato, obsoletissime quinquedentato, deciduo. Corolla e petala 5, summo calycis limbo inter ejusdem dentes inserta, decidua. St a $m$ in a 10 , imo calycis limbo uniseriatim inserta, longe exserta, aequalia; fil a m e $\mathbf{t}$ a subulata, antherae biloculares, ovato-subglobosae, longitudinaliter dehiscentes. Ov a ri $\mathrm{n} \mathrm{m}$ infernm ...... St y 1 u s filiformis; stigma obtusum.

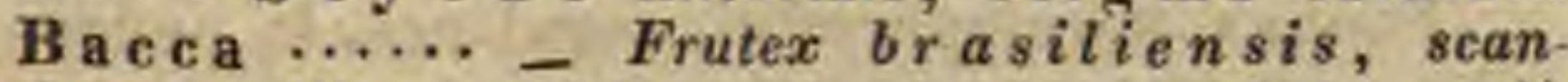
dens; foliis oppositis, coriaceis, integerrimis, ovalibus, spicis densis, terminalibus axillaribusque paniculatis, bracteatis, floribus minutis, aureo-luteis.

Chry sosta ch y \& Pohl Plant. Brasil. II, 65, t. 143. Meisner Gen. 110. (78.)

G092. Agathisanthes BLUM. Flores dioici, dense capitati. Masc. Cal yx quin. quepartitus, laciniis imbricato-conniventibus. $\mathrm{C} \mathrm{o-}_{0}$ rolla nulla. Stamina subdecem; filamenta brevissima, disco plano inserta, a n th era e didymae. Ovarii rudimentum nullum. Fem. Calycis limbus superus, brevis, quinquedentatus. Co. rolia nulla. Ovarium inferum, uninvalatum. Stylus brevis, bifidus, discam planum perfocans. D rupa baccata, umbilicata, nucleo compresso, monospermo. Em bryo exalbuminosus, inversus. - Arbor javanica, vasta, centum et viginti pedum altitudine; foliis confertis, oblongis, integerrimis, coriaceis, penninerviis, capitulis longe pedunculatis, axillaribus lateralibusve, solitariis aut geminis.

Ag at his a n thes Blume Bijdr, 645. DC. Prodr. IIT, 10. Meisner Gen. 110. (79.)

6053. Ceratestaelnys $B L U M$. C a Iyci s limbus superus, integer. Corollae petala suboeto, parva. S $\mathrm{tam}$ in a $8-15$, inaequalia. Ovarium biovulatum. Stylus brevis; stigmate bifido. Drupa baccata, calyce coronata, nunc compressa, monosperma. E m bryo exalbuminosus (?) inversus. - Arbor javanica, proce$\mathrm{ra}$; foliis sparsis, oblongis, integerrimis, glaberrimis, subtus glaucis, spicis axillaribus, foliorum casu lateralibus, solitariis, floribus dense capitatis, processubus filiformibus, spongiosis intermixtis.

Cerat osta ch y s Blume Bijdr. 644. DC. Prodr. III, 23. Meisuer Gen. 110. (78.)

6094. IRobua $D C$. C a l y $\times$ tubo ovato, cam ovario connato, limbi superi, quinquefidi lobis brevibus, obtusis. Corolla e petala 5 , calycis lobis alterna et longiera. S ta m in a $20-30$, libera, petalis longiora. Ovarium ...... St y lus filiformis; stigma subeapitatum. Fruetus ovatus, intehiscens, oligospermus. - Arbores indicae; foliis alternis, obovato-oblongis, acutis, glabris, impunctatis, saepissime serratis, pedunculis axillaribus simplicibus, floribus distantibus, subspicatis, pedicellis brevissimis, sub calyce bi-tribracteolatis.

B o b u a DC, Prodr. IIT, 23. Meisuer Gen. 110. (78.) B o b u Hermann Zeyl. 9. Atlanson Fam, IK. 88, E ugenio ides Lina, Flor, Zeylan, 192. L a u rus Buruann Flor. Zeyl, $t, 68$.

GOD5. Migamea KÖNIG. C a lyx quinquefidus, laciniis oblongis, obtusis. Coroltae petala 5, ealyce dnplo longiora, ovata. St a min a 5 , corolla breviora; f il a m e n $t$ a ereeta, basi annulo carnoso, nectarifero cohaerentia, brevia, planinscula, laevia, an therae cordatae. Ovarium inferum. Stylus globosus v. pyramidalis; $8 \mathrm{tigmata} 3$, erecta, compressa, apice retusa. Drupa turbinata, calyce quinquepartito, maximo coronata, laciniis duabus minoribus, coriaceis, oblongis, obtusis, obscure nervosis. - Frutex altissime scandens, in cinnamometis ceylonensibus crescens, caule erecto, brevi, simplieissimo, annulis protuberantibus notato, more Dracaenae foliorum fasciculo erecto terminato, ramo primario unico, e foliorum fasciculo emergente, basi simplici, mox in ramos alternos, patentes, breves, foliorum fasciculo pariter terminatos, post foliorum lapsum elongatos, demum hamatim recurvos diviso, foliis caulis primarii multis, cuneiformibus, ramulorum subternis, vix petiolatis, lato-lanceolatis, basi attenuatis, tenuissime venoso-reticulatis, glabris, pedunculis axillaribus erectiusculis, subdichotome divisis, filiformibus, angulatis, glabris, rubris, floribus racemosis, breviter pedicellatis.

Bigamea König mse. Wormia Vahl in Scrift, of Naturhistorie Selskabet. Kiobenh, 18to. VI, 104. 


\section{Drdo CCLXII. Alangieae.}

ALANGIEAE DC. Prodr, IrT. 203. Bartling Ord. nat. 424. Meisuer Gen, 153. (110.) Wight et Arnott Prodr. I. 325. ALANGIACEAE Lindley Introduct. edit. 1I. p. 39.

Arbores v. Frutices, in Asia tropica indigeni, inermes v. interdum ramis nonnullis spinescentibus armati. Foli a alterna, simplicia, petiolata, epunctata, integerrima v. obtuse lobata. Stipulae nullae.

Flores hermaphroditi, regulares, in axillis foliorum fasciculati v. corymbosi.

Calyx tubo campanulato, cum ovario connato, limbo supero, quinque- v, decemdentato, rarius sex-octodentato.

Corollae petala laminae carnosae, calycis faucem vestienti inserta, ejusdem laciniis numero aequalia et alterna, longe linearia, aestivatione convolutiva, sub anthesi deflexa, decidua.

Stamina cum petalis inserta , cum corolia hexa-octopetala iisdem numero aequalia et alterna, cum penta- v. decapetala duplo v. quadruplo petalorum numero. Filamenta basi villosa, nune filiformia libera, nune (dum stamina petalis numero aequalia) brevia, per paria cohaerentia. A n ther ae introrsae, biloculares, loculis linearibus, appositis, parallelis, connectivo angusto discretis, longitudinaliter dehiscentibus, distinctae v. filamentis per paria cohaerentibus omnes in tubum cylindricum, stylo pervium coalitae.

Ovarion inferum, uniloculare v. biloculare. Ovula in loculis solitaria, ex apice cavitatis pendula, anatropa. Stylus filiformis, simplex, staminibus paullo longior, basi in pulvinar depresso-conicum dilatatus. Stigma truncatum, dilatatum.

Dropa ovata, costata, parce carnosa, calycis limbo umbilicata, putamine subosseo, unibiloculari, mono-dispermo.

Sвмв inversum, compressiusculum, testa membranacea. A lb u m e carnosum, friabile.

Emвryo intra albumen orthotropus. Cotyledones foliaceae, planae. Radicula cylindrica, longa, supera.

Ordo dubiae nonnihil affinitatis, a Combretaceis, praeter albuminis praesentiam et cotyledonum indolem, facie etiam diversus, judice cl. Roberto Brown per Marleam Hanamelideis accedens.

Fructus edules. Radices aromaticae.

6096. Alangium $L A M, C$ a 1 y $x$ tubo eampanulato, cum ovario connato, limbo supero, quinque-decemdentato. Coroll a e petala 5 v, 10, tori laminae carnosae, calyeis faucem vestienti inserta, ejnsdem dentibus alterna, linearia, aestivatione convolntiva, $8 \mathrm{nb}$ anthesi reflexa. St a mina eum petalis inserta, duplo v, quadruplo eorundem numero; filament a filiformia, libera, basi villosissima, a $\mathrm{t}$ h herae distinctae, introrsae, biluculares, lineares, longitudinaliter dehiscentes. O vari um infernon, uniloculare, "vulo unico, ex apice loculi pendulo. Stylus simplex, basi in pulvinar epigynum dilatatus; $\mathrm{tig}$ ma truncatum, dilatatum. Drupa ovalis, costata, calyeis limbo coronata, putamine osseo, monospermo. Sem en inversum. Embryo intra alhumen carnosum friabile orthotropus, cotyledonibus foliaceis, planis, radienla longa, supera. - Frutices indici; ramis nonnullis saepe spinescentibus, foliis alternis, exstipulatis, integerrimis, punctatis, floribus axillaribus paucis, fasciculatis, breve pedunculatis.

A I a ngi um Lam. Dict , 174. Vahl symb. 1. 61. Cor. rea Annal. Mus. X. 161. DC. Prodr. III, 203. Wight et Arnoit Prodr. $I$. 325. Meisner Gen. 153. (110) A ugola m Adans. Fam. II, 85. A n g 1 a $\mathrm{m}$ i a Scopoli Introduct, n. $\mathbf{2 8 0}$.

6097. Dilarlea $R O X B$. Cal $\mathrm{y} \times$ tubn cam. panulato, cum ovario connato, limbo supero, ob. tuse sex-nctodentato. Corollae petala 6 v. 8 , tori laminae carnosae, calycis faucem vestienti inserta, ejusdem dentibus alterna, linearia, aestivatione convolutiva, sub anthesi reflexa. Stamina 6 v. 8 , cum petalis inserta, iistem alterna; filain ent a brevia, per paria cohaerentia, basi villosa, a therae in tubum cylindrienm coalitae, introrsae, biloculares, lineares, loculis discretis, longitadinaliter dehiscentibus. O varium inferum, biloeulare, ovulis intra loculos solitariis, ex apice cavitatis pendulis, anatropis. Stylus simplex, basi in pulvinar epigynum dilatatus. Drupa ovalis, parum earnosa, calycis limbo umbilieata, patamine biloculari, dispermo. Semina inversa, compressa. E m b ryo intra albumen carnosum orthotropus; cotyledonibus foliaceis, planis, radicula supera. - Arbuscula indica; foliis alternis, exstipulatis, petiolatis, inaequaliter corda. tis, acuminatis, integerrimis v. obtuse dentuto-subLobatis, rubro-nervosis, pedunculis axillaribus corymbosis, petiolo brevioribus.

Marlea Roxburgh Plant. Corom. IIT. t. 283. DC. Prodr. IV. 267 in nola. Meisner Gen, 153. (110.) Lindley in Bot, $n e g, 1838, t, 61$. S $t$ y I id $\mathrm{i}$ u m Loureirn Flor, cochinch. I. 272. non alior. Stylis Poiret Supplem. V. 260. P a a is a u via Jussieu in Dict, sc. nat. LI, 158 .

\section{Drdo CCLXIII. Rhizophoreae.}

LORANTHACEARUM genus Jussien. BHIZOPHOREAE R. Browu in Flinders Voy. Ir. 549. Tuckey Congo 437. DC. Prodr. III, 31. Bartling Ord. nat. 319. Arnott in Annal. of nat. his. I 359. Pa letu viers Saviguy in Lam. Dist. IV. 696. RHIZOPHORACEAB Liadley Introduct. II. p. 40. Meisuer Gen, 119. (84.)

Arbones v. frotices, in littoribus maritimis inter tropicos erescentes, ramis oppositis, ramulis tetragonis. Folia opposita, petiolata, simplicia, coriacea, penninervia, integerrima. Stipulae interpetiolares, utrinque solitariae, convolutae, deciduae.

Flores hermaphroditi, regulares, in pedunculis axillaribus $\mathrm{v}$. Lerminalibus, bi-trichotomis, interdum in capitulum approximati.

CALYx saepissime basi bractea cupulaeformi stipatus, rarissime ebracteatus, tubo cum ovario v. cum ejusdem basi connato, limbo supero v. semisupero, quadri-duodecimpartito, persistente, laciniis aestivatione valvatis. 
Corollas petala calycis laciniis numero aequalia et alterna, annulo carnoso plus minus manifesto, inter calycis tubum et ovarium protruso extus inserta, sessilia, integra et plana, v. bifida et basi conduplicata, lobis integris v. laciniatis.

Stauiva cum petalis inserta, duplov. triplo eorundem numero, rarius multipla, saepissime iisdem geminatim opposita. Filamenta filiformia v. subulata, libera. An the rae introrsae, biloculares, basi v. dorso supra basim insertae, longitudinaliter dehiscentes.

Ovarivм inferum v. semiinferum, parte adnata bi-tri-quadriloculari, loculis biovulatis, rarissime uniloculari, sexovulata, parte libera solida, in $s \mathrm{t}$ y $\mathrm{l} \mathrm{u} \mathrm{m}$ filiformem v. conicum, stig mate integerrimo v, bi-tridentato terminatum, continua. Ovula ex apice anguli centralis loculorum collateraliter pendula, anatropa.

Fructus coriaceus, calycis limbo persistente, patentiusculo cinctus v. coronatus, aborta unilocularis, monospermus, apice Stemisis exalbuminosi, inversi, cotyled o nibus duobus planis instructi, mox germinantis, $\mathrm{radi}$ c u l a longissima, clavata v. fusiformi perforatus.

Rizophoreac seminibus intra pericarpium cum stirpe matte cohaerens germinantibus, et radices in terram agentibus singulares, hinc Oenothereis, et mediantibus generibus anomalis, sed manifeste affinibus, ad ordinis calcem recensitis, Lythrariaceis affines, illine judice cl. R. Brown ad Cunoniaceas simplicifolias accedere creduntur.

Species ex America unica huedum cognita, eadem fortassis etiam in Africae littore orientali obvia, plurimae in Asia, imprimis insulari vigent.

6098. Thizopleora $L A U$. C a $\mathrm{y} \times$ tuho cum orarii basi connato, limbi quadripartiti laciniis tubum duplo v. triplo superantihus. CorolI a e petala 4, annulo carnoso summum calycis inhum vestienti extus inserta, ejusdem laciniis atterna, acuminata, apice nnda. Sta $m$ in a $8-12$, cum petalis inserta, guatuor isdein opposita; $\mathrm{fil}$ amenta brevissima, subnulla, a ntherae introrsae, biloculares, oblungo-lineares, acnminatae, basi insertae, conniventes, longitudinaliter dehiscen tes. $\mathbf{O}$ varin $\mathrm{m}$ semiinferum, parte adnata filoculari, qnadriovulata, parte libera solida, ovata, carnosa, sensim in styl um brevem conicum attenuata, stig ma te bidentato. Fractus coriaceus, subovatus, supra hasim calycis limbo reflexo cinstus, abortu unilocularis, monospermus, apice se$m$ in is inversi, mox germinantis radicula elongata, clavata perforatus - Arbores littorales tropicae; foliis oppositis, integerrimis, glabris, stipulis interpetiolaribus caducis, pedunculis axillaribus bi trifidis $v$. dickolomis, calyce bractea cupulaeformi suffulto, floribus magnis, alabastris ovoideis, laevibus.
Rhizophora Lam. Dict. VT. 169. Thouars in Desvaux. Journ. Bat. II. 3t. t, 4. Kunth in Humb. et Bonpl. Nov. Gen, et sp. III 446. Blu ine Enum. plant. Jav, 91. Wight et Arnott Prodr. I, 310. Arnott in Annal. of nat. hist. I, 361 . R hizophorae sp. Lian. et Auct. Meisuer Gon, 119. (85.)

a. MANGLE. „Stamina 8. Petala concava, coriacea, sramea unicum oppositum foventia, versus margines induplicatos villosa. - Peduaculi ex axillis foliorum hornotivorum orti, petiolis sublongiores, bi-trifidi v. dieho. tomi, flores plus minus pedicellati." Arnott 2. c. - Spe. cies in Asia, Africa el America tropica ob. servalae. - R. Ma $\|$ gl e Lian. part. Jaeq. Amer. t, 89. Cutesb. Carolin, II, t. 63. Gärtn, t. 45. f. 1. Vel. Inzo Flor. Flum, $V, t, 1$, R. w uerou a ta Lam, $t, 396$. f. 2. R. c a ndelaria Wall. non DC.

b. A $\ddot{E} R O P E$. ${ }_{s}$ Stamina nune 8 , saepius 11 v. 12 . Petala plana, submeisbranacea, glaberrima. - Pedunculi petiolo malto breviores, ex axillis foliorum nnnotinorum orti, erassi, subuattlori, flares sessiles." - Arnott l. c. - Species moluccana. - R. conjugata L. R. caudelaria DC. R. apiculata Blum. Pee-Ka ndel Rheede Malab. VI. 61. t. 34. M a ng i m caudelarium Rumph Amboin. 1II, 108, t, 71, 72.

6095. Ceriops ARNOTT, Cal y $\mathrm{x}$ tubo cum ovarii basi connato, limbi quinquepartiti laciniis tubum duplo v. triplo snperantibus. Corolla e petala 5, annulo carnoso summum calycis tubum vestienti extus inserta, ejnsdem laciniis alterna, ovalia, emarginata, apice setigera, plana, Sta$m$ in a 10 , cum petalis inserta, iisdem geninatim opposita, erecta; filamenta petalis subdimidio breviora, antherae introrsae, biloculares, cor. dato-ovatae, obtusae, filamentis multo breviores, durso paullo supra basim aflixae, longitudinaliter dehiscentes. Ovarinm semiinferum, parte adnata triloenlari, sexovulata, parte lihera solida, ovata, carnosa, apice in $8 \mathrm{t} \mathbf{y} \mathrm{lum}$ stamina superantem desinente; $s \mathrm{t} i \mathrm{~g} \mathbf{m}$ a $\mathrm{t}$ e simpliciuseulo. Frnctus coriaceus, subovatus, supra basim calycis limbo patentim reflexo cinctus, abortu unilocularis, monospermus, apice $8 \mathrm{eminis}$ inversi, mox germinantis radicula elongata, elavata perforatus. - Arbores in Asia et Nova-Hollandia littorales; folits oppositis, obovalibus $v$. obovatis, integerrimis, glabris, stipalis interpetiolaribus caducis, pedunculis petialum subaequantibus, apice cymam densifloram, subcapitatam ferentibus, calyce bractea cupulata suffulto, floribus parvis, vix pisi magnitudine, alabastris ovoideis.

Ceriops Arnott in Annal, of Nat, hist, $t$. 363. R h i. zophora decandra Roxb. et Rh. timoriensis DC.

6100. In andelia WIGHT et $A R N$. C a$1 y$ x tubo cum ovario connato, limbi quinquepartiti laciniis linearibus, tubum triplo v. quastrnplo superantibus, patentibus. Corollae petala 5, annulo carnoso, snmmum calyeis tubum vestienti inserta, membranacea, glabra, basi linearia, subeanaliculata, nltra medinm bifida, laciniis in fila plurima capillaria, Innga inaequaliter fissix. Stain ina $30-40$, enm petalis inserta; filamenta subulata, capillaria, calycis lacinias subaequantia, a ntherae introrsae, bilocnlares, nblnngae, nb. tusae, parvae, dorso paullo supra basim affixae, Iongitudinaliter dehiscentes. Ovarin m inferum, uniloculare, sexovalatum, st y lo terminali, filifor. $\mathrm{mi}$, stamina subaequante; $s \mathrm{t} \mathrm{i}$ in a te tridentato. Frn ctus coriaceus, oblongns, sepra basim ealycis limbo patente cinctus, uniloenlaris, ahorta manospermus, apice exserto seminis inversi, mox germinantis r a dienla elongata, elavato-snbulata, acntissima perforatus, - Arbor parva, Malabariae littora incolens; foliis oppositis, anguste elliptico-oblongis, obtusis, integerrimis, gla- 
bris, stipulis interpetiolaribus deciduis, pedunculis petiolo longioribus, di-trichotomis, quadri-novemfloris, floribus majusculis, interdum hexameris, alabastris prismaticis, calyce bractea cupulata suffulto.

$\mathrm{K}$ and e $1 \mathrm{i}$ a Wight et Arnott Prodr. $I$. 310. Arnott in Annal. of nat. hist. I. 365. Meisuer Gen, 119. (85.) R hizo. phor a Kandel Limn. Ts jerou Kandel Rheede Malab. VI. $t .35$.

6101. Enuguiena $L A M$. Calyx tubo turbinato, cum ovarió connato, limbi octo-quatuordecimpartiti laciniis tubum subaequantibus. Corolla e petala 8-14, annolo carnoso summum calyeis tubum vestienti inserta, ohlonga, bifida, basi conduplicata v. convoluta, stamina retinentia. S $t$ a m in a 16-2t, cum petalis inserta et geminatim opposita, tandem elastice ab iisdem resilientia; filamenta filiformia, petalis sulsdimidin hreviora, alternatim inaequilonga, a $n t h$ erae introrsae, biloculares, lineares v, oblongre, aeutae, basi insertae, longitudinaliter dehiscentes. Ovariu in inferum, bi-tri quadriloculare, locnlis biovulatis, stylo filifurmi staminum longitudine; st igmate bi-quadridentato. Fruet us coriacens, turbinatus, calycis limbo coronatus, apice hand exserto se min is inversi, mux germinantis radi. cula elongato-cylindrica perforatus. - Arbores $v$. arbusculae, Asiae et Novae-Hollandiae lit. tora tropica incolentes; foliis oppositis, integerrimis, glabris, stipulis interpetiolaribus deciduis, pedunculis axillaribus, uni-tri-multifloris, calycibus ebracteatis, alabastris fusiformibus v, ovoideis.

B r u g u ier a Las. Dict. IV, 696, t. 397. Blume Enum. pl. Jav. I. 92. Wight et Arnott Prodr. I. 311. Aruort in Annal, of nat, hist. T.365. Meisner Gen. 119. (85) R h izophora gyma or biza Linn. Gären. $I, 213, t$. 43. $f$. 2 . M а и g i и вusph Amboin, III. $t, 68.69,70,78, \mathrm{~K}$ a nd e I et Karl, KandeI Rtieede Malab. VI. t, 31_33. P a le tuveria Thouars.

Q10\%. Carallia ROXB. Caly $\mathrm{x}$ tubo subgloboso, eum ovario connato, limbi superi, quinque-septemlubi lobi breves, triangulares, aestivatione valvati. C o rolla e petala $5-7$, annulo carnoso summum calycis tubum vestienti inserta, orbienlata, unguiculata. S $\mathrm{t}$ a m i n a $12-14$, $\mathrm{cum}$ petalis inserta, iisdem aequalia; filamenta filiformi-subnlata, alterna breviora, a $\mathrm{the}$ ra e introrsae, biloculares, oblungae, erectae v. incumbentes, Iongitudinaliter dehiscentes. Ovarium inferum, uniloculare, nni-triovulatum, annulo carnoso epigyno, styli stamina aequantis basim cingente; stigma te lato, peltato. B a ce a monosperma. Semen reniforme. - Frutices Asiae tropicae, sempervirentes, glabri; folits oppositis, rigidis, supra lucidis, dentatis $v$. serratis, peduncu. lis axillaribus crassis, brevibus, rigidis, bis-bifidis $v$. trifidis, plurifloris.

Carallia Roxburgh Plant. Corom, IIT. 8, t. 211. Flor. Ind. II. 48t. R. Brown in Tuekey Congo 437. DC. Prodr. III. 33. Wight et Arnott Prodr. $T$. 311. Arnott in Annal. of nat. hist. $I$. 370. Meisuer Gen 119. (85.) B a r a I. de i a Thouars Gen. madigasc, $n, 82$. DC. Prodr. I, 732. Bara a l tia Stendel Nomenel. 10t, D i a to ma Loureiro Flor. cochinch $\boldsymbol{I}$. 362. Petal om a DC. Prodr. III. 294. Ca t a li u m Hamilt, msc. De m i d of i a Dennst. z. Hort. Malab. IV. 13.

\section{* LEGNOTIDEAE.}

6103. Dryptopetalum $A R N O T T, \mathrm{C}_{\mathrm{a}}$ Iy $x$ liber, quadri-quinquepartitus, laciniis ovatis, aestivatione valvatis. Co roll a e petala $4-5$, sub disci perigyni, octo-decemerenati margine libern inserta, calycis laciniis alterna et sobbreviora, la- te cuneata, subunguiculata, apice fimbriato-lacera, aestivatione involuta. St a mina $8-10$, cum petalis inserta, alterna iisdem opposita paulle breviora; filamenta subulato-filiformia, aestivatione incurva, an the rae introrsae, biloculares, globosae, dorso insertae, longitudinaliter dehiscentes. Ovariu m liberam, ovato-globosum, carnosum, quinquesuleatum, quinqueloculare, loculo nno saepius abortivo. O $\mathbf{n} \mathrm{l}$ a in loculis $4 \ldots \ldots$. Stylus filiformis, brevis; stigma peltatum, quinquepartitum, laciniis linearibus, stellato-reeurvis, apice emarginatis. B a c c a pisiformis, pulposa, subquinquelocularis. Se min a in loculis gemina, oblonga, apice contracta, pendula, testa crustacea, rugnlosa. Embryo in axi albuminis carnosi teres; cotyledonibus semiteretibns, radicula snpera paullo hrevioribus. - Frutex $v$. arbor penangiana; foliis oppositis, coriaceis, penninerviis, venosis, oblongo-ovalibus, lreviter acuminatis, subintegerrimis, supra medium obsolete paucidentatis, basi in petiolum brevem subangustatis, stipularum delapsarum cicatricibus interpetiolaribus, floribus axillaribus fasciculatis, pedicellatis, pedicellis petiolo brevioribus, medio articulatis.

Dryptopetalum Arnott in Annal. of nat. hist.I. 372. Mierotropis coriacea Wall.

6104. Cassipourea $A U B L, C$ a $1 \mathrm{y}$ * eampanulatus, quinquefidas, laciniis aestivatione valvatis. Corollae petala 5 , imo calyei inserta, ejusdem lariniis alterna et longiora, basi attenuata, pinnatifido- $v$. palmatifido-fimbriata. $S \mathrm{t}$ a $\mathrm{m}$ i n a $20-40$, imo calyci inserta, ejusdem laciniis breviora, uniseriata ; fil amenta filiformi-subnlata, an the rae introrsae, biloculares, oblongae, dorso insertae, longitudinaliter dehiscentes. Ovarinm liberum, sessile, hemisphaericum, triloculare. Ovala in loculis gemina, pendula. Stylu s simplex, persistens; stigma obtusum. Capsula ealyce cincta, trilocularis, trivalvis. S e $\mathrm{m}$ in a in loculis abortu solitaria, dependentia, basi semiarillata. Embryo intra albumen carnosum rectua, cotyledonibus planis, radicula supera. Arbores $v$. frutices, in America et Africa tra. pica crescentes; folïs oppositis, subpetiolatis, ovalibus, acutis, penninerviis, integerrimis $v$. obsolete dentatis, stipulis interpetiolaribus lanceolatis, pedunculis axillaribus congestis $v$, solitariis, pedicellis uniftoris, basi bracteatis.

C a s s ip o urea Aublet Guian. I, 599, $t, 211$. R. Brown in Tuckey Congo 423. DC. Prodr. IIL. Meisn. Gen, 119. (8t.) T it a Scopoli Introduct. $n$ 967. Le gín o tis Swartz Prodr. 84. Flor. Ind, occid. 968, $t, 17$. - Richae ia Thouars

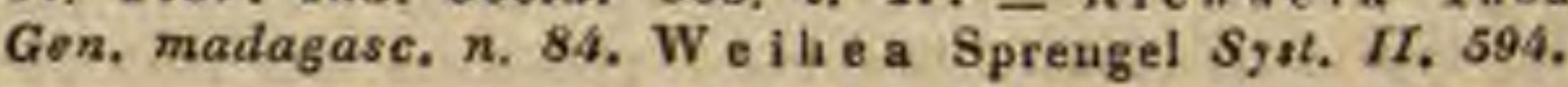

\section{Ordo CCIXIV: Pleiladelpheae.}

PHILADELPHEAE Don in Edinb, new philosoph. Journ. I. 133. DC. Prodr. IIT, 205. Lindley Introduct. edit. II. p. 42.

Frutices, foliis oppositis, simplieibus, petiolatis, subintegerrimis v. crenatis sive serratis, nervosis, epunctatis, deciduis. Stipnla e nullae.

Flores hermaphroditi, regulares, albi, odorati, in pedunculis axillaribus oppositis, v. terminalibus trichotome cymosis aut subpaniculatis.

CAlYXX tubo turbinato v. campanulato, cum ovario connato, limbo supero, quadri-decem- 
dentato v. partito, laciniis aestivatione valvatis, persistentibus.

Corollas petala sub annulo epigyno carnoso, calycis faucem marginante inserta, ejusdem laciniis numero aequalia et alterna, obovata $v$. oblonga, aestivatione imbricata v. induplicatim valvata.

Stamina cum petalis inserta, duplo v. multiplo eorundem numero, uni-biseriata. Filamenta filiformia v. plano compressa. Anthera introrsae, biloculares, ovatae v. subgloboso-didymae, longitudinaliter dehiscentes.

Ovarion cum calyeis tubo connatum, inferum v. vertice plus minus exserto semisuperum, tri-quadri-decemloculare. $0 \mathrm{v} u \mathrm{I}$ a in placentis e loculorum angulo centrali exsertis v. adnatis plurima, adscendentia v. pendula, imbricata. Styli loculorum numero, nunc omnino distincti, nunc plus minusve cohaerentes v. omnino connati. Stigmat a linearia v. clavata, discreta v. coalita.

Capsola calyce corticata, tri-decemlocularis, vertice exserto septicide v. loculicide dehiscens, v. tubo juxta calycis nervos irregulariter rupto aperta.

Semina plurima, imbricata, adscendentia v. inversa. T e sta membranacea, reticulata, utrinque relaxata, ad umbilicum subtubulosa, lacera, nucleum multo minorem includens. A1b u m e n carnosum.

Enввуо in axi albuminis crassi, ejusdem fere longitudine. Cotyledones breves, semieylindricae v. ovatae, plano-convexae. R adicula longa, umbilico proxima, supera v. infera.

Philadelpheae in Europa australi, America boreali, Japonia et India superiori spontaneae, ob calycis lacinias aestivatione valvatas, stylos saepissime distinctos, semina albuminosa et folia epunctata a Myrtaceis, quibuscum olim confusat, omnino removendae, ab Onagrarieis, quibus plurimis notis propinguae, staminum numero, testa seminum relaxata et albuninis praesentia diversae, aretius fortassis, mediante imprimis Deutzia, ad Saxifragaceas Hydrangeas accedentes, et in illarum contubernium olin revocandae.

6105. Philladelphuas $L I N N$. Ca $1 \mathrm{yx}$ tubo obovato turbinato, cum ovario connato, limbi superi, quadri-quinquepartiti laciniis aestivatione valvatis. Corollae petala 4 v. 5 , snb annulo carnoso epigyno inserta, calycis laciniis alterna, obovata, aestivatione eonvolutiva. S $t$ a min a plarima, cum petalis inserta; fil ame nta compres. so-plana, subulata, a n therae introrsae, biloenla res, ovato. v. subgloboso-didymae, lengitudinaliter dehiscentes. Ovariu m in:ernm, quadri quinque rarius octo-decemloculare, $0 \mathrm{v}$ ula in placentis loevlornm angula centrali adnatis plurima, plariseriatim imbricata, pendula. St yli $4-5$, fitifor mes, basi coaliti, superne plus minus distireti;
Stig m a t a oblunga v. linearia, discreta v. coalita. Ca psula coriacea, calyce corticata, quadri-decemlocnlaris, apice breviter exserto locnlicide quadri-denenvalvis, valvis medio septiferis, indivisis v. tandem septicide bifidis. S e m in a plurima, pendula, plariseriatim imbricata, oblonga, testa membranacea, ntrinque relaxata, reticalata, ad umbilienm fimbriata, nucleum malto minorem includens. E $m$ bryo in axi albuminis earnosi orthotropns; cotyledonibns ovatis, planoconvexis, radicala longa, cylindrica, supera.-Frutices in Europa australi et in America boreali te mperat a indigeni; foliis oppositis, epunctatis, petiolatis, simplicibus, dentatis $v$, subintegerri. mis, floribus corymboso-cymosis subpaniculatis, v, rarius axillaribus, braeteatis, albis, saepe suaveolentibus.

$\mathrm{Ph}$ iladolphus Lian. Gen, n. 614. Schkuhr $t$. 121. Gärtner $I, 173 . t$. 35. Lam, $t, 420$. Guisupel Hotz. Art. $t$, d4. Bot. Mag. t. 1478, Bot. Reg. t. 570, II. 1839, t. 32, 39. DC. Prodr. IIT. 205. Meisner Gen. 109. (78.) Sebrader in Lin. naea XII. 388. S y ring a Tournef. Inst. 389. nou Lian.

6108. Decumaria $L I N N$. Cal y $x$ tuho. campanulato, cum ovario connato, limbo septemdecemdentato. Coroll a e petala $7-10$, sub annulo carnoso epigyno inserta, ealycis laciniis alterna, oblonga, aestivatione imbrirata. $\mathbf{S} t$ a $m$ in a cum petalis inserta, triplo eorundem numero, solitarie iisdem alterna et geminatim opposita, uniseriata; filamenta filiformia, an therae introrsae, biloculares, globoso-didymae, longitudinaliter dehiscentes. Ovariu m vertice breviter exserto inferum, septem-decemloculare. $O \mathrm{val}$ a in placentis loeulorum angulo centrali adnatis plurima..... St ylus simplex, crassus, in discum radiis stigmatosis loculornm numero exsculptum expansus. Capsula ovoidea, ealycis tubo septemdecempervio corticata, semisupera, stylo stigmateque coronata, septem-decemlocularis. juxta tubi calycini nervos irregulariter dehiscens. Sem in a plurima, oblonga, testa membranacea, relaxata..... - Frutex boreali-americanus, sarmentosus; foliis oppositis, epunctatis, petiolatis, simplicibus, integerrimis $v$, apice dentatis, glabris, gemmis rufo hirtis, floribus terminalibus subcorymbosis, parvis, albis, odoratis.

De e u m a ria Lian. Gen, $n, 597$. Iam. $t$. 403. Bosc in Aot, soc, h, n, Paris, 1.76. t, 13. DC, Prodr. IIT, 206. Meinner Gen. 109. (28.) Fors y th a Walter Carolin. 154, non Vabl.

610\%. Deutzia THUNB. Calyx tubo campanulato, cum uvario connato, limbo supero, quinquedentato. Corolla e petala 5 , snb annulo epigyno earnoso inserta, calycis laciniis alterna, wbovalo-sblonga, aestivatione valvatim induplicata. Stam in a 10 , cum petalis inserta, alterna iisdem opposita breviora; fi la m e n ta compresso plana, sabulata $\mathbf{v}$, breviter triluba, lobo intermedio antherifero, antherae introrsae, biloculares, subghboso-didymae, longitndinaliter dehiscentes. Ovari um inferum, tri-quadriloculare. Ovula in placentis rarnosis, e loculorum angulo centrali porrectis plarima, pluriseriatim imbricata, adseendentia. Styli 3 v. 4, filiformes, erecti, demun eiongati; st igmata clavato-decurrentia, carnosa. Capsula coriacea, calyce corticata, diseo epigyno nmbilicata, tri-quadrilocnlaris, septicide tri-tetracocca, coccis basi et apice cohaerentibus, placentis tandem cavis, longitudinaliter bipartitis. Semin a plurima, adscendentia, multiseriatim imliricata, wblonga, compressa, testu memtiranacea, reticulatim venosa, basi ad umbilicem tulualuse re149 * 
laxata, irregulariter fissa, apice in alam brevem producta. Embryo in axi albuminis cornei orthotropus, clavato-subcylindricus; cotyledo. nibus brevissimis, obtusis, radienla umbilien proxima, infera. - Frutices humiles, in India su. periore et Japonia indigeni, pilis stellatis scabri; ramis laxis, saepe pendulis, folits oppositis, epunctatis, breve petiolatis, simplicibus, crenatis v. serra. tis, stipulis nullis, floribus thyrsoideis, speciosis.

De utzia Thumberg Nov. gen, 19. Flor. japon, 10. t. 24. Gartuer f. III. 30. t. 184. DC. Prodr. IV. 16. Don in Edinb. new philosoph. Journ. 189? III 164. Wallich Plant. As. rar. II, t. 191. Bot. Reg.t. 1718, N, 5. 1840. t, 5. Zuecariul in Siebold Flor. Japon, 17, t. 6_8.

\section{Drdo CCLX. Denothereate.}

ONAGRARUM seet. II. et III. Jussien Gen, 317, EPILOBIACEAE Venten. Tabl, IIT, 307. ONAGRARIAE Jussirm in Annat. Mus. III. 315. DC. Prodr. IIT. 35. Mem, III. Pa. ris. 1892 4. c. ic. Bartling Ord nat. 318. exel. sect. A. ONAGRACEAE Liudlev Introduct, edit. II. p. 35. Meisuer Qen. 120. (85.) ONAGREAE Spach Suites a Buffon ID. 330 . Nouv, Annal, se, nat, IV, 16it. Nouv. Annal. Mtus, $1 V .321$

Herbae v. prutices, caule ramisque teretibus v. angulatis, plerumque imperfecte nodosis. Foli a opposita v. alterna, simplicia, penninervia, integra, integerrima v. serrata, epunctata. Stip ula e nullae.

Flores hermaphroditi, regulares v. rarius irregulares, nunc axillares solitarii, nunc in racemos v. spicas dispositi, saepe fugaces.

Calyx herbaceus v. coloratus, tubo cum ovario connato, saepissime longe ultra ovarium producto, limbo quadripartito, rarius tri- v. bipartito, lobis per aestivationem valvatis, persistentibus v, deciduis.

Corollat petala (rarissime defieientia) summae calycis fauci, tori lamina aequaliter marginatae $\mathbf{v}$. in glandulas plus minus manifestas tumenti inserta, ejusdem laciniis numero aequalia et alterna, magis minusve distincte unguiculata, interdum emarginata v. bifida, aestivatione contorta, deciỏua.

Stamiva cum petalis inserta, nunc iisdem numero aequalia et alterna, nunc dupla, unibiseriata, rarissime uno v. altero sterili petaliformi petalis pauciora. Filamenta filiformia v. subulata, libera. An the rae introrsae, biloculares, erectae v. incumbentes, longitudinaliter dehiscentes. Pollinis granula triangularia, saepissime filis cohaerentia.

Ovariom inferum, saepe tori margine glanduloso-coronatum, plerumquę quadriloculare, rarius biloculare. Ovula in loculis plurima, angulo centrali inserta, rarins pauca v, subdefinita, adscendentia v. pendula, anatropa. StyI u s filiformis. Stigmata loculorum numero, linearia, intus papillosa, rarius coalita.

Frvetus capsularis v. baccatus, rarius nucamentaceus, quadrilocularis v. bilocularis, interdum septorum obliteratione unilocularis, loculicide v. septicide dehiscens, valvis medio septiferis, v. columna placentifera demum libera angulis septante.

Semiva plurima, rarius abortu panca v. solitaria, adscendentia v. pendula. Test a crustacea $v$. membranacea, aequabilis $v$, in alam producta, nune ad chalazam apicalem in marginem membranaceum fimbriatum $\mathbf{v}$. in comam producta, $r$ haphe plus minus distincta.

Eиввуо exalbuminosus, orthotropus. $\mathbf{C}_{0-}$ tyledones foliaceae v. subcarnosae, basi saepe biauriculatae. R a dicula conica v. cylindrica, umbilico proxima, supera v. infera, aut rarius centripeta.

O e n o the re a e hinc Halorageis, albuminis praesentia, et Philadelpheis, praeter eandem notam etiam staminum in plerisque numero majori distinctis, illine Lythrarieis, ovario cum calyce nunquam concrescente diversis affines, per totum fere orbem diffusae, in regionibus temperatis extratropicis, imprimis novi orbis copiosae, nee in America aequinoctiali infrequentes, parcius in veteris orbis climate calido generantur.

Radices nonnullarum edules. Plurimae florum decore ornatissimae.

TIRE IIS I. JUSSIEVEAE DC. Prodr. III. 52. Caly cis tubus ultra ovarium haul productus. St a min a petalis numero aequalia v. dupla. Fructus capsularis, septicide dehiscens. Semin a inappendiculata.

6105. Prieurea $D C$. C a ly $\mathrm{x}$ tubo longe fusiformi, trinervi, cum ovario connato, limbi superi, tri- v. interdum quadripartiti laciniis acutis, persistentibus, Corolla e petala 3 v. 4 , sub disri epigyni, depressi, fere obsoleti margine inserta, ejusdem laciniis aequilonga, lanceolata. St a mina $4, \mathbf{c n m}$ petalis inserta, iisdem alterna et breviora; fil amenta filiformi-subulata, an therae introrsae, biloculares, ovales, dorso insertae, lungitudinaliter dehiscentes. Ovarium inferum, triloculare. $\mathrm{O} \mathbf{v} u \mathbf{l}$ a in loculis plurima, angulocentrali pluriseriatim inserta, pendula, anatropa. S t yl us filiformis, brevissinus; stig ma capitatum. Ca p 8 u a eylindrico-fusiformis, torulosa, triloenlaris, indehiscens. Semin a plurima, pendula, ovalia, minima, testa chartacea, rhaphe longitudinali, elevata. Embryon is exalbuminosi, wrtho. tropi cotyledones obtusae, radicula brevis. sima, sopera. - Herba Africae tropicae, paludosa, glabra, ramosissima; foliis alternis, sessilibus, oblongo-linearibus, integerrimis, floribus axillaribus solitariis, brevissime pedicellatis, folio brevioribus.

Prieurea DC. Prodr. IIT. 58. Mem. III. 14. $t$. 2. Melaner Ger. 120. (85.) J ussie ua Prieurea Guillem. et Perrot. Flor. Seneg. I. 294.

6109. Jussiaea LIVN. C a l y $x$ tube $c y-$ lindraceo v.prismatieo, cum ovario connatu, supra ovarinm hand producto, limbi snperi, quadri-quinquepartiti laciniis acutis, persistentibus. Curolla e petala 4 v. 5, disci epigyni, eonici, sulcati v. depressi, quadri-quinquelobi margini inserta, calycis laciniis alterna, obosata, patentia. Stamina 
8-10, cum petalis inserta, iisdem breviora; $f$ iI amenta filiformia, antherae introrsae, biloculares, ovatae v. oblongae, dorso insertae, longitudinaliter dehiscentes. O v a $\mathbf{r}$ i $\mathbf{~ m}$ inferum, quadri-quinqueloculare. Ovula in loculis plurima, angulo centrali pluriseriatim appensa, anatropa. Stylus simplex; stigma capitatum, quadri-quinquesulcum. Capsula disco epigyno coronata, costata, quadri-quinquelocularis, septicide quadri-quinquevalvis, valvis a costis persistentibus solutis, deciduis, placentis centralibus liberis. S emina plurima, oblonga v. angulato - tetragona, interdum ovulorum coalitione bilocularia, locnlo altero vaeno, pendula, testa shartacea. E m b r y onis exalbuminosi, orthotropi cotyledones obtusae, radicula brevissima, umbilico proxima, snpera, - Herbae, frutices v, rarissime arbores, in regionibus tropicis totius orbis, imprimis in paludosis crescentes; foliis alternis, plerumque integerrimis, floribus axillaribus, solitariis v. brevissime pedicellatis, saepissime basi bibracteolatis, luteis $v$, rarius albis.

J us s i a a Linn. Gen, n, 538, Gärtner I, 154. $t, 31$. Andrews Bot. Heposit. t. 621. Hnmb. et Bonpl. Plant. aequinoct. $t, 3$. Kunth in Humb. el Bonpl. Nov.gen, et sp. VI 96 . t. 530_533. Reichenb. Ic. exot, t. 57, 75. Bot. Mag, t, 2122 2830. DC. Plant, rar. hort. Genev. 1.4. Mem, IIL.8 Prodr. IIT. S9. Melsuer Gen. 120. (85). C u b o s pe $\mathrm{r}$ m u na Loureiro Elor, cochinch. 337, Vigier a Fl. Flum, IT, t. 73. 74.

6110. Luduvigia $R O X B$. Calyx tubo cylindraceo v. turbinato, cum ovario connat", limbi superi, quadri quinquepartiti laciniis acutis, demnm deciduis. Corulla e petala 4 v. 5 , sub disci epi. gyni, conici, suleati margine inserta, calycis laci. aiis alterna, obovata, patentia. Sta m ina 4 v. 5 , cum petalis inserta, iisdem alterna et breviora; filamenta filiformi-subulata, antherae introrsae, biloculares, ovatae v. oblongae, dorso insertae, lungitudinaliter dehiscentes. Ovari a m inferum, quadri quinqueloculare. Ovula in lore. lis plurima, angulo centrali pluriseriatim inserta, appensa, anatropa. Stylus filifurmis; stigma capitatum, crassum. Ca psula diseo epigyno coronata, elongatı-eylindrica $v$. turbinata, quadrilo. cularis, septicide quadrivalvis, placenta centrali libera. Seuin a plurima, obovata v. oblonga, pendula, testa chartacea. E m br y on is exalbuminosi, orthotropi cotyledones obtusae, radicula brevissima, umbilico proxima, supera. - Herbae indicae, paludosae; folits alternis, breve petiola. tis, anguste lanceolatis, integerrimis, floribus axil. laribus solitariis, sessilibus, bibracteolatis, Luteis.

Ludwigia Roxburgh Flor. ind, edit. Wallich, $T, 440$. DC. Pradr. III, 38. Mem. III. t. 2. Wight et Arnott Prodr. I. 336. Meisuer Gen, 120. (86.) Ludwigia perennis Lim.

6111. Ismardia $D C$. Cal $\mathrm{y} \times$ tubo brevi, ovato v. subcylindraceo, cum ovario connato, limho snpero, quadripartito, persistente. Carollae petala 4 , sub disei epigyni depressi margine inserta, calycis laciniis alterna, iistem aequilonga v, breviora, saepissime nulla. Stam in a 4 , cum petalis inserta, calycis laciniis opposita et hrevinra; fil a ment a filiformi-subulata, antherae introrsae, biloculares, ovatae, derso insertae, Iongitudinaliter dehiseentes. O v a $r \mathrm{i}$ a m inferum, quadriloculare. $0 \mathrm{vala}$ in loculis plurima, placentis septiformilus, ex angule centrali prominentibns utrinque inserta, pendula. St y lus filiformis; stigma capitatum. Capsula obovata v. subcylindrica, qnadricostata, quadrilocularis, loculi- cide quadrivalvis, axi septifero persistente, septis cum placentis lamellaribns alternantibus. S e min a plarima, ovata, testa chartacea. Embryon is exalbuminisi, orthotropi c ot y l e d o n e s obtnsae, radicula brevissima, nmbilico proxima, supera. - Herbae aquaticae v. paludosae, in temperatis hemisphaerae borealis, imprimis America e, rarius in Africa tropica crescentes; foliis alternis $v$. oppositis, integerrimis v. serratis, foribus axillaribus sessilibus $v$, breve pedicellatis, interdum racemum terminalem formantibus.

Is nardia DC. Prodr. III. 59. Meisner Gen.120. (86.) Ludwigia Elliott Carol. I. 214, Spreogel Syst. I. 444.

a. DANTIA DC. l.e. C orolla nulla.- Is nardia Linu. Gen. n. 156. Jussieu Gen, 333. Lam, $t$, 77. Schkuhr t. 23. D a n ti a Thouars Gen. madagase, n, 49.

b. LUDWIGIARIA DC, l. c. Corolla e petala ealycem aequantia v. miaiua. Lud wigia Linn. Gen. n, 153. Jussieu Gen, 319. Laa, t, 77. Gärtuer 1, 158, t, 31.

TIRIBUS II. EPILOBIEAE. Calyx tubo supra ovarium saepissime plus minus producto. Stamina duplo petalorum numero. Fructus capsularis, loculicide dehiscens, polyspermus. S emina nuda, fimbriata v. papposa.

6112. Gayoplaytum $A D R$, JUSS. CaIyx tubo tetragono, cum ovario connato, supra ovarium vix producto, limbo quadripartito. Corolla petala 4, summo calycis tubo inserta, ejusdem laciniis alterna, obovata. Stamina 8 , cum petalis inserta, uniseriata, alterna iisdem opposita breviora, antheris efoetis sterilia; filam ent a complanato - subulata, an th era e introrsae, biloculares, orbiculatae, longitudinaliter dehiscentes. Ovari u inferum, biloculare, $0 \mathrm{vula}$ in laculis plnrima, axi centrali utrinque inserta, adscendentia, anatropa. Sty 1 u s filiformis, brevis; stigma magnum, globosum, sulco transverso obsolete bilobum. Ca psula membranacea, compresso-tetragona, bilocularis, quadrivalvis, valvulis duabns oppositis angustioribus extrorsum revolutis, dualus latioribus medio septum cum axi centrali diutius cohaerens gerentibus. S e mi $\mathbf{n}$ a in Inculis plurima, oblongo-ovata, uniseriata, adscendentim imbricata, testa membranacea. E m b r y o$n$ is exalbuminosi, orthotropi, clavato-cylindrici cotyledones obtusae, radicula conica, infera. - Herba chilensis, annua, uni.tripollicaris, glaberrima, basi nuda, superne ramosa, foliosa; foliis infimis oppositis, reliquis alternis, linearibus, subfalciformibus, integerrimis, floribus axillaribus solitariis, sessilibus, folio triente brevioribus, luteis.

Ga yo phytu in Adr. Jussleu in Annal, sc, nat. XXV. 18. $t$. 4. Meisner Gen, 120. (86.) Spach in Nouv. Annal. Mus. IV. 33t, Oenothera micrantha Prest.

611 3. Splnaerostigma SERING. CaIy $\mathbf{x}$ tubo inferne tetragono, cum ovario connato, supra ovarium producto, infundibuliformi v. cyathiformi, limbi quadripartiti laciniis distinetis v. per paria cohaerentibus. Co ro 11 a e petala 4 , summo calycis tubo inserta, ejusdem laciniis al. terna, obovata v. cuneata. Stam in a 8 , eum petalis inserta, alterna iisdeun opposita breviora; filament a filiformi-complanata, antherae intror$s a e$, bilocolares, longitudinaliter dehiscentes. $0 \mathrm{v}$ a$r$ i $\mathrm{m}$ inferum, quadriloculare. 0 v n la in locnlis plarima aut rarissime paeca, angulo centrali unica serie inserta, adscendentia, anatropa. Stylus 
filiformis; stigma subglobosum, erassum, indivisum. Ca psula tetragena, subcylindrica v. eoniea, quadrilocularis, luculicide quadrivalvis, placenta filiformi, libera. Se min a plurima, adscendent:m imbricata, ovalia v. obovata, laevia. E inbryonis exalbuminosi, orthotropi cotyled o. nes plano-convexae, basi biauriculatae, rad i cula nmbilicum attingens - Verbae boreali-americanae et chilenses, annuae, ramosae, saepissime graciles; foliis alternis, sessilibus $v$. peliolatis, integerrimis $v$. denticulatis, floribus axillaribus, citrinis.

Sphaerostigma sect. Deuotherae Seringe in $D C$. Prodr. III. 46. Meisner Gen. 120, (86.) 0 n o 2 a r is Rafinesque Flor. Ludov. 96 . C h a $\mathrm{m}$ is $\mathrm{s}$ o a i a Liuk in Jahrb. der Gewächsk. 1818, p. 186. Heteros temu m Nattall. A gas. sizia Spach in Suites a Buffon $I V$. 3a7. Holostig ma Spach in Nouv. Annal. Mus. 332, O e not he rae sp. Ca. vanill. $t$. 398. Ruiz et Pavon Flor. Peruv. $t, 317$. Liudley Collect, t. 10. Bot. Reg. t. 1040.

614. Ineriolix $R A F$. Caly $x$ tubo inferne tetragono, enm ovario connato, breviter $8 \mathrm{u}$ pra ovarium prodncto, infundihuliformi, limbi quadripartiti laciniis cristato-carinatis. Corolla e petala 4 , summo calycis tulo inserta, ejusdem laciniis alterna, obovata, undulato-crenulata. St am in a 8 , cum petalis inserta, alterna iisdem opposita breviora; f i l a $\mathrm{m}$ e $\mathrm{n}$ t a lineari-complanata, brevissima, a $\mathrm{n} t \mathrm{~h}$ e $\mathrm{r}$ a $\mathrm{e}$ introrsae, biloeulares, langitudinaliter dehiscentes. Ova ri nm inferum, quadriloculare. Ova 1 a in loculis plurima, angulo centrali biseriatim inserta, adscendentia, anatropa. Stylus filiformis, medin geniculatus; stigma peltatum, disciforme, erenulatum, Ca p sula coriacea, eylindrica $v$, elavata, oetostriata, septis evanidis demum unilocularis, apice loculicide quadrivalvis, placenta tetraquetra, Jibera. Semina plurima, adscendentia, oblonga, angulata, laevia, ad chalazam apicalem marginata. Embryonis esalbuminosi, orthotropi cotyledones planoconvexae, basi biauriculatae, radicula brevissima, umbilieum attingens, infera. - Herbae boreali americanae, basi suffruticosae, erectae, ramosac, glabriusculae; foliis alternis, subsessilibus, serratis, floribus axillaribus solitariis, sessilibus, citrinis.

Meriollx Rafinesque in Americ. Monthl. Magaz. 1819. Calylophis Spach Suites d Buffon IV, 349. Nouv. An. nal. Atus. JV. 337. Oenothera serrulat a Hooker Exot. Flor, t. 140 .

41 15. Demotherre LINN. Caly $\mathrm{dnbn}$ inferne cylindrico, enm ovario connato, longe smpra ovariam producto, filiformi, limbi quadripartiti laciniis acntis, rellexis, saepe per paria coliaerentibus. Corolla e petala 4 , annulo sommum calycis tuhum marginanti, integro $v$, quadrilubo inserta, limbi laciniis alterna, brevissime ungniculata, saepissime obcordata, aequalia, patentia. Stamina 8 , cum petalis inserta, uniseriata, aequalia $v$. alterna isdem opposita breviora; filamenta filiformia v, complanato-subulata, recta v, adscendentia, an therae introrsae, biloculares, dorst insertae, longitudinaliter dehiscentes. Ova rin m inferum, quadrilocnlare. Ovala in loealis plurima, angulo centrali uni-biseriatim inserta, adscendentia, anatropa. Sty ln s filiformis, apice plerumque incrassatus; s t if ma quadripartitum, laciniis lineuribus, obtnsis. C a $\mathrm{p}$ \& u l a ewriacea v. sublignosa, prismatico-tetragona v. clavata, quadrilocularis, loculisi de quadrivalvis, valvis medio septiferis, eolumna seminifera libera. Semina plurima, hurizuntalia $\mathbf{v}$. imbricatim adscendentia, testa crustacea v. spongin- sa, erassissima, interdum ad chalazam submarginata, umbilico basilari. Eubryonis exalbuminosi, orthotropi cotyled ones plano-convexae, obtusae, radicula brevis, conica, nmbilicnm at. tingens. - Herbae interdum suffrutescentes, in America temperala et calidiore indigenue; foliis radicalibus saepissime rosulatis, in petiolum triquetrum angustatis, caulinis alternis, sessilibus v. brevissime petiolatis, integerrimis $v$. denticulatis, rarius sinuatis $v$, pinnatifidis, floribus axillaribus, solitariis, sessilibus $v$, brevissime pedicellatis, spicam terminalem simplicem formantibus, ante anthesim saepe nutantibus, noctu expansis $v$. rarius diurnis, flavis, albis, purpureis, roseis v. violaceis, saepissime post anthesim mutabilibus.

Oe not hera Liun, Gen,n.469. exel, sp. DC, Prodr. Irt. 45. exel. seet. 1. Fischer et Meyer Index Sem. hort. Petropolit. 1I. 1835. p 44, exel, seet. VI. Meisuer Gen, 120. (86.) 0 u a gra Tournef. Inst, 302, t, 156. Ue nothere ae Spach in Nouv. Annal. Mus, $I V .338$.

1. A nogra Spach. Ovula adscendentia, uniseriata, superposita, inappendieulata. Ca psula subcoriacea, liaearis, tetragona. Se mina parva, laevia, algulosa. Flores diurni, rosei, aestivatione penduli. - Anogra Spach in Nouv. Annal. Mus. IV. 339. B a u ma nni a Spach Suiles a Buffon $1 V .351$. (Bot. Reg. $t, 1142$.)

2. Allochroa Fisch, et Meg. Ovula adsceadentia, biseriata, imbricata, inappendiculata. C a psuta subeartilaginea. elavato-cylindracea, obscure tetragona. Se an in a parva, subfusiformia, scrobiculata. - Flores nocturni, fugaces, lutei, aestivatione erecti. - Alloehroa Oeaotherae seet. 2. Fiseher et Meyer Index. som. Petrop. 1835, 11. 4i. O en o the ra Spach Suiles a Buffon. IV. 353, Nouv. Annal, Mus, 1V. 341. t, 30. f. 3. (nurray Comment, Gotting. V. t. 9. Jacq. Ic, rar, t. 455, 256. Hort, Vindob. t. 172. Ruiz et Pavou Flor. peruv. t. 315. b. Hosker Exot, Flor, t. 183. Bot. Reg. t. 147. Bot. Mag. $t, 365.2403 .3361 .3392$.

3. Megapterium Spach. O v uIk adseendentia, uniseriata, fubricata. apiee aristata. Ca ps u la coriacea, ellipsoidea, subeompressa. teiraptera. S e mi u a rugosa. apice marginatu. - Flores diurni, lutei, aestivalione erecti. - Megapterino Spach Suites a Buffon IV. 363. Nouv. Annat. Mus, IV. 350. (Bot. Mag,t. 1699 . Sweet Fl. Gard, I, 5.)

4. Onagra Spach. Ovula liorizontalia, biseriata, ses. silia. C al y e is laciuiae dorso inappendiculatae. Cap$s$ al a coriacea, subeylindrica v, oblongo-copica, tetragona, quadricostati. S e m in a compresso-subquadrata, integumento exterinrl fungnso. laevi. - Flores nocturni, fugaces, aestivatione erecti. - $\overline{0}$ a a $\mathrm{r}$ a Girtner t. 32. f. 1. Spacil Suites a Buffon IV, 357. Nouv. Annal. Mus. IV. 35t. Pleurostemo n Ratimesq. in Journ. Phys, LXXXIX, z5s. Pleuraudra Ratinesq. Flor. Ludnv. 95. (Miller Ic, $t, 189$. E. B. $t$, 1534. Bot. Mag. c. 1974. 2048.)

5. Pachylophis Spach. Ovala horizontalia, biseria1a. sessilia. Cal y cis laciniae dorso cristato-carinatae. Ca p s a la coriacea, oblongo-coniea, eristato-tetragona, cristis crassis, tmberculatis. Semina ovalia, subeylia. dracea, irappendiculata. Flores rosei, nocturni, fugaces, acstivatione erecti. $-\mathrm{P}$ a cli $510 \mathrm{ph}$ is Spach Suiter de Buffon IV. 36s, Nouv. Annal. Mur. IV. 356. t. 30. f. 1, 0 t, ea es p itos a Nattall Hot. Mag. t, 1593.

6. Lavauxia Spach, Ovnla horizostalia, bisetiata, sexsilia. C a I y c is laciniae dorso inappendicnlatae. C a ps I la coriacea, ellipsoidiea v. obovira, rugosa, tetra. quetra, quadricostati. S e mun a compresso-subquadrata, iategumento exteriore erasso, crasticen, grasulaso, nd chalazam lacunnso. Hepresso. - Flores carnet $v$. raro Aavi, nocturni, fugaces arstivatione erecti. $\mathrm{L}$ ava u $\mathrm{xia}$. Spach Suites d Buffon $I V$. 367. Nouv. Annal. Mus. IV. 357, t. 31, f t t Wav, IC, t, 399. Ruix et Pavon Flor. Peruv, t. 318. f 6. Bet. Reg, t, 763, 1479 Bot, Mag. 4. 2566. Sweet Fl. Gard, t, $294, I T . t$. 105.)

7. H brevi affixa. Capsula cartilaginea, elavata, obovata v. subovata, quadrideatata. tetraptera v. tetraquetra, dissepimentis membrauaceis. S e $\mathrm{m}$ in a subovata, laevias 
minuta, inappendieulata. - Elores rosei iv. raro citri$n i$, nocturni, fugaces, aestivatione erecti. - H a r tma nnia Spach Suites d Buffon IV. 370. Nouv. An. rat. Mus. IV. 360. (Cav. To, t. 279. 400, Ruiz et Pavon Elor. Peruv. $t$. 31s. f. a. Bot. Mag. $t$. 447. 469.)

8. Kn eiffi a Spach. Ovula horizontalia, funlculo brevi affixa. Capsula cartllaginea, clavata, obovata, v. subglobosa, truncata, tetraquetra, quadricostata, dissepimentis chartaceis. S e mina subovata laevia, minuta, inappendiculata. - Flores citrini, diurni, aestivatione ereeti. - Kueifita Spach Suites a Buffon IV. 373. Nouv. Annal. Mus, IV. 364. (Bot. Mag. $t$. 332. 355. 1606. 1624. 3545. Bot. Reg. t. 15t1. Sweet Fl. Gard. $t, 184$.

9. B I e n oderma spach. O vola suberecta, plurima, fuaiculo inmediatim affixa. Capsula subcoriacea, cla. vata, truneata, eristata-tetraquetra, quadricostata, dis. sepimentis uembranaceis. Se ni na angulata, minuta, testa crustacea, maceratione macilaginosa. - Flores parvi, flavi, aestivatione erecti. - B l en a od erma Spach in Nouv. Annat. Mus. IV. 406.

10. X ylopleurum Spaeh. Ovala funiculo elongatosuspeusa. Capsula sublignosa, dissepimentis demsm evanidis unilocularis, elavata v. subfusifornis, sulcata, octocostata, apiee quadrivalvis. Se uf na subovata, minuth, laevia. - Flores diurni, rosei, aestivalione cernui, - X y lo ple u $r$ u m Spach Suites \&Buffon $I V$. 378. Nouv. Annal. Mus. IV. 369. (Hooker Exot. Flor t. 80. Bat. Mag. t. 3189.)

B1 16. Codetise $S P A C H$. C a Iy $\mathrm{x}$ tubo inferne subeylindrico v. tetragono, eum ovario connato, supra ovariom producto, infundibuliformi, intus barbato, limbo quadripartito, lobis deflexis. Coro 11 a e petala 4 , summo calycis tubo inserta, ejnsdem Iaciniis alterna, obovata, apiea emarginata. Sta m in a 8 , cum petalis inserta, uniseriata, alterna iisdem oppusita breviora; filam e nta complanato-filiformia, a $n$ therae introrsae, biloculares, oblongae, longitudinaliter dehiscentes. Ovari $\mathbf{~ m}$ inferum, quadrilocnlare. Ovala in loculis plurima, angulo centrali inserta, uniseriata, adscendentia v. horizontalia. S $t$ y 1 a 8 filiformis; stig m a quadripartitum, lobis ovalibus v. lineari. bus. Ca p s u a coriacea, subeylindraceo-tetragona, quadrilocularis, loculicide quadrivalvis, placenta tetragoaa, libera. Sem ina plurima, angu lata, testa ernstacea, chalaza apicali lata, margine membranaceo-fimbriato cincta. Embryonis exatbuminosi, orthotropi cotyledones crassac, plano-cunvexae, radicula brevissima, umbilicum attingens. - Herbae californicae et chilenses, annuae, ramosae; foliis alternis, basi in petiolum angustatis, integerrimis $v$. denticulatis, fioribus axillaribus solitariis, roseis v. purpureis, saepe amoenissime albido, luteo $v$. sanguineo variegatis.

Godetia Spach Suiles d Buffon IV. 386, Nouv. An. nal. Mus. IV. 387. $t$. 30. f. 2. Liudley in Hot. Heg. $t .1899$. 1849. 1856. 1880. Meisaer Gen. 120. (86.) Oe a ot herate a p. Cav. Ic.t.396. f. 2. t.397. Ruiz et Pavon Flor. Poruv. 317. 318. Lehmana in $N, A, N, C . X I V$. . 45 . Reielsenb. Magaz, t. 47. 150. Bot. Mag, t. 358. 2753, 2832. 2889. Bot. Reg. t, 662, 1119. 1220, 1221. 1505, 1587.

B11\%. Crateriearpium $S P A C H, \mathrm{C}$ a 1 y $\times$ tubo inferne prisuatico tetragono, subqua drialato, supra ovarium producto, infundibuliformi limbi quadripartiti laciniis erectis, mucronatis, Corolla e petala 4, annalo membranaceo quadridentato, summum calycis tuham vestienti inserta, ejustem laciniis alterna, cuneiformia, bifida, $\mathbf{S} \mathbf{t a}$ mina 8 , biseriata, alterna petalis opposita longiora, demissius inserta; fil a m e n t a capillaria, a nth e rae introrsae, biloculares, ellipticae, utrinque emarginatae, longitudinaliter dehiscentes. $O$ variu m inferum, quadriloculare. Ovula in loculis suhsena, angulo centrali inserta, uniseriata, adscendentia, avatropa. Stylas filifurmis; stig ma quadridentatum. Ca p sula submembranacea, cylindracea, clavata, tetragona, sub apice tetraptera, dissepimentis demum evanidis nnilocularis, apice quadrivalvis, hians, placenta tenui. S emin a 16 -24, adscendentia, isnbimbricata, obovata, testa chartacea, ad chalazam apicalem margine membranaceo cincta. Embryon is exalbuminosi cotyledones ovales, plano-convexae, radi. e ula conica, umbilicum attingens. - Herba peruana, multicaulis, basi suffruticosa; foliis alternis, sessilibus, sublinearibus, integerrimis, junioribus saepe in vetustiorum axillis fasciculatis, floribus axillaribus solitariis, sessilibus, petalis purpureis, rubro-venosis.

Craterie arpi um Spach in Nouv. Annal. Mus. IV. 397. O e nothera s u b a lat a Ruiz et Pavon Flor, Peruv. t. 316. $f .8$.

G1 $1 \mathrm{~S}$. Boisalervalia $S P A C H . \mathrm{C}$ a $\mathrm{I}$ y $\mathrm{x}$ tubo inferne oblongo-cylindrico, quadricostato, cum ovario connato, supra ovarium producto, infuadibuliformi-tetragono, limbi quadripartiti laciniis ereetis, acuminatis. Corollae petala 4 , annulo membranaceo, quadridentato, calycis tubum vestienti inserta, ejusdem laciniis alterna, obovata, profunde biloba, reticulato-venosa. Stamina 8 , biseriata, alterna petalis opposita demissius inserta ; fila m e n t a filiformi-complanata, antherae introrsae, biloculares, lineares v. ellipticae, longitudinaliter dehiscentes. $O$ v a $\mathrm{r}$ i u $\mathrm{m}$ inferum, quadriloculare. Ovula in loculis panca, angulo centrali inserta, uniseriata, adscendentia, anatropa. Stylus filiformis, sursum incrassatus; stigu a quadrifidum. Ca p 8 u l a chartacea, oblongocylindracea $v$. eonica, quadrilocularis, loculieide quadrivalvis, placenta tetragona, basi et apice attenuata, libera, Se mina 16_20, adscendentia, subimbricata, ovalia v. obovata, testa crustacea, basi et apice marginata, chalaza apicali orbienlata. Embryonis exalbuminosi, orthotropi cotyledones plano-convexae, basi profunde emarginatae, radicula conica, umbilicum attingens, infera. - Herbae chilenses, annuae, ramosissimae, subtomentosae; foliis in/imis oppositis, reliquis alternis, sessitibus, dentatis, floribus in apice ramulorum axillarium, interdum brevissimorum glomerulatis, bracteatis, carneis v. purpureis.

B o is duvalía Spach Suites d Buffon IV, 238. Nouv. Annal. Mus. IV. 398.

a. Dictyopetalum Fisch. ot Mey. Petala infra tabi calycini taucem inserta. S tamina petalis alterna majora, minoribus triente longiora, ealyeis lacialas superan. tia, a $\mathbf{t}$ he $r$ a e lineares, medio dorso affixae. PI ace $\mathrm{a}$. ta dimidia fere parte superiore asperma. - Dicty opetalum sect. Oenotherae Fiseber et Meyer In. dex sem. hort, Petropolit. 1835. IT, p. 45 . O e no the. ra couciana Dos in Sweet El. Gard. II, $t$, 138. 0 . h um if us a Liadley in Bot Reg. $t, 1829$.

b. PACHydiun Fisch, et Meg. Petala inter calyeis lacinias iaserta. St a m ina minora petalis alteran tolo demisslus inserta, vix faucem superantia, majora caly. eis lacinias subaequantia, a a the ra e ellipticae, supra basim iosertae. $P I$ a c e $n t$ A apice breviter filiformi asper. mo. - Pachydf a m sect. Oe notherae Fischer et Meyer $l$. c. Oenothera deasiflora Lindley in Bot. Reg. $t, 1593$.

6119. Clarkia PURSH. Caly $\mathrm{x}$ tubo inferne subcylindrico, octocostato, cum ovario connato, breviter supra ovarium producto, limbi quadripartiti laeiniis aequalibus, interdum per parin cohaerentibns. Corolla e petala 4 , summo calycis tubo, annulo glanduloso quadrilobo marginato inserta, longe unguiculata, unguibus apice saepissime bidentatis, Jaminis rhombeis, indivisis r. pro- 
funde trilobis. Stamina 8 , cum petalis inserta, alterna isdem opposita breviora, antheris efoetis sterilia; filamenta filiformi-subulata, a $\mathbf{n} \mathbf{t h}$ e$\mathbf{r}$ a e introrsae, biloculares, oblongae, longitndinaliter dehiscentes. Ovarium inferum, tri-quadriloculare. Ovula in loculis plurima, angulo centrali inserta, nniseriata, adscendentia. Stylus filiformis; 8 t igm a tri-quadripartitum. C a p sula coriacea, tri-quadrilocularis, apice tri-quadrivalvis. Se mina plurima, nniseriata adscendentia, testa grannlosa, chalaza faciali lata, margine fimbriata. Embryonis exalbuminosi cotyledones carnosae, plano-convexae, radicula brevis, infera. - Herbae boreali-a merican a e, annuae v. biennes; foliis alternis, breve petiolatis, integerrimis $v$. dentatis, floribus axillaribus solitariis, sessilibus, uestivatione nutanțibus, petalis purpureis v. lilacinis.

Cla rki a Pursh Flor. Bor. Amer. I. 260. Nuttall Gen. 1. 249. DC. Prodr. III. 82. Meisuer Gen, 120. (86.) Lindley in Bot. Reg, n. 1100.

a. PHakostoma Spach. Petaloram Iamina Indivisa. - Phaeostoma Spach Suites d Buffon IV. 392. Nouv. Annal. Mus, IV. 394. (Bot, Reg t, 1575. 1981. Bot. Mag. t. 3592. Sweet Fl. Gard. II. t. 209.)

b. CLARKIA Spach. Petalor a m lamina profunde trilo. ba. - Clarki a Spach Suiles d Buffon IV. 394. $t$. 35. Nouv. Annal. Mus. IV, 395. (Pursh Op. cit, t, 11, Bot. Reg, t, 1100. Bot, Mag, t. 2918. Sweet Ft. Gard. II. t, 157.)

6120. Euelnaridium FISCH. et MEY. Calyx tubo inferne cylindrico, eum ovario connato, longe supra ovarium producto, filiformi, limbi quadripartiti laciniis aequalibus, apice saepissime cohaerentibus. Corolla e petala 4 , annulo obsoleto calyeis faucem marginanti inserta, ejusdem laciniis alterna, breviter unguicalata, lamina euneata, triloba. S t a m i n 4 , cum petalis inserta, iisdem alterna, sterilibus interjecis nullis; fil amenta filiformi-subnlata, alterna breviora, antherae introrsae, biloculares, obIongae, longitudinaliter debiscentes, Ovu Ia in loculis plurima, angulo centrali inserta, nniseriata. Siylas filiformis. Stigma quadrilobum, lobis obtusis, alternis multo brevioribus. C a psula coriacea, quadrilocularis, quadrivalvis. Semi n a plurima, adscendentim imbricata, plana, hine membranaceo-marginata. $\mathbf{E} \mathbf{m}$ b r y o...... Her ba californica, annua, adscendens, minutissime pubescens; foliis infimis oppositis, reliquis alternis, petiolatis, ovatis, integerrimis, floribus axillaribus solitariis, sessilibus, purpureo-roseis.

E uch aridium Fischer et Meyer Index sem.hort. Pe. tropolit. 1835, II, $\rho$. 36. Lindley in Bot. Reg. t, 1968. Hooker in Bot. Mag, t, 3589. Meisner Gen, 120. (86.)

61z1. Epilobimm $L I N N$. Cal y $x$ tuho inferne tetragono, cum ovario connato, brevissime supra ovarium producto, limbo quadripartito. C nrolla e petala 4, summo calycis tubo annolo glanduloso marginato inserta, ejusdem laciniis alterna, ovata v. obcordata. St a m in a 8 , cum petalis inserta, adscendentia v. declinata; fil a m e n$\mathbf{t}$ a filiformia, basi aequalia $v$, dilatata, a $\mathbf{t} \mathbf{h}$ e ra introrsae, bilocnlares, ellipticae v. orbiculatae, longitudinaliter dehiscentes. O va ri n m infernm, quadrileculare, $\mathrm{O}$ v u I a in leculis plurima, angulo centrali inserta, pperposita, adscendentia, anatropa. Stylus filiformis; stigma elavatum, quadripartitum. Caps u l a lineari tetragona, quadrilocularis, locnlicide quadrivalvis, placenta tetraquetra, angulis septante decidua. Semina plurima, adscendentia, testa crustacea, tenui, ad ehalazam apicalem longe comosa. Embryonis ex- albuminosi, orthotropi coty ledones planae, rad ieula brevis, umbilico proxima, infera. - Herbae $v$. rarius suffrutices, in temperatis totius or bis, imprimis tamen hemisphaerae borea. lis crescentes; foliis alternis $v$. oppositis, integerrimis $v$, undulato serrulatis, floribus axillaribus solitariis $v$. terminalibus spicatis, in spicis alternis, unibracteatis, corollis purpureis, roseis $v$. carneis.

E pilo b i um Lina. Gen, n, 421. Gärtner $1,157, t, 31$. Kunth in Humb. et Bonpl. Nov. gen, et sp. VI, 94. DC, Prodr. III 40. Meisuer Gen. 120. (86.) Cha maenerion Touruefort Inst. 157.

a. CHAMAENERION Tausch Hort, canal. 1. Flo res irregulares. Petala ovara. Genitalia deflexd. Filamen. ta basi dilatata. - Folia alterna. Ch a maenerfon Spach in Nouv. Annal, Mus, IV. 401. (Fior. dan, t. 289. 555. E. B, t. 1942. Bot, Mag, t, 76, Reichenb. Iconogr. t. 341, 348.)

b. LYSIMACHION Tausch Hort, canal, 1. FI o res regulares. Petala obcordata. Ge n itali a adscendentia,Folia inferiara opposita, superiora alterna. Ep filo. bi um Spach Op. cit. $t$. 403. (Vlur. dan. $t$. 322, 347 . $922,1029,1387$, E. B. $t .8381948,2000,2001$, Reichenb, Iconogr. t. 170. 180. 189. 190. 197_200. Venten. Cels. t. 92. Ruiz et Pavon Flor, peruv, t. 314. Bot. Mag. t. 2001. A. Richard Flor. Nov, Zeel, t. 36.)

c.? CR0SSoSTIGMA Spach. Flores regulares. Petala profunde biloba. Stami a a biseriata. Stigma oblique truncatum, concavum, demum explanatum, subpel. tatum, laciniato-fimbriatum. - Folia allerna. - C ros. sostigui Spach Op. cit. $I V$. 40s. E. minutum Liudley.

61:2. Zauselnmeria PRESL. Calyx tubo inferne lineari tetragono, cum ovario connato, sopra ovarium globoso inflato, longe producto, infundibuiformi, colorato, limbi quadripartiti laciniis lanceolatis, reflexis. Corollae petala 4 , summo ealycis tubo inserta, ejustem laciniis alterna et-aequilonga, obovata, bifida, ereeta. Stam in a 8 , cum petalis inserta, biseriata, subaequalia, inclusa; filam enta filiformia, an the rae introrsae, biloculares, lineares, incumbentes, longitudinaliter dehiscentes. O v a $\mathbf{r}$ i m inferum, quadriloculare. Ovala in loculis plurima, angulo centrali inserta, adscendentia. Sty I u s filiformis, exsertus; stigma capitatum, quadrilobum. C a p s l a lineari-tetragona, unilucularis, qnadrivalvis, coiumna centrali seminifera libera. Semina plurima, oblonga, sursom imbricata, ad chalazam apicalem longe papposa. E m bryo..... Suffrutices culifornici decumbentes, ramosissimi, incano-tomentosi; foliis oppositis, linearibus $v$. lineari-lanceolatis, integerrimis $v$. denticulatis, floribus in spicas racemiformes, bracteatas, erectas dispositis, sessilibus $v$ brevissime pedicellatis, coccineis.

Z в и $\$$ chne ria Presl in Belig. Haenk. IT, 28, t. 52. Melsner Gen. 120. (86.) Spaeh in Nouv. Annal. Mus. V. 405.

TERE III. 35. Caly $\mathrm{x}$ tubo supra ovarium producto v. eidem aequali. St a mina duplo petalorum numero. Fruetus capsularis, Joculicide dehiscens, polyspermus. Se min a alata.

B123. II ontinis LINN. F lo r e 8 abortu dioici. Caly x tubo cum ovario connato, supra ovarium haud producto, limbo supero, brevissime quadridentato. Curolla e petala 4, summo calycis tubo inserta, limbi laciniis alterna et multo majora, ovato-subrotunda. Stam in a 4, cam petalis inserta, iisdem alterna; filamenta filiformisubulata, an ther ae introrsae, bilocnlares, in- 
cambentes, Iongitudinaliter dehiseentes, $0 \mathrm{v}$ ari um inferum, biloculare, Ov u l a plurima, axi centrali tetragono utrinque biseriatim inserta, adscendentim imbricata. Stig ma crassum, bilobum. C a p s u l a coriaceo-lignosa, calycis limbo coronata, bilocularis, loculieide dehiscens. S e mina in Ioculis 6_8, dissepimenti axi tetragono biseriatim inserta, adscendentiı imbricata, compressa, testa membranacea, hine sursum in alam obtusam producta, endopleura carnosa, tumida. Em b r y o n is exalbuminosi, orthotropi radicula infera. - Frutex capensis, glaberrimus; foliis alternis, lanceolatis, acutis, integerrimis, crassiuscule coriaceis, glaucis, floribus femineis alaribus et terminalibus solitariis, mascelis in apice ramulorum axillaribus, subracemosis, albis.

Montinia Linn. Gen, n. 1432. Thunb. Nov, gen, 1.28. Smith Spicileg. 1. 15. Gärtner I. 170, $t$. 33. Lam. $t .808$. DC, Prodr, III. 35. Meisner Gen, 120. (86.)

6124. Hanya MOC, et SESS. C a 1 y x tubo inferne cum ovario connato, longe snpra ovarium producto, infondibuliformi-cylindrico, limbi quadripartiti laciniis oblongo-linearibus, acntis, dependentibus, intus coloratis. Coro 11 a e petala 4, summo calycis tubo inserta, ejusdem laciniis alterna et breviora, ovalia, patentissima. S ta m in a 8 , cum petalis inserta, exserta; fi 1 ame nt a filiformia, an the rae introrsae, biloculares, oblongae, incumbentes, longitudinaliter dehiscentes. O v ari a m inferum, quadriloculare? Ovala plurima, adscendentia, imbricata. Stylus filiformis; stigma globosum. Ca p 8 u l a lignosa, quadrilocularis, quadrivalvis. Semina plurima, compressa, adscendentim imbricata, superne in alam membranaceam producta. - Frutex mexic an $u s$; foliis alternis, petiolatis, ovatis, integerrimis, floribus mag$n i s$, in supremis foliorum axillis sessilibus, ex albo roseis, ramulis, foliis junioribus calycibusque pube tomentosa velutinis.

H a u y a Moçino et Sessé Flor, Mex. ex DC. Mem, IXI. 2. t. 1. Prodr. IIT. 36. Meisner Gen, 120, (86.)

TIRIEUS 1\%. FUCHSIEAE DC. Prodr. III. 36. C a ly x tubo supra ovarium producto. Stamina duplo petalorum numero. Fructus baccatus, polyspermus.

6125. Fuclasia PLUM. Flores hermaphroditi v, interdum aborto polygami. C a I y x tobo basi subgloboso v. ovato, cum uvario connato, supra ovarium constricto v. strumusn, longe prodncto, infundibuliformi v. cylindrico, colorato, limbo quadripartito. Corolla e petala 4 , snmmo calycis tubo inserta, ejusdem laciniis alterna snbaequilonga $\mathbf{v}$. breviora, convoluta, patentia $\mathbf{v}$, marginibus reflexa, integra $\mathbf{v}$. biloba, rarissime nulla. St a mina 8 , enm petalis inserta, uniseriata, exserta v. biseriata et inclusa; fil amenta filifurmia, anther a e introrsae, biloculares, incumbentes, longitudinaliter dehiscentes. Ovarium inferum, quadriluculare. Ovula in loculis plnrima, angulo centrali pluriseriatim inserta, anatropa. Stylus filiformis; stigma capitatum, quadrisnleum v, quadrilobum. B a ce a pulposa v. exsucea, quadrilocularis. Se mina in loculis plurima, obovato-oblonga, angulata v. rarins reniformia, testa membranacea, umbilico basilari, Emb r y o nis exalbuminosi, orthotropi recti v. homotrope arcuati cotyledones plano-convexae, obtusae, radic nla brevis, nmbilico proxima. - Suffrutices v. frutices, interdum arborescentes, in America temperata et calidiore, nec non in NovaZeelandia crescentes; foliis alternis, oppositis verticillatisque, integris, pedunculis axillaribus, unifloris, solitariis v. aggregatis, plerumque nutantibus, rarius terminalibus cymoso-paniculatis, floribus coccineis, rubicundis $v$, rarius roseis.

Fuehsia Plumier Gen, 14. Liun, Gen, n, 128. DC. Prodr. III. 36. Cambessed, in St. Hilaire Flor. Brasil. $t$. 272. Meisner Gen, 121. (87.) Q u el u si a Vandelll in Römer Script. IV. t. 7. f. 10, N a husia Schneevogt Io, n. 21. Dorvalia Commers, msc. Skinuera Forster Char. gen. 5. $t .9$.

a, BNCLIANDRA Zuce. FIores polygami, Petala sab anthesi plana v. marginibus reflexa, apice saepius tridentata. St a min a brevissima, aequilonga, alterua petalis opposita in tubum ealycis deflexa. B a c c a oligosperma.

E a cli a n d r a Zuecarini Novar. stirp. fasc, II, 335.

ce. Brebissonia Spach. Semina reniformia. Embry o curvatus. - Brebiss on ia Spach in Nouv. Annal, sc. nat. IIT. 175. Nouv. Annal. Mus. IV. 329. F. microphylla Kunth in Humb. et Bonpl. Nov. gen, et sp. $t .834$.

$\beta$. Lyciopsis $S_{p a c h}$. S emina angulata. Embryo rectus. - Ly eiopsis Spach in Nouv. Annal. so. nat. III. 176. Nouv, Annal. Mus, IV.329, F. th y $\mathrm{m}$ ifoli a Kunth Op. cit. t. 535. (Bot. Reg. t. 1480. N. S. $1838, t .66$.

b. FUCHSIA Zuce. Plores hermaphroditi. Peta la sub anthesi saepissime convoluta, interdum nulla. S $t$ a m I $n$ a plus miaus exserta, alteraa petalis opposita breviora, omina recta. B a ce a polysperma.

$\gamma$. Kiersehlegeria Spach. Pedicelli axillares, penduli. S e sa in a angulata. - Folia sparsa v. sub. verlicillata, petioli basi incrassata persistente, de. mum spinescente. - Kierschlegeria Spach in Nouv. Annal. sc. nat. III. 176. Nouv. Mem. Mus, IV. 330. (Andrewn Bot. Reposit. t. 120, Bot. Mag. t. 1024. Bot, Reg. t. 1048. Presi in Reliq. Haenk, $t$. s1.)

f. Fuchsia Spach. Pedicelti axillares penduli. Se. m i n a angulata. - Folia opposila, petioli basi haud spinescente. - Fue hs I a Spreh in Nouv. Annal, se. nat. IIT. 177. Nouv, Annal. Mus. IV. 330. (T h il co Feulllé Observ, III, 64, t, 49. N a hus i a Sehneevogt Io. $n, 21 . Q$ a el usi a Vandelfi $l$. c. Flor. Flum. $I V$. t. 6. (Lam, t, 282. f. 1. Rulz et Pavon Flor. Peruv. t. 329-32s, Duhan. Arbr. edit. 1. t. 13. Bot. Mag. t. 97. 2507. 3498. Bat. Reg, t. 847. 1059, 1556. 1805. N. 5. 1838, t, 1. St. Hilaire Flor. Brasil, $t, 134,135$. Hooker Jc, $t, 65$.

E. Sch ufia $S$ pach. Flores terminales, in paniculam cymosam, subtrichotomam dispositi, - Folia oppo. sita v. subverticillata. F. a rbores cen s Sims Bot. Mag. $t$. 2620. Bot. Reg. $t$. 943.

c. SKINNERA Forst, Calyeis tabus supra ovarium strumoso ventricosus. Peta la minima, squamaeformla. Ba e e a polysperua, seainibus miautissimis inordinate supra placeutam eonfertis. - Frutex Novae.Zeelandiae. - S k i n e r a Forst. l. c. A. Ricliard Flor, Nov, Zeel. 331. Spach in Nouv, Annal. se. nat. III. 178. Mem, Mus. IV. 330. Fa ehsi a exeorticata Linn.f. Lam,t, 282. f. 2. Liadl. in Bot. Reg. $t, 857$. Link et Otto $16 b i l d, t, 46$.

TRIIBUS 『. LOPEZIEAE Spach in Nouv, Annal. sc. nat. IV. 162. Caly $\mathrm{x}$ tubo supra ovarium producto. Petala $4 \mathrm{v}$. interdum nulla. S t a mina 2 v. 1 . Fen etus capsularis, polyspermus.

6126. Semeiandra $H O O K$, et $A R N$, CaI y $\times$ tubo basi subgloboso, cum ovario connato, supra ovarium longe producto, subineurvo-infundibuliformi, colorato, limbi quadripartiti laciniis elongatolinearibus, propendentibns, postica paullo breviore. Corollae petala 4, summo calycis tubo, dun inter laciniam posticam et laterales inserta, doo ad basim laciniae antieae subadnata, angostissime linearia, 
calyeis limbo breviora. Stamina 2 , cum stylo in columnam calycis tubo postice adnatam, longe exsertam coalita, apice libera, filiformia, posticum anantherum, superne in laciniam petaloideam expansum, antici anthera bilocularis, ohlonga, incunbens, loculis parallelis, longitudinaliter dehiscentibus. Ova ri u m inferum, quadriloculare. Ovula plurima, pluriseriata. Stylus cum stami. nibus connatus, apice libero subulatus; st $\mathrm{ig} \mathrm{m}$ a subglobosum. Ca psula globosa, quadrilocula. ris, loeulicide quadrivalvis, colomna tetraptera persistenti, angulis septante, faciebus seminifera. Semina plurima, pluriseriata, minuta, muricula ta...... Frutex mexicanus, pubescens; foliis oppositis v. alternis, ovatis v, oblongis, utrinque pubescentibus, basi in petiolum angustatis, subintegerrimis, racemis terminalibus foliosis, pedicellis graci libus, folium florale superantibus, fructiferis deflexis, sub fructu incurvis, floribus sanguineis, sesquipolticaribus.

Semeiandra Hooker et Arnott ad Beechey 291,t.59.

612\%. Hiesenbaelhia PRESL. Calyx tube basi ovato, cum ovario connato. Ionge supra ovarinin producto, colorato, limbi quadripartiti laciniis lanceolatis, postiea majore. Corolla nulla Stamen unicum, $8 \mathrm{nmmo}$ calyvis tubo insertum, ejusdem laciniae anticae oppositum, breviter exrertum ; filamen $t \mathbf{n m}$ complanato - subulatom anthera introrsa, bilocularis. linearis, dorso inserta, longitudinaliter dehiscens. Ovarin $\mathbf{m}$ inferum, quadriloculare. Ovula in loculis plurima, pendula. St ylu s filifurmis, basi hine tubu calycis adnatus, breviter exsertus; stigma peltato-eapitatum. C a psnla ohlonga, quadrilocularis, apice loculieide quadrivalvis, valvis medio septa placentam centralem retinentia gerentibus. Semina plurima, pendula, ovalia, angulata, rugosa. $\mathrm{E}$ mbryonis exalbuminosi, orthotropi cotyled ones foliaceae, planae, radic ula conica, obtusa, supera. - Herba mexicana, ramosa, glandulosopubescens; foliis alternis, petiolatis, lanceolatis, acuminatis, inaequaliter serratis, racemis terminalibus, simplicibus, foliosis, pedicellis gracilibus, folio florali brevioribus.

Riese aba $\mathrm{e}$ hi a Presl in Reliq. Haenk. Ir. 36 t. 54.

6128. Ilplamden $H O O K$, et $A R N, \mathrm{C}$ aly $x$ tubo basi subglobuso, cum ovario connato, breviter supra ovarium producto, eoLorato, limbi quadripartiti laciniis lanceolatis, tubo longioribus, erectis, duabus posticis saepe inter se cohaerentibns, Co rull a e petala 4 , summo calycis tubo inserta, ejusdem laciniis alterna et multo breviora, breviter unguieulata, obovato rotundata, postieum majus. St a mina 2, cum petalis inserta, calycis lacinis anticis opposita et multo breviora; filamenta filiformia, libera, antherae introrsae, biloculares, oblongae, incumbentes, loculis parallelis, longitudinaliter dehiscentihus, Ovarin m inferum, quadrilneulare. Ov ula in Ineulis solitaria...... St y lus filiformis, inclusus; 8 tigma capitatum. Ca psul a globusa, quadrilnenlaris v. alortn trilocolaris, loculieide quadrivalvis, columna tetraptera persist"nte, angulis septante, faciebus seminifera. Semina in luculis solitaria, ala brevi warginata .....-Frutex mexicanus, pubescens, ramosus; foliis oppositis, subsessilibus, oblongo-lanceolatis, utrinque pubescentibus, subintegerrimis, floribus longe pedicellatis, corymboso-racemosis, terminalibus, petalis purpureis.

Diptandra Hooker et Arnoul ad Beechey 291, 2. 60.
6129. Lopezia $C A V$. Caly x tubo subgloboso, eum ovario connato, limbi superi, quadripartiti lasiniis culoratis, anguste lanceolatis, antica a tribus posticis subsecundis remota. Corol. Ia e petala 4 , summo calycis tubo inserta, ejus. dem laciniis alterna, longe unguieulata, duo pos. tica unguibus teretibus apice glandulosa, $\mathrm{cum}$ lamina anguste elliptica articulatis, anticorum un. guibus planis eum lamina ovata v. suborbiculata continuis. St a m in a $2, \mathbf{c u m}$ petalis inserta, ealycis laciniae anticae et posticae opposita, anticum sterile, apice in laminam petaloideam, oppositum fertile et stylum primum amplectentem expansum, demum elastice resiliens, postici filamentum complanato-subulatum, basi stylum amplertens, a $n$ he ra introrsa, bilocularis, ovata v. oblonga, Jorulis parallelis, lengitudinaliter dehiscentihus. Ovari u m infermm, quadriloculare. Ovula in loculis plurima, pluriseriata, pendula, anatropa. Stylus filiformis, brevis; stigma capitatum. C a psula globosa, quadrilocularis, loculieide quadrivalvis, columna tetraptera, persistente, angulis septante, faciebus seminifera. Semina plurima, pluriseriata, minima ......-Herbae erectae $v$ suffrulices m ex $i$ ca $n i$; foliis alternis $v$, inferioribus interdum oppositis, petiolatis, dentatis, racemis caulem ramosque terminantibus foliosis, multifloris, pedicellis gracilibus folio florali longioribus, floribus purpureis $v$, roseis.

L opezia Cavanill. Ic. I. 12, \& 18. Jussien in Mem. Mus, II, 317. t. 30. f. 4. Bot. Mag. t. 254. Jacq. Collect.

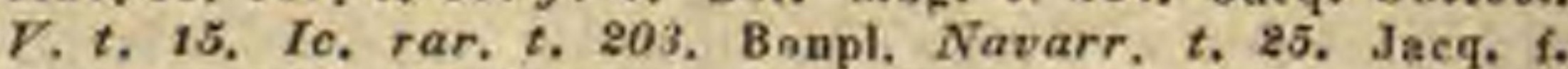
Eclog. t. 109. 110. Sehrank Hort. Monac, $t, 20$. N. A. N. C. IX. 90. Kunth in Humb. et Bonpl. Nov. gen. et sp. VI, 95. DC. Prodr. III. 62. Meisner Gen. 121. (ס7.) P is a u r a Bouato Monograph. 1793, c. ic.

THEIIUS VI. CIRCAEACEAE. Cal y x tubo ultra ovarium haud producto, limbo bilobo. Petala 2. Stamina 2. Fructus bilocularis, indehiscens. Semina in loculis solitaria.

6130. Circaea TOURNEF. Caly $\mathrm{x}$ tubo obovato, cum ovario connato, supra ovarium constricto, brevissime producto, fimbi bipartiti laciniis aequalibus, acutis. Corolla e petala 2, disco summun calycis tubum replenti inserta, limbi laciniis alterna, obcordato.bifida. $\mathrm{S} t \mathrm{a} \mathrm{m}$ in a $2, \mathrm{cum}$ petalis inserta, iisdem alterna; filamenta filiformia, antherac introrsae, biluculares, sub. rotundo-didymae, dorso insertae, longitudinaliter dehiscentes. $O$ vari $\mathrm{m}$ inferum, bilocnlare. Ovula in loculis solitaria, dissepimento infra apicem appensa. Stylus filiformis; $8 \mathrm{tig} \mathrm{ma}$ incrassatum, emarginatum. Fructus pyriformis, pilis uncinatis hispilus, subcoriaceus, bilocularis, indehiscens. Semina in loculis solitaria, dorso convexa, facie plana, supra medium umbilicata, testa chartacea. E m b r y un is exalbuminosi, recti, umbilieo paralleli cotyle dones oblongae. obtnsae, radien la infera, - Herbae perennes, in temperatis et frigiliusculis hemisphaerae borealis a $m p$ higene, erectae $v$, e basi repente adscendentes; foliis oppositis, petiolatis, ovatis v. basi cordatis, denticulatis, membranaceis, pubescentibus v. laevibus, racemis terminalibus et lateralibus simplicibus, strictis, floribus albis, pedicellis fructiferis deflexis.

Circa e a Tournefort Inst. 155. Lín. Gen, n. 24. Lam. t. 16. Gïrtner 1 . 114. t. 24 Schkuhe $t$, 2. Flor. dan. t. 210. E. B, $t, 1056$. 1057. Curtis Flor. Lond, $I t, t, 3$, DC. Prodr. III, 63, Meisuer Gen, 162, (87.) Kunih Flor, Berolin 1, 168. 
TRIBUS VII. GAUREAE, C a ly $\mathrm{x}$ tubo supra ovarium producto. Sta min a duplo petalorum numero. Fructus nucamentaceus, mono-tetraspermus.

6131. Gaura LINN. Cal y $x$ tubo inferne tri-tetragono, cum ovario connato, longe supra ovarinm producto, recto v. saepius deflexo, limbo quadripartito aut rarius tripartito. Co roll a e petala 4 v. rarius 3 , annulo summom calycis tuhnm marginanti inserta, ejusdem laciniis alterna, a equalia, saepissime ungniculata, snbsceunda, rarius sessilia, cruciatim patentia. S t a m in a 8 , v. rarius 6 , cum petalis inserta, uniseriata, alterna iisdem op posita breviora; fil amenta filiformia, saepissime declinata, a $\mathbf{n}$ th e ra e introrsae, biloculares, lineares v. ellipticae, ins:nmbentes, longitndinaliterdehiscentes. Ova ri u $\mathrm{m}$ inferum, quallriloculare, v, rarius triloculare. $0 \mathrm{v} \mathrm{u} \mathrm{la} \mathrm{in} \mathrm{loculis} \mathrm{solitaria,} \mathrm{v.} \mathrm{interdum} \mathrm{in} \mathrm{al-}$ ternis gemina, anguio centrali paullo infra apicem appensa, anatropa. Stylus filiformis, declinatus; $8 t$ igmat a $3 \mathrm{v}$. 4, linearia v, brevia, obtusa. N nx lignosa, tri-tetraquetra $\mathbf{v}$, tetraptera, apice truncata $\mathbf{v}$. acuta, dissepimentis evanidis unilocularis, mono-tetrasperma. Se mina oblonga v. obovata, testa membranacea. Embryon is exalbuminosi, orthotropi cotyledones crassiusculae, exterior interiorem introrsmm convolutam involvens, $r$ ad $i$ en la brevis, conica, vaga. - Herbae v, suffeutices, in America septemtrionalicalidiore cres. centes; foliis radicalibus rosulatis, in petiolum trigonum angustatis, nonnunquam lyratis, caulinis alternis, integerrimis, denticulatis v, sinuatis, floribus terminalibus spicatis, sessilibus, bracteatis, albis, roseis, rarius flavis, post anthesim rubescentibus.

G a u ra Linn. Gen, $n, 470$, Gärtuer $I T$. 205. Kuath in Humb, et Bonpl. Nov, gen, et sp. VI. 92. DC. Prodr. 1H . 44. Meisn. Gen, 121. (86.)

a. GAURIDIUM Spach. Flores tetrameri. Tubi calycini pars libera sub authesi erecta. Co rolla e petala uugue lato, brevissimo, cruciatim patentla. S ta m $\mathrm{i}$ in a subde clinata. $s t \mathrm{igmata}$ filiformia. O v a ri u m quadriloculare, loenlis uuiovulatis. Nux ovali. v. oblougo-conica, estipitata, tetragoua, quadricostara, transversim rogo sa. apice attenuata et rruneata, subtetrasperma. Gauridi u m Spach Suiles d Buffon IV. 379. Nouv. Annal, se. nat. IV. 374. (Cavall. Io, $t$ 285, Bot. Mag. t. 388. Kunth in IIumb. et Bonpl. Nov. gen. et sp t. 529.)

b. GAURA Spach. Flores tritetrameri. Tubi calyciai pars lihera sub antbesi porreeta v. deflexa. Corollae petala ungue angitsto, subsecuida. St a mi u a decli. nata. Stigua ta brevia, crassa. Ovaria m quadrilo. culare, Joculis ualovulatis v, alterais biovulatis. N ux tri-tetraquetra v, eristato-ietraptera, estipitata, apice truacata, mono-tetrasperma. - G a ura Spach Suites d. Buffon IV. 38t. Nouv. Annal. Mus. IV. 375. (Gärtner $t$. 127. Cav. Ic. t. 396. f. 1. Bot. Mag. $t .399)$

c. SCHIZOCARXA Spach. Plo res tetrameri. Tubi ealy. cini pars libera sab anthesi declinata. Corollae pe tala ungue augustato, subsecuida. S $t$ a m i n a declinata. Stigmata beevia, crassa. 0 var l a a quadríocalare. loculis uaiovulatis v. alternis biovulatis. N a $\times$ laesis, a med a in stipitem crassissimuts, obconicum, obsolete oetogonum attenuata, superne tetraquetra v. tetragona, pyramidata, quadrisulea, apice denua in deftes qua tuor acutos fissa, mono-tetrasperma. - Schizocary a Spach in Nouv. Ammal. se. nat. IV. 381.

613\%. Stenosiphon SPACH. C a $1 \mathrm{y} x$ tubo inferne ovali, plano ennvexo, cum ovario connato, Ionge snpra ovarium producto, filiformi, limbo quadripartitu. Coroll a e petala 4, summo calyeis tubo inserta, ejusdem laciniis alterna, nnguieulata, duo postica majora. Sta $\mathrm{m}$ in a 8 , cum petalis inserta, uniseriata, alterna iisdem opposita longiora; fil amenta filiformia, complanata, declinata, antherae introrsae, biloculares, oblongae, incumbentes, longitudinaliter dehiscentes. Ovariam inferum, uniloculare. Ovula 4 , ex apice cavitatis pendula, anatropa. Stylus filiformis, apice incrassatus; st ig mat a 4 , brevia, obtusa. N ux coriacea, ovata, truncata, compressiuscula, submarginata, utrinque tricostata, dorso convexa, costa media crassiore, facie planiuscnla, costis aequalibus, unilocularis, abortu monosperma. Semen ovatum ...... - Herba $t$ ex $a n a$, suffruticosa, ramosa; ramis virgatis, foliosis, foliis alternis, sessilibus, lineari lanceolatis, integerrimis, uninerviis, rigidis, floribus dense spicatis, unibracteatis, spicis terminulibus, elongatis, floribus albis.

Steuosiph on Spach in Nouv. Annal. Mus, IV. 38s.

\section{GENERA DUBIA.}

6133. Gongylocarpus SCHIEDE et DEPPE. Flos axillaris, sessilis, Caly x tubo inferne cum ovario connato, com ramo et petiolo conferraminato, longe supra ovarinm producto, libero, gracili, faucis annulo glandaloso, limbi patentis, quadripartiti laciniis linearibus, apice eucullatis, Corolla e petala 4, summo ealycis tubo inserta, ejusdem laciniis alterna et breviora, obovato-cuneata. Stamina 8 , cum petalis inserta, calyeis lacinias aequantia; fil am ent a filiformisubulata, a n th erae introrsae, biloculares, ovatae, longitudinaliter dehiscentes, Ovarium inferum, biloculare...... S ty In s filiformis, brevis; st igma capitatum. Drupa turbinata, cum ramo ulterins florifero, illine cum petiolo folii. fero concreta, putamine lignoso, biloculari. S e m i$\mathrm{na}$ in loculis solitaria, inversa. E m bryon is exalbuminosi, orthotropi cotyledones planae, radicula exserta, supera. - Hcrba mexicana, annua, glabra; caule erecto, laxa, rubescente, ramis axillaribus brevibus, foliis alternis, ovato-lanceolatis, acuminatis, acutis, basi in petiolum angustatis, remote urgute denticulatis, remote et breviter ciliatis, floribus in axillis foliorum rameorum solita. riis, fructibus turbinatis, difformibus, ad similitudinem monilis sese exeipientibus.

Gongylocarpus Chum. et Schlecht. in Limnaea $V$. 5\%7. Meisuer Gen, 121. (86.)

OBServatio. S pho u dy I a n t a Presl Reliq. Haenk, IT. 35. $t$. 53. eat iguotae mihi plautae rauus, ramulis apice foliorum ruilimesto instructis, innain Uredine tnmeutibus, et oyarium inferum, calycis limbo coronatum meatieatibus. Ejus. aodi degenerationes, miro formae perfeetioris ludibrio botanicum decipientes, ia Cissorum ramis saepissime vidi.

\section{Ordo CCLXVI. Halorageae.}

ONAGRARUM genera Jussieu Gen. 318. Annal. Itus. III. 315. HALORAGEAE R. Brown in Flinders Voy. II 549. DC. Prodr. IIL. 65. Bartling Ord. nat. 314. Liadley Introduct, edit, II, p. 37. HYGROBIAE Richard Analys. fr. 34. CERCODIACEAE Jussieu in Diet, sc. nat, VTI. 441.

Herbae aquaticae v. suppretices terrestres. Folia opposita v. verticillata, in paucioribus alterna, simplicia, integerrima v. dentata, in aquaticis submersa plerumque pectinato-pinnatisecta, emersa incisa v, integra. Stipulae nullae.

Flores hermaphroditi v, abortu unisexua- 
Jes, monoici, regulares, inconspicui, saepius incompleti, in axillis foliorum sessiles, solitarii v. glomerati, saepe basi bibracteolati, interdum foliis floralibus abbreviatis verticillato spicati, rarius pedicellati, interdum paniculati.

Calyx tubo tereti, angulato v. eostato, cum ovario connato, limbo superu, saepissime quadrifido v. quadripartito, rarius trifido, interdum bifido, nonnunquam truncato, integerrimo, fere obsoleto.

Corosca in quibusdam nulla, in plerisque petala summo calycis tubo inserta, ejusdem laciniis numero aequalia et alterna, plerumque longiora, subconcava, aestivatione valvata $v$. imbricata, sub anthesi patentia, decidua.

Stauina cum petalis inserta, nunc calycis laciniis numero aequalia et opposita, nune dupla, v. interdum duplo numero quadrante pauciora, interdum cum calycis limbo obsoleto unicum. Filamenta filiformia. Antherae introrsae, biloculares, oblongae v. ovatae, basi v. dorso insertae, longitudinaliter dehiscentes.

Ovarium inferum, saepissime loculis tot quot laciniae calycis, bi-tri-quadriloculare, locuis uniovulatis, rarius uniloculare, quadriovulatum, v. cum calycis limbo truncato et stamine unico uniovulatum. Ovula ex apice loculorum pendula, anatropa. Styli tot quot ovula, saepius brevissimi v. subnulli. Stig $\mathrm{m}$ a ta villosa v. penicillata.

Fructus nucamentaceus, saepissime calycis límbo coronatus, bi-tri-quadrilocularis, v. typice aut interdum abortu unilocularis.

Semina in loculis solitaria, inversa, testa membranacea, rhaphe longitudinali et chalaza apicali manifestis. Albumen carnosum, plus minus copiosum, testae adhaerens.

Емвкуо in axi albuminis orthotropus, ejusdem dimidio longior aut rarissime brevior, cylindricus. Cotyledones breves, obtusae. Radicula cotyledonibus longior, umbilico proxima, supera.

Halorageae aquaticae per totum orbem diffusae, majori numero in temperatis et frigidiusculis hemisphaerae borealis generantur, terrestres fruticosae in Asia tropica et subtropica rarae, frequentissime in Nova-Hollandia vivunt.

Ordinis Oenothereis arctissime affinis distinctio in ovulorum pendulorum numero, fructus indole, et albuminis, etsi parci, praesentia posita, habitu imprimis diverso corroboratur. Trapa inter utrumque ordinem media.

6134. Hippuris LINN. F lo re a hermaphroditi v. abortu unisexuales, Cal y x tubo ovato-subgloboso, tereti, cum ovario connato, limbo supero, brevissimo, integerrimo. Stamen unieum, calycis limbo insertum; fila m entum eraste filiforme, anthera introrsa, bilocularis, cor- data, dorso inserta, loculis parallelis, ante anthe. sim longitudinaliter conniventibus, stylum am. plectentibus, rima longitudinali apertis. Ova ri u inferum, uniloculare, ovulum unienm, ex apice loculi pendulum, anatropum. Styl u s sobu. latus, hine papillosus. Drupa carnosa, calycis limbo coronata, putamine lignoso, monospermo. Seme $\mathbf{n}$ inversum. Embryo albuminis strato tenuissimo inclusus, orthotropus, cylindricus, $c$ o. tyledonibus brevissimis, radicula obtusa, supera. - Herbae in inundatis temperatis et frigidiusculis hemispha era borealis obviae; caule simplicissimo, erecto, folits quaternis, senis-duodenisque, verticillatis, linearibus, acutis, integerrimis, inferioribus saepe longioribus, floribus axillaribus solitariis, sessilibus, abortu interdum unisexualibus.

H ip puris Linn. Gen, n. 11. Retz Observ, III, 7. t, 1. Lam. $t .5$. Hellenius Dissert. de Hippuride, Aboae. 1786. 4. et in Usteri Delect. I. 10 t. 1. Gartuer II. 24. t. 84 . Jussieu in Annal. Mus. III. 323. $t, 30 . f .3$. Flor. dan, $t, 87,1261 . \mathrm{k}$. B. t. 763. Reicient. Iconogr. $t, 86$. DC, Prodr. III. 71. Nees jun. Gen. plant. II. fasc. 8. t. 14. Meisner Gen, 129, (87.) L im n ope uce Vaillant in Act. Academ. Paris, 1719,t, 1. f. 3. Pinastella Dillen. Nov, gen. 168, (De ovulo efr. Schleiden in $N, A, N, C . X I X .49, t$. $5 ., f .66-69$.

6135. Myriophyllmm VAILL, FIores monoici. Calyx tubo tetragono v. teretiusculo, eum ovario cunnato, limbo supero, quadripartito. Co rolla petala 4, summo calycis tubo inserta, ejusdem laciniis alterna, in floribus masculis longiora, in femineis minima, reflexa, v, interdum nulla, Stam in a 8 , rarius 6 v. 4 , cum petalis inserta, in floribus femineis nulla; fil a m en t a filiformia, a n the ra e introrsae, biloculares, linearitetragonae v. subrotundae, basi insertae, longitudinaliter dehiscentes. Ovariu m inferum, in floribus masculis efoetum, in femineis quadriloculare. Ovula in loculis solitaria, ex apice anguli centralis pendula, anatropa. Styli 4 , brevissimi; stigmata crassa, villosa. Fruetns tetracocens v. abortu dicoccus, coccis nueamentaceis, stylo superatis, indehiscentibus, monospermis. S e m en inversum, testa membranacea. $\mathbf{E} \mathbf{m b}$ r yo in axi albuminis carnosi, parei orthotropus, cylindricus, coty ledonibus brevissimis, radi cula tereti, supera. - Herbae in fluminibus et aquis quietis o mnium fere climatum obviae, in temperatis hemisphaerae borealis multo copiosiores, natantes, sub anthesi emergentes; foliis oppositis v. verticillatis, pectinato-pinnatisectis, floribus axillaribus solitarits, sessilibus, basi bibracteolatis, interdum foliis floralibus abortivis v. rudimentariis verticillato-spicatis, superioribus masculis, inferioribus femineis.

M y rioph y 11 u m Valliant. Act. Academ, Paris, 1719. b. 2. f. 3. Liun, Gen, n. 1066, Sehkubr t. 296. Gärtner I. 331. L. 68. Jussieu in Annal. Mus. III. 321, f. 8. B. B. t. 83, 218, FI. dan, t, 68t, 1046. Labillard. Nov, Holl, t. 220. DC. Prodr. III, 68. Nees jun. Gen, plant, II. fase. 8. $t .13$. Meisaer Gen. 128. (87.) Pe n ta pteroph y llum Dillen. Nov. Gen, 7. Pentapteris Haller Helv, I, 45t, Bny. d ría Flor. Flum, $I$, t. 150. ? H y las Bigelow msc.

6138. Serpicula LINN. F lores monoici. Cal y x tubu cum ovario connato, octonervi, limbo supero, quadrifido, decidno. Corollae petala 4 , summo calyeis tubo inserta, ejusdem laciniis alterna et majora. Sta mina 4 , cum petalis inserta, iisdem alterna, in floribus femineis nulla; fil a m e nta filiformia, anther a e introrsae, biloculares, oblongae, dorso affixae, longitudinaliter dehiscentes. Ov a ri um inferum, uniloculare, in floribus masculis efoetum. Ovula 4 , ex apice cavitatis pendula, anatropa. Stigma ta 4 , sessilia 
mamillaeformia. Nux globosa, octocostata, stigmatibus persistentibus coronata, unilocnlaris, abortu monosperma. S e $\mathbf{m}$ e $\mathbf{n}$ inversum, testa membranacea. $\mathrm{Emb}$ ryo in axi albuminis carnosi orthotropus; cotyledonibus brevissimis, radicula tereti, supera. - Herbae in paludosis regionum tropicarum et subtropicarum obviae, repentes, ramosae, glabrae v, scabriusculae; foliis alternis $v$. oppositis, integerrimis $v$. denticulatis, fioribus axillaribus, masculis longe pedicellatis, femineis et hermaphroditis subsessilibus, bibracteolatis.

Se r pi cul a Linn. Mant, 16. Lam. $t$, 758, König Annal. of Bot, I. S44. DC. Prodr. III. 65. Cambessed, in St. Hi. laire Flor. Brasil. II. 250. Meisa. Gen, 122. (87.) L a ure m be rg i a Bergius Cap. 350 .

613\%. Proserpinaca LINN. Calyx tubo cum ovario connato, tri-tetraquetro, limbi superi,|tri-quadripartiti laciniis erectis, cum tubi angulis alternantibus. Corolla nulla. Stamin a 3 v. 4, summo calycis tubo inserta, ejusdem laciniis opposita et breviora; filamenta brevissima, a $\mathrm{t}_{\mathrm{he}}$ a introrsae, biloculares, oblongae, erectae, longitudinaliter dehiscentes. Ova ri $\mathbf{m}$ inferum, tri-quadriloculare. Ovula in loculis 80litaria, ex apice cavitatis pendula, anatropa. Stigmata 3 v. 4 , sessilia, acuta. Drupa exsucca, subspongiosa, tri tetraptera, calycis limbo coronata, putamine osseo, triloculari. Sem in a in $/ 0$ culis solitaria, inversa, cylindrica. Embryo in axi albuminis earnosi orthotropus, eylindricas; cotyledonibus brevissimis, radicula elongata, supera. - Herbae aquaticae, bor eali-americanae; foliis oppositis, pectinato-pinnatifidis, vel superioribus emersis serratis, floribus axillaribus sessilibus, glomeratis.

Proserpi n a ca Linn. Gen, n, 102. Lam, t. so. Jussieu in Annal. Mrus. III. 320, t, 30. f. 1. DC. Prodr. III. 67. excl. sect. 2. Meisner Gen. 122. (87.) Trixis Mitehell in Ephem. N. C. 1748, n, 23, c. io. Gärtner 1. 115. $t, 24$. ? Ptil o p b y II u m Nuttall Gen, II, 211. Pu rshia Rafinesq. in New-York Medic. Reposit. II. Hexad, V. 350, Journ. phys. LXXXIX, 25\%.

6138. Thaloragis FORST. F lores hermaphroditi. Caly $x$ tubo tereti, quadri-octocostato v, tetragono, cum ovario connato, limbi superi, quadripartiti laciniis erectis, acutis. Corolla petala 4, summo calycis tubo inserta, ejusdem laciniis alterna et longiora, encullato-concava, Stamina 8, cum petalis inserta; filamenta filiformia, brevia, an therae longae, lineari-tetragonae, basi insertae, longitudinaliter dehiscentes. Ovari um inferum, bi-quadriloculare. Ov u$1 \mathrm{a}$ in loculis solitaria, ex apice anguli centralis pendula, anatropa. Styli 4 , breves v. interdum subnulli; $8 \mathrm{t}$ i g $\mathrm{m}$ a $\mathrm{t}$ a penicillato-pubescentia. Dru p a exsucea, costata v, angulata, calycis limbo coronata, bi-quadrilocularis, loculis monospermis, v. abortu unilocularis, monosperma. Se min a inversa, cylindrica, testa membranacea. E m bry o in axi albuminis carnosi orthotropus, cylindricus; cotyledonibus brevissimis, radienla elongata, snpera. - Herbae v. suffrutices terrestres, in Asia tropica, frequentius in Nova-Hollandia et Nova-Z e landia crescentes; foliis inferioribus oppositis, superioribus saepe allernis, integerrimis, dentatis $v$. incisis, floribus in foliorum bracteaeformium axillis sessilibus $v$. brevissime pedunculatis, solitariis $v$. aggregatis, spicas v, racemos terminales, interdum paniculatos formantibus.

Haloragis Porster Char. gen. $t$. 3t. Heritier Stirp. I. 82. Labillard Nov, Holl. t, 128, 129. Jacq. IC. rar. T. t, 69. ndlicber Alakt, t. 15. Brongniart ad Duperrey t. 68-70. Meisuer Gen, 122. (87.) Cercodia Murray in Comment. Götting. 1780, III, 3, t, 1. Gärtuer I. 164 35. f. b. A. R Ichard Flor. Nov. Zeel. 324. C e reodea Lam. $t .319$. Go nocarpus Thunb. Flor. Japon. 5, 2,15 Gärtn, f. 2so. $t$. 22s. $f$. 8 , Go n a to c a r p us Willdenow $s p e c$. $I$. 690. Gonjocarpus Köuig in Annal. of Bot. $T$. 546.

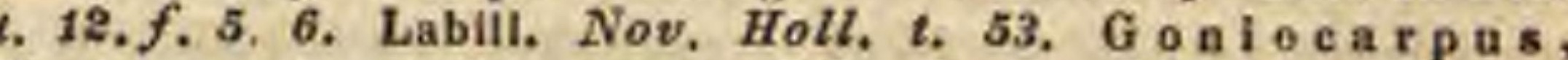
Haloragis et Cercodia DC. Prodr. III. 66, 67.

6139. Ioudonia $L I N D L$. C a l y $\mathrm{x}$ tubo tetraptero, cum ovario connato, inter alas ruguloso, alis in pedicellum subdecurrentibus, cum limbi superi, quadripartiti lobis alternantibus. Corolla e petala 4, summo calycis tubo inserta, ejusdem laciniis alterna et longiora, cucullato-concava. Stamina 8 , cum petalis inserta; fil amenta filiformia, brevia, anther a longae, lineari-tetragonae, biloculares, longitudinaliter dehiscentes. Ov a $\mathbf{r}$ i $\mathbf{m}$ inferum, uniloculare. Ovula 2 v. 4 , ex apice loculi circa columnam tenuissime filiformem, pendula, anatropa. Styl $\mathbf{n}_{8}$ quadripartitus, lobis teretibus, brevibus; stig matibus subelavatis, oblique truncatis, discoloribus. D rup a baccata, clavato-tetragona, calyeis limbo, staminum petalorumque rudimentis nee non stylis superata, sarcocarpio fibroso-spongioso, endocarpin cartilagineo, monospermo. S em en inversum. E $m$ b r yo in apice albuminis carnosi brevis, seminis trientem aequans, orthotropns; cotyledonibus brevissimis, obtusis, radicula cylindrica, supera. - Herba Novae-Hollandiae austrooccidentalis, suffruticosa, glaberrima; caule erecto, tereti, sesquipedali, glauco v. sordide violaceo, virescente basi foliato, superne saepius aphyllo, foliis alternis, linearibus, integerrimis, coriaceis, panicula terminali corymbosa, bracteis ad basim ramorum foliaceis, superioribus petaloideis, flores aureos aequantibus, deciduis, drupis Pisi mole, clavato-tetrapteris, viridi-glaucis, sarcocarpii crassi fibris ab endocarpii pariete externoad peripheriam radiantibus, reticulo spongioso, tenaci combinatis.

L o u d o n i a Lindley $\mathcal{S}_{\text {wan-River }} \mathrm{XLIT}$. XLIII. o, ic. G1l s e hroe a r y on Endlicher in Annal. Wiener Mus. $I$. 209. Nov. Stirp. Mus. Vindob. Dec, n, 88 .

OBSERVATio. Mejonetes, genus a el. R. Brown in Flinders Voyage $I I .850$, commemoratum, dimidiae fructificationis partium suppressione ab Haloragi distinctum, non novi.

\section{* TRAPEAE.}

B140. Trapa LINN. Calyx tubo cūm ovarii basi connato, limbo semisupero, quadripartito, aestivatione valvato, demum patente, persistente, lobis spinescentibus. Co rolla e petala 4, sub disco annulari carnoso, ovarii verticem exsertum eingente, undulato-plicato inserta, calycis laciniis alterna, aestivatione imbricata, marginibus plicato-undulata, sub anthesi patentia, decidua. S ta mina 4, cum petalis inserta, iisdem alterna et breviora; filamenta filiformi-subulata, anthe ra e introrsae, biloculares, ovatae, medio dorso insertae, longitudinaliter dehiscentes, Ovari u m semiinferum, biloculare. Ovala in loculis solitaria, dissepimento panllo infra apicem appensa, anatropa. Stylus cylindricus, simplex; 8 t i g m a depresso-hemisphaerieum, obtusam. Fructus turbinatus, nucamentaceus, coriaceosubcorneus, calycis limbo acuto spinescente biquadrispinosus, apice exserto disco indnrato vestitus, vertice umbilicatus, abortu unilocularis, monospermus. S e m en inversum, testa membranacea, adnata, in parte superiore spongioso-inerassata, E m- 
bryonis exalbuminosi, orthotropi cotyled on es valde inaequales, altera maxima, crassissima, farinosa, altera minima squamulaeformis, paullo demissius inserta, radicula levissime incurva, supera, sub germinatione fructus verticem perforans, plumula minutissima, intra cotyledonem minorem latens. - Herbae natantes, in lacubus $E u$ ropae mediae rarue, in Asia tropica et centrali frequentius obviae; foliis exstipulatis, submersis oppositis, pinnatisectis, radiciformibus, superioribus alternis, emersis in rosulam confertis, petiolatis, rhombeis, denticulatis, petiolis per anthesim medio ventricosis, cavis, floribus axillaribus solitariis, breve pedunculatis, semine eduli

Trapa Lian. Gen. n, 157, Lam. t. 73. Schkohr $t .25$. Gärtner I. 127, $t, 26$. Roxburgh Plant. Corom, t. 234. Braaw Ic. chin. t. 22, DC. Prodr. III, 64. Nees jua. Gen, plant. II. t. E. T ribuloides Touruefort Inst. 43t. Sh riag a ta Jones Asiat. Research, $I, 350, I V, 253$. De germinatione efr. Mirbel in Annal. Mus, XTI. 4n. t. 19. Sprengel Anleit. ed, 2, I. 40. t. 10. DC, Organogr. t. 55.

\section{Ordo CCLXVII. Lythrarieae.}

SALICARIAE Jussieu Gen, 330. CalyCanthemaE Venten. Tabl. II. 298. LYTHRARIEAE Jussieu in Dict. sc. nat. $X X V I T$. 453. DC. Mem. soc. phys. Genev. IIT. 2. p, 63. Prodr. III. 75. Barthug Ord. nat. 316. Meisner Gen. 117. (83.) LYTHRACEAE Lindley Introduct, edit. II. p. 100.

Herbae, fruticbs v. abrores, ramis saepissime tetragonis. Foli a opposita v. verticillata, rarius in eadem interdum stirpe simul alterna, simplicia, penninervia, integra, saepissime integerrima, petiolata v. sessilia, interdum glanduloso-punctata. Stipulae nullae.

Flores hermaphroditi, regulares v. rarius irregulares, in foliorum axillis solitarii, glomerati, fasciculati v. cymosi, rarins foliis floralibus abbreviatis bracteaeformibus spicati v. racemosi, rarissime paniculati, pedunculis pedicellisve basi, medio v. saepius apice bibracteolatis, bracteolis interdum alabastrum includentibus, persistentibns v. deciduis.

Calyx liber, persistens, tubulosus v. campanulatus, rarius urceolatus, tri-multidentatus, tubo saepissime nervoso v. costato, recto v. rarissime obliquo, basi gibboso v, subcalcarato, limbi dentibus plus minusve profundis, nunc uniseriatis, aequalibus, aestivatione valvatis, nune biseriatis, dentibus alternis exterioribus angustioribus, saepe etiam brevioribus, interdum minutis v. fere obsoletis, aestivatione interiorum latiorum, valvatim accumbentium commissurae incumbentibus, tubi costis in medios limbi dentes excurrentibus.

Corollae petala (rarissime deficientia), summae calycis fauci inserta, ejusdem dentibus interioribus numero aequalia et alterna, exterioribus dum adsunt opposita, sessilia v, unguiculata, obovata, ovata v, oblonga, aequalia v, rarissime postica majora, tenera, aestivatione imbricata, margine saepissime plicatoundulata, sub anthesi patentia, decidua, interdum fugacissima.
Stamina calycis tubo prope faucem, medio v. paullo supra basim inserta, ejusdem nervis continua, petalis numero aequalia et alterna, rarissime pauciora, saepissime dapla v tripla, uni-plariseriata, inclusa v. exserta, aequalia v. inaequalia, omnia fertilia v. rarissime nonnulla sterilia. Fila menta filiformia, libera, aestivatione recta v. inflexa. Antherae introrsae, biloculares, ovatae, ellipticae v, oblongae, dorso insertae, erectae v. incumbentes, longitudinaliter dehiscentes.

Ovaruum liberum, sessile v, breviter stipitatum, rarissime basi annulo carnoso cinctum v. glandula unilaterali stipatum, bi-tri-quadriquinque-sexloculare, interdum (septis basi coalitis, supra basim abbreviatis v. apice fatiscentibus) subuniloculare. Ovula in placentis dissepimenti medio v. loculorum angulo centrali adnatis, aut semiseptorum basim connectentibus plurima, rarissime pauca, adscendentia v. horizontalia, anatropa. Stylus terminalis, simplex, plus minus longus. Stigma simplex, obtusum v. capitatum, rarissime emarginatobilobum.

Capsula membranacea v. rarius coriaceosublignosa, calyce (rarissime aucto) basi cincta v. inclusa, bi-plurilocularis, v. saepissime septis sub maturitate obliteratis unilocularis, irregulariter rumpens, circumscissa v. regulariter loculicide valvis dehiscens, valvis medio septa v. septorum rudimenta gerentibus, placentis in columuam persistentem, liberam coalitis.

Semisa plurima v, rarius pauca, ovatoangulata v. cuneata, aptera, v. plano-compressa, membranaceo-marginata v. alata, testa coriacea, umbilico in his marginali, in illis basilari. A lb u me n nullum.

Euraxo orthotropus. Cotyled ones saepissime suborbiculatae, plano-convexae, basi biauriculatae, rarissime semicylindricae. Radicula brevis, umbilicum attingens.

Lythrarieae ab Elatineis stylo simplici et seminum fabrica diversae, ab Oenothereis ovario libero facillime distinguendae, maximo numero in regionibus tropicis Americae generantur, in Africa aequinoetiali paullo quam in Asia frequentius observatae, in universum in temperatis extratropicis hemisphaerae utriusque multo quam inter tropicos rariores. Plurimae hygrobiae, quaedam late per orbem diffusae, nonnullae littorales, fruticosae et arboreae e regionibus temperatis exules, nullae alpinae.

Vis in nonnullis adstringens, quaedam tinctoriae.

TRIIBUS I. EULYTHRARIEAE. S e mi. n a aptera. 
6141. Cryptotheea BLUM. C a I y $\mathrm{x}$ lafundibuliformis, quadrifidus. Coroll a e petala 4 , calyci inserta, minima v, nulla, $\mathrm{S}$ ta min a 2 , opposita, fundo calyeis inserta, an the rae subrotundae. Ovarium....... Stylus lateralis; stig ma obtusam. Capsula calyce cincta, unilocularis, superne irregulariter circomscissa, receptaculo centrali demum libero. Semina plurima..... - Herbae javanicae, paludosae, suffruticosae, ramosae; caulibus angulatis, foliis oppositis, breve petiolatis, lanceolatis $v$. lineari-lanceolatis, basi latioribus, semiamplexicaulibus, pedunculis axillaribus, multifloris.

Cryptotheca Blume Bijdr. 1128. DC. Prodr. III. 76. Meisuer Gen. 117. (83.)

6142. Sulrremia BELLARD. Cal y x tubuloso-campanulatas, limbi oetudentati dentibus alternis exterioribus minimis, interioribus ovatis, acutis, erectiusculis.C o roll a e petala 4 , sommo calycis tubo inserta, ejusdem dentibus minoribus opposita, minima, fugacia. St a mi na 2 , tobo ealycis inserta, opposita, inclusa; fil a me $n$ t a filiformia, a $n t h$ era e introrsae, biloculares, suhglobosae, longitudinaliter dehiscentes. Ovarin m liberum, sessile, biloculare. Ovula in placentis hemisphaericis, dissepimento utrinque adnatis plurima, anatropa. StyI a s filiformis; s tigma capitatum. Caps ula ob. longa, calyce stipata, septo demum obliterato nnilocularis, hivalvis, placenta centrali libera. S emin a plurima, ovata, plano-convexa, testa coriacea, laevi. Embryon is exalhuminosi, orthotropi cotyled ones orbiculatae, planiusculae, radienla obtusa, umbilicum basilarem attingens. - Herba in oryzetis It a $l i$ a e superioris crescens, spithamea, subsimplex, tenella; foliis oppositis, ellipticis, sessilibus, integerrimis, floribus axilluribus solitariis, scssilibus, albidis.

S uffrenia Bellardi in Act. Academ. Taurin. XrIr. 445, t. 1. f. 1. DC. Prodr, III, 76. Meisn, Gen, 117. (83.)

6143. Rotala LINN. Caly x membranaceus, tubulosus, tri-quinquedentatus, alternis minoribus nullis. Corolla petala 3 v, 5, summo calycis tubo inserta, ejusdem laciniis alterna et aequilonga, obovata, fugacissima. St a m in a $3_{-5}$, medio ealyeis tuho inserta, petalis alterna; filamenta filiformia, antherae introrsae, bilocalares, ovatae, longitndinaliter dehiscentes. Ov arium liberum, sessile, triloculare. Ovula in placentis loculorum angulo centrali adnatis plorima, anatropa. Stylus brevissimus; stigma capitatum. C a p s u la ovata, calyce inclusa, dissepimentis snb maturitate obliteratis unilocularis, trivalvis, placenta centrali libera. $\mathrm{S} \mathrm{e} \mathrm{m} \mathrm{in} \mathrm{a} \mathrm{plurima,}$ compressa, laevissima, nitida. - Herbae inter tropicos Asiae et Am ericae observatae, humiles, glabrae; foliis oppositis v. verticillatis, oblongis v. linearibus, sessilibus, patentibus, integerrimis, floribus axillaribus, solitariis, sessilibus.

Rota 1 a Lian. Mant. 175. St. Hilaire in Mem. Mus.II. 381. DC. Prodr. 1II. 75. Chamisas et Sellechteud in Linnaea V. 567. Wight et Arnott Prodr. 1. 303. Meisner Gen, 177. (83.) - ? Ortegioides Solander msc. Eutelia R. Brown msc.

B144. Peplis LINN. Cal y $x$ persistens, campanulatus, duodecimfidus, laciniis sex latioribus erectis, sex alternis angustioribus, subnlatis, patulis, Co roll a e petala 6 , summo calycis tubo inserta, ejusdem laciniis angustioribus opposita, minima, fugacissima, saepe nulla. St a m in a 6 , caIycio tulo inserta, ejusdem laciniis latioribus op. posita, vix exserta; fil am enta filiformia, antherae introrsae, biluculares, subrotundae, lon. gitudinaliter dehiscentes. Ovarium ovato-subglobosum, biloculare. Ovala in placentis semicylindricis medio dissepimento utrinque adnatis plurima, anatropa. Stigma sulssessile, capitatum. Ca psula calyce cincta, subglobosa, membranacea, bilocularis, evalvis, tandem irregalariter rupta. Semin a plurima, obovato-acuminata, plano-eonvexa, testa subcoriacea. Embry on is exalbuminosi, orthotropi cotyled ones ovatae, compressae, radien la acuminata, umbilieum basilarem attingens. - Herbae annuae, in inundatis Europae et Asiae temperatae obviae, ramosae, decumbentes, glabrae; foliis oppositis v. alternis, sessilibus, obovatis $v$. lineari spathulatis, integerrimis, floribus axillaribus, solitariis, sessilibus.

Peplis Lian. Gen, n, 446. Jassieu Gen. 333. Sehkahr t. 99. Gürtaer I. 237. t, 5t. Flor, dan, $t$. 64. Curtis Flor. Lond. t. 27. DC. Prodr, IIT. 76. Meisaer Gen. 117. (83.) Portula Dillen. Gen. 7. Monch Method. 431. GI a uco ides Micheli Nov. Gen, 18. C habraca Adanson Fam. II. 234. G I a u x Valllant Bot, Paris. 80, t. 15. $f$. 5 .

DIDIPLIS Rafinesq. C a l y $\times$ campanalatus, quadrifidus. Corolla nulla. Stamina 2. Stigmata 2. Capsala bilocularis, polysperma. - Herba boreali americana; fo. lits angustissime linearibus, inferioribus oppositis, supremis alternis, floribus axillaribus, sessillibus.

Didiplis Rafinesque in Atlant. Journ. 1833. n. 6. p. 23. Peplis dia adra Nuttall in De. Prodr. III. 27.

6145. Ameletia DC. Cal y x bibracteolatus, persistens, caropanulato-tubulosus, lobis quatuor erectis, ovatis, acutis, conniventibus, cum totidem dentiformibus, minimis alternantibus. Corolla nulla. Stam ina 4 , ealycis tubo inserta, ejusdem lobis majoribus alterns, breviter exserta; fil amenta filiformia, anthe rae introrsae, biloculares, ovatae, longitudinaliter dehiscentes. Ov a r i m liberum, sessile, biloculare ..... StyI n s filiformis, simplex; stigma eapitatum. Ca psula ovata, membranacea, bilocularis, septifrage bivalvis. Se mina plurima........ Herbae ind $i$. ca e, repentes, foliis oppositis, obovatis, subsessilibus, integerrimis, spicis axillaribus sessilibus, dense bracteatis, floribus in axillis bractearum longe acuminatarum sessilibus, solitariis.

Ameletia DC. in Mem. soc, Genev, IIT. 2, p. 82. t. 3. f. a. Prodr. III. 26. Wight et Arnott Prodr. I, 303. Meisner Gen, 117. (83.) Peplis indiea Willd. A a manula repens Rottl. DC.

B146. Ammanmin HOUST. Caly x bibracteolatus, persistens, campanulatus, octo-quatuordecimdentatus, dentibus alternis exterioribus multo angustioribus, saepe minimis v. obsoletis, saepissime patentibns, tubo plicato quadri-quatuordecimnervio, nervis in dentes excurrentibus, $C_{0}$ roll a e petala $4-7$, summo calycis tubo inserta, ejusdem dentibns angustioribus dum adsunt opposita, aequalia, saepius nulla. Stamina imo v. medio calyris tubo inserta, ejusdem nervis continua, exserta $v$, inclusa, nunc petalis numeru aequalia et alterna, nune dupla, biseriata, superiore iisdem alterna, inferiora opposita; fil a menta filiformia, antherae introrsae, biloculares, subrotundae, dorso insertae, longitudinaliter dehisentes. Ovariu m libernm, sessile bi-tri-quadri-quinqueloculare. Ovula in placentis loculorum angnlo eentrali adnatis plurima, anatropa. Stylus simplex, persistens; stigma capitatum. Capsnla calyce cincta, inclusa v. exserta, subglobosa, tenuissime membranacea, bi-quinquelocularis, ra- 
rius septis sub maturitate obliteratis unilocularis, nunc irregulariter rupta, nunc septicide $v$. septifrage dehiscens, septis tune cum placentis persistentibus cohaerentibus, a valvulis solutis Se m in a plurima, minima, angulata, testa coriacea. Embryonis exalbuminusi, orthotropi coty led one $s$ orbiculatae, basi auriculatae, radicula brevissima, obtusa, umbilicum basilarem attingens. - Herbae aquaticae, glaberrimae, in regionibus tropicis et subtropicis totius orbis, rarius in $A m$ erica obviue; caule saepissime tetragono, ramis axillaribus oppositis, foliis oppositis, sessilibus, integerrimis, floribus axillari. bus sessilibus v. breviter pedunculatis, bibracteolatis, parvis, pedunculis simplicibus $v$, varie divisis.

A m m a n i a Houston ex Linn. Gen, n. 155. Jussien Gen. 333. Kunth in Humb. et Bonpl. Nov. gen, et sp. IV. 189. DC. Mem. soc. h. n. Genev. III, 2. p. 79. Prodr. III. 77. St. Hilaire Flor, Brasil, III, 132. Wight et Aruott Prodr. I. Meisner Gen, 137. (83)

a. EUAMMANNIA. O v a riu m bi-quinqueloculare. Ca $\mathrm{p}$ s u. I a bi-quinquelocularis, septicide v. septifrage dehiscens. C o ro 11 a e petala $4-7$, interdum nulla. $S$ t a $m$ i $\mathrm{n}$ a petalis numero aequalia v, dupla. (Lam, $t, 77, f, 1,2$. Willd. Hort. Berol, $t$. 7. Delile Flor, aegypt. $t, 18, f, 2$. Roxburgh Plant. Corom. t. 133. DC. in Mem. soc. h. n. Genev. IIT. t. 3. f. B. St. Hilaire Flor. Brasil. t. 187. Is nardia e $\mathrm{sp}$. Ruiz et Pavon Flor. Peruv, $t .85$. f. 6. Amanniae sect. Tritheca et Diplostemon Wight et Araott l. c. Sellovia Roth s. Winterlia S pr. (supr. n. 5204.) suspieantibus cl. Wight et Arnott est A. pentandra Roxb., placentis pro semine uaico descriptis.

b. CORNELIA, Ovarium biloculare. Capsula septis demum obliteratis unilocularis, irregulariter transversim rupta, C o roll a e petala $4-5$. Stamia a petalis nu. mero aequalia. - Corneli a Arduin Specim I. 8.t.1. Ammanniae sect. Haplocarpaea et Ditheca Wight et Aruott l. c. (A. indiea Lam, et A. verticillata Lam. $t$. $77, f .3$.

c. ? MIRK00A. C a I y $x$ petaloideus, campanulatus, ad medium quadrifidus, laeiniis triangulari-ovatis, alternis minoribus uullis. Corolla e petala 4 , obovata, calyce duplo longiora. Stamina 4 . O varium late obovatum, guadrilobum, quadriloculare. Sty I a s ovarif longltudine. Capsu la demum unilocularis. - Flores majusculi, in spicas braoteatas, subimbricatas dispositi, in axillis bractearum solitarit, breviter pedicellati, pedicello cum braeleae cordato.ovatae petiolo brevi connato. - A m ma a i a e sect. Mirco o a Wight et Arn. l. e. A. rotuadifolia Hamilt. Roxb. DC.

314\%. Nesaea CoMMERS. C a l y $\mathrm{x}$ per sistens, bibracteolatns v. ebracteolatus, hemisphae rico-campanulatus, decem-duodecim-quatuordecim dentatus, dentibns alternis exterioribus angustioribus, saepe corniformibus, patulis, interioribus triangularibus, ereetis, tabi costis dentium numero $v$. duplis, primariis in dentes excurrentilus. CorolIa e petala 5,6 v. 7 , summo calycis tubo inserta, ejusdem dentibus exterioribns opposita, patentia, aequalia. Stamina medio calyeis tnbo inserta, ejusdem nervis continua, petalis numero dupla, vniseriata, exserta, aequalia v. alterna longiora; fil amenta filiformia, antherae introrsae, biloculares, ovatae, dorso insertae, longitudinaliter dehiscentes. Ovarium liberum, sessile, globosum $v_{\text {, subglobosum, tri-quinque- rarins sexlocu- }}$ lare, 0 v u $\mathrm{I}_{\text {a }}$ in placentis e loculorum angulo centrali prominulis plurima, anatropa. Stylus sim. plex; stigma capitatum. Capsu i calyce tecta, globosa v. subglobosa, tri-quinquelneularis, loculi cide tri quinquevalvis, valvis medio septiferis, placentis coadunatis solutis. Semina plurima, ovata, angulata, testa coriacea. Embry on is exalbuminosi, orthotropi cotyledones plano con- vexae, radicula conica, nmbilicum basilarem attingens. - Herbae glabrae $v$. pubescentes $v$. suffrutices glaberrimi, in $A m$ erica tropica et boreali calidiore, $\mathcal{S}$ e $n$ e $a m b i$ a et insulis ma $u r$ itianis crescentes; foliis oppositis, interdum ternatis simulque oppositis et allernis, sessilibus v. petiolatis, integerrimis, pedunculis axillaribus, uni. multifloris, basi $v$. apice bibracteolatis, interdum abbreviato corymbosis, floribus flavis, purpureis v. cae. ruleis.

Ne sa a Commers. ex Jussieu Gen, 332. Kunth in Humb, et Bonpl. Nov, gen, et sp. VT, 191. St. Hilaire Flor, Brasil, III, 138. Tol y p u ma E. Meyer mse.

a. DECODON Gmel. Peduneuli coryaboso-multiflori, basi bibracteati. S ta mi na 10 , alterna multo longiora. - Herba boreali-americana, pubescens, floribus purpureis. - De codo a Gaeliu Syst. 677. DC. Prodr. III. 90. Lythrum verticillatum Einn.

b. HEIMIA Link et Otto. P edunculi uniflori, ealyce basi bibracteolato. St a $\mathrm{m}$ i a a saepius 12 , subaequilonga. - Frutices Americae tropicae, glaberrimi, floribus Favis. - H e i in I a Link et Otto Ic, 63, t, 28. DC. Prodr. IIT. 89. Ch r y solig a Hoffmans. Verzeichn. Ginorla Flor. Mex, non Jacq.

c. NESAEA. Comm. Pedua e uli uniflori, bibracteolati v. tri-multiflori, ьяsi bibracteati, pedicello intermedio bibraeteolato. Sta m I n a saepius 12 v. 14 , subaequilon. ga. - Herbae mauritianae et senegambicae, glaber. rimae, foribus caeruleis v. purpurascentibus, - N es a e a DC. Prodr. 90. Guillem. et Perrot. Flor. Seneg. t. 69. 70. Trotula Commers. msc. Lythrum trifloram Lina. A mmannia dodecandra DC. in Mem. soc, h, $n$, Genev, III. l. 2.

6148. Pemplais FORST. Calyx tubo turbinato, duodecimsulcato, limbi duodecimfidi Iobis patentiusculis, alternis exterioribus minoribus. Coro 11 a e petala $6,8 n m m o$ calycis tubo inserta, ejusdem laciniis exterioribus opposita, obovata, aequalia, patentia. St a m i n a 12 , medio calycis tubo biseriatim inserta, alterna inferiora petalis opposita breviora; fil am enta filiformia, a ntherae introrsae, biloculares, ovato-subglobosae, incumbentes, longitudinaliter dehiscentes. Ovarinm liberum, brevissime stipitatum, sulhglobosum, triloculare. $\mathrm{O}$ v $\mathrm{I}$ a in placentis locularum angulo centrali adnatis plurima, anatropa. Stylus brevissimns; stigma magnum, capitatum. C a p sula calyce cincta, subglobosa, septis demum obliteratis unilocularis, snpra basim irregulariter cireumseissa, placenta basilari brevi, triloba, Se m in a plurima, angulata ..... - Frutex in Asia tropica littoralis, pube brevissima, ad. pressa canus; foliis oppositis, oblongo-lanceolatis, integerrimis, perlunculis axillaribus, solitariis, unifloris, basi bibracteolatis, floribus albis.

P em $\mathrm{p}$ h is Forster Char. Gen. t. 34. Jussieu Gen. 334. DC. Prodr. IIT. 84. Meisner Gen, 118. (8t.) L y the m Pe mph is Linn, Lam, t. $408 f$. 2. Mangium porcel. I a nic a m Rumph Amboin. III. $t$, s4.

6145. Hythermm LINN. C a I y x persistens, eylindrico-tubulosus, octo-dnoderimdentatus, dentibus alternis exterioribus minoribus, tubo octo-duodecimeostato, costis in dentes excurrentibus. Coroll a e petala 4 v. 6 , summo ealyeis tubo inserta, ejnsdem dentibus minoribus opposita, patentia, aequalia $v$, rarissime inaequalia. S $\mathrm{t}$ a min a 8 v. 12, imo v. medio calyeis tubo inserta, ejusdem nervis continua, exserta $v$, inclusa, nunc petalis numero aequalia et alterna, nunc dopla, biseriata, superiora iisdem alterna, inferiora (quorum nonnnlla interdum abortiva) opposita; filamenta filiformia, a n thera e introrsae, biloculares, basi v. snpra basim aflixae, longitudinaliter dehiscentes. 
Ovarium liberum, sessile, biloculare. Ovula in placentis dissepinento utrinque adnatis plorima, anatropa. Stylus simplex; stigma eapitatum v. obtusum. Capsula calyce tevta, oblonga, nembranacea, bitocularis, nunc irregnlariter rupta, nunc septicide bivalvis, dissepimentis a placentis in unicam hasilarem bilobam cohaerentilus solutis. Semin a plurima, plano-convexa v, angulata, testa coriacea. E mbryon is exalbuminosi, orthotropi cotyledones orbiculatae, basi anriculatae, radieula conira, unbilicum basilarem attingens. - Herbue annuae v. perennes, inlerdum suffruticosae, rarius frutices, in $t$ e $m p$ eratis et calidioribus totius orbis crescentes; folits alternis, oppositis $v$, verticillutis, integerrimis, fioribus axillaribus solitariis v. pluribus, pedunculo communi, brevi insidentibus, purpureis $v$, rarius albis.

L y thrum Lins. Gen, n. 604. exel. sp. Jussieu Gen. 332. Gärtner 1 . 269, t, 62, Kunth in Humb, et Bonpl. Nov. gen. et sp. VI. 192. DC. in Mem.'soe. h, n. Genev, III. 2. p. 77. Prodr. III. 80. St. Hitaire Flor. Brasil. III. 129. Meisner Gen, 117. (84.) Sali e a ría Touruefort Inst, 253.

a. ? AMMANNIOIDES DC. $l$. $c$. Corolla nulla ? Sta un ina 4-6. Caly x tubuloso-eampanulatus. - L. u u $\mathrm{m}$ u uIarifolium Loisl.

b. HYSSOPIFOLIA DC. $l$. c. Stamina petalis numern trieute panciora. - Flores in arillis foliorum solitarii, haud spicati. - H y s so pifolia C. Bauhin Pin. 218. P y thagorea Rafiaesq. in Journ, phys. LXXXIX. 96. Mozula Ratinesq. Ibid. XCT. 7t, Pentaglos $8 \mathrm{~ms}$ Forsk. Descript, 11. (Jaeq. Flor, austr, t. 133, E. B. t. 292. Bot. Mag, t. 1812, Schrauk Hort, monae, 2 , 22.) c. SALICARIA DC. $l$. c. Stamin a duplo petalorum namero:- Flores in axillis superioribus plurini, foliorum abbreviatione fere verticillati $v$. spicato-race. mosi. (Jaeq. Flor, austr, $t, 12$, Flor, dan, $t, 671$. E. B. t. 1061. Bot, Mag. t. 1003. Royle Himalay. t, 44.f. 1.)

d. ANISOTES Lindl. Pet al a duo superiora reliquis duplo v. quadruplo majora. S ta m $\mathrm{ina} 6.0 \mathrm{v}$ a $\mathrm{r}$ il loculi inaequales.- A a is o te s Lindley Introduct. edit. II. p.101. et app. 4ht. L. a $\mathrm{n}$ o m a $1 \mathrm{um}$ St. Hilaire Flor, Brasil,t. 186.

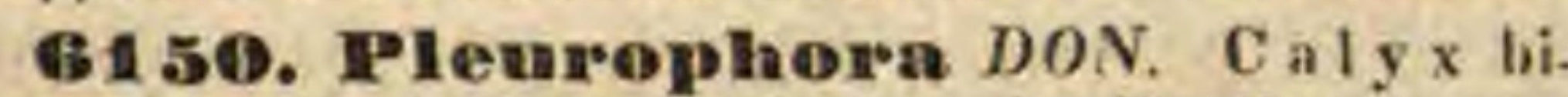
bracteolatus, tubulosns, tubo longitudinaliter costato, limbi plicati dentibns decem v. quatuorderim, alternis exterioribus spinescentibns, patulis, interioribns ovatis, mucronatis, erertis v. conniventi bus. Corolla e petala $5-7$, summo ealyeis tubo inserta, dentibus exterioribus "pposita, oblunga, nnguienlata, erectiusenla. S $\mathrm{t}$ i $\mathrm{m}$ in a $5 \mathrm{v} .7$, rarius plura, imo calycis tubo inserta, breviter exserta; filamenta filiformia, antherae intror sae. biluculares, cordato uvatae, longitudinaliter dehiscentes. 0 va ri u m stipitulo brevi calycis tubo hinc adnato excentrice insidens, ovato oblongum, compressinsculam, inaequilaterum, unilocnlare. O vula ia placenta parieti hinc adnata pauca, adscendentia, anatropa. S t y l u s suliterminalis; stig in a simplex. Fructus .... Herbae chilenses annuae, $v$. suffrutices; ramis tetragonis, foliis oppositis, oblongo-lanceolatis v. lineuribus, integerrimis, saepissime pungentibus, spicis lermina. libus, dense imbricato-foliosis, bracteolis saepissime spinescentibus.

Ple ur ophora Don in Edinb, new philosoph. Journ XII, 112. Hooker Bot. Miscell. T. 225. Pöppig et EudJ. Nov gen. et sp. 11. 67. $t$. 293. Meisner Gen. 117. (88.) L y th r i sp. Colla plant, chil. $t, 14$.

8151. Cuphea JACQ. Ca 1 y x persistens. tuhulosus, tubo basi postice gibbo v, ealcarato, nerveso-costato, adscendente, limbo plicato, saepe ampliato, inaequaliter duodecimdentato, dentibus alternis exterioribus minoribus, interdum obsoletis, interiuribus triangularibus, postico saepe la tiore, tubi nervis in dentes medios excurrentibus. Corolia rarissime nulla, saepissime petala 6 , summo calycis tubu inserta, ejusdem dentibus minoribus opposita, unguienlata, duo postiea pleruuque majora, saepe infra basim glandula aucta. St a in ina 11, ealyeis fauei diversa altitudine inserta, inclusa, inaequalia, quorum sex dentibus calycinis exterioribus petalisque opposita, dnobns pusticis demissius insertis, quinque dentibus majoribus uppusita, uno postico deficiente; filamenta brevia, antherae introrsae, biloculares, ellipticae, parvae, longitudinaliter dehiscentes. Ovarium liberum, nune sessile, ima basi cupnla glandulosa cinctnm, v. brevissime oblique stipitatum, postice glandula interdam obsoleta stipatum, oblongam, compressum, biloculare, loenlis inaequalibus, altero minore saepe vacuo, dissepimento apice in fila soluto, mox evanido. Ovnla 2 v. plurima, placentae filiformi, medio dissepimento adnatae funiculis adscendentibns inserta, anatropa. Stylus suluatas, incurvus; stigma capitatum, emarginato-bilsbum. Capsula oblonga, compressiuscala, tennissime membranacea, calyce cincta, septo obliterato unilocularis, demum hine fissa, placenta colnmellari libera. Sem in a panca v. plurima, lenticulari-eomplanata, testa coriacea, aptera, umbilico marginali. Embryo. nis exalbuminusi, orthotropi cotyledones orbicnlatae, radienla brevissima. umbilicum attingens. - Herbae v. suffrutices, saepe viscosi, in $A \mathrm{me}$ rica tropica indigeni; foliis oppositis $v$, verticillatis, aut interdum simul allernis, integerrimis, pedunculis interpetiolaribus, uni- $v$. rarius multifloris, saepius cernuis, saepissime bibracteolatis, floribus violaceis, roseis $v$. albis.

Cu phea Jacquin Hort. Vindob, IT, 83, t, 177. Cavanill. Ic. $t, 350-382$. St, Hilaire in Mem, Mus, II, 37, $t, 4$. f. 26 _28. Kunth in Humb, et Bonpl. Nov, gen. et sp. $V I$. 196. t. 550 552. Bot, Mag. $t$, 2201. 2580, Bot, Reg, t. 558, Hooker Erot, Elor, t. 16i. DC. Prode, Itt, 83, St. Hitaire Flor. Brasil. III, 94. $t, 182-185$. C uphea, Melanilum et Parsons ia P. Brawne Jam. 217 et 199, t, 21. f. 2. M eI a n i u et $\mathrm{C}$ up he a Sprengel Syst, $I T$. 454. B a I s a in o a a Vandelli in Romer Seript. i10. 2. 4. M elvitla Auders. mse. Duvernay a Desp. mse, B a aksia Doubey mse.

615\%. Acisanthera P, RROWN. Cal y ventrlcosns, quinquefidas, sinubus inappendiculatis. Coroli a e petala 5. Stam in a 10, antheris sagittatis, versatilibus, C a p 8 a la calyce tecta et coronata, bilecularis, biplacentaris, polysperma. Herba jamaicensis; erecta, ramosa, ramulis tetragonis, foliis oppositis, ovatis, trinervies, crenatis, floribus alterne axillaribus, solitariis.

A cis anthera P. Browoe Jam. 217, t. $22 f$. 1 . Jassieu Gen, 332. Poiret Supplem. I. 111. DC, Prodr. IIT. 88. Meisner Gen. 118. (84.) Rhexia Acisanthera Lion. Amoen. Academ. V. 396.

6153. Crenea $A U B L$. Cal y x persistenz, nrceolatus, limbi quadrifidi lohis aequalibus, late triangularihus, minoribus interjectis nullis. C orollae petala 4 , summo ealycis tubo inserta, ejusdem laciniis aiterna, obovata, aequalia, patentia. Stam in a 12-15, calyci surra basim inserta, exserta; filamenta filiformia, antherae introrsae, biloculares, oblongae, erectae, longitudinaliter dehiscentes, Ovarinm liberum, sessile, subglobosum, quadri-quinqueloeulare. Ovala in placentis loculorum angulo centrali adnatis plurima ....Stylus filiformis; stig ma oblongnm, indivisum. Ca p sula ealyee cincta, suhglobosa, membra. nacea, septis obliteratis unilomnlaris, indehiscens, placenta centrali libera. Semina plarima, mini 
ma........ Herbae interdum suffruticosae, in $m a-$ ritimis Gnianae crescentes, nodosae; ramis te tragonis, foliis oppositis, petiolatis, oblongo-ovatis v. subspathulatis, integerrimis, glabris, pedunculis axillaribus folio brevioribus, uni-multifloris, floribus albis.

Crene A Aublet Guian, I. 523 t. 209. Lam. $t, 40 z$. Jussicu Gen. 332. G. F. W. Meyer Essequeb 186. DC. Prodr. III. 90. Meisner Gen, 118. (84.)

6154. Dodlecas LINN, $F, C$ a I y $x$ persistens, tubo urceolato, limbi quadrifidi laciniis deltoideis, patentibus, minoribus interjectis nullis. Corolla petala 4 , summo calycis tuho inser ta, ejnstem laciniis alterna, snborbiculata, breviter unguiculata, patentia. St a m ina 12 , ealycis tubo paullo infra petala inserta, iisdem breviora; fil a m e $t$ a filifurmia, in tubum derurrentia, antherae introrsae, biloeulares, oblomgae, adnatae, longitudinaliter dehiscentes. Ovarin m liberum, sessile, quadriloculare. Ovula in piacentis loralorum angulo centrali adnatis plurima, anatropa. Stylus filiformis. flexuosus, exsertus; $8 \mathrm{t} \mathrm{i} \mathrm{g} \mathrm{m}$ a obtusum. Capsula calyce cincta, subglobosa, septis obliteratis unilocularis, quadrisalvis, placenta centrali libera, subglobosa, stipitata. S e m in a plurima, obovato-acuta, testa coriacea. E m b r y onis exalbuminosi, orthotropi eotyledones orbiculatae, planiusculae, radicula nmbilicum basilarem attingens, - Frutex surinamensis, glaberrimus; ramulis tetragonis, foliis oppositis, obovato-oblongis, integerrimis, pedunculis axillaribus, paullo infra apicem bibracteatis, uni-v rarius bifloris.

D o decas Linn. Fil. Supplem. 36 et 245 Jussieu Gen. 323. E. Meyer in N, A. N, C. XII, s00. DC. Prodr. III.91. Mieisn. Gen, 118, (84.)

6155. Gimoria $J A C Q$. C a I y x persistens, campanulatus, sexfidus, laciniis lanceolatis, acuminatis, patentissimis, minoribus interjectis nullis. Corollae petala 6 , summo calycis tubo inserta, ejusdem laciniis alterna, suborbiculata, unguiculata, patentia. Sta min a 12 , calycis tubo inserta, exserta; filamenta filiformia, antherae biloculares, reniformes, incumbentes, longitudinaliter dehiscentes. Ovarium liberum, sessile, quadriloculare. Ovnla in plarentis loculornm angulo eentrali adnatis plurima ...... Sty lus filiformis, longe exsertus; stigma capitatum. Capsula ralyce cincta, subglobosa, quadrisulca, septis obliteratis unilocularis, quadrivalvis, placenta centrali libera, subglohosa. Semin a plurima ......

Frutex antillanus; foliis oppositis, subsessitibus, lanceolatis, integerrimis, pedunculis axillaribus, solitariis, unifloris, ebracteatis, folio brevioribus, caeruleis, magnis.

Gin o rg i Jacquin Amer. 148. $t$. 91. Jussieu Gen, 331. DC. Prodr. III, 91. Meisner Gen, 118, (84.) Gin o r a Linn. Gen, n, 605. Lam, t. 407. G en or i a Persoon Encheir. II, 9 Rosa del $\mathrm{R}$ io Hispan.

G156. Crislea LöFFL. Ca ly persis tens coloratus, tubulosus, ucto-dnodecimdentatus, dentihns alternis exterioribus multu minoribus, interioribus erectis, tubo obsolete striato. Corol. la e petala 4_6, summo caly cis tubo inserta, ejusdem dentibus exteriorihus opposita, oblonga, unguiculata, aequalia. St am in a imo calycis tubo inserta, petalis numero dupla, uniseriata, longe exserta; filamenta filiformia, antherae introrsae, biloculares, oblongae, dorso insertae, longitudinaliter dehiscentes. Ovari u m liberum, sessile, biloculare. $O \vee \mathbf{v} l a$ in placentis hemisphaericis, dissepimenti basi utrinque adnatis plurima, anatropa. Stylus filiformis, exsertus; stigma indivisum, subelavatum. Capsula sulghlobsa, calyce inclusa, dissepimento obliterato unilocnlaris, bivalvis, platentis coalitis, liberis. Se $m$ ina plurima, cuneata, testa coriacea, serobicnlata. $\mathrm{E}$ mb ryo nis exalbuminosi, orthotropi $r$ a d i c n i a umbilicum basilarem attingens. - Frutices $v$, arbores inermes, in Asia, Africa et Americatropic a crescentes; foliis oppositis, integerrimis, subtus pallidioribus, glabris $v$. incano-tomentosis, glandulis nigris punctatis, pedunculis axillaribus multi. floris, floribus rubris.

G ris le a Löfliog $I t, 245$. Linn. Gen, $n$. 474. Kunth in Humb. et Bonpl. Nov. gen, et sp. VI. 184. Roxburgh Plant. Corom. I. 29. t. 31. DC. Prodr. III 93. Wight et Araott Prodr. I. 307. Messner Gen, 117. (84.) Woodfordia Sa. lisbury Parad, $t, 42$.

B15\%. Adenaria $H, B, K, C$ aly $x$ persistens, turbinato-eampanulatus, limbi quadri-quinquefidi lobis aequalibus, minoribus interjectis nullis. Corolla e petala 4 v. 5, summo calycis tubo inserta, ejusdem laciniis alterna, aequalia, unguículata. St amin a 8 v. 10 , calyci supra basim inserta, uniseriata, exserta; filam en ta filiformia an the rae introrsae, biloculares, ovatae, dorso insertae, longitudinaliter dehiscentes. Ovarin m liberum, stipitatum, bilocolare. $O \mathrm{vula}$ in placentis hemisphaericis, dissepimento utrinque adnatis plurima, anatropa. Stylus filiformis, inclasus st ig ma bilohum. C a p 8 u I a calyce cincta, globosa, membranacea, septo obliterato unilocularis, indehiscens, placenta centrali liliera. Sem in a plurima, obuvato-cuneata, angnlata, testa subernstacea, laevi. Eub ryonis exalbuminosi, orthotropi cotyledones orbiculatae, subfoliaceae, $r$ adicula obtusa, umbilicum basilarem attingens, Arbores inermes, in America tropica indigenae; foliis oppositis, breviter petiolatis, integerrimis, membranaceis, sublus calycibus cum petalis et ovario punctis glandulosis conspersis, umbellis axillaribus oppositis, brcvissime pedunculatis, multifloris, petalis albis.

Ade naria Kunth in Humb, et Bonpl. Nov, gen, et sp. VI. 185. t. 549. DC. Prodr. HI. 91. Meisuer Gen, 118. (84.) Hooker Ic, t, 116.

6158. Antherylium ROHR. CaIys quadripartitus, laciniis acutis, erectiusculis, minoribus interjectis nullis. C or o 11 a e petala 4 , inter calyeis lacinias inserta, iisdem subaeynilonga, obovato-oblonga, plicato-undulata, unguieulata, patentissima. Stamin a 12 - 16 , imo calyci inserta, exserta; filamenta filiformia, antherae introrsae, biloculares, oblongae, adnatae, apice revo. Intae, longitudinaliter dehiscentes, Ovarium liberum, sessile, tri-quadriloculare. Ovula in placentis loculorum angulo centrali adnatis pinrima, anatropa. St y $\mid$ us filiformis, flexuosus; st igma capitatum. Ca p s u I a basi calyce cincta, obovato tri-tetragona, septifrage tri-quadrivalvis, valvis deciduis, columnam placentiferam, tri-tetraquetram, persistentem, stylo superatam nudantibns. Se min a plurima, minima........Arbor antil. lana, glabra; ramulis subtetragonis, foliis oppositis $v$. alternis, breve petiolatis, ovatis, integerrimis, supra pulvimum breviter bispinosum insertis, pedicellis axillaribus fasciculatis, ebracleatis, petiolum superantibus, folio multo brevioribus.

A n t he ry $1 \mathrm{Inm} \mathrm{Rohr}$ et Vahl in Act, soc, h, n, Hafn. II. p. 211, t. 8. DC. Prodr. III, 91. Meisu. Gen. 118. (89.)

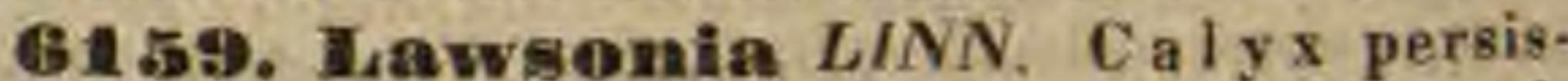
tens, quadripartitus, laciniis acutis, patentibus, ni- 
noribus interjectis nullis. Co ro 11 a e petala 4 , inter ealycis lacinias inserta, obovata, unguiculata, patentia. Stamina 8 , imo calyci inserta, ejusdem laciniis geminatim opposita; filamenta filiformi-subulata, a $\mathbf{n}$ herae introrsae, biloculares, ovato-subcordatae, longitudinaliter dehiscentes. Ovarium liberum, sessile, subglobosnm, quadriloculare. $O \mathrm{vula}$ in placentis loculorum angulo centrali adnatis plurima, horizontalia, anatropa. Stylus filiformis, simplex; $8 \mathrm{tigma}$ quadridentatum. B a c c a salyce cincta, globosa, exsucea, membranacea, quadriluenlaris. Sem in a in loculis 6-8, horizontalia, cuneata, angulata, testa crassa, subernsa. Lim bry onis exalbuminosi, orthotropi, cylindriei cotyledones semicylindricae, ra d i cula cotyledonibus brevior, obtusa, nubilicnm basilarem attingens. - Frutex in Asia tropica et Africa bo reali obvius, glaber, inermis $v$. ramulis spinescentibus armatus; foliis oppositis, subsessilibus, ovali-lanceolatis, integerrimis, floribus terminalibus, paniculatis $v$ corymbosis, albis.

Law 80 ni Linn. Gen. n. 482, Lam. $t$. 296. Desfost. Flor, Atlant. I. 325. DC. Prodr. IIT. 90. Wight et Arnott Prodr. I. 30n. Meisuer Gen, 118. (84.) Al c a n na Gärta. $1 I$. 133. $t$. 110. Hen a seu A Ihena a Arabum. A I canna Rumph. Amboin. IV, $t, 17$. M afl-a ns chi Rheede Malab. I. 73. $t, 40$.

6160. Abatia $R U I Z$ et $P A V$. Caly $x$ tnbo hrevissimo, turbinato, fauce pilis filamentosis clansa, limbi quadripartiti laciniis lanceolatis, intus coloratis, aestivatione valvatis. Corolla nulla. St a min a $20-30$, calycis tubo inserta, uniseriata, exserta; filamenta filiformia, antherae introrsae, biloculares, cordato-ovatae, longitudinaliter dehiscentes. $O$ v a $\mathbf{r}$ i $\mathbf{m}$ liberum, sessile, septo supra basim deliquescente incomplete biloculare. Ov ula in placentis semiseptorum margini adnatis plurima, anatropa. Stylus simplex; st i $\mathrm{g}$ m a truncatum. C a p sula subglobosa, incomplete bilocularis, Ioculicide bivalvis, valvis sublignosis, a semiseptis margine placentiferis, basi coalitis demum solutis. Se min a plurima, angulata, testa crustacea, reticulata, E mb r y o n is exalbuminosi, orthothropi cotyled ones semicylindricae, $r a$ dicula obtusa, umbilicum basilarem attingens. Frutices peruan $i$, pube fasciculata cinereo-tomentosi; foliis oppositis, petiolatis, exstipulatis, crenatis, floribus terminalibus, racemosis, pedicellis uni. floris, solitariis $v$. fasciculatis, bracteatis.

A batia Ruiz et Pavon Prodr. 68, t, 14. Kunth in Humb. et Bonpl. Nov. gen. et sp $\nu$ 358. $t$, 186. DC. Prodr. 1. 303. Don in Edinb. new philosoph. Journ, X. 121.

TRIBUS II. LAGERSTRÖMIEAE DC. Prodr. III. 92. Semin a alata.

6161. Diplusodon $P O H L$. C a $1 \mathrm{y} \times$ persistens, hibracteolatus v. ebracteolatus, tubo sub. campanulato, duodecim- v. multinervi, profonde duodecimdentato, dentibns alternis exterioribns angustioribus, rarissime obsoletis, interioribus la tioribus, triangularibus. Coroll a e petala 6, summo calyeis tubn inserta, ejusdem dentibus exterioribus oppesita, brevissime nnguiculata, corrugata, patentissima, aequalia. Stam in a $12-40$, calycis tubo infra medium inserta, nniseriata, exserta; $\mathrm{fi}_{\text {- }}$ I a menta filiformia, antherae introrsae, biloculares, ellipticae, dorso insertae, longitudinaliter dehiscentes, demum revolntae. O va rium liberum, sessile, globosum, septis duobus, ima basi coalitis caeterum distinctis incomplete biloculare. Ovala in placenta basilari depressa, semiseptorum basim connectente plurima, complanata, anatropa. Styl $\mathbf{s}$ filiformis, curvatus; stig m a capitatum. Caps u la calyee ciucta, incomplete bilocularis, loculicide bivalvis, valvis medio semiseptiferis, placenta centrali depressa, libera. Se mina plurima, complanata, testa coriacea, ala anguste marginata, nmbilico laterali. $\mathbf{K}$ m b r y o $\mathrm{n}$ is exalbuminosi, orthotropi c ot yle d ones suborbiculatae, basi biauricalatae, $r$ a dic u I a brevissima, nmbilicum attingens.Herbae, suffrulices $v$. frutices brasilienses;'tramis axillaribus oppositis, saepe tetragonis, foliis oppositis $v$. rarissime verlicillatis, integerrimis, saepe costatis $v$. arcuatim nervosis, floribus axillaribus solitariis, sub sessilibus $v$. breviter pedunculatis, foliorum imminutione racemum, $v$. internodiorum abbreviatione interdum capitulum formantibus, pedunculis apice $v$. rarius infra apicem bibracteolatis, petalis colore vario, nunquam caeruleis.

Diplus od on Polil in Flora 1827. p. 150. Plant. Brasil, I. 82, t. $66-8 t$, DC. Prodr IIY. 94. a. St. Hilaire in Nouv. Anual, sc. nat, 1.332. Flor. Brasil. IIT. 143. t.188. 189. Dip I o d o n Spreng. Gen. n. 1963. Pöppig Nov. gen. el p. II. 66. t. 192. Priedlandia Cham. et Schlechtend, in Linnaea $I, 348$, D u b y a e DC. msc.

B 1 G\%. Luafoensia $V A N D E L L, \mathrm{C}$ a $1 \mathrm{y} \times \mathrm{per}-$ sistens v, deciduus, bibracteolatus, tubo campanulato, limbi plicati dentibus sedecim ad viginti quatuor, exterioribus saepe minoribus v. fere obsoletis, interiores membranaceos aestivatione tegentibns. Corolla e petala 8 - 12 , summo calycis tuho inserta, ejasiem laciniis exteriorilsus opposita, unguiculata, corrugata, aequalia. Sta m in a 16_-24, calycis tubo infra medium inserta, ejusdem dentibusopposita, longe exserta; fil a men ta filiformia, a ntherae introrsae, biloculares, ovato-ublongae, dorge insertae, versatiles, longitudinaliter dehiscentes. Ovarin liberum, breviter pedicellatum, subglobosmm, septis basi cualitis, superne. distinetis inesumplete biloculare. $O \mathrm{v}$ u $1 \mathrm{a}$ in placenta basilari semiseptorum basiu connectente plurima, complanata, anatropa. Stylas filiformis, longissimus; stigma subeapitatum. Capsola corticusa, incomplete bilocularis, loculieide bival. vis v, apice irregulariter plurivalvis, placenta centrali depressa, libera. Se m ina plurima, complanata, testa coriacea, membranaceo-cirenmalata, ambilico Jaterali. E m b ry on is exalbuminosi, orthotropi cotyledones orbiculatae, basi hiauriculatae, radienla hrevis, umbilicum attingens. Arbores v. frutices, in America tropica crescentes; foliis oppositis, integerrimis, apice uniglandulosis, floribus axillaribus solitariis, $v$, in racemos ter. minales breves aut in paniculas dispositis, magnis, pedunculis solitariis, uniftoris, angulatis, apice v. paullo infra apicem bibracteolatis, bracteolis sero deciduis $v$, caducissimis, petalis albis $v$, pallide ruseis.

L of oe nsi a Vaudelli ex Romer Script. 112. t. 7.f. 13 . DC, in Mem. soc, phys. Genev, III. 2. p 86, Prodr. III. 94. Pobi Plant. Brasil. I1. 14t. St. Hilaire Flor. Brasil. IIT. 137. Meisner Gen. 117. (83) Calyplectus Ruiz et Pavon Prodr. 73. Kuuth in Humb. et Bonpl. Nov. gen. et p. $V I, 189$.

a. Calyplectus. B racte o fa e eadueissimae. Peta I a 10 v. 12. S t a min a 20-24. - Kunth Op. eit. t. 548 . 1. et B. DC. in Mem. soc. phys. Genev. III. t, 1. Pohl Op. cit. t. $197-199$. St. Hilaire Op. cit. $t, 19 t$.

b. PTYCHODON. Bracteola e diatins persistentes. P e. tala 8. Stamina 16. Ptyehodou Klotseh msc. L. a um alariaefolia St. Hilaire Op, cit, $t, 190$.

B f 63 . Playsoealymma $P O H L$, Caly $x$ persistens, bibracteolatus, turbinato eampanulatus, 151 * 
octodentatus, coloratus, fructifer inflatus, dentibus aequalibus, minoribus interjectis nullis. Corolla e petala 8 , summo calycis tubo inserta, ejusdem dentibns alterna, obovata, berviter nnguiculata, aequalia. Stamina $2 t$, imo calyci inserta, longe exserta, calycis dentibus geminatim, petalis solitarie opposita; fil a m e $\mathrm{ta}$ filiformia, antherae introrsae, biloculares, lineari-elliptieae, dorso affixae, conectivo antice convexo, carnoso, longitudinaliter dehiscentes. Ovari um li herum, sessile, hemisplaaerico-tetragonum, quadriloculare. Ovula in placentis loculorum angulo centrali adnatis plurima, adscendentia, anatropa. Stylus longe exsertus, simplex; stig ma capitatum. C a p 8 u l a calyce vesiculoso cincta, tenuissi me membranacea, septis obliteratis unilocularis, indehiscens, placenta centrali libera. Se m in a plurima, complanata, testa coriacea, ala membranacea cineta, umbilico laterali. E mbryonis exalbuminosi, orthotropi cotyled on es suborbisnla tae, basi biauriculatae, ra di cula brevissima, umbilicum attingens. - Arbor brasiliensis, ramosissima, ligno rubente, florescentiae tempore aphylla; foliis oppositis, petiolatis, obovatis v. ellipticis, integerrimis, utrinque pilis brevissimis, adpressis scabris, paniculis terminalibus opposite ramosis, nudis, laxis, pedunculis basi bibracteatis, apice bibracteolatis, bracteolis magnis, orbicularibus, concavis, alabastrum includentibus, calycem floris explicati amplectentibus, persistentibus, petalis purpureis.

Ph y 8 o eal y m ma Pohl Plant. Brasil. T. 99. t. 82. 83. DC. Prodr. III. 89. St. Hilaire in Nouv. Annal. se, nat, I. 13, Flor. Brasil. III, 141. Meisner Gen. 117. (83.)

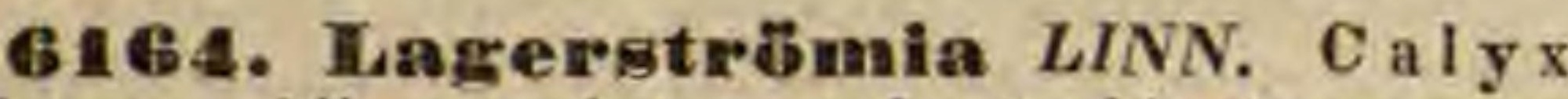
persistens, bilsracteolatus, tubu torbinato-campanulato, laevi v, plicato-sulcato, limbi sexfidi lobis aequalibns, sinu rotundato distinetis, minoribus interjectis nullis. Corolla e petala 6 , summo calycis tubo inserta, ejusdem laciniis alterna, obovato oblonga, breviter unguiculata, aequalia. Sta m in a 18-30, imo calyci inserta, longe exserta, subae. qualia v. sex exteriora longiora; fila menta filiformia, a n the rae introrsae, biloculares, oblongae, dorso insertae, longitudinaliter dehiscentes. Orari u m liberum, sessile, tri-sexloculare. O v a I a in placentis loculorum angulo centrali adnatis plurima, anatropa. Sty In s exsertus, simplex; $\mathbf{s}$ i $\mathrm{g}$ m a capitatum. C a p 8 u la calyce cineta, tri-sexloeularis, loculicide tri-sexvalvis, valvis medio dissepimenta a placentis condunatis soluta gerentibus. Se m in a plurima, oblonga, compressa, horizontalia, testa memhranacea, margine superiore in alam membranaceam producta, umbilico basilari. En b ryonis exalbuminosi cotyledones orbiculatae, radicula nmbilicum attingens. - Arbores $v$. frutices Asiae tropicae; ramis tetragonis, foliis oppositis v. summis alternis, integerrimis, pedunculi axillaribus, in paniculam v. racemum terminalem dispositis, apice bibracteolatis, bracteolis caducissimis, floribus purpureis $v$, albis.

L a g erstrô u ia Lìn. Gen, n 667. DC, in Mem. soc, phys. Genev, III, 2, 71. Prodr, III, 93. Mrisuer Gen, 117. (83.)

a. SIBIA DC, 2. c. CaI y cis tubus laevis. Stamina 6 exteriora molto longiora et crassiora. Lagerstróm ia Lian. I. c. S i b i Kämpf. Amoen, 855. V o laga glo. b o s a Garin. $t, 133$. (Bot. Mag. $t$, 405. Roxburgh Plant. Oorom, t. 66.)

b. MÜNCehausla DC, l, c. C a ly eis tubus laevis. Sta. mina subaequalia. - Münehh a usia Linne Mant. 153. Jussieu Ger. 33t. B a a v a Camelli ex Ray Hist. III. App, 80. c. ADAMBEA DC. 2 . c. Cal y e is tabus longitudinaliter plicato-suleatus. St a m i na suisaequalia. - Adambea Lam. Dict. I. 39. A d a m b o Rheede Malab. IV. $t .20$. 22. A r j u a Jones in Asiat. Research. IV. 301. (Rox burgh Plant. Corom, $t$, 63.)

B 1 65. Duabanga $H A M I L T$. C a ly x per sistens, campanulatus, crassissimus, ad medium sexfidus, laciniis ovatis, acutis, incurvis, minoribus interjectis nullis. Corolla e petala 6 , summo calyeis tubo inserta, ejusdem laciniis alterna, ovato. oblonga, obtusa, aequalia, undulata. Stamina circiter 8, perigyna, aequalia, corolla longiora; fil amenta snbulata, antherae lineares, incumbentes. Ova ri u conicum, sex-octoloculare. Ovula in loculis plurima. Stylus compressus, flexuosns, staminibus longior; stigma peltatoconvexum, margine lobatum, Capsu la calyci patenti insidens, subrotunda, sex-octolocularis, loculi cide sex-octovalvis, valvis medio septa duplicata gerentibus, eptis alternis latioribns, margine utroque revolutis, utrinque cum septi contigui angustioris margine in placentam, in loculi angulo centrali sublateralem confluentibus, axi cavo. S em in a plurima, lineari-oblonga, testa dara, utrinque in appendicem filiformem spongiosam produeta. Embryon is exalbuminosi, recti cotyledo. n es cordato-oblongae, viridi punctatae, $r$ a di $c$ uI a cylindriea, seminis basim respieiens. - Arbor indica, magna; ramis verticillatis, horizontalibus, ramulis laevibus, glabris, tetragonis, foliis oppositis, brevissime petiolatis, distichis, lineari oblongis, basi cordatis, apice acuminatis, integerrimis, supra nitidis, subtus pallidioribus, costis carinatis, lineatis, venosis, paniculis axillaribus et terminalibus, folio brevioribus, ramis oppositis, angulatis, glabris, apice paucifloris, pedicellis teretibus, ebracteatis, flore brevioribus, floribus magnis, albis.

D u a bauga Hamilton in Linn. Transact, XVII. 178. Lagerströmia grandiflora Roxburgh Flor, ind. II. 503. D u y a bag ya sise B a u rhola Tripurens. Chokros a 1 Camrup.

B1 16B. Fation $D C$. C a 1 y x persistens, tubo campanulato, limbi sexpartiti lobis triangularibus, erectis, minoribus interjectis nullis. Corolla e petala 6 , summo calycis tubo inserta, ejusdem laciniis alterna, ublonga, nnguiculata, patentiuscula, undulata. Stamina $24-30$, imo calyci inserta, exserta, quorum sex longiora, sterilia (?); fil amenta filiformi - subulata, restivatione infle$x a$, a $\mathbf{t h}$ era e ovatae, biloculares, longitudinaliter dehiscentes. Ovari um liberum, sessile, ovatooblong am, triloculare ......S ty 1 ns filiformis, longe exsertus; sti gma simplex. Fructus... - Arbor v. frutex nepalensis; ramis teretibus, subgriseis, ad originem ramulornm subnodosis, ra. mulis fasciculato-verticillatis, tetragonis, glabris, gracilibus, foliis oppositis, ovalibus, integerrimis, penninerviis, brevissime petiolatis, superne glabris, atro-viridibus, subtus pube velutina brevissima candicantibus, pollicem longis, semipollicem latis, pedunculis axilluribus folium aequantibus $v$, superantibus, gracilibus, ramosis, tri-quinquefloris, pedicellis unifloris, ebracteatis,

Fatio a DC. Prodr. III. 88, et in Denkschrift. der allgem. schweiz. Gesellsch, f. nat. Wiss, I. 98. t. 3. Meisn. Gen. 118. (84.)

\section{GENERA DUBIA.}

G1B\%. Symmetroia BLUM. C a $1 \mathrm{y} \times \mathrm{cam}$ panulatus, sexfidus. Coro 11 a e petala 6 , calyci 
inserta, parva. Stam in a 12, enm petalis inserta, alterna breviora, demum inflexa, marcescentia. Ovarin liberum, disco cinctum, quadriloculare, loculis biovnlatis. Stylas crassus; $s \mathrm{tig}$ ma obtusum, tetragonum. Dru p a baceata, umbonata, calyce vestita, mono-di-rarius tripyrena, pyrenis reniformibus, fibroso-arillatis, monospermis. E mbryo in albumine inversus, curvatus. - Arbor javanica; foliis oppositis, obovatis, obtusis, ob. solete denticulatis, coriaceis, glabris, tenuiter paral. lele venosis, corymbis axillaribus brevibus, floribus parvis.

S y mmetrin Blume Bijdr, 1130, DC. Prodr. III. 94. Meisner Gen, 118. (84.)

G168. Pliysopodium DESV. Calyx pedicello articulato, tumido insidens, turbinatus, quinquedentatus, extus glaber, intus piluso-strigosus. Corolla e petala 5 , ovali-oblonga. S $\mathrm{t}$ am in a 10, petalis duplo longiora, alterna paullo breviora, antherae biloculares oblongae, incumbentes. Ovarin m chlongum. Stylus capillaris; $8 \mathrm{tig}$ in a subulatum. Fruet ns..... Frutex borbonious, volubilis; caule tereti, folis alternis, elongato-lanceolatis, submucronatis, rigidis, integerrimis, glaberrimis, floribus spicatopaniculatis, secundis, bracteolatis.

Phy 8 opodi in mesvaux in Annal. se. nat. IX. 403. DC. Prodr. III. 94, Meisner Gen, 118, (84.) Ruid Ps y lo$x$ y 1 o o n Neraud. genus a cl. Gaudichaud ad Fregcinet. 30. inter Lythrarieas uominatum.

\section{Classis LX. MIymiflorae.}

Herbae, suffrutices, frutices, saepissime arbores. Folia opposita, rarius verticillata $\mathbf{v}$, alterna, simplicia, triplinervia $\mathbf{v}$. penninervia, integerrima v. serrata. C a lyx cum ovario connatus v. liber, lobis per aestivationem valvatis. Corolla e petala calycis fauci inserta, ejusdem laciniis numero aequalia, rarissime nulla. Stamina cum petalis inserta, nune duplo eorundem numero, nunc indefinita, libera $v$. polyadelpha aut interdum monadelpha; antherae longitudinaliter v. poris dehiscentes. Ovari u m pluriloculare, rarissime uniloculare, loculis saepissime multiovulatis. E m b ry o exalbuminosus, saepissime curvatus.

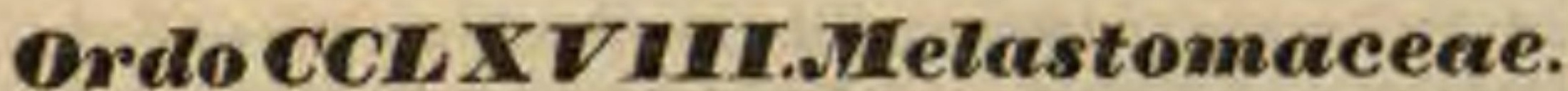

MELASTOMA Jussieu Gen. 328, Dict, sc, nat, XXIX 507. Bonpland, Molast. et Rhex. Paris. 1809. fol. MELASTO MACEAE R. Brown in Tuekey Congo 434. Don in Mem. Wern. soe, IV. 281. DC. Prodr. III. 99. Memoire sur les Melastomacees Paris. 1828 4. Martius Nov.gen, et sp. IIT. 160. Bartling Ord. nat. 328. Chamisso in Linnaed IX. 368. 428. $X, 32,217$. Blume in Flora 1831, p. 465. Lindley Intro duct, edit, IT, p. 41.

Arbores, fretices v. supprotices, rarius HERвав, caule ramisque teretibus aut tetragonis, nodosis. Folia opposita aut rarissime verticillata, altero ejusdem paris interdum minore, simplicia, integra, integerrima, rarius crenulata v. serrata, in petiolum, interdum inflato-tumidum angustata, tri-novemnervia, $v$. tripli - quintupli - aut septuplinervia, nervulis transversis plus minus manifeste reticulata, rarissime penninervia, epunctata. Stipulae nullae.

Flores hermaphroditi, regulares, in cymas paniculatas v. contractas plerumque dispositi, rarius solitarii, nudi v, varie bracteati.

$C_{A L X X}$ tubo campanulato, urceolato v. oblongo-tubuloso, nunc plane libero, nunc nervis staminum numero ovario plus minus cohaerens, aut taudem tota superficie accrescens, limbo saepissime quinque- rarins quadri- v. sexpartito, rarissime tripartito, quandoque integro, lobis aestivatione valvatis, persistentibus v. deciduis, interdum lobulis minoribus interjectis auctis.

Corollae petala calycis fauci ope laminae carnosae, tubum intus vestientis, et in annulum plus minus tumentis inserta, calycis laciniis numero aequalia et alterna, breviter unguiculata, aestivatione contorta.

Stanina cum petalis inserta, duplo eorundem numero, nunc omnia aequalia et fertilia, nune alterua petalis opposita minora v. efoeta, rarius rudimentaria v. omnino supressa. Filamenta filiformia, libera, aestivatione induplicato-inflexa. A $\mathbf{n}$ thera e terminales, biloculares, aestivatione pendulae, interstitiis inter calycis parietem interiorem et ovarium immersae, ovatae v. elongatae, apice saepissime in rostrum angustatae, loculis parallelis, apice poris saepissime in unum confluentibus, rarissime rimis longitudinalibus apertis, basi nonnunquam calcaratis, connectivo plerumque plus minus ultra Joculos deorsum producto, cum filamento articulato, ad articulum saepissime varie appendiculato.

Ovariom nunc omnino liberum, nune nervis tubi calycini adhaerens, apice nudum v. setosum, pluriloeulare, loculis plerumque dimidio v. simplici petalorum numero. Ovula in placentis dissepimentis adnatis, v. e loculorum angulo centrali exortis, rarius juxta loculorum basim subparietalibus, plurima, anatropa. Stylus simplex. Stigma indivisum.

Froctos plurilocularis, polyspermus, nune calycis tubo demum concrescente baccatus, nunc libero capsularis, intra eundem reconditus aut rarius nndus, loculicide dehiscens, valvis medio septiferis, placentis saepe in columnam centralem coalitis.

Semisa plurima, testa crustacea, nunc cochleata, umbilico ventrali, nunc ovoidea, oblonga v. angulata, umbilico basilari, rhaphe laterali, plus minus inerassata. Endopleura membranacea. Alb umen nullum.

Еивв уо semini conformis, rectus v. curvatus; cotyledonibus aequalibus v. altera ex- 
teriore in seminibus cochleatis multo majori, radicula umbilico proxima.

Melastomaceae in America tropica copiosissime crescentes, in America boreali subtropica et temperata (usque ad $40^{\circ}$ L. B.) rarae, et in Asia et Africa aequinoctiali haud frequentes, hine Lythrarieis conterminae, illine Myrtaceis proxime accedentes, singulari antherarum aestivatione et fabrica facillime distinguuntur. Memecyleae ad calcem ordinis recensitae, ovarii cum calycis arctiori cohaesione, fructus et seminis fabrica diversae, inter Melastomaceas et Myrtaceas mediae, Olinieis aretius adhuc ad Myrtaceas accedentibus proxime affines sunt.

Genera omnia demum accuratius perpendenda et retractanda, eorundem per tribus dispositio nimis arbitraria.

SUEATED I. MELASTOMEAE Seringe ex DC. Prodr. III. 100. Antherae apice uni-biporosae.

TIRIEUS I. LAV OISIEREAE DC. Prodr. III. 100. A $n t h$ e $r$ a e apice uni-biporosae. Ovari um liberum, apice saepissime glabrum. Ca p sula sicca. S emina recta, ovata v. angulata. - Species omnes americanae.

6169. Meriania $S W A R T Z$. C a l y $\mathrm{x}$ tnbo campanulato, libero, limbi quinque - sexlobi lobis basi latis, dilatato-meinbranaceis, apice subulatis. Corollae petala 5 v. 6 , calycis fauci inserta, ejusdem lobis alterna, ovalia v. obovata. S t a min a 10 v. 12 , cum petalis inserta, alterna iisdem opposita breviora, a $\mathbf{t}$ h erae apice ohtusae, bi porosae, connectivo basi brevissime calcarato. $O \mathrm{v}$ arinm liberum, depressiuscule globosum, glabrum, quinque-sexloculare, loculis multiovulatis. S tyIn s simplex; stigma subclavatum. Capsula calyce vestita, quinque-sexlocnlaris, loculicide de. hiscens, placentis semilunatis. Se min a plurima, minima, cuneato-angulata. - Arbores $v$. frutices, antillani, brasilienses et peruani; foliis oppositis, petiolatis, trinerviis $v$. subquinquenerviis, denticulatis, glabris $v$, vix in nervis tomentosis, floribus axillaribus, solitariis, pedicellatis, albis aut purpureis.

Meriania Swartz Flor. Ind. occid. IS. 824. $t .15$. Don in Mem. Werner, soo. IV. 322. Tussae Flor, Antill. t. 6. DC. Prodr, III, 100, Mem, I. 13. Meisn. Gen, 114. (81) Wrightia Solauder msc.

61\%0. Axinaea RUIZ et $P A V$. Calys tnbo cyathiformi, libero, limbo quinque-sexdenticulato, persistente. Corolla e petala 5 v. 6, calycis fauci inserta, ejusdem dentibns alterua, ovalia. Stamin a 10 v. 12 , cum petalis inserta, alterna iisdem opposita breviora, an therae apice obtusae, biporosae, connectivo basi in calear simplex producto. Ovarium liberum, globosum, vertice suleatum, glabrum, quinque-sexloculare, loculis multiovalatis. Stylus simplex; stigma acutum. Capsula ealyce vestita, quinque-sexloeularis, loculicide dehiscens, S emina plorima, minima, angulata. - Arbores frondosae v. frutices, in Peruvia crescentes; folits oppositis, petiolatis, ovato-lanceolatis v. late cordatis, coriaceis, dentatis v. crenatis, quinquenerviis, reticulatim venosis, supra rugosis $v$. laevibus, sublus tomento brevissimo, fusco tectis, floribus terminalibus, corymbosis v. subracemosis, magnis, purpureis v. albis.

A xi n a e a Ruiz et Pavon Prodr. 57. t. 12. Syst, 122. Dou in Mem. Werner. soc. IV, 319. DC. Prodr, IIT $10 t$. Mem. I, 13. Meisner Gen. 114. (81.)

6181. Clanstemaea DC. Calyx tubo campanulato, libero, limbo trnneato, integerrimo. Cor 11 a e petala 5, calyeis fauci inserta, olova. ta. Stam in a 10 , cum petalis inserta; filamenta plana, antherae lineares. acutae, uniporosae, connectivn basi in appendicem amplam, rotundam, fortassis concavau producto. Ovarinm liberum, glabram, quinquelveulare, loculis multiovalatis. Stylus filiformis; stigma punctum pruinosum. Ca psula calyce vestita, quinquelocularis, apice loculicide quinquevalvis. Se mi na ..... - Frutex americanus, glaberrimus, $M_{e-}$ rianiae facie; foliis oppositis, petiolatis, ovalibus, trinerviis, integerrimis, coriaceis, floribus in apice ramorum ramulorumque subumbellatis, pedicellatis, ebracteatis, amplis.

Chastenae a DC. Prodr. III, 102. Mom, I, 13. Meis. ner Gen, 114. (81.)

B18\%. Lavoisiera DC. C a 1 y $x$ tubu campanulato, libero, limbo quinque-decemlobo v. dentato, saepissime deciduo Corolla e petala 5-10, calycis fauci inserta, ejnsdem dentibus alterna, ovalia v, obovata. St a m in a $10-20$, cum petalis inserta, alterna isdem oppotita breviora. antherae ovatae, rostro brevi, uniporoso, connectivo longinseulo, deorsum clavato v. emarginatobilobo. Ovariam liberum, glabram v, vertice sulcato-setulosum, quinque deremloculare, loculis multiovulatis. Stylus filiformis; $8 \mathrm{tig} \mathrm{ma} \mathrm{ineras-}$ satum. Capsula calyce vestita, vertice concavo urnaeformis, quinque-decemlocularis. Se mina plurima, oblongo-obovata, reticulata, umbilico subbasilari.-Frutices brasilienses; ramis plerumque erectis, densis, fastigialo-dichotomis, interdum scoparïs, inferne aphyllis, foliis oppositis, decussantibus, sessilibus, cicatrices lineares, horizontales relinquentibus, floribus terminalibus, inter summa folia sessilibus $v$. breviter cymulosis et bracteatis, roseis, purpureis, violaceis, flavis $v$. albis, speciosissimis.

Lavoistera DC. Prodr. 1IT, 102. Mem, I. 14, t. 2. Martius Nov. gen. et sp. 1II. 131. t. 263_272. Chamisso in Linnaea IX. 369. Meisuer Gen, 114. (82.)

61\%3. Davya $D C$. Caly $\mathrm{x}$ tubo campanulato v. ovato-oblongo, libero, dentibus $10-12$, in limbum integram, snbmembranaceum connatis. Corolla e petala 5 _ 6 , calycis fanci inserta, obovata, patentia. Stamina $10-12$, cum petalis inserta, subaequalia, a $\mathbf{t h}$ er a e rostratae, nniporosae, connectivo e basi elongata $v$. binodulusa pus. tice in calcar simplex $v$. apice setoso divisum sursum producto. Ovari um liberum, vertice depresso-glabrum, quinque-sexlocnlare, localis multiovalatis. Styla s filiformi-clavatus; $8 \mathrm{tigma}$ truncatum. C a p 8 la calyce vestita, quinque-sexlocularis, loenlieide quinque-sexvalvis. Semina plarima, recta. - Arbusculae in America tropica indigenae, ramis oppositis brachiatisve, patulis, subteretibus, glabrae v. imprimis in partibus junioribus lepidoto-tomentosae; foliis oppositis, petiolatis, latiusculis, ovatis v. oblongis, tri-quinquenerväis, floribus corymboso paniculatis, flavis. 
Davy a DC. Prndr. IIT. 105. Mem. I, 17. t. 3. Martius Nov. gen, el sp. III. 184, t. 261. Meisuer Gen, 114. (81.)

61\% 4. Adelbertia MEISN. Cal y x tubo turbinato, libero, limbi dentibus quinque, subulato acuminatis, Corollae petala 5 , calycis fauci inserta, ejusdem dentibus alterna, obovata. Sta $\mathbf{m}$ i n a 10 , cum petalis inserta, alterna iisdem opposita breviora, a ntherae rostratae, uniporosae, connectivo e basi breviter acnminata postice in calcar elavatum, simplex sursum producto. O variu m liherum, ovoideo-oblongum, glabrum, triloculare, loculis mnltiovulatis. Stylus crassius. culas, sursum attenuatus; stig ma punctiforme C a p 8 a 1 a .....-Arbuscula brasiliensis, pube stellulata ferugineo-pulverulenta; foliis oppositis, petiolatis, elliptico-oblongis, trinerviis, subcoriaceis, supra lucidis, margine revoluto integerrimis, paniculae terminalis aphyllae ramulis trifloris.

A delbertia Meisuer Gen. 114. (81.) Davya seet. altera Chamisxo in Linnaea IX. 372.

61 1 5. Graftenrieda DC. C a 1 y $x$ tubo oblongo, libero, limbi campanulati dentibus brevissimis, obtusis. Corolla e petala 5, calycis fanci inserta, ejusdem dentibus alterna, obovata. St a m in a 10 , cum petalis inserta, alterna iisdem opposita breviora, a nthera e lineares, acutae, uniporosae, basi in appendicem simplicem, setnsam productae. Ovarium liberum, vertice con vexum, glabrum, quinqueloculare, loculis multiovulatis. Stylus filiformis; stigma acntum. Capsula ovata, calyce vestita, quinquelocularis, apice locnlicide dehiscens. Sem in a plurima, angulata, recta. - Frutex Novae-Andalusiae; ra mulis teretibus, glabris, foliis oppositis, breve petiolatis, orbiculatis, subcordatis, integerrimis, supra glabris, nitidis, subtus pulverulentis, trinerviis, thyrso terminali paniculato.

Graffenrieda DC. Prodr. IIT, 105, excl. sect. 2. Mem, I, 20. Meisner Gen, 114. (81.) nou Mart, R hex i rot undifoli a Bonpl. Rhex. $t .25$.

B1 1 . F. In lato, libero, limbi dentilus quatuor dorso incrassatis, carinatis. Corolla e petala 4 , calycis fauci inserta, ejusdem dentibus alterna, obovata. Sta$\mathbf{m}$ in a 8 , cum petalis inserta, alteraa iisdem opposita paullo minora, a nthera e oblongo-lineares, uniporosae, e basi connectivi supra filamenti insertionem caleare subnlato acutae. Ovarium libe. rum, glabrum, quadriloculare, loculis multiovulatis. St y I a s filiformis; stigma punetiforme. Capsula calyce tandem rupto velata, quadrilocu. laris, locolicide quadrivalvis. Semin a plurima, scobiformia, in placenta spongiosa erecto-imbricata. - Frutices brasilienses, glabri; foliis oppositis, petiolatis, ovalibus $v$. oblongis, trinerviis $v$. argute serratis, florum cymis terminalibus.

Huberia DC. Prodr. III. 167. Mem, I. 61, $t, 10$. Martius Nov, gen. et sp. IIT, 146. in not, t, 276. f, 2, Chamisso in Linnaea IX, 373. Meisuer Gen. 114. (81.)

B 18\%. Beharia CHAM. C a I y $x$ tubo turbinato-subcupulaeformi libero, limbi gexpartiti laciniis lanceolatis, dorso incrassatis, carinatis, erectis, tubum superantibus, deciduis. Corollae petala 6 , ealycis fanci inserta, ejnsdem laciniis alterna, cuneato-obovata. Sta min a 12 , cum petalis inserta, alterna iisdem opposita paullo minora, antherae oblongae, nniporosae, connectivi basi in calcar subulatum produrta. Ovarium liberum, vertice glandulis sex piligeris coronatum..... Stylus filiformis; stigma punctiforme. Cap- s u la globosa, calyee truncato cincta, quadrilocnlaris, loculidice quadrivalvis. Semina plurima, recta. - Frutex brasiliensis; ramis tetragonis, pubescentibus, foliis oppositis, petiolatis, elliptico. lancealatis, triplinerviis, calloso-serratis, cymis ter. minalibus solitariis $v$, in paniculam foliosam collectis.

Be hurfa Chamisso in Linnaea IX. 376. Meisuer Gen. 114. $(81$.

G1 18 . Centraclenaia $G$. DON. C alyx tubo subtetragono-campanulato, libero, limbi quadripartiti laciniis late triangularibus, acutis. Coro Il a e petala 4, calycis fanci inserta, ejusdem laciniis alterna, obovata. St a mina 8 , cum petalis inserta, alterna iisdem opposita minora, anthe $\mathrm{r}$ a e ellipticae, uniporosae, majores connectivo in calcar elungato-cnneatum, minores in appen dicem glandulaeformem productae. Ov arin m liberum, vertice setarum verticillo simplici, quadriloculare, loculis multiovulatis. Stylus brevis; st igma subeapitatum. Cap 8 u la calyce vestita, quadrilocularis, loculicide quadrivalvis. Se min a plurima, clavato-elliptiea, echinata, umbilico basilari. - Suffrutex mexicanus; ramis tetragonis, pilosis, foliis oppositis, altero minimo, altero multo majore, ramum ex axilla explicante, oblongo-lanceolatis, acutis, valde inaequilateris, integerrimis, ciliatis, membranaceis, triplinerviis, racemis axillaribus paucifloris.

Centrade nia G. Don Syst, II. 765. Meisner Gen, 114. (8I.) Plagiophy IIu m Sehlechtend, in Linn. XIII. 429. Rhexia inaequilateralis Cham. et Sehlechtend. in Linnaea $\nu$. 567 .

B18. If Irachyeentrum MEISN. Calyx tubo campanulato, libero, limbi constricti dentibus quinque, brevibus, acutis, deciduis. C orolla e petala 5, calycis fauci inserta, ejusdem dentibus alterna, obovata. Stam in a 10 , eum pe. talis inserta, aequalia, ad inferius floris latus dejecta, an thera e lineares, uniporosae, aequales, connectivo basi breviter et obtuse sursum producto. Ovarium liberum, vertice quinque-septemgibbosum, quinque-septemloculare, loculis multiovulatis. Stylus filiformis; stigma simplex. Cap sula globosa, calyce vestita, quinque-septenloenlaris, loeulicide quinque-septemvalvis. Semi na plurima, angulata, recta. - Herba peruana; caulibus ex eadem radice pluribus, elatis, ramulis tetragonis, petiolis, pedunculis foliisque subtus pube rufescente velutinis, folits oppositis, longe petiolatis, ovalibus, septemnerviis, crenatis, supra bullatis, glabris, thyrso terminali paniculato, floribus bibracteolatis.

Brachycentrum Meisner Gen, 114. (81,) Graffenriedia excelsa DC. Rhexia excelsa Bonpl. Melast. $t .34$.

B180. Pyramia CH AMISSO, C a ly x tubo urceolato, libero, limbi lobis quinque- v. sex brevibus, persistentibus. C or oll a e petala $5-6$, calycis fauci inserta, ejusdem laciniis alterna, ovata. Stam in a $10-12$, cum petalis inserta, aequalia, a ntherae elongatae, subfalcatae, uniporosae, connectivo deorsum incrassato, basi postice bigibboso, exappendiculato. Ovarinm liberum, vertice setis coronatum, quinque - sexloculare, loculis multiovalatis. St y lus filiformis, basi hispidas, apice demum incurvas; $8 \mathrm{tigma}$ punctiforme. $\mathrm{C}$ a $\mathrm{p}$ suI a intra calycem demum apice constrictum libera, quinque - sexeostata, quinque - sexlocularis, loculieide quinque-sexvalvis, columna placentifera tandem libera. Semina plurima, pyramidata, reeta, 
laevia v. granulata. - Frutices brasilienses, pilis stellatis $v$. ramosis tomentosi ; foliis oppositis, breviter petiolatis, trinerviis, panicula terminali con tracta, subcapitata.

P y $\mathrm{ram}$ i a Chamisso in Linnaea IX. 458. Meisner Gen, 114. (81.) Osbeckia pityrophy IIa DC.

6181. Centromia DON. Calyx tubo oblongo, libero, setis retrorsis undique hispido, limbo coarctato, integro. Coroll a e petala 5 , ca. lycis fauci inserta. Sta min a 10 , cum petalis inserta, antherae longissime rostratae, uniporosae, basi processu longo subulato, acutissimo instructae, Ovarium in collum tubulosum elongatum desinens, basi quinqueloculare. Stylas ovarii collo inclusus; $8 \mathrm{tig} \mathrm{ma} \mathrm{obtusum.} \mathrm{Ca} \mathrm{p} s \mathrm{u}-$ 1 a quinquelocnlaris. - Arbor peruana; ramulis dense ferrugineo-tomentosis, foliis petiolatis, amplis, elliptico-acuminatis, coriaceis, integerrimis, penninerviis, reticulato-venosis, supra glabris, nitidis, subtus fusco-tomentosis, demum glabratis, panicula terminali, magna, brachiata, floribus magnis, purpureis.

Centronia Don in Mem. Werner. soc. IV. 314. DC Prodr. III. 106. Meisuer Gen, 114. (81.) Osbechia pe ruviaua Pavon msc.

618\%. Trumeneia DC. Ca Iy x tubo cylindraceo, vix turbinato, libero, limbo truncato, snbintegerrimo. Corolla e petala 5 , calycis fauci inserta, ovata. Stamina 10 , cum petalis inserta, a nthera e elongatae, rostratae, unipurusae, exappendiculatae. Orarinm liberum, basi decagonnm, apice subcyathiforme ..... Stylus filiformis; sti $\mathrm{gm}$ a hemisphaericum. Fructus .... - Frutex brasiliensis, scandens; ramulis ob. tuse tetragonis, petiolis pedunculisque glabriusculis, hine inde pilosiusculis, foliis oppositis, ovalibus, basi subcuneatis, apice mucronato-acuminatis, quinquenerviis, integerrimis, ciliatis, utrinque pilosulis, thyrsi terminalis elongati ramulis trifloris, setis sub floribus nonnullis bractearum locum tenentibus.

T r u n a $r$ i a DC. Prodr. III. 106. Mem. I. 20. Meisner Gen. 114. (81,)

8183. Thymelnanthera $D C$, Calyx tubo ovato-globoso, libero, limbi quinquepartiti lobis linearibus v. setaceis, persistentibus. Corol. 1 a e petala 5, calycis fauci inserta, ejnsdem lobis alterna, ohovata. Stamina 10 , cum petalis in serta, alterna iisdem opposita minora v. castrata, antherae ovato-cylindricae, rostro longissimo, uniporoso, connectivo fliformi, elongatu, basi binoduloso. Ovari um subglobosum, liberum, tri-quinqueloculare, loculis multiovulatis. Stylus filiformis, apice incrassatus; st igua obtusum. Cap s u la calyce vestita, tri-quinquelocularis, apice locnlieide dehiscens. S e mina plurima, recta. angulata v, cuneata. - Frutices $v$, suffrutices, in America tropica indigeni; caule ramisque obsolete tetragonis, dense hirsutis $v$. pubescentibus, saepe glutinosis, foliis oppositis, petiolatis, ovatis $v$. oblongis, serratis, nervis quinque ad novem pilosis v. hirtis, cymulis ramulos terminantibus $v$. in thyrsum collectis.

Rhynehanthera DC. Prodr. III. 106. Mem. I. 21. Martius Nov. gen, et sp. III, 120. $t, 239.260$. Cliamisso in Linnaea IX. 377. Meisuer Gen, 114. (89.) Probnscidea Richard mac. R hexiae sp. Bonpl. Rhex, t.11. Mela sto. matis sp. Aublet $t, 160$.

8184. Bacquetia DC. Ca ly x tubo glo. boso, libero, limbi quadripartiti lobis latis, fere triangularibus, vix acutis, persistentibus. Coro l- la e petala 4 , calycis fanci inserta, ejusdem lobis alterna, ohovata. Sta min a 8 , enm petalis inserta, aequalia; fil am enta glabra, antherae ob. longae, uniporosae, connectivo vix manifesto, exappendiculato. Ovarium liberum, apice valvis subincrassatis, truncatum et quadrituberculatum, quadriloculare, loculis multiovulatis. Sty l u s filiformis; stigma acutum. Capsn l a quadrilocalaris, apice loculicide dchiscens. Semina plurima, cuneato angnlata. - Frutex Novo_Granatensis; ramis glutinosis, foliis breve petiolatis, ellipticis, trinerviis, laevibus, subintegerrimis, pedicellis ad apices ramorum ternis, floribus violaceis.

B n equeti a DC. Prodr. III, 110. Mem. I, 22. Meisner Gen. 114. (8I.)

6 1 85. Cambessedesia $D C$. Calyx tubo campanulato, libero, limbi quinquepartiti lobis brevibus, acutis, persistentibus. Corollae petala 5, calycis fauci inserta, ejusdem lobis alterna, obovata. Stamina 10 , cum petalis inserta, aequalia, a ntherae subulatae, uniporosae, basi breviter bilobae, connectivo deorsum parum produnto. Ovarium liberum, ovatum, triloculare, loculis multiovulatis. Sty I us filiformis; stigma acutum. Capsula coriacea, calyce vestita, ovato-globosa, trilocolaris, loenlicide trivalvis. Semina plnrima, angulata v. ovata, umbilico lineari. - Frutices brasilienses, erecti v. adscendentes, dichotome ramosi; caule ramisque tetragonis, basi aphyllis, foliorum cicatricibus ornatis, folits subsessilibus, decussatis, verticillatis $v$. interdum ramulorum axillarium abortu fasciculatis, ovatis, oblongis v. sublinearibus, serratis, dentalis aut rarius integerrimis, nervis tribus aut quinque parum manifestis, floribus speciosis, miniatis, purpureis $v$. flavis, versus caulis et ramorum apicem terminalibus et axillaribus, cymas thyrsoideo-contractas $v$. laxe paniculatas constituentibus, bracteis interdum heteromorphis, nonnunquam vacuis, pilis saepe glanduliferis $v$. clavatis.

C a mbess edesia DC. Prodr. IIT, 100, Mem, I. 20. excl. sp. Martius Nov. gen, et sp. ITI, 125. 268, 263, Chamisso in Linnaea IX, 381. Meisuer Gen, 114. (81.) R he$\mathrm{x}$ i a e $\mathrm{s} \mathrm{p}$. Bonpl. Rhe $x, t .58,60$.

B186. Clnaetostoma DC. Caly x tubo cylindrico, nervoso, limbo extus setarum annulo obvallato, laciniis quatuor v. quinque subulatis, persistentibus. Corollae petala $4-5$, calycis fanci inserta, ejusdem laciniis alterna, obovata, patentia. Stamina $8 \ldots 10$, cum petalis inserta, alterna iisdem opposita breviora, sabconformia, antherae cylinilricae, uniporosae, connectivo nune lineari-elongato, nnne brevi, basi bilobo. Ovari n m lihernm, cylindricum, triloculare, loculis multiovulatis. Siylus filiformis; stig ma subsapitatum. C a p s u la rylindrica, calyce vestita, trilocularis, loculicide trivalvis. Se m in a plurima, ovata, subineurva, retieulata, umbilieo laterali. Fruticuli brasilienses, ericoidei, aridiusculi; caule inferne aphyllo, foliorum cicatricibus annulato, ramis fastigiatis $v$, divergentibus, foliis sessilibus decussatis, acerosis, exsuccis, floribus terminali. bus solitariis, minusculis, purpureis, antheris flavis.

Cha eto s to ma DC, Prodr.IIT, 112, Mem, I. 23. Martius Nov. gen, et sp. IIT. 128. t, 264. Chamisso in Linnaea IX. 381, Meisuer Gen, 114. (81.)

618\%. MTeismeria $D C$. Cal y x tubo campanulato-subgloboso, libero, limbi laciniis quatuor. Ianceolatis, acuminatis, persistentibus. Corulla petala 4, calyeis fauci inserta, ejusdem 
Lobis, alterna ovalia, patentia. Stamina 8 , cum petalis inserta, alterna iisden opposita minora, antherac ovatae v. cylindricae, rostro uniporoso, majorum connectivo dilatato-carnoso, deorsum producto et antice bianrienlato, minorum simpliciter producto v, subnullo. O va rin m liberum, ovatam, glabrum, biloculare, loculis multiovulatis. Stylus filiformi-subelavatus; $s t i g m$ a subcapitatum. C a p ula calyce vestita, bilocularis, loculicide bivalvis. Semina plurima, oblonga v. obovata, recta. - Herbae brasilienses, hirsutulae; ramis oppositis v. sparsis, foliis oppositis, sessilibus, ovatis, trinerviis v. subuninerviis, cilialaserrulatis, inflorescentia cymoso-paniculata, floribus violaceis, parvulis.

Meisneria DC. Prodr. IIT. 114. Mem. I. 20. Martius Nov, gen. ot sp. III, 118. $t$, 258. f. 1. 2. Melsuer Gen. 114, (88.)

6u88. Siplaanthera $P O H L . C$ a l y x tubo ovato-campanulato, libero, limbi laciniis quatuor, lanceolatis, acuminatis, persistentibus. Corollae petala 4, calycis fauci inserta, ejusdem lo. bis alterna, ovalia, patentia. Stamina 4 , cum petalis inserta, iisdem et squamulis quatuor mini mis alterna, exserta, antherae ovatae, rostro longo uniporoso, connectivo haud producto tumide biauriculato. Ova ri u m liberum, ovatum, glabrum, biloculare, loculis biovulatis. St y I u s fusiformi clavatus; stig ma subeapitatum. Cap suI a calyce vestita, bilocularis, loculicide bivalvis. S emina plurima, obovata, recta. Herbae bra. silienses, pusillae, erectae, glanduloso-pilosae; foliis oppositis, sessilibus, ovatis, penninerviis, floribus dense capitatis, foliaceo-bracteatis, capitulis axillaribus et terminalibus, breve pedunculatis, corollis roseis.

Siphanthera Pohl Plant, Brasil. I, 102, $t, 84.85$, DC, Prodr. III, 12t. Martius Nov. gen. et sp. 1II. 120, in not, $t, 158 . f$, 3, Meisner Gen. 115. (82.)

6489. Salpinga $M A R T$. Caly (ubo campanolato, libero, froxtifero elongato tubaefor. mi, Iongritudinaliter suleato, limbi dentihns quatuor v. quinque brevissimis, persistentibus. Co roll a e petala 4 v. 5 , calycis fauci inserta, ejusdem dentibus alterna, lanceolata, acuta, conniventia. Stau in a $8-10$, cum petalis inserta, subaequalia, antherae cylindrieae, uniporosae, connectivo in clavulam elongato. Ovarinm liberum, cylindri. cum, vertice concavam, glabrum, triloculare, loculis multiovalatis. C a ps u la calyce vestita, trigono-cylindrica, trilocularis, Loenlicide trivalvis, valvis medis septiferis, columna seminifera filiformi, libera. S e m in a plurima, depresso-semielliptica, umbilico basilari, earuncula centripeta transversa, profunde rimata - Herbae brasi lienses, molles; caule ramisque tetragonis, foliis oppositis, petinlatis, serratis, tri-quinquenerviis, floribus secundis, in cymas scorpioideas dispositis.

$\mathrm{S}$ a $1 \mathrm{ping}$ a Martius. Nov. gerz. zet sp. IIt. 114. t. 256. DC. Prodr, III, 112, Mem, I, 24, Meisuer Gen, 114. (81.) A u lac id I u m Richard msc.

61D0. Fertolonia $R A D D$. Caly $x$ tubo eampanulato, libero, fruetifero late alato-triquetro, limbi lobis quinque obtusis, distinctis v. in marginem integram concretis. Co r o I la e petala 5, calycis fauci inserta, ejusdem lobis alterna, obovata. St a m i a 10 , enm petalis inserta, subaequalia, antherace cylindrieae, uniporosae, connectiv", vix prominulo. Ovariu m liberum, ovatum, depressinsculum, glabrum, triloculare, Inculis multiovulatis. Stylus brevis, subclavatus; sti g ma punetiforme. Capsala calyee vestita, trialata, trilocularis, vertice depresso tririmosa, colomella centralis abbreviata, tandem libera, e basi placentas lineares porrigens. Semin a plorima, subsemilunari-trigona, tuberenlata. - Herbae in Brasiliae sylvis primaevis, locis umbrosis, suffocatis vigentes, procumbentes; foliis oppositis, petiolatis, cordatis, quinque-plurinerviis, subintegerrimis $v$. crenatis, ciliatis, inflorescentia cymosa, pedicellis brevissimis $v$, subnullis, floribus albis, roseo-purpureis $v$, roseis.

Bertolo ala Raddi Mem. Plant. brasil. addend. S. DC. Prodr. IIT. 113. Mem, I, 25. Martius Nov, gen, et sp. 1IK. 116. h, 257. Chamisso in Linnaea LX. 383. Meisner Gent. 114. (81,) Triblemma Martius msc. Rhexiae sp. Boupl, Bhex, $t, 52 \_55$.

8191. Withobiume BONG. C a I yx tubo eampanulato, cum ovario connato, Jimbo superi, obsolete trilobo, lobis rotundatis. Coroll a e petala 3, calyeis fauci inserta, ejusdem lobis alterna, rotundata, emarginata. Stamina 6 , cum petalis inserta, snbaequalia, antherae clavatae, uniporosae, poro ad medium hiante, connectivo basi vix producto. Ovari u m semiadnatum, globosum, glabrum, triloculare, loculis multiovulatis. StyIns filiformis, rectus, sub stigmate punctiformi nonnihil constrictus. Capon la globosa, trilocularis, loculieide trivalvis, valvis medis septiferis, placenta centrali, medio seminifera, tandeu libera. S e min a plurima, pyriformia, parum curvata, hine convexa, illine concava, laevia. - Herba brasiliensis, rupicola, tenera, subacaulis; foliis oppositis, petiolatis, cordatis, quinquenerviis, integerrimis, floribus terminalibus, paucis, pedicellatis, purpureis.

Li th o b I a m Bongard in Mem. Acailem. St. Peterab, VI. Ser, II. 140, t. 8. f. 2 .

B192. Sonerila ROX 1 . Caly x tubo whlongu v. subtrigono, saepe murieato, nervis tribus cum ovario cohaerente, limbi trifidi laciniis deciduis. Corolla e petala 3 , ealycis fauci inserta, ejusdem laciniis alterna, ovato lanceolata, acnta. Stam in a 3 , cum petalis inserta, iisdem alterna, anth erae lineari-oblongae, apice biporosae, basi eutarginatae, exappendiculatae. Ovari nu tubi calycini nervis adhaerens, superne truncatum, glabrum, trioculare, loculis mnltiovnlatis. Sty i s filiformis; stigma obtusum. Capsula turbinata, unargine calyeis intus incrassato.coronata, triloeularis, superne valvalis brevibus dehiscens. Sem in a plurima, cuneato-angulata, difformia, aspera. - Herbae annuae v, fruticuli, in Asia tropica indigeni; ramis teretibus, foliis oppositis, plerumque disparibus, altero fere abortivo, basi saepissime obliquis, integerrimis $v$. dentatis, membranaceis, nervosis, hirsutis, pedunculis axillaribus et terminalibus, racemosis $v$. fasciculatis, pauci-multifloris, floribus roseis.

Sonerila Roxburgh Flor. ind. edit. Wall. t. 180. Jaek in Hook. Bot. Mise. Ir. 63. Blume in Flora 1831. p. 490. Wallich Plant, As, rar. II, 1, Wight et Arnots Prodr. I, 321. Meisner Gen, 114. (81.) Cassebeeria Deanst. ad Hort. Malab. IX, 65.

a. EUSONERILA Blume $l$, c, C a I y $\times$ hirsutius, vix augalatus. Petala ovata, acuta, bssi lata. Ca psuta tur152 
binata, valvulis tribus, bipartitis dehiscens. - Folia opposita, altero subabortivo, basi dimidiato.cordata, (Wallich Plant. As, rar. $t$. 102. Zeaker Plant. ind. t. 18.)

b. TRIGONOCAPSA Blume $l$. c. Cal y $\times$ glabriusculus. trignons. Petala ovatolanceolata, ntrisque acuta. Cap. s a I a turbinata, basi attenuata, trigona, valvulis tribus indivisis dehiscens. - Folia opposita, subaequa. lia, basi vix abliqua, (Royle Himalay. $t$. 45.)

TIREUS II. RHEXIEAE DC. Prodr. III. 114. Antherae apice uniporosae. O varium liberum, vertice plerumque glabrum. Capsula sicea. Semin a cochleata, - Species americanae.

6193. Dieramanthera PRESL, C a ly x tubo globeso, libero, limbi quadripartiti laciniis ovatis, serrulatis, setis interjectis distinctis. Corolla nulla, Sta min a 8 , calycis fauei inserta, alterna ejusdem laciniis opposita majora, antherae obtusae, uniporosae, minorum connectivo basi biauriculato, majorum bisetoso. Ovarium liberum, biloculare, loeulis multiovulatis. S $t \mathbf{y}$ Ius flexuosus, sursum valde incrassatus; stigma obtusum. Capsula calyce vestita, bilocularis, loculicide bivalvis, eolumella clavato-fungosa. $\mathrm{Se}$ mina plurima, cochleata. - Herba brasilien sis, pusilla, hirsula; caule simplici v. subramoso, foliis oppositis, sessilibus, oblongo-lanceolatis, trinerviis, serratis, floribus axillaribus, solitariis, bre vissime pedicellatis, parvis.

Dierananthera Presl in Symb. bot. I. 75. $t$. 50 . Chamisso in Linnaea IX, 385, Meisuer Gen, 115. (82,)

6194. Poteranthera BONG. Cal $\mathrm{y} x$ tubo ovali-globoso, libero, limbi quinqnepartiti laciniis lanceolatis, acuminatis, integerrimis, pilo glanduloso terminatis. Co ro 11 a e petala 5 , calycis fauci inserta, ejusdem laciniis alterna, ovalia, pilo glandulifero terminata. St a min a 5 , cum petalis inserta, iisdem alterna, a ntherae cylindricae, apice oblique truncatae, biporesae (?), connectivo basi breviter bianriculato. $O$ va ri $\mathrm{m}$ liberum, subglobosnm, triloculare, loculis multiovulatis. Styins filiformis, rectus; stig ma subcapitatum. Capsula calyce vestita, trilocularis, loculicide trivalvis, placenta centrali, trigona. Semina plu. rima, cochleata. _ Herbabrasiliensis, pusilla; caule subsimplici, erecto, tetragono, foliis oppositis, sessilibus, subdecurrentibus, linearibus, enerviis, pilis paucis, rigidis, glanduliferis margine et apice ornatis, floribus axillaribus, solitariis, breviter pedunculatis, parvis, albis.

Poteranthera Bongard in Mom, Loadem. St. Po. tersb, VI. Ser. II, 137, $t, 8, f$. 1.

6195. Spenmera MART. Calyx tubo subgloboso, libero, limbi quadri-quinquepartiti la ciniis brevibus, triangularibus. Corolla e petala 4 v. 5 , calycis fauci inserta, ejusdem lariniis alterna, lanceolata, acuta. Sta mina 8 - 10, cum petalis inserta, aequalia, antherae eylindricae, uniporosae, connectivo simpliciter producto, haud appendiculato. Ovari n m liberum, bi-triloculare, loenlis multiovulatis. Stylns ineurvos, infra s t i g ma truncatom constrictus. Ca ps u la calyce velata, membranacea, bi-trilocularis, irregulariter rumpens. Semin a plurima, renifurmi-cochleata, echinulata. - Herbae brasilienses, erectae v. adscendentes, molles, flaceidae, glabrae $v$, parce et Iongiuscule pilosae; caule ramisque tetragonis, foliis oppositis, petiolatis, membranaceis, quinque-sep- temnerviis, saepissime ciliato-serratis, inflorescentia terminali cymosa, paniculato-ramosa.

Spennera Martius Nov. gen. et sp. IIT. 112. $t, 255$. DC. Prodr. III. 115. Mem. I. 28. Meisner Gen. 115. (88.) Rhexias sp. Bonpl. Rhex. t. 38-40.48. 49. Melasto. mat is sp. Aublet Guian, $t$. 169 . J a rava a Scopoli In. troduct, n, 948, part.

C196. Noteroplaila $M A R T$. C al y $x$ tubo campanulato, libero, limbi quadri-quinquepartiti laciniis anguste triangularibus, acntis. Corolla e petala 4 v. 5 , calycis fauci inserta, ejusdem laciniis alterna. S tam in a $8-10, \mathrm{cnm}$ petalis inserta, alterna isdem opposita minora, a n therae cylindricae, uniporosae, connectivo in ligulam apice nodoso-incrassatam, in staminibus minoribus multo breviorem producto. Ovarium liberum, bilocnlare, loculis multiovulatis. Stylus flevunsus, infra $8 \mathrm{tigma}$ punetifurme constrictus. Cap $8 \mathrm{ula}$ ealyce velata, memhranacea, bilocularis, loculicide bivalvis. Semina plurima, renifurmia, punctata. - Herbae brasilienses, paludosue, erectae v. radicantes, glabrae $v$, sparsim pilosulae; caule tetragono, parce rumoso, foliis oppositis, subsessilibus, subtrinerviis, integerrimis $v$. serrulatis, floribus uxil. laribus, solitariis, parvis, albis, roseis v, purpurascentibus.

Noterophila Martius Nov. gen. et sp. IIr. 110. t. 254. Meisner Gen. 115. (82.) Mie roliefae $\mathrm{sp}$. DC. Melastoma bivalvis Aubl. Guian. $t$. 155. $f$, a. Ja rava a Scopoli Introduot, n. 948. partim.

B19\%. Nierolieia $D U V$, Calyx tubo campanulato, libero, limbi quinquepartiti laciniis subulatis. Corolla petala 5 , calycis fauci inserta, ejusdem laciniis alterna, obovata. Stamin a 10 , cum petalis inserta, alterna iisdem opposita multo minura, an therae nvato-eylindrieac, rostro uniporosae, majorum connectivo in appendicem clavatam, minornm in appendicnlam brevissimam producto. Ovariu m liberum, triloculare, loculis inultiovulatis. S t y I n s filiformis, adscendens; st igm a acutum. Caps ul a calyea velata, membranacea, trilocularis, loculicide trivalvis. Semina plurima, cochleata, punctata. - Fruticuli v. rarius herbae, brasilienses, pube dum adest simplici v. glandulosa; ramis plurimis, erectis v. fasti. giato-ramulosis, inferne aphyllis, tetragonis, foliis oppositis, sessilibus, plerumque parvis, obsolete tri. nerviis, floribus breviter pedunculatis, bracteis oppositis ad basim fultis, in axillis foliorum superiorum solitariis, sparsis v, subcorymbosis, albis, violaceis v. purpureis.

Microlicla Don in Mem. Werner. Soc. IV. 301. DC. Prodr. III. 117. excl. sp. Martius Nov. gen, et sp. III. 105. t 251. 252. Chanisso in Linnaea IX. 386. Meisner Gen. 115. (82.) Melastoma $t r i v a l v i s$ Aublet Guian, $t, 155$. b. R hexiae sp. Auct,; Bonp1. Hhex, t. 59. J a ravaea Seopoli Introduce. n, 948, part.

6198. Fritzselaia $C H A M$. Calyx hemisphaerico-cnpuliformis, liber, limbi quadripartiti laciniis angustis, acutis, sinu lato patente sejanctis. Corolla e petala 4 , calyeis fanci inserta, ejusdem laciniis alterna, ellipsoidea, acuta. Stam in a 8 , cum petalis inserta, alterna iisdem opposita minora $\mathbf{v}$, aequalia, heteromorpha, an $t h e-$ ra e ovoideo-oblongae, uniporosae, staminum cum petalis alternantium connectivo areuato in appen. dicem bifilam producto, oppositorum vix producto, bilobo v. bicalloso. O varium liberum, quadriloeulare, loculis multiosulatis. Stylus filiformis, declinatus; stigma punctiforme. CapsuIa ealyee vestita, globosa, quadrilocularis, apice locu- 
licide quadrivalvis. Semina plurima, reniformia, pnnctata. - Suffrutices brasilicnses, glaberrimi, Serpylli facie; foliis oppositis, petiolatis, floribus terminalibus solitariis, rubris $v$. purpureis.

Fritx, chia Chamisso in Linnaea IX. 397. Meisner Gen. 115. (82.)

61199. Ermestia DC. Calyx tubo ovoideo, libero, limbi quadripartiti laciniis angustis, acuminatis. Corolla e petala 4 , calycis fauci inserta, ejusdem laciniis alterna, patentia. Sta mina 8 , cum petalis inserta, aequalia, a $\mathrm{t}$ he rae oblongae, rostro attenoato uniporosae, connectivo arcuato, basi postice breviter et obture calcarato, antice bisetoso appendiculato. Ov a $\mathrm{ri} \mathbf{~ m}$ liberum, quadriloculare, loculis multiovulatis. Stylus filiformis; stigma punctiforme. Capsula calyce vestita, subglobosa, quadriloeularis, locolieide quadrivalvis, Semina plurima, cochleata, sulcata, punctata. - Herba Novo-granatensis, tenera, Spennerae facie, pilis glanduliferis, raris hirlella; foliis appositis, petiolatis, cordato-ovalibus, acuminatis, denticulato-setosis, quinquenerviis, floribus paniculatis.

Er nesti a DC. Prodr. III. 121. Mem, I. 30. Chamisso in Linnaea IX. 400. Meisner Gon. 115. (82.) Rhexia tenell a Bonpl. Rhex, $t, 30$,

6200. Ithexia $R, B R$. Cal y x tubo basi nvato-ventricoso, libero, apice in collum angnstato, limbo quadrifido. Corolla e petala 4, calycis favei inserta, ejusdem laciniis alterna, obovata. Stamina 8, com petalis inserta, antherae ovatae, apice uniporosae, connectivo haud prodncto, exappendiculato. $O v$ a $r$ i m liberum, quadriloculare, losulis multiovnlatis. Stylus filiformis; st igma acutum. Capsula intra calycem libera, quadrilocularis, loculicide quadrivalvis, placentis pedicellatis, semilonatis. Semina plurima, cochleata. - Herbae boreali-americanae, laeves; caulibus erectis, tetragonis, foliis opposilis, sessilibus, integerrimis, linearibus, lanceolatis $v$. ovatis, trinerviis, floribus in cymam corymbosam dispositis, ternatis, purpureis $v$. luteis.

R h ex i a Linn. Gen. n, 468, exel. sp. B. Brown ex Don in Mem. Werner. soc. IV. 297. Nuttall Gen, r. 244. DC. Prodr. III, 191, Meisner Gen, 115. (82,) Bonpl. Rhex. t, 44. excl, reliq.

620 1. Heteronoma $M A R T$. Caly $\mathrm{x}$ tubo cylindrico, libero, sursum ampliato, brevissime quadridentato. Carollae petala 4 , calycis fanci inserta, ejusdem dentibns alterna, obovata. Stamina 8 , cum petalis inserta, alterna iigdem opposita minora, antherae lineares, acuminatae, uniporosae, connectivo basi producto antice bicalcarato, staminum minornm breviore. Ova ri m liberum, quadriluculare, loculis multiovalatis. Stylus filiformis; stigma punctilorme. Ca p s u la calyce inclusa, quadriloenlaris, loculi cide quadrivalvis. Semina plurima, cochleata, striata, punctata. - Herbae v. suffrutices, in $A m e$ rica tropica crescentes; ramis tetragonis, foliis opposilis, petiolatis, altero cujusvis paris multo minore, quinque v. plurinervitis, floribus roseis $v$. violaceis, in paniculas brachiatas dispositis.

H eteronoma Martius Nov. gen, et sp. III, 140.t.273. Heter on ma DC. Prodr. HI. 192. Mem I. 32. Mem.soe. phys. Genev, VII. Link et Otto Abbild, $t, 24.37$. R hexi a diversitolia Bonpl. Rhex. 4. 45. et Pachyloma DC. Prodr, III. 122.

480\%. Nireterocentrom $H O O K$. et $A R N$ Caly $x$ tubo campanulato, adpresse setoso, limbi quadripartiti laciniis lanceolatis, acuminatis. Co- rolla petala 4, calyeis fauci inserta, ejustem laciniis alterna, late ubovata. Sta mina $8, \mathrm{cum}$ petalis inserta, alterna iisdem opposita minora, antherae oblongae, obtusae, uniporosae, sta minom longiorum connectivo stipitato, ad artienIum setis duabus clavatis instructe, breviornm basi bigibboso. Ovarin m liberum, glabrum, quadriloculare, loenlis mnltiovulatis. Stylus filiformis; st igma acutum. Ca psula ealyee inclusa, quadrilnenlaris, loculicide quadrivalvis. S e m in a.... - Herba mexicana; caule basi lignoso, ramulis tetragonis, hispidis, foliis oppositis, petiolatis, oblongis, integerrimis, utrinque setosis, penninerviis, floribus terminalibus, thyrsoideis, albis, subpaniculatis.

Heterocentron Hooker et Arnott ad Beechey. 290.

6203. Dxyspora DC. Caly x tubo oblongo, libero, limbi quadrilubi lobis ovatis, mueronatis. Corollae petala 4, calyeis fauci inserta, ejusdem lobis alterna, lanceolata, acuta. Stam ina 8 , cum petalis inserta, alterna iisdem "p. posita minora, an thera e longe cylindricae, uniporosae, basi emarginatae, connectivo ultra locuIns haud producto, basi in calcar breve producto. Ovarium liberum, quadrilnenlare, loculis multiovulatis. Stylus filiformi-clavatns; stigma acutum. Capsula calyce inclusa, quadrilocularis, loculicide quadrivalvis. S e mina plurima, minima, scobiformia, vix curva, utrinque aristata, umbilico terminali, concavo. - Suffrutices nepalenses; ramulis tetragonis, petiolisque pilis crassis barbatis conferte vestitis, foliis oppositis, elliptico-oblongis, acuminatis, denticulatis, quinqueseptemnerviis, superne glabris, subtus pube stellata floccosis, in nervis sublanatis, thyrso terminali paniculato, floribus albis, subcernuis, calycibus pube stellata, minima conspersis.

Oxyspora DC. Prodr. III. 123. Mem. I, 33. t. 4. Wallich Plant, As, rar, t, 88, Meisier Gen, 115, (82.) Arthrostema pauicula tum Don.

6204. Tricentrum DC. C a 1 y $\times$ tubu ovato, libero, limbi quadripartiti lohis angustis, acntis, apice trisetosis. Co ro IIa e petala 4 , calycis fauci inserta, ejusdem laciniis alterna, oblonga v. ovalia. Stamina 8 , cum petalis inserta, aequalia; filamenta glabra, a $\mathrm{n}$ h hera e lineares, rostratae, uniporosae, connectivo basi tricalcarato, calcaribus duolus superis, uno pistico, O varin m liberum, glabrum, quadriloculare, loculis multiovulatis, Sty Ins filiformis; stigma acutum. C a p s u la calyee inclusa, quadrilocularis, loculicide quadrivalvis. Sem ina plurima, cochleata. Suffrutex brasiliensis, prostratus, crassiculus, pilis glandulosis hispidus; ramulis subtetragonis, foliis oppositis, petiolatis, ovalibus, mucronatis, quinquenerviis, villosis, floribus in foliorum superiorum axillis breve pedicellatis, bibracteolatis.

Tricentrum DC. Prodr. III. 123. Mem. I. 34. Chamisso in Linnaea IX. 401. Meisner Gen. 115. (82.)

6205. DIareetia $D C$, Caly $\mathrm{x}$ inbo obiongo v. cylindraceo, lihero, limbi quadripartiti lobis anguste lanceolatis. Corolla e petala 4 , ealycis fauei inserta, ejusdem laciniis alterna, ovalia, acnta. Stamina 8 , cum petalis inserta, alterna iisdem opposita saepe panllo minora, ant herae oblongo-lineares, uniporosae, connectivo plus minus producto, basi antrorsum breviter bianricalato. Ovari n jiherum, glabrum, quadriloculare, loculis multiovulatis. Stylus filiformis; $s t \mathrm{igma}$ punctiforme, Capsula calyce velata, quedrilo$152 *$ 
cularis, loculicide quadrivalvis. Semina plurima, cochleata, umbilico oblique basilari, punctata. Suffrutices $v$. frutices subvirgato ramosi, in pascuis subalpinis Brasiliae crescentes, saepe pube glan. dulosa subviscosi; foliis oppositis, subsessilibus, trinerviis $v$. uninerviis, saepe angustis, basi cordatis, margine revolutis, floribus in supremorum foliorum axillis solitariis, breve pedunculatis, bibracteatis, racemos breves constituentibus, albis $v$. rubescentibus.

Marcetia DC. Prodr. III, 124. Mtem, I. 35. t. 5. Martius Nov. Ben. et sp. IIT. 102, t. 248. Chawisso in Linnaea IX. 401. Meisner Gen, 115. (82.) Rhexiale sp. Bonpl. Hhex, $t, 57$.

8206. Trembleya DC. Cal y $\mathrm{x}$ tubo ova to, saepe sursum angustato, limbi quinquepartit laciniis subulatis v, linearibus. Coroll a e petala 5 , calycis fauci inserta, ejusdem laciniis alterna. St am in a 10, cum petalis inserta, alterna isdem opposita minora, a $\mathrm{n}$ h e r a e ovato-oblongae, rostro brevi nniporosae, majurum connectivo in ligulam obcordatam v. simplicem longe producto, minoram breviore, angustiore. Ovarium liberum, glabrum, quinqueloculare, loculis multiovulatis, Stylus filiformis; $8 \mathrm{ti} g \mathrm{~m}$ a punctiforme. Ca psula calyce velata, quinquelocularis, loculieide quinquevalvis. Semina plarima, oblonga, leviter curvata, punctata, umbilico basilari. Frutices brasilienses, glabri, tomentosiv. canescentes; foliis oppositis, sessilibus v, petiolatis, oblongis $v$. linearibus, integerrimis, uni-trinerviis, floribus axillaribus solitariis $v$. cymulosis, flavis $v$. violaceis.

Trembley a DC. Prodr. III, 125. Mem, I, 37. Marthus Nov. gen. et sp. III. 103. Cliamisso in Linnaea IX. 488. Meisner Gen. 115. (82.)

a. JACOBIA DC. l. c. Caly eis turbinati, snperne vix constricti lacialae subulatae. P et a 1 a ovalia, mueronata. A ntherarum coneectiva breviter appendiculata. Flores favi, solitarii. (Martius Op. cit. $t$. 249.)

b. ABRAHAMIA DC. $\boldsymbol{l}$. $c$. C aly eis urceolati laciniae subulatae v. lineares. Petala obtusa. A n thera rum connectivum late appendiculatum. - Elores purpuras. centes, pedicellati, solitarii v. cymulosi. (Martius $O_{p}$. cit. $t$. 250.)

c. ERIOLEMA DC. $l$. c, C aly $\mathrm{c}$ is apice vix constricti extus undique lanati lobi oblongi. Petala obtusa. A ntherarum connectiva late appendiculata, - Flores axillares, sessiles, flavi.

6\%or. Adelobotrys $D C$. Calyx tubo subcampanulato, limbo breviter et obtase quinquedentato. Corolla e petala 5, calycis fauci inserta, ejusdem dentibns alterna, ovalia, Stamina 10, cum petalis inserta, a $n$th e ra basi bifureatae, apiee bivalves (?) Ovari u m...... Ca ps u l a quinquefariam dehiscens, colnmella centrali libera, fibris quinque in stylom coenntibus superata. Semina....... Frutex guianensis, scan. dens; ramis teretibus, foliis oppositis, junioribus utrinque rufo-villosis, adultis praeter nervos glabriusculis, petiolatis, ovato-cordatis, acuminatis, serratociliatis, quinquenerviis, floribus ad apices ramorum cymoso-capitatis, confertis, albis.

Adelobotrys DC. Prodr. III. 127. Mem, T. 38. Meinner Gen. 115. (88.) Melasto mra seandens Aublet Guian, t, 172,

THBIISUS III. OSBECKIEAE DC. Prodr. III. 127. Antherae apice uniporosae, Ovari um liberum v. adnatum, vertice saepissime setis v. squamis coronatum. Se min a cochleata. - Species amphigeae.
8805. Lasiamdra DC. Caly $\times$ tubo subcampanulato, libero, limbi quinquepartiti lobis angustis, acuminatis. Corollae petala 5 , calycis fauci inserta, ejusdem lobis alterna, obovata. Stamina 10 , cum petalis inserta; fil a m enta glabra v. saepius pilosa, an $\mathbf{t}$ herae elongatae, breviter rostratae, nniporusae, connectivo basi intus varie hiauriculato. O varium basi calyei subadhaerens, superne liberum, setis coronatum, quinqueloculare, loculis multiovulatis. St y I n s filiformis; stigma punctiforme. Capsala intra caly cem libera v. leviter adnata, quinquelocularis, apice loculicide quinquerimosa. Semina plurima, reniformi-oblonga, pnnctata, umbilico basilari.

Arbores $v$. saepius frutices, in America tropica crescentes, plus minus setosiv. strigosi, ligno molli, fragili; ramis tetragonis, foliis oppositis v. verticillatis, integerrimis, tri-quinquenerviis, floribus terminalibus, paniculatis, speciosis, violaceis, roseis, rubris $v$, puniceis, singulis ante anthesim bractearum convexarum pari mox deciduo inclusis.

Las iandra DC. Prodr. III. 127. Mem. I. 48, $t$, ?. Martius Nov, gen. el sp. III, 93. t. 241_244. Chamisso in Linnaea 1X. 431. Presl $S$ ymb. t. 45. Meisuer Gen, 116. (82.) R hexiae s p. Ruiz et Pavon t. 323. $f$. $a$. Bonpl. Rher. t. 12, 36, Bot. Mag, t, 214. Bot. Reg. t. 323, 664.

6209. Iracairea $D C$. Caly $\mathrm{x}$ tubo ovato, libero, limbi quadripartiti Iobis aenminatis, persistentilus. Cor olla e petala 4 , calycis fauei inserta, ejusdem laciniis alterna. Sta min a 8 , cum petali* inserta, alterna iisdem opposita hre. viora, fila mentis glabrinsculis, alternorum filamentis superne latere interiore pilos glandolosos, uniseriatos gerentibus, an therae lineares, uniporosae, connectivo elongato, basi introrsum aurienlato. Ovarium libernm, apice setis glandulosis hirtum, quinqueloculare, loculis multiovulatis. Stylus filiformis; stigma simplex. Capsula calyce velata, quadrilocularis, loculicide quadrivalvis. Semina plurima, ovata, hine ad umbilicum subtruncata. - Frutices Americae tropicae, petiolis foliisque novellis rufo-villosis; foliis oppositis, petiolatis, ovalibus, mucronatis, coriaceis, integerrimis, supra glabris, adultis subtus subvelutinis, subtrinerviis, florum thyrso terminali, paniculato, villosissimo.

M a ea irea DC. Prodr. IIT. 109. Mom. I. 3.9. t. 6. Chamisso in Linnaea IX, 381, Meisuer Gen, 116. (82.)

B2 10. Chaetograstra $D C$. Calyx tuho turbinato, extus piloso v. squamoso, libero, Jimbi quinquepartiti lobis persistentibus. Corolla e petala 5, ealycis fanci inserta, ejosdem laciniis alterna, obovata. Stamina 10 , cum petalis inserta, subaequalia; fil am enta glabra, antherae oblongae, nniporosae, connectivo basi in calcar simplex v. bifidum producto, aut obtuse bituberculato. Ovarium liberum, apice setosum v. denticulatum, quinqueloculare, loculis multiovulatis. St yI ns filiformis; stigma simplex, Capsula calyce velata, quinquelocularis, apice Ioculicide quinquerimosa. S em in a plurima, reniformi-oblonga, umbilico subbasilari. - Frutices, suffrutices v. herbae, in America tropica crescentes; caule ramisque tetragonis, cum foliis oppositis, petiolatis, triquinquenerviis, integerrimis v. vix serrulatis, setosis, strigosis aut villosis, inflorescentia paniculata, floribus in glomerulis axillaribus terminalibusque sessilibus aut pedunculatis, singulis bractea solitaria, persistente munitis, calycibus fructiferis immutatis $v$. lacinüs excrescentibus et calvescentibus auctis, petalis roseis, violaceis $v$, purpureis. 
Chaetogastra DC. Irodr. III. 131. Mem. I. 47. Martius Nov. gen. et sp. III. 99, excl. sp. octandris. Chamisso in Linnaea IX. 447. Meisner Gen. 116. (82.)

a. MONOCENTRA DC, $l$. c. Cal y x tubo obovato v. turbiato. A ntherarum connectivum basi in calcar sim. plex productum. 0 ₹ a $\mathrm{r} \mathbf{\mathrm { u }} \mathrm{m}$ apice dentatum. - Frutices peruani, Lasiandrae facie, Roribus amplis, pur. pureis, - Rhexia s p. Bonpl. Hhex, $t$. 4.9.

b. DIOTANTHRRA DC. $\boldsymbol{l}$, $c$. C a l y $\times$ tubo obovato, ebracteato. Antherarum consectivum basi in calcar bifi. dum productum v, obtuse biauriculatum. - Flores albi v. rosei. - Rhexiae s p. Ruiz et Pav, Flor. Peruv. t. 319. f. b. t. 320, f. b. Banpl, Rhex, t, 1. 6. 7. 8, 10. 13. 15, 19, 21, 22, 26, 31, 37. 43, 58 M e rinniae s p. Venten. Choir t, 34. (Mart, Op. cit. $t$. 245. Bot. Mag. t. 2836. 3481.)

c. ? BRACTEARIA DC, $l, c, C$ a 1 y $x$ tubo obovato, piloso braeteis sex, triseriatis, liberis cinetus. Antherae basi brevissime biaurieulatae. - Frutex peruanus, foo ribus violaceis. - Rhexia conferta Bonpl. Rhex. 2. 20 .

B2 11. Antlurostemma $P A V O N$. C a Iy $x$ tubo turbinato v. campanulato, extus piloso v squamosn, limbi quadripartiti lobis persistentibus. Corollae petala 4, calycis fauci inserta, ejus dem laciniis alterna, obsoleta. Sta min a 8 , cun petalis inserta, subaequalia; fil am e n ta glaberri ma, anthe ra e oblongae, uniporosae, connectivo longinsculo, hasi obtuse biauriculato. Ovari u m liberum, apice setosum, quadriloculare, loculis multiovulatis. St y In s filiformis; stigma simplex. Ca psul a calyce velata, quadrilocularis, apice loculicide quadrivalvis. Semina plurima, eo. chleata. - Herbae v. suffrutices, in $A$ merica $t$ ro. pica crescentes, habitu vario, olim in genera pluru segregandae, v. partim Chaetogastris aliisque generibus jungendae.

A ribrastem a Pavon ex Don in Mem. Werner. soc. IV. 292. DC. Prodr, III, 135. Mem, I. 50. Chamisso in Linnaea $I X$. 452. Meisuer Gen. 116. (83.) Mela n i u Riehard msc.

a. CHAETOPETALUM DC. $t$, $c$, Petala ovalia, apice in setau desinentia. A u the ra e requales, connectivo haud appendiculato. $O$ v a $\mathbf{i} \mathbf{u} \mathrm{m}$ apice quadridentatnm. S e mi. a reniformia, nee vere cochleata. - Herbae basi suf. fruticulosae, floribus albis $v$. flavis. - Rhexise $s$ p. Bonpl. Rhex, $t, 5$, et 29.

b. BRACHYOTUM DC. l. c. Petala subaristata, convo luta. A uthera e aequales, connectivo brevissime biauriculato. $0 \mathrm{v}$ a $\mathrm{r} \mathrm{i} \mathrm{m}$ apice setigerum. - Suffrutices. Rhexia e s. Ruiz et Pavoa Flor. Perto. $t$. 318, $f, a$ 319. f. b. Bongl. $t$. 14.

c. LADANOPSIS DC, $l, c$, Petal a obovata, expansa. An thera e subaequales, connectivo longiusculo basi hreve biauriculato. Capsula apice quadrisetosa. - Herbae v. suffrutices. - R hexla s p. Aubl. Guian, t. 129 Bonpl. Hhex, t. 7. 35.

d. TRIFURCARIUM DC. l. $c$. A n the $\mathrm{rat} u \mathrm{~m}$ connectivum basi is appendicem tridentatam v. trisetosam prodnctum.

e. MONOCHAETIM DC. $l$. c. A n t berarum connectivum in calcar simplex $v$. emarginatum adscendeus, aut in setam ex ipsa bast ortam productum. - Rhexiac s p Ruiz et Pavon Flor. Peruv, t, 320, f. a. Bonpl. Rhex. t. 3. 16. 18 .

B21 1 . Heeria $S C H L E C H T$. C al y $\times$ tubo campanulato-cylindraceo, rigide setoso, libero, limbi quadripartiti laciniis triangularibus, cuspida. tis, persistentibus. Corollae petala 4 , calycis fauci inserta, ejusdem laciniis alterna, cuneato obovata. Stam i n a 8, cum petalis inserta, alterna petalis opposita minora, an therae uniporosae, staminum majorum connectivo basi in calcar elon gatum, hifidum producto, minorum calcare abhreviato, biglanduloso. Ovarium liberum, apice setosum, quadriloculare, loculis mnltiovulatis. Sty-
I us filiformis, declinatus; stigma obtusum. Ca p s u la calyce inclusa, quadrilucularis, loculicide quadrivalvis. S em i na plarima, cochleata. Fruticulus mexicanus; caulibus depressis, radicantibus, ramulis erectis, adpresse setosis, foliis oppositis, petiolatis, late ovatis, obtusiusculis, trinerviis, crenulatis, ciliatis, glabriusculis, flore terninali solitario, longe pedunculato.

II e r i a Schlechtead. in Linnaea XIIT. 432.

6213. Svitramia $C H A M$, Cal $\mathrm{y} x$ bracteis ramentaceis calyptraeformibus, ternis v. pluribus caducis fotus, tubo subgloboso, nervoso, glaberrimo, vernicoso, libero, limbi quinquelobi lobis obtusis, persistentibus. Corolla e petala 5, calycis fauci inserta, ejusdem lobis alterna, obcordata. Sta m ina 10 , cum petalia inserta, a equalia, a $\mathbf{n}$ the rae ovatae, obtusae, uniporosae, connectivo basi paullnlum incrassato, exappendiculato. Ovari m globosum, liberum, apice setosum, quin. queloculare, loculis multiovalatis. Sty In s brevis, clavatus; 8 tigm a punetiforme. Capsu I a quinquelocularis, loculicide quinquevalvis, placentis Innulatis. S e m in a plurima, minima, cochleata, laevia. - Suffrutex brasiliensis, subvelutinostrigosus, inflorescentia glabra, vernicosa; ramis brachiatis, lignosis, obtuse tetragonis, foliis oppositis, sessilibus, ovatis, acutis, subnovemnerviis, setis validis adpressis, panicula foliosa, subfastigiata, subglobosa.

S vitramia Chamisso in Linnaea $I X$. 445. Meisn. Gen, 116. (82.)

G214. Triboralnima $A U B L, C$ a I y x basi cinctus involuero duplici, utroque e bracteis duabus connatis, tube turbinato, libero, squamis imbricatis vestito, limbi quinquelobi lobis lanceolatis. Corolla e petala 5, calycis fauci inserta, ejusdem lobis alterna, ovalia. S $t$ amina 10 , cum petalis inserta, aequalia, a nther a lineari-acuminatac, uniporosae, connectivo basi obtuse biauriculato, Ovarin libernm, apice seiosum, quinqueloculare, loculis multiovulatis. St ylus clavatus; stigma pnnctiforme. C a psula quinquelocularis, loculieide quinquevalvis. Sem in a plurima, cochleata. - Frutex guianensis; ramulis telragono teretibus petiolisque squamuloso-scabris, foliis breve petiolatis, ovatis, basi obtusis, apice acutis, integerrimis, quinquenerviis, subtus setoso-hirsutis, superne adpresse villosis, villis inter nervos confluentibus, floribus subterminalibus, paucis.

T i b o u h i a A Ablet Guian, I, 446, t, 177. DC. Prodr. IIT. 143. Meisner Gen. 116. (83.) Savastaula Necker Elem, n. 795. Melasto matis s p. Don.

6215. Diplostegium $D O N$. Caly $\mathrm{x}$ calyptra duplici, cucullata, hispida inclusus, limbo quinquefido, persistente. C o roll a e petala $5 . .$. Stamina 10 , a n the rae sulaequales, basi biau. riculatae. Ovarium....... Stig ma punctatum, prninosum. Ca p s u la baccata, quinquelocularis. Sem ina..... - Frutex brasiliensis; caulibus teretibus, dense cano-pilosis, foliis ovatis, acutis, integerrimis, petiolatis, quinquenerviis, subtus sericeo-pilosis, supra scabris, pedunculis terminalibus, trichotomis, trifloris, floribus magnis, roseis.

Diplostegium Don in Mem. Wern. soc. IV. 296. DC. Prodr, $T I T, 152$.

6216. Tristemma JUSS, Ca $\mathrm{yx}$ basi multibracteatus, tabo nervis cum ovario cohaerens, extus prope limbum pilosum annulo simpliei v. tripliei instructus, limbo quadri-quinquepartito. Coro Ila e petala 4 v. 5, ealycis fauci inserta, 
ejusdem laciniis alterna, unguiculata. Stam in a 8 v. 10 , aequalia, antherae subarcuatae, unipo rosae, basi subauriculatae. Ovarium nervis decem tubi calycini cohaerens, apice setosum, quadri-quinqueloenlare, loculis multiovnlatis. Sty I u s filiformis; stigma obtusum. Capsula calyce inclusa, quinquelocularis, apice loculicide quinquevalvis. S e m in a plarima, cochleata, tuberiulata. - Suffrutices in Africa tropica crescentes; caulibus tetragonis, foliis oppositis, tri-quinquenerviis, floribus capitatis, involucratis.

Tristem un Jussieu Gen. 329. Venten. Choix t. 35. DC. Prodr. III. 144. Guillemin et Perrot. Flor. Seneg. 311. Meisuer Gen, 116. (83.) Melas to matis s p. Don.

6\% 1\%. Pleroma DON. C al y x bracteis duabus sub anthesi caducis involutus, tubo ovato. nervis cum ovario cohaerente, limbi quinquepartiti lobis deciduis. Coroll a e petala 5, calycis fauci inserta, ejusdem laciniis alterna, obovata, $\mathbf{S}$ t a m ina 10 , cum petalis inserta, subaequalia; fil ament a glabra, a n th e ra e elongatae, uniporosae, basi arcuatae, connectivo stipitiformi basi breviter biauriculato. Ovari um nervis decem tubi calycini cohaerens, apice setosum, quinqueloculare, loculis multiovulatis. Stylus filiformis; $8 \mathrm{tig}$ ma punctiforme. Capsula baceata, quinquelocularis. Semina plarima, cochleata. - Frutices in $A m e^{-}$ rica tropica indigeni, Lasiandrae facie; foliis oppositis, supra setosis $v$. pubescentibus, subtus villosis, pedunculis axillaribus simplicibus $v$. trifido ramosis.

Ple rom a Don in Mem, Wern, soc. IV. 293. DC. Prodr. III. 151. Meisner Gen. 116. (83.)

6818. Taelnopodium $B L U M$. C a I y tnbo ovato-oblongo, nervis cum ovario cohaerente, limbi quinquefidi laciniis lineari-subulatis. Corol 1 a e petala 5 , calycis fauci inserta, ejusdem laciniis alterna, ovali-oblonga, obtusa. S $t$ a $\mathrm{m}$ i n a 10 , cum petalis inserta; filamenta basi pilorum corona cincta, antherae oblongae, rostratae, nniporosae, exappendiculatae (?) $\boldsymbol{O}_{\mathrm{v}}$ arium ner vis decem tubi calycini cohaerens, quinqueloculare, loculis multiovulatis. Stylns filiformis; stig ma ohtusum. Capsula calycis limbo coronata, quinquelocularis, apice quinquevalris. Se mina plurima, cochleata (?) - Fruticulus indicus; ramulis teretibus, rufescenti-hispidis, foliis oppositis, petiolatis, cordato-oblungis, acuminatis, denticulato-crenatis, quinquenerviis, rugosis, pilis rufulis conspersis, cymis axillaribus, contractis, obsolete braeteatis, calycibus rubro marginatis, petalis albis.

L a ehnopodium Blume in Flora 1831, p, 487. Meis. ner Gen. 116. (82.) Melastoma rubro. I imbatum Link et Otto Ic, select, $t, 41$.

6\%1D. Dielastoma BURM. C a ly $x$ tubo ovato, inferne cum ovarii basi connato, squamulis setisve dense obtecto, limbi quinque- v, rarius sexfidi, decidni laciniis cum appendicibns totidem alternantibus. Coroll a e petala $5-6$, ealyeis fauci inserta, ejusdem laciniis alterna, ovalia. Sta mina 10 v. 12 , cum petalis inserta, alterna iisdem opposita paullo minora, rarissime deficientia, a ntherae oblongo-lineares, subarcnatae, uniporosae, connectivo stipitiformi, elongato v. brevi, antice biauriculato $\vee$. emarginato. 0 va rin m semiinferum, vertice libero setigerum, quinque-sexloculare, loculis multiovulatis. Styl ns filiformis, apice subincrassatus; $s \mathrm{tig}$ m a punctiforme. $\mathrm{C}$ a $\mathrm{p}$ su la baceata, quinque-sexlocularis, irregulariter rumpens. S e min a plurima, cochleata. _ Frutices
Asiae tropicae, sacpissime strigoso-asperi; foliis oppositis, petiolatis, integerrimis $v$. serrulatis, nervosis, pedunculis terminalibus, fasciculatis $v$, corymboso paniculatis, interdum solitariis, pedicellis basi bibracteatis, floribus amplis, albis, roseis $v$. purpureis.

M elasto im a Burmann Flor. Zegl, 72. Blume in Flora 1831. p. 476. Wight et Arnott Prodr. I. 324. Meisner Gen. 116. (83.) Miquel Comment, II, 12. A c i n o d e n d ro n Linu. Gen, ed. I, n, 363. Melastomatis s p. Lion. DC. Bot. Mag. 2 . 529, Labillard. Nov. Caled, $t, 64$.

6820. Dtamthera BLUM. C aly x tubo ovato, inferne cum ovarii basi connato, squamulis palmato-ciliatis muricato, limbo quinquefido, Corolla petala 5, calyeis fauci inserta, ejusdem laciniis alterna, obovata. Stam in a 10 , cum petalis inserta, aequalia, a n $\mathrm{b}$ e $\mathrm{r}$ a e oblongo-lineares, subarcuatae, sursum attenuatae, uniporusae, antice ad basim constricto - biauriculatae, connectivo indistincto. Ova ri u m semiinferum, vertice libero setosum, quinqueloculare, loculis multiovulatis. Stylus filiformis. Stigma ponctiforme. Bacea quinquelocularis, pulposa. Sem in a plurima, cochleata. - Frutex moluccanus; ramis teretibus, glabris, extimis compresso-tetragonis, petiolis nervisque foliorum subtus setis sparsis adpressis, foliis oppositis, elliptico-lanceolatis, acuminatis. integerrimis, quinquenerviis, membranaceis, scabriusculis, pallide viridibus, nervis subtus caerulescentibus, paniculae terminalis, trifidae v. tricholomae ramis sub. triftoris, floribus parvis, albidis, lateralibus bi. braclealis, intermedio brevissime pedicellato, ebructeato.

0 tanthera Blume in Flora 183t, p. 488. Melsner Gen. 116. (83.) M elasto ma molu c c a u am Blum.

62 1. Dsbeekia LINN, Calyx tulo ovato v, oblongo, inferne eum uvarii basi connato, saepe setis a basi palmatis v, pube stellata aut rarissime simplici vestito, limbi quadri quinquefidi laciniis cum totidem appendicibus alternantihus. Corolla e petala 4 v. 5 , ealycis fanci inserta, ejusdem laciniis alterna, ovata v, obovata. St a m ina 8 v. 10 , cum petalis inserta, subaequalia, a $\mathrm{nthe-}$ ra oblungo-lineares, subarcuatae, rustratae, uniporosae, connectivo ad basim incrassato, antice breviter bicalcarato v. biauriculato sive mutico. Ovari um semiinferum, vertice libero, conico setosum, quadri-quinqueloculare, loculis multiovnlatis. Stylus filiformis, infra apicem incrassatus; stigma punctiforme. Capsula sicea, calycis tubo sursum truncato inclusa, quadri-quinquelocularis, superne loculicide quadri-quinquevalvis. S e mina plurima, cochleata. - Frutices $v$. suffrutices, in Asia et Africatropica crescentes, plerumque setoso-asperi; ramulis magis minusve tetragonis, foliis opposilis, rarissime verticillatis, nervosis, subintegerrimis, floribus terminalibus, saepe capitatis, bracteato-involucratis, nunc solitarïs, rarius racemosis $v$. subcorymbosis, purpurascentibus, speciosis.

Os beckla Linn. Gen, $n$, 467. Don in Mem, Werner. soe. IV. 292. DC. Prodr. III. 138. excl. sect. 1-3. Hooker Exot. Flor. 2. 37. Bot, Reg. $t, 542,565.674$. 1475. Blume in Flora 1831, p. 473. Wallich Plant. As. rar. $t .240 .251$. Meisuer Gen, 116. (83,) Miquel Comment. Ir. 72. M elas. to matis s p. Palis. Flor. Owar. t. 41.

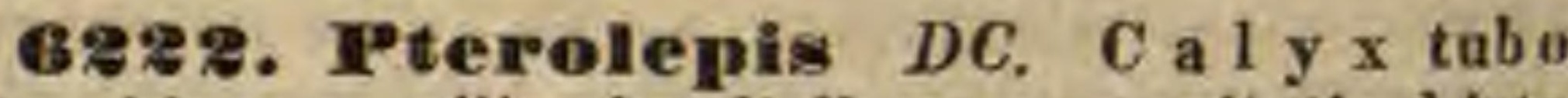
ovato-oblongo, pilis simplicibus v. capitatis hirto v. strigoso, limbi quadri-quinquefidi laciniis peraistentibus, cum appendiculis totidem elongatis, pertinatis alternantiluss. Coro 11 a e petala 4 v, 5 , ca. 
Iycis fauci inserta, ejusdem laciniis alterna, obovata v. oblonga, Stamin a 5 v. 8 (?), cum petalis inserta; filamenta glabra, antherae lineares, falcatae, rostratae, uniporosac, connectivo basi bilobulato v. binodi. $\mathrm{O}$ v a ri $\mathbf{u}$ apice setosum, quadri-quinqueloculare, loculis multiovulatis. Stylus filiformis, stig ma capitatum. C a psula calycis tubo inclusa, ejustem limbo persistente coronata, quadri-quinquelocularis, loculicide quadriquinquevalvis. S e in i n a plurima, cochleata Frutices brasilienses, tomentosi v. strigosi; foliis oppositis, nervosis, integerrimis.

Pterolepis sectio $0 \mathrm{~s}$ beckiae DC. Prodr. IIT. 140. Miquel Comment. II, 72. Rhex ia e s p. Bonpl. Rhex, t, 32 . 35. 45.

6823. Chaetolepis DC. Caly x tubo ovato, apice setoso, limbi quadripartiti laciniis persistentibus, cum appendicibus totidem simplicibus, setosis alternantibus. Co rolla e petala 4 , calycis fauci inserta, ejusdem laciniis alterna, obovata. St a mina 8 ; fil am entagrabra, an the rae obtusae, uniporosae, connectivo basi breviter biauriculato. O vari u m apice setis ucto coronatum, quadriloculare, loculis multiovalatis. StyI u filiformis, superne incrassatus; st igma simplex. Ca psula calycis tubo inclusa, limbi persistentis laciniis coronata, quadrilosularis, Juculicide quadrivalvis. Semina plurima, cochleata. Suffrutex Americae a stralis, ramosissimus; ramis teretibus, strigoso-scabris, folits oppositis, brevissime petiolatis, ovatis, integerrimis, quinquenerviis, utrinque adpresse strigoso scabris, subtus pallidis, floribus solitariis, subcorymbosis, pedicellatis, flavis.

Chaetolepis rect. Os beckiae DC, Prodr. IT. 140. Miquel Comment, II, 72. Rhexia microphylla Bonpl. Rhex, $t, 8$.

Bas 4. Mierollepis DC. Cal y $x$ tubo oblongo, suburceolato, inferne cum ovarii basi connato, pube stellata vestito, limbi quinque- v. rarius sexilentati $v$. lobati dentibus $\vee$. laciniis cum appendiculis totidem minimis, palmato-ciliatis alternantibus. Curolla e petala 5 v. 6 , calycis fauci inserta, ejusdem dentibus v. laciniis alterna, ovata. Stamina 10 v. 12 , cum petalis inserta; filamenta glabra, antherae lineares, falcatae, uniporosae, nunc subaequales, connectivo brevi, ad articulum tumido, in ligulam bifurcam v, bilobam producto, nunc dissimiles, connectivo nutico sive appendiculato. O vari um semiinferum, vertice libero setosum, quinqueloculare, loculis multiovulatis. Stylus filiformis, infra apicem incrassatus; stigma punctiforme, Capsula sicea, calycis tubo truncato inclusa, quinquelocularis, loculicide quinqueralvis. Sem in a plurima, cochleata. - Herbae brasilienses, setoso-asperae; ramis saepissime tetragonis, foliis oppositis, nervosis, floribus terminalibus.

Micralepis sect. Osbeckiae DC. Prodr. III. 139. Miquel Comment, II. 72.

\section{GENUS DUBIUM.}

BE35. Aciotis DON. CaIyx tubo globoso, carnoso, limbo coaretato, quadridentato, persistente. Corolla e petala 4, apice oblique aris. tata. Stamina 8 , connectivo deorsum elongato quasi biarticulata, an therae erectae, hasi nudae. Ovarin m..... C a psula baccata, guadrilocularis. Semina cochleata, - Herba antilla. na, glabriuscula, perennis, virens, caulibus pluri- bus, erectis, tetragonis, spithameis, ramosis, folits petiolatis, elliptico-oblongis, acuminatis, trinerviis, subtus purpureis, supra intense viridi lucidis, floribus terminalibus, spicato-racemosis, parvis, roseis, baccis globosis, purpureis, grate acidis, edulibus.

A ciotis Don in Mem. Wern. soc. IV. 300. DC.Prodr. III. 152. Mem, I. 54. Meisuer Gen, 116. (82.)

TREIBES IE. MICONIEAE DC. Prodr. III. 152. A ntherae uni-biporosae. Ovarium adnatum. Fruetus baccatus. Semina haud cochleata. - Species potissimum americanae.

82 26. Romssenuxia $D C$. Cal y $x$ tubo hemisphaerico, glabro, cum ovario connato, limbi superi, quadripartiti lobis late lanceolatis, persistentibns. Corollae petala 4, calycis fauci inserta, ejusdem laciniis alterna, obovata. Sta m ina 8 , enm petalis inserta, subaequalia, a nth erae oblongo-lineares, uniporosae, connectivo brevi, exappendiculato. $\mathbf{O}$ va $\mathbf{r} \mathbf{i} \mathbf{m}$ inferum, vertice exserto squamis quatuor ciliato-spinosis coronatum, quadriloculare, loculis multiovulatis. Stylus filiformis; stigma simplex. Fructus..... - Frutex madagascariensis; ramis obtuse tetragonis, demum teretibus, glabris, ad nodos subsetosis, foliis oppositis, petiolatis, ovali-oblongis, acutis, trinerviis utrinque glabris, ad nervos subtus et ad margines integerrimos adpresse subsetosis, cymis terminalibus bi-trifidis, calycis tubo glaberrimo, limbi lobis setoso-ciliatis.

Rouss e a uia DC, Prodr. III, 152. Mom, 54. exel. sect. 2. Meisser Gen. 113. (81.) Melas toma ehrysophy II a Desrouss.

62:\%. Dielhaetanthera. Calyx tubo hemisphaerico, glabro, cum ovario connato, limbi superi, quadripartiti lobis latis, obtusis, persistentibus. Corollae petala 4 , calycis fanci inserta, ejusdem laciniis alterna, obovata. Stamina 8 , cum petalis inserta, alterna iisdem opposita sterilia, antherarum connectivo brevi, fertilium anth era e oblongae, breves, uniporosae, connectivo longissimo, basi bisetoso. Ovarium infernm, vertice exserto setosnm, quadrileculare, loculis multiovulatis. Stylus filiformis; stigma simplex. Cap 8 u a calyce adnata, quadrilocularis, vertice breviter exserto loculicide quadrírimosa. S e mina plurima, angulata, nitida. - Frutex madagascariensis; ramulis obtuse tetragonis, demum teretibus, ad insertionem foliorum nodosis, setis adpressis scabridis, folits oppositis, petiolatis, ovalioblongis, acuminatis, integerrimis, trinerviis, supra glabris, subtus ad nervos adpresse setosis, cymis trichotomis.

Rousse auxia articulata DC. Prodr. III. 153. Melastoma articulata Desrouss.

6928. Heandra RADD. Caly $\mathrm{x}$ tubo urceolato v, subinfundibuliformi, inferne $\mathrm{cum}$ ovarii basi connato, limbi quinque-sexpartiti, rarissime quadripartiti laciniis duplicatis, exterioribus subulatis ante interiores late ovales sitis, Corollae petala 5 v. 6 , calycis fauci ingerta, ejusdem laciniis alterna, lineari-lanceolata. Stam in a 10 v. 12 , cum petalis inserta, subaequalia, a nthera e subulatae, nniporosae, basi breviter biauriculatae, connectivo obsoleto. Ovarium ima basi adnatum, quadri-sexloculare, hirtum. Stylus filiformis, basi villosus; stigm a punctiforme. B a cc a sicca, calyce tunieata, quadri-sexlocnlaris. Se$m$ in a in placentis carnosis plurima, obovata, an- 
gulata, rhaphe latinseula percursa. - Frutices orasilienses, setosiv. hirli; foliis oppositis, petiolutis, altero interdum minore, tri-septemnerviis, saepe papilloso-scabris et margine serratis, floribus glomeratis, involucratis.

$\mathrm{L}$ e a d ra Raddi in Mem, soc. ital. 1820, p. 6. DC. Prodr, III. 153, Mem. 55. Martius Nov. gen. et sp. III. 153. $t$. 283. Meisner Gen, 120. ( 80 )

6229. CHidemia $D O N$, Cal yx tube eylindrico, inferne cum ovarii basi connato, limbi quinque- rarius quadri-sexpartiti laciniis herbaceis, simplicibus. Corolla e petala 5 v. 6 , rarins 4 , calycis fanci inserta, ejusdem laciniis alterna, anguste ovata $\mathbf{v}$, obovato-oblonga, patentia v. reflexa. Sta mina $10 \mathrm{v}, 12$, rarius 8 , cum petalis inserta, subaequalia, antherae subulatae, uniporosae, basi breviter producta subbilobae, connectivo haud manifesto. O v a r i $\mathrm{m}$ ima basi adnatum, tri-quadri-sexloculare, hirtum, loeulis multiovulatis. Stylus filiformis; stig ina punctiforme v, capitatum. B a c c a carnosa, calyce inferne succulento, superne exarido-tunicata, tri-quadri-sexlocularis. Sem in a in placentis simplicibus v. bifidis piurima, parva, obovata, dimidiato-oblonga $v$. angulata, puncticulata, rhaphe lineari pereursa. - Frutices Americae tropicae, plerumque pilosi, hirsuti $v$, hirli; ramis ramulisque angulatis $v$. teretibus, foliis oppositis, petiolatis, altero saepe minore, tri-septuplinerviis, saepe dentatis, floribus axillaribus $v$. terminalibus, solitariis $v$. interdum aggregatis, aut in cymas $v$. thyrsos brachiatos aut rarius secundos dispositis, bracteolatis, parvis, albis $v$. roseis, saepe holosericeo-nitentibus, baccis saepe edulibus.

Clidem I a Don in Mem, Werner soc. IV̌. 306. Mar tius Nov. gen. et sp. IIT, 151, t. 881. 282. C Iide mia DC. Prodr. III, 15s. Mem. 58. et Ts ch a d y a DC. Prodr. III. 155. Mem. 58. t. 9. Melastouatis s p. Aublet Guian. t, 165-167. Valil Ic, Amer, IT. t. 18 et 22. Bonpl. Melast. t. 3. 39. 59. Bot. Mag, $t, 1971$. S a g r ate a e s p. DC.

6230. Jueumala CHAM, C a 1 y $x$ tubo campanulato, inferne cum ima basi ovarii connato, limbi dentibus quinque, intus membrana subtili nexis, circumscisse deciduo. Corolla e petala 5 , calycis fauci inserta, ejusdem dentibus alterna, ovata. Stamina 10 , cum petalis inserta, aequalia, antherae uniporosae, connectiri dorso incrassati basi in calcar breve obtusum producta. Ovarium ima basi adnatom, triloculare, loculis unultiovulatis. Sty Ius filifurmis; stigma punctiforme. B a ce a exsucea, calyce cortieata, trilocularis. Semina plurima, pyramidata, laevia. Frutices brasilienses; ramulis compressiusculis, foliis oppositis, petiolalis, tri quinquenerviis, cymulis in thyrsum terminalem brachialum, saepe pulverulento-subincanum disposilis, bracteis parvis, deciduis, floribus albis $v$. roseis.

J a e u d a Chamisso in Linnaea $I X$. 456. Meisner Gen. 113. (81.) Graffenrleda Martius Nov, gen, ot sp. III 144. $t$, 276. non DC. 0 sbeckiae s p. DC.

6931. Irymaspora DC. C a ly x tubo ovato-globoso, hispidissimo, inferne cum ovarii basi connato, limbi quinquepartiti lobis ubtusis. Corolla petala 4 , ealycis fauci inserta, ejusdem laciniis alterna, lineari-ublonga, patentia. S tam in a 10 , cum petalis inserta, subaequalia, a $n$ therae oblongae, lateribus compressae, conniventes, uniporosae, connectivo indistincto. $0 \mathrm{v}$ ari a m inferne adnatum, decemloculare, Ineulis multiovulatis. Stylns filiformis; stig ma pel. tato-capitatum. B a c c a calyce earnoso inclusa, decemlocularis, placentis membranaceis, undique densissime seminiferis. Se m in a nidnlantia, oho. vata, puncticulata. - Frutices brasilienses; ramis teretibus, hispidis, foliis oppositis, petiolatis, basi subinaequalibus, quintuplinerviis, acuminatis, dentato-serratis, ad nervos hispidis, inter nervos sparsim setosis, floribus axillaribus v. e caule ramis. que lateralibus, pedunculis simplicibus, basi bracteaiis, fructibus mujusculis, hispidissimis.

M yri aspora DC. Prodr. III. 165. Mem. 59. Mar. tius Nov, gen, ot sp. III, 154, in not, t. 282. f. 2. S. eisaer Gen. 113. (80.) H a mas tris Martius mse.

G23\%. Tococa $A U B L$. C al y x tubo campanulato, nudo, glabro, inferne cum ovarii basi connato, limbi urceolati, quinquedentati dentibus latis, brevibus, obtusis, stepe ciliatis. Corollae petala 5, calycis fauci inserta, ejusdem dentibus alterna, obovata. St a min a 10 , cnm petalis inserta, aequalia; fila m enta brevia, subuliformia, antherae subulatae, uniporosae, connectivo distincto nullo. Ova $\mathbf{r} \mathbf{i} \mathbf{m}$ inferne adnatum, quinque-sexloculare, loculis multiovulatis. St ylus cylindricus; $8 \mathrm{ti} \mathrm{g} \mathbf{m}$ a peltatum, convexum. Bacca carnosiuscula, calyce velata, quinqueloenlaris. Se mina plurima, obovata, puncticulata, rhaphe latiuscula; placentis carnosis affixa. - Frutices brasilienses, saepe hirti; foliis oppositis, allero saepe minore, tri-quinquenerviis, petiolatis, peliolis, imprimis foliorum majorum instructis vesica foliacea, longitudinaliter biloculosa, nunc infra folii paginam circumscripta, nunc antice cum ejusdem lamina confluente, floribus nunc solitariis, terminalibus, rami axillaris evolutione lateralibus, nunc in thyrsum $v$. racemum congregatis, petulis albis $v$, roseis.

Tococa Aublet Guian. I. 438. 1. 174. Don in Mem. Wern, soc, IV. 303. DC. Prodr. IIt. 165. Martius Nov. gen, et sp. III. 146, $t, 277,278$. excl. seliq. Meisuer Gen, 118. (aO.)

B233. Mrymidome $M A R T$. C a l y x tubo campanulato, nudo, glabro, inferne cum ovarii basi connato, limbo dupliei, interiore membranaceo, annolari, obsolete sexsinuato, exterioris sexdentati dentilus late triangularibus, cum interioris lobis alternantibus. Corolla e petala 6 , calycis fanci inserta, limbi interioris lobis opposita, anguste obovata. Stam in a 12 , cum petalis inserta, subaequatia; fil amenta filiformia, an $t$ he rae cylindricae, unipurusae, connectivo distincto nullo. Ova ri u m inferne adnatum, triloculare, loculis multiovnlatis. Sty l ns subelavatus; stig ma subhemisphaericum. B a c c a membranacea, caly. cis limbo duplici coronata, Irilocularis, Se mina in loculis pauca, pyriformia, dorso convexa, facie plana, rhaphe filiformi perenrsa. - Frutex brasiliensis, dirhotome $v$. irregulariter ramosus, pilis patentibus, glanduliferis hirtus; foliis oppositis, petiolatis, denticulutis, valde disparibus, altero mojore, obovato-oblongo, acuminato, vesiculifero, vesica ovata, superne biloba, postice libera, antice intra folium producta, altero minore, late ovato, acuminato, cordato, haud vesicato, floribus alaribus, solitariis.

M y rmidoue Martius Nov. gen, et sp. IIT. 149, in not. Meisuer Gen. 112. (80,) Tococa macrosperma Martius Op. cit. $t$. 279 .

6234. IInjeta $A U B L$. Caly x coloratug, tubo ovato-oblongo, bracteato, plus minus bispido, inferne rum ovarii basi connato, limbi quinquedentati dentibus subulatis. Corolla e petala 5. calycis fanci inscrta, ejusdem dentibus alterna, obovata. St a mina 16, cum petalis inserta, sub. 
aequalia; filamenta filiformia, antherae cylindricae, uniporosae, connectivo basi binoduloso v, bicalcarato. O variu m inferne adnatum, quinqueloculare, apice truncato glaberrimum, loculis multiuvalatis. Stylus cylindricus; stigma peltatum, concavum. B a ce a calyce carnusulo ves. tita, quinquelocularis. Se mina plurima, obovata, angulata, recta. - Frutices Americae tropicae, hirti; ramulis compresso-teretibus, ad nodos tumidis, foliis oppositis, petiolatis, altero majore intra laminam vesicato, fioribus paucis v. solitariis, in axillis foliorum, imprimis majorum sessilibus, calyoibus rubris, petalis roseis $v$. albis.

M a jet a Aublet Guian, I. 443 t. 176. DC. Prodr. III. 166. Mem, 1. 60. Maríus Nov. gen et sp. III, 150, $t, 280$. Mleisner Gen, 112. (80.) Tococa sp. Don.

6235. Caloplaysa DC. Calyx tubo oblongu, demum subrotundo-lagenario, inferne $\mathrm{cum}$ ovarii basi eonnato, limbi quadripartiti lobis brevibus, latis, setis plumoso edilatis. Coroll a e petala 4, calycis fauci inserta, ejusdem laciniis alterna, obovata. St a in in a 8 , $\mathrm{cum}$ petalis inserta, suliaequalia; fila mentá plana, apice attenuata, antherae oblongae, uniporisae, exappendiculatae. Ovarinm inferne adnatum, quadrilucolare, loculis multiovulatis. Sty lus filiformis; stigma simplex. Capsula baceata, calyce velata, quadritneularis. Semin a plurima, ovato-angulata (?) - Frutex brusiliensis; ramis teretibus, petiolisque setis rigidis, patentibus hispidis, foliis oppositis, cordatis, acutis, septuplinerviis, dentatis, ciliatis, supra sparse setosis, subtus ad nervos setigeris, inter nervas minute glandulosis, vesicis utrinque ad basim petioli subrotundis, cymis axillaribus confertis, paucifloris, brevibus.

C a lophys a DC. Prodr. III. 166. Mem, I, 60. Meisner Gen, 112, (80.)

6236. Nedinilla $G A U D I C H, C$ a I y $x$ tubo ovoideo, turbinato $v$, eylindraceo, cum ovario connato, ecostato, limbo supero, truncato v, obsolete dentato, rarissime irregulariter fisso. Corolla e petala $4 \mathbf{v}, 5$, rarins 6 , calycis fauci inserta, oblique ovata, crassiuseula, Stamina 8 v. 10 , rarius 12 , subinaequalia, a $n t h$ er a e $8 n-$ bulatae, arcuatae, uniporosae, basi conneetivo antice emarginato-subbilobo, postice unicalcarato, cum anthera confluente. Ova $\mathbf{r}$ i $\mathbf{m}$ adnatum, apice glabrum v. rarissime puheseens, quadri-quinque-v, rarius sexloculare, loculis multiovulatis. Sty $\mathrm{lu}$ s filiformis, interdnm inferne tumidus; 8 tig ma parvam, obtusam. Ba cea elongato-ovoidea v, ovoideo - globosa, calycis limbo coronata, laevinscula, recta, rhaphe excurrente notata.

Frutices moluccan $i$, glabri $v$. rarissime pube stellata tecti, interdum radicantes et pseudoparasitici; ramis teretibus v. angulosis, foliis oppositis $v$, verticillatis, petiolatis v. sessilibus, integerrimis $v, r a$ rissime minutissime denticulatis, nervosis, interdum etiam penninerviis, cymis $v$. umbellis nunc simplicibus, paucifloris, nune paniculato.compositis, multifloris, axillaribus $v$. terminalibus, floribus roseo-albidis, pedicellis rubicundis.

Med in illa Gaudichaud ad Freycinel 484, t. 106. DC. Prodr. III. 167. Blume in Flora 1831. p. 508. Mem, I. 61. Rumphia I. 11, $t, 1-3$. Melsuer Gen, 113, (80.) G all a ria Schrauk msc. Melast ou atis sp. Linn. Blum. DC.

a, CAMPSOPLACUNTIA Blume Flora 1831. p.509. Caly. E Is tubus ovatus, linbus cylindraceo-tubulosus, sub. truncatus v. rarius fissus. Place nta e lamiuae instar utrinque ister localos inflexae. - Frutices glabri, fo liis verticillatis, petiolatis, inflorescentia cymoso- pauciflora, axillari, pedicellis basi articulatis, ebracteatis. (Blume Rumphia t.1-3. Gaudich. Op. cit.t. 106.)

b. SARCOPLACUNTIA Blume in Flora 1831. p. $510, \mathrm{C}$. I yeis tubus obovatus v. subglobosus, limbus brevis. truacatus v. denticulatus. PI a e e u ta e crassae, caruo. sae, baceae ideo pulposae, stminibus nidulantibus. Frutices glabri, folits oppositis, aut rarius verticil. latis, petiolatis $v$. sessilibus, pedunculis axillaribus aut terminalibus oymoso pauci.multifloris, pedicellis medio bibracteolatis.

e. HYPENANTHE Blume in Flora 1831. p. 517 . Ca I y cis tubus obovato-oblougus, limbus breviter quadrilobus. Petala trapezoidea, alterna angustiora. Ovarium vertice libero stellato-pubescens. S e m in a seabriuscula. - Frutex ramulis, pedunculis foliisque subtus pilis stellatis tomentosis.

d. DACTYLI0TA Blume in Flora 1831. p. 518, C a I yeis tubus subglobosus, limbus brevis, subintegerriaus. S $t$ vI us pectarin anuulari cinetus. - Erutex ramulis, pe. dunculis foliisgue subtus furfuraceo-tomentosis,

623\%. Triplectmum DON. C a y x tubu subinfundibnliformi, carnoso, libero, limbo truncato. Corolla a petala 4 , calyeis fauci inserta, duo distincta, oblonga, obtusa, recurvata, duo in unicum late obovatum, emarginatum coalita. Stam in a 8 , cum petalis inserta, aequalia, a $\mathbf{t h e -}$ rae oblongo lineares, elongatae, uniporosae, connectivo basi antice bi-postice nnicalearato. Ovari n m liberum, stipitatum, ovale, glabrum. St yIn 8 subulatus, incurvus .... - Frutex ind $i$ cus, glaber, ex articulis radicans; foliis oppositis, subrotundo-ovalibus, carnosis, trinerviis, integerrimis, breve petiolatis, paribus saepe in ramulis lateralibus brevibus solitariis, pedunculis axillaribus solitariis, unifloris.

Triple etrum Don ex Wight et Amott Prodr. I.324. Meisner Gen, 113, (80.)

6238. Pachyeentria $B L U M$. C a l y x tubo eyathiformi, inferne cum ovarii basi connato, infra medium constricto, limbo obsolele quadridentato. Corolla e petala 4, calycis fanci inserta, ejusdem dentibus alterna, ovata, acuminata. Stam in a 8 , calycis fauci inserta, aequalia, anthe$r$ a e oblongo-lineares, rectinsculae, rostratae, uniporosae, postice ad basim in ealear crassum, earnosum productae. Ovarinm inferne adnatum, apice libero conico, angulato, quadriloculare, loculis multiovulatis. Stylus filiformis, suleatus; $8 t$ i $5 \mathrm{~m}$ a parrum, obtusum. B a c e a globosa, calycis tubo constricto coronata, quadrilocularis. Semina plurima, ovalia, Iaevia. - Frutices $j a$. vanici, parasitici, glabri; ramis teretibus, extimis compressis, pedunculisque punctis atropurpureis $v$. fuscis adspersis, foliis oppositis, petiolatis, oblongis, trinerviis $v$, subtriplinerviis, integerrimis, floribus corymbosis, terminalibus et axillaribus, parvis, roseis, pedicellis medin bibracteolatis.

$\mathrm{Pa}$ ch y cen tria Blume in Flora 1831. p. 519. Meisner Gen, 113. (81,) Melastom atis s p. Blume. DC.

6239. Pogonanthera BLUM. Calyx tabo cyathiformi, subquadrangulo, inferne cum ovarii basi connato, limbo quadridentato. Co rolI a e petala 4, ealycis fauci inserta, ejusdem dentibus alterna, lanceulata, acuminata, medio utrinsecus tumida $v$. denticulo instrueta. S $t$ a $\mathrm{m}$ ina 8 , cum petalis inserta, subaequalia, antherae oblongae, acutae, rectae, uniporosae, postice barbatae. 0 varin m inferne adnatum, apice libero cunicum, hirsutum, quadriloculare, loculio multiovulatis. Stylus filiformis; 8 tigma parvum, obtusum. B a c e a globosa, calycis limbo eoronata, quadrilocularis, pulposa. Se m ina plurima, ova- 
lia, laevia. - Frutices moluccani, interdum pseudo parasitici; ramulis teretibus, petiolis pedunculisque punctis lepidotis et furfuraceis notatis, foliis oppositis, petiolatis, ovato-oblongis, basi subauriculatis, tri-v. subquinquenerviis, integerrimis, glabris, floribus terminalibus paniculatis, parvis, rubicundis, pulvere resinoso oblectis.

Pog onathera Blume in Flora 1831. p. 820. Meis. ner Gen, 113. (81.) Me lastoma pulveruleutum Jaek, Blum.

6240. Allomorphia BLUM. Calyx tubo oblongo-tubnloso, inferne cum ovarii basi connato, limbo breviter quadridentato. Corolla e petala 4 , calycis fanci inserta, ejusdem dentibus alterna, ovata, acuta. St a mina 8 , cum petalis inserta, alterna iisdem opposita paullo breviora, antherae lineares, acutae, rertae, uniporosae, basi emarginatae, omnino exappendienlatae. $O$ varium inferne adnatum, quadriloculare, loculis multiovulatis. Stylus filiformis; stigma simplex. F ruct u s exsuccus, ovato-oblongus, calyce vestitus, quadrilocularis. Se min a .... - Frutex in in sula Pulu-Pinang crescens; ramis quadrangulis, ferrugineo-punctatis, folits oppositis, longe petiolatis, ovatis, integerrimis, glabris, quin quenerviis, paniculae terminalis parvae ramis divaricatis, floribus minutis, albido-roseis.

All o m o r p hi a Blume in Flora 1831. p, B22. Meisner Gen. 112. (80.) M elastoma ex igu u m Jack.

624 4. Calyeogonium $D C$. Caly $x$ tubo cum ovario connato, subgloboso, tetra-pentagono, angulis acutis, cum nervo medio loborum conti. nuis, demum increscentibus, limbi quadri-quinquepartiti lohis patentibus, oblongo-linearibus, tubo longioribus. Co ro 11 a e petala 4 v. 5, calyeis favei inserta, ejusdem lobis alterna, obovata. Stam in a 8 v. 10, cum petalis inserta, aequalia, antherae oblongae, uniporosae, basi exappendieulatae, connectivo haud manifesto. Stylu s filiformis; $8 \mathrm{tig}$ a punetiforme. B acca subrotunda, quadri-quinqueangulata, calycis lobis coronata, quadri-quinquelocularis. Se min a plurima, ovato-angulata, umbilico lineari. - Frutices do mingenses; ramis teretibus, petiolis foliisque subtus pube stellata, floccosa, molli, subrufescente tomentosis, foliis oppositis, breve petiolatis, ovato-oblongis, tri-quinquenerviis, basi obtusis, subcoloratis, integerrimis, superne glabris, floribus terminalibus, solitariis, geminis $v$. ternis, albis, brevissime pedi. cellatis, calycibus pube stellata, sparsa quasi punctatis.

Cal yeog o n i m DC. Prodr, III, 168. Mem, I. 76. Meis. ner Gen. 112. (80.) Caly copteris Rich. mec. Melasto matis sp. Vahl, Swartz.

6248. Dssaea DC. Ca I y tubo cum ova rio connato, supra ovarium hand producto, limbi lobis quatuor, brevibus, acutis, Corolla e petala 4, calycis fanci inserta, ejusdem lobis alterna, lanceolata, acuta. St a min a 8 , cum petalis inserta, brevia, aequalia, antherae uniporosae basi obsolete biauriculatae. Ovari um adnatum, vertice glabriusculum, quadriloculare, loculis mul tiovalatis. Stylus filiformis; s tigma simplex. Ba c c a subglobosa, calycis lobis coronata, quadrilocularis. Semina plurima, ovato-angulata. Frutices $A$ mericae tropicae; ramulis teretibus $v$. tetragonis, petiolis foliisque glaberrimis $v$. hirtis, foliis oppositis, triplinerviis, floribus axillaribus so. litariis $v$. thyrsoideis, parvis.

0 s a e a DC. Prodr. III. 168, Mem. T, 64. Melsner Gen. 113. (80.) Melastom at 1 s $5 \mathrm{p}$. Linn. Aubl. Guian, $t, 164$, ,
Bonpl. Melast, $t, 36-38$. Maietate $s$ p. Veuten. Choix t. 33.

6343. Sagraea DC. Calyx tubo cum ovario connato, ultra ovarium haud producto, lim. bi lobis quatuor, brevibus. Corolla e petala 4 , calycis fauci inserta, aequalia, an the rae unipo. rosae, basi obsolete biauriculatae. Ovarium adnatum, vertice glabrum, quadriloculare, loculis multiovulatis. Stylus filiformis; $8 \mathrm{tigma}$ obtusum. C a p s la baceata, calycis limbo coronata, quadrilocularis. S emina plurima, parva, ovatoangulata. - Frutices Americae tropicae, a Clidemiis fortassis haud separandi, ut plurimum hirti; foliis oppositis, petiolatis, tri-septemnerviis, floribus axillaribus congestis $v$. cymosis aut paniculatis.

$\mathrm{S}$ agrae a DC, Prodr. III, 170. Mem, I, 66. Meisner Gen. 113. $(80$,$) M e Ias tom at is s p. Linu. Vahi Ic. t, 18$, Boupl. Melast, $t, 39$. 50 .

G24 4. Tetrazysia RICH. C a ly x tubo globoso v. urceolato, cum ovario connato, supra ovarium producto, breviter quadridentato. Coro 11 a e petala 4, calycis fauci inserta, ejusdem dentibus alterna, obovata. Stamina 4 v. 8 , cum petalis inserta, antherae lineares, uniporosae, basi obtusae. Ovari u m adnatum, glabrum, quadriloeulare, loculis multiovulatis. St y I u s filiformis; stior m a panctiforme. Cap sula baceata, ealycis limbo coronata, quadrilocularis. Se m in a plurima, cuneato-angulata, nitida, umbilico lineari. - Frutices antillani; ramis, petiolis foliisque subtus albido-furfuraceis $v$. lepidotis, folits oppositis, petiolatis, ovalibus $v$. oblongis, trinerviis, discoloribus, cymis terminalibus trichotomis, floribus albis, ebracteolatis.

Tetrazygia Richard mse. ex DC. Prodr, IIT. 172. Mem, I. 76. Meisu. Gen, 112. (80.)

a TETRASTEMON DC. $l$. c. Stamina 4. - Thyrsus pa. niculaeformis. - Melas to ma tet $\mathrm{randr} u \mathrm{~m}$ Swartz. b. OCTOSTEMON DC. t. c. St a min a 8 . - Thyrsus co. rymbiformis. - Melastomatis sp. Liun. Jaeq. Amer. t. 84. Bonpl. Melast, $t .10 .13,34$.

6245. Heterotriclnuma $D C$. C a 1 y x tubo ovato - globoso, cum ovario connato, limbi quinque-octopartiti lobis basi dilatatis, apice subulatis, elongatis. Co rollae petala 5 v. 8 , calycis fauci inserta, ejusdem lobis alterna, ovalia. Stamina 10 v. 16, cum petalis inserta, aequalia; $\mathrm{fi}$ I amenta glabra, antherae oblongae, uniporosae, basi vix gibbosae. Ova rium adnatum, vertice glabro umbilieatum, quinque-octoloculare, loculis multiovulatis. Stylns cylindraceus; stigma punetiforme, pruinosum. Cap sula baceata, subglobosa, calycis limbo coronata, quinque-ostolocularis. Sem in a ..... Frutices d om ingen$s e s$, setis rigidulis hispidi, et pubestellata, tomentosa, inter setas intermixta velutini; foliis oppositis, petiolatis, superne setosis, subtus ad nervos hispidis et inter nervos velutinis, cymis terminalibus trichotomis, umbellatis, floribus albis v. purpureis.

Heterotriehum DC. Prodr. IIr. 173. Mem, I.68. Meisuer Gen. 113. (80.) Melas to mat is sp. Swartz. Desr, Bonpl. Melast, t. 4.

8246. Dissoehaeta BLUM. C a $1 \mathrm{y} \times$ tubo oblonge, obscure tetragono, cum ovario connato, supra ovarium prodneto, limbo breviter et obsolete quadridentato. Corolla e petala 4 , calycis fauci inserta, ejusdem dentibus alterna, ovata v. ovato-oblonga. Stamina 4 v. 8 , cum petalis inserta, alterna iisdem opposita dum adsunt saepe 
sterilia, anthera e oblongo-lineares, uniporosae, saepissime rostratae et coronatae, rarius rectae et obtnsae, dorso prope basim connectivo lamellato, biaristato v. rarius indiviso. Ovarium adnatum, quadriloculare, loculis multiovulatis. Stylus filiformis, subclavatus; st ig a punctiforme, pruinosum. Ba ce a elliptico-globosa, fere exsucca, calycis limbo coronata, quadrilocularis. Semina plurima, cuneata, angulata. - Frutices moluccani, sarmentosi; ramulis, pedunculis, calycibus folitsque subtus pube stellata, conferta $v$. sparsa ob. sessis, foliis oppositis, petiolatis, elliptico-oblongis, integerrimis, subquinquenerviis, supra glabris, subtus plerumque discoloribus, floribus terminalibus v. axillaribus paniculatis, pallide roseis, caerulescentibus $v$, albidis.

Dissochaeta Blume in Flora 1831, p 492. Meisner Gen. 113. (89.) Melastomatis $s$ p. Blume, Jack, DC.

a. EUDISSOCHAETA Bium, $l, c$ C a ly $\mathrm{c}$ is limbas cyathiformis, subquadridentatus. Corolla e petala ovato. oblongat, obtuxa v. abtusiuscula. Antherae basi aut dorso-aftixae, connectivo bifido v. indiviso. Ovarium apice pilis stellatis subsericeum.

b. DIPLECTRIA Blum, $l$, c. Caly cis limbus eylindricus, cum tubo continuus, truncatus. Coroll a e petala ova. ta, acuminata. Antherae basi affixae, ibidem antice erispatulae, postice breviter biauriculatae. Ovarium apice glabrum.

B:4\%. Aplectrum $B L U M$. C al y $x$ tubo ovato-globoso, cum ovuris connato, limbo supra ovarium producto, truncato $v$. obsolete quadridentato. Co rolla a petala 4 , calycis fauci inserta, ejusdem dentibns dum adsunt alterna, ovata, acu. ta v. obtusiuscula. Stamina 8 , cum petalis in. serta, alterna iisdem opposita sterilia, antherae ovales, erassac, uniporosae, inappendiculatae. Ovari um adnatum, glabrum, eristis quatuor coronatom, quadriloculare, loculis multievulatis. Stylus filiformis; $8 \mathrm{tigma}$ punctiforme, pruinosum. Bace a subglobosa, calyce coronata, quadrilocularis. Sem in a plorima, cuneiformia.Frutices moluccani, sarmentosi, Dissochaetarum facie, glabri; foliis oppositis, petiolatis, ellipticooblongis, integerrimis, subquiuquenerviis, margine interpetiolari junctis, ftoribus subpaniculatis, axillaribus et terminalibus, parvis, albidis.

A pleotrum Blame in Flora 1831, p. 502 . Meisner Gen, 112, (80,) Melastoma viminale Jack.

B245. Comostegia DON. Cal yx tubo cum ovario connato, limbo indiviso, conico, calyptraeformi, sub anthesi ad basim circumseisso $\mathrm{v}$, irregulariter rupto. Ci rolla e petala 5 v. 6 , calycis fauci inserta. Sta mina $10-16$, $\mathbf{c m m}$ petalis inserta, antherae uniporosae, basi saepius biauriculatae. Ovarium inferum, tri-octoloculare, Inculis multiovulatis. Sty lus filiformis; $8 \mathrm{ti} \mathrm{gma}$ capitatum v. peltatum. Cap sula baccata, tri-netolocularis. Semin a plurima, ovoideo-angulata. - Arbores $v$. frutices, in Americ a tropica crescentes; foliis oppositis, petiolatis, thyrsis panieula tis, terminalibus, floribus saepius albis.

Conastegla Don in Mem. Werner, soc. IV. 316. DC. Prodr. III. 173. Mem. I.69. Meisuer Gen, 112. (80.) C a1 y cotomus et Bruguiera Richard msc. Melastoma$t$ is s p. Auct.

a. ERIOSTBGIA DC, l,c. Alabastrum globosum, hispidum, abrupte acuminatum, - Melas toma Mutisit Bonpl. Melast. t. 58.

b. EUConostegIA DC. l. c. Alabastrum ovatum, apice obtusum v. subacutum, glabrum v. subvelutinum. M eI a s to mat is sp. Vahl. Swartz. Bonpl. Melast, $t, 31$. 41. 46, 51. 57. 55, 57. 60 .
62 49. Diplosenea $L I N D L . C$ a I y $x$ tubo cum ovario connato, limbo indiviso, conico, calyptraeformi, sub anthesi ad basim circnmscisso. Corolla e petala 4 , ad marginem disci carnosi, ovarium tegentis inserta, lanceolata. Stamina 8 , cum petalis inscrta, an $t$ hera e ovatae, uniporosae, basi bicalcaratae. Ova riu in infermm, disco carnoso coronatum, yuadriloeulare, loculis multiovis latis. Styl us falcatus, clavatus; $s$ t $\mathrm{g}$ in a simplex. Fruetus..... Frutex madagascariensis, fortassis parasiticus, glaberrimus; ramis carnosis, dichotomis, junioribus compressis, fere Visci ramos referentibus, foliis oppositis, oblongis, retusis, carnosis, tricostatis, aveniis, receptaculis oleiferis intra parenchyma latentibus, floribus parvis, ut videtur al bis, in racemos axillares, breves dispositis, calycis tubo receptaculis oleiferis exsculpto.

Diploge nex Lindley in Brandes Quaterl. Journ. Oct. 1828. p. 129. Meisaer Gen, 112. (80.)

6950. Diploeluiton $D C$. $\mathrm{Cal}$ y $\times$ tubu bibracteolato, eylindrico, inferne cum ovarii hasi connato, limbo obtuse quinque-sexdentato. Corolla e petala 5 v. 6 , calycis fauci inserta, ejusdem dentibus alterna, obovata $\mathbf{v}$, oblonga. Sta $\mathbf{m}$ i $\mathbf{n}$ a 10 v. 12 , cum petalis inserta, aequalia, anthe$r$ ae unipornsae, basi introrsum breviter emarginato-bilobae. Ovari u m ima hasi adnatum, vertice exserto nudnm v. setosum, quadri-quinqueloculare, loculis multiovulatis. St ylus filiformis; stig m a peltatum v, capitatum. B a c ca sicea, calyce vestita, quadri-quinquelocularis. Sem in a plurima, ovata, angulata. - Arbusculae v. frutices dichotomi, in America tropica crescentes; ramis obsolete tetragonis v. compressis, foliisque subtus pube stellata densa, aurea, ferruginea $v$. fulvescente adspersis, foliis oppositis, petiolatis, majusculis, altero saepe minore, integerrimis $v$. crenatis, nervis crassis, subtus prominulis, inter nervos subcostatoreticulatis, thyrso terminali, pyramidato, floribus ante anthesim parvis, bractearum deciduarum pari involucratis, petalis holosericeo-nitentibus, albis, roseis $v$, aureis.

D I p I o chito on Spreng. Gen, n, 1720. D iploehita DC. Prodr. III. 176. Mem. I. 7t. Martius Nov, gon. et sp. III. 142. $t$. 274. Meisuer Gen. 113. (80.) C thit o $\mathrm{n}$ i g Don in Mem. Perner. soc. IV, 3it. Fo th erg ill a Aablet Guian. I. d61, $t$. 175. L e o a ie en ia Scopall Introduct. $n .963$. Me I as tomatis s p. Vahl. Boupl. Melatt, 6. 18. 32.33.

6251. Flayllopas $D C, \mathrm{C}$ a I y $x$ tubo turbinato campanulato, inferne $\mathrm{com}$ ovarii basi cobaerente, limbi breviter quinquelobi tobis setoso-ciliatis. Corollae petala 5 , calyeis fanei inserta, ejusdem Iobis alterna, late ovata, abrupte mueronata. St a $\mathbf{m}$ in a 10 , cum petalis inserta, aequalia, a $\mathbf{n}$ therae infra mueronem terminalem biporosae, basi exappendiculatae. O va ri um ima basi adnatum, vertiee setosum, quinqueloculare, loeulis multiovulatis. Stylus filiformis; stigma punctiforme. Frnet us......-Frutex brasiliens is ramis dichotomis, obsolete tetragonis, junioribus setis rufis aclpressis villosis, adultioribus glabris; foliis opposilis, oblongis, acuminatis, elongatis, trinerviis, integerrimis, superne sparse setosis, sub. tus pallide rufis, pube stellata minima pubescentibus, pedunculis axillaribus solitariis, unifloris, supra medium foliaceo-bibracteatis, petalis purpureo-violaceis.

Phyllop us DC. Prodr. III, 127, Mem, I.72. Martius Non. gen. ot sp. III. 143, t. 275. Meisner Gen, 119. (80.)

6252. Ji enriettea $D C$. C a l y $x$ tubo campanulato, cum ovario conuata, limbi Iobis 5, latis, $153 *$ 
obtusis. C or ollae petala 5, calycis fauci inserta, ejusdem lobis alterna, ovata, Stamina 10 , cnm petalis inserta, aequalia, an $t$ herae crassae, apice longe rostratae, uniporosae, basi bifidae. Ovarium adnatum, quinqueloculare, loculis multiovulatis. Stylus cylindricus, hirtus; stigma eapitatnm, obtusnm. B a c e a succosa, quinquelucularis. S e mina...... Frutex guianensis; ramulis subteretibus, pube rufa, adpressa sub. strigosis, foliis oppositis, breve petiolatis, ovalibus, mucronato-acuminatis, triplinerviis, supra viridibus, subtus rufo-velutinis, pedunculis e foliorum delapsorum axilis tri-quadrifloris, calycibus rufo-villosis.

Henriettea DC. Prodr. III, 178, Mem, I, 73. Meis nerGen, 112, (80.) M e las to ma su c cos a Aublet Guian. 2. 162 .

B253. Loreya $D C$. Calyx tubo campanulato, cnm ovario connato, limbo supero, subtrnncato. Curolla e petala 5 , calycis fauci inserta, ovata, basi subeordata, obtusa. St a min a 10, cum petalis inserta, aequalia, antherae ovatae, obtnsae, uniporosae, basi subgibbusae. Ovari u m adnatum, quinqueloculare, loculis multiovulatis. Stylus filiformis; stigma capitatum, fere pentagonum. B a e a calyce coronata, quinquelocularis. Sem in a...... - Arbor guianens is, glabra; foliis oppositis, petiolatis, ovalibus, triplinerviis, cum nervulis duobus lateralibus, integerrimis, cymis lateralibus, multifloris.

L n re y a DC. Prodr. ITI, 178. Mem. $I, 23$. Meisner Gen, 113. (80.) Melastoma arboresceas Aublet Guian, $2,163$.

6254. NIarumia BLUM. Caly $\mathrm{x}$ tubo subinfundibuliformi, hirto, inferne sum ovarii basi connato, limbi quadrifidi laciniis oblongo-lineari bus, persistentibus. Corolla e petala 4 , calycis fauci inserta, ejusdem laciniis alterna, inaequilatera. Stam in a 8 , enm petalis inserta, alterna iisdem opposita breviora, antherae lineares, areuatae, rostratae, uniporosae, ima basi appendice setacen-fissa instructae. Ova rinm inferne adnatum, vertice libero conieum, villosum, quadri loculare, loculis multiovulatis. Stylus filiformis, apice ineurvus; stigma punetiforme. Ba cea ovoidea, calyce coronata, quadrilocularis. Se mina plurima, rectinscula, rhaphe excurrente hinc marginata. - Frutices Asiae tropicae, sarmentosi; foliis oppositis, petiolatis, oblongis, nervosis, inter nervos juxta apicem confluentes transverse venuloso-reticulatis, integerrimis, discoloribus, supra glabris, subtus cum ramulis pedunculisque pube stellata tomentosis v. furfuraceis, cymis axillaribus, páci-multifloris, bracteatis, floribus magnis, roseis v. coccineis,

M a r um i a Blume in Flora 1831. p. 503. Rumphia I. 17. t. 4. 5. Meisner Gen, 113. (81.) Mela sto uat is sp. Jack. Blume, DC.

6255. Creoelniton BLUM. Caly $x$ tubo bibracteato, globoso, cum ovario connato, limbo breviter supra ovarinm producto, obsolete repando-quadridentato. Coroll a e petala 4 , calycis fanci inserta, ovato-rotundata, obliqua. S $\mathrm{tami}$ n a 8 , cum petalis inserta, aequalia, a $\mathrm{n}$ th erae oblongae, crassae, arcuatae, breviter rostratae, uniporosae, basi antice brevissime apieulatae. O vari u m adnatum, vertice glabrum, quadriloeulare, loculis multiovulatis. St y l u s crassus, quadrangulus; s ti g m a parvum, obtusum. B a cea exsucca, globosa, calycis limbo coronata, quadriloenlaris. Semina plurima, cuneato-oblonga, rhaphe lineari marginata. - Frutices moluccani, scandentes; folïs oppositis, petiolatis, ovatis v. ellipticooblongis, integerrimis, subquinquenerviis, supra glaberrimis, subtus furfure conspersis, pedunculis axillaribus et terminalibus, apice dilatatis et umbellato-multifloris, floribus singulis ante anthesim bracteis duabus carnosis inclusis, magnis, roseis.

Creochiton Blume in Flora 1831. p. 506, Meisner Gen. 113. (80.) Melastomatis s p. Blum. DC.

B256. Phyllagatliès BLUM. Calyx tubo oblongo, inferne cum ovario connato, limbo supra ovarium producto, quadrifido. Corollae petala 4, ealycis fauci inserta, ejusdem laciniis alterna. Stam in a 8 , cum petalis inserta, aequalia, antherae areuatae, rostratae, uniporosae, basi inappendiculatae. Ovari um inferne adnatum, quadrileculare, loculis multiovulatis. St y lus longus; 8 tigma obtusum. B a c ca quadrilocularis ..... - Frutex sumatranus; foliis oppositis, maximis, subrotundis, septemnerviis, subtus punctis ferrugineis lepidotis, petiolis longissimis, ciliatis, floribus in capitula axillaria, pedunculata dense congestis, bracteis quinque $v$. sex, late cordatis, nervosis, involucratis, purpurascentibus.

Phyllagath is Blume in Flora 1831. p. 302. Meis. ner Gen, 112. (80.) Melastoma rotunditoli um Jack.

6258. Deearhaphe MIQ CaIyx tubo ovato-oblongo, decemeostato, inferne cuin ovarii basi cohaerente, limbo membranaceo, breviter quinquedentato. Corolla e petala 5 , calycis fauei inserta, ejusdem dentibus alterna, obovata, concava, reflexa. St a m in a 10 , cum petalis inserta, longe exserta, aequalia, a n $t$ herae lineari-faleatae, uniporosae, basi utrinque in auriculam obtusam, flexuosam, productae. Ova ri um in fundo calycis minimum, semisuperum, glabrum, triloenlare, loculis multiovulatis. Stylus eylindricus; stigma punctiforme. B a ce a calycis limbo incrassato, hiante coronata, decemcostata, trilocularis. Semina plurima, pyramidato-subtriquetra, umbilico lineari, laterali. - Frutex surinamensis; foliis oppositis, quinquenerviis, irregulariter denticulatis, paniculae terminalis ramis brachiatis, decussatis, ramulis plerumque trifloris, floribus sessilibus, bracteis lineari-lanceolatis, plerumque deciduis, pube stellata, alba, pilis selosis, sparsis intermixta.

Decar ha phe Miquel Comment. II.84, t, 10. J.F. M elastoma pleurocarpum E. Mey.

6258. Mieomia RUIZ, et $P A V$. C aly $x$ tubo campanulato $v$. globoso-nreeolato, inferne cum ovarii basi connato, limbo membranaceo, breviter quinquedentato, persistente $\mathbf{v}$. circumscisse deciduo. Corolla e petala 5 , calycis fanci inserta, ejusdem dentibus alterna, ovata v. oblonga. Stamina 10 , eum petalis inserta, aequalia, a $n$ therae cylindricae, nniporosae, connectivo basi nonnihil deorsum prodncto. Ovarium inferne adnatum, nudum $\mathbf{v}$. tomentosum, tri-quinquelocnlare, Inculis multiovulatis. Stylus filiformis; stig m a punetiforme v. capitatum. B a c ca globosa, umbilicata, ealyce membranaceo v. earnoso velata, tri-quinquelocularis. Sem in a plurima, obovata, oblonga, angulata, rhaphe lineari. - $A r$ busculae $v$. frutices Americae tropica oppositis, foliis oppositis, petiolatis, quinque-septemnerviis, subtus saepe tomento tenuissimo cincrascente v. ochroleuco tectis, thyrsis terminalibus paniculatim elongatis $v$. contractis, floribus parvis, bibracteatis, albis, baccis violaceis, rubris $v$. purpureis. 
Miconia Ruiz et Pavon Prodr. 60, Syst. 104. Don in Mem. Werner. soc. IV. 315. DC. Prodr, III, 121. Mem. I. 74. Martius Nov. gen, etsp. III. 156. Meisa. Gen, 113. (80.)

a. LEIOSPHABRA DC. L. c. Calyeis tubus fruetusque globosi, glaberrimi. - Flores congesti $v$. in thyrsi terminalis ramis uniseriati. Folia trinervia, setis ciliata. - M e I a 5 to m a ti s s p. Aublet Guian, . 154. 156. 157. Boupl, Melast. t. 2, 26. 27.

b. ERIOSPHAERA DC. $l$. c. A la bastrum tomentosum. Cal y cis tubus subglobosus, limbus brevissimus. B a cc a globosa. - Folia subtus tomentosa. Paniculae ter. minalis incanescentis rami oppositi, floribus secus rachim subsimplicem congestis. - H y poxa a $\mathrm{h}$ us Richard msc. M elastomat is 8 p. Linn. Rich. Bonpl, Melast, $t .1$, 6. 11, 15, 23. 24, 47. 62, (Martius Op. cit. $t$. 284.)

c. EUMICONIA DC. l. c. C aly e is tubus subeampanulatus. - Flores secus panioulae ramos sparsi. - M e. 1 a 8 ta a tis 5 p. Linn. Aublet Guian. $t$. $138,159$. 170 171. Boupl. Melast. $t, 7$. 16, 17. 21. 22, 25. 26. 29. 35. 40. 43, 49. 83. 56. Bot. Reg. t. 363.

Bะ55. Dxymenols DC. C a ly x tubo obovato-turbinato, inferne cum ovarii basi connato, limbi dentibus quinque, callosis, brevissimis. Co. rolla e petala 5 , calycis fauei inserta, ejusdem laciniis alterna, lanceolata, acuminata, S t a m ina 10 , cum petalis inserta, aequalia; $\mathrm{fi}$ a me $\mathrm{n}$ ta late subulata, antherae lineari oblongae, obtusae, oniporosae, connectivo haud distincto. O v a $r$ in m semiadnatum, tri-quinquelosnlare, loculis multiovalatis. St y lus fitiformis; $8 \mathrm{tig}$ a pnnetiforme. Ca psula baccata, calyce persistente velata, tri-quinquelocularis. S e mina plurima, obovata, angulata. - Arbores $v$. frutices glaberrimi, in America tropica indigeni; romulis tetragonis, ad nodos tumentibus, foliis oppositis, petiolatis, oblongis, integerrimis, trinerviis, paniculis terminalibus brachiatis, pyramidalibus, floribus parvis, bibracteolatis, albis.

$0 \times$ y m r r is DC. Prodr. TIT. 190. Mem. Y. 78. Martius Lhv. gen. et sp. III. 157. t, 285 . Meisuer Gen, 113, (80.)

8260. Cremanimun $D O N$. C a l y x tubo hemisphaerico v. campanalato, inferne cum ovarii hasi connato, limbo breviter quadri-quinquedentato. Corolla e petala $\$ v+5$, ealyeis fauci inserta, ejusdem dentibus alterna, obovato-rotundata. Stamina 8 v. 10 , cum petalis inserta, aequalia; filamenta subulata, antherae breviter cylindricae, v. cuneatae, apice truncato late biporosae, connectivo indistincto. Ovariu m semiadnatum, tri-quinqueloculare, loculis multiovulatis. Stylus filiformis $v$. clavatus; $\mathrm{tigma}$ capitatum. B a e e a globosa, umbilieata, cum calyce ad limbum circumseisso tandem connata, tri-quinque lucularis. Semin a plurima, oblonga v. semiellip. tica, rhaphe lineari. - Frutices v. arbusculae, in America tropica crescentes; foliis petialatis, decussatis, intererrimis $v$. subserratis, paniculis ter minalibus brachiatis, floribus parvis, albis, bibracteatis, bracteolis saepe minimis, baccis caerulescentibus v. rubro-violaceis.

Cremanium Don in Mem. Wern. soc. IV. 310. DC, Prodr. IIT. 191. Mem, I 78. Martius Nov. gen, et sp. III.

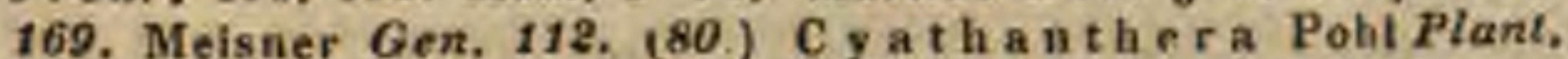
Brasil. II. 130, t. 188. Meisner Gen, 112. (80,) M e I a s to matis a p. Swartz. Boupl. Melast, $t .8 .9 .12,19.48$.

8261. BIakea LINN. Caly $x$ tubo basi squamis quatuor $v$. sex, latis, cruciatis $v$, triseriatis munitus, campanulatns, inferne cum ovarii basi connatus, limbo membranaceo, sexlobo v, sexientato, persistente. Coro 11 a e petala 6 , calycis fanci inserta, ejusdem lobis alterna. Stamina 12-16, cum petalis inserta, a nthera magnae, in annolum coadunatae, apice obtnso poro gemino hiantes, basi processu brevi, calcariformi instractae. Ovarium semiadnatum, sexloculare, loculis multiovulatis. Stylns filiformis; 8 tigma capitatum v. peltatum. C a p s u a baccata, calyce co. ronata, sexlocularis. S e mina plurima, ovato-angulata. - Arbores $v$. frutices Americae tropicae; foliis oppositis, petiolatis, tri.quinquenerviis, coriaceis, supra glabris, nitidis, subtus saepissime dense ferrugineo-tomentosis, pedunculis axillaribus teretibus, unifloris, nudis, oppositis v. solitariis, fo. lio brevioribus, saepe ferrugineo-tomentosis, floribus magnis, speciosis, roseis.

B Iake a Linn. Gen, n, 810. Jussieu Gen. 328. Aublet Guian, 2 . 210. Don in Mem. Worner. soc. IV. 323. DC. Prodr, III. 195. Mom. I. 80. Meisuer Gen. 118. (80.) T opo be a Aublet Guian. $I$, 476, t. 189. Valde $\mathrm{s}$ i a Ruiz et Pavou Prodr. 6r. t. 11. Bellu cia Necker Elem, n, 833. Drepanandrum Necher Elem. n. 293. A patiiia Des. vaux in Hamilt. Prodr. 42.

6962. Sareopyramís $W A L L$. Cal yx obverse pyramidalis, inferne cum ovarii basi connatus, limbo truncato, quadridentato, dentibus compressis, ciliatis. Corolla e petala 4, calycis fauci inserta, ejusdem dentibus alterna, ovalia, acuta. Stamina 8 , cum petalis inserta, anthe$r$ a e reetae, biporosae, basi simplices. O vari um semiadnatum, vertice infundibuliformi-quadrilobum, quadriloculare, loculis multiovulatis. Ca ps u la quadrata, apice quadrialata, quadrilocularis, quadrivalvis, valvulis foliaceo-dilatatis, S emina plurima, cuneato-triangularia. - Herba nepalensis, carnosa, erecta; foliis oppositis, petiolatis, allero cujusvis paris minore, ovalibus, acutis, trinerviis, integerrimis, floribus cymosis, roseis.

S areop y $\mathrm{r}$ mis Wallich Flor. nepal. I. 32. t. 23. DC. Prodr. III, 485, Mem, I. 80, Meisuer Gen, 114, (8t.)

SURondDo II. CHARIANTHEAE Seringe in DC. Prodr. 1II. 196. A thera e rimis longitudinalibus dehiscentes.

B263. Clareianthus $D O N, C$ aly $x$ tubo ovato, suburceolato, cum ovario connato, limbo supero, patente, obtusissime quadrilobo, persistente. Co rolla e petala 4, calycis fauci inserta, ejusdem lobis alterna, erecta, ovalia. Stam ina 8 , cum petalis inserta, snbaequalia, a nther a e obIongo-clavaeformes, rima duplici longitudinaliter dehiscentes, conneetivo exappendiculato. $O \mathrm{v}$ aria in inferum, quadriloculare, placentis lunatis, multiovulatis. Stylus filiformis, exsertus; stigin a simplex. Ca p 8 u la baceata, globoso-nmbilicata, quadrilucularis, valvis quatnor subdehiscens. Semina plurima, ovata, umbilico magno, laterali. _ Frutices antillani, erecti; foliis oppositis, petiolatis, quinquenerviis, integerrimis $v$, rarius calloso-serratis, floribus in cymam corymbosan, trichotomam dispositis, purpureis.

Charianthus Don in Mem. Werner. soc. IV. 327. DC. Prodr. III. 196 Mem. I, 81, Meisner Gen, 111. (80.) Chat a a thera et Tetrazygos Richard mac. Melas. to $\mathrm{m}$ at is s p. Vahl Ic. Amer, t. 16. Boupl. Melast, $t, 44$.

6364. Chaenopleura $R I C H$. C alyx tubo cum ovario connatu, limbo snpero, obtuse quinquedentato. Coroll a e petala 4, valycis fanci inserta, ejusdem dentibus alterna, subrotunda. S t a mina 10 , cum petalis inserta, iisdem vix longiora, ant herae longitudinaliter birimosae, con- 
nectivo basi obtuse biauriculato. Ovarium inferum....... Sty lus clavatus; st igma orbiculatum. B a ce a (?) tri-quadrilocularis. Se min a.... - Frutex domingensis, glaberrimus, Miconiae facie; joliis oppositis, petiolatis, oblongo lanceolatis, basi obtusis, apice ucuminatis, serraturis distantibus, ciliiformibus, tri- $v$, fere triplinerviis, thyrsi terminalis elongati ramulis oppositis, fere racemosis, floribus carneo-albis.

C ha en ople ur a Richard msc. ex. DC. Prodr. III. 197. Mem. I. 83. Meisuer Gen. 11t. (80.) Me las to ma steu o botrys Richard in Bonpl. Melast. $t$. 30 , excl. synou.

6265. 16. 6essia BLUM, Caly x tubo hemisphaerico, eum ovario connato, setis ramosis muricatn, limbo indiviso, calyptraeformi, circum scisse deciduo. Corollae petala 4, ealycis fauci inserta, obovata. Stamina 8 , cum petalis inserta, aequalia, an the rae ovatae, rima duplici longitudinali dehiscentes, connectivo dorsali carnoso, inappendirulato. Ov a ri u m inferum, quadrilocalare, placentis basilaribus, multiovulatis. Sty lus filiformis, sursum attenuatus; stigma simplex. B a c c a sicca, subglobosa, depresso-umbilicata, quadrilocnlaris. Se min a plurima, cuneata, angnlata. - Frutex arborescens, javanicus, glaber, ramulis teretibus, extremis obsolete tetragonis; foliis oppositis, brevissime petiolatis, ovali-oblongis, utrinque angustalis, trinerviis, integerrimis, pedunculis axillaribus terminalibusque, uni- $v$. fasciculatopaucifloris, pedicellis medio bibracteolatis, floribus caeruleis, magnis.

K ibessia DC. Prodr. III. 196. Mem, I. 81, Blume in Flora 1831. p. 324, Meisner Gen, 119. (79.) M e I a s to ma a z u reum Blum.

6265. Ewyeluia BLUM. Calyx tubo hemisphaerico, cum ovario connato, limbo supero, cum tubo continuo, truncato, obsoletissime quadridentato. Corollae petala 4 , calycis fauci inserta, ejusdem dentibus alterna, ovata, acuta. St a mina 8, eum petalis inserta, aequalia,' a nther a c oblongae, ntrinque obtusae, rima dupliei dehiscentes, connectivo carnoso, basi postice in denticulum brevem producto. Ova ri a m infernm, quadriloculare, placentis ad basim loculorum parietalibus, multiovulatis. Stylus filiformis; $s \mathrm{tig-}$ m a acutum. B a c ca globosa, calycis limbo coro. nata. Semina plurima, cuneata, angulata. Frutex $v$, arbuscula glabra, amboinensis; ramis teretibus, ad nodos incrassatis, foliis oppositis, bre vissime petiolatis, ellipticis, integerrimis, trinerviis, pedunculis axillaribus paucifloris, pedicellis medio bibracteolatis, floribus parvulis, caeruleis.

E w yekia Blume in Flora 1831, p. 525. Rumphia $I, 23$. 6. 8. Meisner Gen, 11t. (80.) - 2 P ternandra Jack in Malay. Miscell. IT. App. p. 3. Honker Bot. Miscell. Comp. I. 157. Wight et Arnott Prodr, I.324, Meisner Gen, 111. (79.)

698\%. Astronia BLUM. C aly x tubo hemisphacrico, eum ovario connato, limbo snpero, quinquefido, persistente, C o ro 11 a e petala 5 v. 6 , calycis fauei inserta, ejnsdem laciniis v. dentibus alterna, obovata. Sta mina 10 v. 12 , cum peta lis inserta, ant hera transversae, dolabriformes, rima duplici longitudinali dehiscentes, inappendi culatae. $O$ va $\mathrm{r}$ i $\mathrm{m}$ inferum, bi-quadriloculare, placentis in basi loculorum multiovalatis. St y $1 \mathrm{u}$ s filiformis; 8 t i $\mathrm{gm}$ a magnum, peltatum. C a p s nla bi-quadrilocalaris, ab apice secundum longitn. dinem dehiscens. Semin a plurima, basilaria, paleaceo-scobiformia. - Arbores moluccanae, gla. bellae; ramulis tetragonis, extremis, petiolis, perlunculis calycibusque fusco lepidotis, folis oppositis, longiuscule petiolatis, oblongis, acuminatis, integerrimis, trinerviis $v$, triplinervits, discoloribus, inflorescentia terminali et axillari paniculata, floribus parvulis, purpurascentibus, abortu diclinibus.

Astronia Blume Bijdr. 1080. Flora 1831. p. 826. Rumphia I. 20, t. 6.7. DC. Prodr. III. 197. Mem.I. 84. Meis: ner Gen. 111. $(81$.$) Pha r macu a papetarium Rumph$ Amboin. IV. 134, t. 69

6\%68. Spatinamelra GUILL. et PERROT. Cal y x tubo turbinato, cum ovario connato, limbo campanulato, repande quadridentato. Corollac petala 4, ealycis fanci inserta, ejusdem dentibus alterna, in connm conniventia, mox decidua. Stamin a 8 , cum petalis inserta, subaequalia, a $\mathrm{n}$ the$r$ a e longitudinaliter birimosae, connectivo crasso, arcuato, dorso cavitate oblonga exsculpto, basi postice in calcar conicum, antice fissum, filamenium recipiens producto. Ov a $\mathrm{r}$ i $\mathrm{m}$ inferum, uniloculare. 0 v ula $7-8$, placentae e fundo loculi adscendenti inserta. B a e e calycis limbo coronata, uniloenlaris, mono disperma. Se mina hemis. phaerica, fructus cavitatem replentia, testa crassa. Embryonis exalbuminosi cotyledones carnosae. - Arbor senegambica, trigintapedalis; trunco gracili, ramis patentibus, teretibus, glabris, foliis oppositis, sessilibus, ovato-oblongis, trinerviis, integerrimis, floribus parvis, caeruleis, in paniculas axillares corymbosas dispositis.

$\mathrm{S}$ pathandra Gaillemin et Perrot. Flor, Seneg. 1.313. t. 71. Meisuer Gen, 111. (80.)

\section{* MEMECYLEAE.}

6269. Tremecylon $L I N N$. C a ly x tubo hemisphaerico v. subgloboso, cum ovario connato, limbo supero, brevissimo, obtuse quadridentato, repando v. subintegerrimo. Co rolla e petala 4 , calycis fauci inserta, ejusdem dentibns alterna, ovalia. Stamina 8 , cum petalis inserta, iisdem plerumque longiora; fil a ment a filiformia, libera, a thera biloculares, Joculis connectivi postice incrassati, inferne in rostram incurvum produeti faciei antieae adnatis, basi rimula brevi dehiscentibus. Ovari $\mathbf{n} \mathrm{m}$ inferum, uniloculare, ovulis 4-10, placentae basilari brevissimae insertis. Stylns filiformis; stigma simplex. B a cea calycis limbo coronata, unilocularis, abortu monosperma v. rarius disperma. Sem en nueamentaceum, erectum, testa crnstacea. Embryonis exalbuminosi cotyled on es foliaceae, contortuplicato-convolutae, radicula adscendens. - Frutices in Asia tropica et Africa capensi et insulari tropica indigeni; ramulis tetragonis, ad nodos tumidis, foliis oppositis, exstipulatis, impunctatis, junioribus trinerviis $v$. paucinerviis, nervis lateralibus intra marginem combinatis, adultis uninerviis, coriaceis, integerrimis, floribus axillaribus fasciculatis $v$. racemoso-capitellatis, pedicellis basi bibracteatis, apice bibracteolatis, petalis caeruleo-violaceis.

M e m e ey lon Linn. Gen, $n$. 481. Lam, $t$, 284. Gärtuer II. 206. $t$. 187. et 483, $t$. 179. Thouars Observ. 57. Roxburgh Plant. Corom, t. 81. DC. Prodr. III. 5. Wiglit et Arnott Prodr. I. 319. Meisuer Gen, 111. (79.) V ali ka th a Adauson Fam. II. 84, Sc u tu la Loureiro Flor. cochinch. 7. Meis. ner Gen. 111. (79.)

G9 8. Nilowriria JUSS, C a ly $\mathrm{x}$ tubo turbinato, cum ovario connato, limbo supero, urceolato, quinquedentato, Coroll a e petala 5, ealycis fanci inserta, ejusdem dentibus alterna, basi lata, 
plicato-crispa. Stam in a 10 , cum petalis inserta, iisdem longiora; fil amenta filiformia, libera, antherae biloculares, loculis connectivi postice incrassati, inferne in rostrum incurvum producti faciei anticae adnatis, apice rimula brevi dehiscentibus. Ovari n m inferum, uniloculare, ovulis pluribus, placentae basilari brevissimae insertis. Sty I s fififormis; 8 tigma simplex. B a c ca calycis limbo coronata, unilocularis, subtetrasperma ..... - Frutices $v$, arbores, in America tropica crescentes; ramis nodosis, junioribus telragonis, foliis oppositis, exstipulatis, penninerviis, integerrimis, coriaceis, punctato asperis, pedunculis axillaribus, uni plurifloris, calycibus basi bibracleolatis.

Mouriria Jussieu Gen, 320. Lam. t. 360. DC. Prodr. III. 7. Meisner Gen, 111. (79.) Mo u riri Aublet Guian. I. 458. t. 180. Petal o u a Swartz Prodr, 73. Flor. Ind. occid. II. 831, t. 14

62 1 . Guilalingia $H O O K$, Ca ly $x$ tubo hemisphaerico, inferne cum ovario connato, superne libero, limbo clauso, angulato, sub anthesi irregulariter rupto. Corolla e petala 5 , laminae discoideae, imum ealycis tubum vestienti, radiatostriatae inserta, subrotunda, crispata. Stam in a 10 , cum petalis inserta et iisdem longiora; $f$ iIam enta filiformia, declinato-subsecunda, antherae biloculares, loculis connectivi postice incras. sati, basi in rostrum breve producti faciei antieae adnatis, apice poris geminis dehiscentibus. Ovari u m inferum ...... S ty lus filiformis, cum staminibus declinatus; $8 \mathrm{ti} \mathrm{gma}$ truncatum. B a $\mathbf{c} \mathrm{ca}$ globosa, calycis vestigiis coronata, biloenlaris (?) loculis pulposis, monu-dispermis. Semina ovalia, subangulata. Embryonis exalbuminosi radi cula ad umbilicum versa. - Arbor martinicensis, ramosissima; foliis oppositis, exstipulatis, penninerviis, integerrimis, pedunculis axillaribus fasciculatis, supra medium articulatis et ad articulum bibracteatis, calycibus basi bibracteolatis, fructu eduli.

Guilding i a Hooker Bot. Miscell. I. 122, t.30. Meis. ner Gen, 111. (79.) 0 II s be a DC. Prodr. III. 31. teste Arnott in litt.

\section{* OLINIEAE Arnott.}

827\%. Olimia $T H U N B$. C al y $x$ tubo basi bibracteolato, inferne cum ovario connato, supra ovarium producto, campanulato-pentagono, obsolete quinque- $\mathbf{v}$, rarissime quadridentato. Cor o Ila e petala 5 v. rarissime 4 , calycis fauci inserta, ejusdem dentibus alterna, spathulata, obtusa, supra basim pubescentia. Squannla e 5 v. 4, pe talis alternae, obovatae, darsn puberulae, conniventes. Stamina 5, ealycis fauci sab squamulis inserta; filam enta brevissima, inflexa, a n.thera biloculares, globoso-didymae, longitndinaliter dehiscentes. Ovarium inferum, oblongum, apice truncatum, quadri-quinqueloculare, loculis triovulatis, ov u $\mathrm{i}_{\mathrm{i}}$ angulo centrali insertis, superpositis, pendulis. Stylus subulatus, calyce brevior; $\mathbf{s}$ ti g $\mathbf{m}$ a elongatum, incrassatum, obtusum. B a cca drupacea, exsucea, oblonga, infra apicem caly. cis limbo cieatrisata, putamine lignoso, incurvo, tri-quadriloculari, loculis aborta monospermis. S emina ovalia. E mbryonis exalbuminosi, spiralis cotyledones vix distinctae. - Arbores capenses; ramulis subtetragonis, foliis oppositis, coriaceis, penninerviis, integerrimis, exstipulatis, impunctatis, floribus axillaribus et terminalibus den. sissime trichotome-cymosis, bracteis deciduis suffultis.
OIInia Thunberg in Bomer Archiv. II. I. p. S. Flor. Cap. 194. DC. Prodr. II, A1. Klotsch in Ollo et Dietr. Gar. tenzeit. IV. 1836. p. 25, ot in Litt. 19. Decembr. 1839. Cremastostemon Hort. Sideroxylon cymosum Lian, f. Plectronia ventosa Hort.

6283. DIIrehinitum SCHOTT. Calyx tubo basi bibracteolato, ovato, eum ovario connato, limbo supero, quadrifido, lobis ovatis, erectis. Corolla e petala 4, calycis fauci inserta, ejusdem lobis alterna, oblonga, obtusa. Stam ina 4 , cum petalis inserta, iisdem alterna et multo longiora, (rarissime 5 v, 6); fil a m en ta filiformia, aestivatione flexnosa, sub anthesi stricta, an $t h$ erae biloculares, basi insertae, oblongae, longitudinaliter dehiscentes. Ova $\mathbf{r} \mathbf{i}$ in inferum, biloculare. Ovula in loculis plurima, placentae carnosae, dissepimento adnatae, dorso eonvexae margini unica serie inserta, pendula. Stylus filiformis, flexuosus; stigma simplex. B acea subglobosa, calycis limbo coronata, bilocularis, abortu oligosperma. S e m i na cochleata, testa cornea, crassa. Em bry on is exalbuminosi, cylindrisi, arcuati c atyledones vix distinctae. - Arbuscula brasi. liensis; foliis oppositis, decussatis, petiolatis, integerrimis, coriaceis, nitidis, epunctatis, exstipulatis, cymulis lateralibus brachiatis, paucifloris, floribus intermediis sessilibus, lateralibus breviter pedunculatis, bibracteolatis, fusco-violaceis, calyce cryptis parvis globosis, oleiferis instructo, fructu atro-violaceo, eduli.

Myrrhinfum Schott in Sprengel Cur. post, 404. Martius Nov, gen, et sp. IIT. 172 t, 291. Felleianiu Cambessed. in St. Hilaire Flor. Brasil. 11. 375. 4. 157. Tetrastemou Hooker et Arnott Bot, Miscoll, III. 317.

6274. Temzlia $E N D L$. Calyx tubo basi bibracteolato, subglobuso, cum ovario connato, limbi superi, quinquepartiti laciniis arntis, patentibus. Corollae petala 5 , calycis fauci inserta, ejusdem laciniis alterna, obovata, ohtusa. St a mi n a plnrima, cnm petalis inserta, isidem breviora; $\mathrm{fi}$. I amenta filifurmia, flexuosa, a ntherae bilocuI ares, subgloboso-didymae, conuectivo dorso incrassato, loculis longitudinaliter dehiscentibus. Ovarium inferum, biloculare. Ovula in lueulis gemina, dissepimento superposite inserta. Sty I us filiformis, elongatus, flexuosus; $s t i g m$ a simplex. B a cé a subglobosa, ealyeis limbo reflexo coronata, abortu unilocularis, pulposa, monosperma. $\mathrm{S}$ eme n cochleatum, testa crustacea, dura. $\mathbf{E}$ mb r y on is exalbuminosi, cylindriei, spiralis cot yl ed one 8 vix distinetae. - Frutices Novae-Hollandiae tropicae et subtropicae, pube squamulosa furfuracei; foliis oppositis, coriaceis, integerri. mis, epunctatis, exstipulatis, floribus axillaribus breve pedunculatis, solitariis, roseis.

Feuzlia Endlicher Atakt. 19, t. 17. 18.

\section{Ordo CCLXIX. Myrtaceae.}

MYRTI Jussien Gen. 323. MYRTEAE Jussieu in Dict. sc. nat. XXXIV, 94. MYRTOIDEAE Ventenat Tabl. III.317. MYRTINEAE DC. Theorie elem, 216. Meisuer Gen. 106. (75.) MYRTACEAE R. Brown in Flinders Voy, II, 546, DC. in Dict. elast. V. 11. et notis 1826. Prodr. IIT. 207. Bartling Ord. nat, 330. Lindley Introduct edit, II. p, 43.

Arbores v. Frutices, rarissime ивевав, ramis teretibus v. saepius angulatis. Folia opposita, rarius alterna v, verticillata, simplicia, integra et integerrima, rarissime serrata, v. teretia ant semiteretia, aut saepius plana, 
penninervia, nervis transversis saepe in nervos margini parallelos combinatis, plerumque coriacea, saepissime glandulis oleiferis, parenchymati immersis pellucido-punctata, basi in petiolum angustata. Stipulae plerumqne nullae, rarius ad basim petiolorum geminae, minimae, caducae.

Flores hermaphroditi, regulares, rarissime staminum inaequali longitudine subirregulares, nunc axillares solitarii, nune spicati, cymosi, corymbosi v, paniculati, nunc capitati, nudi v. involucrati, saepissime basi bibracteolati, albi, rosei, purpurei, flavi, nunquam caerulei.

Calycis tubus juxta totam longitudinem v. basi cum ovario connatus, limbus quadri-quinque aut plurifidus v. partitus, persistens v. deciduus, lobis aestivatione valvatis, interdum integer, aestivatione clausus, sub anthesi operculatim secedens.

Corollae petala disco calycis faucem marginanti, plerumque in laminam v. pulvinar ovarii verticem coronans continuo inserta, limbi calycini lobis numero aequalia et alterna, aestivatione imbricata v. convolutiva, rarissime nulla, v. cum calycis limbo operculiformi penitus coalita.

Stamina plurima, cum petalis inserta, rarissime iisdem numero aequalia et alterna, saepe dupla v. tripla, nonnulla tunc ananthera, saepissime multipla, indefinita, pluriseriata et plerumque ommia fertilia. Filamenta filiformia v. linearia, nunc libera, nunc inferne plus minus monadelpha v. in fasciculos petalis oppositos coalita, rarius in urceolum hinc abbreviatum, illine in laminam petaloideam, fornicatam, in stylum pronam, saepissime sterilem productum, intus antheriferum coalita. An therae biloculares, loculis parallelis, contiguis v. sejunctis, longitudinaliter dehiscentibus.

Оуавичм inferum v. semiinferum, disco carnoso tectum, nune uniloculare, ovulo unico v. pluribus, e placenta basilari brevissima erectis, anatropis, nunc bi-multiloculare, ovulis in placentis, e loculorum angulo centrali exsertis, plurimis, plerumque pendulis et anatropis, rarissime solitariis, angulo centrali peltatim insertis, amphitropis. Stylus terminalis, aut rarissime in ovario uniloculari sublateralis, simplex, nudus v. apice barbatus. Stigma terminale aut rarissime laterale, indivisum.

Factus saepissime calycis limbo coronatus, nunc unilocularis, abortu monospermus, siccus, indehiscens, v. apice incomplete bivalvis, nune bi-multilocularis, et tune v. capsularis, apice loculicide v. septicide dehiscens, aut rarissime indehiscens, loculis polyspermis $v$. interdum monospermis, quandoque diseo epigyno opereulatim secedente apertus, aut bacca- tus indehiscens, loculis polyspermis v. abortu obligo- aut interdum monospermis.

Semisa recta, angulata, teretia v. compressa, testa crustacea v. membranacea. Alb u m e n nullum.

Enвryo rectus, v. arcuatus aut spiraliter convolutus. Cotyledon es saepissime breves, obtusae, non raro cum radicula in massam homogeneam coalitae, rarissime foliaceae. Radicula saepissime crassa, umbilico proxima.

Myrtacea e inter tropicos Americae, et in Nova-Hollandia imprimis copiosae, parcius Asiam et Africam aequinoctialem inhabitant, rarissime in Europa meridionali, in America boreali et antaretica vivunt. Chamaelaucieae, quarum numerus in dies major innotescit, et plurimae adhuedum in nostris etiam phytophylaceis latent ineditae, Novam-Hollandiam solam incolunt, Leptospermeae ingenti per hunc continentem numero difusae, in Asia tropica sparsim reperiuntur. Myrteae in America tropica copiosissimae, in veteri orbe multo rariores. Barringtonieae inter tropicos amphigeae, Lecythideat omnes americanae.

Plurimae oleo volatili aromatico scatent, nonnullae resiniferae, quaedam adstringentes, baccae aliarum gustui gratae. Lecythidearum semina edulia. Vix non omnes florum decore insignes.

SUBORDO T. CHAMAELAUCIEAE DC. Prodr.1II. 208. St ami na saepissine definita, nonnulla plerumque sterilia. Ovarium uniloculare, ovulis basilaribus solitariis v. pluribus. Ca psula monosperma, indehiscens v. apice incomplete bivalvis. - Frutices NovaeHollandiae, saepissime ericoidei, foliis oppositis $v$. rarius alternis, punctatis, exstipulatis v, bistipulatis.

62 ร 5. Caly cothrix $L A B I L L$. B ract e ola e geminae, carinatae, persistentes. Ca lyx tubo basi eum ovario connato, longe supra ovarium pro. dueto, cylindrico, graeili, limbi quinquepartiti, persistentis lobis basi ovatis, apiee in setam, saepe elongatam desinentibus. C oroll ae petala 5, ealycis fauci inserta, ejusdem laeiniis alterna, ovata, acuta. St amina $10 \mathrm{v}$. plurima, cum petalis inserta, omnia fertilia; fil a menta filiformia, libera, inaequilonga, a nther a e biloculares, subglobosae, longitudinaliter dehiscentes. O varium inferum, uniloculare. Ov u ta 2, e placenta basilari, saepe filiformi erecta, anatropa. Sty lns filiformis, stamina aequans; st $\mathrm{i} \mathrm{gm}$ a simplex, $\mathrm{C}$ a $\mathrm{p}$ 8 u la quinquecostata, unilocularis, abortu mono. sperma, indehiscens. S e m en erectum, exalbuminosum. Em bryo orthotropus, - Frutices No. vae-Hollandiae tropicae et extratropic a e; foliis sparsis, confertis, teretiusculis, saepissi. me breviter petiolatis, et stipulis duabus minimis, rigidis, setuliformibus stipatis, floribus axillaribus so. litariis, subsessilibus v. in apice ramulorum congestis, purpureis, albis v. luteis. 
Calyeothrix Meisner Gen, 307. (76.) Sehaner Monogr. $t$. 6. B. C al y thrix Labillard. Nov. Holl, $I I, 8$. t. 146. R. Browa in Bot, Reg t. 409. DC. Prodr. III. 208. A. Richard Sert. Astrolab, t.16. A, Cuuningh. in Bot. Mag. t. 3323. Lindley $\mathcal{S}_{\text {wanthiver }}$ t, 3, B.

6\% 6. Hilhotskya SCHAUER. B r a t e olae geminae, paleaceae, carinatae, inaequales, ima basi hine connatae, persistentes. C a I y x tubo oblongo, decemcostato, cum ovario connato, limbi quinquepartiti lobis brevibus, scariosis, obtusis. Corolia e petala 5, calyeis fauci inserta, ejusdem laciniis alterna et majora, obovata. St a mina plurima, cum petalis inserta, exserta, inaequilonga, umnia fertilia; f i l a m e n t a capillaria, antherae biloculares, subglobosae, loculis ex apice paullo divergentibus. Ovarium inferum, nniloculare. O v $\mathrm{I}$ a in placenta basilari gemina, erecta, anatropa. Stylus filiformis, exsertus, glaber; stig ma punctiforme. C a p s a 1 a oblonga, deremenstala, unilocularis, abortu monosperma, indehiscens. S e m e n erectum, exalhnminosum. Embryo orthotropus. - Frutex Novae-Hollandiae austro-occidentalis; foliis oppositis, exstipulatis, confertis, acerosis, tetragonis, glabris, floribus axillaribus solitariis, sub sessilibus, luteis, v. terminalibus capitatis, violaceis.

$\mathrm{L}$ hotsk y a Sehauer in Lindley Introduct. edit. $\boldsymbol{I}$. p. 493. et in Linnaea X. 309. Monogr. $t$, 7. Lindley Swan. River 7. Meisuer Gen. 107. (75.)

B98ซ. Thryptomene ENDL, Bracteola e geminae, distinctae, caducissimae. Ca ly $\mathrm{x}$ tubo obconico, decemcostato, cum ovario connato, supra ovariam haud produeto, limbi quinquepartiti laciniis petaloideis, indivisis. Corolla e petala 5 , calycis fauci inserta, ejusdem laciniis alterna, orbieulata. Stam in a 10 , cum petalis inserta, omnia fertilia; filamenta filiformi-subolata, antherae biloculares, loculis globosis, discretis, e connectivo glandula terminato pendulis. Ovar i $\mathbf{m}$ infernu, nniloculare. Ovvla $2-4$, e placenta basilari subpeltata erecta, anatropa. StyI us hrevissimns, imberbis; $8 \mathbf{t i g m a}$ capitatum, C apsula ubeoniea, unilocularis, apiee truncato fatiscens, abortu monosperma. S emen erectum exalhominosum. E $\mathbf{m}$ hr $\mathbf{y}$ o orthotropus. - Fruticulus Novae-Hollandiae austro-occidentalis; foliis oppositis, exstipulatis, semiteretibus, strictis, mucronatis, pedunculis axillaribus, solitariis, oppositis, unifloris, folio multo brevioribus.

Th r y p tome ne Eadlicher in Annal. Wiener. Mus, II. 102. Nov, stirp. Mus. Vindob. Dec. p.72. Schauer Monogr.t.6.

627 8. Pileanthus LABLLL. BracteoI a e geminae, connatae in involucellum undique clausum, demum circumscissum, basi campanulata persistente, apice calyptraeformi deciduo. Cal y x tubo cum ovario connato, limbi decemfidi Inbis in. tegris. Corolla e petala 5 , calycis fauci inserta, ejusdem lobis alternis opposita, integra. S tamin a 20 , cum petalis inserta, omnia fertilia; filamenta libera, simplicia v. nonnulla interdum bifurca, antherae lorulis geminis, approximatis v. disjunctis. Ovarium inferum, unilocnlare. Ovula $2-7$, e placenta brevi ereeta, anatropa. Stylus filiformis, imberbis; stigma snbeapitatum. Cap $\mathbf{s} \mathbf{1}$ a unilocularis, apice fatiscens, mono-oligosperma. Se m in a erecta, exalbuminosa Embryo orthotropus. - Frutices Novae-Hol. landiae austro-accidentalis; folits oppositis, exstipulatis, subsemiteretibus, floribus axillaribus $v$. subterminalibus, pedunculatis.
Pile a n th os Labillard. Nov. Holl, IT, 11, t, 179, Jas ieu in Annal. Mus. XIX, 432. Destont, in Mem. Mrus. t. 3. f. a. DC. Prodr. IIT. 209. Meisner Gen. 107. (75, Endlicher in Annal. Wiener. Mus. II. 196.

B2ร9. Verticoralia DC. Bracte ofa e geminae, concavae, dorso muticae $v$ mucronatae, florem primum includentes, sub anthesi hinc: Iongitudinaliter secedentes $v$, patentes, deciduae v. persistentes. Cal y x tubo cum orario connato, limbi quinquefidi lobis palmatipartitis, laciniis barbatis v. plumosis, extus interdum lobulis comosis, supra tubum reclinatis, auetus. Corolla e petala 5 , caly. cis fauci inserta, ejusdem laciniis alterna, integra v. palmatipartita. St a m in a 20 , cum petalis inser ta, alterna ananthera, ligulaeformia v. trifida, fertilium filamenta subulata, antherae biloculares, connectivo simplici v. in glandulam pellucidam producto. Ovarinm inferum, uniloculare. Oval a 2-10, e placenta basilari ereeta, anatropa. Stylus filiformis, inclusns v, exsertus, nudusiv. barbatus; $8 \mathrm{tig}$ m a capitatum. Capsula unilacularis, abortu monosperma, indehiscens. Se in en erectum, exalbuminnsum. - Frutices in NovaHollandia occidentali, imprimis australi, rarius in tropic a crescentes; foliis oppositis, saepius confertis, exstipulatis, semiteretibus $v$. triquetris, floribus terminalibus corymbosis, albis, roseis v. rarius luteis.

Verticordia De. in Diet, clats, hist, nat, XI. 400 . XVI. S65. Prodr. IIT, 208, Eadlicher in Enum. plant. Hïgel. 46. Annal. Wiener, Mus, II, 193. Meisner Gen, 10z. Lindley $S$ wan-River $t, 2, A$. Sehauer Monogr, $t, I V, B$. Dip Inchue R. Browu msc. Chrysorrho te Lindtey in Bot. Mag. Comp. II.357. Swan.River t. 1. Ch a ma el aucif sp. Destont, in Mem. Mus. V. 42, $t, 4, V .272 . t .19$.

a. EUVERTICORDIA Schauer 2, e. Calyeis lobi haud appendiculati.

b. Calymmatantius Sehauer 2 , e. Calyeis lobi ap. pendiculis comosis, reversis, tubum velantibus iustructi.

B280. Chamaelaueium DESF. B r a :te ol a e geminae, concavae, dorso mucrunatae, florem primum includentes, sub anthesi patentes, basi secedentes. $C$ a ly $x$ tubo basi cum ovario connato, supra ovarium producto, limbi qoinquefidi baciniis indivisis, sulpetaloideis. Co rolla e petala 5 , calyeis fanei inserta, ejusdem laciniis alterna, ovata. St a mina 10 , cum petalis inserta, alterna ananthera, ligulaeformia, integra, fertilium filamenta subulata, antherae bilnculares, conneetivo simpliei $v$. in glandulam pellueidam pro. dueto. Ovarium infernm, uniloculare. O $\mathrm{rula}$ 5_10, e placenta basilari erecta, anatropa. St yI us filiformis; st igma capitatum. C apsnia unilocularis, indehiscens, oligosperma. Semina erecta, exalbuminosa. Embryo orthotropus. Frutices Novae-Hollandiae austro-occidentalis; folits oppositis, saepius confertis, exstipulatis, semiteretibus v. lineari-triquelris, floribus axillaribus $v$. terminalibus, breviter pedunculatis, albis.

Chamaelaucium Desfont. in Mem. Mus. $\nu .39$ t. 3. f. B. DC. Prodr. IIT. 209. Mieikuer Gen. 107. (75.) Endlicher in Annal. Wiener. Mus, II. 1 si2.

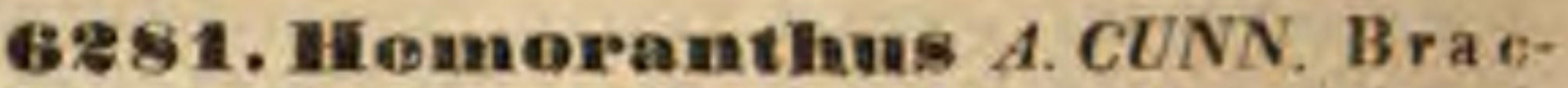
teola e geminae, cucullatae, altera alteram involvens, sub anthesi basi secedentes, calyptratim dejectae. Caly x tubo ovato, quinquecostato, inferne cum ovario eonnato, limbi quinquepartiti lobis e basi ovata in cuspidem eapillaceam, petala superantem prodnetis. Corollae petala 5 , calycis fanei inserta, ejusdem lobis alterna, suborbicularia, con154 
niventia. Stamina com petalis inserta, aiterла sterilia, fertilia 10 , biseriata, alterna petalis opposita altins inserta, sterilia totidem geminatim ante petala sita; fil a menta brevissima, complanata, sterilia fertilibus conformia, an $t$ he ra e biloculares, loculis turgidis, e connectivi basi pen. dulis. Ovarium inferum, uniloculare. Ovnla 3.5 , e basi erecta, anatropa. St ylus subulatus, longe exsertus, apice barbatus; stigma punetiforme, Ca p sula quinquecostata, unilocularis, aborta monosperma, indehiscens. S em en erectum, exalbuminosum. Em b ry o orthotropus. - Frutices Novae-Hollandiae arientalis, glabri; foliis confertis, accrosis, exstipulatis, floribus versus apices ramulorum axillaribus, breviter pedicellatis, plerumque fasciculatis.

Ho mor a $\mathrm{th}$ o 8 A. Cunuingh. ex Schauer in Lindley Introduct, edit, II. p. 440. et in Linnaea X. 310. Monogr. $t .3$ Meisner Gen, 107. (76.) E u o s a n the s Cunuingh. msc.

628\%. Darwinia $R U D G$. B r a $\mathrm{c}$ e 0 lae geminae distinctae, carinatae. Calyx tubo pentagono, inferne cum ovario connato, supra ovariem producto, cum limbi quinquepartiti lobis ovatis, obtusissimis deciduo, CorolIa e petala 5, calycis fauci inserta, ejusdem laciniis alterna, sulorbirulata, conniventia, decidua. Stamina 20 , calyeis fauci inserta; alterna sterilia, fertilibus ante petala sitis approximata; fil a m e $\mathbf{t}$ a brevissima, lineari-complanata, a $n$ the rae biloculares, subglobosae, longitudinaliter dehiscentes. O v a $\mathbf{r} \mathbf{i} \mathbf{~ m}$ inferum, uniloculare, O v 1 a 2 , e basi erecta, anatropa. S t y l a 8 filiformis, longissime exsertus, infra $s \mathrm{tig} m$ a terminale harbato - plumosus. C a p 8 u la pentagona, monosperma, indehiscens. Semen erectum, exalbuminosum. E mbryo orthotropus, - Frutice Novae-Hollandiae orientalis, decumbentes, ramosissimi; foliis exstipulatis, acerosis, spar. sis, confertis, glanduloso-punctatis, floribus termi nalibus fasciculato-confertis, paleis scariosis interstinctis, albis $v$, roseis.

Da $\mathrm{r}$ winia Rudge in Linn. Transact. Xr. 299. $t .22$. Don in Edinb. new philosoph. Journ. Apr. 1829. p. 84. Meisner Gen, 107. (26.) Sehauer Monogr. t. 2. D.

B283. Folyzome ENDL. F l ores supra receptaculum planum, involucratum sessiles, singuli bracteolis duabus membranaceis, carinatis, distinetis stipati. Caly x tubo obconico, basi cum ovario connato, zonis cartilagineis multiannulato, limbo brevissime quinquefido. Corolla e petala 5 , calycis fauci inserta, ejusdem laciniis alterna, membranacea, ovata, erecta. St a m in a 20 , cum petalis inserta; filam enta brevissima, complanato-subulata, alterna ananthera, fertilibus conformia, a $n$th e rae biloculares, subglobosae. Orari a m inferum, uniloculare. Ovula 2, basilaria, erecta, extrorsum anatropa. Stylus compressus, apice attennatus; stigma terminale, subcapitatum. Fruetus...... Frutex Novae-Hollandiae austro-occidentalis; ramulis alternis verticillatisque, foliis confertis, exstipulatis, aceroso-triquetris, capitulis terminalibus, sessilibus, involucri foliolis subcoriaceis, pluriseriatis, coloratis.

Polyz one Endlicher in Annal. Wiener Mus. II. 490. Nov. stirp. Mus. Vindob. Dec. 80.

6884. Cenetyllis DC. Bracteolae geminae, distinctae. Ca l y x tubo eylindrico, pentagono, inferne cum ovario connato, limbi quinquefidi lobis obtasis, integris. Corolla petala 5 , calycis fauci inserta, ejustem laciniis alterna, ova- ta, acuta, subscariosa, persistentia. St a m in a 20 , cum petalis inserta, isdem breviora, alterna sterilia; filam enta filiformia, sterilia fertilibus con formia, antherae biloculares, globosae, longitudinaliter dehiscentes. Ovarium inferum, nniloculare. Ovula 5-6, e basi erecta, anatropa. Stylus filiformis, exsertus, infra $s t i g m$ a terminale barbato-plumosus. Ca p su la quinquecostata, unilocularis, abortu monosperma, indehiscens. Sem en erestum, exalbuminosum. Embryo orthotropus, - Frutices Nova e-Hollandiae orientalis et australis; foliis exstipulatis, confertis, lineari subtriquetris, glanduloso punctatis, floralibus linearibus, planis, submembranaceis, floribus terminalibus, subcapilatis.

Genetyllis DC. in Dict, class, hist, nat, XI, 400 . Prodr. III. 209. Meisuer Gen. 107. (75.)

6285. II edaroma $L I N D L$. B racte ol a e geminae, distinctae, carinatae, Ca I y $\mathbf{x}$ tubo cylindrico-pentagono, inferne enm ovario connato, limbi quinquefidi lobis obtusinsculis. Corollae petala 5, calycis fauci inserta, ejusdem laciniis alterna, ovato-lanceolata, carinata, conniventia. S ta. mina 20 , cum petalis inserta, iisdem breviora, al. terna sterilia ligulaeformia, truncata, fertilium filam en ta subuiata, a $n t h$ e $r$ a e biloculares, globosae, postice poris dehiscentes. Ovari um inferum, uniloculare. 0 vnla $2-5$, e basi ererta, anatropa. St y 1 u 8 filifor:nis, exsertas, infra s tigma terminale barbatus v. glaber. Capsu I a nnilocularis, abortu monosperma, indehiscens. - Fru. tices Novae-Hollandiae austro-occidentalis, suavissime olentes; foliis oppositis, exstipulatis, ovato-lanceolatis, obtusiusculis, basi subcordatis, planis, foliis involucrantibus latioribus, colora. tis, capitulis paucifloris.

He da rom a Lindley Swan-River VII, t. 2. $f . B$, G e. netyllis citriodora Endl.

6\%86. Francisia. B racte o l a geminae, distinctae, earinatae. C a ly x tubo cylindricopentagono, inferne $\mathrm{cum}$ ovario connato, limbo breviter yuinquedentato. Corollae petala 5 , calycis fanei inserta, ejusdem dentibus alterna, ovatasuborbiculata, conniventia. St a m in a 20 , cum petalis inserta, iisdem breviora, omnia fertilia, alterna petalis opposita fil amentis trifidis, lobo intermedio antherifero, lateralibus sterilibns, alterna simplicia, snbulata, a n the ra e biloculares, subglobosae, longitudinaliter dehiscentes. Ovari n m inferum, uniloculare. Ov u la 2 , e basi erecta, ana. tropa. Sty lus filiformis, longe exsertus; stig$m$ a infra apicem hamatum laterale, glandulosum, pilosum. Caps ala unilocularis, aborta monosperma, indehiscens. Sem en erectum, exalbuminosum. E mb r y o orthotropus. - Fruticuli Nova eHollandiae orientalis, simplices v. ramosi; foliis oppositis, confertis, exstipulatis, lineari-trique. tris, glanduloso-punctatis, floralibus conformibus, floribus terminalibus, capitato-aggregatis.

F r a n e is i Eudlicher Plant, australas, rar, inedit.

B28\%. Triplnelia $R$. BROWN, F tores capitato-aggregati, bracteati, bracteis extimis capitalum cingentibus latioribus, exteriores steriles, longe pedicellati, pedicellis bracteolis subternis terminatis, interiores fertiles, breviter pedicellati, inter bracteolas duas, in apice pedicelli subsecundas sessiles. Caly x tubo oblongo, quadrialato, alis angustis, transversim rugoso-undalatis, inferne cum ovario connato, superne constricto, limbi qua. 
dripartiti laciniis membranaceis, angustis, C orolla e petala 4 , calyeis fauci inserta, ejusdem laciniis alterna, ovata. Stamina 8, cum petalis inserta, iisdem breviora, omnia fertilia ; fila ment a subulata, an thera e biloculares, subglobosae. Orarium inferum, uniloculare. Ovulum unieum, e basi erectum, anatropum. Stylus filiformis, exsertus, glaber; s $t \mathrm{ig} \mathbf{m}$ a punctiforme. Fruetus......-Fruticulus Novae-Hollandiae austro-occidentalis, humilis, graci. lis, glaber; ramulis virgatis, foliis exstipulatis, dense imbricatis, lanceolatis, mucronatis, eapitulis terminalibus.

Triphelia R. Brown msc. Actinodiam Schaver in Lindley Introduct, edit, II. p. 440, et in Linnaea X.311. Monogr. $t, 1 . B$.

\section{GENUS DUBIUM.}

6898. Bartlingia BRONGN, C a 1 y $\mathrm{x}$ tubo subhemisphaerico, basi bibracteolato, limbi quinquefidi laciniis tubo duplo longioribus, oblongis, obtusis, intus villosis, aestivatione imbricatis. Corollae petala 5 , calycis basi inserta, subrotunda, minima, squamaeformia, plana. Stamin a 10 , cum petalis inserta, inclusa, alterna iisdem opposita breviora; fi lamenta filiformia, a $\mathrm{n}$ thera e biloculares, ovato-subrotundae, loevlis longitudinaliter dehiscentilus. O v a $\mathrm{r}$ i u $\mathrm{m}$ liberum, compressum, hine suleatum, snblanceolatum, nniloculare. $O$ su l a gemina, lateri sulcato affixo, horizontali anatropa. Stylus terminalis, subulatus, brevis. Stigma simplex. Fruetus ...... Suffrutex Novae-Hollandiae orientalis; ramis gracilibus, fastigiatis, foliis alternis, obovatis, retusis, integerrimis, glabris, glandulis oleiferis immersis, breve petiolatis, basi bistipulatis, stipulis brevibus, cuneiformibus, acutis, floribus ad apices ramulorum congestis, subglomeratis.

B artling i a Brouguiart in Annal. sc. nat. X, 373, in not. Meisner Gen. 107. (76.)

SUIB ARED II. LEPTOSPERMEAE DC. Prodr. III. 209. Stamin a saepissime indefinita, libera v, polyadelpha, rarissime monadelpha. Ovarium bi-multiloculare, loculis multiovulatis v. rarius uniovulatis. Capsula loculicide v. septicide dehiscens, rarius indehiscens. - Frutices in Nova-Hollandia copiose, parcius in Asia tropica crescentes; foliis oppositis $v$. alternis, exstipulatis, integerrimis $v$, rarissime serrulatis, punctatis, interdum phyllodineis.

6289. Astartea DC. Caly $\mathrm{x}$ tubo hemisphaerico, cum ovarii basi connato, limbi quinquepartiti lolis semiorbieulatis. Corolla a petala 5, calycis fauei inserta, ejusdem laciniis alterna, orbieulata. S ta m in a plurima, cum petalis inserta, in phalanges 5 , iisdem aiternas coalita; fila m enta superne libera, antherae biloculares, incum. bentes, longitudinaliter dehiscentes. O varium semisuperum, triloculare, Ineulis multiovalatis. Stylus brevis; stigma capitatun. Capsnla semisupera, trilocularis, luculieide trivalvis. S e. m in a plurima. - Frulex insulae Diemen;foliis oppositis, exstipulatis, junioribus in axillis fasciculatis, linearibus, carnosis, floribus axillaribus, solitariis, fasoiculatis.

A startea DC. in Dict, class, hist, nat, XI, 400.
Prodr. IIT. 210. Meisner Gen. 107. (76.) Melaleuca faseicula ris Labillard. Nov. Holl. $t, 170$.

6290. Tristania $R$. BR. F i o res subcorymbesi. Caly $x$ tubo turbinato, inferne rum ovarii basi connato, limbi quinquepartiti laciniis erectis, persistentibus. Coroll a e petala 5, calycis fauci inserta, ejusdem laciniis alterna, patentia. S ta mina 15-25, cum petalis inserta, basi in phalanges 5 , petalis oppositas, ternatim v. quinatim brevissime coalita; fil amenta filiformia, a nther a biloculares, incumbentes, longitudinaliter dehiscentes. Ovarium semisuperum, triloculare, loculis multiovulatis. Stylus filiformis; st ig m a obtusum. C a p sula semisupera, trilecalaris, locnlicide trivalvis. Semina plurima. Frutices Novae-Hollandiae; folits alternis, exstipulatis, lanceolatis, floribus pedunculatis, subcorymbosis, luteis.

Tristania R. Brown in Aiton Hort. Kew. II. 4. 417. Bnnpl. Navarr. $t$. 30. DC. Prodr. IIr. 210. Sehott in Wiener Zeitsohrift 1830. 1II. 772. Linnaea 1831. Litterat, Bericht 54. Meisuer Gen. 107. (76.) Melaleucae s p. Bot. Mag. t. 1058. Andrews Bot. Reposit. $t .485$.

BR91. Symeanpis TENOR. F l ores capitati, basi connati. Caly $x$ tubo turbinato, cum ovario connato, limbi quadripartiti laciniis erectis, persistentibus. Corolla petala 4, calycis fauci inserta, ejusdem laciniis alterna, patentiuscula. Stamina plurima, cum petalis inserta, paullo longiora, libera; filamenta filiformia, an thera e biloculares, incambentes, longitudinaliter dehiscentes. Ova $\mathrm{r}$ i $\mathrm{m}$ inferum, tri-quadrilvecolare, loculis multiovulatis. St y I u f fliformis, stigma obtusum. C a p s u I a infera, tri-quadrilocularis, apice loculicide tri quadrivalvis. Sem in a plurima, clavata, - Arbor Novae-Hollandiae; foliis oppositis verticillatisque, exstipulatis, floribus dense capitatis, connatis, albis, capitulis axillari-terminalibus, pedunculatis.

Synearpia Tenore Index Sem. Hort. Neap. 18.3. p. 12. Ka mptzi a Nees Dissert. Mratislav, 1850 fol.c. ic. Tristania albens A. Cuar. Metrosideros glameruliflora Smith.

Gaga. Hoploostemon SCHOTT, FIores corymbosi. Caly $x$ tubo turhinato, cum ovario connato, limbi superi, quinquepartiti laciniis reflexis, basi appendiculatis, deeiduis. Co roll a e petala .5, calycis fanci inserta, ejusdem laciniis alterna, patentia. Stamina plurima, in phalanges 5, petalis oppositas, cristaeformes, longe unguiculatas, bifidas, patentes coalita; fila menta apice libera, filiformia, a n therae biloculares, incumbentes, longitudinaliter dehiscentes. Ovari u m infernm, trilocnlare, loenlis multiovalatis. Sty $\mathbf{l a s}$ filiformis; $8 \mathrm{tigma}$ capitatnm. Capsu $\mathbf{l}$ a infera, trilocularis, Inenlicide trivalvis. S e mina plarima, - Frutices Novae-Hollandiae; foliis alternis, exstipulatis, planis, integerrimis, floribus subcorymbosis, albis.

Lophostemon Schott in Wiener Zeilschrift, 1830. III. 772. Linnaea 1831. Litterat. Bericht. 54. Meisner Gen. 107. $(76$.

6283. Ihamanelaea GALDICH. F l o res axillares, sessiles. Cal y $x$ tubo hemisphaerico. limbo quinqnepartito, decidno. Cornlla petala 5 , calycis fanci inserta, ejusdem laciniis alterna et longiora, obovato-spathulata. Stamina plurima, cum petalis inserta, in tubnm subarcuatum qninquefidum coalita, lobis petalis oppositis, snperne in filamenta plurima filiformia solntis, antherae biluculares, incumbentes, longitudi$154 *$ 
naliter dehiscentes. Ovari am liherum, triloculare, loculis maltiovalatis. Stylus filiformis; 8 tig m a suleapitatam. Ca p s a la calycis tabo incrassato inclusa, trilocularis, septicide trivalvis. Seminab plurima. - Arbor Novae-Hollandiae austro-occidentalis; foliis sparsis, exstipulatis, lineuri-lanceolatis, coriace is, trinerviis, integerrimis, floribus axillaribus solitariis, sessilibus, post folia delapsa lateralibus, fusco-rubris.

$\mathrm{L}$ a marchea Gaudichaud ad Freycinet, 483. t. 110. Meisuer Gen. 107. (76.)

629 1 . Calothannas $L A B I L L$. F lores axillares, sessiles. C a ly x tubo subhemisphaerico, limbo quadri-quinquelobo, persistente. Corolla petala 4 v. 5 , calycis fanci inserta, ejusdem lobis alterna. Stamina plurima, cnm petalis inserta, in phalanges 4 v. 5 , iisdem oppositas, longissime exsertas, liberas v. basi interdum geminatim cohaerentes coalita; fil a menta apice libera, filiformia, nonnulla interdum sterilia, antherae biluculares, basi insertae, longitudinaliter dehiscentes. Ovarium liberum, triloculare, loculis multiovulatis. Stylns filiformis; stigma simplex. C a p sula calycis tubo basi ramn adnato inclusa, trilocularis, apice loculicide trivalvis. Semina plurima ....... Frulices Novae-Hollandiae austro-oc cidentalis; foliis sparsis, confertis, exstipulatis, teretiusculis, floribus axillaribus, sessilibus, coccineis, spicam apice comosam formantibus.

Calotham nus Labillard. Nov, Holl, Ir, 25, $t, 154$. R. Brown in Aiton Hort. Kew. IT. 4. 417. Bot. Mag. $t .1506$, Bot. Reg, t. 1099. DC. Prodr. III. 211. Meisuer Gen. 107. (26.) Bilitotia Colla Fipul. App. 2, t, 23. B a udin ia Leschenault moc.

6295. IBerufortia $R, B R$. Flor e s axillares sessiles. Ca 1 y $\times$ tubo turbinato, inferne cum ima ovarii basi connato, limbi quinquepartiti lobis acutis. Corolla e petala 5, calycis fauci inserta, ejusdem laciniis alterna. Stam in a plurima, eum petalis inserta, in phalanges 5, petalis oppositas, longe unguienlatas eoalita; $i l$ a $m$ en $t$ a apicelibera, filiformia, a n therae biloculares, basi insertae, divaricato-bilobae, lobis deciduis, exstinctoriiformibus. Ovari u m ima basi adnatum, triloculare, lecolis uniovnlatis. St y I 8 filiformis, flexuosus; stigma simplex. Capsula calycis tubo incrassato, basi ramo adnato inclnsa, trilocularis, indehiscens. S e m in a in loculis solitaria, peltata. Frutices Novae-Hollandiae austro-occi dentalis; foliis nunc exstipulatis, oppositis, de. cussatis, nunc sparsis, sessilibus, planis, multinerviis, floribus in axillis foliorum sessilibus, spicam densam, abbreviatam, apice comosam formantibus.

Beaufortia R. Brawn in Aiton Hort. Kew. Ir. 4. 418. Bot. Beg. t. 18. Bot. Mag, t, 1733. Colla Hort, Ripul. t. 29. DC. Prodr. IIT. 211. Meisuer Gen, 107, 176.)

G296. Selhizopleura LINDL. FIores terminales eapitati. Cal y $\mathrm{x}$ tubo turhinato, libero, limbi quinquepartiti lobis acutis. Corolla e petala 5, calyeis fauei inserta, ejusdem lobis alterna. Stamina plurima, cum petalis inserta, in phalanges 5, isdem oppositas, longe unguiculatas coalita; fil a m enta apice libera, filiformia, a nthera e biloculares, basi insertae, apiee bilobae, lobis latere transversim dehiscentibus, decidnis. Ova rium liberum, triloculare, loculis uniovulatis. Stylus filiformis; stigma simplex. Caps la chartacea, calycis tubu incrassato, sessili in elusa, trilocularis, iadehiscens. $\mathrm{Semina}$ in locu- lis solitaria, peltata. - Frutices Novae-Hol. landiae austro-occidentalis; foliis appusitis, exstipulatis, imbricatis, trinerviis, floribus terminalibus dense capitatis, capitulis subinvolucratis.

Schizoplear a sect. Beaufortiae Lindley Swan-River IX. M a $\mathrm{g} l$ es i a Lindley $o_{p}$. eit. t. 3. $f$. $a$. B e a u forti a D a pieri A. Cunningh. Bot. Mag, t. 3272.

699 8. Comothamantus $L I N D L$. FI o res terminales capitati. C a l y $\mathbf{x}$ tubo subhemisphaerico, libero, limbo quadridentato. C orolla e petala 5 , calycis fauci inserta, ejnsdem dentibus alterna. Stamina plurima, cum petalis inserta, in phalanges 5, iisdem oppositas coalita; filamen. ta superne libera, filiformia, an therae bilocula. res, filamentis continuae, longitudinaliter dehiscentes. Ovari u m liberum, triloeulare, Joenlis uniovulatis. St y lus filiformis; stigma simplex. Capsula calycis tubo, basi cum ramo connato inclusa, trilocularis, indehiseens. S e min a in loculis solitaria, peltata. - Frutex Novae-Hollan. diae austro-occidentalis; foliis oppositis, exstipulatis, planis, lineari-lanceolatis, trinerviis, subvenosis, scabris, floribus terminalibus spicato-capitatis, bracteis late ovatis, pubescentibus, demum deciduis sejunctis, calycibus lanatis, fructibus pubescentibus.

Cou othat nus Lindley Swan-River 9 .

G298. Melalemese LINN. Flores spicati, eapitati, sessiles v, ramo immersi. Ca ly $x$ tubo subhemisphaerico, cum ovario cohaerente, limbo supero, quinquedentato v. quinquepartito. Corollae petala 5, calyeis fauci inserta, ejusdem laciniis alterna. Stam in a plurima, cum petalis inserta, in phalanges 5 , petalis oppositas coalita; fil amen $t$ a superne libera, flliformia, anthe ra e biloculares, incumbentes, longitudinaliter dehiscentes. Ovarium adnatnm, triloculare, loculis multiovulatis. Sty I us filiformis; $8 \mathrm{tigma}$ obtusur. Capsula valyeis tubo basi cum ramo connato inclusa, trilocularis, apice trifariam dehiscens. Sem in a plurima, angulata. - Arbores $v$. frutices, in Nova-Hollandia copiose crescentes, in India orientali rarius provenientes, sed ob olei aromatici copiam celebres; foliis alternis $v$. opposilis, exstipulatis, basi aequalibus, planis $v$. teretiusculis, floribus spicatis $v$. capitatis, sessilibus $v$. ramo immersis, albidis, flavidis v. purpurascentibus.

M ela le u e a Linn. Mant, 14. Gürtn, I. 173, t, 35, exel, fig. med. Smith Exot. Bot. I. t, 34_36. 55. 56. Labillard. Nov. Holl. t. 165, Vent. Mralm, t. 7. 76, 112, Bot. Reg. t, 103. 410. 477, Andrews Bot. Reposit, $t, 200$, 278. 47i, R. Brown in Aiton Hort. Hew. edil. 2. IV. 410. Colla Hort. Ripul. 15 37. App. t. 4. Sweet Flor. Austral, t, 10. DC. Prodr. IIT. 211. Nees Plant, offic. Suppl. IIT. t. 18. Sehauter in Otto et Dietr. Gartenzeit. 1835. III, 161. Meisner Gen, 107. (76.) Cajuputi Adanson Fam, II. 85. Metrosideri s p. Cavanill. Ic. $t .333$-336. Gírtner $t, 34, f, 6$.

6295. Eualesmia $R, B R$. Flures umbellati. Ca ly $\times$ tubo turbinato, cum ovario connato, limbo snpero, quadridentato. Coroll a e petala 4 , ealycis fauci inserta, in operculum quadristriatum, deciduum arete connata. $S t$ a $m$ i n a plurima, $c u m$ petalis inserta, in phalanges $\$$, ealycis dentibus alternas basi cualita; fi lam enta superne libera, capillaria, interiora sensim minora, a $\mathbf{t} \mathbf{h}$ e $\mathrm{r}$ a e subglobosae, biloculares, Iongitudinaliter dehiseentes. 0 v ariu m inferum, quadriloculare, loculis multiovulatis. Sty lus cylindracens, simplex; stig ma obtusum. Capsula calycis tubo lignoso inclasa, quadrilosularis, apice quadrifariam dehiscens. Se- 
mina plurima. - Frutex Novae-Hallandiae australis, tri-quinquepedalis; ramulis tetragonis, angulis marginatis, foliis oppositis $v$. suboppositis, petiolutis, exstipulatis, saepius aversis, lanceolatis $v$. oblongis, coriaceis, compactis, integerrimis, marginatis, glautis, resinoso punctatis, venis vix emersis, anastomosantibus, umbellis lateralibus paucifloris, pedunculo pedicellisque ancipitibus.

Kude su a $\mathrm{R}$. Bsown in Flinders Voy. II. 599. $t$, 3 , DC. Prodr, III. 216. Sweet Flor, austral, $t$, 21. Meisner Gen. 107. (67.)

8300. Euealyptus HERIT. F lo res solitarii pedunculati, v, uubellati. C a 1 y $x$ tubo obovato v. suligloboso, limbo clanso, operculiformi, sub anthesi circumscisse decidno. C o roll a operculo intus adnata $v$ rarius in laminam tenuem solubilis, seorsim decidua. Stamina plurima, calycis fanci inserta; filamenta filiformia v. linearia, antherae biloculares, ovatae v. subglobosae, longitudinaliter dehiscentes. $O$ v a ri u m liberum, quadriloculare, loculis multiovalatis. Sty In s cylindraceus, simplex; stigma obtusum. Capsula calycis tubo cupulaeformi inclusa, quadri- v, aborta trilocularis, tri-quadrifariam dehiscens. Se m in a plurima, - Arbores Novae-Hollandiae, excelsae, saepe resiniferae; foliis phyllodineis, alternis v. oppositis, aversis, coriaceis, integerrimis, saepissime parallelinerviis, plerumque glaberrimis, pedunculis axillaribus, brevibus, unifloris, apice bibracteolatis $v$. sacpissime umbellam tri-quindecimfloram gerentibus, umbellae involucro longe ante anthesim deciduo.

Eucalyptus Heritier Sert. 18. Smith in White Voy. 331. t. 25. Nov, Holl. 12, Exot, Bot. II, t. 84, Linn. Trans. act. III. 284. Lam. t. 492. Cavanill, Ic. $t, 340$, 34t. Labillard. Voy. t. 13, 20, Nov. Holl. t, 150_154. Boupl. Navarr. $t .13$. Liak et Oito Mbibild, $t$. 45. Reichenb. GartenMagaz. $t$, 42. Bot Reg, $t, 947$, DC, Prodr, III, 216. Colla Hort. Mipul. App. 4. i. 1. Nees Plant, offic. Suppl. I. t. $1 t$. Meisuer Gen, 108. (76.) Met ros ideri s p. Gärtuer t.34.f. 1 .

BSO1. Angoplnora $C A V$. F I o res corymhosi Cal y $\times$ tubo turbinato, quinquecostato, limbo quiuquedentato, Co rolla e petala 5 , annulo calycis faucem unarginanti inserta, ejusdem dentibus alterna. St am in a plurima, cum petalis inserta; fil a menta filifurmia, libera, a $t$ herae hiloeulares, ovatae, incumbentes, longitudinaliter dehiscentes. O v a r i u m calycis tuho inclusum, triloculare, luculis pluriovulatis. Stylus cylindraceus, simplex; stigma acntum. Cap 8 ula calycis tubu sublignoso corticata, obovata, trilocula ris, loculicide trivalvis. Semina in loculis solita ria v. panca. - Frutices Novae-Hollandiae orientalis; foliis oppositis, rarius in ramulis sub. alternis, exstipulatis, sessilibus $v$, petiolatis, integerrimis, coriaceis, venosis, glaberrimis v. setoso-hispidis, floribus corymbosis, albis.

A ngophora Cavanill. Ic. IV. 2t. t, 335. 337. DC Prodr. III. 229. Meisner Gen. 108. (76.) Metroside r * p. Gärtaer t. 34. f. 2. Veaten. Malmais. $t$, 2. Bot, Mag. t. 1960 .

6398. Callistemon $R$. BR. Flores spicati, sessiles $v$. ramnlo immersi, C'al y $x$ tubo hemisphaerico, cum ovario connato, limbi superi, quinquepartiti lobis obtusis v. acutis. Coroll a e petala 5 , ealycis fauci inserta. St a m in a plurima, cum petalis inserta, longe exserta; fil am enta filiformia, libera, a n thera e biluculares, incumbentes, longitudinaliter dehiscentes. Ovarium adnatum, triloculare $\mathbf{v}$, quinqueloculare, loculis mnltiovulatis. Stylus filiformis; stigma capitatum.
Ca p s n la ealyeis tubo basi eum ramo connato inclasa, tri-quinquelocularis, apice tri-quinquefariam dehiseens. S e m in a plurima. - Frutices NovaeHollandiae; foliis alternis, exstipulatis, rigidis, elongatis, verticalibus, v. planis horizontalibus, floribus in spicis apice comosis sessilibus, v. ramulo immersis.

Callistemon R. Brown in Bot, Reg, n, 393. DC. Prodr. ITI. 223, Meisner Gen, 108. (76.)

a. EUCALLISTEMON, Limbi calycini lobi obtusi. Ova ri a m triloculare. - Folia verticalia. (Bot. Reg. t. 393. Sweet Flor, austr, $t$, 29.)

b. PENTAgonaster. Limbi calyeini lobi aeuti. Ova. ri u m quinqueloculare. - Folia horizontalia, - P en$\mathrm{t}$ ag on a s t e r Klotsch in Otto et Dietr. Gartenseit, 1836. IV. 113. Calo tham i s p. Hort. (Bot. Reg. 1838,t.7.)

6303. Netrosideros $R, B R$. Flore 8 axillares v. terminales, pedunculati. C a l y $x$ tubo campanulato, inferne cum ovarii basi connato, tereti, limbo quinquefido $\mathbf{v}$, quinquedentato. Corolla e petala 5 , annulo calycis faucem marginanti inserta, ejusdem laciniis alterna. Sta m in a 20-100, cum petalis inserta; fil amenta filiformia, longissime exserta, libera, antherae biloculares, dorso supra basim insertae, longitudinaliter dehiscentes, $O$ varium semiinferum, bi-trilosulare, locolis multiovulatis. Stylus cylindricus; stigma simplex v. capitatum. Capsula intra calycis tuhum libera, bi-trilocularis, loculicide deliscens. Semin a plurima, aptera, - Arbores $v$. frutices, in Nova.Hollandia et Nova-Zeelandia, in Moluccis, Capite bonae spei et insulis Sandwicensibus crescentes; foliis oppositis $v$. alternis, exstipulatis, integerrimis, floribus axillaribus terminalibusque, pedunculatis.

Metrosideros R. Benwn in Flinders Voy. $1 I$, sa7, DC. Prodr. III. 224, Meisuer Gen, 108. (z6.)

a. EUMETROSIDERoS. Ca psula bilocularis. Stig ma simplex. - Folia opposito. - N an I Adans. Fam, II. 88. Metrosideros vera Rumph Amboin, III, 16. $t .7$. Lindley Collect, $t, 18$.

b. AGAlmanthuS. Capsula trilocularis. Stigma simplex. - Folia opposita. - (Gärtner t. 34. f.8.9. Cav. Ic t. 337. Veuten.,MaLm. t. 46. Labillard. Nov, Caled. t. 60. Gnudieliand ad F́regeinet t. 85. A. Riehard Flor. Nov, Zeel, t, 37. Ilooker ad Beechey $t, 12$.

c. GLAPHYRANTHUS. C a p s a I a tritocularis. Stig ma capitatum. - Eolia alterna. - K u n z e a Reichenb. Oonsp. n, 4661. Leptospermi sp. Forst. Smith Exot. Bot. t. 59. (Veat. Malm t. 46 )

8304. Eremaea $L I N D L$. F lores terminales, aggregati. Ca ly $x$ tubo eampanulato, inferne cum ovariil basi connato, limbo quinquedentato. Corolla e petala 5 , annulo calycis fancem marginanti inserta, ejusdem dentibus aiterna. Stamina plurima, cum petalis inserta, irregulariter polyadelpha v. omnino libera; filam ent a filiforinia, a ntherae biloculares, basifixae, obovatae v, oblongae, rimis lateralibus oblique dehiscentes. Ovarium semisuperum, bi-triloculare, loculis multiovulatis. Stylus brevis; stigma simplex. Capsula calyce cyathiformi, ramo adnato, haud immerso inclusa, bi-trilucnlaris, loculicide dehiscens. Semin a plurima, adscendentia, cuneata. Frutices Novae-Hollandiae austro-occidentalis; foliis alternis, exstipulatis, semiteretibus, glabris v. pilosis, floribus in apicibus ramulorum solitariis v. pancis, aggregatis, bracteis imbricatis inclusis.

Eremae a Lindley Swan.River XI. Metrosideros pauciflara End.

BBQ5. Billiottia $R$. BR. F I o res axilla- 
res capitati. Calyx tubo turbinato, cum ovario connato, limbo supero, quinquepartito, deciduo. Corollae petala 5 , calyeis fanci inserta, ejusdem laciniis alterna, breviter unguiculata, orbicnlata. St a mina $10-20$, cum petalis inserta, iisdem breviora; filamenta filiformi-subulata, libera, a $\mathbf{t}$ hera e biloculares, longitudinaliter dehiscentes. Ov a rium inferum, triloculare, loculis multiovulatis. Stylu s filiformis; stigm a capitatum. C a p sula calyee adnato eincta, trilocularis, loculicide trivalvis. Semina plurima, compressa. Arbusculae $v$. frutices Novae-Hol $l$ a n $d i a \bar{e}$ a ustro-occidentalis; foliis alternis, exstipulatis, lineari-lanceolatis, trinerviis, floribus in axillis foliorum sessilibus, in capitula globosa, densa congestis, albis.

Billiottia R. Brown in Journ. geograph. Soe. I. 19. Leptospermi sect. Ag on is DC. Prodr. III. 226. L ep tos permi s p. Labillard. Nov. Holl. $t, 148$.

6306. IIy poealymma $E N D L$. F lores axillares, capitati. C al y x tubo campanulato, cum ovario connato, limbo supero, quinquepartito. Corolla e petala 5, calycis fauci inserta, ejustem laciniis alterna, breviter unguiculata, orbiculata. St a m in a $20-30$, cum petalis inserta, iisdem longiora; filamenta filiformi-subulata, anthe$\mathrm{r}$ a e biloculares, longitudinaliter dehiscentes, $\mathrm{O}$ varium infernm, biloenlare, loculis multiovulatis. Sty lus filiformis; $s t i g m a$ capitatum. Fructus...... - Frutices Novae-Hollandiae a ustro-oceidentalis; foliis oppusitis, exstipulatis, lineari-lanceolatis, mucronatis, floribus axillaribus sessilibus $v$. brevissime pedicellatis, cupitatis, scarioso-bracteolatis, roseis $v$, persicinis.

H y pocal y m ma sectio Leptospermi Endlicher Enumerat. plant. Hügel, 50.

630\%. Feriealymma ENDL. F lores axillares $v$. terminales, sessiles. Cal y $x$ tubo $\mathrm{ey}$ lindrico, inferne cum ovarii basi connato, snpra ovarium producto, eum limbo quinquefido decidao. Corolla e petala 5, calyeis fauci inserta, ejusdem laciniis alterna, breviter unguieulata, orbieulata. St a m in a 20_30, cum petalis inserta, iisdem breviora; fil amenta filiformi-subulata, anther a e biloculares, longitudinaliter dehiscentes. $0 \mathrm{va} \mathrm{ri} \mathrm{m}$ m semiinferum, triloculare, loculis uniovulatis. Stylus filiformis; stigma capitatum. Capsula semisupera, trilocularis, loculicide dehiscens. Se$\mathrm{mina}$ in loculis solitaria. - Frutices Nova - $^{-}$ Hollandiae austro-occidentalis; foliis alternis, exstipulatis, ellipticis, subinaequilateris, floribus axillaribus terminalibusque sessilibus, solitariis, bracteolis membranaceis carinatis, calycis tubum velantibus.

Perical y m a sectio Leptospermi Endlicher in Enumerat, plant. Hügel. 51 .

B308. Salisia LINDL. F lo res corym bosi. Cal y x túbo ima basi cum ovario connato, supra ovarium producto, eampanulato, limbo quinquedentato. Corolla petala 5 , calycis fauci in serta, ejusdem dentibus alterna, breviter ungnieu lata. Stamina 30 , cum petalis inserta, isdem al. terna et Iongiora; fil am enta libera, filiformisubulata, a n thera e biloculares, longitudinaliter dehiscentes. Ov a ri $\mathbf{m}$ inferum, depressnm, quinqueloculare, loculis rima leculicida, marginibus elevatis connivente, etiam in alabastro apertis, mul. tiovulatis, ovulis placentae orbicalatae, excentrice peltatae margini insertis. St y lus filiformis; $8 \mathbf{t}$ g. ma capitatum. Fractus...... - Frutex $N_{0}$.
vae-Hollandiae austro-oceidentalis; ramulis foliisque alternis, exstipulatis, obovatis, planis, coriaceis, obsolete trinerviis, pubescentibus, floribus laxe corymbosis, roseis.

S a I is i a Lindley $S$ wan-River $x$.

6309. Heptospermuma FORST. Flor es sparsi, axillares. C a ly $\mathbf{y}$ tubo campanulato, cum ovario connato, limbo quinquefido, supero $v$. semisupero, deciduo v, rarius persistente. CorolI a petala 5, calycis fauci inserta, ejusdem laciniis alterna, breviter unguieulat $a$, orbieulata. $\mathbf{S t}$ a mina $20-60$, cum petalis inserta, iisdem brevio. ra vix longiora, fil a menta filiformia, libera, anth erae biloculares, longitudinaliter dehiscentes. Ovarium inferum v. semisuperum, quadriquinqueloculare, loculis multiovulatis. Stylus filiformis; $8 \mathrm{tig}$ ma capitatum. C a p sula infera v. semisupera, quadri-quinquelócularis, apice loculicide dehiscens. Sem in a plurima, minima, oblonera, compressa. - Frutices $v$, arbores, in NovaHollandia et Nova-Zeelandia crescentes; foliis alternis, exstipulatis, integerrimis, floribus pedicellatis, solitariis, sparsis, nudis $v$. scariose bracteolatis, albis.

L e p to s per u u m Forst. Char. gen. 36. Gärtaer $I, 174$. t. 35. (exel. f. 1. 2.) Smith in Linn. Transact. MII. 260 . Cavanili, Ic. IV. 16, t. 330, 331, Labillard. Nov, Holl.t. 147. Wendlaud Sert, Hannov, $t$. 14. 15, Bot. Mag. t. 1810, 2695. Meisner Gen. 108. (76.) L e p to s per in i sect. Eule pto. s pe f m u m DC. Prodr. III. 297.

G3 10 . Fabricia GARTN. F l o res axillares, brevissime pedicellati. C a l y x tubo campanulato, cum ovario basi connato, limbo semisupero, quinquefido, deciduo. Cor a I l a e petala 5, calycis fauci inserta, ejusden laciniis alterna, breviter unguiculata, orbieulata, S $\mathbf{t}$ a $\mathrm{m}$ in a plurima, cum petalis inserta, iisdem breviora; filamenta subulata, antherae biloculares, ovatae, longitndinaliter dehiscentes. Ovarium semiinfernm, multiloculare, Iocnlis pluriovulatis. Sty In s simplex; st igma capitatum. Ca p sula multilocularis, semisupera, calycis tubo adnato basi cincta, apice loculicide dehiscens. S em in a pauca, alata. - Frutices Novae-Hollandiae orienlalis; foliis alternis, exstipulatis, obovatis $v$. oblongis, integerrimis, glaucescentibus, punctatis, floribus axillaribus, solitariis, brevissime pedicellatis, albis.

$\mathrm{F}$ a b ri c i a Gărtner $I$. 175. $t$. 35. Swith in Linn, Transact. III. 265. Bot, Mag. t. 1304. DC. Prodr. III. 229. Meisuer Gen. 108. (76.)

631 1. IBackea LINN. Flores axillares, sessiles v. pedunculati. C a I y x tubo turbinato, cum ovario connato, limbo supero v. semisupero, quinquefido, persistente. Corroll a e petala 5, calycis fauci inserta, ejusdem laciniis alterna, breviter unguiculata, orbiculata. St a m in a $5 \mathrm{v} .10$, cum petalis inserta, iisdem breviora; fil a m enta filiformi-subulata, libera, a $\mathbf{t}$ h e $r$ a e biloculares, longitudinaliter dehiscentes. Ova ri $\mathbf{~ m ~ i n f e r a m ~}$ v. semiinferam, bi-tri-quinqueloculare, loeulis multiovulatis. St y l u f fliformis; $t \mathrm{igma}$ eapitatum. Ca psula infera $v$. semisupera, bi-triquinquelocnlaris, apice loculicide dehiscens. S ein in a plurima, angulata, testa crassa. - Frutices Novae-Hollandiae et Asiae tropicae; foliis oppositis, exstipulatis, saepissime acerosis, floribus axillaribus, nunc solitariis, sessilibus v. pedunculatis, nunc umbellatis.

Bae ck ea Lian. Gen, n. 491. Osbeck It, L, 1. R. Brown in Flinders Yoy, II. 548, Gärtner I. 157, $t, 31$. Smith in Lisn, Transact, HI, 238, Bot. Mag. t,2127, 2802,3160. Colla 
Hort. Ripul, t. 6. DC. Prodr, IIT, 229. Meisil. Gen, 108. (76.) I mbrica ria Simith in Linn. Transact, III. 259. Jung i a Gärtner I. 175. t. 35. Molli a Gael, Syst. 420. Cedrela Loureiro Flor. oochinoh. 199. Leptosper un i s p. Labill. Nov, Caled. t. 61. 62.

SUIB IRE IIII. MYRTEAE DC. Prodr. III. 230. St a m in a indefinita, libera, 0 varium bi-pluriloculare, loculis multiovulatis. Bace a bi-plurilocularis, loculis abortu saepissime monospermis. - Arbores $v$. frutices, in regionibus tropicis subtropicisque totius orbis, imprimis Americae crescentes; foliis oppositis, exstipulalis, punctatis, integerrimis.

6312. Somneratia LINN. F. Calyx tabo campanulato, ima hasi cum ovario connato, quadri-sexfido, lobis acutis. Corolla e petala 4-6, calycis fanci inserta, ejnsdem lobis alterna, rarius nulla. Stamina plurima, cum petalis inserta, pluriseriata; filamenta filiformia, libera, a ntherae biloculares, dorso insertae, longitudinaliter dehiscentes. Ovarium semisuperum, multiloculare, loculis multiovulatis. Stylas simplex; stig ma subcapitatum. Ba cea semisupera, calyce cincta, subglobosa, membranacea, decem quindecimlocularis, septis tenuibus. Semin a plurima, in pulpa carnosa nillulantia, eurvata. Embryonis exalbuminosi, curvi cutyledones foliaceae, breves, ranaliculato convolutae, inaequales, radicula longa, teres. - Arbusculae indicae; ramis tetragonis, foliis oppositis, exstipulatis, ovalibus, crassiusculis, uninerviis, subaveniis, impunctatis, integerrimis, floribus solitariis, magnis.

Sonueratia Linn. f. Supplem. 38. Jussieu Gen. 325. Buchanan in Symes Ava III. 313. t. 25. DC. Prodr. IIT. 231. Wight et Arnott Prodr. I. 327. Meisner Gen, 108, (72.) A ubletia Gärtner 1 . 379, $t$, 78 . non Alior. $\mathrm{Pag}$ a pate Sonnerat Voy, 16, t. 10. 11. Blatti Rheede Malab, III 40. M a ng i um e s e ol a re Rumph Amboin, III, $, 73,74$.

6313. Nelitris $G A B T N$. C a 1 y $\mathrm{x}$ tubo obovato, cum ovario connato, limbo supero, quadri-quinquedentato. Coroll a e petala 4 v. 5 , caIycis fanci inserta, ejusdem dentibus alterna. S tain in a plurima, annulo epigyno pluriseriatim inserta ; fil a m e nta filiformia, libera, antherae biloculares, dorso insertae, longitudinaliter dehiscentes. Ovarium infernm, quadri-decemloculare, loculis biovulatis, ovulis collateralibus, adscendentibus. Stylus filiformis; stig ma capitatum. B a c c a calycis limbo coronata, loculis submonospermis. S e m in a teretiuscula v. compressa, testa ossea. Embry onis exalbuminosi, rectins. culi cotyle dones minutae, ovato-lanceolatae, radie ula elongata, crassa. - Frutices moluccani; foliis oppositis, exstipulatis, ovatis v, oblongis, nitidis, impunctatis, uninerviis, integerrimis, floribus axillaribus pedunculatis, bibracteolatis.

Nelitris Gärtner I, 134, t. 27. Lindley Colleot, 16. DC. Prodr. MII. 231. Meisuer Gen, 108, (77,) De cas perw u

6314. Camponamesia RUIZ et PAV. Calyx tubo subgloboso, cum ovario connato, limbi superi, quadri-quinquepartiti lobis ovatis. Corolla e petala 4 v. 5 , calycis fanci inserta, ejasdem llaciniis alterna. St a mina plurima, cum petalis inserta, pluriseriata; fil a me n ta filiformia, libera, antherae biloculares, dorso insertae, longitudinaliter dehiscentes. Ov ariu m inferum, septem v, decemloculare, loculis pluriovulatis, ovu- lis placentae centrali insertis. Stylus simplex; stig m a subpeltatum. B a cc a depresso-globosa, calycis limbo coronata, septis evanidis unilocularis. S em ina 10_12, subreniformia, placentae centrali carnosae unica serie eircumposita, nidalantia. Embryonis exalbuminosi, arcuati cotyledones radiculae aequilongae. - Arbores Americae tropicae; foliis oppositis, exstipulatis, petiolatis, pellucido punctatis, integerrimis, pedunculis in axillis foliorum aggregatis, floribus bibracteolatis, albis.

C a mom a uesia Ruiz et Pavon Prodr. 72. $t, 13$. Syst. 128. Lindley Collect. 16. Kunth in Humb, et Bonpl. Nov. gen, et sp. VI, 150, t. 147, DC, Prodr. III, 232. Meia. uer Gen, 108. (77.)

63 15. Psidium LINN. CaIyx tubo cum ovario connato, limbo supero, primum clanso, sub anthesi quadri quinquepartito. Coroll a e petala 4 v. 5, calycis fauci inserta, ejusdem laciniis alterna. St a m in a plurima, calycis fauci et disco epigyno pluriseriatim inserta; filamenta filiformia, libera, antherae biloculares, dorso insertae, longitudinaliter dehiscentes. Ovarium inferum, quadri-multilocnlare, placentis in loculo. rum angulo centrali bipartitis, pagina interiore multiovulatis. Stylns simplex; stigma capitatum. B a ce a calycis limbo coronata, quadri-multiloevlaris. Semin a plurima, reniformia, testa ossea v. rarissime membranacea. Embryonis exalbuminosi, curvati v. spiraliter convoluti ra dicula longa, umbilicum spectans. - Arbores v. frutices, in Asia et frequentius in America tropica crescentes; foliis oppositis, exstipulatis, integerrimis, pellucido-punctatis $v$. epunctatis, pedunculis axillaribus, oppositis, uni-plurifloris, floribus bibracteolatis, albis, baccis viridibus v. luteis.

Ps idium Linn. Gen, n. 615. Aublet Guian, $t, 190,191$. Jacq. Hort. Schönbr, $t, 366$. Lambert in Limn. Transact, XI. c. 12. Sabiue in Horticult. Transact, IV t, 11. Liudley Collect. t. 16. Bot, Mag, t, 1779, 205t, Bot, Reg. t, 622, 1079. DC. Prodr. III, 232. St. Hilaire Flor, Brasil. IT. 277. t. 136 -139. Wight et Arnott Prodr. I. 328. Meisner Gen. 108. (77.) G u a i a a Tournef. Inst. $t$. 443. Gärner T. 185. t. 38. P s id i u et B a rehard i Necker Elem, n. 327 et 728 ,

G316. Ilyrtas TOURNEF. Caly $x$ tubo cum ovario connato, limbo supero, quadri- v, quinquefido. Corollae petala 4 v. 5 , calycis fanci inserta, ejusdem laciniis alterna. St a m in a indefinita, saepissime plurima, calyeis fauci et diseo epigyno pluriseriatim inserta; filamenta filiformia, libera, an $t$ hera e biloculares, doræo insertae, longitudinaliter dehiscentes. $0 \mathrm{v}$ a $\mathrm{r}$ in $\mathrm{m}$ inferum, bi-tri. rarius quadriloculare, placentis in loculorum angulo rentrali saepissime bipartitis, pagina interiore multiovulatis, rarins indivisis, biovolatis. St y l o s simplex; $8 \mathrm{t} i \mathrm{~g}$ a terminale. B a e c a calycis limbo coronata, bi -tri-v, rarius quadrilocularis, interilum abortn monosperma. S emin a plerumque hippocrepica, testa saepissime ossea. Embry on is exalbuminosi, curvati cotyled ones brevissimae, semicylindricae, radic a la cotyledonibus multo longior, umbilicum spectans. - Frutices $v$, arbores, in $A m$ erica $t r o$ pica, rarius in Asia a equinoctiali, Europa a ustrali, et in regionis antarcticae insulis temperatis crescentes; foliis oppositis, exstipulatis, integerrimis, pellucido-punctatis, pedunculis axillaribus unifloris, floribus bibracteolatis, albis v. rubris, baccis nigris v. rubris.

M y rt u \& Tournefort Inst, t. 409. Linn Gen, n, 617, exci. sp. Gärtner $I$. 184. St. Hilaire Flor. Brasil, II. 292. Wight et Arnott Prodr. 1. 328. Meisner Gen. 108. (77.) M y r tu s et $J_{0 . s}$ s inia DC. Prodr. IIT, 337. 338. 
a. LEUCOMYRTUS DC. $l, c$, FI o r es albi. $S$ e mi $i$ a subhippocrepica, matura in loculis irregulariter dispersa.

c. Myrtillus. Flores quadrifidi, oligandri. Leantria Soland. ex Forster Comment. Götting. IX. 45. (Humb. et Bonpl. Plant. aequinoct. $t$. 4. Gaudichaud in Annal, so. nat. $V$. t, 2. $f$. 5.)

B. Jossinia. Flores quadrifidi, polyandri. Jossini a Commers. msc, DC, Prodr. III. 337. Eug e $a$ i a s. p. Lam.

$\gamma$. En m y $r$ us. Flores quinquefidi, polyandri. (Miller Ic. t. 184. $f$. 1. Gärtner t. 38. Duhamel Arbr. edit. Nov. I. t. 43. Humb. et Bonpl. Nov. gen. et sp. $t$, 539. St. Hilaire Flor. Brasil. $t$, 140. 141.)

b. RHODOMYRTUS DC. $t$. c. Flores rosei. Semina compresso plana, in Joculis biseriata. - Species indica. M. tom entos a Aiton Bot. Mag, $t$. 250 .

G31\%. ITyreia $D C$. C a l y x tubo cum ovario connato, limbo supero, quinquelobo. Cor o lla petala 5, calycis fanci inserta, ejusdem lobis alterna. St amina plurima, ealycis fanci et disco epigyno pluriseriatim inserta; filamenta filiformia, libera, antherae biloculares, dorso insertae, longitudinaliter dehiseentes. Ova r i u m inferum, bi-rarius triloculare, locnlis biovulatis, ovulis angulo centrali subcollateraliter insertis. Stylus simplex; stigma terminale. Bac ca ca lycis limbo coronata, abortu saepissime unilocala ris, mono-disperma. Se min a subglobosa, testa membranacea v, coriacea. $\mathbf{E} \mathbf{m}$ br y o $\mathbf{n}$ is exalbu minosi cotyle dones foliaceae, corrugato - contortuplicatae, radicula e incumbentes. -. Arbores v. frutices Americae tropicae; foliis oppositis, exstipulatis, pellucido punctatis, integerrimis, flori bus cymoso-paniculatis, bibracteolatis, albis, baccis nigris $v$, rubris.

M y re i a DC. Prodr. 1II, 242. St. Hilaire Flor, Brasil. II, 297. $t$, 242. 843. Meisner Gen, 108. (77.) M y r ti s p A uet. Humb. et Bonpl. Nov. gen. et sp, t. 544_546. E ng eIl a e s. Aublet Guian, to 195, 200, 201. Jacq. Collect. II, $t, 4$.

B53 18. IIrariferea $S T$. HIL. Cal y $x$ tubo cum ovario connato, limbo supero, clanso, suh anthesi in lobos quatuor, saepe inaequales et irregulares longitudinaliter fisso. Corollae peta la 4 , ealyeis fauei inserta, ejusdem lobis alterna, saepissime nulla. S tam in a plurima, calycis faue pluriseriatim inserta; filamenta filiformia, antherae bilocnlares, dorso insertae, longitudinaliter dehiscentes. O v a ri $\mathbf{~ m ~ i n f e r u m , ~ b i - t r i l o c u - ~}$ lare, loculis biovulatis, ovulis ex angulo centrali adscendentibns. Stylus simplex; stigma acutum. Bacea .... - Arbores $v$. frutices brasi lienses; foliis oppositis, exstipulatis, pellucido. punctatis, integrerrimis, floribus cymoso paniculatis, axillaribus torminalibusque, bibracteolatis.

Marlierea St. Hilaire Flor, Brasil, IT, 373, t, 186. Meisner Gen, 108. (77.)

633 19. Calyotrantlies SW ARTZ. C aI y x tubo enm ovario eonnato, limbo snpero, clan$80,8 u b$ anthesi circumseisse soluto, operculiformi, hine latere adhaerente, patente, demum deciduo. Corolla petala 5 , calycis fauci inserta, miniun, saepe abortu nulla. Stamina plurima, disco epigyno pluriseriatim inserta ; filamenta filiformia, libera, anthera e biloculares, dorso affixae, longitudinaliter dehiscentes. 0 va $\mathrm{r}$ i $\mathrm{m}$ infernm, biloculare, loculis bi-multiovulatis. St yI $\mathrm{g}$ simplex; $\mathbf{s}$ tig $\mathrm{ma}$ terminale. Bacea abortu nnilocularis, mono-tetrasperma. Se min a ...

Arbores v. frutices Americae tropicae; foliis opposilis, exstipulatis, pellucido-punctatis, integer- rimis, pedunculis simplicibus v cymoso-ramosis, floribus bibracteolatis.

C a I y ptran the s Swartz Flor. Ind, occid. II, 917, $t, 15$. St. Hilaire Plant. us. Brasil. t. 14. Flor. Brasil. II, 370. t. 155. DC. Prodr, III, 265. Meisner Gen. 108. (77.) traculfa et $\mathbf{Z u z}$ y gi um P. Browne Jam, 239. 260, t. 37. $f$. 2. $t$. 7. $f$. 2. Chytralia Adanson Fam. $I T, 80$. Ca. I y p tra $\mathrm{a}$ th a Jussieu in Diot. se, nat. VI. 274. non allor.

8320. Syzyginm $G \not ̈ R T N$. C a ly x tubo cum ovario connatu, limbo supero, integerrimo $v$. repando. Corolla e petala $4 \ldots 5$, calycis fauci inserta, in calyptram coalita, sub anthesi dejecta. Stamina plurima, ealycis fanei inserta; filamenta filiformia, libera, a n therae biloculares, dorso insertae, longitudinaliter dehiscentes. $0 \mathrm{va-}$ rim inferum, biloculare, loculis pluriovulatis. Stylu's simplex; stifma acutum. Ba cea abortu unilocularis, mono-disperma. S e mina globosa. Embryonis exalbuminosi cotyledones crassae, carnosae, subhemisphaericae, ra dic ulae brevissimae, retractae peltatim insertae. - Arbo. res $v$. frutices, in $A$ sia et $A f r i$ ca tropica crescentes; foliis oppositis, pellucido-punctatis, integerrimis, pedunculis axillaribus el terminalibus, cymosis $v$, corymbosis.

S y z y i u m Gärtaer $I, 166, \ell, 33$. DC. Prodr. IrI, 259. Guillem. et Perrnt. Flor. Seneg. I. $t, 72$. Wight et Arnott Prodr I. 329. Melsner Gen. 108. (77.) O p a Lonreiro Flor. cochinch. I. 17\%. Calyptranthus Bluue Bifdr, 1089. Jamboliferae, Eugeniae, Myrti et Calyptrau. this sp. Anet.

63\%1. Caryophyllus TOURNEF. Calyx tubo cylindraceo, cum ovario eonnato, limbo supero, quadripartito. Coroll a e petala 4 , calycis fauci inserta, ejusdem laciniis alterua, calyp. tration cohaerentia, sub anthesi dejecta, Sta min a plurima, annulo carnoso tetragono, calycis faucem marginanti inserta, in phalanges 4 approximata; filamenta filiformia, libera, anthera e biloculares, dorso insertae, longitudinaliter dehiscentes. O vari n m inferum, biloculare, loculis multiovulacis. Stylus simplex; stig u a ob. tusum. Bacea sicea, calycis limbo coronata, biv. abortu unilocularis, di-monosyerma. Semina cylindracea v. semiovata, Em bryonis exalbuminosi cot y l ed on es crassae, carnosae, extus concavae, intus sinuosae, $r$ a $d$ i $\mathbf{n} I$ a e rectae, retractae, superae peltatim insertae. - Arbores molucc $a$ nae, ob florum praestans aroma nunc inter tropicos passim cultae; foliis oppositis, exstipulatis, co. riaceis, pellucido-punctatis, integerrinis, cymis terminalibus, $v$, in dichotomia ramorum subcorymbosis, floribus bibracteolatis.

Caryophyllus Tournefort Inst. 432. Linn. Gen. $n$. 669. Gärtner $I$. 167. 2 . 33. Hooker in Bot. Mag. t. 2749. 2750: DC. Prodr. IIT. 262. Meisner Gen. 108. (77.) M y $t$ ti sp. Kunth. Eugeniae sp. Willd.

4832. A emena DC. Caly x tubo turbinato, eum ovario connato, limbo snpero, truncato, juniore subinvoluto. Corolla e petala 5, calycis fauci inserta, minima, distantia, interdum nulla. Stamina plurima, calycis fauci inserta; filamenta filiformia, libera, an $\mathbf{t h}$ era e bilnculares, dorso insertae, longitudinaliter dehiscentes. Ovari a m inferum, trilocalare. Styln 8 brevis, simplex; 8 t ig ma obtusum. B acea globosa v. ovalis, monosperma. Sem en subrotandum, crassnm. Embryonis exalbuminosi eotyledones conferruminatae. - Frutex glaberrimus, in Nova-HoLlandia orientali extratropica indigenus; folitis oppositis, exstipulatis, pellucido-punctalis, 
integerrimis, cymis trifloris, in thyrsum terminalem paniculatum dispositis, floribus albis.

Acmen a DC. in Dict. class. hist, nat, XI, 446. Prodr. III. 262. Meisner Gen, 108, (77.) Metrosideros flori b u nd a Smith. Venten. Malmais, 2.75.

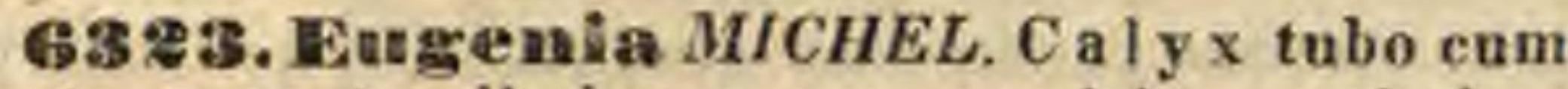
ovario connato, limbo supero, quadri-v. rarissime quinquelobo. Cornll a e petala 4 v. 5, calycis fauci inserta, ejusdem lacinis alterna. Sta min a plurima, calycis fauci et disco epigyno pluriseriatim inserta; filam enta filiformia, antherae biloculares, dorse insertae, longitudinaliter dehis. centes. Ovari n m inferum, biloculare, placentis e medio dissepimento porrectis, bilobis, facie interiore multiovulatis. Stylus simplex; stigma terminale. B a c c a calycis limbo coronata, abortu saepissime unilscularis, mono-disperma. S emina crassa. Embryonis exalbuminosi cotyledon es crassae, carnosae, plus minus in massam cum radi $c$ u l a brevissima continuam coalitae. $-\mathrm{Ar}$. bores $v$. frutices, in $A$ sia et $A$ merica tropica crescentes; foliis oppositis, exstipulatis, pellucidopunctatis, integerrimis, floribus in axillis foliorum sessilibus $v$. pedunculatis, solitariis $v$. cymosis, bibracteolatis, albis, baccis nigris v. rubris.

E u ge $n$ i a Michell Nov.gen, 226. t, 108. Linn. Gen, n, 616, excl, sp. Aublet Guian, $t, 195,196,199$. 202. Jaeq. Fragm. t. 45. f. 2. Bot. Mas. t, 1236. 1249. 2223. DC, Prodr. IIT. 262. Wallich Plant, As. rar. t, 108, 161. Bot. Reg. t. 1033. St. Hilaire Flor. Brasil, t, 149-154. Meisn. Gen. 199. (77.) Delessert Ic. select. III. $t$. 76. PII n i a Linne Mant. 243. Flon Flum, V.t. 46. 47. G u a p r $\mathrm{i}$ u m Jussieu Gen, 324. Greggia Gartuer 1 . 168, $t, 33$. O 1 inthia Lindley $\mathrm{Col}$. lect. $n, 19$. M y rti s p. Venten. Malm, $t, 60$. Humb. et Bonpl. Nov, gen. et sp. t. 54t_343. 546. Bot. Mag. t. 867. Bot, Reg, $t, 1044$. Lindley Collect, $t, 19$, Nees Plant. offic. Suppl. V. t. 19. 20. M y re i a e s p. DC. Bot. Mag. t. 3153.

B37 4. Jambosa $R U M P H, C$ a 1 y $x$ tubo cum ovario connato, turbinato, basi attenuato, fance nltra ovarinm producta, dilatata, limbi quadrifidi lobis subrotundis. Corolla e petala 4 , summae calycis fauci inter ejusdem lobos inserta, lata, concava, obtusa. Stam ina plarima, calycis fauci et diseo epigyno pluriseriatim inserta; fil am enta filiformia, stricta, an therae biloculares, dorso insertae, lengitudinaliter dehiscentes. Ovarin m biloculare, loculis multiovulatis. Stylus simplex; $8 \mathrm{tigma}$ terminale, acutum. B a cc a calyce ampliato, grumoso carnoso vestita, ejnsdem limbo coronata, abortn mono-disperma. S em in a angulata. Embryonis exalbnminosi cotyledones carnoso-corneae, marginibus conferruninatae, rad i c u la subeylindrica, intra cotyledunes latens. Arbores in Asia et Africa tropica indigenae; foliis oppositis, brevissime petiolatis, exstipulatis, pellucido-punctatis, integerrimis, cymis lateralibus terminalibusque, folio multo brevioribus, paucifloris, simplicibus, pedicellis lateralibus oppositis et uno terminali, floribus ebracteolatis, amplis, cum pedicello articulatis, fructu eduli.

J a ubos a Rumpl Amboin. T. 121. DC. Prodr. III. 286. Wight et Arnotl Prodr. T. 332. Meisner Gen, 109. (72.) $\mathrm{J}$ a mbos Adanson Fam, $\boldsymbol{I r}, 88$. Eugen ia s p. Lian. Smith Exot, Bot, I, t, 61. Correa in Annal, Mus. $t, 25, f, 2$. Pallisot Flor. Owar, t, 70. Bot. Mag, t. 1696. 2230. Bot. Reg, 8. 627. 1033.

SUBDIRED IV. BARRIVGTONIEAE DC. Prodr. III. 288. St a m in a plurima, saepe monadelpha. Ovari um inferum, bi-pluriloculare, ovulis definitis v. plurimis. B a c ca corticata, uni-plurilocularis, mono-oligosper- ma. - Arbores in Asia et Ameriea tropica crescentes; foliis alternis, rarius oppositis v. verticillatis, exstipulatis, impunctatis, integerrimis v. serratis.

6325. Trarringtonia FORST. $\mathrm{C}$ a $I_{y}$ tubo nvato, cnm ovario connato, limbi superi, birarits tri-quadripartiti laciniis ovatis, obtusis, con. cavis, persistentibus. Corollae petala 4 , annulo epigyno staninifero extus inserta, magna, coria cea. St amina plurima, annulo carneso epigyno pluriseriatim inserta; filamenta longe filformia, libera, an therae biloculares, dorso insertae, longitudinaliter dehiscentes. Ovari $\mathbf{m}$ inferum, bi-quadriloculare, loculis bi-sexovulatis, glandula epigyna annulari styli basim vaginante. Stylus filiformis; stigma simplex. Bacea fibrosa, tetragona, e basi ventricosa pyramidata $s$. oblonga, calyeis limbo coronata, abortu nnilocularis, endocarpio subpyrenaceo, monospermo. S emen obovatum, pendulum. Embryonis exalbuminosi, elliptico-globosi cotyledones cnm radienla supera in massam homogeneam, carnosam arctissime coalitae. - Arbores indica $e$; folits oppositis $v$ verticillatis, exstipulatis, confertis, petiolatis, obovatis, epunctatis, integerrimis, crenatis $v$. serratis, floribus amplis, in thyrsum terminalem dispositis, pedicellis unibracteatis.

B a rring to n i a Forster Char. gen. 38. Gärtner II.98, 1. 101. Blame Bijdr. 1096. Wight et Arnott Prodr. I. 333. Meisuer Gen, 109. (77.)

a. BUTONiCA Lam. Caly els limbus hi- rarius tripartitus. Ovarium quadriloeulare. B a c ca basi veutricosa, sursum pyramidato tetragona.

B ut a n l ca Lam. Diet. 1. 515, Jussien Gen. 326. Barring toni a Porst. Op. eit. t, 38. DC. Prodr. III. 288. Gandichaud ad Frejcinet 483. ใ. 107. C o in mers o n a Somerat Voy. t. 8. 9, Mi tr a ría Gmel. Syst, 799. H utt um Adanson Fam. II. 88.

b. STRAVADIUM Juss. Ca/yeis limbus quadripartitus. Ovarium biloenlare. Fruetus oblongus, costato. tetragonus.

S travadium Jussieu Gen. 326. DC, Prodr. III. 289. Stravad I a Persoon Encheir. 1r. 30. Meteo r u* Loureiro Flor. cochinch. II. 498. Me n i che a Sopaerat Voy. 138, t, $92,93$.

6326. Carreya ROXB. Caly $x$ tubo globoso, cum ovario connato, limbo supero, quaitripartito, persistente. Corollae petala 4, annnlo epigyno calycis faucem marginanti inserta, ejusdem laciniis alterna, ovata v. oblonga, obtusa, patentia. St a m in a plurima, cum petalis inserta, triseriata: filamenta fliformia, basi in annulum connata, superne libera, extima et intima ananthera, intermedia fertilia, a $\mathbf{n} \mathbf{t}$ e $\mathbf{r}$ i s bilocularibus, dorse insertis, longitudinaliter dehiscentibus. Ovari n m inferum, quadriloculare, loenlis multiovnlatis, glandola epigyna annulari, styli basim vaginante. Stylus filiformis; $8 \mathrm{tig}$ mi a subcapitatum, obsolete quadrilobum. B a cca eorticata, calyeis limbo coronata, quadrilocnlaris. Semina plura, in pulpa carnosa nidulantia. E ubryo exalbuminosus; cotyledonibns $\mathrm{ctm}$ ra. dicula in massam homogeneam, earnogam conlitis. - Herbae $v$. arbores, in Asia tropica crescentes; folits alternis, exstipulatis, versus apices ramorum approximatis, breve petiolatis, cuneatoobovatis, erenulatis v. serratis, epunctatis, floribus spicatis, sessilibus $v$. pedunculatis, subeorymbosis, rubris $v$. luteo-virentibus.

Carey a Roxburgh Corom. III, 13. t, 217. 218, DC. Prodr. III. 295, exel, sp. Bamilton in Limn. Transact, $X V$. 
97. Wight et Arnott Prodr. I. 334. C a m b e a Hamiltou Mry sore IIT. 187.

B39\%. Custavia LINN. C a 1 y $x$ tubo turbinato, cum ovario connato, limbo supero, in tegerrimo v. quadri-sex-octolobo. Corolla e petala $4-8$, calycis fauci inserta, ejusdem lacinits alterna, ovata, subaequalia. Stamina plurima; filamenta filiformia, basi monadelpha, ungui bus petalorum subadnata, a n therae biloculares, oblongo-lineares, erectae. Ovari um inferum, quadri sexloculare, locolis multiovulatis. St y las brevis; stigma obtusum, suleatum. C a psula coriacea, ovata v. subglobosa, calycis cieatrice notata, tri-sexlocularis, evalvis. Semina in quo. vis loculo pauca, ovata, membrana coriacea vestita, e funieulo Iongo, plicato, columnae centrali af fixo suspensa. Embryon is exalbuminosi, carnosi cotyled o nes magnae, subaequales, extus convexae, intus planae, radicula brevissima, ob. tusa. - Arbores A mericae tropicae; folits alternis, exstipulatis, magnis, impunctatis, integerrimis $v$. serratis, glabris, racemis terminalibus paucifloris, floribus bibracteolatis, magnis, albis, speciosis.

G ustavia Linn. Amoen. academ. VIII. 266. $t, 5$. Linn. f. Supplem. 5t. Poiteau in Annal. Mus. XrII. IS6. t. 5. 6. 7. DC. Prodr. III. 289. Meisner Gen, 109. (77.) P irig a r a Aublet Guian, I. 487. 2. 192. 193. Kunth in Humb. ot Bonpl. Nov, gen. et sp. VII. 261. S p a Il anza al a Ne. eker Elem. n. 733. Teif hmeyera Scopoli Introduct. n. 1212 .

\section{GENERA DUBIA.}

6328. Foetidia COMMERS. Caly $\mathrm{x}$ tubo tetragono-hemisphaerico, cum ovario connato, limbi quadripartiti lobis persistentibus, demum reflexis. Corulla nulla. $\mathrm{Sta}$ in a plurima, disci epigyni, tetragoni margini inserta; filamenta eapillaria, libera, a n therae biloculares, ovatae, dorso insertae, longitudinaliter dehiscentes. 0 vari u $\mathrm{m}$ inferum, quadriloculare ..... Stylus filiformis; stigma quadrifidum. B acca exsucca, tetragona, vertice plana, subnucamentacea, quadrilocularis, loculis mono-dispermis. - Arbor ma $u$ ritiana; foliis alternis, exstipulatis, in ramulis confertis, sessilibus, ovalibus, utrinque attenuatis, obtusis, integerrimis, glabris, epunstutis, pedunculis in superiorum foliorum axillis solitariis, unifloris.

Foetidia Cowmers, in Jussieu Gen. 325. Lam. Dict. II. 457, t. 419. DC, Prodr, IIT. 295. Meisuer Gen, 109. (77.)

6383. Catingra $A U B L$. F 1 o r e s ..... Dru p a v. ba cea globosa aut ovata, calycis limbo quadripartito coronata, cortice carnoso, vesi culis oleo aromatico foetis punctato, nnilocularis, monosperma. - Arbores guianenses; folits oppositis v. subalternis, ovalibus, utrinque acuminatis, integerrimis, pellucido-punctatis.

Cating a Aublet Guian. I. 511. t, 203. Jussieu Gen. 325. DC. Prodr, 1IT, 294. Meisner Gen, 109. (77.)

8330. Compoui $A U B L$. F lo res ..... B a c c a ovata, caly cis limbo quinquepartito coronata, uniloeularis, monosperma. S e m e n magnum. - Arbor guianensis, procera; foliis alternis, versus ramulorum apices confertis, longe petiolatis, obovatis, acutis, basi cordatis, glabris.

Co u p o i A Aublet Guian, Suppl, 16, t, 377, DC, Prodr IIT. 295. Meisner Gen. 109. (77.)

OBSERVATI0. M ongesi a Flor. Flum. $V_{0} t, 105.106$. flore Eugeniae, foliis oppositis, serratis, ex icone nimis rudi collocari nequit,
SUROERD V. LECYTHIDEAE Richard ex Poiteau in Mem. Mus. XIII. 141. S ta mina plurima, in urceolum hinc abbreviatum, illine in ligulam petaloideam, sterilem v. antheriferam productum coalita. 0 varium plurilnculare, loculis multiovulatis. F r uetus siccus v. carnosus, indehiscens $v$. disco epigyno operculatim secedente apertus. - Arbores A m e r ica e cropicae, foliis alternis, epunctatis, integerrimis $v$. rarius serratis, stipulis nullis $v$. caducis.

833 1. Couratari $A U B L$. Calyx tubo turbinato, cum ovario connato, limbi superi, sexlobi lobis subaequalibus, deciduis. Curulla e petala 6, disei epigyni pulviniformis margini inserta, calycis lobis aiterna, subaequalia, basi inter se et cum urceolo staminifero coalita. Ureeolus staminifer cum petalis insertus, hine brevissimus, illine in ligulam petaloideam, eucullatam, apice dilatatam, papillis lamellisque obsitam, in stylum incumbentem productus. S $\mathrm{ta}$ in a fertilia e hasi urceoli pluriseriata; fila menta brevia, anthe$r$ a e biloculares, dorso insertae, longitudinaliter dehiscentes. Ovarium inferum, triloculare, loculis multiovulatis. Stylus brevis; $s \mathrm{tigma}$ simplex. C a p 8 u la coriaceo - sublignusa, oblonga, subtrigona, limbi calycini cicatrice notata, disco epigyno pulviniformi teeta, septis evanidis unilocularis, colnmna centrali triquetra, libera, in discum continua, et cum illo operculatim secedente. Semina plurima, in fundo capsulae in acervos tres digesta, erecta, lanceolata, foliaceo-compressa. Embry on is exalbuminosi, membrana pro. pria tecti, conduplicati cot y 1 ed on es foliaceae, radiculae crassissimae incumbentes. - Arbores Americae tropicae; foliis alternis, exstipulatis, epunctatis, integerrimis, racemis axillaribus terminalibusque, pauci-multifloris, bracteatis, pedicellis brevibus, bibracteolatis.

Co u r a ta ri Aublet Guian, 11. 723. $t$, 290. A. Riehard in Annal. sc. nat, I. 329. t. 21. Poiteau in Mem. Mus, XIIT. 159. t. 8. Raddi Plant. Brasil. Addend. 25. f 2. DC. Prodr. III. 294. Cambessed. in St. Hilaire Flor, Brasil. II. 379. t. 159. Meisner Gen. 109. (78) Le c y th o p s is Schrank in Münchner Denkschrift. VII. 24t.

633:. Leeytluis LÖFFL, C a ly $x$ tubo turbinato, cum ovario connato, limbi superi, sexpartiti lobis subaequalihus, deciduis. Corolla e petala 6, disci epigyni pulviniformis margini inserta, calycis lobis alterna, subaequalia, basi inter se et cum staminum urceolo coalita. Ureeolns staminifer cum petalis insertus, hine brevissimus, illine in ligulam petaloideam, cucullatam, apice dilatatam, papillis v. Lamellis imbricatis obsitam, in stylum incumbentem productus. S t a min a fertilia e basi nrceoli pluriseriata; filamenta brevia, a ntherae biloculares, dorso insertae, longitudinaliter dehiscentes. O varium inferum, biquadri-sexloculare, loculis plnriovulatis. Stylus brevis; stigma simplex. Ca p 8 u la coriacea v. lignosa, limbi calycini cicatrice notata, bi-sexlocnlaris, disco epigyno operculatim secedente aperts. Semina in loeulis panca v. solitaria, columnae centralis basi affixa, ovata v. oblonga, membrana carnosa tecta. Embryo massa carnosa, homogenea. - Arbores $v$. frutices Americae tropicae; foliis alternis, exstipulatis, epunctatis, integerrimis $v$. serratis, racemis axillaribus et termina- 
libus bracteatis, interdum ramosis, floribus pedicellatis, bibracteatis.

Le c y th is Lötfling It. 189. Linn. Gen, n, 664. Jacq. Amer. t. 109. Aublet Guian, t. 283_289. Lam. t. 476. Poitean in Mem. Mus. XIII. 143.t, 2. 3. 7. Kunth in Humb. et Bonpl. Synops. III. 424. DC. Prodr. IIT. 290. Canbessedes in St. Hilaire Flor. Brasill. II. 377, t. 158. Meisner Gen, 109. 128.) (De germiaatione efr. Theuars Ess. III. 32. c. ic.) - E s e hweile ra Mart. ex DC. Prodr. $I I I$, 293., genus a me nunquam visum, calycis limbo retroverso et tubo applicato, plus minus adnato, a Lecythide diferre dieitur.

6333. BBertholletia $H U M B$, et $B O N P L$. Caly x tubo subgloboso, cum ovario connato limbo supero, bipartito, deciduo. Corollae petala 6, disci epigyni pulviniformis margini inserta, subaequalia, ima basi inter se et cum staminum urcenlo coalita. Urceol as staminifer cum petalis insertus, hine brevissimus, illine in ligulam peta loideam, cncullatam, apice dilatatam, lamellis imbricatis obsitam, in stylum incumbentem productus. St a m i na fertilia e basi urceoli pluriseriata; filamenta brevia, clavata, antherae terminales, biloculares, ovatae, longitudinaliter dehiscentes. Ovarinm inferum, quadriloculare, loculis quadriovulatis, ovulis loculorum angulo centrali per paria superposite insertis. Stylus subulatus, incurvas; stigma simplex. Capsula subglobosa, lignosa, intus carnosa, septis evanidis unilocularis, columna centrali libera, disco epigyno parvo, papilloso, operculatim secedente aperta. Semina 16-20, columnae centrali affi$x a$, erecta, triangularia, dorso convexa, testa ossea, rugosa. Em bryo massa carnosa, homogenea. - Arbor Americae tropicae, celsissima; ramis alternis, junioribus apice foliosis, foliis al. ternis, exstipulatis, magnis, oblongis, integerrimis, epunctatis, coriaceis, floribus spicato-racemosis', ochroleucis, fructibusque magnis.

Bertbolletia Humb. et Bonpl. Plant. aequinoct. $r$. 128. $t$. 36. Kunth Nov, gen, ot sp. VII. 260, Poiteau in Mem. Mus. XIII, 148, t. 4. et 8. DC. Prodr. MII. 293. Meisn. Gen, 109. (78.) T o u c a Richard Anal, fr. 84.

633 4. Connoupita $A U B L$. $\mathrm{C}$ al y $\mathrm{x}$ tubo turbinato, cum ovaris basi connato, limbi superi, gexpartiti lobis subaequalibus, deciduis. Cor olI a e petala 6 , disci, ovarii vertieem exsertum eingentisimo margini inserta, calycis lobis alterna, subaequalia. Ur ce oIns staminifer cum petalis insertus, hine brevissimus, illine in ligulam petaloideam, cucullatam, antheriferam, in stylum incumbentem productus. St a m in a e hasi urceoli minuta, effoeta, ex apice ligulae fertilia; filam enta brevia, anther a biloculares, longitudinaliter dehiscentes. Ovarium inferum, sexloculare; ovulis in placentis e loculornm angulo centrali prominentibus plnrimis. Stig m a sessile, stellatum, hexagonum. C a p s u la globosa, crustacea, limbi calycini delapsi cicatrice annulata, evalvis, sarcocarpio carnuso, demum deliquescente, endocarpio tunc intra epicarpium libero, volubili. Sem in a plurima, in pulpa nidulantia, ovata, membrana coriacea, funiculata, \{villosa, hine fissa terta. E m b r y o$n$ is exalbuminosi, subrotundi, involuti, compressi cotyled on es magnae, foliaceae, nervosae, plicatae, currugatae, sub radicula clavaeformi curvatae. - Arbores Americae tropicae; foliis alternis, exstipulatis, petiolatis, oblongo-cuneatis, subcrenulatis, stipulis parvis, cadueis, racemis simplicibus, trunco ramisque innascentibus, bracteatis, floribus amplis, sordide ablentibus $v$. incurnatis, bibracteolatis.
Co uroupita Anblet Guian. IT. 708, t. 282. Tussae Flor, Antill, II, 45, t, 10. 11. Poiteau in Mem. Mus, XIII. 132. Turpin Atlas IT. 2. DC. Prodr. III. 293. Meisner Gen. 109. (78.) Pontoppidana Scopoli Introduct. 4. 849. Is holtz ia Riehard msc.

\section{GENERA PENITUS DUBIA.}

B335. Crias $L I N N$. C a I y tubo cum orario connato, limbo supero, parvo, quadrifido, obtuso, persistente. Corolla e petala 4 , coriacea, S t a m ina plurima, disco quadrato inserta; filamenta basi serie quintuplici connata, interiora brevissima, a $\mathbf{t} \mathbf{h}$ e $\mathbf{r}$ a reniformes, minimae. Ovarium inferum ....Stigma sessile, cruciatum, staminibus incurvis reconditum. D rup a ovata, octosulcata, calyce coronata, nucleo oblongo. - Arbor jamaicensis, subalpina, excelsa, vix ramosa; foliis breviter petiolatis, longissimis, oblongis, basi cuneatis, integerrimis, pedunculis brevibus, multifloris, fioribus magnis, albis.

Gria s Linn. Gen, n, 659. Swartz Observ, 215. Smith in Rees Cyolop-15. DC. Prodr. III. 296.

B336. Crossontylis FORST. C a $1 \mathrm{y} x$ tubo turbinato, tetragono, cnm ovarii basi connato, limbi quadripartiti laciniis ovatis, acutis, persistentibus. Corolla e petala 4 , inter calycis lacinias inserta, iisdem aequilonga, elliptica, breviter unguiculata. Stamina circiter 20 , cum petalis inserta, basi in urceolum, interjectis filis brevibns, ciliatis coalita; fil a menta superne libera, filiformia, antherae parvae, subrotundae. Ovari n m semisuperum. Sty lus cylindricns, staminum longitudine; tigma cruciatim quadrilobum, lobis patentissimis, trifidis. B a c ea semisupera, hemisphaerica, multistriata, unilocularis. Semin a plura, suloglobosa, circa receptaculum centrale, colnmnare collocata. - Arbor taitensis; ramis patentibus, teretibus, scabriusculis, articulat is, foliis oppositis, petiolatis, integerrimis, glabris, lucidis, petiolis laevibus, semiteretibus, pedunculis axillaribus, pedicellis aggregato subumbellatis, medio articulatis, unifforis, floribus viridibus, semipollicaribus.

C ros sostylis Forster Char. gen, t, 46. el Msc. ex Guillem. in Nouv. Annal, sc. nat. VII, 359. DC. Prodr. III. 296. Meisuer Gen. 107, 126.

6338. IPetalotoma $D C$. Calyx tubo campanulato, limbi octofidi laciniis aentis. C orolla e petala $6-8$, ungue filiformi, limbo subrotondo, inciso. Dise us earnusus, crenatus. Stamina 10, disco (?) inserta; antherae subrotundae. Stylus filiformis; s tig ma quadri-quinquefidum, fobis ovatis, solutis, patentibus. Ba cca subrotunda, ealycis limbo coronata, monosperma. - Arbor cochinchinensis; ramis brachiatis; foliis oppositis, ovatis, glabris, integerrimis, racemis brevibus, subterminalibus, floribus croceis.

Petal o to m a DC. Prodr. III. 294. MeisnerGen, 107. (77.) Di ato m a Loureiro Flor. cochinoh. I. 362.

6383. Fe thodammia $J A C K$. C a 1 y $x$ tnbo cum ovario connato, limbo supero, quadrilobo. Coro 11 a e petala 4, calycis lobis duplo longiora. St a min a plurima, petala aequantia. O va r i um inferum, uniloculare, placentis parietalibns duabus, plariovulatis. St y 1 u ansimplex, rectus. B a c ca subglobosa, unilocularis, oligosperma. Se mina parietalia. - Arbuscula sumatrana; foliis oppositis et alternis, breve petiolatis, subtriplinerviis, integerrumis, stipulis linearibus, minutis, pedunculis axillaribus, brevibus, unifloris.

Rhodamnia Jack ex Hooker Bot. Miscell. Comp. I, 153, Meisuer Gen, 107, (76) 


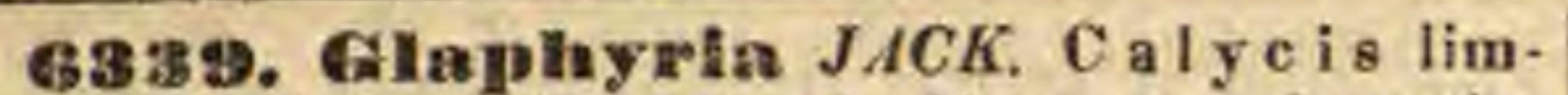
hus quinquelobus. Petala 5 . B a c e a quinqueloenlaris, polssperua. Semina in quovis loculo axi biseriatim inserta. - Arbusculae indicae; foliis alternis, minutis, stipulatis, pedunculis axillaribus, paucifloris.

G la ph y ria Jack in Linn. Transact. XIV. 295. DC. Prodr. III. 29 Meisner Gen. 109. (77.)

\section{MYRTACEIS AFFINES.}

\section{* GRANATEAE.}

6344. Fumiea TOURNEF. C a Iy x coloratus, coriaceo-subcarnosus, tubo turbinato, inferne cum ovario connato, supra ovarium ampliato, quinque-septemfido, lobis aestivatione valvatis. Corolla e petala $5-7$, calycis fauci inserta, ejusdem laciniis alterna, elliptico-lanceolata, aestivatione imbricata. Stam in a plurima, calycis tubo moltiseriatim inserta, inclusa; filam enta filiformia, libera, anthera e introrsae, biloculares, ovatae, dorso supra basim insertae, Innyitudinaliter dehiscentes. Ovarium inferum, e carpidiis biseriatim superpositis, seriei inferioris quinque vel novem anguli centralis basi, superioris tribus versus parietem placentiferis, compositum, loculis multiovulatis. St y l u g filiformis, simplex; stigma eapitatum. Ba c c a sphaerica, coriacensubearnosa, calyeis limbo coronata, multilocularis, loeulis biseriatim superpositis, dissepimentis membranaceis sejunctis. Semina plurima, pulpa snc. cosa, pellurida inclusa. Embry o n is exalbuminosi, urthotropi cotyled ones foliaceae, spiraIiter convolutae, $r$ a di $\mathrm{e}$ u a oblonga, brevis, acuta. - Arbuscula, in Mauritania indigena, florum decore nobilis, et ab frutuum saporem mortalibus gruta, $a b$ iisdem nunc per Europam a $u \& \ell$ rale $m$ et regiones tropicas totius orbis propagata, ramulis spinescentibus armata; foliis oppositis, verticillatis $v$. sparsis, saepe in axillis fasciculatis, integerrimis, impunctalis, glabris, stipulis nullis, floribus ramulos terminantibus subaggregatis, totis coccineis.

$\mathrm{P}$ u u i c a Tournef. Inst. 401. Linn. Gen, n, 618, Gärtner I. 183, t. 38. Sehkuhr $t$, 31. Poit, et Turp. Arb. frut. 22. Bot. Mag, t. 634. 1832. Nees in N, A. N.C. XT. 410.t. 1t. B. Don in Edinb. new philosoph. Journ I.134. DC. Prodr. III.3. Wight et Aruott Prodr. I, 327. Meisner Gen, 107. (75.)

\section{Classis $\mathbf{I X I . ~ B e s i f l o r a e . ~}$}

Herbae, frutices v. arbores. Folia sparsa v. rarius oppesita, simplicia v. saepius composita. Stipulae saepissime petiolo adhaerentes, rarissime nullae. F l ores regulares. C a lyx liber v, rarius cum ovario connatus, laciniis aestivatione imbricatis. Coro1lae perigynae petala libera. Stamina indefinita v. rarissime subdefinita. Ovari a plura, rarissime solitaria, libera $v$. inter se ant cum calyce coalita, uni-multiovulata. Fructus nucamentaceus, drupaceus, baccatus v. rarius follicularis, mono-polyspernus. Semina exalbuminosa. E m b ry o orthotropus.

\section{Dralo CCLXX. Pomacene.}

ROSACEARUM tribus I. POMACRAE Jassiea Gen, 334. DC, Prodr. II, 626. POMACEAE Lindley in Limn, Trans. act. XIIT, 93, Battling Ord nat, 399. ROSACEARUM sub. ordo POMbAE Lindley Introduct. edit. II. p. 145.

Arbones v. fretices, inermes v, ramulis minoribus spinescentibus armati. Folia alterna, petiolata, nune simplicia, integra, pinnatiloba v. palmatiloba, nunc composita, imparipinnata, saepissine serrata. Stipulae ad basim petiolorum geminae, liberae, plerumque caducae.

Flores hermaphroditi v. interdum aborta unisexuales, racemosi, corymbosi v. subumbellati, rarius eymosi v. solitarii, albi v, rubri.

Calyx tubo cum ovario connato, limbo supero, quinquepartito, laciniis per aestivationem imbricatis, marcescenti-persistentibus v. deciduis.

Corollar petala quinque, calycis fauci, satpissime tori annulo carnoso marginatae iuserta, ejusdem laciniis alterna, inter se aequalia, aestivatione imbricata, decidua v. rarissime persistentia, interdum nulla.

Stranina cum petalis inserta, multiplo eorundem numero subdefinita. Filamen $\mathbf{a}$ a filiformia v. subulata, libera. An therae introrsae, biloculares, longitudinaliter dehiscentes.

Ovaria e carpidiis quinque, nune tribus v. duobus, rarissime unico, cum calycis tubo et inter se plus minus connatis uni-bi-tri-quinqueloculare, axi centrali nullo, vertice toro tecta v. nuda. Ovula in loculis plerumque gemina, collateraliter adscendentia, anatropa, rarissime solitaria v. plurima. St y li loculorum numero, simplices, liberi v. basi plus minus coaliti. Stigmata simplicia.

Frucrus baccatus, calycis limbo coronatus, intra carnem tubo calycino vestitam pericarpium proprium eartilagineum, sutura centrali dehiscens, v. osseum, indehiscens includens, loculis abortu saepissime monospermis.

Semina adscendentia, testa coriacea v. cartilaginea, rhaphe ad chalazam apicalem producta percursa, endopleura membranacea. A Jb umen nullum.

EnвRyonis orthotropi cotyledones carnosae, plano-convexae v. rarissime convolutae, germinatione foliaceae. $\mathbf{R}$ adi cula brevis, conica, infera.

Pomaceae in temperatis hemisphaerae borealis obviae, et passim ob fructus edules sapidos cultae, a reliquis Rosifloris ovariorum cum calycis tubo cohaesione diversae, easdem Myrtaceis nectunt.

B34 1. Cyalomia TOURNEF, C a Iy x tuho campanalato, enu ovario connato, limbi quinquepartiti lobis foliaceis. Co rolla e petala 5 , ealyeis fanci inserta, ejusdem laciniis aiterna, orhisulata. St a mina plurima, cum petalis inserta; filamenta filiformi-subniata, antherae subrotundae, biloculares, incuıbentes, longitudinaliter de- 
hiscentes. Ovarin m inferum, quinqueloculare, loculis mnltiovulatis, ov ulis adscendentibus, anatropis. Sty li 5. Po m um quinqueloculare, loculis polyspermis, endocarpio cartilagineo. S e min a adscendentia, testa mneilaginosa. Embryonis exalbuminosi, orthotropi co ty led on es convexaplanae, radic ula infera. - Frulices $v$, arbusculae, in Europa media et Asia maxime oriental $i$ crescentes; foliis alternis, integerrimis $v$. serratis, subtus saepe lunalo-tomentosis, bistipulatis, floribus solitariis $v$. paucis subumbellatis, conspicuis.

C y d o n i a Tournefort Inst. 632, $t$. 405. Persoon Encheir. IT. 40. Thouin in Annal. Mius. IX, t. 8. 9. DC, Prodr. 1I, 638, Meisner Gen, 106. (75.) C yd o n i a et Chate no me les Lindley in Linn. Transaot. XIII, 97, coll. Bot. Reg. n, 905. P y $\mathrm{r}$ i s p. Liun. Tbuub. Jacq. Flor, austr. $t, 342$, Bot. Reg, $t, 692$,

634\%. Prus $L I N D L$. C aly x tubo urceolato, cum ovario connato, limbo supero, quinquedentato. Corolla e petala 5 , calycis fanci inserta, ejusdem laciniis alterna, suborbiculata. Stamina plurima, cum petalis inserta; filamenta filiformi-subulata, antherae subrotundae, biloenlares, longitudinaliter dehiscentes. Ovarium inferum, quinqueloeulare, rarius bi-triloculare, loculis biovulatis, ovulis collateralibus, adscendentibus, anatropis. Sty $1 \mathrm{i} 5$, distincti v. basi coaliti. $P o \mathbf{m} \mathbf{m}$ quinqueloculare, rarius bi-triloculare, loculis dispermis, endocarpio cartilagineo. S e m in a collateralia, erecta, testa cartilaginea. E mbryonis exalbuminosi, orthotropi cotyledon e 8 convexo-planae, rad i $\mathrm{cula}$ infera. - Arbores, arbusculae $v$. frutices; folits alternis, simplicibus $v$. pinnatis, serratis, bistipulalis, cymis terminalibus, patentibus, multifloris, bracteis subulatis, deciduis.

Py rus Lindley in Linn, Transact, XIII.92, DC. Prodr. II. 633. Meisner Gen. 106. (75) P y r a s, M a lus et $\mathrm{S}$ or. bus Tournef. Inst. 404. 406. Py rus et S a rbus Lina. Gen, n. 626. 623. Pyrophorum et Apyrophorum Necker Elem. n. 221. et 722. Laz a rolus, H a Imia et A ucuparia Medikus. Aroniae sp. Pers.

a. PYROPHORUM DC. l.e. Petala patentia, plana. Sty I i 5. omnino liberi. P o m u m clavatum, turbinatuar v. subglobosum, basi haui umbilicatum. - Folia simpli. cia, eglandulosa. Pedicelli simplices, umbellati. P y. ru \& Touruef. l. c. (Jacq. Flor, austr. $t .107$, Gărner t. 87. f. 2. Duhau. Arbr, edit, nov, VI, t, 57. Pallas Flor. Ross. I. t. 9. Wallich Plant, As, rar. t. 173, 189. Bot. Reg. L. 1154. 1207, 1248.

b. MALUS DC. $l$. c. Petala patentia plana. Styll 5 , basi subcoaliti. P o m u m saepius globoso-depressum, basi unbilicatum. - Folia simplicia, eglandulosa. Pe. dicelli simplices, umbellati. $\mathrm{M}$ alus Tournet, $l, c$. (FInr, dall, $t$, 110i. Miller Ic. $t, 269$. Pallas Flor. ross. I. $t, 10$, Bot. Mag, t. 207.)

c. ARIA DC. l. c. Petala patentia, plana. Styli saepius 2-3. liberi. Po m a m globosum. - Folia simpli. cia, eglandulosa, subtus albo.tomentosa. Flores race. moso-corymbosi, pedunculis ramosis. - Crataegus A ri a Linu. Flor. dan. t. 302. Duham. Arbr. edit, nov. IV. $\ell .34$.

d. TORMINARIA DC. $l$. c. Petala patentia, plana, subunguieulata. Styli 2-5, basi counexi, glabri. Ponu un basi turbinatum, subexsuccum. calveinis lobis deciduis truncatum. - Folia simplicia, lobato-angulata, adulta glabra. - Flores corymbosi, pedunculis ramo. sis. - Crata e us torninalis Lian. Jacq. Flor. austr. $t$. 443. (Hook. Fl, Ror. Amer. L. 68.)

e. ERiolobus DC. $l$. c. Petal a patentia, plana, subunguiculata, apice subtrideutata. Styli 5, elongati, basibus hirsatissiais subconnexi. P o u u m globosum, glabrum, ealycinis lobis utrinque tomentosis coronatum. - Folia palmatiloba, glabra. Flores corymbosi, pedanculis simplicibus. - Crataegus trilobata Labillard. Plant. Syr. Dec, IV. t. 10.

f. SORBUS DC. l. c. Petala patentia, plaua. Styli 2-5, liberi. P о ш и ü globosam v. turbinatum. - Eolia pin. natisecta $v$. imparipinnata. Flores corymbosi, pedunoulis ramosis. - Sorbus Linn. Gen. n. 693. A ue u. paria Medik. (E. B, 2331. Gärtaer $t$, 87.)

g. ADENORHACHIS DC. $\boldsymbol{l}$. $c$. P et a l a patentia, unguicu-

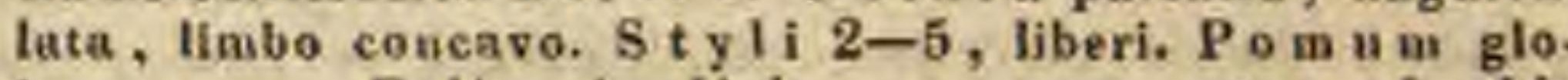
bosum. - Folia simplicia, superne secus rhachin glandulifera. Flores corymbosi, pedunculis ramosis. - Aroniae sp. Pers. Crataegus arbutifolia Linn. $f$.

h. CHAMAEMEspilus DC. $l$. c. P e tala erecta, ennui. ventia, concava. St y 1 i 2 . P o m u m ovataa. - Eolia simplicia, eglandulosa. Flores capitato.corymbosi. Crataegus Chamaemespillas Jacq. Flor, austr. t. 231 .

634. (1) steomeles $L I N D L . C$ a l y x tubo campanulato, eum ovario connato, limbi superi, quinquefidi laciniis lanceolatis, acntis. Coroll a e petala 5 , calyeis fanci inserta, ejusdem laciniis alterna, oblonga, plana, patentia. Stam in a plurima, calycis fauci inserta; filam enta filifurmi-subulata, strieta, antherae subrotundae, biloculares, longitudinaliter dehiscentes. Ovarium inferum, quinqueloculare, loculis uniovulatis, $0 v \mathrm{u} I$ i s $\mathrm{c}$ basi erectis, anatropis. Styli 5, liberi, exserti, infra medium barbati. P om u m ealycis limbo stylisque coronatum, ovatum, lanatum, quinqueloculare, locnlis monospermis, endocarpio osseo. Semina erecta ..... - Frutex sandwicensis; foliis alternis, imparipinnutis, foliolis integerrimis, stipulis geminis, subulatis, floribus subcorymbosis, bracteis sub calyce oppositis, subulatis, deciduis.

Osteomeles Liadley in Linn. Transact. XIII. 98. 6. 8. DC. Prodr. II. 633, Meisner Gen, 106. (74.) P y x u s anthyllidifolia Smith.

6344. Jiespilius LINDL. Caly x tabo turbinato, cum ovario connato, limbi quinquepartiti laciniis foliaceis. Coro 11 a e petala 5 , calycis disco uagno mellifluo inarginati fauci inserta, ejusclem laciniis alterna, suborbiculata. St a min a plurima, cum petalis inserta; fil a m e $\mathbf{t}$ a filiformi-subulata, antherae subrotundae, bilueulares, longitudinaliter dehiscentes. $O$ va $r$ in $m$ inferum, quinqueloculare, loculis biovulatis, ov u li s collateralibus, e basi erectis, anatropis. Sty li 5, distineti, glabri. P vm a m turbinatum, calycis limbo coronatum, vertice areola lata, nuda, quinqueloeulare, loculis abortu monospermis, enduearpio osseo. S e min a erecta, testa membranacea. Lmbryonis exalbuminosi, orthotropi cotyledones convexo-planae, $r a-$ dic ula infera. - Arbusculae in Europa media et boreali abviae, sylvestres spinosae, circuratae inermes; foliis alternis, simplicibus, lanceolatis, serrulatis, bistipulatis, floribus magnis, subsessilibus, subsolitariis, bracteis persistentibus.

Mespilus Lindley in Linn. Transact. XIIT, 99. DC. Prodr. II, 633. Meisuer Gen, 106. (75.) Mespilus ge Tm a niea Linn. Gärtu, t. 87, f. 1. Duham, Arbr, T, t. 3. Pallas Flor. ross. I. $t, 13, f, 1$. Me s pillo p bor a Necker Elem. n, 724.

6345. Amelamehier MEDIK, Calyx tubo turbinato, cum ovario connato, limbo supero, quinquedentato. Coroll a e petala 5 , calycis fauci inserta, ejusdem dentibus alterna, lanceolata. Stau in a plurima, cam petalis inserta, iisdem subbreviora; fil amenta filiformi-subulata, an the ra e ovatae, biloculares, longitudinaliter dehiscentes. O va ri n m inferum, tri-quinqueloculare, loculis semisepto parietali bipartitis, incomplete sexdecemlocellatum, Jocellis uninvulatis, ovnlis e basi erectis, anatropis. Styli $3_{-} 5$, ima basi enaliti. P o m nu calyeis limbo coronatem, tri-quinquelocnlare, loculis abortu monospermis, endocarpio osseo. Semina erecta, testa membranacea. 
Embryonis exalbuminosi, orthotropi cotyledone convexo-planae, radie nla infera. - Arbusculae in Europa media et australi, nec non in America boreali et Japonia indigenae; foliis alternis, simplicibus, serratis, bistipulatis, floribus racemosis, albis, bracteis linearilanceolatis, deciduis.

A mela uchier Medikus Pflanz. Geschl, 1793. Mönch Method. 682. Liadley in Linn. Transact, XIIT. 100. Bot. Reg. 117 1. 1589. DC. Prodr. II. 632. Meisner Gen, 106. (75.) Torrey et A. Gray Flor. of North-Amer, 1.473 Petro meles Jacq. f. msc. A ronia Persoon Encheir. II, 42. exel. sp. Nuttall Gen. I. 306. Siebold et Zuccarini Elor. Ja. pon. t. 42. Mespili s p. Lina. Jacq. Flor, austr, t. 300.

834. P. Peraplaylluma NUTT. C aly x tubo urceolato, cum ovario connato, limbo supero, quinquelobo. Co ro 11 a e petala 5 , calycis fanci inserta, ejusdem laciniis alterna, late obovata, unguiculata. S $t$ a m in a 20 , cum petalis inserta, exserta ...... Ovarin m inferum, bi-triloculare, loculis semisepto parietali bipartitis incomplete quadrisexlocellatum, locellis uniovulatis, o v u 1 is e basi erectis, anatropis. Sty li $2 \ldots 3$, ima basi coaliti. P o m n m calycis limbo coronatum, fere siccum, carpidia 2 v. 3, omnino libera, incomplete bilocellata, cartilaginea, disperma includens. S e m i n a erecta, angulata, compressa, testa cartilaginea. $\mathbf{E} \mathbf{m}$ bryonis exalbuminosi radicula infera. - Frutex boreali-americanus, ramosissimus; ramis tortuosis, foliorum delapsorum cicatricibus annulatis, inermibus, foliis in apice ramulorum aggregatim alternis, linearibus, acutis, obsolete serrulatis, subtus pubescentibus, stipulis nullis, corymbis bi-quadrifloris.

Peraphyllum Nuttall in Torrey et A. Grag Flor. of North-Amer. 1.474 .

63.4\%. Cotoneaster MEDIK. C a ly x tubo turbinatu, cum ovario connato, limbo supero, quinquedentato. Corolla e petala 5 , calycis fanci inserta, ejusdem laciniis alterna, "vata, erecta. St aIn i n a $20-50$, calycis fauci inserta, ejusdem limbum aequantia; filam enta subulata, antherae ovatae, biloculares, longitudinaliter dehiscentes, $0 \mathrm{va}$ ria $2-5$, dorso cum calycis tubo coalita, inter se distineta, biovulata, o vulis collateralibus, e basi erectis, anatropis. St y li $2-5$, P yrenae $2-5$, eaiycis tubo inclusae, dorso eidem adnatae, inter se distinctae, epicarpio parce carnoso, endocarpio osseo, abortu monospermo. S e $\mathrm{m}$ in a erecta, testa nembranacea. E m b r y o $n$ is exalbuminosi, orthotropi cutyledones convexo-planae, radicula infera. - Frutices in Europa media et australi, nec non in Nepalia crescentes; foliis alternis, simplicibus, integerrimis, subtus lanatis, corymbis lateralibus patentibus, bracteis subulatis, deciduis, petalis parvis, persistentibus.

Cotone as ter Medikas Pflang. Geschl. 1793, Lindley in Linn. Transact, XIII. 101. t. 9. Bot. Reg. t. 114. 1187. 1299. 1305. DC. Prodr. II. 632. Ledebour Ic. $t$. 269, 274. Meisner Gen, 106. (75,). Mespill sp. Linn. Flor. dan. t. 112.

6348. Hesperomeles LINDL. Cal y x tubo brevi, cum ovario connato, limbo supero, patentissimo, rigido, quinquedentato. Co roll a e petala 5 , calycis fauei inserta, ejusdem laciniis alterna et longiora, concava. Stamina 20 , cum petalis inserta, calycis limbo breviora; fil a m en ta subulata, an $\mathbf{t}$ erae ovatae, biloculares, Jongitudinaliter dehiseentes. Ovaria 5 , dorso cum calyeis tubo coalita, inter se libera, nniovulata, $0 \vee \mathrm{u} \perp 0$ eresto, anatropo. Styli 5 , distincti. Fruetus ..... - Frutices peruani, inermes v. ramulis spinescentibus armati; foliis alternis, simplicibus, cordatis $v$. oblongis, serratis, subtus lanuginosis, sive cuneatis, apice trilobis, utrinque glaberrimis, floribus corymbosis.

Hesperomele s Lindley in Bot, Reg. n. 1956. Erio. botryae sp. Liadl. DC. Mespili sp. Ruiz et Pav.

6349. Eriobotrya LINDL. Caly x tubo campanulato, lanato, cum ovario connato, limbo su. pero, quinquedentato. Co rol I a e petala 5 , calyeis fauci inserta, ejusdem laciniis alterna, ovato-oblonga, intus barbuta. S ta m in a $20-40$, cum petalis inserta, calycis limbo breviora; fil am en ta subulata, a nth erae ovatae, biloculares, longitudinaliter dehiscentes. Ova rium inferum, quinqueloculare, loculis biovulatis, ov nlis collateralibus, e basi erectis, anatropis. Styli 5 . Po m n m ealycis limbo coronatum, quinque-va abortu triloculare, loculis monospermis, endocarpio cartilagineo. S emina erecta, testa cum endocarpio confusa. E m b ry onis exalbuminosi, orthotropi, subglobosi cotyledones hemisphaericae, radicula brevissima, inter cotyledones retracta, infera. - $\mathrm{Ar}$ busculae chinenses et nepalenses; ramulis tomentosis, foliis alternis, bistipulatis, crasse coriaceis, serratis, subtus racemisque terminalibus compositis lanatis, bracteis subulatis, deciduis.

Eriobotry a Lindley in Linn. Transact. XITI. 109. excl. sp. americ, DC. Prodr. 1I, 631. Meisu. Gen, 106. (75,) Mespilus japonica Thunb. Vent. Malm $t$. 19. Bot. Reg. $t .368$. Dekin Annal. 8en, sc. phys. $11,368, t, 32$.

9350. Plactínia LINDL. C alyx tubo campanulato, cum osario connato, limbo semisupero, quinquedentato. Corolla e petala 5, calycis fauci inserta, ejusdem laciniis alterna, reflexa, Stam in a circiter 20 , cam petalis inserta; fila m e nt a filiformi-subulata, a n the ra e ovatae, biloculares, longitudinaliter dehiscentes. Ovarium semisuperum, biloculare, septo completo v. in axi hiante, loculis biovulatis, ov u lis collateralibus, e basi erectis, anatropis. Styli 2, Fruetuy calyce carnoso inclusus, bilocularis, loculis monospermis, endocarpio chartaceo. Semina erecta, testa cartilaginea. $\mathrm{Em}$ l $\mathrm{r}$ yo...... Arbores in Asia tropica et in California observatae; foliis alternis, simplicibus, coriaceis, sempervirentibus, integerrimis v. serratis, paniculis terminalibus, corymbosis, fructibus parvis, glabris.

Photinia Lindiey in Linn. Transact, XIII. 103. DC, Prodr II. 631. Meisner Gen, 106. (65.)

a. EUPHOTINIA Lindl. in Bot, Heg, n, 1956. O var $1 \mathrm{~nm}$ cuarpleie biloculare. Crata $\mathrm{eg} I$ s p. Thuab. Bot. Mag. t. 2105. (Bot. Reg. t. 491.)

b. MYRIOMAla Lindl. in Bot, Reg. n. 1956. Ovarium semibiloculare. P y $r$ us integerrima Wall.

6351. Chamaemeles LINDL, C a l y $\mathrm{x}$ tubo turbinato, eum ovario connato, limbo supero, amplo, truneato, remote quinquedentato. Corolla e petala 5, calycis fauci inserta, ejusdem dentibus alterna, ovata, breviter unguiculata, eroso-denticulata. Stamin a $10 \_15$, cum petalis inserta, iisdem breviora; filamenta filiformi-subulata, antherae ovatae, biloculares, longitudinaliter dehiscentes. Ovarium inferum, nniloculare, biovulatum, ovulis geminis, e basi erectis, anatropis. Stylus simplex; stigma emarginatum. Fructus ...... Cotyledones convolutae. - Frutex maderensis; foliis allernis, simplicibus, coriaceis, obovatis obsolete crenatis, nitidis, stipulis deciduis, racemis axillaribus, folium aequantibus, bracteatis.

$\mathrm{C}$ h a $\mathrm{m}$ a e meles Lindley in Linn. Transact, XIII. 104. t. 11. DC. Prodr, II, 631. Meisuer Gen, 106. (74.) 
6352. Thaphiolepis $L I N D L$. C a $I \mathrm{y} x$ tubo infundibuliformi, cum ovario connato, limbo supero, quinquepartito, deciduo, laciniis subulatis. Coroll a e petala 5, calycis fauei inserta, ejusdem laciniis alterna, lanceolata, patentia. St amin a 20 , cum petalis inserta, calycis limbo breviora; filament a filiformi-subulata, an the ra e ovatae, biloculares, longitudinaliter dehiscentes. Ovarin m inferum, biloculare, loenlis biovulatis, ovulis collateralibus, e basi erectis, anatropis. Styli 2 , basi coaliti. Pom um globosum, calycis limbo deciduo disco carnoso elansum, biloculare, loculis monospermis, endocarpio chartaceo. S e $\mathrm{m}$ i $\mathrm{n}$ a erecta. Embryonis exalbuminesi, orthotropi cotyledones convexu planae, radical a brevissima, inter cotyledones retracta, infera - Frutices in dic $i$; foliis alternis, sempervirentibus, co. riaceis, reliculatis, crenulatis, stipulis subulatis, $r a$. cemis terminalibus, suepe bracteis squamosis, persistentibus obsitis, petalis albis, filamentis plerumque rubentibus.

$\mathrm{R}$ haphiolepis Lindley in Bot, Reg. $\ell$, 486, coll. $n$, 1956. Collect, t. 3, Linn. Transaet, XIII, 10s, DC. Prodr. II. 630. Meisuer Gen, 106. (75.) Crataegus indica Lian. Bot. Mag. t. 1726.

6353. Cratnegus LINN. C a l y $\mathrm{x}$ tubo urceolato, cum ovario connato, limbo supero, quinque. fido, persistente v. deciduo. Cor oll a e petala 5, calycis fauci inserta, ejesdem laciniis alterna, patentia, orbiculata. S t amina 20 v. plura, cum petalis inserta; filamenta filiformia, antherae ovatae, biloculares, longitndinaliter dehiscentes. Ovarium inferum, bi-quinqueloculare, loculis biovulaits, ovulis e basi erectis, anatropis. Sty1 i 2-5, liberi. Po m a m ovatnm, carnosum, calycis limbo v, disco carnoso clausum, bi-quinqueloculare, locnlis monospermis, putamine ossen. S e min a erecta, testa membranacea. E $\mathrm{mb} \mathbf{r} \mathbf{y}$ on is exalbuminosi, orthotropi cotyled ones convexo planae, radicnla infera. - Frutices spinosi, in Europa, India et America boreali obvii; foliis alternis, subintegerrimis, v, varie lobatis aut incisis, stipulis deciduis, corymbis terminalibus, bracteis subulatis, caducis.

Cratreg us Linn. Gen. n, 623, exel, sp. Jaeq. Flor. austr. t. 292. Lindley in Linn. Transact. XIII. 105. DC. Prodr. 11. 626, Bot. Reg, t, 1128, 1151, 1161, 1810, 1846. 1847. 1858, 1855, 1857. 1860, 1868, 1874. 1884, 1885, 1890. 1897. 1910. 1912. 1933. 1939. 1957. M es pili s p. Auct. Gärtuer $t .87$.

6354. Stranvaesia LINDL. C a 1 y x tubo turbinato, libero, limbo quinquedentato. Corolla e petala 5, calyeis fauci inserta, ejnsdem dentibus alterna, sessilia, oblonga, apice emarginata, concava, basi barbata. St a m in a 20 , cum petalis inserta, patentia, calycis limbo longiora, alterna breviora; filamenta filiformi-subulata, antherae ovatae, biloculares, longitudinaliter dehiscentes, Ovarin m liberum, quinqueleculare, Ioculis biovulatis, ovulis collateralibus, adscen. dentibus, anatropis. Stylus apice quinquefidus; stigmatibus compresso-reniformilius. Capsala intra ealycis tubum limbi dentibus conniventibus clansum ossea, fragilis, quinquelocularis, loculicide quinquevalvis, loculis dispermis, Sem in a collateralia, erecta, compressa, oblonga, testa cartilaginea. E mbryonis exalbuminosi, orthotropi cotyled on es convexo planae, radienla exserta, infera - Arbor n epalensis, sempervirens, glaucescens; foliis alternis, coriaceis, lanceolatis, acutis, serratis, stipulis subulatis, corymbis multifloris, floccoso-villosis, floribus albis, calycibus fructiferis aurantiaceis.

Stranvaesia Lindley in Bot. Reg. t, 1956. Crataegus glauca Wall.

\section{Ordo CCLXXI. Calycantheae.}

ROSACEIS affines Jussieu Gen. 342. Nees in N.A, N. $C$. $X r$. 105. MONIMIACEIS affines Jussieu Annal, Mus, XIV. 119. CALXCANTHEAK Lindley in Bot. Heg. n. 404 . DC. Prodr. III. 1. Bartling Ord, nat. 325. Meisner Gen, 106. (75.) CALYCANTHINAE Link Enumerat. II. 66, CALYCAN. THACEAB Lindley Introduct. edit. II, p. 159.

Frutices aromatici, caule tetragono, axibus lignosis quatuor, axim centralem cingentibus, ramis inermibus. Folia opposita, petiolata, integerrima, scabriuscula. Stipulae nullae.

Flores foliis coaetanei v. praecoces, terminales v. axillares, solitarii v. pedicellati, regulares, hermaphroditi v. saepe steriles.

CaLYx coloratus, subcarnoso-coriaceus, tubo brevi urceolato, limbi laciniis plurimis, multiseriatis, imbricatis, conformibus, v. extimis bracteaeformibus, intimis petaloideis.

Corolna nulla.

Stamina plurima, annulo carnoso, calycis faucem marginanti, et demum claudenti inserta, plurima, extima fertilia, interiora sterilia, persistentia v. decidua, libera v. basi coalita. Fi l a menta brevia, subulata v. filiformia. A ntherae extrorsae, biloculares, ovatae v. oblongae, adnatae, longitudinaliter dehiscentes.

Ovaria plurima, calycis tubo intus undique inserta, libera, unilocularia, ovulo unico, e basi loculi adscendente, anatropo, rarius geminis, altero minimo, efoeto, ex apice loculi pendulo. Styli singulis ovariis singuli, terminales, simplices, exserti, filiformes v. compresso subulati; stigmate indiviso, obtuso terminati.

Acrenua plurima, tubo calycis carnoso inclusa, subossea, monosperma.

Senten unicum, erectum, testa membranacea. Albu men nullum.

Eмввхо rectus. Cotyledones|foliaceae, convolutae. R a dic u la infera.

Calycantheae in America boreali et Japonia spontaneae, Rosaceis affinitate proximae, a Monimiaceis, ovariorum dispositione consimili donatis, albuminis defectu longius recedere creduntur.

6355. Chimonanthus $L I N D L$. C a l y $x$ tnbo brevi, urceolato, limbi lobis pluriserialibus, imbricatis, extimis bracteaeformibus, intimis majorihus petaloideis, omnibus ovatis, obtusis. S tamin a 10, annulo ealyeis faucem marginanti inserta, alterna sterilia, subuliformia, alterna fertilia; fil am ent is filiformibus, basi demum concrescentibus, persistentibus, a ntheris ovato-ollongis, extrursis, bilocularibus, adnatis, longitudinaliter dehiscentibus. Ovaria $6-10$, calycis tubo inser- 
ta, libera, unilocnlaria, o vulo unico, adscendente, anatropo. Styli terminales, filiformes, exserti; stigmata obtusa. A ch enia pauca, calycis tubo carnoso inclusa, subcornea, monosperma. Se in e n adscendens. E mbryon is exalbuminosi, recti cotyledones foliaceae, spiraliter convolutae, radicula infera. - Frutex japonicus; floribus praecocibus, ad annotinorum foliorum axillas solitariis, odoratissimis, foliis oppositis, integerrimis, exstipulatis, cortice et ligno inodoro.

$\mathrm{Chimonanthus} \mathrm{Lindley} \mathrm{in} \mathrm{Bot.} \mathrm{Reg.} t$. 45t. DC. Prodr. IIT. 2. Turpin Atlas II. 3. Meisner Gen. 106. (75,) Meratia Nees in N. A. N, C. XI, 107. $t, 10$. C a I y c an. thus praceox Lins. Aiton Hort. Kew. ed. 1. 2. t. 10. Bot. Mag, t. 466.

B356. Calyenutlans LINDL, C a 1 y $x$ tubo brevi urceolato, limbi lobis multiserialibus, imbricatis, omnibus coloratis, carnoso subcoriaceis, lanceolatis, intimis minoribus. Corolla nulla. Stamina plurima, annulo carnoso calycis fancem clandenti inserta, inclusa, pluriseriata, inaequalia, decidua, exteriora duodecim fertilia; filamentis brevissimis, antheris oblongis, extrorsis, bilocularibus, adnatis, longitudinaliter de hiscentilus. Ovaria plurima, calycis tubo undique inserta, libera, nnilocularia, ov a lo unico, adscendente, anatropo, rarius geminis, altero ex apice loculi pendulo, minimo. Styli terminales, compresso-subnlati, exserti; s ti g m a t a obtusa. A chenia plurima, calycis tubo carnoso inclusa, subcornea, monosperma. Semen adscendens. Embryonis exalbuminosi, recti cotyledones folias:eae, spiraliter convolutae, $\mathrm{r}$ adi $\mathrm{cula}$ infera. - Frutices boreali-americani, aromatici, brachiato-ramosi; foliis oppositis, petiolatis, integerrimis, estipulatis, floribus coaetaneis, ramulos terminantibus, atro-rubentibus.

Calye a nth us Lindley in Bot. Reg. t. 404. Nees in N. A, N, C, XI, 107. DC, Prodr, 1I. 2. Turpin Atlas II. 3. Meisner Gen, 106. (75.) Buittneria Duhamel Arbr. I. 114. B e ureria Adanson Fam. II. 204. P om padoura Bonehor Monogr. Caly ea nthi sp. Lina. Sehkuhr $t .139$. Willd, Hort, berol, t, 80, Bot Mag. $t, 503$.

\section{Drdo CEXXXII. Hosacene.}

rosaceat Jassieu Gen. 334. exel. pl. DC. Prodr. II 525. exel. pl Lindley Introduct, edit. II, 143. excl. Poas ceis. BOSACEAE, DRYADEAE et SPIRAEACEAE Bartling Ord, nat, $460_{-} 403$.

HERBAB, FrUtices v. ARBores, saepissime aculeatae. Folia alterna, sessilia, saepissime pinnatim v. digitatim composita, rarius foliolis conflnentibus v, lateralibus abortientibus s:mplicia, serrata. Stipulae petiolo inferne adnatae, saepissime foliaceae.

Flores hermaphroditi v. abortu unisexuales, regulares, varie dispositi, saepissime cymosi v. corymbosi, albi, rubri v. flavi.

Catyx liber, tubo brevissimo explanato, $v$. plus minus elongato, limbi quadri-quinquefidi, rarius tri-novemfidi laciniis aestivatione valvatis, interdum bracteolis adnatis, cum limbi laeiníis alternantibüs auctus.

Cовоциar petala perigyna, ealycis laciniis aumero aequalia et alterna, breviter unguiculata, aestivatione imbricata, interdum nulla.
Stamina cum petalis inserta, saepissime indefinita, rarius laciniis calycinis numero aequalia et opposita. Fil a m enta filiformia, libera. Anthera e introrsae, biloculares, Jongitudinaliter dehiscentes.

Ovaria saepissime plurima, calycis fundo verticillatim v. ejusdem tubo inordinate, v. receptaculo e calycis fundo assurgenti undique inserta, rarissime subdefinita v. solitaria, unilocularia, saepissime uniovulata, rarius bi- v. multiovulata. Ovula pendula v. adscendentia, anatropa. Styli in singulis ovariis singuli, terminales v. plus minus manifeste laterales, filiformes v. subulati, simplices, persistentes v. decidui. Stigmata simplicia, interdum penicillata.

Fructus ex acheniis plurimis, monospermis, siccis v. rarissime baccatis, calycis tubo inclusis v. receptaculo demum saepe aucto impositis, compositus, rarius achenio unico intra calycis tubum induratum contento, v. e capsulis pluribus follicularibus, mono-polyspermis, sutura ventrali dehiscentibus constans.

Senisa erecta v. pendula, testa membranacea $v$. coriacea, rhaphe et chalaza manifestis. A lbumen nullum.

Embryonis orthotropi cotyledones carnosae, plano-convexae, v. rarius foliaceae, radicula umbilico proxima, superav. infera.

$\mathbf{R}$ os a cea e in temperatis et frigidiusculis hemisphaerae borealis maximo numero generantur, trans aequatorem nonnisi infimae formae obviae sunt.

SUECIRID I. ROSEAE DC. Prodr. II. 596. Calyx tubo ventricoso, fauce constricto. St amina indefinita. Ovaria plurima, calycis fundo inserta, ovulo unico, pendulo. A ch e$n$ i a calycis tubo baccato inclusa. Semen pendulum. - Suffrutices v. arbusculae; folits imparipinnatis, rarissime nullis, stipulis foliiformibus.

635\%. IResn TOURNEF. Calyx persistens, ebracteolatus, tubo ventricoso, fauce constricta et disco convexo carnoso coaretata, limbi quadri-v. saepissime quinquepartiti laciniis foliaceis, saepissime pinnatisectis, aestivatione imbricatis, persistentibus v. deciduis. Corollae petala $4-5$, calycis fauci inserta, ejusdem laciniis alterna. Sta nin a plurima, cum petalis inserta; fil amenta libera, antherae biloculares, longitudinaliter dehiscentes. Ov aria plurima, fundo tubi calycini insidentia, libera, unilocularia, ovulo unico, pendulo. St y li laterales, e calyce exserti, liberi v. inferne plus minusve connati ant demum concrescentes; st $\mathrm{igm}$ at a incrassata, integra. Achenia plurima, tubo calycis carnoso v. cartilagineo inclusa, ossea, ad latus stylo oppositum comosa. Semen inversum. Embryonis exalbuminosi radin ula supera. - Frutices, saepissime aculeati; foliis sparsis, imparipinnatis, foliolis serratis, stipulis petiolo adnatis, floribus termi- 
nalibus, solitariis $v$, pluribus subcorymbosis, formae, etiam in semiplenis plenisque nobili decore, et odoris suavitate omnes regni vegetabilis delicias longe superantibus, et inter pulcherrimos horti terraqueiflores, venustatis principatum suo generi vindicantibus.

R o s a Tourmefort Inst. 408. Linn. Gen, n, 631. Redouté et Thoré Monogr. 1817_1820, c. ic. Lindley Monogr. 1820. c. ic.

a. RHODOPSIS. Calycis limbus quadripartitus. C orolla e petala4. Ros a seric ea Royle Himalay.t, 42.f.2.

b. RHODOPHORA. Caly $\mathrm{c}$ is limbus quinquepartitus. Corolla e petala 5. R hodop hor a Necker Elem, $n, 784$. Ros a e sp. Auct.

6358 . Ir enthemin DUMORT. C a I y x persistens, ebracteolatus, tubo globoso, dense aculeato. hirto, fance constricta, et disco carnoso coarctata, limbi quinquepartiti laciniis foliaseis, integerrimis, aestivatione imbricatis, deciduis. Corolla e petala 5 , calycis fauci inserta, ejusdem laciniis alterna, ob cordata, basi macula semieirculari notata. Sta mina plurima, cum petalis inserta; filamenta libera, antherae biloculares, longitudinaliter dehiscentes. Ovaria plurima, fundo tubi calycini insidentia, libera, unilocularia, ov u 1 o unico, pen dulo. St y li laterales, e calyce exserti, liberi, villosissimi; stigmata simplicia. A $e$ henia plurima, tubo calycis baceato, intus setoso inclusa, ad latus stylo oppositum glaberrima, ossea. S e me n inversum. Eubryon is exalbuminosi $r$ adicula supera. - Fruticulus Asiae mediae, ramosissimus, aphyllus, stipulis in folii simplicis, cuneato obovati, integri v. bifidi, ambitu argute serrati, glabri, glauci, reticulato-venosi speciem connatis, rarissime inter stipularum apicem liberum folii rudimentum gerentibus, aculeis substipularibus geminis, subre. flexis, decurrentibus, floribus terminalibus, solitariis, breve pedunculatis, petalis aureis, basi intus macula atropurpurea pictis.

H a I the mia Dumartier Dissert. Tournay. 1824. 8 . Lowe a Lindley in Bot. Heg, t, 1261. R ho dops is Ledebour Flor, alt, Ir. 224. Kos a berberifolia Pallas in Nov, Act. Petropolit. X, t, 10, f. S. Ledebour Ic. t. 370 .

SUB(1) DIII. DRYADEAE Vent, Tabl. III. 349. C al y x aestivatione valvatus v. imbrieatus, nudus v. bracteolis cum laciniis alternantibus. S ta min a indefinita v, interdum definita. Ovari a solitaria v. pauca, aut saepissime plurima, receptaculo convexo v. stipitiformi insidentia, uni- v. biovulata; ovulo pendulo v. ertecto anatropo, sive arlscendente, interdum amphitropo. Stylus terminalis v. lateralis. Achenia plurima, calyci expanso imposita, v, pauca aut solitaria, ejusdem tubo inclusa. S e m e n pendulum v, adscendens. Herbae v. frutices; foliis digitatim aut pinnatim compositis, rarius simplicibus.

§. 1. DALIBARDEAE Torr. et A. Gray. $\mathrm{F} t$. B. A. I. 449. Cal y x ebracteolatus, saepissime imbricalus. Stamina indefinita. Ovaria plurima. Stylus terminalis v. subterminalis. Radicula supera.

6359. Dalibarda LINN. Calyx fundo concavus, limbe quinque-sexpartitus, ebracteolatus, aestivatione subimbricatus, persistens, Corolla e petala 5_6, ealyci inserta, ejusdem laciniis alter- na, aequalia v. majora. St a m in a plurima, cum petalis inserta; filamenta libera, antherae biloculares, longitudinaliter dehiscentes. 0 va ri a $5-10$, in fundo calyeis sessilia, libera, unilocula. ria, ovnlis 2, pendulis. Styli subterminales, breves; stigmata simplicia. A chenia 5 - 10 , calyce inclusa, sicca, intus subcartilaginea, mutica. Se men aborta unicum, inversum. Embry on is exalbuminosi radicula supera. - Herbae humiles, in America boreali et antarctica, nec non in Nepalia crescentes; foliis longe petiolatis, cordatis, saepe integris, interdum trisectis, crenatis $v$. dentatis, stipulis peliolo adnatis, pedunculis scapiformibus, unifloris v. corymboso-multifloris.

$\mathrm{D}$ alibarda Linn. Spec. edit. 1. p. 401. Richard in Michaux Flor. Bor. Amer I. 299. $t$. 27, excl. reliq. et in Nestler Potentill. 16. t. 1. DC. Prodr. III. 568. Meisuer Gen, 104. (74,) Hooker Ic, t, 76. Torrey et A. Gray Flor. of North-Amer, I. 449. $\mathrm{R}$ u bi $8 \mathrm{p}$. Linu. Smith Ic, inedit. t. $19,20$.

6360. Rubus LINN. C a ly $\mathrm{x}$ explanatus, limbo.quinquepartitus, ebracteolatus, persistens. Corollae petala 5 , calyci inserta, ejusdem laciniis alterna et majora. St a mina plurima, cum petatis inserta; filamenta libera, an therae biloculares, longitudinaliter dehiscentes Ovaria plurima, receptaculo convexo inserta, lihera, unilocularia ovulo unico v. rarius geminis, eollateraliter pendulis, altero minore effoeto. St y li subterminales, filiformes; stigmata simplicia $v$, subeapitata. Drupae succosae, supra reeptacuIum conicum, subearnosum baceatim congestae. S e men inversum. F mb ryon is exalbuminosi $r$ adic ula supera. - Herbae $v$, saepius frutices, plerumque sarmentosi et aculeati, polymorphi, in regionibus temperatis tolius orbis, parcius inter tropicos crescentes; foliis alternis, simplicibus, ternatis, digitatis $v$, imparipinnatis, stipulis petiolo adnatis, floribus terminalibus et axillaribus, paniculatis v. corymbosis, rarius solitariis.

Rubus Lian. Gen, n, 864. Sehkuhr t, 135. Gärtaer $I$. 350. $t$. 73. f. 9 . Miller Ic, $t$. 293 . Schreber Decad, t. 8, Smith Ic. inedit. t. 60-61. Exot. Bot. II, $t, 86$, Flor. dan. $t, 1$. 134, 788, 1165, 1213. E. B. t. 715, 826. 827, 1585, 2933. 2442. 2572. Nestler Potentill. 16. Nees et Weihe, Rubi germanict. Bonn, 1820. Pursh Flor. Bor. Amer. t. 16. Waldstein et Kitaibel Plant, Hung rar, t. 141, 268. Bot, Mag, t, 1783. 3453. Bot, Reg, t. 461, 496, 854, 1368, Kunth in Humb ot Bonpl. Nov. gen. et sp. FI, t. 557,558 . Wallich Plant, As, rar. 4. 234. Hooker Flor, Bor, Amer, t, 59-62. Endlicher Atakta t. 35. Torrey et A. Gray Flor, of Norlh-Amer. I. 449. ? Cy Iactis Rafuesque in Sillim. Journ. 1819. p. $37 \%$. Journ, Phys. 1819. p. 97.

\section{\$. 2. FRAGARIEAE Torr. et A. Gray $F l$.} B. A. I. 435. C alyx aestivatione valvatus, bracteolatus. Stamina indefinita. Ovaria plurima. Styli laterales v. terminales. Radicula supera.

6361. Fragaria LINN. Cal y $x$ fundo convexus, limbo quinquepartitus, explanatus, extus quinquebracteolatus, aestivatione valvatus, persistens. Cor oll a e petala 5, ealyei inserta, ejusdem laciniis alterna et majora. Stamina $20 \mathrm{v}$. plurima, enm petalis inserta; fil ament a libera, a $t h$ era e biloculares, longitndinaliter dehiscentes. Ovaria plurima, receptaculo convexo insidentia, distincta, unilocularia, ova 10 unieo, adscendente, anphitropo. Styli laterales v. subbasilares; stig m a ta simplicia. A che nia plurima, receptaculo aucto carnoso-succulento, tandem de156 
ciduo imposita. Semen adscendens. Embryoni s exalbuminosi r a di cula supera. - Herbae in temperatis hemisphaerae borealis obviae, etiam in America australi extratropica et in Moluccis crescentes, nemmi non notae, perennes, caespitosae, soloniferae; foliis alternis, ternatis, $v$. interdum foliolorum lateralium abortu simplicibus, foliolis inciso-serratis, stipulis petiolo adnatis, floribus in apice caulis subcorymbosis, albis v. flavis.

Fragaria Tournefort Inst, 152. Linn. Gen, n. 633. Nestler Potentill. 17. Duchesue Monograph. d. Frais, Paris, 1765. 8. DC. Prodr. IIT. 569. Torrey et A. Gray Flor, of North-Amer. I. 4h7.

a. Fragaria Smith. Flores albi. Receptacula fructufera edúlia.

b. DUCHESNEA Smith. Flores flavi. Receptaeula insipida. - Du ches ne a Smith in Linn. Transact, $X$. 373. (Bot. Reg. t. 61, Andrews Bot, Reposit. t. 475.)

6368. Comararama LINN. C a I y x coloratus, fundo convexus, limbo quinquepartitus, explanatus, extus quinquebracteolatus, aestivatione valvatus, persistens. Co roll a e petala 5 , calyci inserta, ejusdem laciniis alterna et multo minora, acuminata. Stamina circiter viginti, eum petalis inserta, iisdem aequilonga; fil amenta libera, antherae biloculares, longitudinaliter dehiscentes. Ovaria plurima, receptaculo convexo insidentia, distincta, unilocularia, ov ulo nnico, infra apicem suspenso, pendulo. Styli laterales; stimmat a simplicia. A $\mathrm{e}$ h e $\mathbf{n}$ i a exsucca, in receptacnlo magno, ovato, spongioso-carnoso sessilia. Seme $\mathbf{n}$ inversum. E mbry on is exalbuminosi $\mathbf{r}$ ad icula supera. - Herba Europae mediae perennis, paludosa, repens; foliis alternis, imparipinnatis, foliolis argute serratis, stipulis petiolo adnatis, caulem vaginantibus, floribus in apice caulis et ramorum subcorymbosis, atro-purpureis.

Co m a rum Linn. Gen, n, 638. Gắrtner 1. 349. t. 73. Torrey et A. Gray Flor, of North.Amer. I. 447. Schkuhr t. 138. Pote intillae $\mathrm{sp}$. Auct.

6363. Potentilla $L I N N$. Cal y x fundo concavus, limbo quadri-quinquepartitus, explanatus, extus quinquebracteolatus, aestivatione valvatos, persistens. Corollae petala 4 v. 5, ealyci inserta, ejusdem laciniis alterna et majura. Sta m ina circiter 20, cum petalis inserta; fil a menta libera, anthera e bilocnlares, Inngitudinaliter dehiseentes. Ovaria plurima, receptaculo convexiasculo insidentia, distincta, nnilocularia, ovulo unico, infra apicem suspenso, anatropo. Styli laterales; stigmat a simplicia. A chenia exsuc$c$ a, in receptaculo plusminus convexo, piloso $v$. hirsuto, exsuceo sessilia. S e m en inversum. E mbryonis exalbuminosi radicula supera. - Herbae ut plurimum perennes et caespitosae, rarius frutices, in hemisphaerae borealis regionibus temperatis et frigidis magno numero, rarissime $t r a n s$ Cap ricornum crescentes; foliis alternis, floralibus saepe oppositis, ternatis, digitatis $v$. imparipinnatis, foliolis crenatis, serratis $v$. incisis, stipulis petiola adnatis, pedunculis alaribus, oppositifoliis, pseudo-axillaribus terminalibusque, uniftoris, saepe in corymbos dispositis, floribus albis, flavis aut rarius rubris.

Potentilla Linz. Gen, n, 638. Schlechtend. in Berl. Magaz. VII. 283, Nestler Monogr. Paris 1816. Lehmann Mo nogr, Lips. 1820. Suppl, I. 1853, DC. Prodr. II. S71. exci. Comaro. Meisuer Gen. 104. (73.) Torrey et A. Gray Flor, of North-Amer, T. 436. Q u in quefolium et Peutaphyi loides Touruef, Inst, 153. Giirtner I. 349. Argentina Blackw. Herb. t. 6. Torm a tilla Tournef. Inst. 153, Lian. Gen, $\pi, 156$. a. TORMENTilla Linn. C a ly c is limbus quadripartitus, quadribracteolatus. Cor oll a e petala 4 - ischkuhr t. 136. Flor. daa. $t$. 589 . Curt. Lond. V. $t .35 . \mathrm{E}, \mathrm{B}$. t. 863. 864.)

b. POTENTILla Linn. Caly cis limbus quinquepartitus, quinquebracteolatus. C o ro II a e petala 5. - Fior. dan, t. $271.799 .1035 .1390,1578$. E. B. t. 88, 89,1384, 2329. Jacq. Flor, austr. $t, 114,116,220$. 406. Seringe Mut. Helvet, t. 4-8. Hooker Exot, Flor, t. 88, Ledebour Ic, t. 133, 328. 331, 332, 334. Hooker Flor. Bor. Amer. t. 63-67. Wallich Plant, As, rar, t, 298, Royle Hima. lay, t, 40. Bot. Mag. t. 2984, 3676. Bot. Reg.t, 1478. 1498, 1496.) B o o ti a Bigelov Flor. Boston. II. 206. Tri choth a l a m u s Lehmana in $N, A, N, C, X, 585, t, 49$.

§. 3. ChaMAerodeat Torr. et A. Gray. Fl. B. A. I. 433 . C al y x valvatus, nudus v, bracteolatus. S ta m in a $5-10.0$ v a $\mathrm{r}$ a $5-10$, v. interdum plura. Sty li laterales v. terminales. Radicula supera.

6364. II orkellia $C H A M$, et SCHLECHT. C a 1 y $x$ tubo campanulato, limbo quinquefido, extus quinquebracteolato, aestivatione valvato, persistens. C o r o 1 I a e petala 5, calyci inserta, ejusdem laciniis alterna et breviora, ob. longo-elliptica. S $t$ a m i n a 10 , biseriata, cum petalis alterna, iisdem opposita, demissius inserta; fil a menta libera, a ntherae biloculares, lon. gitudinaliter dehiscentes. Ovaria plurima, receptaculo cunico inserta, libera, unilocularia, o v n lo unico, pendulo. Styli subterminales, basi incrassata artieulati; stig m a simplex. A $\mathrm{c}$ h en i a plurima, styli basi apiculata. Se men inversum. Embryonis exalbuminosi radie n l a supera. Herba californica, perennis, erecta, piloso visci. da; foliis radicalibus petiolatis, imparipinnatis, quinquejugis, foliolis suboppositis, suborbiculatis, dentatis incisisque, superioribus confluentibus, cauli. nis alternis subsimilibus, pinnatifidis, stipulis amplexicaulibus, foliorum radicalium petiolo adnatis, caulinorum liberis, in bracteas transeuntibus, panicula terminali multiflora, apice racemosa, floribus breviter pedunculatis, erectis, bibracteatis.

Horkelia Chamisso et Sehlechtend, in Linnaea II. 27. Hooker in Bot. Mag. t. 2980. Meisuer Gen. 104. (73.) Tor. rey et A. Gray Flor, of. North. Amer. I. 434.

6365. Chamaerlnodes $B U N G$. C a ly $x$ campanulatus, limbo quinquefido, ebracteolato, aestivatione valvato, persistente. Corolla e pe tala 5 , calyei inserta, ejusdem laciniis alterna, obovata, calycem aequantia v. superantia. S ta m in a 5, cam petalis inserta, iisdem opposita; fila$m$ e $n$ ta libera, a $n t h$ e ra e biloculares, longitadinaliter dehiscentes, $O$ varia 5 v. 10 , rarius $p l n-$ ra, fundo ealycis insidentia, libera, unilocularia, ovulo unico, pendulo. Styli laterales; stigma ta simplicia, A c h e ni a $5-20$ v. plurima, ea lyce inclusa, stylo deciduo mutica. Semen inversum. Embry onis exalbuminosi radieula supera. - Herbae Asiae mediae, suffruticosae, glanduloso-pilosae; foliis alternis, tripartitis v. bitriternati-multipartitis, stipulis linearibus, floribus subsolitariis $v$. paniculatis, albis $v$. purpureis.

Chamathod os Bunge in Ledebour Flor, alt. I. 499. Ledebour Ic, 1,257 . Meisuer Gen. 104. (73.) Torrey: et A. Gray Flor. Bor, Amer. I. 432. S i b b ald i a e s. Lian. Laxmann in Nov. Comment, Petropolit, 1713. t. 6. f. 2.

6368. Dryadamthe. F 1 or e s abortu dioici, Cal yx fundo coneavus, limbo quadrifidns, extus quadribracteolatus, aestivatione valvatus, persistens. Corolla e petala 4, calyci inserta, ejusdem laciniis alterna et majora. Sta min a 4 , 
in floribus femineis ananthera, cum petalis inserta, iisdem alterna; filamenta libera, an therae biloculares, longitudinaliter dehiseentes. 0 v aria in masculis nulla, in femineis 4, breviter stipitata, libera, unilocularia, ovnlo unico, penduLo. Styli laterales, recti; stigmata capitata. Achenia ..... Herba pusilla, dense caespitosa, in summis alpium altaicarum jugis crescens, sericeo-subvelutina; foliis ternatis, foliolis lateralibus bidentatis, medio tridentato, stipulis petiolo adnatis, caulem amplectentibus, floribus ramos terminantibus subgeminis. zen. 25.

Sib baldia tetrandra Bunge Vorzeichn.all,Pflan.

635\%. Sibloaldia LINN. Calyx fundo concavus, limbo quinquefidus, explanatus, extus quinquebracteolatus, aestivatione valvatus, persistens. C or oll a e petala 5, calyci inserta, ejusdem laciniis alterna, lineari spathulata. Sta m in a $\mathrm{cum}$ petalis inserta, nune 5 isdem alterma, nunc 10 aiterna et opposita; filamenta libera, a $n$ therae biloculares, longitudinaliter dehiscentes. Ovaria 5 - 10 , in fundo calycis sessilia, libera, unilocularia, ovulo unico, pendulo. Styli laterales; s tigun a simplicia. A $\mathrm{c}$ h en ia 5 _ 10 , ealycis fundo inclusa, stylo deciduo mutica. S e m en inversum. Embryonis exalbuminosi radicula supera.

Herbae in Europa et in $A s i a m e d i a$ et borea $\bar{l} i$, nec non in America arctica indigenae, sericeov. sparsim pilosae, eglandulosae; caulibus procum bentibus, foliis alternis, foliolis integerrimis $v$, inciso-dentatis, intermedio cuneato, integro $v$. tripartito, stipulis lineari-lanceolatis, floribus corymbosis, albis v. flavescentibus.

Sibbaldia Linn. Gen, $n, 393$, excl. sp. Gïrtner $I$. 384. t. 23. Flor, dan. t. 32, DC. Prodr. If. 586, excl. sect, 2. Bunge in Ledebour Flor, alt. 1.428 , Ledebour Ic. $t$. 276. Meisuer Gen. 104. (73.)

\$. 4. SANGUisorbeaE Torr. et A. Gray Fl. B. A. I. 428. C a ly x aestivatione valvatus v. rarius imbricatus, nudus v. bracteolatus, fruetifer clausus, induratus. Corolla saepius nulla. Stamina pauea $(1-15)$, rarius plura. Ovaria $1-2$, rarius plura. Styli terminales v. laterales. Radicula supera.

6365. Amimonia TOURNEF. Calyx basi nudus, persistens, tubo tarbinato, ad apicem extus sub limbo spinulis uncinatis multibracteolato, fauce intus annulo glanduloso constricta, limbo quinquepartito, aestivatione snbimbricato, demam sursum eonnivente. Corullae petala 5, calyeis fauci sub margine disci inserta. St a m in a $12-20$, cum petalis inserta; fil ament a libera, ant the$r$ a e biloculares, longitudinaliter dehiscentes. 0 va ria 2, libera, unilocularia, ov u lo unico, pendule. Styli terminales, exserti; stigmata dilatata, subbiloba. A ch e nia 1_2, subeartilaginea, caly ce indurato, clauso, superne spinulis plurimis, uncinatis lappaces tecta. $\mathbf{S}$ e m e $\mathbf{n}$ inversum. $\mathbf{E}$ mbryonis exalbuminosi $\mathrm{r}$ a d i e n $\mathrm{l}$ a supera. Herbae perennes, in temperatis hemisphaerae borealis obviae; foliis alternis, imparipinnatis, stipulis petiolo adnatis, floribus racemoso-spicatis, terminalibus, luteis, pedicellis basi unibracteatis, medio bibracteolatis.

A grimonia Tournefort Inst. 155. Nestler Potentill. 16. DC. Prodr. II. 587. Kuuth Flor. Berolin, I. 201. Meis uer Gen, 104. (73.) Agrina on i a sp. Lina. Sclikubr. t. 128, Gairtner t, 73, Flor, dan, t, 588, E. B. t, 1335.
6369. Aremonia NECK. C alyx involucello decem duodecimfido calyculatus, tubo turbinato, ad apicem extus sub limbo bracteolis quinque, demum corniculatis aucto, fauce intus annulo glanduloso constricta, limbo quinquepartito, aestivatione valvato, demum sursum connivente. Corollae petala 5, calycis fauci sub margine disei inserta. Sta mina 5 _ 10 , cam petalis inserta; $\mathrm{f}$ lamenta libera, antherae biloculares, Iongitudinaliter dehiscentes. Ovaria 2, lilera, unilocularia, ovulo unieo, pendulo. Styli terminales, exserti; $8 \mathrm{t}$ i g mat a dilatata, subbiloba. $\mathbf{A}$ c h e nia 2, v. aborta 1, submembranacea, calyce indarato, clauso, superne bracteolis induratis quinquecalyculato tecta. Se m e $\mathrm{n}$ inversum. E $\mathrm{n}$ b r y nis exalbuminosi r a di c u l a supera. - Herba perennis, in Italia superiore et Carniolia indigena, villosa; fotiis radicalibus interrupte pinnatis, foliolis ovali-subrotunais, cuneatis, serratis subincisisque, caulinis ternatis, stipulis ovali acuminatis, floribus subfasciculatis, parvis, flavis.

A remonia Necker Elem, n. 768, DC. Prodr. II. 588. Meisuer Gen, 104. (73.) A grim a n i oi des Tournefort Inst. 155. A mo n ia Nextler Potentill. 17. S pallanzan $t$ a Pollini Giorn. Fis. Pav. 1816. p. 187. c, ic. Plant, Veron.t. t. Agrimonia agrimonioides Liun.

63\%0. Alehemilla TOURNEF. Flores hermaphroditi. Cal y x tubo urceslato, fauce disco annulari constricta, limbi octopartiti laciniis biseriatis, exterioribus multo minoribus, aestivatione imbricatis, deciduis. Corolla nulla. Sta mina 1 - 4, annulo calycis faucem coronanti inserta, ejusdem laciniis exterioribns opposita; filame nt a brevia, filiformi-subulata, a $\mathrm{t}$ herae uniloculares, transversim bivalves. $O$ v a $\mathrm{r}$ a $1-4$, in fundo calyeis substipitata, libera, nnilocnlaria, ovulo unico, adscendente. Styli basilares, filiformes; stigmata capitellata. A ehenia $2-4$, calycis tubo inclusa, suberustacea. Sem en prope basim affixum, adscendens, fere orthotropum. E mbryonis exalbuminosi ra d i $\mathrm{c}$ u la supera. Herbae perennes, rarius annuae, in temperatis et alpestribus totius orbis crescentes; foliis alternis, circumscriplione reniformibus, sublobatis v. digitatim tri- v. quinque-, rarius pinnatipartitis, stipulis petiolo adnatis, floribus terminalibus, axillaribus et alaribus, subcorymbosis $v$, fasciculato-glomeratis, pedunculatis, ebracteatis.

A I chem 111 a Tournefort Tnst. 289. Kunth in Humb. et Bonpl. Nov. gen, ot sp. VI, 223. DC. Prodr. II. 589. Meisner Gen, 105. (75.)

a. ALChembla Lian. Gen, $n, 165$. C a 1 y $x$ octofidns, Iacinis alterais paullo minoribus. Stamina 2-4. Species perennes. - (Sehkuhr t. 26, E. B. $t$, 246. 597. Fior, dan. $t$, 49, 693. Kunth Op. cit, t. 560, 561.)

b. APHANES Ling. Gen, $n, 166$. C alyx octofidus, rarissime florum nownullorum decemfidus, lacioiis alternis minimis, dentiformibus. Stamiua 1-2. - Species annuae, - (Flor, dail. t. 973, B. B. t. 10t1.)

B371. Adlemostoma HOOK. et $A R N$. Cal y $x$ infundibuliformis, tabo quinquangulato, limbi quinquepartiti Iaciniis brevibus, rotundatis, mueronulato-acutis, fauce intus glandulis quinque, transversim oblongis, carnosis. Corolla petala 5, calycis fanci inserta, ejusdem laciniis alterna, uvato-subrotunda, brevissime unguiculata. Stamina 15 , calycis fanci inserta, petalis subaequilonga; filamenta filiformi-subulata, anthera e biloculares, subgloboso-didymae, longitudinaliter dehiscentes. Ova ri um unicum, sessile, ovato-subcompressum, apice oblique truncato pubeseens, uniluculare. Ovulum unicum, (v. gemina $156^{*}$ 
collateralia), ex apice cavitatis pendulum, anatropum. Stylus sublateralis, e basi flexuosa adseendens; stigma obtusum, subinerassatum. Fructus..... - Frutex californicus, rigidus, glaberrimus, ramosus; ramis virgatis, foliis fasciculatis, lineari.jliformibus, brevissime petiolatis, busi stipula minutissima suffultis, fasciculis stipula com. muni, bifida munitis, floribus fasciculatis, in pani culam terminalem, aphyllam dispositis, parvis, albis, bracteis plurimis imbricatis sustentis.

A denos to wa Hooker et Arnott ad Beechey 139.t.30. Torrey et A. Gray Flor. of North-Amer, I. 430.

638\%. Acaena $V A H L$. Flores herma phroditi. Calyx tubo oblongo, subechinato v. laevi, onneato-compresso, tri-rarius quadri-quinqueangulari, angulis in aristas apice glwehidatas excurrentibus, fauce constrista, limbo quadri-rarius tri-quinquepartito, persistente, Corolla nulla. Sta mina 2 -5, calyeis fauci inserta; filamenta filiformia, a $\mathrm{th}$ er a biloculares, longitudinaliter dehiscentes, Ovaria 1_2, calyeis tubu inclusa, libera, unilocularia, ov u l o unico, pendulo. Styli terminales, breves; stigmata peni. cillata. A ehen in m tubo ealycino indurato, echinato-glochidato, setis apice glochidatis tri-quinquearistato, limbo persistente coronato inclusum. Seme $n$ inversum. Embryonis exalbuminosi $r a-$ dic ula supera. - Herbae v. suffrutices erecti, procumbentes $v$, repentes, in montanis frigidis $M e x i c i$, et in temperatis et frigidiusculis hemisphaerae australis crescentes; foliis alternis, imparipinnatis, foliolis serratis v. incisis, stipulis pe. tiolo adnatis, spicis axillaribus et terminalibus, glo. bosis v. cylindricis.

A ea en a Vahl Enum. 2. 273. DC. Prodr. II. 592. Mels. ner Gen. 105, 174.)

a. EUACAENA DC. l.e. $\mathrm{C}$ a 1 y $\times$ undique glochidibus armatus, - A ca $n$ a Linn. Mant. 200. Ruix et Pavon Elor. Perū. t. 103. f. a. t. 104. f. 1. b. Jurq. f. Eclog. I. t. 55. A n ei o tri s p. Thunb. Gärtn. $t$. 32, fig. inf.

f. ANCISTRUM DC, l. c. $\mathrm{C}$ al y $\mathrm{x}$ apice in aristas glochidatas 3-5 desiuens. - An cistrum Porst. Char. gen. t. 2. Lam. t. 22. Ruiz et Pavon t, 103. f. b. c. t. 105 . f. 2. c. Gärtner $t$. 32. $f i$. sup

B3 r3. Sanguisorba LINN. Flores hermapliroditi. Cal y $x$ tubo turbinato, fance disen annulari constricta, limbi quadripartiti, colorati laciniis aestivatione imbricatis, deciduis. Corolla nulla. Stamina 4, annulo calycis faucem coronanti inserta, ejusdem laciniis opposita ; filau enta elongato-filiformia, flaceida, a $\mathbf{t} \mathbf{b}$ erae biloculares, longitudinaliter dehiscentes. $O \mathrm{v}$ a $\mathrm{r}$ i $\mathrm{n} \mathrm{m}$ unienm, tubo ealycis inclusum, uniloculare, ov a Io unien, pendulo. Sty I a terminalis, simplex; st igma dilatatum, pectinato-lacinulatum. A theni u m tubo calycis persistente, suberoso-indurato, quadrangulari inclusum. Sem en inversum. $\mathbf{E} \mathbf{m}$. bryon is exalbuminosi radieu la sapera. - Herbae perennes, in temperatis hemisphaerae borealis crescentes, glaberrimae, caulibus erectis, superne ramosis; foliis alternis, imparipinnatis, foliolis petiolulatis, serratis v, rarius integerrimis, stipulis petiolo adnatis, floribus terminalibus, densissime spicatis, sessilibus, bracteatis bibracteolatisque.

S a ngu is o rb a Lian, Gen, $n$, 146. Lam, $t$. 85. Flor. - dan. t. 97. E. B. $t$ 1312. DC. Prodr. II. 593. Nees Gen. pl. II. 2. 78. Meisner Gen 105. (74.) Pi mi pinellae sp. Tournef. Gärtuer $T, 161, t .38$.

B38 4. Poterimm LINN. Flores polygrami, r, monoici, femineis in eadem spica superioribus. Ca Iy $x$ tuho basi tarbinato, fasce disco an. nulari constricta, limbi quadripartiti laciniis aestivatione imbrisatis. Co ro I I a nulla. Stamina $20-30$, annulo ealyeis faucem coronanti inserta; fil a m enta elongato-filiformia, flaceida, an the$\mathrm{r}$ a e biloculares, longitudinaliter dehiscentes, $0 \mathrm{va}$ ria 2 v. rarius 3 , tubo calycis inclusa, libera, unilocularia, ovulo unieo, pendulo. Styli terminales, exserti; $8 \mathbf{t i g} \mathbf{m}$ a $\mathbf{t a}$ penicilliformia. A chenia 2 v. rarius 3 , calyeis tubo suberoso indurato v. subbaceato, quadrangulari incluxa. Semen inversum. Embryonis exalbuminosi radicula supera - Herbae, suffrutices $v$. frutices, in $\boldsymbol{E}$ u $r$ o pa media, regione mediterranea et insulis $C$ an ar $i$ is crescentes, interdum ramulis spinescentibus armati; foliis allernis, imparipinnatis, foliolis serratis, stipulis petiolo adnatis, floribus terminalibus, densissime spicatis, sessilibus, basi bracleatis bibracteolatisque.

Poteriu an Lina. Gen, n, 1059. DC. Prodr. IT. 894. Meisuer Gen, 105. (74,) Pimplinella Adansou Fam. II. 293. P im pia ellae s p. Tournef. Gärta.

b. RYTIDOPOTERIUM DC. l. c, C a I y cis tulus fructifer rugosux v. tuberculatus. - Caules herbacei $v$. ima basi suffruticosi. Spicae globosae. - (Sehkulir t. 300. B. B. t. 860, Gârtner t, 32. Waldst. et Kitaibel Plant, rar. Hung. t. 198. Desfont. Flor, allant. t, 25t.)

b. LEIOPOTERIUM DC. $l$. $c$. Ca 1 ye is tubus fructifer lae. vis, subbrecatus. - Caules fruticosi. Spicas cylindri. cae. - (Bot. Mag. t. 2341,)

6385. I, Inucosialea ECKL, et ZEYH. Flores hermaphroditi. Calyx tubo obeonico, brevi, apice obturato, limbi quinquefidi lubis ovatis, obtusis. Corolla petala 5, libera, laneeolato acuminata, patentia. S ta $\mathrm{m}$ in a 10 . subexserta, phalanges dnas formantia. Ovaria 2_3. Styli terminales, liberi, exserti; st $i$ gu ata uncinatoreflexa, sublaciniato-incrassata. A chen ia $2-3$, membranacea, calycis tubn indurato inclusa, saepissime abortu solitaria. Sem in is inversi cotyledones carnosae. - Erutex capensis, glandulosopunctatus; foliis interrupte imparipinnatis, foliolis subtus albido sericeis, stipulis petiolo adnalis, racemis axillaribus densifloris, floribus tribracteatis, bractea antica maxima imo pedicello, lateralibus minoribus basi subcoalitis ejusdem medio insertis.

Leneosidea Ecklou et Zeylier Enumerat. Plant, cap. 265.

63\%6. Tetraglochin PÜPP. Flores dioici. Mas c. Caly x tetraphylles. Coro lla nulla. Stamina 2 ; filamenta filiformia, anthera e cordatae, biloculares, longitudinatiter dehiscentes. F e m. C a I y x tubo ovato, late quadrialatu, limbo supero, quadripartito, persistente. O va r i u m unicum (?) uniluenlare, ovulo nnico, pendulo. Styli 3_4 (?) brevissimi; stig mata penieillata. A chenium eylindricum, tubo ealycino late quadrialato, limbo persistente coronato inclusnm et cohaerens. Se m e $n$ inversum. $\mathrm{E}$ mbryon is exalbuminosi radicula supera. - Frutex bipedalis, andium ch.ilensium incola, erectus; ramulis strictis, stipulis vaginantibus margine barbatis, petiolos mentientibus, aphyllis, apice spinescentibus, foliis axillaribus fasciculatis, tinearibus, margine revolutis, pedunculis axillaribus, solitariis v. pluribus, brevissimis, unifloris.

Tetraglochi a Pöppig Fragm. Synops. 26. Margyricarpus a latus Gillies.

B38 \% . PoIylepis RUIZ et PAV. F I ores hermaphroditi. C a I y $x$ tubo turbinato, tri-tetraptero, superne denticutis pluribus, spiniformibas instructo, fauce coarctata, limbi tri-quadripartiti la- 
ciniis aestivatione imbricatis, persistentibus. Corolla nulla. Stamina 5-20 v. plurima, calycis fauei inserta; filamenta filiformia, an therae villosae, bilocnlares, longitudinaliter dehiscentes. Ovarium unicum, eglyeis tubo inclusum, uniloculare, ovulo unico, pendulo. Stylus terminalis, brevis; 8 tigma multipartitum. A chenium tubo calycino tri-tetraptero, indurato, superne subspinoso, limbo persistente eoronato arcte inclusum. Semen inversum. Embryonis exalbuminosi radicula supera. Frutices v, arbores, in andi $u$ peruanarum jugis crescentes; foliis alternis, ternatis $v$. imparipinnatis, foliolis crenatis $v$. integerrimis, subtus sericeis, stipulis petiolo adnatis, pedunculis axillarihus, multifloris, floribus racemosis, sub. sessilibus, bracteatis.

Poly lepis Ruiz et Pavon Prodr. 34. 2,15 . Kunth in Humb. et Bonpl. Nov, gen. et sp. VI. 229. DC. Prodr. IT. 591. Meisuer Gen. 105. (24.)

638 8. II Flores hermaphroditi. Cal y $x$ tulo compressotetragono, fauce constricta, limbi quadri-quinque partiti laciniis extus ad basim spinula brevi, dentiformi instructis, persistentibus. Corolla nulla. Sta mina 2, calycis fauci inserta; filam ent a brevissima, a $\mathrm{ther}$ a biloculares, didymae, longitudinaliter dehiscentes. Ovarium unicum, calycis tubo inclusnm, uniloculare, ovulo nnieo, pendulo. Stylus terminalis, brevis; $8 \mathrm{tig} \mathrm{ma}$ penicil. liforme. Acheni um tnbo calycino teretiusculo, baccato, limbo persistente coronato, quadrispinnloso inclusum et cohaerens. S e m en inversum. $\mathrm{E}$ mbry onis exalbuminosi radicula supera. - Frutex in $A$ merica tropica et subtropica trans a equatorem monticola, foliosus; foliis alternis, imparipinnatis, foliolis angustissime linearibus, integerrimis, stipulis petiolo adnatis, floribus axillaribus solitariis, sessilibus.

Margy ricarpus Ruizet Pavon Prodr. 7. t. 33. Flor. Peruv, I. 28. t. 8. f. d. Kunth in Humb, et Bonpl. Nov. gen. et sp. VI. 200. DC. Prodr. II. 591. Meisner Gen. 105. (74.)

6359. ClifPortia LINN. Flores dioici. Calyx tubo urecolato, limbo trifido. Corolla nulla. Masc. Sta mina circiter 30 , ealycis fauci inserta; fil a menta filiformia, a $n t h$ e rae biloculares, longitudinaliter dehiscentes. F e m. Ova ria 2, calycis tubo inclusa, libera, unilocularia, ovalo unico, pendulo. Styli laterales; stigmata elongata, barbato-plumosa. A ehenia 1 v. 2, calycis tubo inclasa, membranacea. S e m e n pendulnm. Eubryonis exalbuminosi radicula supera. - Frutices ca penses, foliis alternis trifoliola. tis, foliolis lateralibus minimis $v$, cum intermedio coalescentibus, folium simplex referentibus, stipulis petiolo adnatis, floribus axillaribus, subsessilibus.

Cliffortla Linn. Hort. Cliffort, t, 30. Gen. n. 1133. Lam, t. 807. DC. in Annal, sc. hat, 1. 497. Prodr. II. 595. Cliffortia et Morilandia Necker Elem, n. 765. 766. N e a ax Gärtuer I. t. 32.

§. 4. Cercocarpeat Torr, et A. Gray Fl.B. A. I.426. Caly $x$ imbricatus. S $t$ a $m$ ina plurima. Ovarium unicum. Stylus terminalis. Radicula infera.

88 80. Purshia DC. Caly $x$ tubo campanulato-ubeonico, limbi quinquepartiti laciniis ovatis, obtusis. Cornlla e petala 5, calycis fauci inserta, ejusdem laciniis alterna, ovata, breviter ungaiculata, patentia. St am ina circiter 20 , calycis fauci inserta, petalis breviora; fil amenta filiformia, an therae bilocnlares, subgloboso-didymae, longitudinaliter dehiscentes. Ovarium unicum, (rarissime 2) ovato-oblongum, apice in stylum attenuatum, uniloculare. O vulu m unicum, snturae ventrali paullo supra basim insertum, adscendens, anatropum. St y lu s subulatns, exsertus, hinc longitudinaliter stigmatosus. A che ni um ovatum, acuminatum, calyce longins, monospermum. S emen adscendens. E mbry on is exalbuminosi, orthotropi radicula infera. - Frutex boreali-americ anus, ramosissimus, inermis, corlice cinereo, ramulis lateralibus brevibus, e gemma squamosa ortis, foliis in ramulis confertis, basi cuneatis, apice inciso bi trilobis, supra villosis, subtus cano-tomentosis, stipulis obsoletis, floribus subsessilibus, luteis.

Pu r s hia DC. in Transact. Linn, soc. XII 157. Prodr. II. 541. Bot. Reg. t. 1446. Hooker Flor. Bor. Amer. $I$. t. 58. Meisuer Gen, 103. (73.) Torrey et A. Gray Flor. of North-Amer. I. 428, T I g a re a Pursh Flor, Bor. Amer. I. 33. t. 15. K и а z e a Spreng. Syst. II, Mas.

6351. Cercoenrpus $H$. B. K. C alyx coloratus, tubo clongato cylindraceo, persistente, limbo turbinato, sinuato-quinquelobo, deciduo. Corolla nulla. St a mina circiter 20 , calycis fauci inserta, exserta; fil a m en ta filiformia, a $t$ herae biloculares, subgloboso-didymae, longitudinaliter dehiscentes. Ovarinm unicum, sessile, ovato-oblongum, apice in stylum attenuatum, uniloculare. O vulu m unicum, suturae ventrali paullo supra basim insertam, adscendens, anatropum. Stylus terminalis, longissime exsertus; stigm a clavatum. Achenium coriaceum, ealyeis tubo persistente inclusam, stylo plumoso longissimo caudatom, monospermum. S e in en adscendens. E m bryon is exalbuminosi radienla infera. - Arbusculae v. frutices, in imperio mexicano et $A$ meriea borea$l i$ oc cidentali crescentes; foliis alternis, serratis, coriaceis, stipulis petiolo adnatis, floribus axillaribus, umbellato-fasciculatis, bracteatis.

Cereocarnus Kunth in Humb. et Bonpl. Nov. gen. sp. VI. 233, t, 659. DC. Prodr. 1I. 589. Meisuer Gen, 105. (24.) Hooker To t, 322_324. (finedit.) Torrey et A. Gray Flor. of North-Amer. I. 427 .

§. 5. EUDRYADEAE Torr, et A. Gray $F l$. B. A. I. 426. C aly x valvatus, nudus v, bracteolatus. Stamina plurima. Ovaria plurima. Stylus terminalis. Ra di cula infera.

G38\%. WValdsteinia WILLD. C alyx tubó turbinato, fance annulo crenulato coronata, limbo quinquepartito, extus quinquebracteolato, aestivatione valvato, persistente. Co rolla e petala 5 , calyci inserta, sessilia, ejusdem laciniis alterna et majora. Stamina plurima, cum petalis inserta; filamenta libera, antherae biloculares, longitudinaliter dehiscentes, 0 va ria 2 _, fundo calyeis stipitulis brevibus, ima basi connatis inserta, libera, unilocularia, ovulo unico adscendente. Styli terminales; stig mata simplieia. A $\mathbf{c h}$ e n a 2 -6, coriacea, stylo deciduo apice umbilicata. S emen erectum. Embryon is exalbuminosi radic nla infera. - Herbae potentilliformes, $\boldsymbol{H u n g a -}$ riam et Transylvaniam incolentes; folits ternatis v. palmatis, tri-quinquefidis, stipulis petiolo adnatis, caulibus gracilibus adscendentibus, oligophyllis, apice dichotome corymbosis, floribus flavis,

Waldsteinia Willdenow in N. Verhandl. Berl. na uurf. Fround. IT, 106. c. A. f. t. Waldstein et Kitaibel Plant Hung, rar, t. 77. Nestler Polentill. 17. t, 1. Bot. Mag. t.2595, DC. Prodr. II, 653. Rachel in Limnaed XII. I. 6. 
6383. Comaropoís L.C. HICH. C a I y x tubo turbinato, limbo quinquepartito, ebracteolato, aestivatione valvato, persistente. Corollae petala 5, ealyei inserta, ejusdem laciniis alterna et majora. Stamina plurima, eum petalis inserta, fiI a me $n$ ta libera, a $n t$ lo e ra e biloculares, longitudinaliter dehiscentes. Ovaria $5 \ldots 10$, in fundo caJycis sessilia, libera, unilocularia, ovulo nnico, adscendente. St y $\mathrm{li}$ filiformes, subterminales; $8 \mathrm{tig}$ mata simplicia. A chenia 5 10 , calyce inclusa, sicea, submembranacea, mutica. Semen erectum. Embryonis exabuminosi radicula infera. Herbue Dulibardae facie, in America et $A$ siu boreali, nec non in America antarctica crescentes; foliis trisectis, lobis cuneatis, integris v. lateralibus bipartitis.

Comaropsis L. C. Richard in Nestler Potentill. 16. t. 1. DC. Prudr. II. 555. Meisuer Gen. 104. (74.) D a Ii. bardae sp. Mlichaux Flor. Bor. Amer. t, 28. Stephan Mem. soc. nat. Mosq. I. t. 10. Bat. Mag. t. 1367. R ub i s p. Smith Io, inedit, t, 63, Cavanill. Ic, t, 413. Wa $1 \mathrm{~d}$ s te i. u i a sp. Tratuinick.

6384. Sievergina WILLD, Calyx tubo brevi, turbinato, limbo quinquefido, extus quinquebracteolato, aestivatione valvato, persistente. Corolla e petala 5, ealyci inserta, ejusdem laciniis alterna et aequilonga v. majora. Stamina plurima, cam petalis inserta; fil amenta libera, anthe$r$ a biloculares, longitudinaliter dehiscentes. Ovari a plurima, receptaculo brevi subeylindraceo inserta, libera, unilocularia, ovulo unieo, adscendente. Styli terminales, continui, subulati; stigmata papulosa. A chenia plurima, receptaculo brevi subeylindrico inserta, sty lo continuo nudo aristata. Senen adscendens. Embryonis exalbuminosi radicula infera, - Herbae perennes, in alpibus Europae mediae, Asiae borealis, nec non in $A m$ erica bureali et arctica crescentes, saepe stoloniferue; foliis rudicalibus interrupte pinnatis, caulinis integris $v$. trilobis, bistipulatis, caulibus unifloris.

$S$ ie ver $s$ i a Willden ow in Berl.Magaz. $V .398$. R. Browa in Parrys. first Voy. App, p. CCLXXVI. $t$. C. Bot. Mag. t. 2858. Chamisso et Sehlechtend. in Linnaea, II. 4. Mels: ner Gen, 104. (73.) A d a ms i a Fischer msc. B u $\mathrm{ch}$ a ve a Reichenb. Consp. 167. Ge i sect. Oreogeum Seriuge in DC. Prodr. II. 553 . G e $\mathrm{i}$ et D r y a dis s s. Lina.

6385. Fallugia. Ca 1 y $x$ tubo brevissime turbinato, limbo explasatus, quinquefidus, extus minutissime quinquebracteolatus, aestivatione valvatus, persistens. Curo 11 a e petala 5 , calyei inserta, ejusdem laciniis alterna et subaequilonga, obovata. Stam ina plurima, cum petalis inserta; $\mathrm{f}$ i 1 am ent a libera, anthera biloculares, longitudinaliter dehiscentes, Ovaria plurima, fundo calycis insidentia, libera, uniloenlaria, ov n lo unico, adscendente. St y li terminales, continui, filiformes; st igmata papulosa. A ehenia plurima, calycis tubo inclusa, stylis continuis, barbato-plumosis, longissime exsertio aristata. Semen adscendens. Embryoris exallsuminosi radicula infera. Frutex mexicanus, ramosissimus; ramis pilosis, foliis alternis, cuneato-linearibus, tri-quinquefidis, stipulis lineari-lanceolatis, fioribus subcorymbosis.

Sieversia paradoxa Don in Linn. Transaet. XIV. 576. $t, 22 . f .7-10$.

6386. Gevm LINN. Calyx fundo coneavas, limbo quinquefidus, explanatus v. subcampanulatus, extns quinquebracteolatus, aestivatione valvatus, persistens. Corolla e petala 5 , calyci inserta, ejusdem laciniis alterna et majora. Sid- mina plurima, cum petalis inserta; fila menta libera, anthera e biloculares, longitudinaliter dehiscentes. Ova ria plurima, receptaculo columnari inserta, libera, unilocularia, o v n lo unico, adscendente. Styli terminales, jnflexi v, geniculati; $s$ tigmata simplicia. A $\mathbf{c}$ h en i plurina, receptaculo conico v. subelavato-cylindrico, exsucco inserta, stylo indurato, inflexo v. geniculato aristata. $\mathrm{S}_{\mathrm{e}}$ men adscendens. Embryonis exalbuminosi radie ula infera. - Herbae perennes, in temperatis hemisphaerae borealis, rarius in $A m e-$ rica ausirali extratropica crescentes; foliis radicalibus imparipinnulis, foliolo terminali plerumque majore, caulinis sparsis, saepissime ternatis, stipulis petiolo adnatis, floribus in apice caulis solitariis v. saepe pluribus, corymbosis.

G e u m Linn. Gen, n. 867. Nestler Potentill. 16. exel. pl. Seringe in DO. Prodr. II. SBO. excl, seet. 3, et 4. Fischer et Meyer Index. Sem, horl. Petropolit, 1837. III. 33. C a r y op h yll a ta Touruetort Inst. 151. Mönch Method.661

a. CARYOPHYLlaStrum, C al y $\mathrm{c}$ is laciniae post anthesim reflexae Styli articulus superior inferiore multo brevior. A chentora in cupitulum sessile. Petala vix unguiculata. Flores erecti, plerumque parvi. Fiseh. et Meyer $t$. o. - Caryophyllas tru m Seringe in Mem. soc. h, n. Genev. II. 138. et in DC. Prodr. l. c. lexcl. pl. (Murray Comment. Gätting. V. 2. Jaeq. Hort. Vin. dob.t.175. Ic, rar, t.93. Flor, dan, t, 672. E. B. t.1400.)

b. CALLIGBUM. Cal y e is laciniae post antiesim reflexae. St y $l i$ articulus superior interiorem subaequans. A $c$ hen forum capirulum subsessife. Petala vix unguiea. lata, calyce atulto majora. Flores ereeti, speciosi. Fiseher et Meyer l. c. (Bot, Reg. t. 1088. Sibthoip Flor. graec. $t$. 485.)

c. CARYOPhyllata. Caly c is fructiferi laciuiae erectae v. patentes. Sty 1 i articutus superiore inferiorem sub. aequans. A cheniorum capitulum stipitatum, stipite brevissimo v, calycem subexcedente. P etala vix v. louge unguiculata. Flores erecti v. cernui. - C a ry oph y ll at a Seringe $l$. $c$. Fior. dan. $t$, 292. 2874. E. B. t. 106.)

838\%. Cowania DON. Calyx tubo turbinato, limbo quinquefido, ebracteolato, aestivatione valvato, persistente. Corolla e petala 5, calyei inserta, ejusdem laciniis alterna et majora, obovata. Stamina plurima, cum petalis inserta; filamenta libera, antherae bilueulares, longitudinaliter dehiscentes. O varia 5_11, fundo ca. lycis inserta, libera, unilocularia, ovulo unico, adscendente. Styli terminales, villosi; stigniata simplicia. A c he n ia 5_11, calyce inclusa, st y lis plumosis, longissime exsertis aristata. Semen erectum. Embryonis exalbuminosi radicula infera. - Frutex mexicanus, ramosissimus; ramulis brevissimis, foliosis, dense lanatis, foliis alternis, lineari-cuneatis, apice tripartitis, margine revolutis, stipulis membranaceis, adnatis, foribus in apice ramulorum solitariis, sessilibus, aureis,

C ow a n ia Don in Linn. Transact, XIV. 574. t. 22. f. 1. Meisuer Gen. 104. (74.)

8385. Coluaria R. BR. C a y x tnbo campanuiato, demum elongato turbiaato, decencostato, limbo quinquefido, extns quinquebracteolato, aestivatione valvato, persistente: Corolla p tala 5, calyci inserta, ejusdem laciniis alterna et majora. Stamina plurima, cum petalis inserta; filamenta libera, antherae biluenlares, longitudinaliter dehiscentes. Ova ria plurima, receptacalo brevissimo in fundo calycis inzerta, libera, unilucularia, ovulo onico, adscendente. St y li subterminales, recti, basi incrassata articulati; st ig mata simplicia. A chen i a plarima, reseptacalo brevissime colunnari inserta, tubo calycis inclusa, 
scrobiculato-rugosa, sty lo basi articnlata deciduo mutica. Semen adscendens. Em hry on is exalbuminosi radicula infera. - Herba Asiae mediae, perennis; foliis radicalibus breve petiolatis, interrupte pinnatisectisy lobis obovatis, crenatis, utrinque molliter tomentosis, pilisque sparsis hispidis sub. tus canescentibus, caulinis inter stipulas connatas sessilibus, integris $v$. trifidis, floribus terminalibus solitariis, rarius binis v. ternis, erectis, stipulaceobracteatis, calycibus purpurascentibus, petalis favis.

Coluria R. Brown in Parrys first Voy. App. p. CCLXXVI. in not. Bunge in Ledebour Flor. alt, II. 264. Laxmannia Fiseleer msc. Dryas geotdes Pallas It.

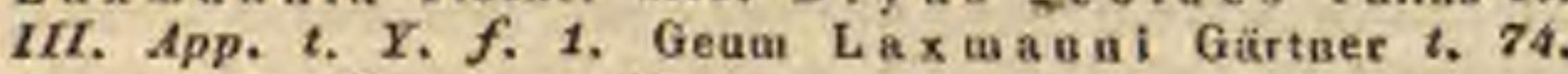
G. potentilloides Ait.

G385. Dryas LINN. Cal yx tubo subconcavo, limbo octo-novempartito, ebracteolato, aestivatione valvato, persistente. Corollae petala 8_9, calyci inserta, ejusdem laciniis alterna et majora. Stamina plurima, cam petalis inserta; $f i-$ la $m$ enta libera, antherae biloculares, longitudinaliter dehiscentes. Ovaria plurima, in fundo calycis sessilia, unilocularia, o v ulo unico, adscendente. Stylus subterminalis; stigma simplex. A ch en ia plnrima, stylis barbato-plumosis caudata. Semen adscendens. Em bryon is exalbuminosi radicula infera. - Suffruticuli in montibus celsioribus Europae et Asiae mediae, non in $A m$ er $i$ ca boreali et arctica crescentes; foliis simplicibus, ovatis v. subcordalis, crenatis v. integerrimis, subtus albo-tomentosis, floribus albis, majusculis.

Dry a s Lin o, Gen, n, 637. Sehkuhr t, 137. Gírtner $I, 358$. $t$. 74. E. B. $t$. 451. Flor. dan. $t, 31.1216$. Nestler Poten. till, 16. DC. Prodr, IT. 549. Meisner Gen, 104. (73.)

SUEOIRDQ III. SPIRAEACEAE DC. Prodr. II. 541. C al y x aestivatione imbricatus v. rarius valvatus. $\mathrm{S}$ t a $\mathrm{m}$ in a indefinita. Ovaria saepissime 5, verticillata, rarius 2 v. solitaria, bi-multiovulata, ovulis pendulis v. adscendentibus. Folli culi capsulares, dehiscentes, mono-polyspermi. - Frutices $v$. arbusculae, rarius herbae.

\section{§. 1. SPIREAE VERAE. Semina aptera.}

6390. Therria $D C$. Caly x tubo brevissimo, limbi quinquepartiti, patentissimi lobis ovatis, tribus truncatis, duobus ealloso-submueronatis, aestivatione imbricatis. Co roll a e petala 5 , calycis fauci inserta, ejusdem laciniis alterna, orbiculata, unguicnlata, patentissima. Stamina circiter 20, calycis fauci inserta, exserta; filamenta filiformia, antherae ovatae, biloenlares, longitudinaliter dehiseentes. Ovaria $5 \ldots-8$, in fundo calycis sessilia, unilocularia, libera, O vu Inm unisum, suturae ventrali appensum, anatropm. Styli terminales, recti; $8 \mathrm{tigmata}$ vix incrassata. Ca ps u la e globosae ..... - Suffrutex japonicus, inermis, ramosus; cortice laevi, virescente, ramis virgatis, ramulis lateralibus brevibus, e gemma squamosa ortis, foliis alternis, ovato-lanceolatis, grosse et inaequaliter serratis, penninerviis, conduplicatis, serraturis acutis, submucronatis, stipulis duabus, lineari-subulatis, rigidiusculis, floribus in ramulis saepissime solitariis, pedunculatis, luteis, cultura facillime plenis.

Ke r ri a DC. in Transact. Linn. soc, X11. 156. Prodr. I1. 501. Meisuer Gen. 103. (23.) $R$ u bus $j$ a pou icus 1. Corchorus japonicus Thunb. Andrews Bot. Reposit. t. 587. Bat. Mag. t, 1296, Spirae a japonica Camb.
6391. Spiraea LINN. C a ly x tubo concavo $v$, campanulato, limbo quinquepartito, persistente, laciniis aestivatione remotis, Corolla e petala 5, calyeis fanci inserta, ejusdem laciniis alterna, ovata, unguiculata, patentissima. Stam in a 20 , rarius $30-60$, calyeis fanei bi-pluriseriatim $v$. fasciculatim inserta, longe exserta; filam en $t$ a filiformia, libera, antherae biloenlares, longitudinaliter dehiscentes. D ise us carnosus cum ealycis tubo connatus, margine adnato obsoleto, v. libero crenulato v. dentato. Ovaria 5 , rarias 3 v. 12 , in fundo calycis sessilia v. breviter stipitata, unilocularia, libera. Ovula $2 \_15$, suturae ventrali biseriatim inserta, pendula $v$. rarissime adscendentia, anatropa. Styli terminales, recti $v$. rarissime $e$ basi geniculata adscendentes; $8 \mathrm{tigm}$ a $\mathrm{ta}$ plus minus incrassata v. dilatata, integra, Folliculi capsulares $3_{-12}$, liberi v, rarissime in capsulam subcoaliti, sutura ventrali apice bivalves. Semina 2 - 15, pendula v. rarissime adscendentia. E m br y on is exalbuminosi, orthotropi radicula umbilico proxima, supera $v$. rarissime infera. - Herbae $v$. suffrutices $v$, frutices, in temperatis hem is phaerae borealis crescentes; foliis allernis, simplicibus $v$. simpliciter aut composite imparipinnatis, stipulis geminis, petiolo adnatis, interdum minimis v, penitus "bsoletis, floribus axillaribus terminalibusque, racemosis, corymbosis, cymosis, paniculatis $v$, interdum fasciculatis, albis v. rarissime roseis, nonnunquam abortu polygamis $v$. dioicis,

S pira e a Linn. Gen, n, 630, Gärtner $I$. 337. Cambessed. in Annal. so, nat. 1. 229. exel. seet, 4 et 5. DC. Prodr. II. 541. Meisner Gen, 103. (73.) Kunth Flor. Berol. I. 202. Spiraea, VImaria, Fillpendula et Barba caprae Tournef. Inst, 389. 141, 150 et 151.

a. PHYSOCARPUS Cambess. Ova ria ima basi coalita, bi-triovulata, ovulis primum horizontalibus, demum nno adscendente, reliquis pendalis. Dis c us cum tubo calycino penitus connatus. C a p 8 i I a e membranaceae, inflatae. - Folia indivisa, stipulata. - P h y socarpus Spiraeae sectio Cambessed. $l$. c . Seringe $l$. o. - ? I ntorus Rafin. Sp. opulifolia Linn. Duham. Arbr. edit. nov. VI, $t, 14$.

b. CHAMAEDRYoN Ser. Ovaria libera, pluriovalata, ovulis pendulis, Discus inferne cum calycis tubo connarus, superue liber. Capsulae haud inflatae. Frutices, Folia integra $v$, dentata, exstipulata. Flores hermaphroditi. - Chamaedryou et Spiraearia Seringe l. c. Spirate a Cambessed. $l$. c. exel. Arunco. (Jacq Hort. Vindob. $t, 140$. Duham. Arbr, edit, nov. VI. t, 13. Waldst, et Kitaibel Plant, rar. Hung. t. 227. 235. Bot. Mag. t. 2426. Kunth in Humb. et Bonpl. Nov. gen. ot sp. VI. t. 562. Cambessed. Op. cit, t. 25, 26.)

c. SORBARIA Ser. Ovaria basi coalita, pluriovulata, ovolis peadulis. Diseus totus cum ealycis tubo connatus. Capsulae liberae, haud inflatae. - Frutex folils pinnatifidis, tipulatis. - Sorbaria Seringe 1. c. Scbizonotus Linaley in Wallich Catalog. $n$. 703. Spiraea sorbifolla Linu. Pallas Flor. Ross. t. 24.

d. ARUNCUS Ser. Oraria libera, pluriovulata, ovulis pendulis. Dis cus inferne cum calycis tubo connatus, superne liber, erassissimus. C a ps a la haud inflatr. Herba foliis tripinnatisectis, exstipulatis, floribus abortu dioicis. - Aruneus Seringe l. c. Spiratea Aruacas Linn.

e. ULMaria Mönch, Ovaria libera, biovulata, ovulis pendulis. Discus obsoletus. Capsulae rostratae, rectae v. contortae, - Herbae perennes; folitis pinna. tijidis, stipulatis. - U $1 \mathrm{~m}$ a ri a Mônch Method, 662. Cambess, l. c. (E., B., $t, 960$. Jacq. Hort. Vindob, t. 89. Pallas Flor, Ross, t. 27, 28. Cambess. Op, cit. t. 16.)

6392. Neillia $D O N$. Cal yx tubo campanulato, limbi quinquefidi laciniis erectis, ovatis, apice cuspidatis, Co roll a e petala 5, calyeis fau- 
ci inserta, ejusdem laciniis alterna, ovato-subrotunda, brevissime unguieulata. Sta mina circiter 20 , calycis fauci inserta, inaequilonga; fil a m e n t a filiformia, antherae biloculares, subglobosae, longitudinaliter dehiscentes. Ova rium unicum, sessile, uniloculare. Ovula plura, juxta suturam ventralem biseriatim adscendentia, anatropa. StyIu 8 subterminalis, glaber; stigma simplex, obtusum. Folliculus capsularis, sutura ventrali dehiscens, polyspermus. Semina adscendentia. Emb ryo in axi albuminis (?) carnosi orthotropus, radicula infera. - Frutices nepalenses, inermes, Spiraeae opulifoliae facic; folits alternis, simplicibus, peliolatis, duplicato-serratis, stipulis caducis, foliaceis $v$. membranaceis, acutis, floribus terminalibus $v$, rarius lateralibus, racemosis, albis.

Neillia Don Nepal, 228. DC. Prodr. IT. 546. Meisner Gen, 103. (73.)

6393. Aillemia MÜNCH. C a ly $\mathrm{x}$ tubulosocampanulatus, decemnervis, fauce constrictus, limbo quinquedentato. Corolla e petala 5, calycis fauci inserta, ejusdem dentilous alterna, elongatolanceplata, basi in unguem angustata. St a m ina 20 , tubo calycis infra petala inserta, remotiuscule biseriata, inclusa; filamenta bresissima, anth e rae hiluculares, lungitudinaliter dehiscentes. Ovaria $3-5$, in fundo calycis sessilia, inclusa, libera, unilocalaria. OvnIa 2 , suturae ventrali $8 \mathrm{u}-$ pra medinm inserta, subeollateralia, adscendentia. Styli terminales, breves; stigmata truncata. Follieuli capsulares 5, v. abortu pauciores, lineari-subfalcati, breviter e calyce exserti, sutura ventrali dehiscentes. S e mina 2 , v, abortu unicum, adscendentia. E m bryonis exalbuminosi, orthotropi radieula infera. - Herbae boreal $i$ a m e ric a n a e, perennes; foliis alternis, trifoliolatis, foliolis petiolatis, serratis, stipulis minutis $v$. maxi. mis, floribus longe pedicellatis, axillaribus terminalibusque, albido-roseis.

Gillen i a Mönch Method. Supplem, 286. Nuttall Gen. 1. 307. DC. Prodr. 1I, 576, Spire a e sect, Gillenia Cam. bessed, in Annal. sc, nat. I.367. t, 17. f. 2. t. 28. Meisner Gen, 103. (73.) S p. tif otialata Lian. Bot. Mag.t.489. Sp. stipulat a Willd. Barton Med. bot, $t$. 6 .

639 4. Nuttallia TORR. et A. GRAY. Flores dioici. Cal y x liber, campanulatus, quinquefidus, feminarum supra basion transversim secedens. Corolla e petala 5, oblongo-ovalia, breviter nnguienlata. Masc. S $t$ a $\mathrm{m}$ in a biserialia, superiora subiena, 5 ad marginem calycis inserta, inferiora 5 versus medium tubi; filamenta brevia, incurva, staminum inferiorum arcte deflexa, an $t h e-$ rae subrotundae. Ovarii rudimentum nullum. Fem. Sta mina nt in masenlis, efoeta, Ovaria 5 , libera, unilocularia, oblique obovata, glaberrima, biovulata, ov ulis collateralibus, ex apice cavitatis pendulis, stylo paullo infra apicem intrörsum laterali, filiformi, basi articulato, demum deciduo; stigmate dilatato. Ca p sula e suhdrupaceae, abortu 2-3 v. interdum solitariae, siceinsculae, obliqne obovatae, subincurvae, a bortu monospermae, eudoearpio chartaceo. S e $\mathrm{men}$ inversum. $\mathrm{E} \mathrm{m}$ b ry 0 nis exalbuminosi, orthotropi cot y l edones late obovatae, compressae, radienla supera. Arbor in Americaboreali-oceidentali sylvatica; foliis ex eadem cum floribus gemma nascentibus, alternis, cuneato -oblongis, apiculatis, basi in petiolum brevem angustatis, integerrimis, pubescentibus $v$. glabris, racemis pendulis, bracteis membrana- eis, acuminatis, floribus albis, odore amara amygdalino.

Nuttalli a Torrey et A. Gray Flor. of North Amer. I. 412. Hooker ad Beechey 336. $t .82$.

\section{GENUS AFFINE.}

6395. Brayera KUNTH. Calyx tubo basi bibracteolato, turbinato, fauce intus annulo membranaceo constricta, limbi decempartiti laciniis biseriatis, qninque exterioribus multo majoribus, oblongo-lanceoiatis, obtusis, reticulato-venosis, stellatim patentibus, quinque interioribus alternis, minoribas, spathutatis. Corolla e petala 5, calycis fanci inserta, minima, linearia. Sta mina circiter viginti, cum petalis inserta; filamenta libera, inaequilonga, a $n t$ herae biloculares, longitudinaliter dehiscentes. 0 va ria 2 , fundo calyeis insidentia, libera, unilocularia, ovulo unico v. geminis, pendulis. St y l i terminales, e calyeis fauce exserti, sursum incrassati; stig m a ta subpeltatim dilatata, crenato-lobata, Fruetus ..... Arbor abyssinica, sexagintapedalis, ob vires anthelminthicas celebris, ramulis tomentoso-villosis, foliorum delapsorum cicatricibus annulatis, foliis confertim alternis et interrupte imparipinnatis, foliolis oblongis, serratis, margine et nervis subtus villosis, stipulis petiolo basi dilatata semiamplexicauli adnatis, floribus in cymas repetito dichotomis, divaricato-flexuosis, pedicellis basi bractea ovata stipatis.

B ra yera Kuuth in Brajer Notice Vermifug. 182d. 8. c. ic. Dict. hist. nat. II 501. c. ic, DC. Prodr. II. 588. Meisner Gen, 103. (73.) Freseuius in Mus. Senkenberg. II. 162. H a gen I a Willd. $S p$. $I I, 331$. C us so s. B a u Kesla Bruce Voy. 22, 23. alata.

TRIBUS II. QUILLAJEAE. S emina

6396. IRageneekia $R U I Z$ et $P A V$. Flores dioici. Ca 1 y $x$ tubo hemisphaerico, libero, limbi qninquepartiti laciniis aestivatione subimbrieatis. Corulla e petala 5, calycis fauci inserta, ejusdem laciniis alterna, sessilia, orbiculata. M a s c. St a min a 16-20, cum petalis uniseriation inserta; filamenta subulata, libera, aequalia, antherae introrsae, biluculares, oblongae, dorso snpra hasim insertae, longitudinaliter dehiscentes. Ovarii rudimentnm nullum. Fem. Stamina efoeta. Ovaria 5, libera, ovulis plurimis, suturae ventrali biseriatim insertis, anatropis. Styli 5 , terminales; stigmatibus dilatatis, Cap $8 \mathrm{ul}$ a e 5 , coriaceae, calceiformes, radiatim patentissimae, uniloculares, polyspermae, sutura ventrali superne hiantes. S e mina plurima, biseriata, obovato.cnneata, depressa, apice alata, transverse imbricatim sibi incumbentia, testa tenuissima, endopleura crassiuscula, adnata, umbilieo panllo supra basim. ventrali. Embryonis exalbuminosi, orthotropi cotyledones ellipticae, convexo-planae, radicula infera. - Arbores peruanae; foliis allernis, simplicibus, argute serratis, stipulis petiolaribus geminis, minutis, floribus terminalibus, masculis corymbosis, femineis solitariis.

K a g en e e ki a Ruiz et Pavon Prodr. 134. t. 37. Kunth in Humb. et Bompl. Nov. gen. et sp. VI. 236. DC. Prodr. IT. 547. Don in Edinb, new philosoph. Journ, XII. 111. Meisner Gen. 103. (72.) L y daea Moliaa Chili edit. 2. p. 300.

B398. Quallaja MOLIN. Flores polygami. Ca I y $\mathrm{x}$ tubu hemisphaerieo, libero, limbi quinquepartiti laciniis aestivatione valvatis. Discu carnosus, calycis tubo adnatus, in lobos quin- 
que, lacinias usque ad medium vestientes effusus. Cor o lla e petala 5, calycis fauci inserta, eiusdem laciniis alterna, sessilia, spathulata. St a mina 10 , quinque petalis opposita fundo disci, totidem subejusdem lobis mediis limbi laciniis inserta; filam en ta subulata, libera, antherae introrsae, biloculares, ovatae, basi emarginatae, dorso insertae, longitudinaliter dehiscentes. $O \mathrm{v}$ a $\mathrm{ria} 5$, in fundo ealycis sessilia, unilocularia, in axi cohaerentia, ov ulis plurimis, suturae ventrali biseriatim insertis, anatropis. Styli 5 , terminales, liberi; $s \mathbf{t i g -}$ in a tibus oblique depressis. Ca ps u la e $\overline{5}$, coria. eeae, oblongae, obtusae, patulae, uniloculares, bivalves, polyspermae. S e m i na plurima, biseriata, compressa, transversim imbricata, apice alata, testa tenui, endopleura crassinseula, adnata, nmbilico paullo supra basim ventrali, Em bryon is exalbuminosi, orthotropi cotyledones ellipticae, radicula infera. - Arbores chilenses; foliis sparsis, simplicibus, integerrimis, stipulis petiolaribus geminis, caducis, pedunculis terminalibus et axillaribus, subquadrifloris, bracteatis, flore intermedio femineo, reliquis ovariis efoetis masculis.

Quill aj a Molina Chili ed. 2, p. 298. Jussieu Gen. 444. Kuath in Humb. et Bonpl. Nov. gen, et sp, VI. 236. in not. DC. Prodr. II. 547. Don in Edinb, new philosoph. Journ. XII, 110, Meisner Gen, 103. (22.) $\mathrm{S}$ m e g mader mos Ruiz et Pavon Prodr, 133. t. 31.

B358. Vauquelina $C O R R$, F 1 o r es her.maphroditi. Calyx tubo hemisphaerico, libero, limbo quinquepartito. Corolla e petala 5, calycis fanci inserta, ejusdem laciniis alterna. Stam ina 15-20, cam petalis inserta, exserta; fil a m e n ta filiformi-subulata, a $\mathrm{th}$ erae introrsae, biloculares, oblongae, longitudinaliter dehiscentes. Ova$r i a$ quinque, in nnicum quinqueloenlare coalita. Ovula .... Styli 5 , distincti; stigmata capitata. Capsula calyce persistente cincta, pentagona, ligneo-coriacea, pentacocra, coceis unilocularibus, bivalvibus, dispermis. Se m in a collateralia, erecta, superne alata ... - Arbor mexicana; foliis alternis $v$. rarissime oppositis, simplicibus, argute dentatis, stipulis petiolaribus geminis, minutis, floribus in apice ramorum corymbosis, albis.

$\mathrm{V}$ a uquelin ia Correa in Humb. et Bonpl. Plant. aequinoct, 1 , 141, $t$. 40. Nov, gen, et sp. VI. 238, DC, Prodr, II. 847. Meisuer Gen. 103. (72.)

6399. Lindiloya $H, B, K, C$ alyx tubo turbinato, limbo quinquepartito. Corolla petala 5 , calyeis fauci inserta, eiusdem laciniis alterna, brevissime unguienlata, patentia. St a m in a 15-20, disco annulari calyeis faucem marginanti inserta; antherae lanceolatae, basi uncinato-reflexa, cruribus inaequalibus, connatis, biloculares, 0 v a ri a 5 , in nnicum quinqueloculare coalita. Ovala in quovis loculo 2, collateralia, infra apicem affixa, pendula. Styli 5, terminales; stigm a ta subclavata. C a p u la calyce persistente suffulta, ovato-pentagona, lignosa, quinquesuleata, quinquelocularis, loculicide quinquevalvis, loculis di- v. abortu monospermis. Semina margine meubranaceo eincta .... - Arbor mexicana, glaberrima; foliis sparsis, simplicibus, integris, crenulatis, stipulis petiolaribus geminis, floribus ad apicem ramulorum axillaribus, solitariis, pedunculatis, bracteatis, albis.

L i nd Ie y a Kuath in Humb. et Bonpl. Nov. gen. et sp. V1. 240, t. 562. DC. Prodr. II.548. Meisner Gen, 103. (72.)

6400. Duphromia MART. et ZUCE. C a Iy $x$ quinquepartitus, laciniis linearibus, elongatis, detu um revolutis. Corolla nulla? .... Stami. na 5 , imo calyci inserta, ejusdem laciniis alterna? fil amenta basi in urceolum connata, sursum complanata, dilatata, quatuor per paria coalita, quintum libernm, apice filiformia, persistentia, a ntherae ..... Ovarinm ..... Stylas persistens, filiformis, a basi ad medium barbatus, demum tripartibilis. C a p su la calyce et staminibus cincta, stylo superata, cylindrico-subtrigona, triloeularis, septicide trivalvis, valvis navicularibus, marginibus introflexis conniventibus, columna centrali tenui, trigona, demum tripartibili. Semin a in loculis solitaria, oblonga, compressiuscula, pendula, testa membranacea, superne in alam lanceolatam, integerrimam expansa, umbilico ventrali, lineari. E mb r y o intra albumen (?) tenue, in basi seminis incrassatum rectus, c otyled onibus ovato-lanceolatis, planis, subearnosis, ra di cula brevi, eylindrica, infera. - Arbor brasiliensis; foliis alternis, simplicibus, integerrimis, coriaceis, subtus candicantibus, stipulis nullis, floribus racemosis.

E u phro n ia Martius Nov. gen, et sp. I. 121, t. 73.

SUEORTO IV. NEURADEAE DC. Prodr. II. 548. Flor e s hermaphroditi. C aly $x$ tubo cum ovariis concrescente. Corolla e petala 5. Stamin a 10 . Ovaria 10 , coalita. F r u c u s capsularis, loculis monospermis. S e min a pendula. - Herbae foliis sinuatopinnatifidis $v$, bipinnatifidis, bistipulatis.

6401. Neurada B. JUSS. Cal yx tubo brevissimo, demum eum ovariis concrescente, limbi quingnefidi lobis ovatis, tandem loculis excrescentibus, imbricatis. Corolla e petala 5, calycis fauei inserta, ejusdem laciniis alterna et breviora. $\mathbf{S}$ tamina 10 , cam petalis inserta; fil amenta subnlato filiformia, libera, an thera e ovato-subglobosae, biloculares, longitudinaliter dehiscentes. $O \mathrm{va}$ ri a 10, libera, verticillata, ovulo unico, pendulo. Fruetus depressus, carpidiis decem, dorso cum ealyce muricato coalitis, ventre distinetis, hiantibus. Se min a in funiculis ex axi floris adscendentibus solitaria, pendula, ossea. Embry onis exalbuminosi, corvati entyledones oblangae, radicula obliqna. - Herba in Afrieae mediterranea e arenosis vegetans, basi lignosa, tomentosa; foliis alternis, sinuato-pinnatifidis, foliaceo-bistipulatis, foribus axillaribus solitariis, subsessilibus, semine intra capsulam germinate, integumentis seminalibus in adultae plantae collo superstitibus.

Ne u rada B. Jussieu in Linn. Gen. $n$ 587. Gärtaer $I$. 169. t. 32, Lam. t. 393. DC. Prodr. IT. 548. Meisuer Gen. $10505(75$.

640\%. Geieluma LINN. C alyx tubo brevissimo, demum cum ovariis concrescente, limbi quinquefidi lobis acuminatis, aestivatione subimbricatis. Co rolla e petala 5, calycis fauci inserta, einsdem laciniis alterna et multo majora, obovata. S t am in a 10, cum petalis inserta; fil amenta filiformi-subulata, libera, persistentia, demum spinescentia, a ntherae biloculares, subglobosae, longitudinaliter dehiscentes. Ov ari a 5 v. 10, fundo calycis insidentia, cum eiusdem tubo et inter se coalita. ovnlo unico, pendulo. Styli 5 , filiformes, breves; stigmata subcapitata. Cap sn la depressa, quinque-decemloeularis, loculis tandem in axi hiantibus, monospermis. Se mina pendula. Embryonis exalbuminosi cotyledones folinceae, radicula obliqua, supera. - Herbae capenses, suffrutescentes; foliis alternis, pinnatisectis $v$. decompositis, floribus amplis, flavis. 
G r i e 1 a m Lian. Gen, $n$, 1235. Burmann Geran, 1. Gärtner I. 180, t. 36. Sweet Geran, IT. t. 171. DC. Prodr. II. B69. Meisuer Gen, 105. (74.)

6403. Amooremxia MOC. et SESS. C aIy $x$ quinquepartitus, tubo brevissimo, lobis oblongis, acutis. Coroll a e petala 5 , calyce majora, ad ejusdem basim inserta, Stam in a circiter 20 , uniseriata, petalis breviora, apice obtusa v. emarginata. Ovari a m ovatum. liberum, trilueulare, multiovnlatum Stylus filiformis, acutns. Capsula ovata. - Herba mexicuna; foliis alternis, longe petiolatis, bistipulatis, palmatifidis, lobis apice serratis, basi fece membrana foliacea junctis, pedunculis solitariis, oppositifoliis, subterminalibus, erectis, apice inflexis, unifloris, floribus amplis, rubellis.

A more $u \times$ it Moc. et Sesse Flor, mex, ex DC. Prodr. II. 638. Meisuer Gen. 105. (74.)

\section{Ordo CCEXXIII. Aneygdaleae.}

ROSACEARUM tribus AMYGDALEAE Jussien Gen, 140, DC. Prodr. II. 529. Bartling Ord, nat. 404. Lindley Intro duct, edit. 2, p. 146. DRUPACEAE DC. Flor. Ir. IV. 479.

Frutices v. arborgs, inermes v. ramulis spinescentibus armatae. Folia alterna, simplicia, integra, serrata, penninervia, petiolo cum lamina continuo, saepissime basi v. apice glandula depressa instructo. Stipulae liberae, caducae.

Fuoars regulares, hermaphroditi v. rarius abortu unisexuales, praecoces v. foliis coaetanei, in racemos, corymbos v. umbellas dispositi, rarius geminati v. solitarii,-pedicellis bracteatis.

Caly $\times$ liber, quinquefidus, deciduus, laciniis aestivatione imbricatis.

Cogoldas petala 5, perigyna, annulo carnoso, interdum fere obsoleto, ealycis tubum vestienti inserta, limbi laciniis alterna, breviter unguiculata, aestivatione convolutiva.

Stamina cum petalis inserta, multiplici eorundem numero subdefinita, aequalia, omnia fertilia. Fil a m e $t$ a filiformi-subulata, Hibera. Antherae introrsae, biloculares, ovatae v. subglobosae, longitudinaliter dehiscentes.

Ovarier unicum, uniloculare, rarissime plura, libera. Ovula gemina, ex apice cavitatis collateraliter pendula, anatropa. Stylus terminalis v. rarius sublateralis, simplex. StigII a capitatum.

Drupa sarcocarpio carnoso v, coriaceo-fibroso, putamine osseo v. lignoso, bivalvi, abortu saepissime monospermo.

Semen funiculo e basi loculi adseendendenti appensum, testa membranacea v. subcoriacea.

Embryonis exalbuminosi, orthotropi coty ledones carnosae, plano-convexae, germinatione foliaceae, radicula brevissima, supera, plumula manifesta.

A my gdal e a e, quarum plures ob fructuum carnem sapidam v. semina oleosa ab fantiquis- simis temporibus cultae, maximo numero in temperatis hemisphaerae borealis generantur, paucae in regionibus tropicis vigent.

Ordo fructus indole, acidi hydrocyanici in foliis praesentia, et ejusdem in pericarpiis nonnullarum copia ab affinibus facillime distinctus, quibusdam notis Terebinthaceas Anacardieas revocat.

B s0s. Pyomm GARTN. Calyx tubo cyathiformi, limbo sexdentato, basi annuliformi, persistente. Corolla e petala 6, calycis fanci inserta, ejusdem dentilus alterna. S t a min a 12-18, cum petalis inserta; filamenta filiformia, anthe r a biloculares, longitudinaliter dehiscentes. Ovarium sessile, uniloculare. $O$ vula 2 , ex apice loculi collateraliter pendula, anatropa. S t y I u s terminalis; stigm a subpeltatum. D $\mathrm{rap}$ a sicea, transverse oblouga, putamine subreniformi, medio contracto, abortu monospermo. Sem en inversum. Embryonis exalbuminosi cotyledones cras. sissimae, radicula brevissima, supera. - Arbores Asiae tropicae; foliis alternis, oblongis, integerrimis, basi subtus plerumque biglandulosis, racemis axillaribus et lateralibus, solitariis aut confertis, saepe tomentosis, floribus parvis, uribracteatis.

P y gе um Gartuer $T$. 218, $t$, 46, Colebrooke in Linn. Transact. XII. 360, t, 18. Meisner Gen. 202. (72.) Polydoutia Bluae Bijdr. 1104. Meisner Gen. 102. (72.) Poly. storthia Blume Flor. Jav. Praef. VIIT.

C405. Annyallalus $L I N N$. C al y x tubo urceolato-subcampanulato, limbi quinquepartiti laciniis aestivatione imbricatis. Coroll a e petala 5, ealycis fanci inserta, ejusdem laciniis alterna, S tamina $15-80$, cum petalis inserta; filamenta filiformia, libera, an therae bilocolares, longitadinaliter dehiscentes. Ovarium sessile, uniloculare. $O$ v ula 2 , ex apice lueuli collateraliter pen. dula, anatropia. Stylus terminalis; stigma capitato-subpeitatum. D r u p a coriaceo-fibrosa $v$. carnosa, putamine rugoso-foraminuloso, abortu monospermo. Semen inversum. Embryonis exalbumiaosi, orthotropi cotyled on es carnosae, radicula supera. - Frutices $v$, arbusculae, in temperatis calidioribus he mis $p$ hat a e borealis cres. centes; foliis ulternis, stipulatis, integerrimis v.serratis, junioribus conduplicatis, floribus subsessilibus, solitariis $v$. geminis, e gemma squamosa ante folia erumpentibus.

A m y g d a 1 u s Linn. Gen, n, 619. Jussieu Gen. 34t.

a. AMYGDALOPHORA Neck. Dr up a pubeseenti velutina, cortice fibroso, exsucco, irreguhriter secedente. - A a y ditophora Necker Elem. n. 217 . A mygdalus Tournefort Inst. 408. DC. Prodr. II. 530.

b. PERSICA Tournef. Dr a pa earnosa, epicarpio velatino v. glabeirino. - Pers i a Touruef. Inst.400. DC. Prodr. II. 3.31. Trichocarpus Netker Elem. n. 718.

640B. Fromates LINN. Calyx tubo orceolato-hemisphaerico, limbi quinquepartiti laeiniis aestivatione imbricatis. Coro 11 a e petala 5 , ealycis fanci inserta, ejusdem laciniis alterna. Sta mi. na $15-30$, cum petalis inserta; fil amenta filiformia, libera, a $\mathrm{t}$ ls e ra e biloculares, longitudinaliter dehiscentes. Ovari u sessile, uniloculare. Ovu I a 2 , ex apice loculi collateraliter pendula, anatropa. St y I u s teruinalis; stig ma subpeltatureniforme, integrum. Drup a carnosa, putamine laevi $v$, sulcato, nec rugoso-foraminuloso, aborin manospermo. Semen inversum. Bmbryon is 
exalbuminosi, orthotropi cotyledones crassae, radicula supera. - Arbores $v$. frutices, in temperatis et calidioribus hemisphaerae borealis obvii, in America et Asia tropica rariores, foliis alternis, stipulatis, integerrimis $v$. serratis, basi saepe glandulosis, inflorescentia e gemmis squamosis erumpente, saepe praecoci, varia, fructibus cultura cicuratis deliciosis.

Pron us Lina. Gen, $n, 620$.

a. ARMENIACA Tournef. D r upa extus velutina, putamine línc obtaso, illinc acuto, compressiusculo, ad margines utrinque sulcato, caeterum laevi. - Folia juniora con. volutiva. Flores folits praecociores, e gemmis squamosis orti, solitarii $v$, pauci subsessiles. - A r m e n i a c a Tournef. Inst, 399. Jussieu Gen. 341. DC. Prodr. II. 831 .

b. PRUNUS Tournef. Drupa extus pruinosa, putamine utriaque acuto, compressinsculo, ad margines subsulcato, caeternm laevi, - Folia juniora convolutiva. Flo. res solitarii $v$. gemini laterales, praecoces $v$, una cum foltis e gemmis propriis erescenles. - Pru nus Tour. nef. Inst.398. Jussieu Gen. 331. P r un o p hor a Necker Elem, n. 719. (Ledetour Ic, $t, 13$. Bot. Reg. t. 1135.)

c. CERASUS Juss. Drupa glaberrima, putamine subglo hoso, laevi. - Folia juniora conduplicata. Flores nunc in pedicellis unifloris e gemma squamosa erum. pentibus. umbellato-fasciculatis, folits praecociores, nune terminales, racemosi, post folia evoluti.

Cerasu s Jussien Gen. 340. DC. Prodr. IT. 335.

r. Cerasoophora Necker Elem. n.720. Flores umbellati, pedicellis unifloris, e gemma ortis. C e rasi $s \mathrm{p}$. Tournef. (Wallich Plant. 1s. rar, $t, 143,181$. )

P. $\mathrm{P}$ a d u s. Flores racemosi, e ramo orti.

a. Padi veri. Folia caduca, Cerasi sp. Tournef. (Flor. dan. t. 205. Jacq. Flor, austr, t. 227.)

b. Laurocerasi. Folia coriacea, persistentia. L a a $r$ oc e r a s us Tournef. Inst. 628 .

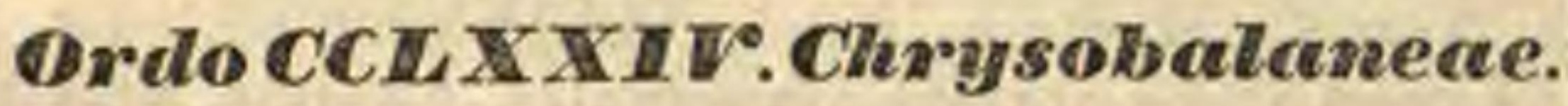

ChrysobalangaE R. Brown in Tuckey Congo 433. DC. Prodr. II. 525. Bartling Ord. nat. 405. Meisner Gen. 101. (71.) CHRYSOBALANACEAE Lindley Introduct, edit. IT. p. 158.

Arborks v. protuces, inermes v, rarissime ramulis spinescentibus armati. Folia alterna, simplicia, integerrima, penninervia, coriacea, petiolo eglanduloso. Stipula e liberae, deciduae.

Flones hermaphroditi v. aborta unisexuales, saepissime plus minus irregulares, racemosi, subspicati v. paniculati.

Caryx tubo turbinato v. campanulato, basi plus minus inaequilatero v. subcalcarato, limbi quinquefidi laciniis aestivatione imbricatis.

Corollas pelala 5 , calycis fauci inserta, ejusdem laciniis alterna, breviter unguiculata, saepe inaequalia, quandoque nulla.

Stamiva cum petalis inserta, triplo v. multiplo eorundem numero, subdefinita v. indefinita, in altero floris latere, quo calyx productior, saepe majora et fertilia, in altero breviora, sterilia v. nonnunquam rudimentaria. Fil am en $t$ a filiformi-subulata, libera, aestivatione erecta, complicata v. circinnata, sub anthesi exserta. Antherae introrsae, biloculares, longitudinaliter dehiscentes.
Ovarium unicum, in fundo calycis sessile v. saepius stipiti ejusdem tubo hinc adnato impositum, uniloculare, biovulatum, v. rarissime biloculare, loculis uniovulatis. Ovula e basi erecta, collateralia, anatropa. Stylus lateralis v. fere basilaris, simplex, filiformis; stigma simplex.

Drupa sessilis v. stipitata, sarcocarpio carnoso v. fibroso, putamine osseo, fere bivalvi, uniloculare, abortu monospermo, v. rarissime biloculari, dispermo, rarius Bacca crustacea.

Semex erectum, sessile, testa membranacea. A lb umen nullum.

Embryonis exalbuminosi, orthotropi cotyle dones carnosae, crassae, marginibus interdum conferruminatae, radicula brevissima, infera.

Chrysobataneae in regionibus tropicis totius orbis, imprimis Americae indigenae, ab Amygdaleis, quibus proxime affines, calyce saepissime basi ob adnatum ovarii stipitem inaequali, staminibus alterius floris lateris imperfectioribus, ovulis et seminibus erectis, nee non acidi hydrocyanici defectu facillime distinguuntur.

649\%. Clarygobalnmus LINN. C a l y x tubo turbinato-campanulato, limbi quinquepartiti laciniis subaequalibns, aestivatione imbricatis. Coroll a e petala 5, calycis fauci inserta, ejusdem laciniis alterna, subspathulata, decidua. Sta mina $15-30$, calycis fauci inserta, alterius lateris non. nulla awanthera, libera; fil a m e n ta subulata, exserta, a nthera e biloculares, longitudinaliter dehiscentes. Ovarinm sessile, hirsntum, uniloculare, ovulis geminis, e basi erectis, collateralibus, anatropis. Stylus basilaris, filifurmis; $8 \mathrm{tigma}$ oltusum. D r г a pellicnla tenni, pulpa pauca, putamini aretissime adhaerente, putamine quinqueangulari, subquinqnevalvi, abortu monospermo. Semen erectum. Lm bryonis exalbuminosi, orthotropi cotyledones crassae, carnosae, ra dicula brevissima, infera. - Frutices $v$, arbusculae in America tropica et boreali sublropica, nec non in Africa aequinoctiali crescentes; faliis alternis, stipulatis, integerrimis, paniculis axillaribus et terminalibus, ramis dichotomis, bracteatis, floribus albidis.

Ch r y ko hala nas Lian. Gen. n. 62t. Jaeq. Amer. t. 94. Lam. t. 428, Kunth in Humb. ot Bonpl. Nov. gen. et sp. VI, 244. Nuttall Gen, I. 301. DC. Prodr. II. 525. Meisner Gen, 102. (72.) I c a co Plumier Gen, 43, t, 5.

6409. Elistella LINN. Cal y x tuho brevi, basi inaequilatero, cum ovarii stipite connato, limbi quinguepartiti laciniis subaequalibus, aestivatione imbricatis. Curollae petala 5, calycis fauci inserta, ejusdem laciniis alterna, brevissime ungniculata, decidua. Stam in a $3-15$, calycis fauci inserta et hasi in annulum coalita, fertilia nnilateralia $3-9$, sterilia in altero floris latere ${ }^{2}$ abbreviata v. nulla; fila m e n a subulata, longe exserta, aestivatione circinnata, anth erae biloculares, longitudinaliter dehiscentes. Ovari um stipiti calycis tubo hinc adnato insidens, exsertum, extns et intus villosum, unilocnlare, ovulis geminis, e basi erectis, collateralibus, anatropis. St y Ins basila$157^{*}$ 
ris, filiformis, barbatus; stig ma truncatum. Bace a sieca, obovato-clavata, suberustacea, monosperma. S e m en erectum. E m b r y on is exalbuminosi, orthotropi cotyle dones carnosae, marginibus conferruminatae, radicula brevissima, infera. - Arbores v. frutices, in America tropica crescentes; foliis alternis, integerrimis, stipulatis, floribus in racemos simplices $v$, ramosos, $v$, in pani. culas subcorymbosas, axillares $v$. terminales dispositis, plurimis ovario efoeto abortivis.

H irtell a Liun. Gen. n.80. Lam, $t$. 138. AubletGuian. t. 98. Vaht Symb. II, t. 3t. Gärtuer f. III, 40, t. 158. (cotyledonibus perperam pro albumine deseriptis). Kunth in Humb. et Bonpl. Nov. gen. et sp. V1. 224. $t$ 365. DC. Prodr. II. 328. Zuecariai Nov. stirp. fasc. 1. 372. Meisner Gen, 102. (72.) $\mathrm{C}$ ormib u e a Ruiz et Pavon Prodr. 10, t. 2. non Flor. peruv. C a us e a Scopoli Introduct. n. 928 . B a1 a u tfum Desvaux in Hamill. Prodr. Flor. Ind. occid. 34. Meisner Gen. 102. (72). B r a y a Flor. Flum. IV. t. 1.

B409. Fieamin $A U B L E T$. C a ! y $\mathrm{x}$ tubo turbinato, aequilatero, limbi quinquepartiti laciniis aestivatione imbrisatis. Corolla nulla. Sta un i a 3-10, calycis fauci inserta, libera, alterins lateris saepissime ananthera; filamenta snbulata, brevia, an the rae biloculares, longitudinaliter dehiscentes. Ovari am in fundo calycis sessile, extus et intus villosum, uniloculare, ov ulis geminis, e basi erectis, collateralibus, anatropis. St y lua basi. laris, fliformis; $8 \mathrm{tigma}$ truneatum. Drupa stipitata, olivaeformis, carnosa, putamine lignoso, abortu monospermo. S e m en erectum. Embryonis exalbuminosi, orthotropi cotyledones carnosae, crassissimae, radi cula brevissima, infera. - Arbores v. frutices America tropicae; foliis alternis, stipulalis, integerrimis, sublus incanis, floribus parvis, in spicas terminales dispositis, basi bi. bracteolatis.

L Ic a in i a Aublet Quian. $I$. 119, $t$, 45, Lam, $t, 122$. DC. Prodr. IT. 587. Zuecariai Nov. stirp. fasc, I. 391. in not. Meisuer Gen, 101. (72.) He d y e re a Sehreber Gen, n, 409 Romer et Seliultes Syst. I. 348. Mant. 258.

Q410. II 1 oquilea MART. et ZUCC. Ca Iy x tubo brevi, basi inaequilatero, cum ovarii stipite connato, limbi quinquepartiti laciniis sabaequalibus, aestivatione imbricatis. Coro 11 a e petala 5 , calycis fanci inserta, eiusdem laciniis alterna, decidua. Staminu indefinite plurima, calyeis fauci inserta, basi in fascienlos plures v. in annulum coalita, onmia fertilia v, alterius lateris ananthera; $f$ il amenta subulate-filiformia, longe exserta, aestivatione complieata, antherae biloculares, Inngitudinaliter dehiscentes. Ovarin m stipiti calyeis tubo hine adnato insidens, exsertum, extus et intus lanatum, unilocalare, ovulis geminis, e basi erectis, collateralibus, anatropis. Stylns basilaris, filiformis, inferne barbatus; stigma trnncatum. Drupa ovata v. subglobosa, sicea v, car nosa, putamine lipnoso, abortu monespermo. Sein en erectum. E in br y onis exalbuminosi, orthotropi cotyledones crassissimae, carnosae, radic ula brevissima, infera. - Arbores $v$. frutices Americae tropicae; folis alternis, stipulatis, coriaceis $v$. membranaceis, costato-venosis, integerrimis, saepissime subtus lanatis, discoloribus, floribus nunc axillaribus, racemos simplices, pendulos, nune terminalibus, paniculas ereclas formantibus, bracteatis.

M o q u ll e a Martius et Zuccarini Nov, gen, et sp. II. 79. t. 166. Zucearini Nov, stirp. fasc. r. 387. A e ta Wil! denow $\mathcal{S}_{p}$, III, 717. M o q u fie a Aublet Guian. I. 521, $t, 208$. DC. Prodr. II. s26. Meisuer Gen, 102, (72.) C о u е pi a Aubl.
Op, cil. I, 507, t, 221. DC, 2 . o. A ei o a Aublet Op, cit. $I$. 680, t. 280. DC. l. c. D u 1 a cl a Necker Elom, n. 1236.

G411. 11 brevi, basi inaequilatero, cum ovarii stipite connato, limbi quinque partiti laciniis subaequalibus, aestivatione imbricatis. Corolla e petala 5, calycis fanci inserta, ejusdem laciniis alterna, decidna. St a m in a $15-20$, calycis fauci inserta, basi in annulum coalita, omnia fertilia, v, alterius lateris ananthera; filamenta subulata, antherae biloculares, longitndinaliter dehiscentes. Ovarium stipiti ealycis tubo hin: adnato insidens, exsertum, bileculare, loculis uniovulatis, o v ulis e basi erectis, anatropis. Stylus basilaris, filiformis; stigma truncatum. Drupa ovoidea v. sphaeriea, cortice fibroso, putamine osseo, abortu uniloculari, di- v. aborta monospermo. Semin a erecta. Embryon is exalbuminosi, orthotropi cotyled on es carnosae, ra dicula brevissima, infera, - Arbores in America et Africa tropica crescentes; ramulis villosis, foliis alternis, stipulatis, integerrimis, subtus discoloribus, floribus racemoso-paniculatis v. corymbosis, bibracteolatis, albo-roseis.

Parinari um Jussieu Gen. 342. Lam. . 429. DC. Prodr. II. 526. Guillemin et Perrot. Flor. Seneg. I. 272. t. 61. 62 Meisner Gen. 102. (72.) Parinari Aublet Guian. I. 514. t. 204. 206. D ugort i a Seopoli Introduct, n. 956. Petro. c a r y a SchreberGen, $n, 629$. - P e $\mathrm{r}$ o c a r y a Jach in $B o o$. ker Bot. Miscell. II, 220. ovario demum cum ealyce cuncrescente, et embryone albuminoso inverso multum differt.

641\%. Thelyma THOUAR. Calyx campanulatus, basi hine in tubulum brevem productus. Corollae petala 5. Stamina 10 , basi coalita, sex fertilia, quatuor alterius lateris ananthera; fil amenta tenuia, antherae biloenlares, longitudinaliter dehiscentes. $O$ v a $r$ i $\mathrm{n} \mathrm{m}$ biovulatum, Sty I u 8 lateralis. Bace a (?) rugosa, intus villosa. Semen erectum. E m b r y on is exalbuminosi c otyledones crassae, inaeguales, plicatae, nna alteram involvens, radicula infera. - Arbores madagascarienses; foliis alternis, bracteis glandulosis.

Thely a Thouars Gen madagasc, $n$, 72, DC, Prodr. IT. 587. Meisner Gen, 102. (72,)

64 13. Grangeria COMMERS. Calyx obtuse quinquefidus, Corolla e petala 5, calycis fauci inserta, eiusdem laciniis alterna, decidua. Stamin a 15 , calycis fauci inserta, subinaequalia; $f-$ I a menta subulata, antherae biloculares, longitudinaliter dehiscentes, Ovariu unilosulare, lanuginosum ...... S $t y \mid$ u s basilaris, filiformis, glaber; stigma simplex. Drupa olivaeformis, putamine triquetro, osseo, monospermo. Semen erectum. Embryonis exalbuminosi, orthotropi cotyledones carnosae, radicula infera. Arbor borbonica; foliis allernis, stipulatis, integerrimis, glabris, floribus axillaribus et terminalibus, spicato-racemosis.

Qrangeria Commers. ex Jussieu Gen, 340. Lam. Diet. III. 21. t. 427. DC. Prodr. II. 527. Meisner Gen. 102. (72.)

C414. Proinsepia ROYLE. Caly x tubo brevissime cyathiformi, limbi quinquepartiti laciniis obtusis, aestivatione imbrieatis. Corollae petala 5 , calyeis faci inserta, ejusdem laciniis alterna, breviter unguieulata, orbiculata. Stamin a $30-$ 40 , calyeis fauci inserta, pluriseriata, libera; filamenta subulata, inaequilonga, antherae bilocnlares, longitudinaliter dehiscentes. Ovarium sessile, uniloculare. Ovula ......Stylus terminalis; stigma orbiculare, capitatum. Bacea 
coriaeea, ovata, inaequilatera, stylo Iaterali appendiculata, abortu monosperma. Semen erectum, testa striata. Embryonis exalbuminosi cotyledones erassae, ra dicula infera. - Frutex $h i$ malayanus, ramulis spinescentibus, foliis alternis, fasciculatis, coriaceis, petiolatis, lanceolatis, junioribus integerrimis, adultioribus serratis, pedunculis infra spinas nascentibus, ramosis, bracteis membranaceis, lanceolatis, dentato-ciliatis, floribus albis, baccis purpureis, seminibus oleosis.

Prinsepla Royle Himalay, 206, t. 38. f. 1. Meisner Gen, 102. (72.) C y cula Liadiey msc.

\section{GENERA DUBIA.}

6415. Hecostemon MOC. et SESS. CaI y $x$ quinquepartitus, lobis ovato-lanceolatis, acntis, patentibus, coloratis, deciduis, parte inferiore persistente, circulari, superne glandulosa et staminifera. Co rolla nulla. Stam in a circiter 20 , disco calycino inserta; filamentis brevissimis, antheris, Iongis, erectis, basi insertis. Ovarium liberum, ovatum, pubescens, quinquesulcatum, in st $y \mathbf{l n m}$ filiformen, acntum desinens. - Frutex mexicanus; foliis ovalibus, integris, penninerviis, stipulis duabus subulatis, pedunculis trifidis, trifloris, calyce fusco-purpureo.

Lecostemon Moçino et Sesse Flor. mex. inedit. $c x$ DC. Prodr. II, 639. Meisner Gen. 101. (72.)

6416. Trilepisivam THOUAR. Calyx apice crassus, quinquefidus, ovario haud adhaerens. Corolla nulla. Stamina plurima, pluriseriatim e calyce exserta; filamenti s tenuibus, Tub as inter stamina et pistilium ligulis tribus terminatus. Ovarium in fundo calycis uniovulatum. Stylus tubo longior, apice bifidus; stigmatibus tomentosis. Fructus ......-Arbuscula madagascariensis; foliis alternis, lanceolatis, junioribus stipulis caducis involutis.

Trilep is i um Thounrs Gen. madagasc, n, 74. DC. Prodr. II. 639. Meisuer Gen, 101. (72.)

B41\%. Stylobasium DESF. Calyx urceolatus, obtuse quinquelobus, coloratus. CorolIa nulla. Stamina 10, hypogyna, antheris bilocularibus. Ovarium obovatum, uniloculare, biovulatum, e basi lateraliter stylnm filiforıem, apice capitatum gerens. Dr a pa unilocularis, subrotunda, monosperma (?) calyce cincta, S e men ...Frutex Novae-Hollandiae orientalis; folits alternis, subspathulatis, integerrimis, glabris, floribus abortu saepe polygamis, in axillis superioribus breviter pedicellatis.

Stylobasi u m Desfont, in Mem. Mus, V., 37, t, 2. DC. Prodr, Mr. 92. Meisner Gen. 101. (72.)

\section{Classis HXII. Legumeinosae.}

Herbae, frutices v. arbores. Folia alterna, composita. Flores irregulares v. regulares. Calyx liber, aestivatione imbricatus v. rarius valvatus. Cor oll a e perigynaev. hypogynae petala calycis Iaciniis numero aequalia, v. abortu panciora, inter se inaequalia, imbricata, v. aequalia valvata, rarius nulla. $\mathbf{S} t \mathrm{a}-$ In in a duplo petalorum numero v. indefinita. Ovarium simplex, uniloculare. Le gumen v. Iomentum. E $m$ b ryo exalbuminosus, rectus v. curvatus.

\section{Ordo CCLIXV. Papálionaceae.}

PAPILIONACRaE et LOMENTACEAE Linn. Praelect. edit, Gieseck. 415. PAPILIONACEAE et CAKSALPINIEAR R. Browi in Flinders Voy. II. B51. LRGUMINOSAE Jas. sieu Gen, 345. DC. Prodr. II, 93. Mem, Legum. Paris 1825. o. ic. 4. excl. Mimoseis, Detarieis et Swartzieis.

Herbae, frutices v. arbores, caule ramisque teretibus v. irregulariter angulatis. F oli a primaria opposita, reliqua alterna, impariv. rarius abrupte pinnata, saepe unijuga cum impari et ideo trifoliolata, rarius palmatim triplurifoliolata, nonnunquam foliolo terminali, lateralibus abortivis, superstite unifoliolata, rarius nulla, petiolo tune phyllodineo-dilatato, foliiformi spurie simplicia, petiolo communi interdum in cirrhum producto. Stipulae ad basim petiolorum geminae, variae, persistentes v. deciduae, interdum spinescentes. Stipell a e petiolulos stipantes plus minus manifestae v. unllae.

FLOBEs hermaphroditi v. interdum abortu unisexuales, irregulares, racemosi, spicati v. capitati, rarius paniculati v. solitarii, nudi v. bracteati, pedicellis saepissime bracteolatis, calyce non raro bibracteolato.

Cazyx liber, gamophyllus, pentamerus, foliolis plus minus cohaerentibus, subaequalibus, magis minusve inaequalibus, duobus posticis saepe connatis, interdum in unicum concretis, labium superius, a duobus lateralibus cum antico in labium inferius cohaerentibus plus minusve distinctum formantibus, laciniis per aestivationem imbricatis $\mathbf{v}$. subvalvatis.

Corolrae petala quinque, tori laminae imum calycis fundum v. interdum ejusdem tubum vestienti, et in annulum magis v. minus manifestum tumenti inserta, saepissime inaequalia, heteromorpha, in corollam papilionaceam v. subpapilionaceam, rarissime subregularem disposita, posticum (vexillum) aestivatione extimum complicatum, heteromorphum, duo lateralia (alae) inter se conformia, duo antica (carina) apice saepissime cohaerentia, aut rarius penitus connata, unicum simulantia, interdum nonnulla, rarius omnia abortiva.

Staniva cum petalis inserta, duplo eorundem numero, decem v. interdum abortu panciora. Fil amenta nunc omnia libera, nune in tubum clausum, $\mathbf{v}$. in vaginam hine fissam coalita, et ideo monadelpha, nunc uno postico (vexillo obverso) a reliquis distincto, caetera in vaginam'connata, v. rarissime in fasciculos duos isostemones collecta et ideo diadelpha, apice omnia semper distincta. An the r a e introrsae, biloculares, erectae v. incumbentes, aequales, v. alternae heteromorphae aut rarius abortivae.

Ovarium simplex, sessile v. stipite interdum tori processu annulari vaginato instructum, e foliolo unico, calycis foliolo antico op- 
posito, longitndinaliter complicato, ad margines, valvatim coalitos v. rarius introflexos, ovulifero compositum. Ovula juxta suturam vexillo obversam saepissime plura, biseriata, rarius solitaria v. subsolitaria, amphitropa v. anatropa. Stylus filiformis, simplex. Stigma terminale v. infra styli apicem laterale, indivisum, nudum v. barbatum.

Fructus: legumen longituditualiter bivalve, uniloculare, interdum marginibus introflexis biloculare, nune infer semina isthmis transversis interceptum, in loculos plures, monospermos, pericarpio continuo divisum, v. pericarpio inter semina constricto in articulos dilabens ( $10 \mathrm{~m}$ e $\mathrm{ntum}$ ), rarius indehiscens, polyspermum v. abortu monospermum.

Semixa juxta suturam vexillarem alternatim biseriata, plus minus reniformia v. ovalia, funieulo plus minus distincto, interdum in carunculam expanso. Testa laevis. Endople ura membranacea, interdum tumida. Albumen nullum v, pareum.

Embryo curvatus v. rectus. Cotyledones plus minus crassae, germinatione foliaceat, $\mathbf{v}$. hypogeae, carnosae.

Papilionacea e nullo climate exules, maximo numero in regionibus tropicis subtropicisque generantur, in universum in hemisphaera orientali quam in America copiosins crescentes, et in hemisphaera boreali frequentius quam in australi obviae.

Plurima humano generi ntiles. Genera reformanda,

TIRE Annal. Wiener Mus. II, 65. C oroll a papilionacea. Stamina 10 , libera. L e gum en bivalve, rarissime indehiscens et tunc calyce brevius, Embryonis cotyledones germinatione foliaceae, radicula incurva. - Folia simplicia v. palmalim trifoliolata, rarissime imparipinnata.

SUETTRIIBUS I. EUPODALYRIEAE Benth. in Annal. Wiener Mus. H. 65. Ovarium pluriovulatum. Le guminis suturae haud introflexae.

§. 1. CISTRopicaE Benth, l, c. Folia plerumque trifuliolata.

6418. Anagyris $L I N N$. Ca I y x campanulatus, quinquedentatus $\mathrm{v}$. semiquinquefidus. $\mathrm{C}_{0}$ rolla papilionaceas vexillu un breviter nnguiculatum, sulsotundum, complicatum, carinae rectae, obtusae petalis liberis, a la s conformes, olylongas, obtusas panflo snperantibus. Sta in ina 10 , libera. Ovarium lireviter stipitatam. pluriovulatum. Stylus filifurmis, rectus; stigma terminale, minutum. L e $\mathrm{g}$ um en stipitatum, oblongo-lineare, compressum, bivalve, extus sacpe isthmis irregulariter interruptum. - Frutices, in Europa mediterranea, in insulis Canariis, nec non in Nepalia indigeni; foliis palmatim tri foliolatis, foliolis integerrimis, stipulis geminis, in unicam oppositifoliam connatis, racemis brevibus, paucifloris, floribus flavis.

A n agyris Touruefort Inst, 4t5. Lim. Gen. n, 509. Lam, $t$. 328. DC. Prodr. II, 99. MLem. Legum. t, 4, f. 3. Beutham in Annal. Wiener Mus. II. 66. Mieisuer Gen. so. (57.) - Piptanthus Sweet Fl. Gard, $t$, 264. Meisuer Gen, 8t. (57.) Baptisia nepalensis Hooker Exot, Flor, $t, 131$, Thermopsis nepalensis DC.

B 1 19. Pielkeringia NUTT. Caly x campanulatus, subtruncatus, repando-quadridentatus dentibus subaequalibus. Co rolla papilionareae vexillum orbiculatum, emarginatum, complicatum, a la 8 oblongas vix superans, carinae rectae, obtusae petala libera, alis conformia et acgui. longa. Stamina 10 , libera. Ovarinm breviter stipitatum, multiovulatum. Sty In s filiformis, in curvus; st igma minutum. Le gnm en ...... Frutex boreali-americanus, humilis, ramosis. simus; ramulis subspinescentibus, foliis sessilibus, trifoliolatis, sempervirentibus, foliolis oblongo-cuneiformibus, junioribus subpubescentibus, floribus axillaribus sessilibus, solitariis.

Piekeringi a Nuttall msc. ex Torreg ot A. Gras Flor. of North-Amer. I. 389 .

64:26. 'Tluermopgis R. BR. Caly x oblongus v. campanulatus, apice quinquefidus, subbilabiatus. Corolla e papilionaceae vexill um breviter unguiculat nm, late orbiculatum, apice emarginatum, lateribus reflexum, a las oblongas subac. quans, carina e subrectae, obtusae petala dorso connata. Stamina 10, libera. Ovarium subsessile, pluriovulatum. Stylus subincurvus, basi vix dilatatus; stig ma terminale, parvum. Le g $\mathbf{u}$ men compressum, oblongo-lineare v. falcatnm. - Herbae perennes, sericeo-villosac, in Asia et America boreali indigenae; foliis palmatim trifoliolatis, superioribus nonnunquam simplicibus, stipulis ovatolanceolatis, distinctis, saepius foliaceis, racemis terminalibus, floribus pedicellatis, geminis v. verticillatis, ebracteatis, flavis

The rmopsis R. Brown in Aiton Hort. Kew. edit. 2. III. 3. DC. Prodr. I1. 99. Ledebour Flor. Alt. II, 111 Bentham in Annal, Wiener Mrus. II. 99. Meisner Gen. 81. (57.) Torrey et A. Gray Fl. of North Amer. I. 387. Th e r $\mathrm{m}$ I a Nuttall Gen. I. 282. S c o l o b us Rafinesque in Journ. Phys. LXXXIX.89. Sop hor a e s p. Pallas Astragal. t. 90. f. 1. 2.

64\%1. Haptisia VENT. Caly x campanulatns, apice quadri-quinquefidns, subbilabiatus. Corollae papilionaceae vexillum breviter unguiculatum, orbiculare, apice emarginatum, lateri. bus reflexum, a la 8 oblongas subaequans $v$. paulto brevior, e a rina subincurva, alis subaequilonga, petalis dorso connatis. St a min a 10 , libera, filamentis glabris. Ovarium stipitatum, dense plnriovulatum. Stylus incurvus v. falcatus, basi dilatatus, apice attenuatus; $8 \mathrm{tigma}$ parvum. L eg $\mathrm{umen}$ stipitatum, inflatum. - Herbae borealiamericanue; folits simplicibus v. palmatim trifoliolatis, stipulis distinctis, parvis $v$, foliaceis, inflorescentia terminali, racemosa, pedicellis ebracteolatis, corollis flavescentibus, caerulescentibus $v$, albidis.

B a ptis i a Venten. Decad, 9. R. Brown in Aiton Hort. Kew, edit. 2. IIT, 5, DC, Prodr. IT, 100. Mem, Legum, t.4. f. A. Bentham in Annal. Wiener Mus. II. 66. Meisner Gen, 80. (57.) Torrey et A, Gray Fl, of North-Amer. I. 389. Podalyria Richard in Michaux Flor. Bor. Amer. I, 263. Venten. Cels, t.56, Bot. Mag, $t, 1099$. 1177. Crotalops is Miehan msc. So phorae 5 p. Lima. Bot. Mag. t. 509. Cotalariae sp. Lian.

\$, 2. CAPENSES Bentl. l, $c, \mathrm{C}$ aly $\mathrm{x}$ basi intrusus. 
Beutham in Annal. Wiener ALss. IT. 69. G a in pholobil s p. Labillard. Nov. Holl. $t$. 135. Chorozematis s p. Smith. Mirbeliat sp. Bot. Reg. t. 1434. Podolobil sect. 2. DC.

64:8. Po ellolobiuma $R . B R$. C a l y x cam panulatus, ad medium bilabiatns, labio superiore bifido, inferiore tripartito. Co roll a e papilionaceae vexill um brevissime unguiculatum, rotundatum, a las oblongas vix superans, earina obovato-oblonga, snbrecta, obtusa, alas subaequans. Stamin a 10 , libera, filamentis glabris. Ova ri um stipitatum, simplici serie pluriovulatum. Stylu s filiformis, incurvus; stig ma terminale, tenue v. capitatum. Legumen stipitatum, oblongo-lineare, subteres. Sem in a estrophiolata. - Frutices Nova e-Hollandiae; foliis plerisque oppositis, simplicibus, coriaceis, lobatis, spinosis, stipulis minutis, setaceis, patentibus, inflorescentia axillari, racemosa, bracteis minutis, deciduis, bracteolis nullis, floribus luteis.

Podolobium R. Brown in Aiton Hort. Kew. edit. 2. III. 9. Bot. Mag. t. 1/477. DC. Prodr, 11, 103, excl, sect. 2 et 3. Meisner Gen. 80. (57.) Bentham in Annal. Wiener Mus. II.70. P ult ea e a e 8 p. Andrews Bot. Reposit.t.320.

6425. Isotropis BENTH. Calyx profunde quadrifidus, lacinia suprema latiore breviter hidentata. Corollae papilionaceae vexillum late orbicnlatum, emarginato_bifidum, a la s obovatas, subfalcatas paullo superans, e a rina incurva, compressa, alas snbaequans. St a $\mathrm{m}$ in a 10 , a basi libera; filamentis glabris. Ovarium sessile, dense pluriovulatum. Sty lus filiformis, incurvus; $s$ tigma minntum, subeapitatum. Le g $u$ men oblongum, submembranaceum, inflatum. Semina estrophiolata. - Herbae humiles, in Nova-Hollandia australi indigenae, basi procumbentes; foliis alternis, simplicibus, stipulatis v. exstipulatis, pedunculis elongatis, unifloris, nunc solitariis axillaribus, nunc in racemum laxum, terminalem, pauciflorum dispositis, bracteolis ad basim calycis geminis, ungustis, saepe deciduis.

1sotropis Bentham in Enum. plant. Hügel. 28. An. nal. Wiener Mus, 11, 70. Meisner Gen. Suppl. C a III is tachy a Swith in Linn, Transact, IX. 267, nou Vent.

6430. Drtinotropiss BENTH. Calyx basi attenuatus, profunde bilabiatus, labio superiore longiore breviter bifido, inferiore tripartito. Corollae papilionaceae vexillam late orbicalatum, a las oblongas paullo superans, carin a oblonga, subrecta, acuminata, alis brevior. Stamina .... Ovariu m breviter stipitatum, villosum, pluriovulatum. Stylus brevis, incurvos, glaher; stigma capitatum. Legumen ...... Suffrutex Novae-Hollandiae austro-occi dentalis, humilis, basi ramosus; ramis adscendentibus, pubescentibus, folits alternis, exstipulatis, sessilibus, lineari-lanceolatis, acutissimis, pungentibus, coriaceis, marginatis, floribus pedicellatis, in axillis superioribus $v$. ad apices ramorum racemosis, calycibus pilosis, labii superioris concavi dentibus acutis, petalis luteis. n. 70 .

0 rthotropis Bantham in Lindley Swan-River XVI,

6431. Chorozena LABILL. $\mathrm{C}$ a l y $\mathrm{x}$ ad medium v. brevius bilahiatus, labio soperiore lato, breviter bifido, inferiore tripartito. Corolla e papilionaceae vexillum rotundatum, emarginatum v, bifidum, a las oblongas, basi angustatas vix superans, carina alis brevior, ventricosa, obtnsa, Stamina 10 , libera; filamentis glabris. Legumen sessile v. breviter stipitatum, dense plu- riovulatum. Stylus brevis, uncinato-recurvus, glaber; stigma obliquum v. subrectum, tenue v. capitatum. Leg um e n sessile v. subsessile, ovatum, ventricosum, intus nudum. Semina estro. phiolata. - Herbae, suffrutices $v$. frutices, in Nova. Hollandia crescentes, procumbentes $v$, adscenden. tes; foliis alternis, erectis, simplicibus, integerrimis v. spinoso-dentatis, coriaceis, saepe glabris, stipulis parvis, subulatis, inflorescentia racemosa, racemis subterminalibus, laxis, nudis, v, axillaribus, floribus in racemum terminalem, foliosum approximatis, pedi. cellis brevibus, bibracteolatis, floribus rubris v. aurantiaceis, calycibus basi saepe attenuatis, disco staminifero tertiam $v$. quartam calycis partem aequante, rarius calycibus basi rotundatis, disco brevissimo.

Choroze wa Labillard. Voy. 1.403. R. Brown in Aiton Hort. Kew. edit, 2. III, 8. DC. Prodr. II. 102. Meisner Gen, 81, (s7.) Beatham in Annal. Wiener Mus, II. 71.

a. Eechorozema Beatl. l. c. Herbae v. suffrutices, procumbentes, adscndentes v. subseaudeutes. Folia ovata, lanceolata v. late linearia, integerrina v. dentato spisosa. R a e emi termiales, laxi, nudi. Pul tene a 8 p. Andrews Bot. Reposit. t. 434. Dill w y uize sp. Smith. Bot. Reg. $t$, 1514, (Labillard. Op. cit, t. 21. Bonpland Nav. t. 35. Bot. Reg. t. 1513, 1528. Bot. Reg. 1838. t. 10. Sweet Flor, austr. c. 40.)

b. ACIPHyluUM Benth, $l$, c. Frutienlt saepissime erec. ti. Foli a linearia, pungentia, sparsa v. ternatim ap. proximata, integerrima. P ed u n e u i i breves, axillares, solitarli v. gemini in raceman terminalem foliatum ap. proximati, (Bot. Reg. $t$. 986. Bot. Mag. $t, 3607$.)

643\%. Compholobium SMITH, $\mathrm{C}$ aly $x$ profunde quinquefidus, subaequalis. Cor o Il ae papilionaceae vexillum amplum, explanatum, a Ias oblongas paullo superans, carina obovatooblonga, alas subaequans, recta v. parsm incurva, apice obtusa. Stam ina 10, libera; filame nt is glabris. Ovari $\mathbf{m}$ breviter stipitatum, pluriovulatum. Stylus filiformis, incurvus; stigma te. nue, capitatum. Le $g$ n $\mathrm{m}$ en inflatum, subsphaericum. Semina estrophiulata. - Frulices v. suffrutices $\mathrm{Nov}$ a e-Hollandiae, folits allernis, compositis, nunc palmatim tri quinquefoliolatis, nune impa. ripinnatis, foliolo terminali inler par supremum sessili, stipulis parvis, subulatis $v$. nullis, inflorescentia axillariv. subterminali, pedunculis unifloris, solitariis, $v$. ad apices ramorum racemoso-corymbosis, bracteolatis, calycis laciniis aestivatione valvatis et interdum carina lana subtili barbatis, corollis luteis, rarius rubris $v$. aurantiaceis, leguminibus glabris.

Gom pho I o bin m Smith in Linn. Transact. IV. $220,1 \mathrm{X}$. 249. exel. sp. Exot. Flor, t, 8. 85, Labillard. Nov, Holl, t, 133. 134. Aadrews Bnt. Reposit. t. 642. R. Browu in Aiton Hort. Kew. edit. 2. III. 11. DC, Prodr. II, 105, Bot. Mag. t. 1533. Bot. Reg, $t, 1668,1490,1563.1574,1614$. Bot. Reg. 1839. t. 43. Reichenb, Ic. exot. t. 76, 97. 243. Meisner Gent, 81. (57.) Beutham in Annal. Wiener Mus. II. 72.

SUBTRIBUS 1I. PULTENEAE Benth. in Annal. Wiener Mus. II. 78. Ovarium biovulatum. Le gumin is suturae haud introreflexae. - Frutices v. suffrutices Novae-Hollandiae, foliis plerumque simplicibus.

6433. Burtomia $R \cdot B R$. Caly $x$ profunde quinquefidus v. quinquepartitus, subaequalis. Curollae papilimaceae vexillam breviter unguieulatum, orbiculatum, a lis obovato-oblongis longius, carin a alas subaequans, incnrva, acutiuscula v. subrostrata. St am in a 10 , libera; filamentis glabris. Ovarin m sessile, biovulatum. Stylus saepins e basi dilatata subulatus, glaber v. hine barbatus; st igma tenue, imberbe. L e- 
64a:. Cyclopia VENT. Cal y $\mathrm{x}$ quinque fidus, faciniis subaequalibus $v$. inferioribus parum longioribus, ante anthesim subincurvas, per anthesim basi intrusns. Corull ae papilionaceae petala subaequilonga, v exill u m rotundatum, basi complicatum, ungue brevi, recurvo, a lae oblongae, obtusae, plica transversali falcatae, carina incurva, inflexo-rostrata, obtusa. Sta m in a 10 , libera, v. noanulla basi connata, filamentis ditatatis. Ovari u m sessile v. breviter stipitatum, glabram, simplici serie pluriovulatum. St y Ins incurvas, hine barbatus; stigma parvum. Le g amen plano-compressum, oblongum, coriaceum. Semina strophiviata. - Frutices capen ses; folits sessilibus, palmatim trifoliolatis, v. summis interdum unifoliolatis, foliolis subsessilibus, margine nune planis $v$. vix revolutis, nune margine utroque revoluto subteretibus, stipulis nullis, inflorescentia axillari, pedunculis brevibus, unifloris, braeteis ad basim pedicelli geminis, crassiusculis, coriaceis, saepe inaequalibus, altera alteram amplectente, bracteolis nullis, floribus flavis.

C yelopia Venter. Decad, D. 8. R. Brown in Aiton Hort. Kew. edit. 2. III. 5. DC. Prodr. II. 101. Ecklon et Zeyl. Enum, pl cap. 153. E. Meyer Comment. 3. Vogel in Lin. naea X. 595. Beotham in Annal. Wiener Mus. IT. 67. Meiswer Gen, 8t. (5s.)

a. EUCXCLOPIA Beath. l, $c$, Calycis laciniae ovatae, tubo breviores v. subaequilongae.

b. IBBETSONIA Benth, $l, c, \mathrm{C}$ al y c is laciniae lanceolatae, aeuajuatae, tubo louginers, saepius fuaequates. l b bets onia Sims in Bot. Mag. C. 1259. Sophora 8 p. Berg. Bura. Gallegate s p. Thunb. Goupholo. b i $8 \mathrm{p}$. Audrews Bot, Reposit, $t, 487$.

64:3. Podealyria $L A M$. C a ly $x$ amplus, quinquefidus, laciniis subaequalibus $\mathbf{v}$. inferioribus profundius distinetis, ante anthesim subincurvus, per anthesim basi intraxus. CoroIl a e papilionaceae vexillum amplam, rotundatum, emarginatum, ungue brevi, recurvo, alas obovatas, obliquas paullo superans, carina alis brevior, late whovata, parum incurva, obtusa. Stamina 10 basi brevissime connata, caeterum libera, glabra. Ovarium sessile, villosum, pluriovulatum. Sty I us filiformis, supra ovarium geniculato-adscendens; stigma parvum. Legumen ovale v, oblangum, coriaceum, turgitum, villosum. Semina striphiolata (?), - Frutices c a penses; foliis al ternis, simplicibus, stipulis subulatis, saepe deciduis, pedunculis solituriis, uni-bifloris, rarius tri-quadri. fioris, bractea ad basim pedicellorum $v$, in pedunculis unifloris supra ejusdem medium solitaria, forma va riu, ante anlhesim decidua, pedicellis ebracteolatis, floribus purpureis, roseis $v$, albis.

Podalyria Lam. t. 327. R. Browa in Aiton Hort. Hew, edil, 2, III, 6. Bot. May, t. 753 3. 1580, 1923. Bot. Res. ¿ 869, DC. Prodr, II, 101. Ecklon et Zeyher Enum, pl.cap. 155. E. Meyer Comment. 4. Bentham in Innal. Wiener Mus. II. 67. Meisner Gen. 81. (57.) A pho r a Necker Elem, $n$. 137. Sopborae sp. Rets Observ, I. 56. H y pocalyp ti s. p. Thuab. Flor, cap. 569 .

\$. 3. TropiCaE Benth. $\boldsymbol{l}$. c. Calyx heteromorphus. Folia ampla, simplicia.

6424. Dallowsien WALL. Caly x bre vis, dilatato-campannlatus, ore subintegro, basi eircumbeissus. Corollae papilionaceae vexil. la m breviter unguiculatum, latissime obcordatum, a las subfalcato-ublengas paulle superans, carina ineurva, obtusiuscula, alis vix brevior. Sta min a 10, libera, filamentis glabris. O vari u m subsessile, pluriovulatum. Styins incurvus, glaber, basi parum dilatatas; stigma minutum. Legumen plano-compressum, oligospermam. Em bry o pleurorhizeus. - Frutex indicus; folits petiolatis, unifoliolatis, amplis, subcoriaceis, glubris, inflorescentia axillari subracemosa, bracteis et bracteolis magnis, foliaceis, calycem includentibus.

Dathousica Wallich Catalog, $n$, 3339. Bentham in Annal. Wiener Mus. 1X. 69. Podaly ría bracteata Roxburgh Plant, Corom, t. 259. An huc Delaria Desvanx Anzal. so, nat, IX, 406, 6. 59, 53. Meisner Gen. 80. (57.) calyce spathaceo (?) a Dalhonsiea diversa?

§. 4. AUSTRALASICAE Benth. $\boldsymbol{l}$. $\boldsymbol{c}$. F oli a simplicia v. rarissime trifoliolata. Legumen turgidum.

6425. Irachysema $R . B R$. C a ly $x$ quinquefidas, parum inaequalis, tubo ventricoso. Corollae papilionaceae vexillum alis multo brevins, reflexum, a la e oblongae, earinam compressam, rectam acquantes. St am in a 10 , libera; filamentis glabris. Ovariu m stipitatum, stipitulo Lasi vaginula cincto, pluriovulatum. St y $1 \mathrm{a}$ \& filiformis, elongatus; 8 tigma parvam. Le g amen ventricosam, polyspermum. - Suffrutices NovaeHollandia e, procumbentes; foliis alternis, simplicibus, ovatis $v$. ovalibus, integerrimis, mucrunatis, racemis axillaribus et terminulibus paucifloris.

Brachysema R. Browa in Aiton Hort. Kew. edit. 2. III. 10, Bot. Reg. t. 118. 642. Bot. Mag. $t$. 2008. DC. Prodr. II. 105. Meisuer Gen, 81. (57.) Beatham in Wiener Mus. II. 69.

6436. Callistaelays VENT. Calyx ad medium bilabiatus, labio superiore bifido, inferiore tripartito. Corollae papilionaceae vexillum breviter unguiculatum, rotundum, a I a 8 oblongas superans, carina ovato-oblonga, sulrecta, obtuea, alas aequans. St a m in a 10 , libera, filamentia glabris. Ovarinm subsessile, dense pluriovulatum. Stylus fliformis, incurvus; stigua terminale, tenue v, capitatum. Legumen ovatum, sessile, coriaceum, subturgidum, junius transversim spurie multiloenlare, maturum septis exsiccatis intus transversin lineatum. S e m in a strophiolata. - Frutices v. suffrutices Novae-Hollandiae; folits sparsis v. verticillatis, simplicibus, integris, subtus sericeis, stipulis minutis v. nullis, inftorescentia terminali, racemosa, bracteis parvis, pedicellis bibracteolatis, floribus luteis, ovario villosissimo.

Call istach ys Vent, Malm, t, 115. Bot. Mag, t, 1925. Bot. Beg. t. 216. DC. Prodr. It. 104. excl. sp. 3 . Meisuer Gen, 81, (57.) Beutham in Annal. Wiener Mur, 1I, 69.

G42\%. Oxylobium ANDR, CaIy x semiquinqnefidus, bilabiatus, labio superiore bifido, inferiore tripartito. Corolla e papilionaceae ve$x$ ill $\mathrm{nm}$ breviter nnguiculatum, rotundatum, a las oblongas superans, carina uvato-oblunga, obtusa, alas aequans. St a mina 10, libera, filamentis glabris. O va ri um subsessile, dense pluriovulatum. Sty lus filiformis, incarvus; st ig ma terminale, tenue v. capitatum. Le g n m e n ovatum, acutum, sessile, coriaceum v, vix membranaceum, turgidum, uniloeulare, valvalis intus laevibus. $S$ e in in a estrophiolata. - Fruticuli v. suffrutices NovaeHoll andia e; foliis verticillatis v. sparsis, simplicibus, integris, subtus sericeis, stipulis minutis $v$. nullis, inflorescentia racemosa, terminali et axillari, bracteis parvis, floribus luteis $v$, croceis, ovario villosissimo.

0 x y I o b i u m Aadrews Bot. Reporit, $t$, 492. Bot. Rez. 6. 392, 913. Bot. Mag. t. 15st, 2962, 3249. R. Brown in Aiton IIort. Kew, edit, 2. IIL. 9, DC, Prodr. II, 103. exel. sp. 4 et 6 . Sweet Elor. Auter, 4. 5 . Meisner Gen. 80, (37.) 
gnmen ovatnm v. subrotundum, subventricosum. Semina estrophiolata, - Frutices v. suffrutices Novae-Hollandiae; foliis sparsis, simplicibus v. trifoliolatis, subulatis, integerrimis, stipulis nullis, foribus ad apices ramulorum glomeratis, v. terminalibus corymbosis, pedicellis brevibus, bibracteolatis.

Burtonia R. Browa in Aiton. Hort. Hew, edit. 2. III. 12. DC. Prodr. II 106, Meisuer Gen, 81, (58.) Beuthan in Annal. Wiener Mus. II. 73.

a. EUbUrtonia. Folia trifoliolata. Pedicelli axilla. res, ad apices ramulorum glomerati. Gompholob i $i$ s. p. Suith.

b. PHYLlotiuar, $F$ olia simplicia. Cory mbi terminales. (Lisdl, in Bot, Reg, $t, 1600$. )

6a34. Jaeksonata $R$. BR. Calyx profunde quinquefidus v. quinquepartitus, aequalis. Corollae papilianaceae vexillum late rotundatum, emarginatum, a 1 as obovato oblongas vix superans, carina obovato-oblonga, sulincurva, obtusa, alar subaequans. Sta $\mathrm{m}$ in a 10 , libera; $\mathrm{f}$ 1 amentis glabris. Ovarium subsessile v. stipitatum, biovulatum. Stylus filiformis, adscendens; st igma tenue v. capitatum. Leg um en ovatum v. oblongum, compressum v. plus minus ventricosum, valvnlis intus pubescentibus. Sem in a estrophiolata, - Frutices v, arbusculae Novae-Hollandiae; ramis rigidis, nonnunquam vimineis, ramulis nunc compressis, phyllodineis $v$, alatis, nunc angula. tis $v$. terelibus, apice suepe spinescentibus, foliis ad squamas brevissimas, rigidas, acutas redactis $v$, omnino nullis, stipulis nullis, inflorescentia laterali $v$. terminali, pedicellis brevibus, solitariis, geminis $v$. racemosis, saepe minute bibracteolatis.

$\mathrm{J}$ acksonia R. Brown in Aiton Hort. Hew. edit. 2. III. 12. DC Prodr. II. 107. Meisuer Gen. 81. (55.) Bentham in Annal. Wiener Mus, II, 73.

a. EUJACKSONIA Bezth, $l$, c. Sta $\mathrm{m}$ in a m filamenta hasi aequalia. L e g u me n plus minus ventrieasum. - Rami erecti, G om pholob i s p. Labillard. Nov, Holl, t, 136. Bonpl. Navarr, t. 11, (Loddig. Bot. Cab, t, 487. Hügel Bot. Arch. t. 5.)

b. PTERONEMA. St a m in u filamenta nsque ad mediun bialata. L e g $u$ m en plano-compressum, - Ramí penduli.

6435. Daviesia SMITH, C a ly x campanulatus, a agulatus, subaequaliter quinyquedentatus v. subbilabiatus. Corollae papilionaceae vexil. In m lunge ungnieulatum, a las obovat-oblongas superans v. basi ab iisfem distans, ca rina alas subaequans, obovata, incurva, v, sobfornicata, ob tusa. St a m in a 10 ; fil a me $\mathrm{t}$ is dilatatis, liberis v. subinde imprimis inferioribus basi connexis. Ovarium breviter stipitatum, oblongum, prope basim biovulatum. Stylus filiformis, incurvus, glaber; sti $\mathrm{gma}$ terminale, minutum. L egumen plano-compressum, sutura altera rectiuscula, altera valde incurva subtriangulare. Semina strophiolata. - Fruticuli v. suffrutices Novae-Holtandiae; ramis teretibus $v$, angulatis, foliosis v, aetate aphyllis, foliis v. ramulis phyllodineis alternis $v, s u b$. oppositis aut interdum ternato verticillatis, simplicibus, coriaceis, upice saepe spinescentibus, inflorescentia axillari $v$, in speciebus aphyllis laterali, rarius terminali, floribus racemosis $v$, rarius solitariis, pedicellis ex axilla bractcae scaviosae $v$. membranaccae, nudis $v$. bracteolatis, bracteis plerumque brevissimis, rarissime maximis involucrantibus.

Daviesia Smith in Linn. Transaet. IV. 222. IX. 255. Labillard. Nov, Holl, $t, 137$. R. Brown in Aiton Hort. Kew. edit. 2. III. 20. Andrews Bot. Reposit. t, 304. Bot. Mag t. 1758. 3196. Bot. Reg. t. 728. Loddig. Bol, Cab. t. 43. DC. Prodr, IT. 113. Melsuer Gen. 81. (58.) Benthas in Annal. Wiener Mus, II. 75, Eadlicher Ibid. 189.
6436. Wiminaria SMITH. Caly x campanulatus, angulatus, subaequaliter breviter quinquedentatus. Corollae papilionaceae petala unguiculata, subaequilonga, ve $x i l l$ um late obovaium, a la e oblongae, ca rin a rectinscula, oblonga. $\mathrm{Sta}$ in a 10 , flamentis liberis, glabris, Ovari in sobsessile, biovulatum. Stylus capillaris, apice incurvus, nudus; stigma minutum. Legumen ovoideum, indehiscens. Semin a estrophiolata. Frutex Novae-Hollandiae orientalis et insulae Diemen; ramis virgatis, striatis, apice paniculatis, adultis aphyllis, junioribus folia pauca, unitrifoliolata gerentibus, floribus racemosis, bracteis parvis, scariosis, inferioribus ovatis, superioribus setaceis, bracteolis nullis, floribus luteis.

Viminaria Smith in König Annal. of. Bot, I. 507. Linn. Transact, IX, 261. Exot, Bot, t. 27, Bot. Mag. t, 1190 . R. Browa in Aiton Hort. Kew, edit, IT, IIL, 13, DC. Prodr. IT. 107. Meisner Gen, 81. (58.) Besth. in Annal. Wiener Mits. II. 76. Daviesia deutata Venten. Choix. $t, 6$. Sophora $j$ u uce a Sclirader Sert. Hannov. $t .3$.

6438. Splnaerolobium SMITH, Cay $\mathbf{x}$ bilabiatus, labio soperiore majore bifido, in feriore tripartito. Corolla e papilionaceae vexil. I $\mathrm{nm}$ late obovatum v. rotundatum, a I a 8 obovatooblongas vix superans, e a rina oblonga v. obovata, obtusa v, acuminata, recta, inenrva v. breviter rostrata, alas subaequans, rarius paullo superans. $\mathrm{S} t$ a m in a 10, libera; filamentis glabris. Ovari. u m stipitatum, biovulatum. Sty 1 a s filiformis, incursus, glaher, versus apicem saepius hine membrana longitudinali anctus; $s t i g m$ a terminale, parvum. Le g n m e n oblique stipitatum, subplobosum. Semin a ....... - Fruticuli v. suffrutices, in Nova-Hollandia extratropica indigeni; ra. mis virgatis, junceis, teretibus $v$, compressis, adullis aphyllis, junioribus saepius folia pauca simplicia, tenuia, alterna $v$. opposita, exstipulata gerentibus, pedunculis lateralibus v. rarius terminalibus, binatis, bifidis $v$. laxe tri-quadrifloris, interdum oppositis $v$. ternutim verticillatis, bracteis minutissimis, bracteolis subnullis, calycibus glabris, saepe maculis nigris, oblongis notalis, corollis luteis.

Sphaerolobium Swith in König Annat. of Bot, 1 . 509. Linn. Transact. $I X$. 261. Bot. Mag. t. 969. Latillard. Nov, Holl, t. 138 R. Braws in Aiton Hort. Kew, edit. 2. III. 14. DC. Prodr. II. 107. Meisner Gen. 81. (55.) Bent bam in Annal. Triener Mus $I I, 76$,

6438. Föa HÜGEL. Caly x basi attenuatns, labio superiore truneato, breviter bidentato, inferiore tripartito. Corolla e papilionaceae vexillum late orbiculatum, explanatum, al as obovato-oblongas superans, e a $r$ in a isenrva, alis paul. lo. brevior. Sta m in a 10 , libera, filamentis glabris. Ovarium stipitatum, biovulatum. Stylus filiformis, incurvus, glaber; $8 \mathrm{ti} \mathrm{gma}$ longe barbatum. Le gum en longe pedicellatum, subsphaericam. Semina .... - Herba Novae-Hollandiae austro-occidentalis, perennis, glaberrima; ramis adscendentibus, foliis alternis, exstipulatis, anguste linearibus, integerrimis, crassiusculis, subaveniis, superioribus parvis, floralibus bracteaeformibus, floribus in racemum terminalem dispositis, pedicellis calyee brevioribus, apice bibracteolatis, corollis flavis, leguminibus glaberrimis.

R o ë a Hägel msc. ox Bentham Enumerat, Plant. Hä. gel. 34. Annal, Wiener Mus, II. 77, Meisuer Gen. Suppl.

Ga35. Playlleta $D C$. C a Iy $x$ campanulatus, semiquinquefidus, laciniis duabus superioribus latioribus, brevioribus. Corollae papilionaceae vexillum ovatum, unguieulatum, carinae subae138 
quilongum, a $\mathrm{t}$ a e angustae, oblongae, carina obovato-oblonga, subineurva, obtusa v. brevissime rostrata breviores. Sta $\mathrm{m}$ in a 10 , basi inter se et cum petalis plus minus connexa, caeterum libera. Ovarium sessile, biovulatum. Stylus basi dilatata rigidus, apice incurvus; $8 \mathrm{t}$ ig ma terminale, ohtasum. Legumen ...... - Suffrutices $v$. fruticuli Novae-Hollandiae; foliis confertim sparsis $v$. interdum ternatim approximatis, simplicibus, lineari-subulatis, margine saepissime revolutis et supra tuberculato-scabris, stipulis nullis, floribus axillaribus, subsessilibus, versus apices ramorum approximatis, bracteolis foliaceis, calyce longioribus.

Phyllota Bentham Enumerat. plant. Hügel. 34. Annal. Wiener Mus. II. 77. Pulte na e ae sect. 2. P hyllo ta DC. Prodr. II, 113 ,

64.6. A otans SMITH. Caly x campanulatus, bilabiatus, labio superiore bifido, inferiore tripartito. Corollae papilionaceae vexillum alas oblongas paullo superans, unguiculatum, orbiculatam, carina incurva, obtusa, alas suhaequans. Stam in a 10, libera, filamentis glabris. Ova rium subsessile, biovalatum, villosum. Stylus filiformis; stigma minutum. Leg a men coriaceum, ovoidenm. Sem in a estrophiolata. - Fruticuli Novae-Hollandiae; folitis ternatim verticillatis $v$. sparsis, stipulis nullis, pedicellis axillaribus, brevibus, unifloris, ebracteolatis, corollis luteis.

A ot us Smith in König Aunal of Bot. I. S04. Lian. Transact. IX, 297. Labillard. Nov, Holl, $t$ 132. R. Brown in diton Hort. Hew. edit. 2. III. 14 DC. Prodr. II, 109. Meisuer Gen. 8t, (58.) Benthaen in Annal. Wiener Mus. 11. 78. Palte na eas sp. Venten. Malmais. $t .35$.

64 41. Dillwy nia SMITH. C al yx eam pannlatus, breviter bilabiatus, labio superiore late bifilu. $v$ emarginato, inferiore tripartito. Co rolI f e papilionacae vexill um unguienlatum, fatissimum, lamina dnplo latiore quam longa, emarginato bifidum, alas angustas, oblongas paullo superans, c a rina alis brevior, subrecta, obtusa. Stam ina 10 , libera, filamentis glabris. Ovarium subsessile, bisvulatum. Sty lus incurvns, filiformis, glaber; $8 \mathrm{ti}$ ma tenue v. subcapitatum. L e g n m en ovatum, ventricosum. Semin a strophiolata. - Fru. tices Novae-Hollandiae; folits alternis, simplicibus, subulatis, integerrimis, margine involutis, saepe tortis, stipulis nullis, inflorescentia saepius terminali, racemoso corymbosa, nonnunquam axillari, glomerata, corymbulis uni-trifloris, ad apicem ramuli brevissimi axillaris aphylli, pedicellis brevibus, bibracteolatis.

Dillwynia Smith in Köniz Annal. of Bot. I. 510 . Iinn. Transact. 1X. 262. excl. sp. R. Brown in Aiton Hort, Hiow, odit, 2, IIT, 15. Bot. Mag. n. 22s7. DC. Prodr, II, 108 Meisner Gen, 81. (58,) Bentham in Annal. Wiener Mus. IT: 78 .

a. DICLWYNIASTRUM DC. 2, c, Cal y $x$ basi attenuatus, labio superiore bifido. Dis c as petala et stamina ge. rens, fere ad medium calycis aduatus. Petala et $8 \mathrm{ta}$ m i n a decidua. - (Smith Exot. Bot, I, t, 25, 26. Bot, Mag. t. 944. 1525. 13/15. Loddig. Bot. Cab. t. 559.582.)

b. XeROPETALUM R. Browa 2 . c. C a 1 y $\mathrm{x}$ basi rotundatus, labio superiore rotundato-truncato. D i scus bre. vis. Petala et at a mina marcescenti-persistentia. Eutaxiae sp. Sweet Flor. austr, t. 2. (Bot. Mag. t. 2247. Hügel Bot, Arch, t, 8\},

84 42. Eataxia $R . B R$. Caly $x$ incurvatoeampanulatus, bilabiatus, labio superiore lato, bifido, inferiore minore tripartito. Corollae papilionaceae vexillum orbiculatum, a las ublongas paullo superans, earin a vix incurva, obtusa, alis paullo brevior. Stamina 10 , libera, filamentis glabris. Ovarin subsessile, biovulatum. Stylus brevis, uneinatus; stig ma tenue, subeapitatum. Legum en subsessile, ovatum, subcompressum v. parum ventrieosum. Sem in a strophiolata. - Suffrutices v. fruticuli Novae-Hollandiae, glabri; foliis oppositis, simplicibus, rigidis, planis v. subconcavis, exstipulatis, floribus axillaribus, subgeminis, pedicellis bibracteolatis, petalis marcescenti-persistentibus.

E utaxia R. Browa in Aiton. Hort. Hew. edit, 2, IIL 16. DC. Prodr. II. 109. Meisner Gen, 81. (58.) Benthitu in Annal. Wiener Mus. MI. 29. Dill w y in i o bov ata La. bill. Nov. Holl, $t, 140$. Bot. Mag, $t, 1274$.

B443. Castrollobiuma $R, B R$, Calyx campanulatus, apice quinquefidus, bilabiatus. Corolla e papilionaceae petala breviter unguiculata, vexillum late orbiculatum, emarginatum, alas oblongas paullo superans, carina oblonga, obtusa, alis parum brevior. Sta min a 10, libera, filamentis glabris, O varium stipitatum, biovulatum. Stylus filiformis, adscendens; stigma tenue, subeapitatum. L e g $\mathbf{n}$ m e n stipitatum, ovoideo-subglobosum, ventricosum. Semin a strophiolata. Fruticulus Novae-Hollundiae; foliis simplicibus, ternatim $v$. quaternatim verticillatis, stipulis setaceis, inflorescentia terminali, breviter racemosa, bracteolis nullis.

G a strolobi n m R. Brown in Aiton Hort. Kew. edit. 2. $I I I$, 16. Bot. Reg. $t$. 41t, Loddig. Bot. Cab. t. 70. Turpin Atlas, XVIII. t, 176. DC. Prodr. II. 110. Meisner Gen. $8 t$. 158.) Bentham in Annal. Wiener Mus. 11 . 80 , Lindley Swan. Fiver t. 5. $B$.

64 44. Fuchilus $R, B R$. C a l y x profunde bilabiatus, labio superiore maximo, incurvo, bifido, inferiore brevi, bipartito. Corolla papilionaceae petala breviter unguiculata, vexill u m latissimum, emarginato-bifidum, a l a s oblongas paullo superans, e a rina oblonga, obtusa, parum incorva, alis parum brevior. Stamina 10 , libera, filamentis glabris. Ovarin m subsessile v. stipitatum, biovulatum. Stylus adscendens, filiformis; stigma tenue, subeapitatum. Leg um en plus minus stipitatum, compressum v. subventricosum, villosum, biovulatum. Se m in a strophiolata. - Fruticuli Novae-Hollandiae; foliis alternis v. oppositis, simplicibus, stipulis parvis, setaceis, floribus axillaribus, pedicellatis, bracteolis setaceis.

R u chilus R. Brown in Aiton Hort. Kew, edit. 2. MIT. 17. Bot. Reg. 2. 403, Loddig. Bot, Cab, t, 60, DC. Prodr, II. 110. Meisner Gen. 81. (58.) Beutham in Annal. Wiener Mus. IT. 80.

6445. Spadostyles BENTH. C a 1 y x profunde bilabiatus, labio superiore maximo, bifido, inferioris tripartiti laciniis angustis, brevioribus. Corolla e papilinnaceae petala unguiculata, ve$\mathrm{x}$ ill $\mathrm{um}$ rotundatum, al as oblongas superans, earin a obovato-oblongs, subinenrva, obtusa, alas subaequans. Stamina 10 , libera; filamentis glabris. Ovarium sessile, biovulatun, glabrum, Sty 1 us basi compresso-dilatatus, apice subulatus, uncinato-incurvus; stigma tenue. Legumen ovoideum, ventricosum, stylo persistente acuminatum. Semina strophiolata. - Frutices NovatHollandiae, glabri; foliis alternis v. ternatim verticillatis, simplicibus, integerrimis, stipulis setaceis, patentibus, floribus axillaribus pedicellatis, in racemos terminales foliatos approximatis, bracteolis duabus setaceis, calyci adpressis.

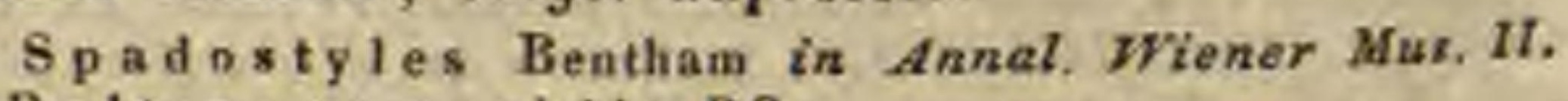
80. Pultenaea euchila DC.

B446. Pultemaea SMITH. Caly x eampanulatus, semiquinquefidus, subaequalis v. laciniis 
dnabus superioribus latioribus altius cohaerentibus subbilabiatus. Corollae papilionaceae vexil$1 \mathrm{um}$ rotundatum, integrum $\mathrm{v}$, emarginatum, a $\mathrm{las}$ oblongas superans, e a rin a oblonga $v$. obovata, recta, saepius obtusa, alas subaequans v. interdum paullo longior. Stamina 10 , libera, filamentis glabris, nudis. Ova rinm sessile, biovulatum, villosum. Stylus subulatus, glaber, deciduns, rarius hasi villosa parum dilatatus; stigma tenue. Legumen ovatum, eompressum v. subventricusum, acntum v. obtusum. Semina strophiolata, - Fruticuli Novae-Hollandiae; foliis alternis, simplicibus, integerrimis v. apice bilobis, stipulis scariosis, saepe intrafoliaceis, nonnunquam imbricatis, rarius nullis, infiorescentia terminali $v$, axillari, floribus solitariis $v$. capitatis, bracteis scariosis, apice saepe bifidis, $e$ stipulis duabus folii abortivi formatis, interdum nullis, bracteolis scariosis $v$, rarius subfoliaceis, calyci adliaerentibus, et illo saepissime brevioribus, rarissime subnullis, floribus luteis, carina saepius purpurascente $v$, intensius colorata. seminum strophiola in plurimis postice incisa, interdum biloba $v$, integra.

Pulten a e s Smith in König Annal. of Bot. I. S02. Linn. Transact. IX. 245. Labillard Nov, Holl. I. t, $130,13 t$. Andrews Bot. Reposit. t. 98, 574. Rudge in Linn. Transact. XI. $t .93$ _25. Bot. Mag. $t$, 433. 967. 1394, 1588. 2081. 2859. 3254. Bot. Reg. t, 1584, 1632. 1694. R. Brown in Aiton Hort. Kew. edit. 2. IIT, 17. Meisn. Gen, 81. (58.) Beutham in Annal. Viener Mus, II, 81. P ulte a e a Hoffwans. Verzeichn, 191. Pultenaea sect. Hy menota DC. Prodr. 11.110.

644\%. Sellerothamungs $R$. BR. C al y yuinquefidus, bilabiatus, hasi bibracteolatus, Corollae papilionaceae carina alarnm longitudine. Stam in a 10, libera. O va ri um pedicellatum, biovalatum. Stylus adscendens, filiformis; stigm a simplex. Leg umen ventricosum. - Frutex Novae-Hollandiae, microphyllus, nondum de. scriptus.

$\mathrm{S}$ clerotham nus $\mathrm{R}$. Brown in Aiton Hort. Kew. edit. 9. HIT. 16 DC. Prodr. II. 109 Meisner Gen. 81. (58.) Beathum in Annal. Wiener Mus. II, 83.

SUIB'TEIBE TII. MIRBELIEAE Benth. in Annal. Wiener Mus. II. 83. Legum in is sutura utraque v. superior seminifera introflexa. - Frutices Novae-Hollandiae; foliis simplicibus.

6448. IIfrbelia SMITH. Calyx quinquefidus, bilahiatus. Corolla papilionaceae vexillum obovatum $v$, orbicnlatum, integerrimnm v. brevissime emarginatum, a $\mathrm{l}$ a 8 chlongas paultu superans, carina subrecta, obtusa, alis multo brevior, petalis dorso connatis. Sta mina 10 , li hera, antheris uniformibus. Ovarin sessile, bi pleriovulatum. Stylus brevis, uncinato-ineurvus, glaber; $s t i g m a$ capitatum. Legumen ovoidenm, ventricosum, bivalse, lengitudinaliter subhiloculare, valvarum margine seminifero longe, altoro breviter intruftex, valvis coriaceis, apice bifidis. Sem in a 2 v. plura, estrophiolata. - Fruticuli Novae-Hollandiae, saepius procumbentes; folits alternis, oppositis v. ternatim verlicillatis, in tegerrimis, plerumque reticulatis, exstipulatis, flori bus axillaribus, subsessilibus, bracteolis calycis basi adpressis, corollis caeruleis, purpurascentibus v. lu teis.

Mirtielin Smith in König Annat. of Bot. II. SII Linn, Transacl. IX. 265. R. Brown in Aiton Hort. Kew ed 2. III. 21. DC. Prodr. II 114, Mrisuer Gen, 81, (88.) Beatham in Ainal, Wiener Mus, II. 84. a. EUMIRBEliA Benth. l. c. Ovarium biovulatum. Folia reticulata. - Pultena a e s p. Andrews Bot. Reposit. $t$. 351. Chorozeatis 8 p. DC. (Venter. Malmais. $t$. 119. Bot. Reg. t. 1041.)

b. DIPLOLOBIUM Benth. l. c. Ovarium pluriovulatum. Folia linearia, pungentia, haud reticulata.

B4 4. Dielnosema BENTH, C a ly x campanulatus, bilabiatus, Jabio superiore bifido, inferiore tripartito. Corollae papilionaceae vexilI $\mathbf{~ m}$ latissimum, apice bilobum, a las parvas longe superans, carin a recta, obtusa, alis panllo brevior, petalis dorso connatis. Stam in a 10, libera, antheris uniformibus. Ovari um sessile, multiovulatum, sutura superiore inflexa subbiloculare. Stylus uncinatus, latere interiore breviter barbatus; stigma capitatum. Legumen.... Frutex Novae-Hollandiae austro-occidenlalis, Aspalathi spinosi fere facie; ramis procumbentibus, lignosis, virgatis, foliis sessilibus, ad basim spinae rigidae, patentis fasciculatis, linearibus, obtusiusculis, margine revolutis, glabris, floribus axillaribus, solitariis, sessilibus, calyce sericeo-pubescenie, corolla flava.

Dichnse ma Bentham Enumerat. plant. Hügel, 35. Annal. Wiener MLs. II. 84. Meisner Gen. Suppl.

6450. Feptosema BENTH, Cal y $\mathrm{x}$ profonde bilabiatus, labio superiore brevissime bifido, inferiore tripartito. Corollae papilionaceae vexill $\mathrm{nm}$ breviter unguiculatum, lanceolatum, alis semisagittatis vix longins, ca rin a recta, obtusa, alis longior et latior, petalis dorso connatis. Stamina 10 , libera, antheris uniformibus. Ova rium sessile, pluriovulatum. Sty I a filiformis, uncinato. incurvus; s tig ma parvum. Legumen ovatum, sutura seminifera subinflexa, altera aruta sectione transversali cordiforme. Semina plura, reniformia, estrophiolata. - Frutex Novae-Hollandiae borealis, non satis notus, aphyllus; ramis inter gemmas alatis, gemmis nunc bracteam unicam, lanceolato-linearem, scariosam, rufescentem, nunc capitulum densunt, sex oct offorum ferentibus, calycis laciniis scariosis, rufescentibus, ovariis quatriovulatis, leguminibus villosissimis.

L e ptos eu a Beath. in Annal. Wiener Mus. II. 84.

TIR IRES II. LOTEAE DC. Prodr. II. 115. Corolla papilionacea. Stamina 10 , monadelpha v. diadelpha. Legumen bivalve, continuum. E mbry on is cotyledones germinatione foliaceae, radicnla incnrva. - Folia unifoliolata v. palmatim tri-plurifoliolata, aut saepissime imparipinnata.

SER'Th IIEUS I. GENISTEAE DC. Prodr. II. 115. Legumen uniloculare. S tamina saepissime monadelpha. - Folia simplicia $v$. palmata, rarius pinnata. Caules sacpissime fruticosi.

8451. IIIovea $R, B R O W N$. Caly x bilabiatus, labio superiore lato, retuso v. semibifido, inferiore minore, tripartito, Corolla e papilionaceae vexillu m explanatum, al a e oblongae, vexilIn lireviores, carina obtusa longiores. St a mi na 10, monatipha, filamento vexillari plns minus libero, vagina fissa, an the $\mathrm{r}$ is alternis ovatis, dorso affixis, alternis ohlongis, adnatis. Ovarium hi-triovulatum. Stylus filiformis, adscendens, flaber; stigma obiusum, nudum. Leg umen subrotundum $158 *$ 
obliquum, ventricosum. Sem in a strophiolata. Suffrutices v. frutices Novae-Hollandiae; foliis alternis, simplicibus, bistipulatis, floribus axillaribus purpureis $v$. violaceis, pedicellis solitariis $v$. geminis, unifloris $v$, ramulosis.

$\mathrm{H}$ ove a R. Brown in Aiton Hort, Kew. edit. 2. IV. 275. Bot. Reg, t, 280. 463. 614. 1512, N. S. 1838 t, 62. Bot. Mag. t. 1642. DC. Prodr. II. 115. Sweet Flor. anstr, $t, 13$. Beath. Enum. plant. Hügel, 36. Hügel Bot. Arch. t. 7. Meis. ner Gen. 82. (58.) Poiretia Smiti in Linn. Träsact. 1X. 304, uon Cav. Ph y 8 i carpos Poiret Suppl.

645\%. Clagiolobiam SWEET. Cal y x bilabiatus, labio superiore lato, retuso, inferiore tripartito. Corollae papilionaceae vexillum pianum, subrotundum, emarginatum, alas carinae obtusae parallelas et aequilongas superans. Stamina 10 , filamento vexillari reliquis nonnisi basi alhaerente subdiadelpha. Ovarium sessile, biovulatum. Stylus sublateralis, persistens; st igm a subcapitatum. Le $g$ n m e n oblique transversum, coriaceum, inflatum, dispermm. Senuina stro. phiolata.-Frutices Novae-Hollandiae orientalis; foliis alternis, simplicibus, spinoso-dentatis, stiputis spinescentibus, floribus axillaribus breve pedicellatis, confertis, caeruleis v. purpureis,

Plagiolabium Sweet Flor, austr. t. 2. Don Syst. II. 127. Meisner Gen, 85. (60.) H o ve a choroze in $\mathrm{i} 6 \mathrm{o}$. Ii a DC.

6453. Hallage $L I N D L$. Caly x bilabiatus, labio superiare hifido, inferiore tripartito. GorolIa e palionaceae vexillum plannm, subrotun dom, emarginatum, a las earinae ohtusae parallelas ct aequilongas superass. Stam in a 10 , monadelpha; fila mento vexillari semilibero, anthe ris umnibus confuruibus. Ovarium pauciovulatum. Stylus subulatus, adscendens; s $t \mathrm{ig}$ m a $\mathbf{~ o b}-$ tusum. Legumen...-Frutex Novae-Hallandiae orientalis, foliis allernis, simplicibus, breve petiolatis, late ovatis, integerrimis, bistipulatis, floribus axillaribus geminis, e squamis imbricatis, aridis, deciduis erumpentibus, pedicellis bibracteolatis, bracteolis setaceo-jiliformibus, calycis longitudine, corollis aurantiaco et purpureo variis.

$\mathrm{L}$ alage Lindley in Bot. Reg. $t$. 1722. Meisner Gen. 82. (5t.) - ? P I a t y ehil um Delaun. Herb. Amat. t. 187. DC. Prodr. II. 116.

6454. Flatylobium SMITH. C a ly x bilabiatus, labio superiore maximo, rutundato, bifido, inferiore trifido. Corollae papilionaceae vexilI $\mathrm{m}$ planum, subrotundnm, euarginatum, a $I$ as carinae obtasae parallelas et aequilungas longe su perans. Stamina 10 , monadelpha. Ovarium subsessile, multiovulatum. Stylus brevis, subu. latus; stigma obtusum. Le gu m e n compresso planum, sutura dorsali alatum, polyspermum. Sein ina strophiolata. - Frutices Novae-Hollandiae orientalis; foliis oppositis, simplicibus, bistipulatis, floribus axillaribus flavis, vexillo basi rubro, calyce basi scariose bracteolato.

Platy to bl a m Smith in Linn. Transact. 1I. 350. Nov. Holl. t, 6. Vent. Malm, t. 31. Bor, Mag. $t$. $469,1508.1520$. R. Browu in Ait. Hort. Kew. ed. 2, IV 266. DC. Prodr. II. 126. Meisuer Gen. 82. (58,) Chellacoce a Salisbury Prodr. 412.

6455. Bossiner VENT. C a l y x bilabiatus, Labio superiore majore bifido, inferiore tripartito. Corolla e papilionaceae vexill nm planam, subrotundam, euarginatum, a las carinae obtusae parallelas et subaequilongas superans. St a m in a 10 , monadelpha, vagina integra. O va r i u messile, piuriurulatum. Sty lus filiformis; stig ma obtu- sum. Legum en pedicellatum, plano-compressum, sutura utraque incrassatum, polyspermum. - Frutices v. suffrutices Novae.Hollandiae, nunc ra. mulis compressis aphylli, nunc foliis alterais, simpli. cibus, bistipulatis instructi, floribus flavis, purpureo variegatis, pedicellis bracteolutis.

Boss ia a Venten. Cels. t, 7. Swith in Linn Trans. aet. IX. 302. R. Brown in Aiton Hort. Kew. edit. 2. IV. 266. Bot, Mag. t, 1144, 1493. 2491. Bat, Keg, t. 306, Sweet Flor, austr, t. 19. 20. 81. Meisuer Gen, 83. (58.) P lat y lo. bit s p. Vent. Malm. t. S5. Audrews Bot. Reposit. t. 191. 205. 286. Bat, Mag. t. 863 .

6456. Coodian $S A L I S B$. Cal y x hilabiatas, labio superiore breviore semihifido, inferiore trifido. Corolla e palionaceae vexillum planum, subrotundum, emarginatum, alas carinae truncatae subacquilongas soperans. Stam in a $\mathbf{1 0}$ monadelpha, vagina integra. $O$ va riu m paciovalatum. Stylus subulatus, adscendens; stigma obtnsum. Leg um en stipitatum, oblique transversam, plano-compressum, dispermum. Semina strophiolata. - Frutices Novae-Hollandiae; foliis alternis, trifoliolatis, floribus racemosis, flavis.

Go od ia Salisbury Parad, t. 41. Bot, Mag. t, 958. 1310. R. Brown in Alton Hort. Kew edit. 2, 1V. 269. DC. Prodr. II. 117. Meisuer Gen, 82. (58.)

645\%. 'Temaletoma $R, B R$. C a $1 \mathrm{yx}$ eampanulatus, quinquedentatns, dente infimo productiore. Corollae papilionaceae vexillum ovato-ohlongum, patens, ca rina oblonga, recta, a las parallelas paullo snperans, vexillum aequans. Stamina 10, monadelpha v. filamentu vexillari profundius distincto subdiadelpha. $O$ vari u m mltiovulatum, Stylus subulatus; stig ma obtusum. Leg umen pedicellatum, plano compressum, poIyspermnm. Semina strophinlata.-Frutices Novae-Hollandiae; foliis alternis, simplieibus, cu. neiformibus, retusis, mucronatis, floribus axilluribus, solitariis, magnis, puniceis, pedicellis bibracteolatis.

Te a pleton 1 a R. Brown in Aiton Hort. Kew. edit, 2. IV. 269. Bot. Reg. $t, 383,859$. Bot. Mag. $t$. 2088. 2338. DC. Prodr. II. 118. Meisuer Gen, 83. (59.) Rafuila retusa Veat. Malm, t. 53 .

6458. Seottia R. BR. Calyx campanalatus, quinquedentatus, dentibus subaequalibus. Coruliae papilionaceae vexillum complicatum, a lis oblongis, earinam aequantibus brevius. Stamina 10 , monadelpha, vagina integra. Ova ri u m stipitatum, tri quadriovulatum. St y lus subulatus; stigma simplex Legumen stipitatam, compresstam, sutnra utraque incrassatum, tritetraspermum. Semin a strophiolata. - Frulices Novae Hollandiae austro-occidentalis, diffuse ramosi; ramulis verrucosis, foliis oppositis, simplicibus, subsessilibus, denticulatis, ftoribus axillaribus solituriis, subsessilibus, calyce bracteolis inbricatis, exterioribus duabus brevibus persistentibus, tribus interioribus multo majoribus, cymbiformibus caducis cincto.

Scottia R. Brown in Aiton Hort. Kew. edit. 2, IT'. 268. Bot. Reg. $t, 1233$. 1266. Meisuer Gen, 83. (59.) Scol. te a DC. Prodr. II. 118.

G45\%. Tentmin THUNB. Caly $\mathrm{x}$ quinquefidus, lacinia infima saepissime angustiure, reliquis distinetis v. plus minus coalitis. Corolla e papilimaceae vexillum subrotundum, carina obtusa v. rostrata. Stam in a 10 , monadelpha. 0 variu un sessile v. stipitatum, multiovulatum. Stylus filifurmis; stigma capitatum. Legumen lanceolatum, compressum, polyspermum. - S $u f$ frutices capenses, glabri, siccatione saepe nigri- 
cantes; foliis cuulinis alternis, simplicibus, sessilibus, amplexicaulibus, integris, floralibus oppositis, flori. bus flavis.

R a $\mathrm{n}$ ia Thunberg Flor. Cap. 563. E. Meyer Comment. 11. 0 e d m a $n$ ni a Thunt. Act. Holm, 1809. p. 281. $t$. 4 . $\mathrm{R}$ af n i a et V as coa DC. Prodr. II, 118, 119.

a. VASCOA DC. l. c. Carina obtusa, - Foli a amplexicaulia. Cratalaria a mplexieaulis Linn.

b. RAFNIA DC. l, c. C a rina rostrata. - Folia sessilla. (Delessert Ic. select. III. $t$, 62.)

440B. Felecynthis $E$. MEY. Calyx quinquefidus, lacinia infima angustiore. Co roll a e papilionaceae vexillum subrotundum, carina subfornicata, truncata. Sta min a 10 , monadelpha. Ovarium stipitatum, pauciorulatum. Stylus filiformis; stigma capitatum. Leg n men stipitato-resupinatum, compressum, submonospermnm, sutura snperiori subalatum. - Suffrutices c apenses, Rafniae facie; foliis caulinis alternis, simplicibus, sessilibus, integris, floralibus oppositis, floribus axillaribus terminulibusque, solitariis $v$. corymbosis.

Pelecynthis E. Meyer Comment. 13. Meisner Gen. 83. (59.) R a f niae s p. Thuob. Rekl. et Zeyh.

a. COLовотвоPIS E. Mey. $l$. c. Carina superins dilatata, truncata.

ь. нувотворis E. Mey. . c, Carina galeato-trunca. ta, dorso gibba.

c. CAMinotropis E. Mey. 2. c. Caria a fornicata, obtusa.

64 61. IBorbomia $L I N N$. C a ly x basi attenuatus, guinquefidus, laciniis aequalibus, spinosoacuminatis. Corollae papilionaceae vexillum extes hirtum, apice emarginatum, earin a obtusa. $S t$ a $m$ in a 10, monadelpha, tubo antice fisso. O $\mathrm{ra}$ rium moitiovulatum. Stylus filiformis; stigma capitatum, subemarginatum. Leg umen lineare, plano-compressum, calyce multo longius, polyspermum. - Frulices capenses; foliis alter nis, simplicibus, basi multinerviis, amplexicaulibus, exstipulatis, floribus axillaribus $v$, ad apices ramo rum capitatis.

B orbon ia Limn, Gen, n, 857, Lam. t, 619. Jacq. Hort. Schänb̈r. t. 217. 218. DC. Prodr. II. 120. E. Meyer Com ment. pl. Afr. austr. 15. Meisner Gen. 83. (59.)

646\%. Aelnyromia WENDL. Caly $\mathrm{x}$ tuho brevi, basi intruso, limbi quinquedentati dente in. fimo longiore, bifido. Corollae papilionaceae vexillum subrotundom, earina rostrata. Sta m in a 10 , filamento vexillari libero diadelpha. Ovariom multiovolatum. Sty I u s filiformis stig ma acutum. Le g $\mathbf{u}$ u e $\mathbf{n}$ lanceolatum, compressum, polyspermum. Semina strophiolata. -Frutex Novae-Hollandia e, Borboniae facie; ramis sparse sericeo-pilosis, foliis alternis, simplicibus, lanceolatis, aculis, margine sericeo-villosis, floribus axillaribus solitariis, pedicellatis, fiavis.

A chyronia Wendiand Obs. bot. 39. Hort. Herrenh. I. $t$, 12. DC. Prodr. II. 120. Meisuer Gen, 85. (60.)

64468. Linparia LINN. Cal y x tubo brevi, basi intruso, limbi quinqnefidi lobis quatnor superioribus lanceolatis, acutis, subaequalibus, infimo longissimo, elliptico, petaloideo, Coroll a e papilionaceae, glabrae vexillum ovali-oblongum, al ae oblongae, altera alteram aestivatione involrens, c a $r$ in a recta, angusta, acuta, biceps. Sta mina 10 , filamento vexillari liberis diadelpha. Ovarium sessile, brevissimum, panciovulatum. Stylus filiformis; stigma capitatum. Legumen ovatum, oligospermum. - Frutices capen ses, glabri; foliis alternis, simplicibus, lanceolatis, pungentibus, mullinerviis, floribus in capitulum sub. sphaericum dispositis, late bracteatis.

L i paria Linn. Mant. 156. excl. kp. Loddig. Bot. Cab. t. 642. DC. Prodr. II. 121. Meisner Gen. 85. (60.) Le acadeudron splendens Burm.

G4S4. Pristleya DC. Cal y x subaequaliter quinquefidus, bilabiatus. Coroll a e papilionaceae, glabrae vexillam subrotundum, breviter stipitatum, alae ubtusae, subfalcatae, carina incurva, retusa $v$. subrostrata, bipartibilis. Stamina 10 , filamento vexillari libero diadelpha. Ovarium sessile, multiovulatum. Sty Ins filiformis; stigma capitatum, interdum postice dente acuto auctum. L e g umen plano-compressum, ovali-oblongum, tetra-hexaspermum. - Frutices capenses; foliis alternis, simplicibus, integerrimis, exstipulatis, floribus flavis $v$ rarissime violaceis, in capitula subumbellata v. subspicata dispositis.

Pristleva DC. Mem. Legam. 190. Prodr. IT. 12t. excl. sp. E. Meynr Comment. 17. Meisner Gen, 84. (60.) Walpers in Linnaea X $1 I I .468$.

a. ISOTHEA DC. l. c. CaIyx basi intrusus. Corollae carina incurva, subrostrata. Pristle y a Eeklnn et Zeyh. Enum, 164. Borboufae et Liparlae sp. Thunb. Bot, Reg. t. 8. (DC. Legum. t, 29. 30.)

b. AINSoTheA DC. l, c. Caly $\mathrm{x}$ basi haud intrusus. Ca. $r$ in a minas incurva, erostris, superne latior, rotundata. Xiphothee a Eehton et Zeyh. Enum. 166. Borboniae et Lipariae sp. Lían. Thuab. Bot, Mag. t. 2223. 3216. (DC. Legum, t, 32. 33.)

64G5. Amplaithalea $E C K L$, et $Z E Y H$. C a I y x subaequaliter quinquefidus, bilabiatus. Co rulla e papilionaceae vexill a m breviter stipitatum, subrotundum, reflexum, a I a e rectae, oblungae, earin a recta, obtusissima, bipartibilis. St a $m$ in a 10 , filamento vexillari reliquis hine ima basi adnato submonadelpha, Ovariu un lineare, multiovulatum. Styl us rectiusculus; stigma subcapitatum. Le g u u e n subsessile, plano-compressum, ovalioblongum, polyspermum, - Fruticuli capenses; fotiis alternis, simplicibus, integerrimis, exstipulatis, floribus roseis $v$. violaceis, terminalibus, in spiram foliosam v. fasciculatim disposilis, unibracteatis.

A mplith a lea Echlon et Zeyber Enumerat, 167, exel. 8p. Walpers in Linnaea XIIT. 470. Meisuer Gen, 80. (60.) Cryphiantha Eckion et Zeyter Op. cit. 17t. Meisner Gen. 85. (60.) $1 \mathrm{ng}$ enhoussi a E. Meyer Comment, 20. excl. sp. Pristtey ate sp. DC. Legum, $t$. $3 t$.

6460. Hathriogyae ECKL. et ZEYH. C a ly $x$ bilabiatus, labio superiore bifido, inferiore tripartito. Corollae papilionaceae vexillum oh.ongum, emarginatum, complicatom, a I is falcatis, basi processu oblique transverso auctis, subaequilongom, e a ri na arcuata, acuta brevias. St amina 10 , filamento vexillari libero diadelpha. Ovarium ovatum, pauciovnlatum. St ylus filiformis; st $\mathrm{igma}$ obtusmu. Legnmen calyce inclusum, ovale, compresenm, stylo rostratum, mono dispermum. - Fruticuli capenses; foliis simplicibus, integerrimis, exstipulatis, floribus sessilibus, axillaribus et terminalibus, solitariis v. aggregatis, luteis

I. a th ringyne Rcklon et Zeyher Enum, 170. Meisner Gen. 84. (60.) H e u du s a B. Mteyer Comment, 153. Meisuer Gen. 84. (60.)

6465. Coelialion VOGEL. C a I y $x$ subaequaliter quinquefidos. Corolla e papilionaceae ve $x$ illu n breviter stipitatum, subrotundum, rereflexnm, a la e rectae, oblongae, carina recta, olotusa, bipartibilis. Stamina 10 , monadelpha, 
vagina superne fissa. Ova rin multiovulatum. Stylus rectiusculus; s tig m a subcapitatum. Leg $\mathbf{u m e} \mathbf{n}$ sessile, plano-compressum..... Frutices capenses; foliis alternis, simplicibus, contortis v. involutis, supra sericeis $v$. hirsutis, subtus glabris, exstipulatis, floribus axillaribus congestis, $v$. in spicam terminalem foliosam dispositis.

Coetid i um Vogel msc. ex Walpers in Linnaea xIIr. 479. Ingentoussiae sp. E. Mey. Awphitaleae sp. Eekl. et Zeyh.

6468. Epistennum $W A L P$. C a I y $\mathrm{x}$ bilabiatus, labio superiore quadripartito, inferiore integro longiore, carinato. Corotla e papilionaceae ve $x$ ill u m stipitatum, orbienlatum, reflexnu, a I a e lanceolatae, falcatae, carinae petala falcata, apice cohaerentia. S t a m in a 10, filamento vexillari libero diadelpha, $\mathrm{O}$ ₹ a ri u m lanceolatum, panciovulatum. Stylus filiformis, incurvus; $8 \mathrm{tigma}$ capitatum. Legrumen....-Fruticulus capensis, ramosissimus; folïs alternis, simplicibus, utrinque sericeis, imbricatis, floribus subsessilibus, capitatis.

$\mathrm{B}$ p is te m u $\mathrm{m}$ Walpers in Linnaea XIII. 473.

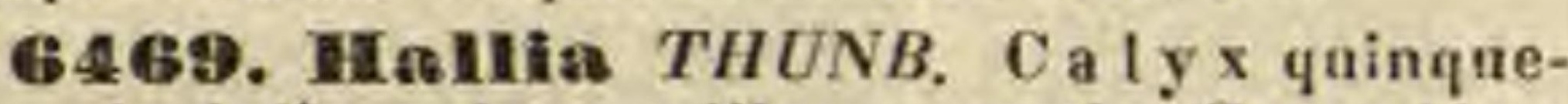
fidus, laciniis subaequalibus, acntis. Co rolla e papilionaceae vexill um ovatum, al a e oblongae carinam obtuam superantes. S $t$ a $\mathrm{m}$ in a 10 , monadelpha, vagina integra, O v a ri s m brevissime stipitatum, uniovulatum. Stylu s filiformis; stigma capitatum. Le g nmen compres. sum, membranaceum, monospermum. - Herbae suffruticosae, in Capite bonae spei indigenae; foliis alternis, simplicibus, integerrimis, stipulis petiolo adnatis, floribus axillaribus, solitariis, brevissime pedicellatis, purpureis.

H a llia Thusberg Prodr, 2, Flor. cap. 593. Desvaux Journ, Bot, III. 125. t. 6. f. 30. Bot. Mag. $t$, 1850 . DC. Prodr. II. 129. Meisner Gen, 38. (59.) Il ed y a a ri sp. Thusb. G I y cines s p. Jacq. Hort. Schönbr. $t$. 232.

648. H. Heylandia $D C$. Ca 1 y $x$ bilahiatus, labio superiore trifido, inferiore tripartito, laciniis aevis, subaequalibus. Co rolla e papilionaceae vexillum incombens, a las lanceolatas et carina m oblique trnneatam, acuminatam superans. S $t$ a $m$ in a 10 , monadelpha, vagina integra. Ovarium oni-biovulatmm. Stylus filiformis, e basi geniculata adscendens; st $\mathrm{i}$ im a subcapitatum, pilosum. Leg o m en ovatnm, compressnm, stylo mucronatom, mono-dispermum. - Herbae indicae, suffruticosae, pilosae, dichotome ramosae; foliis alternis, exstipulatis, simplicibus, brevissime petiolatis, oblique corlato - ovatis $v$. cordatosubrotundis, floribus axillaribus solitariis, subsessi libus, parvis, flavis.

He ylandia DC. Prodr, II. 123. Legum, 198, t, 34, Wiglit et Arnott Prodr. 180. Meisuer Gen. 83. (50,) H a llita hirta Wilt. Hedysarum latebrosum Linn. CrotaIaria uniflora Roxb.

64) 1. Fequalenia $D C, C$ al y $x$ campanulatus, quinquefidus, laciniis acntis, infima pro. ductiore, Corulla e papilionaceae vexillum ovale, a l a e oblongae, unguiculatae, e arin a dipetala, alas et vexillum aequans. Stamina 10 , monadelpha, vagina snperne fissa. Ovarinm sessile, uniovulatum. Sty lus brevis, incurvus; $8 \mathrm{tioma}$ subeyathifurme. Leg u m e n ovale, cmupressum, styli basi uncinatum, monospermem. - Suffruti. ces, in Capite bonae spei et in Senegambia crescentes; foliis alternis, bistiputatis, simplicibus, obcordatis; penninerviis, mucronulis, foribus axillaribus, minimis, subconfertis, sessilibus.
Requienia DC. Mem, Leg, 224, t, 37, 38, Prodr. "II 168. Guillem, et Perrot. Flor. Seneg. t. 168. Meisuer Gen. 83. (59.) Podaly ria ob eordata Lam, $t$. 328. $f, 5$,

B.4\%. Crotalaria LINN. Cal yx quinquelobus, subbilabiatus, labio superiore bi-inferiore trifido. Corollae papilionaceae vexill a m magnum, cordatum, basi callosum v. squamulosum, c a $r$ i n falcato - acuminata $v$, rarius obtusa. St a m i a 10 , monadelpha, vagina integra v. superne fissa. Ovarium bi multiovulatum. StyI 8 lateraliter barbato-pubescens. Leg u in en turgidam, alvis ventricosis, inflatis, rarissime plano-compressum, di polyspermum. Sem in a reniformia, compressa. - Herbae $v$ frutices, in regionibus tropicis Asiae et Americal copiose, parcius in Africa subtropica crescentes; foliis simplicibus v. palmatim tri quinque-septemfoliolatis, stipulis bracteisque nunc minimis $v$. deficienlibus, nunc maximis, interdum adnato-decurrentibus, floribus saepissime flavis.

Crotalari a Linn. Gen. $n, 862$. Gärtner $I I$, 148. De. Prodr. It. 124. Wiglit et Arnott Prodr. I, 180. Meisner Gen. 82. (58.)

a. EUCROTALARIA. Legumen ventricosum, oblongum polyspermum. (Bot. Mag. t. 1933. 2027.)

b. SPHAEROCROTALE. Leg a men subglobosum, inflatum, oligospermum,

c. CHRYSOCALYX. Leg amen subglobosum, apice com. pressum, polyspermum. Ch rysocaly x Guillem. et Perrot Flor. Seneg. I. 157. t. 42.

d. CYRTOt.uBUS. Le g a men ovatum, inflatum, styli basi hamatum, gibbum, disperaum. - C yrtolobus R. Browu in Wallich Catalog. n. $54 \overline{32}$,

e. CLAVUi.IOM. L e g ume n Ionge stipitatum, oblongum, utrinque obtusua. ventricosum, polyspermum. - Clav uli u u Desvanx in Annal. sc. nal, IX, 407.

f. PRIOTROPIS, L eg am en plano-compressua, ellipticam, brevissiae stipitatum, apice acuminatum et styll basi recta terminatum. - Priotropis Wight et Ar. nott Prodr. I. 180, ia not.

g. AMPHINONIA. Le g u m n sessile, subrotundum, muricatn-rugosum, monospermum. - A at phinomia DC. Prodr. II. 529. Coninarus decumbens Thuab, in Römer Archiv, I, 1,t, 1, H e r ma a $\mathrm{n}$ a $\mathrm{t} r \mathrm{iph}$ y $1 \mathrm{l}$ a Liua.

8483. Huppinus TOURNEF. Caly $x$ pro fnnde bilabiatas, labio superiore breviore bi - inferiore trilido. Corolla e papilionaceae vexillum lateribus reflexis, alae postice superne coalitae, $\boldsymbol{c a -}$ rin a acuminata, bipes. St a m in a 10 , monadelpha, vagina integra, a $\mathrm{n}$ h e $\mathrm{r}$ is alternis oblongis, alternis subreniformibus. O va $\mathrm{rium}$ bi-multinvalatum. Stylus filiformis, incurvns; stigma terminale, subrotundum, barlatum. L e g um en coriaceum, ohlongam v. lineare, compressum v. teretinsculnm, di-pulyspermum, isthmis oblique transversis inter semina interceptum, - Herbae, suffrutices $v$, frutices, in temperatis calidioribus et subtropicis, rarius inter tropicas totius orbis, in America boreali copiosissime crescentes; foliis digitatime tri-nullifoliolatis, saepissime quin. quefoliolatis, rarissime abortu simplicibus, stipulis petiolo adnatis, pedunculis oppositifoliis terminalibus, floribus spicatis $v$, racemosis, suepe verticillatis, unibracteatis, saepissime bibracteolatis.

L up u us Tournefort Inst, 213. Linn. Gen.n. 1176. Gärtner IT. 324 t. 150. DC. Prodr. II. 406. Agardh fil. Sjnopsis Generis Lupini. Lundae, 1834. 8. Meisner Gen. 83. (59.)

B484. Xeroearpus GUILLEM. et PER. Caly $\mathbf{y}$ quinquefidus, laciniis subaeqnalibus, snbulatis. Corolla e papiliouaceae petala subaequalia, vexillum oblungum, acutum, al a e oblongo enltriformes, carina resta, petalis apice concavo 
cohaerentibus. Stam in a 10, monadelpha, tubo hine fisso. Ovarium multiovulatum. Stylus filiformis, strictus; stig ma capitatum. L e g um en acinaciforme, subinflatum, membranaceum, sutura superiore dehiscens, polyspermum. Sem in a reniformia. - Herba seneg ambica, annua, humisfusa, ranosissima, villosissima; foliis pinnatim trifoliolatis, foliolis ellipticis, medio majore, stipulis linearibus, subpalulis, deciduis, floribus in race. mos axillares et terminales breves dispositis, roseis, bibracteolatis.

Xerocarpus Guillem. et Perrot. Flor. Seneg, I. 169. t. 44. Meisuer Gon. 85. (60.)

6485. Fothoia PERS. Caly $\mathrm{x}$ quinquefdns, laciniis duabus superioribus faleatis, furnicato-conniventibus. Corolla e papilionaceae vexil. $1 \mathbf{u m}$ oblongo-obovatum, reetum v, apice leviter ineurvum, a la e oblongae, vexillo paullo breviores, carin a dipetalam v. apice parum cohaerentem aequantes. Stam ina 10 , monadelpha, tobo hine fisso. Ovarium multiovulatum. Stylus filiformis, strictus; $\mathbf{s t i g m a ~ c a p i t a t u m . ~ L e g ~} \mathbf{n}$ m en lineare, utrinque acuminatum, compressum. Se min a compressa. - Herba Asiae tropicae, annua, prostrata, pilis mollibus longiusculis conspersa; foliis petiolutis, palmatim trifoliolatis, foliolis subsessilibus cuneato-oblongis, subcarnosis, stipulis foliaceis, oblongis, pedicellis solilariis v. geminis, oppositifoliis, medio setaceo-bracteolatis.

Rothla Persoon Encheir. 11, 638. DC. Prodr. I, 195. Meisuer Gen.82, (59.) et 85. (61.) Dill w y n i a Roth Catalect. III. 71. W estoni a Spiengel Syst. III, 230. H a rpele m a Jacq. f. Eclog. II. $t$. 129, inedit. Go etz e a Rei-

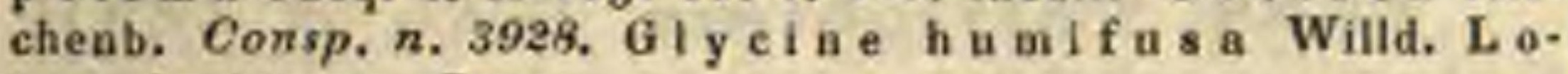
tus indicus. Desr.

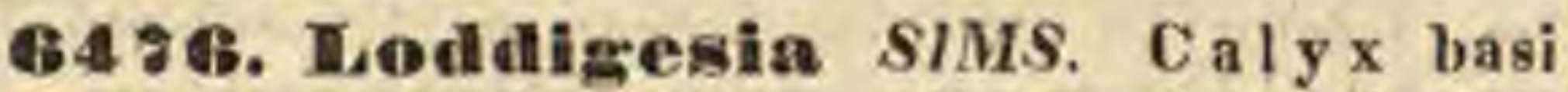
intrusus, campanulatus, aequaliter quinquedentatus. Corolla e papilionaceae vexillum alis et carina multo brevius. Stamina 10 , monadelpha, vagina integra. Ova ri um oblongum, biquadriorulatum. Stylus filiformis, adstendens; stig ma acutum. Le g $\mathbf{m}$ m $\mathrm{n}$ lineare, compressum, di-tetraspermum. - Suffrutex capensis, humilis, ramosissimus; foliis trifoliolatis, foliolis obcordatis, mucronatis, stipulis subulatis, deciduis, floribus terminalibus, umbellatis.

L o dd ig e s i a Sians Bot. MIag. t. 965. DC. Prodr. II. 136. Meisner Gen. 84. (59.)

648\%. IIypoealyptus THUNR. Ca I y basi intrusns, quinquedentatus, dente infimo lingiore, acutiore. Corollae papilionaceae vexil$1 \mathbf{~ m ~ s u b r o t u n d u m , ~ e m a r g i n a t u m , ~ r e f l e x u m , ~ a ~ l a ~ e ~}$ sbtn*ae, subfalratae, $\mathrm{c}$ a $\mathrm{r}$ in a incurva, acutiuscula, S tam in a 10, monadelpha, vagina integra. O varium lanceolatum, compressum, multiovolatum. Sty Ins e basi genienlata adscendens; stigma acntum, inflexum. Le g $\mathrm{nm}$ en substipitatum, lanceolatum, compressum, polyspermum. - Frutex capensis, glaberrimus; foliis alternis, petiolatis, palmatim trifoliolatis, foliolis obcordatis, mucronatis, integerrimis, complicatis, stipulis nullis, floribus terminalibus congestis, purpureis.

H y poc al y pt us Thunberg Prodr. 124. DC. Prodr. II. 135. Meisner Gen, 83. (59.) Delessert Ic, select, III, 135. Crotalaria cordifolia Lian.

B48. Hebeekia THUNB. C aly x nblique campanulatus, quinquedentatus, sinubus rotundatis. Corolla e papilionareae petala noguiculala, vexill um ovatum, deflexum, ala e carina $\mathbf{m}$ incurvam, subfornicatam, acutiusculam superantes. Stam ina 10 , monadelpha, vagina hinc: fissa. O va r i um breviter stipitatum, multiovulatrm. Stylus filiformis; stigma obtusum. Leg $\mathbf{n}$ m e n cylindrieum, polyspermum. - Suffrutices $v$. frutices c a p e n s es; foliis trifoliatis $v$. foliolorum lateralium abortu unifoliolatis, aut interdum aphylli, petiolo foliaceo-subdilatato.

L e be c k i a Thunb. Prodr. 2, Flor, cap. 561. DC. Prodr. IT. 136. Walpers in Linnaea XIIT. 476 Lebeeki a et Stiza E. Meyer Comment. 31. et 33. Lebeckiae s p. Calobota et Acauthobotryae sp. Ecklon et Zeylier Enum. 191_192.

a. PHYLLODIUM Walpers $l$, $c$. Folia nulla, phyllodia angusta. Le beckia e sp. E. Mey. Bekt, et Zeyh.

b. PHYLLODIASTRUM Walpers $l$. c. Folia unifoliolata, petiolo foliolo conformi. Lebeck iae $\mathbf{s}$. E. Mey. Eckl. et Zeyh.

c. CALOBOTA Walpers l. c. Folia trifoliolata. Calycis subiuflati dentes obtusi, - Calobota Eckl. et Zeyh. l. o. Le bechise sp. E. Mey.

d. ACanthobotrya Walpers 2. c. Folia trifoliolata. Calycis dentes acuti, - Acanthobotryae sp. Ecki et Zeyl. $l$. c. Stiza F. Meyer $l$. $c$.

64\%9. Vhborgia THUNB. C a I y x oblique campanulatus, quinquedentatus, sinubus rotundatis. Corolla e papilionaceae petala unguibas calyeem subsuperantibus, vexillum ovatum, deflexum, a lae carina incurva, subfornicata, acutinscula breviores. St a m in a 10 , monadelpha, vagina hine fissa. Ovari u m stipitatum, subsexovulatum. St ylus filiformis; stig ma obtusum. Le g $\mathbf{n}$ in en stipitatum, compressum, sutura vexillari v. utrinque alatum, coriaceum v. saepins membranaceum, mono-dispermum. - Fruticuli capenses; foliis palmatim trifoliolatis, inferioribus saepe fasciculatis, racemis terminalibus, rhachi ramulisque saepe subspinosis, floribus luteis v. raro subrubentibus.

Viborgi a Thunberg Flor. cap. 560. (sub Wibargia) DC. Prodr, II. 135. Delessert Ic, select. III, $t, 64$. B. Mey. inumeral, 28. Walpers in Linnaed XIIT, M76. Meisner Gen. 83. (59.) A e a n thobotry a Eeklon et Zeylier Enum. 192. excl. sp. - ? A cropodium Desvaux in Annal, so, nat, IX. 408 .

6480. Dielnilus $D C$. Calyx profunde bilabiatus, labio superiore bi-inferiore tridentato, dentibus acutis. Corolla e papilionaceae vexilI u oblongum, $c$ arina obtusa brevius, al is caIycem paulle superantibus longius. St a mina 10, monadelpha, vagina superne fiesa. Ovarium li. neare, rectum, multiovulatum $S t y J$ us filiformis; st igma minute capitatum. Legumen..... Suffrutex capensis, glabriusculus; foliis palmalim trifoliolatis, foliolis linearibus, acutis, petiolo brevi, stipulis obsoletis, floribus ramulos axillares terminantibus, nutantibus.

Diehflus DC. Mem. Legum, 201, $t$, 35. Prodr. 11 . 136. Meisuer Gen. 82. (55.)

6481. Colobotus $E$. MEY. Cal y x campanolatus, limbo brevissime bilabiato, labio inferiore bidentato, snperiore obsolete tridentato. $\mathrm{Co}_{\mathbf{0}}$ rollae papilinnaceae ve $\times$ ill $\mathbf{n m}$ lreviter nnsuiculatum, a la e carinam fornicatam bicipitem aequantes. Stam in a 10 , monadelpha, vagina superne fissa .......-Fruticulus capensis, Aspalathi facie; foliis trifoliolatis, stipulis hine cum petiolo brevissimo, illinc inter se in ochream bidentatam connatis, foliis convoluto-teretiusculis, canescentibus, pedunculis terminalibus, brevibus, uni bifloris, floribus parvis.

C ol o bo t u \& E. Meyer Comment, 156. Meisn.Gen, 82.(58)

648\%. Angalathus LINN. Ca I y $x$ cam- 
panulatus v. tubuleso-campanulatus, quinquefidus v. quinquedentatus, laciniis subaequalibus. Corollae papilienaceae vexillum breviter stipi tatum, alae faleatae, obtusae, carinam bicipitem aequantes. Stam in a 10 , monadelpha, vagina superne fissa. Ovarium panciovulatum. StyIus filiformis, adscendens; st $\mathrm{igma}$ obtusum. Legumen oblongum, saepe obliquum, monotrispermum. - Frutices $v$, suffrutices capenses; fo liis palmatim tri-quinquefoliolatis, petiolo brevissimo prima fronte fasciculatis, foliolis planis, v. trique tro-subulatis, stipulis nullis $v$. folioliformibus, flori bus axillaribus solitariis v. terminalibus, capitato spicatis.

Aspalathns Linn. Gen, n, 860. Lam, t. 620. Bot. Mag, t. 829. 1289. 2925. 2399. DC. Prodr. 1T. 137. Meisner Gen. 81. (59.) E riocal y x Necker Elem, $n, 1331$. S cali gera Adanson Fam. II. 323. A spalathus et Buehen. roedera Ecklon et Zeyher Enum. 191. A ulaciutbus F. Meyer Comment. 156. Meisuer Gen. 84. (60.) fid. Benth. in Annal. Wiener Mus, I1, 142.

6483. Sareocalyx $W A L P . C$ aly $\mathrm{x}$ canpanulatus, quinquefidus, laciniis curvatis, undulatis, duabus superioribus apice emarginatis. Corolla papiliunaceae vexillum unguiculatum, oblongam, a la e longissime stipitatae, obtusae, carina cunformis, bipes. Stam in a 10 , monadelpha, vagina superne fissa. Ovarium lineare, multiovulatum. Sty l us filformis, incurvas; st ig ma capitatum. Legumen...... Frutex capensis, rumosus; foliis fasciculatis, ternis $v$. pluribus, lineari-subulatis, subtrigonis, carnosis, mucronulatis, floribus terminalibus et lateralibus breviter pedicellatis, calyce bracteis tribus, ovatis, suborbiculatis, mucronatis, intus concavis, carnosis involucrato.

$\mathrm{S}$ a reocal $\mathrm{y} \times$ Walpers in Linnaea $\mathrm{XIIt}$. 479 .

6484. Eneliporra ECKL, et ZEYH. CaJy $x$ tubulosus, qquinquefidus, laciniis subaequilongis, infuma angustiore. Corolla e papilionaceae vexillum suhorbiculatum, reflexum, alae obliquae, obtusae, ca rinam brevissimam, areuatam, retusam superantes. Stamina 10 , monadelpha, vagina superne fissa. Ovariu m pasciovulatum. Stylus filiformis, glaber; stigma capitatum. Le gum en turgidum, stylo flexuoso terminatum, subtetraspermum. - Suffrutex capensis, repens, hirsutus; foliis simplicibus, integerimis, exstipula. tis, ramis folio squamaeformi fultis, racemis terminalibus pedunculatis, ovatis, pedicellis basi bractea setacea stipatis.

Euch1ora Echlon et Zeyh, Enum, 17t. Meisner Gen. 83. (59.) Miferotropis E. Meyer Comment, 65.

6485. Nellolobiuma ECKL. et ZEYH. Caly $\mathrm{x}$ bilabiatus, labiis suhaequalibus, inferiore semibifido, superioretridentato. Corolla e papilionaceae $\vee$ exillum stipitatum, sribeordatnm, ad latera reflexum, al a s superne dilatatas su perans, carina fornicata alis brevior. Stamina 10 , munadelpha, vagina superne fissa, Ova$r$ i $n$ in bi-multiovulatum. S $\mathrm{t}$ y 1 u $\mathrm{s}$ filiformis stigin a simplex. Le g u in en lineari-oblongum, apiculatum, rectnm v. arenatum, oliguspernum, inter semina torulosnm. - Fruticuli capenses, saepissime petiolis spinescentibus armali, plerumque ylanduloso- $v$. vernicato viscilli; foliis trifoliolatis bistipulatis, floribus in spicas terminales $v$, oppositi. folius dispositis, tribracteatis.

Mellolobium Eeklon et Zeyh. Enum, 188, Sphin gi i u B. Meyer Comment, Q5, Meisuer Gen, 82. (59,)
6486. Heptis $E$. MEY. C a I y x tubulosus v. subprismatieus, semi-quinquefidus, laciniis rectis, acutis, infima paullo profundios distincta.C o r o 11 a e papiliunateae v ex $i / 1$ um substipitatum, ovali arn. minatum, a i e apice rotundatae, multo breviores, c a rin a parum inenrva, bipes. S $t$ a m in a 10 , monadelpha, vagina integra. Ovarium panci-multiovulatum. Stylus filiformis, glaber; $8 \mathrm{tigma}$ obtusum. Leg $\mathbf{n}$ en calyee paullo longins, sub. clavatum, stylo hamatum, turgidulus, oligo-polyspermum. - Suffrutices capenses, graciles, decumbentes; foliis trifoliolatis, stipulis solitarïs, unitaterulibus, lanceolatis $v$, setaceis, floribus lutescentibus, subsessilibus, bractea setacea suffultis.

Leptis E. Meyer msc ex Ecklon et Zejh. Enum, 174. Meisuer Gen. 84. (60) Lipoz ygeos s p. L. Mey.

6.38\%. Hotomonis ECKL, et ZEYH. C alyx quinquefidus, laciniis acuminatis, subaequalibus. Corollae papilionaceae vexillam forso puberulum, hreve unguiculatum, a las oblongas, obtusiusculas, e a $r$ in a e arcuatae aequilongas multum superans. Stam in a 10 , monadelpha, vagina superne fissa. Ovariu in multiovulatum. Stylus filiformis; stigma depressum. Legnmen oblongum, acutum, suharenatum, polysper. mum. - Suffrulices capenses; fotiis trifoliolatis, fotiolis lateralibus minoribus, stipulis solitariis, lateralibas, floribus subsolilariis pedunculatis, bractea setacea suffultis, flavis $v$. caerulescentibus.

Lotonon is Echlon etZeyher Ënum. 176. Meisner Gen. 84. (60.) Ononidis sect. Lotononis DC. Prodr. 11 . 166. Lipozygeos s p. E. Mey.

\subsection{IPolylebiuma ECKL. et ZEYH.} Cal y $\mathrm{x}$ quinquefidus, laciniis subaequalihus, aeutis. Corolla e papilionaceac petala subaequilonga, vexillum stipitatum, suborbiculatum, acutum, al a ebtusae, c a ri n a arcuata, acuta, St amina 10 , monadelpha, vagina superne fissa. Ovarium moltiovnlatum. Siylas filiformis; stigma acoinm. Legumen sessile, linearioblongum, utrinque acutum, stylo apicnlatum, turgidulum, polyspermum. - Herbae capenses, suffrutescentes; foliis trifoliolatis, foliolis laterali. bus minoribus, stipulis saepissime solitariis, lateralibus, floribus flavis, umbellatis, subsessilibus, brac. teis saepius subpedicellatis involucratis.

Poly lobium Eeklon et Zeyher Enum 180. Meisuer Gen, 84. (59.) Lipox ygeos sp. E. Meyer Comment.

6489. Heoboralea DELIL. C a I y x campannlatus, trifidus, laeinia infima setacea in. divisa, lateralibus sursum conniventibns, semibifidis. Corollae papilionaceae vexillum ovatum, longe nnguiculatus, a I a e margine plicato rugosae, carinam obtusam aequantes. St ami. na 10 , monadelpha, vagina superne fissa. Ovarin m multiovulatum. Sty $1 \mathrm{u}$ s filiformis, adscendens; stig un capitalum. Le g $\mathbf{n}$ m en oblongum, apice oblique truneatum, tetra-hexaspermun. Herbae annuae $v$. perennes, suffruticulosae, in $\mathrm{Ca}$ pite bonae spei et in regione nediterra. nea indigenae; foliis palmatim tri quinquefolialatis, stipulis solitariis, unilateralibus, floribus axillaribus subterminalibusque, solicariis v. aggregatis.

Leoborde a Delile in Leon de La-Borde Voyage $t .1$. Meisuer Gen E8. (61) Boissier Voy. Esp. 197. L. 42. Copuitis E. Meyer Comment. 81.

6490. Krebsia ECKL, et ZEYH. Calyx trifidns, laeinia infima lineari, lateralibus sursum cenniventibus, semilifidis. Corollae papilionaceae vesillum sabrotundum, expansum, cari. 
na arcuata, obtusa, a 1 a $s$ snperante brevius. Stam ina 10 , monadelpha, vagina superne fissa. Ovarium pauciovulatum. St y I u s filiformis; stigma subbilobum. Le gnm en lineari-oblongum, stylo brevi apiculatum, subturgidum, pentaheptaspermum. - Fruticuli capenses; foliis tri foliolatis, stipulis duabus folioliformibus, floribus caerulescentibus, unibracteatis.

K rebsia Echlon et Zeyh. Enum, 179. Teli na R. Mey. Comment, 67. excl. sect. 3. Meisner Gen, 84. (60.)

8491. Histia $E, M E Y$. C a l y x trifidus, lacinia infima angustiore, lateralibus semibifidis. Corollae papilionaceae ; arina alas et vexilJum snperans. Sta m in a 10 , monadelpha...... Ovarium ..... L e g $n$ m en lineari-compressum, lateribus flexuoso-anfractuosum. - Herba e apen$s$ is, repens; caule ramisque filiformibus, foliis petiolatis, tri quinquefoliolatis, foliolis sublinearibus, intermedio longiore, stipulis ovato-lanceolatis, liberis, petivlo multo brevioribus, racemis oppositifoliis, subspicatis, floribus luteis.

Listia E. Meyer Comment. 80 Meisner Gen, 84. (60.)

6492. Adiemoenrpus $D C$. C a ly x bila biato-bipartitus, labio superiore bipartito, inferio re productiore, trifido. Corolla e papilionaceae vexillu m obovato-oblongum, patens, al as obtusas c a $\mathrm{rin}$ a $\mathrm{m}$ incurvam aequantes superans. $\mathrm{S} t \mathrm{a}-$ mina 10 , monadelpha, tubo hine fisso. Ovarin m multiovulatum. Stylus filiformis, adscendens; stigma capitatum. Le g $\mathbf{u}$ m en oblongum, plano-compressum, glandulis stipitatis obsitum, oli gospermum. - Arbores $v$, frutices, in Europa austro-oceidentali crescentes; ramis divaricatis, foliis trifoliolatis, saepe aggregatis, foliolis complicatis, stipulis petiolaribus, floribus terminalibus, racemosis, luteis, pedicellis bracteolatis.

A d e n o c a r p us DC, El. fr, Suppl. Bj9., Prodr, II, 138. Meisner Gen. 83, (59.) Boissier Voy. Esp. t. 4t. 42. C ytis i sp. Lam. Herit.

6193. Duomis LINN. C alyx campanalatus, quinquefidus, laciniis angustis, infima productiore. Corollae papilionaceae rexill um amplom, flabellato-striatum, dorso carinatum, laterihus explanatum, a 1 a e carinam rostratam, atrinque supra unguem saccato-impressam aequantes. St a m in a 10 , monadelpha, v, filamento vexillari interdum libero diadelpha, superne latiora. Ovarin m paciovnlatum. Stylus filiformis, longissimns, medio geniculatim adscendens; stigm a subcapitatum. Leg $\mathbf{n}$ m e $\mathbf{n}$ turgidum, oligospermum, - Herbae v. suffrutices, in Europa media parce, copiose in regione mediterra$n$ e a crescentes; foliis pinnatim trifoliolatis, rarius unifoliolatis, interdum imparipinnatis, stipulis saepissime petiolo adnatis, floribus luteis aut purpureis, axillaribus et terminalibus, sessilibus $v$. saepius pedunculatis, pedunculis muticis v. folii floralis abor. tivi petiolo aristatis, uni-multifloris.

On on is Linn. Gen, n, 863. Gärtaer $M T, 343$. t, 134. DC. Prodr. II. 158. (sect. Euononis excl. sect. 2.) Meisner Gen. 84. (60) Kunth Flor. Berol. II. 219. $\Lambda$ no $n$ is Tournef, Inst, 229. A no nis et Natrix Mobnch Method, 157, 158.

a. NA TRIX DC, l. o. Folli a simplicia v. trifoliolata. Flores axillares pedanculati, flavi. - Natrix Morch l.c. (Cavanill. Ic, $t$. 192. Desfont. Flor, atlant, $t, 186$. Vea. ten. Cels. $t, 32$, Bot. Mag. $t, 2450$, )

b. NATRIDIUM DC, $t$. c. Foli a simplicia v, trifoliolata, F Iores axillares pedunculatl, purpurascentes $v$. rarins albi. (Jacq. Flor, austr, t. 49, App. Cavaaill. Ic, t, 169. Desfont. Flor, atlant, t, 190. Bot. Reg. t. 1447.)

c. BUGRANA DC, $t$. c. Foli a simplicia v. trifoliolata.
Flores sessiles v. brevissime stipitati, purpurei v rarius albi. (Jacq. Hort. Vindab, I. t. 93. Desfout, Flor. allant. t. 189, 192, 193. Teuore Flor. Neap. M. t. 67.)

d. BUGRANOIDES DC, l. c, Foli a simplicia v. trifoliola ta. Flores sessiles v. subsessiles, llavi. (Jaeq. Flor. austr. $t, 240$. Cavanill. 1c. t. 153. 159. $f$. 2. Desfost. Flor. atlant. $t$. 185.

e. PTERoNoNiS DC, $l$. c. Folia saltem inferiora imparipinsata, plurijuga.

6454. Erimacea BOISS. C a I y $x$ tubulo. sus, denum inilato-globosus, quinquedentatus, dentibus aequalibus, aeutis, inferioribns sursum inflexis. Corolla e papilionaceae petala angusta, longe unguiculata, a $l$ a $e$ basi $c$ arina e obtusae adnatac. S $t$ a $m$ i n a 10 , monadelpha, vagina integra. Ovarium multiovulatum. Stylus adscendens; stig in a capitatum. Le g u men lineare, compressum, tetra-hexaspermum. - Fruticulus is is a nicus, opposite ramosissimus, ramulis spinescentibus horridus; foliis paucis, oppositis, ovalibus $v$, oblongis, simplicibus, deciduis, capitulis paucifloris, breviter pedunculatis, bracteolatis, floribus caeruleo-purpureis.

Kriuace a Clusius Hist. I, 107. ic. Boissier Voy, Esp. 145. Anthyllis Erinace a Lian. Andrews Bot. Beposit. t. 15. Bot. Mag, t. 676 .

B495. Ulex $L I N N$, C a l yx bibracteolatus, bilabiato bipartitus, labio superiore bi-, inferiore tridentato. Corollae papilionaceae petala subaequilonga, vexill um emarginatum, adscendens, a la e patentes, carina laxa. $\mathbf{S}$ tam in a 10 , monadelpha, vagina integra. Ova ri u m paucievulatum. Sty I us filiformis, adscendens; stigma capitatam. Legu men vix ealyce longius, turgidum, oligospermum. - Frutices in Europa wustra. li o re indigeni, ramosissimi, rumulis spinescentibus, foliisque mueronato pungentibus armati, floribus solitariis, luteis.

Vle x Linn. Gen, $n, 88 t$, excl. sp. Lam, $t, 62 t$, Gärtner IT. 330, t. 151. E., B. t. 748, 743. Loisl. Not, t. 6. f. 8. DC. Prodr, II, 141. Meisuer Gen, 82, (59.)

6496. Stamracanthas LINK, Calyx bilabiato-bipartites, labio-superiore profunde bifido, inferiore tridentato. Corollae papilionaceae vexillum etuarginatum, conduplicatum, a li a lanceolatis, acutis paullo longius, carina e obtusae aequilongum. St a m in a 10 , monadelpha, $\mathrm{O}$ va ri u m multiovulatom. Stylus filiformis, adscendens; stig ma capitatum. Le gumen longe exsertum, plano eompressum, pilosum, polyspermum. - Frutex lusitanicus, griseo-pilosus, aphyllus, spinis plurimis armatus, ramulis oppositis, cruciatim divaricatis, junioribus squamulis mini. mis, ovalibns, acutis instructis, floribus flavis, in ramulis brevibus, ramosis, e spina enatis, pedicellis squamula fultis, bracteola sub calyce minuta.

Stauracanthus Link in Schrader N. Journ, II. 2. 52. DC. Prodr. Ir, 144. Meianer Gen. 82. (59.)

649\%. Spartion DC. C a l y x spathaceus, superne fissus, apice scariosns et minute quinquedentatus. Corollae papilionaceae vexillum amplum, reflexum, a la e laxe patentes, carina dipetala, porrecta paullo breviores. S ta mina 10, monadelpha, vagina integra. O vari n m lineare, multiovulatum. Stylus subulatus, adscendens; stigma oblongum, spongiosum, sub styli apice intus longitudinaliter adnatum. Le g $\mathbf{n}$ m e $\mathbf{n}$ elongato-lineare, compressum, polyspermum. - Frutex Europae a ustralis; ramis virgatis, terelibus, foliis paucis, lanceolatis, floribus in rucemos terminales, laxos dispositis, flavis. 
Spartium DC. Prodr. II. 145. Koch Synops. 151. Meisner Gen. 82. (59.) Spartlanth as Link Enum. II. 223. Reichenb. Flor. excurs. 3t8. Spartium junce um Linn. Duham. Arbr. edit. nov. II. t. 22. Bot. Mag. t. 85. Sehkubr. . 195.

6408. Sareoplayllom $T H U N B$. Cal yx quinquefidus, laciniis subaequalibus, duabus superiuribus divarieatis. Corolla e papilionaceae vexillum breviter unguiculatum, ovatum, reflexum, a la e carinae paullo longiori, obtusae adpressae. St amina 10 , monadelpha, alterna breviora an theris oblongis, alterna longiora antheris subrotundis. Ovarium lineare, multiovulatum. St yIns filiformis, adscendens; $8 \mathrm{tigma}$ capitatum. Legum e n elongato-lineare, subfaleatum, compressum, polyspermum. - Frutex c a pensis; foliis versus apices ramulorum fasciculatis, filiformi. bus, carnosis, medio articulatis, floribus, lateralibus pedicellatis, flavis, ebracteatis.

Sarcophyllum Thunb. Prodr. 2. Sims in Bot. Mag 2. 2302. DC. Prodr. IT. 137. Meisner Gen, 83. (59.) S a rcopby 11 us Thunb. Fl, cap. 2, 573.

6499. Sarothamners WIMM. Caly abbreviato-campanulatus, bilabiatus, labio superiore emarginato-bidentato, inferiore paullo longiore, tridentato, utroque apice tandem searioso. Coro Il a e papilionaceae vexill $\mathbf{n m}$ suborbiculatum, basi cordatum, complicato-concavum, a las obtusas et carin a m ntrinqne supra unguem saccatoimpressam, serius propendentem superans $\mathbf{S ~ t}$ a $\mathbf{m ~ i -}$ n a 10 , monadelpha, vagina hine fissa. O v a ri u m multiovulatum. Stylus longissimus, teres, apicem versus parum dilatatus et interne canalieulatus, snb anthesi gyratus; stigma terminale, utrinque declive. Leg $\mathbf{n m}$ en lineari-oblongam, compressum, polyspermum. Semin a caruncula bilaba, decidna. - Fruticulus in Europa media et a ustrali indigenus; ramis ereetis, virgatis, angulatis, inermibus, foliis simplicibus trifoliolatisque, exstipulatis, floribus axillaribus solitarits, pedunculatis, nutantibus, aureis, pedunculis superne tribracteolatis.

Sarothamaus Wimmer Flora $v$. Schles. 278. Koch Synops. $13 t$, Kunth Flor. Berolin. I, 216. S partium Rei. elieub. Fl, Germ. exc, 519. Meisuer Gen, 83. (59.) S pa rt i um s c a pa ri u m Lian. Flor. dan, t, 313. Gartuer t, 153. $f$. 4.

6500. Cenenta $L A M$. C aly x campanu latus, bilabiatus, labio superiore bipartito, inferiore parum longiore, plus minus profunde trifido. Corolla e papilionaceae vexillum ovatum, explanatum, carina obtusa, utrinque supra unguem saceatu-impressa, demum elastice promissa. St a m in a 10 , monadelpha. Ova rium plnriovalatum. Stylns subulatus, adscendens; stigma in apine styli introrsumlaterale. Leg $\mathrm{n}$ men compressum v rarius subturgidum, oligo-polyspermum. S e m i n m strophiola lunata, persistens. - Frutices inermes $v$ spinosi, in Europa media et austra $l i$ obvii; foliis simplicibus $v$, rarius trifoliolatis, st $i$ pulis exilibus $v$, obsoletis, floribus terminalibus et axillaribus, solitariis v. saepius spicuto-racemosis, luteis.

Ge a is ta Lam. Dict. II. 616. t. 619. DC. Legum. 204. t. 36. Prodr, II, 154. Koch Symops, 152. Kunth Flor. Berolin. I, 217 . Q e n is t a Lian, et $\mathrm{S}$ p a r ti u m Lian. Gen.n, 858 et 859 . exel. sp. Genista, Scorpins, Genistoides et Genistella Mónch Meth, 132. Voglera et $S a l z w e d e l i a$ Flor. Wetteraw. 1T. 498. ss. Ge n is ta e sp. Jacq. Flor. austr. t. 208. 209. Io. rar. t. 356. Hort. Vindob. t. 190 B. B. t. 44. 132, Brotero Phytogr, $t, 54.55$. Desfont, Flor atlant, $t, 183$. Waldst, et Kitaibel Plant. rar. Hung. t, 84 153. Teuore Flor, neap. t, 66. C y tis i s p. Jacq. Ic, rar. t. 147. S p artil s p. Jaeq. Ic. rar. t. S5s. Cavanill. Ic. t. 126. Desfout. Flor, atlant, t, 178, 181, Veat. Cels, t, 17, 18,
6501. TiBetama BOISS. Cal y x campanulatus, labio superiore tr-tncato-bidentato, inferiore breviter tridentato. Corolla e papilionaceare vexillum oblongum, patens, a 1 a e carinam aequan. tes. Stamina 10 , monadelpha. Ovarium biovulatum. Stylus subulatns, adscendens; stigin a terminale, capitatum, pilosinsculum. L eg u$m$ en ovatum, inflatum, indehiscens, monospermum. - Frutices mediterranei, virgati, aphyl. Ii; racemis lateralibus multifloris, floribus albis $v$. flavis.

Ret a ma Boissier Voy. Esp. 143. S partinm mono. s perm um Lina. Bot. Mag. C. 683. et Sp. s p ha eracarp u m Linu.

65418. Troielnasman WALP. Caly y bilabiato-bipartitus, labio superiore bipartito, inferiore tridentato. Corollae papilionaceae petala aequilonga, vexill $\mathbf{n m}$ late uvatum, suborbiculatum, a la e ovali-ellipticae, obtusae, carina bipes, arcuata, obtusa. S t a m i n a 10 , monadelpha, vagina integra, interdum filamento vexillari subdistincto fere diadelpha, omnia fertilia. Ovari m lineare, sex-decemovnlatum. Stylus filiformis; tigma capitellatum. Le gum en compressum, lineare, chartacenm, polyspermum. Suffrutices capenses et caucasici; foliis trifolialatis, bistipulatis, floribus axillaribus, umbellatim racemosis, flavis.

Triehasma Walpers in Linnaea XIIT. 510. Chas. mones sp. R. Meyer. C y $t i x a s t o m e$ atosus Andrews Bot. Reposit. . 237. et C y tisus calyeinus Beberst. Loddig. Bot, Cab, t, 673 .

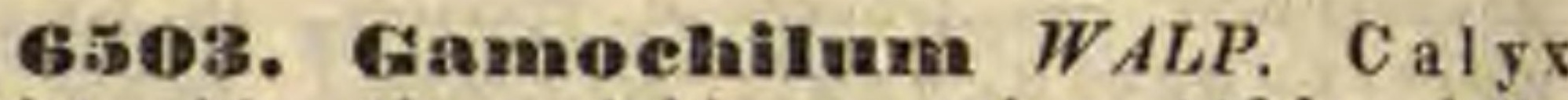
bilabiato-bipartitus, labio superiore bifido, inferiore integro, carinam includente. Co roll a e papilionaceae vexill u m suborbiculatum, emarginatum, a lae cuneato-obovatac, conniventes, carina bipes, arcuata, acuminata. S $t$ a $m$ in a 10 , monadelpha, omnia fertilia, vagina integra. $O$ v arin un lineare, pluriovulatum. St y Ius filiformis, adscendens; st ig m a capitatum. Legumen compressum, lineare, sericeuı, polyspermum.Frutices capenses, sericei; folits trifoliolatis, stipulatis, floribus terminalibus, umbellatis.

$G$ a mo chilum Walpers in Linnaea XIII. 509. Argy. rolobli sp. Eekl. et Zeyh. Chasmones sp. Mey.

6504. Argyedobinm ECKL. et ZEYH. Caly x bilabiatus, labio superiore bi-, inferiore tridentato. Coro i l a e papilionaceae vexillum extus pubernlum, semiorbiculatum v. obovatum, a 1 a eblongae, apice latiores, obtusae, e arina bipes, obtusissima. Stamin a 10 , manadelpha, vagina integra v. plusminus fissa. Ovari u m multiovulatum. Stylus filiformis, adscendens; stigm a terminale, capitatum, extrorsum declive. Legumen lineari-ensiforme, subcompressum, utrinque acutum, stylo apiculatum, polyspermum. Frutices $v$, suffrutices, in regione mediterranea occidentali, et in Capite bonae spei crescentes; foliolis trifoliolatis, petiolatis v. subsessilibus bistipulatis, floribus flavis, subsolitariis v. racemosis, uni-bibracteatis.

Areyrolohfum Ecklon et Zeyher Enum. 184. Wal. pers in Linnaea XIIT. 506. C h a 5 m o n e B. Meyer Comment. 71. exel. sp. Boissier Voyag. Esp. 147. C y ti-s us a rgea. te us Linn.

6505. Cytisma LINN. C a I y x bilabiatus, labio superiore truncato v. bidentato, inferiore tridentato, Co r o 11 a e papilionaceae vexilln m ovatum, amplum, a la e carinam obtusam, genita. 
lia includentem aequantes. St a m in a 10 , monadelpha, vagina integra, alterna antheris minoribus v. interdum efoetis. Ovarium multiovulatum. Stylas subulatus, adscendens; stigma ohliquam, antrorsum declive. Legumen lineari. cosuplanatum, polyopermum, sutura vexillari in crassata v. anguste alata. - Frutices $v$, arbusculae, in Europa media et regione mediterrane a crescentes; foliis trifoliolatis, floribus fascicu latis $v$, racemosis.

C yt is us Lian, Gen, n. 877. DC. Prodr. II, 153, excl. sp. pl. Koch Synops. 154. exel. sp. Linn.

a. TUBOCYTISUS DC. l. c. C al y $\mathrm{x}$ tabo labia superante. - Viborgia Mónch Method, 132. Chamaecytisus Link Handb. II, 154. (Jacq, Fl, austr. t, 20, 33. Waldst. et Kituib. Plant, rar, Hung, $t$, 132. 183. 238. Bot. Reg. t. 1191.)

b. CALYcotomi DC.l.c. Cal y $x$ eampanulatus, basi eir. cumseisse deciduus. - Cal y coto a $\mathrm{e}$ Link in Schrad. n. Journ. II, 2, so. C aly cot o m o n Hoffmans. Verseichn. 166. S p a $\mathrm{rti}$ u s pi uos u m Lian.

c. LABURNUM DC. $l$, c. C a I y $\times$ tubo brevi. labiis hiantíbus. - (Jacq. Flor, austr. t. 306, 387. Waldst. et Kituib. Op, cil. t. 260.)

d. ALBURNOIDES DC. l. c. C a ly $\times$ tubo brevi. Legume n monospermum. - Species lusilanicae et cana rienses.

6508. Anthyllis LINN. Calyx tubulosus v. campanulatus, ventricosus, limbo quinquefidus, plus minus bilabiatus. Coroll a e papilionaceae alae carinae supra nnguem adhaerentes. carin a obtusa $v$. breviter acuminata, ntrinque supra unguem saceatu-impressa. St a m ina 10 , monadelpha $\mathbf{v}$. diadelpha, flamentis superne dilatatis, Ovari um stipitatom, bi-decemovulatum Stylus filiformis; stigma capitellatum. Legumen calyce ventricoso, membranaceo, clauso obtectum, mono-dispermnm. - Herbae v. frutices, in Europa media et regione mediterra nea obvii; foliis imparipinnutis, interdum trifoliolatis $v$, abortu simplicibus, floribus axillaribus et terminalibus, aggregatis.

Anthyllis Limn. Gen, n, 864. DC. Prodr, Ir. 168. excl. sp. Kuath Flor. Berolin. 1. 220.

a. VULNBRARIA. Caly $x$ ventricbso tubulosus. O vari u m blovulatua. Stylus elongatus, medio genieulato.adscendeus. L e g u m a longe stipitatum, monospermum. membranaceum, sutura exteriore dehiscens. - Vulneraria Mobeh Mothod. 146. (Sehkulir t, 196. E. B. t. 196.)

b. BARBA JOVIS. C a Iy $\mathrm{x}$ ventricoso campanulatus. O va riu m pluriovulatum. St y lu s brevissimus, sensim ad. scendens. L eg u me a brevissime stipitatum, aonosper. mum. coriaceum, Indehiscens. - Barba Jovis Moncb Method. 258. Pogouitis Reicheab. Flor. germ. 516. (Duham. Arbr, II, t, 67. Jacq. Flor, austr, t, 195. Bot. Mag. $t, 1927$.

c. PHYSANTHYLLIS. Calyx campanalato-ventricosus. Ovarium biovulatam, Sty lus elongatus, medio ge. siculato-adscendens. L eg u m a longe stipitatum, di spermun, medio septo transverso constríctum, membranaceua, sutura exteriore dehiscens. - Physa athyl IIs Boissier Voy. Esp. 162. A. tetraphylla L.

d. Cornicina. Caly $\times$ ventricoso tubulosus. Ova $r i$ um plariovulatua. St y I us elongatus. L e g a me a stipitatam, oligosperaum, gyratum, seplis transversis discinctam, coriaceum. marglue exteriore deliscens. - C ornieina Boissier $V_{o y .}$ Esp. 162, A a thyllidis sect. Corufeina DC. t. c. (Cav. Ic. t. 39. f. 2. t. 40.) H y as en o $\mathrm{e}$ a $\mathrm{rpa}$ a Savi Flor. Pisan. II. 205. excl. sp. Medicago circinnata Gärtn. $l$. $c$. Schkuhr $t, 312$.

SUETERETS II. TRIFOLIEAE DC, Prodr. II. 171. L egumen uniloculare. S t amin a diadelpha. - Folia saepissime palma- tim tri-quinquefuliolata, rarissime imparipinnata, primordialia alterna. Caule's herbacei, rarius suffrulescenles.

650\%. Medieago LINN. Caly x eampa nulatus, quinquefidns, laciniis subaequalibus v. duabus superioribus breviorilus. Coroll a e papilionaceae vexillum alas et carinam superans, carina obtusa, cum alis supra unguem saccato-impressa. Sta min a 10 , filamente vexillari libero diadelpha, apice aequalia, O varium uni-plnriovulatum. Stylus glaber; stig ma capitatum. Le g um en falcatum $\mathbf{v}$ cochleatum, mono-polyspermum. - Herbae v. frutices inermes, in Europa media et australi erescentes; foliis pinnatim trifoliolatis, rarissime imparipinnatis, stipulis petiolo adnatis, plerumque incixis, pedunculis axillaribus, uni-bi- $v$, spicalo-multifloris, floribus saepissi. me flavis.

Me di ca go Linn, Gen, n, 1214. Gärtwer II, 348, t, 155. Seriage in DC. Prodr. $I$, , 171 , excl. sect. 1.

a. LUPULARIA Ser. Leg nuina compressa, falcata v. subcocbleata, glabra v. pubescentia. margine integro. centro pervia. - (Jacq. Hort. Pindob. I. t. 89, E, B. t. 1016.)

b. SPIROCARPOS Ser. Leg um i na cochleato-orbiculata, mono-pleiocycla, centro clausa, glabra v. pilosa, margine intezro, rugoso v. spisoso. - $\mathbf{M t}$, s eutell a Gärn. , c. et, - ? Diploprion Visiani Flor, Lib. 48. $t, 19, f .2$.

8508. Trigomella LINN, C a ly $x$ campanulatus, quinquefidus v. quinquedentatus. C orolla e papilionaceae vexill um et a lae patentes, ca rina brevissima, obtusa. Stamina 10 filamento vexillari libero diadelpha, superne aequalia. Ovarin m pluriovulatum, rectum. Stylns filiformis, glalier; $s \mathrm{t} \mathbf{i g m a}$ obtusum. Le g $\mathbf{n}$ m en lineare v. oblongo-lineare, compressum v, cylindricum, acuminatum, saepe nervoso-striatum $v$. rugosum, polyspermum. - Herbae graveolentes, in regione mediterranea et Asia media obviae; foliis pinnatim trifoliolatis, lerminali petiolulato, stipulis petiolo adnatis, minutis, floribus subsolitariis, racemosis v. umbellato-capitatis.

Trig a nell a Limi. Gen, n, 1213. Gäriner IT, 332. Se ringe in DO. Prodr. 1T. 181. Meisuer Gen. 85. (6t.)

a. GRAMmOCARPUS Sering. l. c, FI ores capltati v. um. bellati. L e g a in e u ovarum, longitudinaliter nervosum, longe rostratum. - Meliloti s p. Anet. (DC. Hort. genev. $t$. 16. Reichenb. Ic, exot, t. 12. Plant, erit, t. 343. 344.)

h. FOENUM GRAECUM Sering. 2. c. FIores sessiles, solitari, v. gemini. Le g u longe rostratua, loagitadinaliter reticulatum. - Foen a m graecum Tournef. Inst, 230. Gätner $\bar{l}$. $c$.

c. BUCERAS Sering. l.c. Flores racemoso-umbellati. Leg a me n eyliadracen-compressum, subarcuatum, retieu. latum, nervosum. - B u ceratis s p. Möach Method. 143. (Sibthorp Flor graec, $t$, 762.)

d. Falcatula. Serigg. $l$. o. Flo res umbellati. L eg ame a compressua, falcatum, retheulatum, mueronatum. - Faleatula Brotero Phytogr, 160. B uceratis op. Māoch $l$. o. (E. B, t. 1047. DC. Te. plant. Galt. rar. t. 29.)

6509. Pocoelian $S E R$, C a Iy $x$ campanulatus, quinquedentatus. Coroll a e papilionaceae vexillum oblongum, alas et carinam conformes, obtusas superans. Stamina 10 , filamento vexillari libero diadelpha, superne aequalia. Ova rium biovulatum. Sty In filiformis; $8 \mathrm{tig-}$ ma capitatum. Le g $\mathrm{n}$ in $\mathrm{n}$ ovale, compressum, membranaceum, transverse rugosum, samaroi$159 *$ 
deum, sutura vexillari anguste alatum, mono-dispermum. - Herba cretica, Meliloti facie; foliis pinnatim trifoliolatis, foliolis dentatis, stipulis petiolo adnatis, exiguis, floribus racemosis.

Pocackla Seringe in $D C$. Prodr. II. 185. Reichenb. Iconogr. $t$. 678. Meisner Gen, 85, (61.) Trifolium Meliflotus cretica Lian.

6510. Delilotus TOURNEF. C a I y campanulatus, quinquedentatus, dentibus subaequalibus, elongatis. C o r o 11 a e papilionaceae a la earinae obtusae supra ungnem adhaerentes. Stamin a 10 , filamento vexillari libero diadelpha, superne aequalia. Ovarinm stipitatum, binctoovulatum, rectum. Stylus glaber; stigma terminale, declive, L e g u m e calycem immutatum superans, mono-tetraspermum, membranaceum v. coriaceum, indehiscens, rugosum v. venosnm. - Herbae erectae v. adscendentes, glabrae, in Europa media et regione mediterranea obviae; foliis pinnatim trifoliolatis, foliolis saepe argute dentatis, stipulis petiolo adnatis, racemis axillaribus et subterminalibus elongatis, floribus favis v. rarius albis.

Melilotus Tournef. Inst. 406. $t$. 229. Jassleu Gen. 336. Seringe in DC, Prodr. II, 186. Melsuer Gen, 85. (6t.) Kunth Flor. Berolin. 1, 295. Trifoli i sp. Lian,

a. COELORUTIS Seringe $l$, c. L e g u in a lacunoso-rugosa, - (Flor. dan. . 934. Waldst, et Kitaibel Plant. rar. Hung. t. 26. 42. 266.)

b. PLAGIORUTIS Seringe $l$. c. L e g u mina transverse et subarcuatim rugosa.

c. CAMPYLORUTIS Seringe $l$. c. Legumina ovata v. obovata, arcuatim dense venosa.

B511. Trifoliune TOURNEF. Calyx eampanulatus v. tubulosus, quinquefidus v. quinquedentatus, subbilabiatus, laciniis v. dentibus elongatis, lineari-subulatis. Corolla e papilionaceae, plerumque marcescenti-persistentis v exilIum alas, al ae carinam obtusam superantes. St a min a 10; fil am ento vexillari lihero diadelpha, nonnunquam versus apicem dilatata. Ovarium uniloculare, uni pluriovulatum. StyIns glaber; stigma terminale, obtusum, capitatum, v. utrinque, rarius nonnisi antice declive. Le gumen parvum, uniloculare, mono-tetraspermum, nunc sessile, tubo calycino indurato et ad faucem constricto inclusum, nune stipitatum et exsertum, tennissime membranaceum, indehiscens, irregulariter ruptile. - Herbae notissimae, in $r e$ gionibus temperatis orbis terrarum ob. viae, saepissine caespitosae et procumbentes $v$, re pentes; foliis ternatis $v$, interdum quinatis, petiolo communi nonnunquam supra foliolorum lateralium originem productis, stipulis petiolo adnatis, floribus capitatis, umbellatis $v$. dense spicatis, bracteatis, axillaribus subterminalibusque, corollis purpureis, violaceis, albis, ochroleucis v. flavis.

Trifoli um Tournef. Inst. 298. Jussieu Gen. 355. Savi Trifol. Flor, 1810. Seringe in DC. Prodr. II. 189. Koch Synops.167. Trifoliu m, Calyeomorphum, Mist y 1 . lis, Lupioaster, A moria, A maxenus et Paranes us Prest Sywb, I. $4 \bar{b}$.

a. LAGOPUS Kach l, c. F Iores in spica subrotanda v. oblonga sessiles. Calycis faux interne liaea elevata. calloss, saepe pilosa v. anaulo piloratn obsita, demuu plerumque clausa. L e gu me a ealycis tubo foclusust. Trifolii sect. Lagopus, Phleastram et Eutriphy II u m Sering. l.c. Trtfolla m Pres! l. c. $t .33$. (Jacq. Flor. austr. $t$, 386. Waldst, et Kitaib. Plant, rar. Hung. t. 36.)

b. Calycomorphum Presl $l$. c. Flores fertiles in ca. pitulo pauci, subsessiles, deflorati reflexi, eal $l y$ cis tauce iatas nuda, flores steriles serius excrescentes. globoso-congesti, calyces fruetiferos tegentes. - Trifolii sect. Trichocephalu m Koch $l$. c. Tr. sub. terra u e m Lina. E. B t. 1048.

c. FRAGIFERA Koch l, c. Flores in capitulo v, spica subrotunda sessiles. Cal y eis faux uuda, aperta, dorsum cum dentibus dnobus superioribus valde auctum, inflatum, meabranacenm, reticulato-venosum. $\longrightarrow \mathrm{G}$ a. learia Presl $l$. c. Trifolil sect. Vesieastrnm partim Sering. $l$. $c$. T. fragiferum L. T. resupinatum L. $T$, tomentosum Linn.

d. VESICASTRUM Koeh $l$. $c$. Flores in spica subrotunda v. osali sessiles. C aly cis faux interoe nuda, tubns demum aequaliter veutricoso-inflatus, inter dentes duos superiores parum fissus. Corolla persistens, demum scariosa. - Vesicas tru in Sering. part. Mistyllus Presl $l$. c. Tr, vesiculosnm Savi. T, reenrrum Waldst. et Kit. $t, 165$. T. spumosum L. Gärtner $t, 153$.

e. LUPINASTER Möach. Flores in capitulo longius v. brevins pedicellati. Cal y e is faux nuda et aperta, dentes duo superiores breviores, infinas reliquis longior. Corolla demum scariosa, vexillo complicato. $0 \mathrm{va}$ rium stipitatum. - L u pinaster Mönch Method. Suppl. 50. Presl $l, c, \ell, 32$. P e a t a phy 11 u m Persoon Encheir, 11. 352. Da ct y ph y 11 u m Rafibesq. in Journ. Phys. LXXXIX, 261. (Kuuth Legam, t, 53. Hooker Elor. Bor. Amer. t. 50. Bot. Reg. t. 1070,)

f. TRIFOLIASTRUM Sering. $l$. $c$, Flores in capitulo $v$. in spica subrotunda longius ant brevius pedicellati. Ca. Iy cis faux nuda et aperta, dentes duo superiores Iongiores v. subaequales. C o rolla demum scariosa, ve. xillo complieato. - Koeh $t$. $c$. B r a chy dou t f um Rel. chenb. Fl. excars. 491. part. A uo ria Presl l. c. t.30. 31. Mic rant he mum Presl l.c. (E. B. t, 1063.) Jacq. Hort. Vindob. $t$. 60,)

s. CHRonosemium Sering. l. c. Flores in capitulo v. in spica lougius nut brevius pedicellati. Ca 1 y c is tanx nuda et aperta, deates duo superiores breviores v, aequobles. Corolla demun scariosa, vexillo convexo, margine anteriore deflexo et plerumque suleato. L e g nwe $\mathrm{n}$ in ealyce stipitatum. - Koch l. c. Lo to phyl. 1 u a Reiclienb. Plant. crit, $n$, 7. A matenus Presl l. c. (E. B, t, 945, 1256, 1257.)

h. PARAMBSUS Presi l. c. Flores in capitalo globoso deuse sessiles. Caly cis faux nuda et aperta, dens intimus longior, recurvus. Corolla demum marcescens, calvptratim secedens. Leg u m e n exsertum. - Trifo. liu in strictum Waldst. et Kitaib. Plant rar. Hung. t. 37. T. I a vig a $\mathrm{t} \mathrm{um}$ Desfont. Flor, allant, $t, 208$.

651:. 1 oryenaivan TOURNEF. CaIyx subcampanulatus, bilabiato-quinquedentatus, dentibns duobus superioribus latioribus. Corollae papilionaceae al ae vexillum superantes, antice cohaerentes, medio bulla transversali inflata, carina obtusa. $S \mathrm{t}$ a $\mathrm{m}$ ina $10 ;$ fil a $\mathrm{m}$ en to vexillari libero diadelpha, alterna apice dilatata. Ovarium bi-pauciovulatum. Stylus rectus; stigma capitatum. Leg umen turgidum, calyce subinclusum, di-pentaspermum. - Herbae v. suffrutices, in Europa australiore indigeni; foliis trifoliolalis, stipulis liberis, foliolis conformibus, pedunculis umbellatim multifloris.

Dory cni um Tournef. Inst. 211. Delile Flor, aegypt. t. 40. Seringe in DC. Prodr. II, 205. Presl Symb. l. 11. Meisner Gen. 85. (61.) Loti sp. Liun.

6513. Deryemopsis BOISS. C a $1 \mathrm{y} \times \mathrm{ta}$ bulosus, subbilabiato-quinquedentatus. Co rollae papilionaceae vexillum abrupte unguicnlatum, a la inter se distinctae, carinae ubtusae adhaerentes. St a min a 10 , filamento vexillari libero diadelpha, aequalia. Ovarium hiovnlatum. Sty las adscendens; 8 t igma capitatum. Legumen calyce vix inflato inclusum, ovatum, reticulatum, indehiscens, monospermum. - Herba mediterranea, perennis; fuliis imparipinnatis, triquadrijugis, foliolis oblongo-linearibus, capitulis terminalibus, multifloris. 
Doryenopsis Boissier Foy. Esp. 163. Anthyllis Gerardi Linn.

65 14. Thoters $L I N N$. Caly x campanula tus, quinquefidus v. quinquedentatus. Coro 1 a e papilionaceae vexillum rotundatum, patens, a la e praeter lobi basilaris impressionem aequabiles, margine superiore conniventes, $\boldsymbol{c}$ a $\mathbf{r}$ in adscendens, angustato rostrata. Stam ina 10 , filamento vexillari libero diadelpha, glterna longiora apice dilatata. Ovari um multiovulatum. Sty I us e basi geniculata adscendens, filiformi-subulatus, glaber; stigma obtusum v. subcapitellatum. Leg u m e n lineare, rectum v. rarius arcuatum, cylindraceum ant compressum, apterum, polyspermum, uniloculare $v$. septulis transversis inter semina distinetum, in valvas duas contractiles dissiliens. - Herbae in Europa media et boreali rarae, in regione mediterranea et Cana$r i$ is frequentissime obvine, erectae $v$. diffusae, procumbentes; foliis ternatis, stipulis liberis, folioliformibus, pedunculis axillaribus et subterminalibus, apice uni-bi-multifloris, floribus umbellatis, folio florali suffultis, flavis, rarius albis $v$, roseis.

L o t u s Linn. Gen, n, 897. Seringe in DC. Prodr. Ir. 209. Meisner Gen, 85. (60.) Kuntl Flor. Berolin. I. 234.

a. KROKERIA Ser. $l$. c. Legu m e turgidum, curvatum. - Flores 1-2. - Krokeria Mönch Method, 143. Lo tus edulis Linn. Cav. Ic. $t, 157$.

b. LOTEA Ser, l, c, L egume n eompressum, longum. Flores subumbellati. - Lotea Medikus Phil. Bot. I. 204. Noneh Method. 15t. (Cavanill. Io, $t, 163 . \mathrm{Vi}$. viani Flor, $L i b, t, 17, f, 13$.

c. EULOTUS Ser. $l$, $c$. L e g u e n cylindraceum, longum. - Flores corymbosi. - (Schsulir t.211, Flor. dau. t. 991. E. B. $t$, 925, 2091. Cavanill. Ic,t, 156, 164. Vent. Cols. 1. 57. Waldst, et Kitaibel Plant, rar. Hung. L, 229. Bot. Mag. t, 1365. Reiclienb. Ic. exot, $t, 80$.

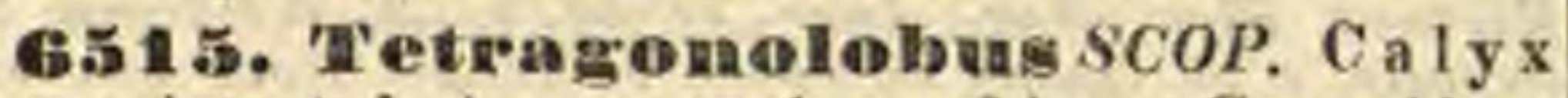
campanulato-tubulosus, quinquefidus. Corolla e papilionaceae alae vexillum superantes, margine superiore conniventes, $c$ a $r$ in a rostrata, adscendens. Stamina 10 , filamento vexillari libero diadelpha, alterna longiora apice dilatata. 0 vari m multiovulatnm. Si y I a flexnosus, superne incrassatus; stig m a cavum, canalisolatum v. subbilabiatum. Le ig $u$ en rectum, subcylindricum, quadrialatum, polyspermum, isthmis cellulosis inter semina intereeptum. - Herbae in Europa media et a ustrali indigenae; folis pinnatim trifoliolatis, foliolis subalternis, petiolo alato, stipulis liberis, folioliformibus, pedunculis axillaribus unibifloris, floribus folio florali stipatis.

Tetragonolobus Scopoli Flor, carn. $I I, 87$. Mönch Method. 164. Seriuge in DC. Prodr. II, 215. Meisuer Gen. 85. (60.) Delessert Ic, select. III. $t$. 11. S c a ndalida Necker Elem. n, 1306. Loti s p. Linn. Jacq. Flor. austr. t. 361, Gërtaer 2. 153. Bot. Mag. t. 151. Desfont. Elor, atlant. $t .210$.

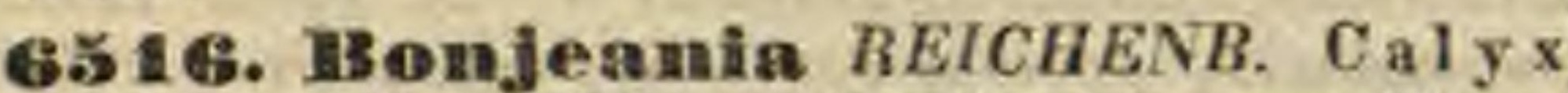
campanulato-quinquefidus, dentibus inaequalibus, adscendentibns. Corolla e papilionaceae vexil$1 \mathbf{n ~ m ~ a ~ l a s ~ l i b e r a s , ~ m a r g i n e ~ s u p e r i o r e ~ p r a e t e r ~ d e n - ~}$ tem baseos cavam impressione longitudinali antier marginatas paullo superans, earina recta, obtusa. St a mina 10 , filamento vexillarilibero diadelpha, alterna longiora, apice dilatata. Ovarium multiovulatom. St y lus filiformis; stigma capitatum. L eg $\mathbf{n}$ m en polyspermum, isthmis cellulosis inter semina distinetum. - Herbete perennes, in Europa australi indigenae; foliis pinnatim trifoliolatis, stipulis foliolis conformibus, pedunculis brevissimis, subumbellatim plurifloris.
Bonjeania Reichenb. Flor, excurs, a0z. Iconogr. t. 1000. (exel. L. microphylto Hook.) Koch Synops. 177. L otus hirsutus Lina. et L. rectus Lina.

651\%. Hosaekia DOUGL. Caly x tubnlosus v, subcampanulatus, quinquefidus v. quinque. dentatus. Corollae petala unguiculata, subaequilenga, vexill $\mathrm{u} \mathrm{m}$ adscendens, a lae patentes, carin a rostrata. Stam in a 10 , filamentu vexillari libero, saepe eastrato, diadelpha. Ovari n m multiovulatum. St ylus subulatus, rectus; stigma capitatum. Leg n m n cylindricum v. compressiusculum, rectum, laeve, apterum, polyspermum. Herbae boreali-americ anae, interdum suf. frutescentes; foliis imparipinnatis $v$. pinnatim trifoliolatis, stipulis plerumque minimis, glandulaeformibus, rarius scariosis $v$. subfoliaceis, pedunculis uni-tri- v. umbellatim multifloris, bractea uni-trifoliolata sub floribus.

Hos a e k l a Donglas msc. Bentham Bot. Reg. t. 1257. Torrey et A. Gray Flor. of North-Amer. I, 323. Ho s a c kit a et Loti sect. Microlotus Bentham in Linn. Transact. $X V I T, 364$.

a. EUHOSACKIA Torr. et A. Gray l. c, U m b ella e multiflorae. Corolla calyce losgior. Vexillum longe unguiculatum, ungue remoto. Carina obtusa. L egume n fere rectum, sabcompressum v. rarissime planum, sursum haud attenuatum. - Herbae ut plurimum pe. rennes; folits quinque-quindecimfoliolatis, rarissime trifulialatis, stipulis membranaceis $v$. subfoliaceis, $v$. minulis, glandulaeformibus. - Lotus pina azus Hooker Bot. Mag, $t$. 2913. (Bot. Reg. $t, 1237,1977$ )

b. DREPA NOLOBUS Nuttall mac. U m bellae muliflorae, rarius unitriflorae. Corolla calyce longior. V ex 1 . 1 um longe usguiculatem, ungue remoto, Cariua obtusa. Legumen incurvum, eyliodricum, apice atteana. to-rostratua. - Herbae interdum suffrutescentes; fo. liis pinnatim quinque-septemfoliolatis, rarius trifoliolatis, stipulis minimis, glandulaeformibus, nigri. cantibus.

c. MiCROLOTUS Torrey et A. Gray $l$. c. Ped a u e $1 \mathrm{i}$ umbellatim usi-triflori. Corolla calyce longior. V e. $\mathrm{x} / 11 \mathrm{um}$ breviter unguicalatus, ungue approximato. C a rina subrostrata. L e g u a e rectam, subcoupres. sum, apice haud attemuatuon. - Herbae nt plurimum annuae; folits pinnatim quinque-septemfoliolatis, stipulis minimis, glandialaeformibus, - Loti sect. MI. e rolotas Bentliam 2 . c. A n is olotus Beruhardi Index. Sem. Hort. Erlang. 1837. ex Linnaea Litteratur. 1838. p. 75.

d. PSYchopsis Nuttall. msc, Pedunculi uniflori. Da. rolla calycen profande quiaquefidum vix superans. Vexillum breviter unguiculatum, ungue approxiaato.

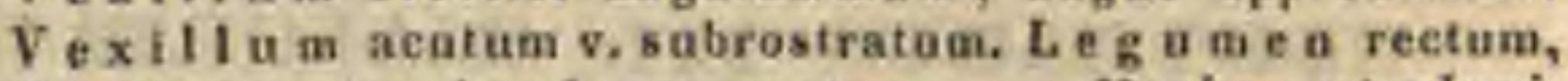
lineare, apice hand attenuatum. Herbae ut plurimum anruae; folits pinnalion trifoliolatis $v$. rariur unifoliolatis, stipults minutis, glandulaeformibus, nigricantibus. - Lotus serleeus Pursit. Trigonella america a Nutt.

6518. Syrmatiam VOGEL. Caly x campanulato tubulosus, subaequaliter quinquedentatus. Coroll a e papilionaceae petala unguiculata, subaequilonga, vexillum et a la e oblongae, carina rostrata. Stam in a 10 , filamento vexillari libero diadelpha. Ovari um.... Stylus earvatus; stigma subcapitatum. Legumen compressum, di-monospernum, inter semina isthmis cellalosis disjuncta contractum, apice louge caudatum, - Suffrutices chilenses, glabri v. pilis albis tomentosi; foliis pinnatim tri-quinquefoliolatis, stipulis obsoletis, pedunculis axillaribus brevibus, umbellatim tri-plurifloris.

S y $r$ tn at i am Vogel in Linnaea $X$ 501. Meisuer Gen. 85. (60, Hos a ckia tomentasa Hook. et Ara.

65 19. Parelhetars IIMILT. Calyx campanulatas, quadrilidus, tacinis aequilatis, in- 
fima longiore. Corollae papilionaceae vexilIn m incumbens, Jate obovatum, emarginatum, a la s carinam obtusam includentes superans. Stam i n a 10 , filamento vexillari libero diadelpha. Ovariuni.... Stylus glaber; stig in a obtusum. Leg a men gibbum, polyspermum. Sem in a subrotunda. - Herbae indicae, perennes, reptantes; foliis palmatim trifoliolatis, petiolis lon$g$ is, erectis, stipulis membranaceis, pedunculis axillaribus solitariis, unifloris, erectis, petiolum aequantibus, medio bibracteolatis, floribus purpureis.

Parochetus Hamilt. ex Don Prodr. 240. DC, Prodr. II. 402, Wight et Aruott Prodr. I. 251.

B520. Podolotus BENTH. Cal y $\mathrm{x}$ ova to-tubulosus, obsolete bilabiatus. Coroli a e papilionaceae a lae vexillum subaequantes, earina subrostrata, Stamina 10 , filamento vexillari libero $v$, basi cum reliquis connexo diadelpha. Ovari um stipitatum, nultiovulatum. Stylus filiformis; stigna capitatum, obliqunm. Legumen stipitatum, lineare, rectum, subteres, polyspermum. - Herba indica, procumbens, ramosa, glabra; foliis imparipinnatis, septem-multijugis, stipulis parvis, scariosis.

Podolotus Bentham in Royle Himalay. 198.

6521. Velianospermum WALPERS. Cal y x ebracteolatus, profunde bilabiatus, labiis subaequilongis, superiore bi- inferiore tridentato. Corullae papilionaceae ve $\mathrm{x}$ i I I u m glabrum a l a s superuns, carina erecta, apice rotundata, bifida, vexillo longior. St a m in a 10 , filamento vexillari libero diadelpha, Ovarium ntroque margine hirtum, multiovulatum. Stylus filiformis, glaber; stig ma capitellatum. Legumen complanatum, tetra-hexaspermum, seminibus protulierantihns subtorosnm, Jevissime subfalcatum. Sein ina umbilico ventrali estrophiolato, funiculo brevi affixa. - Herba capensis, pusilla, erecta, annua; foliis anguste obovatis, terminali sessili, floribus solitariis, oppositifoliis, pedunculis capillaceis, supra medium articulatis, bibracteolatis, petalis vix calyce majoribus, aurantiacis.

Melinospermum Walpers in Linnaea XIII. 597. $\mathrm{C}$ al y cotome E. Meyer Comment. plant. Afr. austr. 113. uou Link. Teplirosia pusilla Pers.

SUE'TREDS HIT. GALEGEAE DC. Prodr. 1I. 243. S t a min a saepissime diadelpha. _ Folia pinnatim trifoliolata v. multijuga cum impari, princordialia opposila. Cau les fruticosi v. arborei, rarius herbacei.

65\%2. Petalostemaon L. C, RICH. C a I y x saepe glandulosus, turbinato-campannlatus rectus v. nonnihil incurvns, quinquedentatus v, rarius quinquefidus, dentibns conniventibus, snbae qualibus, nudis v. barbato-plumosis. Corolla petala 5, unguibus filiformibns $\mathbf{v}$. linearibos, qua tuor subconformia, unguihus tubo stamineo usque ad apicem adnata, posticum (vexillum) libernm limbu obeordatov. oblongo, conduplicato. St a mi na 5 , monadelpha, tubu hinc fisso. Ovarium sessile, biovulatum, ovulis collateralibus. Stylus filiformis; stigma simplex. Le gumen calyce inclusum, compressum, membranaseum, indehis cens, monospermum. Sem en lenticulari-renifor me - Herbae boreali-amerioanae, ul pluri mum perennes, glanduloso punctatae; foliis impari- pinnatis, stipulis minutis, setaceis, pedunculis oppositifoliis, floribus dense spicatis v. capitatis.

Petaloste mon L. C. Richard in Michaux Flor. Bor. Amer. II, 48, DC. Prodr. II. 243. Meisner Gen, 89. 163. Totrey et A. Gray Flor. of North.Amer. I. 309.

a. EUPETALOSTEMON. Caly eis quinquedeurati dentes nudi vix plumosi. Co roll a e petala unguitus filiformibus, lamina subrotuada, - Spicae cylindricae, bractcae su. bulatae. - Dale a e sp. pentandrae Vent. Choix, $t, 40$. (Michx, Op. cit. t, 37.)

b. KUHNISTRA Lam. CaI y eis profunde quinquefidi, fere quinquepartiti laciniae plumosae. Co rolla e petala liuearia, sensim in unguem augustata. - Flores dense capilati, bracteis scariosis, subrofundis, involucran. tibus munili, - K a hnistra Lau. Dict, III, 370 . Veaten, in Act. soc, h. n. Paris, p. 113. C yli pogon Rafiaesque in Journ, Phys. LXXXIX, 97, excl. sp.

65z3. I alea LIN N, Calyx saepe glandulosus, turbinatu-campanulatus, quinquedenta. tus, dentibus subulato-aristatis, infimo paullo productiore. Corollae papilionaceae vexillum li. berum, breve, ubcordatum, adscendens, a la et e arina unguibus tubo stamineo usque ad medium adnatae. S $t$ a $m$ in a 10 , rarissime 9 , monadelpha, tubo hine fisso. Ovarium sessile, biovulatum, ovulis collateralihus. Stylus filifurmis; st igma simplex. L e gum e n calyce inclusum, compressum, membranaceum, indehiscens, monospermum. S e me n lenticnlari-reniforme. - Herbae $v$. frutices, in America boreali indigeni, punctato-glandulosi; foliis imparipinnatis, multijugis $v$. rarissime unijugis, subtus punctatis, stipulis minutis, setaceis, spicis terminalibus $v$. oppositifoliis, densis, saepe capitatis, rarissime racemis laxis, floribus unibracteatis, violacco-caeruleis, nonnunquam luteis.

Dalea Linn. Hort. Cliffort. t. 363. L. C. Richard in Michaus Flor. Bor. Amer. II. 56, t. 38. Willdenow Hork, Berolin, t, 89. Kunth in Humb, et Bonpl. Nov, gen, et sp. VI. 480. Mimos, t. 47, 49. Hooker E.xot, Flor, t. 43, DC. Prodr. II. 244. Meisner Gen. 89. (63.) Torrey et A. Gray Flor. of North Amer. II. 307. P a ros ell a Cavanill. Elench. hort Madrit. Ps or a le a e $\mathbf{s}$ p. Cavauill. Ic. t.86,325.394. Cylipogon Rafinesq. part.

8524. Amorplare $L I N N$. C a I y x obconico-campanulatus, quinquefidus v. quisquedentatus. Corolla e vexill om coneavum, nnguiculatum, erectum, alae et carina defieientes. S $t a m$ in a 10 , ima basi monadelpha, longe exserta. Ovarium sessile, biovulatum. Stylus filiformis, rectus, glaber; stigma simplex. L e g um en compressum, oblongnm, ineurvum v. lunulatum, glandaloso-tuberculatum, sero dehiscens, mono-disper mum. Semin a oblongo ovalia $v$, subreniformia. Frutices $v$. suffrutices boreali-americani; foliis imparipinnatis, folinlis multijugis, punctis glandulosis, pellucidis, tandem nigricantibus conspersis, plerumque stipulatis, racemis spicatis virgatis, terminalibus, saepe aggregatis $v$. in apice ramorum paniculatis, floribus confertis, caeruleis v. albidis, pedicellis cum calyce articulatis.

A morpha Linn. Gen, n. 369. Miller Ie, t. 27. Selikubr t. 197. Lam, $t, 62 t$. Bot. Mag. $t$. 2112. DC. Prodr. II. 256 Meisuer Gen. 89. (63.) Torrey et A. Gray Flor. of North. Amor. 1. 305. Bouafid ia Necker Elem, n. 1364.

6525. Eygenlnardtia $H, B . K$. Calyx tubuloso-campanulatus, quinquedentatns, dentibus acutis, duobus superioribus remotioribus, infimo productiore. Corollae subpapilionaceae vexil i $\mathbf{m}$ oblongnm, basi cuneato-unguiculatum, reflexum, alae et carina dipetala vexillo breviores, oblongo-spathulatae, liberae. Stamina 10, filamento vexillari libero diadelpha. Ovarium bre. 
vissime stipitatum, biovalatum. St y I u 8 apice unsinatus; stigma obtusum, papillosum. L e gumen..... Arbor mexicana, inermis; foliis subimparipinnatis, calycibusque glanduloso-punctulatis, foliolis stipellatis, stipulis petiolaribus, liberis, racemis terminalibus, solitariis, floribus breviter pedicellatis, albis, interdum hexapetalis, endecandris.

$\mathrm{B}$ y se n hardtia Kunth in Humb. et Bonpl. Nov, gen. et sp. VI. 491. $t$. 592. DC. Prodr. II, 257. Meisuer Gen. 89. (63.)

6526. Fsoralea LINN. C al y x plerumque glanduloso-tuberculatus, campanulatus, limbi quinquefidi, bilabiati lacinia infima productiore. Corolla papilionaceae vexillum marginibns reflexum, a lae et earina liberae. Stam in a 10 , filauento vexillari libero, $v$. inferne distincto, -811perne cum reliquis coalito diadelpha, a ntherae conformes v. alternae steriles. O va ri um sessile, nniovulatum. Stylus filiformis; stigma capitellatum. Leg nmen calyce inclusum, membranaceum, indehiscens, monospermum. Semen interdam cum endocarpio coalitum. - Frutices $v$. rarissime herbae, inter tropicos totius orbis et in America boreali crescentes, glandulosi; foliis imparipinnatis, saepissime unijugis, interdum foliolorum lateralium abortu unifoliolatis, nonnunquam squamaeformibus, stipulis geminis, petioli imae basi adnatis, floribus axillaribus et terminalibus, spicatis v. capitato-conglomeratis, bracteatis, interdum pedunculis uni-trifloris, corollis albis, caeruleis v. violaceis.

Psoralea Linn, Gen, n, 894. Lam, t, 614. Jacq. Hort. schönbr. t. 184. 223, 230, Bot. Mag. t. 466. 665. 2063. 2090. DC. Prodr. II. 216. Hooher Flor. Bor. Amer, t. 51-53. Meisner Gen. 86. (61.) Torrey et A. Gray Flor. of NorthAmer. I. 299. Dorychnium et Ruteria Mónch Me thod, 253. P uik a denia Elliot Carolin. II. 198.

652\%. Dtotropis BENTH. Cal y $\mathrm{x}$ quin quefidus, laviniis aentis, infima paullo productiore Corolla e papilionaceae vexill um latum, exappendiculatum, alas carinae breviori basi ntrinque calcaratae adhaerentes sulbsuperans. Stam in a 10, filamento vexillari fere ad basim libero subdiadelpha. Ovarium paciovulatum. Stylus filiformis, adscendens; $\mathbf{s t i g m a ~ c a p i t a t u m . ~ L e g ~} \mathbf{m} \mathbf{m}$ e cylindricum, compressiusculum, stylo mucrona tum, trispermum, isthmis inter semina interceptum. - Herba capensis, decumbens; ramis filiformibus, adscendentibus, hirsutiusculis, foliis trifoliola tis, stipulis subulatis, petiolo utrinque adnatis, ca pitulis terminalibus multifloris, floribus roseis.

Ototropis Benth. in Annal. Fiener. Mrus. IT. 148. Oustropis Dou Syst. II. 214. Lotas mierophyllus Hook. Bot. Mag. t. 2808.

6528. Hildrosia E. MEY. C a Iy x quinquefidus, laciniis subaequilongis, superioribus plus minus profonde partitis. Corolla e papilionaceae vexillnm striatum, basi utrinque appendienlatum, al as hine calearatas ad basim earinae adhaerentes superans, carina incurva, obtusissima, vexillo longior. Stamina 10 , filamento vexillari libero, basi geniculato diadelpha. ${ }^{\circ} \mathrm{O}$ a ri $\mathrm{n} \mathrm{m}$ sti pitatum ...... Stylus filiformis, exsertus, gla ber; stig m a capitellatum, hispidulum. L e g um en stipitatum, compressnm, oblique ovatum dispermum, ad basim fere angulo recto inflexum. - Frutex capensis, Ononidis v. Psoraleae facie, hirtus, glanduloso-glutinosus; foliis trifoliolatis, foliolis obovatis $v$. lanceolatis, recurvato-mucronatis, transversim bullato-undulatis, terminali petiolu- lato, stipulis ovatis, acuminatis, floribus axillaribus solitariis, pedunculatis, nutantibus.

\section{Hidrosia E. Meyer Comment, 89.}

6529. Byemosporra $R . B R$. Cal y x profunde quinquefidus, laciniis subaequilongis, postica latiore, apice breviter bifida, Corolla e papilionaceae vexillum latum, rutundatum, a la carinse obtusae adhaerentes. St a m in a 10 , filamento vexillari libero diadelpha. Ovariam sessile, multiovulatum. Stylus filiformis; stig ma obtusum. Le g n me oblongum, inflatum, sutara seminifera rectum, altera convexum, polyspermum, valvis scariesis, transversiu venosis. - Herba indica, suffruticosa, diffuse ramosa, pubescens; folits pinnatim trifoliolatis, foliolis setaceo-bistipellatis, stipulis subulatis, racemis terminalibus, multifloris, pubescentibus $v$. pilosis, bracteis scariosis, ovato-lanceolatis, acuminatis, striatis, floribus parvis, purpureis.

Py cnospora R. Brown mic. ex Wight et Arnott Prodr. I, 197.

6530. Indigofera $L I N N$. C alyx parvus, nrcenlato - campanulatus, quinquedentatus v. quinquefidus, laciniis subaequalibus, acuminatis. Corollae papilionaceae vexillum subrotundum, reflexum, a la e carinam basi utrinque calcaratam v. gibbain aequantes. Stamina 10 , filamento vexillari libero diadelpha, antherae mucronatae, conformes v. alternae steriles, Ovari u m subsessile, bi-multiovulatum. Stylus filiformis; stigma eapitellatum. Legumen teretiusculum v, tetragonum, rectum v. falcatum, polyspermum, v. abortu unnospermum, inter semina isthmis membranaceis solubilibus distinctum. Semin a cubica. - Frutices, fruticuli v, herbae, in regionibus tropicis et subtropicis totius o $r b i s$ crescentes, saepissime pilis utrinque cuspidatis, medio affixis muniti; folits imparipinnatis, multijugis, rarius unijugis, interdum foliolorum lateralium abortu unifoliolatis, quandoque nullis, petiolo-subulato, stipulis petiolo inferne adnatis, stipellis minutis, nonnunquam deficientibus, pedunculis axillaribus, uni-, bi-v. racemoso-multifloris, pedicellis basi unibracteatis, floribus roseis v. purpureis, interdum albis.

In d ig of e ra Linu, Gen, n, 989. Gärtner II. 317, t, 148. Lam. t. 626. Jaeq, Hort, schönbr, t, 234, 235. 365. Ic, rar. t, 359. 571. Veaten. Choix t. 30. 44. Humb. et Bonpl. Nov. gen el sp. VI. 455, t. 580. DC, Prodr. II, 221. A. Rleliard Flor. Seneg. t. 46-48. Bot. Mag. $t, 3000.3065$, Meisner Gen. 86. (62.) S p ha erid io pho ram Desvaux in Journ. Bot. III, 125. t, $6, f$. 35 , H e m is p a do a Endlicher Alakt. I. t. 3. - ? Diploa y x Rafinesque Flor. Ludov.

6531. Dxyrampluis $W A L L$. C al y $x$ profunde bilabiatus, labio soperiore bidentato, inferiore tripartito, laciniis omnibus acutis. Corollae papilionaceae petala subaequilonga, vexillu m apice attenuato-acuminatum, plicatum, carina rostrata. Stamina 10 , filamento vexillari libero diadelpha. Ova ri u m brevissime stipitatum, compressum, elliptico-rhomboideum, ntrinque angustatum, uniovulatum (?) Sty I us longus, basi hirsutus; $s$ tigma minute capitatum. Leg amen ovatum, compressum, villosissimum, monospermum. - Frutex nepalensis; folis olovatis, retusis, coriaceis, mucronulatis, subtus ramulisque sericeo-villosis, racemis axillaribus, brevibus.

$0 x$ y r a $\mathrm{ph}$ is Wallich Catalog. n. 5348. Meisner Gen, 84. (60,) Crotalaria maceosty 1 a Don.

6532. Slyeyrluiza TOURNEE. Calyx ebracteolatus, tubuloens, basi gibbus, quinque- 
fidus, laciniis duabus superioribus altins coalitis subbilabiatus. Corolla e papilionaceae vexillum ovato lanceolatum, rectum, a la e et carina biceps recta. Sta $m$ in a 10 , filamento vexillari libero diadelpha. Ovari um sessile, bi-quadriovnlatum. Stylus filiformis; $\mathbf{s}$ tigma simplex. Leg uu en ovatum v. oblongum, compressum, saepe echinatum, di-tetraspermum. Se min a reniformia, compressa. - Herbae perennes, in temperatis hemisphaerae borealis crescentes; rhizomate dulci, foliis imparipinnatis, multijugis, racemis axillaribus, spicatis, multifloris, floribus albis, violaceis v. caeruleis.

Gi yeyrhiza Touraefort Inst, 2to. Liun. Gen, n, 882. Lam, t, 625. Pallas Voy. t, 80, 8t, f. 1, 2. Jecq. Hort, Vin. dob, $t, 95$. Waldateln et Kitaibel Plant, rar. Hung. $t, 21$. DC. Prodr, II. 247. Meisner Gen. 89. (63.) Liquiritia Mônch Method. 152.

B533. Galega TOURNEF. C a l y $\mathrm{x}$ ebracteolatus, campanulatns, quinquedentatus, dentibus subulatis, subaequalibus. Co rollae papilionaceae vexilla m obovato-oblongum, a la e liberae, carina obtusa. Stam in a 10 , monadelpha, filamento vexillari ad medium distincto, ant hera e conformes. Ovarin m sessile, multiovulatum. Stylus filiformis, glaber; stigma terminale, punctiforme. Leg $\mathrm{nm}$ en teretiusculum, torulosum, oblique striatum, polyspermum. Se mina cylindracea. - Herbae perennes, erectae, glabrae, in Europa australi et Oriente indigenae; foliis imparipinnatis, multijugis, stipulis ovatis v. lanceolatis, semisagillatis, racemis axillaribus, simplicibus, multifloris, floribus albis $v$. caeruleis.

Ga leg a Tournef. Inst. 222, Miller Ic, $t, 137$. Lam. t. 625. Bot. Reg. t, 326. Bot. Mag. t. 2192. DC. Prodr. II, 248. Meisuer Gen, 89. (63.)

6534. Oyelogyne BENTH. Cal y x campanulatus, semiquinquefidus, laciniis inaequalibus. Co rolla a papilionaceae vexillum orbiculatum, emarginatum, complieatum, alas et carinam superans, a la e breves, oblongae, carina alis longior, valde incurva, obtusa, petalis a basi connatis. Stamina 10 , filamento vexillari libero dia delpha. Ovari um breviter stipitatum, pluriovula tum. Stylus incurvas, apice circinnato-involu tus, latere interiore stigmatifer et longe barbatus. Leg $\mathrm{u}$ men inflatum, oblong um, intus nudum... - Herba Novae-Hollandiae austro-occidentalis, ut videtur perennis, Phacarum americanarum nonnullarum habitu; caule erecto, flexuoso, tomentoso villoso, stipulis foliaceis, late semicorda. tis, foliis imparipinnatis, folialis sex-septemjugis, obovato-ablongis, supra glabriusculis, subtus laxe canescenti-villosis, pedunculis ereetis, folio longioribus, floribus subsessilibus, sparsis, v. pseudo verticillatis.

C y clogyne Benth. ex Lindley Swan River $\mathrm{X} V I$.

6535. Calotropis $D O N$. C alyx campanulatus, quinquefidus, laciniis filiformibus, aequalibus. Curollac papilionaceae vexillum ovatum, erectum, a l a e c rin a incurva brevio. res. Stamina 10 , filamento vexillari libero diadelpha, $O$ va ri $\mathbf{n}$ m stipitatum, multiovulatum. Sty las incurvus; stigma pilosum. Le gr men lineare, compressum, ntrinque acutum, polyspermum. Semina ....-Herba Novae-Hollan. diaeborealis, pubescens; foliis imparipinnatis, foliolis sex-septemjugis, oblongo-cuneatis, retusis, mucronatis, stipulis lanceolato-subulatis, semisagit- tatis, racemis axillaribus multifloris, floribus caeruleis, alis cum vexillo basi albo, flavo maculato.

C a 11 otropis Don Syst. II. 228. Meisuer Gen, 85. (63.) Galega trieolo r Hooker Exot, Flor, $t, 185$.

6536. Polytropia PRESL, C a I y x campanulatus, glandulosus, quinquefidus, laciniis lanceolatis, acuminatis, infima longiore. Corollae papilionaceae ve $\mathrm{x} i 11 \mathrm{um}$ supra unguem angulatobidentatum, a la e cum e a rina conformi a basi ad medinm connatae. St a m i na 10 , filamento vexillari libere diadelpha, Ovarium sessile, biovulatum. Stylus filiformis, glaber; $8 \mathrm{tig}$ in globosum. Legu un en stipitatum, ellipticun, ntrinque acutum, stylo mucronatum, reticulato - venosum, abortu monospermum. Semen ovoideum, compressum, strophiolatum. - Frutex c apensis; ramis simplicibus, decumbentibus, foliis bipinnatis, apice simpliciter imparipinnatis, tri-quadrijugis, pin. nis infimis aut rarius etiam mediis petiolatis, trifoliolatis, foliolis linearibus, stipulis ovatis, a petiolo distinclis, pedunculis axillaribus, elongatis, apice breviter racemosis, paucifloris, floribus pendulis, luteis, parvis, ebracteatis.

Poly tropia Presl Symb. I. 21, $t, 12$. Meisner Gen. 88. (62.)

653\%. Chaetoenlyx DC. Cal y glandulis spinuloso-setiferis hine inde onnstus, quinquefido-bilabiatus, lahii superioris laciniis subulatis, recurvis, inferioris adpressis. Cor ollae papilionaceae vexillum subrotundum, emarginatum, e arina a lis conformis. Sta mina 10, diadelpha, filamentis interdum basi tantum connexis. Ovarium lineare, multiovulatum. Stylus compresso-filiformis, villosus. Legnmen ..... Herbae caribeae, frutescentes, volubiles; foliis imparipinnatis, bijugis, foliolis ovalibus, mucronatis, stipulis lanceolalo-linearibus, patenti-deflexis, pedicellis axillaribus unifloris, fasciculatis, floribus flavis.

Chaetoealyx DC. Mem. Legum. 262. Prodr. II. 243. Meisner Gen. 87. (62.) B 8 n n ing ha as i a Spreng. Syst. III. 245. Gl y cine vicentina Bot. Reg. $t, 799$.

6538. Apodynomene E. MEY. Calyx bractea spathacea, ovata, arida, nervosa, semibifida, sub anthesi decidua inclusus, quinquefidns, laciniis subaequalibus. Co r o l la e papilionaceae vexill nm amplum, extus hirsutum, a la e medio carinae dorso rectangulae adhaerentes. Stamina 10 , monadelpha, filamento vexillari ima basi distineto, superne cum reliquis cohaerente. Ovarium hirsutum. Sty I u s angustissime linearis, aversus inferne barbatus. Le gum en complanatum, late lineare, polyspermum. Se min a transverse oblonga v. pyriformia, umbilion basileri, strophiola tenuissima, candida. - Suffrutices capenses; foliis imparipinnatis, stipulis ovatis, aridis, nervosis, persistentibus, floribus magnis, luteis v. rubentibus. 111.

A pody nomene E. Meyer Comment. Plant. afric.

a. RPIBRISSONIA E. Mey. l. c. Stylus harbatus. Semi a a oblonga. Tephrosia gra adifiora Pers.

b. EPIREINERiA E. Mey. l. c. Styl a s imberbis. Se min a pyriformia.

6539. TTeplarosia PERS. C a l y $\mathrm{x}$ ebracteolatus, subeampanulatus, quinquefidus, laciniis duabus superioribus profundius fissis, antica prodoctiore. Cor 011 a e papilionaceae vexillum suborbiculatum, reflexo-patentissimum, extus hirsutum, carinam et alas carinae adhaerentes 
vix superans. S ta m in a 10, monadelpha v. filamento vexillari libero diadelpha, decidua, a $\mathrm{n}$ th er a e conformes. O v a r i $\mathbf{~ m ~ s u b s e s s i l e , ~ m u l t i o v u l a t u m . ~}$ Stylu s filiformis; stigma obtusnm, pubescens. Dis cus annularis. Le g $\mathbf{u}$ m en lineare, compressum, rectum $v$. falcatum, sessile v. stipitatum, continuum $v$. isthmis transversis inter semina interceptum. Semina compressa v. angulata. Arbores, frutices, suffrutices et herbae, in region $i$ bus tropicis, et parcius in subtropicis totius or bis crescenles, plerumque pube sericea; foliis imparipinnatis, plurijugis $v$. rarius unijugis, stipulis petiolaribus liberis, rarissime spinescentibus, stipellis nullis, racemis terminalibus, oppositifoliis et axillaribus, floribus fasciculato congestis, rarius pedicellis axillaribus solitariis, uni-bifloris, floribus albis, carneis $v$. violaceis.

Thephrosia Persoon Encheir. II. 328. Kanth in Humb, et Bonpl. Nov. gen. et sp. VI. 458. DC. Prodr. II. 248. Wight et Arnott Prodr. I. 209. Meisuer Gen. 89. (63.) Cr a e ca Lín. Flor. Zeglan. 139. Amoen, III. 28. Need. h a $\mathrm{m}$ i a Scopoli Introduct, n. 1496.

a. REINERlA Mönch Suppl. 44. Caly e is dentes lineari subulati. St a mina mosadelpha v, diadelpha. - G a l e g a e sp. Jacq. Ic, rar. t. S75. (Humb. et Bonpl. Op. cit. t. 577. A. Ricbard Flor. Seneg. t. 49.)

b. CRACCOIDES DC. $b$. c. Cal y eis lobi e basi latiusenla acuminato-subulati. S sa min a monadelpha. Stylus barbatus. Di s e us obsoletns. Galega e s p. Jacq. Ic. rar. t. 150. (Humb. et Bospl. Op. cit. t. 578.)

c. BRISSONIA Necker Elem, $n, 1348$. Calye is lobi e basi latiusenla acuminata subelongati. St a mina monadelpha. St y I us lateraliter barbatus. Legumen plus minus velutiaum $\mathrm{v}$, hispidum. - Erebin th $\mathbf{s}$ Mtitchel Gen. 210. Galegate s p. Tussac Flor. Antill. $t .20$.

d. MUNDULEA DC, $l$. c. Cal y $\mathrm{x}$ truncatus v, breviter deutatus. Stamina monadelpha. Stylus glaber v. barbatus. R a c e m i axillares erecti, saepe paniculatl.

6540. Crafordia $R A F$. Cal yx campanulatus, quinquefidus, laciniis subaequalibus. Co. rolla e papilionaceae vexill u in magnum, refle. xuin, a l a e adpressae, basi auricalatae, earin a ob. tusa alis longior. Sta m in a 10, diadelpha. Ovari n m lineare. Stylus filiformis. Stigma punctifurme, glabrum. Le g $\mathbf{u m}$ e $\mathbf{n}$ lineare, torulosum, striatum, subdispermum. Sem in a oblongo-reniformia. - Herba boreali-americana, volubilis; foliis imparipinnatis, foliolis sessilibus, oblongis, mucronatis, pedunculis folio longioribus, subspicatis, bracteis scariosis, subulatis, persistentibus, ciliatis. II. 523 .

Crafordia Rafinesque Spocchio 1,156 . DC. Prodr.

6541. YBrongmiartia $H, B, K$, Calyx bibracteolatus, turbinato eampanulatus, bilabiatus, labio superiore bidentato, inferiore trifido, laciniis acuminatis, infima carinata. C oro lla e papiliona ceae vexillum suborbiculatum, emarginatum, patentissimum, ala e vexillum subaequantes, $c$ a$r$ in am paullo superantes eique adpressae. S $t$ amina 10 , filamento vexillari libero diadelpha. Dis cus tubulosus v, annularis, O va riu stipitatum, 7_9ovulatum. Stylus subulatus; stigma subeapitellatum, Le gumen stipitatum, cultriforme, compressum, subheptaspermum, intus substantia spongiosa vestitum, bivalve. Se min a lenticularia. Embryo rectus. - Frutices $A$ meri cae tropicae; foliis imparipinnatis, bi quinquejugis, stipulis petiolaribus geminis, foliaceis, pedunculis axillaribus, geminis, unifloris, articulatis, corollis incarnatis $v$. violaceis, carina flavida.
B rong niartia Kunth in Humb, et Bonpl. Nov, gen. et sp. VI. 465. t. 587. 588. DC. Prodr. II. 476.

65 4. Penalten $H, B, K$. C a 1 y x bibracteolatus, subcampanulatus, profunde bilabiatus, labio superiore apice bilobo, inferioris tripartiti lacinia media longiore, carinata Corolla e papilio. naceae vexillum suborbiculatum, emarginatum, cucullatum, a la e vexillum superantes, carinam aequantes, eidem adpressae. St a $\mathbf{m}$ in a 10 , filamento vexillari libero diadelpha, Dis cus cyathiformis. Ovari u m sessile, quinqueovulatum. Stylus subulatas; st ig ma simplex. Leg um en breviter stipitatum, oblongum, compressum, ad suturam seminiferam memhranaceo-alatum, immaturum uniloculare. Se min a...... Frutex Americae tropicae, sericeo-lanuginosus; foliis subimparipinnatis, pedunculis axillaribus unifloris, geminis $v$. ternis, bracteis magnis, caducis, floribus violaceis, vexillo supra unguem macula alba notato. Peralte a Kunth in Humb. et Bonpl. Nov. gen, et sp. VI. 469. t. 589. DC. Prodr. II. 424.

6548. Xiphoearpus PRESL. Caly x urceolato-campanulatus, quinquedentatus, dentibus ovatis, duobus supremis inter se subeoslitis, infimo productiore. Corollae papilionaceae vexillam orbiculatum, extus velutinum, reflexo-patentissimum, a la e $c$ arin a $m$ emarginato-bifidam aequantes. St a $\mathbf{m}$ in a 10 , filamento vexillari libero, basi genieulato diadelpha, O v a ri u m breviter stipitatum, multiovulatum. Stylus filiformis, adscendens, hine barbatus; $8 t i g m$ a obtusum. L egumen stipitatum, elongato-lineare, compressum, polyspermum, bivalve, valvis planis. Semina reniformia. - Arbor in dica; ramis striatis, pube adpressa sericeis, stipulis caulinis, subulatis, foliis alternis, imparipinnatis, multijugis, foliolis lanceolutis, mucronatis, elevato-penninerviis, subtus sericeis, racemo terminali stricto, multifloro, pedicellis fasciculatis, minute bracteatis, calycibus sericeis, corollis albis.

Xiphoc a rpus Presl Symb. I. 13, t. 7. Meisner Gon. 89. (63.) Te phrosia caudida DC.

65.4. Homelhoenarpars $H, B, K$. C a l y x urceolato campanulatus, obsoletissime quinquedentatus. Corolla e papilionaceae vexill u m suborbiculatum, emarginatum, snbobcordatun, reflexo-patentissimum, a la e vexillnm et carinam subaequantes, huic adhaerentes. St a m in a 10 , filamenfovexillarilibero, v. superne reliquis adhaerente diadelpha. Ovarin m breviter stipitatum, multiovulatum. S tyI s filiformis; stigma ohtusum v. subglobosum. Le g $\mathbf{u}$ m e $\mathbf{n}$ breviter stipitatum, oblongo-lanceolatam, complanatum, membranacenm, aboriu monodispermum, indehiseens. Se mina compressa, reniformia. - Arbores Americae tropica $;$ foliis imparipinnatis, plurijugis, foliolis oppositis, saepe pellucido punctatis, stipulis persistentibus v. deciduis, stipellis nullis, racemis terminalibus et axillaribus, pedicellis medio articulatis, ad articulum bibracteolatis, floribus rubris $v$. violaceis.

L a achoearpus Kunth in Humb. et Bonpt. Nov. gen. et sp. V1, 383. DC. Prodr. 1L. 259, excl. sp. Meisues Gen, 89. (63.) R obiniae s p. Jacq. Amer, t, 177. f. 49.

6545. Givieidia $K U N T H$. Calyx urceolatus, limbo obliquo, obsolete quinquedentato. Corolla e papilionaceae ve $x$ i ll u m subrotundum, emarginatum, reflexo-patentissimum, a la e liberae vexillum aequantes, $c$ arinam paullo superantes, Stamina 10 , fllamento vexillari libero diadelpha. Ovarin stipitatum, subdeceu160 
ovulatum, Stylus filiformis; stigma urceolatum. L e g u m en stipitatum, longum, compressum, subtorulosum, margine incrassatum, coriaceum, bivalve, oligospermum. Se min a lenticulari-compressa. - Arbores antillanae, inermes; foliis imparipinnatis, exstipellatis, racemis axillari. bus simplicibus, floribus roseis, pedicellis basi et apice articulatis.

GIiricidia Kunth Synops, IV. 80 , in not. Robinia mit is Jacq. Amer. $t, 129$.

6546. TEolbinise LiNN. Cal y x urceolatocampanulatus, subbilabiatus, labio superiore troncato $\mathrm{v}$. emarginato bidentato, inferiore trifido, lobis acutis, infimo vix productiore. Coro 1 l a e papilionaceae vexill $\mathrm{m}$ orbiculatum, reflexo-patentissimum, a la s liberas et carinam bicipitem vix superans. Stam in a 10 , filamento vexillari libero diadelpha. Ovari u in stipitatum, subvigintiovalatum. Stylus filiformis, pubescens; stigma obtusum v, urceolatnm, puberulum. Le g $\mathbf{n}$ m e $\mathbf{n}$ stipitatum, elongatum, compressum, ad suturam seminiferam marginatum, bivalve, polyspermum. Semin a reniformia. - Arbores $v$. frutices, in America boreali indigeni; stipulis petiolaribus liberis, interdum spinescentibus, foliis imparipinnatis, foliolis stipellatis, racemis axillaribus, simplicibus, pendulis, floribus albis $v$. roseis, cum pedicello articulatis, pedicellis basi bractea caduca munitis, leguminibus glabris $v$. hispidis.

Ro b in ia Linn. Gen, n. 879. exel. sp. pl. Duhamel Arbr II. t. 16-18. Kunth in Humb. ot Bonpl. Nov. gen. et sp. VI. 392. DC. Mem. Legum, 273. Prodr, II, 261. Torrey et A. Gray Flor, of North-Amer, I. 294. P s e u d a c a ci a Tour. uel. Inst. 417.

654\%. Ripitaen $V E N T$. CaI y x urceola to-can panulatus, oblique truncatus, minnte quin quedentatus, dentibus duohus superioribus brevis simis. Corolla e papilionaceae petala oblonga, conniventia, vexillum retusum alis subbrevius, $e$ arin a alis longior. Sta $\mathrm{m}$ ina 10 , subexserta, filamento vexillari libero diadelpha. Ovarium stipitatum, maltiovulatam. Stylus filifor mis, glaber; stigma obtusum. Legumen stipitatum, lineare, compressum, mueronatum, bivalve, polyspermum, valvis planis. S e min a lenticularia. - Frutices do mingenses, Galegae v. Robiniae facie; foliis imparipinnatis, exstipellatis, stipulis caulinis setaceis, floribus axillaribus, racemosis, albis v. roseis, leguminibus glabris.

P'oit a a Venten. Choix t. 36. DC. Prodr, IJ. 263.

8548. Sabinea DC. Caly x eyathiformicampannlatus, subintegerrimus. Corolla papilionaceae vexillum obovatum, patens, carinam superans, a la e oblongae, carina obtusissima cu euliformi breviores. Stam ina 10 , filam ento vexillari libero diadelpha, apice cum earina incur va, quatuor reliquis dimidio breviora. Ovarin m stipitatum, multiovulatum. Stylus filiformis, uneinatus; $8 \mathrm{tigma}$ obtusum. Leg $\mathbf{n m}$ en stipitatum, compressum, longe lineare, stylo mucronatum, biralve, polyspermum. Se uinu reniformia, compressa. - Frutices antillan $i$, inermes; foliis abrupte pinnatis, foliolis mucronatis, glabris, pedicellis axillaribus unifloris, fasciculatis, corollis purpurascentibus.

S abinea DC. Prodr. II, 263, Meisner Gen, 88, (63.) Robiuia florida Vahl Symb, IIT, $t$. $z 0$.

6549. Coanrsetia DC. Caly x campanu latus, quinquefidus, laeiniis acuminatis, duabus superioribus pauflo brevioribus v. altius coalitis.
Coro Ilae papilionaceae vexill um obcordatum, longitudine latius, a lae carinam obtusam panllo superantes. Sta $\mathrm{m}$ in a 10 , filamento vexillari libe. ro diadelpha. Ovari a m sessile, mnltiuvulatum. Stylus incurvus, basi crassus, glaber, superne filiformis, nntique barbato villosus; stigma capitatum, glabriustulum. L e g $\mathbf{n}$ m e n compressum, apice angustatum, stylo mucronatum, bivalve, penta-octospermum. S emina compressa, reniformia. - Frulex peruanus, albido-tomentosus, foliis abrupte pinnatis, multijugis, foliolis ovatis, parvis, petiolo apice in setam desinente, $v$, rarius foliolum impar imperfectum gerente, stipulis subulatis, pedunculis axillaribus bi-trifloris, folio breviaribus, floribus flavis.

C oursetia DC. Prodr. II, 264, Meisner Gen. 88, (63.) Lathyrus fruticasus Cavanill. Ic. $t .89$.

6550. Glottidium $D E S V$. C a ly $\mathrm{x}$ campanulatus, snboblique truneatus, obtuse quinquedentatus, dentibus subaequalibus. Cor olla e papilionaceae vexillum reniforme, brevissimum, latissimum, vix unguiculatum, a la e ovali-oblongae, carinae petala supra medium cohaerentia, Sta$m$ in a 10 , filamento vexillari libero diadelpha, Ovarium stipitatum, pauciovulatum. Stylus brevis, apice incurvus; stig ma acntum. Le gnm en longe stipitatum, elliptico-oblongum, compressam, atrinque acutam, stylo mucronatum, dispermum, epicarpio coriaceo-bivalvi, ab endo. carpio membranaeeo, semina includente soluto. Semin a transverse oblonga, compressa. - Herba annua, glabra, in America boreali calidiore indigena; foliis primordialibus simplicibus, ovatis, reliquis abrupte pinnatis, multijugis, petiolo in setam desinente, racemis axillaribus, paucifloris, floribus parvis, flavis.

Glottidium Desvaux Journ, Bot. III. 119. $t, 1$. DC Prodr. IT, 266. Meisner Gen. 88. (63.) Torrey et A. Gray Flor. of North.Amer, $I, 266, \mathrm{Rob}$ in a ves i caria Jacq. Ic. $\operatorname{rar}$, t. 148.

6551. Seslormia PERS. Caly $x$ bibraoteolatus, cyathifo mis, quinquedentatus v. quinquefidus, dentibus v. laciniis subaequalibns. Corolla e papilionaceae petala subaequalia, vexill u m subrotundum, complicatum, nudum v. intus supra unguem appendicibus duabus filiformibus anctum $v$. bicristatum, a l a cultriformes, hine uncinato-auriculatae, e ar i n a biceps, semilunata, cuenlliformis, vix emarginata. $\mathrm{S} t$ a $\mathrm{m}$ in a 10 , filamento vexillari libero diadelpha, tubo basi inflato. Ova rium brevissime stipitatum, multiovalatum. Stylus uncinatus; stigma clavatum. Legumen elongatum, gracile, compressum v, cylindrieum, suturis incrassatis, polyspermum, inter semina contrastum et isthmis transversim multiIocellatum. Se min a transverse cylindraceo-oblonga. - Frutices $v$, herbae, in regionibus tropicis totius orbis, nec non in $A$ merica bo. reali calidiore crescentes; foliis abrupte pinnatis, multijugis, petiolo in setam producto, stipulis minimis, deciduis, foribus axillaribus, racemosis, plerumque flavis, rarius rubentibus, nigro-punctalis. Ses b a u i a Persoon Encheir. II. 316. exel. sp. Desvaux Journ. Bot. III, 120, t. 4. f. 5. Kunth in Hutmb. et Bonpl. Nov. gen. et sp. VI. DC. Prodr. II. 264, Guillem. et Perrot, Flor. seneg. I. 197. 8. 50. Bot. Reg. t. 873. Meisuer Gen. 88. (63.) Ses b a n Poiret Dict. VIT. 127. Emerus Schumach. in Dansk. Selskab. Afhandl, IV. 127. A e $8 \mathrm{c}$ h y $\|$ ome nes s p. Linn, Jaeq. Ic, rar, t, 564. Cav. Ic, $t, 314$.

6552. Tllerminiers GUIL. el PERROT. C a l y $\mathrm{x}$ bilabiato-bipartitus, labiis acutis, integer. 
rimis, carinatis, superiore breviore. Corolla e papilionaceae vexillum subrotundum, complicatum, a la e dolabriformes, carinam dipetalam, apice obtusissimo cueullatam paullo superantes. Stami. n a 10 , monadelpha, tubo antice usque ad basim, postice ad medium fisso. Ovari um sessile, villosum, multiovulatum Stylus filformis, arcuatus, glaber; stigma obtusum. Legnmen linearioblongum, compressum, demum spiraliter tortum, stylo apieulatum, hexa-lecaspermum, inter semina subtorosum. Se in in a reniformia. - Frutex s en eg a $m b i c u s$, trunco crasso, ligno levissimo, aculeis conicis, duris, ramis et foliorum rhachi subtus insidentibus armatus; foliis abrupte pinnatis, multijugis, foliolis alternis, ovali-oblongis, apice emarginatis, petiolo communi in acumen desinente, stipulis lanceolatis, magnis, utrinque ad basim petioli supra aculeum sitis, persisfentibus, racemis axillaribus paucifloris, folio brevioribus, floribus magnis, aurantiaceis, pedicellis basi bractea parva, caduca munitis.

Herm iniera Guillemin et Perrot. Flor. Seneg. I.201. 2. 51. Meisuer Gen. 88, (63.)

6553. Agnti RHEED. Cal y x eampanulatus, truncatus, repando-quinquedentatus, gubbilabiatus. Cerolla e papilionaceae vexillum ovali-oblongum, a lis oblongis brevius, e a rin a maxima, faleata, obtuse acuminata, petalis basi et apice distinctis. Stam in a 10 , filamento vexillari libero diadelpha, subexserta, vagina basi superne auriculata. Ova ri $\mathbf{m}$ stipitatum, multiovulatum. Stylus filiformis, rectiuseulus; stigma obtusum. Legumen basi in stipitem brevem angastatum, elongato-lineare, compressiusculum, polyspermum, inter semina contractum et isthmis transversim multilocellatum. Sem in a ovalia. $-A r$ busculae in Asia tropica crescentes, cito crescen tes, brevi duraturae; folits abrupte pinnalis, mallijugis, stipulis lanceolatis, caducis, racemis axillaribus, bi-quadrifloris, floribus maximis, leguminibus pendulis, pedulibus et sesquipedalibus.

A g a ti Rlieede Hort, Malab, I. 95, t, 51. Rumph Amboin I. t. 76. Adankon Fam, II. 326. Desvaux Journ. Bot. III. 120. t. 4. f. 6. DC. Prodr. IX, 266. Wight et Arnott Prodr. $I$. 266. Meisuer Gen. 88. (63.) A eschynomene grandiflora Linu.

6554. Daublontomia DC. Calyx cam panulatus, subtruncatus, minutissime quinquedentatns. Corollae papilionaceae vexill am $8 \mathrm{nb}-$ rotundnm, longitudine fere latius, breviter unguiculatum, patens, al a e obovato-oblongae eari$n$ a m obtusissimam subsuperantes. Stamina 10, diadelpha, filamento vexillari libero et vagina basi geniculatis. Ov a ri u m stipitatum, multiovulatum. Stylus filiformis, glaber; stigma obtasum. L e g u m e n longe stipitatum, oblongum, compressum, utrinque acutam, coriaceum, suturis utrinque in alam membranaceam productis tetrapternm, polyspermum, isthmis inter semina trans. versim multilocellatum, indehiscens. Sem in a subgloboso-reniformia. - Frutices mexicani, inermes; foliis abrupte pinnatis, multijugis, stipulis subulatis, persistentibus, racemis axillaribus, folio brevioribus.

D a n bentonia DC. Mem. Legum, 258. Prodr, 11, 267. Meisner Gen, 88, (63.) Pis c I di a pu u cea Cavanill. Ic. c. 316, A e s e h youne $10 \mathrm{ng}$ if oll a Cavanill, Ic.t.318.

6555. Dipllysa $J A C Q$. C a I y $x$ quinquefidus, laciniis duabus superioribus subrotnndis, trihus inferioribus acutis, infima carinata longiore. Corollae papilionaceae vexillum oblongum, reflexum, al a e adscendentes, ca rin a mifalciformem aeutam superantes. S $t$ a $m$ i $n$ a 10 , filamento vexillari libero diadelpha. Ovarium stipitatum, pluriovulatum. Stylus filiformis, carina longior; $8 \mathrm{t} \mathbf{i g m a}$ acutum. Le gum en lineare, compresso-planum, obtusum, uniloculare, pentahexaspermum, utrinque acutum, vesica longitudinali membranacea, maxima, inflata, e sutnris oppositis orta, tandem, vesicis sive destructis sive integris, transversion in frustra delabens. Semina oblonga, compressiuseula. - Arbuscula carthagenensis, inermis, ramosa, Mimosae facie; foliis imparipinnatis, subquinquejugis, foliolis alternis et oppositis, pedunculis axillaribus, bi-trifloris, long $i$ tudine foliorum, floribus flavis.

Diphys a Jacq. Amer 208. t. 181. f. 51 . Edit, pict. t. 262, f. 39. Sebreber Gen n, 1104, Lam, t, 605. DC. Prodr. II. 269. Meisuer Gen. 88. (63.)

6556. Corymella $D C$. Caly x subbilabiatus, quinquedentatus, dentibus patulis, linearisubulatis, duobus superioribus vix brevioribus. Corolla e papilionaceae petala brevissime unguiculata, carina obtusa. Stamina 10, filamento vexillari libero diadelpha, subaequilonga. Ovarium multiovulatum. Stylus glaber, clavaeformis. Leg $\mathrm{g}$ m en lanceolatum, compressum, polyspermum. S e mina.....- Frutices domingenses; fotiis abrupte pinnatis, multijugis, petiolis apice stipulisque mucronato spinosis, ramis junioribus pubescentibus, pedicellis axillaribus unifloris, fasciculatis, floribus purpurascentibus.

Corynella DC. Mem, Legum. 281. Prodr. H, 207. Meisuer Gen. 88. (63.) C a r y u itis Spreugel Syst. IV. $\mathbf{8 6 3}$. Robinia poly a ntha Swartz.

855ร. Caragana $L A M$. C a ly x tubulosus, quinquedentatus. Corolla e petala aequilonga, vexillum alis et carina e rectae, obtusae incumbens. St am in a 10 , flamento vexillari libero diadelpha. Ovarin messile, multiovulatum. Sty lus filiformis; stigma terminale, truncatum. Le gumen sessile, junius compressum, demum subcylindricum, stylo mucronatum, polyspermum. Semina suliglohosa. - Arbores $v$. frutices, in Asia media crescentes; folits abrupte pinnatis, multijugis, foliolis mucronatis, petiolo apice setoso $v$. spinescente, stipulis saepe spinescentibus, pedicellis axillaribus, unifloris, saepe fasciculatis, floribus flavis $v$, rarissime albis, vexillo saepius versicolore.

C a ragana Lam. Dict, I, 615, $\ell$, 602, f. 1. 2, excl. 3. DC. Prodr. IT, 268. Ledebour Jc. t. 464. Meisner Ger, 89. (63.) Robinia e s p. Pallas Elor, ross, $t$, 42_45. $H$.

6558. Chesmeya $L I N D L$. Calyx tubuIosns, subbilabiatus, labiis aequalibus, superiore bidentato, inferiore trifido. Corolla e papiliona. ceae petala recta, obtusa, a la e vexillo breviores. Stamina 10, filamento vexillari libero diadelpha, carina inclusa. Ovarium multiovulatum, stylo glabro; stigmate terminali, simplici, vix capitato. Leg am en compressum, demum teres, stylo rostratum, pulpa sicea faretum. Sem in a plurima. - Suffrutex euphratensis, ramosissimus, diffusus, undique dense tomentosus; ramulis herbaceis, divaricatis, foliis imparipinnatis, quadrijugis, foliolis subrotundis, apiculatis, stipulis ovatis, reflexis, pedunculis unifloris, sub apice bibracteolatis, floribus luteis, spinosis, vexillo tomentoso.

Ches ne y a Liadley in It. Chesneg inedil, c, io. (Herb. Chesn. n. 177.)

655. II urceolato-campanulatus, breviter quinquedentatus. $160 *$ 
Corollae papilionaceae vexillum orbiculatum, demum replicatom, a la e acutissimae, auriculatae, $c$ a $r$ in a obtusa, rectiuscula. S $t$ a $m$ i $n$ a 10 , filamento vexillari libero diadelpha, subaequilonga. Ovarium stipitatum, multiovulatum. Stylus filiformis, glaber; stigma terminale, obtusum. $\mathbf{L}$ e $\mathbf{n m}$ en stipitatum, inflatum, ovatum, durum, oligospermum, ad suturam seminiferam depres sum. Sem ina ovalia, subcompressa, parva, lae via, - Frutex sibiricus, Caraganae v. Ammodendriffacie; foliis abrupte pinnatis, foliolis bijugis, petiolis apice stipulisque spinescentibus, pedunculis axillaribus bi-triftoris, floribus purpurascentibus.

H a Ifmode ndron Fischer ex DC. Mem. Legum. 283. Prodr. 11, 269. Meisuer Gon. 88. (63.) Halodeudron DC. $m s c$, R a bi n ha Halodendron Lina. f. Pallas Flor. ross. $t$. 36 . Carag an a argentea Labi. $t$. 607. $f, 3$,

6550. Calophaea FISCH. Cal yx ur ceolato campanulatus, quinqnefidus, laciniis acaminatis, duabus supremis approximatis. Corollae papilionaceae vexill um obovato oblongum, reflexum, a la e anguste oblongae, carin a m obtusam superantes. Stam in a 10 , filamento vexillari libe ro diadelpha, Ovarin sessile, multiovalatum. Stylus filiformi-subulatus, basi villoso-hirsutus, rectus, apice incorvus, glaber; $s t i g m$ a terminale. Le u m en oblongum, subeylindricum, stylo mucronatum, extas pilis, aliis mollibus, aliis rigi dis, glanduliferis vestitum, oligospermum. S e min fiovato-oblonga, compressiuscula, - Frutex wolgensis; foliis imparipinnatis, multijugis, stipulis lanceolatis, racemis axillaribus et terminalibus paniculatis, floribus flavis.

Calophac a Fischer msc. ex DC. Prodr. II. 270, Meisner Gen. 88, (63.) Cytisus piua atus Pallas Flor. ross. I. $t$. 47. C. w o I g a ri c a s Linn. f. Duham, $A r b r$, ed. nov. $t .48$.

B561. Collutea LINN. C a Iy x urceolatocampanulatus, quinquedentatus, dentibus subaequalibus. C o r o I l a e papilionaceae vexill a m amplum, orbiculatum, emarginatum, explanatum, disco circumseripto basi bicallosum, a la s angus tas, basi exciso-biauriculatas et $\mathrm{ca} r \mathrm{r}$ am adscendentem, obtusam superans. Stamina 10 , filamento vexillari libero diadelpha. Ovarium stipitatum, multiovnlatum. Stylns filiformis, postice longitudinaliter barbatns; $s t$ igma sub apice styli uncinato laterale. L e g nmen stipitatum, cymbiformi-ovatom, inflato-vesiculosum, scariosum, clanonm v. apice hians, polyspermum. Semina renifurmia. - Frutices inermes, in Europa australi et Asia mediterranea indigeni; foliis imparipinnatis, multijugis, stipulis subulatis, racemis axillaribus, paucifloris, floribus luteis v, purpureis.

Co 1 u te a Linn. Gen, $n, 880$, exel, sp. Miller Ic. $t, 100$ Sehkulir t. 204. Dulam. Arbr. edit. nov, $, t, 22,23$, R. Brown in Aiton Hort. Kew. edit. 2. IV. 325. DC. Prodr. II, 270. Meisner Gen. 88, (63.)

65E2. Swainasona SALISB. C a ly $\mathrm{x}$ r ceolato-campanulatus, quinquedentatus, dentibus duobus superioribus approximatis. Corolla papilionaceae $v$ e $x$ i I I u un amplnm, orbiculatum, emarginatum, explanatum, diseo circumseripto hasi bicallosum, a la s angustas, basi exciso-biauri culatas et carinam adscendentem obtusam superans. St y lus postice longitudinaliter barbatus; stigma terminale. Legumen ovatum, stylo mucronatum, turgidum, polyspermum. Semina .....-Suffutices, in Nova-Hollandia orientali extratropica indigeni; foliis imparipinnatis, multijugis, stipulis deciduis, racemis axil- laribus folio longioribus, floribus purpureis v. coccineis.

S w a in so na Salisbury Parad. 28. R. Brown in diton Hort, Hew. edte. 2. ID, 326. Bot. Mag, t. 1725. DC. Prodr. II. 271. Meisner Gen. 88. (63,) Colutea e sp. Sims Bot, Mag. t. 792. Vic ia e s p. Andrews Bot. Reposit. $t, 139$.

6563. Iussertia $D C$. Caly $x$ urceolatocampanulatus, quinquefidas, laciniis acutis, subaequalibus. Corollae papilionaceae vexillum obovatum, emarginatnm, explanatum, a las et carin a m obtusam superans. Sta $m$ in a 10 , filamen. to vexillari libero diadelpha. Ovarium breviter stipitatum, multiovulatum. Stylus filiformis, adscendens, antice superne barba transversa, postice imberbis; $s$ tigma terminale. Leg umen scario. sum, compressum v. inflatum, sutura seminifera recta, altera arcuata, sero apice dehiscens, polyspermum. Se m in a reniformia. - Herbae annuae $v$, perennes, rarius suffrutices, in Capite bonae $S_{\text {pei }}$ crescentes; foliis imparipinnatis, multijugis, stipulis subulatis $v$. lanceolatis, pedunculis axillaribus, floribus racemosis, nutantibus, purpureis.

Lessertia DC. Astragal. 37. Prodr. II. 271. R. Brown in Aiton Hort. Few, edit. 2, IV. 327. Hooker Exot. Flor. t. 84. Bot. Mag. t. 2964, Sulit $\mathrm{r}$ a Monch Method, 164. Galeg a e sp. Jaeq. Ic. rar. t.576. Colute a e sp. Jacq. Hort. Vindob. III. $t .3$.

6564. Playllolobiume FISCH. Calyx campanulatus, quinquefidus, laciniis acutis, snbaequalibus. Corollae papilionaceae vexillum obovatum, emarginatum, explanatum, lateribus reflexum, c a rin a m obtusam al a s paullo superantem subaequans. S $t$ a $m$ in a 10 , filamento vexillari lihero diadelpha. Ovari um stipitatum, multiovulatum, stylus filiformis, apice incorvus, glaber; st igma subcapitatum, supra pilis barbato-obvallatum. Legumen turgidum, ad suturam compressum, falcatum, hexa-decaspermum, ad suturam superiorem dehisrens. Semin a...... Herba sinica, adpresse pubescens; foliis impari. pinnatis, multijugis, stipulis liberis, racemis axillaribus, folium subaequantibus, bi-sexfloris, bracteis pedicellos brevissimos aequantibus $v$. superantibus.

$\mathrm{Phyllolobium} \mathrm{Fischer} \mathrm{in} \mathrm{Sprengel} \mathrm{Nov,} \mathrm{Prov.} 33$. DC. Prodr. II. 5et. Meisuer Gen. 88. (63.) Vogel in Linnaea Litterat. Ber, 1838, p. 3, in not.

6565. Sylitra $E, M E Y$. Calyx subbilabiato-quinquefidus. Cor olla e papilionaceae carina erecta, apice rotundata, a $l i$ s vexilloque sub. aequilongis brevior. Stamina 10 , monadelpha. Ovarium ...... Stylus glaber; stigma oblique capitellatum. L e gum en scariosum, pellucidum, oblongum, utrinque obtusum, semínibus multo latins, subtrispermum, indehiscens. S e min a ......-Herbu c a pensis, perennis, virgata; foliis simplicibus, breve petiolatis, linearibus, erectis, stipulis subulatis, floribus axillaribus geminis v. solitariis, minimis, breve pedunculatis, leguminibus glabris, ad suturas pubescentibus.

Sylitra E. Meyer Comment. Plant, afric, 114, non Mŏnch.

6568. Sutlherlandia $R \cdot B R$. C a 1 y $\mathrm{x}$ campanulatus, quinquedentatus. Cor ollae papilionaceae vexill $\mathbf{n}$ m oblongum, lateribus replicatis e arin a oblonga eymbitarmi brevioribus, a la e brevissimae. Stamina 10 , filamento vexillari libero diadelpha. Ovarium stipitatum, multiovalatum. Stylus filiformis, postice barba lougitadinali, apice transversa; $8 \mathrm{ti} \mathrm{gma}$ terminale. L eg umen scariosum, inflatum, polyspermum, inde- 
hiscens. Semina reniformia. penses; foliis imparipinnatis, multijugis, stipulis subulato-lanceolatis, racemis axillaribus, floribus purpureis.

Su therlandia R. Brown in Aiton Hort. Kew. edit. 2. IV. 327, DC. Prodr. II. 273. Meisner Gen. 88. (63.) C o. Iutia Möuch Method. 164. Colutea frutescens Lian. Miller $I c, t, 99$.

656\%. Cliantlaus SOLAND. C a 1 y x campanulatus, quinquedentatus, dentibus duobus superioribus altius cohaerentibus. Corollae papilionaceae vexillum ovatum, incumbens v. refle$\mathrm{xum}$, e a rin a m oblongam, cymbiformem aequans, a la e lanceolatae, bаsi exciso auriculatae, carina breviores. St a m in a 10 , filamento vexillari libero diadelpha, alterna breviora. Ovari um breviter stipitatum, multiovalatum. Stylus filiformis, infra apicem uncinatum barbatus; stigma terminale, trnneatum. Leg um e n stipitatum, oblongum, acuminatum, coriacenm, tumidum, transversion ve. nosum, sutura seminifera marginatum, endocarpio membranaceo, lamelloso, polyspermum. S em in a reniformia. Embryonis exalbuminosi radicula incurva, biflexa. - Herbae, suffrutices $v$. frutices, in Nova Hollandia, Nova. Zeelandia et insula Norfolk indigeni, speciosissimi; foliis imparipinnatis, plurijugis, stipulis persistentibus $v$. tandem induratis, floribus axillaribus, racemosis $v$. umbellatis, coccineis, v, albis, purpureo-pictis.

Cli ant hu s Solander mse. ex Lindlet in Hort. Trans. act. New Ser, I. 519. t. 22. Bot. Reg. t. 1725. Meisuer Gen. 89. (63.) Don ia Don Syst. $I I$. 468 . S tre b lo r hiza Endlieher Flor. Norf. 92. C ol u tea e s p. Woodward in Dam. piers Voj. III. 111. t. 4. f. 2.

6588. Carmielnaelia $R$. BR. Caly cyathiformis, quinquedentatus, dentibus brevissimis, subaequalibus. C o ro lla e papilionaceae vexiliom lengitudine latins, suborbiculatum, reflexum, alis carinam obtusam aequantibus subaequilongum. Stamina 10 , filamento vexillari libero diadelpha, Ova ri u m sessile, lineare, quinquesexovulatum. St y 1 u s subulatus, adscendens; stigma obtusum, nudum. Legumen compres. sum, mono-trispermum, replo post valvarum lapsum persistente. Se m in a reniformia, umbilico clauso, sinn nudo. - Frutex Novae-Zeelandiae, ramosissimus, sub florescentia aphyllus; caule ramisque primariis teretibus, tenerioribus v. planocompressis $v$. ancipitibus, stipulis minutis alternatim dentalis, foliis e dentibus ramorum juniorum ternatis v. imparipinnatis subtrijugis, foliolis obcordatis, racemis e ramorum denticulis simplicissimis, pedicellis basi bractea abbreviata, apice bracteolis binis minutissimis, floribus parvis.

C a r n i cha eli a R. Brown in Bot, Reg. t. 92. Meisner Gen. 89. (63.) Lotus a ustralis Forst.

SUERTEIBUS IV. ASTRAGALEAE DC. Prodr. II. 273. Leg u m e n sutura altera introflexa longitudinaliter biloculare v. semibiloculare. - Folia pinnata. Caules herbacei v. suffruticosi.

6569. Splnaeropliysa $D C$. Caly x campanulatus, quinquedentatus, dentibus duobus superioribus remotioribus. Cor oll a e papilionaceae vexillum explanatum, carina obtusa. Sta min a 10 , filamento vexillari libero diadelpha. Ovarium stipitatum, multiovulatum. Stylu s filifor- mis, hine longitudinaliter subbarbatus; stigma obtusum. Le g um en stipitatum, inflatum, sphaericum, durinsculum, sutura carinali introflexa biloculare, polyspermum. Semina reniformia.

Herbae in salsis regionis caspilco-dahuricae et caucasicae indigenae, perennes; folits imparipinnatis, stipulis minimis, racemis axillaribus elongatis, floribus rubris.

S phaerophysa DC. Mem, Legum, 288. Prodr. II. 270. Meisner Gen, 88. (63.) $\mathrm{Ph}$ a $\mathrm{c}$ a $\mathrm{s}$ a $1 \mathrm{~s}$ u la Pallas $I$. IV. $t$ 9. $f, 1$.

65\% (1). Aindenstaedtia FISCH, C a l y x basi bibracteolatus, campanulatus, quinquefidus, lacunis duabus superioribus latioribus, C o rolla papilionaceae ve xill u m alarnm longitudine, carin a minuta. Stam in a 10 , filamento vexillari libero diadelpha. Ova ri um sessile, multiovulatum. Sty I us adscendens; stigma obtusum. L eg um en subcylindricum, uniloculare, polysperinum, medulla maturitate evanescente faretum, complete bivalve, valvis demum spiralibus. - Herbae altaicae, acaules; foliis omnibus radicalibus imparipinnatis, v, foliorum lateralium abortu unifoliolatis, scapis adscendentibus, floribus umbellatis, rubris v. violaceis.

Gūldenstaod tia Fischer in Mem, soc. $h, n$. Mosq. VI. 170, t. 19. DC. Prodr. TI. 307. A strag a Ii s p. Pallas Astragal, t. 66. DC. Astragal, t. 49.

65\% 1. Placa $L I N N$. C al y $x$ tubulosus r. campanulatus, quinquedentatus, dentibus duobus superioribus remotioribus. Corollae papilionaceae vexill $\mathbf{n m}$ a $l$ a 8 aequans $v$. superans, $c$ arina obtusa. St amin a 10 , filamento vexillari libero diadelpha. Ovari n m sessile v. stipitatum. St y lus adscendens; s $t$ igma capitatum. Le gum e n subturgidum, sutura carinali haud introflexa seminifera tumida uniloculare, polyspermum. S emin a reniformia. - Herbae perennes, interdum suffruticosae, in temperatis et frigidis hemisphaerae borealis potissimum alpicolae; caulibus erectis $v$. procumbentibus, foliis imparipinnatis, stipulis a petiolo distinctis, floribus axillaribus, racemosis, spicatis v. capilatis, bracteatis, purpurascentibus, caerulescentibus, albis v. ochroleucis.

P h a ca Linn. Gon, n. 891. DC. Astragalog. n, 111, t, 1 . Kunth in Humb. et Bonpl. Nov, gen, ot sp. VI, 495. Torrey et A. Gray Flor. of North-Amer. 1. 342.

a. EUPHACA. Foli a imparipiunata, plarijuga, rarius nnijuga, interdum unifoliolata. - (Jacq. Ic. rar. t, 151. Flor, dan, $t, 81,856,1396$, Kunth Op, cit, $t, 585.586$. Ledebour Ie, , 330. Hooker Flor. Bor. Amer, $t$, 56. 56. - 2Eropha ea Boissier Voy, 176. Ph. baetica L.

? b. OROPHACA Torrey et A. Gray l. c. Folia palmatim trifoliolata. (Hook. Op. cit. t, 55.)

65ร8. Dxytropis $D C$. Caly x tubulosns v. campanulatus, dentibus duobus superioribus remotioribus, C o r o I l a e papilionaceae vexill um a las aequans $v$. superans, ca $r$ in a summo dorso in mucronem exsertum desinens. Stamina 10 , filamento vexillari libero diadelpha, Ovarium sessile v, substipitatum, multiovulatum. St y Ius adscendens; $8 \mathrm{tigma}$ obtusum v, subcapitatum. Le gumen sutura vexillari seminifera introflexa incomplete v. fere complete bilocellatum. S e mina reniformia, - Herbae in Europa media rarae, in $A s i a$ et $A m e r i c a b o r e a l i$ et $s u b a r c-$ tica frequentius obviae; foliis imparipinnatis, pedunculis axillaribus $v$, radicalibus multifloris, floribus spicatis, pupurascentibus $v$, albis, rarius caeruleis, ochroleucis v. flavis. 
Oxytropis DC. Astragal. 19. 2, 2-6. Prodr. IL. 248. Bot, Reg, $t$. 1054. Ledebour Ic. $t .54,55,279.281,282,285$, 288. 292. 315, 381, 451, 457. A s $t$ i a a 1 i s p. Linn. Jacq. Flor, austr. t, 51. 167. Flor. dan t, 10i1. Pallas Astragalog. t. 27. 37. 49-46. 49-52, 56. 57. 66. 71-80. S pie si a Necker Elem, $n, 1311$.

65ร ร. Astragalus $D C$. C aly x tubulosus $v$, campanulatus, quinquedentatus, dentibns dusbus superioribns remotioribus. Corolla papilionaceae vexillum al as acquans v. supe. rans, ca rina obtusa. Stam in a 10 , filamento vexillari libero diadelpha. Ovarinm sessile v. substipitatum, multiovulatum. S $t$ y 1 n $g$ adscen. dens; $s t \mathrm{tgma}$ obtusum v. subcapitatum. Le g nmen forma varium, sutura carinali introflexa incomplete v. fere complete bilocellatum, polyspermum v. oligospermum. Se $m$ in a reniformia. Herbae v. suffrutices, in temperatis hemisphaerae borealis, imprimis in Asia media obvii, trans capricornum rari, erecti $v$. prostrati; foliis imparipinnatis $v$. petiolo apice producto, haud raro spinescente, abrupte pinnatis, rarissime ad jugum unicum cum impari redactis ternatis, v. foliolorum lateralium abortu simplicibus, stipulis petiolaribus geminis, liberis v. saepe inferne petiolo adnatis, quandoque in vaginam connatis, floribus terminalibus et axillaribus, racemosis, spica. tis $v$. capitatis, interdum solitariis aut geminis, bracteatis, purpureis, violaceis, albis, caeruleis, ochroleucis $v$. flavis.

As $t r$ agal u s DC. Astragalog. Paris, 1802.p. 22, c. ic. Prodr, II. 281. Kunth in Humb. et Bonpl. Nov, gen, et sp. VI. 492. Ledebour Ic, t, 88, 95, 103, 284, 286, 287, 280 300. 307. 316. 318. Hooker Flor. Bor. Amer. t. 57. Bot. Mag, t. 3268, Bot, Reg, $t, 1324$. A $5 \mathrm{tr}$ a gali $8 \mathrm{p}$. Linn. et Auct. Pallas Astrag. icc. $p l$.

65\% 4. Fiserralla LINN. Caly x campanulatus, quinquefidns, laciniis daabus superioribus remotioribus. Coroll a papilionaceae vexill u m a las et carinam obtusam superans. Stamin a 10, filamento vexillari libero diadelpha. 0 variu in sessile, multiovalatum. Stylus filiformis; stigma obtusum. L e gum en plano-compressum, dorso utrinque sinuato dentatum, biloculare, bivalve, dissepimento valvis contrario. S emin a plurima, reniformia. - Herba in ruderatis Europae mediterraneae et in Oriente obvia, diffusa, pubescens; foliis imparipinnatis, multijugis, foliolis obcordatis, dentato-incisis, pedunculis axillaribus, folio brevioribus, floribus parvis, caerulescentibus, spicam ovatum formantibus.

B is e ru la Linn. Gen, n, 893. Giesecke Ic. fasc. I.t. 17 Gärtwer II, 340. t. 154. Lam. t. 682. DC. Prodr, II, 307. Pelecin us Tournef. Inst. 234 .

\section{ASTRAGALEAE DUBIAE,}

65\% 5 . Illomalobus NUTT. C a ly x quin. quedentatus. Corollae papilionaceae $c$ arina obtusa $\ldots$... Stylus brevis, recurvus. Legumen lineare v. oblongum, valde compressum, pleiospermom, suturis nec introflexis, nec tumidis. Semin a funiculis longis. - Herbae borealia mericanae, subalpinae, perennes, Phacarum facie, leguminibus fere Viciae; folis imparipinnatis, interdum unifoliolatis, racemis axillaribus $v$, radicalibus.

Hom a lobus Nuttall ex Torrey et A. Gray Flor, of North-Amer, I. 350 .

a. ERVOIDEAE Torr. et A. Gray $\boldsymbol{l}$. c. Caulescentes, follis pinnatis, foliolis multijugis, exsiceatione nigresceatibus, haud rigidis, racemis pleromque geminis, leguminibas meubranaceis, plus ninus stipitatis. - Orobus dis. par Nutt. F ha a uigrescens Hook.

b. GBNiStoldeAE Torr. et A. Gray l. c. Caulescentes rigidae, minute canescentes, ramosae, foliolis linearibus v. subulatis. paucijugis, interdum defieientibus . petiolis persistentibus, noununguam dilatatis, legunibibus sessilfibus.

e. DRABELLAB Torr. et A. Gray l. c. Acanles, caespito sae, bumiles, argenteo-canescentes, folis plyyllodineis v. tri-quiuquefoliolatik, esufertis, stipulis scariosis, connatis, imbricatis, leguniuibus sessilibus, demum re. supinatis.

65\% 6. Kentroplnyta NUT'T. C a 1 y $x$ campanulatus, profunde quinquefidus, laciniis subaequalibus. Corolla e papilionaceae vexillum oblongum, reflexum, carina e petala ubtusa, dorsu cohaerentia, alis hreviora. Ovarium tri-quadriovulatum. L e g u m e n partim calyce inclusum, ovatum, uniloculare, coriaceo membranaceum, mono-dispermum. - Herbae boreali-americanae, humiles, caespitosae, diffuse ramosae, cano-pubescentes, stipulis plus minus inter se cohaerentibus; foliis pinnatim tri septemfoliolatis, foliolis linearibus, haud articulatis, persistentibus, rigidis, apice spinosis, floribus parvis, ochroleucis, in axillis foliorum geminatim v. ternatim sessilibus.

Kentrophyta Nuttall ex Torrey et $A$. Gray Flora of North Amer. I. 353.

658 \%. Harpalyee MOG et SESS. C a l y x bibracteolatus, deciduus, bilabiatus, labiis lanceolatis, acuminatis, aequalibus, integris. Coroll a e papilionaceac vexill u obovatum, al a e hine anriculatae, carina biceps, elongata, acuminata, subintorta. S $t$ a m in a 10, monadelpha. Ovarinm ..... Stylus filiformis, cum carina incurvus. Le g u men biloculare (?), compresso-planum, basi angustatum, superne ovato-oblongum, stylo mucronatum, tetra-pentaspermum ..... Herba mexicana, basi suffrutescens, erecta; foliis imparipinnatis, pedunculis axillaribus folio longioribus, racemosis, floribus magnis, roseis.

Harpaly ce Moc. et Sess. Flor. Mex. ex DC. Prodr. II. 593. Meisner Gen. 90. (64.) Megastegia Dou Syst. II. 468. Astragali s p. Pavon msc.

TIRIBUS HE. VICIEAE DC. Prodr, If, 353. Corolla papilionacea. Stamina 10 , diadelpha. $L$ e $g$ u $m$ e $n$ bivalve, continuum. Embryonis cotyledones crassae, germinatione hypogeae, ra di cula incurva. - Folia saepe abrupte pinnata, petiolo communi in setam v. cirrhum producto.

65y 8. Cleer TOURNEE. Calyx basi postice gibbus, quinquepartitus, lobis aenminatis, duobus posticis vexillo inenmbentibus. Co rolla e papilionaceae vexillum ohovato-oblongum, a a e vexillo breviores, e a rin a m bieipitem superantes. St a min a 10, filamento vexillari libero diadelpha; fil ament a alterna sub apice incrassata, a $n$ therae conformes. Ovarinm sessile, multiovulatam. S t y 1 a \& filiformis, adscendens; $8 \mathrm{tigma}$ truneatum, incrassatum. Le gam en rhomboideum v. ovale, turgidum, dispermum. S e mina gibbosa, mucronata, arietis caput referentia. - Herbae annuae, inter segetes Europae australis, in Oriente, Asia media et India obviae, pilis glandulosis consitae; foliis impari- $v$ abruptepinnatis, petiolo apice cirrhifero, foliolis oppositis, infimis alternis, omnibus stipulisque nervosis, ser- 
ratis, pedunculis axillaribus solitariis, articulatis, unifloris, post anthesim deflexis.

C i c e r Touruefort Inst, 389. t, 210. Liun. Gen, $\pi, 1189$. Gärtuer $I T$. 326, t. 151. Sehkuhr $t, 202$. Lam, $t, 632$. Bot. Mag. t. 2247. DC. Mem. Legum, t, 54. Prodr. II. 354. Meisner Gen. 92. (6s.) Wight Ic. t. 20.

65\%9. Pisum TOURNEF. Calyx campanulatus, quinquefidus, laciniis elongatis, foliaceis, duabus superioribus brevioribus. Coroll ae papilionaceae $v$ exill um amplum, reflexum, a la e carina breviores. $\mathbf{S t a m i n a ~} 10$, filamento vexillari libero diadelpha, antherae conformes, Ovarium sessile, multiovulatum. Stylus e basi geniculata adscendens, subfaleatus, lateribus compressus, externe complicato-canalieulatus, interne carinatus, et sub stigmate terminali, depresso villosu-barbatus, Legumen oblongum, polyspermum. Semina globosa, umbilico elliptico. Herbae in maritimis hemisphaerae borea. $l i s$ et in $A s i a$ media obviae, nonnullae incertae originis, passim cultae, annuae, glabrae; foliis abrupte pinnatis, apice cirrhosis, stipulis amplis, pedunculis axillaribus, uni-bi-multifloris.

$\mathrm{P}$ is u $\mathrm{m}$ Tournefort Inst. 215. Linn. Gen, n, 870. exel. sp. Gärtner II. 331. t. 152. DC. Prodr. II, 368. Turpin Atl. II. Meisner Gen, 98. (65.)

6580. Ervam TOURNEF. Caly x quinquefidus, laciniis linearibus, aenminatis, subaequalibus. Coroll a papilionacea vix calycem superans. $S t a m$ in a 10 , filamento vexillari libero diadelpha, antherae conformes. Ovari um sessile, pauciovulatum. St y I a s filiformis, adscendens, sub gtigmate terminali capitato, v. infra apicem in trorsum laterali clavato-incrassatus. Le g $\mathbf{m}$ en oblongum, compressum, di-tetra-hexaspermum. Sem in a orbicularia v. subglobosa. - Herbae annuae, in temperatis hemisphaerae borealis ob. viae; foliis imparipinnatis, multijugis, apice cirrhosis, stipulis semiovatis v. semisagittatis, pedunculis axillaribus elongatis.

Er v u m Liun. Gen. n, 874, Gärtner IT. 328. t. 151. DC. Prodr. II. 366. Meisner Gen, 92. (65.)

a, LENS Tournef. S ty 1 us substigmate introrsum lateral ciliatus. - L e a s Tournef. Inst. 210 . Schkubr $t$. 202.

b. ERVILIA Link. Stylus sub stigmate terminali circa eircum pilosus. 0 vari u m nadulato plicatum. $L$ e g a me toruloso-nodosam. - Ervilia Link Fnum. II. 240. (Gärtu. l. e.)

e. LENTICULA, Sty I us sub stigmate terminall circacircum pilosus. Ovarium laeve. - (Scbibur $l$. c. E. B. t. 970. 1223. Flor, dau, t. 95. 639.)

6581. Vieia $L I N N$. C a ly x campanulatus v. rarins suburceolatus, quinquefidus v. quinquedentatus, laciniis sive dentibus aequalibus ant doolus superioribus brevioribus. Corolla e papilionaceae, longe exsertae v exill u m explanatum, adscendentes. Stamina 10 , filamento vexillari libero diadelpha, antherae conformes. Ovarin m sessile v. breviter stipitatum, pluriovulatum. StyI os filiformis, adscendens, apicem versus nunc undique, nune nonnisi externe piloso barbatus, ra. rissime imberbis; stigm a terminale, capitellatum. Le g umen compressum v. turgidum, di-polysperuoun. Semina subglobosa, lateribus compressiuscula, umbilieo ovali v. lineari, strophiola conforıni, demum evanida tecto. - Herbae ut plurimum scandentes, in regionibus tempera$t i s$ totius or bis obviae; foliis abrupte pinnatis, plurijugis, apice cirrhosis, cirrho saepissime ramoso, rarius simplici, mueroniformi, stipulis plerumque se- misagittatis, pedunculis axillaribus, uni- bi- $v$, racemoso multifloris.

Vi c i a Lian. Gen, n, 873. Gärtuer $I I$. 325, t. 15t. V i. $\mathrm{c} i \mathrm{a}$ et $\mathrm{F}$ ab a Tournef. Inst, 221. 122. DC. Prodr. II. 354.

a. FABA Tournef. $S t$ y 1 u s sub stigmate antrorsum incrassatus, quasi bilabiatns. L e g u m e n plerumque targidum. torulosum. - Foliola subsucculenta. Cirrhi rudimen. tarii mucroniformes. - Faba Tournef. l. c. Moneh Method, 147.

b. VICIA Rivin. Styla s sub stigmate extrorsum pilorum cucullo stipatus. - Flores in axillis sessiles, - Vi cia Rivin Pentap. irreg. t. 56. Wiggers i a Flor. Wellerav. 3. excl. sp.

c. Eavicla. Legumen inter semina isthmorum rudi. mentis spongiosis instruetum. - (Jacq. Fl. austr. t. 34. Hort, Vindob, t, 146. B, B. $t, 30,334,481$, 498. Waldst. et Kitaibel Plant, rar, Hung. t, 133.

B. Vicioides Mönch Meth. 148. Ist hmorum inter semina rudimenta nulla. (Flor. dan, $t, 699$. )

c. CRACCA Rivin. Stylus sub stigmate clavato circacircum pilosus. Le gume a iatus laeve. - Pedunculi elongati, multifori. - C га с с a Rivin. $2,52.0$ х уро. go n Rafiesq. in Journ. Phys. LXXXIX. (Jacq. Flor. austr. t. 229. 364. E. B. t. 79. 1168. Waldst. ot Kitaibel Op. cit. t. 254. Ledebour Ic. $t, 50.108 .366 .368 .481 .5$

858\%. Latliy rus $L I N N$. C a l y x urceolato-campanulatus, quinquefidus $v$, quinquedentatus, laciniis dentibnsve duobus snperioribus brevioribus. Corolla e papilionaceae calycem superantis vexillum basi saepe ntrinque appendiculato-gibbum, a la e carinam orbiculatam, e basi inflexam aequantes. St a min a 10, filamento vexillari libero diadelpha v. monadelpha, vagina sive integra sive fissa, a ntherae conformes. Ovari nm sessile, multiovulatum. Stylus e basi refracta rectus, superne complanato - dilatatus, extas convexinsenlus, intus concavus, villoso-pubescens; stigma terminale, stylo vix latius, abbreviatum, truneatorotandatum, retusum. Le g $\mathbf{n}$ en compressum, apterum v. sutara superiore alatum, polyspermum. Sem in a globoso-compressiuscula, umbilieo ovali, strophiola conformi, demum evanida. - Herbae, ut plurimum scandentes, in regionibus temperatis totius orbis obviae; foliis abrupte pinnatis, cirrihosis, interdum phyllodineis, uni-bi-plurijugis, stipulis semisagittatis, pedunculis axillaribus, unibi-multifloris.

L a th y r us Linn. Gen. n. 1186. Gärtncr IT, 330, t, 152.

a. APHACA Tournef. Inst. 223. V exill u m ecallosum. L egumen apterum. - Folia ad cirrhum redaota, Stipulae maximae - (Miller Ie, $t$. 43. E. B. $t, 1167$ )

b. OCHRUS Tournef. Inst. 219. V e $x 111 \mathrm{u}$ m basi bicallosum. Le gu me n sutura superiore bialata. - Petioli inferiores phyllodinei, cirrhosi.

c. Clymenum Tournef. Inst. 218. Vexillum basi bicallosua. Leg umen apterum, - Petioli inferiores phyllodinei, eirrhosi. (Bot, Mag. $t$, 263.)

d. NISSOLIA Tournef. Inst, 656. Vexill u m ecallosum. Legumea apterum. - Petioli omnes phyllodinei, aphylli, oirrhosi. (E. B. $t, 112$.

e. EULATHYRUS. Vexill u m ecallosum, Leg u m en ap. terum. - Petioli omnes folioligeri, cirrhosi. - Lathyrus Tournef. Inst, 217. C icerell a Mönch Me. thod. 163. (E. B. t. 670, 1108. 1255. Bot. Mag. t, 60. 111. 115. 160. Jacq. Hort, Vindob, t. 86. DC. Io, plant. Gall, rar. t, 32.) - Astrophi a Nuttall ex Torreg ot A. Gray. Flor, of North Amer, $\boldsymbol{I}$. 278. quomodo a Lathyro differat assequi uequeo.

6583. Orobus TOURNEF, Calyx campanulatus, quinquefidus, laciniis daabus superioribus paullo brevioribus. Corolla e papilionaeeae, calycem superantis vexillum ecallosmm, a la e carina obtusa breviores. $\mathrm{S}$ ta $\mathrm{m}$ in a 10 , filamento ve- 
xillari libero diadelpha, antherae conformes. Ovarium sessile, multiovulatum. Stylus semiteres, sursum ampliatus, facie interiore barbatus; st $\mathbf{i} \mathbf{g}$ a terminale, stylo vix latius, abbreviatum, retusum. L e g um en compressum, valvulis post an thesim spiraliter turtis. S e $\mathrm{m}$ in a subglubosa, umbilico lineari, obsolete carunculato. - Herbae erectae, ut plurimum glabrae, in temperatis hemisphaerae borealis obviae; foliis abrupte pin. natis, mucrone herbaceo terminalis, paucijugis, stipulis semisagittatis, pedunculis axillaribus multi. floris.

0 rob u s Tournef. Inst, 214. Linn. Gen, n, 871. Gärtner II, 327. t, 131. Selikuhr t. 200. Jaeq. Flor, ausir. $t, 39$ Desfont. Corollar, t, 62, 63. Flor, atlant. $t$. 196. Wald t. et Kitabel Plant, rar. Hung. $t$ 118, 126. 242. 243. B. B. t. 169, 518, 1046, 1153, Flur. dan, t. 338, 339, 78t, 1170. 1126. Ledebour Ic, t. 483_485. Bot. Mag. t. 675. 2937. Bot. Reg. t. 1763. Hook. Ic, t. 72. Platystylis Sweet Flor. Gard. $t$, 239. Sibthorp Flor, graec. t. 2937. (Bot. Mag. t. 2796.)

TRE ITS IV. HEDYSAREAE DC. Prodr. II. 307. Coroll a papilionacea. St amin a 10 , monadelpha v. diadelpha. L e g u me $n$ transversim in articulos monospermos secedens, $\mathbf{E}$ mbryonis cotyledones foliaceae, radicula incurva. - Folia uni-lrifoliolata v. imparipinnata, saepissime stipellata.

SUB'TEIISUS I. CORONILLEAE DC. Prodr.II. 308. Fl or es umbellati, Le $g$ um in a teretia v, compressa.

6584. Seorpiurus LINN. Caly $x$ quinquefidus, laciniis aegualibus, acutis. Corolla e papilionaceae carina biceps. St a m in a 10 , filamento vexillari libero diadelpha, alterna sublongiora, sub anthera nonnihil dilatata. Ovarium suleatum. Stylas filiformis, acutus. Le gamen revolutum, subspirale, constans articnlis $3-6$, monospermis, longitudinaliter sulcatis, nervis sae. pe aculeatis $\mathbf{v}$, muricatis. S e $\mathbf{m} \mathbf{i} \mathbf{n}$ a oblonga $\mathbf{v}$. ovalia, umbilico ventrali. E mbry onis replicati cotyledones lineares. - Herbae me diterraneae, annuae; foliis simplicibus, integris, in petiolum angustatis, stipulis coulitis, oppositifoliis, membranaceis, lineari lanceolatis, pedunculis axillaribus, folio longioribus, uni quadrifloris, floribus flavis aut rarius purpureis.

3 corp i u r u s Linn, Gen, n. 876. Gärtuer 1 T. 345. t. 155. Viviani Flor. $L_{7} b$, t. 19, f. 4. DC. Prodr. II. 308. Meisuer Gen, 90. (64.) S corploides Tournef. Inst. 226. S e or pi us Loisleur Flor, Gall. 468.

6585. Coromilla LINN. Caly $\mathrm{x}$ breve campanulatus, sinuato-quinquedentatus, dentibus duobus superioribus ap proximatis, subcoalitis. Corollae papilionaceae petala unguibus calycem aequantibus, carina acuta. Stamina 10 , filamento vexillari libero diadelpha. L e g umen teretinsculum, gracile, demum in articules oblongos, monuspermos secedens, S e mina ovata v. cylindracea, umbílico ventrali, - Frutices $v$. herbae, in Europa media parce, copiose in regione mediterranea crescentes; foliis imparipinnatis, stipulis liberis, $v$. in unam oppositifoliam coalitis, pedunculis axillaribus, apice flores umbellatos, pedicellatos gerentibus, floribus roseis v. flavis.

C ornnill a Linn. Gen, $n, 883$. exel. sp. Necker Elem. N. 1319. DC. Prodr. III. 309. Meisner Gen. 90. (64.)

a. EMRRuS Tourn. Petalorum ungues calyce triplo lougiores. Leg a me n articulis subcoutinuis, vix sece dentibus. - $\mathrm{E}$ mer us Tournef. Inst. 418 Miller $I_{c}$. t. 132. Desvaux Journ. bot. III. 121, t. 4. f. 9.

b. CORONILLA Tourn. Petalor u m ungues vix calyce longiores. L e g u e a compressiusculum, articulis definite secedentibus. - Coron illa Tournef. Inst. 419 . Desvaux Journ. Bot. IIT. 119. $t .4 . f .3$, (Miller Ic. t. 289. Jacq, Flor austr. t. 27t. Hort. Vindob. $t .25$. Cavanili. Ic. t. 153. Selirank Hort. Monac, t. 71. Bot. Mag. t. 13, 185, 258, Bot, Reg. t. 820.)

6586. Arthrolebium DESV. Cal yx ebracteatus, taliuloso - campannlatus, subaequaliter quinquedentatus. Coroll a e papilionaceae carina minima, compressa. St a min a 10 , filamento vexillari libero diadelpha. Le g a m e $n$ subangula. tum, in articulos plarimos, monospermos, indehiscentes, cylindraceos secedens. S em in a ovato-cylindracea, nmbilieo ventrali. - Herbae mediterraneae, annuae, glabrae; foliis imparipinnatis, stipulis nuliis $v$. parvis, in unicam oppositifoliam coalitis, floribusflavis, capitatis, capitulo ebracteato,

Arthrolobium Desvaux in Journ. Bot. III. 121. t. 4. $f$. 10, Meisuer Gen. 90 , (64.) A strol a b i a m DC. Prodr. II, 311, O ratite podis sp. Linn. Cav, Ic, $t, 37,41$.

658\%. Drenithopeas LINN. Caly x bracteatus, tubuluso-eampanulatus, subaequaliter quinquedentatus. Corolla e papilionaceae carina minima, compressa. St a min a 10, filamento vexillari libero diadelpha. Leg um en compressum, articulis plurimis, monospermis, indehiscentibus, utringue aequaliter truncatis, nervoso-rugosis constans. Semina cylindriea, umbilico ventrali. Herbae Luropae mediae et australis, villosae, annuae; foliis imparipinnatis, stipulis parvis, petivlo adnatis, pedunculis axillaribus, apice umbellulas pauciftoras gerentibus, floribus flavis, albis $v$, roseis, bractea foliacea pinnata, capilulum subtendente.

Ornithopns Linn, Gen. n. 884. excl. sp. Flor. das. t. 730. E. B. $t$. 369. Desvaux Journ. Bot. III. 121. t. S. f. 14 . DC, Prodr. Il. 311. Meisuer Gen. 90. (64.) O r nithopo. di u mouraef. Inst. 224. Mónch Method, 121.

6589. Hippoerepis $L I N N$. Cal $\mathrm{y} x$ quinquefidus, laciniis aequalibns, acutis. Co roll a e papilionaceae carina biceps. S $\mathrm{ta} \operatorname{m}$ in a 10 , filamento vexillari libero diadelpha. Li e $\mathrm{g}$ a me $\mathrm{n}$ compressum, articulis plurimis ad suturam seminiferam semicirculariter excisis, indehiscentibns, monospermis, secedentibus. $\mathrm{S}$ e $\mathrm{m}$ in a reniformia, curvata v. angulata, umbilico ventrali. - Herbae $v$. suffrutices, in regione mediterranea crescentes; foliis imparipinnatis, floribus flavis, nune axillaribus solitariis, nunc sessilibus, saepius in apice pedunculi axillaris umbellatis.

Hippoerepls Linn. Gen, n. 885. Lam. t, 630. Jacq. Ic, rar. t. 149. K. B. $t .31$. Tenore Flor. neap. $t, 69$. DC. Prodr. 1I. 312. Meisuer Gen. 90, (65.) Ferram equia um Tournef. Inst. 225.

6589. IBonaveria SCOP. Calyx bilabiatus, labio superiore bifido, inferiore tripartito. Co rolla e papilionaceae petala unguibns calycem subsuperantibus, e arina acuta. St am in a filamento vexillari libero diadelpha. L e $g$ u men compressum, isthmis interceptum, suturis incrassatis, snpera bisulea, continuis, haud in articulos secedens. S emina compresso-tetrangula, umbilico ventrali. - Herba Europae australis, Coronillae facie, pedalis, glauca; foliis imparipinnatis, floribus umbellato-fasciculatis, flavis.

B o n a veria Seopoli Introduct. 1420. Necker Elem. $n$, 1320. Desvaux Journ, bot. III, 60. $t$. 4. $f$. 7 . S e eurigera
DC. Fl. fr. IV. 609. Prodr. II. 313. S e curilla Pers. 
Encheir. II. 314. Se u ridaca Touraef. Inst, 224. Lam. t. 629. Gärtuer 1I. 337. $t, 153$. Coronilla S e uridaca Linn.

\section{SUT'TIBIIES III. EUHEDYSAREAE} DC. Prodr. II. 313 . Flores racemosi v. spicati. Legum en compressum.

B5DO. Diplacea LOUR. Cal y x bracteolis duabus lanceolati $\theta$, quinquefidus, persistens, lobo infimo longiore. Corolla e papilionaceae vexill u m trigono-rotundatum, emarginatum, adscendens, a l a e ovatae, vexillo breviores, carinae petala libera, vexillum aequantia, longe unguiculata. Sta mina 10 , in phalanges duas, pentandras coalita. Ovari a 2 , oblonga, compressa, recta, stylis distinctis, subulatis; stigmatib u 8 crassiusculis. Le gumina 2 , compressa, articulata, acuminata, articulis ovatis, striatis, inaequalibus. Sem in a nvata, compressa. - Arbor cochinchinensis; foliis imparipinnatis, subseptemjugis, foliolis subsessilibus, ovatis, parvulis, oppositis et allernis, pedunculis axillaribus geminis, unifloris.

D iph a e L Loureiro Flor. cochinch. 554. DC. Prodr. II. 313. Solulus a rbor Rumph Amboin. V. 2. 128.

G5D1. Fietetia DC. Calyx bracteolis duabus caducissimis, campanulatus, quinquefidus, lobis dnobus superioribus obtusis, brevioribus, tribus inferioribus acuminatis, suhspinosis. CorolI a e papilionaceae vexillum subrotundum, complicatum, carina obtusa, alis paullo brevior. St a min a 10 , filamento vexillari libero diadelpha. Ovarium stipitatum, pluriovulatum. Stylus filiformis, glaber; stig ma obtusum. Leg a m e n stipitatum, compressum, oligospermum, nune continuum, isthmis inter semina interceptum, nunc articnlatum, articulis monospermis, nonnullis abortivis, nec striatis nec verrucosis. Sem in a compresso-plana, ovalia, basi truneata. - Frutices antillani, glaberrimi, stipulis caulinis spinescentibus armati $v$, rarius subinermes; foliis imparipinnalis, foliolis exstipellatis, apice in mucronem spinosum productis, flaribus axillaribus, laxe racemosis $v$. solitariis, flavis, ad apicem pedicellorum artioulatis.

Pictetia DC, Mem, Legum, NI. t. 47. Prodr.IT, 314. MeisnerGen. 91. (63.) A es eh y nomenes s p. Jaeq. Hort.

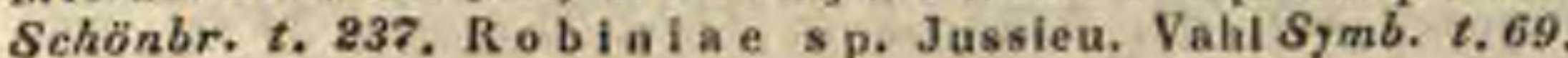

B5\$2. Brya P. BROWN. Calyx bilabiatoquinquedentatus, Co r o I I a papilionacea. Stamina 10 , monadelpha. Le gum e n biarticulatam, articulis monospermis, dehiscentibus, compressis, sutura snperiore recta, inferiore convexa, articulo superiore saepe nullo, - Arbores America e tropicae, spinis stipularibus; foliis pinnatim trifoliolatis, foliolis sessilibus, pedunculis axillaribus, unibifloris, folio brevioribus.

B ry a P. Browne Jam, 299. DC. Prodr. IT, 421. A I d ina Adansoa Fam. Ir. 328.

8593. Drongearpman PALIS. C a 1 y $x$ bracteolis duabns, persistentibus, quinquefidus, subbilabiatus, laciniis omnibus acutis. Corolla e papilionaceae vexill $\mathrm{nm}$ latum, integrum, earinae obtusae petala dorso leviter cohaerentia. Sta $\mathrm{m}$ in a 10 , filamento vexillari libero diadelpha. Ovari um stipitatum, plariovulatum. StyI us filiformis, glaber; stigma obtnsum. Legu. men stipitatum, pluriarticulatum, artienlis oblongis, utrinque angnstatis, compressiusculis, longitudinaliter striatis, verruculosis, monospermis, distincte secedentibus. Semina compressa. Frutices in Asia et $A m$ erica tropica indigeni; foliis unifoliolatis $v$. imparipinnatis, foliolis glabris, acuminatis $v$. retusis, racemis axillaribus, brevibus, paucifloris.

Or m o ea r p u Palisot Flor. Owar. 1. 95. $t$, 58. Desvaux in Journ, bot. III. 122, t. 3. f. 16. DU. Prodr. II. 315. Wight et Arnott Prodr. I. 217. Meisuer Gen. 91. (63.) Hed ysarum sesamoides Willd.

6594. Amieia KUNTH. Calyx eampanulatus, quinquefidus, Iaciniis duabus superioribus maximis, rotundis, duabus lateralibus minutis, infima oblonga, carinato.coneava. Corollae papilionaceae vexillum suborbienlatum, emargi. natum, cordatum, adscendens, a las et carinam superans, a la e carinae applicitae. Stamina 10 , monadelpha, tubo stamineo superne fisso, a $n$ thera c conformes, ellipticae. Discus brevis, urceolatus. Ovarium sessile, quinqueovulatum. St yIns filiformis; stigma obtusum. Legumen lineare, compressum, quinqueartieulatum, articulis monospermis, ntrinque truncatis, secedentibus. Semin a compressa. - Frutex Novo-Granatensis, scandens; foliis imparipinnatis, foliolis bijugis, pellucido-punctatis, pedunculis axillaribus, solitariis, flexuosis, quinque sexfloris, floribus alternis, longe pedicellatis, glandulose-punctatis, flavis, pedicellis basi bibracteatis, bracteis orbiculato - reniformibus.

A m i c i a Kanth in Kumb. et Bonpl. Nov, gen. et sp. VI, 512, t. 600. DC. Prodr. II. 315. Meisner Gen. 91. (63.) Z y g o meris Flor. mexic.

B5D5. EPQiretia VENT. Caly $\mathrm{x}$ campa nulatus, bilabiatus, labio superiore subbidentato, inferiore breviter tridentato. Corolla papilionaceae vexillum semiorbiculatum, emarginatum, reflexo-patentissimum, ala e vexillum superantes, patentissimae, foveolato rugosac, c arina falcata. St a m in a 8-10, monadelpha, tubo integro, nonnisi tandem hine fisso, a ntherae alternae ovato-ellipticae, alternae minores, snbrotundae. Discus nullas. Ovarium brevissime stipitatum, tri-quadrinvulatum. Stylus filiformis; stig ma depresso-capitatum, puberulum. Legumen compressum, tri-quadriarticulatum, articulis utrinque truncatis, monospermis, secedentibus. $\mathrm{Se}$ m in a reniformia. - Frutices volubiles, in $A \mathrm{me}$ rica tropica indigeni; foliis saepissime punctis nigricantibus conspersis, graveolentibus, abrupte pinnatis, bijugis, foliolis stipellatis, stipulis a peliolo distinctis, racemis axillaribus, solitariis, brevibus, floribus alternis, pedicellatis, punctato.glandulosis, pedicellis basi bibracteatis.

Potretia Venten. Choix $t$. 42. Desvaux Journ, Bot. III. 122, t. S. f, 17. Kanth in Humb. ot Bonpl. Nov, gen. et sp. VI. 510. DC. Prodr. II. 315. Vogel in Limnaea XII. 51. Meisner Gen, 91. (63.) Turpinia Persoon Encheir. II. 314. non alior. Glyeine punctata Willd.

6596. MI y piad enus $D E S V$. C a l y x braeteolis duabus, persistentibns, subeampanulatus, quinquedentatus, dente infimo productiore. Corollae papilionaceae petala stipitata, subaequilonga, vexillum erectum, complicatum, al a e foveolato rugosae, carina obtusa. $\mathrm{S} t a \mathrm{~m}$ in a 10 , monadelpha, vagina integra; a $\mathbf{t h}$ erae ...... Ovarium sessile, multiovulatum. Stylus curvalus; $8 \mathrm{tigma}$ simplex. Legnmen multiarticnlatum, artieulis subcompressis. Semina subquadrangula. - Suffrutices Americae tropicae, punctis glandulosis conspersi; foliis abrupte pinna161 
tis, bijugis, foliolis approximatis, stipulis geminis, floribus axillaribus, solitariis, breviter pedunculatis. M. y riaden us Desvaux in Journ. Bot. IIT. 121, t. 4. f. 11. DC. Prodr. II, 316, Meisuer Gen, 91. (64.) Vogel in Linnava XII. 55, Ornithopus tetraphyllus Linn.

652ร. Gelssaspis WIGHT et $A R N$. C alyx membranaceus, usque ad basim bilabiatus, labiis subaequalibus, oblongo-lanceotatis, superiore integerrimo, inferiore pone apicem utrinque dente aucto. Corollae papilionaceae vexillum magnum, primum incumbens, demum reflexum, a la e anguste oblongae, obtusae, erectae, carinam aequantes, carina e incurvae petala semiovalia, obtusa, dorso apice breviter coalita, $\mathrm{S}$ a $\mathrm{m}$ in a 10 , monadelpha, aequilonga, an the rae conformes. Ovarium biovulatum. Stylus compressus; stig ra simplex. Le gr $\mathbf{u}$ e $n$ bi- v, abortu uniartieulatom, articulis glabris, reticulato-venosis, medio tumidis, margine utroque tenuibus, monospermis. Se mina..... Herbae $v$. suffrutices procumbentes, in Asia tropica indigeni, omnibus partibus praeter stipularum et bractearum margines glabri; foliis abrupte pinnatis, bijugis, foliolis approximatim alternis, cuneato-obovatis, retusis, basi inaequaliter bi-quadrinerviis, dentatis, stipulis semisagitlatis, lanceolatis, ramulos juniores penitus includentibus, ciliatis, racemis axillaribus $v$. terminalibus longe pedunculatis, bracteis magnis, orbiculatis, oblique cordatis $v$, busi semisagittatis, multinerviis, reticulato-venosis, denticulatis, margine setoso ciliatis, floribus inlra quamvis bracteam solitariis pedicellatis.

Geis s a sp is Wight et dsuott Prodr. I. 217. Meisner Gen. 91. (64.)

6598. HInylacium BENNET. Calyx bibracteolatus, quadrifidus, lacinia postica vix emarginata. Corollac papilionaceae vexillum anguiculatum, biauriculatum, cum alis subaequalibus cohaerens, $\mathrm{c}$ a rin a e petala connata. Stam in a 10, flamento vexillari libero diadelpha, a nthera e conformes. Ovarinm uniovulatum. Sty 1 us filiformis; stigma simplex. Legum en subrotundum, compressum, reticulato-nervosum, monospermum. S em en compressum, ovale. - Herba indica, volubilis; foliis alternis, trifoliolatis, stipulis distinctis, foliolis stipellatis, floribus parvis, axillaribus, racemosis, bractea membranacea, durante et peracta anthesi aucia, demum revoluta, compresso-cucullata inclusis.

Phylacium Bennett in Horsfeld Plant, jav. rar. 159, $t, 43$.

6595. Zornia GMEL. Calyx campannlatus, bilabiatus, labio superiore oblaso, emarginato, inferiore trifido. Co roll a e papilionaceae, imo calyei insertae vexillum orbiculatum, marginibus revalutum, alae oblongae, carina e petala Innulata, dorso cohaerentia, Stam ina 10 , monadelpha, alterna breviora, an therae alternae ovatae, alternae globosae. Ovarinm sessile, piuriovulatum. Stylus filiformis; stigma obtusam. Leg amen sessile, quadri-sexarticulatum, compressum, articulis secetentibns, monospermis, muricatis. S emina sobreniformia. - Herbae $v$. suffrutices, diffusi aut erecti, in regionibus tro picis totius orbis, nec non in America boreali calidiore indigeni, pellucilo-punctati; faliis in apice petioli conjugatis v. quaternatis, sti. pulis sugitlatis, inferioribus lanceolatis, superioribus majoribus bractearum locum tenentibus, spicis ter- minalibus et axillaribus flexuosis, floribus alternis, sessilibus, bibracteolatis.

Z o r n i a Guelin Syst. 1076. L. C. Richard in Michaus Flor. Bor. Amer. 1I. 76. Kuath in Humb. et Bonpl. Nov. gen, et sp, VI, 514. Desvaux Journ Bot. III, 124, t. S. f. 25 , DC. Prodr. II. 316. Meisner Gen. 91, (64.) Wight et Arnot Prodr. I. 217. Torcey et A Gray Flor, of Norlh-Amer. 1. 353. A no ny a Walter Flor. Carolin. 181. Hed y 8 a ri s p. Lian, et Auet.

BBo6. Stylosamtlnes LINN. Flores polygami. Herma phr. saepissime steriles. CaIy tubo longo, filiformi, limbo profunde bilabiato, labio superiore quadrifido, laciniis snpremis altius connatis, inferiore elongato, integro. Corollae papilionaceae, calycis tanci insertae vexillu m suborbiculare, a 1 a e oblongae, liberae, leviter transversim plicatae, carina longiores, carin a incurva, snbrostrata, apice integra. Stamina 10 , monadelpha, an the rae alternae sub. rotundae, medifixae, alternae oblongae, adnatae. Ovarinm intra calycis tubum sessile, minutum, bi-triovulatum. Stylus antherarum longitudine, filiformis; sti $r$ m a minutum, rarins subcapitatum, F em. fertiles. Caly $x$ corolla et stamina nulla. Ovari um sulsessile, erectum, biovalatum. StyI us brevis, uncinatus; stigma incrassatum, subterminale. Le g um en sessile, saepius biarticulatum, artienlis compressis, inferiore nunc sterili, stipitiformi, nune monospermo, superiore monospermo, secedente, apice stylo persistente hamato. S e m e n lenticulari-cumpressuu. - Herbae v. suffrutices, erecti sive prostrati, saepissime viscosi, inter tropicos totius orbis crescentes; foliis pinnatim trifoltolatis, foliolis oppositis, cum impari sacpissime distante, rarissime inter lateralia subsessili, stipulis petiolo adnatis, striatis, foribus in spicam densam, axillarem $v$. terminalem approximatis, singulis ad axillam folii $v$. bracteae stipularis breviler pedicellatis, pedicello bracteae adnato, nunc solitariis, bi-tribracteolatis, nunc binis, altero perfecto, altero abortivo, stipiliformi, rarius utroque perfecto.

Stylos an thes Swartz Prodr. 108. Act, Holm, 1789. p. 296. t. 11. Flor. Ind. occid. 1280, $t$. 25, Lam. $t$. 629. Pulisot Flor. Owar. t, 77. Kwath in Humb, et Bonpl. Nov. gen, ot sp. VI, 506. t. 594-596. DC. Prodr. It, 317. Wight et Aruott Prodr. I. 218. Meisuer Gen. 91. (64.) Vogel in Linnaea XII. 63. Bentham in Linn. Transact. XVIII, 160. Hed y s ari sp. Liua.

G601. Arrachis $L I N N$. F lores polygami. Herm a p $r$, steriles. Caly $x$ tubo longo, filiformi, limbi subbipartiti labio superiore breviter quadridentato, inferiore tenui, integro. Corollae papilionaceae, calycis fauci insertae vexillum snluorbieulare, al a e oblongae, liberae, transversim leviter plicatac, c a rin a incorva, rostrata. St am in a 10 , monadelpha, flamento vexillari interdum abortivo, antherae alternae subrotundae, medifixae, alternae oblongae, adnatae, Ovariam intra tubum calycis subsessile, minntum, bi-triovulatam. St y I us antherarum longitutine; stigma minutum v, nullum. Fe in. fertiles. Caly x, curolla et stamina nulla. Ovarium toro mox elungato, reflexo, rigido stipitatum et cum eo continuum, acutum, uniloculare, ovulis $2-3$, uniseriatis, anatropis. Stylus brevissimus, subnnllus; stigis a terminale, suhdilatatum. Le gume n hypogaenm, oblongum, crassum, retienlatum, indehiscens, subtorulosum, di-trispermum. Semina irregulariter ovoidea; cotyledonibus crassis, radicula recta, brevi. - Herbae humiles, saepe 
prostratae, in America tropica indiprenae, nonnullae in regionibus calidioribus totius orbis nune cultae; foliis petiolutis, abrupte pinnatis, foliolis oppositis, bijugis, exslipellatis, stipulis basi peliolo adnutis, striatis, floribus in spicam densam axilla. rem saepe approximatis, singulis in axilla bractene biauriculatae, stipulaeformis solitariis, brevissime pedicellatis, bracteis duabus linearibus oppositis, ad apicem pedicelli sitis.

A r a ch is Linn. Gen, $n, 876$. Lam, t, 615. DC. in Mem. Xegum. 6. 20.f. 105. Prodr. IT. 474, Meisaer Gen. 97. (68.) Beutham in Linn.. Transact. XVIIL. 158. Arach nida Plu. mier Gen. $t$. 37. A r a chid uo ides Nissol Act. Paris, 1723. p. 387, $t$. 19 . C h a m a e b a I a in us Rumph Amboin. IV. 296. t. 156. M u a d u b I Maregrav. Brasil. 37.

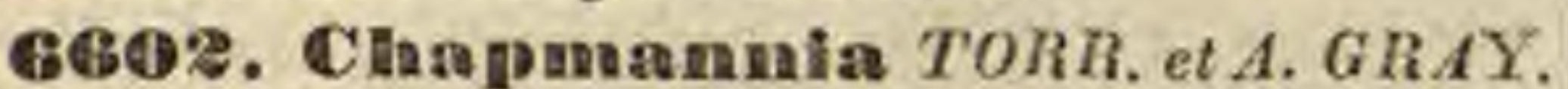
Flores polygami. Hermaphr. saepissime steriles. Caly $x$ tubo filformi, limbo breviter quinquefido, lacinia infima paullo longiore. Corolla papilionaceae, ealyeis fauei insertae vexillum suborbiculare, al a e obovatae, carina incurva, apice bifida, vexillo subaequilonga. Stamina 10 , monadelpha, alterna Iongiora, a $t$ h e rae conformes, oblungae. Ova rium subsessile, glabrum, bi-triovulatum. Stylus filiformis, glaber, obtusus, longe exsertus; stigm a minutum (v. capitatum?) F e m. fertiles. Ca ly x, corolla et stamina nulla, O va ri a m subsessile, erectnm, hirsutum, bi-triovulatum. Stylns lrevissimns, incurvos; stig un a terminale, obliquum, incrassatum. Lreg um en uni-triartieulatum, artienlis indehiseentibus, oblongis, turgidis, hispidis, monospermis. $\mathbf{R}$ adicn l a recta. - Herba boreal $i-a m e r i c a-$ $n a$, suberecta, hirsuta, viscida; foliis irregulariter imparipinnatis, stipulis liberis, membranaceis, deciduis, racemis terminalibus, laxis, subcompositis, peduncul is uni-trifloris, foribus ad axillam bracteae ovatae sessilibus, bibracteolatis.

Cha pmannia Torrey et A. Gray Flor. of NorthAmer. I. 355. Bentham in Linn. Transact. XVIII. 161.

6603. A desumia $D C$. C a Iy $x$ basi campanulatus, quinquefidns, laciniis acutis, subaequalibus. Corollae papilionaceae vexillum primam complicatum, incumbens, demum adseendens, a la e plicato-rugosae, oblongae, $c$ a $r$ in a m obtusam incurvam aequantes v, superantes. Stamina 5 v. 10 , libera, approximata, a $\mathrm{th}$ era e conformes. Ovarium sulisessile, pluriovulatum. Stylus filiformis, adscentens; stigma simplex, Legumen compressum, subfalcatum, sutura vexillari reeta, incrassata, earinali sinuato-excisa, bi-multiarticulatum, articulis laevitus $\mathbf{v}$, mericatis, secedentibns, monospermis. Sem in a compresso-reniformia. - Ilerbae v. frutices, in America australi extratropica et in Capite bonae spei crescentes, nonnulli balsamiflui; foliis abrupte pinnatis, multijugis, foliolis saepe denticulatis, rhachi in aristam, interdum spinescentem desinente, stipulis lanceolatis, pedunculis axilluribus unifloris, foliorum superiorum abortu racemum terminalem constituentibus.

Ades mia DC. Mem, Logam, 305. Prodr. IT. 318 Hook. et Arnott ad Beechey 18. Bot. Miscell. III. 188. Meisver Gen. 91. (64.) $\mathrm{P}$ at a g on ium Selirank in Münchiner Denkschrift. 1808. p, 21, E. Meyer Comment, pl. Afr. 122.

a. Patagoniom DC. l. c. Stamina dao superiora la teralia basi cum vexillo connata. Hedysari sp. Jacq. Ic. rar. t. 568 .

b. CHAETOT\&ICHA DC. $l$, $c$. Stamina omnia libera. Heterolom a Desvauz msc. Lo a dania Berteromsc. (Hoocker ad Becchey t, 2, Bot, Miscell, t, 104, 10s. Bot. Reg. t. 1720,)
6504. HEathkea SCHUM. Calyx campanulatus, quadrifidus, la cinia suprema semibifida. Corolla papilionaceae vexillum ovatnm, emarginatum, basi bicallosum, roflexum, ala e ovatae, erectae, conniventes, carin a falcato-semiorbiculata, obtosa. St a m in a 10 , monadelpha, tubo hine fisso. Dis c us annalaris. Ovarium pedicellatum, multiovulatum, Stylas $\ldots$. L eg umen pedicellatum, compressiusculum, suturis inter semina contraetis moniliforme, articulis $3-5$, monospermis, ellipticis, striatis, extremo acuminato. Semina ovalia, compressa. Frutex Africae tropicae, bi-tripedalis, ramosissimus; foliis imparipinnatis, foliolis sex-octojugis, ulternis obovato-oblongis, obtusis, mucronatis, stipulis lanceolatis, marcescentibus, rucemis axilluribus tri-sexfloris, folio brevioribus, bracteolis sub calyce geminis, lanceolatis, corollis flavis, rubro striatis, 129.

Rathkea Sehumacher Dansk. Selsk, Skriff. IV.

6605. Aeselnymonneme LINN, Calyx decidue bibracteolatus, brevi eampanulatus, bilabiatus, labio superiore bifido v, bidentato. CorolI a papilionaceae petala subaequilonga, vexilI u m subrotundam, a la e oblongae, foveolato-rugosae, carina eymbiformis, basi bipartita. Stamina 10, in phalanges pentandras coalita, a ntherae conformes. Ovarium stipitatum, multiovulatum. St y lus filiformis, curvatus; stigma subsimplex. L egum en stipitatum, compressum, e calyce exsertum, sutura vexillari recta, carinali sinuata multiarticulatum, styli basi reflexo-nneinata apicnlatum, articulis secedentibus, monuspermis. Semina enmpressa, - Herbae v. frutices, in regionibus tropicis subtropicisque crescentes; foliis subimparipinnatis, multijugis, bistipulatis, racemis axillaribus aut rarius terminalibus, floribus saepissime flavis.

A es chy nom e ne Linn. Gent, n. 8s8. Desvaux Journ. Bot, III, 124. t. 6. f. 26. DC. Prodr, II. 320. Wight ot Arnott Prodr. 1 . 216. Vogel in Linnaea XII. 81. Torrey et A. Gray Flor, of North-Amer, I, 355.

a. EUAESCHYNOMENE Vogel l.c. Stipulae basi appen. diculatae, caducae, bracteacque tenui-membranaceae, striatae. L. egu $u$ in u a sutura carisalis parom v. vix sinuara. (Lam. $t$ 6e9. f. 1. Palisot Elor. Owar. $t, 83$. Flor. Flum. VII. t, 119.)

b. OCHOPODIUM Vogel l. c. Stipalae basifixae, hand appendiculatae, subpersisteates, bracteaeque rigide membranaceae, nervoso-striatae. L e g u $\mathrm{m} \mathrm{I}$ a $\mathrm{u}$ m sutura earinalis profunde sinuata. Hedysarl sp. Poir. Flor. Flum, DII, t, 1 s3.

GeOs. Sämmeringia MART, Calyx basi bracteolis duabus, persistentibus, bilabiato bipartitus, labio superiore compresso, a pice mucronato bifido, inferioris trifidi laciniis acutis, lateralibus intermedia longiore. Corolla e papilionaceae v exillum late orbiculatum, erectum, complicatum, a la e oblongae, foveolato-rugosae, carin a m dipetalam obtusam superantes. Stamina 10, in phalanges duas pentandras coalita, antherae conformes. O vari nm stipitatum, bi-quinqueovalatum. Stylus filiformis, adscendens; stigma capitatum. Legum en stipitatum, compressum, e calyce exsertum, bi-quinquearticulatum, articulis secedentibus, marginatis, monospermis. Semin a compressa. - Herba brasiliensis, paludosa, ramosa; foliis abrupte pinnatis, rhachi aristata, stipulis membranaceis, adnatis, racemis axillaribus paucifloris, bracteutis, floribus albis, scariosis. 161 * 
S ö mmeringia Martius Dissert, 1828. c. ic. Meisner Gen. 91. (64.)

6BDr. Motsellaya ENDL. Calyx basi bracteolis duabus, persistentibus, bilabiato-bipartitus, labio superiore compresso, emarginato, in cumbente, inferioris trifidi. patentiusculi laciniis acntis, aequalibus. Corollae papilionaceae ve$x$ ill $\mathrm{nm}$ obovato-oblongum, adscendens, a $\mathrm{a}$ e oblongae, foveolato-rugosae, $\mathrm{c}$ arin a m dipetalam, obtusam aequantes. Stamina 10 , monadelpha, tubo ima basi integro calloso, superne longitudinaliter fisso, an therate conformes. Ova rium stipitatum, multiovulatum. Stylus filiformis, adscendens; stigma simplex. Leg nmen stipitatum, compressnm, inclusum, sutura utraque sinnata multiartieulatum, articulis delabentibus, hine subtruncatis, inde rotnndatis, marginatis, monospermis. Sem in a compressa. - Frutex Africae tropicae orientalis, erectus; ramulis alternis, simplicibus, setoso hispidis, foliis abrupte pinnalis, multijngis, foliolis obovato-oblongis, basi inaequilateris, quadrinerviis, stipulis parvis, scarioso-membranaceis, racemis axillaribus, paucifloris, folio brevioribus, floribus nutantibus.

Kots chy a Endlicher in Nov. Stirp. Mus. Vindob. Dec, $n, 6$.

6608. Smaitlnia $A I T$. Cal y x basi bracteolis duabus persistentibus, bilabiato-bipartitus,

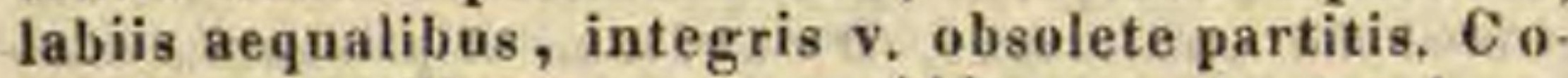
rollae papilionaceae vexillum subrotundum, patens, a la e oblongae, transversim plicatae, carina e petala durso apice leviter cohaerentia. S t amina 10 , in phalanges pentadelphas coalita, a ntherae conformes. Ovarium sessile, quadrisexovulatum. St y I a s. filiforuis, adscendens; stigma simplex. Legumen compressum, pli cato quadri-sexarticulatum, calyce inclusum, articulis orbicularibus, delabentibns, monospermis. Se min a compresso-reniformia. - Herbae procumbentes, in Asia et Nova-Hollandiatropica indigenae; foliis abrupte pinnatis, paucijugis, foliolis ciliatis, adpresse setosis, stipulis semisagittatis, racemis axillaribus, paucifloris, floribus flavis.

$\mathrm{S} \mathrm{m}$ it hi a Aiton Hort. Kew. edit. I. IIT. 469. t. 13. Salisbury Parad, Lond. $t$. 92. Lam. $t$. 627. Desvaux Journ. bot. IIT. 121. t. 4. f. 28. DC. Prodr. 1I. 323. Wight et Arnott Prodr. I. 221. Meisner Gen. 91. (64.) Petag a a a Gmelin Syst, 1028.

6609. Howrea NECK. Cal y x campannlatus, reticulato-venosus, scariosns, aequaliter quinquefidus, fructifer inflatus, connivens, Co rolla papilionaceae vexillum obcordatum, alae ohlongae, transversim plicatae, c a r in a obtusa. St amin a 10 , filamento vexillari libero diadelpha, a ntherae conformes. Ovari um subsessile, quadri-sexovulatum. Sty I us filiformis, adscendens; $8 \mathrm{t} \mathbf{i} \mathrm{gma}$ simplex. Leg $\mathbf{n}$ m en articulis 4_6, planis, orbiculatis v. semiorbieulatis, intra calycem plicato-retrofractis, catenulatim cohaerentibus, monospermis. Se m in a compresso-reniformia. Herbae in Asia tropica indigenae, erectae; fo. liis pinnatim trifoliolatis, $v$. foliorum lateralium abortu unifoliolatis, stipulis setaceis, floribus terminalibus, racemosis.

Lourea Necker Elem, n, 1318. Desvaux Journ, Bot. IIT. 122. t. 5. f. 18. DC. Prodr. II, 323. Wight et Arnot Prodr. 1. 221. Meisner Gen. 9t. (65.) C hristla Mōnch Suppl. 39. Hed ysarum Vespertilionis Limo. Jacg. Ic, rar, $\ell, 566$.

B610. Uraria DESV. C a 1 y $\mathrm{x}$ pilosus, profande bilabiatas, labio superiore bifido, infe- riore tripartito, fruetifer hand mutatus, Corolla papilionaceae vexillum obovatum, a la eblongae, transversiu rngosae, $c$ arina obtusa. Stain in a 10, filamento vexillari libero diadelpha, antherae conformes. Ovarium bi-pluriovulatum. St y l u 8 adscendens, sursum incrassatus; $8 \mathrm{ti} \mathrm{gma}$ obtusum. Leg um en articulis $2-6$, ovatis, plicato retrofractis, intra ealycem nidulantibus, monospermis. S e m in a compresso-reniformia. - Herbae interdum suffruticosae, in Asia tropica indigenae; foliis pinnatim trifoliolatis $v$. imparipinnatis, interdum foliorum lateralium abortu simplicibus, stipellatis, stipulis membranaceis, lanceolatis, acuminatis, longitudinaliter striatis, superioribus bractearum vices gerentibus, caducissimis, pedicellis in bractearum axillis geminis, unifloris, racenos longos, simplices formantibus.

Uraria Desvaux in Journ. Bot, IIT, 129, t. 5. f, 19. DC. Prodr. IT, 32t. Wallieh Plant. As, rar. t, 110. Wight et Arnott Prodr. I. 221. Meisner Gen. 9t. (65.) Doodia Rox. burgh Hort. calc. 99. He d y s a ri s p. Linn. Jaeq. Io. rar. t. 567 .

G6 1 1. Necopus BENNET. C a ly x pilosus, campanulatus, quadrifidus, lacinia postica bidentata. Corollae papilionaceae vexillum obovatum, a la e minores, obovatae, carin a pe. tala apice cucullato-connato mucronulata. Stam ina 10 , filamento vexillari libero diadelpha, a n. thera e conformes. Ovarium breve stipitatum, biovulatum. Stylus adscendens; stigma eapitatum. L e gumen longissime stipitatum, membranaceum, oniloculare, monospermum, rarius articulatim biloculare, dispermum. S e men compresso-reniforme. - Herba javanica, sesquipedalis, a basi diffuse ramosissima; foliis alternis, simplicibus, plurimis, caducissimis, stipulis distinclis, stipellis duabus parvis, racemis terminalibus, ovatis, dense comosis, e fasciculis plurimis, bibracteatis compositis, pedicellis plurimis abortivis, fertilibus post anthesim apice recurvatis, floribus minimis, leguminibus inter pedicellos bracteasque persistentes nidulantibus. t. 32 .

M e copus Bennett in Horsfeld Plant, jav, rar. 154.

6618. Nieolsomia $D C$. Cal y $\mathrm{x}$ quinquepartitus, laciniis lanceolato-subulatis, barbatis. Corollae papilionaceae, calyce brevioris vexil. I $\mathrm{nm}$ subrotundum, a la e oblongae, carinae obtusae aequilongae. $\mathbf{S}$ t a m in a 10 , filamento vexillari libero diadelpha, ant herae conformes. 0 varium sessile, multiovulatum. Sty I 8 filiformis, adscendens; stigma simplex. Le g um en rectum, exsertum, articulis plurimis, compressis, semiorbiculatis, monospermis, sutura convexa dehiscentibus. Sem in a compresso-reniformia. - Herbae in America tropica indigenae; foliis pinnatim trifoliolatis, foliolis stipellatis, ovalibus v, oblongis, stipulis a petiolo distinctis, subscariosis, bracteis stipularibus majoribus, pedicellis in bractearum axillis geminis, racemos terminales, conferlos, fere paniculatos constituentibus, floribus parvis, caeruleopurpureis.

Nieolsoni a DC. Mem, Legum, VII. L, 51. Prodr. II. 325. Meisuer Gen, 91. (65.) Peicottetia DC. in Annal. sc, nat. $V .95$. H ed y s a ri s p. Liun. Kunth.

8613. Ananthrosyme E. MEY. C a Iy bilabiatus, labio sup eriore bifido, inferiore tripartito. Coroll a e papilionaceae petala calyee $p a-$ rum longiora, subaequalia, carina demum reflexa. Stam in a 10 , filamento vexillari libero dia- 
delpha, antherae conformes. Ovarium subsexovulatum. Stylus filiformis, glaber; stig ma simplex. Le g $\mathbf{u m e n}$ lineari-subfalcatum, compressum, articulis subsenis, haud sponte secedentibus, neque clausis, subquadratis, monospermis. Semina compresso-reniformia, - Herba c a pensis, erecta; caule tomentoso, foliis pinnatim trifoliolatis, foliolis subtus et ad margines tomentosis, supra in nervis hirsutis, panicula terminali villosissima, densiflora, pedicellis bracteas vix aequantibus. An arthrosyue E. Meyer Comment, plant, Afr. austr. 124.

6914. Dollimeras. Calyx decidne bibracteolatus, campanulatus, quadridentatus, dentibus ovatis, supremo panllo latiore, rotundato $v$. emarginato, infimo angnstiore. Corollae papilionaceae vexilln m subrotundum v. obcordatum, patens, a lae carinam obtusam, basi utrinque biauriculatam aequantes. St a m in a 10 , monadel. pha, tubo basi integro, superne postice fisso. $0 \mathrm{va}$ rium sessile, paueiovulatum. Stylus filiformis; stigma subcapitatum. Leg $\mathbf{n m}$ en panciarticulatum, articulis compressis, chartaceis, sutura vexillari recta continuis, carinali sinuata convexis, disco retieulatis, secedentibus, monospermis, vix apertis. S e min a reniformia, compressa. - Fru. ticuli indici, ramosissimi; foliis pinnatim trifoliolatis, stipellis setaceis, stipulis lineari-lanceolatis, nervosis, racemo terminali, bracteis cuspidatis, bracteolisque setaceis deciduis.

Dollinera Endlicher msc, 1839. Ototropis Sehauer Index, sem. Hort. Wratislaw. 1839, non Beuth.

6845. Desmoditum $D C . \mathrm{C}$ al y $\mathrm{x}$ saepis. sime basi decidue bibracteolatus, ad medium bila. biatus, labio superiore bifido, inferiore tripartito. Corolla e papilionaceae vexill um subrotundum, a la e oblongae, carina m rectam, obtusam superantes. S $t$ a mina 10 , filamento vexillari libero diadelpha, rarius monadelpha, antherae conformes. Ovariu in sessile, multiovulatum. StyI 8 filiformis, adscendens; stig in a capitatum. Le gumen multiarticalatum, articulis secedentibus, compressis, monospermis, uembranaceis sive coriaceis, indehiscentibus v. vix apcrtis. Sem in a compresso-reniformia. - Herbae v. suffrutices, in regionibus tropicis copiosae, parcius in sub. tropicis crescentes; foliis pinnatim trifoliolatis v. foliolorum lateralium abortu unifoliolatis, foliolo terminali bi-lateralibus unistipellatis, racemis terminalibus, ut plurimum laxis, pedicellis e bractearum axillis solitariis $v$. ternis, filiformibus, unifloris, floribus purpureis, caeruleis $v$. albis.

Desmodium DC. Mem. Legum. Prodr. II, 325. Wight et Arnott Prodr. I. 225. Tarrey et A. Gray Flar. of North-Amer. . 356. Des modi um et Hed y s a rum Desvaux in Journ, Bot. I1I, 122. $t$. 5. f. 15. et 22. Kunth in Humb. et Bonpl. Nov, gen, et sp. VI, 516, s27. Hed y s a$r i$ s p. Liau.

a. EUDESMODIUM DC. l. c. $\mathrm{C}$ a 1 y $\mathrm{x}$ basi bibracteolatus, Iacl. nifs duabus superioribus altius cohaerentibus. S ta m $\mathrm{f}$ n a monadelpha. Leg uminum articuli coriacei. indehiscentes, subelliptici, utrinque truncati. - Suffrutices. foliis pinnatim trifoliolatis, pedunculis axillaribus solitarits, petiolo brevioribus, apice umbellatim $v$. co. rymbose mullifloris, pedicellis unifloris, floribus albis. - Dendrolobium sect. Desmodif sp. Wight et Aruott l.e. He d y s a r i s p. Linn. Jacq. Hort, schönbr. t. 297. (Labillard. Nov. Caled, t, 71-72.)

b. PLeURolobium DC. l. c. Stam in a diadelpha. Le. g u mi $\mathbf{~ u ~ m ~ a r t i c u l i ~ m e m b r a n a c e l , ~ f e r e ~ q u a d r a t i , ~ l a t e r e ~}$ inferiore tautam convexo demum dehiscentes. - Folia unifoliolata $v$. pinnatim trifoliolata, foliolis lalerali. bus minimis, - Pteroloma Desvaux msc. Hedysa. ri s p. Liun. Jacq. Ic, rar. t. 562.

c. Chalariug DC. $l$. o. Stamina diadelpha. Legam in um articuli nembranacei indehiseentes, ovates v. orbiculati, rarius obloggi, utroque latere convexi v. superiore rectiusculi, ad utramque extremitatens angnstati. - Eolia pinnatim trifoliolata $v$. saepius unifoliolata. floribus laxe racemosis, pedicellis e quavis axilla ternis. - Hed ys a ri s p. Jacq. Hort. schönbr. t. 298. Swartz Observ. bot. t. 6. f. 1. Bot. Reg. t. 356 . Palisot Flor. Owar. t. 18. Kunth in Humb, et Bonpl. Nov. gen, et sp. t. 597. 598.

6816. Dicervan $D C$. Calyx adpresse bibracteolatus, bilabiatus, labio superiore integerrimo v. apice bidentato, inferioris trifidi lacinia media paullo longiore. Corolla e papilionaceae vexill u m obovatum, a la e oblongae, carinam obtusain, reetam aequantes. S $t$ a $m$ in a 10 , ad medium monadelpha, supra medium diadelpha, anthe rite conformes. Ovarium hi-triovulatum. Stylus filiformis, adscendens; stigma capitatum. Leg ume n bi-triarticulatum, articulis membranaceis, orbieulatis, planis, reticulato-venosis, inermibus, terminali stylo persistente mucronato, monospermis. Se in ina eompresso-reniformia. Frutices indici; foliis trifoliolatis, floribus luteis, pedicellis unifloris, plurinis, in foliorum v. bractearum axillis aggregatis.

Dicerua DC. Mem. Legum. 326. Prodr, II. 339. Wight et Arnott Prodr, I. 230, Meisuer Gen. 21. (65.)

a. PHYLLODIUM DC. $l$. c. Folia loage peliolata, unijuga cum impari, foliolis stipellatis, floralia bifoliolata, inpari abortivo, lateralítis lineatis, bracteaeformi. bus, petiolo in setam desinente. Flores in foliorua floralium axillis plurimi, pedicellis brevissimis. St f pulae a petiolo et inter se distiuctae. - Phyllodiom Desvaux Journ. Bot, IIT. 123. t. 5. f. 24. H ed y sarum pulebellum Lian. (Burmann Zeyl, t. 52,)

b. APHYLLODIUM DC. $l$. c. Folia trifoliolata, foliolis subaequalibus, exstipulatis, e petioli apice ortis, floralibus ad stipulas redactis, racemis teraisalibus ideo subnudis. Pedteelit 2-4, e stipularum axillis orti. Stipulae concretae, oppositifoliae, - Hedysarum biarticulatom Lian. (Burmano Zeyl, $t$. 50. f. 2.)

GB1\%. Taverniera $D C$, Caly $x$ bibracteolatus, semiyuinquefidus, bilabiatus, laciniis lanceolato-Jinearibus, acuminatis. Corolla e papilionaceae vexillum subobovatum, a la e calyce breviores, carin a obtusa, vesillum aequans. $\mathrm{S} t \mathrm{a}-$ m i n 10 , filamento vexillari libero diadelpha, reeta v, apice subinflexa, a $n t h$ er a e conformes. $O$ varium sessile, biovalatnm. Stylus filiformis, longus, flexuosus; stigma capitatum. Legumen biarticulatum, articulis orbiculatis, planocompressis, monospermis. S e mina compressorenifurmia. - Suffrutices orientales; folitis pinnatim trifoliolatis $v$. foliolorum lateralium abortu unifoliolutis, stipulis basi inter se coalitis, pedicellis axillaribus unifloris, solitariis v. pluribus, sive in racenos axillares folia longe superantes dispositis, roseis aut albis.

Taveruiera DC. Mem. Legum. VIr. $t$. 52 . Meisner Gen. 91. (65.) Hedysarum sparteu u Burmana Flor. ind. t. st. f. 2.

6618. III 18dysarum JEAUM, C a I y x quinquefidus, laciniis linearibus, subulatis, subaequalibus. Corollae papilionaceae vexillum ainplum, a la e carina oblique truncata multo breviores. Stamina 10 , filamento vexillari libero diadelpha, apice abruptim infracta, antherae conformes. $O$ vari um multiovulatum. Stylus filiformis, adscendens; stig ma subcapitatum. Letg umen articulatum, articulis compressis, urbi- 
culatis, medio inter se connexis, ad utramque suturam convexis, disco laevibus, pilosis aut muricatis, monospermis. Semina compresso-reniformia. - Herbae v. suffrutices, in temperatis et frigidiusculis hemis phaerae borealis crescentes; foliis imparipinnatis, racemis axillaribus spicatis, floribus majusculis, purpureis, albis v. ochroleucis.

H od y 8 a r u meaume in Desvaux Journ. Bot. HII, 61, exel. sp. DC. Irodr. II. 3io. Meisier Gen. 9t. (65.) Tor rey et A. Gray Flor. of North-Amer. I. 359. Be hinolobi in Desvaux Journ, Bot. III, 123, ᄂ. 5. f, 20.21. Hed y. sa ri sp. Linn.

a. ECHinolobium DC. l. e. L eg a i $\mathrm{i}$ a um articuli in diseo villosi, costati, muricati ₹. glochidati. (Gïrtuer II. t. 155. Bieberst. Cent. t, 63. Bot. Mag. t. $996.125 t$. Ledebour Flor. Alt. $t$, 51. 59, 489. Reichenb. Iconogr. t. 411.$)$

b. LEIOLOBIUM DC. $l$. c. L e $\mathrm{g} \mathrm{um} \mathrm{nt} \mathrm{um}$ articuli laeves. (Jacq. Flor, austr. t, 168. Bot, Reg. t. 815. Martius Amoen. Monac. $t$. 16.)

8619. Dunbryelnis TOURNEF. C a l y qninquefidus, laciniis subulatis, subaequalibus. Corolla e papilionaceae vexillum obovatum v. oblongum, a la e carina oblique truncata breviores. Sta in in 10 , filamento vexillari libero diadelpha, a nthera e conformes. Ovarium uniovulatum. Stylus longissimus, medio geniculato adscendens; stig ma eapitellatum. Legum en subsessile, uniarticulatnm, compressum, indehiscens, monospermum, lacunoso-reticulatum, margine superiore seminifero crassiore, recto, inferiore tenniore, curvato, saepissine dentato, spi noso v. lobato. Semen subreniforme. - Herbae annuae $v$. sacpius perennes, rarius suffrutescentes, in Europa et Asia media indigenae; foliis imparipinnatis, stipulis margine exteriore coalitis, ideo oppositifoliis, spicis axillaribus et terminalibus longe pedunculatis, floribus rubris $v$. albidis.

0 nobryeh is Tournefort Inst. 211. Gärtner IT. 318. c. 148. Desvaux Journ. Bot. 1Il. 125. t. 6. f. 33. 34. DC. Prodr. II. 394. Meisner Gen. 91. (65.) Hedysari s p. Lima.

a. EUBRYCHIS DC. l. o. Legumen obliquum, in diseo rugosum v. aculeatum, hinc dentatum v. futerrupre cristatum. - Hed y sarl s p. Jaeq. Flor. aust. t. 352 Waldst. et Kitaibel Plant. rar. Hung. t. 111.

b. HYMENOBRYCHIS DC. l. c. Legumen faleatum v. subarbienlatum, disco rogosum v. subaculeatum, hinc in cristam membranaceam, vix subdeatatam expassum. - Il edysari s p. Desfont. Flor, atlant, t, 201. Annal, Mus, XII. t. 13. Bieberst. Cent, t, 35, Delite Flor. cegjpt. t. 39, $f .1$.

DENDROBRYCHIS DC. $\boldsymbol{t}$. $\boldsymbol{c}$. Legu me a laeve, inerme, ecristatum. - Caulio frulescens. Hedy s a rum cor n a $\mathrm{t}$ a $\mathrm{m}$.

d. ECHINOBRYCHIS DC. l. c. L e g u me a trigonam, subineurvum, dorso aculeatun. - Folia unifoliolato (Plucknet Almag. t, 433, $f, 1$, )

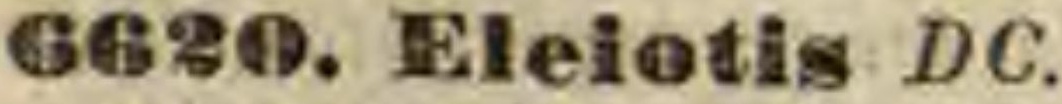

Ca I yx eampanulatus, subtruncatus, obsolete quinquedentatus $\mathrm{v}$ quinquefidus. Corollae papiliunaceae vexill $\mathrm{nm}$ obovatum, alae oblongae, earin a obtusa. Stamina 10 , filamento vexillari libero diadelpha, antherae conformes. Ovarium uni-biovalatum. Stylus filiformis; stigma subcapitatum. Leg $u$ in en compressum, uni biarticulatum, submembranacenm, sutnra superiore recta, crassiore, inferiore curva, articulis semiovalibos, monospermis. Sem in a oblonga, vix compressa, umbilico ventrali. - Herbae indicae, procumbentes, tenellae; eaulibus triquetris, folits petiolutis, pinnatim trifoliolatis $v$, abortu unifoliolatis, siipulis par vis, acutis, adpressis, racemis axillaribus, folio multo longioribus, pedicellis geminis, unifloris, distantibus, Jloribus parvis.

Eleiotis DC. Prodr. 11. 348. Wight et Arnott Prodr. I. 231. Meisuer Gen. 91. (65.) Hed y s a r m sorariam Lian. O a obryehis sororia Desvaux Journ, Bot, MII. t. 6. $f .3 t$

962 4. Dxydimm BENNET. C a I y campanulatus, subbilabiatus, Jabio superiore bifido, inferiore tripartito. Corolla e papilionaceae vexil. I nu obovatum, a la e ublongae, ea rina obtusa. S ta min a 10 , filamento vexillari libero diadelpha, a ntherae conformes. Ovarium ..... Leguin en compressum, nembranaceum, articulatim biloculare, dispermum, rarius uniloculare, monospermum, sutura subrecta, dilatata. - Herba indica, longissime repens, parum ramosa; foliis alternis, longe petiolatis, trifolialatis, foliolis orbiculari-obovatis, retusis, terminali longius petiolulato, bistipellato, lateralibus unistipellatis, stipulis parvis, distinctis, racemis axillaribus, folio paullo longioribus, paucifioris, pedicellis unijloris, plerumque binis ex axilla bracteae nervoso-striatae, caducae ortis.

$0 \mathrm{xydium}$ Beunett in Horfield Plant. jav, rar, 156. Eleiotis Rottlert Wight et Arn.

6892. Campylotropis BUNG. Calyx campanulatus, bilabiatus, labio superiore integerrimo v, emarginato, inferioris tripartiti lacinia media angustiore, productiore. Corolla e papilionaceae vexillum plicatum, acutum, carina falcato inflexa, acuminata. St a mina 10 , filamento vexillari libero diadelpha. Ovarinm ..... StyI $\mathbf{s}$ inflexus, superne glaber. Legumen obovatum, sutura superiore rectilinea, planum, membranaceum, indehiscens, monospermum. - Frutex chinensis; foliis pinnatim trifoliolatis, fo. liolis inlegerrimis, stipulis caulinis subulatis, sub. pungentibus, persistentibus, racemis axillaribus, bracteis indivisis, unifloris, pedicellis patentibus, eum calyce caducissime bracteolato articulatis, floribus purpureis, saepe resupinatis.

Campy lotropis Bunge Plant, Mong. ehin. Dec, $I$.

BG23. Lespedeza L. C. RICH. C a 1 y x basi bibracteolatus, quinquepartitus, laciniis subaequalibus. Corolla papilionaceae vexillum obovatum, a la eblongae, carina transversim obtusa. Stamina to, filamento vexillari libero diadelpha, antherae confurmes, Ovarium uniovulatum. Stylus filifurmis; 8 tigma sulcapitatum. Leg am en lenticulare, compresso planum, inerme, indehiscens, monospermum. Sem e n compressum. - Herbae $v$. suffrutices, in America boreali et Asia media obviae, nonnullae lale per regiones tropicas et $s u b$ tropicas diffusae; foliis pinnatim trifoliolatis, folialis integris, intermedio longius petiolulato, stipulis setaceis, spicis pedunculatis $v$. subracemosis, bracteis trifidis, bifloris, floribus violaceo-purpureis aut ochroleucis, vexillo purpureo-maculalo, rarius albis.

Lespedeza L. C. Richard in Michaux Flor. Bor. Amer, II, 70, t. 39. 40, Desvaux Journ. Bot, IIt. 124. t. 6. f. 28. DC. Prodr. II. 348, Meisner Gen, 91. (65.) Hedy. sari s p. Linn.

6824. Ebenus LINN. Cal y ultra medinm quinquefidus, tabo demum ventricoso, laciniis lineari-subulatis, corollam aequantibus. Corolla papilionaceae $\mathbf{v}$ e $\mathrm{i}$ ll um oblongum, a $\mathrm{ta}$ minimae, vix tubum aequantes, $c$ arina obtusa, inflexa. Stamina 10, monadelpha, alterna bre- 
viora, antherae conformes. Orari um sessile, uni-biovulatum. Stylus sublateralis, filiformis; 8 tigma obtusum. Leg u m en subrotundum, mono dispermum. - Herbae v. suffrutices $m$ edit erra. ne $i$; foliis imparipinnatis, uni-quinquejugis, foliolo terminali sessili, stipulis a petiolo distinctis, pedunculis axillaribus elongatis, spicis densis, floribus rubellis.

K b e u u s Linn. Gen. 895. Desfont. in Aet, soc, $h, n$. Paris. I. 21. $t$. 3. DC. Mem. Legum, t. s3. Meisuer Gen. 91. (64.) Authyllidis s p. Linn, Bot. Mag. t. 1092. H edy s ari $s$ p. Vahl $S y m b$. II. $t, 41$,

SUETREUE III. ALHAGEAE DC. Prodr. 11. 352. Flores racemosi v. spicati. Le g u min a teretiuscula.

6625. Alhagi TOURNEF. Calyx quinqquedentatus, dentibus parvis, subaequalibus. Corollae papilinnaceae petala subaequilonga, vexill n m obovatum, complicatnm, a la e oblongae, carina recta, obtusa. Stamina 10 , filamento vexillari libero diadelpha. Ovarium lineare, pluriovulatum. St ylus filiformis, glaber; stigma acutum. Le gumen stipitatam, sublignosum, teres, oligospermum, isthmis hinc inde irregulariter strangulatum, haud articnlatum, indehiscens. Sem ina renifurmia. - Suffrutices $v$. herbae, in Oriente, regione caucasica et Nepalia crescentes; foliis simplicibus, stipulis minimis, pedunculis axillaribus spinosis, floribus rubris, secus pedunculos racemosis, paucis.

Al hag i Tournefort Corollar. 54. $t .489$. Desvaux in Journ. Bot. III, 120, t, 4. f.4. DC. Prodr. II. 552. M a n $\mathrm{n}$ a Doa Prodr. 246. He dy sa ri s p. Lian.

6626. Alysicanpus $N E C K$. C a lyx per. sistens, tubulosns v. subeampanulatus, quadrifidus, laciniis aequilongis, suprema emarginata $\mathbf{v}$. bifida. Corolla papilionacea, parva, Stamina 10 , filamento vexillari libero diadelpha. $0 \mathrm{va}$ ri um pluriosulatum. Stylus filiformis; stigma acutum. Le g umen teres $v$, suhcompressnm, in articulos plurimos, clausos, ntrinque aequales, monospermos secedens. Semin a reniformia. Herbae v. suffrutices, in Asia et Africa tropica et subtropica crescentes; foliis simplicibus, linea ribus, ovalibus $v$. rotundatis, saepe polymorphis, stipulis et bracteis stipuliformibus scariosis, racemis oppositifoliis $v$. terminalibus, floribus pedicellatis, plerumque geminis, bracteis deciduis, corollis saepissime purpureis, vix calyce longioribus.

Alysicarpus Necker Elem. n. 13t5. Desvanx Journ. bot. III. 120. t. 4. f. 8. DC. Prodr. II. 352. Wight et Ar. nott Prodr. I. 232. H alli a Jeaume in Journ, Bot. MI. 60. Fabrieia Scopoli Introduct. $n, 1407$. Heilysari sp. Linu. Bot, Mag, t. 1722, Wendi. Hort, Herrenh, $t, \delta$,

6в2\%. Irremontiera $D C$. C a l y $x$ campanulatus, subtruncatus, vix quinquedentatus, dentibus minimis, acutis, subdistantibus. Corolla papilionacea, calyce triplo longior. Sta min a 10, filamento vexillari libero diadelpha. $L$ e g $\mathrm{a}$ men articulis plurimis, monospermis, subeompressis, ad suturas pruminulis, utraque extremitate truncatis, demum secedentibus. S e m in a uvata, umbilico laterali. Embryonis cotyledones foliaceae, ubovato-oblongae, radicula ineurva. - Frutex mauritianus; folits simplicibus, ab. longis, pube brevissima canescentibus, brevissime pe tiolatis, utrinque angustatis, stipulis minimis, dentatis, haud scariosis, racemis axillaribus, subspicatis, floribus parvis, purpureis.
Bremontiera DC. Prodr. II. 353. Meisner Gen. 91. (64.)

6B28. Thinadinocarpus $V O G$. C a lyx campanulatus, quinquedentatus. Corollae papilionaceae petala subaequilonga, a la e foveolatorugosae, carina apice rotundata. Stam in a 10 , monadelpha, vagina superne fissa, a n thera e oblongae, conformes. Ova rium sessile, lineare, multiovulatum. Styl us elongatus, curvatus; stigma simplex. Legumen sessile, teres, elongatum, transverse articulatum, articulis cylindricis, utrinque truncatis, secedentibus, indehiscentibus, monospermis. Semina lenticulari-compressa. E m b ryon is radicula exserta, subrecta, apice parum curva. - Frutices Americae australis, volubiles; foliis abrupte pinnatis, quadrijugis, floribus axillaribus solitariis $v$, racemosis.

Rh adinocarpus Vogel in Linnaea XIT, 108.

B69. Wigsolia $J A C Q$. Caly x urecelatocampanulatus, quinquedentatus, dentibus dusbus superioribus magis approximatis. Corolla e papilionaceac vexillum suborbiculatum, emarginatum, reflexum, a Ias et $\mathbf{c}$ arina $m$ superans. $\mathbf{S} \mathbf{a}-$ mina 10 , monadelpha, tubo snpra fisso, persistentia. Ovarium subsessile, bi-triovulatum. StyI $\mathrm{s}$ adscendens; $s \mathrm{tig}$ a capitatum. Leg $\mathbf{u m e n}$ teretiusculum, articulis $2-3$, monospermis, truncatis, secedentibus, indehiscentibus, supremo apice in alam membranaceam, obtusam, inferne cnltriformem, superne parum incrassatam excurrente. Se mina oblonga. - Frutices $A$ mericae tropicae, volubiles; foliis imparipinnatis, bijugis, stipulis petiolaribus liberis, floribus in axillis foliolorum verticillato-congestis, racemosis, luteis $v$, albo-flavescentibus, pedunculis basi unibracteatis, infra apicem articulatis.

Nis soli a Jacq. Amer. 198, t, 179. f. 44. Hort, Vin dob. $t, 167$. excl. reliq. Gartner 11. 309, $t, 145$. Kunth in Humb. et Bonpl. Nov, gen, ef sp. VI, 504. Vogel in Lin. naea XI. 179. Nissolliae sectio Nissolia ria DC. Prodr. II. 257.

TER IEUS 『. PHASEOLEAE Benth. in Anna!. Wiener Mus, II. 381. Corolla papilionacea. Stamina 10, monadelpha. Leg umen hivalve, continum v. isthmis interceptum, nec tamen in articulos secedens. E mbryonis cotyledones crassae, germinatione hypogeae v. epigeae, radicula incurva. - Folia pinnalim trifoliolata $v$. rarius plurijuga, saepissime stipellata.

SULTRETEUS I. CLITORIEAE Benth. in Annal. Wiener Mus. II, 112, Ov a rium pluriovulatum. Vexill um exappendiculatum, saepius amplum. Sta me n+vexillare liberum v. medio connatum, haud geniculatum. S emina estrophiolata. - In/lorescentia simpliciler $v$. fasciculatim racemosa. Bracteae et bracteolae saepius majusculae, striatae, rarius parvae v. nullae.

6530. Amphicarpaen ELL. Flores dimorphi, ramorum superiorum perfecti, saepissime steriles, camorum inferiorum procumbentium 
incompleti, plerumque fertiles. Floribns com. pletis: Calyx tubuloso-campanulatus, quinquedentatus v. dentibus duobus superioribus roalitis subaequaliter quadridentatus. Corolla e papilio. naceae vexillum late obovato-oblongem, subsessile, alis majus, basi obsolete auricnlatum, incumbens, partimque reliqua petala amplectens, a l a e longe nnguiculatae, lamina oblonga, basi calcare brevi calloso, carina petala libera, alis conformia et aequilonga. St a m in a 10 , filamento vexillari libero diadelpha, a $\mathrm{n} t \mathrm{~h}$ er a e uniformes. Dis. c: us vaginifer. Ovarium stipitatum, quadriovulatum. Stylus filiformis, glaber; stigis a parvum, capitatum. Le er nmen lineari-oblongum, compressum, subgladiatum, tri-tetraspermum. F loribus imperfectis: Calyx nullus. Corolla nolla v. vexilli rudimentum. Sta $m$ in a nolla $v$. 5 - 10 , ovario breviora, quoram 3 v. 4 antheris perfectis, reliqua ananthera; filamenta omnium libera. Ovari u m subsessile, calyce brevins, unitriovulatum. Stylus brevis, recurvus, demum elongatus, exsertus. Legn m en obovatum v. pyriforme, mono-dispermun, plerumque hypogaeum. - Herbae boreali-americanae, annuae, volubiles $v$, sarmentosae; caule ramosissimo, retrorsum pubescente $v$. fusce piloso, foliis pinnatim trifoliolatis, foliolis rhombeo-ovatis, stipellatis, stipulis striatis, racemis petalifloris solitariis v. geminatis, saepe subcompositis, bracteis stipuliformibus orbiculatis, persistentibus, duabus oppositis in unicam connatis, racemis apetalis subconformibus, pedunculis paucifloris, filiformibus, bracteis distinctis.

A mphie a rpaea Elliott in Journ. Academ. Phila. delph. I. 372. Nuttall Gen. II, 213. DC. Prodr. II, 383. Meisner Gen. 93. (66.) Beutham in Annal. Wiener. Mus. II. 112. Torrey et A. Gray Flor. of North-Amer. I, 291. $\mathrm{S}$ a vi a Rafinesq. in New.York. Medic. Heposit. II. Hex, V. 350. X y pherus Rafiaesque in Journ. Phys. LXXXIX. 260, Cryptolobus Sprengel Syst. IIr. 218. part. Faleata Guelin Syst. 1131. Q1 y e i nes s p. Linn. Wendl, in Römer Archiv. 1. t. 2. Hegetsebweiler Comment. $t .5$.

BS331. Inzmasia $D C$. Calyx tubo cylin drico, limbo oblique truncato, dentato. Corolla e papilionacae petalar unguibus tubum aequantibus, vexillo complicato, alis et carinae subaequali incumbente. Stam in a 10 , fifamento vexillari libero diadelpha, antherae conformes. Ovari um sessile, panciovnlatum. Stylns medio ab. ruptim dilatatus, apice attenuatus; $8 \mathrm{tigma}$ terminale, obtusum. Leg $\mathbf{n m}$ en basi attenuatum, compressum, bivalve, oligospermum, valvis inter semina torulosis. Semina .... - Herbae nepalenses, scandentes; foliis pinnatim trifoliola. tis, folialis ovatis, stipellatis, terminali a reliquis distante, stipulis minutis, racemis axillaribus, folio saepe brevioribus, bracteolis duabus setaceis calycis basi adpressis, leguminibus pube brevi, conferta velutinis.

Du mas ia DC. Mem. Legum. VI, t, 4h. 45. Prodr. IT. 241. Meisuer Gon, 87. (62.) Bentham in Annal. Wiener MLss, II. 112.

8B32. Fareraria $D C$. C a 1 y x campanu latus, obtusiusenle bilabiatus, labio superiore in tegro v. vix bidenticulato, inferiore trifido. C o ro Ilae papilionaceae vexillam obovatum, a I a e carinam rectam, obtusam, dipetalam aequantes. St a min a 10 , monadelpha, Ovarinm lineare, multiorulatum. Stylas filiformis; stigma mi nute eapitatum, pubescens. Le g n me n lineare, basi attennato-stipitatum, stylo apiculatum, bivalve, polyspermum. Semina ..... - Frutices in- dici, scandentes, stipulis a petiolo distinctis, de. cidnis; foliis pinnatim trifoliolatis, foliolis amplis. ovatis, acutis, reticulato-nervosis, basi stipellatis, racemis axillaribus compositis, ramosis, floribus pe. dicellatis, geminis $v$, lernis, flavescentibus.

Pueraria DC. Mem. Legum, 252, t. 43. Prodr, II. 240. Meisuer Gen. 87. (62.)

6633. Cologania $H, B, K, \mathrm{C}$ a l y x tubuloso-campanulatus, quinquedentatus, saepissime dentibus duobus superioribus in unicum integerrimum connatis quadridentatus, dente inferiore productiore. Corulla e papilionaceae vexill a m obovato-orbieulatum, emarginato-bilobnm, patens, basi alas et carinam amplectens, alae carina longiores eique adhaerentes. Stam in a 10 , filamento vexillari libero diadelpha. Discus vaginifer. Ovarium stipitatum, multiovulatum. Stylus filiformis, glaber; stigma obtusum. Legumen lineare, hispidissimum .... - Suffrutices Americae tropicae; pilis retrorsis hispidi, procumben. tes $v$. volubiles, foliis trifoliolatis, stipellatis, terminali a reliquis distante, nonnunquam abortu uni. foliolatis, floribus axillaribus, geminis, pedunculatis, violaceis, calycibus basi minute bibracteolatis.

Cologa n i Kunth in Humb, et Bonpl. Nov, gen. et sp. IYT. 411. Mimos. 205. t. 57. 38. DC. Prodr. II. 236. Meisuer Gon, 87. (63.) Bentham in Annal. Wiener Mus, II. 112 .

6B3 4. Amplaodus LINDL. C a l y x tubo basi intruso, limbi bilabiati labio superiore bidentato, inferiore trifido, laciniis subulatis. Corolla e papilionaceac vexill u m basi utringue dente auctum, reflexum, al a e et carina lineares. Sta$m$ in a 10 , filamento vexillari libero diadelpha, Ovarium sessile, multiovulatum. Stylus filiformis, glaber; st $\mathrm{i} g \mathrm{ma}$ capitatum. Le gumen lineari-oblongum, compressum, bivalve, polyspermum, inter semina torulosum. Se min a oblonga, compressa, arillo earnoso, crasso cincta. - Frutex Americae tropicae, volubilis; foliis trifoliolatis, foliolis stipellatis, ovatis, rigide mucronatis, racemis axillaribus, brevibus, floribus magnis, purpureis, calycibus ebracteolatis.

A $\mathrm{mphod}$ a s Lindley in Bot. Reg, t.1101. Meisner Gen. 94. (67.) Bentham in Annal. Wiener Mus. II. 112.

6633. Clitoria $L I N N$. C a ly x tubulosus, apice quinquefidus, laciniis superioribus ovatis, acuminatis, supremis saepe altius cohaerentibus, infima angustiore. Corolla e papilionaceae ve$x$ illu m amplum, suborbiculare, emarginatum $v$. bifidum, dorso nudum, basi angustatum, exappendieulatum, a la e oblongae, extrorsum faleatae, carinae adhaerentes, c a $r$ in a longissime stipitata, parva, incurva, breviter rostrata, acuta, alis brevior, petalis apice connatis. Stamina 10 , monadelpha $v$. filamento vexillari sublibero diadelpha, antherae uniformes. Discus vaginifer. Ovarium stipitatum, multiovulatum. StyI us incurvas, apice plus minus dilatatus, subtus longitudinaliter barbatus ; $8 \mathrm{tigma}$ capitatum. Leg n m e $n$ stipitatum, lineare, plano-compressum, sutura utraque incrassata, valvulis enerviis, exalatis. Semina plura, plana, estrophiolata, - Herbae $v$. frutices, in America et $A$ sia tropica crescentes, saepe volubiles; foliis pinnatim tri-plurifoliolatis, foliolis oppositis, cum impari distante, stipulis subpersistentibus, saepe lineat is, stipellis setaceis $v$, interdum subnullis, pedunculis axillaribus, uni-bifloris v, racemiferis, bracteis stipulis subsimi. 
libus v. saepius majoribus, bracteolis bracteas superantibus, lineatis, calyce brevioribus $v$. longioribus, floribus amplis, purpurascentibus, caeruleis, albis v. rubris.

Clitoria Linn. Gen. n. 869. Gärtner 11. 321. DC. Prodr. 1I, 233. excl. sect. 3 et 4. Bentham in Annal. Wie. ner Mus. II. 114. Meisner Gen. 86. (62.) Te r n a te a Tournef. in Aet. Academ. Paris. 1706. C. 1, Clitorius Petiver in Rai Hist. III. N a $\mathrm{a}$ else a Descourt. in Annal, soc. Linn. Paris IV. 7. t, 1 .

a. TERNATEA Kunth. Folla plurifoliolata. Bracteolae calyce breviores. Caulis volubilis v, scandens, - Species gerontogeae. - Teruate a Touruef. $l$, $c$. Kunth in Humb, el Bonpl. Nov. gen. et sp. VI. 415. (Gärtner l. o. t. 149. Veuten. Choix, t, 26,)

b. EUCLITORIA DO. Folia trifoliolata. Bracteolae calyce breviores. Caulis volubilis v. scandens. - Species americanae et madagascarienses. - Clitoria Kunth $t . c$. partim. Clitoriae seet. Euclitoria DC. $l$. c. excl, sp.

c. BRACTEARIA Benth. Folia trifoliolata. Bracteolae calyeem aequantes v. superantes. Caulis fruticosus. Species americanae.

6B36. Newroearpuma DESV. Caly tubulosus, apice quinquefidus, laeiniis superioribus ovatis, acuminatis, supremis saepins altius connatis, infima angustiore. Co roll a e papilionaceae vexillum amplum, suborbiculare, emarginatum v. bifidum, dorso nudum, hasi angnstatum, exappendieulatum, a I a oblique oblongae, extror sum falcatae, carinae adhaerentes, carina longissime stipitata, parva, incurva, breviter rostrata, acuta, alis paullo brevior, petalis dorso apice connatis. St a m in a monadelpha, v, filamento vexillari sublibero diadelpha, a $\mathrm{n} t \mathrm{~h}$ e $\mathrm{r}$ a uniformes. Ovarium stipitatum, lineare, pluriovalatum. Stylus incurvus, apice plus minus dilatatus, subtus longitudinaliter barbatus; $s \mathrm{tigm}$ a capitatum. L e g u m en stipitatum, oblongo-lineare, subcompressum, subfaleatum, bivalve, valvulis convexis, medio nervo longitudinali prominulo, exalatis, intus isthmis cellulosis, interdum evanidis submultiloculare, Semin a subglobosa, estrophiolata. - Frutices $v$. herbae, in America tropica crescentes, volubiles $v$. suberectae; foliis pinnatim trifoliolatis, foliolis oppositis cum impari distante, stipulis persistentibus, saepe lineatis, pedunculis axillaribus, uni-bifloris v racemiferis, bracteis stipulis subsimilibus, bracteolis majoribus, lineatis, acuminatis, calyce ut plurimum brevioribus, floribus amplis, purpurascentibus $\bar{v}$. albis, corollis nonnunquam abortivis.

Nenrocarpum Desvaux in Journ. Bot, 1814, I. 75. Kunth in Humb, ot Bonpl. Nov. gen. et sp. VI. 406. Mimos. t. 59, 60. DC, Prodr, 11. 235. Presl symb. t. 9. Meisuer Gen. 86. (62.) Bentham in Annal. Wiener Mus. II. 116. R bo m b if oli um L. C. Richard msc. Crotalarlae s p. Aublet Guian. $t, 305$. - Status abnormis, corollis abortivis: M a rti a Leandro de Sacram, in Münehner Denkschrift, III. 233. t. 12. Zuccarini Nov. stirp. fasc, $I, 337 . t$. 14. Meisner Gen.86. (61.) Martí us ía Scbultes Mant. I. 69. DC. Prodr. II. 236.

BE3\%. Vexillania BENTH. Caly x campanulatus, breviter quinquedentatas, dente infimo majore. Corolla e papilionaceae vexill um breviter unguiculatum, late orbiculatum, basi an. gustatum, complicatum, subcallosum, exappendiculatum, dorso nudnm, a l a s late semiorbiculatas, introrsum subfaleatas, carinae adhaerentes superans, ca ri n a breviter unguienlata, oblonga, incurva, apice obtusa, alis panllo brevior, petalis đorso connatis. S $t$ a $m$ in a 10 , monadelpha, a ntherae uniformes. Ovarium subsessile, pluriovulatum. Stylus incurvus, apice attenuatus; stigma maximum, capitatum. Leg nmen coriaceum, oblongo - lineare, subcompressum, sutura vexillari anguste bialata, carinali nuda, valvulis convexis, dorso versus medium nervo prominulo, acuto, longitudinali subalatis. $\mathrm{Sem}$ in a subglobosa. - Frutices Americae tropicae volubiles; foliis trifoliolatis, foliolis oppositis, cum impari distante, stipellatis, stipulis lineatis, pedunculis axil. laribus, apice subracemosis, bracteolis linearibus.

Vexillaria Bentham in Annal. Wiener Mus. II. 117. Pilanthus Poiteaumsc. - ? Neurocarpi sp. Desvaux.

8639. Centrosema DC: $\mathrm{C}$ al $\mathrm{y} \times$ late et breviter campanulatus, quinquedentatus $\mathbf{v}$ : quinquefidus, interdum laciniis duabus supremis connatis quadrifidus, lacinia infima longiore. CorolI a papilionaceae vexill um late orbiculatum, alis longius, basi angustatum, complicatum, exappendieulatum, dorso calcare brevi, obtuso anctum, ungue brevi, extus gibbo, a la e oblique obovatae v. oblongae, falcatae v. subrectae, e a rina alis vix brevior, late semiorbiculata, ineurva, oltnsa, petalis dorso connatis, brevissime unguiculatis, Stamina 10 , monadelpha v. filamento vexillari plus minus libero diadelpha, antherae uniformes, Ova ri um sulsessile, multiovulatum. Stylus incurvos, glaber, apice membranaceo-dilatatus, extremitate barbatus, stigmatosus. L eg am en subsessile, lineare, plano-compressum, sutura utraque incrassatum, valvolis utrinque longitudinaliter prope marginem nervo tenui notatis. S e m in a compressa, estrophiolata. - Frutices $v$. herbae a m e ric an a e, volubiles; foliis trifoliolalis aut interdum subquinquefoliolatis, foliolis oppositis, cum impari plus minus distantibus, stipellatis, nonnunquam lateralium abortu unifoliolatis, stipulis lineatis, acuminatis $v$. acutis, pedunculis axillaribus solitariis $v$. binis, paucifloris, bracteis inferioribus stipulis conformibus, suprema saepe orbiculata, subcucullata, amplexicauli, bracteolis majoribus calyci adpressis, striatis, corollis albis, roseis, violaceis, coccineis $v$. ochroleucis, vexillo extus pubescente $v$. villoso.

C e n tro se m a Bentham in Annal, Wiener Mus, II, 117 . Torrey et A. Gray Flor. of North.Amer. I, 290, CIt to ria e sect. Centrosema DC. Prodr. II. 234. Clitoriae sp. Linn. Salisbury Parad. Zond. t. 51. Bot. Reg. t, 268. B ud of phiae sp. Kunth in Humb. et Bonpl, Nov, gen, et sp. t. 391 . S te gan o trop is Lehmenn Index Sem, Hort. Ham. burg, 1826. ex Linnaea 1828. Litterat, Ber, 11. - ? Ple ctr o tr o p is Sehuhmach, in Danske Selskab, Skrifi,IV, 112.

6639. Periandura MART. C a lyx late et breviter campanulatus, quinquedentatus, dentibus quatuor superioribus brevibus, duobus snpremis subconnatis, quinto infimo longiore. Corolla e papilionaceae vexillum late orbiculatum, alis longins, basi angustatum, complicatum, exappendiculatum, dorso nudum, ungue brevi, lato, convexo, a la e oblique obevatae v. oblongae, subfalcatae $\mathbf{v}$. rectae, $\mathbf{c}$ a $\mathbf{r}$ in a alis vix brevior, late semiorbiculata, incurva, obtusa, petalis brevissime unguiculatis, dorso connatis. Stam in a 10 , monadelpha, v. filamento vexillari plus minus libero subdiadelpha, an thera e orbiculares, nniformes. Ovarium subsessile, multiovulatum. St y 1 a s incurvus, glaber, hand dilatatus; stigma capitatum. Le g umen subsessile, lineare, plano-compressum, sutura utraque subinerassata, utrinqué obscure uninervi, styli basi persistente acuminatum. S emina compressa, estrophiolata. - Frutices $v$. herbae, in America australi crescentes, volubiles $v$, suberectae; foliis trifoliolatis, foliolis 
oppositis, cum impari distante, stipellatis, stipulis acuminatis, lineatis, pedunculis uni-plurifloris, axillaribus $v$. subracemosis, bracteis stipulis subconformibus, bracteolis majoribus, calyci adpressis, striatis, corollis saepius coccineis.

Periandra Martius ex Bentham in Annal. Wiener Mus, II. 121, Clitoria e sect. Glycinopsis DC. Prodr, II. 235. Clitoria coecinea Sehrad. Glyeyribiza mediterranea Flor. Flum. VII, t, 143.

6640. Fintysema BENTH. Cal y x late et breviter campanulatus, quinquedentatus, dentibus brevissimis, latis, duobus supremis subconnatis, infimo evidentiore. Co roll a e papilionaceae vexillum late orbiculatum, alis longins, basi angustatum, complicatum, exappendiculatum, dorso nudum, angre brevi lato, convexo, a la e oblique obovatae, e arin a alis vix brevior, late semiorbiculata, incurva, obtusa, petalis brevissime unguiculatis, dorso connatis. Stamina 10 , monadelpha, filamento vexillari ima basi et supra medium libero, an therae reniformes, orbiculares. Ova ri $\mathbf{~ m ~ s u b s e s s i l e , ~ l i n e a r e , ~ i n c u r v u m , ~ p l u r i o - ~}$ vulatum. Stylus incurvus, subteres, glaber, versus apicem attenuatus, summo apice in stig$\mathrm{m}$ a breve, ligulaeforme, subciliatum expansus. $L$ eg nmen ovato-oblongum, subfaleatum, plano-compressum, coriaceum, suturis incrassatis, altera incurva, trialata, altera subrecta, bialata, valvulis planis, enerviis. Semina ..... - Frutex a mazonicus, volubilis; ramis tetragonis, ad angulos obsolete alatis, foliis trifoliolatis, stipulatis, foliolis ovatis, acuminatis, lateralibus valde obliquis, coriaceis, stipulis submembranaceis, fuscis, ovatoorbiculatis, subconnatis, pedunculis apice uni-bijloris, bracteolis membranaceo-coriaceis, lineatis.

Platy s e m a Bentham in Annal. Wiener Mus. 1T. 122.

SUETRETES II. KENNED YEAE Benth. in Annal. Wiener Mus. II. 112. Ovarium pluriovulatum. V exillu m biappendiculatum v. nudum. Stamen vexillare basi connatum v. omnino liberum, nunquam geniculatum. S emin a strophiolata v. rarius estrophiolata.

Inflorescentia simpliciter $v$. fasciculato-racemosa, nec nodosa. Bracteolae saepius parvae.

6641. Kennedya VENT. C alyx ad medium fissus, bilabiatus, labio superiore bidentato, inferiore tripartito. Coroll a e papilionaceae v exill u m breviter unguiculatum, obovato-oblongum, alis subaequilongum, reflexum, basi angustatum, biappendiculatum, a la e carinae ultra medium adhaerentes, $\mathrm{c}$ a rin a elongato-oblonga, hinc recta, extns apice parum incurva, acnta, alas aequans v. superans. Sta $\mathrm{m}$ in a distincte diadelpha, filamento vexillari basi recto, inarticulato, a $\mathrm{t} t \mathrm{~h}$ ra e uniformes, Vagin a disci nulla. Ovarium pluriovulatum. Stylns elengatus, filiformis, apice subineurvns, attennatus; $8 \mathrm{t} \mathrm{ig}$ at $\mathrm{e}$ parvo, obtuso. Leg a me n oblongo-liaeare, compressum, intus isthmis eellulosis transversis multiloculare. $\mathrm{Sem}$ in a strophiolata. - Frutices in Nova-Hollandia indigeni, volubiles $v$. prostrati; foliis pinnatim trifoliolatis, $v$. interdum nonnullis unifoliolutis, stipellatis, pedunculis axillaribus paucifloris, bracteatis, floribus amplis, rubris $v$. violaceis.

K e n ned y a Veaten. Malm, $t, 104$, excl, reliq. Gaudich. ad Freycin, $t, 113$. Lindley in Bot, Reg. $t, 1715,1790$. Meisner Gen. 94. (67.) Bentham in Enum, plant. Hilgel. 38, et in Annal. Wiener Mus, II, 182. C a ulin la Moach Suppl, 47.
6842. Ziehya HÜGEL. Caly x campanulatus, bilabiatus, labio superiore bidentato, inferiore tripartito. C oroll a e papilionaceae ve. $x$ ill u m unguiculatum, late orbiculatum, emarginatum, reflexum, basi biappendiculatum, a las oblongas, carinae ad medium adhaerentes superans, ca rina incurva, obtusa, alis brevior v. subaequilonga. St a min a distincte diadelpha, fila. mento vexillari recto, inarticulato, antherae uniformes. Vagina disci nulla. O varin m plariovulatum. Stylus brevis, adscendens, superne in $8 \mathrm{tig} \mathrm{ma}$ subcapitatum, saepius dilatatum $\mathrm{v}$. bre viter appendiculatum desinens. L e $g$ u $\mathrm{m}$ e $\mathrm{n} \mathrm{ob-}$ longo-lineare, compressum, coriaceum, sutura seminifera incrassata, isthmis cellulosis multiloculare. S e min a strophiolata. - Frutices Nova eHollandiae, volubiles; foliis pinnatim trifoliolatis, foliolis stipellatis, pedunculis axillaribus, apice umbellatim multifloris, bracteis et stipulis parvis $v$. rarius foliaceis, caulibus saepe pilis fuscis villosis, corollis coccineis.

$\mathrm{Z}$ i c h y a Hügel in Bot. Arohiv. $t$. 1. Bentham in Enu. merat. Plant. Hïgel, 39, Annal. Wioner Mus. II. 193. Lindley in Bot. Reg. $t, 1839 . t, 52$. K e n a d y a e s p. Vent. Malmais. t, 105. Bot. Mag. t, 2664. Bot. Reg. t. 1421. 1526. 1838.

6643. IPhysolobham BENTH. C a $1 \mathrm{yx}$ campanulatus, bilabiatus, labio superiore bidentato, inferiore tripartito. Coroll a e papilionaceae vexill $\mathrm{um}$ breviter unguiculatum, late orbiculatum, patens, basi exappendiculatum, a las carinae nitra medinm adhaerentes superans, $\boldsymbol{c}$ arina incurva, obtusa, alis brevior v. subaequalis. S tamin a distincte diadelpha, filamento vexillari rec. to, inarticulato, anthera e uniformes. $\nabla$ agina disci nulla. O varium pluriovulatum. Stylus brevis, adscendens; sti gma capitatum, Le gumen coriacenm, oblongum, turgidum, suturis haud incrassatis, intus isthmis cellulosis, saepe demum evanidis multiloculare. S em in a strophiolata, - Frutices Novae-Hollandia e, volubiles $v$. prostrati; foliis pinnatim trifoliolatis, stipellatis, pedunculis axillaribus, laxe paueifioris, subdichotomis, bracteis et stipulis late ovatis, corollis coccineis.

Physolobium Bentham in Hilgel Bot. Archiv, $t, 2$. Enum. Plant. Hügel. 38. Annal. Wiener Mus, II, 123. Ke nued y a e sp. Lindley in Bot, Reg. $t, 1845$.

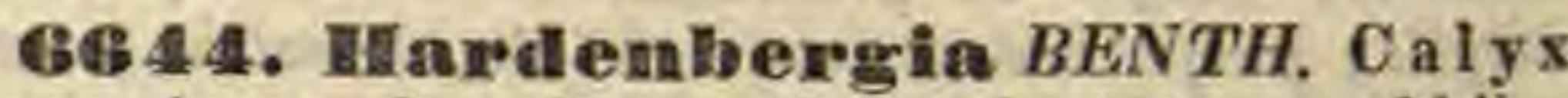
campanulatus, breviter quinquedentatus, subbila. biatus. Coroll a e papilionaceae vexillum orbiculatum, subintegrum, basi angustatum, exappendiculatum, vix unguiculatum, a las oblique obovato-oblongas superans, carin a aliis brevior, iisdem ad medium adhaerens, incurva, obtusa. $S t$ a $m$ in a distincte diadelpha, filamento vexillari basi recto, inarticulato. Vag in a disci subnulla. Ovarium pluriovulatum. Stylus brevis, adscendens, subulatas; stig ma capitatum, subpenicillatum. Leg umen lineare, compressum, intus isthmis cellulosis submultiloculare. Semina strophiolata. - Frutices Novae-Hollandiae, volubiles, saepius glabri; foliis pinnatim trifoliola tis, foliolis stipellatis, stipulis bracteisque minutis, pedunculis axillaribus, multifloris, pedicellis ebracteolatis, calycibus glabris, corollis caeruleis v, violaceis.

H a rde $\mathrm{n}$ bergi a Bentham in Enumerat, plant. Hïgel. 40. Annal. Wiener Mus. II. 124. K e nuedy a e s p. Venten. Malm. $t$, 106, Bot. Mag. $t$, 2169. Bot. Reg. t. $944,1862$. GJyeines si p. Bat. Reg. $t, 298$. 
6645. Leptocyamens BENTH. Calyx eampanulatus, quinquefidus, subbilabiatus. C or ollae papilionaceae vexill um orbiculatum v, obovatum, basi exappendiculatum, ecallosum, a las oblongas superans, carina alis adhaerens, subrecta, ubtusa, alis brevior. St a m in a basi monadelpha, filamento vexillari saepe ultra medinm soluto, omnia aequalia, fertilia, V a g in a disci subnulla. Ovarium sessile, pluriovulatum. Sty Ius incurvus, glaber; stigma terminale, capitatum. L e gum e n lineare, compressum, intus isthmis cellulosis subinultiloculare. $\mathrm{S}$ e m in a strophiolata. - Herbae $v$. suffrutices Novae-Hollandiae volubiles; foliis pinnatim trifoliolatis, foliolis stipellatis, oppositis, cum impari distante, pedunculis axillaribus, simpliciter racemosis, gracilibus, inferioribus brevissimis, uni-quadrifloris, superioribus elongatis, multifloris, floribus in axilla bracteae solitariis, pedicellis infra calycem bibracteolatis, bracteolis parvis, subulatis.

Le p to e y a m u s Bentham in Linn. Transact, XVIIT, 209. Leptolobium Bentham in Annal. Wiener Mus. 11. 124. Ke n ned y a 5 p. Sieb. Labillard. Nov. Caled, t. 70. G 1 y c i. nes sp. Wendl. DC.

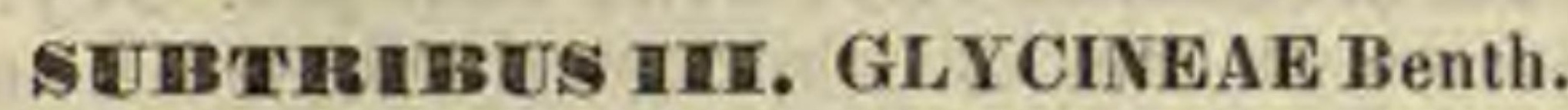
in Annal. Wiener Mus. 1I. 112. Ovarium pluriovulatum. Vexill u $\mathrm{m}$ plerumque biappendiculatum. Stamen vexillare basi connatum v. omnino liberum. Stylus non induratus. S e min a estrophiolata, - Inflorescentia saepissime nodoso-racemosa, flores saepius minimi, bracteolae parvae, rarius striatae.

6646. Jolnaia WIGHT et ARN. C alyx profunde quinquefidus, laciniis angustis, sobulatis, duabus supremis ad medium usque inter se coalitis, infima reliquis paullo longiore. Co roll a e papilionaceae petala calyce breviora, vexillum oblongo-obovatum, alas liberas et carinam obtusam, gamopetalam duplo superans. $\mathrm{S} t$ a $\mathrm{m}$ in a 10, filamento vexillari libero diadelpha, omnia fertilia. Ovarium pluriovulatum. Stylus ensiformis, glaber, sursum attenuatus; stigma capitatum. L e g $\mathbf{n} \mathbf{m}$ e $\mathbf{n}$ lineare, styli basi persistente apiculatum, pilosum, tetra-pentaspermum, isthmis inter semina transversim pluriloeulare. S e min a compressa. - Suffrutices Asiae tropicae, volubiles, pilis retrorsis, bruneis hispidi; foliis pinnatim trifoliolatis, petiolis plus minus pilosis, ovatis $v$. $\mathrm{cu}$ neatis, basi trinerviis, stipellatis, stipellis subulatis, stipulis lanceolatis, scariosis, striatis, racemis axillaribus, primum densis, brevibus, bracteis longis pilosis, demum elongatis, remotifloris, leguminibus reflexis.

John ia Wight et Arnott Prodr. I. 449. Bentham in Annal. Wiener Mus. II, 112. Meisner Gen, 86. (6i.) N oton i a Wight et Arnott Op. cit. 207, mon DC.

G64\%. Cyamopsis DC. Ca ly $\mathrm{x}$ turbinatotubulosus, profunde quinquefidus, laciniis lanceolato-subulatis, acutis, duabus supremis paollo remotioribus. Corolla e papilionaceae petala subaequalia, demum elastice dissilientia, vexill u m subrotundum, al a e oblongae, carin a dipetala, reeta, acuta. S $t$ am in a 10 , monadelpha, an th $e_{-}$ rae uniformes, omnes fertiles. Ovarium lineare, multiovulatum. Stylus crassus, adscendens; stig ma capitatum. Le $g \mathbf{n m e n}$ acinaciforme, longitudinaliter canaliculatum et striatum, sutura vexillari binervosum, stylo persistente rostratum, pleiospermum, isthmis inter semina transversis plurilocellatum. Semina oblongo-cylindracea, utrinque truncata, verrucosa. - Herbae in Asia et Africa tropica crescentes, pilis centro affixis; foliis pinnatim tri-quinquefoliolatis, minutissime stipellatis, stipulis minimis, persistentibus, racemis axillaribus, folio brevioribus, floribus parvis.

C y a mopsis DC. Prodr. IT, 215. Guillem. et Perrot. Flor. Seneg. I. 171, t, 45. Wight et Arnott Prodr. I. 196. Meisner Gen. 85. (61.) Bentham in Annal. Wiener Mus, IX. 112. Cordaca Sprengel Gen, pl. n. 2847, Dolic hos faba eformis Heritier Stirp. $t$, 78, Lupinus trifolia. tus Cavanill, Ic, $九 .89$.

6648. Stenolobium BENTH. Calyx campanulatus, breviter bilabiatus, labio superiore bidentato, inferiore trifido. Co ro 11 a e papilionaceae vexill um obovatum, erectum, basi membrana inflexa ntrinque appendiculatum, alas vix superans, al a e oblongae, carinae adhaerentes, basi subulato-auriculatae, carina oblonga, recta, alis aequilonga, petalis alis conformibus, derso connatis, St a min a 10, filamento vexillari a basi libero, haud geniculato diadelpha, antherae omnes fertiles. Ovarium sessile, mnltiovulatum. Stylus filiformis, hand indurascens, glaber; s tig ma terminale, parvum. L egumen sessile, lineare, elongatum, plano-compressum, sutura ntraque incrassata, polyspermum, isthmis cellulosis inter semina transversim multiloculare. S e$m$ in a reniformia, compressa, estrophiolata. Suffrutices Americae tropicae volubiles; foliis pinnatim trifoliolatis, foliolis ovato-rhombeis, oppositis, impari-remoto, stipellatis, stipellis rigidis, ciliatis, stipulis deciduis, pedunculis axillaribus, elongatis, rigidis, floribus in faseiculos plurimos, saepe multifloros dispositis, subsessilibus, rhachi faseiculorum persistente, nodiformi, braeteis deciduis, bracteolis parvis, subulatis, alabastris haud acuminatis, corollis caeruleis, leguminibus adpresse pubescentibus $v$, glabriusculis. II. 125 .

Stenolobium Bentham in Annal. Wiener Mus,

6649. Soya MÖNCH. C a lyx basi bibrac. teolatus, quinquefidus, laciniis tribus inferioribus rectis, acutis, duabus superioribus ultra medium coalitis. Cor olla e papilionaceae vexillum ovatum, breviter stipitatum, a 1 a s includens, earina oblonga, recta. Stamina 10 , filamento vexillari libero, haud genicnlato diadelpha, omnia fertilia. D is cus vaginifer nullns. O varium sessile, pluriovulatum. Stylus brevis; stigma subcapitatum. Le g n me n oblongum, subfalcatum, membranaceum, di-pentaspermum, isthmis cellulosis inter semina transversim plurilocnlare. S em in a ovata, compressa. - Herba Asia e tropicae, erecta, hispida; foliis pinnatim trifoliolatis, foliolis stipellatis, floribus axillaribus, nuno aggregatis, breviter pedicellatis, nunc racemosis, subpedunculatis.

S ○ y a Môneh Method. 153. Savi Dissert. p. 16. DC. Prodr. II. 396. Meisner Gen. 94. (66.) Wight et Arnots Prodr. I. 247. Bentham in Annal. Wiener. Mus. II, 113. Dolichos Soja Linn. Jaeq. Ic. rar. $t .145$.

BG5๑. Glyeine LINN. Calyx basi bibracteolatus, snbbilabiatus, labio superiore bifido, inferiore tripartito, laciniis lanceolatis, acutis, $\mathrm{Co}_{0}$ rolla e papilionaceae vexillum obovatum, emarginatum, marginilus alas amplectens, a la e vesillum subaequantes, earinae breviori, rectae adhaerentes. St am in a 10, monadelpha, tubo hine fisso, alterna ananthera v. antheris rudimentariis 162 * 
donata. Ovarium sessile, oblongum, obtusum, pluriovulatum. St ylus brevis, subincurvus, glaber; 8 tig m a subeapitatum. Leg um en lineare, compresso - subcylindricum, rectiusculum, styli basi persistente mucronatum, polyspermum, isthmis cellulosis inter semina interceptum. Se mina subovata, estrophiolata. - Herbae v. suffrutices, volubiles, magis minusve pilosi, in Asia et $A m e-$ rica tropica, nec non in Capite bonae spei crescentes; foliis pinnatim trifoliolatis, foliolis stipellatis, stipellis setaceis, stipulis parvis, lanceolatis, racemis axillaribus, interruptis, pedicellis subfasciculatis.

G1 y c ine Wight et Arnott Prodr. 1. 208. Bentham in Annal. Wiener Mus. II. 126. Meisner Gen. 87. (62.) Gl y c i n $\mathrm{Ia}$ bi alis Linn. f. B u ja cia B. Meyer Comment. Plant, afr. 127. Tera mn us P. Browa Jam. 290. Swartz Prodr. Flor. Ind. occid. IIT. 1238. t. 25. Meisner Gen. 98. (66.)

GB5 1. Betemeonrtia $S T$. HIL. Caly infra basim bibracteolatus, campanulatus, ultra medium quinquefidus, laciniis subinaequalibns. Corollae papilionaceae a la et carina obtusae, subinaequales. Stamina 10 , monadelpha, tubo hinc fisso. D i s c us conicus, costatus, ovarii basim cingens. Ovarium sessile, lineare, multiovnlatum. Stylus arcuatus, glaber; stigma terminale, parvum. L e gum e n sessile, polyspermuin. Semina ..... - Suffrutex brasiliensis, decumbens; foliis longe petiolatis, trifoliolatis, floribus in apice pedunculi umbellatis. I. 377 .

Betencourtia St. Hilaire Voyage Distr. Diam.

Bes?. Slnuteria WIGHT et $A R N$. C a l y x bibracteolatus, quadrifidus, laciniis acuminatis, infima et suprema Iongioribus. C orolla e papilionaceae petala longe unguiculata, vexillu in obovatum, exappendicnlatum, marginibus incumbens, a la e liberae, carina gamopetala, subineurva, alis brevior. Stamina 10 , filamento vexillari libero, basi haud geniculato diadelpha, omnia fertilia. O vari u m sessile, pluriovulatum. Stylus compressus, glaber, elongatus, demum flexuosus; st i g m a capitatnm. L e g um e $n$ lineare, compressnm, pilosum, penta - hexaspermum, isthmis celIulosis inter semina transversim pluriloculare. S emina ovata, compressa, estrophiolata.

Herbae Asiae tropicae, volubiles, patentim pilosae; fo liis trifoliolatis, foliolis stipellatis, lateralibus ovatis $v$. ovalibus, terminali rhombeo, stipulis bracteisque lanceolatis, scariosis, striatis, racemis axillaribus, folio brevioribus, multifloris, floribus pedicellatis, bracteolis calycem subaequantibus, scariosis, subulatis.

Shuteria Wight et Arnott Prodr. I. 207. Meisuer Gen, 86. (62.) Bentham in Annal, Wiener Mus, II, 126, - ? G I cine involucrata Wallich Plant. As, rar, $t, 241$.

B653. Cralaetia $P$. BROWN. Calyx basi bibracteolatus, campanulatus, quadrifidus, laciniis imbrieatis, acominatis, superiore latiore, infima lateralibus longiore. C or o ll a e papilionaceae v e$x$ ill $\mathbf{n ~ m}$ ovatum $\mathbf{v}$. suborbiculare, apice patens $v$. reflexum, basi utrinque membrana inflexa, interdum minima appendiculatum, a I a e oblongae, ca rin a oblongo-ovata, subineurva, alis longior, petalis dorso connatis, $\mathbf{S} t$ a $\mathrm{m}$ i $\mathrm{n}$ a 10 , filamento vexillari libero, incurvo, basi nec incrassate nec geniculato diadelpha, omnia fertilia. O v a ri um subsessile, pluriovnlatum. StyIns filiformis, inenrvus, glaber, hand incrassatus; stigma parvum. Legumen lineare, compressum, subree- tum, coriaceum, polyspermum, isthmis cellulosis inter semina transversim pluriloculare. S e mina orbieularia v. subreniformia, estrophiolata. - Herbae $v$. suffrutices, volubiles aut prostrati, in regio. nibus tropicis subtropicisque totius or $b i s$ crescentes; foliis trifoliolatis, foliolis stipellatis, oppositis, cum impari distante, interdum abortu unifoliolatis, racemis axillaribus, saepius paucifloris, floribus in fasciculos dispositis, rhachi persistente, subnodiformi, bracteis deciduis, bracteolis parvis, subadpressis, corollis purpurascentibus, caeruleis $v$. albis, saepe cum staminibus abortientibus.

Gala ct t a P. Browne Jam. 298, Jacq. Io. rar. t. 572. 573. Michaux Flor. Bor. Amer. II. 261. Kunth in Humb, et Bonpl. Nov, gen. et sp. V1. 428. DC. Prodr, II. 237. Wight et Arnott Prodr. I, 206. Meisner Gen. 86. (62.) Bentbam in Annal. Wiener Mus, II. 126. Torrey et A. Gray Flor. of North Amer. 1. 287. B r a d u u r y a Rafin, Ludov, 104. S weetia DC. Prodr. II. 381 . O donia Bertoloni Lucubr. 1822. p. 35. DC. Prodr. II. 239. G ron a Loureiro Flor. coohineh, 56t. DC. Prodr. II. 239.

6654. Kiesera REINW. Caly x campanulatus, basi gibbus, quinquedentatus, dentibus inaequalibas, infimo longiore. Corollae vexill $\mathbf{~ m}$ orbiculatum. Sta mina diadelpha. Stylus sursum planinsculus, introrsum villosus, L egum en lineare, compressum, apice adunco, polyspermum. S em in a orbiculata, compressa. - Frutex javanicus, sericeo-tomentosus; foliis pinnatis, racemis terminalibus, floribus magnis, Robiniae Pseudacaciae, albis, vexillo discolore.

$\mathrm{K}$ ieser a Reinwardt in Sylloge plant. $I I .11$.

BB55. Villnaminia DC. Calyx ebracteolatus, eylindraceus, obtuse quadridentatus, subbilabiatus. Corolla e papilionaceae vexillum oblongum, a la e carina breviores. St a m in a 10, filamento vexillari libero diadelpha. Ovarium ..... Stylus subulatus, glaber; stig ma acutum. Leg amen stipitatum, lanceolatum, basi attennatum, compressum, apice filiformi terminatum. Semina 12-16. - Frutex caribaeus; foliis imparipinnatis, quinque-sexjugis, stipulis e basi latiuscula longe subulatis, recurvis, racemis axillaribus, folio brevioribus, floribus purpureis.

Vilmorinla DC. Prodr. II. 239. Meisner Gen, 87. (63.)

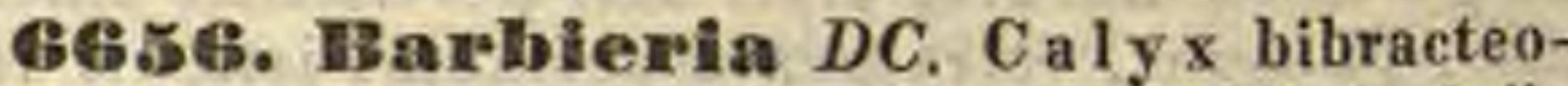
latus, longe tubulosus, limbi quinquefidi laciniis acuminatis, aequalibus. Corolla e papilionaceae petala elongato-oblonga, longissime unguieulata; vexillu m incumbens, a la e carina vexillo aequilonga breviores. Stam ina 10 , filamento vexillari libero diadelpha, inaequilonga. Ovari $\mathbf{m}$ sessile, lineare, villosum, multiovulatum. Sty lns filiformis, postice longitudinaliter barbatus; stigma obtusum. Legr men .....-Frutex Am ericae tropicae; foliis imparipinnatis, foliolis multijugis, stipellatis, racemis axillaribus, folio brevioribus, paucifloris, floribus coccineo-purpureis, stipulis et bracteis acuminatis.

B a r bieria DC. Mem, Legum, IV. 261. t. 39. Prodr. II. 239. Meisuer Gen. 87. (63.)

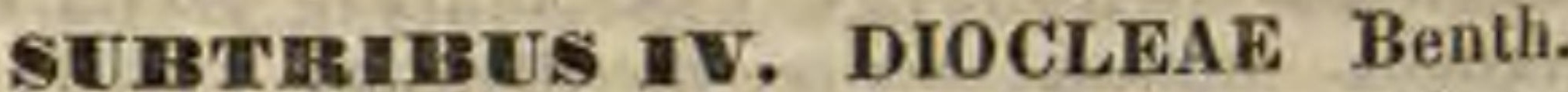
in Annal. Wiener Mus. II. 118. Ovarium plnriovulatum. Vexillum saepius biappendiculatum. Stam en vexillare ima basi liberum, dein saepissime cum reliquis connatum. Stylus hand induratus. - Inflorescentia nodosoracemosa. 
665\%. Collaea $D C$. Calyx campanulatus, quadrifidus, laciniis imbricatis, acuminatis, parum inaequalibus, superiore latiore, infima lateralibus longiore. Corolla e papilionaceae ve$\mathrm{x} i l l \mathrm{um}$ oblongo-ovatum $v$. suborbiculare, apice reflexum v. patens, basi angustatum, utrinque membrana inflexa auctum, ecallosum, a la e oblongae, carina oblongo-ovata, incurva, falcata v. rarius reeta, alas superans, vexillo brevior, petalis dorso connatis. S ta min a 10 , monadelpha, filamento vexillari ima basi et apice libero, medio cum reliquis connato. Dis.cus breviter vaginifer. Ovari um subsessile, pluri-saepe multiovulatum. Stylns filiformis, incurvus, glaber; stigma terminale, parvum. Legumen sessile, lineare, compressum, rectum vel subfalcatum, valvis coriaceis, isthmis cellulosis inter semina transversim multiloculare. Se min a orbicularia v. subreniformia, estrophiolata, - Herbae, suffrutices v. frutices, volubiles $v$. suberecti, rigidi, omnes in America tropica crescentes; folits trifoliolatis, foliolis oppositis, cum impari distante v. unifoliolatis, stipulis saepius deciduis, stipellis subulatis, rigidis, pedunculis axillaribus, supra medium $v$. apice floriferis, floribus in fasciculos paucifloros dispositis, rhachi fasciculorum persistente, nodiformi, bracteis deciduis, bracteolis parvis, subadpressis, alabastris acuminatis, calycibus saepe villosis, profunde fissis, corollis rubris, violaceis v. caerulescentibus.

Collae a DC. Mem. Legum. VI. t. 40. exel, reliq. Prodr, II. 260. Meisner Gen. 87. (63.) Bentham in Annal. Wiener Mus, II, 128. G a l a c ti a e s p. Auet. Bot. Mag. t. 269.

Bваร. BBionia MART. C a lyx tubulosns, apice quadrifidus, laciniis imbricatis, acuminatis, suprema latiore, infima lateralibus longiore. Corolla e papilionaceae vexillum obtongum, rectum, basi angustatum, membrana inflexa utrinque appendiculatum, ecallosum, a l a e oblongae, subrectae, carinae breviter adhaerentes, ca rin a oblonga, subrecta, alas aequans v. panllo superans, vexillo subbrevior, petalis dorso connatis. Stamin a 10 , monadelpha, filamento vexillari ima basi breviter libero. Diseus vaginifer. Ovarinm stipitatum, pluriovulatum. S t y 1 u s linearis, vix incurvus, glaher; stigma terminale, parvam. L e g umen stipitatum, lineare, compressum, coriaceum, polyspermum, isthmis celinlosis inter semina transversim pluriloculare. S e min a subreniformia, compressa, estrophiolata, - Suffrutices $v$, frutices brasilienses, suberectiv. volubi. les; foliis trifoliolatis, foliolis oppositis cum impari distante, coriaceis, interdum unifoliolatis, stipellis subulatis, rigidis, stipulis deciduis, pedunculis axillaribus, supra medium $v$, apice floriferis, floribus in fasciculos paucifloros dispositis, fasciculorum rha. chi persistente, nodiformi, bracteis deciduis, bracteolis parvis, saepe caducis, calycibus coloratis, glabris, corollis speciosis, coccineis.

B Io ni a Martius msc, ex Bentham, in Annal. Wiener Mus. II. 130 .

6659. Camptosema HOOK, et ARN. Calyx campanulatus, subaequaliter quadrifidns, laciniis ovatis, acuminatis, suprema latiore. Corolla e papilinaceae petala subaequalia, vexillum ovato-oblongum, basi utrinque appendicula. tum, a l a e anguste oblongae, basi inferne calloso dentatae, e a rin a e petala elliptico-oblonga, dorso apice connata. Stamina 10 , filamento vexillari libero diadelpha. Ovari u m longe stipitatum, lineare, octo-decemovulatum, Sty lus subulatus, glaber, ovario longior; stigma parvum, obtusum. L e g um en lineari-oblongum, stipite ealycem aequante, stylo longo acuminatum ...... Frutex bonariensis, volubilis; foliis trifoliolatis, foliolis stipellatis, elliptico-oblongis, apice retusis cum mucronulo, supra viridibus, nitidis, subtus pallidis, racemis axillaribus, folio longioribus, pedicellis calycem minute bibracteolatum vix aequantibus, corolla rubra, calyce triplo longiore.

C a mptos e ma Hooker et Arnott Bot, Miscell, III. 200. Bentham in Annal. Wiener Mus. II. 131.

6860. Cleobulia MART. C a 1 y $\mathrm{x}$ thbuloso-campannlatus, apice breviter quadrifidus, lacinia suprema latissima, trnneata, lateralibus ovatis, intermedia parum longiore, acutiuscula, intas sericeus. Corollae papilionaceae vexil$1 \mathrm{um}$ carina longius, reflexo-patens, basi ecallosum, margine utrinque membrana reflexa appendiculatum, a l a e carina dimidio breviores, stipitatae, angnste semisagittatae, liberae, carin a obovato-falcata, valde incurva, latissime subrostrata, petalis dorso connatis. D iscus brevissime vaginifer. Stamina 10, monadelpha, filamento vexillari ima basi libero, an the ra e nniformes. Ovarium pluriovulatum. Stylus ineurvas, glaber, apice vix incrassatus; stigma magnnm, obliquum, basi minutissime penieillatum. Leg umen.... - Suffrutex brasiliensis, volubilis, pilis brevibus ferrugineis tomentoso-pubescens; foliis pinnatim trifoliolatis, foliolis amplis, crassis, supra pubescentibus, subtus tomentosis $v$, subsericeo-villosis, stipellis minutis, setaceis, stipulis parvis, pedunculo axillari pedali, a medio ad apicem dense multifloro, floribus ad quemvis nodum fasciculatosessilibus, bracteis ovatis et bracteolis oblongis, extus villosis, membranaceis, deciduis, calycibus rufovillosis.

Cl e o b u i a Martíns msc. ex Bentham in Annal. Wiener Hus, IT, 131 .

6861. Cratylia MART. Caly s campanulatus v. tubulosus, quadrifidus, lacinia suprema lata, integra v. emarginata, infima angustiore, sublongiore, intus sericeo-villosus. Cor olla e papilionaceae petala breviter unguiculata, vexill u m alis paulto longins, orbiculatum, basi nudam, exappendiculatum, a l a e obovatae, liberae, basi auriculis subadbaerentibus, carina alis vix brevior $\mathbf{v}$, aequilonga, subincurva, oblonga, obtusa, erostris, petalis dorso connatis. D is c a s subnudus. St a mi n a 10 , monadelpha, filamento vexillari ima basi libero, antherae uniformes. Ova. rin m pluriovulatum. Stylns incurvus, glaber, apice vix incrassatus, truncatus; stig ma terminale. Le g u m e n oblongum, plano-compressum, crassiusculum, suturis vix incrassatis, exalatis. Semin a compressa, umbilico parvo, oblongo. Frutices Americae tropicae, volubiles; foliis pinnatim trifoliolatis, stipellatis, stipulis infra in sertionem haud productis, parvis, racemis axillaribus, floribus secus pedunculum in fasciculos sive spiculas dispositis, bracteis caducis, pedicellis brevibus, bracteolis calyci adpressis, parvis, deciduis, floribus albis $v$, roseo-violaceis, calyce et corolla sericeo-villosis, legumine tomento brevi, denso vestito.

Cratylia Martins mre, ex Bentham in Annal, Wie. ner Mus. II. 131.

BBB:. Dieclea H. B, K. Catyx campanulatus, quadrifidus, laciniis aestivatione imbricatis, superiore latiore, integra v. emarginata, infima angustiore, intus adpresse sericens $v$, rufo 
villosus. Corollae papilionaceae vexillum alis longias, orbiculatum, medio nudam v. breviter bicallosum, margine utrinque membrana inflexa appendiculatum, a la e obovatae $v$. oblongae, liberae, intus auriculis subadhaerentibus, carina alis brevior v. subaequalis, incurva, obtusa v, rostrata, petalis secus longitudinem subplicatis, dorso connatis. Di s c u s breviter vaginifer v. subnudas. Stamina 10 , medio monadelpha, filamento vexillari ima basi libero, a $n t h$ e $r$ a e uniformes. Ovarium subsessile, pluriovulatum. Stylus incurvus, glaber, versus apicem saepe incrassatus, truncatus; stig m a terminale. Le g u m en oblongum, plano-compressum, crassiusculum, coriaceum, sutura vexillari incrassata, saepius anguste bialata. S e min a transversa, compressa, umbilieo lineari strophiola tenui, demum libera. - Frutices Americae tropicae, volubiles; foliis pinnatim trifoliolatis, foliolis oppositis cum impari distante, stipellis minutis, setaceis, stipulis variis, racemis axillaribus, elongatis, floribus in fasciculos $v$. spiculas secus pedunculum crassum dispositis, spicularum sive fasciculorum rhachi brevi, incrassata, persistente, bracteis cito deciduis, pedicellis brevibus, bracteolis calyci adpressis, ovatis $v$. orbiculat is, deciduis $v$, subpersistentibus, floribus caeruleis, violaceis $v$. subalbis, legumine saepissime demum tomentoso $v$, villoso.

Di o cle a Kunth in Humb. et Bonpl. Nov. gen, ot sp. VI. 437. DC. Prodr. II. 403. Meisner Gon, 93. (66.) Bent. bam in Annal, Wiener Mus. IT. 132. H ymenospron Sprengel Gen, pl, n. 2880 .

a. PACHYLOBIUM Benth. $2, c$. C a 1 y els Iabium superius latissimum, obtusissimum, emarginatum. Corolla vexillum prope basim medio leviter bieallosum, margine utrinque membrana appendiculatum. Carina obtus rostrata, alis saepe dimidio brevior. L e g $\mathrm{m}$ e a sutura superiore incrassata (haud alata?) - Stipulae infra insertionem productae.

b. EUDioclea Benth l. c. C al y e is labium superius lanceolatum, integrum. Cor a I l a e vexillum glabrum, medio nudum $\nabla$. leviter bieallosum, margine utrinque membrana appendiculatum, C a r i na obtusa, erostris, alas subaequans v. parum brevior. L $6 \mathrm{~g} \mathrm{u}$ m e n sutura superiore anguste bialata. - Stipulae planae, lanceolatae, infra insertionem haud productae. - Doli chi s p Jacq. Amer, t. 123. Fragm, t, 88. (Humb, et Bonpl. Op.
cit. t. 579 .

B6B3. Camavalia $D C$. Caly $\mathrm{x}$ tubulosus, bilabiatus, labio superiore maximo, truncato v. emarginato-bifido, lobis lato-rotundatis, inferiore parvo, integro v. hifido. Corolla e papilionaceae vexillu m amplum, saborbiculatum, emarginatum v. bifidum, basi angustatum, complicatum, intus bicallosum, margine membrana inflexa ntrinque appendiculatum v, nudum, nngue brevi, a $l$ a $e$ oblongo-lineares, falcatae, basi late anriculatae, a carina subliberae, auriculis inter se cohaerentibus, e arina alis aequilonga v. longior, vexillo brevior, basi ovata v. ovato - oblonga, incurva, apice obtasa v, aeuminato-rostrata, rostro inflexo v. spiraliter torto, petalis dorso connatis, brevissime unguiculatis. Disens vaginifer. Stamina monadelpha, v. rarius filamento vexillari ima bas et supra medium libero subdiadelpha, a $\mathrm{n} t \mathrm{~h}$ e $\mathrm{r}$ a uniformes. Ovarin m snbstipitatum, lineare, plnriovulatum. Stylns incurvas, glaber, apice subdilatato-truncatus; sti $\mathrm{g}$ mate terminali, L e gubmen oblongum v. lineare, compressum, subfalca tum, coriaceum, sutura vexillari subincrassata valvis utrinque prope suturam nervo longitndinal anetis, sutura carinali nuda, isthmis cellulosis in ter semina transversim multiloculare, S e $\mathrm{m}$ i $\mathrm{n}$. ovato-subrotunda, compressa, umbilico lineari, estrophiolato. - Herbae volubiles, in regionibus tropicis subtropicisque totius orbis crescentes; foliis pinnatim trifoliolatis, folialis oppositis cum impari distante, stipellis minutis, setaceis $v$. nullis, stipulis parvis, orbiculatis $v$. verrucaeformibus, racemis axillaribus, elongatis, spicaeformibus, rhachi alternatim ramosa, floribus ad quemvis nodum solitariis $v$. geminis aut ternis fasciculatis, subsessilibus, pendulis, bracteis orbiculatis, calyci adpressis, caducis, calycibus saepe nigro-maculatis, corollis roseis, albis $v$, purpurascentibus.

Canavalia DC. Prodr. 1L. 403. Wight et Arnott Prodr. I. 252. Meisuer Gen. 92, (66.) E. Meyer Comment. pl. Afr. 148. Benthain in Annal. Wiener Mus. II. 34. C an a vali Adanson Fam,II. 326. M a l o c c b i a Savi Dissert. 1824. p. 15, et 1825. p. 1. Dollich i s p. Linn.

a. COCHLITROPIS Bentb. $l$, c. C al y e is labium superius truncatum v. acuminatum. Coroll a e yexillum basi margine exappendiculatum. C a rin a acuminato-rostrata, rostro inflexo v. spiraliter torto. A n the ra e oblongae v. sublineares. L e $\mathrm{g}$ u $\mathrm{m}$ e $\mathrm{n}$ ignotum.

ce. Valic a na. Caly c is labium inferius trifidum.

$\beta$. Licavana. Cal y cis labium inferius integrum.

b. EUCANAVALIA Benth. 2. c. Cal y eis labium superius emarginato-bifidum. Corolla e vexilium margine prope basim membrana inflexa utrinque auctum. Ca $\mathrm{r}$ in a incurva, ohtusa, haud acuminata. A a therae ovalioblongae v, suborbiculares.

$\gamma$. Mo nodon E. Meyer $t$. c. $\mathrm{C}$ a 1 y $\mathrm{c}$ is labium inferius integrum. (Bot. Reg. t. 1199.)

8. Malochia E. Meyer $t$. c. $\mathrm{C}$ a ly $\mathrm{c}$ is labinm inferius trifidum. - N a t t a ma we Banks IC. Íämpf. $t .39$. Cle mente a Cavanill. Anal. cienc, nat. VII. 63. t. 47. Dolichos s p. Linn. Jaeq. Hort. Schönbr. t. 221. Ic, rar, t, s59.

B6B4. Chloryllis E. MEY. Caly x bilabiatus, labio superiore latissimo, rotundato, integro, inferioris trifidi laciniis ovatis. Corolla e papilionaceae vexillu m erectum, oblongum, carina paullo brevias, basi macula lata, appendicibusque brevibus, subcallosis, a la e vexillo breviores, exappendiculatae, c a rin a erecta, dorso leviter incurva, biceps. S $t$ a m in a 10 , leviter incurva, filamento vexillari libero, basi haud articnlato diadelpha. Ovarium lineare, narginibas pubescens, sexovulatum. Stylns basi canalicnlatus, superne attenuatus, teretiuseulus, pilosus; $8 \mathrm{tigma}$ eapitellatum. L e g u m e $\mathbf{n} . . .$. - Herba capensis; caule procumbente, foliis trifoliolatis, foliolis stipellatis, subtrilobato-angulatis, intermedio petiolulato, racemis in ramulis adscendentibus terminalibus, vix pedunculatis, pyramidatis, floribus speciosis, calycibus ebracteolatis, vexillo subcoriaceo, viridi, carina flavo-virente, alis subviolaceis.

Chloryllis E. Meyer Comment.Plant. Afr, 149. Meisner Gen. 98. (66.)

TIEH in Annal. Wiener Mus. II. 113. Vexill um haud appendiculatum. Stamen vexillare liberum. Leg u men indehiscens. Inflorescen-

\section{tia nodoso-racemosa.}

6865. Minemina $A D A N S$. C aly $\mathrm{x}$ eampanulatus, bilabiatus, labio superiore lato, integro v. emarginato, inferioris trifidi lobo medio longiore. Corollae papilionaceae vexillum cordatum, ecallosum, alis et carinae brevibus incumbens, a la e oblongo-lineares, conniventes, basi auriculis inter se cohaerentibus, carin a basi recta apice subfaleata, in rostrum aentum desinens. Stamina 10 , alterna longiora, filamento vexil- 
lari libero diadelpha, ant herae alternae oblongae, alternae ovatae. Ovarium sessile, pluriovulatum. Stylus longus, tenuis, inferne pilosus, apice glaber; stigma minutum. Leg a men indehiscens v. tandem bivalve, lineare, oblongum v. ovatum, mono-oligospermum, inter semina torosum, extus saepissime pilis prurientibus hirtum, intus isthmis cellulosis inter semina transversim plurilocalare. S e mi na rotunda, umbilico lineari zonata. - Suffrutices $v$. frutices longe scandentes; foliis pinnatim trifoliolatis, foliolis stipellatis, oppositis cum terminali remoto, racemis axillaribus, elongatis $v$. brevibus, umbelliformibus, fructiferis saepe pendulis, leguminum pilis saepe fragillimis cutem penetrantibus.

Mucuna Adanson Fam. II. 325. Jussien in Annal. IIus, XI. 76. DC, Prodr. II. 404. Wight et Arnott Prodr. $I$. 253. Meisner Gen. 93, (66.) Z o o ph th a $1 \mathrm{mum}$ et $\mathrm{St} \mathrm{i}$ o olo. b i tu P. Browue Jam. 290. ᄂ. 31 H or nera Neeker Elem, $n$. 1360. Stizolobium Persoon Eneneir. II. 259. Neg retia Ruiz et Pavon Prodr. 86, $t, 21$. Kunth in Humb. et Bonpl. Nov. gen. et sp. VI. 4d3. Citt a Loureiro Flor. cochinch. 557. L a b r a di a Swediauer Mat. Med. $n, 394$. C a r p o po. g o n Roxbargh Flor, ind. $1 T$. 283. M a c r o cer a tid es Raddi Quarant. piant. 13.

a. zoophthalmum R. Brown. t. o. Legumen oblongum suleis tranxversis lamellosum, suturis esulcatis. - Species americanae. (Dolichos urens Liun. Jacq. Amer. t. 182, f. 48.)

b. STIZOLOBIUM P. Browa l, e. L e g u men sulcis trans. versis nullis, suturis esulcatis. - Species americanae ot asiaticae. (Wight in Hook. Bot. Misc. Suppl, t. 13. Bot. Reg. 1838. $t$. 18.)

c. PILLBRA Eadi. L e g u m e oblongnm, sulcis transversis nullis, suturis profunde bisuleatis. - Species asiaticae. - Pillera Eudlicher Flor. Norf. 91. in not. Meisner Gen, 92. (66.) (Wallich Plant. As. rar. $t$. 47 . Wight in Hook. Misc, suppl. t. 14.)

d. CITTA Lour. $t$, $c$. L e gu m e n subrotundum v. oblongum, mono-trispermum, suleis transversis obliquis lamellosum, suturis profunde bisulcatis. (Wight in Hook. Bot, ALisc. suppl, $t, 12$. Illustr. $t, 34.35$.

BEBB. W' enderothia $S C H L E C H T$. C aI yx bilabiatus, labio superiore maximo, rotundato, leviter emarginato, inferioris minutissimi, tridentati dente medio latiore. Corolla e papilionaceae vexillum unguiculatum, complicatum, late ellipticam, dorso sursum curvatum, ecallosum, a lae angustae, carina angusta, apice fere uncinatim curva, bipes. Stamina 10 , filamento vexillari breviori basi et apice libero monadelpha. D is cus urceolaris, membranacens, oblique truncatus. Ova ri um lineare. Sty lug glaber, apice incarvo stigmatifer. Leg um en....$-H_{e r b a}$ mexicana, volubilis; foliis pinnatim trifoliolatis estipellatis, stipulatis, racemis axillaribus breviter pedunculatis, multifloris, pedicellis geminis, calycibus bibracteolatis, corollis violaceis.

We nderothia Schlechtend, in Linnaea XII, 330.

6B68, Erytlatina LINN. C aly $x$ tubulosus, truneatus ant bilabiatas, v. hinc fissus, spathacens. Corollae papilionaceae vexillum obovato-oblongum, exappendiculatum, ecallosum; incumbens, a las et caria a m dipetalam longissime superans. St a mina 10 , recta, vexillnm aequantia, nune diadelpha, nunc filamento vexillari reliquis adbaereute, aut interdum abortivo, magis minusve monadelpha, a $\mathbf{n}$ h e $\mathrm{r}$ a e conformes. Ovarium stipitatum, pluriovulatum. St y $\mathbf{1}$ us glaber, rectus, apice breviter incurvus, subtus stigmatosus. L e g u m e n indehiscens, longum, inter semina compressum, torulosum, stylo indurato rostratum. Semina ovalia, distantia, umbilico lineari. - Arbusculae v. frutices, rarius trunco subterraneo ramis annuis subherbaceae, in regionibus tropicis subtropicisque totius orbis crescentes; caule foliolisque interdum aculeatis, foliis pinnatim trifoliatis, foliolo terminali a reliquis remoto, stipellarum loco glandulis stipitatis, stipulis parvis a petiolo distinctis, racemis elongatis, pedicellis saepe ternatim approximatis, floribus saepe rubicundo-coccineis, speciosis, seminibus saepissime rubro et nigro variegatis, nitidis.

Rrythrina Linn. Gen. n. 855. Lam. Itl, t.608, DC. Prodr. II. 410. Wight et Arnott Prodr. I. 260, Meisu. Gen. 93. (66.) Torrey et A. Gray Flor. of North Amer. I. 281. Corallodend ron Tournef. Inst. 446. Mou rieo a Adanson Fam, II, 318. X y p ha n th us Rafinesq. Flor. Ludov, 103. a. XIPHANTHUS Raf. 1. o. Acaules, racemis floriferis ramisque foliosis anauis e traneo sulterraneo ortis. (Trew Ehret. $t$. 58. Bot. Mag. t. 877 . Roxburgh Plant, Corom, t. 220.)

b. CORALlODENDRON Tournef, l. c. Canlescentes, caulibus saepissime fruticosis, racemos et folla gerentibus.Gelal a Rumph Amboin. IT. 78. (Trew Ehret, $t .8$. Jacq. Observ. III. t, 51. Hort. Schönbr, t. 216, 466. Bertero in Linn, Transact. XIV. t. 12. Roxb. Plant, Corom. t. 219. Andrews Bot. Bep. t. 443, Bot. Mag. t. 877. 2431. 3234. Bot. Reg. $t$. 389. 736. 750, 1246. 1327, 1617.)

6688. Stromgyloblon VOG. C a 1 y x quadrilobus, lobis rotundatis, superiore majore emarginato. Corolla e papilionaceae petala stipitata, vexillum ovato-oblongum, acutum, reflexum, basi bicallosum, a la e subrhombeae, ve. xillo et carina subfalcata, acuminata, cui adpres. sae multo minores. St a $m$ in a 10, diadelpha, $O v$ a. rium longissime stipitatum, uniovulatum. ..... - Frutex sandwicensis; foliis trifoliolutis.

Strongylodon Vogel in Linnaea $X$, 583. Meisner Gen. 93. (66.)

66B9. FEudolpinia WILLD. Calyx tabulosus, quadrifidus, bilabiatus, labio superiore majore obtuso, inferiore acuto, duobus lateralibus brevissimis. Corollae papilionaceae vexillum oblongo-lineare, rectum, a la 8 et $\mathrm{carin}$ a $\mathrm{m}$ angustissimas, calyce breviores longesuperans $\mathbf{S} t$ a nin a 10, flamento vexillari libero diadelpha, a $n t$ he $r$ a $e$ conformes. Orarin m sessile, pluriovulatem. S t yIns subulatus, glaber; stigma obtnsum. Legum e n oblangum, compresso-planum, indehiscens, stylo indurato rostratum. S e in in a plana. - Fru. tices antiltani et mexicani scandentes; foliis unifoliolatis, foliolo oblongo $v$. cordato, basi bistipellato, racemis axillaribus, multifloris, floribus coccineis $v$, roseis, magnis.

$\mathrm{B} \mathrm{u}$ d ol p hi a Willdenow in Neuen Berl. Sokrift. III. 451. Spec. III. 918. Vahl Eclog. IIT, $t$. 30. Tussuc Flor, Antill. t. 22. DC. Prodr. IT. 414. Meiseer Gen, 93. (66.) Ery. thrin ae sp. Linn. Plunier Ic, $t, 102 . f$. 1.

66r (D. Ierter KÜNIG. Cal y x eampanulatus, bilabiatus, labio superiore subintegerrimo, inferiore trifide. Co rolla $\mathrm{e}$ papilionaceae petala subaequalia, vexillum ovatum, recurvum, ala e et earina ineurvae. Stamina 10 , filamento vexillari libero diadelpha, a $\mathbf{n} \mathbf{t} \mathbf{h}$ e $\mathbf{r}$ e conformes. Ovarium substipitatum, biovulatum. Sty Ius subulatus, adscendens; stig ma terminale, snbcapitatum. Le g $\mathbf{n m}$ en indehiscens, stipitatum, plano-compressum, tenne membranaceum, apice monospermum. Semen compressum. - Arbores inermes, $v$, frutices scandentes, in Asia trapica indigeni; foliis pinnatim trifoliolatis, foliolis stipellatis, subrotundo-ovatis, subtus pubescentibus $v$. tomentosis, racemis multifloris, pedicellis ternatim fasciculatis, calyeibus basi minute bibracteolatis. 
B u te a König ex, Roxburgh Plant. Corom. I. 22. t.21. 29. Flor. Ind, III, 244. DC. Prodr, II, 414. Wight in Hook. Bot. Misc. suppl. t. 32. Wight et Arnott Prodr. I. 216. Nees jun. Plant, offic. suppl. I. $t$. 10. Meisner Gen. 59. (68.) P I a s o Rheede Malab, VI, 29, t, 16.17. Adanson Fam, II, 325.

SUBTHEIBUS VII. WISTERIEAE. 0 v arium pluriovulatum. Folia bi-multijuga cum impari.

GE' 1. Wisteria NUTT. Calyx bibracteolatus, campanulato-bilabiatus, labii superioris dentibus duobus approximatis, inferioris lobo intermedio productiore. Corollae papilionaceae ve $x$ illum subrotundum v, obovatum, basi callis duobus in unguem decurrentibus, a la e carinae falcatae, rectae conformes et aequilongae $\mathbf{v}$. breviores. St a min a 10 , filamento vexillari libero diadelpha. Discus vaginifer. Ovariu m stipitatum, multiovulatum. St y lus filiformis; stigma capitatum. Leg a men lineari-oblongum, coriaceum v. sublignosum, seminibus torosum, bivalve, polyspermum. Sem in a reniformia. - Frutices scandentes, in Americaboreali, Japonia et imperii sinensis ditionibus septemtrionalibus obvii; foliis imparipinnatis, tri-multijugis, stipulis minimis, deciduis, stipellis nullis, racemis axillaribus et terminalibus multifloris, floribus caeruleo-lilacinis, decidue bracteatis.

Wisteria Nuttall Gen. II, 115. DC. Prodr. II. 389. Sweet Fl. Gard, $t$. 104. Meisner Gen. 92. (66.) Torrey et A. Gray Flor, of North-Amer. I. 283. Siebold et Zuecarini Flor. japon, $t$. $43-45$. Th y $\mathrm{r} s \mathrm{a}$ th $\mathrm{a} \mathrm{s}$ Blliott in Journ. Academ, Philadelph,I.371. K ra u n hi a Rafinesque in New. York medic. Reposit. II. Hes. $V .350$. G I y cines s p. Linn. Bot. Mag. t. 2083, 2103. Bot. Reg. $t$. 650.

\$6 2. Cyptotropis WALL. Calyx bibracteolatas, labio superiore integro, obtusiuscnIo, inferioris trifidi lobo medio productiore. Co rollac papilionaceae vexillum oblongum, emarginatum, basi bicallosum, reflexum, a la è cuneiformes, abbreviatae, divaricatae, c a ri n a lineari falciformi adscendente, dipetala multo breviores. St a m in a 10 , filamento vexillari libero diadelpha. Discus annularis. Ovari um sessile, multiovulatum. Sty Ius filiformis, spiralis, glaber; stigma subcapitatum. Le g um e n lineari-compressum, polyspermum, bivalve, endocarpio subspongioso, isthmis transversis pluriloculari, secedente. Se mina oblonga, compressiuscula. - Herba ne. palensis, volubilis; radice perenni, foliis imparipinnatis, bijugis, stipulis parvis, lanceolatis, deciduis, floribus laxe racemosis, roseis.

Cyrt otropis Wallich Plant, As. rar. I, 49, t. 68. Meisner Gen. 92. (66.)

6Br3. Aplos BOERH. Cal yx bibracteolatus, carpanulatus, subbilabiatus, dentibus duobus superioribus brevibus, rotundatis, lateralibas fere obsoletis, infimo longiore lanceolato-subulato. Corollae papilionaceae vexill am latum, medio plica longitudinali, reflexum, carina longa, falcata, demum cum staminibus et stylo spiraliter torto. Sta min a 10, filamento vexillari libero diadelpha. Disens vaginifer. O vari um stipitatum, multiovulatum. Stylus filiformis; stig m a emarginatum. L e g n m e n teretiusenlnm, subfalcatum, polyspermum. Se min a reniformia. - Herba $b o-$ rea $l i$-americana scandens, glabra, radiculis tubercula edulia gerentibus, folits imparipinnatis, bijugis, stipulis parvis, stipellis nullis, racemis axillaribus, saepius compositis, pedicellis brevibus, ternis quaternisque e tuberculis rhacheos nascentibus, flo- ribus fusco-purpurcis, odoratis, bracteolis caducissimis.

A ptos Boerhave Lugd. Batav. 11. 53. Mönch Method. 165. Nuttall Gen, II. 113. DC. Prodr. II, 390. Meisner Gen. 92. (E6.) Torrey et A. Gray Flor. of North-Amer. 1. 282. Gl y e ine Api os Linn. Bot. Mag. $t$, 1198.

TEIIBUS VII. EUPHASEOLEAE Bentham in Annal. Wiener Mus. II. 136. $0 \mathrm{va-}$ ri u m pluriovulatum. Vexillum biappendiculatum. Stamen vexillare supra basim saepissime geniculatum, liberum v. rarius medio cum reliquis connexum. Ovarium pluriovulatum. Stylus supra medium induratus. - Inflores. centia nodoso-racemosa.

BEr4. Thaseolus $L I N N$, C al y $\mathrm{x}$ campanulatus v. subtubulosus, apice quadrifidus, v. lacinia suprema bifida quinquefidus. Corollae papilionaceae vexillum orbiculatum, recurvopatens v. subtortum, basi angustatum, margine utroque subauriculatum, membrana inflexa auctum, medio nudum, vel longitudinaliter bicallosum, callis saepe confluentibus, a la e obovatae v. oblongae, supra unguem carinae adhaerentes, apice supra eandem conniventes, $\mathrm{c}$ arina vexillum aequans v. superans, obovata, apice aeuminato-rostrata, rostro spiraliter torto. St a m i na 10 , filamento vexillari libero, supra basim geniculato et saepe appendiculato diadelpha. D iscus vaginifer. Ovarium subsessile, pluriovulatum. Stylus cum carina tortas, basi subulatus, supra medium cartilagineus, subdilatatus, infra stigma subtus barbatus; stigma crassiusculum, basi ciliatum, plus minns obliquum. Leg $\mathbf{n} \mathbf{m}$ en lineare v. faleatum, plus minus compressum v, teretinsculum. Semin u m umbilicus parvus, oblongus, nudus v. strophiola tenui, membranacea auctus. - Frutices $v$. herbae volubiles, prostratae $v$. suberectae, in regionibus tropicis subtropicisque to. tius orbis, imprimis tamen Americae crescentes, passim cultae; foliis pinnatim trifoliolatis, foliolis oppositis, cum impari distante, rarius unifoliolatis, stipellis oblongis, vvatis $v$. subulatis, stipulis persistentibus, lineato-plurinerviis, saepe basi breviter infra insertionem productis, pedunculis axillaribus, supra medium floriferis, floribus in fasciculos paucifloros dispositis, fasciculorum rhachi persistente, nodiformi, bracteis stipulis subconformibus, saepissime ante anthesim deciduis, bracteolis oblongis, ovatis $v$. orbiculatis, lineatis, saepe caducis, calycibus intus glabris, corollis glabris, albis, flavescentibus, rubris v. purpureis.

P h a seolus Linn. Gen. n. 866. Savi Dissert. de Phaseol. 1824. 8. DC. Prodr. IT, 390. Meisner Gen, 94. (67.) Wight et Arnott Prodr. I. 243. Bentham in Annal. Wiener Mus. II. 136. Torrey et A. Gray Flora of North-Amer. IT. 278.

a. DREPANOSPRON Benth, $l, c$, Cal y $\mathrm{c}$ is campanulat lacinia suprema latissima, truncata y. emarginata, inferioris laciniae latae, tubo multo breviores. Corolla e vexillum supra ealycem recurvum, medio longitudinaliter subeallosum. L e $\mathrm{g} \mathrm{m}$ e n latínseulum, compressum, falcatum. - Stipulae infra insertionem haud productae. Stipellae ovatae, obovatae v. oblongae. (Jaeg. Hort, Vindob. $t, 66$.)

b. EUPHASEOLUS Benth. $l$. c. C aly e is campanulati la. cinia suprema latissima, integra v. emareinato-bifids, inferioris laciniae latae, tabo multo breviores. Corol1 a e vexillum supra ealyeem recurvam, ecallosum. L e. g u me n lineare, rectum, compressum. - Stipulae in. 
fra insertionem haud productae, Stipellae ovatae, ob. ovatae $v$, oblongae.

c. Cв в а с а 11 a e. Cal y x lacinia suprema bifida subaequaliter quinquefidas. - Caulis volubilis. (Andrews Bot. Reposit, t. 341.)

P. Bracluy podil. Caly cis lacinia suprema truncata, integra v. vix emargimata. - Caulis herbaceus, volubilis, v. suffruticosus, erectus. (Savi Mem. III. t. 10. Wallich Plant, As. rar. t. 6, 63.)

c. LEPTOSPRON Benth. l. c. C a I y e is eaupanulati laeinia suprema latissima, integra v, emarginata, inferiores angustae, tabum aequautes v. superautes. Corollae vexilium supra calycem recurvum, nudum. Le g a me n lineare, subrectum, compressum. - Stipulae infra insertionem haud productae. Stipellae ovatas, obovatae v. oblongae.

d. STROPHOSTYLES Ell. Caly c is campanulati lacinia suprema Integra v. breviter bifida, inferioris laciaia infima acuta tubo aequilonga v. lougior. Corollat vexillum supra calycem recurvum, ecallosum, alas subae. quans. Le gu m в lineare, subreetum, subteres, saepius pendulum. - Stipulae infra insertionem adnatov. appendiculato-productae. Seminum umbilicus oblon. gus v. oblongo-linearis, estrophiolatus, $-\mathrm{Str}$ opho. styles Elliott Carolin. II. 229. Phasiolns et Pha. s ell us Móneh Method. 240. (Jacq. Observ. III. t. 52.)

e. LASiosproN Bentl. l. o. C a I y $\mathrm{x}$ campanulatus, quinquefidus v. quadrifidus, lacinia suprema emarginata. Corollae vexillua supra calyeem reeurvam, alas sub. aequans. Leg um en laeve, subrectum, subteres, pendulun. U mb hlie us oblongus, strophiola membranacea. - Species brasilienses.

f. MICROCOCHLE Benth, $l$, c. $\mathrm{C}$ a I y $\mathrm{x}$ anguste campanulatus, subaequaliter quínquefidus $\mathrm{v}$. laciniis superiori. bus latioribus. Corolla e vexillum supra calycem re. eurvum, alas subaequans, Carinate rostrum minns quam in reliquis coutortum. L e $\mathrm{g} \mathrm{m}$ e $\mathrm{n}$ liaeare, rectum (compressum?) - Stipulae infra insertionem haud productae. Flores parvi, longe pedunculati. Species mexicanae.

g. MACROPTILIUM Benth. l. c, Cal y x subtubulosus, apice quinquefidus, laciniis superioribas brevioribus, latioribus, omuibus plerumque acutis. Coroll a e petala longe uaguiculata, saepe omaia recta, vexillum apice recurvam, alae multo longiores, latae, intense colora. tae, supra carinam conuiventes. L e $g$ u u e u lineare, subteres. Phas eilli s p. Mónch.

BEF5. Vigma $S A V I$. C a ly x campanulatus, apice quadrifidus, lobo supremo obtuso, integro v. bifido, infimo saepe paullo longiore. Corollae papilionaceae vexill $\mathbf{n}$ m latam, reflexum, basi callo semilunari $v$. falcato et appendicibus duabus, deorsum subgibbosis, a $I$ a e subrhomboideae, hinc hamatae, carin a haud torta, angulo rectiusculo inflexa, subrostrata. S t a m i n a 10, filamento vexillari libero, basi geniculato, hand appendicnlato diadelpha. D i s c u s vaginifer, O va ri u m substipitatum, pluriovnlatum. Sty 1 u 8 canaliculatus; s t ig ma infra apicem laterale, oblongum, ciliatobarbatum. L e gum en teres v. compressiusculum, rectum v. subfalcatum, subtorulosum, isthmis celInlosis inter semina transversim pluriloculare. $\mathrm{Se}$ m in a oblongo-subreniformia, strophiola parva. Herbae suffruticosae, volubiles, in Asia et $A$ me rica tropica, nec non in Capite bonae spei crescentes; foliis pinnatim trifoliolatis, fluribus racemosis, plurimis, $v$. paucis in apice pedunculi crassi sessilibus, calycibus decidue bibracteolatis.

Vig n a Savi Dissert, 1824. p. 16. DC. Prodr. II. 401. Meisner Gen, 93. (66,) Callic y s th a s Endlicher Prodr Flor. Norf. 90. S e ytalis E. Meyer Comment, plant, Afr. austr. 144. Doli chi sect. Unguicularia et Catjang DC. Prodr. II. 400 et 398 .

a. EUVIGNA. Caly cis quadrifidt lacinia suprema integra, obtusa v. acuta. - Flores suboapitati, Ravi. - Vigua Savi $t$. c. Dolichos luteolus Jacq. Hort, Kindob. I. t. 90 . b. CALlycisthus Endi, l. c. Caly e is quadrifidi lacinia suprema integra, obtusissima. - Flores racemosi, albo-rosei.

c. CATJANG DC. l. c. Caly eis quinquefidi laciniae sapremae paullo altius inter se conlitac. $L$ e $g$ u m e n teres, subulato-acuminatum. - ?0toptera DC. Prodr. II. 2 \&O.

d. UNGUICULARIA DC. l. o. C al y cis quinquetidi laciniae suprearae paullo altius inter se conlitae. $L$ e $\mathrm{g} \mathrm{m}$ e teres, in rostrum callosum, subtus concavnm desineas. - Doll chi s p. Jaeq, Hort. Vindob. I. t. 23, HI, $t, 70$.

BBF f. Dolielaos LINN. C a y y campanulatus, limbo bilabiatim quinquefido, laciniis brevibus, latis, duabus supremis plus minus coalitis. Corolla papilionaceae vexillum basi callo semilunari v. falcato anctum, a 1 a e inferne hine: hamatae, carina haud torta, incarva, subros. trata. Stamina 10, filamento vexillari libero, basi calcarato diadelpha. Di seu s vaginifer. 0 vari u m substipitatum, pluriovulatum. Stylus teres v. canaliculatus, superne sensim attenuatus; st igm a terminale, capitatum, hispidulum. L e $g$ u m e n compressum, lineare, falcatum v. rectiusculum, di-polyspermum, inter semina isthmis cellulosis interceptam. S e m in a compressinscula, ovatosubreniformia, strophiola tenui. - Herbae inter tropicos totius orbis crescentes, volubiles $v$. procumbentes; foliis pinnatim trifoliolatis $v$. interdum quinquefoliolatis, stipellatis, impari a reliquis remoto, floribus racemosis $v$. interdum solitariis, bibracteolatis.

Dolichos Linn. Gen, n. 867. Smith Spiciteg. $t, 21$. Bot. Mrag. $t$. 382. Savi Dissert, 1824, p. 15. E. Meyer Com. ment. plant, Afric, 140. Meisner Gen, 94. (67.) Bentham in Annal. Wiener Mus. Ir. 113. Dolichi sect, Radolie hos DC, Prodr. II. 396. Doli chi seet. Eudoli $\mathrm{chos}$ et Macratylama Wight et Arn. 248, 249.

66\% \%. Lablab $A D A N S$. C a ly x campanalato-tubulosus, quadrifidus, lacinia suprema lata, obtusa, tribus inferioribus acutis. Corolla papilionaceae vexillum patens, basi canalienlatum, callis quatuor, duobus superioribus prominentibus, al ae liberae, $c$ a rin a falsata, ad angulum rectum incurva, haud torta. S $t$ a $m$ in a 10 , filamento vexillari inter petali callos recepto, a reliquis libero, diadelpha. Dise us vaginifer. Ovarium stipitatum, pluriavalatum. Stylus compressus, parte superiore subtus barbatus; stigma terminale, truncatum, glabrum. Le g и m en compressum, planum, acinaciforme, juxta ntramque sutnram tulerculato-muricatum, subtetraspermum, isthmis cellulosis inter semina interceptum. Semina ovata, subcompressa, callo fungoso, semicirculari marginata. - Herbae indicae, volubiles; foliis pinnatim trifolislatis, foliolis stipellatis, integris, stipulis patentibus, racemis pedunculatis, basi monophyllis, pedicellis semiverticillatis, calycibus bibracteolatis, seminibus nigris vel fuscis, callo albo.

L a bla b Adanson Fam. 11. 325. Mönch Mothod, 153. Savt Dissert. 182t, p. 15. f. 8, 9. DC. Prodr. II. 401. Wight in Hook. Bot, Miso. Suppl. t. 15. Wight et Arnott Prodr. I. 250. Meisner Gen. 93. (66.) Dolfich os Gärtner 1K. 322. t. 150. Dolich i s p. Linn. Smith Exot, Bot, t. 74. Jacq. Eragm, t. 85. Hort, Vindob, t. 124. Bot. Reg. t. 830.

68\%8. Sphemostylis $E, M E Y$. C a I y x campanolatus, limbo brevi, quinquefido, laciniis quatuor subaequalibus latissimis, rotundatis, quinta paullo longiore, ovata. Corollae papilionaceae vexill um latum, reflexum, basi callo semilunari, appendicibusque deorsum gibbis, a la e 168 
hine hamatae, c arin a hand torta, inflexa, subrostrata. Stam in a 10 , flamento vexillari libero, basi geniculato, haud appendiculato diadelpha. Discus vaginifer. Ova ri u m pluriovulatum. Stylus inferne canaliculatus, superne complanatus et caneiformi-dilatatus, glaber; stigma cristatum, hispidulum. L e g $\mathrm{n} m$ en rectiusculum, compressum, lineare, utrinque angustatum, coriacenm, polyspermum, isthmis fungosis interceptum. S ein in a oblonga, compressiuscula, subquadrata, transversa, linea alba per ventrem excurrente nutata. - Herba capensis, volubilis, basi suffruticosa; foliis trifoliolatis, foliolo intermedio petiolulato, omnibus stipellatis, ovato-oblongis, submarginatis, puberulis, racemis longissime pedunculatis, striatis, paucifloris.

Sphenostylis E. Meyer Comment. plant. Afr. 148. Meisuer Gen. 94. (67.)

66\%5. Paelayrrinizans RICH. Calyx nrceolatus, quadrilobus, lobo superiore lato, emarginato. Corollae papilionaceae vexillnm suborbiculatum, patens, ecallosum, basi biplicatum, plicis alarum ungues involvens, a la e semilunatae, appendice filiformi, e a $r$ in a ineurya, hand torta. S tamin a 10 , filamento vexillari libero diadelpha, alterna breviora, vagina basi tumida, hians. D isc us annularis, crenatus. Ovarium multiovulatum. Styli pars superior glabra, spiraliter torta; stigma magnnm. L e gum en lineare, compressum, rectum, polyspermum, isthmis inter semina interceptum. Se m i n a orbicularia, compressa, umbilieo angustato. - Herbae Asiae tropicae; radice tuberosa, eduli, caule volubili, suffrutescente, foliis pinnalim trifoliolatis, foliolis stipellatis, racemis axillaribus, interdum elongatis, floribus supra rhaches partiales, nodiformes fasciculatis, violacco-caeruleis, calycibus basi decidue bibracteolatis.

Pachy rihizus Richard mse. ex DC. Prodr. II 402. Wight et Arnoit Prodr. Y, 251. Meisner Gen. 93. (66.) Cacara Thouars in Dict. so. nat. $V$. 35 . Dolichos bulbos us Lian.

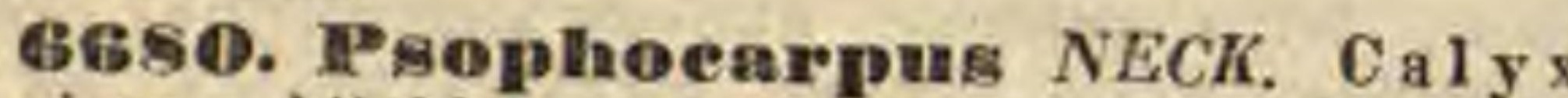
urceolatus, bilabiatus, labio superiore latiore bilobo, inferioris tripartiti lacinia intermedia longiore, omnibus obtusis. Corolla e papilionaceae vexill um subrotundum, reflexum, ecallosum, appendicum et unguis marginibus inflexis, alae oblongae, basi hamatae, stipite vexilli marginibus recepto, carina oblonga, biceps. St amina 10 , filamento vexillari libero diadelpha. D is cus brevis, anuularis. $O$ varium multiovulatum. St y lus glaber; stigma magnum, lanatum. Legumen oblongnm, alis membranaceis longitudinalibus, juxta ntramque suturam geminis quadrialatum, pleiospermum. Semina rotundata. - Herba mauritiana; radice tuberosa, annua, caule volubili, glabro; foliis pinnatim trifoliolatis, foliolis ovato. lanceolatis, acuminatis, glabris, stipulis semisagittatis, pedunculis petiolum aequantibus, apice paucifloris, calycibus bibracteolatis.

Ps op hocarpus Necker Elem, n. 1362. DC. Prodr. II. 403. Wight et Arwott Prodr. I. 252. Meisner Gen. 93. (66.) Botor Adanson Fam, II. 326. Dolichos tetra. go nolobus Lius.

689 1. Diesingia ENDL. C a 1 y x campanulatus, limbo quinquefido, lacinits obtusiusculis, infima longiore, Coro 11 a e papilionaceae vexil. In m subrotundnm, reflexum, bicallosum, appendieum et ungnis marginibus inflexis, a I a e oblongae, basi hamatae, e a rina oblonga, bipes. Sta$\mathrm{m}$ in a 10 , filamento vexillari cum reliquis inferne coalito submonadelpha. Dis ens obsoletus. Orarium multiovulatum. Stylus glaber, falcatus; stigma infra apicem maximum, subglobosum, spongiosum. Le gum en lineari=oblongum, obtusum, alis membranaceis longitudinalibus, juxta utramque suturam geminis quadrialatum, polysperuum, isthmis inter semina interceptum, S emina ovato - subglobosa, umbilico maximo ovali, stro phiola solubili, - Suffrutex brasiliensis, volubilis; foliis pinnatim trifoliolatis, foliolis petiolulatis, stipellatis, terminali a reliquis remoto, stipulis infra insertionem productis, peltatis, racemis axillaribus, longissime pedunculatis, calycibus bibracteolatis.

Dies ing i a Rudlicher in Flora 1832. p. 117. Atakta bot. I. 4. 1. 2. Meisner Gen. 92. (66.)

668\%. Wrabonera WIGHT et $A K N$. C aI y campsnulatus, ad mediom quadrifidus, Iobo supremo apire breviter bifido, laterales nonnihil superante, infimo paulla breviore. Corolla e papi. lionaceae, scariosae, persistentis vexillum petalis reliquis paullo longius, eadem basi late bicallosa amplectens, a la e oblongo-lanceolatae, hine auriculatae, carina falcata, obtusa, alis paullo brevior. Stamina 10 , filamento vexillari libero diatelpha. Ovarin uni-quinqueovulatum StyI us adscendens, inferne glaher, snperne pilosus; s t igma parvam, subcapitatum. Legumen calyce longits, oblonge lineare, compressum, monopentaspermum, inter semina constrictum, isthmis cellulosis interceptum. Sem in a subrotunda, umbilieo et strophiola parva. - Herbae indicae, suffruticosae, volubiles; ramis junioribus foliisque subtus plus minus tomentosis, foliis pinnatim trifoliolatis, foliolis lateralibus late et oblique ovatis, acuminalis, stipellis stipulisque caducis, racemis axillaribus, laxis, bracteis magnis, late ovatis, brac teolis nullis, floribus magnis.

Dunbaria Wight et Arnott Prodr. . 258, Meisner Gen. 93. (66.)

68S3. Theniocarpann $D E S V$. Calyx bilabiatus, quadrifidus, labio soperiore subbidentato, inferiore tripartito. Cornlla papilionaceae vexillum ovatum, al ae calcaratae, carina obtusa, compresso - concava. St a mina 10, filamento vexillari libero diadelpha. Ovari um maltiovulatum. Stylns elongatus, filiformis. Legum en hispidam, compressum, pluriloculare, subarticulatum, margine sinnosum. Semina reniformia, nitentia. - Suffrutex Americae tropicae, volubilis; ramis rufo-hirtis, foliis pinnatim trifoliolatis, foliolis tenuibus, glaberrimis, sinuatodentatis, dentibus mucronatis, lateralibus auriculatis, terminali basi cuneato, apice sublobato, racemis laxis, folio longioribus, floribus subternatis, ca. lycibus ebracteolatis, leguminibus subfalcatis, strigoso-pilosis, aureis, seminibus nitidis.

Ta eniocarpum Desvaux in Annal, sc, nat, $I X, 420$. Meisner Gen. 94. (67.)

6684. Voamdzeâa THOUARS, Flores polygami. He rm a phr. externi, bibracteolati, steriles. Caly x eampanulatus. Corolla papilinnacea, alis horizontalibus. Sta mina diadelpha. Stylus incarvus, hirsutus. Fem, subsolitarii, pedunculo reflexo fertiles. C a I y $\mathrm{x}$ campanulatus. Corolla et stamina nulla. Ovarinm biovulatum. Stylns brevis; stigma nncinatum. Leg umen subterranenm, subrotundum, carnosum, monospermum. - Herba madagascariensis, repens; foliis longe petiolatis, trifoliolatis, glubris, 
foliolis oblongis, impari petiolulato, pedunculo terram intrante, fruetu hypogaeo, edili.

Voandzefa Thouars Gen. Madagase, n, 77. DC. Mom. Legum. t. 20. f. 106. Prodr. II. 724. Meisner Gen. 93. (66.) Vo a u d 4 o u Flaccourt Madagasc. 118. Glyeine - ubterranea Linn. f, Decad, $t, 17$.

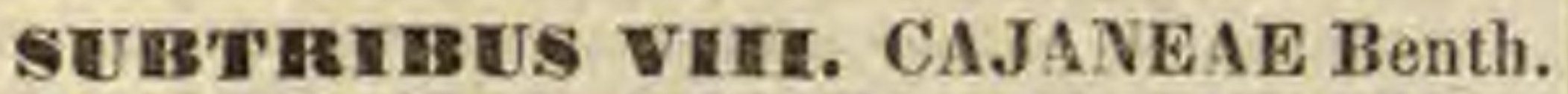
in Annal. Wiener Mus. II. 113. Ovarium pluriovulatum. Legumen bivalve, extus lineis transversis, rectis v, obliquis constrictum.

658.5. Wagella NECK, Calyx ultra me dium quinquefidus, laciniis linearibus, acutis, rectis, duabus snpremis panllo altins coalitis. Corollac papilionaceae vexill um reflexum, carina obtusissima, alis longior. Stamina 10 , filamento vexillari libero diadelpha, a nth e $r$ a e conformes. Ovarium sessile, pluriovulatum. Stylus subulatus, glaler; stig ma obtusum. Le g $u m$ en ovato-cylindricum, turgidum, hexaspermum, inter semina constrictum, bivalve. Se mina ovata, umbilico lineari, strophiolato. - Suffrutex c a p en sis, volubilis, pilis viscoso-glandulosis subhirsutus; foliis pinnatim trifoliolatis, foliolis rhombeis, terminali remoto, racemis axillaribus folio longioribus, floribus longe pedicellatis, distantibus, demum deflexis, flavis, carina apice violacea.

F a gellia Necker Elem. n. 1257. DC. Prodr. II. 389. Meisuer Gen. 94. (67.) E. Meyer Comment, plant. Afr. 138. Gi yciale bituminosa Eina. Lam. t. 609. f. 2, Bat. Reg. $t$. 261 ,

6685. Cajanus DC. Caly $\mathrm{x}$ campanulatus, subbilabiatus, labiis subaequilongis, superiore breviter biffo, inferioris iripartiti laciniis lanceolato-subulatis, sursum curvatis, intermedia paulto longiore, omnibus apice recurvis. Co rolI s e papilionaceae deciduae petala aequilonga, v exill um latum, basi bicallosum, unguis marginibus reflexis, a la e rectae, earina falcata. Stamin a 10 , filamento vexillari libero diadelpha, alterna breviora, antherae conformes. Ovarinm quadri-quinqueovulatum. Stylus adscendens, in ferne pilosus; stigma subpeltatum. L e gu men lineari-lanceolatum, utrinque angustatum, compressum, tri-pentaspermum, lineis inter semina profundis, obliquis toralosum, intus isthmis mem. branaceis transversim pluriloculare. Semina sub. rotunda, subeompressa, umbilico lineari, estrophiolato. - Frutices Asiae tropicae, in America culti, erecti, pubescentes v. velutini; foliis pinnatim trifoliolatis, foliolis ovali-lanceolatis, mucronatis, stipellis breviter subulatis, stipulis lanceolatis, racemis axillaribus pedunculatis, corymbiformibus, bracteis oblongo lanceolatis, caducis, pedicellis ex eadem braclea geminis, floribus flavis, leguminibus hirsuto-pubescentibus.

Cajan as DC. Catalog. Hort monsp. 85. Prodr, IT. 406. Kenth in Humb. et Bonpl. Nov. gen. et sp. VY, 395. Meisuer Gen, 94. (67.) Wrght et Aruoti Prodr. I. 2Sfi. C a fa a Adanson Fam, IT, 326. Thourars Diet, se, nat. VI.166. C y tisus Ca a a a Lian. Jacq. Observ. I. t. 1. C. Psendo. Caj a a Linn, Jacq. Hort. Vindob. $I 1, t, 119$.

68s\%. Atylosia WIGHT et $A R N$. C a lyx campannlatus, profunde bitabiatus, labio superiore panllo breviore brevissime bifido, inferioris tripartiti lacinia media longiore, Corolla e papilionaceae, demnm scarinsae, persistentis vexill n m latum, recnrvatum, ecallosnm, alis et carina subfalcata, olitusa paullo long us. Stam in a 10 , filamento vexilfari libero diadelpha, alterna paullo breviora, antherae conformes. Ovarium subquadriovulatum. Stylus inferne pilosus, apice glaber; stig $\mathbf{m}$ a subeapitatum. Le g u men oblongo-lineare, compressum, subtetraspermnm, extus inter semina subconstrictum, intus septis celiutosis interceptnm. Se min a rotunda, umbilico ovali, strophiola magna, carnosa. - Frutices Asiae tropicae, erecti v. diffusi; ramis villosis $v$, tomentosis, foliis palmatim trifoliolatis, foliolis basi trinerviis, exstipellatis, pedunculis axillaribus, $v$. juxta ramos juniores subaphyllos racemosis, pedicellis ex axilla braeteae geminis, leguminibus villosis $v$, tomentosis.

A t ylosia Wight et Arnott Prodr, I, 25\%. Meisuer Gen. 93. (66.) Collaea trínervia DC. Mem, Legum, $t, 41$.

6838. Cantharosperman $W I G H T$ et $A R N$. Cal y x quadrifidus, laciniis subaequilongis, suprema latiore, apice breviter bifida. Curolla papilionaceae, decidnae petala subaeqquilonga, vexill u m reeurvum v. reflexnm, oblongoobovatum, basi ecallosum, a la e liberae, c a rina falcata. Sta m in a 10, filamento vexillari libero diadelpha, antherae conformes, Ovarium quadri-octoovulatum. Stylus superne cum stig. in a te glaber. Leg u m e n oblongo-lineare, compressum, tri-octospermum, extus inter semina transversim constrictum, intus septis subeoriaceis divisnm. Semina oblonga, transversa, umbilieo strophiola carnusa, bifida. - Herbae Asia e tro. picae, volubiles; foliis pinnatim trifoliolatis, foliolis utrinque plus minus velutinis, stipellis setiformibus, inconspicuis, stipulis deciduis, pedunculis axillaribus, plurifloris.

Cantharosperm um Wight et Arnott Prodr, I. 255. Meisner Gen. 93. (66.) Dolichos s e arabaeaides Lina.

Q685. Pseudarthria WIGHT et ARN. Cal y $x$ obsolete bilabiatus, labio superiore bifido, inferioris tripartiti lacinia media longiore. C or ollae papilionaceae vexill nm rotundatum, alis et carinae obtusae aequilongnm. Stamina 10 , filamento vexillari libero diadelpha, antherae conformes. Ovariam plnriovulatum, funiculis longis. Stylus filiformis, brevis; stigrua capitatum. Leg umen membranaceum, plannm, lineare, apice rotandatam, stylo persistente incrassatam, pilis uncinatis tectum, continuam, inter semina transversim reticulata-ventosem, S e m i n a compressa, subreniformia, estropliolata. - Herbae Asiae tropicae, erectae $v$. diffusae, Desmodiifacie; foliis pinnalim trifoliolatis, foliolis $j u$ nioribus utrinque villosis, stipellis subulatis, stipulis lanceolato-subulatis, scariosis, striatis, racemis axillaribus v. terminalibus, simplicibus aut ramosis, floribus purpureis, pedicellis ex cujusvis braeteae axilla ternis, infra calycem arliculatis.

Pseudarthria Wight et Arnott Prodr. $I$, 299. Meis. ner Gen. 87. (6e.) Hedy sarum viseidum Lina. Glycine viscida Willd.

\$UIB'TERES IX. RHYNCHOSIEAE Benth, in Annal. Wiener Mus. II. 113. L eg ume n biovulatum.

BE90. (1)thodantasn $E$. MEY. CaI y x fere ad basim subbilabiato-quinquefidus, laciniis lineari-subulatis, petala aequantibus, duahus snpremis et infima panllo longioribus. Co rolla e papilionaceae vexilla m basi bicallosum, callis subgiblusis, alas liberas processu hamato aurtas comprimentibus, ea rina incurva, obtusa. Stam in a 10 , filamento vexillari libero, hasi genicu- 
lato diadelpha. Ovarin biovulatum. Stylus filiformis, superne incrassatus; stigma obtusum. L e g um en sessile, rectum, elliptico-oblongum, dispermum, inter semina levissime contractum, intus pervium. Semina subglobosa, strophiola umbilieali brevissima, bipartita. - Frutices ca. penses, erecti, plus minusve sericei; folits infimis uni-reliquis trifoliolatis, exstipellatis, racemis brevissimis, paucifloris, v. floribus subsolitariis, erectis, axillaribus, versus apices caulis et ramorum thyrsos foliosos constituentibus.

Orthodan um E. Meyer Comment. Plant. Afric. 131. Meisuer Gen, 94. (67.)

6691. Eriosema DC. Caly x subbilabiato-quinquefidus. Corollae papilionaceae vexillum basi bicallosum, eallis subgihhosis, a las liberas, processu hamato auctas cumprimentibus, car ina incurva, obtusa. Stamina 10 , filamento vexillari libero, hasi geniculato diadelpha. Ovarium biovulatum. Sty l s filiformis, superne vix incrassatus, demum elongatus, sigmoideo-flexus; st igma obtusum. L e g um en sessile, rhomboi deo-ovatum, inter semina levissime contractum, intus pervium. Semina oblonga, umbilico stro. phisla longa, angusta, bilamellosa. - Herbae suffruticosae, in regionibus tropicis totius orbis et in Capite bonae spei crescentes, erectiusculae, subflexuosae, saepissime glandulis minutis, aureo-nilentibus conspersae; foliis trifoliolatis $v$. interdum unifoliolat is, foliolis exstipellatis, terminali longius petiolulato, racemis axillaribus subspicatis, retrorsum imbricatis et subspicato-capitatis, v. laxis, floribus tunc erectiusculis, corollae vexillo glanduloso-piloso.

Erlosema DC. Prodr. II. 388. (Rhynchosiae sect.) E. Meyer Comment. Plant. Afric. 127. Meisner Gen. 94. (67.) Luriosm a Desvanx in Annal. sc, nat. IX. 421. P y r $\mathrm{r}$ hotrichia Wight et Aruott Prodr. I, 238, in not. G Iy cines s. Vahl. Kunth in Humb, et Bonpl. Nov. gen, et sp. $t$. 872 _574. C y $t$ is 1 s p. Aublet Guian, $t, 306$.

B692. Fhymehosia $D C$. C a ly $x$ nunc bilabiatus, labio superiore bifido, inferioris tripartiti lacinia media longiore, nune ad basim quadripartitus, larinia postiea integra, hifida $\mathbf{v}$, bipartita. Corollae papilionaceae vexillum basi processubus duobus ecallosis, a l a s liberas comprimentibns, carina falcata. Stamina 10 , filamento vexillari libero, basi articulato diadelpha. 0 va ri $\mathbf{m}$ bi- rarius nniovulatum. St y 1 u s subulatus; st i g m a acutum. Legumen oblique ovatum v, oblongum, interdum subfaleatum, compressum unono-dispermum. S e m in a umbilico strophiolato. - Herbae perennes, scandentes $v$. volubiles, rarius suffruticosae, in regionibus tropicis subtropicisque totius orbis crescentes; folis pinna. tim trifoliolatis, rarius unifoliolatis, exstipellatis, saepissime resinoso-glandulosis, floribus axillaribus, racemosis v, solitariis, utplurimum flavis.

R L y nehos is DC. Prodr. II. 384. excl, sect. 2. Wight et Arnott Prodr, I. 237. Torrey et A. Gray Flor, of North. Amer. I. 283. Meisurr Gen. 94. (67.) Co pis m a E. Meyer Comment. Plant, afric, 131. Meisu. Gen, 94. (67, G I y e i n e Nuttall Gen. Amer. II. t14. Kuath in Humb. ot Bonpl. Nov. gen. nat. $8 c$. Philadelph. nat. 80, Philadelph, 18t8. p. 371. G I y e i ne s 8 p. Lian.

a. COPISMA E. Meyer $l, c, \mathrm{C}_{\mathrm{a}} 1$ y $\mathrm{x}$ mareescens, profunde quadrifidus, lacinia iufiana longiore. Uinbilieus et stro. pliola angasta. - Plantae volubiles. - E u r h y u choIc. $\operatorname{rar}, t, 146$, (DC, Ment, L y ci a e cariba e a Jacq. Ic. $\operatorname{rar}, t$, 146. (DC. Ment, Legum. t, 56.)

b. ARCYPHYLLUM Elliott 2. c. part. Caly $\mathbf{x}$ foliaceus quadripartitus, laciaiis asuminatis, corollan aequanti- bus. Legumen calyce longius. Umbilicas? et ca. runcula angusta, - Plantae erectae v, volubiles. - Fo. lia saepins unifoliolata.

c. PHXLLOMATIA Wight et Arnott 2 .c. C a 1 y x follaceus, quadripartitus, laciniis ovali.oblongis, obtusis, corollam aequantibus, Ca $r i \mathrm{n}$ a falcata. $O \mathrm{v}$ a $\mathrm{r} \mathbf{i} \mathrm{m}$ unibiovula. tuu. Legumen sessile, calyce paullo longius, subcompressum, oblique rotundato-ovale v. oblongum, breviter mucronatum. Strophiola lata, bifida. - Gly. cine rufescens Willd.

d. PTYChocentruM Wight et Arnott 2 . c. Cal yx qua. drifidus, lacinis acuminatis, subaequalibus, suprema bifida. Vexillu m cum processuua et unguis narginibus inflexis, Carina faleata. Ovarium biovulatum. Leg u in en sessile, oblongum. S trophiola lata, bifida. - Suffrutioosae, erectae, pubescentes; folitis trifo. liolatis, foliolis dentatis. - R h. c a na DC. R h. 8 a a* v e le ns DC.

e. PITCHERIA Nutt, Caly $x$ profunde et subaequaliter quadrifidus, laciolis acumiastis, infima paullo Iongiore, suprenia bifida. Vexiflum obovatum v. orbiculatum, processuum et unguis marginibus inflexis. Carina fal. cata, Le g umen sessile, basi angustatum, oblongum, conapressum, inono-dispermum. St rophiola parva. Herba borcali-americana. erecta, rigida; folitis trifoliolatis, resinoso-glandulosis, foribus axillaribus solitaris. - Pitcheria Nuttall in Journ. Academ. Philadelph. VII. 93. Torrey et A. Gray Flor. of NorthAmer. I. 285.

f. RURHYNCHOSIA. C a ly e is bilabiati labium superius latius, emarginatum, inferioris trifidi lacinia intermedia longiore. Vexillum ovatum, adscendens, alae ob. longae, vexillo breviores, unguibus filiformibus, appendiculatis, c a $\mathrm{r}$ In a rhomboidea, rostro longo, acuto terminata. Leg u me n menbranaceun, conpressum, ovatum, subaeaminatum, dispermum. - Herba volubi. lis, tomentosa; folits trifoliolatis, foliolis subrotundis, pedunculis axillaribus, geminis, multifloris, foribus luteis. - Rhy a cbosia Loureiro Flor. co. chineh. $56 t$.

6693. Nomismia WIGHTet ARN. C a lyx profunde bilabiatus, labio superiure breviore, bi. fido, inferioris tripartiti lacinia media longiore, omnibus subulatis, sursum faleatis, aestivatione nnicam formantibus. Corolla papilionaceae vexillum basi bicallosnm, alae et carin a falcatae petala libera. Stam ina 10 , flamento vexillari libero diadelpha, Ova ri u m nni - biovulatum. Stylus glaber; stigma terminale. Legumen stipitatum, orbiculatum, compressissimum, monodispermum, valide nervosum v. venosum. Se m inu in strophiola magna, ovalis, carnosa, biloba. Herbae volubiles, pubescentes v, pilosae; foliis pinnatim trifoliolatis, foliolis subtus glandulis resinosis conspersis, stipellis setaceis, minutissimis, racemis axillaribus, calycibus et leguminibus pilosis.

Nom is m i a Wight et Arnott Prodr. 1. 236. Meisn. Gen. 94. (62.) Glyefnes s p. Auct. R hy nehosiatsp. DC.

BS94. Cylista $A I T$. C a 1 y x srariosus, corolla major, profunde quadrifidus, lacinia suprema biloba, lateralibus minoribus, infima maxima. Corollae papilionaceae persistentis vexillum basi bicallosum, a la e lineari-oblungae, basi margine superiore processu hamato, inferiore eallo anctae, e arina e subfalcatae petala apice dorso cohaerentia. Stamina 10 , filamento vexillari libero, basi articulato diadelpha. Ovarinm oblengum, uni-biovulatum. Stylus parte inferiore tenui glabra, adscendente, superiore tumida, $\mathrm{pi}^{\mathrm{i}}$ losa, versus suturam ovarii vexillarem refracta. Le grmen oblique ovale, calyce inclusnm, monospermam. Semen compressum, reniforme, nmbilico parvo, strophiola fere obsoleta. - Suffutices indici, scandentes, pubescentes $v$. villosi; foliis pinnatim trifoliolatis, foliolis oblongis $v$, ovatis, 
acuminatis, stipellis minimis $v$. obsolelis, racemis axillaribus, simplicibus, bracteis amplis, caducis.

C ylis ta Aiton Hort. Kew. III. 512. Roxburgh Plant. Corom, t. 92. DC. Prodr. II. 410, excl, sp. Wight et Aruott Prodr. I. 257. Meisuer Gen. 94. (66.)

6895. Cyamospermuna WIGHT et $A R N$. Cal Jx herbaceus, corolla major, ad basim bilabiatus, labiis subaequalibus, superiore cuneato, bifido, inferiore tripartito, laciniis oblongo-linearibus, infima vix longiore. Co roll a e papilionaceae, persistentis, rigidae vexillum obeordatum, patens, ecallosum, a l a e liberae, carina e subfalcatae, obtusae petala apice breviter eualita. S $t$ a m in a 10, filamento vexillarilibero, basi articulato diadelpha. Ova ri um biovulatum. Styli pars inferior glalra, superior adscendens, tenuis, pilosa; stigma subcapitatum. L e $g$ u m e n vix calyce longins, di- v, abortu monospermum, inter semina constrictum, articulos dnos, sphaericos constituens. S emin a globosa, nmbilico lineari, estrophiolato. Suffrutices indici, volubiles, tomentosi; foliis pinnatim trifoliolatis, foliolis late ovatis, acutis v. acuminatis, stipulis lanceolatis, stipellis setaceis, racemis axillaribus, simplicibus, bracteis late ovalibus, deciduis, legumine tomentoso, seminibus violaceis.

Cy anospermum Wight et Arnott Prodr. I. 239. MeisnerGen. 94. (66.) C ylista e sp. Roxburgh Plant, Co. rom, t. 221, Bot, Mag. t. 1839.

BGSB. Clnrysoselas $E$. MEY. Calyx herbaceus, corollam aequans, profunde quinquefidus, laciniis subaequalibus, lanceulatis, rectis, ad basim subangustatis, infima carinata. Corollae papilionaceae persistentis vexillum magnum, ecallosum, a la e basi semicordatae, carina fornicata. St a $\mathrm{m}$ in a 10 , filamento vexillari libero, basi articulato diadelpha. Ovari u m biovulatum. Stylus parte inferiore hispidula, superiore crassiore glabra, inflexa. Leg um en oblongum, turgidum, induratum, dispermum. Semina reniformia, strophiola parva, hiloba. - Plantae c apenses, suffruticosae, volubiles, glandulis aureo-nitentibus conspersae; foliis pinnatim trifoliolatis, foliolis angustis, elongatis, terminali a reliquis remoto, stipellis nullis, umbellis bi-sexfloris, axillaribus, pedunculatis, spatha arida, bivalvi, stipulis simillima, floribus luteis, seminibus nigris, nitidis.

Ch r y s os cias E. Meyer Comment. Plant. Afric, 139. Meisuer Gen. 94. (66.)

G698. Flemingia $R O X B, C$ a I yx acute quinquefidus, laciniis quatuor subaequalibus, infima longiore. Corollae papilionaceae vexillum ecallosum, nngue marginibus inflexis, carina falcata. St a mina 10 , filamento vexillari libero diadelpha, Ovarium biovulatum. Stylus glaber. L e gumen sessile, ovale, turgidum, dispermum Semina subglobosa, umbilico exiguo, caruncula obsoleta, - Frutices $v$ suffrutices Asiae tropicae, stipulis scariosis, lanceolatis, interdum amplis, plerumque deciduis; foliis petiolatis, digilatim trifoliolatis $v$. simplicibus, subtus glanduloso-punctatis, nervis prominentibus, parallelis, longis, indivisis, stipellis nullis, racemis axillaribus, solitariis $v, a g$. gregatis, interdum paniculatis, floribus confertis, leguminibus plus minus pubescentibus.

Fleming i a Roxburgh Plant. Corom, III. 44. Aiton Hort. Klew, edit. 2, IV. 349. DC. Prodr. II. 351. Wight et Aruott Prodr. I. 241. Deisuer Gen. 94. (66.) MLIII ng to a f a Roxburgh mse.

a. Flemingiastrum DC. $\boldsymbol{t}$, c, Folia digitatim trifoilo

lata. R a c e m i stricti, simpliees, bracteae stipulares sca- riosae, sub quovis fasciculo solitariae, floribus ante anthe. sim dense inbrieatis. Cal y c is lacinia infima elongata. - (Roxburgh Plant. Corom, t. 248.)

b. CHalaria Wight et Arn. l. c. Folia digitatim trifo. liolata. Race an i laxe paniculati, bracteac stipulares sub paniculae ramis et florum fasciculis geminae, minutae, caducae. Cal y cis lacinia infima reliquis paullo longior, onnes breviter lanceolatae. Vexillum basi gíbbo subealloso. - Hedy s a rum li neatam Linn. Burm. Flor, ind. $t$. 53. $f .1$.

e. OSTRYODIUM Desv. Fo lia simplieia. Ra cem $\mathrm{f}$ terminales v. axillares, subramosi, rhachi flexuosa, peduneulis partíalibus brevibus, basi caduce bistipulatis, apice bracteas amplas submembranaceas, persistentes, imbricato-distichas gerentibus, floribus in apice peduncull conferti intra braeteas Inclusis. C a I y e is lacinia infima reliquis paullo longior, subulata. - Ostry odinum Desvaux Journ. Bot. IIt, 119. $t$. 4. $f$. 2. L o u rea Jeaune in Bullet. philomat. Dee. 1812. Mog han a Jeaume in Journ, Bot, III. 61. He d ys a rum strobill ferum Lina.

SUETTERUS $\mathbf{X}$. ABRINEAE Wight et Arnott Prodr. I. 236. St am in a 9, monadelpha. - Folia abrupte pinnala.

6898. Abrus LINN. Caly x campanulatus, quadrifidus v. quadridentatus, dente superiore integro v. bifido. Corolla e papilionaceae vexillum ovatum. Stamina 9 , monadelpha, basi vexilli ungni adhaerentia. Ovarium multiovalatum. Stylus brevis; stigma capitatum. Leg um e n oblongum, compressum, tetra-hexaspermum, isthmis inter semina transversim plurilocellatum. Se m in a subglobosa. - Frutices scandentes $v$, diffusi, in Asiatropica indigeni, nunc per $A f r i-$ cam et America m divulgati; foliis abrupte pinnatis, multijugis, floribus racemosis, pedicellis e nodis tuberculiformibus erumpentibus.

A b r s Linn. Gen. n, 1286. Gärtner $I T, 328$, t. 131. DC. Prodr. II. 381. Meisner Gen. 92. (65.) Wight et Arnott Prodr. I. 236.

\section{GENERA DUBIA.}

6699. Maeranthas LOUR. C a lyx tnbulosus, tomentosus, coloratus, quadrifidus, persistens, laciniis acutis, duabus lateralibus brevioribus. Coroll a e papilionaceae, longae, subclansae vexill u u ovatum, emarginatum, connivens, calyce longius, a la e oblongae, vexillo triplo longiores, rectae, ca rina alis longior, apice acuto, adscendente. St a m in a 10, filamento vexillari libero diadelpha, quatuor reliquis triplo crassiora a $\mathbf{t h}$ eris ovatis, incumbentibus, tenuiorum oblongis, erectis. Ovarium oblongum, teres. StyI 8 filiformis, pilosus; stig ma oltusum, scabriusculum. Leg n men rectum, subteres, crassam, acuminatum, polyspermum. S emina subovata. - Herba cochinchinensis, volubilis, ramosa; foltis trifoliolatis, ovato-rhombeis, pilosis, stipulis filiformibus, pedunculis axillaribus, multifloris, calycibus et corollis albis, legumine eduli.

Ma erat a s Lourelro Flor. cochinch. 563. S, pliales. pro Macranthus Poiret Suppl. 11I. 569. DC. Prodr. II. 382. Meisner Ger. 93. (66.)

CALOPOGONIUM Desv, in Annal. sc, nat, IX. 433. C R$1 \mathrm{yx}$ ebracteatus, profunde quinquefidus, clausus, gla er, laciufis elongatis, subulatis, subaequatlous, punetato-barbatis. Coroila subinclasa, winuta. Leg bmen rectum, depressum, subuncinatum, hirto.pilosum. octosperman. Herba guianensis; caule volubili, tereti, rufercente hirto, foliis pinnatim trifoliolatis, petiolo elongato, foliolis 'tipellatis, ovatis, mueronatis, lateralibus extra gibbosis, utringue adpresse pilosis, hirlit, racemis am. 
bellatis, petiolum subaequantibus, foribus subsessilibus, leguminibus horizontalibus.

CRUMINIUM Desv, in Annal, sc, nat, IX, 423, Calyx cupularis, truacatus. L e $u m \in$ a compressum, planum, utrinque marginatum, polyspermum. - Plantal peruana; caule volubili, suffruticoso, tereti, glabro, foliolis tribus ovato-lanceolatis, abrupte cuspidatis, utrinque glabris, reticulalis. penninervits, stipellatis, stipulis lanceolatis, acutis, scariosis, amplexicaulibus, racemis axillaribus sessilibus paucifloris, calycibus glabris, leguminibus glaberrimis, octopollicaribus, longissime nucronatis, $12-15$ sperais.

TREBS VE. DALBERGIEAE Bentb. in Annal. Wiener Mus. II. 90. Corolla papilionacea. Stamina 10 , monadelpha v. diadelpha. Legumen indehiscens, intus saepe isthmis interceptum. $\mathbf{E} \mathrm{mb}$ ry o $\mathrm{n}$ is cotyledones crassae, carnosae, radicula incurva v. rarius recta. - Folia pinnala, foliolis saepe aller nis, rarius unifolioiuta.

Brob. Cyelolobluan BLNTH. Calyx nrceslato - eampanulatus, quinquedentatus, dentibas superioribus paullo latioribns. C o r o I 1 a e papilionaceae vexillum orbiculatum, emarginatum, alas oblongas vix superans, carina oblon$\mathrm{ga}$, subrecta, alas subaequans, petalis dorso connatis. St a $m$ in a 10, uno vexillari libero, reliquis connexis. Ovarium stipitatum, pluriovalatum, ovulis anatropis. Stylus .... Le gamen stipitatum, orbiculatum, plano-compressum, membranaceum, reticulatum, indehiscens, suturis convexis, vexillari alata, earinali nuda. S e m i na $2-3$ transversa, embryone recto. - Frutex brasiliensis; cortice laeviuseulo, minute verruculoso, ramis junioribus et racemorum rhachi ferrugineo-puberulis, foliis unifoliolatis, foliolis ovatis v. oblongis, utrinque parum angustatis, cum petiolo brevi articulatis, supra glabris, subtus ferrugineo-puberulis, racemis axillaribus et lateralibus folio brevioribus.

Cyclol ob i u m Bentham in Annal. Thener Mus, II. 92 .

Bro1. Amerinanum $P, B R O W N$. Calyx campanulatus, bilabiatus, labio superiore biinferiore trilobo, lobo infimo productiore concavo. Corollae papilionaceae rexillum patentissimum, alas oblongas panllo superans, $c$ a ri na oblonga, rectiuscula, petalis dorso connatis, Stamina 10 , monadelpha, vagina superne fissa. Ov arium stipitatum, subquadriovilatum. St y 1 us brevis; $8 \mathrm{tigma}$ obtusum. Legumen stipitatum, lasceolato-oblongum, compressum, utrinque acuminatum, uniloculare, mono-tetraspermum, bivalve. S e m in a oblonga, radicnla incurva. - Fruti. ces $v$, arbusculae $A$ meric ae tropicae; folitis atternis, unifoliolatis, foliolo cum petinlo arliculato, racemis axillaribus solitariis $v$, compluribus panicula. to-congestis, floribus uniluteralibus, albis, pedicellis basi uni- apice bibracteolatis.

A meri m n u m P. Browne Jam, 28s. t.32. f. 3. Adanson Fam, II. 320. Kunth in Humb. ot Bonpl. Nov, gen, et sp. rimni s p. Swartz. II, 421. Meisuer Gen. 95. (6z.) A m e-

680\%. Corytholobinam BENTH. Calyx..... Corolia.... Legumen curiacenm, sublignosum, ovoideo-glohosum, reticulato-venosum, suturis convexis, seminifera acuta, carinali in alam membranaceo - coriateam semiorbicularem expansa, Semen unienm, subglobosum; coty ledonibns crassis, earnosis, radie ula brevi. incurva. - Arbor v. frutex brasiliensis; foliis unifoliolatis, foliolo amplo, ovato-elliptico, acuminato, penninervio, utrinque glaberrimo, brevissime petiolulato, racemis axillaribus, fasciculatis, brevibus.

IT. 93.

Corytholobiam Bentham in Annal. Fiener Mrs.

6r03. Heeastophyllum $K U N T H, C$ atyx campanulatus, breviter bilabiatus, labio superiore emarginato, inferioris tridentati dente medio productiore. Corolla e papilionaceae petala longe stipitata, vexillum orbiculatum, emarginatum, al a e oblongae v. obovatae, carina alis paullo brevior, oblenga, subrecta, petalis dorso leviter cohaerentibus. Sta m in a 8 - 10 , aequaliter diadelpha v, stamine vexillari libero, a $\mathrm{t} t$ herae terminales, loculis brevibus, ereetis, subdistinctis. Ovarium longe stipitatum, biovulatum, ovulis amphitropis. Sty Ias brevis, filiformis; stigma capitatum. Legumen stipitatum, orbiculare, ovale $v$, ovali oblongum, plano-cotn pressum, plus minus suberusum, apterum, rectum v. subincurvum, indehiscens, mono-v. rarissime dispermum. Semen maguum, reniforme, radicnla brevi, subincurva. - Frutices Americae tropicae, interdum subscandentes; foliis unifoliolatis v. imparipinnatis, exstipulatis, foliolis paucis, saepe amplis, coriaceis, terminali a pari ultimo remoto, paniculis axillaribus, brevissimis, fasciculato-ramosis, subcorymbosis, bracteis parvis, rhachi post florum lapsum persistente, dentata, brateolis parvis, ovatis, sub calyce patentibus, floribus parvis.

B ecast op $\mathrm{y} 1 \mathrm{Hum}$ Kunth in Humb. ot Bonpl. Nov. gen. et sp. VT. 387. E c a s to ph y 11 u m P. Browne Jam. 299. t, 39. f. 1. L. C. Richard in Persoon Encheir. IL. 277. DC. Prodr. II. 420. Meisner Gen. 95. (67.) Bentham in Annal, Wiener Mus. II 93. Pterocarpi sp. Linn. A eouroa Aublet Guian. III. 10. et 753. $t, 301$, D rake in stein is Necker Elem. n. 1344. Ge off r oy a e s p. Pers.

Bร 4. Mreatomelnia $A U B L$. Caly x turbinato subincurvus, bilabiatim breviter quinquedentatus. Corolla e papilionaceae vexill a m orbiculare, basi angustatum, a l a 8 obovatas, obliquas superans, carin a e petala libera, alas subaequantia. Stamina 10, diadelpha, vagina cylindrica, integra. Ovari a m breviter stipitatnu, pluriesnlatum. Stigma obtusum. Le gumen monospermam, suborbiculare, compressum, indehiscens, axi parum ineurvo, suturis convexis, vexillari breviore exalata, carinali in alam membranaceo-coriaceam expansa. - Arbores Americae tropicae; foliis imparipinnatis, foliolis coriaceis, inflorescentia paniculato racemosa, axillari et terminali.

Moutouchi Aublet Guian. II. 248. t. 299. M a uto ue hia Benth. in Annal. Wiener Mus. II, 94. Griese. Iin i a Necker Elem, n. 1358. P terocarpi sect. Mo utouchia DC. Prodr. II. 418. Pterocarpus Draco Lisn. P. officinalis Jacq. Amer. t. 183. $f .92$. P. heu ip te r a Gärta. $t$. 156. $f$. 2 .

Cร๑5. Ptercearpus LINN. Caly x turbinato-subincurvus, bilabiatim breviter quinquedentatus. Corolla e papilionaceae vexill $\mathrm{nm}$ orbiculare, basi angnstatum, a las obovatas, obliquas superans, c a rin a obovato oblonga, petalis liberis, stipite incnrvo, lamina alis subsimili, minore. Stamina 10 , varie connexa, antheris ovatis. O vari n in stipitatum, panciovulatum. Stylus vix incurvus, glaber; stigmate tenui, terminali. Le g umen suborbicnlare, compressum, coriaceum, sublignosnm, indehiscens, ala membranaceo-coriacea undique cinctum, axi valde incnrvo, mucrone styli basim indicante laterali, mo- 
nospermum, vel transversim in foculos $2-3$ monospermos divisum. Se mina oblonga v. subreniformia, compressa, radicula brevi, parum incurva. Arbores $v$. frutices, in Asia tropica crescentes; foliis imparipinnatis, stipulis deciduis, foliolis alter$n i s$, inflorescentia paniculatim-racemosa, axillari $v$. terminali, bracteis bracteolisque deciluis, saepius minutis.

Pteroca rp u s Linn. Gen, n. 854. Roxburgh Plant. Corom. $t$. 116. Bentham in Annal, Wiener Mus, II. 94. Meisner Gen. 25. (62.) Pteroearpi sect. Amphymenium et Sa n ta laria exel. sp. amerie, DC, Prodr. II, 418. 419.

6rDE. Eelnimodiseass BENTH. C a ly x turbinato subincurvus, bilabiatim quinquedentatus. Corollae papilionacea vexillum orbiculatum, apice emarginatum, basi angustatum, a las oblongas, obliquas vix superans, e arinae alis brevioris subeonformis petala longe stipitata, dorso coalita. Sta mina 10 , monalelpha, vagina ventricosa, hine fissa, antheris ovatis, Ovarinm brevissine stipitatum, biovulatum. Styla 8 vixincurvus, glaber; stigmate acnto. Legumen stipitatum, suborbiculare, compressum, coriacenm, indehiscens, setis longis rigidis echinatum, axi recto v. subincurvo, mucrone styli basim indicante subterminali v. plus minns laterali, suturis in alam membranaceam, ambientem, undulatam expansis, transversim in loculos duos monospermos divisnm. Semin a subreniformia, radicula brevi, inenrva. - Arbores Asiae tropicae; foliis imparipinna$t i s$, foliolis alternis, racemis axillaribus paniculatis, bracteis bracteolisque deciduis.

Echinodiscus Bentham in Anzal. Wiener Mus. II. 95. Pterocarpi sect. E chinodiscus DC, Prodr. IT. 418. Weinreichia Reichenb. Consp. J82. Pteroearpi sp. Lam. t. 602. $f$. 4. Hooker in Gray Travels in Africa $\boldsymbol{t}$, $\boldsymbol{d}$. Guillem. et Persot. Flor, seneg. $t$. 54 .

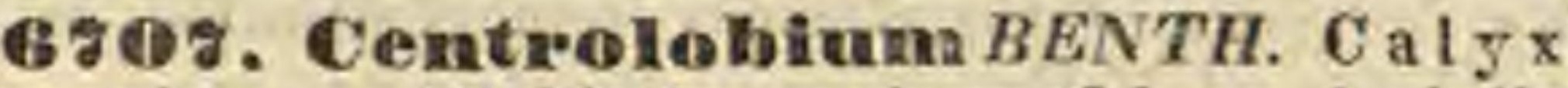
campanulatus, bilabiatim quinquefidas, laciniis duabus superioribus majoribus. Corollae papi. lionaceae vexillum orbiculatmm, alas oblongas $\mathrm{c}$ a $\mathrm{r}$ in $\mathrm{m}$ dipetalam superantes aequans. $\mathrm{S} t \mathrm{a}-$ min a 10 , filamento vexillari libero, reliquis connatis. Ovarium..... Leg umen subsessile, ovatum, vix compressum, coriaceum, sublignosum, indehiscens, stylo terminali mncronatum, diseo ntrinque spinis longis densissime echinatum, sutura vexillari nuda, carinali convexa, apice in alam oblongam, membranaceo-coriaceam, legumine ipso longiorem producta. Semen unicum? Arbor brasiliensis, glabra; foliis imparipinnatis, foliolis subcoriaceis, oblongo-ovatis, penninerviis, breviter mucronatis, inflorescentia terminali, racemoso-paniculata, pedicellis bibracleolatis.

Centrolobium Bentham in Annal. Wiener Mus, IL. 95. Nissolia robusta Flor. Flum. PIt, $t, 85$.

BrOS. Amplnymemiam $H, B, K, \mathrm{C}$ a ly $\mathrm{x}$ campanulatus, quinquedentatus, subbilabiatus, den tibns acutis. Corollae papilionaceae vexilln m alas et carinam vix superans. Stamina $10, \mathrm{mon}$. adelpha, tubo hinc fisso, antheris oblongis. Ovarium sessile, pluriovulatum. Stylns subulatus, pubescens; в tigma oủtusum. L eg amen sessile, compressum, indehiscens, orbiculare $\mathbf{v}$. oblongum, ala membranacea, lata cinctum, basi cordatum, axi incurvo v. rectinseulo, disco tumido, monospermum. S emen subreniforme, $\mathbf{r}$ a die u la uncinato-inflexa. - Arbores Americae tropicae; foliis imparipimatis, foliolis pucis, alternis, petiolulatis, stipulis deciduis, inflorescentia racemosa, axillari et terminali, racemis subsimpli. cibus, paucifloris, floribus flavescentibus, bracteis bracteolisque deciduis.

A m p hy me nium Kanth in Humb. et Bonpl. Nov, gen. et sp. VI, 380. Beutham in Annal, Wiener Mus. II.95. Pterocarpus Rohril Vahl. DC. Apataloa sp ie a ta Aublet Guian, t. 147. f. 5. 6. exel. reliq.

6\%09. Drepanocarpas $C, F, W, M E Y$. Ca l y x tubuloso-campanulatus, breviter quinque. dentatus, dentibus superioribus latioribus. Corolla e papilionaceae vexilln m ovato-suborbiculatum, snbintegram, basi complicatum, angustatum v. truncatum, exappendiculatum, a I a s oblongas, obtusas, basi vix auriculatas panllo superans, e arina recta $v$, subineurva, obovata, erostris, alis brevior v. subaequilonga, petalis dorso connatis. $S t a m$ in a 10 , monadelpha $v$. vagina varie fissa di-triadelpha, antheris oblongis. Ovarium subsessile v. brevissime stipitatum, uniovulatum. Stylus incurvus, filiformis, brevis; stigma tenue. Le gum en stipitatum, fungoso-coriacenm, indehiscens, reniforme v. cochleato-faleatum, planum, apterum, monospermum. Sem en magnum, reniforme, $\mathbf{R}$ ad i $c$ ula inflexa. - Arbores $v$, frutices Americae tropicae; foliis alternis, imparipinnatis, foliolis subalternis, coriaceis $v$. submembranaceis, terminali a pari ultimo distante, stipulis nunc nullis, nunc deciduis, nunc persistentibus, spinescentibus, inflorescentia paniculatim racemosa, racemis axillaribus $v$, terminalibus, fasciculalim ramosis, floribus sessilibus v. brevissime pedicellatis, bracteis exiguis, bracteolis geminis, brevibus, orbi. culatis $v$. ovatis, calyci adpressis, petalis, imprimis vexillo, exlus villosis, ovario villoso, legumine plerumque glabro.

Drepanocarpus C. F. W. Meyer Flor. Essequeb. 238. Kunth in Humb. ot Bonpl. Nov, Gen, et sp. VI. 390 DC. Prodr, 1r. 420, exel. sp. Meisner Gen, 95. (68.) Bent. ham in Annal. Wiener Mus. IT. 95. Nephrosis L. C. Richard misc. S o m merfeld $\mathrm{t} i$ a Sehumacher in Danske Sels. kab. Afhandl. IV. 105. O ruearia Clusius Exot. 47. 48. ic. Pterocarpus apterus Gärtner $t, 156$.

G\% 10 . Naelhaerivm PERS, Cal y $\mathrm{x}$ tubuloso-campanulatus, truncatus, breviosime quinquedentatus v. quadridentatus, dente supremo duplo latiore, emarginato. Corollae vexillum alis parnm longias, ovatum $\vee$. orbiculatum, integram v. emarginatum, basi complieatum, angustatum, truncatum v. vix anricnlatum, exappendiculatum, a la e oblongae, saepins faleatae, e arina inenrva, obtusa, alas aequans v. paullo brevior, saepe breviter rostrata, petalis dorso connatis. Sta min a 10, basi monadelpha, vagina antice v. utrinque fissa, flamento vexillari interdum usque ad hasim libero, antheris oblongis. Ovarinm stipitatum, uniovalatom. Stylus incurvus, filiformis; stigma tenue. Le gu m en stipitatum, compressum, coriaceum, indehiscens, subexcisum, hine convexum, apiee in alam oblongam v. cultriformem, membranaceam, margine exteriore incrassatam, legumine ipso longiorem desinens. Sem en reniforme, radicula inflexa. - Arbores Americae tropicae; foliis alternis, imparipinnatis, foliolis subalternis, coriaceis, terminali a pari ullimo distante, stipulis nullis, nunc deciduis, nunc persistentibus, spinescentibus, racemis axillaribus et terminalibus fasciculatim ramosis, floribus secus ramos ultimos distichis, subsecundis, sessilibus v. brevissime pedicellatis, bracteis parvis, bracteolis duabus orbiculatis, ovatis $v$, rarius lanccolatis, calyci adpressis, corollis saepe extus sericeo-villosis, ovario villoso, legumine glabro v. villoso. 
M achaerium Persoon Encheir. II. 276. Vogel in Linnaea XI. 100. Bentham in Annal. Wiener Mus, II. 97. Nissoliae sect. Gomezium et Maehaerium DC. Prodr, 1I. 257. Nissolla s s p. Jacq. Amer. t. 174.f. 48. Aublet Guian, t. 297.

Gr 11. Ateleia MUC, et SFSS. Flore 8 ..... Le g n men stipitatum, compressum, membranaceum, indehiscens, sutura vexillari recta, anguste alata, carinali convexa, aptera. Se men .... - Arbores a mericanae, vix notae; foliis imparipinnatis, racemis terminalibus, paniculatis.

A teleia Moc. et Sesse Flor, mex, inedit. Bentham in Annal. Wiener Mus, II, 101. P te r o e a r pi sect. A tele ta DC. Prodr. II. 419. sp. 22, Mem, Legum, t. 57, f. 1 .

6ร 12. Irechypterum BENTH. Ca 1 y $x$ campanulatus, oblique truncatus, antice breviter unidentatus. Corollae papilionaceae vexillu m basi callosum, a la e obtusae, basi ciliatae, e a rinae aequilongae, vexillo breviores. St a $m$ in a 10 , filamento vexillari basi et supra medium cum reliquis cohaereate subunonadelpha, antheris ovatis. Ovarin m..... Leg n me n sessile, linearilanceolatum, di-trispermum, indehiscens, sutura seminifera anguste marginata. Se mina ..... Frutex indicus, scandens; foliis imparipinnatis, foliolis oppositis, racemis axillaribus folio longioribus, pedicellis fasciculatis.

B r a e h ypt er um Bentham in Annal. Wiener Mus. 11 . 101. D a l bergiae sect. Bracbypter um Wight et Arnott Prodr. $\boldsymbol{X}$. 264. D a I b e rg fa $\mathrm{s}$ e a ndens Roxb. Plant. Corom, t. 198.

87 13. Pongamia $L A M$, C al y x cyathiformis, oblique truncatus, obsolete quinquedentatus. Corollae papilionaceae vexillum reflexum, alae obtusae carinam rectam aequantes. Sta min a 10 , filamento vexillari libero diadelpha, Ovarinm sessile, biovulatum. Stylus brevissimus; stigma acutum. Leg a m en coriacenm, compressum, ovato-oblongum, recurvato-rostratum, indehiscens, mono-dispermum, valsulis intus concavis. - Arbores v. frutices scandentes, in Asia tropica indigeni; foliis imparipinnatis, foliolis oppositis, racemis axillaribus.

Pong a mi a Lam. Illustr. $t, 600$. Venten. Malm. $t .28$. DC. Prodr. 11.416 . Wallich Plant. As, rar. $t .78,237$. Wight in Hook. Bot. Misc, Suppl. t, 41. Meisner Gen, 95. (63.) Bentham in Annal, Wiener Mus. II, 101. G a l e d u pa Lam. Dict, II. 595. Robiniae sp. Lina. Dalbergiae sp. Auct.

6ra4. Splninetolobiam VOGEL. Ca Iy x campanulato - urceolatus, limbo subtruncato, ebsolete quinquedentato. Co roll a e papilionaceae v e $x$ il l nm patens, a la e carinae rectae adpressae. Ovarin m subsessile, compressum, pluriovalatum. Stylus brevis; stig ma subcapitatum. Leg um en ntrinque attenuatum, apice subuncinatoapienlatum, coriaceo-lignosum, valvis adpresso connatis indehiscens, mono-trispermum. S e $\mathbf{m}$ i $\mathbf{n}$ a eompressinscula. - Arbores brasilienses, Pongamiae facie; folñs imparipinnatis, floribus race-
mosis.

\section{Sphinetolobium Vogel in Linnaea $X I, 417$.}

67 15. Milletia WIGHT et ARN. C a I y x urceolatus, obsolete quinquedentatus. Coroll a papilionaceae vexillum reeurvatum, emarginatum, alis carinam superantibus panllo longius. St a m in a monadelpha, filamento vexillari libero. Ovarium ..... Leg nmen compresso planum. ellipticum v. lanceolatum, acutum, sutaris incrassatis, apteris, indehiscens, mono-dispermum, valvis inter semina eohaerentibus. Sem in a.... - Fratices scandentes $v$. arbores, in $A$ sia tropi ca crescentes; foliis magnis, abrupte pinnatis, foliolis oppositis, stipellis setaceis, racemis axillaribus, plus minus ramosis, floribus majusculis, brevi ter pedicellatis.

Milletia Wight et Arnott Prodr. I. 263. Meisner Gen. Meisuer Gen. 95. (68.)

6r 16. End ospermatim $B L U M$. C a y hilabiatus, labio superiore obtase bilobo, inferiore tridentato. Corollae papilionaceae a la e ea$r$ in a longe unguiculatae. $\mathrm{S}$ ta $\mathrm{m}$ in a 9 , monadel. pha, decimo defieiente. O va rium ...... Leg $\mathbf{n -}$ m en longe pedicellatum, membranaceo-foliaceum, lanceolatum, indehiscens, monospermum. S e men lineare, compressum. - Frutex javanicus, scandens; foliis abrupte pinnatis, foliolis alternis, oblongis, elongatis, basi obtusis, apice brevissime acuminatis, utrinque, imprimis subtus villosis, racemis sub anthesi folio brevioribus, demum longioribus, floribus parvis, calycibus basi bibracteolatis.

E adosperm um Blume in Flora 1815. p. 132. DC. Prodr. II, Meisner Gen. 95. (67.)

6ร 1ซ. Dalbergia LINN. F. C a 1 y x campannlatus, quinquefidus. Cor o 11 ae papilionaceae ve $x$ illu m ovatum, obtusnm, erectum, alas oblongas hinc auriculatas paullo superans, carinae alas subaequantis petala libera. S tamin a $8-10$, monadelpha, vagina postice fissa, v. aequaliter diadelpha, antheris didymis. Ovari n m stipitatum, lineare, compressum, tri-quadriovulatum. Stylus brevis, rectus; $8 \mathrm{tigma}$ crassiusculum. Legum en stipitatum, membranaceum, compresso-planum, reticulato-venosum, oblongum, utrinque angustatum, valvis inter semina connatis, indehiscens, abortu mono-dispermum. Se min a compressa, distantia, em bry o n i s radicula inflexa. - $A r$ bores $v$. frutices, saepe scandentes, in Asia tropic a indigeni; foliis alternis, imparipinnatis, tri-septemijugis, foliolis alternis, floribus racemosis, pedicellis cum basi calycis arliculatis.

D a Ib e r g i a Linn. f. Supplem. 59 , excl.sp. DC. Prodr. IT, 416. excl, sp. Wight et Aruote Prodr. I, 264. excl, sect, I. Meisuer Gen. 95. (67.) Bentham in Annal, Wiener Mus. II. 102. Solori Adanson Fam. IT. 327. Dalbergia sp. Roxburgh Plant, Corom, t, 113-115. 191.

6rils. Trioptolemea MART. Flores abortu unisexuales (?) C a I y x campanulatus, inaequaliter quinquedentatus, dentibus superioribus latioribus, lateralibus minoribus, intermedio longiore, angustiore. Coroll a e papilionaceae vexillum breviter nnguiculatum, basi biauriculatum, alas angustas, oblongas, hine anriculatas parum superans, carinae subrectae, obtusae petala alas subaequantia, apice se invicem involventia $v$. connata. $S^{t}$ a $m$ i n a $9-10$, vagina superne fissa monadelpha, antherarum loculis erectis, apice distinctis. Ovarium stipitatum, lineare, tenue ...... St y 1 n \& brevis, subreetus; stig ma tenue, oblique subtruncatum. Legumen samaroidenm, oblongum, membranaceum, reticulato.venosum, suturis corneis, medio induratum, monospermum. Semen reniforme, compressum, embryonis radicula inflexa. Arbores brasilienses; foliis alternis, imparipinnatis, foliolis ovatis $v$. oblongis, saepe coriaceis, supra nitidis et reticulato-venosis, inflorescentia dichotome cymosa, cymis pedunculatis, axillaribus $v$. in paniculam terminalem dispositis, floribus plurimis, minimis, secus ultimos cymarum ramos ad axillam bracteae persistentis pedicellatis, pedicellis bibracteolatis.

Trloptoleme a Martias ex Bentham in Annal. Wiener Mrus. II. 102. D a l berg i a e sect. B. Yogel in Linnaed 
XI. 196. Pterocarpus frutescens Flor. Flum. VII. t.96. - Semeionotis Sehott in Wiencr Zeitschr. 1830. p. 1216. Melsuer Gen, 95. (68.)

6\%1D. TViseolobium VOGEL. Calyx campanulatus, inaequaliter quinquedentatus, dente infimo longiore, angustiore. Coroll a e papilionaceae vexillum obuvato-orbiculatum, alas oblongas, divaricatas subsuperans, earinae oblongae v. obovatae, obtusae, alas aequantis v, vix brevioris petala dorso connata. Stamina 10, monadelpha v. filamento vexillari libero diadelpha, a nthe rarum localis brevibus erectis, subdistinetis, apice dehiscentibus. Ovarinm stipitatum, li. neari oblengum, compressum, bi-triovulatum. \& tylus parnm incurvus; stigma obliquum. Legumen oblongum, suberectum, plano compressum, membranaceum, indehiscens, laeve v. obsolete reticulatum, medio hand induratum, suturis margine parum conspicuis, mono-dispermun, $\mathbf{S}$ e min a magna, reniformia, embryonis radicula brevi, inflexa. - Arbores brasilienses; foliis allernis, imparipinnatis, saepe multijugis, foliolis membranaceis $v$, rarius subcoriaceis, nervo medio subtus pro. minulo, venis reticulatis, saepius inconspicuis, inflorescentiu paniculato-racemosa, racemis fascicula. to-ramosis, axillaribus terminalibusque, rlachi rufo v. ferrugineo pubescente, floribus sessilibus v, breviter pedicellatis, calycibus bibracteolatis, bracteolis parvis, deciduis.

Mis col o bium Vogel in Linnaea XI. 200. Meisuer Gen. Comment. 67. Bentham in Annal, Wiener Mus, MI, 103. Pterocarpus niger Flor. Flum, VII, t. 91.

68\%0. Platyuniscium $V O G E L$. C a lyx turbinato-campanulatus, breviter quinquedentatus. Corollae papilionaceae vexill nm orbiculatum v. ovatum, al is oblongis v. obovatis, liberis panllo brevius v. aequilongum, carina eblongae v, obtusae, alas aequantis v. paullo superantis, reetae v. incurvae petala dorso inter se connata. S t a min a 10 , monadelpha, vagina superne fissa, a n the$r$ is uniformibus, longitudinaliter dehiscentibus. Ovarium longe stipitatum, lineari-oblongum, compressum, uniovulatum. Stylus filiformis, bre. vis; stigma subeapitatum. Le gumen longe stipitatum, oblongum, subobliquum, plano - compressum, membranaceum, indehiscens, obsolete reticnlatom, medio haud induratum, suturis marginalibus tenuibus v. vix incrassatis, monospermum. S emen compressum, reniforme, e mb ry onis radicula brevi, inflexa. - Arbores $v$, frutices brasilienses; foliis oppositis $v$, ternatim verticillatis, imparipinnatis, stipulis saepe persistentibus, foliolis oppositis v. superioribus alternis, coriaceis, glabris, racemis axillaribus simplicibus v. parum ramosis, saepius fasciculatis, glabris, bracteis bracteolisque parvis, membranaceis, floribusque glaberrimis.

Platymiselum Vogel in Linnaea XI. 198. Meisner Gen, Comment. 67. Beutham in Annal. Wiener Mus. IT. 104. Pterocarpus 1 utens Flor. Flum, VII, t, 92 - ? A werimnum pinnatum Jaeq. Amer, $t$. 177. f. 50 .

6721. Callisemaea BENTH. Calyx herbaceus, laxe turbinato-campanulatus, subincurvos, quinquefidus, bilabiatus, laciniis ovatis. Corollae papilionaceae vexill $\mathrm{nm}$ amplum, ovato-orbicalatum, basi rotundatum, a l a s oblique obovato-oblongas superans, carinac obovato-oblongae, obtusae, subrectae petala dorso connata. Stamina 10, ima basi monadelpha, filamentis vexillari et dorsali fere ad basim liberis, reliquis in phalanges duas oppositas fere ad me- dium connexis, antheris ovatis, uniformibus. Ovarin m longissime stipitatum, oblongum, pluriovulatam. Stylus filiformis, glaber; stigma obtusum, tenue. Legumen longe stipitatum, sublignosum, ohlongum, compressum, indehiscens, sutura vexillari parum incurva, aptera, carinali in alam membranaceam in stipitem decnrrente pro. ducta, polyspermum. Se in in a pendula, embry on is radicula recta. - Arbores $v$. frutices bras ili enses; foliis imparipinnatis $v$, abrupte pinnatis, rhachi in setam desinente, foliolis oblongis, apice relusis $v$. emarginatis, nervis secundariis parallelis conferte lineatis, racemis axillaribus simplicibus, laxis, paucifloris, floribus pedicellatis, pedicellis supra basim bibracteolatis, bracteolis membranaceis, lanceolatis, laxis, cito deciduis.

Callis emaea Beatham in Annal. Wiener Mus. $I l$. 105. Plat y pod i in Vogel in Limaea $X T$. 420.

6ร2:. Diseolobium BENTH. Calyx subherbsceus, turbinato-campanulatus, bilabiatus, labio superiore emarginato-bifido, inferiore trifido. Coro Il a e papilionaceae vexill am orbieulatum, a I a late ohovatas paullosmperans, c a rin a e petala libera, alis conformia, paullo minora. S tamina 10 , filamentis carinali et vexillari fere a basi liberis, reliquis in phalanges duas oppositas ultra medium connatis, antheris ovatis, uniformibus. Ovarium breviter stipitatum, oblongum, biovulatum. Sty I a filiformis, glaber; stigma terminale, tenue. L e $\mathrm{g}$ umen reniforme, suborbiculatum, sutura vexillari emarginata sinu utrinque in discum brevem incumbentem producta, hine orbiculatum, radiatim reticulato-venosum, margine undulatum, indehiscens, monospermum. Semen lunato-reniforme, strophiola erassa, embryon is radicula inflexa. - Frutex brasiliensis; ramis junioribus et petiolis tenuissime canescentibus, foliis alternis, imparipinnatis, stipulis parvis, lanceolatis, deciduis, foliolis alternis v. suboppositis, distantibus, petiolulatis, oblongis, obtusis, subtus subcanescentibus, racemis axillaribus subviscosis, brevibus, subsecundis.

Dis c o l o b $\mathrm{i} u$ m Bentham in Annal, Wiener Mus, 1T. 106.

6793. Piseidia LINN. Caly $\mathrm{y}$ urceolatoeampanulatus, quinquefidns. Corolla e papilienaceae vexillum orbicnlatum, emarginatnm, alas carinam superantes vix aequans. Stamina 10 , diadelpha, filamento vexillari interdum reliquis adhaerente. Ovarium stipitatum, circiter octoovulatum. Stylus glaber; stigma simplex. Leg umen stipitatum, lineare, eompressum, inter semina torulosum, sutura utraque bialata, alis cruciatim patentibus, indehiscens, uniloculare, dipentaspermum, continuum $\mathbf{v}$. hinc inde inter semina constrictum. S emina oblongo-reniformia, radicula uncinato - inflexa. - Arbores $A m e r i$ cae tropicae, inermes; foliis alternis, imparipinnatis, foliolis oppositis, racemis terminalibus paniculatis, floribus pedicellatis, albis, calyce colorato.

Pis cidia Linn. Gen. n.856. Kunth in Humb. et Bonpl. Nov. gen. et sp. V1, 381. DC. Prodr. II. 267. Meisner Gen. 89. (63.) $\mathrm{P}$ is ci p u I a Löffliug It. 275. I $\mathrm{e} \mathrm{h} \mathrm{th} \mathrm{yomet} \mathrm{b} \mathrm{i} \mathrm{a} \mathrm{P.}$ Browne Jam. 276. Ery thri a a $\mathrm{P}$ s e ip ula Lino. Lam, $t, 605$.

6\%84. Plaedloentpra BENTH. Caly turbinatus, subincurvus, quinquedentatus, subbilabiatus. Corolla e papilionaceae vexillum obnvatum, basi in unguem angustatum, a l a s oblongas v. obovatas sulisuperans, carina e latae obsvatae, subincurvae petala alas aequantia, dorso superne concreta. Ovarium sessile, villosum, 164 
pluriovulatum. Stylus filiformis, elongatus; stig ma parvum. Legumen sessile, oblongum v. pyramidatum, crassum, suberosum, indehiscens, longitudinaliter quinquealatum v, costatum, munospermum. Semen reniforme, embryonis radicula inflexa. - Arbores Americae tropica foliis alternis, imparipinnatis, exstipulatis, foliolis alternis, petiolulatis, terminali a pari ultimo remo to, coriaceis, penninervïis, glabris, racemis axillaribus simplicibus $v$, vix ramosis, floribus nutantibus, pedicellis bibracteolatis, bracteolis subulatis, deciduis.

Phellocarpus Bentham int Annal. Wiener Mus. II. 106. Nissolia reticulata Flor. Flum. VII. $t$. 88. et Prerocarpus euliratus Flor. Flam. VIT. $t, 95$.

6\%:5. Geofiroya JACQ. C aly x campanulatus, semiqninquefidus, lobis doohus posticis altins cohaerentibus. Coroll a e papilionaceae vexillum subrotundom, reflexum, a las et earin a $\mathrm{m}$ inter se aequales superans. Stamina 10 , filamento vexillari lihero diadelpha. Ovarium subsessile, biovolatum. Stylus subulatus; stig ma simplex. Le gu men drupaceum, ovato.ellipti cum, molle, putamine lignoso, bivalvi, monospermo. Semen inversum. Em bryonis exaltrminosi, recti radicula supera. - Arbores Americae tropicae, inermes $v$. spinosae; foliis imparipinnatis, racemis axillaribus, simplicibus, floribus pedicellatis, luteis, pedicellis basi unibracteatis.

G e of fro y a Jaeq. Amer. 20z, $f, 62$, Linn, Gen, $n, 878$, Humb. et Bonp!. Plant. aequinoct. 1, 69, $t, 100$. Kunth in Humb. et Bonpl. Nov. gen, et sp. VI. 379. DC, Prodr. II. 476. exti. sp. Neisirer Gen. 97. (69.) Bentham in Annal. Wiener Mus, II. 107, U a a i Maregr. Brasil, 121.

8ร26. Amaliza LAM. C aly x late campanulatus v. subturbinatus, truneatus, brevissime v. breviter quinquedentatus. Corollae papilionaceae vexillnm orbiculatum, emarginatnin $v$. bifidum, ala s oblongas superans $v$. rarissime is dem brevius, carina alas subaequans, ineurva, obtusa, petalis dorso se invicem involventibus v. leviter connatis. Stem ina 10 , munadelpha, vagina superne fissa, v. filamento vexillari libero diadelpha. Ovariu m stipitatum, pauciovulatum, ovulis amphitropis. St y l us brevis, incurvus; stigm a minutam. Leg ume $n$ drupaceum, oboroidenm v. ovoideum, monospermum. Se men pendulum, radicula brevissima, recta, supera. Arbores Americae tropicae, Ormosiae facie; foliis alternis, imparipinnatis, stipulis nunc magnis, cartilagineis, persistentibus, nunc parvis, deciduis v. interdum nullis, foliolis coriaceis, plurijugis, ter minali a pari ultimo distante, inferioribus oppositis, superioribus saepe alternis, stipellis setaceis, rigidis, varius nullis, infiorescentia fasciculato-paniculata, subterminali, calycibus subsessilibus, bracteis braeteolisque parvis vel interdum calycem aequantibus, lancealatis, plerumque caducis.

A ndira Lars. Dict, r, 111. Kunth in Humb. et Bonpl. Nov, gen, et sp. VT. 385. DC. Prodr. It. A25. Meisner Gen 97. (69.) Bentham in Arnal. Wiener Mlus, $1 t$. 107.

a. ARISTOBULlA Mart, msc. Cal y x amplas, apice sub. dilatatus, truncatus, minute quinquedentatus. S $t$ a mi. ma monadelplia,

b. LUMBRicidia Velloxa Flor. Flam. DIT. t. 104. 105. Cal $\mathrm{y}$ urceolatus, apice obtuso quiaquedentatus. St a mi in a filamento vexillari likero diadelpha. Ovarium villos um v, rarius pilis paucis ciliatum, nunqua omnino glabrum, saepius breviter stipitatum. - Voucap a a a Aublet Guian. Stuppl, 10, t, 373. c. EEANDIRA Beath. l. c, C al y x urceolatus v. turbinatas, apice obtuse quinquedentatas, $\mathrm{S} t \mathrm{a} \mathrm{m}$ in a fitamento vexillari libero diadelpha. O vari u m glabrum, longe stipitatum, - Ge off ro a e a $\mathrm{sp}$. Wight in philosoph. Transaet. 1777, t, 70, Lam, t. 602.

6ระร. Wuelnresta BENNET. Calyx campanulatus, basi postice gibbus, quinquedentatus, dentihns dnobus superiorihus minoribus. Corolla e papilionaceae vexill um lineare, sessile, a la et e a rinae petala vix coalita subequalia, longins unguiculata. St a $\mathrm{m}$ in a 10 , filamento vexillari libero diadelpha. Ovari um stipitatum, biovulatum. Sty I u filiformis; stigma acutum. Leg a m en longe stipitatum, ovale, chartacenm, indehiscens, monospermum. S e m en pendulum, integumentis coalitis a nuoleo solutis quasi arillatum. Embryonis exalbuminosi cotyledon es crassae, carnosae, radic ula recta, cotyledonum axi obliqua, inclusa. - Frutex javanicus; folitis imparipimatis, uni-bijugis, foliolis lateralibus suboppositis, racemo terminali simplicissimo, paucifloro, floribus atbis, majusculis.

E u chresta Bennett in Horsfield Plant. Jav. rar. 148. t. 31. A udira Horsfieldi Leschenault in Annal. Mus. XVI. $481 . t, 12$.

68\%8. Dipterix SCHREB. C al y tubo brevissimo, campanulato, limbi laciniis duabus superioribns maximis, oblongis, coneavis, coriaceis, corollam aequantibus, una inferiore minima, integerrima v, tridentata. Corollae papilionaceae petala subaequilonga, brevissime unguieulata, vexillum orbiculatum, emarginatum, patens, a la obuvatae, integrae, $c$ a rina obovata, obtusa, petalis dorsu vix connatis. Stam in a $8-10$, monadelpha, vagina snperne fissa. Ovari nm uniovnlatum, ovulo amphitropo. Stylus brevis, incurvus; stigma terminale, minutum. Legamen drupaceum, crassnm, ovoideum, indehiscens, monozpermum. Semen ovato-nblongum, pendolum, radicula recta, supera. - Arbores Americae tropicae; foliis oppositis $v$. subalternis, abrupte v. subimparipinnatis, exstipulatis, foliolis alternis v. oppositis, latis, coriaceis, saepe stipellatis, glanduloso punctatis, punctis interdum pellucidis, inflorescentia terminali paniculata, pedicellis brevibus, bracteis bracteolisque deciduis, ovario glabro.

Dipterix Schreber Gen. n, 1161. DC. Prodr. II. $4 \mathrm{kr}$. Meisner Gen. 97. (69.) Bentham in Annal. Wiener Mus. II. 110. - Co u marou na Aublet Guían. II, 740. 1. 296. C umaruna Lam. $t$. 601. B a r y o su a Gärtuer 11.73 . t. 93. Hefnzi a Scopoli Introduct. $\pi, 1270$. - Taralen Aublet Guian. II. 745. 2. 298. Boldu cia Necker Elem. n. 1342.

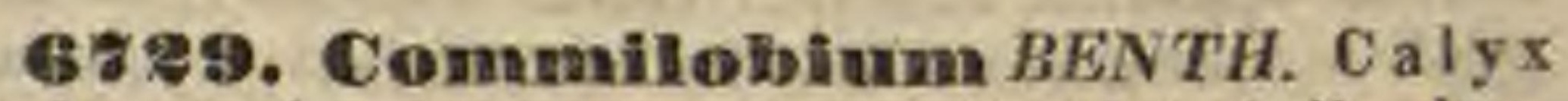
tobo brevissimo, campanulato, limbi laciniis duahus superioribus maximis, petaloideis, corollam aequantibus v. superantibus, una inferiore minima, acuta. Corollae papilionaceae petala subaequilonga, breviter onguiculata, vexill um orbiculatnm, patens, basi alas oblique obovatas, apice bifidas amplectens, carina obovato oblonga, ob. tusa, parum ineurva, petalis dorso connatis. Stain in a 10 , monadelpha, vagina superne fissa. $O$ va rium uniovulatum, ovulo pendulo, amphitropo. Stylus incurvas; stigma terminale, minatum. Legumen ovato-subrotundam, compressum, coriacenm, indehiscens, intus lignosum, cellulosum, cellulis gummiferis, monospermum. Semen pendulnm, strophiola parva, radicula recta, supers. - Arbores brasilienses; foliï imparipinnatis, exstipulatis, foliolis parvis, wulti. 
jugis, vix coriaceis, penninerviis, pellucide punctatis, exstipellatis, inflorescentia racemosa, racemis inferioribus axillaribus, simplicibus, superioribus paniculam terminalem formantibus, floribus amoenis, pedicellatis, bracteis bracteolisque minutis, deciduis.

Commilobin io Bentham in Annal. Wiener Mus, II. 110. Paba S. Iguatii Brasil.

B8:0. IPterodion VOGEL. Caly x tubo brevissimo, copuliformi, laciniis duabns superioribus majoribus, alaefurmibus, suboppositis, tribus inferioribus minimis. Coroll a e papilionaceae, calycis laciniis superioribus minoris petala subsessilia, erecta, aequilonga, apice rotundata. $\mathbf{S} t \mathbf{a} \mathbf{m}$. na 10 , monadelpha, vagina snperne fissa. O vari u m sessile, lineare, st y I u sque compressus; stig m a subeapitatum. Le g a men subplano-compressum suboblongum, indehiscens, circumeirea membranacen-alatum, medio monospermum, loculo seminifero intus sublignoso. Semen $\ldots . .-A r-$ bor brasiliensis; foliis sparsis, imparipinnatis, subtrijugis, foliolis brevi petiolulatis, ovato-oblongis, pellucido - punctatis, glabris, racemo terminali, paniculatim ramoso.

P te rodon Vogel in Linnaea XI. 834.

Br81. Apoplanesia PRESL. Calyx tabo brevi, campanulato, ubsolete nervoso, limbi quinquepartiti laciniis obovato - oblongis, obtusis, trinerviis, coriaceis, demum patentissimis, excrescentibus, tribus superioribus aequalibus, duabos inferiaribus paulla latioribus, vix brevioribus, Corollae petala 5 , vix papilionacea, subaequalia, ublungo-lanceolata, acuta, trinervia, patentia. S tamina 10 , monadelpha, vagina superne fissa, a ntherae uniformes. Ovarium sessile, compressum, glanduloso-verrneulosum, subsericenm, uniovulatum. Stylus filiformis, apice incurvus; s tigma subcapitatum. L e $g$ n in e n subellipticum, compressum, styli hasi mucronatum, verrnculosum, indehiscens, monuspermum. Semen pendulan, umbilico infra medinm ventrali. Embryonis exalbuminosi cotyled on es carnosae, cordatae, radic ula incurva. - Arbor incertae originis; foliis exstipulatis, imparipinnatis, foliolis multijugis, petiolulis verruculoso-glandulosis, floribus spicatis, in paniculam foliatam dispositis.

A po p la a e s i a Presl Symb. I, 63, 6. 41. Meisner Gen, 96. $(68$.

6832. Derrois LOUR. C a Iy x tubulosus, quinquecrenatos. Coroll a e papilionaceae petala duo inferiora in carinam Innatam concreta. S ta m in a 10 , monadelpha. L e $g$ um en oblongam, obtusum, compressissimum, membranaceun, monospermnm. Sem en oblongum, planum. - Frutices sinenses et cochinchinenses, scandentes, inermes, glabri; radicibus carnosis, foliis imparipinnatis, uni-mullijugis, racemis axillaribus $v$. lateralibus.

Derris Loureiro Elor, cochinch, 595, DC. Prodr. II. 415. Meisuer Gen, 95, (68,)

Bร33. Degnellin $A U B L$. Cal $y$ x bilabiatns, labio superiore integro, inferiore irifido. Corollae papilionaceae vexillum alas et carinan inter se aequales superans. Stamina 10 , filamento vexillarilihero diadelpha. Ovarium de. clinatum, anguatum, oblungum, hispidum, rec- tiusculum. Sty lus erectus, capillaris, introrsum infra apicem ad basim hispidus; stigma terminale, capitatum, glandulosum. Le g a men globo. sum, parvum, bivalve, monospermum. S emen sphaerieum, farina obvolutum. - Frutex guianensis; ramis sarmentosis; foliis imparipinnatis, foliolis bijugis, ovalibus, acutis, racemis axillaribus, spicaeformibus.

D e g u e li a Aublet Guian, IT. 750, t, 300, Lam, t.603. DC. Prodr. II. 429. Meisuer Gen, 95. (67.) C y 11 z om a Necker Elem. $n, 1343$.

6ร34. Tatainea $A U B L$. F 10 s.... L $\mathrm{L}$ g u m e n coriaceum, subrotundam, compressum, ab uno latere rugosum, ferruginenm, marginibus membranaceis exaratum, indehiscens, monospermum. Semen magnnm, subrotundum, comolanatum. Embryo rectus. - Arbor guianensis; foliis imparipinnatis, foliolis alternis, ovalibus, glabris, sublus cinereis, rigidis.

Vatairea Anblet Guian, II. 755. $t$, 302. DC, Prodr. 11. 521. Meisuer Gen. 100. (7i,)

6835. II IIIIera LINN. F. Calyx campanulatus, basi truncata, planinscula, limbi quadridentati dente postico obsoleto v. rarius fisso, lateralibus a snperiori remotioribus acutis, antico productiore. Co ro 11 a e papilionaceae vexill um nngue planiusculo calycis tubum sulsuperante, lamina cordato-ovata, integra, plana, a la e stipitatae, oblongae, basi gibbae, carina dipetala, alis brevior, recta. Sta $\mathrm{m}$ in a 10 , monadelpha, vagina basi tumida, antherae ovatae. Ovarium lineare, compressum, multiovulatum. St y 1 a s brevis; stig ma acntum. Le g umen moniliforme, tri-quinquearticulatum, articulis subglobosis, indehiscentibus, hand secedentibus, monospermis, sutnris olssoletis. Semina compresso-reniformia. - Arbor surinamensis; ramis ferrugineis, subverrucosis, foliis alternis, imparipinnatis, bijugis, foliolis oppositis, petiolatis, integerrimis, coriaceis, ovato-oblongis, acutis, supra glabris, venosis, sub. tus sericeis, stipulis nullis, racemis axillaribus et terminalibus, simplicibus, ebracteatis, floribus nutantibus.

Mälle ra Lieu. f. Suppl, 53. 329. DC. Prodr, IT. 259. Meisner Gen. 89. (63.) Co u bla nd I a Aublet Guian. $I V$. 937. $t, 356$.

TERTEUS VII. SOPHOREAE DC. Prour. II. 94. Corolla papilionacea. Stamina 10 , rarius 8 v. 9 libera. L e g u men indehiscens v. bivalve. Embryonis cotyledones foliaceae v. crassiusculae, ra di cula recta v. incurva. Folia imparipinnala v. simplicia.

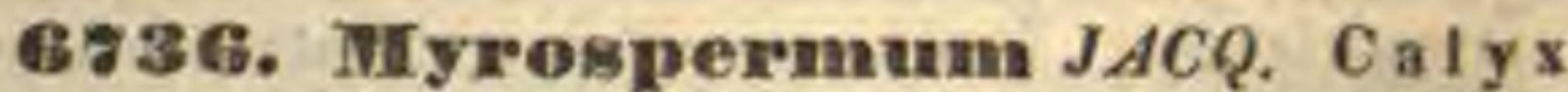
late campanulatus, obsolete quinquedentatus, $\mathrm{C}$ urollae papilionaceae vexillum subrotundoovatum, subcordatum, patentissimum, a la e et c a rin a e petala libera, lineari-lanceolata, vexillo aequilonga. St a mina 10 , libera, fllamenta subulata. Ovari um stipitatum, oblongum, bisexovulatum. Stylus prope apicem lateralis, filiformis; st igma obtusum. Leg amen stipiti basi nudo, apice lato impositum, membranaceum, compressum, hine stylo apiculatum, indehistens, mono disperuum. Semina subglobosa, testa in $164 *$ 
succum balsameum colliquata. Embryonis cotyledones crassae, planae, radicula ineurva. Arbores $v$. frutices Americae tropicae, ob succos balsameos celebres; foliis iniparipinnatis, foliolis coriaceis, alternis, punctis et lineis pellucidis notatis, racemis axillaribus et terminalibus, floribus albis $v$, roseis.

M y ros per m u m Jacq. Amer. 120 . DC. Mem. Legum. $V$. 164. Prodr. 11. 94. Meisuer Gen. 80. (57.) Benthaw in An. nal. Wiener Mus. II. 86. M y roxylon Linu. f. Suppl. 233. et Tolu ife ra Lino, Gen. n. B24,

a. CALUSIA Bert. Stami n um filamenta persistentia. Cal us ia Bertero msc. M yrospermum Jacq. Amer. t. 174. f. 34. Kanth in Humb. et Bonpl. Nov, gen, et sp. VI, s72, $t, 570,571$.

b. MXROXYLON Mutis. S tam i num filamenta decidna. M yroxylon Mutis ex Linn, f. Supplem, 233. BertoIoni Amoen, ital, $t$, 1. Kunth Op. cit, VI, 374. To1. n Ifer a Lian. Gen. 524. (Lam. $t$. 341. Lambert Cin. chon, Append. t. 1.)

6ร8\%. Ealwardsia SALISB. Caly $\mathrm{x}$ inflato-campanulatus, oblique truncatus, obsolete quinquedentatus. Coroll ae papilionaceae vexilI $\mathbf{m}$ breviter ungnieulatum, late obovatum, emarginatum, basi angulatum, a l a e oblongae, stipitatae, basi angnstatae v. vix auriculatae, e a ri na alas subsuperans, ohtusa, recta, petalis dorso se invicem involventibus, subconnatis, apice liberis. St a m in a 10 , libera; filamentis subdilatatis, glabris, O va rium breviter stipitatum, lineare, pluriovulatum. Sty Ins e basi dilatata attenuatus, subincurvns, flaber; st igma tenue. Legumen stipitatum, moniliforme, tetrapterum, unilocnlare, bivalve, polyspermum. Se m i n a subglobosa, estrophiolata. Embryonis radicula subincurva. - Frutices v. arbusculae, in insulis borbonie is et in Nova-Zeelandia crescentes; foliis alternis, imparipinnatis, multijugis, foliolo terminali longius petiolulato, stipulis nullis, floribus axillaribus, aureis, breviter spicato-racemosis.

Edwardsia Salisbury in Linn. Transact, IX. 299. t. 26. DC. Prodr. IT. 97. Meisner Gen. 80. (57.) Bentham in Annal. Wiener Mus. IT. 86. Sophorae s p. Linn. Miller Ic. $t$. 1 . Jacq. Hort. schönbr. $t$, 269. Lam. $t$. 325.f. 1 . et 3. Bot. Mag, t, 167. Duhamel Arbr, IIT, t, 20 ,

8735. Soplaora LINN. Ca ly $\mathrm{x}$ late cam. panulatus, oblique truncatus, obsolete $v$. breviter quinquedentatus. Corollae papilionaceae petala bubaequilonga, vexill u m obovatum v, rotundatum, erectum v. subpatens, in unguem angustatum, ala e oblongae, unguiculatae, hine aurienlatae, carina obtusa, resta, petalis dorso $8 \mathrm{e}$ invicem involventibus, connatis, apice liberis. Stamin a 10; filamentis subdilatatis, glabris, liberis v. interdum basi cohaerentibus. Ovariom subsessile, lineare, pluriovulatum. Stylus e basi snbdilatata attennatus, parnm incurvus, glaber; stigu a tenue. Leg u me n moniliforme, indehiscens, apterum, polyspermum. Se m in a subglobosa estrophiolata. Embryonis radicula incerva $v$ rectiuscula. - Arbores, frutices $v$. herbae, in $A$ sia reali calidiore $i c a$, nec non in America boreali calidiore, aequinoctiali et australi rijugis, foliolo terminali foliis imparipinnatis, plupulis nullis $v$. subulatis ari ultimo distante, stiracemis axillaribus' $v$, terminalibsentia racemosa plicibus, bracteis subulatis $v$, plerumque sim. unifloris, ebracteatis.

8 ip h or a Litn. Gen, $n, 308$. exel. sp. R. Brown in Aiton Hort. Hew. edit. 2. III, 2. DC. t, 4. f. 1. Prodr. II, 95. exel. sp. Meisuer Gen. 80. (57.) Bentham in Annal, Wiener Mus. II. 87.

a. MAYA Benth. l. c, Vexillum integrum. Stamina exserta. - Arbor chilensis, habitu Edwardsiae. S. m a erocarpa Smith.

b. EUSOPHORA Benth. l. c. Vexillum integram. $S t a-$ m In a carina breviora, basi irregulariter monadelpha, Arbores v. frutices, in Asia et America tropica cres. centes. - Broussonetía Ortega Decad, $V .61, t .7$. Virgliliae sp. Cavanill. Ic, $t$. 40t. (Jaeq. Amer. t. 173. f. 1. Lam. t. 325. f. 2,)

c. DichosemaEA Benth. l, $c$. Vexill u m bifidum. Stamin a carina breviora, basi irregulariter monadelpla. Frutex nepalensis. $-\mathrm{S}$ op hora (Disemaea) veluti. n a Lindley in Bot. Reg. $t .1185$.

d. PSEUdOSOPHORA Benth. l. c. Vexill $\mathrm{m}$ integrum. Stam in a carias breviora, libera. E mbryou is tadicula infera. - Herbae sibiricae, stipulis subulalis. Radius ia Reicheab. Consp. $n$, 3ss4. S. a I o pe curojdes L. S. $\mathrm{fl}$ aveseens Ait.

e. ? PAtrinia Raf. Vexill a m integrum. Carina mueronata. S t a mina diadelpha (?) - Herba boreali. americana, vix nota. - $\mathrm{P}$ a t rini a Rafiuesq. in Journ. phys. LXXXIX. 97. Sophora sericea Vent.

6835. Ammoderndron FISCH. C a ly x campanulatus, apice quinquefidus, subbilabiatus. Corollae papilionaceae vexillum orbieulare, hasi truncatum, apice patens, a las obovato-oblongas, basi hine auriculatas vix superans, $\mathrm{e}$ arina recta, obtusa, slis subaequilonga, petalis dorso connatis. Stamina 10 , lihera, antica paullo longiora. Ovarin $\mathrm{m}$ suhsessile, pluriovulatum. StyIns filiformis, incurvus, glaber; stigua par. vum, capitatum, minute penicillatum. Legumen oblongo-lineare, plano-compressum, membranaceum, ala angusta ad utramque suturam marginatum. - Frutex As ia e mediae; foliis bifoliolatis, petiolo ultra foliola producto, spinescente, stipulis subulatis, inflorescentia terminali, racemosa.

A m modendron Fiseher ex DC. Prodr. II. 523. Ledebour Elor. Alt. It. 110. It. t. 91. Meisuer Qen. 80. (57.) Bentham in Annal. Wiener Mus. II, 90. Sop ho ra a rgeute a Pallas in Act. Potropolit. 1792. p. 373, t. 8. S. bif oiia Pallas Astragal. $t$. 91.

68 40. Calperronia $E . M E Y . C$ a l y $x$ eampannlatus, bilabiacus, labio superiore bifido, inferiore longiore. Corollae papilionaceae vexilI $\mathrm{nm}$ orbiculatum, a la s falcato-oblongas, hine auriculatas vix superans, car in a incurva, obtusa, petalis dorso connatis. St a mi na 10 , filamentis basi brevissime coalitis, glabris. O v a $\mathrm{r}$ i n m stipitatum, pluriovalatum. Sty lus glaber, subalates, incurvus; stigma minutum. Le gumen oblongo-lineare, plano-compressum, membranacenm, indehiscens, ad suturam superiorem angustissime alatum, pleiospermum, isthmis inter semina intus distinctum. Semina compressa, reniformia, strophiolata. E m br y o $\mathrm{n}$ is radicula inflexa. Frutices capenses et indici; folits exstipulatis, imparipinnatis, plurijugis, foliolo terminali a pari ultimo distante, inflorescentia racemosa, racemis axillaribus $v$. terminalibus, solitariis $v$. paniculatis.

C a l purnia L. Meyer Comment. 2. Bentham in $\mathbf{A n}$ nal. Wiener Mus. II. 89. Virgiliae sp. Lam. $t, 326$. f. 1. DC. Mem, Legum, t. 4. f. 2. Robiniae s p. Herit. Stirp. t, 75.

6841. Wirginia $L A M$, C a lyx late campanulatus, inaequaliter quinqnedentatus, subbilabiatus, Corolla e papilionaceae vexillum orbiculare, rotundatum, expansum, a las oblique oblongas vix superans, са rina incurva, rustrata, alas subaequans, petalis dorso connatis. St a mina 10 , filamentis liberis $\mathbf{v}$. ima basi subconnatis. 
Ovarin m sessile, pluriovulatum, villosum. StyI us filiformis, incurvas, glaber; stigma minutum. Leg u men oblongum, compressum, coria. ceum, indehiscens, inter semina farctum, suturis obtusissimis apterum. Semin a ovato-reniformia, subcompressa, strophiolata. Embryon is radicala inflexa. - Frutices v. arbores capenses; folitis exstipulatis, imparipinnatis, foliolo terminali a pari ultimo distante, racemis axillaribus terminalibusve, simplicibus $v$. paniculatis.

Virgilia Lam. t. 326. f. 2, (exel. f. 1.) Bot. Mag. t. 1590. E. Meyer Comment. I. 1. Bentham in Annal, Wiener Mus, It. 8s. Podalyria eapensis Andrews Bot, Reposit, t. 347 .

6848. Cladirastis RAF. Ca Iyx cylindraceo - campanulatus, basi suboblique obconicus, apice obtuse quinquedentatns, dentibus subaequalibus, obtusis. C o r o II a e papilionaceae petala longe unguiculata, subaequilonga, vexill um latnm, subrotundum, reflexo-patens, a l a e oblongae, rectae, obtusae, basi subbiauriculatae, carin a e petala distincta, late oblonga, fere recta, obtusissima, basi snbcordato-biauriculata. Stamina 10 , libera, flamentis apice incurvis, liberis. Ovarium stipitatum, lineare, multiovulatum. Stylus glaber, subulatus, incurvus; stigma minutum. 'L e gum en stipitatum, lineare, com. pressissimum, membranaceum, suturis simplicibus, tarde dehiscens, tetra-hexaspermum. S e sn in a oblonga, compressa, ohsolete strophiolata, Embryonis radienla inflexa. - Arbor borealia ni ericana; foliis imparipinnatis, tri-quinquejugis, foliolis plerumque alternis, petiolis basi in gemmae uxillaris hibernaculum dilatatis, stipulis nullis, race$m$ is axillaribus et terminalibus paniculatis, bracteis minutis, caducis, pedicellis filiformibus, ebracteolatis, floribus magnis, albis.

Cladrastis Rafinesq. Nov. gen. 1825. Torrey et A. Gray Flor. of North-Amer. I. 390 . Virgilla Iutea Michx, Arbr, II, t, 78.

6\% A3. Styplomolobiom SCHOTT. Ca1 yx olveonicas, breviter quinquedentatas. Corollae papilionaceae vexillum rotundnm, reflexnm, a las oblongas, basi hine auriculatas vix superans, e arina obtusa, alas subaequans, petalis dorso se invicem involventibus, subconnatis. Sta m ina 10 , filamentis liheris $v$, ima basi vix connatis, glabris, Ovarium breviter stipitatum, pluriovalatum. Stylus filiformis, incurvus, glaber; stigma minutum. L e g u m e muniliforme, apterum, carnosum, indehiscens, polyspermum. Semina ovata, compressa, strophiolata. Embryonis radienla inflexa. - Arbor ja ponica; foliis exstipulatis, imparipinnatis, foliolo terminali a pari ultimo distante, floribus terminalibus racemoso - paniculatis, ex albo subochroleucis, leguminibus pulpa austera repletis.

Styphaolobium Schott in Wiener Zeitschr, 1830. p. 844. Linnaea Litterat. Ber. 1831. p. 84. Bentham in Annal. Fiener Mus. II. S7. Sophora japonica Lisn. Dahamel Arbr. edit. nov. III. t. 2t. De. Mem. Legum. t, 4. f. 1. (Germ.)

Br44. IInerotropis $D C$. Calyx eam. panulatus, basi obtusns, subbilabiatus, labio su. periore bi-inferiore trifido, lobis acutis. Corolla e papilionaceae, imo calyci insertae vexill um obovatum, emarginatum, al a e lineari-oblongae et ca ri na e petala libera vexillo aequilonga. $\mathrm{Stami-}$ n a 10, filamenta libera, adscendentia, antira longiora, Ovarium breviter stipitatum, oblongolanteolatum, tri-quadriovulatum. Stylns subu- latus, adscendens; stigma acutum. Legumen oblongo-ellipticnm, utrinque attenuatum, coriaceo lignosum, tri-tetraspermum, isthmis inter semina pulposis interstinctum, bivalve. Semin a rotundato - tetragona, compressiuscula. Embry onis radicula recta. - Frutices sinenses; foliis imparipinnatis, bijugis, foliolis oblongo-obovatis, coriaceis, nitidis, paniculis axillaribus et terminalibus.

Macrotropis DC.Prodr. II. 183. Meisner Gen. 80. (57.) L a y a Hooker et Arnott ad beechey 189, t, 38. A n a. gy $r$ is foetida Loureir.

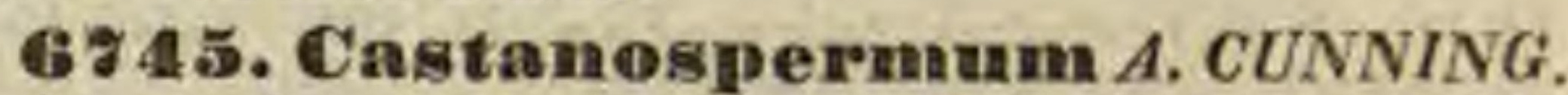
C a I y x coloratus, campanulatus, basi obtusus, snbbilabiatus, labii superioris bifid, inferioris trifidi lobis obtusis. Corolla e papilionaceae, imo calyci insertae vexillum obovatum, ungniculatum marginibus reflexum, al a e vexillo vix breviores, oblongae, obtusae, basi angustatae, carinae petala libera, alis conformia et subaequilonga. S $t$ amina 10 , libera, adscendentia, aequalia. Ovar i u m longe stipitatum, incarvam, multiuvulatum. Stylus filiformis, adscendens; stigma simplex. L e g u m en stipitatum, oblongo-eylindracenm, bivalve, polyspermum, inter semina pulposum. S e$\mathrm{m}$ in a depresse subglobosa, nitida. E m bry on is cotyledones hemisphaericae, carnosae, radicula brevissima, recta. - Arbor Novae-Hollandiae orientalis subtropicae, procera; foliis imparipinnatis, foliolis elliptico-ovatis, integerrimis, glabris, racemis e ramis nascentibus, simplicibus v. ramosis, floribus croceis, leguminibus spithameis, seminibus edulibus.

Castanos permum A. Cnnningh, in Hook, Bot, Mis. cell. 1. 241, t, 51. 52. Meisner Gen, 98. (70.)

6ร 46. Gourliea GILL. C a I y x campanalatus, basi retusus, subbilabiatus, labio superiore late emarginato, inferiore trilobo, lobis retusis. Corolla papilionaceae, ismo ealyei insertae vexill u m orhiculatum, emarginatum, lateribus reflexum, al a e oblongae, obtusae, undulatae, vexillum aequantes, carinae petala oblongo-Ianceolata, incurva, apice cohaerentia. Stam in a 10 , libera, adscenilentia, alterna breviora. Ova $\times$ i $\mathbf{m}$ sessile, gericenm, qualriovulatum. St ylus subulatus, adscendens; stigma punetiforme. Le g nmen oblongo-ovoideum, nucamentacenm, indehiscens, monospermuin, endocarpio membranaceo, transversim plicato. S em en reniformi-oblongom. E m b ryo nis radicula brevissima, vix incorva. Frutex chilensis, ramulis spinescentibus horridus; foliis e gemmis nodosis fasciculatis, imparipinnatis, foliolis tri-quadrijugis, oblongis, integerrimis, floribus versus apices ramulorum spinescentium fasciculato-corymbosis, pedunculis calycibusque pubescentibus, petalis aureo-flavis, praeter carinam venis sanguinensis pictis.

Go urlle a Gulles mse, ex Hooker Bot. Miscell, III 208. t. 106. Meisaer Gen. 98. (70.)

6\%4\%. Brmesta JACKS. Cal y campanulatus, apice quinquefidns, bilabiatos. Corolla e papilionaceae vexill $\mathrm{nm}$ orbiculatum, emarginatum, a las obovato-oblongas vix soperans, c arin a obovata v. oblonga, snbincurva, alas subaequans, petalis dorso se invicem involventibus $v$. liberis. St a m in a 10 , filamentis liberis, basi dilatatis. Ovarin m subsessile, pluriovulatum, vil. losum. Stylus glaher, hasim versas dilatutus, apice inflexus, infra stigma tenne, laterale nunnunquam dente auctus, Leg umen ovali-oblen. gum, compressum, lignosum, vix dehisens, abortu 
mono-oligospermum. Sem in a ovato-suborbieularia, compressa. Embryonis radicula fere reeta. - Arbores America tropieae; foliis imparipinnatis, foliolis suboppositis, terminali a pari ultimo distanle, crassis, coriaceis, penninerviis, stipulis parvis, persistentibus $v$. deciduis, inflorescentia terminali, paniculata, bracteis bracteolisque deciduis, floribus caeruleis $v$. purpurascentibus.

O r m o s la Jacksow in Linn. Transact. $X, 360, t, 25-27$. R. Browu in Aiton Hort. Kew. edit. 2. III. DC. Prodr. II. 97. Meixuer Gen. 80. (57.) Beuthaw in Annal. Wiener MLus. II. 88. To alichiba Adaus. Fam, II, 326. Sophora e sp. Swartz. Robiniae s p. Aubl.

6r48. Diplotropis BENTH. C a $1 \mathrm{y} x$ turbinatus, incurvus, basi attenuatus, apice bilabiatus, labio superiore lato bifido, inferiore minore trifido. Coroll a e papilionaceae, medio calyci insertae petala distineta, subaequilonga, ve$x$ illa m oblongam, integrum, a la e oblongae, concavae, basi subanriculatae, carinae petala alis conformia, sed paullo minora. St a mina 10 , filamentis liberis, basi dilatatis, alternis dimidio brevioribus, antheris uniformibus. Ovarin $\mathrm{m}$ sessile, ovatum, paueiovulatum, villosum. Stylus incurvus; stig m a terminale. Leg amen ovatum, compressum, coriaceum, crassiusculum, prope suturam superiorem utrinque nervo marginatam, indehiscens (?), monospermum $\mathrm{S}$ e m en maximum, reniforme, compressissimum. E m b r y on is radicula brevis, recta. - Arbor brasilie nsis; foliis glabris, imparipinnatis, foliolis alternis, cariaceis, subtus venosis, spicis terminalibus, pedunculatis, subramosis, rhachi crassa, ferruginea, bracteis parvis, persistentibus, bracteolis deciduis, calycibus coriaceis, ferrugineis, petalis crassiusculis.

Diplotropis Bentham in Annal. Wiener Mus. XI, s8.

6ร 49. TiBovdielhin $H B . K, \mathrm{C}$ a $\mathrm{y} \times$ tur binatus, incurvus, hasi attenuatus, apice late quinquedentatus, dentibus aestivatione valvatis. Corolla e papilionaceae, medio calyci insertae petala distineta, unguienlata, Lasi attenuata, exappendiculata, vexilla m latum, emarginato. bifidum, al is oblongis v, obovatis brevius, e a ringe petala ublongo-lanceolata, subrecta, vexillam sub. aequantia. S ta mina 8_10, saepissime 9 , filamentis liberis, inenrvi-adscendentibus, param inaequalibus. Ovari n m stipitatum, plariovulatum, disco erassinsculo. Stylu s filiformis, adscendens, apice inflexus; stigma capitatum. Le gumen oblongo lineare, plano-compressum, indehissens, margine superiore anguste alatum, pleiospermum. S emina oblonga, compressa, estrophiolata. E m bryonis radieula sulureeta. - Arbores Amerieae tropicae; foliis exstipulatis, imparipinnatis, plarijugis, foliolis coriaceis, retusis v saepe emarginatis, brevissime petiolulatis, terminali a pari ultimo distante, racemis terminalibus paniculatis, pedicellis calyce brevioribus, minute bibracteolatis, lycibus coriaceis, nigricantibus, dentibus margine membranaceis, subbilubiatis, floribus albis $v$. caeruleis, petalis erenulatis.

B o w dich fa Kunth in Humb. et Bonpl. Nov. gen. of sp. VI. 376. DC Prodr. IT. sig. Mrisuer Gen. 98, (70) Bentham in Annal. Wiener Mus. $I T$. 89. Se hipls a Martius Reise 1t. 157. Ce bipira Piso Brasil. 78,

6750. Cerets LINN. C a $1 \mathrm{y} \times$ late urceolatus, antice subobliquns, brevissime et obtusissime quinquedentatus. Corulla e subpapilinnaceae petala unguiculata, vexill n m cum al is confortmibus adscendens, $\boldsymbol{c}$ arinae petala libera recta, alis et vexillo majora. S t a min a 10 , libera, adscendentia, antica paullo longiora, Ovarium breviter stipitatum, lineari-oblongum, multiovulatum. Stylus filiformis, adscendens; stig ma ob. tusum. Le g umen oblongum, tenue, comprés. sum, sutura seminifera subalatum, altera dehiscens, polyspermum. Semina obovata, albuminusa. Eubryonis recti cotyledones planae, radicula brevis, plumula inconspiena. Arbores in Europa australi et in America bore ali indigenae; foliis post flores nascentibus, simplicibus, basi cordatis, nervosis, pedicellis unifloris e trunci ramorumque gemmis fasciculatis.

Cereis Linu. Gen, n. 310. Lam, t. 398. Duham. Arbr. t. 7. Gärtaer $I I .303, t, 144$. DC. Prodr. II, 518. Melsner Gen. 99. (71.) Siliquastrum Tournef. Inst. 414.

TTIIBUS VIII. CAESALPINIEAE DC. prodr. II. 470. Corolla irregularis, subpapilionacea v. fere regularis, interdum nulla. Stamin a 10 , v. pauciora, libera v, interdum coalita. E mb ryo rectus. - Folia impari v. abruple pinnata, interdun bi-tripinnata, non. nunquam simplicia.

Bร51. Leptolobium VOGEL. Calyx tubuloso-conicus, basi acuta attenuatus, limbi quinquepartiti laciniis acutiuzculis, duabus soperioribus minus profunde distinetis, Corolla e petala 5, calycis fauei inserta, ejusdem laciniis alterna, subpapilionacee disposita, attenuato-stipitata, quatuor inaequilatera, quinto postien aequilatero. Stamina 10 , cum petalis inserta, omnia fertilia; filam enta filifurmia, ima basi coalita, anth erae oblengae, minutae. Ovarium stipitatum, erectum, compressum, pluriovulatum. StyI 8 compressus, antice curvatus; stigma subsimplex. Leg um en stipitatum, stipite intra calycem persistentem incluso, lineare, compressuplanum, membranaceun, intus sublignosum, indehiscens, mono-trispermum. Sem in a subcompressa, subalbuminosa. $\mathbb{E}$ mb ry o rectus v, curvatus; cotyledonibus planis, radicula exserta, plumula inconspicua. - Arbores v. frutices Americae tropicae; foliis impari v. abrupte pinnatis, stipulis deciduis, floribus racemosis, calycibus basi bibracteolatis.

Leptolo bi um Vogel in Linnaea $X t, 38 s$, Thalesia Martius msc.

a. MESITIS Vogel $l, c$, Foli a abrupte pinnata. E m b ry $o$ eurvatus.

b. RULEPTOLOBIUM Vogel t, o. Rolla imparipinata. $\mathrm{E}$ m br y o plerumque rectus.

6\%ร2. Tachigalia $A U B L$, Cal y cis foliola 5 , obtusa, in tubnm obconieum, obliqunm, striatum coalita. Corolla e petala 5, calycis fanci inserta, ejusdem lobis alterna, inaequalia, intus sericea, postico reliquis minore. S ta mina 10 , cum petalis inserta, exserta; fil a menta libera, basi villısa, inferiora subaequalia, recurva, tria superiora erecta, libera. Ov a ri a m stipite breví, adscendente, calyeis parieti postice adnato, compressum, subtriovalatum. Stylus filiformis, elonratus; stigma bipartitum. Leg u men compresso-planum, oblongum, membranacenm, indehiscens, monospermum. Semen ovale, compressum, tenuissime albuminusnm. Embry on is recti $c 0$ tyledones aubfoliaceae, radicula vix exserta. Arbores Americae tropicae; foliis abruple 
pinnutis, foliolis alternis $v$. oppositis, subtrijugis, floribus secus paniculae terminalis ramos conferte spicatis, flavis, pedicellis supra basim articulatis, ad articulum bibracleolatis.

T a e h i g a I i a Aublet Guian. 1 . 372. $t, 143$. excl. fruet. Lam. $t$ 339, DC. Prodr. II. 487. Meisner Gen, 98. (70, Vogel in Linnaea XI. 593. C ub a e a Sebreher Gen, n, 702. Valenty aia Necker Elem. $n, 1283$. Ta chia Persoon Enchoir. $r$. 459. nou Aubl. Tas s i a Richard. msc.

6F53. Acosminan SCHOTT. Caly x brevis, campanulato-cupulatus, quinquedentatus, dentibus minutis. Coroll a e petala 5, imo calyci inserta, ejusdem laeiniis alterna, subpapilionacee disposita, erecto-patula, inferiora obovato-oblon ga, basi angustata, media oblongo-linearia, parum longiora, stipitata, inaequilatera, posticum rotundatum, emarginatum, breviter ongniculatum. St a min a 10 , eam petalis inserta, exserta, o:n nia fertilia; filam enta subcompresso-filiformia, libera, antherae subrotundae. Ovarium brevistipitatum, compressum, plariovulatum. Sty I as subteres, uncinatns; stigma simplex, Legumen ..... - Arbor brasiliensis, excelsa; fo. liis imparipinnatis, foliolis elliptico-lanceolatis, venulosis, utrinque nitidis, inforescentia in apice ramorum paniculuto-racemosa, ampla, pedunoulis compressis, virgatis, floribus flavis, parvis.

A cos $5 \mathrm{~min}$ Schott in Sprengel Gur, post. ID. 406 . Vogel in Linnaea XT. 395. Meisuer Gen. 98, (70.) S weetia Sprengel Syst. II. 171.

6ร54. IVIORa BENTH. Calyx urceolatocampanulatus, breviter et late quinquedentatus. Corolla e petala 5 , inter calycis lacinias inserta, breviter unguiculata, aequalia. Stam in a 10 , cum petalis inserta, exserta, alterna iisdem opposita fertilia, alterna sterilia clavata; fil a m e n t a libera, fertilinm an therae ovatae, crinito barbatae. Ova r i u m breviter stipitatum, pluriovulatum. Stylus compressus, rectiusculus; stigma terminale, tenue. L e g a m e $n$ coriaceo-lignosum, oblongum, indehiscens, abortn monospermum. Semen magnum, reniforme, exalbuminosum. Embryonis recti cotyled ones crassissimae, snblignosae, radic ula conica, plumula evoluta. Arbor guianensis, ingens; foliis alternis, $a b$ rupte pinnatis, glabris, foltolis tri-quadrijugis, oppositis, floribus densissime spicatis, spicis in paniculas terminales, simplices dispositis, bracteis squamaeformibus, deciduis.

Mora Bentham in Lim. Transact,XVIII, 201, 2, 16.17,

6ร5. Selerollobiam VOGEL. Calycis foliola 5 , oblonga, basi in eupulam persistentem connata. Cor illae petala 5, paulo supra calyeis basim inserta, ejusdem foliolis alterna, angustissime linearia, plana. Sta m in a 10, cum petalis inserta, omnia fertilia; fil amenta libera, compresso-filifornia, apice subulata, basi barbata, antherae rotundo-oblongae. Ovarinm sessile, compressum, oblongum, pluriovulatum. Stylus subteres, rectiusculus; 8 ti gma simplex, callo sum. L e g u men sessile, compresso-planam, ellipteum, lignosum, indehiscens, medio mono.dispermum. Sem e n compressissinnm, albuminosum. E mb голis recti cotyled ones planae, subfoliaceae, rad icula exserta, plamnla inconspicua. Arbores brasilienses; foliis abrupte pinnatis, Jluribus subspicato-racemosis.

Selerolo bitum Vegel in Linnaea Xr. 395.

6\%56. Gleditselnia LINN. Flores her maphroditi v, aborta polygami. Caly eis foliola
$3-5$, basi in enpulam coalita, aequalia. Corolla e petala supra basim calycis inserta, ejusdem laciniis numero aequalia et alterna, inaequalia, nonnulla interdam coalita. S $\mathbf{t a m}$ in a cum petalis inserta, iisdem numero aequalia et alteraa; filame n ta filiformia, libera. Ovariu m sessile, bi-

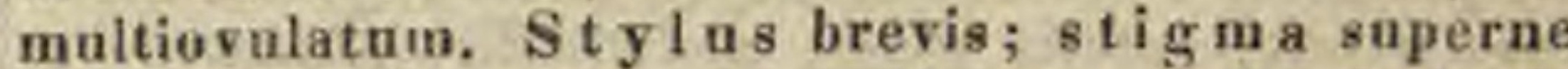
pobescens. Leg nmen continumm, nunc isibmis inter semina transversim pluriloculare, intus pulposum, nunc uniloculare, siccum, mono-polysper inum. Semina compressa, exalbuminosa. E mbryonis recti cotyledones carnosulae, ra dicula exserta, plumula manifesta - Arbores in America boreali et Asia media indigenue; ramis supraaxillaribus saepissime in spinas ramo. sas canversis, foliis abruple pinnatis v. bipinnatis, aut interdum foliolis coalescentibus subsiniplicibus, floribus spicatis, viridescentibus.

Gle dits chia Lian. Gen, $n, 1159$, Gïrtner $I 1,311, t, 146$. Lam. t. 857. Dohamei Arbr, I, t, 105. Edit, nov, IV, $t, 25$. Michaux Arbr. 1I. $t, 10 ., 1 I t, t, 10$ DC. Atent. Legum, $t, 1$. t. 22, f. 109. Prodr, If, 479, Melsuer Gen, 100, (7t.)

685\%. Gymanoladus LAM. Flores abortu dioici. Cal y x tubulosus, quinquefides. Corolla e petala 5, ealycis fauci inserta, ejusdeu la. ciniis alterna et longiora, oblonga. S $\mathbf{t a}$ m in a 10 , cum petalis inserta, inclusa, omnia fertilia, alterna breviora; filament a subulata, libera, antherae ovatae. Ovarinm sessile, pluriovulatum. Stylns compressus, rectus; s tig ma pubescens. Le gumen oblongum, crassum, indehiscens, intus pulposum, polyspermum. Semina compressiuscula, subalbuminosa. $\mathrm{Emb}$ yon is recti $c$ otyledones subfoliaceae, radieula exserta. Arbores boreali-americanae, inermes; ramis apice obtusis, foliis alternis, bipinnatis, pinnis infimis unifoliolatis, reliquis sex octojugis, floribus racemosis, petalis albidis.

G y m u ocladus Lam. Dict. I 733 t. 823. Miehanx Flor. Bor. Amer, t, 31. DC. Prodr. II. 479. Deisuer Gen, 89. (70.) Gailandina dioiea Lian.

6F58. Exostyles SCHOTT. Caly x tubo clavato, limbs tandem inaequaliter trilobo, laciniis inaequilatis, obtusis, revolntis, tandem deciduis. Corolla e petala 5 , medio calycis tubo inserta, brevissime unguieulata, aequalia, imbricatim conniventia. Stamina 10 , cum petalis inserta, isidem breviora, inclusa, omnia fertilia; fil a in enta basi dilatata, libera, a n therae sagittatae, cuspidatae. Ovari u m stipitatum, oblongum, multiovalatum. Stylus subulatus, rectus, teres, exsertus; stigma simplex. Legumen stipitatum, crasse coriaceum, ovatum, ad utramque suturam incrassatum, subtrispermum. Semina ovalia, compressa, albuminusa. Embryonis recti cotyled o nes subcarnusae, radicula brevissima, recta, plnmula inconspiena. - Arbuseulae brasilienses; ramis glabris v. villosis, foliis imparipinnatis, pedunculis axillaribus racemosis, minute bracteatis, floribus atro-purpureis.

Exostyles Schott in Sprengel Cur. post. 406. Eadlicher Atakt. 26. t. 25. Meisuer Gen. 98. (71.)

6859. A guleîa MART. C a 1 y $x$. preenlatus, tripartitus. Corulla e petala 3 , erecto-patentia, breviter unguiculata. $\mathbf{S t a m i n a ~} 3$, calyeis tubo inserta, ejusdem laciniis opposita; filamenta filiformia, a n the rae lineari-oblengae, Inngitudinaliter dehiscentes. Ova rinm lineari-oblonfam, compressum, pauciovulatum. Stylus in-

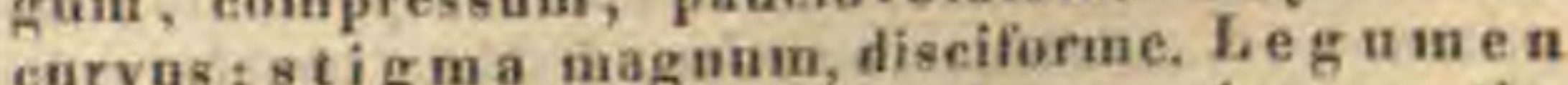
..... - Arbor brasiliensis; ramis curvalia, 
foliis imparipinnatis, foliolis ovato-lanceolatis, glabriusculis, subtus glaucescentibus, quadri-sexjugis, alternis, floribus e ramulis junioribus ante folia nascentibus, dense corymbosis, interdum tetrameris, inflorescentia extus squamis, e gemmarum hybernaculo, pubescentibus munita, calycibus extus fusco-olivaceo-sericeis, petalis albis, pedunculis, filamentis et ovario fusco sericeo-pilosis.

A pule i a Martius Merbar. Brasil. 123.

GrG0. Selhatolobium VOGEL. Caly $\mathrm{x}$ tubo turbinato, limbi quinquepartiti laciniis subaequalibus, oblongis, obtusinsculis, reflexis. Corolla e petala 5, calyeis fauci inserta, ejustem laciniis alterna, subaequalia, unguieulata, Iamina crenulata. Sta mina 10, cum petalis inserta, omnia fertilia, suberecta; filamenta libera, scabrinscula, basi plana latiora, antherae oblungae. Ovarium breviter stipitatum, stipite hinc cum calyce connato, compressum, subdimidiatooblongum, pluriovulatum. Stylus basi rectus, deinde adscendens, compressus, apice attenuatus; st i gm a simplex, acutum. Legum en compressum, obovatum, bivalve, monospermum, epicarpio coriaceo, ab endocarpio membranaceo semen includente solvto. Semen in apice leguminis mag num, oblongum, plano-compressnm, albnminosum, funiculo brevi, filiformi. E m bryon is recti sotyledones plano-compressae, radicula exserta, plumula evoluta. - Arbor brasiliensis, excelsa; folits bipinnatis, foliolis multijugis, supra opacis, subtus pilis albidis, ad nervum medium aureo-nitentibus tectis, floribus plurimis, in racemos axillares et terminales paniculatos dis positis.

Seluizolobiam Vogel in Linnaea Xr. 399.

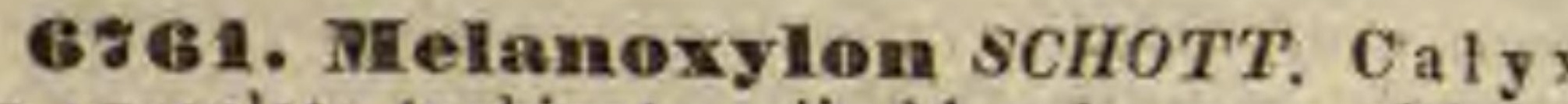
tubo urceolato-turbinato, limbi quinquepartiti laciniis aequalibus, reflexis. Corolla e petala 5 , ealyeis fauci inserta, ejusdem laciniis alterna, subaequalia, obovato - oblonga, basi angustata. Stamina 10 , cum petalis inserta, erecta, aequalia, omnia fertilia; fil a menta libera, compressoplana, apice subulata, basi hirta, antherae lineari-oblongae. Ovarium stipitatum, e tereti compressum, maltiovulatum. St y I n s compressus, glaber, rectus; stigma subsimplex, pilis brevibus fimbriatam. L e g amen counpressum, subfalcatam, endocarpio membranaceo, cum seminibns transversim soluto. - Arbor brasiliensis, excelsa, ligno fusco atro; foliis imparipinnatis, foliolis subtus hirsutis, oblongo-lanceolatis, racemis paniculatis, ferrugineo-tomentosis.

Melan o y y on Schott in Spreng, Cur.post. 406. Meisner Gen, 28. (70.) Perittiu u Vogel in Linnaea.XI. 408.

67 82. PEpplgia PRESL. Cal y $\mathrm{x}$ tabo subeampanulato, basi postice subgibbo, limbi quinquepartiti laciniis subaequalibus, ereetis. Corolla e petala 5, ealycis fauci inserta, ejusdem iaeiniis alterna, oblonga, basi angustata, posticum majus. Stamina 10 , cam petalis inserta, erecta, aequalia, umnia fertilia; filamenta ima basi coalita, glabra, antherae ovatae. Ovarium stipitatum, compressum, acutum, sutura seminifera rectum, altera convexum, ciliatum, basi villosum, multiovulatum. St y I u s brevissimus st igma oblique truneatum, calloso-marginatum, minute fimbriatum. Leg umen compressum, inliis ......- Arbor insulae Cuba, excelsa; foliis simpliciter et abrupte pinnatis, foliolis multiju- gis, stipulis nullis, floribus terminalibus, paniculatis, mediocribus, flavis.

P appigia Presl Symb. I. 15. t. 8. Meisner Gen, 98. (70.) Caesalpinia procera Pöppig.

6\% B3. CTriliandina JUSS. Ca ly x tubo brevi, urceolato, limbi quinquepartiti laciniis subaequalibus. Corollae petala 5 , calyeis fauci inserta, ejusdem laciniis alterna, paullo longiora. Stamina 10 , cum petalis inserta, exserta, omnia fertilia; filamenta libera, subulata, basi villosa, a nthera e ovatae. Ovarium stipitatum, oblongum, compressum, pluriovalatum. Stylus brevis; stigma simplex. Leg nmen ovatum, ventricoso-compressum, extus echinatum, monotrispermum, bivalve. S e min a subglobosa, ossea, nitida, exalbuminosa. Embryonis recti cotyledones crassae, radi cula exserta, plumula manifesta. - Arbores $v$. frutices, in Asia tropic $a$ indigenae, in $A m$ erica $m$ transplantatae; caule et petiolis aculeis uncinatis armatis, foliis abrupte pinnatis, floribus spicato-racemosis, bracteis elongatis.

Guilandina Jussien Gen, 350. Gärtner $I T .315$. t. 148. Lam, t. 336. Selhrank Hort, Monac, t, 68. DC. Prodr. II. 480. Wight et Arnott Prodr. I. 280, Meisner Gen. 98. (70.) Bon d u c Plum. Gen, 25.

6764. Comiteria $H . B . K, \mathrm{C}$ a l y x tubo brevi, turbinato - urceolato, limbi quinquepartiti decidni lacinia infima majore concava, pectinato multifida. Corollae petala 5, ealycis faci inserta, ejusdem laciniis alterna, unguiculata, postico majore. Stamina 10, cum petalis inserta, adscendentia, omnia fertilia; fil a m en t a libera, inferne pilosa, antherae ellipticae, incumbentes. Ovari n m sessile v. stipitatum, compressum, subsexovulatum. St y $1 \mathrm{u}$ \& adscendens, basi enm ovario articulatus; $8 \mathrm{tig}$ in a truncatum, fimbriatum. Legumen oblongum, compressum, sub. spongiosum, mono-tetraspermum, isthmis inter semina transversim pluriluculare. Semina lenticularia, albuminosa. E mb ry o n is recti radicula brevis, exserta. - Frutices Americae trop ic a e, aculeati; foliis alternis, abrupte bipinnatis. racemis terminalibus bracteatis, floribus pedicellatis, luteis, glanduloso-punctatis, pedicellis supra medium articulatis.

Coulteria Kunth in Humb. ot Bonpl. Nov. gen, et sp. VI. 328. t. 568. 569. DC. Prodr. II. 480. Meisuer Gen. 99. (70.) A de no cal y $\times$ Bertero msc, T a ra Muliua Chili 280. Schultes Systo ${ }^{-} \boldsymbol{V}$. 102. Poinciana pectinata Cav.

6\% 85. Cresalpinia PLUM, Caly $\mathrm{x}$ tubo turbinato-nrceolato, limbi quinquepartiti, decidui laciniis reflexis, antica majore, concava. Coru!la e petala 5, calyeis fauci inserta, ejustem laciniis alterna, unguiculata, posticum heteromurphum, intensins coloratum. Stam ina 10, cum petalis inserta, adscendentia, iisdem aequilonga $v$. longiora, omnia fertilia; filament a libera, inferne villosa, ant herae oblongae, in:umbentes. Ovarium sessile v. stipitatum, compressnm, pauciovulatum. Stylus adscendens, basi haud articulatus, apice clavato-dilatatus; $8 \mathrm{tigmate} \mathrm{trun-}$ cato, fimbriato, $\mathbf{v}$. in stigma late peltato-capitatum desinens. Le g $n$ m e $n$ snboblongnm, compressnm, inerme, lignesum v, spongiesum, isthmis inter semina transversim pluriloculare, di-tetraspermum, bivalve. Semina compressa, albuminesa. E mbryo reetns. - Arbores $v$. arbusculae, ut plurimum aculeatae; in $A s i a, A f r i c a$ et $A$ merica 
tropica indigenae, folits alternis, abrupte pinnatis, foribus terminalibus, racemosis, luteis v. flavescentibus.

Caesalpinia Plumier Gen. 28. t. 9. Lina. Gen. n. 516. Gairtaer II. 301. Kunth in Kumb. ot Bonpl. Nov. gen. et $s p$. VI. 326. DC. Frodr. II. 481. Wight et Araott Prodr. I. 280. Meisner Gen, 99, (70.) Vogel in Linnaea XI. 406 ,

a. NUGARIA DC, $l$. c. Le gum i a mono-disperma. Semina crassissima, transversim oblonga. $\mathrm{C}$ al y e es glabri. - Guflandinae sp. Lian. Tikanto Adan. sou Fam. IT. 319 ,

b. 3 BRASILETTIA DC, $l$, $c$. L e g $\mathrm{u}$ i $\mathrm{n}$ a monosperma, atrin. que acuminata, samaroidea, indehiscentia. S e m en plauum, trassverse oblongum, Cal y ces rufovelutini.

c, SAPPANIA DC. $l$. c. Leg n mi n a polysperma, recta, compressa, isthmis imperfectis, valvis exsuccis. S e m i. n a oblonga. Petal a posticua reliquis brevius. C a m pecia Adanson Fam. II. 318, Gärirtn. $t, 144$. Lam. t. 335. f. 2. Humb, et Boupl. Plant, aequinoct. t. 137: Roxburgh Plant, Corom. t. 16.)

d. LIBIDIBLA DC, $\boldsymbol{l}$. c. L e g $\mathbf{u}$ i n a oblonga, lateraliter incurva, spongiosa, valvis inter semina comatis trans. versim multilocularia. - C. Coriaria Kasth Mimos. t. 45. Poinciania eoriacea Jaeq. Amer. $t$. 175. f. 36 .

e. PELTOPHORUM Vogel $L$. $c$. Stig ma late peltato-eapi. tatum. C. d u b i a Spreng.

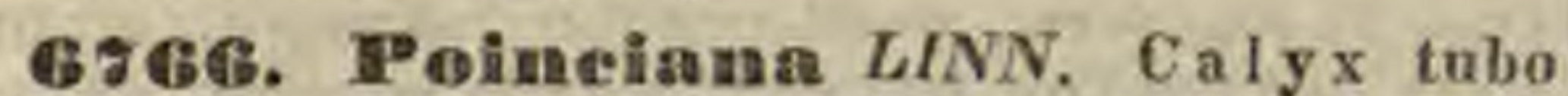
turbinato-urceolato, limbi quinquepartiti, decidui laciniis reflexis, infima majore, toncava. Corol1 a e petala $\bar{\sigma}$, calycis fauci inserta, ejusdem laciniis alterna, unguiculata, posticum majus, heteromorphum. Stamina 10 , cum petalis inserta, longissima, adscendentia, omnia fertilia; filamenta libera, inferne hirsuta, anthera eblongae, incumbentes. O variu m stipitatum, linearioblongrm, compressum, multiovulatum. Stylus flifurmis, basi hand articulatus, adscendens; st igma simplex, truncatum, glandulis minotissimis fimbriatum. Leg n $\mathrm{m}$ e $\mathrm{n}$ lineari-oblongum, compressum, siccum, polyspermum, isthmis transversis inter semina pluviluculare, bivalve. Se min a lenticulari-compressa, albuminosa. Emb r y onis recti cotyled ones planae, radicula exserta, plumula manifesta. - Frulices v. arbusculae, saepissime aculcatae, in $A$ sia et $A$ merica tropica crescentes; foliis imparipinnatis, floribus terminalibus racemosis, aurantiaceis.

Poinicfa n a Tournefort Inst, 39t, Linn. Gen, n, 8ts. Lam. $t$. 333. Gairtner $I Y$. 150. $t$. 150. Kunth in Humb. et Bonpl, Nov. gen, et sp. VI, 333. Mímos, t. 44. DC. Mem, Legum. $t$. 23. f. 111. Prodr, II, 483. Hooker Bot. Miscell, t. 34. Bot. Mag. t. 2884. Wight at Arnott Prodr. I. 282. Meisner Gen. 99. (70.) Poincia Necker Elem, $n, 1282$. Caesalpiniac sp. Swartz.

6ร 6ร. Colvillea BOJ. Calyx coloratus, bilabiato-bipartitus, labio pestico maximo, erecto, coneavo, tri,quadridentato, antico minore, lineari-lanceolato, carinato, patente. Corolla e petala 5, imo calyci inserta, subpapilionacea, posticum minutum, rotundato - reniforme, convolutum, a lateralibus obovatis, basi angustatis tectum, cum iisdem a calycis lacinia postica occultatum, duo antica oblonga, reliquis majora, basi angustata ciliata, juxta calyeis labinm antieum adscendentia. St a min a 10, cum petalis inserta, adscendentia, omnia fertilia; fil a menta filiformia, libera, posteriora breviora, a $\mathrm{n} t \mathrm{~h}$ er a e ovato-oblongae, incumbentes, longitudinaliter dehiscentes. Ovarium sobsessile, lanceolatum, ntrinque angnstatum, compressum, multiovulatum. St ylas filiformis, adscendens; stigma acntum. Leg amen rectum, turgidum, bivalve, polyspermum.
S emina elliptiea, compressa, horizontalia, ntrinque retusa. E mbryonis exalbuminosi, recti cotyledones germinatione foliaceae. - Arbar madagascariensis, quinquagintupedalis; foliis alternis, bipinnatis, pinnis opposilis, multijugis, foliolis linearibus, basi inaequilateris, stipulis setaceis, deciduis, racemis ex apice ramorum et e foliorum supremorum axillis sesquipedalibus, simplicibus aut ramosis, bracteis coloratis, caducis, calycibus et corollis purpureis, flavo marginatis, velutinis.

Colville a Bojer in Bot. Mag. t.3325. el 3326. Monograph, iconogr, absq, text, fol, Meisner Gen, 99, (*0.)

6r6s. VIezoneuron DESV. Cal yx tubo hrevissime urceolato, limbi quinquepartiti lacinia antica fornicata, reliquas breviores, orbiculatas aestivatione includente. Coro I la e petala 5 , calycis fauci inserta, ejnsdem laciniis alterna, unguiculata, posticum minus. Stamina 10 , $\mathrm{cum}$ petalis inserta, adscendentia, omnia fertilia; filaim en ta libera, inferne villosa, a n ther ae oblongae. O v a ri u m substipitatum, pluriovulatum. Stylns incurvus; stigma ..... Legumen compresso planum, ovato-oblongum, indehiscens, oligospermum, sutura seminifera in alam foliaceam, inferne deliquescentem producta. S e min a .....-Arbores Asiae tropicae; foliis abrupte et opposite bipinnatis, petiolo aculeato, floribus in racemos simplices, ebracteatos dispositis.

Mezonearon Desfont. in Mem. Mus. IV. 245. 1.10. 11. DC. Prodr, II, 484. Wight et Arnott Prodr. I. 282. Meisner Gen. $98 .(20$.

6ร 6s. Peterolobium $R, B R$. C a Iy $x$ tabo brevi, urceolato, subcarnoso, limbi quinquepartiti, decidui laciniis subpetaloideis, antica subfornieata. Corollae petala 5, calycis fauci inserta, ejusdem laciniis alterna et paullo longiora, unguiculata, inaequalia. Stamina 10 , cum petalis inserta, adscendentia, omnia fertilia; filamenta libera, infra medium barbata, antherae oblongae. Ovarin m sessile, compressinsculum, glabrum, nniovulatum. Stylus adscendens, glaber, basi margine postico canaliculatus; stig ma dilatatum, pilis brevibus, erectis hirtun. Le gum en aessile, monospermum, margine postico $\mathrm{kn-}$ perne in alam membranaceam obliqquam, obtusam, striatam producto. S e m e n ex apice cavitatis pendulum ..... - Arbores $v$. frutices scandentes, in Asia et Africa tropica indigeni, in caule ramis et petiolis aculeis uncinatis armati, folits abrupte bipinnatis, floribus racemosis.

Pterolobium R+ Brown in Salt. Abyrin, 65. Wight et Aruott Prodr, I. 283. Meisuer Gen, 98. (70.) Re iehardi a Roth Nov. spec, 210. Kantuffa Brace Abyesin. $V$. c. 14. Cacsalpiaia laoerans Roxb.

Gร \%०. Claelotrielitum VOGEL, Cal yx tubo brevi, enpulari, basi aeuto, limbi quinquepartiti laeinis linearibns, glandulosis, quinta infima paullo latiore. Corolla e petala 5, calycis fanci inserta, subrotunda, posticum minus, complieatam, extus nigro-glandulosum. S ta m i n a 10, com petalis inserta, omnia fertilia, inferiora sensim longiora, cum ovario in dentem infimum calycis reclinata; filame nt a plana, membranaceo-alata, apice angustata et glabra, a basi ad medinm fimlriato-ciliata, a n therae oblongae, lasi cordatae. Ovarium sessile, compressum, lineari-olslongum, basi obliquum, multiovalatum. Stylus basi erectns, compressus, apice ampliatus, uncinato-incursus; st $\mathrm{ig}$ m a perforatnm, fimbriatum. Le gumen compressum, lato-lineare, basi obli165 
quum, styli basi apiculatnm, rigide membranaceum, bivalve, glandulosum, pilis ramosis, densis tectum, polyspermum. S e min a subcompressa, rotundata, funiculo triangulari affixa $\ldots \ldots$ E m b r y o rectus .... - Frutices brasilienses; foliis impari. bipinnatis, bistipulatis, stipulis saepius pinnatifidis, floribus racemosis.

CIadotrichi um Vogel in Linnaea XI, 501.

68 8 1 IPomanola $C A V$. C a ly x tubo cupuliformi, basi acuto, limbi quinquepartiti laciniis lanceolatis, acutis, subaequalibus, deciduis. Corolla e petala 5 , calycis fanci inserta, ejusdem laciniis alterna et breviora, breviter unguiculata, posticum minus, concavum, extus nigro-glandulosum. Stamina 10 , cum petalis inserta, adscendentia, omnia fertilia; filamenta filiformia, libera, a basi ultra medium barbata, a ntherae ovatae. Ovari a m sessile, biovulatum. Stylus filiformis; st i g m a capitatum. Le g a men oblon. gum, compressum, glandulosum, bivalve, dispermum. Se un in a ovata.... - Frutex Americae tropicae, pilis glandulosis, nigricantibus consitus; foliis abrupte bipinnatis, bistipulatis, stipulis pinnatifidis, racemis axillaribus, laxis, folio longioribus.

Pomaria Cavanill. Ic. V. 1. $t$, 402. DC. Prodr. $I$. 485. Meisner Gen, 29, (70.)

Gร ร. IIelamostieta $D C . C$ alyx tuho brevissime cupuliformi, limbi quinquepartiti laciniis deciduis, subaequalibus. Corolla e petala 5 , calycis fauci inserta, ejnsdem laciniis et inter se aequalia, elliptica, basi angustata. Sta min a 10 , cum petalis inserta, omnia fertilia, erecta, petalis aequilonga; filamenta libera, basi membranaceo-alata, apice angustata et glabra, a basi ad medium pilis ramosis barbata, a $\mathbf{n} \mathbf{t} \mathbf{h}$ e $\mathrm{r}$ a e ovatae. Ovarium sessile, ovatum, subquadriovulatum. Stylus uncinatus, Legumen compressum, ovato-oblongum, hirsutam. - Suffrutex capensis, humilis; radicibus fasciculatis, cylindricis, cum tuberculis longe fusiformibus mixtis, foliis et calycibus glandulis nigris, sessilibus punctatis, foliis bipinnatis, pinnis bijugis, sex-octofoliolatis, cum pinna terminali sedecimfoliolata, racemis elongatis.

Melan asticta DC. Mem. Legum. 474, t. 69. Prodr. IT. 485. Meisner Gen, 98. (70.)

6\%ร3. Zucengmin $C A V$. Calyx tubo brevissime turbinato, limbi quinquepartiti laciniis oblongis, obtusis, persistentibns, antica panllo longiore, Cor oll a e petala 5, calycis fanci inserta, ejnsdem laciniis alterna et longiora, ovata, subsessilia, posticum brevius, concavum. Stamin a 10 , cum petalis inserta, adseendentia, omnia fertilia; fil a in e $n t$ a filiformia, a basi ad medinm pilosa, alterna breviora, anthera e ovatae. Ova riu m breviter stipitatum, ovatum, uniovulatum (?) Stylus filiforruis; $8 \mathrm{tigma}$ infundibuliforme. Legumen subovatum, compressum, pilis longis crinitum, bivalve, monospermum. $\mathrm{S}$ e m e $\mathbf{n}$ ex apice eavitatis pendulum. ..... - Fruticulus ch $i-$ lensis, ramosus, glandulis glutinosis consitus, folits simpliciter et abrupte pinnatis, foribus racemosis, croceis.

Z u c c ag ai a Cavanill, Ic. V. 2, t. 403, DC. Prodr. II. 486. Meismer Gen 98, (70.)

68\%4. Hofimanseggia CAV. Calyx tubo cupuliformi, basi acnto, limbi quinquepartiti laciniis lineari-lanceolatis, revolutis, persistenti- bus. Corolla e petala 5, calycis fauci inserta, ejusdem laciniis alterna et paullo longiora, nnguiculata, unguibus glanduloso-pilosis, posticum paullo majns. Stam in a 10 , cum petalis inserta, adscendentia, omnia fertilia, vel unum ant alterum eastratum; fil amenta filiformia, a basi ad medium glandaloso-pilosa, an thera e ovatae. Ovarium snbsessile, compressum, multiovulatum. Stylus rectus, subcompressus, apice oblique clavato-ampliatus; stigm a perforatum, fimbriatum. Leg $\mathrm{n}$ men lineare, compressum, rectum v. falcatnm, polyspermum. Semina ovalia, compressa. Herbae perennes $v$, suffrutescentes, in America australi extratropica indigenae; foliis impari-bipinnatis, pinnis folio impari terminatis $v$. saepius abrupte desinentibus, petiolis basi glandulosopilosis, floribus racemosis, flavis, racemis oppositifoliis.

$\mathrm{H}$ of $\mathrm{fmanseg} \mathrm{g}$ ia Cavanill. Io. $I V .63, t, 392,393$. DC. Prodr. II, 484. Meisuer Gen, 99. (70.)

6\% ร5. IParkinsomia PLUM. C a I y x coloratus, tubo brevi, urceolato, limbi quinguepartiti, decidui laciniis reflexis, subaequalibus. Cor olla e petala 5, calycis fanci inserta, ejusdem laciniis alterna et longiora, posticum longius unguiculatum, latius. St amina 10, cum petalis inserta, adscen. dentia, omnia fertilia; fi l a m e n $t$ a libera, aequalia, basi hirsuta, a nt herae oblongae. 0 varium sessile, compressum, sericeo-hirtum, multiovalatum. Stylus subulatus, adscendens; 8 tig m a simplex. Le $\mathrm{g} u$ m en longissimum, acuminatum, inter semina contractum et eompressum, moniliforme, uniloeulare, bivalve. Semin a plura, intra singelos articulos solitaria, oblonga, ntrinque obtusa, nmbilico basilari, albuminosa. Embry on is recti cotyledones oblongae, planiuseulae, radicula exserta, conica. - Arbusculae Americae tropic a e, spinis simplicibus v. tripartitis armatae; foliis ex axillis spinarum geminis $v$. ternis, pinnatis, petiolo communi longissimo, compresso-plano, anguste alato, versus apicem angustato, foliolis alternis, minimis, racemis axillaribus et terminalibus laxis, floribus pedicellatis, suaveolentibus, flavis, petalo pustico basi maculis coccineis picto, pedicellis basi unibracteatis.

Parkinsonia Plumier Gen, 25. Lian. Gen. n. 513 Jaeq. Amer, t. 80. Lam. $t, 336$. Kunth in Humb. let Bonpl. Nov. gen. et sp. VI. DC. Mem, Legum, t. 21. f.112, Prodr. II. 485, Meisner Gen, 98, (20.)

68 \%6. Cadia FORSK. C alyx tubo brevi, late campanulato, limbi quinquepartiti laciniis late triangularibus, aequalibus. Corolla e petala 5 , amnulo late glanduloso, calycis tubum marginant inserta, ejusdem laciniis alterna et longiora, ob. cordata, basi angustata. St a m in a 10 , cum ovario declinata, omnia fertilia; fil am enta libera, basi incrassato-geniculata, apice tereti-subulata, a n ther a evato-oblongae, longitudinaliter dehiscentes. Ovari nm declinatum, stipitatnm, subfalcatum, compressum, multiovulatum. St y lus brevis, crassus, ovario continuus; stigma acutum. Le g $\mathbf{n m}$ en lineare, breviter stipitatum, bivalve, polyspermun. Semina ovata, unbilico basilari. - Frutex inermis, in Arabia felici indigenus; foliis imparipinnatis, foliolis alternis $v$. oppositis, linearibus, pedunculis axillaribus, solitariis, bi-triftoris, floribus albis, demum roseis, majusculis.

C a d i a Porskael Aegypt, 90. Heritier in Magas, encyclop. V. 29. DC. Prodr. IT. 486 . S paendance a Desfont. De- 
cad. phil. 7.259. Lam. t. 948. P a th e iatic a Piceivoll Hort, Panciat. 9. c. ic.

G\%g. HIIsematoxylom LINN. C a I y x colcratus, tubo areeolato, limbi quinquepartiti, decidui laciniis membranaceis, concavis, antiea majore. Corolla e petala 5, calycis fanci inserta, ejusdem laciniis alterna et vix longiora, oblonga, basi cuneato - subnngniculata, aequalia. St am in a 10 , cnm petalis inserta, iisdem aequilonga, unnia fertilia; fila me nta libera, inferne villosa, anthera e ellipticae, tongitudinaliter dehiseentes. Ovarium breviter stipitatum, triovulatum. Stylus brevis, filiformi-subulatus; stigma subturbinato-urceolatum. L e $\mathrm{u}$ m en membranaceum, compressum, oblongo-cultriforme, suturis incrassatis cinctum, mono-trispermum, suturis indehiscentibus per medias valvas disruptum, valvis compresso - navicularibus, altera medio seminifera dimidio angustiore. Semina latissima, transverse lineari-oblonga, compressa, funiculo valvae adnato medio affixa, parce albuminosa. Embryon is transversi cotyledones bilobac, lobis divergen. tibus, radicula inter lobos sita, nonnihil incorva, umbilicum spectans. - Arbor Americae tropicae, inermis $v$, ramis sub foliis spinescentibus armata, ligno tinctorio; foliis paripinnatis bipinnatisve, jugo foliolorum infimo simplici $v$, in pinnam bijugam evoluto, foliolis obovatis $v$. obcordatis, floribus pedicellatis, pedicellis basi unibracteatis.

H a e m a to x y l o i Linn, Gen, n, 525, Lam. C, 340, Kunth in Humb. et Bonpl. Nov, gen. et sp. NT. 325. DC. Prodr. II. 485. Nees jun. Plant offic, 13, t. 3. Meisuer Gen, 99. (70.)

68 9 8. Tannarinelles TOURNEF. C a ly $x$ tubo turbinato, limbi quadripartiti, colorati, decidui lacinia postica latiore, bidentata. Corollac petala 5, calycis fauci inserta, tria (posticum et lateralia) conformia, brevissime unguiculata, adscendentia et reflexa, majora, duo antica setiformia. Stamina 9, calycis fanci inserta, basi connata, quatuor minuta, sterilia, tria alterna, calycis laciniis anticis opposita longa, adscendentia, fertilia, antheris oblongis, longitudinaliter dehiscentibus. Ovarium stipitatum, stipite postice calycis tubo adnato, multiovulatum. Stylus adscentens, apice incrassatus, extas longitudinaliter barbatus; s tigma obtusum. Legumen stipitatum, oblongum, compressum, inter semina torulosum, corticatum, intus inter semina pulposum, transversim plurilocellatum, cortice suberoso-erustaceo, fragili, pulpa unolli, locellis intus membrana vestitis. Se mina compressa, laevia, rhaphe zonata, exalbuminesa. Embry onis recti cot y ledones carnosae, basi inaequales, radieula brevissima, subglobosa, plumula conica. - Arbor indica, in Antillis culta; folits abrupte pinnatis, multijugis, racemis terminalibus, simplicibus, floribus pedicellatis, sparsis, suaveolentibus, pedicellis basi bractea membranacea, magna, rosea, decidua instructis, calyce flavescente, petalis luteis, venis rubris pictis, leguminum pulpa acidula.

T a marind as Touruef. 1nst. 445, Linn. Gen. $n$, 46. Lam. $t, 25$, Gäriuer II. 310, t, 146. Kunth in Humb. et Bonpl. Nov. gen. et sp. DT, 336. Hayne Lraneigew. $t$. 221, DC. Prodr. II. 488, Mem. Legum, t. 24. f. 113. Meisaer Gen, 97. (70.)

6ร 79. Ageoma LOUR, $\mathrm{C}$ a $1 \mathrm{y} x$ pentaphyllus, foliolis subaequalibus, oblongis, basi coalitis. Corolla e petala 5, subaequalia, oblonga. Stamina 10 , adseendentia, alterna sterilia. Leg nmen oblongum, crassum, uniloculare, bivalve, polyspermum. - Arbuscula cochinchinensis, vix nota; foliis oppositis, bipinnatis, foliolis subo. vatis, tomentosis, floribus paniculatis, albis.

A n om a Loureiro Flor. cochinch. 361 . esel. sp. trivalv, Jussieu in Annal. Arus. IX. 327. DC, Prodr. II. 480.

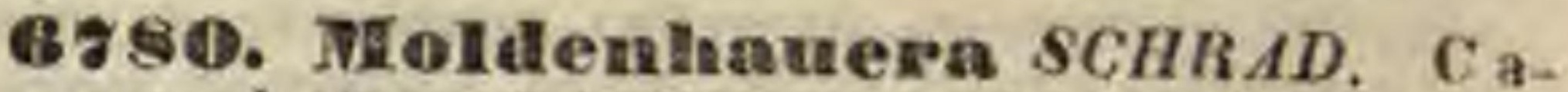
I y pentaphyllus, foliolis ima basi coalitis, aequaibus. Curolla petala 5 , imo calyci inserta ejusdem laciniis alterna, longe unguienlata, lamina plana, oblonga, undulato-repanda, aequalia. St a $\mathbf{m}$ i n a 10 , enm petalis inserta, 9 fertilia unguibus petalorum breviora; filamentis subulatis, liberis, a ntheris ovatis, longitadinaliter dehiscentibus, decimum elongatum, filiforme, an. thera efoeta pilosa. O va ri u m breviter stipitatum, compressum, pluriovulatum. Stylns filiformis; stigma vbtusum. Legumen oblongum, com pressum …. - Fruticuli brasilienses; foliis abrupte pinnatis, bi-trijug is, foliolis coriaceis, oblongis, racemis terminalibus thyrsoideis, floribus flavis.

Molden a a uera Schrader in Götting. gel. Anseig. 1821, p. 718. DC. Prodr. 1T. 488. Poht Plant. Brasil, II. 90. $t, 160$. Meisner Gen, 100. (71.) Doli $\mathrm{ch}$ on ema Nees in Flora 1821. p. 303.

68 81. Cagsian LINN. C a ly x pentaphyl. Ius, foliolis vix ima basi coalitis, plns ninus inaequalibns, deciduis. Corolla e petala 5, imo ca lyci inserta, ejusdem laciniis alterna, unguienlata, plus minus inaequalia. Stam in a 10 , cum petalis inserta, inaequalia $v$. rarins aequalia, tria postica saepe sterilia, interdum quinque alterna deficientia ; fil am en ta fliformiav. subulata, libera, a nthe rae biloculares, apice rima brevi v. poro dnplici dehiscentes, basi simul apertae, Ovarium sessile v. saepissime stipitatutn, multiovalatum. St y I u s filiformis; stigma simplex v. minute ciliatum, interdum incrassato-tumidum. L e g u men teres v, compresso-planum, lignosum, coriacenm $v$. membranaceum, indehiscens $v$. bivalve, uniloculare v. septis transversis multilocellatum, interdnm pulpa farctum, polyspermum. Semina septis parallele v. contrarie compressa, albaminosa. Embryo rectns. - Arbores, frutices, suffrutices v. herbae inermes, in regionibus tropicis et sublropicis totius orbis crescentes; foliis alternis, simpliciler et abrupte pinnatis, foliolis unimultijugis, integerrimis, stipulis petiolaribus gemi. nis, petiolis saepissime glandulosis, floribus ut plurimum flavis.

C a ssi a Liun. Gen, n. 3t4. Kuath in Humb, et Bonpl. Nov. gen, et sp. VI. 337. Colladon Monographie des Catrea Montpell. 18t6, 4. c. icc. DC. Prodr. II. 469. Vogel, Syn. opsis generis Cassiae, Berolini, 1837. 8. Linnaea XI.651. Cas s i a et Se a na Tonrnef. Inst, 390. Cha maecas s ia, Se nua et Chamaecrista. Breyn Prodr. II, 28, C as sia et $\mathbf{C}$ hama ecrista Mbach Method. 345. Cassia et $\mathbf{C a}$ hartocarpus Persoon Encheir. I. 459. C a ss i a et B a c-

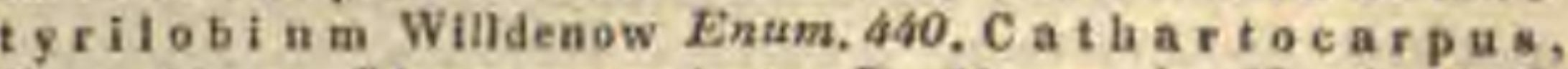
Cassia et Chamaecrista E. Meyer in N. A. N. C. XIT. 805 , Cassia, Chamaefist ula et Cathartocaxp as G. Don Syst, II. 438 .

a. FISTULA DC. l.c. C a 1 y eis foliola obtasa. S a mina ombia lertilia, subaequalia. A ntherae oblongae v. ovatac superne rima dimidia et saepe foramine basilari dehiscentes. L e g n me n eylindricum v. e cylindrico compressum, lignosum, iadebiscens, septis transversis multiloeelfatum, plerumque pulpa repletum. Sem in a horizontalia, compressa, septis iacumbeatia.

Cas 8 i a Gärtner II. $t, 147$. C a thartocerpus Persoon Encheir. I. 459. Bactyrilobinm Willdenow Enumerat, 440. (Nectoux Voy. Aegypt. t. 4. Jacq. Fragm, t. 85, $f$. 3. Colladon Monogr, t. 1. Nees jub. 
pl. offic. 14. t. 4. B a r y $\mathrm{x}$ y 1 o n Loureiro Flor. cochinch, 326.

b. CHAdAaEFistula $D C$, C a 1 y $\mathrm{c}$ is foliola obtusa ve acutinscula. Stamia inaequalia, inferiora autheris fer tillibs, erssso quadrangularibus, apice biporosis, summa (3) sterilia minora, difformia. L e gumen cyliudricun *. subeonpressum, liguosum, indeliscens, v. suhmembranacean, subtebiscens, septis transversis multiloculirre, saepe pulpa repletum. S e mi a a compressa, infe riara semper horizontalia.

C hath a ec a s s ia Breyn. Prodr, $I T, 28$.

ce. X y fobium Vogel $t$. c. Legamen ligaosum; inde hiscens, seminibus horizontalibus. - Arbores $v$. frutices. (Retiq. Houst. t. 17. Jacq. Fragm. $t, 85 . f .4$. )

b. Fiacbamaefistula Voge! 2 . d. Leguaco subreres, membrasacenu v. coriaceum, subdehiscens. Semin a horizontalia. - Erutices v. arbusculae. (Jacq. Ic, $r a r$, t. 23. 120. Frafm. t. 58 100, 101, f. 1. Kunth Mrimos t. 38, 40. Colla Hort. Ripul. t. 34. Bot. Reg. t, 1492. Colladon Monogr, $t$, 11. Vellozo Flor, Flum. LV. $t, 62-64)$

7. Herpetica DC, 2 , c. I, eg n men rhombeo-prismaterm, membradaceum, utrinque foliaceo-alatam, dehiscens. S em tua horizontalia. - Herba americana. (c. herpetica Jacq. Observ. $t .45 . f$. 2.)

J. Oncolabium Vogel $l$. c. Legumen e compresso tamidum, dehiscens. S e mina tantum inferiora sem. per Lorizontalia. - Frutices $v$, herbae. (Jacq. Ic. rar, $t, 71$. 72, Bot, Reg, $t, 83$. Schrank Hort, monac. t. 26.)

c) PROSOSPERvi Vogel $t$. c. Caly cis folfola obtusa v. obtariuseuh. S 1 a m i i a inaequalia, inferiora antheris fertilibus, crasso-quadrangularibus, apice biporosis, sumar (3) sterilia, difformia, minora. L e gumen compressub, algustum, septis tranversis maltiloculare, subeoriaceum. S e mi a a verticaliter compressa, valvis parnlbela. - (Jacr. Io, rar. t. 459. Cav. Io, t, 561, )

d. CHAM AESENNa l, c. C a ly cis foliola obtusa v, ob:usinscala. Sta mina inaequalia, inferiora fertilia, antheris crasso quadrangularitius, apice biporosis, summa (3) sterilia minora, difformia. Le g um e n compressum, septis transversis completis v. obsoletis multiloculare, aerobrabaceun v, coriaceum, dehiscens. S e m t n a plerunque compressa, verticalia, in latitudinem fructus exteusa, funieulo longiora v, aequilonga. (Sehkuhrt, 113, Jaeq. Hort. schönbr. t. 203. 970, To, rar, t, 74. 460. Bot. Mag. t, 810, Bot. Reg. $t, 1310$, Kunth Mimos. $t .43$. Colladon Monogr. t. 2. 4. 13.)

e. SENNA DC. 2 . c. Cal y eis foliola obtusa v. obtusius cula. St a mi i a inaequalia, inferiora fertilia, antheris crasso-quadrangularibus, apice biporosis, summa (3) sterilia miaora, difformla. $L$ e g u me n compressum, sep tis transversis, complecis $v$, absoletis multiloculare, sub. coriaceum, vix deliscens. S e m i $a$ a plernmque conipres. sa, verticalia, in tatimdinem fructus extessa, funicalo eloagato breviora. - Frutices, arbores $v$. herbae.

S e nn a Touraefort Inst, 390. Gärtner IT, 312. (Nectoux Voy, $t$, 2. Delile Aegypt. t. 27. $f .1$. Hayne $A r z$. neigew. $I X, 1,40$ 43, Kuuth Mimos, $\ell, 41, f .42$. Flor. Flum, $(V, t, 78$.

f. PSILORHEgMA Vogel $l$, e. Calye is foliola obtusa St a m in a 10 , fertilit, antheris subaequalibus, angus. tis, qundrangulari-linearibus, apice rima brevissima dehisceutibus, suturat parte iudehiscente glabra. L e gu m en compressum, septis transversis completis $\mathrm{v}$. incom pletis multilaculare. S emina verticalia. - Erutices atstralavici, parvi, glutinosi, paucae species brasilien. ses. (Ginulichand ad Freyc. t. 11t. Bot, Reg. t. 1322. Colla Hort. Ripul. App. IIT, t. 10. IV. t, It, 1322 Flum, IV, $t, 79$, )

g. LASIORHEGMA Vogel $l, c$. Calycis foliola obtusa, acuta v. aeuminata. S ta mina 10 , 8 . abortu $9-5$ fertilia, antherae saepe inaequilongae, angustae, quadrangulari-lineares, apice rima brevissima sletiscentes, sotarae parte indehiscente villoso-barbata. L e z u me compressum, coriaceum, septis trausversis completis v. incoupletis multilocalare. $\mathrm{S} \mathrm{em}$ in a verticalia.

c. A bs us DC, l. c, I uf 1 oresceutia terminalis. Faulculus squamaeformis. (Jacq. f. Eolog. ¿. 53.) $\beta$. Baseophyllum DC. $l$. c. Inflorescentia ter. minalis. Fua $i c u$ us filiformis.

$\gamma$. Cha maecrista DC. l. c. Inflorescentia axil. laris. F u niculus squamaeformis.

C fi utu acerista Breyu Prodr. $T I .29$.

ce. Xerocarpus Vogel l. c. Calyx totus scarlosus, nervosa-striatus. (Cav. Ic. t. 600, Kunth Mim, t, 36.)

B. E u ch a ma e eris $t$ a Vogel $t$. c. C a $\mid$ y $x$ membranacens. Grimald I a Sehraak in Münchner Denkschrift. 1808. p. 103. (Jacq. Hort. Sohönbr, t. 480, Kunth Mimos. t. 37. Collad. Monogr, t. 10-20. Bat. Mag. t. 3435.)

68\%, 耳abielnea GAUDLCH. C a 1 y x pentaphyllus, foliolis ima basi coalitis, acutis, aequalibus. Corolla e petala 5 , imo ealyci inserta, ejusdem laciniis alterna, obovato-orbiculata, brevissime unguiculata, aequalia. $\mathbf{S}$ amina 2 , antheris in fundo calycis subsessilibns, altera breviore, longitudinaliter bivalvi, altera longiore basi bisaceata, pollinifera, apice in acumen sterile obtusutn, valvula transversa subapertom producta. Ovarium breviter stipitatum, ovali lanceolatum, compressissimam, bi-pluriovulatnm. Stylus filiformis; stigma acutum. Legnmen compressum, oblongam, dispermum. S e min a ovali - ob. longa, strophiolata ..... - Frulices NovaeHollandiae austro-occidentalis, glabri; foliis imparipinnatis, foliolis uni-quadrijugis, ob. longis, subcartilagineis, spinoso-mucronatis, racemis axiltaribus, floribus luteis.

L a biehea Gaulicbaut ad Fregoinet 485, t. 112. DC. Prodr. 11. 507. Beuth. in Enum. Plant, Hügel. 41.

6r83. Nifetrocynia THOUAR. Calyx tubo campanalato, limbi quinquepartiti lobis lon. gis, eoleratis. Corolla e petala 5. St amina 10 filamentis hirtis, antheris apice insertis. Ovarium stipitatum, hirtmm. St y I us longitudine staminum. Leg a m e breve, subreniforme, verrueosum v. plicatum, monospermum. Frutex madagascariensis; foliis abrupte pinnatis, multijugis v. comjugatis, foliolis curiaceis, elliptico-obovatis, emarginatis, floribus dense spicatis.

Metroeynia Thouars Gen, madagasc. $n, 76$. DC. Prodr. II, 507. Meisner Gen. 98. (70.)

6834. Cymometren LINN. Caly x ebracteolatus, tube brevi, limbi quadripartiti, decidni Iaciniis reflexis, apice penicillatis, postica latiore, binervi. Corolla e petala 5 , annulo ealyeis faucem marginanti inserta, unum ejusdem laciniae posticae oppositum, reliqua cateris alterna, omnia subaequalia, oblonga, lanceolata. St a mina 10, cum petalis inserta; fil a m en ta filifurmia, libera, a $\mathbf{n}$ h e $r$ a e ovatae, apice bifidae, longitudinaliter dehiscentes (?) O vari um subsessile, compressum, subbiovulatum. Stylus subulatus, reetus; stigma eapitatum. Leg a m e sutura seminifera recta, altera arcuata subsemiorbiculatom, erassum, turgidnm, subcarnosnm, verrucosum, vix dehiscens, monospermum. Se m e $n$ eavitatem implens, umbílieo ventrali suturae medio insertum. E mbryonis exalbuminosi, recti eotyledones crassae, rotundato-subcordatae, radicula bre vissima, retracta. - Arbores Asiae tropicae; foliis bifoliolatis, floribus trunco $v$. ramis innascentibus fascicalatis, rubris, leguminibus esculentis, rufis,

Cу nometra Linu, Gen. n. 519. Lam. t. 33t, DC. Prodr, 11. 509. excl. sect. 2. Meisaer Gen, 98, 220.1 C y 1 Q in ori u w Rumplt Amboir, I. 163.

Br 85. Selhotia $J A C Q$. Ca I y x basi bibracteolatus, infundibuliformis, limbi quadripartiti laci- 
niis ovalibus, obtusissitnis, postica maxima, emarginata $v$. bifida, Oorolla e petala 5 , ealycis fauci inserta, ejusdem laciniis majora, unguiculata, posticum majus obovatum, obtusissimum, laciniae posticae oppositum, roliqua iisdem alterna, ovato elliptica. St a mina 10, cum petalis inserta, basi plus minus monadelpha, snperne libera, alterna breviora, an $t$ herae "vatae, longitudinaliter debiscentes. Ovarinu stipitatum, stipite brevissimo v. tubum staminenu aequante, ovatnm, com. pressum, piuriovulatum. Stylus filiformis, Inngissimns, primum spiraliter retrorsm tortas, demum purrectus; stig sua capitatom. Legnmen eoriaceum, ovato-ellipticum, margine soperiori v. utroque alatum, mono-hexaspermum, valvulis demum a sutaris persistentibus solutis. S e m i n a compressa, ovali-subslohosa, subreniformia, umbilice ntado v, arilto copulateformi maximo cincto. E mbryonis exalhuminosi, recti cotyled ones carnosae, radicula brevissima. - Arbores capenses; foliis pari v, abortu interdum imparipinnatis, foliolis coriaceis, floribus paniculatis, speciosis.

S elrotia Jaeq. Collect. I. 93. DC. Prodr. II. 307. Walpers in Linnaea XIII. 539. S c otia Thuab. Flor. cap. I. 389 ,

a. THEODORA Medik. Semina umbilico nudo. - Theo. d o r a Medikus Mlonograph. Mank. 1786. p. 16, c. ic. Ecklon et Zeyher Enumerat. 261. S $\mathrm{c}$ hot tia Jaeq. IC. rar. $I, t, 75$. Aulrews Bot. Reposit, $t$. 348, Afze. llus in Bot. Afäg. t, 1153, G ua i a e u capense Líu. b. UMPUALOBLOLDES DC. $l, c$, Semin a umbilicus arillo cupuliformi, toaximo, osseo, vitelfino ciactus. - Seliotia Jacq. Fragm, 23. t. 15. f. 4. Hooker Exot. Flor. 2, 159, Ecklou et Zeyter Enumerat, 261. 0 m phalobium Jacq. f. Eclog. $\vec{\gamma}$. 2, juedit, non Gärtn.

6986. Allodxylona LOUR. Caly x tetraphyllus, foliolis aculis, pilosis, deciduis, infimo faleato, incurvo, subdupio longiore. Curollae petala 5 , inaequalia, calyce longiora. S ta min a 10 , distineta. Ovari u m longinscolum, curvam, compressum. St y lus filiformis. Le gumen lignosum, Jaeve, falcatum, monospermum. Semen oblongum, curvum, arillatum. - Arbor cochinchinensis, verum lignum Aloës largiens; ramis erectis, foliis alternis, simplicibus, petiolatis, lanceolatis, integerrimis, floribus terminalibus.

A loêx y lo n Loureiro Flor. coehinch. 327. DC, Prodr, II. S18. Meikner Gen. 98.

GrS\%. IPeltogyine VOGEL. Calyx tetraphyllus, foliolis ima basi coalitis, oblongis, ovalibus, concavis, pellucidu-punctatis, pustico reliquis vix latiore. Co rollac petala 5 , imo ealyei inserta, nnum ejusdem laciniae posticae oppositum, reliqua caeteris alterna et paullo longiora, subaequalia, suboblonga. Sta min a 10 , cum petalis inserta, omnia fertilia; fil a menta filiformia, glabra, libera, an $\mathbf{h}$ e rae longitudinaliter dehiscentes. Ovarinm sessile, compressum, ovale, basi brevissime attenuatum, panciovulatum. StyI t s tereti-compressus, suberectus; stigma peltato_capitatum, Le gum en .....-Arbor $v$, fru lex brasiliensis; foliis alternis, bifoliolatis, jolivitis elliptico-ablongis, subfalcatis, apice obtusis $v$, mucronulatis, rigide membranaceis, reticulato venosis, floribus in apice ramulorum racemosis, pe dicellis subaureo tomentosis.

Peltogyne Vogel in Linnaiea $\searrow r$, 610.

6r88. Il ymemaer $L I N N$. C a ly $\mathrm{x}$ coriaceus, tubo urceolato-eampanulato, limbi quadriyninquepartiti laeiniis posticis plus minus inter $8 \mathrm{e}$ connatis, Corolla e petala 5, summo calycís tuho inserta, ejusdem laciniis alterna, inaequalia, posticum plerumgue eymbiforme majus, antira non raro deficientia. S $t$ am in a 10 , cum petalis inserta, omnia fertilia; fil amenta filiformi-subulata, libera, antherae longitudinaliter debiscentes. $O$ varium sessile $v$ stipitatum, quinque-multiovulatum. Stylus subulatus; stigma obtusum. Legumen lignosum v. coriaceum, laeve v, verrucosum, turgidum, indehiscens, pulpa exsacca farctum, mono-pleiospermum. Semina ovatosubglobusa, testa lapidea. Embryon is exalhnminosi, recti eotyledones carnosae, radicula inter cotyledunum margines abseondita. - Arbores Americae tropicae, inermes, resinosae; folis atternis, conjugutis, stipulis petiolaribus geminis, pedunculis terminalibus et axillaribus, rumosis, multifloris, bracteatis, floribus subracemosis, albis.

H y me n a e a Lisn. Gen. $n$, 512, Gärtaer $I I$. 305. Kunth in Humb, et Bonpl, Nov. gen. et.sp, NT. 321. DC. Prodr. II. 511 .

a. COURBaril Plum, Co rollae petala 5, inaequalia. 0 variu un sessife v. stipitatum, imlierbe, L e gu in en lignosua, laeve, pulpa exsucea, farinoso-filaneutosa repletuas. - Co а rbaril Plumier Gen, $t, 36 . \mathrm{H}$ у ш е. n a e a Hayne Arzneigew. XI, t, 6-16. Nees Plant, of: fic. Suppl, V, 2, 17, (Giartnert, 145. DC. Mem, Legum, t, 26. f. 120 . Kusib $O_{p}$, cit. $\ell$. 566.)

b. TRACHYLOBIUM Hayn. Corollae petala 3, subaequalia, longe unguiculata. Ovariam stipitatum, barbatam. L e g u m en coriacea-suberosua, verrucosam, pulpa exsucea, solida farcium, - T ra e hy labium Hinye in Flora 1827. p. 743. Arzneigew, $X I, t, 17-19$. T a atroujou Jassien Gen, 35I. in not. (Gärtaer $t$, 139.)

6883. Cumlotretus RICHARD. CaIy x ventricoso-campanulatus, subbilabiato - quinquefidus v. quinquedentatus, labio superiore bi-inferiore trimero. Corolla petala 5 , imo calyci inserta, ejusdem dentilıns v. latiniis alterna, unguiculata, saepe paullo inaequalia. Stamina 10 , $\mathrm{cnm}$ petalis inserta, omnia fertilia, lihera; fila menta filiformia, a nthera e oblongae v, ovatae, longitudinaliter debiscentes. O va ri um sessile, uniloculare, pluriovulatum. Stylns subulatus, adscendens; $8 \mathrm{tigma}$ capitatum v. obliquum. Le g um e n sessile, sieen, lineari oblongum, compresso-planum, indehiscens, abortu mono-dispermum. Sem in a lenticulari-compresea, albumiaosa. Embryonis recti cotyledunes plasae, radicula obtusissima. - Arbores $v$, saepias frutices, scandentes et cirrhosi, in America tropica indigeni; stipulis deciluis, foliis allernis, bilobis, interdum cum foliis conjugatis mixlis, racemis terminalibus et axillaribus, fluribus abbis v. flavescentibus, pedicellis basi unibracteatis, medio bibracteolatis.

Ca alotret us Riehard mse. Spreagel Gen.pl.n, 1813. a. L a cara Sprengel Syst. $I$. 332. Ba a hínia Kusth in Annal se, nat. T. 48 Nov, gen, et sp. VT, 310. Bosgard in Mlem. Acalem. Petersb. VI. Ser, t. PT, 109, B a u hit il a e seet, Caulotretus DC. Prodr. II, JtG., S ehuetla Raddi Plant, bras. add. 32. $f .4$,

a. EUCAULOTRETUS. Calyeis aestivantis apex obtusus. Stigma eapitafum. - Ba uhiniae $5 \mathrm{p}$. Linn. Jacq. Amer, t, 173. f.3. Aubl Guian, t, 14a. Bot, Mag.t. 1133 . Basgard $O p, c i t, t, 1 \perp^{5}$

b. TYLOTAEA Pog. Calyets aestivantis apex deutibns efongatis coronsus. Sitgma suboblique traneatum, marginibus callosuat. - Vogel in Linnaea XIII. 319 .

PERLEB1A Mart, Reis. 555. Arbor Grasfliensis, Bauhinise cujusdan parvifolias facie, acoleis stlpularlsur valldis, a Baulinits leguwise wultifoenlari, fere Prosopeos, diversa.

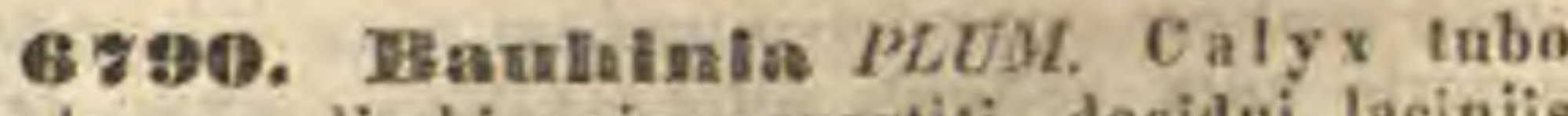
cylindraceo, limbi quinquepartiti, decidui lacinis lingissimis, liberis $v$. inter se, rihaerentibus, in ligulae formam reflexis. Co ro 11 a e petala 5, summa 
valyeis tubo inserta, ejusdem laciniis alterna, longe ungrieulata, paullo inaequalia. St a m in a 10 , cam petalis inserta, ima basi monadelpha, omnia fertilia $v$, alterna ant interdum plura sterilia $\mathbf{v}$. ananthera; filamenta filiformia, an $t$ herae incumbentes, longitudinaliter dehiscentes. Ovari um longe stipitatum, multiovulatum, Sty I u s arcuatus; stigma obtusnm. Le gumen stipitatum, lineare, compressum, bivalve, polyspermum. Semin a compresso-lenticularia, albuminosa. Embryonis recti cotyledunes planae, radicula obtusissima. - Arbores $v$, fruties interdum aculeati, in Asia, Africa et America tropica indigeni; foliis alternis, plus minus profunde bilobis, stipulis petiolaribus geminis, floribus racemosis, lateralibus $v$, terminalibus, interdum solitariis v. ternis, oppositifoliis, pedicellis basi unibracteatis, medio bibracteolalis, corollis albis, luteo-rubentibus $v$. purpureis,

Ba uhiaia Plunier Gen, t. 13. Pauletia Cavanill. $\Gamma$. 5. Kunib in Annal. sc. nat. I. 84. Bongard in Jiem. Academ. St. Petersb. VI. Ser. Tom, IV. p, 116. B a u b iniac sp. Linu. et Auct.

a, PAULeTiA. Stamina 10 , omnia fertilia v. alterna sterilia. O varfi stipes liber. - P a uleti a sect. B a u. hin iae DC. Prodr. $I I$. 5i3. B a uhinlae sp. Lína. Jacq. Amer, t. 177. Fragm, t, 15.f. 1. (Cav. 1c.t. 409.410.)

b. AMARIA. St am ina 10 , omaia fertilia, 0 var $i \mathrm{i}$ stipes calyeis tabo hise adnatus. - A m a ri a Mutis in Sem. Nuev. Granad, 1810, p. 28. ox DC, Prodr. II. 519.

c. SYMPHYOPODA. St a th 1 n a 10 , tria fertilla, longissima, reliqua minima, sterilia. Ora $\mathrm{r}$ ii stipes cum calycis tubo hine counatus. - S y mp y o poda sect. Bauhiniae DC. 1. e. Mem, Legum. $t$, zo.

d. PHANBRA. St a mi a 10 , tria fertilia, longissima, re liqua minima, sterilir, $O$ varit stipes brevissimus. Phanera Loureirn Flor, cochineh. 46. (Roxburgh Plant. Corom, $t$. 285.)

689 1 . Casmanes KUNTH, Ca Iy $x$ tubo brevi, cylindracen, limbi quinquepartiti, decidni lacinis longissimis, linearibus, inter se cohaerentibus, in ligulae formam reflexis. Corolla e petatala 5, summo calycis tnbo inserta, ejusdem laciniis alterna, longe unguiculata, subaequalia. Stamina 10 , cum petalis inserta, 9 sterilia, in ferne coalita, minuta, decimum liberum, fertile; filamenta elongato, anthera incumbente, longitudinaliter dehiseente. O va rium longe stipitatnm, multiovulatnm. Stylus arcuatus; stigma infra styli apicem crassum, prominulum. Le gumen stipitatum, sicenu, late lineare, compressum, bivalve, polysperrum. Seu ina compressa, albuminosa. Embryon is recti cotyleton es planae, radienla ubtusissima. - Arbo res v. frutices erecti, inormes, in America $t$ ro. pica indigeni; foliis alternis, plus minus profunde bilobis, stipulis petiolaribus geminis, racemis terminulibus et axillaribus, floribus albis, roseis v. rubris, pedicellis basi unibracteatis, supra basim bibracteolatis.

C asparia Kanth in Annal. sc. nat. I. 85. Nov, gen. et sp. DT. 319. B a u bi n i n Cavanill. Ic. D. 3. t. 404-407. B a u hi n i a e s p. Lian. Miller Rc, t, 61. Jacq. Hort. schönbr.
$t$. 100 . Bot. Mag. t. 1709

6892. Hinmboldtia VAHL. Caly $\mathrm{x}$ basi bibracteolatus, tubo turbinato, limbi quadripar titi, decidui lacinia postica panllo majore, binervi. Corolla e petala nune quinque, uno ealyeis laciniae posticae opposito interdum nonnihil majore, eaeteris cnm reliquis alternantibus, nune tria, nempe duobus anticis nullis, $\mathrm{Sta}$ in a 5 , enm petalis inserta, iisdem alterna, omnia fertilia; fila- menta filiformia, libera, an ther a e versatiles, iongitudinaliter dehiscentes. Ovarium stipitatum, stipite calyeis parieti postice adnato, nhlique oblongum, multiovalatum. Sty!ns subula. tus; $8 \mathrm{ti}$ g m a capitatum. Leg umen oblongum, compressum ... - Fruticuli inermes, in $A$ s ia tropica indigeni; foliis abrupte pinnatis, subtus glandulis adpressis instructis, stipulis foliaceis, infra punctum insertionis deorsum productis, pellatis, racemis axillaribus, pedicellis basi unibracteatis, apice bibracteolatis.

H u mbold tia Vahl Symb. IIT, 106. DC, Prodr. II, 488, R. Brown in Wallich Plant. As. rar, IIT, 17, t. 233. Wiglit et Arnott Prodr. I. 284. Meisuer Gen, 100, (71.) B a ts $\mathrm{cth}$ i a Vahi $s y m b$. IIT. 39. 6.56 .

6ช93. AmLerostia $W A L L$. C alyx basi bracteolis duabus coloratis, tubo eylindrico, limbi quadripartiti, decidni laciniis subaequalibus, patentissimis. Corolla e petala 5, calyeis fauci inserta, unum ejusdem laciniae posticae oppositum maximum, obeordatum, unguiculatam, duo lateralia cuneiformia, divaricato patentia, et totidem antica, minuta, subulato-hamosa calycis laciniis alterna. Stamina 10 , cum petalis inserta, ad. scendentia, norem in tubnm longum coalita; fil a. m e n tis superne liberis, alternis brevioribus, decimum posticum distinetum, basi cum ovarii stipite coalitum, ant herae omnes fertiles, incumbentes, longitudinaliter dehiscentes, alternae breviores. Ovarium stipitatum, exsertum, stipite cum calycis pariete postice connato, subfalcatum, compressum, quadri-sexovulatum. Stylus filiformis, revolutus; sti $\mathrm{gma}$ convexum. Le gumen oblongum, compressum, acuminatum, subpentaspermun..... Arbor martabanica, quadragintapedalis, stipulis deciduis; folits amplis, abrupte pinnatis, sex-octojugis, racemis axillaribus maximis, coccineis, pendulis, floribus speciosissimis, petalis rubicundis, postico et lateralibus apice macula lutea orbiculari ocellatis, legumine coriaceo, rubro.

A mherstia Wallich Plant. As, rar. I. 1. t. 1. 2. Meisuer Gen. 98. (70.)

Bg 4 4. Heterostemon $D E S F$. $\mathrm{C}$ a ly $\mathrm{x}$ basi bracteolis duabus connatis calyculatus, tubo longo, gracili, limbi quadripartiti laciniis oblongis, acutis, subaequalibus. Co roll ae petala 3 , ealycis fauci inserta, nno ejusdem laciniae posticae opposito, duobus alternis, omnibus obovato- oblongis, subaequalibus. Stam ina 8 , calyeis fauci inserta, longa, declinata, inferne monadelpha, saperne libera, pilosa, tria antica longiora, fertilia, antheris ovatis, longitudinaliter dehiscentibus, reliqua sterilia, antheras efoetas, bilobas gerentia. $\mathbf{0}$ varium longe stipitatum, exsertam, stipite postice eum calyeis tubo connato, oblongum, compressum, multiovulatum. S t y I us filiformis, elongatus, arcuatus; stigm a obtusum. Legumen planum, utrinque angustatum, suturis incrassatis marginatum, polyspermum. S e mina ..... Arbor brasiliensis; foliis abrupte pinnatis, petiolo alato, foliolis linearibus, obtusis, emarginatis, glabris, antice excisis, floribus magnis, paucis, corymbosis.

Heterostem on Desfont, in Mem. Mus. I, 284, t.12, DC. Prodr. IT. 358, Meisner Gen 97. (70.)

6ร95. Jomesia ROXB. C a l y $x$ basi bibracteolatus, coloratus, infundibuliformis, tubo carnoso, limbi quadripartiti laciniis obtusis, patentibus. Co roll a nulla. Stamin a $3-9$, annulo carnosulo, calycis faucem marginanti inserta; 
fil a m e n ta elongato-filiformia, lihera, flexuosa, an $\mathbf{t h}$ er a e reniformes, longitudinaliter dehiscentes. O va ri $\mathbf{m}$ stipitatum, exsertum, stipite hine cum calycis tubo connato, ovato-oblongum, multiovulatum. Stylas filiformis, declinatus; stigma simplex. Legumen falcatum, subturgidum, reticulatum, tetra-octospermum Semina ovatosubglobosa.... - Arbores $v$. frutices seandentes, inermes, in Asia tropica indigeni; foliis abrupte pinnatis, foliolis bi-quinquejugis, coriaceis, stipulis intrafoliaceis, racemis subfasciculatis, floribus ru. bicundis.

Jones i a Roxbureh in Asiat, Research, IV.355. Flor. Ind. 'IT. 212. DC. Prodr. II. 487. Bot. Mag. t, 3018. Wight et Arnott Prodr. 1I. 487. Meisner Gen. 79. (70.) Sarae a Burmanu Flor, ind. 85. $t$. 25. $f$. 2. Linu. Mant. 98. A s jog a m Reede Malab. $V$, 117. 6.59.

6ร๖G. A fzellà SMITH. Ca I yx basi mi nute bibracteolatus, velutinus, tubo turbinato, limbiquadripartiti laeiniis coneavis, obtusis, postica latiore. Corollae petala 3 , calycis fauei inserta, posticum ealycis latiniae posticae oppositum maximum, longe unguiculatum, limbo transversim oblongo, emarginato, longitudinaliter plicato, duo lateralia minutissima, lanceolata. S tamin a 9 -10, cum petalis inserta, quorum 7 v, 8 fertilia, 2 sterilia capillaria, fertilium filament a longissime filiformia, libera, antherae cordatae, bilocula. res, longitudinaliter dehiscentes. Ovarin m sti pitatum, ventricosum, velutinum, multiovulatum. Sty lus longus, arcuatus; $8 \mathrm{tig}$ m a obtusum. Leg um e n ovato-oblongum, compressum, indehiscens, polyspermun, isthmis inter semina transversim pluriloculare. S e m in a ovata, compressiuscula, nmbilico basilari arillo carnoso, copulaeformi cincto. Embryonis exalbuminosi cotyledones carnosae, radicula retracta, - Arbor Africae tropicae occidentalis; folis abrupte pinnatis, foliolis quadri-quinquejugis, coriaceis, ovato-ellipticis, glabris, stipulis deciduis, floribus paniculato-racemosis.

A fzelia Smith in Linn. Transaot, ID. 221. DC. Prodir. IT. 507. Guillem. et Perrot. Flor, seneg. 263, t, 57, Meisner Gen, 97. (70,) ? $\mathrm{P}$ a n с ov i a Willdenow Spec. 11 . 286.

6รจซ. Antlaonota PALIS, Calyx basi bracteolis duabus in involucellum bilobum coalitis, quadrifidus, coloratus, laciniis tribns lanceolatis, acutis, postica latiore emarginata. Corollae petala 2, calycis tubo inserta, ynum longe, unguiculatum, limbo cochleariformi, emarginato-bilobo, alterum complanatum, spathulato-rotundatum. St a m in a 9, calyeis tubo inserta, dno fertilia longissima, reliqua sterilia calycis limbo paullo longiora; filamenta filiformia, antherae subglobosae. Ovarium stipitatum, ovatum, compressum, multiovulatum. Stylus filiformis; stig$\mathrm{ma}$ infra styli apicem prominulum. Leg $\mathrm{n}$ men compresso-planum, indehiscens, rugis transversis subreticulatum, polyspermum. Semina orbiculata, plana. - Frutex Africae tropicae; folüs exstipulatis, abrupte pinnatis, foliolis bi-trijugis, coriaceis, elliptico-oblongis, acuminatis, petiolo communi tereti, racemis axillaribus, brevissimis.

Anthonota Palisot Flor. Owar. I. 70, 2. 48. Lam z. 953 . DC. Prodr, II. 510. Desvaux in Annat, sc, nat, IX. 4.30. Meisner Gen, 97, (70.)

6ร98. Intsia THOUAR. Calyx basi eampanulatus, quadripartitus. Corolía petalum unieum, unguiculatum, ovario oppositum. Stato in a 9 , quorum tria fertilia, longiora, declinata.
Le g a m e n oblungum, compressum, tri-tetraspermuin, inter semina medulla faretum. S e min a oblonga. - Arbor madagascariensis, procera; foliis imparipinnatis, bijugis, floribus corymbosis.

Int s i a Thouar. Gen, Madagase. n. 75. DC. Prodr. $I T$. 500. Meisner Gen, 97. (70,)

6รฐจ. Palovea $A U B L$, C al y x basi bracteolis duabus, in involucellum bilobnm coalitis, tubo obeonico, ex involucello exserto, limbi quadri-quinquepartiti laciniis patentibus. Corollae petala 3 v. 4 , ralycis fanci inserta, ejusdem laciniis alterna et panllo breviora, oblonga, uno v. altero margine interiore antherae rudimentum gerente. Stamina 9, cum petalis inserta; filam e $\mathrm{n} t$ a elongato-filiformia, aestivatione replicata, an therae oblongae, incumbentes, longitudinaliter dehiscentes. 0 v a riu m stipitatum, lineare, compressum, pluriovulatum. Stylns fitiformis, aestivatione biplicatus; stig ma terminale, subrotundum. Legumen oblongum, compressum, bivalve, hexa - heptaspermum. S e min a ..... Frutex guianensis; foliis alternis, simplicibus, ellipticis, utrinque acuminatis, integerrimis, glaberrimis, floribus ad apices ramulorum subumbellatis, pedicellis imbricato-bracteolatis.

Pal ovea Aablet Guian, I. 365, t, 141, Lam, t, 323. DC. Prodr. II. 518. Meisner Gen. 79, (70.) Ginuania Scopoli Introduct. n. 1366.

6800. Eperua $A U B L$. Ca 1 y $\times$ tubo brevi, urcenlato, limbi quadripartiti laciniis aestivatione imbricatis, deciduis, postica latiore. Corollae petalum unicum, calyeis fauci insertum, cjusdem laciniae posticae oppositum, basi cueullatum, subfimbriatum. Stamina 10, calyeis fanci inserta; fil a me nt a longe filiformia, basi incrassata, subvillosa, in annulum brevem coalita, a ntherae oblongae, incumbentes, longitudinaliter dehiscentes. Ovarinm stipitatum, compressum, quadriovulatum. Styln s filiformis, elongatus; stig ma subcapitatum. Leg a men compressum, subfaleiforme, siceum, coriaceum, junius subtomentosum, bivalve, mono-dispermum, S e m $i$ n a reniformia. Arbor guianensis; folitis abrupte pinnatis, foliolis bi-trijugis, ovatis, acuminatis, nitidis, panicula longe pedunculata, pendula, e racemis plurimis, distantibus composita, fioribus rubris.

E perua Aublet Guian. I. 369. t. 169. DC. Prodr, Ir. z10. Meisner Gen, 97. (70,) R ot $\mathrm{m}$ а а $\mathrm{n}$ i a Necker Rlem, $n$. 1284. P a z e ra Willd. Spec. II. 540.

6801. Parrivon $A U B L$. Ca 1 y x glaber, tubo brevissimo, limbi quadripartiti laciniis oblongis, obtusis, concavis, postica duplo latiore, elliptica. Corolla e petalum unieum, snmmo calycis tubo insertum, ejnsdem laciniae posticae oppositum, eandem multo superans, inferne snbeucullatum, glabrum. St a mina 10, ealycis tubo inserta; fil a. mento postico libero diadelpha, alterna breviora, a $\mathbf{n}$ th e ra e oblongae, longitudinaliter dehiscentes. Ovarium stipitatum, compressum, glabrum, quadriovulatum. Stylus glaber; stigma aentiasculum. L e g n m e $\mathrm{n}$ crassum, compressum, ovale, bivalve, monospermum. Semen …‥ Arbor guianensis; foliis abrupte pinnatis, $\overline{f a-}$ liolis tri-quadrijugis, ovatis, acuminatis, nitidis, floribus racemosis, purpureis.

Parivo a Aublet Guian, II, 757. t. 303, 304. DC. Prodr. II. G10, Kunth zwei Abhandl. 15. $t$. 3. $f$. $a$. Meisner Gen. 97. (70.) A dleria Necker Elem. $\pi$. 1286. Dimorpha Willd. Spec, III. 971. Rudge in Linn. Trantact, IX, t. 20.

6802. Crudya WILLD. C a l y $\mathrm{x}$ basi 
bibracteolatus, tubo brevi, obconico, basi antice subgibbo, fauce obliqua, limbi quadripartiti, decidui, laciniis inaerualibns, Corolla nulla. Sta$\mathrm{m}$ in a $8 \mathrm{v} .10$, calycis fanci inserta; filame $\mathrm{nta}$ longa, libera, basi dilatata, antherae subrotun. dae, longitudinaliter dehiscentes. Ovarium stipitatum, exsertum, stipite cum ealycis tubo connato $(?)$, ovatum v. incurvum .... Stylus filiformis, rectus $v$. incurvus; $s \mathrm{tig} m$ a incrassat $\mathrm{mm}$, obtusum. Le g a m e n coriaceum, crassum, indehiscens, mono-dispermum. - Arbores guianen. ses; foliis glabris, impuripinnatis, foliolis allernis, integris, racemis axillaribus, simplicibus.

Crudya Willdenow Sp. II, 539. DC. Prodr. II. 519. Touchirou L. C. Richard msc. Cradia Schreber Gen, n. 711. Cy clas Schreber Gen, n. 712, excl, fruct. A pa la-

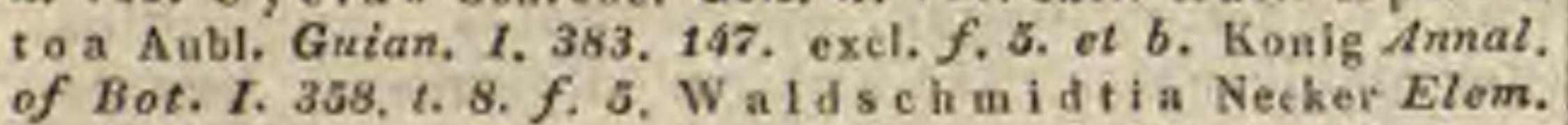
$n$. 1405. To a c bi ro ua Aublet Guian, $1.385, t$, 148, Lam. t. 339. - Vou ar a a Aublet Suppl, 12, t, 3i2,

BS03. Nacrolobium $S C H R E B$. Caly x bibracteolatus, tubo lrevi, hemisphaerieo - urceolato, limbi quadripariti lacinia postica integra v. bifida. Corolla e petalnu posticum maximnm, unguiculatum, ungue basi cum ealyeis tubo connato, adscendens, aestivatione plicatum v. galeatum, reliqua minima $v$. plane abortiva. Stamin a 3 , calycis fauci inserta, ejosdem laciniis anticae et lateralibus inserta, omnia fertilia ; filam e n ta brevi-subulata, libera, antherae ovatae, basi emarginatae, glanduloso-scabrae, longitudinaliter dehiscentes. Ovarin m stipiti enm ealyeis pariete postice connato impositum, oblique oblongum, compressum, nni-biovulatum. Stylus longissimas, primum spiraliter involuto-reflexus; stigin a ohtnsum. L egumen stipitatum, compressum, coriaceum, monospermum. Se mina ..... - Arbores Amerie a e tropicae; foliis abrupte pinnatis, floribus racemosis.

Macrolobinm Schreber Gen, n, 62. Willd. Spec, I. 186, Vogel in Linnaea $Y I .411$.

a. OUTEA Aubl. B racteola membranaceae. Caly cis laciniae membranaceae. Petal a m posticum aestivatione lougitudiasliter plícatan, marginibus nedaiatum, reliqua minuta v. nulla. - 0 u te a Aublet Guian, 1, 28. t. 9. Iussieu Gen, 347. DC. Prodr, 11.510 . Kauth zwei Abhandl. 13,

b. VoUAPA Aubl. Bracteolae corlaceae, Calycis laciaiae membranaceae. P e tal u m posticum aestivatione galeato incurvom, reliqua nulla (2) - Vo a a pa Aublet Guian, 1. 25. t. 7. 8. Jussieu Gen. 350. DC. Prodr. Ir. 511. Kunth swei Abkandl. 14. t, 2. f. E. M a e rolobi um Vabl Enum, II, 37. Kr a egeria Necker Elem. n. 1389.

๔. Scytodium Vogel 2 . c. Bracteola e coriaceae. CaIy cis Iaciulae coriaceae. Petalum posticum plicatum, lateralia minora.

6804, Codaneigam SOLAND. C a I y $\mathrm{x}$ utrin que tomentosus, tubo abbreviato-turbinato, tandem explanato, limbi quinquepartiti, deeidui laciniis acutiusculis, subnoncavis, aestivatione imbri eatis. Coralla e petalum unieura, calycis fauci insertnm, inter ejusdem lacinias posticas situm, sub unguiculatam, isstem hrevius, saepe nullum. St a mina 2, sumno calyeis tabo inserta, lateralia; fil a m enta libera, erassinscula, apice subnlata, antherae ovato-oblongae, adnatae, longitudinaliter dehiscenteg. Ova riu m (interdum ovaria 2) stipitatum, stipite cum calycis tnbo hine connato, oblique ovatam, compressiusculum, hixtom, hiovulatum, ovulis snperposite pendulis. St y 1 as subulatus, incurrus, glaber; sti simplex, obtusum. Legumen siccum, inde- hiscens, velutinum, intus pulposum, abortu manospermum. S e in en ovatum, compressiusculam, albuminosum. Em bry onis recti c oty led ones subrotundae, basi emarginatae, foliaceae, radi. c u la sopera. - Arbores Africae tropicae, ramosissimae, trunco tortuoso ; foliis imparipinnatis, bijugis, foliolis coriaceis, floribus in paniculam ter. minalem ramosam dispositis.

Codarium Solander in Vahl Enumerat. I. 302. II. 400. Afzelius in Sehrader $n$. Journ. II, 233. Kunth zwei 1bhandl. 17. t. 2. $f$. b. Meisuer Gen. 100, (71.) D i a lii s p. Willd, in Römer Archiv. I. 31. t. 6. Guillem. et Perrot Flor, seneg. t, 59.

6805. Dialluma $L I N N$. C al y x utrinque tomentoso-hirtus, quinquepartitus, laciniis oblongis, obtusis, subaequalibus, aestivatione imbricalis. Corolla nulla. Stamin a 2 , sub disei orbiculati, calycis fundo adnati margine brevissime libero inserta, ejusdem laciniis posticis opposita et panllo breviora; fila m enta subulata, libera, antherae filamento breviores, ellipticae, basi emarginatae, longitudinaliter dehiscentes. Ovariu in disci centro sessile, ovatum, compressiuseulum, tomentosum, biovulatum, ovalis superposite pendulis. St y lus teretinsculns, brevis, declinatus; $8 \mathrm{tigma}$ obtusum. Leg nm en ovale, compressum, indehiscens, crustaceum, sutura seminifera sulco exaratum, saepissime monosperinum. Semen pendulum, albumine crasso, corneo. Cotyle don es foliaceae. - Arbores in Asia, Africa et America tropica crescentes; folits imparipinnatis, foliolis paucis, alternis, floribus paniculatis, bracteis solitariis, parvis, caducis, pedicellos subtendentilus.

Diall u m Burmann Flor, ind. 12, Linné Mant. 24 Afzel in Schrader n. Journ. II. 238. Vaht Enum. I. 303. Meisner Gen. 100. (71.) Benaet in Horsfield Plant. jav. rar. 136. $t$. 30. A ro u n a Aublet Guian, I. 16. t, 5. Kusth zwel Abhandl, 16, $t, 3, f, B$. Cle y ria Necker Elem, n. 897.

6806. Copaifera $L I N N$. Calyx profunde quadripartitus, deciduns, laciniis ovato-lanceolatis, acutis, concavis, patentissimis, aestivatione imbricatis. Corolla nnlla. Stamina 10, imo calyci inserta, illoque paullo longiora; filamenta libera, subaequalia, areata, a $\mathrm{n} t \mathrm{her}$ a biloeulares, longitudinaliter dehiscentes. 0 v arium breviter stipitatum, ovatum, compressiusculum, bilocnlare. Sty 1 a s filiformis, incurvas, staminum longitudine; stig ma obtusum. L eg amen stipitatum, oblique ellipticum, lentículari compressum, monospermum, bivalve. Sem en ellipticum, arillo baccato involutum, albnminosum. Embryonis recti radicula sublateralis. - Arbores Americae tropicae, inermes, e trunco inciso succum balsameum plorantes; foliis allernis, impari- v. saepius abrupte pinnatis, foliolis oppositis aut rarius allernis, inaequilateris, racemis in paniculas axillares et terminales dispositis.

C. opa ifera Linn. Gen. n, 5a9. Desfont. in Mtem. Mrus. VII. 375.c. io. Kunth in Humb et Bonpl, Nov, gen, ot sp.VII, 265. t. 659. DC. Prodr. II, 508. Hayne Araneiğew. $2,12-93$. Linnaea $I, 418$, Nees Plant, offic. Suppl. I, t. 16, 17, It, t. 19. 20. Meisner Ger, 97. (21,) C o p it iv a Jacq. Amer, 123, $t, 86$. Co a poib a Maregr. Brasil. 130. Piso Bras. 56.

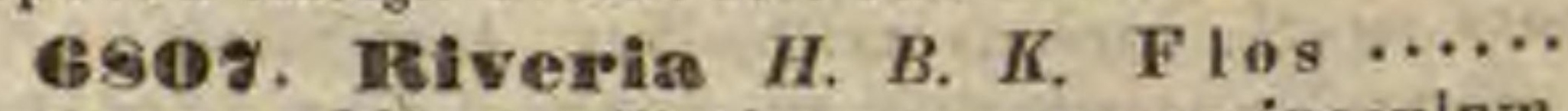
Le gum en oblique ellipticum, compressinseulam, stípitatum, mucronatum, coriaceo-chartaceum, bivalve, monospermum. S e $m$ e $\mathbf{n}$ oblongo-reniforme, ad ventrem, nbi affixum, substantia alba, friabili munitum, testa chartaceo-membranacea. Embryonis exalbuminosi, semini conformis radicula infra apicem embryonis sita, deorsum 
spectans, - Arbor peruana, inermis; foliis alternis, imparipinnatis, interdum ternatis, subcoriaceis, rhachi alata, pedunculis subterminalibus, abortu monocarpis.

Riveria Kunth in Humb. et Bonpl. Nov, gen, et sp, $\nu I I, 267 . t$. 659, bis.

6808. Iraw iviekia ROXB. Calyx tetra-pentaphyllus, foliolis ima basi coalitis, ovatis, concaviusculis, aequalibus, patentibus. Corolla nulla $\mathrm{S}$ t a m in a 8 v, 10 , imo calyci inserta; filamenta filiformi-subulata, libera, alterna breviora, a ntherae ovatae, apienlatae, longitudinaliter dehiscentes. Orari nm sessile, biovulatum (?) St y l u s brevis, adscendens; stigma magnum, peltatum. Leg u in en lanceolatum, compressum, apice monospermum, bivalve. S e m e cuneatum, plano-compressum. ..... - Arbores indica e, inernes; foliis conjugatis v, abrupte pinnatis, bijugis, stipulis parvis, deciduis, racemis axillaribus paniculatis, floribus sordide flavescentibus.

Hardwiekia Roxburgh Plant. Corom. IIT. $t$, 209. Flor. Ind. 11. 425. DC. Prodr. II. 486. Wight et Arnot Prodr. I. 284. Meisuer Gen, 97, (69.)

6809. Ceratonia LINN. Flores poly gami v. dioici. Calyx parvus, quinquepartitus, deciduns. Corolla nulla. Stam ina sub disei hypogyni, peltati, obsulete quinquesinnati, calycem excedentis margine inserta, calycis laciniis opposita, patentia; fil a menta filiformia, libera, a nther a e elliptico-oblongae, ntrinque emarginatae, longitudinaliter dehiscentes, O v a ri u m breviter stipitatum, subfalcatum, multiovalatum. Sti gma sessile, subcapitatum, obsolete emarginato-bilobum. Leg u m en lineare, compressnm, suturis crassissimis, bisuleatis cinctum, coriaceum, indehiscens, intas inter semina isthmis pulposis transversim plurilocellatum, locellis monospermis, enducarpio cartilagineo. Semin a obovata, com. pressinscula, umbilico basilari, testa cornea, endopleura membranacea, albumine pareo, carnoso. Embryon is recti cotyledones planiusculae, earnosae, radicula brevissima, acuta, plumula minuta, conica. - Arbor in regione mediterranea indigena; trunco crasso, foliis alternis, sempervirentibus, imparipinnatis, foliolis bi-trijugis, ellipticis, subundulatis, coriaceis, supra nitidis, racemis axillaribus, pedunculatis, puberulis, purpurascentibus, floribus parvis, leguminibus majusculis, muco-saccharo scatentibus.

Ceratonia Limn. Gen. n. 1167. Duhamel Arbr. II. t, 70. Cav. 1c. $t, 113$. Fasano in 1ot. Neapolit, 1787. p. 298. t. 18. f. 2. Lвm, t. 859. DC. Mem, Legum. t. 23. f. 114. Prodr. II, 486. Nees jun. Plant, offic. IV. $t, 19$. Meisner Ger. 100. (21.) Silliq a a Tournef. Inat. 344.

8810. Brownea JACQ. C a 1 y x tubo elongato, persistente, limbi quinquepartiti, decidui laciniis longis, duabus v. quatuor per paria cohaerentibus. Corollae petala 5 , summo calyeis tubo inserta, longissime unguienlata, snbaequalia. Sta m in a $10-15$, cum petalis inserta, in tubum hine fissum coalita, omnia fertilia. $O v$ ari u m stipitatom, sex-septemovulatum. Stylus filiformis;stig ma acinaciforme, compressum. Semina ovata, compressa, fibris fungosis obvoluta. - Arbusculae Americae tropicae inermes, speciosae; ligno flavescente, duro, foliis paripinnatis, foliolis integerrimis, inflorescentia terminali, floribus racemosis v. plus minus dense spicato-capitatis, bracteatis, coccineis $v$, albis, pedicellis apicem versus bibracteatis, bracteis in tubum infundibuliformen, bilobum connatis.

B row n a Jaeq. Amer, 194. t. 121. Fragm, t, 16-23. Linn. Gen, n, 833, Lam. t. B7s, Kunth in Humb. el Bonpl. Nov, gen, et sp, VI, 312. DC. Prodr. II. 476. Meisne Gen. 97. (69.) Hermes i as Löflling It. 278.

\section{* MORINGEAE.}

BS1 1. Norimsa JUSS. C a I y $x$ quinquepartitus, laciniis oblongis, subaequalibus, aestivatione imbricatis, Corollae petala 5, perigyna, oblongo-linearia, dno postica paullo longiora, adscendentia, aestivatione imbricata. Stam ina 8 v. 10, disco cupuliformi calycis basim vestienti inserta; fil ament a basi complanata, in tubum antice fissum conniventia, basibus libera, supra medium connata, apice distincta, inaequalia, postica longiora, omnia fertilia, v, alterna calyeis laciniis opposita breviora, ananthera, antherae introrsae, uniloculares, oblongo-ovatae, dorso affixae, longitudinaliter dehiscentes, peltatim patentes. Ovariom pedicellatum, uniloculare, placentis parietalibus tribns, nerviformibus. Ovula plurima, uniseriata, pendala, anatropa. Stylus terminalis, simplex, subclavatus, apice incrassatus. C a p s la siliquaeformis, rostrata, tri-polygona v, costata, torulosa, unilocularis, trivalvis, valvis medio semina uniseriata, dissepimentis transversis fnngosis distincta gerentibus. Semina ovato-trigona, angulis apteris $v$. in alam membrana. ceas expansis, chalaza apicali suberosa. Embryonis exalbuminosi, orthotropi cotyledones plano-convexae, carnosae, radicula brevissima, supera, pl a mula polyphylla. - Arbores inermes, in Asia tropica indigenae, in Africam et Americam introductae; foliis bi-tripinnatis, cum impari, foliolis saepe caducissimis, stipulis deciduis, racemis paniculatis.

M ori g a Burmann Zeglan, 162. Jussleut'Gen, 368. Gärtaer II. 314 . DC. Mem. Legum. C. 21. Prodr. II. M78. R. Brown ad Denham. 33. Decalsne in Nouv. Annal. sc. nat, IV. 203. Wight et A ruott Proalr, I. 178. H y per a a ther a Porsk. Descripl. 67. Vabi Symb. I. 30. A n a ma Lenrelro Flor, cochineh. 342 . If y pelite Suith Rees Cyelop. XrX. Alandin a Necker Elom, n. 1203.

a. BALANUS. S emina aptera. M. apter a Gărtner sp. t. 147. Decaisne Op. cit. t. 4. Bala nus myrepsica Beloa. Obs, 126.

b. MORING $A$. S e m in a triptera. (Lam. $t, 33 \%$, Gấrtuer t. 147. Burmann Zeglan. $t$. 75. Ruaph Amboin I. $t, d 7$. 75. Rheede Malab, VI, I, 11.)

\section{Drdo CCLXXVI. Swartzieae.}

SWARTZIEAE DC. Prodr. 429. Bartling Ord, nat. 413.

Aввоввs inermes, in America et Africa tropica indigenae, foliis alternis, imparipinnatis v. simplicibus, bistipulatis:

Fuores hermaphroditi, subirregulares, racemosi.

CaLyX aestivatione connato-clausus, sub anthesi valvatim quadri-quinquelobus, v. hinc longitudinaliter ruptus.

Conolrae petala 5 , hypogyna, plus minus ve inaequalia, aestivatione imbricata, saepissime abortu tria v. unieum, interdam nulla. 
Stamina hypogyna, v. rarissime perigyna, nunc 9 v. 10 , nunc indefinite plurima, interdum subunilateralia, libera, aequalia v. nonnulla majora, minoribus interdum sterilibus. Anthera biloculares, longitudinaliter dehiscentes.

Ovarium unicum, stipitatum, e carpidio unico compositum, uniloculare. Ovula juxta suturam plura, biseriata. Stylus brevis, ovario continuus; stigm a simplex. mum.

Legumen bivalve, uniloculare, oligosper-

Skmina nuda v. arillo carnoso instructa. A I bu men nullum.

Embryonis c otyled on es crassae, ra dicula brevis, uncinato-incumbens.

Swartzieae calyce valvatim rupto, staminum numero saepius aucto, et eorundem insertione hypogyna a Papilionaceis Caesalpinieis, quibus mediante Baphia arctissime affines, diversae, per Aldinam ad Detarieas, huic ordini interim subjunctas, sed fructu drupaceo diversas, accedunt. Detarium Copaiferam pluribus notis revocat, Cordyla staminum insertione perigyna soli Aldinae comparanda, illine ad Mimoseas vergit.

B812. Baphia AFZEL. C a I y x calyptraeformis, longitudinaliter sub carina raptus, sub vexillo erectus, demnm deciduns. Coroll a e vexillum patens, subrotundum, alae lineares, vexilli longitudine, carina acuta. Sta mina 10 , distincta. L e g $\mathbf{u}$ en falciforme. Semina sex, lenticularia. - Arbor guineensis; folizs imparipinnatis, bijugis cum impari, foliolis ovali-oblongis, acuminatis, nitidis, pedicellis axillaribus, duobus $v$. tribus unifloris, floribus albis.

B aphia Afzelius ox Loddig. Bot. Cab, t, 367. DC. Prodr. II, 424. Meisuer Gen. 95. (68,)

6813. Zollernia MART. C a ly x integer, lateraliter fissus, reflexus. Corolla e petala 5 , hy. pogyna, subaequalia Stamina 9 -13, hypogyna; fila m enta brevissima, antherae erectae, lineares, acuminatae, omnes fertiles v. nonnullae minores. Ovariusn basi angustatum, lanceolatum, compressiusculum, plariovulatum. Stylus brevis, ovario continnus, recurvus; stigma acntum. L e g m en stipitatum, bivalve, oligospermnm. Se m in a exarillata. E m bryonis exalbuminosi radicula uncinatim inflexa, - Arberes $v$. frutices inermes, in Bras ilia indigeni; folies alternis, simplicibus, integerrimis $v$. spinoso-dentatis, bistipulatis, racemis axillaribus et terminalibus multifloris, pedicellis bibracteatis.

Zollernia Martius in N. A. N. C. XIII. p. XIII. C. C,D. Meisner Gen. 95. (68,) A cidand ra Martius mse, ad Duperrey t, 75 .

6814. Svartala WILLD, $\mathrm{C}_{\text {a }} \mathrm{y}_{\mathrm{e}}$ is $\mathrm{f}_{0}$ liola 5 , aestivatione in alabastrum ovato-globosnm arcte coalita, sub anthesi valvatim rupta, reflexa. Corolla nulla vi. petalum unicum laterale hypogynum, rarins tria, duobus minoribus, St a m in a $10 \mathrm{v}$. indefinite plurima, hypogyna; fil a m en$t$ a filiformia, libera, ovario opposita, aequalia v. nonnulla longiora, a n th e ra e biloculares, staminum minorum saepe efoetae. O varium sessile $v$. stipitatum, subfaleatam, compressum, pluriovulatum. Stylus brevis, ovario continuus; $8 \mathrm{tigma}$ truncatum. L e g n n e n bivalve, oligospermum. Semina arillata. Embryonis exalbuminosi cotyledones crassae, radic ala brevis, uneinato inflexa. - Arbores Americae tropicae; foliis alternis, simplicibus $v$. imparipinnatis, foliolis coriaceis, integerrimis, floribus axillaribus racemosis. Swartzi a Willd. Spec. II. 129. DC. Prodr. II. 423. Meisner Gen, 95. (68.)

a. TOUNATEA DC. $l$, c. Flores apetall. L e $g u m$ en apice aduncum.

To un a te a Aublet Guian. I. 550, t, 218. S wartz ia Schreber Gen, $n, 1227$. Gy $\mathrm{u}$ a $\mathrm{n}$ h is $\mathrm{trop}$ he Poiteau msc.

b. POSSIRA DC. l. c. Cor olla monopetala v. rarius tripetala.

Possira Aublet Guian. $I T, 934, t$. 355. Rittera Schreber Gen, n, 219. Vahl Plant. Am. I. t. 9. Symb. II. $t$ 34. Correa in Annal. Mus. IX. t, 34. f. 2 , Ho el zella Necker Elem, n. 1383. (DC. Mem. Legum. t. 58-60.)

6815. Aldina. C a ly x cupuliformis, coriacens, aestivatione valvatus, irregulariter quadri-quinquelobus. Cor o 11 a e petala 5 , perigyna, ampla, irregulariter imbricata. St a min a plurima, perigyna, anthera eblongo-lineares. Ovarium stipitatum, pluriovulatum. Sty lu s basi latus, filiformis, acutus; stig ma parvum. Fructas.... - Arbor guianensis; foliis imparipinnatis, foliolis magnis, coriaceis, floribus albis, in racemos longos dispositis.

Allan i a Benth, in Hooker Journ. of Bot, I1. 91. ex Orbigny Dict. Hist. nat. I, 282, uon Endl. supr. n. 1168.

\section{* DetarieaE.}

6816. Detarium JUSS, C al y $\mathrm{x}$ quadripartitus, lacinis aequalibus, aestivatione imbricatis. Corolla nulla. Stamina 10 , imo ealyci inserta; filamenta filiformia, basi vix coalita, alterna paullo Iongiora, exserta, antherae biloculares, ovales, dorso affixae. Ovarium sessile, villosum, uniloculare, ovalis duobus, suturae superposite insertis. Stylus filiformis, revolutus; s tigma capitatum. D rupa orbiculata, erassa, sarcocarpio farinaceo, fibris intertexto, putamine osseo, extus rugoso, ambitu marginato, laevi, monospermo. S e m e n cavitati conforme, latere umbilicatum. Em bry onis exalbuminosi cotyled ones crassae, subfarinosae, radic ula umbilico proxima, brevis, conica, inclusa. Arbor senegambic $a$; foliis alternis, subimparipinnatis, foliolis alternis, quadri-quinquejugis, ovali-oblongis, obtusis $v$, emarginatis, integerrimis, floribus paniculatis, dichotome racemosis, semine eduli.

Detarium Jassieu Gen. 365. DC. Prodr. II. 521. Guillem. et Perrot. Flor. Seneg. 1.269. t. 60. Meisner Gen. 100. (71.)

B81\%. Cordyla LOUR. Cal y x tubo turbinato, limbi quadripartiti laciniis aestivatione valvatis, sub anthesi reflexis. Corolla nulla. S 2 a mina plurima, calycis fauci biseriatim inserta, longe exserta; filamenta capillaria, libera, antbera e bilocnlares, subgloboso-didymae, glandula pedicellata terminatae. Ovarinm longe stipitatum, exsertum, oblongo-ellipticum, compressum, uniloculare. $O$ v ula plura, suturae ventrali biseriatim inserta, oblongo-pyriformia. Stylus bre- 
vis, ovario continuus; stigm a brevissime bilobum. Drupa ovoidea, corticosa, intns pulposa, oligosperma. Semina nidulantia. Embryonis exalbuminosi cotyled on es carnosae, radieula teres, incumbens. - Arbor Africa tropicae; foliis alternis, imparipinnatis, foliolis quadriquinquejugis, alternis, integerrimis, stipulis caducissimis, floribus simpliciler racemosis, calyce cum pedicello articulato.

Cord y la Loureiro Flor. eochinch, 500. DC. Prodr, II. 521. Meisner Gen. 100. (71.) Cord y ll a Persoon Encheir. II. 260: C a I y c a u dra A. Rieliard Flor. Seneg. I. 30, t. 9, coll. p. 232.

\section{Drdo CCIXXVII. Alimeseae.}

LEGUMINOSARUM genera Jussieu Gen. 346. MiMo. SEAE R. Brown in Flinders Voy. II, S51. Brown Dissert, 130. DC. Prodr. II, 424. Bartling Ord. nat, 416, excl. Detarieis.

Arbores v. Frutuces, rarius herbas, inermes v. aculeis aut spinis armatae. Folia alterna, abrupte, saepissime bi-tripinnata, rarius imparipinnata, interdum irritabilia, nonnunguam foliolis abortivis et petiolo verticaliter dilatato spurie simplicia. Stipulat liberae, saepissime spinescentes, rarius obsoletae.

Fuores hermaphroditi, saepissime abortu polygami, regulares, spicati v. capitati, rarius paniculati v. corymbosi, flavi, albi, rosei v. rubieundi.

Calxx liber, quadri-quinquefidus v. partitus, laciniis aestivatione valvatis v. rarissime imbricatis.

Corollas petala calycis laciniis numero aequalia et alterna, ejusùem basi v. distincte hypogyne inserta, libera v. plus minus in tubum coalita, laciniis aestivatione valvatis v. rarissime imbricatis.

Stamina petalis rarissime numero aequalia, saepissime dupla v. multipla, definitorum alterna abortiva, cum petalis inserta et nonnunquam iisdem inferne adnata v. ovarii stipiti imposita, plus minus exserta. Filamenta filiformia v. ligulaeformia, libera v. inter se in tubum coalita. Anthera e biloculares, longitudinaliter dehiscentes, saepe glandula pedicellata superatae.

Ovarion unicum (rarissime plura, libera), sessile v. stipitatum, e carpidio unico compositum, uniloculare. Ovu la juxta sutaram plura, biseriata, anatropa. Stylus terminalis v. sublateralis, simplex, filiformis; stig ma simplicissimum.

Frocros: L e gumen nune longitudinaliter bivalve, uniloculare, v. isthmis inter semina transversim pluriloculare, siccum v. pulposum, nune indehiscens, v. in articulos monospermos, a replo persistente solutos secedens, rarissime valvis longitudinalibus angustis a replo lato solutis spurie quadrivalve.

Semiva juxta suturam plura, biseriata, ho- rizontalia, sicca v, arillata. Albumen saepissime nullum.

Embryo orthotropus. Cotyledones magnae, carnosae, germinatione ut plurimum epigeae. R a dicula brevis, recta. Plumula inconspicua.

Mimose a in regionibus tropicis subtropicisque totius orbis magno numero crescentes, in Nova-Hollandia imprimis copiose reperiuntur, floribus regularibus, staminum numero et insertione, nec non corollae saepius gamopetalae aestivatione valvata a Papilionaceis, foliis bipinnatis et embryone recto a Swartzieis facillime distinguendae, mediante Erythrophlaeo, genere vix e Parkiae affinitate removendo, Detarieis arcte accedentes.

Plurimae gummiferae, nonnullarum partes adstringentes.

TRIIBIS I. PARKIEAE Wight et Arnott Prodr.J. 279. C a ly cis et corollae aestivatio imbricata staminibus tune hypogynis, v. subimbricata staminibus perigynis.

6818. Erythroplataevan $A F Z E L$. F lores hermaphroditi, regulares. Caly $x$ quinquefidus, subimbricatus. Corolla e petala 5. Stamin a perigyna. Legumen compressom, bivalve, polyspermum. - Arbor Africae tropicae, excelsa; foliis bipinnatis, foliolis oppositis, racemis terminalibus et lateralibus.

Erythirophlaeum Afcelius msc. ex $R$. Brown in Oudney, Denh, et Clappert, Narrat. 235. G. Don Syst. II.424.

6S1S. Farkia $R$. $B R$. F l ores polygami. Calyx longe cylindraceus, limbi bilabiati labio superiore bi- inferiore trifido, laciniis inaequalibus, aestivatione imbricatis. Coroll a e petala 5 , imo calyci inserta, breviter exserta, posticam paullo latius, aestivatione conniventi-imbricata. S $t$ a m ina 10 , hypogyna, exserta; filamenta ima basi monadelpha, operne distincta, filifurmia, flexuosa, antherae oblongo-lineares, dorso sppra basim insertae. Ova ri $\mathbf{~ m ~ l i n e a r e , ~ s n b a r c u a t u m . ~}$ Stylus lateralis, longissimus; stigma simplex. L e g u m e lineare, subfalcatum, compressum, epicarpio bivalvi, endocarpio in loculos monospermos, sarcocarpio farinaceo tectos solubili. Semina plurima, oblonga. Embryo exalbuninosns. Arbores Africat et Asiae tropicae, inermes; foliis bipinnatis, pinnis foliolisque multijugis, stipulis minutis, floribus purpureis, speciosissimis, in capitula longissime pedunculata, clavata, basi $c y$ lindrica, saepissime masculiflora, apice globosa, hermaphrodita dispositis.

Parkia R. Brown in Oudn. Denh, et Clappert. Nar. rat. 234. Guillem. et Perrot. Flor. Seneg. 1. 232. Wight et Arnott Prodr, 1, 279. Meisner Gen, 96. (69.) Inga biglo. bo s a Palisot Flor. Owar. II. 53, t. 90.

SUBTRIBUS I. ACACIEAE Wight et Arnott Prodr. I. 267. Caly cis et corollae aestivatio valvata.

8920. Ademantluera LINN. Flores hermaphroditi. Cal $\mathbf{y}$ : cupulaeformis, hreviter quadri-quinquedentatus, Co rotlae petala 4 v. 5, imo calyci inserta, lanceolata, omnia libera v. basi $166^{*}$ 
subcoalita. S t a min a 8 - 10 , cum petalis inserta, exserta; fil amenta filiformia, libera, antherae biloculares, subglobosae, glandula pedicellata, sphaerica terminatae. O variu m substipitatum, glabrum, multiovulatum. St ylus filiformis, flexuosus; stigm a acutum. Legumen lineare, compressum, membranaceum, bivalve, intus inter semina transversim pluriloculare, subtorulosum. Semin a exarillata. - Arbores $v$, frutices, in As ia tropica crescentes; foliis bipinnatis, racemis subspicatis, terminalibus v, e supremorum foliorum axillis.

A dena $n t$ her a Linn. Gen. n, 526. Lam, $t .334$. Jacq. Collect. IV. t. 23. DC. Prodr. II. 446. Wight et Aruott Prodr. II. 271. Wight Io. t. 80. Meisner Gen, 96. (68.) Clype aria Rumpl. Amboin. IIT. $t, 112$.

QS21. Frosopis LINN. F lores polygami, hermaphroditi et masculi. Ca l y x cupulaeformis, quinquedentatus. Corolla e petala 5 , imo calyci inserta, oblongo-linearia, libera, aestivatione valvata, Stamina 10 , cum petalis inserta, breviter exserta; fil a m e n a filiformia, basi coalita, a ntherae ovato-oblongae, biloculares, glandula pedicellata, decidua terminatae. Ovarium sessile, glabram. Stylus filiformis; stigma simplex. Legumen lineare, cylindricmm, subcompressum, torulosum, intus pulposum, irregulariter in frustra secedens. Semina ovato-oblon. ga. E m bry o exalbuminosus. - Arbuscula indica, inermis v. aculeis sparsis armata; foliis bipinnatis, pinnis uni-bijugis, foliolis subdecemjugis, oblongo-linearibus, spicis axillaribus filiformibus, solitariis, aggregatis.

P r os o pis Lian, Mant. 68, Roxbargh, Plant. Corom. 1.63. Wight et Arnott Prodr. I. 271. Meisuer Gen. 96. (68.) Prosopis seet. A den ops is DC. Prodr. II. 446.

BS\%\%. Hagomyelnimm BIEBERST. F10res hermaphroditi, plurimi abortientes. Calyx cupnlaeformis, quinquedentatus. Corollae petala 5, imo calyci inserta, oblongo-linearia, libera, aestivatione valvata. Stamin a 10 , eum petalis inserta, breviter exserta; fil a m en ta filiformia, libera, an therae ovato-oblongae, biloculares, glandula minima, pedicellata terminatae. Ovari um brevissime stipitatum. Stylus filiformis; gtigma simplex. Le gum en stipitatnm, indehiscens, sutura introflexa bipartitum, subdidymum, incurvum, utrinque obtusum, indehiscens, pulpa farctum. Sem in a ovato-oblonga, compressa. E mbryo exalbuminosus. - Suffrutex in Caucaso, Oriente et Sen ega $\overline{m b} i$ a crescens, aculeis sparsis armatus ; folits alternis, paripinnatis, pinnis triquadrijugis, foliolis subdecemjugis, subtus pubescentibus, spicis gracilibus, laxis.

L a g on y chiu m Bieberst. Suppl, 28s, DC. Frodr. II, 448. Delessert Ic. select, IIT. $t$, 75. Meisner Gen, 96, (69.) Acaeia $S$ tep haniana Bieberst.

6893. Algarobia BENTH. Flores polygami, hermaphroditi et masculi. Caly $x$ eupulaeformis, quinquedentatus. Co ro 11 a e petala 5 , vatione valvata, St a mina 10, petalorum basi v. ovarii stipiti inserta, breviter exserta; fil a in ent a filiformia, libera, a n therae ovato - oblongae, biloculares, eglandulnsae. Ova ri n m stipitatum, villosum. St ylus filiformis, areuatus; stig ma truncatum. L e g n men continuam, compressum, lineare, intus polposum, saepissime toralosum, v. inter gemina isthmis constrietum, haud artieula. tum, indehiscens. Sem i na plurima. E m b ry o exalbuminosus. - Arbores v, rarius frutices, in $A$ me rica tropica et boreali calidiore crescentes, saepissime aculeis stipularibus horridi; foliis alternis, saepe fasciculatis, conjugato v. duplicato paripinnatis, spicis axillaribus, solitariis, geminis $v$. ternis, floribus virescentibus v, sulphureis.

A 1 garobia Bentham Plant. Hartweg. 13. Threy et A. Gray Flor. Bor. Amer, 399. P r o so p i s sect. A I g a r o b i a DC. Prodr, II. 446. P ros o $\mathrm{P}$ is Kunth Mim, 106,t.33. Nov. gen, et sp. VI. 306.

6S84. 耳imeorphandira SCHOTT. Ca. ly $x$ urecolatus, quinquefidus. Coro 11 a e petala 5 , patentissina, staminifera. St a mina abortiva totidem, petaloidea, spathulata, unguiculis linearibus. Lom e n $\mathbf{t}$ um lignosum, polyspermum, Iatice balsameo farctum. - Arbor brasiliensis, pro. cera; foliis bipinnatis, foliolis oblongis, (sitpra nitidis, subtus hirsutis, spicis terminalibus paniculatis, floribus luteis.

Dimorphandra Sehott in Sprengel Cur. post. 404.

68\%5. Fillaen GUILLEM. et PERROT. F lores hermaphroditi. Ca ly $\mathrm{x}$ turbinato campsnulatus, quinquefidus. Coroll a e petala 5 , imo calyci inserto, spathulato lanceolata. Stamin a 10, cum petalis inserta, exserta; fil am enta libera, antherae biloculares, didymae. Ovarium stipitatum, pluriovulatum. L e g u m e n stipitatum, lignosum, ovato-ohlongum, sutura seminifera rectum, altera convexum, compresso-planum, bivalve. Sem in a arillo carnoso inclusa. Embryo albamine corneo cinctus. - Arbor senegambica, inermis ; foliis bipinnatis, foliolis alternis, magnis, ovato-oblongis, floribus composite spicatis.

Pill a e a Guillem. et Perrot. Flor, Seneg. I. 242, $t .55$. Meisser Gen, 96. (69.)

68\% 6. Cailliea GUILLEM, et PERROT! Flores polygami, hermaphroditi cum neutris. Calyx cupulaeformis, breviter quinquedentatus. C o r o 11 a e petala 5, imo calyci inserta, lancenlata, libera $v$. inferne in tubum coalita. Sta$\mathrm{mina} 10$, cum petalis inserta; fil amenta filiformia, libera, a nth era biloculares, subglobosae, glandula pedicellata, sphaerica terminatae, in floribus nentris nullae. Ovarium sessile, vitlosum. Stylus filiformis, flexuosus; stig ma cyathiforme. Legnmen lineare, subcompressum, tortum, intus isthmis inter semina pluriloculare, indehiscens. S e mina exarillata. $\mathbf{E}$ mb r y o exalbuminosus. - Frutices in $A s i a$ el $A$ frica tropic a indigeni, spinis stipularibus armati; foliis bipinnatis, pinnis multijugis, foliolis plurimis, linearibus $v$. oblongis, floribus in spicas axillares, oblongas, cylindricas dispositis, infimis cujusvis spicae neutris, filamentis anantheris, longius exsertis, heterochrois.

C aillie a Guillem. et Perrott. Flor. Seneg. I, 239. Dichrostachys Wight et Arnott Prodr. I. 271 . Meisner Gen. 96. (68,) M imos a cinere a Linn, Roxb. Plant, Corom. t. 174. Desmanth us triehostach y De.Legum, $t .67$.

882\%. Weptoslottis DC. Flores polygami. Calyx coloratus, quadridentatus, Corotla e petala 4 , ligulaeformia $\mathrm{x}$. nulla. Stamina 8 ; fil a m e $n$ tis liberis, in floribus inferioribus lignlaeformibus, planis, sterilibus, in snperioribus filiformibus, erispatis, antheriferis. Stylus filiformis, Legumen.....- Herba b oreali-a mericana, erecta, glabra, aculeis parvis, uncinatis, secus caulem, petiolos pedunculosque horrida; stipulis subulatis, foliis bipinnatis, pinnis quinque-sexjugis, foliolis multijugis, oblongis, mucronatis, subtus nervis paucis anastomosantibus distincte et $\sin$ gulari modo reticulatis, pedunculis axillaribus solitariis, capitulis globosis, floribus albis. 
L. eptoglottis DC. Mem. Legum, 461. Meisner Gon. 96. (68.)

8888. Desmantlatas WILLD. F lores polygami, hermaphroditi et neutri. Cal y x campanulatus, quinquedentatus. Cor olla e petala 5, hypogyna, spathnlata, calyce longiora, aequalia. Stam in a 10 v. rarissime 5 , hypogyna, exserta; fil a m ent a libera, eapillaria, florum inferiorum ananthera, saepissime membranaceo v. petaloideo dilatata, antherae ovatae, biloeulares. Ovarium sessile. Stylus fitiformis; 8 tigma simplex. L e g $\mathbf{n}$ m en continumm, siceum, compressnm, bivalve. Semina plurima, Embryo exalbuminosus. - Herbae v. suffrutices inermes, saepe natantes, inter tropicos totius orbis crescentes; foliis alternis, duplicato-paripinnatis, saepe sensitivis, stipulis petiolaribus geminis, capitulis axillari. bus, pedunculatis, ovatis $v$. subglobosis, floribus bracteatis, albis, flamentis fertilibus saepissime flavis.

Desmanth us Willdenow Speo. IV. 1044. Kunth Mimos. 115. Nov. gen. et sp. VT, 261. DC. Prodr, IT. 463. excl. sect. 3. Wight et Arnott Prodr. I, 270. Meisuer Gen. 96. (68.)

a. NEPTUNIA DC. l. o. Fila me nt a sterilia plana, membranaeeo v. petaloideo-ditatata. Le $\mathrm{g} \mathrm{u} \mathrm{m}$ i n a oblonga, tetra-octosperma, - Herbae aquaticae.

Neptunia Loureiro Flor, cochinch, 804. Guillem. et Perrot Flor. Seneg. I, 238. M i ai os a e s p. Lina. MilIer Ie, $t$. 282, $t$, 2. Humb. et Bonpl. Plant. aequinoct. t. 16. Roxburgh Plant, Corom. t. 119.

b. DESMANTHA DC. l. o. Fila menta sterilia vix dila tata. Leg u $\mathrm{m}$ in a linearia, polysperaia. - Frutices $v$. suffrutices terrestres. - Mimos a e sp. Linn. Jacq. Hort. Vindob. $t, 80$. (Kuuth Mim, t, 35.)

889. Sehrankia WILLD. Flores polygami, hermaphroditi et masculi. C a I yx brevissime urceolatus, quinquedentatas. Corolla hypogyna, infundibuliformis, limbi quinquefidi, regularis laciniis aestivatione valvatis. Stam ina $8-10$, rarius 12 , imae corollae v. ovarii stipiti inserta, exserta; filam en $t$ a filiformia, libera $v$. ima basi coalita, a a $\mathbf{t h}$ era e oblongae, biloculares. Ovarium breviter stipitatum. Stylas filiformis; stigma simplex. Legumen muricatoechinatum, siccum, continum, subtetragonum, valvis tenuibns angustis a replo lato solutis spurie quadrivalve. S emina plurima, oblonga, lentienlaricompressa. E m b r yo exalbuminosus. - Herbae perennes, aculeatae, sensitivae, in America tropica et bor ali o alidiore indigenae; radice saepe tuberosa, caule procumbente v, adscendente, foliis alternis, duplicato-paripinnalis, stipulis petiolaribus geminis, capitulis axillaribus globosis, solitariis $v$. geminis, floribus roseis v. purpurascentibus.

$\mathrm{S}$ c h r a nkia. Wildenow Spec. IV. 1041, Kuath in Humb et Bonpl. Nov, gen. et sp. VI. 260. DC. Prodr. II. 443. Meisner Gen, 86. (68.) Torrey et A. Gray Flor. of North Amer. $I$. 400. M i u o s a $\mathrm{s}$ p. Lisn. Miller Ic, $t, 182 . f .1$ Vent. Choix $t, 28$.

6830. Darifinatomia DC. F lores her maphroditi. Ca ly $x$ eampanulatus, quinquedentatus. Corolla e petala 5 , imo ealyei inserta, lanceolata, libera. Stamina 5 , cnm petalis inserta, iisdem alterna et longiora; fil a m e n ta filiformia, libera, an therae biloculares, subglobosae. Ovari um sessile. Stylus filiformis, flexuosus; stigm a minutam, infundibuliforme. Legumen Ianceolatum, compressum, membranaceo-coriaceum, bivalve, tetra-hexaspermum. S e min a obovato ovalia, compressa, funiculo brevissimo. E mbry o exalbuminosus. - Herbae b oreali-americanae, perennes, inermes, glabrae; stipulis setiformibus, foliis bipinnatis, pinnis foliolisque multijugis, capitulis axillaribus, solitariis, pedunculatis, floribus albis.

D a rlington i a DC. Mem, Legum. 427, t. 66. Prodr. IT. 443. Meisner Gen, 96. (69.) Torrey et A. Gray Flor. ofNorth Amer. I. 401.

6831. IIfunosa $A D A N S$. F lorey polygami, hermaphroditi et masculi. Cal y x brevis, suburceolatus, integer, quadri-quinquedentatus v. irregulariter laciniatus. Corolla hypogyna, subinfundibuliformis $v$. turbinato-eampanulata, persistens, limbi qnadri-quinquefidi regularis laciniis aestivatione valvatis. Stamina nusc hypogyna, nunc imae corollae $v$, ovarii stipiti inserta, simplici, duplici v. triplici petalorum numero, longe exserta; fil amenta filiformia, libera $v$, ima basi coalita, anthera e biloenlares, suborbiculatae, longitudinaliter dehiscentes. Ovarium basi attenatum v. stipitatum, compressum, obliquum. StyIus terminalis, fififormis; stigma simplex. Le g um en compresso-planum, apice rostratosubulatum, articulatum, articulis clausis, a replo persistente solutis, monospermis. Semina sub. lenticularia. E m b ry o exalbuminosus. - Arbores, frutices, suffrutices $v$. rarissime herbae, saepissime aculeatae, inter tropicos totius orbis crescen. tes; foliis alternis, conjugato-digitato-impari $v$. duplicato-pinnatis, capitul is axillaribus, solitarits, geminis $v$ paniculatis, floribus saepissime roseis.

Mi mos a Adanson Fam. II. 319. Gärtner II. 344. Willd. Spec. IV, 1028. Kunth Mímos, 1, Nov, gen, ef sp, VI. 248. DC. Prodr. 11.425. Melsner Gen, 96. (68.) M i mi a s a s p. Liag. a. EUMiMOSA DC, 2,c. Leg u to in a compresso-mosiliformia, replo ad articulos contracto. - Flores rosei. (Kanth Mimos, t. 1 -8. 10.)

b. HABBASIA DC. $l$, c. Legumina compressa, replo haud contracto, articulis plurimis, latitndine brevioribus. hispidissimis. - Flores albi. (Kunth Mimos. t. 9. DC. Mem. Legum. t. 63.)

E. BATAUCAULON DC, l.c. Legum In a compressa, replo haud contracto, iaermia v, aculeata, articulis glabris $v$. vix pubescentibus. (Roxbargh Plant. Corom, t, 200.)

B83\%. Entada ADANS, Flores polygami, hermaphroditi et masculi. C a 1 y $x$ copulaeformis, quinquedentatus. Cor ollae petala 5, imo calyci inserta, lanceolata, basi subcohaerentia. Stamina $10-25, \mathrm{cum}$ petalis inserta, breviter exserta; fil a m enta filiformia, libera, subflexuosa, an therae biloculares, suligloboso-didymae, glandula sphaerica terminatae. Ova ri am sessile, glabrum. Stylus terminalis, fliformis, flexuosus; stig ma simplex. Le g amen compressnm, articulatum, valvis in membranas duas separabilibus, articulis monospermis, a replo persistente solntis. Se mina crassa, exarillata. Embryo exalbuminosus. - Frutices in $A s i a$ et America tropica indigeni, scandentes, inermes; foltis bipinnatis $v$. conjugato-pinnatis, rlachi sacpe in cirrhum producta, floribus dense spicatis, albis.

E n ta da Adanson Fam, II. 318, L. C. Riehard mac. DC. Legum, 619. t. 61. 62, Prodr, II. 429. Wight et Arnoti Prodr. I, 267. Meisner Gen. 96. (68,) Gigalobium P. Prodr. $T$. Browne Jam. 362. P u r a e tha Lian. Amer. $t$. 183. f,03.

6533. Gagnebina NECK. Flores hermaphroditi. Caly $\mathbf{x}$ brevis, suburceolatus, quinquedentatus. Corolla petala 5 , hypogyna, obongo-linearia, aestivatione valvata, persistentia. St am in a 10, cum petalis inserta, exserta; filam enta filiformia, libera, a $\mathrm{th}$ erae ovato $-0 b$. longae, biloculares, apiee bifidae. 0 va riu m ses. 
sile, villosum. Stylus elengato-filiformis; stigma simplex. L e g u en complanatum, exsnceum, indehiscens, sutura utraque membranaceo-alatum, intus transversim pluriloculare, loculis monospermis. ..... - Frutices mauritiani et borbo$n i c i$, inermes, glabri; foliis bipinnatis, foliolis linearibus, inter se aequalibus, glandula ad basim petioli et inter paria pinnarum superiora, spicis axillaribus cylindricis, flavidis, leguminibus glabris.

G a g u e b i a Necker Elem, $n$, 1296, DC. Mem. Legum. 432, .64. Meisner Gen, 96. (68.) Mímos a ta maris ei na Lam, et M imos a pterocarpa Lam.

6834. Aeacia NECK. Flores polygami, hermaphroditi et masculi, C a 1 y x turbinatus, urceolatus v, campanulatus, quadri-quinquedentatus. Corolla hypogyna, infundibuliformis v, turbinato- ant tubuloso-campanulata, limbi quadri-quinquefidi laciniis aequalibus, aestivatione valvatis. St a mina $10 \mathrm{v}$. plurima, imae corollae v, ovarii stipiti inserta, exserta; fil a menta capillaria, libera v. ima basi monadelpha, anthera e biloeulares, longitudinaliter dehiscentes. Ovarium sessile v. stipitatum. St ylus filiformis; st ig ma simplex v. infundibuliformi-capitatum. L e g $\mathbf{n}$ m e $\mathbf{n}$ continuum, exsuccum, bivalve. Semin a plurima, ovato-oblonga. Embry o exalbuminosus. - $\boldsymbol{A r}$ bores aut rarius frutices, inermes $v$. saepissime aculeis stipularibus armati, in regionibus tropicis et $s u b t r a p i c i s$ totius orbis, copiosissime in Nova-Hollandia crescentes; foliis alternis, duplicato-paripinnatis, $v$. foliolis abortivis, petiolo phyllodineo dilatato spurie simplicibus, floribus dense spicatis $v$, capilatis, albis, roseis $v$. saepius flavis.

A c a cia Necker Elem, n, 1297. Willd. Spec, IV. 1049. Kunth Mimos. 24. Nov. gen, et ip. VI. 265. DC. Prodr. II. 448. Meisner Gen, 96. (68.)

a, RHACOSPRRMA Mart. Catalog. Hort, monac. 188, FoIi a omnia v. pleraque iit planta adulta abortiva, petiolis In pliyllodia, plus minus folliformia mutatis. (A c aci a e a phy 1 la e Auet. Wendlaud, de Acaciis aphyl. lis Commentatio. Mannov. 1820. 4.)

b. ACACIAE VERAE. Foli a bipinata. Mimos a e $s$ p. Lina. et A uct. Jueq. Io, rar, t, 198, 633. Vent. Malmais, t.61. Cels. t. 20. Roxb. Corom, t. 149. 175. 225. (Kunth Ifimos. t. 25-32. Nees jun. Plant. offic. Suppl.3. t. 15.) S t a c b y ch ry s u mojer Hort. Maurit, 114.

B835. Waelhellia WIGHT et $A R N$. Flores polygami, hermaphroditi et masculi. Calyx campanulatus, quinquedentatus. Corolla imo calyci inserta, gamopetala, tubulosa, quinquefida, laciniis aestivatione valvatis. Sta in ina plurima, eam petalis inserta, exserta ; fil a menta filiformia, libera, antherae subglobosae, biloculares. Ovarinm sessile. Sty $\mathbf{l u s}$ filiformis; $s \mathrm{tigma}$ obtusum. L e g u m en cylindricum, turgidum, pulpa farctum, vix dehiscens. S e m i n a biseriata. Embryo exalbuminosus. - Arbuscula indica, spinis stipularibus armata; foliis allernis, bipinnatis, pinnis quadri-octojugis, glandula sub jugo infimo et interdum supremo, foliolis multijugis, linearibus, glabriusculis, petiolis pedunculisque pubescentibus, floribus capitatis, capitulis axillaribus pedunculatis, subglobosis, geminis $v$, ternis.

Vachellia Wight ef Arnott Prodr, I, 272. Meisner Gen.96. (68.) Ald i a a B. Meyer Comment, 17i, in not. M imesa Farnesiana Linn. Acaela Farnesiana Willd.

6836. Z7ygia $P . B R O W N$, Flores polygami. C a I y x tabulosus, quinquedentatus. CorolI a imo ealyci inserta, infundibuliformis, quinquefida, Jaeiniis aestivatione valvatis. Sta $m$ in a plnrima, eum petalis inserta; fil a menta in tubum filiformem, aestivatione spiraliter tortum, demum longissime exsertum coalita, apice breviter libera, antherae biloculares, globoso-didymae. Ovari um lineari-oblongum. Stylus terminalis, filiformis, staminibus longior, cum iisdem in alabastro tortus; $8 \mathrm{tigma}$ aeutum. Legumen com. planatum, membranacenm, isthmis inter semina arcte concretis distinctum, intus siccum, laeve. $\mathrm{S}$ emina plura, transversim obovata, complanata. Embryo exalbuminosus. - Arbores $v$. frutices, in America et Africa tropica, nec non in Capite bo nae spei crescentes; foliis bipinnatis, floribus umbellato-paniculatis v. spicato-capitatis.

$\mathrm{Z}$ y g i a P. Browne Jam, 279, t. 22. f. 3. E, Meyer Comment. 164. Meisier Gen. 96. (68.) $1 \mathrm{n} g$ a $\mathrm{Z}$ y g f a DC. Mom. Legum, $t, 63$.

6838. Inga PLUM. Flores polygami. Caly 8 tubuloso-campanulatus, quadri-quinquefidus v. dentatus. Corolla imo calyci inserta, gamopetala, tubulaso-infundibuliformis, quadri-quinquefida, laciniis ovato-oblongis, aestivatione valvatis. Stamina 10 v. plurima, cum petalis inserta, longe exserta; filamenta inferne in tubum plus minus longum coalita, superne filiformia, a ntherae biloculares, subgloboso-didymae. Ovari um lineari-oblongam. St y I u s terminalis, filiformis; $s$ tig ma subcapitatum $v$. depresso-capitatum v. subpeltatum. Le g um e n lato-lineare, compressum, transversim septatum, bivalve, pulpav. farina repletum. S e min a plnra, lenticularia. E mb r yo exalbnminosus, - Arbores v. frutices, in America et Asia tropica crescentes, inermes v. aculeis stipularibus armati; foliis alternis, simpliciter, conjugato $v$. duplicato paripinnatis, petiolo interdum alato, saepissime inter pinnas glanduloso, foliolis. integerrimis, capitulis globosis $v$. ellipticis, rarius spicis cylindricis, axillaribus et terminalibus.

Ing a Plumier Gen, 13, $t, 25$. Willdenow Spec. IV. 104 Kunth Mimos, 35. Nov. Gen. et sp. VI. 248. DC, Prodr. II. 432. Meisner Gen, 96. (69.) A mo s a Necker Elem, $n, 1295$. Mi mos a e s p. Linn.

a. STRXPHNODENDRON Mart. Stam in a decem. L e gum en lineare, compressum v. leviter couvexum, jadebiscens, curiaceun, intus earnosum et incomplete sep. tatum, maturitate baecans. Se in in a plura, in funicalis filiformibus pendula, dura, te st a cartilagiaea, nucleum album arcte obducente.

Stryphnodendron Martius Herb. Brasil. 117. Mimos a Barba de Timam Flor. Flum. $x t$. $t$. $?$.

b. EUINGA. Leg a m e traasverse spurie septatum, lineare, teres v. planua, coriaceum, intus molle, tasdem quasi baceans, vix regulariter dehiscens. Testa no. cleum viridem, mollem laxe ambiens, extus pulpa mucilaginosa, sacehariaa obducta.

In g a Martius Herb. Brasil, 113. M I m os a e sp. Flor. Flum. $X I .1 .3 .4$. 9. 11. 12. 21. 42. 44. 45. (Kunth Mim, 2. 11-14.)

c. PITHecolobium Mart, Sta mina plurima. Legume a lineare, planum v. leviter convexum, ad margises acutiusculum, hand articulatum, rectum vo pluries cochleatum, duriusculo-coriaceum, bivalve, valvis intus (pleruwque coloratis et) teuniter pulposis, pro seminibus leviter impressis. S e m i u a lentiformia, fanieulo filiformi, arilto subdimidiato obducta, testa nitida, dura, nucleum album, durum arete involvente.

Pithecolobium Martins Catalog. Hort. monae. 188. Herb. Brasil. 114. Mi mos a s p. Jaeq. Hort, Schönbr. t. 398. Fragm, t. 34, f, 1. Flor, Flum. XI. t, 13. (Kunth Mim, $t, 18$ )

d. ENTEROLOBIUMI Mart. S $t$ a m in a plurima. L egumen coriaceum, fidehíscens, reniformi-mesenteriforme, intus caraosum, endocarpio pergameneo subloculasum. S emin a elliptica, testa dura, funieulo filiforml. 
Enterol obium Martius Herb. Brasil. 128. Mimos a e sp. Flor. Flum.

6S38. Afromgea ST. HIL Calyx glo bosus, inflatus, quinquedentatus. Corolla hypogyna, infundibuliformis, ealyce longior, limbo quinquedentato. St a m in a plurima, exserta; filament a basi coalita, eapillaria, crispula, anthera e biloculares, parvulae. O varia 6 ! oblonga, subtrigona, vix arenata, villosissima, polysperma.
St y li totidem, longissimi, capillacei; stig mata capitata. Fruetus...-Arbuscula brasilien$s i s$; ramis glabratis, novellis hirto-tomentosis, foliis alternis, petiolatis, puripinnatis, foliolis quadrijugis, amplis, integerrimis, subtus rufo villosis, stipulis caducis, racemis terminalibus et extraaxillaribus, ferrugineo tomentosis.

Af fon s e a St. Hilaire Voy. Distr, Diam, Bras, I, 386,

\section{A P P E N D I X.}

\section{Genera dubiae sedis et non satis mota.}

\section{a. Corolla nulla.}

6839. Adelantlaus. F I o res dioici. CaLy $x$ tetraphyllus, Stamina 4 . Stylus radiatus. - Suffrutex c a pens is, scandens; ramis filiformibus, foliis alternis, petiolatis, oblongis, obtusis, subsinuatis, denticulatis, pilosis, supra viridibus, subtus fuscis, petiolis villosis.

Cavanilla Thuab. Prodr. 31. Moldentauera Spreng. Syst, $x, 373$.

6840. Aniba $A U B L E T$. Caly x sexpartitus, laciniis ovatis, concavis. Cor o I I a nulla. Stam in a 8 , receptaculo inserta, a ntherae biloculares. Ovari um liberum, subrotundum. St $\mathbf{y}^{-}$ lus brevis; stigma obtusum ....-Arbor guianensis, quadragintapedalis, ligno aromatico, citrino; folits oppositis $v$, verticillatis, petiolatis, ova to-oblongis, acutis, integerrimis, glabris, floribus axillaribus racemosis, minimis, pedunculo filiformi.

A n ib a Aublet Guian, $x_{0}$ 328. $t, 136$. Ced rota Sehreber Gen, $n$. 660 .

6841. Apactis THUNB. Calyx corollinus, tetraphyllus, foliolis subrotundis, crenatis, concavis, inaequalibus, oppositis latioribus. Stamina 16 _20. Ovarium superum. Stylus ... - Arbor japonica, erecta, ramosissima; ramis alternis, teretibus, punctato-scabris, erectis, foliis in ramulis alternis, petiolatis, ovatis, acutis, serratis, basi integerrimis, nervosis, glabris, subtus pallidioribus, petiolis semiteretibus, sulcatis, floribus in ultimis ramulis racemosis, racemis saepe ovatis, demum oblongis, pedunculo pedicellisque villoso-scabris.

Ap a ctis Thunberg :Flor. Japon. 11. 191.

6742. Augea THUNB. Calyx quinquepartitus, persistens, laciniis ovatis, erectis, coneavis. Corolla nulla. Ureeolns brevis, perigynus, decemdentatus. St a min a 10 ; fil a m e i s brevissimis, arceolidentibas insertis, an theris erectis, subulatis, sulcatis. Ovarinm..... St ylu s filiformis, brevissimus; \& tig ma simplex.
Capsula baccata, decemlocularis, decemvalvis. Semina plurima, membrana obvoluta. - Herba capensis, annua, carnosa, glabra; radice fusiformi, caule a basi ramoso, ramis alternis, simplicibus $v$. ramulosis, teretiusculis, suberectis, foliis oppositis, connatis, teretibus, obtusis, internodia superantibus, floribus inter folia lateralibus, solitariis, geminis v. ternis, pedicellis erectis, unifloris.

A u g e a Thunb. Flor. cap. 386. Sprengel Gen, n. 1875. Harwey Genera of South Afric. Plant. 409 .

6843. IBarbeain THOUAR. C a Iyx monophyllus, profunde quinquefidus, laciniis coneavis, membranaceis. Corolla nalla. Stamina numerosa; fil amenta complanata, brevia, fundo ealyeis inserta, anth erae oblongae, sagittatae. Ova riu m superam. Styli 2, breves, erassi, hirsuti. Ca p s u la biloba, bilocularis, localis monospermis. Se mina affixa, semiarillata, - Frutex madagascariensis, Prockiis fortassis affinis, debilis, sarmentosus, vicinis plant is adhaerens, sub siccatione nigrescens; ramulis flexibilibus, debilibus, foliis alternis, petiolatis, ovatis, oblongis, gluberrimis, lucidis, floribus fasciculatis, pedunculo communi compresso.

B arbenia Thouars Gen, madagase, n. 18.

6944. Batis P. BH. Flo res dioici. Masc. A ment $\mathrm{m}$ conico-oblongram, obtusum, compactum, squamis unifluris, subrotundis, obtusis, latiusculis, basi convexis, margine concavis, quadrifariam imbrieatis. Perigoni n m spathacenm, monophyllum, subrotundum, obtusum, compressam, squama paullo brevius, decumbens. Stamin a 4, squama doplo longiora; fil a m e nta subulata, patula, an the rae oblongae, didymae, incumbentes. Fem. Amenti ovati-oblongi, obtusi, carnosi squamae uniflorae, flore multo breviores, cordato-subrotundae, acuminatae, planinseulae, remotae, quadrifariae, persistentes. Ovarinm amento acretnm, subovatum, acutum. Stigma sessile, magnum, bilobum, capitato-subrotuữdum, 
villosum. B a c c a e succulentae, uniloculares, in synearpium oblongum, obtusum coalitae. Semina 4, triangularia, acuminata. - Frutex in $A m e$ rica tropica littoralis, salsissimus, quadripedalis, caulibus lignosis, fragilibus, diffusis, procumbentibus, cinereis, ramis oppositis, junioribus erectis, tetragonis, quadrisulcatis, viridibus, foliis oppositis, oblongis, superne crassioribus, versus basim attenuatis, succulentis, facie planis, dorso convexis, sessilibus, amentis axillaribus solitariis, oppositis, breviter petiolatis, viridibus, fructibus flavis.

Batis P. Browne Jams, 1. 356. Linn. Gen, n, 1104. Jacquin Amer, $260, t, 40 . f .4$.

8945. DidymeIes THOUAR. F 1 ores dioici. Masc. Ra e em us compositus. Perigonium squanulae 2. Anthera e 2, sessiles, enneiformes, basi junctae, extrorsum dehiscentes. Fem. Spica simplex, supraaxillaris. Perigoni um squamulae 2 , ovariorum dorso insertae, $O$ varia 2, monosperma, ovata, interne sulcata. Stigmata sessilia, biloba. Drupa dnplex $v$, abortu unica, ovatae, stigmate superatae, carnosae, putamine osseo, solido, apice acuminato, superne reticulato, monospermo. S e m en ovato acuminatum, funiculo brevi, ex apice descendente, integumento coriaceo. Embryo exalbuminosus, inversus; cotyledonibus crassis, semiellipticis, interne planis, vetustate coalescentibus, ra di ${ }^{*} \mathrm{cu}$ la brevi, cylindrica, supera, - Arbores mada gascariensis, coma patula; foliis alternis, petiolatis, integerrimis, floribus parvis.

Di d y meles Thouars Gen, madagasc, $n, 89$, Hist, Veg. Afr. austr. 9. t. 1 .

6846. IDilobela THOÜAR. Calyx tetraphyllos. Corolla nulla. Stamina 4. Ovarium unicum. Fruetus.... - Arbor mada. gascariensis, excelsa; foliis alternis, apice bi. lobis, glandula ex nervo primario producto, lobis angulosis, floribus parvis, paniculatis.

Dilobefa Thouars Gen. madagasc. 21.

834\%. Donzelnia TENOR. Flores polygami, Herma phr. Calyx liber, e squamulis sex semiorbienlaribus, ovarium amplexantibus. Stamina 6. Ovarinm ovatum. Stigma sessile, glanduloso-carnosnm, patelliforme, sexlobatum, lohis bifidis. Po mu m globosum, depressum, stigmatibus coronatum, sexloculare, loculis di-trispermis. Semina rngoso-nueamentacea. Fem. Omnia nt in hermaphroditis praeter stamina, Arbuscula bonariensis, sempervirens, spinosa; foliis coriaceis, lucidis, ovatis, obtusis, venosis, obiter erenatis.

Donzellia Tenore Catalog. Sem. hort. Neap. 1839.

8848. Thindera THUNB. Perigoninm corolinum, hexaphyllum, foliolis ovatis, obtusis. Stam ina 6, ovario inserta, perigonio multoties breviora, antherae minutae. Ovarium superum, ovatum, globrum. Stylns erectns, perigonio paullo brevior; stigm at a 2 , reflexa. Cap. sula bilocularis. - Frutex japonicus, laxus; ramis ramulisque alternis, flexuosis, glabris, patentissimis, foliis in apice ramulorum aggregatis, petiolatis, oblongis, acutis, integris, supra viridibus, glabris, subtus pallidis, villosis, floribus ter minalibus parvis, umbellam simplicem formantibus.

$L$ in dera Thunberg Flor. japon. 9. 145. $t, 21$.

6842. II adueãa THOUAR. Calyx mo- nophyllus, quinquelobus, planus. Corolla nulla. Sta mina numerosa, calyei inserta, antherae trunci apici insertae. Ovarium unicum. Stylns staminibus longior; stig m a $t$ a 3 . B a e c a ovata, acuminata, stylo persistente, tri. v. abortu disperma. Se mina ovata, basi umbilicata, apice acuminata. A 1 b u men carnosum. Em b ry o inversus, planus, latitadine seminis, viridis, $x$ adienla brevi, crassa. - Frutex madagascariensis, erectus, Flacourtiae fortassis affinis; foliis alternis, ovatis, dentatis, spinis axillaribus, floribus axillaribus solitariis.

M a n ne i a Thouars Gen, madagaso, $n, 19$.

6S50. Findella LOUR. F lo res monoici, in amento filiformi, stricto, e squamis parvis, carnosis, trigonis imbricato, inferiores masculi, superiores feminei. Perigonium nullum. Masc. Anther a una, subovata, ad basim squamae amenti sessilis. Fem. Ovari nm subrotundum. Stigmat a 2 , subulata, patentia. D r u p a subrotunda, vesiculoso-succosa, putamine lacunoso, bilocularis (?) nucleis compresso-ovatis. - Arbor cochinchinensis, octopedulis; caule tortuoso, fusco, ramis patentibus, foliis sparsis, petiolatis, oblongis, subacutis, aliis integerrimis, aliis interrupte serratis, glabris, amentis lateralibus brevibus, drupis rubris, acidis, edulibus, extus vesiculoso-succosis.

Morella Loureiro Flor. cochinch. 669. - A Chloranthaceis fruetu biloculari et folils sparsis longe distat.

6851. Ilnysena NORONH. Cal y $\mathrm{x}$ quinque-sexfidus, minimus. Co rolla nulla. S ta min a $10-12$, et plura, calyce multo longiora; filamenta tenuissima, debilia, antherae oblongae, acuminatae. $\mathbf{O}$ v a riu in superum, minimum, quadriovulatum. Styli 2 , lineares. Testa fragilis, inflsta, membranacea, acuminata, unilocularis. Se m e n unicum superstes, crassum, fundo affixum, undique liberum, integumento coriaceo, tomentoso-carnoso, zona longitudinali glabra. C otyledones carnosae, in massam solidam coalitae, radienla lateralis, protuberans, - Frutex v. arbuscula madagascariensis; folius alternis, breviter petiolatis, ovato-acutis, marginibus undulatis.

Pb y s e a Noronh, ex Thouar. Gen, madagasc, $n, 20$. $V$ aronthe Herb. Jass.

B852. IPlegorloiza MOLIN. C al y x nullas. Corolla monopetala. Capsula unilocularis, monosperma.

Plegorhiza Molina Chili ed. germ. p. 312.

B853. Pterotuma LOUR. Perigonin m pentaphyllum, foliolis ovatis, concavis, coriaceis, patentibus, persistentibus. Stam in a 15; filamenta subulata, plana, calyce longiora, antherae snbrotundae, biloenlares. Ovarin m superum, ovatum. Stigma sessile, simplex. Utric u I ns oblongus, acutus, coriacens, univalvis, a latere dehiscens, monospermus. Sem e n ovatooblongum, alatum, ala multifida, basi adnata, in longitudinem seminis extensa. - Frutex cochinchinensis, magnus, procumbens; foliis alternis, parvis, ovato-lanceolatis, integerrimis, glabris, racemis axillaribus, floribus parvis.

Ptero tu m Loureira Flor. eochinch, 358.

685̆4. Douilamuam $B L A N C O$. $\mathrm{C}$ a 1 y $\mathrm{x}$ liber, quadri-quinquefitus. Corolla nulla. Stamina 4 v. 5 , inter ealycis laciniss inserta, antherae ovales, uniloculares. O varium liberum, conicnm, compressum, bisulenm. St y 1 u 8 incur- 
vus; stigma capitatum. Capsula eompressa, bisulca, bilocularis, polysperma. S e m in a minima, in axi capsulae. - Arbor philippinica; foliis oppositis, brevissime petiolatis, floribus axillaribus, racemosis.

Q u il a m u m Manuel Blanco Flora de Filipinas 851 .

6855. Selhoustioea SCHUM. F lores dioici. Masc. Perigonin m gamophyllum, basi intrusum, in lacinias duas, semibifidas rumpens. Stamina 8 ; filame nta basi connexa, elastice expansa. Antherae ovatae, biloculares. Fem. Perigon in m brevissimum, urceolatum, obsolete quadridentatum. Ovarium magnam, subrotundum, compressinsculum, utrinque sulco exaratum, tomentosum. Styli 2 , longi, erecti, subulato-planiusculi, margine revoluti, extus puberuli, intus viscoso-stigmatosi. Peri c a r pi n m biloculare, Ioculis monospermis. - Frutex guineen$s i s$, orgyalis; ramulis teretibus, pubescentibus, foliis alternis, ovatis, subacuminatis, cordatis, obtuse et remote serratis, subcoriaceis, glaberrimis, trinerviis, costatis, transversim venosis, subtus basi in axillis nervorum quadriglandulosis, junioribus involutis, stipulis geminis, minutis, racemis masculis axillaribus compositis, floribus minutis, sessilibus, glomeratis, bracteis solitariis, racemis femi neis simplicibus, floribus solitariis, sessilibus, sparsis, vix bracteatis, rhachi ad basim singuli floris biglandulosa.

Sehousboea Sehumacher in [Danske Selskabs Af: handling. IV. 223.

8856. Stixis LOUR. Periguninm corollinum, campanulatum, hexaphyllum, foliolis oblongis, carnosis, revolutis. Stam in a 16 , receptaculo inserta, perigonio snbaequalia, exteriora breviora, antherae oblongae, stantes. Ovari n m superum, pedicellatum, ovatum, pilosum. St y 1 u s brevis, crassus; stigmat a 3 , rotunda. D r u p a ovata, carnosa, cortice punctato, nucleo oblongo-ovato, solido, monospermo. Frutex cochinchinensis, magnus, scandens, acirrhus, inermis, ramosus, longissimus; foliis alternis, oblongis, acuminatis, integerrimis, venosis, duris, racemis axillaribus, simplicibus, longis, flore purpureo et viridi variegato.

$\mathrm{S} t \mathrm{x}$ is Loureiro Flor, cochinch, 361.

\section{b. Corolla gamopetala.}

695\%. Baitaria RUIZ et $P A V$, Calyx tetraphyllus, persistens, foliolis duobus inferioribns subulatis, a superioribus lanceolatis, quadruplo latioribus remotis. Co rolla hypogyna, tubo calycem aequante, eylindrico, recto, limbi quinquepartiti laciniis lanceolatis, patentibus. St a mina 18 (interdum 14-19), imae corollae inserta, ejusdem tubum aequantia; fil a m en ta capillaria, alterna breviora, anthera e biloculares, oblongo-lineares, inferne bifidae, incumbentes. Ovari $\mathbf{m}$ ovatum. S t y 1 u s subulatus, erectus, staminum longitudine; stig ma trifidum. Ca ps u l a ovata, acuminata, triquetra, trilocularis, loculicide trivalvis, valvis medio placentiferis, S e min a plurima, sublentiformia, - Herba peruviana, acaulis; radice viscosa, folitis lineari-lanceolatis.

B a it a ri a Ruiz et Pavon Prodr. 53, $t, 36$, Syst. 111.

8558. Calibra elnoa $L L A V$, et $L E X A R Z$ $\mathrm{C}$ a 1 y $\mathrm{x}$ pentaphyllus, foliolis linearibus, integris, erecto-patentibus, subaequalibus. C o rolla longi- tudine calycis, gamopetala, infundibuliformis, tubo teretiusculo, brevi, fauce angulata, limbi plicato. quinquelobi lobis ad medium cordato-acuminatis, infimo fovea excavata, palati instar intus prominente. Stamina 5 , ad basim tubi corollae inserta, inclusa; fil amenta inaequalia, an therae subrotundae. Ova ri um conicum. Sty I us filiformis, staminum longitudine; $s t i g m$ a obtusum. Capsula coniea, unilocularis, bivalvis. Semin a plurima, angulosa, receptaculo eonico affixa. - Herba mexicana, Convolvuli facie; caule pro. cumbente, tereti, ramis alternis, subdichotomis, foliis alternis, oblongis, integerrimis, glabris, floribus solitariis, parvis, violaceis, pedunculis foliis brevioribus, e dichotomia enatis.

C a librachoa Llave et Lexarza Nov. Neget. Des. oript. 11.3.

6859. Cerium LOUR. Cal yx quinquepartitus, persistens, laciniis subulatis, erectis. Corolla gamopetala, campanulata, vix calyce longior, liubo suberecto, quinquefido, laciniis sinubusque rotundatis. Sta $m$ in a 5 , corollae tabu inserta, exserta; fil am enta subulata, erecta, antherae oblongae, incumbentes. Ovarium liberum, subrotundum. Stylas subulatus, staminibes aequalis; stigma crassiusculum. Ba cea parva, globoga, multilocularis, loculis regularibus, polygonis, monospermis, versus peripheriam simplici ordine dispositis. Se min a parva, angulata. - Herba cochinchinensis, annua; radice repente, caule sesquipedali, simplici, erecto, tereti, foliis allernis, petiolatis, lato-lanceolatis, subintegerrimis, multinerviis, glabris, spicis terminalibus longis, simplicibus, erectis, bracleis filiformibus, floribus albis.

C e ri u m Loureiro Flor, cochinch. 168.

6860. Coddingtenia $B O W D I C H$. Ca I y bibracteolatus, superus, brevis, obsolete quin. quedentatus. Corolla tubulosa, quinquefida, tubo longissimo, gracili. Sta m in a 5, non exserta. Sty I us unitus; stig ma simplex. - Planta interdum parasitica; folits oppositis, coriaceis, lanceolatis, odoratis, floribus axillaribus, fasciculatis. Coddingtonia Bowdich Madeira 398.

Gse1. Corallophyllum $H, B, K, C$ a1 yx profunde octopartitus, coloratns, laciniis lineari-subspathulatis, uninerviis, corollam superantibus, subaequalibns, membranaceis, Co roil a hypogyna, tubnlosa, limbo octodentata et plieata, basi ventricosa, octonervia. Sta m i na 8 , corollae medium versus, inter nervos, quatuor altius inserta, inclusa, antherae biloculares, loculis nonnisi apice inter se cohaerentibus, intus secundum longitudinem dehiscentibus. Ovarium mperum, sessile, hemisphaericum, ad circumferentiam multi(16?) Ioculare, axi centrali crassissimo. Ovu la in loculis solitaria, angulo interiori affixa, adscendentia. Stylus subsubulatus, corolla brevior; stig ma subeapitellatum. Frnetns.... Herba mexicana, parasitica; caulibus caespitosis, carnosis, inferne clavato - incrassatis, superne corymboso-ramosis, multifloris, bracteosis, ramis confertis, foliis (?) profunde et irregulariter laciniatis, carnosis, squarrosis varieque inter se connatis, floribus sessilibus, caeruleis.

Corallophyllum Kunth in Humb. el Bonpl. Nov. gen, ot op, VII. $2=6$. $t, 660$, bis, - Le un o a Llave et Lexarza Nov. Veget. Descript, I, 7, cui auctores neapsulam pyriforaem anilecularea, oetovalvem, polyspermam, seminibus minutissim!s" tribuant, certe eadea plauta. 
6862. Dasus LOUR. Caly $\mathrm{x}$ tubnlosus, brevis, coluratus, breviter quinquefidus, lobis obtusis. Corolla supera, gamopetala, campanulata, undique pilosissima, limbo quinquefido, calyce duplo longiore. S ta min a 5 , basi corollae inserta; filamenta brevia, antherae biloculares, stantes. O v a r i n m subrotundum, calyce vestitum. Stylus filiformis, corollae longitudine; Btigma quinquefidum, laciniis oblongis, erectis. B a sea calycina, eompresso-rotunda, umbilicata, monosperma. S em en sphaeroideum. - Arbor cochinchinensis, mediocris; ramis expansis, foliis lanceolatis, integerrimis, undulatis, subtus tomentosis, verticillis axillaribus, floribus albis, sessilibus.

D a s us Loureiro Flor, cochinch. 175.

6863. Duvaueellia BOWDICH. Cal y x tubulosns, quadrifidus. Coroll a tubulosa, regu. laris, tubo longo, limbo quadrifido, lobis lanceolatis. St a min a 4, intra tubum, Sty lus 1; stigma ..... Fruetas superus, dispermus. Herba tenuissima, pulcherrima; foliis linearibus, fasciculatis, floribus laxe paniculatis, corolla intus al$b a$, extus rosea.

Duva ue ellia Bowdieh Madeir. 396.

6864. Ir ydropyxis RAF. Ca ly $\mathrm{x}$ bibrac teolatus, persistens, quinquepartitus, laciniis duabus interioribus minoribus. Corolla crateriformis, limbo inaequaliter quinquelobo. S $\mathrm{ta} \operatorname{m}$ in a 4 , cornllae inserta, didynama, antheris hastatis. Ovarinm superum. Stylas simplex; stigma capitatum, trilobum. Cap s ul a triangularis, unilecularis, polysperma, circumscissa, placenta centrali libera. - Herba in paludibus Luisianae vegetans; caulibus prostratis, repentibus, floribus axillaribus solitariis, pedunculatis.

H ydropyxis Rafinesque Flor. Ludov, 94.

6855. Keiria BOWDICH. $\mathrm{C}$ a $\mathrm{l}$ y $\mathrm{x}$ bibracteolatus, tubulosus, sexfidus v. oetofidus. $\mathrm{C}_{0}$ roll a hypogyna, quadrifida, regularis. S t a m ina 4, corullae inserta, ejusdem limbum aequantia. Fructus globosus, drupaceus, nuce fragili, septemsulcata, monosperma. - Arbor magna; foliis alternis, cordatis, uninerviis, glaberrimis, floribus terminalibus subcorymbosis, aggregatis, luteis.

\section{Keiria Bowdieh Madeir. 396.}

6866. Mratthissonia RADD. Calyx quinquefiedus. Co rolla hypocrateriformis, tubo longo, limbi quinquefidi laciniis linearibus, singulis extus ad basim callesitate squamaeformi. S t a m in a in tubum connata. C aps u l a bilocularis. S emina angulata, reticulata. - Herba brasiliensis; foliis alternis, cordato-acuminatis, integerrimis, pubescentibus, floribus paniculatis.

Matthis son ia Raddi Quarant, plant. Brasil, 1t.f.7.

6867. Noltia SCHUMACH. Flores polygami. Mas e, Caly $\mathbf{x}$ quadrifidns, sericeo-tomentosns, lacinis aentis, adpressis, Coroll a subeoriacea, tnbulosa, ealyce triplo longior, limbi quadrifidi laciniis acutis, erectis, margine inflexis. $S t$ a $m$ i n a receptaculo inserta, octo v. plura; fil ain enta inaequalia, quatuor saepe reliquis duplo longiora, corolla dimidio breviora, inferne pubes centia, distincta v. basi binatim ternatimve coalita, an thera e subulatac, erectae. Hermaphr. Ca. Iy x maris, Co rolla maris, basi magis ventricosa. Stamina 7-8; fil amenta calycis longitudine, distincta, tenuissima, a n therae steriles, minutae. Ovarinm superum, ovatum, sericenm, in s t y $\mathrm{ln} \mathrm{m}$ sululatum attenuatum; st i $\mathrm{gma}$ acntum. Bacca ovata, obsolete tetzagona, pyramidata, glaberrima, unilocularis, tetrasperma. Semina oblonga, hine convexa, inde obtusangula, cartila. ginea, pulpa mucosa inclusa. - Frutex guin e ensis, ramnsissimus, bi-qualripedalis; ramulis teretibus, ferrugineo-tomentosis, divergentibus, procumbentibus, foliis alternis, distichis, ellipticis, obtusis, integerrimis, subaveniis, supra glabris, viridibus, subtus albido-sericeis, stipulis nullis, floribus axil. laribus, solitariis $v$. ternis quaternisve, sessilibus, parvis.

Noltia Schumacher in Danske Selskabs Afhandl. III. 209.

6868. Detas JACK. Cal yx octopartitus. Corolla gamopetala, limbo octolobo, lobis rotundatis. Stamina 8 , eorollae lobis alterna et aequilonga, an the rae sulsagittatae. Ovarium superum, glubosum, octoloculare, loculis monospermis. Si g m a sessile, magnum, radiatn-octolobum. B ace a oetosperma. Semina intus angulata. - Frutex sumatranus; ramis longis, junioribus tomentosis, foliis alternis, petiolatis, lanceolato-oblongis, acuminatis, integerrimis, glabris, stipulis parvis, angustis, spicis $v$. racemis axillaribus geminatis, folio brevioribus, multifloris, pedicellis ternatis, floribus parvis, albis, bracteis minutis.

Oct a s Jaek in Hooker Bot. Mag. Comp, I. 219.

6965. Palladia $L A M$. C a 1 y $x$ gamophyllns, infundibuliformis, coloratus, tubo brevi, limbi quadrifidi laciniis obovatis. Corolla gamopetala, infundibuliformis, tubo longo, octoplicato, limbi octufidi laciniis oblongis. Stam in a 8 ; filaun entis corollae tubo ultra mediam longitudinis suae adnatis, rigidis, persistentibus, Ovaria 2 , libera. Stylus inter ovaria positus, simplex, compressus, ad margines denticulatns; $\mathrm{tig}$ in a $t \mathrm{i}-$ b us 2, patulis terminatus. Capsula e 2, oblongae, prismatico-clavatae, chartaceae, rigidae, dorso convexae, sulco ventrali exaratae, uniloculares, hivalves, placenta ad suturam ventralem longitudinali, demum libera, minutissime papilloso scabra, valvis demum spiraliter contortis. Semin a plarima, parva, angulata, testa simplici, coriacea, te. nui. E m b r y o intra albumen carnosum eylindricus; cotyledonibus brevissimis, radicula centripeta. - Planta inter Forsterianas incertae originis.

Palladia Lam. Illustr, $t, 285$. B I a k wellia Gärtner IT. 269. t. 117 ,

S8\%0. Pentaceros G, $F, W . \mathrm{C}$ al y $\times$ quinquepartitus, patens, Iaciniis ovatis, acuminatis, nervosis, venosis, intus coloratis. Corolla unlla. Co ron a infundibuliformis, ovarium ambiens, tubo brevi, limbo plano, quinquepartito, laciniis apice dilatatis, retusis, plicatis, corniculum clavaeforme, acuminatum emittentibus. Antherae 5, subrotundae, apice coronae laciniis infra corniculum basique tubi inferiori parti externe adnatae. 0 va. r i u in snbglobosum, quinquesulcatum, glandulosopunctatum. Stylus subulatus, coronam hand superans; stigma subeapitatum. - Frutex guianens is, scandens, aculeatus; foliis alternis, ovatooblongis, subserratis, glandula mellifera in costa notatis, floribus minutis, in umbellis axillaribus glomeratis.

Pentaceros G. F. W. Meyer Elor, Essaqueb, 136.

6981. Playla LOUR. Involnerum polyphyllan, ovatum, multiflorum, foliolis spathulatis, 
acuminatis, coarctatis. Caly x diphyllus, foliolis lanceolatis, coneavis, erectis. Corolla gamopetala, tubulosa, irregularis, limbo brevi, patente, quadrifido, laciniis subaequalibus, supremal enarginata. Stamina 4 , bino ordine infra os tubi inserta; fil am enta brevia, an therae bilobae, subrotundae. Ovarium supernm, subrotundum. Sty I us hrevis; stigma crassiusculum. Pericarpi u mullum. Semina solitaria, nuda, receptaculo communi filiformi, nudo undique affixa. - Herba chinensis, annua; caule repente, ramis adscendentibus, foliis oppositis, lanceolutoovatis, acuminatis, glabris, basi inlegerrimis, superne serratis, pedunculo laterali solitario, elon. guto, unifloro, flore albo-violaceo.

$\mathrm{P}$ h y la Loureiro Flor, cochinch. 83.

68\%2. Poraqueilon $A U B L$. Calyx minimus, quinquedentatos. Corolla gamopetala, quinquepartita, laciniis oblongis, ovatis, acntis, extus convexis, intus coneavis, cavitate medio membrana transversa biloculata, loculo superiore Iongitudinaliter bi- inferiore trilocellato, locello intermedio majore. Stam in a 5, corollae laciniis alterna; filamenta crassa, extus convexa, intus concava, utrinque marginata, margine incurvo, antherae cum filamento artieulatae, oblongotetragunae, truncatae, biloculares, loculis connectivo lato marginibus recurvo intus adnatae, in rotae molendinariae speciem inter se cohaerentes. Ovarium liberum, subrotundum. Stylus brevis; stigmata 3, ovata. - Arbor guianensis, quinquagintapedalis, apice ramosa; foliis alternis, petiolatis, ovatis, acutis, integerrimis, glabris, floribus axillaribus spicatis, minimis, albis.

Poraque ib a AubletiGuian. I. 103. t. 47, B arreria Scopoli Introduct. $n, 767$.

6573. Ifapourea $A U B L$. Calyx quinquepartitus, lobis subrotundis, intus villosis. $\mathrm{C}$ orolla hypogyna, rotata, intus villosa, quinquefida, lubis subrotundis, patentibus. St a mina 5 , corollae tubo brevissimo inserta, ejnsdem lobis alterna, antheris bilocularibus. Ovarinm subrotundum, villosum. Sty I us longus, eapillaris; stigmat a $3{ }_{-4}$, filiformia, patentia. - Frutices v. arbusculae guianenses; foliis verticillatis, imparipinnatis, foliolis alternis, subsessilibus, oblongis, integerrimis, petiolo communi inter foliola spinulas parvas gerente, floribus axillaribus aggregatis, sessilibus.

Ra paurea Aublet Guian, I, 198, t.78, C a max Selireber Gen. n. 365

BS\% 4. Hochefortia $S W A R T Z$. C a ly x quinquepartitus, lacinits ovatis, ohtusis. Corolla hypogyna, gamopetala, tubo brevi, pentagono, limbi quinquepartiti laciniis ovatis, oblungis, patentibus. Stamina 5 , eurollae fanci ad sinus inserta; filamenta brevia, subulata, antherae oblongae. Ovari um snperum, sobrntundam, compressiusculnu, villosum. Styli 2 , filamentis breviores, subulati, villosi; $8 \mathrm{tigmata}$ subplumosovillosa. Peric arpin m subglobosum, bilnculare. Semina nonnulla, angulata. - Frutex antillanus, tri-quadripedalis; cuule ranoso, erecto, inermi, ramis subdivisis, flexuosis, teretibus, spinosis, spinis prope petiolorum busim solitariis, porrectis, foliis lernatim fasciculatis, alternatim confertis, petiolatis, cuncatis, obovatis, integerrimis, utrinque glabris, subtus pallidioribus, leviter nervosis, rigidiusculis, pedunculis terminali-axilluribus, subdicho- tomis, confertis, cymosis, foliis brevioribus, floribus parvis, virescentibus $v$, albidis.

Rochefortia Swartz Prodr. 33. Flor. Ind, occid. I. 352. t. 11 .

6885. IRotula LOUR. Caly x eyathiformis, quinquepartitus, persistens, lacinilis acutis. Corolla hypogyna, quinquepartita, laciniis ovatis, planis. St amina 5 , corollae basi inserta et breviora; filamenta snbulata, antherae sagittatae. Ovarin m subrotundum. Stylus turbinato-linearis, planiuseulus, staminibus aequilongus ; $s \mathrm{tigm}$ a emarginat $\mathrm{m}$. B a ce a subrotunda, aquosa, unilucularis, tetrasperma. Semin a extus ovata, intus curva. - Planta cochinchinen$s i s$, paludosa; caule fruticoso, quadripedali, simplici, suberecto, tereti, inermi, rumis brevissimis, simplicissimis, foliis ovato-oblongis, integerrimis, sessilibus, floribus terminalibus congestis, dilute violaceis, baccis pisi mole, rubris.

Rotula Loureiro Flor, cochinch. 149.

\section{c. Corolla dialypetala.}

68\%6. IBalingayum BLANCO. Calyx superus, quinquefidus. C $0 r$ o 11 a e petala 5 , ap. pendiculis duabus lateralibus cueullatis. Stamina 5, corolla breviora. Antherae compressae, in mucronem desinentes. Stylus lirevis; stigma $t$ a 3 , biloba. Capsula unilocularis, hexasperma. - Herba philippica, procumbens, repens; foliis alternis, sessilibus, basi dentibus $v$. lo. bulis aliquot auctis, floribus solitariis.

B a ling a y u m Manuel Blanco Flora de Filipin, 187.

858\%. Bembix LOUR. Caly x liber, tripartitus, laciniis ovatis, coneavis, erectis. Corolla e petala 5, ovata, concava, ealyce paullo longiora. St a m in a 10 ; fi lam enta filiformia, alterna longiora, petalorum basi inserta, iisdem breviora, antherae biloculares, erectae. Ovarinm ovatum. Styli 3, oblongo-turhinati, bisuleati, erecti. Stigmata verticaliter compressa, emarginata. B a e ca parva, nvata, trilocularis. Semina..... - Frutex coohinchinensis, scandens, ecirrhosus, inermis, ramosus; foliis oppositis, cuneiformibus, integerrimis, glabris, racemis subterminalibus, parvis.

\section{B e a bix Loursiro Flor. cochinchin. 346.}

8988. Calisperman LOUR, Calyx quinquefidus, patens, minimus, persistens, läeiniis acutis. Corollae inferae petala 5, ovata, concava, patentia. Sta mina 5 , petalis inserta et aequalia, a therae subrotundae. Ovarium subrotandum. Sty I us filiformis, staminibus longior; stig ma crassiusculum. B a c e a subrotunda, suc. culenta, unilocularis, polysperma. Semin a subrotunda, minima, in peripheria nidulantia. - Frulex co chinckinensis, scandens, longus, ramo$s u s$, inermis; foliis alternis, ovato-lanceolatis, crenatis, glabris, racemis plurimis oblongis, simplicibus, subterminalibus, floribus albis.

Cal is perm a m Loureiro Flor. cochinch, 193.

8589. Casimiroa $L L A V$. et $L E X$. Caly $x$ brevis, quinquepartitns. C o rollae petala 5 , revoluta. Stamina 5 , receptacnlo inserta; filam ent a snbulata, petala subaequantia. Ova $r$ i m sessile; stigma hemisphaericum, olsolete quinquepartitum. B a c ca sulglobosa, pulpa sapidissima referta. Semina 5 , pollicaria, cortice vitellino. - Arbor mexicana, mediocris, ramosa; $167 *$ 
foliis pinnato palmatis, quinis-septenis, petiolatis, lanceolatis, glabris, integris, subvitellinis, floribus racemosis, baccis mali majoris molle.

Casimiroa Llav. et Lexarz. Nov, Veget. Descript. II. 2. Istactzapotl Mexic. Z a pote bla neo Hispan.

6S84. Coelopynan JACK. C a ly x liber, quadripartitus, patens. Corolla e petala 4 , calyce longiora, patentia. Stamina 8 , alterna breviors. Ovarium diseo annulari angulato semiimmersnm. Stylus brevissimus; 8 tigma obtu sum. Drupa ovata, acuta, putamine biloculari, leculo altero majore lanato, semilunari, monospermo, alterum minorem, vacuum, oblique superum amplectente. - Arbor javunica; ramis simplici. bus, apice foliosis, foliis alternis, petiolatis, ellipticis, obtusis v. emarginatis, coriaceis, costatis, integerrimis, margine revolutis, supra glabris, subtus tomentosis, racemis axillaribus ramosis, folio brevio. ribus, parvis, flavescentibus, bractea parva, acuta stipatis. I. 280 .

Coelopyrum Jack ex Hooker Bot. Mag. Comp.

BS81. Commi pleora $J A C Q . C$ a 1 y x parvus, campanulatus, juadridentatus, Coroliae petala 4, ealyce multo majora, oblonga, concava, acuta, erecta, superne patula, apicnlo inflexo. St a mina 8 , receptaculo inserta, inclusa; filasu e n ta subulata, libera, alterna breviora, anthera eblungae, acutae. $O$ v a ri rudimentum nullum. F e m,......-Arbor madagascariensis, resinam elusticam fundens; foliis alternis, petiolatis, lanceolatis, auctis, serrulatis, basi biauriculatis, pedunculis e gemmis ex axillis foliorum delapsorum ternis v. pluribus, brevissimis, unifloris.

C о m i ipli or a Jacq. Ḧort. Schönbr. IT. 67. $t$. 249. Vaé s. Voa-héne Madagase.

588\%. Dielaror LOUR. Calyx ganophyllus, tubo oubgloboso, limbe brevi, quadridentato, patente. Corolla e petala 5, ovato-lanceolata, crassa, patentia, ealyce longiora. Sta mina 15 ; fil a menta fliformia, inaequalia, omnia corolla breviora, antherae suhovatac, planiusculae, biloculares, stantes. Ovarium subrotundum, calyce clausum. Siyli 4 , crassi, filamentis subaequales; stig ma ta ovata, emarginata. B a $\mathrm{c}$ ea calycina, subrotunda, quadrilocularis, polysper. ma. Sem in a subrutunda. - Erutex arborescens, in Cachinchina et China indigenus; ramis patentibus, foliis oppositis, sessilibus, lanceolatis, subserratis, glabris, racemis terminalibus, corymbosis, corolla extus alba, intus cum staminibus cae rulea.

D i chro a Loureiro Flor, eochinch, 368.

6853. Dobera JUSS. Cal y x urceolatns, quadridentates. Cornllae petala 4 , calyce longiora. S tam inum filamenta 4, subulata, basi in tubum tetragonum connata, a nt herae erectae. Squamulae 4 , inter stamina et petala. Ova rium snpernm. Stylus brevis; $8 \mathrm{tigmata} 2$ Frnetus ovatus, tubereulosus, carnosus, intos suceoso viscidus, monospermns. - Arbor arabi ca, Dober dicta; foliis oppositis, petiolis basi incrassata flavescente, floribus terninalibus confertim spicato paniculatis, fructu eduli.

Dober a Jussieu Gen, 425. To m e x Forskael Aegypt, 82 .

B884. Wneila BLANCO. F lor es monoiei. Mas c. Calyx quinquelobus. Corollae petala 5 , calycis laciniis alterna, minima. Stami- n a 5, basi petalorum inserta. ( $)$ va ri n m sterile. F e in. C a ly x eum ovarii basi connatus, limbo supero, quinquedentato. Corullae petala 5 v.plura, minntissima. Stamina 5 v. plura, sterilia. D rupa sicca, coriacea, superne in alam membranacean, stylis duohns minimis terminatam producta, uniloeslaris, monosperma. S e m e n globosum. Frutex philippinensis, inermis, rumulis uncinatis scandens; foliis alternis, imparipinnatis, foliolis lanceolatis, serratis, floribus monoicis, masculis racemosis, femineis paniculatis.

En ril a Manuel Blanco Flora de Filipin, 709.

6855. Floseopa $L O U R$. C a I y infundibuliformis, pilosns, coloratus, persistens, limbi trifidi laciniis ovatis, curvis, patentibus. CorolI a e petala 3, ovata, erecta, calyei aequalia. Stamina 6 ; fil a m en ta subulata, corolla longiora, antherae lobis binis, subrotundis, Ovarium superum, compresso-ovatum, bilobum. Stylns subulatus, staminibus longior, inflexus; s $\mathrm{tig} \mathrm{ma}$ crassiusculum. C apsula subovata, biloba, bilocularis, loculis monospermis. Se m in a compressoovata, cornea, suleis multis in orbem radiata. Planta cochinchinensis; caule fruticoso, scandente, ecirrhoso, simplici, longo, tereti, foliis alternis, lanceolatis, integerrimis, vaginantibus, multinerviis, basi ciliutis, supra scabris, subtus laevibus, floribus parvis, dilute violaceis, in spicas tenues, rigidas, fasciculatas, in scopae formam fastigiatas dispositis.

Fl oscop a Loureito Flor, cochinch, 238.

BSSB. Creiselinia FORST. F lores polygamo-dioiei. He rma phr. Caly x superus, quinquedentatus. Coroli is pentapetala. Stamin a 5. Ovarium triloculare (?), loculis uniovalatis. Styli 3 , cylindrici, brevissimi ; st i g matibus simplicibus. Mas c. C al y $x$ quinquedentatus. Corolla pentapetala. Stamina 5, antherae subrotundae quadriloculares. - Arbuscula Novae-Zeelandiae; ramis erectiusculis, ramulis divaricatis, sulcatis, cortice fusco-olivaceo tectis, foliis alternis, petiolatis, oblongis, coriaceis, basi inaequalibus, hinc attenuatis, inde rotundatis, integerrimis, obtusis, utrinque glabris, supra nitidis, subtus opacis, venosis, paniculae terminalis ramis divergentibus, bractea suffultis, pedunculis subtrifidis, floribus masculis femineis interpositis

Griselinia Forst. Prodr, 401. Sprengel Pugitl. 1,63. S e o n Il a Forster Gen t. 20. (Anne planta a cl. Martius in Münchner Denkschrift. 1816-17. p. 151, $t, A$, descripta eadem?)

688\%. Hireptaea LOUR. Flores polygamo-dioiei. Hermaphr. Calyx triphyllus, foliolis ovatis, concavis, patentibns. Corollae petala 10 , ovato-ohlonga, subrotata, calyce longiora. Stamina circiter 100; fil amenta filiformia, corolla breviora, antherae lineares, erectae. Ovarium subrotundum. Stylus crassus, staminibus aequalis; 8 tig m a septempartitum, laciniis canaliculatis, patentibus. B acca subrotunda, septemlocularis, polysperma. S e m in a subrotanda. Flor. mase, Caly $x$, corolla et $s$ ta $\mathrm{m}$ ina ut in hermaphroditis. Ovarium nullum. - Arbor cochinchinensis, parva; ramis expansis, foliis alternis, petiolatis, ovatis, integerrimis, venosis, glabris, pedunculis lateralibus multifloris, floribus albis, bacea viritli, diametro bipollicari.

He p ta a Loureiro Flor. cochinch. 807.

6888. Irippomaniea MOLIN. Calyx 
quinquepartitus. Corolla e petala 5 , ovata. Ca psula quadrilocularis.

II i p po ua u ic a Molina Chili ed. Germ, p. 312.

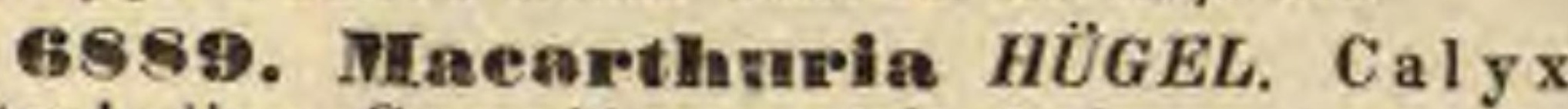
pentaphyllus. Corolla e petala 5, hypogyna, ealyeis foliolis alterna, oblonga, basi in unguem angustata. Sta mina 10, hypogyna, omnia fertilia, filamenta inferne in cnpulam laxam coalita, superne filifurmia, libera, antherae subglobosodidymac, hiloculares, longitudinaliter dehiscentes. Ovarinm liberum, tri-quadriloculare. Ovnla in loculis gemina, e basi anguli centralis collateraliter adscendentia, anatropa, basi strophiola copulaeformi cincta. Styli 3 - 4 , filiformes; $s \mathrm{tigmata}$ subtruncata. Fructus......-Frutex NovaeHollandiae austro-occidentalis, folis ignotis; ramis elongatis, simplicibus, cymis fasciculiformibus, sessilibus, bi-decemfloris, squamosobracteatis, juxta totam fere ramorum aphyllorum longitudinem dispositis.

Ma carthuria Hügel msc. Endlicher Enum. Plant. Hügel. 11.

68\$0. IIfacharisia THOUAR. Caly $\mathrm{x}$ turbinatus, quinquefidus, laciniis revolntis. Cor 11 a e petala 5 , basi ealycis inserta, linearia. St a m ina 10, in nrceolum basi coalita, denticulis totidem interjectis; fil a m e nt a superne libera, filiformia, an therae biloculares, dorso insertae, latere dehiscentes. O va ri u m subrotundum, quinqueloculare, loculis biovulatis. Stylus simplex, longitudine staminum, Ca 8 u l a clavata, basi calyce persistente stipata, decemsuleata, quinquelocularis, loculicide quinquevalvis, valvis medio septiferis, cum receptaculo centrali conniventibus. Semina in loeulis solitaria, funieulo brevi inferiori receptaculi centralis dimidio appensa, superne in alam longam, cultriformem expansa, testa coriacea. Embryo intra albumen carnosum inversus, viridis, cotyledonibus foliaceis, planis, lanceolatis, $r$ a dicula cylindrica, supera. $-A r$. buscula madagascariensis; ramis oppositis, erectis, confertis, virgatis, foliis oppositis, petiolatis, obtusis, dentatis, floribus parvis, in umbellis axillaribus glomeratis.

M a charis ia Thouars Hiat, veg. Mfr. austr, 49.t, 14.

6891. NIonetia HERIT. Flores abortu dioici. Ma s c. Cal yx campanulatus, irregnlariter bi-quadri-quinquefidus, laciniis distinetis v. varie cohaerentibus. Corolla e petala 4 v. 5, hypogyna, ealycis laciniis alterna, linearia, sta min a $6 \mathrm{v}$. 7 , hypogyna, petalis alterna v. biseriata, filamenta crassa, libera aut geminatim ternatimve coalita, an the ra e introrsae, biloculares, erectae, apiculatae, longitudinaliter dehiscentes. F e m. C a l y x et coroll a maris. St a m in a abortiva $4-5$, petalis alterna. Ovarin m liberum, bilocnlare, dissepimento tenuiter membranaceo. Ovala in loeulis solitaria, ex apice dissepimenti pendula, $\mathbf{S t i}$. ma sessile, globosum, fungosum, irregulariter lo- batum. Bacea disperma. Semina orbicularia, plano-convexa, inversa, testa tenui. Embryo lenticularis, exalbuminosus, cotyledonibus carnosis, cordato-orbiculatis, r a dic u la e rectae, elongatae, superae hasim tegentibns. - Frutex capens is; ramis oppositis, tetragonis, divaricatis, spinosis, foliis oppositis, petiolatis, ovatis, pungentibus, integerrimis, glaberrimis, floribus axillaribus, glomeratis, brevissime pedunculatis, baccis albis.

Monetia Heritier Stirp. $t, 1$. Harwey Genera of South Afric, plant. 411. A 2 im a Lamark Illustr, $t, 807$. Jussieu Gen, 425. - S e m in a secundum el. Gärtner f. III. 247. $t$. 225. erecta, albumen parcun, radicula supera.

6852. Drixa THUNB, Calyx brevissimus, quadripartitus. C o ro 11 a e petala 4 , tubi calycini margini inserta, ejusdem laciniis alterna et multo majora, elliptico-obovata, aestivatione imbricata, sub anthesi patentia. Stamina $4, \mathrm{cnm}$ petalis inserta, iisdem alterna et duplo breviora; fil a menta crassa, subulata, antherae erectae, ovales, longitudinaliter dehiscentes, O va ri $\mathrm{n} \mathrm{m} . .$. Stig ma urceolatum, quadrilobulatum, in angulis stamina recipiens ...... - Frutices japonic $i$; foliis alternis, integerrimis, exstipulatis, floribus racemosis.

Orix a Thunberg Flor.Jap. 3. Miquel in Bullet. Neer. land, 1839. p. 461.

6893. Sassia MOLIN. C aly x tetraphyllus. Corolla e petala 4 . S $\mathrm{\ell}$ amin a 9 . C a p sua bilocularis, disperma.

S a s s a Molina Chill ed. germ. p. 311 .

6894. Trise euss WILLD. Ca I yx quinquedentatus. Corollae petala 5 . Stamina 5 . Capsula trilocularis, loculis monospermis.

Trisecus Willd, ex Röm, et Soluultes Syst. DI. 64t.

6895. Trujanoa LLAV. et LEXARZ. Spica sulpinnata, spiculis alternis, pedunculis communibus axillaribus et terminalibns insertis. F lo res minuti. Caly x duplex, exterior trifidas, spiculae insidens, interior quinquefidus. Co rolla e petala 5 , erecta, ovata. Anth erae 5 , subsessiles, glandulis totidem rubris alternae. Ovari $u$ m depressum. Stylus brevissimus; stigma trifidum. Semen unicum, subcorneum, lentiforme, visco indutum, pellicula maturitate rubra tectam. - Arbor mexicana, mediocris, ramosa; foliis alternis, imparipinnatis, foliolis ovatis, oppositis, breviter petiolulatis, integerrimis, supra gla. bris, subtus pubescentibus. II. 1.

$$
\text { Truj a uo Llave et Lexarza Nov. Veget. Deseript. }
$$

T a mpo a Anblet Guian, Suppl, 35, $t, 388$. C a ly x quíquepartitus, laciolis ovatis, acutis..... B a c ca globo. sa, striata, unilocularis, cortice erasso. carnoso, intus pulpa suecosa. S e mina plurima, subrotnada, anguiata. ulba. - Arbor guianensis, succo viscoso, luteo foeta, trigintapedalis, apice ramosa; folits alternis, petiolati, ovato-oblongis, acuminatis, integerrimis, glabris, fructi. bus axillaribus, racemosis. 


\section{GENERA NONDUM DESCRIPTA.}

1. ADHUNAA Flor, Flue. $\nu, t ; 118$.

2. AESCHRION Flor, Flum. $I, t, 152$,

3. BARBERINA Flor, Flum. $V$. $t, 117$.

4. BENJAMIINA Flor. Flum. IIT. t. 139.

5. BERTEROA Zippelius ex Macklook in Bijdr, tot. de nat. Wetensk. V. 142. Ferrusac Bullet. XVIII. 92.

6. BLEPHARISTEMMA Beath. ex Wallich Calalog. n, 6320.

7. BoNaMiCa Flor. Fluss. $I$. $t .50$.

B. BOREA Zippelius ox Macklock in Bijdr, tot. de nat. Weiensk, V. 142. Ferrusac Bullet. XVIIT. 92.

9, BOSCA Flor. Flum. IV. $t, 11$.

10. BURECd Zippelius ex Macklock in Bijdr. tot. de nat. Wetensk. V. 142, Ferrusac Bullet. XVIII. 98.

11. CALYPTERIS Zippelins ex Macklock in Bijdr. tot. de nat. Wetensk. V. 142. Ferrusac Bullet. XVIII. 98.

12. CANiCIDIA Flor. Flum. $I V, t, 139$.

13. CARPOCALYMMA Zippelins ex Macklock Bijdr. tot. de nat. Wetensk, $\nu$. 142. Ferrusac Bullot. XVIIT. 92 ,

14. CATONIA Flor. Flum. IV. $t .8$,

15. CELSA Flor. Flam, IV. t. 93.

16. CheObula Flor. Flua. IV, $t, 136$.

17. Consueghia Caldas. Semin. Nov, Granad, 1810.

18. CYNOTOXICUM Flor. Flum. IV. $t, 186$ - 188.

19. CXRTONORA Zippelius ex Macklock in Bijdr, tot. do nat. Wetensk. V. 142, Ferrusao Bullet. XVIII.92.

20. DEMOCRITEA Flor. Flum. $I V, t, 106$.

21. DISTREPTA Miers Travels in Chili II. 599.

22. DONATOPHORUS Zippelius ex Macklock in Bijdr. tot. de nat. Wetensk, V. 142. Ferrusac Bullet.
XVIII. 92 .

23. DULACIA Fior. Flua. 1. $t$, zs.

2'. DUNALIA R. Brown in Salt. Abjss, LXIV, (Didynam. angiosp.)

25. DXSEMONE Forster Comment. Gölting. $L X, 45$, (Dioica.)

26. EPIGENIA Flor. Flum, $I V . t, 138$.

27. HESIODA Flor. Flum. IV. $t, 140$.

28. ISOPTERIS Wallich Catalog. n, 7261.

29. IVONIA Flor. Flam. III, t. \&.
30. KUGLA Bertero ex Lindley Introduct. ed. 2. p. 438.

31. LERETIA Flor. Flum, III, $t, 2$.

32. LEUCANTHA Zippelius ex Macklock in Bijdr. tot, de nat. Wetensh, $\nu$. 142. Ferrusac Bullet. XVIII.92.

33. MAPA Flor. Flum. I. $t, 153$.

34. MELANIUM Zippelins ex Macklock in Bijdr. tot, de nat, Welensk, V. 142. Ferrusac Bullet, XVIII. 92.

35. MICHOXIA Flor. Flum. $\nu$. t. 103.

36. MNASSEA Flor. Flum. $1 V ., t, 147$.

37. NANGHA Zippelius ex Macklock in Bijdr, tot. de nat. Welensk, V. 142, Ferrusac Bullet. XVIIL. 92.

38. NARDA Flor, Flum, $I I T, t, 24$.

39. PEETOCARPUS Zippelius ex Maoklook in Bijdr. tot de nat. Wetensk. V. 142. Ferrusac Bullet. XVIII. 92 .

40. PERONIA Wallich Catalog. n. 7543.

41. PETAGNA Rafinesq. Specehio.

42. Petalostema R. Brown in Salt. Abysin, $X L I V$.

43. PLATYSTIQMA R. Brown in Wallich Catalog. n. 7523. non Benth.

44. POMBEA Caldas Semin, Nov. Granad. 1810.

45. POMETIA Flor. Flum. III. $t, 87$.

46. POROCILLAEA Miers Travels in Chili II. 599 .

47. ROMANA Flor. Flua. $T$. $t, 147$.

48. RUTILlA Flar. Flum. IV. $\iota, 19$.

49. SALDANHA Flor. Flum. III. t, 257.

50. SARCOCALYX Zippelius ex Macklock in Bijdr. tot. do nat. Wotensk. $\nu$. 142. Ferrusac Bullet. XVITI. 92.

51. SERJANIA Flor. Flum. . $t .35$.

52. STEPHANOSTOMA Zippelins ex Macklock in Bijdr. tot. de nat. Wetensk. V. 142. Ferrusac Bullet. XVIIT. 98 ,

53. TENOREA Rafinesq. Specchio.

54. THEVETIA Flor. Flum. I. $t, 151$.

55. TURRETTA Flor. Flam. $P, t, 115$.

56. Valenzuelia S. Mutis Semin, Nov. Granad. 1810.

57. VIGIA Flor. Flum. IX, $t, 128$.

58. VIVIANIA Rafinesq. Specchio. 
SUPPLEMENTUM I. 


\section{Ordo T. Dintomeaceas.}

Diatomaceas plurimas verisimiliter e reguo vegetabili esse eliminandas, olim jam monuimus, earum natura animalis nunc argumentis, etsi nuper iterum impuguatis, satis per se adhue validis, evicta plerisque videtur.

\section{Ordo II. Floridace.}

54. Splanerococens $A G A B D H$.

f/1. STENOGRAMMA, Harv. Frous membranacea, plana, enervis. A pothe ef a liaearia, nerviformia, in froade sparsim sessilia, granulis minutissimis repleta.

Stenogram a Harvey in Hooker ad Beechey 408.

\section{Ordo VII. Fencacene.}

\section{NInerecystis $A G A R D H$.}

„Fructus maculae abnormes, in foliis radicalibus sparsae, coloris abscurioris; constantes sporidis latescentibus, granulatis, ellipticis (in perisporiis cuneatis, ligulinis inclusis ?) Frons: eaulis filiformis et folia ensiformia vesiculae petiolatae insidentia, disereta, Agardh in $N, A . N, C, X I X$. 283. t. 26. 27. et 28. f. 1-10.

$110 / 1$. Playllospora $A G A R D H$. F r o n 8 e canle explanato et foliis distichis, discretis, tandem fructiferis, rugosis, tuberculatis constans. Tubercula poro pertusa, intus includentia fila articulata, simplicia, et sporidia massa sporacea, nigro-fusca repleta, extus margine hyalino cincta.

Phyllospora Agardh N. A. N, C. XIX, 311, Fucus e a mo s u s Labill. Nov. Holl, t. 28. f. 11-13,258. Turaer Fuc. $t, 142, \mathrm{~F}$. M enziesil Turner $t, 27$.

\section{Cloussis III. Fungi.}

Vastissimae elassig dispositio, quam quatuor ab hine annis duce Hilastri Friesio proposuinus, nova Fuogorum genera acervatim nostris diebus proposita non capit, reformandi enim singulorum ordinum characteres, novis limitibas cireamscribendae tribus, et aliis genera sedibas collocanda, ut advenarum gregi detur locus. Qui itaque in libri nostri supple. mento genera vel a clarissimo Friesio inter Hymenomycetes nuper exstructa, v. in celeberrimi Corda variis libris evulgata desiderant; ignoscant velim homlni occupatissimo et longi laboris taedio fesso, verenti simul in bac orbis vegetabilis regione, inquilinis senatus mycologief discordils vexata, et minime sibi proh dolor familiari, ultra virium modulum relatoris personam sustinere.

\section{Drdo XVII. Ricciaceat.}

454. IRieela MICHEL.

Lindenb. in $N, A, N, C, X V I T, 413, t, 19 \_32$, Nees Leberm, IV. $38 s$.

45.5. Spla aerocarpus MICHEL. IV. 361 .

Liudent, in N. A. N. C. X $\nu I I T$, 496. Nees Leberm.

456. Dxymitra BISCHOFE.

Lindenb: in N. A. N. C. XVIIT, 491, 1. 35. Nees Leberm. IV. 379. Tesseliniale sp. Dumort.

A5\%. Conginia RADD.

Lindenb, in N. A. N. C. XPTI, 413, t. 33_34. Nees Leberm. IV. 373 Tesselinia s p. Dumort.

458. SEDGWICKIA Bowd. excl. syn. cit. delenda, verisimiliter ad Lunulariam amandanda. Ait on i a Forst. Via. sub Nr. 467 .

\section{Ordo X VII. Anthocerotene.}

459. Anthoceros MICHEL,

Nees Leberm. IV. 387.

a. Eu anthoceros. Frons costata.

b. Anthocerites Cord. Frons costata. A. dichotomns Radd, in Act, Academ. Sen, IX, c. 4. A, Raddit Corda Rhizosp. et Hep. t. . ., f, $11-18$.

450. Niondelea HOOK.

Bot, Misc, I. 117, t, 27.

461/1. CLADOBRYUM Nees ex Linaley Introduct. edit. II. p. 414. Monoclea BI amii Nees Hepat. Jav. Character generis nondum editus.

\section{Ordo XII. Taryeoniaceae.}

461. Trargion 1 Mina MICHEL.

Nees Leberm. IT. 295.

\section{Ordo XX. Mrarchantiaceae.}

483. Cheimunalatia RADD. F 1 o r es $m$ a sculi disciformes, frondi immersi $v$, in ea sessiles. Cap ituli feminei rhachis incrassata, lobata, radiis nullis. In v o l u cru m nullum. Involncell a loborum marginibus continua, brevi tubulosa. Caly ptra persistens, sporangii basim cingens. Sporangium medio circumscissum, pedicello brevissimo, immerso, solubili, - Terrestres, fronde crassa, confertim areolata et poroso scabra.

Grimmaldia Raddi in Opusc. sctent, Bologn. II. 358. Nees Leberm, IV. 221. Ple uro ehiton Corda msc. Syndonisce et Mannia Corda in Opits Beitr. 646. Marchantia fragrans Balbis.

463/1. Duvalia NEES. Flores masculi..... Capituli feminei rhachis incrassata, integra. Involacrum nullum. Involacella discreta, brevia, annularia. C a l y $\mathrm{p}$ tra persistens et perigonii basim cingens v, evanescens, $\mathbf{S}$ p ora ngi um supra medium opereulo circumscissum, pedicello brevissimo, immerso. - Saxicola, fronde infirma, medio subincrassata, obsolete areolata, eporosa.

Duvalia Nees in Berlin. Magaz. VIT, 271, t. 10. LeBerm, IV. 245.

\section{Finmbriaria NEES.}

Zeberm. IV, 259. Hypenantron Corda in Opils Beitr. I. 648. D ietyochiton Corda mse.

485. Fegatells MICHEL.

Nees Leberm. IV, 179. Conocephalas Hill. non Blum. (infr, $n, 1869$.) Nomina cum el. Nees commodins permutands, ne novum pro genere Blumeano introducendam. Cy o o e phalum Wigger. Holsat, 82.

46B. Tumularia MICHEL.

Nees Leberm. IV. 11. S e d w i ckta Bowdich supr, $n$, 458. exel. omn, synon.

\section{6\%. Plagioelnasman LEHM.}

Plantae Europae australis, nepalenses, eanarienses et pernanae. Nees Leberm, IV, 33, Otiona Carda in Opitz Beitr. I. 33. S e d g w fek i a Biseholf in N, A, N, C. XVII. 1079 t. 10. f. 4. non Bowd. A It o d l a Forster Gen, 147. in Comment. Gotting. IX. 46. R a pinla Linn. $f$. Suppl. 462. Amoen. Academ, [X, t, 15. f. B, Reboullita wa de. rens is Raddl. 
46g/1. Antroceplualus LEHM, F lores maseuli disciformes, semiimmersi. Capitali fructiferi monanthi rhachis nulla. Involnc $r \mathbf{n m}$ nullum. I nvol ucell um subglobosum, subtus paleaceo barbatum, apice transversim bivalve, $\mathrm{C}$ aIy tra persistens, inaequaliter rupta. S p or a ngi i m sessile, extrorsum spectans, laciniis valde inaequalibus dehiscens. - Herbula nepalensis; frondibus caespitosis, sinuoso crenulatis, glaucoviridibus, hinc illine fusco-purpureis, fructificationibus in medio sulco frondis seriatim dispositis.

Antrocephalus Lehmann in N. A, N. C. XVIrT. 682, $t, 52$.

\section{Rebouillia $R A D D$.}

Nees Leberm, IV. 197. Asterella Palis. R haciocarpon et A ehito a Corda in Opitz Beitr. I, 649. Me$s$ oreg m a Corda?

488/1. Sauteria NEES. Flore s masculi ..... (iapituli feminei rhachis bi-quinquepartita, lobis usque ad basim discretis, radiis interjectis nullis v. denticuliformibus. In vo I $\mathbf{c}$ er a m nullum. Involncell a discreta, rhacheos lobis adnata, cum iisdem tubum declinatum formantia, ore lato dehiscentia. Caly ptra persistens, irregulariter rampens, involucrum aequans $\mathbf{v}$. superans. S porangium globosum, semi-quadri-sexvalve, pedicello immerso. - Herbulae alpinae, fronde subsimplici, papilloso-arealata et porosa.

$\mathrm{S}$ anteria Nees Leberm. IV. 139. H a m p e Nees me. L u nula ria a l pina Bischoff in $N$. A, N. $C, X V I, t, 67$. f. $22 \_28$.

469. Dumortiera NEES.

Leberm. $I V .45 . \mathrm{H}$ y $\mathrm{g}$ o $\mathrm{ph}$ il a Mackay Flor. Hibern.IT. 53. H y g r o p y la Taylor in Linn. Transaet. XVITT. 390. - Spathy sia Nees Leberm, 178.

4\%. NIareluantia $M A R C H$,

Nees Leberm. IV. 57 .

a. AStromarchantia Nees $l$. c. Re cepta c u lu m femineum centrale.

b. CHLAMIDIU M Corda in Opitz Beitr. I. a47. Re ce p ia. c a I u m femineuar excentrieum.

47 1. Preissia NEES. F lore $\mathrm{s}$ a seuli peltati pedunculati, v. disciformes in sinubus loborum frondis sessiles. Ca pituli femin ei rhachis radiata, radiis membrana frondiformi junctis, subtus floriferis. Involncra mono-triantha, radiis alterna. In vo I n cella quadri-quinquefida, $\mathrm{Ca}$ lyptra persistens, apice oblique rumpens. Spora $\mathrm{ng}$ i u $\mathrm{m}$ in lacinias plures irregulariter dehiscens. - Vegetatio frondosa, parcius furcala, ex apice imprimis articulatim innovans,

Prels sia Nees Leberm. IV, 113. Pretssia et Cho. m locarpon Cordain Opitz Beitr. . 647 . M are hant com utata ot M, quad rat a Auet.

\section{Drdo XXI. Iungemmanniaceac.}

Júngermanniacearum genera infra e sententia clarissimi Nees ab Exenbeck exponi jam posse, meenm laetantur bo tanici cordatiores, qui probe perspeetum habent, olim a nobis repudiandas fuisse divisiones varits introductas aucto. tanti virl verbidoneis stabilitas eharaeteribus, et ipsissimis tanti virl verbis atro notatas caleulo, Hodie absolato Neesia. no volumine, cujus ture nonnisi particulam prae manibus habuimus, aliter jam res se habent et euncta apte cohaerent, et exponi possunt ia opere, in quo non reformandum fuit, sed exponendum, ut tandeu habeatur hodierni systematis bo taolei una imago, et quid in tali aedifieio sit sanum, quid ipsa mole sua laborans peritos poscat artifices, appareat.

TRREUS 1. FRONDOSAE Nees Leberm. III. 309. Sp orang i um ad basim quadrivalve v. irregulariter quadridentatum. In vo lucrum saepissime monophyllum. Involu- cell a m membranaceum v. nullum. - Vegetatio frondosa, v. late foliacea, foliis subconfluentibus. Plantae terrestres, limnobiae.

SECTIO I. METZGERIEAE Nees Leberm. III. 47 9. I u v o l u ce 11 u m nullum. F ructificatio utraque e latere ventrali costae frondis emergens, bractea monophylla amphigastrioide suffulta. Antheridia costae squamae involucralis inserta.

47. NIetzgeria RADD, Frnctificatio e latere ventrali cstae mediae frondis, adscendens. Fem. Involuerum monophyllum, ventricosum, incumbens, demum bipartitum. Inv ol n c ell um nullum. Gerinin a pauca. Calyptra longe exserta, obtusa, carnosa, setis rigidis hirsuta, stylo non coronata. S porangi um ovali-subrotundum, quadrivalve. E la t eres plerique a picibus valvularum contractis inhaerentes, carnoso-erecti, persistentes, utrinque attenuati et clausi, monospiri, fibra lata, gyris tabo aequalibus v. angustioribus. Masc. in distincta planta. Involuera ut in femineis, costae subtus et a latere alternatim inserta, ventricosa, costa media praedita. Antheridia intra quodvis involucrum 2-3, costae filamento brevi inserta, subglobosa, involncri ventre recondita, - Herbulae truncigenae, saxicolae $v$. rarius terrestres, in locis umbrosis humidiusculis vigentes, frondibus linearibus, dichotomis, costatis, marginibus costaque saepe ciliatis, costa discreta, limbo membranaceo, tenui, e simplici cellularum strato formato, radiculis in costa sparsis, brevibus, papilliformibus $v$, cylindricis, gemmis in frondium sterilium lacinits attenuatis aggregatis, ovalibus, cellulosis, coloratis, partubus vivis foliaceis a costatae latere ventrali nascentibus, $v$. ex involucris luxuriantibus ortis, deciduis v. persistentibus.

Metz geria Raddi in Mem. sac, Ital, XVITI, 45, $t, 7$. f. 1. Nees Leberm. IIT, 481, IV. XXVIII. non Corda. E c hia o mitrinm Corda apud Sturm. II. 22, 23, t. 22. Nees Leberm. I. 103. E eli in ag y n a Dumort. Syllog. 83. $t_{4}, 2$. f. 28. Fas ciola Dumortier Comment. 114. J n agermani ia fureata Linn. Hook. Br. Jung. $t, 55,56$. J, p a b e sce as Schrank. Hook. Op. oit. t, 23. J. fucoides Sw. J. ulvoides Nees.

SECTIO II. ANEUREAE Nees Leberm. III. 419. In voluc e $11 \mathrm{am}$ nullum. Fructus e latere frondis ventrali juxta marginem, aut ex ipso margine oriens. Ant he ridia in lobulis lateralibus dorsalia.

4รF/1. Trielnostyliam CORDA, Fructificatio feminea frondis paginae dorsali juxta marginem imposita. Involucrum et involucell u m nullun. Cal y ptra subclavata, herbacea. S porang inm ovale, hinc rima hians. Elate res columnulae centrali, deorsum abruptae, pendulae inserti. Antheridia in frondis superficie sparsa, nuda, ovalia, filamento brevi praedita. - Frondes enerves, e ventre medio repentes, carnosae, laciniis oblongis v. cuneiformibus, obtusis, lobulatis et undulatis.

Trichostylium Corda apud Sturm. Ir, 26. 27. p. 116. t. 34. Nees Leberm, III. 475. IV. XXVIXI. - Genus a cl. Nees non visum.

4\%a/2. Aneura DUMORT. Frnctifi$c$ atio feminea marginalis $v$, inframarginalis adscendens. I n v o l u e r u m breve, tenue, laceram. I n v o I u c e I I a $\mathbf{m}$ nullum. G e $\mathbf{m}$ in a pauca. Ca 1 y p tra longe exserta, cylin- 
drica, carnosa, demum erasse chartacea, parce radiculoso-puberula v. tubereulata, stylo haud mu cronata. Sporangi n m oblongum, quadrivalve. Elateres plerique cum sporis decidui, nonnulli valvularum apicibus contractis adhaerentes, comoso-erecti, persistentes, apice attenuati et clausi, monospiri, fibra lata, gyris tubo amplioribus. Ma s c. in diversa stirpe. Involueram marginale, breve, lobuliforme. Ant herid a involucris a dorso immersa, globosa, flamento brevissimo. Herbulae terrestres, in humidis uliginosis, muscosis, juxta scaturigines et ad rivulorum ripas vegetantes, fronde enervi, aequabili, carnosa, e cellulis parvis, conformibus conflata, radiculis per totam paginam inferiorem sparsis.

A neura Dumortier Comment. 115. Syllog. 85. $t$. 2. f. 23. Nees Leberm, III, 423. IV. XXVIII. Koe mexia Raddi in Mem. Soc, ital. XVIII, 48, t. 7. f. 2. a. Metzgeria Corda apud Sturm 1T. 19. 20, p. 57. t. 15. Nees Leberm. I. 90. nou Raddi! Sar com It ri u m Corda Op. cit. IT. 26, 27. p. 120, 2. 35. G y m o mitrii sp. Hueben, B I a. siae sp. Fries, Link. Jungermannia pinguis Link. Hook. Op. cit, $t$. 45. J. pal m at a Hedwig Theor. gen, ed. 2. t. 20. f. $5-7, t, 21 . f, 1-3$.

SECTTC III. HAPLOLAENEAE Nees Leberm. III. 313. Involacellum nullum. Fructus e sinu frondis apicali dorsalis.

4\% \%/3. BBasia MICHEL. Fructificatio feminea perfecta costae frondis immersa, pednneulo ex apice emergente. Invol ucrum nullum. Involucellum nullum, nisi stratum cellulare cavi costalis interius, primitus discretam, utriforme, apice suo fruetus superficiei affixum, mox evanescens, v. cavitati costali accrescens, saepe omnino nullom, G erm in a sterilia plura, in costae superficie superiore sparsa, nuda, alia ad ejus apicem congesta, fertile unicum, internum. S p oran gi um elliptico-globosum, basi calloso-truncatum, ad callum usque quadri (nonnanquam quinquesex.) valve. El ater es circa basim affixi, mediocres, ntrinque attenuati, dispiri. Sporidia subrotunda, centro obscuriore. Mas c. Antheridia frondi nervoqne immersa, subtus magis pro. minula et sq $\mathbf{n}$ amula dentata tecta, subglobusa v. ovalia, granulis foeta, filamento nullo. - Herbulae terrestres, limosae, fronde costa media, interdum obsoleta praedita, radiatim dicholoma, pinnatifido-sinuata, e cellulis conformibus, in casta protractis conflata, amoene viridi et vegeta, radiculis plurimis e costa media provenientibus, propagulis in globulos intercellulares, parti membranaceae frondis immersos, subtus prominulos, virides compactis, minutis, subglobosis, pellucidis, gemmis in utrictlos infra apicales solitarios geminosve, frondis costae immersos, tubuloque adscendente praeditos collectis, demum per tubulos exclusis, subglobosis, polyedris.

B I a s i a Michell Nov. Gen, 14, t. 7. Linn. Gen, n. 959 Schmidel Dissert, de Blasia. Erlang. 1759. 4. Dumortie Comment. 115. S,llog, 81. t, 2. f. 20. Corda apud Sturm. II. 19. 20. p. 49, t. 13, 22, $23, p, 83, t, 23,26$ et $27, t, 36$. Nees Leberm. III. 39t. IV. XVII. Jungermanni a Blas i a Hooker Brit. Jungerm. t. 83.84.

47 2/t. Symaphyogyna NEES et MONT. Fructificatio feminea. Involucrum squama rigidnla, varie fissa, genitalia tegens, e nervo frondis orta, plana v. subconvolnta. Germin a plurima, basi connata in globum carnosum stylis tiberis coronatum, unico fertili centrali immerso. Ca l y p tra e germinibus sterilibus concretis crassa et coriacea, stylorum reliquiis coronata, pedunculum cum sporangio includens, demum rupta, ore sty- lis fimbriato. S poranginm oblongum, pedanculo basi subbulboso. Elateres parietales, fusiformifiliformes, flexuosi, opaci, dispiri, fibris latinsculis, coloratis, arete contrarieque contortis. Sporidia globosa, minute granulata. Fruetificatio mascula in ejusdem cum feminea $v$. in diversae frondis pagina superiori, juxta nervom disposita. Invol u cri foliola imbricata, incisa, membranacea, bullata. Antheridia filamento brevi suffulta, depresso-globosa, incumbentia, - Herbulae tropica e; fronde lineari, dichotoma, membranacea, nervo medio dístincto praedita, e nervi pagina superiore fructum promente, subtus per intervalla e nervo radicante, $v$, inferius in stipitem radicantem et repentem abeunte.

$S$ ymplyogyua Nees et Moatagn. in Nouv. Annal. sc. nat. $V$. 66. Jungermannia brastiliensis Nees et Martius Ic. select, ergptog. $t, 15 . J$. ph y Il a in th us Hook. J. $r$ hizobola Hook.

$4 \% 2 / 5$. IPellia RADD. Fructificatio feminea infraterminalis, e dorso frondis emergens, v. fronde a latere continuata spurie terminalis. Involucrum breve, subcyathiforme, ore lacero-dentato. Involu cel I n m nullum. Germin a plura, longa, ore dilatato. Caly p tra exserta v. inclusa, germinibus sterilibus paucis, imprimis inferne conspersa. Sporang i um globosum, quadrivalve. Elateres e basi sporangii orti, intricati, praelongi, dispiri, solubiles. S poridia ovalia, laevia. Mase. Antheridia (?) globosa, enstae frondis a tergo inmersa. - Herbulae terrestres, uliginosae, ripariae, frondosae, costa media indeterminata, tractu frondis medio paullo crassiori indicata.

Pellia Raddi in Mem, soc, ital, XVIIn. 49, t. 7. f. 5 . Corda apud Sturm II. 19, 20, p. 59. t, 16. 26. 27. p. 141, t. 39. Nees Leberm. IIT, 357, IV, XXVIT. S copulina Dumort. Comment. 11s. Syllog. 129, G y m n o mit rit sp. Hueba. J ung erm a nni a e piphy 11 a Linn. Hedwig Theor. Gener. t. 23_25. Hooker Brit. Jungerm, t. 47. (Do Pellise structura anatomica vide Schleiden in Wiegmann Archiv. 1839. 4. Heft, p. 281.)

SEC'TIST. DIPLOMITRIEAE Nees I eberm. III. 313. Involu crum breve, involucellum chartaceo-membranaceum cingens.

4ร2/6. IsIytia. Fruetifie atio feminea e costae termino infra frondis apicem emergens, demum dorsalis. I nvo lncrum quadri-quinquepartitum, laciniis laceris. Involncellnm involuero longius, herbacenm, tubulosum, subangaIatum, ore lacero-denticulato. Germina 8-20. Ca ly ptra chartacea, involucello brevior v, aequilonga, subeampanolata, vertice lacero. Sporang i $\mathbf{u}$ m quadrivalve. Elateres capsulae parietibus undique inserti, filiformes, longiusculi, dispiri, decidni. S p o r a e subglobosae, granulatae. M a s c. dorsales, costae impositi, foliolis dentatis incumbentibus tecti. Anth eridia plurima, obovata, filamentis brevibus. - Herbulae terrestres, uliginosae, fronde simplici $v$. bifida, costa media ante apicem limbi membranacei desinente, radiculosa praedita, ampligastriis nullis, floribus masculis in eadem $v$, in diversa stirpe.

Diplolaena Dumortier Syllog. 82. t, 2. f. 21. Neen Leberm. III. 335, IV, XXYII. DII a e n a Dumort. Comment, 114. Diplomitrii sp. Corda. Cordaca Nees in Flo. ra 1833, II. 401. Corda apud Sturm II, 2697. p. 125. t, 36. Jungermannfa L yellif Hook, Brit. Jung. t. 88. J. B I y til Flor, dan. $t$, 2004.

SECTI W. CODONTEAE Nees Leberm. III. 313. Involuerum dorsale subcampanu- 
latum. Involucellum nullum. Capsula irregulariter quadrivalvis v. lacera, valvis ex parte deciduis. - Foliatio discrela, succuba, laxissima.

4 g 2/7. Fossombronia RADD. F ructificatio feminea: Involucrum in caule terminale, post innovationem dorsale v. furcationi impositum, gamophyllum, obconico - eampanulatum, ore amplo, aperto, crenato $\mathbf{v}$, dentato. Involucellum nullum. Germina pauca, in fundo involucri deoperta. Sporangia globosa, irregulariter quadrifida, valvulis erosis, tenuibus, apice denique evanescente. Elateres parietales nndique affixi, breves, decidui, dispiri. Masc. dorsales, e caule gregarie absque ordine erumpentes, erecti, nudi, immixtis partibus germiniformibus, - Herbulae pusillae, limnobiae; caule repente, simplici $v$. innovando-diviso et furcato, foliis discretis, latiusculis, succubis, lobatis et undulatis, mollibus.

Fos som bronf a Raddi in Att. soc. Ital, XVIIT, 40. t. 5. f. 4. 5. Nees Leberm. 111. 317. IV. XXVIT. Codo. ni a Dumortier Comment, 111. Syllog. 30, t, 1. f, 1, J u n. germannia pusill a Schmidel Analys. t. 22. Hooker Brit. Jungerm. 1. 69 .

T' III. 135. S porangi um membranaceum, rarius firmius, ad medium v. profundius valvatum, pedunculo brevi. Involucella in ramulis brevibus terminalia, brevia, compressa v. angulata subtusque carinata. C a I y p tra in omnibus. - Folia incuba, subtus lobulata v. auriculata. Ramifieatio pinnala. Plantae corticolae v. saxicolae.

AF\%/8. Lejeunia LIBERT, Fructifio atio feminea in ramulis terminalis, ant his brevissimis e caulis latere ventrali infra folia oriens. Involucri folia duo, profunde biloba. Involucellum subsessile, teres v. angulatum, apice truncatum v. mucronatum, foliaceum. Germina pauca. Calyptra obovata, tenui-membranacea, reticulata, persistens, stylo coronata, infra verticern rumpens. Sporang i um in pedunealo brevi annulato-articulato, genieulis acute prominulis, globosum, membranacenm, ad medium quadrivalve, valvis conniventibn. El a teres apicibus valvarum affixi, erecti, tabo apice truncato et dilatato - aperto, tenuissimo, monospiri v, subdispiri, persistentes, S porae majuscnlae, irregalares v. ovales aut oblongae, subangulatae. Masc. in diversa stirpe v.ramo, Ra m uli staminigeri oblongi, dense bifariam imbricati. Folia involucralia basi ventricoso-produeta, concava, am. plectentia, lobulo ventrali majore, plano. Antheridia intra basim ventricosam foliorum solitaria, globosa, filamento brevi, - Herbulae in aliis muscis $v_{\text {, in }}$ plantarum diversarum cortice et foliis parasiticae, nonnullae rupicolae v. terrestres, caespitosae, $e$ dorso amphigastriorum v. infra amphigastria e caule radicantes, plerumque tenues et laxissimae, nonnullae, imprimis epiphyllae, inordinatim et subfasciculatim ramosae, ramis e caulis latere ventrali nascentibus, foliis rotundatis $v$. acutiusculis, incubis, basi subtus complicatis, lobulo parum discreto, planiusculo, involuto, nunquam saccato, interdum leviler plicato, amphigastriis ut plurimum bidentatis $v$, rarius integris, rarissime nullis.
Lejeunia Libert in Annal. gen. sc. phys. PI. 379. c. ic. Dumortier Comment. III. syllog. 32, $t, 1, f$. 3. Corda in Opilz Beitr. I. 652. Nees Leberm. I. 100. (ex part.) III. 255. ID. XXVI. Jungermanuia serpyllifolia Lina. Hook. Brit. Jungerm. $t$. 42. J. c a I y ptrifolia Hook. Op. cit, $t$. 43. J. in in utiss ima Smith Hook. Op. cit. $t, 38$, Suppl. $t, 3$, J. h a matif oll a Hook, Op, cit. $t, 51$.

4ร : 9. PPreagmaieoma DUMORT. Fructificatio feminea in ramulis terminalis $v$. subterminalis. Involacram diphyllum, foliolis subconformibus, profunde bilobis. Involuc ellum porrectum, depresso-planum, subeordatum cum mucrone, bilabiatum, ventre obtuse carinato, textura folioram, Germina plura, Calyptra demum globosa, tenui chartacea, persistens, stylo coronata, infra verticem disrumpens. $S_{p}$ oranginm in pedunculo brevi, bullulato-celluloso, haud articulato globosum, membranaceum, ultra medium quadrivalve, valvis erecto - patentibus, El a teres parietibus internis valvularnm a medio apicem versus affixi, erecti, tubo apice truncato et aperto, dispiri, persistentes. Sporae subglobosae, plerumque angulatae, M a s c, in diversa stirpe. Ramuli staminigeri elavati, densius imbrieati. Folia involneralia basi nonnibil ventrieosa, lobulo infero majori. A nt he ridia intra basim ventricosam foliorum gemina, innata, globosa, filamento brevi. - Herbulae rupicolae v. corticolae, pulvinatae, e caule infra amphigastria et ex amphigastriorum dorso repentes, inordinatim $\mathrm{ra}$ mosae, ramis infra folia e caulis latere ventrali nascentibus, rigidulis ; folits rotundatis, incubis, subtus lobulo inflexo, haud saceato, levi sinulo disereto instruetis, amphigastriis integris v. rarius bidentatis.

Phragmicoma Dumortier Commont, 12. Syllog. 35. t, 1. $f$. 4. Nees Leberm, III, 245. IV. XXVI. Jung erm a nni a Ma c k ail Hooker Brit. Jangerm, . 53. Le je uui a s p. Spreng.

4\% 2/10. Frullanta RADD. Fructificatio fe mine a in ramulo proprio terminalis. Involucrum di- v. tetraphyllum, foliolis subdifformibus, lobulatis, nec anriculatis. InvolucelI $\mathrm{m}$ porrectum, breve, dorso convexiusculo, saepe bicarinato, ventre medio ventricoso - carinato, apice subretuso cnm mucrenulo tubuloso, bilabiatum, textura foliornm. Germ in a 2. Caly ptra pyriformis, tenuis, persistens, stylo coronata, infra verticem rumpens. Sp orangium subglobosnm, tenue, ultra medium quadrivalve, demum campanulatum, valvis patulo ereetis. El ateres parietibns interioribus valvularam a medio apicem versus affixi, adscendentes, apice truneati et aperti, monospiri, persistentes. S $\mathrm{s}$ or a e parvae, subpolyedrae. M a s c. in diversa stirpe. R a mali staminiferi breves, ovales v. obovati, obtusi, disticho-imbricati. Folia involucralia ventricosa, profonde bifida, laciniis subaequalibus, majusculis, amphigastriis exiguis v. nullis. Antheridia intra inflatam folioram basim solitaria v. gemina, globosa, filamento gracili, septato, - Herbulae corticolae, e caule infra amphigastria repentes, vario modo plumoso-ramosae; caule tenui, rigidulo, foliis incubis, subtus plerumque lobulo inflato, ad basim fere discreto, diversiformi, amphigastriis distinctis, integerrimis $v$, bidentatis.

Frullania Nees Leberm. IIT, 209. IV, XXYrT.

a. JUBULA Dumort. Involucellum dorso bicarimalatum. Stylus mediocris. Foli a subtus lobalo a caule disereto, plerumque convoluto vesiculari. Amphigastir i a bifida.

Rrullania Raddi in Mem, soc. ilalian. Moden, 
XVIIT. 20. t. 2. f. 2. J ubula Dumortier Comment. 112. Syllog. 56. t. 1, f.5. Corda apud Sturm 11. 26. 27. p. 144. $t$, 40. Jungermannia dilatata Lina. Hook. Brit. Jungerm. $\ell$. 5 . J. ta a a $\mathrm{r}$ is c ifolia Lian. Hook. Op.cil.t. 6. J. H u t chins ia e Hook. Op. cit.t.1. Le je unia e s p. Corda apud Sturm $t .12$.

b. BRYOPTERIS Nees. I nvol a ce II u m triquetrum, dorso laevi. Stylas longus. Folia subtus jobulo inflexo, plano, parvo, haud discreto. Amphigastria truacata, dentata. - Species omnes exoticae.

B ryopteris sect. Frullaniae Nees Leberm, III. 211. In not. S c hult bes ia. Raddi Cryptog. brasil. 10. Jungermannia filleina Swartz. Hooker Musc. exot. $t$. 142.

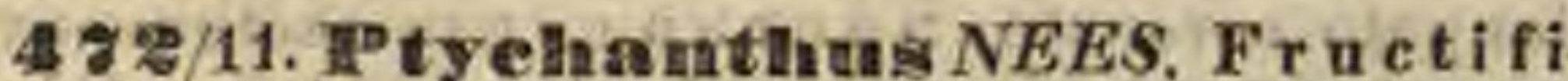
cat io feminea ex angulo ampligastriorum sessilis, deorsum spectans. Involucrum praeteramphigastrium nullum, rarius foliolo exiguo accedente. I n volucellum oblongum, basi attenuata sessile, octo-decemsulcatum, primo obtusum, subumbonatum, demum dentibus angulorum numero, brevibus, incurvis dehiscens. Caly ptra pyriformis, vertice rumpens ..... M a s c. ..... Herbulae indicae; ramis primariis e surculo pro cumbente $v$, repente, sparsim ramosis $v$. pinnatis, folits incubis, imbricatis, basi plica inflexa instructis, amphigastrïs aut subquadratis, truncatis, aut sub. rotundis, integris $v$. retusis, integerrimis v. repanlo-dentatis, nec bifidis.

Ptyehanthus Nees Leberm, IIT, 211, in not. Jun germannfae sp. Nees et Lehm. - An hue Frulla nioi de s Raddi Cryptog. Brasil. 13.

48\%/12. WEallothees DUMORT. Fructificatio femine a in ramis lateralis, subses. silis. Involncri folia 2 v. 4, reliquis saepe minora, cum amphigastrio unico ad basim ramuli sito in ramulo florifero solum obvia. Involucell n m subter foliis e caulis latere egrediens, divergens, ovatum, biconvexum, ore bilabiato, integro v. inciso, textura foliorum. Germina plura, basi v. medio nonnihil ventricosa, stigmate dilatato, repando, Caly ptra globosa, tenui chartacea, persistens, infra verticem disrumpens. Spora n gi m pedunculo brevi, involucellum vix superante, crassinsculo, celluloso, haud articulato globosum, membranaceum, reticulatum, ad mediom quadrivalve, valvulis erecto-incurvis. Elatereg valvularum parietibus interioribus undique inserti, filiformes, utrinque attenuati, decidai, dispiri, tubo sub maturitate evanescente v. obsoleto, spiris angustis. Sporae majusculae, sphaeroideae, subangulatae. Fruetifieatio masen la in diversa stirpe. Ra m u li staminiferi breves, oblongi. F oIi a involueralia reliquis minora, aretissime disticho imbricata, basi inflata, convexa, ad medín usque bifida, laciniis subaequalibus, obtnsis, concariusculis. Antheridia axillaria, solitaria, sphae rica, crassa, fllamento brevi. - Herbulae rupicolae v. truncicolae, speciosae, pinnatim compositae, decompositae et supradecompositae, densis stratis crescentes ; ramis infra folia ex infero caulis latere egredientibus, obtusis, folìis incubis, profunde bilobis, lobo utroque plano v. infero margine reflexo, amphigastriis utrinque in caule decurrentibus et saepe cum folii proxime subjecti lobulo inferiore connexis, cauli appressis margineque saepe reflexis.

M a d ot hec a Dumortier Comment, 111. Syllog. 30, t, 1 . f.2. Nees Leberm. III. 157. IV. XXVI. B elilineinia et A a to $1 \mathrm{ria}$ Raddi in Att, soc. italian. Mod. XVIII, $18,19$. t. 1. f. 1. Por ell a Dillen. Hist. Mrusc. 459. t, 68. Lian. Act. Ups. 174t, p, 83, (Dickson in Linn, Transact. IIT, 239, t, 20, f. 1.) Jungermanaía la evigata Linn. Hooker Brit. Jungerm. t. 35. J. plat y p hylia Linn. Hook. Op. eit. t. 40. Suppl. $t, 3$. Lej e u $\mathrm{n}$ la e is. Corda apud Sturm II. t. 26 .

4\%\%/13. FEndalla DUMORT, Fruetificat i o fem in a in ramulo brevi terminalis $y$. ex dichotomia adscendens. I n vo I u e r i folia dao, profundius biloba. Involucellum trancatom, integervimum, depressum $v$. terétiusculum, ore truncato. Germina plura, stigmate radiato-dentato. Calyptra pyriformis, tenuis, diu persistens, stylo coronata, infra verticem rumperis. S porangin m ovale, profunde quadrivalve, valvulis erecto-patulis, tenuibus, laxe reticulatis, intus noduloso-striatis. Elateres valvarum parietibus interioribus undique imprimis basim versus affixi, dispiri, utrinque attenuati, decidui. Spora magnae, glwbosae. Fruetifieatio masunl a in eadem stirpe. $R$ a m $\mathrm{u} / \mathrm{i}$ staminiferi breves, obtusi, distiche imbricati. F o lia invelncralia minora, basi subinflata, lobulo ventrali minore. Herbulae corticolae v. rarius saxicolae, e flexura folii repentes, irregulariler pinnatim ramosae; caule tenui, laxo, folís incubis, subtus lobulo inflexo, plano, haud profunde discreto, amphigastriis nullis.

$\mathrm{R}$ a dula Nees Leberm, III. 143. IV, XXVI, R a du I a sectio Radulot y pus Dumortier $s$,llog. $38, t, 1 . f$. 6 . Comment, 112. J u a erman n 1 a complanata Linn. Hooker Brit, Jungerm. t. 81. C a ndolle a complan a ta Raddl in Alt, soc, ital. Mod. XVIIT. 24, $t .1 . f .3$.

TREIBU Hir. PTILIDIA Nees Leberm. III. 99. S porang ium solidum, rectum, ad basim usque quadrivalve. El at eres dispiri, decidui. In vo lu cell um nunc nullum v. cum involucro polyphyllo lacero connatum, diehotomiae impositum, nune tubulosum, ehartaceum, ramulum terminans. - Folia incuba, multifida, laciniis ventralibus antrorsum inflexis, lobulum formantibus. Ramificatio plumulosa. Corticolae, saxicolae et terrestres.

4 g $/ 14$. Ptilidiuma NEES, F r a ctificatio feminea ramigena, terminalis. Involu $\mathrm{c}$ i folia pauca, subconformia. Involucel Ium líberum, teres, membranacemm, ore connivente, subplieato, denticulato. Germ in a plara. Caly tra coriaceo-chartacea. Sporanginm ovatum, usque ad basim quadrivalve. Elateres fibra dapli. ci, nudi. Sporae sphaerieae. Fruetificatio mag $\mathbf{c} \mathbf{l}$ a in diversa stirpe. $\mathbf{R}$ a m $\mathbf{n}$ li staminigeri incurvi. Folia involueralia cum suis amphigastriis minora, arete imbricata, basi valde ventricosa, antheridis in cojosvis angulo duobus v. nnico. - Herbulae in truncis, saxis et ad terram limosam vegetantes; foliis incubis, decurvis, fissis, ciliatis.

Ptilldium Nees Leberm. I. 95, HI, 117. IV. $X X Y$. Jungermanulae sect. B I e pliarozia Dumortier $\delta y l$. log. 46. J. cilia ris Linn. Hooker Brit. Jungerm, $t .65$.

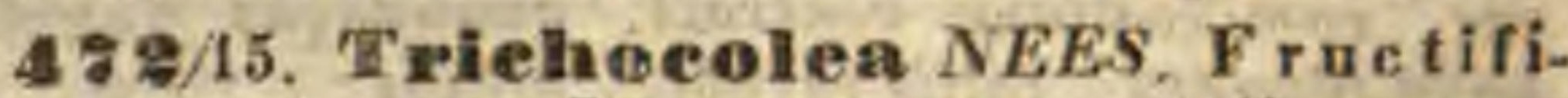
eatio feminea: Involucrum cauligenum e dichotomia, teres, coriaceum, ore irregulariter patulo, e foliis plurimis, setaceo-laceris, basi in tubum concretis constans. Involuceli a m nullum v. cnm involucro confluens. Germin a plara, primum bulbo obconieo, laevi imposita, demum peduneulo longo sublata, pedanculo a bulbo intruso et annulo artieulari secedente discreto. C al y p t ra nulla. Sporanginm usque ad basim quadrivalve, rigidum. El ateres fibra duplici praediti, decidui. Sporae sphaericae, laeves. M a sc. A n- 
theridia in superiori eaulis latere axillaria, globosa, filamento brevi, foliis involucralibus caulinis similibus. - Herbulae uliginosae, epigreae, pinnatim compositae et decompositae, foliis incubis, multifidis.

T richocolea Nees Leberm. III. 103.IV. XXV. T h r ie hol e a Dumort. Comment. 113. Thricole a Damort $s, l$ log. 66. $t .1 . f .8$. J a a germannia tomeutella Ehrh. Hook. Brit. Jungerm. . 36 , J. I a n a ta Hooker Musc. exot. t. 186.

TERIBUS IV. MASTIGOPHOREAE Nees Leberm.III. 87. Sp o rang i m coriaceum, ad basim quadrivalve, valvis recurvis, saepe incisis. El ateres dispiri. Invol ucrum terminale, v. ramulo proprio, brevi, laterali impositum, polyphyllum, foliolis imbricatis, profunde partitis, interioribus basi connatis. I nvolucellu m nullum. - Folia incuba, divisa, quandoque lobulo ventrali aucta, decurva. Ramificatio pinnata, ramis apice attenuatis, radicantibus. Terrestres, muscicolae.

4\% $8 / 16$. Semaltmera. Fructificatio feminea versus apicem caulis in ramulo proprio. brevi lateralis. I nvol a c r a m polyphyllum, ovato- v. clavato-imbricatum, e foliis et amphigastriis majoribus et magis incisis compositum, interioribus basi connatis, I n vo la cellum nullam. Germina plura. Sporangium globosum, usque ad basim quadrivalve, subcoriaceum, valvis latiusculis, recurvis, margine irregulariter inciso v. subdentato. Elateres valvalarum parietibus interioribns undique adhaerentes, decidui, filiformes, dispiri. Sporae subangulatae. Masc. Fruetificatio mascula in ramulo magis inferiori, trifariam imbricato, foliis involueralibus subconformibus. Antheridia $2-3$, subglobosa, filamento longo, multiseptato. - Herbulae ut pluri mum tropicae, epigeae, erectae $v$. adscendentes, amphigastriis bi-plurifidis, basi saepe calcaratis, ramulis furcatis $v$. dichotomis, rarius simplicibus, apice attenuatis, decurvis, secundis, teretibus, nonnunquam apice radicantibus.

Mastigophora Nees Leberm. IrT. 89. IV. XXV. Jungermannia Woodsii Hooker Brit. Jungerm. $t, 66$.

482/17. Selhisma DUMORT. Fruet if icatio feminea ramulo florifero elongato terminalis. I nvol u erum gamophyllum, sex-octofidum, e foliolis tribus v. quatuor bifidis conflatum. Involucell um nollum. Germina plura. CaIy $\mathrm{p}$ tra ovata, in fundo involueri latens. S pora $n$ g i m globosum, quadrivalve. E la teres fibra duplici nnda, Fructificatio masenla haud disereta. Antheridia in axillis foliorum involncralinm, conformium, basi inflatorum globosa, subsolitaria. - Herbulae terrestres, ut plurimum tropi cae, ramificatione ventrali, quandoque flagellari haud pinnata, folitis incubis, bifidis.

S c his un D Dumortier Comment, 114. Syllog. 77. Nees

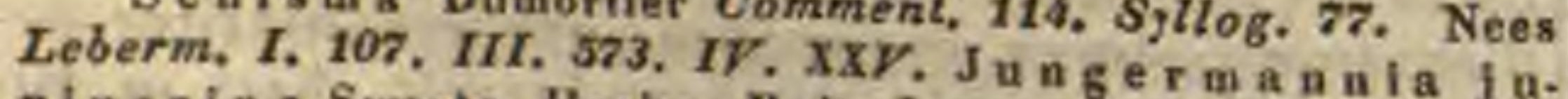
$n$ i perfn a Swartz. Hooker Brit, Jungerm, t. et Suppl, t, 1 .

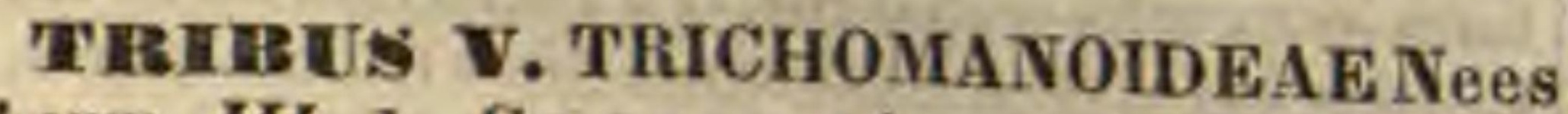
Leberm. III. 1. S porangium solidum, rectum v. tortum, ad basim quadrivalve. Involucellum ex inferiori caulis latere sessile v. ramulo brevi impositum, membranaceum, v. pendulum, carnosum et clausum. El a t e res dispiri, nudi. - Ramificatio vage subpinnata, saepius in flagella abiens. Holia subtus haud complicata. Terrestres.

4 8/18. Shysiotiunan NEES. Fructificatio femin ea in ramulo brevissimo laterali infera. Invol u er i foliola plura, inferiora minora, supremum amplissimum, convolutum, bi-trifidum. Invo I uce $11 \mathrm{um}$ fertile membranaceum, oblongolanceolatum, decurvum, sterilia et magis inferiora cylindrica, laevia, apice integro, pertuso. Germi na plura, Caly ptra tenuis, obovata, stylo elongato coronata. S p or an g i m rectum, ovale, irregulariter dehiscens, valvulis deciduis. E la ter es dispiri, decidui. S por a subglobosae, obsolete polyedrae. Fructificatio maseula ..... Herbulae epigeae, caespitoso-pulvinatae, sphagnoideae; foliis incubis, secundis, arcte reticulatis, subtus auricula inflata praeditis, amphigastriis nullis.

$\mathrm{P}$ hysiotium Nees Leberm. III. 75, IV. XXIV. J u ngermania cochleariformis Hooker Brit. Jungerm. $t$. 68. J. $s \mathrm{ph}$ a g noides Hooker Musc. exot. $t$. 47 .

48\%/19. III IPpetium NEES. Fructificat i o $\mathrm{fem}$ in ea in ramulo involucrali brevi, ex amphigastrii axilla v. magis latera versus orto, adscendente terminalis. Invo I u eri foliola complura, parva, diversiformia, undique imbricata. Invol ncellum membranaceum, elongatum, teretinsculum, obtuse triplicatum, ore denticulato $v$. integro, nonnunquam hinc fissum, Germina 2-3. C a l y p tra membranacea, tennis, stylo coronata. Sporangi um rectum, ad basim quadrivalve. Elateres e fibra duplici, ad speciem nudi. Sporae subglobosae, laeves. Fruetificatio masc. Antheridla in ramulo spiciformi v. turioniformi, dense imbricato, ex amphigastrii axilla orto. - Herbulae; foliis incubis, saepe apice dentatis et decurvis, ramis ventralibus plerisque flagelliformibus, microphyllis, aut apice saltem in flagella abeuntibus.

Herpetium Nees Leberm, III. 27. IV. XXIV. M a st i. gophora et Herpetium Nees Leberm, I. 101. Ple a r o$8 \mathrm{c}$ h is m a ti s sect. 2 et 3 . Dumortier Syllog. 69.

a. LEPID0ZIA Dumort. C a u Iis pinatim ramosus, ramis aliis obtusis, aliis apice flagellatim attenuatis. Folia snepe distantia. $R$ a m us fructifer lateralis, neque ex amphigastrii angulo oriundus. $\mathrm{R}$ a muli involucralis folia latiuscula, imbricata, apice aeute bi-quadridenticulata. In vol ucelli os dentieulatum. Nees l. c. Lepidozla seet. Pleuroschismatis Dumort. Syllog. 69. Mastig op h or a Nees Leberm. $I$. 101. J u m a n i a reptans Linn. Hooker Brit. Jungerm, t.75.

b. MAStigobryum Nees $l$. e. Ca n Iis fureatim ramosus, ramis obtusis, flagellis ventralibus ex amphigastriorum angulis raro deficientibus. Folla fmbricata, obliqua, apice plerumque tridentata. A m p higastria latiuscula, textura foliorum, vix revera defieientia. $\mathrm{R}$ am alus masculus et femineus ex amphigastriorna angulo nascens. R a muli involueralis foliola parva, angustata, subsquarrosa, apice acute incisa. In $v$ olncelli os obtuse trilobum, hine profundius fissum. Nees l.c. Pleuroschismatypus sect. Pleurosehismat is Dumortier Syllog. 70. Herpetiam Nees Leberm. 1, 101. Jungermannia trilobata Lins. Hooker Brit. Jungerm, 2,67 .

4ร \%/20. Calypogeis $R A D D$. F em. InvoIncellum carnosum, pendalum, setulis erectis hirtum, apice canli adnatum, juxta punctum adhaesionis sive latere emittens setam e fundo incrassato adscendentem. C a l y $\mathrm{tr}$ a inclusa, membranacea, libera. Sp orang i um tortum, quadrivalve, valvulis angustis, demum patentibns et contortis. Mase. An the ridia in ramulo brevis. 
simo, apice capitato, ex amphigastrioram angulo nascente, aggregata, involucro lacero cincta. Prop a g u l a capitata. Herbulae repentes; foliis incubis, integris v. bifidis, flagellis caulis ventralibus nullis v, raris, involucellis subterraneis, amphigastriis bifidis.

C a l y poge i a Raddi in Att, soc. tilalian, Moden. XVIrI. 4. t. 6. f. 3. exel. sp. Corda apud Sturm II, 19. 20. p. 38. t. 10, Nees Leberm. $I, 101, I I T, 7, I V, X X I V$, C in einnulus Dumort. Syllog. 72. $t, 1 . f, 11$. Jungermannia Tricho ma nis Liun. Hooker Brit. Jungerm, t. 79.

Tre IEUS WI. GEOCALYCEAE Nees Leberm. II. 385. S porangi um solidum, rectum v. contortum, usque ad basim quadrivalve. El a teres dispiri, nudi. In vo luc e ll u m nudum, pendulum, vel carnosum et saccatum. Folia succubo-imbricata. Ramificatio vaga. - Terrestres, interdum gemmiparae.

4 2/21. Comgy lauthers NEES. Invol ucell um longum, chartaceum, pendulnm, radiculoso-villosum, apice cauli adnatum, juxta punetum adhaesionis demum dehiscens. Calyptra involucelli fundo affixa, cnm capsnla ad ejusilem os adscendens, demum apice rumpens. S p o r a ngi m medunculo basi nudo, quadrivalve, valvulis angustis, obliquis, tortilibus. El a teres .... Herbulae arctissime repentes; foliis succubis, ad. scendentibus, integris, amphigastriis nullis, involucellis longis, cylindricis, fibris retrorsum appressis villosis, pro ratione plantae magnis.

Gongylanthas Nees Leberm, II. 405. IV. XXIII. Calypogeia ericetoram et C. fragifera Raddi in Ait, soc. italian. Moden, XVIII, t. 6. f. I. et 3.

4 \%/22. Geocalyx NEES. Involucell $\mathbf{u}$ m carnosum, pendulum, glabrum, apice canli adnatum, juxta punctum adhaesionis v. e latere setam $e$ fundo incrassato adscendentem emittens. Ca ly ptra inclusa, membranacea, libera. S p o rangium pedunculo basi coronula cyathiform lacera cincto, quadrivalve, valvulis angustis, rectis, striatis, demum patentibus. Elate res duplicati, haud vaginati. Propagula foliis innata. - Herbulae repentes; foliis succubis, involucellis radiculoso-hirsutiusculis, subterraneis, amphigastriis bifidis.

Geo cal y x Nees Leberm, IT, 395. ID. XXIIT, C al y pogei a Dumortier Syllog. 73, $t, 1, f, 12$. J a ngermanui g raveolens Schrad. Bkart Jungerm. t. 9. f. 67 .

4. $2 / 23$. Saceogyna DUMORT. In volucellum chartaceum, oblique pendulnm, saceiforme, glabrum, ore membranaceo marginato, primum clauso, demum late aperto, lobalato. C aIy tra involucelli fundo affixa, basi cum eodem connata, apice rumpens. Sporangium pedunculo basi nudo, quadrivalve, valvulis angustis, rectis. - Herbulae procuinbentes, laxe repentes; foliis succubis, subhorizontalibus, integris, amphigastriis integris, dentatis, involucellis obconicis, oblique in terram descendentibus, oris margine producto affixis.

S a e c o g y a D Dumortier Comment, 113, Syllog. 74, t, 2 . f. 13. Nees Leberm. $I T$. 389. IV. XXIIII. S y e k o re a Corda apud Sturm II. 19. 20. p. 41, 2,11 . Ju ngermannia viticulos a Lino.

TTEIISUS VIK. JUNGERMANNIDEAE Nees Leberm. IV, 22. S p o r a $\mathrm{ng}$ i um solidum, rectum, ad basim usque quadrivalve. Elat eres dispiri, nudi. Involucellum caulis v. rami apici insertum, membranaceum, plerumque exsertum, rarius involucro inclusum. Folia succubo-imbricata, Ramificatio vaga. Terrestres $v$. muscicolae, saepe gemmiparae.

4r8/24. Cymmoseyplats CORDA. Involuc rum nullum. Involucell a m in ramulo brevissimo laterale, magnum, fissum v. bilabiatum. Ca Iy ptra inclusa, a basi solubilis. Spora $n$ i um ad basim usque quadrivalve, submembranaceum ..... - Herbula summopere dubia, soli generis auctori nota; foliis succubis, semiverticalibus, adscendentibus, integris et integerrimis, amphigastriis nullis, caule exili, repente, infra involucellum innovationem recurvam promente.

G y m noscy phus Corda apud Sturm II.26, 27,p. 158. t. 42. Nees Leberm. II. 381. IV. XXIII,

4 \% 2/25. Cheiloseyplans CORDA. In voI n cri folia et amphigastria discreta pauca, a caulinis diversa et iisdem minora. Invo I u c ellum in ramulo proprio brevissimo laterale, profunde trifidum v, subbilabiatnm, plerumque laeve. C aI y tra demum clavata, subchartacea, inclusa v. involucello longior, et involucellum simulans, apice irregulariter rumpens. Sporangium nsque ad basim quadrivalve. Elateres fibra duplici, nudi, decidui. - Herbulae prostratae, radiculis ad basim foliorum ortis laxe repentes; foliis in dorso caulium decurrentibus, integris $v$, apice retusis, imbricatione succuba, subhorizontaliv. interdum paullo magis declivi, amphigastriis bifidis, cauli incumbentibus, textura foliorum.

Chell as e y ph u s Corda apud sturm $I$. 19. 20. p. 35. t. 9. Dumortier Syllog. 67. $t, 1$, f. 9. Nees Leberm. IT. 559. Marsupellae sp. Dumort. Comment. 114. Jungerma nui a poly an thos Linn. Hooker Brit, Jungerm, $t, 62$. J. pallescens Ehrh.

4\% 2/26. Happanthas NEES. Involucrum nullum, nisi folia ramuli fruetiferi pauca, reliquis minora, ab involucello remota. In voluce Il $\mathbf{u m}$ in ramulo proprio brevissimo laterale, subfusiforme, incurviusculnm, teres, inferne crassius, ore tri-quadrifido, laciniis integerrimis, inaequalibus, tenuibns. C a ly p t ra chartaceo-spongiosa, cum involecello cohaereng et illo brevior, parte superiore ab inferiore cum fructu secedente. S porangium usque ad basim quadrivalve, Elateres fibra duplici, demum nudi. - Herbula in uliginosis Sudetorum reptans; foliis succubis, leviter declinatis, in dorso caulium decurrentibus, apice bidentatis, amphigastriis integris, basi dentatis, apice attenuatis, textura foliorum, caulibus incumbentibus.

H arpant hus Nees Leberm, II, 351, IV, XXII. J n uermanula Flotoviana Nees olim.

4 \% $\% / 27$. Thopheolea NEES. Involncri folia et amphigastria discreta, pauca, a caulinis diversa, majuscula. Involue e $11 \mathbf{n} \mathrm{m}$ in caule v. ramis primariis terminale, innovatione solitaria superveniente saepissime demum laterale v, axillare, liberum, inferne tabulosum, superne acute triquetram, ore trilobo, dentato-cristato, superius saepe profundius fisso. Germina plurima. Cal y ptra ovalis, membranacea, inclusa, basi solubilis, v. apice rumpens. Capsula usque ad basim quadrivalvis. El ateres fibra dupliei, nudi, decidai. Involnera maseula difformia, minora, dense imbricata, eapitulum tandem ex apice proliferum formantia, Antheridia globosa, flamento longiusculo. Herbulae medioeres v. grandiusculae, 
tenerae, procumbentes, laxe $v$. arctius repentes, plerumque pallidae, foliis succubis, subhorizontalibus, rarius semiverticalibus, in dorso caulium decurrentibus, apice bi-pluridentatis, amphigastriis patulo incurvis, anple reticulatis, bifidis, lacinils incisis, nonnunquam amphigastriis cum foliis proximis cohaerentibus.

L oph o col e a Nees Leberm. II. 321. IV. XXII, J u ngermanniae sect. Lo phocolea Damortier Syllog. 77. Jungermannia bidentata Lian. Raddi in Att. soc. ital. Moden, XIX, t. 4. Hooker Brit. Jungerm, t. 30. J. heterophyll a Scbrad. Hooker Op. cit, $t, 31$.

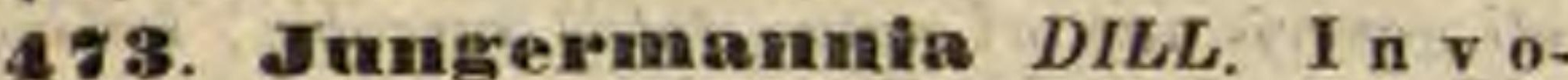
lu cri folia basi connata v. saepius discreta. Involucellum in caule ramisve terminale, liberum, teres v. angulatum, ore denticulato, terminali dehiscens. C a l y pt ra membranacea, tenuis, inclusa, rarissime prominens. Sporangium us. que ad basim quadrivalve. El a teres fibra dupliei, nudi. Mase. Antheridia globosa, filamento brevi, folierum involueralium axillis inserta, in eadem v, in diversa stirpe. - Herbulae ubivis terrarum obviae; foliis succubis.

J u german i a Dillen. Muse. 479. Lian. Gon. $n$. 955. exel. sp. pl. Nees Leberm, IV. XXII.

a. NEMOROSAE, In v o la e ell u m teres v. parumper com pressum aut plicato-angulatum, rectum. C a u li s primarius a secundario non diversns, transiens. - Folic plus minus complicata, biloba. Amphigastria nulla. Nemorosa dehiscentes Nees Leberm, I. 22s. Jangermanniae seet. Diplophyll um Dumort. syllog. exel. plur.

b. COMMUNES. I $\mathrm{n}$ v o $1 \mathrm{u} c \mathrm{e} 11 \mathrm{u} \mathrm{m}$ teres $\mathrm{v}$. angulatum, rectum. Caolis vage ramosus, v. simplex v. subpinnatas. - Folia distantia, explanata. Amphigastria nulla v. folits conformia aut diversiformia. Jungermanniae coamunes Nees Lebermt. I. 867. exel, J. scalari. Jungermanniae sect. A phozia, Lophozi a, Cephal ozia, A athella et Blepharostoma Dumort, Syllog. 44. pro parte, et Pleuroschismatis sect. 0 d a nto.s ch 1 s m a Dumort. S fllog. 68 .

473/1. Plastoehillat NEES et MONTAGN F e m. In volu c ri diphylli foliola a caulinis haud diversa. I nvol ucell u m terminale $\mathrm{v}$. in ramulo brevi laterale, sub anthesi saltem a terge et ventre compressum et primo decurvum, laeve, ore oblique truncato, nudo, ciliato v. dentienlato, demnm gubbilabiato. Germina plurima. Sporangium firmum, usque ad basim quadrivalve. Elateres mediis valvis inserti, longi, dispiri, decidui. Mas c. vel spiciformes, distichi, eaule sive ramo ex apice continuo, foliis involucralibus minoribus arcte imbricatis, vel in angulo foliorum snperiorum conformium, densius imbricatorum. - Herbulae terrestres, saxicolae, rivulares, speciosae, caule pri mario procumbente $v$. repente, ramis saepe erectis aut procumbentibus, raro radiculas agentibus, simplicibus, bifidis $v$. dendroideis, foliis succubis, aliis dimidiatis, saepius subsecundis, margine dorsali recto $v$. reftexo in dorso eaulis decurrente, ventrali plus minus areuato, plerisque denticulato v. ciliato, in aliis bilobis, lobo dorsali plerumque minore, sursum reflexo, amphigastriis saepissime nullis.

P I a g i o h 1 a Nees et Montagne in Nouv. Annal. tc. nat. $V$. 52. Nees Leberm. III. 515. IV. XXII. Lindenber Spec, Hepatic, fasc, 1, 2 Notarisia Colla in Mem. Acadom. Turin, XXXIX, 53. t. 25. R a dulate sect. Plagio chila et Seapania Dumortier Syllog. 38. Canido le a s p. Raddi in $A t t$, soc. ital. Moden, XiX, J u n e r m a n i a e asplenioideae et nemorosarum subdivisio $I_{\text {. Nees. }} L_{e}$ berm, I, 151_924. J. s pi u u I bs a Dieks. Hook. Brit. Jung. $\boldsymbol{t}$, 14. J. deciple ns Hook. Op, cit, $t$. 59 . J. as p J. Jung. des Linn, Hook. Op. cit. 2, 13. J. res n pi nata Hook. Op. cit, c. 23, J. and u I a t a Linn. Hook. Op. cit, $t, 22$. J. p I nffolia Hook. Op. cit, $t$. 67 . J. nemoros a Hook. Op cil. t, 21. J. u mbrosa Sehrad. Hook. Op, cit. t. 34. Suppl, t. 3 .

TRII I US WIIT. GYMNOMITRIA Nees Leberm. IV, 21. Involucell um nullum v. cum involucro connatum. Caly p tra involucro cincta et recondita $v_{\text {c }}$ eedem longior. Spora n gi i m quadrivalve, membranaceo-chartaceum. Elat eres dispiri, nudi. - Erectae, distiche $v$. tristiche foliosae, folits indefinile succubis. Fructificalio terminalis.

48. Allieutaria CORDA. F em. InvoI ucellum in canle terminale, cam involncro arceolari inclusum et eidem inferne cohaerens, ore regulariter denticulato. Ca ly ptra inelnsa, membranacea. S poranginm ad basim nsque quadrivalve. E la teres fibra duplici, nudi. M a sc. A nth eridia globosa, foliorum involucralium axillis inserta. - Herbulae, caulibus innovando ramosis, serpentinis, radiculosis, rigidulis, foliis succubis, amphigastriis simplicibus, rigidulis, patulis, integerrimis.

Aliteularia Corda apud Sturm II. 19. 20. p. 32. $t .8$. Dumortier syllog. 79. $t$. 2. $f$. 18 . Nees Leberm. II. 448. IV. $X X I$. Me s o p hylla sp. Damort. Comment, 112. Jungerman nia scal aris Schrad. Hooker Brit. Jung. t. 6t.

4.4/1. Sareoseyphus CORDA. F em. Involucri folia verticaliter bilabiatin connata v. basi saltem cohaerentia. Invol uc elI u m involucro ad apicem fere innatum, ore quadri-sexdentato, squamulas totidem in fauce involucri sistens. $\mathrm{Ca}$ lyptra inclusa. Sporanginm usque ad basim quadrivalve. El a t er e s fibra dupliei, nudi. Ma sc. Anth eridia globosa, foliorum basi saccatae filamentis brevibus insidentia. - Herbulae caespitosae, erectae, foliis distichis, succubis.

Sareos ey phu s Corda apud Sturm TI. 19. 20. p. 25. t. 5. Nees Leberm. 1, 122, IV. XXI. M a r 8 u p i Dumortier Syllog.77. t. 2. f.17, M ars a p ell a e 8 p. Dumortier Comment. 114. Jungermanaia emargla ata Ehr, Hooker Brit, Jung. $t$, 27 .

48 4/2. Gymanomitroienan. NEES. InvoIn eri foliola canlinis conformia, arete conniventia. Involucell am nullam. Cal y ptra brevis, vertice rumpens, involncro inclusa. S poran g i um quadrivalve, globosum. Elateres fibra duplici, nodi. Antheridia in ramulo distineto axillaria.-Herbulae alpestres; foliis distichis, amplexicaulibus, succubis, margine crassiore saepissime discoloribus, apice integris, bidentatis bifidisve.

Gy mo mitrium Nees Leberm. I, 113, IV, 21. A cole a Dumortier $s y l l o g .76, t$. 2. $f$. 15 . G y m n o m it ri i s. Corda apud Sturm. IT. t. 4. J n ngermannia concin. n a t a Lighe. Hooker Brit. Jung. $i$. 3. Ekart Synops. $t .8$. f. 63, e. 13. f. C. 113 .

474/3. Haplomitrium NEES. Invol ucri foliola caulinis conformia, demum patala, laxa. In volucell um nullum. Cal y ptra longa, vertice rumpens, carnosula, exserta. S p or a n grium quadrivalve, oblongum. Ela tere a fibra simplici, primum folliculo inclusa. S p o r a e ternatim cohaerentes. Antberidia in stirpe distincta axillaria, globosa, - Herbula alpicola, radice crassiuscula, caule erecto, foliis tristichis, ovato-oblongis, repandodentatis.

Haplomitri nm Nees Leberm. I, 109. IV. XXI. M niopsis Damortier Comment. 114. Syllog. 75. t. 2.f.14. G $\mathrm{g}$ momitrit s p. Corda apud Sturm II. t. 3. J u ng er" man a ia Hook eri Sonith E. B, t. 2555. Hooker Brit. Jung. t. $5 \%$. 


\section{Drdo XXIE. Bryaceae.}

$505 / 1$. Wardia $H O O K$. et $H A R V$. Cal y ptra dimidiata. Sporangi um terminale, basi aequale. $O$ perculum rostro conieo, incurvo, $e$ o. I umellae tandem exsertae adnatam. Peristomi um simplex, membranaceum, erectum, breve, crenulatum, longitudinaliter et transversim striatum, irregulariter fissum. - Muscus capensis, aquaticus, Scoulerine facie, diversifolius, seta laterali et terminali, insigniter hygrometrica.

Wardia Harvey et Hooker in Bot. Mag. Comp. II. 183. $t, 25$.

5๑5/2. Trotalontinam $H O O K, \mathrm{C}$ a l y p $\mathrm{r}$ a mitraeformis, hinc fissa. S p or ang i um terminale, turbinatum, basi aequale, o pereul u m longe co. nico-rostratum, decidaum, col umella inelusa. Peristomii simplicis dentes sedecim, elongati, siccitate reflexi, singuli e ciliis tribus articulatis compositi, - Muscus insulae Diemen, aquaticus.

Trid on ti um Hooker Ic, $t$, 24s.

505/3. E⿸丆inemia NOTAR. Caly ptra mitraeformis. Sporang inm terminale, apophysatum, opercul n in conoideam, deciduum, col umella inclusa. Peristomii simplicis dentes triginta duo elongati, siecitate erecti v. reflexi, hand torti. - Muscus in Europa australiore alpicola.

Ra i o eria Notaris Syllab. Musc. 1.

50 12. Selhlothe imain $B R I D$.

Se hizodon Swartz Annot. Bot. 91.

\section{Ordo XXVI. Polypodiacene.}

\section{BQ3. Aerostielnuman $L$.}

Sori venis venulisque omuibus, simal et parenchymati insidentes.

a, POLYBOTRYA Humb. Venae pinnatae haud anastomosantes.

a. Poly botrya Presl Pterid, 230, t, 10. f. 7 -11. Ve. n a e pinnatae, imamersae, teaues, simplices, apice obtuso, libero desinentes, paginaa superiorea trondis sterilis lineantes, infimae in dentium v. Jaciniarua si. nus excurrentes. Sor u * frondis fertilis dissimailis pa ginam inferiorem totam, rarius et superiorem obtegens.

P. $01 \mathrm{fe} \times \mathrm{s}$ i a Radd. Prest Pterid. 232, t, 10. f. 13-16. 20. 2t. Ve n a e pinuatae, simplices $\mathbf{v}$, furcatae, venu lisque parallelae, apice libern, acuto v. punctiformi inerassato desinentes, nane immersae, mane otríaque elevatae, costuliformes. Sor us frondis paginam in feriorem totam, rarius et superiorem obiegens. Elaphoglos $\mathrm{xum}$ et Rhipidopteris Schott.

b. ACROSTICHUM. Venae veunlaeve anastomosantes.

c. A cou iopteris Presl Pterid. 236, t. 10. f. 7. Ve nae pinatae, parallelae, subtus costaeformes, simplices $v$. ad basim furcatae, apice veunlis in arcum triangularea anastonosantes, veunla secundaria cla. vata, libera, apicem arcus contiuuante. Sor $\mathbf{s}$ totam frondis fertilis, subdissimilis pagisam iaferiorea obtemens. - Acrostichum subdiaphau m Hook. et Grev.

B. Stenosemia Presl Pterid. 237, 1, 10. f. 24. Venae pinnatae, jmmersae, apice libera, acuro desinentes. infimae oppositae in arcuu transversim elongatum, ro tundato-obtusissimuas, bi tri.quadringulatum anasto mosantes, angulis apice venulas simplices v. rarissi me furcatas, versus siaum frondis directas emittentibus. Sor us frondis fertilis, dissimilis totam peginam Inferiorem obtegens. - Poly botry a a urfta Blum. Flor. Jav, $t, 1$. et $P$. cic u ta ria Blum. Op, cit, $t, 2$.

$\gamma$. C am p i u mest Pterid. 238. t. 10. f. 22. 23. Venae pinnatae, immersae, tenuissimae v. crassae costaeforme, pinnato-veuulosae, saepe apice libero, puctiformi - incrassato v, obluso desinentes, ve u u- lae oppositae in arcus obtosissimos $\mathrm{v}$. acute friangulares anastomosantes, supremae interdum in maculas irregulares confluentes, venalis secundariis ex apice arcuum solitariis, liberis $v$, in sinum arcus mox superioris excurrentibus. S or us totam frondis paginam inferiorem obtegeas. - A crostieh a m eordat u m Wall. A. virens Wall. A. repandu m Blum. A. subcrenat u m Hook. et Grev.

S. Neuroplatyceros Pluckn. Venae inferne sub. ramosae, flabellatae, crassae, costaeformes, apice acuto, libero desiuentes. superne tenues el ramosae, venulis in areolas trapezoideas, magnas, elongatas anastomosantes. Sor us pagiane inferioris frondis partea superiorem obtegens. - Platy cerium Desv. Presl Pterid. 229. t. 10. f. 12. Alcicornium Gaudich.

E. A crostichum Presl Pterid. 240. t, 11. f. 3. Ven a e tenaes, ramosissimae, venulisque aequilatis in areolas hexagonas, latitudine longiores aunstomosantes, subtux parum elevatae. Sorus totam frondis paginam inferiorem obtegens. A. reticulatum Kaulf. A, obliquam Blam. A. crassifolium Wall. A. aureum Lios. A. Inaequale Willd. A. speciosum Wiild. A. Requienianum Gaud:

5. P oecilopteris Eschw. Ven a e pinnatae, elevatae, ramosae. Venulae prominulae v. imatersae, in areolas irregulariter angulatas anastomosantes, areolis hiuc inde venulam secundariam, liberam, apice globaloso - incrassatam emittentibus. So r u s paginam inferiorem frondis dissimilis obtegens. - Presl Pterid, 241. $t, 10 . f, 18,19,2,11, f, 1,2$, B o Ib it is Schott.

$\eta$. G y m o pteris Presl Plerid, 242, t, 11, $f$. t 7 . Venae ramosissimae, prominalae $v$, immersae, te. nues. Ve aulae primariae in areolas hexagonas, subrotundas, v. irregulariter paralielogrammas lateri. bus curvatis auastomosantes, secundariae in areolas minores conflientes v. liberae, apice globoso-inerassa. tae, simplices v. furcatae, rectae aut i.amatae. S orus pagiuam inferiorem apicis frondis similis v. dis. similis obtegens. - G y m n o pteridis s p. Bernhard.

aa. Gymnopteris Presl l. c. Frons apice fertilis vo frondes dissiniles. Venae immersae v. prominulae, Ve u $\mathrm{f}$ ae in areolas hexagonas anastomosantes. H y me nolepis Kaulf. (infr, u. 627.) A erostich um spieatun Linn. Leptochilus Kaulf. (inir. n. 625.) A. axillare Cav, A. nummalarifolium $\mathrm{S}_{\mathrm{w}}$, A, obtusifolium Willd. A. querelfolium Retz. A. alienum Sw.

bb. Anapausia Presi 1 , $c$. Froudes dissimiles, coriaceae $v$. herbacear. Ve nat immerkae v. elevatae, costaeformes. Ven u lac in areolas transversim et irregulariter parallelogrammas lateribus curvatis aasto. mosautes. - A. uieatianlfolium Sw. A. acuminatum Willd.

\section{Filenafonitis LINN.}

V en a e ramosissimae, in areolas hexagonas, ut plurimum elongatas anastomosantes. So rl lineares, angosti, venarum veuularuaque dorso insidentes. I nd u 8 i a m nullum.

\section{G05. Antrophyoum KAULF.}

a. Antrophy am Blam. Hemionitidis Sect. Pres1. 6. b. Lox ogramma Blum. Presl Pterid. 214. $t .9 . f .8$. c. Polytaenium Desv. Loxogrammatis sp. Presl.

\section{Aymagogramue DESV.}

Sori dorso veaarum venularumque pinnatarum furcatarumve insideates, demam conflaentes et totam frondis paginam inferiorem tegentes. V e u a e immersae, tenuissitnae at flabellato multifurcatae, venalis apice libero punctiformi v. acutissimo desiuentibus. Presl Pterid. 217. t. 9. f. 10. $12-15$

a. NEUR0GRAMMA Presl t.c. V en a e creberrimae, flabel. lato-multifurcatae, venulis apiee panetiformi-incrassa. tis. G. reniformis Mart. G. pedata Kaulf. G. rofa Desv. G, tomentosa Desv, G. jasanica BI. G. serrulata BI. G. caudats Wall. G, affinis Wall. G, vestits Wail.

b. CALOMELANOS Presi $t$, c. Vo n a e creberrimae, llabellato-multifurcatae venulaeque apice acotae jmmersae, frondis paginam superiorem lineantes. G. trifoliata Desv. G. tartarea Desv. G. peruviana Desv. G, triangularis 
G. flavescens Kaulf. G. chrysophylla Kaulf, G, sulphurea Desv. G, aurea Desv.

c. CETERACH Adans. Vena distantes, superiores simplices, inferiores furcatae, venulaeque divergentes, apice acutissimo desinentes. Frons subtus paleis imbrica. tis v. tomento denso tecta.

\section{BQ7. Grammitis $S W$.}

a. GRAMmitis Presi Plerid, Ven a simplices v. furcatae, venularque apice libero desinentes.

c. Eugrammitis Presl. Venae simplices apice acutae, infimae in sinus laciuiarum directae.

8. Xiphopteris Kaulf. Venae simplices in apicem dentis excurrentes, in superiore frondis parte angulo acutissimo exorientes et, soriferae. Micropteris Desv.

$\gamma$. Chllopteris Presl. Ve nae fureatae, venulis apice globuloso terisinatis, superiore sorifera.

b. SYNAmmia Presl Pterid. Ven ulae supremae in areum acutum anastomosantes, areolam hexagonam formantes, infima superior libera sorifera, et venula secua. daria ex apice areus emergens apiee globuloso-jucrassa. ta. Grammitis elongata Sw.

BQ8. Cryptogramma $R$. BR.

Vid. supr. in text, exel. A 11 o suro Beruh. (v. infr. 622. a.) et synon. $\mathrm{Ph}$ or ol ob us Desv.

\section{Selliguea BORY.}

a. SElliguea Presi Pterid. 215. t. 9. $f, 16.17 . \mathrm{V}$ e na e pinnatae, parallelae, ramosissimae. Ve u u la e primariae in areolas hexagonas plus minus regulares, secundariae in areolas minores, irregulariter angulatas anaxto. uosantes v. literae, apice globuloso inerassatae, simplices v. furcatae, rectae ant hamatae. S orl dorso venularum, serie linealt contiguarum impositi, continui v. rarius interrupti. D i a g ra m me Blum.

b. Microgramima Presl Pterid, 213. t. 9. f. 7. Ve na e pinatae, ramosae. Venulae in areolas, (costales transversim oblongas, medias majores et margitales heragonas) anastomosantes, areolis mediis venulas secundarias in rete irregulare coeuntes, v. liberas apice panctiformi inerassatas continentibus, marginalibus ve nulam liberam deflexam exserentibus. $S$ o r 1 dorso venulae secundariat intra areolam mediam inserti, ovales, uniserlales. Polypodium persicariaefollum Schrad.

609/1. Stegnogramma $B L U M$, Vena e pinnatae, simplices, inferiores oppositae in arcum auctangulum coenntes, supremae apice libero, aento desinentes. Ven ul a e ex angulo arcus solitariae, inferiores in sinum areus superioris, supremae in sinum laciniarum frondis excurrentes. So ri dorso venarum insidentes, lineares. In d us i m nullum. - Filix javanica, rhizomate repente, frondibus sparsis, herbaceis, pinnatis.

S teguogramme Blume Fil. Jav. 173. Presi Pterid. 209. t.9. f. 5, G y m a o r a mme Stega ogramue Blum. Flor. Jav, t, 44 .

609/2. Sphaerostephamus J. SMITH. $V$ en a pinnatae, venulis in marginem lacinia rum excurrentibus clavato-incrassatis, infimae contignae in arcum coalescentes. S ori oblongi, utroque margini receptaculi eristaeformis, glandulosi, e dorso venae inserti paralleli, demum in lineam confluentes. Indusium hyalinum, receptaculo innatum, margine fimbriato sorum cingens. Filix indica; fronde pinnata, pinnis pinnatifidis.

S pha e rostephanus J. Smith in Fr. Bauer Fil.
5 . Kunze Farren. Fräut. $t$. 11. 12.

610. MIeniscium $S C H R E B$.

Venae pinatae, costueformes, parallelae, apice obtn. so, libero desinentes. Venulae plurimae, oppositae in arcam triangularem anastomosantes, ex uplce areus venulam secundariam, liberam, elavatam exserentes. So venut. 9. f. 6. Fr. Baner Fil, $t, 40$.
611. Taenitis $S W A R T Z$.

Sorus per venas et venulas ipsumque parenchyma linea angusta, costae utrinque parallela, venis contraria, intramarginali, costae v. margini propiori excurrens.

a. Pleurogramme Presl Pterid, 223. t, 10. f. 2. Ven a e pinnatae, distantes, imaersae, simplices, apice libero, punctiformi desinentes. Ple u $\mathrm{r}$ o $\mathrm{g} r \mathrm{amm}$ e sect. A utrophyi Blume Flor. Jav. 69. Micropteridis sp. Desv. T a e n itis linearis Kaulf. T. pumila Kaulf. T. gramisifolia Hook.

b. PTEROPSIS Presl Plerid. 225. t. 10, f. 3. Vena e im. mersae, ramosae, venulis in areolus hexagonas anasto. mosantes. Sor us utrinque margini approximatus, contiauus s. rarius interruptus. C hilo gramme seet. Antrophyi Blume Flor. Jav. 7o. Pteropsidis sp. Desv. T a e nitis lanceolata Kaulf. T, angustifolia Spr. T. tricuspidata Spr. T. fureata Willd.

c. TAENITIS Presl Pterid, 226, t. 10, f. 4. Ven a e pin* natae, immersae, ramosae, venulis in areolas hexago. uas anastomosantex. S or us utrinque a margine et costa subaequidistaus, continuus v. Interruptus. T. blechnoides Swartz. T. interrupta Hook. et Grev.

OBSERVATIO. A Taenitide uou longe distare videtur genus mihi non satis perspectum :

CERATODACTYLIS J. Swith ex Fr. Bauer Fit. $t .36$. P i n n la e fertiles mutato coutractae, narginibus revolatis membranaceis, indusiformibus, dorsum totum pinnulae tegentibus. So ri lineares, fureati. S porang is venas furcatas, parallelas, per totam longitudiaem oceupantia. - Filix mexic an a, frondibus stipilatis, sestertium pedem aequan. tibus, glabris, tripinnatis, pinnis superioribus mutato-con. tractis, fertilibus, pinnulis sterilibus alternis, petiola. tis, oblongo-ellipticis, basi obliquir, serrulatis, venosis, venis subsimpliciter dichotome ramosis, fertilibus contractis, linearibus, subfalcatis, non raro ternalim divisis.

612. MIonogramma COMM.

Ven a e nullae Presl Pterid, 206. t. 9. f. 1.

613. Ademoplaoras GAUDICH.

Genus Judice el. Presl Pterid. 178. Polypodio jungendum. Synogya 0 a y chium Reinw. et Lecanopteris Bl. h. I. delenda. Vid. infr. N. $617 / 1$.

\section{Notoclalaema $\boldsymbol{R}$. $B R$.}

Sor us per veas venulasque et ipsum parenehyma linea marginali decurrens, setis v. pilis frondis velatus.

a. NOTOChlakna Presl Pterid. 224, t, 10. f. 1. Venae pinnatae, immersae, tenuissimae, uni-bi-trifureatae venulaeque apice acuto desinentes parallelae. Sorus continuus, pinnarum pinnularumque marginea continue vestiens. - Marginaria Bory h. I. delenda. Vid. n. 615. $f$.

b. DRYMOgLOSSUM Presl Pterid. 227, t, 10, f. 5, 6. Veu a rauosissimae, imnersae, tenuissimae. V e nulae primariae in areolas hexagono-subrotundas anastomosantes, secundariae liberae, simplices v. ramosae, reetae v. hamatae, obtusae. Sori frondis simplieis, dissimilis marginem vestientes, Pteropsidis 8 p. Desv. No. toehlaena piloselloides Kaulf.

\section{B 1ิ5. Polypertĩuma LINN.}

a. EUPOLYPODIUM. Venate piunatae, apice libero globo. so-punctiformi v. elavato, simplices $\mathbf{v}$. furcatae. S or i In apice venarum simplicium ve venulae superioris ve. narum furcatarum, nunc in dorso medio venarum venularuaque. Poly podi u m Presl Pterid. 176.

c. C ten opteris Blum. ? Ve na simplicissimae, apice incrassato monosorae.

$\beta$. Di cra uop teris Blum. Ven a e furcatae, venula superiori apice sorifera.

$\gamma$. Phegopteris Presl. S or 1 'dorso medio venaram venularumve obtusarum aut apice globoso-inerassatarom iuserti. L as trae a Bory part.

b. GONIOPTERIS Presl Pterid, 181, t, 7, f, 9_11, Vena e piunatae, simpliees, apice libero breviter ante marginem frondis desinentes, infimae aliquot superiores cum totidem inferioribus oppositis in areum acutangulum ana. stomosantes, venula ex apice anguli iu siaum laciniarum frondis aut in sinum anguli proxime superiorls excurrente, apice interdum elavata. S o r I medio venarum dorso inbidentes. (Fr. Bauer Fil, $t$. 38,) 
c. Pleocnemia Presl Pterid, 183, $t$. 7. $f$. 12, V e na e pinuatae, superiores furcatae, infimae oppositae, in ar. cum obtusissime angulatum confluentes, angulis quatuor totidem venulas in sinum laciniaram frondis connivendo excurrentes gerentibus, veuulis extimis cum venis proxime superioribus areolam hexagonam formantibus. Sor I in medio venularum dorso. Poly podium Le ac e a n u m Gadich, ad Freyc. t, 6.

d. AMBLIA Presl Pterid, 184. t. 7. f. 22. Ve nae pinnatae, parallelae, apice libero obtuso. Venula e supe. riores cum proxime oppositis in areus obsusos elongatos confluentes, infima e vena inferiori supra basim emer gens, elongata, libera. So ri medio venularum dorso inserti. Polypodium juglandifolium Humb.

e. GONOPHLEBIUM Blam. Vena pinnatae, apice globuloso desinentes, ramosae, Ve nulae oppositae in ar cum triangularem, acutum anastomosantes, areolas antice rhoobboideas efformantes, infima ex axilla superiori areolae costatis emergens, libera, apice globoso incrassato sorifera, et veuula secundaria ex apice areus cujusvis orta apice globuloso pariter sorifera Presl Pterid. $185 . t, 7 . f$. $13,14$.

f. MARginaria Presl Pterid. 186. $t, 7, f .23-32$, Ven a e pinnarae, ramosae. Venula e superiores cumpro. xime oppositis in arcus angulatos confluentes, areolas hexagonas formantes, infima e basi v. supra basim venae inferioris emergens libera, apice globoso v. elavato sorifera, venulae seeundariae ex apice arcuum solitarie ortae, apice globoso pariter soriferae, supremae marginales e duobus hexagonii augulis exeurreates. Marg iII a ri a Bory in Dict, class. VT. 587, X. 176. ad Duperr. t. 3t. f. 2. Char. erron. (Fr. Bauer Fit. t. 14.)

c. Pleuragonium Presl $t$. c. Frondes dissimiles, simpllees, coriaceae, fertiles angustiores.

B. Margla ariae propriae Presl l. c. Frondes conformes, simplices $v$, saepius pinnatifidae aut pingatae, coriaceae $v$, rarius lierbaceae.

g. CYRTOPHLEBIUM R. Brown in Horsfield Plant. Jav. rar. 4. V e n a e pinnatae, eostaeformes, parallelae, ramosae, apice libero globuloso desiaentes. Ve a u la e oppositae in areum sinuato-pluriangulatum anastomosantes, infima ex axilla superiori ad basim venae inferioris emergens, libera, dorso v. apice globuloso sorifera, supremae in areolas irregulares confluentes. Ven nl a e secundariae ex angulis areus ortae liberae, apice globuloso soriferae. C ampylo ne u r um Presl Pterid. 189. t. 7. $f .15,21$,

h. PHLEBODIUM R. Brown in Horsfield Plant, Jav, rar, 4. Venae ramosissinae in areolas irregulares, venulae in areolas hexa-octogonas confluentes, areolas interae venulas secundarias duas v, trex, apicibus coadunatis sorum gerentes emittentibas. Pleopeltidis sp. Presl op. eit. t. 2. f. 36. t. 8. f. 1.

i. DYCtIOPTERIS Presl Pterid, 194, t. 8. f. 6. 8. 13. $V$ en a tenues, ramosissimae, venulaeque in areolas hexagonas, inaequales anastomosantes, reticulam densum formantes, marginales apice libero, obtuso desinentes. Sori venularum anastomosi insidentes. P. a tteu a tum R. Br.

k, Phymatodes Presl Pterid. $t, 8, f, 9$. Ven a e piana. tae, ramosissimae. $V$ e $n$ u la e primariae in areolas majores, secundariae in minores anastomosantes $\mathbf{v}$, apice libero globoso incrassatae v. clavatae, simplices v. furcatae. rectae aut hamatae. S ori venularum anastomosi v. apicibus liberis insidentes.

c. R uphy matodes Presil l.c. Venae immersaev.elevatae, nunquem costaeformes. Areolae omnes v. saltem primariae hexagonae.

B. A naxetum Schott, Venae valde elevatie, costaeformes, venulae immersae, tenuissimae, vix conspieune, areolas hexagonas $\vee$. parallelogrammas aut irregulares foribantes. Pleuridiam Presl (Fr. Bauer Fil. $t, 29$.

$\gamma$. Drynaria Preal. Ven ae saepissime valde elevatae, costaeformes. Areolae primariae transversim parallelogrammae, venulis eurvato-areuatis. secusdariae parvae, subquadratae v. parallelograsmae, aut irregulariter hexagonae.

aa. Dipteri, Reinw. Syllog. IT.3. Frondes fertiles sterilibus similes. Mieros or us Link. bb. Eudrynaria. Frondes fertiles dissimiles. Drynari a Bory.

I. AglaomorpHA Schott. Frondes dissimiles, sterilium venis eostiformibus ramosissimis, venulis primarils transversim arcuatis, in areolas irregulares anastomosantibus, secuadariis minores efformantibus $v$. liberis obtasis, simplielbus aut furcatis, rectis $v$, hamatis. Frondis fertilis bipinnatifidae, contractae venae bifureatae, cruribus apice in sori subimmersi receptaculum coeuntibus. P s y g a i u m Presl Plerid. $t$. 8. f. 21. 22.

\section{Bif f. Ileopeltis $H U M B$.}

$V$ e n e ramosissimae, in areolas irregulares, venulae in areolas hexagonas ₹. octogonas anastomosantes, areolis iaterne veaulas secandarias plures, apícibus coadunatis sorum gerentes emittentibus. Pleopelitids sp. Presl. (Pr. Bauer Falic, t, 18.)

\section{6 \% . Niplaobolus KALLF.}

Ve n a e venulaeque areolatim anastomosantes, saepissime vix conspicuae. Presl Pterid. 200, t. 8. f, 17.

a. NIPHOBOLUS Presl. Sori globosi.

b. CXCLOPHORUS Presl. Sori anuulares.

c. SCYTOPTERIS Presi. Sorí confluentes.

61 $1 / 1$. Hecanopteris REINW. Ven a pinnatae, distantes, prominulae, apice monosorae. Venulae immersae, tenuissimae, in areolas hexagonas anastomosantes, secundariae liberae, apice globuloso-incrassatae, rectae $\mathbf{v}$. hamatae, $\mathbf{S}$ or $\mathbf{i}$ apicibns dentium frondis cartilagineornm et exeavatorum immersi, ovali-subglobosi, magni. - Filix javanica; fronde coriacea, lineari-lanceolata, pinnatifida, laciniis ovato-subrotundis, inciso-dentatis.

L e c a n pteris Reinwardt in Flora 1825, Beilag. 48 . Blame Enum. pl. Jav. IT. 120. Presl Plerid. 202, z. 8,f.23. 0 y y hi um Reinwardt in Sylloge plant. II. 2.

61\%/2. Calymmodom PRESL. Vena e pinnatae, distantes, immersae, in apicem dentium frondis excurrentes. Sorus subglobosus, dentis dilatati et acuti apiei insidens, in d nsio spurio ex ejusdem margine sursumflexo et subcucullato. Filix javanica; frondibus fasciculatis, subcoriaceis, simplicibus, in parte inferiori (sterili) grosse et remote serratis, in superiori (fertili) pinnatifidis, sinubus rotundatis, apicem versus uno latere sterilibus, altero fertilibus.

C a I y mod on Presl Pteria. 203, t. 9. f. 1. Paly po. di um eucullatum Neesiet Bl. Taealtis eucullata Blum.

\section{Cheilanthes $S W$.}

a. Cheilanthes Preal Pterid. 159, t. 6. f. 15-17. Ve. n a e pinnatae, infimae saepe furcatae venulacque divaricatae apice soriferae. Sori marginales apice crenae v. dentis reflexo tecil.

b. HYPOLEPIS Berah. Ven a e pinnatae, inferiores fureatae, superiores simplices, venula superiore sorifern. Sori in ioferiore latere sinuum lacioiaram v. dentium froudis, indusio marginali semilunari. Hypolepis Presl Pterid, 161, t. 6. f. 24.

\section{Tomelnitis LINN.}

$\mathrm{V}$ e $\mathrm{n}$ a $\mathrm{e}$ in areolas inaequaliter hexagonas anastomosan. tes, venulis duabus $\nabla$, quatuor in sinus laciniaram frondis conniventibus, apice sorum anguste semilunatum gerestibus. Presl Pterid. 162. t. 6. f. 29.

620. A cliantum LINN.

Ven a e flabellato - pinnatae, creberrimae, immersae, tenuissimae, pluries furcatae, venulis parallelis. Presl Pterid. 155. $\ell$. 6. f. $8-14$.

621. Cassebeera $K A U L F$.

Ven a e pinnatae, creberriune, immersae, tenaissinae, pluries furcatae, venulis apice anastomosantibus. Presl Ple. rid. $154, t, 6 . f .6,7$.

622. Fteris $L I N N$.

Agardb Fil Revisio specierum generis Pteridts. Lun dae, 1839.8. 
a. Allosorus Presl Pterid, 15t, t, 6. f, 2-5. Ve uae pinnatae, ereberrimae, immersae, uni-bi-tri-quadrifurcatae, venulis parallelis, apice elavulato-Jibero terminatís Sori marginales, primum subrotundi, discreti, mox in unieum linearem, continuum conflueates, indusio marginali continuo, membranaceo-scarioso, plano v. plicato et frondis margine revoluto, crenato-plieato tecti. Allosor us Bernh. Phorolobus Desv. (Fr. Bauer Filic. t. 5.)

b. A MPHIBLESTRIA Presl Pterid, 150, t. 6. f. 1. Ve n a e pinnatae, distantes, costaeformes, ramosissimae. Venulae in areolas hexagonas, inaequales anastomosantes, areolis inter areolas primarias miuoribus, venulas secundarias, simplices v, ramosas, rectas v, lacurvas, apice capitato libero desinentes emitrentibus. Sori lineares, continui et interrupti, in dus io augusto, searioso.

e. LITOBRochia Presi Pterid. 148, $t$, 5. f. $20.24,25$ $V$ en ae immersae, tenues, in areolas hexagonas, elongatas v. breves anastomosantes, areulis extus venulas, apice obtuso libero terminatas emittentibus, So r i lineares, contíai, fa dus i o scarioso continuo v. interrupto.

d. CAMPteria Presl Pterid. 146, t. J. f. 19. 26. Ve na e pinnatae, inmersae, tenues, infimae oppositae, in arcum angalatum obtusissimum, venulas quinque aut rarius sex, in siaum laciniarum frondis directas emittentem aiastomosantes, reliquae furcatae, venulis parallelis, apice clavulato libero terminatis. So rus liuearis, contimus, in d us io scarioso, continuo.

e. MONOGONIA Presl Plerid. 146, $t$, 5 , $f$. 15. V e na piunatae, erebrae, in marginem frondis excurrentes, simplices, infiuae oppositae, in angulum rectum, apice venulam emittentem anastomosantes, venula in frondis sinum excurrente. Sor us linearis, continuos, indusio searioso continuo. Pteris palustris Poir.

f. EUPTERIS. V e n a e pinnatae, erebrae, simpliees v. saepius uni-bifurcatae, teaues, veaulaeque apice obtuso libero terminatae, venulis parallelis $\mathbf{v}$, rarissime divergentibus. Sor us libearis, contiauus, indus io scarioso, coutinuo, Pteris Presi Plerid, 143. t. 5. $f .16$ 18. 23.

693. Jamesomia HOOK.

Ve na pimatae, bi-trifureatae, veaulaeque in marginem frondis excurrentes. Sori minimi, ad basim costae et ve naram sit1, mox conflueutes. Fr. Bauer, Filic. $t$. 13. A 110 sorisp. Presl.

\section{B24. EB leclanuman $L I N N$.}

a. BLECHNUM Willd. PresI Plerid. 101, t.11, f. 11, Hap lopteris Presl Pterid, 161, t, s. f. 21

b. LOMARIA Willd. Presl Pterid. 141, t. $5, f, 17,22,-$ Leptostegia Dou Vid. sub n. 635.

625. LEPTOCHILUS KanIf. Genus svadente el. Pres] deleadam Vid. supr. sub n. 603 . $\eta$. aa.

\section{Vittaria SMITH.}

Ve a a plunatae, simplices, elongatae, ante marginem rondis desinentes. Sor i lineares, duplicaturae marginis frondis (indusinm bivalve praebent1) immersi, Presi Plerid.
165. t. 6. f. 18.

627. HYMENOLEPIS Kaulf. Gellus moneate cl. Pres! delendum Vid. supr, sub n. 603. $\eta$. aa.

\section{Struthiopteris WILLD.}

Cfr. Presl Plerid, 175, $t, 6 . f, 20-23$.

\section{Dradea $L I N N$.}

$\mathrm{V}$ e nae pinuatac, sinulices. $\mathrm{S}$.

insidentes, globosi. in cato, sorum iovolvente, con proprio membran aceo forni. involuto, in formam baceae coalescente.

a. CALYPterium Bernh. Venae elevatae, in frondeste. rili dissimili ramosissimae, veaulis in areolas irregulariter et elongate hexagonas conflneatibus, margivalibus libere desiuentibus, in fronde fertili horizontales, cras: sae, apicé libero elavata, medio veutila transversa, te. nui, areolam quadratam efformante connexae, 0 no te. Presl Pterid. 96, t. 3. f. 15-17. 0, seasibilis Lian.

b. RAgIOPTERIS Presl Plerid. 9s. 4, 3. f. 9. 10. Ve. nate immersae, in fronde sterili dissimili tenues, fur. catae, supremae simplices, veaulis subdivergentibas in fronde fertili erassae, simplices, apice clavatae. 0 . o b t a s il o b a Schkuhr.

\section{Asplemian LINN.}

a. ASPLeniUm Presl Pterid, 104, t. 3. f. 8. 11, 19-23. Venac pinastae, crebrae, simplices v. ani-bifurcatae, venulaeque parallelae, apice libero punetiformi acuto termiuatae v. areu transverso conjunctae.

c. Thamnopteris Presl l. c. Venulae apice aren transverso conjunctae. Sori per frondis paginam sparsi, indusils versus costam liberis. A. Nidus Linn.

$\beta$. Eursplenium. Venae et venulae apice liberae. Sori per frondis pagiuam sparsi, induslis versus costam liberis. (Fr. Bauer Filic, t. 30.)

$\gamma$. Darea Juss. Vo a a et venulae apice liberae. Sori in pianularua profande incisarum lobulis solitaril, margiuales. (Fr. Bauer Filic. t, 6.)

b. PLENASIUM Pres! Pterid. 109. $t$. 3. $f$. 13. Venae pisaatae, infra medium furcatae, venulaeque parallelae ia marginea froodis, infimae conniventes in sinum laciniarum excurrentes. I a d us i a m reflexum. A s ple a i u m aureum Blam.

c. Hemidyctium Presi Plerid. 110, t, 3. f. 24-26. Ven a e creberrimae, pinnatae, simplices v. fureatie, venunulaeque parallelae, versus marginem ramosae et in areolas trapezoideas anastomosantes, ante marginem frondis iu costulam uargini porallelam desineutes. Aspl, margiuatum Linn. Aspl. Douglasii Hook, et Grev.

631. Allantodia $R$. $B R$.

Venae pinnatae, simplices, medio dorso soriferae. Athyrii sp. Presl. (Fr. Baner Isilic. t, 16.)

\section{B3\%. Hoodila R. $B R$.}

Ven a e subtus prominulae, in areolas hexagonas, uni. biseriales, anastomosantes, angulis duobus superioribus veauliferae. Venulae parallelae, simpliees v. furcatae, apice libero desinentes. Pres1 Pterid, 92. $t, 3 . f$. 18.

G33. WVoodwandia SMITH.

Venae Immersae, in areolas inaequales anastomosantes, areolis costalibus elongatis, costae parallelis, medis hexagonis ad angulos superiores externos venulas liberas, simplices v, furcatas gerentibus. Presl Pterid. 99. t. 3. f. 6 . 7. 12. Fr. Bauer Filic. $t$. 17 .

\section{E34. Scolopendrium $S M I T H$.}

Sori lineares, venis veuulisve proxime sibi oppositis in. serti. Ladusium sori inferioris versus costam, superioris versus marginem frondis liberum.

a. EUSCOLOPENDRIUM. Ve na e pinnatae, uni-bifureatae, veoulis parallelis apice libero in punctum inerassato $v$. acuto terminatis. Sori oppositi, inferior in venae inferioris erure superiori, superior in venae superioris crure inferiori. Indusio $r$ um oppositorum margines contigui v. distantes. S colo pendri um Presl Plerid. 118, t. 4. f. 15. 16.

b. ANTIGRAMMA Presl Pterid. 120. t. 4. f. 9. 10. Veuae pinnatae, fureatae, venulis parallelis a medio versus marginem frondis in areolas inaequaliter et elongate hexagonas anastomoxautibus, areolis angulo superiori venulas breves, liberas emittentibus. Sori in venularum parte inferiori oppositi, inferior in venae inferioris crare superiori, superior in venae superioris crure in. feriori, I adusiorum oppositorum margines contigui v. distantes. Seol opendrii sp. Auet.

c. CAMPTOSORUS Link. Venae in areolas hexagonas, biseriatas aastomosantes, augulis areolarum marginalium veuulas liberas, simplices v. furcatas enittentibus. So ri tineares, in areolis costalibus et in venulis marginalibus solitarii, $\mathbf{i}$ n $d \mathbf{n}$ s fo hornm versus marginen froudis, Illorum versus costam libero, in areolis secun. dae seriei oppositi, inferioris indusio versus costan, superioris opposita directione libero. Ca mptosor as Link Enum. hort, Berol. II. 69. Pres! Pterid. 121. t. 4. f. 8. Asplenium rhizophyllam Lian.

635. Dayelnitum $K A U L F$.

Fr. Bauer Filic. t. 11, L e ptostegia Don Nepal 14. Allos ori spec. Presl.

638. Diplazinm $S W A R Z$.

Sori amues v. saltem infimi bilaterales. Indusia in so. 
ris bilateralibus conereta, superiore versus costam primariam, inferiore versus costulam libero.

a. EUDIPLAZIUM. Ven a e immersae, tenues, pinnatae, simplices v. supra basim furcatae, venulaeque paralle. lac ante marginem apice libero, acuto desimentes. Sor i infini v, omues bilaterales. Di plazium Presl Pterid. III. t. 3. f. 14. t. 4. f. $t_{-5}$.

b. ANISOGONIUM Presl Pterid. 115. t. 4. f. 6. 13. 18. Ven a e immersae, tenues, pinnatae, iufinae oppositae, in arcum acutum, ayice venuliferum anastomosantes, superiores liberae, ante marginein frondis apice obruso termiuatae, aut rarius praeter supremum in arcus apice venuliferos coalitae, venulis ex apice arcus exorientibus in concavitatem arcus mox superioris $v$. in narginem froadis excurrentibus. Sori in venis infimis bilaterales, in reliquis simplices.

c. DIGRAMmariL Presl Pterid. 116. t. 4. f. 12, 17, Venae inmersae, pianatae, infimae oppositae, in arcum angulatum, angulis venuliferum anastomosantes, venulis duabus v. tribus in siaum laciniarum connivendo excurrentibus, superiores fureatae v. simplices, venulis subparallelis. Sori in venis infimis bilaterales, in reliquis simplices. Asple a inm a mbig u um Swartz.

d. OXYGonium Presi Pterid, 117, t. 4. f. 7, 14, Venae pinnatae, crebrae, supra prominulae, uni.bifureatae, rarius simplices, venulaeque parallelae versus marginem frondis areu acutangulo, aplee veualifero anastomosan. tes, venalis ex apiee angulorum emergentibus liberis, acutis. Sor 1 bilaterales, aut venulae e furcatura primaria superiori, aut e secundaria fateriori, v. veuis vetu. lisque omnibus impositl. Aspleni un ovatum Wall.

63\%. Didlymoclilaena DESV.

Venae flabellato-pinuatae, iwmersae, tenues, uniquinquefurcatae venulaeque subparallelae, superiores simplices, apice soriferae. Su r $\mathfrak{i}$ apici venulae superioris simplicis inserti, oblongo-elliptici, i a d as ío erista longitudinali affixo, marginibus libero. Presl Plerid. 89. t. 2. $f$. 28. Fr. Bauer Filic. $t .8$.

\section{B38. Nephrolepis SCHOTT.}

Veua e pinuatae, densissimae, immersae, apice punctiformi naguo longe a margine frondis terminatae, bifurcatae, venula superiore breviore apice sorifera. Presl Pterid. 78.

t. 2. f. 14. Fr. Bauer Filic. $t, 35$, et $t . A$.

\section{Neplorodium $L, C, R I C H$.}

a. EUNEPHRODIUM. V e n a e pinnatae, ivdivisae, subtus prominulae, infima superior (rarius plares) cum infima inferiore proxime contigua in sinum acutum anastomasans, venula ex angulo superiare in sinum arcus, si ad. est proximi v. saepius in sinum laciniarum excurrens. Sori venarum dorso infra medium inserti. Nephro. di um Presl Pterid. 80. t. 2. $f$. 5. 6. 11. Fr. Bauer Filic, $t$, 48, $B$.

b. OLEANDRA $C A V$, Venae pinnatac, subhorizontales, deasissinae, simplices v. furcatae, venulaeque parallelae, fere is marginem frondis excurreates, subrus promíulae. So ri dorso venae v, venulae iosideates. Presi Pterid. 27, t. 2. f. 12, Ol e a nd ra Cav. Praelect. $n$, 623. Neuronia Don Nep. 6. Ophiopteris Reinw. in Syllog. pl. II. 3. Fr. Bauer Filic. t. 45. B.

c. DRXOPTERIS $A D A N S$. V e a a e pinuatae, immersae $v$. subtas promluulae, ante marginem apice obtnso terminatae, liberae, guse omaes simplices, nuac infimae v. omnes furcatae, nune intimae v. omnes pinnatim ramosae, venulis divergentibns, simplfeibus. Sor in medio venarum v. veuulae superioris dorso. - Lastraea Presl Pterid. 73. t. 2. f. 3. 4. 8-10. 15-18, Fr. Bauer Filic. t. 45. A. L a stre a e s. Bory.

c. E adryopteris. Venae omnes simplices, infimae ia sinum laciniarum excurrentes.

$\beta$. Thelypteris Schott. Venae omes v. saltem inferiores fureatae, infimae in sinum laciaiarum excurrentes.

$\gamma$. Arthrobotrys Presi $t$. c. Venace inferiores pin. uatim ramosae, superiores $v$. suprease furcatae. Sori in venula infiwa stperiori.

6L0. Aspidium $S W A R T Z$.

a. POLYSTICHUM Roih. V en ae pinatae, alternae, fere in marginem frondis excurrentes, inferiores furcatae v. bifureatae, superiores simplices. Sori medio venae dorso sub foreaturn insideutes. Presl Pterid, $82, t, 2$. f. 7. 13. Fr. Bauer Filic. t. $48 C$. T e etaria Cav. Ru. mo hria Radd. H y p opeltis Rieh.

b. PHANERophlebia Presl Pterid, 89. c, 2, $f$, 19, Ve. a a pinnatne, pinnatim ramosae, vesula infima superiore et infina inferiore libera, dorso sorifera, superio ribus in areus inaequales, acutos anastomosantibus, dorso soriferis, suprenis ante marginem frondís arcuatim desineatibus. Aspidinm nobile Schlecht. (Pr. Bauer Filic, $t, 49, A$,

c. CYCLODIUM Prest Pterid, 85, t. 2, f, 20, 21, Ven a e pianatae, simplices, inferiores superiores cum inferioribus oppositis in arcum plus minus acutum anastomosantibus, venula ex angulo areus superiori ia sinua anguli proximi exeurreate. Sori mellio venae dorso insidentes. As pidil sp. Will. Kaulf. Blum. (Fr. Bauer Filic, t. 48, B.)

d. CYRTOMIUM Presl Pterid, 86, t. 2. f. 26. Venae tenues, in areolas irregulares et inaequales abastomosantes. Areolae costales angulo inferiore interno venu Lam unam, reliquae angulis superioribus venulam v, venulas duas aut tres exserentibus, venu $\mathrm{f}$ is rectis, $\mathrm{li}$ beris, acutis, nedio dorso soriferis, areolarum marginalium apice punctiformi termialis. A s pidiam falca. to m Swartz. A. ea ryotid e u m Wall. (Fr. Bauer Fy. lic. $t, 49, C$.

e. SAGBNiA Presi Pterid, 86. to 2. f, 28-25. Venae tenues, in areolas hexagonas anastomosantes, areolis costalibus elongatis, superioribus saepe ad angulum inferiorem internum venuliferis, venolis liberis apice sori. feris. Sori unac in dorso venarum areolarna media. rum, nune in apice venularum liberarum.

f. EUASPIDIUM. V e n a e pinnatae, distantes, costaeformes, plus miaus flexuosae, ramosissimae. Venulae primariae in areolas inaequales, secundariae in areolas míores, iaterne venuliferas anastomosantes, venuI a e secundariae simplices $v$. ramosae, rectae $v$. incur. vae, apice acutiusculo desinentes. Aspidium Presi Plerid. 67. t, 2, f, 27,

c. As pidium Presl 2 c. A reola e primariae hexago. noideae. Fr. Bauer Filic. $t$. 33.

B. Bat hmium Presl l. c. Areolae primariae parallelogrammae, latere anteriore et posteriore curvato.

\section{Cystopteris BERNH.}

$V$ en a e pinuatae, inferiores pinnatim ramosae, superio. res furcatae, summae simplices, venulaeque aute marginem irondis desinentes, veauta infima superiore medio dorso sorifera. Presl Plerid. 92. t, 3. f. 1. - H y menoc y stis c. A. Mey. delentur h. I. Vid. infra n. $648 / 1$.

64 A/I. Aerophoras PRESL. Venae pinnatae, inferiores pinnatim ramosae, superiores furcatae, summae simplices venulaeque ante marginem v. prope marginem frondis desinentes, venula infima superiori medio dorso sorifera. I n d ns i m suborbiculatum, basi aflixum, versus marginem frondis liberum. - Filices indicae, frondibus pinnatim decompositis.

A crophorus Presl Pterid. 93. $t, 3, f .2$. Aspi d i $u$ in nodos u m Blum. Le u costegla Presl Pterid. 94. t. 4. $f$. 11 quae Davallia immersa Wall. nonaisi venulis fere in ipso frondis margine desinentibus, soris ideo submarginalibus et indusits subrentformibus diversa, haud separanda videtur, caeterum frobdis pagina superiore pallida, foferiore sorifera intensius viridi, nitida, adaodum siogularis.

\section{Iindsaea $D R Y A N D$.}

a. LINDSAEA Presl Pterid, 131, t. 5. f. 1. 2. Venae fla. bellatae, uni-bi-tri-quadrifureatat.

b. Schizoloma Presi Pterid. 132. t. 5, f, 8. Venae ramosissimae, in areolas hexagonas anastomosantes. Sebizoloma Gaudich. Hymenotomia Gaudich.

\section{Davallia SMUTH.}

Sori inframarginales globosi $v$. lineares, venae v, vonulae insidentes; indasio laterali, semiorbiculato v. ob. longo aut lineari, margine superiore libero.

a. MICBOLEPLA Presl Plerid, 124, t, 4. f. 21-23. Ve. na pinatae venulaeque ante marginem frondis apice 
clavato desinentes, infimae pinnatim venulosae, mediae fureatae, superiores simplices, venulis infimis superioribus apice soriferis. S o ri globosl, a margine frondis remoti, indusio semiorbiculari, scarioso, margine superiore truneato, demum sorum dimidium obtegeute.

b. SACCOLOMA Kaulf. Ven ne pinnatae, simplices v. furcatae, venulaeque ante uarginem apice acuto desinentes. Sori in apice ouminm venularum v. superiorum subglo. bosi, dentium dorsum occupantes, inframarginales, indu. sio semiorbiculari, herbaceo, demum scarioso, margine superiore late rotundato. S a c colo ma Presl Pterid. 125. $t$, 4. $f, 19.20$.

c. Davallia Pterid. 127, t, 4. $f$. 24 -29. Ven a fronde fertili pinnatae, simplices $v$. furcatae, venula superiore tunc sorifera, tenues v. apicen versus incrassatae, in fronde sterili apice acuto ante marginem fron. dis terminatae. Sori globosi, inframarginales, dentis dorsum v. sinum occupantes, ind us i o orbiculato, scarioso, dimidio superiori libero, v. semiorbicalato, mar gine superiore reetilinie truncato, v. latissime obtuso.

$c$. H a m a t a Cav. Frondes coriaceae, steriles simpli ces, venis uni-bifurcatis venulisque parallelis, tenuibus, fertiles dissimiles, pinuatifidae, venis simplicibus crassiusculis, apicem versus incrassatis. So r i in dorso dentium. Indusi u m orbiculatum, dimidio superiore libero. Presi $l, c$.

P. Pachypleuria Presl 2 . c. Frondes coriaceae, conformes, venis plurimis, apicem versus lineari cla vatis, inferioribus angulo acutissiano furcatis, venulis tenuioribus. Sor i in sinu dentlum. In d a $\mathrm{s}$ i m orbiculatum v. reniformi-orbiculatum, dimidio superiore liberum.

$\gamma$. Colposoria Presl 2 , c. Frondes coriaceae. con formes, venis plurimis, tenuibus, aequallbus, inferioribus angulo acuto furcatis. Sori in sinu dentinm immersi, ind ns i u m semiorbiculatum, nargine sa. periore recto v. latissime obtuso. - W i b e Ii a Bernh. (Er. Bauer Filic, $t, 27$.

d. Odontosoria Presl. 1. c. Frondes coriaceac v. herbaceae, couformes, venis tenuissimis, simplicibus v. furcatis, sterilibus apice punetiformi instructis. Sori in dorso dentium infra apicales, superfieiales, minuti. Indusin a semiorbiculatum, margine superiori truneato.

d. $?$ STENolobus Presl Pterid, 129, t, 4, f, 30. Ve na pinnatae, uni-bi-trifurcatae, superiores simplices, venulaeque parallelace. Sori dorsum dentis occupautes, lineares, elongati, indusio scarioso, lineari-urceolato, margine libero truneato.

e. PRosaptia Presi Pterid, 165. $t, 6, f, 19,25 . V$ e n a pinnatae $\vee$. flabellato-unilateraliter pinnatae, simplices v. furcatae. Sori in apicibas venarum venularúmque frondis margini immersi, indusio proprio nullo? D a vallia contigua Swartz. D. Emersoni Hook. et Grev.

\section{IDickmonia HERIT.}

a. BALANTIUM Kaulf. Vena pinatae, subtus elevatae, crassiusculae, inferiores furcatae, venulaeque superio res aplce soriferae. I a d us i a m eartilagineum, coria çeum v. herbaceam, veram semilunare, spuriom dissimile, operealiforme, convexum, utrumque pateas. Pres Plerid, 136. t, 5. f. 3. 4. Fr. Bauer Filic, $t, 20$.

b. CULcita Presl Pterid. 135. $t, 5, f .5$, V e na e pinna tae, subtus elevatae, simplices $v$. furcatae, simplices apice soriferae. Ind usi n m coriaceun, utrumgue fornicato-semiluabum, patens. D. C u leita Lina.

c. SITOLOBIUM Desv. Ve a a e pinnatae, pinnatim ra mosae, infima saperiore, subinde etiam interiore apice sorifera, supra puneto impresso, sorum indicaute bo. tata. I nd ns i n m seariosum, vernm semilunare, spu rium dissimile, e deute frondis reflexo efformatum, spu culiforme, utrumque patens.

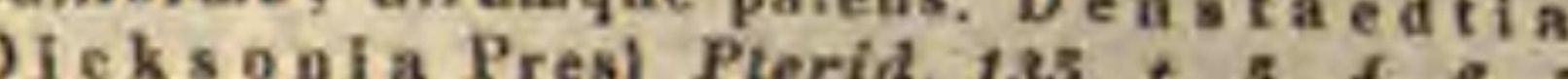

d. LEPTOPledria Prest Pterid. 136, t, $5, f, 9$ - 11 , V e na pinnatae, uni bifurcatae, venulis parallells, sub margiue frobdis apice punetiforml magno termieatis, superioribus apice soriferis. Indasi um verum coris ceum, semilunare, coucavum, demum patens, spurium conforme, e dente froudis. Dleksonia abrupta Bory. e. ? PATANiA Presl Plerid. 127. $t$. 5. $f$. 12-14. V e n a pinnatae, fureatae, inferiores bi-trifureatae, venulis sterilibus apice libero acutis, infiais superioribus, nonnunquam etian inferioribus apice punetiformi incrassato soriferis. I ndus i u m tenuiter coriaceum, pateraeforae, integerrimum, nonuisi basim sori iavolucrans, persi. stens, parte superiore e frondis dente matato. Dickson ia obtusifolia Willd. D. e ros a Kunze.

OBSERVATIO. Genus Dicksoniae ex el. auctore affine, fortassis ad Allosoros referendum, sed mihi quo ad characte. rem non satis intellectum, eat:

PAFSIA St. Hilaire Voy, Distr. Diam, 1, 381. Sori foraa varii (subrotundi, lineares), submarginales, in fidusio ante dehiscentiam undique inclusi. Indusium planum, membranaceum, tenuissimum, duplext superius e nargine frondis ortam, alterum interius cum ipsoast continum, frondis paginae npplicitum omnino obtegens, interins dehincens, post dehiscentiam reclinatum, et tune sorus, In medio fere indusif. marginibus haud laceri. - Filix brasiliensis bi-tripedalis, apice imprimis viscosa, Pteridum quarundam facie, stipite tereti, hirlello glanduloso, fronde-tripli. cato-pinnata, pinnis primariis patulis, distantibus, arcua. tis, secundarits oblongis, obtusissimis, lobatoincisis, crenulatis, subpubescentibus, superioribus confluentibus, subflabellato cuneatis, rhachibus glanduloso hirsutis, primariis flexuosis.

B45. Cillootionua $K A U L F$.

Ve na pinnatae, crassiusculae v. tenues, subtus proninulae v.immersae, simplicex $v$. furcatae, venulaeque apiee soriferae. Presl Pterid. 67. $t$. 11. $f .8-10$. Fr. Bauer Fil. t. 25. Pinonia Gaudich. De paria Hook. et Grev, Fill. t. 154. Fr. Bauer Filic. $t$. 44, B.

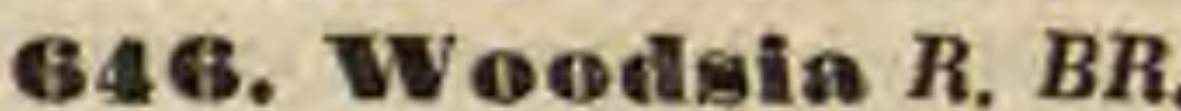

$V$ en a pinnatae, simplices $v$. bifurcae, venulis divergentibus, superiore medio sorifera. Phy se un $\mathbf{s} \mathbf{i} \mathbf{u}$ Kaulf. Presl Pterid. 66. t. f. 11 .

647. SACCOLOMA. Genus delendum. Vid. supr. n. 643. b.

B48/1. EIymenoeystis $C, A, M E Y$. Vena pinnatae, simplices, infimae inferior et superior apice sorifera. Indusium suro globoso substratum, sphaericum, apice ore lacero dehiscens. - Filicula caucasica, glabriuscula; fronde pinnatisecta, pinnis oblongis, pinnatifidis, lobis obtusiusculis, oblongis subovatisve, obtuse dentatis v. subintegerrimis, stipite basi paleaceo.

H y menoc ysti \& C. A. MeyerVerzeichn, cauc. Pfanz. 229. Fr. Bauer Filic. $t$. 3 .

648/2. Hypoderris $R$. BR. V e nae pinnatae, alternae, parallelae, venulis retienlatim anastomosantes, $80 \mathrm{ris}$ anastomosium angulo impositis. I n d s i u soro globoso substratum, membranacenm, reticulatum, margine fimbriatum. - Filix insula e $T_{r}$ initatis; fronde stipitata, simplici, membranacea, subcordato-auriculata, acuminata, costuta.

H y poderris R. Brown in Wallich Plant, As. rar, I. 16. in not. Fr. Bauer Filic. $t, 1$.

849. Splaseropteris $R$. $B R$.

Venae pinnatae, inferiores farcatae, infima superior medio dorso sorifera, simplex. Fr. Bauer Filic. t. 22. P era ne m a Don. Presl Pterid, 65. 2. 1. f. 21.

\section{Thyrsopteris $K U N Z$.}

$V$ e n a in fronde sterili dissimili pinnatae, infimae farcatae v. bifurcatae, mediae fureatae, superiores simplices. $V$ e na frondis fertilis ad rhachin meram reductae, thyrsum paniculatam, supradecompositum referentes. Sori pianati, peduneulati, semiglobosi. In d us i u coriaceum, canpanulatum, ore cireulari apertum, margine integro. Kunze Farrenkräut. $t$. 1. Presl Pterid. 66. $t$. 2. $f$. 1. 2. Pr. Batter Filic. $t, 44 . \mathcal{A}, \mathrm{P}$ ante ularia Colla in $\mathrm{Mem}$. Acad. Tu. rin, $X X X I X .33, t, 64$. ? C h o nt a Molina Chili 156.

B5 1. Hemitella $R, B R$.

a, EUHEMTRLiA, Vena e pinnatae, simplices. Sort in basi veaae Infimae superioris cajusvis laciaiae solita- 
rii. Hemiteli a Presl Pterid, 57, t, 1. f. 14. H. cape $\mathrm{n} s$ is $\mathrm{R}$. Br. Fr. Bauer. Filic. $t, 42.1$.

b. CNEMIDARIA Presl. V e n a pinnatae, infimae oppositae, iu areum angulatum venuliferum anastomosantes, venulis duabus v. tribus ia sinum laciniarua frondis connivendo excurrentibus, venae superiorifurcatae, venulis parallelis. Sori medio dorso venularum inserti. Cn emidaria Presl Pteridogr, 56. t. 1, f. 16. 17. 18. Fr. Bauer Gen. Filic. $t$. 4. Indusium in Cnemidariis Presl. ut in Hemitelia capensi dimidiatum video.

65\%. Alsoplilla $R, B R$.

a. HAPLOPHLEBIA Mart. Crypt, 64, V e n a e pinaatae, simplices, rarius una v. altera fureata. $S$ or $i$ in dorso medio venarum siuplieium. A Is o phila e seet. 1. Presi. Plerid. t. 1. f. 19, 20.-? G y m no $\mathrm{p}$ h a era Blume Enum. Pl, Jav. 242.

b. DiCRANOPHLEBIA Mart. Crypt, 67. Ve n a e pinnatae, uni- v. rarius bifurcatae. $S$ or $i$ in ala fureaturae veuarum Inserti. - A I s o p hillae sect. 2. Presl Pterid. 6. t. 1. f. 6. (Fr. Bauer Gen. Filic. $t$. 9, et 21.)

c. METAXYA Presl Pterid. 59. t. 1. f. 5. Ven a e pinatae, simplices v. furcatae venulaeque parallelae. Sor I In venarum venularumve dorso 2 -4seriati v. rarius solitarif. - Fr. Bauer Filic. $t, 42, B$. Chnoophora rostrata Mart. Crypt. t. 39. A mphidesmium Schott Gen. flic, t, 8. in not. Trichapteris Parker. Polypodium Parkeri Hook. et Grev. Fil. t. 238.

d. TRIChIPTERIS Presl. V e a a pinnatae, simpliees v. a basi furcatae veaulaeque parallelae apice iucrassatae. Sori in medio venarum venalaruaque dorso kolitariae. cuhconfluentes. Triehopteris Presl Pteridogr. 58. t. 1. f. 10. Fr. Bauer Gen. Filic. t. 34. A I sophila e sect. Cha ooph ora Mart. Crypt. 63.

653. Cyatlaea SMITH.

a. SchizocAENA J, Smith in Fr. Bauer Gen. Fil. $t$. 2, Veuae nune siaplices v. superiores fureatae, nunc pinnatim ramosae, venulis alternis, simplicibus. Sori in medio venarua venularumve dorso. R e cepta e ulu w gibbosun v. disciforme. Cy athe a e sect. Eucy. at the a Presi Pterid. 55, t. 1. f. 8.

b. NOTOCARPIA Presl Pterid, 54, t, 1. f, 9, et 15, V ena ani-bi-tri-furcatae. $S$ o $r i$ in ala furcaturae venarum. Receptac ulum globosum v. clavatum. (Fr. Bauer Gen. Filic, $t$, 23.)

c. DISPHENIA Presl Pterid. 55. Venae pinnatae, inferiores bifureatae, superiores furcatae. $\mathrm{S}$ or $\mathrm{i}$ in ala furcaturae venarum venularumve inserti. ReceptacuIn m globoso-obovatum, denum bipartitum, lobis clavatis, divergentibus. - (Presl t. 1. f. 13.) - C. arborea Swith. C. aculeata Willd.

d. CNEMIDARIA Presi Pterid. 56. Ven a e pinnatae, infimae oppositae, in arcum augulatuor, venuliferum anastomosantes, venulis duabus v, tribus in sinatu laelniarum frondis conoivendo excurrentibus. S o ri medio venularum dorso inserti. R e cup $\mathrm{tac}$ a 1 u m globosum, míntum. (Presl t, 1. f. 16, 17, 18.) - Heniteliae sp. Kaulf. C y at hea horrida Smith.

654. Nattonia $R$. BR.

Ve ua ramosissimae, venulis Inferioribus in areolas hexagonoideas confluentibus, superioribus uni-bifurcatis, IIberis. Presl Pterid, 68. Fr. Bauer Fitlic. $t .43$.

655. Ceratopteris BRONGN.

Fr. Bauer Eilic, $t, 12$.

656. Parlkeria HOOK,

Fr. Bauer Filic. t. 50 .

\section{Ordo XXIII. Hymenophylleae.}

65\%. IIymenophyllum SMITH.

Fr. Bauer Filte, $t .32$.

658. Trielnomanes $L I N N$.

Fr. Bauer. Filic, $t, 31$.

658/1. Loxsoma|R. BR. S porang'ia circa venam intra frondis marginem longe exsertam, usque ad apicem fructiferam inserta, stipitata, oblique annulata, pilis clavatis mixta. In du si u m coriaceum, suburceolatum, in sinubus dentium frondis subintramarginale, ore truneato integro, imam columellae fructiferae partem cingens. - Filix $\mathrm{No}$ $v a e-Z e e l a n d i a e ;$ caudice horizontali, fronde stipitata, coriacea, glabra, subtus glauca, decomposita, laciniis lanceolatis, dentato-pinnatifidis, marginibus sinuum soriferis, costatis, oblique remote venosis, venis furcatis, venula superiore fertili.

Lox $50 \mathrm{ma}$ R. Brown msc, A. Cunningh. in Bot, Mag. Comp. II, 366, t. 31, 32, Fr. Bauer Fillic, $t, 15$.

\section{Drdo XXVIIL. GLeicheniacae.}

\section{Gleielnenia SMITH.}

a. MERTENSIA Willd. V en a e pinnatae, unl-bi-trifureatae, veuulis divergentibus v. paralielis. Sori dorso medio venulae superioris, rarissime simul inferioris inserti, tri-malticapsulares. Merteasia Willdenow Spec. $\nu$. 73. Prenl Plerid. 80, t, 1. f. 7. 12. Pr. Bauer Fil. t, 39. Di eranopteris Bernhardi in Sohrad.n. Journ. 1806. II. 38. t. 3. f. 13 .

b. STICHERUS Presl Pterid. 51. Venae reticulatae. Sori biseriales. Mertensia laevigata Willd. Gleiehenia lanigera Don.

c. GLEICHENIA Swith. Venae pinnatae, simplices, alternae, apiee obtaso intra marginem frondis desinentes. Sorus in apice vease infimae superioris cujusvis laciniae solitarius, immersus, uni-tri-quadricapsularis. G I e ichen i a Preal Pterid. 48, t. 1. f. 1, 2. Fr. Bauer Filic. t. $4 t . A$.

\section{Platyzoma R. BROWN.}

a. CALYMElla Presi Pterid. 48, $t, 1, f, 3$, Ve na e pinnatae, simpliees, neutangulae, longe a margine frondis replicato cuculliformi desinentes. Sor $u s$ in apice venae Infimae superioris eujusvis laclaiae solitarius, superfieialis, tricapsularis. Gleiehenia mferophylla $R$. Br, et Gl. alpi n a R. Br. (Fr, Bauer Filic. t. 41. B.)

b. EUPLATYZOMA. Ven a e pinnatae, simpliees, horizon. tales, longe a margine frondis revoluto cuculliformi desinentes. Sori in apieibus venarum singularam siaguli, superficiales, tri-quadricapsulares. P I a t y $z \circ \mathrm{m} \mathrm{a}$ R. Br. Presl Pteridogr. 49. $t$. 1. f. 4. Fr. Bauer Filic. t. $41, C$.

\section{Ordo XXIX. Schizaeaceae.}

\section{6er. Sehizaea SMITH.}

Fr. Bauer Fil, $t, 19$.

683. Hygodlum $S W A R T Z$.

Fr. Bauer Fil, t. 28.

\section{Drdo XXX. Osmandaceae.}

665. Demunda $L$.

Fr, Bauer Filic, $t, 46,1$.

B8s. Toutea WILLD.

Fr. Bauer Filic, $t$, 46. B.

Drdo XXXI. Marattiaceae.

6อร. In aulfussia $B L U M$.

Griffiths in Aviat, Research, XX. $t, 18$.

689. Anglopteris HOFFM.

Fr. Bauer Fit. $t, 10$.

669. Danaea SMITH.

Fr. Bauer Fil. $t$, 7 .

Bร0. Marattia $S W A R Z$.

Fr. Bauer Fil, $t, 26$.

\section{FILICES FOSSILES.}

68r/1. Seolecopteris ZENK. Frona pinnata, pinnis integris, uninerviis, venis pinnatis, juxta totam longitudinem soriferis. Sporangia 
ovato-acuminata, terna $\mathbf{v}$. plura in stipitulo brevi sessilia. - Lapis chalcedonius.

Scolecopteris Zenker in Linnaea, XI. 509. $t .10$.

\section{Drdo XXXIL. Opleioglossene.}

G93. II elmintinostachys KAULF.

Fr. Bauer Filic. $t$, 47 .

684. Hotryeloimm $S W$.

Fr. Bauer Filic. $t, 47, A$.

\section{Drelo XXXVI, Lycopodiacede.}

6D5. IP sillotum $R B$.

Tmesipteris Beruh. Endlicher Iconogr. 2.85 .

\section{Ordo XXXVיIII. Cycadeaceae.}

Miquel in Dietr. of Otlo Gartenz. 1838. VT. p. 321. Vriese et Hoeven Tijdschr. 1838. p. 409. Bullet Belgic. 1838. p. 82 et 129. Bullet. Neerland. 1839. p. 44.

\section{r 0.4. Cyeas LINN.}

Frondi $\mathrm{u}_{\mathrm{m}}$ rbachis pinnulaequel ssingula e vernatione eireinatae.

ซ D5. Enceplanalatog $L E H M$.

Frondium rhachis pinnulaeque rectae, hae imbricatae, faciebus sibí invicem applicitae.

\section{Zzamia LINN.}

Frondin m rhaehis veratione circinata, pinnulae rectae, imbricatae, faciebus haud sibl invicen applicitis.

OBSERVATIO NECESSARI $\boldsymbol{h}$, Zamias americanas, seu Zamias genuinas, praeter characteres e florum masculorum fabrica desumendos, etiam spinnis cum rhacheos processu manifeste articulatis" a Zamiis Novae-Hollandiac et Capitis bonae Spei ineolis, quarum spionae vel obsoletissime ariculatae $\mathrm{v}$, ominino decurrentes, ${ }^{n}$ genere posse distingul, auctore cel. Dryandro monult el. R. Brown Prodr. 348. Cl. Reichenbach Consp. p. 40. Zamiae et Arthrozamiae noda proposuit vocabula, ego Arthrozamiae spectans etymon, Zamias auericanas niunis eum rhacheos processu manifeste articulatis" tali nomiue desigaatas certissimum patans, nitilominus Brownio Dryandroque, et mori inter bolauicos recepto adhae. reas, Eucephalaril nomen, optimis characteribus et praeelaris iconibes ab auctore suo stabilitum pro speeiebus capensibus et australicis non recipere non potui. Hodie Arthrozamiae auctor (Handbuch des natürl. Pflanzen-Systems p. 60, in not,) Encephalartum Lehmanni sil i Arthrozamiam dictum asserit, ego erraris convicor, quia botanieum grae. cae lingaae peritum Zamias npiunis v, obsoletissime articnlatis v. omnino decurreotibus" Arthrozamiàu dicere noluisse, innocens eredidi. Fortassis Artozamiam dicere voluit, sed ${ }_{n} \mathrm{Ar}$ throzamia" ubique seripsit.

\section{CYCADEACEAE FOSSILES.}

709. Zamaites BRONG.

W. P. Schimper et Moug. Plant. foss. Vosg. t, 18. f, 1 . จ1 1. Nilsonia BRONGN.

W. P. Schimper et Moug. Plant. foss. Vosg. t, 18. f. 2 ,

\section{Dralo XXXIX. Balanophoreae.}

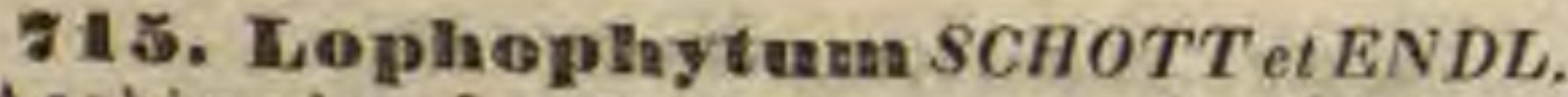
A $\mathrm{r}$ eh ime dea Leandro de Sacram, ex St. Hilaire in Nouv. Annal se, nat. VII, 32.

\% 16. Dmibroplaytema POEPPIG.

Nov, Gen. et Sp, $I I$, 40, $t$, 155.

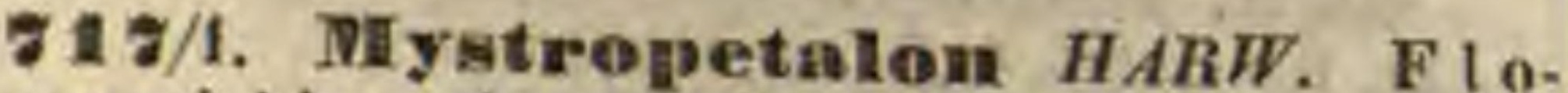
res monoici in eodem eapitulo, inferiores feminei, superiores masculi, singuli basi bractea antica, libera, bracteolisque duabus lateralibus minoribus, basi postice coalitis muniti. II a seuli sessiles. Perigoniu m triphyllum, foliolis spathulatis, apicibus concavis, antico libero, saepissime minore, duobus posticis inter se coalitis. Stam in a 2, foliolorum posticorum perigonii apicibus coneavis cohaerentibus inserta et iisdem breviora, libera, conniventia; filamenta brevissima, antherae biloculares, oblongae, versatiles, longitudinaliter dehiscentes. Ovarii rudimentum. Feminei: receptaculi carnosi, hemisphaerici, nudi, cum fructu decidui centro umbilicato solitarie insidentes. Perigon i u m tubo subgloboso, cum ovarin connato, limbo supero, tubuloso v. snbgloboso, trifido v. tridentato. Ovarium inferum, subglobosum .... Stylus terminalis, fliformis, longe exsertus; $s t$ igma truncatum. F ruetus ellipticus, epicarpio carnoso, succulento, endocarpio crustaceo, massa carnosa, in particulas innnmeras, minimas collabente fuetus. - Herbae capens es, epirhizae, carnosae; stipite subclavato, basi squamis laxe imbricato vestito, superne dense fiorifero.

Mystropetalon Harwey in Annal. of nat. Hist. IT. 386, t. $19,20$.

719. CyHopsolle ENDL.

Langsdorfía indiea Arnott in Annal. of nat, hist. II. 36. Hooker Ic. $t$. 205. 206.

g 2 1. Helosis RICH.

Lathra eo phila Leandro de Sacram, ex St. Hilaire in Nouv. Annal. sc, nat. VII. 32 .

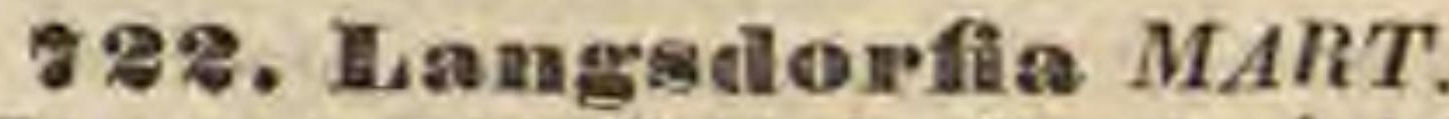

Th o n ing ia Vahl in Dansk. Selskab. Skrivt, $\nabla \mathbf{I}$ 124. $t$. 6. planta guineensis, ex icoue et descriptione pessima a Langsdorfia nou distinguenda, et verisimiliter congener.

\section{Ordo XI. Cytineare.}

g:3. Cytimas LINN.

Thy rsine Gleditseh verm. Abhandl. 199.

\section{Ordo XIL. TRaffesiacene.}

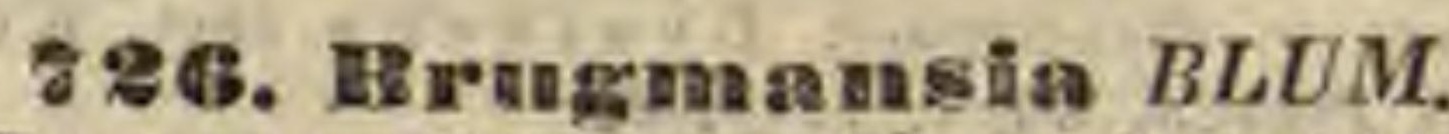

$\mathrm{Z}$ ippeli a Reicheab. Pflans.-Syst, 164.

\% ร. HEa frlesia $R, B R$.

Jack in Bot, Mag. Comp, $T, 259, t, 14$.

\section{Drdo XIII. Granineare.}

\%8/1. Hileplanarellaloa. S picula e hermaphroditae, uniflorae. G I $\mathbf{u} \mathbf{m}$ a e v. Pale a e 2 , compresso carinatae, mnticae, obtuse mucronatae, brevissime stipitatae, inferior quinquenervis, nervo medio (carina) marginalibusque denticulato-ciliatis, superior paullo brevior trinervis, carina denticulato-ciliata. Squa mula e 2 , carnosae, acinaciformes. Stamina 6 . Ovarium sessile. Styli stigmata longa, plumosa. - Gramen in inundatis In diae orientalis proveniens; culmis gracilibus, basi longe repenlibus, articulis cylindraceis, pubescentibus, caeterum laevibus, foliis subglaucescentibus, linearibus, acutis, supra lineatis et tactu scabris, margine subsimplici scabro, spicis paucis, distantibus, subsecundis; in paniculam nutantem alternatim dispositis, spiculis solitariis, in pedicelli curvati apice cyathiformi articulatis, subsessilibus.

$\mathrm{Ziz}$ a nia ciliat a Spreng. Griffiths in Journ. Asiat. soc. Bengal. 1836. $V$. 570, $t$, 24, $f, t$, Leersia cilliata Roxb. Pharus ciliatus Retz.

\%8/2. IPotamoelalos GRIFFITH. S piculae hermaphroditae, uniflorae. G l umae v. P a l e a e 2, sessiles, apici pedicelli continuae, vix compressae, inferior major quinquenervis, in aristam rectam desinens, nervis denticulato ciliatis, superior mutica, acuminata, trinervis, carina denticulato-scahra. Squa mula e 2 , magnae, extris gibbo-carnosae, glabrae v. apice ciliatae. Śt a mina 6 , filamentis longe exsertis. Ovarium sessile. 
Styli 2; stigmata plumosa. Caryopsis.... - Gramen indicum, natans, dense caespitosum, culmis submersis longissimis, hinc illinc radiculas capillaceo-ramosus emiltentibus, emersis vix pedalibus, glabris, vaginis submersis et semiemersis magnopere cellulosis, incrussatis et quasi inflatis, emer sis longioribus, cylindricis, minus cellulosis, foliis lanceolotis, basicordatis, obtusis, apice subeucullatis, rigidis, tactu scabris, panicula erecta, axi ad ejus originem subito angustuto, ramis infimis subverticil. latis, divaricatis, superioribus alternantibus, adscendentibus, spiculis ramis adpressis, subsecundis, inferioribus geminatis, inaequaliter pedicellatis, superioribus solitariis, longius pedicellatis, pedicellis clavatis, infra medium constrictis et annulo rubro insignitis, spicularum infimarum curvatis.

Pot a mo chlo a Griffitis in Journ. Asiat. soc. Bengal. 1836. $V .571 .4$. 24. $f$. 2, Z Zizania arlstata Kunth. Leersia aristata Roxb. Pharus aristatus Retz.

733. IIY

Dele synonyma. Vid, supr. n. $728 / 1$. 728/3.

\%38/1. ID platax SOL.

Diplax Solaud. mse. ex Bennet in Horsfield Plant. Jav, rar. 11. Grameu Novae'Zeelaudiae, indescriptum, a Microlaeua staniaibus duobus diversnu.

240. Yheptaspis $R$. BR.

Horsfield Plant, Jav, rar. t, 6 ,

\% $43 / 1$. Chiomaclane R. $B R$.

"Coix arundinacea Willd, geaus propriam efformat, a Colce diversum defecin veri involucei osseo-cartilaginei, in hac planta eaim insolucrum auctorum gfuma inferior locustae femineae est, ut in Sclerachne, a qua Chionachne distinguitur praesertiar figura et textura uniformi glumae inferiurls locustae fettinear, et iasuper kpica locustis mascalis pluribus, nec uniea, etiam habitu." R. Browa in Horsfeld Plant. Jav. rar, 15.

7 43/2. Gelleraelane R. BR. Flores spicati, spieae androgynae, fasciculatae, singulae involuero monophyllo, foliaceo inclusae, constantes spiculis duabus v. rarius tribus, una v. rarius duabus inferioribus femineis, sessilibus, altera mascula, pediculata. M a sc. Spicnla e biflorae. GI am a e 2 , subaequales, nervosae, herbaceae. Palea e 3 , membranaceae. Fem. Spieula e biflorae, flore inferiore neutro, superiore femineo. Gl ana e 2, inferior dimidio inferiore cartilagineo, pedicellum spieulae masculae amplectens, margine altero equitans, superiore compressa, semiberbacea, nervosa, gluma saperior membranacea, acuminata. Neutr. Palea 1. Fem. perf Palea e, angnatae, acutae. Stylus bifidas; stig m sta hispidula. - Gramen javanicum, gabrum; culmo ramoso, geniculato, foliis planis, ligula brevissima, ciliata.

$\mathrm{Sel}$ e raebne R. Brown in Harsfeld Plant, Jav, rar. 15. $t, 4$.

- 43/3. Polytaea $R . B R$. Spicae terminales masculae, axillares androgynae, infra femineae; utriusque rhachi ad articulos singulos, bifloros solubili. Ma s c. Spieulae biflorae. G I uma e 2. Stamina 3. Squa un lae hypogynae 2. Fem. spieula e biflorae, flore inferiore nentro, superiore femineo. G 1 u ma e 2 , inferior cartilaginea, rhachin angustain amplectens, nervosa, alata, superior laevis, acuminata. Neutr. Pale a 1, glumae superiori conformis. F em. perf. Paleae 2 . Squamula hypogynae nullae, Stig. mata longissima, colorata. - Gramen $j a v a n i$. cum, elatum; foliis planis, margine asperis, ligula brevi, ciliata, articulis femineis spicae androgynae spicula neutra, univalvi, herbacea, articulum amplectente stipatis, spiculae nusculae flore superiore paullo praecociore.

Polytoe a R. Brown in Horsfield Plant. Jav, rar. 20, $t .5$.

\% 4.1. Teekera FRESEN. Spiculae hermaphraditae, uniflorae. G I u ma e 2, minimae, truncatae, subaequales, muticae, Pa lea e 2 , snbaequales, inferior trinervis, Jonge aristata, snperiorem breviter aristatam amplectens. S qu a m uI a e 2, ovario breviores. Sta mina 3 . Ovarin m sessile. Styli 2; stigmata plumosa. Caryop$8 \mathrm{i}$ s glabra, oblongo-elliptica, a dorso et ventre compressa, paleis tecta. - Gramen abyssinicum, ramosum; foliis planis, latis, vaginis tumi. dis, spicis linearibus, cylindricis, spiculis pedicellatis. $t, 8$

B e c k e $r$ a Fresenius in Mus. Senkenberg. II. 132.

ร5\%. Ataxia R. BR.

„Gluma locustan trifloram subsequaus. Floseulus Inferior masculus bivalvis, intermedius neuter, uterque dorso aristatus, terminalis hermaphroditus diander. - Gramen habitu et structura inter Anthoxanthum et Hierochloam medium, pariterque odoratum, gluma inaequivalvis, floseuli a basi brevissima, persistente rhacheos conjunctim solubi. les, valvula superior hermaphroditi flosculi uninervis, staminibus axibus valvularum oppositiv," Bennet in Hors. field Plant, Jav, 8, t. 3.

ร 7. Stentotaplarman TRIN.

Henstow in Annal. of nat. hist, I. $t, 11$.

ร ช 6/1. 'Thysanolaena NEES. S p i e la e biflorae, flore inferiore nentro, snperiore hermaphrodito. G $1 \mathrm{um}$ a e 2 , inaequales, flosenlis breviores, muticae, inferior minor. Neutr. Palea herbacea, integra, mutica, glabra. Herma phr. Pal ea e 2, muticae, inferior herbacen-membranacea, trinervis, longe ciliata, superior minor et angustior, lineari-lanceolata, meinbranacea. $\mathbf{S} q \mathbf{n}$ am u l a e exignae, rotundatae, integerrimae. Sta. mina 2. Ovarinm.... Styli 2, basi coaliti; $s \mathrm{tig}$ a $t$ a ciliata. Caryopsis.....-Gramen indicum, elatum; foliis latis, rigidis, clabris, racemo amplo, supradecomposito, ramis plurimis, elongatis, filiformibus, basi callosis, sparsis, ap. proximatis, ramulis laevibus, oligostachyis, spieu. lis valde minut is.

T b y s a ol a e a Nees in Edinb, new philosoph, Journ, XVIIT. 180, A grostis Roxb.

\% 8. Toplaolepis DECAISNE.

Lop hole $\mathrm{p}$ is Decaisne in Archiv. Mus, I. 147, in not. Holboellia Wallich et Hook, uou Holboeflia Wallieh Flor, nep. infe. a. $4700 / 1$.

ร3. Greenia NUTT. Spicn la e uniflo. rae. G I n m a e 2 , coriaceae, subaequales, flure paullo longiores. Pale a e 2 , inferior sub apice aristata, arista demnm spiraliter torta. - Gramen boreali-americanum, annum; panicula multiflora.

Greenia Nuttall in Americ, philosoph. Transact. V. 142.

830. Rappontagram SCHREB.

? C oret h r um Vahl in Danske Selskabet Skrifl, IV. 85.

859. Aing LINN.

Hooker Ic, t, 150.

88 8/1. Hopluoelalaena NEES, SpienI a e multiflorae, floribus hermaphroditio, rhachillae artieulatae callig truncatis insertis. GIumae 2, membranaceae, obsolete uni-trinerves, flosenlis breviores, Pal a a 2, inferior chartaceo-rigida, 
plurinervis, apice membranacea, bifida, lobis praemorso-dentatis, inter lobos setam rectam exserens, superior plano-complicata, lateribus medio dentatolaceris, apicem versus serratis, apice emarginata. S qua m ula e truncatae, connatae. Sta mina 3. Ovari um oblongo-lineare, glabrum. Styli 2, breves; $s \mathrm{tigm}$ at a parva, plumulosa. Cary o p sis ... - Gramina boreali-americana, mollia; foliis brevibus, inflorescentia simpliciter racemosa, nuda, spiculis bromoideis, oblongo-linearibus, speciosis, antheris violaceis.

Lophoehlae na Nees in Jardine Annal. of nat. hist. I. 284. Hooker ad Beechey 403, $t, 93$.

\section{Coellachne $R . B R$.}

Endlicher Iconogr. $t, 2$.

DQ4. Arumelingaria $\mathrm{RICH}$.

Rupprecht Bambus. 21, t. 1_3. 15. Spieulae bi-multiflo. rae, summae steriles, in panicula depauperata.

904/1. Artlarostylidinan RUPPR. $\mathrm{S}_{\mathrm{p}} \mathrm{i}$. culae multiflorae, floseulis uno v. duobus infimis unipaleaceis, neutris, reliquis hermaphroditis, Ionge pedicellatis, artienlatim secedentibus, summo tabescente. Glumae 2. Paleae florum hermaphroditorum 2. Squamula e $3 . \mathrm{St}$ am in a 3 . O vari um glabrum. Styli 2, basi plerumque discreti; 8 tigmata pilosa v. plumosa, Caryopsis... - Gramina Americae tropicae; spiculis pedicellatis $v$. sessilibus, in racemos simplices $v$. paniculatos dispositis.

A rthrostylidium Ruppreeht Bambus. 27. $t$. 3_5.

908. Clamsquen KUNTH.

Rupprecht Bambus. 30. $t, 6$ - 11 . Dendragrostis Nees in Linnaea 1X. 467.

DO5. Nereostachys SPRENG.

Rupprecht Bambus. 36. $t$, 10 .

DO $/ 1$. Cintallara KUNTH. S p i c u la e multiflorae, florilus infimis summoque imperfectis, cylindricae, teretiuscnlae, arcuatae, pedicellis fiosculorum subelongatis, crassis. G I u m a e 2 , muticae. Pal a e 2 , snperior lata, inferiorem subaequans. Squa u u la e 3 , duabus quandoque connatis, raro hebetatae. Stamin a 6 . Sty 1 u s plerum que brevis, in $8 \mathrm{tigmat}$ a $\mathbf{3}$ secedens. Caryopsis ovalis, styli bulbo persistente aucta. - Gramina America e tro picae, arborescentia, caespitosa, rumosa; ramis junioribus pungentibus, foliis planis, brevissime petiolatis, flosculis subdistichis.

Guadua Kunth Synops. I. 253. Agrost. 433. Gram. 141. Rupprecht Bambus. 38, $t$. 15, 16. B a w bus a e s p. Humb, et Bonpl. Plant. aequinoct, $t, 20,21$.

\section{Nasters JUSS.}

Spieulae pauciflorae, floribus inferioribus unipaleaceis, imperfectis, nonuisi penultimn hermaphrodito, bipaleaco, palea interna fovea et carina flosculum ultimum imperfectua longe pedicellatua retinens aut eum marginibus arete involvens. P a lea e flosculorum superiorum nervis paucis, valde prominentibus, costiformibus. S q a a u uIae 3. Stamina 6 . St $\mathrm{l}$ us profunde bi-tripartitus. Rupprecht Bambus. 42, $t, 12$. Dele S chizostachy um Nees.
Vid. n. $908 / 1$.

DO8/1. Seluizostaelnyuman NEES. S p icula glomerato-congestae, bracteis latis, scarissis interstinctae, triflorae, flosenlis saltem duobus supremis bipaleaceis, sterilibus gemmiferis.
Gemma (spicula vivipara) trivalvis, Gemma (spicula vivipara) trivalvis, sterilis, v. in flosculo tertio penultimo organa sexus utriusve includens, palea interior flosculi tertii pedicello bremulae nullae. Stamina 6 . Signeta. Squastigmatibus 8 , brevibus, pubescentibus longus; mina indica et brasiliensia arborescentia, Bambusarum facie.

Sehizostachy um Nees in Mart. Flor, Brasil. Ir. 535. Kunth Agrost. 434. Rupprecht Bambus. 43, $t, 16.17$.

\section{DQS. IBambusa SCHREB.}

N. $907 / 1$.

a. BAMBOS. Floseulorum rhachis abscondita, Flos. culi inferiores marginibas paleae planis ciliatisque flores superiores $1-3$ correspondentes arcle cingentis, spicula inde (evoluta quasi) bifida, lineari-lanceolata. $\mathrm{Pa}_{\mathrm{a}}$ lea exterior interaa plerumque brevior. Rupprecht $l$. $c$. t. 11 .

b. ARUNDARBOR Bauh, FIo sculorum rhachis, saltem basis eorum, visibilis; palea externa margine subglabra, inferne contracta, involuta, spicula integra, ovato - lanceolata, palea exterior Interna plerumque brevior. Rupprecht $l$. c. $t .12 .13$.

c. DENDROCALAMUS Nees. Floseulorum rhachis ab. scoudita. Spleulae ovatae. Palea exterior ovata, margine arcte cingens paleam exteriorem flosculi superioris. Rupprecht l, e. $t, 12$.

\section{He ellasa RHEED.}

Me l o c a n a Trinius. Rupprecht Bambus. 63.

918. Polly tantherix NEES. Spicula e tri-quadriflorae, florum inferiorum uno alterove sterili, glumis simili, snmmo tabescente. G l n mae 2 , collaterales, profunde bifidae, laciniis bi-trifidis, omnibus longe setaceis, tertia dum adest minima. $P$ aleae 2 , inferior chartacea, ex apice bidentato v. bisetoso longe setigera, superior minur, integra, marginibus inflexis, flexnrae angulis ciliatis. S qua mula e lanceolatae, integrae, ciliatae. Stamina 3. Ovarium apise hirsutum. Styli 2 , distantes; $8 \mathrm{t}$ i $\mathrm{g}$ m a t a plumosa. Caryopsis....- Gramina boreali-americana; spica squarrosa, rhachi articulata, spiculis distichis, alternis, geminis, rhachi oblique parallelis, subsessilibus.

$\mathrm{P}$ ol y a ntherix Nees in Jardine Annal. of nat, hist. 1. 284. Hooker ad Beechey 404. A e gil o p s H y strix Nutt.

D25/1. Wossia WALL. et GRIFF. Spicnla e biflorae, flore inferiore masculo, superiore hermaphrodito. GI um a e 2, dissimiles, exterior chartacen-cartilaginea, plana, apice in cuspidem producta, interior chartacea, mutica, carinato-navicularis. Palea e 2 , floris inferioris masculi bi-, snperioris hermaphroditi trinerves. Squa mulae 2, enneatae, dentatae. Stamina 3. O vari n m sessile. Styli 2 ; 8 tigmata plumosa. Caryopsis... - Gramen ind ic um, procerum, fluitans, caespitosum; folits longissimis, acuminatissimis. planis, nervo centrali crassissimo albo, ligula indivisa, dense ciliata, spica compressa, articulata, rhachi flexuosa, excavata, spiculis in quovis articulo duabus, altera sessili, altera pedicellata, spiculae pedicellatae flosculo utroque saepius masculo.

Vos s i a Wallich et Griffiths in Journ, Asiat, Soc. Beng. 1836. $V$. 572. $t$. 23. Is c hae $\mathrm{m}$ um cuspidat am Roxb.

938. A retlineram PALIS.

Arthraxon Palisot $A_{g}$ rost. 111, $t$, 21. f. 6. Pleuroplitis Trinius l. c. Lucaea Kunth l. $c$.

\$48/1. Fratnatherenan NEES. SpicuI a e in rhachi articulata geminae, heterogamae, altera sessilis sesquiflora, altera pedicellata, neutra. Spien a perfecta bifiora, flore inferiore nentro, unipaleaceo, superiore hermaphrodito. Glum a e 2 , subaequales, acutae $v$. apice acute bidentatae, inferior plana, bi-sexnervis, superior complicata, a dorso implicata. Pa le a e glumis breviores, floris neutri unica, mutica, hermaphroditi 2 , inferior acuminata, apice minute bidentata, dorso 
prope basio emittens setam medio geniculatam, tortam, superior exigua, lineari-subulata, bidentata, interdum deficiens. Sq u a $\mathrm{m}$ u la e latae, truncatae, plicatae. Stamina 3 . Ovariam sessile. Styli 2 , distineti; $8 \mathrm{tigmata}$ villosa. S picula neutra subuniglnmis, gluma plana, acuta, nervosa, glumae alterius et flosenli radimento minuto. - Gramina indica, repentia, ramosa; foliis brevibus, amplexicaulibus, spica parce dichotoma, ad genicula plus minus barbuta, spicularum sterilium pedicello ciliato.

B a trather um Nees in Edinb. new philosoph. Journ. XVIIT. 180. A adropogon la uceolatus Roxb.

94 $8 / 2$. Hologramiana NEES. S p iculae in rhachi angusta geminatae, quadrifariae, polygamae, subeonformes, altera sessilis, monoica, setiyera, altera pedicellata, mascula, subsetigera. Gl $\mathbf{m}$ a e 2 , nervasae, inferior herbacea, plana, attenuata, apice bifida, spiculae sessilis octonervis, angustior, mascnlae quinque-septemnervis, latior, superior carinata, chartacen-membranacea, spiculae sessilis apice setigera, pedicellata, mutiea. S p icn la e sessiles biflorae, flore inferiore sessili masenlo, mutico, superiore femineo. Pale a e 2 , membranaceae, subaequales, ciliatae, flosculi superioris inferior ex apice bifido setam validam laevem, inferins carinatam exserens. Squamula e crassae, trigonae, obconicae, truncatae. St a mina 3. Styli graciles, basi conjuncti; $8 \mathrm{ti} \mathrm{gm}$ at a laxe penieilliformia. Caryopsis libera. Spienla pe. dicellata biflora, flore utroque masenlo. Pa le a e 2, subaequales, muticae. - Gramen indicum, perenne; culmis duris, gracilibus, vaginis internodio brevioribus, striatis, superne tuberculatis et hispidis, foliis angustis, acuminalis, planis, rigidulis, striatis, scabris, ad basim contractam utrinque plica callosa praeditis, glaucescentibus, ligula ciliata, spica solitaria, rhacheos articulis pedicellisque compressis, plumuloso-ciliatis.

Holog a mium Nees in Edinb. new philosoph. Journ. XVIIT, 185. Andropogon nervosus fottlet.

\section{Lepeocereifs TRIN.}

Spiculae is rlachí augusta barbulata geminatae, ideo quadrifariae, heterogatuae, conformes, seriebus duabus enntiguis sessilibus bifloris, floseula inferiore neutro, allisque duobus masculis v. neutris muticis. G/umae 2, inferior utriusque geaeris herbacea, multiuervis, apice tridentata v. integra, superior spienlae sessilis chartacea, eariuata, trinervis, maseulae submembranacea, trinervis, lateribus ia. fexa. Flos culus uterque naipaleaceus, inferior neater, palea membranacea, acutiuseula, ciliata, superior in spicula sessill heruaphroditus, angustissime linearis, in setan fle. xuosam, basi tortam abiens. S qua nu la e magnae, coloratae, erassiusculae, obconicae, fatrorsum convexae, extrarsum canaliculatae, emarginatae, angulis acutis, subbicoraí. bus. Stam I a 3 . Sty Ii basi contigui; stigma ta axper. gilliformia. Ca ry ops is basf augustata, obmsa, stylorum basi bimueronulata. Spiculae maseulae floris inferioris palea membranacea, lanceolata, sursum noaaibil dilatata, apice trideatata, eiliata. - Grsmina basi repentia, adscea dentia, ramosa, nodis barbatis, follis linearibus, acutis, eirca basim barbatis, ligula brevissima, spica termisali in apice culmi longe exserto. quandoque geminae v. plures, Nees in Edinb. new philosoph. Journ, $X V I I I$. 183. A a d ropogan eariasur Lina. A. serratus Retz. A. maliicom o s Trin.

Dร 1. Iselhaeman $L I N N$.

Dele A rti raxou Palis. Vid. supr, n. 937.

\section{Ordo XILII. Cyperaceae.}

9833. Diplacrounar $R, B R$.

Endlicher Ieonogr. $t, 25$.

988. Clanetosporas $R, B R$.

Dele Cyathocoma Nees. Vid. u. 968/1.

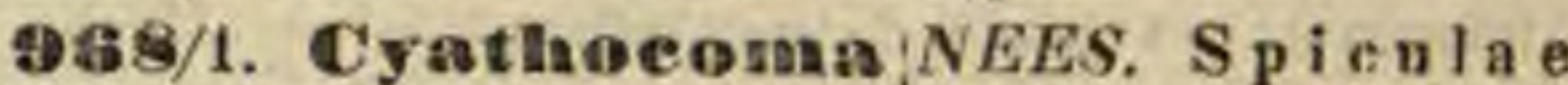
uni-biflorae, hermaphroditae. Palea distiche imbricatae, inferiores vacuae. Perigonii setae quinque v. sex, capillares, superne pubescentes, basi in nrceolum membranaceum connatae, v. liberae, dilatatae, ovarium aeqnantes v. breviores et inaequales, $\mathrm{Sta}$ mina $5-6$. Ovari $\mathbf{m}$ m trigonum; stylo trifido, basi continua conies inerassato. Caryo psis....-Herbae capenses, rigidae; culmis trigonis, foliatis, foliis canaliculatis, margine' scabris, spiculis fasciculatis v. spicatis, in spicas axillares et terminales flexuosas dispositis.

a. EUCYathocoma Fenzl msc. Perigonit setae basi in urceolum connatae, ovarii loagitudiue. - Culmi ar. ticulati, ad articulos fragiles.

C y a thoco m a Nees in Linnaea IX. 300. Kunth Cy. perogr. 322.

b. IDELERIA Kunth. Perigo a iI setae basi dilatatae, liberae, isaequilongae.

Ide leria Kunth Cyperogr. 310. Carp ba hex a ud $\mathbf{r}$ a Nees.

95 ร/1. Platylepis KUNTH. S pientae hermaphroditae. $P$ alea e 2 , aequilongae, braeteae multo minori, cuneatae v. lanceolatae, membranaceae contrariae, antice coalitae, postice liberae, leviter convexae, subrotundae, apice angnstato-acuminatae, subspongioso-coriaceae, florem obtegrentes. Perigonium nullum. Stamin a $2-3$. Ovarium complanatum; s tylo bifido, hasi aequali. C a r yo p s is breviter stipitata, inclusa, obovato clavata, hiesnvexa, calva, punetulata. - Herbae capenses et brasilienses, caespitosae, basi foliatae, spicis solitariis ternisque, subglobosis, involucro diphyllo suffultis.

Platylepis Kusth Cyperogr. 269.

995. Isalepis $R, B R$,

c. NEMUM Palis. Paleac ia rhachilla persistentes. Sta mina 2 ? Sty Ius complanatus, bifidus, hasi param constricrus, hand eiliatus, deciduus. Caryopsis leatica. lari-compressa.

Nemu un Palisat ex Desvans Prodr. Flor. Ind, oceid. 13. Kunth Cyperogr. 220. Schoea as spadiceus Vahi. Pag. 119. f. NEmuM Palisot deleatur. Vid. supr. 999. c.

\section{Ordo $\mathrm{XLIV}$. Centrolepialeae.}

100S. Centrolepis LABILL.

Endlicher Ieonogr, t. 49 .

\section{Drelo XIID. Emiocantoneae.}

1922. Eribeaulon GRONOV.

D u p a ty a Flor. Fium. $I$. $t$. $85-87$. - c. PAEPALAN. ThUS Mart. (Deless. Ic. Nelect. III. $t, 95-98$,

\section{Drdo XIEII. Xyrideae.}

1025. Xyris LINN.

b. Po matox y ris Eadlicher Ieonogr. 8.13.

102\%. Mayaea $A U B L$.

Coletia Flor. Flum. I. 79.

Ordo XEVIII. Commelynaceae.

1030/I. Furdannia ROYLE. Perig on ii exterioris foliola 3 , ealycina, interiora 3 longiora, petaloidea, sessilia. Stamina 6; filamenta 170 * 
omnium barbata, alterna perigonii foliolis exterioribus opposita fertilia, antherarum loculis parallelis, alterna sterilia, connectivo bieruri, triglanduloso, Ovarin declinatum.... Stylus fliformis; stig m a tridentatum.... - Herba indica; foliis radicalibus ensiformibus, acutis, scapo racemoso, pedicellis confertis, basi vagina membranacea munitis, floribus caeruleis.

M n rda n n i a Royle Himalay. 403, $t .95$. C a m mel y u a scapiflora Roxb.

103 1. Tradeseantia $L I N N$.

Bot. Mag. t. 3051,3506 .

103 1/1. Themantia SCHLIDW. P e r igonii exterioris foliola 3 calyeina, persistentia, in teriora 3 petaloidea, unguiculata, marcescentia, tertio dissimili, concavo. Stam ina 6 , superiora ternatim approximata, barbata, inferiorom filamento medio imberbi, lateraliom antice barbatis, adscendentia, basi dilatata, an herae oblongae, medifixae, loculis parallelis, contiguis, staminum superiorum difformibus. O va $\mathrm{r}$ i u m triloenlare, declinatum.... St y Ins glaber, adscendens; stigma capitatum. Capsula obtuse trigona, erecta, tornlosa, trilocularis.... S e m in a plurima, compressa. - Herba mexicana; folüs ovato-lanceola. tis, acuminalis, plicato-nervosis, margine crispis, supra pilosis, vaginis integerrimis, umbella terminali, nuda, pedunculo pedicellisque glanduloso-pilosis, floribus purpureo-roseis.

T innanti a Seheidweiler in Otto et Dietrich Gartenseit, 1839. VII, p. 365.

103 1/2. Spiromema LINDL. P erigonii exterioris foliola 8 calycina, interiora petaloidea fogacissima. S tam in a 6 , aequalia; filamentis spiralibns, an theris cordatis, petaloideis, loculis juxta basim transversis, Ovarium triloculare, ov ulis horizontalibus, globosis, snperpositis. Stigma simplex.... - Herba mexi cana, fragrans, Sansevierae quodammodo facie.

Spironema Liadley in Bot. Aeg. 1840. Append, 26.

\section{Ordo XEIX. Alismacene.}

103 \%. Whlaea $H U M B$, et $B O N P L$.

Species altera boreali-americana: Heteras t y lus Hooker Flor, Bor, Amer, II, 171, t, 183.

\section{Ordo L. Butomacene.}

1045. Hy rellecleis RICH.

Eadilcher Iconogr. $t$. 37 .

1046. Hinnoeharis PLLIV.

Endlicher Iconogr. $t, 26$

\section{Ordo HII. Juncaceae.}

1051. Astelina BANKS et $S O L$.

Genus fortassis rectius Melanthaceis appropinquandum.

1053. Hitn patea $A U B L$.

Pōppig Nov. gen. et sp. 168 ,

1056. Xerotes $R$. BR.

Bot. Reg, 1839, $t, 3$.

1959. Callectasiar $R$. BR,

Eudlicher Tconogr. t. 38.

\section{Drdo LIII. Dlelanthaceae.}

Cir. A. Gray in Annal. Lyc, nat, hist, New-York. IV. et Diss. Melanthacearuna Americae septemtrionalis Revisio. Nov. Fbor. 1837. Ordo multis modis reforanandas, faterim sequentia sufficiant :
TERTE 1. VERATREAE. Caules scapiformes, saepe foliosi. Flores racemosi v. spicati. Styli breves; stigmata vix non semper distincta.

SUE'TEREU I. MELANTHEAE. G. 1062. 1077 .

\section{B8. Toffieldia HUDSON.}

A n therac cordato-subrotundae, biloculares, sina affixae, futrorsae v. in nonuullis innatae. Sty li brevissimi, stigmatibus simplicibus v. subcapitatis. C a p s u la triloba, tripartibilis, carpidis gibbosis, intus et superne ad dorsum dehiseentibus. Se win a oblonga, subarcuata angulata v, utringue subulato-caudata. - Caules scapiformes, flores spicati v. racemosi, albidi, virescentiflavidi $v$. rarius sordide cocoinei, pedicellis solitarits, geminis $v$. ternis, bracteis parvis stipatis. A. Gray 2 . c. Synonyuis adde: Con radia et Le ptilix Rafinerq. Nov. gen. 3.

a. TOFFIELDIAE VERAE A. Gray l.c. S pica e v, racemus spicatus geouinus, modo florendi centripeto, pedicellis saepissime solitarils. Antherae introrsae. Semina ecaudata. - Herbae glabrae.

b. TRIANTHA A. Gray $l$. $c$. S pic a racemiformis, e fas. ciculis alternis, saepe trifloris, modo florendi centrifogo. A utherae innatae. - Herbae caulibus et pedicellis pulverulento-pubentibus $v$. glandulosis. Triautha Nutt. 2. c. part. T. pubeus Dryand. et T, g I u $t$ in o. s a Willd. Hook. Flor. Bor. Amer, t. 19t. - Sectlo ex el. A. Gray per Narthecium Melanthaceas Juncaceis connectens.

\section{G3. Pleea MICHX.}

Charact. reform. ex A. Gray l. c. Perigon i um corollinum, hexapliyllum foliolis lanceolatis, basi subcoalitis, eglandulosis, stellatim patentis imis. S $t$ m i n a 9-12! cam perigonil foliolis inserta, iisdem breviora; filamenta subulata, selacea, a ntherae liaeares, biloculares, basi bifida insertae, versatiles, introrsae. 0 varium trllabum, triloculare. Ovula plurima. Styli breves, subulati, ovarii lobos terminantes; $s t i g$ mata simplicia. C a p s a la coria. cea, ovata triloba, trilocularis, tripartibilis, lobis carinatis, introrsum dehiscentibus. S e mi na oblonga, apice setaceoeaudata. - Caules graciles, junciformes, o rhizomatibus caespitosis, radicibus fibrosis, rubris. Folia Meraque radicalia, disticha, sempervirentia, arida, angustissima, acutissima, radicalium vaginae equitantes, caulinorum convoluto amplectentes, marginibus haud coalitis, racemus simplex, plerumque sexforus. Bracteal spathacede, fo. liorum superiorum vaginis similes, pedicollos solitarios, bibracteolatos ineludentes.

1064. Noling $M I C H X$.

Ex seutentia cl. A. Gray 1 . c. propter antheras istropsas, stylos subaullos coalitos, nec non pedicellox saepe ag. gregatos et medio articulatos ad Asphodeleas referenda.

\section{Xeroplayllum $M I C H X$.}

A. Gray Op. cit. p. 128, Perigoni i foliola eglandalosa. Antherae subrotudo-ovatae, biloculares, basi et apice emarginatae, sinu affixae, extrorsae. 0 va $r i a m$ subglobasum, e carpidits tribus, biovulatis, arcius conuatin compositam; stigmatib us totidem lineari.filifornibus, revolutis coronatum. C a p s a Ja subglobosa, subtriloba, coriacea, loculieide dehiscens, loeulis dispermis. Se mina collateralia, erecta, ohlonga, sulicompressa, testa meubranacea, apice plas misus producta. - Caulis basi fero bulbescens, radicibus furosis. Folia complura, arida, seta. cea, radicalia numerosissima, in caespilem densum con. ferta, angustissime lineari selacea. Racemus simplex, thyrsiformis, demum elongatus, pedicellis filiformibus, basi bracteatis $v$. ebracteatis et bibracteolatis. Flores spe. ciosi, albi.

\section{Trelonias LINN.}

F I ores hermaphroditi, rarius polygami, v, abortu dioiei. Perigonij foliola ligulatav. linearia, patentia. Stamia a perigonio demum longiora, antherae subrotuadae, bilo. culares, basi bifidae, sinu insertae, extrorsae, 0 s a ri um trilobus, stignatibus lineari-elongatis coronatum, Caps a la subaembraucea, tere obcordato-triloba v. ovaídea, trisulea, polysperma. Semina linearia v. oblonga, utrinque nembranaceo appendiculata v. alata. 
a. EULELONIAS. + Flores bermaphroditi, quandoque po-is Iygami. Stigmata revoluto pateutia. Caps u la lobis superne gibboso-productis et divergentibus quasi tricor. nis, loculiejde trivalvis, Semina plurima, linearia, utrinque appendiculata. - Radix carnosa. Folia vix non omnia radicalia, conferta. Scapus simplex, fistulosus. llacemus spicatus, ovatus v. cylindraceus, den. sus. Flores pedicellis ebracteatis $v$, decidue bractea. tis purpurascentes. Antherae caeruleae. - Helon i as bullata Liun. Bot. Mag, $t$. 247. Redout, $t, 13$. Synonymon C y a o tr is Raf. delestur. Vid. infr. n. 1066/2.

b. Chamaelirium Willd. $l$. c. Flores dioiei, maseuli ovarii rudimento quaudoque instract, fealnei filameutis parvis, sterilibus donati. Perig o n i foliola anguste linearia, abtusa. C a psula ovoidea, superne septicide (et loculicide ?) debiscens, loculis 4-8spermis. S e m iu a oblouga, vix compressa, ntrinque late membranaceo-alata. - Radix praemorsa. Caulis gracilis, super. ne subnudus. Folia radicalia plura, obovato-spathulata $v$, oblonga, caulina sparsa, angustiora. Hacemus spicatus, tandem nirgatus, densiflorus. Flores pedicel lis ebracteatis $v$. decidus bracteatis albi. - Chamaelirium Willd. Ophiostacliys Delile. Dieli. uoth rys Rafinesq. Noogen. p.3. Helonias dioica Pursh. H. p u mil a Jacq. Ic, rar, t, 253. H. I ut ea Ait. Bot. Mag, $t$, 1062. Ver a trum inte a m Linn.

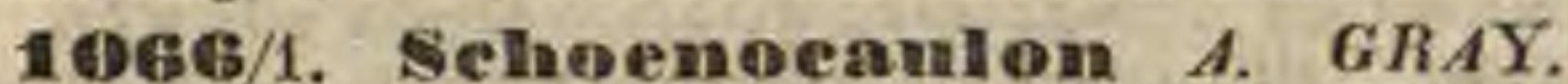
Flores hermaphroditi. Perigonii herbacei, hexaphylli foliola lineari-oblonga, obtusa, sessilia, hasi excavata, eglandulosa, hasi vix coalita, suberecta. Stamina 6 , cum perigonii foliolis inserta, iisque longiora, fi la m en ta subulata, a ntherae reniformes, loculis apice confluentibus subunilocnlares, demum peltatae. Ovarium trilobnm, triloculare. Ovula in loeulis 6-8. Styli 3 , perbreves, ovarii lobis contioni; stigmata simplicia, minuta. Ca ps ula trilocularis, tripar. tibilis, lobis chartaceis, introrsnm dehiscentibus. Semina plurima, corrugata, superne alata. Herba boreali-americana et mexicana, glaberrima; bulbo tunicato, foliis omnibus radicalibus, caricinis, angustissimis, elongatis, aridis, subcanaliculatis, scapo simplicissimo, pergracili, floribus parvis, arcte sessilibus, singulis bractea minuta stipatis, spicam densam formantibus.

Schoenocaulon A. Gray in Annat. Lye. New-York IV. 187. As a grae a Lindley in Bot. Reg. 1839. t. 33. Veratrum officinale Schlecht. Nees Plant. affic. Suppl. t. 4, Helonias dabia Michx.

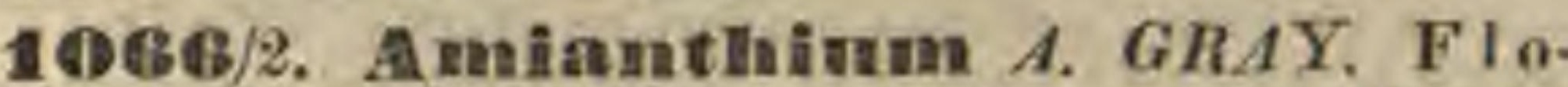
res hermaphroditi. Perigonium corollioum, hexaphyllum, foliola ovalia v, obovata, sessilia, basi vix coalita, eglandolosa, patentia. Stamin a 6 , cum perigonii foliolis inserta, iisdem aequalia v. longiora; fil a m en t plerunique capillaria, a ntherae reniformes, fere innatae, loenlis apice confluentibus subnniloculares, demum peltatae. Ovarium trilobum, triloculare, lobi uno alterove interdum abortivo. Ovula pansa... Styli $\mathbf{3}$, filifermes $v$. subulati, ovarii lobos terminantes. Capsula membranacea, turgida, triloba, tripartibilis, lobis follienlarilus, intus superne dehiscentibus, mono-tetraspermis. Se m ina lanceolata v. linearia, compressa, utringue membrana cea, v. teretia, oblonga, testa laxa, demum car nosa.... Herbae boreali-americanae; caule scapiformi, basi saepe bulboso, foliis gramincis, inferioribus plus minus confertis, vaginantibns, racemo simplici $v$. composito, multifloro, floribus albidis, saepius longe pedicellatis, bracteis plerumque brevissimis stipatis.

A mi a atbium A. Gray in Annal. Lyo. of New-York IV. 121. Cy a o tris Rafinesq. in Americ. Monthl. Ma. 6az. 1819. Chrosperma Rafinesque Noogen, 3, B elo. dias la eta Ker. Bot. Mag. 4, 803, 1540. H. e r y turo. sperma Michx. H. angustifolia Mehx. Antheri. c u m trig y u u Jaeq. Jc, rar, 2 . 419.

1068. Veratriman TOURNEF.

A. Gray in Annal. Lyc. New. York IV, 117. Flores polygani. Perigoulf foliola eglasdutosa. An the rae sub. glaboso-reniformes, sinu inseriae, Joculis apice confluentibus subuailoculares, demum peltatae.

a. Stenanthium A. Gray l. c. Perigonif foliola an. guste lanceolata, subulato-acuminata, basi subdilatata, staminibus multo Iongiora. - Caulis gracilis, bari bulbosus. Folia graminea, caulem haud vaginantia, Panicula virgata. - V. a ag us tifoliam Pursh.

b. VERatrum A. Gray l. c. Perígon it follola obovata v. oblonga, vix acuta, basi plus minus angustata, sta. minibus demou extrorsum pateotibus subduplo longiora. - Caules robusti, foliosi. Folia late ovata v. oblonga, plicato-nervosa, caulem vaginantia, superiora sensim minora. Panicula plerumiue pyramidata, racemis simplicibus. (Jасч. Fl. austr. t. 335. 336. FI. dall. t. 420. Nees jun. Gen, pl. $11, t, 10$.

$1968 / 1$. Leimanthitum $W I L L D$. Flores plernmque polygami. Perigon i um corollinum, hexaphyllum, foliola unguieulata, basi biglandulosa, stellato-patentia, persistentia, Sta$\mathrm{m}$ in a 6 , unguibus foliolorum perigonii inserta, filamenta isdem plus minus adnata et breviora, antherae reniformes, sinu insertae, loculis apice conflnentibus subuniloculares, demnm peltatae. Ovari a m trilobum, triloculare. OvuIa.... Styli breves, subulati, ovarii lobos terminantes; stigmat a simplicia, minuta. Cap8 ul a ovata, membranacea, turgida, triloba, tripartibilis, lobis follieularibus, intas, imprimis superne dehiscentibus, tetra-decaspermis. S e m in a compressa, late membranaceo-alata. - Herbae borea $l i$ am ericanae; caulibus plerumgue superne puberulis, elatis, foliis linearibus $v$. lanceolatis, elongatis, rarius latioribus et quasi petiolatis, racemis mvltifloris, paniculum pyramidatam constiluentibus, floribus ochroleucis v. flavo-virentibus, demum luridis, pedicellis bractea brevi stipatis.

Leim anthium Willdenow in Berl. Magaz, II. 24. excl. sp. A. Gray in Annal, Lyc, New-York, IV, 1th, M ela athium virginienm Lina. Lam. $t$, 260. M. hybri du w Walt. M. monoieum Walt. Helonias virginfer Sims Bot. Mag. t, 285.

1068. Zy sademus MICHX.

Flores hermaphroditi. Perigoufum corollinam, he xapbyllum, foliola sessilia, subenafita, basi glandulis binis, saepe conuatis instrueta, pateatissima, persistentia. Stamin a 6 , cum perigonii foliolis isserta, lisdem subaequilon. ga; filamen ta basi dilatata, a n the rae cordatae, kinu affixae, Inculis apice confluentibus subaniloculares, demum peltatae. Ovar i u trilobam, triloculare. $0 v a$ la in loculis plurima. St y li breves, subulati, ovarii lobos sensim atte. uastos terminantes; st ig nuata simpliela $v$. subcapitata. C a p s uI a ovato-conofdea, coriaceo-isenubranacea, subtrilo. ba, superne tripartibilis, Iobis intus dehiscentibus, loculis hexa-actospermis. Semina oblanga, aptera, apice v, vix membranaceo appendiculata. - Herbae bo pe ali-ameri. canae et sibiricae; caulibus basi bulbescentibus $v$. thizomatibut repentibus instructae, inferne foliosae, fo. lits gramineis, inflorescentia plerumque paniculata, ramit paucis subsimplicibus, bracteis subspathiformibus, floribus albidis, extus virescentibus. A. Gray L. c. Lindley Bot. Beg. 1839. C. 67. Helonias bracteata Síus. Bot. Mag. i. 1703. Melanthium sibirieum Lion.

SUETTEIBUS II. UVULARIEAE. Gen. 1078-1083. Ex, sententia cl. Gray Liliaceis adscribendae.

107\%. A movillaria $R, B R$.

Endlicher Iconogr, $t, 3$.

4อร จ. Kreysista $T E I C H E N B$.

Tripladenia Don in Proceed, Lint, soc, 1839, An nal. of nat. hist, IV, 282, Claracter ita emeadaudus: 
Perigonium eorollinum, hexaphyllum; foliola sessi. lia, basi eampanalato - conuiventia, biappendieulata appendieulis trifidis. St a m in a 6 , cum perigonlt foliolis inserta, lisden breviora; filame nta subulata, antherae extrorsae, erectae, biloculares, lougitudiualiter dehiscentes. Folia amplexicaulia, late ovato-lanceolata, pedunculus in. fra medium articulatus, ad articulum tribracteolatus. Ovalorum, fruetus et seminum deseriptionem el. Danii verbis proferimus : ${ }_{0} 0 \mathrm{vu} 1$ a campylotropa. Pericar $\mathrm{p} i \mathrm{u}$ m subbaceatum, triloculare, trivalve, loculicido-dehisceus, loculis nono-dispermis. S e mi a a suborbiculata, hinc eonvexa, inde angulata v. concaviuscula, glabra, aitida, colore succinea, hilo maxime fangoso strophiolata, chalaza orbiculata, coneava, fusca, rhaphe dimidio seminis vix breviore, elevata, testa tenui, wembranacea. A 1 b и m e в coptosam, corneum, album. Embryo oblongas, albus, hiac convexas, inde planlusculus. more Graminum extra albumen locatus, eidemque facie plana applicitus, funiculo maxime strophiolato solammodo obtectus, extremitate radienlari paullo crassiore."

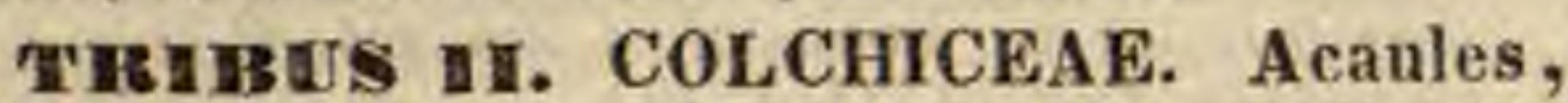
floribus e trunco subterraneo ortis, pedicellis hypogaeis. Styli graciles, liberi v. plus minus connati.

1085. Fulboeditum LINN.

a. M e rendera Ram. Bot. Mag. $t, 3690$.

$1085 / 1$. Weldenia SCHULT. FIL.

Vid, N. 1315. L e u cocri a u muttall ex. A. Gray Annal. of Lyc. New-York $I V, 110$. A n the rae biloculares, lineares, basifixae. Ovarif loculi pluriovulati. Stigm a ta lamellatodilatata. Capsula membranacea, haud inflata, subglobosa, loculis 5_6speruis. Semina biseriata, subglobosa. ? Ge a n $t$ bi a Rafin.

\section{Drdo III. Pontederacear.}

108\%. Heterantluera $R U I Z$ et $P A V$. B a chozia Flor. Flum. L, $t, 18$.

\section{Dralo $\mathbf{L}$. Hitiacear.}

1091. Tullipa TOURNEF.

Bot. Reg. 1838, t. 46.

1095. Caloehortus PURSH.

a. EUCALOCHORTUS Hook, ad Beech, $t$. 94 .

1096. Fritillaria LINN.

a. FRITILl ARIA Tournef. Hook. Flor. Bor. Amer, $t, 193, f$. a. b. PETILIUM Linn. Hook. Op. eit, $t, 193, f$. $b$.

1698. Tilliom $L I N N$.

Siebold et Zuce. Flor, japon. $t$. 12_14, ot 41.

1100. Fumbia SPRENG.

Bot. Mag. t. 3657, 3663, Bot, Reg. t, 1839, t, 50.

1104. IB Inatiforalia SMITH.

Endlicher Ieonogr, $t, 27$.

1 10\%. Triteleia $H O O K$.

Bot. Reg. t. 1921. Poppig Nov. gen, ot sp. t, 139. Elar. Bor, Amer. $t, 198, f, B$.

149S. 'Tristagna PÖPPIG.

Nov, gen, et ip, II. 28, t, 140.

1119. Hesperoseorilam $L I N D L$.

Hooker Flor. Bor. Amer, t, 198. $f, a$.

111 . Calliprora $L I N D L$.

Bot. Mag. t, 3588. 3552.

1112. Bessera SCHULT. F. Bot, Reg. 1839. t. 94.

115. Alö TOURNEF,

e. BoWIBA Harw. (DC, in Mem, soc, $h, n$, Genev, $P I, t, 2$,)

$11 \mathrm{~B}$. Wueen $L I N N$.

Miquel in Bullet. Neerland, 1839, p, 48.

11 \&. Iha elnemalia $J A C Q$.

Bot. Reg+ $t, 1945$.

1:5. IDrimian $J A C Q$.

Miquel in Bullet. Neerland. 1839. p. 40.
12\%. IDambernya LINDL.

Bot. Reg. 1839. $t .53$.

12 12. Camassia $L I N D L$.

C y a notris Raf, mse. in Herb. mus, Caesar, non in Am. Monthl. Magaz. Vid, supr. N. 1066/2.

130 . Seilla $L I N N$.

Bot. Mag. 1839, t, 63 .

1136 . 18 añasedìa $L I N D L$.

Bot. Mag. t, 3788.

$138 / 1$, Nectaroseorollum $L I N D L$. Perigonium hexaphyllom, foliolis semiherbaceis, interioribus dissimilibus, subunguicnlatis, omnibus persistentibus, demum cartilagineis, in fructu imbricatim conniventihus. Stam in a 6 , imis perigonii foliolis inserta, filamenta subulata. $O \mathbf{v a}$ rium depressum, triloculare, poris in vertice septurum crassissimorum tribus mellifinis. Ov n la plurima, e basi loculorum adscendentia. Stylu 8 subulatus, brevis; stigma simplex. Capsula perigonio tecta, trilocularis, focolicide trivalvis, valvis medio septiferis, dorso medio poro mellifluo. Semina compressa, atra. - Herba sicula, bulbosa, Allii odore; floribus umbellatis, pedicellis flariferis cernuis, fructiferis erectis, rigidis.

Nectaroscordon Lindley in Bot. Heg. $t .1913$. Allium siculum Ueria.

1148. Anthrogodiank $R, B R$.

Endlieher Iconogr. $t, 28$,

150. Thlaysanetlates $R, B R$.

Bot. Reg. 1840, t. 4 ,

1453. Troiceryne R. $B R$.

Endlicher Iconogr, $t, 61$.

1159. 'Tulbaghia $L I N N$.

Bot. Mag. $t .3547,3535$.

1 1 BQD. Hiamella $L A M$.

Post Diauellam iuseratur:

DUCHEKIA Kozteletzky Med, pharm,Bot, I, 213. P e r Ig o n i m sexpartitun, lacinils tribus exterioribus erectis, totidem interioribus majoribus profundius distiactis, conniveatibus. S $t$ a m in a 3 , perigonii laciails iuterforibus inserta, duo approximata, glabra, tertium longins, subsetacesm, villoso-pilosum, a nthera dissimili, Ovarinm trigonum, album nitidum. Stylus staminum longitudine, persistens; stigma depresso-subrotundam. B a e $c$ a polysperma. Sem in a oblonga, umbilico lineari. - Herba Africaetropicae occidentalis; caulo simplici, anguloso, fo. liis confertim alternantibus, vaginantibus, basi squamis magnis imbricatis, panicula simpliciter ramosa. D i a triandra Afzel,

1162. Eustreplaus $R, B R$.

Eudlicher Iconogr. $t$. 4 .

1 (8). Waxmanmia $R . B R$.

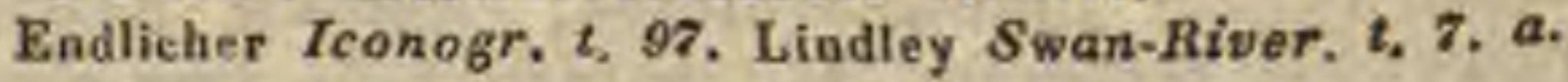

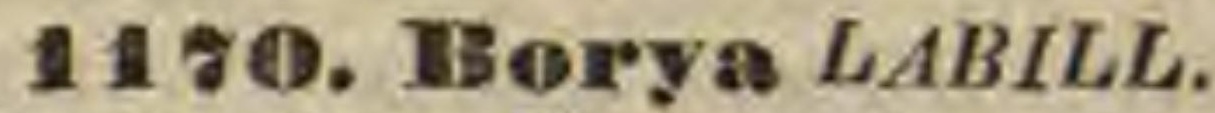

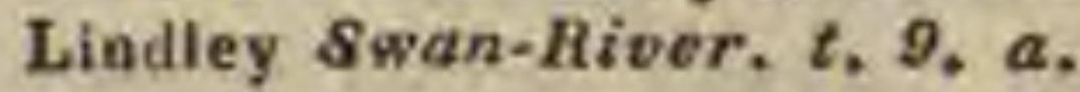

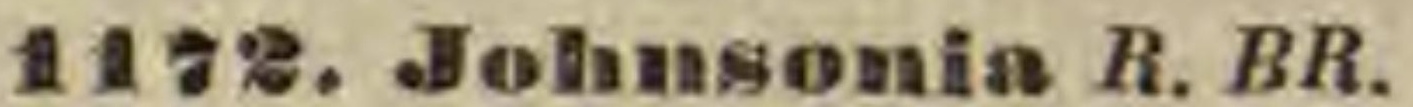

Lindley Swan-River, $t, \pi, b$.

194. Ginitesia $L I N D L$.

Pöppig Nov. gen, et sp. II. 27, t, 138.

\section{Drdo IDI. Smillaceae.}

1\%ซ. Troilliem MILL.

Rayle Himalay, $t, 93$. f. 1. Flor. Bor. Amer. $t, 199$.

180. Streptopus L.C.RICH.

Hooker Flar, Bor. Amer, $t, 188,189$.

$180 / 1$. Prosartes $D O N$. Flores hermaphroditi. Perig onium corollinnm, hexaphylInu, campanulatom, aequale, deciduru, foliolis 
hasi foveolatis v, saecatis. Stam in a 6 , basi folio. lorum perigonii inserta, simulque decidna; anthe ra e erectae, adnatae. Ovarium triloculare. O vula in loculis 2, e placentae apice pendula.... Stig un at a 8 , hrevissima, recurvata. Bac ca trilocularis. Semina in locnlis solitaria $v$, rarius gemina... - Herbae boreali-americanae, perennes, pube ramosa vestitae; rhizomate multicipiti, caulibus teretiusculis, foliis sessilibus, dilatatis, inflorescentia terminali, umbellata, baccis rubris.

Prosartes Don in Proceedings Linn. soc. 1839. 48.

11 183. Sunailacina $D E S F$. t. 190 .

Royle Himalay. $t$. 94. f. 1. 2. Hooker Flor. Bor. Amer

194. Smillax TOURNEF.

Endlicher Iconogr. $t, 39$.

1191. Aspidistara $K E R$.

? Plectogy ue Liak in Otto et Dietr. Gartenzeit. 1834. II. P. 266.

198. Dplaiopogen $A I T$.

Royle Himalay. . 96. f. 1 .

\section{Drdo H DIR. Dioscorece.}

1201. Dioseorea PLUM.

Colla in Mem, Aoadem. Turin, XXXIX, t. 51.

\section{Ordo IX. Burmanencece.}

$1218 / 1$. Aptenta NUTT. Perigonium tubuloso-campanulatum, basi ovario adnatum, limbi sexfidi laciniis tribus exterioribus lato-ovatis, amplis, totidem interioribus parvis, oblongo-linearibus. Stamina 3 , medio perigonio inserta, filamentis brevissimis, dorso in membranam latam, semiorbicularem abeuntibus, antice antheriferis, antherarum locnlis disjunctis, transversim dehiscentibus. 0 vari $\mathbf{~ m}$ uniloculare, placentis parietalibus tribus bifidis, multiovulatis. Stylus inclusus, apice trifidus, Tobis divergentibus, incrassatis; stigmatibus crassinsculis. Capsu I a perigonii apteri sexnervis basi obtecta, unilocularis, irregulariter inter nervos rumpens. S emin a plurima, ovoidea, minima, testa reticulata, subadpressa. - Nerba boreali-americana; caule simplici $v$. apice vix ramoso, gracili, erecto, semipedali, glaberrimo, laevi, foliis minute squamaeformibus, alternis, paucis, racemo terminali laxo, tri-quinquefloro.

A pteri a Nuttall Journ, Academ, Nat. sc. Philadelph. VII. 64. t. 9. f. 1. ex Bentham Plant. Hartweg. 67.

12 i $8 / 2$. Dietycostega MIERS. P e rig oni m tubulos $\mathrm{nm}$, ovario adnatum, superne liberum, limbi sexfidi laciniis alternis minuribus. S $t$ a m in a 3 , flamentis trevissimis, an the ra e loculis disjunctis, transversim dehiseentibus, O vari u m.... Stylns simplex; 8 tigmata 3 . C a p sula nnilocularis, polysperına, apice trivalvis, valvis medio placentiferis. Se m in a miauta, scobiformia, testa laxa, retieulata, pellucida, nucleo quintuplo longiore. - Herbae brasilienses; radice fibrosa, squamis membranaceis, ciliatis, incanis tecta, caule ereoto, subflexuoso, pallide purpurascente, subsoli. tario, rarius ramos paucos, alternos, erectos proferente, foliis bracteiformibus, subsessilibus, adpressis, inflorescentia terminali, dichotome ramosa $v$. subumbellato cymosa, floribus purpurascentibus, pedicellatis.

Diet y osteg a Miers in Proceedings Linn. soc. 1839 Annal. of nat, hist, V. 133.
1: 18/3. Cymboearpa MIERS. Perigonium tabulosum, ovario adnatum, superne liberum, limbo sexfido, laciniis alternis minoribus. S tam in a 3 , filamentis brevissimis, antherae loculis disjunctis, transversim dehiscentibus. Ovari u in gibbosu-trigennm, uniloculare, placentis parietalibus tribus. Sty Ins simplex; stigmata triloba, lobis gibboso-rotandatis, cornubns duobus snbulatis, erectis instructis. Capsu I a unilucularis, hinc angulo unico superne dehiscens. Se mina plnrima, scobiformia, testa reticulata, nuclenm vix excedente.-Herbae brasili enses; radice fibrosa, caule simplici, subfexuoso, erecto, albescente, foliis sessilibus, bracteiformibus, erectis v. adpressis, inflorescentia dichotome spicata pauci. flora, floribus flavescenti-albidis, basi bractentis, cum pedicellis brevissimis, apice abrupte geniculatis.

C y a b o carpa Miers in Proceedings Linn, soc. 1839. Annal. of nat. hist. $Y .133$.

$1218 / 4$. Stemoptern MIERS. P e rig 0nin m ovario adnatum, supra liberum, subinfundibuliforme, fauce targida, intus sacenlis tribus aueta, limbi sexpartiti laciniis acutis, aestivatione marginibus induplicatis, tribus alternis brevioribus. Stamina $\mathrm{B}$, fanci adnata, flamentis complanatis, e margine sacculorum orientibus, bifurcatis, ramulo singulo antherifero alato. Ovari um turbinatum, uniloculare, placentis parietalibus tribus. S $t$ y I u s longitudine staminum; s $t$ ig $\mathbf{m}$ a $t$ a 3 , recurvata, apice glandulifera. C a psn la unilocularis, polysperma, apice fissuris tribus dehiscens. Semina plurima, scobiformia, testa nnclenm vix excedente, reticulata, areolis elongatis, obliquis. - Herbae brasilienses; radice fibrosa, caule erecto, subdichotome ramoso, ramis subflexuosis, pallidis, subpurpurascentibus, folïs paucis, sessilibus, erectis, bracteaeformibus, pallidis, inflorescentia terminali, uniflora, floro majusculo, ebracteato, purpurescente.

Stemoptera Miers in Proceedings Linn. soc. 1839. Annal. of nat. hist. $V .134$.

1 19. BBumanmia LINN.

Royle Himalay, t, st. f. $t$.

\section{Ordo I.XI. Iridecte.}

1 \& 20. Sigyrinelufum $L I N N$.

Bot. Mtag. 1. 3509, 3594. Hook, 10, t. 218, 219.

1982. Cipman $A U B L$.

Marlea Bot, Mag, $t, 3713$.

1236. Iris LINN.

Bot. Reg. $1840, t, 1$. Royle Himalay. $t, 90.91$.

12:8/1. Cypella HERB.

$\mathrm{Ph}$ a locallis Herb. in Bot. Mag, $t$. 3710. vix nisi seminibus compressis alatis differt, A lo phia Herb. in Bot. Mag. n. 3779. - Genera Trifurcaria Herb. 1. c. et Be a tonia Herb. $l$. $c$. quae e Cypellae contubernio videntur, e phrasibus mancis collocari nequeunt.

$12 \cdot 8 / 2$. II delrotania $L I N D L$. P e rigon i m corollinum, superum, hexaphyllo-partitum, subeampanulatum, laeiniis subaequalibus, mucronatis, exterioribus cuneatis, interioribus cordatis, unguiculatis, supra unguem zona triangulari melliflua fasciatis. Stamina 3 , perigonii laciniis exterioribus basi inserta; filamenta in tubum longau coalita. Antherae basifixae, loculis connectivum marginantibus. O va ri a $m$ inferum, vertice exserto conico. O v a la in loculoram angulo centrali plurima. Sty lus filiformis, apice trifidus, laciniis tripartitis, linearibus, convolntis, intermedia nana, antheris opposita. Fructus .... - 
Herba mexicana subalpina, caule sesquipedali, monophyllo; folio ensiformi, plicato, spatha cucullata, foliacea, quadri-quinqueflora, floribus $f u-$ gacissimis, e pedunculo gracillimo pendulis.

II y d r o ta e ni a Lindley in Bot. Reg. 1838, $t$. 69 .

1 289/1. ERightalla $L I N D L$. P erig o $\mathrm{n}$ i m corollinum, superum, triphyllo-partitum, laciniis basi imbricatis, convolutis, infra medium constrietis, limbo concavo, revoluto, demum spiraliter tortis. Stam in a 3 , perigonii laciniis opposita; filamenta in tubum longe exsertum coalita, a ntherae liberae, erectae, lineares. Ovari um inferum, triloculare. Ovula plurima.... St $\mathbf{i g} \mathbf{m}$ a $\mathbf{t}$ a $\mathbf{3}$, bipartita, dorso appendiculata, antheris opposita, laciniis linearibus, apice papillosis. Capsula papyracea, trilocularis, apice breviter exserto loeulicide trivalvis. Semin a plurima, subglobosa, punctata, rhaphe et chalaza manifestis. - Herba mexicana; foliis equilantibus, plicatis, vaginantibus, floribus terminalibus, intra spatham bivalvem fasciculatis, pedunculis sub anthesi decurvis, fructiferis strictis.

$\mathrm{R}$ ig i dell a Lindley in Bot, Reg. 1840, $t, 16$.

1234 . Fatersomain $R, B R O W N$.

Endlicher Iconogr. t, 50, Liadley in Bot. Reg. 1839. t. 60 . Embryo ex cl. Lindley $t$. $o$. embryo minimus.

\section{CAladiolens $L$.}

Bot, Mag. $\ell .3680$.

124. Tromtbretia $D C$.

Tritoui a Bot. Reg. 1838, $\imath .35$.

\section{$124 \%$. Trielnomema $K E R$.}

? Nemast y If s Nuttall in Americ, philosoph, Trans. act. $V$. p. 157. Gelasi a e Herbert in Bot. Mag. $t$, 3779.

1248. Croengs TOURNEF.

Bot. Reg. t. 1987, 1993. New.Ser, 1839, t. 40.

\section{GENUS IRIDEIS AFFINE.}

$1248 / 1$. Tecoplinaea BERTERO. P e rigonium semisuperum, campanulatum, decidunm, tubo brevissimo, limbi sexpartiti laciniis biseriatis, exterioribus mucronatis. Stamina 6 , perigonii fauci inserta, inclusa, ima basi coalita, tria fertilia collateralia, quorum unum laciniae exteriori duo interioribus opposita, fil amen$t$ is subulatis, a $n t h$ e $r i s$ bilocnlaribus, dorso insertis, versatilibus, longitudinaliter dehiscentibus, basi antice calearatis, totidem ananthera. longiora, subpetaloidea, lanceolata, laciniis duabus exterioribus et interiori opposita. O $\mathrm{r}$ a $\mathbf{i}$ m semiinferum, triloenlare, vertice exserto, conico. Ovul a plura, loculorum angulo centrali biseriatim inserta. Stylus filiformis; $8 \mathrm{tigm}$ a capitatum, trisuleum. Capsula semiinfera, trilocularis, apice loculicide trivalvis. Sem in a plurima, oblonga.... Herba chilensis, monticola, vernalis, fugacissima, tenerrima; bulbo radicali fibroso, folio radicali unico, lineari, apice acuminato-cuspi. dato, longitudinaliter plicato, carinato, flaccido, basi vagina membranacea incluso, scapo erecto, univ. rarius bifloro, infra apicem obsolete bibracteolato, flore cyaneo.

Tecophilaea Bertero msc, ex Colla Plant. chil. Mem. Turin. XXXIX. p. 19. t. 35. P by g a a th a s Poppig Nov, gen, ot sp. II. 2t. t. 200. Poppigia Kunze in Reichenb. Consp. p. 212, $a$.

\section{Drdo LXII. IIremodoraceae.}

1ะรซ. Anigosanthas LABILLARD.

Líndley Bot, Reg. $t, 2012, N, 5,1839,37,64 . S \mp a$ River t, 6. f. B.
$125 \% /$. Andinostemanan $L I N D L$. Perigoni nm corollinum, extus lanatum, tubo basi cum ovario connato, elongato, limbo aequali, sexpartito, reflexo. Sta $m$ in a 6 , fauci perizonii inserta, longe exserta, aequalia, a $\mathrm{th}$ e $\mathrm{ris}$ linearibus, rectis, Ovari um semiinferum, trilocalare. Ovula in placentis sphaericis, e loculorum angulo centrali prominentibus plurima. Stylus subulatus, basi tripartibitis...S $\mathrm{S}$ i g m a simplicissimum. Fruetus.... Herba Novae-Hollandiae austro-occidentalis, acaulis; radice multicipiti, foliis spithameis, compresso-teretibus, acuminatis, erectis, glaberrimis, pedicellis brevibus, unifloris, erectis, apice bracteas quasdam membranaceas gerentibus, floribus sesquipollicaribus, extus viridibus, tomentosis, limbi laciniis angustissimis, reflexis, aequilongis.

Androstem ma Lindley Swan.River XLVT.

1258. Conostylîs $R$. BR.

Liudley Swan-River $t$, 6 . f. a.

1258/1. Blancoa LINDL. Perigon i m corollinum, extus tomentosum, inferne cum ima ovarii basi connatum, elongato-campanulatum, limbo erecto, sexdentato, aequali, tubo inter lacinias plicato. Anthera e 6 , subsessiles, basi laciniarum perigonii insertae. $O$ v a $r$ i $\mathbf{m} \ldots .$. C a p s l a nueamentacea, fere libera, perigonii fundo persistente inclusa, trilocalaris, loculieide trivalvis, valvis medio septa seminifera apice stylis cohaerentia gerentibus. - Herba Novae-Hollandia e asstro-occidentalis, acaulis, Barbaceniae facie; foliis equitantibus, incanis, retrorsum falcatis, acuminatis, scapum aequantibus, scapo palmari, furfuraceo-tomentoso, pone basim monophyllo, supra medium squama unica, cucullata, rigida, uniflora instructo, apice bitrifloro, floribus magnis, nutantibus, extus pedunculisque plumoso-villosis,

B I a n co a Lindley $S$ wan-River $X L K$.

125. Tribonantlaes ENDL. P erigoni m arachnoideo-lanatum, tabo basi cum ovario connato, supra ovarium producto, limbi sexpartiti laciniis patentibus. Corona faucis petaloidea, hexaphylla, foliola perigonii laciniis opposita, exserta, cuneata, trifida, lobo medio basi antherifero. Stamina 6 , filamenta nulla, a ntherae foliolorum coronae lobo medio dorso insertae, inclusae, lineares, sagittatae. O var i um inferam, triloculare. Ovu I a in placentis e Iocnlorum angulo centrali prominentibus plurima, amphitropa. Stylus e basi dilatato - conica cylindriens; stigma fusiforme, brevissime trilobum. Fruetus....- Herba Novae-Hollandiae austro-oc ciden talis; tuberibus radicalibus ovatis, subfascieulatis, caule simplici, apice lanato, oligophyllo, foliis aversis, inferne planis, apice teretibus, basi vaginantibus, floribus terminalibus, capitalo-congestis, bracteatis.

Tribonanthes Eadlicher Nov. Stirp. Mrus. Vindob. Dec, $n, 34$.

\section{Dralo LXIII. HIypoxideae.}

1364. IIypexis LINN.

Bot. Mag. 6. 3696. Royle Himalay, t, 91. f. 3.

\section{GENUS DUBIUM.}

1964/1. Pauridia HARW. P e rigon i $\mathbf{~ m}$ supernm, campanulatum $v$. patens, profunde sexpartitum, tubo brevi, amplo, persistens. 
Stamina 3 , perigonii laciniis interioribus inserta. An thera $e$ lateraliter dehiscentes, Ovari u m inferum .... Stylus profunde sexpartitus, laciniis tribus brevissimis, recurvis, alternis longis, linearibus, ereetis, conniventibus v. patentinsculis. Capsula indehiscens. Semina glolosa, testa nigra, granulata. - Herba c a pensis, minuta, Hypoxidis facie; foliis radicalibus subulatis $v$. canaliculatis, scapis uni-bifloris, medio bibracteatis, floribus albis.

Pauridia Harwey Genera of South:Afric. Plant.341. Ixia minuta Thunb.

\section{Ordo EXIV. Amearyllideae.}

Iz ro. Sternhergia WALDST, et KIT. Bot. Reg, t. 2008 .

1\%ระ. Cooperia HERB.

Bot. Mag. t, 3727. S ceptranthus Graham in Edinb. new philosoph. Journ, 1838. p. 413.

I2\% 3. Annaryllfs LINN.

c. HABRANTHUS Herb. Bot. Reg. t.1967. Bot. Mag, t. 3596 . d. SPREKELtA Heist. Bot, Reg. 1840. t. 33.

e. HIPPEASTRUM Herb. Bot, Mag. t. $37 z 1$.

12\%

Pentla a dia Herb. in Bot, Reg. 1839, t, 68.

1282. Eustephia $C A V$.

Ph yeella Lindl. Bot. Reg. t. 1943.

1284. Chrysîphiala $K E R$.

S ten omes s on Herb. Bot. Mag. t. 3615. 3803.

1289. Panerotium LINN.

c. ISMENE Herb, Hot. Mlag. $t, 3675$.

d. LIRIOPSIS Reichenb. E I is e a a Herb. in Bot, Heg, 1838. App. p. 47.

12\%5. Alströneria LINN.

Bot. Reg. 1839, t. 13.

\section{Ordo IXV. IBromeliaceae.}

1301. Aechmea $R U I Z$ et $P A V$.

Pöppig Nov. gen. et sp. t. 159.

1398 . Bullbergla THUNB.

Bot. Mag, t. 3304. Póppig Nov, gen, et sp, t. 157 .

1363/1. Cryptanthes KLOTSCH. $\mathrm{Pe}$ rigonii superi, sexpartiti laciniae exteriores cal y cin a e, basi connatae, dorso acnte convexae, interiores petaloid e a e, longitudinaliter convolutae, superne vix apertae, aequales. S $t$ a $m$ in a 6 , annulo epigyno carnoso inserta; filamenta filiformia, tria perigonii laciniis interioribus basi adnata, a n the rae lineares, dorso supra basim affixae, basi bilobae, erectiusculae. Ovarium inferum, triquetrum, triloculare. Ovnla plarima, globosa, exappendiculata. St y I u 8 filiformis; s tigma ta 3 , convoluta, fimbriata. Fruetus.... - Herba brasiliensis, epiplyyta; folits linearilanceolatis, acuminatis, margine dense aculeolatis, floribus in vaginis foliorum immersis.

Cryptanthus Klotseh in Otto el Dietr. Gartenzeit. 1836. IV. p. 296. - ? Tillandsia a caulis Lindl. in Bot. Reg. $t, 1157$.

1305 . Piteafrnia HERIT.

Pöppig Nov. gen et sp, t. 158.

1306. Tillandsia LINN.

Fig. Bot. Reg. t. 1157. fortassis ad Cryptanthum Klotsch $1303 / 2$ spectat.

1314 . Pevriretia $R U I Z$ et $P A V$.

Pöppig Nov. gen, et sp, II. At. t, 156. Re a e a 1 mi a Feruille IIT. 59, $t, 39$. P a y a Mol. Bot. Reg. 1840, $t, 11$.

13 4 4/. Dasylirion ZUCCAR. F lo res dioici. Masc. Perigoninm hexaphyllam, v. ad basim usque sexpartitum, petaloideum, foliolis biseriatis, inter se aequalibus v. exterioribus parum brevioribus. Stamin a 6 , libera; fil am enta medio parum incrassata, antherae introrsae, biIoculares, dorso affixae, utroque latere longitudinaliter dehiscentes. Gland $\mathrm{u}$ l a e 6 , ad basim staminum, ovarii rndimentum simulantes. Ovarii radimentum nullam .... F e m. ignot.

Das y 1 i riou Zucearini in Otto et Dietr. Gartenseit. 1838. VI. 1258, excl. flor, fem. emend. p. 303, Y u c c a e sp. Karw. Schlechtend.

$1314 / 2$. Fifeelntia KLOTSCH. Flores dioici. Masc,.... Fem. Perigonii ima basi ovario inferne adnati, sexpartiti laciniae exteriores ca lycin a e, basi connatae, aequales, ovatae, concavae, erectae, interiores corollinae, liberae, exterioribas duplo longiores, ovato-lanceolatae, concavae, erectae, basi nudae. Stamin u m rudimenta 6 , subulata, libera. Ova rium ima basi adnatum, pyramidali-trigonum .... StyI a s brevissimus; stig mata 3 , subulata, saperne papillosa, patentia, demum erecto-subcontorta. Fructus.... - Herba mexicana, perennis; caudice subnullo, foliis congestis, subulato-linearibus, longissimis, crassis, serrato-spinosis, pungentibus, patenti recurvis, scapo sexpedali, floribus parvis, in spicam compositam dispositis, sessilibus, patentibus, bracteis membranaceis, aridis, minutis suffultis.

$\mathrm{H}$ echti a Klotsch in Otto et Dietr. Gartenzeit. 1835. IIT. p. 400. D a s y 1 ir il Zuce. flores feminei a el. Zuccarini Op. cit. 1838. VI. p. 258. descripti, ex ejusd. Op. p. 303. ad Hechtiam spectaut.

1315. WELDENIA schult. $f$. Genus h. I. delendum et supra sub n. $1085 / 1$ collocasdum.

\section{Drdo IXVI. Orchidene.}

1316. Plewrothallis $R$. $B R$.

Bot. Mag. $t, 3682$,

$1316 / 1$. StenogIossum $H . B . K$.

Hooker Jc, $t$. S1. Genus monente cl. Lindley Bot. Mag. Comp. II. 356. ob perigonil foliola exteriora lateralia vix cum columase pede coliaerentia, bue a. 1359 , transferendum.

1320 . IIy yxamthus PÖPP. et ENDL.

Genus e seatentia cl. Liadley a Plearothalli aon diversum.

1325. Stelis SWARTZ.

Hooker 1c, t. 62, Annal, of nat. hist. IT, t. 17,

13 I. Testrepia KUNTH.

Restrepia nostra teataculata monente cl. Lisdiey ad Pleurothallin referenda.

1330. (Dberonia $L I N D L$.

Liadl. Sert. Orehid, $t, 8, f, a, b$.

1347 . Coelogyme $L I N D L$.

Bot. Mag. t, 3767, Bot. Reg. 1840, $t, 24$.

$1348 / 1$. Faxtomia LINDL. Perigonim labello conformi regulare, hexaphyllum. Col um a erecta, teres, subclavata, perigonio paullo brevior, rima stigmatis transverse verticali, sub rostello. Anther a terminalis, opercularis, decidua. Pollinia 8, angusta, clavata, apice cohaerentia. - Herba manillana, caespitosa, pseudobulbosa; foliis plicatis, racemo multifloro, radicali, foliorum longitudine, floribus pulchre roseis.

Paxt on i a Lindley Bot, Reg, 1838, $t, 60$.

1351. MIegaelinium $L I N D L$.

Bot. Mag. $t .3573$. 
135.. Eolbopleyllmm THOUAR. Bot. Reg, t. 1964. 1970. New.Ser. 1838. t. 57.

1353. Cirrinopetaluma LINDL.

Pollinia 4, per paria connata. Bot. Reg. 1838, $t, 11$. 1359. STENoGLOSSUM H, B. K.

Genus h. I. delendum. Vid. supr. n. 1316/1.

1363/1. YBryobium LINDL. Perigonii snbvillosi foliola exteriora ovata, conniventia, lateralia basi aequalia, interiora lineari lanceolata, truncata, breviora et angustiora, inter exteriora reflexa. $\mathbf{L}$ a b e $l 1 \mathrm{um}$ ovatum, indivisum, inappendiculatum, basi constrictum, Columna nana. Anthera bilocularis. Pollinia octo, incumbentia. - Herba antillana, pusilla; caule carnoso, vaginato, unciali, foliis duobus, carnosis, aveniis, anguste oblongis, emarginatis, floribus minutis, herbaceis, in capitulum breve pedunculatum congestis, pilis stellatis rigidis, obtusis, aëre repletis laxe vestitis.

Bry ol o b i u windley Introduct. edit, 2, p. 446. Bot. Feg. 1838, Append. p. 79 .

\section{A porrum BLUM.}

Bot. Mag. $t, 3608$.

1366. Polystachya HOOK.

Bot. Mag. $t, 3707$.

1369. Denalrobinam SWARTZ.

Bot. Mag. t. 3643. Bot. Reg. 1838, t, 65. 1839, t, 20,22, 37. 64. Eudl. Ieonogr. t. 99. Royle Himalay, t. 88. f. 2. Lindley Sert, Orchid. $t, 3,18$.

1369/1. Hexameria $R, B R$. Pe rigoni i erectiusculi foliola subaequalia, exteriora lateralia cum pede colnmnae connata, in saccum maximum, calcar obtusum aemulantem basi producta. I a b ell u m e basi calcaris ortum, ungniculatum, lamina superne indivisa, basi biseta. Colnmna brevissima. Anthera stigmati bilobo parallela, bilocularis, Pollinia ceracea, in quovis localo 3 , duo inferiora collateralia, tertinm superius, omnia apice acuto affixa corpusculo septiformi, loculum longitudinaliter bipartienti et cum eodem deciduo. - Herba javanica, epiphyta, nana; caule ramoso, foliis distichis, mucronatis, basi in petiolum brevem, semivaginantem angustatis, racemis terminalibus, paucifloris.

Hexameria R. Brown Horsfeld Plant, Jav, 26, $\imath$, 7 , - ? B I u mia Meyen misc.

\section{9/2. Appendieula $B L U M$.}

Charact. 8 ub n. 1483 .

1369/3. Cryptoglottis BLL

Charact, sub, n. 1484 .

13\%1. Epialendram LINN.

Bot. Mag, t. 3565, 3595, 3631, 3637, 3638, 3666, 3765. 3778. 3791. Bot. Reg. t. 1961. New-Ser. 1838, t, 27. 53, 1899. t. 11. 1840. c. 6. 34. Bateman Orchid. Mexic, $t, 10$-12.

13 7 1/1. Sehomburgkin LINDL. $\mathrm{Pe}$ rigonii patentis foliola libera, basi aequalia, exteriora interioribus conformia. $\mathrm{L}$ a b ell u $\mathrm{m}$ dissimile, membranaceum, trilobum, cucullatum, basi cum margine columnae connatum, supra basim tumidum, venis lamellatis. Columna marginata. Pollinia 8. - Herba guianensis, epiphyta; rhizonate, repente nudo, annulato, pseudobulbigero, foliis coriaceis, scapi terminalibus vaginatis, bracteis spathaceis, floribus speeiosis, racemosis, congestis.

S e ho mb u rgki a Lindley Sert. Orchid, $t, 10$, et 13. Bot. Mag. $t$, 3729.

13 1/2. Thartwegia LINDL. Perig 0n ii patuli, colorati foliola exteriora lateralia basi producta, labello adnata, interiora paullo minora. L a bellum cum columna connatum, basi gibbosum, limbo ovato, basi calloso. Col nm na... Anthera quadrilocularis. Pollinia 4, olivaceopurpurea, filis replicatis. - Herba Americae tropicae, epiphyta; caule monophyllo, folio coriaceo, ovato-lanceolato, lentiginoso, caulem teretem aequante, pedunculo capillari, arcte vaginato, folio multoties longiore, apice florifero, floribus parvis, purpureis, perigonii foliolis acutis, labelli limbo basi albo, calloso.

H a r twegia Lindley Bot, Reg. $n, 1970$.

13 \% \% Ponera LINDL.

Nem a conia Knowles et Westc. Flar. Cab. 127.

13 8. Imassavola $R . B R$.

Bot. Mag. t. 3728. 3789. Bot. Reg. 1839. 4. 5. 1840. t. 39

13\%9. Inelia LINDL.

Bot. Reg. t. 1947. New-Ser, 1839, t. 26. 27, 54. 1840. t. 4t. Sert. Orchid. t. 28. Bot. Mag, t. 3804. 3810. Bateman Orchid. Mexic. t. 9.

138D. Cattleya LINDL.

Bot. Mag. t. 3656, 3669, 3695, 3711, 3748. Lindl. Bot. Reg. 1838. t, 2. Sert. Orchid, t. 5. f. 1. t. 28. Bateman Orchid, Mexic. $t, 13$.

$1380 / 1$. Barlieria KNOWL. et WESTC. Perigonii foliola membranacea, patentissima, exteriora interioribus conformia et aequalia. $\mathbf{L}$ abell n m columnae adpressum, planum, integerrimum, nudum, cuneatum cam apiculo. Column a petaloidea. Anthera quadrilocularis, carnosa, septorum marginibus membranaceis. Pollinia 4, caudiculis totidem ligulatis, reflexis per paria connata: - Herba mexicana, epiphyta; pseudobulbis fusiformibus, foliis angustis, membranaceis, nervosis, pedunculis longis, gracilibus, squamosis, terminalibus, apice ramosis, floribus magnis, conspicuis, nutantibus.

Barkeria Knowles et Westeott Floral, Cab. $t .49$. Lindley in Bot. Reg. 1840, p. 29.

138\%. Teptorles LINDL.

Bot. Mag. $t, 3734$. Libdl. Sert, Orchid. $2,11$.

1335. PIetia RUIZ et PAV.

Fr. Bater Orchid. Fruct, t. 1. 6. 8. 9. 10. fig, infr. Bot. Mag. $t .3736$.

$1385 / 1$. Pesomeria LINDL. Perigonii foliola exteriora snbaequalia, libera, caduca, interiora conformia, basi colnmnae adnata, persistentia, Iabell um posticum, cum basi columnae connatum, basi gibbosum, limbo indiviso, convoluto. Co l u ma clavata, semiteres, clinandrio dentato. Poll in i a 4 , cuneata. Herba mauritiana, terrestris; caule tetragono, folits membranaceis, plicatis, racemo laterali simplici, bracteis caducis, radicibus crassis, simplicibus, fibrosis.

Pesomeria Lindley in Bot. Heg. 1838. App. p. 5. Bpidendrum tetragon um Thouars Orehid. t. 33. 34.

1388. Phajus LOUR.

Lindl, Bot. Reg. 1838, t, 33. Sert. Orchid, t. 23.

$1389 / 1$. A eantheplaippinan $B L C M$.

Genus huc e numero 1434. transferendum.

1399/2. Cryptoelnilins WALL.

Genus hac e namero 1450. transferendam. Vid. Lindley in Bot. Reg. 1838, t, 23.

139 . Soplhromitis LINDL.

Bot. Mag. $t .3677$. 3709, Lindl. Sert. Orchid, 5. f. 2,

139\%/1. Physinga $L I N D L$, Perigonii foliola exteriora menbranacea, aequalia, basi 
connata, in teri or minora, exterioribus inferne oblique adnata, 1 a b e $11 \mathrm{n} \mathrm{m}$ carnosum, tubereulatum, indivisum, columnae inferne connatum, sacco vesicaeformi basi auctum. Columna carnosa, nana, biloba, ima basi antherifera. Pollinia 4 , filis duobus geminatis pulvereis adnata. Stigma area supra vesicae faucem minuta, madida, bidentata. - Herba Americae tropicae; caule prostrato, ancipiti, dense distiche folioso, foliis crassissimis, amplexicaulibus, ovato-lanceolatis, purpurascentibus, striatis, scapo terminali, filiformi, ramoso, vaginis arcte vestito, floribus paucis, parvis, in apice ramorum, herbaceis, purpura diluta suffusis.

P b y s ing a Lindley in Bot. Reg. 1838. p. 32.

$138 \% / 2$. Drymoda $L I N D L$. Perigonii valde inaequalis et irregularis foliolum posticum erectum, liberum, lateralia exteriora cum pede longissimo columnae connata, subrhomboidea, acuminata, sessilia, postico multoties majora, interiora nana, libera. Labellum cum pede columnae articulatum, trilobum, convexum, Iobo medio deflexo. Col um na nana, semiteres, auricula longa, petaloidea, utrinque porrecta, basi in pedem longissimum, linearem, canaliculatum elongata. Anthera terminalis, opercularis, eristata, bilocularis. Pollinia 4 , accumbentia, glandulae carnosae, globosae, grnmosae, separabili adnascentia. - Herba indica, minuta, epiphyta, pseudobulbosa, ut videtur aphylla, scapis radicalibus vaginatis, unifloris.

Dry mod a Lindley Sert. Orchid. $t, 8 . f . c$.

1399. Aspasia $L I N D L$.

Bot. Mag* $t .3679$.

1403/1. Daetylostylis SCHEIDW. P erigonii explanati, demum reflexi foliola exte rior a ovata, obtusa, aequalial, basi libera, interiora unguieulata, transversa, fimbriata, Lab e $11 \mathrm{um}$ cum basi colnmnae connatum, navieuliforme, fimbriatum, adscendens, basi glandula lata, bilobata cinctum. Col um na elongata, arcuata, elastica, applanata, glandulis stipitatis ad latera clinandrii, rostello longissimo, adscend ente. Anthera subbiloeularis, ineumbens. Poll inia 4, ovata, candicula plana, glandula oblonga, minima. - Herba brasiliensis, epiphyta; foliis lanceolatis, acutis, carinatis, margine revolutis, distichis, racemis terminalibus, cernuis, floribus bracteatis, pedicellis ante anthesim deflexis, geniculatis, demum erectis, perigonit foliolis exterioribus viridibus, interioribus flavis labelloque albo fimbriatis.

Da etylostyli s Scheidweiler in Otto et Dietr. Gar. tonzeit. 1839. VII. p. 405 .

1404. Cirrinaen LINDL.

Bot. Mag. $t$. 3726 , Bot. Reg, t. 2005.

140B/1. Agamigia $L I N D L$. Perigonii patentis foliola aequalia, lateralia exteriora basi haud producta. L a b e $11 \mathrm{c} \mathrm{m}$ liberum, mobile, indivisum, concavum, hypochilio parvo, ab epichilio crista transversa, glandulosa distincto. Col $\mathbf{m}$ m a erecta, semiteres, marginata, apice ntrinque brachio acuto, patulo aucta. Anthera ecristata, Rostell um elongatum. Pollinia 4, collateralia, per paria connata, caudicula lineari, glandula parva, ovali. - Herba Americae tropicae; rhizomate repente, pseudobulbis monophyllis, racemo radicali erecto, tri-quadrifloro, folio multo breviore.
A g a $\mathrm{n}$ is i a Lindley in;Bot. Reg. 1839. Append, p. 46. 1840. $t$. 32 .

140\%. Traxillaria $R$. et $P$.

c. EUMAXILLARIA Lindl. Bot. Reg. $1838, t .8$,

140\%/s. Stemia LINDL. Perigonii explanati foliola exteriora lateralia basi obliqua, interiora subconformia. $\mathrm{L}$ a b e $11 \mathrm{um}$ cum basi coIumnae continuum, indivisum, concavum, disco appendiculatum. Co I $\mathbf{u} \mathbf{m}$ n a semiteres, basi prodneta, apice rotundata, mutica. Anthera bilocularis. Pollinia 4 , linearia, geminata, basi sejuncta, postica minima, caudienla subquadrata, acuta, pubescente. - Herba Americae tropicae, epiphyta, acaulis, ebulbis; foliis oblongis, basi angustatis, apice recurvis, floribus radicalibus solitariis, ovarii basi bracteata.

St en i a Lindley in Bot. Reg. $n, 1991$.

140\%/2, Fumtleya BATEM. P erig on ii explanati, aequalis foliola exteriora lateralia basi antice involuta, vix obliqua, interiora conformia. L a b e ll n m planum, indivisum, rhomboideum, unguiculatum, patens, basi longe fimbriatum, cum colnmnae pede libero articnlatum. CoI $\mathrm{m}$ na clavata, apice cneullata, margine alata, Anthera bilocalaris, mutica. Pollinia 4 . Herbae Americae tropicae, caulescentes; foliis ligulatis, distichis, floribus axillaribus, solitariis.

H untley a Batem. ex Lindl. Bot. Reg. n. 1991. Bot. Reg. 1839, t. 14, Sert, Orchid, 26.

1410. 'Trolehocentrum PÖPP. et ENDL. Lindley Bot. Reg. t. 1951. A coid ium Lindl mic.

14. IBifrenaria $L I N D L$.

Bot. Mag. $t$. 3597 .

144. Dierypta $L I N D L$.

Fr. Bauer Orchid. fruct, $t, 5$.

1415. Covenia LINDL.

Bot. Mag, $t, 3660$, Bot, Reg, 1838, t, 13.

1416 . Alamemia $L L A V$, et $L E X$. Annal, sc. nat. $I I T, 452$.

1415. Cyemoelhes LINDL.

Sert, Orchid. t. 16. Bateman Orchid, mexic. $t .5$.

180. Catasetuma RICH.

Bot. Reg. 1838, $t$. 63. Bot. Mag. $t$. 3727. Bateman Or. chid. mexic. $t, 2$. Monachan thas Lindley Bot. Mag. t. 360t, 370s. Bot. Reg. t. 1951. M or mo des Lindl. Batem. Orchid. $t .14$.

1420/4. Cyelosia KLOTSCH. Perigonii incurvo-ovato - conniventia foliola aequalia, membranacea, exterior a basi inter se connata, lateralia labello supposita, ejusdem ungui adnata. Lab ellum eum colnmnae basi continuum, ecalcaratum, planum, nudum, trifidnm, breviter unguiculatum. Colnm a elongata, semiteres, tortuosa, apice longe apiculata, antice concava. Anthera incomplete bilocularis, terminalis, apiculata. Pollinia 2 , ovata, postice biloba, e a adi $c$ ula plana, demum elastice contractili, gla nd $\mathbf{I}$ a cartilaginea, globoso-subcompressa. Herba mexicana, epiphyta, ramis densissime appositis, carnoso-incrassatis, subfusiformibus, foliorum exuviis vestitis, folits distichis, basi vaginantibus, scapis subradicalibus, floribus racemosis, unilaterali adscendentibus.

C y clos i a Klotsch in Otto et Dietr. Gartenzeit. 1838. VI. p. 305. Anne Cataseti sp. Marmodes pardina Batein?

14. 1. Stanhopea $H O O K$.

Lindl. Bot, Reg. 1838, t, 5., 1839, t, 1, Sert. Orchid. 1. 1. 20. Bateman Orchid, L. 7. 15. 
142. GÁngora RUIZ et PAV.

Bot. Mag. t, 3687 , Bot, Reg. $t, 1616$.

\subsection{Coryantlies HOOK.}

Bot. Mag. $t$. 3757 .

1425. Peristera $H O O K$.

Bot. Reg. t. 1953. Bateman Orchid. Mexic, t. 8.

148\%. Cymbitimm $S W$.

Lindley Sert. Orchid. $t$. 4. 14. Bot. Reg. 1840, $t$, 25.

\section{Aeropera LINDL.}

Bot. Mag, t. 3563.

1429/1. Seleropteris SCHEIDW. Perigonii patentis foliola exteriora libera, aequalia, membranacea, interiora multo angustiora, spathulata, columnae parallela, carnosa. Lab ell u in unguicnlatum, cum basi columnae continuum, saccatum, utrinque cornutum. Col um a semiteres, areuata, compressa, apice truncata, rostello longissimo, gynizo applanato, exsucco. Anthera membranacea, incmmbens, subbilocularis. Pollinia 2, elongata, compressa, caudienla elongata, obspatbulata, glandula ovali. - Herba brasi$\boldsymbol{l}$ iensis, epiphyta; pseudobulbis tetragonis, monophyllis, foliis ovato-oblongis, acuminatis, glabris, coriaceis, quinquenerviis, racemis radicalibus squa. mosis, filiformibus, pendulis, multifloris, atro-purpureis, floribus flavis, carnosis, labelli saccati apice purpureo.

Scleropteris Scheidweiler in Otto et Dietr. Gar. tenzeit, 1839. VIr. p. 40\%.

143 . Gramanatopinglinam $B L U M$. Bot. Reg, 1839. p. 65 .

1434. ACANTHEPHippiUM Blum. Genus h. I. delendum et supra sub n. 1389/, collocandum.

1440. Fun 40 pluia $R$. BR.

Bot. Reg. $t .1972$.

1441. Dipodiuma $R, B R$.

Bot. Reg, t, 1980 ,

143. Zygopetallam $H O O K$.

Bot. Mag, t. 3585, 3674, 3686. 3812.

144. Cyrtopedirma $R$. BR.

Lindley Sert. Orchid. $t$. 12. Tylochitus Nees in Preuss, Gartenb. Derhandl, VIIT. 191, $t .3$,

1445. CInysis LINDL.

But. Mag. $t .3617$.

1448. Cyrtopera LIVDL.

Royle Himalay. $t, 88$.

1448/I. Cloaenanthe LINDL. Perigonii ringentis foliolnm exterins posticum erectum, lateralia connata, columnae basi prodnetae adnata, saceata, porrecta, interiora basi valde obliqua et inferne colnmnae adnata, revoluta, exterioribus majora et magis nembranacea, $L$ ab e $1 \mathrm{l} \mathrm{um} \mathrm{cum} \mathrm{columna} \mathrm{connatum,} \mathrm{basi} \mathrm{in} \mathrm{calcar}$ cum colomnae basi productum, trilobom. Anthera antice truncata. Pollinia 2, pyriformia, in cau. dieulam linearem deflexa, - Herba brasiliens is epiphyta, nondum descripta.

$\mathrm{C}$ b a en a in the Lindley in Boc, Reg. 1838, App. 38.

1450. CRYPTochiluS Fall, Genus h. I. delendum et supra sub v. $1389 /$, collocanducs.

\section{Trielnopilia LINDL.}

Bot. Mag. t. 3739 .

154. Comparettia PöPP, et ENDL. Lindley in Bot. Feg. 1838, $t, 68$.

$1454 / 1$. Quekettia LINDL. Perigoni cylindracei foliola exteriora linearia, aequalia, basi gibbosa, lateralia connata, interiora conformia, aequilonga. $\mathbf{L}$ abe $I l \mathbf{n} \mathbf{m}$ oblongam, inte- grum, muticum, cum columna parallelum, bазі excavatum, bicallosum. C ol $\mathbf{n} \mathbf{m}$ na semiteres, erecta, apice utrinque auriculata. Anthera unilocularis. Pollinia 2, postice exeavata, candicula lineari, glandula minuta, - Herba pusilla, incertae originis, Pleurothallidis facie; foliis teretibus, maculosis, panicula capillari, tripollicari, floribus parvis, flavis, perigonii foliolis et labello cellularum lutearum majorum, rhaphidibus repletarum copia refertis, columnae perigonium subaequantis auriculis acutis, inflexis.

Q ueketia Liadley in Bot. Aeg. 1839. Append. p. 4.

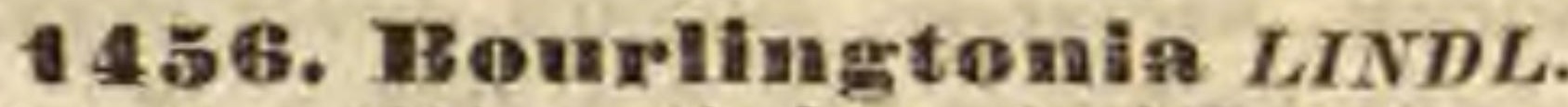

Bot. Reg. 1839. t. 44. Sert, Orchid, t. 2.

1460. Dreiding SWARTZ.

Fr. Bauer Orchid. gen, t. 7. Bot. Mag, t, 3568, 3581 . 3603. 3705. 3712, 3733, 3806. 3807. Bot. Reg. t. 1994. 2006. New-Ser, 1838, $t, 48,1839, t, 42,57,1840, t, 10,14$. Sert. Orchid, $t, 27$, Bateman Orchid. Mexic, $t, 1,3,4$.

$146 \%$. Paelayplayllama $H, B . K$.

Hooker Ic, t. 117 .

148. Bicluaen LINDL.

Pöppig Nov. gen. et sp. t. 105, 106.

1465. Cyrtochatuma $H$. B. K.

Bot. Reg. 1838. t. 44. 1839. 2, 62, Sert. Orchid, t. 7. 25. Bateman Orchid. Mexic. t. 6.

1468. Delontoglosgumn $H . B . K$.

Bot. Reg. 1859, t. 48. New-Ser. 1840, t. 30.

146\%. Ir rassian $R$. BR.

Bot. Mag, t. 3577, 3794. Sert, Orchid, t. 6.

1468\%/1. In iltosain LINDL. Perigonii explanati foliola sessilia, exteriora lateralia cum interioribus conformibus, revolutis basi connata. $L$ abe $11 \mathrm{~cm}$ maximum, dilatatum, indivisum, sessile, cum columna leviter connatum, basi lamellatum. Columna nana, semiteres, apice aurita. Anther a.... Po 11 in ia 2, caudieulae oblongae ad. nata. - Merba brasiliensis, epiphyla, pseudabulbosa; scapis unifloris, vaginatis, squamis equitantibus, floribus speciosissimis.

Milt o ni a Lindley in Bot. Reg. n. 1976, t. 1992. Sert. Orchid. t, 2t. Bot. Mag, 2. 3793. Macrochilus Wetsc. et Knowl. Floral. Cab, t. 45 ,

1469. Phalaenopsis $B L U M$.

R. Brown in Horsfield Plant, Jav, rar, 28, t, 8, Bot. Reg. 1838. 2. 34.

\section{Camarotis LINDL.}

Sert, Orchid. t. 19

1480. Saceolabian LINDL.

Sert. Orchid. $t, 17$.

1483. APPENDICULA Blum. Deleatur h. I. supra sub n. $1369 / 2$ collocanda.

1484. CRYPtoglotTIS Blum, Delentur h. I. supra sab a. $1369 / 3$ collocanda.

148\%. Sareanthua LINDL.

Fr, Baner Orchid, gen, $t, 9$, Bot. Mag. $t, 3571$.

1493. A ש̈rides LOUR.

Lindley Sert. Orchid. t, 15, 30.

1501. Calanthe $R, B R$.

Lindley Sert, Orehid. $t, 9.24$.

I5061. TIalachademia LINDL. Perigonii resupinati foliola exteriora lateralia connata, apice reflexa, libera, galeam formantia, posticum cordatum, acuminatum, interiora minima, squamaeformia, rotundata. Lab e IJ um carnosum, margine revolutum, basi nucronatum, cum columnae pede galeae adnato artienlatum. Columna antice bicirrhosa, basi longe prodac- 
ta; stigmate lineari-oblongo. Anthera bilocularis, decidua. Pollinia 2 , ceracea, sessilia, glandula molli, cubica, nuda. - Herba brasiliensis, repens; pseudobulbis monophyllis, scapo radicali, floribus carnosis, p. 67 .

$\mathrm{M}$ a I a $\mathrm{c}$ h a de $\mathrm{n}$ i a Lindley in Bot, Reg, 1839. Append.

$1508 / 2$. Centropetalum $L I N D L$. Perigonii foliola libera, labello duplo minora. $\mathbf{L}$ a bell $\mathbf{u m}$ obovatum, indivisum, nudum, basi appendice parva, excavata anctum. Columna petaloidea, convolnta, basi imo labello adnata. Anthera membranacea, unilocularis. Pollinia 4, distineta, geminatim candiculis duabus adscendentibus affixa. - Herba peruana; foliis distichis, carnosis, linearibus, falcatis, pedunculis solitariis terminalibus, floribus luteis, dimidium pollicem latis, columna denticulata, labello integerrimo.

C e n tropeta I u m Lindley Sert, Orchid, $n, 21$, in not.

150\%. Orellis LINN.

Fr. Bauer Orchid. fruot, t. 2.

15iz. Aceras $R$ BR.

Royle Himalay, $t .78, f .1$.

151\%. Penistylus $B L U M$.

Royle Himalay, $t .87 . f$. 2 .

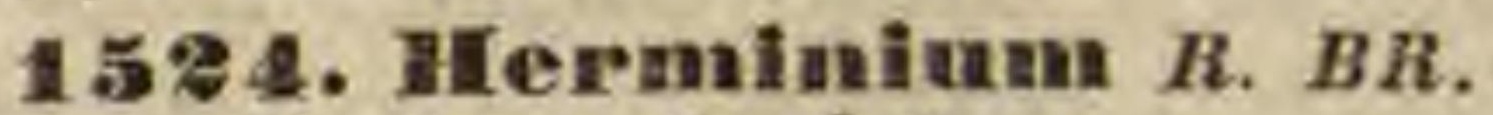

Royle Himalay, $t .87 . f$. 3 .

\section{5\%6. Cymorelis THOUAR.}

Bot. Reg. t. 1998.

1534. IBantholina $R$. BR. bot. 49.

Endlicher Iconogr. $t$. 40. I a th rista Swartz Annot.

1536. Satyrimm SWARTZ.

Lindley Orchid, 335. Bot, Mag, t. 1512,

1536/1. Satyrleliam LINDL. Perigonii foliola libera, secunda, patentia, exteriora aequalia, interioribus conformia. Labe 11 um posticum, patens, planum, acuminatum, basi bicalearatum. Col umna gracilis, libera. Anthera recta, resupinata, biloeularis. Stig $\mathrm{ma}$ in apice columnae minutum, truncatum Pollinia caudiculis duabus, connatis glandulae unicae (stigmatis apici) adylutinatis, - Herba capens is, spithamea, Orchidis facie, glaberrima; radicibus testiculatis, foliis anguste lanceolatis, acutis, caulem vaginantibus, spica sesquipollicari, laxiuscula, floribus albis, purpura suffusis, bracteas ovatas, retrofractas superantibus.

S at y rid I u Lindley Orehid. 345.

1536/2. Avieeps LrNDL. Perigoni ringentis foliola exteriora in labium inferins tridentatum coalita, interior a nulla. Lab el$1 \mathbf{n m}$ galeatum, basi bisaccatnm. Col umna teres, elongata, sub galea recondita, $S t i g m$ at is bilabiati labium posticum maximnm, emarginatum, anticum ntrinque in brachinm porrectum productum. Anth era resupinata, caudicalis nudis, secus stigmatis brachia productis, glandulis duabus nudis. - Herba capensis, pumila, foliosa; radicibus testiculatis, floribus axillaribus inter folia abditis.

Aviceps Liadley Orchid, 343, - ? Satyrium pium il n m Thunb.

\section{Disa BERG.}

Lindley Orchid. 347 .

A. EUDISA. A $\mathrm{n}$ th er a erecta. (Berg Flor, Cap, $t, 4, f, 7$ Bot. Reg. $t, 926$.

b. CALODISA. A u th e r a supina. c. Repandra Lindley $l, o$, Perigonif galea ineumbens, postica, calearata. Labellum oblongum v. li. neare, foliola interiora supiaa, faleata. - Elores spicati.

8. Phlebidia Lindley l. e. Perig onil galea infundibularis, recurva, labellum oblongum. foliola iateriora supina, unidentata. - Caulis uniflorus. D. longi. corais L.

$\gamma$. Vagina ria Lindley 2 . c. Perigonil galea antica, horizontalis, labellum oblongum, foliola interiora lobata, auriculaeformia. - Flores sessiles, terminales, subsolilarii.

d. Pardogloss a Lindley $l$. c. Perigonil galea antica, saceata, labelfum oblonguat, utriaque in angufam acutum productum, foliola iateriora falcata, snpiaa, apice callosa. - Ftores corymbosi.

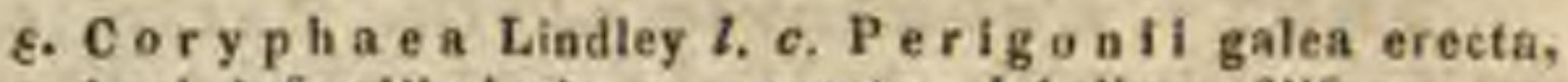
basi infundibularis v. saceata, labellum filiforme v. acuminatum. - Flores saepius corymbosi, bracteis magnis, membranaceis sustenti.

5. Ste nocarpa Lindley 2 . c. Perigonit galea erecta, basi infundibularis, labelluas apice dilatatum, lo. batnm, foliola interiora supina, falcata, basibus pro. ductis autherae adnata, - Flores lare racemosi.

$\eta$. Oregura Lindley $l$. $c$. Perigonit galea incum. bens, infundibularis, labellum oblongnm, foliola interiora supina, faleata. libera. - Flores laxe spica$t i$, folia setacea, oaulis calamiformis. D. porrecta Swartz. Ker in Brandes Journ, V. t. 5. f. 1.

9. Trichochila Lindley l. c. Perigouit galea in. cumbens, ealearata, labellum lacerum, sessile v. saepius unguiculatum. - Flores laxe spicati v, subso. litarii, foliola angustissima. (Bauer Iltustr. t. 14.)

t. Disella Lindley $l$. c. Perigonil galea postica basi saceata, labellum filiforme. foliola interiora erecta. - Flores dense spicati, minuti, folia saepiut filiformia, Bat. Reg. $t, 324$.

$1537 / 1$. II onademia LINDL. Perigonii ringentis foliola libera, exteriora membranacea, supremum galeatum, basi in calear productum, interiora carnosa, subconformia. Lab e ll n m liberum, oblongum, earnosnm, plannm. Col um na nana, bipartita, clinandrio carnoso, elevato, truncato, in basi labelli sito, staminodiis liheris. Anthera resupinata. Pollinia candiculis in glandula nnica connatis. - Herbae capenses; radicibus testiculatis, foliis et facie Ophrydis.

M on ad enia Lindley Orchid. 456. D is a e sp. Swartz Bot. Reg. $t$. 210.

153 \% 2 . Sehizodium LIVDL. P erigoni ringentis foli ol a exteriora libera, canaliculata, supremum basi calearatum, interiora nana, apice carnosa, inaequaliter biloba $v$. oblique torta, basi saepius auriculata, per baseos medium columnae adnata. La bell $\mathbf{n}$ m liberum, lineare, acnminatum, perigonii foliolis exterioribus aequale, sapra basim constrietum, hypoehilio concavo, membranaceo, epiehilio carnoso, canalienlato. C oI um na bipartita, clinandrio carnoso, elevato, truncato v, exeavato, ad basim labelli sito. A nthe $r$ a resupinata $v$. horizontalis, rostelli brachiis truncatis v. acuminatis et contortis. Polliniorum glandnlae 2, nudae. - Herbae capenses; tuberculis radicalibus pedunculatis, foliis radicalibus ovatis $v$. obovatis, petiolatis, patentibus, caule saepe flexuoso, ad flexuras squamis vaginato, racemis la. $x i s$, paucifloris, $v$. flore solitario, terminali, floribus parvis, pedicellis filiformibus.

$\mathrm{S}$ e h izodi u m Liadley Orchid, 358, D is a e sp. Swartz. Thunb. Orehidis sp. Linn.

$1538 / 3$. Penthea LINDL. Perigoni ringentis foliola exteriora membranacea, libera, aequalia $\mathbf{v}$, inaequalia, intermedium ecalca- 
ratum, saepe diversiforme, interiora diversiformia, anthera utrinque adnata, saepins carnosa. L a bellum lineare, simplex, liberum, perigonii foliolis interioribus multo angustius, a col u m a clinandrio saepius trilobo sejunctum. Anthera terminalis, erecta v. reclinata, loculis parallelis, basi productis et saepe divergentibns, brachiis elinandrii incumbentibus. Pollin a glandulis duabus, nudis. - Herbae capenses; foliis vaginaeformibus v. angustissimis, radicalibus planis, floribus corymbosis aut spicatis, nunc solitariis aut geminis.

Penthea Lindley Orchid. 360. Dis a e sp. Thunb. Swartz.

$153 \% / 4$. Forfiearia $L I N D L$. Perig on i concavi, ringentis foliola exteriora libera, concava, intermedio antico majore, mutico, lateralia aestivatione imbricante, interiora libera, subulata, aestivatione abrupte bis flexa. Lab e l$1 \mathrm{n} \mathrm{m}$ earnosum, truncatum, libernm, nanum. A nthera reclinata, loculis parallelis, approximatis, glandulis duabus triangularibus, imbricantibus, nudis, stigmate adnato, excavato, simplici. Herba capensis; foliis rigidis, linearibus, acutissimis, caule brevioribus, racemo laxo, octo-decemfloro, bracteis membranaceis, acuminatissimis, ovario brevioribus.

Forficaria Lindley Orchid. 368.

$153 \% / 5$. Hirerselnelia $L I N D L$. Perigon i patentis foliola exteriora inaequalia, supremum galeatum, inflatum, dorso calcaratom, lateralia superans, interiora sub galea abseondita, carnosa, collateralia, basi anriculata, apice dolabriformia, colnmnam duplo superantia. Lab ell am oblongum, carnosnm, integerrimnm. Col um a nana, bipartita, stigmate carnoso, elevato, coneavo, ad basim labelli sito, rostello tripartito, laciniis lateralibus angustioribus, acuminatis, appendice dorsali, lineari, bilobo, utrinque tuberculato, ante antheram sito. Anthera horizontalis, loculis parallelis, abbreviatis. Pollinia glandulis duabus maximis, truncatis, corneis, dentatis. Herba capensis; radicibus tuberculiformibus, foliis setaceis, floribus paucis, magnis, speciosis.

Herschella Lindley Orchid. 362. Dis a gramini. foli a Ker in Brandes Journ. VI. 44. $t, 1, f .2$,

$1537 / 6$. IBrelnyeorythis LINDL. P erigonii obliqui, subglobosi foliola exterio$r$ a inaequalia, supremum convexum, muticum, lateralibus liberis multo minus, interiora ovata, obtusa, ereeta, basi obliqua, medio carnosa, exteriori supremo duplo longiora, lateralibus duplo breviora. I a b e I I n m perigonii foliolis exterioribus lateralibns majus, coriaceum, basi cavom, apice dilatato tridentatum. Ant h e ra reclinata, bilocularis, pedicellata, elinandrio maximo, ovali, intra cavitatem labelli abscondito adnata. Pollin i glandulis duabus nudis. - Herba capens is; caule pedali v, longiore, foliis magnis, ovatis, acutis, dense imbricatis, floribus inter folia superiora axillaribus, iisdem brevioribus.

B r a chycoris Lindley Orchid. 363.

1538/7. Ceratamdra LINDL. Perigoni bilabiati folio I m exterius supremum cum interioribus in galeam, saepius antice pendulam conglutinata, I a teralia exteriora patula, libera. Labell um unguiculatum, lunatum, columnae faciei adnatum, nudum $v$, appendice carnosa, apice libera auctum, Col um a hippocrepica. St igma parvum, trilobum, in sinu brachiorum verticale. Anthera resupinata, loculis distantibus, - brachiis stigmatis adnatis. Poll in ia glandulis nullis.

Herbae capenses, siccatione nigrescentes; foliis lineari-setaceis, basi dilatatis, caulem totum vestientibus, radicibus fasoiculatis, longis, carnosis, tomentosis, floribus dense spicatis.

C e rat a nd ra Lindley Orchid, 363.

a, EUCERATANDRA Lindl. t, c. Stig matis brachia angusta, distantia, omaino ferri equini forma. - Hip popodium Harwey msc. Pterygodium atratum Swartz, (Bauer Illustr. t, 16.)

b. EUOTA Lindl. l. c. Stigmatis brachia dilatata, conniventia, galene speciem formantia. - Cal ot a Harwey mic.

$1539 / 1$, Dmanatodifanden $21 N D L$. Perigonii ringentis foliolum exterius supremum et interiora lobata, apice fornicata, in galeam agglutinata, lateralia libera, patula, Lab ell um sessile, hastatum, colvmnae adnatum, appendice membranacea, tubulosa auctum. Columna membranacea, truncata; st ig mate horizontali, brachiis incurvis. Anthera erecta, loculis distantibus, subparallelis, basi truncatis. Pollinia glandulis nullis. - Herba capensis; radicibus testiculatis, foliis duobus $v$. tribus, cordatis, ovatis, basi amplexicaulibus, supremo a floribus distante, multo minore, spica elongata, multiflora.

$0 \mathrm{mmat} o \mathrm{di}$ um Lindley Orchid. $365.0 \mathrm{phry} \times \mathrm{v}$ oI neris L. Pterygodinu voluere Swartz. Ker in Brandes Journ, IX. t. 4. f. 1.

1540. Coryeimm SWARTZ.

Lindley in Bot. Reg. 1838. 4. 45. Orchid, 368.

1544. Gastroalia $R, B R$.

Endlicher Iconogr. $t, 5$, Lindley Orchid. 384.

1544. Ceratopsis LINDL. Perigonii foliola exteriora et interiora subaequalia, parallela (?) libera, tenera. L a be $11 \mathrm{um}$ ovatum, nudum, basi calcaratum, indivisum, sub apice tuberculatum. Co $1 \mathbf{n} \mathrm{mna}$ minima, truncata, apice in fronte bicirrhosa. A n $t$ hera pedicellata, terminalis, incumbens, bilocularis, eristata. Pollinia granulata, sectilia. - Herba Indiae orienta$l i s$, palmaris, aphylla, squamis scariosis vaginata.

Ceratops is Lindley Orchid. 383. Li modor um rose $\mathrm{u}$ m Don.

1544/1. GAMOPLEXIS Falconer in Royle Himalay. 367. Herba himalayeasis, nondum descripta, Orobanches facie, perigonio gamophyllo. Lindiey Orchid. 384.

1545. Epipogivan GMEL.

Lindley Orchid, 383.

1553. Epipaetis HALL.

Fr. Bauer Orchid. gen, t. 19. 20.

1558. Aetheria BLUM.

Hue Goodyera oeulta Thouars Orchid, t. 28, P I atyle p is A. Rich. in Mem, soc. h, n. Paris. IV.34. t. 6.f.4.

1559. Coodyerra R. BR.

Synonymon Thouarsii et Ptalylep is A. Rich. deleantar. Vid. supr. B. 1558.

1569. Anoectoelailus BLUH.

Lindley Bot. Reg, $t, 2010$.

15\% 9. Cryptestylis R. BR.

Fr. Bauer Orchid. Gen, t, 17. 18. Endl. Iconogr. t. 14.

1580. Caloeluilus $R$. BR.

Endilicher Iconogr. $t, 17$.

$1586 / 1$. Nacilonaldia GUNN. Perigoni i patentissimi foliola aequilonga, conformia, interiora angustiora. La b e 11 u m perigonii foliolis interioribus simile, omnino calvum. Co $1 \mathrm{um}$ na brevis, clinandrio postice elevato, carnoso, 
trilobo, lobis lateralibus declivibns, nunc appen- mobili aucta. Col um na elongata, arcuata, indiculatis. Anthera tomentosa, antice intrusa, fra medium semiteres, marginata, superius alata, valvis membranaceis. - Herbae Novae-Hol- alis marginantibus, basi liberis, falcatis, apice landia e, flexuosae, ad quamvis flexuram folio lineari instructae; floribus luteis $v$. purpureis, terminalibus, solitariis $v$, rarius geminis aut:pluribus.

M acd onaldi a R. Gunn mso. Lindley Swan. Riv. $I$. Orchid. 385.

a. MACDONALDIAE VeraE. Lindl. 1 . $c$. Clinandrii lobi Jaterales obsoleti. (Lindley $S_{\text {wan-Riv, }}$ t. 9. B.)

b. BIAURELLA Liadl, $\boldsymbol{l}$. c c Clinandrii lobus medins obsoletus, laterales appendiculati. Thelymitra venosa $R, B r o w n$.

1588. Ilicrotis $R$. BR.

Endlicher 1conogr. t. 15, Lindley Orchid. 395.

1589. Acianthus $R \cdot B R$.

Endlicher Iconogrr, t, 16. Lindley Orohid, 396.

1590. Cyrtostylis $R, B R$.

Liudley Orchid, 398.

1591. Chileglettis $R, B R$.

Lindley Orchid. 386.

1592. Drioehilus $R, B R$.

Eudlicher Iconogr. $t$. 6. Lindley Orchid, 427, Diplo. d i u m Swartz Annot, bot, 50.

15S3. Calladenia $R \cdot B R$.

EUCALADENIA Endl, 2 . o. Iconogr. $t$. st. Lindl. Or. chid, 417, b. CALONEMA Lindl. Swan-Riv, LIT. Perigo. nif foliola exteriora et interiora ringentir, longissime acuminata, labellum integrum, nuargine saepius fimbriatum. LindI. Op. eit. t. 58. a. - e. LEPTOCERAS R. Br. Eadl. l. o. Genus proprium Lindl, Orchid. 415.

1594 . Clossodlia $R, B R$.

Lindley Orchid. 423.

a. EUGLOSSODIA Endl. Colu nu a supra antheram haud producta. Ieonogr. $t .41$.

b. ELYTRANTHERA. C al u m a a supra antheram producta.

1595. Pterostylis $R . B R$.

Lindley Orchid. 387 .

1598. Hyperantilug $R$. BR.

Endlieher Iconogr. $t$. 7. Lindley Orchid. 392.

159\%. Corysanthes $R, B R$.

Lindley Orchid, 393.

b. STELEOCORYS Eadl. Iconogr, t, 18.

c. CORYBAS, Hue censente cl. Lindley $\mathrm{C}$ a I c e a ri a Blam, inf $r, n, 1599$.

4598. Caleya R. BR.

Endlicher Iconogr. $t$. 8. C ale a u a R. Be. Lindley Or. chid. 428.

1598/1. Drakaea LINDL. Perigonii foliola linearia, subaequalia, exteriora lateralia labello supposita, omnia reflexa. L a bell $\mathbf{n}$ m unguiculatum, ungue longissimo, medio articulato, Iamina peltata, convexa, marginibus reflexa, cum pede suo mobilis, decidua. Co I umna semiteres, elongata, clavata, basi utrinque auriculata. Anthera terminalis, persistens, loculis approximatis. Pollinia 4 . Rost ell um ovatom, acuminatum, convexum. - Herba Nova Hollandiae a us tro-occidentalis; radicibus lanatis, apice bulbiferis, folio radicali unico, coriaceo, subrotundo, cordato, scapo erecto, pedali, glabro, squamula infra medium solitaria unifloro, labello basi tuberculato, crinito, angustato, utrinque dente retrorso aucto.

D rakae a Lindley $S$ wan River LV. F. 3. Orchid.

$1598 / 2$. Spieulaea LINDL. Perigonii foliola linearia, subaequalia, exteriora lateralia la. bello supposita, omnia erecto-patentia. LabelI $\mathbf{n ~ m}$ unguiculatum, ungue elongato, tereti, inarticulato, lamina peltata, lineari, apice appendice circa antheram in cucullum brevem quadrilobum confluentibus, lobis lateralibus longioribus. A nther a terminalis, persistens, loculis approximatis. Stigma meniscoideum. - Herba Novae Hollandiae austro-oceidentalis, spithamea, glabra, verisimiliter fusca; folio radicali unico, coriaceo, cordato, acuminato, scapo medio unisquamato, racemo multifloro, bi-tripollicari, perigonii foliolis exterioribus fliformibus, spathulatis, interioribus angustis, apice haud dilatatis, labelli lamina carnosa, supra medium affixa, basi angustata, ciliata, retusa, apicis appendice ovali, membranacea.

Sple ula a Lindley $\mathcal{S}_{\text {wan-River }}$ 66. $f$. 4, Orehid.

1599. Calcearia BLUM.

Blum. Ic. f. 33. Censente cl. Lindley ad $\mathrm{C}$ o r y $\mathrm{s}$ a $\mathrm{n} t \mathrm{th}$ is (a.1597.) sect. c. Corybas referenda.

1600. Callopogon $R . B R$.

Lindley Orchid. 474.

1801. Pogomia JUSS.

Lindley Orchid. 413. Species antarcticas: P. te trap hy I. I a m Pöpp. et Endl. et C a íopogonem Lessouli Bronga. in genus propriam Codonorchis 1001/1. coujaugit cl. Lindl. In Pogonia: Perigonium irregulare subringeus. L a b ell u m liberum, ecallosum, cum columna elongata parallelum, trilobum, diseo lameltato, eristato y. villoso. CoI u m n a elongata, clavata, marginata v. semiteres, apice subaurieulata. Anthera stipitata, bilocularis. Pollinia 2, sulcata.

1601/1. Codonorehis LINDL, Perigonii campanulati folio la libera, exteriora et interiora aequalia. $L$ a b ell u m unguiculatum, ovatam, medio seriatim glandulosum. Columna elongata, alata, stigmate longitudinali lineari. A n th e $r$ a apiculata, membranaceo-marginata. Pollinia bina, compressa, farinosa. - Herbae in America antarotica indigenae; tuberculis sphaericis caudicem descendentem terminantibus, caule uniftoro, basi vagina membranacea cincto, foliis verticillatis, membranaceis, scapo nudo, flore bractea eucullata suffulto.

Codonorchís Lindley Orehid, 410. Pognata tetrap hy ll a Pöppig et Endl. Nov, gen, et sp. t.122. C al o. pogon Lessonil Brongn. ad Duperr. $t, 32, f, 1$.

160\%. A rethusa GRONOV.

Fr. Bauer Orćhid. Fruct. $t$. 7, Lindley Orohid. 426.

1603. HIaplostellis A. RICH.

Lindley Orehid, att.

1604. Chloraea LINDL.

Orchid, 399.

1605. A sarea $L I N D L$.

Orokid, 407. Gavilu Feaill, Obs, t. 18.

1606. Bipinnula JUSS.

Lindley Orchid. SOS. $^{2}$

1606/1. Cleisten L. C. RICH. Perigonif conniventis foliola libera, exteriora aequalia, interiora latiora, magis membranacea. Lab e 11 um oblongum, membranaceum, liberum, circa colnmnam convolutum, integrnm v. trilobum, basi concavum, bicallosum, cum columna articulatum, medio lamellatum. Co l um na libera, elongata, clavata, semiteres, clinandrio dentato. A nthera pedicellata, inflexa, bilocularis, loculis discretis, - Herbae guianenses, terrestres, Uvulariae facie; radice tuberosa, foliis numerosis, basi oucullatis, caulem simplicem a basi vestientibus, floribus axillaribus, nutantibus, foliis brevioribus.

Cleistes Riehard Orehid. europ. 9, in not, timad o$r$ un grandifla r um Aublet Guim, 1, 321. 
160\%. Limodorum TOURN.

Lindley Orchid, 398. C e u tros is Swartz Annot,bot,52. noa Thouar.

1608. Cephalanthera L. C. RICH. Lindley Orchid, iti.

1609. Crybe LINDL.

Orchid. 425.

1609/1. Anthogonivam WALL. Perigonium tubulosum, apice ringens, foliolis exterioribus in tubum longum connatis, lateralibus postico latioribus, apice obliquis, interioribus spathulatis, collateralibus, apice oblique inflexis. $\mathrm{L}$ a bell $\mathbf{n m}$ integerrimum, apice truneatum, apiculatum v. obsolete trilobnm, columnam amplexans eique semiadnatum, intns nudnu. Col u m na semiteres, clavata, stigmate excavato. Anthera terminalis, bilocularis, stipitata, loculis disjunctis, parallelis. Pollin ia 4, apicibus per paria connata. - Herba indica, fortassis epiphyta et e tribu removenda, acaulis; radicibus fibrosis, foliis latis, gramineis, scapo radicali, basi vaginato, apice racemoso.

Anthogonium Wallich Catalog. n. 7398. Lindley Orchid. 425 .

1610. Cyathoglotis PÖPP. et ENDL. Lindley Orchid. 430.

161 . Sobralia RUIZ. et PAV.

Lindley Sert. $t$, 29. Orchid. 430.

161 . Episteplaium $H, B . K$.

Lindley Orchid. 432.

161 \% 1 . Erythrorelhis BLUM. Perigonii erecto-conniventis foliola conformia, exteriora et interiora subaequalia. Labell n m carnosum, concavum, ima basi cum columnae ungue concretum, limbo erecto, sublobato. Columna brevissima, unguiculata, subincurva, clavata. Anthera terminalis, opercularis, bilocularis. Pollinia 2, conduplicata, solidiuscula, libera. Capsula siliquaeformis, inanis, rimis $2-3$ longitudinalibus dehiscens. Semina membranaceo-marginata.

Herba javanica, terrestris, aphylla; caulibus sarmentosis, nodoso-articulatis, ad nodos radicantibus, squamis solitariis foliorum loco instructis, floribus laxe spicatis.

Erythrorchis Blume Rumph. I. 200. Cyrtosia altis sim a Blume $O p$, cit, $t, 70$.

\section{Cyrotosia BLUM}

Specie altera a Cl. Blume Rumph. I, 199, t. 69. nune exelusa, eharacter ita stabiliendus: Perigonil conniventis foliola conformia, exteriora et interlora subaequalia. $\mathrm{L}$ a b e JI u u carnosum, concavum, ima basi columnae ungui conti. nuam, limbo ereeto, iategerrimo. Colu ma brevissime unguienlata, subineurva, apice subfornicata. An thera termlaalis, opercularis, bilocularis. Polliaia 2, tereti-faleata farinoso-pulposa. Capsula siliquaeformis, carnosa, intus pulposa indehiscens. Semina globosa, testa solida. - Herba javanica, terrestris, caulescenz; caulibus erectis, continuiv, folits nanis, squamaeformibus instructis, floribus lare spicatis, medioeribus.

1614. Wamilia LINN.

Fr. Bauer Orchid. Gen, t. 10. 11. Blume Rumphia 196. 8.67 .68 .

\section{Thelyelaiton ENDL. \\ Iconogr, t. 29.}

$1616 / 1$. Amblostoma SCHEIDWEIL. Perigon ii subconniventis foliola exteriora aequalia, basi connata, concava, apice inflexa, interiora angustiora, reflexa, apice inflexa. L a b e 11 u m cuneiforme, intus bicristatum, cum col um a truncata in urceolnm connatum, parta libera adscendente, digitato-trifida. A n- thera quadrilocularis, applanata, late cordata, obtusa. Pollinia 4, sphaeriea, per paria cohaerentia. - Herba mexicana, epiphyta; caule erecto, simplici, folioso, articulato, basi vaginato, foliis lanceolatis, sessilibus, subcoriaceis, obtusis, subcarinatis, mucronatis, floribus in apice caulis racemosis, parvis, alternis, pedicellatis, bracteatis, racemo simplici $v$. subramoso, cernuo, perigonii foliolis exterioribus intus purpureo-punctatis, interioribus et labello flavescentibus.

A mblostoma Seheidweiler in Otto et Dietrich Gar. tenzeit. 1838. VI. p. 383.

1618. Cyprofpeditum LINN.

Bot. Reg. $t, 199 t$.

\section{Drdo LX IR. Zingiberaceae.}

1625. Hoscoüa SMITH.

Royle Himalay, $t, 89$.

1631. Fitemealnuia LINN.

Pöppig Nov. gen, et sp. t, 134-136.

\section{Ordo LXIX. Camaceac.}

1641. Thalia LINN.

Pöppig Nov. gen, et sp. $t, 132-133$.

1643. Plneyniena WILLD.

Püppig Nov, gen, et sp. t. 125_128.

1644. Crallinea MEX.

Pöppig Nov. gen, et sp. t. 129-131.

1646. Camma $L$.

Bot. Reg. $t$. 2004,

\section{Ordo LXX. Mrisacene.}

1650. TiRavenala $A D A N S$.

Eadlicher Iconogr. t. 42.

\section{Drdo LXXI. Pajadeae.}

\section{5\%. Najas WILLD.}

Hook. Flor, Bor. Amer, $t, 184$.

1659/1. Fhyllogpadix HoOK. F lores dioici? Masc.... Fem. S path a pedunculum oppositifolium terminans lata, convoluta, incurva, superne in laminam elongatam, acuminatam producta. Spadix 8 patha inclusns, antice flores uniseriatos imbricatos, marginibus utrinque squemas oblongas subimbricatas gerens. Ovaria sessilia, late ovata, subglobosa. Stylus brevis, crassus; $\mathbf{s t i g m ~ a ~ c a p i t a t u m . ~ F r u e t ~ u s ~ . . . . ~ - ~ H e r b a ~ i n ~}$ Americae borealis ora occidentali aquatica; radice nodosa, fibris albidis et foliorum veterum reliquis vestita, caulibus brevibus, vaginatis, foliis linearibus, elongatis, gramineis, subcoriaceis, siccitate nigrescentibus, nervosis, obsolete costatis, integerrimis. t. 186.

Phyllospadix Hooker Flor, Bor. Amer. If. $17 t$.

\section{Zamanelaellia MICHEL.}

Stamen wuac unieum, anthera biloculari apievlata, nunc duo in unicum eoalita, anthera quadriloculari blapieulata. O varia numero varia. Steinheil in Annal. sc. nat. IX. 87. t. 3. 4. f. a.

$168 \% / 1$. Trallodule. F I o r e 6 dioici. M a s c. solitarii in axillis foliorum sessiles. Perigo $\mathrm{ninm}$ nullum. Stamen 1; filamentum elongatum, antheris duabus, dorso adglutinatis, altera paullo demissius inserta, minore, utraque biloba, polline in massam viseidam eonglomerato. Fem. .... Herbula Zanichelliae facin, in a estuariis $M a-$ dagascariae observata; radicibus reptantibus, 
foliis gramineis, basi vaginantibus, fere Zosterae, sed multoties minoribus, apice truncato tridentatis, stipula interpetiolari nulla.

Diplanthexa Thouars Gen, madagasc, n.7. Steinheil in Annal, se, nat, IX, 98, $t, 4$. f. $b$.

1664/1. Cyenogeton ENDL. Flores hermaphroditi, spicati. Perigoni m ealycinum, hexaphyllum, foliolis sessilibus, acstivatione valvatis, sub anthesi patentibus, deciduis. Sta min a 6 , perigonii foliolis adnata; antherae biloculares, loculis oppositis, diseretis, longitudinaliter dehiscentibus. Ovaria 6 , libera, sessilia, dorso convexa, a latere compressa, faciebus contigua, unilocularia. Ovala 2, suturae ventrali prope basim contigue superposita, anatropa, superins minus. Stylus terminalis, brevis, intus stigmatosus. Nucula e 6, compressae, falcatae, putamine coriaceo, abortu monospermo. S em en falcatum, testa membranacea. Em bry o exalbuminosus, macropodus, homotropus, extremitate radiculari infera. - Herbae Novae-Hollandiae, aquaticae; foliis gramineis, basi vaginante scapum simplicissimum amplectentibus, spica terminali stricta, laxiflora.

c y cnotegan Endlicher in Annal. Wiener Mus. II. 210. Iconogr, $t, 73$. Triglo chin procerum R. Br.

$1684 / 2$. Ouvirandra THOVAR. F lores hermaphroditi, Perig o ni um coloratum, triphyllum, foliolis squamaeformibus. Stamina 6 , inaequalia; fil am enta subulata, inferne dilatata, a nthe rae bilocnlares, basifixae. Ov a ria 3 , ses* silia, lagenaeformia, libera, unilocularia, 0 v ula 8 , ex imo loculo adscendentia, anatropa. Stylus terminalis, intus stigmatosus. Nacalae rostratae, coriaceae, abortu mono-dispermae. S emina erecta, testa membranacea v. subspongiosa, longitudinaliter plicata, membrana interna tenni. $\mathbf{E}$ mbryon is exalbuminosi, orthotropi extremitas radicularis infera, obtusa v. subapienlata, cotyledon crassa, juxta radiculam biauriculata, ibidem fissa, plumulam adpressam exserens. - Herbae aqua. ticae, in Africa tropica indigenae, perennes; radice tuberosa, eduli, foliis omnibus radicalibus, petiolatis, parallelogramice reticulato venosis, areolis plenis, $v$, parenchymate in immersis deficiente pertusis, scapis e foliorum congerie ortis, apice in spicas binas $v$. ternas, breves divisis, spicis prima juventute approximatis et spatha membranacea, rostrata, basi circumscissa calyptratis, floribus parvis, odoratis.

Ouviraudra Thouars Gen, madagase, $n$. 3. Deeaisne in Delessert. Ic, select, III. 62, t. 99, 100. H y drogeton Persoon Encheir. I. 40. O a vira ndo u Madagase. (Folli figura apud Mirbel Elem, $t, 26, f .4,3$

\section{LEMNACEAE.}

Ordinis aune in plura genera divisi, et monente cl. Schlei den Aroideis adseribendi, monographiam nuper proposuit vir de re berbaria inter nostrates longe meritissimus, quem magnum facile puto, et credo libenter. Acutissimum illan naturae scrutatorem hoc loeo presso pede tanto libentias sequor, quanto acrius nostra ab illo carpuntur. Wol. fiam Horkelii sive Horkeliam Reichenbachii Lemuam minorem habuisse facills error, mibi vago rumori incaute credenti et Hilis imputandus, qui f́nenta saa sab medio col. locant, et inanem tituloram umbram iavidiose proponuat.

„Herbulae liberae, natantes v, submersae, arrhizae $v$. mono-polyrhizae, radicibus calyptra terminatis. V a s a spiralia rudimentaria transitoria (in pistillo), v. conspicua (in tota planta). Axis ad punctum redactus, cum fo- liis in frondem confluens. F ron s singula planta completa, ex rima una basilari v. duabus lateralibus prolifera, prole nuda v. stipulis duabus membranaceis ancta. Hibernaculum bulbillus antumno fundum aquae, vere superficiem petens. Inflorescentia spadix, ob axim suppressum fere nullus, $s p$ ath a urceolato-membranacea, staminum evolutione irregulariter fissa. Flores monoici. Masc. Mono-diandri. Fil a menta filiformia. Antherae biloculares, loculis subglobosis, apice contiguis, basi remotissimis, biloculatis, rima longitudinali, laterali dehiscentibus. Pollen globosum, muricatum, rima unica (?) donatum. F em. Ovarium uniloculare, uni-mnltiovulatum. Ovulu m anatropum, v. hemianatropum, v. atropum, integumentis binis. Stylus continuus. $S \mathrm{t} i \mathrm{~g} \mathbf{m}$ a expanso infundibuliforme. Fructus utriculas mono-polyspermus, indehiscens, v. c a p sula circumscissa. Semen integumentis binis, externo coriaceo- carnoso, interno membranaceo, endostomio indurato (operculo in germinatione embryotego.) $\mathbf{E m -}$ b r y o in axi albuminis carnosi rectus, mono-cotyledoneus, gemmula deorsum (radiculam) spectans, in rimnla laterali, ra dicula supera, infera v. vaga." Schleiden in Linnaea XIII. 389 .

1689. WoIfria HORK. Flos $\mathrm{m}$ a seulus nnicus, fi l a $m$ e $\mathrm{t} \mathbf{n} \mathrm{m}$ breve erassiusculum. F los f e $m$ ine us unicus. Ovarium uniloculare, ov $\mathrm{u}$ lo unico, erecto, orthotropo. S t y I n s brevis. Utriculns monospermas. Sem e n erectum. Embryonis turbinati radicula supera, Herbula in A $\mathrm{g}$ y $\mathrm{p}$ to crescens; vasis spiralibus transitoriis $v$. nullis, novella nuda, frondibus rima unica basilari hiantibus, ovalibus, tenuissimis, geminatim oppositis, arrhizis, rimae labio inferiore producto, appenso, hyalino, floribus in pagina superiore frondis erumpentibus.

Wolf i a Horkel msc. Schleiden in Limnaea XIII, 389. non Spreng. nec Eadl. Horkeli a Reieheab, ex Bartl, Ord. nat. 116, non Cham. Le in na by alina Delile.

$1688 / 1$. Hemma SCHLEID. F I n r s masculi 2, altero praecocius evoluto, Filamenta filiformia, recurva. Ovarium uniloenlare, ovnlo erecto, horizontaliter hemianatropo. Stylu 8 elongatus, recurvus. Utriculas monospermns, indehiscens. S emen in fundo affixum, horizontale. E mbry on i s conici radienla vaga. Herbulae aquaticae, vasis spiralibus transitoriis $v$. null is, novellae nudae, fronde rimis duabus basilaribus hiante, floribus e rima lateraliter prodeuntibus.

Le m a Schleiden in Linnaea XIII. 390. Wolfi a sect. L e m a a e Endl. Gen, n. 1668, non Horkel.

a. LENTICULA. Frondes obovato-subrotundae, crassiuseulae, ternatim quaternatimque, rarius plaries cobaerentes, monorhizae, stipite frondis novellae discreto, iragili.

Lem a minor Lino. Hooker Flor. Lond. t. 121. t. 120. Brosgniart in Archiv. bot. IT. t. 12. f. 1 .

b. STAUROGETON Reicheob. Flor, excurt, 10. Prondes lanceolatae, repando-dentatae, teaues, in stipitem elongatua, persistentem atteanatae, ideo multifarie aggregatae, praeter floriferas submersae.

Lem a a tris a I c a Lius. Hook. Op. cit, $t$, 119.

$1668 / 2$. TeInatophace $8 C H L E I D$. Spa- 
dix brevissimus, sed discernendus. Flores masculi 2. Filamenta recurva, medio dilatata. Ova ri um uniloculare, bi-multiovulatum, ovulis erectis, anatropis. Stylus elongatus, recurvus. C a p sula membranacea, circumscisse dehiscens, di-polysperma. S e m in a erecta, albumine parcissimo. E in b y on is ovati plumula maxima, ra dicula infera. - Herbula aquatica, vasis spi. ralibus transitoriis $v$. nullis, novellae nudae frondibus rimis binis basilaribus hiantibus, obovatis v. suborbiculatis, adultis subtus vesiculoso convexis, frondis novellae stipite discreto, fragillimo, adultis ideo solitariis, floribus e rima lateraliter prodeuntibus.

Telmatophace Sehteiden in Linnaea XIII, 391 L e mu $\mathrm{n}$ a $\mathrm{g}$ i b ba Lian. L. C. Richard in Guillem. Arehiv. Bot, II. t. 6. Brongniart Ibid. t. 11. f. 2, - Ad T e Imataplacen el. Schleiden spectare videtur etiam: Le m n a a r r h iza Mlich. de qua efr. Hoffmana in Hoeven et Vriese Tydrchrift. IP. 288_333, et in Wiegmann Archiv 1840. I. 138. c. iconibus anatomiam frondis egregie illustrantibus.

$1689 / 3$, Spinodela SCHLEID. Flores masculi 2. Fila m enta inferne angusta. Flores fem. Ovarium biovulatem, ovulis erectis, anatropis. St ylus.... Fructus....-Herbula aquatica, polyrhiza, vasis spiralibus per totam plantam conspicuis, fronde planiuscula, palmatinervia, polymorpha, orbiculari-obovata, apice acuto $v$. obtuso, novella stiputis binis, inferiore et superiore, membranaceis aucta,

S p trodela Schleiden in Linnaea XIII. 391. L e m n a poly $\mathrm{r}$ iz a Lina.

\section{Dralo LXXII. Aroideae.}

De ovulis Aroidearum cfr. Sebleiden in Wiegm. Archiv 1839, IV. 286. De cellulis raphidiformibus Eundem $I b i d, ~ V, 231$.

1649 . Pistia LINN.

De penitiori ovulf et embryonis structura cfr. Horkel in Annal. of nat. hist, 1, 236. De speciebus Vid. Schleiden in Otto et Dietrich Gartenzeit, 1838. VI. p. 17.

16F0. Ambrosinh BASS.

Cesati in Linnaea $X I$. 281, $t, 5$.

167 . Typhomians SCHOTT.

Dele eit. Wight in Hook. Bot. Misc, Suppl. t. 3. Vid. infr. n. $1678 / 1$.

\section{Sagromatum SCHOTT.}

Blume Rumph, I, 123. Baccae mono-dispermae.

1858. Therioploomana BLUM. Sp atha basi convoluta. S $\mathrm{S}$ a $\mathrm{ix}$ inferne interrupte androgynus, genitalibus, rndimentariis infra et supra stamina confertis, apice subnlato nudus, Antherae distinetae, biloculares, loculis poro terminali dehiscentibus. Ovaria plnrima, libera. Ovnla $3-8$, ereeta, fundo affixa. Stigma terminale, sessile, orbieulatum. B a c c a e oligo-v. abortn monospermae.... - Herba indica, humilis, acaulis; radice tuberosa, foliis longissime petiolatis, cordato-hastatis, nervosis, scapo solitario, basibus interioribus petiolorum cincto, spatha concolori, marginibus crenata.

Ther i o p on um Blune Rumphia $I, 128$. A r n m eren a t tm Wight in Hook. Bot. Misc. Suppl, t. 3. T y pho.
n if sp. Sehott.

1680 . Pythomiana SCHOTT.

Thomsonia Blume Rumph, I, 149.

1681. A anorplaoplatius BLEM.

Biume Rumph. I. $138, \mathrm{Emb}$ y o exalbuminosus, semini conformis, orthotropus, viridulus, intus earnosus, albus, extremitate radiculari gemmulis aliquot minutis germinantibus
instructa.

1695. Peltandra $R A F$.

Baccae monospermae. Rensselaerja Beck Bot. ex Darlingt. Elor. cestr. 530. L e c a n ti a Torrey Comp. 358.
1890. Platlodendrean SCHOTT.

a. Euphilo de ndro a Sehott. Bot. Mag. t, 3621. Bot. Reg. t. 1958.

1693. Pinellia TENOR. Spatha inferne tubuloso-convoluta, supra basim constricta, superne fornicata. Spadix interrupte androgynus, parte feminea spathae adnata, a mascula interstitio nudo et stricturae spathae processu septiformi libero sejuncta, genitalibus rudimentariis nullis, nunc interdum masculis $v$. femineis omnibus efoetis, appendice sterili filiformi, longe exserta. Antherae plurimae, confertissime sessiles, areolatim coadunatae, didymae, loculis oppositis, Jongitudinaliter dehiscentibus. Ov a $\mathrm{r}$ i a plurima, in parte spadicis antica confertim sessilia, libera, unilocularia. Ovulum unicum, basilare, orthotropum. Sty lus terminalis, conicus $v$. filiformis, cum s tigmate parvo, subpeltato persistens. B a cca e uniloculares, monospermae. $\mathrm{S}$ e $\mathrm{m}$ e $\mathrm{n}$ e funicalo crasso erectum. $\mathbf{E} \mathbf{m b} \mathbf{r y o}$ in vertice albuminis dnri, superne cavitate infundibulari exsculpti antitropus, cylindraceo-subulatus, extremit a te radiculari umbilieo e diametro opposita, supera. - Herbae indicae, tubere radicali depresse globoso perennantes; foliis solitariis $v$. pluribus fasciculatis, longe petiolatis, integris et ternatisectis, in petiolo bulbillum globosum, apiculatum nutrientibus, scapo radicali supra basim cum petiolis squamis membranaceis e tubere ortis velatam etiam bulbifero, spatha viridi, intus inferne sordide violacea.

Pi nellia Tenore Sem. hort. Neap. 1830. Atheruru s Blume Rumph. I. 135. t. 31. et 37. $f$. F. Hemic a r purus Nees Index Sem, Hort. Wratislaw, 1839. $n, 1$. Arum fornicatum Roth. A. subulatum Desv, A. triphyllum Houtt. A. te ra at um Thunb.

\section{Aglaonema SCHOTT.}

Blume Rumpk. $x$, 130. E m b r y o semini conformis, ex. albuainosus, sofidus, ad extremitatem radicularem squatnulis aliquot munitus.

170\%. Gymuostaelnys R. BR.

Endlicher Iconogr, $t .9$.

\section{Drdo IXXIV. Pandaneae.}

\section{1\%13. Freycinetia GAUDICH.}

Bennett in Horsfield Plant. Jav. rar, 31, t. 9. Ut cl. Bennett eurlositati satisfaciam, illud observo, me in speciminibus Norfolkicis Freycinetiae embryonem non vidisse, et ideo non descripsisse, vidisse utique in speciei duplicis fructibus, a beato Chamisso solita benevolentia communicatis, et ideo embryonis situm iu charactere generis, in nonnullis jam emendando, indicasse.

17 13. Carlud ovien RUIZ et PAV.

Baccae perigonlis demun carnosis superue futer se connatae, S e mi in a plurima, adseendentia, testa coriacea, rhaphe ariliformi, strophiola magna, carnosa. Em br yo in basi albuminis cornei - extremitate radiculari umbilico proxima. - Pöppig Nov. gen. et sp. IL. 36. t. 151. 154. f. $1-15$.

17 1. Cyelantlaws POIT.

Pöppig Nov, gen, et sp. 1I, d8, t. 159, 154, f. A-K.

1715. Wettimin $P O ̈ P P$.

Se m e n e basi placentae parietalis erectum, obovatum, testa membranacea, rhaphe arillaeformi, carnosa. - Pöppis Nov. gen. et sp. II. 39, t. 153. 154. f. $a_{-i}$.

\section{Dralo IXXV. Patonce.}

1798/1. Pinanga RCMPH. Flores monoici, in eodem spadice simpliciter ramoso, rarissime simplici, spatha dupliei, interiore saepius incompleta cincto, in scrobiculis sessiles, bracteis obsoletis cum rhachi coalescentibus, mascnli bini femineos singulos stipantes. Mase. Caly $x$ tri- 
partitus, laciniis subcarinatis, haud imbricatis. Corolla tripetala, petalis aestivatione subvalvatis. St amin a 6 - 15 ; fil ament a brevia, saperne distincta, $v$. in torum carnosulnm confluentia, antherae lineares, basifixae. Ovarium rudimentarium v, nullum. F em. Caly $x$ triphyllus et Coroll a tripetala conformis, aestivatione convoluta. St a m in a rudimentaria v, nulla. Ovari $\mathrm{um}$ uniloculare, ovulo unico, in fando lateraliter affixo. Stylus nullus $v$, brevis. Stig mata 3 , vix distincta et saepius confluentia, Ba $c$ c a fibrosa, monosperma. A l b u m en ruminatum. Embryo subbasilaris. - Palmae moluceanae, plerumque humiles, sylvicolae; caudice arundinaceo, gracili, stricto $v$, subflexuoso, annulato, laevigato, inermi, frondibus terminalibus, pinnatisectis, rarius fissis, segmentis plicatis, acuminatis, summis apice truncato-dentatis, spadicibus infra frondes solitariis, spathis membranaceis v. coriaceis, cito deciduis, parce ramosis, ramis subfastigiatis, ad latus aut distiche $v$. undique foveolatis, floribus albilis $v$. stramineis, masculis binis longe majoribus, unicum femineum stipantibus, fructibus ellipsoideis, parvis.

P in ang a Rumph Amboin. 1. 5. Blume Bullet. Neer. Jand, 1838. p. 65. Aumph. t. 106_107. inedit. A re e a g10bulifera Lam. et Areca sylvestris Lour.

1ร2\%/2. Kentia BLUM. Flores monoici, in eodem spadice fascienlato-ramoso, spatha triplici, interiori incompleta cincto, in scrobiculis sessiles, bracteis haud distinetis cum rhachi coa. lescentibus, masenli bini femineos singulos stipantes. Masc. Calyx tripartitus, laciniis earinatis, hand imbrieatis. Corolla tripetala, petalis aestivatione valvatis. Stamina 6 , fil amenta brevissima, basi connata, antherae lineares, basifixae. Ovarii rudimentum. Fem. Calyx triphyllus et Corolla tripetala, dissimilis, aestivatione convoluta. Staminum rudimenta nulla. Ovarium uniloculare, ovulo in fundo affixo. Stylus brevissimus; stigmata 8 , distincta. B a c ca parce fibrosa, monosperma. Albumen aequabile. Embryo basilaris. - Palma archipelagi indici, saxatilis, elata; caudice gracili, annulato, laevigato, infra petiolorum partem basilarem cylindricam longe vaginantem subincrassato, frondibus omnibus terminalibus, pectinato-pinnatisectis, segmentis reduplicatis, apice subbifidis, spadicibus infra frondes verticillatis $v$. solitariis, spathis coriaceis, deciduis, duplicato-ramosis, ramis arrecto-fastigiatis, ramulis undique in scrobiculis superficialibus flore unico femineo minore, binis masculis majoribus lateralibus stramineis obsesso, fructibus ellipsoideis, parvis.

Kentia Blume in Bullet, Neerland, 1838. p. 64. Rum. phia $t$, 106. inedit.

1\%2\%/3. Dneosperma BLUM. Flores monoici, in eodem spadice duplicato-ramoso, spatha tripliei, interiore incompleta cineto, in serobiculis sessiles, bracteis obsoletis cum rhachi coalescentibus, masculi bini femineos singulos stipantes. M a s c. C a ly x tripartitus, laciniis carinatis, haud imbricatis. Corolla tripetala, petalis aestivatione valvatis. Sta min a 6 ; filamenta crassiuscula, libera, antherae sagittatae, basifixae. Ovarii rudimentum. Fe $m$. Calyx triphyllus et Coroll a tripetala conformis, aestivatione convoluta, S t a min u m rulimenta. Ova rium triloculare, Joculo unico fertili, ovnlo in fundo lateraliter affixo. Stigmata 3 , sessilia, arcte cenniventia, Baeca gramosa, monosperma. Albumen ruminatum. E m b ry o basilaris, - Palma elegans, in humidis maritimis archipelagi indici gregaria; caudice elato, gracili, annulato, aculeato, frondibus terminalibus, petiolis basi longe vaginantibus, pectinato-pinnatisectis, segmentis reduplicatis, acuminatis, spadicibus infra frondes solitariis, spathis coriaceis, post anthesim deciduis, inferne duplicato- superne simpliciter ramosis, ramulis fastigiatis, pendulis, in scrobiculis bracteatis flore femineo unico minore, a binis masculis lateralibus luteis stipato, fructibus globosis, parvis.

0 a co s p e m a Blume in Bullet. Neerland, 1830, p. 64. Rumph, t. 88, et 103. inedit.

\section{Areea $L I N N$.}

Character secundua cl. Blume Bullet, Neerland, 1838. p. 63. (Rumpli. $t, 99,100$. 102. A, O. 101. 109, 104. 128. 128.) Ita, nune exclusis $\mathrm{P}$ in ang a Rumph. et pluriebus speclebus, stabllitus :

Plores monoici, lo eodem spadiee ramosissimo ant simpliciter ramoso, spatha duplici, utraque completa eincto sessiles, obsolete bracteati, femiaei solitarli in alis dilatatis ramalarum antice tantum floribas maseulis obsessuram. M a s c. C a l y x tripartitus, lacinils carinatis, hand imbricatis. Corolla tripetala, petalis aestivatione valvatis. Stamina 6-9; fil am enta subulata, ima basi cohaerentia, a $t$ hera e lineares, basifixae. 0 varii rudimentum. Fem. Ca I y x triphyllus et Corolla tripetala, aestivatione con. voluta. Staminum radimenta. 0 va $x$ i am triloculare, pleramque trilobum. Ioculo noieo fertili, ov ulo is fando affixo. Stig a a ta 3 , sessilia, discreta. Ba e ca fibrosa, monosperma. A I b и ш e rominatam. B ub r y o basilaris.

1531. Bramia BLUM.

Mart, Palm. 186.

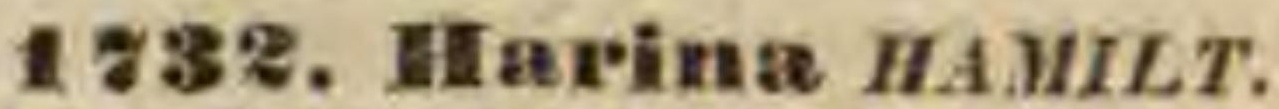

Mart. Palm, 188.

8 33. Intantea $R$. et $P$,

Mart. Palni, 189.

1734. Anenga LABILL.

Mart. Palm. 191.

1835. Caryota LINN.

Mart. Palm, 193.

1 336. Calamus LINN.

Mart. Palm. 203.

1\%3\%. Walacea REINW.

Mart. Palm, 200.

4. 38 . Plectoconia $M A R T$.

Mart. Palm, 199.

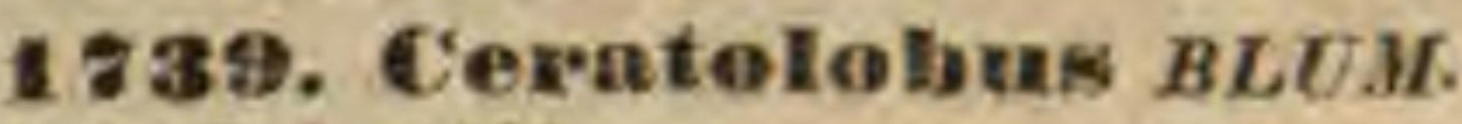

Mart, Palm, 196.

1\% 40 . Dacamonenogs $B L U, H$.

Mart. Palm. 198.

1\%44. \$agres GÄRTV.

Raphia Comm. Mart. Palm. 217.

1ะ 4\%. Detroxylon ROTTB.

Mart, Palm, 214,

1 83. Mauritia LINN.

Mart. Palm. 218 ,

17 24. Hepialoerryant $M A R T$.

Mart. Palm. 218

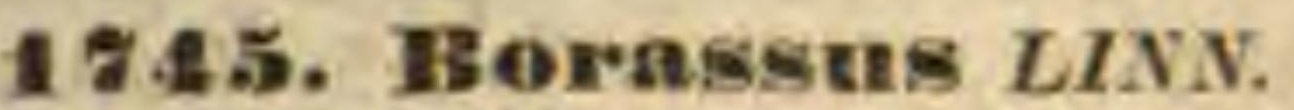

Mart. Palm. 219.

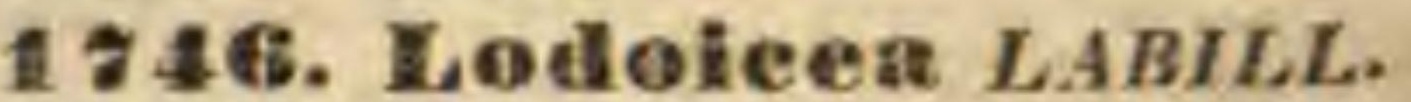

Mart. Palm. 222.

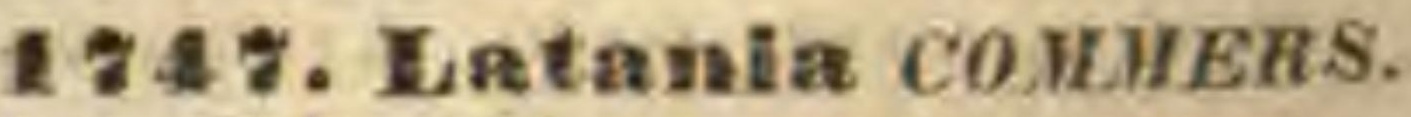

Mart. Palm. 294.

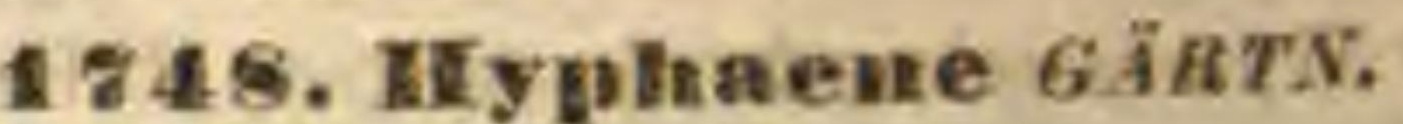

Mart. Palm. $28 \%$.

1. 95. TBentinta Ba BERAY.

Mart. Palm, 229, f. 139. Keppleria Mart. apud Endl. n. 1750 .

1727 
1750. KEPPLERIA Mart. Genus nune ab ipso suo auctore cum Beatiakia junetum.

1.51. Geonoma WTLLD.

Mart. Palm. 230. Vo u a Aubl. Guian, II. Append. 99. 1ร5. II

Mart. Palm. 230.

175\%/1. Iguanuma BLUM F lor es polygamo-monoici, in eodem spadice simplicissimo, spathis duabus tubulosis completis cincto, e rhacheos foveolis bilabiatis emergentes, masculi bini femineos v. hermaphroditos singulos stipantes. Ma s c. C a ly x triphyllus, aestivatione convoluta. Co roll a tripetala, petalis aestivatione valvatis. Stamina 6-9; filamenta subulata, basi cohaerentia, anthera e lineares, dorso affixae. Fem. Calyx triphyllus et Corolla tripetala, aestivatione convoluta. Staminum rudimenta. 0 vari um nniloculare, ad basim binis rudimentariis stipatum. Stigm a simplex, sessile. Herma phr. Calyx et corolla ut in femineis. Stamina $6-9$, antheris ovato-oblongis. Ovarium simplex; stigmatibus tribus conniventibus obsessum. Ba cea monosperma. A Ibumen... - Palma indica, humilis; caudice arundinaceo, tenui, annulato, inermi, frondibus subterminalibus, pinnatisectis, petiolorum basibus cylindraceis, tandem uno latere longitudinaliter fissis atque defluentibus, segmentis subtrapezoideis antice eroso-dentatis, spadice inter frondium bases emergente, spathis duabus membranaceis, spadice increscente apice perforatis, in pedunculo magis minusve persistentibus, indiviso, sursum incrassato, undique foveis margine bracteaeformi elevato, transverse bivalvi cinctis exsculpto, floribus virescentibus, bracteolatis, immersis, fructibus baccatis, olivaeformibus, albidis.

$1 \mathrm{~g}$ u anura Blame in Bullet, Neerland. 1838. p. 66. Rumph, t. 117, inedit.

1752/2. Calyptrocalyx BLUM. Flores polygamo-monoiei, in eodem spadice simplicissimo, s $\mathrm{p}$ at ha simplici, incompleta cincto, sub bracteis squamaeformibus rhacheos foveolis immersi, masculi bini femineos v. hermaphroditos singulos stipantes. Caly x triphyllus, foliolis cucullatis, arcte convolutis, Corollastripetala, petalis aestivatione valvatis. S $t$ a $i n$ a plurima, fiI a m e n ta subulata, basi in discum carnosum confluentia, an therae lineares, incumbentes. F e m. St a minum rudimenta nulla. Ovarinm incom. plete triloculare. Stigma simplex, sessile. Herma phr. Stamina complura. Ovarin m superne in stylum brevem attenuatum. Stig m at a 3 , coalescentia. B a ce a exsucca, grumosa, monooperma.... - Palma indica, procera; caudice crasso, annulato, laevigato, frondibus terminalibus, pinnatisectis, petiolorum basibus margine in fibras fissilibus, segmentis linearibus, acuminatis, reduplicatis, spadicibus elongatis, inter frondium bases nutantibus, spatha longitudinaliter aperta, coriacea, in pedunculo persistente, floribus in rhacheos excavationibus squama oblectis reconditis, bibracteatis, glumaceis, fructibus subglabosis.

Cal yptrocaly $x$ Btume Bullet. Neerland. 1838. p. 66, Bumph, t, 102, d, et t. 118. inedit, A reca s pica. ta Lam.

1752/3. Cymtostachys BLUM. Flores monoici in eodem spadice corymboso-ramoso, spatha duplici (?), utraque completa (?) cincto, e foveolis rhacheos emergentes, masculi bini femineos singulos stipantes. Ma s c. Ca l y x triphyllus. C o- ro Il a tripetala, Stamin a 6 , filamenta complanata, basi unita, a nthera eblongae, basifixae. Ovarii rudimentum. Fe m. Caly $x$ triphyllus et Corolla tripetala, aestivatione convoluta, Staminum rudimenta. Ovari um uniloculare, ov uI o ex apice loculi pendulo. Stig mat a 3 , sessilia, divergentia. Fructus.... - Palma moluccana, gregaria, paludosa; caudice elato, gracili, annulato, inermi, frondibus terminalibus pinnatisectis, segmentis reduplicatis, apice saepe bifidis, spadicibus infra frondes nascentibus, magnis, solitariis, spathis fugacibus vestitis, duplicato-ramosissimis, ramis divaricatis, ramulis fastigiato-pendulis, subtortuosis, tomento subtilissimo, granuloso obductis, undique in alveolis inter flores masculos binos femineos singulos foventibus.

Cyrtostachys Blume, in Bullet. Neerland. 1838. p. 66. Rumphia $t$. 120. inedit.

1753. Coryglha LINN.

Mart. Palm. 231.

1ร54. Wivistona $R . B R$.

Mart. Palm, 238.

1ร55. Ihemala RUMPH.

Mart. Palm. 230.

1\%56. Bablhea MART.

Mart. Palm. 243.

1ร5\%. Copernieia $M A R T$.

Mart. Palm, 243.

1\%58. Sabal ADANS.

Mart. Palm. 255.

1 ร59. Chasmaa erop $L I N N$.

Mart, Palm. 247.

1860. Troithrinax $M A R T$.

Mart. Palm, 247.

1\% 61. Finapis LIVN. $F$.

Mart, Palm. 253.

1 \% B. Tharinax LIVN.

Mart. Palm. 234.

1\%63. Plhoenix LINN.

Mart. Palm, 257.

\section{Ordo IXXVI. Capressinate.}

1\%93. Parolinia. n. 3020 .

Pachylepis Brongn. Supr. in text. non Lessing

1954. Cryptomeria DoN. A menta mascula spicata. S qu a ma e antheriferae rotundatae, adpresse imbrieatae, sessiles, Antherarum loculi 5 , connati, basi squamarum omnino adnati, antice foramine amplo dehiscentes. Ovula erecta. Strobili solitarii, globosi, squarrosi, squamis e pericarpio tri-sexdentato bracteaque lanceolata, acuminata, inferne concretis compositis. Sem ina 4 v. 6 , compresso-angulata, vix alata. - Arbor ja ponica, procera, sempervirens; foliis fere Araucariae Cunninghamii, quinquefariis, subulatis, viridibus, vcrticaliter compressis, vix pollicaribus, amen. tis masculis in spicam terminalem aggregatis, femineis solitariis, globosis.

Cryptomeria Dou in Annal. of nat, hist, $\boldsymbol{I} .233$. Cupressus japonica Thubb.

\section{Ordo IXX II. Abietimene.}

1598/1. Arthrotaxis pon. Amenta mascula solitaria, multiflora, eapitata, laxa. Squam a e antheriferae longe unguiculatae, subfastigiatae. Antherarum loculi 2, bivalves, distantes, 
divaricato patentes. Ovula 3 , pendola. Stro. bili squamae indefinitae, lanceolatae, acutae, regione seminifera incrassata. Se min a $2-3$, compressa, margine altero alato. Arbusculae ins $u$ la e Diem en, sempervirentes, facie Lycopodiorum; foliis imbricatis, amentis terminalibus solitariis, sessilibus.

A r throt a xis Don in Annal, of nat. hist. I. 234.

\section{Drdo IXXVII. Taxineae.}

1 T9S/1, Torreya ARNOTT. F lo res dioici, axillares. Mas c. Am enta primum globosa, demum elongata, basi bracteis quadrifariam imbricatis cincta. S $t$ a min a plnrima, juxta axim conferta; filamenta gracilia, brevia, antherae loculis 4 , e connectivo subpeltato, dimidiato subtus pendalis, parallelis, postice longitudinaliter dehiscentibus, demum divaricatis. Fem. A menta gemmiformia, uniflora, solitaria $\mathbf{v}$. bina, bracteis imbricatis cincta. Di s e us hypogynus nullus. Ovu I n m solitarium, in centro bractearnm sessile, orthotropam, apice pertusum. Semen nudum, nuciforme, basi bracteis hand mutatis stipatum, testa crassa, extus carnoso-coriacea, intus fibrosa, endopleura crustacea, dura. Embryo in apice albuminis subcartilaginei, ruminati axilis, antitropus, cotyle donibus connatis, per germinationem linearibns, discretis, e basi seminis erumpentibus, radi $\mathbf{c}$ u la apice $\mathrm{cum}$ albumine concrescente supera. - Arbor boreali-america$n a$, mediocris, glaberrima; ramis patentibus, ra mulis distiche furcatis, petiolis decurrentibus angulatis, foliis approximatis, solitariis, distichis, brevissime petiolatis, linearibus, mucronatis, supra convexiusculis, viridibus, nitidis, subtus pallidioribus, glaucescentibus, nervo lato, utrinque rubro limitato.

Torrey a Arnott in Annal. of nat. hist, $I, 130$. Hooker Ic. $t$, 232. 233. T axus montan a Nutt.

1800. Poaldenrpms HERIT.

Benet in Horsfield Plant. Jav. rar. $t .35, t, 10$.

\section{CONIFERAE FOSSILES.}

\section{Voltzia BRONGN.}

Mas c. A in entam simplex, ovale $r$. cyliadrico-ovale, breviter pedunculatum, squamulis antheriferis spatiulatis, apiculatis, apiculis densissime imbrieatis. Fem. Fruct. Strobilus eyliadeico oblongas, laxe squamosus, squamis e basi lineali unguiforui dilatatis, tri-quinquelobis, lobo medio cheteris majore et productiore, omnibus derso prominentia lignosa, lougitudinali iastruetis, et ideo bj-quadrisulcatis. Sem ina in squamae parte superiore gemlna (?) laversa, obovata, micropyle valde produeta quasi pedicellata, ala triangulari cincta. - Arbores Araucariis similes, in terra psammitica poecili sepultas; folite in cadem specie varits, brevioribus et longioribus, conicis incurvis, $v$. planis et etrietis, perpendiculariter v. oblique intertir, polystichis. W. P. Schimper et Mougeot Plant. foss, Vorg',21. z. 6 - 15 .

181 1/. Whaldingera. Masc. Amentn m compositum ovale, amentis partialibus plarimis, confertis, ovalibus, squamis bractealibus persistentibus obtectis. Fem. Fruct. Strobila s oblongus, squamis e basi hand exeavata angusta dilatatis, subtriangularibus, apice acuminatis, coriaceis v. lignosis, tenui striatis, dorso linea v. plica transversali notatis. S e m in a solitaria, inversa, obovata, regularia, sessilia, ala symmetrica, persistente eincta. - Arbores in terra poecili fossiles, ramorum et foliorum dispositione ac forma Dammaram referentes; foliis horizontaliter insertis, latius- culis, late obovato-ellipticis et elongato-oblongis, obtusis, tenuistriatis, planis $v$. subconcavis, basi angustiore vix decurrentibus, biseriatim v. undique patentibus.

A Ibertia W. P. Schimper in Mem, soc. K, n. Strassb. II. W. P. Sehimper et Mougeot Plant. fost. Voug. 14. t. 1_5, non E. Mey.

$1816 / 1$. Strobilites SCHLMP. et MOUG. Strobilus obovatus, e squamis latis, apice truncato eroso-denticulatis. - Terra psammitica poecilis.

Strobilites W. P. Schimp. et Mougeot Plant. foss. Vosg. $2 t, t, 16, f, s t$.

\section{Drdo LXXX1. Piperaceae.}

Piperacearum genera ita collocanda:

$1819 / 1$. Mullera MIQ. F l o res dioiei, amentacei, nudi, e cyatho carnoso, transverse fisso, gibboso sursum erumpentes. Mas c. Stamina 5-10 v, plura, uni-biseriata, pilis setiformibus mixta, filamenta brevia, crassa, antherae biloculares, loculis connectivo crasso separatis, longitudinaliter extus latere dehiscentibus. $\mathbf{F}$ e m. O va ri um nniloculare, ovulo nnico, e basi erecto, orthotropo. Stig ma sessile, tri-quadrilobum, lobis linearibus, puberulis. B a c ca e subglobosae, hasi cyatho carnoso suffaltae. Semen erectum. E m b r y o in apice albuminis antitropas, turbinatus, radicula supera. - Frutices javanici, monticoli, arborescentes, erecti $v$. scandentes; foliis petiolatis, tripti- septuplinerviis, coriaceis, glabris, subtus albidis, floribus sessilibus, in rhachi gracili, demum interdum incrassata, baccis remotiusculis, aromaticis, rubicundis.

Muldera Miquel Comment. II. 34. t. 4. f. 6. Piper b a cea tu m Blume Verhandl. Batav, Genott. $I X, t, 1 . f, 3$. Piper recurvatum Blume Op. cit. t. 2. f. 4.

\section{Pliper LINN.}

a. CUBBBA Miq. Flores dioici. A me uta pedunculata, oppositifolia, maseula miaora. Bracteae peltatae. Stamia $2-5$; filamenta teretia, antherae ovoideae, blloculares. 0vari a m sessile. Stigma bifidum, lobis linearibus, acutis, hispidulis. Baccae basi constrictae, sparie pedicellatae. - Frutices $v$. arbusculae Atiae tropicae. Folia allerna, petiola. ta, tri-multiplinervia, membranaeea $v$. coriacea, in stirpibus sesu divervis saepe heteromorpha. Amenta ad caulium nodos oppositifolia, feminea fore ra. cemora.

C u be b a Miquel Comment, I. 10 28, It, 33, t. 4 . f, $a$, , 5. f,,$a$.

c. M e I a m I ri. Stigmata sessilia. P. Cubeba Linn. Mique! Camment, T. t. $t$. 2. et affin.

$\beta$. B e etla. Stylas brevis. P, majoscalam Blam. P. Betele Linn.

b. PEPERI. FIores polygami, lermaphroditi v, feminei. A m e n ta oppositifolia. Bra e teac peltatae. Stam i. na 2 , lateralia; fil a me a ta brevia, crassa, a the$r$ a e biloculares, conueetieo crasso. O $v$ a r i um sessile. Stig a a quadri-quinquefidum, lobis linearibus, B a $c$ e a e sessiles v. bast eonstrictae, liberae v. conastae. Frutices $v$. arburculae, erectae aut icandentes, in Asia tropioa crescentes. Eblia alterna, petio. lata, tri-multiplinervia, Amenta in ramis novelli, oppositifolia, elongata, remotiflora.

Piper Miquel Comment, II, 35. $2,4 . f . C$, Piper u i g r u Lina.

c. MACROPIPBR Mig. Flores hermapliroditi. A menta axillaria, solitaria $v$. aggregata. $\Lambda$ atherac $3 \mathrm{v}$, fadefioitae, sessiles; oblongae, quadrisulcae. O var o u sessille. Stigmata 3 , sessilia, punctiformia. Baccac sessiles. - Frulices $v$, suffrutices, in ins a $l i$ a 0 cea. ni pacifioi indigeni; fulits alternie, petiolatir, petiolis plerumque vaginantibus $v$, ex integro mem. branaceis. 
Ma eroplper Miquel Comment. II. 36, t. a. f. D. P. Iatifolium Forst. P. methysticum Forst. Guillem. in Delessert Ic. select. IIT, $t, 89$.

d. POTHOMORPHE Miq. Fi or es hermaphroditi. A m e n t a axillaria, pedunculata, solitaria v. plura, umbellata. Bracte a e peltatae, margine villoso fimbriatae. S $t$ a mi. na 2 , laterelia; filamenta fillformia, brevia, a u the $x$ a e renlformes, loeulis apice confluentibus uniloculares, adnatae, transversim dehiscentes. Ovarium sessile, Stig mata 3 , sessilia, eylindraceo-filltormia, recurvata. B a c c a e triangulares, obovato-kurbinatae. Suffrutices in Asia et America tropica crescentes; folits alternis, petiolatis, interdum peltatis, digitalo-multinerviis, membranaceis, sublilissime pellucido.punctatis, petiolis inferne membranaceo-dilatatis, semiamplesicaulibus.

Poth o m or p b e Miquel Comment,II, 36, $t, I V, f, E$. Hekeria Kunth in Linnaea XIII. 564 . P. peltat um Linn. P. u mbell a t um Linn. Jaeq. Hort. Schönbr. t. 216, P. sidaefollu m Link et Otto Ic. t. 6 .

e. ARTANTHE Miq. Flores hermaphroditi. A m e n ta oppositifolia, solitaria. B racteac nune apice inflexo. peltatae et margine ciliato-fimbriatae, nunc infiexo-eueullatae, subeonchaeformes et plerumque glabrae. $\mathrm{S} t$ a min a 3 v. 4, rarkssime 2. A nt he rae biloculares, ovatae v. reniformes. 0 va rium sessile. Stigmata 3 rarissime 2, plecumque filiformi-subulata. B a c e a e pres. sione triaugulares. - Frutices Americae tropi cae; folits alternis, pauci. v. rarissime digitinervits, saepe inaequilateris, stipulis oppositifalits $v$. terminalibus, convoluto-navicularibus, interdumper dorsum petiolo adnatis, petiolo ideo utrinque mem. branaceo-alato.

Art a the Miquel Comment, $1 T .40$, partim. Schil. leria Kunth in Linnaea XIII, 6r6. Piper a equale Vahl. P. caudatutu Vahl. P. macropli y 11 um Swartz. P. e a llos u in Ruiz et Pav. t. 53. a. P. C a r. punya Ruiz et Pav. $t$. 58, $b$, P. Churuma a Ruiz et Pav, 2, 58. b. P, hetero phy 11 um Ruiz et Pav. t. 56. a. P, If ne a tum Ruiz et Pav, 2,60, a. P. a u $\mathrm{r}$. $\operatorname{tam}$ H. B. K. P. barbatum H. B. K. P. catalpae. follum H. B, K. P. cornifolium H. B. K. P. cor$x$ us ans H. B.K. P. 6 u manense H. B. K. P. g randifolium H. B. K. P. I anceaefolium H. B. K. P. Ianxifoliam H. P. K. P. oblongum H. B. K. P. riparium H. B. K. P. rude H. B. K. P. varieg a $\mathrm{t}$ ш H. B. K. P. velntinum H. B. K.

f. STEFFENSIA Kunth, Flores hermaphroditi, A m e $\mathrm{t}$ a oppositifolia, solitaria. B racteae vel apice inflexo-peltatae, margice ciliato fimbriatae, $v$, inflexo-cueullatae, subeonchaeformes, plerumque glabrae. S ta min a $3-5$, a $n$ therae biloculares, subglobosae. Stig mata 3 , (rarissime 2) sessillia. BaEcae obeonicae, tri-polygonae, basi plus minus coalitae. - Frutices v. suffruti. ces Americae tropicae; folils alternis, penniv. rarius digitinervits, saepissime inaequilateris $v . o b$. liquis, Atipulis oppositifolits $v$. in apice ramorum terminalibus, interdum axillaribus et petiolo ideo utrinque membranacea alato per dorsum adnatis,

Steffensia Kunth in Linnaea XIIT. 609. A r tan the Miquel Comment. IT. 40, partim. Piper a dur c u in Liun. Jaeq, Ic, rar, $t$. 210. P. t u be r c u ta $t u$ u Jacq. Ie. rar. $t$. 211. P. geniculatum Swartz. P hirsuta a Swartz, P. nitlidu swartz. P. s ca b r u m Swartz. P. r a g os u u Vahl Eclog. I. t. 2. P. a cutifoli um. Ruiz et Pas. $t, 64$. a. P. a $\mathrm{g}$ ust $\mathrm{i}$ foliza Ruiz et Pava t. 57. a. P. eroeat a m Ruiz et Pav. 2. 55, a. P. a bliqu um Ruiz et Pav, $t$, 63. $a$ P. secundum Ruiz et Pav. 1. 62, b. P, eucaly pti folium Rudge Guian, 8 . 6 , P. Rs periusculum Hervium H. B, K.

g. MICROPIPER Miq. F' I ores hermaphroditi. A ment a axillaria et termíalia, remotiflora. B r a c tea e peltatae, subfoliaceae. St amina 2 ; filamentis erassin, bre vibus, an theris subglobesis, bilocularibus, conate tivo erasso. O vari u m sessile. Stig ma sessile, pentcillato hispidam. Baceae liberae. - Suffrutices $v$. herbae, in $A s i$ a et $A$ merica orescentes, sucoulen. zae; foliis alternis, oppositis v, verticillatis, arvents gracilibus, remotifloris, demum elongatis, fliformibus, baccis plerumque exsuccis, deciduis.

Mieropiper Miquel Comment. II. 39. t. 4. f. G. t. 8. 9. $2 \mathrm{D}$ ug a g ella Gaudichaud ad Freycinet 513. Piperis et Peperomiae sp. Auct. Hook. Exot. Flor. t. 21. 22, 38 .

h. PEPEROMIA Miq. Flores hermaphroditi, Amenta axillaria et terninalia. Bir a ctea e peltatae, crassae. Stamina 2 v. plura; filamentis brevibus, a ntheris bilocularibus, subglobosis. 0 varium sessile. Stigm a sessile, peltatam, umbonatum, ambitu pilosum. B acea liberae. - Herbae, suffrutices v. frutices carnosi, in regionibus tropicis et subtro. picis totius orbis crescentes; folits allernis verticillatisve, amentis densis.

\section{2\%. Ihamea GAUDICH.}

1823. Dttonia SPRENG. Floreg hermaphroditi, racemosi v. spicati, pedicellis basi bractea breviter petiolata, apice saccato galeata suffultis. Perigoni um nullum. Sta mina 4 (interdum 5 v. 6) hypogyna; fil am enta brevia, antherae biloculares, subrotundo reniformes. Ovari um sessile, nnilocnlare. Ovulum unieum, e basi erectum, orthotropum. Stylus brevissimus v. subnullus; $s$ tig mata 4 , rarius 5 v, 6 , crassiuscula, recurva. B a c a exsucea, monosperma, subrotundo-elliptica v. suleato-tetraquetra. Se me n basi impressa affixum. Em bryo in apice albuminis antitropus, turbinato-clavuliformis, radicula supera. - Frutices $A$ mericae tropicae, Piperis facie, dichotome ramosissimi; folits alternis, petiolatis, reticulato-penninerviis, $v$, digitinerviis, stipulis ramos terminantibus convolutis, inflorescentiis oppositifoliis, solitariis, baccis anisatis.

Otto a ia Sprengel $N$. E. $T, 235$. Serronia Guillem. in Delessert Ic. III. $t$. 90. Miquel Comment. II. $t$. 4. f. J. a, OTTONIA Kunth. Plor es racemosi v, rarius spicati. Stamina 4. Stigmata 4. Folia pensinervia. Ottonia Kunth in Linnaea $X I I I$. 377. Piper ovat $\mathrm{m}$ Vahl Eclog. I, t. 1. (Sprengel Grunds, t, 3. f. 4. 5. Delessert Ie, seleet. III. $t$. 90.)

b. ENCKEA Kunth. Flores spicati. Stamina $5 \mathrm{v}, 6$. Stigmata 3 v. 5. Foll a digitinervla, - Enckea Kunth in Linnaea XIIT. 590. Piper medium Jaeq. Ic. rar, t. 8. P. ungui eulat u $m$ Ruiz et Pav. $t, 57 . b$. P. I a evigat a m Humb. et Bonpl. Nov, gen, et sp.t.3. P. gl aucescen s Jacq. f. Eclog, $t, 67$.

$1823 / 1$. Tippelia BLUM.

Vid. supr, in textu n. 1821 . Bennet in Horsfield Plant. Jav. $\operatorname{rar}, 76, t, 16$.

\section{Ordo IXXXII. Seamereae.}

1825/1. Anemiopsis NUTT. Flores in spadice conico, involuero penta-octophyllo, colorato, persistente cincto dense sessiles, singuli bractea subrotanda, colorata suffulti. Périgonium nullum. St am ina 6_8; filamenta brevissima, an $t$ h era e biloculares, lineari-oblongae, adnatae. Oyarium...... Styli $3-4$, exserti. Fruetus cum spadice coalescentes, ca psula uniloeulares, apice trivalves, subhexaspermae. Se min a snbrotunda, punetulata. - Herba californica, subaquatica, perennis; foliis radicalibus confertis, oblongo vvalibus, basi cordatis, glabris, subtus subglaucescentibus, petiolis pubescentibus, basi dilatatis, vaginantibus, ex axillis stoloniferis, caule puberulo, monophyllo, capitulo solitario, Anemones cujusdam forem simulante terninato.

A ue mi a Nuttall in Annal, of nat, hint, I. 136. A в e$\mathrm{m}$ i o ps is Hook. 2 . $c$, ia not. et ad Beechey 390, $t, 99$,

1828, OUVIRANDRA Thouars. Genus h. 1. delendam. Vid. supra $1662 \%$. 
Dralo IXXXIIT. Ceratophylleae.

18\%5. Ceratoplaylluzar LINN.

Sclileiden in Linnaea $X I$. s13. A. Gray in Annal. Lyc, New-York, IV.

\section{Drdo IXXXV. Podosteanmeate.}

$1831 / 1$. IIydrobryum. Spath a tubulosa, apice irregnlariter rupta. Fl os pedicellatus. Pexigoninm nullum. Stamina 3 , collateralia, basi connata; fil amenta lateralia ananthera, subulata, breviora, intermedium lineare, bifidum, cruribus singulis a ntheram unicam, bilocularem gerentibus, dente inter crura nullo. Ovari um biloculare. Stigma sessile, bilobum, lobis inaequalibus. Ca p s u I a costata, bilocularis, bivalvis, valvis aequalibus, dissepimento placentifero lilero parallelis. Semina plurima, imbricata. Herbulae indicae, aquaticae, Jungermanniarum facie.

Podostemmi sp. Griffiths in Asiat. Besearch, XX. 103. $t, 17$.

\section{Tydrestaelnys THOUAR.}

"Seminis lategumentam celluloso-verruculosum. Albumea nullum. Embryo dicotyledoneus, ovatus. Caules brevissimi, tuberiformes. Folia quasi radicalia, ramifornia (an veri ra. mi ?) indivisa v. pinnatim semel aut pluries divisa, foliolis (an foliis) iu rliachi vulgo sexseriatis, aequalibus v. plus minus fuaequalibus, capilliformibns $\mathrm{v}$. vesiculiformibus $\mathrm{v}$. planis (diversa Lycopodiorum folia aemulantibus). Spicae diversi sexus in diversis plantis, uaa v. plures centrales, siaplices, scapis longis insidentes, feminei langiores, Planta. ginum spicas referentibus, masculis brevioribus, subovatis." Adr. Jussieu in Delessert IC. select. TIT. 55. t. 91-94.

\section{Ordo LXXX VIF. Betulacear.}

1841. AIneas TOURNEF.

Pöppig Nov. gen, et sp. t. 198. f. $C$.

184\%. Fagus TOURNEF.

Pöppig Nov, gen, et sp. t, 194-197.

\section{Drato XCIR. MRorece.}

1856. THomas TOURNEF:

A mp a lis Bojer Hort. Maurit, 291. Morus ma uritiana Auet.

$185 \%$. Thacluma NUTT.

Delile in Bullet, soc, agr, dep.del Herault. Juill, 1835.

1860. Worstenia $P L V M$.

b. Dorsten ia Hooker Ic. $t$. 220.

\section{Ordo XCIII. Artocarpeae.}

1861. ISrosimamin SWARTZ.

Pöppig Nov. Gen. et sp, t, 148. G a la c to de udr o n Humb, Bot. Mag. t. 3723. 3728.

1869. Antiaris LESCHEN.

Bennett in Hordield. Plant, Jav, rar. 58, $t, 13$.

1883. DImedia RUIZ et PAV.

Póppig Nov, gen, et sp. t. 143-147.

$1863 / 1$, Trymatococeus PöPP. Flores androgyni. Involu erum aullum. Recepta c u I $\mathbf{m}$ globosum, vertice gerens flores maseulos plurimos, intus fovens femineum unicum, Ma s c. Perigonium trifidum. Stamina 3 ; filamenta sursum dilatata, antherae biloculares, ad. natae. F em. Ovari um intra receptaculum apice pervium nidulans, unileculare. Ovulum unicuin .... Sty li exserti, bifidi, ernra verrucis stigmatie is spiraliter circumdata. Drup a receptaculo carnoso, floribus masculis persistentibus co- ronato inclusa, monosperma. Sem en pendulum, globosum, testa coriacea, umbilico magno, orbiculari. Finbryonis exalbuminosi cotyledones carnosae, hemisphaericae, radic ula.... Arbor Americae tropicae, mediocris; foliis alternis, petiolatis, oblongis, longe acuminatis, integerrimis, penninerviis, floribus axillaribus, solitariis, nutantibus, Pisi mole. t. 142.

Trymatococẹs Pöppig Nov. gon. et sp. II. 30 .

1864/1. Poviromina AUBL. Flores dioici, corymbosi. Masculi ebracteati. Perigoni u quadripartitum. Stamina 4 ; filamenta filiformia, exserta, ima basi coalita, antherae snbglobosae, quadriloculares. Fem. ebracteolati. Perigoninm tubulosum, e basi ovata sursum angustatum, ore exiguo pervium. Ovarin m sessile, uniloculare. O v u 1 um nnicum .... St ig ma sessile, exsertum, trilobum, lobis rotundatis. Ca ps ula coriacea, perigonio baceato inclusa, bivalvis, valvula altera plana seminifera. Semen parietale, testa coriacea. E mbr yonis exalburuinosi cotyledones convexo-concavae, radicula umbilico oblique contraria, incurva, - Arbores $A m$ ericae tropicae, succo aqueo scatentes; trunco fistuloso, rumis nodosis, foluis alternis, trilobis $v$. palmatis, junioribus stipula terminali, spathaeformi tectis, pedunculis axillaribus geminis, corymbosomultifloris, fructu eduli, vinoso.

Po u r ouma Aublet Guian. II. 891, 2.341 . Jussiea Gen, 206. Pōppig Nov. gen, et sp. I1, 29, t, 141.

\section{Ceeropia $L$.}

Masc. Perigo ai um subbidentatum, rima transversali hians. Fem. Perigo $n$ ium ore contractum, subiate. grum. Bennet in Horsfield Plant. Jav, rar. 49.

$1865 / 1$. Vlusanga CHR. SHITH. F lores dioici, sessiles, dense congesti, squamis bracteiformibus interstincti. Perigonium tubulolosum, subintegrum. Masc. Capitula panicnlata. Perigonium patens. Stamen 1. Orarii rudimentum nullum. Fem. Capitulum spicatum. Perigoninm ore coaretatum. Ovarin m.... Sty Ins filiformis. Stigma penicillatum. A chenium perigonio porsistente tectum, ovato-elliptienm, compressinsculam, sablignosum. Arbor Africae iropicae occidentalis; folits digitatis, foliolis integerrimis, stipulis maximis, coriaceis, calyptraeformibus, integris, capitulis masculis subglobosis, femineis oblongis, crassis.

Musanga Chr. Swith ex $n$. Brown in Tuekey Conge 453. Bennet in Horsfield, Plant. Jav, rar. 49.

\section{Coussapoa $A U B L$.}

"Cotyledones subfoliaceae, plano-convexse." Bennett in Horsfield Plant. Jav. rar. 49. Pöppig Nov. gen. et sp.t. 147.

\section{7 . IIyrianthas $P A L I S$.}

F1. mas culi sessiles, dense, eapitati, capitulis lobatis, panieulatis. Perigonium quadripartitum, Sta mia a 4 ; filamentis plus minus inter se cohaerentibus. O varit rudimeatum nullum. - Stipulae spathaeformes convolatae. Florer marculi in receptaculis crassiusculit, ramosis, pedicellos. Hoveniae dulcis incrassatos e longin. quo referentibus. Bennett in Horsfield Plant. Jav. rar. 50.

\section{Comocephalus BLUH.}

Perigonium tubulosum, quadrifidum, demam quadripartitum. 0 v u $I$ u m uaicum, erectum, membranis circa aperturam apicalem is funiculi superioris speciem elosgatis. S ty 1 us nullus; $s t f_{g}$ a a simplex, unitaterale. S $e$ men erectum. A I b a me n tenuissimam. R a di $c$ ula supera. Ben. nett in Horsfield Plant. Jav, rar. 47, t, 19.

18\% 0. Cymoeeginaliam BLUM.

Genus fortassis, observante el. Beanett in Horafield Plant, Jav, rar. 49, ad Mlopeas referendaw. 
1871. Troplins $P, B R$.

Hooker Journ, of Bot, $t, 121$.

1872. Po u rouma Aubl. Genus supr. n. 1864/2 collocandum.

\section{Ordo XCIV. Urticacene.}

\section{8\%9. Urtica TOURN.}

b. URERA Gandieh. Henslow in Jardine Annal. of nat. Hist. I, 341, t, 12.

$1880 / 1$. Milalaisia $B L A N C O$. F 1 ores dioici. Masc, axillares, spicati. Perigoninm campanulatum, trifidum. St a min a 3 , aestivatione induplicata, elastice prosilientia, a nther a e biloeulares. O vari um sterile, villosum. Fem. axillares, receptaculo carnoso immersi. Perigonin m tridentatum, dentibus emersis, receptaculi verrucas sistentibus. O v a ri $\mathbf{n} \mathbf{m}$ immersum. S $t i g-$ mata 2 , elongata. B a cea maturitate emersa, stigmatibus coronata, monosperma. - Frutex $p h i$. lippinensis, scandens; foliis alternis, serratis, apice tridentatis.

Mala isia Man. Blanco Flora de Filippinas, 789.

1.884. Bähmeria JACQ.

Endlicher Iconogr. $t, 86$.

1885. Parietania TOURN.

e. POUzolzIA Gaudicb. Bennett in Horsfield Plant, Jav. 64. $t$. 14. $\mathrm{M}$ emorialis Hamilton msc.

1889. Cumnera $\boldsymbol{L}$.

Flores hermaphroditi v. monoici. b. Perpens um Bennett in Horefield Plant. Jav. rar, $70 . t, 15$. Genus, si recte judico, Halorageis approximandum.

\section{Drdo XCV. Camnabineae.}

\section{Cammabis TOURNEF}

Fom, Perigoni um urceolatum, tenuissime membra naceum. $0 \mathrm{v}$ a $1 \mathrm{am}$ pendulum, eampylotropum. Schleiden in

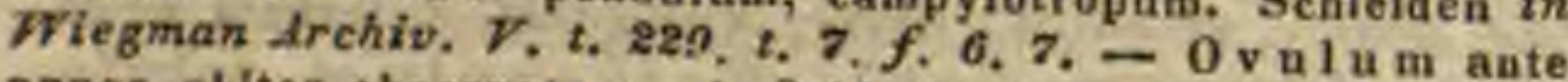
annos abiter observatum, ci. Sehleidenii sententiam (Linnaea $X I$. 536.) nimil faciens, perperam erectum dixi.

1891. IItumulus TOURNEF:

Fem. Perigonium urceolatum, hyaliunm, obsoletissime denticulatum. Kanth Flor. Berolin. II. 189. O v uI и m pendulum, campylotropou Schleiden $l$. $c$.

\section{Ordo XCV. Antidesmene.}

1898/1. Falconeria ROYLE. Flores dioici. Mas c. Perigoninm bipartitum. Stamina 2 , disco annulari in centro floris inserta, calycis laciniis alterna; fil a menta filiformia, a nthera biloba, lobis apice affixis, verticaliter dehiscentibus. F e m. Perigon i n m maris. Ovari n m ovoiden, liberum, biloeulare. Stigmata 2 , brevissima. Fruetns bacciformis, bilocnlaris. Semina in loculis solitaria, pendala, laevia. Embryonis albuminosi radicula supera. F Arbores indica ; folits alternis, breve petiolatis, membranaceis, dentato-serratis, stipulis caducis, petiolis basi interdum glanduliferis, floribus capitellatis, capitellis in spicam dispositis, singulis antice bractea foliacea, cordato-acuminata, lateraliter bracteolis duabus crassis, suffultis.

F a l coneria Royle Himalay, 364, t, 98, f, 2. et 3 .

\section{PUTRanJiveae.}

1894. Putranjiva WALL.

Endlicher Iconogr, t, 19.

$$
\text { ** FORRESTIEREAE. }
$$

1896/1. Piptolepis BENTH. Flores hermaphroditi. A m e n ta gemmiformia, axillaria, e squamis membranaceis, decussatim imbricatis, per anthesim saepius deciduis, exterioribus minoribus, vacuis. F l o r e s sub quavis squama solitarii v. terni, pedicellati. P e rigo ni n m minimum, tetraphyllum, foliolis dentiformibus, inaequalibus, sub anthesi deciduis. Stamin a 7 (interdum 6 v. 8 ?) $8 \mathrm{nmmo}$ pedicello imposita; fil a m e n t a filiformia, an therae biloculares, oblongae, basifxae, loculis oppositis, longitudinaliter dehiscentibus. Ovarium inter stamina sessile, ovoideum, biloculare. Ovnla in loculis bina, collateralia, apiei septi appensa, anatropa. S ty $\mathbf{l}$ n 8 terminalis, cylindricus; 8 tig m a capitatum, obsolete bilobum. Fruetus... - Frutex mexicanus, octo-decempedalis; ramis oppositis, teretibus, glabris, junioribus versimiliter pubescentibus, foliti, sub anthesi nullis, oppositis, breve petiolatis, ovatis $v$. ovato-oblongis, obtusis, integerrimis, basi cuneatis, coriaceis, penninerviis, supra glabris, subtus tomento laxo pubescentibus, gemmis floriferis axillaribus, saepe fasciculatis.

Piptolepis Bentham Plant. Hartweg. 29.

\section{Drdo XCLX. Salicineae.}

1903. Salix $L I N N$.

Hooker Flor. Bor, Amer. t. 180_ 182.

\section{Ordo CI. Chenopodeae.}

1912/1. Craya HoOK. et ARN. Flores dioici, ebracteati, spieato-subracemosi. Masc. Perigonium quinquepartitum, laciniis aequalibns, inappendiculatis. Stamina 5 , receptaculo inserta, perigonii laciniis opposita. S quamulae nullae. Fem. Perigoni nm monophyllum, marginato-alatum, compressissimum, apice emarginatum, mutieum, intus supra medium utriculatum. Ovari $\mathbf{m}$ in fundo ntrieuli sessile, anguste oblongum, apice attenuatum, uniloculare, uniovulatum. St y lus subulatus, basi articulatus; stigm a t a 2, filiformia, exserta, hirsuta. Utriculus compressus, orbiculatus, perigonio aucto, membranaceo, venoso inclusns, styli basi apiculatus. Semen verticale, compressum, testa membranacea, pericarpio tenni arcte adhaerens. $\mathbf{E} \mathrm{m}$ b r yo hippocrepiformis, periphericus, $r$ a di c ula infera. - Fruticulus boreali-americanus, erectus, ramosus; ramis apice spinescentibus, cortice albido tectis, junioribus pubescentibus, foliis solitariis $v$. fasciculatis, oblongo-lanceolatis, integerrimis, basi cuneatis, junioribus puberulis, carnosulis.

Gra y a Hook, et Arn. ad Beechey 387. Hooker Ic. t. 281. Chenopodium spinosum Hooker Flor, Bor. Amer, II, 127.

$1920 / 1$. Didymantling ENDL. Flores unisexnales. M a sc..... F em. axillares, gemini, patentes, basi connati. P e rigoni nm tubo subcylindrico, fauce squamulis 5 clausa, limbi quinquepartiti lobis venosis, demum anetis, scariosis. Filamenta 5, hypogyna. Ovarium ovatum, nniloculare, uniovulatum. St y 1 a s bipartitus. Utriculas memliranacens, perigonii tubo indurato inelusus. Semen verticale, compressum, testa membranacea. Embryo peripherieus, albumen farinacenm cingens, radicula supera. Fruticulus Novae-Hollandiae austro-occidentalis, humilis, ramosus; foliis anguste lanceolatis, piloso-canis, apice recurvis, floribus axillaribus, ebracteatis.

Didy manth us Eadlicher Nov, Stirp. Mus, Vindeb. Dec, $n$, io. Iconogr. $t, 100$. 
1923. Foubieva MOQ.

A m brin a Spach Suites d Buffon $V$. 295. excl. sp.

1931. Driganthera.

01 ig a ndra Lessing supr. n. 1931. non infr. n. 29 't1.

1933. Tellaxys MoQ.

Botry di um Spach Suites d Buffon $V$. 298, excl. sp.

1938 . Ammealera JUSS.

Ex Decaisne in Nouv. Annal, sc, nat. IV, 197. B ract e o I a e 4, duae inferiores minimae, deciduae, daae superiores carinato-concavae, dorso lougitudinaliter membranz:ceo-alatae, florem includentes. Peri go ni u m quinquepartitnm, laciniis subaequalibus, exterioribus latioribus, apice inflexis, aestivatione imbricatis. Anredexa et Bouss inga ulti a (1938) vix differuat.

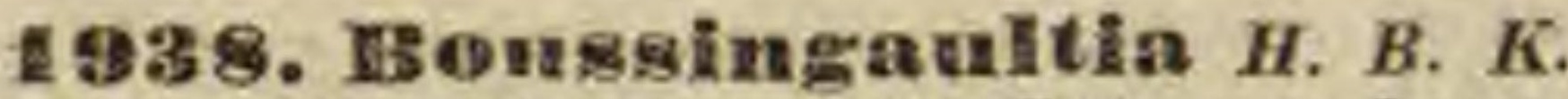

Boussingaultia, ad quam oi fallor U 11 u c as Lozauo in DC. Prodr, III, 360, (infr. p.972.) spectat, ab Anredera vix differt.

\section{Ordo CII. Anarantaceae.}

1954/1. Gogsymianthus HoOK. Flores hermaphroditi, tribracteati. Perigon inm pentaphyllum. St a mina 5 ; fil a m enta subniata, libera, anthera e nniloculares, denticulis interjectis nullis. Ovarium uniloculare, nniovulatum. Styl is brevissimns; $8 \mathrm{tigma}$ emarginato-bilobusu. Utriculns stylo coronatus, evalvis, monospermos. S e m en lenticulari-reniforme, testa crus. tacea. E m bryo arcuatus, periphericus, albumen farinaceum cingens, radicula supera. - Herbae boreali-americanae, perennes; caulibus procumbentibus, flexizosis, lanatis, foliis radicalibus elongato-spathulatis, caulinis oppositis, multo minoribus, subsessilibus, ovatis, integerrimis, plus minus sericeo-lanatis, floribus axillaribus, dense aggregatis, lana copiosa tectis.

Goss y pia ut hus Hooker Ic, t. 251 .

SUTTRERES 1. AERVEAE. Flores hermaphroditi.

1963. Trielniniem $R$. BR.

Lindley in Bot, Reg. 1839, $t, 28$.

196\%. Centrostaehys WALL.

Endlicher Iconogr. $t, 20$.

1981. Pupalia $M, A R T$.

$\mathrm{S}$ y a m a Jones in Ariatic. Hesearch, IV, 161,?

SUETERBES IIY. AMARANTEAE. Flores polygami v. hermaphroditi. Utriculus circumscissus $\mathrm{v}$, indehiscens.

15\% 1/1. Albersia KUNTH. Flores monoiei, tribracteati. Perigoninm tri- rarissime pentaphyllum. Stamina 3 v. 5 , libera; filamenta subulata, antherae biloculares, stamino dia nulla. Ovarium nniloculare, uniovulatum. Stylus brevissimus; stigmata 8 , filiformia. Utriculns membranaceus, indehiscens, cum calyce decidnus. S e m e n lentienlari-resiforme, ereetiusculum, umbilico nudo. Em br yo hemicyclicus, peripherieus, albumen farinaceum eingens, radieula infera. - Herbae inter tropicos totius orbis spontaneae, per regiones temperatas divulgatae, annuae, erectae $v$. diffusae, plerumque glabratae; foliis sparsis, integerrimis, floribus glomeratis, spicato-paniculatis, axillaribus et terminalibus.

Albersia Kunth Flor, Berolin. Ir, 144. A maranus Blitum Lion. E. B. $t$. 2212. A. Iividus L. A. pros. tratus Balb. A. olerace as L. A. polystachy us L. A. polygonoides L.

I9\%1/2. Seleropus SCHR.AD. F lores monoiei, tribracteati. Perig on ium triphyllum.
Stamina 3 , libera, fil amenta subulata, antherae biloculares, staminodia nulla. Ovarinm nniloculare, uniovulatum. St ylus brevissimus; stigmata 2 , filiformia. Utriculas compressus, granuloso tuberculatus, irregnlariter rumpens. Sem en lenticulari-reniforme, erectinsenlum, umbilico nudo. Embry o....-Herba antillana, Albersiae polygonoidis facie; floribus masculis solitariis, in supremis foliorum axillis sessilibus, femineis pluribus, in pedunculis axillaribus parvis, crassiusculis, cuneiformibus, squamulosis, subdichotomis, post anthesim majoribus, cartilagineo-induratis, cum fructu deciduis.

Selerop us Schrader Index Sem, hort. Götting. 1835. Amarantus crassipes Sehlechtend, in Linnaea $V T, 757$.

198 3. Chamisson $H . B . K$.

Adde Synonymon All ma n a ia $R$. Brown in Wallich Catalog. n. 6890 -6892. Wight et Arnott in Hooker Journ. of Bot. 226, 2. 128.

19ร 8. Deeringaa $R, B R$.

Hasskarl in Bullet. Neerlatd, 1839. p. 65. Endl. Ieonogr. t. 62 .

\section{GENUS DUBIUM.}

1989/1. Tryphera RLEM. Perigonium corollinnm, pentaphyllum, foliolis duobns interioribus minoribus. Stamin a 8 , rarissime 9 v. 10, hypogyna, a n th e ra e biloculares, extrorsae. Styli 5, subulati. Capsula membranacea, e alyce immutato inclusa, pentagona, quinquelocularis, loculis polyspermis. Funiculus seminum dilatatns, saceiformis com appendice. A I b n m en farinosum. Emb ryo periphericus, curvatus, radicula centripeta. - Planta javanica, albido-tomentosa; caulibus lignosis, nodosis, foliis obovatis, ternatim verticillatis, capitulis intrafoliaceis $v$. terminalibus.

Try phera Blume Bijdr. 549 .

\section{Ordo CRE. Polygoneae.}

1982. Friogonum L. C. RICH.

Hooker Flor, Bor. Amer, t, 175-177, Ic, t, 250.

$198 \%$. Folygonmen $L I N N$.

Babbiagt, in Linn, Transact, XVIII, 93, - a. BISTORTA. Bot. Reg. 1839. $t$. 46. c. PERSICARIA Polygonella Michx. Stopinaca Raf. e. CRPHALOPHiLON Meisner. $\gamma$. A mpelygonam Liadl. in Bot. Heg. 1838. App. p. 63. P. eloinense Meisn. A chesina triquetrum, perigonio baccato inclusum.

1994. Cerratomonon MEISNER.

Polygonum owenit Bojer in Nouv. Annat, sc. nat. IV, t. 9. ofr. Meisuer Ibta, VIT, 288.

192\%. Triplaris LINN.

Selionburgh in Annal, of nat, Aint, I. 264, M ag o. u i a Flor. Flum. $1 V, t, 60$.

1995. A antigenem ENDL.

Hooker ad Becchey $t$. 69.

\section{ordo CIV. Nyctagineae.}

2007. TRicycla Cav, Observatio de T orreg a Spreng. deleatur; est enim mouente el. Araott Clecodeadri sp. vid. n. 3708 .

2008. Bugenvillea COMHERS.

Orbigny Voy, ic.

2011. Neea RUIZ el PAV.

Pöppig Nov, gen. et sp. $11,45, t, 161,168$.

101 \&. Figonia $P L U M$.

Presl Symb. t, 56. Delessert IC, telect, MT. $t, 87$. Eudi. Iconogr. t. 30. Torrubia Flar. Flum. IIT. t, 150. Bes sera Flor. Flua. IF, $t$, 2. Pallavia Flor. Flan. $I V$. t, 12. C o 1 a mella Flor. Flumi. $I V, t, 17$. 


\section{Dralo C. MTonimiacece.}

2017. Citrosma RUIZ et PAV.

Flores monofel v. dioici. Pobpig Nov. gen. et sp. t. 144 .

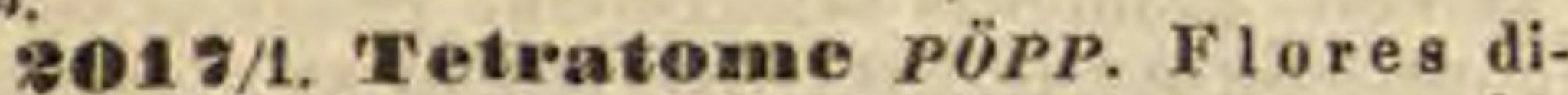
oici. Masc. Perigoni u m clavato-campanulatum, fauce dilatatum, limbi quadrifidi laciniis duabus oppositis aestivatione interioribus in appendicem serrato-laceram, in alabastro inflexam, demum erectam desinentibus. Stam in a indefinita, perigonii tubo quadriseriatim inserta, inclusa, $\mathbf{f}$ I amenta brevissima, connectivo dilatato, antherae subrotundae, biloculares, loculis oppositis, apice confluentibus, ambitu longitudinaliter dehiscentibus. Fem. Perig on in campanulatum, ad medium usque cum ovariis connatum, Jimbo supero, aequaliter quadrifido. Ovaria plurima, perigonii parieti undique insidentia, unilocularia. Ovolnm unicum, pendulum. Styli simplices, inferne distincti, apice breviter exaerto inter se coaliti; stigmata indistincta. Drupae intra perigonium excrescens paucissimae. ....Arbores $v$, frutices Americae tropicae; foliis oppositis, petiolatis, integerrimis $v$. mucronato-serratis, pedunculis axillaribus, solitariis v. geminis, tri-multifloris.

Tetrat ome Pöppig Nov. gen, et sp. IT. 46. 8.163.

2018. Hedyearya FORST.

A. Cunningh. in Annal. of nat. hist. I. 380 .

FO19. IBolaton JUSS.

Ruizia Pavon. supra n. c. Endl. Iconogr, 2 , 21, non Cav, infr. a. 5342 .

\section{GENUS DUBIUM.}

PQ19/1. TI ollinealia RUIZ. et PAV. P erigonium ovatum, ventricosum, limbo quadrifido vix aperto, laciniis ovatis, obtusis, fructiferam dilaceratum. Stam i n a plurima; filamenta nulla, antherae cnneiformes, receptaculo insidentes. Ovaria plurima, ovata. Styli nulli. Stigmata subulata. Drupa e oblongae, carnosae, in receptaculo plano sessiles. Semen oblongum, cortice membranaceo tectum. - Arbores $v$. frutices Americae tropicae; foliis oppositis, petiolatis, integerrimis $v$. serratis, pedunculis axillaribus, multifloris.

Mollinedia Ruiz et Pavon Prodr, 72, $t, 15$.

20? 1. Laurelia JUSS.

Pa voula Ruiz supr. a. e. non Cav. infr. n. 5275.

202:. ID orypliora ENDL.

Iconogr. $t, 10$.

\section{Drdo CD. Hawineae.}

80:3. Cinmanamem BURM.

Wight Ic. $t, 129-127.130,131,134-141$,

2054. Deoten $A U B L$.

Senneberia Necker Elem, $n, 796$.

3060. Titsaea JUSS.

Eadlicher Teonogr. $t$, 44, Wight Ic, $t, 132, \mathrm{D}$ a r w i. $\mathrm{n} \mathbf{i}$ a Denust. Hort, Malab. $\boldsymbol{V} .9$.

Menestrata Flor. Flum. $V$. 2. Genus lanrineam collocari nequit. Quid Lialiarea Arruda in Koster Trav. 493?

\section{Oralo CWII. Sametalacea.}

:DY 4. Chapetruma $R, B R$.

Endlicher fconogr, t. 45.

:075. Leptomeria $R$. BR.

c. OXYMERIA Endi. Iconegr. $t, 74$.
2056. Comandira NTTT.

Hooker Flor. Bor, Amer. $t, 179$.

2081. Ditia A. CUNNINGH. Annal. of nat, hist. 1 . 376 .

3084/1. Cervantesia RUIZ. et PAV. Perigonium campanulatum, regulare, quinquepartitum, aestivatione valvatum, fructiferum carnosum. Discus in fundo floris semiquinquefidns, perigonio triplo brevior, in fructu persistens, ejusdem parti inferiori adnatus, lobis liberis rotundatis, cum perigonii laciniis alternantibus, aequalibus. Stamina 5 , perigonii laciniis opposita, iisdemque supra basim inserta; fil am e n t a subulata, brevia, libera, aequalia, antherae biloculares, loculis subdiscretis, longitudinaliter dehiscentibus. O va ri u m liberum, in stylum crassum desinens.... S t i g m a emarginatum, subbicorne. Fruetus ovatns v, sphaeriens, indehiscens, monospermus, calyce persistente, aucto obtectus, eique inferne adnatus, pericarpio tenui, crustaceo, a medio ad basim fungoso. Semen cavitati conforme, inferne perforatum, testa membranacea, simplici, Embryonis in parte superiore albuminis locati radic ula supera. - Frutices $v$. arbores peruanae, inermes; foliis sparsis, simplicibus, integris, cymis axillaribus et terminalibus subdichotomis, floribus subsessilibus, racemosis, bracteatis.

Cerva n tes i a Ruiz et Pavon Prodr. 31.t.7. Cayanilles Ic. $V$, 49, $t, 475$, Kunth in Humb. et Bonpl. Nov. gen. et sp. VII, 190.

\section{Grublbia BERG.}

Grubbia et Strobilocarpus Klotsel in Linnaec XIIT. 379. - Strobiloearpus a Grubbia, quantum e charac. tere a cl. Klotsch 2 . c, proposito judicare licet, nonnisi capitulis multifloris differt. Secandum el. Decaisne iu Nouv. An. nal. sc. nat, XII. 158. Gr ubbi a ab 0 phir a distiguenda, utrique generi ovarium prima juventute biloculare, et antherae valvulis dehiscentes. (Cfr. Harwey Gen, Cap, 410.) Affinitas dubia, locus fortassis prope Bruniaceas aptior, quam in Santalacearum vieinia.

2069. PSEUdANTHUS Sieb. Gents h, I. delendum. Vid. infra n. $5845 / 1$.

\section{Ordo CIX. Daphnoideae.}

\section{Daplune LINN.}

Pöppig Nov. gen, et sp. $t, 191$, Bot. Reg. 1838, $t, 56$.

2098. Pinelea $B A N K S$.

a. THECANTHES Wickstr. (Endlieher Iconogr. $t, 1 t$. ) b. HETEROLAENA B. Bot. Reg. $1838, t, 24$, c, PHXLLOLAENA E. Bot. Mag. t. 3721.

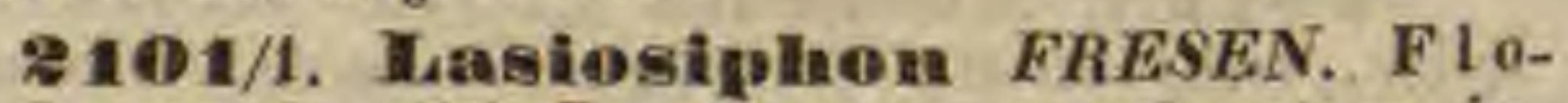
res hermaphroditi. Perigeninm coloratum, infundibuliforme, tubo basi ventricoso, limbo quinruefido, fareis squamulis decem, cum limbi laciniis alternantibus. Stamin a 10 , biseriata, quinque fauci inserta limbi laciniis opposita, subexserta, quinque alterna intra tubum inclusa. Orari um uniloculare. O v u 1 m unieum, pendulum, anatropum. Stylus lateralis, filiformis; stigma capitatum. Fructus.....- Frutex abyssinicus; foliis sparsis, lanceolatis, glaucis, floribus in capitula involucrata dispositis, congestis, extus hirsutis, perigonii tubo basi ventricoso, hirsutissimo.

Lasiosiphon Fresenius in Flora 1838. p. 602. - ? Passerina involucrata Zeyh.

2105. Wielsströmia ENDL.

Iconogr, 2,2 ,

* HERNANDIACEAE.

210\%/1. Sareostigma WIGHT et ARN. Flores dioici. Masc..... Fem. Involncrum 
basi in vo In ce ll o brevissimo, campanulato, quinquedentato einctum, infundibuliforme, quinquefidum, laciniis oblongis, recurvis, tubo toro adnato repleto. S ta $m$ in a sterilia 5 , linearia, 1 perigonii laciniis alterna. Ovari $\mathbf{x}$ m libernm, oblongo-cylindraceum, hirsntum, uniloculare. OvuI $\mathbf{~ m}$ unicum, ex apice cavitatis pendulum. Stigma magnum, carnosum, integrum, deciduum. Drupa oblonga, compressa, putamine rngoso. Semen.... - Frutex indicus, scandens, ramosus; foliis alternis, breviter petiolatis, oblongis, acuminatis, integerrimis, glabris, venosis, floribus in racemo simplici, spicato, longo sessilibus, racemis aggregatis $v$, solitariis, e ramulorum nodis a casu foliorum ortis.

Sarcostigma Wight et Arnott in Edinb. new, phi. losoph. Journ. XIV. 299.

\section{Ordo CXI. Elaeagneae.}

211 2. Fippopinae $L I N N$.

De tori lamina perigonii tabum vestiente efr. Sehleiden in Wiegm. Archiv, 1839. IV. p, 291, t, 8, f, 11.

2113. Shepheralia NUTT.

Hooker Flor. Bor, Amer. t, 178.

\section{Ordo CXIIL. Protaencene.}

2130. Adenamthos $L A B I L L$.

Endlicher Iconogr. inedit.

2131. Symaphaea $R, B R$.

Endlicher Iconogr. $t, 32$.

2133. Comospermum $R$. BR.

a. Euconos permum Endl. Iconogr. t, 31. b. $\mathrm{C}$ b i. I n r s R. BR, Eadl. Teonogr. $t, 46$.

2133. Stirlingia ENDL.

Iconogr. $t, 23$.

2134. Franklandia $R, B R$.

Bndlicher Iconogr. $t, 68$,

2135. Symplnyonema $R, B R$.

Endlicher Iconogr. 2. 12.

21 4 \%/1. IIamglesia ENDL. P e rigon i $\mathbf{n}$ m tetraphyllum, foliolis subspathulatis, demum revolutis. Antherae 4 , apicibus concavis folioloram perigonii immersae. GI andula hypogyna, semiannularis. Ovarium stipitatum, uniloculare, biovulatum. Stylus supra basim decli. natam incrassatos; stig ma conicum. Follieulus coriacens, abortn monospermus. Semen apterum. - Frutices Novae Hollandiae; folits pinnatifidis $v$. lobatis, glandulis cutaneis amphigenis et hypogenis, racemis terminalibus lateralibusque corymbosis, pedicellis filiformibus, geminatis, paribus unibracteatis, basiftoris. n. 31 .

M a a gles ia Endlieher Nov, Stirp. Mas, Vindob. Dec.

2143. Grevillea $R, B R$.

a. Lis sostylis R. Br. Endl. Iconogr. t. 33.

214. Iflakea SCHRAD.

Endlicher Ieonogr, t. 24 .

2146. Xylomelum SMITH.

Endficher Iconogr, $t, 47$. 48 .

\& 150 . Helfela LOUR.

Bennett in Horsfield Plant, Jav, rar, $81,2,18$.

\section{Ordo CXIV. Aristolockieat.}

Dehiscentia Aristolochiearum sphalmate locnlicida dieta, est enim septicida.

2161. Freterotropa MORR. et DECAISN.

Bot. Mng, t. 3246 .
216\%. Aristolochia TOURN.

Bot. Mag. $t, 3640.3756$. 3769.

2183. Isragantia $L O U R$.

F1. hermaphroditi v, unisexuales. Stamina 6. v. 9, rarius 5 v. 8 . St ig mata 3,6 v. 9 , rarius 4 v, 5 , lineari,subulata, erecta. Capsula siliquaeformis, quadrilocularis, quadrivalvis. S e m i n a ovato-triquetra, transversim rugosa. Suffrutices geniculatim flexuosi, decumbentes $v$, suberecti, folits reticulatim venosis, spicis laterallbus v, asillaribus, paucifloris. Bennett in Horsfield Plant. Jav, rar. 43. 1. 11. A p a m a Lan. Dict, t. 21. T rime riz a Lindl. infr. n. 2166 nounisi floribus dielinibus differt.

2164. Thotten ROTTB.

Semina numerosa, oblongo-ovata, obsolete triquetra, semine Foenugraeci majora, snperficie rugosa, callosa, cinereo-albicantia König msc, ex Bennett in Horsfeleld Plant. Jav. rar. 45 .

2166. TRIMERIZA Lindley. Genus delendum, a Bragantia Lour. $(n, 2163)$ non diversum.

\section{Ordo CXV. Vepentheae.}

216\%. Nepenthes LINN.

Korthals in Verhand, over nat. Gesch, der neederl. overs. Besitt. $t, 1-4$.

\section{Drdo CXVI. Plantagineae.}

2168. LittoreIIa LINN.

Nees jon. Gen. Plant, ic.

\section{Ordo CXVIA. Plumbagineae.}

2 เซ ?. Statice WILLD.

Bot. Mag. t. 3701, 3776, Bot, Reg, 1839, t. 6 .

2174. Plumbago TOURNEF.

Ledebour. Ic. C. 21.

\section{Ordo CXIX. Dipsacene.}

2190. Morima TOURNEF.

a. Dioto $\mathrm{c}$ a 1 y x DC. (Lindl. Bot, Reg. 1840. t, 36.) b. A canthocal y $x$ DC. As aphes Sprengel Cur. post, 222.

2194. PterocephaIns VAILL.

Webb et Berth. Flor, canar. $t$. 80 .

\section{Drdo CXX. Compositce.}

I. TUBULIFLORAE,

\section{TIRIBUS 1. VERNONIACEAE.}

\section{Diospermum LESS.}

Delessert Ic, select, $I V, t, t$.

2905. Decaneuman $D C$.

A PHYLlockphallum $D C$. Delessert Ic. neleci, IV. t. 2. DC. $\mathrm{Hem}, T \mathrm{X}$, , 1.

\section{IItoplophyIImm $D C$}

Endlicher Iconogr, $t, 34$.

\section{1\%. BIanehetia $D C$.}

Mem. IX, $t, 2$.

2324. Albertinia SPR.

a. ANISOTRICHIA $D C$. (Delessert $I c$, select, $I V, t$, 4.) b. ISOTRICHIA DC. (Delessert op, cit. IV. 2. 5.)

2230. Cleresta $A R R A B$.

Delessert Ic. seleet. $I V . t$. 6 .

2239. Centanuopis $B O J$.

Delessert Ic. select. IV. $t$. 7 .

2\%41. 1Bojeria $D C$.

Mem. IX, t. 39.

2244. Andromaelhis $H, B$.

Liabi sp. Less.

c. PLATyLepidea DO, Prodr. $V I T$. 26.5. Ca pitulam eirciter trigintifleram. 1 a v ol u or i sqqomae Jatae, istimae obtusissimae. Platyle $\mathrm{p}$ is Lessiag in Linnaea IV. 40t, et 407. aoa Rieh, Konth. 
9847. Cacosmuks $H . B . K$.

Clairvillea DC. Prodr. V. 636. (infr. 11. 2573.)

TIEISES II. EUPATORIACEAE.

7255. Phalaeraea $D C$.

Delessert Ic. select, ID. $\iota, 8$.

2ะ50. Amalsechaeta $D C$.

Delessert Ic. select. $I V, t, 9$.

2981. Adenostemana FORST.

Delessert Ic, select, IV. t. 10. Hook. Ic. t. 238, 239,

28\$3. Kenamin $D C$.

Delessert Ic, select. IV, $t, 11$.

2365. Falafoxân $L A G A S C$.

Hooker Ic. t. 148.

Z26S/1. Carminatin $M O C$. Capitulum multiflorum, homogawum. Involucri eylindriei squamae denae $\mathbf{v}$. duodenae, subimbrieatae, lineares, acuminatae, striatae, siccae, exteriores breviores, interiores corollas aequantes. R e ceptacul um angustum, nudum. Coroll a e tubulosae, apice vix hiantes, dentibus subnullis. Antherae connatae. Stigmata inclusa. A chenia prismatica, pentagona, elongata. Pappi setae denae, longe plumosae, molles, albae. - Herba mexicana, annua, erecta, glabra, simplex v. opposite ramosa; foliis oppositis, petiolatis, ovatis, grosse dentatis, papyraceis, racemo elongato, capitula solitaria v. subfasciculata, breviter pedicellata gerente, corollis subrubentibus.

Carm in atia Moę. et Sesse Flor. Mex, ex DC. Prodr. VII. 267. Delessert Ic, select. IV. $t, 98$.

2968/2. Disymapluta $D C$. Cap italum quingueflorum, homogamum. In v o l u c ri biseriati squamae lanceolato-lineares, apice acuminatae, quinque exteriores laxae, totidem interiores erectas aequantes. R e epta culum angustum, nudum. Co roll a e fere cylindraceae, quinquedentatae. Stig mat a elongata, longe exserta. A chenia pentagona, obpyramidata. P a p us biserialis, corolla paullo longior, setis ntrinsque seriei conformibus, scabris. - Herba montevideensis, Kuhniae v. Clavigerae facie, pube brevissima velutino-canescens; folis alternis, linearibus, integerrimis, utrinque punctatis, ramis apice paniculatocorymbosis et involucris velutino-tomentosis, capilulis pedicellatis, corollis et setarum pappi apicibus purpurascentibus.

Dis y nap hi a DC. Prodr, PII, 267.

2ะร \%. Decaclareta $D C$.

Delessert Ic. select. $I V . t, 13$.

2ะ 4. Daclinian $D C$.

Delessert Ic, select, IV, $t, 14$.

3ะ55. Conoeliniume $D C$.

Delessert Ic. select, IV. t. 15.

จะร ช. Campyloelinian $D C$.

Delessert $7 c$, select. $I V, t, 16$.

2\%g8. Bulbostylis DC.

Delessert Io, select. IV. I. 17.

TREIBES III. ASTEROIDEAE.

\%300. B Ellàiastrama MICHEL.

Bellidiaster Dumort. Flor. Belg. 66.

230?. 'T'Pipoliman NEES.

Eury bia Gray Brit. Plant, $I$, 464.

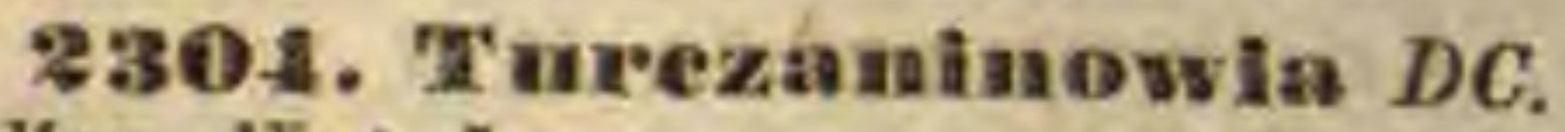

Mem, 1X, t. 5 .

230./1. Towmsendisa HOOK. C a pitn$1 \mathrm{um}$ multiflorom, heterogamum, floribus radii uniseriatis, ligulatis, fenineis, disci tubulosis, hermaphroditis. I n vo I a c ri ovati squamae imbricatae, lineari-subulatae. Receptaculum nudum, alveolato-punetatum. Corolla e radii ligulatae, margine involutae, dis ci tubulosae, limbo quinquedentato. Stig in a glabra? Achenia sericea. Pappus uniserialis, radii paleaceosubulatus, inaequalis, disci pilosus, elongatus, seabriusculus, - Herba boreali-americana, acaulis; radice lignosa, fusiformi, foliis radicalibus confertis, linearibus, subspathulatis, integerrimis, adpressis, sericeis, capitulo solitario, sessili, foliis immerso, floribus luteis.

Town se udia Hooker Flor, Bor. Amer, I, 16, $2,119$. DC. Prodr. VII. 272.

230\%. Podocoma CASS.

? Podopappus Hooker Bot. Mag. Comp. II. so.

2318. Dlearia MöNCH.

H a $x$ to n i Caley ex Don in Edinb, new philosoph. Journ. 1831. p. 272 .

233\%. Erigerom $D C$.

a. BUERIGERON DC. Texranea Colla Mem. Academ. Turin, XXXVIIT, 11. $t$. 23. Stenactis speciosa Hook. Bot. Mag. $t$. 3606. (Hooker Flor. Bor. Amor. t. 120.)

b. TRIMORPHAEA DC. (Hook. Op. cit t. 121. 123,)

e. ElEUTHerogrRON DC. (Hook. Op. cit. t. 122,)

233\%. Stenactis NEES.

Bot. Reg. 1577. Bot. Mag. $t .3606$.

8349. IBraelhyeome CASS,

B rachys tephium Less. infr. n. 279\%. cum synon.

2355. Iherilia $D C$.

Delessert Ic. select. IV. $t, 18$, Hook, Ic, $t, 240$.

2364. Grindelia WILLD.

Bot. Mag. t. 3739 .

23\%4. Fresenia $D C$.

Endlicher Iconogr. $t$. 35.

2375. Bigelowia $D C$.

Mem, IX, $t, 5$.

23983. Is lepharisperman $W I G H T$.

Delessert Ic. select. IV. t. 19.

\$400. Gymanariluena DESF.

Fra nkia Steudel in Schimper Herb. arab. n, 899.

2401. 'Thespis $D C$.

Delessert Ic, solect. IV, $t, 20$.

2403. Ferthelotin $D C$.

Delessert Ic. solect, $I V, t, 21$.

2405. Conyza LESS.

b. DiMORPHANTHES Cass. (Delessert Ic. select. $I V, t, 22$.

2410. Bacelararis LINN.

Delessert Ic. select, IV. t. 23 -25. Hook. Ic. t. 68. 241. 242.

24.8B. Inula.

d. LIMBABDA DC. Erithe is Gray Bril. Plant. Il. 664.

243 1/. Asterialea LINDL, Capitnlum multiflorum, heterogamum, floribus radii uniseriatis, ligulatis, femineis, disci tubulosis, hermaphroditis. Involncri hemisphaerici squamae inbricatae, exteriores subulatae, interiores lineares. Receptacul um planum, ebracteolatum, areolis elevatis. Coroll a e radii ligulatae, tridentatae, disci tubulosae, quinquedentatae, apice glandulosae. Anthera e basi setoso-appendieulatae. A $c$ hen ia erostria. Pap pus setis uniserialibns, basi subscabris, apice barbellato-subplumosis, annolo sullo. - Herba Novae Hollandiae a ustro-occidentalis, erecta, ramosa, Asteris Novae Angliae facie, undique pilis mollibus, ramentaceis pulverulenta; caule corymboso paniculato, foliis alternis, linearibus, semiamplexicaulibus, mar-
gine revolutis, utrinque, imprimis subtus scabrius- 
culis, involucri squamis exterioribus squarrosis, apice setaceis, glabris, inferius glanduloso pilosis, ligulis semiunciam longis, ut videtur albis.

Asteridea Lindley Swan-Rivor $X X I \nu$.

$2436 / 1$. Ningrothamanss $D C$. Capi$t \mathbf{~} l \mathrm{um}$ multiflorum, heterogamum, floribus radii uniseriatis, ligulatis, femineis, disci tubulosis, hermaphroditis. In vol u cri biseriati squamae exteriores minores, acuminatae, interiores longiores, obtusae, margine submembranaceae. R e ceptaculum.... Corolla e radii ligulatae, disci tubulosae, quinquedentatae. St a m in $\mathbf{n}$ m filamenta glabra, antherae breviter bicandatae. Stylus apice bifidus, ramis patulis. A 6 henia obovata (?) albo villosissima. Pap pus biserialis, strietus, flavidus, setis viginti, dentato-scabris, exterioribus decem paullo brevioribus, interioribus rigidioribus. - Suffrutex capensis, Cypselodontiae habitu; ramis teretibus, apice nudis, monocephalis, foliis alternis, linearibus, integerrimis, subtus adpresse tomentosis, superne glabris, ramis apice et involucris tomento rufo, brevissimo subvestitis, corollis flavis.

Mingrothamuus DC. Prodr. VIT. 286.

2436/2. Cypselotontia DC. C a p it uI $\mathrm{m}$ multiflorum, treterogamum, floribus radii uniseriatis, ligulatis, neutris, disci tubulosis, hermaphroditis. Involueri pluriseriati, imbrieati squamae lineares, exteriores subsquarrosae. R e cepta $\mathbf{c u l u m}$ alveolis margine dentatis. Corolla e radii ligulatae, disci tubulosae, profunde quinquefidae. St a minum filamenta brevia, hirtella, antherae in apicem coriaceum productae, basi bicaudatae, caudis barbatis. Styli florum disci lobis subadglutinatis, obtusis, dorso ad apicem puberulis. A ch en ia radi i abortiva, glabra, basi pilorum penicillo eincta, disci obovata, rufo villosissima. P a p us setis crassiusculis, albis, dentato-scabris, radii paucis, disci multiserialibus. Suffrutex capensis, ramosissimus; ramis striatis, apice subaphyllis, monocephalis, foliis alternis, obovato-oblongis, subobtusis, basi cuneatis, mucronatis, integerrimis, subtus canescenti-villosis, superne glabris, uninerviis, capitulis terminalibus, solitariis, nudis, corollis flavis.

Cy pselodontia DC. Prodr. VII. 286.

243\%/1. Hoelastetteria DC. Capitu In m multiflorum, discoideum, homogamum. In volueri squamae pluriseriales, subaequales, lineari-lanceolatae, acuminatae, rigidae, dorso nervulis subtristriatae. R e ceptaculum hirsutofimbrilliferum. Coro 11 a e tubulosae, lobis linearibus, tubnm aequantibus. Antherae breviter candatae. Styli rami erecti, oblongi, dorso subconvexi, A e h en ia subturbinata, erostria, a basi villosa, villis acheniam superantibus, pappum externum mentientibus. I' a P p a s paleolis 10 , linearibus, acuminatis, dense ciliatis, subsquamellosis. - Herba arabica, glabra, erecta, basi ut videtur suffruticulosa; caule anguloso-striato, ramoso, ramis apice monocephalis, foliis alternis, ovalibus, minute denticulatis, basi in petiolum attenuatis, ad petioli basim subariculatis, capitulis terminalibus, luteis.

Hochstetteria DC. Prodr. VII. 257. Mem. IX. t, G.

2440. Telehia BAUMG.

Bot. Mag. $t, 3466$.

3444/1. Cryptadia $L I N D L$. Ca pitu 1 u m multiflorum, heterogamum, floribus omnibus tu- bulosis, radii pluriseriatis, femineis, squama glabra subeartilaginea, aenta involutis, disei maseulis. Involueri campanulato-hemisphaerici, extus bracteis foliaceis sincti, foliola subuniserialia, rotundata. Re cepta cul u m carnosum, totum paleis diaphanis, laceris serratisque bracteolatum. C orolla e radii graciles, quadridentatae, disci infundibuliformes, quadrilobae, $A$ n th e ra e ecandatae. Ovaria disci filiformia, inania, radii obovata. Pap p us radii pluriserialis, aristatus, aristis corollam subaequantibus, palmatim fissis, scabris, disci campanulatus, subplicatus, ostolobus, laciniis inaequalibus, plumosis, corollam subaequantibus. - Herba e uphratica, perennis; radicibus longissimis, perpendicularibus, spinosis, collo clavato, caulibus vix semiuncialibus, induratis, circa collum verticillatis, folits angustis, erectis, basibus suis capitula sessilia ferentibus.

Cry ptadia Liadley in Chesney It. inedit.c.ic, (Herb. Chesney $n, 201$.

\section{TRIAUS TV. SENECIONIDEAE.}

\section{Blennosperma LESSING.}

Synops, 267. DC, prodr. VII. 28s. A p a I us DC. prodr. V. 507. Unxia anthemidifolia Bertero. Colla Mem, Academ. Turin, XXXVIII. t. 32.

\section{Silphimm $L I N N$.}

Bot. Mag. $t, 3525$.

24ร ซ. IBerlandiera $D C$.

Delessert Ic, select, $1 V, t, 26$.

248 8/1. Tulocarpus HOOK, et $A R N$. C apitu 1 n m paciflorum, heterogamum, flore radii unico, ligulato, femineo, disci tribus v. quatuor masculis. I nvo I u c r i cylindracei, hexaphyli, biseriati foliola exteriora tria majora, aequalia, striata, acuta, interiora scariosa, unienm floriferum. R ee eptacnli paleae involueri foliolis interioribus similes. Co rolla radi i ligulata, apice tridentata, tubo gracili, basi dilatato, dis ei tubulosa, tubo longo, gracili, limbo campanulato, profunde quinquefido. Antherae exsertae, viridescentes, filamentis dense barbatis. St y l u o florum disei paulInlum exsertos, indivisus, puberulus. A chenium in quovis eapitulo unicum, magnum, obovato-0blongum, compressum, basi dorso callo magno, rugoso, tetragono. P a p p a nullns. - Herba mexicana, glabra; caule tereti, folitis oppositis, netiolatis, ovato-lanceolatis, serratis, corymbis lateralibus terminalibusque compositis, floribus flavis.

T u Jocarp us Hooker et Arnott ad Beechey 298, t. 63.

2483. Pintllosia OSSA.

Delessert Ic. select. $I V . t, 27 . f .1$.

2484. Tetranthus $S W A R T Z$.

Delessert Ic, select, $I V . t, 27, f$. 2 ,

2485. Euphrosine $D C$.

Delessert Ic, select. IV. $t, 28,-$ ? $\mathrm{C}$ y $\mathrm{cl}$ a $\mathrm{c}$ hata Fresenius Index Sem, hort. Francof. 1836.

3490. DIezalezia $D C$.

Delessert Ic, seleot, IV. $t, 29$.

2491/1, Floomia ARNOTT. Ca pitulum heterogamum, floribus radii quinis, ligulatis, femineis, disci tubulosis, masculis. Involucri biseriati squamae exteriores quatuor $v$ quinque patenti-recurvae, interiores circiter quinque erectae. Re ceptaculi paleae oblongae, membranaceae, uninerves. Corollae radii ligulatae, trifitae, di s e i tubulosae, infundibuliformes. Sty Ins florum femineoram bifidus, ramis linearibus, revolu- 
tis, florum masculorum simplicissimns, aequalis, apice glaber, deorsum pubescens. A shenia radii obcompressa, utriuque marginata, oblonga, ecorticata, laevia, apice brevissime bicornuta. Suffrutex zeylanicus, Bidentis et Deluciae habitu, glabriusculus; folits oppositis, petiolatis, indivisis $v$. biternatim sectis, mucronato-serratis, pedunculo terminali nudo, gracili, elongato, monocephalo.

Mo o nia Arnott in N. A.N. C. XVIII. 348. DC. Prodr. VII. 289.

2496. Wedelia $J A C Q$.

Wedelia et Niebuhria Necker Elem. n. 55.86.

250ะ. Wollastomia $D C$.

Mem. IX, $t, 7$, Endlicher Ioonogr, $t, 88$.

2505. KEnmfordia $D C$.

Delessert Ic, select, $I V, t, 30$.

2513. Telnimacea MÖNCH.

Bot. Reg, 1838, t, 27.

3515. Dracopis CASS.

Bot. Mag. 3716 .

251\%. Andrievxia $D C$.

Delessert Ic. select, IV. $t, 3 t$.

2518. Amomosteplaimu $D C$.

Delessert Ic. select, $I V, t, 31$.

2520. Aymmopsis $D C$.

Hooker Ic, $t, 145$.

ใธะรั. Plniloglogsa $D C$.

Delessert Ic, select. IV. $t, 33$.

2526. Chrysostemma LESS.

Hooker Bot, Mag. $t .3588$.

25\%7. Calliopsis REICHENB.

Hook. Bot. Mag. t. 3507.3511.

2598/1. Epilepis BENTH. Capitnlum multiflorum, heterogamum, floribns radii uniseriatis, ligulatis, nentris, disci tubulosis, hermaphroditis. I n v o I u e r i campanulati, duplicis, snbimbricati squamae exteriores oblongae, obtusae, interioreg ovales, margine membranaceae. $R$ e c e p$t$ a culi plani paleae subhyalinae, apice trifidae, acheniorum lateri exteriori applieitae, simul deciduae. Corolla e radii ligulatae, ligula ovali-oblonga, multinervi, dis e i tubulosae, quinquedentatae. A chenia obcompressa, margine ntrinque villosissima, facie interna praeter lineam villosam glabra. Pap pus biaristatus. - Herba mexica$n a$, erecta, hispida, Verbesinae facie; foliis oppositis, pinnatisectis, segmentis cuneatis lanceolatisve, integris, grosse dentatis v. pinnatifidis, superioribus confluentibus, capitulis corymboso-paniculatis.

Epile p is Bentham Plant. Hartweg. 17.

25\%9. Coreopsis LINN.

Hook, Bot. Mag. t. 3960. 3505. 3586.

253\%. Dyedaea $D C$.

Delessert Ie. ielect. $I V \cdot t, 34$.

\$539. Hitelianthus $L$,

Hooker Bot. Mag. $t, 3510$. 3689 .

2539. Flonmensin $D C$.

Delessert Ic, select. IV. $t, 35$.

25.47. Cosmass $C A V$.

Lindl, Bot, Reg. $t, 2007$. N. S. 1838, t, 15.

254\%. Kipoelhaeta $D C$.

Delessert Ic, select, ID. $t, 36$.

2554. Danantia $D C$.

Delessert Ic, select, $I V$. $t, 37$.

2558. Dligogyne $D C$.

Delessert $I c$, select. IV, $t, 38$. Hooker Ic, $t, 101$.
9558/1. Frapephora. C a p itulum pluriflorum, heterogamum, floribus radii subquinis, uniseriatis, ligulatis, neutris, dis c i denis-vicenis, tubulosis, hermaphroditis. Involucri biseriati squamae exteriores quinque subfoliaceae, patentes, interiores scariosae, erectae, flosculos radii semiinvolventes. R e e ptac u l u m angustum, plannm, paleis achenia includentibus. Coroll a e rad i i ligulatae, ovatae, emarginatae, disci tubulosae, fauce ampliata, limbi lobis quinque subrevolutis. A chenia radii abortiva, disci oblongo-cylindracea, hispida, apice in aristas duas persistentes producta. - Herba Africae tropicae orientalis; caule erecto, tereti, hispidulo, foliis oppositis, petiolatis, ovalibus, utrinque attenuatis, obsolete serratis, subtrinerviis, hispido-pubescentibus, pedunculis axillari-terminalibus, solitariis v. ternis, monocephalis, floribus luteis.

2561/1. Chromolepis BENTH. Ca p it $\mathbf{l}$ l u m multiflorum, heterogamnm, floribus radii ligulatis, femineis, disci tubulosis, hermaphroditis. Invol neri bi-triseriati squamae exteriores foliaceae, interiores subbiseriales, margine membranaceas subsuperantes, Receptaculi plani paleae lineares, membranaceae, concavae, apice coloratae, flores subaequantes. Cor olla e radii ligulis late Jinearibus, bi- quinquedentatis, dis c i tubulosae, quinquedentatae, glabrae, abrupte in faucem dilatatae. Antherae apice appendiculatae. Stigmat a disci cono brevi, hispido terminata. A chaenia radii triquetra, glabra, calva, d isci pubescentia, obcompressa, tetragona. $\mathbf{P}$ a p p us paleis duabus, acutissimis, laceris. - Herba $m e x i$ c ana, paludosa, subacaulis, perennis; radice fibris crassis fasciculata, folits radicalibus longe petiolatis, glabris, aliis integris, longe lanceolatis, obsolete crenatis, basi longe angustatis, aliis pinnatisectis, segmento ultimo folits simplicibus subsimili, inferioribus uni-quinquejugis, parvis, oblongo-linearibus $v$. lanceolatis, scapis folia superantibus, nudis $v$. unibructeatis, monocephalis, apice pubescentibus, involucris glabris, floribus disci flavis, radii intus concoloribus, extus virescentibus.

Chromolepis Bentham Plant. Hartw. 40.

\section{Chrysanthellum RICH.}

Delessert Ic, select. $1 V, t, 39$.

256\%. Delueia $D C$.

Delessert Ic. select. IV. $t$. 40 .

2573. Clairvillea Do. Genus delendum, est eaim Cacosmia H. B. K. supr. n. 2247.

\$581/1. Adenopappus BENTH. C a pi$t \mathbf{n} 1 \mathbf{u m}$ multiflurum, heterogamum, floribus radii ligulatis, femineis, disci hermaphroditis, tubulosis, quinquedentatis. Invol u cri squamae uniseriatae, in cnpulam campanulatam, apice dentatam connatae. R e e pt a $\mathbf{c}$ I u m.... A eh enia linearis, apice glandulis 5 , brevissimis, obtusis coronata. Sem en intra achenium stipitatum. - Herba mexicana, erecta, Tagetis facie, glabra; foliis oppositis, lanceolato-acuminatis, obtuse serrulatis, basi in petiolum brevissimum angustatis, petiolis in vaginam connatis, glabris, penninerviis, glandulis pellucidis, rubris punctatis, pedunculis ad apices ramorum pluribus, subcorymbosis, apice incrassatis, capitulis flavo-virentibus, involucri squamis eglandulosis.

A denopapp a s Bentham Plant. Hartweg. 41.

2589/1. Chaetlyymenia $H O O K$, et $A R N$. 
Cap it u I u m mitiflorum, heterogamum, floribus radii ligulatis femineis, disci tubulusis, hermaphroditis. Involucri patentim campanulati squamae paucae, subbiseriales, inaequales, laxe imbricatae, ovatae, subacuminatae, vix foliaceae. Rec e p t a c ulum nudum. Cor olla e radii ligulatae, obovatae, disei tubulosae. Styli rami attenuati, pilosi. A $\mathrm{c}$ h en $\mathrm{i}$ a oblonga, basi attennata, angulata, angulis pilosis. Pap pi setae rigidae, subvicenae, corollae tubulosae longitudine, piloso.hispidae, basi utrinque ala incisa membranacea anctae. - Herba mexicana, subsimplex, glabra; caule tereti, foliis elongatis, lineari-lanceolatis, subpunotatis, trincrviis, oppositis basique connatis, pedunculis terminalibus axillaribusque, longissimis, nudis, floribus majusculis, aureoflavis. t. 62 .

Chathymenia Hooker et Araott ad Beochey 298.

2583. Caillardia FOUG.

Hook. Bot. Mag. t. 3551 .

2584. IBalduina NUTT.

E ndorim a Rafin, in Americ, Monthl, Mragaz. 1819.

2595. Leptopodia NUTT.

Le p to e a r ph a Ratin. in Journ. phys. LXXXIX, 260.

2555/1. A elnyraelhaena SCH $U$ ULR. Ca p it u I u m multiflorum, heterogamum, floribus ra dii parvis, subligulatis, neutris, disci tubulosis, hermaphroditis. Involucri biseriati squamae lanceolatae, exteriores foliaceae, subeonvolutae, flores radii involventes, interiores planae, margine scariosae. Recepta $\mathbf{c} \mathbf{n}$ I u m planum, paleis inter radium et discum uniseriatis, caetera nudum, alveolato-subfimbrilliferum. Córolla e radii breviter subligulatae, apice hinc fissae, genitalium rudimenta gerentes, disci tabulosae, quinquefidae. Antherae ecaudatae, articulo antherifero longiusculo. St y li rami teretinsculi, puberuli. A chenia elongata, basi attenuata, longitudinaliter striata, secus nervulos scabrida, radi i calva, disci papposa. Pappus amplus, biserialis, paleis decem, membranaceis, obtusis, exterioribus dimidio brevioribus, interioribus quinque junioribus circa corollae tubum convolutis. - Herba A merica e boreali-ocoidentalis, villosa, Hecubaeam v. Scorzoneram habitu referens, subcanescens; pilis aliis longis, aliis brevissimis, fortassis glandulosis, caule subsimplici, apice nudo, mo nocephalo, foliis alternis, linearibus, sessilibus, integerrimis, corollis longe tubulosis, e sicco purpureis.

A chyrachaena Schauer Delect. Sem. Hort. Wra. tislaw, 1837. DC. Prodr. IIr. 292.

2595. Espejon $D C$.

Delessert Ic. seleet. $I V$. $t$. $\Delta t$.

25 98 . Cercostylos LESS.

$\mathrm{G}$ ü n th e ri a Spreng. Syst. $I I T, 449$.

2598. IIImenoxys CASS.

Hook. Ic, t, 146 ,

2599. Ceplaniophora CASS.

b. ACTINELla $D C$, P tile pida Rafin.

2601. Furrielia $D C$.

Bartling Sem, hort. Götting. 80. Linnaea Lillerat, Ber. $X I I, 80$. Bot, Mag, t. 3758 .

3803. Helemitam $L I N N$.

B ras s a v ol a Adans. Fum, $I T, 127$.

2805/1. Trinclinertia. $\mathrm{C}$ a $\mathrm{p}$ i t $\mathrm{u}$ I $\mathrm{u}$ m multiflerum, heterogamum, floribus radi 5-7 ligulatis, femineis, disci tubulosis, herma phroditis. Involueri ovati, imbricati squamac subtriseriatae, interiores longiores, obtusae, striatae. Receptaculnm convexum, epaleatum, punctatum. Corollae radii ligulatae, apice tridentatae, disci tubulosae, quinquedentatae. G enitalia disci inclnsa. A $\mathbf{c}$ henia prismatico-teretiuscnla, pubescentia. Pap pi paleae decem, ovali-oblongae, apice subdentatae, obtusae, uniseriales, sibi invicem contortim incumbentes. - Herba guianensis, dichotome ramosa, erecta, teres, puberula; foliis oppositis, breviter petiolatis, ovatolanceolatis, utrinque subacuminatis, grosse dentatis, triplinerviis, glabris, petiolo venisque subtus puberulis, capitulis e dichotomis pedicellatis, solitarits, Pisi magnitudine, corollis flavis.

S ehomburghia DC, Mem, IX, t, 9, Prodr. VIT. 293. non Lindl.

2BDS. Ireculbuen $D C$.

Delessert Ic, seleot, $I V . t .43$.

3608. Calliehroa $F$, et $M$.

Bot, Mag. t,3719, Bartling in Linnaea Littber, XIT, 89. 2609. Inasthenia LINDLEY.

Bot. Reg. $t$. 1893.

2611. A regroxiphinm $D C$.

Mem. $I X, t, 8$, Hooker IC, $t, 75$, A rg y rop hy tou Hooker Bot, Mag. Comp. II. 163.

2618. Lemarnatian $D C$.

Delessert Ic. select. ID. $t$. 44 .

2818. Vargasia $D C$,

Delessert To, solect, IV. $t, 47$.

8628/1. Thayia HOOK. et $A R N$. Capitnl $\mathbf{~ m}$ multiflorum, heterogamum, floribus radii ligulatis, femineis, disci tubulosis, hermaphroditis. Invol u cri hemisphaerici squamae oblongae, acutae, basim florum radii eorumque achenia involventes. R e ce pt a culi plani paleae lineares, inter discum et radiom pluriseriales. Corolla e radii ligulatae, disci tubulosae, quinquedentatae. Sty li rami recurvati, appendiculati. A chenia oblonga, basi attenuata, ra di i glabra, calva, discí pilosa, p a p p o persistente, rigido, basi plumoso. - Herba cal ifornica, decumbens, patentim hispido-pilosa, ramosa; ramis monocephalis, foliis alternis, lineurilanceolatis, inferioribus pinnatifidis, superioribus integris, corollis luteis.

L a y i a Hooker et Arnott ad Beechey 148. DC. Prodr. FII, 294.

\section{IBlepharipappus $Н О О К$.}

Eriopappus Arnott in Lindley Introduct, edit, $I r$. p. 443.

2694. MIarselnallin $W I L L D$.

Bot. Mag. t. 3704,

3699. IIradaría $D C$.

Eudlicher Icongr, t, 36. Madia elegan s Doa. Bot Mag. $t$. 3548.

2831. Tollatia ENDL.

$0 \times$ y u r a DC. Lindley Bot, Reg, t. 1850.

2833/1. Tepidestephamas $B A R T L$. C a p it ul u m multiflorum, heterogamum, floribus radii ternis v. quinis abbreviato-ligulatis, femineis, disci tubnlosis, hermaphroditis. Invol neri biseriati foliola exteriora achenia radii involventia, interiora plana, submembranacea. Recepta $c \mathbf{u} \mathbf{1} \mathbf{u} \mathrm{m}$ nudum. Corolla e radii abbreviato-ligulatae, tridentatae, disci tubulosae. A chen ia lineari-obovata, compressa, decemeostata, $r$ adii glabra, p a p p minuto, annulari, disci seabra, pappo biseriali, serie utraque e paleis quinque membranaceis, oblongis, nnguieulatis, interna corollam et involucrum aequante, externa duplo breviore, - 
Herba californica, annua, diffusa, subvillosa; foliis sparsis, linearibus, semiamplexicaulibus, integris, capitulis terminalibus solitariis, longe pedunculatis, oblongis, ligulis flavis, demum fuscis, pappi paleis nitidissimis, ad lentem fimbriato ciliolatis.

Lepidos tephanus Bartling Ind. Sem, hort. Götting. 1837. ex Linnaea Litteratur. XII, 82 .

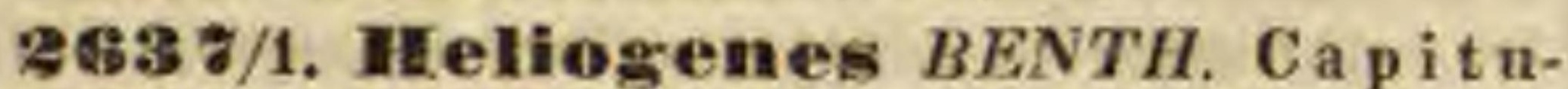
la m multiflornm, heterogamnm, floribns radii uniseriatis, ligulatis, femineis, disci hermaphroditis, tubulosis. Invo In cri uniseriati squamae 12_15, lanceolatae, basi margine membranaceae, complicatae, achenia radii involventes. $R$ ecept a c $\mathbf{u} \mathbf{~ u m}$ cylindraceo-conicum, paleis membranaceis, achenia involventibns. Corolla e ra di i ligulatae, disc i tubulosae, quinquedentatae, basi dense pilosae, abrupte in faucem dilatatae. Anth e rae ecandatae, apice appendiculatae. Stigmata obtusa, subtruncata, nec cono nec penicillo superata. A cheni a obovoiden-oblonga, erostria, paleis involuta. Pa p p a nullus. - Herbae me xic anae, paludosae, adscendentes, basi radicantes; foliis oppositis, dentatis, pedicellis monocephalis, nudis, ex axillis superioribus ortis.

Heliogenes Bentham Plant, Hartweg. 42.

268s. Matrieariar $L I N N$.

Seet, a. 1. DIABASIS DC. Prodr. VII. 297. C ap it u la diseoidea. Corolla e quinquedentatae. Reeeptaculum sphaericum, Papp us nullus. M. corym bifera DC.

265\%. Channysperma LESS.

Hooker ad Beechey $t$. 64 .

2884. Stevia $C A V$.

a. Chactostevia Bot. Reg. 1838. $t .59$.

26S: 2. Erioelation LINDL. C a p ituI um multifloram, homogamum. Involucri hemisphaerici squamae imbricatae, dense lanatae. R ee p ta c uli coniei paleae late membranaceae, apice appendiculatae, flores aequantes. C oroll a e tubulosae, ina basi glanduloso-pilosae, limbo quinquedentato. Antherae ecaudatae. Stigmata truncata. A c h en i a erostria, teretia, glabra. P a ppus nullus. - Herba Nova Hollandiae austro-occidentalis, lanugine densa albida, caulis pyramidati ramis rigidis, adscendentibus, monotricephalis; foliis alternis, lineari-oblongis, sessilibus, internodia paullo superantibus, capitulis in apice ramorum inter folia sessilibus, disco conico, flavo.

Eriocladiu an Lindley $S_{\text {wan }}$ River $x X I V$.

ะชะร/1. Pithocarpa LINDL. Capitu$1 \mathrm{um}$ multiflorum, homogamum. Invol ucri tur binati squamae multiseriales, imbricatae, exteriores subulatae, intimae petaloideae, radiantes. Receptaculam conicum, nudum. Corolla tubulosae, quinquedentatae. A n thera e lana tenui baseos cohaerentes. Sti gmata... A $\mathrm{c}$ hen ia erostria, oblonga, pubescentia. Pa p p us nullus. - Herbae NovaeHollandiae austro-occi. dentalis, lanugine tenui, decidua vestitae; caule subaphyllo, foliis paucis, distantibus, lineari-lanceolatis, sessilibus, ramis monocephalis $v$. corymbosis, involucri basi sublanati squamis exterioribus acntis $v$. purpureo-apiculatis, interioribus candidis, obtusis.

\section{Pithoearpa Lindley $S_{\text {war-Biver }} \mathrm{XX} I I T$.}

2830/1. Tawrencella LINDL. Ca pitaIn multiflorum, homogamnm. Involucri hemisphaerici, imbricati squamae exteriores herhaceae, sphacelatae, interiores petaloideae, radiantes. R e ceptaculnm planum, nadum. Corot la tubulosae, quinquedentatae. Antherae ecaudatae, basi rotundatac, filis arachnoideis colligatae. Stig m a t a conica, dorso glandulosa. A ch enia erostria, compressa, glandulosa. Papp u s multiserialis, setosus, setis aequalibus, serratis. - Herba Novae Hollandiae austrooccidentalis, annua, glanduloso-subpubescens; foliis oppositis et alternis, linearibus, obtusis, indivisis, pedunculis axillaribus et terminalibus monocephalis, lanatis, involucri squamis exterioribus ovatis, acutis, marginatis, interioribus elongatis, apice subdentatis, amoene roseis.

L a w rencella Lindley Swan.River XXIII,

2\% 39/2. Xyrotiantive LINDL. Capitul u m multiflornm, homogamum. Involucri campanulati, imbricati squamae exteriores concavae, rotundatae, subscariosae, interiores radiantes, apice appendice petaloidea auctae. Recepta $\mathrm{cu}$ In m planum, nudum. Coroll a e tubulosae, quinquedentatae. Antherae pilis arachnoideis caudatae. Stigmat a truncata. A chenia erostria, lanata. Pa p p s paleaceus, biserialis, corolla longior, paleis plumosis. - Herba Nova e Hollandia e austro-occidentalis, glaberrima; foliis alternis, sessilibus, oblongo-lanceolatis, membranaceis, ramis strictis, monocephalis, pedunculo omnino nudo, capitulis sestertiam lineam longis, fuscis, nitentibus, Xyridis capilulum referentibus, squamis voblongis, obtusis, interioribus appendice brevi, alba radiantibus.

\section{$\mathrm{X}$ y ridant he Lindley Swan-River XXIII.}

\section{3\%. Ieptorlayncinus LESS.}

a. APHANORHYNCHUS Less, Chrysocoma squam a ta Hooker Bol. Mag. t. 3625 .

b. MORNA Lindl. Bot. Reg. 1838. t. 9 .

2794. BRACHYSTRPHIUM Less. deleator, est enim B ra ch y com a Cass. supr. n. 2349. Ejus loco inseratur:

2754. Asterosperna LESS. C a pitu$1 \mathrm{~nm}$ radiatum. Stylus disci ramis cono brevi pubeque adscendente obsesso superatis, Achenium exalatum, erostre, plano-compressum, bicostatum. Pap pus conformis, biserialis, serie exteriore brevi, interiore Ionga. - Fruticulus capensis, ramosissimus, Asteri hyssopifolio similis, hirsuto-canescens; foliis sparsis, linearibus, capitulis solitariis, in ramis superne aphyllis, radio caeruleo, disco luteo.

Asterosperma Lessing Synops. 389. DC. Prodr. VTI. 299.

\section{2รจด. I. Igularia CASS.}

Siebold et Zucearial Flor, Jap. 2, 35. Royle Himalay. t. 60. f. 2 .

\section{S11. Seneelio $L$.}

q. Canarienses sect. Rericallides. Bot. Reg. 1839. $t, 7$.

2812/1. Crocilliume HOOK. Ca $\mathrm{p}$ itu $I$ um multiflorum, heterogamum, radiatum, floribas radii ligulatis, femineis, disci tubulosis, hermaphroditis. Involueri uniseriati, multipartiti squamae lanceolatae, glabrae, sobpatentes, Ree p ta cu 1 um conicum, nudum, alveolatum. Styli rami apice $8 \mathrm{mmmu}$ pilosi. A chenia radii nuda, obovata, compressa, tuberculosa, crenato-marginata, glaberrima, disci papposa, pappo aequali, setis hirsutulis. - Herba $A m$ ericae boreali-occidentalis, annua, humilis; caulibus simplicibus $v$. ramosis, foliis glabris, radicalibus lyrato-pinnatifidis, laciniis paucis, caulinis parvis, linearibus, integris $v$. laciniatis, in axillis lanatis, capitulis in ramis solitariis.

Crocldium Hnoker Flor. Zior. Amer. I. 335. t. 118. DC. Prodr. VII. 301 . 
TETEUS V. CYNAREAE.

2814. Tetradymia $D C$.

La got h a m n s Nuttall mse.

ZS54. Hapletaxis $D C$.

Mem, $I X, t, 10$.

2962. Cousinia CASS.

Klehw. Plant. casp. $t, 37$.

2864. Auelnera $D C$.

Mem. $I X, t$. 11 ,

\%89\%. Cirgivm TOURNEF.

a. 1. ODONTOLEPIS Boiss. ex DC. Prodr. DII. 304. Iuvolucri globosi squamae imbricatae, apice spinosae, sub spiua quasi dilatato-involutae, utrinque spiaulam lateralem gerentes.

\section{LABIATIFLORAE.}

TTEIBUS VI. MUTISIACEAE.

DRVISIO I. BARNADESIEAE DC. Prodr.

VII. 1. Gerbereis substituatur.

\section{Sehllechtendalia LESSING.}

DC. Prodr. VII, 2 .

2900. Diaeantha LESS.

Fx DC. Prodr. VII. 3. est Barnadesise sectio 3.

2901. Thasyphylluma $H, B, K$.

DC. Prodr. VII. 3.

2903. Nardophyllum Hook. et Arn. Genus ob antheras bisetas hoc loco delendum, et Eumutisieis pone Flotoslam U. 2908/, inserendum.

2904. Fulealdea POIR.

DC. Prodr. PIT. A.

* 2905 Gerbera Burm. *2906. Berniera DC. ${ }^{*} 2907$. L a siopus Cass. Genera ob antheras caudatas Enmutisieis sul 1. $2929 / 4-2929 / 6$ accensenda.

DIVISI II. EUMUTISIEAE DC. Prodr. VII. 4.

2908. Flotovia SPRENG.

DC. Prodr. VII. 10.

2908/1. Nardophyllum $H O O K$. et $A R N$. DC. Prodr. VII. 10, Hac ex n. 2903. transferendum.

2909. Seris LESS.

DC. Prodr. VIT, 19.

2S1 1. Centroelinium DON.

Cl. DC. Prodr. DII. 35, est Onoseridis sectio III.

* 2912. Chaet a chtaena Don. Genus delendum, est enim Onoseridis sect, 2. (n. 2925.)

2913. Chuguiraga JUSS.

DC. Prodr, VIT. 9. Jo a n nes i a Pers, Encheir, II, 383. Joannea Sprengel Syst. III. 382 .

2914. Meguinia $D C$.

Prodr. DIT. 22. S p ad o a i Lessiug supr. 2914. pon Fries (supr. v. 30\%.)

a. SPADONISMA DC. l. c. Corollae lobi tubo longio. res v. subaequales. A e h e $\mathrm{n}$ i a velutina. - Species americanae. (DC. Mem, IX. $t, 13$.

b. ? SIPHONISMA DC. $\boldsymbol{l}, \boldsymbol{c}, \mathrm{C}$ or o 11 a e lobi tubo multo breviores. A chen ia pubescentia $v$. glaberrima. - Species sanguebariensis.

29 1 5. Goelnatin $H, B . K$.

Sectiones Cyclolepsis Don. Cyclopis Guillem. Arch, Bot. II. 468. non Moq. et Anastraphia Don. cl. DC. cum Donio tanquam genera admittit.

2918. Proustia $L A G A S C$.

DC. Prodr. VII, 27.

a. FUProustia Endl, $\boldsymbol{l}$, c. b. BACCHARoIDES DC. t.c. A fhenia pilosa. Pappus albus, apice penicillatas. Frutex chilensis, capilulis trifloris, laxe paniculatis. P. haccharoides Hook. et Arn. c. LEUCORYPHE Endl. $l$. c. Thelecarpaea DC. $l$. $c$, d. HARMODIA Dos.

9918. Calopappus $M E Y E N$.

Capitulam quinqueflorum, homogamum, disceideum. In 50 lo eri eylindracei squamae lineari-subulatae, basi subdilatata subinbricatae, laxe erectae, exteriores hine iade serrato-splatosae, floribus breviores. Receptaculum angustum, nudum. Corollac glabrae, bilabiatae, labio exteriore tridentato, interiore bipartito, revoluto. A a therac basi longe eaudatae. St y li rami abbreviati, apice his. piduli. A c henia teretiuscula, glabra, erostria, Pappus triserialis, paleis eirciter quindecim, linearibus, acumina. tis, integerrimis. Reliq. Vid. sub. n. 2964.

Calopappus Meyen Reise I. 315. DC. Prodr. VII. 28. Delessert Ic. select, IV, t, 79, Genus infra s. म. 2964 delendum.

2925. Dnoseris $D C$

Prodr. VII. 486, exel, seet. 3.

a. EUONOSERIS DC. 1 . $c$. Re eеptaeulam omina nudum. - Herbae perennes, subacaules, scapis nudis, folits ad collum rosulatis. 0 a os e r is Cassini Opasc. 1T. 97. Lessing Synops, 119. (Kuath Op, cit, t, 304, 305.)

b. CLADOSERIS DC. $t$. $c$. Receptacul u m brevissime pilosum v. fimbrillifernm. Herbae annuae, canles. centes, ramosae, sparse foliosae. Clad os eris Lessiug in Linnaea $\mathcal{V}, 341$. Chaetachlaena Don in Linn. Transact, XVI. 256, supr. в. 2912.

3926. Hestypus H, B. K.

Hilarif a DC, mse.

\section{2}

DC. Prodr, DIT, 12.

a. EUOLDENBURGIA DC. $l$. c. Involucri squamae acuminatissimae, apice glabriasculae, subrecurvae. (DC. Mem. IX. $t, 12$.

b. SCYTALA DC, l, c. Involucri squamae extus undique dense tomentosae, parce acuminatae, in copulam urceo. Jatam conniventes, strictissime imbricatae. Scytala E. Meyer msc.

2929/1. Ansliaea $D C$. Capitulum triflorum, homogamum. Involn eri eylindracei squamae lanceolatae, aenminatae, imbrieatae, exteriores breves, intimae elongatae, disco tamen breviores. Recepta $\mathrm{cul} \mathbf{u} \mathrm{m}$ angustum, nudum. Cor oll a e basi tubulosae, bilabiatae, labio exteriore tri-interiore bifido, lobis elongatis, apice acutis et subcallosis, saepe revolntis. Antherarum appendices oblongae, obtusae, caudae longae, vix subbarbatae. Stylus basi aequalis; stigmata 2 , exserta, brevissima, obtusa, glabriuscula, saepe inaequalia, acuta, altero interdum abortivo. A $c$ h enia teretia, utrinque attennata, villosa, sessilia, erostria. Pa p p us uniserialis, setis eleganter plumosis. - Herbae perennes, in montibus Indiae o rientalis crescentes, Liatridis $v$. Lobeliae facic; foliis radicalibus petiolatis, cordatis $v$. ovatis, caulibus erectis, simplicibus, floribus purpureis.

A insliaea DC. Prodr.VIT, 13, Liatris latifolia Dot.

2929/2. Chionoptera DC. Capitnlum multiflorum, heterogamum? radiatiforme. I nvo. I n e r i campanulati squamae pluriseriales, exteriores foliaceae, dentatae, intimae lanceolatae, integerrimae, flosculorum radii labia exteriora aequaniia. Receptaculum nudum. Corolla e omnes bilabiatae, $\mathbf{r}$ a di i circiter quindecim, labio exteriore elongato, apice subtridentato, interiore breviore et teneriore bifido, dis c i longe tubulosae, labiis aequilongis, exteriore tridentato, interiore bipartito. A ntherae radii effoetae (?), disci subcor. neae, basi bisetae, setis crassis, puberulis, longiusculis, A chenia radii... dis ei compressa, hine subalata, oblonga, erestria, juniora subpnbentia, adulta glaìra. P a p p us pluriserialis, albissimus, setis Iongis eleganter plumosus. - Herba chilensis andicola, glaberrima, Taraxaci obovati $v$. Loxodontis chilensis facie; folits rosulatis, in petiolum brevem angustatis, late ovatis, denticulis callosis, acutis marginatis, corollis disci et radii flavis, glaberrimis.

Chionoptera DC. Prodr. VT, 16. Delessert Ie. we. lect, IV, $t, 25$. 
2989/8. Carmelita $C L, G A Y, C$ a it uI n multiflorum, heterogamum, radiatiforme, floribus radii femineis, disci hermaphroditis. Invol ucri campanulati squamae pluriseriales, subaequales, lineares, aeutae, exteriores foliaceae, dorso villosae, interiores membranaceae, glabrae. $\mathbf{R}$ eceptaculum nudum. Corolla e radii feminei uniseriales, bilabiatae, labio exteriore ligulaeformi elongato, tridentato, interioris brevioris, bipartiti lobis obtusis, arcuatim inflexis, dis c i aeque bilabiatae, labiis aequilongis. Antherae appendice coriacea, bisetae, setis longis, pilosis, radii efoetae. Sty li cylindrici, ramis obtusis, linearibus, erectis. Achenia radii effoeta, disei.... P a p u s radii et disci pluriserialis, albissimus, setis linearibus, integris $v$. vix apice denticulatis. - Herba chilensis, andicola, perennis, subacaulis, monocephala; foliis subradicalibus rosulatis, lineari-subspathusatis, obtusis, utrinque villosissimis, integerrimis, capitulo inter folia sessili, magno, floribus flavis.

Carmelita Cl, Gay mse, ex DC. Prodr. NII, 14.

2929/4. Gerbera GRONOV.

Genus supr. n. 2905 delendum, et in sequentes sectiones subdividendum.

a. BUGERBERA DC. $l$. c. Ge r b e r a Less.

b. LEPTICA E. Mey, msc. Pilos elloides Less.

2939/5. Dreoseris DC. Capitulum moltiflorum, heterogamum, radiatiforme, floribus radii femineis, disci hermaphroditis. I n vo lucri squamae bi-pluriseriales, lineari-lanceolatae, acuminatae, interiores longiores. Receptac u I um nudum. Corollae disei pilosinseulae, bilabiatae, labio exteriore tri-interiore paullo minore bidentato, ra dii glabrae, labio exteriore ligulaeformi tridentato, interioris multo minoris bipartiti Iobis linearibas. Anther a d is ci appendice lineari-lanceolata, elongata, caudis longis, apice sublaceris, radii efoetae. S'ty li basi oblongo-tamidi rami breves, obtusi. A ch enia oblonga, erostria, eparse pulerula, haud papulosa. $\mathbf{P}$ a $\mathbf{p}$; biserialis, setacei setae aequales, serratae. - Herbae perennes, in India orientali monticolae, Gerberae et Onoseridis facie, foliis radicalibus lyratis $v$. pinnatifidis aut dentatis, subcoriaceis, supra glabris, subtus tomentosis, scapo tomentoso, mono cephalo, floribus flavis.

0 noseris DC. Prodr. VII, 17, Chaptaliagossypina Royle Himalay, $t, 59, f$. 2 .

\section{9/6. Bermiera $D C$.}

Prodr. VIT, 18. Delessert Io. select, IV, t, z7. Generis sapra u. 2906 delendi, charaeter sequentibus emendaadus et augendus: I a valueri subcampanulati, bi-triseriati squamae lasceolato-lineares, acuminatae, disco paullo breviores. Receptaculam nudum, alveolatum. Co rollae omnes basi tubufosae, bilabiatae, labio exteriore tridentato, ereeto, interiore bipartito, revolato. A n thera longat, appendi. eibes lanceolatis, acuminatis, caudis longis, apice summo tantum barbatis. Stylus hasi haud bolbosus, subinclusus, lobis obovatis, obtusis, dorso ad apicem subpuberulis. A che. ni a elongata, pubero scabra, angulata, breviter rostrata. deciduis.

\section{9/7. Lasiopus CASS.}

DC, Prodr. VII. 18, Generi snpr. n. 2907 delendo, pluribus speciebus capensibus et madagaseariensibns aucto, addatur syaonymon Epiclia as tra a Boj. moc,

\section{Dieoma CASS.}

DC. Prodr. VII. 36. Generis sect. sint:

A. EUDICOMA DC. $l$. c. C a pitu Ia homogama, discoidea. S f y l us basi haud bulbosos. A c heula decemcostata, villosa. Pappus florum omatum biserialis, setis exte. rioribus lineari setiformibus, interioribus liaenci-lanceo. latis, margine seariosis, onuibus plus mimus serratis. - Herbae indicae et senegambicae, ramosissimae, to. mentosae; folits oblongis, integerrimis, mollibus. capitulis ramos axillares brevissimos terminantibus, corollis albidis. - Le ucoph y ton Lessing. X ero. pap pus Wallich msc.

b. Microcoma DC. 1 . c. Capitula heterogama, discoldea, floribus radii uniseriatis sterilibus, brevissime tubulosis sive bilabiatis. S t y 1 us basi hand bulbosus. A che $\mathrm{n}$ i a disci decemcostata, basi villosa, radii abortiva. Pappus radii squamellis setiformibus vix scabridis, disei biserialis, exterior setiformis, deciduus, interior squamellis basi subdilatato-membranaceis, plus minus ciliatoplumosis. - Herbae capenses, Eudicomae facie. Steiro enm a DC. VII. 36. D, capensis Less.

c. RHIGIOTHAMNUS Less. S t y 1 us basi haud bulbosus.

d. MACLEDIUM Less. S t y I $\mathrm{n}$ s basi bulbosus.

e. PTERoComa DC. $l$. c. C a pit u la homogama, diseoidea. S t y I us bast haud bulbosus. A chen $i$ a turbinata, villosissima. Pappus florum omaium setis omnibus longe plumosis. - Herba capensis; caule subaraneoso, folits lineari.lanceolatis, longissimis, glabris, capi. tulis paniculatis, involucris multiseriatis, nitidissi. mis, corollis purpureis.

2931. Printzia CASS.

DC. Prodr. VII, 13, - ? L i o y di a Necker Elem, $n, z$. 2932. Feratieinm LAGASC.

DC. Prodr. VII. 38.

a. PARDISIUM DC. $l$. c. A chen ia dense papulosa, breviter rostrata. (Vahl Act. soc. hafn. $I, t, 1$.)

b. LEIOCARPUM DC. l. $c$. A ch en ia epapulosa, glab́ră, longe rostrata.

2934. Chaptalia $V E N T$.

Species indicae ad Oreoserin DC. n. $2929 / 5$ et Bernie$r$ i a m DC. n. 2929 referendae.

293\%. Dxyalon LESS.

$0 \times$ yod o a DC. Prodr, VIT. 43.

2940. Hueilia CASS.

DC. Prodr, VII. 46.

a. EULUCILIA DC, $l$, c. A c he nia sericeo-villosa, Corolla e feminese tenuissime ligulatae. - Species brasilienses; folits acutis, L ucili a Cass. Less.

b. LUCLCIOIDES DC. l. c. A cheni a glabra. Corolla e fenineae tenuissime tubulosac. - Species chilensis; folits obtusis. Gnaphalium frigidum Püpp.

2943. Polyacliyrus $L A G$.

DC. Prodr. VII, 53. Mem, IX, t. 15.

\section{TRIBUS VIT. NASSAVIACEAE.}

98 4. Triptiliom RUIZ et PAV.

a. EUTRIPTILION. DC. Prodr. V1I. 50.

b. STrONGYloma. A ca uth oph yll am Hook. et Aen. l. e. Strong y 1 o ma DC. Prodr. VII. S2.

948. Pramargyrum $L A G$. DC. Prodr. VII. 53.

a. ANARGYRUM DC. $l$. c, Pappi paleae biseriales. Hami et folia glabra. $\mathrm{P}$ a $\mathrm{a}$ a $\mathrm{r}$ y $\mathrm{ri}$ s $\mathrm{p}$. Gill. Hook, et Arb.

b. PIPTOSTrmia DC. l. c. Pa p pi paleae biseriales. Rami apice conferte velutini, folia glabra. (DC. Mem. IX, $t, 16$.

c. EUPANARGXRUM DC. $l$. $\bullet$. P a p pi paleae ..... vix volucrum aequantes. - Caulis cum folits lineari subu. latis argenteo-sericeu». P a a a r g $\mathrm{y} \mathrm{r} \mathrm{um}$ Lagasca 1 . $c$. Pan ag y r us Lagasca Amen, nat. 1 , 33. Cassini Dict. XXXIV. 225.

8955. MHoselnaria $H U I Z$ et $P A Y$.

M ascaria Persoou Encheir. TI. 379.

2956. Heweevia $L A G$.

DC. Prodr. VIT. 56.

a. EULeUCERIA DC. 2, e. Pappi setae breviter sed di stinete plunosae, basi in anualum concretae. I uvo. Iucrum bi-triseriale. Trixidis sp. Hooker Exot. Flor. t. 101. (Delessert Ic. seleot. IV. C. 85-67.)

b. MACRoBotrys DC. l. c. Pappi setae vix seabrae, ima basi subpolyadelphae, ia annulum non concretae. Involaeri squamae quadriseriales, imbricatae, obtasate. (Deless, Op. cit. $t, 89$. ) 


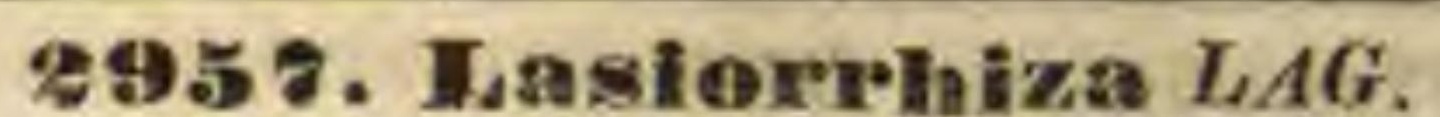

Chat ra e DC. 1, c. Prodr. VIY. 38.

a. LASIORRHIZA DC. 2 . c. In v olu cri campanolati squamae obtusiusenlae. - Herbae acaules, scapis mono cephalis. DC. Il. cc. (Delessert Io, IV. t. 89.)

b. MACLOVIA DC. $l$. $c$. I nvolue r I turbinati squamae acuminatae. - Herbae caulescentes, monocephalae involucro valde lanuginoso.

c. LEUCERIOIDES DC. 2 . c. Involucri campanulati squamae acominatae. - Herbae caule ramoso, polyce phalo. - Cassiopea Don l. $c$. (Delessert Op. cit. t. 90.91.$)$

\section{Perezia $L A G$.}

a. ClarioneA DC, Prodr, VII, 60.

c. Euclarionea Endl. l. c. Clarionella DC. 2 . c. 8. Drozia Less. (Delessert 1c, select. $I V . t, 93$. y. Euperezia. Involucri multiseriati foliola Janeeolato-linearia. Foli a pinnatipartita, lobis sinuato. dentatis, deutibns spinosis. C a p it ula paniculata, longe petiolata. Perezia DC. Prodr. VII. 62, De lessert Tc. select. IV. $t$. 94. $\delta$. A s t e r o s e r is Endl. 2. c. Clarionoides DC. L. c. - Observatio ad ealcem generis delenda.

2983. dectartia $D O N$.

Perezia Llave et Lexarz. Nov, gen, Mexic. I, 25. non alior.

- 2964 CALOpappuS Meyen Vid. supra 2918/.

\section{LIGULIFLORAE.}

\section{THIBUS VIIL. CICHORACEAE.}

2966/1. IPiplostemma HOCHST. et $S T$. C a pitul um pluriflorum, homocarpum. InvoI u crum imbricatum, spinosum, bracteatum. Receptacnli paleae apice acute incisae, floribus breviores. Coroll a exteriores ligula ovali-oblonga patente, interiores basi tubulosae, limbo ad latus interius fisso, eaeterum quinquefido, lobis dorso scabridis, A ehenia turbinata. Pappus duplex, exterior paleis quinque obtusis, ellipticis, interior setis 5, longioribus. - Herba arabica, ut videtur annua, a basi ramosa, rigida; foliis longe decurrentibus, lanceolatis, acuminato-aristatis, integerrimis, reticulato-venosis, utrinque punctatis, capitulis ad collum sessilibus, confertis, secus ramos in dichotomiis et oppositifolitis solitariis, folits floralibus, inter folia et squamas magnitudine ambigentibus, cinctis, floribus flavis.

Diplostemma Hochst. et Steudel in Plant. arab. Schimp. n. 853. DC. Prodr, VII, 75.

\section{z983. Hedypnois TOURNEF。}

$R$ hag adiolotdes Valliant Aet. Academ. Pariv. 172t, 25 5 . II yoseris LINN. 1721.

Taraxacou astrum Vaillant Act, Academ, Paris.

\section{9\%}

Leontodontaides Mieheli Gen, $31, t, 38$.

2966/2. IItanselera BOISS. CapituI n m multiflorum, homoearpum. Involneri campanulati squamae pluriseriatae, imbricatae, margine membranaceae, calloso-acuminatae. $\mathbf{R}$ e ce pta culi paleae basi carinatae, apice acuminatae, acheniis longiores. Corollae ligulatae. Arheni a conformia, obpyramidata, pentagona. P a $\mathbf{p}$ p us nniserialis, paleis quinque scarioso-pergamaceis, basi latis, florum exteriornm brevibus, snbobtusis, interiornm longioribus, acuminatis. Herba hispanica, perennis, acaulis, glabra; radice cylindracea, simplici v. parum ramosa, foliis radicalibus exterioribus obovatis, dentatis, ceteris oblongis, pinnatilobatis, lobis dentatis, scapo folitis duplo v. triplo longiore, erecto, monocephalo, floribus flavis.

H a en selera Boissier in DC. Prodr. VII. 83.
298 8/1. Calais $D C$. C a p itulum multiflornm, homocarpnm. Involuer u m duplex, exterins brevius, ealycnliforme, tri-hexaphyllnm, interins cylindraceum, deca- dodecaphyllum, squamis biserialibns. Receptaculum epaleatum. C o $\mathrm{r} 01 \mathrm{l}$ a e lignlatae, involnerum aequantes. Achenia teretia, apice attenuata, rostrati, mnricata v. scabrida. Pa p p n paleis quinque, nniserialibus, basi late scarioso-dilatatis, sibi invicem contortim incumbentibus, apice in setas breviter scabridas desinentibus. - Herbae cal ifornicae, annuae, glabrae; radice simplici, exili, foliis radicalibus elongatis, utrinque acuminatis, linearisublanceolatis, nunc integerrimis, saepius medio inciso-pinnatifidis, lobulis acuminatis, scapis nudis, monocephalis, folia aequantibus $v$. superantibus, corollis flavescentibus,

Ca 1 a is DC. Prodr. NII. 85. Hy menonema Hooker Elor. Bor. Amer, I. 300.

a. EUCALA1S DC. 2 . e, Invo Iu erum calyculo brevi, distiucto. P a p pi paleae basi scariosae, dilatatae, sensim in setam productae. - Scapi apice furfuracei.

b. CALOCALAIS DC. l. c. I n vola o rum basi squamis 3-4 brevibus instrnetum. $\mathrm{P}$ a p pi paleae searlosae, apice bifidae, e sinu setam proferentes. - Scapi'cau. lesve apice glaberrimi,

2983. Mieroseris $D O N$.

BeIlardia Colla Mem. Academ. Turin, XXxpIIr. 40. $t, 34$, non alior.

\section{Oreophila $D O N$.}

? A m b l a clrea i um Turczaninow moc.

29S\%. Seriola GXRTN.

A chyrophorus Vaillant Act. Academ, Paris, 1791. non Scop.

2988/1. Iretabasis DC. Capitulum multiflorum, subhomocarpum. Involncri biseriati, squamulis paucis calyculati squamae acuminatae, dorso spinellosae. Receptaculi paleae tenues, scariosae. Corolla e lignlatae. Áchenia lineari-teretinscula, radii breviter, disci longe rostrata. Pap p us uniserialis, radii squamellosus, brevissimus, disci elongatus, plumosus. - Herba Robertiae facie, in monte $h_{y}$ meto Atticae crescens; foliis plerisque radicalibus, hirtellis, runcinato - pinnatifidis, lobis acutis, sinubus obtusis, caulibus a basi ramosis, glabris, subnudis, apice monocephalis, floribus luteis, exterioribus subtus rubentibus.

Metabasis DC. Prodr. VIt, 97 .

2988/2. Phalacrouleris DC, Ca pituI n m mnltiflorum, homecarpum. Involneri biseriati squamae acuminatae, exteriores breviores, laxinsculae, interiores duplo longiores, subconcavae. Receptac uli paleae lineares, membranaceae, involuerum aequantes. Corolla e ligulatae. A chenia linearia, teretiuscula, glabra, in rostrum elongatum, apice callosulum producta. $\mathbf{P}$ a $\mathbf{p}-$ pns subnullas, paleolis minimis, in coronulam subeoncretis. - Herba in montibus insulae Gos crescens, annua, erecta $v$. subdiffusa; foliis inferioribus petiolatis, pinnatifidis, lobis acuminatis, terminali majore, caulinis paucis, sessilibus, nunc pinnatifidis, nune basi dentatis, ramis floriferis elongatis, monocephalis, corollis flavis, involucro setoso-hispido.

Phalaeroderis DC. Prodr. VTI. 97.

2994. Urospermina SCOP. 1721.

Tragopogonoides Vallast Act. Academ, Paris.

2958/1. Nueroderis $D C$. Capitulum muitiflorum, homocarpum. Involnerj biseriati $174 *$ 
squamae exteriores breves, lineares. R e captaculum nudum. Corolla e ligulatae. Achenia oblonga, teretinscula, longitudinaliter striata, apice in collum breviter producta. P a p $\mathbf{p}$ s uniserialis, plnmosus. - Herba a $\approx$ orica, perennis; foliis radicalibus ellipticis, basi cuneata integerrimis, caeterum rrosse duplicato-serratis, superne setis sparsis hispidis, secus margines longe ciliatis, scapo nudo, apice corymboso, squamis ad basim pedicelli elongati et involucri parvis, lineari-subulatis, floribus flavis. Ait.

Microderis DC. Prodr, PIT, 127. Crepis rigens

3คD\&. Fierialinm $D E S F$.

Refich ardía Roth Bot. Abhandl. 35. Mōnch Meth, 16.

300\%/1. Zollikoferata $D C$. Cap itu $\mathrm{lnm}$ multiflorum, homocarpum. Involncri ovatooblongi, imbrieati squamae margine scariosae, exteriores breviores. Recepta $\mathrm{c}$ I $\mathrm{l}$ m nudum. Corolla e ligulatae. A chenia cylindracea, vix subtetragona, erostria, subtiliter striata, glabra v. brevissime pubescentia, ima basi corniculis quatuor retrorsis instructa. P a p $\mathbf{8} 8$ pluriserialis, sessilis, pilosus, mollis. - Herbae mediterraneae, glabrae, ramosae; foliis pinnatilobatis, lobis dentibusve demum apice albo-callosis, floribus tuteis.

Z ollik of e ria DC. Prodr. VII, 183, Mem. IX, $t, 18$. non alior. Sonehus chondrifloides Desf.

3003. Sonelnus LINN.

DC. Prodr. VII, 184. excl. sect. 3. Dele Launea Cass.

a. ANoLeptus DC. $\boldsymbol{l}$. $c$. A e h e n f a apice attenuata, fere rostrata. - Species capenses.

b. EUSONCHUS DC, $l$. $c$, A ch e $\mathrm{i}$ a apiec truncata. (Delessert Ic, select. IV. $t .97$.

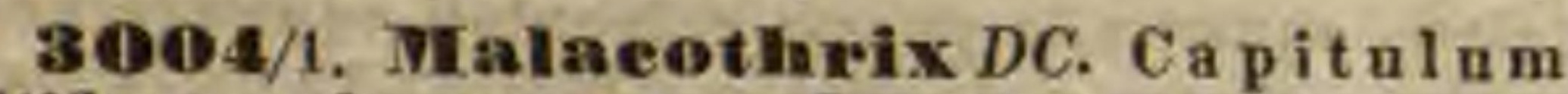
multiflorum, homocarpum. Involueri late campanulati, bi-triseriati squamae imbricatae, sublineares, margine scariosae. $R$ e ce pta c n I um nudum. Coro il ae anguste lignlatae, lineares, exteriores longiores. Achenia glabra, obovata, erostria, Pa p pns uniserialis, setis linearibus, argenteis, vix subserratis. - Herba californica, Nejae facie, annua, acaulis, junior villis longis, albis, mollibus barbata, adulta plus minus glabrata; radice simplici, perpendiculari, foliis radicalibus rarissime indivisis, plerisque pinnatipartitis, rhachi lobisque linearibus angustissimis, scapis erectis, cylindricis, monocephalis, folia duplo superantibus, floribus in capitulo innumeris, flavis.

Melacothrix DC. Prodr, VII, 198.

3004/2. Youngia CASS. C a p i $\mathrm{t}$ i $\mathrm{n} \mathrm{m}$ multiflorum. Involucrum cylindraceum, octophyllum, squamis accessoriis circiter quinque caIyculatam. Receptac u I um nudum. Corolla ligulatae, ad apicem tubi pilosae. A ehen ia oblonga, compressa $v$, in eodem eapitulo subtrigona, longitudinaliter striata, erostria, utrinque subattenuata. Pa p pus pilosus, uniserialis, filiformis, vix subdenticulatus, albus. - Herbae ind $i \mathrm{cac}$, mauritianae, japonicas et chinenses, Lampsanae facie, saepius glabrae v. basi pubescentes, apice paniculatae; folitis inferioribus petiolatis, lyratis, pinnatifidis $v$. grosse dentatis, membranaceis, caulinis paucis, capitulis parvis, flavis.

Youngi a Cassini Opusc. phytolog, III.86. DC. Prodr. VII, 192, Prenauthis sp. Thuab. Blum. Wall, Chondrilla sp. Poir.

3005. Preanantines $G A R T N$.

h. NABALUS Cass. Es op o n Rafin, Flor, Ludov. 146,
3065. Chorisana $D O N$,

Chorisis DC. Prodr. PII. 177.

300\%. Plhoenixopus $\mathrm{KOCH}$.

a. PHoEnIXopus Cass. Phaenopus DC. Prodr. VII. 176.

300\%. Brochyrlaampinous $D C$. C a p it u $1 \mathbf{~ a ~ m}$ decem-quindecimflorum, homocarpum. Invo I ucri oblongi, imbricati squamae acuminatae, margine seariosae. R e e pta cul u m nudum. Corolla e ligulatae. A chen ia oblonga, muricata, in rostrum breve sensim attenuata, hand angulata, ecostata. Pap p u 8 plariserialis, pilosus, mollis, albus. - Herbae inter tropicos totius orbis crescentes, erectae, glabrae, ramosae; fo. liis runcinatis, dentatis, capitulis racemoso-spicatis, floribus luteis.

B ra e hy rha w p hus DC. Prodr. VII. 176. Delessert Ic. select. ID. $t, 96$. Lactuca in t y bacea Jacq. $I c$. rar. 1. t, 162. Sonchi et Prenanthis sp. Auct.

3009. Chomdirilla TOURN.

Pyrrhopappus DC. Prodr, VII. 144.

3011. Willemetia NECK,

A spide in m Zollikof. msc.

30 14. Nemanelinemes CASS.

E n d o p te ra sect. 2. DC. Prodr. VII, 179.

3015 . Fatyona CASS.

Eudoptera sect. 1. DC. Prodr. VIT. 178.

3017. Whabulotheea CASSINI.

Dict, se. nat. XLPIIT. 424. M i cror b y ne h u s Lessiag l. c. A m moseris Endl. 1. c. L a u u e a Cassini Op. cit. $X \times V, 231$.

3018. Troelnoseris $P O ̈ P P$. et $E N D L$. 1837 .

$\mathrm{M}$ a e r o r h y $\mathrm{n} \mathrm{ch}$ i u m Reiehenb. Ind, sem, hort. Dresd.

\section{0\% 1. Forklhamsia $M O ̈ N C H$.}

Barkhusenia Hoppe in Flora 1829. p. 510 , Closirosperm u mecker Elem, $n .97$.

302 1/1. Fouligia SPRENG. C a p itu I u multiflorum, subhomocarpum. Involneri im. bricato-calyculati squamae exteriores biseriatae, breves, demum patulae. Receptaculi paleae membranaceae. Corolla e ligulatae. Achenia teretinscula, laevia, radii breviter, disci longe stipitata. Pap p us uni. biserialis, conformis, pilosus, albissimus. - Herba insularum ma$r i s$ ionii, ramosa, pilosa; foliis radicalibus runcinatis, lobo terminali majore, dentato, caulinis amplexicaulibus, basi pinnatifidis, ramis floralibus nudis, teretibus, monocephalis, involucris hispidis, floribus luteis.

Rodigi a Sprengel N. E. I. 273, excl. sp. DC. Prodr. VII. 98.

3021/2. Ammogeton $S C H R A D . C$ a $\mathrm{p}$ it $\mathrm{u}$ I $\mathrm{m}$ multiflorum, heterocarpum. Involu erum imbricatum, tri-quadriseriale. Receptaculi paleae lineari-lanceolatae, acuminatae. Coro 11 a e ligulatae. A chen i abcompressa, glabra, laevia, radii erostria, disci brevissime et crasse rostrata. Pap pus pluriserialis, albus, setis subseabris. - Herba borcali-americana, perennis, acaulis, praeter involucra glabra; foliis radicalibus lineari-lanceolatis, elongatis, utrinque attenuatis, integerrimis, nervo medio complanato et fere trinervulato, scapis folia aequantibus, teretibus, nudis, involucris imprimis basi albo lanuginosis, floribus luteis.

A m mogeton Sehrader Catalog. Sem, hort. Góting. 1833. p. 1. DC, Prodr. VII. 98.

3028/1. Dabyaea $D C$. C a pitu In multiflorum, homocarpum. In volucrum campanu- 
latum, imbricatum. Recept a cul a m nudum. C orollae ligulatae. Achenia plano-compressa, striata, in collum crassum, breve producta. $\mathbf{P}$ a $\mathrm{p}$. p n s pluriserialis, pilosus, albns. - Herbae in India orientali, Nova-Hollandia et Armenia observatae, erectae, subramosae; foliis indivisis, dentatis, capitulis paucis, subcorymbosis, involucris extus hispidis v, aculeolatis, corollis flavis.

D u b y a a DC. Prodr, VII, 247.

a. HIERACIDIUM DC. $l$. c. Involucri squamae adpres. sae. A ch en i margine haud tutiereulata. II i e $r$ a e f u m hi s pi dum Wall. (DC. Mem. 1X. t. 19.)

b. SONCHIDIUM DC. $l$. $c$. I a v o I u $\mathrm{er}$ i squamae squarrosae. A chenia margine tubereulato-seabra. L as io pus Don in Sweet Fl, Gard, $I, t, 346$, non Cass.

c. MULGEdUM Cass, DC. Prodr. VII, 501, Royle Himalay, t, 61.

3028/1. Anisorinamplaus $D C$. Capitn l $\mathrm{nm}$ multiflorum, subhomocarpum. In v ol u cri calyculato inbricati squamae lato-lineares, exteriores subbiseriales, breves, interiores subbiseriatae, elongatae. R e ceptacul u m nudum. C oroll a e ligulatae. A chenia oblonga, compressa, striata, rostrata, rostro exteriorum brevi, interiorum longiore. Papp a 8 pilosus, multiserialis, subochrolencus. - Herba capensis, perennis, Hieracii v. Hypochaeridis facie; radice crassa, cylindracea, foliis radicalibus oblongis, basi subattenuatis, subretrorsum dentatis, glabris, caulinis paucissimis, linearibus, integerrimis, caule subnudo, basi sulcato, glabriusculo, apice parce ramoso, subtricephalo, involucrisque pilis rigidis, nigris hirto, floribus luteis.

Anis orhamphas DC. Prodr. MII. 251

3030/1. Agoseris $R A F$. C a p it a 1 a m inultiflorum, homocarpum. In vol u c r i subconici, imbricati squamae latae, extus plus minus villosiusculae. Receptac ul um nudum. Corollae ligulatae. A e hen i a teretinscula, brevissime rostrata. P a p p us pilosus, albus, rigidinseulus, setis subdenticulatis, basi haud dilatatis. - Herbae boreali-americanae, praeter involucra pubescenti-lanata glabrae, subacaules, Scorzonerae facie; foliis subradicalibus glaucescentibus, subintegerrimis, scapis folia paullo superantibus, teretibus, monocephalis, floribus luteis.

Agoseris Rafinesq. Flor. Ludov. 58. Troximon Sims Bot. Mag. $t$. 1667. Nuttall Gen. Amer. IT. 122. Hooker For. Bor. Amer. I. 300, t. 104. Bot. Mag. t. 3462. DC. Prodr. VII. 258. non Gärtı.

\section{GENERA INCERTAE SEDIS.}

3032/1. Anisopappus HOOK. et $A R N$. Ca pitulum heterogamum, radiatum, floribus radii uniseriatis, ligulatis, femineis, disci tubnlosis. In v ol ucri squamae lineares, imbricatae, plurimae, pubescenti-tomentosae. R e c ept a c u lum dense paleatum. Antherae basi bisetosae. St y1 ns disci ramis apice obtusis, inappendiculatis. A chenia conformia, lineari-tetragona, exalata, erostria, paleolis pluribus, brevibus, inaequalibus, setisque quatuor, multo longioribus, inter se inaequalibus coronata. - Herba sinensis, erecta, dense puberula; foliis alternis, oblongo-li nearibus, obtusis, dentato-serratis, ramis florigeris monocephalis, subterminalibus, corymbosis.

An is o p a p us Hooker et Arnottad Beech, 196. DC. Prodr, VIr. 253. - 2 Verbesina chinensis Lins.

3032/2. Arrowsmilhia $D C$. C a p ituI $\mathrm{m}$ multiflornm, heteroganum, floribus radii uniseriatis, lignlatis, femineis, disci tubnlosis, regulariter quinquedentatis, hermaphroditis v. fortassis sterilibus. In vol a cri campannlati, imbricati squamae subciliatae, exteriores ovatae, acntae, subcoriaceae, interiores oblongae, obtusae, apice membranaceae. Receptaculam planum, fimbrillis v, paleis lineari-setaceis, rigidis onustum. Corollae omnes tabo medío villoso-tomentoso. Antherae ecaudatae. Styli rami breves, obtusi, dorso puberuli. Ac he nia calva, radii compressa, disci teretiuscula, glabra, areola basilari subcornea- Suffrutex capensis, ramosus, Eclopis v. Oederiae facie; ramis teretibus, glabris, foliis alternis, usque ad ramulorum apices confertis, patulis, sessilibus, semiamplexicaulibus, persistentibus, rigidis, lineari-lanceolatis, mucronato pungentibus, integerrimis, supra glabris, subtus junioribus albo-tomentosis, demum glabriusculis, capitulis terminalibus, solitariis, luteis.

Arrows ithia DC, Prodr. VII. 254. Delessert IC. select. $T V, t, 100$.

3032/3. Cadiseus E. MEY. Capitulum multiflorum, heterogamum, floribus radii uniseriatis, late ligulatis, femineis, disci exterioribus hermaphroditis, fertilibus, tubulosis, quinquedentatis, subbilabiatis, centralibus sterilibus? Inv olacri uniseriati spuamae $8-10$, in cupulam octo-decemdentatam connatae. Receptac n lum convexum, alveolatum. An therae ecaudatae? S ty li rami apice summo barbati. Achenia fertilia teretia, striato-sulcata, apice breviter rogtrata, basi subvillosa, caeternm sparse puberula, embryone tereti, elongato, sterilia linearia, laevia. $\mathrm{P}$ a p p 8 fertilium squamellis decem, rigidulis, setiformibus, scabris, basi subdilatatis, persistentibus, sterilium omnino setiformibus. - Herba capensis, aquatica, glabra; caule tereti, ad nodos inferne radicante, foliis alternis, semiamplexicaulibus, linearibus, elongatis, integerrimis, plurinerviis, pedunculis oppositifoliti, nudis, monocephalis, corollis albis.

\section{Cadiscus E. Meyer msc. ex DC. Prodr. PIT, 254.}

303 $/ 4$, Doliehogyne DC. Capitulnm sex-octoflorum, homogamum. Invol u cri oblongi squamae imbricatae, acuminatae, exteriores foliaceae, interiores longiores; scariosae. R e c e p tac n lu m nudum. Co rolla e tubulosae, subaequaliter quinquedentatae. S ta min a m filamenta brevia, antherae ecandatae, apice appendiculatae. Stylus teres; stigmata 2 , exserta, crassa, distincta, elongata, acuta. A chenia teretiuscula, elongata, pubescentia. P a p p $\mathbf{s}$ uni biserialis, setis sublamellatis, scarioso-rigidulis, nee plamosis, nee denticulatis. - Suffrutices b on a rienses et chilens es, ramosi; folits alternis, sessilibus, linearibus, margine revolutis, capitulis ad ramulorum apices solilariis, foliis supremis subcontiguis, floribus flavis.

Dolichog y ne DC. Prodr. VII, 256.

3032/5. Clachia DC. Capitul n m multiflorum, radiatum. Involue ri ovato-campanulati squamae pluriseriales, exteriores foliaceae, obovatae, apice denticulatae, reliquae subseariosae, integerrimae, mucronatae. Rece ptaculum nudnu. Flores radii quinque, anguste et breviter ligulati, steriles, disei decem, tubulosi, subbilabiati, quinquedentati, ad fancem haud dilata. ti, hermaphroditi. Antherae basi brevissime caudatae. St y 1 i .... A chenia obcompressa, 
erostria, oblonga, glabra. P a p us pluriserialis, setosus, albissimus. - Herba chinensis, tenella, glaberrima; radice exili, caule a basi ramosissimo, tenui, ramis oppositis, foliis inferioribus oppositis, superioribus alternis, rigidulis, obovatis, glaueis, apice serratis, basi angustata integerri. mis, eapitulis ad apices ramorum solitariis, foliis vix ab involucri squamis exterioribus distinctis obvallatis, involucri squamis intimis corollisque flavis.

Elactria DC. Prodr. VII. 236. Delessert Ic. seleot. IV. ᄂ. 99.

303 \%/6. Ginaplualopsis $D C$. Capitula multiflora, dioica? Maseula: Involuerum campanulatum, squamis exterioribus subfoliaceis, valde lanatis, interioribus scariosis, glabris, acnminatis, subuniseriatis. R ecepta cu inm nudum, subconvexum. Corolla e tubulosae, minute quinquedentatae. Anther a e subsessiles, ecaudatae, Stylus inclusus, bifidas, ramis glabris, subdifformibus. Achenia stipitata, subangulata, tenuissima, elongata, inania (?). P a p pus paleis quinque, ereetis, scariosis, basi latiusculis, apice acuminatis, saepe subtrifidis, corolla longioribus. Fem.... - Herba mexicana, Micropi facie, erecta, ramosa, tota niveo tomentosa; foliis alternis, oblongis, obtusis, capitulis terminalibus, sessilibus, solitariis, floribus flavis.

G naphalopsis DC. Prodr. VIT. 258.

303\%/7. Tshlestrophe DC. Capita I m pluriflorum, heterogamum, floribus radii tribns, ligulatis, femineis, disci quinque, tubulosis, quinquedentatis, hermaphroditis, sterilibus? In volncri cylindrici, disco dimidio brevioris squamae lineares, truncatae, approximatae, dorso hirsutae. Receptac ulnm planum, angustum, nudum. Co ro 11 a e radii ligulatae, obovatae, ante squamas sitae. Styli radii bipartiti, elongati, acnti, disci ramis exsertis, apice capitellatis. A cheni a omnia gracilia, villosa, apice lamellis $2-5$ mollibus, elongatis, piliformibus pappi loco instructa, radi subtrigona, disci tenuissima. - Herba mexica$n a$, multicaulis, erecta, basi indurata, suffruticosa; ramis teretibus, lanatis, foliis alternis, linearibus, integerrimis, enervits, capitulis ad apices ramorum paucis, congestis, corollis aureis.

Psilostrophe DC. Prodr. DIT. 261.

3038/8. Trimetra MOC. Capitulum multiflorum, radiatum, ligulis uniserialibns, fe mineis, disci tubulnsis, quinquedentatis, hermaphroditis. Invo In crum campannlatum, biseriale, squamis exterioribus quinque v. sex foliaceis, maRecepta culis, interioribus totidem membranaceis. in radio bifidi, in disco trifidi, ramisoblongae. Styli cilibus, revolntis, hispidis, ramis exsertis, gracea, glabra. Pa, hispidis. A chenia cylindramis, quadri-quingus membranacens, coronifor. canus, ramosus, rlaberrias. - Suffrutex mexi. positis, subtriquetris, integus, carnosus; foliis oplis in foliorum ramorumegerrimis, crassis, bulbilsis, capitulis terminalibuse axillis ovalibus, carno. solitariis, flavis.

Trimetra Moçino Flor. atex. inedit. ex DC. Prodr.
262 . VIT. 262.

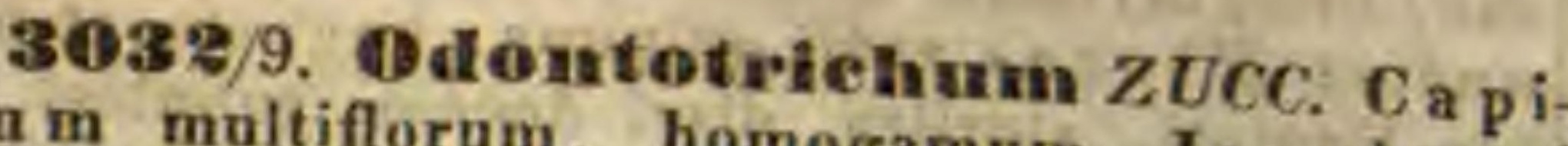
taln m multiflorum, homogamum. Involucri cylindrici squamae uniseriatae, octo v. decem, erecto-adpressae. Corolla e tubulosae, quadri-quinquefidae, regulares, Stamin $\mathbf{m}$ m filamenta gla- bra, a $n$ thera e eeaudatae. Stigm ata semiteretia, obtusa. Achenia elliptica, utrinque attenuata, multistriata. Pappus uniserialis, cadncus, brevis, setis inaequalibus, dentatis. - Herba mexicana, perennis, ramosa; foliis alternis, ra. dicalibus petiolatis, caulinis basi auriculato-amplexicaulibus, multifidis, lobis linearibus, subtus albidolanatis, capitulis corymbosis, floribus albis.

0 dontotric h u $\mathrm{m}$ Zuccarini Plant, nov. fasc, $r$. 31 . DC. Prodr. VII, 260.

303: $2 / 10$. Pplaryosponas $M E Y E N, C$ apitulum sex septemflornm, homogamum, discoideum. Inv o I n e r um campanulatum, heptaphyl. Ium, biseriatim imbricatum, foliolis hirsutis, oblongo-lanceolatis, obtusis, earinatis, quatuor exterioribus. Recepta c ulum nudum, punctatum. Corolla e tubulosae, supra basim globosam constrictae. Antherae lineares, obtusae, exelnsae, fil a m e n o rum parte superiore incrassata. Stigin a ta 2 , exserta, divaricata, apice crassa. $\boldsymbol{A} \boldsymbol{c} \mathbf{h}$ enia quinqueangularia, $\mathbf{P}$ a p us uniserialis, subplamosus. - Frutex chilensis; caule striato, glanduloso-hirsuto, dense folioso, foliis alternis, subfasciculatis, triangularibus, dentato-lobatis, obtusis, subtus venosis, capitulis corymbosis, in spicam longam, cylindraceam aggregatis.

0 phryosporus Meyen Reise I, 402. DC. Prodr. VII. 260.

3038 2/11, Tretazantlous MEYEN. Capitulum homogamum, discoidenm. In vo l nc r u m campanulatum, polyphyllum, foliolis biseriatis, lineari-lanceolatis, acuminatis, glabris, involucris latioribns marginatis. Reeeptaculum nudum, nigro-punctatum. Coroll a e tubnlosae, regulares, quinquepartitae, dentibus haud reflexis. Ant h e ra longe exsertae, basi connatae, ecaudatae, apicibus acuminatis distinctae, filamentis latis, laevibus, infra apicem incrassatis. Stigmat a 2 , inclusa, styli basi incrassata. A c h eni a rostrata, subquinquangularia, striato-sulcata, longa. Papp u s persistens, multiserialis, setosus, subserratus. - Herbae chilenses, ramosae; foliis allernis, semiamplexicuulibus, pinnatifidis v. bipinnatifidis, stipulatis.

VII. 289.

Metazanthus Meyen Reise T, 356. DC, Prodr.

$303 \% / 12.5 y m c e p l i a l a m t h a n B R T L$. C apitula sena, umbellato-capitata, in glomerulum aggregata, centrale discoideum, peripherica radiantia, uni-biligulata. Involuerum proprium triphyllum, uniseriale. Receptaculum hirsuto-fimbrillifernm. A che ninm erostre, tetragono-compressum. P a p a s nniserialis, paleis in setas scabras, inaequales fissis. - Herba $m$ exicana.

Syneephalantha Bartling Index. Sem, hort. Göt. ling. 1836. p. 6. DC. Prodr. VII. 262 .

303\%/13. Hefptorearplat R. BROWN. Capitul um multiflorum, discoidenm, homogamum. Invo I ucrum turbinatum, imbricatum, seariosum. Recept a c u l u m paleis distinctis, deciduis onustum. Corolla e tubulosae, uniformes, glabrae, limbo revolnto. Antherae exsertae, lasi bisetae. Stigm at a fliformia, acuta, hispidala. A ehenia.... Pappus uniserialis, pilosus. Frutex brasiliensis, ramosissimus, decumbens? folïs alternis, integerrimis, subtus incanis, capitulis axillaribus et terminalibus, fasciculatis, glabratis, squamis sessilibus, obtusiusculis, enervits, textura uniformibus, inter se et cum receptaculi paleis. 
Piptocarpha R. Brown in Linn, Transact, XII, 121. DC. Prodr. VII. 261.

\section{Ad p. 502. et 503. GENERA PENITUS DUBIA.}

13. GLYPhiA Cass, adde Synon. Gly eideras Cass. Dict. sc. nat, LIX. 63. et 73 .

14. GÜNTheria Spr. deleatur est enim u. 2596. Cerco. st y 1 os Less.

15. GIBBARIA Cassiai in Dict. sc. nat, $X V I I I$. 599, $\mathrm{XXX}$, 324. 333. C a pi $t$ u I a multiflorum, radiatan, floribus radii ligulatis, femineis, uniseriatis, disci masculis, regularibus. In rol u c x un disco aequale, hemisphaericum, squanis pauciseriatis, imbrieatis, apice spines. contibus. Receptacul a m planum, undum. A chaen i a radii brevia, erassa, dorso gibba, dis ci sterilia, compressa, striata, pappo coroniformi dimidiato, brevissimo, irregulariter lacero. - Stirps capensis, ramosa; folits alternis, longis, semiteretibus, acutis, uninervits, subsemiamplexicaulibus, glabriv, capilu lis terminalibus, solitaritis, disco croceo, ligulis su. perne albis, subtus croceis.

16. MUNNOzIA Ruiz et Pav. Prodr, 188, t. 33. C a pit u I $u$ u multiflorum, heterogamum, radiatum, floribus ra dii ligulatis, uniseriatis, femineis, tridentatis, disci infundibuliformibus, hermaphroditis, limbo campannlato, quinquedentato. I a v o l ucru u campanulatum, imbricatum, squamis intimis angustis, apice tridentatis. Receptaculun favosum, eiliatum. A chenia obovata, truncata, striata. P a p pas pilosus. - Plantae peruanae, suffruticosae, tomentosae $v$. hirsutae; caulibus erectis, ramosis, striatis, folits oppositis, petiolatis, capitulis subcorymbosis $v$. solitarits.

17. HYSTERONICA Willd. Berl. Mag. 1807, 140. In voluerum subaequale. Corollae tubalosae. Stylus florum femineorum caralla duplo longior. Stig ma simplex. P a p p n duplex, interior paleaceus, exterior setosus, hispidus. - Herba bon ariensis, setoso. hispida, ramosa; ramis elongatis, monocephalis, foliis lineari lanceolatis, sessilibus, obsolete decurren. tibus, integerrimis, avenits, in costa et ad margines patentim pilosis, capitulis terminalibus, solitarits.

18. ONOPIX Rafinesq. Ludov, 59. C a p it u $\mathrm{l}$ u m multiflorum. Involuerum ventricosum, imbricatum, parce calyeulatum, squamis earinatis, mucronatis, plerumque spinosis. Re e ptac u I um carnosum, piloso-fimbrillife rum. Coroliae tubulosae, inaequales. quinquefidae. Stig ma simplex. P a p pus pilosus. - Herbae $l u d o$ vicianae, ramosae; folits pinnatifidis, lobis spi. nosis, capitulis solitarits.

19. SERINIA Rafinesq. Ludov, 149. Involn crum enneaphyllum, patulum, post authesim connivens. A che a i a oblonga, apice ealva. - Herbal ludoviciana, caespitosa; folit radicalibus sinuatis, caulinis integris, angustis.

\section{GFNERA NONDUM DESCRIPTA.}

1. BRACHEILEMA R. Brown in Salt. Abyzin. LXIX.

2. GOMESIA Llav. in Heg. trim, Mexic. 1832, p. 40. non. R. Br.

3. OTEIZ A Llav, in Reg. trim, Mexic, 1832, p. $4 t$.

4. KOANOPHYLLUM Arruda ex Koster Brasil. IT. 496.

5. LASIOCRPhaluS Sehlechtend. in Berl, Magaz, 1818.

6. TRICHOSTEMMA R. Browa in Sall, Abyssin. LXIV.

\section{Drdo CXXI. Calycereae.}

\section{GENUS CALYCEREIS AFFINE.}

3036/1. Cevallia LAGASC. Capitu $\mathrm{lum}$ multiflorum, floribus omnibns fertilibns, in $\mathbf{r}$ cepta culo obsoleto, hirsutissimo subsessilibus. Involucri subfoliacei, multipartiti, demum reflexi laciniae lineari-setaceae, hispidae. C a l y x tubo ellipsoideo, tereti, cum ovario connato, limbi superi, breviter eyathiformis laciniis decem lineari-setaceis, tubum longe superantibus, inaequilongis.
Cor olla nulla. Sta mina 5 , disci epigyni calycis faucem vestientis margini inserta, limbi laciniis aestivatione exterioribus opposita et subaequilonga; filamenta libera, brevissima, anthe$r$ a e introrsae, basifixae, bilocnlares, erectae, longe lineares, inferne in tubum pentagonum approximatae, snperne discretae, connectivo lineari subpetaloideo, mutico, longe ultra loculos producto auctae, longitudinaliter dehiscentes. Ovarin inferum, oniloculare. O val a m unicam, ex apice Ioculi pendulum, anatropum. Sty las brevissimus, simplex, cylindricus; s $\mathrm{tigm}$ a terminale, clavato-cylindricum, crassum. A cheninm teres, calycis limbo superatum. S emen inversnm. Embryo in apice albuminis carnosi, eopiosi minutus, orthotropus, cotyledonibus subfoliaceis, divarieatis, margine involutis, radicula obtusissima, umbilico proxima, supera. - Herba mexicana, perennis, Echinopis facie; foliis alternis, sessilibus, recurvato-patentissinis, oblong is v. late linearibus, sinuato-pinnatifidis, sinubus laciniisque obtusis, supra pube simplici rigidissima retrorsum seabris, immixtis setis longioribus hispidissimis, subtus breviore, plumosa incano tomentosis, capitulis oppositifoliis, longe pedunculatis, globosis, canescentibus, hirsutissimis.

Cevalli a Lagasea Nov, gen, et sp. 1t. t. 1. Spreng. Gen, n, 935. Torrey et A. Gray Flor. of North.Amer. $t$. 536. Feazl Ic, inedit. Petalanthera Torrey msc.

\section{Ordo CXXIII. Goodeniaceae.}

\section{Seaevola LINN.}

DC. Prodr. VIT, 505.

b. XEROCARPA Don $l$. 6 .

c. G y m nostegia Benth. in Enumerat, plant. Hīgel 68. Stigmatis indusium nudum v. sub lente subtilissime ciliatum. (Labill, $t, 78,79$.

B. Euxerocarpaea. Stigeatis indosium manifeste elliatum.

Xerocarpaea DC. 7 . c. (Cav, Ic, $t, 509$. Labill. 2. 80.) Goodeniae sp. Andr. Bot. Repasit. t. 29. Sinss Bot. Mag. $t, 287$.

c. POGONANDRA DC. l. $c$. Pogonanthera Don $t$, $c$. B a ud in ia Leschenault mic.

e. SCAEVOLARIA DC, $l$. c. Ovarium uniorulatam? Indusinm ciliatum. Antherae imberbes. Corollac alis laciniarua parallele veasis. Sc. gra a diflora Beath.

3041. Cyphia BERG.

Ordo C y phiacea e DC. Prodr, VII, 497.

3043. Coodenia SMITH.

DC. Prodr. PIT. 518. Colle ma Anders, mse.

a. A MPHichiL A DC. $i, c$. G. pumilio $\mathrm{R}$. Br.

3050. Pentaphragma $W A L L$.

Alph. DC, Prodr. VIT. 495, Indusiam stigmatis uulfuw. Genus fortassis Campanulaceis accensendum.

\section{Ordo $\boldsymbol{C} \times \mathbf{X}$. Lobeliaceat.}

305 \%. Monopsis $S$ ALISB.

b. Holostigma Don $l$. $c$, DC. Prodr, VII, 359, C n rolla e limbus dimidiatus. Stigna integrum. Flores dioici. - Herbae Novae-Hollandiae iropiear, Aloribus racemoso spicatis abortu marculis, fomineis aril. laribus solitaritr. L. di of ea R. Br.

e. ISOLOBUS DC. Prodr. VII. 359, Coralla e limbus dimidiatus. Stig m a bilobum. Flores hermaphraditi, Herbae indicae, inflorescentia paria, (Bot. Mag. 1, 2639. Bot. Reg. t. 733.)

3058/1. 'Troimeria PRESL.

lofr. u. 3070. Capsula longe avoidea, apice bivalvis DC. Prodr. VIr, 357. cui Lobellae sect. - 
3080. Hawrentia MICHELI.

Nov. Gen, 18. Hippobroma Don t. c. Solenanth is Isotsmae sect, DC. Prodr. VII, 412.

se61/1. Selerotheea $D C$. Calyx tubo ovoideo, eum ovario connato, limbi superi lobis 5, patentibus v. reflexis, tubo subiongioribus. C orolla summo calyeis tubo inserta, dorso longitudinaliter fissa, bilabiata, petalis duobns superioribus inter se distinctis, cum tribus inferioribus in labium trifidum coalitis, basi cohaerentibus. Stamina $5 \ldots$. Ovarium .... Stigma bilobum. Ca ps ul a infera, indurata, bilocnlaris, globosa, apice acuta, poris rotundis duobas, dissepimento alternis vertice dehiscens. Semin a parva, globosa. - Arbor taitensis, biorgyalis ; ramis teretibus, lignosis, foliis ovato-acuminatis, basi acutis, laevibus, dentatis, coriaceis, calloso-dentatis, pedicellis axillaribus, uniforis, folio dimidio brevioribus, paullo infra medium bibracteatis, lobis calycinis demum caducis.

Selerotheca DC. prodr. VII. 356. Lobelia arborea Forst.

3062. II Ieterotoma ZUCC.

Endlicher Iconogr. $t, 53$.

3083. Pratia GAUDICH.

a. Bernonia Endl. Piddingtonia DC. Prodr. VII. $34 t$.

\section{Fittelia REICHENB.}

Kittelia Reichenb. Pflanzensyst. 186. C y a n e a Gaudich. supr. n. 3065 non Zoolog.

3070. TRIMERIS Presi. h. 1. del. supra sub n. 3058/ collocanda, ejus loco inseratur:

3080. Rinymelnopetalmm FRESEN. Cal y x tubo obconico - eampanulate, cum ovario connato, limbi superi, quinquepartiti laciniis foliaceis, lineari-lanceolatis, subulatis. Corolla summo calycis tubo inserta, tubo hinc longitudinaliter fisso, laciniis cohaerentibus, petalnm nnicum canalieulatum, rostriforme mentientibus. St a mi$\mathrm{n}$ a 5 , cum corolla inserta, fil amenta inferne distincta, superne et a $\mathbf{n}$ h er a e, quarum duae in feriores apice longe barbatae, in tulum connatae. O varinm infernm, biloculare, placentis dissepimento utrinque adnatis, multiovulatis. Stylos inelusus; stigma bilobum. Frnetus ... Planta abyssinica; trunco orgyali, cavo, apice folioso, foliis confertis, lanceolatis, acuminatis, basi angustatis, integerrimis, racemis longis, bracteatis, Rhy nehopetalom Fresenius in Flara 1838, p. 603. Mus. Senkenberg. III, 66, $t, 4$. DC. Prodr. VII. 396,

\section{Ordo $\boldsymbol{C X X V}$. Campanulaceas.}

307 4. Campanumaea $B L U M$.

a. CAMPANUMAEA BI. Alph, DC. Prodr, VII, 423, Ovarium triloenlare.

๖. CODONOPSIS Wall. Cat, n, 1300, 130t, Alph, DC. Prodr

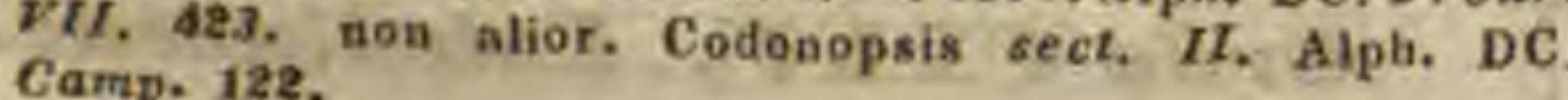

c. SYNCHLAENA Alph, DC, 2, c. Involucrum cum calyeis basi connatom.

B. ApochlaeNa Alph, DC, 2 , o. Involuerum 1 . bernm.

30\% ร. Codlomopsis W $A L L$.

Wahlenbergia seet. Megasauthes Alpb. DC. Prodr, DII. 434.

3058. Nieroedon $A L P H, D C$.

Prodr. VIT. $32 t$

a, EUMICROCODON Alph. DC. l. e. O varium vertice exserto conico. C a p u la vatvis terminalibas quinque, parti adaatae aequilongis dehiscens. S e ni na uitida. b. COElothecA. Alph. DC, $l$. o. Ovarium totum infe. rum, vertice planum, tubo calycis brevius. Ca p $s u$ la superue valvis dehiscens, tuboque ealycis ab apice ad basin inter lobos fisso demum aperta. S emina ovoidea, obscure trigona, sub lente punctata. - Herba ca. $p e n s i s$, facie Anastaticae hierochunticae.

Bor9. Wahlenbergia SCHRAD.

a. EDRAIANTHA. Genus proprium $\mathbf{E}$ draianth $\mathrm{r}$ s Alph. DC. Prodr. VII. 448. propter fructum apice valvis irre. gularibus, delabentibus apertum, persistentem, erateriformen, vacuum.

b. AIKINIAM et $f$. NESOPHILAM conjungit cl. Alph. DC. Prodr. VIT, 426, novam addit:

PHYTEUMOIDES Alph. DC. Prodr. VIT, 461. Floras pentameri, corolla fere quinguepartita. Fructu $s$ dimerus, elongatus, obconicus. Sem i na elliptica, utrinque subacuta, nitida, compressa. - Herba capentis; floribus sessillibus, spicatis.

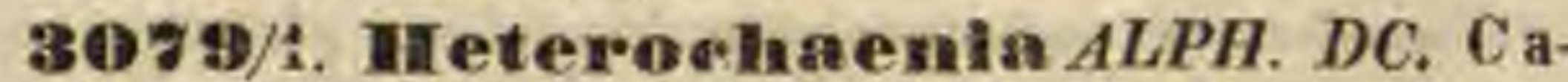
ly x tubo obconico, glabro, eum ovario connato, limbi superi, profunde quinquefidi lobis ovato-acaminatis, ciliatis, aestivatione subimbricatis. Corolla summo calycis tubo inserta, campanulata, subquinquefida. Sta min a 5 , eum corolla inserta, libera, filamentis basi latioribus, 0 varin m inferum, triloculare.... Sty 1 n s cylindricus, a basi pilosus, corolla sublongior; st ig m a $\mathrm{ta}$, ovata, crassinscula. Ca psula cylindracea, lobis calycinis longior, incurva, trilocularis, apice primum Ioculieide trivalvis, dein ima basi inter calycis nervos decem dehiscens, demum limbo delapso, tubi nervis ab apice deorsum solntis. Semina plurima, ovoideo-trigona, sub lente punctata. - Herba borbonica, basi sublignosa; caule uni-bipedali, glabro, medio dense folioso, basi simplici, superne rumis simplicibus, foliis alternis, sessilibus, longe lanceolatis, acuminatis, subciliatis et argute serratis, penninerviis, nervis lateralibus parallelis, dentibus regularibus, uni-biset is, floribus axillaribus et terminalibus, pedicellis bratea multo longioribus, corolla sordide lutea, pollicem longa, maculis purpureis quinque, capsula erecta, subpollicari, glabra.

Heterochaenia Alph. DC. Prodr. VII. 442. C ampanula ensifolia Law. Wa hlenbergiaensifolia Alph. DC. Camp. 162.

308\%. Playterma LINN.

a. PHYSOPLEXIS Endl. S y noto ma Don Syst. III. 766. Alph. DC. Prodr. DII. 450.

b. RAPUNCULUS Endl. $a$. Hedranth um Don l.e. Alph. DC. $l, c$. Flores sessiles, eapitati $v$. dense spicati. C a s s 1 a bi-triloeularis, poris lateraliter versus atedium aperta. (Jaeq. Ic. rar. 333.) $\beta$. Podant th a m Don l. c. Alph. DC. l. c. Flores breviter pedicellatl, laxe spicato-racemosi, $2-3$ in axilla cujusvis bractege. Caps u 1 a trilocularis, poris lateraliter versus apicen aperta.

3085. Campanula LINN.

b. EUCODON Aiph. DC, Rou cela Dumort, E rinia Nonlet Nouv, Annal. sc. nat. $2 X, 120$.

3089. Symalny andires $A L P H . D C$.

Prodr. VII. 494.

a. ANOTOCALYX Alph. DC. 2. c. MeIa a c a I $\mathrm{g} x$ Eadi, l, c.

b. OTOCALYX Aiph. DC. 2. c. Sercio to B Endl. l. c.

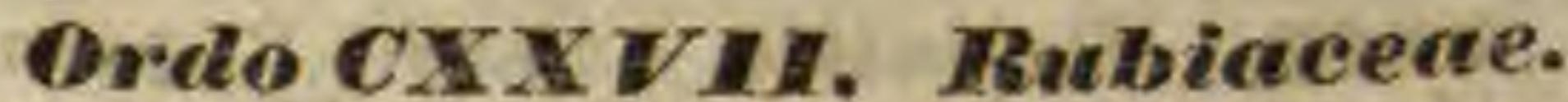

3098. Vaillsatia $D C$.

Webb ot Berthel, Flor. Canar, t, 79.

3 f Q Cr. Creiamella $L$.

Bot. Rę. 1839. $t$. 55 .

3135. Crusea CHAM, et SCHL.

Hooker ad Brechey. $t$. 99. $B$. 
312\%. Mitracarpum ZUCC.

Hooker ad Beechey t. $99 . A$.

3154 . Faramea A. RICH.

b. TETrambriUm. A ntoniana Tussac Flor. Antill. II. $t, 16$.

31 1 60. IPavetta LINN.

Wight $I \mathrm{c}, t, 148$.

3161. Ixorea LINN

Wight Ic. $t, 149-151,153.184 \_186$.

3180. IPa edaria $L$.

Korthals in Friese et Hoeven Tijdschr, VI. 55. R e usi a Dennst. Hort. Malab. VII, 18 .

3 152. Guettarda VENT.

a. CADAMBA Soun. (Wight Ic. $t, 40$.

b. GUetTARDARIA DC. Sa r d i ia Fl. Flum. $1 I I, t, 163$.

3224. Gabicea $A U B L$.

Hooker Io, $t, 247 . \mathrm{P}$ a i v a Flor. Flum, III, $t, 16$.

32* S/1. Selhizostigma $A R N . C$ a l y $\mathrm{x}$ tubo globoso, eum ovario connato, limbi superi, quinquepartiti laciniis lanceolatis. Corolla supera, infundibuliformis, extus hirta, intus pubescens, ad medinm usque quinquefida, laciniis lineari-lanceolatis, patulis. Antherae 5, in fance corollae sessiles, lineares, obtasae. Ovari um inferum, multiloeulare. Ovnla plurima.... Stylus filiformis, antheras longe superans. Stig ma quadri- septemfidam, laciniis linearibns, patulis. $B$ a cca globosa, costata, hirsuta, calycis laciniis foliaceis, patentibus coronata, quadri- septemlocnlaris. Semina plorima. - Herba zeylanica, decumbens $v$. subrepens, hirsuta; caulibus simplicibus, foliis oppositis, longiuscule petiolatis, oblongo-lanceolatis, integerrimis, supra viridibus, parce pilosis, subtus pallidis, stipulis interpetiolaribus late ovatis, acutis, membranaceis, floribus axillaribus, solitariis, alternis, subsessilibus, basi bracteis duabus stipularibus suffultis.

S ehizostig ma Arnott in Annal, of nat. hist, IIr. 20.

3236. Antlhoeeplaalns $A, R I C H$.

Cephalidium A, Rich, in Mem, soc. h, n. Paris. IV. 280.

\section{Dentella FORST}

Bertuchia Dennst, Hort. Malab. IX, 39,

3. $40 / 1$. I a a ma ysela ewia FISCH. et MEY. Cal y $\times$ tubo hemisphaerico, cum ovario ennnato, limbi snperi, quadri- quinquefidi laciniis cum totidem denticulis alternantibus, Coroll a supera, tubulosa, calyce brevior, fauce barbata, limbo quadridentato. Sta mi na 4, corollae fauci inserta, inclusa, Ov a ri $\mathbf{m}$ inferum, biloculare, multiovulatnm. Stig ma bifidum. Cap su I a bilocularis, indehiscens. Se mina plurima, angulata. Herba in oryzetis Lencoranensibus observata, annua, Oldenlandiae facie, ramosissima, diffusa, scabriuscula, subglabra; folits oppositis, sublinearibus, basi attenuatis, stipularum loco setis utrinque duabus $v$. tribus, floribus axillaribus, geminis, ternis $v$. quaternis, subsessilibus, parvis, corollis minutis, albis.

Karamys hew ia Fiseher et Meyer in Bullet. soc. nat. Mosq. 1838. p. 266.

3244. ARgostemMa Wall. Genus b. l. delendam, et infra sub n. 3287/1 collocandum. Ejus loco inseratar :

32 44. Teptopetalum HOOK, Caly x tubo ovato-subgliboso, cum ovario connato, limbo snpero, quadridentato. Coro IIa supera, quadripartita, laciniis elongatis, lineari-spnthnlatis, angustissimis, patulis, utrinque glabris. St a mi na 4, imae corollae inserta; filamenta filiformia, co. rollae lacinias aequantia, antherae oblongae, versatiles. Ova ri $\mathbf{m}$ inferum, biloculare. $O$ vula plurima....St y 1 us filiformis, apice crassior; stigma emarginatum. Ca p s l a hemisphaerica, compressiuscula, dentibus calycinis coronata, bilocularis, vertice rima loculicide dehiscens. Srem in a plurima, minnta, angulata. - Frutex mexicanus, glaber; ramis angulatis, folits oppositis, sessilibus, ovalibus, acutiusculis, basi subcordatis, stipulis late triangularibus, brevibus, acutis, interpetiolaribus, corymbis terminalibus, trichotomis.

Leptopetalu m Hooker ad Beechey 295, $t, 61$.

$3 \% 51 / 1$. Hereluea $L I N N$, Calyx tuboovato, cum ovario connato, limbi superi, quinquedentati, persistentis dentibus membranaceis, erectis. Coro 11 a supera, infundibaliformis, fance barbata, limbi quinquefidi lobis aestivatione valvatis. Stamina 5, corollae fauci inserta; filamenta brevia, antherae exsertae. Ovari nm infernm, biloculare, disco epigyno carnoso, demum aucto. Ovula in placentis hemisphaericis, medio dissepimento utrinque insertis plurima. Sty Ins fli. formis; s t ig m a bipartitum, lobis lincaribus, conniventibus. Capsula disco coronata, bilocalaris, bipartibilis, coccis indehiscentibus? S e mi $\mathbf{n}$ a plurima, aptera.... - Frutex javanicus, humilis; folitis oppositis, pedalibus, obovato-oblongis, acuminatis, glabris, stipulis interpetiolaribus integris, persistentibus, spicis longissimis, filiformibus, floribus parvis, in glomerulis subdistantibus per rhachin sparsis.

L e r c lie a Linn. Mant, 155. Bennett in Horsfield Plant. Jav. rar, 98, t, 23. Co dari a Linu, msc, - ? X a $\mathrm{n}$ th op hy. t $u$ m Blum.

3254/1. Choristes BENTH. Caly $\mathrm{x}$ tubo turbinato, cum ovario connato, limbo supero persistente, laciniis quatuor brevibus, dentiformibus. Corolla supera, tubo brevi vel brevissimo, late infundibuliformi v. subeampanulato, limbo quadrifido. Stamina 4, corollae fanci inserta; filamentis brevibus, antheris linearibus, exsertis. Ovari am inferum, biloculare. Ovala in placentis dissepimento utrinque insertis plarima.... Stylus brevis; stigmata 2 , elongata, concreta. C a p s u la caly cis limbo coronata, biloenlaris, in coceos duos apice breviter leculicide dehiscentes secedens, placentis margini interiori affi. xis. Semina plurima, aptera. - Frutices mexicani, ramosissimi; folits oppositis, petiolatis, stipulis interpetiolaribus, minutis, inflorescentia terminali, laxa, dichotome cymosa, pauciflora.

Choristes Bestham Plant, Hartweg. 03.

3265. Fovvardia $S A L I S B$.

Bot. Mag, $t$, 3781, Bot. Reg, 1840, $t, 37$.

3\%66. TIamettia $M U T$.

Guagn ebina Flor. Flum. I. $t, 115$.

39 ร 7 . Ferdimandusa $P O H L, C$ a ly $x$ tubo oblongo, enm ovario connato, limbo supero, eyathiformi, quadridentato, deciduo. Corolla smpera, infundibuliformis, trbo cylindrico, fauce dilatata, nuda, limbi quadripartiti Iobis ovatis, oblique emarginatis, revolutis. Stam in a 4 , medio corollae tubo inserta, breviter exserta, subdidynama; filamenta filiformia, antherae bilocolares, incumbentes, vtraque extremitate involutae. Ova rium inferum, bilnculare, Ov n$1 \mathrm{a}$ in placentis magnis, dissepimento utrinque insertis plurima, peltatim adscendentia. StyI us 
simplex; stigma bilamellatum. C ap 8 I a co- dehisceus. Se mina plura, horizontalia, aptera. Vid, n. 3227. riaceo-sublignosa, ellipsoidea, bilocularis, septicide bivalvis, valvis demum bifidis, a calyce longitudinaliter fisso secedentibus. Se in in a plurima, peltata, ala membranacea, ad micropylen inferam emarginata cincta.... - Arbores brasilienses; foliis oppositis, brevissime petiolatis, coriaceis, integerrimis, stipulis interpetiolaribus ovatis, cuspidatis, fugacissimis, floribus cymoso-corymbosis, paniculam terminalem formantibus.

Ferdinandus a Pohl Plant, Brasil, II. 8. t. 106108. - Fenzl Dissert. inedit.

32ร9/1. Crossopteryx FENZL. .... C a p 8 u l a cartilagíneo-crustacea, ecostata, bisulea, calyeis limbo deciduo late areolata, bilocularis, loculicide bivalvis, valvis,medio septiferis, apice vix fissis. S e m in a in quovis loculo $7-15$, placentae hemiellipsoideae, peltatae, carnosae foveolis dorsalibus inarginatis, duo faciei commisurali semiimmersis, peltatis, compressis, oblongis, adscendentim imbricatis, testa in marginem membrana ceum multipartito lacerum venulosum ambientem expansa. Embryo in axi albuminis parci, earno si rectus, cotyledonibus planis, ovalibus, ra dicula infera. - Frutex Africa boreali orientalis tropicae; ramulis foliisque utrinque hirtis, demum glabris, oppositis, lato ovalibus, char taceis, penninerviis, subtus venulosis, stipulis liberis, adpressis, e basi late ovata cuspidatis, pubescentibus, deciduis.

Crossoptery $x$ Fenzl in Nov. stirp. Mus, Vindob. Dec, $n, 51$.

\section{Namelea $L I N N$.}

a. PLATANOCARPUM Endl. Korthals Nauol. $t, 18$.

b. MITRAGYNE Korth. Nancl, 19. Flores supra receptaculan eommune sessiles, calyeis limbo truncato v. ob. solete dentato. Capsulae distiuetae, polyspermae. Na ucle a parvifolia Roxburgh Plant. Corom. $t .89$. Gärta. t. 30. N. a f riean a Willd. - ? Mamboya Blanco Flor. Filip, 140.

c. NAUClearia DC. Calyeis laciaiae lanceolatae. Na $\mathrm{u}$. cl e a Korth. Naucl. 17. exel. sp.

d. PENTACORYNE DC.

e. UNCARIA Schreb, Deless. Ic, select. IV. $t$. 81 .

3284. Canephora JUN.

Dele C e phalidi a m Rich. Vid. supra n, 3236.

Post n. 3279. Adde:

OBSERVATIO Cinchonaceis e cl. Lindley sententia adnumerandum genus.

SULIPA Blanco Flor. Filip. 479. C a I y $x$ tubo enm ovario connato, limbi superi, decempartiti lacinils alternis minoribus. Corolla calyce quadruplo major, bilabiata, labio altero bi-altero tripartito. Stamina 4 ; fil a menta sobnulla, a ntherae late lineares, exsertae. Stylus tubl corolliai longitudine; $\$ \mathrm{t} \mathrm{ig} \mathrm{m}$ a bilamellatum. Drup a calyee coronata, auce quinqueloculari. Se mina plurima, intra pulpam superposita. - Arbor luzanensis; folits op. positis, lanceolatis, integerrimis, breve petiolatis, floribus axillaribus, solitarils, bractea caduca.

328\%/1. Argostemma $W A L L$.

Genus hue ex n. 3244 translocandum. Species, praeter plurimas indicas, una e Sierra Leona. - Bennett in Horsfield Plant, Jav, rar, 92, 2,22 ,

325\%/2. Nennoenlyx HOOK.

Ovarium biloculare! Fruetus indehiscens. Arnott in Annal. of nat. hist. IIT. 20. Genus a praecedente fortassis haud diversum, hue ex n. 3225 tranferendum.

3305. Garedenia ELL.

b. KUMBaYA E. Bertu eh ia Dennst, Hort, Malab, IV, 58. $3313 / 1$. Alberta $E$. MEY.

Ovula in loculis plura, horizontalia. Fruetus in

33 13/1. A eramthera $A R N$. Calyx tubo oblengo-turbinato, cum ovario connato, limbi superi, quinquefidi laciniis linearibus. Corolla supera, tubulosa, extus hirsutissima, intus glabra, ultra medium quinquefida, laciniis erectis, spathulatis, retusis, aestivatione valvato plicata. St a min a 5 , imae corollae inserta et dimidio breviora, erecta; fil amenta filiformia, subpapil. losa, antherae innatae, oblongo-lineares, connectivo apice in mucronem longinscule ultra loculos producto. Ovarin $\mathrm{m}$ inferum, pseudo-biloculare, dissepimentis dnobus oppositis, axim haud attingentibus, placentam bilamellatam, divaricatam gerentibus. $O$ v 1 a plurima.... S ty 1 u filiformis, diseum bulbiformem perforans; stigma clavatum, muriculatum. B a eca sicca, membranacea, hirta, lineari-oblonga, compressiuscula, calyeis limbo erecto coronata, intus pulposa, pseudobilocularis. Se min a plurima, minuta, globosa, papillosa, in placentae lamellis nidalantia. A I b umen corneum. - Herba zeylanica, humilis, simplex, hirsuta, habitu cyrtandraceo; foliis oppositis, petiolatis, oblongo-obovatis, obtusis, basi angustatis, membranaceis, integerrimis, supra viridibus glabris, subtus pallidis, pari supremo multo reliquis minore, pilis rigidis, acutissimis, fortassis urentibus, stipulis interpetiolaribus indivisis, triangularibus, ovatis, acutis, pedunculis ex axillis supremis brevibus, flores fastigiatos, breviter pedicellatos gerentibus, corollis caeruleis.

A c r a n thera Arnott in Annal, of nat. hitt. III. 21, 3325. NEUROCALYX Hook. Genus supra sub n. 3237/, colloeandum.

3327t ALBERTA E. M. Genus supra sub n. $3313 / 1$ collocandum.

\section{Dralo XXVIII. Lomicereae.}

3333. Abelia $R$. $B R$.

Zuccariai in Siebold Flor. japon. 1. 67. t. 34. Alph. DC, in Biblioth. univ, Genev. Jan, 1839.

3335. Leyeestria $W A L L$.

Hook. in Bot. Mag. t. 3699. Lindley in Bot. Heg. 1839. $t .2$,

\section{Diervilla TOURNEF.}

Fractus: Capsula erastaceo-indurata v. membrana. eea, summa tubi ealycini parte styli basim ineludente coronata, loculicide bi- v. rarissime trivalvis, valvis medio sep. tum margine iscrassato seminiferum gerentibus. Semina plerumque hine erista v. ala tenui, cellulosa, a vertice ad basim produeta cincta, testa membranacea, saepe reticulata v. foveolata. Zuecarini in Siebold Flor, japon. T.68, t.29-33. Alph. DC. in Biblioth, univ, Genev. Jan, 1839. C al ys phyr $\mathrm{m}$ Bunge Enum. plant. Chin. bor. 34.

3339. Calysphyrum Bung. Genus delendum, a Diervilla Tournef, (3336.) non diversum.

3340. Wibtriemusm LINN.

e, OPULUS Tourn. (Siebold Flor, jap. $t, 37,38$. )

\section{GENUS LONICEREIS AFFINE.}

3341/1. Alsemosmin A, CUNNINGH. Calys tubo cum ovario connato, limbi superi, quadri-quinquefidi, decidai laciniis ovatis, aestivatione valvatis. Co rolla supera, infundibuliformis, tubo elongato, fauce imberbi, limbo quadripartito, regulari, laciniis aestivatione valvatis, ovatis, acutinsculis, margine sinuato repandis. $\mathrm{S} t$ amina 5, corollae fanci inserta, ejusdem laciniis alterna, aequalia; fil amenta brevia, a ntherae breviter exsertae, biloculares, longitudinali- 
ter dehiscentes. Ovari um inferum, biloculare, loculis bi- quinque $\mathbf{v}$, indefinite multiovalatis. StyI us filiformis, elongatus, staminum longitudine; 8 ti $\mathrm{g}$ a depresso-capitatum, indivisum. B a cca turbinata, obovata, glabra, unilocularis, polysperma v. abortu oligosperma. S e min a obovata, curvata, obtusa, latere exteriore convexa, interiore angulata, medio interiore umbilieata, testa brunea, laevi, crassa, rugulosa, reticnlata. $\mathrm{E}$ m b r y o in basi albuminis carnosi copiosi minutus; cotyledonibus subfoliaceis, sibi incumbentibus, radi cu l a brevi, crassa, obtusa, ab nmbilico remota, pl umula inconspicua. - Frutices NovaeZeelandiae, erecti, sempervirentes, bi- tripedales; foliis alternis, exstipulatis, petiolatis, oblongis, subintegris $v$. lobatis, petiolis basi dilatatis, floribus axillaribus, lateralibus v. terminalibus, solitariis aut fasciculatis, subracemosis, bracteatis, odoratissimis. II. 209.

A 1 s u os orfa A. Cunningh, in Annal, of nat. hist.

\section{Ordo CXXX. Jasmineae.}

3344. NGemoniora HUMB, et BONPL.

a. BOLIVARIA Ch. et Sohl. Caly $x$ quinquepartitus. C o. rolla fatus glabra. Filame a ta brevia. Ovarlum ovoldeum, basi nudum. Stigm a capitulato-subbilobum. - Herbae glabrae, erectae, pedales. Griesebach Gent. 20.

b. MENODORA Humb, et Bonpl. Caly $x$ decem-quatuor. decimfidus, lacinfis linearibus, erectis. C o roll a e faux hirsuta. Filamenta longa, terminalia. Ovarium didyaum, baxi disco carnoso immersum. Stig ma late eapitato planum. - Herba caespitosa, hirsuta, caulibus plurimis, procumbentibus, apice adscendentibus, spithameis, Griesebach Gont. 20.

\section{Dralo CXXX. Oleaceae.}

334\%. Hinociera SWARTZ.

M in uti a Flor. Flum. $1, t, 47$.

3349. Dlea LINN.

a. GYMNELAEA Eadl. Iconogr. t. 54 .

3350. Notelaea VENT.

Endlicher Iconogr, $t, 85$.

3353. Fraxinus TOURN.

c. ORNUS Desv. (Hooker ad Beecbej t. 87.)

3354. Fentanesia LABILL.

Desfontainesi a Hoffmans. Verzeiehr, 170.

\section{Drdo CXXX1. Loganiacede.}

3360. Ignatia $L, F$.

Gürtner IT. 477, t. 179.

3362. Antonia POHL.

Eudlicher Iconogr. $t, 56$.

TRIBUS 1\%. bis. COELOSTYLEAE. C ap sula bilocularis, polysperma.

Ad hunc tribam verisialiter etiam Spiegelia (infr, n. 3586.) revocanda.

3363/1. Coelostylis TORR, et $A, G R$. Caly x quinquepartitus. Corolla hypogyna, infundibuliformis, campanulata, fance nnda, limbi quinquepartiti laciniis aestivatione valvatis. St amina $\overline{5}$, medio corollae tubo inserta, inclusa. 0 varium bilocnlare. 0 vala in placentis dissepimento utrinque insertis plurima, amphitropa. Stylus simplex, infra medium articnlatus, articulo superiore cavo; stigma subfusiformi subelavatum, pilosum, apice glanduloso nudo, sub- emarginato, Capsula....-Herba floridana; caule tetragono, foliis oppositis, integerrimis, stipulis interpetiolaribus, liberis, persistentibus, floribus axillaribus, subsolitariis.

Coelostylis Torrey et A. Gray mac. es Endlicher Nov. stirp. Mus. Vindob. Dec. n. 41 . lconogr. t. 101.

3364. Logramia $B, B R$.

a. EUOSMA Andr. Endl. Ieonogr, $t, 57$.

b. STOMANDRA R. BR. Eadi. Iconogr. 1.58.

3365. Creniostoma FORST.

A. Cunaingh. in Annal. of nat. hist. IT. 45. A s pilo. bi um Banks et Soland. mzo.

338\%. Fagraea $H U M B$.

K a hlli a Reinw, in Syllog. Plant, II. 7. U tanfa Dou Syst. IV. 663 .

33\%0. Gïrtmera $L A M$.

a. GARTNERA LAM. C a 1 y $\mathrm{x}$ breve campanulatus, quiaque. dentatus, basi bibracteatus. St a m in a fauei corollae Inserta, inclusa. Ovariu m blloculare, loculis uniovalatis, placentis minimis, septo basi adnatis. Stylus exsertus; st $\mathrm{ig}$ a a lobis setaceis, patentibus. B a c ca dipyrena, pyrenis chartaceis, dorso-eonvexis, ventre planis. - Vaginae stipulares integrae v, margine fimbria. tae. Meisaer Gen, 259. A n d e rso n i a Willd. ef Böm. et Schult. Syst. $V .21$.

b. SYKESIA ARNOTT, C a I y $\mathrm{x}$ turbluatus, dewum late cupulatus, repando.guinquedentatus, deutibus acutis. $\mathrm{Co}_{0}$. rolla tubo ad antherarum insertionem barbato. $0 \mathrm{va}$ ri u m calyef subadnatum, truacatum. B a c ca erustacea, libera, utrinque suleo betata, bilocularis. Semina orbieularia, plasocenvexa. - Vaginae longetubulosae, pedicelli apice bibraoteolati. Meisner $l$, o.

c. FRUCTESCA DC. Calyx turbiaatus, taba libero $v$. ovario subadnato, ultra mediam quinquefidus, lacinils lineari subulatis. Co roll a ..... B a c ca oblouga, aeuta, subangulato-suleata, bilecularis, S e os la a nblonga, asuta. - Vaginae juniores integrae, demum fissae et apice leviter et aeule bidentatae. Paniculae contractae flores conferti. Fruetesca DC, msc, ex Meis. ner $l$. 0 .

d. ? AETHEONEMA DO. Cal $\mathrm{y} \times$ amplissimus. C orolla tubus latus. A ntherae 5, lineares, intra tubam sessiles, tres corollae lobls alteruse, daae lisdem oppositae. - Bracteolae 2 , a calyce paullo remotae. A et b eane ma Gärtnerae sect, DC. mse, ex Meisner Comment. 167. G. va ginata Sieber Herb. Maurit. 2. n, 32 . non Poir.

Post $\mathrm{n} \cdot 3371$ Inseratur:

\section{GENUS DUBIOM.}

CODONANTHUS G. Don Syt, $I V, 168$. Cal y $\mathrm{x}$ quin. quefidns, laeinits ovalis, acuths, eillatis. Corolla eampanu. lato-urceolata, obloggo-veatricosa, limbo guinquefido, erecto. $\mathrm{S}$ a mina 5 , corollae tubo inserta. Ovarium ovatum. Sty I a sifidus; stigmata 2 , rotuedata. Fruetus... Arbor Africae troplcae oocidentalia, me. diocris ; folits oppositit, oblongo-lanceolatio, integriz, undulatis, breve petiolatis, floribus arillaribur geminio v. ternits, pedicellatis, pendulio, albis, bracteis subsa. gittatis.

\section{Ordo CXXXI. Apocymacect.}

\section{3ร5. Pacouria $A U B L$.}

A I st o uia Seopoli Introduct, $n, 871$.

\section{Direlodinms FORST,}

Endlicher Iconogr. $t, 59$.

3378/1. Carpodinas $R$. BR. Calyx quinquedentatus. Co roll a infandibuliformis, pilosa, quinquefida, Iaciniia lanceolatis, obliquis, reflexis. Antherae 5, sagittatae, conniventes. Ovarinm.... Stylus unus; stigma rotundum. Fruetus aurantiformí, bilocularis? S emina plurima, compressa, in pulpa nidulantia. - Frutices $A f r i c a e t r o p i c a e ;$ folits oppositis, 
ovato-lanceolatis, cirrh is axillaribus, floribus geminis, axillaribus, subsessilibus.

Carpodinus R. Browa msc, ex Don Syst. IV. 100. Sweet Pishamin Colonorum in Sierra Leoua.

3388. Cerbera LINN.

Calpiearpum G. Don Syst. IV. 100.

3838.9. Dellarosia JUSS.

Henslow in Annal. of nat. hist. 1 . 345 .

3396. Talbernaemontama LINN.

Rei cha rdi a Deanst, z. Hort. Malab. VI. 47.

3398/1. Comopluaryngla $G, D O N, C$ aIyx quinquefidus. Corolla hypogyna, infundibuliformis, limbi quinquefidi laciniis in spiram tortis, extus villosis, fauce constricta, nuda, S tamin a 5 , corollae fauci inserta, a $n t h e r a$ e triangulares, in conum exsertum eohaerentes. O varia 2 , ovulis ad suturam ventralem plarimis. S ty In s unus, filiformis, sursum incrassatus; stig ma apice bifido. Follieuli ventricosi, dorso convexi, facie plani, carnosi, polyspermi. Sem in a plurima, altero latere convolnto-biloba.... Frutices $v$, arbores madagascarienses, lacte caustico scatentes; foliis oppositis, corymbis terminalibus.

Conopharyugia G. Don Syst, IV. 94. Plumerla retusa Law. Planeria longifolia Lam.

3399. Aspidos Toerma $M A R T$, et $Z U C C$ Macaglia Vahl Dansk. Selskab. Skrift. VI. 107, Ostreocarpus L. C. Rich. msc.

3406. Loelh nera REICHENB.

Catharant us G. Dou Syst. IV.95. Vinca rosea Linn. Gärtaer $I I, 172, t, 117, f . s$.

\section{D. Eelnites P. BROWN.}

Genus fortassis divideadum, a G. Don in sequentia divulsum.

a. BCHITES G. Don Syst. IV, 72. C o roll a hypoerateriformis, fauce nuda. Ant he rae inclusae. S qu a muIae hypogynae 5, distinctae v. rarius coalitae. Foll1. cull graciles. - Species americanae pleraoque.

b. CHONEMORPHA G. Don. Syst. $I V$. 76. C o roll a infan. dibuliformis, fauce auda. Antherae inclusae. S quam ula e hypogynae 5, distinetae v, coalitae. Folli e u li graciles. - Species indicae.

c. AGANOSMA G. Don Syst, IV, 77. Co rolla infandibuliformis, fauce nuda. A a thera e iaclusae. $S$ qua m aI a e hypogynae 5, longae, coalitae. Stylus crassus; $8 \mathrm{tig}$ mate conico, basi angulato, apice mueronato. Species indicae. Bot. Mag. t. 1919.

d. EXothostbmon G. Don syst. IV. 82, Corolla infundibuliformis, fauce pilosa. Anthera subexsertae. Squamulae hypogyaae 5, liberae. Eehitis sp. Vahl Eclog. c. 5. Kuath.

3410/1. Mamullevilla LINDL. C alyx pentaphyllus, foliolis erectis, intus annulo pectinato auetns. Coroll a hypogyna, campannlato-infundibularis, fauce tuboque esquamatis, limbi quinquefidi laciniis subaequilateris. Stamin a 5 , imo corollae tabo inserta, anth erae inclusae, lanceolatae, apice membranaceae, in connm circa stigma conniventes. Ovari am biloculare, ovulis juxta axim utrinque plurimis. S tyl us unus; st i s ma conicum, a latere quinquefoveatam, basi campanulatum, quinquelobum, apice bieuspidatum. Annulus hypogynns quinquelobns, carnosus, lobis truncatis. Follic uli....-Frutex bonariensis, volubilis; foliis oppositis, petiolatis, membranaceis, cordato-oblongis, supra glabris, subtus glaueis, in venarum axillis villosis, stipulis pectina. tis, racemis axillaribus longe pedunculatis, nutantibus, multifloris, floribus magnis, candidis, odoratissimis, secundis.

Ma n devilla Liadley in Bot. $\operatorname{Reg}, 1840, t, 7$.
3416/1. Skytanthus MEYEN. Calyx quinquepartitus. Corolla hypogyna, hypocraterimorpha, basi angustata, tubo fauceque esquamatis, limbo regulari, quinquelobo. An ther a e 5 , basi tubi insertae, distinctae, membranaceae, biloculares, subsessiles, connectivis appendiculatis, tubo longioribus. Ovaria $2 \ldots$ Sty I us unus, filiformis, apice dilatato. Stig m a crassum, subglobosum, verrucosum, apice bipartitum. Folliculi 2, maximi, compressi, falcati, subulati.... - Suffrutex peruanus; caule procumbente, puberulo, foliis oppositis alternisque, lanceolatis, acutis, integris, coriaceis, supra subfuscis, glabris, sublus glaucis, farinosis, floribus terminalibus axillaribusque cymosis, bracteis parvis, lanceolatis, acutis, pedunculis calycibusque hirsutis, corolla glabra, coriacea, purpurea.

$\mathrm{S} k \mathrm{y} t$ a $\mathrm{t}$ h u s Meyen Reiso $I$. 376.

3492. Apoegmenm $L I N N$.

Hooker Flor. Bor. Amer. t. 139. 140.

\section{Cryptollepis $R$, BR.}

? C udicia Hamilt. msc.

3424/1. Haemadietyom LINDL. C alyx quinquefidas. Corolla hypogyna, hypoeraterimorpha, limbi reflexi laciniis quinque aequalibus, dilatatis, tabo intus squamulis quinque inclusis, cum limbi laciniis alternantibns, fauce nuda. St a$m$ in a 5 , imo corollae tubo inserta, inclusa, antherae sagittatae, medio stigmati cohaerentes. $O$ varia 2 , ovulis ad suturam ventralem plurimis. Stylas unus, filiformis; $8 \mathrm{tigma}$ capitatum, GIa ndula e 5, hypogynae, calycis laciniis alternae. Folliculi.... - Erutices Americae tropicae, volubiles; foliis oppositis, venis sanguineis reticulatis, racemis axillaribus, floribus flavo virentibus.

Hae madictyon Lindley in Hortic. Transact, $V I, 7 t$. Eehites nutans Sims Bot. Mag. $t$. 2473.

34\%G. IAalloveria R. BR.

Endlieher Iconogr, t. 75 .

3430. IKixia BLUM.

H asseltia Blum. Ribatalia Don Syst. IV, 86 .

TIRIBUS V. GELSEMIEAE Fenzl msc. Se min a peltata, ad extremitatem cotyledonarem, superam comosa. S $\mathrm{ti}$ g $\mathrm{m}$ a quadrifidum, lobis revolutis.

34304 . Gelsềmiun JUSS. $\mathrm{C}$ a 1 y $\mathrm{x}$ quinquepartitas, aequalis, C o rolla hypogyna, infundibuliformis, limbi quinquefidi laciniis aequalibus, obtusis, aestivatione imbricatis, sub anthesi patentibus. S ta mina 5 , imo corollae tubo inserta, aequalia, subexserta; filamenta subulata, antherae biloculares, oblongae, basifixae, loenlis aequalibus, parallelis, basi discretis. Ovaria 2 , ad suturas ventrales coalita, ovulis in placenta suturali plurimis, biseriatis, oblique adscendentibus, semianatropis. Stylus filiformis, simplex; stig ma bipartitum, lobis cum ovariorum dorso parallelis bipartitis, laciniis lineari-filiformibus, revolutis. Folliculi 2, distincti, elongati, teretes. S e min a plurima, peltata, cuneato-linearia, compressa, extremitate supera latiore comosa, inferiore longe attenuata nuda, Embryo in axi albuminis carnosi tenuis rectus; coty led onib a s linearibus, radicula tereti, elongata, recta brevioribns. - Frutex boreali-americanus; foliis oppositis, petiolatis, simplicibus, lanceolatis, 
integerrimis, floribus axillaribus, fasciculatis, pedicellis imbricato-bracteolatis, corollis luteis.

Gels e mi um Jussieu Gen. 150. L. C. Riehard in Mi. chaux Flor. Bor, Amer, I. 120. Nuttall Gen, I, 171. Fenzel Dissert. inedit, Gel s e mi u $\mathrm{i}$ m Catesby Carolin. I. t. 63. Bignonia sempervireas Linn.

\section{GENERA DUBIA.}

5. VAHEA LAM. Genus fortassis idem ac URCEOLA Roxb. n. 3395. Synonymoin est F a te $r$ na Noronh.

6. CERCOCOMA WALL. Cal y x brevis, quinquedentatus. Corolla infundibuliformis, tubo tereti, limbi quinquepartiti laciniis patentibus. Stamina inelusa. Folli. c uli 2 , divaricati, horizontales, crassi, elongati, acuminati, bivalves, polyspermi. S e m in a lanceolata, apice attenuata, eoma longa, stipitata. - Frutex indicus; ramis verrucosis, folits oppositis, glabris, oblongis, acuminatis, panioulis corymbosis, bractois plurimis, oppositis, ovatis, acutis.

Cer cocom a Wallich Catalog. n. 1623. G. Don Syst, IV. 83.

7. TAYOTUM BLANCO. Cal y $x$ campanulatus, quinquedentatus. C oro lla infundibuliformis, limbo quinquefido. Stamina 5 , corollae fauci inserta; filamenta brevissima, a $n$ ther a e biloculares, basi bifidac. 0 varium ..... Styius crassus; stigma ovale. Caps a la calyce demua bifido inclusa, uailocularis, bivalvis. Semina plurima, laminis duabas affixa, medio scta inferne bifida instructa, - Frules manll lanus; folits oppositis, subtus villosit, saepe rugoris, inte gerrimis, floribus axillaribus umbellativ.

T a y o t u m Manuel Blanco Elor, do Filipinas 105.

\section{Ordo CXIXII. Asclepiadeae.}

$343 \%$. Cormacelninia ENDL.

Nov, stirp. Mus, Vindob. Dec, p. 18. in not. B r a chylep is Wight et Arn. l. c. non infr, n. 3482.

344. Hybanthera ENDL.

Iconogr. $t .63$.

3445. Asteplinamus $R, B R$.

Corolla subcampanulata v. suburceolata, laciniis interdum elongatis. Folliculi laeves. Semina comosa. Species, prater capenses, madagascarienses et chilensis. Decaisne in Nouv. Annal, sc. nat. IX. 341.

344\%/1. Comounitma FENZL. Calyx quinquepartitus. Co rolla subcampanulata, quinquepartita, fauce coronata forniculis 5 , subulatofliformibns, brevissimis, ante sinus positis, basi triangulari intus prominulis, decurrentibus. $\mathrm{Co}_{0}$ rona staminea nulla. Ant h e ra e appendice membranacea terminatae. Pollin ia compressa, reniformia, apice attenuato affixa, pendula. $\mathbf{S}$ ti $\mathrm{gma}$ cylindrico-conicum, obtusum, integerrimum. F o 1liculi solitarii, elongato-cylindrici, apice attennati, stricti, laeves. Semin a plurima, ad umbilicum comosa. Herba Africae borealiorientalis tropicae incola, annua, erecta, ramosa, glabriuscula; foliis oppositis, linearibus, acutis, uninerviis, aveniis, margine revolutis, floribus interpetiolaribus, solitariis v. binis, brevissime pedicellatis, minimis, viridi-flavescentibus.

C o nomitra Feuzl in Nov. stirp. Mtus. Vindob, Dec, n. 74 .

348/1. Glossonema DECAISN. C a1 yx quinquepartitng. Corolla subcampanulata, profunde quinquefida, laciniis erectis, saperne pagina superiore taberculo carnoso instructis, fauce coronata squamis quinque, ante sinus positis, apice trilobis, lobo medio subulato, contorto. C orona staminea nalla. $\Delta \mathrm{n}$ therae appendice mem. branacea terminatae. P nllinia subcurvata, oblonga, apice aftixa, pendula. Stigma apicula- tum, obsolete bilobum. Follic n li basi et apice attenuati, spinis innocuis echinati. Semina comosa. - Herba arabica, perennis, ramosa, folio. sa, incano-pilosa; foliis sinuato-dentatis, floribus extraaxillaribus paucis, subsessilibus, petiolum longitudine aequantibus.

Gl a s o nem a Decaisne in Nouv, Annal, sc, nat, IX. 335. t. 12. $f . d$.

3454/1. Steinheilia DECAISN. C a yx quinquepartitus. Cor ol la campanulata, quinquefida, laciniis erectis, acutis, crassinsculis, demum tortis, fauce squamulis 5 , radiantibns, sinubus alternis, carnosis, flavidis clausa, tubo ima basi foveolis 5, cum squamulis alternantibus, Corona staminea nulla. Anthera e membrana oblonga, stigmati incumbente terminatae, lateraliter et superne cornua bina, cartilaginea, atra, Incida emittentes, stigmatis corpusculo affixae. Pollinia longe pendula, subcompressa, clavata. S tigma muticum. Folliculi... - Herba arabica, perennis, caulem unicum annuum, spithameum emittens; folits incanis, eleganter venosis, pedunculis extraaxillaribus, erectis, plurifloris, floribus pedicellatis, pedicellis basi bracteolatis.

Steinfreflia Decaisne in Nouv. Annal, sc, nat, IX, 339. t. 19. f. e. Ascle pias radicans Forsh.

3456. Sarcostemuna $R$. $B R$.

Endlicher Iconogr. $t$. 64 .

$3856 / 2$. Deenema DECAISN. Caly $\mathrm{x}$ quinquepartitus. Co rolla rotata, quinquepartita. Corona staminea daplex, decemplicata, v. cyathiformis decemfida, laciniis inaequalibus, columnam superantibus, medio in appendicem subulatam productis. Anthe rae appendice nembranacea terminatae. Pollinia apice affixa, pendula. Stig ma apiculatum. Folli e uli....- Frutex madagascariensis, erectus, ramosus, Sarcostemmatis facie; caulibus aphyllis, articulatis, umbellis lateralibus et terminalibus.

Deeanema Decaisne in Nouv. Annal. so. nat. IX. 338. t. 12. f. g. A s c lepias a p h y 11 a Boj.

345\%. Phillbertia $H, B, K$.

DiOrbigny Voy. Bot. Te.

3458. Doemia $R, B R$.

Decalsue in Nouv, Annal, to. nat, IX, 336, t, 12, $f, f$.

3464. Cynoetomam E. MEY.

Cy athella Decaisue in Nouv, Annal, sc, nat. $T X$, 332. t. 12. f. 6 .

346./. Bunlowria HARWEY. C aly quinquepartitus. Corolla rotata, quinquepartita. Corona staminea campanulato-urceolata, simplex, limbo truncato, integerrimo. Antherae appendice membranacea terminatae. Pollinia oblonga, apice incrassato affixa, obtusa, pendula. Stigma depressum, subpentagonum, Follienli.... - Suffrutex capensis, volubilis; foliis oppositis, longe petiolatis, ellipticis, breviter nucronatis, umbellis axillaribus, multifloris.

B un bu r I a Harwey Genera of South Afric, Plant. 417.

3464/2. Pyenomenrom DECAISN. CaIy $x$ quinquepartitus. Corolla campanalata, tubo subventricoso, limbi quinquepartiti lacinits dorso angulato carinatis, superne contortis, sina carnoso brevi glandiformi, extrorsam prominente interjecto. Coro na staminea simplex, membrasacea, cyathiformis, columnam superans, plicata, subdecemlobulata, irregulariter lacera v, denticulata. Antherae appendice membranacea, majuacula terminatae. Po Ilinia obtusa, pesdula. Stigma 
obtusum, sinuato-pentagonnm. Folli culi .... - Herbae madagascarienses, erectae, simplices; foliis oppositis, linearibus, interdum margine reflexis, juneiformibus, umbellis pedunculatis $v$. sessilibus, extraaxillaribus v. terminalibus, densifloris, Alliorum umbellas referentibus.

P y en o n euron Decaisne in Nouv. Annal, so. nat. IX. 340, t. 12. f. c.

$3464 / 3$. ITorrenia LINDL. C a ly x quinquepartitus. Corolla rotata, quinquepartita. Corona staminea tubulosa, quinqueangularis, quinqueloba, lobis dentibns minutis interjectis valvatim conniventibus, genitalia omnins tegentibus. Antherae appendice membranacea terminatae. Pollinia pendula, margine onperiore dehiscentia. Stigma convexum, apiculatum, bilobum, Follic uli ....- Suffrutex bonarien$s i s$ volubilis, incanus; foliis hastato-trilobis, cymis subsessilibus, floribus magnis, odoratissimis.

M or renia Lindley in Bot. Reg. 1838. Append, p. 81 , Cy n a cham od orat um Hook. et Ara.

3465. Vincetoxicum $M O ̈ N C H$.

C y nathum Decaisne in Annal, sc. nat. IX. 332. t. 12. f. $a$.

\section{B\%. Solenostemma HAYN.}

A gelia Decaisne in Nouv. Annal. to. nat. IX, 331. t. 12. $f . g$.

\section{1. IKamalnita $R$. $B R$.}

Decaisne in Nouv. Annal. sc. nat. IX, 329, t, 11. f. f.

3471/1. Dmeivema ARNOTT. C a 1 y x quinquefidus. Cor o 11 a campanulata, quinquepar. tita, tubo brevi. Corona staminea summo flamentorum tubo imposita, pentaphylla, foliolis membranaceis, tenuibus, planis. An thera e appendice membranacea terminatae. Pollinia compressa, anguste oblonga, apice affixa, ad curvaturam appendieulorum in apiculum adscendentem desinentium pendula. Sti g m a conico-rostratum, elongatum, apice subbiapiculatum, eorpusculis elongatis, apice capitellatis, Folliculi.... Frutex capensis, volubilis, glaber; folits opposi. tis, angustis, cymis interpetiolaribus, diffusis, dichotomis, paucifloris,

Oncinema Arnott in Edinb. new philosoph. Journ. XVIT, 261. Periploc a capensis Raxb. msc.

$345 / 1$. Selhizostemna DECAISN. C alyx quinquepartitus. Corolla tubo ventricoso, limbi quinquefidi laciniis elongatis, tubum subsuperantibus. Co r o na staminea pentaphylla, foliolis membranaceis, corollae facem superantibus, apice inciso-bilobis, intus simplicibus. Anthera appendice membranaeea terminatae, Pollin ia cla vata, processum demum adscendentium curvaturae affixa, pendula. Stig m a acumine elongato bipartito. Follic ali elongati, laeves. Semina plurima, ad umbilieum comosa. Herbae brasi. lienses, perennes, erectae, simplices, tomentosae, foliis oppositis, floribus extraaxillaribus, interdum ad caulis apicem congestis, umbellatis, subcymosis. Se hizos te m m a Decaisne in Nouv, Annal. sc, nat,
344 .

34 6/1. Calostigma DECAISN. C a l y x quinquepartitus. Coroll a campanulata, tubo ventriceso, limbi quinquepartiti laciniis longissimis tortis, reflexis. Coron a staminea pentaphylla, fo liolis tubum corollae superantibns, apice emarginatis, intus ligula auctis, carnosis. Anth e ra appendice membranacea terminatae. Poll in i linearia, processum demum adscendentiom curvaturae affixa, pendula. Stig ma elongatom, stria- tum, apice dilatato peltatum, undulato crispatum, Folli euli... - Frulex brasiliensis, volubilis, tomentosus; ramulis pilis flavidis dense vestitis, umbellis extraaxillaribus, pedunculo brevi, floribus longe pedicellatis.

C a los tigma Decaisne in Nouv. Annal. sc, nat, IX. 343. $t, 12 . f, h$.

\section{8\%. Arauja BROT.}

Phys 1 a nthus Mart. et Zuce. $l$. $c$.

34.8. Callotropis R. BR.

Decaisne in Nouv. Annal. sc, nat. IX. 328.

3479. Pentatropís $R, B R$.

Decaisne in Nouv. Annal, sc, nat. IX, 327, $t, 11$.

3484. Gomplaocarpus $R$. BR.

Species arabicae, afrieanae tropicae et madagascarienses. Decaisue in Nouv. Annal. sc, nat. IX, 324. $t, 11, f . d$.

\section{Acerates ELL.}

Corolla subpatala, nec reflexa. Cor on a staminea pentaphylla, foliolis basilaribus curvatis, columnam stipitatam superantibus, carnosis, fintrorsum concavis medioque carinato-cristatis, squamis ligulatis antherisque alteruantibus summo filamentorum tubo impositis. Deeaisne in Nouv. Annal. sc. IX. 329, t, 11, f. c. A a a $\mathrm{t}$ he rix Nutt. Gen. I. 169. Pol yot us Nuttall in Americ, philosoph. Transact, $V_{0} 199$.

3489. Podlostigna ELL.

Dele Syuon, A a a the $r+x$ Nutt.

3490. Asclepias $L$.

Hook. Flor. Bor. Amer, t. 141-144.

B4D3. Aspidoglossam $E$. MEY.

Diplogloss um Meisner Gen, 269. Cynanchum a urleulatum et C. Roylei Wight et Arnott, nonnisi stigmate apiculato differt.

\section{Bregea $E$. MEY.} 223.

Pterophor a Harwey Genera of South Afric. Plant.

\section{Gonollobus L. C. RICH. \\ Bot. Mag. $t, 3786$.}

345/1. Pherotrielais DECAISN. Calyx quinquepartitus. Co rolla campanulata, quinquepartita. Corona staminea pentaphylla, foliolis planis, emarginatis. Antherae appendice membranacea fere destitutae, transversim dehiscentes. Pollini a .... Stigma corpusculis lobis ipsis impositis. Folli culi... - Planta incertae originis, non satis nota, pilis longis tecta; foliis oppositis, umbellis solitariis, erectis, corollis barbatis.

Pher otrichis Decaisne in Nouv. Annal. se, nat. IX. 322. Asclepias villos a Balbis in Mem. Academ. Turin. PII. 386 .

3496. Mtatelea $A U B L$.

Decaisne in Nouv, Annal, se, nat. IX, 321, t, 11. f. b.

3498. Gymmeman $\boldsymbol{R} . \boldsymbol{B R}$.

Decaisne in Nouv. Annal. sc, nat. IX, 286.

a. EUGYMNEMA Decaisne Op. cit, $t$. 11, $f, a$.

3500. 'Tyloplaora $R, B R$.

Decaisne in Nouv. Annat, sc, nat. IX, 273, t. 10, f. c.

3501. IIIoya $R$. BR.

Decaisue in Nouv. Annal. se, nat, IX, 972.

3ธด 1/. Centrostemma DECAISV. C alyx quinquepartitas. Corolla quinquefida, limbo abrupte reflexo, faece annulo erecto, barbato. Corona staminea summo flamentorum tubo inserta, pentaphylla, foliolis basi longe calearatis, apice longe acuminatis, stigma superantibus. Antherae appendice membranacea terminatae. Pollini a clavata, basi affixa, erecta, conniventia. Stigma subdepressum. Folliculi... Frutex javanicus, volubilis; folits oppositis, subcoriaceis, venosis, umbellis interpetiolaribus termi- 
nalibusque, multifloris, floribus longe pedioellatis, erectis.

Centrostemma Decalsne in' Nouv. Annal. sc. nat. IX. 221. t. 10. f. c. Cyrtoceras Benaett in Horsfield Plant. Jav, rar, 90, t, 2t. H o y a multiflora Blum. $\mathrm{H}$ o y a c or i a ce a Lindley in Bot. Reg. 1839. $t .18$.

$3501 / 2$. Asterostemma DECAISN. Ca1 y $\times$ quinquepartitus. C o roll a rotata, profunde quinquefida, laciniis oblongo-lasceolatis. C or on a staminea brevis, carnosa, colorata, eyathiformis, quinqueloba, lobis antheris oppositis, lunatis v. tridentatis. Antherae appendice membranacea terminatae. Pollinia obelavata, basi affixa, erecta. Stigma obtusum, rotandatum, papillosum. Ovaria subglobosa, stylis brevibus rostrata. Folliculi....-Suffrutex javanicus, volubilis ; foliis oppositis, membranaceis, hirsutis, umbellis interpetiolaribus, breviter pedunculatis, subcapitatis, paucifloris, floribus majusculis, receptaculo carnoso insidentibus.

Asterostem ma Decalsue in Nouv. Annal. se, nat. IX. 27t, $t, 10$.

3504/1. Feekea ENDL. C a ly $\mathrm{x}$ quinquepartitus. Corolla tabo brevi, limbo quinquepartito, patente. Coron a staminea summo filamentorum tabo inserta, basi corollae postice adnata, decemfida, laciniis alternis antheris oppositis tripartitis, lobo intermedio majore, basi intus processu recto aucto, alternis nanis, indivisis. Anthe $r$ a e appendice memhranacea terminatae, PolIin ia basi affixa, incumbentia. Stigma depresso-conicam. Follieali...-Frutex capen$s i s$; caudice epigaeo tuberiformi, subgloboso, rugoso, ramis e caudicis apice simplicibus, subvirgatis, foliis oppositis, sessilibus, ovatis, cuspidatis, undulatis, pilis brevibus, subcanescentibus, umbellis extraaxillaribus subsessilibus, tri- quinqueftoris, floribus albidis.

F n c ke a Endlieher in Nov, stirp. Mus. Vindob. Dec. 21. Iconogr. $t$. 81 . C y a a $\mathrm{n}$ e h u $\mathrm{m}$ cris pum Jacq. Fragm, t. 34, f. 5 .

35อร. II arsdenia $R . B R$.

Deeaisue in Nouv. Annal, sc, nat, IX, 294.

35 11. Pergularia $L$.

Decaisne in Nouv, Annat. sc, nat, $1 x$. 276.

3516. NIferostemma $R . B R$.

Endlicher Ieonogr. $t .80$.

3515. Ceropegia $L$.

Decaisne in Nouv. Annal, sc, nat. IX. 262, t, 9, f, a, b. Triplosperma Don Syst. IV. 134.

3521. Bueeresia WIGHT, et ARN.

Desmidorehis Ehrenb. Decaisue in Nouv. Ansat. sc. nat, $I X, 265, t, 9, f . c$.

3523. Caralluma $R \cdot B R$.

Decaisne in Nouv. Annal, sc. nat. IX, 267, $t, 9, f . d$.

\section{Drdo CXXXIV. Gentianeae.}

3533. A gathodes DON.

Hen rice a in Bullet, soe, philomat. 1824.

3534. Frasera WALT.

Hooker Flor, Bor. Am, t, 153, 154.

3535. Thalenia BORK.

Species boreali americanae. Hooker Flor. Amer, t, 155. 156.

3536. Chiromia LINN.

Valerandia Neck. Elem, n, 663 .

3540/1. Ixamthus GRIESEB. Calyx involuerato-bracteatus, quinquefidus, Iaciniis planis. Corolla hypogyna, rotata, quadrifida, marcescens. St a mina 4, corollae tubo inserta; fila- menta basi aequalia, anthe $\mathrm{r}$ a e incumbentes, loculis connectivum distinctum superantibus, longitudinaliter dehiscentibus, immutatis. Ovarinm valvularnm marginibus ad medium fere introflexis semibiloculare. Ovula in placentis suturalibus plurima. St y 1 a 8 terminalis, declinatus; st igma indivisum, capitatum. Capsula semibilocularis, bivalvis. S em ina plurima, minima. - Herba insulae Teneriffa, perennis, glutinosa, erecta; foliis oppositis, cordato-ovatis, acuminatis, cyma terminali ampla, dichotoma, bracteis triangularibus, cum flore conglutinatis, corollis flavis.

Ixant hus Griesebach Gentian, 129. Exa e um vis. cos u in Smith Ic. pict, III. 18 .

$3540 / 2$. Tippion SPRENG, Calyx ebracteatus, campanulatus, quinquefidus, Cornlla hypogyna, infundibuliformis, demum supra capsulam torta, limbo guinquefido. Stam ina 5 , corollae tubo inserta; fil a menta basi in vaginam denticulis interpositis coalita, antherae biloenlares, connectivo in apiculum produeto, longitudinaliter dehiscentes, immutatae, 0 v a ri n m nnilocalare. $\mathrm{O} v \mathrm{u} \mathbf{l}$ a in placentis suturalibus plarima. Stylus terminalis, reetus; stigma capitatum, indivisum. Ca psula unilocularis, bivalvis. S emin a plurima, minima. - Herbae in India orientali et America tropica indigenae; foliis oppositis, palmatinerviis, floribus parvis, fulvis, in axillis foliorum aggregato-sessilibus.

Hip pian Sprengel $S y s t . I$. sos. Grieseb. Gent. 133. Slevog tia Reicheab. Consp. n, 3492, Gentiana verticillata Linn.

3541. Cieendia ADANS.

Flores tetrameri. Sect. e. S l evog ti a delenda. Vid, supra n. $3540 \%$ et $3540 \%$.

3543/1. Zyygostigna GRIESEB. Cal yx tobo brevi, quinquepartito, laciniis carinatis. Co ro lla hypogyna, infundibuliformis, limbo quinquepartito. S $\mathrm{ta} \mathrm{m}$ i $\mathrm{n}$ a 5 , corollae tubo ingerta; fil amenta basi aequalia, antheraterectae, biloeulares, longitudinaliter dehiscentes, immutatae $\mathbf{v}$, uno anfractu subtortae, hine revelutae. Ovarium valvularum marginibus introflexis semibilocalare. Ov ula juxta introflexos valvalarum margines plurima. Stylus rectus; stigmata bicruria, conglutinata, ereeta. Caps a la semibilocularis, bivalvis, Semina plurima. - Herbae bonarienses, erectae $v$, adscendenteg; foliis oppositis, superioribus angustioribus, floribus terminalibus solitariis $v$, dichotome cymosis.

Zygostigma Griesebach Gentian, 150, S a b batia austratis Cham. et Sehl. Erytbraea uaiflora Hook.

3544. Canseora LAM.

Pootía Dennst, z. Hort, Malab. X, 32.

$354 \%$. Chlora LINN.

Blackstonia Hadson Flor, angl, 146.

a. XANTHANTHUS Grieseb. Gent. 116. Flares oeto-bexameri. C a ps u Ia unilocularis. A n the rae iamutatae. S ty 1 u s bine divisus, cum stigmatum figura variabllis, deciduas.

b. URANANTHUS Grieseb. Gent, 1t8. Flores caerulei, basi al o maculati, pentameri. Caps u I a e valvulae intus paullo productae. A ut herae demua recurkatae. Sty ius indivisus, persixteas: stigastio lameliis ovato-subrotundis. - America tropica, - L Is i a n th us

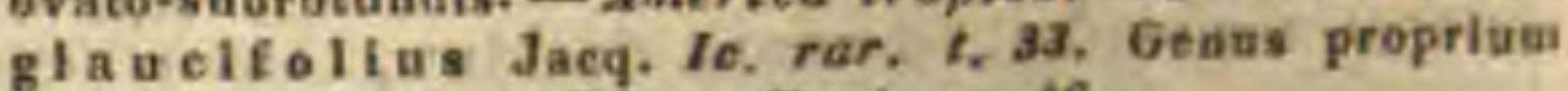
secuadum Benthaw Plant. Hartweg. 46.

3550. Hisynathas $A C B L$.

Lis y a n thus Anblet Guian. I. 810 . Griesebach Gent. 
173. Lisianth us Limn. Suppl. 134. non Lis i a nthins P. BR.

a. MACROCARPAEA Grieseb. $\boldsymbol{l}$. c. Frutescentes, capsula elliptico-oblonga, calycem quater superante, corolla deeldas, flaccida, tubo superne ampliato. (Smith Io. pict. I. $t, 29$. Ruiz et Pav. Flar, peruv, $t, 124,125,127$.

b. SPHAERoCarpaEa Grieseb, l. c. Frutex, capsula globosa, calycem aequante. Lisyanthus fruticosus Cham.

c. CHORIOPHYLLUM Grieseb. $t$. c. Frutex corollae tubo elongato, eylindrico, subgibbo, lobis patentibus, eapsula biloculari, placentis eomplanatis, utrinque septo adnatis.

d. Chelonanthus Grieseb. 2 . c. Herbaceae, annuae, rarissime perennes, suffruticosae, capsula globosa v. ovoidea, calycem ad summum ter superante, corollae diutius persistentis fauce sensim ampliata, elongata, a fundo aeque amplo vix strictura distineta, cum lobis conflua, - (Aubl. Guian, t, 79_81. Gärtner t, 183, Ruiz et Pav, $t$. 122, Martius $t, 171$ 178.)

355\%/1. Telanthus GRIESEB. C a ly x quinquepartitus, pentagonus v. alatus, laciniis aequalibus. Corolla hypogyna, infundibuliformis, tubo supra ovarium constricto, fance in limbum quinquefidum continua. Stamina 5 , imo corollae tubo inserta; fi l amenta basi aequalia, inaequilonga, antherae incumbentes, muticae, Iongitudinaliter dehiscentes, immutatae. $0 \mathrm{v}$ a$\mathbf{r} \mathbf{i} \mathbf{~ m}$ valvularum marginibus introflexis biloculare v. semibiloculare. $O \mathrm{v}$ ula in placentis valvularum margini interiori insertis, utrinque connatis v. discretis plurima. Stylus filiformis; $\mathrm{stig} \mathrm{ma}$ capitatum v. umbraculiforme. C a p s u l a valvularum marginibus placentiferis introflexis bilocnlaris v. semibilocularis, bivalvis, Semina plurima. Frutices v. suffrutices antillani et mexicani; foliis oppositis, sessilibus $v$, petiolatis, floribus gracilibus, albis $v$, flavis.

L ei a n th os Griesebach Gention, 196. L is i a n thi us P. Brown Jam, 157, 2. 9. f. 2, 1, 2. L is ianthus Linn. Mant. 43.

a. LISIANTHIUS Grieseb. t. c. St $\mathrm{g} \mathrm{gma}$ eapitulatum.

b. OMPHALOSTIGMA Grieseb. $l$. c. Stigma umbraculiforme.

3554. Prepasa MART.

Hooker Ic. t. $225,226$.

3554/1. Tachiadenus GRIESEB, Ca $1 \mathbf{y} \times$ quinquepartitus, laciniis carinatis $v$. dorso ala saepe apicem versus dilatata auctis. C or o11 a hypogyna, hypocraterimorpha, decidua, tubo tenui, apice in campanam ampliato, limbi quinquefidi lobis expansis, supra incumbentibus. Stam ina 5 , corollae tubo inserta; fil amenta basi aequalia, antherae erectae, immutatae, longitudinaliter dehiscentes. D i s c u s hypogynus carnosus, ovarii basim cingens. Ov a ri u m uniloculare. Ovala in placentis suturalibus plurima. Sty lus filiformis; stigma capitulatum. C a p sula unilocularis, bivalvis, valvularum marginibus parnm introflexis, intus discretis. S em in a plurima.

Herbae v. suffrutices madagascarienses; foliis oppositis, inflorescentia terminali, floribus albis, corollae tubo gracili, elongato.

Tachiade nus Griesebach Gentian, 200. Lisiant hi sp. Lam. $t$. 103. $f, 3$.

3555/1. Leiothammas GRIESEB. Ca1 y 8 quinquepartitus, apterus, imbricatus, laciniis subaequalibus, concavis, Cor oll a hypogyna, hypocraterimorpha, demum decidua, tubo aequali, cylindrico, limbi quinquepartiti lobis subinaequalibus, a tubo distinctis, expansis, supra incumbentibus. St a m i na 5 , membranae annuliformi imum corollae tubum vestienti inserta; filam ent a inaequalia, an $\mathbf{t h}$ erae erectae, sagittatae, demum arcuato-revolntae. Dis cus hypogynus nullus. Ovarium biloculare. Ovula in placentis medio septo insertis, intus utrinque discretis plurima. Stylus filiformis; stigma bilamellatum. Ca p s la bilocularis, bivalvis. S e mina plurima. Frutex andicola; foliis oppositis, petiolatis, pedicellis axillaribus, late bracteatis, incurvis, terminali unico.

Le i ot h a mus Griesebach Gen, 205.

3560. Selntibleria MART.

A p o ph r a g ma Grieseb. Gentian. 163. Cfr. Benth, in Annal. of nat. hist, II. 442.

3565. Villargỉa VENT.

b. LIMNANTHEMUM Gmel. Grieseb, in Annal, of nat, hist. I. $6, t, 1$.

\section{Drdo CXXXVI. Labiatae.}

3692/1. Fladermannia BUNG. Caly $x$ tubulosus, elongatns, tredecimnervis, obsolete bilabiatus, labii superioristri-inferioris bidentati dentibns muticis, conniventibus, fance annulo piloso clausa. Cor oll a tubo tenuissimo, calycem aequante, intus glabro, limbo campanulato-ampliato, supra medinm bilabiato, labio snperiore erecto, integro, inferioris longioris, recti, apice trilobi lobis Iateralibus rotundatis, lobo intermedio lateralibus breviore et latiore, apice emarginato-bilobo. Stamina 2 inferiora fertilia, sub labio superiore adscendentia, inferiori aequilonga, superiorum rudimenta nulla; fil a m en a fauci corollae inserta, edentata, anthera e lineares, unilocnlares, filamentis parallelae, margine connatae, connectivo inarticulato, postice in appendicem producto, appendicibus medio convergentibus, apice divergentibus, clavaeformibus, loculum alterum cassum, fertili saepius aequilongum gerentibus. Sty li apice bifidi lobus superior brevissimus, rectus, inferior longior, revolutus; stigmata terminalia, minuta. A ch eni a sicca, laevia. - Herba perennis, in Tauria et Arabia observata, Zizyphorae tenuioris facie; foliis oppositis, lanceolatis, angustatis, floralibus subconformibus, verticillastris axillaribus, distinctis, calycibus hispido-pilosissimis, corollis calyce duplo longiuribus.

Fla dermannia Bunge in Bullet. Academ. St. Pe. tersb. VI. n. 11, et 12. Zizy phora ta u rica Bieberst.

3639/1. Atelamelira LINDL. Calyx bilabiato bipartitus, mollis, labio superiore bi-inferiore tridentato. C o r oll a tubo brevi, fauce porrecta, nuda, limbi bilabiati labio superiore latiore, emarginato, inferioris tripartiti lacinia media majore, concava. Stam ina 4, inclusa, inferiora longiora, antherae glabrae, loculo altero adscendente fertili, altero descendente casso. Styl us brevissime bifidus, lobo superiore minimo. Achenia ....-Herbae Novae-Hollandiae austro-occidentalis; foliis oblongis v, oblongo-lanceolatis, incano sericeis $v$, tomentosis, floribus axillaribus solitariis $v$. spicato-confertis.

A tel a ndra Lindley $S$ wan-River. xx. t. 5. f. $a$,

3538. Hacoceplnalum $L$.

d. MOLDAViCA Benth, dele eit. Sweet $F l$. Gard, $r, t, 28$.

3638/1. TaIlemintia FISCH. et MEY. Caly $x$ tubulosus, quindecimnervius, rectus, ore recto, quinquedentato, dente supremo majore. Corolla tubo tenui, incluso, fauce parum ampliata, limbi bilabiati labio superiore carinato, 
complicato-clanso, ala lata cineto, apice emarginato, inferioris patentis, trifidi lobo medio majorei, retuso. S $t$ a $m$ in a 4 , adscendentia, inferiora breviora; filam enta basi barbata, antherae per paria approximatae, biloculares, locnlis divaricatis. Stylus apice subaequaliter bifidus, lobis subulatis; stigma ta terminalia. A ch enia sieca, laevia, nuda. - Herbae orientales, annuae v. biennes, pube minuta, retroversa adspersae; caulibus erectis, ramosis, foliosis, foliis radicalibus petiolatis, subovatis, dentatis, caulinis mediis subpetiolatis, oblongis, serratis, superioribus subsessilibus, subintegerrimis, floribus axillaribus verticillatis, utrinque ternis, pedicello erecto, fructifero rigido, dilatato, plano-compresso, verticillis bracteis quatuor dilatatis, ciliato-dentatis cinctis, calycis elongati dentibus mucronatis, conniventibus, corollis caeruleis.

L a llemanti a Fischer et C. A. Mey. Index sext, sem. hort. Petrop. 1839. p.53. D r a co e p hal um canes cens Linn. Sweet Fl. Gard, I. t, 28. D, p e I t a t u m Linn, D. i b eri c u m Bieberst.

\section{Drdo CXI. Verbenacear.}

3653/1. Cryptoealyx BENTH. Calyx tenuissime membranaceus, obsolete dentatus. Corolla hypogyna, bilabiata, labiis erectis, superiore brevissimo bifido, inferiore elongato trifido. St a min a 4, corollae tubo inserta, didynama, inferiora longiora, omnia fertilia. Ova ri $\mathbf{n}$ m biloculare, loculis uniovulatis. St y lus terminalis; $8 \mathrm{tig}$ ma oblique capitatum. Fructus sponte bipartibilis, calyce et pericarpio evanido, dipyrenus. Semina in pyrenis solitaria. Embryonis exalbuminosi radicula infera. - Herba guianensis, annua, ramosa, $e$ basi procumbente, radicante adscendens; foliis oppositis, petiolatis, ovato-rhombeis, grosse dentatis, basi cuneata integerrimis, spicis ovoideooblongis, axillaribus, solitariis $v$. glomeratis.

Cry p to e a l y x Benth. in Annal. of nat. hist. II. 446.

369.4. NIallopliona ENDL. C a 1 y $x$ qua. dripartitas, persistens, laciniis linearibus. Co rolla hypogyna, infundibuliformi tubulosa, tubo recto, aequali, ealycem superante, limbi quadrifidi laciniis aequalibus, obtusis, erectinsculis, $\mathrm{S}$ t a$m$ in a 4 , corollae fanci inserta, breviter exgerta, aequalia. O va ri $\mathbf{m}$ quadriloculare, loculis unio volatis. Stylus filiformi-subulatus, exsertus; stig ma obtusnm. Drupa sicea, globosa, fragilis, quadrilocularis, axi hiante. Semina in locnlis solitaria, erecta.... Frutices Novae-Hollandiae austro-occidentalis, dense lanatotomentosi; foliis oppositis, subsessilibus, rigidis, capitulis terminalibus solitariis $v$. corymbosis, floribus bracteatis, bracteis exterioribus involucrantibus, floribus albis.

M a II o p h or a Eadlicher in Annal. Wiener Mus, II. 206.

3 F 00. Vitex LINN.

E p hi a li s Soland. msc.

37(1) 1. Premina LINN.

Bald ingera Dennst. $z$. Hort. Malab, V. 31 .

3r98. Clerodicudiron $\boldsymbol{R} . \boldsymbol{B R}$.

Co r a c c bi n i a Savi in Mem. sc, italian, Moden, XXI. p. 187. e. ic.

3\%15. Symphoreuna ROXB.

? A u alectis Vahl in Dansk. Selsk, Skrift, VI, 90.

\section{Ordo CXII. AIyoporineae.}

3\%33. MIyoporvin BANKS et SOL. Endlicher Iconogr. $t, 65$.
3\%33/1. Dasymalla ENDL. C a lyx quinquepartitus, fructifer vix auctus. Coroila hypogyna, infundibuliformis, tubo calycem superante, fauce aequali, limbi bilabiati labio superiore bilobo, inferiore trifido, subaequilongo. S $t$ amina 4, imo corollae tubo inserta, inclusa, subdidynama. Ovari um incomplete quadriloculare, septis interruptis, loculis uniovalatis. Ovu la pendula, anatropa. St y I u s terminalis; stigma acutnm, bifidum. D r u p a baceata, pntamine quadriloculari, tetraspermo. S e m i n a inversa. E m b r y o.... - Fruticuli Nova e-Hollandiae a ustro-ocoidentalis, dense lanati; foliis oppositis, oblongo-obovatis, integerrimis, pedicellis axillaribus fasciculatis, $v$, in cymas oppositas, in racemum terminalem dispositas collectis, flo. ribus purpurascentibus, corollae tubo basi intus barbato, fauce nuda. n. 18.

Da s y all a Endlieher Nov. Stirp. Mus. Vind, Dec,

3ร34. Pholldila $R, B R$.

Eadlieher Ioonogr. $t, 66$.

3ร35. Eremoplaila $R$. BR.

Corolla hypogyoa, ringeus, tubo amplo, labiis subaequilongis, superiore fornieato, breviter emarginato, inferiore aequaliter trilobo. St a $\mathrm{m} \mathrm{Ia} \mathrm{a} 4$, imo corollae tubo in. serta, iuclusa, didynama.

3ร36. Stemoelhilus $R, B R$.

Eadlicher Iconogr, $t, 92$.

\section{Ordo CXIII. Cordiacene.}

\section{Coralia R. BR.}

Firensia, Borellia et Varronia Necker Elem n. 434.435 .437 .

3r39/1. Warromia DC. Calyx campanulatus, decemstriatus, inaequaliter dentatus, saepe rumpens, dente unico calyptraeformi, alabastrum obtegente. Cor oll a hypogyna, infundibuliformis, tubo calycem aequante, limbo rotato, brevissime et obtuse quinquelobo. Stamina 5 , corollae tubo inserta, ejusdem lobis alterna, exserta. Ovarinm .... Stylus staminibus brevior, bis bifidus; stigmatibus incrassatis, Drupa calyce cineta, apice producto mainmillata, putamine biloculari, loeulis monospermis. Se mina... - Arbusculae in America tropica et Abyssinia indigenue; foliis alternis, subsinuatis v. subdentatis, floribus albis, saepe polygamis.

Varronia DC. msc. ex Meisner 278. (186.) Cordiac et Varroniae sp- Auct.

374:/1. Cortesia CAV. Calyx tubulo. sus, minute decemdentatus. C oroll a hypogyna, tubulosa, tubo calycem aequante, limbi quinquepartiti, patentis laciniis rotundatis. Stamina 5 , medio corollae tubo inserta, ejusdem lacinils al terna, exserta; filamenta basi incrassata, filiformia, antherae ovatae, incumbentes. $O$ varinm ovatum ...... Stylus filiformis, apice bifidus; tigmatibus globoso-peltatis, Bac ca ovata, calyce cincta, disperma. Se min a hinc plana, inde convexa. - Frutex bonariensis, ramosissimus; foliis alternis, sessilibus, cuneiformibus, apice trifidis, glabris, pagina utraque tuberculatis, tuberculis albis, pilum candidissimum gerentibus, floribus solitariis, sessilibus, ut plurimum terminalibus.

Cortes ia Cavanill. Ic. IV. $53, t, 377$. 


\section{Ordo CXIIII. Asperifoliae.}

3843. Ehretia LINN.

Exclusis sp. Kuuth Op. cit.t. 208. 209. Vid. infr, n. 3743/1. Iutrostylls G. Don Syst. IV. 391. B hretia spinosa Jacq. Amer. t. $80, f, 18$.

3743/1. Amerina $D C$. C a I y $x$ turbinatoeampanulatus, irregulariter lobatus v. subintegerrimus. Corolla hypogyna, subinfundibuliformi, tubo longo, superne ampliato, limbo patente, aequali, quinquepartito. Stamin a 5, corollae fauei inserta, exserta v. subexserta. $O$ v a ri u m psendo. biloculare, placentis duabus semilunatis, per laminam dorsalem parieti affixis, in centro loculi subcontignis, singulis utrinque ov u $1 \mathrm{am}$ unicum gerentibus. Stylus filiformis, apice bifidus, stigmatibus acutis. Fructus drupaceus, calyee capuliformi einctus, depresso-globosus, quadrilocularis, loculis monospermis … - Frutices $v$. arbores Americae tropicae; foliis oppositis v. ternis, integerrimis, corymbis axillaribus brevibus, calycibus tomentosis, corollis glabris.

A merina DC. mse. ex Meisner Gen, 278. (188.) Eh re. tia e $s$. Kunth in Humb. et Bonpl. Nov. gen, et sp. t. 208. 209.

3ร4. Cr. Crabowskya SCHLECHT.

Arnott in Linnaea XI. 484 .

3\% 4. Tournefortia $R$. BR. $\nu, 189$

? E uploca Nuttall in Amerio, philosoph. Transact.

3ซ49/1. Halgania GAUDICH. Calyx campanulatus, quinquefidus. Corolla hypogyna, rotata, quinquepartita. S t a m in a 5 , imae corollae inserta, ejusdem laciniis alterna; filam enta brevissima, libera, anth erae introrsae, biloculares, ovato-oblongae, basi emarginata insertae, in acumen membranaceum lineare productae, in conum quinquepartibilem cohaerentes, loculis apice rima brevi dehiscentibus, O varium sessile, biloculare, loculis indivisis $\mathbf{v}$. semisepto ex axi producto incomplete bilocellatis. $0 \mathrm{v} \mathbf{a}$ a in localis gemina, collateralia, in medio dissepimento semianatropa, micropyle supera. Stylus filiformis, simplex; stig ma eapitatum, minutum. Ca psu la coriacea, subcylindrica, bilocnlaris, bipartibilis, loculo altero minore effoeto, fertili monospermo. S e men pendulam. E m bry o $\ldots . .$. Fruticuli Novae-Hollandiae austro-ocoidentalis; foliis sparsis, ellipticis v. linearibus integerrimis, v. cuneatis dentatis apice trilobis, exstipulatis, corymbis terminalibus $v$. lateralibus ebracteatis, floribus caeruleis.

H a Ig a n ia Gaudich. ad Freycinet, 448. $t$. 59, Endli. cher in Annal, Wiener Mus. II, 204.

3.5 . Heliotreplum LINN.

a. EUHELlotroplum. - Piptoclaina G. Don Syst. IV.364, H. s u p i n u m Linn. H, ma l a b a r l c u m Retz.

\section{GENUS DUBIUM.}

3\%5\%/1. Pentaearya DC. Caly $x$ quinque-sexpartitus, laciniis dnabus maximis, spathulatis, patentibus, reliquis minoribus, linearibus, erectis. C o ro il a subinfundibuliformis, limbo quinque-sexlobo, plicato, patente. Stamina 5 v, 6, corollae tubu inserta, inclusa. Ovarium quinqueloculare, quinquelobum. Stylus brevis; stigma eapitatum, penicillatum. Nuculae 5, scabrae, monospermae. - Herba oceanica, hi. spida, adscendens; foliis lanceolat is, integerrimis, racemis terminalibus glomeratis, saepius bijidis.
Pentacarya DC. ex Meisner Gen. 279. (187,) L ithospermum incau um Forst. Heliotropium anoma I u m Hook, et Arn.

3\%5\%. Eelhimu TOURNEF,

Species indicae fide Meisuer Gen, 281. (190.) sistunt genus :

MACROTOMIA DC. C oroll a tubulosa, ealyce brevior, apice breviter quinquedentata. S $t a m$ in $\mathrm{um}$ filamenta corollae tubo peaitus adoata, antherae ad medium tubi sessiles. Nuces 4 , v. aborta solitariae, ovatae, acumina. tae, rugosae. - Herbae indicae, Echii facie.

\section{3\%58. Eelnioelaillom DESF.}

Chilech i um Ratin. in Annal. gen.sc, phys, VIIT. 269.

3\% BQD. Steenlananera REICHENB.

Cerinthoides Boerh. - Quid PI a ty nema Schrad.? genus cl. Liadley latroduct. 525. post Steeahumeram locatum.

3r61. Withosperanuma TOURNEF.

e/1. AMSINCKIA. Corolla e faux plicata. Nuces trigonoovoideae, rugosae. Cotyledoa es profunde bipartitae. Amsinckia Lehmann Delect, sem. hort, Hamb, 1831. p. 7 . B en th a m i a Lindley Introduct, ed, 2, p. 2a1, non Bot. Reg.

3\% BR. DIacromenta DON.

Philonomia DC. msc.

3786. Menesthinin KNDL.

Strobil a G. Don Syst. $I V, 825$.

3ร 6 $/ 1$. Caryoloplna FISCH. et TRAUTTV. Calyx profunde quinquefidus. Coroll a hypogyna, hypocraterimorpha, tubo calyce breviore, fauce fornicibus elongatiz, papillosis elausa, limbo quinquelobo, obteso. An th erae 5, corollae fauci inserta, inclusae. Ovarium quadrilobum. Stylus simplex; st igma acutum. Nuces 4, ovatae, reticulato-rugosae, basi rotundatae, umbilico sublaterali, margine intus appendicula cuculliformi, areolam insertionis tegente auctae. Herba europaea, erecta, ramosa; foliis ovatis, obsolete dentatis, hispidis, inferioribus longe petiolatis, superioribus sessilibus, pedunculis axillaribus diphyllis, racemis conjugatis, subcapitatis.

Cary ol o p a Fischer et Traattv. Index sem, hort.Petrop. IIr. 31. Melsuer Gen, 280. (188,) P entaglattis Tausch in Flora 1899. p. 643. Au chusa sempervirens Linn. E. B. t. 45. Hooker Flor. Lond, 4. t. 21 , B u gl 10 s $5 \mathrm{i}$ p. Gärtn. $t, 62, f, 1$.

\section{3\%68. Amellausn LINN.}

a. BAPHORHIzA Link. - ? C a m p y lo e a r y $u$ m DC, mse. ex Moisner Gen, 280. (189.)

c. BUGlossum Gärtn. $t$. 67. f. 2. (exel. 1.)

3868/1. Noritzia DC. C a lyx quinquepartitus. Corolla hypogyna, infundibuliformis, fance fornicibus quinque fimbriato-barbatis coronata, limbi quinquefidi lobis oblongis, hispidis. S ta$m$ ina 5 , corollae tubo inserta, exserta. Ovari um quadrilobum. Sty Ins filiformis, exsertus; stig ma subeapitatum. Nuces 4 (abortu saepe solitariae) chartaceae, oblique subovoideae, facie et vertice acutae, nitidae. - Herba brasilien$s$ is; radice lignosa, caule simplici, ramulis cymiferis, cymis scorpioideis.

Moritzia DC. msc. ex Meisner Gen, 280. (188.) Anehus a ciliata Chamisso.

3768/2, Antipleytaran $D C$. Caly $x$ quinquepartitus. Corolla hypogyna, hypocraterimorpha, tubo calycem aequante, faeie fornicibus brevibus, obtasissimis, eiliato-papulosis clausa, limbi quinquepartiti lobis rotundatis. Sta $\mathrm{m}$ in a 5, corollae tubo inserta, inclusa. $O$ v a $r$ i m quadrilobnm. Stylus filiformis, inclusus; s $\mathrm{tg}$ ma simplex. Nu e s 4, ovato-trigonae, basi excavata receptaculo insertae, intus siylo subadnatae, clausae v. minutissime apertae, minute reticulato-rugulo- 
sae. - Frutices $v$. herbae $m e x$ i c $a n a$ et $a u$ stro-americanae; foliis oppositis, saepe subconnatis, integerrimis, ciliato-strigosis, cymis scor. pioideis, floribus paucis, albis.

Antiphytum DC. msc. ex Meisner Gen. 280. (188,) A u chusa oppositifolia Humb. et Bonpl. Nov. gen. et sp.t. 200.

3\% 4. Hobostemon LEHM.

$\mathrm{E}$ chiops is Reichenb. Handb. 192.

3ร ช ร. Treaclaystemen $D O N$.

Psilostem on DC. msc.

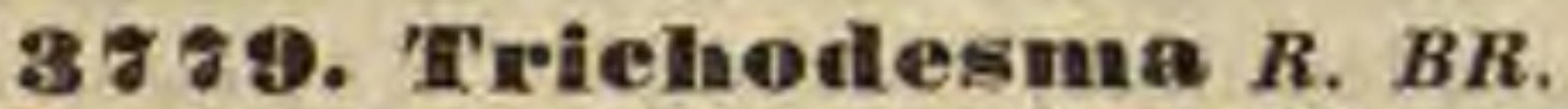

Trichoder m a Link Handb, $I$. 588. sphalm.

\& ร ร 9 /. Friedrielnst halia FENZL. C aIy $\mathbf{x}$ quinquefidus, demum partitus, vesieuloso-anctus, laciniarum marginibus valvatim replicatis pentapterus. Corolla hypogyna, hypoeraterimorpha, fauce pervia, gibbis quinque, cum limbi quinquepartiti laciniis mueronato euspidatis alternantibus. S ta $\mathbf{m}$ in a 5 , corollae tubo inserta, a $n$ therae subsessiles, exsertae, acuminibus subulatis tortilibus in conum conniventes, dorso villoso-tomentosae. Ovarium quadrilobum. StyI u simplex; stigma acutum. Nux abortu unica, maxima, orbicularis, margine papilloso denticulato, inflexo, umbilico ventrali latissimo, coneavo styli basi oblique adnata. - Herba Africae boreali-orientalis tropicae, perennis; fo. liis alternis et oppositis, sessilibus, striguloso-leprosis, fioribus longe pedicellatis, demum pendulis, racemoso-paniculatis, speciosis, albidis, fauce flavis.

Friedrichsthalia Feazl in Nov, stirp. Mus, Vind. Dee. $n, 61$.

37 94/1. Feetoearya DC. Calyx quinquepartitus. Corolla hypogyna, infundibuliformis, tubo calyce breviore, fauce elansa, nuda, limbi quinquepartiti lobis obtasis. Stamina $\mathbf{5}$, corollae tuho inserta, inclusa, $\mathrm{O}$ v a ri m quadrilubum. Stylus brevissimus; stigma.... N u ces 4 , geminatim approximatae, patentissimae, oblongae, hirtellae, superne subconcavae, margine pectinatae, aculeis apice tenuissimis uncinulatis. - Herbae chilenses, ramosae, diffusae, hir sutae $v$, pubescentes; floribus remote spicatis, subsessilibus, demum patenti recurvis, albis.

Pectocary a DC. msc. ex Meisner Gen, 279. (188.) - P Cryptantha Lehmano ex Fisch. et Meyer Index. Sem. hort, Petrop. 1835, p. 35, - ? K tenos permum Lehmann Delect, Sem. Hamb. 1837. Linnaea Litterat. Ber. $X I T, 84$.

3784/2. Suelntelemia KAREL. CaIyx quinquefidus, demum valde ampliatus, vix campanulatus, lobis ovatis, conniventibus. Corolla hypogyna, infundibuliformis, tubo brevi, fauce fornicibns clansa, limbi quinquefidi lobis obtusis. A $n t h$ e $r$ e 5 , intra corollae fancem sessiles. Orarium quadrilobum. Stylus marcescens; s tigma.... Nuces 4 , oblongae, incurvae, convexae, margine ciliolato-serratae, dorso laeves, umbilico laterali, plano. - Herba caspico-caucas ic a, multicaulis, ramosa; foliis alternis, demum albo-punctatis, racemis terminalibus bracteatis, floribus parvis, caeruleis.

Suehtelenia Karelin ex Meisner Gen, 879. (188.) Cynoglossum calyoinum C. A. Mey.

38 84/3. Caceinia $S A V$. Cal y $\times$ costatosubpentagonus, ultra medinm quinquefidas, lobis ereetis, lanceolatis, fructifer ampliatus, lobis introflexis nuces foventibus, Corolla hypogyna, hypocraterimorpha, tubo gracili, calycem aequan- te, fauce fornicibus obtusis clausa, limbi quinquepartiti Iaciniis linearibus, situ inaequalibus. St ain in a 5 , corollae fauci inserta, exserta, anthe$r$ is quatuor sessilibus, quinta longe stipitata, versatili. Ovarium quadrilobum. Stylus filiformis, longe exsertus; stigma acutum. Nuces 4, coriaceae, depressae, umbilico lato, laevi styli basi adnatae, margine denticulato-cristatae, dorso laeves. - Herba persica, adscendens; foliis angustis, glaucis, subcarnosis, ciliato-serratis, scabris, floribus subracemosis, interdum tetrameris.

Caccinia Savi Corollar. bot. 1. t, 1. f. 1-6. ex Meisner Gen. 280. (188.) A n is a $a$ the $\mathrm{r}$ a Rafin. Flor. tellur. n. 740. L y copsis Rauwolf $I t, t, 22$, Borrag iu is s p. Russ. Veat. Cels, t. 100.

\section{Drdo CXIIV. Comvolvalaceate.}

3\% 1. Evolvulus LINN.

Meri a a Flor. Flum, ILI, $t, 109$.

3ร93. Ireweria $R, B R$.

Sedder a Steudel et Hochst. in. Herb. Schimp. Arab. n. 849. et 884 .

3รD9. IPalmia ENDL.

Hew itti a Wight in Madras Journ, 1837, ex Linnaea Litterat. Ber. X11. 213.

3800. Polymeria $R$. BR.

Endlicher Iconogr, Ł. 76 .

380\%. Aniseia CHOIS.

В om b y cos permu m Presl Reliq. Hänk, IX, 137, $t, 71$, e solo frueta ab A nis ei a distinqui uequit.

3503. Convolvulus $L$.

Quid Ely throstamna Bojer Hort. Mauril. 230. ge. nus inter $\mathrm{J}$ a c que montiam Chois. et Convolvulum collo. catum.

3819. Dusmoellt TOURNEF.

? L e ptocallis G. Don Syst. IV, 260.

$$
\text { * }
$$

Merremia Dennst. 2. Hort, Malab,VIIT, 27, Kudici$\mathrm{V}$ a 11 i Rheede Malab, VIIT. $51, t, 27$. Convolvulacea dubia, elrrhis oppositifoliis singularis.

3915. Eryeithe ROXB.

C a to ui a Valil in Dansk. Selskab. Skrifi. VI, 98.

\section{Ordo CXIV. Polemoniaceae.}

3824. Gillia RUIZ. et PAV.

a. Collomioides. Hügelia Beath. Welwitsehia Reicheob, Handb, 194.

e. LEPTOSIPHON Benth. - ? Le ptod a ctylon Hooh. et Arn. ad Beechey 369. 4. 89. Phlox, Hookeri Dougl, in Hooker Flor. Bor. Am,

g. EUGILIA (Hook. Io. 2. 235.) - Quid Courtoisia Reichenb. Handb, 194.

382. IPollemgnimm TOURNEF.

Hooker Elor. Bor, Amer. t. 186-160.

3825. Cobaea $C A V$.

Bot. Mag, $t, 3780$.

\section{Ordo CXLVI. Fydrophylleae.}

3529. Nemophila BART.

Bot, Mag. $t, 3774$.

3830. Eutoen $R \cdot B R$.

Bot. Mag. t. 3706. Bot. Reg, t, 1784.

3831 . Flancelfa JUSS.

Bot. Mag, $t, 3703$.

\section{Drdo CXIVII. Solanaceae.}

3838. Fablana RUIZ et PAV.

Liadl, in Bot. Reg. 1839, h. 39. 
3841. Nicotiana LINN.

Sairanthus G. Don Syst, $Y V, 467$. Nicetiana gluti nos a Linu. Andrews Bot. Reposit. t. 484 . N y c tagella, Tabacum et $\mathrm{T}$ ab acina Reichenb. Handb. 201.

3848/1. Laureria SCHLECHT. Cal y x quinquepartitus, alato-pentagonus, persistens. Cor olla hypogyna, tubulosa, limbo brevi, quinquelobo, recto. St a $\mathrm{m}$ i na 5 , corollae tubo inserta, inclusa; fila menta basi villosa, antherae sublineares, basifixae, longitudinaliter dehiscentes. Ovari n m biloculare, dissepimento multiovulato. Stylus simplex; stigma bilamellatum. Cap sula bilocularis, bivalvis? Semina plurima, in dissepimento medio processnbus brevibns lamelliformibus affixa, reniformia, impresso-punctata. E mbryo intra albumen cylindricus, laeviter curvatus. - Frutex mexicanus, non satis notus; foliis alternis, breve petiolatis, ovatis $v$. lanceolatis, integerrimis, pilis stellatis, floribus ut videtur lateralibus, solitariis.

L a u reria Schlechtend. in Linnaea VIII. 513.

3847. HYOSEy anum TOURNEF.

Physoclaena G. Don $S y s t . I V$. 470 . H y os cy a mus phy sal o des Linn. Bot. Mag. $t, 852$, Sweet Fl, Gard, t, 13. et H. orientalis Linn. Bot, Mag. $t$. 2414. Sweet $F l$. Gard, $t, 12$.

3851. Ihysalis LINN.

Cacabus et Phys a 1 is exel. sect. 4 et 5 . Bernhardi in Linnaea XIIT, $360,361$.

3851/1. MIargarantleus SCHLECHT. Calyx subeampanulatus, quinquelobns, fractifer inflatus. Corolla hypogyna, subglobosa, obtuse pentagona, limbo brevissime quinquedentato, intus pilosiuscula. Stamina 5 , corollae tubo inserta, inclusa, conniventia, a nthera e longitudinaliter dehiscentes. 0 va ri $\mathbf{n}$ m biloculare, placentis dissepimento adnatis, multiovulatis. StyIn s simplex, corollam aequans; stigma trnncatum. B a ce a calyce inclusa, bilocularis, oligosperma. Semina lentienlaria, laevia. Em bryo intra albumen carnosum curvatus. - Herba m ex $i$ cana, dichotome ramosissima, pube brevi, parca; foliis sub ramificationibus solitariis, petiolatis, ovatis, acutis, integerrimis $v$. dente uno alterove magno, interdum obsoleto instructis, floribus subalaribus, solitariis, pedunculatis, deflexis, corolla par$v a, e$ virescenti pallide violacea, baccis viridibus, parvis, seminibus respectu baccae magnis, lutescentibus.

Margaranthus Sehlechtend. Index Sem. hort, Hallens, 1838, ex Linnaea Litterat. Bericht. XIIT, 99.

385\%. Atropa LINN.

Atropa rhomboldea Hooker Bot, Miscell. $t, 37$. est B us beekia Martias Catalog. Hort, Monac, 69. abs. que charaetere.

\section{GENUS DUBIUM.}

$386 \% /$. Acenanthera G. DON. Calyx quinquepartitus. Corolla hypogyna, infundibuliformis, fauce villosa, limbo quinquefido. St a mina 5 , corollae tubo inserta, inclusa, a n thera mucrone terminatae. Ovarium biloculare, loculis univolutis. Styl us simplex; stigm a elongatum, papillaeforme, pilosum. Fruetus...... Frutices c apenses; folits suboppositis, ramis apice spinescentibus, floribus axillaribus, sessilibus, fasciculatis $v$, rarius solitariis.

Acoeauthera G. Dou Syst. IV. 485. Cestri sp. Thubl. Law, $t, 112, f, 2$.
3569/1. Mrettermielnia MICK. Calyx campanulatus, inaequaliter quinquefidus, laciniis duabus posticis, tribus anticis. Cor oll a hypogyna, infundibuliformis, tubo amplo, limbi aestivatione plicati laciniis quinque brevibus, aequalibus, valvatis. Stamin a 5 , imo corollae tnbo inserta, inclusa, inaequilonga; fil am ent a filiformia, antherae biloculares, basifixae, longitudinaliter dehiscentes. Ovarium biloculare, ovulis plurimis juxta dissepimenti basim bi-triseriatim confertis, adscendentibus, anatropis. Stylus simplex, adscendens; stigm a bilamellatnm, laminis margine revolutis. C a p s l a coriaceo-lignosa, ovato-cylindracea, bilocularis, apice septifrage bivalvis, dissepimento libero, valvis demum semibifidis. Semina plurima, e dissepimenti basi adscendentia, longe linearia, utrinque acuminatoattenuata, curviuscula, dorso convexa, facie concava, aptera, umbilico prope basim introrsum laterali, testa chartacea, endopleura spongiosa. $\mathbf{E}$ mb $\mathbf{r} \mathbf{y}$ in axi albuminis carnosi rectus, cotyledonibus linearibus, earnosis, radiculam cylindricam, inferam aequantibus. - Arbor brasiliensis; foliis alternis, breve petiolatis, ellipticis, penninerviis, integerrimis, nitidis, floribus terminalibus, subsolitariis $v$. pluribus, subracemose fasciculatis, ebracteatis, speciosis, albis $v$. roseis.

Metterniehia Miekan Deloct. Flor. et Faun, Bra. sil. III. t. 1. Fenzl Dissert, msc.

\section{Ordo CXIIX. Serophutarineae.}

3893. Serophullaria TOURNEF.

Quid C e ramanthe Reichenb, Pflanz, Syst. 198?

3985. Angelomia HUMB. et BONPL. Bot. Mag. t. 3754 .

390\% 1 . Anthotroelne ENDL. Calyx quinquefidus. Corolla hypogyna, infundibuliformis, tubo sursum ampliato, limbi rotato quinquelobi lobis obtusiusculis. St a m in a 5 , omnia fertilia, corollae fauci inserta, exserta; fil a menta subulata, flexuosa, a ntherae snbbiloculares, loculis confluentibus, rima transversali unica apertis. O varium biloculare, placentis dissepimenti basi utrinque adnatis, multiovulatis, ovulis adscendentibus, anatropis. St y la s simplex; stigma capitatum, emarginatum. C a p sula globosa, bilocularis, quadrivalvis, septo membranaceo, inferne medio placentifero, libero. S e min a plarima, adscendentia, basi incurva, reticulata. Emb ryo in axi albuminis carnosi; cotyledon ibus brevissimis, obtusis, radienla tereti, basi homotrope incurva, umbilico prope basim laterali parallele contigua. - Frutex Nova e-Hollandiae austro-occidentalis, densissime lanato-tomentosus; foliis alternis, crassis, junioribus axillaribus subfasciculatis, floribus in foliorum juniorum axillis solitariis, subsessilibus, parvis, violaceis.

Anthotroche Endlieher Nov. Stirp. Mus. Vindob. Dec. $n, 9$,

3906. Duboisia $R$. BR.

Eadlicher Iconogr. $t$, 77 .

393 1. IIazus LOUR.

Endlicher Iconogr, t. 102.

3932. Limnophila $R$. BR.

A m buli a Lam. Dict, $I, 128$,

3938. Mrorgania $\boldsymbol{R}, \boldsymbol{B R}$.

Eadlicher Iconogr, t, 103. 
3940/1. Bacopa AUBL. Calyx pentaphyllus, foliolo postico maximo, anticis angustioribus, lateralibus interioribus lineari-carinatis. Corolla hypogyna, subrotata v. eampanulata, aequaliter quinquefida. $\mathrm{St}$ a $\mathrm{m}$ in a 5 , corollae tubo inserta, omnia fertilia, corollae laciniis alterna, a nth e ra e biloculares, Ioculis linearibus, parallelis, longitudinaliter dehiscentibus. $\mathrm{O}$ v a $\mathbf{r} \mathbf{i} \mathrm{m}$ biloculare, placentis dissepimento ntrinque adnatis, multiovalatis. Stylus simplex; stigma bilamellatum. C ap sul a membranacea, vix dehiscens, dissepimento toto fere placentifero. $\mathrm{S}$ e min a plurima, scrobiculata. Embryo in axi albuminis carnosi, copiosi orthotropus. - Herbae Americae tropicae, paludosae, glabrae; foliis oppositis, pedunculis axillaribus, solitariis v. fasciculatis, unifloris, setaceo-bibracteolatis, corollis caerulescentibus $v$, albis.

B a c o pa Aublet Guian. I. 128. t. 49. Bentham in $4 n$. nal. of nat. hist. II, 443 .

3942. Achetaria CHAM.

? Montir a Aublet Guian, II. 637. $t .257$.

3944. Antielnaris ENDL.

Endlicher Iconogr, t, 93.

3951. Ni creantlaemum L. C. RICH.

St. Hilaire in Nouv, Annal, sc. nat, $X I, 167$. G I a b Ifer a Gmelin Syst. 32. Pinarda Flor. Flum. I. t. 82.

3953. 'Tomenia LINN.

Bot. Mag, t, 3715.

3960. IBuelnanera LINN.

Endlicher Iconogr. $t, 78$.

3982. Wulfenia JACQ.

Hooker Flor. Bor, Amer, $t, 171$.

3984. Cyminamatira $P A L L$.

Hooker Flor. Bor. Amer, t. 178.

3ఏத9. Harveya HOOK.

St amina medio corollae tubo inserta. PIacenltae bipartitae. Harwey Gen. of South Afric. Plant. 249.

3999/1. Aulaya $H A R W$. Caly $x$ eampanulatus, semiquinquefidus. Corolla hypogyna, tubuloso-clavata, leviter incurva, limbi subaequa. liter quinquefidi laciniis brevibns, latis, imbricatis. Stamina 4 , imo corollae tubo inserta, inclusa, didynama, a ntherae didymae, loculo altero fertili, marginibus conniventibus apice solum aperto, altero sterili subulato. Ovariu m biloculare, placentis dissepimento ntrinque insertis, reniformibus v. Innulatis, multiovulatis. Stylus filiformis; stigma lineare v. subclavatum. C a p8 ala....- Herbae capenses, parasiticae, orobanchoideae, simplices $v$, ramosae; foliis squamaeformibus, imbricatis, floribus speciosissimis.

A u I a y Harwey Genera of South Afric, Plant, 249. Orobanctre squamosa Thunb. et 0robanehe eapens is Thunb.

4002. Centranthera $\boldsymbol{R}, \boldsymbol{B R}$.

Purs hia Dennst. z. Hort. Malab. IX, 68.

4003. Drthoearpus NUTT.

Hooker Flor. Bor. Amer. t. 173.

4023/1. Cobamba BLANCO. Caly $\mathrm{x}$ eylindricus, incurvns, quinquefidus, laciniis acntis. Corolla calyce major, bilabiata, labiis bifidis, superioris laciniis divaricatis, inferioris latioribus, S t a m in a 4, corollae inserta, duo collateralia, tertio infimo, quarto reliquis majore summo, inter labii superioris lobos, antheris sessilibus, mag. nis. Ovariam libernm, cylindricom. Stylus staminibus brevior; stig ma bifidum, laciniis revolutis, Ca p sula unilocularis. Semina plurima, globosa. - Herba in insulis philippinis crescens, graveolens; foliis oppositis, sessilibus, ellipticis, integris, glabris, floribus terminalibus, geminis.

$\mathrm{Co}$ b a b a Man. Blanco Flora de Filipinas, 510 .

4023/2. Tala BLANCO. C a 1 y $x$ acute quinquedentatus, dente postico majore. Corolla tubo incurvo, compresso, limbo inaequaliter quadrifido, lacinia postica majore, breviter emarginata. St a m in a 4, didynama, per paria conniventia, antherae globulo parvo insertae. O varium conicum. S ty I a s staminibus brevior; s tigma trilobum, lobo postice bilamellatc. Caps n la bilocularis, polysperma. - Herba in humidis insularum philippinarum crescens; foliis oppositis, lanceolatis, serratis, subtus foveola. tis, pubescentibus, petiolis cohaerentibus, floribus solitariis, sessilibus.

T a I a Manuel Blanco Flora de Filipinas 484.

4025. Haberlea FRIDW.

Endlicher Iconogr, $t, 69$.

\section{Drdo Cll. Acanthaceae.}

403\%. NeIsonia $R$. BR.

Endlicher Iconogr, $t, 79$.

404\%. Fuellia LINN.

Endlieher Iconogr, t. 104.

40B 1. Farlerin LINN.

C $\mathrm{r}$ a b b a Harwey Genera of South Afric, Plant, 276, coll. 417 .

40\% 2/1. Tasseggera ENDL. C a ly x ad basim quinquepartitus, laciniis lateralibus paullo latioribus. Co rolla hypogyna, ringens, labio superiore erecto, snbfornicato, emarginato, inferioris tripartiti, patentis laciniis subaequalibns, obtusis. Stamina 4, corollae tubo inserta, inclusa, didynama, antherae biloculares, loculis insertione inaequalibus, obtusis, margine ciliolatis. Ovari u m biloculare, loculis uniovulatis. St y l u $8 \mathrm{sim}-$ plex; stigma obtusum. Ca p 8 a la chartacea, rostrata, bilocularis, disperma, septo ad parietes incrassato, ad axim sulco interrupto rostroque incrassato cartilagineis, loculicide bivalvis, valvis mox bipartitis. Semin a compressa, retinaculis late cymbiformibus, obtusis subtenta, testa humectata in vasa spiralia soluta, - Fruticulus Africae tropicae boreali-orientalis, depressus; caudiculis lignosis, fasciculatim ramosis, ramis squamis coriaceis imbricatis, folits faseiculatis, lineari-lanceolatis, acuminatis, submucronatis, pilis mollibus candicantibus, pedunculis axillaribus solitariis, unifloris, bibracteolatis.

Rus seggera Endlicher Nov. Stirp. Mus. Vindob. Decad. 46. Iconogr. $t .94$.

40\% 9/2. Selnwaben ENDL, C alyx ad basim quinquepartitus, lacinia antica paullo latiore, Coro I l a hypogyna, ringens, fance antice ventricosa, postice intus biappendiculata, labio superiore ereeto, subfornicato, emarginato, inferioris longioris, patentis, trifidi lobis obtusis. St a mina 4 , corollae fanci inserta, sub labio superiore adscendentia, didynama, a n the rae loculis inaequalibus, confluentibus, basi barbulatis subuniloculares. 0 va $\mathbf{r}$ u m biloculare, loculis uniovalatis. Stylus simplex; stigma bilobum. Capsula chartaces, bilocularis, loculicide bipartibilis. S emina compressiuscula, retinacalis late bilobis subtensa, testa humectata in vasa spiralia soluta, Herba Africale tropicae boreali-orienta$l$ is, annua, simplex, nodis tumidis; foliis opposi- 
tis, ellipticis, integerrimis, floribus axillaribus, solitariis, sessilibus.

$\mathrm{S} \mathrm{ch}$ wabe a Endlicher Nov. Stirp. Mus, Vindob, De cad. 91 .

\section{0\%\%. Phlogacanthus NEES.}

Hooker Bot. Mag. $t, 3783$.

105\%/1. Selhaueria NEES. Cal yx quinquepartitus, laciniis aequalibus, elongatis, setaceis. Coroll a hypogyna, bilabiata, tubo longo, labio superiore complicato angusto, inferiore tripartito, aequali. Stamina 2 , corollae tubo inserta, a $\mathbf{t h e r a e}$ biloculares, loculis contiguis, mntiris. Ovarium biloculare, loculis biovulatis. Stylus filiformis; stig ma subclavatum, bilobum. C a psula unguicnlata, bilocularis, disperma? .... Frutex brasiliensis; ramis ad articulos tumidis, folitis oppositis, oblongo-lanceolatis, acuminatis, panicula terminali densa, flava.

$\mathrm{S}$ eh a ueria Nees Index Sem. hort. Wratisl. 1838. ex Linnaea Litterat. Ber, 1839, t. 119. Jus ticia caly tric ha Hook. Exot, Flor, $t, 212$. J. e a l y e otri ch a Link et Otto Abbild. $t$. 53. Bot. Mag. $t$. 2816. J. flavie o ma Lindley Bot. Reg. $t .1027$.

409\%. Hostellularia REICHENB.

Rost ellula ría Reichenb. Pfanzen-Syst. 190. R os te lI a ri a Nees supr. 4079, non Zoolog.

409\%/A. Hypoestes SOLAND.

Endlieher Iconogr. $t, 105$.

\section{Drdo CLI. Bignoniaceae.}

4105. Sesamum LINN.

a. EUSESAMUM (Eadl. Teonogr, t, 7o.)

4106. Calampelis DON.

Endlieher Iconogr, $t$, 95 .

411. Tourretia DOMB. Bot. Mag. t. 3749 .

4112. Argalia DON.

Endlicher Iconogr. $t$. $7 t$.

4115 . Inearanda JUSS.

Kordelestris Arruda ex DC. Revis. Bignon, 15.

4116. Keylheria MART.

T a beboui a Gomez Obs, bot. Ir, 7, t, 3, DC, Revis. $B i g n, 14$. (Flor. Flum. $V Y, t, 54$.$) habitu, calyeis lacinits in-$ tegerrimis, corollae glabrae tubo infundibuliformi, lobis mag. nis a Zeyheria diversa, donec fruetus cognitus fuerit, dis. tinguí satis non potest.

$41 \mathrm{AB} / 1$. Thigezum BURCH. C al y $\mathrm{x}$ campanulatus, quadri-quinquedentatus, dentibus subaequalibus. Corolla hypogyna, tubo brevi, fauce ampla, infundibulari, limbi quinquelobo subbilabiati lobis subaequalibus, antico medio majore. St a $m$ in a corollae tubo inserta, quinque v. interdam septem fertilia, duobus anticis nonnihil longioribus, breviter exsertis, antherae biloculares, locnlis erectis, parallelis, basi discretis, muticis. Ova rinm biloculare, ovulis ad dissepimenti margines utrinque plarimis, anatropis. Stylus simplex; stig ma bilamellatum. Caps a la subrostrata, chartacea, bilocularis, bivalvis, valvis dissepimento plano, marginibus utrinque seminifero contrariis. S e mina plurima, transversa, compressa, orbiculari-elliptica, maxima, ala membranacea, lata, eroso-sinuata cincta. Embryonis exalbuminosi, orthotropi radicnla centrifnga. Frutices capenses, distorti; ramis alternis $v$, trichotome brachiatis, horizontalibus, spinescentibus, foliosis, foliis ramulorum novellorum alternis, breve petiolatis, ternatis, annotinorum fasciculatis, plerumque simplicibus, obovato- $v$. ovali-oblongis, integerrimis, floribus axillaribus, solitariis, rarius binis $v$. ternis, breve pedicellatis, in ramis annotinis e foliorum fasciculo erumpentibus, luteis, speciosis.

Rhigoz um Burchell Trav. I. 299. et 389. Fenzl Dissert. inedit. Rhizog u m Harwey Gen, of South Afric. Plant, 235.

4 16/2. Catophractes DON. Calyx spathaceus, hinc fissus, inde sexdentatus. Coroll a hypogyna, infundibuliformis, limbo sexlobo, patente, aequali. St a $\mathrm{m}$ in a $6 \mathrm{v}$, rarius 7 , subaequalia, exserta, a n therar a m loculi paralleli, e medio sursum connati. O va ri um abbreviatum, conicum, biloculare....-Frutex namaquen$s i s$, erectus, spinosus; foliis fasciculatis, simplicibus, serratis, floribus lateralibus, subsessilibus, speciosis, albis.

C a tophractes Don in Proceed. Linn. soc. 1839.p.4.

$411 \% /$. Pajanelia $D C$. $\mathrm{C}$ a 1 y $\mathrm{x}$ coriaceus, oblongus, pentagonus, in dentes quinque acutos fissus. Coroll a hypogyna, coriacea, tubo brevi, lato, fauce ampla, campanulata, hiante, limbi lobis quinque, subrotundis. Stam in a corollae tubo inserta, quatuor didynama, cum quinti rudimento subaequilongo, a $\mathrm{t}$ h e $r$ a e biloculares, loculis divaricatis, subreflexis. Ova ri n m biloculare, ovulis ad dissepimenti margines utrinque plnrimis, horizontalibus, anatropis. Stylus filiformis; stigma bilobum, clavatum. Capsula plana, lanceolata, utrinque alis latis appendiculata, bilocularis, bivalvis, valvis dissepimento marginibus utrinque seminifero contrariis. Semina pla. rima, transversa, compressa, utrinque in alam membranaceam expansa. Embry on is exalbuminosi, orthotropi radicula centrifuga. - Arbor indica; foliis imparipinnatis, multijugis, foliis dimidiato ovato-cordatis, acuminatis, integerrimis, panicula terminali ampla.

P a ja a elia DC, Revis. Bignon, 14. Bignonia multijug a Wallieh Plant. As, rar. $t, 95.96 . \mathrm{Paj}$ a a $\mathrm{ell}$ Rhe ede Malab. I. $t, 43$.

$4118 / 1$. Fleterophagma $D C$. Calyx campannlatus, bilabiato-bipartitus, labio superiore bifido. Corolla hypogyna, tubo lato, limbi patentis lobis quinque aequalibus, obtusis, undalatis. St a $\mathrm{m}$ in a corollae tubo inserta, inclusa, 4 didynama cum quinti rudimento, a $n$th erae biloculares, loculis subdivaricatis, glabris. Ova rinm disco glanduloso cinetum .... S ty I u s filiformis; stig ma bifidnm, lobis subulatis. Capsula rigida, oblonga, acuminata, bivalvis, quadrilocularis, septo crasso cruciato, lobis valvis contrariis angustioribus, margine seminiferis. S e mina horizontalia, compressa, alata....-Arbor indica; foliis imparipinnatis, quadri-quinquejugis, foliolis ovato-oblongis, serratis, paniculis terminalibus, amplis, villosis.

Heterophragma DC. Hevis, Bignon, 13. Bigno. nia quadrilo eularis Roxburgh Plant. Corom, $t$. 145.

412\%/1. Lumalia $D C$. C al $\mathrm{y} x$ bilabiatus, labio superiore minute bi- inferiore tridentato. Corolla hypogyna, longe tubuloso-infundibuliformis, obsolete bilabiata, limbi lobis quinque subrotundis, parum inaequalibus. S $\mathrm{t}$ a $\mathrm{m}$ in a corollae tubo inserta, inclusa, quatuor didynama cum quinti rudimento, an the ra e biloculares, loculis divaricatis, ad latus internum longe et dense bar-

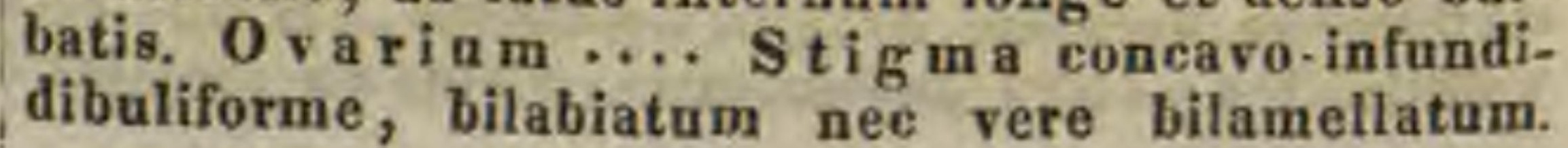


Fruet us....- Frutices brasilienses, scandentes; foliis oppositis, bifoliolatis, petiolo commu$n i$ in cirrhum simplicem elongato v. mutico, foliolis petiolulatis, cordatis, acuminatis, floribus axillaribus terminalibusve paniculatis, minute bracteatis.

L u ndia DC. Revis. Bignon. 12.

$4122 / 2$. II Iamsea $D C$. Calyx bilabiatus, labio superiore bi- inferiore trifido, laciniis subulato-elongatis, tubo basi demum circumscisso. C o r o I la hypogyna, infundibuliformis, fance lata, limbi subbilabiati lobis subrotundis. St a min a corollae tubo inserta, inclusa, quatuor didynama eum quinti rudimento, a $\mathrm{n}$ th er a e bilocalares, loculis divaricatissimis, glabris, umbone hirsuto penicilliformi inter loculos e basi antherae orto, 0 va ri um disco carnoso excentrice insidens, ovali-oblongum, compressum, utrinque glabrum, ad margines pilos apice glandulosos gerens.... Stylns filiformis, supra ovarii basim articulatus; stig ma bilamellatum. Fructus... - Frutices brasilienses, scandentes; foliis oppositis, petiolatis, bifoliolatis, petiolo in cirrhum trifurcatum producto, foliolis ovatis, acuminatis, quinquenerviis, floribus axillaribus terminalibusque paniculatis, ramis lateralibus trifidis $v$. trichotomis.

M a n s o a DC. Revis. Bignon, 12.

$41 \mathrm{a3} / 1$. Arrabialaea $D C$. Calyx eupuliformis, breviter quinquedentatus. Corolla hypogyna, recta, subhypocraterimorpha, tnbo tereti, calycem longe superante, limbi lobis ellipticis, obtusis, aequalibus. $\mathrm{S}$ ta $\mathrm{m}$ in a corollae tubo inserta, inclusa, quatnor did ynama cum quinti radimento subaequilongo, anth er a e biloculares, loculis oppositis, erectis, dorso affixis. O va ri u m biloculare, ovulis ad dissepimenti margines utrinque plurimis .... S t y 1 u s cylindracens, simplex; stigma brevissime bifidum. Cap sula siliquaeformis, compressa, lato-linearis, utrinque acuta, laevis, bilocularis, bivalvis, valvis dissepimento marginibus utrinque seminifero parallelis, $\mathrm{S}$ e mina plurima, alata. - Frutices brasilienses, scandentes; ramis junioribus foliisque subtus pube canescenti tectis, foliis oppositis, pinnatim trifoliolatis $v$. unijugis, petiolo in cirrhum simplicem desinente, panicula laxa, multiflora.

Arrabidaea DC. Revis. Bignon, 10. Bignonia Sago Flor. Flum. B. Ag a us, Castus Cham. B. $c$ orchor oides Cham.

4124. Bimmonia LINN.

Dele cit. Roxb. $t$. 145. Vid. n, $4118 / 1$ et Wallich t. 9596. Vid. n. $4117 / 1$.

424/1. Nouletia. Cal y $x$ cupuliformis, quinquedentatus, dentibus longe cuspidatis. Co roll a hypogyna, ventricoso-campanulata, limbo quinquelobo, subaequali. St a $\mathrm{m}$ in a 4 , corollae tubo inserta, cum quinti sterilis rudimento, a ntherae biloculares, loculis divaricatis $v$. adscendentibus, intus ad margines barbato-ciliatis, $0 \mathrm{va-}$ ri um biloculare, ovulis ad dissepimenti margines ntrinque plurimis, horizontalibus, anatropis. S tylas filiformis; stigma bilamellatum. Capsula tetraquetra, tetraptera, alis subcoriaceis, venosis. biloenlaris, bivalvis, valvis dissepimento margiaibns utrinque seminifero parallelis. S emina plurima, transversa, compressa, in alam membranaceam expansa....-Frutices brasilienses, scandentes $;$ foliis simplicibus $v$. pinnatim trifoliolatis.

C us pidaria DC. Hevis, Bign, 9. uon supr.

4127. METTERnichia Miek. Geaus h. I. delendum. Vid. suprá u. $3869 / 1$ inter Solauaceas.
4128. FerdinandUSA Pohl. Genus delendum h. I. Vid. supra inter Rubiaceas n. 3277/\%.

4132. GRLSEMIUM Juss, Genus h. I. delendum. Vid, supra n. $3430 \%$ inter Apocyneas.

413 \% 1 . Psilogyme $D C$. Cal y x subcam. panulatus, pentagonns, late et aequaliter quinquedentatus. Corolla hypogyna, hypoeraterimorpha, extas hirsuta, tubo obconico, calyce duplo longiore, lobis quinque ovatis, obtusis, aequalibus, patentibus. St a m in a 4 fertilia, quinto sterili; filamenta basi barbata, antherae loculis divaricato reflexis, glabris, ovarinm...... Sty lu s filiformis; stigmata 2, subulata. Fructus... - Frutex brasiliensis, Viticis facie; foliis oppositis, junioribus pubescentibus, unifoliolatis v, digitatim tri-quinquefoliolatis, foliolis obovatis, subsessilibus, pedunculis axillaribus trifidis.

Psilog y ne DC. Revis. Bignon, 16.

413\%/2. Eravaisia $D C$. Calyx bibracteolatus, quinquepartitus, lobis ovalibus, obtusis, quincunciatim imbricatis. Corolla hypogyna, subinfundibuliformis, eampanulata, quinqueloba, lobis subaequalibus, obtusis, extus glabra, intus sparsim pilosa. Stamina 4 fertilia, cum quinti rudimento vix manifesto; filam enta basi hirsuta, caeterum subpilosa, antherae biloculares, loculis contiguis, basi mucrone calcaratis, Ovarium ovato-conicum. Stylus filiformis; stigm a subeapitatum. Fru ctus....-Frutex carac as anus, scandens; ramis pubescentibus, cylindricis, apice alternatim compressis, foliis oppositis, petiolatis, simplicibus, ellipticis, integerrimis, paniculae terminalis ramis oppositis, subcorymbosis.

\section{Bravalsia DC. Revis. Bignon, 17.}

$4132 / 3$. Peltospermun DC. Flores .... Cap s u la lignosa, valvis planis, suborbiculatis, erassis, extus subpulverulento velutinis, septo verisimiliter valvis parallelo. S e mina orbiculata, ala latissima undique cincta, funieulo umbilicali libero, centrali. Embry on is exalbnminosi cotyledones 2, maximae, planae, orbiculatae, basi cordatae, radieuIa brevi, plumula inconspicua. Arbor guianensis; folitis subalternis, simplicibus, obovatis, emarginatis, obtusis, supra lucidis, subtus lineatis, glaucis.

Peltosperm um DC. Aevis. Bignon, 17, Bignonfa latisiliqua Poir. - Apatatoae galanensis Aub. let Guian. ᄂ. 147. f. $\bar{s}$. semen, a cl. Candolle hac citatum, quomodo ab Aspidospermatis (3399.) seminibus differat, non video.

\section{Ordo CLIL. Gesmeraceae.}

\section{A esehinanthus $J A C K$.}

Semi na peadula, apice nuclei affixa, basi monotricha, apice mono di-polytricha. R. Brown in Horefield Plant. Jav. nar. 115. Dele Orythia et Agalmyla Bl. Vid. infr. n. 4136/1.

\section{Tysfonotus $D O N$.}

S e m i a utringue monotricha, pili superioris apice affixa. R. Browi in Horsfield Plant, Jav, rar, 116.

\section{6 . ILiebigin.}

Trom ms o rffia Blum. l. c. (1826.) R. Brown is Horsfield Plant. Jav, rar, 117, non Martius. (1825.) supra n. 1955.

Q136/1. Agralmyla BLUM, Caly $\mathrm{x}$ quinquepartitus, aequalis. Corolla h ypogyna, tabulosa, incurva, fance dilatata, limbo obliquo, quinquelobo, subbilabiato. Stamina antherifera 2 , an $t$ h eris exsertis, loctris parallelis. 0 vari a m. .. Stigma bilamellatum, lobis aequalibus. Ca p 8 I a siliquaeformis, elongata, pseudoquadrilocularis, bivalvis. Semina plurima, pen- 
dula, apice nuclei affixa, utrinque monotricha. Herba javanica; caule radicante, petiolisque hirsutis, foliis alternis, oblongis, acuminatis, denticulatis, basi subaequalibus, margine subtusque pubes. centibus, floribus axillaribus, fasciculatis. Ag a 1 m y a Blume Bijdr. 767. excl. sp. see. R. Brown
in Horsfield Plant. Jav, rar, 116. Ory thi a Blume. Flor. Jav. Praef. VII, non. Don.

$413 \%$. Chivita HAMILT.

Stigma labio superiore abortiente v. nano, inferiore bilamellato. Semina pendula, inappendieulata. R. Brown in Horefield Plant. Jav, rar. 117.

435. Didymoearpus $W A L L$.

Se m I n a inappendiculata, sessilia. R. Brown in iHorsfeld Plant, Jav, rar. 117.

4139 . Streptocarpus $L I N D L$.

Sem in a inappendieulata. - Speeies plurimae madagascarienses. R. Browa in Horsfield Plant, Jav, rar. 119.

\section{0 . IBaea COMM.}

Semin a inappendiculata. $R$. Brown in Horsfeld Plant. Jav, rar, 120.

4140/1. Loxocarpus $R$, BR. C al y x quinquepartitus. Coroll a hypogyna, tubo brevi. Stamina antherifera 2 , a $\mathrm{nth}$ erarum loculis divergentibus. Sti $\mathrm{g} \mathrm{m}$ a indivisum. Capsula calyce paullo longior, hinc dehiscens, placentis angustissimis. S e m in a erecta, funiculis capillaribus elongatis. - Herba indica, annua, incana; foliis omnibus radicalibus petiolatis, scapis apice subcorymbosis.

L o хосатрus R. Brown in Horsfield Plant. Jav. rar. 120.

4141. Loxotis $R, B R$.

R. Brown in Horsfield Plant. Jav, rar. 115.

14\%. Chlossanthus KLEIN.

Caly $x$ aeativatione valvatus. R. Brown in Horsfeld Plant, Jav. rar. 121.

442/1. Monophyllea $R$. BR. Calyx quinquepartitus, laciniis ovatis, aestivatione imbricatis. Cor oll a hypogyna, bilabiata, labio superiore bilobo, inferiore trilobo. Stamina antherifera 4 , antherarum loculis divergentibns. Ovarium basi disco dimidiato instruetum. Stig ma indivisum. Caps ula calyce tecta, ruptilis, semibilocularis. - Herba sumatrana, glabra; folio unico caulem simplicissimum terminante, sessili, costato, integro, racemis corymbosis, subseriatis ex ipsa basi folii.

Mon ophyllea R. Browa in Hordield Plant, Jav. rar. 121 .

\section{Ihoxomia $J A C Q$.}

Cal $\mathrm{yx}$ aestivatione valvatus. R. Brows in Horafield Plant, Jav, rar, 103, t, 28.

\section{3/1. Platystemma WALL.}

Cal y $x$ aestivatione valvatus. Ovari um basi disco annulari cinctum. Vid. sub n. 4151. R. Brown in Horsfeld Plant, Jav, rar, 121.

4143/2. Quintilia. Calyx quinquangularis, quinquefidus, aequalis. Coroll a hypogyna, subrotata, limbo patente, quinquelobo, snbaequali, Sta mina corollae tubo inserta, 4 sabdidynama, quinto abortivo, antherae reniformes, uniloculares, transverse dehiscentes, $0 \mathrm{v}$ arin m globosum, psendo biloculare. Stylus brevis; $\mathrm{ti \textrm {g } m a}$ capitatum. Capsula calyce inclusa, placentis involntis carnosis, undique seminiferis pseudo-quadrilocularis, irregulariter dehiscens. Semin a angulata, subgyrata. - Herba javanica, annua; caule carnoso, subsimplici, inferne repente, folits subsessilibus, oppositis, alternis majo- ribus, forma et magnitudine quam maxime disparibus, majoribus oblongis, acutis, basi oblique rotundatis, inaequilateris, paucinerviis, oppositis minimis, semilunatis, stipulaeformibus, inflorescentia e foliorum minorum axilla subcorymbosa, floribus caeruleis, obsolete bracteatis.

Mi quella Blume in Bullet. Neerland, 1838. p. 94. Staurantheraesp. R. Br.

4 13/3. Stauranthera BENTH.

C a 1 y x plicatus, sinubus in dentes productis. Vid. supra i. 4152. R. Brown in Horsfield Plant. Jav, rar. 120, excl. sp. see.

414. Epithema BLUM.

R. Brown in Horsfield Plant. Jav, rar, 120.

414. Thabdothammus $A, C U N N$.

Placentae utrinque seminiferae. S emina albuminosa. R. Browa in Horsfield, Plant, Jav. rar, 121.

416. Cyrtandra FORST.

R. Browa in Horsfield Plant. Jav, rar, 122. Geto. a la Banks et Sol. msc.

$414 \%$. Whitia $B L U M$.

R. Brown in Horsfield Plant, Jav, rar, 12.

4 14. Fhymehotheu m BLUM.

R. Browa in Horsfield Plant. Jav, rar, 122. Cory santhera Wall. Vid. n. 4163.

419. Fielaila CUNNINGH.

R. Brown in Wallich Plant. Jav. rar. 122.

4150. Tasparinia.

Centronia Blum. (1826.) supra n. 4150. R. Brown in Horsfield Plant. Jav, rar. 192, non Don (1823.) infra n. 6181 .

4151. Platystema Wall, Genus h. I. delendam. Vid. supra n. $4143 / \mathrm{s}$.

4152. Stauranthera Benth. Genus h, 1. delendum. Vid. sopra n. $4143 / 3$.

4153. CORYSANTHERA Wall. Genus deleadum, idem ac Rhynchothe um Blum. n. 4148 .

415.5. Gesmera $M A R T$.

DC. Prodr. VIT. 326.

a. EUGESNERA DC. l. $c$. $\mathrm{C}$ al y $\mathrm{c}$ is laciniae ovato-laneeo. Jataev. lato-lineares, haud valvatae. C o roll a colorata, saepius coceinea, fauce modice hiante. C a psula obtusa v. seasim attenuata. (Bot. Mag, t. 3725.3738. 3744. 3787.)

b. PRASANTheA DC. l. c. exel. syn. Caly e is laciniae ovatae, longe acuminatae, per aestivationem stricte valvatae. C a p \& u l a abrupte et longe rostrata. G. prasinata Ker Bot. Reg. $t, 428$.

461. Tapina $M A R T$.

Tapein otes DC. Prodr. VIT, 544.

4163. Allopleetws $M A R T$.

Lophi a Desvaux in Hamill, Prodr. Flor. Ind. occid. 47. Virey a Rafinesq. Speceh.

4166 . 'Trevirana WILLD.

A c himenes DC. Prodr, VII. 535.

$416 \%$. Cloxinia HERIT.

a. Paliavana Velloz, Eu g $10 x$ in $i$ a DC, Prodr, VII, 533,

b. SINNINGIA Nees. Hemiloba et Sinning la DC. $l, c$.

$416 \% / 1$. Sollemoplhora BENTH. Caly tubo inferne cum ovario connato, supra ovarium producto, longe quinquefido. Coro 11 a perigyna, tubulosa, apice ampliata, limbo Jate quinquefido, vix patente. St a min a corollae tubo inserta, quatuor didynama, inclusa, eam rudimento quinti, a $n$ h hera e per paria cohaerentes. Ovarium infernm, glandulis geminis epigynis posticis, uniloculare, placentis duabus parietalibus bifidis, 0 v nI a plurima. St ylus apice incrassatus; $8 \mathrm{tigma}$ subinfundibuliforme, Caps u la bivalvis...... Frutex mexicanus, bi-quadripedalis; ramulis 
minute puberulis, foliis oppositis, petiolatis, ovatis, $\mid$ serta, inclusa, quatuor didynama, quinto aeque acuminatis, duplicato - serratis, basi angustatis, fertili breviore, fil am enta basi hirsuta, a nobliquis et valde inaequilateris, cujusvis paris valde therae biloculares, cordato-sagittatae. Ovariu m inaequalibus, pedicellis axillaribus solitariis, opposi- teres, basi glandvlis quinque einctum. Stylus tis, supra medium bibracteolatis, unifloris, floribus coccineis, calycis parte libera subcolorata.

Sole nophora Bentham Plant. Hartweg. 68.

4 a 10. Bellonia PLUM.

Tussae Flor, Antill. I. t. 30 .

41 I 1/1. Pamentiera DC. Calyx spathaceus, hine fissus, limbo acuto, integerrimo, deciduns. Corolla subeampanulata, tubo lato, brevi, fauce hiante, limbi quinquelobi lobis subaequalibus, patentibus, irregulariter angulatis. Stamin a fertilia 4 didynama, cum quinti rudimento, a nthera e loculis basi disjunctis sagittatae. G I a nd u l a erassa, quinque-sexloba ad basim ovarii, sub frnctu persistens. Ovarium...... Stigma bilamellatum. Fructus carnosus, indehiscens, teres, sulcatus, acuminatus, costis obtusis notatus, intus bi-quadrilocularis, S e mina parva, subrotunda. - Arbor mexicana; foliis oppositis.

Parmentiera DC, Bevis. Bignon, 19. Qua uxhichotl Hernand. Mex. 90. Crescentia edulis Moçino.

41 1/2. Leartomia DC. Involuerum calyeiforme, ovatum, subinflatum, membranaceum, acute tri-quadrifidum. Caly $x$ intra involuerum inclusus et illo triplo brevior, quinquepartitus, lobis acuminatis. Cor olla infundibuliformis, fauce obconiea, hiante, limbo obtusissime quinquelobo, subringente. Stam ina 4 fertilia, filamentis glabris, antheris erectis, obtusinsculis, loculis basi subdiscretis, caeterum parallelis. $O$ v a riu m .... Stylus filiformis; stigma oblique dilatatum, concavum. Fructus.... Frutex mauritianus; foliis oppositis, simplicibus, oblongis, lanceolatis, acuminatis, integris, pedicellis axillaribus v. oppositifoliis, uni-trifloris, sub involucro bibractealatis.

Boutonia DC. Revis, Bignon, 18. Bignonia Bojer mso.

451/3. Colea BOJ. Calyx campanulatus, quinquedentatus. Corolla hypogyna, tubo infundibuliformi, fauce ampla, limbo quinquefido, bilabiato. St a mina imo corollae tubo inserta, inelnsa, didynama; fil a menta basi barbata, antherae biloculares. Ovarinm basi glandulis quinque cinctum, ovato-cylindricum. Stylus filiformis; s $t \mathrm{igma}$ late bilamellatum. Capsula oblongo-cylindrica, stylo longo candata, verrucosa, bilocularis. Sem in a imbricata, alata, - $A r$ bores mauritianae; foliis oppositis exstipulatis, $v$. verticillatis stipulatis, imparipinnatis, floribus terminalibus, paniculatis, v. ramis fasciculatim insertis.

Colea Bojer Hort. Maurit. 220. Bignonia Colei Hook, Bot. Mag. 2 , 2817. et B ignouia Telfairiae Hooker Bot. Mag. $t$, 2976 .

Pose Coleam collocandum:

ARTHROPHYLLUM Bojer Hort. Maurit, 221. et DC. Revis. Bignon. 18, absque charactere. BIgnonia arti. c u la t a Desfont. DC. Organograph, $t, 39 . f .1$.

41 8 3. Troipinmaria PERS.

Dele eit. Tanaecium pinnatum Jacq. Vid. $4173 / 1$.

$4193 / 1$. Figelia $D C, C$ aly $x$ campanulatus, bilabiato-quinquefidus. Co ro ll a hypogyna, infundibuliformis, nervosa, limbo amplo, quinquefido, bilabiato. Stam in imo corollae tubo infiliformis; $s \mathrm{tig}$ m a bilamellatum, lobis lanceolatis. Ba c c a subglobosa. Semina plurima, in pulpa nidnlantia. - Arbor in Africae austraorientalis littoribus tropicis obvia; foliis alternis, impari-pinnatis, quadrijugis, foliolis serratis.

Kigelia DC. Revis. Bignon, 18. Crescentia p iunat a Jacq. Collect. III, 203, t, 18, Ki g eli-k e i a Mozamb.

\section{Ordo CIIII. Pedalineae.}

4181. Josepluinia VENT.

Endlicher Iconogr. $t, 106$.

\section{Ordo CIIV. Orobancheae.}

\section{8\%. Epiphegus NUTT.}

Eudlicher Iconogr. $t$. 80 .

484. Conoplaolis $W A L L R$.

Endlicher Iconogr. $t$. 81 ,

4 86. IBoselnwiakia C, A. MEY.

Stellara Fischer msc. Orobanches sp. Hooker Flor. Bor. Amer, $t, 167,168$.

\section{Anoplanthrs ENDL.}

a. EUANOPLON E. (Eadl, Iconogr, $t, 72$.)

4 19. IIyohanehe THUNB.

Endlicher Iconogr, $t, 82$.

\section{Drdo CIV. Utricularinae.}

\section{1983. Utriemiaria $L I N N$,}

St, Hilaire in Nouv. Annal. sc, nat. $X I, 149$.

419. Genlisea $S T$. $H I L$.

St. Hilaire in Nouv. Annal, so, nat. XI.165, $t, 5$. U tri. cularia aphylla Flor. Plum. I. t. 48.

\section{Ordo CLVI. Primutaceae.}

4204/1. Pelletiera $S T$. HIL, Caly x quinquepartitus. Corollae petala 3 , hypogyna, calyce multoties breviora, ovata, nnguiculata, distantia. Stamin a 3 , petalis opposita et eorundem basi inserta. Antherae biloculares, didymae, longitndinaliter dehiscentes. Ovarinm nniloculare, placenta orbiculari, libera, geptiformi. OvuIa 2 , placentae faciebus peltatim inserta, amphitropa. Stylus filiformis; stigma capitatum. C a p sula globosa, juxta totam longitudinem bitrivalvis, valvis integris v. demum bifidis. S e m in a 2, cymbiformia, dorso convexa, faciei concavae centro umbilicata. Em bry o in axi albuminis rectus, umbilico parallelns, - Herbula brasiliensis, glaberrima, Asterolini facie; caule quadrangulo, folits oppositis, floribus axillaribus solitariis, albis.

Pelletlera St. Hilaire in Mem Mus. IX, 195. Nouv. Annal, sc, nat, $X I, 5, t, 4$.

4213 . Centumenlus LINN.

St. Hilaire in LNouv. Annal. sc, nat, XI, 87.

4213. Anagallis LINN.

St. Hilaire in Nouv. Annal. sc, nat, XI, s9.

4215. Samolng TOURNEF.

St. Hilaire in Nouv. Annal. sc. nat, XI, 97.

\section{GENUS NON SATIS NOTUM.}

4215/1. Evparea BANKS. $C$ alyx pentaphyllus. Cor olla e petala 5 v. 12 , oblonga, ca177 
lyce longiora, patentia. Stamina 5 . Ovarinm liberum.... Sty I us simplex. Cap 8 u la chartacea, stylo setaceo snperata, unilocularis, indehis cens, placenta centrali libera, globosa, fungosa, scrobiculata. Semina plurima, dorso convexa, faciei obsolete angulatae centro umbilicata, testa coriacea, elevato punctata. E m b ryo in axi albuminis carnosi rectus, umbilico parallelus, cotyledonibus oblongis, subfoliaceis. - Herbula Novae Holla ndiae, procumbens, Nummulariae minimae facie, floribus phoeniceis.

E u pare a Banks ex Gärtner I, 230, t. 50.

42 16. Selnwenkia LINN.

M a the a Flor, Flum. $I . t, s t$.

\section{Ordo CIVII. DIyrsinece.}

4281. VIy roline $L I N N$.

Hosta Flor. Flum. I. t. 124. Pecki a Flor. Flum. $I$. t. 134. 135. $\mathrm{Z}$ a c y $\mathrm{t}$ h a Flor. Flum, VIT. $t .9$.

4292. Arulisia SWARTZ.

Piekering i a Nuttall Annal. of nat. hist. New-York VII. Coll. Torrey et A. Gray Flor. of North-Amer. I, 256. - Ni ara Deunst. z. Hort. Malab. D. 28.

42a3. Embella JUSS.

D z m eria Dennst. z. Hort. Malab, V, 11, 12.

4828. Jacquinia $L I N N$.

B onelli a Bertero Colla hort. Ripul. App. III.

423\%/I. Corymoearpus FORST. C aIy x liber, pentaphyllus, foliolis oblongis, concavis, deciduis. Corollae petala 5 , subrotunda, calyce paullo majora, coneava, ungue angusto. Pa rapetala 5, adscendentia, oblonga, acuta, petalis alterna et paullo minora, singula ancta corpusculo glandalaeformi globoso. Stamina $\mathbf{5}$, e basi petalerum; anthera e erectae, oblongae. Ovarium supernm, globosum. Stylus brevis, filiformis; stigma obtasum. Nux turbinato-clavata, oblonga, monosperma. - Arbor NovaeZeelandiae, spectabilis, Ardisiae facie, ramosa; ramis teretibus, patentibus, glabriusculis, apice foliosis, folits alternis, petiolatis, obovatis v. ovatooblongis, obtusis, integerrimis, glaberrimis, laevibus, panicula terminali simplicissima, racemosa, floribus parvis, albis, pedicellatis.

Coryn acarpus Forster Char. gen, $t, 16$, All. Cunningh, in Annal. of nat. hist. IV. 260. Mer reti a Solan. der mse.

\section{Ordo CLVIH. Sapotaceae.}

4234. Declinusa MART. C a y $x$ quinquepartitus, laciniis imbricatis. Corolla hypogyna, campanulata, tubo brevi, cylindrico, fance barbata, limbo quinquepartito, erecto-patente. St am in a 5 , corollae tubo inserta, ejusdem lacinits opposita, sterilia nulla; filame nta subulata, antherae extrorsae, erectae, ovato-globosae, apiculatae, biloculares, longitudinaliter dehiscentes. Ovarium dense pilosum, quinquesexloculare...... S t y 1 ns brevis, eylindricus; $8 \mathrm{t}$ i g m a depresso - capitatum, quinquelobum. Fruetus.... Arbor brasiliensis, magna, ligno rubello; folitis versus ramulorum apices confertis, obovata-ablongis, supra glabris, subtus tomentoso-subferrugineis, floribus supra foliorum annotinorum cicatrices glomerato sessilibus.

Ecellinusa Martius Herbar. Brasil, 177.

1236. Labatia $S W A R T Z$.

Stam is a 4, sphalmate quinque dicustur, $-G$ u a p e ba Gomez Mem. Otissip. III, 104. $t, 2$.
4243. FIimuseps LINN.

Labourdonneia Bojer Hort, Maurit, 199. Genus absque charaetere post Mimusopen collocatum, mibi penitus ignotum est.

4246/1. Azsoola BLANCO. C a lyx quadripartitus, Coroll a hypogyna, tubo brevi, limbi laciniis novenis-undenis, lanceolatis, biseriatis. St a m in a corollae fauci inserta, 9 v. 10 , a n therae subsessiles, magnae, in aristam desinentes. Ovarium globosum.... Stylus longissimus; st igma quasi lobulatum. Drupa oblonga, monosperma. S e men oblongum, testa fragili, umbilico ventrali, lato. - Arbor Philippinarum; foliis versus apices ramulorum confertis, lanceolatis, racemo terminali.

A z a o l a Man. Blanco Flora de Filipin, 408.

4246/2. Pallaquium BLANCO. Calyx sexpartituz, laciniis biseriatis. Corolla gamopetala, quinque-sexpartita. Sta in in a corollae fanci inserta, ejusdem laciniis geminatim v. ternatim opposita; filamenta complanata, basi coalita. Ovarium .... S t y I u s staminibus longior; stig ma simplex. Pom um ovale, stylo coronatum, sexloculare, loculis monospermis, - Arbor philippica; foliis in apice ramorum approximatis, obtuse lanceolatis, integerrimis, supra lucidis, subtus villosis, floribus axillaribus solitariis, longe pedicellatis.

Pa I a quium Man. Blanco Flora de Filipinas 403.

4249. Diospyros LINN.

Wight Ic. $t, 182.183 .188 .189$.

\section{Ordo CWIX. Hbenaceace.}

\section{IRymia ENDL.}

Diplo a em a Don Syst. IV. 42.

425\%. Stymax TOURNEF.

Siebold et Zucc. Flor. japon, $t, 46$.

435\%/1. Pterostymax SILB. et ZUCC. C a lyx campanulatus, tubo cum ovarii parte inferiore connato, limbo semisupero, quinquedentata. Co roll a e petala 5, ealyeis fauci inserta, ima basi vix cohaerentia, spathulata, aestivatione contorta. Stamina 10 , cam petalis inserta; filamenta basi in tubum coalita, alterna breviora, anthera e erectae, adnatae, lineares, biloculares, longitudinaliter dehiscentes. O varium semiinferum. Ovula in placentis e loculorum angulo centrali prominentibus plura, biseriata, inferiora pendula, superiora ereeta. Stylas subulatus, simplex, barbatus, supra basim articulatus; stig ma truncatum, quinquecrenatum. D ru pa semisupera, calycis nervis excrescentibus quinquealata, vertice exserto conico, styli basi mucronata, sublignescens, sicca, abortu mono-disperma ..... Frutex japonicus; foliis alternis, petiolatis, ovatis, cuspidatis, penninerviis, argute serratis, pilis stellatis adspersis, floribus in ramulis axillaribus et terminalibus, in paniculas subcorymbosas, multifloras congestis, subdistichis, pedicellatis. t. 47 .

Pterostyrax Siebold et Zucearini Elor, japon, 94.

\section{Dielidanthera MART.}

P1 u e hi a Flor, Flum, $I V, t, 20$.

4254/. Euelea LINN. F. F lores dioici, Masc. Calyx cupoliformis, quadri-quinquedentatus. Corolla hypogyna, campannlata, limbo profunde quadri-quinquefido, aestivatione imbricatim contorto. S tam in a triplo loboram corollae numero, biseriata, exteriora imae corollae in- 
serta et geminatim ejnsdem lobis opposita, inte- Discus? ... O varium quinqueloculare, locuriora hypogyna, antherae erectae, filamento lis uniovulatis.... Sty Ins filiformis, exsertus; continuae, acuminatae, biloculares, loculis longi- $s \mathrm{tig} \mathrm{ma} \mathrm{minute} \mathrm{capitatum....} \mathrm{-} \mathrm{Suffrutex} \mathrm{No-}$ tudinaliter dehiscentibus, rima inferne connivente, vae Hollandiae austro-occidentalis, rasuperne patente. $O \mathrm{varii}$ rudimentum. F e m. Ca- mosissimus, pedalis; foliis glabris, inferne imbricalyx et coroll a maris. Staminum loco ciliorum tis, basi subvaginantibus, apice subulatis, acerosis, series hypogyna. Ovari um biloculare. Ovala floribus albidis, in spicam terminalem densam, ovain loculis gemina, dissepimento prope apicem col- tam, lobis calycinis cuspidatis exsertis, dispositis.

lateraliter appensa. Sty lus bipartitus; stig ma plus minus emarginatum. Drupa carnos a, patamine abortu uniloculari, monosperma. S e men globesum, sulco longitudinali profundo. $\mathbf{E}$ m b r y o in axi albuminis copiosi, cartilaginei rectns; cotyledonibus foliaceis, radicula elongata, supera. - Frutices capenses; foliis alternis, integerrimis, floribus axillaribus, racemosis.

E ucle a Linn. Syst, XIII, 747. - Harwey Gen, of South-Afric, Plant, 2 is.

425\$. Symploeos HERIT.

Bentham in Linn Transact, XVIIT, 225, $t$. 18, Ste m. matosi ph on Pohl Plant, Brasil. IT. 86. t. 157.-159. ? Dee a dia Loureir, Flor, eochineh, 385.

4264. Colnmellia $R U I Z$ et $P A V$.

Eudlicher Iconogr. $t$, 84 .

\section{Ordo CLX. Epacrideae.}

426g/1. Solemiseia $D C$. Calyx quinquepartitus, bracteolis quatuor, geminatim oppositis. Cor oll a hypogyna, elongatn-tubulosa, gracilis, tubo basi intus nudo, fauce barbato-velutina, limbi quinquefidi lobis linearibus, demum revolutis, superne barbatis. Stam in a 5 , medio corollae tubo inserta, exserta; fil a m enta flifurmia, a $n t h$ e $r$ a lineares, simplices, incumbentes. Squamulae hypogynae nullae, Ovarium.... Stylus simplex; stigma obtnsum. Fructus ....- Suffrutex Novae Hollandiae austrooccidentalis, glaber; foliis ovatis, sensim acuminato-pungentibus, coriaceis, integerrimis 8 . vix subdenticulatis, erectis, subtus glaucis, substriatulis, supra laevibus, floribus axillaribus solitariis, sessilibus, pollicem longis, erectis.

Soleniscia DC. Prodr. VII, 737,

426 8/2. Stomarrlhema $D C . \mathrm{C}$ a $1 \mathrm{y} \times \mathrm{pen}-$ taphyllus, foliolis acuminatis, bracteis quatuor brevioribus obtusis cinctus. Corolla infundibuliformis, tubo calycis longitudine, intus barbato, limbi quinquepartiti lobis acuminatis, superne barbatis, conniventibus. Antherae 5 , in fauce corollae subsessiles, inclusae, lineari-oblongae. $\mathbf{S} q \mathbf{u}$ am u la e hypogynae quinque, distinctae. Ovari um quinqueloculare, loculis uniovulatis. Stylus filiformis; stig ma subcapitellatum. Fructu $\mathbf{s} \ldots$. - Suffrutex Novae Hollandiae austro-occidentalis, erectus, ramosissimus, glaberrimus, rigidulus; foliis sparsis, erectis, acuminato-subpungentibus, extus striatis, convexis, intus laevibus, floribus in axillis superioribus sessilibus, solitariis.

Stomarrhen a DC. Prodr. VII. 738.

4\%83. Teveopogon $R$. $B R$.

Pero a Pers. Ench. $\bar{I}$. 174.

4\%ร3/1. Atherocephala DC. Calyx quinquepartitus, bibracteolatus, laciniis membranaceis, basi subdilatatis, in acumen subulatum, corolla longins productis. Corolla hypogyna, infundibuliformis, limbi quinquepartiti lobis angustis, revolutis, dense barbatis, apice summo nudis. St a min a 5, medio corollae tubo inserta, exserta; filamenta filiformia, antherae dorso infra medium insertae, oblongo-lineares, simplices.

erocephala DC. Prodr. YII, 755,

4.8. Iysinema $R, B R$.

Juli e ta Leschen. mas.

4883. Lebethanthus ENDL,

Allo d ap e Endl, supr. s, n. c, non Zoolog.

\section{Drdo CLXI. Ericacene.}

42DG. Seyphogyme BRONGNIART.

Brongu. ad Duperr. t. Si. Beath. in DO. Prodr. VIL, 209. $0 \mathrm{mphal}$ o earyon supr. in text.

4289. Coillostigma KLOTSCH.

Benth, in DC. Prodr, $\mathcal{V I}, 76$.

a. KUCOILOSTIGMA Benth. l.c. Cojlostigma Klotseh, 4300. Syndesmanthas KLOTSCH.

Benth, in DC. Prodr. VIT. 76 .

a. RUSYNDESMANTHUS Benth. Syadesmanthus Klotseh.

4301. Sympieza LICHT.

Bentham in DC. Prodr, VII. 705.

a. EUSYMPIEZA Benth.

\section{Simo elheilms BENTH.}

In $D C$. Prodr. VIT. 702,

b. THAMNUS Klotsch. Thoracosperma Klotseh in Linnuea $I X .350,(\mathrm{n} .4308$.

c. BUSIMOCHILUS Benth, $\boldsymbol{l}$. c.

4306. Eremia $D O N$.

Benth, in DC, Prodr. VII. 699.

a. EREMIASTRA Benth, Ovarium sesslle, quadriloca. lare. - Eolia terna. Bracteas approximatae.

b. PODEREMIA Benth. O vari um longe stipitatum, quadriloculare. - Folia terna. Bracteae remotae.

c. MiCREREMIA Benth. O va ri um biloculare. Sta ui na saepias octo. - Bracteae approximatae.

d. HEXASTEMON Klotsch. Ov a ri in messile, biloculare. Stamin a saepius sex. - Bracteae approsimatae.

4308. THORACOSPERMA Klotseh deleatur. Vid. supra a. $4302 . \mathrm{b}$.

\section{Blaeria $L I N N$.}

Benth, in DC. Prodr. VII, 697.

a. LEPTOBLAERIA Benth. Flores peduneniati. Bracte a e a calyce remotae.

b. PYCNOBLAERIA Benth. FI or es dense capitati. B rac. te a e calyci approximatae.

4313 . Friea $L I N N$.

Benth, in DC. Prodr. DII, 614.

a. ECTASIS Benth. A a thera e terminales. Corolla varia.

1. Callicodon Benth. - 2. Desmia Don. - 3, Polydesmia Benth. -4 . Chromostegia Benth. -5 . Eriodessafia Don. - 6. Amphodea Salisb.- 7, Geissostegia Beath.8. Gigandra Salisb. - 9. Pelostoma Salisb. - 10. Didymanthera Benth.

b. SYRINGODEA Benth. A n therae laterales. Corolla tubulosa longa, limbo ereeto v. recurvo-patente.

11. Eurylepis Benth. - 12. Callibotrys Salisb. - 13. Pleurocallis Salisb. - 14. Evanthe Salisb, - 15, Chona Don. - 16. Oetopera Benth. - 17. Dasyanthes Benth. 18. Baetridium Salisb.

c. STELLANTHE Benth. An therae laterales. Corolla hypocraterimorpha, limbo plano, stellatim patulo.

19. Myra Salisb. - 20. Ceramus Salisb. - 21. Euryloma Don. - 22. Platyloma Benfh, -23 . Callista Don, - 24. Cya177 * 
tholoma Beath. - 25. Platyspora Salisb. - 26. Lamprotis Don.

d. EUERICA Benth. A n the ra laterales. Corolla urceolata, ovata, campanulata v. globosa, limbo erecto v. recurvo patente.

27. Eurystegia Beath. - 28. Trigeanma Salisb. - 29. Oxyloma Beath. - 30. Pseuderemia Benth. - 31. Pachysa Don, - 32. Anaclasis Benth. - 33. Hermes Benth. Hermes et Diphilus Salisb. - 34. Loxomeria Salisb. 35. Eremocallis Salisb. - 36. Pyronium Salisb. 37. Gypsocallis Salisb. - 38. Ceramia Doa. - 39. Ephebus Salisb. - 40. Orophanes Salisb. - 41. Leptodendron Beuth. - 42. Heliophanes Salisb. - 43. Lophandra Don. - 44. Melastemon Salisb. - 45. Eurystoma Benth. - 46. Polycodon Benth. - 47. Elytrostegia Benth. 48. Arsace Salisb. - 49. Chlorocodon Benth.

\section{$481 \%$. NI Tenzlesia SMITH.}

c. DABoEcia Don. B o retta Neek. Elem, n, 351. Dele Candollea Baumg, v. infr. d.

d. ARcimBALDA. C a a dollea Baung. msc.

\section{18. Andromedia $L I N N$.}

a. CASSIOPE Don. DC. VII, 610 .

b. POLifolia Buxb, A ndromeda Don. DC, VIT, 606. Daphne Lian. ex Smith in Rees Cyclop. $V . X I$.

c. CASSANDRA Don. DC. VIT. 610. L yonia Reichenb. Flor. excurs. 414. D ipla ri a Raf. msc. B a u man $\mathrm{n}$ a DC. mse. A a drom eda Gärtner I, 304, t, 63. C ha. maed a phote Buxb. Aot. Petrop. I. 241. $t$. 8. $f .1$. Mönch Method. 457.

d. ZENOBIA Don. DC. VIT. 597. A. $\mathrm{r}$ a e e m o s a Linn.

e. LEUCOTHOE DC. VII. 601. - $\epsilon$. E a le u cot ho DC. l. e. Leucothoe Don. - $\beta$. Maria DC. l. c. A ndromeda mariana Linn. Bot. Mag. 2, 1579. $\gamma$. Agauria DC. 2. c. Agaristae s. p. Don. (Bot. Mag. $t, 2660,3286$. Kunth $t$. 263. Pohl $t, 121$, $-\delta$. A g a stia DC. $l$. c. Agaristae sp. Don. (Pohl t. 122.)

4318/1. Dxyclendreum $D C$. C a 1 y x quinquepartitus. Cor olla hypogyna, ovata, quinquedentata. S ta mi n a 10, imae corollae inserta, fil a menta crassiuscula, pilosa, antherae oblongae, loculis apice discretis, acuminatis, muticis. Ovarium quinqueloculare, loculis multiovulatis. St y lus simplex, crassinsculus, pentagonus; stigma obtusum. Caps a la pyramidata, pentagona, quinquelocularis, loculicide quinqnevalvis, valvis medio septiferis, placenta basilari, quinqueloba. Sem ina plurima, acicularia. - Arbor boreali-americana, glabra; foliis alternis, petiolatis, oblongis, acuminatis, serratis, gustu acidulis, paniculis terminalibus, polystachyis, floribus subsecundis, albis.

0xydendrum DC. Prodr. VII. 601. Andromeda a r b o re a Limn. Bot, Mag. $t .905$.

\section{9 . Eyomia NUTT.}

loter species dele $\mathbf{A}$ adromedam a r boream Linn. Vid. supra n. 4318/, et A u d r om. m a r i a u a m Linn. 4318. f. Androm. racemos am Linn. 4318, d.

\section{Thibaudia $P A V O N$.}

Thibaudia DC. Prodr. VII. 860 . Choupalon Adans. Eam, II. 164. - Agapetes Dou. DC. Prodr. VII. 553. Cavifuium Thouar. S y mph ys ia Presi. Ta us chia Preisler. A a d reusia Dunal in DC. Prodr. VIT. 506. Peyrus a Richard msc. H or a e m a n a i a Vahi in Dansk. Selsk.
Skrift. VI. 120.

$4336 / 1$. Anthegterva HOOK. C a ly tubo cum ovario connato, pentaptero, limbi superi, quinquedentati dentibus ovatis, erectis, acutis. Co roll a calycis limbo inserta, conico urceo. lata, quinquealata, quinquedentata, dentibus acuminatis, erectis $v$. erecto patentibus. S $\mathbf{t}$ a mi. n a 10 , imae corollae inserta, inelusa; filamen. t a monadelpha, antherae biloculares, loculis longissime rostratis, apice rima elongata dehiscentibus, 0 varium inferum, quinqueloculare, loculis multiovulatis. Stylus filiformis, simplex; stigma acutum. B a c a coriacea, pentaptera, calycis limbo coronata, quinquelocularis. Se min a plorima. - Frutex peruanus, in truncis annosis pseudoparasiticus, glaber, Thibaudiae et Macleaniae facie; ramis strictis, foliis alternis, sessilibus, lanceolatis, coriaceis, trinerviis, integerrimis, floribus axillaribus racemosis, majusculis, pedicellis elongatis, basi unibracteatis, versus medium bibracteolatis.

A it th opterus Hooker Ic, t, 243. DC. Prodr. VII. 578.

\section{GENERA DUBIA.}

\section{$433 \%$. Brossaea $P L U M$.}

Lam. $t$. 11t. $f$. 3. E pige a e sp.: Swartz, sed calyx adnatus.

438 \% 1 . Ameelnamia $D C$. $\mathrm{C}$ a $\mathrm{yx}$ imo ovario adnatus, basi turbinatus, quinquefilus, lobis ovatis, acutis, persistentibus. Corolla oblonga, quinquefida. St a m in a 10 , filamentis puberulis, antheris bilocularibus, muticis, apice biporosis. Ovari n m subglobosum, superne velatinum. Stylus filiformis. Capsula globosa, ima parte calyei adnata et ab eo cincta, quinquelocularis, loculicide quinquevalvis, valvis medio septiferis, axi persistente fere pentaptero. Semi$\mathrm{n}$ a in quovis loculo 1 v. 2. - Suffrutices brasilienses, erecti, Andromedae v. Gautierae facie; foliis alternis, coriaceis, margine revolutis, medio uninerviis, venis lateralibus pinnatis, subtus imprimis prominulis, mucrone nigricante e nervo medio orto terminali, racemis terminalibus, v. e supremis foliorum axillis, bracteolis ad basim pedicellorum subulatis.

Amechanla DC. Prodr. VIT, 579.

4338. Azallea $L I N N$.

Loisele u ria Desv. DC. Prodr, VIr, 714, Chamaecistus Gray non Don. (4340.)

4338/1. Osmathamenus $D C$. Calyx quinquefidus. Cor olla hypogyna, hypocraterimorpha, tubo supra medium gibbo, limbi quinquepartiti, patentis lobis subrotundis. S $\mathbf{t}$ a $\mathbf{m}$ in a 5 , imae corollae inserta, ejusdem laciniis alterna, inclusa; filamenta filiformia, antherae subrotundae, apice dehiscentes. Ov a rium quadriloeulare, loculis multiovulatis. Sty lus brevis, inclusus; st i g ma eapitatum, obtuse quadrilobum. C a p a l a subglobosa, quadrilocularis, quadrivalvis. Se min a plurima, linearia.... _ Frutices sibirici, erecti, ramosi; foliis alternis, persistentibus, coriaceis, breve petiolatis, ovatis, mucronulatis, supra glabris, subtus petiolisque ferrugineis, fragranti-aromaticis, floribus ad apices ramorum confertis, subumbellatis, breviter pedicellatis, albis v. roseis, gemmis floralibus squamosis, ciliatis.

Os mothamnus DC. Prodr, VII, 715, Azalea fragran 8 Adans.

4340. Plhod ot hammas REICHENB.

A dodendrou Neck. Elem. n. 354. Ch a maecis tus Don. Syst. III, 845. non Gr. (4338.) Le du m Miehel. non Lian.

\section{1. TR hadiodendron LINN.}

a. ANTHODENDRON Reichenb. A z a l a Desy. DC. Prodr. $V I T .715$. The is Salisb. mse.

e. EURHODODRNDRON. Lois le uria Reichenb. Flor. excurs. 1. 416, in not. B everin cki a Salisb. moc.

d. BOORAM. B а ramia DC, Prodr, VII, 720 .

4344. Hedmm LINN.

Da Ii a Adans. Fam. Ir. 165. 


\section{ERICACEIS AFFINES.}

\section{* CYRILLEAE.}

4344/1. Cyrilla GARDEN. Caly x quinquefidus. Corolla e petala 5 , hypogyna, calycis laciniis alterna. Sta min a 5 , cum petalis inserta, iisdem alterna; fil am ent a subulato-complanata, an the rae cordatae, biloculares, longitudinaliter dehiscentes. Ovarium toro brevi, carnoso insidens, biloculare. 0 vala in loculis solitaria, pendula. Stylus brevis; stigmata 2 , patentia, acuta. C a p sula carnosa, stylo mucronata, bilocularis, bivalvis, disperma v. abortu monosperma. Semin a inversa, Embryo.... - Frutex boreali-americanus; foliis alternis, lanceolatis, obtusiusculis, membranaceis, venosis, integerrimis, racemis lateralibus elongatis, aggregatis.

Cy rilla Garden ex Linn. Mant. I. 5. Jaeq. Collect, I, 162. Ic, rar. I, t, 47,

4344/2. Cliftomia BANKS. C a l yx pentaphyllus, minimus. Corolla petala 5, hypogyna, calycis foliolis alterna et multo majora, spathulata, subunguienlata. Stamina 10 , cum petalis inserta, alterna iisdem opposita breviora, filamenta bidentata, infra medium dilatata. Anthera e ovato-subrotundae, biloculares, longitudinaliter dehiscentes. $O$ va ri um quadriloeulare, ov nla in loculis solitaria, pendula. Stigma sessile, subpeltatum, obsolete quadrilobum, Drupa exsucca, quadrialata, quadrilocularis. Semina in loculis solitaria, inversa. E m bryo in axi albuminis carnosi cylindricus; cotyledonibus brevissimis, radicula elongata, supera, - Arbor boreali-americana; foliis alternis, breve petiolatis, integerrimis, racemis terminalibus, brevibus, densis, floribus albis, pedicellis fructiferis nutantibus.

Cliftonia Banks ex Gärtner $f$. III, 246. $t$, 225. M y1 o c a r y m Willdenow Enum 454. Pursh Flor. Bor. Amer. t. 14. Bot. Mag. $t$, 1625. W a Iterian a Fraser msc.

\section{* Pyrollaceae.}

434\%. CIadothammus BUNG.

Tol m i a a Hooker Flor. Bor. Amer. II, 44.

4348. Chimoplaila PURSH.

Hooker Flor. Bor. Amer. t. 138.

434. H. Hrolla TOURNEF.

a. PXROLA Salisb. (Hooker Flor. Bor. Amer.t.134-137,

b. MONESES Salisb. B ry op ht a $1 \mathrm{mum}$ E. Meyer Preussens Pflanzeng. 101.

\section{Ordo CLXII. Umbelliferae.}

\section{8\%. Morsfieldia $B L U M$.}

Fruetus hispidus, evittatas. - Frutex procerus. Folia ad apices ramorum conferta, maxima, peltata, palmata, subtus pilis stellatis intricato-lanata. Panicula termiaalis ramosissima. Capitula numerosissina subsessilia, in ramulis vltimis spication disposita. Flores minuti, brevissime pedicellati, pedicellis bibracteatis.

Jav, rar, 123, t. 26.

4406/1. Homatoeanuma FISCH. et MEY Calyeis margo obsoletus. Petal a obovata, apice biloba, cum lacinula inflexa tridentata. F ruc tus a latere compressus, subovatus, stylopodio pulvinato, stylis divaricatis; meriearpia quinquejuga, jugis aequalibus, membranaceis, univittatis, lateralibus marginantibus, valleculis univittatis, commissura bivittata. Carpophorum liberum, bipartitum. Semen dorso convexum, facie planum, - Herba ca ucasica, alpestris, perennis, gracilis, glabra; caule tenui, striato, subramoso, ramis elongatis, subaphyllis, foliis radicalibus supradecompositis, laciniis plerumque profunde bi-trifidis, lacinulis angustis, sublinearibus, mucronulatis, foliis caulinis supremis simpliciter pinnatis, laciniis elongatis, sublinearibus, umbellae octo-quatuordecimradiatae radiis inaequalibus, umbellulis subvigintifloris, involucris involucellisque pentaphyllis, fo. liolis setaceis, involucellorum umbellulas aequanti. bus, floribus parvis, albis, demum dilute roseis.

L o m a to $\mathrm{car} \mathbf{\mathrm { um }}$ Fiseher et C. A. Mey. Index sext. hort. Petropolit. 1839. p. 60. S e s eli al pi n u m Bieberst. 440\%. IBumium $\mathrm{KOCH}$.

e. CONOPODIUM DC. - ? Deringa Adans. Fam, IT. 498.

4414/1. Atemia HOOK, et ARN. Caly. e is margo quinquedentatus, persistens. Peta la obcordata, cum lacinula inflexa. Fructus subglobosus, a latere compressns, didymus, laevissimus. M ericarpia dorso jugis quinque filiformibus, subprominnlis, aequalibus, aequidistantibus, lateralibus ante marginem positis, valleculis et commissura angusta evittatis, Carpophorum integrum, tenue. S em en tereti-convexum, facie planinsculnm. - Herba boreali-americana, glabra, bipedalis; caule tereti, superne ramoso, oligophyllo, foliis pinnatis, pinnis duabus v. tribus, angustissime linearibus, basi et apice attenuatis, vaginis elongatis, angustis, umbella composita, subdecemradiata, involucellis polyphyllis, foliolis parvis, subulatis, floribus albis.

A te n l a Hook. et Arnott ad Beechey p. 349. - ? E d o s. mi i a Nutt. ex Torrey et $A$. Gray Flor. of North-Amer. $I$. 612. „valleculis univittatis et eommissura bivittata" ex el. auctoribus ab Ateuia verisimiliter non differt.

44 4/2. Neuropliyilum TORR, et GRAY. Calycis limbus quinquedentatus, dentibus lanceolatis, persistentibus. P etala obovata, apice inflexa. Fruetus stylopodio conico, stylisque brevibus, divergentibus coronatus, ovatus, a latere compressus, jugis dorsalibus filiformibus, vix prominulis, Jateralibus marginalibus carinatis, valleculis trivittatis, commissura quadrivittata. $\mathbf{S}$ e m e $\mathbf{n}$ tereti-convexum, facie planiusculnm. - Herba boreali-americana, perennis, glabra; foliis simpliciter trisectis, segmentis longis, linearibus, integris, subtus prominentim tri-quinquenerviis, supremis indivisis, umbellae radiis longis, involucri foliis $2-4$ subulatis $v$. interdum obsoletis, involucellis penta-hexaphyllis, floribus albis.

Neurophyllum Torrey et A. Gray Flora of INorth. Amer, I. 612.

4462/1. Euryptera NUTT. Calyeis limbns quinquedentatus, dentibus lanceolatis, deciduis. Petala cuneato-oblonga, apice cuspidato inflexa. Fructus reniformi-orbicularis, ntraque extremitate emarginatus, compressus, margine lato, tenui, disco impresso; mericarpia jugis vix prominentibus, aequidistantibus, approsimatis, valleculis univittatis, vittis latis, commissura bivittata. S e men complanatum, dorso subeoneavum. - Herba boreali-americana, glabra; foliis ternatim divisis, segmentis late cordatis, sublobatis, grosse mucronato-dentatis, involucro nullo, involucellis unilateralibus, multipartitis, floribus fiavescentibus.

E nryptera Nuttall ex Torrey et 1. Gray Flor. of North-Amer, I. 629.

$4468 / 2$. Leptotaenla NUTT. Ca ly $c$ is 
limbus obsolete quinquedentatus. P et a la obovata v. oblonga, acumine inflexo. Fruct us oblongo-ellipticus, stylopodio inconspicuo, stylisque divergentibus, compressus, margine crasso spongioso cinctus, jugis filiformibus, lateralibus cum margine confluentibus, valleculis evittatis, sexoctostriatis, commissura evittata. Carpophornm bipartitum. S e men complanatum. - Herbae boreali-americanae, perennes, glabrae; radicibus tuberosis, folits biternatisectis, involucro nullo, involucellis unilateralibus, multipartitis, floribus fuscis $v$. flavis.

Lep totaenia Nuttall ex Torrey et $A$. Gray Flora of North-Amer, I, 630 .

448\%/1. Barysoma $B U N G$. Calyeis limbus quinquedentatus. C o rolla e petala obovata, emarginata, cum lacinula inflexa. Fructus ellipticus, a dorso compressus; mericarpia quinquejuga, valleculis quadrivittatis, vittis linearibus, ad basim fere mericarpii productis, co mmis s u ra sexvittata, vittis utrinque tribus, clavatis, contiguis, inaequalibns, abbreviatis. - Herba с а ис а sica; foliis sinuato-pinnatifidis, subtus cano. tomentosis, involucri foliis setaceis.

B a r y $80 \mathrm{~m}$ a Bunge Index sem. hort. Dorp. 1839. $n, 4$.

44\%9/1. Eurytaenia NITT. Calycis limbus quinquedentatos. Pet a la.... F ructns stylopodio depresso stylisque recurvis superatus, ovatus, a dorso lenticulari-compressus, glaber, margine angusto cinetus, jugis dorsalibus approximatis, filiformibus, intermediis carinatis $\mathbf{v}$. anguste alatis, lateralibus remotis, crassis, suberosis, marginantibus, valleculis univittatis, commissura bivittata, vittis erassis, contiguis. Carpophorum bipartitum.... Herba borealia mericana, glabra; foliis bi-tripinnatisectis, segmentis distantibus, anguste linearibus, acutis, umbel. lis terminalibus, multiradiatis, involucris et involucellorum foliolis pluribus, tri-quinquefidis.

Eurytatia Nuttall ex Torrey et A. Gray Flor. of North-Amer. 1. 633 .

4491. Cymopterus $R A F$.

Nattall in Journ. Academ. Philadelph, VII. 28. Torrey et A. Gray Flor, of North-Amer. I. 693.

a. EUCYMOPTERUS Torr. et A. Gray l. $c$, Caly e is deutes subulati. Peric a p f u m tenue, commissura cireiter octovittata, carpophoro nullo.

b. PHYLLOPTERUS Nutt. msc. C al y cis dentes minuti. Peric a $p$ i um subsuberosum, commissura quadrivittata, carpoptoro nullo.

c. LEPTOCNEMIA Nutt. msc. Caly c is dentes minuti. Eructus alae erassiuseulae, subspongiosae, alternae obsoletae, commissura sexvittata, carpophoro Iibero, bipartito.

d. PTERYXIA Nutt. mse. C a l y $\mathrm{c}$ is dentes distincti, laneeolati. Fruet a s alae latae, commissura quadri-decemvittata, carpophoro libero, bipartito. S e I in u m torebin thi a u mooker Flor. Bor. Amer, $2,95$.

4515/1. Glyeosman NUTT. Calycis limbus obsoletus. Petala obovata, emarginata, acumine brevissimo, inflexo. Fruct us stylopodio depresso stylisquue brevissimis coronatus, linearioblongus, a latere compressinsenlus, solidus, glaber, mericarpiis quinquejngis, jugis acute ca rinatis, valleculis evittatis. Carp o phora m bifidum. - Herbaboreali-americana, perennis, bi-tripedalis; odore anisato, foliis biternatisectis, segmentis inciso-serralis, umbellis oppositifolit et terminalibus, involucro involucellisque nullis, flori-
bus albis.
G I y cos ma Nuttall in Torrey et A. Gray Flora of North.Amer. I. 639 .

45: ci s margo obsolete et obtusissime quinquedenta. tus. P e ta la ovato-acuminata, integra, cum acamine inflexo. Fruetus stylopodio depresso, decemcrenato, heptapterus, jugis primaris (?) omnino evanidis, secundariis (?) in alas membranaceas expansis; meri carpia a dorso compressa, commissura plana, lata, evittata, medio sulco longitudinali notata, externum quadrialatum, alis duabus commissuralibus totidemque dorsalibus, internum trialatum, alis duabus commissuralibus, dorsali unica, altera evanida, valleculis latis, evittatis. Semen lanceolatum, marginibus involutum, vittis tenuissimis, circiter duodecim cinctum. Carpophor n mipartitnm. - Herba in arch $i$. pelagi graeci insula Zacyntho indigena; caule acute triquetro, foliis radicalibus pinnatipartitis, partitionibus trisectis, segmentis basi confluentibus, ovato-oblongis, margine late et irregulariter crenatis, lobulis apice callosis, umbella terminali circiter duodecimradiata, lateralibus minoribus, circiter octoradiatis, involucri involucellorumque foliolis linearibus, acutis, margine membranaceis, floribus luteis, centralibus et umbellarum lateralium abortu masculis.

He p tap ter a Reutter in Mom. soc. phys. Genev. VIrT. $302, t .5$.

4540/1. Dpoialia LINDL, F l ores polygami. Caly cis limbus obsoletus, quinquedentatus, aequalis. Petal a ovata, acuminata, acumine inflexo. Fruetus teres, ovalis. Mericarpia jugis primariis tribus, angulos obsoletos referentibus, valleculis planis. $\vec{v}$ it ta e jugornm primariorum solitariae, minutae, secundariorum maximae, solitariae, commissurales duae maximae et duae obsoletae. Sem en involutnm, - Herba per. sica, galbanophora, erecta, minute scabra; caule elato, robusto, foliis bipinnatis, bijugis, foliolis oblongis, obtusis, serrulatis, decurrentibus, umbellis terminalibus et lateralibus compositis, involucro sub. nullo, involucellis polyphyllis, floribus pallide flavis.

0 poidla Lindley in Bot. Reg. 1839. p. 66 .

4543/1. Cymapiam NUTT. C a 1 y $\mathrm{c}$ is limbus obsoletus. Pet a 1 a late obovata, emarginata, apiculo inflexo. Fruct as ovalis, a lateribus modice contractus, stylopodio minuto, depresso, stylis longis, reflexis; mericarpiis quinquejugis, jugis acute carinatis, aequidistantibus, valleculis tri-quinquevittatis, commissura quadrivittata. $\mathrm{C}$ a rp o ph oru m bipartitum. Semen sectione transversali profunde reniforme, sinn angulo prominu10. - Herba boreali-americana, perennis, robusta; foliis biternatisectis, involucro nullo, involucello laterali, oligophyllo, floribus albis.

C y a pium Nuttall in Torrey ot A. Gray Flora of North-Amer. 1. 640.

4543/2. Deweya TORR. et A. GRAY. C aIyeis limbus quinqnedeatatus, dentibus subulatis, persistentibus. Petal a obovata v. obcordata, apicalo longe inflexo. F r u ctus stylopodio depresso, stylisque longis gracilibus superatus, oblongo-ellipticus, a latere compressus, glaber, meric arp i is quinquejugis, jugis elevatis, subalatis, lateralibus marginalibus, valleculis trivittatis, commissura quadrivittata. S e me $\mathrm{n}$ intra pericarpium liberum, sectione transversa semilunare. - Herba boreali-americana, perennis, glabra; folizs omnibus radicalibus, simpliciter pinnatisectis, $s 6 g$ - 
mentis late ovatis $v$. cordatis, acute multidentatis, umbellis multiradiatis, exinvolucratis, involucellis tetra-pentaphyllis, foliolis lanceolatis, integris v. cuspidato-bi-tridentatis, floribus pallide flavis. I. 641 .

Dewe y a Torrey et A. Gray Flora of North-Amer.

4543/3. II usenîmm 'NUTT. Calycis limbus quinquedentatus, persistens. Petala obovata, apiculo inflexo. Frnctns stylis graeilibus, reflexis superatus, ovatus v. ovato-oblongus, a latere compressus; merie a riis quinquejugis, minute seabris, jugis filiformibus, acutis, valleculis bi-trivittatis, commissura quadrivittata. Carpo phorum bifidum. Sem en marginibus leviter introflexis. - Herbae boreali-americanae, humiles, resiniferae, foetidae; radice fusiformi, caudice brevi $v$. a basi dichotome ramoso, foliis bi-tripinnatifidis, involucro nullo, involucello laterali, oligophyllo, foliolis rigidis, angustis, floribus flavis v. albis.

Musenium Nuttall in Torrey et $A$. Gray Flora of North-dmer. I. 642. Seseli divaricatum Pursh. Bot. Mag, t. 1742.

4549/4. Apiastrum NVTT. Calycis limbus obsoletus. P etal a suborbiculata, integra, concava, apice haud inflexa. Fructus stylopodio minuto stylisque brevissimis ad commissuram valde contractus, didymus; meriearpiis ovatoglobosis, quinquejugis, jugis parum elevatis, rugulosis, valleculis univittatis, earpophor $\mathrm{rm}$ bifidum. S e min a basi et apice incurva, facie excavata. - Herbae californica e, annuae, humiles, glabrae, dichotome ramosae; foliis multipartitis, laciniis anguste linearibus, umbellis axillaribus sessilibus, pauciradiatis, involucro et involucellis nullis, floribus albis.

A piastrum Nuttall ex Torrey et A. Gray Flora of North-Amer. I. 643 .

\section{Ordo CLXIII. Araliaceae.}

4556/1. Irassaia ENDL. Cal $\mathrm{y} \times$ invoIncello tetraphyllo, tnbo cum ovarii basi connato, limbo semisupero, truncato. Co or oll a e petala summo calycis margini inserta, in calyptram hemisphaericam, apice umbilicatam, longitudinaliter multistriatam, deciduam coalita. S $\mathrm{t}$ a $\mathrm{m}$ in a $\mathrm{cum}$ corolla inserta, 13; fil a menta tereti-subulata, anthe rae lineares, dorso supra basim insertae, patentes. Ovariuin somisuperum, turbinato-conicum, vertice exserto multicostatum, tredecimloculare, septis enneatis, crassis. Ovnla in loculis solitaria, granulosa. Stigma sessile, radiatum, centro depressum, ambitu tredecimlobum, lobis brevibus, cum ovarii costis continuis, prímum conniventibus, demum erectis, apice truncato-stigmatosis. Fruetus..... Arbor Novae Hollandiae tropicae; folits in apice ramorum alternatim confertis, longe petiolatis, peltatim septemquatuordecimfoliolatis, foliolis petioli apice dilatato complanato, orbiculato radiatim insertis, petiolulatis, oblongis, subobtusis, basi subcordatis, remote subserratis, stipulis intraaxillaribus, adnatis, e basi late ovata elongato-acuminatis, dense imbricatis, racemis terminalibus pluribus, pedicellis brevibus, erassis, busi bracteae delapsae cicatrice notatis, apice glomerato dense plurifloris, per rhachin elongatam, simplicissimam, strictam sparsis.

Bras s a i Eudlicher Nov, Stirp. Mus. Dindob. De cad, $n, 100$, Iconogr, $t, 114,116$, Plantau integram videsis apud Flinders Vog. II.38.tab. 9. ad dextram, juxta viam syl. vaticam.

\section{Ordo CLXIV. Ampelideae.}

4566. Cissus LINN.

Wight Ic. t. 144. 145. In g e h h o u s I a Dennst, z. Hort, Malab. VII, 48 .

$456 \%$. Vitis LINN.

Wight Ic. t. 28. 170, 171, 177, 178. Illustr. $t, 57$,

4569. Teea LINN.

Wight Illustr. $t$. 58 .

\section{Drdo CLIV. Comeate.}

\section{Corrams TOURNEF.}

b. TANYCRANIA E. (Siebold et Zuce. Flor. Japon, t. 50,) 4579. Polyosma Blum. Genus h. 1. delendum. Vid. infra n. $4678 / 1$.

\section{Drdo CLXVI. Horanthaceae.}

4584. Visemm LINN.

Korthals Loranth. Jav, 57. Sehleiden in Wiegm, Ar. chiv, V. t, 7. Griftitis in Linn, Transact, XVIII, 7t,

4584/1. Ginalloa KORTH. F 10 res monoici. M a 8 c. Ca ly $x$ tri-quadripartitus. St a mina 3 v. 4 , fil a me nt a brevia, an $t h$ erae biloculares. F e m. Calyx tri-quadripartitus. Ovari um unileculare, uniovulatum. Sty lus brevis. Stigma capitatum. B a c $\boldsymbol{c}$ a compressa. S emen materie viscosa cinctum. Embryo in albumine carnoso inversus, - Frutices moluccani, parasitici; ramis vaginatis, foliis oppositis, floribus spicatis.

Gina 11 o k Korthals Loranth. Jav. G4.

4585. Tupeía CHAM, et SCHL.

Genus secuudum el. Korthals Diss. de Tupeia 1838. propter ovula plura, ex apice columellae centralis pendula, Santalaceis accensendum. Ceterum Viscum antarctiua Forst. et plantas a cl. Auetore descriptas congeneres esse, vix mihi persuadeo.

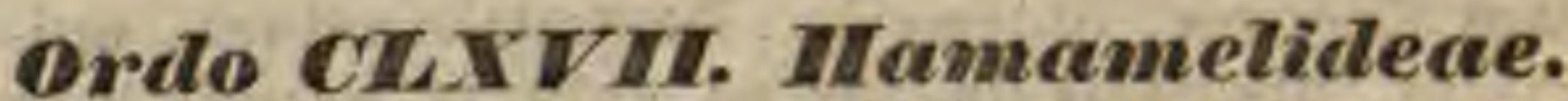

4590. Trielnoeladus PERS.

Flores abortu dioiei. E a bryo in axi albuminis carnosi orthotropus; cotyled on Ibus ovatis, planis, radic u la longa. Harwey Genera of South-Afric, Plant. 128.

\section{Ordo OLI VIII. Bratiaceae.}

4600. Berardia BRONGN.

? $\mathrm{P}$ ty $\times 0$ st oma Vahl in Naturhist, Selikab. Skrift. VI. 96.

\section{Ordo CLXX. Saxif ragaceae.}

\section{3\%. Nimmoia WIGHT.}

Petala 4 et stamina 4, nee 5, ut typographus exseripsit.

4632/1. Hoykinia NUTT. C a ly $\mathrm{x}$ tubo turbinato, demum urceolato, cum ovario connato, limbi quinquepartiti laciniis triangularihns, patentibus. C or o II a e petala 5 , inter calycis lobos inserta, iisdem longiora. Stamina 5 , cum petalis inserta, iisdem alterna et breviora; filamenta filiformi-subulata, an therae biloculares, longitudinaliter dehiscentes. O va ri u $m$ inferum, bi-triloculare, placentis dissepimento $\mathrm{v}$, angulo centrali adnatis, multiovulatis. St y 1 i $2-3$, breves; stigmata simplicia. Capsula calyce vestita, bi-trilocularis, bi-trirostris, inter rostra dehiscens, placenta centrali polysperma. Semina plarima, ho- 
rizontalia, ovoidea glabra.... Herbae bo reali-americana , foliosae; foliis alternis, palma. tilobis, inciso-dentatis, dentibus mucronatis, petiolis basi vix stipuliformibus, floribus parvis, corymbosocymosis.

Boykin la Nuttall in Journ. Academ. Philadelph. VII. 113. Torrey et A. Gray Flor, of North-Amer, I. 576.

\section{8\%. Hepuropetalum ELLIOT.}

Pyxidanthera Múhleub. Catalog.

\section{I I euchera LINN.}

Calyx tubo adnato. Torrey et A. Gray Flor. of NorthAmer. 1.577.

a. EUHEUCHERA Torr. et A. Gr. l, c. C aly $\mathrm{x}$ tubo ob. conico v. eampanulato, limbi lobis brevibus, aequalibus, pateatibus. Petal a pleramque persistentia, demum revoluta v. contorta. Filame uta et $s t y l i$ filiformes, exserti. - Panicula effusa. (Hooker Flor. Bor. Amer. t. 79. Bot. Reg. t. 1302.)

b. HERUCHEA Torr, et A, Gr, l, c, Caly $x$ tubo campanulato, fauce obliqua, limbi laefniis erectis. P e ta I a persistentia. Filamenta et styli subulato-filiformes, inelusi v. demuan vix exserti. - Flores magni, in paniculis contractis $v$, thyrsoideis. (R. Brawa in Frankl. Narrat. $t$, 29,

c. HOLOCHLOA Nuttall mso, Cal y x tubo eampanalato, limbi lobis erectis, subinaequalibus. Petala minuta, saepe fugacia $\nabla$, nulla. F II ame nta et st y li brevis. simi, subulatl, inclusi. - Flores plerumque magni, glomerati v. spicati. (Bot. Reg. t. 1924.)

d. HEOChERELLA Torr, et A. Gr. $l$. c. Cal y $x$ tubo obeonico, limbo rotato, aequalt. Petala parva, fugacia. Filamenta et st y li subulati, brevissimi. - Flores parvi, in paniculis angustis, laxis.

4639/1, Tolmiea TORR. et A. GRAY. Calyx tubo infundibuliformi, libero, basi subinaequali, demum hine longitudinaliter fisso, limbi quinquepartiti laciniis subinaequalibus, aestivatione imbricatis. Corolla e petala 5, summo ealyeis tubo inserta, filiformia, recurva, persistentia. Stamin a 3 , cum petalis inserta, calycis lobis tribus superioribus opposita, breviter exserta; filam entis subulatis, antheris magnis, reniformibns, bilocularibus, loculis apice confluentibus. Ovari n m liberum, oblongum, basi attenuatum, nniloculare, placentis duabus ad suturas parietalibus multiovulatis. Styli 2 , elongato-subulati, divergentes; stigmata obtusa. Capsula calyce hine fisso vestita, unilocularis, birostris, inter stylos dehiscens. Semina plnrima, globosa, minima, testa muricato-hispida. - Herba boreali-americana, perennis; radice fibrosa, foliis cordatis, incisis, caulinis allernis, stipulis scariosis, adnatis, floribus in racemo elongato gracili, pedicellis bracteis duabus setaceis, deciduis, fructiferis erecto-patentibus.

To $1 \mathrm{~m}$ iea Torrey et A. Gray Flor. of North-Amer. 1. 382. noa Hook. Heuchera Menziesil Hooker Flor. Bor. Amer. t. so.

\section{Mitellopsis MEISN.}

c. Mitellastra. Petala pinnatifida. Stamin a 5 , pe talis alterna; fil amentis brevibus. Stig mata simplicia. C apsula semisupera. Miteli a s tra sect. Mi tella e Torrey et A. Gray Flor. of North.Amer. I. 586 .

4641. Intella TOURNEF.

Mirellacect. B nmitell a Torrey et A. Gray Flo. ra of North-Amer. I. 584 .

464\%. Tellima $R, B R$.

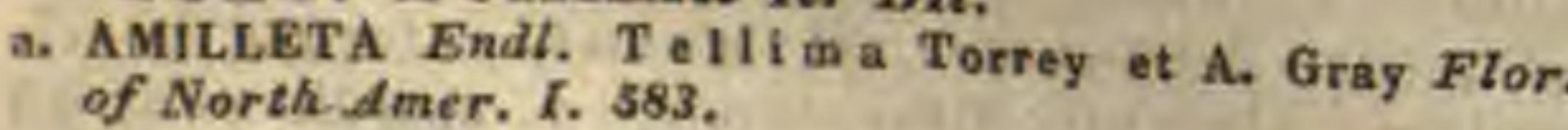

b. ALLETiMA Endl. Lit h o ph rag m a Nuttall in Journ Academ. Philadelph, VIT, 26. Torrey et A, Gr. 2 , c.

c. Lithophragmella Torr. et A. Gr. l, c. Caly $\mathrm{x}$ eyathiformi campanulatus, vix adhaerens. Pet a I a spa. thulato-cuneiformia, integra, - Folia radicalia reni. formia, obsolete tri-quinqueloba, caulina trifida.

\section{Tharella LINN.}

Torrey et A. Gray Elor. of North-Amer. I. 587.

a. EUTLARELLA Torrey et A. Gr. $l$. c. Seapas nudus, racemus simplex, petala oblonga, unguiculata. (Bot. Mag. ใ. 1589.)

b. ANTHONEMA Nutt, msc. Caulis alternifolius, flores paniculati, petala filiformia v. subulata, ? B I o n di a Necker Elem, n. 786. Hook. Elor. Bor. Am, t, 77. 78.

4844. II Ioteia MORR et DEC,

$\mathrm{Si}$, quod nune asserunt auetores, Hoteia et Astilbe Don, 4645. revera plantae congeneres, posterius incomplete ab auctore suo descriptum supprimeadum, et prius egregte stabilitum servandum erit.

4 64 4 . Neillia DON. Caly $x$ quinquefidus, lobis ovatis, cuspidatis. Coroll a e petala 5, calyeis fauci inserta, subrotunda. Stam in a 20 , cum petalis inserta, biseriata, exserta. O varinm unieum, liberum, uniloculare... Ca ps u la follieuliformis, stylo coronata, unilocularis, latere interiore dehiscens, polysperma. Semina sphaerica, nitida, adseendentia. Embryo in axi albuminis carnosi, copiosi orthotropus, eotyledonibus ovalibus, radieula crassa, infera. - Frutices inermes, nepalenses, Spiraeae opulifoliae facie; foliis simplicibus, cordatis, ovatis v. trilobis, acuminatis, duplicato-serratis, bistipulatis, floribus racemosis, albis.

Neillia Don Prodr. 228. DC. Prodr. IIT. 547.

4665. Iry dirangea $L I N N$.

Slebold et Zuccarini Flor. japon, $I, 101, t, 51-64$.

4688/1. Cardindra SIEBOLD et ZUCC. Flo res marginales steriles, calyce ampliato, tripartito, petaloideo, reticulato, corolla et genitalibus rudimentariis. Fertilibus: C a l y x tubo cum ovario connato, limbo supero, quinquedentato. Coro 11 a e petala 5 , annuli epigyni margini inserta, sessilia, ovata, aestivatione valvata. Stamina plurima, enm petalis inserta, pluriseriata; filamenta filiformia, antherae biloculares, basi affixae, loculis connectivum sursum dilatatum marginantibus obcordato-truncatae. O va ri u m infernm, incomplete triloculare, placentis septorum superne deliquescentinm marginibus adnatis, multiovulatis. Styli 3 , distineti, conniventes; stig mat a subterminalia, introrsum lateralia. C a p s la calycis limbo stylisque coronata, basi tri-superne unilocolaris, vertice inter stylos foramine aperta, semiseptis margine placentiferis. Semina plurima, adacendentia, testa reticulata, adnata, basi et apice in aैlam extensa, E m b r y o in axi albuminis dense carnosi orthotropns; cotyledonibus brevissimis, spathulatis, radicula eylindrica, infera. - Suffrutex japonicus; caulibus herbaceis, bipedalibus, ramosis, foliis alternis, petiolatis, oblongis, acutis, serratis, penninerviis, exstipulatis, floribus corymbosis, marginalibus radiantibus.

Cardiandra Siebold et Zuecarini Flor. japon, $\boldsymbol{I}$. 119. $t$. 65 .

46FO/I. Jamesia TORR. et A. GRAY. F lores polygami. Cia l y x campanulatus, inferne cum ovarif basi cohaerens, profnnde quinquefidus, laciniis ovato-lanceolatis, subinaequalibus, persistentibus. Coro 11 a e petala 5 , oblonga, obtusa, basi angustata, concava, intus minute pubescentia, marginibus aestivatione induplicatis. Stamina petalis numero aegualia v.j duplal (?), fil a mentis subulatis, petala superantibus. 0 va- 
ri um ovoideo-conicum, tri- (interdum 4- 5-) loculare, loculis incompletis, placentis crassis multiovulatis, in axi vix cohaerentibus. Styli longi, basi plus minus cohaerentes, exserti; stig mata terminalia, parva, truncata. Fructus...... Frutex boreali-americanus; foliis oppositis, petiolatis, serratis, subtus canescentibus, cymis axillaribus et terminalibus, parvis, paucifloris, ramulis pedicellisque cum calycibus pubescentibus. I. 593.

Jamesia Torrey et A. Gray Flora of North-Amer.

46 8 8/1. Pollyosma $B L U M$. C a ly $\mathrm{x}$ tubo subturbinato, cum ovario connato, limbi superi, quadripartiti lobis acutis, persistentibus. Corolla e petala 4, summo calycis tubo inserta, linearia, aestivatione valyata, demum revolnta. S tamina 4, cum petalis inserta, iisdem alterna et paulo breviora; fil a m e nta filiformia, a $n$ thera e lineares, basifixae, biloculares, longitudinaliter dehiscentes. Ovari u m inferum, uniloculare, placentis duabus parietalibus multiovulatis, ovulis adscendentibus, orthotropis. Stylus filiformis; $8 \mathrm{ti} \mathrm{g}$ a simplex. B a ce a exsucea, calycis limbo coronata, abortu monosperma. S em en adscendens, Embryo in apice albuminis copiosi carnosi minutus, ovatus, antitropus, $r$ a dicu la umbilico e diametro opposita, supera. - Arbores $v$. frutices, in Asia tropica et Nova Hollandia orientali crescentes; foliis oppositis, exstipulatis, integerrimis $v$. serrulatis, racemis terminalibus $v$, rarius axillaribus, pedicellis medio tribracteolatis, floribus numerosissimis albidis, odoratissimis, quandoque pentameris.

Polyos ma Blume Bijdr. 658. Bennett in Horefield Plant, Jav, rar, 193, $t$. 40 , It teae s pee, Wall.

\section{* ROUSSEACEAE.}

46S0. Toussea SMITH.

Eadlicher Iconogr, t. 107. R ous s a e a DC. Prodr. VII. 522. R o a s e a u vi Bojer Hort. Maurit. 246.

\section{** BREXIACEAE.}

4681/1. Ixerba A. CUNN. Calyx liber, pentaphyllus, persistens, laciniis aestivatione imbricatis. Coroll a e petala 5 , disco hypogyno inserta, membranacea, unguiculata, aestivatione subimbricata, decidua. S ta m in a 5 , hypogyna, petalis alterna; filamenta subulata, antherae ovato-acuminatae, erectae, basifixae, biloculares, longitndinaliter dehiscentes. D i s e u s hypogynus carnosus, quinquelobus, lobis cum staminibus alternantibus, retusis, integerrimis. O variu m su. perum, ovato-pentagonum, quinqueloculare, locolis biovulatis, ovulis collateralibus, pendulis. Stylus ovario continuus, angulatus, sursum attenuatus; stigma simplex. Fractns...... Arbor Novae Zeelandiae, vigintipedalis, elegans; ramis teretibus, glabris, cortice rugoso, foliis alternis, petiolatis, exstipulatis, ad apices ramulorum saepe verticillato-confertis, elongato-lanceolatis, acuminatis, obtusiusculis, coriaceis, remote calloso-serratis, utrinque glabris, superne nitidis, subtus pallidioribus, floribus albis, terminalibus, corymbosis, pedunculis plerumque trichotomis.

I $x$ e r b a A. Cunningh, in Annal. of Nat. hist, III. 249.

Ordo CLXXII. Mlenispermaceae.

SUBORID I. MENISPERMEAE.

468\%. Coeeulus $D C$.

Wight Illustr. $t, 7$.
4696. Gynostemma BLUM.

Geous secundum cl. Decaisne. Archiv. Mus, I. 147, in not. fortassis Cucurbitaceis accenseadum.

\section{Hingtoereme WALL.}

Genus secundum cl, Decaisne Archiv, Mus, I, 163, in not. a G y nocephalio Blum. (supra n. 1870.) non diversum.

\section{SUBOIEDO II. LARDIZABALEAE.}

LARDIZABALEARUM, aune in propriom ordinem evectarum, geaera secuadum cl. Decaisne mouographiam in Archiv. Mus. I., 143_213, cujus olim noasisi synopsim perbrevea piae maaibus babui, ita exponenda :

9. 1. MADAGASCARIENSES. Flores dioici, foliolis duplici serie ternatim dispositis, staminibus inferne monadelphis, antheris introrsis, drupa monosperma, embryonis cotyledonibus planis, divarieatis.

\section{Burasaia THOUAR.}

Fl ores dioiel. Caly $x$ hexaphyllus, foliolis concavis, exterioribus minoribus, crassis, ovalibus. C or olla peta. la 6 , oblongo-ovalia, breviter ungukulata, inferne caruosa, exteriora majora, ad marginem superiorem eroso-denticulata. S ta mi a a 6 ; f il a me a i a inerassata, iaa basi monadelpha, antherae introrsae, biloculares, adnatae, loculis cou. nectivum superantibus muticae, 0 v a rif rudimentum nullam. Fem. Calyx et corolla maris. S tamina 6 , abortiva. $0 v a r i a 3$, uniloeularla. $0 \vee u \perp u m$ unieum, pendulum, anatropum. S ti g m a sesslle, peltatua. D r up a e 3, substipitatae, putamine sulcato, papilloso.viscoso, endocarpio inter eotyledoues promineate. S e m e a pendulum. A I b u m e a carnosum. E a bryonis cotyledones planae, divaricatae, radicula supera. - Frutex madaga ccarientis, de. bilis; foliis alternis, longe petiolatis, trifoliolatis, foliolis ovatis, integerrimis, coriaceit, racemis axillari. bus paucifloris. - Decaisne in Archiv.Mus, I, 197, t, 13,f,c.

§. 2. ASIATICAE, Flores monoici, foliolis simplici v. duplici serie ternatim dispositis, staminibus liberis v, monadelphis, antheris extrorsis.

\section{700. Akebi̊a DECAISN.}

F I o r e s monoiei. Masc. C a I y $x$ triphyllus, foliolis ovato-lanceolatis, concavis, subaequalibus, aestivatione subvalvatis. Corolla nulla. Sta $m$ in a 6 , biseriata, subaequalia, libera; f i l a me n $t$ a cylindracea, primo erecta, dein incurva, a utherace extrorsae, tiloculares, adoatae, loculis connectivam superantibus muticale. 0 v a ri o r a m rudiaenta 6. Fe m. C a I y x triphyllus, follolis subrotundis, coneavis. Corolla nulla. S tamina 6-9? nana, abortiva. Ovaria 3-9, tunc triseriata, distineta, oblongo-cylindracea, unilocularia. 0 ₹ula plurima, parieti foveolato v, papilloso atfixa, prinum orthotropa, demuan anatropa. S tylus ovario contiusus, brevis, cylindricus. Stig ma peltatum. Fruc. t as ..... - Frutices $j$ a ponio $i$, scandentes; folitis al. ternis, pellatim digitatis, tri-quinguefoliolatis, foliolis apiculatis, integerrimis v. repando-dentatis sublobatisve, racemis axillaribus, peduneulis androgynis ima basi squa. matis, paucifloris, floribus femineis inferioribus, longius petiolatis, roseis. - Decaisue in Archiv. Mus. I. 195.t.13. f. A, B. Rajania quinata Thunb.

4ro0/1. Holboellia WALL, Flores monoici. C al y x hexaphyllus, foliolis crassiusculis, exterioribus ovatis, aestivatione valvatis, interioribus angustioribus, oblongu-lanceolatis, concavis, tenuiter nervatis. Cor olla e petala 6 , biseriata, parvula, nunc scutiformia carnosa, nnne lanceolata, membranacea. Stamina 6, libera; fil amenta linearia, erassinscula, in tubum conniventia; antherae extrorsae, biloculares, adnatae, loculis connectivo brevioribus apiculatae. Ovarioram rudimenta 3 , subulata v, conoidea, carnosa. F em. Calyx et corolla ut in maribus. St a mina 6 , minuta, antheris abortivis subclavata. Ovaria 3 , distincta, conoidea, unilocularia. O v ula plurima, parieti pilosulae seriatim immer- 
sa, anatropa v. semianatropa. Stig ma sessile, conicum, subobliqunm. B a c c a e polyspermae, stigmate persistente apiculatae. $\mathrm{S}$ e min $\mathbf{m} \mathbf{m}$ testa chartacea, basi et latere umbilicata. Albumen copiosum, carnoso-cornenm. Embryo parvus, radicula cotyledonibus subaequali. - Frutices $n e_{-}$ palenses, scandentes, magni; foliis alternis, peltatim digitatis, racemis axillaribus, paucifloris, floribus albis, extus purpureo-tinctis, baccis purpureis, esculentis.

HoIl b o elli a Wallich Flor. Nepal. 24. $t, 16.17$. Decaisne in Archiv. Mus. 1, 193. $t, 12 . f, B$.

\section{4\% (1). Stammionia $D C$.}

Flores monoici. Caly $x$ hexaphyllus, foliolls carnosis, exterioribus oblongo-lanceolatis, inferae aestivatione valvatis, superne subimbricatis, interioribus linearibus, aequalibus. Corolla nulla. Stamina 6; filamentis in tubum coalitis monadelpha, a $n$ therae extrorsae, biloculares, adnatae, loculis connectivo brevioribus apiculatae. Ovarior u m rudimenta 3 , conoidea ve pyriformia, carnosa. Fem. Caly $x$ et corolla maris. Stamina 6 abortiva, nana, filamentis brevissimis, earnosis, 0 varia 3 distineta, cylindracea, unilocularia. Orula plurima, parietibus pili. feris v, cellulosis inserta. St ylif breves, ovaris continul; stig mate capitato-peltato. Fructus ..... - Frutices jap onici et chinenses, verisimiliter scandentes; folits pellatim digitatis, foliolis integris, apiculatis, racemis axillaribus paucifloris. floribus longe pedicellatis, majusculis, pedunculis e squamarum congerie ortis. Stauntoni a DC. Syst, I, 513. Prodr. I. 96. Decaisne in Archiv. Mus. I. 191. t. 11, f. $C$.

\section{4\% (1). Parvatia DECAISN.}

Flores monoici. Masc. Cal yx hexaphyllos, foliolis earnosis, exterioribus ovatis, aestivatione valvatis, interioribus, lanceolatis, subeoncavis. Cor olla e petala 6 , biseriata, oblonga-lanceolata, medio angustata, acuta, eras. siuscula, subaequalia, exteriora subpatula. Sta mi na 6 , fil amentis ln tubum eoalitis monadelpha, a ntberae extrorsae, adaatae, biloculares, loculis connectivo brevioribus apieulatae. 0 y a r 1 o r a m rudimenta 3 , tenuia, eylindra cea, earnosa. Fem. Caly $x$ ut in mare. Corolla e petala 6 , lanceolata, subeoncava, crassiuscula. $S$ t a mi in a 6 , minima, abortiva, longiuscule apieulata. 0 v a ri a 3 , libera, ovoidea, unilocularia. 0vula plurima, parieti pilifero inserta, minima, orthotropa, S $t i g m a$ sessile, conoideum, acutum. Fruetus...... - Frutex nepalensis, scandens; foliis alternis, trifoliolatis, foliolis intogris, glaberrimis, inflorescentia axillari racemosa, racemis nudis, laris, paucifloris, floribus forma et magnitudine iis Hollboelliarum similibus, - Decaisne Archiv. Mus. I. 190, t. 12.f. A. Stauntonia Brunoniana Wall.

g. 3. AMERICANAE, Flares dioici, foliolis duplici serie ternatim dispositis, staminibus monadelphis, antheris extrorsis.

\section{4ร93. Hardizabala $R U I Z$ et $P A V$.}

Floren diofei, Masc. Caly $x$ hexaphyllus, foliolls biseriatis, carnosis, exterioribus ovatis, aestivatione valvatis, iuterioribus angustioribus, spathulatis, acuminatis. $\mathrm{C}_{0}$ rolla e petala 6 , bliseriata, oblongo-v. lineari-lanceolata, acutiuscula, exteriora paullo latiora. Stamina 6 , fil a. ne a tis in tubam coalitis monadelpha, a ot the rae extrorsae, ndatate, biloculares, loculis connectiva brevioribus apiculatae. 0 varior am radimeata $2-3$, plas minus atte. nuata. Fem. Cal y $x$ maris. Corolla petala exteriors spathulata, inferne margíaibs plas minus inflexa, concava, crassiuseula. S t a mina 6 ; fif am entis brevibus, carnosis, a n theris oblongis, abortivis. Ov a r fa 3 , eylindra. eea, unilocularia. $0 \vee$ ul a pluriana, parieti alveolato seriebas oeto alternantibus immersa, eanpylotropa. S $\mathrm{f}_{\mathrm{g}}$ m a sessile, conicum. B a c ca e polyspermae; stigmate persistente api. culatae. S e un in a compressa, subreaiformia, testa charta. cea, fusca. Albume n copiosom, carnoso-eorneum. E mbry on Is minuti, subturbinati radicala cotyledooibis brevibus subaequalis. - Frutices chitenies, scandentes; folits aliernis, bi-triternatisve, foliolis integris v. crenato-dentatis, glaberrimis, nitidis, inflorescentia axillari, pedunculo basi bractea una, subreniformi, coriacea suf. fulto, in mascalis plurifloro, feminarum unifloro, flori. bus purpureis, pedicellatis, pedicellis bracteolatis. Decaisne Archiv. Mus. I. 187, t. 11. f. 1.

\section{Boquilla DECAISN.}

Flores dioiei. Mas c. Caly $\mathrm{x}$ hexaphyllus, foliolis membranaceis, subaequalibus, exterioribus ovatis, interio. ribus obovatis, aestivatione subimbricatis. Corolla pe. tala 6 , biseriata, exteriora trinervia. S $t a m$ in a $6, f i l$ ameutis in tubum coalitis monadelpha, a n therace extror. sae, adnatae, biloculares, loculis connectivo brevioribus breviter et obtuse mueronatae. 0 v a ri o $\mathrm{r} \mathrm{m}$ rudimenta 3 , co. noidea, carhosa. F em. C a l y $\bar{x}$ ut in mare. C or oll a e petala oblongo-lanceolata. Sta min a 6 , abortiva, nana; $\mathrm{fil}^{\mathrm{i}}$ mentls brevissimis, breviter acuminatis. Ovaria $3-6$, distincta, oblongo-cylindracea, uniloeularia; o v ulfs paucis longitudinaliter biseriatis, subsessilibus, anatropis, endo. carpii textu celluloso secus ovula tumido cavitatem fere bi. partiente. Styli breves, ovarís continul; s tigmat a conoidea, demum depressa. B a c c a e substipitatae, subglobosae, oligospermae, stigmate persistente apiculatae. Semin a ovata, testa tenui, chartacea. A 1 b u m e n carnosum, copiosum. E m b ryo minutus, radi cula brevi et rotundata; cotyledonibus tenuioribus. - Suffrutex chilen. $s i s$; folits trifoliolatis, foliolis integris v. repando-lobatis, inflorescentia axillari, pedunculis solitariis, binis $v$. ternis, floribus albis, congestis, pedicellatis, Berberi. dum floribus similibus. - Decaisne in Archiv. Mus. I. 188. t. 11. f. B.

\section{Ordo CLX $\mathbf{x}$ III. Myristicene.}

4508. NIyristien LINN.

Virola Aubl. Flor. Flum, $x, t, 30$.

\section{Ondo CLXXIV. Anomaceat.}

4F1:/. Saceopetalum BENNETT. CaI y $x$ triphyllus. C o rolla e petala 6 , hypogyna, biseriata, exteriora ealyeina, interiora valvatim cohaerentia, tandem libera, basi saceata. $\mathbf{S t a m i -}$ na plurima, receptaculo globoso multiseriatim inserta; anthera e sessiles, extrorsae, biloculares, longitudinaliter dehiscentes. O va ri a plurima, libera, unilocularia. Ovnla 8 -10 biseriata. Sti gmata sessilia, subhemisphaerica. C a rpidia stipitata, polysperma. - Arbor javanica; ramis floriferis denudatis, foliis serotinis, alternis, basi subcordatis, apice aeuminatis, integerrimis, minutissime pellucido-punctatis, floribus solitariis v. quandoque binis, pedicellatis, e foliorum delapsorum axillis prodeuntibus, majusculis.

Saccopetalum Bennett in Horefield Plant, Jav. rar. $165 . t .35$.

\section{Ordo CLX X VI. Mlagnotiacene.}

4735. Tallauma JUSS.

Hooker Ic, . 2 208-212.

4 ร $\%$. IIIagnolia LINN.

Liriopsis, Xulania, Tulipastrum et Lirianthe Spach Suites d Buffon VIT. 460-485.

4 ร39. Nilielnelia LINN.

Wight Illustr, $\boldsymbol{t}$. 5 .

48.43. IIIfeium LINN.

Cymbostem on Spach Suites a Buffon VII, 444. IIlicium flaridanum $L$.

\section{Drdo CLXXVII. Dimeniacene.}

\section{Sehumaelneria $V A H L$.}

Wight Illustr. $t, 4$.

4758. A Aretrema JACK.

Wight Illustr. t. 3 .

4\%5. Tetracera LINN.

B ö hli ug ia Dennst. z. Hort. Malab. V. 8. 


\section{Ordo OLXX III. Ramucataceae.}

4\%8. Clematis LINN.

E. Clem, g la u ca et orientaligenus M e clat Is Spach Suiles \& Buffon PIT. 272. constitutum est.

$4 \%$ \%. Thalletrum TOURNEF.

c. $\beta$. Syndesmon Hoffmans. Anemonanthe Spach Suites a Buffon VIT. 239.

4\%8. Allomis DILL.

a. Consiligo DC. A douis p y renalea DC. est Adona a th e Spach Suiles o Buffon VII. 227.

4\% 83. Ranumeulus WALL.

b. RANUNCULASTRUM DC. Ranuneulas asiaticus est $\mathrm{C}$ y p rianthe Spach Suites a Buffon VII. 220 .

475/1. Dxygroaplis BUNGE. Ca lyx herbaceus, pentaphyllus, foliolis aestivatione imbricatis, persistentibns. Coroll a e petala $13-15$, hypogyna, oblongo-linearia, supra basim intus callo transverso instructa. St a $\mathrm{m}$ in a plurima, hypogyna. Ovaria plurima, unilocularia, ovulo unico erecto. A e h en i a plurima, supra receptaculam hemisphaericum congesta, membranacea, a dorso compressa, utrinque uninervia. S e $m$ e $n$ ereetum. - Herba in summis Asiae borealis montibus vegetans, glaberrima, pusilla; foliis omnibus radicalibus petiolatis, suborbiculatis v. ovato-oblongis, integerrimis $v$. apice grosse et obtuse tridentatis, scapo nudo, unifloro, floris diametro semipollicari.

Oxygraphls Bunge Vorseichn, altai, Pflanz. 46. Ficaria glacialis Fisch.

4786. Caltha LINN.

c. Populago DC. Caltha natans Pall. est Th accla Spach Suites d Buffon VII. 295.

\section{4\%98. Delplainitam TOURNEF.}

a. CONSOLIDA DC. Delph in ium Spach Suites d Buffon VII. 351. et A co aitella Spach Op. cit. VII. 358 . (D. Aconiti Linn.)

c. DELPhinellum DC. Phledinfum Spach Op. cit. VII. 351 .

e. STAPHYSAGRIA DC, $\mathrm{S}$ ta $\mathrm{p}$ hy $\mathrm{s}$ agria Spach $O p$, cit, VII. 347.

\section{ordo CLXXIX. Berberideae.}

4808. Diplaylleia L. C. RICH.

Embryo in basi albuminis copiosi brevissimus, rectus.

48 1 1. Epimedium LINN.

a. MICROCERAS Deeaisn. (Bot. Mag, $t, 3745.3751$.

4815/1. Croomia TORR. Calyx tetraphyllus, foliolis late ovalibus, subcoriaceis, persistentibas. Corolla nulla. Stamina 4 , calycis foliolis opposita; fil a m enta crassa, an the rae oblongae, oblique introrsae, immobiles, loculis remotiusculis, juxta totam longitudinem dehiscentibus. Ovari um globoso-0vatum, uniloculare, ovulis 4-6, suspensis, anatropis. Stig ma sessile, minutum, capitatum. Fr u ctus sicens, indehiscens (?) coriaceus, ovatus, in rostrum breve, obtusnm attenuatus. Se min a 12, ex apice loculi pendula, arillo carnoso, fimbriato inclusa, testa ernstacea, Iongitudinaliter rugosa, rhaphe et chalaza manifestis. Embry o intra basim albuminis earnosi minimus. - Herba boreali-americana, perennis; rhizomate horizontali, ramoso, caules plures, simplices, basi squamis membranaceis vaginatos exserente, folizis in apice caulis approximatis $v$, congestis, ovatis, basi cordatis, membranaceis, integris, quinque-novemcostatis, costis apice convergentibus, venis reticulatis, pedunculis axilla- ribus bi-trifloris, pedicellis filiformibus, medio arti. culatis, floribus parvis, albo-virentibus et purpureis.

Croo ui a Torrey in Annal. Lyc. New-York, IV, t, 7 . Torrey et A. Gray Flora of North-4mer. I. 663.

\section{Dralo CLIXX. Papaveraceae.}

\section{Argemone TOURNEF.}

Wight Illustr. $t, 11$.

\section{Fapaver TOURNEF.}

Elkan, Tentamen monographiae generis Papaver, Ho. giomont. 1839. 4, - Cal omecon et $\mathrm{P}$ a paver, cum sect. Meconium, Rhoeadiam, Meconella, Árgemonidiam et Meeonidium Spach Suites a Buffon VII. 5.

483\%. Platystemon BENTH.

Bot. Mag. $t$. 3750 . B ooth i a Douglas mso.

\section{Ordo CLXXXI. Croceźferce.}

4848/1. Clamsia TROTZKY. Caly $x$ tetraphyllus, foliolis conniventibus, duobus lateralibus basi saceatis. Co rollae petala 4 , hypogyna, unguiculata, limberetuso. S ta $m$ in a 6 , hypogyna, tetradynama, edentula. Stigma subsessile, bilamellatum, lamellis ellipsoideis, demum patulis. Sili q a bivalvis, compressa, valvis planinsculis, enerviis, placentis dorso obtusis, septo enervi. S e mina plurima, uniserialia, pendula, alata, funiculis filiformibus, liberis. Embry on is exalbuminosi cotyledones planae, radiculae adscendenti accumbentes, - Herbarossica, in caule setulis, in inflorescentia pilis capitatis vestita; folits simplicibus, alternis, racemis terminalibus ebracteatis, floribus purpurascentibus.

C I a us i a Trotzky Index sem. Hort. Casan. 1839. Hesperis aprica Poir DC.

$4853 / 1$. Paelny nearum BUNG. Cal y x tetraphyllus, foliolis patulis, duobus lateralibus basi saceatis. Co roll a e petala 4, hypogyna, late obovata, integra, patentissima. St a m in a 6 , hypogyna, tetradynama, edentula. Stigma capitatum, Sili qua bivalvis, linearis, compressa, valvis nervo crasso venisque prominulis percursis, septo enervi, laxe reticulato, medio linea diaphana notato. Semin a plurima, biserialia, pendula, compressa, immarginata, funiculis brevibus, setaceis, liberis. Embryonis exalbuminosi cotyledone s planae, radicnla subrimalis, adscendens. Herba alt a ica; pilis adnatis, bipartitis canescens, foliis alternis, integerrimis, siliquis subicospermis,

Pa chyneurum Bunge Cat. sem. Hort. Dorpat. 1839. Draba graudiflora C. A. Meg. Braya Meyeri Bugg. Eutrema plliferum Turezan.

4858. Maeropodium $R, B R$.

Hooker in Bot. Mag. $t, 3805$.

1894. MIorettia DC:

Nectouxia DC. Syst, II. 149 .

\section{Tomgruea.}

Pachypodiam Webb et Berth. supr. n, 4905. Hon LindI, $n, 3413$.

\section{Erysimum LINN.}

b. CUSPIDARIA DC. (Bot. Mag. $t, 3757$. )

$4943 / 1$. Traillia LINDL. Calyx tetraphyllus, basi aequalis, patens, C o rolla e petala 4, hypogyna, obovata, integra, unguiculata calyce parum longiora. S tamina 6 , hypogyna tetradynama, libera, edentula, Ovari um unilo culare, ovulo unico, ex apice loculi pendulo, Sty lus brevis, crassus; stigma simplex, snbeap tatum. Silic u la nucamentacea, indehiscens, ru $178^{*}$ 
gosa, monosperma, stylo lato, rigido, foliaceo coronata. Semen pendulam. Embryonis exalbuminosi cotyledones ovales, planae, radiculae ad. scendenti incambentes. - Herba mesop ot amica, annua, Carrichterae Vellae facie; ramis crassis, rigidis, hirsutissimis, spicis longis, rigidis, crassis, hinc illine fructiferis, foliis paucissimis, oblongis, in petiolum decurrentibus, floribus parvis, sulphureis.

$\mathrm{Tr}$ a 1111 a Lindley in $I t$. Chesney, inedit. ex litt. 18. Mart. 1840.

4962. Selhouwia $D C$.

Hooker Ic. $t .223$.

\section{Drdo CLXXXI. Capparideae.}

4995. Niebuhria $D C$.

Wight Ic, t. 174.

\section{Drdo CEXIXIV. Besedacene.}

5011. Hesedia LINN.

E resda Spach Suites d Buffon VII. 102. Reseda alba Sibth. et R. fruticos a Jacq.

\section{Ordo CLXXXV. Nympleaeaceae. * SARRACENIEAE.}

5023/1. Hellamplhora BENTH. Perigon i f foliola $4,5(v, 6$ ? ) hypogyna, libera, aestivatione valde imbricata, subpetaloidea. Stamina indefinita, hypogyna; anthera e biloculares, oblongo-lineares, versatiles, loculis oppositis, longitudinaliter dehiscentibus. $0 \mathrm{v}$ a ri um trilocalare. Ovula plurima, placentae axili plariseriatim affixa, anatropa. Stylus simplex, apice truncatns; st i g m a parvum, obsolete trilobum, minute ciliatum. C a p sula trilocularis, trivalvis, polysperma. S e mina obovata, compressa, te sta fusca, laxiuscula, in alain membranaceam, ambientem expansa. E $\mathrm{mb} \mathbf{r y}$ o in basi albuminis copiosi orthotropus, parvus, cotyled onibas minutis, radic a la umbilico proxima. - Herba in uliginosis Guianae perennans; foliis omnibus radicalibus, petiolo tubuloso amphoraeformi, ore obliquo margine subrevoluto, scapo erecto, apice simpliciter racemoso, glabro, floribus nutantibus, albis v. pallide roseis.

Hell a m p h or a Bentham in Annal, of nat. hist. V. 47.

\section{Ordo CCXIXVI. Cabombeae.}

5024. Caloomalo $A U B L$.

Schleiden, in Wiegmann Archiv. V. 230, t. 7. f. 8. 9.

\section{Ordo COKXXVIII. Cistineae.}

5029. Helianthemun TOURNEF.

f. LECHEOIDES Dun. Triehasterophyllam Willd. mse. ex Link Jahrb. III. 69. Röm, et Schult, Mant. t. 350. H. glo meratu $\mathrm{m}$ Lagasc.

\section{Ordo CCXXXCX. Drosercecue.}

5033. Drosera LINN.

Drosera et E s e ra Necker Elem, n, 858, 859.

\section{Ordo CXC. Violariene.}

5046. Amplainerhox SPRENG.

A uptirilioge Reichenb. Pfanz.. Syst, $\$ 69$.

\section{Ordo CXCII. Frantseniacene.}

5053/1. Anisadenia WALL. Caly $x$ pentaphyllus, ovoiden-conicus, foliolis tribus exterioribus intra marginem scariosum glandularum stipitatarum serie simplici. Cor olla e petala 5 , hypogyna, longe unguiculata, libera, ungue intus medio barbato, basi lamina lineari, decurrente aucta. S t a m in a 10, hypogyna, in tubum gracilem, basi hine gibbum coalita, quinque fertilia ealycis foliolis opposita filiformia, alterna sterilia dentiformia, a ntherae biloculares. Ovarium sessile, triloculare, dissepimentis in axi contiguis, colnmella centrali nulla. Ovula in loculis gemina, juxta internum dissepimentorum marginem paullo infra apicem collateraliter appensa, anatropa, micropyle supera, Styli 3 , filiformes; stig mata turbinata, oblique truncata. Capsula mina in loculis gemina, collateralia, pendula. Embryo in axi albuminis orthotropus, radicala longa, supera, - Herba nepalensis, Trientalis facie; caule simplicissimo, erecto, circa apicem foliifero, foliis alternis, confertissimis, subsessilibus, membranaceis, ellipticis, penninerviis, integerrimis, supra glabris, subtus sericeis, stipulis scariosis, minutis, fugacissimis, racemo terminali spicaeformi simplicissimo, floribus brevissime pedicellatis, demum cernuis, bractea seariosa, multinervi, decidua, primum antica, mox subspiraliter torta posticum calycis latus occupante, bracteolis duabus inaequalibus, basi utrinque squamulis stipularibus fugacibus auctis. A n is a den i Wallich Catalog. n. 1810. Meisner Gen. Comm, 96. Fenzl Dissert. inedit.

\section{Drdo CXCIV. Samydeae.}

5060. Casearia JACQ.

Be do usia Denust. z. Hort. Malab, $\boldsymbol{V}$. so.

5060/1. Eueeraea MART. Caly x basi bibraeteolatus, quadripartitus, aequalis. Corolla nulla. St a $m$ in a 16 , imo calyci inserta, fertilia octo, quornm alterna calyeis laciniis opposita longiora, totidem sterilia fertilibus interjecta et basi coalita, squamaeformia, fimbriata, a n th erae ovatae, erectae, biloculares. Ova ri n m liberum, nniloculare, ovulo unico $\mathbf{v}$, duobus prope basim parietalibus, adscendentibus. Stig ma sessile, radiato quadri-8expartitum. B a c c a sicca, coriacea, unilocularis, mono-disperma. Semin a oblique erecta, basi arillo multifide lacero, gelatinoso membranaceo cincta. - Arbuscula bra silien sis; ramulis patulis, foliis alternis, petiolatis, serratis, glabris, stipulis caducissimis, floribus minutis solitariis $v$, binis aut ternis in rhacheos paniculato-ramosae foveolis sessilibus, bractea bracteolisque geminis lateralibus, basi connatis, coloratis cinctis.

Euce ra ea Martius Nov, Gen, et spec. III. 90, t.238.

\section{Dralo CXCV. Bixaceae.}

5068. Phoberos LOUREIR. FI ores hermaphroditi. Cal y x octo-decem duodecimpartitus, laciniis biseriatis, basi intus biglandulosis, persistentibus. Corolía nulla. Stamina plarima, a $t$ herae biloculares, processu linguaeformis auctae. 0 varium uniloculare, placentis parietalibus tribus v. quatuor, hi.triovulatis. St y lus filiformis, S tig ma obsolete tri-quadrilobum. B a cca coriacea, pulpa gelatinosa repleta. Semin a $2-6$, in funiculo longo reclinata, rhaphe libera. Em bryo in axi albuminis carnosi orthotropus, 
cotyledonibus foliaceis, radicula supera. Arbusculae v. frutices Asiae tropicae; spinis axillaribus, foliis alternis, petiolatis, coriaceis, venosis, glabris, basi biglandulosis, floribus in racemos $v$. corymbos axillares paucifloros, dispositis, inconspicuis.

Pli o b eros Loureiro Flor. cochinch. 389. Wight et Aruott Prodr. I. 29, B e n e t in Horsfeld Plant. Jav. rar. 187. $t, 39$, exel. Dasyanthi synon. Rhinanthera Blume Bijdr. 1121. L i m o i a Gärtner $I$. 278, $t$, 58, non Linn. S colo p i Sehreber Gen, n. 846.

5069. RHINANTHERA Blum. Genus delend. Vid. 5068*.

\section{0 \%. Proekia P. BROWN.}

Stylus filiformis. Stigma vix ampliatum, obsolete tri-quadrilobum. 0 v a ri m tri-quadriloculare, septis com. pletis. Bace a tri-quadriloeularis, polysperma. Se mina plurima, longitudinaliter suleata, transversim rugosa. Folia serrata, racemi terminales, pauciflori. - Bennett in Horsfield Plant, Jav. rar, 191. Cfr. 5072/1 5072/.

50) 2/4. Thiodia BENNETT. F lor es polygami. Caly x quadripartitus, laciniis aestivatione imbricatis. Corolia nulla. Stamina plurim a.... G la nd ula e staminibus et ovario circumpositae minutae, persistentes. Ovarium uniloculare, placentis parietalibus quatuor, bi-triovalatis. St ig m a subsessile, peltatum, quadrilobum. B a c ca unilocularis, oligosperma. Semina laevia. - Arbuscula Indiae occidentalis; foliis elliptico-lanceolatis, acuminatis, serratis, floribus axillaribus, fasciculatis, hermaphroditis et dioicis in distinctis individuis.

Thiodia Bennett in Horsfield Plant. Jav. rar. 192. Lightfootia Swartz Prodr. 83.

50ร \%/2. Aplaloia BENNET. Flores hermaphroditi, Calyx quadri-quinquepartitus, laciniis aestivatione imbricatis. Co rolla nulla. S tamina plurima, disco lato, glandaloso inserta. Ovarium nniloculare, in stylum brevissimum attenuatum, placenta parietali unica, multiovulata. Stig ma peltatum, orbieulato-emarginatum. B a c c unilocularis, octo-decasperma. Semin a laevia. - Arbusculae madagascarenses; folitis subintegerrimis $v$. serratis, pedunculis axillaribus solitariis $v$. fasciculatis.

Aphloia Bennett in Horsfeld Plant. Jav. rar. 192. L $\mathrm{udia}$ heterophylla Bory $I$. fort. $t$. 24 .

\section{0ร3. IBanara $A U B L$.}

$0 \mathrm{variam}$ uniloculare, placentis parietalibus 6. Sty. $1 \mathrm{us}$ filiformis; s tig ma depressum, parum ampliatum, obsolete sexlobum. B a c c a placentis irregulariter inter se concretis sperie multilocularis. Semina plurima, longitudina. liter suleata, iransversim rugosa. - Bennett in Horffield Plant. Jav, rar, 191.

\section{OS1. Melieytus FORST.}

A. Cnaningh, in Annal. of nat, hist, IP. 256.

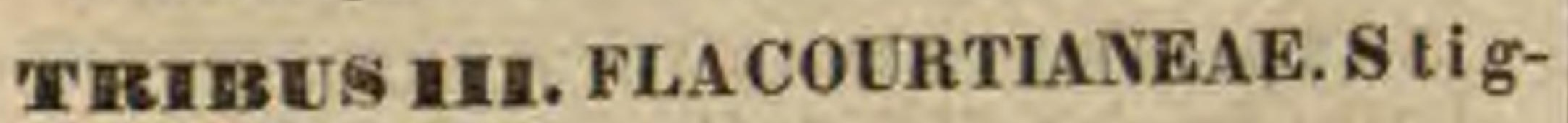
ma multiplex.

5081/1. Kylosma G. FORST. Flores dioici. C a l y $\mathrm{x}$ quadri-quinquepartitus, laciniis aestivatione imbricatis, C or olla nulla. Diseus margine octo decemglandulosus, stamina et ovarium eingens. Ovariam uniloculare, in $s \mathrm{ty}$ ln m brevissimum attennatum, placentis parietalibus duabus, bi-quadriovulatis. Stigma parum incrassatum, obsolete bilobum. B a c e a unilocula. ris, oligosperma. - Arbores $v$. frutices insula rum Oceani pacifici; folits reticulato-venosis, floribus axillaribus fasciculato-racemosis.

X yo m a G. Forst. Prodr. 380. Bennett in Horsfield Plant. Jav. rar, 191. M y ro x y 10 n J. R. Forst. Char. gen, 63.

\section{Drdo CXCVI. Homatineae.}

5089/1. Trimeria HARWEY. P e rigoni um tubo brevissimo, subnullo, limbi sexpartiti laciniis biseriatis, concavis, obtusis, interioribus majoribus. Stam ina 9 , in fasciculos perigonii laciniis interioribus oppositos approximata, fasciculis cum glandulis magnis, subciliatis alternantibus. Ovari um liberum, uniloculare, placentis parietalibus tribus, uniovulatis. Styli 3 , brevissimi. Cap 8 u la unilocularis, trivalvis, valvis medio placentiferis. $\mathbf{S}$ e $\mathbf{m}$ in a 3 , v. abortu unieum, aril. lata? - Arbor capensis; foliis alternis, crenatis, petiolatis, trinerviis, glabris, circumsoriptione ad. modum variis, spicis axillaribus petiolo brevioribus. Trimeria Harwey Genera of South-Afric. Plant, 417.

\section{Ordo CXCWII. Passiftoreate.}

5103. TIodeeca LAM.

a. MIOROBLEPHARIS W. et Ara. (Endi, Iconogr. $t .114$, 115. Wight Ic, $t, 179$,)

b. BLEPHARANTHU's W. et Arn. (Wight Ic. $t$, 201,)

\section{Drdo CXCIX. Loasene.}

5111. Nientzelia $L I N N$.

a. OLIGOSPERMA Endl. E um entzella Torrey et A. Gray Flor. of North-Amer. I. 532.

b. MACrosperma Endl. Trach y $\mathrm{ph}$ y $\mathrm{tu}$ m Nuttall meo ex Torrey et A, Gray $l$. $c$.

\section{Drdo CCII. Cucurbitaceae.}

5141/1. Felnineeystis TORR. et A. GRAY. F l o r es monoici. M a c. Cal yx explanatus, laciniis 6, filiformi-subulatis, corolla brevioribus. P e tala 6 , imo calyci inserta, in corollam rotatocampanulatam basi coalita. St amina 3 , diadelpha, imo calyci inserta; filamenta brevia, a n therae sigmoideae, connatae. F em. Caly x tubo subgloboso, cum ovario connato, limbo supra ovarium constrieto, explanato, sexfido. Coroll a maris. Stamina 8 , abortiva, brevissima, distincta. Ovarium .... Stylus brevis; stigmata 2 , magna, late obcordata, conniventia. Fructus subglobosus, inflatus, setoso-echinatus, membranacens, primum aquosus (apice elastice dehiscens?) demam siceus, bilocularis, tetraspermus, loculis basi spurie bilocellatis, demum bipartibilihus, carpellis reticulato fibrosis. S e mina magnă, exarillata, ereeta, obovato-oblonga, compressa, basi bidentata, marginibus obtusis. - Herba borealiamericana, annua, scandens; foliis palmatim quinquelobis, cirrhis trifidis, floribus parvis, virescentibus, masculis composite racemosis, femineis in eadem axilla solitariis $v$, in pedunculo brevi glomeratis.

Echinocystis Torrey et A. Gray Flora of North. Amer. I. 542. Mo mordi $e$ a e chinata Mithlenb. Steyos Iobata Michx.

$5143 / 1$. Disenanthera TORR. et A.GRAY. F lores monoiei. Mase. Calyx eam petalis 5 ovatis in coro 11 a m explanatam, rotato-quinque. lobam coalitus. St a mi n u columna brevissima, in discum peltatum, orbieularem, margine antheriferum desinens, a ntherae transversim adnatae, in annulum polliniferum supra et infra intra marginem crista ciliata cinctum confluentes. F em. C aly $x$ inferne cum ovario connatus, supra ovarium in tubum filiformem productus, limbo obso- 
leto. Corolla fere ut in maribus. Stamin am rudimenta nulla, O vari $\mathrm{m}$ inferum, triloculare, ovulis circiter 6 , erectis v, adscendentibus. Stylus .... Fruetus gibbosus, echinatus, demum unilocularis. Semin a pauca, magna, compressa....- Herba tex a na; folits pedatifidis, cirrhis simplicibus, floribus albis, minutis, masculis composite racemosis, femineis in eadem axilla solitariis, pedunculatis.

Discanthera Torrey et A. Gray Flora of NorthAmen, 1.697 .

$5145 / 2$. Hytidestylis $H O O K$. et $A R N$. Flores monoici. Masc, Caly x longe tubulosus, coloratus, constrictus, limbi dentibus quinque minutis, demum recurvis. Corolla e petala 5, summo calycis tubo inserta et quasi cum eo coalita, lanceolata, basi nuda. Col n m a staminea longitudine fere tubi calycini, rugosa, superne laevis. Antherae (3?) lineari-elongatae, tortuosae, in massam brevi cylindraceam coalitae. Ovarinm nullum. Fem. Pe tala basi tubereulis incrassata. Ova ri m calyci adhaerens, oblique ovale, hispido-echinatum. S ty I u s elongatocylindraceus, tubi caly cini longitudine, rugosns; s tigma capitatum, laeve. Fr u t us .... Herba guatemalensis; caule gracili, cirrhoso, foliis alternis, tenui-membranaceis, cordatis, angulato-dentatis, breve petiolatis, utrinque sub lente scabris, floribus masculis corymbosis, corymbis paucifloris, longiuscule pedunculatis, floribus femineis solitariis, breve pedunculatis, ad basim pedunculi masculi insertis.

Rytidostylis Hooker et Arnott ad Beechey 424. t. 97. $A$, (Inedit.)

515\%. Aromovia LINN.

Hook. et Arn, ad Beechey t. 97. B. (inedit.)

\section{Dralo CCIV. Cactene.}

Cactearum genera ex sententia cels. Principis Salm-Dyck ita per tribus ordinanda.

TIEIIB US I. MELOCACTOIDEAE SalmDyck. Flores ex axillis tuberculorum trunci com munis aut cephalii proprii in vertice trunci, tubulosi, tubo brevi, glabro, foliolis paucis, minutis, coloratis instructo, limbo patulo. Bacea oblonga, laevis, nitida, plerumque rubra et perigonio marcescente coronata. - Frutices aculeati v. rarissime inermes, carnosi, axi ligneo medullifero destituti, globosi $v$. cylindracei, tuberculati, tuberculis spira liter dispositis distinctis, v. verticaliter et in costas coalit is.

MELOCACTUS C. Bauh. n. 5154. b.

ANHALONIUM Lem. (Ariocarpus Scheidw,)

MAMMILLARLA Haw. n. 515\%, a.

TRE IISUS II. ECHINOCACTOIDEAE $\mathrm{Salm}$ Dyck. Flores e tuberculis spinigeris tubulosi, tubo abbreviato, rarissime glabro, foliolis plus minus numerosis spiraliter instructo, limbo expanso. Bacca ovoidea, foliolis persistentibus squamata, rarissime laevis. - Frutices aculeati v. setosi, carnosi, axi ligneo medullifero destituti, globosi v. cylindracei, tuberculati, tuberculis verticaliter dispositis, saepissime in costas longitudinales coalitis.

DISCOCAC'CUS Pfeiff. n. 5155.

ECHINOCACTUS Linn, n. 5155.

TIRIBIS IIL. CERASTREAE $\$ a l m$-Dyck. Flores e tuberculis spinigeris trunci aut verticis lanati cephaloidei, tubulosi, tubo elongato, foliolis nnmerosis ex axillis setiferis spiraliter instructo, limbo magno, expanso. Bacea ovoidea, foliolis persistentibus squamata, setosa v. aculeata. - Frutices aculeati v. setosi, carnosi, axi ligneo medul. lifero praediti $v$, rarius destituti, globosi $v$, elonga$t i$, stricti $v$. reptantes, simplices v. ramosi, costati v. angulosi.

? ASTROPHYTUM Lem.

ECHINOPSIS Zuec. n. 5156.

PILOCBREUS Lem.

CEREUS Haw. n. 5157.

TIR IIB US IV. PHYLLANTHOIDEAE SalmDyck. Flores e crenis lateralibus ramorum aut terminales, tnbulosi, tubo plus minus elongato, inermi, foliolisque glabris, remotis, saepe coloratis instructo, limbo regulari aut obliquo, expanso v. reflexo. Bacca costata v. compresso-angulata, plerumque laevis, nitida, rubra. - Frutices inermes $v$, subsetosi, pseudo-parasitici, ramosi, caule ramisque membranaceo-dilatatis compressissimis, nervo medio lignoso.

PHYLlOCACTUS Link. n. 5158.

BPIPHYLLUM Pfeiff, n. 5159.

TEI IB US V. RHIPSALIDEAE Salm-Dyck. Flores e crenis ramorum v, terminales, rotati, parvuli. B a e ca laevis, plerumque pisiformis, pellueida, perigonio marcescente coronata. - Frutices squamulosi, inermes v. subsetosi, pseudoparasitici, carnosuli, ramosi, caule ramisque gracilibus, teretibus v. angulosis, aut membranaceo-dilatatis, compressissimis, nervo medio lignoso.

RHIPSALIS Gärtn. n. 5160. a.

LEPISMIUM Pfeiff. a. 5160 , b.

? HARIOTA DC, n. 5160 , c.

THRIIEUS VI. OPUNTIACEAE Salm-Dyck. Flores e tuberculis spinigeris, rotati, magni, rosacei. Bacca tuberculata, late umbilicata, plernmque ficiformis, setosa v, aculeata. - Frutices foliosi, foliolis subulatis, mox marcescentibus, deciduis, aculeisque biformibus, setaceis, penicillatim collectis et rigidissimis, epidermide secedente quandoque tunicatis, carnosi, axi ligneo praediti, articulis compressis aut cylindraceis, tuberculato-areolatis.

OPUNTIA Tournef. n. 5161.

TIRIBUS VII. PERESKIEAE Salm-Dyck. Flores plerumque terminales, solitarii v. subpaniculati, saepe subpedunculati, rotati, magni, rosacei. Bacca globosa, foliolis instructa, aculeata $v$. setosa. - Frutices v. arbores foliosae, foliis normalibus planis, petiolatis v. sessilibus, squamis deciduis, aculeatae, carnoso-lignosae, ramosae.

PERESKLA Plum. n. 5162.

\section{Ordo CCVI. Portulaceae.}

51 4. Portaliaca TOURNEF.

Lindley Bot. Reg, 1840, t. 31 .

5196. Hewista PURSH.

Bx ieone nuper a el. Hooker, non in Flor. Bor. Amer. sed ad Beechey $t$. 86 . edita, apparet capsulam esse unilocularem, basi valvis sex dehiscentem, et enbryanem hemicyclicum.

\section{Dralo CCVII. Caryoplayllecie.}

5245. Cypseplatia.

a. DICHOGLOTTIS Fisch. et Mey. Hagen i Mönch Melk. 61.

\section{Ordo CCVIII. Pligtolacencene.}

5254. Sestuferia LÖFFL.

Benth. in Linn, Transael, XVIIT. 235, t, 19. 


\section{Drdo CCX. Sterculiaceae.}

53 16. II Ilieteres $L I N N$. b. ISORA Sch, et E. (Wight Ic. t, 180.)

5320. Stereulia LINN.

$\beta$. Eustereulia. (Wight Ie. $t, 181$ )

\section{Drdo CCXI. Bütneriacene.}

$5324 /$. Heacothamanus LINDL. Inflorescentia oppositifolia, apice racemosa. B racteola hypocalyeina persistens, tripartita. C a l y x petaloideus, persistens, campanulatus, quinquepartitus. C o rolla nulla. St a m in a caly. ei adnata, quinque fertilia cum totidem sterilibas alterna; filamenta libera, sterilia membranacea, fertilium a nther a cordatae, obtusae, longitudinaliter dehiscentes, Ovarium fundo staminifero calycis semiimmersum, conicum, ventri. cosum, triloculare. Ovula in loculis gemina, colIateralia, erecta. St y l u s setaceus, glaberrimis.... - Frutex in Nova Hollandia a us tro-occidentali monticola, incano-tomentosus; foliis subrotundo-ovatis, cordatis, inaequaliter dentatis, majoribus tripollicaribus, stipulis semicordatis, pedunculis oppositifoliis, apice racemosis, bracteolis foliaceis, calycibus diametro uncialibus, extus hirsutis, intus tomentosis, albis, striis quinque discoloribus.

L e uc oth am nas Liadley Swan-River $X I X$.

5328/1. Sarotes LINDL. In florescent i a corymbosa. Cal y $x$ membranaceus, pentagonus. Corolla e petala 5 , cucullata. S $t$ a m in a 5 , antherarnm apice elongato bilobo. Ovarium quinqueloculare. Ovula in loculis gemina, superposita. Stylus supra basim scopaeformis.... - Frutex Novae Hollandiae austro-oceidentalis; foliis ternatim verticillatis, linearibus, margine revolutis, obtusis, ramulisque incanis, pilis nullis fasciculatis, pedunculis stellato-tomentosis, apice paucifloris, corymbosis, floribus maximis, caerulescentibus.

S a rotes Lindley Swan-River $X I X$.

5355. Selnilleria REICHENB. n. 738.

Microlaena Wallieh supra n. 5335 . non R. Brown

\section{Ordo CCXIII. Dipterocarpeae.}

5395. Vatiea LINN.

Wight Ic, $t$. 164 .

\section{Ordo CCXV. Temstribniaceae.}

54 14. Saureaja WILLD.

Bennett in Horsfield Plant, Jav, rar. 170, $t, 3637$.

\section{Brdo CCXVI. Clesiacear.}

5443. Crapeinia LINN.

Wight Ic. $t, 102-105,112-116,120-121$.

5444. Stalagmites MURR.

Xantho e h ymus Roxb. Wight Ie, $t .192$.

5448. Tlesua LINN.

Wiglit Ic, $t, 117,118$.

5448. Calophyllum LINN.

Wight Ic, t, 106_108, $110,111$.

$5455 / 1$. Seala BLANCO. Caly x liber, triphyllus. Coro 11 a e petala 6 , biseriata, exteriora ealyce duplo majora, interiora minora. Stamina plurima, anthera sessiles, magnae, approxi- matae. Ovarium libernm, globosum. Stigma in ovarii vertice punctiforme, B a c c a globosa, depressa, integumentis tribus, unilocularis. Semin a plurima, angulata, - Arbor philippica; foliis alternis, lanceolatis, integerrimis, floribus oppositifoliis, solitariis.

So ala Man. Blaneo Flora de Filippinas. 437.

\section{Drdo CCXIIII. Diacineae.}

5498/1, Dmilesia BLANCO. Caly $x$ liber, quinquepartitus. C o r o 11 a e petala 5, sessilia, calycis laciniis alterna, apice bifida. St am in a 10 , alterna petalis opposita breviora, sterilia, fertilium antherae rotundae. Ovarivm lentieulare, villosum. Stylas brevissimus; 8 tig ma breviter bifidnm. Drupa baccata, compressa, emarginatobiloba, bilocularis, dipyrena, pyrenis cordiformibus. - Arbor philippica; foliis alternis, lanceolatis, integerrimis, supra asperis, subtus setosis, petiolis basi bistipulatis, floribus in racemum compositum dispositis, calyce extus tomentoso.

Quilesia Blanco Flora de Filippin, 176.

\section{Ordo CCXXIV. Aurantiacede.}

5501. ILimomia LINN.

Wight Ic. $2,175$.

5502. Glyeosmis CORR.

Wight Ic. $t$. $16 \%$.

\section{Drdo CCXXI. Mrellacene.}

5518/1. IFenromia WIGHT. Caly $x$ quinquefidue, rarius quadrifidus. Corolla $\mathrm{e}$ petala 5 v. rarius 4 , basi inter se et cum tubo stamineo coalita. T u b s stamineus infundibuliformi-cylindricus, apice decemdentatus, inter dentes antherifer, anth era exsertae, apice mucronatae. Dis c us hypogynus tubulosus, ovarinm et styli basim vaginans. Ovarium sessile, quinqueloculare. Ovula in locnlis gemina, angulo centrali superposite inserta. Stylus filiformis; stig ma discoideo-capitatum. Ca p $\mathrm{n} l$ a quinquelocularis, loculicide quinquevalvis, valvis medio septiferis, a columna centrali, seminifera secedentibus. Semina in loenlis abortu solitaria, ala introflexa cincta, nmbilico ventrali. Embryo intra albumen carnosum, tenue rectus; cotyledonibus foliaceis, radicula umbilieo proxima, supera. - Frutices in dic $i$, erecti; apice approxima tim foliosi, foliis imparipinnatis, foliolis oppositis, bi-plurijugis, glabris, pedunculis axillaribus, uni. plurifloris, floribus albis, fragrantibus.

Mun ronia Wight Illustr, t. 147. t. s4, Bennett in Horfield Plant. Jav, rar. 176, t. 38. T a r rate a pinna. ta Wallich Plant, at. rar. $t$. 119. Liadley in Bot. Reg. t. 1413.

5519. Turreat LINN.

Bennett in Horefield Planl. Jav, rar. 127. $t .38$.

5520. Nielia $\boldsymbol{L}$.

Wight $7 c, t, 160$.

5.525. Milnea ROXB.

Wight Ic, t. 166.

5539. Walsura WALL.

Wight Illustr, $1, \delta 5$.

5548. Curarea LINN.

Wight Ic, $t, 146$.

Drdo CCXXVI. Cedrelaceae.

5552. Chilk rassia $A D R$. JUSS.

Wight Illustr. $t, 56$. 
5553. Clnlorexylom DC.

Wight Illustr. t. 57 .

5558. Cedirela $L$.

b. To on a E. (Wight Ic. $t, 161$.)

\section{Ordo CCXCL. Erythroxylom.}

559\%. Erythroxylon LINN.

b. SETHIA Kunth. (Wight Illustr. $t$. 48.)

\section{Ordo CCXXX. Sapindacear.}

5B10. Sapinders LINN.

Wight Illustr. $t, s t$.

5625. Diplopeltis ENDL.

Lindley Bot. Reg. 1839. $t$, 69 .

5638/1. Deinboellia SCHUMACH. Flo. res polygamo-monoici. M a $8 \mathrm{c}$. C a lyx inaequalis, pentaphyllus, foliolis subovatis, concavis, erectis, duobus exterioribus fere duplo minoribus. Coro 11 a e petala 5 , receptaculo inserta, ovato-oblonga, coneava, erecta, basi intus lanata, calyce vix longiora. Stam in a $16-20$, annulo intra corollam inserta, erecta, aequalia, a n th e r a e oblongae, erectae. 0 v a ri i rudimentum. H e r m a p hr. Calyx, corolla et annulns ut in maribus. St a $\mathrm{m}$ in a 16 , receptaculo circa ovarii basim inserta, marcescentia, antherae ovatae, compressae, steriles. O va ri $\mathbf{m}$ m subrotundum, didynum v. rarissime trilobum, tomentosum. Sty I us crassiusculus, erectus, persistens; stig m a acutum, integrum. B acea binae $v$, abortu unica, rarissime cum tertiae rudimento, coriaceae, pubescentes, monospermae. Sem en magnum, pulpa mucosa inclusum. - Frutex guineensis, erectus, subcinereus; foliis sparsis, paripinnatis, foliolis petiolatis, suboppositis, ellipticis, subcoriaceis, integerrimis, subtus pilosiusculis, stipulis nullis, racemo terminali, decomposito, pyramidali, floribus subglomeratis, pedicellis brevissimis, basi bracteolatis.

Deinboelli a Schumacher in Danske Selskab. Afhandling. IV. 16.

\section{* MELIOSMEAE.}

5839. Meliosma $B L U M$.

Millingtonfa Roxb. Wight Illustr, t. 33.

\section{Ordo CCXXTL. Rhizoboleae.}

5643. Anthodiseas G.F. W. MEY.

Corolla e petala concava, arete cohaerentia, disco hypogyno inserta, per anthesim calyptrae modo decidua. Sta a i n a basi brevissime monadelpha, filamenta filiformia, tortuosa, minute glandulosa, interfora breviora. Ant he. ra e biloculares, longitudinaliter dehiscentes. 0 varium loculis $14-20$. 0 v $u 1 \mathrm{a}$ in loculis solitaria, peltata, latere interiore affixa, - Folia alterna vel opposita, in caule articulata, trifoliolata, foliolis coriaceis, lucidis. Beatham in Linn. Transact. XVIII, 237, $t, 20$,

\section{Drilo CCXXXIV. Pittosporeat.}

566 1. Pittosporum LINN.

Wight Illustr, $t$, 70 .

56BG. Sollya LINDL.

Bot. Reg, 1840, $t, 3$.

5680. Tüberlinia ZUCC.

Bentham Plant, Hartweg. 35.

\section{Ordo CCXXX VI. Celastrineae.}

56ร5. I, Lplapetalum WIGHT.

Wight Ie, $t, 151,162$.
5696. Evomymus TOURNEF.

Beunett in Horsfeld Plant Jav, rar. , 28.

56ร D. Cellastrus LINN.

Wight Illustr, t. 72.

5686. Plewrostylia WIGHT, et ARN.

Wight Ic, $t, 155$.

5688. Elaeodendrom $J_{A C Q}$. Malab.

Wight Illustr, $t$. 71 . P arilla Dennst. $z$, Hort.

5690. Paclaystima RAF. n. 2984.

Oreophila Nuttall supr. $n$, 5690 . non Don supr.

\section{Ordo CCXXXVII. IIIppocra" teacear.}

5ร 100. IITpoentea LINN.

Wight Illustr. $t, 46.47$.

\section{Drdo CCXXXVIII. Hicinene.}

57 เ1 2. SK imamia HUNB.

Secundum el. Gärtner $f$. III. 242, $t$. 225. semina inversa, embryo in suprema albuminis carnosi parte minutus, radicula supera.

\section{Ordo CCXXXIX. Rhammear.}

5ร 15. Ventilago GARTN.

Wight Ic. $t, 163$.

5724. Seantia COMMERS,

Wight Illustr, $t$. 73. A doli a Lam. T. 44.

5\%8\%. Cormomema REIN.

Arrabidea Steudel Nomencl. ed $\boldsymbol{I I}$.

5ร 28. Colubrima $L, C, R I C H$.

Wight Illustr. $t, 84$.

\section{Ordo CCXIIII. Enpleorbiaceat.}

5\% 80. Stillimgia GARD.

Stillingfleet a Bojer Hort, maturit. 284.

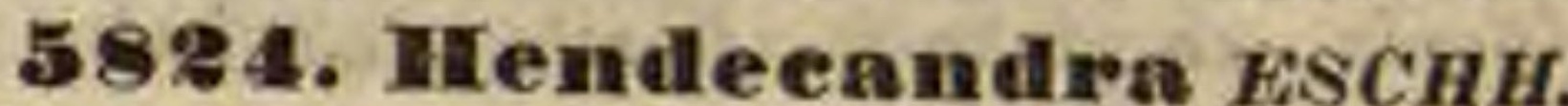

Hook. et Arnott ad Beechey 389, t. 91.

$5845 / 1$. Fiseudamthus SIRB. Flores monoici. M a s e. Caly x coloratus, sexpartitus, laciniis linearibus, biseriatis, erectinsculis. C orolla nulla. Sta $\mathrm{m}$ ina 6 , inaequilonga, circa ovarii rudimentum coalita, antheris extrorsis, dorso affixis, longitudinaliter dehiscentibus. F e m. Cal yx rudis, quinque-sexpartitus, laciniis lanceolatis, dorso carinatis, nargine membranaceis. Corolía nulla. Ovari nm triloculare, loculis biovulatis, ovulis ex angulo loculorum centrali superposite pendnlis, anatropis. Styli \$, simplices, revolnti, intus stigmatosi. C a p s u l a abortn unilocularis, monosperma, ab apice ad basim sexvalvis, colnmna centrali membranacea, apice seminifera. S e men inversum, carnncula calyptraeformi. E mbryo intra albumen carnosum eylindricus, - Fruticuli Novae Hollandiae, ericoidei, ramosi; ramis ramulisque oppositis et verticillatis, folits alternis, dense imbricatis, coriaceis, carina marginibusque papilloso-asperis, sessilibus, utrinque stipula adnata, in caulem decurrente auctis.

Pse udanth us Sieber ex Spreng. Cur. post. 25, Guillem. in Dict. hist. nat. XIV. 318 . Endlicher Atakt, $t .11$. (fig. ovarit sub grossificatione examinati erronea). Decaisue in Nouv. Annal, sc. nat, XII. 257.

$5958 / 1$. Stylodiseus BENVET. F lor es dioici. Masc. Caly x pentaphyllus, fuliolis con- 
cavis, Corolla nulla. Sta min a 5, aequalia, filamentis columnae centrali usque ad medínm adnatis, antheris intra calycis foliola nidulantibus, $O$ varii rudimentum discus stipitatus, obsolete quinquelobus. F em. Caly $\mathbf{x}$ quinquepartitus. Glandulae 5, calycis foliolis oppositae. Ovarium triloculare, loculis biovulatis. St y li 3 , simplices. B a c c a trilocularis, loculis dispermis. - Arbor indica, magna; foliis sparsis, stipulatis, petiolatis, pinnatim tri-quinquefoliolatis, foliolis petiolulatis, articulatis, stipellatis, floribus numerosissimis, parvis, in paniculas axillares dispositis.

$\mathrm{Sty}$ lodis cus Beanett in Horsfeld Plant. Jav, rar. 133. $t .29$.

589\%. IBlnytis LOUR. Flores polygamodioici. H e rmaphr. Calyx tri-sexpartitus, laciniis obtusis, patentibus. Co rolla nulla. S ta mi$n$ a 3 , receptaculo inserta, fil a m e $t$ a filiformia, erecta, calyce longiora, an $t h$ era e bilobae. Ovariu m longiusculum. Stigm at a 3 , sessilia, bifida, reflexa, B a c c a compresso-ovata, rugosa, flaccida, unilocularis, trisperma. S emina parva, ovata. F e m. C a l y $x$ multipartitus, laciniis lanceolatis, pilosis, patentibus. Corolla nulla. Stamin a nulla. Ovari $\mathbf{n m}$ et fructus ut in Hermaphr. - Frutex cochinchinensis, suberectus; ramis expansis, foliis alternis, ovato-oblongis, subacuminatis, integerrimis, glabris, spicis terminalibus congestis, longis, tenuibus.

$\mathrm{R}$ hy tis Loureiro Flor. cochinch, 811 .

5888/1. Baceaurea LOUR. Flores polygamo-dioici. He rm a $\mathrm{p}$ hr. C a I y $x$ quinquepartitus, laciniis ovatis, inflexis, carnosis, persistentibus. Coro 11 a nulla. St a m in a $6-8$, receptaculo inserta; fil am enta brevissima, antherae subrotundae, biloculares. O varin m subrotundnm. Stig ma concavum, laciniatum. Fructus abortivus. Fem. Calyx pentaphyllus, foliolis oblongis, carnosis, inflexis. C or o li a nulla. Ova ri u m subrotundum. Stig ma sessile, magnum, lenticulare, papillosum. B a c a subrotunda, tri-quinquelocularis, loculis monospermis? Semina ovata, subcompressa. - Arbores cochinchinenses; foliis sparsis, integerrimis, racemis e ramis $v$. caule pendentibus, masculis parvis, femineis multo majoribus.

B a e e a ur e a Loureiro Flor. cochinch, 812.

$5888 / 2$. Lumamaja $B L .4 N C O$. Flores dioici. Mas c. Caly x tri-tetraphyllus, foliolis concavis, rotundatis. Corolla nulla. Stamina plurima, in stipitem coalita, polyadelpha. Fem. StyI us unus; stigmat a 3 , simplicia. Capsula sexlocnlaris, loculis monospermis. - Arbuscula $p h i$ lippinensis; foliis alternis, brevissime petiolatis, serratis, floribus axillaribus spicatis.

L u m a a ja Man. Blanco Flora de Filippin, 821 .

$5888 / 3$, Lumasia BLANCO. F lores dioici. Caly x triphyllus. Co rolla tripetala. Mase. Stamina 3 . Fem. Sta $\mathrm{m}$ in a 3 sterilia, Ovari um triangulare, stellatum. Styli 3 ; stigmata emarginata. Ca p su la triangularis, stellatim trivalvis. S e mina in loculis solitaria, arillo cartilagineo, tubuloso, truncato inclusa, - Arbor $p h i$ lippica; foliis sparsis, lanceolatis, floribus axillaribus racemosis.

L u n a i a Manuel Blanco Flora de Filippinas 783.

observatio. Caelebogyne J. Smith. genus Euphorbiacenm, australasicum, Sapif aquifolii facie, sine antheris in horto Kewensi fructificans, nondum descriptum est. Vid. Annal. of nat. hist. IV, 68.

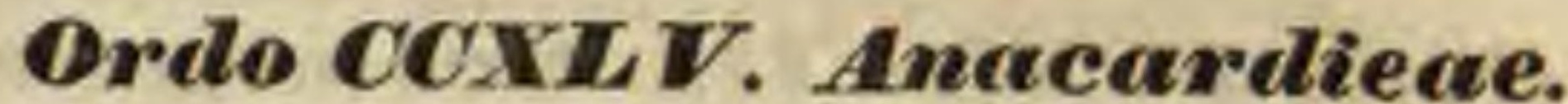

5รด\%. IBotryceras WILLD.

La u rophyll us Thunb. Harwey Genera of South. Mf. ric. plant. 64.

5919. Bachamania ROXB.

Wight Ic, t. 101.

5921. Poupartia COMM.

Quid SHAKUA Bojer Hort, maurit. 82. genus inter Spondiam et Poupartiam nominatum.

59?4. Anaphrenimm E. MEY.

Heeria Meisn. supr. 5924 non Schlecht. n. 6212.

5986/1. Dphioearyon. Caly x imbricatus. Cor olla e petala 3 , ovata, concava, D r up a coriacea, glabra, sphaerica, nuce dura, glabra, bivalvi, uniloculari, monosperma. E m b r y o n is exalbuminosi radicula maxima, crassa, deorsnm nonnihil attenuata, subspiraliter torta, $c$ a udiculus filiformis, flexuosus, cotyledones duae, foliaceae, penninerviae. - Arbor guianensis, excelsa; trunco glabro, cortice laevi, cinereo, foliis imparipinnatis, foliolis petiolulatis, tri-sexjugis, lanceolato-ovatis, acuminatis, integerrimis, subcoriaceis, venosis, glabris, nitidis, petiolo communi supra canaliculato, glabro, floribus paniculatis, paniculis in ramulis terminalibus, subinde axillaribus, ramosis, floribus brevissime pedicellatis, uninerviis, confertis.

The $\mathrm{S}$ nakenut Tree of Guiana Shomburgh in $A n$ nal. of nat. hist. $\mathscr{V}, 202$.

\section{Trattiniekia WILLD.}

Trattinickiac congener $v$. proxime affinis:

DACRYODES Vahlin Dansk, Selsk. Skrift, V1, 116. C a 1 y x monophyllus, hemisphaericus, persistens. Corolla e petala 3 . S ta mina 6, cun glandulis totidem alteruaatia. Stylus brevis, indivisus; st i g m a planum. D r u pa ovata, exsucea, monosperma. - Arbor excelsa, ex Puertorico, ubivul. go Tabanuco; ramis cortice cinerascente, punctis elevatis, griseis adspersis, glabris, folits petiolatis, sparsis, conjugatis v. ternatis, foliolis petiolatis, alternis, eesquipollicaribus, ovato.oblongis, integerrimis, obtusis, coriaceis, tenuissime venosis, petiolis subtus convexis, supra planis, annulis tenuissime cicatrisatis, partialibus brevissimis, racemis axillaribus et terminalibus simplici. bus, pedicellis sparsis, unifloris, raro bifloris.

\section{Ordo CCXIVI. Barseraceate.}

593ซ. Hedwiglia SWARTZ.

Caproxylon Tussac Flor. antill, ID, $t, 30$.

5968/1. Fierasma $L I N D L$. F I ores polygami. Calyx brevissimns, quinquefidus. Corollae petala 5 , calyce longiora. Stamina 5, petalis subaequilonga, villosa, an thera e subrotundae. Ovaria 3 , receptaculo subrotundo, tumido insidentia. St yli 8 , basi coaliti, apice divergentes; stigmatibus simplicibus. Drupae 3, globosae, uniloculares, bivalves, in receptaculo late haemisphaerico remotiuseulae. - Arbor $j a$ $m a i c e n s i s$, vix nota, ob corticem amarissimum celebris; foliis alternis, imparipinnatis, racemis versus apices ramulorum axillaribus, paniculatis.

Pier a $5 \mathrm{ma}$ Lindley Medic, Bot. 208. Quassia excels a Swartz.

Ardo CCXIVII. Connaraceae.

59 48. Commarus LINN.

Wight Illustr. t. 63 . 


\section{Dralo CCXILIII. Delenaceae.}

5959. Delnma SCHREB.

Wight Illustr, t. 69 .

\section{Ordo CCXIIX. Simambaceae.}

5965. Samadera GÄRTN.

Wight Illustr. $t, 68$.

\section{Ordo CCL. Zanthoxylaceae.}

59ร5. Toddalia JUSS.

Wight Illustr, $t$. 66 .

\section{S. A cronyelhia FORST.}

C y mi n o $8 \mathrm{mat}$ Gärtn. Wight Illustr. 2 . 65 .

5980. Ailanthus DESF.

Wight Illustr, t. 67 .

\section{Drdo CCLI. Diosmeae.}

5993/1. Hemomia $L I N D L, \mathrm{C}$ al y $x$ pentaphyllus, foliolis duobus exteriorihus multo majori bus, coneavis, involuerum bivalve referentibus. Corolla hypogyna, gamopetala, hypocraterimorpha, tubs brevi, apice subobliquo, limbi quinquepartiti laciniis oblique patentibus, postica paulfo breviore. St a $\mathbf{m} \mathrm{i}$ a 5 , in tubum corollae adnatum intus pubescentem coalita, an therae 2, corollae laciniae posticae alternae fertiles, in apice tubi staminei sessiles, ovatae, obtusae, tres inferiores steriles, exsertae, cornutae, glandalosae, intermedia triloba. Ovarium subrotundum, quinqueloculare, disco cyathiformi, crenato immersum. Ovula.... Stylus filiformis, glaber; stigma acute quinquelobum. Capsula pentacocea, coecis bivalvibus, endocarpio cartilagineo, elastice soluto. S em in a in loculis solitaria, sinu umbiticata, testa crustacea, fragili. E mbryonis exalbuminosi, arcuati radicula elongata, inflexa, inter cotyle dones bilobos, conduplicatos, haud corrugatos inclusa. - Frutex antillanus; folits oppositis, trifoliolatis, foliolis obovatis, obtusis, racemis axillaribus, paucifloris, floribus speciosis, purpureis.

Le mo n i a Lindiey in Bot, Reg. 1840,, .89.

\section{Ordo CCIII. IRetacene.}

BDag. Tetradielis STEV.

Bunge in Linnaea $X I V$, 161. $t, 1$.

\section{Dralo CCLIII. ZygophyDeare.}

6034. Fagonia TOURNEF.

Wight Itlustr, $t, 64$.

\section{Ordo CCLV. Linear.}

605B. Iinmm $L I N N$.

Sectiones v. genera sequentia proponit el. Reichenbacb Handb. des nat. Pflans, Syst. 306.

a. CATHARTOLINUM Retehenb. Stigmata capitellata. Antherae erectae. - Exslipulatae. L. catharcticum L. L. virginiasum L. L. gallicum L. L. corymbulosum Reichenb. L. alternum Lam, L. bicolor Desf. L, sardoum Mill. L. agreste Brot. L. tenaifolium L. L. suffraticusum L. L. salsoloides DC.

b. LINUM Reichenb. Stig mat a inerassato clavats, petalis concolora. A nt herac sub anthesi horizontaliter incumbentes. - Esstipulatae. L. usitatissimum L. L. humile Mill. L. bologyaum Relehenb. L. difasum Sehrad. L. inaequale Presl. L. strictum L. L. narbonease L. L. laeve Scop. L. Sieberi Reichenb. L. viscosum L. L, hirsutum L. L. davuricum Schult.

c. ADENOLINUM Reichenb. $S t i g m$ a ta imposita, antheriforuia, flava. A o the rae sub authesi horizontaliter iveumbentes. - Exstipulatae. - L. austriacum L. L. marginatum Poir. L. angustifolium Hads. L. pallescens Ledeb. L. perenne L. L. alpieola Reichenb. L. alpinum L. L. sibiricum DC. L. pyrenaeum DC. L. nervosum W. K,

d. L1NOPSIS Reichenb. Stig u ata capitellata. - Stipu. latae. - L. aethiopleum Thunb. L. quadrifolium L. L. africanum L. L. maritimun L. L. corynbosum Pöpp.

e. XANTHOLINUM Reichenb. Stig mata oblongata, horizontaliter incuabeutia. - Stipulatae. - L. nodiflorum L. L. campanulatum L. L. tauricum W. L. capitatum Kit. L. flavum L. L. arboreum L.

f. Macrolinum Reichenb. $S t i g m a t a$ imposita, reniformia. Fila me uta fertilia utrinque unidentata, praeter sterile rudimeatum filamentis alternum. L. trigynum Smith.

\section{Drdo CCL I. Oxalidene.}

6058. Dxalis LINN.

m. BIOPHYTUM DC. Wight Illustr, $t$. 62.

\section{Ordo CCLDII. Balsamineae.}

BD60. Impatiens LINN.

Lindley in Bot. Reg. 1840, t. 8. 9. Wight Illustr. t.61.

\section{Ordo CCIII. Combretaceae.}

Bด 6. 'Terminalia LINN.

a. CATAPPA Gärta. (Wight, Ic, t, 172. 195.)

\section{Drdo CCLXIL. Allangieae.}

6096. Alangium LAM.

Wight Ic. t. 194.

\section{Dralo CCLXIV. Phèladelpheae.}

6106. Deeumaria LINN.

${ }_{n} \mathrm{~S}$ e mina pluriasa, imbricata, iu angulo centrali loculorum e basi subulato-attenuata suspensa, tes ta membranacea, reticulata, apice in appendicem crassam, obtusam, cellulosam, nucleum oblongam aequantem producto. $\mathrm{E}$ mb r yo oblongo linearis, teres, albumine tenuissimo, grapa. luso cinctas, cotyledonibus semiteretibus, $r a d f c u-$ $1 \mathrm{a}$ in umbilieum spectantem aequantibus. Torrey et A. Gray Flora of North-Amer. I. 592. Genus ex cl. autoribus, quibus Philadelpheae Saxifragacearum sectio, eua Deutzia ad Hydrangeas referendum."

\section{Drdo CCKIV. Denothereac.}

6118. Eulobus NUTT. Caly x tubo lineari-tetragono, eum ovario connato, vix supra ovarium produeto, limbi subeampanulati, quadripartiti laciniis aequalibus. Corollae petala 4, summo calycis tubo annulo glanduloso, crasso, marginato inserta, rhombeo-obovata. Sta m in a 8 , cum petalis inserta; fil amenta filiformia, alterna breviora, antherae oblongae, staminum longiorum supra medium dorsi insertae, versatiles, breviorum medio dorso alfixae. Ovarinm inferum, quadriloculare. Ovu la in loculis plurima, angulo centrali inserta. Stylus filiformis; stigma capitatum. C a p sula lunge linearis, tetragona, strit:ta, refracta, incomplete quadriloeularis, septis tenuissimis, angustissimis, valvis adhaerentibus. Semina plurima, oborato-oblonga, exappendiculata, erecta... - Herba californica, annua, virgatim ramosa; caule fistuloso, foliis sparsis, inferioribus oblongis, inaequaliter pinnatilobis, superioribus linearibus, subsessilibus, denticulatis, flo- 
ribus juxta ramos virgatos axillaribus, majusculis, petalis albis, demum rubris, fugacibus.

E u lobu s Nuttall in Torrey et A. Gray. Flor. of North-Amer. 1 . Bts.

6183. NIomtinia $L I N N$.

Secundum cl. Harwey Genera of South Afric. plant. 10t. placentae parietales, In centro cavitatis combinatae, basi et apice interruptae. $\mathrm{E} \mathrm{mb} \mathbf{r} \mathrm{y}_{\mathrm{o}}$ in albumine (endopleura?) tenui, carnoso, cotyledonibus ovatis, obtusis, radicula elongata.

6129. Hopezia $C A V$.

Bot. Reg. 1840. t. 40.

\section{Ordo CCLXVI. Halorageae.}

\section{Myrioglayllum $V A I L L$,}

Torrey et A. Gray Flor. of North. Amer. I. 528.

a. SPHONDYLOPHYLLUM Torrey et A. Gr. Fiores octandri. Petala caduca, Cocei dorso estriati. - Folia verticillata, M. spicat um L. et M. verticilla$t \mathbf{u m ~ L}$.

b. SPHONDYLASTRUM Torrey et A.Gr. Fl o res tetrandri v. hexandri. Petal a subpersistentia. Cocei dorso unibistriati. - Folia verticillata. M, he te rop hyllum Michx. et M. s e abrat u michx.

c. Ptiluphyllum Nutt. Flores tetrandri. Petala subpersisteutia. C o c ci dorso estriati. - Folia alterna $v$, nulla. P tilo p h y $1 / \mathrm{um}$ Nuttall Gen, II, 212. P u rs hi a Rafinesque in New. York medic. Reposit. II. 361. H y l as Bigelow msc.

\section{Ordo CCLX VII. Lythramieae.}

6143/1. Hypobrielhia M.O.CURT. Ca 1 y hemisphaerico-campanulatus, quadrilobus, laciniis alternis minoribus nullis v, calliformibus. Co roll a nulla. St a min a $2-4$. O va rinm globosum, biloculare. Stylus subnullus; stigma bilobum. Capsula globosa, tenuissime membranacea, irregulariter rumpens, placenta globesa, crassa. Semina plurima, ratione capsulae magna, obovato-oblonga, adscendentia, testa membranacea. - Herba boreali-americana, aquatica, submersa; foliis oppositis, linearibus, pellucidis, floribus axillaribus, sessilibus, minutis.

Hypobrichia M. 0. Curtis in Torrey et A. Gray Flor. of North-Amer. 1 . 479. P tilin a Nuttal mse. D idi p i is Reffiuesq. in Allant. Journ, 1833, n, 6, p.,23. P e plis diandra Nutt.

\section{Dralo CCI X VIII. Mielastomaceae.}

6200. Ihexia $R, B R$.

Torrey et A. Gray Flora of North-dmer, I. 476.

a. EURHEXIA Torrey et A. Gray l. c. A it the rae longe lineares, basi plus minus productae v, saceatae, conueetivo inferne appeadice setacea aucto. Stylas sub. deflexus. C a 1 y x tubo supra ovarium producto, campaDolia lanceolata $v$. linearia. Flores purpurei, rarius albi. (Lam. $t, 283, f .1-3$, Boupl. Rhex, 1. 44.)

b. CALORHEXIA Torrey et A. Gray $l$. c. A n therae oblongae, strictae, appendice setacea nulla, rarius calcare obsoleto. C al y $\times$ tubo breviter supra ovarium producto, eampauulato, - Folia ovata, parva, Flores purpureoviolacei. (R h cillos a Miehx. Pursh Flor. Bor. Am. t. 10.) c. RHEXANTHA Torrey et A. Gray $l$, c. Anthera e linea ri.oblongae, strictae, erectae, appendice nulla. C a I y x tubo supra ovarium constricto, eampanulato. - Calyx brachiato-ramosus, folia linearia, flores lutei. R. Iu. te a Walt, Pursh Flor. Bor. Am. t. 10.

\section{Drdo CCIXIX. Myrtaceae.}

6290. Tristania $R, B R$.

Bennett in Horsfield Plant, Jav, rar. 127, t, 28.

6325. Barringtonia FORST.

a. BUTONICA Lam, (Wight Ic, t. 152.)

83 26. Careya ROXB.

Wight Io. $t, 147$.

\section{Ordo CCLXXII. IRosaceae.}

63รจ. CLifrortia LINN.

Dele synonymon Nen ax Gărtn. Vid. supr, n. 3106.

\section{Ordo CCLXXV. Papilionaceae.}

6475. Westonia SPRENG.

Rot hia Pers. supr. n. 6475 cum synonymis, noa $R o$. th i a Schreb. n. 3023.

6535. Aceorombona.

Cal o tropis Don. supr. n, 6535, non R. Br, n. 3478.

6ร27/1. Crepialotropis $W A L P, \mathrm{C}$ a $1 \mathrm{y} x$ urceolatus, quadridentatus, dente postico maximo, ovato, breviter acuminato, intus ima basi piloso, lateralibus triangularibus, doplo brevioribus, infimo lanceolato, acuminato, attenuato, posticum longitudine paullo superante. Cor o ll a e papilionaceae, glabrae vexillum unguiculatum, orbiculatum, incumbens, al a e cuneato-obovatae, auriculatae, breviter unguiculatae, vexillo paullo breviores, carinae basi adhaerentes, carina bipes, petalis inferne et apice margine superioris coalitis, alas aequantibus. St a m in a 10 , monadelpha, vagina integra. Ov a ri um stipitatom, hirsutum, compressum, laneeolatum, oniovalatum. Stylas attenuatus, sensim filiformis, glaber; stigma terminale, infundibuliforme. Le g umen ..... Frutex brasiliensis; caule volubili, cum ramis et petiolis ferrugineo pubescente, foliolis pinnatim trifoliolatis, foliolis petioli longitudine, ovatis, acuminatis, lateralibus obliquis, paullo minoribus, terminali stipellis duabus setaceis munito, stipulis ovuto-acuminatis, adpressis, aculeiformibus, persistentibus, racemis axillaribus, floribus remotis, violaceis, quaternatim fasciculatis, calycibus bibracteolatis, bracteolis ovato-orbiculatis, membranaceis, margine ciliatis, ferrugineis, caducissimis.

Crepidotropis Walpers in Linnaea XIV. 296.

6\%9\%. Anthonota PALIS.

? Westi a Vahl in Dansk. Selsk, Skrift. VI. 118.

\section{Ordo CCLXXII. Mimoseae.}

6835. Wachelia WIGHT et $A R N$.

F a r ues i a Gasparini Descript. Nov. gen. 1839. ex Lin. naea Litteraturber. 1839. 


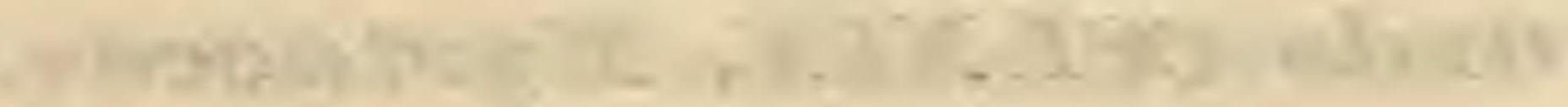

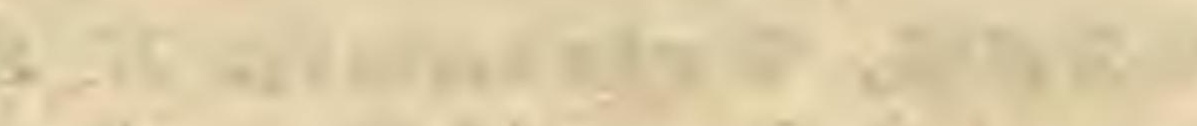

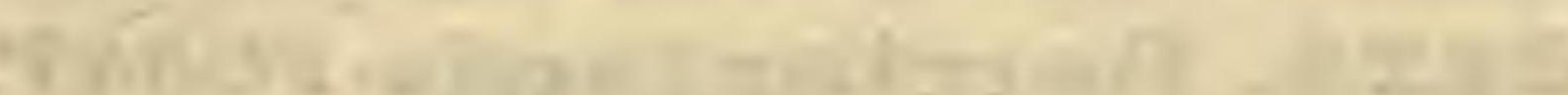

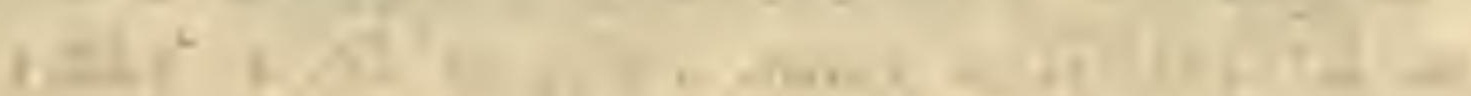

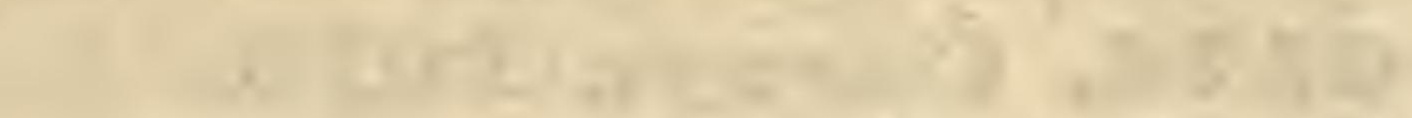

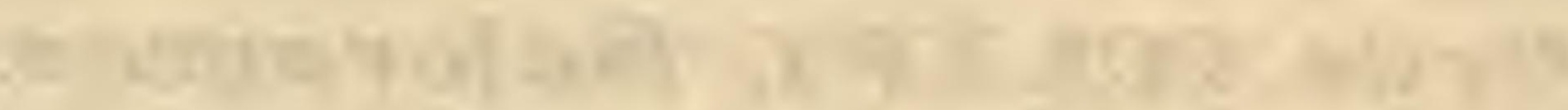

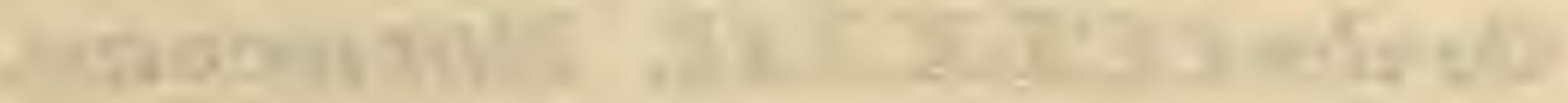

EXPICIT. KAL, NOV, M.D.C.C.C.X.X.X.X.

$\operatorname{lin} \rightarrow$

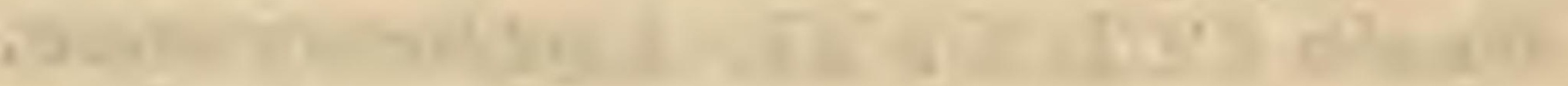

$\frac{7}{7 x}$

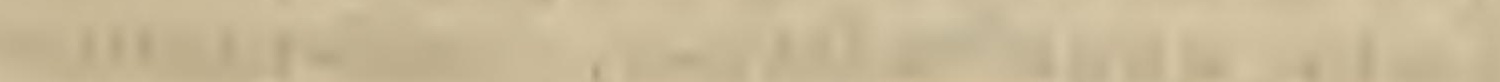

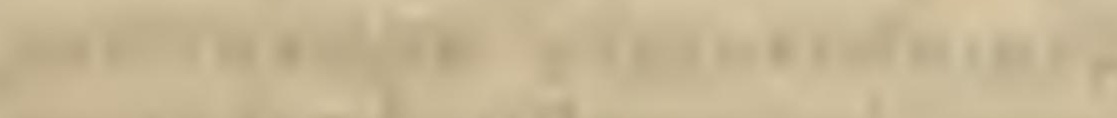

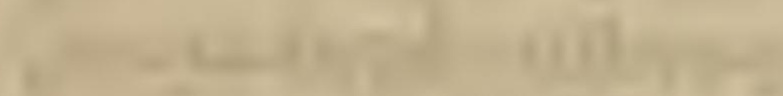

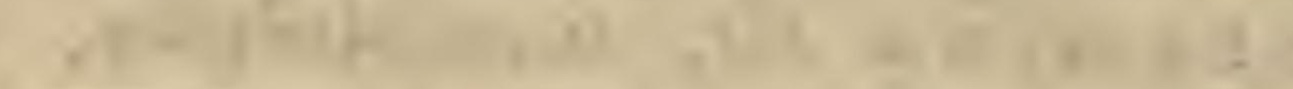

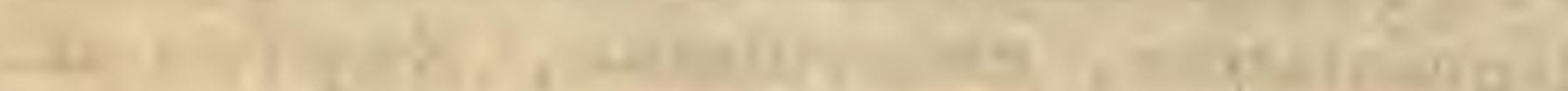

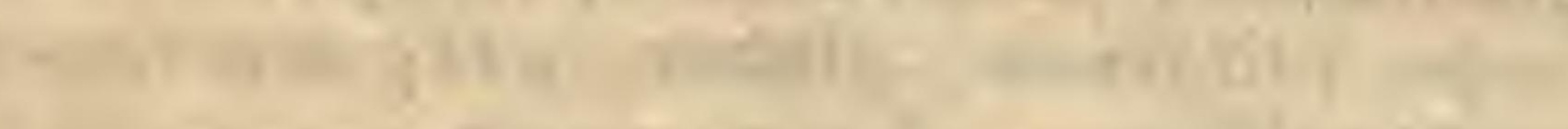

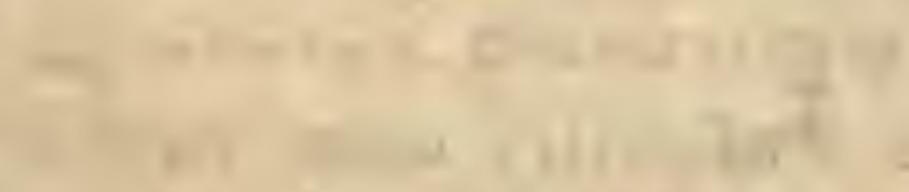

(2)

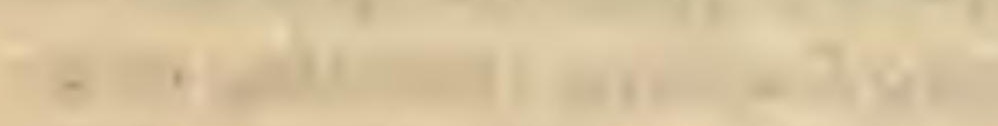

$4-1$

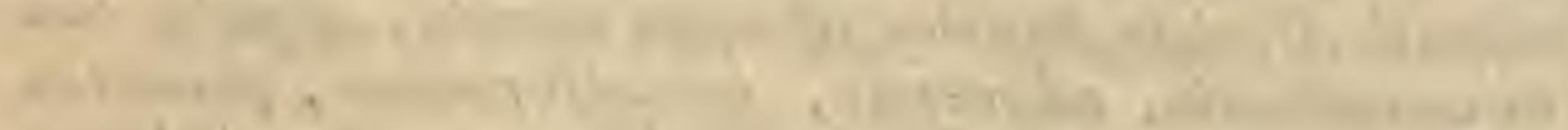

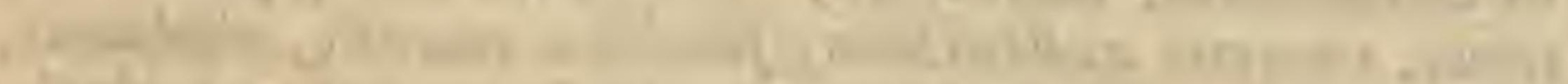

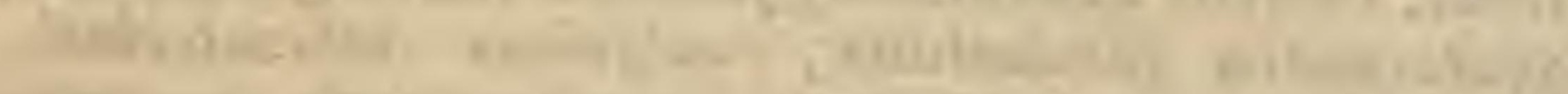

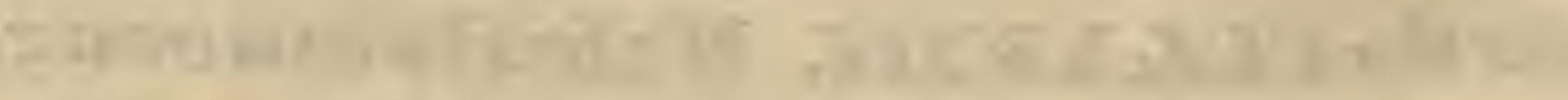

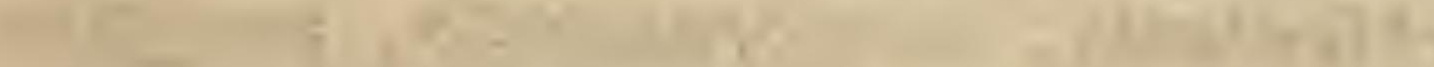

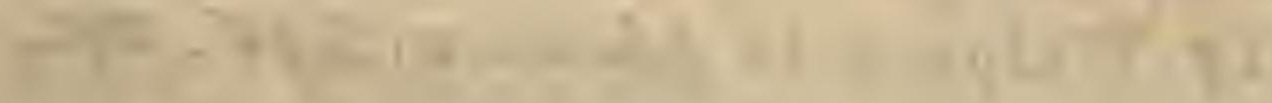

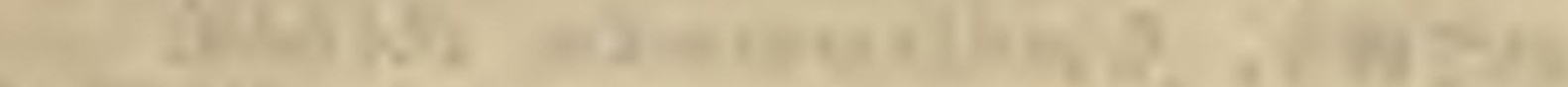

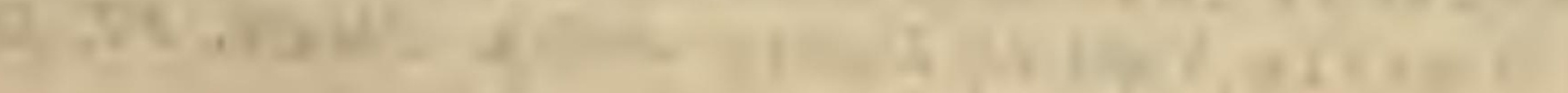

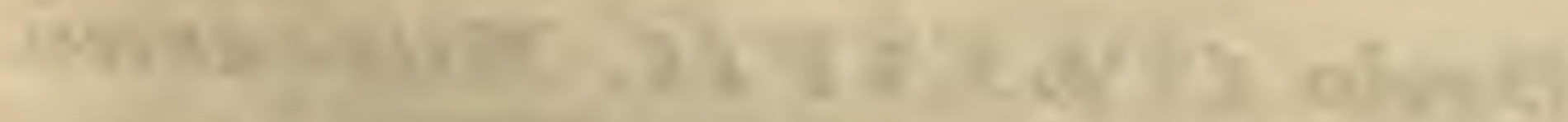

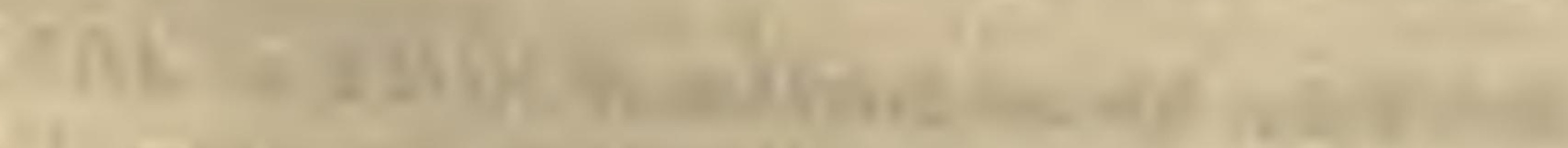




\section{(Numeri asteriseo $\left(^{*}\right)$ signati etiam in Supplemento quaerendi sunt.)}

\section{A.}

Abalon Adans. n. 1066. Ahama Adans. n. 1050. Abapus Adans, n. 1290. Abasin Kämpf. n. 580\%. Abasoloa L, et Lex. p. 502.2. Abatia Ruiz et Pav. n. 6160. Abazicarpus Andrz. n. 4854 . Abelia $R$. Br. n. 3333 . * Abelicea Hon. Belli n. 1849, a. Abelmoschus Med. n. 5281 . Abena Neck. n. 3685. Aberemoa Aubl. n. 5721 . Abies Brongn, n. 1810. Abies Linn. n. 1795. Abies Tournef, n. 1795. c. ABIETINAE p. 259 et 1372 . Abilgaardia $V a h l$ n. 1003. c. Ablania Aubl. n. 5361 . Abola Adans. n. 808. Abolaria Adans. n. 3725 . Abolboda $H$. et Bonpl. n.1026. Abrahamia DC. n. 6206. b. ABRINEAE p. 1301. Abroma Jacq. n. 5330 . Abronia Juss. n. 2002. Abrotanella Cass. n. 2705. Abrotanoides DC. в. 2775 . b. Abrotanum Tournef. n. 269\%. c. Abrus Linn, 6698. Absinthium Tournef. n. 2694. Absus DC. n. 6781. g. 5 . Abumon Adant, n. 1102. Abuta Barrer, n. 4687. Abuta Loureir. n. 1805. Abuta Póppig 4691 . Abutiloides Endl, n. 5293. a. Abutilon Gärtn. в. 5292. Acacia Neok. n. 6834. ACACIEAE p. 1323. Acaena $V a h l$. n. 6372 . Acaena Linn, n. 6372. a. Aeaju Tournef. n. 5916. Acajuba Gärtn. n. 5916. Acalypha Linn n. 5787. ACALYPHEAE p. 1111. Acanes Adans. i. 2881. ACANTHACEAE p. 696 et 1405. ACANTHEAE p. 702. Acanthephippiam Blum.n.1389/, Acanthobotrya $E$ et $Z$, n. 6479 . Acanthobotrya $W_{\text {alpers }} 6778$. d. Acanthocalyx DC. n. 2190 . b. * Acanthecarpha $D C$. n. 2522 . b. Acanthocarya Arrud, n. 5642 . Acantlodium Delil. n. 4072. Acanthoglossum Blum. n. 1437. Acantholatena DO. n. 2'21. a. Acantholepis Less. n. 2848. A eanthonychia DC. n. 5201 . Acanthophora Lamx n. 91. b. Acanthophyllum C.d. M. n. 5253. Acanthophyllum Hook, et Arn, n. 2947. b.

Acanthophyton Less, n. 2977. Acanthoprasium Benih, n.3658.e.
|Acanthosperma Arrabo n. 3036. Acronia Presl n. 1617. Acanthospermum Sch. n. 2479. Acronodia Blum, n. 5389 . Acanthospora Spreng. n. 1309. Acronyehia Forst, n. 5978.* Acanthoxanthium DC. n, 2480. b. Aeropera Lindl. n. 1429.* A eanthus Tournef. n. 4071. Acrophiorus Presl, 641/1.

Acarna Cass. n. 2860, b. Acarna Vaill. n. 2886. Acaste Salisb. n. 1238. Accorombona Endl. 11. 6535.* Acer Mönch. n. 5558. Aceranthus .Mr. et Dec. n. 4813. Aceras $R, B r$, n. 1512, * Acerates Elliot, n. 3488. * Aceratium $D C$ n. $538 \%$ a. ACERINEAE p. 1055. Acetabularium $E$. u. 430 . C.m. $\beta$. Acetosae Campd. v. 1993. e. Acetosella E, n. 6058. c. Achaetostevia $E$. n. 2264. a. Achania $S$ w. n. 5278 . Aeharia Thunb, n. 5107. Achariterium Bluff. et F. n.2752. Achetaria Cham, n. 3942. * Achillea Neck. n. 2610. Aehimenes Vahl. n. 3954. Achimenes $P$. Brown, n. 4157 . Achimenes $D C$. n. 4166.* Achiton Carda n. 468.* Achlya Nees n. 38. Aehlys $D C$, n. 4805 .

Achnanthes Bory, n. 6. Aehueria Palis n. 869. a. Achnodon Link, 11. 750. e. Achnodouton Palis. n. 750. e. Achras $\boldsymbol{P}$. Brown, n. $42 \%$. Achroanthes Raf. n. 1385. Achromolaena Cass. n. 2726. b. Aehupalla Humb. n. 1314. A chymus Soland. n. 1871. Achyrachaena Schauer $1.2585 / 1$. ACHXRANTHEAE p. 302. Achyranthes Linn. n. 1966. Achyrastrum Neck. n. 2974. ACHYRIDEAF p. 382. Achyrocline DO, n. 274. Achyronia Wendl. n. 6462 . Achyropappus $\boldsymbol{H}, \boldsymbol{B} . \boldsymbol{K}, \mathrm{\textrm {n }}, 2587$ Achyropappus Bieberst, n.2868. Achyrophorus Scop. n. 2987.* Achyrospermum Blum. a. 3671 . Acin Willd, n. 6410

A cianthus $R$. Br. n. 1589. * Aeicarpha Juss. n. 3036. Aeidandra Mart. n+ 6813. Acidoton Sw. 11. 5822.

Aerocentron Cass. n. 2871. a. Acrocentron $D C$ n. 2871 , u. Aerocephalum Cass, n. 2761, b. Acrocephalus Benth. n. 3572. Acrocomia Mart, n. 1768. ACRODICLIDIA p. 319.

Acrodiclidium Nees, n. 2042. Acrodryon Spreng. n. 3280 . b. Aeroglochín Sehrad. n. 1934. Acrolasla Presl. n. 5410. Acrolepis Schrad, n. 993. b. Acrolophoides DC, n. 2871, t. $\beta$. Aerolophus Cass. n. 2871. t.

\section{Acropodinm Desveaux n. 64} Acropteris Link. n. 630 . b.
Acroptilion Cass. n. 2893 .

Acrosanthes $E$. et $Z$, n. 5191. Aerospelion Bess. n. 863. d. Acrospermum Tode n. 283. Aerospermum Tode n. 403. b. Acrosporium Nees n. 220. Acrostemon Klotesch, n. 4303. Acrostichum Linn. n. 603. * Acrostichum Presl n. 608. b. 2. * Acrothaminium Nees. p. 21. d. \&o Aerotome Benth. n. 3656. Acrotrema Jack n. 4758. * Acrotriche $\boldsymbol{A}$. Br. n. 4275 . Acrozus Spr. n. 5388. Actaea Linn. n. 4799. Actaea Loureir. n. 4766. Actegiton Bl. n. 5693 . Actephila Blum. n. 5867.

Actia Adans, n. 6087. Actidium Fries n. 374. Actimeris Rafin. n. 2530. Aetinanthus Ehrenb. n. 4388. Actinea Juss. n. 2599. b. Actinella DC. n. 2599. b.* Actinocarpus R. Br. n. 1043. Actinocenia DC. n. 2685 . c. Actinochloa Willd. n. 84\%. Aetinochloris Endl. 1. 839. c. Actinocladium Ehrenb, n. 238. Aetinodaphne Nees. n. 206\%. Aetinoderminm Nees. и. 336. Actinodium Schauer, n. 6287. Actinodon Brid, n. 576. A einodontium $S c h w a ̈ g r$. n. 576. Actinolepis DC. n. 2590 . Aetínomeris Nult. n. 2530. Actinophora Wall. p. 999. Actinophora Bafin. p. 29. Actinophyllum $R$. et P n. 4559. Actinoptera DC, n. 2496. c. Actínoseris E. n. 2909, a. Actinospermum Ell, n. 258k. b. Acilepis Don n, 2204. a. Acinaria Targ. 120. g.

Acinodendron Linn. u. 6219 .

Acinodontinm Schwägr. n, 5\$6. Aeinos Mönch. n. 3617. c. A cinotum DC. n. 4845 . d. Acinula Fries n. 286. Acioa Aubl, n. 6410. Acioniscium Endl, n. 317. an Aciotis Don n. 6225 .

Aciphylla $D C$. n. 2577, e. Aciphylla Forst. 11. 4442. Aciphyllum Benth, n. 6431. b. A eis Sweet. n. 1266.

Aeisanthera $P . M r$. n. 6152. Acispermum Neck. म. 2529. Ackama A. Cunningh. n. 4657 . Actinidia Lindl. p. 841 . Actinonema Pers. p. 31. b.
Acladium Link n. 223. Acladodea $\boldsymbol{R}, \boldsymbol{P}$. n. 5616 . Acleía $D C$, «. 2810. Aclisia E. Mejer n. 1029. Acmadenia $B$. et $\boldsymbol{W}$. f. n. 6019 .

Acmella Rich, n. 2553, a. A emena $D C$. n. 3622. Acnida Mileh. n. 1914. Acnistus Schott. n. 386t. Acecanthera G. Don. n. 3867/, . Acoídium Lindl. n. 1410.* Acolea Dum. 474/. Acolium Fée. n. 129. a. Acoloxochitl Hernand. n. 1229. Acoma Adans. n. 5086. Aconiopteris Presl. n. 603. b. ct." Aconitella Spach. 479. b. a. * Aeonitum Tournef, n. 4797. Aconogonon Meisn, n. 1986. f. Acontia Hill. .1. 4t2. d. Acontias Schott. n. 1687. Aconychia Fenel, n. 5202. b. Acormos Endl. n. 317. b. ACOROIDEAE p. 24n.) Acorus Linn. n, 1708. Acosmium Schott. n. 6753. Acosmus Desv. 1n. 556\%. Acosta Loureiro n. 4323. c. Acosta Huiz et Pav, n. 5265. ACOTYLEDONEAE p. 1. Acouron Aubl. n. 6703. Acourtia Don. n. 2963. * Acquartia Jacg. n. 3855. ACRAMIPHIBRYA p. 258. Acraathera Arn. n. 3313/2. Acratherum Link, n. 775 . Acremonium Link, n, 222. Acridocarpus. G. et P. n. 5576 . Aeriopsis Blum. n. 1401. ACROBRYA p. 42.

Acracentroides $D O$. n.2871. t. $r$. Aetinospora Turez. n. 4801. Actinostachys Wallich, H. 662. Actinothyrium Kunse, n. 361 . Aetinofus Labill. n. 4378. Aculeosa Pluckn. n. 3081 . Acuna Fuiz et Pav. n. 43 h. Acyntha Cammel, 11. 1113. Adaetylus Endl, n. 1619. a. Adamaram Adans, n. 6076. a. Adambea Lam. n. 616\%.e. Adamboe Rheed, n. 6164. c. Adamia Wallich. n. 4672. Adamsia Fisch, n. 6384. Adamsia Willd, 11. 1135. Adansonia L. n. 5297. Adelantlus Endl. 10. 6839 . Adelbertia Meisn. n. 6174. Adelia $L$, n. 5825 .

Adelia $L . C$. Fich, n. 1896. Adelobotrys DC. \#. 6207 . Adenacanthus Neet, n. 4050 . Adenachaema $D C, n .2668$. Adenandra Willd, n. 6015. Adenanthera $\operatorname{Linn}$. it. 6820 . Adenanthos Labill, n. 2130. *

Adenaria $\boldsymbol{H}$, B. K. n. 6157. Adeuaria Rafin, n. 4339 . $179 *$ 
Adenarium Raf. n. 5229.

Adenilema Blume n. 4666. Adenium $R o ̈ m$. et $S c h$. p. 584 . Adenobasium Presl. n. 5362. Adenocalyx Bert. n. 676 '. Adenocarpus DC. n, 6492 . Adenocaulon Hook. n. 2287. Adenocrepis Blum. n. 5873 . Adenocyclns Less. n. 2196. Adenodus Lour. n. 5334. a. Adenogramma Reichb. n. 5195 . ADENOGRA MMEAE p. $95^{\prime} \mathrm{k}$. Adenolepis Less, n. 2543. Adenolinum Reich. в. 6056. c.* Adenoncos Blum, n. 1491. Adenonema Bumg, n. 5240. d. Adenopappus $B$ enth. n. 2581/ Adenopeltis Bert. n. 5770 . Adenophora Fisch. n. 3088. Adenophorus Gaudich. n. 613. Adenoplayllum Pers. n. 2575. Adeaopsis $D C$. u. 6821.

Adenorhaclis $D C$, n. $63 \% 2$. g. Adenorhoplum $P \circ h l$ n. 5805 . Adenosacme Wall. n. 3253.

Adenosepalum $S p$. 546'. B. b. $\gamma$. Adenosma R: Br. n. 4033 . Adenosolen $D C$, n. 2698 . Adenostegia Benth. n. 4005. Adenostema Forst. u. 2261. * Adenostemon Pers. n. 2036. c. Adenostoma Blum. p. 695. Adenostoma Hook et A. n.6371. ADENOSTYLEAE p. 368. Adenostyles Cass. n. 2283. Adenostylis Blum, n. 1548 . Adenotrachelium $N$. n. 2052 . c. 3 . Adenotriehia Lindl. n. 2811. XII. Adenoxys Endl, n. 6058. b. Adesmia $D O$. n. 6603 . Adhatoda Herm, n. 4083 . a. Adhatoda Nees n. 4083. Adlumaia El $F l, p, 133^{\prime}$. 1 . Adiantum binn. 15. 620 . * Adiua Salis 6. n. 3280 . e. Adinandra Jack n. 5428 . Adisea $B l$, и. 5819 . Adleria Neck 6801.

Adlumia $\boldsymbol{H}_{a}$ fin. n. 4837 . Adodendron Neck. n. 4340. Adolia Lam, n. 5724 .

Adonanthe Spach. n. 4778 * Adolphia ateisn n. 5732 . Adonia $D C, n .4778$. a.

Adenis Dillen. n. 4778. Adopogon Neek. n. 2982. Adoxa Linn n. 4550.

Adrastea $D C$ แ. 4752 . Adriania Gaudioh. n. 5820 . Adupa Bose n. 1003. b. c. Adyseton $D C$, n. 437'. Adyseton Scopol. n. 4874 . Aechmanthera Nees. n. 4055. Aechmea Huiz ot Pav. a. 1301. Aecidium Pens. b. 182. Aecidium Hill. n. 39'. Aecidium link n. 189, a. Aegeria Adans, n. 5706. Aegerita Pers. I. 299. AEGERITEI p. 25. Aegialina Schult, n. 889. v. Aegialitis $\boldsymbol{R}$ Br. n. 2173 . Aegialitis Trin n. 889 . b. Aegiceras Gärtn. n. 4233 . Aegiceras Green. n. 528. AEGICEREAE p. 738. Aegilops Linn, n. 918. Aeginetia Limn, n. 4190. A eginetia Cav, n. 3265 . Aegipbila Jacy n. 3713 . ARGIPHILEAE p. 687. Aegira Fries, n. 50 . Aegle Torr. n. 5513. Aegochlon Benth. n, 3821.
Aegomarathrum Koch. n.4525. b. Ageratoides $D C$. n. 2253. b. Aegonychiou Gray, n. 3761. a. Ageratum Linn. n. 2259. Aegopodium linn, n. 4'05. AGGREGATAE p. 350. Aegopodoxys Endl. n. 6058. f. Agihalid Prosp. Alp. n. 5498. Aegopogon Willd, n. 815. Aegoprieon L. n. 5769.

Aeluropus Trin, n. 876. a. Aeolanthus Mart, в. 3578 . Aëranthus Lindl. n. 1495 . Aèrídes Loureir. n. 1493. Aërides Roxb-n. 1353. Aërides Swartz. n. 1473. Aérisma Endl, n. 277. a. Aërobion Spreng. n. 1493. Aërope Endl. n. 6093. b. Aérophyton Eschweil. n. 247. Aërophyton Megen, n. 28.

Aërva Forsk. n. 1968. AERVEAE p. 302 et p. 1377. Aeschinanthus Jack, n. 4134 . Aesehrion $\mathrm{Fl}$. $\mathrm{Fl}$. p. 133 4. 2 . Aeschynomene Linn. n. 6605. Aesculus L. n. $56^{\prime}+1$.

AETHALINEI p. 27.

Aetbalium Link: n. 320 .

Aetheilema $\boldsymbol{R}, \boldsymbol{B r}$. n. ${ }^{4} 063$.

Aetheolaena Cass. n. 2811. XIV. Aetheonema DO, 3370 . d. *

Aetheopappus Cass. n. 2871. 1. Aetheorhiza Cass. n. 3022. a. 2. Aetheria Blum. n. 1558.* Aethionema $\boldsymbol{B}, \boldsymbol{B r}$. n. 493 '. Aethionia Don, n. 2930. Aethiopis Tournef n. 3597. e. Aethusa Linn, n. $442 \%$. Aextoxicum Rutz et $\boldsymbol{P}$. n. 5881 Affonsea $\mathcal{S t}$. Hil, n. 6833. Afzelia $S$ mith. n. 6796. Afzelia Whrh. п. 516. Afzelia Gmel. n. 3995. Agalmanthus Erdl. n. 6303 . b. Agalmyla BIum. n. $4136 /$, Aganippea DC. п. 2637. Aganippea Flor. mex: p. 503. Aganisia Lindl. n. 1406/, Aganolobus DC. n. 4908 . a. A ganosma G. Don. n. 3409 , c, * AGAPANTHEAE p. 141.

Agapanthes Herit. n. 1102. Agapetis Don. n. $4333 . *$ Agardhia Cabrer. n. 81. Agardhia Gray. n. $5 \%$ ' b. Agardhia Spreng. n. 6068. AGARICINI p. 40. Agaricon Adans. n. 4'77. c. Agaricus Linn. n. 453. Agarista $D O$. n. 2523. Agarista Don. n. 4318 . g. * Agarnm Bory. в. 103. Agasillis Spreng. n. 4 't66. Agassizia Chav, n. 3994. Agassizia Spach. n. 6113. Agastachys $R, B r \cdot$ n. 2136. Agastia $D C, n \cdot 4318$, e. $\delta$.* Agasyllis Hoffm. n. $4485 \mathrm{k}$. Agathaca Nees. n. 2999 . b. Agathea Cars. n. 2299. Agathelpis Chois. n. 3727. Agathis Salisb. n. 1798. Agathisanthes Blum, n. 6092 . Agathodes Don. n. 3533 . Agathomeris Delaun. n. 2727. Agathophyllnm Juss, n. 2038 . Agathophytam Mroq. n. 1922. Agathoswa Willd, it. 6021. Agathyrsus Don. n. 3028. Agati Rheed, n. 6553. Agave Linn. n. 1297.

AGAVEAE p. 181.

Agauria $D$ C. n. 4318 . e. $\%$ *

Agdestis Moc. et Sess. nt. 468 ? Agenium Neos, n. 950, a. Agenora Don, n. 2987.
Aglaea Pers. n. 12'1'.

A glaia T,our. n. 5524 .

Aglaja Noronh n. 4757 .

A glaomorpha $S$ chott. n. 615 . d. Aglaonema Schott. n. 169'. *

Aglossa $D C$. n. 2496 . d.

A glossa $D C-n, 2759$. a

Agnanthus Vaill. n. 371'.

A guns castus $T$. n. 3700 . a.

A gonis $D C$. n. 6305 .

Agoranthus Endl. n. 4719. b.

Agoseris Rafin, n. 3030/,

Agostana Salisb. n. 441\%.

Agraphis Link. n. 1123.

Agrianthus Mart. n. 2267.

Agricola Schrank n. 3703.

Agrimonia Tournef, n. 6363.

Agrimonioides Tournef. a.6369.

Agriodaphne Vees, n. 2052. b.

Agriodendron Haw, n. 1115. g.

Agriogongyle Endl, n, 4974. a. Agriophyllum Bieberst. n. 1959. Agriphyllum Juss. n. 2814 . Agropyrum Palis. n. 913. b.

Agrostemma $L$. n. 5250. b.

Agrosticula Raddi. n. 809 . AGROSTIDEAE p. 88.

Agrostis Linn, n. 810 . Agrostopliyllum Blum, n. 1500. Agylophora Neck. n. 3280. d. Agyrium Eries, n. 399 . Ahovai Tournef. n. 3387. Aidelns Spreng. n. 3979. c Aidia Loureir, u. 3331 .

Aikinia $\boldsymbol{R}, \boldsymbol{B r}, \mathrm{n} .4144$. Aikinia Salisb. n. 3079 . b. *, Aikinia Wallich. n. 928. Alanthus Desf. n. 5980.* Ainsliaea $D C$, n. $2929 /$. Aiolotheca $D C$. n. $2 * 66$.

Aira Linn, n. 859, * Airochloa Link. n. 889. a. Aititara Marcgr. n. $176 \%$. Aitonia Forst. n. 467. Aitonia L. E. n. 55 t8. AIZOIDEAE p. $9^{\prime} 77$. Aizoon Linn. в. 5165. Aizoon Andrew. n. 5170. Aizooulia Tausch, n. 4634 . b. A izopsis $D O$. n. 4880 . e. $\Lambda$ jax Haw. n. 1289 . b. A jovea $A u b L$, n. 2050. Ajuga Linn. n. 3680 . AJUGOIDEAE p. 631 . Akebia Decaisn. n. 4700 .* Akeesia Juss. B. $561^{4}$. Alaeospermum Neck. n. 4409. Alagoptera Nees. p. 257. Alatuania Llav et Lex.n. 1416.* Alandiaa Neck, п. 6811 . ALANG!EAE p. 1184 . Alangium Lam, n. 6096. * Alania Endl. n. 1168. Alareonia $D C$. n. 2495 . Alaria Grev. n. 108. Albersia Kunth, n. 1971/1. Alberta E. Mfoy. n. 3313 Albertia Schimp. n. $181 \mathrm{~s}$ Albertinia Spreng. n. 2221. * ALBERTINIBAE p. 361 . Albikia Presl. n. 988. Albrandia Gaud. n. 1855. Albuea Linn. 1133. Albucea Reichenb. n. $113 \%$.
Agretta Eckl. n. 1243.

Agrophyllum Neck, n. 6036. b. Agyneia $\operatorname{Linn}$. a. $\mathbf{5 8 4 3}$. Airopsis Desv. n. 860 . Alafia Thouar, p. 586. 1. Alateruus Tournef, a. 5722. a.

Alburnoides $D C$. n. 6505. d. Aleaea $L$, n. 5270 . b. Alcanna Gärtn. n. 6159.

Alchemilla Linn, в. 6370, a. Alchimilla Tournef. n. 2072. Alchornea Sol. n. 5796.

Aleicornium Gaudich, n. 603. c." Alcina Cav, n. 2'78. Alciope $D C$. 1. 2290.

Aleithoê Don, n. 2960, b. \&. Aldama Llav, ot Lex. n. 2520. Aldeaen $R$ uiz et Pav. n. 3831 . Aldina Endl. u. 6815.

Aldina Adans, n. 6592.

Aldina E. Mey. n. 6835. Aldrovanda Monti. n. 5034.

Alectoria Achar. n. 178.

Alectorolophus Hall. n. 4017.

Alectra Thunb. n. 4000.

Alectryon Gärtn. 5627.

Aledryon A. Cann. n. 5627. Alepiden Laroche n. 4385 .

Alepyium R. Br. n. 1005.

ATethopteris Sternb. n. 68\%.

Aletris Linn. n. 1259.

Aleuria Fries, n. 430. C.

Aleurisma Link. n. 210.

Alenrites Forst. n. 5802.

Aleuritia Endl, n. 4199. b.

Aleurodendron Reinw. n. 5356 .

Alexis Salisb. в. 1626.

Alfonsia Funth. n. 1771.

Alfredia Cass. n. 2896.

ALGAE p. 1.

Algarobia Benth. n. 6823 .

ALHAGEAE p. 1287.

Alhagi Tournef. n. 6625 .

Alhema srab n. 6159.

Alibertia A. Rich, n. 3229.

Alibum Cess, n. 2246.

Alicteres Neck. n. 5315. c.

Alisma Juss. n. 1041.

ALISMACEAE p. 127 et 1356. 
Aloides Boerh, n. 1211. ALOINEAE p. 143.

Alomia $\boldsymbol{H}, \boldsymbol{B}, \boldsymbol{K}$, u. 2254.

ALOMIEAE p. 366.

Alonsoa Raiz et Pav. n. 3830. Alopecuroides DO. n. 2760. b. Alopecuros Benth, n. 3650 . al. Alepecurus Linn. n. 747.

Alophia Herb. n. 1228/.

Alophium Cass. n. 2871. ff.

Alophochloa Reichenb. n. 889. b. Aloysia Orteg. n. 3684. b. Alphitomorpha Wallr. n. 277. c. Alphitonia Russ. n. 5729. Alpinia Linn. n. 1632. Alpinia Plum. n. 1631.

ALPINIEAE p. $22 \%$.

A Iseis Sehott. n. 3268.

Alseodaphne Nees, n. 2030.

Alseuosmia $A$. Cunn. n. 3341/1. Alsidium $A g$. n. 92 .

ALSINACEAE p. 955.

Alsinanthe Fenzl. n. 5227. 11. Alsinanthus $C$. n. 523\%. b. 5235 . Alsinastrum $E$. n. 5475 . c.

Alsine Wahlenb n. 5257.

Alsine Tournef. n. 3977.

ALSINEAE p. 955.

Alsinella Benth. n. 5240. b.

Alsinella Dill. n. $522 \%$.

Alsinella Hartm, n. 5227.

Alsinoides Vaill, n, 5182.

Alsodea Mart, et Zucc. n. 5047.

Alsodeia Thouars, nt. 50'7.

ALSODINE AE p. 911

Alsomitra Blume 11. 5122. b.

Alsophila 17. Brown n. 652.* Alstonia $R, B r$. в. 3408 .

Alstouia Linn. n. 4259.

Alstonia Scop. n. 3375.*

ALSTONIEAE p. 583.

Alstroemeria Linn. 1. 1295.*

Altensteinia H. B. K, n. 1576. Alternanthera Forsk. n. 1956.

Alternaria Nees. n. 189.

Althaea $L$ n. 5270 , a.

Althaeastrum $D C$, п. 5270. a.

Althenia Petit. n. 1663.

Altheria Thouar. n. 5338.

Altingia Noronk. n. 1902.

Altora Adans. u. 5840 .

Alymuia Neck. n. 2'75.

Alypum Tournef. n. 3725.

Alysicarpus Neck, n. 6626.

Alysidium Kunze n. 220.

Alysium- $A g$. n. 8 ' .

ALYSSINEAE p. 866.

Alyssoides $D C$. n. 4869 . b.

Alyssoides Modik. a. 4869 .

Alysson Medth. n. 4867 .

Alyssum Linn. n. 487\%.

Alyssum Adans, n. 4865.

Alytosporium Grev. n. 223.

Alytosporium Link, p. 21 . d. $\delta$.

Alyxia Banks. n. 3393.

Alzatea $\boldsymbol{R}, \boldsymbol{P}$. n. 5698 .

Alziniana Dietr. n. 5698 .

Amagris Raf. n. 820 .

Amainua Aubr n. 3314.

Amalia Hort. Hisp. H. 1306.

Amanita Fries, n. 453. VII. M. Amanoa $A u b l$ n. 5852.

Amansia Bamx, n. 101.

Amansites Brongn u. 122 . b. Amaracarpus Blum, n. 3179.

Amaraens Mönch, n. 3607.

AMARANTACEAE p.300et1377.

AMARANTFAE p. 303.

Amarantus Linn. n. 1972.

Amarenus Prest, n. 6511. g.

Amaria Mutis. n. 6790. b.

AMARYLLIDEAE p. 174.

Amaryllis Linn. n. 1273.*

Amasonia Linn. n. 3711 .
A masperma $\operatorname{Raf}$, n. 62. Ambelania Aubl, n. 337\%. Amberboa Pers, n. 2865. Amberboi Isn. n. 2865. Ambinux Comm. n. 58.2. Amblachenium Turos. n. 2984.* Ambleia Benth. n. 3650 . h. Amblia Presl. n. 615 d. * Ambliodum Palis. n. 557 . Amblirion Rafin, n. 1098. a. Ambloma Endl. n. 3210. d. $\beta$. Amblostoma Soheidw. n. 1616/1 Amblyglottis Blum, n. 1501 . Amblygonou Meisn. n. 1986 . b. Amblylepis E. n. 2276. a. Amblyocarpnm $F$. et $x$. n. 2776 . Amblyodon Palis. n. 543. Amblyolepis DC. n. $260 \%$. Amblyopogon F.et.M. n.2365.B. $\beta$. Amblyopsideae $D C$. n. 2865. B, Amblysperma Benth. n. 2924. Ambora Juss, n. 2014.

Ambraria Cruse. n. 3106.

Ambraria Heist, n. 3105.

Ambrina Spach. u. 1923.*

Ambroma $L$, n. 5330 .

Ambrosia Tournef. n. 2'82.

AMBROSIEAE p. 403.

Ambrosinia Cass. n. 1670.*

Amechania $D C$. n. $4337 /$.

Amelanchier Med. n. 6345 .

Ameletia $D C$. n. 6145 .

AMELLEAE p. 371.

Amellus Cass. n. 2292.

Amellus Adans. n. $230 \mathrm{t}$.

Amellus P. Brown. n. 2'199.

AMENTACEAE p. 272.

Amerimuma $P$. Br. n. 6701.

Amerina DC. n. $3743 / 1$.

Amethystea Linn. ". 3677 .

Amethystoides Benth. n. $3575 . \mathrm{g}$. Amberstia Wall. n. 6793.

Amianthium A. Gr, n. 1066/2. Anica noctara Rumph. n. 1103. Amicía Funth. n. 659't.

Amirola Pers. n. 562\%.

Amitella Endl. n. $462 \%$, a.

Ammannia Houst. n. 6146 .

Ammanioides $D C$. n. 6149. a.

Ammi Tournef. n. 440't.

AMIMINEAE p. 768 .

Animios Mönch. n. 4400 . b.

Ammobium $\boldsymbol{R} \cdot \boldsymbol{B} \boldsymbol{r}$. 1. 2723.

Ammocharis Herb. n. 1274.

Ammodendron Fisch. n. 6739.

Ammoides Adans. n. 4400 .

Ammogeton Schrad. n. 3021/

Ammonilla Bengal. n. 5379.

Ammophila Hort. n, 820.

Ammoseris Pōpp. et E. n. 3017.*

Amuyrsine Pursh. n. 4343.

AMOMA p. 223.

AMOMEAE p. 221.

Amomocarpum Brongn. n. 1652. A momun Linn. n. 1626.

Amonia Nestl. n. 6369 .

Amoora Roxb. n. 5528.

Amordiea Neck, n. 5133.

Amoreuxia Mog, et S. n. 6403. Amoria Presl. H. 6511. f.

Amorpha Linn n. 6542.

Amorphophallus $B l$ n. 1681 . "

Amosa Neck n. 6337.

Ampacus Rumph. u. 5972 . g.

Ampalus $B$ oj. "u. 1856. *

Ampelanus $\operatorname{Rafin}$. n. 3

AMPELIDEAE p. 796. 822.

Ampelopsis L. C. Rich. n. 4566. Ampelosicyos. Thouars, n. 5123. Ampelygonam $L$, n. 1986. e. $\gamma$. Amperea Adr. Juss, n. 5813 .

Amphania Banks. n, 5409 .

Ampherephis Kunth. n. 2807.
Amphiachyris DO. n. 2361. b. Amphiantlus Torr. n. 3978. Amphiblestria Presl, 622. b. * Amphibolis Agardh. p. 230. AMPHIBRYA p. 76.

Amphicalea DC, n. 2616. a. Amphicalyx Blume n. 4323 . Amphicarpaea n. 6630.

Amphicarpum Raf. n. 763.

Amphichila DC. n. 3043 . a. *

Amphicome Rogl n. 4109.

Amphiconium Nees p. 21. h.

Amphicorda Fries n. 270.

Amphiderris $\boldsymbol{B}$. Br. n. 2147 . b.

Amphidesmium Schott. n. 652. *

Amphidium Nees n. 514.

Amphidonax Nees n. 825 .

Amphidoxa DC, n. 2750.

Amphiglossa $D C$. n. 2759.

Amphiglottis Salisb. n. 1371.

Amphilasia DC. n. 2765 , b.

Amplilochia Mart. n. 6058.

Amphiloma Fries 172. B.

Amphiloma E. n. 2155. b.

Amphifophium Kunth, n. 4121 . Amphinomia DC, n. 64t2. f.

Amphiotis DC. n. 3240 d.

Amphiphytam Schwe in, n. 403.a. Amphipogon $R, B r$. n. 827 .

Amphirhapis $D C$. n. 2377.

Amphirhinum Green n, 547.

Amphirrhoge Reich. n. 5046. *

Amphirrhox Spreng. n. 5046.

Ampliscopia Nees n. 409\%.

Amphisporium Link. n. 291.

Amphistephinm DC, n. 2319, b.

Amphitalea Eckl et Zey, n.6465.

Amphodea Salisb. n. 4313. a. b. *

Ampliodus Lindl. n. 663'.

Amphoradenium Besv. n. 613.

Amphorchis Thouar. n. 1529. et 1532.

Amplioriseus Targ. n. 49. d.

Amphymenium $\boldsymbol{H}$. B. . n. 6708

Amphymenium DO. n. 6705 .

Amphytoides Besm. n. 1665.

Amramatico Flac. n. 2167.

Amsinkia Lehm. n. 3761. e/s.

Amsonia Walt. n. $340 \%$.

Amura Schult, n. 5528.

AMYGDALEAE p. 1250.

Amygdalophora Neck. B. 6405.a.

Amygdalus Linn. n. 6405.

AMXRIDEAE p. 1139.

Amyris Linn. n. 5947.

Anabaena Adr. Juts. n. 5785.

Anabaina Bory. ni. 41.

ANABASEAE, p. 299.

Amabasis Linn, n. 1949.

Anabata Willd, p. 586. 3.

Anacalypta $R \bar{h} L$, n. 519.

Anacampseros Limn, n. 5179.

Anacampseros Tournef: $\mathbf{n} \cdot 4662$.

Anacamptis $L, O$, Bion, n. 1503.

Awaeamptodon Brid, n. 570.

ANACARDIACEAE p. 1127.

Anacardium Rotst. n. 5916.

Anacardium Lam. n. 5917.

ANACHARIDEAE p. 161.

Anacharis Rich, n. 1207.

Anaclasis Benth. n. 4313. d. 32.*

Anacalosa $B t$ fi. 5496 . b.

Anactidea DC. n. 2669. a.

Anactilaena DC. n. 2726. b.

Anactis Cass. n. 2860. c.

Anacyclus Pers. n. 2643.

Anadeaia $\boldsymbol{R}, \mathrm{Br}$. n. 2142

ANAGALLIDEAE p. 733.

Anagallidium Grieseb. n. 3531.

Anagallis Linn. n. 4213. *

Anaglypha DC, n. 2359.

Anagyris Linn, n. 6418 .

Anaitis $D C$. n. 2557.

Analectis Vahl. n. 3715. *

Avamenia Venten, n. 4775. Anamirta Calebr. n. 4693. Ananas Gïrtin. n. 1300. Ananas Tournef. n. 1299. Ananassa Lindl. n. 1299. ANANDRAE p. 1.

Anandria Siegesb. n. 2933. Ananthocyclus Vaill, н. 2683. Ananthopes Hafin. n. 1028. a. Ananthrix Nutt, n. 3488 .

Anapausia Pr. n. 603. b. y. bb, * Anapera Endl. n. 6216. b.

Anaphalantias Endl. n. 2868. c. A naphalis DO, n. 2768.

Anaplirenínu $E$, Meg. n. 592\%. Anapodophyllum Tourn, 1.4806. ANÁPOREAE p. 233.

Anarmoxa Miers n. 4627.

Anargyrum DOC. m. 2948. a. *

Avarrhioum Deif, n, 3890 .

Anarthria $n, B r$, n. 1016.

Anarthrosyne E. Mey. n. 6613 .

Anasillis E. Mey. n. 5908.

A nasser Juss. \#. 33E5.

Anastatica Gär/n: v. 4895 .

ANASTATICEAE p. 872.

Anastrabe E. Mey. n. 3917.

A nastraphia Don. n. 2915 . «. $\beta$.*

Anatheram Palit. n. 950. at.

Anatropa Ehrenb. 11. 6029.

Anavinga Gärin. n. 5060 . n. $\gamma$. Anavinga Rheed, н. 5060 . a. $\beta$. Anaxagorea St Hil. n. 4719.

Anaxanthus Endl. n. 4719 , a.

Anaxeton Cass. b. 2766.

Anaxeton Gärtn, 1. 2741. a.

A naxetum Schott. 11. 615. $\beta$. * Aublatim Tournef. n. 4189. b.

Ancathia $D C$ n. 2863. 
Androsace Tournef. n. 4197. Anisosciadinm DC. n. 4520. ANDROSACEAE p. 730. Anisosticte Bartl. n. 5421.

Androsaemum All, n. 5464. B. f. Anisotes Lindl, n. 6149. d. Androsaemum Tournef, n. 5'64. Auisothea DC. 646'. b. Androsetpia Brangn. n. 946.

Androstemma Lindl, n. 1257/, Andryaln Linn, n. 3025 .

Andryaloides $D C$. n. 2405, a.

Andrzeiowskia Reich. n. 4847. Anecio Neck. n. 2811.

Aneilema $R . B r$. n. 1028. b.

Aneimia Swartz n. 661.

Anemagrostis Trin, n. 810. b.

Anemanthus Eindl. n. 4773. b.

Anemarrhena Bunge \#. 1139.

Anemia Nutt, n. 1825/,.

Anemiopsis Hook. n. 1825/1.

Anemonanthea $D C$. n. 4773. b. $\delta$.

Anemone Haller n. 4773 .

Auemonanthe n. 4772 .

ANEMONEAE $D C$. p. 845 .

Anemonospermos DC, n. 4773 . b. $\varepsilon$.

Anesorhiza Ch, et Sch. n. 4420. Anethum Tournef. n. 4467 .

Anetia Enall. n. 5088.

Aneura Dumort. n. $472 / 2$.

Anenra Endl. n. 4900. a.

ANEUREAF p. 1338.

Aneuriseus Presl, n. 5410.

Angelica Hoffm n. 4456 .

ANGELICEAE p. 778.

Angelicoides $D C$. n. 4462 . f.

Angelonia $\boldsymbol{H}$. et $\boldsymbol{B}$. n. 3885 . *

Angelopogen Pöppig. n. 4581.

ANGIANTHEAE p. 4 '41.

Angianthus Wendl, n. 2714.

Angidium Lindl, n. 1427. e.

ANGIOGASTERES p. 29.

Angiopteris $H \circ f f m$ n. 668 . *

Angiopteris Milchell. n. 629.

Angioridium Grev. n. 316. a.

Angelam Adans. в. 6096.

Angolamia Seop. n. 6096.

Angophora Cav. n. 6301.

Angostura R. et Seh, n. 5990.

Angraecum Thouars, n. 1498.

Anguillaria $A$ Br. u. 1072.*

Anguillaria Gairın n. 4222.

Anguina Michel n. 5140 .

Anguloa Ruiz et Pav, n. 142\% Anguria Linn. n. 5128.

Anhalonium Lemair. 5154. a.

Anhaltia Schwabe n. 34.

Anhebecarpaea $D C$, n. 2297 . b.

Ania Lindl. n. 1391.

Anila Aubl. n. 6840.

Auidrum Necker n. 4546.

Anigosanthus Labill. n. 125\%.*

Anigozia Salisb. n. 1257.

A piotun Soland. i. 2107.

Anisacantha $n, B r$, n. 1919.

Anisactis DO. n. 4497 . e.

Auisadenia Wall, n, 5053/,

Anisauthera Raf, It. 3784/3.

Anisanthus $\boldsymbol{S}_{\text {weet. }}$ n. 1239 .

Anisanthus Willd. n. 333t.

Aniseia Chois. n. 3802 . *

Anisochaeta DC. n. 2260.*

Auisoehilus Wall. ir. 3577 .

Anisodus Link n. 3848.

Anisogonium Presl, 636. b. =

Anisolotus Bernh. n. 6517. c.

Anisomeles $\boldsymbol{n}$. Br. u. 36 t9.

Anisomeria Don 5262. b.

Anisomeris Prest. n. 3320.

Anisomitra $E$. n. 3566 . a.

Anisonema Adr. Juss. ․ 5853.

Anisopappus $H$. et $A$, n. 3032/.

Anisopetala $D C$, u. $6048 . \mathrm{m} . \gamma$.

A nisopetalum Hook n. 1352.

Anisophyllum Haw. 5766 .

Anisopogan R. Br, n. 867.

A viserhampus $D$ O , n. $3028 / 1$.
Anisotrichia $D C$, n. 2224 . a.

Anisum Adans, n. 4410, e.

Anixia Fries. n. 287.

Ankenda Herm. n. 5978.

Anneslea Wall. n. 5406.

Anneslea Andrews. 5018.

Anocarpum DC. n. 4955 . b.

Anoda Pav. n. 5287.

Anodontium Brid. n. 483 a.

Anodopetalum A. Cunn, n. 4654.

Anoecochilus Blum, n. 1569. *

Anoectangium Hedw. 574.

Anoectangium $\mathcal{S}$ chwägr. n. 489.

Anoectochilus Blum, n. 1569.

Anoegosanthus fieich. n. 1257.

Anogeissus $\mathrm{Wall}$. n. 6082.

Anogra $S$ pach. n. 6115. 1.

Anoleptus DC. 3003. a. *

Anoma Lour, n. 6779. et 6811.

Anomalantlus Klotsch. n. 4299.

Anomatheea Fer. n. 1237.

Anomaza Laws. n. 1237.

Anomodou Hook et Tayl, n. 584.

Anomopteris Brongn, n. 682 .

Anomostephium $D C$. n. 2518 .

Anoma $\operatorname{Linn}$. n. 4723.

ANONACEAR p. 830 .

ANONEAE p. 833.

Anonis Tournef. n. 6493.

Anouyma Walt. in. 6599.

Anonymos Walt. n. 2270.

Anoplanthus Endl. n. 4189. *

Anoplanychia Fenzl. n. 5202. a.

Anoplon Wallr. n. 4189.

Anopterus Labill. n. 4678.

Anosmia Bernh. в. 45/2.

Anosporum Nees 992.

Anotea DC. n. 5275. a* $\gamma$.

Anotis DC. n. 3240 . d.

Anetocalyx B. DC. н. 3089.a. *

Anredera Juss. n. 1937.

ANREDEREAE p. 297.

Antacantlius L, C. Rich. n. 3L64.

Antenuaria $\boldsymbol{R} . \boldsymbol{B} r$. n. 2767.

Antennaria Link. 280.

ANTENNARIEAE p. 450 .

Antenmularia Reichenb. n. 280. Antenoron $\boldsymbol{M a}$ inn. n. 1986 . c.

Anthelia Dum, 473. b.

Anthema Medik. n. 5271 .

ANTHEMIDEAE p. 428.

Anthemis $D C$. и. 2639

Anthemoides Less. u. 2626. a re.

Anthephora Schreb n. 785.

Anthactinia Bory 5099. e. $\beta$.

ANTHERICEAE $p+147$.

Anthericlis $R a f$, 1502 .

Anthericum Linn. n. $11^{145}$.

Autherura Lour. n. 3150 .

Antherylium Rohr. n. 6158 .

Anthiaa Fries и. 268.

Anthistiria Linn, n. 945.

ANTHOBOLRAE p. 328 .

Authobolus $\boldsymbol{R}, \boldsymbol{R}$ r. n. 2087.

Anthoeephaitus A. Rich. n. 3236 .

Anthocercis Labill. n. 3902.

Anthocerites Cord, n. 459 . b. *

Anthoceros Michel n. 459 . *

ANTHOCEROTEAE p. 43.

Anthochlamys Fenzl. n. 1952.

Anthochloa Nees 886 .

Anthochortus Nees 1013.

Anthacleista $A f \approx$. p. 577 .

Anthodendron-Neck. a. 4341. a. Anthadiscas C.W.Mej n.5643.* Anthodiscus Mart, n. 5701 .

Anthodon F, P. n. 5701.

Anthogonium Fall. n. 1609

Autholoma Labill, n. 546 ?

Antholyza' Linn. म. 1239.
Antholyza Cunonia Linn, n.1239.

Anthonema Nutt, n. 46 '3. b. * Anthonota Palis. n. 6797.

Anthopogon Nute. H. 849.

Anthopterus Hook, n. 4346/.

Anthora DC. и. 4797. a.

ANTHOSPERMEAE p. $52 \%$.

Anthospermum Linn. n. 3105.

Anthostema A.J. n. 5767 .

Anthotium $\boldsymbol{R}$. $\boldsymbol{B r}$, п. 3049 .

Anthotroche Endl. n. $3902 / 1$

Anthoxanthum Linn, n. 756.

Anthriscus $\mathrm{Hoffm}$. n. 450 .

Anthrocarpum Meyer. n. 141.

Anthurium Schott, n. 1702.

Anthyllis Linn. n. 6506 .

Anthyllis Adans. n.5212. et 5216 .

Antiaris Leschen, u. 1862. *

Anticharis Endl. n. 39'4t.

Antichorus L. n. 5371. A.

Antidaphne Pöppig n. 4582.

Antidesma Linn, n, 1892.

ANTIDESMEAE p. 287, et 1376.

Antigona Flor. Flum, n.5060.

Antigonon Endl. n. 1999.

Antigramma Presl. n. 634. b. *

Antilyssus Haller n. 174.

Antiphylla $\mathrm{Haw}$ orth n. 4634 . a.

Antiphytum DC. n. $3768 / 2$ :

Antirhoea Comm.n. $319^{\prime}$.

Antirrhinastrum Char, n.3892.b.

ANTIRRHINEAE p. 673.

Antithrixin $D C$. n. 2771.

Autitragus Gärtn, n. 745. a.

Antitrichia Brid. n. 584.

Antjar Javan. n. 1862.

Antodon Neck. n. 2990. a.

Antoiria Raddi n. 472/,

Antomarehia Holl. n. 6012 .

Antonia Pohl. n. 3362 .

Antouia R. Br. n. 4141.

Antouiana Juss. n. 3154 . bo *

ANTONIRAE p. 575.

Antrocephalus Lohm, n. 467/, .

Antrophyom Kaulf. n. 605. *

Antrophyum Blume в. 605. a.*

Antschar Horsf. n. 1862.

Antsjar Javan, n. 1862 .

Antura Forsk. n. 3372 .

Anvillea $D C$. n. 2443.

Anychia $L$ C. Bich. n. 5202 . f. Aopla Lindl. n. 1523.

Aotus Smith. n. 6140.

Apaetis Thunb, n. 68H1.

Apalatoa AubI. n.6802. et 4132/3

Apalus DC. n. 2464. *

Apama Lamt. n. 2163.

Apargia Willd. n. 2990.

Aparine Mbinch. n. 3100 .

Aparine Neck, n. 3160.

Aparina Tournef, n. 3100.

Aparistlımium $E, 5792$.

Apatauthus Vivian. p. 502. 1 .

Apatelia DC. u. 5 ' 33 .

Apatilia Cesv. n. 6361.

Apaturia Lindl, n. 1393.

Apeiba $A u b l$. n. 5364 .

Apeuula Neck. n. 3086. a.

Apera Palis. n. 810 . b.

Aperiphracta Nees. n. 2052. a APFTALAE p. 264 .

Aphaea Tournef. n. 6582. a.

Aphanamixis $\boldsymbol{B l}$. n. 5528 .

A phamanthe Link. n. 526 ?

A phananthemnim $\mathcal{S}_{p}$. n. 5029 . a.

Aphanes Lirn. ․ 6370. b.

Aphania Bl. 0. 5615.

Aphanochilus Benth, n. 3588 . a.

Aphanopetalam Endl. n. 4650.

Aplanorliynches Sess n. 2732.a.

Aphanostemma St, Hil n. 4781 .

Aphamostephus $D C ., n .2356$.

Aphelandra $\boldsymbol{B}$. Br. в. 4074 .

A.PHEL. ANDREAE p. 703.

Aphelexis Boj. n. 2743.

Aphelexis Don, n. 2742. $\varepsilon$.

Aphelia $\mathrm{H}, \mathrm{Br}$. в. $100 \%$

Aphilax Salisb, n. 1028, b.

Aphloia DC, n. 5072. b.

Aphlota Benn. u. 5072/r.

Aphora Neck, n. 6423.

Aphozia Denn. n. 473.b.

A phragma $n \cdot B r \cdot$ n. 2158 . b.

Aphragmia Nees. n. 4044.

Aphragmus Andrz. n. 4925.

APHYLLAE p. 1.

APHYLLANTHEAE p. 151.

Aphyllanthes Tourn, n. 1171 .

Aphyllanthes Dal, n, n. 3071 .

Aphyllocarpa Cavan. n. 665.

Aphyllocaulon Lagasc. n. 2905.

Aphyllodium $D C$. n. 6616 . b.

Apliyteia Linn. n. 724.

APIACEAE p. 762 .

Apiastrum Nutt. n. $4549 / 1^{*}$

Apiera Haw: n. 1115. a.

A pinella Neck. н. 4396.

Aplos Boerh. n. 6673.

APIOSPOREI p. 23.

Apiosporium Bunge n. 274.

Apisea Blum. n. 1490.

Apium Hoflm. n. 4393.

Aplectrum Blum. n. 6247 .

Aplectrum Nutt. n. 1309.

Aplodon $R . B r, n .502$, b.

Aplophyllum Cass, n. 2916. 1.

Aplotella Kutz, n. 1. b.

Apluda Linn. n. $9 \div 8$.

Apochlaena A. DC. n. 3074 . b. *

APOCYNACEAE p. 577, et 1395.

APOCYNEAE p. 574. et $37 \%$.

Apocynum Linn. n. 3422.

Apodanthes Poit, p. 76.

Apodanthus La Pylaien. 503. e

Apodotes Benth, n. 3583. c. 
Arache Neek. n. 5841. b. Arachnida Plum. n. 6601.

Arachnimorpha Desv. ".. 325
Araelmion Schwoin. n. 342 .

Arachnis Blum. n. 1473.

Arachnoides Blume. n. 652.

Aracium Neck, n. 3027.

Aragoa $\boldsymbol{H}, \boldsymbol{B} . \boldsymbol{K}$. n. 3989.

Aralia Linn. n. 4558.

ARALIACEAE p. 793.

Araliastrum Vaill. n. 4551.

Arapabaca Plum n. 3568.

Arancaria Juss. n. 1797.

Arauearites Endl, n. 1808.

Aravia Broter. n. $3477 . *$

Arbol de Manitas n. 5307 .

Arbor ovigera Rumph. n. 2108.

Arbor Veruicis Aumph. n. 5912.

Arbutus Tournef. n. 4325 .

Arceuthobium Bieberst n. 4583.

Archangelica Hoffm. n. 4457 .

Archemora $D C$, n. 4472.

Archidium Brid. n. 477 .

Archimedea Leandr. n. 715.*

Arehytaea $M$. Z . n. 5418.

Arcimbalda Endl. n. 4317. d.*

Arction Cass. n. 2856.

Aretium Lam. n. 2856.

Arctocrania Endl. 11. 4574. a.

Arctogeron DC. n. 2309.

Arctopus Linn, n. 4524 .

Arctostaphylos Adans, n. 4327.

ARCTO'EAR p. 463.

Aretotheca Wendl. n. 2835.

Aretotheca Vaill n. 2830.

ARCTOTIDBAE p. 463.

Aretotis Gärtn in. 2830.

Arcturus Benth. n. 3879. b.

Areyphyllum EUl. n. 6692. b.

Arcyria Hill. n. 309.

Ardinghelia Comm. n. 5849.

Ardisia Swartz. n. 4222.*

ARDISIACEAE p. 734 .

Arduina Linn, n. 3372 .

Areea Linn. 1. 1728. *

ARECINAE p. 245.

Aregma Fries. n. 190.

Arelina Neck, n. 2846.

Aremonia Neck. n. 6369.

Arenaria L. n. 5234.

ARENARIEAE p. 967.

Arenga Labill, n. 1734.*

Arethusa Gronov. n. 1602.*

ARETHUSEAE p. 216.

Aretia Gaudin. n. 4198.

Aretia Link, n. 4199. a.

Aretia Linn. n. 4197. a.

Aretiastram $D C$. n. 2186 . b.

Arganía Schousboe n. 4239.

Argelia Der. n. $3467 . *$

Argemone Tournef. n. 4821. ARGEMONEAE p. 855.

Argemonidium Spach. n.4823.

Argentina Blackw, n. 6363.

Argolasia Juss. n. 1256.

Argophyllaea $D C$. n. 2317. b.

ARGOPHYLLEAR p. 822.

Argophyllum Forst n. 4679.

Argostemma Wall. n. $3287 / 1$.

Arguzia $A \mathrm{~mm}$ и. 3747 .

Argylia Don. n. 4112.*

ARGYLIEAE p. 711.

Argylium Wallr. n. 353.

Argyreia Lour n. 3810.

Argyrochaeta Lav. n. 2489. c. Argyrocome Gärtn, n. 2741. at Argyrelepis Spach, in. 5029. d. Argyrolobium $\boldsymbol{E}$. ef Z. n. $650 \%$. Argyrophyton Hook. n. 2611. * Argyroxiphium DC, n. 2611.* Argyrothamaia $P, B r$. n. 583 \%. Aria $D C$. n. 6342. e.

Ariocarpus Scheidw. n. 5154, a. Arisaema Mart. n. 1674.
ARISAREAE p. 234.

Arisarum Tournef. n. 1673.

Aristea Soland. It. 1232.

Aristella Külz. p. 2.

Aristella Trin. n. 798. b.

Aristida Linn, n. 801.

Aristidium Endl, n. 847. b.

Aristobulia Mart, n. 6726. a.

Aristolochia Tournef. n. 2162.*

ARISTOLOCHIEAE p. $3{ }^{\prime} 4$ et 1379.

Aristotela Adans. n. 2828.

Aristotelia Herit. n. 5 t32.

ARIST0TELIACEAE p. 102\%.

Arjoona Cav, n. 2071.

Arjuna Jon. n. 616\%. e.

Armania Berter. n. 2531.

Armeniaca Tournef. n. 6406. a.

Armeria Willd. n. 2171.

Armodorum Kuhl et $H$. n. 1441. Ascium Schreb. n. 5460.

Armoracia Rupp. 11. 4882. c.

Aruebiá Forsk, n. 3761. d.

Aruica Linn. n. 2800.

Aruoglosson Endl. n. 2170. c. Arnoldia Blume. n. 4649.

Arnoldia $D C$ n. 2672. g.

Arnopogon Willd. n. 2994.

Arnoseris Gärtn. и. 2472.

Arnottia A. Aich. n. 1532.

CROIDEAE p. 232. et 1370 .

Aromadendrum Blume. n. 4736.

Aromaria Benth. it. 3576 . 1.

Arongana Pers. n. 5468.

Aronia Pers, n. 6345 .

Aronicum:Neck. n. 2804.

Arophyllum Llav, et Lex, n. 1376.

Aroton Nees. n. 5827.

A rouna $\mathbf{A u b l}$. v. 6805 .

Arpitium Neck, n. 4447.

Arratidaea DC. n. $4123 /$.

Arrabidea Steud n. 5727.*

Arracacha Baner oft. n. 4534.

Arrhenachne Cass. n. 2410.

Arihenatherum Palis. n. 865 .

Arrhenopterum Hedw. n. 865.

Arrowsm thia DC, n. 3032/2.

Arrozia Schrad, п. 734.

Arrudea St. Hil. n. 5439.

Atsace Salisb. n.4313. d. 48.*

Arrabotrys R. Brown, n. 4720.

Artanema Don, n. 3954.

Artanthe Miq. n. 1820. f.*

Artedia Linn. n. 4495.

Artemisia . Ltinn. n. 2694.

ARTEMISIEAE p. 438.

Artemisioides $D C$. n. 2253. e.

Arthratherum Palis. n. 801. c.

Arthraxon Palis. n. 937. *

Arthrinium Kunze n. 231.

Arthrobolus Andrg. n. 4968.

Arthrobotrys $\mathrm{Pr}$. n. 639. c. . $^{*}$

Arthrodactylis Forst. n. 1711.

Arthrolobium Desv. 1. 6586.

Arthrolobus Stev. n. 4946.

Arthronaria Fries. n. 125.

Arthronia Achar. n. 123.

Arthrophyllum Blume. n. 4562.

Arthrophyllum Boj. n. 4171/s.

Arthropodiam F. Br. n. 1146.* Arthropogon Nees. n. 95\%.

Arthrosfachya Link. n. 864 .

Arthrostemua Pav, n. 6211.

Arthrostigma Endl. n. 2121. a

Arthrostylidium $B u p p r$, n. 904/1.

Arthrostylis $\boldsymbol{B} . \boldsymbol{B r}$. n. 978 . b.

Arthrotaxis Don. n. 1761/1.

Arthrozamia Reichenb. n. 706. ARTOCARPEAE p. 279 et 1375.

Artocarpus Linn. n. 1868.

ARTORHIZAE p. 157.

Aruba Aubl. n. 5964.

Aruba Nees et Mart. n. 5989.
Arum Linn, n. 1676.

Aruncus Ser. n. 6391. d.

Arundina Blum n. 4387 .

ARUNDINACEAE p. 90 .

Arundinaria Hich. n. 904 .

Arundinella Raddi n. 951.

Aruado Linn. u. 821.

Arversia Cambess. n. 5213.

Asagraea Lindl, n. 1066/1.

Asaphes DC, n. 5985.

Asaphes Spreng. n. 2190. b. *

Asarea Lindl. n. 1605. *

Asarina Tournef. n. 3892 . a.

ASARINAE p. 344 .

Asarum Tournef, n. 2160.

Ascaricida Cass. n. 2204. i.

Ascarina Forst, D. 1818.

ASCLEPIADEAE p. 586 et 1397.

Asclepias Linn. n. 3490 .

Ascobolus Pers. n. 429.

Ascophora Fries. n. 383.

Ascophora Tode, n. 255.

Ascoxyta Libert, n. 366.

Asera Sehott. n. 5073.

Aseroë Labill. n. 357.

Aséyrum L. n. 5463 .

Aseimotrichum Corda. n. 230.

Asjogam Rheed, u. 6795.

Aspalathus Linn. n. 6482.

ASPARAGEAE p. 150.

Asparagus Linn. 1. 1164.

Aspasía Lindl, n. 1399.*

A spasia E. Mey. n. 3650 . h.

Aspegrenia Pöpp et E. n+1321.

Aspelina Cass n. 2811.

Aspera Monch. в. 3100. a.

Aspergillus Michel. n. 229.

ASPERIFOLIAE p. 644 et 1402 .

Asperocaulon Grev. n. 66.

Asperoeoecus Lamx, n. 10'.

Asperugo Tournef. n. 3785 .

Asperula Linn. n. 3103.

ASPHODELEAE p. 139 et 144.

Asphodeline Reichenb, n. 1142.

Asphodeloides Mönch. n. 1141.

Asphodelus Linn, H. 1141.

Aspicarpa L. C. Rich. H. 556't.

Aspidalis Gärtn. w. 2843. b.

Aspideinm Zollik. n. 3011. *

Aspidistra Ker n. 1191. *

ASPIDISTREAR p. 155.

Aspidinm $S$ wartz, n. 640 .

Aspidinm Presl. n. 640. f. a.

Aspidocarpus Neek v. 5716.

Aspidoglossum E. Mey. n. 3493.

Aspidopterys A. J. n. 5570 .

Aspidesperma M, et Z. n, 3399.*

Aspilia Thouar. ‥ 2519.

Aspilobium Banks et $\boldsymbol{S}$. n.3365.*

Aspleniopteris Sternb. \#. 1847.

Aspleníum Linn, n. 630.*

Asprella Host. n. 921.

Asprella Humb n. 916.

Asprella Schreb. n. 728.

Assa Houttuyn u. 4765 .

Assonia Cav. n. 5345.

Astartea $D C$, n. 6289. a.

Astelia Banks. et Sol v.1051. *

AETELIEAE p. 131.

Astelma DC. n. 2742, a.

Astemma Endl. n. 1126. a.

Astemma Less. n. 2456.

Astephananthes Bor7. v. 5098. b.

ASTEPHANEAE $\mathrm{p} .589$.

Astephanus $R, B r$. n. 3h45. *

Aster Nees. n. 2301.

Aster Adans. n. 2302.

Asteracantha Nees. n. 4060.

Asteranemia Reich, n. 4773 . b. $\gamma$

Asteranthos Desfont. n. 4262 .

Asteranthus Loureir. n. 5087. ASTEREAE $\% .372$.

Asterella Palis. n. 468 .

Asterias Renealm. n. 3528, a.

Asteridea Lindl. 2431/1.

ASARINEAE p. 371.

Asterixca Meger. n. 137.

Asteriscium Cham, et S. n. 4370.

Asteriseus Mönch. n. 244.

Asterocarpus Eckl, n. 5682.

AsterocephaIns Vaill. It. 2195.

Asterocliaete Nees n. 968 . b.

ASTEROIDEAE p, 371.

Asterolinon Link et $H_{\text {. n. }} \mathbf{4 2 0 5}$.

Asteroma DC. p. 31. b.

Asteromaea Blum. n. 2346.

Asteropeia Thouars n. 5092.

Asterophora Dittm n. 302.

Asteropsis Lesx. n. 2770, b.

Asteropterus DO, n. 2772. at.

Asteropus $S_{p} r .5336$.

Asteroseris Endl. u. 2962. b. \&.*

A sterosperma Less, n. 2794. *

Asterosporium Kunze n. 196.

Asterostema Dec, n. 3501/2.

Axterothecium Wallr. It. 296.

Astherothrix Cass, n. 2996, e.

Astianthus Don. 1. 4123.

Astilbe $\mathrm{Ham}$. n. 4645.

Astoma DC. 4547 .

Astomaea Heich. n. 4547.

ASTRAGALEAE p. 1277.

Astragalus DO. ‥ 6573.

Astrantia Tourn. n. $438 \%$.

Astrapaea Lindl. n. 53h9.

Astrephia DC. H. 2182.

Astrocarpus Neek. n. 5013.

Astrocarynu C.M.G. M, n.1769.

Astrocoma Neek. n. 4599.

Astrodeadrou Dennst. n. 5320, b. 
Athronia Neck, n. 2553. a.

Athruphyllum Lour. n. 4221 . a. Athymalus Neck. n. 5766 . Athyrium Presl. n. 631 . Atocion Oth. n. 5248. g. Atractium Link n. 206. et 260. Atractolobus Tode 339 Atractylis Cass. n. 2860. Atragene Linn. n. 4769. Atraphaxis Linn. n. 1995. Athraxyle DC.n. 2874, a. Atrema DC. n. 4548. Atriehoglottis Endl, n. 1470. b. Atrichum Palis, n. 560. c. Atriplex Linn. n. 1912. ATRIPLICEAE p. 293. Atropa Linn. n. 3857 . * Attalea $\boldsymbol{H} \boldsymbol{B}, \boldsymbol{K} . \mathrm{n} .1770$.

Atunus Bumph. n. 5319. Atylosia $W_{i g h t}$ et Arn, n. 6687. Aubertia Bory. n. 5972 . g. Aubertia Palis. n. 588. Aubletia Lour. u. 5716. Aubletia Gärtn. n. 6312 . Aubletia Jacq. H. 3685. d. Aubletia Rich, n. 5994. Anbletia Schreb. n. 5364 . Aubrietia Adans. n. 4868. Auchenangium Brid. в. 520 . Auchera $D C$. n. 286'. * Aucuba Thunh. n. 4575 . Ancuparia Med. n. 6342. Audibertia Benth. n. 3598. Audibertia Benth. n. 359 '. Audounia Brown. n. 4602. Auduinella Bory. n. 59. Auganthus Link. n. 4199 . b. Augea Thunb. 6842. Augea Retz. n. 1256. Augia Lour. n. 5926. Augusta Leandr. n. 2916. Augusta Pohl. n. 3259. Augustea DC. n. 3259. Aukuba Kämpf. n. 4575. Aulacia Lour. n. 5507. Anlacidium Bich, n. 6189. Aulacinthus E. Mey, n. 6482 . Aulacomnion Schwägr. n. 549 . Aulacophora DC. n. 2806. e. Aulacorhynchus Nees. n. 965. Aulacospermum Ledeb. n. 4039. Aulax Berg. a. 2119.

Aulaxanthus Elliot. n. 770.

Aulaxina Nutt, n. 770 .

Aulaxina Fée p. 33. f.

Aulaya Harw. n. 3999/1.

Auliza Salisb. n. 1371 .

Aulaxis Haworth n. 463't. g.

AURANTLACEAE p. $10^{\prime} \% 3$.

Aurelia Cass. n. 236\%.

Aureliana Catesb. n. 4551.

Auricula Endl, n. 4199. a.

Auricularia sries n. 437 . f.

Auricularia Link, в. $40 \%$.

AURICULARINI p. 38.

Anrinia Desv. n. 4872.

Australina Gandich, p. 285.

Avena Linn. .1. $86^{\prime}$.

AVENACEAE p. 95.

Averrhoa Linn. It. 6059.

Avicennia Linn. n. 3722.

AVICENNIEAE p. 638.

Aviceps Lindl. n. 1536/2.

Avieularia Meisn. n. $193 \hat{6}$. g.

Avoira Savane Aubl. n. 1764.

Avonia E. Mey, n. 5176. a.

Axanthes Blum, n. 3226.

Axia Lour. H. 2189. et p. 313.

Axillaria $B a f n$. n. 1181 .

Axinen Ruiz et Pav. n. 6170.

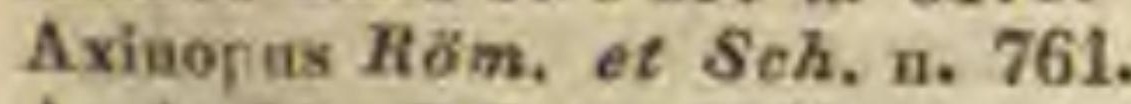

Axolophia DC. n. 5269. a.

Axonopus Palis, n. 768.

\begin{tabular}{l|l} 
Axonopus Palis, n. 768. & Ballota Benth. n. 3658. b. \\
Axouotechium Fenzl. n. 518*. & BALLOTEAE p. 627.
\end{tabular} \begin{tabular}{|l|l} 
Axyris Linn, n. 1913. & Baloghia Endl, n. 5811.
\end{tabular} Aydendron Nees, ot M. n. 2040. Balsamea Gled. n. 5930. A yenia $\mathbf{L}$. $\mathbf{5 3 3 2}$. Aylmeria Mart. n. 5217. Aypi Bauh. n. 5808. Azadiraclsta Adr. Juss.n. 5521. Azalea Linn, 1. 4338. * Azalea Desv. n. 4341. a. Azanza Mog. et Sess. n. 5283. Azaola Blane. n. $42 t 6 / 1$. Azara Ruiz et Pav. n. 5075 . Azederach Tourn, n. 5520 . Axima Lam n. 5711 et 6891. Azolla Lamarck. n. 668. Azorella Lamarck. n. 4366. Azorella Labill. n. 4362. Azosma Corda n. 233. Azygites Fries n. 245 .

\section{B.}

Babiana Fer, n. 1238.

Babounya DC. n. 2651. b.

Bacazia Ruiz et Pav. n. 2901. b. Baccalaria Gray n. 121. c. Baecaroides Linn, n. 220\%. i. Baecaurea Lour. n. 5888/. BACCHARIDEAE p. 387. Baccharis Linn. n. 2410, * Baceharoides $D C$, n. 2918. b. * Bache Aubl. u. 1743.

Baconia DC. n. 3162 .

Bacopa Aubl. n. $399^{\prime} 10 \%$.

Bactridium Kunze n. 219.

Bactridium Sal. n. 4313. b. 18. Bactris Jacg. n. 1765.

Bactyrilobium W'tlld. n. 6781 .

Bactyrilobium Willd. n. 6781. a Badamia Gärtn. n. 6076. b.

Badaroa Bert. n. 5146.

Badianifora Linn, n. 4743.

Badiera $D C$. n. $56^{4} 48$.

Badula Alph.DC. n. 4221. b.

Baea Com. n, 4140. *

Baeckea Linn, u. 6311.

Baeobotrys Forster n. 4227.

Baeometra Salisb. n. 1077.

Baeomyces Pors.n. 167.

Baeothryon Nees. n. 1000 b. $\gamma$

Bagalatta Roxb. n. 4687 .

Bagassa Aubl. n. 1875.

Bahia DC. n 2591.

Baillieria Aabl. n. 2462 . b.

Baillouviana Gries. n. 66.

Baitaria Ruiz et Pav. n. 6857.

Balanghas Burm, n. 5320. b.

Balauites Del. n. 5498 .

Balanophora Forst. n. 718.

BALANOPHOREAE p. 72. et 1352.

Balatiopteris Gärtn, n. 5319.

Balantium Desv. n. 6h08.

Balantium Kaulf. n. 64t. a. *

Balanus Endt. n. 6811. a.

Balardia Camb. n. 5218 .

Balbisia $D C$. n. 2820 .

Balbisia Cav, n. 6050 .

BALBISIEAE p. 461 .

Baldingera Gärtn. n. 753.

Baldiugera Dennst. n. 3701 . * Baldingerla Neck. n. 2683. Balduina Nutt. n. 2584. *

Balduina Elliott. n. 2584. a. Balduina Fafin, n. 5098 . b.

Balessam Bruc, n. 5930 .

Balexerdia Comm. n. 2073.

Balfouria $n, B r$, n. 3496 , *

Balingayum Blanc, n. 6876 .

Balinspermum $\mathbf{B l}$. и. 5823 .

Ballota Linn, n. 3658 .
Balsamia Vittad, n. 351.

BALSAMIFLUAE p. 289.

Balsamina Gärtn, n. 6060 .

BALSAMINEAE p. 1173.

Balsamitae $D C$. n. 2670 . f.

Balsamodendron Funth. n. 5930 . Balsamona Vand. n. 6151.

Balsamorhiza Hook, n. 2506. c. Baltimora Linn. n. $2 \nless 70$.

.

Bambos Retz. n. 909. *

Bambusa Schreb. n. 909. *

BAMBUSEAE p. 102.

Bamia $R, B r$. n. 5281 .

Banas a Aubl. n. 5073 .

Banava Cam, n. 6162 . b.

Bancalus Rumph, u. 3280 . b.

Baneroftia Macfad. n. 5382 .

Bandura Burm. n. 2167.

Banffya Baumg. n. 5245. c.

ngia $\mathrm{Ag}$ n. 44.

Banisteria L. n. 5597 .

Banjolea Bowd. p. 708.

Banksea König. n. 1638.

Banksia Linn. 2157.

Banksia Domb. n. 6151.

BANKSIEAE p. 343.

Baphia Afzel. n. 6812.

Baphorhiza Link. n. 3768 . a.

Baptisia Vent. H. 6421.

Baraultia stewar. o. 6109.

Barba eaprae Tourn. u. 6391. Barba Jovis Münch, n. 6506, b. Barbacenia Vand. n. 1261.

Barbarea $R ., B r$. n. 4851 .

Barbellína Cass. n. 2858.

Bl. Fl, n. 1334. 3 .

Barbeuia Thouar, n. 6843.

Barbieria DC. n. 6656 .

Barbula Hedow. n. 535.

Barbula Lour. n. 3720.

Barelaya Wall, n. 5022.

Barkania Ehrenb, n. 1837.

Barkeria $K n$, et $\boldsymbol{W}$. n. $1380 \%$.

Barkhausia Mönch n. 3021.

Barkhausenia Hopp. n. 3021.

Barleria Linn. n. 4061 . *

BARLERIEAE p. 701.

Barnadesia Linn. n. 2901.

BARNADESIEAE p. 1385.

Barnardia Lindl, n. 1136. *

Barola Adans. n. 5946.

Barosma Willd. n. 6020.

Barreria Scop. n. 6872.

Barringtonia Forst, n. 6325. * BARRINGTONIEAE p. 1233.

Barthesia Commers. n. 4221 . b. Bartholina R. Br. n. 153'. * Bartliugia Brongn, n. 6288.

Bartlingia Reich. n. 3111.

Bartolina Adans. n. 2578.

Bartonia Sims. n. 5112.

Bartonia Mizhlenb, a. 3542.

Bartonia Pers. 1t. 3542.

Bartramia Hedw. n. 550 .

Bartramea Gürtn. n. 5372, b.

Bartselia n. 4013. a.

Bartsia Linn, n. 4013.

Baryosma Gärtn. n. 6728.

Baryosma Röm, et Sch, n.6020.

Barysoma Bung. n. $4477 /$.

Baryxylou Lour. n. 6781. a.

Basella $L i m$, n. 1939.

BASELLEAE p. 297.

Baseophyllum DC. n. 6781 . g. $\beta$,

Basilaea Juss. n. 1128.

Bassia Linn. n. 4242.

Bassia Allion, n. 1927.

Bassovia Aubl. n. 3855 .

Bastardia Kunth, n. 5293.

Basteria Houtt. n. 2844.

Batatas Chois. n. 3307.

Bataueaulon DC. n. 6831. c.

Batemania Lindl. n. 1412.

Bathelium Achar. n. 15\%.

Bathmium Presl. n. 540. £. $\beta *^{*}$

Batis P. Br. n. 684t.

Batrachinm DC. n. 4783. a.

BATRACHOSPERMEAE p. 4.

Batrachospermum Foth. n. 50.

Bathratherum Nees. n. 948. *

Batschia Gmel. n. 3761.

Batschia Thunb. n. 4691.

Batschia Vahl. n. 6792.

Battarea Pers. n. 359.

Baudinia Lesch, n. 6294.

Baudinia Lesch. n. 3039. c.*

Bauera Kennedy n. 4665.

BAURRACEAE p. 813.

Bauhinia Plum. n. 6790 .

Bauhinia Cav. n. 6791.

Bauhinia Kunth, n. 6789 .

Baumannia $D C$. n. 4318 . c."

Baumannia Spach. n. 6115. 1.

Baumea Gaudich. n. 977. b.

Baumgartenia $S_{p r}$. n. 1170.

Baumgartia Mónch n. 4687 .

Baxtera Reich. n. 3512.

Beatonia Herb, 1228/.

Beatsonia Roxb. n. 5053. b.

Beaufortia R. Br. n. 6295 .

Beauharnoisia $n$. $P$. n. 5 tz33.

Beaumaria Herb. Del. n. 5432.

Beaumontia Wall. n. 3411.

Bechium DC. n. 2208.

Beckea Burm, n. 4597. b.

Beckera Fresen n. 749/1.

Beckman nia Host. n. 749.

Becklard ia A. Fich n. 1496.

Bedfordia $D C$. n. 2816.

Bedous ia Dennst. n. 5060. *

Beera Palis. n. 988.

Beesha Rheede. n. 910 .

Beetla Endl. n. 1820. a. $\beta$. " 
Beloperone Nees. n. 4082. Belostemma Wall. n. 3499. Belon Adans, n. 5513. Belvisa Mirb. n. 627. 630 . Belvisia Desv. n. 4263.

Bembix Lour. n. 5595 et 6877 . Benedicta $D C$. u. 2853. b.

Berineasa Savi n. 3135.

Benjamina Fl. Fl. p. 1334. 4. Bennetia Gray n. 2853.

Benthamia Lindl. n. 4573 .

Benthamia Lindl, p. 3761. e/ Benthamia A. Rich, n. 1517. Bentinkia Berry. ․ 1749. Benzoin Nees, n. 2057.

Benzonia Schum, n, p. 566. 3. Bequerela Brongn. n. 964. b. Berardia Brongn. n. 4600 . * BERBERIDEAE p. 851 .

Berberis Linn. n. 4814. Berchemia Neck. n. 5710.

Berchtoldia Presl. n. 779.

Bergenia Mönch, n. 4634. d. Bergera Kön, n. 5505.

Bergeretia Desv. n. 4877. c. Bergia L. n. 5476.

Bergkias Sonn, n. 3305. e.

Beringeria Neok. n. 3658 . a.

Berinia Brign. n. 3022. A. 3.

Berkeleya Grev. n. 14.

Berkheya Ehrh. n. 284t.

Berkheyoides Less, n. 2839. 1).

Berlandiera $D C$, n. 2477 .

Bermudiana Tournef. n. 1220.

Bernardia Houst. n. 5825 .

Bernardia Vill. n. 2856.

Bernhardia Willd, n. 695, b.

Berniera DC. n. 2929/.

Bernonia Endl. n. 3063 . a. *

Berija Klein. n. 2059.

Berrya Roxb. n. 5379.

Bersamat Fresen, n. 4572.

Bertera Sweet. n. 1239.

Berteroa DO. n. 4867.

Berteroa Zippel. p. 133't. 5.

Berthelotia $D C$. n. 2'03. *

Bertholletia Humb, et B. n. 6333 .

Bertiera Aubl. n. 3295.

Bertiera Aubl. n. 3295. a.

Bertolonia DC. n. 2957.

Bertolonia Fadd. n. 6190.

Bertolonia Rafin. n. 3604 . a.

Bertolonia Spr. n. 5t33.

Bertuehia Dennst. n. 3238 . a. * 3305. b. *

Berula Koch. n. 4412.

Berzelia Brangn. i. 4596.

Berzelia Mart. n. 1977.

BESLRREAE p. 719.

Besleria Flum. n. 4158.

Bessera Schult, n. 1112 .

Bessera Schult. Fil n. 3759.

Bessera Spreng. в. 5030.

Bessera Fl. El. n. 1012. *

Beta Tourn, n. 1924.

Betckea DC. n. 2187.

Betencoutia St Hil. n. 6652 .

Bethencourtia Chois n, 2811. b. Betoniea Linn. n. 3650.

Betula Tourn. n. 1840 .

BETULACEAE p. 272 et 1375. Betulites Göpp. p. 273.

Beurreria Jacq. n. 3746 .

Bearreria Adans, n. 6356.

Beverinckia Salisb. n. 4314 . c.

Beyrichia Cham, n.*39'3.

Beythea Endl, 5386.

Bhesa Ham, n. 5692.

Biarum Schott. n. 1665.

Biaslia Vand, n. 1028.

Biassolettia Presl. n. 5359.

Biassolettia Koch. M. 4514.

Biatora Fries 166.

Biaurella Lindl. n. 1586/, b.
Bichenia Don. n. 2921. a. Bichy Lunan. n. 5320 . f. Bicornella Lindl. n. 1535. BICORNES p. 746 .

Bidaria Endl, n. 3498. b. Biddulphia Gray. n. 21. Bidens Linn, n. 2541. BIDENTIDEAE p. 413. Bidonia Adans, n. 442. d. Biebersteinia Steph. n. 6044. BIEBERSTEINIEAE p. 1165. Bifolitum Fl. Wett. n. 1183. a. Biforia Hoffm, n. 4546 . Biforis Spr. n. 4546 .

Bifrenaria Lindl. n. 1411. *

Bigamea König. n. 6095.

Bigelowia $\boldsymbol{D C}$. n. 2375 . *

Bigelowia Smith. n. 1896.

Bigelowia $s p r$. n. 3120 .

Bignonia Juss, n. 412\%.

BIGNONIACEAR p. 708. et 1406. Bihai Plum. n. 1647.

Bikkia Reinw. n. $325 \%$.

Bllabrella Lindl. n. 1527.

Belimbi Rheed. n. 6059. a.

Billardiera $S$ m. n. 5668 .

Billardiera Möneh, n. 5085.*

Billardiera Pahl. n. 3158.

Billbergia Thunb. n. 1302. *

Billiotia Coll. n. 6294 .

Billiotia DC, n. 3328.

Billiottia $R, B r$, n. 6305 .

Binectaria Forsk, it. 4243. b.

Binia Noron, n. 3348.

Bintagor Rumph. n. 5448 .

Bionia Mart, n. 6658.

Biophytum $D C$. n. 6058 . m. *

B iotia Cars, n. 2628.

Biotía $D C$, n. 2316.

Bipinnula Commers.! n. 1606.

Biporeia Thouar. n. 5965.

Birolia Bellard. n. 5475. b.

Bischofia Blum. n. 598'.

Biscuculla Borkh. n. 4837.

Biscueullata March, n. 4836. b. Biscutella Linn. n. 4889.

Bisernla Linn. n. 657't.

Bistella Delille n. 4631.

Bistorta Tournef. n. 1986. a. *

Bivonaea $D C$, n. 4929.

Bivonaea Moc. et Sers. n. 5200 . Bivonea $\mathrm{Kaf}$. n. 5807.

Bixa Linn. n. 5061.

BIXACEAE p. 917.

Blaekburuea Kunth n. 5973.

Blackburnia Forst. n. 5773 .

Blackstonia Huds, n. 3547,*

Blackstonia Scop. n. 5440.

Blaekwellia Commers. n. 5087.

Bladhia Thunb. n. 4222 . a. $\beta$.

Blaeria Linn. n. 4309. *

Blainvillea Casx, n. 2447.

Blairia Houst, n. 3690.

Blakea Linn. n. 6261.

Blakwellia Gärtn. n. 6869 .

Blanchetia DC, n. 2217.*

Blancoa Lindl, n, 1258/.

Blandfordia Andr. n. 3350 .

Blandfordia Smith n. 1104 *

Blakkara Adans. n. 510 .

Blasia Fries. n. $472 / \%$.

Blasia Micheli. n. 472/3.

Blatti Rheedr. u. 6312.

Blaxinm DC. n. 2672. c.

Blechnum Linn, и. 624. *

Blechua P. Br. n. 4091.

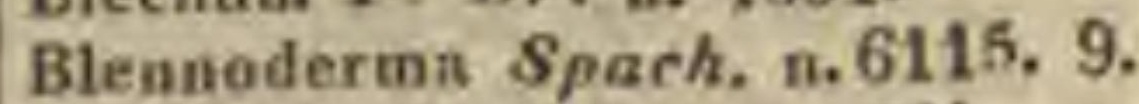

Blennoria Mougeot, n. 204.

Blennosperma Less. n. $246^{\prime}$ t. *

Blepharacanthus Nees, n. 4070 .

Blepharanthos $S_{\text {mith, n. }} \mathbf{5 1 0 3}$. b.

Blepharidium DC. ๓. 5647 . c.

Blepharipappus Hook. n.2623.
Blepharis Juss. n. 4068.

Blepharispermum $W$. n. 2393. * Blepharistemma Benth. p.133\%.b. Blepharochloa Endl. n. 728/. Blepharodon DC. n. 2381. b. Blepharolepis Neer. n. 5194. Blepharolepis DC. n. 2741. b. Blepharophyllum $F I$. n. 4296. c. Blepharostoma Dum, n. 473. b. * Blepharozia Dum. n. 472/14.

Blephilia Rafin. n. 3601. Bletia Ruiz el Pav, n. 1385. Blighia Kon, n. 5614.

Blinkworthia Chois n. 3811. Blitanthus Reichenb, n. 1934.

BLITEAE p. 295.

Blitum Limn, n. 1921.

Blochmannia Weig. n. 1997.

Blondia Neck, n. 4643.

Bluffia Nees. n. 772.

Blumea DC. n. 2413.

Blnmenbachia Schrad. n. 5118. Blumenbachia Koel. n. 950. b.

Blumia Mejen. n. 1369/1,

Blumia Nees, n. 4735.

Blumia Spr. n. 5414 .

Blysmus Panz. n. 1000 . b. $\beta$.

Blytia Endl. n. 472/.

Blyxa Thouar, n. 1210.

Boabab P. Alp. n. 5297 .

Bobaea A. Hich. n. 3197.

Bobartia Linn. n. 1232.

Bobartia Peliv, n, 2513.

Bobea Gaudich n. 3197.

Bobu Herm. n. 6094

Bobua $D C$. n. 6094 .

Bocagea St, Hil. n. 4709.

BOCAGEAE p. 830.

Boccouia Plum, n. 4816.

BOCCONIBAE p. 855 .

Boebera Less. n. 2576.

Boebera Willd n. 2577.

Boeberioides $D C$, n. 2577. c.

Böhmeria Gaud. n. 188\%. a.

Böhmeria Jacq. в. 1884. *

Boenainghausenia Rehb. 11. 6026. Boenninghausia $S p r$. 1. 6537 .

Boerhavia Linn, \#. 2000.

Bohadschia Prest. n. 5056.

Bohatschia Crantz, n. 4878.

Boisduvalia Spach. n. 6118.

Boissiaer Venten, n. 6455.

Bojeria $D C$. и. 2241.

BOJERIEAE p. 363.

Bolanthus Ser, n. 5246. n. $\alpha, d$. Bolax Commers. n. 4368.

Bolbidium Lindl. n. 1427. d.

Bolbitis Schott, \#. 603. b. 5.* Balbophyllum Thouar, n.1352. *

Boldoa Cavan. n. 2010.

Boldoa Juss. n. 2019.*

Boldu Feuill. 1. 2029.

Bolducia Neek n. 6728 .

Boleto-Liehen Juss, n. 434 , at $\alpha$.

Boletus Dill. I. 478.

Boletus Michel. n. 435 .

Boleum Desv. в. 4958.

Bolivaria Ch. et Schl, us. 334t. "

Boltonia Herit. nt. 23/3.

Bomarea Mirb. a. 1295. a.

BOMBACEAE p. 987.

Bombax $L$, n. 5300 .

Bombicella DC. n. 5277 . d.

Bombyeilaena $D C$. n. 2421. b.

Bombycospermum Pr. n. 3802.

Bonafidia Neck, n. 6524 .

Bonamia Thouar. n. 3795 .

Bonamica Fl, Fl. p. 1334. 7.

Bena Nex fiafin. n. 3805.

Bouapartea Huiz. of P. n. 1309

Bouapartea Willd. n. 1297.

Bonarota Mich. a. 3980 .

Bonatea Willd. n. 1527.

Bonaveria Scop. n. 6789.

Bonduc Plum. n. 6763.

Bonellia Bert. n. 4228.

Bougardia C. A. Meg. n. 4809.

Bonjeania Beichenb. n. 6516.

Bonnavia Raf. n. 5614 .

Bonnaya Link et Otto. n. 3948.

Bonnemaisonia Ag. n. 98.

Bonnetia Mart. it. 5417.

Bonnetia Sohreb. n. 5422.

Bouplandia Cav. n. 3818 .

Bonplandia Willd. n. 5990.

Bontia Pet. n. 1369.

Bontia Plum. n. 3737 .

Boophane Herb. n. 127\%.

B00PIDEAE p. 503 .

Boopis Juss, n. 3034.

Booram Endl. n. 43/1. d.

Boothia Dougl. n. 4832."

Bootia Wall. n. 1214.

Bootia Bigel. w. 6363. b.

Bootia Ser. n. 5246. a. $\beta$.

Boquila Decaisn, n. $4704 . *$

BORASSINAE p. 250.

Borassus Linn, n. 1745 .

Borbonia Linn, n. 6461.

Borea Zippel. p. 1334. 8.

Borellia Neck, n. 3738 .

Boretta Neck, n. 4327. c. *

Borkhansèmia Fl. Wett.n.4839.a.

Borkhausenia Roth, n. 3919.

Borkhausia Mönch. n. 3021."

Boronia Smith, n. $600 \%$.

BORONIEAE p. 1154.

BURRAGINBAE p. 64\%.

Borraginoides Boerh. n. 3779.

Borrago Tourn, n. 3778.

Bocrera Ach, n, 172, c. $a$. et 178.

Borreria Mey, n. 3120.

Borrichia Adans. n. 2445. 
Bowiesia Grev. n. 94. e. Bowlesia Ruits et Pav, n.4365. Boymia Adr. Juss. n. 5974. Boykinia Nutt. n. $4632 /$. Brabeium Linn, n. 2139.

Brabyla Linn. n. 2139.

Brachanthemum DC. n. 2665. Bracheilema R. Br. p. 1391. 1.* Brachyachyris Spreng. n. 2361. Brachyanthemum DC. u.2369. b. Brachyearpaea DC, в. 4976. Brachyeentrum Meisn. n. 5320. Brachyehiton Schk. n. 2920. Brachyclados Don. n. 2920. Brachycome Cass. n. 2349. * Brachycoris Lindl: n. $153 / \mathrm{s}^{*}$

Brachyeoris Schrad. u. 3925.

Brachycorythis Lindl, n. 1537/6. Brachyderea Cass, n. 3022. A. 3. BrachydontiumRéch.n. 6511.f. Brachyelytrum Palis. n. 803. Brachyglossa $D C$. n. 2317. a. Brachyglottis Forst, n. 2291. Brachygyne Cass. n. 2710. b. Brachylaena $\boldsymbol{R}, \boldsymbol{B r}, \mathrm{n}, 2411$. Brachylepis Hook. et A.n. 3482. Brachylepis $W$. ot $A$. n. 3437 . *

Brachylepis $C$. A. Mey, n. 1949. Brachylobos DC. 4850 . b. Brachymenium Hook. I. 539. Brachymeris DC. n. 2679. Brachyodontium Fürnr. n. 516. Brachyodus Furnr. n. 516.

Brachyolobes Allion. n. 4850 . b. Brachyotum DO. n. 6211.b.

Brachypetalum Lun, n. 5029. a. Brachyphyllum Brongn, n, 1816. Brachypodinm 6674. b. $\beta$.

Brachypodium Brid. n. 507.

Brachypodium Pal. n. 899 . b. et 913 . e.

Brachypteris $\boldsymbol{A}$. F, n. 5582 .

Brachypterum $\boldsymbol{W}$. ot $A$. n. 6712 . Brachyrhamphus $D C$, n. $3007 /$, Brachyrhynchos Less. H. 2812 . Brachyris Nutt. n. 2361.

Brachyscome Cass, n. 2349.

Brachysema R. Br. n. 6425 .

Brachysteleum Reich. n. 507.

Brachystelma $\boldsymbol{R} \cdot \boldsymbol{B} \boldsymbol{r}$. n. 3517 .

Bracliystemma Don. n. 5237 .

Brachystemum L. C. Rich. 3605. b.

Brachystephium Less. n. 279'.* Brachystephium Less. n. 2349.* Brachystylis $\nu C$. n. 4506 . b. Brachystylis E, Mey. n. 2679. Brachytrichum $R \delta h l$. п. 509. Brachytropis $D C$. n. 5647 . i. Bractearia Benth. n. 6635 . c. Bractearia $D C$. н. 6210 . c. Bradburya Rafin, n. 6653. Bradlaeia Neck. n. 4485. Bradleia Banks, n. 5855 . Bradleia Fl. Fl, n. 5046 . Bradypiptum $D C$. i. 4939 . с. Bragantia Lour. n. 2163 . * Bragantia Pell, n. 1958 . d. Brahea Mart. u. 1765.* Bramia Lam. it. 3940 . c. Brandesia Mart n. 1957. b. Brandonia Reich, n. 4195. Brandtia Kunth, n. 870 . Brameria Neck n. 2513. Brasenia Sehreb. n. 5025. Brasilettia $D C$. n. 6765 . b. Brassaia Endl n. 4556/1. Brassavola Adans, n. 2603. Brassavola $\boldsymbol{B}$. Br. n. 1378 . * Brassia $B$. Br. n. 1467 . Brassica Limn. n. 4949 .

Brassieastrum Linn II. 4949. b.

\begin{tabular}{l|l} 
BRASSICEAE p. 882. & $\begin{array}{l}\text { BRUNONLACEAE p. } 505 . \\
\text { BrathydiumSpach, n. 5464. B, m. }\end{array}$ Brunsvia Neck. в. 5827.
\end{tabular}
Brathys Mut. n. 5464 . B, n. Bravaisia $D C$. n. $4132 / 2^{*}$
Braunea Willd. n. 4687 .

Bravoa Llav, et Lex. n. 1292. Braya Sternb, et Hopp. n. 4912 . Braya $F l, F l, n .6408$.

Brayera Kunth. n. 6395.

Brebissonia Spach, n.6125. a. c. Bredemeyera $\boldsymbol{W}$. 5654. Breea Less. n. 2887. Bremontiera DC. 6627. Breonia A. Rich. n. 3285. Breteuillia Buch. n. 2813 . a. Brewer Adans. n. 551. Breweria $\boldsymbol{R}, \boldsymbol{B} \boldsymbol{r}$. n. 3793 . * Brexia Thouars. 4681 . BREXIACEAE p. 823 . Breyaia Forst. n. 5847. b. Breynia Plum, n, 5000. e. Breyniastrum $D C$. n. $\$ 000$. e. Briarea Corda n. 225. Brickellia Rafin, n. 3821. f. Bricour Adans. n. 4943. Bridgesia Bert. n. 5602 . Bridgesia Hook. n. 2943 . Bridgesia Hook. et Arn. n. 5263. Briedelia $\boldsymbol{W}$. n. 5839.

Brignolia Bertol. n. 4426 . Brignolia $D C$. п. 3231. Brillantaisia Palis. p. 708. Brindonia Thouar. n. 5443. Brissocarpus Bischoff. n. 457. Brissonia Neck. n. 6539. c. Briza Linn. n. 883. Brizopyrum Link, п. 876. a. Brocehia $D C$. n. 2696. d. Brochinia Schult. F: n. 1304. Brodiaea Smith, n. 1106. BROMEAE p. 98 .

Bromelia $\operatorname{Linn}$. n. 1300.

BROMELIACEAE p. 181.et 1361. Bromfeldia Neck. 5806. Bromus Linn. 900.

Bronguiartella Bory. n. 69.

Brongniartia Blum, n. 2016.

Brongniartia $B . \boldsymbol{H}, \boldsymbol{K}$. n. 6541. Brounia Kunth n. 5055 .

Brosimum Swartz, n. 1861. * Brossaea Plum, n. 4337. *

Brotera Cav. n. 5344.

Brotera $\mathrm{Fl} F \mathrm{Fl}$ n. 5365 .

Brotera Spreng. n. 2572.

Brotera Willd. n. 2849.

Broteroa DC. n. 2572.

Broughtonia $R . B r$. u. 1381.

Broughtonia Wall. n. 1342.

Broussaisia Gaud. n. 4673.

Broussonetia Gratel, n. 69.

Broussonetia Ort. n. $6735 . \mathrm{b}$.

Broussonetia Vent, n. 1858.

Browallia Lirn, n. 3y03,

Brownea Jacg. n. 6810.

Brownetera L. O. Nich, n. 1802. Brownlowia Rox. 1. 5374 .

Brucea Mill. n. 5970 .

Bruchia Schwägr. n. 480.

Bruckmannia Nutt. n. 749.

Bruckenthalia Retch, n. 4312.

Bruea Gaud, n. 1873.

Brugmansia Bernh, n. 4845 . a. Brugmansia Blism, n. 726 . *

Brugmansia Pers, n. 3845 .

Bruguiera Lam. n. 6101.

Bruguiera Rich. n. 6248.

Braguiera Thouar. n. 608 '

Brunella Mönch. n. 3624 .

Brunellin Ruiz et Pav n. 5971. Brunfelsia Blum. n. 3905. Brania Linn. n. 4597 . a. BRUNIACEAE p. 805 .

Brumichia Banks n. 1998.

Brunonia Smith, n. 3037.

BRUNONLACEAE p. 505.
Brunsvigia Her, n. 1274 .

Brya $\boldsymbol{P}$. Br. n. 6592 . Bryantlius Gmel, n. 4317. a.

BRY ACEAE p. 1345. Bryobiua Lindl n. 1363/1, Bryochisium Link, n. 289 . a. Bryocladium Kunze p. 31. Bryocles Salisb́, n. 1100. Bryon Adans, n. 483. Bryonia Linn, n. 5130 . BRYONIEAB p. 936.

Bryophthalmum E. Mey. n. 4349. b. *

Bryophyllum Salisb, 4617.

Bryopogon Link. n. 178.

Bryopsis L amx. 80.

Bryopteris Nees. n. $472 / 10^{*}$ b.

Bryum Linn, n. 542 .

Bubalina Rafin, n. 3315 .

Bubon Linn. n. 4466.

Bubonium $D C$. n. 2426 . b.

Bubroma Schreb. n. 5334 .

Bueanaphyllum Pluk, o. 5023 . Buecinoides Endl, n. 430. A. e. $\beta$. Buceo Wendl n. 6021.

Buceulina Lindl. n. 1531. Buceras Ser. n, 6508. c.

Buceras $\boldsymbol{P}$. $\boldsymbol{B}$ r. n. 6075 . Bucerosia $W$. et Arn. n. 3521. Buchanania Kunth. n. 5919.*

Buchauania Roxb. n. 5919.

Buchavea Reich. n. 6348 .

Bucheuroedra Eckl. et Zejh. n. 6482 .

Buchia $\boldsymbol{H}$ B. $\boldsymbol{K}$. n. 3683 .

Buchnera Linn n. 3960 . *

BUCHNEREAE p. 684 .

Buchozia Herit. n. 3117.

Buchozia Fl. Flum. H. 1087. Bucida $\operatorname{Linn}$ n. 6075 .

Bucklandia Brongn. n. 1784.

Bucklandia $\boldsymbol{n} \boldsymbol{B} \boldsymbol{r}$. n. 4594 .

Bucklaudia Sternb n. 1785.

BUCKL.ANDIEAE p. 805 .

Buequetia DC. n. $618^{\prime}$.

Buda Adans. n. 5218.

Buddleia Linn. n. 3971.

BUDDLELAE p. 687 .

Buddleioides Benth, n. 3583. g

Bueckia Nees, n. 972.

Buena Cavan. n. 3235 , b.

Buena Pohl, n. 3275.

Buffonia Sauv, n. 5225.

Buffonia $\mathcal{L}$ n. 5225 .

Bugenvillea Comm. n. 2008. * Buglossoides n. 3768 . d.

Buglossoides Tausch, n. 3768. d.

Buglossum и. 3768 , e.

Buglossum Gärtn: n. 3768. c. *

Buglossum Tournef. n. 3768.

Buglossus Wahienb. n. \$43. Bugrana DC. n. 6493. e.

Bugrano des $D C$. n. 6493. d.

Bugula Benth. n. 3680 , a.

Bagula Tournef. n. 3680.

Bülowia Schuhm. п. 5094.

Büttneria Duh. n. 6356.

Büttneria L.bffl, n. 5331 .

BÜTTNERIACEAE p. 595.

BÜTTNERIEAE p. 597.

Bujacia E. Mey. n. 6650 .

Bulbilis Rafin. n. 887 .

Bulbine Linn, n. 1145. c.

Bulbocapnos Bernh. n. 4839 . c. Bulboerstanum Ad. n. 406 . b. Bulbocastanum Lagaso.n. 4407. Bulbochaete $A_{g}$. n. 58 . Bulbocodiam Linn, n. 1085. * Bulbocodinm Redout, n. 1058. b. Bulbophyllum Thowars. B. 1350. Bulbospermum Blum, n. 1193. Bulbestylis $D C$. n. 2278 . * Bulgaria Eries. n. 428. Bullaria DC. n. 184.

Bulliarda $D C$. n. 4607 . b.

Bulliardia Junghun n. 353. Bulliardia Necker. n. 4714

Bulta Batt. n. 453. 1V. e.

Bumelia Swarts 11. 4238.

Bunburia Harwey n. $3 t 6 \% / 4$.

Bunchosia L. C. Fich. n.5586,

Bungea $C$. A. Mey. n. 4014.

BUNIADEAE p. 887.

Bunias $\boldsymbol{R}$. Br. n. 4973.

Bunias Desv. n. 4897.

Bunias Haller 11. 4973. a.

Bunias Monch. 4973. Db.

Businm Koch 4407.

Bunium Lagasc. n. 4400.

Buphane Herk, n. 1274. c.

BUPHTHALMEAE p. 396.

Buphthalmuns Neok. n. 2439.

Bupleurum Tournef. n. 4 M4

Buprestis Spreng. o. 4414 .

Buramia $D C$. n. 4341. d. *

Burasaia Thouars u. 4699 .

Burcardia Schmiel n. 428.

Bureharnia R. Br, n. 1069.

Burehardia Duham. n. 3712.

Burchardia Neck, n. 6315.

Burchellia R. Br. n. 3315.

Burdaehia $A \quad J$ n. 5588 .

Bureca Zippel. p. 133ł. 10.

Burghardia Scopol. n. 5057 .

Burghartia Necker n. 5057.

Burglaria Wendl u. 5705.

Burgsdorffia Mönch. n. 3655 . d.

Burmannia Linn. n. 1219.

BURMANNLACEAE p. 163. p. 1359.

Burueya Cham et Sohl. n. 3197.

Burielia DC. n. 2601.

Bursa pastoris Tourn, n. 4927. 
Cacalianthemum Dill. n. 2809. a. Cacao Tourn, n. 5333.

Cacara Thouar. N. 6679 .

Caecinia Sav, n. $378^{4} t / 3^{\circ}$

Cachrys Tourn. n. 4525. a.

Caconapea Chams. n. 39t0. b. Cacosmia $H, B, \quad K$, n, 2247. * Cacoucia Aubt. n. 6088.

CACTEAE p. 942.

Cactus Haworth. n. 5154. b.

Cactus Linn. n. 5154.

Cadaba Forsk. n. 4993.

Cadamba Sonn, n. 3192, a. *

Cadetia Gaudich. n. 1317.

Cadia Forsk. n. 6776.

Cadiscus E. Mey. p. 3032

Cadmus Bory. n. 47, et 56 .

Caenopteris Berg, n. 630. b.

Caeoma DC, n. 182 . a.

Caeomurus Link. n. 181. b.

Caesalpinia Plum. n. 6765 .

CAESALPINIEAE p. 1253 et 1310.

Caesarea Cambess. n. 6052.

Caesia Fl. Flum. n. 5727.

Caesia $R, B r$. n. 1151.

Caesulia Roxb, n. 2'338.

CaEsulieaE p. 395.

Caetocapnia Link et $O$ n. 1292.

Caidbeja Forsk. n. 1887.

Cailliea Guill. et P. n. 6826.

Cainito Tussac. n. 4234.

Cajan Adans. n. 6686.

CAJANEAE Benth. p. 1299.

Cajanus DC. n. 6686.

Cajophora Prest. n. 5117.

Cajuputi Adans. n. 6298.

Cakile Tournef. n. 4899.

CAKILINEAE $D C$. p. 87 .

Calabura Plukn. H. 5380.

Caladenia $R, B r$. n. 1592.*

CALADIEAF p. 236.

Caladium Vent. n. 1684.

Calais DC. n. 2979/.

Calamagrostis Adans. n. 817.

Calamaria Dillen. v. 693.

Calamina Palls, n. 945 et 948 .

Calamintha Mönch. n. 3617. a.

Calamites Suckow. n. 602.

Calampelis Don. n. 4106.

Calamus Linn. n. 1736.

Calanchoë Pers. n. 4616.

Calandea DC. n. 4999.

Calandrinia Funth. n. 5179.

CALANDRINIEAE p. 950 .

Calanthe $R$. Br. n. 1501.*

Calathea G. F. W. Meyer. 1644.*

Calantrica Batt, n. 453. VIl, k. Calboa Cav, n. 3806.

Calcearia Blum. n. 1599."

Calecolar Löffl. n. 5041 .

Calceolaria Feuill. n. 3882.

Calceolus Benth, n. 3576. a.

Caleitrapa Cass. n. 2871. aa.

Caleitrapa DC. n. 2871.

Caleitrapoides Vaill. n. 2871.v.

Caleothrix Desf. n. 18.

Caldasia Willd. n. 3818.

Caldasia Mutis. n. 721.

Caldasia Lagasca n. 4508.

Caleluvia Don. n. 4661.

Calea R. Br. n. 2616 ,

Caleacte DC. n. 2616 . c.

Caleacte Less. H. 2612.

Caleana $\boldsymbol{R} \cdot \boldsymbol{B r}$. n. 1598.

Calebrachys DC, n. 2613, b.

Calectasia $R, B r$, n. 1059. *

CALECTASIEAE p. 132.

Calendula Neck, n. 2822.

CALENDULACEAE p. 461 .

Calenduleae p. 462.
Calepina Adans, n. 4966. Caleya $\boldsymbol{R}, \boldsymbol{B r} . \mathrm{n}, 1598$. Calibrachoa Llav. et L.n. 6858. Calieium Achar, n. 36\%. Calicodon Benth. n. 4313. a. 1.* Calimeris Cass. n. 2305. Calinea Aubl. n. 4761. Calinux Rafin, n. 2082. Caliphyllum Gaud. n. 463\%. Calispermum Lour. n. 6878. Calla Linn. n. 1697.

CALlaCEAE p. 232. et 239. Callanthe $\boldsymbol{R}, \boldsymbol{B r} . \mathbf{n} .1501$.

CALLEAE p. 239.

Callianthemum O.A.M. n. 4779 . Callibotrys $\mathrm{Sal}$. n. 4313. b. 12 . " Callicarpa Linn. n. 3712.

Callicephalus $C$. A. M. n. 2871.e. Callichroa Fiserh, et M, n. 2608.* Callicoeca Schreb. n. 3140. Callieoma Andrews n. 46!8. Callicomis $n . B r$, n. 4649 .

Callicornia Burm. n. 2772, a. Callicysthus Endl. n. 6675 . b. Callidrynos Ner. p. 1074.

Calligeum Enal, n. 6386. b. Calligouum Linn. n. 1989. Calligonum Lour. n. 4766. Callilepis $D C$. n. 2615. Calliopea Don. n. 3022. A. 2. Calliopsis Eieich, в. 2527. Calliopsis $S_{\text {weet }}$, n. $6048, \mathrm{~m} . \boldsymbol{\beta}$. Callipeltis Stev, n. 3099.

Calliphysa $F$ et $M$. n. 1989, b. Calliprora Kindl. n. 1111. * Callipteris Bory. n. 636. Callirhoé Nutt. n. 5271. Calliroë Link. n. 1273. g. Callisace Fisch. n. 4465 , Callisemaea Benth. n. 6721 . Callisia Löffl, n. 1030. Callista D, Don, n. 4313, * Callista Lour. N. 1617. Callistachya Rafin. n. 3980 . Callistachya $\$$ mith, n. 6429 .

Callistachys Vent. n. 6426. Callistemua Cass. 11. 2320. Callistemon R. Br. n. 6302 .

Callistephus Cass. n. 2320. Callisthene Mart. n. 6067. Callisthenia Spreng. ․ 6067 . Callithamnion Lyngb. n. 61. Callitriche $\operatorname{Linn}$. n. 1830. CALLITRICHINAE p. 268. Callitris Venc. n. 1792. Callixene Commero. n. 1187. Callophora DC. n. 2496. b. Callopisma Mart. n. 3548. Callostylis Blum. в. 1390.

Callotis $R$. Br. n. $23^{4} 5$.

Calluna Salisb. u. 4316.

Callybrium Weber. n. 560. e.

Calobota Eckl, et Zeh. n. 6478.c. Calobotrya Spach. n. 4682. Calocalais $D C$. n. $2978 /$, b. Calocephatus $\boldsymbol{R}, \boldsymbol{B} \boldsymbol{r}, \mathrm{n}, 2718$. Calocera Fries. n. 414.

Calochilus $\boldsymbol{R} \cdot \mathbf{B r}$, n. 1580 ,

Calochortus Pursh. n. 1096. a. * Calodendrum Thunb. 11. 6014. Calodisa Endt. n. 1537. b.

Calodium Lour. n, 2067.

Calodracon Benth, n. 3638. b. Calodryum Desv. n. 5517.

Calogyue $\boldsymbol{R} . \mathrm{Br}, \mathrm{n} .3044$.

Calomecoi $S_{\text {pach. n. }} 4823$.

Calomelanos Pretl, n. 606. b. * Calomelissa Benth. w. 3617, b. Calomeria Vent. n. 2727.

Calonema Lindi. n. 1593.

Calonyetion Chois. n. 3805.

Calopappus Mejen, n. 2918/,

Calophaca Fisoh, n. 6560.

CALOPHYLLEAE p. 1027.
Calophyllum $L$, n. 5448. Calophysa $D C$. n. 6235 . Calopogon $R, B r$, n. 1600 . * Calopogonium Desv. n. 1301. Calopsis Palis, n. 1021. Caloptilium Lagasc. n. 2949. Calorhabdos Benth. n. 3981. Calorhexia T. et A, Gr, n. 6200 Calorophus Labill. n. 1021 Calosacme Mall, n. 4137. Calosanthes Blum, n. 4119. Calosphace Benth, n. 3597, h. Calostachys Benth, n. 3650 . d Calostemma R. Br, n. 1287.

Calostigma Schott. n. 1690. b. Calostigma Decaisn. In. 3476/1. Calostoma Desv. n. 32\%.

Calota Harw, n. 1537/, b. * Calothanmus Labill. n. 629\%. Calotlieca Funth. n. 885.

Calotheca Stcudel. в. 809.

Calothixix Ag. n. 43.

Calothyrses $R$. Br. M. 21/43. f. Calothyrsus Spach n. 5641.

CALOTROPIDEAE p. 592.

Calotropis Don. n. 6535.

Calotropis $\boldsymbol{R}, \mathrm{Br}$. n. 3478 .

Calozinuia Endt, n. 2493, c.

Calpandria Bt, I. 5546.

Calpicarpum G. Don. n. 3359,*

Calpidia Thouar, n. 2012.

Calpurnia E. Mey. n. 6740.

Caltha Linn. n. 4786 .

Caltha Vaill. n. 2522.

Calthoides B. Juss. n. 2828.

Calusia Bert. n. 6736. a.

Calycadenia $D C$. n. 263/.

Calyeandra A, Rich, n. 6817 .

CALYCANTHEAE p. 1239.

Calyeanthms Lindl. a. 6356.

Calyeera Cavan. n. 3035.

CALYCEREAR p. 503.

CALY CIEAR p. 12.

CALYCIFLORAE p. 1176.

Calycium Aehar. n. 129, b.

Calycium Chev, n. 129. a.

Calycium Elliott, u. 2365. b.

Calycium Pers. n. 129.

Calycobolus Willd. n. 3794.

Calycogoninu $D C$, u. 6241 .

Calycomorphum Presl. n. 6511. et 6511 . b.

Calycophyllum $D C$. n. 3263.

Calycopteris Lam. n. 6078.

Calyeopteris Bich. n. 6241. Calycosoros Schmidt. n. 3011

Calycothrix Labill. n. 6275 .

Calycotome $E$. M Teg. n. 6521.

Calyeotome Link. n. 6505. b.

Calyeotomon $\boldsymbol{H} \circ \mathrm{ffm}$, n. 6505, b. Calycotomus Nich, n. 6248.

Calyculns Endl. n. 430. A. c. Calydermos Lagase. n. 2613. Calydermos $R$ uiz et $P$. n. 3850 . Calylophis Spach, n, 6114. Calymella Presl, n. 660. a. Calymenia Nutt. n. 200't.

Calymmatanthins $S c h$, n. 6279. b. Calyminodon Prest. n. 617/2. Calymperes $S$ wartz n. 521 .

Calyplectus Nuiz et $P$, n. 6162 . Calypogea Dumort. n. $472 / 22$. Calypogeia Haddi n. $472 / 20^{\circ}$

Calypso Salisb. n. 1439.

Calypso Thouar. n. 5702.

Calypteris Zippel. p. 133\%. 11. Calypterim Bernh, n. 629. a." Calyptocarpus Less. I. 2560.

Calyptranthes $S$ wartz. n. 6319 . Calyptranthus Blum, u. 6320 . Calyptranthus Juse, n. 6319.

Calyptridium Nutt, n. 5183.

Calyptrion Gingins. n. 5045.

Calyptroealyx Blum. n. 1752/2 Calyptrocarya Nees. n. $96 \%$. b. Calyptrospermum Dietr. n.33\% Calyptrostylis Nees. n. 966. c. $\beta$. Calysphyrum Bung. n. 3336 . *

Calyssosporium Corda n, 261.

Calystegia $\boldsymbol{R} . \boldsymbol{B r}, \boldsymbol{n}, 3801$.

Calythrix Labill. n. 6275.

Calytriplex $R$. of $C h$, n. 3940. c.

Calyxhymenia Orteg. n. 2004 .

Camagnoc Aubl, n. 5808 .

Camara Cham, n. 3695. a.

Camarea St. Hil. n, 5561.

Camaridium Lindl. 11. 1427. e.

Camarotis Lindl, n, 1476. *

Camassia Lindl, n. 1129.

Camax Schreb, n. 6873.

Cambania Commers, n. 6524.

Cambea Hamilt. n. 6326.

Cambessedea Kinth, n. 5919.

Cambessedea $W$. et $A$, n. 5918 .

Cambessedesia $\boldsymbol{D C}, \mathbf{n}, 6185$.

Cambogia L. n. 5919.

Camelina Orants, is 4919.

CAMELINEAR p. 877.

Camellia Linn. n. 5425.

CAMELLIEAE p. 1022 ,

Cameraria Plum. n. 3401.

Cameraria Dillen. n. 5482.

Camirium Bumph. n. 5802.

Cammartim DO. 11, 4797, e.

Campanaria Endl. n, 4773. a, e.

Campanistrum Heich, n. 3650. e.

Campanopsis $B$ Br. u. 3079 .

Campanula Linn. u. 3085. * b.

CAMPANULACEAE p. 509 . et 1392.

Campanumaea $B t$, n. 307 \%. a. * Campderia A. Fich, n. 1262 b. Campderla Lagasc. n. 1426 .

Campecia Adans. n. 6765. c. 
Camutia Bonat, n. 2473. c.

Canacorns Tournef. u. 1646. Canala Pohl. n. 3568.

Canalia E,, F, Sch. n. 2100.

Cananga Aubl, n. 4721.

Canaria Linn. n. 3076.

Canarina Juss u. 3076 .

Canarium Linn, n. 5936.

Canavali Adans. n. 6663.

Cancellaria $D C$ ก. 5275 , a. $\beta$.

Candarum Reich. a. 1681.

Caudollea Mirbel. n. 617.

Candollea Faddi. u. $473 / 1$.

Canella $P$. Br n. 5457 .

Canello Dombey n. 4742.

Canephora Juss. n. 3284. *

Canicidia El. El. p. 1334. 12.

Canua Linn. n. 1646 .

Canuabis Tourn, n. 1890. *

CANNABINEAE p. 286, et 1376.

CANNACEAF p. 225.

Cannephora Lam. n. 3315 .

Cannomois Palis, n. 1021.

Camophyllites Brongn. ఓ. 1651.

Canonanthus Don. p. 511.

Causcora Lam. n. 35\%4. *

Cansjera Juss. n. 2103.

Cantharellùs Adans. n. 451. *

Cantharifera Rumph. n. 2167.

Cautharospermum $W_{i g h t}$ et $A$. n. 6688 .

Canthium Linn, n. 3175 ,

Cantua Juss. n. 3824.

Cantua Willd. n. 5055.

Capellia Blume n. 4746 .

Caperouia St, Hil, n. 5831 .

Capia Damb. n. 1198.

Capillaria Pers. p. 21. d. c.

Capitularia Flörk. n. 168. $\varkappa$.

Capnia Venten, n. 145. b.

Capnites DC. n. 4339. c.

Capnites Endt. n. 4839. b.

Capnocystis Juss, n. 48'?2.

Capnoides Boerh, n. 4839.

Capnoides DC. и. 4839 . b.

Capuoplyylum Gärtn, и. 4t70.

Capnorchis Borkh. u. 4836. a.

Cappa DC. n. 2426. е.

CAPPAREAE p. 891 .

Capparidustrum DC, n. 5000 , c.

CAPPARIDKAE p. 889.

Capparis Linn, n. 5000.

Capparis Plum. n. 5000, b.

Capraria Linn. n. 3921.

CAPRIFOLIACEAE p. 566.

Caprifoliam Tournef. n. 3337.

Capriola Adant. n. 836.

Caproxylon Juss. n. 5937.

Capsella Venten. n. 4927.

Capsicum Tournef. п. 3854.

Capala Endl. u. 430 . A. d. $\beta$.

Capura Linn, n. 2092.

Caracalla ErdL. в. 6674. b. c.

Caragana Lam. n. 6557.

Caraguata Plum. n. 1307.

Caraipa Aubl. n, 5420.

Carallia Hoxb. n. 6102.

Caralluma $\boldsymbol{R}$. $\boldsymbol{B r}$. п. 3523.*

Carambola Enall. и. 6059 . ь.

Caranaiba Marcgr. n. 1757.

Caranga $\mathrm{Vahl}$, n. 39 '1.

Carapichea Aubl n. 3141.

Carara Caesalpin. n. 4975. b.

Carbeni Adans. n. 2872.

Cardamite Linn. n. 4859.

Cardaminopsis C. A. Mey. n. 4854. f.

Carianàum Könch. n.4850, a. Cardamomum Rumph. n. 1626. Cardamon DO. i. H932. d.

Cardaria Desv, n, 4932. a.

Carderima Cass+ n. 254 .

Cardiaca Lam. घ. 3645 , d.
Cardiaea Mönch, u. 3647. a. Cartonema R, Br. n. 1035.

Cardiandra Sieb. et, Z. n. $4668 /$. Carum Koch. n. 4to6.

Cardiocarpou Brongn. n. 703. Carum Linn. n. 4406. a.

Cardiocarpus Reinw. n. 5658. Carumbium Reinw. n. 5779.

Cardiocaryon Endt. n. 2128. b. Caruncularia Haw, H. 352 . fo

Cardioerinum Erdl. n. 1098. e. Carapa Aubl. n. 55't'.

Cardiolepis Raf, n. 5722. a. $\beta$. Carusia Mart. n. 5583. b.

Cardiolepis Wall $r$, n. 4932. a. Carvi DC. H. 4406. a.

Cardionema DC. n. 5200. a.

Cardiopetalum $\mathcal{S}$ chl.n. 4726.

Cardiopteris Wall. p. 1074 .

Cardiospermum L. n. 5598.

Cardiotheca Ehrenb, n. 3890.

Cardispermum Traut. u. 2672, a.

CARDOPATEAE 2.467.

Cardopatium Juss. n. 2810.

Cardopatum Pers. u. 2849.

CARDUINEAE p. 476.

Carduncellus Adans n. 2877.

Cardnoides Less. n. 2839. c.

Carduus Adans. n. 288't.

Carduus Gärtn. n. 238'.

Carelia Less. и. 2266.

Careya Roxb. n. 6326. *

Cargillia R. Br. n. 4248.

Carica Linn. n. 5119.

CARICEAE p. 110 , et 932.

Carichtera $D C$. n. 4959.

Carieteria Scop. n. 5371. a.

Caridocbloa Nees. n. 768.

Carionanthus Schott. n. 2192.

Carissa Linn. n. 3372.

CARISSEAE p. 578.

Carlina Tournef, n. 2859.

CARLINRAE p. 468.

Carlowizia DC. n. 2859. d.

Carludoviea Ruis. et Pav. n. 1713 .

Carmelia $D C, \mathrm{n}, 4777$. d.

Carmelita Cl. Gay n. 2929/3.

Carmichaelia Grev. n. 107.

Carmichaelia $\boldsymbol{R}, \boldsymbol{B r}$. n. 6568 .

Carminatia Mog. n. 2268/1

Carmona Cav. i. 3743.

Caroides $D C$. и. 4407. b.

Caroli-Gmelina Fr, WeU. n. $4850, \mathrm{~b}$.

Carolinea L. H. 5298 .

Carolinia Ner. p. 110'.

Carota DC. n. 4497 . b.

Caroxylon Thunb. n. 194\%.

Carpanthus Alaf. v. 688.

Carpesium Linn, n. 2775.

Carpha Banks. n. 968. a.

Carphalea Juss. a. 3269 .

Carphephorus Cass. n. 2271.

Carphobolus Schott. n. 220\%. d.

Carpholoma Don, n. 2755.

Carphostephiam Cass. n. 2621. a.

Carpinus Linn, n. $18+3$.

CARPOBOLEI p. 29.

Carpobolus Michel. a. 337.

Carpobolus Schwein. n. 462.

Carposalyuma Zip. p. 133's. 13.

Carpoceras A. Rich, แ. $\mathbf{4 7 6 .}$

Carpoceras Link, n. 4885 . b.

Carpodesmia Grev. n. 120. e.

Carpodetes Herb. n. 128t.

Carpodietus Slorat. n. 5691.

Carpo:Linas $\boldsymbol{R}, \boldsymbol{B} \boldsymbol{r}$, n. $3378 /$

Carpodontos Labill, n. 5't03. a.

Carpolobia Don, n. 5655 .

Carpolyza Salisb. n. 1263.

Carponema DC. n. 4978 . a.

Carpophyllam Grev. H. 121. a. Carpopodium DC. n. 4978 . g. Carpopogon Roxb. n. 6665. Carpotroche Endl. n. 5066 .

Carteretiat A. Rich, n. 1332.

Cartesia Cas\%. и. 2209.

CARTHAMEAE $\mathrm{p} .475$.

Carthamus Berkh. n. 2974.

Carthamus Tournef. u. 2875 .

Carthodium Soland, n. 2721.
Carvifolia Vaill, n. 4454.

Carya Nutt. H. 5889.

Caryochloa Spreng. p. 109. d.

Caryochloa Trin. ถ. 734.

Caryolobis Gärtn. n. 5392.

Caryolopha Fisch, et Trauttv. n. $3767 /$,

Caryophy Haster $R u m p h$, n. 3150 .

Caryophyllastrum $S$ er n. 6386.a.

Caryopliyllata Tournef. n. 6356.

CARYOPHYLLEAE p. 955.

CARYOPHYLLINAE p. 945.

Caryophyllum Mënch. n. 5244 . a. b.

Caryophyllus Tournef. n. 6321 . Caryopteris Bung. n. 3692 .

Caryota Lin, n. 1705 . *

Casalea St Hil. n. 4782.

Casearilla Adans, n. 5827.

Cascarilla Endl. n. 3274. b.

Casearia Jacq. n. 5060. *

Casia Tournef. n. 2078.

Casimira Scop. n. 5620.

Casimiroa Llav ot Lex. n. 6879.

Casparea Kunth. n. 6791 .

Cassandra Don. n. 4318. c. *

Cassebeera Kaulf. u. 621. *

Cassebeeria Dennst. n. 6192.

Casselia Dum, a. 3760.

Casselia Nees, et Mart, n. 3688.

Cassida Tournef. n. 3626 .

Cassidocarpus Presl. a. 4370 .

Cassine L. n. 5704.

Cassiaia R. Br. n. 2726.

Cassinia R. Br. н. 2714 .

CASSINIEAE p. 443.

Cassiope Don. n. 4318 , a. *

Cassiopea Don. n. 2957. c. *

Cassipourea Aubl. n. 6104.

Cassumunar Colla. n. 1622.

Cassapa $\boldsymbol{H}$. et $\boldsymbol{B}$. n. $331 \mathrm{l}$.

Cassuta Gray. n. 3816.

CASSUVikaE p. 1127.

Cassuvium Rumph, n. 5916.

Cassyta Gray. ․ 3816.

Cassyta Linn. n. 2067.

CASSXTEAE p. 323.

Castalia $D C$. n. 5020 . c.

Castalia Salisb. n. 5020.

Castalis DC. n. 2672. e.

Castanea Tournef. n. 18'48.

CASTANEAE p. 273.

Castanospermum $A$. Cunn. n. 6745.

Castella Tarp. n. 5965.

CASTELLEAE p. 1148.

Castelia Cass, n. 3690.

Castiglionia $\boldsymbol{R}, \boldsymbol{P r}$, n. 5806.

Castilleja Mut. n. 400't.

Castilloa Cerv, n. 1876.

Castorea Plum. n. $\mathbf{3 7 0 9 .}$

Casuarina Rumph. n. 1838.

CASUARINEAE p. 270.

Catabrosa Palis. n. 881.

Catachyon Ehrenb. n. 325. b.

Catagyna Palis. p. 119. g.

Catalium Hamilt. n. 6102 .

Catalobus C. A. Mey. n. 4854 .

Catalpa Jass. n. 4143.

Catananche Tournef. n. 2976.

Catapodium Link. n. 899 . b.

Catappa Gürin. n. 6076. a.

Cataria Mónch. n. 3636.

Cataseopium Brid. n. 518.
Caryocar Linn. n. 56'2.

Caryodaphne Blum, n. 2037.

Catasetum L. O. Rich. n. 1420.*

Cataterophora Steud. a. 781. b.

Catenaria Rafin. no 120. g.

Catenaria Rouss. n. 62.

Catenella Grev. n. 92.

Catepha Lechen. n. 4362.

Catesbaea Linn. n. 3286.

Catevala Medik. n. 1115. a.

Catha Forsk. 11, 5678.

Cathanthes Richard. n. 1038.

Catharaathns G. Don. a. 3406. *

Cathartoen:pus Pers. n.6781. a.

Cathartolinum Reichenb. n.

6056. a. *

Catharinea Ehrh n. 560 . c.

Cathea Salisb. a. 1600.

Cathestecum Presl. n. 833.

Cathetus Lour. a. 5847. b.

Cathurgia Endl, n. 430 . A. b. $\beta$

Catillaria Achar. n. 165.

Catimbium Juss. n. 1621.

Catinga Aubl. u. 6329.

Catisus Endl. n. 420. C, I. c.

Catipes $D C$ n. 2767. a.

Catjang $D C$. n. 6675 . c.

Catocarpuen DC, n, 4955. a.

Catonia Fl. Fl. p. 133't. 14.

Catonia Mönrh. n. 3029.

Catonia Vahl. n. 3815. *

Catophractes Don, n. $4116 / 2^{\text {* }}$

Cattleya Lindl i. 1380. *

Caturus L. n. 5787.

CAUCALINEAE p. 785.

Cauealis Linn. n. 4501.

Caucanthus Forsk, n. 559t.

Caulerpa Lamx. и. 83.

Caulerpites Brongn. n. 122. a.

Canlinia $D C$. п. 1660.

Caulinia Mönch. n. 6642 .

Caulinia Willd. n, 1655.

Canlinites Brongn. n. 1665.

Caulogaster Corda. n. 259.

Cauloglossum Fries. n. 326.

Caulophyllum L. C, Rich. n. 4810. b.

Caulotretus Rich. n. 6789.

Causea Scop. n. 6'403. 
Celosia Linn, n. 1975.

CELOSIEAR p. 304.

Celsa Fl. Fl. p. 133't n. 15.

Celsia Linn. n. 3879.

Celtide AR p. 276.

Celtis Tournef. n. 1851.

Cenangium Fries n. 378.

Cenarrhenes Labill, n. 2137.

Cenchrus Linn. n. 783.

Cenia Commers, n. 2685.

CENOCOCCEI p. 28.

Cenococcum Eries. n. 323.

Cenolophiam Koch. is. 4434.

Cenolophon Blum. n. 1637.

Cenomyce Achar, n. 168. "

Centaurea Less. n. 2871.

Centaurella L. C. Rich, n. 3542 .

CENTAURIEAE p. 471.

Centauriuu DC. n. 2371.

Centaurium Hall. n. 2894.

Centaurium Pers. n. 3542.

Centauropsis Boj n. 2239.*

Centella Linn. 1. 4355. b.

Centipeda Less. n. 2396.

Centotheca Desv. n. 877

Centrachaena Schott. n. 2671. b

Centradenia G. Don. n. 6178.

Centranthera $\boldsymbol{R}$. Br. n. 4002 .

Centrantherum Cass, u 2207.

Centranthus DC. n. 2185.

Centrapalus Cass. n. 220 '. i.

Centroclinium Don n. 2911 .

Centrolaena DC. n. 2k81. b.

CENTROLEPIDEAE p. 119 1355.

Centrolepis Labill. n. 1006.

Centrolobium Benth, n, 6707 .

Centronia Blum, n. 4150.*

Centronia Don, n. 6181 ,

Centropetalum Lindl, n. 1506/2.

Centrophorum Trin n. 950 . c.

Centropodium Burch. a. 1992.

Centropogon Presl, n. 3069.

Centrosema $\boldsymbol{D C}$, n. 6638 .

Centrosia A. Rich, n. 1501.

Centrosis Swartz, n. 1607.*

Centrospermum Kunth. n. 2479.

Ceutrospermum $S p r$, n.2671, b.

Centrostachys Wall, n. 1967.

Centrostemma Dec. n. 3051/,

Centunealus Linn. n. 4212.

Cepa Tourn. a. 1137, d.

CEPHAELIDE AE p. 531.

Cephaélis $S$ wartz, n. 3140.

Cephalandra Sehrad in. 5142.

CEPHALA N THEAE p. 530.

Cephalanthera L. C. Hich. n. 1608.

Cephaliuthus Linn. n. 3138.

Cephalaria Sehrad, n. 2192.

Cephrelis Vahl. o. 3140.

Cephaleuros Kunze, a. 248.

Cephalidium A, Aich, n. 3236.*

Cephaliua Thonn. n. 2381.

Cephalocereus $P$ feiff n. 5157 , a.

Cephalocladium Heieh, a. 227. a.

Cephaloedium Kunze, n 236, b.

Cephalohyptis Benth. n. 3583.1 .

Cephalonoplos Neck. n. 2887, e.

Cephalopappas $N$. et $M, n .2951$.

Cephalophilon Meisn, n.1986. e.*

Cephalophora Cav, n. 2599. *

Cephalophoras Lem. n. 5157.a.

Cephaloschoenus Nees. n. 966. c. $\gamma$.

Cephaloseris Pöpp. n. 2913.

Cepbalostigma A. DC. n. 3073 . CEPHALOTEAE p- $4^{\prime}$.

CEPHAL.OTRICHEI p. 22.

Cephalotrichum Link. n. 269.

Cephalotus Labill a, 4628.

Cephaloxis Palis, n. 550.

Cephaloxys Desv. in. 10\%9. c.

Cephalozia Dum. B. 473 b. $*$
Ceracella Fries. u. 430.R. b. e. $\mid$ Cerinthoides Boerh, n. 3760.* Ceraia Lour. n. 1369.

Ceramanthe Reichenb. n. 3883.* Ceriops Arn. n. 6099.

Ceramia Don, n. 4313, d. 38. * Ceriscus Gärtn. n. 3304. a.

CERAMIEAE p. 5.

Ceramiom Ag. n. 62.

Ceramium Blum, a. 2163.

Ceramium Reinw. n. 637 .

Cerophora Rafin, n. 4t2. c.

Ceramoplora Nees. n. 2052, e. Cerophyllum spach, n. 4682. b. Ceramus Salisb. n. 4313. c. 20.* Ceroxylon Humb, ot Bonpl. n. Ceranthe Reichenb. u. 3753. a. 1733.

Ceranthera Palis. n. 50'7.

Ceranthera Rafin. n. 3855.

Ceranthus Schreb. n. 3347.

Cerasophora Endl. n. 6406. c. k. Cerasus Juss, n. 6406

CERASTIEAB p. 969.

Cerastites Gray. n. 4822.

Cerastium Huds, n. 5239.

Cerastium L. n. $524 \mathbf{4}$.

Ceratandra Lindl, n. 1537/, .

Ceratanthera Hornem, n. 1621.

Ceratiola L. $C$. Bich. n. 5762 .

Ceratiosicyos Nees. n. 5106.

Ceratites Link, n. 182, b.

Ceratiun Alb. ot Sehw. H. 262. Ceratium Blum. n. 1392. Ceratocarpus Buxb. в. 1910.

Ceratocaryum Nees. n. 1014. Ceratocaulis Bernh, a. 3845 , id. Ceratocephalus Arönch. 11. 4784 . Ceratocephalus Vaill. n. 2541 Ceratoehilus Blum, n. 1487.

Ceratochilus Lindl, n. 1421.

Ceratochloa Palis. n. 900.

Ceratocoreta $D C$. n. 5371 . b. $\%$. Ceratodaetylis J. Smith, p. $13 \pm 6$. Ceratodon Brid. n. 528. Ceratogonou Meisn. n. 1991.* Ceratolaena $D C$. n. 2479 . b. Ceratelepis Cass. n. 2950. Ceratolobus Blum, a. 1739. Ceratonema Hoth. n. 235.

Ceratonia Linn. n, 6909.

Ceratopetalum Smith, u. 4651 . Ceratop hora Humb. n. 447 . c.

CRRATOPHXLLEAE p. 267 et 1375.

Ceratophyllum Linn. n. 1829. Ceratopsis Lindl, n. 1544. * Ceratopteris Brongn, в. 655 . Ceratosanthes Just, n, 5140 . Ceratoschoenus Nees. n. 966. d. Ceratosinapis $D C$, n. 4950 . b. Ceratospermum Pers. n. 1911. Ceratosporium Sehwein, n, 196. Ceratostachys Blum. a. 6093.

Ceratostemma Just n. 4334.

Ceratostigma Bunge, n. 2175. Ceratostoma Fries. n. 378. b.

Ceratostylis Blum, n. 1485.

Ceratotheca Endl н. 404.

Ceratoxys Endl. n. 6058. i.

Ceraunia Achar. n. 168. ש.

Ceraunion Wallr. n. 328.

Cerbera Juss, n. 3387.

Cerbera Linn, n. 3388 .

Cerbera Loureir. n. 3038. a.

Cereis Linn. a. 6750 .

CERCOCARPEAE p, 1245 .

Cercocarpus $\boldsymbol{H} . \boldsymbol{B}, \boldsymbol{H}$. n. 6381 Cercodea Kam. n. 6138 .

Cereodia DC. n. 6138, *

CERCUDIACEAE p. 1195.

Cercostylos Less, n. 2596 .

Cerdana Ruiz et Pav, n. 3738.

Cerdia Mog et Seos. a. $\$ 211$.

Cerebrina Endl. a, 403. e.

Cerefolium Haller, $\mathrm{n}, 4505$.

Ceresia Pers. 11. 761.

Cereus Haw. и. 5157.

Cerinthe Linn. a. 3753.

Cerinthe Beiehenb, at 3753. b.
Ceruchis Gärtn. n. 2553.

Cervantesia Ruix et P. n. 208\%/1.

Cervaria Gärtn. n. 4462 . d.

Cerviana Minuart, n. 5186.

Cervicina Del. n. 3079 . e

Cervina Gray. n. 119. b.

Cervispina Dill. n. 5722 . a. $\beta$.

Cesatia Endl. 11. 4357.

Cestichis Thouars. It. 1340. b.

CESTRINEAE p. 667.

Cestrinoides DC. n. 289\%. d.

Cestrinus Cass, n.2894 et 2894 e. Cestrum Linn, u. 3865.

Ceterach Adans, n. 606. c.*

Cetraria Alhan, n. 175.

Ceuthospora Fries. n. 366.

Cevallia Lagase. n. 3036/, .

Chaenactis DC. n. 2593.

Chaenanthe Lindl. n. $1448 / 1$.

Chaenanthera Bich. n. 6263.

Chaenomeles Lindl. n. 6341.

Chaenostoma Benth. n. 3968.

Chaerophyllum Lagase, n. 4505.

Chaerophyllum Linn, n. 4506.

Chaetacanthus Nens. n. 40\%2.

Chaetachlaena Don. n, 2912. *

Chaetactis $D C$. n. 2365. a.

Chaetaea Jacq. n. 5331.

Chaetanthera Humb, et Bonpl. i. 2962.

Chaetanthera Fuiz et Pav. u. 2921.

Chaetanthes $\boldsymbol{R} \cdot \boldsymbol{B r}, \mathrm{n}, 1010$.

Chaetaria Palis, и. 801. a.

Chaetobromus Nees. n. 871. b.

Chaetoealyx $D C$. и. 6537.

Chaetochilus Vahl. It 4216 . 5060. b.

Chaetocyperus Nees, u. 1000.

Chaetolepis DC. n. 6210.

Chaetomium Kunze. n. 275.

Chaetonychia $D C$, n. 5202. d.

Chactopappa $D C$. a. 2342.

Chaetopetalum DC. n. 6214 .

Chaetophora $A_{g}$. n. 34 .

Chaetophora Nutt. in 2342 .

Chaetopain Grev. n. 235.

Chaetospera $\mathrm{Ag}$. n. 68.

Chaetospora $\boldsymbol{R}$. Br n. 968."

Chaetostachys Benth, u. 3585. d.

Chaetostevia n. $226 k$ h.

Chatetostoma DO. n. 6186.

Chaetostroma Corda n. 285.

Chaetotricha DO. n. 6603, b.

Chaeturus Link. n. 814

Chailletía $D C$. n. 5758.

CHAILLETIACE,AE p. $110 \%$.

Chaiturus Mö́nck, u. 36ł7. b.

Chaixia Lapeyr, n. $402 \%$.

Chakiatella Cass, n. 2521.

Chatens Lour. v. 5506.

Chaleeios DO . A. 2860 . a.

Chalaria Wight et A. n, 6697.

Chatarium DC. Mt 6615. C

Chalarimm Poit, a. 2500.

Chamaebalanay $B$ semph. n. 6601 .
Cervaua Forsk, n. 244'.

Chabraea DE. n. 2957.*

Chaetephora Brid. и. 587. b.

Chaetium Nees. 1n. 777.

Chatocrater Huiz et Pav, n.

Chaetogastra $D C$. n. 6210.

Chaetotropis Kunth. a. 812.

Chamaebuxus Dill. n. 5647 .

Chamaecassia Bregn, n. 6781. B.

Chamaecerasus Tourn. n, 3337 et 3337 . B.

Chamaecistus Don. n. 4340.* Chamaecistus Gray. n. 4338 . *

Chamaeclema Mönch. ㅁ. 3636. f。

Chamaeclinis Mart. n. 696. b.

Chamaecrista Breyn. n. 6781. g. $\gamma$.

Chamaecyparissus DO. n.2651.a.

Chamaeeytisus Link. u. 6505, a.

Chamaedaphue Buxb. n. 4318 .

Chamaedaphne Mitch. in. 3188.

Chanaederea Willd. n. 1719.

Chamaedryon Ser, n. 6391, b.

Chumaedrys Tourn, n. 3679.

Chamaefistula $D C$. n. 6781 , b.

CHAMAELAUCIEAE p. $122 \%$.

Chamaelaueinm Desf. n. 6280.

Chamaelea Tourn. n. 5954.

Cbasaaeledon Link. n. 4338.

Chamaeleon C. Bauh, n. 2849.

Chamaeleon Cass. n. 2859. e.

Chamaelisum $D C$, n. 4919. a.

Chamaelirium ERzlld, n. 1066, b.*

Chamaemela $D C$. n. 2669. c.

Chamaemeles Lindl. n. 6354 .

Chamaemelum $D O$. n. 2639. a.

Chamaemespilns $D C$, n. 63't2. b.

Chamaenyces Batt.4.453. VII.k.

Chamaenerion Tourn. n, 6121.

Chamaepeuce Alpin. n. 2839.

Chamaepitys Tourn. B. 3680 .

Chamaeplium Wallr. a. 4906. a.

Chamaeraphis R. Br. n. 780 .

Chamaerepes $S$ preng. n. $15 / 1$.

Chamaerhodos Bang. II. 6365.

CHAMERHODEAE p. 12!\%.

Chamaeriphes Ponted. n. 1759.

Chamaerops Linn. n. 1759."

Chamaeseiadium C. A. Mey. B. 4408

Chamaesenna n. 6781. d.

Chamaesideritis Feicheab. B. 3650 . 5 .

Chamaestephanum W. n. 2587.

Chamagrostis Borkh, a. 746 .

Chamarea Eckl. et Z. מ. 4 h9. 
Chasmone E. Meg. ‥ $650 \%$. Chasmone Presl. n. 3668. b. Chastenaea DC. n. 6171. Chatelania Neck. n. 2979. Chaulmoogra Roxb, n. 5085. Chauvinia Bory. n. 83. Chayota Jacq. n. 5147. Cheilanthes Swartz. n. 618.* Cheilanthes $P r$. n. 618. a. * Cheilococea Salisb. n. 6454. Cheilopsis Moq. n. 4069.

Cheilosa Bl. n. 5821 .

Cheiloseyphus Corda n. 472/25 Cheilyctis Rafin, n. 3600 , b. Cheiranthera A. Cunn. n. 5665. Cheiranthodendron Larr.n.5307. Cheiranthus $\boldsymbol{R}, \mathrm{Br}$, n. 4848 . Cheiri Adans. n. 4818 , a. Cheiroides DC. n. 4848. b.

Cheirolophus Cass. n. 2871. n. Cheiropsis C. A. M. n. 4908. c. Cheiropsis DC. n. 4768. e. Cheirospora Moug. п. 196. Cheirostemon $\boldsymbol{H} . \boldsymbol{B}$. n. $530 \%$. Cheirostylis Blum, n. 1571. Chelldonium Tournef. n. 4819. Chelonanthera Blume a. 1347. a. et 1436.

Chelonanthus Grieg, n. 3550. d. * Chelone Linn. n. 3908.

Chenocarpus Neck, n. 3921. Chenopleura Hich, n. 6264 . CHENOPODEAE p. 292 et 1376. Chenopodium Linn, n. 1930. Chenorrhinum DO. n. 3891 . Cheobula EI. Fl. p. 1335. 16. Cheramela Rumph. n. 3851. Cherina Cass. 1. 2921. b. Cherleria Hall, n. 5227. 8. Chesneya Lindl. n. 6558. Chevreulia Cass, n. 2939. Chilastandra Benth, n. 3635. a Chiazospermum Bernh. n. 4834 . Chichaea Presl, n. 5320. a. $\beta$. Chichrassia A. Juss, n. 5552 . Chićionaea Comm, n. 3200 . Chiliadeuus Cass. n. 2433. a. Chilianthus Burch, n. 638. Chiliophyllum DC. n. 2512. Chiliotriehum Cass. n. $229 \%$. Chilmoria Hamilt. n. 5085. Chilocarpus Blum. n. 3380. Chilochium Raf. n. 3758.* Chilochloa Palis, n. 750. a. Chilodia $\boldsymbol{R}, \boldsymbol{B r}$. n. 3628 . Chiloglottis $\boldsymbol{R}, \boldsymbol{B r}$. n. 1591.* Chilogramma Blum, n. 611. b.* Chilopsis Don. n. 4117.

Chilopteris Presl, u. 607. a. $\gamma . *$ Chiloschista Lindl, n. 1477. Chilurus $n . B r . \mathrm{n}, 2132$. b. * Climarrhis Jacq. и. 3260 . Chimaza $\boldsymbol{R}, \boldsymbol{B r}$. n. 4348 . Chimoearpus Don. n. 606\%. Chimonanthus Lindl. n. 6355 . Chimophila Pursh, n. 4348, * Chiococea P. Br, घ. 3167. Chiodecton Achar. n. 138. Chionachne $\boldsymbol{A}, \boldsymbol{B} \boldsymbol{r}$. n. $743 / 1$. Chionanthus Limn, a. 33/4. Chione DC. e. 3196.

Chionolaena DC. n. 2407. Chionolepis DO. n. 2744. c. Chionopterus $\boldsymbol{D C}$. n. $2929 \%$ Chionostemma DC.. n. 2741 . Chionotria Jaek. u. 5515.

Chionyphe Thienem. p. 20. a. Chirita Hamilt. n. 4137.* Chironia Linn, n. 3536. * Chironia Schmidt. n. 3528. CHIRONIEAE p. 600.

Chiropetalum A. Juss. n. 5830. Chisgenes Salisb, n. 4323 . a. Chisocheton $B l$, n. 5530 .
Chitonia Don. n. 6250. Chitonia Mog. et Sess. n. 6032. CHLAENACEAE p. 1014. Chlaenobolus Cass. n. 2415. Chlamidia Banks, et Sol. n 1101.

Chlamidium Corda n. 470, b.* Chlamydophora Ehrenb. n.2701. Chlamysperma Less. n. 2677. * Chlamysporum Salisb. n. 1150. Chlenobolus Cass. n. 2414.

Chlidanthus Lindl. n. 1281. Chloanthes $\boldsymbol{R}, \boldsymbol{B}$ r. n. 3691 . Chloerum Willd. n. 1026. Chloopsis Blume n. 1152. Chlora Linn. u. 3547. *

Chloraea Lindl. n. 160\%* * CHLORANTHACEAE p. $274 n$ Chloranthus Swartz. n. 1819. Chloraster Haw. n. 1289. i. CHLORIDEAE p. 92. Chloridium Link n. 235. Chloris S Swarts. U. 839. Chloroeoceum Grev, n. 26. Chlorocodon Benth, u. 4313. d. 49. *

Chloromyron Pers. n. 5434. Chloroniton Gaill. n. 56. Chlorophora Gaud. n. 1857. Chlorophytum Ker, n. 1147. Chlorophytum Pohl, n. 3120. Chloroxylon DC. n. 3553 .

Chloryllis E. Mey. n. 6664. Chnoophora Kaulf. n. 652. d. Choiromyces Vittad. n. 349. Choisya Kunth. n. 6001. Chokrosal Camrup. n. 6165. Chomelia Fl. Fl. n. 5705. Chomelia Jacq. n. 3163. Chomelia Linn. n, 3293. b. Chomiocarpon Corda n. 471.* Chona Don. n. 4313. b. 15 ." Chondodendron $R$, el $P$. n. 4687 . Cloondrachae $\boldsymbol{R} . \mathbf{B r}$, n. 986, a. Chondrachyrum Nees n. 880 . Chondría $A_{g}$. n. 91.

Chondrilla Tournef. n. 3009.* Chondrocarpus Nutt. n. 4355 , a. Chondropetalum Rotub. II. 1020 Chondrophyllum $B$. n. 3528. f. Chondrosea Haw. n. 4634. b. Chondrosium Desf. n. $84 \%$.

Chondrospermum Wall. n. 3345. Choudrus Lamx. n. 94. b.

Chonemorpha G. Don. n. 3409.

Chonta Molin. n. 650.*

Chorda Lamx, n. 112.

Chordaria Ag. n. 113.

Chordaria Link. n. 112.

Chordostylum Tode n. 257 et 413.

Choretrum R. Br. n. 2074.* Chorilaena Endt. n. 6010.

Choriophyllam Gries. n.3550. c.* Choripetalum $A l p h, D C, n, 4224$. Chorisia H. B. K. п. 5299.

Cherisis DO. n. $3006 . *$

Chorisma Don. n. 3006 . *

Chorisma Lindl. n. 6048. 1.

Chorispermum $\boldsymbol{R}, \boldsymbol{B r}$. n. 4900 Chorispora DC. n. 4900.

Choristacliys Endl. u. 2098. d. Choristea Thumb. n. 2849, a. Choristes Benth, n, 3254\%. Chorizandra $\boldsymbol{R}$. Br. n. 986 . b. Chorizanthe $R, B r, n 1981$. Chorozema Labill. Hi. 6t31. Choteekia Op. et C. n. 3587 . Choupaton Adans. n. 4333 . Chresta Arrab, n. 2230.*

Christannia Presl. n. 5077.

Christia Mönch. u. 6609.

Christiana DC. n. 5375.
Christima Rafin. n. 3265.

Christolea Camb. n. 4914.

Christophoriana Tourn, n, 4799.

Chromochaeta $D C$. n. 2802. b.

Chromochiton Cass. n. 2726. b. Chromolaena $D C$. ni. 2273. Chromolepis Benth. n. 2561/1. Chromosporium Corda n. 209. Chromostegia Benth. n. 4313. a. $4 . *$

Chronobium DC. n. 4623, a. Chronopappus DC. n. 2227. Chronosemium Ser. n. 6511. g. Chroolepus Ag. p. 21. h. Chrosperma Raf. n. 1066/2. Chrysa Rafin, n. 4792, a.

Chrysaetinium Kunth, n. 2245. a. Chrysanthellina Cass. n. 2562. Chrysanthellum $R i c h$. n. 2562. CHRYSANTHEMEAE p. 432. Chrysanthemoides $T$, n. 2825. Chrysanthemum $D C$. n. 2671. Chrysanthemum Less. n. 2667. Chryseideae $D C$. n. 2865. A.

Chryseis Less. u. 2865. Chryseis Lindl, n. 4827.

Chryseum DC, n. 4407. a.

Chrysiphiala Ker. n. 1284.*

Chrysis Renealm. n. 2538.

CHRYSITRICHEAE p. 115.

Chrysitrix Linn. n. 985.

CHRYSOBALANEAE p. 1251.

Chrysobalanus Linn. II. 6407.

Chrysobaphus Wall. n. 1569.

Clirysobotrya Spach. n.4682. c. Clirysocalyx G. et P. n.6472. b. Chrysocoma Cass. n. 2385.

CHRYSOCOMEAE p. 382.

Chrysocoptis Nutt. n. 4792 . b. Chrysodraba DC. n. 4880. d.

Chrysoglossum Blum, n. 1327. Chrysogonum Bauhin, n. 4809. Chrysogonum Linn. n. 2471. Chrysoliga Hoffm. n. 6147. b. Chrysomallum $T h$. n. 3700 . b. Chrysomelea Tausch, n. 2528. Chrysophania Kunth. n. 2510. Chrysophora DC. n. 4522. b. Chrysophyllum $\operatorname{Linn}$. n. 4234. Chrysopia Noron. n. 5440. Chrysopogou Trin. n. 950. c. CHRYSOFSIDEAE p. 384 . Chrysopsis Nutt. n. 2373. Chrysorhiza $D C$. n. 3183. d. Clirysorhoë Lindl. n. 6279. Chrysosclas E. Mey, n. 6696. Chrysosplenium Tourn. n. 4638. Chrysostacliys Pohl. n. 6091. Chrysostemma Less. n. 2526. * Chrysurus Palis. n. 894. b. Chthonia Cass. n. 2250. Chudaria Forsk, n. 5176. a. $\alpha$. Chakrasia A. J. n. 5552. Chuncoa Pav. n. 6079.

Chnquiraga Juss. n. 2913. * Chusquea Kunth. n. 906. Chylodia Rich, n. 2521. Chysis Lindl. n. 1445. Chytraculia $P$. Br. n. 6319 .

Chytralia Adans. n. 6319.

Ciborium Endl. n. 430 . A. d. $\gamma$. Cibotium Kaulf. n. 645. *

Cieca Linn. n. 5851. Cicendia Adans. n. 3541. * Cicer Tourn. n. 7578 .

Cicerella Mönzh. n. 6582. e. Ciehlanthus Endl, n. 4586. e. $\propto$. CICHORACEAE p. 493.

Ciehorium Tournef. n. 2978.

Cieonia $D C$, n. 6048. m, $\alpha$.

Cícuta Linn. n. 4391.

Cicuta Tournef. n. 4532.

Cieca $D C$. n. 5098. 6.

Cienfuegia Willd. n. 5279.

Cienfugosia Cav. n. 5279.

Ciliaria Haw. n. 4634. i.

Cilieiocarpas Corda. n. 330.

Cilieipodium Corda n. 260.

Cimicifuga Linn, n. 4802.

Ciminalis Burkh. n, 3528 .

Cinara Tournef. n. 2882.

Cinchona Kinn. n. 3274.

CINCHONACEAE p. 545 .

CINCHONEAE p. 553.

Cincinnalis Desv. n. 614.

Cincinnulus Dumort. n, $472 /{ }^{\circ}$

Cinelidium $S$ wartz. n. 543.

Cinclidotus Palis. n. 496.

Cineraria Cass. n. 2311.

Cineraria Less. n. 2797.

Cinna Linn. и. 808.

Cinnamodendron E. v. 5458.

CINNAMOMEAF p. 316.

Cinnamomum Burm. n. 2023. *

Cinogasum Neck, 6827.

Cionisaceus Vahl, el H, n. 1548.

Cionium Ditımar. n. 317. d.

Cipadessa $B l$. n. 5523.

Ciponima Aubl. 4259.

Cipura Aubl. n. 1222.

Circaea Tournef. n. 6130.

CIRCAEACEAK p. 1194.

Circinaria Pers. n. 395.

Circiunaria Fée n. 166.

Circinotrichum Nees. n. 211.

Cirinosum Neck. n. 5157.

Cirrhaea Lindl. n. 140'4.

Cirrholus Mart. n. 305.

Cirrhopetalum Lindl. n. 1353.

Cirsellium DC. n. 2860. d.

Cirsioides DC, n. 2854. b.

Cirsium Less. n. 2889.

Cirsium Tournef. n. 2887. * 
Clappertonia Meisn. n. 5370.

Clarionea DC. и. 2962. *

Clarionella $D C$. u. 2962, a. $\pi$.

Clarionoides $D C$, n. 2962, a. $\delta$.*

Clarisia Ruiz et P. n. 1839, a.

Clarkia Pursh. u. 6119.

Clarkia Spach, o. 6119. b.

Clasterisporium $\operatorname{Schw}$, n.203, a.

CLATHRACEAE p. 22.

Clathraria Mant. u. 1785.

Clathroidastrum Bich, a. 312, e.

Clathroides .Mich. n. 309. b.

Clathropteris Brongn n. 687.

Clathrus Mich. 4 + 355 .

Clandea Lamx. n. 102.

Clausena Burm. n. 5581.

CLAUSENEAE $W$. et $A$. p. 1045.

Clausia Trotzk, n. 4848/1.

Clavaria Vaill. n. 415.

Clavarieí p. 35.

Clavatella Bory. "a. 31 .

Clavena $D C$. n. 2885.

Clavi Secalis p. 16, d.

Clavi Veter. p. 16. d.

Clavigera DC. n. 2269.

Clavija Ruiz et Yav. u. 4230.

Clavnlium Desv. n. 6472, d.

Claytonia Linn, n. 5180.

Cleanthe Salisb. n. 1232.

Cleanthes Don, D. 2960. a.

Cl idion Blume n. 5795.

Cleisostoma Blum. n. 1482.

Cleisostoma Brid, u. 498.

Cleistes L. C Rich, п. 1606/1.

Cleitria Schrad. n. 2832.

CLEMAIDEAE p. 8\%".

Clematis Linn n. 4768 .*

Clematitis Endl. n. 2162. a.

Clematitis Tourn. n. 4768. b.

Clematopsis $B \circ j$, n. 4768, b.

Clementea Cav. n. 668.

Clementea $C a v$. n. 6663. b. $\delta$.

Cleobulia Mart. n. 6660.

Cleome $D C$. n. 4985.

CLEOMEAE p. 890.

Cleomella $D C \boldsymbol{C}$, n. 4983.

Cleomena Palis n. 803.

Cleonia Linn. n. 3625.

Cleophora Gärtn. 1. 1747.

Cleria Fl, Fl, n. 5701 .

Clermontia Gaud. n. 3068.

Clerodendron Linn. n. 3708.*

Clethra Linn, n. 4320.

Clethria P. Brown. n. 355 . e.

Cleyera Humb. n. 5411.

Cleyria Neok. n. 6805.

Clianthus Soland, n. 6567.

Clibadium Linn. n. 2'462, a.

Clidemia Don, n. 6229.

Cliffortia Linn. n. 6379.

Cliftomia Banks n. $4344 / 1$.

Climacium Web. ot M. n. 585. Clineliuia Feuill. n. 5647. d.

Clinopodium $\operatorname{Lin} n$, n. 3617.

Clintonia Dougl. n. 3052.

Clintonia Rafin. n. 1183, b.

CLINTONIEAE p. 510.

Cliostomum Eries. n. 144.

Clissosporium Fries. 15. 242 .

Clistax Mart. n. 4102.

Clithris Fries n. 378. a.

Clitocybe Fries. n. 453 . VII. e. Clitopilus Fries. n. 453 . V1. d. Clitoria Linn, n. 6635 .

CLITORIEAE p. 1287.

Clitorius Peliv, n. 6635.

Clivia Lindl. n. 1291.

Clomenocoma Cass. B. 2578.

Clomion Adans. n. $288 \%$.

Clompanus Rumph n. 5320. a. $\approx$.

Closirospermum Neck. n, 3021. *

Closterandra Belang. n. 482,

Closterium Nitzsch, n. 21.

Clugnia Comm, n. 4750 .
Clusia $L$, n. 5438 .

CLUSIACEAE p. $102 \%$.

Clutia Boerh. n. 5840.

Clnytía Ait. n. 5840.

Cluzella Bory n. 17.

Clymenum Tourn, u. 6582, e.

Clypea Blume n. 469\%.

Clypearia Rumph. n. 6820

Clypeola Linn, n. 4877.

Clypeola. Neck n. 4970.

Cnazonaria Cord. u. 413.

Cnemidaria Presl n. 651. b. * et 653. d."

Cnemidia Lindl. a. 1566.

Cnemidostachys Mart. et Z. $n$. 5781.

Cueorum Linn, n. 5954 .

Cnesmone $P, B I$, n. 5783.

Cnesmosa Bl. n. 5783.

Cuestis Juss. n. 5950.

Cnestoidea $D C$. n. 5949. b.

Cníeus Schreb. n. 2887.

Cnicus Vaill. n. 2872.

Cuidia Thunb. n. 387.

Cnidium Cuss, n. 4 '436.

Cuidoseolus Polit. n. 5807 .

Coa Plum, n. 5700.

Coapia $P i_{s o}$ n. 5466.

Coapsiba Marcgr. n. 6806.

Cobaea Cav, n. 3825, *

Cobamba Blanco. n. 4023/1.

Coburgia Herb. и. 1273, e.

Coburgia Herb. n. 1264. b.

Coburgia Sweet. n. 1285.

Coecinia $W$. et A. n. 5139.

Coecabolus Wallr, n. 366.

Coecochloris Spreng, n. 1029.

Coceocypselum $\boldsymbol{S}$ wartz, n. 3191.

Coceoderma Hunze n. $8 \%$.

Coccogalium DC, n. 3100 .

Coccoloba Jacq. n. 1990.

Coccophora Grev, n. 120 . b.

Coccopleam Ehrenb. n. 281.

Coecosperma $\mathrm{Kl}$. n. 4294. b.

Coccospora Wallr. n. 193.

Coecotriehum Link n. 215.

Cocculus DO. и. 4687. *

Cocblearia 'Foch. घ. 4882, d.

Cochlearia Tourn. n. 4882.

Cochlia Blum, n. 1349.

Cochlidiospermum R. B. 3979, b.

Coehlidinm Endl, n. 430, C. m. $\beta$.

Cochlidinm Kaulf. n. 612.

Coehliospermum Lag. n. 1941.

Cochlitropis Benth. n. 6663 . a.

COCHLOSPERMEAE p. 1017.

Cochlospermum Kunth. n. 5405.

Cochranea Miers. p. 638.

COCOINEAE p. $25 \%$.

Cocos Brongn. n. 1783.

Cocos Linn. n. 1772.

Codaria $L$ n. $3251 / 1$.

Codarium Siland. п. 680\%.

Codda-pana Reed, n. 1753.

Coddingtonia Bowd. n. 6860 .

Codia Forst. n. 4647.

Codiaeum Rumph, n. 5818.

Codiam Stackh, n. 81 .

Codon Rogen n. 3837.

Codosanthe Mart. n. 4159. a.

Codonanthemum Flotzzoh. n. 4299.

Codonantbus G. Don. p. 1359.

Codonia Dum. n. $472 \%$,

Codonia Sprengt. n. 3079.

Codonia Vahl. n. 4260, a.

CODONIEAE p. 1339,*

Codenoblepharum Sehw. n. 515.

Codenocarpus A. Cunn. n. 5265.

Codonophora Lindl. n. 4168.

Codonoprasem Beich. n. 1137. c.

Codonopsis Walt. n. 4075, *

Codonorehis Lindl, n. 1601/1.
Codonostigma Bl, n. 4297.

Codylis Raf. n. 38 M.

Coelachue $\boldsymbol{R}, \boldsymbol{B} \boldsymbol{r}$. n. 882.*

Coelantha Fröl. n. 3528. b.

Coelauthum E. Mey. n. 5190.

Coelanthus Willd. n. 1264,

Coelebogyne J. Smith, p. 1425.

Coelestinia Cass. n. 2258.

Coelia Lindl. n. 1343.

Coelidinm Vogel. M. 6467.

Coelocauton Link, 1. 175.

Coelocline A. DC, n. 4716 .

Coelpglossum Lindl. "1. 1520.

Coelogyne Lindl, n. 1346.

Coelopyrum Jack, n. 6880.

Coelorhachis Brongn, a. 927. c.

Coelorutis Ser, a. 6510 , a.

COELOSPERMEAE p. 792.

Coelospermum Blum, n. 3211.

Coelosporinm Link. n. 3235.

Coelostylis Torr. et A. Gray. n. $3363 / 1$.

Coenogonium Ehrenb, ․ 164. Coenorhachis $D C$, n. 2689. c. Coffe $D C$, n, 3153 . a. Coffea A. Fich, a. 3152, a.

Coffea Linn, n. 3152.

COFPEACEAE p. 521.

COFYREAE p. 532.

Cogswellin Schult, n. 4459. b.

Cogylia Mol. n. 4703.

Coilantha Borkh. n, 3528.

Coilopliyllum Morr. n. 5023.

Coilostigma Benth n. 4298. *

Coilostigma B1. n. 4398. a.

Coilostigma Endl. 11. 2/29, an

COLLOSTIGMEAE p. 751 .

Coinogyne Less. ut 2658.

Coix Linn, n. 743 .

Cola Bauh, n. 5320. f.

Colax Lindl. n. 1407. a.

Colbertia Salisb. n. 4747 .

COLCHICACEAE p. 133 et 1538.

COLCHICEAR p. 137.

Colchícum Tournef. n. 1086.

Coldenia Linn. n. 3749.

Coleauthus Seid. n. 805 .

Colebrookia Smith. n. 3590.

Coleoides Benth, n. 3575 , b.

Coleonẹma B. et $\mathbf{W}$. u. 6016 .

Coleosanthus Cass. n. 2278.

Coleostephus Cass. 11. 2670.

Coletia FZ. FZ. n. 1027.

Coleus Cav, et Sech, u. 355 . b.

Coleus Loureiro n. 3576.

Colicodendron Mart. ш. 4999.

Colignonia Endl, n. 2001.

Collabium Blum, n, 1370.

Collacystis Kunze, p. 23.

Colladoa Cav. n. 951.

Colladoa Pers. n. 785.

Colladonia DE. n. 4527.

Colladonia Spreng. n. 3146.

Collaea $D C$ n. 6657 .

Collaen Zindl. n. 155'

Collaea Spreng. n. 2562.

Collania Schult, F. n. 1277.*

Collarinm Link, n. 215.

Collema Andr. n. 30\%3.

Collema Hoffm, n. 162.

COLLEMACEAE p. 14.

Colletía Comm, n. 5730 .

COLLETIEAE p. 1099.

Colletotrichum Carda. n. 385.

Collizuaja Mol. n. 5771.

Collinaria Ehrh. n. 889, b.

Collinsia Nutt. n. 3897.

Collinsonia Linn, n. 3613.

Collioras Cham, n. 3695. b.

Collomia Nutt. ". 3820.

Collomioides Endt. n. 3821. a.

Collophora Mart. n. 3376.

Collybia Fries. n. 453 . Vil.

Colobachue Palis, a. 747. b.

Colobanthus Bartl. n. 5193 .

Colobanthus Trin. n. 863, a.

Colobium Roth. n. 2989.

Colobotropis E. Mey. 11. 6460, a.

Colobotus E Mey. в. 6481.

Colocasia $R$ ay. n. 1683.

COLOCASIEAE p. 236.

Colocynthis Tourn. n. 5131 .

Cologania $\boldsymbol{H}, \boldsymbol{B}, \boldsymbol{K}$, n. 6633.

Colomandra Neck. n. 2059.

Colona Cav. u. 5378.

Coloumaria Rafin no 355 . a.

Colonnea Bueh, a. 2583.

Colophanes Don. n. 4046.

Colophouia Comm, n. 5936.

Colpias E. Mey. n. 3912.

Colpotlium Trin. n. 807.

Colpowa Wallr. n. 378. a.

Colpoon Berg. n. 2077.

Colposoria Presl n. 643. c. $\gamma$ *

Colquhounia Wallich. n. 3692.

Colsmanuia Lehm, n. 3764.

Colubrina L. C. Hich, n. 5728. *

Columbaria Thouill. n. 2195. c.

Columbia Pers. n. 5378.

Columbra Comm. n. 4686.

Columella Comm, \#, 5275. a. $\beta$.

Columella FI. FV. n. 1012.*

Columellea Jacq n. 2779, a.

Columellia Lour, n. 4566 .

Columellia Ruiz et P. n. $426 \%$,

COLUMELLAACEAE p. 745 .

Columiea Plum, n. 4157 .

COLUMSIFEREAE p, 978.

Coluria $\boldsymbol{A}$. Br. п. 6388 .

Colutea Linn, 11. 6561 .

Colutia Möneh, в. 6566.

Colvillea Bof, n. 6767 .

Colymbea Salisb, n. 1797 . 
CONFERVEAE p. 5.

Confervites Brongn, n. 75.

Congea Roxb. n. 3714.

Conlandra $S$ chrad. n. 512\%.

CONIANDREAE p. 935.

Coniangium Fries n. 131.

CONIFRRAE p. 258.

CONIFERAE FOSSILES p. 373.

Coniocarpon DC. и. 127.

Couiocybe Achar. n. 130.

Conioloma Flörk. ‥ 127.

Coniomorpha Otth, n. 5248. c.

CONIOMYCETES p. 16.

Coniophora DC, II. 437. d.

Conioselinum Fisch, n. W4t8.

Coniosporium Link. a. 273.

Coniosporium Link. n. 308, a.

CONIOTHALAMI p. 11.

Coniothele $D C$. n. 2487 .

Conites Sternb. n. 1784.

Conium Desf. n. 4450 .

Conium Linn, v. 4532.

Conjugata Vamh. n. 5 \%.

CONNARACEAE p. 1139.

Connaroidea DC. 11. 5949, a.

Connarus Kunth. n. 5949.*

Connarus Linn. в. 5948 .

Conocarpodendron Boerh. n 2120 et 2124 . a.

Conocarpus Adans. n. 2120. Conocarpus Gürtn, n. 6081.

Conocephalus Blum, n. 1869." Conocephalus Hill. n. 465.* Conoelinium DC. и. 2275.*

Conogyue $R, B r$. n. 2143. e. Conolioria Aubl. n. 5047.

Conomitra Fenzl, n. 3447/1.

Conomorpha $A l p h$. DC. n. 4218. Conopharyngia G,D. n 3398. a. Conopholis Wallr. n. 418t. * Comophora DC. n. 2806. b. Conoplea Link. n. 235. Conoplea Pers. n. 192. Conopodium DC. n. 4407. e. CONOSPERMEAE p. 338.

Conospermum Smilh, n. 2132.*

Conostegia Don. n. 6248.

Conostephium Benth. u. 4266 .

Couostomun $S_{\text {wartz. n. } 554 .}$

Conostylis $R$. Br. n. 1258.*

Conostylus Pohl. n. 4218.

Conothamaus Lindl. n. 6297.

Conotriehia A. Rich, n. 3266.

Conradia Mart. n. 4169.

Conradia Nutt. n. $399 \%$.

Conradia Rafin, n. 1062.

Conringia Presl, n. 4908. e.

Consana Adans. n. 4977.

Consiligo DC. n. 4778 . b.

Cousolida $D C$. n. 4796 . a.

Consuegria Cald. p. 1334. 17.

Contarena Adans. n, 2239.

CONTORTAE p. 570.

Comaleum L. C. Rich, n. 2114.

Couvallaria Desf. n. 1183.

CONVALLARISAE p. 154 .

Convallarites Brongn. a. 1787.

CONVOLVULACEAE p. 651 et 1403.

Convolvuloides Mö́nek, n. 3808.

Convolvalus Linn. A. 3803. *

Conyza Don. n. 1426. e.

Conyza Less. n. 2405.*

CONYZEAE p. 387.

Conyzoides Tourn, n. 2775.

Cookia Gmel. n. 2098.

Cookia Spr. a. 5507.

Cooperia Herb. n. 1272.*

Copaia E. n. 4115, a.

Copaifera Linn, n. 6806.

Copaiva Jacy, n. 6906.

Copernieia Mart n. 1757. *

Copistua E. Mey. it. 6692.

Copuitis E, Mej, *. 6490. 89.
Coprinarius Fries. n. 453. UI. a. CORRIGIOLEAE p. 956.

Coprinus Pers. n. 423. II. Corsinia Raddi. n. 457. Coprosma Forst. n. 3109. Coptis Salisb. n. 4792 .

Coquebertia Brongn. n. 6813. Coquito de Chile n. 1776.

Coralledendron Tourn, n.6667.b.

Coralloides $\boldsymbol{H}$ off $m$. и. 159.

Coralloides Tournef. u. 415.

Corallophyllum $\boldsymbol{H}, \boldsymbol{B}, K, \mathrm{n} .6861$. Corallopsis Grev. n. 93.

Corallorhiza Hall. n. 1339.

Corbichonia Seopol. n. 5184.

Corbularia Haw. n. 1289. a.

Corchorus L. n. 5371 .

Cordaea Nees. n. $472 / 6$

Cordaea Spr. n. 66t7.

Cordia Linn. n. 3738, *

CORDIACEAE p. $6+3$.

Cordiera A. Rich. n. 3220.

CORDIEREAE p. 545.

Cordiopsis Desv. n. 37t0.

Cordyla Blum. n. 1578.

Cordyla Lour. n. 6317.

Cordylia Pers. n. 6817.

Cordyline Comm. n. 1166.

Cordyloearpus Desf. n. 4901.

Cordylogyue E. Mey, n. $3^{4} 66$.

Corema Don, n. 5760.

Coremium Link, n. 226.

COREOPSIDEAE p. 411.

Coreopsis Linn. n. 2529.*

Coreopsoides Mönch. n. 2529.

Coreosma Spach. n. 4682, b.

Coreta P, Brown, n, 5371. b.

Corethrogyne $\boldsymbol{D C}$, n. 2298.

Corethropsis DC. n. 2871. z.

Corethrostylis $E$. u. 5326 .

Coretoides DC. a. 5371. b. $\beta$. CORIANDREAE p. 792.

Coriandrum Linn, n. 4549.

Coriaria Niss, n. 5596.

Coridium $S p$. n. 5464. B. b. $\varepsilon$

Corindum Tournef. n. 5598.

Corion Link n. 4546.

Coriphaea Lindl. u. 1537. b, \&. *

Coris Tournef. n. 4211.

Corispermam A. Juss. n. 1951.

Cormigonus Rafin, u. 3257 .

Cormonema Reiss. n. 5727. *

CORMOPHYTA p. 42.

Cornacchinia Endl. n. 3437. *

Cornatehinia Sav. n. 3708, *

CORNEAE p. 798.

Cornelia Ard. n. 6146. b.

Cornicina Boiss, n. 6506. d.

Cormicularia Aehar, n. 178.

Cornicularia Hoffm. n. 175. b.

CORNICULATAE p. 808.

Cornidia Fuiz et P. n. 4671.

Cornneopiae Linn, n. 744.

Cornulaea Del. n. $19 ' 18$.

Coraus Tournef. n. $45 \%$.

Cornutia Gärtn. n. $369 \%$.

Cornutia N. L. Burm. n. 3701.

Cornutia Plum, n. 3714.

Corokia 1. Curn, n. 5751 .

Coronit impersalis Tournef: 1096. b.

Corona Solis Tourn, n. 2538. CORONARIAE p. 129.

Coronilla Linn, n. 6585.

CORONILLEAE p. 1280.

Coronopis Hall. n. 4975. b.

Coronopus Tourn n. 2170. b.

Corozo Jacq. n. 1771 .

Corradoria Mart. n. 69.

Corraderus Gray. n. 17.

Correa S mith, и. 6012.

Correas Hoffm. n. 6012.

Correia Vellos. n. 5958

Correoides Endl. n. 60n9. a.

Corrigiola Linn. u. 5197 .
Cortesia Cav. n. 3742/,

Cortia DC. n. 4468 .

Corticia Eries. n. 423. d. Corticium Pers. p. 21. d. $\delta$.

Corticium Pers. n. 437. d.

Cortinaria Fries. n. 448. d.

Cortinaria Fries. n. 453. V.

Cortusa Linn. n. 4200.

Cortusina E. et Z. n. 60'45. m. Corvisartia $D C$, n. 2426, a.

Coryanthes Hook. n. 1423.*

Coryanthas Nutt. n. 3600 , b.

Corybas Salisb. n. 1597. c.*

Corycarpus Zea. n. 903.

Corycium Swartz. n. 1540.*

Coryeium $S$ wartz, n. 1540.

CORYDALIDEAE p. 859.

Corydalis Vent. n. 4839.

Corylopsis Sieb. et Z. n. 4589.

Corylus Tourn. n. 184t.

Corymbium Linn, n. 2233.

Corymbocephalon Meisner n. 1986. e. $\beta$.

Coryuandra Sohrad. n.4988. a. Coryne Nees. n. 403. b. Corynelia Achar. n. 388.

Corynella $D C$. n. 6556 .

Corynephora Ag. n. 31.

Corynephorus Palis, n. 856.

Coryneum Fries. n. 203.

Coryneum Nees. и. 203. a.

Coryuitis Spr. n. 6556.

Corynocarpus Forst. n. 4232/1.

Corynodesmium Wallr. n.236. b.

Corynoides Endl. n. 415. a.

Corynostylis Mart. et Z. 1.5045 . Corynotrichum DC. n. 2887. d.

Corypha Linn. n. 1753. *

CORYPHINAE p. 252

Corysanthera Wall. n. 4148.*

Corysauthes $R, B r$. n. 1597 .*

Corythaeanthus Nees. n. 4067.

Corytholobium Blum, n. 6702.

Coseiniam Colebr. n. 4692.

Coscinium Endl, n. 312. a.

Coscinodon Spreng. n. 519.

Cosmea Willd n. 2542.

Cosmelia $R$. Br. n. 4285.

Cosmia Dombey n. 5179.

Cosmibuena Ruiz et P. n. 3275.

Cosmibuena Ruiz ot $\boldsymbol{P}$. n. 6408.

Cosmos Cav. n. 25/2.*

Cosmostigma Wight. n. 3506.

Cosmus Pers. n. 2542.

Cossignia Comm. n. 5623.

Costa El. Fl. n. 5993.

Costaria Grev. n. 108.

CoSTI p. 225.

Costus Linn. n, 1638.

Costus Pers. n. 1632.

Cotinus Tourn, n. 5905.

Cotoneaster Med. n. 6347.

Cottaea Kunth. n. 831.

Cottendorfia Schult F. n. 1311.

Cotula Gärtn. n. 2683.

Cotula Vaill, n. 2685.

COTULEAE p. 437.

Cotylanthera Blum. n. 3870.

Cotyle DC. n. 4620. b.

Cotylea Haw, n. 463\%. h.

Cotyledon $D C$. 1. 4618 .

Cotyledon Gaudin, n. $463 \%$.

Cotylephora Meisn, in, 5308 .

Cotylephyllum Link. 1. 4620 . b.

Cotyliseus Desv. n. 4975 . c

Conblandia Aubl. n. 6735 .

Couepia Aubl. n. 6410.

Coulteria $\boldsymbol{H}, \boldsymbol{B}, \boldsymbol{H}$, n. $676 \%$.

Couma Aubl. n. 3379.

Coumarouna Aubl. n. 6728 .

Compoui Aubl. n. 6330.

Couratari Anebl. n. 6330.

Courbaril Plum, n. 6788. a

Couroupita Aubl. n. 633t.

Coursetia $D C$. n. $65^{\prime} 49$.

Courtoisia Nees. n. 1003, b, c.

Courtoisia Reich. n. 3821. g.*

Cousinia Cass. n. 2862.

Coussapoa Aubl. n. 1866.*

Coussarea Aubl. n. 3158.

Contarea Aubl. n. 3278.

Coutoubea Aubl. n. 3553.

Covelia Neck n. 3121.

Cowania Don. n. 6387.

Coxia Endt, n. 4209.

Crabbea Harw. n. 4061 .

Craeca Linn. в. 6539.

Cracea Rivin. n. 6581. c.

Craccoides DC. n. 6539. b.

Craepalia Schrank. n. 912.

Craepaloprumnon $\boldsymbol{E}$. n. 5079, b.

Crafordia Rafin, n. 65, 40 .

Crambe Tourn, n. 4967.

Cranichis $S_{\text {wartz. n. } 1574 .}$

Craniolaria Linn, n. 4174.

Craniospermum Lehm. n. 2763.

Craniotome Reichenb. n. 365'

Crantzia Lag. n. 4908 . e.

Crantzia Nutt. n. 4356.

Crantzia Schreb. n. 5975.

Crantzia Scop. n. 4163.

Crantzia Swartz. n. 5968 .

Craspedia Forst, a. 2721.

Craspedium Lour. n. 5334. b.

Craspedon Fée. p. 33. d.

Crassicola DC. n. 2397. a.

Crassina Scepin. n. 2493. a

Crassocephalus $M$. n. 2791.

Crassula Adans. n. 4615 .

Crassula Haw. n. 4610.

CRASSULACEAE p. 808.

CRASSULEAE p, 809.

Crataegus Linn. n. 6353. 
Cristaria Sonn. n. 6086. Cristatella Nutt. a. 4989. Critamus Besser. n. 4401. Critesium Raf. n. 917. b. Crithmum Tournef. n. 4449. Critonia Gärtn. n. 2268. a. Critonia P. Brown, n. 2279. Crocanthemum Spach, n. 5029-f Crocidium Hoak. n. 2812/, Crociseris Reich. n. 2811. I. h. Crocodia Link, n. 173. Crocodilium DC. n. 2871. Crocodilodes Adani, n. 284t. Crocodilodes $V$ atll. n. 2860. Crocodylium Vaill. n. 2871. w. Crocoxylon E. Z. n. 5688. Crocus Tournef n. 1248. * Crodisperma Poit. n. 2521. Cronartium Fries, n. 182. b. Croomía Torr. n. 4815/, Crossandra Salisb. n. 4073. Crossocephalum Erröl. n. 3528. d. Crossolepis Less. p. 444. Crossopetalum P. Br. n. 5689. Crossopetalum Roth. n. 3528. Crossophyllum Spach. n. 546h. B. b. 0 .

Crossopteryx Fenzl. n. 3279/, . Crossostephium Less. n. 2606. Crossostigma Spach, n. 6121. c Crossostylis Forst, n. 6836 . Crossotoma Dan. n. 3038 . d. Crotalaria Linn. n. 6472 . Crotalaria Linn. n. 6421. Crotalopsis Michx. n. 6421. Croton L. 5827 .

CROTONEAE $B l$. p. 1118. Crotonopsis Rich. il. 5826 . Crowea Smith. n. 6007. Crozophora Nöck. 5829. Crucianella Linn. n. 3102.* Crueiata Tournef. n. 3100. e. CRUClat TAE p. 861.

Crucibulum Endl. n. 430. C. m.ch. Cruciella Leschen, n. 4364. b. CRUCIFERAE p. 861. Crucigenia Morren. u. 19. Crucita Lofft. n. 195t. "s. Cruckshanksia Hook. et Arn. n. 3137.

Crudia Schreb. n. $\$ 802$. Crudya Willd. n. 6802. Crumenaria Mart. n. 5748. Cruminium Desv. p. 1302. Crupina Cass. n, 2870. Crusea A. Rich. n. 3169. Crusea Cham. n. 3127. Crusea Cham. et Schl. n. 3125.* Crybe Lindl, n. 1609,* Cryphaea Brid. n. 589. Cryphaea Hamilt. n. 1819.

Cryphia $\boldsymbol{R}, \mathbf{B r}$. n. 3629. Cryphiantha Eckl. ot Z. n. 6465 . Cryphiospermum Palis, n. 2453. Cryphím Palis. n. 521. Crypsis Aic. n. 715.

Crypta Nutt. n. 5475. a. Cryptadia Lindl. n. 244t/1. Cryptandra Smith, u. 5742 . Cryptautha Lehm. n. 3784 Cryptanthus Klotsch. 11. 1303/, Cryptarrhena R. Br. n. 1458 Crypteronia Blum. в. 5756 . Cryptina Rafin, n. 5475 . Cryptocalyx Benth i. $3683 /$, Cryptocarpha $\boldsymbol{R}$. Br. n. 3036. Cryptocarpus H. B. K. n. 1936. Cryptocarya $R$. Br. n. 2036. CRYPTOCARYKAE p. 318. Cryptochilns Wall. n. 1389/, Cryptocaryne Fisch, n. 1671. CRYPTOCORYNEAE p. 23/. Cryptodracon Benlh, n. 3638 . c. Cryptogenis Nich. n. 655 . \begin{tabular}{|l|l} 
Cryptoglottis Blüm. 1369/s. & Curatella Linn, n. 4759.
\end{tabular} Cryptogramma Grev. n. 655 . Cureas Adans. n. 5806. Cryptogramma R. Br. n. 608.* Curculigo Gürtn. n. 1263. Cryptogyne DC. n. 2710, b. Curcuma Linn. n. 1623. Cryptolepis $\boldsymbol{R}, \boldsymbol{B r}, \mathrm{n}$. 3424.* Cryptolobus $S p r$. n. 6630. Cryptolobus Wall. p. 586. Cryptomeria Don. n. 1794./1. Cryptomyces Grev. n. 373 . Cryptopetalom Cass n. 2251. a. Cryptopetalum Hook. n. 4637. Cryptophragmium Nees. n. 4078. Cryptopodia Röhl, n. 575. c. Cryptopus Lindl. n. 1496. Cryptosete Hook. n. 551. Cryptospermum Young.n. 3097. Cryptosphaeria Grov. n. 394. Cryptosporinm Funze n. 197. Cryptostegia $R$. Br. n. 3431. Cryptostemma $R$. Br. n. 2886. Cryptostoum Schreb. n. 4265 Cryptostylis $\boldsymbol{R}$. Br. n. 1579 . Cryptotaenia DC. n. 4409. Cryptotheca Blum. n. 6141. Cszernaevia Turczian, n. 4448. Cteisium Richard, n. 663. Ctenium Panz. n. 843. Ctenopteris Blum. n. 615. a. d.* Cubaea Schreb. n. 6762 Cubeba Miq. n. 1920. a. *. Cobospermum Lour. n. 9109. Cucifera Delil, n. 1748. Cueubalus Tourn. n. 5251. Cuenila Blum, n. 1493, a. Cucullaria Buxb. n. 3099. Cucullaria Pers. n. 432 . a. Cucullaria Rafin, n. 4836. b. Cucullaria Schreb. n. 6071. Cucullifera Nees. n. 1011.

CUCUMERINAE p. 938. Cucumeroides Gärtn. n. 5130. Cucumis Linn, n. 5137. Cucurbita Linn. n. 5138. CUCURBITACEAE p. 934. Cucurbitaria Gray n. $39 \%$. CUCURBITEAR Ruiz el Pav. n. 4320 . Cudicia Hamilt. n. 3424. * Cnitlauzinia Llav, et L. n. 1469. Cujette Plum. n. 4171 . Culcasia Palis. a. 1689. Culeita Presl, n. 64t. b. * Culcitium II. et B. n. $280 \%$ Culhamia Forsk, 4. 5320, f. Cullamia $n$. Br. n. 2840. Cumada Jon, n. 3565. a. Cumaruna Lam. n. 6728. CUMINEAE p. 783.

Cuminia Colla. n. 3652.

Cumisum Linn. n. 4488. Cummingia Don. n. 1155. Cuncea Hamilt. n. 3114. Cunila Linn, n. 3614. CUNILEAE p. 618.

Cunninghamia $\boldsymbol{R}$. Br. n. 1796. Cunninghamia Schreb. n. 3193. Cunouia Buttn, n. 1239. Cunouia Linn. и. 4662 . CUNONIACEAE p. 813. CUNONIEAE p. 817. Cupameni Adans, n. 5787. Cupania Plum, n. 561\%. Cuphantha DO. n. 3337 . B. e. Cuphea P. Br. n. 615L. Cupi Aheede n. 3293. b. Cupia DC. B, 3293. b. Cupia Röm. et Soh. n. 3293. b. CUPRESSINAE p. 258.

Cupressites Brongn, n. 1812. Cupressus Tournef, a. 1791.

CUPULIFERAE p. 273.

Curanga Juss. n. 3940 .

Curania Röm. et Sch, a. 3941. Cycledium Wallr. v. 381. Curtisia Aiton, n. 4577 . Curtisia Schreb. n. 5972, d. Curtopogon Palis, n. 801. a. Cururu Plam. n. 5603. Cuscuta Tournef. n. 3816.

CUSCUTEAE p. 655.

Cusimbua DC. n. 2582. b.

CUSPARIEAE p. 1150. Cuspidaria $D C$. n. 4124/,

Cuspidaria Link. n. 4908 . b.

Cuspidella DO. n. 2395. b.

Cuspidia Gärtn, n. 2843. b.

Cussambium Rumph, n. 5621.

Cusso Bruc, n. 6395.

Cussonia Comm. n. 5469 .

Cussonia Thunb. n. 4552.

Culteria Grer. n. 105. a.

Cuttera Bafin. n. 3598. b.

Cutubea Mart, n. 3553 .

Cuviera DC. n. 3215.

Cuviera Koel. n. 915. b.

Cyamopsis DC. n. 6647.

Cyananthus Wall. n. 3826.

Cyanastrum Cass. n.2865. A. $\beta .1$.

Cyanea DC. n. 5020 .

Cyanea DC. u. 2571. UI.

Cyanea Gaud. n. 3065. *

Cyanea Renalm, u. 3528. et 3528. h.

Cyanella Linn, n. 1144.

Cyanitis Reinw. n. 4672 .

Cyanocephalus Pohl. n. 3583, f. Cyanopsis Blum, n. 2206.

Cyanopsis Cass. n. 2865. A. $\beta$. Cyanoseris Hoch, n. 3008, b,

Cyanospermum Wight et Arn. B. 6695 .

Cyanothamnus Lindl, n. 6005. Cyanotis Don, n. 1032.

Cyanotris Rafin n. 1066/2* *

Cyanus Baumg. n. 2871 .

Cyathanthera Pohl. I. 6260 .

Cyathea Smilh, n. 653 .

CYATHEACEAR p. 63.

Cyathella Decaísn. n. 346\%. *

Cyathia $P$, Brown. n, 34t.

Cyathidium Cass. n. 2853. a.

Cyathilliom Blum, n. 2206.

Cyathoellne Cars. n, 2398.

Cyathocoma Nees. n. 968, 1.

Cyathodes $\boldsymbol{R}, \boldsymbol{B r}$. n. 4271 .

Cyathodium Lehm, n. 462.

Cyathoglottis Pojpp. of Endt. n. 1610.

Cyathoides Michel, n. 34h.

Cyatholoma Benth, u. 4313. s. .

Cyathophora DO. n. 2496. a. Cyathophorum Palis. n. 587.

Cyathostyies Schott, n. 3853 .

Cyathula Loure ir, n. 1971

Cyathus Haller. a. 3h's.

Cybele $\mathrm{Fright}$ et Sal. n. 2156.

Cybelion Spreng. 11. 1452.

Cybiantlius Mart. 1t. 4220.

CXCADEACEAE p. 70. et 1352 CYCADEACEAE FOSSILES P. 72. et 13.52

Cyeadites Brongn. no. 712.

Cyeas Linn, n. 704.

Cyclachaena Fresen, u. 2'886. *

Cyclamea Tournef, n. 4201.

CXCLANTHEAE p. 242. et 2'63.

Cyclanthera Schrad. u. 5443.

CYCLANTHEREAE p. 939.

Cyelanthus Poit, n. 1714.

Cyclas Sehreb, u. 6802.

Cyclobothra Don, n. 1095. b. Cyclocarpaea $D C$ n. 4865.6 . Cycloderma Klotzseh n. 327. Cyclodinm Presl. n. 640. c. * Curtia Cham, et Schl, n, 3560. Cyclogyne Benth, n. 6534.

Cyclolepis Don, n. 2915. a. E.*

Cyclolepis Moq. n. 1929.

CXCLOLOBEAE p. 292.

Cyclolobium Benth, n. 6700 .

Cyclomyces Hunse 549 .

Cyclophorus Dest. n. 617.

Cyclopia Vent. n. 6422.

Cyclopogen Presl, N. 1547. b.

Cyclopoma Endl. n. 315. c.

Cyclopsis Zwill. n. 2915. *

Cycloptera $\boldsymbol{R}, \boldsymbol{B} r$. n. $2143 . \mathrm{g}$.

Cyclopteris Brongn, n. 677.

Cyclosanthes $P o p p p$. n. 1714 .

Cyclosia Flotesch in. 1420/

Cyclosperma Bonnemais, n. 42 .

Cyclospermum Lag. in 4397. b.

Cyclostegia Benth. n. 3588. b.

Cyclostemon Bl. n. 5837.

Cyclotella Kïtz. n. 1. a.

Cyclotheca Endl. n. 3078. b. *

Cycnia Lindl. n. 6't1t.

Cyenium E, Mog. n, 3963.

Cycnoches Lindl, u. 1418. *

Cycuogeton Endl. n. 166\%/1.

Cydonia Tournef. n. 6341.

Cylactis Rafin. ․ 6360 .

Cylichnium Wallr. a. 315 . b.

Cylicheus Targ. n. 94. A.

Cylicodaphe Nees. n. 2058.

Cylindria Loureir. p. 343.

Cylindrocline Cais. n. 2419.

Cyliadrolobus Blum. n. 1392.

Cylindropus Nees. nt. 964. a.

Cyliudrosporium Grev, n. 183.

Cylindrosorus Benth. n. 2719.

Cylipogon $A$ afin, в. 6522 . b.

Cylista Ait. ".. 6694.

Cylizoma Neck. n. 6733.

Cymanthus $E$. n. 52't6. a. $\beta$.

Cymaria Benth, n. 3681 .

Cymation Spreng. H. 1071.

Cymbachne Rets. u. 927 . b.

Cymbalaria Chav, n. 3891. c. 
CYNOMORIE AE p. 74.

Cynomorium Miehel. n. 717. Cynomorium Rumph. n. 6784. Cynontodium Hedw, n, 538. Cynophalla DC. a* 5000. d. Cynophallus Fries n. 358. a. Cynopsole Endl. a. 719. Cynorchis Thouar. n. 1529. v. 1526 .

Cynorrhiza Eekl, et Z. n. 4k6' Cynosbata DC, n. 60/8. c. Cynoseiadium DO, n. 4423. Cyuosurus Linn. n. $39 \%$. Cynotis $H o f f m, n, 2836$. Cyuotoxieum $F l . F l$. p. 1334. 18 Cynthia Don. n. 2982. Cypella Herb. n. 1228/, Cypellium Desv. n. 4252 . b. Cypellon Targ. n. 94. b. CYPERACEAE p. 109. et 1355. CXPEREAF. p. 118.

Cyperus Linn. n. 1003.

Cyphelium Achar, n. 129, a. Cyphelium Chev, n. 129. b. Cyphella Fries. n. 409.

Cyphia Berg. n. 3041. *

Cyphiella Prest. n. 3041 . e.

Cyphorima Rafin. n. 3761. c. Cyprianthe Spach. n. 4783.* CXPRIPEDIEAE p. 220. Cypripediam Linn, n. 1618.

Cypselea Turpin. n. 5173.

Cypselodontia DC, n. 2463/1.

Cyrbasium Herit. в. 4166.

Cyrilla Gard, in. 4344/1.

CXRILLEAE p. 1413 . *

Cyrta Benth. n. 3583. e.

Cyrta Loureir. n. 4255.

Cyrtaadra Forst. n. 4146. *

CYRTANDRACEAE p. 715.

Cyrtanthus Ait. n. 1279.

Cyrtanthus Herb. n. 1279.

Cyrtoearpa $\boldsymbol{H} . \boldsymbol{B}, \boldsymbol{K}$, n. 5897. Cyrtocerus Benn, i. $3501 /$.

Cyrtochilum H. B. K. R. 1464. Cyrtocodon Benth, n. 3996. b. Cyrtodon $\boldsymbol{B}, \boldsymbol{B} r$, n. 502, a. Cyrtogyne Haworth. n. 4614 . Cyrtolepis Less, n. 2644.

Cyrtolobus $A, B r$, n. 6472. e. Cyrtomium $\boldsymbol{H}$. B. $\boldsymbol{K}$. n. 1465 . Cyrtonema Sehrad, n. 5125. Cyrtoaora Zippel. p. 1334. 19 Cyrtopera Lindl. n. 14t6. * Cyrtophlebium R.Br.n.615.g." Cyrtophyllum Reinw. n. 3367 . Cyrtopodium Brid, n. 551. Cyrtopus Brid, n. 575. b. Cyrtorhyneha Nute. n. 4771 . Cyrtosia Blum, n. 1613. * Cyrtospermum Rafin. n. 4409. Cyrtostachys Blum, n. $1752 \%$ Cyrtostigma Enal. n. 2129. b. Cyrtostylis $\boldsymbol{R}, \boldsymbol{B r}, \mathrm{n}, 1590$. * Cyrtotropis Wall. n. 6670. Cystanthe $\boldsymbol{A} . \boldsymbol{B} r$. n. 4289. Cystapophysium Reich.n. 503 Cysticapnos Beerh, n. $48^{4} 2$. Cystopteris Bernh, n. 641. * Cystoseira $A_{g}$. n. 120. Cytheraea DO, и. 5920. b. Cytheris Lindl. n. 1389. CYTINEAE p. 75. et 1352. Cytinus Limn, n. 722. Cytispora Ehrenb. n. 367. CYTISPOREI p. 31.

Cytisus Kinn, n. 6505.

Caackia Andr. n. 1145. b.

Czernya Presl, n. 824.

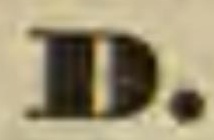

Daboecia D. Don, 4347. e. * Dacrina Fries n. $26 \%$.
Dacryanthus Endl. n. 4292, a. Dasyphyllum $\boldsymbol{H}$. B. K. n. 2901, * Dacrydium Sol, n. 1801. Dacrynyces Nees. n. 401. Dacryodes Vahl, n. 593h. * Dactylaena Schrad, n. 4986. Dactylanthus Haw. n. 5766. Dactylicapnos Wall. n. 4835. Dactyliota Blum. n. 6246. d. Dactylis Linn. n. 892.

Dactylinm Nees. n. 224. Dactyloctenium Willd. n. 837. Dactyloides Tausch, n. 4634. c. Dactylon Vill. n. 770.

Dactylophyllum Benth, n. 3821 .e. Dactylostylis Scheidw. n. 1403/1 Dactyphyllum Hafin. n. 6511. e. Daedalea Pers. n. tyt6.

Daemonorops Blum. a. 1740. Dahlia Cavan, n. 2449.

Dahlia Thunb. n. 4590.

Dais Linn. n. 2093.

Dalbergaria Tuss. n. 4163.

Dalbergia Tuss. n. 4163.

Dalbergia Linn. f. n. 6717 .

Dalbergia Vogel. n. 6718.

DALBERGIEAK p. 1302.

Dalea Gärtn. n. 3730.

Dalea Linn. n. 6523.

Dalea $P$. Br. n. 2279.

Dalechampia Plum, n. 5768 .

Dalhousiea Wall. n. 6't2\%.

Dalia Adans. n. 4344.

Dalibarda Linn. в. 6359.

DALIBARDEAE p. 1241.

Dalrympelea Roxb. n. 5671 .

Daltonia Hooker, n. 577.

Damasoninm Juss. n. 1043.

Damasonium Schreb. n. 1213.

Damatris Cass. p. 503. 11.

Dameria Dennst. n. 4223. "

Damironia Cass. 2742. a.

Danuara Gárln. n. 5935

Dammara Rumph. и. 1798. e 5892.

Daminacanthus Gärtn. f. n. 3178. Dampiera R. Br. I. 3040. Danat Coll. n. 2811. XII. Danäe Modik. n. 1188. b. Danaea Alion, 4540 .

Damaea Smith. n. 669 .

Danaida Link. n. 1188. b.

Danais Comm, n. 3267.

Dangervilla $F l . F l$. n. 5990.

Danielia DC. n. 4615 . a.

Danthonia $D C$. n. 871.

Dantia Thouar, n. 6111. a.

Daplue Linn, n. 2092.*4318.

Daphuidium Nees. n. 2065.

Daphniken Pohl. n. 5700.

Daphniphyllum $\mathbf{B l}$. n. 5755.

Daphaitis Spreng. n. 5907.

DAPHNOIDEAE p. 329. et 1378.

Daphuopsis Mrart, n. 330. a.

Darea Juss. n. 630. a. $\gamma$.

Dargeria Cham. ot Schlecht. n. 3993.

Darlingtonla DC. n. 6830.

Darluca Hafin. n, 3154. b.

Dartus Loureir. n. 3872.

Darwinia Dennst. n. 2066. *

Darwinia Rudg. n. 6282.

Dasauthera Rafin. ․ 3909.

Dasus Lour. ח, 6262.

Dasya Ag. n. 66.

Dasyanthera Presl. n. 5078. Dissyanthus $D$. Don. n. 4313 . b.
17. *

Dasycephala Borkh. n. 3528. c. Dasycephala DO. n. 3123. b. Dasycladus Ag. n. 73 .

Dasylirion Zuce, n. 1314/, Dasyloma $D C$. n. 4422 . Dasymalla Endl. II. 8733 .

Dasynema Schott. n. 5362 .
Dasypogon $R, B r$. a. 1057 . Dasyscyphus Fries. u. 430, B. g. Dasystemon DC. и. 4603. Dasystephana Ren, n. 3528. b. Dasystona Raf. n, 3996, c.

Dasytricha Lamx. n. 74.

Datisea Linn, n. 5016.

DATISCEAE p. 897.

Datura Linn, n. 3845 .

DA TUREAE p. 663.

Danbentonia DC. n. 6554 . Daubenya Lindl. n. 1127, * DAUCINEAE p. 784.

Daucus Tournef. n. 497 .

Davallia Smith, n. 643.*

Daviesia Lam, n. 1170.

Daviesia Smith, n. 6435

Davilla Vell. n. 4763.

Davya $D C$. 口 6173.

Davya Mog. et Sess, n. 5414

Dawsonia Lamx. in. 92.

Dawsonia $\boldsymbol{A} B r$. n 565 .

Dayenia Mill. n. 5332.

Debraea $\boldsymbol{R}$, et $S c h$ a 6073 .

Decaehaeta $D C$. n. 272. *

Decadenia Ehrenb. n. 5484. b.

Decadia Lour. n 6259 .

Decaisnea Brongn. n. 1587.

Decaisnea Lindl, n. 1566.

Decaloba $D C$. n. 5098 c. $\alpha$.

Decanema Dec. n. $3456 \%$.

Decaneurum $D C$ n. 2405 .

Decarhaphe Miq. n. 6257.

Decaria $D C$. n. 5099, b.

Decasehistia $W_{\text {. }}$ et $A$. n. 5285.

Decaspermum Forst. n. 6313.

Decaspora $\boldsymbol{R} . \boldsymbol{B r}$. n. 4277.

Decemium Raf. n. 3827.

Deckera Sehultz. n. 2999.

Deelieuxia $\boldsymbol{H}, \boldsymbol{B}, \boldsymbol{K}$. п. 3169.

Decodon Gmel. n. 6147. a

Decostea Ruiz et P. n. 4576 .

Decumaria Limn. n. 6106.*

Deeringa Adans, n. 4407. *

Deeringia $\boldsymbol{R} . \boldsymbol{B r}$. n. 1978.*

Defforgia Lam. n 4676 .

Deguelia $A u b l$ n. 6733 .

Dehaasia $B l u m$. n. 2032.

Deidamia Thouar. n. 5097 .

Deilosma C. A. M. n. 4903. b. Deiuböllia Schum. n. 5638/.

Dejanira Ch. el Schl. n. 3548 .

Delaria Desv. p. 1255.

Delesserites Brongn. n. 122.

Delila Dum. n. 5218.

Delilia $s_{p r}$ n, 2457 .

Delima Linn. n. 4766.

DELIMEAE p. 842.

Delisea $\operatorname{Lamx}$, n. 93.

Delisella Bory n. 72

Delissea Gaudich, n. 506\%.

DELISSEACEAE p. 522.

Deloderium Cass. n. 3021.

Delostoma Don. n. 4122 .

Delostylis Raf. n. 1177 .

Delphinastrum $D C$. n. 4796. e. Delphinellum $D C$. n. 4796. b. Delphinimm Tourn, n. 4796.* Deltocarpus Herit. n. 4913.

Delucia DC. n. 2567 . *

DEMATIEI p. 20.

Dematium Pers. n. 235.

Demetria Lag. n. 2364.

Democritea Fl. $F t$. p. 1334. 20.

Demidium DC. n. 2751.

Demidofia Dennst. n. 6102

Demidofia Gmel. n. 3788 .

Demidovia $H \circ$ offm. n. 1176, a.

Demidovia Pall. n. 5164.

Demoeritea $D C$, n. 3118.

Denckea Raf. n. 3528. d.

Dendragrostis Nees. n. 906 . \&.
Delesseria $\operatorname{Lam} x$, n. 100. d.

Dendranthema $D C$. n. 2670 . e. Dendrarabis $C . A . M$. n. $4854 . \mathrm{d}$. Dendrina Fries. n. 209. Dendriuu Desv. n. 4343. DENDROBIEAE p. 190.

Deudrobium $S_{\text {warts. n. }} 1369 . *$ Dendrobrychis DC. n. 6619. e. Dendrocalamus Nees. u. 909. c. * Dendrochilum Blum. n. 131.

Deadrocrambe DC. n. 4967. e.

Dendrocolla Blum, n. 419.

Dentidia Lour n. 3575.

Diaphyllum $\mathrm{Hoffm}$, n. 4414.

Diarina $R a f$. n. 903

Diarrhena Palis n. 903

Diarthron Turez n. 2096.

Diaseia DC. n. 1244.

Diascia Link n. 3887.

Diaspasis $\boldsymbol{R}, \boldsymbol{B r}$. n. 3039 .

Diastella Salisb. n. 2124. b.

Diastrophis E. et M. n. 4890 .

Diatoma $D C$ n. 8 .

Diatoma Lour. n. 6102 et 6337.

DIATOMACEAE p. 1. et 1337.

Diatropa Dumort. n. 4/14.

Diazeuxis Don. n. 2910.

Dicaeoma Nees. n. 185.

Dicalyx Lour. n. 5407.

Diearpaea Presl n. 5258.

Dicarpella Bory. n. 69.

Dicarphus $R$ af, n. 442 , a.

Dicella Gries. n. 5587.

Dicentra Borkh. n. 4836 .

DICENTREAE p. 859.

Dicera Forst. n. 5385 . c. 5387.

Diceraudra Benth, n. 3622 .

Diceratium Ait, n. 4846 .

Dicerma $D C$. n. 6616 .

Diceroearyum $B o j$. n. 4180 .

Diceros Lour. n. 4023.

Diceros Pers. n. 3954. 
Deppea Ch. et Schl. n. 3136.

Dermasea Haw. n. 4634. e.

Diascia Link. n. 5887

Dermatocarpon Eschw. n. 157. Diasia DC. u. 1244.

Dermatodea Vent. n. 173.

Dermea Fries. n. 379.

DERMEI p. 32.

Derminus Fries. n. 448. e.

Derminus Fries, n. 453 . IV.

Dermoeybe Fries. n. 453. V. a

Dermodium Nees. n. 306 . e.

Derris Lour. n. 6722.

Deschampsia Palis. n. 857.

Descliea Flor. mex. n. 3166.

Descurainia $W$. et $B$. n. 4906 . d. et $\mathrm{e}$.

Descurea Guett. n. 4906. e.

Desfontainea $\boldsymbol{R}$. et $\boldsymbol{P}$. n. 3875 .

DESFONTAINEAE p. 669.

Desfontainesia Hoffm, n. 3554. * Desfontenaea $\boldsymbol{F l}$. $\boldsymbol{F l}$. p. 1125.

Desmantha $D C$. n. 6828. b.

Desmanthus Willd. n. 6828.

Desmarestia $\operatorname{Lamx}$. n. 111.

Desmaretella Bory, n. 57.

Desmatodon Brid, n. 533.

Desmia D. Don. u. 4313. a. 2.*

DESMIDIEAE p. 3 .

Desmidium $A_{g}$. n. 24 .

Desmidorchis Ehrenb. n. 3521. *

Desmoearpus Wall, n. 4993. b.

Desmochaeta $D C$. .. 1970.

Desmoehaeta Kunlk. n. 1971.

DESMOCHAETEAE p. 303.

Desmodium Desv. n. 6615 .

Desmoucus Mart. n. $176 \%$.

Desmos Lour. n. 4717. b.

Desmotrichum Blum, n. 1369.

Despretzia Funth, n. 759.

Desvauxia $R . B r, n .1006$.

DESVAUXIEAE p. 119.

DETARIEAE p. 1322.

Detarium Juss. n. 6816.

Dethardingia $N$. et $M$. n. 1774.

Dethawia Endl. n. 4 435.

Detridinm Nees. n. 2299. a.

Detrioides Less. n. 2299, a.

Detris Adans. n. 2299. b.

Deutzia Thunb. n. 6107 .

Devauxia Palis, n. 878. a

Deverra DC. n. 4427.

Deverraria DC. и. 4t27. a.

Devillea Bert. ․ 1307.

Deweya T. et A. Gr. n. $4543 / x$. Deyeuxia Clar. n. 818 .

Diabasis $D C$. n. 2669. a. 1. *

Diacaecarpium Blum. p. 547.

Diacalpe Blum. p. 648 .

Diacantha Lag. n. 2901.

Diacantha Less. n. 2900. *

Diaehea Fries. n. 313.

Diadenium Pöpp. et E. n, 1453.

Diagrammaria Presl. n. 636, c. *

Diagramme Blame. a. 609. a.

Dialesta $\boldsymbol{H}$. B. $\boldsymbol{K}, \mathbf{n}$. 2219.

Dialium Linn, n. 6805 .

Dialium Willd. n. 6804.

DIALYPETALAE p. 762.

Diamorpha. Nutt. n. 462 '.

DIAMORPHEAE p. 812.

Diamoste Cham. n. 3926, b.

Diamphora Mart. n. 250.

Diana Comm. n. 1160.

Dianella Lam, n. 1160. *

DIANTHEAE p. 970.

Dianthera Sat. n. 4093.

Dianthoides Endl. n. 3821. d. Dianthus $L$. n. 5244.

Diapensia $\operatorname{Linn}$, n. 4345 .

DIAPENSIACEAE p. 760.

Diaphora Loureir. p. 119. b.

Diaphorapthus Mejen, n. 2943.

Diaphyllum Hoffm. n. 4414 .

Diarina Rafin. n. 903.

Diarrhena Palis. n. 903.
Diaspasia R. Br. n. 3039.

Diastella Salisb. n. 212\%. b.

Diastrophis $\boldsymbol{E}$. et $M$. n. 4890 .

Diatoma $D C$. n. 8.

Diatoma Lour. n. 6102 et 6337 .

DIATOMACEAE p. 1 et 1337.

Diatropa Dum, n. 4t14.

Diazeuxis Don, n. 2910.

Dicaeoma Nees. n. 182.

Dicalyx Lour. n. 5407.

Dicarpaea Presl. n. 5258.

Dicarpella Bory. n. 69.

Diearphus Rafin, n. 4i2, a.

Dicella Grieseb. n. 5587 .

Dicentra Borkh. n. 4836.

DICENTREAE p. 859.

Dicera Forst. n. 5385 . c. 5387.

Dicerandra Benth. u. 2622.

Diceratium Aiton, n. 4846.

Dieerma $D O$. n. 6616.

Dicerocaryum Bojer. n. 4180 .

Diceros Lour. n. 4023.

Diceros Pers. n. $395 \%$.

Dicerus $E$, n. 5385 , c.

Dichaea Lindl. n. 1463.

Dichaena Fries. n. 393.

DICHAENEI p. 33.

Dichaetanthera Endl, n. 6227.

Dichelachue Endl. a. 796.

Dichelomitrium Endl. n. 3566, d.

Dichilus $D C$. n. 6' $\$ 80$.

Dichloria Grev, n. 111.

Diehodou Bartl. ni. 5241 , a.

Dichoglottis Fisch. et Moy. n. 5245. a.

Dichoudra Forst. n. 3788.

DICHONDREAE p. 652.

Dichopetalum Thouar, n. $\mathbf{5 7 5 8 .}$

Dichorisaudra Mikan, n. 103's.

Dicltosema Benth. n. 6449.

Dichosemaea Benth, n. 6738. c.

Dichosma DC. n. 6021.

Dichosporium Nees. n. 293.

Dichostylis Palis. n. 999. b.

Dichotophyllum Dillen. n. 1829.

Dichroa Lour. n. 6882.

Dichroaathus Webl, et Berth. a. 4846 . b.

Dichrocephata $D C$. n. 2396.

Diehroma Cav. n. 3986. b.

Dichromena Neer. n. 976. b.

Dichromena Rich, n. 976 .

Dichrostachys Wight et Arn. n. 6826 .

Dicknekeria $F l$. Fl. n, 2148.

Dicksonia Ehrh. a. 595.

Dicksonia Herit. n. 640.

Diclidanthera Mart. n. 5253.

Dieliderma Bonnemais. n. 62.

Dielinothrys Raf. a. 1066. b.*

Dicliptera Juss. u. 4093.

DICLIPTEREAE p. 706.

Diclis Benth, H. 3889.

Diclytra Borkk. n. 4836, b.

Dicnemon $S_{c h w a ̈ g r}$ a, 582.

Dicoceum Corda. n. 202.

Dicoma Cass. n. 2930. *

Diconangia Mitchel. n. 4677.

Dicorypha Spreng. n. 4588.

Dicoryphe Thouars, a. 4588.

Dicrananthera Presl. n. 6193.

Dicranilla Fenzl, n. 5243. e.

Dieranophlebia Mart, a. 652. b.

Dieranopteris Bernh, n, 659, a.*

Dicranopteris Blum. n. 615. a. $\beta$."

Dieranem Hedw. n. 527.

Dicrobotryon Willd, n. 3192, b.

Dicrypta Lindl. n. 1414.

DICTAMNEAE p. 1159.

Dietamuus Linn. n. 602\%.
Dicraeia Thouar, ni. 1832.
Dietycia Rafin. n. 355. c. Dietydium Schrad, n. 314. Dictylema $R$ af. n. 55 .

Dietyocarpus Wight. n. 5289. Dictyochiton Oorda. n. 464.

Dictyomenia Grev. n. 90.

Dietyonema $A_{6}$, n. 248.

Dictyopeplos Hasselt. n. 358 . e.

ictyopetalum Fisch. ot Meg. n. 6118 . a.

Dietyophora Desv, n. 358. e. Dictyophyllum Lindl. n. 686 , Dictyopteris Lamx. n. 90. et 105. c.

Dictyosiphon Grev. n. 106.

Dictyostega Miers. n. 1218/s.

Dictyota Fries. n. 105.

Dictyota Lamx. n. 105. b.

Dictyotites Brongn, n. 122, c.

DICYPELLIA p. 320.

Dicypellium Nees. n. 2045.

Didelta Cass, n. 2843, a.

Diderma Pers, n. 318.

Diderota Comm. n. 3389.

Didesmus Desv, n. 4969.

Didiplis Hafin. p. $6143 / 1$.

Didiscus DC. n. 4361.

Didymandra Willd, n. 1906.

Didymanthera Benth. n. 4313.

a. 10 , *

Didymanthus Endl. n. 1920\%.

Didymeles Thouar. n. 6845 .

Didyminm Schrad, n. 317.

DIDYMOCARPEAE p, $\mathbf{7 1 5}$.

Didymocarpas Wall. n. 4138 .

Didymocephalon Meisn, n. 1986. e. $\alpha$.

Didymochiton $B l$, n. 5535 ,

Didymochlaena Desv. a. 637.

Didymocrater Mart. n. 249.

Didymodon Hedw. n. 530.

Didymoglossum Desv, n. 658.

Didymonema Prest. n. 981.

Didymosporium Nees, n. 195.

Didymotoce Endl. n. 3240. d. $c$.

Diectomis Kunth. n* 947 .

Diectomis Palis, n. 948.

Dieffenbachia Schott. n. 1692.

Dienia Lindl n. 2336.

Dierbachia Spreng, n. 3866.

Diervilla Tournef, n. 3336 . *

Diesingia Endl. n. 6681 .

Dieterica Seringe n. 4661 .

Dietes Saltsb, n. 122\%.

Dietrichia Trattin. nt 4615 . h.

Digenia $A_{5}$. n. 88.

Digera Forsk, u. 1969.

DIGITALEAE p. 676.

Digitalis Tournef. n. 3915.

Digitaria Juss. At 836.

Digitaria Seop, n. 770.

Diglossus Case. n. 2580.

Diglottis Nees. et Mart, n. 5991.

Diglyphis Blum. u. 1360 .

Digonocarpus Ft. Fl. n. $561 \%$.

Digraphis Trin. n. 753. b.

Dilaena Dumart. n. $472 / 6$.

Dilatris Berg. A. 1254.

Dilepis Endl. a. 960. a.

Dileptimm Rafin. n. 4932. f.

Dilepyrum Michx. n. 803.

Dilepyrum Raf. n. 793.

Dilivaria Juss, n. 4069.

DILLENEAR p. 839. et 840 .

Dillenia Heist. n. $310 \%$.

Dillenia Linn, n. 4749.

DILLENIACEAE p. 839.

Dillwynia Roth. n. 6475 .

Dillwynia Smith, n. 6\%41.

Dillwyniastrum $D C$. a. $6^{\prime \prime} 41.3$

Dilobeia Thouar. n. 6846.

Dilobos Endl, 4. 4115 .

Dilochia Lindl, n. $13^{\prime} 45$.

Dimaeria Lindl. n. 6048. b.

Dimereza Lab. n. 5614 .

Dimeria Endl. n. 936. b.

Dimeria Raf. n. 755 .

Dimer ia $\boldsymbol{B}, \boldsymbol{B r}$. n. 936.

Dimerostemma Cass, p, 503.12.

Dimetia Wight. et Arn, n. 3240.c.

Dimetopia $D O$. n. 4358.

Dimia Spreng. n. 3458.

Dimocarpus Lour. n. 5617.

Dimorpha Willa. n. 6801.

Dimorphandra SchoLt. n. 6824.

Dimerphanthes Cass, n. 2405.b.*

Dimorphopetalum Bert.a. 4627 .

Dimorphotheea Paill. n. 2672. a.

Dinema Lindl. n. 1372.

Dinemaadra A. Juss, n. 5565.

Dinetus Endl. n. 3797. a.

Dinkleria Neck, n, 47 '.

Dioclea $\boldsymbol{H}, \boldsymbol{B}, \boldsymbol{K}$, n. 6662

Dioelea Spreng. n. 3766.

DIOCLEAE p. 1292.

Diodia Linn. n. 3123.

Diodols Pohl. n. 3131 .

Diomedea Cass, n. 24't5.

Diomedes Haw. M. 1289. c.

Dionaea Ellis. n. 5037 .

Diorthodon DC, n. 26't3. b.

Diorygua Eschweit. 11. 147.

Dioseorea Plum. n. 1201 .

DIOSCORKAE p. 157.

Diosma Berg. n. 6017.

Diosma Lour. il. 5981.

DIOSMEAE p. 1149.

Diospyros Linn. n. 4249. .

Diostomaea Spenn. I. 1551.

Diotanthera $\boldsymbol{D C}$. n. 6210. b.

Diothonea Lindl. n. 1373.

Diotis Desf. n. 2650.

Diotis Sehreb. n. 1911.

Diotoealyx $D C$. n. 2190 . a. 
Diplodon Spreng, n. 6161 . Diplogenea Lindl. n. 6249. Diploglossum Meion. n. $3493 . *$ Diplogon Rafin. n. 2373. Diplogonia Palis. n. 828. Diplolaena Dumort. n. 472/. Diplolaena $\boldsymbol{B}, \boldsymbol{B r}$, n. 6011 . Diplolepis R. Br. n. 347 4. Diplolobium Benth. n. 6448. b. Diplomeris Don. n. 1528. DIPLOMITRIEAR p. 1339. Diplomitrinm Corda. n. $472 /$. $^{\text {* }}$ Diplonema Don, n. 4250. * Diplonyx Rafin. u. 6530. DIPLOPAPPEAE p. 376. Diplopappus DC, n. 2321. Diplopappus Less, n. 6381. Diplopeltis Endl. n. 5625. * Diplopetalon $S_{p r}$. n. 5614 . Diplophractum Desf. n. 6377 . Diplophragma A. Br. n. 2158. a. Diplophiragma Wight et Arn. n. 3240 . a.

Diplophyllum Dum, n. 473. a.* Diplophyllum Lehm. n. 3979. a. Diplopogen R. Br. n. 828. Diploprion Visian. n. 6507. b. Diplopterys A. J. n. 5567. Diplosastra Tausch. n. 2527. Diplospora De. n. 3176 .

Diplosporium Link. n. 221. Diplostachium Palis, n. 696. Diplostegium Don. n. 6215. Diplostemma Hochst. n. 2966/1. Diplostemon Wight et Arn. n. 6146. a.

Diplostephium Cass. n. 2319. Diplostephium Kunth. n. 2319. b. Diplostoma Link. n. 332. Diplotaxis $I C$. n. 4955.

Diplotheminm Mart. n. 1774 . Diplothrix DO. и. 2548. Diplotropis Benth. n. 6748 . Diplusodon Pohl, n. 6161. Dipodium R. Br. n. 1441.* Diporialum Wendl, n. 5959. Diposis DC. n. 4375 . DIPSACEAE p. 353.

Dipsacus Tournef. n. 2191. Diptera Borkh. n. 4634. g. Dipteracanthus Nees. n. 4043. Dipteris Reinw. n. 615. k. $\gamma$. aa.* Dipterix Sehreb. n. 6728.

Dipterocalys Oham, n. 3684. a. DIPTEROCARPEAE p. 1012. Dipterocarpes Gärın, n. 5392. Dipterocome Fisch. ot Mley. n. 2424.

Dipterygia Prest, n. 4370. Dipterygium Decaisn, n. 4936. Diptherium Ehrenb, n. 321 . Dipyrena Hook. n. 3689 . Diracodes Blum, n. 1629. Dirca Linn. n. 2091.

Dirina Fries. и. 171.

Disa Berg. n. 1537 .

Disaccium DO. n. 4948.

Disandra Linn, \#. 3975.

Disarrhenum Labill. n. 755.

DISCANTHA F p. 762.

Diseanthera Torr. et A. Gray. n. $5143 / 1$.

Discapophysium Reiehenb. n. 503. b.

Discaria Hook. ․ 5731.

Discelium Brid, u. 517 .

Dischidia $\boldsymbol{R} . \mathbf{B r}$, n. 3508 .

Dischisma Chois. n. 3728.

Discocactus Pfeiff. n. 5155 .

Discoealea $D C$. n. 2616. a.

Discocapnos Cham. et Schlecht. n. 4840.

Discoceuia $D C, \mathrm{n} .2685$. a.

Discolobium Benth, n. 6722 .
Discomela Rafin, n. 2538. Discopleura $D C, 4398$.

Discopoda DC. n. 2541. e. Diseoseris Endt. n. 2909. b. Discovium Rafin. p. 889.

Disella Lindl. n. 1537. b. a. * Disemma Labill, u. 5100.

Disemone Banks. et Sol. n. 1889. a.

Disparago Gärtn. n. 2758.

Disparella $D C$. n. 2758, a.

Dispeltophorus Lehm. p. 880 .

Disperis Swarlz. n. 1543.

Disphenia Prost. n. 653 . c. *

Disporum Salisb, n. 1082.

Dissochaeta Blum, n. 6246.

Dissodon Grev. et Arn, n. 502. a.

Dissolena Lour, p. 586. 4 , Distasis DC. n. 2324.

Distephana Juss. a. 5104, b.

Distephanus Cass. n. 2215.

Distephia Salisb n. 5101. b.

Distichactis Endl. n. 2353. a.

Distichia Brid. n. 575. c.

Distichlis Haf. n. 876, a.

Distichmas Raf. p. 119. e.

Distimus Raf. n. 1003. a.

Distrepta Miers, p. 1334. 21.

Distreptus Cass. n. 2231. c.

Distylis Gaudich, n. 3045.

Disynanthus Rafin, n. 2767, a

Disynaplia DC. n. $2268 / 2^{*}$.

Ditassa R. Br. и. 3459 .

DITASSEAE p, 590.

Ditaxia Rafin. n. 3879, a.

Ditaxis Vahl. n. 5832.

Ditheca Wight et Arn.n.6146. b. Ditiola Fries. n. 42\%.

Ditoea Banks et Sol. n. 5221.

Ditriehumm Timm. n. 530 .

Ditrichum Cass. n. 2551.

Dittmaria Spreng. n. 6073.

Diuris Smith. u. 1584.

Dizonium Willd. n. 2457.

Dobera Juss. n. 6883.

Dobinea Ham, n. 5560.

Dobrowskya Presl. n. 3056 .

Dodartia Tournef. n. 3930.

Dodecadenia Nees. n. 2063.

Dodecantheon Linn. n. 4202.

Dodecas Linn. n. 615\%.

Dodonaea $L$. n. 5626.

Dodonaea Plum n. 5896.

DODONAEACEAE p. 1072.

Doemia $\boldsymbol{n}, \boldsymbol{B r}$, n. 3458 . *

Dolichandra Cham. n. 4118 . a

Dolichlasium Lagaso. n. 2961.

Dolichogyne DC: n 3032/.

Dollehouema Nees. n. 6780.

Dolichos Gärtn, n. 6677 .

Dolichos Linn, n. 6676.

Doliehostylis Cass. n. 2904.

Doliocarpus Roland. n. 4761 .

Dollinera Endl, n. 6614.

Dóllingeria Nees, n. 2314.

Dolomiaea $D C$. n. 2855.

Dolophragma Fenzl. n. 5232.

Dombeya Cav. n. 5346.

Dombeya Herit. n. 4111.

Dombeya Lamarck. n. 1797.

DOMBEYACEAE p. 1001.

Donacodes Blum, n. 1628.

Douatia Forst. n. 4630.

Donatophorus Zipp.p. 13\%4, 22.

Donax Palis. n. 821.

Dondia Spreng. n. 4383.

Dondisia DC. n. 3216.

Dondisia Neck, n. 4971.

Dondisia Reichenb, n. 4383.

Donia Don. n. 6567 .

Donia Less. n. 2133. đ.

Donia F. Br. n. 1983.

Donia R. Br, n. 236 .
Donioides DC, n. 2433. d. Dontostemon Andrz. n. 4904. Donzellia Tenor. n. 6847. Doodia $\boldsymbol{R}$, Brown. n. 632. * Doodia Roxb. n. 6610 .

Doosera Roxb. n. 5185. a. Dopatrium Hamilt. n. 3947. Doraena Thunb. n. 3873. Doranoxylon Ner. p. 1074. Doratanthera Benth. n. 3961. Doratium Soland. a. 4577.

Doratolepis Benth. n. 2736. Doreadion Adans. n. 509.

Doreaceras Bunge. n. 4140 .

Dorema Don. в. 4460.

Doria Adans. n. 2376.

Doria Less. n. 2828. a.

Doriena Dennst. n. 5978.

Doritis Lindl. n. 1435.

Dorobaea Cass. n. 2811.

Doronicum Linn, n. 2802.

Dorstenia Plum, n. 1860.

DORSTENIEAE p. 277.

Dortmanna Rudb. n. 3058. c.

Dorvalia Comm. n. 2125.

Doryanthes Correa. n. 1296.

Doryehnium Mönch. n. 6526.

Doryenium Tournef. n. 6512

Doryenopsis Boiss. n. 6513 .

Doryphora Endl, n. 2022. *

Dothidea Fries. n. 384.

DOTHIDINI p. 33.

Donglasia Lindl. n. 4196.

Donglassia Schreb. n. 2050.

Douma Lam, n. 1748.

Doupea Cambess. n. 4951.

Draba Linn, n. 4880.

Drabella $D C$. n. 4880, a.

Drabella Torr. et A. Gray. n. 6575 . c.

Dracaena Vandelli n. 1167.

Dracocephalum Linn. n. 3638.*

DRACONTIEAE p. 240.

Dracontium Linn, n. 1704.

Dracophyllum Labill. n. 4292.

Dracopis Cass, n. 2515, *

DRACUNCULINAE p. 234.

Draenneulus Bess. n. 2694. a. Dracuneulus Tournef. n. 1679. Drakaea Lindl, n. 1598/,

Drakensteinia Neck. n. 6703.

Draparnaldia Bory. n. 49.

Draparnaldina Bory. n. 50.

Drapetes Lam. n+ 2097.

Drapiezía Blum, n. 1083.

Dregea E. Mey. n. 3494. *

Dregea Eckl. et Zejh. n. 4463. Drepanandrum Neek. n. 6261 . Drepania Juss. n. 2979.

Drepanocarpus $\boldsymbol{C}$. F. W. Mey. n. 6709.

Drepanolobus Nutt. n. 6517. Drepanophyllum Hoffm, 4401 . Drepanophyllum Rich, n. 596. Drepanospron Benth. n. 667\%. a. Drimia Jacqu. n. 1125. *

Drimyphyllum Burch. n. 2455. Drimys Forst. n. 5742.

Drimyspermum Reinw, n. 2109. Dripax Noronh. n. 5047.

Droquetia Gaudich, p. 285.

Drosanthe $S_{p a c h}$. n. 5464. A.b. Drosera Linn, n. 5033 . * DROSERACEAE p. 906.

Drosocarpium Spach, n. 546'. B. b. $\delta$.

Drosophyllum Link. n. 5036. Drozia Cass. n. 2962. a. $\beta$, * Drummondia DC. n. 4640, a. DRUPACEAE p. 1250. Drupasia Rafin, p. 31 . Drusa DC. n. 4372.

Dryadanthe Endl, n. 6366.

DRYADEAE p. 1240. et 1241.

Dryandra Humb. n. $580 \%$.

Dryandra $\boldsymbol{R} . \boldsymbol{B r}$. n. 2158.

Dryas Linn. n. 6389.

Drymaria W. u. 5220.

Drymoda Lindl. n. 1397/,

Drymoglossum Prest, n. 614. b.*

Drymonia Mart. n. 4160.

Drymophila $\boldsymbol{A}, \boldsymbol{B r}, \boldsymbol{n} .1179$.

Drymophloeus Zipp. p. 257.

Drymosphace Benlh. n. 3597. c.

Drynaria Bory. n. 615. k. *

Dryobalanops Gärtn. n. 5393.

Dryopeia Thouar. n. 1543.

Dryophilum Sehwein. n. 282.

Dryopteris Adans, n. 639. c.

Drypetes Vahl. n. 5874 .

DRXPIDEAE p. 974 .

Drypis Michel v. 5252.

Dryptodon Brid. n. 492.

Dryptopetalum $A r n$. n. 6103.

Duabanga Hamilt. n. 6165.

Dubautia Gaud, n. 2625.

Duboisia $R, B r$. n. 3906, *

Dubrueilia Gaud. n. 1882.

Dubyaea $D C$. n. 3027/.

Dubyaea $D C$. n. 6161 .

Duchekia Kostel. p. 1358.

Duchesnea $S$ mith, n. 6361. b.

Duchesnia Cass, n. 2431.

Duchola Adans. n. 5793.

Dudresneya Bonnem. n. 51.

Dufourea Achar. n. 158.

Dnfourea Bory. n. 1835.

Dafourea Gren. 5227, 5. 5234. c.

Dufourea Funth. n. 3794.

Dufresnia $D C$. n. 2180.

Dugagelia Gaud, n. 1820. b. *

Dugaldea Cass, n. 2599. b. 
Dypsis Noronh. n. 1729.

Dysehoriste Neer. n. 4041.

Dysemone Forst. p. 1334. 25.

Dysmicodon Endl. n. 3086 . b.

Dysoda Lour. n. 3117.

Dysodea Pers. n. 3182.

Dysodia Cav. n. 2577.

Dysodium L. C. Rich. n. 2478. b.

Dysophylla Blum, и. 3587 .

Dysosmia DC. n. 5098. d.

Dysoxylon $\mathbf{B l}$ n. 5529 .

Dysphania $\boldsymbol{A} . \mathbf{B r}$. n. 1953.

Dyssodia Cav. n. 2577.

Dyssodia Willd. n. 2576.

\section{E.}

Earina Lindl. n. 1346.

Eatonia Raf. n. 880.

Ebelingia Reichenb. n. 5967.

EBENACEAE p. 741 et 1410.

Ebenoxylon Lour. n. 4247.

Ebenus Comm, n. 4249. a.

Kbenus Linn. н. 662'.

Ebermeyera Nees. n. 403 '.

Ecastophylium $\boldsymbol{P}$. Br. n. 6703 .

Ecbalium L. C. Bich, n. 5132 .

Eceilia Fries, n. 453. VI. a.

Ecelinusa Mart. n. 4234/1.

ECCREMOCARPEAE p. 709.

Eceremocarpus $\boldsymbol{R}$, et $\boldsymbol{P}$, n.4107.

Eedysanthera Hook, et Arn, n. 3.48.

Echeandia Ort. n. 1158.

Echenais Cass. n. 2891.

Echeveria DC. n. 4621 .

Echinacauthus Nees. n. 4058.

Eehinaeea Mönch. n. 2513.

Echinalysinm Trin. n. 898.

Eehiuanthus Neck. In, 2847.

Echinaria Desf. n. 832.

Echinella Achar. n. 22.

Eehinella DC. и. 4783. e.

ECHINRLLEAR p. 3.

Echinobotryon Corda, n. 235.

Eehinobrychis $D C$. n. 6619. d.

Eehinocaeti Willd, n. 5154. a.

Echinocactus $L$. ot $O$. nt. 5155 .

Echinocarpus Blum, n. 5062.

Echinocaulon M. n. 1986. d.

Echinoehloa Palis, n. 778.

Echinocystis Torr, et A. Gr. u. $5141 /$.

Eehinodiseus Benth, n. 6706.

Eehinodium Poir. II. 2479.

Eehinodorns L. C. Rich. u. 1041 .

Eehinogyna Dum, n. 472. *

Eehinolaena Desv. n. 789.

Eehinolema Jacq. n. 3036.

Eehinolobium Desv. n. 6618.

Echinomitrium Corda n, 472 .

Echinonyetanthus Lem, H. 5156.

Echinophora Tournef. n. 4522 .

Echinoplaca Fee, n, 165.

Eehinopogon Palis. n. 808. c.

Eehinops Linn, n. 2847.

ECHINOPSIDEAE p. 466.

Echinopsilon Mog. n. 1927.

Echinopsis Zuec, n. 5156.

Echinopus Tourn, n. 2847.

Eehinosehoenus Nees, n. 976. a

Echinospermum $\mathcal{S}_{\text {wartz. }}$. 3786 .

Echinosphace Benth, n. 3597. I.

Eehinosphaera Sieb. n. 6812.

Echinostachys E. Mey. n. 3579 .

Echinus Lour. n. 5887.

Echiochilon Desf. n. 3758. *

Eehioglossum Blum, n. 1488.

Echioides Desf. n. 3765 .

Eehioides MEnch, n. 3772.

Eehiopsis Reich. n. 3774. *

ECHITEAE p. 583.

Echites $\boldsymbol{P} . \boldsymbol{B} \boldsymbol{r}$, n. 3409. *

Echium Tourn, nt 3757. *
ECHMATACANTHI p. 698.

Ecklonia Horn. n. 109.

Ecklonia Steud, n. 969.

Eelipta Linn. n. 24'6.

ECLIPTEAE p. 396.

Eeliptoides Endl. n. 2452. a Eelopes Gärtn, n. 2782.

Eetadium E. Meg. n. 3423.

Eetasis D. Don. n. 4313 . *

Ecthrus Lour. n. 4821.

Ectocarpus Ag. n, 71.

Ectocarpus Bory. n. 71 .

Ectosperma Vamh. n. 79.

Eetostroma Fries. p. 31. e. Ectrosia $\boldsymbol{R}, \mathrm{Br}, \mathrm{n}, 896$.

Edechi Löffl. n. 3192. b.

Edmondia DC. n. 2742. c.

Edosmia Nuth, n. 4414/,.

Edraiantha $A . D C$. n. 3079. a.*

Edwardia Saf. n. 5320. f.

Edwardsia Neok n. 2541.

Edwardsia Salisb. n. 6737.

Egenolphia Schott, n. 603. a

Egeria Ner. p. 566.

Egletes Less. n. 2659.

Ehrenbergia Mart. n. 6031.

Ehreabergia Spreng. n. 3314.

Ehretia Linn, n. 3743, *

EHRETIACEAE p. 644 et 645 .

Ehrhaxdia Scop. n. 2050.

Ehrharta Thunb, n. 734.

Eichwaldia Ledeb. n. 5491.

Einomenia Raf. p. 345.

Ekebergia Sparm, n. 5538.

Elachia $D C$. n. $3032 / \mathrm{s}^{\text {. }}$

Elachistea Duby. n. 60.

Elachothammus DC. u. 2408.

ELAEAGNEAE p. 833.

Elaeagnus Limn, n. 2115.

Elaeis Jaeq. n. 1771.

EL A EOCARPEAE p. 1011.

ELAEOCARPEAE VERAE p. 1011.

Elaeocarpus $L$, n. 5384 .

Elacococea Comm, n. 580\%.

ELAEODENDREAE p. 1087.

Elaeodendron Jacg. n. 5688 .

Elaeoselinum Koch. n. 4498.

Elaphoglossum Schott. n. 603.

Elaphomyces Nees, n. 328.

Blaphrium Jacq. n. 5931.

Elate Ait. n. 1693.

Elate Endl. n. 1810.

Elateriospermum $B l$. u. 5800 .

Elaterium Jacq. n. 5141.

Elaterium Tourn, n. $\mathbf{5 1 3 3 .}$

Elatine Dill. n. 3891.

Elatiue L. I. 5 h 75 .

ELATINEAE p. 1036.

Elatinoides Chav. u. 3891. d.

Elatostemma Forst. n. 1880.

Eleanthus Presl. n. 1348.

Electra $D C$. n. 2561.

Blegia Thunb. n. 1020.

Eleiotis DC. म. 6620 .

Elemifera Plum. n. 5947.

Elengi Endl. в. 4243. a.

Eleocharis $R, B r$. n. 1000 . c.

Eleogiton Link. n. 999, a.

Eleogonus Nees, n. 1000 . e.

ELEPHANTOPEAE p. 362.

Elephantopus Linn, n. 2231.

Elephantosis Less. n. 2231 .

Elephas Tourn, n. 4016.

Elettaria Hheedr. n. 1627.

Eleusine Gärtn. n. 841.

Eleutheria Palis. n. 575. a.

Eleutherochaeta $D C, n .2821$. b.

Eleutherogeron DC. n. 2332. d et 2322. c.

Eleutherolepis DC. n. 2821. c.
Eleutherostemon Klotzsch. n. 4311. b.

Eliaca Camb. n. 5469.

Elichrysum DC, 1. 2741.

Eliouturus Kunth, n. 944.

Elisanthe Endl. n. 5246, b. $\gamma$.

Elisena Herb. n. 1288. d.

Ellinia Nutc, n. 5012.

Elliottia Mählenb. u. 4321.

Ellipsaria DC. n. 4932. b.

Ellisia Linn. n. 3828.

Ellisia $\boldsymbol{P}, \boldsymbol{B r}, \mathbf{n}, 3709$.

Ellisius Gray. n. 66.

Ellobocarpus Kaulf. n. 655.

Ellobum Blum. n. 3709.

Elmigera Reich. n. 3909.

Elodea Adans. n. 5465.

Elodea $\boldsymbol{L}$. C. Rich, n. 1206.

Elodea Spach. a. 5465.

ELODEAE p, 1038.

Elodes Spach, n. 5465. b.

Elphegea Cass. n. 2368.

Elpidophora Ehrenb. n. 372.

Elsholtzia Fich. n. 6334.

Elsholtzia Willd. n. 3588.

ELSHOLTZIEAE p. 612 .

Elutheria $P$. Br, n. 5543.

Elvasía $D C$, n. 5957 .

Blvira Cass, n. 2457.

Elymus Linn, n. 915.

Elyna Schrad. n. 961.

Elyaanthus Palis. it. 977.

ELYNEAE p. 111.

Elythrostamma Boj. n. 3803 .

Elytranthe Blum. i. $4586 . \mathrm{k}$.

Elytranthera $E$. n. 159 '. b. *

Elytraria Vahl. n. 4031.

Elytropappus Cass. n. 2757.

Elytrophorus Palis. n. 898.

Elytrospermum C. A. Meg. n 1000. a.

Elytrostegia Benth. n. 4313. d. 47.

Embelia Juss, n. 4223.

Embira Piso, n. 4714.

Emblica Gärtn. n. 5850.

Embolium Endl. n. 312, b.

Embolus Batseh, n. 312 . e.

Embolus Hall. n. 269.

EMBOTHRIEAE p. 342

Embothrium Eorst, n. 2152.

Embryopteris Gartn. n. 4249. b.

Emericia Röm, ę Sch. в. 3 H16.

Emerns Schum. n. 6551 .

Emerus Tourn, n. 6585. a.

Emex Neck. n. 1992.

Emilia Cars. n. 2793.

Eminium Blum, n, 1676, b.

Emmenanthe Berth, n. 3832.

Emmeorliza Pohl. n. 3326.

Empedoclea Rafin. u. 3655 , b. Enpedoclea St, HiI. n. 4762 .

EMPETREAE p. 1105.

Empetrum Tourn. n. 5761 .

Empleurum Soland. n. 6023.

Empusaria Reich, n. 1333.

Enaleida Cass. ‥ 2580.

ENANTIOBLASTAE p. 119.

Enantiotrichum E. Mej, n. 2819.

Enargea Soland n. 1187.

Enarthrocarpus Labill. n. 4970.

Encalypta Hedw. n. 537.

Encelia Adans. n. 252\%.

Encephalartos Lehm, n. 705. *

Encephatium Link, n. 402.

Enchidium Jack, n. 5838.

Encholirium Mart. n. 1313.

Enchylaena $R$. Br. n. 1925.

Enchysia Prest, n. 3060. b.

Enckea Kunth, n. 1823. b. "

Eaeliandra Zuco, n. 6125. a.

Eneoelia Hill. n. 430.

Encoelites Brongn. n. 122. f.

Eneoeliua AB. a. $10 \%$

Encyanthus Lour. n. 4326.

Eneyclia Hook. n. 1374.

Encyonema Küts. n. 13.

Endiaudra $\boldsymbol{R} . \boldsymbol{B} \boldsymbol{r}$. n. 2033.

Endiplus Rafin, n+ 3831.

Endichera Presl, n. 3326.

. 2051.

ENDOCARPEAE p. 14.

Eudocarpon Hedw, n. 157.

Eudodaca Raf. p. 345.

ENDOGENAE $p$. 58.

Endogone Link, n. 345.

Endogonites Brongn, n. 1778.

Endoleuca Cass. n. 2753.

Endophyllum Lev. n. 181. a.

Kadopogon Nees. I". 4075 .

Endoptera DC. n. 3014."et 3015,*

ENDORHIZAD p. 76.

Endorima Rafin. n. 2584.

Eadospermum Blum, n. 6716 .

Endotriche Fröl. a. 3528. h.

Endotropis Endl. n. 3462 .

Endrach Elac, n. 3812.

Endrachium Juss. o. 3812.

Endressia Gay. n. 4946.

Enemion Rafin. n. 4791.

Euerthenema Bowm. n. 314.

Engelhardtia Lesch. n. 5892.

Engyzostoma Gray. n. 395.

Enhalus L. C. Rich, n. 1212.

Enhydra Lour. n. 2574.

Enhydra Pers. n. 2574.

Enueapogon Dest, n. 830, a.

Enodium Link. A. 888.

Enourea $A u b l$. n. $560 \%$.

Eurila Blanco, n. 688\%.

ENSATAE p. 159 et $16^{4}$.

Enslenia Nutt, ‥ 3483.

Enslenia Rafin. n. 4015. a.

Entada Ndant, n. 6832.

Enteridiam Ehrenb. n. 321.

Enterographa Fte, n. 156. 
Epigaea Linn. n. 4322.

Epigea Swarts. n. 4337.

Epigenia Fl. Fl. p. 134's. 26.

Epigenia Fl. Fl. n. 4252 . a.

Epigynauthus Zipp. p. 232.

Epilepis Benth. n. 2528/1.

Bpilithes Blum. n. 2013.

RPLLOBIEAE p. 1189.

Epilobium Linn. n. 6121.

Epimedium Linn, n. 4811.

Epipaetis Fenill, n.160' et 1605. Epipactis Hall. n. 1553.

Epiphanes, Blum. n. 1543.

Epiphegus Nutt. n. 4182.

Epiphora Lindl. n. 1408.

Epiphyllum Herrm. n. 5158.

Epiphyllum Pfeiff. n. 5159.

Epipogium Gmel. n. 1545 .

Epireineria E Mey. n. 6538.

Epirhizanthos Blum. n. 4192.

Episcia Mart. n. 4164 .

RPISCIEAE p. 620.

Episperma Rafin, n. 62.

Epistemum Walp. n. 6468.

Epistephium $H$. B.K. n. 1612, *

Epistyliem $S$ warts. n. 5858.

Epithema Blum. n. 4144.

Epithinia Jack. \#. 3219.

Rpitrachys $D C$. n. 2887. b.

Epochnínm Link. n. 213.

ERUISETA p. 58.

EQUISETACEAE p. 58.

Equiserum Linn. n. 601.

Eraclissa Forsk. n. 58'1. a.

Eragrostis Palis. n. 876 . b.

Erangelia Renealm. n. 1265.

ERANTHEMEAE p. 705.

Eranthemum $\boldsymbol{R}, \boldsymbol{B r}$. ก. $408 \%$.

Erauthis Salisb, n. 4788 .

Erasma $R, B r$. p. 808.

Erato DC, M. 2366.

Ercilia Adr. Juss, n. 5263.

Erebinthus Mitoh, n. 6539, e.

ERECHTITEAE p. 454.

Erecbtites $\operatorname{Rafin}$ n. 2790.

Erechtitoides DC. n. 2809 . b.

Ereciphyllam Less.n. 2741. d.

Ereicotis $D C$. n, 3240 . d. $\varepsilon$,

Eremaea Lindl, n. 630\%.

Eremanthe Spach, n. 546't. B. g.

Eremanthis $D C$. n. 2761. a.

Eremauthus Less. n. 2224. b.

Eremia Don. n. 4306 .

Ereniastrum Benth, n. 4306. a. *

Eremocallis Sal.n. 4313. d. 35 .

Eremocephala $D C$ n. 2700 . b.

Eremodon Brill. H. 502.

Eremogone Fenzl, n. 5234. a.

Eremogongyle Endl. n. 4974, b.

Eremophila $R$, , $\mathbf{r r}$. n. 3735. *

Eremosis DO, n. 2220. b.

Eremosporus Spach, n. 5464 .

Eremostachys Bung. n. 366.

Eremosyne Endl. n. 4629.

Ereaurus Bieb. n. 1440 ,

Erexda Spaeh. 1. 5011. *

Eria Zindl. n. 1363.

Eriachue R. Br, n. 869.

Eriachne Patis. n. 869. b.

Ertanthera Benth, It. 3645, b.

Erianthern Nees. в. 4099.

Erianthins Rich, n. 94 .

Erica Linn. n. 4313. *

ERICACEAE p. 750 et 1411.

Erieala Ben, n. 3528. e.

Ericalia Ren. n. 3528.

Ericinella Klotzsch. a. 4310.

Eiricocarpum Dun, и. 5029. b.

Ericocarpum $S_{\text {pach. }}$ a. 5029. b.

Erieogalium DO, n. 3100. g.

Ericoila Barkh. As 3528. e, f. g. h.

Erigenia Nutc. n. 4359.

ERIGEREAE p. 377.
Erigeron Cass. n. 2332. a. Erigeron $D C$. n. 2332.

Erigeron Don. n. 2413.

Erima-Tali Rheed, n. 3815.

Erimatalia Rém. et Schult. 3815.

Erinacea Boiss, n. 6494.

Erinacea Lamx, n. 94. c.

Erinaceus Michel, n. 442. a. Krinesia Don, n. 2908.

Erinia Noul. n. 3085, b.

Erinium Link, p. 21.

Erinus Linn. n 3928.

Eriobotrya Lindl. a. 6349.

Eriocachrys DC. n. 4529.

Eriocalia Smith, n. 4378.

Eriocalyx Neek. n. 6482.

Eriocarpha Cass. H. 2522.

Eriocaulon Gron. 11. 1022.

FRIOCAULONEAE p. 122.

ERIOCEPHALEAE p. 441.

Eriocephalns Linn. n. 2710.

Eriochifas R. Br. n. 1592.

Eriochloa Kunth, n. 767.

Erioebrysis Palis. In. 938.

Eriocladinm Lindl. n. 2692/,

Friocline Cass, n. 2825.

Eriocoma Funth. n. 2522.

Eriocoma Nutt, a. 799.

Eriocoryne $D O$. n. 2854. c.

Erioeyela Lindl. n. 4429.

Eriodaphue Nees. 11. 2027. b.

Eriodendron DC, n. 5302.

Erioderma Fée. n. 174. a.

Eriodesmia D. Don, n.4313. a. $5 . *$

Erioglossum $B t$, n. 5614 .

Erioglossum G. ot P. n. 5614 .

ERIOGONEAE p. 305.

Eriogoaum $L, C, R$, n. 1972 .

Eriogynia Hook. n. 4636.

Eriolaena DO. n. 5354.

ERIOLAENEAE Arn. p. 1003.

Eriolema $D O$. n. 6206 ,

Eriolepis Cass. n. 2887. b.

Eriolobus DC. n. 63:2.

Erione Sch. E. n. 5302, d.

Exiopappus Am, n. 2623. "

Eriope $\pi$. et B. n. $358 \%$.

Eriopetalum Wight, n. 3520 .

Eriophorum Lirn. в. 1001.

Eriophorus Vuill. n. 3052 .

Eriophyllum Lag. n. 2591.

Eriophyton Benth, n. 3667.

Eriopoda $D C$. ‥ 2635. b.

Eriopogon Endl. n. 939. b.

Eriopus Brid, n. 587. b.

Eriosema $D C$, n. 6691.

Eriosolena Blum. n. 210\%.

ERIOSPERMEAE p. 156.

Eriospermum Jacq. n. 1196.

Eriosphaera $D C$. n. 6258.

Eriosphaera Less. n. 2739.

Eriosphaeria Benth. n. 3583.g.

Eriosporangium Bert. 11. 397.

Eriostachys, Benth. n. 3650 . c.

Eriostegia $D C$. n. 6248 . a.

Eriostemoides Endl. n. 6009. b.

Eriostemou Less. n. 2854.

Eriostemon Smith, H. 6006 .

Eriostomum $\boldsymbol{L}$ et $\boldsymbol{H}$. n. 3650 . c.

Eriostylis $B . B r . n$ n. 2143. c.

Zriosynatphe $D C$. n. 4161 .

Eriotheca Seh. et E. n. 5301.

Eiriothrix Less. n. 2788.

Eriothymas Benth. A. 3620, a.

Eriotis DC. u. 4432, n.

Eriphia $\mathbf{P}, \boldsymbol{B r}$. n. 4158.

Erismia Rudg. n, 6073.

Erithalia ken. n. 3528 . h,

Erithalis Forst. 1. 3197.

Erithalis P. Br. n. 3207 .

Erithia Gray. n. 2:26. 1. *

Eiritrichium Schrad. แ. 3770.
Eriudaphus Nees. n. 5089.

Ermannia Cham, n. 4856. b.

Eruestia DC. n. 6199.

Ernodea Swartz. u. 3115.

Erastingia Neck. n. 5612.

Erobatos $D C$, n. 4794 . c.

Erodendrum Salisb. n. 2123.

Erodium Heril. n. 6015.

Erophaca Boiss, n. 6571. a.

Erophila $D C$. n. 4881.

Erophoron Tausch, n. 4634. d.

Erosma Both, n. 1859.

Erotium Sol: n. 5412.

Erpetion DC. n. 5040 .

Erpodius Brid. n. 574.

Eruca Tourn. a. 4956.

Erucago Tourn. n. 4973.

Erucaria Gärtn. แ. 497't.

ERUCARIEAE p. 887.

Erneastrum DC. n. 4952 . a.

Erucastrum Presl. n. 4952.

Ervilia Link. a. 6580. b.

Ervoideae $T$. et A. G. n.6575.

Eevum Tourn, n. 6580.

Eryeibe Roxb. n. 3815 .

ERY CIBE AE p. 655.

Eryngium Tourn. n. 4386.

Erysimastrum $C$. A. Mey. n. 4908. d.

Erysimum Link, n. 4906. a.

Erysimum Linn. n. 4908. *

Erysimum Tourn, n. 4906.

Erysibe Rebent. n. $27 \%$.

Erysiphe $\boldsymbol{B}$. Hedw. n. 277.

Erythracanthus Nees. n. 54 .

Erythraea Ren. n. 3543.

Erythrina Linn, n. 6667.

ERY THRINEAE p. 129 '

Erythroearpus Bl. n. 5817 .

Erythrochilus Reinw. n. 5790.

Erythrochiton $N$. et $M$. n. 5992 .

Erythroeistus Dun. n. 5028. d.

Erythodaum Thouar. ‥ 3187.

Erythrodes $B l_{\text {um }}$, n, 1563.

Erythrogalium $D C$. n. 3100, i.

Erythrolaten $S$ weet. n. 2888.

Erythronium Linn. n. 1090.

Erythopalum Blum, n. 5148.

Erythrophlaeum Afzel. n. 6818 .

Erythropogon DC. n. 2754 .

Erythropsis Lindl, n. 5320. a.

Erythrorchis Blum. u. 1612/.

Erythrorhiza L. C. R. n. 4350

ERVTHROSPERMEAE p. 922.

Erythrospermum Lam. 1. 5083. Erythrostictus Schl. n. 1070.

ER X'THRO X YLEAE p. 1065.

Erythroxylou $L$. п. 5597. *

Escallonia Mutis. n. 467\%.

ESCALLONIEAE p. 813 et 822.

Eschenbachia Monch. n. 2405. b.

Eschholtzia Cham. n. 4827.

Esehweitera Mart. n. 6332.

Escobedia Ruiz et Pav, 14. 3990.

Eseabeckia $B L$, n. 5308.

Esenbeckia Brid. n. 590.

Esenbeckia Kunth. 11. 5997.

Esenbeckia Sehott. n, 5997.

Esera Neck. n. 5033. *

Esmarchia Reich, n. 5241. d.

Esopon Rafin, a, 3005, b.

Espejoa DC. n. 2595. *

Espeletia Mut, и. 2' +76 .

Espera Willd. n. 5379.

Espinosa Lagasc, n. 1982.

Esterbazya Mik. n. 3993.

Esula Haw. n. 5766.

Ethanimin Salisb, n. 1632.

Ethulia Cass. n. 2200.

Ethulia Gärtn. n. 2422.

E THULIEAE p, 356.

Euacaena $D C$. ㅍ. 6372 . a

Eoacrocentron $D C$.n. 2871 . a $\beta$.

Euageratum $D L$. n. 2259. a.

Eualarc onia E. n. 2'95. a.

EUALSI NEA E Fensl p. 964.

EUAMELLEAE p. 371.

Euammautia E. 11. 6146 . a.

Euandira Benth. n. 6726. c.

Euangelica $D C$. n. 4456 . a.

Euanoplon Endl. n. 4189. a. *

EUANTHEMIDEAE p. 329.

Euauthemis DC. n. 2639. b.

Euauthoceros E. n. 459. a.

Euaparine $D C$. n. 3100 . b.

Euapium DC. n. 4393 . ถ.

Enaploppus DC. n. 2381. e.

EUAPOCYNEAE p. 581 .

Enarabis C. B. Mey. n. $485 \%$. c.

Euaretotis DC. n. 2830. a.

Euardisia A. DC. n. 4222. a.

Euargyreia $E$. n. 3810 . b.

EUAROIDEAE p. 235.

EUASCLEPIEAE p. 593.

Kuaspidium Endl. u. 6'0. f. *

Euasplenium Endl. n. 630. a. 3.

EU A STERE AE p. 372.

Kuathrixia $D C$. n. 2770.

Euatriplex $C$. A. M. n. 1912, a.

Elazara Don. n. 5075.

EUBACCHARIDEAE p. 390.

Eubarnadesia E. n. 2901. a.

Eubartonia Endl. n. 6433. a.

Eubasis Salisb. n. 4575 .

Euberkheya $D O$. n. 2844 . d.

EUBIGNONIEAE p. 712.

Eubrachyrhynchos $D C$. n.2812.3.

Eubrachyris DC. n. 2361, a.

Eubrychis DC. n. 6639. a.

EUBUCHNEREAE p, 685.

Eucacalia DC. n. 2306. a. 
EUCLIDIEAE p. 972.

Euclidium R. Br, n. 4896.

Eucliuia DC, n. 3304. b.

Enelisia Nutt. n, 4852.

Euclitoria $D C$, n. 6635. b.

Euenemis Brid. n. 582.

Eucnemis Lindl, n. 1426.

Eucodon Alph.DC. n. 3085. b.* Eucoilostigma Benth, n. 4298. a

Eucolocasia Seholl. n. 1683. a

Eucomis Heril. n. 1128.

Enconocarpus DC. n. 6081 .

Euconosperwum E. n. 2132. a.

Euconostegia $D C$. n. 6248 . b.

EUCONYZEAE p. 389.

Eucoreta E. n. 5371. b. $c$.

Eueormos Endl. I. 316. d.

Encosia Blum. n. 1556.

EUCRASSULEAE p. 809.

Euerepis Endl. n. 3022. a.

Euerosia Ker. n. 1283.

Kucrotalaria Endl. n. 6'72. a. Eucryphia Cav. n. 5/03.

EUCRXPHIEAE p. 1016.

Eucryptocarya E. n. 2036. a. Eucyathea Prel. n. 653. a. *

Eucyathocoma Fenzl. n. $968 / 1$. a. Eucyclopia Benth. n. 6422. a. Encymba E. n. 4009. b.

Eucyubidium Lindl. n.1427. a. Eucymopterns Torr, et A. Gr. n. 4491 . a. *

Eucyphia Presl. n. 3041. a.

EUC YRT ANDREAE p. 718 .

Eudacinus Rafin. n. 330.

Eudecaloba Endl. n. 5098. c.

Eudema Iumb. et B. n. 4921.

Eudendrophthoë Endl. n. 4586 . e. $\beta$.

Eudesmia $R ., B r$. n. 6299 .

Eudesmodium $D C$. n. 6615. a.

Eudianthe Reichenb. n. 6249. b.

Eudicoma DC. n. 2930. a. *

Eudioclea Benth. n. 6662. b.

Endiodia $D C$. n. 3123 . a.

Eudiosms DC. n. 6017.

EUDIOSMEAE p. 1156.

Eudiplazium Endl. n. 636 a. Eudiplostephîm $D C$. и. 2319. a.

Eudisa Endl. n, 1537. a. *

Eudissochaeta Blum.n. 6246. a.

Eudolichos Wight, et A. n. 6676 .

Eudoronicum DO. n. 2802. a.

Eudorus Cass. n. 2811.

Eudraeophyllum Endl, n.4292.b.

EUDRYADEAE p. $12 \% 5$.

Eudrynaria Endl. n. 615. k. $\gamma$. bb. *

Rudryopteris Endl. n. 639. c. n.* Eudysodia $D C$. n. 2577. a.

Eueclipta DC. n. 2446. a.

Eueclopes $D C$, n. 2782, a.

Euelephantopus Cess. u. 2231. a. EUERICEAE p. 753.

Euerigeron $D C$. n. 2332, a. *

Enevax DC. n. 2420, a.

Eufaramea DC, n. 3154. a.

Eugahnia Endl. n.982. b.

EUGAILLARDIEAE p. 420 .

Eugalenia Fenzl, n. 5166. b.

EUGALINSOGEAE p. 425.

Eugamelia Fl. Mex. n. 2457.

EUGARDENIEAE p. 558.

Sugenia Mich, n. 6323.

Eugenioides Linn. n. 6094.

Eugerardia Benth. n. 3996.d.

Eugerbera DC. 2929/.

Eugesmera $D C$. n. 4155 . a. *

EUGESNEREAE p. 721.

Eugilia Benth n. 3821. g. *

Euglinus Fenzl, n. 5186, a.

Englossodia Endl. n. 1594. a.

Eugloxinia $D C$, n. 4167 , a. *
Eugnaphalium DC, n. 2746. a. Knonoseris DC, n. 2925. a. * Eugochnatia E. n. 2915, a. Euosanthes Cunn, n. 6281. Eugrammitis Presl.n. 607. a. ce." Euosma Andrews n. 3364. a. * EUGUETTARDEAE p. 539. Eugymnema Dec. n. 3498. a. * Eugynandropis Endl, n. 4984 . b. EUHAMAMELF.AE p. 803.

Euharpalinm $D C$. n. 2536. a. Ruhedyotis Wight et Arn, n. 3240, e.

EUHEDYSAREAE p. 1281. EUHELENIEAE p. 421.

Euhelianthemum Lun. n.5029, c. Euhelichrysum $D O$. \#. 2744. a. EUHELICTEREAE p. 992.

Euhelicteres E. n. 5315. a.

EuheliotropiumEndl, n.3751. a.*

Euhelonias Endl. n. 1066. a.

Euhemitelia Endl.651. a. *

Euheracleum $D C$. n. 4477. b.

Euheteropterys $\boldsymbol{E}$, n. 5575 . b.

Euheuchera Torr. et A. Gray. n. 6517. a.

Euhydrocotyle $D C$. n. 4355 .

Euhymenoxys $D C$. n. 2598.

Euinga E. n. 6837.

EUINULEAE p. 393. Eujasonia $D C$. n. 2433 . b.

Eulachauodes $E$. n. 2818, a.

Eulalia Kunth. n. 943.

Eulasiospermum DC. n. 2653. a.

Eulathyrus E. n. 6582. e.

Euleptolobium Vog. n.6751. b.

Euleptospermum $D C$, n. 6309 .

Euleneothoe $D C$, n. 4318. e. a.*

Euliatris DC. n. 2270. a.

Eulibanotis DC. n. 4432. b.

Eulirion Endl. n. 1098. d.

Eulobus Nutt. n. 6118/,

EULOGANIEAE p. 576 .

Eulomatia E. n. 3155. a.

Eulophia $\boldsymbol{R}$. Br. n. 1440.*

Eulophus Nutt. n. 4543.

Euloranthes Endl. n. 4586. a.

Eulotus Ser. n. 6514. c.

Eulucilia $D C$, n. 2940. a.*

Eulychnis FenzI. n. 5250. c.

Eulychnophora $D C$, n. 2223.

Evlycium $E$. n. 3863 . a.

EUIXTHRARIEAE p. 1198.

Entmachia DO, n. 3170.

Eumaxillaria Lindl, 1. 1407. c.*

Eumelampodium $D C$. n. 2478, a.

Eumelichrus Endl. n. 4270, a.

Eumentzelia Torr. et $A$. Gr. n. 5111 .

Eumetrosideros E. n. 6303, a.

Eumiconia DC. n. 6258. c.

Eumicrocodon Alph. DC. n. 3078. A.

Eumimosa DO, n. 6831. a.

Eumirbelia Benth. n. 64t8. a.

Eumitella Torr. et A. Gr. n. 4641 .

Eumonarda Benth, n. 3600, a.

Eumonoceras E, n. 5385, a.

Eumonopsis E. u. 3057. a.

Eumonosis DC. n. 2220. а.

Eumorpha Eekl, etZeh. n. 6048. m. $\beta$.

Enmorpha Endl. n. 316 . b.

Eumorphia $D C$ แt. 2636.

Eumorphoides DC. n. 2668 . b.

Eumundia E. n. 5651. a.

Eumutisia Less. n. 2917.

EUMUTISIEAE p. 482 . et 1385.

Enmyrodia $D C$. n. 5313. a.

Einmyrtus DC. n. 6316. a. $\gamma$.

Eumephrodium Endl. n. 639. a.

Eunomia $D C$. n. 4930.

Eunychia Fenzl. 11. 5202. c.

Euoedería $D C$. п, 2635, a.

Euoldenburgia $D C$. n. 2927, a.*| Eurybia Cass. n. 2317.

uphaseolus Benth, n. 6674.
Eurybia Gray. n. 2302. *

Eurybiopsis $D C$. n. 2306.

Eirycles Salis. 128.

Suosmites DC. n. 2784. a.

Euota Lindl. n. 1537/, b.

Enothonna E. n. 2828. b.

Euozothamnus $D C$. n. 2738. c.

Eupanargyrum DC. n. 2948. c.*

Euparea Banks. n. 4215/,.

EUPARONYCHIEAE p. 956 .

EUPA TORIACEAE p. 365.

A 366.

2446 , a.

Eupatorium Tournef. n. 2280. EUPECTIDEAE p. 365.

Euperezia Endl, n. 2962, a. $\gamma$. Eupetalacte DC. n. 2765. a.

Eupetalostemon $\boldsymbol{E}$, n. 6522. a. Eupetalum Lindl. n 51 b3.

Eupeucedaum $D C$. n. 4462 . b. Euphaca E. n, 6571. a.

Euphania $D C$. в. 2263. a.

EUPHASEOLEAE p. 1296.

Euphilodendron Schott. n. 1690.

Euphlomis Benth. n. 3664. a. Euphorbia L. n. 5760 .

EUPHORBIACEAE p. 1107.

EUPHORBIEAE p. 1108.

Enphorbium Juss, n, 5766.

Euphoria Comm. n. 5617.

Euphotinia Lindl, n. 6350. a.

Euphrasia Tournef. n. 4011.

Euphrasioides в. 3959. b.

Euphronia Mart. et Z. n. 6400.

Euphrosyne DC. n. 2486."

Bupliymatodes Presl. n. 515.

k. a. *

Eapiqueria DC. n. 2253. a.

Euplatyzoma Endl. n. 6626.* Euploca Nutt. n. 3747. *

EUPODLAYRIEAE p. 1254.

Eupolanisia Endl. n. 4988. c. Enpolyalthia Blume n. 4713. a. Eupolychaetia $\nu C$. n. 2780. b. Eupolypodium Endl. n. 615. a.* Enpomatia $\boldsymbol{B} . \boldsymbol{B r}$, n. 4730.

EUPUMATIEAE p. 835.

Euporana E. n. 3797. b.

Eaporophyllum $D C$. n. 2582, a. Eupratia E. n. 3063. b.

Euprenanthes i. 3005. a.

Enproustia Endl, n. 2918. a. * Eupsittacanthus E. n. 4596. h. ce. Eupteris Endl. H. 622. f.

Eupterolophins DO. n. 2871.g. $\zeta$. Euptychotis DC, n. 4400 , a.

Eupyrena Wight et Arn. w.3198. Eupyrrocoma $D C$. n. 2382. a.

Euranthemum E. n. 4087. a.

Eurhaphe $E$ n. 3240 . d. $\gamma$.

Eurhaphis Trin. n. 830 c.

Eurhapouticum DC, n. 2894, b. Eurhexia Torr, et A. Gray. n. 6200 , *

Eurhodendron Enall. n. 4321. c.* Eurhyuchosia Endl. n. 6692. f. Eurhynchosia Wight et $A r n$, n. 6692, a.

Euriosma Desv. n. 6690.

Eurothia Neck. n. 314.

Eurotia Adans. n. 1911.

Eurotium Link. n. 243.

Eurya Thunb. n. 5410.

Euryale Salisb. n. 5018.

EURYALEAE p. 89.

Euryandra Forst. 11. 4763.

Euryanthe Schl. 1. 5431 .

Enrybasis Brid n. 520 .

Eurycoma Jack. n. 5952.

Eurydice Pers. n. 1243.

Eurylepis D.Don. n. 4313. b.11.*

Euryloma D. Don. n. 4213 . c。 21. *

Euryops Cass. n. 2819.

Euryptera Nuts. n. $4462 / 1$.

Euryspermum Salisb. n. 2120.

Eurystegia D. Don. H. 4313. d. 27 . *

urystoma Benth. n. 4313. d.

45.

Eurytaenia Nutt, n. 4479/1.

Eurytlualen Renealm. 1. 3528.

Eurythalia Borkh. n. 3528.

Eusalaxis Benth, n. 429\%. a.

Eusamyda DO. n. 5059, a.

Eusaussurea $C, A, M$, n. 2853, b.

Euscaphis $\mathcal{S}, Z$. n. 5672.

Euscepes Targion. p. 9.

Euscolopondrium E. n. 634. a. *

Euselago E. n. 3731 , a.

Euselia Neck. n. 3100.

BUSENECIONEAE p. 455.

Euseriphinm $D C$. n. 2761. b.

Eusesamum Endl. u. 4105. a.*

Euseseli DC. n. 4430 . e.

Eusideritis Benth, n. 3655 . c.

Eusimochilus Benth. n. 4302, c.*

Eusiun Koch, n. 4413. a.

Eusonchus DC, n. 3003 . b. *

Eusonerila Blum, n. 6192. a.

Eusophora Benth. n. 6738, b.

EUSPERMACOCEAE p. 526.

Eusphatee Benth. n. 3597. a.

Eusphaerantlus $D C$. n. 2395. a.

Euspiros Targion, n. 90.

Eustachya Rafin. n. 3980.

Eustachys Desv. n. 838.

Eustathes Lour. n. 5633.

Eustegia Fries. n. 382.

Eustegia R. Br. n. 3455 .

Eustellaria Fenzl. n. 5240. b. 
Eutrema $\boldsymbol{R}, \boldsymbol{B}_{\boldsymbol{r}}, \mathrm{n}, 492 \%$, Eutriana Trin. n. 847. Eutrichilia $E$. n. 5541. Eutrichogyne $D C$, n, 2763. a. Eutricholepis E. n. 2868. a. Eutrichosanthes $W_{i g h t}$ ot Arn n. 5130, b.

Eutriphyllam $S e r$. n. 6511. a. Eutriptilion $D C$, n. 2947, a. * Eutrixis E. n. 2960. b. EUTUSSILAGINEAE p. 371. Euvateria Arn, n. 539'\% a. EUVERNONIEAE p. 356. Euverticordia $\delta c h$, n. 6279, a. Euvicia E. n. 6581. b. ce. Eavigaa E. In. 6675. a. Eaxanthium $D C$. n, 2480. a. Euxanthosia DC. n. 436't a. Euxenia Cham, n. 2454. RUXENIEAE p. 398.

Euxerocarpaea E. n. 3038. b. $\beta$." Euxyris Endl. n. 1025. a. Enyphes Targ. n. 105. b. Euzanthoxylua E. n. 5972, a. Ruzinnia E, n. 2493. a. Euzonum Link. n. 4956. Evallaria Neck, n. 1183. a. Evandra R. Br. p. 984. Evanthe Salisb. n. 4013. b. 14.* Evax Gärin. n. 2t20.

Evea Aubt. n. 3140 , a.

Evelyna Pópp. et Endl.n. 1323.

Evernia Achar. 1, 178.

Evodia Forst. n. 5996.

Evodia, Gärtn. n. 2038.

Evodia St, Hil. a. 5997.

Evolvalus Linn, 11. 3791. *

\section{EVONYMEAE p. 1085.}

Evonymodaphue Nees, n. 2041. Evonymoides Soland. n, 5627.
Evonymus Tournef. n. 5676 . Evopis Cass.n. 281t.

Evostma Willd. n. 3222.

Evosmia $H$. et $B$. n. 3222.

Ewyckin Blum, n. 6266.

Exacum Linn, n. 3539.

Exadenus Gries, n. 3561.

Exarrhena $A . B r$. n. 3773 .

Exeipula Eries, n, 369.

Excoecaria L. n, 5772 .

Excremis Willd. n. 1160.

Exidia Fries. 10. $40 \%$.

Exilaria Grev. 1, 4 .

Exitelia Blum, n. 5357.

Exoacantha Labill. n. 4523.

Exocarpus Labill. n. 2088

Exogonium Choir. n. 3803. d.

Exogonium Mlog. ot S. n. 3806.

Exermatostoma Gray. n. 39\%.

Exosporiam fuct. n. 384 .

Exosporium Link. n. 236. b.

Fixostemma L. O, Rieh n+3269.

Exostyles Sehott, n. 6758 .

Exothen Macfad, n. 5928.

Exothostemon G. Don, n. 3409,

Eyselia Reichenb. n. 2659.

Eysenhardtia $\boldsymbol{H}, \boldsymbol{B}, \boldsymbol{K}$, n, 6525 ,

\section{E.}

Faba Tourn, n. 6581. a.

Faba Sti. Ignatii Bras. n. 6729. Fabage Enall, n. 6036. a.

Fabage Tourn, 11. 6036.

Fabiana Rutz et P. n. 3838 , *

Fabrieia Adans. n. 3585.

Fabricia Gärtn, n. 6310.

Fabricia Seop, n. 6626.

Fabrieia Thunb, n. 1263.

Fabronia Raddi. n. 567.

FACELIDEAE p. 488.

racelis Cass, 1. 29'2,
Fagara Adans, n. 5972, a. Fagara Jacq. n. 5972. b. Fagara Lam. n, 5972. e. Fagarastrum Don. n. 5940. Fagelia Neck. n. 6685. Fagonia Tourn, n. 603't. * Fagopyrum Tourn, a. 1987. Fagraea Thunb. n. 3367. Fagus Tourn. n. 1847. Falearia Rivin, a. 4401 . Falcata Gmel. n. 6630. Falcatula Brot. 11. 6508. d. Falconeria Royl. In. 1892/1. Falkia Linn. f. n. 3789.

Fallugia Endl, n. 6385.

Faraniea Aubl. n. 3154

Faramevides $D C, n, 3154$. e.

Farinaria Sow, n. 220.

Farnesia Gasp. n. 6835.

Farobaea Sehr. n. 2811, I. e. Farsetia Turra, a. 4865.

Varsetiana $D C$. n. 4865 . a.

Fasciata Gray. n. 103.

Fasciola Dum. in 472 .

Faterna Nor. p. 1397. 5. *

Fatioa $D C$, औ. 6166.

Fatoua Gaud. p. 278.

Fatraea Thouar. u. 6076. b.

Faujasia Cass. n. 2787.

Faustula $D C$, n. 2738. a.

Favolus Fries, n. 452.

Favolus Palis, n. 447 . f.

Favonium Cass. 11. 2st3. a.

Feaea Spreng. n. 2549 .

Fedia Adans, n. 2178.

Fedia Mönch. n. 2183.

Féea Bory. n. 658.

Fegatella Mich. n. 465. *

Felicia Cass. n. 2297. a.

Felicia DC. n. 2297.

Felicia Less. 1. 2298.

Feliciana Camb. 1. 6273 .

Fenzlia Benth. n. 3821. d.

Fenzlia Endl. n. 6274.

Ferdinanda Lagase. n. 2509.

Ferdinandea Pohl. u. 3277/.

Ferdinandusa Pohl. n. 3277/1.

Fereiria Vand, u. 3977.

Fernandezia Ruiz et $P$. n. 1461 .

Feruelia Comm, n. 3290.

Feronia Corr. u. 5512.

Ferraria Linn. n. 1230.

Ferreola König. n. 4247.

Ferrum equinum, Tournef. n. 6588.

Ferula Tourn. n. 4459.

Ferulago Kach, u. 4459, a.

Ferularia DC. n. 4459. b.

Festuca Linn. n. 899.

FESTUCACEAE p. 98.

Feuillea Pers, n. 5121.

Fevillea Linn. n. 5121.

Fibigia Koêt. n. 836.

vibigia Med. n. 4865 . e.

Fibraurea Lour. n. 4687.

Fibrillaria Pers. p. 21. d. $\gamma$.

Fibrina Fries. n. 430. B. e.

Fiearia Dill. n. 4785 .

FICEAE p. 277.

Fichtea $\boldsymbol{C} . \boldsymbol{H}$. Soh. n. 2983.

Ficinia Schrad. и. 997.

FICINIEAE p. 117.

Fieoidea Ditl. n. 5165 .

Fiens Tourn. n. 1859 .

Fidelia Schaltz. n. 2990. c.

Fieldia A, Cunn, n. 4149. *

Fieldia Gaud, n. 4172 .

Filago Tourn, n. 2752.

Filago Willd. n. 2420.

FILICES p. 58.

FILICES FOSSILES p. 66 et 1351.

Filicites Brongn, n. 709.

Filipendula Tourn, u. 6391.
Fillaea Guill. et P. n. 6825. Fimbriaria A. Juss. n. 5563.

Fimbriaria Nees. n. 46't. * Fimbrillaria Cass. n. 2ł05. d. Fimbristylis Vahl. n. 998. Finekia Illotseh. n. 4305. Findlaya Bowd. p. 734. Fingerhuthia Nees. n. 751. Finlaysonia Wall. n. 3432. Fintelmannia Kunth, n, 960.* Firensia Neck. n. 3738. * Firmiana Mars. n. 5320. k. Fischera Spreng. n. 4362. Fischera Swartz. n. 4343. Fischeria $D C$. n. 3515. Fissidens Hedw. n. 599. Fissilia Comm. n, 5492 . Fissuriaa Fée, n. 135, d. Fistula DC. n. 6781, a.

Fistularia Grev. n. 86. a. Fistulina Bull. n. 4/3.

Flabellaria Cav, n. 5569.

Flabellaria Chev. n. 447 . d.

Flabellaria Lamx. n. 81.

Flabellaria Sternb. n. 1779.

Flacourtia Comm. n. 5079.

FLACOURTIANEAE p. 917.

Fladermannia Bunge. n. 3602/, Flagellaria Linn. n. 1054.

FLAGELLARIEAE p. 131.

Flammula $D C$, n. 4768 , b.

Flammala Fries, n. 453, IV, f. Flaveria Juss, n. 2571.

FLAVERIEAE p. 418.

Fleischeria St. et $H, \mathrm{n}, 2997 . \mathrm{b}$.

Plemingia Hoxb. n. 6697.

Flemingiastrum $D C$. n. 6697 . a.

Fleurya Gaud, n. 1879. d.

Flindersia $R . B r$. n. 5554 .

Flocearia Grev. n. 226.

Floerkea Spreng. n. 3088.

Floerkea Willd. n. 6065.

Florestima Cass. n. 2'489.

FLORIDAE p. 7 et 1337.

Floriada Nor. n. 5677.

Floseopa Lour. n. 6885.

Flotovia Spreng. n. 2908 .

Flourensia Camb. n. 5233.

Fluggea Rich. u. 1192.

Flügea Witld. n. 5860.

FLU VIALES p. 229.

Flnvialis Mi=h, n. 1656.

Focken Endl. n. $350 \% / 1$.

Foeniculum Adans, n. 4425.

Foemum Graecum Tournef. n. 6508. b.

Foetidaria St. Hil. n. 30't.

Foetidia Comm. n. 6328.

Fontanesia Labill. n. 335'.

Fontinalis Linn. n. 592.

Forbesia Eokl, n. 1263.

Forestiera Poir. n. 1896.

FORESTIEREAE p. 288 et 1376.

Forficaria Lindl. B. 1537/1.

Forgesia Comm. n. 4676.

Fornicaria Blum. n. 1493. c.

Fornicium Cass, n. 2895 .

Forrestia A Rich. n. 1036.

Forrestia Baf. в. 5726.

Forsgardia $\mathrm{Fl}, \mathrm{Fl}$, n. 6 n87.

Forstera Linn. f. n. 3095.

Forstera Linn. n. 3095 . b.

Forsteronia $C, F, \mathbb{W}, M e j$. n. 3417 . a.

Forsythia $V_{a h l}$, n. 3356.

Forsythia Malt. n. 6106.

Fosselinia Scop. n 4577.

Fossombronia Raddi. n. $472 / x$.

Fothergilla Aubl, n. 6250.

Fothergilla $\operatorname{Limn}_{\text {, n, } 4593 .}$

FOTHERGILLEAE p. $80^{\circ}$

Fougeria Mö́nch. n. 2470.

Fougeronxia DE, u. $2^{\prime} 470$.

Fonquiera Kunth, n. 5054. FOUQUIERACEAE p. 914.

Foveolaria Meisn, n. 5362.

Foveolaria Ruiz et P. n. 4252. b.

Fragaria $\operatorname{Lin} n$, n. 6361.

FRAGARIEAE p. $12 ' 1$.

Frageria $D C$. n. 2957.

Fragifera Koch. n. 6511. e.

Fragillaria $\mathrm{Ag}$. n. 92.

Fragillaria Lyngb. n.10.

FRAGILLARIE AE p. 1.

Fragosa Ruiz et Pav, n, 4366.

Franea Mich. n. 5053.

Franciscaea $D C$. n. 4615 . b.

Franciscaria $D C$. n. 4615. b.

Franeiscea Pohl. n. 390\%.

Francisia Endl. n. 6286.

Francoa Cavan. n. 4626.

FRA NCOACEAE p. 812.

Francoeuria Cass, n. 2431.

Frangula Tourn, n, 5722. b.

FRANGULACEAE p. 1081.

Frankenia Linn. n. 5053.

FRANKENIACEAE p. 913.

Frankia Stend, n. 2400. *

Franklandia $\boldsymbol{R}, \boldsymbol{B r}$. n. 2134 .

FRANKLANDIRAE p. 339.

Franklinia Marsh, n. 542\%, b.

Franquevillia Gray. n. 3541. a.

Franseria Cav. n. '2451.

Frasera Walt. n. 3543 .

Erauenhofera Mart. n. 5685.

FRAXINEAE p. 573.

Fraxinella Tourn. n. 602\%.

Fraxinns Tourn, n. 3353. *

Freemania Bof. n. 2743.

Freesa Eokl. n. 1242.

Freirea Gaud, n. 1885. b.

Fresenia $D C$. n. 2374.

Freuchenia Eokl. n. 1223.

Freyeinetia Gaud, n. 1712. 
FUMARLACEAE p. 854 et 858. GALINSOGEAE p. 425. Funaria Hedw. n. 556 .

FUNGI p. 16 et 1337.

Fungoides Mich, u. 315 .

Funifera Leandr. de Sacram. n. 2106.

Funkia Denest. n. 6084.

Funkia Spreng. n. 1100. *

Funkia Willd, n. 1051.

Furcaria DO. n. 5277. a

Furcaria Desv. n. 655.

Furcellaria Lamx. n. 114.

Furcroya Vent. n. 1298.

Fusanns Linn: n. 2077.

Fusarium Nees n. 205.

Fuscina Schrank. n. 527. 528. 580. 599.

Fusicoccum Corda n, 197.

Fusiconia Palis, n. 549.

Fusidium Fries. n. 198.

Fusidium Link. n. 214.

Fusisporium Fries. n. 214.

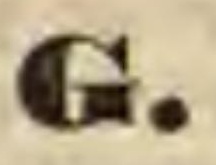

Gabertia Gaud. n. 1431. Gärtnera Lam. n. 3370 . Gärtnera Rets. n. 3092. Gärtnera Sohreb. n. 5572.

GAERTNEREAE p. 577. Gagea Raddi n. 51't. Gagea Salisb. n. 1093.' Gagnebina Neck, n, 6833. Gaguedi Bruc. n. 2123. Gahmia Forst, n. 932. Gaiodendron G. Don. n. 4586. Gaillardia Foug. n. 2583. * GAILLARDIEAE p. 420. Gaillardotella Bory. n. 32. Gaillionia A. Rich. n. 3132. Gaillionia Rud. n. 62.

Gaillona Bonnem, n. 66. Gaillonella Bory, n. 11. Gaimardia Gaud. n. 1007. Galaetia $P . B r$. n. 6653 . Galactites Mönch. n. 2879. Galactodendrum $\boldsymbol{H}$. n. 1861. * Galanga Rumph. n. 1632. Galanthus Linn, n. 1265. Galardia Lam, n. 2583. Galasia Cass, n. 2998. Galatea Cass. n. 2303. Galatella Cass. n. 2303. Galathea Herb. n. 1273. Galathea Salisb. n. 1233. Galativaria Rouss. 1. 50.

Galax Linn. n. 4350. Galaxia Thunb, n. 1235. Galbanophora Neck. n. 4466. Galbanum Don. n. 4486 . Galdicia Ner. p. $110 \%$.

Gale Tourn. n. 1839. b. Galeana Llav. et L. p. 502 . 4. Galeandra Lindl. n. 14t2. Galearia Presl. n. 6511. * Galedragon Gray. n. 2191. Galedupa Lam, n. 6713. Galega Tourn. n. 6533.

GALEGEAR p. 1270.

Galenia Limn. n. 5166.

Galeobdolon š̈̈nch n. 3645 , b. Galeola Lour. n. 1617.

Galeopsis Linn. n. 3648.

Galeperdon $W e b$. n. 322.

Galera Blum, n. 3566.

Galera Fries. n. 453. IV. c.

Galericularia $A$. Ham, n. 3626. d.

GALIACEAE p. 520 .

Galiastrum Heist, n. 5186.

Galinsoga Ruiz et P. n. 2619.

Galinsogaea Zucc, 1. 2619.

Galinsogea Less, n. 2620. Galipea Aubl. n. 5990 . Galium Linn. n. 3100 503. 10.

Galphimia Cav, n. 5590.

Galurus $\mathcal{S p r}$. n. 5787.

Gauja $D C$. n. 5371. d.

Garcia Bohr. n. 5797.

Garcinia $L$, n. 5443.

GARCINIEAE p. 1026 .

Gardenia Ell. n. 3305.

GARDENIEAE p. 557.

GARDNERIE AE p. 575 .

Garrya Dougl. n. 1900.

GARRYACE AE p. 288.

Garnga Roxb. n. 5938.

GASTRODIEAE p. 212.

Gastronema Herb. 1279.

Gaudinia Gay. n. 5258.

Gaudinia Palis. n. 864.

Gaura Lam. n. 5030, a.

Gaura Linn. n. 6131.

GAUREAE p. 1195.

Gautíera Kalm, n. 4323.

Gautiera Vitt. n. 35't.

Gavilea Pöpp. n. 1655.

Gaya Gaud. n. 4447.

Gaya H. B. K. n. 5290 .

Gayoides $E$. n. 5293. b. Gallaria Schrank. n. 6236. Gallorheus Fries, n.453. VII. f. Galophthalmum Nees et $\boldsymbol{M}$. p.

Galopina Thunb, n. 3107 .

Galordia Beusch, n. 2583.

Galorhoeus Haw. n. 5766 .

Galvania Vand. n. 3146.

Galvezia Domb. n. 389'.

Galvezia Ruiz et P. n. 5969.

Gamoearpha DC. n. 3033. Gamochilum Walp. n. 6503.

Gamolepis Less. n. 2656.

GAMOPETALAE p. 346.

Gamoplexis Falc, n. 1544/1.

GANDOLA Rumph. n. 1939.

Gandsulinm Rumph. n. 1630.

Ganitroceras E. n. 5385. b.

Ganitrus $G a ̈ r t n$ n. 538 t. b.

Gansblum Adans. n. 4881.

Ganymedes Haw. n. 1289. f.

Garciana Lour, n. 1061.

Gardenia Gärtn. u. 330\%. a.

Gardeniola Cham. n. 3318.

Gaedneria Wall. n. 3361.

Gardoquia Ruiz et P. n. 3618.

Garidella Tourn, u. 4793.

Garuotia Brongn. n. 761 .

Garovaglia Endl. n. 590.

Garuleum Cass, n. 2354.

Gasparinia Endl, n. 5150. *

Gasteria $D u v$, n. 1115. e.

GASTEROMYCETES p. 22.

GASTEROSPORAE p. 13.

GASTEROTHALAMI p. 13.

Castonia Comm. n. 4555 .

Gastridium Blume n. 1369.

Gastridium $L_{2 n} g b$, n. 85 .

Gustridium Palis. n. 811.

Gastroearpha Don. n. 2955.

Gastrochilus Don. n. 1490.

Gastrochilns Wall. n. 163k.

Gastrodia $R \cdot B r$. n. 154 '. *

Gastroglottis Blum, n. 1328.

Gastrolobium $\boldsymbol{R}, \boldsymbol{B r}$. n. 6443 .

Gastrolychais Fenzl. 11. 5250, d.

Gastromeria Don. p. 67\%.

Gastrophyeus Link. n. 91. b.

Gattenhofia Neck. n. 2672, a.

Gatyona Cass. n. 3015. *

Gaudichandia $\boldsymbol{H}, \boldsymbol{B}, \boldsymbol{K}$. п, $\mathbf{5 5 6 4}$.

Gaulthiera Linn. n. 4323.

Gauridium Spach, n. 6131. a.

Gaylussaeia Funth. n. 4329.

Gayophytum 2. Juss, u. 6112.| Gerberia Scop. n. 5313. b.

Geissorhiza Ker. n. 1246.

(nstegia Benth. n. 4313. a 7.

Geitonoplesium $A . C$. n. 1163.

Gela Loureir. n. 5978.

Gelasine Herb, n. 1247.

Gelatina Rafin. n. 403.

Gelatinaria Flörke. n. 148.

Gelidium Lamx. n. 94. d.

GELONIEAE p. 1396.

Gelonium Gärtn. n. 5614.

Gelonium Roxb. n. 5817.

Gelseminium Catesb. n. 3430/.

Gelseminm Juss. n. $3430 \%$.

Gembanga Blum, n. 1753.

Gemella Lour. n. 5605.

Gemmularia Raf. n. 290.

Gendarussa Nees. n. 5083.

GENDARUSSEAE p. 70\%.

Genea Vitt. n. 352.

Genesiphylla Herit. u. 5847. a.

Genetyllis $D C$. n. 6284 .

Genicularia Rouss. n. 59.

Geniosporum Wall. n. 3570.

Geniostoma Forst, n. 3365 .

Genipa Blum. n. 3306.

Genipella $L$. C. R. n. 3229.

Genista Linn, n. 6500 .

GENISTEAE p. 1259.

Genistella Mönch. n. 6500 .

Genistoides Mönch. n. 6500.

Genlisea St. Hil. n. 419'.

Genlisia Reichenb. и. 1233.

Genoplesinm R. Br. n. 1582 ,

Genoria Pers. n. 6155.

Genosiris Labill. n. 1234

Gentiana Linn. n. 352s.

GENTIANEAE p. 599 et 1399. Gentianella Bork. n. 3528 .

Genoflexa Link. n. 54. a. GEOCALYCEAE p. $13 \% 3$.

Geoealyx Nees. n. $472 / 28$.

Geochorda $\mathrm{Ch}$, et Seh n. 3974.

Geodorum Jacks. n. 1433.

Geoffroaea $W_{i g h t}$ n. 6726 .

Geoffroya Jacq. n. 6725 .

Geoglossum Pers. n. 417.

Geonoma Willd. n. 1751.

Geophila Bereg. n. 1085. a.

Geophila Don. n. 3139.

Geopogon Endl n. 839, d.

Geopyxis Pers. n. 420. C. 1.

Georchis Lindl, n. 1557.

Georgia Ehrh. n. 497. b.

Georgia Spreng. n. 2449.

Georgina Willd. n. 24/49.

Geotrichum Link. n. 223.

GERANIACEAE p. 1166.

Geranium Herit, n. 6046.

Gerardia Linn. n. 3996.

GERARDIEAE p. 690 .

Gerascanthus $\boldsymbol{P}$. Br. n. 3738, a.

Gerbera Burm. n. 2905,

Gerbera Gronov. n, 2929/1.

GERBEREAE p. 481 .

Germanea Benth, n. 3575. a. Germanea Lam. n. 3575.

Gerontogea Cham. et $S \mathrm{chl}$. n. 3240 . $\mathrm{g}$.

Geropogon Linn. n. 2992.

Gersinia Ner. n. 1352.

Geruma Forsk. n. 4570.

Geryonia Schrank. n. 4634. d. Gesnera Mart. n. 4165. *

GESNERACEAE p. 715 et 1407 .

Gesneria Plum, n. 4169.

Gesnouinia Gaud. n. 1885. d.

Gethioides Col. n. 1137. c.

Gethyllis Linn. n. 1290.

Gethyra Salisb. n, 1631.

Getonia Banks, et S. n. 4146, *

Getonia Roxb. n. 6078.

Geum Linn. n. 6386.

Geunsia Blum. n. 3718.

Geunsia Fl. mex. n. 5179.

Ghinia Schreb, n. 2696.

Gibbaria Cass. p. 1391. 15.

Gibbera Fries. p. 390.

Giesekia L. n. 5261 .

GIESEKIEAE p. 977 .

Gifola DC. n. 2752. a.

Gigalobium P. Br. n. 6832.

Gigandra Salisb. n. 4313. a. 8.*

Gigartina Lam.x. n. 94. f.

Gigartinites Brongn, n. 122. e.

Gigarum Caesalp. n. 1676. a.

Gilia Ruiz et Pav. n. 3821. "

Gilibertia Gmel. n. 5516.

Gilibertia Ruiz et $P$. n. 4554 .

Gillenia Mönch. n. 6393.

Gilliesia Lindl, n. 1174.

GILLIESIACEAE p. 152.

Gimbernatia $R$. et $\boldsymbol{P}$. n. 6079.

Ginalloa Korth, n. 4584/,.

Gingidium Forst, n. 4442

Ginginsia $D C$. n. 5187.

Ginko Kämpf. n. 1813.

Ginnania Dietr. n. 4554 .

Gimnania Scop. n. 6799 .

Ginora Linn, n. 6155.

Giuoria $\mathrm{Fl}$, mex. n. 6147. *

Ginoria Jacq. n. 6153.

Girardia Gray. ㅍ. 46.

Girardinia Gaud. n. 1879. e.

Girodella Gaill. n. 14.

Gisopteris Bernh, n. 663.

Gissonia Salisb. n. 2120.

Githago Desf, n. 5250, a.

Glabraria $\operatorname{Lin} n$, n. 2059.

Gladiolus Tourn, n. 1239.

Glandularia $D C$. n. 2368 . b.

Glandularia Gmel. n. 3685. do

Glandulifolia Wendt. n. 6015.

Glaphyranthus E. n. 6303 . C.

Glaphyria Jack. п. 6339.

Glastum DC. n. 4938, a.

Glauciam Tourn, n. 4826.

Glaucoides Mich, n. 6144.

Glaucopis Brid. n. 527. 
Globnlina Link. n. 54. b. Glochidion Forst. n. 3855. Glochidionopsis Blum, n. 5854. Gloiadictyon Ag. n. 16. Gloionema $A_{g}$. n. 23 .

Glomera Blum, n. $150 \%$ GLONIEI p. 32.

Glouium Mizhlenb. n. 376.

Gloriosa Linn. n. 1099.

Glossanthus Klein. n. 4142, *

Glossarrhen Mart. et Z. n. 5044 . Glossaspis Lindl, n. 1514. Glossocardia Cass, n. 256'. Glossoearya Wall. p. 638. Glossocoma Sehreb. n. 4580. Glossocomia Don, n. 3075 . Glossodia $\boldsymbol{R}$. Br. n. 1594. Glossogyne Cass. n. 2566. Glossonema Dec. n. 3448/ . Glossopetalum Schreb, n. 569 Glossophylla $D C$. n. 2726. Glossopteris Brongn. n. 679. Glossosperunm Wall. n. 5356. Glossostemon Desf n. 5350. Glossostephanum $\boldsymbol{E}$, M. M. n. 3468. Glossostigua Arn. n. 3976. Glosspstylis Cham, n. 4000. Glossula Lindl. n. 1514. Glossula Raf. n. 2162. Glottidium Desv. n. 6550. Gloxinia Herit, n. 4167.

GLUMACEAE p. 77.

Gluta Linn, n. 5914.

Glutago Comm. n. 4586, a.

Glutinaria Comm. n. 2368.

Glyceria Nutt. n. 4355.

Glyceria $\boldsymbol{R}, \mathrm{Br}$, и. 878 .

Glycideras Cass. n. 1391. 13. Glyeine Linn, n. 6650. Glycine Nutt. в. 6692. GLXCINE,AE p. 1291.

Glycosma Nuu, n. 4515/ Glycosmus Corr. 11. 5502 . * Glyeyphylla Rafin. n. 4323 . a Glyeyrrhiza Tourn. n. 6532. Glypha Loureir. 10. 3038 , a. Glyphia Cass. p. 1391. 13.

GLYPHIDEAR p. 12.

Glyphiphyllaea DC. n. 2614. b.

Glyphis Achar. n. 139.

Glyphocarpus $R, B r$. n. 552 . Glyphomitrion Brid, n. 507. Glyphomitrinm $S \mathrm{chw}$. n. 508 . GLYPTOSPERMAE p. 830. Gmelina Linn, n. 370\%.

GNAPHALIEAE p. 441.

Giaphalium Don, n. 2746.

Gasphalium Tourn, n. 2650.

Gnaphalium Vaill. n. 3420.

Gnaphalodes Tourn. n. 2421.

Gnaphalopsis DC. n. 3032/6.

Gnemon Rumph. n. 1805.

Gnephosis Cass. n. 2717.

Guesiopersea Nees. n. 2027.

GNETACEAE p. 262.

Gnetum Linn, n. 1805.

Gnidia Linn. n. 2100.

Gochuatia $\boldsymbol{H}, \boldsymbol{B}$. $\boldsymbol{K}$. n. 2915.

Godetia Spach, n. 6116.

Godinella Lest, n. 4207. c.

Godovia Pers, n. 5427.

Godoya $\boldsymbol{B}, \boldsymbol{P}$. n. 5427 .

Goeppertia Nees. n. 2051.

Goeppertia Nees, n. 1644.

Goethea $N$. et $M$. n. 5275. d.

Goetzea Reichenb. n. 6475.

Goetzea $\mathbf{W y d t}$. u. 4256.

Gohoria Neck. n. $440 \%$.

Goldbachia $D C$. n. 4944.

Goldbachia Trin, n. 951.

Goldfussia Nees, n. 4056 .

Gomara Adant. n. 4610 . 4 Grammatotheca Presi.n. 3051.
Gomeza $\boldsymbol{R}$. Br. n. 1455 . Gomezia Llav. p. 1391. 2. Gomezia Mut. n. 3187. Gomezium $D C$. n. 6710 Gomortega $\boldsymbol{R}$ et $\boldsymbol{P}$. n. 2036. Gomphandra Wall. n. 5497. Gomphea Schreb. n. 5958. Gomphocarpus R. Br. n. 3484. Gompholobium Smith. n. 6432. Gomphonema $\mathbf{A g}$. n. 5.

Gomphophorus Brid, n. 462. Gomphostemma Wall n. 3673. Gomphostylis Wall, n. 1347.
Gomphrena Linn. n. 1958. GOMPHRENEAE p. 301.

Gomphus Fries. n. 453. I. Gomutus Rumph, n. 1734. Gomutus Spreng. n. 173'. Gonatocarpus Willd. n. 6138. Gongora Ruis et P. n. 1422. Gongronema $E$. n. 3498 . Gongycladon Link, n. 52. Gongylanthus Nees. n. 472/21. Gongylocarpus Schied, et D. n. 6133.

Goniocarpus DO. n. 6138. Goniocarpus $\mathbf{F o ̈ n}$. n. 6138. Goniocaulon $D C$, n. 2865. A. $u_{\text {, }}$ Goniochiton $\boldsymbol{B} \boldsymbol{l}$. n. 5536.

Gonioma $E$ Mey. n. 3402.

Goviophlebium Blum. n. 615. e. Goniopteris Presl. n. 615. b. * Goniosporium Link. n. 231. c. Goniostemma Wight el Arn.n. 3443.

Goniothalamus Blum, n. 3713. d. Gonocarpus Hamilt. n. 6086. Gonoearpus Thunb. n. 6138. GONOLOBEAR p. 59 '

Gonolobium Pursh. n. 3495. Gonolobus $L, C$. Rich. n 3495. Gonophtebium Blum, n. 615. e.* Gonospermum Less. n. 2688. Gonostemon Haw, n. 3524. b. Gouotheca Blum. n 3239.

Gonas Lour. n 5970.

Gonyanthes Blum. n 1218.

Gonytrichum Nees n. 239.

Gonzalagunia Ruiz ot Pav, n. 3235. a.

GOODENIACEAE p.505. et 1391. Goodia Salisb. n. 6456

Goodyera $R . B r$. n. 1559.

Gordonia Ellis. n. 5424.

GORDONIEAR p. 1022

Gorteria Gärtn. n. 2841.

Gorteria Lam. n. 2844.

GORTERIEAE $\mathrm{p} .465$.

Gossampinus Schk. n 5302, c. Gossypianthus Hook. n. 1954/le Gossypium L. n. 5286.

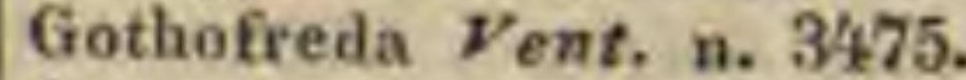

Gouania Jacqu, n. 5746.

GOUANIEAE p. 1102.

Gouffeia C. A. Mey. n. 5230.

Gouffeia $\mathrm{Hob}$. et Curt. n. 5234.d. Goupia $A u b l$. n. 5696.

Gourliea Gill, n. 6746.

Govenia Lindl. n. 1415. *

Grabowskya Sehlecht, n. 3745.*

Graeilaria Grev. 1. 94. f.

Graemia Hook. u. 2599. a.

Graffenrieda $D C$. n. 6175 .

Grafienrieda Mart. n. 6230 .

Grafia Reichenb. n. 4537 .

Grahamia Gill. n. 5177.

GRAMINEAE p. 77. et 1352.

Grammanthes $D C$. n. 4613 .

Gramuarthroo Cast, n. 2801.

Grammatocarpus Presl. 1. 6115.

Grammatophyllum $B t, n \cdot 1431$. * Grammatotheea Presl.n. 3051 . Gonogona Link, n. 1559.
Grammita Bonnemais, n, 69.

Grammitis Swartz. n. 607. *

earpus Ser. n. 6508. a. Guidonia Plum, n. 5059.

Grammonema $A_{g}$. n. 10.

Grammoseiadium $D C$. n. 4516. Guilandina Juss. n. 6763.

Granadilla Tournef. n. 5098 . GRANATEAE p. 1236.

Grangea Adans, n. 2397, a,

GRA NGEINEAE p. 388.

Grangeria $\mathrm{Comm}$. n. 6413 .

Graphephorum Desv. n. 823.

GRAPHIDEAE p. 12.

Graphiola Poit. n. 372 .

Graphis Eschw. n. 135. d.

Graphis Fries. n. 136.

Graptophyllum Nees. n. 4081.

Gratelonpella Bory. n. 69 .

Grateloupia $A_{B}$. n. 97.

Grateloupia Bonnemais. n. 66 . Gratiola $\boldsymbol{R}, \boldsymbol{B r}, \boldsymbol{n}, 3946$.

\section{GRATIOLEAE p. 678 .}

Griumullera Reich. p. 230.

Gravenhorstia Nees. n. 4606.

Graya Hook. et Arn. n. 1912/,

Greenia Nuft. n. 793.

Greenia Wight, et Arn. n. 3251 .

Greggia Gärtn. n. 6323.

Gregoria Duby. n. 4198 .

Grevillea $\boldsymbol{R}, B r$. n. 2143 .

GREVILLEAE p. 340

Grevilleanum L. C.Beck, n. 515. Grewia Juss. n. 5376 .

Grewia L. n. 5376. a.

GREWIEAE p. 1006.

Grias Linn. n. 6335.

Grielum Limn. n. 6402.

Griesebachia Flotsch, n. 430't. Grieselinia Neck. n. 6704.

Griffinia Ker n. 1275.

Griffithia $R, B r$. n. 508 .

Griffithia Wighe et Arn. n. 3302. Griffithsia Ag. n. 63.

Grimaldia Schrank, n, 6781. g. $\beta$. Grimmaldia Haddi n. 563. * Grimuia Ehrh, n. 490.

Grimmia Hedw. n. 509. Grindelia Willd. n. 2364.

Griselinia Fornt. n. 6886.

Grislea Löffl. n. 6156.

Grobya Lindl. n. 1428.

Grona Lour. n. 6653.

Gronovia Linn, n. 515

Grossularia Trurnef. n. 4682. GROSSULARIEAE p. 823.

Groutia G. et Perr. n. 5489.

Grubbia Berg. n. 2085.

GRUBBIACEAE p. 327.

Grahlmannia Neck. n. 3120 .

GRUINALES p. 1166.

Grumaria Kunze p. 21. e. $\beta$.

Grumilea Gärtn. n. 3156.

Guadua Funth n. 909 , *

Guagnebina Fl, Fl, n. 3166. Guaiacana Tournef. n. 4249 , a. GUAIACANAE p. 741 .

Guaiacum Plum. n. 60't1.

Gnaiava Tournef n. 6315 .

Guanabanus Plum. n. 4723.

Guandiola Ste, n. 2472.

Guapea Gemez, n. 4236. *

Gnapurium Juss, n. 6323.

Guardiola $H$. el $B$. n. 2472.

Guarea $L$. n. 5543 . *

Guariruma Cass. it. 2917. c.

Guatteria Ruiz, et Pav. n, 4721.

Guaxuma L. n. 5334.

Guazumoides $D C$, n. 5371. e.

Guepinia Bastard. n. 4886.

Gimepinia Fries. n. 408.

Guettar da Vere. n. 3192.

Guettardaria DC. n. 3192, b.

GUETTARDEAE p. 538.

Guevinia Molin, n. 2140.

Güldenstaedtia Fisch. n. 6570 .

Güldenstaedtia Neck. n. 1911.

Guildingia Hook. n. 6271 .

Guilielma Mart. u. 1766.

Guilleminea $\boldsymbol{H}, \boldsymbol{B}, \boldsymbol{K}, \mathbf{n}, 5223$.

Guilleminea Neck, n. 4580.

Guisdilia Gill. n. 5987.

Güntheria Andrz. n. 4952 . b.

Güntheria Spreng. p. 2596. *

Güntheria Trevir. n. 457 .

Guioa Cav. n. 5614 .

Guizotia Cass. n. 2507.

Gumillea Ruiz et Pav, n, 4660 .

Gumteolis Hamilt. n. 4002.

Gundelia Tourn. n. 2232.

Gundelsheimera Cass, n. 2235.

Gunuera Linn. n. 1889. *

GUNNERACEAE p. 285.

Gunuia Lindl. n. 1478.

Gupia Jaume St. Hil, n. 5696.

Gnssonea A. Rich. n. 1480.

Gussonea Prest, n. 978. b.

Gussonia $\delta_{p r}$. n. 5772.

Gustavia Linn. n. 6327.

Gutierrezia Lagasc, 1. 2586.

GUTTIFERAE p. 1012.

Guzmannia Ruiz el P. n. 1308.

Gwillimia Retler n. 4737 .

Gyalecta Achar. n. 170.

Gyas Salisb. n, 1385.

Gymmacanthus Nees. n. 4036.

Gymnachaena Reich. n, 2762.

Gymnactis $D C$. n. 2365. b.

Gymnadenia $\boldsymbol{B} . \boldsymbol{B r}, \mathrm{n} .1509$.

Gymnandra Pall, n. 398'.

Gymuanthemum Cass. n. 2205. b.

Gymnanthera $\boldsymbol{R}, \boldsymbol{B} \boldsymbol{r}, \mathrm{n} .3435$.

Gymnauthes $\boldsymbol{S}_{\text {w. n. }} \mathbf{5 7 7 2}$. 
Gymnostacliys $R ., B r$, n. 1707. * | Hagea Vent. n. 5216. Gymnostachyum Nees. n. 4086. Hagenbachia $N$. et $M$. n. 2149. Gymnostegia Benth, n. 3038 . Hagenia Eschw. n. 172. C. 4 . b. $c$. *

Gymnostephium Less. n. 2340. Hagenia Willd, n, 6395. Gymnostichum Schreb. n. 916. Haidingera Endl. n. 1811/, Gymnostomum Hedw. n, 483. Gymuostyles Juss, n. 2718. Gymnothrix Palis. n. 781. b. GYNANDRAE p. 185. Gynandropsis $\boldsymbol{R}, \boldsymbol{B r}$. n. 4984 . Gynanthistrophe Poit. n.6814. a. Gynapteina Blum n. 4560. Gynerium $H . B . K$. n. 826. Gynestum Poit. n. 751. Gyneterium Spreng. n. 2417. Gynheteria Willd. n. 2t17. Gyuocardia Roxb. n. 5085. Gynocephalium Blum. n. 1870. Gynochtodes Blum, n. 3210. Gynoon A. Juss. n. 5856 . Gynopachys Blum. n. 3310 . Gynopleura Cav, n. 5109. Gynopogon Forst, n. 3393. Gynostemma Blume n. 4696. Gynostoma $D C$. n. 5363 . b. Gynotroches Blum. n. 5453. Gynoxys Cass, n. 2805. Gynura Cass. n. 2792.

Gypsocalis Salisb. n. 4313. d. 37. *

Gypsophila L. n. 5245. * GXRATAE p. 59.

Gyrinops Gärtn. n. 2110. GYROCARPEAE p. $32 \%$. Gyrocarpus Jacq. n. 2068. Gyrocephalus Pers. n. 408. Gyrodon Opat. n. 448 . d. Gyrolophium Kunze. n. 439. Gyromia Nutt n. 1178. Gyromium Wahlenb. n. 145, b. Gyrophora Achar. n. 145. b. Gyropodium Hitehe. n. 324. Gyrostachys Pers. n. 1547. a Gyrostemon Desf. n. 526t. GYROSTEMONEAE p. 978. Gyrostomum Fries. n. 143. Gyrotheca Salisb. n. 1255. Gyrotrichum Spreng. n. 211. Gytonanthes Rafin. n. 2178.

\section{III.}

Haasia Blum. n. 2032.

Habbasia $D C$. n. 6831 . b. Habenaria Willd. n. 1925. Haberlea Friv, n. 4025 . * Haberlia Dennst. n. 5898 . Hablitzia Bieb. n. 1935. Habranthus Herb. n. 1275. * Habrothamaus Endl. n. 3867 . Habzelia A. DC, n. 4715 . Hacquetia Neck. n. 4383. Hacub Vaill, n. 2232.

Hadestaphyllum Dennst. n.5914. Haemadietyon Lindl. n. $342 t / 2$. Haemanthus Linn, n. 1278. Haemaria Lindl, n. 1'60. Haematococeus $\mathrm{Ag}$. n 27. Haematosperuum $W$. p. 1117. Haematostrobus Endl. p. 76. Haematoxylon Linn. n. 6777. Haemax E. Mey. n. 3446. Haemocarpus Nor. n. $5^{\prime}+68$. Haemocharis Salisb. n. 5416. HAEMODORACEAE p. 170.

Haemodorum Smith. n. 1253. Haemodorum Wallr. n. 4183. b. Haemospermum Reinw. n. 3365 . Haenkea Ruiz et $P$. n. 4260, a. Haenkea $R . P$. n. 5680.

Haenkea Salisb. n. 5175 .

Haenselera Boiss. n. 2976/1 .

Hagea Biv. n. 5212.

Haplophylium A. Juss, n. 6028. Haplophyllum Less. n. 2917. e.
Haplostellis A. Rich. n. 1603. * Haplostemum Rafin. p. 119. c. Haplostephium Mart. n. 2222. Haplostylis Nees. n. 966. Haplotaxis DC. n. 285\%. * Haplotella Endl. n. 1. b. Haplotrichum Eschw, n. 230. Haplotrichum Link. в. 227. a. Hardenbergia Benth, n. 664t. Hardwickia Roxb. n. 6808 . Harina Hamilt. n. 1732. Hariota Adans. v. 5160. Harisonia Neok. n. 2850. Harmala Mönch. n. 6025. Harmodia Don. n. 2918. d. * Haronga Thouar. n. 5468.

Harongana Lam. u. 5468. Harpalium Cass. n. 2536. Harpalizia DC, n. 2536. b. Harpalyce Don. n. 3005. b. Harpalyce Mos. et S. n. 6577.

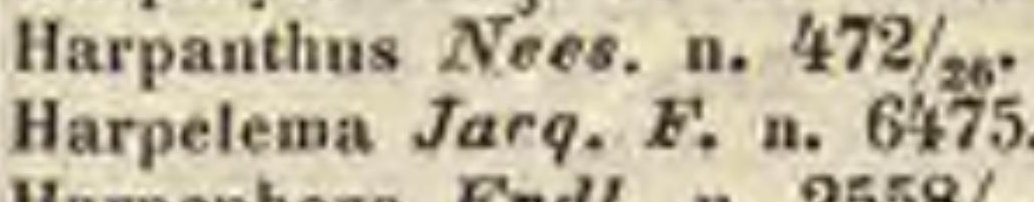
Harpephora Endl. n. 2558/, Harpochloa Kunth. n. 842. Harpulia Roxb. n. 5614 . Harrachia Jaeq. F. n. 4073. Harrisonia Adans, n. 489. Harrisonia Hook. n. 3512. Harrisonia $\boldsymbol{R} . \boldsymbol{B r}$. n. 5967. Hartighsea $A$. J. n. 5532. Hartmannia DC. n. 2632. Hartmannia Spach. 11. 6115. 7. Hartogia Th. n. 5687.

Hartwegia Lindl. n. 1371/2. Hartwegia Nees. n. 1147.

Harweya Hook: n. 3999. Hasselquistia Linn. n. 4 't81. Hasseltia Blum, n. 3430. * Hasseltia $\boldsymbol{H}$. B. $\boldsymbol{B}$. n. 5360 . Hastingia Kön. n. 5330.

Hastingia Smith. n. 3670 . Hauya Mog. et $S$. n. 6124. Havetia $H$. B. K. n. 5435 . Haworthia Duv. n. 1115. b. Haxtonia Cal, n. 2318. * Haylockia Her b. n. 1271. Haynea Retohenb. n. 5273. Haynea Schum, n. 1882. Haynea Willd. n. 2202. Hebanthe Mart. n. 1958. c. Hebe Juss. n. 3979 . c. Hebea Pers. n. 1239. Hebeandra Bonpl. n. 5652. Hebecarpaea DC, n. 2297. a. Hebeclinium DC. n. 2276.

Hebelia Gmol. n. 1062.

Hebeloma Fries. n. 453. IV. Hebenstreitia Linn. n. 3727.

Hebephora $D C$. n. 2414 . b. Heberdenia Banks, n. 4222. a, re. Hebradendron Grah, it. 5446. Hecastophyllum Kunth. n. 6703. Hecatea Thouar, n. 5794.

Hecatonia Lour. 4783. d. Hechtia Klotzsch. n. 1314/2.

Hectorea $D E$. n. 2243.

Heenbaea DC. n. 2606. *

Hedaroma Lindl. II. 6285.

Hedeoma Benth, n. 3615 . b.

Hedeoma Lour. n. 5250 .

Hedeoma Pers. n. 3615.

Hedera Linn. n. 4560 .

HEDERACEAE p. 793.

Hedraiophyllum Less. n. 2915. b.

Hedranthum Don. n. 3082. b. a. *

Hedwigia Hedw. n. 489.

Hedwigia Hook, n. 574.

Hedwigia Med, n. 1028, a.

Hedwigia $S_{\text {wartz. n. }} 593 \%$.

Hedyearpus Jack, n. 5877.

Hedycarya Forst. n. 2018. *

Hedychínm Kö́n. n. 1630. Haplopteris Presl, n. 624. a. *| Hedyerea Sohreb. n. 6h09.
Hedyosmum $S_{\text {wartz. n. } 1817 .}$ HEDYOTIDEAE p. 548 . Hedyotis Lam. n. 32't0. Hedypnois Gärtn. n. 297\%. Hedypnois Tourn, n. 2073. * HEDYSAREAE p. 1280. Hedysarum Desv. n. 6615. Hedysarum Jeaum. n. 6618. Heeria Meisn, n. 592\%. * Heeria Schlecht. n. 6212. Heimea Neck. n. 474.

Heimia $L$, et $O$, n. 6147. b. Heinsia $D C$. n. 3300 .

Heinzelmannia Neck, n. 2940. c. Heinzia Scop. n. 6728.

Heisteria Berg. n. 5650.

Heisteria $\boldsymbol{L}$ n. 5491.

Hekeria Kunth. n. 1820. d. *

Hekorima Rafin. n. 1180.

Heleastrum DO. n. 2315.

Helenia Linn, n. 2603.

HELENIEAE p. 420.

Helenium Linn, n. 2603. *

Heleochloa Host. n. 745. b.

Heleochloa Palis. n. 809.

Helepta Rafin. n. 2506.

Helia Hart. n. 3552.

Heliaetis Kü̈tz. в. 19.

Heliamphora Benth, n. 5023/1.

HELIANTHEAE p. 405.

Helianthemum Tourn. n. 5029.

Helianthus Linn. n. 2538. *

Heliehroa Rafin. n. 2513.

HELICHRYSEAE p. 44 .

Helichrysum DC. n. 2741.

Helicia Lour. n. 2150 .

Helicobolus Wallr. n. 366.

Helicodontium $S \mathrm{chw}$. n. 572 . e.

Helicomyces Link. p. 21. h.

Heliconia Gärtn. n. 1649.

Heliconia Linn. n. 1647.

HELICONIEAE p. 228.

Helicophyllum Brid. n. 587. a.

Helicosporium Nees. n. 237.

Helicotrichum Nees. n. 237.

Helieta Cass. n. 249\%.

HELICTEREAE p. 991.

Helieteres $\boldsymbol{L}$. n. 5316 .

Helicteroides $D C$. n. 5117 .

Helierella Bory. n. 19.

Heligme Blum. n. 3419 .

Helinus E. Mey, n. 5745.

Heliocarpus $L$. n. 5367.

Heliogenes Benth. n. 2637/, .

Heliophanes Salisb, n. 4313. d. 42.*

Heliophila N. Burm, n. 4978.

HELIOPHILEAE p. 888.

Heliophthalmum Rafin, n. 2514.

HELIOPSIDEAE p. 405.

Heliopsis Pers. n. 2506.

Heliosperma $E$. n. 5246. b. $\boldsymbol{c}$

HELIOTROPICEAR p. 64'.

Heliotropium Linn, u. 3751.

Helipterum $D C$, n. 2742.

Helitophyllam Blum, n. 2150.

Helixanthera Lour. n. 4586.

Helleboraster Mönch, n. 4789.

HELLEBOREAE p. 847.

Helleborine Pers. n. 1538.

Helleboroides Adans, n. 4788 .

Helleborus Adans, n. 4789 .

Helleborus Mänch. n. 4788.

Hellenia Retz. n. 1638.

Helleaia Willd. n. 1635.

Helleria N. et $M$. n. 5487.

Hellwingia Adans. n. 5071.

Helminthia Juss n. 3000.

Helminthora Fries. п. 51.

Helminthosporium Fries. n. 236.

Helminthostachys Kaulf. n. 673 . $^{*}$

Helminthotheea Vaill. n. 3000 .

Helmintechortos Link, n. 94. f. 
HELOBIAE p. 126.

Helonias Linn. p. 1066. * Helonias Willd, n. 1062.

Helophytum E. ot $Z$. n. 4607. Helopodium DC. n. 168. c\%. Helopus Trin. n. 767.

Helosciadium Koch, n. 4397. HELOSIEAE p. 74.

Helosis Rich, n. 721. Helospora Jack, n. 3298.

Helotioides Endl. n. 430. A. c. $\alpha$, Helotinm Pers. n. 426. Helotium Tode n. 411. Helvella Linn. n. 43' HELVELLACEI p. 36.

Helvellae pezizoideae Fries. n. 434. $\pi$. $c$.

Helvellopsis Endl. n. 430. C. m. Helwingia Willd, n. 2090. HELWINGIACEAE p. 328. Helxine Linn, n. 1986. h. Helxine Req. n. 1886.

Helygia Blum. n. 3419 .

Hemarthria $\boldsymbol{R}, \boldsymbol{B r}, \mathrm{n}, 925$.

HEMEROCALLIDEAE p. 139.

Hemerocallis Linn. n. 1143.

Hemesotria Rafin, n. 2182.

Hemiachyris $D C$. in. 2362.

Hemiadelphis Nees. n. 4037.

Hemiandra $\boldsymbol{A}$ Br. n. 3631.

Hemianthus Nutt, n. 3951.

Hemiareyría Fries. n. 308. b.

Hemicarpha Nees, n. 987. a.

Hemicarpurus Nees. n. 1693.

Hemichlaena Schrad. n. 993.

Hemichlaena Schrad, n. 993, a

HEMICHLAENEAE p. 117.

Hemichoriste Wall, n. 4080.

Hemichroa $\boldsymbol{R}, \boldsymbol{B r}$. n. 1961.

Hemiclidia $\boldsymbol{R}$. Br. n. 2159.

Hemicyclia $\boldsymbol{W}$. et $A$, n. 5816.

Hemicyphe Corda. n. 258.

Hernideptium Presl. n. 630. c.*

Hemidesmas $\boldsymbol{R}$. Br. n. 2438 .

Hemigenia $\boldsymbol{R}, \boldsymbol{B} \boldsymbol{r}$. n. 3632 .

Hemiloba $D C$, n. 4167. b. *

Hemilobos E. 11. 4115. b.

HEMIMERIDEAE p. 672.

Hemimeris Kunth, n. 3880.

Hemimeris Thunb, n, 3886 .

Hemionitis Linn. n. 604 .

Hemiphragma $\mathrm{Wall}$. n. 3987.

Hemipilia Lindl. n. 1516.

Hemipus Endl, n. 927. a.

Hemiragis Brid. n. 572. c.

Hemisacris Steud, n. 890.

Hemiseumata Bisch. n. 45 t.

Hemisinapsium Brid. n. 540 .

Hemíspadon Endl. n. 6530.

Hemixphace Benth. n. 3597 .

Hemistemma Comm. n. 4757.

Hemisteptia Bung. n. 285/. b.

Hemistoma Ehrenb. n. 3662. a.

Hemitelia Fanlf. n. 653. \&. *

Hemitelia $\boldsymbol{A}$. Br. n. 651 .

Hemitome Nees, u. 4074 .

Hemitomus Herit, n. 3880.

Hemixera $\boldsymbol{E}$, n. 5216. a.

Hemizonia $D C$. n. 2630 .

Hemna Rafin, n. 45\%, c.

Hempelia Mejen, n. 56.

Hemprichia Ehrenb. n. 939.

Henanthus Less. n. 2386. a.

Henckelia Spreng. n. 4138.

Hendecandra Esch. n. 582\%.

Henicostemana Blum, n. 3562.

Hema Arab. n. 6159.

Hesotogyaa DC, n. 2ł12. b.

Heuricea Lem,-Lis, n. 3533 .

Heurieia Cass. n. 2313.

Henriettea $D O$. n. 6252 .

Henschelia Presl. n. 4705.

Henslera Lagase, n. 4540 .
Henslowia Wall. n. 1905.

HENSLOWIACEAE p. 291. Hepataria Rafin. n. 403. d.

Hepatica Dill. n. 4774 .

HEPATICAE p. 42.

Hepetis $\mathcal{S}$ wartz. n. 1305.

Heptaca Lour. n. 6887.

Heptapleurum Gärtn. n. 4561.

Heptaptera Reutt. n. 4527/, .

Heracantha $D C$. n. 2359 . :

Heracantha Link. n. 2874.

Heracleum Hoffm. n. 4477 . b.

Heracleum Linn. n. 4477.

Herbertia $S$ weet. n. 1227.

Herbichia Zaw. n. 2811. I. d.

Herculea Eries. n. 326.

Herderia Cass. n. 2201.

Hericium Fries. n. 421.

Hericium Pers, n. 442 .

Heritiera Ait. n. 5319.

Heritiera Gmel. 1. 1255.

Heritiera Retz. n. 1635.

Heritiera Schrank. n. 1062.

Hermannia $L$. n. 5430 .

HERMANNIEAE DC. p. 999.

Hermas Linn. n. 4530.

Hermes Salisb. n. 4313. d. 33.

Hermesia $\boldsymbol{H}$. et B. n. 5796.

Hermesias Loffl. n. 6810.

Herminiera $\boldsymbol{G}$. ot $\boldsymbol{P}$. n. 6552 .

Herminium R. Br. n. 1524. *

Hermione Gaw. n. 1289. h.

Hermodactylus $R \cdot B r$. n. 1036 . b.

Hermodactylas Tourn, n. 1226.

Hermupoa Löffi. n. 5008.

Hernandia Plum. n. 2103.

HERNANDIACEAE p. 332 et 1378.

Herniaria Tourn, n. 5198.

Herorchis Lindl, n. 1507. b.

Herpestes Gürtn. n. 39't0.

Herpetica $D C$. n. 6781 , b. $\gamma$.

Herpetiam Nees. n. 472/10

Herpotrichum Frles. p. $21^{\circ}$. f.

Herpysma Lindl. n. 1568.

Herrera Adans. u. 3207.

Herreria $H$, et $P$. n. 1195.

HERRERIEAE p. 156.

Hersehelia Bowd, n. 3851.

Herschelia Lindl, n. 1537/s.

Hertia Less. n. 2828. c.

Hertia Neck. n. 2819.

Hernehea Torr. et $A, G r$. n. 4639. b. *

Hesioda $\mathrm{Fl}$. $\mathrm{Fl}$. p. 1334. 27.

Hesiodia Mönch, n. 3655. d.

Hesperantha Fer. n. 12't5.

Hesperanthemum $E$, n. 4087 . c

Hesperanthus Salisb. n. 1245.

HESPERIDES p. 1039.

Hesperidium DOC. u. 4903 . a

Hesperidopsis DC. n. $490 \%$.

Hesperis Linn. n. 4903.

Hesperomeles Lindl. n. 6348 .

Hesperoscordum Lindl, n.1110.*

Hesperothymas Benth, n. 3616 a.

Hessea Berg. u. 1268.

Hetaeria Endl. n. 1060.

Heteracia F. et M. n. 3024.

Heteractis DO. n. 2826.

Heterandra Palis, n. 1087. b.

Heterauthemis $\mathcal{S}$ ch, n. 2671. b.

Heteranthera $R$, et $P$, n. $1087 . \mathrm{b}$,

Heteranthesia Benth. n. 3626, b.

Heteranthia $N$. et $M$. n. 3955 .

Heterocarpella Turp. n. 21.

Heterocentron II. el A. n. 6202.

Heterochaenia A, DC. n. 3079/2,

Heterochaeta DC N. 2330.

Heterochroa Bung. n, 5245. b.

Heterocoma DC. n. 2203.

HFTEROCOMEAE p. 357 .

Heterocylix Benth u. 3575 . e.
Heterodendron Desf. n. 5955.

Heterodon Meisn. n. 4605.

Heterographa Fée. n. 3993.

Heterolaena Endl. n. 2098. b. *

Heterolepis Bert. n. 2811. XII.

Heterolepis Cass. n. 2838.

Heteroloma Desv. n. 6603. b.

Heteromelisson Bent/h n.3617. g.

Heteromeris $S$ pach. n. 5029. f.

Heteromorpha Cass. n. 2838.

Heteromorpha Cham, et Schl.n. $4+15$.

HETERONEMEA p. ' 48.

Heteronoma Mart. n. 6201.

HETEROPAPPEAE p. 379.

Heteropappus Less. n. 2336.

Heterophragma $D C$. n. 4118/

Heterophyllum Boj. n. 5331 .

Heteropogon Pers. n. 950. d.

Heteropterys $H$. B. $\boldsymbol{H}$. n. 5575 .

Heteroptyeha DC. п. 4400 . с.

Heterosciadium $D C$ n. 4380 .

Heterosperma Cav. n. 2565.

Heterosperarum Willd. n. 2565.

Heterosphace Benth, n. 3597. 1

Heterosphaeria Grev. n. 377.

Heterostega Desv. n. 847. c.

Heterostemma $W$. et $A$. n. 3505.

Heterostemon De if. n. 6794 .

Heterostemum Nult. n. 6113.

Heterostylus Hook n. 1037. *

Heterotaxis Lindl. n. 1414.

HETEROTHALAMEAE p. 372.

Heterothalamus Less, n. 2295.

Heterotheca Cass. n. 2365. b.

HETEROTHECEAE p. 383.

Heterotoma Zucc, n. 3062, *

Heterotrichnm Bieb, n. 2853.

Heterotrichum DC. n. 6245 .

Heterotropa $M$. ef $D$. n.2161. *

Heterozyges Bung. n. 6031.

Heterya Rafin. n. 3830.

Heuchera $\boldsymbol{L}_{i n n}$. n. 4639.

Heucherella Torr. et A. Gray. n. 4639 . d. *

Heudelotia A. Sich. n. 5930.

Heudusa E. Mey. n. 6466.

Heurnia $\boldsymbol{R}$. Br. n. 3527.

Hevea Aubl. n. 5 \%99.

Hewittia Might. n. 3799. *

Hexacentris Nees. n. 4029.

Hexactina Willd, n. 3314.

Hexadica Lour. n. 5884.

Hexaglottis Vent. n. 1242.

Hexagona Poll. u. 447. f.

Hexalobus Alph. DC. n. 4818 .

Hexameria $\boldsymbol{R}, \boldsymbol{B}$. n. n. $1369 /$,

Hexanthera Endl. a. 5060 . a.

Hexanthas Lour. n. 2059.

Hexaptera Hook, n. 4935.

Hexarrhena Presl n. 752.

Hexasepalum Bartl. n. 3122.

Hexastemon $\mathrm{Kl}$. n. 4306. d.

Hexisea Lindl. n. 1348.

Heyderia Fries. n. 417.

Heydia Dennst. n. 5839.

Heylandla $D C$. n. 6470 .

Heymassoli Aubl. n. 5490 .

Heynea Roxb. n. 5540.

Hibbertia Andr. n. 4753.

HIBISCEAE p. 982.

Hibiscus L. n. 5277.

Hieorius $R a f$. n. 5899.

Hidalgoa Less. n. 2473.

Hidalgoa $\mathrm{Ll}$. et $\mathrm{L}$. n. 2478 .

Hidrosia E. Mey. n. 6528.

Hieracidiun DC, n. 3027/1.

HIER ACIE AE p. 501.

Hieracinm Tourn. n. 3026.

Hierauthemam E, u. 3752, a.

Hierochloa Gmel. n. 755.

Hieroehoutis Medik. n. 4896.

Hierocimum Benth, n. 3569. b.

Hierocontis Adans. n. 4895.

Hieronia $F l, F l$. n. 4763 .

Higginsia Blum, n. 3289 .

Higginsia Pers. n. 3288.

Hilaria $H . B . K$. n. 752

Hilleria $\mathrm{Fl}, \mathrm{Fl}$. n. 5256.

Hillia Jacq. n. 3277.

Hilsenbergia Boj, n. 5349 .

Himanthalia $L y n g b$, n. 119. a

Himantia Fries. 11. 437. c.

Himantoglossum Spr. n. 1512.

Himantophyllum Spr. n. 1291 .

Himatanthus Willd n. 3330.

Himeranthus $E$. n. 3860 .

Hingeha Roxb. n. 257't

Hiorthia Neck. n. 2643.

Hipo Camell. n. 1862.

Hippagrostis Fumph. n. 778 .

Hippeastrum Herb. n. 1273. e. *

Hippia Linn. n. 2709.

HIPPIEAE $\mathrm{p}$. 440 .

Hippioides DC. ․ 2696. e.

Hippion Schmidt, n. 3528.

Hippion $S p r$. n. $35 \%$

Hippobroma Dan. n. 3060. d. *

Hippebromus $E$. et $Z$. n. 5637.

HIPPOCASTANEAE p. 1075.

Hippocastanus Tourn. n. 5641.

Hippocentaurea Sch. n. 3541. b.

Hippochiron E. n. 3536. a.

Hippocratea $\boldsymbol{L}$. n. 5700 . *

HIPPOCRATEACEAE p. 1090.

Hippocrepis Linn. n. 6588.

Hippodium Gaud. n. 637.

Hippomane $L$. n. 5777 .

HIPPOMANEAE p. 1109.

Hippomanica Mol. n. 6888 .

Hippomarathrum D. n. 4430 . c.

Hippomarathrum $L$. n. 4525 . h. 
Hollia Sieber. n. 582.

Holmskioldia Retz. n. 3670 . Holochloa Nutt. n. 4639 . c. * Hologamium Nees. n. 498/, Hololachna Ehrh. n. 5'79. Hololepis DO. n. 220't. b. Holomitrium Brid, n. 49'. Holomitrium E. n. 3566 . c. Holopetalum $D C$. n. 6047. b. Holophyllaea $D C$. n. 2614. Holophyllum Less. n. 2690. Holophyllum Less. n. 2917. Holoregmia Nees, n. 4174 .

Holoschoenus Link. n. 999, a.

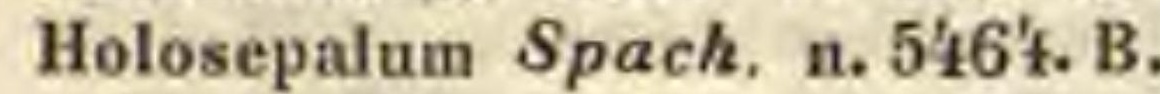

Holostemma $\boldsymbol{R}, \boldsymbol{B} r$, n. 3460 . Holosteum $L$ n. 5239.

Holostigma Don. n. 3057. b. *

Holostigma Spach. n. 6113.

Holostyla DO. u. 3225 .

Holotome Benih. n. 4379 .

Holothrix $L, C$, Hich. n. 1513. Homaid Adans, n. 1675.

HOMALINEAE p. 922.

Homalium Jacq. n. 5086.

Homalobus Nutt. n. 6575 .

Homalocarpus $D C$, n. 4773. b. 5 .

Homalocarpus $H$. et $A$. n. 4974 . Homalocenchrus Mieg. n. 728. Homalocline Cass, n. 3022. B. Homalonema Sokott. n. 1695. Homalotes $D C$. n. 2686.

Homalotheca Cass. n. 2746. c. Homanthis Kunth. n. 2962. Homback Adans, n. 5000. a. Homeoplitis Trin. n. 941. Homeria Vent. n. 1224.

Homochroma $D C$. n. 2371.

Homoeocladia Ag. n. 15.

Homoglossum Salisb. n. 1239.

Homogyne Cass. n. 228't.

Homoianthus Bonpl, n. 2962.

HOMONEMAE p. 1.

Homonoia Lour. n. 5885.

Homoranthus A. Cunn, n. 6228.

Hondbessen Adans. n. 3180.

Honkeneja Ehrh, n. 5229.

Honkenya Willd. n. 5370.

Honorius Gray. n. 113'.

Hoodia Sweet. p. 598.

Hookeria $H$. et $J$. n. 587. a.

Hookeria Salisb. n. 1106.

Hookeria Schleich. n. 506.

Hookia Neck n. 289\%.

Hoorebekia Corn. n. 2331. a.

Hopkirkia $D C$. n. 2597.

Hopkirkia Spreng. n. 2448.

Hoplophyllum DC. n. 2213 . *

Hoplotheca Nult. n. 1959.

Hoppea Reichenb. n. 2799.

Hoppea Rnxb. n. 5496.

Hoppea Willd. n. 354'.

Horan Adans. n. 6083.

HORDEACEAE p. 103.

Hordeum Linn. n. 917.

Horkelia $\mathrm{Ch}$ et $\mathcal{S} \mathrm{chl}$. n. 636 t.

Horkelia Reioh. n. 1668. *

HORMINEAE p. 616.

Horminum Linn. n. 3603.

Hormimum Tourn. n. 3597. d.

Hormiscium Kunze. n. 189.

Hormosira Endl. 11. 120. a.

Hornemannia $L$ ot $O$. n. 3952

Hornemannia Reich. n. 3931.

Hornemannia Vahl. n. 4333 . "

Hornera Neck. n. 6665.

Hornia $D C$. n. 3152. b.

Hornseluchia $B$. n. 5472 .

Hornsehuchia Nees. n. 4257.

Hornstedtia Retz. n, $162 \%$.

Horsfieldia Blum, n. 4387.

Hortensia Ju६s, n. 4669.
Hortia Pand, n. 6000. Hosackia Dougl. n, 6517 . Hoslundia Vahl. n. 3682. Hosta Fl. Fl. n. 4221. * Hosta Jacq. n. 3697. Hosta Trattin. n. 1100. Hostana Pers. n. 3697. Hostea Willd, n. 3496. Hostia Mönch, n. 3021. Hoteia M. et D. n. 4644. Hottonia Linn. n. 4214. HOTTONIEAE p. 73'\%. Houstonia Andr. n. 3265. Houstonia Linn, n. 3240. d. $\partial$ Houttuynia Houtt. n. 1242. Honttuynia Thunb. n. 1825. Hovea $R$. Br. n. 6451 .

Hovenia Thunb. n. 5721. Hoya R. Br. n. 3501. * HOYEAE p. 595 .

Huanaca Cavan, n. 4373. Huberia $D C$. n. 6176 .

Hubertia Bory. n. 2811. VI. Hudsonia Linn. n. 5031.

Hudsonia Robins. n. 6075.

Huertea $\boldsymbol{R}$. et $P$. 1. 5923 . Hufelatadia Nees. n. 2031. Hugelia Benth. n. 3821 , a. Hugelia $\boldsymbol{R}, \boldsymbol{B r}$, n. 6013 . Hugelia Heich. n. 4361. Hugonia L. n. 5' 104 .

HUGONIACEAE p. 1016. Hugueninia Reich. n. 4906, e. Hulthemia Dum, n. 6538.

Humaria Eries. n. 430. c. k. Humata Cav. H. 643. c. a."

Humbertia Comm. u. 3812 .

Humboldtia Neck. n. 35't0.

Humboldtia Ruiz et P. n. 1325.

Humboldtia Vahl. n. 6792.

Humea Roxb. n. 5374 .

Humea Smith. n. 2727.

Humida Gray, n. 42.

Humiri Aubl n. 5486.

Humiria Juss n. 5 ' 186 .

HUMIRLACEAE p. 1039.

Humirium Mart. n. 5't86.

Humulus Linn, n. 1891.

Hunnemannia Sweet. A. 4828.

HUNNEMANNIEAE p. 857.

Hunteria Roxb. n. 339\%.

Hunteria $F l$ mex, n. 2582, a. $\beta$. Huntleya Bert. n. $1407 /$ 。

Huperzia Bernh. n. 696. a. Hura König n. 1621.

Hura L. n. 5776 .

Hutchiala $W$. et $A$. n. 3522.

Hutehinsia $A_{S}$. n. 69.

Hutehinsia Bory. n. 69.

Hutchinsia $\boldsymbol{R} . \boldsymbol{B r}$, n. 4931.

Huttum Sdans. n. 6325, a.

HYACINTHEAE p. 14 '.

Hyacinthus Linn. n. 1120 .

Hyaenanche Lamb. n. 5876.

Hyala Herit. n. 5216.

Hyalis Don. n. 2919.

Hyalis Salisb. n. 1243.

Hyaloa $D C$. n. 2371. a.

Hyalolepis DC. n. 2712 .

Hyalostemma Wall. n. 4729.

Hyhanthera Endl. n. 3444. *

Hybanthus Jacq. n. 5041 .

Hybotropis E. Mey. n. 6460. b.

Hybridella Cass. u. 2512.

Hydastylis Salisb, n. 1222.

Hydatiea Neck, n. 4634 . g.

HYDNEI p. 39.

Hydnoearpus Gärtn, n. 5085. Hydaocaryon Wallr. u. 352.

Hydnophytum Jack. n. 3185.

Hydnora Thunb, n. $72 \%$.

Hyduum Linn, n. 442.

Hydrangea Linn, n. 4668 .
HYDRANGEAE p. 820.

Hydranthelium Kunth, n. 3956. Hydrastis Linn. n. 4777 .

Hydrilla Rich, n. 1208.

Hydrobryum Endl. n. 1831/, .

Hydrocera Blum, n. 6061.

Hydroceratophyllum Vaill, n. 1829.

HXDROCEREAE p. 1173. HYDROCHARIDEAE p. 160.

Hydrocharis Linn, n. 1216.

Hydrochloa Hartm. n. 878.

Hydrochloa Link. n. 877. b.

Hydrochloa Palis. n. 731.

Hydroclathrus Bory. n. 107.

Hydrocleis L.C. Rich, n. 1045.* Hydrococeus Link n. 30.

Hydrocoryne Schwabe n. 35.

Hydrocotyle Tournef. n. 4355 . Hydrocotyle $\operatorname{Lin} n$. n. 4355.

HYDROCOTYLFAE p. 763.

Hydrodyction Roth. n. 55 .

Hydrogastrum Desv. n. 78.

Hydrogera $W_{e b}$. n. 254 .

Hydrogeton Pers. n. 1828. *

Hydroglossum Willd. n. 663.

Hydrolea Kinn. n. 3333.

HYDROLEACEAE p. 660.

Hydrolia Thouar. n. 3833.

HYDROLINEAE p. 2.

Hydrolinum Link. n. 14.

Hydromistria G. E. W. Mejer n. 1215.

Hydromyeus Raf. n. 401 .

Hydronema Carus. n. 38.

HYDROPELTIDEAE p. 901.

Hydropeltis $L$. $C$. Aich, n. 5025 . Hydrophora Tode. 253.

Hydrophorus Batt. n. 453. II.

Hydrophylax Linn. n. 3113.

HYDROPHYLLEAE p. 658 . e 1403.

Hydrophyllum Tournef. n. 3827 .

Hydropiper $E$. n. 5475 . b.

Hydropityon Gärtn. n. 3932.

Hydropogon Brid. n. 491.

HYDROPTERIDES p. 67.

Hydropyrum Link. n. 731.

Hydropyxis Rafin, n. 6864 .

Hydrosolea Mart. n. 86. a.

Hydrostacliys Thouar, a.1836.*

Hydrotaenia Lindl. n. 1228/ar

Hydrotriche Zucc. u. 3945 .

Hydrurus Ag. n. 17.

HYGROBIAE p. 1195.

Hygrocrocis Ag. 13. 37 .

Hygromitra Fries. n. 408 . e. 432. a.

Hygrophila Mack. n. 569. *

Hygrophila $\boldsymbol{R}, \boldsymbol{B r}, \mathbf{n} \cdot 4039$.

HXGROPHHLEAE p. 698.

Hygropyla Tayl, n. 469 . *

Hygroryza Nees. n. 783. *

Hylacium Palis, ‥ 3213.

Hylas Bigel. n. 6135. c. *

Hylogyne Knight et Sal. n. 215\%.

Hylophila Lindl, a. 1561.

Hymenachne Palis. n. 770.

Hymenaea Linn, n. 6788, a.

Hymenaudra $A_{p} \hat{h} . \quad D C$ : n. 4222. b.

Hymenanthe Fenzl. n. 5249. a. Hymenanthera $\boldsymbol{R}, \boldsymbol{B r}$. n. 5049 .

Hymenanthes Blum, n. 434. e. Hymenantherum Cass. n. 2579. Hymenella Fries. n. 398.

Hymenella Mog. et Sess. n. 5228. Hymenena Grev. H. 100.

Hymenidium Lindl, n. 4437 .

Hymenobryehis $D C$. п. 6619. b. Hymenocallis Herb. n. 1288. a. Hymenocalyx Zenk, n. 5281.

Hymenocardia Wall. u. 1899.

HYMENOCARPI p. 14.

Hymenocarpus Savi. n. 6506. d. Hymenocentron Cass. n. 2871.v. Hymenochaete Palis. n. 1000, a. Hymenocrater Fisch, ot Mey. n. 3669 .

Hymenocystis C. A.Mey. n. 648\%. Hymenodyetion Wallr. n. $3270^{\circ}$. Hymenogaster Vittad, n. 353. HYMENOGASTEREI p. 30 . Hymenogyne Haw. n. 5163.

Hymenolaena $D C$. n. 4538.

Hymenolepis Cass. n. 2689.

Hymenolepis Kaulf. n. 629.

Hymenolobus Nutt, n. 4927.

HYMENOMYCETFS p. 34 .

Hymenonema Cass. n. 2996.

Hymenonema Hook, n. 2978/1.

Hymenopappus Herit. n. 2595 .

Hymenophallus Nees. n. 358. et 1351.

Hymenophyllum Smith, n. 657.

Hymenophysa C. A. Mey. n.4933.

Hymenopogon Palis, n. 564 .

Hymenopogon Wall. n. 3276.

HYMENOSPORAE p. 14.

Hymenopteris Mantell. n. 676.

Hymenopyramis Wall, p. 638.

Hymenoria Achar. n. 141.

Hymenoseyphus Nees. n. 430.

A. d.

Hymenosphace Benth.n.3597, b.

Hymenospron $S p r$. n. 6662.

Hymenostachys Bory. n. 658.

Hymenostomia Gaud. n, 642. b.

Hymenostomum $\boldsymbol{R}$. Br. n. 484 .

Hymenostylium Brid, n, 485.

Hymenota $D C$. n. 6446 .

HYMENOTHALAMI p. 14.

Hymenothecium Lagasc. n. 855.

Hymenotomia Gaud. m 642.

Hymenoxys Cass. n. 2598. 
HXPOCHAERIDEAE p. 495. Hypochaeris Linn. n. 2985. Hypochnaea Fries. n. 301. Hypochums Fries, n. 266. Hypocrea Fries. n. 397. Hypocyrta Mart. n. 4159. Hypocystis Tourn. n. 723. Hypoderma Nestl. n. 201. Hypodermium Link. n. 201. Hypoderris $n$. Br. n. $648 / 2$. Hypodiscus Nees, n. 1012. b. Hypodrys Pers. n. 443.

Hypoelyptum $\boldsymbol{R}, \mathrm{Br}$, n. 987 . b. Hypoestes Sol. n. 4097 .

Hypogaeum Pers. n. 328. Hypogynium Nees, n. 950. a. Hypolaena $R . B r$. n. 1011.

Hypolepia Rafin. n. 401 . Hypolepis Bernh, n. 618. b *

Hypolepis Palis. n. 990.

Hypolepis Pers, n. 723.

Hypolyssus Pers. n. 432.

HYPOLYTREAR p. 116.

Hypolytrum $L, C$ Rich, n. 988.

Hypomarathrum $R$ iv. n. 4430, a.

Hypopeltis Fich, n. 6'0. a. *

Hypophialium Nees, n. 993 . b

Hypophoestum Gray, n. 2871.
Hypophyllocarpodendron Boerh. n. 2125.

Hypopithys Dillen. n. 4352.

Hypoporum Nees. n. 96'. c.

Hypopterygium Brid, n. 587. a. Hyporhodius Fries, n. $4 / 8$, b. et 453. VI.

Hypospila Fries. n. 392.

Hypothronia Schrank, n. 3578.

Hypoxanthus Rich. n. 6258. b. HYPOXIDEAE p. 173.

Hypoxis Linn, n. 1264. *

HYPOXYLA p, 31 .

Hypoxylon Bull, n. 396.

Hypsanthes Endl. n. 2122. b.

Hypsela Presl, n. 3054.

Hyptianthera Wight et Arn. n. 3303.

HYPTIDEAE p. 610.

Hyptis Jacq, n. 3583.

HYSSOPEAE p. 617.

Hyssopifolia $D C$, n. 6149. b.

Hyssopus Linn. in 3615 .

Hysterangium Vittad, n. 359.

Hysteria Reinw. n. 1546.

Hysterina Fries. n. 135, a.

Hysterium DC. n. 370 , b.

Hysteroearpus Langsd n. 637.

Hysteronica Willd.p. 1391. 17.

HYSTEROPHYTA p. 16.

Hystrix Möneh. n. 916.

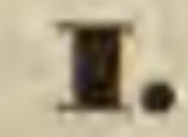

Theridastrum DC, n. 4887. b. Iberidium $D C$, n. 4887 . a

Iberis Dillen, n. 4886 .

lberis Kandir. n. 4932.

Iberis Linn. - n. 4887.

Ibetsonia Benth. n. 5422 .

Ibidium Salisb, n. 1547. a.

Ibira Marcgr. u. 4714 .

Ieacina Adr. Juss. n. 5488.

leaco Plum, n. 6407.

Icacorea $A u b l$. n. 4E22, a. $\psi_{\text {. }}$

Ichnanthus Palis. n. 771.

lehnocarpus $R$. Br. n. 3410 .

Iehthyomethia $\boldsymbol{P}, \boldsymbol{B r}$. n. 6723 .

Ichthyosma Sehlecht, n. 714.

Iehthyothera Mart. n. 2461.

Ieiea Aubl. n. 5932.

lcotorus Raf. n. 6391, a.

Ietodes Bigel. n. 1705.

Ideleria Funth, n. $968 /$, , b.

IDIOTHALAMI p. 12.

Ifloga DC, n. 2763 . b.
Ignatia Linn. n. 3360. *

Ignatiana Lour. n. 3360 .

Iguanura Blume n. 1752.

llea Fries. n. 86. a.

Ilex L. n. 5705 .

llex Pluckn, n. 5631.

Ilex Tourn n. 1845.

ILICINEAE p. 1091.

llicioides Dumort, n. 5707.

ILLECEBREAE p. 956.

Illecebrum Tourn. n. 5199.

ILLICIEAE p. 838.

Illicium Linn. n. 4743. *

Illigera Blum. n. 2069.

ILLIGEREAE p. 324.

IIlosporium Mart. n. 261.

llyogeton Endl. n. 3957.

Imatophyllum Hook. n. 1291.

Imbricaria Comm. n. 524t.

Imbricaria Fries. n. 172. C. $\beta$

Imbricaria Smith. n. 6311.

Imhofia Herb. n. 1274. a.

Impatiens Linn, n. 6060. *

Imperata Cyrill. 940.

Imperatia Mónch. n. 5244. c.

Imperatoria Linn. n. 4462 . g. Imperialis Juss. n. 1096. b.

Impia Dodon. n. 2752. a.

Inearvillea Juss. n. 4110.

INCARVILLEAE p. $\mathbf{7 1 0}$.

Incillaria Fries. n. 124 .

ludigofera Linn. n. 6530 ,

Inga Mart. n. 6837. b.

lnga Plum. n. 6837.

Ingenhousia Dennst, n. 4566 . Ingenhoussia $E . M e y$, n. 6465 .

Ingenhouzia Bert. n. 2820.

Ingenhouzia Mog. et Sess. n. 5296.

Inocarpns Forst. n. 2107.

Inoeybe Fries, n. 453 . IV. c.

Inoloma Fries, n. 453. V. c.

Institale Fries, n. 300.

lutsia Thouar. n. 6798.

Intybellia Cass, n. 3019, b.

Intybellia Monn. n. 3022. A. 1. Intybus Fries. n. 3022. A. 1.

Inula Gärtn. n. 2426. *

INULRAE p. 393.

Inulopsis $D C$. $n$. 2381. $f$.

Involueraria Ser. n. 5140, c.

lödes Blum, n. 4689.

Ipecacuanha Arrud. n. 3140.

Ipbiona $D C$ n. 2432.

Iphisia Wight et Arn, n. 3480. Ipo Camell. n, 1862.

Ipomaea Chois. n. 3803. c.

lpomaea Jacq. n. 3803.

Ipomeria Nutt, n. 3821. f.

Ipomopsis L. C. Rich, n. 3821. Ipsea Lindl. 1386.

Iresine Wilta. п. 1954.

Iria Rich, n. 1003. e.

1riartea Ruiz et $P$. n. 1733, *

tridaps Comm. म. 1868, a.

IRIDEAE p. 164. et 1359.

Iridion Burm, n. 5038 .

Irian Blume n. 5607.

Irio DC. n. 4906. d.

Iris Limn. u. 1226, *

Irlbachia Mart. n. 3551.

Iron P. Brown, i. 5050 .

Iroucana Anbl, n. 5060 . a, $\beta$.

Irpex Eries, n. 440.

Irsiola P., Brown, n. 4566.

lsachne $\boldsymbol{R}, \boldsymbol{B r}$, н, 773 .

Isanthera Nees. n. 3871.

Isanthus H. C. Rich, n. 3592.

Isanthes Less. n. 2906.

Isaria Pers. n. 270.

ISATIDEAE DC. p. 880 .

Isatis Linn, n. 4938.

Isaura Comm, n, 3510.
Isauxis Arn, n. 539\%. b.

Ischaemum $L_{i n n}$, n. 951.

Ischarum Blum, n. 1675. b.

Isertia Schreb. n. 3234.

ISERTIEAE p. 547.

Isidorea A. Rich. n. 3256 .

lsidrogalvia Ruiz et $\boldsymbol{Y}, \mathrm{n}, 1062$.

Isika Adans, n. 3337. B.

Isis Trattinik n. 1226.

Ismelia Cass. n. 2671.

Ismelia $D C$. n. 2671. c.

Ismelioides $D C$, n. 2671, d.'

Ismene Herb. n. 1288.

Isnardia Limn. n. 6111. a.

Isocarpha $\boldsymbol{A}, \mathrm{Br}$, n. 2257.

socarphoides $D C . \mathrm{n}, 2258$.

Isochilus $\boldsymbol{R} . \mathbf{B r}, \mathrm{n}, 1375$.

Isodon Sehrad. n. 3575. e.

ISOETEAE p. 68.

Isoetes Linn, n. 693.

Isolepis Link. n. 999. a.

Isolepis $\boldsymbol{R}, \boldsymbol{B r}, \mathbf{n} .999$.

Isolobus $D C$. n. 3057. e. *

Isomeria Don. n. 2204. g.

Isomeria Prest. n. 3041. b.

Isomeris Nutt. n. 4990.

Isomerium $\boldsymbol{R}, \boldsymbol{B r}$. n. 2132. c.

Isonema Cass. n. 2206.

Isonema $\boldsymbol{A} \boldsymbol{B r}$. n. $\mathbf{3 4 1 4}$.

Isopetaloidea $D C$. n. $60^{4}$. $\beta$.

Isopetalum Eckl. et Zejh. n. $6048 . \mathrm{m} . \beta$.

Isopetalum Sweet. n. 6048. g. Isophyllum Hoffm, n. 4414 .

Isophyllum Spach. n. 5463. b. Isoplexis Lindl. n. 3915. b. Isopogon $\boldsymbol{R}$. Br. n. 2122.

lsopteris Wall. p. 1334. 28.

Isopyrum Adans. n. 4774.

Isopyrum $A$. Aich. n. 4790 . b.

Isopyrum Kinn. n. 4790.

Isopyrum Reich. n. 4790, a.

Isora $S c h . F$. 5316. b.

Isostigma Less. n. 2570.

Isostylis $\mathrm{A}, \mathrm{Br}$. n. 2157. b.

Isothea $D C$. n. 6464. a.

Isothecium Brid. n. 573.

Isotoma $\boldsymbol{R}, \boldsymbol{B r}, \mathrm{n} .3060$. e.

Isotria Raf. n. 1601.

Isotrichia $D C$. n. 222\%. b.

Isotropis Benth. n. 6429.

Isotypus $\boldsymbol{H}, \boldsymbol{B}, \boldsymbol{K}$, n. 2929.

Istactzapotl Mex, n. 6879.

Isthmia Ag. n. 7.

Itea Linn. n. 4677.

Ittnera Gmel. n. 1655.

Ityphallus Fries. n. 358. d.

lva Linn. n. 2185.

IVEAE p. 403.

Ivira $A$ ubl, n. 5320. a. $\beta$.

Ivonia $\mathrm{Fl}$. Fl. p. 1334. 29.

Lxanthus Grieseb. n. 3540\%.

Ixanehenus Cass. n. 2352.

Ixerba A. Cunn n. 4681/x.

Ixeris Cass. n. 3012.

lxia $\operatorname{Linn}$. n. 1243.

lxianthes E. Mey. n. 3913.

Ixianehenus Less, n. 2352.

Ixiolaena Benth. n. 2734.

Ixiolirion Fisch. n. 1293.

Ixionanthes Jack. n. 5557 .

Ixodia $\boldsymbol{R}, \boldsymbol{B r}, \mathrm{n}, 2724$.

Ixodia Soland. n. 5025.

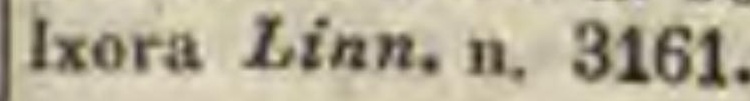

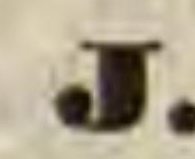

Jaborosa Juss. n. 3861.

Jaca E. n. 1868. a.

Jaeaeoides $D C$. n. 2871. g.

Jacaranda Juss. n. 4115. *

Jacea $D C$, n. 2871 . f.

Jackia Bi, n. 5657 .

Jackia Spreng. n. 5355.

Jackia Wall. n. 3329.

Jacksonia $\boldsymbol{R}, \boldsymbol{B r}, \mathrm{n}, 6434$.

Jacksonia Rafin. n. 4988.

Jacobaea Tournef. n. 2811.

Jacobia $D C$. n. 6206. a.

Jacosta E. Mey. n. 2680.

Jacquemontia Belang. n. 2657.

Jaequemontia Chois, n. 3803. ᄂ.

Jacquinia Linn. n. 4228. *

Jacquinia Mutis. n. 5381.

Jägeria $H, B, K$ n. 2497.

Jalambicea Llav, et Lex. n.1215.

Jalapa Tournef. n. 2003.

Jambolifera Linn, n. 5978.

Jaubos Adans. n. 6324.

Janbosa Rumph. n. 6324.

Jamesia Torr, et A. Gray. n. $4670 \%$.

Jamesoni Hook - n. 623. *

Jania Schult. n. 1077.

Janipha Kunth. n. 5808 .

Janraja Plum, n, 1200.

Janusia Adr. Juss. n. 5562.

Japotapita Plum. n. 5958.

Jaracatia Macgr. n. 5119.

Jarava Ruiz. n. 798. e.

Jaravaea Scop. n. 6195. et 6197.

Jaroba Marcgr. n. 4172.

Jasione Linn. n. 3071.

JASIONEAE p. 514.

JASMINEAE p. 570. et 1395.

Jasminum Tourn, n. 3342.

Jasonia Cass. n. 2433. b.

Jatropha Funth, n. 5806.

Jatropha Pohl. n. 5806.

Jatus Rumph n. 3703.

Jaumea Pers. n. 2600.

Jeffersonia Barten. n. 4807.

Jenkinsonia $\boldsymbol{S}$ weot, n. 6048 . k.

Jirasekia $W$, Schmidt. n. 4213.a.

Joachimia Tenore n. 749.

Joannea Spreng. n. 2913.

Joannesia Pers. n. 2913.

Jodanthns Torr. et $A$. Gray. 
Juglans Linn. n, 5890. Juliana Llav, et Lex, n. 6033. Julieta Leschen. n. 4282. * JULIFLORAE p. 270. Julocroton Mart. n. 5828.

JUNCACEAE p. 130 . et 1356. JUNCAGINEAE p. 127.

Juneago Tourn. n. 1039.

Junearia Clus. n. 5214.

JUNCEAE p. 130.

Juneus $D C$, n. $10^{\prime}+9$.

Juncus Desv. n. 1049. a.

Jundzillia Andrz, n. 4932, a.

Jungermannia Dillen. n. 473.*

JUNGERMANNIACEAE p. 15. et 1338.

Junghansia Gmel. n. 4577 .

Jungia Gärtn. n. 6311.

Jungia Linn. f. n. 2954.

Jungia Mönch. n. 3597. h.

Juniperites Brongn, n. 1814.

Juniperus Linn. n. 1789.

Jurinea Cass, n. 2898.

Jussiaea Linn. n. 6109.

JUSSIEVEAE p. 1188.

Jussievia Houst, n. 5807 .

Justicia Nees. n. 4089 .

JUSTICIEAE p. 703.

\section{面.}

Kadsura Juss, n. 4731.

Kadua Cham, et Schl, n. 3240. i. Kageneckia Ruiz et $\boldsymbol{P}$.n.6396. Kahiria Forsk. n. 2200.

Kalanehoẻ Adans. n. 4616.

Kalbfussia $\boldsymbol{S}_{\text {chulz. n. } 3001 .}$

Kalenehoë Haw, n. 4616.

Kali Tourn. n. 194t.

Kallias DC. n. 2506. b.

Kallstrómia Scop. n. 6031.

Kalmia Linn. n. 4339.

Kalosanthes Haw. n. 4615. b.

Kämpferia Linn. n. 162\%.

Kampmannia Rafin. n. 5872 . d.

Kampzia Nees. n. 6291.

Kanahia $R . B r$. n. 3471 .

Kandelia Wight et Arn.n.6100.

Kaniram Thouar. n. 3359.

Kantuffa Bruc. n. 6796.

Karamischewia Fisch. el Meg. n. $3240 \%$.

Karatas Plum, n. 1300.

Karelinia Less. n. 2402.

Karpathon Raf. p. 570. 2.

Karwinskia Zucc. n. 5723.

Kataxera E. n. 6216. c.

Kaulfussia Blum. n. 667.

Kaulfussia Nees, n. 2341.

Kayea Wall. n. 5449.

Keerlia DC. n. 2355 .

Keimadracon Benth. n. 3638. a.

Keiria Bowd, n. 6865.

Keithia Benth. n. 3620.

Kennedya Vent. n. 6641.

KENNEDYEAE p. 1290.

Kentia Blum. n. 1727/s.

Kentia Blum, n. 4713. c.

Kentranthas Neck, n. 6185.

Kentrophyllum Neck. n. $28 \$ 7$.

Kentrophyta Nutt, n. 6576.

Keppleria Mart, n, 1749. *

Keranthus Lour, n. 1369.

Keraudrenia Gay. n. 5327.

Keraselma Nees, n. 5766.

Kermesia Endl. M. 5262, a.

Kernera Medil, n. 4882 . b.

Kernera Willd. n. 1660.

Kerneria Mönch, n. 2541.

Kerria DC. n. 6390.

Ketmia Tourn, n. 5277.

Kenlia Molin, n. 2036. c.

Keurva Forsk, -n. 1711.
Khaya A. Juss. n. 5550 . Kibara Endl. n. 2016. Kibatalia Don, n. 3430. * Kibera Adans. n. 4906. f. Kibessia Blum. n. 6265.

Kieksia Dum. n. 3891. d. Kielbal Adans. n. 801. c.

Kielmeyera $M$. Z. n. 5419 . Kiersehlegia Spach. u. 6125. b. Kiesera Reinw. n. 6654 .

Kieseria Nees. n. 5417. Kigelia $D C$. n. $4173 /$.

Kigellaria Linn. u. 5082. Kingia $\boldsymbol{R}, \boldsymbol{B r}, \mathrm{n} .1057$.

KINGIACEAE p. 132. Kingstonia Gray. n. 4634. i.

Kinkina Adans. n. 3274.

Kirganelia Juss. n. 5845.

Kissi E. n. 5425. b.

Kitaibelia $\boldsymbol{W}$. n. 5268.

Kittelia Reichenb. n. 4065. *

Kíxia Blum. n. 3430.

Klaprothia Kunth, n. 5113.

Klasea Cass. u. 2897. c.

Klausea Cass. n. 2897.

Kleinhovia $L$. n. 5335.

KLEINHOVIEAE p. 999.

Kleinia Jacq. n. 2582.

Kleinia Just. n. 2600.

Kleinia Linn, n. 2809.

Klotzschia Cham. n. 4381.

Kluckia Andrz. n. 4906. a.

Klugia Schlecht. n. 4142.

Kuappia F. Bauer n. 4141.

Knappia Smith, n. 746.

Knautia Coust. n. 2193.

Knautia Linn, n. 2193. a.

Kneiffia Spach. n. 6115. 8.

Knemia Lour, n. 4707.

Kuightia $R$. Br. n. 2151.

Kniphofia Mönch, n. 1114.

Knorrea Moc. et Sess. n. 5937.

Knowltonia Salisb. n. 4775.

Knoxia Linn, n. 3134.

Koanophyllum Arrud, p. 1391.4.

Kobresia Willd. n. 962.

KOBRESIEAE p. 111.

Kochia Roth. n. 1928.

Kochia $A . B r$. n. $192 \%$.

KOCHIEAE p. 295.

Koeberlinia Zucc. n. 5670. *

Koelera Willd. n. 5080.

Koeleria Pers. n. 889.

Koellea Biria n. 4788 .

Koellia Mónch. n. 3605. b.

Koelpinia Pall. n. 2971

Koelrentera Hedis, n. 556.

Koelreutera Murr. n. 5261.

Koelreuteria La.rm. n. 5622.

Kohautia Cham, et schlecht. n. 3240 . h.

Kohlrausehia Kunth, n, 5244.b. Kolbea Schlecht. n. 1077.

Kolbia Palis. n. 5105.

Kolleria Prest. n. 5166. a.

Kolowratia Presl. n. 1640.

Konig Adans. n. 4870.

Koniga $\boldsymbol{R}, \boldsymbol{B r} . \mathrm{n}, 4870$.

Konnigia Comm, n. 5345.

Königia Linn, n. 1985.

Koon Gärtn. n. 5621.

Kopsia Blum. In. 3390.

Kopsia Lumort. n. 4183, a.

Kordellestris Arrud. n. 4115.

Kosaria Forsk. p. 279.

Kosteletzkya Presl. n. 5276.

Kotschya Endl. n. 6607.

Krameria Löfft, n. 5656.

Krapfia DC. n. 4783 . b.

Krascheninikovia Güld, n. 1911.

Kraseheninikovia Turez, n.5236.

\begin{tabular}{l|l} 
Kraunhia Raf. n. 6671. & Lagenophora Cars. n. 2351. \\
Krebsia Eckl. ot Zegh, n. 6490. & Lagerströmia Linn. n. 616t.
\end{tabular}

Kreysigia Reich, n, 1079. Krigia Schreb. n. 2981.

Krokeria Reck. n. 4717.

Krokeria Mönch. n. 6514. a.

Krubera Hoffm, n. 4450 .

Kruegeria Neck, n. 6803. b.

Ktenospermum Lehm, p. 3784/1.

Kugaja DC. n. 2582. e.

Kugia Bert. p. 1334. 30 .

Kuhlia Kunth, n. 5074 .

Kuhlia Reins, n. 3367.

Kuhnia Linn. n. 2268.

Kuhnistra Lam, n. 6522. b.

Kumara Mredik. n. 1115. d.

Kumbaya Endl. 3. 3305. b.

Kundmannia Scopol. n. 4426.

Kunthia Dennst, n. 5938.

Kunthia $\boldsymbol{H}$. et $\boldsymbol{B}, \mathrm{n} .1722$.

Kunzea Reich. n. 6303. c.

Kunzea Spr. n. 6380.

Kurrimia Wall. n. 5692.

Kutsehubaea Fizch. n. 3312.

Kyberia Neck, n. 2348. a.

Kydia Roxb. n. 5353.

Kyllingia Linn, n. 1003. b.

Kyrtanthus Gmel. n. 3308.

\section{I.}

Labatia Scop. n. 5705.

Labatia Swartz. n. 4236. *

LABIATAE p. 607. et 1400 .

LABIATIFLORAE p. 480 . et 1385.

Labichea Gaud, n. 6782.

Labillardiera $\boldsymbol{R}$, Sch. n. 5668.

Lablab Adans. n. 6677.

Labordia Gaud. n. 3363.

LABORDIFAE p. 575 .

Labourdonneia Boj. n. 4243 .

Labradia Swed, n. 6665.

Labrella Fries. n. 362.

Laburnum DC, n. 6505. c.

Lacara $s_{p r}$, n. 6789.

Laearis Hamilt. n. 5972. b.

Lacathea Salisb. n. 5424. b.

Lacellia DC. n. 2865. A. B. 2.

Lacepedea $\boldsymbol{H}$. B. $K$. n. 5703 .

Lachanodes DC. D. 2818.

Lachenalia Jacq. n. 1124.

Lachnaen Linn, n. 2094.

Lachnagrostis Trin. n. 818.

Lachnanthes Elliot, n. 1255.

Lachnopodium Btum, n. 6218.

Lachnospermam Willd. n. 2755.

Lachnostoma $H, B$. If. n. 3452 .

Lachum Rete. n. 430. B.

Lacis Lindl. n. 1834.

Lacis Mart, n. 1833. a.

Lacis Sehreb. n. 1833.

Lacistema $S_{\text {wartz. n. }} 1907$.

LACISTEMEAE p. 291.

Lactuca Linn. n. 3008.

LACTUCEAE p. 498.

Ladanopsis DC. n. 6214. c.

Ladannm Spach. p. 5028. b.

Laelia Adans. n. 4973. b.

Laelia Lindl. n. 1379. *

Laennecia Cass. n. 240\%.

Laetia Löffl. n. 5071 .

Lafoensia Vandell. n. 6162.

Lafuentea Lagasc. n. 4022.

Lagarinthus E. Mey. n. 3485.

Lagasea Cav. n. 2237. a.

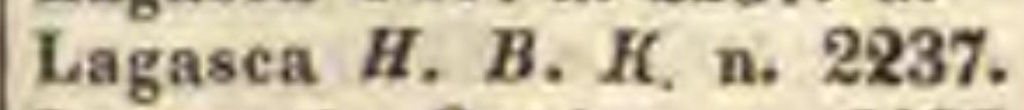

Lagenaria Sering. n. 5136.

Lagenias E. Mey. n. 3559 .

Lagenifera Cass, n. 2351.

Lagenium Brid. 11. 547.

LAGERSTRÖMIEAE p. 1203.

Lagetta Juss. n. 2106.

Lagochilus Bung. n. 3646 .

Lagoecia Linn. n. 4518.

Lagony chium Bieberst. n. 6822.

Lagopsis Benth, n. 3657, - a.

Lagopns Ser. n. 6511. a.

Lagoseris Bieberst. n. 3019.

Lagothamnus Nutt, n. 2814. *

Lagotis Gärtn. n. 3984.

Lagunaria Don. n. 5282.

Laguneularia Gürtn, n. 6082.

Lagunezia Soop. n. 5086. b.

Lagunea Cav. n. 5244.

Lagunea Loureir. n. 1986. b.

Laguranthera $C$. A. Meg. n. 2853. A. $\beta$.

Lagurostemon Cass. n. 2853.

Lagurostemon C. A. Mog. $n$.

1853. a. $*$.

Lagurus Linn, n. 862.

Lahaya $R$, et $S c h$. n. 5216.

Lalage Lindl. n. 6453.

Lallemantia Fisch, et Mey, n. $3638 / 1$.

Lamanonia Fl, Fl, n. 4664 .

Lamarchea Gaud. n. 6293.

Lamarckea Pers. n. 3844.

Lamarckia Hort. n. 5688.

Lamarekia Mönch. n. 895.

Iamarkia Olivi n. 81.

Lambertia Smith. n. 2145.

LAMIEAE p. $62 \%$.

Laminaria Lamx, n. 108.

Laminarites Brongn, n. 122. g.

Lamiopsis Dum. n. 3645. b.

Lamiotypus Dum. n. 3645 e.

Lamium Linn. n. 3645.

Lamouronxia $\mathrm{Ag}_{\text {g. n. }} 102$.

Lamourouxia Bonnemais, n. 61.

Lamourouxia $\boldsymbol{H}, \boldsymbol{B} . \boldsymbol{K}$. n. 4008.

Lampra Lindl. n. 4311.

Lamprocarpus Blume n. 1029.

Lamprocarya $\boldsymbol{R} . \boldsymbol{B r}$. n. 981.

Lamprostachys Boj, n. 3671 .

Lamprotis D. Don. n. 4313. e. Lampsana Vaill. n. 2967.

LAMPSANEAE p. 493.

Lampijang Rumph, n. 1622. 
Lappa Tourn, n. 2892. Lappago Schreb. u. 786. Lappula DC. n. 5372. a. Lappula Mönch. M. 3786. Lapsana Tourn. n. 2967.

Larbrea Ser. n. 5242.

Larbrea St. Hil. n. 5240. b. $\delta$.

Lardizabala Ruiz et P. n. 4703.*

LARDIZABALEAE p. 828.

Laretia Gill, ot Hook. n. 4371 .

Larix Tourn, n. 1795. d.

Larochea Haw. n. 4615 a.

Larrea Cav. n. 6038.

Lasallia Merat. n. 145 . a.

Lascadium Rafin. n. 5838.

Lasehia Fries. n. 407.

Laserpitium Tourn, n. 4492.

Lasia Brid. H. 581. h.

Lasia Lour. ". 1701.

Lasiagrostis Link. n. 795.

Lasiandra $D C$, n. 6208 .

Lasianthea $D C$. n. 25't

Lasianthera Palis. n. 4671.

Lasianthus $D C$. n. 5424 . a.

Lasianthus Zucc. n. 2544.

Lasiobotrys Spreng. If. 178.

Lasioeephalus $S \mathrm{chl}$. p. 1391 . 5

Lasiochloa Funth, a. 893.

Lasiocorys Benth. n. 3659 .

Lasionema Don, n. 3272.

Lasiopera Link et Hoffm. n. 4013. b.

LASIOPETALEAE p. 5322.

Lasiopetalum Sims. n. 5325.

Lasiopogon Cass. n. 2749.

Lasieptera Andrz. n. 4932.

Lasiopus Cass. u. 2907.*2927/\%.

Lasiopus Don, n. 3027/1.

Lasiorhegma Vogel. n. 6781. g.

Lasiorhiza Lagase. n. 5957 . *

Lasios Targ. n. 91. a. et $9 \%$. f

Lasiosiphon Fresen, u. 2101/1

Lasiosperma Lagase, n. 2653.

Lasiospermum Fisch. u. 2997. b.

Lasiospora Cass. n. 2997. b.

Lasiospron Benth. n. 6674. e.

Lasiostemon Schott, n. 3990 .

Lasiostemum Lees, et Mart, n. 5990.

Lasiostoma Schreb. n. 3359

Lasthenia Cass. n. 2610.

Lasthenia Lindl, n. 2609.

Lastraea Bory. n. 615. a. $\gamma$.

Latania Commers. n. 1747.*

Laternea Turp. n. 355, a

Laterradea Basp. n. 29.

Lathraea Linn, n. 4188 .

Lathraeophila Leandr. n. 721.*

Lathriogyne Eckl. et Z, n. 6466.

Lathrisia Swartz. n. 1534.*

Lathyrus Limn. n. 6582.

Latipes Kunth, n. 788.

Latouria Endl. n. 3048. a.

Latreillea $D C$. I. 2460 .

Laugeria Jacq. 1. 3192 , b.

Laugeria Ruiz et Pav, n. 3192 .

Laugeria Yaht, n. 3192. d.

Laumea Cass, n. 3017.

Launzea Buchan, и. 5919.

Laurea Gaud, n. 1822.

Laurelia Jass. n. 2021.

Laurembergia Berg. n. 6136.

Lanrencia Lamx. ". 91. a.

Laureatia Neok. n. 3060.

Laureria Schlecht. n. 3843/,

Lauridia Eokl. et Zeyh. n. 5688 .

LAURINEAE p. 315. et 1378.

Laurocerasus Tourn, n. 6406 . c. $\beta$. b.

Lauroplayllus Thunb. n. 5907.*

Laurus Burm. n. 6094.

Laurus Tourn, n. 206!

Lavandula Linn, 1. 3585.
LAVANDULEAE p. 611.

Lavanga Meisn. n. 5511 .

Lavatera $\boldsymbol{L}$. n. 5269.

Lavauxia Spach, n. 6115. b.

Lavenia $S_{\text {wartz. n. }} 2261$.

Lavoisiera $D C$. n. 6172

LAVOISIERE AE p. 1206.

Lavradia Velloz. n. 5051. Lawrencella Lindl. n. 2730/1.

Lawsonia Linn. n. 6159.

Laxmannia Fisch. n. 6388.

Laxmaunia Forst. 11. 2455.

Laxmannia $R, B r$. n. 1169 .

Laxmania S. G. Gmel,n. 3102.

Laxmanuia Smith. n. 5978.

Laya Hook. et Arn. n. 67't's.

Layia Hook, et Arn. n. 2622. *

Lazarolus Med. n. 63t2.

Leaeba Forsk. n. 4637.

Leandra Radd. n. 6225 .

Leangium Link. n. 318 . d.

Leantria Soland. n. 6316. a. $\kappa$.

Leathesia Gray. n. 31.

Leavenworthia Torrey. n. 4862.

Lebeckia Thunb. n. 6478.

Lebetanthus Endl, u. 4233. *

Lebetina Cass. n. 2576.

Lebretonia $S$ shr. n. 5275. c.

Leeanactis Eschw. n. $13 \%$.

Leeananthus Jack, n. 3323.

Lecanidion Endl. n. 381.

Lecanocarpus Nees. n. 193'\%.

Lecanopteris Prest. n. 613. *

Lecanopteris Reinw. n. 617/1.

Lecanora Achar. n. 172.

Lecauora Eversm. n. 166.

Leeanotis Esch, n. 13'.

Lechea Cass. n. 2529.

Lechea Linn. n. 5030.

Lecliea Lour. n. 1028. a.

Lechea Spach, n. 5030. a.

Lechenaultia $\boldsymbol{R}$. Br, n. $30^{\prime} \nprec 3$.

Lecheoides Dunal. n. 5029. f.

Lecheoides Spach, n. 5030 . b.

Lechidium Spach. n. 5030.

Lecidea Achar. n, 165.

LECIDINEAE p. 14.

Lecokia DC. n. 4528.

Lecontea A. Rich, n. 3181.

Lecontia Torr, n. 1085. *

Leeostomum $M$, et S. B. 6415.

LECYTHIDEAE p. 123 t.

Lecythis Löfft. n. 6332.

Lecythopsis Schr, n. 6331.

Ledebouria Roth. n. 1076.

Ledeburia Link, n. 4t10. b.

LEDOCARPEAE p. 1169.

Ledocarpon Desf. n. 6050.

Ledonía Dun, n. 5023, b, et e.

Ledum Mich. u. 43\%1.

Leea Linn. n. 4569 .

LEEACEAE p. 796. et 797.

Leersia Hedw. n. 519. et 537 .

Leersia Sol. It. 728.

Leeuwenhoeckia $E$. M. M. 53's7.

LEGNOTIDEAE p. 1166.

Legnotis Swartz. n. 610'.

Legouzia Dur. n. 3086 . a.

LEGUMINOSAE p. 1253.

Lehmannia $S_{p r e n g}$ n. 3312 .

Leiachena $D C$. u. 2758. b.

Leiachenium $D C$. n. 238L. a

Leianthus Gries, n. 3552/.

Leiaparine $D C$. n. 3100 . e.

Leiblinia Endl, n. 07.

Leibnitzia Cass. n. 2933.

Leighia Cass. It. 2535.

Leighia Scop. n, 2200.

Leimanthime Willd. n. 1067/1

Leinkeria $S_{\text {cop. 1. } 2148 .}$

Leiocarpum DC. n. 2932. b. *

Leiocarpus Blum. \#. 58't.
Leiocarpus $D C$. n. 6032 .

Leiochrysum $2 C$. n. 2742. e. Leioderma Pers. n. 398.

Leiogalium DC. n. 3200, n.

Leiogonia $D C$. n. 2368. e.

Leiolobium DC. n. 6518. b.

Leiolobium Reich, n. 4919. b.

Leiophallus Fries. n. 355 . c.

Leiophyllum Pers. n. 43 '3.

Leiopoterium $D C$. n. 6374 . b

Leiorreuma Eschw, ․ 146.

Leiospermum Don, n. 4656.

Leiospermum Wall. n. 1962.

Leiosphaera $D C$. ก. 6259. a.

Leiospora C. A. M. n. 4856.

Leiostroma Fries. n. 437. a

Leiothamnus Gries. n. 2355/.

Leiotheca Brid n. 510.

Leiotulus Ehrenb. n. 4'77'.

Leiphaimos Schl. II. 35 to. b.

Lejeunia Dum n. 472 . *

Lejiea Hill, u. 2493. a.

Lemalis Fries. 11. 405.

Lemanea Bory. n. 52.

Lemanina Bory. n. 50.

Lemmatium DC. n. 2612. *

Lemna Juss. n. 691.

Lemna Schleid, n. 1668/1.

LEMNACEAE p. 232 . et 1369.

Lemniscia Schreb. n. 5383.

Lemniscus Targ. n. 91. a.

Lemnopsis Zipp, p. 270.

Lemonia Lindl. n. 5993/1.

Lemonia Pers. n. 1239.

Lenidia Thouars, n. 4750.

Lennoa $\mathrm{Ll}$. et $\mathrm{L}$. n. 6861.

Lens Tourn, n. 6589, a.

Lentago $D C$. n. 33't8, b.

Lentibularia Vaill, n. 4193.

LENTIBULARIEAE p. 723.

Lenticula n. 6580. e.

Lentieula Endl. n. 1668/1, a.

Lenticula Mich. u. 1668.

Lentiscus Tourn. n. 5893. b.

Leobordea Del. n. $6^{\prime} 489$.

Leocarpus Link. 11. 318 . c.

Leonia Ll, et L. n. 3597. k.

Leonia Ruiz ot P. n. 4231.

Leonicenia Scop. n. 6250 .

Leonotis Pers. n. 3663.

Leontice Linn. u. 4810.

Leontícoides $D C$. n. 4839 . d.

Leontodon Adans, n. 3010.

Leontodon Linn. n. 2990.

Leontodontoides Mich. n. 2975.

Leontonyx Cass. n. 2740.

Leontopetalum Tourn. n.4810, a. Leontophth
$2616 . d$.

Leontopodium $R$. Br. n. 2769.

Leonurus Linn. n. 3647 .

Leouurus Tourn. n. 3563.

Leopoldia Herb. n. 1273.

Leopoldinia Mart. n. 172\%.

Leotia Hill. n. 432.

Lepaehys Less. n. 2516.

Lepachys Rafin, n. 2516. a.

Lepanthes $S$ wartz. h. $132 \%$.

Lepargyreia Rafin. n. 2113.

Lepechinia Willd, n. 3653.

Lepeocercis Trin, 14. 969.

Lepeostegeres Blum. 11. 4586 . p.

Leperiza Herb. n. 123 '.

Lepia Desv. n. 4932.

Lepicephalus Lag. n. 2192.

Lepicline Cass. 11. 2741.

Lepidadenia Nees, n. 2062.

Lepidagathis Willd. H. 4065.

Lepidanthus Nees. n. 1015.

Lepidaploa Cass. n. 220\%. h.

Lepideilema Trin. n. 911.

Lepidiastrum $D C$. в. $4932 . \mathrm{g}$.

LEPIDINEAE p. 878.

Lepidium $\boldsymbol{R}$. Br. n. 4932.

Lepidoearpodendrou Boerh. n. 2123.

LEPIDOCARYINAE p. 2' 48 .

Lepidocarynm Mart. n. 1744. *

LEPIDODENDREAE p. 70.

Lepidodendron Brongn, n. 699 .

Lepidofloyos Sternb. n. 699. b.

Lepidoma Achar. n. 166.

Lepidonema $\boldsymbol{F}$. et $M$. n. 2983.

Lepidopappus $\mathrm{Fl}$. mex. n. 2589.

Lepidophorum Neck. n. 2647.

Lepidophyllum Brongn. n. 700.

Lepidophyllum Cass. n. 2363.

Lepidopilum Brid. n. 591.

Lepidopogon Tausch. n. 2'19.

Lepidosperma Labill. n. 973.

Lepidostachys Wall. n. 1898.

Lepidosteplianus $B$. n. 2633/1.

Lepidostrobus Brongn. n. 702.

Lepídostrobus Lindl. n. 701.

Lepidotis Palis, n. 696. b.

Lepidotospernia $\boldsymbol{R}$, $\theta t S \mathrm{ch}$. $\mathrm{n}$. 973. a.

Lepidozia Dum. n. 472/19* a.

Lepigonum Fr. n. 5218.

Lepionurus $\mathbf{B l}$. n. 5489 .

Lepiota Fries. n. 453. VII. d.

Lepironia Rich. n. 986.

Lepisauthes Bl. n. 5609.

Lepismium Pfoiff. n. 5160. b

Lepistemon Blume. n. 3804.

Lepistoma Blum. n. 3439.

Leposma Blum, n. 3439.

Lepra Hall. n. 126.

Leprantha Duf. n. 148.

Lepraria Achar. n. 126.

Lepraria Fries. p. 21. d.

Lepropinacia Vent. n. 140.

Lepta Lour. n. 5695.

Leptacantlus Nees. n. 4059.

Leptadenia $\boldsymbol{R}$. Br. n. 3514 .

LEPTADENIRAE p. 597. 
Leptogium Fries, n. 163. Leptoglossa $D C$. n. 2759. b. Leptoglottis $D C$, n. $682 \%$. Leptogyne Ell, n. 2414. a. Leptohymenium $S c h w$. n. 569. Leptolaena Thouar. n. 5399. Leptolobium Benth. n. 6645. Leptolobium Vogel. n. 6751. Leptomeria $\boldsymbol{R}$. Br. n. 2075. * LEPTOMITEAE p. 4 . Leptomitus A $_{\text {B }}$. n. 38 Leptomorpha $D C$. n. 2845. b. Leptonema A. Juss. n. 5852. Leptonemia Nutt. n. 4491. Leptonia Fries. n. 453. VI. c. Leptopetalum Hook. n. 3244. Leptophyta $D C$ n. 2772 . Leptophytus Cass. n. 2772. b. Leptopleuria Presl. n. 644. d. Leptopoda Nutt. n. 2585. * Leptopora Rafin; n. 4'47. b. Leptopyrum $\boldsymbol{H}$ af. n. 864. Leptopyrum Reich. n. 4790 . b. Leptorhynchus Less. n. 2732. Leptormus DC. n. 4978 . b. Leptosema Benth n. 6750 . Leptosiphon Benth. n. 3821 . Leptosolena Presl. n. 1633.

LEPTOSPERMEAE p. 1227. Leptospermoides $D C$. n. 2204. c. Leptospermum Forst. n. 6309. Leptospron Benth. H. 6674. e. Leptostachya Mitch. n. 2690. Leptostaehya Nees. n. 4085. Leptostachys Meger. n. 8'0. Leptostegia Don, н. 635. * Leptostelma Don, n. 2332. a. Leptostemma Blum. n. 3509. Leptostomum $\boldsymbol{R}$. Br. n. 54t. Leptostroma Fries. n. 360.

Leptostylis $C . A$. M. n. 4854 . e. Leptosyne $D C$. n. 2488.

Leptotaenia Nutt. n. 4't62/2. Leptotes Lindl, n. 1382.

Leptothamnus $D C$. n. 2391.

Leptotheca Schwägr. n. 5t5. Leptothrium Kunth. n. 93\%. Leptothyrium Kunze. n. 360. Leptrina Rafin. p. 952. Leptuberia Rafin. n. 126. Lepturus $R, B$ r. n. 922. Lepuropetalum Ell. n. 4637. * Lepyrodia R. Br. n. 1018. Lepyrodiclis Fonzl, n. 5230 . Lerchea Linn. n. 3251/4 Lerchia Hall. n. 1941. Leretia Fl. Fl. p. 1334. 31. Leria $D C, \mathrm{n}, 2935$.

LERIEAE p. 487.

Lerouxia Merat. n. 4207. c. Leskia Hedw. n. 572.

Lespedeza $\boldsymbol{L}, \boldsymbol{C}, \boldsymbol{R}$, n. 6623 . Lessertia $D C$. n. 6563.

Lessingia Cham. n. 2383.

Lessonia Bert. n. 4386.

Lessonia Bory. п. 108.

Lestadia Kunth. n. 2399.

Lestibodea $D C$. n. 2672. b.

Lestibudesia Thouar. n. 1976.

Lettsomia Roxb. n. 3810.

Lettsomia $\boldsymbol{R}$. P. n. 5413 .

Leucacantha Gray. n. 2871.

Leucadendron Herm, n. 2120.

Leucadendron Linn, n. 2123.

Leueantha Zipp. p. 1334. 32.

Leucanthemoides DC. n. 2668. a.

Leacanthemum Tourn. n. 2667.

Leucas $R$. Br. n. 3662 .

Leuceria Lag. n, 2956. *

Leucerioides DC, n. 2957. c. *

Leuchaeria Less, n. 2956.

Leucocarpon A. Rich. n. 5065.

Leucocarpus Don, u. 3936.
Leucocephala Hoxb. n. 1022. b. Lignidium Link, n. 321. Leueochrysum $D C$. n. 2742. d. Ligularia Cass. n. 2799. Leucocoryne Lindl. n. 1105. Leucocrinum Natt. n. $1085 /$ Leucodon Schwägr. n. 580. Leucoglossa $D C$. n. 2670, a. Leucogramma Meyer. n. 135. Lencoium Mönch. n. 4845. Leucojum Linn: n. 1266. Lencolaena $\boldsymbol{R}$. $\mathrm{Br}$. n. $436 \%$. Leucoloma Brid. n. 534. Leucomeris Don. n. 2928. Leucomyrtus $D C$. n. 6316. a. Leuconotis Jack. n. 3382. Leuconymphaea Boerh, n. 5020 . Leucophanes Brid, n. 52\%. Leucophora $D C$. n. 4522, a. Leucophyllum $\boldsymbol{H}$. et $\boldsymbol{B}$. n. 398 Leucophyta $R$. Br. n. 2720.

Leucophyton Less. n. 2930. a. k. Leucoploeus Nees. n. 1012. Lencopogon $\boldsymbol{R}, \boldsymbol{B r}$. n. 4243 . Leucopsidium DC. n. 2661. Leucopsis DC. n. 2381. d. Leueoryphe Endl, n. 2918. b. *
Leueosceptrum Sm. n. 3679. a. Leucosia Thouar. n. 5758. Leucosidea $E$. et $Z$. w. 6375. Leucosinapis $D C$. n. 4950 . e. Leucospermum $R$. Br. n. 2124. Leucospora Nutt, n. 3929. Leucosporus Fries. n. 448. d. Leucosporus Fries. n. 453 . VH. Leucostegia Presl. n. 6' $1 / 1$. Leucostemma Benth. n. 5240 . c. Leucostemma Don. n. 2741. e. Leucothammus Lindl, n. 532't/, Leucothea Moc. et S. n. 5414. Leueothoé Don. n, 4318 . e. * Leucoxylon Blum. n. 5430 . Leukeria Lag. n. 2956.

Leuzea $D C$. n. 2895.

Levenhookia $\boldsymbol{R}$. Br. n. 309 \% Levisanus Schreb. n. 4599.

Levistieum Koch. n. 4'53.

Lewisia Pursh. n. 5196. *

Lexarza Llav. n. 5313. a.

Leycestria Wall. n. 3335. *

Leyssera Linn. n. 2772.

LEYSSERFAE p. 451.

Lhotskva Schauer. n. 6276.

LIABEAE p. $36 \%$.

Liabum Adans, n. 2245.

Liagora $\operatorname{Lamx}$. p. 9.

Liatris Cass. n. 2270. a.

Liatris Schreb. n. 2270.

Libanotis Crantz. n. 4432.

Libanotis Scopol. n. 4t 41 .

Libanus Colebr. n. 5928.

Libertella Desm. n. 200.

Libertia Dum, n. 1100.

Libertia Lejeune. n. 900.

Libertia Spreng. n. 1221.

Libidibia DC. n. 6765. d.

Licania Aubl. n. 6409 .

Liearia Aubl. II. 2045.

Licavaua $E$, n. 6663 . a. $\beta$.

Licea Schrad. n. 306.

LICHENES p. 11.

Lichenoides Bisch, u. 45'. a. Lichina $\mathbf{~} g$. n. 115.

Linostigma Klotsch, n. 6055. $4+16$.

Lichtensteinia $\boldsymbol{W}$. 1 . 4586 . f. Lichtensteinia Willd. n. 1071 Liemophora $A g$. n. 4.

Licuala Rumph. n. 1755. * Lidbeekia Berg. n. 2655. Lieberkuhaia Cass, n. 2936. Liebigia Endl. v. 4136. Lightfootia Herit. n. 3072/. Lightfootia Schreb. n, 32 \% Lightfootia $S$ wartz. II. 5072 .
Ligularia Duval. n. 4634. 9.

LIGULIFLORAE p. 493, et 1387.

Ligusticum Lagasc. n. 4453 .

Ligusticum Linn. n. 4442.

Ligustrum Tourn. n. 3352.

Lilae Tourn. n. 3355.

Lilaea $H$, et $B$, n. 1037. *

Lilenia Bert. n. 5075 .

LILIACEAE p. 139. et 1358. Liliastrum Link. n. 1145. b.

Lilio-Asphodelus Tourn, n. 1143. Lilio-Narcissus Tourn, n. 1273. Lilium Linn, n. 1098.

Limacea Lour. n. 4687.

Limacia Dietr. n. 5080.

Limaeium Fries. n. 453. VII, i.

Limatodes Blum. n. 1503.

Limbarda Adans. n. 2426. d, *

Limboria Achar. n. 142.

LIMBORIE AE p. 13.

LIMEAE p. 976.

Limeum Forsk. n. 5841. a.

Limeum Linn, n. 5258.

Limia Vand, n. 3700. b.

LIMNANTHEAE p. 1475.

Limnanthemum $\mathrm{Gm}, \mathrm{n}, 3565$. b. * Limnanthes $R, B r$. n. 6066 .

Limnas Trin. n. 748.

Limnetis Rich. n. 846.

Limnia $\operatorname{Linn}$, n. 5180.

Limuobium L. C. R. n. 1215.

Limnocharis $H$. et $B$. n. 1046.

Limnochloa Reichenb, n. 1000 $\gamma$.

Limnopeuce Vaill. n. 6134.

Limnophila $R$. Br. n. 3932.

Limodorum Tourn, n. 1607.

LIMONEAE p. 10 '4.

Limonia Gärtn. n. 5058. *

Limonia $L$, n. 5501 .

Limosella Linn. n, 3977.

LINACEAE p. 1170.

Linagrostis Lam. n. 1001.

Linanthus Benth, n. 3821 . b.

Linaria Tourn, n, 3891.

Linariastrum Chav. n. 3891 . e. Linarioides A. $D C$. n. 3079 . e.

Linekia Lyngb, n. 32 .

Lindackeria Sieb. n, 5000. a.

Lindackeria Presl, n. 5064.

Lindenbergia $L$, el $O$. n. 3925.

Lindera Thunb. n. 6848.

Lindernia All. n. 3958.

Lindernia $\boldsymbol{B}$. Br. n. 3957.

Lindleya $\boldsymbol{H} . \boldsymbol{B}, \boldsymbol{K}$, n. 6399.

Lindleya Funth. n. 5060. b.

Lindleya Nees, n. 5416.

Lindnera Reichenb. n. 5373. b.

Lindsaca Dryand. In. 642. *

LINEAE p. 1170.

Linharea Arrud. n. 2066. *

Liniphyllum Less, n. 2921. b.

Linkia Cav. n. 2138.

Linkia Pers. n. 3875.

Linnaea Gronov, n. 3332.

Linociera Swartz. u. 3347 .

Linopsis Heichenb. n. 6056. d.*

Linostoma Fall. n. 2102.

Linosyris Lobel. n. 238!

Linozostis $E$. n. 5786. a.

Linscotia Adans. n. 5258.

Lisum Linn, n. 6056. *

Línia Elliote. n. 3473.

Liparia Lunn. n. 6163.

Liparis L. C. Rich. I. 1340. Lipocarpha Nees. n. 987. b.

Lipocarpha $\boldsymbol{R}, \boldsymbol{B} r$. n. 987.

Lipochaeta $D C$. n. 2547. *

Lipostoma Don, n. 32'6.
Linconia Linz, n, 4601.

Lipotactes Blum. n. 4586. c.

Lipotriche Less. n. 2547 .

Lipotriche $\boldsymbol{B}, \boldsymbol{B r}$, n. 2498.

Lipozygis E. Mey. 1. 6488.

Lippia Linn. n. 368\%.

LIPPIEAE p. 633.

Liquidambar Linn. n. 1902.

Liquiritia Mönch. n. 6532.

Lirianthe Spach. n. 4737. *

Liriodendron Linn. n. 4740 .

Liriope Herb. n. 1288. d.

Liriope Lour. n. 1192.

Liriopsis Reichenb. n. 1288.

Liriopsis Spach, n. 4737.

Lisianthins $P, B r$. n. $355 \mathrm{z} / 4$ 。

Lisianthus Linn. n. 3552/,

Lissanthe $\boldsymbol{R}, B r . n .4272$.

Lissochilus $R, B r . \mathrm{n}, 1447$.

Lissostylis $R, B r$. n. 2143 . a,*

Listera R. Br. n. 1552.

Listeria Neck. n. 3240. g.

Listeria Rafin. n. 3240. g.

Listia E. Mey. n. 6491.

Lisyanthus Aubl. n. 3550. *

Litehi Sonn. n. 5617.

Lithachne Palis, n. 764.

Lithagrostís Gärtn. n. 743.

Lithabium Bong. n. 6191.

Lithocarpus Blum, n. 1846.

Lithocarpus Blum. n. 4252.

Lithophila Swartz, n. 5205.

Lithophragma Nutt. n. 4642 , b. *

Lithophragmella $T$, et $A, G r$, n. 4642. e.

Lithosanthes Blum. n. 3206.

Lithospermum Tourn. n. 3761."

Lithoxylon Endl. n, 5863.

Lithraea Miers. n. 5904.

Litobrochia Presl. n. 622. c. *

Litri Chilen. n. 530\%. a.

Litsaea Juss, n. 2066.

Litsea Lam. n. 2059.

Littaea Tagliab, n. 1297. i. 
Lomandra Labill. n. 1053. Lomaria Wiltd, \{ีn. 624. b. Lomatia $\boldsymbol{B}, \mathbf{B r}$. n. 2155 .

Lomation Targ. n. 94. a. Lomatium Rafin, n. 4459 . b. Lomatocarum $\boldsymbol{F}$, et $\boldsymbol{M}$. n. $4406 / 2$. Lomatogonium A. Br. n. 3539. Lomatolepis Cass. n. 3016.

Lomatophyllum Willd. n. 1116. LOMENTACEAE p. 1253. Lomentaria Lyngb. n. 91. b. Lonas Adans. n. 2687. Loncharion Targ. n. 94. d. Lonchitis Linn. n. 619. *

Lonchocarpus $\boldsymbol{H}, \boldsymbol{B}, \boldsymbol{K}$, n. $654^{\prime}$. Lonchopteris Brongn. n. 685. Lonchostoma Wikstr. n. 3877. Londesia F. et M. n. 1926. Longehampia $D C$, n. 2772. b. Lonicera Desf. n. 3337. Lonicera Plum. n. 3228. Lonicera Plum. n. 4586. LONICEREAR p. 566. et 139\%, Lontarus Rumph. n. 1745. Lopezia Cav. n. 6129.

LOPEZIEAE p. 1193.

Lophandra D. Don. n. 4313. d. 43.*

Lophanthus Benth. n. 3635. Lophanthus Forst, n. 5336.

Lophatherum Brongn. n. 897.

Lophia Desv, n. 4163. * Lophidium Fich. n. 662 .

Lophiola Fer. n. 1252.

Lophiolepis Cass. n. 2887.

Lophira Banks, n. 5397.

Lophiros Targ. n. 90.

Lophium Eries, n, 375.

Lophoeachrys DC. n. 4525. c. Lophochlaena Nees. n. 878/, .

Lophocolea Dum, n. $472 / \mathrm{m}$.

Lophodermium Chev, n. 370, a. Lopholaena DC. n. 2808.

Lopholepis Dec, n. 787. Lopholoma Cass, n. 2871. r.

Lopholomoides DC, n.2871, u. $C$ Lophopetalum $\boldsymbol{W}_{\text {ight. }}$ n. 5685. * LOPHOPHYTEAE p. 73.

Lophophytum Sch.et E. n. 715. * Lophopterys A. J. n. 5577.

Lophosciadium DC. n. 4493. Lophospermum Don. n. 3895. Lophostachys Pohl. n. 4092.

Lophostemon Schott. n. 6292. Lophozia $D$ umz, n. 473 . b. * Lopimia N. et $M$, n. 5275. b. LORANTHACEAR p. 799. et 1189.

Lorentea Lagasc. n. 2250.

Lorentea Less. n. 2251.

Lorentea Orteg. n. 2556.

Loreya $D C$. в. 6253.

Loroglossum L, C, Rich, n.1512. Loropetalum $\boldsymbol{B}$. B $\boldsymbol{B}$. n. 4591 . b. Lotea Medik. n. 6514. b. Lotea Ser. n. 6514. b. LOTEAE p. 1259.

Lotononis DC, n. 6487 .

Lotophyllum Reich. n. 6511 . g. Lotos DC, n. 5020 . b.

Lotus Linn, n. 6514.

Loudonia Bert. n. 6603. b.

Loudonia Lindl. n. 6139.

Louichea Herit. n. 5206 .

Lourea Neck, n. 6697. c.

Loureira Cav. n. 5814.

Loureira Meisn. n. 5944.

Lowea Lindl. n. 6358.

Loxanthera Blum. n. 4586. g. Loxanthus Nees. n. 4076. Loxocarpus $\boldsymbol{R}, \boldsymbol{B} \boldsymbol{r}$. n. $4140 / 1$. Loxoearya $\boldsymbol{R}, \boldsymbol{B}$. n. 1009 .

Loxodon Cass, n. 2938.

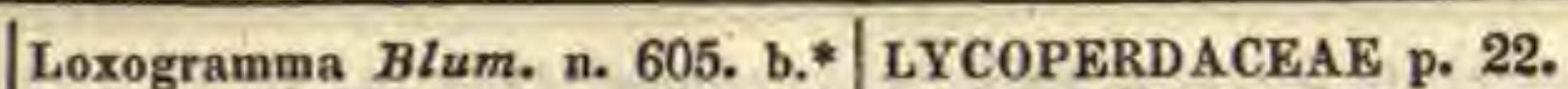

Loxogramma Presl. a. 605. c.* LYCOPERDEI p. 28. Loxomeria Salisb. n. 4313. d.* Lyeoperdon Tourn. n. 333.

Loxonia Jack. n. 4143.

Loxophyllum Blum. n. 4143.

Loxophyllum Flotssch. 1.. 449. Loxostoma Benth. n. 3662. b.
Loxostylis Spreng. n. 5908. Loxotis $R, B r$. n. 4141 . * Loxsoma $R ., B r$. n. 658./1. Lozania Seb. Mut. n. 6074.

Lubinia Commers, n. 4210. Lubinia Link. et Otto. n. 4209. Lucaea Kunth, n. 937. Lucernaria Rouss. n. 54. b. Lucianea DC. n. 3283.

Lucilia Cass. n. 2940.* Lucilioides DC. n. 2773 . b. et 2940. b.

Lucinium Pluckn. n. 5947.

Lueiola Smith. n. 1047.

Lueulia Sweet. $n 3271$.

Luenma Jussieu n. 4241.

Lueya DC. n. 3240.1.

Ludia Lamarck. n. 5070.

Ludolfia Willd. n. 904.

Ludovia Pers. n. 1713.

Ludwigia Linn. n. 6111. h.

Ludwigia Roxb, n. 6110.

Ludwigiaria $D C$. n. 6111. b.

Luffa Tourn. n. 5134.

Lugoa $D C$. n. $26^{\prime} 1$.

Lühea $\boldsymbol{W}, \mathrm{n} .5365$.

Lühea $\boldsymbol{W}$. Schmidt, n. 3724 .

Luida Adans. n. 492 . et 493.

Luisa Gaud. n. 1427. b.

Lumanaja Blane. n. $5888 / 2$

Lumbricidia Velloz. n. 6726. b.

Lumnitzera Jacq. $f$. n. 3573.

Lumnitzera Willd, n. 6084.

Lunana Blane, p. 1125.

Lunanaea $D C$. n. 5320 .

Lunaria Linn. n. 4863.

Lunasia Blane. n. $5888 / 3$.

Lundia DC. n. $4122 /$.

Lundia Puer. n. 5919.

Lundia Thonn, el Schum, n. 5067.

Luntia Neck, n. 5827.

Lunularia Michel. $u$. 466. *

Luperia DC. n. 4845. b.

Lupinaster Mönch. n. 6511. e. Lupinus Tourn. n. 6473.

Lupularia $\mathcal{S} e r$, n. 6507 . a.

Lupulinaria A, Ham. n. 3626. a.

Lupulus Tourn, n. 1891.

LURIDAK p. 762.

Lusaceia Spreng. n. 4329.

Luteola Tourn. n. 5011. a.

Luthera C. H. Schuts. n 2982.

Lütkea Bongard. n. 4636.

Lutrostylis G. Don. n. 3743 . *

Luvunga Ham. n. 5511.

Luxemburgia St. Hit, n. 5052.

Luziola Juss. n. 735.

Luzula DC. n. 1047.

Lazuriaga $R . \quad B r$. n. 1163.

Luzuriaga $\boldsymbol{R}$ uiz et $\boldsymbol{P}$. n. 1186.

Lychnanthus Gmel. n. 5251.

LYCHNIDEAE p. 971.

Lyehnis Tourn, n. 5250 .

Lychni-Scabiosa Boerk. n. 5193. a.

Lyebnocephalus Mart. n. 2226. Lychnoides $D C$. n. 2193, a. Lychnophora Mart, n. 2223.

Lychnophoroides $D C$, n. 2223. Lyciobatos Eindl. в. 3863. b. Lyciopsis $S_{p a c h}$, n. 6125. a. $\beta$. I.yciothamnos $E$. n. 3863 . c. Lycium Linn. n. 3863.

Lyeoctonum DC. n. 4797. h.

Lycogala Michel, n. 322.
Lycopersicum Tourn. n. 3856.

LYCOPODIACEAE p. 69 . et 1352.

Lycopodiolithes Schloth. n. 697. Lycopodites Brongn. n. 697.

Lycopodium Brongn. n. 696. a Lycopodium Linn. n. 696.

Lyeopsis Bauh, n. 3784/3.

Lycopsis Lehm. n. 3765.

ycopsis Linn. n. 3767.

Lyeopus Linn. n. 3595.

Lycoris Herb. n. 1273. b.

Lycoseris Cass. n. 2910.

Lyeurus Funth. n. 80\%.

Lydaea Molin, n. 6396.

Lyellia $\boldsymbol{R} . \boldsymbol{B r}$, n. 562.

Lygeum Linn. n. 741.

Lyginia $R . B r$. n. 1017.

Lygistoides $D C$. n. 3235 .

Lygistum $\boldsymbol{P}$. $\boldsymbol{B r}$, n. 4266 .

Lygodesmia Don. n. 3005. c.

Lygodium Swartz. n. 663.

Lygodysodea Ruiz et Pav. n. 3182.

LYGODYSODEACEAE p. 520. Lyncea Cham, et Schl, n. 3992. Lyngbya $\mathrm{Ag}$. n. 42.

Lyngbya Gaill, u. 71.

Lyngbyella Bory, n. 72 .

Lyonia Nutt. n. 4319. *

Lyonia Rafin, n. 1986. c.

Lyonia Reich, n, 4318. c.

Lyonnetia Cass, n. 2642.

Lyonsia $\boldsymbol{R}$. Br. n. 3420 .

Lyperanthus $R, B r . n$. 1596.*

Lyperia Benth. n. 3969.

Lysigonium Link. n. 11.

Lysimachia Mönch. n. 4207.

LXSIMACHIEAE p. 732.

Lysimaehion Tausch. n. 6121. b.

Lysimandra Endl, n. 4207.

Lysimastrum Endl. n. 4207. b.

Lysinema $R, B r$, n. 4282 . *

Lysionotus Don, n. 4135.

Lysipomia $\boldsymbol{H}$. B. $\boldsymbol{K}$. n. 3053.

Lyssanthe Knight et Salisb. n. 2143. a.

Lyssostylis $R, B r$. n. 2143 a.

Lysurus Fries. n, 356.

LYTHRARIEAE p. 1198.

Lythrum Linn. n. 6149.

\section{III.}

Maagoni Adans, n. 5549.

Maba Forst, n. 4247.

Mabea Aubl. n. 5798.

Maburnia Thouar. n. 1219.

Macaglia Vahl. n. 3399. *

Macalianea Aubl. n. 5454.

Macairea DC. n. 6209 .

Macanea Juss. n. 545t.

Macaranga Thouar, n. 5789 .

Macarthuria $\mathrm{Hüg}_{\mathrm{g} .}$ n. 6880 .

Macbridea Fll, n. 3642 .

Macdonaldia Gunn. n. 1586/.

Machaeranthera Nees. n. 2311.

Machaerina Vahl. n. 971 .

Machaerium Pers, n. 6710.

Machaonia $\boldsymbol{H}$. et $\boldsymbol{B}$, n. 3135 .

Macharisia Thouar. n. 6890.

Machilus Nees. n, 2028.

Machlis DC. n. 2704.

Mackaia Gray. n. 120. g.

Macleania Hook. n. 4336.

Macledium Cass. n. 2930.

Macledium Less, n. 2930. d. *

Macleya $R . \quad B r$, n. 4817.

Maclovia DC. n. 2957. b. *
Lyraea Lindl, n. 1350.

Maclura Nutt. n. 1857. *

Macnabia Benth, n. 4305.

Macoubea Aubl. n. 5455 .

Macoucoua Aubl. n. 5705.

Macradenia $A, B r . n .1457$.

Maeraea Lindl. n. 6053.

Macrandria $W$. et $A$. x. 3240 . b.

Macranthera Torr. n. 3994.

Mac ranthus Lour. n. 6699.

Macranthus Poir. n. 6699.

Macrauchenium Brid, n. 542. a.

Macria F. Mey, n. 3731. b.

Macrobotrys $D C$. в. 2956. ь. *

Macrocapnos Royle. n. 4836. e.

Macrocarpaea Gries. n. 3550. a.*

Maerocarpus Bonnem, n. 71.

Maeroceras Dec. n. 4811. b.

Macroceratites Raddi, n. 6665 .

Macroceratium DC. n. 4847.

Macroebilus Presl. n. 3066.

Macrochilus Kn. et $W$, n. 1467/s.

Macrochiton Bl. n. 5532 .

Macrochloa Kunth. n. 797.

Macroenemum $\boldsymbol{P} . \boldsymbol{B} \boldsymbol{r}$. n. 3261.

Macrocnemum Vell. n. 3273.

Macrocystis Ag. n. 110. *

Macrodon Arnott. n. 577.

Macrogyne $L$. et $O$. n. 1191.

Macrolepis A. Rich, n. 1368.

Macrolinum $K l$, n. 4300 , b.

Macrolinum Feich, n. 6056. f. *

Macrolobium Sehreb, n. 6803.

Macrolobium Vahl. n. 6803. b.

Macromelissa Benth. n. 3617. f.

Macromeria Don. n. 3762. *

Macromerum Burch, n. 4991.

Maeromitrium Brid n. 511.

Macronax Raf. n. 904.

Macronepeta Benth, n. 3636. e.

Maeropiper Miq. n. 1820. c. *

Macropodium $\boldsymbol{H} . \mathbf{B r}$. n. 4858 . *

Macroptilium Benth. n. 6674. g.

Macrorhynchus Less. n. 3018.

Maerorhynchium $\boldsymbol{R}$. n. 3018.

Macroscepis $H$. B. $K$. n. 3453 .

Macrosolen Blum, n. 4586. 1. 
Mahonia Nutt. n. 4814. b. Mahurea Aubl, n. 5422. Mainea Fl, Fl, n. 5659. Mairania Neck, n. 4327. Maireria Scop. n. 4246. Mairia DC. и. 2296.

Mairia Nees. n. 2296. a. Maiten Feuill. n. 5680. Majanthemum $\mathcal{M}$. в. 1183, a. Majeta $A u b l$. n. 623t. Majorana Mönch. n. 3609 . Malabaila $\mathrm{Hoffm}, \mathrm{n}, 4473$.

Malabaila Tausch, n. 4537 . Malabathrum Burm. n. 3023. Malachadenia Lindl. n. 1506/, Malache Trew, n. 5275. a. $\beta$. MALACHIEAE p. 970. Malachium Fr. n. 5242. Malachodendron Cav, n. 5423. a. Malacothrix $D C$. n. $3004 / 1$. Malachra $L$, n. 52't1.

Malacmaea Griseb, n. 5586. Malacocephalus $T$. n. 2895. b. Malacochaete Nees. n. 1000. a. Malaisia Elanco. n. 1880/1. Malanea Aubl. n. 3193. Malaspinea Presl. n. 4233. MALAXIDEAE p. 186. Malaxis Swartz, n. 1337. Malaxis Thouars. n. 1340. Malbrancia Neck, n. 5948. Malcolmia $R$. Br. n. 4902. Malesherbia $\boldsymbol{R}$ et $\boldsymbol{P}$. n. 5108. MALESHERBIACEAE p. 928. Malistaehys E. и. 2098. e. Mallea A. Juss. n. 5522. Mallococea Forst. n. 5376. a. $\alpha$. Mallogonum Fenzl. n. 5189. Mallophora Endl. n. $369^{\prime} t / 1$. Mallotus Lour. n. 5819. Malocehia Sav. n. 6663. Malocchia $E$, Mej. n. 6663 . b. $\delta$. Malope L. n. 5267.

MALOPEAE p. 979.

Malosma Nutt. n. 590 \%. b. Malpighia $L$, n. 5585.

Malpighia Plum. n. 5631.

MALPIGHIACEAE p. 1057. Maltebrunia Kunth, n. 729. Malus Tourn, n. 6342 . Malva $L$. n. 5271 .

MALVACEAE p. 978.

Malvastrum $D C$. n. 5271 .

Malvaviseoides n. 5275, a. $\gamma$.

Malvavisens Dill, n. 5278.

Malvaviseus Gärtn. n. 528 t.

MALVEAE p. 980.

Mamboya Blanco, n. 3280. h.* Mammea $\boldsymbol{L} . \mathbf{n}$. 5442.

Mamillaria Haw, n. 515\%, a.

Manabea Aubl, n. 3713.

Mauaelia Bowd. p. 734.

Maneauilla Plum. n. 5777.

Mandevilla Lindl. n. 3410/1.

Mandihoen Pis. n. 5808.

Mandijba Marcgr. n. 5808.

Mandiacca Linn, n. 5808.

Mandragora Tourn. n. 3859.

Manettia Mutis, n. 3266. "

Manga Rumph, n. 5915.

Mangaiba Marcgr. n. 3373.

Manghas Burm. n. 3338.

Mangifera Linn, n. 5915.

Mangium Rumph, в. 6101.

Mangle E. n. 6098. n.

Manglesia Endl. n. 2142/.

Manglesia Lindl. n. 6296.

Manglietia Blum. n. 4738.

Mangostawa . Rumph. n. 5443 .

Manicaria Gärtn. n. 1752. *

Manihot DC. n. 5281 .

Manihot Plum. n. 5808.

Manisuris Linn, n. 932.
Manium Scop. n. 442 . d. Manna Don, n. 6625. Mannia Cord. n. 463 . * Mansoa DC. n. $4122 /$ Mantellia Brongn. n. 713. Mantisalca Cass. n. 2867. a. Mantisia Curt, n. 1621. Manulea Linn. n. 3970. MANULEAF p. 685. Manungala Blanc n. 5965. Mapa Fl. Fl. p. 1334. 33. Mapania Aubl. p. 119. a. Mapouria A. Rich. n. 3149. Mapouria Aubl, n. 3149. Mappa A. J. n. 5788. Mappia Schreb. n. 4761. Maprounea Aubl. n. 5769 . Maqueria Comm, n. 5972. e. Maquira Aubl, n. 1863. Maralia Thouars. n. 4553. Maranta Plum. u. 1642. MARANTACEAE p. 225. Maranthes Blum. n. 5357. Marasmodes DC. n. 2699. Marathrum $H$. et $\vec{B}$, u. 1833. b. Marathrum Rafin, u. 4430 . c. Marattia Swartz. n. 670.* MARATTIACEAE p. 65. et 1351. Marcelia Cass. n. 2639. a. Marcetia DC, n. 6205.

Marcgravia Plum. n. 5461 . MARCGRAVIACEAE p. 1029. Marchantia March. $f$. n. 470 . * MARCHANTIACEAE p. 4\%. et 1337.

Marckea C. C. Hich. n. 3844. Marcorella Neck. n. 5722 , a. c. Mareniga Salisb. n. 1626. Marenteria Nor. n. 4717. b. Margaranthus $\boldsymbol{S}$ chl. n. 3851/1. Margaripes DC. n. 2767. b.

Margaris $D C . \mathrm{n} .3166$.

Margarita Gaud, n. 2300.

Margaritaria Linn. $f$. n. 5882. Margarospermum $R$. n. 3761, d. Marginaria Bory. n. 614. a. * et Marginaria A. Bich. n. 109. Margotia Boiss. n. 4499.

Margyricarpus $\boldsymbol{R}$. et $P$. n. 6378. Maria DC. n, 4318 . e. $\beta$. *
Marialva Vand. n. 5433 .

Marialvea Mart, v. 5433.

Marianthemum Sehr. n. 3085. a. Marianthus $\boldsymbol{H}_{\ddot{u}}$. n. 5664 .

Marica Schreb. 1. 1222.*

Marignia Comm. n. 5935 .

Marila $\mathcal{S}_{\mathbf{w}}, \mathrm{n}, 5421$.

Maripa Aubl. n. 3814.

Mariseus Vahl. I. 1003. b. a.

Marlea Roxb. в. 6097.

Marlierea St. Hil. n. 6318.

Marmoritis Benth. n. 3637.

Marquisia A. Rioh, n. 4177.

Marrubiastrum Linn, n. 3647. b. Marrubiastrum M. v. 3655. a. MARRÚBIEAE p. 627.

Marrubium Linn. n. 3657 .

Marsaua Sonn. n. 5506.

Marschallia Schr. n. 2624. *

Marsdenia $R$. Br, n. 3507 . *

Marsilaea Linn, n. 691 .

Marsilaea Neck. n. 689.

MARSILAEACEAE p. 67.

Marsippospermum D. w. 1049. b. Marsupella $D$. n. $472 /{ }_{25}$ et $474 / 1$. Marsupia Dum. n. 47\%/1.

Marsypianthes Mart. n. 3582.

Marsypocarpus Neck. n. 4927.

Martagon Endl. и. 1098. b.

Martella Scop, n. 421.

Martia Leand. n. 6636.

Martia $S p r$. v. 5465.

Martineria Fl. Fl, n. 5419 .
Martinezia R. et P. n. 1767. Martinieria Guill. n. 6051 . Martiusia Schult. n. 6636. Martrasia Lag. n. 2954. Martrasia $S p r$. n. 2956. Martyuia Linn. n, 4175. MARTYNIACEAE p. 723.

Marumia Blum, n. 6254. Marumia Reinw, n. 5414. Maruta Cass. n, 2640. Mascaguia Bert. n. 5568. Maschalanthe Blum, n. 3226 . Maschalanthus Schulz. n. 568 . Maschalarrhen $S_{p} r$. n. 549. b. Maschaligalium $D C$. n. 3100 . f Maschalocarpus $S_{p} r$. n. 568. Maschalostachys $\boldsymbol{B}$. n. 3626 . Masdevallia $\boldsymbol{R}$. et $\boldsymbol{P}$. n. 1449. Massonia Linn, n. 1126.

Mastacanthus Endl. n. 3720. Mastichinia Benth. 11. 3610. a. Mastigobryum Nees. n. 472/19. b. Mastigophora Nees. n. $472 / 16^{\circ}$ et $472 / 1$.

MASTIGOPHOREAE p. 1342. Mastigophorus Cass. n. 2945. Mastixia Blum n. 4578.

Mastocarpos Targ. n. 94. f.

Mastrucium Cass. n. 2897. b.

Matamoria Ll. et L. n. 2231. s, Mataxa $\boldsymbol{S}_{p r}$. n. 2653. b.

Matayba Aubl, n. 5612.

Mateatia $\mathrm{Fl}$. $\mathrm{Fl}$. n. 5320 . a. $\beta$. Matelea Aubl. n. 3496 .

Mathea $\mathrm{Fl}$. Fl. n. 4216.

Matisia H. B. n. 5314 .

Matourea Aubl. n. 3940, a.

Matrella Pers. n. 935.

Matricaria Linn. n. 2669. *

Matricarioides $D C$. n. 2696. c.

Matthewsia Hnok. n. 4922.

Matthiola $\boldsymbol{R} . \mathbf{B r} \cdot \mathrm{n}, 4845$.

Matthiola Plum. n. 3192. b.

Matthisonia Raddi. n. 6866.

Mattia Sohult, n. 3782.

Mattonia $\boldsymbol{R} . \boldsymbol{B r}, \mathrm{n} .654$.

Mattonia Smich. n. 1627.

Mattuschia Gmel. n. 1824.

Mattuschkea Sehreb. n. 3128.

Mauchartia Neck. n. 4397. a.

Mauduyta Comm, n. 5965.

Mauhlia Thunb. n. 1126. a.

Mauneia Thouar. n. 6849.

Maurandia Orteg. n. 3893.

Mauria Funth. n. 5903.

Maurieon Adans, n. 6667.

Mauritia Linn. n. 1743.

Maurocenia M. D. n. 570's.

Maxilluria $\boldsymbol{R}$. et $\boldsymbol{P}$, n. 1407.

Maximiliana Mart, n. 1775.

Maximiliania Schrank. n. 5405.

Maya Benth. n. 6738. a.

Mayaca Aubl. n. 1027. *

Mayarsa $D C$. n. 2671. f.

Mayepea Aubl. n. 3347.

Mayna Aubl. n. 4734.

Mayna Raddi, 1. 5066.

Maytenus Feuill n. 5680.

Mazentoxeron Labill. n. 6012.

Mazus Lour. n. 3931. *

Meadia Catesb. n. 4202.

Meborea Aubl, n. 5879.

Mecardonia Mart, n. 3940, a.

Meclatis Spach. n. 4768.

Meconella Nutt. n. 4831.

Meconella Spach. n. 4823.

Meconidium Spach. n. 4823. *

Meconium Spach. n. 4823 .

Meconopsis $V_{i g}$. n. 4822.

Meconostigma Schott. n.1690. e. Mecopus Benn. n. 6611.

Mecosa Blum, n. 1515.

Medeola Gron, n. 1178.

Medicago Linn, n. 6507.

Medicusia Möneh. n. 2999.

Medinilla Gaud, n. 6236.

Medium Tourn, n. 3085. a.

Medusa Lour. n. 5329.

Medusea Haw. n. 5766.

Medusina Chev. n. 4h2. c.

Medusula Eschw. n. 137.

Meerburgla Mönch. n. 5208.

Meesia Hedw. n. 557.

Meesia Gärın, n, 5960.

Megacarpaea $D C$, n. 4891.

Megaclinium Lindl, n. 1351.

Megalangium Brid. n. 546.

Megalurus Link. n. 899. c.

Megapterium Spach, n. 6115. 3.

Megasanthes $A . D C$. n. 3075. *

Megasea Haw. n. 463\%. d.

Megastachya Palis. n. 876. b.

Megastegia Don. n. 6577 .

Meisneria DC. n. 6187.

Meissarrhena $\boldsymbol{B}$. Br. p. 708.

Meisteria Scop. n. 2202.

Mejonectes $R . B r$. p. 1197.

Melachne Schrad n. 981.

Melaenia Dum. n. 1380.

Melaleuca Linn. n. 6298.

Melamiri Endt. n. 1820. a. (6* *

MELAMPODIEAE p. 402.

MELAMPODINEAE p. 398.

Melampodium Linn. n. 2478. a.

Melampyrum Tourn. n. 4018.

Melanchrysum Cass. n. 2845.

Melaneonium Link. n. 193.

MELANCRANIDEAE p. 116.

Melancranis $V a h l$, n. 990.

Melandrium Röhl. n. 5246. e.

Melania Brid. n. 518.

Melanium $P$. Br. a. 6151 .

Melanium $R i c h$, n. 6211.

Melanium Zipp. p. 133\%. 34. 


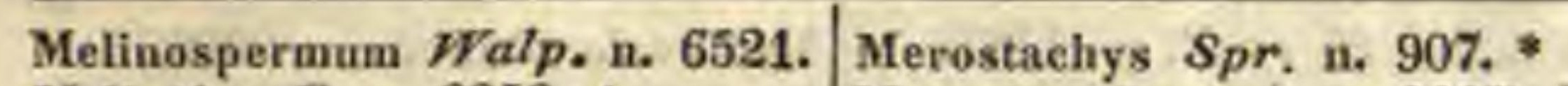
Melioides E, n. 3353. b. Meliola Fries. n. 386. Meliosma Bl. и. 5839. * MELIOSMEAE p. 1074. Meliphlea Zucc. n. 5272.

Meliphyllum Benth. n. 3617. e. Melissa Linn, n. 3617. MELISSINAE p. 618.

Melissoides Benth. n. 3575, d. Melistaurum Forst. n. 5060. a. $\gamma$. MELITTEAE p. 623. Melittis Linn, n. 3640. Mella Vend. n. 3940 . c. Mellolobium $E$, et $Z$. n. 6485 . Melo Tourn. n. 5137. Melocactus Tourn. n. 515\%. b. Melocamia $\boldsymbol{H}$. et $\boldsymbol{T}$. и. 910. * Melochia L. n. 5337.

Melodinus Forst, n. 3378, * Melodoram Lour. n. 4717. a Melongena Tourn, n. 3855. Melopepo Tourn, n. 5138. Melosira Ag. u. 11.

Melothria Linn. n. 5126. MEL. THRIEAE p. 936 . Melvilla And. n. 6151 . MEMECYLEAE p. 1222. Memecylon Linn, n. 6269. Memecylon Mitch. n. 4322. Memorialis $\mathrm{H}_{\alpha \mathrm{m}}$, n. 1885. e. * Menais Linn, n. 3742. Menarda Comm. n. 58'6. Mendezía $D C$. n. 2490. * Mendozia Vell n. 4030. Meneghinia Endl. n. 3766. * Menestoria $D C$. n. 3299. Menestrata Fl, Fl, n. 2066. . Meniehea Sonn. n. 6325. b. Meniocus Desv. и. 4866. Meniscium Schreb. n. 610. * Meniscosta Blam, n. 4688. MENISPERMACEAE p. 825 . Meuispermum Tourn, n. 4685. Menispora Pers. n. 211.

Menoceras $\boldsymbol{R} . \mathrm{Br}$, n. $30^{\prime}$ t7. a. Menodora $H$. et B. n. 334 . * Menonanthes Hall. n. 3564 . Menoavillea DC, n. 4893. Mentha Linn. n. 3594 . MENTHEAE p. 612. Meutzella Linn. n. 5111. MENYANTHEAE p. 605. Menyauthes Linn. n. 3564 . Menziesia Smith. u. 4317. Meosehium Palis, n. 951. Mephitidia Reinw. n. 3190. Meratia Cass. n. 2457. Meratia Nees. n. $635 \overline{\text {. }}$ Jerciera A DC. и. 3091. Merckia Borkh, n. 472 . a. Merckia Eisch. n. 5231. MERCKIEAE p. 966. Mercurialis $\boldsymbol{L}$, о. 5786 . Merenderiv Ram. n. 1085. Meretricia Ner. u, 566. Merettia Gray, n. 29. Meriam Burm, n. 5918. Meriana Fl. Fl. n. 3791 . Meriana Trew. nt. 1240 Meriandra Benth. n. 3596. MRRIANDREAE p. 613. Meriania Swarts. n. 6169. Merida Neck. n. 5174 . Meridema Don, n. 4651 . a. Meridiana Linn. n. 517\%. Meridion $\mathrm{Ag}$. u. 3.

Merimea Camb. n. 5477. Meriolix Raf. a. 6114. Merisma Pers. n. 437. i. Merisostigma D. Willd. n. 1236. Merizomyria Poll. n. 4h. Jerosporiutu Corda, a. 264
Merremia Dennst. n. 3807. * Merretia Sol. n. 4232/, Mertensia $\boldsymbol{H}$. B. $\boldsymbol{K}$. n. 1853. Mertensia Roth, n. 67. Mertensia Roth. n. 3760 . Mertensia Willd. n. 659. b. * Merulius Hall. n. 445. Mesanthus Nees. n. 1012. MESEMBRYANTHEMEAE p. 945.

Mesembryanthemum $L$. n. 5163. Mesembryanthus Neck. H. 5163. Mesembryou Adans, u. 5163. Mesenterica Pers. p. 20. b. Mesenterium Endl, n. 403. d. Mesitis Vog. n. 6751. a. Mesocentron Cass. n. 2871. y. Mesoclastes Lindl. II, 1427. Mesodactylus $\boldsymbol{W}$. u. 1619 . b. Mesodetra Rafin. n. 2603. b. MESODMEAE p. 65.

Mesogloia Ag. n. 51. Mesogramma $D C$. n. 2796. Mesona Blum. 1. 3571 . Mesophylla Dum. n. 476 , Mesoregma Corda. n. 468. * Mesosphaeria B. n. 3583. n. Mesosteirus $D C$. n. 2693. b. Mespilodaphne Nees. n. 2039. Mespilophora Neck. n. 6344. Mespilus Lindl. n. 6344.

Messerschmidia Ass. H. 3787.

Messerselmmidtia Kunth, n. 3748 . Messerschmidtia Linn. n. 3747 . Messerschmidtia $\boldsymbol{B}$, et $\boldsymbol{S} c h$. n. 3748.

Mestotes Sol. n. 5758.

Mesua $L$. n. 5'47.

Metabasis DC . n. 2988/,

Metabolus Blum, n. 3237.

Metachilum Lindt. n. 1367.

Metaguanthus Endl. n. 2689.

Metalasia $R, B r$. n. 2753.

Metalasioides DO. n. 2781. a.

Metaplexis $R, B r$. и. 3169.

Metastelma $R . B r$ n. 3419.

MF.TASTELMEAE p. 589 .

Metaxia Presl. n. 652. c. *

Metazanthus Mejen. it 3032/1

Meteorina DC. u. 2772. a.

Meteorium Brid. n. 589.

Meteorus Lour. n. 6325. b.

Methonica Herrm. n. 1099.

Methorium Sch, E. n. 5314.

Methyscophyllum Eokl. et Z, 5942.

Metopium DC. n. 5905. b.

Metopium $\boldsymbol{P}$ Br. n. 5905 . b.

Metrocynia Thouar. n. 6783. Metrodorea St. Hil. in, 5998 . Metrosideros R. Br. n. 6303 . Metroxylon Rottb. 10. 1742.* Metternichia Mlik. n. $3869 \%$

Metzgeria Corda. n. 472/2.

Metzgeria Raddi. n. 472 , *

METZGERIEA $F$ p. 1338.

Metzleria Prest. H. 3055.

Meum Tourn. n. 4445.

Meyenia Nees, u. 4028.

Meyenia Schlecht n. 3867.

Neyera Pers. n. 2574.

Meyera Sohreb. n. 2574.

Meyeria DO. в. 2614.

Mt ynia Link. b. 3191.

Mezoneuron Desv. n. 6768.

Mibora Adans. 19. 746.

Micarea Eries. ‥ 160.

Michauxia Herit, n. 308'.

Michelaria Dum, n. 900.

Michelia Linn, n. 4739 . *

Michoxia Fl. Fl. p. 1334. 35.

Miconia Ruiz of P. A. 6258 .
MICONIEAE p. 1215.

Mieraetis $D C$, n. 2552.

Micraea Miers, p. 605.

Mieraloa Blas. n. 26.

Micranthemum L. C. R. n. 3951.* Micranthemum Presl. n. 6511. f. Micranthea Desf. n. 58'55. Micranthera $A . D C$. n. 4222 . Micranthera Chois. n. 5433. Micranthes T. n. 463'. e. Micranthus Pers. Wendl. n. 4097 . Micrasterias Ag. n. 19. MICRASTERIEAE p. 3. Micrelium Forsk, n. 2446. a. Micreremia Benth. n. 4306. c. Mieroblepharis $W$.et $A$. u. 5103.a. Microcala $L$. et $\boldsymbol{H}$. n. 3541 . Mierocalia A, Rich. n. 2351. Mierocarpaea $\boldsymbol{R}$. $\boldsymbol{B} \boldsymbol{r}$. и. 39 ' 9 . Microcarpaea Benth. n. 3976. Mieroceras Dec. n. 4311. a. Mierochilus Presl. n. 1562. Microehloa $R, B r$, n. 834. Microcladia Grev. n. 99. Mierocochle Benth. u. 6674 . f. Microcodon A. DC. n. 3078 . * Microcoelia Lindl. n. 1356. Microcoleus Desm. n 40. Microcoma $\boldsymbol{D}$ C. n. 2930. b. Microcorys $\boldsymbol{R}, \mathrm{Br}$ n. 363 t. Microcos $L$, n. 537€. a. $\beta$. Microcrater Endl. n, 378. Microderis DC. n. 2998/, Microderris DC. n. 2790 . b. Microdon Chois. n. 3730. Microelus $W$. et A. n. 5872 . Microglossa $D C$. n. 2369. Microgomphus Benth, n. 4301. b. Microgramma Presl. n. 609. b. * Microgyne Cass. n. 2710. b. Mierogyne Less. n 2334. Mierolaena $\boldsymbol{A} . \mathbf{B r}$. ฉ. 738 . Mierolaena Wall, n. 5355. Microlema $R, B r$. n. $3^{\prime} 447$. Microlepia Presl. n. 643, a. * Microlepis DC. n. 6224. Microleuconymphaea $B$ n. 1216. Mierolicia Don. n. 6197. Microlonehus DE, n. 2867 . Mierolophus Cass. n. 2s71. Mierolotus Benth. n. 6517. Microlotus T. et A. Gr.n.6517. c. Micromega $2 g$. n. 18. Micromelum Bl. n. 5509. Micromeria Benth, n. 3516 . Mieropera Linall, n. 1479. Micropetalum Pers. 1. 5234. b. Micropetalum Pers. n. 5240. b. of. Mieropetalum Tausch. n.4634. i. Mieropiper Miq. n. 1820. g. * Micropleura Lagasc. n. 4360. Micropodium DC. n. 4952. b. Microporus Palis. n. 4t7. e. Micropsis DC. n. 2421.

Micropteris Desv. n. 607. ๙c. 3.* et 611. a. *

Mieropus Linn. n. 2421.

Mierorhachis $D C$, n. 2689, a. Mferorhinum E. i. 3891. b. Microrhynchus Less, n. 3017 .

Microsaceus Blum, n. 1475.

Mierosemina Labill, n, 5415 .

Microseris Don. n. 2982. *

Microsorus Link. n. 615. k. $\gamma$. aa. *

Mierosperma Hook. n. 5141. e. Mierospermum Lag. p, 502.7. Microsphace Benth, n. 3597. g. Mierostachys A. J. n. 5781. Mierostegium Neen. n. 942. Microstemma $\boldsymbol{R}$. Br, n. 3516 Microstephium Less. n. 2837.

Microstylis Nutt. n. 1335.

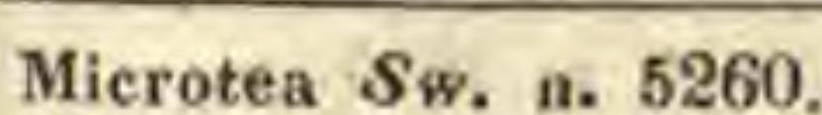

Mierothouarea Thouars, n. 790.

Microtis R, Br. n. 1588. *

Microtrema Klotzsch. n. 4307.

Mierotrichia $D C$. n. 2388.

Microtropis E. Mey. n. 6484.

Mierotropis Wall. n. 5681.

Mierurus Endl. n. 922. b.

Mida A. Cunn. n. 2081. *

Midotis Fries, n. 410.

Miegia Schreb, n. 979.

Miegia Neck. u. 3026.

Miegia Pers, n. 904.

Mielichhoferia Hornseh, n. 520.

Mieria $\boldsymbol{L} \boldsymbol{l}$, et $\boldsymbol{L}, \mathrm{n}, 2588$.

Miersia Lindl. u. 1175.

Mikania Willd. n. 2282.

Miliarium Mönch n 762 .

Milinm Linn. n. 762

Miliusia $A . D C$ n. 4712 .

Milla Caa. n. 1109.

Millegrana Sur. n. 5173.

Milleporum $S p$. n. 5464. B. b. ?.

Milleporus Batsch. n. 447. e.

Milleria Cass, u. 2458.

MILLERIEAE p. 399.

Milletia $W$, et $A$ n. 6715.

Millina Cass. n. 2991.

Millingtonia Linn. $f$. u. 4125 .

Millingtonia $\operatorname{Roxb}, \mathrm{n}, 5639$.

Millingtonia Roxb. n. 6697.

Millotia Cass. n. 2733.

Milnea Roxb n. 5525 .

Miltonia Lindl. n. 1467/,

Miltus Lour. n. 5261.

Mimetes Salisb. n. 2125.

Mimosa Adans, n. 6831.

MIMOSEA E. p. 1323.

Mimulus Linn. n. 3935

Mimusops Linn. n. 4243.

Mina Llav, et $L$. n. 3806.

Mindium Adans. n. 3084 . 
Mitrophora Neck, n. 2184. Mitrospora Nees, n. 966. b. Mitrula Fries. n. 418.

MITRULINI p. 38.

Mitseherlichia Kunth, n. 2011. Mnasium Schreb. n. 1053.

Mnassea $\boldsymbol{F l}, \boldsymbol{F l}$. p. 133 \%. 36.

Mnemion Spach. n. 5040.

Mnemosilla Forsk. n. 4833.

Mnesiteon Rafin, p. 502, 6.

Mnesithea Funth. n. 926.

Mniarum Forst. n. 5221.

Mniopsis Dum. n. $474 / \mathrm{s}$.

Mniopsis Mart. n. 1831.

Muium Dill. n. 549.

Moacurra Roxb. n. 5757.

Mocanera Juss. n. 5408.

Mocina $D C$. n. 2916.

Mocinna Lagasc. n. 2616. c.

Modecer Limn. n, 5103. *

MODECCEAE F. 927.

Modestia Cham, n, 3926. a.

Modiola Mönch. n. 5273.

Moehnia Neck. n. 2845.

Möhringia L. n. 5235.

Mönchía Ehrenb. n. 5241. e.

Monchia Medik n. 1137, a,

Mönehia Roth. n. 4867.

Mösslera Reich. n. 4603.

Moghania Jeaum. n. 6697. c.

Mogiphanes Mart. n. 1957, e.

Mogorium Juss, n. 3342.

Mohlana Mart. n. 5256.

Mohria Swartz. n. 664.

Mokusin Cibot. n. 356.

Moldaviea Münch, n. 3638. d.*

Moldenhauera Schrad. n. 6780.

Moldenhauera $\mathcal{S}_{p r}, \mathrm{n} .6839$.

Molina Cav. n. 5572.

Molina Less. n. 2410.

Molina Ruiz ot Pav, n. 2410.

Molinaea Bert, n. 1776 .

Molioaea Juss, n, 5614 .

Molineria Colla, n. 1263.

Molinia Mönch. n. 888.

Molle Clus. n. 5901.

Mollia Gmel. n. 467\%.

Mollia Gmel. n. 6311.

Mollia M. ot Z. n. 5366 .

Mollia Schrank. 11. 535.

Mollinedia Ruiz et P. n. 2019/4.

Mollisia Fries, n, 430. A. b.

MOLLUGINEAE p. 952.

Mollugo Linn. n. 5186.

Molopospermum Koch, n, 4510.

Molpadia Cass, n. 2440.

Molthia Lehm. n. 3756.

Molueen Tourn, n. 3668 .

Molueella Linn. n. 3668 .

Moly Mönch. n. 1137. a.

Mombin Plum. n. 5920. a.

Momordica Linn. n. 5133.

Momordiea Neck. n. 5141.

Monachanthus Lindl. n. 1420 .

Monachne Palis. n. $\mathbf{7 7 0}$.

Monactineirma Bory. n. 5098. b.

Monactis H, B. $K$, n. 2501 .

Monadenia Lindl. n. 1537/1.

Monanthes Haw. n. 4623. c.

Monarda Linn, n. 3600.

MONARDEAE p. 613.

Monardella Benth, n. 3606.

Monarrhenus Cass. n. 2418.

Monella Herb. n. 1279.

Monema Grev. n 14.

Monenteles Labill, n. 2416.

Monerma Palis. n. 929 . b.

Moneses Salisb. n. 4349 . b. *

Monetia Herit. n. 5711.

Mongezia $\mathbf{F l}$. $\mathrm{Fl}$. n. 5059 .

Moniera Linn. n. 599\%.

MLnilia A. Rich. n. 120, a.

Monilia Fill. n. 225.
Moniliformia Lamx, n. 120, a. Morinda Vaill. n. 3183. Monilina Bory, n. 50. Monimia Thouar, n. 2015.

MONIMIACEAE p. 313.

MONIMIEAE p. 313.

Monka ddans. n. 447, e.

Monniera P. Br. n. 3940. e.

Monnina $R$. $P$. n. 5652.

Monocaryum R. Br. n. 1084.

Monocentra $D C$, n, 6210, a.

Monocera Elliott, n. 843.

Monocera Jack. n. 5385.

Monochaetum DC. n. 6211. e.

Monochila Don. n. 3043. d.

Monochilus Fisch. ot Mey. n. 3686.

Monochlaena Cass, n. 2710. a. Monoclilaena Gaud, n. 637.

Monochoria Presl.n. 1088. b. $\beta$. Monoclea Hook, n. 460 . * Monocosmia Fenzl. n. 5181.

MONOCOTYLEDONES p. 76 .

Monocystis Lindl. n. 1639.

Monodon E. Mey. n. 6663. b. $\gamma$. Monodonta DC. n. 2516. c.

Monodora Dunal. n. 4725.

Monodynamis Gmel.n. 3366.

Monodynamus Pohl. n. 5916.

Monogonia Presl. n. 622. e. Monogramma Comm. n, 612.

Monogramme Comm, n. 612.

Monogyria DC. n. 2372. e.

Monolepis Schrad. p. 299.

Monolophus Wall. n. 1636.

Monolapia DC. n. 2674.

Monomeria Lindl, n. 1358.

Monophyllea $R . B r$. n. $4142 / 1$.

Monopogon Prest. n. 866.

Monoporina J. S.Pr. n. 5421.

Monopsis Salisb. n. 3057 . a. *

Monorchis Mentz. n. 1335.

Monosis DC. n. 2220.

Monotaxis Brangn. n. 5833.

Monothera Rafin. n. 343.

Monotoca $\mathrm{R} . \mathrm{Br}$. n. 4274 .

Monotris Lindl. n. 1521.

Monotropa Nutt. n. 4351.

MONOTROPEAE p. 761.

Monotropsis Sehweinitz n. 4354

Monsonia Linn. $f$. n. 6047 .

Monstera Adans. n. 1698.

Yontabea Pöppig. n. 4265.

Montagnate $D C$. I. 2522.

Montanoa LIav. et Lex. n. 2522.

Montbretia DC, n. 1242.

Montezuma Mog. et Sess. n. 5309.

Montia Houst. n. 536\%.

Montia Michel. n. 5182.

Montinia Linn. n. 6123.

Montira Aubl. n, 39i2.

Moonia Arn. n. 2491/,.

Mooreroftia Chois. n. 3813.

Moquilea Mart. et Zucc. n. 6410.

Moquinia DC. n. 2914. *

Moquinia Spreng. $f$. n. 4686 .f Mora Benth. n. 6754 .

Moraea Linn, в. 1224.

Moranda Scop, n. 5343.

Morchella Dillen. n. 435.

MOREAE p. 277. et 1375 .

Morelia A. Rich. n. 3324.

Morella Lour. in. 6850.

Morelosia Llav. et L., n. 4261. Morelotia Gaud. n. 981.

Morena Llav. et Lex. n. 3806. Morenia Ruiz et Pav. n. 1721. Morettia DC. n. 489 4. * Morgania $R . B r$. n. 3938 .

Moricandia $D C, n$. 495 '.

Morilandia Neck, n. 6379.

Morina Tournef. A. 2190 .
MORINDEAE p. 539.

MORINEAE p. 353.

Moringa Juss. n. 6811.

MORINGEAE p. 1321.

Morisia Gay. n. 4947.

Morisia Nees. n. 966, a.

Morisonia Plum. n. 5002.

Moritzia $D C$. n. $3768 /$.

Mormodes Lindl. n. 1420,

Morna Lindl. n. 2732. b. *

Morocarpus Scopol. n. 1921.

Moronobea Aubl. n. 5440 .

MORONOBEAE p. 1026.

Morphixia Ker. n. 1243.

Morrenia Lindl. n, 3464/3

Morsus Ranae Tourn. n. 1216. Morus Tourn, n. 1856.

Morysia Cass. n. 2692.

Moscaria Pers. n. 2955.

Moscharia Ruiz. et P,n. 2955.

Moschifera Molin. n. 2955.

Moschosma Reich, n. 3573.

MOSCHOSMEAE p. 608.

Moschoxylon Adr. J, n. 5542.

Mosiega Spreng. n. 2955.

Mosla Hamilt. n. 3615. a.

Mougeotia Ag. n. 5t. a.

Mongeotia H. B. K. n. 5338.

Moulinsia Camb, n. 5613.

Mourera Aubl. n. 1833.

Mouriri $A u b l$. n. 6270.

Mouriria Juss, n. 6270.

Mouroucoa Aubl. n. 4246 .

Moutabea $A n b l$, n. 4265.

Moutan DC. n. 4804. b.

Moutouchía Aub1. n. 6704.

Mozima Grteg. n. 5814.

Mozula Rafin. n. 6149. b.

MUCEDINES p. 19.

Muceron Fries, n. 453. VI. e.

Mucilago Hoffm, u. 445 .

Mucilago Michel. n. 308. a. et 320.

Mueizonia $D C$. n. 4620. c.

Mucor Alichel. n. 251.

MUCORINI p. 21.

Mucronea Benth. n. 1980.

Mueuna Adans. n. 6665.

Mühlenbergia Schreb. n. 803

Mullera Linn, $f$. n. 6735 .

Münchhausia Linn. n. 6164. b.

Muldera Miq. n. 1819/1.

Mulgedium Cass, n. 3028. *

MULINEAE p. 765.

Mulinum Pers. n. 4369.

Mulli Feuill, n. 5901.

Mundia Kunth, n. 5651 .

Mundubi Maregr. n. 6601.

Mundulea DC. n. 6539. d.

Munickia Reich. n. 2163.

Munnicksia Dennst. н. 5085.

Munnozia Ruiz et, $\boldsymbol{P}$. p. 1391.

Munronia Wight. n. $5518 / 4$.

Muntingia L. n. 5380 .

Munychia Cass. n. 2298.

Maralta Adans. n. 4768 .

Muraltia Neck. n. 5650.

Murdannia Royle. n. 1030

Muricaria Desv. n. 4965.

Murieia Lour, n. 5133.

Murraya Kon. n. 5506.

Mturucuia Tournef. n. 5099.

Musa Tournef. n. 1648.

MUSACEAE p. 227. et 1368.

Musanga Chr. Smith. n, 1865/.

Muscari Tourn. n. 1118.

Muscaria Haw. n. 363\%. c.

MUSCI p. 46.

MUSCI HEPATICI p. 42.

Muscites Brongn. 1. 600 .

Musenium Nutt. n. $4543 / 3$.

Musineon Rafin, n. 4 i30. c.

Musocarpum Brongn, n. 1654 .

Mussitenda Linn. n. 3313.

Musschia Dumort. n. 3090.

Mussinia Willd. n. 2845 .

Mutisia Linn, f. n. 2917.

MUTISIACEAE p. 480. et 1385.

Mutisiastrum Less. n. 2917. b.

MUTISIEAE p. 481.

Myagrum DC. n. 4919.

Myagrum Tourn. n. 4919.

Myanthus Lindl. n. 1420.

Mycaranthes Blum. n. 1361.

Mycaridanthes Blum, n. 1361 .

Myeelis Cass. n. 3007. b.

Mycena Fries. n. 453. VII. c.

Mycetia Reinw. n. 3296. c.

Mycinema Fries. p. 21. d.

Mycobanche Pers. n. 217.

Myeoderma Pers, p. 20. c.

Mycogone Link, n. 217.

Mycomater Fries, p. 16, a.

Myconla Lapegr. n. 4024.

Mycoporum Meyer. n. 152.

Mydonotrichum Corda. n. 385.

Myginda Jacq. n. 5689.

Mylanche Wallr. 11. 4182 .

Mylinum Gaudin. n. 4454.

Mylitta Fries. n. 288.

MYLOCARPI p. 13.

Mylocarpum Willd. n. 43t't/2.

Myoda Lindl. n. 1570.

Myogalum Link. n. 1134.

Myonima Comm. n. 3203 .

MYOPORINEAE p. 642.

Myoporum Banks et Sol. n. 3733. *

Myopsia Presl. n. 3062.

Myoschilos Ruiz et Pav, n. 2084.

Myoseris Link. n. 3019. b.

Myosotis Linn. n. 3772 .

Myosoton Mönch. n. 5242.

Myosurus Dillen. n. 4780. 
Myroxylon Forst. n. 5081/1. Myroxylon Linn. $f$. n. 6736 . Myrrhidium $D C$. H. 6048. i. Myrrhininm Schott. n. 6273. Myrrhis Scopol. n. 4513. Myrsidinm Rafin. n. 73. Myrsine Linn. n. 4221. * MYRSINEAE p. 734.

Myrsiphyllum Willd. n. 1465. MYRTACEAE p. 1223.

MYRTIFLORAE p. 1205.

Myrtillus $K$, n. 6316. a. $\epsilon$.

Myrtiphyllum P. Br. n. 3147.

Myrtus Tourn, n. 6316.

Myscolus Cass. n. 2966.

Myson Adans. n. 447. a.

Mystacidium Lindl. n. 1499.

Mystropetalum Harw. n. 717/1, Mystroxylon E. Z. n. 5688 .

Myurus Endl. n. 922, a.

Myxa E. n. 3738 . b. «.

Myxacium Fries. n. 453. 1v. h. Myxodes Targ. n. 105. b.

MYXOGASTERES p. 25.

Myxomphalos Wallr. n. 286.

Myxonema Fries. n. 48.

Myxopyrum Blum, n. 3358.

Myxosporium Link. n. 200.

Myxothecium Kunze n. 279.

Myxotrichum Kunze n. 239.

Myxotryx Fries. n. 48.

\section{I.}

Nabalus Cass. n. 3005 . b. *

Nabea Lehm. n. 4315.

Nablonium Cass. n. 2652.

Nacearia Endl. n. 68.

Nacibea Aubl, n. 3266.

Naemaspora Ehrenb. n. 365.

Naematelia Fries. n. 402.

Nagassarium Rumph. B. 54t7.

Nageja Gärtn, n. 1895.

Nahusia Schneev. n. 6125. b. \& NAJADEAE p. 229. et 1368.

Najas Willd, n, 1656. *

Nama Linn, n. 3835.

Nananthea DC. n. 2666.

Nandina Thunb. n. 4815.

Nangha Zippel. p. 1334. 37.

Nasodea Banks. n. 2073.

Nanodes Lindl n. 1398.

Nanophytum Less. n. 1947.

Nanophytum Less. n. 2783.

Nanosilene Otth, n. 5246. b. $\beta$.

Napaea $\boldsymbol{L}$. n. 5289.

Napellus $D C$ n. 4797 , d.

Napimoga Aubl, n. 5086. a.

Napoleona Palis. n. 4263.

NAPOLEONEAE p. 745.

Napus Tourn, n. 4949.

Naravelia DC. n. 4770 .

Narawael Herm, n. 4770 .

NARCISSEAE p. 178.

Nareissus I.tinn, n. 1289.

Narda Fl, Fl. p. 133/. 38.

Nardophyllam Hook. ot Arn, n. $2908 / 1$ :

Nardosmia Cass. n. 2285.

Nardostaehys $D C$. n. 2179.

Nardus Linn, n. 920.

Naregamia Wight et Arn. n. 5518.

Narthecium Gerard. n. 1062.

Narthecium Möhring n. 1050.

Narvalina Cası. n. 2568.

Nasella Trin. n. 798. a.

Nasmythia Huds. n. 1022. a.

NASSAUVIACEAE p. 489 . et 1386.

Nassavia Comm. n. 29\%t.

Nassavia Fl. $\mathbf{F l}$. n. 5605 .

Nassovia Pers. n. $29 \%$.
Nasturtioides Medik. n. 4932. f. Neoceis Cass. n. 2790.

Nasturtiolum Gray. n. 4931 . Neogaya Meisn. n. 4447.

Nasturtiolum Medik, n. 4975. a. Neolacis Cham. n. 1833. a.

Nasturtinm Boerh. n. 4932. d. Neottia Linn. n. 1551.

Nasturtium $\boldsymbol{R}, \mathrm{Br} .4850$.

Nastus Juss. n. 908. *

Natridium DC. n. 6493. b.

Natrix Mänch. n. 6493.

Natsiatum Ham. n. 4697.

Nattamame Banks. n.6663. b. $\&$.

Nauchea Deso. n. 6635.

Nauclea Linn. n. 3280 . *

Nauclearia DC. n, 3280 . c. *

NAUCLEAE p. 557.

Naucoria Fries. n. 453. IV. d.

Nauemburgia Mönch. n. 4206.

Nauplius Cass. n. $24+1$.

Navaea Webb. et Berth, n. 5269. b.

Navarretia Ruiz et P.n. 3821. h. Navia Borkh. n. 509.

Navia Mart. n. 1310.

Navicula Bory. n. 1. c.

Navieularia Bert. n. 789. b.

Navicularia Fabric, n. 3655. b.

Nazia Adans. n. 786.

Nebelia Neck, n. 4597. a.

Nebelia Sweet. n. 4600.

Neckera Hedw. n. 575 .

Neckeria Gmel. n. 5208.

Neckeria Ssopol. n. 4839.

Nectandra Berg. n. 2101.

Nectandra Rottb. n. 204'.

Nectandra Roxb. n. 2102.

NECTANDREAE p. 319.

Nectaribothrium Ledeb. n. 1094.

Nectaroscordum Lindl. n.1137/1.

Nectouxia DC. n. 4894. *

Nectouxia $\boldsymbol{H}, \boldsymbol{B} . \boldsymbol{H}$. n. 3843.

Neetris Schreb. n. 5024.

Neen Ruiz et $P$. n. 2011.

Needhamia Cass. n. 2568.

Needhamia $\boldsymbol{B}, \boldsymbol{B r}$. n. 4279.

Needhamia Scop. n. 6539 .

Neesia Blum, n. 5308.

Nefflea Benth, n. 3879 . c.

Negretia Ruiz et P. n. 6665.

Negundium Raf. n. 5559.

Negundo Möneh, n. 5559.

Nehemia Endl. n. 5376. a. $c$.

Neillia Don. n. 4644/,

Neja G. Don, n. 2372 .

Nelitris Gärln. n. 6313.

Nelsonia $\boldsymbol{R}, \boldsymbol{B} r$. n. 4032 . *

NELSONIEAE p. 697.

NELUMBIA p. 898 .

NELUMBIACEAE p. 902.

Nelumbium Juss. n, 5026.

Nelumbo Tournef. u, 5026 .

Nemaconia Knowl. n. 1377. *

Nemalion $\mathrm{Ag}$. n. 82.

Neniania Gray - n. 396.

Nemaspora Pers. n. 200

Nemastylis . Nutt. n. 1247.

Nematanthus Nees. n. 1012. a.

Nematanthus Schrad, n. 4162.

Nematogonum Desmaz. n. 223.

Nematoplata Bory. n. 10.

Nematora Ede. p. 33. a.

Nematospermum L. C. Rich, n. 1907.

Nematostigma Dietr. n. 1221. Nematrix Fries. n. 48.

Nemanchenes Cass. n. 3014.

Nemedra Juss. n. 5527.

Nemesia Vent. n. 3888.

Nemia Berg. n. 3970 .

Nemopanthes Rafin. n, 5707.

Nemophila Bart. n. 3829. -

Nemum Palis. n. 999. c.

Nenax Gärtn. n. 3106.

Nenax Gärtn, n. 6379.

Nenuphar Heyne u. 5021.
Neottidium Link. n. 1551.

NEOTTIEAE p. 212.

Nepa Petiv. n. 3724.

NEPENTHEAE p. 345 . et 1379. Nepenthes Linn, n. 2167.

Nepeta Linn. n. 3636.

NEPETEAE p. 622.

Nephelaphyllum Blum. n. 1338.

Nephelium Linn. n. 5617.

Nephrandra Coth, n. 3700. h.

Nephrandra $R . B r$. n. 3507. b. Nephrodium Rich, n. 639. Nephroia Lour. n. 4687.

Nephrolepis Schott. n. 638. * Nephroma Achar. n. 174. d.

Nephrosis $L, C$. Rich. n. 6709. Neptunia Loureir, n. 6828. at Neraudia Gaud. n. 1884. c.

Nerija Roxb. n. 5688.

Nerine Herb. n. 1273. i.

Nerium Gärtn, n. 3429.

Nerium $\boldsymbol{R}, \boldsymbol{B r}$, n. 3427.

Nertera Banks. n. 3187.

Nervilia Comm. n. 6147.

Nesaea Comm. n. 6147. e.

Nescidia A, Rich. n. 3172.

Neslia Desv. n. 4942.

Nesophila $A l p h . D C$.n. 3079. f.*

Nestlera Spreng. n. 2779.

Neuberia Eckl. n. 1240.

Neudorfia Adane n. 3817.

Neuracanthus Nees. n. 4066.

Neurachne $\boldsymbol{A} . \mathbf{B} \boldsymbol{r}$. n. 792.

Neuractis Cass. n. 2563.

Neurada B. Juss, n. 6401.

NEURADEAE p. 1249.

Neuroealyx Hook, n. 3287/2.

Neurocarpaea $\boldsymbol{A}$. Br. p. 566 .

Neurocarpaea $\boldsymbol{R}, \boldsymbol{B r}$. в. 3313 .

Neurocarpon $W$. et $M$. n. 105 .

Neurocarpum Desv, n. 6636.

Neurochlaena Less. n. 2786.

Neurogramma Presl, n. 606. a.*

Neurolaena $\boldsymbol{R}, \boldsymbol{B r}$. n. 2786.

NEUROLAENEAE p. $45^{\prime}$.

Neuroloma Andrz. n. 4856. a.

Neuroloma Rafin. n. 883.

Neuronia Don. n. 639. b.

Neuropeltis Wall. n. 3796.

Neurophyllum Nutt. n. $4414 /$

Neuroplatyceros Pluckn, n. 603 .

Neuropogon Nees et $\mathrm{Fl}$. n. 178.

Neuropora $6 o m m$, n. 3194.

Neuropteris Brongn. n. 680 .

Neuropteris Desv. n. 622 .

Neurosperma Rafin. n. $5 \mathrm{t33}$.

Neurotropis DC. n. 4885. d.

Neuwiedia Blum, n. 1620.

Nhandiroba Plum, n. 5121.

NHANDIROBEAE p. 933.

Niara Dennst. n. 4222.

Nibora Rafin, n. 3946 .

Nicandra Adans. n. 3850 .

Nicandra Schreb. n. 3369.

Nieolsomia $D C$. n. 6612.

Nicotiana Linn, n. 3841. *

NICOTIANEAE p. 662.

Nidorella Cast. n. 2370.

Nidularia Fries. n. 3'3.

NIDULARIACEI p. 29.

Niebuhria DC. n. 4995 , *

Niebuhria Neck. n. 2496. *

Niebuhria Scop. n. 2470.

Niercmbergia Ruiz ot Pav. n. 3839.

Nigella Tourn, 11. 4794 .

Nigella Mönch, n. 4794. c.

Nigellaria $D C, n$, 4794, b.

Nigellastrum Mönch, n. 4794, a.

Nigrina Linn, n. 3992.

Nigrina Thunb. n. 1819.

Nigritella $L$. C. Bich. n. 1541.

Nilsonia Brongn. n. 711. *

Nima Hamilt. n. 5966.

Nimnoia Wight n. 4632.

Nintooa $D C$. n, 3337. B, a.

Niobaea Willd. n. $126 \%$.

Niobe Salisb. n. 1100.

Niota Lam. n 5965.

Niotoutt Adans n. 5930.

Nipa Thunb. n. 1717.

Niphobolus Kaulf. n. 617. *

Nirbisia G. Don. n. 4786. a.

Niruri Achar. n. 5847. b.

Nisa Noronh. n. 5091.

Nissolia Jacq. n. 6629.

Nissolia Tourn, n. 6582. d.

Nissoliaria $D C$. n. 6629.

Nitelium Cass. n. 2930. c.

Nitella $A_{g}$. n. 76.

Nitophyllum Grev. n. 100.

Nitophyllum Neck. n. 474 .

Nitrangium E. n. 3093. b.

Nitraria L. n. 5714 .

NITRARIACEAE p. $109 \%$.

Nivaria Mönch. в. 1266.

Nivenia $\boldsymbol{R} . \boldsymbol{B}$ r. n. 2127.

Nivenía Vent. n. 1233.

Nobula Adans. n. 3108.

Nocea Cav. n. 2287. b.

Noceaea Jacq. n. 2273. a.

Noccaea Reichenb. в. 4931.

Nodularia Link. n. 52.

Nodularia Mert. n. 53.

Noggerathia Sternb. n. 1781.

Noisettia Kunth, n. 5042 .

Noisettia Mart et Z. n. 5043 .

Nolana Linn, n. 3817. *

NOLANACEAE p. 655.

Nolanea Eries. n. 453 . VI.

Nolina $L$. C, Nich. в. 106\%.

Nolinea Pers. n. 1064.

Nolletia Cass. n. 2389.

Noltea Eckl, n. 3731.

Noltea Reichenb. n. 5725. 
Notylia Lindl. n. 14 t 8 . Nouletia Endl. n. 4124/1. Nowodworskya Presl n. 812. NUCULIFERAE p. 607.

Nugaria $D C$, n. 6765, a.

Nummularia Rumph. n. 3508. Nunnezharia Ruiz et P. n. 1719. Nunnezia Willd. n. 1719. Nuphar Smith. n. 5021.

Nuttallia DC. n. 5707.

Nuttallia Dicks, et B. n. 5274. Nuttallia Torr, et A. Gr, n. 639\%. Nuxia Comm. n. 3972. Nuytsia R. Br. n. 4587.

Nyalelia Dennst. n. 5525 .

Nyetagella Reichenb. n. 3841.* Nyetago Juss. 11. 2003.

NYCTAGYNEAE p.310. et $137 \%$. Nyctanthes Linn. n. 3343 .

Nyctelaea Scop, n. 3828.

Nyeterinia Don, n. 396'.

Nyeteristium Ruiz et P. n. 4234 .

Nycterium Vent. и. 3855.

Nyctophylax Zipp. p. 225 .

Nylandtia Dumort, i. 5651 .

Nymphaea Boerh, n. 5021.

Nymphaea Nock. n. 5020.

NYMPHAEACEAE p. 898.

Nymphanthus Lour. n. 38's\%. b. Nympheanthe Reich. n. 3565. a.

Nymphoides Tourn. n. 3565. b.

Nymphosanthas Rich, n. 5021.

Nypa Rumph, n. 1717.

Nyssa Linn. n. 2086.

NYSSACEAE p. 328.

Nyssanthes R.Br. n. 1965.

\section{(1.)}

Obaejaca Cass. n. 2811. Obeliscaria Cass. n. 2516.

Obeliscotheca Vaill. n. 2514. Obentonia $V_{\text {ell. }}$ n. 5990.

Oberouia Lindl. n. 1330, Obesia Haw. n. 352\%. h.

Obione Gärtn. n. 1912. c.

Obolaria Linn. n. 4026.

Obolaria Siegesb, n. 3332.

Ocellularia Meyer. n. 154 .

Oehanopappus E. B. 2868. b.

Ochetopliila Püpp. n. 5733.

Ochna Schreb. n. 5959 . *

OCHNACEAE p. 1141.

OCHNEAE p. 1142.

Ochopodium $\boldsymbol{Y}_{\text {og. }}$ n. 6605. b.

Oehradenas Del. n. 5010.

OCHRANTHACEAE p. 1035.

Ochranthe Lindl. n. 5474 .

Ochrocarpus Thouar, n. $\mathbf{5} 433$.

Oeluroma $S_{\text {W. n. }} 5306$.

Ochrosanthus Don, n. 3043. a.

Oelitosia Juss. n. 3389.

Ochroxylum Schreb. n. 5972. d.

Ochrus Tourn, n. 6582, b.

Ochtlrodium $D C$, n. 4897 .

Oeimodon Benth. n. 3569. a.

OCIMOLDEAE p. 608.

Ocimum Linn, n. 3569.

Ockenia Dietr. n. 6015.

Ockia Dietr. n. 6015.

Ocotea Aubl. n. 205t.

Ocotea Gärln. n. 20'42. b.

Octadenia $R, B r$. n. 4870 .

Oetarilium Lour. n. 2083.

Octas Jack. n. 6868.

Octavia DC. n. 3205 .

Oetaviania Vilt. n. 329.

Octoblepharis Sehreb. n. 522.

Oetoblepharum Hedw. n. 522.

Octodiceras Brid. n, 598.

Octodon Th́onn, n. 3119.

Octogonia Klotzsch. n.4302. d.

Dctomeria $R, B r$. n. 1322.
Oetopera D.Don. n. 4313. b. 16." Oligandra Less. n. 294. Octospora Hedw. n. 430. Octostemon DO. n. 6244. b.

Odiua Roxb. n. 5898 .

Odollam Rheed. n. 3388.

Odonectis $R a f i n$, n. 1601.

Odonia Bert. n, 6653.

Odonites Spreng. n. 4414.

Odontandra Funth. n. 5547.

Odontarrhena $C$. A. M. n. 4875 .

Odontella $A g$. n. 9.

Odonthalia Lyngb. n. 90.

Odontia Fers. n. 442 . a.

Odontites Hall. n. 4010

Odontocarpa Neck. n. 2081.

Odontocarpla $D C$. n. 2211.

Odontoglossum H. B.K. n. 1466.*

Odontognathia $D C$. n. 2874 . b.

Odontolepis Boiss. n. 2857. a. 1.*

Odontoloma $H . B . K$. n. 2197.

Odontolophus Cass. u. 2871. q. Odontopetalum DC. n. 60'77. a.

Odontophyllum DC. n. 2782. b.

Odontoptera Cass n. 2830.

Odontopteris Bernh. n. 663.

Odontopteris Brongn, n. 681 .

Odontoschisma Don. n. 473. b.

Odontosoria Presl n. 643. c. d. *

Odontospermum Nock, n. 2445.

Odontostemma Benth. n. 4238.

Odontostoma Endl. n. 336. d.

Odentostylis Blum. n. 1352.

Odontotrichum Zuce. n. 3032/9

Odostemon Naf. n. 4814 . b.

Oeceoclades Lindl. n. 1492.

Oechmea Juss. n. 1301.

Dedemium Link. n. 240.

Dedera Crants. n. 1167.

Oedera Linn. n. 2635.

Dederia DC. n. 2635.

Oedipachne Link, n. 767.

Oédipodium $\boldsymbol{S c h w a ̈ g r . ~ n . ~} 500$.

oedmannia Humb. n. 6459.

oedogonium Link, n. 56.

Oedycia Raf. p. 31.

oenanthe Linn. n. 4418 . a.

0enocarpus Mart. n. 1726.

Oenoplea Hediv. n. 5719 .

Oenoplia Sehult. B. 5719.

Denothera Linn, n, 6115.

Oenothera Spach, n. 6115. 2.

OENOTHEREAE p. 1188.

Oeonia Lindl. n. 1497.

Depata Rheod. n. 3722.

ogcerostylus Cass. n. 2711.

0 giera Cass. n. 2500.

Ogiera Spreng. n. 2454 .

oglifa DC. n. 2752. b.

o-Higginsia $\boldsymbol{A}$. et $\boldsymbol{P}$. n. 3288 .

Ohlendorfia Lehm, n. 3900.

Oidium Link. n. 220.

Oiospermum Less. n. 2198. *

Okenia Dietr. n. 6015.

Okenia Schied. n. 2006.

OLACINEAE p. $10 \% 1$.

$0 \operatorname{lax}$ L. n. 5492.

Olbía Med. n. 5269. b.

Oldenburgia Less. n. 2927.

Oldenlandia Linn. n. 3240. g.

Olea Linn. n. 3349.

OLEACEAE p. 571 . et 1395.

Oleandra Cav. n. 6396. *

Olearia Mönch, n. 2318. *

Oleaster E. n. 3349. b.

OLEINEAE p. 571.

OLERACEAE p. 291.

Olfa ddans, n. 4790 , a.

Olfersía Raddi, n. 603, a. $\beta$. *

Oligaerion Cass. n. 2626.

Oligactis Kunlh, n. 2244. b.

Oligacoce Willd. n. 2182.

Oligadenia Ehrh. n. 5484. a.

Oligandra Less. n. 1931. *
Oliganthera Endl. n. 1931.

Oliganthes Cass. n. 220\%. f.

Oligarrheaa $\mathrm{R}$. Br. n. 4280 .

Oligocarpha Cass. n. 2411.

Oligocarpus Less. n. 2823.

Oligochaeta $D C$. n. 2897. d.

Oligodora $D C$. n. 2778.

Oligoglossa $D C$. n. 2680.

Oligogyae $D C$. n. 2558 , *

Oligolepis Cass. n. 2395. c.

Oligomeris Camb. n. 5012.

Oligophyllon Lers. n. 2960. b. $\alpha$.

Oligosperma Endl. n. 5111. a.

Oligosporus Cass. n. 269\%. a.

Oligotrichum DC. n. 260. c.

Olinia Thunb. n. 6272.

PLINIEAE p. 1223.

Olinthia Lindl. в. 6323.

Olisbea DC. n. 6271.

Olisia Benth. n. 3650 . f.

Oliveria Vent. n. 4519.

Olivia Gray, n. 26.

Olmedia $\boldsymbol{R}$. et $\boldsymbol{P}$. n. 1863.

Olocarpha DC, n. 2630 . b.

Olopetalum Ftotzsch, n. 6047. b

Olympia Spach. n. 5464. B.

Olyra Linn. n. 764.

Omalantius $A$. $J$. n. 5779.

Omalanthus Less. n. 2686.

Omalia Brid. n. 572 . b.

Omalocline Cass. n. 3022. B.

Omalotheea $D O$. n. 2746 .

Ombrophytum Pöpp. n. 716.*

Ommatodium Lindl. n. 1539/1.

Omoea Blum. n. 1487. b.

Onphaeomekia $E$. s. 2075 . b.

Omphalandria $\boldsymbol{P} . \boldsymbol{B r}$. n. 5793 .

Omphalea $L$. n. 5793.

Omphalia Fries, n. 453 . VII. b. Omphalium Roth. n. 3780.

Omphalobioides $D C$. n. 6785 . b.

Omphalobium Gairtn. n. 5949.

Omphalobium Jacq. n. 6784. b.

Omphaloearpus Palis. n. 4245.

Omphalocaryon $F l$, n. 4296. b. *

Omphalococea Willd. ․ 3713.

Omphalodes Tourn. n. 3780.

Omphalomitra Endl. n. 434.

Omphalophora Brid, n. 559.

Omphalospora Bers. n. 3979. b.

Omphalostigma Gr. n. 3552/, b.

Onagra Tourn, n. 6115.

ONAGREAE p. 1188.

Oncidinm Fries. 11. 239.

Oncidium $S_{\text {wartz. n. } 1460 . *}$

Oncinema Arn. n. 3471/,

Oncinus Lour. n. 4232 .

Oncoba Forsk, n. 5067.

Oncobyrsa $A g$. o. 12.

Oncocladinm Wallr. n. 227. e.

Oncogastra Mart, n. 5159. b.

Oncolobium Vog. n. 6781. b. $\delta$.

Oncoma Spreng. n. 4133.

Oncomyees Flotzsch., и. 436.

Oncophorus Brid. n. 525.

Oncorhynchus Lehm. в. 5004.

Oneosperma Blum. n. $1727 / \mathrm{s}$.

Oneosporum Putt. n. 5665 .

Oncostemum A. J. n. 4225.

Onens Lour. n. 1203.

Oneylogonatum Kön, n. 601. b. Oneillia $\mathrm{Ag}$. n. 102.

Onobroma DC. n. 2876.

Onobrychis Tourn. n. 6619.

Onoclea Linn. n, 629.

Ononis Linn. a. 6493.

Onopix Rafin. p. 1391. 18.

Onopordon Vaill, n, 2881.

Onopteris Neck. n. 630, A.

Unoseris Less. I. 2925, *

Onosma Linn. ․ 375k.

Onosmodium $L, C . R . x .3755$.
Oligothrix Cass. n. 2795.

Onosuris Rafin. n. 6113.

Onotrophe Cass. n. 2887.

Onychium Blum. n. 1369.

Onyehium Kaulf. n. 635. *

Onychium Reinw. n. 617/s

Onygena Pers. n. 301.

ONYGENEI p. 25.

Oocephalus Benth. n, 3583 . h.

Ooelinium DC. n. 2274. *

Oococea $D C$. n. 5620.

Oomorphaea $D C$. n. 2700 , a.

Oospora Wallr. n. 220.

Opa Lour. n. 6320.

Opegrapha Eschw. n. 135. a.

Opegrapha Pers. и. 135.

Opereularia A. Rich. n. 3097.

OPERCULARIEAE p. 521.

Opereulina Silva da Manso. n. 3807.

Opetiola Gärtn. n. 1003. b. «.

Ophelia Don. n. 3532.

Ophelus Lour. n. $529 \%$.

Ophiala Desv, n. 673.

Ophiocaryon Endl. n. 5926.

Ophioderusa BIum. n. 672.

OPHIOGLOSSEAE p. 65 et 1352.

Ophioglossnm Linn. n. 671 .

Ophiopegon Ait, n. 1192. *

OPHIOPOGONEAE p. 156.

Ophiorrhiza Linn. n. 3245.

Ophioscorodon Wallr, n.1137. b.

OPHIOSPERMEAE p. 73\%.

Ophiostachys Del. n. 1066. b. *

OPHIOXYLEAE p. 579.

Ophioxylon Linn. n. 3385.

Ophioxylon, Pers. n. 3389.

Opghira Linn. n. 2085.

Ophispermum Lour, n. 2111.

Ophiurus Gärln. n. 924.

OPHRYDEAE p. 208.

Ophryosporus Mey. n. 3032/10.

Ophrys Linn, n. 1542. 
Oreosplenium Zahlbr, n. 4633. Orthotrichum Heds. n. 509. Oresigonia Schlecht, n. $280 \%$. Oresigonia Willd. n. 2803. Oresitrophe Bunge. n. 4646. Orgya Stackh. n. 108. Oriba Adans. n. 4773 . b. 8 . Oribasia Fl. mex, n. 2803. Oribasia Schreb. n. 3209 . ORIGANEAE p. 616. Origanum Linn. n. 3608. Orimaria Rafin. n. 4414. Orites $R . B r$. n. 2147. Orithyia Don. n. 1092. Oritina R. Br. n. 2147. b. Oritrophium Kunth, n. 2301. a. Orium Desv. n. 4877 . b. Orixa Thunb, p. 738. Orixa Thunb. n. 6892.

Orlaya Hoffm. n. 4496 . Ormenis Cass. 11. 2645. Ormocarpum Palis, n. 6593.

Ormosia Jack, n, 6747. Ormosolenia Tausch, n. 4487. Ormyearpus Neck. n, 4971. Ornithidium Salisb. n, 1400. Ornithocephalus Hook. n. 1403. Ornithochilus Wall. n. 1493. e. Ornithogalum Link. n. 1132.

Ornithoglossum Salisb, n. 1071. Ornithopodium Tourn, n. 6587. Ornithopteris Bernh, n. 661 . Oruithopus $\operatorname{Linn}$, n. 6587. Ornithoxanthum Link, n. 1093. Ornitrophe Juss. n. 5605. Oruns Pers. n. 3353 . e. * Orobanche Linn. n. 4185. OROBANCHEAE p. 725, et 1406. Orobanchoides E. n. 3959. a. Orokinm Reich, n. 4925. Orobus Tourn. n. 6583. Orolanthus E. Meq. 1. 3578. ORONTLACEAE p. 239. ORONTIEAE p. 240. Orontium Linn. n. 1706. Orontium Pers. n. 3892. Oropetimm Trin. n. 923. Orophaca $T$. et $A$. Gr. n. 6571.b. Orophanes Salisb. n. 4313 . d. 40. *

Orophea Blum. n. 4711.

Orostachys Fisch. n. 4620. a. Oroxylum Vent. n. 4124. Orphium E. Mey. n. 3538.

Orsinia Bert, n. 2252. Orsinia Bert, n. 2433. a. Ortega L. n. 5214. Ortegia Löff. n. 5214. Ortegioides Sol. n. 6143. Orthanthera Wight. 11. 3513. Orthocarpaea DC. n. 5315, a. $\alpha$. Orthocarpis Nutt. n. 4003. * Orthocentrum Cass. n. 2887. Orthoceras $\boldsymbol{R}, \mathbf{B r}$. n. 1583. Orthoclada Palis. ne 901. Orthodanum E, Mey. n. 6690. Orthodon Bory. n. 501. Orthodon Ser. n. 52'1. d. Orthodontium $S$ chw. n. 513. Ortholeueas Benth, n. 3662 . c Orthonepeta Benth, n. 3636 . g. ORTHOPLOCEAE p. 887. Orthopodium Benth. n. 367s, b. Orthopogon $\mathbf{A}, \mathbf{B r}, \mathbf{n} .778$. Orthopyxis Palis, n. 542. a, et 549.

Orthoselis DO. n. 4978, d. Orthosiphon Benth. n. $357 \%$. ORTHOSPERMAE $D C$, p. 763. Orthosporum $\boldsymbol{R} . \boldsymbol{B r}$. p. 295. Orthostachys $\mathrm{B}$. Br. n. 3751. a. Orthostemon R. Br. n. 3515 . Orthotheea Bria. n. 495. Oxthothecium $8 \subset$ s, $E$. a. 5315. Orvala Linn. n. 3645 . a. 0vieda Linn. n. 3708. Ovieda Spreng. n. 1236. Orthotropis Bent. n. 6430 . Orthrosanthus Sweet, n. 1220. Ortiga Fexill. n. 5116. Orucaria Clus. n. 6709. Orychophragmus $B$. n. 4953 . Orygia Forsk. 11. 5184. Orythia Blum, n. 4136/s. Oryza Linn, n. 729.

ORYZEAE p. 78.

Oryzopsis Bich, n. 793. Osbeckia Linn. n. 6221. OSBECKIEAE p. 1212.

Oseampia Mönch. n. 3768, a. Oselllaria Bosc. n. 39.

Oscillatoria Vauch, n, 39.

OSCILLATORINAE p. 4.

Osmanthus Lour, n. 3349. c. Osmites Cass. n. 2784.

Osmitopsis Cass, n. 2785.

Osmodium Raf. n. 3755.

Osmorrhiza Rafin. n. 4515 .

Osmothamuus DC. n. $4338 / 1$.

Osmunda Linn. n. 665.

Osmunda $S_{\text {cheuchz. n. } 630 .}$ OSMUND ACEAE p. 65. et 1351. Osmundaria Lamx. n. 117.

Ospriosporium Corda. n. 385. Osproleon Wallr. n. 4195.

Ossaea DC. n. 6242.

Osteomeles Lindl, n. 6343.

OSTEOSPERMKAE p. 462.

Osteospermoides $D C$. n. 2672. d.

Osteospermum Linn. u. 2825.

Osterdamya Neck. n. 935.

Osterdyekia Burm. n. 4662.

Ostericium Hoffm. n. 4t55.

Ostodes Blum. n. 5803 .

Ostracoccum Wallr. n. 272.

Ostracoderua Fries. n. 299.

Ostreocarpus L. C. H. n. 3399. *

Ostropa Fries. n. 390.

Ostrya Mich, n. 1842.

Ostryodiom Desv, n. 6697. c.

Oswalda Cass, n. 2462, b.

Osyricera Blum. n. 1326.

Osyris Linn, n. 2078.

Otaehyrium Nees. n. 770.

Otandra Salisb. n. 1433.

Otanthera Blum. n. 6220 .

Otanthus Link. n. 2650.

Otaria Kunth. n. 3491.

Oteiza Llav. p. 1391. 3.

Othera Thun b. p. 738.

Othlis Schott. n. 4761.

Othonna Linn. n. 2828.

OTHONNEAE p. 462:

Othrys Noronh, n. 5003.

Otidia Lindl. n. 6048. e.

Otiona Corda. n. 467 . *

Otiophora Zuce. n. 3133.

otites Otth, n. 52'18, b.

Otocalyx $A . D O$. n. 5089. b. Otochilus Lindl. n. 1342. Otochlamys $D C$. u. 2682. Otophylla Benth. n. 3996. a. Otopteris Lindl, n. 678. Otostegia Benth, n. 3661.

Ototropis Benth. n. 6527 . Ototropis Schauer. n. 6614. 0 ttel-Ambel Rheede. n. 1213.

Ottelia Pers. n. 1213.

Ottilis Gärtn. и. 4569.

Ottoa Runth. n. 4417. Ottonia Spreng. n. 1823. Oudneya $R, B r$, n. 4849 . Onratea Aubt, n. 5958. Ourisia Comm. u. 3986. Onrouparia Aubl, n. 3280. d. Oustropis Don. n. 6527 . Outea Aubl. n. 6803. a. Onviraudra Thouar, n. $1664 / x$.

Oxydium Benn, n. 6621 . 6118. b.
Ovilla Adans, n. 3071 .

OXALIDEA F p. 1171.

Oxalis Linn. n. 6358. *

Oxera Labill. n. 4133.

Oxleya $A . C$. n. 5555.

Oxyaudra $D C$. n. 5593. a.

Oxyanthera Brongn. n. 1505.

Oxyanthus $D C$. n. 3307 .

Oxybaphus Herit. n. $200 \%$.

Oxycarpus Lour. n. 5443.

Oxyceros Lour. n. 3304. a.

Oxyeoceos Tourn. n. 4331.

Oxydendrum DC. n. 4318/s.

Oxydenia Nut, n. 840 .

Oxydon Less. n. 2937. *

Oxygonium Presl. n. 636. d.

Oxygonum Burch. n. 1988.

Oxygraphis Bung. n. $4785 / 1$

Oxylobium Andr. n. 6427.

Oxylobus Moc. n, 2263 . b.

Oxyloma B. n. 4313. d. 29. *

Oxyodon $D C$. n. 2937.

Oxymeria $E$. n. 2075 . c.

oxymeris $D C$. n. 6259 .

Oxymitra Bisch. n. 456 . *

Oxymitra Blum, n. 4713 . b.

0xynepeta Benth, n. 3636. b. Oxypappus $D C$. n. 2598.

Oxypetalum $R$. Br. n. 3475 .

Oxypheria Hort. n. 2727.

Oxypogon Rafin. n. 6581. c.

oxypolis Rafin. n. 4471.

Oxypolis Rafin. n. 3472 .

Oxyramphis Wall. n. 6531.

Oxyria Hill. n. 1983.

Oxys Tourn. n. 6058.

0xyspermum $E$. et $Z$. n. 3101.

Oxyspora $D C$. n. 6203.

0xystelma $\boldsymbol{R}, \boldsymbol{B r}$. n. 3481 .

Oxystoma Eschw, n. 135. b.

Oxystophyllum Blum, n. 1365.

Oxytropis DC. n. 6572.

Oxyura $D C$. n. 2631 .

Oyedaea $D C$, n. 2532. *

Ozodia $W$. et $A$. n. $451 \%$.

Ozonium Link. p. 21. d. $\beta$.

Ozophyllum Schreb. n. 5993.

Ozothamnus $R$, Br. n. 2738.

\section{P.}

Pachíra Aubl. n. 5298.

Pachites Lindl, n. 1519.

Paehycalyx Klotzsch, n. 4302 . e.

Pachycarpus E, Mtey. n. 3486.

Pachycentria Blum. n. 6238.

Pachychilus Blum. n. 1385.

Pachydendron Haw. n. 1115. g.

Pachyderma Blum. n. 3351 .

Pachyderris Cas 4. n. 2386. b.

Pachydium Fisch, et Mey. n.

Pachylaena Don. n. 2922.

Pachylepis Brongn, n. 1793. *

Pachylepis Less. n. 3020.

Pachylobium Benth. n. 6662, a.

Pachylobus Don, p. 1139.

Pachyloma $D C$. n, 6201 .

Pachylophis Spach, n. 6115. 5.

Paehyma Fries, n. 290.

Pachyne Salis6. n. 1388.

Pachynema $R, B r$. n. 4756.

Paehyneurum Bung. n. 4853/1.

Paehynotom $D C, \mathrm{n}, 4845$, a.

Pachyphragma DC, n, 4885, a.

Pacliyphyllum H.B. K. n. 1462.*

PACHYPLEUREAE p. 777.

Pachypleuria Prest.n. 643. c. $\beta$.*

Pachyplearum Ledeb. 11. 4451.

Pachypleurum Beich. n. $4 \pm 47$.

Pachypodium Lindl. n. 3'13.

Pachypodium Nutt, n. 4915.

Pachypodium Webb, et Berth. 4905. *

Pachypteris Brongn. n. 675 .

Pachyrhynehus DC. n. 2756.

Pachyrrhizus Kioh, n. 6679.

Pachysa Don. n. 4313. d. 31.*

Pachysandra Michx. n. 5870.

Pachystemon $\mathbf{B l}$. n. 5778 .

Pachystima Raf. n. 5690 . *

Pachystoma Blum. n. 1385.

Pachystylum DC. n. 4978. e.

Pacouria Aubl. n. 3375 .

Pacourina Aubl. n. 2202.

Pacourinops!s Cass. n. 2202.

Pacoury Abbev. n. 5456.

Padavara Rheede. n. 3183. b.

Padina Adans. n. 105. a.

Padus E, n. 6406. c. $\beta$.

Paederia Linn, n. 3180 .

PAEDERIEAE p. 538.

Paederota Linn. n. 3980.

Paeon DC. n. 4804.

Paeonia Tourn, n. 4804.

PAEONIEAE p. 850.

Paepalanthus Mart, n.1022. c.

Paesia St, Hil. p. 1350.

Pagamea Aubl. n. 3371.

Pagapate Sonner. n. 6312.

Paiva Fl. Fl. n. 3224. "

Pajanelia $D C$. n. 4117/.

Palacozamia Endl. n. 708.

Palafoxia Lagasc. n. 2265.

Palamoxys E, n. 6058. a.

Palaquium Blanco. n. $4246 / 2$.

Palava Cav, n. 5266.

Palava $R . B r$, n. 5414 .

Palavia Mönch, n. 5266.

Paleolaria Cass, n. 2265.

Paletuveria Thouar, n. 6101.

PALETUVJERS p. 118 t. 
Panderia Fisch, et M. н. 1917. Parthenium Linn. n, 2489. Pandora Noronh, n. 5401.

Pandorea E. n. 4114. a.

Pandurella Küts. p. 1.

Panetos Rafin, n. 3240, d. oे.

PANGIACEAE p. 922.

Pangium Rumph, n. 5035.

Panieastrella Michel. n. 783.

Panicastrella Mönch. n. 832.

PANICEAE p. 82.

Panícularia Coll. n. 650. c. *

Panicum Linn, n. 770.

Panisea Lindl, n. 1347. c.

Panke Feuill, n. 1889. b.

Pannaria Delis. n. 172. B.

Panopia Nor. n. 5789.

Panzera Willd. n. 6800.

Panzeria Mönch, n. 3647. c.

Papaver Tourn, n. 4823. *

PAPAVERACEAE p. 854 .

Papaya Tourn. n. 5119.

PAPAXACEAE p. 932.

PAPILIONACEAE p. 1253.

Pappea Eckl. el Zcjh, 11, 5635.

PAPPOPHOREAE p. 91.

Pappophorum Schreb. n. 830.*

Papularia Forsk. n. 5168. a.

Papularia Fries. n. 180.

Papyria Thunb, n. 1290.

Papyrius Lam. n. 1858.

Papyrus Willd, n. 1003, a.

Paquerina Cass, n, 2350.

Paragnathis Spreng. n. 1528.

Paragramme Blum. n. 616.

Paralea Aublet. n. 4249. c.

Paramesus Presl. n. 6511.

Paramignya Wight, n. 5510 .

Paranomus Salisb. n. 2127.

Parapetalifera Wendl. n. 6020.

Parapodium E. Mey. n. 2448.

Paraphysia DC. n. 2865. A. ơ

Paratropia DC. n. 4561.

Pardanthus Fer. n. 1231.

Pardisium Burm. n. 2922.

Pardoglossa Lindl. n. 1537.

b. $\delta$. *

Parentucellia Viv. n. 4011.

Pariana Aubl, n. 919.

PARIDEAE p. 153.

PARIETALES p. 903.

Parietaria Gaud, n. 1885. a

Parietaria Tourn, n. 1885, *

Parilium Gärtn. n. 3343.

Parinari Aub7. n. 6411.

Parinarium Juss. n. 6't11.

Paris Linn. n. 1176.

Parita Scop. n. 5283.

Paritium Adr. Juss, n. 5283.

Parivoa Aust. n. 6801.

Parkeria Hook. n. 656. *

PARKERTEAE p. $6 \%$.

Parkia R. Br. п, 6819.

PARKIEAE p. 1323.

Parkinsonia Plum. n. 6775.

Parmelia Eries. n. 172.

PARMELIACEAE p, 15.

Parmentaria Fée. n. 149.

Parmentiera DC. n. 4171/1.

Parnassia Tournef. n. 5039 .

PARNASSIEAE p. 908.

Parochetos Hamill. n. 6519 .

Parolinia Endl. n. 1793. *

PARONYCHIEAE p. 955. et 956.

Paropsia Noronh, n. 5095.

PAROPSIEAE p. 925.

Parosella Cav, n. 6523.

Parrotia C. A. Mlejer n. 4592.

Parrya $n, B r$. n. 3417.

Parsonia P. Br. n. 6151.

Partheniastrum DC. n. 2489, a.

Partheniastrum Nissol. n. 2189.

Parthenichaete DC. n. 2489. b.

PARTHENIEAE p. $40 \%$.
Parthenoxys E. n. 6058 . g. Parvatia Decaisn. n. 4702. * Pascalia Orteg. n. 2504. Paschanthus Burch, n. 510\%. Pasithea Don, n. 1157. Paspalum Linn. n. 761. Passalia Soland. n, 5047.

Passerina Linn. n. 2095. Passiflora Juss. n. 5098.

PASSIFLOREAE p. 924. Passoura Aubl. n. 5047.

Pastinaca Tourn. n. 4473.

Patabea Aubl. n. 3142.

Patagonica Dill. n. 3741.

Patagonium Sohrank. n. 6603.

Patagonula Linn, n. 3741.

Patania Presl. n. 6t4. e. *

Patella Chev, n. 381.

Patellaria Fries, n. 172. et 381. A. $\beta$.

Patellaria Pers. n. 166.

Patersonia $\mathbf{R}, \mathbf{B r}$. n. 1234. *

Patima Aubl. n. 3232.

Patrinia Don. n. 2179.

Patrinia Juss. n. 2178.

Patrinia Hafin. n. 6738. e.

Patrisia L. C. Bich, n. 5093.

Patrisia Rohr. n. 5758.

Pauletia Cav, n. 6790.

Paullinia L. n. 5603.

Paulownia Sieb. et Zucc. n 3916.

Pauridia Harw, n. 1264/1.

Pautsavia Ju5s. n. 6097.

Pavate Ray. n. 3160.

Pavetta Linn, n. 3160.

Pavia Boerh. n. 5641.

Pavinda Thunb. n. 4602.

Pavonia Cav. n. 5275.

Pavonia Ruiz. n. 2021.

Peautia Comm. 4668.

Peya Scop. n. 3158.

Pecila Lepell, n. 320.

Peckia Fl. Fl. n. 4221. *

Pecopteris Sternb. n. 684.

Pecten DC. n. $450 \%$. a.

PECTIDEAE p. 36\%.

Peetidium Less. n. 2249.

Pectidopsis DO. n. 22'48.

Pectinaria Benth, n. 3583. o.

Pectinaria Haw. p. 598.

Pectinastrum Cass, n. 2871. dd.

Pectinellum DC. n. 2259. b.

Pectis Cass. n. 2249.

Pectís Linn. n. 2250.

Pectocarya DC. n. $3784 /$,

Pectophytum Kunth. u. 4367.

PEDALINEAE p. 723. et 1409.

Pedalium Linn, n. 4177.

Pediastrum Mejen. n. 19.

Pedicellaría $D C$. n. 4985 . a.

Pedicellia Lour. n. 563't.

Pedicularis Tourn. n. 4015 .

Pedieularoides Benth. n.3996. c.

Pedilanthus Neck. n. 5765.

Pedilea Lindl. n. 1336.

Pedilonia Presl. n. 1251.

Pedilonium Blume n. 1369.

Peganum Linn. n. 6025.

Pegesia Hafin, n. 3996. c.

Pegia Colebr. n. 5899.

Pegolettia Cass. u. 2436.

Peixotoa A.J. n. 4588.

Peixotopterys Griseb. n. 5575. a.

Pekea Aubl. n. 5642.

Pelargoninm Herit. n. 60's8.

Pelecinus Tournef. n. 6574 .

Pefecynthis E. Mey. n. 6460.

Pelexia Poil. n. 2554.
Patella Weber. n. 430.

Paxtonia Lindl. n. 1348/,

Peirescia Spreng. n. 5162.
Peliosanthes Andrews, n. 1194. Peperidium Lindl. n. 1631.

Peliostomum Benth. n. 3901.

Pellacalyx Korthals, n. 4667.

Pelletiera St. Hil. n. 420\%/,

Pellia Raddi n. $472 /$.

Pellionia Gaud. n. 1883.

Pelostoma Salisb.n. 4313. a.9.*

Peltandra Aafin. n. 1685, *.

Peltanthera Rolh, n. 3416.

Peltaria Linn, n. 4878.

Peltidea Achar. n. 174.

Peltidium Zollik, n. 3011.

Peltigera Willd, n. 174.

Peltocarpus Zipp. p.1314. 39.

Peltodon Pohl. n. 3581.

Peltogyne Vogel. n. 6787.

Peltophorum $V_{\text {og. }}$ n. 6765. e.

Peltophorus Desv. n. 932.

Peltopsis Raf. n. 1664.

Peltospermum DC. n. 4132/3.

Pemphis Forst, n. 6148.

Penaea Linn. n. 2116.

Penaea Plum, n. 56's.

PENAEACEAE p. 33\%.

Penicillaria Chev. n. 412.

Penicillaria $\mathcal{S}_{\text {wartz. n. }} \mathbf{7 8 2}$.

Penicillium Link, n. 226.

Penisetum Rich, n. 781.

Pennantia Forst. n. 5754.1

Pentaeaena Bartl. n. 5401.

Pentacalia Cass. n. 2807. b.

Pentacarya DC. n. 3752/

Pentaceros G. F. W. n. 6870.

Pentachondra $\boldsymbol{R} . \boldsymbol{B r}$. n. 4278.

Pentacoryna $E$. n. 3280 . e.

Pentacoryne DC. n. 3280.

Pentacrypta Lehm. n. 4535.

Pentadactylon Gärtn. n. 2138.

Pentadesma Don. n. 5445.

Pentaglossum Forsk, n. 6149. b.

Pentaglottis Tausch, n. 3767/1.

Pentaglottis Wall. p. 99\%.

Pentagonaster $K l$. n. 6302. b.

Pentaloba Lour. n. 5048.

Pentameranthes $D C, \mathrm{n} .2451, \mathrm{a}$.

Pentameris Palis. n. 871. b.

Pentanema Cass. n. 2430.

Pentanoma Mog. et Sezs. n. 5972. d.

Pentanthera Don, n. 4341. a.

Pentanthus Hook. et Arn. n. 2953.

Pentanthus Less, n. 2948. a. Pentapasma E. n. 5731. a.

Pentapeltis Endl. n. 4354. c.

Pentapera Klotzsch, n. 4314.

Pentapetes L. n. 53 t3.

Pentaphorus Don. n.2915. a. $\gamma$.

Pentaphragma Wall. n. 3050.*

Pentaphragma Zuce, n. 3 ' 50 .

Peataphylloides Tourn, n. 6363.

Pentaphyllum Pers, в. 6511.

Pentapogon $R, B r \cdot-n, 819$.

Pentaptera Roxb, n. 6077.

Pentapteris Hall, n. 6135.

Pentapterophyllum Dill, n.6135.

Pentarhaphia Lindl. n. $\mathbf{4 6 9}$.

Pentarhaphis Kunth. n. 851.

Pentaria DC. n. 5099. a.

Pentarrhinum E. Mey. n. 3492.

Pentasachme Wall, n. 3454.

Pentaspermum DC. n. 6275 . 6 ק. 5276.

Pentataxis Don, n. 27/4. c.

Pentatropis $\boldsymbol{R}$. Br. n. 3479. *

Penthea E. n. 2901. e.

Penthea Lindl. n, 1537/3.

Penthorum Linn, n. 4625.

Pentlandia Herb. n. 1277.

Pentstemon Herit. n. 3909.

Pentzia Thunb, n. 2700.

Peperi Endl. n. 1820. b.

Peperialia Reich, n. 1819.

Peperomia Mig. n. 1820. h.
Peperomia Ruiz et $\boldsymbol{H}$. n. 1820

Peplidium Delil. n. 3950.

Peplis Linn. n, 6144.

Pepo Tourn. n. 5138.

PEPONIFERAE p. 933.

Pera Mutis. n. 5880.

Peraltea $H$. B. $K$, n. 6542 .

Perama Aubl. n. 3128.

Peramibus Raf. n. p. 411.

Peranema Don. n. 649, *

Peraphyllum Nutt, n. 6346.

Percursaria Bonnem. n. 45.

Perdicium Lagasc. n. 2932.

Perebea Aubl. n. 1874.

Pereilema Prest. n. 816.

Pereskia Plum. n. 2162.

Pereskia Fl. Fl. n. 5700 .

Pereuphora Hoffmans, n. 1897.b.

Perezia $D C$. p. 493.

Perezia Loss, n. 2962, a. $\gamma$ *

Perezia Llav. n. 2963. *

Pergularia Linn, n. 3511. *

PERGULARIEAE p. 595.

Periandra Camb. n. 5233.

Periandra Mart. n. 6639.

Periballia Trin. n. 859.

Peribotryon Fries. n. 267.

Pericallis Don. n. 2811.

Perical ymma Endl, n. 6307 .

Perichaena Fries. n. 307.

Periclymenum Tourn. n. 3337.

Pericouia Alb, et Schw. n. 269.

Periconia Nees. n. 241.

Periconia Tode. n. 257.

Perideridia Reich, n. 4543 .

Peridermium $\operatorname{Link}$. n. 182. c.

Peridium Sehott, n. 5880.

Perilla Linn, n, 3591.

Perilomia H. B. K. n. 3627.

Periola Fries. n. 285.

Peripherostoma Gray, n. 396.

Periphragmos Huiz et Pav. n. 
Persoonla $W$. n. 55t't. PERSO0NIRAE p. 339.

Pertusaria $D C$. n. 155. Perularia Lindl, n. 1510. Pervinca Tourn. n. 3405. Perymenium Schrad, n. 2545. Pesomeria Lindl. n. 1385/ Petagna Rafin, p. 133'. 41. Petagnana Gmel. n. 6603 . Petagnia Gusson. n. 4380. Petalacte Don. In. 2765. PETALANTHAE p. 729. Petalanthera Nees, n. 2016. Petalanthera. Torr. n. 3036/, Petalidinm Nees, u. 4045. Petalolepis DC. n. 2738. h. Petalolepis Less. n. 2765. Petaloma DC. n. 6102. Petaloma Roxb. n. 60's. Petaloma $S_{\text {wartz. n. } 6270 .}$ Petalopogon Reiss. n. 5737.

Petalostemma R.Br.p. 1334.42. Petalostemon $L$, O. Rich, n. 6522.

Petalotoma DC. n. 6337. Petamenes Salisb. n. 1239. PETASITEAE p. 370. Petasites Tourn. n. 2256. Petesia Bartl. n. 3292.

Petesia P. Br. n. 3254.

Petesioides Jacq. 14. 4217.

Petilium Linn. n, 1096, b. *

Petitia Gay, n. 4433.

Petitia Jacq. n. 3705 .

Petiveria Plum, n. 5255 .

PETIVERIEAE p. 975.

Petraea Houst, n. 3710 .

Petrobium $R . B r$. n. 2455 .

Petrocallis R. Br. n. 4879.

Petroearvi Tausch. n. 4531.

Petrocarya Jack. p. 1252.

Petrocarya Sohreb. n. 6411 .

Petrogeton Eekl, et Zeyh. 4610. b.

Petromarula Alph. DC. n. 3083.

Petromeles Jacq. $f$. n. 6345.

Petrophila R. Br. n. 2121.

Petrophila Brid, n. 475 .

Petrophile Inight ot Salisb. n. 2121. b.

Petroselinum Hoffm. n. 4394.

Petunga DC. n. 3289.

Petunia Juss. n. 3840.

Peuce Lindl. n. 1807.

PEUCEDANEAE p, 778.

Peucedanum Linn, n. 4462.

Peumus Nees. n. 2036. c.

Peumus Pers. n. 2019.

Pexisperma Rafin, n. 86. c.

Peyrousa Rich. n. 4333 . *

Peyrousea DC. n. 2681.

Peyronsia $\mathcal{S}_{\text {weet. n. } 1236 .}$

Peziza Dillen. n. 430.

Pfaffia Mart, n. 1958, b.

Phaca Linn. n. 6571.

Phacelia Juss. n. 3831. *

PHACIDIACEI p. 32.

Phacidium Fries. n. 371.

Phacocapnos Bernh. n. 4838.

Phacorrhiza Grev. n. 413.

Phacorrhiza Pers. n. 284.

Phacosperma Haw. n. 5179.

Phaecasium Cass, n.3022. A.3

Phaenocoma Don, n. 2764.

Phaenoglossa DC. n. 2759. c.

Phaenogyue $D C$. n. 2710, a.

Phaenopoda Cass, n. 2731.

Phaenopus DC. n. 3007. a.

Phaescarpus M. ot Z. n. 5630 .

Phaeomeria Lindl. p. 224.

Phaeopappus DC. n. 2865. B. $氏$.

Phaeostoma Spach, n. 6119, a,

Phaêtusa Gärn. 1. 2550. a.
Phagnalon Cass. n. 2406.

Phajus Lour. n. 1388. *

Phalacraea DC. n. 2255.

Phalacrocarpum $D C$, n. 2687,

Phalacroderis DC. n. $2988 / 2$.
Phalaerodiscus Less. n. 2667 .

Phalaerodiscus Less. n. 2667.
Phalacroglossum DC. n. 2667 . a.

Phalaeroloma Cass. n. 2337.

Phalacromesum Cass. n. 2417.

Phalaenopsis Blum, n. 1469.
Phalangium Burm. n. 12 't.

Phalangium Houtt. n. 1240.

Phalangium Juss, n. 1145. a.

PHALARIDEAE p. 79.

Phalaris Linn. n. 753.

Phaleria W. Jack. n. 2109.

Phalerocarpns Don, n. 4323. a. Phallaria Schum. n. 3214.

Phallo-Boletus Mich. n. 435.

PHALLOIDEI p. 30.

Phallus Mich. n. 358.

Phalocallis Herb. n. 1228/1.

Phaloé Dumort, n. 5224 .

Phalolepis Cass. n. 2871. e.

Phanera Lour. n. 6790. d.

Phanerophlebia Presl, n.640, b.*

Phania DC. n. 2263.

Pharbitis Chois. n. 3808 .

Pharium $W$. Herb. n. 1112.

Pharnaceum Linn, n. 5187.

Pharus P. Br. n. 739.

Phaseum Linn. n. 478.

Phasellus Mönch, n. 6674. d.

PHASEOLAE p. $128 \%$.

Phaseolus L. n. 667\%.

Phasgonon Walk. n. 108.

Phasiolus Möneh, n. 6674. d.

Phaylopsis Willd, n. 4097.

Phebalium Vent. n. 6009.

Phegopteris Pr. n. 615. a. $\gamma . *$

Phelipaea Desv. n. 4183.

Phellandrium Linn, n. 4418.

Phellina Endl. n. 437 . e.

Phelline Labill. n. 5986.

Phellocarpus Benth, n. 6724.

Phellopterus Nutt. n. 4491 . b.*

Phelonitis Chev. n. 306. a.

Phelypaea Thunb. n. 723.

Phemeranthas Rafin. n. 5178. a.

Phenakospermum Endl. p. 229.

Pherotrichis Deo, n. 3495/1.

Phiala Fries. n. 430 . A.

Phialis Spreng. n. 2591.

Phibalis Wallr. n. 430 . c. i.

Philactis Sehrad. n. 2492.

PHILADELPHEAE p. 1186.

Philadelphus Linn, n. 6105.

Philagonium Blum. n. 5983.

Philesia Comm, n. 1189.

PHILESIRAE p. 157.

Philibertia H. B. K. n. 3457. * Philippia Klotssch. n. 4311.

PHILIPPODENDREAE p. 1004.

Philippodendron Poit. n. 5358.

Philocrena Bong. n. 1835.

PHILOCRENACEAE p. 268.

PHILODENDREAE p. 237.

Plilodendron Schott. n. 1690.*

Philodice Mart, n. 102\%.

Philoglossa $D C$. n. 2525. *

Philogyne Haw. n. 1289 . g.

Philomeda Noronh. n. 5958 .

Philonomia DC. n. 3762. *

Philonotis Brid, n. 551 .

Phllonotis Reich. n. 4783, e.

Philostizns DO. n. 2871 . bb.

Philotheea Fudg. n. 6008.

Philotria Rafin, n, 1206.

Philoxerus $\boldsymbol{F}, \mathbf{B r}$, n. 1954. b.

PHIL YDREAE p. 132

Philydrum Banks, n. 1061.

Phippsia R. Br. n. 806.

Phlaeoseoria Wallr. n. 393.
Phleastrum Ser. n. 6511. a.

Phlebia Eries, n. 436.

Phlebidia Lindl. n. 1537 . b. $\beta$. *

Phylliraea Tourn. n. 3349. c.

P. Phyllites n. 1667.

Phleboearya $R, B r$. n. 1260.

Phlebodium R. Br. n. 615 .

Phlebophyllum E. n. 4048 .

Phlebopteris Brongn. n. 686.

Phledinium Spach. n. 4796. c." Phlegmatium Fries, n. 453 , V.
Phlegorhiza Molin, n. 685̄2.

Phleogena Link. n. 301 .

Phleum Linn, n. 750.

Phloeoconis Fries. p. 16. b.

Phloeospora Wallr. n, 199.

Phlogaeanthus Nees. n. 4077.

Phlomidopsis Link. n. 3664, b.

Phlomis Linn. n. 366\%.

Phlomoides Möneh. n. 366\% b.

Phlox Linn. n. 3819.

Phlyctene Endl. n. 281. b.

Phlyetidium Wallr. n. 369.

Phlyetis Wallr. n. 172. A. $\alpha$.

Phoberos Lour. n. 5068. *

Phoebe Nees. n. 2026.

PHORBEAE p. 316.

Phoenicanthemum Bl. n. 4586 . d.

Phoenicaulis Nutt. n. 4859.

PHOENICINAE p. 253.

Phoenicites Brongn. n, 1780.

Phoenix Cav. n. 1759.

Phoenix Linn, n. 1763.

Phoenixopus Cass. n. 3007. a.*

Pholidandra Neok. n. 5990.

Pholidia $R, B r$. n. 3734. *

Pholidocarpus $B$ l. n. 1745 .

Pholidota Lindl. n. 1344.

Pholiota Fries. n. 453. IV.

Pholiurus Trin. n. 922. d.

Phoma Fries, n. 365.

Phoracis Rafin. n. 77.

Phorima Rafin. n. 447. f.

Phormium, Forst. n. 1101.

Phorolobus Desv. n. 622, a. *

Phosanthus Rafin, n. 3234.

Photinia Lindl. n. 6350.

Phragmicoma Dum, n. $472 \%$.

Phragmidium Link. n. 190.

Phragmites Trin, n. 824 .

Phragmites Adans. n. 939.

Phragmotrichum Kunze. n.191.

Phreatia Lindl. n. 1362.

Phrissotrichia Brid, n. 506.

Phrygia Gray. n. 2871.

Phryma Linn. n. 3690.

Phrynium Willd. n. 16'3.

Phtheirospermum $\boldsymbol{B}$. n. 4001.

Phthirusa Mart. n. 4586 . i.

Phu DO. n. 2186. e.

Phucagrostis C.n. 1657, et 1659.

Phycella Linal. n. 1282, *

Phycomater Eries. n. 25.

Phycomyces Kunze. n. 256.

Phyganthus Pöpp. n. 12't8/,

Phygelius E. Mey. n. 3911 .

Phyla Lour. n. 6871.

Phylacimm Benn. n, 6598.

Phylacteria Pors. n. 437. g.

Phyliea $L$. n. 6738.

PHYLICEAE p. 1100.

Phyllachue Forst. ㅍ. 3095. a.

Phyllactis Pers. n. 2186. a.

Phyllagathis Blum, n. 6236.

Phyllamphora Lour. n, 2167.

PHYLLANTHEAE p. 1119.

Phyllanthera Blum. n. 34\%.

Phyllantherum Rafin. n. 1177.

Phyllanthus Linn. n. 5847. b.

Phyllanthus Miq. n. 5158.

Phyllartius Neck, n. 5158 .

Phyllerium Eries. p. 21. e. $\gamma$

Phyllinema Blum, n. 257's.

Phylloeactus Link. n. 5158.

Phyllocalymna Benth, n. 2713.

Phyllocephalum $B l$. n. 2205. a. *

Phyllocharis Fée. p. 33. c.

Phylloeladus L. C. R, n. 1802 .

Phyllodes Lour. n. 1643.

Phyllodiastrum Walp. n. 6478. b.

Phyllodium Dexv, u. 6616. a.

Phyllodium Walp. n. 6478. a.

Phyllodoce Salisb. n. 4317. b.

Phyllodoxys $E$, n. 6958 . k,

Phyllogenes Targ n. 9'. a.

Phyllogonium Brid. n. 597.

Phyllolaena E. n. 2098. c.

Phyllolobium Fisch, n. 6465 .

Phylloma Knr. n. 1116.

Phylloma Link. n. 86.

Phyllomatia $W$. et A. n, 6692, e.

Phylloneja $D C$. n. 2372. b.

Phyllonoma $\boldsymbol{W}$. n. 5699.

Phyllophora Grev. n. 94. a.

Phyllopodium Benth. n. 3966.

Phyllopfa Fries, n. 403. a.

Phyllopus DC. n. 6251 .

Phyllospadix Hook. n. 1659/1.

Phyllospora Ag. n. 110/,

Phyllostegia Benth. n. 3674 .

Phyllostemma Neck. n. 596\%.

Phyllosticta Pers. p. 31. a

Phyllota Benth. n. 6439 .

Phyllotium Endl. n. 6433. b.

Phymaspermum Less. n. 2663.

Phymatanthus Lindl. n. 6048 .

h. $\beta$.

Phymatidium Lindl, n. 1464.

Phymatium Chev. n. 328.

Phymatium Link. n. 114.

Phymatodes Presl. n. 615, h."

Phymosia Lesv. n. 5272.

Physa Thouars. n. 5185. a.

Physalis Linn, n. 3851.

Plysanthillis Boiss. n. 6506. e.

PHYSARE.I Fries, p. 26. 
Physurus C. L. R. n. 1562. Physydrum Rafin. n. 85. PHYTELEPHANTEAE p. 2'2. Phytelephas R. et P. n. 1716. Phyteuma Linn. n. 3082. * Phyteuma Lour. n. 3641. Phyteumoides $A . D C$. n. $3079 . *$ Phyteumoides $S m$, n. 3247 . Phyteumopsis Juss, n. 2642. Phytoconis Bory. n. 126. Phytoerene Wall. n, 4698. PHXTOCRENEAE p. 828. Phytolacea Tourn. n. 5262. PHYTOLACCACEAE p. 975. PHXTOLACCEAE p. 976. Phytoxys Molin. n. 3651 . Piaranthus $\boldsymbol{R}, \boldsymbol{B r}$. n. 3526 . Picea Link. n. 1795. b. Pickeringia Nutt. n. 6419. Piekeringia Nutt. n. 4222. Pienocomon Dal. n. 2886. Picnocomon Wallr. n. 2192. Pienomon Lob. n. 2886. Picoa Vitt. n. 3+7.

Picotia R. et Sch. n. 3780. Pieradenia Hook. n. 2602. Picramnia $S$ wartz. n. 5941. Picrasma Blum. n. 5972. g. Picrasma Lindl, n. 5966/1.

Pleria Lour. n. 4154. * Picridium Desf. n. 3002. * Pieris Linn. n. 2999.

Pierium Sehrob. n. 3553. Picrophloeus Blum, n. 3568. Picrorhiza Aoyle. n. 3985. Pierosia Don. n. 3030.

Pictetia DC. n. 6591.

Piddíngtonia $D C$. n. 3063 . a. Pierandia Blum, n. 5878.

Pierarda Adans. n, 2200. Pierardia Roxb. n. 5878.

Pleris Don. n. 4318. f.

Pigea De. n. $50^{\prime}+1$.

Pilaere Fries, n. 303.

Pilant bus Poit.

Pilea Lindl. n. 1882.

Pileanthus Labill. n. 6278.

Pilearia Lindl. H. 1493. d.

PILEATI p. 38.

PILEOLARES p. 35.

Pilidium Kunze, n. 371.

Piligena Schumach, n. 301.

Pilipogon Brid. n. 531.

Pilitis Lindl, n. 1290.

Pillera Endl. n. 6665. c.

Pillularia Linn, n. 690.

Pilobolus Tode. n. 25't.

PILOCARPEAE p. 1152.

Piloearpus Vaht. n. 5999.

Pilocerens Lem. n. 5157. a.

Pilogyne Schrad. n. 5127.

Pilophora Jacq. n. 1752.

Pilophora Wallr. n. 255.

Plloselloides Less. n. 2905. b. et $2929 / \mathrm{s}$ b.

Pilostyles Guill, n. 725.

Pilotrichum Palis, n. 589.

Pimelea $B$. et $S$. n. 2098. *

Pimelea Lour. n. 5936.

Pimpinella $\operatorname{Linn}$, n. 4410.

Pimpinella Adans, n. 637t

Pinalia Hamilt, n. 1363. b.

Pinanga $R$. n. $1727 /$, et 1728 .

Pinarda Fl. Fl, n. 3951 . *

Pinardia Cass. n. 2671.

Pinaria DC. n. 4845. c.

Pinaropappus Less. n. 3031.

Pinastella Dill, n. 6134.

Pindaiba Piso, n. 4714.

Pineda Ruiz ol P. 1. 5076.

Pinellia Tenor, n. 1693. *

Pingraea Cass. n. 2410.

Pinguieula Tourn, n. 4195.
Pinillosia Ossa. n. 2/83. *

Pinites Lindl. n. 1806.

Pinknea Pers, n. 3264.

Pinkneya $L$. C. R. n. 3264 .

Pinonia Gand. n. 645. *

Pinus Brongn. n. 1809.

Pinus Link. n. 1795. a.

Pinus Linn. n. 1795.

Pinzona $M$. et $Z$. n. 4760.

Piparea Aubl. n. 5060, a. $\delta$.

Piper Linn, n. 1820.

PIPERACEAE p. 265. et 1373. Piperella Prest. n. 3616 . b.

PIPERITAE p. 264.

Piptanthus $S_{\text {iveet. }}$ n. 6418.

Piptatherum Palis, n. 794.

Piptocarpha $R \cdot B r$. n. 3032/14

Piptocarpha $H$. et A. n. 2908.

Piptoceras Cass. n. 2871. e.

Piptochaetium Presl. n. 798. a.

Piptoclaina G. D. n. 3751. a.*

Piptocoma Cass. n. 221't.

Piptolepis Benth, n. 1896.

Piptopogon Cass. n. 2087.

Piptostemma Don. n. 2948, a.*

Piqueria Car. n. 2253.

Piquerioides $D C$. n. 2253. b.

Piratinera Aubl. n. 1861.

Pireunia Bert. n. 5262. b.

Pirigara Aubl. n. 6327.

Piringa E. n. 3305 , c.

Piripea Aubl. n. 3960.

Piriqueta Aubl, n. $505 \%$.

Pisaura Bonat, n. 6129.

Piscidia Linn, n. 6723.

Piscipula Löffl. n. 6723 .

Pisocarpium Link. n. 330.

Pisolithus A. et $\$ c h w$. n. 330.

Pisonia Plum. n. 2012 .

Pisonia Rottb. n. 42'77.

Pistacia Linn, n. 5893.

Pistia Linn, n. 1669. *

PISTIACEAE p. 233.

Pistillaria Fries. n. 284.

Pistolochia Raf. n. 2162. b.

Pistorinia DC, n. 4619 .

Pisum Tourn, n. 6579.

Pitavia Molin, n. 5969.

Piteairnia Herit, n. 1305.

Pitcheria Nuth. n. 6692, e.

Pithecolobium Mart. n. 6837. c.

Pithecoseris Mart. n. 2228.

Pithecurus Willd. n. 950 . b.

Pithocarpa Lindl, n. 2727/,

Pithosillum Cass, n. 2811. VI. Pithyranthus $V_{i v}$. n. 4427. b.

Pitonia DC, n. 3269. a.

Pittocarpinm Link. n. 320.

Pittonia Funth, n. 3747.

Pittonia Plum. n. 3747. et 3748.

PITTOSPOREAE p. 1081.

Pittosporum Sol. n. 5661 .

Pitumba Aubl. n. 5060, a. $\gamma$.

Pityrodia $\boldsymbol{B}, \boldsymbol{B r}$, n. 3702.

Placea Miers. n. 1282.

Placodium Fries. n. 172. A. \&. Placoma Gmel. n. 3111.

Placostigma Blum. n. 1490.

Placuntium Ehrenb, n. 1490.

Placus Loar. n. 2414. a.

Pladaroxylon E, n. 2818. b.

Pladera Sol. n. 3544.

Plagianthus Ebrst. n. 5311.

Plagiobothrys $F$. et $M$, n. 3769 .

Plagiochasma Lehm. n. 467.

Plagiocheilus Arn, n. 2707.

Plagiochila Dum, n. 473/,.

Plagioloba $C . A$. M. n. 4903. d.

Plagiolobium $S$ weet, n. 6452.

Plagiophyllum $S c h l$, n. 6178.

Plagiopoda $n, B r$. n. 2143. a.

Plagiopus Brid. п. 553.

Plagiorutis $S_{\text {er. }}$ n, 6510. b.
Plagiostemon Fl. n. 4302 . a.

Plagiostoma Benth, n. 3662. e. Plagiotaxis Wall. n. 5552.

Plagiotis Benth. n. 3583. d. Plagiotome $D C$. n. 2790, d. Plagius Herit. n. 2697.

Plananthas Palis. n. 696. a.

Plancia Neck. n. 3026.

Planeina Fries. n. 426.

Planera Gmel. n. 1849.

Planetanthemum E. n. 4087. b.

Planorhachis DC, n. 2689. b.

PLANTAGINEAE p. 346.et 1379

Plantaginella Vaill. n. 3977.

Plantago Linn. n. 2170.

Plappertia Reichenb, n. 5 h58.

Plaso Rheed, n. 6670.

Platanaria Gray, n. 1700.

PLATANEAE p. 289.

Platanocarpum E. n. 3250. a. * Platanocephalus Vaill. n. 3138. Platanthera $L, C, R, n .1515$. Platanus Linn. n. 1901. Platea Bl. n. 5495.

Plateclipta $D C$. n. 2\$46. b.

Platisma Blum. n. 1490.

Platisma $\mathrm{Hoffm}$. n. 172 . C. $\beta$.

Platouia Mart. n. 5456.

Platonia Kunth. n. 906.

Platonia Rafin. n. 3648. a.

Platostoma Palis. n. 3570 . b.

Platunium Juss. n. 3370.

Platycapnos DC. n. 4844 .

Platyearpaea $D C$. n. 25 4 . a.

Platycarpha Less. n. 2210.

Platycarpum $H$. el $B$. n. 4129.

Platycerium Desv. n. 603. b. d.*

Platycheilus Cass, n. 2960. d.

Platycheilus Less. n. 2960. a.

Platychilum Del. n. 6453.

Platyeodon $A, D C$, n. 3077.

Platyeoelae $D C$. n. 2181. b.

Platycrater $S$. et Z. u. 4669.

Platygalium $D C$. n. 3100 . m.

Platygramma $\mathbf{M}$. n. $\mathbf{1 3 2}$. et 136.

Platylepidea DO. n. 2244. a. *

Platylepis A. Bich. n. 1556.

Platylepis Funth, n. 987/1.

Platylepis Less. 11. 2244. a. *

Platylohium Smith. n. 6454.

Platyloma Benth, n, 4313. c.22."

Platylophus Cass. n. 2871. f.

Platylophus Don, n. 4653.

Platymene DC. n. 4362 . a.

Platymerium Bartl. n. 3322.

Platymiscium Vogel. n. 6720.

Platynema Sehrad, n. 3760.

Platynema $W$. A. a. 5593.

Platypetalum $R$. Br. n. 4923.

Platyphyllum Vent. n. 177.

Platypodium Vogel, n. 6721.

Platyporus Pers. n. 447. f.

Platypteris Kunth, u. 2550. c.

Platyrhaphinm Cass. n. 2889. c.

Platysema Benth. n. 6670.

Platyspermum Hoffm. n. 4497 . a.

Platyspermum Hook. n. 4926.

Platyspora Salisb, n. 4313. c. 25. *

Platystemma Wall. n. 4143/1.

Platystemon Benth. n. 4832.

PLATYSTEMONEAE p. 858.

Platystigma Benth. n. 4830.

Platystigma $\boldsymbol{R} . B r$. p. 1334.43.

Platystylis Blum. B. 1334.

Platystylis $S$ weet. n. 6583.

Platyzoma $\boldsymbol{R}, \boldsymbol{B r}$. n. 660 .

Platzia $R$. et $P$. p. 502. 8.

Plaubelia Brid. n. 532.

Plaubelia Brid. n. 583.

Plaxerium Willd, n. 938.

Plecostoma Derv. n. 336. b.

Plectaneia Thouar. it. 3407.

Plectanthera $M$. of $Z$. n. 5052 . Plectocarpon Fée. n. 173.

Plectocephalus Don, n. 2871. 1.

Plectocomia Mart. n. 1738, *

Plectogyne Link, n. 1191. *

PLECTRANTHEAE p. 609.

Plectranthus Herit. n. $\mathbf{3 5 7 5}$.

Plectritis $D C$. n. 2184.

Plectrocarpa Gill. n. 60\%0.

Plectronia Linn. n. 3173.

Plectronia Lour. n. 4551.

Plectrotropis Schum. n. 6638.

Pleea L. C. R. n. 1063. *

Plegmatium Fries. p. 21. g.

Pleionactis $D C$. n. 2244. a.

Pleione Don. n. 1347.

Plenasium Presl. n. 630. b. *

Plenkia Rafin. n. 5185. a.

Pleocarphus Don, n. 2952.

Pleocnemia Presl. n. 615. e. *

Pleopeltis $H$. et B. n. 616. *

Pleopeltis Presl. n. 615. h. *

Pleotheea Wall. p. 566.

Pleroma Don, n. 6217.

Plethiosphace $B$. n. 3597. f.

Pleurachne Schrad. n. 994.

Pleurandra Labilll. n. 4754.

Pleurandra Rafin, n. 6115. h.

Pleuranthe Salisb. n. 2123.

Pleuranthus Rich, n. 1002.

Pleurhaphis Torr. n. 855 .

Pleuridium Presl. n. 615. k. $\beta$.*

Pleurocallis Sal. n. 4313. b. 13.*

Pleurocephalum $C$. n. 2761. b.

Pleurochiton Cord. n. 463 .

Pleurodesmia Arn. n. 4751 .

Pleurogaster DC. n. 3175. b.

Pleurogoninm $P r$, n. 615 . f. a. *

Pleurogramme $B l$. n. 611. a. *

Pleurogyue Eschsch, n. 3529.

Pleurolobinm DC, n. 6645. b. 
Podalyria Lam, n. 6423. Podalyria Fich. n. 6423.

PODALYRIEAE p. 1254.

Podanthum D. n. 3082. h. $\beta$. *

Podanthus Lag. n. 245\%.

PODAXIDEI p. 28.

Podaxis Desv. n. 325. a.

Podaxon Fries. n. 325.

Podeilema $\boldsymbol{R}, \boldsymbol{B r}$. n. 649 .

Poderemia Benth, n. 4306. b. * Podia Neck, n. 2871. V.

Podisoma Link. n. 187. $\alpha$.

Podocarpus Herit, n. 1800.

Podochilus Blum. n. 1490.

Podoeoma Cass, n. 2307.

Podogyne Hoffm. n. 4984. a.

Podolepis Labill. n. 2736.

Podolobium R. Br. n. 6428.

Podolobus Rafin, n. 4916.

Podolotus Benth. n. 6520.

Podoneja DC, n. 2372. a.

Podopappus Hook. n. 2307.

Podophyllum Linn, a. 4806.

Podopterus H. et B. n. 1996.

Podoria Pers. n. 4996.

Podosaemum Kunth. n. 803.

Podosperma Labill. n. 2731.

Podosperma Less. n. 2993.

Podospermum DC. n. 2993.

Podosphaeria Kunze. n. 277. b.

Podosporium Schw. n. 236. a.

PODOSTEMEAE p. 268 et 1375.

Podostemou $\boldsymbol{L}$. C. $\boldsymbol{R}$. n. 1832.

Podostigma Ell, n. 3489. *

Podostrombinm F. p. 23.

Podotheca Cass, n. 2731.

Poecilodermis Sch. E. n. 5320. c.

Poecilopteris E, n. 603. b. 6. *

Pōppigia Bert, n. 3706.

Pupplgia Kunze. n. 12:8/1.

Poppigia Prest. n. 6762.

Pogogyue Benth, n. 3623.

Pogonandra DC. n. 3038 . c.

Pogonanthera Blum. n. 6239.

Pogonanthera Don, и. 3038, *

Pogonantherum Palis, n. 9'4.

Pogonatum Palis, n. 560. b.

Pogonetes Lindl, n. 3038. d.

Pogouia Andr, n, 3733.

Pogonia Juss. n. 1601.

Pogonitis Heich, n. 6506. b.

Pogonopsis Presl. n. 952.

Pogonura DC. p. 493.

POGOSTEMEAR p. 612.

Pogostemon Desf. n. 3586.

Pogostoma Schrad. n, 3923.

Pohlana N. et M, n. 5972 . e.

Pohlia Hedw. n. 547.

Pohon Upas Mal. n. 1862.

Poidium Nees, n. 859.

Poikadenia Ell. n. 6526.

Poikilopteris Eschw, n. 603. b. Poincia Neek, n. 6766.

Polnciana Linn. n. 6766.

Poiretia Cav, n. 4288.

Poiretia Gmel, n 32\%0. d. \&.

Poiretia Smith, n, 6451.

Poiretía Vent. н. 6595.

Poitaea Vent, n. 6547.

Poivraea Comm, n. 6086.

Polanisia $\boldsymbol{R}, \boldsymbol{B r}$. п. 4988 .

Polanisia Rafin. n. 4988.

Polemannia Berg. n. 1122.

Polemannia $E$. ef $Z$. n. 4/31.

Polembryum A. Juss. n. 5997.

POLEMONIACEAE p. 656. et

1403.

Polemonium Tourn. n. 3822,

Polianthes Linn, n. 1103.

Pollfolia Buxb, n. 4318. b. *

Poliun Tourn, n. 3679 .

Polla Ad. n. 499 . et 542 . c.

Pollalesta Kunch, n. 220\%. f.
Pollia Thunb. n. 1029.

Pollichia Med. n. 3779.

Polliehia Pers. n. 3645. d.

Pollichia Soland. n. 5208.

Pollichia Willd, n. 3645. b.

POLLICHIEAE p. 959.

Pollinia Spreng. n. 950. e.

Poloa DC. n. 2320.

Polpoda Presl. n. 5194.

PolpodeaE p. 954.

Polyacantha Gray. n. 2871.

POLYACHYRIDEAE p. 499.

Polyachyeus Lag. n. 2943.

Polyaetidium $D C$. n. 2329 .

Polyactis Less. n. 2329.

Polyactis Link. n. 227. c.

Polyactium $D C$. n. 6048 . f.

Polyadenia Ehrenb. n. 548 t.

Polyadenia Nees. n. 2060.

Polyalthia Blum. n. 4713.

Polyangium Link. n. 3't0.

Polyanthea $D C$. n. 5098. c. $\delta$.

Polyantherix Nees. n. 918. "

Polyarrheua Cass, n. 2297. b.

Polybotrya $H$. et B. n. 603. a, *

Polycardia Juss, n. 5677.

Polyearena Benth. n. 3965.

Polyearpaea Lam. n. 5216.

POLYCARPEAE p. 960 .

POLYCARPICAE p. 82\%.

Polyearpon Lb̈ffl. n. 5212.

Polycenia Chois. n. 3726

Polycephalos Forsk, n. 2395. c.

Polychaete E. n. 226\%. c.

Polychaetia Less. a. 2780.

Polychaetia Tausch. n. 2980.

Polyehilos $K$. et $I$. n. 1482.

Polychlaena Don, u. 5277. b. $\delta$.

Polychroa Lour. a, 1972.

Polyehroma Bonnem, n. 63.

POLYCNEMEAE p. 302.

Polycuemum Linn. n. 1960.

Polyeodon Benth, n. 4313. d. 46."

Polycoma Palis. n. 65.

Polydesmia $B$, n. 4313. a. 3. *

Polydesmia Benth, n. 3583. m.

Polydontia Blum, n. 6404.

Polygala E. n. 5647.

POLYGALEAE p. 1077.

Polygalon DC. n. 5647, h.

Polygaster Fries. n. 346.

Polygonastrum Mönch. n. 1122. Polygonatum Tourn. n. 1181.

POLYGONEAE p. 30\%. et 1377.

Polygonella Mich. n. 1986. c."

Polygonifolia Vaill. n. 5197.

Polygonoides Tourn, n. 1989, a.

Polygonum Linn. n. 1986. *

Polygonium Tourn. n. 1986. g.

Polyides $1 \mathrm{~g}$. n. 87.

Polylepis Less, n. 2297. a.

Polylepis $R$, et $P$. n. 6377.

Polylobium $E$, et Z. n. 6488.

Polymeria $R . B r$.

Polymnia Linn, n, 2475.

Polymnia Neck, n. 2475, a.

Polymiastrum $L$. u. 2475, b.

Polymorphum Chev. в. 393.

Polymorphus Naumb, n. 428.

Polymyces B. n. 453. VII, k.

Polyodon Kunth, n. 850.

Polyodus Targ, n. 91. a.

Polyosma Blum. n. 4678

Polyosus A. Rich. в. 3157 .

Polyotus Nutt. n. 3488. *

Polyozus Lour. n, 3157 .

Polypappus Lers. n. 2407.

Polypara Lour. n. 1825.

Polypera Ficin. n. 330.

Polyphaeum $A_{B}$. n. 117.

Polyphema Lour. n. 1868. a.

Polyphragmon Desf. 1868 , a,

Polyphyllon Less. n. 2960. b. $\beta$.
Porella Dill. n. 472/12*
Poria Hill, n. 447 . b.

POLYPODIACEAE p. 59. et Porina Achar. n. 155.

1345.

Polypodiolithes Sternb. n. 708.

Polypodium Linn, n. 615 .

Polypogon Desf. n. 813.

POLYPOREI p. 39.

Polyporus Fries. n. 447.

Polyporus Mich. n. 447. e.

Polypremum Adans. n. 2181.

Polypremum Linn. n. 3241.

Polypteris Less. n. 2506.

Polypteris Nutl, n. 2265.

Polypteris Nutt. n. 2594.

Polyrhaphis Trin, n. 830 . b.

Polysaceum Desp, et DC. 330.

Polysealis Wall. p. 303 . b.

Polysehistis Presl. n. 852.

Polyseias Forst. n. 4556.

Polysiphonia Grev. n. 69.

Polyspora $S$ weet. n. 5424. a.

Polystaehya Hook n. 1366.

Polystegia Reich. n. 1278.

Polystemon Don, n. 4664 .

Polystica Fries. n. 447, a.

Polystichum Roth. n. 64 .

Polystigma Meisn. n. 5708.

Polystoma Gray. n. 336. a.

Polystorthia Blum. n. 640\%.

Polystroma Clem. n. 140.

Polytaenia $D C$. n. 4479.

Polytaenium Desv. n. 605. c. *

Polythrincium Kunze. n. 234.

Polytoea $\boldsymbol{R}, \boldsymbol{B r}$. n. $743 / 3$.

Polytrichum Linn. n. 560 .

Polytropia Presl, n. 6536.

Polyzone Endl. n. 6283.

POMACEAE p. 1236.

POMADERREAE $R$. p. 1101.

Pomaderris Labill, n. 5743 .

Pomangium Reinw. n. 324\%.

Pomaria Cav. n. 6771.

Pomatia Nees. n. 2044. a.

Pomatiderris Kunth, n. 5743.

Pomatium Gartn. f. n. 3296.

Pomatoderris Schult. n. 5743.

Pomatoxyris Endt. a. 1020. b.

Pomax Soland. n. 3096.

Pombalia Vand. n. 5041.

Pombea Caldas p. 1334. 44 .

POMEAF p. 1236.

Pomereulla Linn. n. 874.

Pometia Fl. Fl, p. 1334. 45.

Pometia Forst, n. 5617.

Pompadoura Bouch, n. 6356.

Pompholyx Endl n. 284. a.

Ponaea Schreb. n. 5601.

Ponceletia A. Br, n. 4287.

Ponceletia Thouars, n. 8'6.

Ponera Lindl. n. 1377. *

Pongamia lam. n. 6713.

Pongati Rheede. n. 3092.

PONGATIEAE p. 519.

Pongatium Juss, n. 3092.

Pongolat Rheede, n. 1894.

PONTEDERACEAE p. 137. et 1358.

Pontederia Linn, n. 1088.

Ponthieva $\boldsymbol{R}$. Br. n. 1573.

Pontoppidana Scop. n. 6334.

Pootia Dennst. n. 3544. *

Popowia Endl. n. 4710.

Poppya Neck. n. 5133.

Populago DC. n. 4786 . e.

Populus Tourn. n. $190 \%$.

Porana Burm. n. 3797.

Poranthera Rudg. n. 5859.

Poraqueiba Aubl. n. 6872 .

Porcella R, et $\boldsymbol{P}$, nt 4717. a

Porcellites Cass. n. 2986 . et 2987.

Porlieria Ruiz ot P. n. 6039.

Porocillaea Miers. p. 1334. 46.

Porodothium Fries. n. 152.

Poronia Willd, n. 396.

Porophora Mejer. n. 155.

POROPHYLLEAE p. 420.

Porophyllum Gaud. n. 4634 . b.

Porophyllum Vaill. n. 2582.

Porostema Schreb. n. 2044. b.

Porotheleum Fries. n. 444.

Porothelium Eschw. n. 152.

Porotrichum Brid. n. 585, a.

Porpa Blum. n. 5372, b.

Porphyra Ag. n. 86, b.

Porphyra Lour. n. 3712.

Porphyrautha $F$. Il. 523\%. c.

Porphyranthus Don. n. 30 \%3. c.

Porphyrion $T$. n. 463'

Porrum Tourn. n. 1137. d.

Portalesia Meyen. n. 2949.

Portenschlagia Tratt. n. 5688 .

Portesia Cav. n. 55'11. b.

Portlandia P. Br. n. 3258.

Portula Dill. n. 6144.

Portulaca Tourn. n. 5174. *

PORTUlaCACEAE p. 946.

Portulacaria Jacq. n. 5175.

PORTULACARIEAE p. 949.

Portulacea $H$. et A. n. 5192.

Posidonia Kón. n. 1660.

Posoqueria Aubl. n. 3308.

Posoria Rafin. n. 2308.

Possira Aubl, n, 6814. b.

Potalia Aubl, n. 3369.

POTALIEAE p. 574 . et 576.

Potameia Thouar. p. 340.

Potamochloa Griff. n. 728/2.

Potamogeton Linn. a. 166'b.

Potamophila R. Br, n. 730.

POTAMOPHILAE p. 229.

Potamophyllites Br. n. 1667.

Potamopitys $B u x b$. n. 5475 , e. 
Prieurea $D C$. n. 6108.

Primula Linn. n. 4199.

Primula Lour. n. 4668.

PRIMULA CEAE: p. 729. et 1409.

PRINCIPES p. 244.

Prinos L. n. 5706.

Prinsepia Royle i. 6414.

Printzia Cass. n. 2931. *

Prionacbne Nees. n. 931.

Prionanthes Schrank, n. 2960. b. $\gamma$.

Prionitis Delabr. n. 4401.

Prionium E. Mey. n. 1048.

Prionopteris Wall. n, 649.

Prionotes $\boldsymbol{R}, \boldsymbol{B} \boldsymbol{r}$. n. 4284.

Prionotophyllum Less.n. 2920. d. Psenderemia Benth, n. 4313.

Priotropis Wight ot Arn. n. 6472. e.

Prismatanthus Hook. et Arn. n. 4012 .

PRISMATOCARPEAE p. 516.

Prismatocarpus Alph. $D C$. n. 3080.

Prismatocarpus Herit. n. 3086.

Pristleya $D C$, n. 6464 .

Pristleya Flor. Mex. n. 2522.

Pristleya Meyen. n. 29.

Pristocarpha E. Mey. n. 2690.

Priva Adans. n. 3690.

Proboscidea Rich. n. 6183.

Proboscidea Schmidel. n. 4175 .

Prockia $P . B r$. n. 8072 . *

Prockiaria $D C$. n. 5072, a.

PROCKIEAE p. 918.

Procris Comm, n. 188\%. b.

Proiphys Herb. n. 1286.

Prolifera Vauch. n. 56.

Pronacrou Cass. n. 2465.

Pronaya Hïg. n. 5667.

Propolis Fries. 11. 423. a.

Prosaptia Presl. n. 643. e. *

Prosartes Don, n. 1180/, .

Proselia Don. n. 2921. c.

Proserpinaca Linn, n. 6137.

Prosopia Reich. n. 4015 . b.

Prosopis Kunth. n. 6823.

Prosopis Linn, n. 6821.

Prososperma Vogel. n. 6781.

PROSTANTHEREAE p. 621.

Prostea Comm. n. 5608.

Prostheminm Kunze n. 363.

Prosthesia Blum, n. 50'7.

Protea Linn. 11. 2123.

PROTKACEAE p. 336. et 1379.

Proteinia $E$. n. 5246. a. $\gamma$.

Proteopsis Mart, n. 220\%. b.

Protiun Burm, n. 5929, *

Protocoeeus Ag. 1. 28.

Protomyces Unger. p. 16. b.

Protonema $A g$. p. 2i. f.

PROTOFHYTA p. 1.

Protosphaeria Turp. 26.

Proustia Lagasc, n. 2918. *

Proustia Lagasc, n. 4378.

Prunella Linn. n. 3624.

Prunophora Neck. n. 6406. b.

Prumus Linn, n. 6406.

Prunus Tourn. n. 6406. b.

Psacalium Cass, n. 2807. at.

Psalliota Fries. n. 453. III. e.

Psamma Palis. n. 820.

Psammochloa Endl. n. 915. a.

Psammophila Fenst n. 5227.12.

Psammotropha Eckl, ot Zegh. n. 5189 .

Psanacetum DE. n. 2696. b.

Psathyra Comm. n. 3200.

Psathyra Fries. n. 453 . III, b.

Psatura Poir. n. 3200.

Psaturochaeta DC. n. 2546.

Psectra E. n. 2847. c.

Pselium Lour. n. 4686.

Psephellus Cass. n. 2871. m.

Psolanum Neck, n. 3856.
Psephellus Fisch, et Mey. n. Psychine Desfont. n. 4963. 2865. B. $c$.

Pseudacacia Tourn. n. 6546.

Psendachne Fndl. n. 801. b.

Pseudaleia Thouar, n. 5493.

Pseudaleioides $T h$, n. 549\%.

Psendangeliea $D C$. n. 4456 . b.

Pseudanisomeles $\boldsymbol{B}$. n. 3680 .

Pseudanthus Sieb, n. 5845/,.

Pseudarctotis DC, n. 2830, b.

Psendarthria Wighl et Arn. n. 6689 .

Pseudastillie DC. n. 4644 .

sendelephantopns 2231. c.

\section{d. 30 . \\ Pseudevax DC. n. 2420. b.}

Psendiosma Adr. Juss. n. 5981. Pseudoarabis $C, A, M$. n. 4854. a. Psendoathrixia $D C . \mathrm{n}, 2770$. h.

Pseudocapsicum Mönch. n. 3855. Pseudo-Chamomilla DC. n. 2669. d.

Pseudocistus Dunal. n. 5020. d. Pseudocormos Endl, n. 317. e. Psendodictamnus $M$. n. 3658 . a. Pseudofumaria Borkh. n. 4839.a. Pseudoglinus Fenzl, n. 5185. b. Pseudolinum DC. n. 4919. b. Pseudolirium Endl. n. 1098. c. Pseudomelissa Benth n.3616. $\mathrm{c}$. Pseudosophora Benth, n. 6738.d. Pseudostemua DC. n. 3272.

Pseudostylis Endl. n. 318. a.

Psendothapsus Benth.n. 3879. a.

Pseudothlaspi Magnol. n. 4887. Pseudothymbra Benth. n. 3610.e. Psendotunica Fenzl. v. 5244. d. Pseudo.Vanda Lindl. n. 1427. Pseudozinnia $E$. n. 2493. b.

Pseva Rafin. n. 4348.

Psiadia Jacq. n. 2368.

PSIADIEAE p. 383.

Psidium Linn. n. 6315.

Psidopodium Neck, n. 640.

Psiguria Neck. n. 5128.

Psilathera Link. n. 875, c.

Psilobium Jack. n. 3321.

Psilocarpaea DC. n. 3541. b.

Psilocoelae DC. n. 2181. c.

Psilocybe Fries. n. 453. III. c. Psilogyne DC. n. $4132 / 1$.

Psilonema C. A. Mey. n. 4073 .

Psilonia Fries. n. 211.

Psilophyllum $D C, \mathrm{n} .2781$. b.

Psilopilum Brid, n. 561.

Psilorhegma Vogel. n. 6781, f. Psilostema Klotsch. n. 3174.

Psilostemon DC. n. 3777. *

Psilosteum DC. n. 2656. b.

Psilostrophe DC. n. 3032/,

Psilostylis Andrz. n. 4848. b.

Psilostylum DC. n. 4906. e.

Psilothamnus $D C$, n. 2657.

Psilothonna E. Mey. et DC. n 2656. r.

Psilotriehum Blume n. 1962.

Psilotum R. Br. n. 695. *

Psilotum Swartz. n. 695. b.

Psilurus Trin. n. 921.

Psittacanthus Mart. n. 4586. h.

Psittaeoglossum Llav. et Lex. n. 1417.

Psophocarpus Neck. n. 6680.

Psora Frier. n. 122. A. $\gamma$.

Psora Hoffm. n. 166.

Psoralea Linn. n. 6526.

Psorophytum Sp. n. 5464. B. e.

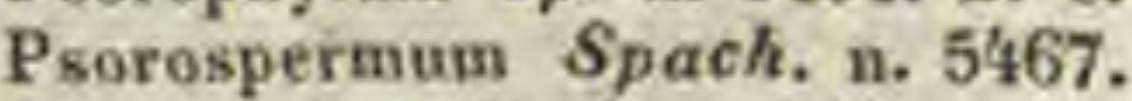
Psychauthus Raf. n. 5647. a.

Psychechilus Kuhl et Hass. n. 1536.
PSYCHINEAE p. 885.

Psyehopsis Nutt, n. 6517. d.

PSYCHOTRIEAE $\mathrm{p}, 530$.

Psychotrophum P. Br. n. 3147.

Psyehrophila DC, n. 4786. b.

Psydrax Gärtn. n. 3175 .

Psygmatella Kütz. n. 4.

Psyguium Presl. n. 615, 1. *

Psyllium Tourn. n. 2170. a.

Psyllocarpus Mart. n. 3131.

Psyloxylon Neraud. n. 6168.

Ptaeroxylon E. Z . n. 5636.

Ptarmica Tourn. n. 2648.

Ptelea Linn. n. 5977.

PTELEACEAE p. 1145.

Ptelidium Thouar. 5683.

Pteracanthus Nees. n. 4053. b. Pterandra A. J. n, 5589, a.

Pterandra Jack. n. 6266.

PTERANTHEAE p. 959.

Pteranthus Forsk. n. 5206.

Pterigeron DC. n. 2332. c.

Pterigospermum Targ. n.105.a.

Pterigynandrum Hedw. n. 568 .

Pterilema Reinw. n. 5892.

Pteris Linn, n. 622. *

Pterisanthes Blum. n. 4568.

Pterium Desv. n. 895.

Pterium Dess. p. 109, a.

Pterocarpus Linn. 11. 6705.

Pterocarya Kunth. n. 5891.

Pterocaulon Elliott, n. 2415.

Pterocaulopsis DC. n. 2415. b.

Pterocelastrus Meisn, n. 5682.

Pterocephalus Vaill. n. 2194.

Pterochilus Hook, n. 1335.

Pterochlamys Firch, n. 1917.

Pterococcus Pall. n. 1989. c.

Pterocoma DC. n. 2930. e. *

Pterodon Vogel. n. 6730.

Pterogonium Swartz, n. 568.

Pterolaena $D C$. v. 5352. b.

Pterolepis DC. n. 6222.

Pterolepis Schrad. n. 1000 , a.

Pterolobium Andrz, n. 4885. a.

Pterolobium $\boldsymbol{R}, \boldsymbol{B r}$, n. 6769.

Pteroloma Desv. n. 6615. b.

Pteroloma steud. et Hochst. n. 4936 .

Pterolophoides $D C$. n. 2871, t. $\epsilon$. Pterolophus Cass. n. 2871. g. a. Pteromarathrum Koch. n. 4526.

Pteronema Endl. n. 463\%. b.

Pteroneuron DC. n. 4860.

Pteronia Linn, n. 2386.

Pterononis DC. n. 6493. e.

Pteropappus Less. n. 2296. a.

Pterophora Harw. n. 349\%. *

Pterophora Neck, n. 2386. c.

Pterophorus Vaill. n. 2386.

Pterophylla Don, n. 4658.

Pterophyllum Brongn. n. 710.

Pterophyllum Nutt. n. 4792. c.

Pterophyton Cass. n. 2530.

Pteropodoxys E, n. 6058. d.

Pteropogon DC. n. 2748.

Pteropsis Desv. n. 614. b.

Pteropsis Presl. n. 611. b.

Pteroselinum Reich. n. 4462 . a.

Pterospermum Schreb. n. 5352.

Pterospora Nutt. n. 4353.

Pterostegia Fisch, et Mey. n. 1979.

Pterostelma Fight. n. 3502. Pterostigma Benth. n. 392\%.

Pterostoechas Ging. n. 3585. c

Pterostyrax Sieb. et Z. n.4252/1. Pterota P. Br. n. 5972 . b.

Pterotheca Cass. II. 3019. a.
Psychotria Linn. n. 3147.

Psyllocarpus Pohl, n. 3169. Pterostylis $\boldsymbol{R}, \boldsymbol{B r}$. n. 1595. *

Pterotheca Presl, n, 966, e, $q$, Pterothrix DC, n. 2773. Pterotropis DC. n. 4885 . e.

Pterotum Lour: n. 6854. Pterula Fries. n. 412.

Pterula Fries. n. 268.

Pterygium Swartz. n. 1539. *

Pterygophyllum Brid. n. 587. a.

Pterygota $S c h, E$, n. 5321. Pteryxia Nutt, n. 4491 . c. Ptilepida Rafin. n. 2599, b.

PTILIDEAE p. 1341.

Ptilidium Nees. n. $472 /$. $^{\circ}$

Ptilina Nutt. n. 6143/,.

Ptilininm Rafin. n. 4398.

Ptilocnema Don. n. 1344.

Ptilophyllum Nutt. n. 6135. c.* Ptilostemon Cass, n. 2889. a.

Ptilostephium $H, B$, K. n. 2621.

Ptilota $\mathrm{Ag}$. n. 89.

Ptilotrichum C.A.Mey, n. 4876.

Ptilotus R, Br. n. 1964 .

Ptilurns Don. n. 2958.

Ptychanthus Nees, n. 472/.

Ptychocarpa $A, B r$, n. 2143. b.

Ptychocentrum Wight ot Arn. n. 6692. d.

Ptychodea Willd, n. 32'18.

Ptychodon Klotsch. n. 6162. b.

Ptychosperma Labill. n. 1730.

Ptychostomum Hornsch. n. 539.

Ptychotis Koeh. n. 4400 .

Ptyxestoma Vahl. n. 4600 , *

Puccinia Pers. n. 185.

Pueraria DC. n. 6632.

Pugionium Gärtn. n. 4898.

Pulicaria Gärtn. n. 2434.

Pulina Adans. n. 126.

Pulmonaria Hoffm. n. 173.

Pulmonaria Tourn. n. 3759.

Pulsatilla Tourn. 4773. a. c. 
Pygeum Gärtn. n. 6404. Pylaiella Bory. n. 71. Pylaisaea Desv. n 571 . Pyramia Cham. n. 6180. Pyramidium Benth. n. 3575 . f. Pyramidium Brid. n. 486. Pyramidula Brid. n. 486. Pyrarda Cass. n. 2397. c. Pyrenacantha Hook. n. 1893. Pyrenaria Blum. n. 5429. Pyrenastrum Eschw. n. 149. Pyrenium Tode n. 400.

Pyrenochia Link, n. 38\%.

PYRENOMYCETES p. 31 . PYRENOTHALAMI p. 13. Pyrenothea Fries. n. 148. Pyrenula Achar. n. 150. Pyrenula Fec. n. 141. Pyrethraria DC. n. 2643. a. Pyretlırum Gärtn, n. 2670.

Pyrethrum Med. n. 2553.

Pyrgosea $S$ weet. n. 4610 . e. Pyrgus Lour. n. 4222. a. $\alpha$. Pyrispora Rafin. p. 30. Pyrobolus Weinm. n. 2/3. Pyrochaeta DC. n. 2381. c. Pyrochrna Eschw, n. 132. Pyrola Salisb, n. 4349. a. * Pyrola Tourn, n. 4349. * PYROLACEAE p. 760. et 1413 Pyrolirion Herb. n. 1273. b. Pyronium Sal. n. 4313. d.36. Pyrophorum Neek, n. 6342. Pyrostoma $C, F, W$, M. n. 3698. Pyrostria Comm, n. 3204. Pyrostria Roxb. n. 3198. Pyrrhanthus Jack, n. 6084. Pyrrhopappus $D C$, n. 3009. * Pyrrhosa Blum. n. 4708 . Pyrrhosia Mirb. n. 617.

Pyrrhotrichia Wight et Arn. u. 6691.

Pyrrocoma Hook, n. 2382.

Pyrularia L. C. Nich. n. 2082. Pyrus Linn. n. 6312.

Pythagorea Lour. n. 5087. Pythagorea Rafin, n. 6149. b. Pythion Mart. n. 1681.

Pythium Nees. n. 38.

PYTHONIEAE p. 236.

Pythonium Schott. n. 1680. * Pytys E. n. 1809.

Pyxidanthera L C. Rich, n.43'6. Pyxidanthera Mühl, n. 4637. * Pyxidaria Lindl. n. 3958. Pyxidium Ehren, n. 478. Pyxidium Schreb. n. 168, c. Pyxine Fries, n. 146. PXXINEAE p. 13.

Pyxipoma Fensl, n. 5171.

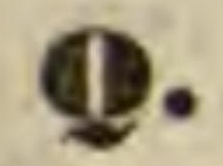

Quadrella DC. n. 4999. Quadria Ruis et Pav. n. 2140 . Qualea Aubt. n. 6069. Quamoclit Tourn. n. $3806 . *$ Quapoya Aubl. n. 5437. Quararibea Aubl. n. 5313. b. Quassia DC. n. 5962. Quekettia Lindl. n. 145t/1. Queltia Haw. n. 1289. d. Quelusia Vand. n. 6125, b. \&. QUERCINAE p. 273. Quereus Linn. n. $18 * 5$. Queria Lüft. n. 5226. Quilaumm Blane, n. 6854 . Quillaja Molin. n. 6397. QUILLAJEAE p. $12 \% 8$. Quillesia Blane, n. 5497/1. Quinaria Lour. n. 5507. Qninelianaliam Juss. n. 2070. Qniaetia Cass, n, 2728.
Quinquefolium Tourn, n. 6363. Rauwolfia Ruiz et P. n. 3706. Quinquina E, n. 3274. a. Quintilia Endl, n. 4143/2. Quintinia Alph. DC. n. 4675 .

Quisqualis Rumph. n. 6089. Quivisia Comm. n. 5516. Quoia Ner. n. $110 \%$. Quoya Gaud. n. 3719.

\section{TR.}

Rack Bruc. n. 3722.

Racoma Forsk. u. 5168. a.

Racomitrium Brid. n. 493.

Racopilum Palis. n, 588.

Racoplaca Fee p. 33. b.

Racoubea $\mathrm{Aubl}$. n. 5086 . b.

Raddia Bertol. n. 764.

Raddisia Leandr. n. 5701.

Rademaehia Thunb. n. 1868.

Radia A. Rich, n. 1262. b.

Radicula Dill. n. 4850 . b.

Radiola Dill. n. 6057.

Radiusia Reich. n. 6738. d.

Radula Dumort. n. 472/13.

Radulotypus Dumort. n. $472 / 13$ *

Radulum Fries. n. 438.

Rafflesia $\boldsymbol{R} . \boldsymbol{B} \boldsymbol{r}$. n. 727.

RAFFLESIACEAE p. 75.et 1352. Rafnia Thunb, n. 6459.

Ragiopteris Presl. n. 629. b. * Raillarda Gaud. n. 2815.

Raineria Not. a. 505/3.

Rajania Linn, n. 1200.

Ramallina Achar. в. 177.

Ramaria Holmsk, n. 415 . b.

Ramatuella $\boldsymbol{H}$. R. K. n. 6080 .

Ramondia $L$, C. Rich. n. 4024.

Ramondia Mirbel, n, 663.

Ramontehi Endl, n. 5097. a.

Ramphosperumu A. n. 4950 , c. Ramtilla DC. n. 2507.

Ramularia Rouss, n. 86. b.

Ranaria Cham. в. 3964. b.

Rancagua Pöpp. ę E. n. 2610.

Randalia Petive. n. 1022. a.

Randia Houst. n. 330't.

Ranmanissa Endl, n. 4988. b.

RANUNCULACEAE p. $8^{\prime}+3$.

Ranuneulastrum $D C$. n. $4783 . \mathrm{b}$.

RANUNCULEAE p. 816.

Rannnculus Haller. n. 4783.

Rapa Tourn. n. 4949.

Rapanea Aubl. n. 4221. a.

Ripatea Aubl. n. 1053. *

RAPATEAE p. 131.

RAPHANEAE p. 885.

Raphanis $D C$. n. 4972.

Raphanis Mönch. в. 4882 . c.

Raphanistrum $D C$. n. 4971.

Raphanistrum Tourn, n. 4971.

Raphanus Tourn, n. 4972.

Raphia Palis. n. 1741.

Raphistemma Wall. n. 3472.

Rapinia Lour, n. 3092.

Rapistrum Berger. n. 4966.

Rapistrum Boerh. n. 4968.

Rapistrum Haller, n. 4942.

Rapistrum Medik. n. 4967. b. Rapourea Aubl. n. 6873.

Rapunculus Endl, n. 3082 . b.

Rapuneulus Tourn, n. 3082.

Rapuntium Cheval, n. 3085 .

Rapuntium Lobel. n. 3082.

Rapuntium Tourn. n. 3058.

Raputit Aubl. n. 6990.

Raspailia Brongn, n. 4598.

Raspalia PresI. n. 812.

Rathkea Sohum, u. 660\%.

Ratibida Rafin. n. 2516. b.

Ratonia, DC. n. 5614 .

Ratzebmrgiaj Kunth, n. 928,

Rauwolfia Plum. n. 3391.
Ravẻnala Adans. n. 1650 .*

Ravensara Sonner. n. 2038.

Ravia Nees. et Mart. n. 5990.

Razoumowskia $H o f f m$, n. 4583.

Razumovia Spreng. n. 2727.

Razumovia Spreng. n. 4002.

Reaumuria Hasselq. n. 5480 .

REAUMURIACEAE p. 1037.

Rehis Spach. n. 4682. b.

Rebouillia Raddi n. 468.

Reboulea Kunth. n. 880.

Recehia Sessé et Moo. n. 4767.

Receveura $F l$. $F l$, n. 5464. B. n.

Redoutea $V_{\text {ent. n. } 5279 .}$

Redowskia Cham. et Schlecht. n. 4981 .

Reevesia Lindl, n. 5318.

REEVESIEAE p. 993.

Regmatodon Brid n. 578.

Rehmannia Libosch. n. 3914.

Reichardia Dennst. n. 3396.

Reichardia Roth. n. 3002. *

Reichardia Roth. n. 2993.

Reichardia Hoth. n. 6769.

Reichelia Schreb, n. 3833.

Reiehenbachia Spreng. n. 2009.

Reichenbachia Spreng. n. 179.

Reifferseheidia Presl. n. 4748.

Reimaria Fluegg. n. 760 .

Reineria Mönch. n. 6539. a.

Reluwardtia $D u m$, n. 6056.

Reinwardtia Nees. n. 5414.

Reiuwardtia Spreng. n. 3794.

Reissekia Endl. n. 5747.

Rejouia Gaud. n. 3396.

Relbunium E. n. 3100. o.

Relhania Gmel, n. 4577 .

Rellania Herit, n. 2781.

Relhanioides DC. n. 2773. a.

Remijia $D C$. n. 3273.

Remirea Aubl, n. 979.

Remusatia Schott, n. 1682.

Renanthera Lour. n. 1473.

Renealmia Feuill. v. 1314.

Renealmia Houtt. घ. 3565.

Renealmia Linn, n. 1631 .

Renealmia Plum. n. 1306.

Renealmia $\boldsymbol{R} . \boldsymbol{B r}$. n. 1221.

Rensslaeria Beck. n. 1685. *

Repandra Lindl. n. 1537. a.

Requienia $D C$. n. 6 671 .

Reseda Linn, n. 5001. *

Resedella Webb. et B. n. 5012. RESTIACEAE p. 120.

Restio Linn. n. 1021.

Restrepia Hunth. n. 1329. *

Resupinaria Benth. n. 3635 . b.

Retama Bois. n. 6501.

Retauilla Brongn, n. 5734 .

Retieularia Baumg. n. 173.

Reticularia Bull. n. 321.

Reticularia Bull, n. 181. a.

Retigerus Faddi. n. 358. e.

Retiuaria Gärtn, n. $57^{4} 6$.

Retiaiphyllum $\boldsymbol{H}$, et $\boldsymbol{B}$. n. 3208 .

Retiporus Balsch a. 447. c.

Rettbergia Raddi n. 906.

Retzia Thunb, n. 387e.

RETZIACEAE p. 669.

Reussia Dennst, n. 3180.

Reussia Endl, n. 1089.

Reutera Boiss. n. 4411.

Rex Amaroris Rumph, n. 5658. Reynaudia Kunth, n. 758.

Rhaburbarum Tourn. n. $199 \%$. Rluabdia Mart. n. 374t.

Rhabdium Wallr. n. 2.

Rhabdocanlon Benth. n. 3620 . c.

Rhabdocriaum Reich. u, $109 \%$.
RELHANIEAE p. 452.

Renggeria Meisn. n. 5436.

RESEDACEAE p. 895 .

Rhabdosporium Chev. n. 196.

Rhabdothamnus $A$. Cunningh, n. 4145 .

Rhabdotheen Cass, n. 3008. a. et $301 \%$.

Rhachicallis $D C$. n. 3240 . k.

Rhaciocarpon Cord. n. 468.*

Rhacodinm Pers, p. 21. i.

Rhacoma $D C$. n. 2895 . a.

Rhacoma $L$ n. 5689.

Rhacosperma Mart, n. 6834. a.

Rhadinocarpus Vog. n. 6628.

Rhagodia $R . B r$. n. 1932.

Rhagodiolus Tournef. n. 2970.

Rhagrostis $B u x b$. n. 1950.

Rhakiocarpon Corda n. 468 .*

RHAMNEAE p. 1094.

Rhamnopsis Reich. n. 5079. a.

Rhamnus Juss. n. 5722.

Rhamphicarpa Benth, n. 3962.

Rhanterium Desf. n. 2425 .

Rhaphidospora Nees. n. 4098.

Rhaphiolepis Lindl. n. 6352.

Rhaphis Linn. f. n. 1761. *

Rhaphis Lour. n. 950. c.

Rhaponticum Cass. n. 2894.

Rhaptostylum $\boldsymbol{H}, \boldsymbol{B}$, n. 5713.

Rhazya Decaisn. n. 3'03.

Rheedia Linn. n. 5450.

Rhetsa Wight et Arn. n. 5972. f.

Rheum Linn, n. 1984.

Rhexantha $E$. n. 6200 . *

Rhexia $\boldsymbol{R}, \boldsymbol{B r}, \mathrm{n} .6200$.

RHEXIEAE p. 1210.

Rhigiothamnus Less. n. 2930. e.*

Rhigozum Burch. n. 4416/,

Rhinacanthus Nees. n. 4090.

Rhinaetina Less. n. 2322.

Rhinactina Willd. n. 2954.

RHINANTHACEAE p. 670 .

Rhinanthera Blum. n. 5069.

Rhinanthus Benth, n. 4017.

Rhinanthus Bieberst. n. 4016.

Rhinium Schreb. n. 4765 .

Rhinocarpus Bert, n. 5916. 
Rhodomenia Grov. 94. e. Rhodomyrtus DC. n. 6316. b. Rhodonema Mert. n. 66. Rhodophora Neck, n. 6357. b. Rhodopsis Endl, n. 6357. a. Rhadopsis Ledeb. n. 6358. Rhodora Linn. n. 4341. b. RHODORACEAE p. 750.

Rhodothammus Reich, n. 4340 . * Rhodoxys E. n. 6058, h. RHOEADES p. 854 . Rhoeadium Spach, n. 4823. * Rhomalium Enill. n. 4900. b. Rhembifolium $L$. C. R. n. 6636 . Rhopala Aubl, n. 2148 .

Rhopalum Endl. n. 430 A. b. $\gamma$. Rhopium Schreb. n. 5879. Rhuacophila Blum, n. 1161. Rhus Linn. и. 5905. Rhus Tourn, n. 5905 . c. ce. Rhyma Scop, n. 5447. Rhynchanthera DC. n. 6183. Rhynchelytrum Nees. n. 769. Rhynchocarpa Schrad, D. 5129. Rhynchocarpus Less. n. 2783. Rhyuchopetalum Fres. n. 3070.* Rhynchopsidinn $D C$. n. 2783. Rhynehosia $D C$. n. 6692 .

Rhynchosia Lour. n. 6692. f. RHYNCHOSIEAE p. 1299.

Rhynchospermum Reinw. n.2333. Rhynehospora Vahl. n. 967.

RHYNCHOSPOREAE p. 112.

Rhynehostylis Blum, n. 1480 .

Rhynchotheca Ruiz et Pav, n. 6049.

RHYNCHOTHECEAT p. 1169.

Rhynea $D C$. n. 2725.

Rhysospermum Gärtn, n. 3350.

Rhyssolobiam E. Mey. n. 3470 .

Rhytiglossa Nees. n. 4084.

Rhytis Lour. n. 5887/.

Rhytisma Fries. n. 373.

Rhytispermum Link, n. 3761. a.

Riana Aubl. n. 5047.

Ribes A. Rich, n. 4682 , b.

Ribes Burm, n. 4223.

Ribes Linn, n. 4682 .

Ribesia DC. a. 4682, b.

RIBESIACEAE p. 823.

Ribesioides Limn, n. 4223 .

Ribis Berland. n. 4683.

Riceia Fl. Fl. n. 105 . a.

Riceia Michel, n. 45\%. *

RICCIACEAE p. 43. et 1337.

Rieciella A. Braun. n. 454 . b.

Ricciocarpus Corda. n. 454 . c.

Richaeia Thouar. n. 6104.

Richardia Kunth. n. 1696.

Richardia Linn. n. 3126.

RICHARDIEAE p. 238.

Riehardsonia Funth, n. 3126.

Richardsonia Neck, u. 474 .

Richea Labill. n. 2721.

Richea $\boldsymbol{R} . \boldsymbol{B} \boldsymbol{r}$, в. 4291 .

Richeria Vahl. n. 5861 .

Ricinocarpus Boerh. n. 5827.

Ricinocarpus Desf: n. 5812.

Ricinoides Tourn. n, 5827.

Ricilus Tourn. n. 5809 .

Rienophora Pers. n, 436.

Ricotia Linn, n. 4864 .

Ridan Adans. n. 2530.

Ridelia Cham, n. 3684. at

Ridleia Vent, n, 5338 .

Riedelia Trin. n. 951 .

Riedleia DC. n. 5338.

Riencourtia Cass. n. 2459.

Riesenbachia PresI. n. 6127.

Rigidella Lindl. n. 1229/,

Rigiophyllum Less. n. 2782 . c。

Rigoearpns Neck, n. 5131.

Rima Sonner. n. 1868. e.
Rimella Rafin, p. 29.

Rindera Pall, n. 3781. Rinorea $\mathrm{Aubl}$. n. $50^{\prime} 47$.

Ripidium Trin. n. 942.

Ripogonum Forst. n. 1185.

Rissoa Arn. n. 5504.

Ritehiea $\boldsymbol{R} . \mathbf{B r}$. n. $500 \%$.

Ritro E. n. 2847. b.

Rittera Schreb. n. 6814. b.

Rivea Chois. n. 3809.

Riveria $\boldsymbol{H} . \boldsymbol{R}$, K. n. 6807.

Rivinia $L$. n. 5257 .

RIVINEAE p. 976.

Rivularia Bonnem. n. 34.

Rivularia Roth, n. 32.

Rizoa Cav. n. 3618.

Robergia Schreb, n. 5948.

Robertia DC. n. 2988.

Robertia Merat. n. 4788 .

Robertsia Scop. n. 4235.

Robertsonia Haw. n. 463\% g.

Robinia Aubl. n. 6747.

Robinia Herit. n. 6740 .

Robinia Linn. n. 6546.

Robinsouia $D C$. n. 2621.

Robinsonia Schreb. n. 4565.

Robiquetia Gaud, n. 1480.

Robsonia Spaeh. n. 4683.

Rocella $D C$. n. 176.

Rochea DC. n. 4615.

ROCHEAE p. 809.

Rochefortia Swartz. n. 6874.

Rochelia Reich, n. 3787.

Rochelia Röm, ot $\boldsymbol{S} c k$. n. 3786 ,

Rochonia $D C$. u. 2380.

Rodigia Spreng. n. 3021/1.

Rodriguezia Ruiz et P.n. 1455 .

Rodschiedia Gärtn. n. 4927.

Roēa Hügel. n. 6438.

Roehlingia Dennst. n. 4765 . *

Roella Linn. n. 3081.

Roemeria Medik, n. 4825.

Roemeria Faddi n. $472 /$.

Roemeria Thunb. n. 4221 . a.

Roemeria Thunb. n, 5924.

Roemeria Trattin. v. 5005.

Roemeria Zea. n. 903.

Roepera Adr. Juss. n. 6035.

Roeperia Spreng. n. 5812 .

Roeslinia Monch, n. 3536. e.

Roestelia Rebent, n. 182. b.

Roettleri Vahl. n. 4138.

Rogeria Gay. n. 4179.

Rohria Schreb. n. 5759.

Rohria Vahl, n. 284'.

Roia Scop. n. 5549.

Roipc Plum, n. 3183. a.

Rokejeka Forsk. n. 5245. c.

Rolandra Rotts, n. 2234.

ROLANDREAE p. 362.

Roldana Llav. et Lex. n. 2811.

Rolfinkia Zenk. n. n. 2205, a.

Rollandlia Gaud. n. 3067.

Rollinia St. Hil. n. 4724.

Rolofa Adans, n. 5785, a.

Romana FI. FI p. 1334. 47.

Romanzoffia Cham. u. 3836.

Romulea Maralh. n. 1217.

Ronabea Aubl. n. 3148 .

Roncela Dumort. n. 3085. b.

Rosulachine Bosc, u. 5025.

Rondeletia Blum, n. 3254,

RONDELETIEAE p. 550.

Rophostemon Blum. H. 1578.

Roram Adans, n. 683.

Rorella Rupp. и. 5033.

Rorida Büm. et Seh. n. 4985 . b.

Roridula Linn. n. 5038.

Roridula Forsk. b. 4985, b.

Roripa Scop. n. 4850 . b.

Ros-Solis Tourn. n. 5033.

Resa Tourn, 11. 6357.

ROSACEAE p. 124.
Rosalesia Llav. et Lex, p.502, 5. $\mid$ Ruppia Linn. n. 1661.

Roseoa Roxb. n. 3715 .

Roscoea Smith, n. 1625. *

Roscyna Spach, n. 5464. B. k.

Rosea Mart. M. 1954. a.

ROSEAE p. 1240.

Rosenia Thunb. n. 2774 .

ROSIFLORAE p. 1236.

Rosilla Less. n. 2605.

ROSMARINEAE p. 615.

Rosmarinns Linn. n. 3599.

Rossenia Fl, Fl. n. 5990 .

Rostellaria Gürtn. n, 4238.

Rostellaria Nees. n. 4079.

Rostellularia Reich. n. 4079.

Rostkovia Desv. n. 1049.

Rostraria Trin. n. 863. b.

Rosularia $D C$. n. 4620 . d.

Rotala Linn. n. 6143.

Rotheria Mejen. n. 3137.

Rothia I.am. n. 2592.

Rothia Pers. n. 6475.*

Rothia Schreb. n. 3023.

Rothmannia Salisb. n. 330\%. b

Rothnannia Thunb. n. 3305.

Rotmannia Neek. n. 6800.

Rottboella Swartz. n. 774 .

Rottboellia R. Br. n. 927.

Rotthoellia Scop. n. 5490.

ROTTBOELLIACEAE p. $10 \%$.

Rottlera Roxb. n. 5819.

Rottleria Brid, n. 487 .

Rotula Lour. n. 6875.

Rotularia Sternb. n. 692.

Roubieva Moq. n. 1923.

Roucela Dumort. n. 3085 . b.

Rouhamon Aubl. n. 3359 .

Roumea Poit. n. 5080.

Roupala Aubl, n. 2148.

Roussaea DC. n. 4680 . *

Roussea Smith, n. 4680 . *

ROUSSEACEAE p. 823.

Rousseauvia Boj. n. 4680. *

Rousseauxia DC. n. 6226.

Ronsselia Gaud. n. 1885. f.

Roussoa $\mathrm{Rŏm}$, et S $\mathrm{ch}$. n. 46

Roxburghia Jones. n. 1197.

Roxburghia Kön. n. 5492.

ROXBURGHIACEAE p. 157.

Roydsia noxb. n. 5009 .

Royena Houst. n. 3823.

Royena Linn, n. 4251.

Roylea Wall, n. 3660.

Rubentia Comm. n. 5688.

Rubeola Mönch. u. 3102.

Rubia Tourn, n. 3101.

RUBIACEAE p. 520, et 1392.

Rubigo Link. p. 21, e. 9 .

Rubioldes Soland n. 3097.

Rubus Linn, n. 6360.

Rucaria Aubl. n. 5632.

Ruckeria DC. n. 2829.

Rudbechia Adans. n, 6081.

Rudbeckia Linn. n. 2511.

BUDBECKIEAE p. 409.

Rudgea Salisb. n. 3151.

Rudolphia Kunth. n. 6658.

Rudolphia Willd. n. 6669.

Ruellia Iinn, n, 4047. *

RUELLIEAE p. 699.

Ruizia Cav. I. 5342

Rulzia Pav, n. 2019. *

Rulingia $\boldsymbol{R}, \boldsymbol{B r}$, n. 5328.

Rulingia Ehrh, n. 5176.

Rumastra Cambes. n. 1993. b.

Rumex Limn. n, 1993.

Runufordia $\boldsymbol{D C}$, n. $2505, *$

Ruuia Foffm. n. 4390.

Rumia Link. n. 4470.

Rumohria Raddi n. 640, a. *

Rumphia Linn. n. 5925.

Rungia Nees. n. 4092.

Rupifraga Otth. 1 . 5248, e.

Ruppinia Corda. n. 456.

Ruppinia Linn. n. 467.

Ruscus Tourn. n. 1188.

Russeggera Endl. n. 407\%/

Russelia Jacq. n. 3910.

Russelia Linn. $f$. n. 4631.

Russula Fries. n. 453. VII. g。

Ruta Tournef. п. 6027 .

RUTACEAE p. 1159.

Ruteria $D C$. n. 6027. a.

Ruteria Mönch. n. 6526.

Rutidea $D C$, n. 3155 .

Rutidocarpaea $D C$. п. 2672. f.

Rutilia Fl. Fl. p. 1334. 48.

Ruyschia Jaeq. n. 5459.

Ruyschiana Mill, n. 3638.

Ryanea $D C$. n. 5093.

Ryania Vahl. n. 5093.

Rymia Endl. n. 4250 .

Ryparia Bl. n. 5836 .

Ryssopterys $\mathbf{B l}$. n. 5580 .

Rytachne Desv. p. 109.

Rytidophyllum Mart. a. 4168.

Rytidopoterium DC.n. 6374. a.

Rytidosis $D C$. n. 2729.

Rytidostylis $H$. et $A$, n. $5145 / 1$.

Rytiphlaea $\mathbf{A g} .70$.

Sabal Adans, n. 1758.

SABALINAK p. 252.

Sabazia Cass, n. 2452.

Sabbatia Adans. n. 3546.

Sabdariffa $D C$. n. 5277. b. $\gamma$.

Sabia Colebr. n. 5927.

Salicer $A u b l$. n. 3224 . *

Sabinea $D C$. n. $65^{\prime} 48$.

Sabjả-lat Bengal. n. 5927.

Sabsab Adans. n. 761.

Sabulina Reichenb, и. 5227.

SABULINEAE p. 963.

Saccharophorum Neck. n. 939, a.

Saecharum Linn, n. 939. 
Salicaria Tourn. n. 6149. SALICARIEAR p. 1198. SALICINAE p. 290. Salieornia Tourn, n. 1908. SALICORNIEAE p. 292. Salisburia Smith, n. 1803. Salisia Lindl. n. 6308. Salivaria $D C, \mathrm{n}, 2553$. b. Salix Tourn. n. 1903.

Salmacis Rory. n, 5\%. c. Salmalia Sch. E. п. 5303 . Salmasia Sehreb, n. 5034. Salmen $D C$, n. 24t8. Salmia Cav, H. 1113. Salmia Willd, n. 1713. Salmouia Neck. n. 6071. Sulomonia Lour, n. 5646. Salpianthus H. et B. и. 2010. SALPIGLOSSIDEAE p. 675 . Salpiglossis $\boldsymbol{H}$. et $P$, n. 3899 . Salpinga Mart, u. 6180 . Salsa Feuill, a. 1195. Salsola Linn, n. 194k. SALSOLEAE p. 298. Saltia $\boldsymbol{A}$. Br. p. 303. a. Saltia $\boldsymbol{R}, \boldsymbol{B r}$. a. 5207 . Salvadora Linn. n. 2177. SALVADORACEAK p. 349 . Salvertia St. Hifl. n. 6072 . Salvia Linn, n. 2597. SALVIEAE p. $61 \%$.

Salvinia Mich, n. 689.

SALVINIEAE p. 67.

Salviniella Hüb, в, 454. c.

Salzmanaia DC. a. 3143.

Salxwedelia Fl, $\mathbb{W}$. n. 6500 .

Samadera Gärtn, n, 5965 . *

Samandura $L$. .1. 5319.

Samandura Lizn, n. 5965.

Samara $L$. n. 5753.

Samara Supart3. n. 4221 . a.

SAMEUCEAE p. 566, et 569 .

Sambueus Tourn. n. 33 i.

Sameraria Desv, n. 4938, b. SAMOLEAE p. 734.

Samolus Tourn, n. 4215 .

Sampaca Rumph. n. 4739.

Samudra E. n. 3810. a.

Samyda Linn, n. 5059.

SAMYDEAE p. 916.

Sanchezia $R$. ot B. n. 4021.

Sandoricum Cav, n. 5537 .

Sanguinaria Linn, a, 4818 .

Sanguisorba Linn. п. 6373.

SANGUISORBEAE p. $12 \% 3$.

Sauhitaria Leandr. n 2916.

Sanicoria $\boldsymbol{D C}$. n. 4382 . b.

Sanicnla Tourn. 8. 4382.

SANICULEAE p. 766.

Sauseviella fieichenb. n, 1192.

Sanseviera Thunb. n. 1113.

SANTALACRAE p. 32't. et 1378. Santalaria DC. n. 6705 .

Santaloides Linn, n. 5948 .

Santalum Linn, n. 2080.

Santia Savi. n, 813.

Santia $W$. et A. и. 3199 .

Santolina Trurn, M. 2651.

Sanvitalia Gualt. n. 2556.

SAPINDACEAE p. 1066.

SAPINDEAE p. 1067.

Sapindus Linn, n. 5610. *

Sapiam Jacg. n. 5780 .

Saponaria L. n. 5246.

Sapota Mill. n. 4240 .

SAPOTACEAR p. 739, et 1410 .

Sappania DC. n. 6765.

Saproleguia Nees, n. 38 .

Saproma Brid, u. 480.

Saprosma Blum. A. 3159.

Saraea Burm, n. 6795.

Sareanthemam Cass. 1. 2390.

Sareanthus LindL It. 1389, *
Sarcoealyx Walp. n. 6483. Sarcocalyx Zipp. p. 1334. 50. Sarcocapuos DC. n. 4841. Sarcocarpa Don. n. 3038, a. Sareocarpon Blum. n. 4731. Sarcocaulon $D C$. n. $60 \div 7$. c. SARCOCEPHALEAE p. 558. Sarcocephalus $A f x, n .3281$. Sarcochilus $B$. Br. n. 1405 . Sarcocolla Kunth. n. 2117. Sarcococea Lindl. n. 5875 . Sarcocrambe $D O$. n. 4967 . Sarcoglottis Presl, n. 15\%7. d. Sarcographa Fée, n. 137.

Sarcolaena Thouar. n. 5398. Sarcolipes E. et Z, n. 4610, a. SARCOLOBEAE p. 595 Sarcolobus $\boldsymbol{B}, \boldsymbol{B r}$. н. 3497 . Sareomitrium Cord. n. 472 Sarcomphaloides $D C$. n. 5725 . Sarcomphalus $P, B r$. n. 5724 . Sareophyllum Thunb. n. 6498 , Sarcophyllus Thunb. n. 6498. Sarcophyte Sparm. n. 714. SARCOPHYTEAE p. 73.

Surcoplaenutia Blum. u. 6236. b. Surcopodium Corda, u. 236. a. Sarcopodium Ehrenb. п. 437. a. Sareopyramis Wall. n. 6262. Sareoseyphus Corda, n. 474/, Sareoseyplus Fries, n, 430 . B. h. Sarcostemba $R$. Br. n. 3456 , * Sareostigma $W$. et $A$. n. 2107/, Sareostoma Blum, n. 1369. Sareostyles Presl. n. 4671. Sardinia Fl, Fl, n. 3192 . b. Sarea fries. n. 426.

Sargassites Brongn. n. 122. i.

Sargassum $\mathrm{Ag}$, n. 121.

Sariava Reins. n. 5407 .

Saribus Rumph. в. 1755 .

Sarissus Gärtn, n. 3113.

SARMENTACEAF p. 796.

Sarmienta $R$. et $P$. n. 4155 .

Sarotes Lindl. в. 5327/2.

Sarothamnus $\mathrm{Wimm}$. п. 6499.

Sarothra Linn, n. 5464 . B. n. Sarpedonia Adans. n. 4778 , a.

Sarracena Tourn, n. 5023.

Sarracenia Linn. n. 5023.

SARRACENIACEAE p. 901.

Sarracha $R$ et $P$. n. 3852 .

Sarreta $D C$, n. 2897 . a

Sasangaa Nees, n. 5425. a.

Sassairas Nees. n. 2056.

Sassia Molin, n. 6893.

Satureia Linn, n. 3611.

SATUREINEAE p. 616.

Saturnia Mar. n. 1137. a.

Satyridinm Lindl. n, 1536/,

Satyrium Swarte, n. 1536.

Satyrus Bosc. n. 358, c.

Saurauja Willd. n. 5'4t.

SAURAUJEAE p. 1019.

Sauroglossum Lindl, n. 1555

Sauromatum Soholt. n, 1678.

Sauropus BIum, n. 5842 .

SAURUREAE p. 266 . et 1374 .

Saururus Linn. н. 182\%.

Saussuren Cass. n. 2853.

Saussurea Mönch. n, 3636. a

Saussurea Salisb. n. 1100.

Santeria Nees, n. 168/,

Santiera Dec, n. 4096.

Sauvagea Neck, u. 5050.

SAUVAGEAE p. 912.

Sauvagesia Linn, n. 5050.

SAUVAGESIEAE p. 912.

Savastania Neok. u. 6214 .

Savia Rafin, n. 6630.

Savia Willa. n. 5866 ,

Savignya $D C$. n, 4961.

Savinionia $W$, et B, n. 5269. b. $\mid \begin{aligned} & \text { Schizoderma Kunze, n, } 201 . \\ & \text { Schizodium Lindl. n. 1537/z. }\end{aligned}$
Saxifraga $\operatorname{Linn}$, n. $463 \%$. SAXIFRAGACEAE p. 813 . SAXIFRAGEAE p. 813. Scaberia Grev, n. 116. Seabiosa $\boldsymbol{R}$. et $S \mathrm{ch}$ n. 2195.

SCABIOSEAE p. 35\%.

Seabrita Linn, n. 3343.

Seaevola Linn, n. 3038. *

SCAEVOLACEAE p. 505.

Scaevolaria $D C$. n. 3038. e. *

SCAEVOLEAE p. 506.

Scalesia Arn, n. 2512.

Scalia Sims, n. 2736. a.

Sealigera Adans, n. 6428.

Sealigeria $D C$, n. 4544 .

Scandalida Neck. n. 6515 .

SCANDICINAE p. 786.

Scandix Gärtn. n. 4504 .

Scandix Hoff $\mathrm{m}$, u. 4504 , a.

Scapania Dum, n. 473/1

Scapha Noronh, n. 5414.

Seaphis Eschw n. 135. e.

Scaphium Sch, et E. n, 5320. i.

Scaphophorum Ehrenb. 11. 450. Scaphyglottis $P$. et $E$. n. 1413 . Scariola E. n. 3008. a.

Scenedesmus Megen. n. 20

Scenidion Flotzsch. n. 447. g. Seepa Lindl, n. 1897.

SCEPACEAE p. 283.

Seepinia Neck, n. 2336. a.

Seepseothamuns $C h$ n. 3317 .

Sceptranthus Grah. n. 1272 . *

Seeptromyees Corda, n. 228.

Seeura Forsk. n. 3722.

Sehaefferia Jacq, n. 5750 .

Schanginia $C$. A, M. n. 1940.

Sehasmaria Achar. n. 168. \&.

Schauera Lees. n. 2051.

Sehaueria Nees. n. 4082/.

Schefflera Forst. 11. 4558.

Schelhammera $\boldsymbol{R}$. Br. n. 1078. Sehelhammeria Heist. n. 4848 . Selielhammeria Mtönch. n. 957.

Sehelveria $N$ et $M$, и. 3885 .

Schepperia Neck. n. 4991.

scheuchzeria Linn, n. 1040.

Schiedea A, Rich, n. 3168.

Sehiedea Bartl. n. 3126, *

Seliedea $C h$, et Schl, n. 6102. Sehillera Kunth. n. 1820, e. * Sehillera Reich, n, 5355. *

Sehimpera St. et $\boldsymbol{H}$. n. 4982. Sehinus Linn, n. 5901.

Sehinza Dennse. n, 2331.

Schisma Dum n. 472/17.

Schismoeeras Presl, n. 136k.

Schismus Palis. n. 890.

Schistidium Brid. n. 489.

Schistoearpha Less. n, 2545.

Schistogyne $H$ et $A$. n. 4476 . schistophragma Benth, n. 3927. Schistopliyllum Palis. n. 599. Schistostega $W_{\text {. et }} B$. n. 595 . Sehistostephium $K r, n, 2676$. Sehiwereekia Azdrz, "1. 4871. Schizachyrium Nees. в. 950, b. Selizatea Smith. a. $66^{\circ}$. SCHIZAEACEAE p. 6b et 1351. Sehizandra $\boldsymbol{L} . \boldsymbol{C}, \boldsymbol{R}$. n. 4733 . SCHIZANDRACEAE p. 835. Schizangium Barll, n, 3127 . Schizanthes Haw. n. 1289. Schizanthus $\boldsymbol{B}$. et $P$. n. 3898. Schizocaena J. S. n. 653. a. * Schizocarpum Sehrad. n. 5144. Sehizocarya $S_{p}$, n. 6131. e. Sehizochiton $S p r$. n. 5530 .
Scepasma Blum, n. 5857.

Schizodon Fenzl, n. 5241. b.

Sehizodon $S_{\text {W. n. }} 512$.

Schizoglossum E, M. n. 3463.

Schizogyue Cass, n. 2427.

Sehizolaena Thouar. n. 5400.

Schizolobium Vog. n. 6760.

Schizoloma Gaud. n. 642. b. *

Sehizomeria Don, n. 4652.

Sehizonema $A_{g}$. n. 14 .

Schizonepeta $B$. n. 3636. a.

Schizonia Pers. n. 450.

Schizonotus Lindl. n. 6331. c.

SCHIZOPET ALEAE p. 888.

Schizopetalon Hook, n. 4980.

Schizophragma $S$. et $Z$. n. 4670

Schizophyllum Fries. n. 450.

Schizopleura Lindl. n. 6296.

Schizostachyum Nees, 11. 908/1.

Schizostephanium $R$. n. 1288. b.

Sehizostigma Arn. n. 3224/1.

Schizostigma Dec. n. 3'75/,

Schizostoma Ehrenb. n. 332.

Schizotechím Fenzl. n. 5240. a.

Schizotheca $C, A$. M, n. 1912. b.

Schkuluria Mönch. n. 2451. b.

Sehkuhria Roth. 1. 2588.

Schlechteudalia Less. n. 2899.*

Schlechteudalia Spr. n. 5366.

Selilechtendalia Willd. n. 2575.

Schleichera $\boldsymbol{W}$. n. 5621.

Sehleideaia E. n. 3750 .

Schlotheimia Brid. n. 512. *

Sclimalzia Desv. n. 5905. e.

Sehmidelia $L$. n. 5605 .

Schmidtia Mänch. n. 2980.

Sehuidtia Tratt. n. 805.

Schuella Radd. n. 6789 .

Sehoberia C. A. M. n. 1942.

Sehoenefeldia Funth. n. 835.

Sehoenidium Nees. n. 997.

Schoenobiblos Mart. p. 330. b. 
Schultesia Spreng. в, 838. Sehulthesia Radd. n. $472 / 10^{\circ}$ b. Sehultzia Rafin. u. 4026. Schultzia Spreng. n. 4403. Schulzia Spreng. n. 4103. Sehumacheria Spreng. n. 5058. Sehumacheria Vahl. n. 4751. * Schwabea Endl. n. 4072/2: Sehwāgriehenia $\boldsymbol{R}$. n. 5937. Schwägrichenia $S_{p r}$ n. 1257 . Sehwalbea Linn. n. 4007. Schwannia E. n. 5563. Sehwarzia Fl. $\mathrm{Fl}$. n. 5 l60. Schweiggera Mart. n. 5'336. Schweiggeria Spreng. n. 5044. Schweinitzia Ell, n. 4354.

Schweinitzia Grev. n. 325.

Schwenkfelda Schreb. n. 3224 . Schwenkfeldia Willd. n. 322\%. Schwenkia Linn. n. 4216. * Sehyehowskya Endl, n. 1881. Sciadophyllum $P$. Br. n, 4559. Sciadophysium Endl. n. 503. d. Sciadophytum Neck. p. 762.

Seiaphila Blum. n. 1878.

Seilla Linn. n. 1130, *

Scinaia Bivon. n. 92.

Scindapsus Scholt. n. 1699. Sciophila Gaud. n. 1880, a. Sciophila Hell. n. 1183. a. Sciothammus Endl. n. 4463. SCIRPEAE p. 118.

Scirpidium Nees. n. 1000 . c. Scirpus Endl. n, 1000, b. Scirpus Linn. в. 1000. SCITAMINEAE p. 221. Seiuris $N$, et $M$. n. 5993. Sciuris Schrob. n. 5990. Sclaraea Tourn, n. 3597. Sclerachue $R, B r$. n. $743 / r$ SCLERANTHEAE p. 955 . et 962. Scleranthus Linn. n. 5222. Seleria Berg. n. 96't.

SCLERIEAE p. 111.

Sclerobasis $C$. n. 2811. VIII. g. Selerocarpus Jacq. $f$. n. 2523. Selerochaetium Nees. n.973. b. Selerochloa Palis n. 899, a. Selerocoecum Fries. n. 272. Sclerococeus Bartl, n. 3237. Scleroderma Pers. n. 331. SCLERODERMEL p. 28.

Seleroderris Pers. n. 378. b. Sclerodontium Sshwigr. u. 579 . Scleroglossum Pers, n. 283.

Sclerolaena R. Br. n. 1918. Sclerolepis Cass. n. 2262.

Selerolepis Monn. n. 3020.

Sclerolobium Vog. n. 6755.

Scleromitrion $W$, et A. n. 3240. f. Selerophora Chev. n. 130. Sclerophyllum G. n. $30 \geq 2$. A. 3 . Selerophyton Esehw. n. 133. Scleropteris Seheidw. n. 1429/1 Scleropus Schrad. n. 1971/ Sclerosciadium Koch, n, 4t21. Sclerostemma Schott. n. 2195. Selerostylis Blum, n. 5503. Selerothamnus $\boldsymbol{R}, \boldsymbol{B r}, 6447$. Sclerotheca $D C$. n. 3061 . * Selerothrix Presl. n. 5114. SCLEROTIACEL p. 23.

Selerotinm Tode. n. 281.

Seleroxylon Willd. n. 4221, a. Scolecopteris Zenk, n. 687/,. Seolicotrichum Kunze. n. 212. Scolobus Raf. n. 6420.

Scolochloa Koch. n. 821.

Secolopacium $E$, et $Z$. n. 6045 . Scolopendrium $S$ mith, n, 63\%. * Scolepia Schreb. n. 5068, * Scolosanthus Vahl. n. 3164 . Scolosperuum Less. n. 2469.
Scolymanthus $W$. n. 2962 . b. $\varepsilon$. |Sedum $\operatorname{Linn}$, n. 4622. SCOLYMEAE p. 493 . Seetzenia $A$. Br. n. 6042. Seolymocephalus Herm n. 2123. Segestrella Frles, n. 151. Scolymus Cass. n. 2965. Scoparia Linn. n. 3973. Seopolia sdans. n. 4864 . Seopolia Forst. n. 6886. Seopolia Jacq. n. 3849. Scopolia Linn. n. 2092. Scopolia Smich. n. 5975. Scopolina Schult. n. 3849. Seopularia Lindl. n. 1522. Scopulina Dum. n. $472 / 6^{\text {. }}$ Seordium Tourn. n. 3679 . Seorias Fries. n. 265. Scorias Rafin. n. 5889. Seorodonia Benth. n. 3679. f. Scorodonia Tourn, n. 3679. Scorodoprasum M. n. 1137. d. Scorpioides Tourn. n. 6584 . Scorpiura Stackh, n. 90. Scorpiurus Linn, n. 6584. Seorpius Loisl, n. $658 \%$. Seorpius Mönch, n. 6500 . Seorzonera Linn. n. 2997. SCORZONEREAE p. 496. Scorzoneroides $M$. n. 2990. d. Scotanum Adans. n. 4785 . Seotia Thunb. n. 6785. Scottea $D C$ n. 6484 . Scottia $B$. Br. n. 64.58. Scouleria Hook. n. 505. Scribaea $F l . W$. v. 5251. Serobiearia Cass. n.2811. XIV. Serophularia Tourn. n. 3883. SCROPHULARINAE p. 670. Searia Rafin. n. 957.

Seurrula G. Don. n. 4586 . Scutellaria Linn. n. 3626. SCUTELLARINEAE p. 620 .

Seutia Comm, n. 572\%. Seutis Comm. n. 572'. Scutula Lour, n, 6296. Scybalium Sch. et E. n. 720. Scyphaea $C . B . P r \cdot$ n. 5421. Scyphanthus Don. n. 5115. Scyphiphora Gärin, n. 3112. Seyphofilix Thouar. n. 643. Seyphogyne Brongn, n. 4296 , Scyphophorus $D O$. a. 168. $\ll$.

Scytala E. M. n. 2927. b. Scytalia Gärtn. n. 5617. Seytalis E. M. n. 6675 . Scythymenia Ag. n. 36 . Scytodium Vogel, n. 6803. c. Scytonema $\mathrm{Ag}$. n. 45. Scytophyllum E. et Z. n. 5688 . Seytopteris Presl. n. 617. c, *

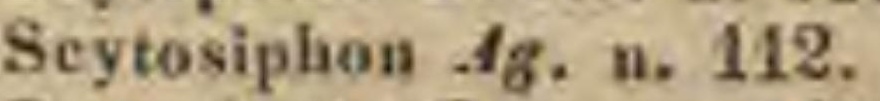
Scytothalia Grev, n. 120. c. Seaforthia $R, B r$. n. 1730 . Sebaea $\boldsymbol{R}, \boldsymbol{B r}$. n. 3558. SEBAEEAE p. 60\%. Sebastiania Bert. n. 2562. Sebastiania Sor, n. 5771. Sehestena Gärtn. n. 3738. Sebifera Lour. n. 2059. Sebipira Mart, n. 6749. Sebophora Neck. n. 4706. Secale Linn. n. 914. Secaunone $R$. Br. A. $3^{\prime}+1$. SECAMONEAE p. 589. Sechium P. Br. в. 5147. Securidaca $L ., n .5620$. Seeuridaea Tourn. n. 6589. Securigera $D C$, n. 6589 . Securilia Pers. n. 6589. Securinega Oomm, n. 5864 . Securinega Lindl. n. 5863. Seddera St, et $\boldsymbol{H}$. n. 3738. SEDEAE p. 811. Sedgwiekia Bowd, n. 466. * Sedgwickia Griff. 11. 4598. Segestria Fries, n. 151. Seguieria $\boldsymbol{L o f f l}$. n. 5253 . Seidlia Fost. n. 5394. b. Seiridium Nees. n. 203, b. Seirococens Grev, n. 120. d. Sekra Adans. n. 496.

SELAGINEAE p. 640 . Selaginella Palis, n. 696. c. SELAGINES p. 68. Selaginites Brongn. n. 698. Selago H. et G. n. 696. a. Selago Linn, n. 3731. Selenaea Nitsch. I. 19. Selenia Nuth. в. 5\$84. SELENIEAE p. 970 .

Selenocarpaea $D C$. n. 4978 . e. Selenocoelae $D C$, n. 2181, a. Selemgyne Cass. n. 2710. b. Selinoides $D C$. 1. 4 162. e. Selinum Gärtn, n. 4462, a. Selinum Hoffm. n. 4454. Selliera Cav. n. 30 2. Selliguea Bory. n. 609. * Selloa $\boldsymbol{H}$. B. $\boldsymbol{K}$. n. $25 \% 9$. Selloa Spreng. u. 2360. Sellowia Roth, n. 520\%.

Semarillaria $\boldsymbol{R}$. et $\boldsymbol{P}$. u. 3603. Semecarpus Linn, n. 5917. Semeiandra $H$. ot $B$. n. 6126 . Semeionotis Schott. n. 6718. Semonvillea Gag. n. 5259. SEMPERVIVAE p. 808. Sempervivum Linn. n. 4623. Senacia Comm. n. 5661 . Senacia Lam. n. 5680. Sendtuera Endl. n. $472 / 26$. Senebiera Poir. n. 4975.

SENEBIEREAE p. 887. Senecillis Gärtn. n. 2798. Senecio Linn. n. 2814. SENECIONEAE p. 454 . SENECIONIDE AE p. 398. Seneciotypus D. n. 2811. 1. U. $^{*}$ Senega $D C$. n. 5647. f. Senkenbergia $F l . W$. n. 4932 f. Seuna Tourn, n, 6781. Seuneberia Neck. n. 2054. * Senra DC. п. 5280 .

Senraea Willd. n. 5280.

SEPEDONIEI p. 18.

Sepedonium Link. n. 217. Septas Linn. I1. 4609.

Septoria Eries. n. 199.

Septosporinm Corda, n. 232. Serapias Linn. n. 1538.

Serapias Pers. n. 1553.

Serda Adans. n. 446. Sergilus Gärın. n. 2410. Seriana Schum. n. 5600. Sericoearpus Nees, n 2310. Sericodon E. n. 3089. b. * Serieophorum DC. n. 2742. f. Seridia Juss. n. 2871. V. Seridioides $D C$. n. 2871 . ee. Seringia Gay. A. 5322. Seringia $\mathcal{S p r}$, n. 5683. Serinia Rafin. p. 1391. 19. Seriola Cass. n. 2985. Seriola Gärtn, n. 2987. Seriphida Less. n. 2694. b. Seriphidium Bess. n. 2694. b. SERIPHIEAE p. 450. Seriphium Less, n. 2761. Seris Less. n. 2909. * Seris Willd, n. 2926. Serissa Comm. n. 3117. Serjania Fl. Fl. p. 133t. 51. Serjania Plum, n. 5600. SERPENTARIAE p. 3 h3.
Sellovia Hoth, n. 6146, a.

Serpentinaria Gray. n. 54. a. Serpicula Linn. n. 6136. Serpillum Benth. n. 3610. b. Serpularia Fries. n. 306. b. Serraea Cav. n. 5280. Serraria Burm. n. 2126. Serratula $D C$. n. 2897. SERRATULEAE p. 479. Serronia Guill, n. 1823. Serruria Salisb. n. 2126. Sersalisia $A, B r$. n. 4237. Serturnera Mart. n. 1958. a. SESAMEAE p. 709.

Sesamella Reich, n, 5013. Sesamoides Tourn. n. 5013. Sesamopteris E. u. 4105. b. Sesamum Linn, n. 4105. * Sesban Poir. n. 6551.

Sesbania Pers, n. 6551.

Seseli Linn. n. 4 '430.

SESELINAE Koch, p. 773.

Sesleria Ard. n. 875.

Sessaea $\boldsymbol{R}$. et $\boldsymbol{P}$. n. 3869.

Sestochilus $K$, et $H$. n. 1353.

SESUVIEAE p. 948.

Sesuvium Linn. в. 5170 .

Setaria Palis. n. 781, a.

Sethia Kunth, n. 5597. b. * Seutera Reich, n. 3473. Seymeria Pursh, n. 3995. Shakua Boj. n. 5291. * Shallonium Rafin, n. 4323, c.

Shawia Forst. n. 2221. Sheffieldia Forst. n. 4215. Shepherdia Nutt, n. 2113.

Sherardia Ditl. n. 310k.

Shorea Roxb. n. 5395.

Shringata Jon, n. 6150 .

Shutereia Chois. n. 3799.

Shuteria $W$. et $A$. n. 6652.

Siagonanthus $P$. et $E$, n. 11409 .

Siagonarrhen Atart, n. 3583 . s.

Sialodes E. et $Z$. n. 5166 .

Sibbaldia Linn, n. 6367. 
Siliqua Tourn. n. 6809.

Siliquaria Forsk, n. 5985. b.

Siliquaria Gray, n. 120. f.

Siliquaria $\boldsymbol{R}, \boldsymbol{B} \boldsymbol{r}, \mathbf{n} .4985$.

Siliquastrum Tourn. n. 6750.

SILIQUOSAE p. 861.

SILPHIEAE p. 401.

Silphium Linn. n. 2474.

Silvia Fl $\quad F I$, n. 3990.

SILYBEAE p. 476.

Silybum Vaill. n. 2878.

Simaba Aubl. n. 596\%.

Simaruba Aubl, n. 5963.

SIMARUBEAE p. 1143.

Simblocline $D C$, n. 2335.

Simblum Flotzsch, n. 358, b.

Simbuleta Forsk. n. 3890 .

Simira Aubl, n. 3149.

Simocheilus Flotzsch. n. 4302 . c

Simochilus Benth, n. 4302, *

Simsia Pers. n. 3533.

Simsia $\boldsymbol{B}, \boldsymbol{B} \boldsymbol{r}$, n. 2133.

Sinapidendron Lowe. n. 4948.

Sinapis Feich, n. 4950. a.

Sinapis Tourn. n. 4950 .

Sinapistrum Mënch, n. 4985.

Sinapistrum Reich. n. 4950 . b.

Singana Aubl. n. 5007.

Sinistrophorum Schr, n. 4943.

Sinningia Nees. n. 4167 . b. *

Sioja Hamilt, p. 1074.

Sipanea $A u b l$. n. 3248.

Siphanthera Pohl. n. 6188.

Siphisia Fafin, n. 2162. c.

Sipho E. n. 2162, c.

Siphoealyx $D C$. n. 4682 . c.

Siphocampylus Poht. n. 3059.

Siphogyne Cass, n. 2710 . b.

Siphomeris Boj. n. 5376. a. $\%$

Siphonanthus Linn. n. 3708.

SIPHONEAE p. 7.

Siphonia Rich. n. 5799.

Siphoaisma DC. n. 2914. b. *

Siphouomorpha otth. n. 5248. f.

Siphonostegia Benth. n. 4012.

Siphonyehia Torr. et A, Gray. n. 5202 . $\mathrm{e}$.

Siphotoxys Boj. n. 3671.

Siphula Fries, n. 158.

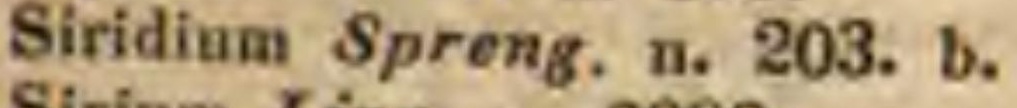

Siripm Linn. n. 2080 ,

Sisarum Adans. n. 4413 , b.

Sistotrema Fries. n. 441.

SISYMBRIEAE p. 873.

Sisymbrium Boerh. n. 4850 .

Sisymbrium Linn. n. 4906.

Sisyranthus E. Mey. n. 3518.

Sisyrinchium Linn, u. 1220. *

Sisyrinchium Tourn, n. 1226.

Sitanion Raf. u. 915. b.

Sitodium Banks. n. 1868.

Sitolobium Desv. n. 644. c. *

Sium Adans. n. 7397.

Sinm Koch. n. 4 M13.

Skimmia Thunb. n. 5712.

Skinnera Chots, n. 3799 .

Shinnera Forst. n. 6125. e.

Skirhoglyphis $D C$, n. 2491 .

Skirrhophorus DC. n, 2715 .

Skitophyllum La.Pilaye n. 694,

Skytanthus Mejen. n. 3416/1.

Slateria Desv. B. 1192.

Slevogtia Heich. n. $3540 / 2$.

Sloana Plum. n. 5363.

Sloanea $L$. n. 5363.

Sloanea Löffl. n. 5364.

SLOANEAE p. 1005.

Smeathmannia Soland, n. 5094.

Smegathamniam E, n. 5246. a. \&.

Snegmadermos Ruiz et Pav。 n. 6397.

Smegmanthe Fenzl. n. 5246. a.
Smelowskia C. A. Mey, n. 4910.
SMILACEAE p. 152. et 1358. Soranthe Salisb. n. 2128. Smilacina Desf. n. 1183.*

Smilacites Brongn. n. 1786.

Smilax Tourn. 1184 .

Smithia Ait, n. 6608.

Smithia Gmel, n. 3812 .

SMYRNEAR p. 788.

Smyrnium Elliote. n. 4392.

Smyraium Linn. n. 4541 .

Soala Blanc, n. $5455 \%$,

Sobolewskia Bieberst. n. 49 k1.

Sobralia Ruiz et Pav. n. 1611.*

Sobrya Pers. n. 2574.

Soceus Rumph. и. 1868.

Sodada Forsk. n. 5000, a.

Sodio Kämpf. n. 1761.

Sömmeringia Mart. n. 6606.

Sogalgina Cass, n. 2620.

Sogaligua Steud, n. 2620.

SOLANACEAE p. 662 . et 1403.

Solandra Linn. $f$. n. 4355 , b.

Solandra Murr. n. 5244.

Solandra $S$ wartz. n. 3846.

SOLANEAE p. 662 . et $66 \%$.

Solanoides Tourn. n. 5257.

Solanum Linn. n. 3855.

Soldanella Tourn. n. 4203.

Soldevilla Lagasc. n. 2968.

Solea Spreng. n. 5041 .

Soleirolia Gaud. n. 1886.

Solena Loureir. n. 5130 .

Solena Willd. n. 3308.

Solenandria Palis. n. 4350.

Solenantha $\boldsymbol{G}$. Don. n. 5749 .

Solemanthis $D C .3060$. *

Solenanthus Ledeb. n. 3783 .

Solenarium Spreng. n. 376.

Solenia Ag. n. 86. a.

Solenia Pers. n. 422.

Soleniscia $D C$. n. 4267/.

Solenocarpus Wight et $A r n$, n. 5900.

Solenogyne Cass. n. 2392.

SOLENOGYNEAE p. 387.

Solenophora Benth. n. $4167 / 1$.

Solenopsis Presl. n. 3060.

Solenopteris Wall, и. 605. b.

Solenostemma Kayn, n. 3467. *

Solenostemon Sohum, n. 3576. c.

Solenostigma Endl. n. 1852.

Solenotiuns DC. n. 3340. a.

SOLIDAGINEAE p. 385.

Solidago Linn, n. 2376.

Solidago Nutt, n. 2376, a.

Solidago $\boldsymbol{P}$. Br. n. 2245 . b.

Soliva Ruiz et P. n. 2708.

Solivaea Cass. n. 2708.

Sollya Lindl, a. 5666. *

Solori Adans. в. 6717.

Solorina Achar, n, 174. b.

Somea Bory. n. 3036 .

Sommera Schlechs. n. 3316.

Sommerauera Hopp. n. 5227.4 .

Sommerfeldtia Schum. n. 6709.

Sommerfeltia Flörk, n. 174 , b.

Sommerfeltia Less. n. 2374 .

Sonchidium DC, n. $3027 /$, b.

Sonchns Linn, n. 3003.

Soucorus Rumph, n. 1624.

Sonerila Foxb. 1. 6192.

Sonueratia Comm. n. 5678.

Sonneratia Linn, $f$. n. 6312 .

Sonninia Heich, n. 3474 .

Sophia Haller, n. 4906 . e.

Sophisteques Comm. n. 5958.

Sophora Linn, n. 6738 .

SOPHOREAE p, 1307.

Sophronanthe Benth, n. 3946.

Sophronia Lioktenst. n+ 1233

Sophronia Pers. a. 358 . e.

Sophronitis Lindl. n. 1397 . *

Sopubia Hamilt. n. 3998.

Soramia Aubl. n, 4761.
Soranthus Ledeb. n. 4428.

Sorbaria Ser. n. 6391. c.

Sorbus Tourn, n. 6342.

Sorghum Pers, n. 950. b. b.

Soria Adans, n. 4896.

Sorindeia Thouar. n. 5895.

Sorocea St. Hil, n. 1864.

Sorocephalus $\boldsymbol{R}$. Br. n. 2138.

Sorosporinm Rudolph. n. 201.

Souari $A u b l$. n. 5642.

Soulamea Lam. n. 5658.

Soulangia Brangn. n. 5740.

Sourolsea Aubl. u. 5459.

Southwellia Salisb. n. 5320. b.

Souza $F l, F l . n$, 1220.

Sowerbaea Smilh. n. 1138.

Soya Mönch. n. 6649.

Soyeria Monn. 2. 3029.

Soymida Adr. Juss, n. 5551.

Spachea Adr. Juss. n. 5591.

Spadactis Cass. n. 2860. e.

SPADICIFLORAE p. 232.

Spadonia Fries. n. 304.

Spadonia Less. n. 2914. *

Spadonisma $D C$, n. 2914, a. *

Spadostyles Benth. 64t5.

Spaendoncea Desf. n. 6776.

Spallanzania $D C$. n. 3255.

Spallanzania Neck. n. 6327.

Spallanzania Pollin. n. 6369.

Spananthe Jacq. n. 4376.

Spanioptilon Less, n. 2883.

Spanotrichum DC. 2784. e.

Sparassis Fries. n. 420.

Sparaxis Her. n. 1241.

SPARGANIOIDEAE p. 241.

Sparganium Tourn, in. 1709.

Sparganophorus Vaill. n. 2199

Sparmannia Thunb. n. 5369.

Spartianthus Link. в. 6497.

Spartina Schreb. n. 846.

Spartium DC. n. 6497.

Spartium Linn, n. 6500 .

Spartium Reich. n. 6499.

Spartothamnus A.Cunn. p. 643.

Spatalanthus $S_{\text {weet. }}$ n. 1246.

Spatalla Salisb. n. 2129.

Spathandra Guill, et $P$. n. 6268

Spathanthus Desv. n. 1053.

Spathe P. Br. n. 5979.

Spathelia Linn. n. 5979.

Spathestigma Hook. et Arn. n. 3925.

Spathicarpa Hook. n. 1691.

SPATHICARPEAE p. 238.

Spathiostemon Blum, n. 5810.

Spathiphyllum Schott. в. 1703.

Spathium Lour. n. 1828.

Spathodea Cham. n. 4118. b.

Spathodea Palis. n. 4118.

Spathoglottis Blum, n. 1384.

Spathularia $\mathrm{Haw}$. n. 4634 . f.

Spathularia Pers. n. 419.

Spathularia St. Hill. n. 5046.

Spathnlea Fries. n. 419.

Spathyema Rafin, n. 1705.

Spathysia Nees. n. 469 . *

Specklinia Lindl. n. 1318.

Specularia Heist. n. 3086 .

Specularia Solan, n. 3057. a.

Spelta Endl, n. 913. a.

Speunera Mart, n. 6195.

Spergella Fenzl. u. 5227. 10.

Spergella Heich. n. 5224.

Spergula $\boldsymbol{L} .5219$.

Spergularia Pers. n. 5218.

Spergulastrum Michx. n. 5240. b. $\rho$.

SPERGULEAE p. 960.

Sperlingia Vahl. n. 3501.

Spermacoce Linn. n. 3121.

SPERMACOCEAE p. 525.

Spermadyetion Roxb, n. 3201.

Spermatura Reioh. n. 4515.

Spermaxyrum Lab. n. 5492.

Spermodon Palis. n. 975.

Spermoedia Fries. p. 16. d.

Spermogonía Bonnem, n. 14.

Spermolepis Haf. n. 4399.

Spermomorphia Link. n. 281. d.

Spermophylla Neek, n. 2626.

Spermoptera $D C$. n. 2671. e.

Sphacelaria Lyngb, n. 72 .

Sphacele Benth, n. 3651 .

Sphacelia Leveill. p. 16. d.

Sphaeraleaea $S t$, Hil, n. 5272.

Sphaeranginm Prest. n. 3958. d.

SPHAERANTHEAE p. 387.

Sphaeranthus Vaill. n. 2395.

Sphaerella Sommerf. n. 28.

Sphaeria Haller. n. 394.

SPHAERIACEl p. 33.

Sphaeridiophorum Desv. n.6530.

SPHAERINI p. 34.

Sphaeriomorphium Link. n. 384.

Sphaerobolus Tode n. 337.

Sphaerocapnos DC. n. 4843.

Sphaeroearpa Schum, n.315. b.

Sphaerocarpaea Griseb. n.

3550 . b.

Sphaeroearpus Michel. n. 455.*

Sphaeroearya Wall. n. 2079.

Sphaerocephalus Lag. n. 2949.

Sphaeroehloa Palis, n. 1022. a.

Sphaeroclinium DC. n. 2669. b.

Sphaerococea DC. n. 5619.

Sphaerocoecus Stackh, n. 94.*

Sphaerogona Link. n. 47.

Sphaerolobium Smith, n. 6437.

Sphaeroma $D C$. n. 5272.

Sphaeromorphaea DC. n. 2703.

Sphaeromphale Reich. n. 151.

Sphaeronema Fries. n. 368. 
Sphinetrina Fries, n. $36 \%$. Sphingium E. Mey. n. 6485. Sphondylium Tourn, n. 4477 . Sphondylococeum $M$. n. 3712. Sphondylophyllum $T$. et $\Delta$. Gr. n. 6135 . a.

Sphyrospermum $P$. et E. n. 4330. Spica Benth. n. 3585 . b.

Spicaria Benth. n. 3583. b. Spicillaria A. Rich. n. 3289. Spiculaea Lindt, n. 1598/x Spieularia Chev. n. 404. a. Spieularia Pers. n. 227. d. Splelmannia Guss. n. 4396. Spielmannia Med. n. 3694. Spiesia Neck. n. 6572. Spigelia Linn. n. 3568. SPIGELIACEAE p. 606. Spilacron, Cass. n. 2871. s. Spllanthes Jacq. n. 2553. Spilanthus Linn. 11. 2553. Spilocaea Fries. n. 188. Spinacia Tourn. n. 1915. Spinifex Linn. n. 791. Spinularia Fouss. n. 111. Spiracantha H. B. K. II. 2235. Spiradiclis Blum. n. 3243. Spiraea Linn, n. 6391. SPIRAEACEAE p. 1240, et 1724. Spiraearia Ser. n. 6391. b. Spiralepis Don. n. 2710. Spiranthera St. Hil. 11. 5988. Spiranthera Hook. n. 5667. Spiranthes $L, C, R$. n. 1547 . Spirastigma Herit. n. 1305. Spiridens Nees. n. 593. Spirocarpaea $D C$. n. 5315, a. $\beta$. Spirocarpos Ser. n. 6507. b. Spirodela Schleid. n. 1668/3. Spirogyra Link. n. 54. c. SPIROLOBEAE p. 297. Spironema Lindl. n. 1031/2. Spirospermum Thouar. n. 4690. Spirostylis Presl. n, $4586 . \mathrm{n}$ Spitzelia Sehultz. n. 2999. Spixia Leandr. n. 5880. Spixia Schrank, n. 2207. Splachnidium Grev. n. 118. Splachnum Linn, n. 503. Splanchnomyces Cord. n. 288. Splanchnonema Gray. n. 394. Spodiopogon Trin, n. 951. SPONDLACEAE p. $113 \%$. Spondias Linn. n. 5920. Spondioides Smeathm. n. 5949. Syondylantha Presl. n. 1195. Spondylastrum $T$. et $A$. Gr. n. 6135. b.

Spondylocladium Mart, n. 228. Spongodium Lamx. n. 81. Spongostemma $\boldsymbol{R}$. n. 9165 . b. Spongotrichum Nees. n. 2317. e. Sponia Comm. n. 1852. Sporendonema Desm. n. 218. Sporidesmium Grev, n. 186. Sporisorium Ehrenb. n. 208. Sperobolus R. Br. n. 809. Sporocephalum CKev, n. 224. . Sporocephalum Chev. n.227. a. Sporochnus Ag. n. 111. Sporoeybe Fries, n. 241. SPORODERMEI p. 17. Sporodesmium Link. n. 186. Sporodinia Link. n. 229. Sporophleum Nees. n. 231. a. Sporotheca Corda. n. 384. Sporotrichum Link. n. 223. Sprekelia Heist. n. 1273. d. * Sprengelia Smith, n. 4288. Sprengelia Schult, n. 534t. Spumaria Pers. n. 319. Spyridium Fenzl. n. 5741. Sigris Targ. n. 105, a.
Squamaria $D C$. n. 172. A. Squamaria Hall, n. 4188. Staavia Thunb. n. 4599 . Stachyanthus $D C$. n. 2229. Stachyehrysum Boj. n. 6834. b. STACHYDEAE p. $6 \approx 3$.

Stachydotypus $D$. n. 3650 . c. Stachygynaudrum $\mathrm{Br}$. n. 696. c. Stachylidium Link. n. 228. Stachymaeris $A$. H. n. 3626 . c. Stachymorpha Oth. n. 5248. d. Stachyobotrys $B$, n. 3679 , e. Stachyotypus $\boldsymbol{B}$. n. 3650 . e. Stachys Linn. n. 3650. Stachytarpheta $V_{a h l}$. n. 3685. a Stachyurus S. ot $Z$. n. 5699. Staekhousia Lamx. 1. 120. c. Stackhousia Smith, n, 5763. STACKHOUSIACEAE p. 1106. Stadmannia Lam, v. 5614. Staehelina Cass. n. 2858, a. Staehelina $D C$, n. 2858 . a. Staehelina Hall. n. 4013. a. Staelia Cham, n. 3129.

Stagmaria Jack. n. 5912. Stalagmites Murr. n. 54t4. * Stammarium Willd. n. 2251. b. Stanhopea Hook. n. 1421. Stanleya Nutt. n. 4916. Stapelit Haw. n. 352\%, a. Stapelia Linn. n. 3524.

STAPELIEAE p. 597. Stapeltonia E. n. 3524. a. Staphylea $L$. n. 5672. STAPHYLEACEAE $\mathrm{p} \cdot 1084$. Staphylodendron Tourn. n.5672. Stapliysagria $D C . \mathrm{n} .4796$. d. Starbia Thouar. n. 4000. Starkea Willd, n. 2245. b. Starkia Juss. n. 2245. b. Statice Tourn. n, 2172. * STATICEAE p. 348.

Stauntonia DC. n. 4701. * Stauracanthus Link. n. 6496. Stauranthera Benth. n. $4143 / 3^{*}$. Staurastrum Meyen, n. 19. Staurogeton $B$, n. $1668 / 1$, b. Staurogyne Wall. n. 4103. Staurophora Willd. n. 4166. Staurospermum Thonn. n. 3127. Stechmamia $D O$. n. 2857 . Steenhammera $\boldsymbol{R}$. n. 3760. * Steffeasia Kunth. n. 1820. f. * Stegania $\boldsymbol{R}, \boldsymbol{B r}$. n. 624 . b. Steganotropis Lehm, 11. 6638 . Stegia Fries n, 382.

Stegia Monch, n. 5269 . c.

Stegilla Reich. n. 382.

Stegionepeta Benth. n. 3636 . c. Stegnogramma Blum, n. 609/1. Stegonotus Cass. n. 2830. Stegosia Lour. n. 927. b. Steinheilla Dec. n. 3454/1 . Steiractis $D C$. n. 2379.

Steirocoma $D C$. n. 2758 . с. e. 2930. b.

Steirodiscus Less, n. 2675.

Steiroglossa $D C$. n. 2654 .

Steirostilpua DC. n. 2758. d. Stelechospermum Blum. n. 5524 Steleocorys E. n. 1597 . b. " Stelephurus Adans n. 750. Stelis Swar/2. n. 1325. * Stellanthe Henth. n. 4313. c. * Stellara Fisch. n. 4186. * Stellaria Debray n. 5239. Stellaria Dill. n. 1830.

Stellaria $\boldsymbol{L}$. n. 5240.

STELLARINAF Fenel. p. 966. Stellaris Mönch. n. 1131.

STELLATAE p. 520 . et 522 . Stellera Linn, n. 2095.

Stellulina Link. n. 54. b.
Stematospermum Palis. n. 908. STEMIONITEI p. 26.

Stemmacantha Cass, n. 289\%, a. Stemmatosiphon Pohl. n. 4259.* Stemmodontia Cass. n. 2496. a. Stemodia Linn. n. 3926. Stemona Lour. n. 1197. Stemonitis Qled. n. 312. Stemonurus Bl. n. 5496 . Stemphylium Wallr. n. 236. Stemoptera Miers. n. 1218/s. Stenactis Cass, n. 2329. Stenactis Nees, n. 2339.
Stenandrium Nees. n. 2054 Stenanthera $R$. Br. n. 4269. Stenanthium A. Gr. n. 1067. a. Stenarrhena Don. n. 3597. e. Stenia Lindl. n. 1407/,

Stenocarpa Lindl. n. 1537. b. 6." Stenocarpus R. Br. n. 2156. Stenochilus $\boldsymbol{R}$. Br. n. 3736 . * Stenocoefium Ledeb. n. 4452. Stenocline $D C$. n. 274 .

Stenoglossum $\boldsymbol{H}, \boldsymbol{B}, \boldsymbol{K}$. n. 1316. Stenoglottis Lindl. n. 1533. Stenogramma Haw. n. 9\%. f. 1. Stenogyne Benth. n. 3675 . Stenogyne Cass. n. 2710. b. Stenolobium Benth, n. 6648 . Stenolobium Don, n. 4124 . Stenolobus Presl. n. 643. d. Stenolophus Cass. n. 2871. h. Stenomesson Herb, n. 128'. * Stenopetalum $\boldsymbol{R}, \boldsymbol{B r}$. n. 4920. Stenophyllum Less, n. 2962, a. $\gamma$. Stenoptera Presl. n. 1547. a.

Stenorhynchus L. C. R. 1547. c. Stenosemia Prest. n. 603. b. $\beta$.
Stenosiphon $S_{\text {pach. n. } 6132 .}$

Stenosiphonium Nees. n. 4052. Steuostemum Juss. n. 3159.

Stenostomum Gärtn. f. n. 3195. Stenotaphrum Trin. n. 774.
Stenotheea Monn. n. 3027.

Stenotium Presl. n. 3058 . b.

Stephananthus Lehm. n. 2410. Stephania Lour. n. 4694. Stephania Willd. n. 5005. Stephanium Sehreb. n. 3146. Stephanocarpus $S_{p}$, a. $5028 . f$. Stephanoeoma Less. n. 2839. Stephanoma Wallr. n. 296. Stephanopappus $D C$. n. 2779, a. Stephanoplysum Pohl. n. 4051 . Stephanostoma Z. p. 1334. 52. Stephanotis Thouar. a. 3510. Sterculia $L$. n. 5320. * Sterculia Seh. E. n. 5320, a. STERCULIACEAE p. 987.

STERCULIEAE p. 993. Sterebeckia Schreb. n. 5007 . Stereocaulon Schreb. n. 169. Stereoderma Blum, n. 3351. Stereodon Brid. n. 566, b. Stereospermum Cham, a. 4131 Stereoxylon $\boldsymbol{R}$. et $\boldsymbol{P}$. n. 4674 . Stereum Pers, n. 437. h. Sterigma $D C$. n. 4946 . Sterigmostemon Bieb. n. 4946. Steripha B. et $S$. n. 3788. Steriphoma Spreng. n. 5005 . Steris Burm. 1. 3833.

Sternbergia W. et $K$. n. 1270. Sterophyllum Brid. n. 567.

Sterrebeekia Link. n. 336. e. Steudelia Mart. n. 4231. Stendelia Presl. n. 5195. Stevartia Forsk. n. 5289. Stevena Andrz. n. 4867. Stevenia $F$. et $A$. n. 4855. Stevensia Poit. n. 3279. Stevia Cav. n. 2264. * et 2684. Stewartia Cav. n. 5423, b. Stibas Comm, n. 3095. at.

Sticherus Presl. 13. 659. b. * Stichocarpus Ag. n. 66. Sticta Schreb, n. 173. Stietis Pers. n. 423. Stictophylla $D C$. n. 2780 . a. Stifftia Mik. n. 2916. Stigmanthus Lour, n. 3217. Stigmaphyllon A. J. n. 5581. Stigmaria Brongn. n. 694. Stigmarota Lour, n. 5097. a. Stigmatanthus $\mathrm{nöm}$. n. 3217. Stigmatidium Meyer. n. 156. Stigmatidinm Mejer. n. 387. Stigmatococea Willd. p. 669. Stigonema $\mathrm{Ag} . \mathrm{n}, 46$.

STILAGINEAE p. 287. Stilago Linn. n. 1891. a.

Stilbe Berg. n. 3724.

STILBINEAE p. 639. Stilbospora Pers. n. 196.

STILBOSPOREI p. 17.

Stilbum Tode. n. 260.

Stillingfleetia Boj. n. 5780 . * Stillingia Gard. n. 5780. *

Stilophora $\mathrm{Ag}_{\mathrm{g}}$ n. 107.

Stilpnogyne $D C$, n. 2789.

Stilpnoides $D C$. n. 2602 . b.

Stilpnopappus Mart. n. 2218. Stilpnophytum Less. n. 2693. Stipa $\operatorname{Linn}$. n. 798. Stipa Trin. n. 798. e.

STIPACEAE p. 87.

Stipagrostis Nees. n. 802.

Stipularia Palis. p. 566. 2.

Stipularia Haw. n. 5218.

Stipulicida $L . C, \boldsymbol{R}$. n. 5215.

Stirlingia E. n. 2133 .
Stixis Lour. n. 6656 .

Stiza E. Mey. n. 6478. d.

Stizolobium $\boldsymbol{P}, \boldsymbol{B r}$. n. 6665 .

Stizolophus Cass. n. 2871. k.

Stobaea Less. n. 2846.

Stockesia Herit. n. 2209. 
Streptostaehys Palis. n. 770. Striaria Grev. n. 107. Striatella dg, n. 6. Striga Lour. n. 3959. Strigia DC. a. 2268. a. Strigilia Cav. n. 4252. b. Striglia Adans. n. 4t6. Strigula Fries, n. 387. STRIGULINI p. 33. Strobila G. Doin, n, 3766.* Strobilanthes Blum, n. 4053. Strobilites Sch, et M. n. 1816/1. Strobilocarpus $K l$. n. 2085. * Strobocalyx Blum, n. 2204. e. Strōmia Vahl. в. 4993.

Stromatosphaeria Grev. n. 396. Strombosia Blum. n. 5752. Strongylium Dittm. n. 321.

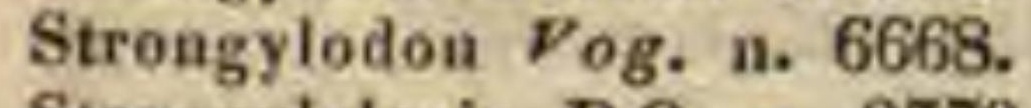
Strongylolepis $D C$. n. 2779 . Strongyloma DC. u. 2947. b. * Strongylosperma Less. n. 284 . Stropha Noronh. n. 1819. Strophanthus DC. n. 2428 . Strophopappus $D C$. n. 2216 . Strophostyles Ell, n. 6674, d. Struchinm P. Br, n. 2199. Struekeria Fl. Fl. n. 6071. Strumaria Jaeq. n. 1269. Stromella Fries. p. 16 . c. Strumpfia Jacq. n, 3218. Strumphia Pers. n. 3218. Struthanthus Mart. n. 4586. o. Struthiola Linn. n. 2099. Struthiopteris Willd. n. 628 . * Struthium Ser. n. 5245. c. STRYCHNEAE p. 574 . et 575 . Stryehnodaphue Nees. n. 2054. Stryehuos Linn. n. 3359. Stryphuodeadron $\boldsymbol{M}$. n. 6837 . a. Stuartia Catesb, n. 5423.
Sturmia Gürtn, n. 3195 . Sturnia Hoppe. n. 746. Sturmia Reich, n. $13 / 0$, a. Stylandra Nutt. n. 3789. STYLIDEAE p. 219. Stylidium Lour. n, 6097. Stylidium Swartz. n. 3093 . Stylimus Rafin. n. 2\$14, a. Stylis Poir. o. 6097. Stylismas Rafin, n. 3791. Styllaria Ag. B. 2. Stylobasium Desf. n. 6417. styloceras 1. J. n. 5773 . Stylochaeton Lepr. n. 1672. Stylocominm Brid, n. 565. Stylocoryna Labill, n. 3225. Stylocoryne Cav. n. 3293. Stylodiscus Benn. a. $5858 / 1$.

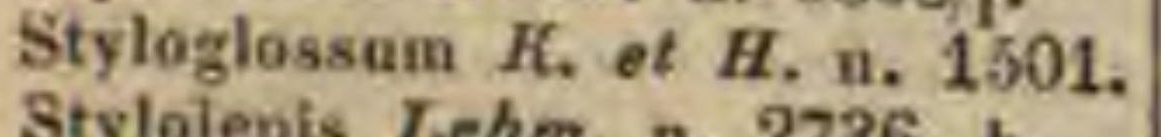
Styloiepis Lehm. n. 2736. b. Styioncerus Labill. n. 2711. Stylanema $D C$. n. 4918. Stylophorum Nutt, n. 4820. Stylosanthes Linn, n. 6600 . Stylurus $K n$. ef $\mathcal{S}$, n. 2143. Stylurus Rafin, n. 4768 . b. Stypandra $R$. Br, n. 1169 . Styphelia Smith. n. 4267. STYPHELIEAE p. 746. Styphuoloblum Schait. n. 6743. Styphonia Nutt, n. 5906. Stypaion Rafin. n. 32. STYRACEAE p. 745 . Styraudra Rafin. n. 1183. a. Styrax Tourn. n. 4252 . Suaeda Forsk. a. 194 L. Suaeda Heich. n. 1927. SUAEDINEAE p. 298. Suardia Schrank, и. 776. Suber Tourn, 11, 1845. Sublimía Comm. в. 1723. Subularia Lirn, a. 4977.
SUBULARIEAE p. 888. Succisa Coult. n. 2195. c. Succisa Vaill. n. 2192. Suceowia Med, n. 4960. Succowia Dennst. n. 5572. SUCCULENTAE p. 808. Suchtelenia Farel. n. 378t/2. Suffrenia Bell, n. 6142. Suillus Mich. n. 448. Sukaki Kämpf. n. 5411. Sulipa Blanc, p. 1394. Sulitra Mönch. n. 6563. Sulzeria $R$. et Sch. p. 586. 3. Sumac $D C$. n. 5905 . b. Sunipia Buch. n. 1433. Suprago Gärtn. n. 2270. b. Suregada Roxb. H. 5883. Suriana Plum. n. 5953. SURIANEAE p. 1140. Surubea Mey. n. 5459. Susum Blum. n. 1055. Sutera Roth. n. 3929. Suteria DC. n. 3144. Sutherlaudia Qmel. n. 5319. Sutherlandia $R . B r$. и. 6566 . Suttonia $A$. Rich, n. 4221, a. Svitramia Cham. n. 6213 . Swainsona Salisb. n. 6562 . Swaumerdammia DC. n. 2737 . Swartzia Ehrh, n. 516. Swartzia Hedw. 11. 530. Swartzia Schreb. n. 6814. a. Swartzia Willd. n. 6814. SWARTZIEAE p. 1321. Sweetia DC. n. 6653 . Sweetia Spr. n. 6753. Swertia Linn. n. 3530. Swertia Ludew. n. 2979. Sehweyckherta C. C. Gmel. n. 3565 . b.

Swietenia $L$. n. 5549.

SWIETENIEAE p. 1053.

Syagrus Mart. a. 1773.

Syalita Adans. n. 4749 .

Syama Jon, a, 1971.

Sychinium Desv, u. 1860, a.

Syckorea Cord. n. 472/23.

Syena Schreb. n. 1027.

Sykesia Arn, n, 3370, b. *

Sylitra E. $M_{\theta}$ ). n. 6565.

Symmetria Blum, n. 6167.

Sympagis Nees, n. 4053 . e.

Symphachue Palis. n. $102 \%$.

Symphocalyx Berl. n. 4682 . e. Symphonia $L$. $f$. n. 5440 . Symphorema $H_{z x b}$. n. 3716. * Symphoria Pers. n. 3334 .

Symphoriearpa Neck, n. 3334.

Symphoriearpus Dill. n. 3334 . Symphyaudra A.DC, в. 3089. * Symphyllaathus $V a h l$. n. 5758.
Symphyochaeta $D C$. Symphyochaeta $D C$. n. 2821. a.
Symphyogyma $N$. ot $M$. n. 472/s. Symphyolepis E. n. 2121. c. Symphyoloma $D C$. n. 4,76 .

Symphyonema $\boldsymbol{R}$. Br. n. 2135. * Symphyopoda DC. n. 6790. c. Symplyyotrichum $\dot{N}$. n. 2301. Symphysia Prest. n. 4333. Symphytum Linn. a. 3776 .

Sympieza Licht, n. 4301 . *

Symplocarpus Salisb. n. 1705.

SYMPLOCEAE p. 744.

Symiploces Linn, n. 4259.

Synaedrys Lindl. p. 275.

Synasdra Nutt, n. 3643 .

Synandra Schrad. n, 4074 .

SYNANTHERAE p. 355. Synammia Presl, n. 607, b. *
Synaphaea $R$. Br, n. 2131. * Synarthrum Cass. n. 2811. VI. Synaspisma $E$, n. 5775 . Synassa Lindl, n. $156 \%$.
Syucarpha DC. n. 2742. b. Syncarpia Tenor. n. 6291. Syncephalantha $B$. n. $3032 / 12$. Syucephalum $D O$, n. 2777. Synchlaena A. DO. n. 3074 .

Synchodendron Boj. n. 2238. Syncoelinm Wallr, p. 21. h. Syneollesia Ag. It. 189. et 242. Syacolostemon $E$. M, n. 3580 . Syndesmanthus $K l$. n. 4300 . a. * Syudesmis Wall. n. 5913.

Syudesmon $H$. n. 4772 . c. $\beta$. * Syndoaisee Corda. n. 463 . Syngonium Schott. n. 1688. Synotia $S$ weet. n. 1239. Synotoma Don. n. 3052. a. * Synoum A, Juss, n. 5531. Synphyllium Griff. n. $39^{\prime}+1$. Syutherisma Schrad. n. 770. Syntrichia $W$. et M. n. 536 . Synzyganthera $\boldsymbol{R}$, et $\boldsymbol{P}$. n. 1906. Syorhynchium Hoffm. n. 1220. Syrenia Andrz. n. 4918. Syringa Linn. n. 3355. Syringa Tourn. n, 6105 . Syringodea $D$. Don. n. 4313 . * Syringosma Zucc, p. 586. Syrrhopodon Sehwägr, n. 498. Systrepha Burch, p. 586.2 Systylium Harnsch, n. 504 . Syurus Endl, n. 922. e. Syzygites Ehrenb. n. 246. Syzygium Girtn. n. 6320 . Szovitsia $F$. et $M$. n. 4500 .

\section{冝。}

Tabacina Reich. n. 3841. Tabacum Reich. n, 3841. Tahaeus Mönch. n. 3841. " Tabebouia Gom, n. 4116 . Tabernaemontana $\boldsymbol{L}$. n. 3396. * Taeea Forst. n. $120 \%$.

TACCACEAE p. 159.

Tachia Aubl. n. 3555 .

Tachía Pers. 11. 6752.

Tachiadenus Grieseb. n. 355 $4 / 1$.

Tachibota Aubl. n. 5084 .

Tachigalia Aubl. n. 6752 .

Tacsonia Juss. 5101.

Tacsonioides DC. n. 5098 . c. $\gamma$.

Taeniocarpum Desv. n. 6683. Taeniopliyllum Blum. n. 1431 . Taeniopteris Brongn. n. 683. Taeniostema Spach. n. 5032. Taenitis Sivarlz, n. 611. Taetsia Medik. n. 1167. Tafalla Ruiz et Pav, n. 1817. TAGETEAE p. 419. Tagetes Tourn. n. 2580 . TAGE'RINEAE p. 419. Tainia Blum, n. 1395. Tala Blanco, n. 4023/ Talauma Juss. p. 4735. * Talguenea Miers. n. 5735 . Taliera Mart. n. 1753. Taligalea Aubl. n. 3711 . Talinastrum $D C$. n. 5178 . b. Talinellum $D C$, n. 5178 . Talinum Adans, n. 5178. Talisia Aubl. n. 5616. Tamara Tonga $R$ h. n. 6059. b. Tamaribdus Tourn, n. 6778 . TAMARISCINEAE p. 1038.

Tamarix L. n. 5484.

Tambourissa Sonner. n. 2014. Tamnus Tourn. n. $12 n 2$.

Tamonea Aubl. n. 3696.

Tampoa Aubl. p. 1333.

Tamus Linn, n. 1202.

Tanacetum Linn. n. 2696.

Tanacetum Neck. n. 2696. a. Tanaecium $S_{\text {wartz. n. }} 4172$. Tangaraea Adans. n. 3228. Tanghinia Thouars, n. 3386. Tanibouea $\mathrm{Aubl}$. n. 6076. a. Tankervillia Link. n. 1385. Tanroujou Juss. n. 6788. b.

Tanyerania Endl. n. 4574 . b. Tapeinia Comm. n. 1233. Tapeinotes DC. n. 4161 . * Tapezia Pers. n. 430. B. f. Taphria Fries. p. 21. e. ce. Taphrina Eries. p. 21. e. d. Taphrospermum $C, A_{\text {. }}$ Mey. n. 4911.

Tapina Mart. n. 4161 . *

Tapinanthus Blum. n. 4586. f.

Tapinia Fries, v. 453. IV, b. Tapiria Juss. n. 3010.

TARCHONANTHEAE p. 331.

Tarchonanthus Linn, n. 2412.

Tardavel Adans. n. 3121.

Tarenna Gärtn. n. 3293. b.

Targionia Michel. n. 461. *

TARGIO NIACEAE p. 44 et 1337.

Tarrietia Blum. n. 5638 .

Tasmannia $\boldsymbol{R}, \boldsymbol{B r}$. n. 4741 .

Tassia Rich. u. 6752 .

Tattia Scopol. n. 5086. a.

Tauscheria Fiseher. n. 4939.

Tauschia Preisler n. 4333. *

Tauschia Schlecht. n. 4512.

Taverniera DC. n. 6617 .

Taxanthema Neck. n. 2172.

TAXINEAE p. 261. et 1373.

Taxites Brongn. 1815.

Taxodium L. C. Rich, n. 179\%

Taxostiche DC. 2741. e.

Taxus Tourn. n. 1799.

Tayloria Hook. n. 506.

Tayotum Blane. p. 1397. 7.

Tazetta $D C$. n. 1289. n. $\beta$.

Tecmarsis $D C$, n. 2240.

Tecoma Juss, in. 4114.

Tecomaria E. n 4114. e. 
Tephrosia Pers. n. 6539.

Teramnus $P . B r \cdot$ n. 6650 .

Terana Adans. v. 437 . b.

TEREBINTHACEAE p. 1127.

TEREBINTHINEAE p. 1125.

Terebínthus 'Juss. n. 5893.

Terebraria Sess. n. 3192. d.

Terfez Leonis Afrieani n. 349 .

Terma E. n. 2847. a.

Terminalia Linn. n. 6076 .

TERMINALIACEAE p. 1180.

Teruatea Tourn. n. 6635.

Ternströmia Vent. n. 5409.

TERNSTRÖMIACEAE p.1017.

Terpnanthus Nees et Mart, n.

5988.

Terrana Coll, n. 2322. a. *

Tertrea DC. n. 3168.

Tessaria Ruiz et Pav. n. 2417.

Tessartironia Turp. n. 20.

Tesselinia Dum. n. 456. et 457.*

Tessiera $D C$. n. 3130 .

Testicularia Klotzsch. n. 342 .

Testudinaria Salisb. r. 1201.

Teta Roxb. n. 119't.

Tetanosia Rich. n. 5490.

Tetilla DC. n. 4627.

Tetracarpum Mónch, n. 2588.

Tetracellion Turcz. n. 4883.

Tetracera Linn, n. 4765 . *

Tetraceratium $D C$. n. 4909.

Tetracme Bunge n. 4909.

Tetracmis Brid, n. 497 , b.

Tetracolium Reinw. n. 2574.

Tetradenia Benth, n. 3589.

Tetradenia Nees, n. 2066.

Tetradiclis Stoven, n. 6029.

Tetradium Lour. n. 5982.

Tetradymia DC. n. 2714.

TETRADYNAMAE p. 861 .

Tetragastris Gärtn. n. 5937.

Tetraglochin Pópp, n. 6376.

Tetragonia Linn. n. 5164 .

TETRAGONIEAE p. 947 .

Tetragonocarpus $C$ o mm, n.516i.

Tetragonolobus Scop. n. 6515 .

Tetragonotheca Dill. n. 2508.

Tetrahit Mönch, n. 3648 .

Tetrahitum Link. et Hoffm. n. 4650. $\mathrm{f}$.

Tetrameles R. Br. n. 5015 .

Tetramerium Gärtn, n. 3154.

Tetramicra Lindl. n. 1383.

Tetramolopium Nees. n. 2312

Tetramorphaea $D C$. n. 2873.

Tetrautha Poit, n. 2459.

Tetranthera Jacq. n. 2059.

TETRANTHEREAE p. 322.

Tetranthus Swariz. n. 2484."

Tetrapasma Don, n. 5731. b.

Tetrapathea DO. n. 5098, a.

Tetrapeltis Lindl. n. 1468.

TETRAPETALAE p. 861.

Tetraphis Hedw. в. 497.

Tetraphyle Eekl. et Zegh. n. 4610. c.

Tetrapilus Lour. n. 3357.

Tetrapitis Hedw, n. 497. b.

Tetraplasium Kunze n. 4627.

Tetrapogon Desf. n. 839. e.

Tetrapoma Turcz, n. 4883.

Tetrapterygium Fiseh, et Mey. n. 4937.

Tetrapterys Cav, n. 5574.

Tetraria Palis. p. 119. g.

Tetrarrhena $R . B r . n .737$.

Tetraspora Ag. n. 86. c.

Tetrastemon $D C$, n. 6244. $\%$.

Tetrastemon Hook, et Arn. n. 6273.

Tetratenium $D C$. n. $447 \%$, a.

Tetratheea $S m i t h$. n. 564 .

Tetrathylax Don, n. 3043. b.
Tetratome Pöpp, n. 2017/1 * Tetrazygia Rich. n. 6263. Tetrazygos Rich. n. 6263. Tetrodontium Schwagr. n. 497.a. Tetrodus DC, n. 2603. b.

Tetroncinm Willd. n. 1038.

Tetrorhiza Renealm. n. 3528 . et 3528. $\mathrm{g}$.

Teucris Benth. n. 3679.' e.

Teucrium Linn, n. 3679 .

Teueropsis Ging, n. 3679. b.

Thacla Spach. n. 4786 . *

Thalamia Spreng. n. 1802.

Thalassia Soland, n. 1658.

Thalasium Spreng. n. 770.

Thalesia Mart. n. 6751.

Thalia Linn. n. 1641.

Thalietrella $A$, Bich, n. 4790, a.

Thalictroides Endl.n. 4772, c. $\alpha$. Thalictrum Tourn, n. 4772 . *

THALLOPHYTA p. 1.

Thamnacantha $D C$. n. 2874. c.

Thamnea Soland. n. $460 \%$.

Thaminia $P . B r$, n. 5071.

Thamnidium Link. n. 251.

Thamnium Klotzsch, n.4298.b.

Thamninu Vent, n. 169.

Thamnochortus Berg. n. 1019.

Thamnomyces Ehrenb. n. 389.

Thamnophora $\mathrm{Ag}, 96$.

Thamnopteris Presl. n. 630. a. $\alpha_{0} *$

Thamnoxys E. n, 6058. 1.

Thamnus Flotzsch. n. 4302. b.* Thanatophytum Nees. n. 289. b. Thapsia Nutt. n. 4491.

THAPSIEAE p. 784.

Thaspium Nutt. n. 4392.

Thaspium Nutt. n. 4298 .

Thaumasia Ag. n. 103.

Thaumuria Gaud. n. 1885. c.

Thea L. n. 5426 .

Thecacoris Adr. Juss, n.'5871. Theeanthes Wiokstr. u. 2098. a.* Theis Salisb. n. 4341. a. Theka Rheed. n. 3703.

Thela Lour. n. 2174.

Thelaetis Mart. n. 351.

Thelasis Blum. n. 1506.

Thelebolus Tode n. 338 .

Thelecarpaea DC. n. 2918. e.*

Thelephora Ehrh, n. 437.

Thelepogon Roth, n. 953.

Thelesperma Less. n. 2569.

Thelotrema Achar. n. 141.

Thelychiton Endt n. 1616. *

Thelyerania Endl. n. 4574. e.

Thelygonum Linn. в. 1888.

Thelymitra Forst. n. 1586.

Thelypodinm Endl. n. 4915.

Thelypteris Schott. n. 639 . e. $\beta$. Thelyra Thouar. n. 6412 .

Thelythamnos Spreng. n. 2626. Themeda Eorsk. I. 9'5.

Thenardia $H, B . K$. B. 3415 .

Theobroma $L$. n. 5333.

Theodora Medik. n. 6785, a.

Theodorea $D E$, n. 2853. $e$.

Theodoria Neck, u. 5320. a. $\beta$.

Theoplirasta Juss. n. 4229.

THEOPHRASTEAE p. 737.

Theriphonum Blum, n. 1678/1 Thermia Nute. n. 6420.

Thermopsis $\boldsymbol{R} . \mathrm{Br}$. в. 6420.

Therogeron $D C$. u. 2331.

Thesiosyris Reich. n. 2072. b.

Thesium Linn. n. 2072.

Thesium $\boldsymbol{R} . \boldsymbol{B r}$. n. 2072. a.

Thespesia Corr. n. 528\%.

Thespis DC, n. 2401. *

Thevenotia $D C$. n, 2861.

Thevetia $\mathrm{Fl}$. $\mathrm{Fl}$. p. 1334. 54.

Thevetia Linn. n, 3387.
Thezera $D C$. n. 5902 . d. Thibaudia $\boldsymbol{R}$. et $P$. n. 4333.* Thiebaudia Colla. n. 1385. Thiga Molin. n. 2021. Thilco Feuill, n. 6125. b. \&. Thileodoxa Cham. n. 3319. Thisantha Eckl. et Z. n. 4612 Thladiantha Bunge n. 5151. Thlaspi Dillen. n. 4885.

THLASPIDEAE p. 870. Thlaspidium Medik. n. 4889 . Thlaspidium Turcz. n. 4887. Thoa Aubl. n. 1805.

Thomasia Gay. n. 5324.

Thompsonia $\mathcal{A}$. Br. n. 5096. Thomsonia Wall. n. 1680 . * Thonningia $\mathrm{Vahl}$. n. 722. *

Thora DC. n. 4783 . c.

Thoracosperma Flotzsch, n. 4306. * et 4302 . b. *

Thorea Ag. n. 65.

Thorinia Bory. n. 50.

Thornthonia Reich, n. 5275 , a. $\beta$.

Thottea Rottb. n. 2164.

Thouarea Pers. n. 790.

Thouarsia Vent. n, 2368.

Thouinia Dombey. n. 4703.

Thouinia Poit. n. 5618.

Thouinia Smilh, n. 3812.

Thouinia $S$ wartz. n. 3347.

Thrasya Kunth, n, 766.

Thelkeldia $\boldsymbol{R}, \boldsymbol{B r}$, n, 1920.

Thícholea Dum. n. 472/15.

Tricolea Dum. n. 472/15.

Thrinax Linn. n. 1762 .

Thrineia Roth. n. 2989.

Thrixspermum Lour. n. 1617.

Thrombium Wallr. n. 148.

Thryallis $L$. n. 5590 .

Thryallis Mart. n. 5583.

Thryptomene Endl. n. 6277.

Thuja Tourn. n. 1790.

Thunbergia Linn. n. 4027.

Thunbergia Mart. n. 3305. c.

THUNBERGIEAE p. 697.

Thuraria Molina n. $425 \%$.

Thurnheissera Pohl, n. 3560 .

Thuya Brongn, n. 1814.

Thyana Hamilt. в. 5618 .

Thylachium Lour. n. $499 \%$.

Thylacites Renealm. n. 3528. et 3528. c.

Thylacosperma Fensl. n. 5233. Thymbra Linn. n. 3621 .

Thymelaea Scop. n. 2092.

THYMELAEAE p. 313.

Thymelina $H o f f m$. n. 2101.

Thymophylla Lagasc. n. 2581. Thymns Linn. n. 3610.

Thyridostachyom Nees, n. 926. Thyrsanthus Schrank. n. 4206. Thyrsine Gled. n. 723 .

Thyrsopteris Kunze n. 650.

Thysanachue Prest. n. 951

Thysanocarpus Hook. A. 4940. Thysanolaena Nees. n. 776/,

Thysanomitrion Sckw. n. 499 .

Thysanotus $R . B r$. n. 1150 . *

Thysanthus EII. n. 6671.

Thysanus Lour. n. 5951.

Thyselinum Adans, 4454 .

Thysopteris Funz. n. 650. *

Thysselinum Rivin, n. 4462. c.

Tiarella Linn . n. 4643 . *

Tiaridium Lehm, n. 3752 .

Tibouclina $\mathbf{A u b l}$. n. 6214.

Ticorea Aubl, u. 5993.

Tiedmannia $D C, \mathrm{n}, \iota_{471}$.

Tigarea Aubl. n. 4765 .

Tigarea Pursh. н. 6380.

Tigridia Juss. n. 1229.

Tikanto Adans, n. 6765 . a.

Tilesia F. W. Mej, n 2533.

Tilia $x$, n. 5373.

TILIACEAE p. $100 \%$.

Tiliacora Colebr, n. 4687.

Tillaea Micheli n. 4607.

Tillandsia Linn. n. 1306.

Timmia Gmel. n. 1279.

Timmia Hedw. n. 559.

Timonius Rumph. n. 3197.

Timutua DC. n. 5647, e.

Tiria $R$. Sch, n. 5614 .

Tinea Spreng. n. 5072, a.

Tiniavia Meisn. n. 1986. h.

Tinnantia Scheidw. n. 1031/1.

Tinus Linn, n. 4320.

Tinus Tourn, n. 3340.

Tipularia Chev. n. 294.

Tipularia Nutt, n. 1502.

Tiquilia Pers, n. 3749. b.

Tíresias Bory, u. 56.

Tissa Adans. n. 5218.

Titania Endl - n. 1331.

Tithonia Desf. n. 2537.

Tithymaloides $J$. n. 6765.

Tithymalus J. n. 5766 .

Tittmannia Brongn, n. 4603.

Tittmannia Reich. n. 3952.

Tuesipteris Bernh, n. 695. at*

Toanabo Aubl. n. 5409.

Tobinia Desv, n. 5972, e.

Toeoea $\mathrm{Aubl}$ n. 6232.

Tocoyena Aubl, и. 3309.

Toddalia Juss. n. 5975.

Todea Willd, n. 666.

Tofieldia Huds. n. 1062.

Tollatia E. n. 2631.

Tolmiaea Hook. n. 4347. *

Tolmiea Torr. et A.Gr. n. $4639 \%$.

Tolpis Adans. n. 2979.

Toluifera Linn, n. 6376. b.

Toluifera Lour. n. 5944.

Tolypangium $E$. n. 3093 . a. 
Tournesolia Scop. n. 5829.

Touroulia Aubl. n. 4565.

Tourretia Domb. n. 4111.

TOURRETIEAE p. 710 .

Tovaria Neck. n. 1183. b.

Tovaria Auiz et P. n. 5006.

Tovomita Aubl, n. 5433 .

Towara Adans. n. 1986. c.

Townsendia Hook, n. 230't/1.

Toxicodendron Gärtn, n. 5605 .

Toxicodendron Thunb. n. 5876.

Toxicodendron Tourn. n. 5905. c. $\beta$.

Toxocarpus Wight et ATn. n. 3442.

Toxophoenix Schott. n. 1769.

Tozettia Savt n. 747. e.

Tozzia Michel. n. 4019.

Trachelium Linn. n. 3087.

Trachinga E. n. 2495 . b.

Trachodes Don. n. $300 \%$.

Trachycarpus $D C$. n. 2812 . b.

Trachydium Lindl. n. 4443.

Trachylia Fries, n. 128.

Trachylobium Hayn. n. 6788. b.

Trachyloma Brid, n. 586.

Trachymene Rudge n. 4362.

Trachynia Link. n. 913 . c.

Trachynotia Michx. n. 846 .

Trachyozus Reich, n. 784.

Trachyphytum Nutt, n. 5111. *

Trachypleurum Reich. n. 441

Trachypodium Brid. n. 591 .

Trachypogon Nees, n. 950. b.

Trachys Pers. n. 784.

Trachyseiadium DC, n. 4397. e.

Trachysperma Rafin.n.3565. a.

Trachyspermum Eckl. et Zegh. n. 4407 . e.

Trachyspermum $t i n k$.n. 4400.b.

Traehystachys Dietr, n. 784.

Trachystemon Don, n. 3777 .

Trachytella $D C$. n. 4766 .

Tradescantia Linn. n. 1031. *

Tragantha Wallr. n. 2280.

Traganum Del, n. 1943.

Tragia Plum. u. 5782.

Tragium Spreng, n. 4410 , b.

Tragoceros Kunth. n. 2491.

Tragopogonoides Vaitl. n.2994.

Tragopogon Linn n. 2995.

Tragopyrum Bieberst. n. $199 \%$.

Tragoriganum Benth, n. 3611. b.

Tragoselinum Tourn, 4410. a.

Tragus Ball. n. 786.

Traillia Lindl, n. 4943/,

Tralliana Lour. 11. 569\%.

Trapa Linn. n. 6140.

TRAPEAE p. 1197.

Trasus Gray, a. 957.

Trasus Palis. n. 977. a.

Trattinickia Pers, 262\%.

Trattinickia Willd. n. 3934. *

Trantvetteria Fisch. et Mey.n. 4798.

Treisia Haw. n. 5766 .

Tremandra $\boldsymbol{R}, \boldsymbol{B} r$. n. $56 \%$.

TREMANDREAE p. 1076.

Tremanthus Pers. n. 4252. b.

Trematodon Rich. n. 526.

Trembleya $D C$. n. 6206 .

Tremella Dillen. n. 403.

TREMELLEI p. 34.

Trentepohlia Hoffm. n. 542 . b.

Trentepohlia Mart. n. p. 21. h.

Trentepohlia Bolh, a. 4978.

Trepocarpas Nutt. n. 4489.

Trepposa Link. n. 86.

Treviraua Willd, n. 4166, *

Trevouxia Seop. n. 5134.

Trewoa Gilt. n. 5735.

Triachae Cass. n. 2946.

Triadenia Spach, n. 5t65. c.
Triadenium Rafin. n. 5465 .

Triadica Lour. n. 5780 .

Triaena Kunth, n. 853.

Trianoptiles Fenzl. n. 969.

Triantha Nutl, n. 1062 . b.

Trianthea $D C$. n. $220 \%$. f.

Trianthema Sauvag. 5168.

Trias Lindl. n. 1354.

Triaspis Burch. n. 5569.

Triathera Desv. n. 848 .

Triathera Roth. n. $8710^{\circ} \mathrm{b}$.

Triblemma Mart. n. 6190 .

Triblidium Fries, n. 371.

Tribonanthes Endl. n. 1259/,

Tribrachia Lindl. n. 1352.

TRIBULEAE p. 1162.

Tribuloides Tourn, n. 6140 .

Tribulus Tourn, n. 6030.

Tricalysia $A$. Rich. n. 3221 .

Tricaryum Lour. n. 3851.

Tricentrum DC. n. $620 \%$.

Tricephalum $D C$, n. 2744. a.

Tricera $\mathcal{S}_{\text {wartz. n. }} 5868$.

Triceraia Willd. n. 5703.

Trieeras Andrz. n. 4845. d.

Tricerastes Presl. n. 5017.

Triceros Lour. n. 59 '5.

Trichachne Nees, n. 770.

Trichaeta Palis. n. 863. c.

Trichanthera Ehrenb. n. 6037.

Tricharia FEe. n. 386.

Trichasma Walp. n. 6502.

Trichasterophyllum $W$. n. 5029.*

Trichaurus Arn. n. 5483.

Trichelostylis Lest, n. 999. b.

Trichera Schrad, n. 2193. e.

Tricheroides $D C$, n. 2193. b.

Trichia Hall. n. 308 .

TRICHIACEI p. 26.

Trichilia L. n. 5541 .

TRICHILIEAE p. $10^{\prime} 48$.

Triehinium $R$. Br. n. 1963. *

Trichipteris Presl, n. 652. d.

Trichlis Hall. n. 5186.

Trichlis Hall. n. 5212.

Triehoa Pers, n. 4691.

Trichocarpaea DC. n. 4503. b.

Trichocarpus Neek. n. 6405. b.

Trichocarpus Schre6, n. 5361.

Trichocentrum $P$, et E. n. 1410.*

Triehocephalum $K$. n. 6511 . b.

Trichocephalus $\boldsymbol{B r}, \mathrm{n} .5736$.

Trichoceros H. B. K. n. 1432.

Triehochila $L$. n. 1537 , b. $\delta$. *

Trichochloa Trin, n. 803.

Trichocladus Pers. n. 4590, *

Trichocline Cass, n. 2923.

Trichocolea Nees. n. $472 / 15^{*}$.

Trichocoma DC. n. 2844. f.

Trichocrepis Vis. n. 3019 , b.

Trichoderma Pers, n. 297.

Trichoderma Link, n. 3779. *

TRICHODERMACEI p. $2 \%$.

TRICHODERMEI p. 25.

Triehodes DC. म. 2844 . e.

Trichodesma $\boldsymbol{R}, \boldsymbol{B r}$, n. 3779 .

Trichodesminm Chev. n. 372 .

Triehodium Auct, n. 810 .

Trichogalium DC. n. 3100 . I.

Trichogamila $P$. Br. n. 4252 , b

TRICHOGASTERES p. 227.

Trichoglottis Blum. n. 1470 .

Trichogonia $D C$. n. 2268: b.

Trichogonium $D C$. n. 4477 . f.

Triehogouus Palis. n. 52.

Trichogyne Less, n. 2763.

Tricholaena Schrad. n. 939 . a.

Tricholea Dum. n. 474 .

Tricholepis DC. n. 2868.

Tricholoma Fries, n. 453 . VIt. h.

Trichomanes Linn. n. 658. *

Trichomitrinm Reich. n. 581, b.

Trichonema $\mathrm{K}_{e} \mathrm{r}$. n. 1247. *
Trichoon Roth. n. 821.

Triehopetalum Lindl. n. 1148.

Trichophora Bonn. n. 39 .

Trichophorum Pers. n. 1001.

Trichophyllum Nutt. n. 2591.

Trichopilia Lindl. n. 1451. *

Trichopodium Lindl. n. 2165.

Trichopteris Park, n. 652.

Trichopterya Nees, n. 868.

Trichopus Gärtn. n. 2165.

Trichosanthes Linn. n. 5140.

Trichosiphon Sch. E. n. 5320, e.

TRICHOSPERMEI p. 25.

Trichospermum Blum. n. 5063.

Trichosphaeria Benth. n. 3583. i.

Trichospira H. B. K. n. 2236.

Trichosporum Don. n. 4134.

Trichostemma Cass. n. 2496.

Triehostemma Linn. n. 3678.

Triehostemma $\boldsymbol{R}, \boldsymbol{B r}$, p. 1391.

Trichostephinm $C$. n. 2496, a.

Trichostephus Cass. n. 2496.

Trichostoma Corda. n. 385.

Trichostomum Hedw. n. 529.

Trichostylium Corda. n. 472/1

Trichothalamus $\mathbf{L}$. n. 6363. b.

Trichothecium Link. n. 221.

Trichotosia Blum, n. 1394.

Trieliceras $D C$. n. 5058 .

Trielinium Fée. n. 266.

Trielinium Rafin. n. 4382. a.

Triclisperma Bafin, n. 56 $47 . \mathrm{g}$

TRIC0CCAE p. 1105.

Tricomaria $\boldsymbol{H}$. et $A$. n. 5584 .

Tricondylus $K$. et $S$. n. 2155 . a.

Tricoryne $R ., B r$. n. 1153.

Tricratus Herit. n. 2002.

Tricuspidaria $\boldsymbol{R}$. P. n. 5390.

TRICUSPIDARIEAE p. 1012.

Trieuspis Palis, n. 872 . b.

Tricuspis Pers, n. 5390.

Trieycla Cavan, n. 2007. *

Trieyrtis Fall. n. 1081.

Tridaetylina $D C$. n. 2670 . d.

Tridax Linn, n. 2622.

Tridens $\boldsymbol{R}$. et Sch. n. 872, b.

Tridentea Haw. n. 3524. d.

Tridesmis $S_{p a c h .}$ n. $5 \neq 71$.

Tridesmus Lour. n. 5827.

Tridia Korth, n. 5478.

Tridontium Hook, n. 505/2.

Trientalis Linn. n. 4208.

Trifoliastrum Ser. n. 6511. f.

TRIFOLIEAE p. 1267.

Trifolium Tourn. n. 6511 .

Trifurearia Herb. n. 1228/1.

Trifurcarium $D C$. n. 6211. d.

Trigemma Sal. n. 4313. d. 28. *

Triglochin Linn. n. 1039.

Triglossum Fisch. n. 304 .

Trigonella Linn. u. 6508.

Trigonia Aubl. n. 5659.

Trigonidinm Lindl. n. 1406.

Trigonis Jacq. n. 5614 .

Trigonocapsa Blum. n. 6192 , b.

Trigonocarpum $\mathbf{B r}$. n. 1653.

Trigonocarpus Fl. fl. n. 5614

Trigonocarpus Wall. p. 615.

Trigonophyllam $G$. n, $463 \%$. b.

Trigonospermum Less, n. 2467.

Trigonostemmum $\boldsymbol{B l}$. n. 5835 .

Trigostemion Bl. n. 5835 .

Triguera Cav. и. 3874.

Triguera Cav. 1. 5294.

Trigula Noronh, n. 4768, b.

Trigynaea Schlecht, n. 4727.

Trilepis Nees. n. 960 . *

Trilepisium Thouar. n. 6416.

Trilisa Cass. n. 2270. e.

Trilium Mill. n. 1177,

Trilix $L$. n. 5381.

Trilophus Fischer, n. 4685.

Trilopus Mitch, n. 4591. a.

Trimatium Fröhl. n. 519.

Trimeranthes $D C$, n. 2451. b.

Trimeria Harw. n. 5080/,

Trimeris Presl. n. 5058/1.

Trimeriza Lindl, n. 2166. *

Trimeriza Salisb, n. 1222.

Trimetra Fl. mex. n. 3032/8.

Trimorphaea Cass. n. 2332, b. *

Trimundia E. n. 5651 . b.

Trinacte Gärtn. n. 2954.

Trinchinettia Endl. n. 2605/s*

Trinia Hoffm. n. 4396.

Trinitaria Bory. n. 111.

Triodea Rafin. n. 957.

Triodia $R \cdot B r$, n. 873.

Triodia Jacq. $f$. n. 872 . b.

Triodia Palis. n. 871.

Triodon DC. n. 3124 .

Triodon Rich, n. 975.

Trionum Med, n. 5277. c.

Trionychion Wallr. n. 4183. a.

Triopterys L. n. 5573.

Triopterys Roxb. n. 5570 .

Trioptolemea Mart. n. 6718.

Triosteum Linn. n. 3338.

Triphaca Lour. n. 5320. b

Triphasia Lour. n. 5500 .

Triphelia $\boldsymbol{A}, \boldsymbol{B r}$. n. 6287 .

Triphora Nutt, n. 1601.

Triphragmium Link, n. 185.

Triphysaria $F$. et $M$. n. 4006.

Tripinna Lour. n. 4173.

Tripinnaria Pers. n. 4173 .

Tripladenia Don. n. 1079. *

Triplaris Linn, n. 1997.

Triplasis Palis, n. 854 .

Triplateia Bartl. n. 5228.

Triplectrum Don. n. 6237.

Tripleura Lindl, n. 1572.

Triplima Rafin. n. 957.

Triplinervium Gaud. n. 4634. e. 
Tritomopteris A. Juss, n. 556\%. Tritonia Ker. ․ 1242.

Triumfetta Gärtn. n. 5372. a. Triumfetta Plum. n. 5372.

Trixago $L$. ot $H$. n. 3650 . e. Trixago Stev, n. 4013 . b. TRIXIDEAE p. 490.

Trixidium DC. n. 2462. c.

Trixis $\boldsymbol{P}, \boldsymbol{B r}$. n. 2960.

Trixis Mitch. n. 6137.

Trixis $S$ wartz. n. 2462. b.

Trizeuxis Lindl. n. 1402.

Trochantha Bung. n. 3529.

Trochera Hich, n. 736.

Trochetia $D C$. n. 5351.

Trochiscanthes Koch. n. 4439.

Trochiscla Fü̈tz. n. 21.

Trochocarpa $R$. Br. n. 4276 .

Trochodendron $S$. et Z. n. 4744 .

Trochoseris $P$. et E. n. 3018. *

Trollius Linn. n. 4787 .

Trombetta Adans. n. 430

Trommsdorffia Mart. n. 1955.

Tromotriche Haw. n. 3524. e.

Tromsdorffia Blum. n. 4136 . TROPAEOLEAE p. 1174.

Tropaeolum Linn. n 6063.

Trophis $P ., B r$. n. 1871.*

Tropidia Lindl. n. 1565.

Tropidoearpum Hook. n. 4907.

Tropidolepis Tausch. n. 2294.

Trotula Comm: n. 6174. c.

Troximon Don. n. 3022. A.'2.

Troximon Gärtn, n. 2982.

Troximon Sims, n. 3030/,

Trujanoa $\mathbf{L l}$. et $\mathbf{L}$. н. 6895 .

Truncaria DC. n. 6182.

Trygonanthus $E$. n. 4586 . a. $\beta$.

Trymalium Fenz1, n. 5744.

Trymatococeus Pöpp, n. 1863/

Tryocephalon $E$. n. 1003 . b. $\beta$.

TRYPETHELIACEAE p. 14.

Trypethelium Spreng. n. 154.

Tryphera Blum. n. 1978.

Tryphia Lindl. n. 1530.

Trysanthus Lour. n. 4355 . a.

Tschudya $D C$. n. 6229 .

Tsinoma $A$, в. 2588, a. $\alpha$.

Tsjana Gmel. n. 1638.

Tubarthera Comm. n. 5729 .

Tuber Mich. n. 350.

Tubera Blum, n. 1493. b.

TUBERACEI p. 29.

Tuberaria Dun, n. 5029. e.

Tuberaria Spach. n. 5029. e.

Tubereularia Tode. n. 207.

Tubercularia Tode, n, $42 \%$.

TUBERCULARINI p. 18.

TUBEREI p. 29.

Tubifera $D C$. n. 2405. c.

TUBIFLORAE p. 641.

Tubilium Cass. n. 243\%. b.

Tubocytisus DC. n. 6505. a.

Tubularia Rouss. n. 86 . a.

Tubulifera $\boldsymbol{G}_{\text {mel }}$. n. 306. c.

TUBULIFLORAE p. 356.

Tubulina Pers. n. 306 . c.

Tuburcinia Fries. n. 216.

Tula Adans. n. 3242.

Tulbaghia Linn, в. 1159. *

TULBAGHIEAE p. 150.

Tulipa Tourn, n. 1091.

TULIPACEAE p. 139.

Tulipastrum Spach. n. 4737. *

Tulipifera Herm, u. 4740 .

Tullia Leav, n. 3605 , a.

Tulocarpus $H$. et $A$. n. $2478 / 1$.

Tulostema Pers. n. 332.

Tuna Dill. в. 5161 .

Tunica Scop. n. 5244. c.

Tupa Don. n. 3058. d.

Tupeia $C h$. et Sehl. n. 4585, *

Tupeicava $P i_{6}$, n. 3973.
Tupelo Adans. n. 2086. Tupistra Ker. n. 1490.

Turbinaria Lamx. n. 121. b.

Turbith Tauseh, n. 4441 .

Turcaninowia DC. n. $230 \%$. *

Turgenia Hoffm. n. 4502 .

Turgosea Haw, n. 4610 . e.

Turia Forsk n. 513'.

Turnera Plum. n. 5056.

TURNERACEAE p. 914.

Turpinia $H$. el B. n. $290 \%$.

Turpinia $\boldsymbol{L} l$. et $\boldsymbol{L}$. n. 2220 . b.

Turpinia Pers, n. 6595.

Turpinia Rafin. n. 5905. e.

Turpinia Vent. n. 5671.

Turraea $\boldsymbol{L}$. n. 5519 .

Turretta Fl. Fl. p. 1334. 55.

Turritella $C . A$. M. n. 4854 . b.

Turritis Dill. n. 4853.

Tursenia Cass, n. 2410.

Tussaea Rifin. n. 1559.

Tussacia Reich, n. 4163.

TUSSILAGINEAE p. 370 .

Tussilago Tourn. n. 2288.

Tweedia $H$. et A. n. 3451 .

Tylacastha $N$. et $M$. n. 3884 .

Tylanthus Reiss. n. 5739.

Tylloma Don n. 2921. e.

Tylochilus Nees. in. 1444.

Tylodisens $D C$, n. 2790 , c.

Tylomium Presl. u. 3058. d.

Tylophora $\boldsymbol{R}, \boldsymbol{B r}$. n. 3500 . *

TYLOPHORE.AE p. 595.

Tylostylis Blum. n. 1390.

Tylotaea Vog. n. 6789. b.

TYMPANIDEI $\mathrm{p} .33$.

Tympanis Tode. n. 380 .

Typalia Dennst. u. 5972. f.

Typha Tourn. n. 1709.

TYPHACEAE p. 241.

Typhalea $D C$. n. 5275, a. $c$.

Typhoderma Gray, n. 37.

Typhodium Link. n. 38t.

Typhoides Mönch, n. 753.

Typhonium Schott. n. 1677.

Typhula Fries. n. 413.

Tyrbaea A. DC. n. 4222, d.

Tyrimuns Cass. n. 2880.

Tytonia Don, n. 6061.

\section{ए.}

Ubium Rumph, n. 1197.

Ucacea Cass, n. 2447.

Ueria Targ. n. 1670.

Ueriana Willd, n. 3309.

Udora Nutt. n. 1206.

Ugena Cav. n. 663.

Uia Aheede. n. 1805.

Ulantha Hook. n. 1549.

Ulassium Rumph, n. 5887.

Ulex Linn. n. 6495.

Ulloa Pers. n. 3862

Ullobus $D O$. n. 3192. e.

Ullucus Loz, n. 1938. *

ULMACEAE p. 265.

Ulu aria Tourn. n. 6391.

Ulmus Linn. n. 1850.

Ulodendron Rhode. n. 701.

Ulospermum $\operatorname{link}$, n. 4450 .

Ulota Mohr. n. 510.

Ulothrix Kütz. n. 42.

Uluxia Juss, n. 4264.

Ulva Lamx. म. 86.

ULVACEAE p. 7.

Ulvasirum $D C$. n. 86, b.

Umari Marcgr. n. 6725.

UMBELLATAE p. 762.

Umbellaria Benth. n. 3583. r.

UMBELLIFER AE p. 762.

Umbellularia Nees. n. 2052. d.

Umbilicaria Hoff m. n. 145.
UMBIEICEAE p. 810.

Umbilicus $D C$. п. 4620 .

Uncaria Burch. n. 4178

Uncaria Sehr. n. 3280 . d. *

Uneinia Pers. n. 968.

Undina Fries. n. 30.

Unedo $\boldsymbol{L}$. et $\boldsymbol{H}$. n. 4325.

Ungeria Sch. E. n. 5317.

Ungnadia Endl. n. 5640 .

Unguicularia $D C$. n. 6675. d.

Unifolinm Hall, n. 1183. a.

Uniola Linn. I. 902.

Unisenuma Rafin. n. 1088. a.

Unona Linn, n. 4717 .

Unxia Linn. n. 2463.

Urachae Trin, и. 794.

Uralepis DC. в. 2867 . b.

Uralepis Nutt, n. 872.

Uramanthe Gaud, n. 3528, d.

Urananthus Gris. n, 3547. b.

Urauia Schreb. n. 1650.

URANIEAE p. 228.

Uraria Desv. n. 6610.

Uraspermum Nutt. n. 4515.

Urceola Roxb. n, 3395 .

Urceolaria Achar. n. 140.

Ureeolaria Achar, n. 172.

Urceolaria Feuill, n. 4155.

Urceolaria Fries. n. 172. A, $\alpha$.

Urceolaria Herb. n. 1277.

Urceolaria Willd. n. 3200 .

Urceolina Reich. n, 1277.

Uredisaria Chev, n. 201.

UREDINE AE p. 16.

Uredo Pers. n. 181.

Urena Linn. n. 5274 .

Urera Gaud. n. 1879. b.

Urginea Steinh, n. 1131.

Urochloa Palis, n. 768.

Urolepis $D C$. n. 2276. b.

Uromyces Link. n. 181, b.

Uropetalum Ker. n. 112 .

Urophyllum $J$. et $\mathscr{W}$. n. 3227.

Urospermum Juss. n. 2994. *

Urostelma Bunge, n. 3469.

Ursinia Gärtn. n. 2627.

Urtica Tourn. n. 1879.

URTICACEAE p. 282, et 1376.

Urvillea $\boldsymbol{H}, \boldsymbol{B} . \boldsymbol{K} . \mathbf{5} 599$.

Ussnea Hoffm: n. 179.

USNEACEAR p. 15.

Ustalia Fries, n. 132.

Usteria Cav. n. 3893.

Usteria Dennst. n. 5787.

Usteria Willd. n. 3366.

USTERIEAE p, 576.

Ustilago Link, n. 181, a.

Usubis Burm. n. 5605 .

Utania Don. n. 3367.

Utricularia Linn, n. 4193 .

UTRICULARINAE p. 723.

Uva Ursi Tourn. n. 4327.

Uvaria Linn. 11. 4717 .

Uvedalia $D C$. n. 2475 . a

Uvedalia $n, B r$. n. 3933.

Uvularia Linn. n. 1080.

UVULARIEAE p. 1357.

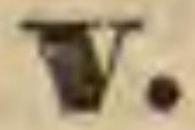

Vacearia Mred. n. 5247.

VACCINIEAE p. $\mathbf{7 5 0}$, et $\mathbf{7 5 7}$.

Vaceinium Linn, n. 4332.

Vachellia $\boldsymbol{W}$. et A. n. 6835 .

Vaginaria Bory. в. 40.

Vaginaria $\boldsymbol{L}, \boldsymbol{C}, \boldsymbol{R}$. n. 995.

Vaginaria Lindl, n. 1557. b. $\gamma$ Valea $L$, p. 586. 5. et 1397.

Vahlia Dahl. n. 53/5.

Vahlia Thunb. n. "4631.

Vaillantia $D C$. n. 3098 . *

Valantia Tourn, n. 3098.

Valdia Plum. n. 3708.

Valdesia $\boldsymbol{B}$. et $\boldsymbol{P}$, n. 6261 .

Valentiana Rafin. p. 570, 1.

Valentinia $S$ w. n. 5631 .

Valentynia Neek, n. 6752.

Valenzuelia Bert. в. 5606 .

Valenzuelia Mut. p. 1334. 56.

Valerandria Neck. n. 3536. *

Valeriana Neck, n. 2186.

VALERIANEAE p. 350.

Valeriauella Bönch, u. 2181.

Valicana $\mathcal{E}$, n. 6663 . a. $\boldsymbol{~}$.

Valikaha Adans. n. 6269.

Vallaris $N ., L$. B. n. 3416 .

Vallea Mut. n. 5389.

Vallesia $\boldsymbol{R}$, et $\boldsymbol{P}$. n. 3384.

Valli-Filix Thouars, n. 663.

Vallisneria Mich n. 1209.

VALLISNRRIEAE p. 161.

Vallota Herb. n, 1273. f.

Valonia Ginn. и. 85.

Valsa Adans. n. 395.

Vanalphimia Lesch. n. 5414.

Vanconseria Dec. n. 4812.

Vanda $\boldsymbol{B} . \boldsymbol{B r}$. n. 1472.

VANDRAE p. 196.

Vandellia Linn. u. 3952.

Vangueria Comm, n. 3191.

Vanguiera Pers, n. 3191.

Vanhallía March, n. 275.

Vanhallia Schult. в. 2163.

Vaniera Lour. n. 1880, b.

Vavilla Swartz, n. 1614.

Vanillosma Less, .1. 220't. d.

Van-Rheedia Plum. n. 5450.

Vantanea Aubl n. 6383.

Vareca Gärtn. n. 5102.

Vareea Hoxb. n. 5048.

Vargasia DC n. 2618.

Vargasia Bert. n. 5618 . "

Variolaria Rouss. n. 395.

Varouthe H. JuEs. n. 6851.

Varronia $\boldsymbol{E}, \mathrm{n}, 3738$, b. $\boldsymbol{\beta}$.

Varronia Linn, n, 3738,

Varthemia $D C$. n. 2428.

Vaseoa DC. n. 5651. et 6459. a. 
Vereia Andr. n. 4616.

Vermicularia Tode. ‥ 385.

Vermifuga $R$. et $P$. n. 2571.

Vermontea Comm. n. 5087.

Vernicia Lour. n. 5804.

Vernonia Sohrob. n. 220'\%.

VERNONIACEAE p. 356.

Veronica Linn. u. 3979.

VERONICEAE p. 687.

Verpa $\boldsymbol{S}_{\text {wartz. n. }} 433$.

Verrucaria $H o f f m$. n. 166.

Verrucaria Pers. n. 150.

VERRUCARIEAE p. 13.

Verrulamia $D C$. n. 3162 .

Vertebraria Rouss. n. 52.

Vertebrata Gray, n. 69.

Verticillaria $R$. $P$. n. 5434.

VERTICHLA TAE p. 697.

Vertiellium Nees, n. 227. e.

Verticordia $D C$. n. 6279.

Verutina Cass, a. 2871. x.

Vesicaria Lam. n. 4869.

Vesicastrum Ser. n. 6511. c.

Vesliugia Fabrio. n. 5165.

Vestia Willd. n. 3868.

VESTIEAE p. 668.

Vexillaria Benth. n. 6637.

Vibo Mönch. n. 1992.

Viborgia Möneh. n. 6505. a.

Viborgia Thunb. n. 6'779.

Viborgloides n. 2/52, b.

Vibrissea Fries. n. 427.

VIBURNEAR p. 566.

Vibaraum Lin', n. 33't0. *

Vicatia DC. a. 4533.

Vicia Linn. n. 6581 .

VICIEAE p. 1278.

Vicioides Mönch, n, 6581. b. $\beta$.

Vieoa Cass a. 2429.

Vietoria Lindl. n. 5019.

Vidua Coult, n. 2195. b.

Vieusseuxia Roche. i. 1223.

Vigia Fl. Fl. p. 1334. 57.

Vigiera $F l, F l$. in: 4674. et 6109.

Vigua Sav. a. 6675.

Viguea Palis. n. 957.

Viguiera $H ., B . K$. n. 2534.

Viguleria Less. n. 2534.

Vilfa Auct. n. 810.

Villanova Lag. n. 2678.

Villanova Orteg. H. 2439. c.

Villaresia $\boldsymbol{R}, \boldsymbol{P}$ n. 5709 .

Villarsia Guett. n. 2356.

Villarsia Aeich. n. 3365. b. *

Villarsia Vent. n. 3565 . *

Vilmorinia $D C$ n. 6655 .

Viminaria Smith. w. 6k36.

Vinca Dum. n. 3406.

Vinea Kinn. n. 3't05.

VINCEAE p. 577 .

Vincentia Boj. n. 5376. b.

Vincentia Gaud. n. 977. a.

Vincetoxienm $M$. n. 3465, *

Viola Tourn, A. 5040 .

VIOLACEAE p. 903.

Violaeoides Miehx. u. 5042.

Viorua Pers. n. 4768 . c.

Viraya Gaud. n. 2732.

Virea Adans. n. 2990. a.

Vireeta $D Q$ n. $32+7$

Virecta Linn. f. n. $32+8$.

Vireya Blume. n. 4341. e.

Vireya Haf. o. 4163.

Virga-uarea Tourn. n. 2376.

Virgaria N. n. 223. et 227. f.

Virgaurea $D C$, и. 2376. a.

Virgilta Cav, u. 6738, b.

Virgilia Berit, n. 2583.

Virgilia Lam. n. 6740.

Virgilia Lam. n. 67t1.

Virgularia Mart, n. 3993.

Virgulariu $\boldsymbol{B}$. ol $\boldsymbol{P}$. n. 3996. d.

Virola Aubl, is. 4706 .
Virsoon Adan's, n. 119. b. Viscago Rohl. n. 5248. et 5249. Visearia Röhl, n. 5249. VISCOIDEAE Rich. p. 799.

Viscoides Jaeq. n. 3148. Viseum Linn. n. 458t.

Visenia Houtt. n. 5356.

Vismia Vell. n. 5466.

Visnaga Gärtn. n. 4'to's.

Visnea L. n. 5403.

Visnea Steud, n. 1261.

VITACEAE p. 796.

Vitaliana Sosst. n. 4193.

Vitex Linn, n. 3700 .

Viticella Dill. n. 4768. a.

Viticella Mitch. n. 4350.

VITICES p. 632.

Vitis Linn. n. 4567 . *

Vittadinia A. Rich. n. 2327.

Vittaria $\mathcal{S}$ mith u. 626.

Vittellaria Gärtn. n. 4241 .

Vittmannia Ture, n. 200\%.

Vittmannia Vahl. n. 5965.

Vittmannia $\mathscr{W}$. A. n. 5725.

Viviania Cav, n. 6053.

Viviania Colla, n. 3328.

Viviania Raddi. n. 474.

Viviania Aafin. p. 1334. 58.

Viviania Rafin. n. 3192. d.

Viviania Willd, n. 22' 't. a.

VIVIANIEAE p. 1169.

Vleckia Rafin. u. 3535. a.

Voacanga Thouar. n, 3397.

Voandzeia Thouar, a. 668't.

Vocason Adans. n. 2538.

Voehy Aubl. o. 6071.

Vochya Vand. n. 6071.

Vochysia Juss. n. 6071.

VOCHYSIACEAE p. 1177.

Vogelia Gmel. n. 1219.

Vogelia Lam. n. 2176.

Vogella Medik. n. 49/2.

Voglera Fl, Wett. n. 6500 .

Vohíria Juss. n. 3540 .

Voigtia Roth. n. 3023.

Voigtia Spreng. n. 290\%.

Voitia Hornsch. n. 482.

Voitia Moug. et Nestl. n. 480 .

Volkaméria Burm, n. 5000, b.

Volkameria Linn. n. 3707.

Volkameria Linn, n. 3708.

Volkameria $\boldsymbol{P} . \boldsymbol{B r}$. n. 4320 .

Voltzia Brongn. n. 1811. *

Volubilaria Lamx. 90.

Volutarella Cass. n. 2865. A. $\beta$.

Volutaria Cass. ni. 2865. A. 3.3.

Volutella Forsk, n. 2057.

Volutella Tode, n. 206. et 405.

Volutella Tode. n. 425 .

Volutellaria Endl. n. 430. A. d. re.

Volvaria $D C$. n. 141 et 170 .

Volvaria Fries. n. 453, 111. f.

Volvycium $R$ af. p. 31 .

Vonkhout Stereb, n. 4' 46 .

Vossia $\boldsymbol{W}$. et Gr. n. $925 / 1$,

Votomita Aubl, n. 4530.

Vonapa Aubl. a. 6803. b.

Vouarana $A u b l$, n. 5614.

Vouctipoua Aubl, n. 6726. b.

Veyra Aubl. в. 3540.

Vroliekia $\mathcal{S}_{\text {preng. ut } 3955 .}$

Vulueraria Möneh. n. 6506, a. Vulpia Gmet, n. 899. c.

\section{W.}

Waeheudorfia Burm. n. 1251. Wahlbomia Thunb. n. 4765 .

Wahlenbergia Blum, n. 3293. a.

Wahleabergia $\boldsymbol{B}, \boldsymbol{B r}$. в. 5757 .

Wahlenbergia Schrad, n. 3079."

Wahlenbergia $S$ chum. n. 2453.

WAHLENBERGIEAE p. 514 .
Waizia Reich, n. 12'2.

Wal-Tiedde Gärtn, n. 4694.

Walafridia E. Mey. n. 3732.

Walchia Sternb. n. 697.

Waldschmidia Wigg. n. 3565 . b.

Waldschmidtia Neck, n. 6702 .

Waldsteinia Willd. n. 6382.

Walkèra Schreb. n. 5960.

Walkeria Ehret. n. 3817.

Wallenia Swartz, n. 4217.

Wallichia $D C$. n. 5355 .

Wallichia Reinw. n. 3226.

Walliehia Roxb. n. 1632 et 3227.

Wallrothia $D C$. n. 4435.

Wallrothia $R \circ$ lh. n. 3699.

Walpersia Reiss. n. 4736.

Walsura $R \circ x b$. n. 5539 .

Walteriana Fras, n. $4344 / 2$.

Waltheria $L i n n$, n. 5336.

Wangenheimia Dietr. n. 455 '

Waugenheimia Mönch, n. 891.

Wardia Hook. et Arn. n. 505/

Warea Nutt. n. 4917.

Waria Aubl. n. 4715.

Warneria Mill. n. 4777 .

Watsonia Mill, n. $12 \% 0$.

Wattahaka $E$. n. 3501. b.

Webbia $D C$, n. 2212.

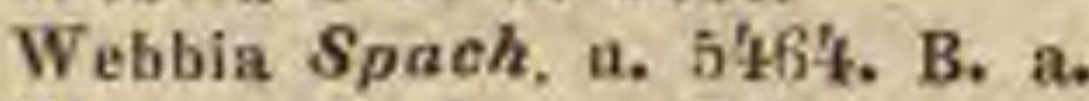

Webera Hedw. n. 5i2. a.

Webera Schreb. o. 3293. b.

Wedelia Jarq. n. 2496. "

Wedelia Löffl u. 2005. b.

Weigela Thunb. a. 3336.

Weigelia Pers. n. 3336.

Weigeltia Alph. DC. u. 4219.

Weihea Eckl. n. 1246.

Weihea Spreng. n. 610\%.

Weingartneria Bernh. n. 856 .

Weinmannia Linn. n. 4655 ,

Weinreichia Reich. в. 6706.

Weissia Hedw. n. 516.

Weissia Sehreb. 1. $\$ 09$.

Weldenia Schult. $f$. n. 1085

Welwitschia Reich. n. 3821. a.

Wenderothia Schleoht. n. 6666.

Wendlandia Bartl. n. 3252.

Wendlandia Willd. n. 4687.

Weudtia Hoffm. n. 4477 . e.

Wendtia Mejen. n. 6051.

Werneria H. B. $\boldsymbol{K}$, n. 2803.

Werniseckia $\mathcal{S}$ cop. n. 5486.

Westia Vahl. n. 6797. *

Westonia Spreng. n. 6475.*

Westringia Smith, n. 3633.

Wettinia Pöpp. n, 1715. *

Whitia Blum. n. 4147 . *

Whitleya $\mathcal{S}_{\text {weet. n. }} 3818$.

Wibelia Bernh, u. 643 . c. $\gamma$. *

Wibelia Hopp в. 3011.

Wiborgia Roth. n. 2619.

Wiedemannia Fisch, et Mey. n.

\section{4 t.}

Wiegmannía Meyen n. 3116 .

Wigandia Kunth. n. 3834.

Wigandia Neck, n. 2758.

Wiggersia Fl. Wetter.n. 6581.

Wightia Spreng. n. 2205. a.

Wightia Wall. n. 4126.

Wickströmia Endl. n. 2105. *

Wiekstrŏmia Sehrad. n. 5416.

Wiekströmia Spreng. n. 2279.

Wilhelmsia Reich n. 5231.

Willdeaowa Cav. n. 2575.

Willdenowia Gmel. n. 325;.

Willdenowia Thunb, n. 1012

Willemeta Maerkl. n. 1927.

Willemetia Brongn, n. 5725.

Willemetia Neck. n. 3011. *

Willemetia $\boldsymbol{R}, \boldsymbol{B r}$. n. 1928.

Willibalda sterns. a. 805 .

Williehia Mut, u. 3956.

Willughbeia Hoxb. n. 3381.

Willaghbeia Schreb. n. 337 h.

Wilsonia Hook. n. 3689.

Wilsonia $\boldsymbol{R}$. Br. n. 3790 .

Wimmeria Schlecht. n. 5684.

Windmannia $P, B r$, n. 4655.

Windsoria Nutl. n. 872. b.

Wintera Murray. n. 4742.

WINTERACEAE p. 836.

Winterana Soland n. 4742.

Winterania $L$ n. 5457.

Winterlia Dennst. n. 5501.

Winterlia Mönch. n. 5706.

Winterlia Spreng. n. 520't.

Wiuterlia Spreng. n. 6146. a.

Wisenia Gmel. n. 5356.

Wissadula Medik. " 5295.

Wisteria Nult. n. 6671.

WISTERIEAE p. 1296.

Withania Pauq. n. 3858.

Witheringia Herit. n. 3853.

Witsenia Thunb n. 1233.

Wittelsbachia M. Z. N. 5405 .

Wodur Anders. n. 5898.

Wolfia Hook, n. 1668. *

Wollastonia DC. n. 2502 .

Woodfordia Salisb. n. 6156.

Woodsia $R, B r$. n. 6't6. *

Woodvillea $D C$. n. 2367.

Woodwardia Smith. n. 633. *

Wooginoos Bruc. n. 5970.

Wormia Rottb n. 4750 .

Wormia Vahl, n. 6095.

Wormskioldia Spreng. n. 100.

Wormskioldia Thon. et Schum.

n. 5058 .

Wrangelia $A g$. n. 64.

Wredowia Eckl. n. 1232 .

Wrightea Roxb. u. 1732.

Wrightia $R$. Br. H. 3429.

Wrightia Soland. n. 6169.

WRIGHTIEAE p. 586. 
Xeranthemum Tourn, u. 2850. Xeranthus Miers. ת. 5177.

Xerobius Cass. n. 2659.

Xerocarpa Don. n. 3038, b. *

Xerocarpus Guillem. et Perr. n. 6474 .

Xerocarpus $D_{o g}$ l. n. 6781. g. $\kappa$.

Xerochloa $\boldsymbol{R} . \boldsymbol{B} r$. п. 929.

Xerolepis $\boldsymbol{D C}$. n. 2626. b.

Xeroloma Cass. n. 2850.

Xeromeria E. n. 2075. a.

Xeropappus Wall. n. 2930. a. *

Xeropetalon Hook, n. 6053.

Xeropetalum Del. n. 5377.

Xeropetalum $R, B r$, n. $6+41$. b. Xerophyllum L. C. Rich. n. 1065. *

Xerophyta Comm. n. 1262. a.

Xerostole E, n. 2121. d.

Xerotes $\boldsymbol{B} . \mathbf{B r}$. n. 1056, *

Xerothamnus $D C$. n. 2358.

XEROTIDEAE p. 132.

Xerotium Bluff. et Fingerh, n. 2752. b.

Ximenia Plum. n. 5490.

Ximenesia Cav. n. 2555.

Xiphidium Aubl. n. 1250.

Xiphion Tourn, n. 1226.

Xiphocarpus Presl., n. 95't3.

Xiphopteris Kaulf. n. 607. a. $\beta . *$

Xiphotheca $E$, et Z. n. 646't. b.

Xolisma Rafin, n. 4319.

Xuarezia Kuiz ot P. n. 3922.

Xyladenius Desv, p. 920.

Xylaria Pers. n. 396.

Xylissus Rafin. n. 401.

Xylobium Lindl. a. 1407/5.

Xylobium Vogel. n. 6781. b. ch

Xylocarpus $1 d r . J$. n. $55^{\prime}+5$.

Xylocarpus Schreb. n. 55th.

Xylodon Ehrenb. n. 440.

Xyloglossum Pers. n. 283.

Xylogramma Wallr. 423. a.

Xylographa Fries. n. 423 . b.
Xyloma Link, 281. a.

Xyloma Pers. n. p. 31. d. XYLOMACEI p. 31. Xylomelum Smith. n. 2146. * Xylomyzon Pers. n. 45. Xylon Tourn. n. 5286.

Xylophagus Link. In. 445 . Xylophylla Linn. n. 58*7. a. Xylopia Linn. 4714.

XYLOPIEAE p. 831. Xylopieroa $P . B r$. n. 4714.

Xylopleurum $S_{\text {pach, n. }}$.6115. 10. Xylosma Forst. u. 5081/1. Xylosteon Tourn, n. 3337.

Xyphanthus Rafin. n. 6667. a. Xypherus Rafin. n, 6630.

Xyridanthe Lindl, n. 2730/2.

XYRIDEAE p. 123.

Xyris Linn. n. 1025. *

Xysmalobium $R$. $B r .3487$.

Xystidium Trin. n. 933 .

\section{Y.}

Yermolofia Belang. n. 3646. Yerva Mora Lud. n. 1854. Youngia Cass. n. $3004 / 2$ * Xucea Linn, n. 1117. Yalania Spach. n. 4737.*

\section{Z.}

Zacyntha Tourn. n. 3013. * Zahibrucknera Reich. n. 4633. Zalaeea Reinw. n. 1737. Zaleya Burm, n. 5168 . b. Zaluzania Comm, n. 3295. b. Zaluzania Pers. n. 2511. Zaluzianskia Neck, u. 691. Zaluzianskya $J$ W.Sch.n.3964. Zamaria Rafin. n. 3293. b. Zamia Lindl. n. 709.

Zamia Linn. n. 706. *
ZAMIAE p. 70

Zamiostrobus Endl, n, 707.

Zamites Brongn. 709. * Zannichellia Michel. u. 1662. *

Zanonia Linn, n. 5122.

Zanonia Plum. n. 1033.

Zantedeschia Spreng n. 1696.

Zanthorhiza Heril, n. 4803.

ZANTHOXYLEAE p. 1145.

Zanthoxylon Kunth. n. 5972.

Zarabellia Cass. n. 2478. b.

Zarabellia Neck. n. 2844.

Zauschneria Prest. n. 6122.

Zapania Juss. n. 368\% a.

Zea Linn. n. 742.

Zehneria Endl. n. 5127.

Zenobia Don. n. 4318. d. *

Zeocriton Palis, n. 917. a.

Zeora Fries. n. 172. B.

Zephyra Don, n. 1154 .

Zephyranthes Herb, n. 1273.

Zerumbet Jacq. n. 1632.

Zerumbet Rumph, n. 1623.

Zeugites $P$, Br. n. 955 .

Zeugophyllites Brongn. n, 1782 .

Zeuxine Lindl, n. 1577.

Zexmenia Llav ot Lex, n. 2547.

Zeyheria Mart. n. 4116. *

Zeyheria Spreng. n. 2437.

Zichya Hülel. n. 6642.

Zieria Smilh, n. 6003.

Zietenia Benth. n. 3650 . i.

Tilla Eirsk, n. 4964.

ZILLEAE p. 885.

Zingiber Gärtn. n. 1622.

ZINGIBER A CEAE p.221 et 1368 .

Zinnia Linn, n. 2493.

Zippelia Blum, n. 182t. *

Zippelia Reich, n. 726. *

Zizania Linn, n. 732.

Zizia Koch, n. 4392

Zizyphora Linn. n. 3602.

Zizyphus $J$, n. $\mathbf{5 7 1 7}$.

Zoegea Linn. n. 2866.
Zollernia Mart. n. 6813.

Zollikofera Nees. n. 3011.

Zollikoferia DC. n. 3002/1.

Zonaria $\mathrm{Ag}, \mathrm{n} .105$.

Zonaria Link, II. 86.

Zonaria Rouss, n. 437,

Zoocarpa Bory. n. 56.

Zoogalactine Sette. n. 28.

Zoophthalmum $P$. $B r$. n. 6665 .

Zornia Gmel. в. 6599.

Zornia Möneh, n. 3638.

Zostera Linn. n. 1659.

Zosterites Brongn n. 1666.

Zosterospermum Palis. n. 976. a.

Zosterostylis Blum. n. 1579.

Zoysia Willd. n. 935.

Zozimia Hoffm. n. 4478 .

Zueca Comm, n. 3149 .

Zuccagnia Cav. n. 6773.

Zueeagnia Thunb. n. 1122.

Zuecarinia Blum. n. 3282.

Zuccarinia Spreng. n. 3329.

Zyzygium $\boldsymbol{P}$. Br. n. 6319 .

Zwingera Hofor. n. 3817.

Wwingera Schreb. n. 5964.

Zygadenus $L \quad O$. Rich. u. 1068.*

Gygia P. Br. n. 6363.

Zygis Desv. n. 3616. b.

Zygnema $\mathrm{Ag}, 54$.

Zyguema Bory. n. 54. a.

Zygodon Hooker n. 514 .

Zygoglossum Reinw. n. 1353.

Zygomenes Salisb. n. 1032.

Zygomeris $\boldsymbol{F l}$. mex. n. 659 '.

Zygopetalum Hook, n. 1443. *

ZYGOPHYLLEAE p. 1161.

Zygophyllum Linn. n. 6036.

Zygostates Lindl. n. 1419.

Zygostigma Grieseb n. 3543/1.

Zygotrichia Brid. n. 53 t. et 585. b.

Zymum Nor. n. 5571.

Zyrphelis Cass, n. 2296. b.

Zythia Fries. n. 368. 
